\title{
FLORA
}

OF THE

\section{SOUTHEASTERN UNITED STATES}

\section{BEING DESCRIPTIONS OF}

THE SEED-PLANTS, FERNS AND FERN-ALLIES GROWING NATURALLY IN NORTH CAROLINA, SOUTH CAROLINA, GEORGIA, FLORIDA, TENNESSEE,

ALABAMA, MISSISSIPPI, ARKANSAS, LOUISIANA AND THE INDIAN TERRITORY AND IN OKLAHOMA AND

TEXAS EAST OF THE ONE-HUNDREDTH MERIDIAN

BY

JOHN KUNKEL SMALL, Ph.D.

CURATOR OF THE MUSEUMS AND HERBARIUM OF THE NEW YORK BOTANICAL GARDEN
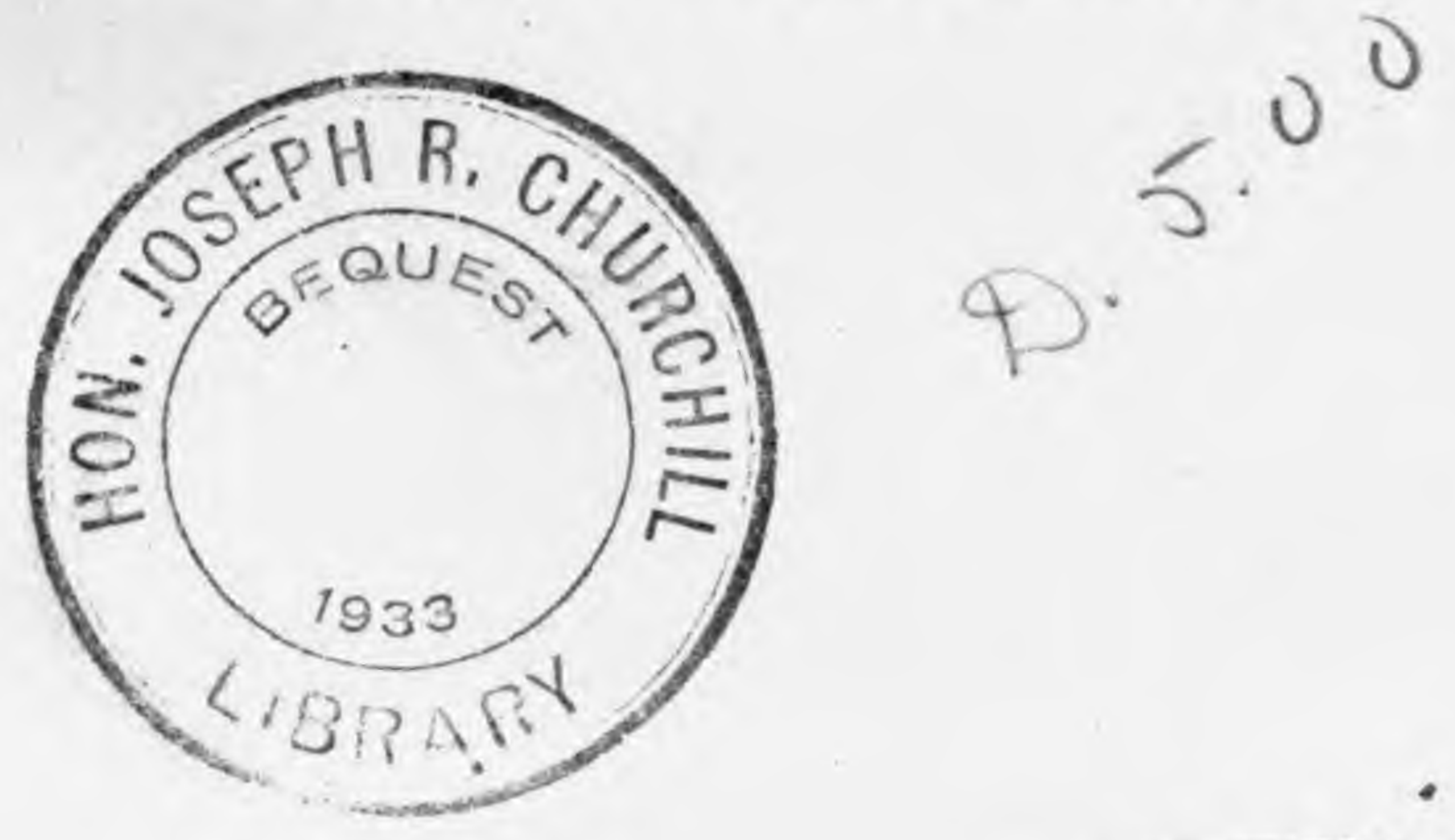

NEW YORK

PUBLISHED BY THE AUTHOR

1903

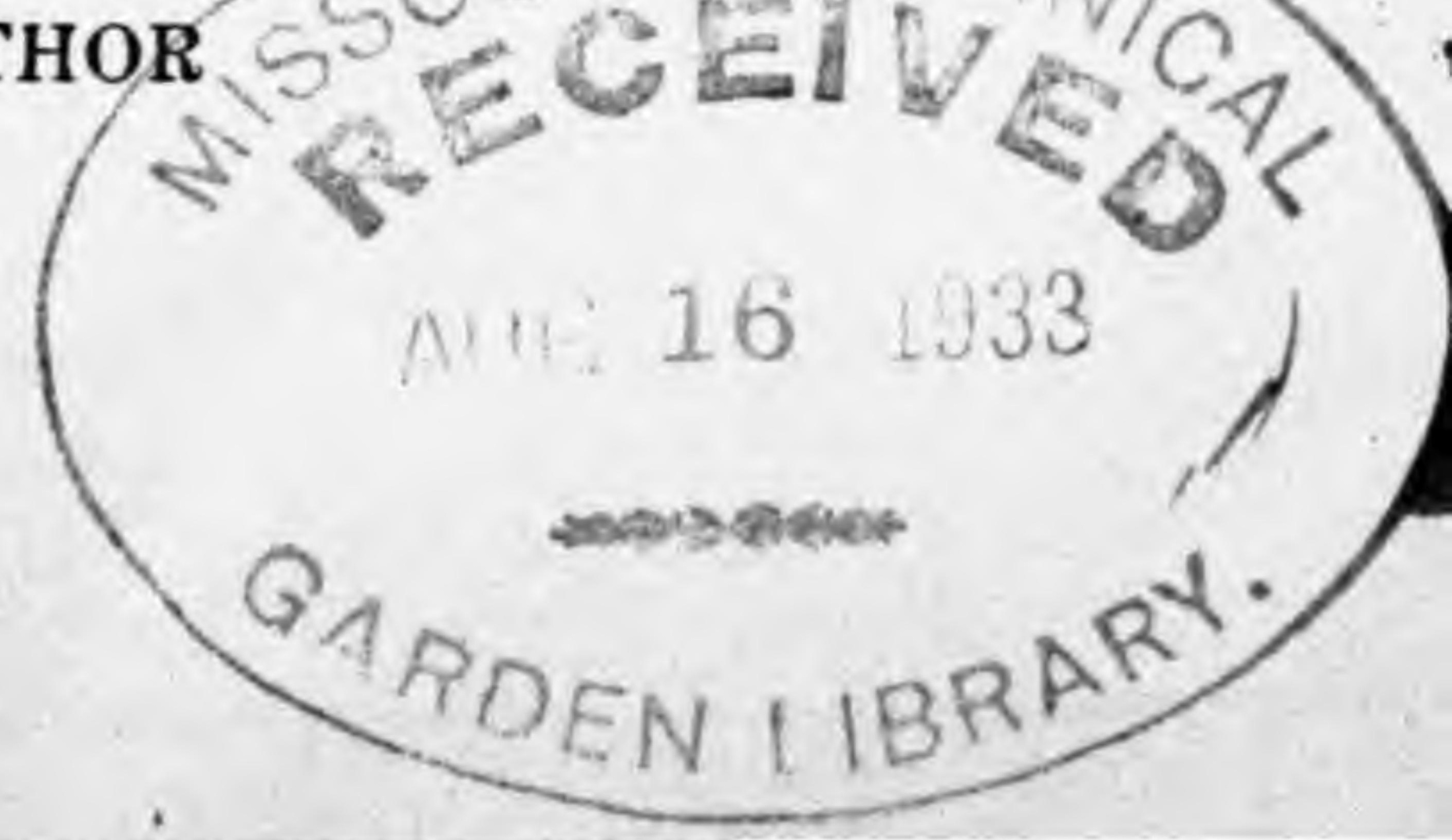


Copyright 1903

BY JOHN KUNKEL SMALL.

PaEsS OF

THE New ERa Printing COMPANY, LANCASTER, PA. 


\section{PREFACE.}

The object of this Flora is to present descriptions of the seed-plants, ferns and fern-allies growing naturally within the southeastern United States as limited by the northern boundaries of North Carolina, Tennessee, Arkansas, Indian Territory and Oklahoma, and the one hundredth Meridian, together with the known geographical distribution of each species. The usual flowering-period is given after the geographical distribution, except in cases where plants bloom throughout the year.

The arrangement of the higher plant-groups is essentially that of Engler and Prantl in their Natürlichen Pflanzenfamilien, except where modifications of the sequence there adopted have seemed to be desirable.

Analytical keys formed by the contrasting of diagnostic characters precede the descriptions of the families, genera and species, while a general key to the orders precedes the main body of the Flora.

The collections on which the work is based are mainly at the New York Botanical Garden. The manuscript of several groups has been prepared elsewhere by specialists, as indicated in the text.

To the custodians of the larger herbaria of the country, I wish to express my thanks for opportunities afforded for the examination of specimens desirable for study, during the prosecution of my investigations. I also take pleasure in acknowledging important assistance by my associates, Dr. N. L. Britton, Prof. L. M. Underwood, Dr. P. A. Rydberg, Mr. G. V. Nash, Dr. J. H. Barnhart and Mr. R. M. Harper; by Mr. C. D. Beadle, Director of the Biltmore Herbarium and his associates; by Prof. W. L. Bray, of the University of Texas, Mr. A. M. Huger of North Carolina, Mr. A. Cuthbert of Georgia and Prof. S. W. Stanfield of Texas.

J. K. SMall.

The New York Botanical Garden, July 22, 1903. 


\section{CONTENTS.}

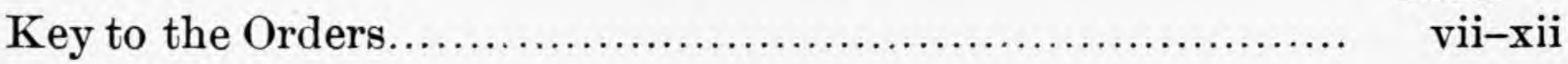

Descriptive Flora........................................... 1-1320

Appendix.....................................................1321-1325

List of Genera and Species published in this Flora.............1326-1341

Table of the Orders and Families...............................1342-1344

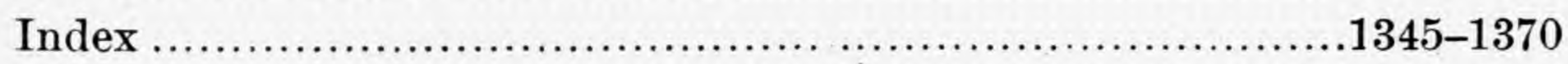




\section{KEY TO THE ORDERS. ${ }^{1}$}

I. Plants without flowers or seeds, but producing spores each of which, on germination, develops into a flat or an irregulur prothallium. The prothallia bear the reproductive organs (antheridia and archegonia). As a result of the fertilization of an egg in the archegonium by a sperm produced in the antheridium a fern or an allied plant is developed.

\section{PTERIDOPHYTA.}

PAGE.

Leaves with broad entire or dissected blades. (Fern-like plants.)

Spores of one kind, minute.

Vernation straight or inclined : prothallium subterranean, yellowish.

Vernation circinate : prothallium terrestrial or epiphytic. green.

Order OPHIOGLOSSALES. Order FILICALES. Spores of two kinds, minute microspores and larger macrospores, borne in sporocarps.

Leaves scale-like or awl-like. (Moss-like or rush-like plants.) Order Salviniales. 19 Sporangia in an apical cone, borne under peltate scales : stems hollow, rush-like.

Sporangia in the axils of small or leaf-like bracts: stems solid.

Order EQuisetales. 20

Leaves narrow or scale-like, flat, borne on erect or creeping stems : terrestrial plants.

Order LYCOPODIALES. 21

Leaves awl-like, often much elongated, borne on a short corm-like caudex : aquatic plants. Order IsOETALES.

II. Plants with flowers which produce seeds. Microspores (pollen-grains) borne in microsporangia (anther-sacs) develop each into a tubular prothallium; a macrospore (embryo-sac) develops a minute prothallium, and together with the macrosporangium (ovule) in whigh it is contained, ripens into a seed.

\section{SPERMATOPHYTA.}

Ovules and seeds borne on the face of a bract or a scale : stigmas wanting. Ovules and seeds in a closed cavity (ovary): stigmas present.
Class 1. GYMNOSPERMAE. Class 2. ANGIOSPERMAE.

\section{Gymnospermae.}

Plants growing by a single terminal bud, with pinnate leaves circinate in vernation : embryo prolonged into a spiral.

Order CYCADALES.

Plants growing by lateral as well as by terminal buds, with scale-like, flat or needle-like leaves not circinate : embryo not prolonged into a spiral.

Order PiNaLES.

\section{Angiospermae.}

Cotyledon 1 : stem endogenous.

Subclass 1. MoNOCOTYLEDONES. Cotyledons normally 2 : stem exogenous (with rare exceptions).

\section{Subclass 2. DiCOTYLEDONES.}

\section{MoNocotyledones.}

Perianth rudimentary or degenerate, the members often bristles or mere scales, not corolla-like, or wanting.

Flowers not in the axils of dry or chaffy bracts (scales or glumes).

Perianth of bristles or chaffy scales.

Perianth fleshy or herbaceous, or wanting.

Fruit baccate: endosperm present.

Fruit drupaceous: endosperm wanting. Order
Flowers in the axils of dry or chaffy, usually imbricated, bracts (scales or glumes).

Order PANDANALES. 34

Order Arales. 225 Order NAIADALES. 36

Perianth of 2 distinct series, the inner series usually corolloid.

Gynoecium of distinct carpels.

Gynoecium of united carpels.

Endosperm mealy.

Endosperm fleshy, horny or cartilaginous.

Order POALES. 48

A. Ovary, and fruit, superior.

a. Herbs, or rarely shrubs or trees, with simple leaves : ovules 2-many in each cavity of the ovary, or solitary only in the case of a few herbs.

Inflorescence not a fleshy spadix.

Inflorescence a fleshy spadix subtended by a spathe.

Order Alismales. 40

Order XYRIDALES. 231

1

9

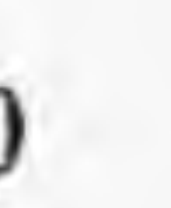

1


b. Trees or shrubs, with pinnately or palmately compound or lobed leaf-blades : ovules solitary in each cavity of the ovary.

B. Ovary, and fruit, wholly inferior or half-inferior.

Endosperm present and usually copious.

Flowers regular : androecium not reduced.

Flowers very irregular : androecium much reduced and modified.

Endosperm wanting.

Flowers regular, monoecious or dioecious : aquatic plants. Order HYDROCHARITALES. 46 Flowers irregular, perfect: terrestrial or epiphytic plants.

Order ScITAMINALES

\section{Dicotyledones.}

A. Corolla wanting, except in the pistillate flowers of Juglans (Juglandaceae).

Calyx wanting, at least in the staminate flowers, except sometimes in Casuarina (Casuarinaceae). Herbs.

Flowers mainly perfect.

Seeds solitary in each carpel or in each cavity of the ovary : endosperm present.

Flowers spicate: styles wanting: stigmas sessile. $\quad 330$

Flowers axillary: styles present. Callitrichaceae in Order EUPHORBIALES. 690

Seeds numerous in each cavity of the ovary : endosperm wanting.

Flowers monoecious or dioecious.
rees or shrubs: flowers monoecious or dioecious, or polygamous.

Podostemaceae in Order Rosales. 494

Leaves represented by appressed whorled scales: stems or branches loosely jointed.

Leaves not appressed scales: stems or branches not loosely jointed.

Fruit 1-seeded: seeds without tufts of hairs.

Ovules 1 or 2 in each cavity of the ovary: flowers not in heads.

Gynoecium 1-carpellary: stigma 1: ovule laterally attached and amphitropous.

Gynoecium 2-carpellary : stigmas 2: ovule erect and orthotropous or pendulous and anatropous.

Pistillate flowers without a calyx : ovule erect and orthotropous.

Fistillate flowers with a calyx : ovule pendulous and anatropous.

Order MYRICALES. 336

Leaf-blades simple.

Fruit a nut or an achene.

Fruit a drupe.

$\begin{array}{ll}\text { Fruit a drupe. } & \text { Oleaceae in Order OLEALES. } 916 \\ \text { Leaf-blades compound : fruit a samara. } & \text { Oleaceae in Order OLEALES. } 916\end{array}$

Ovules many : flowers agregated into dense heads. Altiugiaceae in

Fruit many-seeded : seeds each with a tuft of hairs.

Calyx present at least in the staminate or in the perfect flowers.

Leaves represented by appressed whorled scales : branches loosely jointed.

Leaves not appressed scales: branches not loosely jointed.

Flowers, at least the staminate, in aments, or ament-like spikes.

Leaf-blades simple: ovule pendulous and anatropous.

Pistillate flowers separate at maturity: fruit a nut or an achene. Order FAGAles. 343

Pistillate flowers forming aggregate fruits: fruit drupe-like.

Artocarpaceae in Order URTICALES. 355

Leaf-blades pinnately compound : ovule erect and orthotropous. Order JUGLANDALEs. 332 Flowers, at least the staminate, not in aments.

a. Ovary superior.

Gynoecium of 1 or several and distinct carpels : stigma and style solitary.

Carpel solitary.

Style lateral and oblique.

Style axile, erect.

Ovary neither enclosed nor seated in a hypanthium or a calyx-tube. Flowers not solitary in axils : land plants.

Filaments free and distinct.

Filaments adnate to the sepals or to the calyx-tube.

Flowers solitary in axils; aquatic plants.

Ceratophyllaceae in Order RANALEs. 428

Ovary enclosed in or seated in a hypanthium or a calyx-tube. Stamens borne under the gynoecium.

Allioniaceae in Order CHENOPODIALES. 383 Stamens borne on the hypanthium or adnate to the calyx-tube.

Order THYMELEALES. 818

Carpels several :

Stamens inserted below the ovary.
Stamens inserted on the edge of a cup-shaped hypanthium.

Gynoecium of 2 or several united carpels : stigmas or styles 2 or several.
* Ovary, by abortion, 1-celled and 1-ovuled.

Leaves with sheathing stipules (ocreae).

Order Polygonales. 366

Trees or shrubs.

Anthers opening by slits : ovary not seated in a hypanthium.

Ulmaceae in Order UrTICALES.

Anthers opening by hinged valves: ovary seated in an accrescent hypan-

Herbs or vines.

Lauraceae in Order THYMELEALES.

† Leaves with stipules.

Stipules herbaceous: inflorescence spicate or racemose : leaf-blades palmately veined.

Cannabinaceae in Order URTICALES. 
Stipules scarious or hyaline : inflorescence cymose: leaf-blades pinnately veined.

†† Leaves without stipules.

Stigmas entire.

Stigmas 2-cleft.

Families in Order CHENOPODIALES.

Order CHENOPODIALES. ** Ovary several-celled, or with several placentae, several-ovuled.

Stamens hypogynous, inserted under the gynoecium in the perfect flowers, not

on a disk in the pistillate flowers.

Herbs.

Flowers perfect.

Ovary several-celled.

Fruit baccate or nut-like, or a circumscissile capsule, the carpels terminal on the receptacle. Families in Order CHENOPODIALEs.

Fruit of several carpels, lateral on the receptacle, each carpel circumscissile.

Ovary 1-2-celled.

Penthoraceae in Order Rosales. 494

Stamens not tetradynamous, 4-8: ovary 1-celled.

Stamens tetradynamous: ovary 2-celled.

Order Chenopodiales. 383

Flowers monoecious or dioecious.

Ovules with the raphe towards the axis of the gynoecium.

Ovules with the raphe away from the axis of the gynoecium.

Buxaceae in Order SAPINDa LES. 723

Trees or shrubs.

Gynoecium 5-carpellary, the carpels nearly distinct.

Gynoecium 2-4-carpellary, the carpels united.

Ovary 4-celled: fleshy maritime shrubs.

Ovary 2-celled: plants not fleshy Batidaceae in Order CHENOPODIALES. 383

Stamens perigynous or epigynous, inserted on the,margin of a hypanthium or a disk.

Fruit a samara.

Families in Order SAPINDALES. 723

Fruit not a samara.

Fruit drupe-like or berry-like : shrubs or trees. Order RHamnales. 747 b. Ovary inferior.

Flowers not in involucrate heads.

Fruit 3-winged, splitting into 3 nutlets.

Fruit neither 3 -winged nor splitting into carpels.

Fruit a berry or a drupe, or nut-like.

Caly $\mathbf{x}$ deciduous as a lid : stamens numerous.

Calyx of valvate or imbricated sepals: stamens few.

Stamens as many.as the perianth-members and alternate with them, or fewer.

Herbs, with succulent stems and leaves, or woody below: flowers perfect.

Tetragoniaceae in Order CHENOPODIALES.

Trees or shrubs : flowers dioecious. Nyssaceae in Order AMMIALEs.

Stamens as many as the perianth-members and opposite them, or twice as many.

Styles present.

Ovules mostly on basal placentae, sometimes pendulous : cotyledons not convolute : tree or root-parasites. Order SANTALALES. 1101

Ovules not on basal placentae: cotyledons convolute: not parasitic

plants.
Styles wanting: stigmas sessile. Gunneraceae in Order MYRTALES.

Families in Order MYRTALES.

Fruit a capsule.

Sepals as many as the ovary-cavities or one-half as many.

Calyx regular and the sepals half as many as the cavities in the ovary, or irregular.

Order ARISTOLOCHIALES. 1130

Calyx regular and the sepals as many as the cavities in the ovary.

Sepals (4-5) at least twice as many as the ovary-cavities (2).

Order MYRTALES. 822

Saxifragaceae in Order Rosales. 494

Ambrosiaceae in Order CARDUALES. 1148

B. Corolla present.

* Petals distinct, at least at the base.

Carpels solitary, or several and distinct, or united only at the base.

Stamens at the base of the receptacle, $i$. e., hypogynous.

Flowers in monoecious heads.

Platanaceae in Order RosAlEs. 494

Flowers not in monoecious heads.

Plants with relatively firm stems and leaves, not succulent. Order Ranales. 428

Plants with succulent stems and leaves. Sedaceae in Order Rosales.

Stamens on the margin of a hypanthium (the hypanthium very small in some Saxifragaceae).

Plants without secreting glands in the bark.

Plants with secreting glands in the bark.

Order Rosales. 494

Carpels several and united.

† Ovary superior.

\pm Stamens inserted at the base of the ovary or receptacle.

\& Stamens numerous.

Sepals imbricated.

Calyx deciduous. 
Calyx persistent.

Stigmas pinnatifid: insectivorous plants.

Dionaeaceae in Order SARRACENIALES.

491

Stigmas not pinnatifid : plants not insectivorous (except in Sarraceniales).

Styles or stigmas distinct or united, but not discoid.

Leaves glandular or pellucid-punctate.

Placentae axile.

Rutaceae in Order Geraniales. 658 Placentae parietal.

Canellaceae in Order HYPERICALES. 781

Leaves not glandular.

Placentae pariental: gynoecium with a 1-celled ovary.

Anther-sacs opening lengthwise.

Anther-sacs opening at the top.

Capparidaceae in Order PAPAvERALES. 459

Bixaceae in Order HYPERICALES. 78

Placentae axile or central : gynoecium with a 2-several-celled ovary, (or with distinct carpels.) Theaceae in Order HYPERICALES. 781

Styles or stigmas united into a disk.

Herbs: bog or aquatic plants.

Petals and sepals numerous : leaves with flat blades: aquatic plants. Nymphaeaceae in Order RANALES. 428

Petals and sepals few : leaves with pitcher-like organs : bog plants. Sarraceniaceae in Order SARRACENIALES, 491

Shrubs or trees : plants not aquatic. Clusiaceae in Order HYPERICALES. 781 Sepals valvate.

Stamens with distinct filaments.

Ovary 1-celled : placentae parietal. Capparidaceae in Order PAPAVERALEs. 460

Ovary 2-several-celled : placentae axile or central.

Stamens with united filaments.

Families in Order Malvales. 759 Order MaLvales. 759

\& 3 Stamens few, not over twice as many as the petals.

Stamens as many as the petals and opposite them.

Anther-sacs opening by hinged valves. Podophyllaceae in Order Ravales. 428

Anther-sacs opening by slits.

Flowers monoecious.

Euphorbiaceae in Order EUpHORBIALES. 690

Flowers perfect.

Ovules, or seeds, several or many : embryo coiled.

ovules, or seeds, solitary : embryo straight.

Plumbaginaceae in Order Primulales. 898

Stamens as many as the petals and alternate with them, or more, sometimes twice as many.

Stamens 6 : petals 4 : sepals 2 or 4 .

Families in Order Papavera Les. 460

Stamens, petals and sepals of the same number, or stamens more, usually twice as many as the sepals or petals.

Ovary 1-celled.

Ovules, or seeds, on basal or central placentae.

Herbs.

Families in Order CHENOPODIALES. 383

Trees or shrubs.

Stamens with free and distinct filaments.

Tamaricaceae in Order HyPERICALES. 781

Stamens with partially united filaments, and usually adnate to the corolla.

Ovules, or seeds,

Styracaceae in Order EBENALES. 908

Stigmas 2-cleft.

Anther with an inconspicuous connective.

Stigmas not brush-like. Droseraceae in Order SARRACENIALES. 491

Stigmas brush-like. Turneraceae in Order HyPERICALES.

Anther with the conspicuous connective produced beyond the sacs.

Stigmas entire.

Papayaceae in Order PASSIFLORALES. 805

Stamens with united filaments and no staminodia.

Stamens with distinct filaments.

Staminodia present.

Staminodia wanting.

Families in Order Malvales. 759

Ovary several-celled.

Stamens adnate to the gynoecium.

Parnassiaceae in Order Rosales. 494 Families in Order Hypericales. 781

Stamens not adnate to the gynoecium.

Stamens with wholly or partly united filaments.

Anthers opening lengthwise. $\quad$ Families in Order Geraniales. 658

Anthers opening by pores. Polygalaceae in Order PoLYGALALES. 682

Stamens with distinct filaments.

Anthers opening by pores. $\quad$ Families in Order ERICALES. 876

Anthers opening by slits.

Stigmas or styles distinct and cleft, or foliaceous, or united by pairs.

Order EUPHORBIALES, 690

Stigmas or styles all distinct or all united, neither cleft nor foliaceous.

Stamens 2.

Stamens more than 2

Oleaceae in Order Oleales. 916

Leaves with compound blades.

Leaves with simple blades.

Ovule solitary in each carpel.

Styles distinct : ovule pendulous.

Families in Order GERANIALES. 658 
Styles united : ovule erect or ascending.

Limnanthaceae in Order SAPINDALES. 72
Ovules 2 or more in each carpel.

Flowers irregular: stamens united at the top or converging.

Placentae axile.

Placentae parietal

Balsaminaceae in Order GERANIALES. 658

Violaceae in Order HYPERICALES. 781

Flowers regular: stamens neither united nor converging at the top.

Carpels not circumscissile at maturity.

Placentae parietal.

Placentae axile or central. Styles distinct. Styles united.

Elatinaceae in Order HYPERICALES. 781

Ovary sessile : filaments filiform.

Tiliaceae in Order MALVALES. 759

Koeberliniaceae in Order GERANIALES. 658

Carpelscircumscissile at maturity.

Penthoraceae in Order Rosales. 494

If Stamens inserted on the margin of a disk or hypanthium (perigynous or hypogynous). Stamens fewer than the sepals or the petals.

Stamens as many as the sepals or the petals, or more.

Stamens as many as the petals and opposite them.

Styles and upper part of the ovaries distinct: ovules and seeds many.

Styles united.

Ovules and seeds numerous.

$\begin{array}{lll}\text { Ovules and seeds numerous. } & \text { Moringaceae in Order PAPAVERALES. } & 459 \\ \text { Ovules and seeds solitary or } 2 . & \text { Order RHAMNALES. } & 747\end{array}$

Saxifragaceae in Order Rosales. 494 mens as many as the petals and alternate with them, or more or many.

Styles distinct.

Upper part of the ovaries distinct, at least at maturity.

Upper part of the ovaries united.

Saxifragaceae and Iteaceae in Order RosaLEs. 494 Styles united.

Hypanthium flat or obsolete: disk fleshy.

Plants without secreting glands in the bark. Order SAPINDALES. 723 Plants with secreting glands in the bark. Families in Order Geraniales. 658 Hypanthium cup-shaped or campanulate : disk obsolete or inconspicuous.

† Ovary inferior.

Order MYRTALES. 822

Stamens numerous.

Styles and stigmas united into a disk : water-plants with endogenous stems.

Styles distinct, or united, but not forming a disk with radiating stigmas : land-plants

with exogenous stems.

Styles distinct.

Stamens distinct : stigmas simple: shrubs or trees. Families in Order Rosales. 494

Stamens with united filaments: styles branched : herbs. Order BEgONIALES. 817

Styles united.

Shrubs or trees; not succulents, sometimes woody vines.

Hypanthium not produced beyond the ovary.

Hypanthium produced beyond the ovary.

Escalloniaceae in Order Rosales. 494

Herbs, or shrub-like or tree-like succulents.

Stamens not more than twice as many as the petals.

Styles wanting: stigmas sessile.

Styles present.

Styles distinct.

Ovules several in each cavity of the ovary : fruit a capsule or a fleshy manyseeded berry.

Fruit, if dehiscent, valvate.

$\begin{array}{ll}\text { Fruit, if dehiscent, valvate. } & \text { Families in Order Rosales. } \\ \text { Fruit circumscissile. } & \text { Portulacaceae in Order CHENOPODIALES. }\end{array}$

Families in Order MYRTALES. 822

Order OPUNTIALES. 808

Gunneraceae in Order MYrtales. 822

Ovules solitary in each cavity of the ovary: fruit a drupe or $2-5$ more or less united achenes.

Styles united, or single.

Plants without tendrils.

Ovary enclosed in or surpassed by the hypanthium or adnate to it.

Anther-sacs opening by pores.

Anther-sacs opening by slits.

Ovules solitary in each cavity of the ovary.
Ovules several in each cavity.

Vacciniaceae in Order ERICA LES. 876

Ovary with central or basal placentae.

Ovary exceeding the hypanthium, the top free.

Families in Order MYRTALES. 822

Escalloniaceae in Order Rosales. 494

Plants with tendrils.

Herbs: fruit a pepo: leaf-blades palmately veined.

Shrubby vines: fruit drupaceous, separating into nutlets: leaf-blades pinnately veined.

Rhamnaceae in Order RHAMNALES. 747 
** Petals more or less united.

Ovary superior.

Stamens free from the corolla.

Gynoecium of a single carpel.

Gynoecium of several united carpels.

Filaments united.

Stamens diadelphous.

Stamens monadelphous.

Anther-sacs opening by slits.

Anther-sacs opening by pores.

Calyx and corolla very irregular.

Caly $x$ and corolla regular.

Filaments distinct.

Styles wanting or very short: stigma sessile. Aquifoliaceae in Order SAPINDALEs. 723 Styles elongated.

Ovary several-celled.

ovary 1-celled.

Fumariaceae in Order Papaverales. 460

Oxalidaceae in Order GeranIA LEs. 658

Order Polygalales. 682

Families in Order ERICALEs. 876

Stamens partially adnate to the corolla.

Families in Order ErICALEs. 876 Armeriaceae in Order Primulales. 898

Stamens as many as the lobes of the corolla and opposite them, or twice as many or more. Ovary 1-celled.

Placentae central or basal. $\quad$ Order Primulales. 898 Placentae parietal.

Ovary several-celled.

Upper portion of the ovaries distinct.

Upper portion of the ovaries united.

Fouquieriaceae in Order HYPERICALES. 781

tamens as many as the lobes of the corolla and alternate with them, or fewer.

Corolla not scarious, veiny : fruit various, but not a pyxis.

Gynoecium of 3-6 carpels.

Shrubs or trees: ovules and seeds few. Aquifoliaceae in Order SAPINDALEs. 723.

Herbs, or creeping or tufted shrubby plants: ovules and seeds numerous.

Stamens adnate up to the sinuses of the corolla: creeping evergreen under-

shrubs. $\quad$ Diapensiaceae in Order ERICALES. Stamens adnate to the lower part of the corolla-tube: vines.

Gynoecium of 2 carpels.

Families in Order Polemoniales. 956

Carpels distinct, except sometimes at the apex.

style terminal.

Style basal.

Order Asclepiadales. 933

Carpels united.

Ovary 1-celled, with central placentae.

Dichondraceae in Order POLEMONIALES. 956

Ovary 2-celled, or falsely 4-celled, or if 1 -c

Stamens 2 and opposite each other, or 3.

Order Gentiana Les. 921

amens usually 4 or 5 , if 2 by reduction not opposite each other

Leaves with stipules or stipular lines at their bases.

Leaves with no traces of stipules.

Spigeliaceae in Order Gentianales. 921

Corolla scarious, veinless: fruit a pyxis.

Order POLEMONIALES 956 Ovary inferior.

Stamens with the filaments free from the corolla.

Stamens 10 : anther-sacs opening by terminal pores or chinks.

Stamens 5 or fewer: anther-sacs opening by longitud Stamens adnate to the corolla.

Ovary with 2-many fertile cavities and 2-many ovules: calyx unmodified, at least not a pappus.

Plants tendril-bearing.

Plants not tendril-bearing.

Cucurbitaceae in Order CaMPanUlaLes. 1134

Ovules mostly on basal placentae : plants parasitic.

Ovules variously borne, but not on a basal placenta : plants not parasitic.

Ovary with one fertile cavity.

Ovules numerous on a basal placenta.

Ovule solitary, the placentae not basal.

Order RuBIaLEs. 1104

Flowers not in heads, often in head-1

Primulaceae in Order Primulales. 898

Flowers in involucrate heads.

rder VALERIANALES. 1127 Order CARDUALES. 1148 


\section{FLORA}

OF THE

\section{SOUTHEASTERN UNITED STATES}

\section{Subkingdom PTeridóphyta. ${ }^{1}$ Ferns and Fern Allies.}

Plants containing woody and vascular tissues. They produce spores asexually, each of which, on germination, develops into a prothallium (gametophyte). The prothallia bear the reproductive organs; the female organ is known as an archegone, the male as an antherid. As a result of the fertilization of an egg in the archegone by a sperm produced in the antherid, the asexual state of the plant is developed (sporophyte); this phase is represented by a fern or an allied plant.

\section{Order 1. OPHIOGLOSSÀLES.}

Succulent plants, consisting of a stem and leaf growing from a fleshy rootstock. Sporophyll in the form of a spike or panicle, the sporanges formed from the interior tissues, naked, each opening at maturity by a transverse slit. Spores yellow, of one sort. Prothallia subterranean, devoid of chlorophyll.

\section{Family 1. OPHIOGLOSSÀceae Presl. Adder's-tongue Family.}

Characters of the order.

Veins reticulated : sporanges cohering in one or more distichous spikes.

Terrestrial : spike single, long-stalked.

Epiphytic on palmettos: spikes several, short-stalked. Veins free: sporanges distinct, borne in spikes or panicles.

1. OpHioglossum.

2. Cheiroglossa.

3. BOTRYCHIUM.

\section{OPHIOGLÓSSUM L.}

Low terrestrial plants, with small rootstocks, and slender fleshy roots. Bud for the following year formed at the side of the base of the stem. Leaf solitary, borne on the stem : blade simple, entire. Sporophyll terminal, formed of two rows of large coalescent sporanges. Veins reticulated. Spores sulphur-yellow. AdDER's-Tongue.

Leaf-blades ovate or elliptic-oblong, $3-12 \mathrm{~cm}$. long, with several equal or parallel veins at the base.
Leaf-blades obtuse: areolae with few veinlets.
1. O. vulgatum.

Leaf-blades apiculate: areolae broad, with many veinlets.

Leaf-blades cuneate or cordate at the base, with unequal veins at the base.

Rootstocks slightly tuberous-thickened: leaf-blades lanceolate or ovate with a cuneate base.

Rootstocks globose: leaf-blades ovate with a cordate base.

2. O. Engelmannii. simplenter, $1-4 \mathrm{dm}$. tall, simple, glabrous, bearing a leaf near its middle ; leaf-blade sessile, ovate or elliptic-oblong, $3-12 \mathrm{~cm}$. long, rather firm in texture, distinctly reticulated, with few veinlets within the areolae ; basal veins $9-13$ : spike solitary, $1-2.5 \mathrm{~cm}$. long, erect apiculate.

In moist meadows and thickets, Prince Edward Island to Alaska, south to Florida. Also in Europe and Asia. May to August.

${ }^{1}$ Contributed by Prof. Lucien Marcus Underwood. 
2. Ophioglossum Engelmánnii Prantl. Rootstock cylindric. Stem $8-22 \mathrm{~cm}$. high bearing a leaf ; blade elliptic or lanceolate-elliptic, $3-9 \mathrm{~cm}$. long, sharply apiculate, fleshy but becoming pellucid; basal veins 13 or more, the transverse veinlets oblique, forming broad oblong-hexagonal areolae with numerous veinlets : spike $1.5-2.5 \mathrm{~cm}$. long, apiculate.

In moist grounds, Virginia to Indiana, Missouri, Texas and Arizona.

3. Ophioglossum pusíllum Nutt. Rootstock slightly thickened. Stem slender, $2.5-4 \mathrm{~cm}$. high, bearing a leaf near the base ; blade lanceolate or ovate with a cuneate base ; basal veins 3 , the midvein branching by lateral veinlets which form narrow areolae with no free veinlets: spikes $6-12 \mathrm{~mm}$. long, with $6-14$ sporanges on either side. [O. nudicaule Chapm., not L. f.]

In sandy soil, Georgia to Florida and Louisiana.

4. Ophioglossum crotalophoroìdes Walt. Rootstock globose. Stem relatively stout, bearing one leaf ; blade concave, broadly ovate, $8-30 \mathrm{~mm}$. long, with a cordate base and acute apex ; basal veins 5 , the midvein rarely branched, the lateral veins freely anastomosing, forming short hexagonal areolae with rarely a free veinlet : spikes broad, 4-12 $\mathrm{mm}$. long, with 4-11 sporanges on either side.

In sandy soil, South Carolina to Florida and Texas, Also in tropical America.

\section{CHEIROGLÓSSA Presl.}

Epiphytic plants, with slender fleshy roots. Leaf-blades simple, palmately lobed, bearing several spikes near their bases. Veins reticulated; the areolae without free veinlets.

1. Cheiroglossa palmàta (L.) Presl. Rootstock tuberous, covered with fine woolly chaff. Leaves fleshy ; blades 10-25 cm. long, on a stem nearly as long, palmately divided into $2-9$ broadly spreading lobes, or rarely entire and lanceolate : spikes $2-16$, or rarely 1 , short-stalked, $2.5 \mathrm{~cm}$. long or more. [Ophioglossum palmatum L.]

On palmettos, Florida and tropical America.

\section{BOTRÝCHIUM Sw.}

Fleshy plants, with erect rootstocks, and clustered fleshy roots, the bud for the succeeding year imbedded in the base of the stem. Leaf-blade pinnately or ternately divided, or compound. Sporophyll pinnate or 3-pinnate, with sessile distinct sporanges in rows on either side of its branches, forming large panicles in some species. Veins free. Spores yellow. MoONwort.

Bud for the following year enclosed in the base of the stem: leaf-blades ternate or biternate, attached near the base of the common stem.

Leaf-blades sessile or nearly so: spores maturing in early spring.

Leaf-blades stalked : spores maturing in fall. Leaf-blade biternate, thin.

Leaf-blade ternate, with bipinnate or tripinnate divisions, fleshy.

Bud enclosed in a cavity at one side of the base of the stem: leaf-blades ternate, decompound, sessile at the middle of the stem.

1. B. biternatum.

2. B. tenuifolium.

3. B. obliquum.

1. Botrychium biternàtum (Lam.) Underw. Plant $6-10 \mathrm{~cm}$. high, bearing a single leaf ; blade sessile or nearly so, ternately compound, $8-10 \mathrm{~cm}$. wide, $5 \mathrm{~cm}$. long, with the middle division slightly larger than the lateral ones and like them nearly 3 -pinnate; ultimate segments somewhat lunate, usually $5-6 \mathrm{~mm}$. wide, the outer margin crenate, the lateral margins decurrent on the rachis: sporophyll on a stalk $8 \mathrm{~cm}$. long or longer, 2pinnate : bud smooth or slightly pilose.

On dry grassy knolls, South Carolina to Louisiana. The spores mature in March or April.

2. Botrychium tenuifòlium Underw. A slender plant with a biternate leaf-blade. Stems very slender, $2-4 \mathrm{~cm}$. long, $1-1.5 \mathrm{~mm}$. thick : leaf-blade $3.5-5 \mathrm{~cm}$. long, $3-6 \mathrm{~cm}$. wide, usually consisting of nine segments, the primary divisions nearly equal, or the terminal one sometimes slightly more divided; segments ovate, $1.2-1.5 \mathrm{~cm}$. long by $6-8 \mathrm{~mm}$. wide, thin, sharply serrate, or nearly 2 - or 3 -incised ; petiole $3-6.5 \mathrm{~cm}$. long, very slender; panicle 3-6 cm. long, bipinnate or basely tripinnate below on a slender stalk, $6-22 \mathrm{~cm}$. long.

In low grounds, Alabama, Florida and Louisiana. The spores mature in fall,

3. Botrychium oblìquum Muhl. Plant robust, $1.5-5 \mathrm{dm}$. high. Leaf rising from near the base of the stem on a stalk $2-10 \mathrm{~cm}$. long, or more ; blade ternate, with the three divisions nearly equal, 2-pinnate or somewhat 3-pinnatifid in larger forms, the ultimate segments obliquely ovate or oblong-lanceolate, the terminal one of each division elongated, 1-2 cm. long, the margins crenate or serrate: sporophyll long-stalked, 3-4-pinnate : bud densely pilose, both portions bent in vernation. [B. ternatum Chapm., not Sw.]

In low woods and open places from New Brunswick to Minnesota, south to Florida and Mexico. The spores mature from August to October. 
4. Botrychium Virginiànum (L.) Sw. Plant 2-6 dm. high, the stem slender but fleshy. Leaf-blade nearly or quite sessile above the middle of the stem, spreading, thin, ternate with the primary divisions pinnate or 2-pinnate and the segments 1-2-pinnatifid; ultimate segments oblong, more or less toothed near the apex; epidermal cells flexuous : sporophyll long-stalked, 2-3-pinnate: bud for the following year pilose, enclosed in a glabrous cavity at one side of the lower part of the stem : sporophyll recurved its whole length, the leaf reclined upon it in vernation.

In woods, Nova Scotia to British Columbia, Florida and Arizona. Also in Europe and Asia. Spring

\section{Order 2. FILICÀLES.}

Terrestrial aquatic or epiphytic plants, various in habit. Sporanges developed from the epidermal tissues, on the back or margin of the leaf-blades, or in panicles formed from modified leaves. Spores of one sort. Prothallia with chlorophyll, flat, terrestrial.

Leaves with filmy translucent blades : sporanges sessile on a filiform receptacle.

Leaves with herbaceous or leathery blades: sporanges on normal or Fam. 1. HymenopHyLLACEAE. modified leaf-blades.

Sporanges in panicles or spikes.

Sporanges nearly globose, with a rudimentary ring.

Sporanges ovoid or pyriform, with a complete apical ring.

Sporanges borne on the back or margin of a leaf-blade.

Sporanges scattered, globose, with a more or less complete broad ring, opening vertically : aquatic.

Sporanges arranged in sori, with a complete ring, opening transversely: terrestrial or epiphytic.

Fam. 2. Osmundaceae.

Fam. 3. SCHIZAEACEAE.

Fam. 4. Ceratopteridaceae.

Fam. 5. Polypodiaceae.

\section{Family 1. HYMENOPHyLLÀCeAe Gaud. Filmy Fern Family.}

Membranous, mostly small ferns with filiform or slender creeping or horizontal rootstocks. Leaf-blades usually much divided. Sporanges sessile on a filiform usually elongated receptacle, surrounded by a transverse ring which opens vertically.

\section{TRICHÓMANES L.}

Delicate filmy plants. Leaves usually with much divided blades. Receptacle slenderfiliform, surrounded by a tubular or funnel-shaped indusium which is truncate or slightly 2-lipped.

Leaf-blades entire or slightly pinnatifid, 6-24 mm. long. Leaf-blades 2-3-pinnatifid, 8-27 cm. long.

1. T. Petersii.

2. T. Boschianum.

1. Trichomanes Petèrsii A. Gray. Rootstocks widely creeping. Leaves with a few black hairs along the margins when young; blades entire, or slightly pinnatifid, 6-24 $\mathrm{mm}$. long, 2-4 mm. wide, on a stalk $2-4 \mathrm{~mm}$. long : indusium solitary, terminal, funnelform, expanded and slightly 2-lipped at the mouth : receptacle mostly included.

Under moist rocks, Winston and Etowah Counties, Alabama, and in Georgia and Mississippi.

2. Trichomanes Boschiànum Sturm. Rootstocks wiry, tomentose. Leaves erect or ascending; petioles $2.5-7.5 \mathrm{~cm}$. long, naked or nearly so ; blades $5-20 \mathrm{~cm}$. long, $1.5-3.3$ $\mathrm{cm}$. wide, lanceolate or ovate-lanceolate, 2-3-pinnatifid : leaflets ovate, obtuse, the upper side of the cuneate base parallel or appressed to the narrowly winged rachis; segments toothed or cut into linear divisions : indusia terminal on short lobes, 1-4 on a segment, slightly 2-lipped at the mouth : receptacle partially exserted. [T. radicans A. Gray, not Sw.]

On wet rocks, Kentucky to Alabama and Florida. Also widely distributed in the tropics.

\section{Family 2. OSMUNdàceat R. Br. Cinnamon Fern Family.}

Large plants, with stout often erect rootstocks. Leaves coiled in vernation : blades 1-2 pinnate: veins free, mostly forked, running to the margins of the leaflets or lobes. Sporanges large, globose, with no ring or mere traces of a transverse riug of thick-walled cells, borne on modified contracted leaflets, or in clusters (sori) on the lower surface of the leaflets.

\section{OSMÚNDA L.}

Swamp plants, growing in large crowns, with the fertile (spore-bearing) portions very much contracted, the short-pedicelled naked sporanges on the margins of their rachis-like 
divisions, which are destitute of chlorophyll. Veins forked, regular and prominent. Sporanges each opening by a longitudinal cleft into two halves. Spores green.

Leaf-blades 2-pinnate, fertile at the apex.

Leaf-blades 2-pinnatifid, wholly or partially fertile, or sterile.

Leaflets of sterile leaf with a tuft of tomentum at the base; fertile leaf normally distinct from sterile. $\bullet$

Leaflets of sterile leaf without a tuft of tomentum at the base; leaves fertile in the middle.

1. O. spectabilis.

1. Osmunda spectábilis Willd. Leaves several, clustered, $6-20 \mathrm{dm}$. high ; blades 2-pinnate. Leaflets 1.5-3 dm. long, 5-10 cm. wide, their segments oblong-ovate, or lanceolate-oblong, sessile or slightly stalked, glabrous, finely serrulate, especially near the apex and occasionally crenate towards the truncate oblique or cordate base : sporophylls linearcylindric, panicled, withering and shrivelling with age, greenish before maturity, but becoming dark-brown after the spores have fallen.

In swamps and marshes, New Brunswick to Nebraska, Florida and Mississippi. Also in Mexico. Distinct from the European O. regailis L. May-July. ROYAL FERN.

2. Osmunda cinnamòmea L. Rootstock widely creeping, bearing a cluster of sterile leaves with one or several fertile ones within. Leaves erect or nearly so ; petioles 3 $\mathrm{dm}$. long, or longer, elothed with ferruginous tomentum when young, g]abrous when old ; blades 3-12 dm. long, with merely a tuft of tomentum at the base of each leaflet ; leaflets linear-lanceolate, deeply pinnatifid into oblong obtuse segments : sporophyll 2-pinnate, contracted, soon withering: sporanges cinnamon-colored after the numerous green spores have been discharged.

In wet places, Nova Scotia to Minnesota, south to Florida and Mexico. May-June. Crnnamon FERN.-Forms occur with leaves variously intermediate between the sterile and fertile.

3. Osmunda Claytoniàna L. Rootstock bearing a cluster of ascending or arching leaves, some usually partially fertile and taller than the sterile. Leaves 6-20 dm. long, 1.5-2.5 dm. wide; blades 2-pinnatifid; sterile leaflets linear-lanceolate, without tufts of tomentum at the base, deeply cleft into oblong obtuse segments; some of the leaf-blades contracted at the middle and bearing 2-5 pairs of sporophylls with dense cylindric divisions greenish at first, afterward dark-brown.

In moist or shaded places, Newfoundland to Minnesota, North Carolina and Missouri. May-July.

\section{Family 3. SCHIZAFÀCEAE Reichenb. Curly-grass Family.}

Plants various in habit, with simple or pinnate leaf-blades. Sporanges borne in spikes or panicles, sessile, each provided with an apical ring opening vertically by a longitudinal slit.

Twining: sporanges in ample panicles in the upper portion of the leaf : leaflets palmate.

Erect: sporanges in panicles borne on the elongated lower leaflets.

1. Lygodium.

2. ORNITHOPTERIS.

\section{LYGÒDIUM Sw.}

Twining or climbing plants. Leaves with the lower divisions sterile, variously stalked and lobed, the fertile divisions terminal, panicled. Sporanges ovoid, solitary or in twos, in the axils of imbricated scale-like indusia. Indusia fixed by their broad bases to short oblique veinlets.

1. Lygodium palmàtum (Bernh.) Sw. Rootstock slender, horizontal. Leaves ample ; petioles slender, flexible and twining; blades 4-10 dm. long, their short alternate branches 2-forked, each fork bearing a nearly orbicular 4-7-lobed leaflet, which is more or less cordate at the base with a narrow sinus; surfaces naked; fertile leaflets contracted, several times forked, forming terminal panicles : sporanges solitary.

In moist thickets and open woods, New Hampshire and Massachusetts, to Pennsylvania, Tennessee and Florida; rare or local. Summer. Climbing FERN.

\section{ORNITHÓPTERIS Bernh.}

Erect plants, with creeping or horizontal rootstocks. Leaves with the lower pair of leaflets elongated and often overtopping the blade, bearing numerous panicles of sporanges which are borne in two rows on the back of very narrow divisions. Veins free. [Anemia Sw.] Leaf-blades simply pinnate. Leaf-blades pinnately decompound.

1. Ornithopteris Mexicàna (Kl.) Underw. Leaf-blades $2-4 \mathrm{dm}$. long, on petioles of equal length, with a large terminal leaflet and from 4-6 pairs of lateral ones; leaflets 
ovate-lanceolate, short-stalked, somewhat leathery, smooth and manifestly glossy ; midrib distinct, with oblique parallel veins: sporophylls long-stalked, overtopping the leaf. In dry soil, western and southern Texas and adjacent Mexico.

2. Ornithopteris adiantifòlia (L.) Bernh. Leaf-blades triangular-ovate, $12-20 \mathrm{~cm}$. long, on usually elongated petioles, slightly pubescent, .pinnately decompound; ultimate segments obovate or cuneate, entire or lobed, striate above with numerous flabellate veins.

In sandy soil or coral rock, peninsular Florida. Also in the West Indies and Mexico.

\section{Family 4. Ceratopteridàceat Underw. Floating Fern Family.}

Aquatic succulent plants, floating, or rooting in the mud. Leaves of two kinds, some with flat blades, the sporophylls narrowed, with broadly reflexed margins meeting at the midrib. Sporanges scattered, sessile, each with a broad complete partial or obsolete ring. Sori seated on two or three veins that run down the length of the leaf-blade, nearly parallel to both the edge and the midrib.

\section{CERATÓPteris Brongn.}

Characters of the family. Floating Fern.

1. Ceratopteris thalictroides (L.) Brongn. Leaves tufted; petioles inflated, filled with large air-cavities; blades floating, $15-35 \mathrm{~cm}$. long, simple or only slightly divided when young, 2-pinnate at maturity : sporophylls 2-3-pinnate, erect or ascending, the ultimate segments pod-like.

In deep or shallow water, peninsular Florida and Louisiana. Also widely distributed in the tropies.

\section{FAMily 5. POLYPODIÀCEAE R. Br. Fern FAmily.}

Plants various in habit. Rootstocks creeping or horizontal, elongated, or short and erect. Leaves various, coiled in vernation : blades entire, pinnate, pinnatifid or decompound. Sporanges borne in clusters (sori) on the lower side or margins of the leaf-blades, stalked, provided with a vertical ring, open transversely. Sori frequently with a membranous covering (indusium). Prothallia green.

A. Sporiferous leaf-blades flat, or their edges merely revolute.

Sori without indusia.

Sori covering the leaf-blades or portions of them with a uniform layer.

Sori more or less separated from each other.

Sori roundish, not more than twice as long as broad.

Leaves with petioles jointed to the rootstocks; blades entire, pinnatifid or 1-pinnate.

Veins free; leaf-blades (in our species) pinnatifid or pinnate.

Veins copiously anastomosing.

Veins forming regular ample areolae: leaf-blades pinnatifid.

Veins, or those parallel to the margins, forming irregular areolae: leaf-blades simple.

Leaves ample : veins parallel to the margins with interven-

ing finer areolae.
Leaves relatively small: veins with irregular areolae through-

Leaves not jointed to the rootstocks : blades (in our species) 2-3-pinnatifid or ternate.

Veins free.

Veins connivent, the branches of contiguous groups uniting to form Sori linear. one or more arches.

Leaf-blades simple.

Leaves with very narrow grass-like blades : veins indistinct.

Leaves with expanded blades : veins markedly anastomosing. Leaf-blades 1-4-pinnate: sori marginal.

Sori with indusia.

Indusia formed of the partially altered margin of the leaf-blade.

Sporanges at the ends of veins, borne in a reflexed portion of the leafblade.

Sporanges borne on a continuous vein-like receptacle connecting the

apices of the veins.
Indusia single, formed of the altered leaf-margin.

Indusia double, a membranous one arising within the receptacle.

Sporanges at the apices of unconnected veins or near them.

Sori mostly forming a continuous indusium around the leaf-segments.

Sori minute; indusium usually interrupted, if continuous, leaf-segments small and bead-like.

Indusia specially developed. not from the leaf-margins : sori dorsal.

1. Acrostichum.

2. Polypodum.

3. Phlebodium.

4. Campyloneuron.

5. Phymatodes.

\section{Phegopteris.}

26. GONIOPTERIS.

6. Vittaria.

7. Cheilograman.

13. Notholakna.

10. Adiantum.

8. Pteris.

9. PTERIDIUM.

11. Pellaea.

12. Cheilanthes. 
Sori parallel to the midrib or rachis.

Veins free: sori continuous or nearly so.

Veins anastomosing : sori interrupted, chain-like.

Leaves uniform: veins free between the sori and the margin. 15. ANoHIsTEA.

Leaves dimorphous: veins everywhere anastomosing. 19. LORINSERIA.

Sori wholly or partially oblique to the midrib.

Veins free: sori all oblique.

Sori single on the upper side of a veinlet or rarely crossing it : leaf-blades (in our species) not entire.

Sori confluent in pairs with an apparently double indusium opening in the middle: leaf-blades entire.

Veins united: sori partly parallel to the midrib, partly oblique.

Sori orbicular or nearly orbicular: indusia less than twice as long as broad.

a. Indusia superior.

Sori mostly on the back of the veins.

Indusia orbicular, peltate, fixed by the center.

Veins copiously united, forming areolae.

Veins free.

Indusia reniform, or orbicular with a narrow sinus.

Sori at the ends of free veins: indusia reniform, opening toward the margin of the leaflet.

b. Indusia wholly or partly inferior.

Indusia partly inferior, delicate, fixed by a broad base, enclosing the sorus like a hood.

Indusia wholly inferior, various in shape.

Indusia cup-shaped or somewhat 2-valved.

Indusia nearly orbicular or stellate.

B. Sporiferous leaf-blades closely rolled together; segments necklace-like. Leaf-blades with anastomosing veins : rootstock horizontal.

Leaf-blades with free veins : rootstock stout, erect.

16. Asplenium.

7. Phy lititis.

18. Camptosorus.

\section{ACRÓSTICHUM L.}

Swamp-inhabiting plants, with the leaves growing in crowns. Sporanges spread over the whole lower surface of the leaf-blades, or of the upper leaflets. Veins forming copious areolae without free veinlets.

Sporanges formed on the upper leaflets only.

Sporanges formed on all the leaflets of some leaves.

1. A. aureum.

2. A. lomarioides.

1. Acrostichum aùreum L. Rootstocks erect, solitary, or in masses. Petioles tufted, erect, woody, 1-7 dm. long, flattish, channeled, with two or three alternate pairs of black indurated spurs; blades stiff, leathery, glossy, light green, 10-12 dm. long, 3-4 $\mathrm{dm}$. wide; leaflets 12 pairs or more, rather distant : sporanges confined to the upper half or third of the leaf-blade : venation fine, oblique to the margin.

Southern peninsular Florida. Also in tropical regions.

2. Acrostichum lomarioides Jenman. Rootstocks similar to those of A. aureum. Petioles tufted, erect, somewhat fleshy, 4-7 dm. long, longitudinally ribbed, slightly angular ; blades erect-spreading, 10-12 dm. high, 3-6 dm. wide, slightly reduced at the base, abruptly reduced at the apex ; leaflets spreading, close or crowded, 25-30 pairs, the face turned upward and transverse to the rachis : sporanges covering all the leaflets of fertile leaves : areelae very fine, directed toward the margin.

Southern peninsular Florida. Also in the West Indies.

\section{POLYPÒDIUM L.}

8. 1

Plants with creeping or horizontal rootstocks. Leaves various : petioles jointed to the rootstocks : blades pinnate or simple. Sori hemispheric, dorsal, in one or more rows on either side of the midrib. Indusium none. Veins free or only casually anastomosing.

Both surfaces of leaf-blades naked.

Sori large $(2 \mathrm{~mm}$. broad $)$ : lower segments of the leaf-blade scarcely smaller than the upper.

Sori smaller ( $1 \mathrm{~mm}$. wide or less): lower segments of the leaf-blades reduced.

Leaf-blades with segments $3 \mathrm{~mm}$. wide or less : veins once forked.

Leaf-blades with segments $5 \mathrm{~mm}$. wide or more: veins $2-3$-forked.

Under surface of leaf-blades with scattered peltate scales.

1. P. vulgare.

2. P. Plumula.

3. $P$. pectinatum.

4. P. polypodioides.

1. Polypodium vulgàre L. Rootstocks widely creeping, densely covered with cinnamon-colored scales. Leaves evergreen; petioles light-colored, glabrous, $5-15 \mathrm{~cm}$. long; blades ovate-oblong or narrowly oblong in outline, slightly leathery, glabrous on both surfaces, 7-25 cm. long, cut nearly to the rachis into linear or linear-oblong segments : sori borne about midway between the midrib and the margins of the segments.

On rocks or rocky banks, or rarely on trees, almost throughout eastern North America. Also in Asia and Europe. PoLYPODY. 
2. Polypodium Plùmula H.B.K. Leaves erect or spreading; petioles $2.5-10 \mathrm{~cm}$. long, black, slender; blades narrowly lanceolate, 20-40 $\mathrm{cm}$. long; segments numerous, narrow, entire, blunt, the lower abruptly smaller, the surfaces naked except the black wiry rachis : veins once forked, obscure.

Peninsular Florida. Also in tropical regions.

3. Polypodium pectinàtum L. Leaves spreading or arching; petioles rigid, 5-15 $\mathrm{cm}$. long; blades elliptic-lanceolate, $3-8 \mathrm{dm}$. long, eut to the rachis into horizontal entire or slightly toothed segments, the lower ones gradually reduced to triangular lobes: rachis naked or finely villous; veins pellucid, twice or three times forked: sori of medium size in long rows.

Eastern peninsular Florida. Also in tropical regions.

4. Polypodium polypodioìdes (L.) A. S. Hitchcock. Rootstocks woody, widely creeping. Leaves evergreen; petioles densely scaly, $2.5-4.5 \mathrm{~cm}$. long; blades oblong or oblong-lanceolate, $3-15 \mathrm{~cm}$. long, acute, cut very nearly or quite to the rachis into entire oblong or linear obtuse segments, nearly glabrous on the upper surface, the lower surface and rachis covered with gray peltate scales with darker centers : veins obscure. $[P$. incanum Sw.]

On trees or rocks, Pennsylvania to Illinois and Missouri, south to Florida and Texas. Also throughout tropical America.

\section{PHLEBÒdIUM R. Br.}

Tropical mostly epiphytic plants, with pinnate leaf-blades. Sori round, naked, dorsal, borne on the united ends of two or more free veinlets which are included in the ample areolae formed by the regular anastomosing veins.

1. Phlebodium aùreum (L. ) R. Br. Rootstock short, densely scaly. Leaves ample, 3-6 dm. long; petioles chestnut-colored, naked ; blades 6-15 dm. long, cut nearly to the rachis into broad entire or undulate segments : areolae copious. [Polypodium aureum L.]

On Sabal Palmetto, peninsular Florida. Also in tropical America.

\section{CAMPYLONEÙRON Presl.}

Tropical plants with usually simple and entire leaf-blades. Sori round, naked, dorsal, in one or two rows on either side of the midrib. Primary veins distinct from the midrib to the margin, connected by parallel transverse veinlets forming regular arches. Areolae similar, with two or more large sori.

1. Camplyoneuron Phyllitidis (L.) Presl. Rootstocks stout, scaly. Leaves erect or arching; petioles short or wanting; blades simple, $3-9 \mathrm{dm}$. long, $2.5-10 \mathrm{~cm}$. wide, leathery, acute, gradually narrowed below : areolae in rows of 6-12 from the midrib to the margin. [Polypodium Phyllitidis L.]

Southern peninsular Florida. Also in tropical America.

\section{PHYMATODÈs Presl.}

Tropical plants, often epiphytic, with simple leaf-blades. Sori rounded, naked, dorsal, various in position. Veins forming fine copious irregular areolae with free veinlets spreading in various directions.

1. Phymatodes exíguum (Hew.) Underw. Rootstocks widely creeping, slender, covered with linear ferruginous scales. Leaves elongated; petioles 6-12 mm. long, slender, naked; blades simple, 5-10 cm. long, entire, undulate or barely lobed, gradually narrowed to both ends: sori in one series on free veinlets. [Polypodium Swartzii Baker.]

Climbing on shrubs, Key Largo, Florida. Also in tropical America.

\section{VITTÀrIA J. E. Smith.}

Tufted often epiphytic plants, with grass-like leaves. Sori linear, continuous in 2lipped marginal grooves or intramarginal lines, with the unaltered edge of the leaf-blade produced beyond, and often rolled over them, but without special indusia. Veins obscure but forming a single row of areolae.

1. Vittaria lineàta (L.) J. E. Smith. Leaves $1.5-9 \mathrm{dm}$. long, 2-10 mm. wide, narrowed gradually toward a stout compressed stem, the edges often reflexed : sori in a broad intramarginal line in a slight furrow, the edge of the leaf-blade at first wrapped over it.

On palmettos, middle and peninsular Florida. Also in tropical America. Grass FERn. 


\section{CHEILOGRÁMMA Blume.}

Epiphytes, relatively small, with simple leaf-blades. Sori linear, but the lines sometimes interrupted, nearly marginal. Veins reticulated.

1. Cheilogramma lanceolàtum (L. ) Blume. Rootstocks creeping. Leaves numerous ; petioles 2.5-5 cm. long ; blades simple, 15-32 cm. long, 12-16 mm. wide, entire, often somewhat crisped, tapering both ways, with prominent midrib and obscure immersed veins ; veins anastomosing, the outer ones free and enlarged at their apices: sori antemarginal in a mostly continuous line near the apex. [Taenitis lanceolata (L.) R. Br.]

On trees, Old Rhodes Key, Florida. Also in tropical America.

\section{PTÈrIS L.}

Relatively large plants, with petioles continuous with the rootstock and variously divided leaf-blades. Sori marginal, linear, continuous, occupying a slender or filiform receptacle, connecting the tips of the free veins. Indusium membranous, single, formed from the reflexed margin of the leaf-blade. Veins free.

Lower divistons of the leaf-blades undivided.

Lower divisions of the leaf-blades forked or pinnate.

Leaflets $7-10 \mathrm{~mm}$. wide, the upper scarcely decurrent.

Leaflets $5 \mathrm{~mm}$. wide or less, the upper strongly decurrent.

1. P. longifolia.

2. P. Cretica.

3. P. serrulata.

1. Pteris longifòlia L. Leaves somewhat spreading; petioles $15-30 \mathrm{~cm}$. long, clothed below with pale brown scales; blades oblong-lanceolate, $3-6 \mathrm{dm}$. long; leaflets linear, 4-10 $\mathrm{mm}$. wide, entire, sessile : veins close, usually once branched : indusium yellowish brown.

Peninsular Florida and the Keys, and Louisiana. Also widely distributed in the tropics.

2. Pteris Crètica $L$. Leaves several ; petioles $15-30 \mathrm{~cm}$. tall, straw-colored or pale brown ; blades $15-30 \mathrm{~cm}$. long ; leaflets usually $2-6$ opposite pairs, sessile, the sterile considerably broader and spinulose-serrulate, the lower pairs often parted nearly to the base into 2 or 3 linear segments : indusium pale : veins free, parallel, simple or once forked.

Peninsular Florida and the Keys. Also in tropical regions generally.

3. Pteris serrulàta L. f. Leaves several; petioles $15-22 \mathrm{~cm}$. long, naked, pale or brownish ; blades ovate, $20-45 \mathrm{~cm}$. long, 2-pinnatifid, the rachis with a wing 2-4 mm. wide at the top, thence narrowed downward; leaflets in 6 or more distinct opposite pairs, the upper simple, the lower with several elongated linear segments on each side; the sterile portions spinulose-serrate.

On old walls, South Carolina to Louisiana, doubtless escaped from cultivation. A native of China.

\section{PTERÍDIUM Scop.}

Coarse plants growing in open sunny places, with ternately compound leaf-blades. Sori marginal, linear, continuous, rising from a vein-like receptacle connecting the ends of free veins. Indusium double, an outer formed by the reflexed margin of the leaf-blade and a second, more delicate with the vein-like receptacle.

Ultimate segments of the leaf-blades approximate at the base.

Ultimate segments of the leaf-blades, 4-6 mm. apart at the base.

1. P. aquilinum. 2. P. caudatum.

1. Pteridium aquilinum (L.) Kuhn. Rootstock stout, woody, horizontal. Leaves erect, sometimes $2 \mathrm{~m}$. tall ; petioles straw-colored or brownish, 3-6 dm. long; blades 6-12 $\mathrm{dm}$. long, usually glabrous, ternate, the three divisions each 2-pinnate, the lower leaflets more or less pinnatifid. [Pteris aquilina L.]

In sunny places, throughout North America, Europe and Asia. Variable. BrACkEN. Brake.

2. Pteridium caudàtum (L.) Maxon. Leaves erect, 1-4 m. tall, or sometimes taller; blades 3-4-pinnate; divisions pinnatifid, the ultimate segments narrow, with recurved margins, remote from one another, scarcely decurrent on the rachis except near the apex, the larger with 1-12 similar but shorter segments. [Pteris aquilina var. caudata (L.) Hook.]

In sandy soil, Florida and Texas. Also in the West Indies.

\section{ADIÁNTUM L.}

Graceful plants of rocky hillsides, woods and ravines, with much divided leaf-blades. Petioles and their divisions slender or filiform, polished and shining. Sori short, marginal, borne on the under side of the reflexed and altered portion of the leaflets, which serves as an indusium. MaIdenhair Fern. 
Leaf-blades ovate-lanceolate or deltoid in outline, pinnately compound.

Leaf-blades 1-2-pinnate: leaflets persistent.

Leaf-blades 3-4-pinnate: leaflets deciduous.

Leaf-blades roundish or reniform, dichotomously forked, with pinnate branches. 3. A. pedatum.

1. Adiantum Capillus-Véneris L. Rootstocks creeping, slender, chaffy with light brown scales. Leaves numerous ; petioles very slender, black or nearly so, shining, 7-22 $\mathrm{cm}$. long; blades ovate-lanceolate in outline, 2-pinnate below, 1-pinnate above, membranous, commonly drooping, 1.5-5 dm. long, 1-3 dm. wide at the base ; leaflets cuneateobovate or rhomboid, rather long-stalked, glabrous, the upper margin incised, crenate or dentate-serrate except where it forms the indusia.

In ravines, preferring limestone, Virginia to Missouri, South Dakota and California, south to Florida and Louisiana. Rare or local. Also in warm-temperate regions generally.

2. Adiantum ténerum Sw. Leaves several ; petioles $3 \mathrm{dm}$. tall, glossy ; blades deltoid, 3-9 dm. long, 2-4 dm. wide, 3-4-pinnate ; leaflets articulated at the base, and falling away at maturity, cuneate, the upper edge sometimes angular, broadly and often deeply lobed : sori numerous, roundish or transversely oblong.

In sink-holes in lime-rock, central peninsular Florida. Also in tropical America.

3. Adiantum pedàtum L. Rootstocks slender, chaffy. Leaves numerous ; petioles $2-4.5 \mathrm{dm}$. long, dark chestnut-brown, polished and shining, dichotomously and pedately forked ; blades nearly orbicular or reniform in outline, $2-4.5 \mathrm{~cm}$. broad, the larger divisions 1.5-2.5 dm. long: leaflets oblong, triangular-oblong or the terminal one fan-shaped, all short-stalked, the upper margin toothed, cleft or lobed, bearing the linear-oblong sori.

In woods, Nova Scotia to British Columbia and Alaska, south to Georgia, Mississippi and California. Also said to occur in western Asia. MatdenhaIr Fern.

\section{PELLÀ̀A Link.}

Rock-inhabiting plants, relatively small in size, with pinnate or pinnatifid leaf-blades. Sterile and fertile leaves similar : petioles usually dark colored. Sori intramarginal, borne on the ends of unconnected veins, at length confluent and forming marginal lines. Indusium commonly broad, membranous, formed of the reflexed margins of fertile leaflets more or less modified, and membranous. CLIFF-BRAKE.

Indusium broad : leaflets often narrow.

Leaf-blades 1-2-pinnate.

Leaflets obtuse or barely acute. Petioles and leaflets smooth.

Petioles and leaflets scurfy-pubescent.

Leaflets mucronate or decidedly acute.

Leaf-blades 3-4-pinnate: leaflets numerous.

Indusium very narrow : leaflets broad : rachis zigzag.

1. P. atropurpurea.

2. P. aspera.

3. P. Wrightiana.

4. P. pulchella.

5. P. flexuosa.

1. Pellaea atropurpùrea (L.) Link. Rootstocks short, densely clothed with rusty hair-like scales. Leaves tufted ; petioles $5-15 \mathrm{~cm}$. long, dark purple or nearly black ; blades leathery, lanceolate or ovate-lanceolate in outline, 1-3 dm. long, simply pinnate or 2-pinnate below; rachis dark-brown or purple; leaflets $2.5-5 \mathrm{~cm}$. long, glabrous, sometimes sessile : veins obscure, commonly twice forked.

On rocks, preferring limestone, Ontario to British Columbia, Massachusetts, New Jersey, Georgia and Arizona.

2. Pellaea áspera (Hook.) Baker. Leaves several ; petioles slender, $5-8 \mathrm{~cm}$. long, with scurfy pubescence; blades oblong-lanceolate, 10-15 cm. long, 2-pinnate ; leaflets deltoid-lanceolate or oblong, those next to the main rachis often lobed, all scabrous on both surfaces.

On dry rocks, Texas and New Mexico.

3. Pellaea Wrightiàna Hook. Rootstocks stout, densely chaffy. Petioles crowded, purplish brown, 10-15 cm. long ; leaf-blades lanceolate to deltoid, 10-25 cm. long, 2-pinnate, or 3 -foliolate at the apex ; leaflets mucronulate, the ultimate ones often long and narrow ; spore-bearing ones with margins inflexed to the midrib.

On rocks, Colorado to Texas and California. Also in Mexico.

4. Pellaea pulchélla (Mart. \& Gal. ) Fée. Leaves clustered ; petioles 7-15 cm. long, chaffy at the base, nearly black; blades 7-18 cm. long, triangular ovate, 4-pinnate below, gradually simpler above ; leaflets numerous, oval or cordate-ovate, $2-6 \mathrm{~mm}$. long, stalked, leathery, smooth.

In dry places, western Texas and New Mexico. Also from Mexico to Chile.

5. Pellaea flexuòsa (Kaulf.) Link. Rootstocks slender. Leaves several ; petioles reddish, passing into the zigzag rachis, with deflected and zigzag nearly smooth secondary 
and tertiary divisions; blades ovate-oblong, $15-75 \mathrm{~cm}$. long, 2-pinnate, primary divisions mostly alternate: leaflets roundish ovate or nearly cordate-ovate, $10-20 \mathrm{~mm}$. long, smooth.

On dry rocks, Texas to California. Also in Mexico.

\section{CHEILÁNTHES Sw.}

Rock-inhabiting ferns, often small, usually with pubescent foliage. Leaves various: blades much divided. Sori terminal on the veins, ultimately more or less confluent. Indusium formed of the reflexed margins of the leaflets, roundish, sometimes more or less confluent. Sporanges often much concealed in the scales of tomentum. LiP-FERN.

Indusium not continuous around the leaf-segments.

Leaf-segments glabrous.

Leaf-blades 2-pinnate; lower leaflets not enlarged.

Leaf-blades nearly or quite 3-pinnate; lower leaflets enlarged.

Leaf-segments pubescent and glandular, not tomentose.

Leaf-blades deltoid-ovate : petioles straw-colored.

Leaf-blades ovate-lanceolate; petioles brownish.

Indusium continuous around the margins of the leaf-segments.

Leaf-blades tomentose below, hairy above.

Leaf-blades $5-10 \mathrm{~cm}$. long ; petioles slender, becoming nearly glabrous.

Leaf-blades $15-45 \mathrm{~cm}$. long; petioles stout, densely brown-tomentose.

Leaf-blades scaly and tomentose beneath, white-tomentose above.

1. C. Alabamensis.

2. C. microphylla.

3. C. leucopoda.

4. C. lanosa.

5. C. Feei.

6. C. tomentosa.

7. C. Lindheimeri.

1. Cheilanthes Alabaménsis (Buckl.) Kunze. Rootstocks horizontal, stout, with brown scales. Petioles black, 7-18 $\mathrm{cm}$. long, wiry, rusty-villous at least below; leaf-blades lanceolate, glabrous, 5-25 cm. long, 2-pinnate; leaflets numerous, ovate-lanceolate, acuminate, the lower usually smaller than those above, pinnatifid; segments mostly acute, often auriculate on the upper side at the base: indusia pale, membranous, interrupted by the incising of the segments.

On rocks, Virginia to Alabama, Arkansas and Arizona. Also in Mexico.

2. Cheilanthes microphýlla Sw. Rootstocks with slender brown scales. Petioles dark brown, glossy, rusty-pubescent on the upper side, $10-15 \mathrm{~cm}$. long; leaf-blades ovatelanceolate, $10-25 \mathrm{~cm}$. long, 2-pinnate; lower divisions larger and more deltoid than the upper; leaflets deeply incised or pinnatifid : indusium similar to the leaf-blade in texture, interrupted or nearly continuous.

On shell heaps, Florida. Also in New Mexico and tropical America.

3. Cheilanthes leucópoda Link. Rootstocks stout. Petioles $8-25 \mathrm{~cm}$. long, chaffy at the base ; leaf-blades broadly deltoid-ovate, $5-8 \mathrm{~cm}$. long, 4-pinnate at the base, gradually simpler above, everywhere glandular-puberulent, lowest pair of pinnae inequilaterally deltoid, upper oblong; leaflets short-stalked, the lobules strongly revolute when fertile.

On rocks, Uvalde Cañon, Texas. Also in Mexico.

4. Cheilanthes lanòsa (Michx.) Watt. Rootstocks with pale rusty-brown scales. Petioles tufted, wiry, chestnut-brown, $5-10 \mathrm{~cm}$. long, hirsute ; leaf-hlades evergreen, herbaceous, oblong-lanceolate, $10-22 \mathrm{~cm}$. long, gradually attenuate to the apex, 2-pinnate; leaflets somewhat distant, lanceolate-deltoid, acute, deeply pinnatifid or incised, more or less covered with almost bristly hairs and usually somewhat glandular : sori numerous, covered by the infolded ends of the rounded or oblong lobes. [C. vestita Sw.]

On rocks, Connecticut to Missouri, middle Georgia and Texas.

5. Cheilanthes Feèi Moore. Rootstocks with narrow brown scales lined with black. Petioles densely tufted, slender, at first covered with woolly hairs, at length nearly glabrous ; leaf-blades about as long as the petioles, ovate-lanceolate, $5-10 \mathrm{~cm}$. long, 3-pinnate or 2pinnate with the leaflets pinnatifid, the upper surface slightly tomentose, the lower densely matted with whitish brown woolly hairs; upper pinnae oblong-ovate, the lower deltoid, the lowest distant; leaflets or their lobes minute, the terminal ones slightly larger than the others, all roundish or obovate and much crowded : indusium narrow.

On rocks, Minnesota to British Columbia, Illinois, Texas and Arizona.

6. Cheilanthes tomentòsa Link. Rootstocks densely chaffy with light brown scales. Petioles tufted, 1-2 dm. long, rather stout, densely brown-tomentose; leaf-blades oblonglanceolate, 3-pinnate, 1.5-4.5 dm. long, densely tomentose, especially beneath, with slender brownish white obscurely articulated hairs; leaflets ovate-oblong or oblong-lanceolate, the ultimate division about $1 \mathrm{~mm}$. long, the terminal ones sometimes twice as large as the others : indusium pale, membranous, continuous.

On rocks, Virginia to Missouri, Georgia, Texas, Arizona and Mexico.

7. Cheilanthes Lindheìmeri Hook. Rootstocks slender, chaffy. Petioles scattered, 10-18 cm. long, black-brown, covered with scales and wool when young; leaf-blades ovate- 
lanceolate, 8-20 cm. long, 3-4-pinnate; leaflets crowded, $0.5 \mathrm{~mm}$. long, white-tomentose above, very chaffy beneath.

On rocks, Llano County, Texas to Arizona and northern Mexico.

\section{NOTHOLAENA R. Br.}

Relatively small rock-inhabiting plants with tomentose scaly or powdery foliage. Leaves various: blades 1-4-pinnate or pinnatifid. Sori roundish or oblong, soon confluent into a narrow band. Indusium wanting: sporanges sometimes at first covered by the inflexed leaf-margins. Veins free.

Leaf-blades covered with white or yellow powder beneath.

Leaf-blades 3-4-pinnate at the base.

Leaf-blades barely 2-pinnate.

Leaf-blades deltoid-ovate, white-powdery beneath.

Leaf-blades pentagonal, yellow-powdery beneath.

Leaf-blades scaly or tomentose beneath.

Leaf-blades 1-pinnate. narrow, elongated.

Leaf-blades 3-pinnatifid, oblong-lanceolate.
1. N. dealbata.
2. N. candida.
3. N. Hookeri.
4. N. sinuata.
5. N. Aschenborniana.

1. Notholaena dealbàta (Pursh) Kunze. Rootstock chaffy with narrow brown scales. Petioles tufted, wiry, shining, dark brown, $2.5-4.5 \mathrm{~cm}$. long; leaf-blades triangular-ovate, acute, broadest at the base, 2.5-10 $\mathrm{cm}$. long, 3-pinnate, the rachis black and shining; leaflets ovate or obovate, obtuse, lobed, crenate or entire, small, scarcely $2 \mathrm{~mm}$. long, white and powdery on the lower surface.

On calcareous rocks, Missouri and Kansas to Texas and Arizona.

2. Notholaena cándida (Mart. \& Gal.) Hook. Rootstocks with rigid nearly black scales. Petioles tufted, 7-15 cm. long, wiry, black and shining; leaf-blades deltoid, pinnate, rather shorter than the petioles; leaflets various, the lower with the lowest inferior segments elongated and again pinnatifid, the 3 or 4 successive pairs lanceolate, upper leaflets resembling the segments of the lower, white-powdery beneath, slightly revolute.

On rocks, Texas and New Mexico. Also in Mexico.

3. Notholaena Hoòkeri D. C. Eaton. Rootstocks densely covered with rigid darkbrown scales. Petioles tufted, 10-20 $\mathrm{cm}$. long, reddish brown, wiry, shining; leaf-blades nearly pentagonal, $5-8 \mathrm{~cm}$. in diameter, of 1 terminal and 2 lateral divisions; terminal division pinnatifid into a few toothed segments, the second pair larger than the first ; lateral divisions bearing a single large pinnatifid basal segment on the lower side and above it pairs of smaller ones, covered beneath with pale yellow powder.

On rocks, Uvalde Cañon, Texas, west to Arizona.

4. Notholaena sinuàta (Sw.) Kaulf. Rootstocks very chaffy. Petioles erect, $5-10 \mathrm{~cm}$. long; leaf-blades simply pinnate, $15-60 \mathrm{~cm}$. long; leaflets numerous, shortstalked, roundish or ovate, entire or pinnately lobed, densely scaly beneath, with merely scattered hairs above.

On rocks, San Saba Texas, to Arizona and Mexico. Also in tropical America.

5. Notholaena Aschenborniàna Kl. Rootstocks short. Petioles tufted, $5-8 \mathrm{~cm}$. long, wiry, blackish, densely scaly ; leaf-blades oblong-lanceolate, 10-25 cm. long, 3-pinnatifid; segments lanceolate, cut into linear-oblong, crenate or pinnatifid ultimate segments, pale green above, densely mottled beneath with linear ciliate ferruginous scales and also somewhat mealy; sori black.

On rocks, Texas to southern Arizona and Mexico.

\section{BLÉCHNUM L.}

Coarse swamp plants, with stout rootstocks. Leaves clustered : blades thickish. Sori linear, contiguous or nearly so, parallel to the midrib and usually contiguous to it. Indusium membranous, distinct from the edge of the leaf-blade. Veins free.

1. Blechnum serrulàtum L. C. Rich. Petioles erect, nearly naked, $15-30 \mathrm{~cm}$. long, stout; leaf-blades oblong-lanceolate, $30-60 \mathrm{~cm}$. long, leathery, with $12-24$ pairs of linearoblong leaflets; margins very finely incised : veins very fine and close : fertile leaves with much narrower blades than those of the sterile.

In swamps, Florida. Also in tropical America.

\section{ANCHÍSTEA Presl.}

Large and rather coarse swamp ferns, with short oblong sori sunk in cavities in the leaf and arranged in chain-like rows close to the midribs. Leaves uniform. Indusia tixed by 
their outer margins. Veins forming a single line of areolae next the midrib, then free to the margin.

1. Anchistea Virgínica (L.) Presl. Rootstock stout, chaffy. Petioles stout, $3-4.5$ dm. long, nearly or quite naked, dark-colored below ; leaf-blades oblong-lanceolate, acute, narrowed at the base, $3-6 \mathrm{dm}$. long, $15-22 \mathrm{~cm}$. wide, pinnate ; leaflets linear-lanceolate, usually alternate, or some of them opposite, leathery, glabrous, acuminate, sessile, 7-15 $\mathrm{cm}$. long, deeply pinnatifid into ovate or oblong obtuse segments, their margins minutely serrulate. [Woodwardia Virginica (L.) J. E. Smith.]

In swamps and meadows, Nova Scotia to Ontario, Michigan, Florida, Louisiana and Arkansas.

\section{ASPLÈNIUM L.}

Plants various in habit and habitat. Leaves tufted : blades entire, lobed, pinnatifid or 1-3-pinnate, mostly uniform. Sori linear or oblong, oblique to the midrib or rachis. Veins free. Indusia straight or curved, opening towards the midrib when single. SplfenWORT.

Sori straight or rarely slightly curved, attached to the upper side of a vein.

Leaves with simple crenulate or serrulate blades: plants 4-7 dm. tall.

1. A. serratum.

Leaves with pinnatifid or pinnate blades.

Leaf-blades pinnatifid or pinnate.

Leaf-blades pinnatifid, or pinnate merely below.

Petioles green above, blackish below: leaf-lobes normally rounded.

Petioles black throughout: leaf-lobes normally acuminate.

Leaf-blades pinnate.

Leaflets $0.7-3 \mathrm{~cm}$. long. mostly blunt.

Rachis chestnut-brown or blackish.

Leaflets auricled at the upper side of the base.

Leaflets opposite, oblong : rachis dark brown or black.

Leaflets partly alternate, lanceolate: rachis chestnut-brown. Leaflets not auricled.

Rachis green: leaflets not auricled, crenate.

Leaflets $4-12 \mathrm{~cm}$. long: acute or acuminate.

Leaf-blades 7-9 dm. long.

Leaf-blades $2.5-5 \mathrm{dm}$. long.

Leaf-blades 2-3-pinnatifid :

Texture leathery.

Petioles green: leaf-blades rhombic or obovate, the veins flabellate.

Petioles dark below: leaf-blades ovate-lanceolate.

Texture herbaceous or membranous.

Petioles and the lower part of the rachis chestnut-brown.

Petioles green or greenish.

Leaf-segments linear or oblong, narrow.
Leaf-segments rounded, entire or 2-3-lobed.

Sori more or less curved, sometimes horseshoe-shaped, often crossing to the outer or lower side of the veinlet: large plants.

Leaf-blades 2-pinnatifid ; segments blunt, scarcely crenate.

Leaf-blades 2-pinnate; leaflets acute, toothed or pinnatifid.

2. A. pinnatifidum.

3. A. ebenoides.

\section{A. resiliens.}

5. A. platyneuron.

6. A. Trichomanes.

7. A. dentatum.

8. A. angustifolium. 9. A. firmum.

10. A. Ruta-muraria.

11. A. montanum.

12. A. Bradleyi.

13. A. cicutarium.

14. A. myriophyllum.

15. A. acrostichoides.

16. A. Filix-foemina.

1. Asplenium serràtum L. Leaves in a crown from a stout erect rootstock; blades spatulate or linear-oblanceolate, 4-7 dm. long, crenulate or irregularly serrulate, somewhat leathery ; midrib keeled and often blackish purple beneath; veins free, approximate, onceforked : sori elongated, following the veins of the upper half of the blade from near the midrib half way to the margins: indusia single, the free edge entire.

In swamps, peninsular Florida. Also in tropical America.

2. Asplenium pinnatífidum Nutt. Rootstock short, chaffy. Leaves tufted ; petioles polished, blackish below, green above, 5-12 cm. long, somewhat chaffy below, at least when young ; blades broadly lanceolate in outline, 7-25 cm. long, firm, tapering upward to a long narrow tip, pinnatifid or the lower parts pinnate; lowest segments, or occasionally several pairs, sometimes tapering to a point like that of the apex of the leaf.

On rocks, New Jersey to Illinois and Arkansas, and in the mountains to Georgia.

3. Asplenium ebenoìdes R. R. Scott. Rootstock short, chaffy. Leaves tufted; petioles blackish, 4-10 cm. long; blades lanceolate, variable, 8-25 cm. long, firm, tapering to a very long narrow acuminate apex, pinnatifid, or commonly pinnate below, the segments lanceolate from a broad base, acute or acuminate, irregular, the lower sometimes shorter than those just above : sori several on each segment, straight or slightly curved.

On limestone, Connecticut to Indiana and Alabama. Rare, except at a single locality in Alabama.

4. Asplenium resíliens Kunze. Rootstock short, with black stiff scales. Leaves tufted; petioles blackish and shining, $2.5-5 \mathrm{~cm}$. long; blades rather firm, linear-oblong or linear-oblanceolate, 7-25 cm. long, 1-pinnate; leaflets 4-12 mm. long, mostly opposite, oblong, obtuse, entire or crenulate, auricled on the upper side and nearly sessile, the middle ones the longest, the lower gradually shorter and reflexed: rachis dark brown or black: 
sori oblong, borne about midway between the midrib and the margin of the blade, nearly or quite straight. [A. parvulum Mart. \& Gal., not Hook.]

Often on limestone, Virginia to Missouri, Florida, Texas, New Mexico and Mexico.

5. Asplenium platyneùron (L.) Oakes. Rootstock short. Leaves evergreen, tufted ; petioles purplish brown and shining, $2.5-10 \mathrm{~cm}$. long; blades linear, $2-4 \mathrm{~cm}$. long, firm, pinnate, the rachis chestnut-brown; leaflets 20-40 pairs, lanceolate, subfalcate, alternate or partly so, sessile, crenate, serrate or incised, auricled on the upper side at the base and occasionally also on the lower; lower leaflets gradually smaller and oblong, or triangular : sori 8-12 on each side of the midrib, crowded at maturity. [A. ebeneum Ait.]

On rocks and shaded slopes, Maine and Ontario to Colorado, south to Florida and Texas.

6. Asplenium Trichómanes L. Rootstock short, nearly erect, with blackish scales. Leaves densely tufted, numerous; petioles $2.5-12 \mathrm{~cm}$. long, purplish brown and shining; blades linear in outline, $7-20 \mathrm{~cm}$. long, rather rigid, pinnate, evergreen; leaflets oval or roundish oblong, inequilateral, cuneate at the base, their margins slightly crenate; sori $3-6$ on each side of the forking and evanescent midrib, short, narrowed at both ends.

On rocks, preferring limestone, nearly throughout North America. Also in Europe and Asia.

7. Asplenium dentátum L. Petioles tufted, $5-15 \mathrm{~cm}$. long, naked, blackish below. Fertile leaf-blades $5-7.5 \mathrm{~cm}$. long, with $6-8$ pairs of stalked oblong or rhombic leaflets, the lower side truncate with a curve, the outer edge irregularly crenate; sterile leaves similar but with shorter petioles : rachis naked : sori copious, in parallel rows.

In sandy soil, South Carolina to Florida. Also in the West Indies.

8. Asplenium angustifòlium Michx. Rootstock stout. Fertile leaves usually taller than the sterile. Petioles in a crown, chaffless, or merely scaly at the base, $2-3 \mathrm{dm}$. long, brownish or greenish above; leaf-blades lanceolate, 3-8 dm. long, pinnate; leaflets linearlanceolate or those of sterile leaves lanceolate, in 20-30 pairs, acuminate, entire or crenulate, obtuse or truncate at the base : sori $20-30$ on each side of the midrib, linear, crowded.

In moist or rich woods, Quebec to Wisconsin, Virginia, Georgia and Alabama.

9. Asplenium fírmum Kunze. Petioles $10-20 \mathrm{~cm}$. tall, naked, grayish. Leaf-hlades $15-30 \mathrm{~cm}$. long; leaflets oblong-lanceolate, $12-20$ pairs, blunt-pointed, minutely crenulate, the upper margin abruptly narrowed at the base, the lower obliquely truncate: sori short, not reaching either margin or midrib.

In caverns, peninsular Florida. Also in the West Indies.

10. Asplenium Rùta-murària L. Rootstock ascending. Leaves tufted; petioles naked, green, 5-7 cm. long; blades ovate or deltoid-ovate, 5-12 cm. long, glabrous, evergreen, 2-3-pinnate, or pinnatifid above ; leaflets stalked, rhombic or obovate, mostly obtuse, dentate or incised, cuneate at the base; veins flabellate : sori few, linear-oblong, confluent when mature and nearly covering the leaflet: indusia membranous and delicate.

On limestone, Vermont to Michigan and Missouri, south to Connecticut, Alabama and Arkansas. Also in Europe, Asia and northern Africa.

11. Asplenium montànum Willd. Rootstock chaffy at the summit. Leaves tufted ; petioles naked, slender, blackish at the base, 5-7 cm. long; blades $5-20 \mathrm{~cm}$. long, ovatelanceolate in outline, acuminate, rather firm, 1-2-pinnate; lower leaflets longest, pinnate or pinnatifid, the lobes or segments ovate or oblong; upper less divided, merely toothed or incised ; veins obscure : sori linear-oblong, short, the lower ones sometimes double.

On rocks, Connecticut to Ohio and Arkansas, and in the mountains to Georgia and Alabama.

12. Asplenium Bradleỳi D. C. Eaton. Rootstock chaffy with brown scales. Leaves tufted ; petioles slender, 5-7 cm. long, chestnut-brown ; blades oblong-lanceolate or oblong, acuminate, not narrowed at the base, with 8-12 pairs of short-stalked or sessile oblongovate leaflets; the lower again pinnatifid or pinnate, with oblong obtuse lobes or pinnules, which are toothed at the apex, the upper pinnatifid with dentate or nearly entire lobes: rachis brown : sori near the midrib, covered with the narrow indusia until mature.

On rocks, often preferring limestone, New York to Illinois and Missouri, south to middle Georgia, Alabama and Arkansas.

13. Asplenium cicutàrium Sw. Petioles greenish, tufted, $10-20 \mathrm{~cm}$. long, naked. Leaf-blades 15-38 cm. long, with 10-15 pairs of horizontal leaflets, the lower ones 5-7.5 $\mathrm{cm}$. long, parted into linear or oblong segments which are once or twice cleft at the apex : rachis compressed and often winged : sori mainly in 2 rows.

In swamps, Sumter County, Florida. Also in tropical America.

14. Asplenium myriophýllum Mett. Petioles tufted, $5-15 \mathrm{~cm}$. long. Leaf-blades lanceolate, $8-30 \mathrm{~cm}$. long, 2-3-pinnatifid; segments entire, or 2-3-lobed, each bearing a single vein and a sorus.

On rocks in sink-holes, peninsular Fiorida. Also in tropical America. - A form with narrowly linear leaf-blades $1.8-2.5 \mathrm{~cm}$. wide, and 7-8-lobed widely ascending leaflets, is known as $A$. myriophyllum Biscayneànum D. C. Eaton. 
15. Asplenium acrostichoìdes Sw. Rootstock sinuous. Petioles $2-3 \mathrm{dm}$. long, straw-colored, somewhat chaffy below at least when young; leaf-blades lanceolate in outline, $3-9 \mathrm{dm}$. long, acute or acuminate at the apex, narrowed to the base, pinnate-pinnatifid ; leaflets linear-lanceolate, sessile, acuminate, deeply pinnatifid into numerous oblong obtuse or subacute, slightly crenate segments : sori crowded, slightly curved, or straight, the lower ones often double: indusium light-colored and somewhat shining when young.

In rich moist woods, Nova Scotia to Minnesota, south to Georgia and Louisiana. Also in Asia.

16. Asplenium Filix-foèmina (L.) Bernh. Rootstock rather slender for the size of the plant. Petioles tufted, $0.5-2.5 \mathrm{dm}$. long, straw-colored, brownish or reddish ; leafblades broadly oblong-ovate or oblong-lanceolate, acuminate at the apex, 3-9 dm. long, 2pinnate; leaflets lanceolate, acuminate, short-stalked or the upper ones sessile, 1-2 dm. long, the ultimate divisions oblong-lanceolate, incised or serrate, their lobes or teeth often again toothed, those toward the ends of the leaflets confluent by a very narrow margin to the secondary rachis : sori short, the indusia straight or variously curved, sometimes horseshoe-shaped.

In wet woods and thickets, Nova Scotia to Alaska, south to Florida, Louisiana and Arizona. Also in Europe and Asia. Very variable.

\section{PHYLLITIS Ludwig.}

Large ferns with oblong or strap-shaped mostly entire leaf-blades. Sori linear, elongated, almost at right angles to the midrib and contiguous in pairs, one on the upper side of a veinlet, the other on the lower side of the next contiguous veinlet, thus appearing to have a double indusium opening longitudinally along its middle. [Scolopendrium Adans. ]

1. Phyllitis Scolopéndrium (L.) Newman. Rootstocks short, chaffy with light brown scales. Petioles 5-15 $\mathrm{cm}$. long, fibrillose-chaffy below or sometimes up to the top ; leaf-blades entire, bright green, firm, $2-4.5 \mathrm{dm}$. long, cordate at the base, pairs of sori distinct, 4-15 mm. long, conspicuous: veins free, usually once forked near the midrib. [Scolopendrium vulgare J. E. Smith.]

On shaded limestone cliffs, New Brunswick to Ontario and New York, south to Tennessee. Also in Europe, Asia and Africa. Hart's Tongue.

\section{CAMPTOSÒRUS Link.}

Slender plants, with tapering simple entire or undulate leaf-blades. Sori linear or oblong, several times longer than broad, irregularly scattered on either side of the reticulate veins or sometimes crossing them, partly parallel to the midrib and partly oblique to it, the outer ones more or less approximate in pairs. Indusium membranous.

1. Camptosorus rhizophýllus (L.) Link. Rootstock short, chaffy. Petioles light green, $2.5-15 \mathrm{~cm}$. long, tufted, spreading; leaf-blades rather thin, lanceolate, simple, longacuminate at the apex, cordate, hastate or rarely narrowed at the base, 10-25 $\mathrm{cm}$. long, sometimes with a more or less elongated pair of basal auricles; tip of the leaf and sometimes the tip of one or both of the basal auricles rooting and forming a new plant by the ultimate withering away of its tissue : sori usually numerous, irregularly scattered.

On rocks, preferring limestone, Quebec to Ontario and Minnesota, south to Georgia and Kansas. WALKING LEAF. WALKING FERN.

\section{LORINSËRIA Presl.}

Rather coarse ferns of swamps, with dimorphous leaves and rather large linear sori sunk in cavities in the leaf and arranged in chain-like rows. Indusia rather leathery, fixed by their outer margins and covering the cavity like a lid. Veins forming copious areolae.

1. Lorinseria areolàta (L. ) Presl. Rootstock slender, ehaffy. Leaves of two kinds, the fertile taller than the sterile and their blades borne on longer petioles, $3-6 \mathrm{dm}$. high, their segments much contracted, narrowly linear, 7-12.5 $\mathrm{cm}$. long, 4-6 mm. wide, distant, their bases connected by a very narrow wing along the rachis or quite distinct; sterile leafblades deltoid-ovate, membranous, broadest at the base, or sometimes with one or two small segments below, acuminate, the segments lanceolate or oblong-lanceolate, minutely serrulate, sometimes undulate, their bases connected by a rather broad rachis-wing. [ $\mathrm{Wood}$ wardia angustifolia J. E. Smith.]

In swamps or wet woods, Maine and Michigan to Florida, Louisiana and Arkansas.

\section{ONOCLÈA L.}

Ferns with elongated horizontal rootstocks. Leaves growing separately. Fertile leafblades closely rolled up into berry-like segments, and entirely unlike the broad pinnatifid 
sterile leaf-blades. Sori round, borne on the back of the veins. Indusium very thin and membranous, hemispheric or hood-shaped, fixed at the inferior side of the sorus. Sporophylls unrolling at maturity, allowing the spores to escape, and remaining long after the sterile leaves have been killed by frost. Veins forming small areolae.

1. Onoclea sensíbilis L. Leaves $3-13 \mathrm{dm}$. high ; blades triangular, deeply pinnatifid ; segments lanceolate-oblong, entire, undulate, or the lower pairs sinuate-pinnatifid : sporophylls 3-7 $\mathrm{dm}$. high, persistent over winter, much contracted and with short pinnules rolled up into berry-like closed involucres forming a narrow panicle.

In moist soil, Newfoundland to Ontario and Minnesota, south to the Gulf of Mexico.-Various forms intermediate between sporophylls and foliage leaves occur. Summer and fall. SENSITIVE FERN.

21. TECTÁRIA Cav.

Plants with horizontal rootstocks. Sori round, borne on the back of the leaflets or leaf-segments. Indusium peltate, opening all around the margin. Veins everywhere anastomosing, forming copious areolae, with free included veinlets.

1. Tectaria trifoliàta (L.) Cav. Leaves tufted, 6-7.5 dm. tall ; petioles brownish, scaly at the base ; leaf-blades $3-4.5 \mathrm{dm}$. long, each with a large ovate-acuminate terminal leaflet narrowed or forked at the base, and 1 or 2 lateral leaflets, the lowest mostly forked : primary veins distinct to the margin : areolae fine : sori in 2 rows near the main veins : indusia orbicular, peltate. [Aspidium trifoliatum (L.) Sw.]

In sandy soil, peninsular Florida and Texas. Also in tropical America.

\section{POLÝSTICHUM Roth.}

Coarse plants, often with chaffy foliage. Leaves tufted: petioles not jointed to the rootstock; blades 1-2-pinnate, the sterile and fertile similar. Sori usually borne on the backs of the veins. Indusium superior, centrally peltate, orbicular. Veins free.

1. Polystichum acrostichoìdes (Michx.) Schott. Rootstocks stout. Leaves evergreen, 2.5-8 dm. tall ; petioles densely chaffy ; blades lanceolate, those of the fertile ones contracted near the top, 1.5-6 dm. long, 1-pinnate ; leaflets somewhat leathery, linearlanceolate, $2.5-7 \mathrm{~cm}$. long, falcate, half-hastate at the base, with appressed bristly teeth, bearing the large contiguous sori, which soon cover the whole lower surface near the middle. [Aspidium acrostichoides (Michx.) Sw.] MAS FERN.

In woods and on rocky banks, Nova Scotia to Wisconsin, south to Forida and Mississippi. CHRIST-

\section{DRYÓPTERIS Adans.}

Terrestial plants with erect or horizontal rootstocks. Leaves tufted, the sterile and fertile similar : blades 2-3-pinnate or -pinnatifid : petioles not jointed to the rootstocks. Indusium flattish, cordate-reniform, superior, fixed by the sinus. Veins free or basal veinlets united. Often known as SHIELD-FERNs.

Leaf-blades thin-membranous : veins simple or 1-forked.

Lower leaf-segments reduced to mere lobes.

Rootstock stout, erect, forming a short caudex.

Rootstock slender, horizontal.

Lower leaf-segments little smaller than the central.

Veins forked : leaf-blades dark green, relatively firm.

Veins simple : leaf-blades pale green, thin-flaccid.

1. D. contermina.

2. D. Noveboracensis.

Leaf-blades firm or leathery: veins freely forking.

Leaf-blades 2-3-pinnatifid: veins always free.

Leaf-blades 2-pinnatifid or 2-pinnate: divisions not spinulose.

Indusia large, thinnish, flat: sori midway to the margins. Leaflets or segments broadest at the base.

Fertile and sterile leaflets alike, deltoid or triangular.

Fertile leaflets narrowly lanceolate, unlike the sterile ones.

Leaflets or segments broadest at the middle.

Indusia convex, without marginal glands: sori near the margin.

Leaf-blades 2-pinnate or 3-pinnatifid : divisions spinulose-tipped.

Leaf-blades pinnate: contiguous veinlets united.

3. D. Thelypteris.

4. D. patens.

1. Dryopteris contérmina (Willd.) Kuntze. Rootstocks erect, often $3 \mathrm{dm}$. above the surface of the ground. Leaves in a crown ; petioles narrowly wing-margined at the base ; blades 3-12 dm. long, lanceolate, cordate-acuminate at the apex, rather rigid, narrowed at the base ; leaflets sessile, narrowly lanceolate from a broader base, acuminate, deeply pinnatifid; segments obtuse, obliquely and slightly falcate, copionsly resinous-dotted beneath : sori near the margins : indusia minute, reniform, glandular and pilose, evanescent.

In swamps near Fort Meade, Florida.-The form within our range is known as D. contermina strigòsa (Fée) Underw., to which the above description mainly applies. 
2. Dryopteris Noveboracénsis (L.) A. Gray. Rootstocks slender, horizontal. Leafblades lanceolate, tapering both ways from the middle, $3-6 \mathrm{dm}$. long, membranous, longacuminate, pinnate; leaflets lanceolate, sessile, long-acuminate, deeply pinnatifid, ciliate and finely pubescent beneath, 3-7 cm. long, the two or more lower pairs gradually shorter and deflexed, commonly distant; segments flat, oblong, obtuse, the basal ones often enlarged : veins simple, or those of the basal lobes forked; sori not confluent, borne near the margin : indusia minute, reniform, delicate, glandular.

In moist or swampy woods, Newfoundland to Ontario and Minnesota, south to Georgia, Alabama and Arkansas.

3. Dryopteris Thelýpteris (L.) A. Gray. Rootstocks slender. Leaf-blades lanceolate or oblong-lanceolate, scarcely narrower at the base than at the middle, $3-8 \mathrm{dm}$. long, short-acuminate, membranous, pinnate; leaflets linear-lanceolate, short-stalked or sessile, mostly horizontal, acuminate at the apex, nearly truncate at the base, $3-7 \mathrm{~cm}$. long, slightly pubescent beneath, deeply pinnatifid ; segments oblong, obtuse, or appearing acute from the strongly revolute margins: veins regularly once or twice forked : sori crowded, 10-12 to each segment : indusia reniform, slightly glandular, or glabrous.

In marshes, New Brunswick to Manitoba, south to Florida and Texas. Also in Europe and Asia.

4. Dryopteris pàtens $(\mathrm{Sw}$.$) Kuntze. Rootstocks stout. Leaves several together ;$ blades ovate-oblong, 4-12 dm. long, softly pubescent beneath ; leaflets approximate, linear, acuminate, the broadest pair somewhat reflexed, all cleft three-fourths the way to the midrib; segments numerous, the basal ones longest: veinlets manifest, the lowest ones of adjacent segments often uniting : sori near the margins : indusia very pubescent.

In sandy soil or on calcareous rocks, Georgia and Florida to California.

5. Dryopteris cristàta (L.) A. Gray. Rootstocks densely chaffy. Leaves evergreen ; petioles of the sterile leaves 5-12 cm. long, those of the fertile 1.5-2.5 dm. long; blades linear-oblong or lanceolate, acuminate, gradually and slightly narrowed to the base, rather firm, 3-8 dm. long, pinnate; leaflets lanceolate or triangular-ovate, acuminate, deeply pinnatifid or the lower pinnate, the segments $6-10$ pairs, serrate or incised : sori about midway between the margin and midrib : indusia thin, glabrous.

In wet woods and swamps, Newfoundland to Manitoba, south to Kentucky and Arkansas. Also in Europe and Asia.

6. Dryopteris Floridàna (Hook.) Kuntze. Leaves clustered; petioles 15-25 cm. long, with few ovate scales; blades lanceolate, $45-50 \mathrm{~cm}$. long; leaflets various ; fertile confined to the upper half of the leaf-blade, narrowly lanceolate, cut nearly to the rachis into oblong segments; sterile leaflets broader, shorter below, less deeply cut.

In swamps, Georgia, Florida and Alabama.

7. Dryopteris Goldieàna (Hook.) A. Gray. Rootstocks chaffy. Petioles 2.5-4.5 $\mathrm{dm}$. long, chaffy at least below ; leaf-blades ovate, rather firm, 6-12 dm. long, glabrous or nearly so, dark-green above, pinnate or nearly 2-pinnate; lower leaflets broadly lanceolate, widest at about the middle, $1.5-2.5 \mathrm{dm}$. long, parted into about 20 pairs of oblong-linear subfalcate segments which are serrate with appressed teeth : sori very near the midrib, close together but distinct, large : indusia orbicular, glabrous, persistent.

In rich woods, New Brunswick to Minnesota, south to North Carolina and the Indian Territory.

8. Dryopteris marginàlis (L.) A. Gray. Rootstocks ascending, with dark brown shining scales. Leaves evergreen; petioles $7-20 \mathrm{~cm}$. long, chaffy below ; blades ovateoblong or ovate-lanceolate, rather leathery, 1.5-7.5 dm. long, 1-2-pinnate, acuminate at the apex, slightly narrowed at the base; leaflets numerous, lanceolate, nearly sessile, glabrous, $5-12.5 \mathrm{~cm}$. long, the lower broader and shorter than the middle ones, the upper pinnatifid, the lower pinnately parted into oblong obtuse entire dentate or pinnately lobed segments : sori distinct, close to the margin, covered by the glabrous indusia.

In rocky woods, Prince Edward Island to Minnesota, south to Georgia, Alabama and Arkansas.

9. Dryopteris spinulòsa (Retz) Kuntze. Leaves tufted, evergreen ; petioles bearing scales with dark centers; blades ovate-lanceolate, usually not narrowed below, 2-pinnate; leaflets narrowly triangular or the lower pairs broadly triangular, the ultimate segments oblique, connected by a very narrow wing, with spinulose-toothed lobes : indusia glabrous.

In rich woods, Newfoundland to Alaska and Washington, south to Virginia and Michigan. Also in Europe and Asia. Summer.-Two forms represent the species in our range : one, D. spinulosa intermédia (Muhl.) Underw., has oblong-ovate 2-3-pinnate leaf-blades and oblong-lanceolate spreading leaflets, the lowest unequally triangular-ovate : indusium beset with stalked glands. Its range extends southward to North Carolina and Missouri. The other variety, D. spinulosa dilatata (Hoffm.) Underw.. with broadly ovate or triangular-ovate commonly 3-pinnate blades, lanceolate-oblong ultimate divisions, the lowest often much elongated, and glabrous indusia, ranges as far sonth as Georgia, Tennessee
and Nebraska.

10. Dryopteris unìta (L.) Kuntze. Leaves tufted; petioles brownish, naked, about $45 \mathrm{~cm}$. long; blades $0.5-1 \mathrm{~m}$. long, $12-20 \mathrm{~cm}$. wide ; leaflets narrow, the lower ones not reduced, cleft $\frac{1}{3}$ to $\frac{1}{2}$ the way to the midrib; segments acute : veins pinnate in the broad 
segments, with 6-8 veinlets on each side of the lower ones of contiguous groups : sori near the ends of the veins, mainly in the segments.

In thickets, Florida.

\section{MATTEUCCCIA Todaro.}

Stately ferns with large rootstocks. Leaves in crowns, the sterile and fertile different : blades pinnate or pinnatifid : sori round, borne on the veins of a contracted fertile leaf concealed by their revolute margins. Veins free.

1 Matteuccia Struthiópteris (L. ) Todaro. Fertile leaves 3-5 dm. long; blades simply pinnate, with necklace-shaped leaflets formed of the strongly revolute margins; sterile leaves 6-18 dm. long; blades broadly lanceolate, 2-pinnatifid, the lowest leaflets gradually much shorter: veins pinnate: sori crowded, confluent. [Onoclea Struthiopteris (L.) Hoffm.]

In moist thickets, especially on river banks, Nova Scotia to British Columbia, south to New Jersey and Arkansas. OsTRICH FERN,

\section{PHEGÓPTERIS Fée.}

Low rather tender ferns, with horizontal rootstalks. Leaves few, the fertile and sterile similar: petioles continuous with the rootstocks : blades ternate or 2-3-pinnatifid. Sori round, each on the back of a vein just below its tip or on the middle of the veinlets. Indusium wanting or rudimentary. Veins free. OAK or BEECH-FERN.

1. Phegopteris hexagonóptera (Michx.) Fée. Rootstock chaffy, somewhat fleshy. Petioles 2-4.5 din. long, straw-colored, naked; leaf-blades triangular, as broad as long or broader, $2-3 \mathrm{dm}$. wide, slightly pubescent and often slightly glandular beneath, acuminate ; uppermost leaflets oblong, obtuse, dentate or entire, small, the middle ones lanceolate, acuminate, the very large lowest pair broadest near the middle, pinnately parted nearly to the midvein into linear-oblong obtuse segments : sori mostly near the margin.

In dry woods, Quebec to Minnesota, south to Florida and Louisiana.

26. GONIÓPTERIS Presl.

Rather large ferns of woods and rocky places, with horizontal rootstocks. Leaves pinnatifid or bipinnatifid. Sori on the back of the veins normally without an indusium. Veins connivent, the branches form contiguous groups uniting to form one or more arches. Sporiferous leaves of two sorts, one rigid, pinnatifid toward the apex, the other lax, pinnate throughout, and proliferous. :Sporiferous leaves of one sort, with large terminal leaflets.

1. G. reptans.
2. G. tetragona.

1. Goniopteris réptans (Sw.) Presl. Leaves spreading or procumbent ; petioles $7-25$ cm. long, clustered, grayish straw-colored, slender, naked ; blades 10-30 cm. long, membranous, softly pubescent with branched or stellate hairs, oblong-lanceolate, pinnate, with nearly or quite sessile crenately pinnatifid leaflets, the apex merely pinnatifid, often elongated and rooting: veins pinnate, simple, the basal veinlets often anastomosing: sori on the middle of the veinlets, sometimes with a rudimentary indusium.

On calcareous rocks, middle and peninsular Florida. Also in the West Indies.

2. Goniopteris tetrágona (Sw.) Presl. Leaves erect ; petioles $15-45 \mathrm{~cm}$. long, sometimes slightly villougs; blades 3-6 dm. long, $15-30 \mathrm{~cm}$. wide ; leaflets numerous, spreading, 7.5-15 $\mathrm{cm}$. long, the lowest narrowed at the base and sometimes stalked, deeply pinnatifid, thin-herbaceous, the lower surface and the rachis finely pubescent : sori in rows near the midrib.

In rocky woods, Marion County, Florida. Also in tropical America.

\section{NEPHRÓLEPIS Schott.}

More or less epiphytic plants. Leaves spreading or pendent : blades elongated : leaflets numerous, approximate, jointed at the base, with whitish dots on the upper surface. Sori round, rising from the apex of the upper branch of a vein, usually near the margin. Veins free.

Leaf-blades $7-15 \mathrm{~cm}$. wide: indusia distinctly reniform.

Leaf-blades $20-30 \mathrm{~cm}$. wide : indusia nearly orbicular.

1. N. exaltata.

2. N. biserrata.

1. Nephrolepis exaltàta (L.) Schott. Petioles $10-15 \mathrm{~cm}$. long; leaf-blades various, 3-20 dm. long, 7-15 cm. wide; leaflets lanceolate, sometimes crenulate, the upper side auricled at the base, the lower rounded; the rachis nearly naked : sori almost marginal, covered with firm distinctly reniform indusia.

On logs and stumps, peninsular Florida. Also in the tropics. SwORD OR BOston FERN.

2. Nephrolepis biserràta (Sw.) Schott. Petioles $10-20 \mathrm{~cm}$. long ; leaf-blades 6-12, dm. long, 20-40 cm. wide; leaflets $10-20 \mathrm{~cm}$. long, acute, entire or crenulate, the upper 
side auricled, the lower rounded at the base : rachis nearly naked : sori almost marginaI, covered by nearly orbicular, rather peltate indusia. [N. acuta Presl.]

On the south bank of the Miami River, Florida. Also in tropical regions.

\section{DENNSTAÈDTIA Bernh.}

Rootstocks usually horizontal. Leaves tufted : blades 2-3-pinnatifid. Sori small, globular marginal or nearly so. Sporanges borne in an elevated globular receptacle, enclosed in a membranous cup-shaped inferior indusium, which is open at the top, and on the outer side adherent to a reflexed toothlet of the leaf. Veins always free.

1. Dennstaedtia punctilóbula (Michx.) Moore. Rootstock not chaffy. Petioles: stout, chaffless, pale green and sweet-scented; leaf-blades 3-10 dm. long, lanceolate, acute or acuminate, frequently long-attenuate, usually 3 -pinnatifid, thin and delicate ; rachis and under surface minutely glandular and pubescent : sori minute, each on a recurved toothlet, usually one at the upper margin of each lobe : sporanges few : indusium cup-shaped with a delicate membranous irregular margin. [Dicksonia punctilobula (Michx.) A. Gray.]

On open hillsides, New Brunswick to Ontario and Minnesota, south to the mountains of Georgia and Alabama.

\section{FìuIX Adans.}

Delicate rock ferns. Leaves with slender petioles and 2-4-pinnate blades. Sori roundish, each borne on the back of a vein. Indusium membranous, hood-like, attached by a broad base on its inner side and partly under the sorus, early opening and somewhat evanescent. Veins free. [Cystopteris Bernh.]

Leaf-blades scarcely broader at the base, short-pointed, without bulblets.

Leaf-blades broadest at the base, long-tapering, bearing bulblets beneath.

1. F. fragilis.

2. F. buibifera.

1. Filix frágilis (L.) Underw. Iseaves tufted; petioles $10-20 \mathrm{~cm}$. long; blades thin, oblong-lanceolate, slightly tapering below, 1-3 dm. long, 2-3-pinnatifid or pinnate ; leaflets lanceolate-ovate, irregularly pinnatifid, with a broad central space and bluntly or sharply toothed segments decurrent along the margined or winged rachis, without bulblets : indusia narrow or acute at the free end, early withering.

On rocks and in moist grassy woods, Newfoundland to Alaska, south to Georgia and Arizona. Almost cosmopolitan.

2. Filix bulbifera (L.) Underw. Leaves weak; petioles $10-15 \mathrm{~cm}$. long, lightcolored ; blades elongated, lanceolate from a broad base, 3-8 dm. long, 2-3-pinnatifid or pinnate; leaflets crowded, toothed or pinnatifid : rachis wingless, commonly bearing underneath, in the axils of the leaflets and segments, fleshy bulblets which fall away and propagate the plant : indusia truncate on the free side, early thrown back and withering.

On moist rocks, especially limestone, Quebec to Wisconsin, south to Tennessee and Arkansas.

30. Woòdsia R. Br.

Small or medium-sized ferns, growing in rocky places. Leaves often evergreen, tufted : petioles often jointed above the base and finally separating: blades 1-2-pinnate or pinnatifid. Sori round, borne on the backs of simply forked free veins. Indusia inferior, thin and often evanescent, roundish or stellate, either small and open or early bursting at the top into irregular lobes or segments.

Indusium minute or evanescent, flat, concealed beneath the sorus, its margin cleft into hair-like segments.
1. W. llvensis. Indusium manifest, at first enclosing the sporanges, splitting into jagged lobes.

2. W. obtusa.

1. Woodsia Ilvénsis (L.) R. Br. Leaf-blades lanceolate, $10-25 \mathrm{~cm}$. long, glabrous above, more or less covered with rusty chaff beneath, as are also the slender jointed petioles ; leaflets crowded, sessile, pinnately parted, the crowded segments oblong, obscurely crenate : sori borne near the margins of the segments, somewhat confluent when old: indusium minute, concealed beneath the sorus, its margin cleft into filiform segments, which are inflexed over the sporanges and inconspicuous, especially when mature.

On exposed rocks, Labrador and Greenland to Minnesota, south to North Carolina and Kentucky. Also in Europe and Asia.

2. Woodsia obtùsa (Spreng.) Torr. Petioles not jointed, pale green, 7-15 cm. long; leaf-blades broadly lanceolate, $15-40 \mathrm{~cm}$. long, minutely glandular-pubescent, nearly 2-pinnate ; leaflets rather remote, triangular-ovate, or oblong, pinnately parted into obtuse crenate-dentate segments : veins forked, bearing the sori near the minutely toothed lobes: indusia conspicuous, at first enclosing the sporanges, at length splitting into several lobes. Arizona.

On rocks, Nova Scotia to New York and British Columbia, south to middle Georgia, Texas and
na. 


\section{Order 3. SALVINIÀLES.}

Aquatic or mud-inhabiting herbs, with horizontal or creeping stems, or floating. Leaves various, sometimes filiform, or blades entire, lobed or 4-foliolate. Spores of two kinds (microspores and macrospores), contained in sporocarps. Macrospores germinating into simple prothallia which bear archegones, the microspores forming still simpler prothallia bearing antherozoids.

Plants rooting in the mud : leaves filiform or with 4-foliolate blades.

Fam. 1. Marsileaceat. Plants floating: leaves with entire or 2-lobed blades.

Fam. 2. SAlviniaceaE.

\section{Family 1. Marsileàceat R. Br. Marsilea Family.}

Perennial herbaceous plants rooting in mud, with slender rootstocks. Leaves with 4-foliolate blades, or merely filiform. Asexual propagation consisting of sporocarps borne on peduncles which arise from the rootstock near the leaf-stalk, or are consolidated with it, containing both macrospores and microspores.

\section{MARSÍLEA L.}

Marsh or aquatic plants. Leaves commonly floating on the surface of shallow water ; blades slender-petioled, 4-foliolate. Peduncles shorter than the petioles, arising from their bases or more or less adnate to them. Sporocarps ovoid or bean-shaped, composed of two vertical valves with several transverse compartments (sori) in each valve.

Sporocarps 2-6 on each peduncle: leaves pubescent on both sides.

1. M. macropoda. Sporocarps solitary or rarely 2 on each peduncle.

Leaflets 4-16 mm. broad, obovate or nearly obcordate.

Sporocarps 3-5 $\times 4-7 \mathrm{~mm}$; raphe short, with acute teeth.

Sporocarps $6 \times 8 \mathrm{~mm}$; raphe long, with long hooked teeth.

Leaflets $2-4 \mathrm{~mm}$. wide, more or less falcate.

2. M. vestita.

3. M. uncinata.

4. M. tenuifolia.

1. Marsilea macrópoda Engelm. Plant robust, $10-25 \mathrm{~cm}$. tall. Leaflets $2-5 \mathrm{~cm}$. long, $2 \mathrm{~cm}$. wide, or narrower, usually undulate, pubescent with white hairs on both sides, especially so when young : sporocarps 2-6 on erect branching peduncles, densely villous, 6-8 $\mathrm{mm}$. long, 5-6 mm. thick : raphe short, the lower tooth obtuse, the upper prominent or wanting : sori 10 in each valve.

In muddy places, Texas and New Mexico.

2. Marsilea vestìta Hook. \& Grev. Rootstock slender. Petioles $5-13 \mathrm{~cm}$. high : leaflets entire or toothed: sporocarps 4-8 $\mathrm{mm}$. long, 4-6 mm. wide, with a short raphe, a short and blunt lower tooth and an acute and sometimes curved upper one, densely covered with soft spreading narrow hair-like scales, or in certain forms these are short and appressed or almost wanting : sori $6-11$ in each valve.

In wet sand or in shallow ditches, Kansas to British Columbia, Mexico, Texas and Florida.

3. Marsilea uncinàta A. Br. Plant 6-20 cm. tall. Leaflets nearly glabrous, entire, 10-16 mm. wide, $8 \mathrm{~mm}$. long: peduncles 15-30 cm. long, 2-4 times the length of the sporocarps : raphe long, terminating in 2 approximate teeth, the upper longer and mostly uncinately curved : sori 13-14 in each valve.

In swamps, Louisiana and Texas.

4. Marsilea tenuifòlia Engelm. Plant slender, $5-15 \mathrm{~cm}$. high. Leaflets $2-4 \mathrm{~mm}$. wide, more or less falcate, often slightly truncate and unequally toothed at the apex, appressed-pubescent: sporocarps solitary, 5-8 $\mathrm{mm}$. long, 4-5 mm. wide, the teeth nearly equal, divergent : sori $9-12$ in each valve.

On borders of ponds, Pierdenales, Texas.

\section{PILULÀrRIA L.}

Marsh plants with slender creeping rootstocks and few filiform leaves. Sporocarps globose, longitudinally 2-4-celled, dehiscing from the apex : cavities with parietal cushions bearing microsporanges above and numerous macrosporanges below. Macrospores solitary.

1. Pilularia Americàna A. Br. Leaves filiform, about $2.5 \mathrm{~cm}$. long. Sporocarps $2 \mathrm{~mm}$. in diameter, attached by the side to a short descending peduncle, 3-4-celled : microspores 13-17, not constricted at the middle.

In shallow pools, Arkansas and California. 


\section{Family 2. SALVINIÀCEAE Reichenb. SAlvinia Family.}

Small floating plants, with a more or less elongated and sometimes branching axis bearing apparently 2-ranked leaves. Sporocarps soft, thin-walled, borne 2 or more on a common stalk, 1-celled, with a central often branched receptacle, which bears macrosporanges containing a single macrospore or microsporanges containing numerous microspores.

\section{Azólla lam.}

Minute moss-like reddish or green floating plants, with pinnately branched stems covered with minute imbricated 2-lobed leaves, and emitting rootlets beneath. Sporocarps of two kinds borne in the axils of the leaves, the smaller ovoid or acorn-shaped, containing a single macrospore at the base and a few minute bodies above it, the larger globose, producing many pedicelled sporanges, each containing several masses of microspores.

1. Azolla Caroliniàna Willd. Plants greenish or reddish, $2-4 \mathrm{~mm}$. broad, deltoid or triangular-ovate, pinnately branching, sometimes covering large surfaces of water. Macrospores minutely granulate, with three accessory bodies; masses of microspores armed with rigid septate processes : leaves with ovate lobes, their color varying with the amount of sunlight, the lower usually reddish, the upper green with a reddish border.

Floating on still water, Ontario to British Columbia, south to Florida, Arizona and Mexico.

\section{Order 4. EQUISETÀLES.}

Rush-like perennial plants, with horizontal rootstocks and mostly hollow jointed simple or often much-branched grooved stems, provided with a double series of cavities and usually with a large central one, the branches whorled, the nodes provided with diaphragms. Leaves reduced to toothed sheaths at the joints. Sporanges 1-celled, clustered underneath the scales of terminal conelike spikes. Spores uniform, furnished with 2 narrow appendages (elaters) attached at the middle, coiling around the spores when moist, and spreading, when dry, in diverse ways. Prothallia terrestrial, green, usually dioecious.

\section{Family 1. EQUisetàceat Michx. Horsetail Family.}

Characters of the order.

Theoonly genus.

\section{EQUISÈTUM L.}

Stems annual, of 2 kinds; fertile vernal, simple, soon withering; sterile much branched: stomata scattered.

Stems perennial : spikes rigid-pointed : stomata in regular rows.

Stems rough and tuberculate, prominently ridged.

Stems stout: ridges with 1 line of tubereles: sheaths with 3-keeled lidges.

Stems slender: ridges with 2 indistinct lines of tubercles: sheaths with obscurely 4-keeled ridges.

Stems not tuberculate: sheaths enlarged upward.

1. E. arvense.

2. E. robustum.

3. E. hyemale.

4. E. laevigatum.

1. Equisetum arvénse L. Stems annual, with scattered stomata, the fertile appearing in early spring before the sterile. Fertile stems 1-2.5 dm. high, not branched, soon withering, light brown, their loose scarious sheaths mostly distant, whitish, ending in about 12 brown acuminate teeth ; sterile stems green, rather slender, $0.5-6 \mathrm{dm}$. high, 6-19-furrowed, with numerous long mostly simple whorled 4-angled or rarely 3-angled solid branches, their sheaths 4-toothed, the stomata in two rows in the furrows.

In sandy soil. Newfoundland, Greenland and Alaska, south to North Carolina and California. Also in Europe and Asía.-E. arvense serótinum is an occasional form with a cone terminating the normally sterile plant. Spring. Horsetail.

2. Equisetum robústum A. Br. Stems perennial, stout, tall, evergreen, 1-2.5 m. high, sometimes $2 \mathrm{~cm}$. in diameter, 20-48-furrowed, simple or little branched. Ridges roughened with a single series of transversely oblong siliceous tubercles : sheaths short, cylindric, appressed, marked with black girdles at the base, and at the bases of the dark caducous teeth; ridges of the sheath 3-carinate; branches, when present, occasionally fertile : spikes tipped with a rigid point.

In wet places, Ohio to British Columbia, south to Louisiana, California and Mexico. Also in Asia.

3. Equisetum hyemàle L. Stems slender, rather stiff, evergreen, 6-12 dm. high, with the stomata arranged in rows, rough, 8-34-furrowed, the ridges with two indistinct 
lines of tubercles, the central eavity large, from one-half to two-thirds the diameter; sheaths rather long, cylindric, marked with one or two black girdles, their ridges obscurely 4-keeled; teeth brown, membranous, soon deciduous: stem rarely producing branches which are usually short and occasionally fertile, sometimes with longer sterile branches.

In wet places, especially on river banks, widely distributed in North America, Europe and Asia. SCOURING RUSH.

4. Equisetum laevigàtum A. Br. Stems $3-15 \mathrm{dm}$. high, simple or little branched, pale green, persistent, 14-30-furrowed, the ridges almost smooth. Sheaths elongated and enlarged upward, with a black girdle at the base of the mostly deciduous, white-margined teeth and rarely also at their bases; ridges of the sheath with a faint central carina and sometimes with faint short lateral ones: stomata arranged in single series; central cavity very large, the wall of the stem very thin.

Along streams, especial 1 y in clay soil, New Jersey to British Columbia, south to North Carolina, Louisiana and California.

\section{Order 5. LYCOPODIÀLES.}

Terrestrial or epiphytic plants with spores produced in sporanges borne in the axils of scale-like leaves.

Spores all of one sort and size.

Sporanges 1-celled, transversely 2-valved: stems leafy. Sporanges $2-3$-celled, opening by $2-3$ apical valves : stems and branches
nearly naked.

Spores of two sizes, macrospores and microspores.

Fam. 1. Lycopodiaceae.

Fam. 2. Psilotaceae.

Fam. 3. Selaginellaceae.

\section{Family 1. Lycopodiàceat Michx. Club-moss Family.}

Moss-like plants, with erect, trailing or creeping stems. Leaves often numerous, in 2-several series : blades narrow. Sporanges 1-celled, solitary in the axils of leaf-like or scale-like bracts (sporophylls), sometimes forming compact cones (strobiles). Spores uniform, minute. Prothallia (as far as known) mouoecious, mostly subterranean.

\section{LYCOPÒDIUM L. ${ }^{1}$}

Perennial evergreen plants various in habit. Leaves in 4-16 series : blades 1-nerved. Sporanges 1-celled, in the axils of more or less distant leaf-like bracts or collected into terminal compact bracted cones, transversely 2-valved. Spores of one kind, sulphur-yellow, copious, readily inflammable. Some species are known as Club-Mosses.

Plants with mostly upright stems: leaves and bracts (sporophylls) in alternating zones (cones interrupted).

Leaf-blades appressed, with hollow bases.

Leaf-blades ultimately reflexed, flattened at the bases.

Leaf-blades linear or nearly so, entire or denticulate.

Leaf-blades manifestly broadest above the middle, erose.

1. L. Selago.

2. L. porophilum.

3. L. lucidulum.

Plants with creeping or horizontal stems (rootstocks): cones terminal.

Sporanges globose: bracts and leaves similar.

Bracts 5-6 mm. long, often slightly toothed at the base.

Bracts 8-10 mm. long, usually much toothed.

Leaves in many series, radially spreading: stems arching.

Leaves twisted so as to be in one plane: stems prostrate.

Sporanges transversely compressed, reniform: bracts entirely unlike the leaves.

Stems (rootstocks) prostrate or creeping: leaves nearly in one plane.

Stems (rootstocks) creeping or horizontal, with erect or ascending branches.

Leaves equal, radially arranged (except on twigs of No. 8), in 5 or more series. Cones few, stout, erect. Cones numerous, short, nodding.

Leaves dorsiventrally arranged in 4 series on flattened stems.

Leaves of under row scarcely reduced: terminal branches erect. Leaves of under row reduced to subulate scales: terminal branches horizontally fan-like.

4. L. Chapmani.

5. L. alopecuroides.

6. L. pinnatum.

7. L. Carolinianum.

8. L. obscurum.

9. L. cernuum.

10. L. tristachyum.

11. L. complanatum.

1. Lycopodium Selàgo L. Prostrate portion of the stems very short, rooting, curving upward, thence dichotomously branched and forming tufts $4-17 \mathrm{~cm}$. tall. Leaves densely disposed, appressed or ascending; blades triangular, linear-subulate or subulate, 4-8 mm. long, broadest at the hollow base, entire: bracts shorter than the leaves, triangular: sporanges reniform.

On rocks and shaded cliffs, Labrador, Greenland and Alaska, south to Maine, Michigan and Washington and on the mountains to North Carolina. Also in Europe and Asia.

2. Lycopodium porophilum Lloyd \& Underw. Prostrate portion of the stems short, abundantly rooting, curving upward, thence forking 1-3 times and forming tufts $4-10 \mathrm{~cm}$. tall. Leaves densely disposed, spreading or reflexed; blades very slightly broadened

${ }^{1}$ Revised by Prof. Francis Ernest Lloyd. 
above the middle and somewhat contracted near the base, those between the sporangial regions 6-7 mm. long, broadest at the base, entire or denticulate : sporanges reniform : bracts (sporophylls) 4-5 mm. long, denticulate or entire, acuminate.

On sandstone cliffs, Wisconsin, Indiana, Kentucky and Alabama.

3. Lycopodium lucídulum Michx. Prostrate portion of the stems $5-15 \mathrm{~cm}$. long, rooting, thence usually forking 1-3 times, forming lax clusters 1-3 dm. tall. Leaves numerous, reflexed ; blades linear-spatulate, $8-11 \mathrm{~mm}$. long, acute, erose-denticulate, $1 \mathrm{~mm}$. wide at the base : bracts linear to lanceolate, $3.5-8.5 \mathrm{~mm}$. long, sometimes denticulate: sporanges depressed-reniform.

In cool woods and on damp slopes, Newfoundland to British Columbia, south to South Carolina, Tennessee and Iowa.

4. Lycopodium Chapmánii Underw. Stems creeping or arching, about $3 \mathrm{~mm}$. thick, $18-40 \mathrm{~cm}$. long, simple or occasionally pinnately branched. Leaves numerous; blades lanceolate, 6-7 mm. long, acuminate, curved upward, irregularly toothed, with the lower teeth often branched, or those of the fertile branches appressed, the lower with subulate teeth, upper entire : fertile branches 10-25 cm. long : cones $1.8-7 \mathrm{~cm}$. long, or sometimes longer, about $3 \mathrm{~mm}$. thick : bracts $5-6 \mathrm{~mm}$. long, toothed just above the base, whence they are contracted into subulate tips: sporanges nearly globular.

In sandy bogs, Massachusetts to Florida and Louisiana.

5. Lycopodium pinnàtum (Chapm.) Lloyd \& Underw. Stems 20-30 cm. long, pinnately branched, 1-2 nm. thick. Leaves numerous; blades thin, $8-9 \mathrm{~mm}$. long, linearlanceolate, curved, long-toothed, those of the upper side of the stem smaller, all slightly contracted at the base: fertile branches $25-40 \mathrm{~cm}$. long, their numerous leaves narrower than the stem-leaves : cones $3-12 \mathrm{~cm}$. long, $5 \mathrm{~mm}$. thick : bracts spreading, similar to the leaves of the fertile branches but more gradually tapering: sporanges nearly globular.

In low sandy grounds, southern Georgia, Florida and Alabama.

6. Lycopodium alopecuroìdes $\mathrm{L}$. Stems $5 \mathrm{dm}$. long, or even longer, arching, rooting at the ends. Leaves numerous; blades 5-7 mm. long, lanceolate, and spinulose on the sides of the stem, linear-lanceolate and long-toothed on the upper and lower sides of the stem, and with long hairs near the base on the lower side of the stem : fertile branches $2-3 \mathrm{dm}$. tall, densely leafy, resembling the stem : cones $2-10.5 \mathrm{~cm}$. long, $5 \mathrm{~mm}$. thick: bracts 10-11 $\mathrm{mm}$. long, becoming reflexed, similar to the leaves of the fertile branches but not hairy.

In low pine lands, Long Island to Florida and Mississippi, usually within about 125 miles of the coast. Also in Brazil.

7. Lycopodium Caroliniànum L. Stems prostrate or creeping, 1-15 cm. long, 1$1.5 \mathrm{~mm}$. thick, pinnately branching. Stem-leaves of 2 kinds, the apparently lateral ones ovate-lanceolate, 5-6 mm. long, falcate, recurved, acute, entire, with the midrib asymmetrically placed; leaves of the upper side of the stem 3-4 mm. long, subulate above the broad base : fertile branches slender, $5-22 \mathrm{~cm}$. tall, their leaves few, subulate, $2-3 \mathrm{~mm}$. long, appressed : cones 1-5 cm. long, 2-2.5 mm. thick : bracts triangular, or somewhat constricted above the base, sometimes erose : sporanges compressed.

In sandy bogs, New Jersey to Florida and Mississippi. Also in tropical America.

8. Lycopodium obscùrum L. Stems or branches arising from horizontal rootstocks, becoming bushy and 1-3 dm. tall. Leaves numerous, spreading and curved upward; blades linear-lanceolate, mucronulate, in 8 rows below, in 6 rows above, twisted so as to lie in vertical planes : cones sessile : bracts broadly ovate, papery, erose, subulatetipped : sporanges reniform. [L. dendroideum Michx.]

In woods, Newfoundland to Alaska, south on the mountains to Georgia, and Montana. Also apparently in Japan. GROUND PINE.

9. Lycopodium cèrnuum L. Stems procumbent or arching, 2-3.5 dm. long, somewhat creeping, branching, often in various planes, the ultimate branches nodding and fertile. Leaves numerous, terete, subulate, $3-5 \mathrm{~mm}$. long, spreading and upwardly curved : cones sessile, $5 \mathrm{~mm}$. long: bracts ovate, acuminate, thin-fringed : sporanges minute, transversely flattened.

In sandy soil or pine lands, Florida to southern Mississippi. Also in tropical regions.

10. Lycopodium tristáchyum Pursh. Rootstocks horizontal ; branches becoming erect, or decumbent, repeatedly forking to form several vertically placed flattened branchlets 1.5-2 mm. wide. Leaves of branches appressed or incurved ; blades linear-subulate : fertile branches scape-like, $5-6 \mathrm{~cm}$. tall, usually twice-forked : cones 2,3 or casually $4,2-2.8$ cm. long: bracts ovate, abruptly subulate-tipped. [L. Chamaecyparissus A. Br.]

In woods, Maine to Minnesota, south along the mountains to North Carolina.

11. Lycopodium complanàtum L. Rootstocks creeping; branches erect, repeatedly forked to form several horizontally spreading branchlets, $1.8-2.5 \mathrm{~mm}$. wide. Leaves of 
branches somewhat spreading, linear, with subulate tips : fertile branches erect, $5-8 \mathrm{~cm}$. long, usually twice-forked: cones $15-25 \mathrm{~mm}$. long: bracts ovate, gradually contracter to the subulate tips, toothed.

In woods, Prince Edward Island to Ontario and Minnesota, south to the mountains of North Carolina. Also in Europe and Asia. Christmas-GreEn.

\section{Family 2. PSilotàceae Pritzel. Psilotum Family.}

Perennial slender terrestrial or epiphytic plants. Sporanges sessile in the axils of the leaves, 2-3-celled, opening by valves at the apex. Spores uniform.

\section{PSILÒtUM R. Br.}

Terrestrial or sometimes epiphytic. Stem dichotomously forked. Leaves alternate, reduced to scales. Sporanges 3-celled, opening by 3 valves at the apex. Spores mealy, oval or elongated-reniform.

1. Psilotum nùdum (L.) Griseb. Stems erect, $20-25 \mathrm{~cm}$. tall, 3 -angled at the base, copionsly forked above, the ultimate divisions with 3 wing-like angles: leaves remote, awl-like, 1-1.5 mm. long: sporanges in interrupted spikes. [P. triquetrum $\mathrm{Sw}$.]

In hammocks, South Carolina to Florida. Also in tropical America.

\section{Family 3. Selagineldàceat Underw. Selaginella Family.}

Terrestrial moss-like annual or perennial plants, with much branched stems. Leaves scale-like, uniform and several-ranked, or of 2 kinds and in 2 planes. Sporanges 1-celled, disposed in 4-sided cones, solitary in the axils of bracts, some containing 4 macrospores (macrosporanges), others containing numerous microspores (microsporanges), which develop into small prothallia, those from the macrospores bearing archegones, those from the microspores antherids.

\section{SELAgINÉlla Beauv.}

Characters of the family.

Stem-leaves of 2 kinds, spreading in two planes.

Stems flaccid, creeping; microspores warty.

Stems rigid, ascending; microspores smooth.

Stem-leaves all alike, several-ranked.

Stems erect or ascending.

Cones $2-3 \mathrm{~cm}$. long, slender.

Cones $5 \mathrm{~mm}$, long or less, as stout as the diameter of the stem.

Stems spreading or creeping.

Stems rooting only near the base: leaves with tortuous hairs.

Stems rooting throughout, usually less than $1 \mathrm{dm}$. long: cones $10-15 \mathrm{~mm}$. long: leaves ending in a slender awn.

Lips of the dorsal groove of the leaf-blades glabrous.

Lips of the dorsal groove of the leaf-blades spinose-ciliate.

1. S. apus.

2. S. Ludoviciana.

3. S. arenicola.

4. S. Sherwoodii.

5. S. tortipila.

6. S. rupestris.

7. S. acanthonota.

1. Selaginella àpus (L.) Spring. Annual, pale green. Stems creeping, 5-15 cm. long, flaccid, pinnately branched : leaves in two planes, those of the lower plane ovate, acute, short-ciliate on the margins, those of the upper plane lanceolate short bristle-pointed : cones $6-15 \mathrm{~mm}$. long, obscurely 4 -angled: bracts ovate, acutely keeled above : microspores warty.

In moist shaded ground, Maine and Ontario to the Northwest Territory, Florida and Texas.

2. Selaginella Ludoviciàna A.Br. Annual, dark green. Stems creeping or ascending, 15-30 cm. long, once or twice pinnately branched : leaves in two planes, those of the lower plane broadly ovate, obtuse, with whitish margins formed of sclerotic cells, those of the upper plane lanceolate with slender acuminate tips: cones 1-2 cm. long: microspores smooth.

In shaded ground, Florida to Louisiana.

3. Selaginella arenícola Underw. Roots copious, delicate, $15-20 \mathrm{~cm}$. long. Stems much branched, the branches tufted, slender, $5-8 \mathrm{~cm}$. tall, giving off brown roots near their bases: leaves appressed, narrowly lanceolate, $0.25 \mathrm{~mm}$. wide, ciliate, channeled dorsally, tipped with a spinulose white awn $0.35-0.50 \mathrm{~mm}$. long: cones sharply 4-angled, $2-3$ $\mathrm{cm}$. long: bracts broadly lanceolate, spreading, with $15-20$ cilia on each side: microspores copious, globose-tetrahedral.

In exposed sandy fields, Georgia and Florida.

4. Selaginella Sherwoòdii Underw. Plants forming densely branched compact tree-like tufts $6-8 \mathrm{~cm}$. high. Stems repeatedly branching, erect or ascending, rooting only at the base, rigid ; leaves about 10-ranked, about $1.5 \mathrm{~mm}$. long, closely appressed, grooved 
dorsally in the lower two thirds, ending in a slender white coiled hair $0.7-0.9 \mathrm{~mm}$. long, and with 8-12 minute cilia on each margin; cones less than $5 \mathrm{~mm}$. long, terminal on the branches, the sporophylls similar to the ordinary leaves; macrosporangia three-lobed, the macrospores pale yellow, rugose-reticulate, $0.44 \mathrm{~mm}$. in diameter ; microsporangia roundreniform, the microspores bright yellow, smooth, $44 \mu$ in diameter.

On rocks, mountains of southwestern North Carolina.

5. Selaginella tortípila A. Br. Stems rooting only near the base ; branches! zigzag, 20-25 cm. long, primary ones elongated. Leaves about 6-ranked, loosely imbricated, narrowly lanceolate, ciliate, scarcely channeled, tipped by a contorted or coiled hair : cones 4-5 mm. long, slightly 4-angled: bracts ovate-lanceolate, loosely spreading, dorsally channeled.

On rocky mountain tops, North Carolina and South Carolina.

6. Selaginella rupéstris (L.) Spring. Stems and branches creeping, $5-10 \mathrm{~cm}$. long, zigzag, ascending at the tips ; primary branches short. Leaves closely imbricated, about 8ranked, $0.3-0.38 \mathrm{~mm}$. wide, deeply channeled dorsally, with 6-9 cilia on each side, tipped with a white spinulose awn about $1 \mathrm{~mm}$. long: cones 1-1.5 $\mathrm{cm}$. long, sharply 4angled : bracts similar to the leaves but broader and with shorter awns and more cilia.

On dry rocks, Maine and Ontario to British Columbia, south to Georgia and Missouri.

7. Selaginella acanthonòta Underw. Stems and branches stout, rooting and ascending, softly plumose at the tips. Leaves of the stems in 8-10 regular series; blades about $2 \mathrm{~mm}$. long, gradually tapering into a roughened awn one-half to one-third their length, with about 12 short irregular cilia on each side and similar cilia on either side of the dorsal groove : cones fully $10 \mathrm{~mm}$. long: bracts broadly triangular, ciliate like the leaf-blades.

In sand, near the coast, North Carolina. Summer.

\section{Order 6. ISOETÀLES.}

Submerged, amphibious or uliginous plants, with a cluster of elongated awlshaped leaves rising from a more or less 2-3-lobed fleshy short stem, the leaves with or without peripheral bast-bundles, with or without stomata, bearing a small membranous organ (ligule) above the base. Sporanges sessile in the excavated bases of the leaves, the sides more or less covered with a fold of the inner side of the leaf-blades (velum); those of the outer leaves usually contain spherical, mostly sculptured macrospores, those of the inner contain minute powdery oblong microspores; the former germinate into prothallia bearing only archegones, the latter into prothallia bearing usually only a single antherid.

\section{FAMily 1. ISOETÀCEAE Horan. QUillwort FAMily.}

Characters of the order.

\section{ISOÈTES L. •}

The only genus. Owing to their aquatic habitat and apparently local distribution, these plants are popularly little known. Some species are called QuILLworT.

Velum incomplete or wanting.

Amphibious : macrospores honeycombed-reticulated.

Terrestrial : macrospores tubereulate.

Polygamous : leaves $15-60$, often blackish at the base.

Dioecious: leaves $8-15$, bright green.

Velum complete.

Macrospores dark-colored : leaves $5-6 \mathrm{~cm}$. long.

Macrospores light-colored : leaves $40-60 \mathrm{~cm}$. long.

1. I. Engelmannii.

2. I. melanopoda. 3. I, Butleri.

1. Isoetes Engelmánnii A. Br. Amphibious, usually partly immersed when mature. Leaves 25-100, light green, quadrangular, tapering, 22-50 cm. long, bearing abundant stomata : peripheral bast-bundles present : sporanges oblong or linear-oblong, unspotted : velum narrow : macrospores $400-520 \mu$ in diameter, covered with honeycomb-like reticulations : microspores $24-28 \mu$ long, mostly smooth.

In ponds and ditches, rooting in mud, Maine to Delaware, Pennsylvania and Missouri.-Represented in our range by $I$. Engelmannii Georgiàna Engelm., which has fewer leaves and slightly larger macrospores, and is known from Georgia; and by I. Engelmannii Caroliniana A. A. Eaton, which has stouter leaves. a broader velum and larger brown densely muricate microspores; it occurs in the mountains and middle country of North Carolina.

2. Isoetes melanópoda J. Gay. Terrestrial, with a subglobose deeply 2-lobed trunk. Leaves 15-60, slender, erect, bright green, with a blackish shining base, 12-15 cm. long, 3 -angled, bearing stomata throughout, and well developed peripheral bast-bundles; ligule 
3-angled, awl-shaped : sporanges mostly oblong, spotted, with a narrow velum: polygamous : macrospores $250-400 \mu$ in diameter with low more or less confluent tubercles, often united into worm-like wrinkles, or almost smooth : microspores 23-28 $\mu$ long, spinulose.

On moist prairies and in overflowed fields, Iowa to Illinois, Missouri and Texas. - The Texan form has larger leaves with pale bases.

3. Isoetes Bútleri Engelm. Terrestrial, from a subglobose trunk. Leaves 8-15, bright green, paler at base, triangular, $4.5-18 \mathrm{~cm}$. long, bearing numerous stomata, and with well developed peripheral bast-bundles, thick dissepiments and small air cavities: sporanges usually oblong, spotted : velum very narrow or none : ligule small, triangular: dioecious: macrospores $500-630 \mu$ in diameter, with distinct or confluent tubercles.

On rocky hillsides, Missouri and Indian Territory.-A variety, I. Butleri immaculata Engelm., growing in the barrens about Nashville, Tennessee, has longer leaves, unspotted sporanges and spinulose microspores.

4. Isoetes melanóspora Engelm. Stem flat, slightly 2-lobed. Leaves 5-10, distichous, slender, 5-6 cm. long, light green : sporanges orbicular or nearly obcordate, 1-2 $\mathrm{mm}$. long, covered by the velum : ligule triangular, obtuse : macrospores $350-450 \mu$ long, with distinct or confluent warts, dark-colored : microspores 28-31 $\mu$ long.

In shallow excavations in granite, slopes and summit of Stone Mountain and Little Stone Mountain, middle Georgia.

5. Isoetes fláccida Shuttlw. Leaves 10-35, light green, 4-6 dm. long, submersed or emersed. Sporanges oval, 4-6 mm. long, covered with numerous, or rarely few large flattish tubercles, these distinct or confluent into labyrinthiform wrinkles.

In lakes and ponds, western and peninsular Florida.-A variety, I. flaccida rigida Engelm. from Lake Flirt, is smaller, and has more slender and erect leaves.

\section{Subkingdom SPERMatóphyta. Seed-bearing Plants.}

Plants producing seeds each of which contains an embryo consisting of a short stem (radicle, caulicle or hypocotyl), one, two or several rudimentary leaves (cotyledons) and a terminal bud (plumule). These parts are sometimes partially undifferentiated before germination. Microsporanges (anther-sacs) are borne on modified leaves (filaments) and contain usually several or many microspores (pollen-grains). Macrosporanges (ovules) are borne on the surface of a flat or inrolled modified leaf (carpel) and contain a macrospore (embryo-sac). A macrospore develops the reduced female prothallium; an egg-cell in an archegone of this prothallium is fertilized by means of an elongating tube (pollen-tube), a part of the male prothallium protruding from the pollen-grain (microspore).

Ovules and seeds borne on the face of a bract or a scale : stigmas wanting. Ovules and seeds in a closed cavity (ovary): stigmas present.

Class 1. Gymnosperma E. Class 2. AngiospermaE.

\section{Class 1. GYMNOSPÉRMAE.}

Carpel or pistil represented by a scale or disk upon whose face are borne the ovules (macrosporanges). Pollen-grains (microspores) divide into two or several cells, one of which gives rise to the pollen-tube (male prothallium); a sperm-cell or spermatozoid developed at the end of a pollen-tube directly fertilizes an egg-cell in the archegone of the embryosac (female prothallium) in the ovule (macrosporange).

\section{Order 1. CYCADÀLES.}

Relatively low palm-like plants. Stems scarred with the bases of fallen leaves. Leaves aggregated in a terminal crown: blades pinnate. Flowers in terminal or nearly terminal cones of often numerous approximate scales, or on slightly modified leaves. Staminate cones with peltate or boat-shaped scales supporting several pollen-sacs. Pistillate with two or more ovules on each flat or shield-like scale. Seed drupe-like or nut-like. 


\section{Family 1. CyCAdàCEAE Lindl. Cycas Family.}

Shrubs or trees of tropical or subtropical regions, usually possessing a sticky sap. Leaves (fronds) clustered: blades pinnate: segments variously nerved. Flowers dioecious, without perianth: staminate cones falling away : pistillate leaves or cones accrescent. Pollen-sacs 1-celled, in groups of 2-4, or more. Ovules orthotropous, sessile or nearly so. Fruit an aggregate of nut-like or drupe-like seeds. Embryo in the upper part of the endosperm. Cotyledons 2 ; radicle ending in a spiral.

\section{ZÀMIA L. ${ }^{1}$}

Usually low palm-like plants, with stems usually beneath the surface of the ground. Leaves few or many : blades pinnate : petioles smooth or spiny ; segments with simple parallel nerves, entire or toothed, jointed at the rachis. Flowers in oblong or cylindric cones : scales peltate, spirally arranged. Pollen-sacs numerous. Ovules 2 on each scale, pendulous, sessile. Cones relatively small, glabrous or scurfy. Coontie.

Leaf-segments 10-16-nerved : mature pistillate cones $12-16.5 \mathrm{~cm}$. long, markedly umbonate.

Leaf-segments $20-28$-nerved : mature pistillate cones $6.5-10.5 \mathrm{~cm}$. long, scarcely umbonate.

1. Z. Floridana.

2. Z. pumila.

1. Zamia Floridàna DC. Plants $3-5 \mathrm{dm}$. tall. Leaf-blades ovate or ovate-lanceolate, $20-30 \mathrm{~cm}$. long; petioles about $20 \mathrm{~cm}$. long, unarmed, 3 -angled, silky tomentose at the base, with scattered hairs above: leaf-segments mostly opposite, 28-40, linear, 9-14 cm. long, 3-7 $\mathrm{mm}$. broad, with 5 or 6 obscure teeth at the obtuse apex, glabrous above, with a few scattered hairs beneath, falcate and somewhat twisted, 10-16-nerved, revolute: staminate cones dark brown, oblong, about $8 \mathrm{~cm}$. long and $2.5 \mathrm{~cm}$. thick; peduncles $5-10 \mathrm{~cm}$. long: mature pistillate cones oblong, $12-16.5 \mathrm{~cm}$. long and 6-8 cm. thick, markedly umbonate, densely tomentose with persistent dark brown hairs, peduncles about $10 \mathrm{~cm}$. long, ferruginous-tomentose: seed-bearing scales hexagonal, thick, nearly hemispheric at the outer end. [ $\boldsymbol{Z}$. integrifolia Chapm. in part, not Jacq.]

In dry forests, " flat woods," east coast of Florida below New River.

2. Zamia pùmila L. Plants usually more robust than those of $Z$. Floridana. Leafsegments mostly opposite but sometimes irregularly placed, $32-44$, linear-oblanceolate or linear-oblong, somewhat falcate, 7-11 cm. long, 8-16 mm. wide, slightly serrate at the obtuse apex, mostly straight but occasionally slightly twisted, 20-28-nerved, revolute : staminate cones brown, oblong, about $8 \mathrm{~cm}$. long and $2.5 \mathrm{~cm}$. thick: peduncles $5-10 \mathrm{~cm}$. long : mature pistillate cones elliptic, scarcely umbonate, $6.5-10.5 \mathrm{~cm}$. long and $5-8 \mathrm{~cm}$. thick, densely tomentose with ferruginous partially deciduous hairs: seed-bearing scales hexagonal, thin, somewhat flattened at the outer end. [Z. integrifolia Chapm. in part, not Jacq.]

In moist woods, " hammocks," middle peninsular Florida, particularly on the eastern coast.

\section{Order 2. PINÀLES.}

Shrubs or lofty trees, various in habit. Leaves scale-like, narrow, or needlelike and often collected into bundles, or rarely with expanded blades. Flowers in cones of spirally imbricated scales, the staminate and pistillate usually on the same plant. Staminate cones with scales bearing pollen-sacs. Pistillate cones with scales bearing ovules: in TAXACEAE the pistillate flowers are rarely in cones. Fruit drupe-like, berry-like, or a dry cone. Embryo usually axile.

Pistillate flowers several. with carpellary scales, these sometimes bracted: fruit a cone, either dry or berry-like.

Carpellary scales with bracts, never peltate: ovules inverted : buds scaly: wing accompanying the seed a portion of the carpellary scale.

Carpellary scales without bracts, mostly peltate or fleshy : ovules erect:

buds naked: wing of the seed, when present, a portion of the testa.

Pistillate flowers solitary or 2, without carpellary scales: fruit drupaceous or baccate.

Fam. 1. Pinaceae.

Fam. 2. JUNIPERACEAE.

Fam. 3. Taxaceae.

\section{Family 1. PINACeate Lindl. Pine Family.}

Mostly evergreen monoecious resin-yielding shrubs or trees, often conic in outline. Buds scaly. Leaves rigid, needle-like or flat, alternate, opposite, whorled, or several in a sheath. Anthers 2-several-celled, in more or less elongated cones. Pollen-grains globose, ellipsoidal or lobed. Pistillate aments

\footnotetext{
${ }^{1}$ Contributed by Mr. Herbert J. Webber.
} 
solitary or clustered, consisting of usually numerous spirally disposed bracted scales. Ovules inverted, usually 2 at the base of each scale. Fruit a dry cone formed by the accrescent scales of the pistillate aments. Seeds usually two at the base of each scale, often samara-like, the wing a portion of the carpellary scale. Endosperm copious, fleshy, or somewhat mealy. Cotyledons 2-16.

Leaves several together, surrounded by a sheath at the base: cones maturing the second year.

Cone-scales with dorsal usually spine-armed appendages: leaves mostly in 2 's or 3 's.

Leaves with 2 fibro-vascular bundles: seeds with elongated wings, these free from the scales, and attached to the seeds when they fall.

Leaves with 1 fibro-vascular bundle: seeds with narrow or rudimentary wings, these adnate to the scales when the seeds fall.

Cone-scales with inconspicuous terminal unarmed appendages: leaves in 5 's.

1. Pinus.

Cone-scales with inconspicuous terminal unarmed appendages:
eaves solitary, without a sheath : cones maturing the first year.

Cones drooping: bracts shorter than the scales.

Leaves 4-sided or nearly terete, spreading : anther-sacs opening lengthwise.

Leaves flat, apparently 2-ranked: anther-sacs opening transversely.

Cones erect: bracts longer than the scales.

2. CARyopitys. 3. STROBUS.

\section{PINNUS L.}

Rigid monoecious evergreen trees or rarely shrubs, of great economic importance. Leaves needle-like, 2-3 together or rarely more, each with 2 fibro-vascular bundles, the clusters surrounded at the base by a thin persistent sheath, spreading in all directions. Staminate aments elongated, at the ends of branchlets of the preceding year. Anthers 2-celled, opening longitudinally. Pollen-grains of 3 cells, the 2 lateral cells empty. Pistillate aments globose or slightly elongated, just back of the terminal bud, or on the young twigs : scales crowded. Cones maturing the second year: scales at length hard and spreading, each appendaged below the apex, usually spine-tipped. Seeds samara-like. The plants flower in the spring.

Scales of the pistillate aments stout, each with a short tip which scarcely equals the body in length.

Cones over $7 \mathrm{~cm}$. long.

Cones $16-25 \mathrm{~cm}$. long, the spines of the scales stout and strongly recurved : staminate aments over $5 \mathrm{~cm}$. long : seed-wing over $4 \mathrm{~cm}$. long.

Cones 8-14 cm. long, the spines of the scales small, not recurved: staminate aments less than $5 \mathrm{~cm}$. long: seed-wing less than $4 \mathrm{~cm}$. long.

Leaves not glaucous : cone of an ovoid type when open, flat or depressed at the base : seed-wing $2.5-3 \mathrm{~cm}$. long.

Leaves glaucous : cones of a cylindric or conic-cylindric type when open, rounded at the base : seed-wing $1.5-2 \mathrm{~cm}$. long.

Appendage of the cone scale very thick at the apex, projecting littletif at all beyond the spine.

Appendage of the cone-scale thin at the apex, projecting far beyond the

Cones less than $7 \mathrm{~cm}$. long.

Cones ovoid or globular-ovoid when closed : leaves 15-25 cm. long, about 2 mm. wide.

Cones narrowly conic when closed : leaves 4-12 cm. long, about $1 \mathrm{~mm}$. wide.

Cone-scales readily opening, each with a slender or minute spine towards the front of the appendage, the spine sometimes deciduous or obsolete.

Cones mainly less than $5 \mathrm{~cm}$. long: scales of the staminate aments erosetoothed at the apex : bark of the trunk relatively close and smooth.

Cone mainly over $5 \mathrm{~cm}$. long: scales of the staminate aments, entire: bark of the trunk very rough and shaggy.

Cone-scales tardily opening or permanently closed, each with a'stout spine at the middle or towards the back of the appendage.

Scales of the pistillate aments slender, each with a subulate tip several times the length of the body.

Cones conic when closed, ovoid when open : twigs glaucous.

Cones ovoid when closed, globose-ovoid or depressed when open; twigs yellow.

Scales of the pistillate aments recurved: appendages of the cone-scales relatively thin; spine slender, more or less recurved.

Scales of the pistillate aments ascending: appendages of the cone-scales very thick; spines stout, more or less incurved.

1. P. palustris.

\section{P. Elliottii.}

3. P. Taeda.

4. P. heterophylla

5. P. serotina.

6. P. glabra.

7. P. echinata.

8. P. clausa.

9. P. Virginiana.

10. $P$. rigida.

11. P. pungens.

1. Pinus palústris Mill. A tree of great economic importance, reaching a height of $40 \mathrm{~m}$. and a maximum trunk diameter of $1.5 \mathrm{~m}$., with few irregular spreading branches near the top, the bark separating into large thin plates. Leaves typically 3 in a sheath, $20-40 \mathrm{~cm}$. long, bright green, plumosely crowded at the tips of the branches, partially drooping: sheaths $2-3 \mathrm{~cm}$. long : staminate aments $5.5-8 \mathrm{~cm}$. long : cones $16-25 \mathrm{~cm}$. long, narrowly conic when closed, broadly conic when open, often slightly curved, each scale armed with a stout recurved spine : seed $12-13 \mathrm{~mm}$. long, the wing $4.5-5 \mathrm{~cm}$. long. [P. australis Michx.]

In sandy soil, southeastern Virginia to Florida and Texas, locally inland to the foothills of Georgia and Alabama. Georgia PINe. Yellow Pine. LONG-Leaf Pine.

2. Pinus Ellióttii Engelm. A tree resembling $P$. palustris in habit, but smaller. Leaves 2 or 3 in a sheath, 18-30 cm. long, bright green : sheaths about $1.5 \mathrm{~cm}$. long : stami- 
nate aments $3.5-4 \mathrm{~cm}$. long: cones $10-14 \mathrm{~cm}$. long, broadly conic when closed, ovoid when open, straight, each scale armed with a small straight spine : seed $6-8 \mathrm{~mm}$. long, the wing $2-2.5 \mathrm{~cm}$. long.

In sandy, usually low pine lands, North Carolina to Florida and Mississippi. This species and the preceding furnish the turpentine of commerce. SLASH PINE.

3. Pinus Taèda L. A tree reaching a height of $46 \mathrm{~m}$. and a maximum trunk diameter of $1.5 \mathrm{~m}$., the bark dark, very rough, deeply furrowed, exfoliating in coarse plates. Leaves glaucous, 3 in a sheath, $15-28 \mathrm{~cm}$. long : sheaths $15-20 \mathrm{~mm}$. long: staminate aments $1.5-3 \mathrm{~cm}$. long : cones $10-13 \mathrm{~cm}$. long, narrowly conic when closed, cylindric or conic-cylindric when open, each scale with a thick appendage which projects little if at all beyond the small spine : seeds $6-7 \mathrm{~mm}$. long, the wing usually about $2 \mathrm{~cm}$. long.

In sandy or clay soil, Delaware and Arkansas to Florida and Texas. LoBLoLly or OLD-FIELD PINE.

4. Pinus heterophýlla (Ell.) Sudw. A tree becoming $35 \mathrm{~m}$. tall, with a maximum trunk diameter of $1 \mathrm{~m}$., the bark pale, thick, but not deeply furrowed. Leaves glaucous, 2 or 3 in a sheath, $12-25 \mathrm{~cm}$. long: often stouter than those of $P$. Taeda: sheaths $1.5-2$ $\mathrm{cm}$. long: staminate aments $1.5-2.5 \mathrm{~cm}$. long : cones $9-14 \mathrm{~cm}$. long, narrowly conic when closed, cylindric or conic-cylindric when open, each scale with a thin appendage which projects far beyond the slender spine : seeds 5--7 mm. long, the wing $2-2.5 \mathrm{~cm}$. long.

In swampy pine lands near the coast, South Carolina and Georgia. Pond Pine. Slash Pine.

5. Pinus serótina Michx. A tree reaching a height of $25 \mathrm{~m}$., with a maximum trunk diameter of $9 \mathrm{dm}$., the trunk clothed with a flaky bark and bearing many irregular short branches near the base. Leaves glaucous, 3 in a sheath, 15-25 cm. long, crowded : sheaths about $15 \mathrm{~mm}$. long : staminate aments $1.5-2 \mathrm{~cm}$. long : cones 4-6 cm. long, ovoid or globular-ovoid when closed, very broad when open, each scale with a thick appendage and a minute spine: seeds $3-4 \mathrm{~mm}$. long, the wing nearly $2 \mathrm{~cm}$. long.

In sandy swamps, in the coastal plain, North Carolina to Florida. Black Pine. Pond Pine.

6. Pinus glàbra Walt. A tree reaching a height of $40 \mathrm{~m}$., with a maximum trunk diameter of $1.2 \mathrm{~m}$., the trunk and branches clothed with a relatively smooth and close bark, and bearing spreading branches near the ground, except in the case of very old trees. Leaves glaucous, 2 in a sheath, very slender, $4-8 \mathrm{~cm}$. long, numerous or somewhat crowded: sheaths $5-8 \mathrm{~mm}$. long: staminate aments fully $1 \mathrm{~cm}$. long: cones $3.5-5 \mathrm{~cm}$. long, conic when elosed, ovoid when open, the appendages bearing minute or almost obsolete spines, and often essentially unarmed : seeds about $4 \mathrm{~mm}$. long, the wing usually $1.5 \mathrm{~cm}$. long.

In river swamps or hammocks, South Carolina to Florida and Louisiana. SPRUCE PINE. CEDAR Pine. White Pine. Walter's Pine.

7. Pinus echinàta Mill. A tree reaching a height of $40 \mathrm{~m}$., with a maximum trunk diameter of $1.35 \mathrm{~m}$., the trunk clothed with a coarsely furrowed and very rough bark, without branches on the lower part, except in the case of young trees. Leaves deep green, 2 in a sheath or sometimes three together, $8-12 \mathrm{~cm}$. long, slender : sheaths 10-15 mm. long: staminate aments $1-1.5 \mathrm{~cm}$. long: cones $5-6.5 \mathrm{~cm}$. long, conic when closed, ovoid when open, each appendage armed with a slender spine : seeds $4-5 \mathrm{~mm}$. long, the wing $1.5-2$ cm. long. [P. mitis Michx.]

In sand or clay or on rocky banks, New York to Kansas, Florida and Texas. SHort-Leaved Pine. YelLOW-PINE.

8. Pinus claùsa Chapm. A tree reaching a height of $24 \mathrm{~m}$., with a maximum trunk diameter of $7.5 \mathrm{dm}$., the bark relatively smooth. Leaves deep green, 2 in a sheath, 4-8 $\mathrm{cm}$. long, very slender, rather crowded : sheaths $5-7 \mathrm{~mm}$. long : cones $4.5-6 \mathrm{~cm}$. long, conic when closed, ovoid when open, the appendages of the scales each armed with a stout spine at the middle or behind it : seeds $4 \mathrm{~mm}$. long, the wings about $1.5 \mathrm{~cm}$. long.

In sandy ridges near the coast, Florida and Alabama, SAND PINE.

9. Pinus Virginiàna Mill. A tree reaching a height of $36 \mathrm{~m}$., with a trunk diameter of $1 \mathrm{~m}$., but often much smaller, the bark more or less flaky, the twigs glaucous. Leaves deep green, 2 in a sheath, 4-7 cm. long, rather stout : sheaths 5-8 mm. long: staminate aments $1-1.5 \mathrm{~cm}$. long: cones $5-7 \mathrm{~cm}$. long, narrowly conic when closed, ovoid when open, the appendages of the scales each armed with a curved spine : seeds 4-5 mm. long, the wing fully $1.5 \mathrm{~cm}$. long. [P. inops Ait.]

In sandy soil or on stony ridges, Long Island to Indiana, Georgia and Alabama. SCRUB or Jersey Pine. Poverty Pine.

10. Pinus rígida Mill. A tree reaching a height of $25 \mathrm{~m}$., with a maximum trunk diameter of $9 \mathrm{dm}$., the bark very rough, the twigs yellow. Leaves bright green, 3 in a sheath, $6-12 \mathrm{~cm}$. long, rather stout : sheaths $10-15 \mathrm{~mm}$. long: staminate aments about 1.5 en. long: cones 4-7 cm. long, ovoid when closed, globose-ovoid or depressed when open, the appendages of the scales relatively thin, each armed with a more or less recurved spine.

In sandy or rocky soil, New Brunswick to the Lake Ontario region, Virginia and Kentucky and in the mountains to Georgia and Alabama. Pitch Pine. 
11. Pinus púngens Michx. A tree reaching a height of $18 \mathrm{~m}$., with a maximum trunk diameter of about $1 \mathrm{~m}$., the bark rather smooth but flaky. Leaves light green, 2 in a sheath, 5-10 $\mathrm{cm}$. long, stout, rigid: sheaths $12-14 \mathrm{~mm}$. long: staminate aments 1-1.5 $\mathrm{cm}$. long: cones 8-12 cm. long, ovoid when closed, globose-ovoid or depressed when open, very persistent, the appendages of the scales very thick, each armed with a stout incurved spine : seeds $6-7 \mathrm{~mm}$. long, the wing fully $2 \mathrm{~cm}$. long.

In stony soil or on cliffs, Allegheny Mountains and the Blue Ridge from Pennsylvania to northern Georgia, and locally in the contiguous territory. TABLE MoUNTAIN PINE.

\section{CARYÓPITYS Small.}

Monoecious evergreen shrubs or trees. Leaves needle-like, 2-3 together, or solitary, each with 1 fibro-vascular bundle, each cluster surrounded at the base by a deciduous sheath. Staminate aments clustered at the ends of branchlets of the preceding year. Anthers 2celled, each sac opening lengthwise. Pollen-grains with two lateral empty cells. Pistillate aments borne behind the terminal bud. Cones maturing the second year: scales becoming leathery, with the dorsal thickenings often minutely spine-tipped. Seed-wing very narrow or a mere margin which remains attached to the scale when the seed falls.

1. Caryopitys édulis (Engelm.) Small. A tree often becoming $12 \mathrm{~m}$. tall, with irregularly ridged bark. Leaves 2 or rarely 3 in a sheath, $2-5 \mathrm{~cm}$. long, rigid, dark green : sheaths 6-12 mm. long, early deciduous: staminate aments $6-9 \mathrm{~mm}$. long: pistillate aments oblong-cylindric, short-peduncled : cones ovoid, 4-6 $\mathrm{cm}$. long; scales much thickened back of the apex, each enlargement with a minute incurved tip : seeds ovoid, fully $1 \mathrm{~cm}$. long, the wing about $3 \mathrm{~mm}$. wide, detached from the seeds at maturity. [Pinus edulis Engelm.]

On limestone bluffs or in arid soil, Wyoming to Texas and Mexico. Spring. Nut Pine. Piñon.

\section{STRÒBUS Opiz.}

Monoecious evergreen trees. Leaves needle-like, mostly with 1 fibro-vascular bundle, 5 together, surrounded at the base by a deciduous sheath, the clusters spreading in all directions. Staminate aments in spikes or clusters at the ends of brachlets of the preceding year. Anthers 2-celled, opening longitudinally. Pollen-grains of 3 cells ; 2 lateral cells empty. Pistillate aments slightly elongated, on twigs behind the terminal bud: scales crowded in several series. Cones maturing the second year, drooping: scales becoming leathery, without either dorsal thickening or spine. Seeds winged.

1. Strobus Stròbus (L.) Small. A forest tree of the first economic importance, reaching a height of $52 \mathrm{~m}$., with approximately whorled branches, bark relatively smooth, often shining. Leaves very slender, 5 in a sheath, often rather crowded, $5-10 \mathrm{~cm}$. long, glaucous, nearly triangular in cross-section: sheaths deciduous or fugaceous : staminate aments ovoid or oblong, $8-10 \mathrm{~mm}$. long, glaucous, in dense clusters : pistillate aments narrowly oblong, about $1 \mathrm{~cm}$. in length, glaucous : cones narrowly cylindric, 1-2 dm. long, somewhat tapering towards the apex, more or less curved ; scales at length loosely spreading, thinnish : seeds elliptic, 6-7 mm. long; wing usually about $2.5 \mathrm{~cm}$. long. [Pinus Strobus L.]

In woods. Newfoundland to Manitoba. south to New Jersey and Iowa, and in the mountains to northern Georgia and Alabama. Spring. WHITE PINE.

\section{PİCEA Link.}

Evergreen monoecious trees, with soft wood. Leaves ascending or nearly erect: blades needle-shaped, but short, nearly terete or 4-angled, curved, leaving a prominent base on falling away. Staminate aments arising from the axils of the leaves of the preceding year, or sometimes terminal. Pollen-sacs loosely disposed, opening longitudinally. Pistillate aments terminal : scales closely imbricated: bracts membranous, inconspicuous. Cones maturing the first year, drooping; scales thinnish, persistent, at length spreading. Seeds samara-like, each with a hyaline wing. The plants flower in spring.

Twigs stout, copiously pubescent: leaves over $1 \mathrm{~mm}$. broad, blunt or mucronate : cones persistent.

Twigs slender, glabrate or merely pubescent between the decurrent sterigmata : leaves

1. P. Mariana.

barely $1 \mathrm{~mm}$. broad, acute : cones early deciduous.

2. P. australis.

1. Picea Marlàna (Mill.) B.S.P. A forest tree reaching a height of $30 \mathrm{~m}$., with a maximum trunk diameter of about $1 \mathrm{~m}$. Bark slightly roughened : twigs stout, stiff, copiously pubescent as are usually the sterigmata : leaves stout, curved, 8-12 mm. long, over 1 $\mathrm{mm}$. thick, blunt or mucronate, deep green : cones oval or ovoid, $2.5-4 \mathrm{~cm}$. long, persistent.

In moist soil, Newfoundland to the Northwest Territory, New Jersey and Minnesota, and in the mountains to North Carolina. Black SprUCE. HE BalsaM. TAMARACK. YeW Pine. LASHHorn. 
2. Picea austràlis Small. A forest tree sometimes 35 or $40 \mathrm{~m}$. tall, with a maximum trunk diameter of nearly $1.5 \mathrm{~m}$. Bark relatively smooth : twigs slender, glabrous or merely pubescent in lines between the decurrent sterigmata: sterigmata glabrous : leaves slender, straight or slightly incurved, $8-14 \mathrm{~mm}$. long, barely $1 \mathrm{~mm}$. thick, acute, bright green: cones oblong, oval or ovoid, rarely $2.5 \mathrm{~cm}$. long, deciduous. [ $P$. alba Chapm., not Link.]

On dry mountain slopes or summits, or about ledges of rock, Virginia and North Carolina.

\section{TSÙGA Carr.}

Stately monoecious evergreen trees, with spreading or somewhat declining branches and a brittle wood. Leaves apparently 2-ranked: blades flat, linear, glaucous beneath, articulated at the base of the petiole. Staminate aments on slender stalks arising from the axils of the leaves of the preceding year. Pollen-sacs subglobose, confluent, opening transversely. Pollen-grains 2-lobed or discoid. Pistillate aments solitary and terminal on the branchlets of the preceding year: scales in few series : bracts membranous, inconspicuous. Cones elongated, drooping, maturing the first year: scales at length loose or spreading, persistent. Seeds samara-like, each with a delicately striate wing.

Twigs tomentose with long hairs : cones narrowly ovoid, $1.8-2.3 \mathrm{~cm}$. long : scales nearly erect.

Twigs tomentose with short hairs, or glabrate : cones cylindric-oblong, $3 \mathrm{~cm}$. long:

scales spreading at right angles.

1. T. Canadensis.

1. Tsuga Canadénsis ( $\mathrm{L}$ ) Carr A forest tree reaching a height of $31 \mathrm{~m}$, with a maximum trunk diameter of $1.2 \mathrm{~m}$., clothed with a thin bark which exfoliates in scales. Branches lax, somewhat declining: leaves 6-14 $\mathrm{mm}$. long; blades linear, obtuse, slightly revolute, glabrous, shining, with a furrow along the midrib above, glaucous beneath: twigs reddish, tomentose with long hairs : staminate aments subglobose, $2 \mathrm{~mm}$. in diameter : cones narrowly ovoid, $1.8-2.3 \mathrm{~cm}$. long; scales suborbicular, thinnish, nearly erect, the tips slightly revolute : seeds oblong, $4 \mathrm{~mm}$. long, oblique at the ends; wings $1 \mathrm{~cm}$. long or shorter.

On rocky banks. in woods and ravines, Nova Scotia to Quebec and Wisconsin, south to Delaware, and on the Alleghenies or in their vicinity to northern Georgia and Alabama. Spring. HEMLOCK. SPRUCE PINE.

2. Tsuga Caroliniàna Engelm. A tree rarely reaching a height of $25 \mathrm{~m}$. and a maximum trunk diameter of $1 \mathrm{~m}$., the bark rather smooth. Branches bristly, spreading horizontally : leaves $1.2-2 \mathrm{~cm}$. long; blades linear, obtuse or notched at the apex, glabrous and shining above, glaucous beneath, somewhat revolute : twigs tomentose with short hairs or glabrate: staminate aments ovoid, $3 \mathrm{~mm}$. long: cones cylindric-ovoid, $3 \mathrm{~cm}$. long; scales oblong or nearly so, thinnish, at length spreading at right angles, the tips slightly involute : seeds ovoid, $4 \mathrm{~mm}$. long, covered with resinous glands; wings $1.2-1.5 \mathrm{~cm}$. long.

In ravines and on rocky mountain slopes from southwestern Virginia to northeastern Georgia. Spring. Hemlock. Crag Hemlock. Carolina Hemlock.

\section{6. ÀBIES Mill.}

Small or medium sized monoecious evergreen trees, with spreading or somewhat drooping branches and soft but compact wood. Leaves sometimes apparently 2-ranked, narrow, flattish or strongly keeled and glaucous beneath, leaving no prominent points of attachment in falling away. Staminate aments arising from the axils of the leaves of the preceding year, solitary, subtended by imbricated bracts. Pollen-sacs loosely disposed, opening transversely or nearly so. Pistillate aments lateral, elongated, erect: scales densely imbricated; bracts membranous, conspicuous, deciduous at maturity. Cones maturing the first year, cylindric, erect : scales spreading at right angles. Seeds samara-like.

1. Ables Fràseri (Pursh) Lindl. A tree reaching a height of $25 \mathrm{~m}$., with balsamyielding blisters on the trunk. Leaves curved; blades linear, 1-2 cm. long, flattish, rather thick, slightly keeled beneath, obtuse or notched at the apex, smooth and shining above, glaucous beneath, sessile : twigs pubescent : staminate aments $5-8 \mathrm{~mm}$. long, nearly sessile : cones cylindric, 4-5 cm. long, rounded at each end, their scales fan-shaped, compactly arranged; bracts suborbicular, surpassing the scales, reflexed, erose and apiculate : seeds 4-5 $\mathrm{mm}$. long, each with a short wing which is nearly as broad as long.

On mountain peaks, southern Virginia to Tennessee and North Crolina. Spring. FIr. Silver Fir. SHe Balsam. LASH HORN.

\section{FAMily 2. JUNIPERÀCEAE Horan. JUNiPER FAMILY.}

Usually evergreen dioecious or monoecious trees or shrubs, commonly conic in outline. Buds naked. Leaves opposite or whorled, mostly reduced to ap- 
pressed scales, or sometimes subulate and spreading. Perianth wanting. Staminate aments solitary, variously disposed. Pistillate aments mostly solitary, of few carpellary scales. Ovules naked, erect, 1 or several at the base of each carpellary scale. Fruit a cone of often peltate scales, or sometimes fleshy and berry-like or drupaceous. Seeds wingless, or winged, the wing a portion of the testa. Cotyledons 2 or more.

Plants monoecious : cones dry : scales merely imbricated.

Leaves not scale-like. spreading.

Leaves mostly scale-like. typically appressedland imbricated. Cones elongated : scales not peltate: seeds winged at both ends. Cones nearly globose: scales peltate: seeds slightly winged.

Plants mostly dioecious: cones berry-like or drupe-like : scales fleshy, coalescent.

Leaves subulate and spreading on the mature branches: aments axillary, the pistillate with smaller scales at the top.

Leaves scale-like and appressed on the mature branches: aments terminal, the pistillate with larger scales at the top.

1. TAXODIUM.

2. THUJA.

3. Chama Ecyparis.

\section{TAXÒDIUM L. C. Rich. ${ }^{1}$}

Deciduous-leaved monoecious trees, with lax branches. Bark thin, smooth, fibrous. Leaves narrow, often almost 2-ranked, normally spreading. Staminate aments in panicled spikes or racemes. Anthers stalked on an oblong column, 2-5-celled, crowded, opening longitudinally. Pistillate aments subglobose, sessile on the branchlets of the preceding year, solitary or in pairs: scales peltate, crowded. Ovules erect, 2 on each scale. Cones globose or obovoid, closed, their scales orbicular or oblong, shield-like, each base narrowed into a stalk. Seeds angled, not winged. Testa shining. Embryo with 6-9 cotyledons. Leaves 2-ranked, widely spreading : branchlets horizontal : bark thin, comparatively smooth.

Leaves appressed to the appressed branchlets : bark thick, strongly furrowed.

1. T. distichum.

2. T. imbricarium.

1. Taxodium dístichum (L.) L. C. Rich. A tree sometimes $49 \mathrm{~m}$. tall and rarely $4 \mathrm{~m}$. in diameter above the enlarged base, with soft light, but compact and durable wood. Roots producing hollow conic knees sometimes $2 \mathrm{~m}$. tall : base of the trunk conic, usually hollow, with very prominent narrow longitudinal ridges : bark thin, comparatively smooth : branchlets narrowly horizontal : leaves spreading, 2-ranked; blades linear, often falcate, $1-1.5 \mathrm{~cm}$. long, acute, sessile : staminate aments $1-2 \mathrm{~mm}$, in diameter, in naked drooping panicled spikes: pistillate aments in the axils of the leaves, with crested scales: cones globular, $2.5 \mathrm{~cm}$. in diameter : seeds $8-10 \mathrm{~mm}$. long.

In swamps, in or near the coastal plain, usually along the larger rivers and over calcareous rocks, Delaware to Florida and Texas, ascending the Mississippi Valley to Missouri and Indiana. Spring.-A Mexican species, T. mucrondtum Tenore, may occur in southern Texas. CYPRESs. BALD CYPRESS.

2. Taxodium imbricàrium (Nutt.) Harper. A tree usually smaller than $T$. distichum, sometimes attaining a height of $25 \mathrm{~m}$. and a diameter of $1 \mathrm{~m}$. above the enlarged base, the wood usually heavier and stronger than that of the preceding species, the knees less abundant and short and rounded. Base of the trunk conoidal, hollow, often 3 or 4 times the diameter of the trunk proper, with broad rounded or almost obsolete longitudinal ridges : bark thick, coarse and furrowed : branchlets normally erect: leaves appressed to the branchlets (but on shoots often resembling those of $T$. distichum), incurved : blades subulate, $0.5-1 \mathrm{~cm}$. long, sessile : inflorescence and fruit very similar to that of $T$. distichum.

In lakes, pine-land ponds, creeks and small rivers in the coastal plain, apparently always over a clay subsoil, Virginia (Dismal Swamp) to Florida and Alabama. Spring. POND CYPREss.

\section{THÙJA L.}

Evergreen monoecious shrubs or trees narrowly conic in outline. Branchlets 2-ranked. Leaves scale-like, opposite, 4-ranked, flat or concave, often with a gland on the back, becoming longer and less densely imbricated on the older parts. Staminate aments terminal, solitary, nearly sessile between the leaves. Anthers in 2 or 3 series, 4-celled, stalked. Pistillate aments solitary, terminal, on short twigs, ovoid or oblong: scales opposite, in several series. Ovules 2 or rarely $3-5$, erect at the base of each scale. Cones ovoid or oblong, drooping, persistent : scales dry, spreading. Seeds flat, broadly winged on both sides.

1. Thuja occidentàlis L. A shrub or small tree reaching a height of $18 \mathrm{~m}$., rarely with a trunk diameter of $1.5 \mathrm{~m}$., producing light and soft but durable wood. Branches zigzag : leaves scale-like, appressed, each bearing a gland on the back, those of the branches

\footnotetext{
${ }^{1}$ Contributed by Mr. Roland M. Harper.
} 
5-7 mm. long, sharp-pointed, those of the twigs of two forms, one set opposite, flat, acute, the other boat-shaped, overlapping the edges of the flat ones: staminate aments in depressions, 1.5-2 mm. in diameter : cones oblong, 1-1.3 $\mathrm{cm}$. long, brown, drooping ; scales ovate or oblong, obtuse, with a gland at the apex, at length loose and spreading : seeds elliptic, 5 $\mathrm{mm}$. long, narrowed at each end ; wing 6-7 mm. long, notched at each end.

In swamps and on rocky banks, New Brunswick to Lake Winnipeg, south to Pennsylvania and in the Alleghenies to North Carolina and Tennessee. Spring. Arbor Vitae. White Cedar.

\section{CHAMAECÝPARIS Spach.}

Evergreen monoecious strong-scented trees, with 2-ranked branchlets. Leaves imbricated, scale-like, or sometimes subulate on twigs, opposite, 4-ranked, each with a gland on the back. Staminate aments terminal, sessile or nearly so. Anthers 2-4-celled, in the side of a shield-like scale. Pistillate aments terminal, globose, of several series of opposite scales. Ovules erect, 1-4 at the constricted base of each scale, bottle-shaped. Cones globose, woody : scales more or less angled, thick, with points or knobs on the back. Seeds angled or slightly winged.

1. Chamaecyparis thyoìdes (L.) B.S.P. A small or medium-sized strong-scented tree, reaching a height of $27 \mathrm{~m}$. and a maximum trunk diameter of $1.2 \mathrm{~m}$., producing soft light but compact and durable wood. Leaves scale-like, 1-2 mm. long, 4-ranked, imbricated, covering the branchlets, acute, the lateral keeled, the vertical merely convex; those of twigs subulate : staminate aments $2-3 \mathrm{~mm}$. long, slightly broadened upward: pistillate aments about $2 \mathrm{~mm}$. in diameter, glaucous, their scales with hyaline appendages: cones globose, somewhat angled, $5-7 \mathrm{~mm}$. in diameter; scales at length widely spreading, pointed on the back : seeds narrowly winged. [Chamaecyparis sphaeroidea Spach.]

In swamps and sandy places, mostly near the coast, southern Maine to Florida and Mississippi. Spring. WHITE CEDAR. CYPRESS.

\section{JUNÍPERUS L.}

Evergreen dioecious or monoecious shrubs or trees, with decumbent or erect stems. Leaves in whorls of 3 , subulate, neither appressed nor imbricated, without glands on the back, jointed at the base. Staminate aments axillary, solitary. Pollen-sacs several under each scale. Pistillate aments of $2-3$ rows of fleshy scales. Ovules usually solitary, erect. Cone berry-like by the accrescent scales of the pistillate aments. Seeds 1 or several, enclosed in the cones, wingless. A depressed shrub, with creeping branches : leaves abruptly bent at the base, deeply channeled, rather
abruptly pointed.

A tree or an erect shrub: leaves straight or nearly so, shallowly channeled, gradually acuminate.

2. J. communis.

1. Juniperus Sibírica Burgsd. A depressed radially spreading shrub, with creeping branches, forming extensive patches, seldom rising over $5 \mathrm{dm}$. above the ground. Leaves stout, mostly 8-12 $\mathrm{mm}$. long, abruptly curved at the base, appressed or erect-ascending, densely erowded, abruptly pointed : cones subglobose, 8-10 $\mathrm{mm}$. in diameter.

In dry or stony soil, Labrador to Alaska and in the Appalachian Mountains to North Carolina and Tennessee, and in the Rocky Mountains to Colorado and Utah. Also in Europe and Asia. Spring.

2. Juniperus commùnis $L$. An erect shrub or a narrowly conic tree, attaining a height of $8 \mathrm{~m}$. and a maximum trunk diameter of $0.5 \mathrm{~m}$. Leaves 1-2 $\mathrm{cm}$. long; blades narrowly linear, sometimes gradually narrowed upward into a very sharp point, somewhat concave and glaucous above, keeled beneath, sessile, usually spreading: staminate aments oblong, 4-5 mm. long, sessile : pistillate aments narrowly ovoid, glaucous : cones globose, 6-8 mm. in diameter, dark blue, covered with a bloom : seeds ovoid, about $3 \mathrm{~mm}$. long, more or less flattened, 3-angled below the apex, roughened.

On dry rocky hills, Labrador to the Rocky Mountains, southward to Georgia and New Mexico. Also in Europe and Asia. Spring. JUNIPER.

\section{SABìnA Haller.}

Evergreen strong-scented monoecious or dioecious shrubs or trees. Leaves mostly scale-like, each with a gland on the back, appressed and imbricated at maturity, opposite, sometimes connate at the base, or sometimes subulate on the twigs. Staminate aments very small, solitary or 3-6 together, terminal on the branchlets. Pollen-sacs 3-6 under each ovate or shield-like scale. Pistillate aments subglobose, composed of 2-3 rows of fleshy 
scales. Ovules erect, 1 or sometimes 2 under each scale. Cone berry-like by the acrescent fleshy scales, which enclose the seeds. Seed 1-4, wingless.

Cones 3-6 mm. long: seeds 2-4 mm. long, smooth.

Staminate aments 4-5 mm. long: cones $5-6 \mathrm{~mm}$. long.

Staminate aments $3-4 \mathrm{~mm}$. long: cones $3-4 \mathrm{~mm}$. long.

Cones $8-10 \mathrm{~mm}$. long: seeds $6-8 \mathrm{~mm}$. long, ribbed.

1. S. Virginiana.

2. S. Barbadensis.

3. S. sabinoides.

1. Sabina Virginiàna (L.) Antoine. A shrub-like or conic tree, reaching a height of $30 \mathrm{~m}$. and a maximum trunk diameter of $1.5 \mathrm{~m}$., clothed with a shreddy bark, and with a durable red heart-wood. Leaves often of 2 forms, those on the twigs awl-shaped, spreading, about $1 \mathrm{~cm}$. long, but normally scale-like, appressed, acute, opposite and 4-ranked, or in whorls of $3,1-4 \mathrm{~mm}$. long, with a gland on the back : staminate aments oblong, 3-4 $\mathrm{mm}$. long, numerous : cones ovoid, 5-6 mm. in diameter, blue, covered with a bloom : seeds ovoid, flattened, 3-4 mm. long, smooth, shining. [Juniperus Virginiana L.]

On dry hills and in swamps throughout the United States and southern British America. Spring. Fruit ripe in fall. RED CEDAR. SAVIN.

2. Sabina Barbađénsis (L.) Small. A shrub or tree similar in habit to S. Virginiana, but with shorter and rather thicker leaves, the relatively blunt apex closely appressed. Staminate aments 4-5 mm. long: berry-like cones ovoid or oval-ovoid, 3-4 mm. long. [Juniperus Barbadensis L.]

In sandy or clay soil, Florida to Texas, along or near the coast. Spring. Also in the West Indies.

3. Sabina sabinoides (H.B.K.) Small. A shrub or small tree, reaching a height of $15 \mathrm{~m}$. and a maximum trunk diameter of $3 \mathrm{dm}$., clothed with a shreddy bark and possessing a brown wood. Leaves scale-like, appressed, imbricated, 1-2 mm. long, opposite, or four-ranked, obtuse, minutely fringed: staminate aments oblong, about $4 \mathrm{~mm}$. long: pistillate aments $2-3 \mathrm{~mm}$. long, with very large spreading terminal scales : cones subglobose, 8-10 mm. in diameter, covered with a bloom : seeds ovoid, 6-8 mm. long, flattened, 1-4 in a cone, ribbed. [Juniperus sabinoides (H.B.K.) Sargent.]

On hillsides, mostly in limestone soil, Texas and Mexico. Winter and spring. Mountain Cedar.

\section{FAMily 3. TAXÀCEAE Lindl. Yew FAmily.}

Evergreen monoecious or dioecious shrubs or trees, mostly destitute of resin, with scaly buds. Leaves spirally disposed but usually spreading as if 2-ranked: blades simple, entire, rigid. Aments axillary or terminal ; staminate small, naked or subtended by imbricated bracts. Pollen-sacs under variously shaped scales, opening longitudinally. Pistillate flowers solitary, or one only maturing, consisting of an orthotropous ovule; this sessile, without a carpellary scale. Fruit berry-like, erect, nearly enclosed in the accrescent pulpy aril, or naked. Testa bony or woody. Endosperm fleshy or mealy, sometimes channeled. Cotyledons 2. Pistillate flowers 2 together: pollen-sacs 2 : fruit naked : endosperm channeled.
Pistillate flowers solitary: pollen-sacs 6-8: fruit surrounded by an aril: endosperm even. 2 . TAxus. Pistillate flowers 2 together: pollen-sacs 2 : fruit naked : endosperm channeled.
Pistillate flowers solitary : pollen-sacs $6-8:$ fruit surrounded by an aril: endosperm even. 2 . TAxus.

\section{TÙMION Raf.}

Medium-sized dioecious conic evergreen trees, with a light but hard and compact wood. Branches whorled : branchlets 2-ranked. Leaves spreading as if 2-ranked: blades linear, flat. Staminate aments often crowded, each arising from a set of imbricated bracts, sessile in the axils of the leaves. Pollen-sacs 2 under each scale. Pistillate aments solitary, erect, consisting of 2 ovules, these sessile in a set of persistent bracts. Seeds berrylike, elongated, with a fleshy pericarp. [Torreya Arn., not Raf.]

1. Tumion taxifolium (Arn.) Greene. A low or medium-sized tree, reaching a height of $18 \mathrm{~m}$., with a maximum trunk diameter of $0.9 \mathrm{~m}$., when bruised exhaling a disagreeable odor. Twigs puberulent : leaf-blades linear, $1.5-3 \mathrm{~cm}$. long, slightly narrowed upward, tipped by a hard sharp point, somewhat revolute, longitudinally wrinkled beneath, short-petioled : staminate aments subglobose, $5-7 \mathrm{~mm}$. in diameter, yellow, often crowded, subtended by broadly ovate keeled scales : seed globose-oblong or somewhat obovoid, 3-4 $\mathrm{cm}$. long, smooth, glaucous. [Torreya taxifolia Arn.]

Along the A palachicola River, western Florida. Rare and local. Spring. Stinking Cedar.

\section{TÁxus L.}

Low often diffuse dioecious or rarely monoecious evergreen trees, or shrubs. Leaves spreading as if 2-ranked : blades flat, usually pointed, often scythe-shaped. Staminate 
aments short-stalked, subtended by involucres of several imbricated bracts arising from the axils of the leaves. Pollen-sacs 6-8 under each shield-like scale. Pistillate aments erect, consisting of usually one ovule; this sessile in an involucre of several imbricated bracts. Aril accrescent into a pulpy cup. Seed nut-like, elongated, exposed only at the apex.

1. Taxus Floridàna Nutt. A low tree ranging from $3-6 \mathrm{~m}$. in height, with a maximum trunk diameter of $0.25 \mathrm{~m}$., producing a heavy, hard and compact wood. Branches horizontally spreading; branchlets 2-ranked : leaves 1-2 $\mathrm{cm}$. long; blades narrowly linear, sharply apiculate, revolute, sometimes glaucescent beneath, narrowed into short twisted petioles ; midrib prominent on both surfaces : fruit berry-like; aril bright red, $6-10 \mathrm{~mm}$. long: seed ovoid, $5-7 \mathrm{~mm}$. long, minutely wrinkled, narrowed into a short tip.

On river banks, western Florida. Rare and local. Spring. YEw.

\section{Class 2. ANGIOSPÉRMAE.}

Carpel or pistil a closed cavity formed by the uniting of the margins of a rudimentary leaf, or sometimes of several leaves. The ovules (macrosporanges) are borne on the inner face of this cavity and within it the seeds are matured. A pollen-grain alighting on the stigma (a specialized portion of the carpel) sends out a pollen-tube which penetrates the tissues of the carpel and on reaching an ovule enters its orifice (micropyle), or rarely the pollen-tube enters at the chalaza. Fertilization is effected by a sperm-cell at the end of a pollen-tube coming in contact with an egg cell in the embryo-sac.

Cotyledon 1: stem endogenous. Cotyledons normally 2: stem exogenous (with rare exceptions).

Subclass 1. Monocotyledones. Subclass 2. Dicotyledones.

\section{SUBCLASS 1. MONOCOTYLEDÒNES.}

Stems endogenous, with no distinction into bark, wood and pith, consisting of a ground-mass of soft tissue (parenchyma) in which strands or bundles of wood cells are irregularly distributed. Leaves mostly alternate, sheathing at the base : blades usually parallel-nerved, entire or essentially so, rarely separating by a manifest articulation. Perianth and essential parts of the flower usually in threes or sixes. Embryo with a single cotyledon, the early leaves always alternate.

\section{Order 1. PANDANÀLES.}

Aquatic, or marsh-inhabiting herbs, perennial, mostly with elongated rootstocks. Leaves alternate, with narrow elongated blades. Flowers incomplete and imperfect, in elongated or head-like spikes. Perianth of bristles or scales. Androecium of 2-7 stamens. Gynoecium a single carpel, or rarely of 2 united carpels. Ovary 1-2-celled. Fruit nut-like. Endosperm mealy or fleshy.

Flowers in elongated terminal spikes: fruit hidden among bristles. Flowers in globose axillary spikes : fruit not hidden among bristles.

Fam. 1. TYPHACEAE.

Fam. 2. SParganiaceaF.

\section{Family 1. TYPHÀCEAE J. St. Hil. CAT-tail Family.}

Perennial marsh herbs, with long rootstocks and glabrous foliage. Stems simple, terete. Leaves sheathing at the base : blades linear, sword-like, flat. Flowers monoecious, in dense spikes, these subtended by fugacious bracts; staminate spike above the pistillate. Perianth of several bristles. Stamens 27. Filaments united at the base. Anthers oblong or broadened upward. Ovary 1-2-celled, stalked. Stigmas club-shaped, oblong or rhomboidal. Ovules suspended, anatropous. Accompanying the stamens and pistils are numerous bristles, while among the pistillate flowers are other sterile flowers in the form of club-shaped hairs. Fruit nut-like. Endosperm copious. 


\section{TYेPHA L.}

\section{Characters of the family. Cat-taIl. Reed Mace.}

Spikes with pistillate and staminate portions separated; pistillate with bractlets ; stigmas linear : pollen of simple grains.

Hairs accompanying the pistillate flowers not thickened at the apex.

Hairs accompanying the pistillate flowers with club-shaped tips.

Spikes with pistillate and staminate portions contiguous: pistillate without bract-

lets : stigmas club-shaped or rhomboidal : pollen grains in 4's.

1. T. angustifolia.

2. T. Domingensis.

1. Typha angustifòlia L. Stems $1.5-3 \mathrm{~m}$. tall, slender, not jointed : leaf-blades narrowly linear, 5-15 mm. wide, finely striate-ridged : spikes light brown, 1-4 dm. long ; pistillate portion with bractlets, $0.5-1.5 \mathrm{~cm}$. thick; staminate part separated from the pistillate : stigmas linear or oblong-linear : pollen-grains simple: nutlets terete, not bursting in water: outer coat of seeds not separable from the inner.

In marshes, chiefly along the coast, Nova Scotia to Florida. Summer. Also in Europe and Asia.

2. Typha Domingénsis Pers. Similar to $T$. angustifolia, but larger. Leaf-blades flat or nearly so, the lower ones often $2 \mathrm{~cm}$. broad: spikes 4-6 dm. long, the pistillate portion 10-20 mm. thick: hairs accompanying the pistillate flowers, or most of them, with manifest club-shaped tips. and fall.

In marshes or low grounds, Florida, Texas and California. Also in tropical America. Summer

3. Typha latifòlia L. Stems 1-2.5 m. tall, stout, not jointed: leaf-blades linear, 10-25 mm. wide, contracting much in drying: spikes dark brown or black, $1.5-6 \mathrm{dm}$. long ; pistillate portion destitute of bractlets, $2.5-3 \mathrm{~cm}$. thick; staminate part contiguous with the pistillate: stigmas spatulate or rhomboidal : pollen-grains in 4's: nutlets furrowed, bursting in water: outer coat of the seeds separating from inner.

In marshes nearly throughout North America. Summer and fall. Also in Asia and Europe.

\section{Family 2. SPARganiàCEAE Agardh. Bur-Reed Family.}

Perennial marsh or aquatic herbs, with horizontal rootstocks. Stems erect or floating. Leaves alternate : blades sheathing at the base, narrow. Flowers monoecious, in dense heads on the upper part of the stem and its branches. Heads globose, sessile or peduncled ; staminate uppermost. Spathes bract-like, sometimes remote from the head or its peduncle. Perianth of several (3-6) scales. Stamens mostly 5. Filaments distinct. Anthers oblong, or cuneate. Ovary 1-2-celled. Stigmas slender. Ovules anatropous. Fruit nut-like. Endosperm copious, surrounding the straight embryo.

\section{SPARGÀNIUM L.}

Characters of the family. Bur-REED. The plants flower in spring and summer.

Nutlets stalked, fusiform.

Upper leaves with neither sac-like bases nor hyaline margins : achenes abruptly narrowed into the slender style.

Upper leaves with sac-like bases and hyaline margins : achenes gradually narrowed into the conspicuous styles.

1. S. androcladum.

Nutlets sessile, obovoid or cuneate.

2. S. Americanum. 3. S. eurycarpum.

1. Sparganium andrócladum (Engelm.) Morong. Foliage glabrous or nearly so. Stems 2- $\tau \mathrm{dm}$. tall, more or less branched : leaf-blades linear, attenuate, sometimes quite numerous : staminate heads usually less than $1 \mathrm{~cm}$. thick: pistillate heads $3-7$, sessile or peduncled : bractlets broadest at the eroded apex, as long as the nutlets or shorter : fruiting heads globose, 1-2 cm. in diameter : nutlets fusiform, more or less constricted at the middle, 4-6 mm. long, each abruptly narrowed into a slender style. [S. simplex Chapm., not Huds.]

In swamps or shallow water, Nova Scotia to British Columbia, Florida and Louisiana.

2. Sparganium Americànum Nutt. Similar to S. androcladum, but the stem simple, the lower heads of the inflorescence merely peduncled. Leaves drying green, the upper with more or less sac-like bases and broad hyaline-scarious margins : nutlets slightly angled, each gradually narrowed into a stout conspicuous style.

In low grounds or ponds, Ontario to British Columbia, Pennsylvania, and the Indian Territory.

3. Sparganium eurycárpum Engelm. Foliage glabrous. Stems $8-20 \mathrm{dm}$. tall, branched : leaf-blades linear, attenuate, flat or slightly keeled beneath, the lower ones $9-15$ $\mathrm{dm}$. long, the upper shorter : staminate heads about $1 \mathrm{~cm}$. thick : pistillate heads several, 
sessile or peduncled, accrescent : bractlets broadened upward, as many as the angles of the nutlets, entire or eroded at the apex : fruiting heads globose, $2-2.5 \mathrm{~cm}$. in diameter : nutlets 6-10 mm. long, sessile, 4-5-angled, rounded or depressed at the apex, tipped with the style. Along streams or in marshes, Newfoundland to British Columbia, North Carolina and California.

\section{Order 2. NAIADÀLES.}

Aquatic or marsh-inhabiting herbs, perennial by rootstocks. Leaves various, sometimes reduced to phyllodes, sometimes with both narrow and broad blades on the same plant. Flowers perfect, monoecious or dioecious, usually with an unequal number of parts in the whorls. Perianth wanting or very imperfect. Androecium of 1-4 stamens or sometimes more. Gynoecium of 1 or several distinct or united carpels. Endosperm scant or wanting.

Gynoecium of distinct carpels : stigmas disk-like or cup-like.

Gynoecium of united carpels: stigmas $2-4$, slender.

Staminate and pistillate flowers alternating on a slender spadix, laterally attached : leaves with entire blades.

Staminate and pistillate flowers axillary, attached at the base: leaves with spiny-toothed blades.

Fam. 1. Zannichelliaceae.

Fam. 2. Zosteraceae.

Fam. 3. NaIADACEAE.

\section{FAmily 1. ZANNIChelliàCEAE Dumort. Pondweed FAmily.}

Perennial submersed caulescent herbs. Leaves alternate, sometimes clustered : blades filiform or expanded. Flowers perfect or monoecious, in axillary sometimes peduncled spikes or clusters arising from a spathe. Perianth a hyaline envelope, or wanting. Androecium of 1-4 stamens or rarely more. Filaments distinct, hypogynous in the perfect flowers. Anthers 1-2-celled, extrorse. Gynoecium of several distinct carpels. Ovaries 1-celled. Ovule solitary. Fruit a spike or cluster of drupelets. Endosperm wanting.

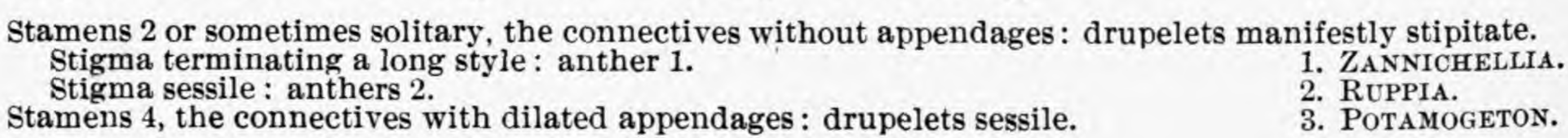

\section{ZANNICHÉLLIA L.}

Delicate submerged herbs, with filiform branching flaccid stems. Leaves alternate: blades slender, entire, 1-nerved, tapering from the dilated base. Flowers monoecious, both kinds in the same axils; staminate of a single stamen : anther 2-4-celled, terminating a pedicel-like filament. Pistillate flowers consisting of a gynoecium of 2-6 sessile carpels. Ovary flask-shaped : stigma peltate or somewhat cup-shaped, with uneven edges, surmounting a long style. Fruit a eluster of somewhat elongated curved stalked drupelets, these ribbed, sometimes toothed on the back. Seed with a coiled embryo.

1. Zannichellia palústris $\mathrm{L}$. Stems filiform, 2-7 dm. long, sparingly branched: leaves numerous ; blades soft, narrowly linear, 2-9 $\mathrm{cm}$. long, acute, 1-nerved : stipules or spathes persistent, separating from the leaves: peduncles very short: pedicels obsolete or wanting: drupelets $2-4$, or sometimes 6 in a cluster, oblong or oblong-falcate, $2-4 \mathrm{~mm}$. long, tipped with the persistent style, maturing under water.

In fresh or brackish ponds or ditches, throughout North America, except the extreme north. Summer and fall. Also throughout the Old World.

\section{RÚPPIA L.}

Submersed delicate herbs, with filiform branching stems and elongated rootstocks. Leaves alternate : blades 1-nerved, tapering to a hair-like apex from a more or less dilated basal sheath. Flowers perfect, terminating spadix-like peduncles. Perianth wanting. Stamens 2 : anthers sessile; sacs large, separate, attached by their backs to the rachis. Pistils 4, sessile : stigmas sessile, peltate. Fruit a cluster of several oblique stipitate drupelets. Embryo with the hypocotyl and the inflexed cotyledonary end immersed.

1. Ruppia marítima L. Foliage deep green. Stems slender, $3-10 \mathrm{dm}$. long, often whitish ; internodes unequal in length : leaf-blades narrowly linear, or filiform, $2.5-4 \mathrm{~cm}$. 
long, attenuate : sheaths membranous, $6-8 \mathrm{~mm}$. long, each with a minute ligule : peduncles filiform, sometimes becoming $3 \mathrm{dm}$. long : drupelets ovoid, about $2 \mathrm{~mm}$. long, oblique or gibbous at the base, 4-7 together, in umbel-like clusters, each on a stipe 1-4 cm. long.

In salt or brackish water on the Atlantic and Pacific coasts and in the interior of North America. summer. Widely distributed throughout the world. DITCH-GRAss.

\section{POTAMOGĖTON L.}

Perennial submerged herbs, with more or less elongated often branching stems. Leaves commonly numerous, often of 2 kinds: submerged of thin texture : floating smaller, of thick texture. Spathe stipule-like, free, or united with the base of the petiole or blade, early deciduous. Peduncles axillary. Spikes mostly erect. Flowers perfect. Perianth wanting or obsolete. Stamens 4. Anthers sessile, the connectives bearing dilated appendages. Pistils 4, distinct, sessile : ovary 1-celled. Stigmas sessile or terminating recurved styles. Fruit of 4 drupelets with a hard or spongy pericarp. Seeds solitary, crustaceous, campylotropous. Embryo hooked. PondweEd.

Stipules axillary, free from the leaf.

Plants with both submerged and floating leaves.

Submerged leaves without blades.

Floating leaves with ovate broadly elliptic or oval blades subcordate or rounded at the base: flowering spikes $3-6 \mathrm{~cm}$. long, 5-6 mm. thick.

Floating leaves with narrowly elliptic blades acute at both ends : flowering spikes 1-2 cm. long, $2.5-4 \mathrm{~mm}$. thick.

Submerged leaves with normal blades.

Blades of submerged leaves of 2 forms.

Blades of submerged leaves all alike.

Submerged leaves with linear or nearly linear blades.

Leaf-blades with coarse cellular reticulation in the middle. Leaf-blades with inconspicuous cellular reticulation.

Submerged leaves with lanceolate or oblanceolate blades. Leaf-blades distinctly petioled.

Leaf-blades sessile or nearly so.

Plants with submerged leaves only.

Leaf-blades broad.

Blades short-petioled or nearly sessile.

Blades clasping the stem.

Leaf-blades linear or filiform.

Blades 1-nerved.

Blades 3-nerved.

Drupelets crested : plants without propagating buds or glands.

Drupelets crestless : plants with both propagating buds and glands.

Stipules adnate to the blades or the petioles of the submerged leaves.

Plants with both submerged and floating leaves : drupelets crested.

Plants with submerged leaves only: drupelets crestless.

1. P. natans.

2. P. Floridanus.

3. P. pulcher.

4. P. Nuttallii.

5. P. heterophyllus.

6. P. Lonchites.

7. P. Zizii.

8. P. lucens.

9. P. perfoliatus.

10. P. Curtissit.

11. P. foliosus.

12. P. pusillus.

13. P. diversifolius.

14. P. pectinatus.

1. Potamogeton natans L. Stems 6-12 dm. long, simple or sparingly branched : leaves various, of 2 kinds, those of submerged leaves reduced to bladeless petioles which perish early ; those of floating leaves with leathery ovate broadly elliptic or oval blades 4-9 $\mathrm{cm}$. long, usually abruptly pointed, many-nerved, rounded or subcordate at the base ; petioles as long as the blades or much longer: peduncles as thick as the stem, $4-9 \mathrm{~cm}$. long : spikes cylindric, $3-6 \mathrm{~cm}$. long, dense : drupelets narrowly obovoid, $4-4.5 \mathrm{~mm}$. long, scarcely keeled : nutlets more or less pitted on the sides, 2-grooved on the back.

In still water or streams, nearly throughout North America: Also in Europe and Asia. Summer.

2. Potamogeton Floridànus Small. Resembling $P$. natans, but more slender. Floating leaves few ; blades narrowly elliptic, $4-7 \mathrm{~cm}$. long, acute at both ends, narrowly revolute, with 7 main nerves; petioles very slender, several times longer than the blades: peduncles stouter than the stem, 4-6 $\mathrm{cm}$. long: flowering spikes cylindric, $1-2 \mathrm{~cm}$. long, 2.5-4 mm. thick.

In the Blackwater River, Florida. Spring and summer.

3. Potamogeton púlcher Tuckerm. Stems 3-6 dm. long, nearly simple, terete, spotted: leaves various; blades of 3 kinds, those of submerged leaves leathery, spatulate ovate or oblong, and those above these flimsy, pellucid, lanceolate, $8-20 \mathrm{~cm}$. long, attenuate, short-petioled ; those of floating leaves leathery, ovate or orbicular-ovate, $4-10 \mathrm{~cm}$. long, obtuse or abruptly pointed, many-nerved, cordate at the base ; petioles as long as the blades or longer : peduncles slightly thicker than the stem, $5-10 \mathrm{~cm}$. long : spikes cylindric, dense, $2-2.5 \mathrm{~cm}$. long: drupelets turgid, 4-4.5 mm. long, abruptly pointed, 3-keeled on the back.

In ponds, Maine to Missouri and Georgia. Summer.

4. Potamogeton Nuttállii Cham. \& Schlecht. Stem slender, $3-20 \mathrm{dm}$. long, flattened, simple or sparingly branched : leaves various; blades of 2 kinds, those of submerged leaves linear, 2-ranked, $5-16 \mathrm{~cm}$. long, 5-nerved, reticulated between the midrib and contiguous 
nerves ; those of floating leaves leathery, oblong, elliptic or obovate, 3-8 $\mathrm{cm}$. long, manynerved, short-petioled: peduncles $2.5-12 \mathrm{~cm}$. long : spikes $1.5-2 \mathrm{~cm}$. long, dense, emersed or partly so: drupelets globose-obovoid, $2.5-3 \mathrm{~mm}$. long, 3-keeled, the middle keel sharp: embryo coiled $1 \frac{1}{3}$ times.

In ponds and streams, Nova Scotia to Ontario and South Carolina. Summer.

5. Potamogeton heterophýllus Schreb. Stems slender, 1-3.5 m. long, flattened, branched : leaves various; blades of 2 kinds, those of submerged leaves lanceolate or narrowly linear-lanceolate, $2.5-8 \mathrm{~cm}$. long, mostly sessile, with conspicuous cellular reticulations; those of floating leaves leathery, oval or elliptic, $1.5-4 \mathrm{~cm}$. long, abruptly pointed, shorter than the petioles: peduncles $2.5-15 \mathrm{~cm}$. long, often thickened upward: spikes 2-4 $\mathrm{cm}$. long, dense : drupelets nearly as broad as long, $1.5-3 \mathrm{~mm}$. long, indistinctly 3 -keeled on the back, abruptly pointed.

In still or flowing water, nearly throughout North America. Also in Europe. Summer and fall.

6. Potamogeton Lonchites Tuckerm. Stems terete, 9-20 dm. long, branching: leaves various; blades of two kinds; those of submerged leaves elongated, lanceolate or oblanceolate, $10-30 \mathrm{~cm}$. long, pellucid ; those of floating leaves thinnish, oblong or elliptic, $4-15 \mathrm{~cm}$. long, many-nerved, usually acute at both ends; petioles fully $\frac{1}{2}$ as long as the blades: peduncles $5 \mathrm{~cm}$. long, slightly thickened upward: spikes cylindric, $2.5-5 \mathrm{~cm}$. long, dense : drupelets as broad as long, $3.5-4 \mathrm{~mm}$. long, 3-keeled on the back, the middle keel prominent.

In ponds and rivers, New Brunswick to Washington, Florida and California. Summer and fall.

7. Potamogeton Zízii Roth. Stems slender, elongated, branching : leaves various ; blades of 2 kinds; those of submerged leaves lanceolate to oblanceolate, $5-15 \mathrm{~cm}$. long, cuspidate or acute, wavy-margined, pellucid; those of floating leaves more less leathery, elliptic, 3-10 cm. long, many-nerved, sessile or nearly so: peduncles thicker than the stems, $5-15 \mathrm{~cm}$. long: spikes $2.5-5 \mathrm{~cm}$. long, not very dense : drupelets nearly as broad as long, 2.5-3.5 mm. long, 3-keeled on the back, abruptly pointed.

In lakes and rivers, Quebec to Montana, Florida, Texas and Wyoming. Summer. Also in Europe.

8. Potamogeton lùcens L. Stems stout, elongated, more or less branched, often profusely so above : leaves all submerged; blades elliptic or lanceolate, or oval above, $5-20 \mathrm{~cm}$. long, acute or acuminate or sometimes mucronate, often serrulate at the apex, mostly 13-nerved, short-petioled or nearly sessile : peduncles $7-15 \mathrm{~cm}$. long, barely thickened upward : spikes dense, $5-7 \mathrm{~cm}$. long: drupelets $3 \mathrm{~mm}$. long, blunt-tipped.

In ponds, Nova Scotia to California, Florida and Mexico. Fall. Also in Europe.

9. Potamogeton perfoliàtus L. Stems slender, elongated, much branched : leaves all submerged; blades suborbicular to ovate or lanceolate, $2-4 \mathrm{~cm}$. long, usually obtuse, often serrulate at the apex, cordate-perfoliate, crisped : peduncles $2.5-3.5 \mathrm{~cm}$. long, about as thick as the stem: spikes $1.5-2.5 \mathrm{~cm}$. long, as long as the peduncle or shorter, often fruiting under water : drupelets obliquely obovoid, $2.5-3 \mathrm{~nm}$. long, obscurely 3 -keeled on the back.

In rivers and ponds, Newfoundland to British Columbia, Florida and California. Also in Europe. Summer and fall.

10. Potamogeton Curtíssii Morong. Stems delicate, filiform, $2-4 \mathrm{dm}$. long, simple or branched ; internodes elongated, naked : leaves all submerged : blades linear-filiform, $1-4 \mathrm{~cm}$. long, $0.5-1 \mathrm{~mm}$. broad, terminating in a hair-like tip, 1-nerved, sometimes with an indication of 2 lateral nerves; stipules hyaline, 6-8 $\mathrm{mm}$. long, obtuse, deciduous : peduncles slender, club-shaped, 6-12 mm. long, erect, axillary near the upper end of the stem : spikes capitate, 4-6 $\mathrm{mm}$. long, 3-6-flowered : fruit not seen.

In tidal creeks, Blackwater River, Florida. Spring and summer.

11. Potamogeton foliòsus Raf. Plants without propagating buds, or glands at the base of each leaf. Stems 3-10 dm. long, flattened, much branched : leaves all submerged, very numerous ; blades linear or filiform, $1.5-5 \mathrm{~cm}$. long, acute, 3 -nerved : peduncles somewhat club-shaped, 8-12 mm. long: spikes short, about 4-flowered : drupelets $1.5-2 \mathrm{~mm}$. long, 3-keeled; middle keel crest-like, undulate or sinuate-toothed, often with tooth-like shoulders at each end.

In streams and ponds, New Brunswick to British Columbia, Florida and California. Summer.

12. Potamogeton pusillus $L$. Plants with both propagating buds and glands at the base of each leaf. Stems filiform, 1-6 dm. long, branched : leaves all submerged, numerous ; blades linear or linear-filiform, $2-8 \mathrm{~cm}$. long, acute, 1-3-nerved, usually 2-glandular at the base : peduncles slender, $6-20 \mathrm{~mm}$. long, or rarely $10 \mathrm{~cm}$. long : spikes $3-10$-flowered, capitate or interrupted : drupelets longer than broad, 1.5-2 mm. long, 2-grooved on the back or with 3 distinct keels, crestless.

In slow streams and ponds, New Brunswick to British Columbia, North Carolina, Texas and California. Summer. Also in Europe. 
13. Potamogeton diversifòlius Raf. Stems elongated, flattened or nearly terete, branched : leaves various ; blades of 2 kinds ; those of submerged leaves linear-setaceous, 2-8 cm. long, acute, 1-nerved ; those of the floating leaves leathery, elliptic or oval, sometimes oblong-lanceolate, $1-2.5 \mathrm{~cm}$. long, obtuse or acute: petioles shorter than the blades or rarely longer : peduncles various, emersed club-shaped, 6-14 mm. long ; submerged, 4-6 $\mathrm{mm}$. long: spikes dense, 4-8 $\mathrm{mm}$. long : drupelets cochleate, about $1 \mathrm{~mm}$. long, 3-keeled ; middle keel crest-like, 7-8-toothed; lateral keels acute or obtuse.

In pools and still water, Maine to Montana, Florida and Texas. Spring and summer.

14. Potamogeton pectinàtus $\mathrm{L}$. Stems slender, $3-10 \mathrm{dm}$. long, or longer, repeatedly forking : leaves all submerged ; blades setaceous or filiform, $2-15 \mathrm{~cm}$. long, 1-nerved or nerveless : peduncles filiform, $5-30 \mathrm{~cm}$. long: spikes interrupted, sometimes elongated ; flowers in approximate whorls or these remote : drupelets cochleate, barely fleshy, $1.5 \mathrm{~mm}$. long, 3-keeled on the back, crestless, but with 4-5 teeth.

In still or running fresh or salt water, Cape Breton Island to British Columbia, Florida, Texas and California. Summer and fall.

\section{FAmily 2. ZOSTERÀCEAE Dumort. Eel-grass Family.}

Perennial marine herbs, with creeping rootstocks and flattened branching stems. Leaves alternate, 2-ranked: blades several-nerved, linear from a sheathing inflated base. Flowers monoecious, both kinds arranged alternately on a flattened spadix; this enclosed in a spathe. Perianth wanting. Staminate flower a sessile 1-celled anther attached to the spadix. Pollen thread-like. Pistillate flower a single pistil with an elongated style and 2 thread-like stigmas, attached by its back to the spadix. Fruit a flask-shaped beaked utricle; this irregularly rupturing. Seeds ribbed : embryo ellipsoidal.

\section{ZOSTÈRA L.}

Characters of the family. EeL-Grass. Grass-wrack.

Leaves $0.5-1.5 \mathrm{dm}$. long, 1-nerved : seeds $1.5 \mathrm{~mm}$. long. Leaves 2-18 dm. long, 3-7-nerved: seeds $3 \mathrm{~mm}$. long.

1. Z. minor.

2. Z. marina.

1. Zostera mìnor (Caval.) Nolte. Stems more or less elongated, often sparingly branched. Leaves few ; blades narrowly linear, $0.5-1.5 \mathrm{dm}$. long, obtuse, 1-nerved, usually about $1-5 \mathrm{~mm}$. broad : spathe $1-1.5 \mathrm{~cm}$. long : fruits flask-shaped, with an oval or broadly oblong body in all about $3 \mathrm{~mm}$. long, 4-5 maturing in a spathe : seeds nearly $1.5 \mathrm{~mm}$. long, smooth or very faintly striate.

In shallow water, Key West, Florida. Also in Europe.

2. Zostera marina L. Stems slender. Leaf-blades linear, ribbon-like, $2-18 \mathrm{dm}$. long, obtuse, 3-7-nerved: spadix $2.5-6.5 \mathrm{~cm}$. long: flowers commonly $10-20$ on each spadix : fruits oblong, fully $3 \mathrm{~mm}$. long, obtuse : seeds nearly cylindric, about $3 \mathrm{~mm}$. long, 20-ribbed, truncate.

In streams or ditches, on or near the coast. Greenland and Labrador to Florida, also from Alaska to California, and on the coasts of Europe. Summer.

\section{Family 3. NAIAdÀceat Lindl. NaIAs Family.}

Submerged herbs, with fibrous roots and slender branching stems. Leaves alternate, opposite or whorled : blades various, dilated and sheathing at the base, mostly toothed. Flowers dioecious, solitary in the axils. Staminate flowers with a double perianth, the outer entire or 4-horned, the inner hyaline, adhering to the solitary stamen. Anther sessile or short-stalked, 1-4-celled, apiculate or 2-lobed at the apex. Pistillate flowers with a single ovary, topped by a short style and 2-4 stigmas. Fruit a sessile drupelet, with a crustaceous pericarp and a membranous epicarp. Seed solitary, filling the pericarp. Embryo conformed to the interior of the seed.

Characters of the family.

\section{NÀIAS L.}

Sheaths oblique, with margins minutely 10-20-toothed.

Leaf-margins with shallow inconspicuous teeth.

Pericarp of the drupelets dull, with 16-20 rows of strong reticulations : leafblades with 80-100 marginal teeth.

Pericarp of the drupelets shining, with $30-50$ rows of delicate reticulations: leaf-blades with 50-60 marginal teeth.

1. N. Guadalupensis.

2. N. flexilis. 
Leaf-margins with prominent sharp teeth.

Sheaths equilateral, with margins entire or coarsely few-tonthed.

Leaves about $0.5 \mathrm{~mm}$. broad, with 15-24 marginal teeth : internodes filiform. $\quad 4 . \mathrm{N}$. gracilis.

Leaves about $2 \mathrm{~mm}$. broad, with 6-10 marginal teeth : internodes stout.

3. N. conferta.

5. N. marina.

1. Naias Guadalupénsis (Spreng.) Morong. Stems filiform or hair-like, $3-7 \mathrm{dm}$. long, widely branched: leaves opposite, sometimes clustered; blades narrowly linear, 10-20 mm. long, acute, often curved, with 40-50 minute teeth on each margin : drupelets $2 \mathrm{~mm}$. long ; pericarp granular, marked with 16-20 rows of rectangular or hexagonal reticulations, the long axis transverse. [N. microdon A. Br.]

In ponds and lakes, Nebraska to Oregon, Florida, Texas and throughout,tropical America. Summer and fall.

2. Naias fléxilis (Willd.) Rostk. \& Schmidt. Stems slender, $2-18 \mathrm{dm}$. long, forking ; internodes commonly armed with teeth : leaves numerous; blades narrowly linear, $1-2.5 \mathrm{~cm}$. long, acute or acuminate, with 25-30 minute teeth on each margin : drupelets ellipsoidal, $2-4 \mathrm{~mm}$. long ; pericarp lustrous, finely sculptured, with $30-50$ rows of square or hexagonal reticulations.

In streams and ponds, nearly throughout North America. Summer. Also in Europe.

3. Naias conférta A. Br. Similar to $N$. flexilis in habit. Leaves slender, the margins with prominent sharp teeth.

In tidal creeks, Milton, Florida. Summer. Also in tropical America.

4. Naias grácilis (Morong) Small. Stems filiform, forking; branches erect or ascending, the internodes $2.5-10 \mathrm{~cm}$. long, with a few teeth near the upper ends: leaves slender; blades $2-4 \mathrm{~cm}$. long, about $0.5 \mathrm{~mm}$. broad, with $15-24$ marginal teeth and few dorsal teeth : sheaths with $2-3$ teeth on each margin : drupelets barely $4 \mathrm{~mm}$. long, slightly oblique ; pericarp with about 25 rows of square or irregular-oblong reticulations. $[\dot{N}$. marina var. gracilis Morong.]

In creeks and ponds, Florida. Spring to winter.

5. Naias marìna L. Stems stout, several dm. long, flattened, branching, commonly armed with tooth-like spines about twice as long as broad: leaves opposite or whorled; blades linear, 10-25 mm. long, about $2 \mathrm{~mm}$. wide, acute, with 6-10 spine-like teeth on each side and sometimes several on the back of the midrib: drupelet oblong, 4-5 mm. long ; pericarp granular, reticulated. [N. major All.]

In lakes, New York to California and Florida. Summer. Also in Europe.

\section{Order 3. ALISMÀLES.}

Marsh or aquatic herbs, with rush-like or spongy tissues. Leaves alternate, various, slender and stiff, or with dilated blades. Flowers perfect, monoecious or dioecious. Perianth of 2 often dissimilar series (sepals and petals). Androecium of 3-6 stamens. Gynoecium of 3-many distinct carpels. Endosperm wanting. Petals nearly similar to the sepals : anthers long and narrow : carpels coherent.

Petals very different from the sepals : anthers short and thick : carpels

not coherent.

Fam. 1. SCheuchzeriaceaE.

\section{Family 1. SCHEUChZERIÀCEAE Agardh. Arrow-grass Family.}

Perennial marsh herbs, with scapes or normal stems. Leaves alternate : blades rush-like, narrow, often very slender from a dilated base. Flowers perfect, in terminal spikes or racemes : perianth of 4-6 members in 2 series, or the corolla wanting, persistent or deciduous. Androecium mostly of 4-6 stamens. Filaments variable in length. Anthers usually 2-celled, extrorse. Gynoecium of 3-6 partially united carpels. Stigmas sessile or nearly so. Ovules 1 or 2 in each cavity, anatropous. Fruit of 3-6 separating dehiscent or indehiscent carpels. Seeds 1 or 2 in each carpel. Embryo straight.

\section{TRIGLÒchIN L.}

Acaulescent marsh herbs, commonly with abbreviated rootstocks. Leaves basal, sheathing each other by their dilated membranous bases : blades narrow, elongated. Scapes slender, erect, simple. Spikes or racemes terminal. Perianth inconspicuous : sepals 3 : petals 3 , remote from the similar sepals, or wanting. Stamens 3-6: anthers 2-celled, sessile or nearly so. Pistils 3-6, 1-celled : stigmas 3-6, sessile or nearly so, plumose. Ovule soli- 
tary, erect. Carpels leathery, 3-6, distinct or partially united until fully mature, each opening by a ventral suture. Seeds solitary, erect, flattened or angled.

1. Triglochin striàta R. \& P. Foliage'glabrous. Leaves basal ; blades slightly fleshy, linear, attenuate, $0.5-2 \mathrm{~mm}$. broad, 2-3 dm. long, erect: scapes erect, solitary or 2 together, angled, about as long as the leaves or longer : racemes $2-15 \mathrm{~cm}$. long, barely if at all interrupted: pedicels 1-1.5 mm. long, not crowded : perianth greenish or light yellow : sepals 3, oval or ovate, obtuse, less than $1 \mathrm{~mm}$. long: stigmas plumose : fruit subglobose, $1.5-2 \mathrm{~mm}$. in diameter, somewhat 3 -winged at maturity : carpels 3,3 -ribbed on the back. [Triglochin triandra Michx.]

In salt marshes, Maryland to Florida and Louisiana. Summer and fall. ARrow-Grass.

\section{Family 2. ALISMÀceat DC. Water-plantain Family.}

Annual or perennial acaulescent aquatic or marsh herbs. Leaves basal : petioles elongated, sheathing at the base : blades flat, several-ribbed, often with spreading or deflexed lobes. Scapes erect or floating, mostly simple to the inflorescence. Flowers perfect, monoecious or dioecious, regular, whorled, disposed in terminal racemes or panicles. Receptacle flat or globose. Calyx of 3 persistent sepals. Corolla white or pink, of 3 deciduous imbricated petals. Androecium of 6 or more stamens. Filaments distinct. Anthers 2-celled, extrorse. Gynoecium of few or many carpels. Ovaries 1-celled. Styles rather persistent. Ovules solitary in each cavity. Fruit a head of flattened achenes. Seeds curved. Embryo horseshoe-shaped

Carpels in a ring on a flat receptacle.

Carpels curved in many series on a convex or globose receptacle.

Flowers perfect or polygamous.

Sepals spreading : pedicels not recurved at maturity.

Sepals appressed : pedicels recurved at maturity.

Flowers monoecious or dioecious.

1. Alisma.

2. ECHINODORUS.

3. LOPHOTOCARPUS.

4. SAgitTARia.

\section{ALÍSMA L.}

Annual, or mostly perennial scapose herbs. Leaves erect or floating: blades severalribbed, without basal lobes, narrowed into petioles. Flowers perfect, in compound or umbel-like panicles. Stamens 6-9, rather perigynous : filaments slender. Carpels few or many, in one whorl on a flat receptacle. Achenes in 1 whorl, 2-3-ribbed on the back, 1-2-ribbed on the sides. Water Plantain.

1. Alisma subcordàtum Raf. Perennial, glabrous or nearly so. Leaf-blades oblong, elliptic, oval or ovate, or sometimes narrower, $3-15 \mathrm{~cm}$. long, usually abruptly pointed, entire, cuneate to truncate, or cordate at the base; petioles often longer than the blades: scapes 1-10 dm. tall, solitary or several together; branches and pedicels in whorls of $3-10$, variable in length : bracts lanceolate or linear, often acuminate : sepals broadly ovate to suborbicular, obtuse : petals white or pinkish, 1-2 mm. long : mature heads 4-6 $\mathrm{mm}$. broad, flat: achenes obliquely obovate, $2 \mathrm{~mm}$. long; beak small, ascending.

In swamps and shallow water, Nova Scotia to North Dakota, Florida and Texas. Spring to fall.

\section{ECHINÓDORUS L. C. Rich.}

Annual or perennial usually acaulescent marsh herbs. Leaves erect or ascending: blades sometimes ample, several-ribbed. Scapes usually surpassing the leaves. Flowers perfect, in whorls disposed in racemes or panicles. Stamens 12-30: filaments often about as long as the anthers. Carpels numerous, inserted on a convex or globose receptacle. Style obliquely apical : stigma simple. Achenes forming a bristly head, leathery, ribbed, and beaked by the persistent style.

Carpels few, usually less than 14 maturing: flowers in terminal umbel-like clusters.
Carpels numerous, many maturing: flowers in terminal panicles, the main axis of

the panicle sometimes greatly elongated.

Scapes creeping near the base : style shorter than the ovary : beak about $1 / 4$ as long as body of the achene.

Scapes erect or ascending: style longer than the ovary: beak fully $1 / 2$ as long as body of the achene.

1. E. parvulus.

2. E. radicans.

3. E. cordifolius.

1. Echinodorus párvulus Engelm. Leaf-blades linear to linear-elliptic, 1-3 cm. long, acute at both ends, longer than the petioles or much shorter: scapes solitary or several together, surpassing the leaves or overtopped by them, topped by a whorl of 2-8 pedicels, these spreading or curved, $5-25 \mathrm{~mm}$. long, unequal in length : bracts white, 
3-5 mm. long: petals white : mature heads $3-4 \mathrm{~mm}$. in diameter: achenes broadly and obliquely obovate, barely $1 \mathrm{~mm}$. long, black; beak minute, sharp, oblique.

In mud, Massachusetts to Ontario and Minnesota, Florida and Texas. Spring to fall.

2. Echinodorus radìcans (Nutt.) Engelm. Leaf-blades ovate or oblong, $5-20 \mathrm{~cm}$. long, obtuse, undulate, truncate or cordate at the base; petioles 1-7 dm. long: scapes elongated, spreading or decumbent, creeping, 3-12 dm. long, often solitary : whorls of the inflorescence remote : pedicels $3-12$, unequal, $1.5-6 \mathrm{~cm}$. long : bracts linear-lanceolate from dilated bases : sepals ovate or orbicular-ovate, rather obtuse : petals white, about $6 \mathrm{~mm}$. long: mature heads bur-like, $7-8 \mathrm{~mm}$. in diameter : achenes cuneate, $2 \mathrm{~mm}$. long ; body 6-10-ribbed; beak about $\frac{1}{4}$ as long as the body.

In ponds and swamps, Illinois and Missouri, to Florida and Texas. Spring and summer.

3. Echinodorus cordifòlius (L.) Griseb. Leaf-blades various, lanceolate to broadly ovate, 4-20 cm. long, obtuse, commonly truncate or cordate at the base; petioles angled, usually longer than the blades: scapes solitary or clustered, 1-5 dm. tall, surpassing the leaves, simple or branched from the lower whorls of the inflorescence : pedicels $7-15 \mathrm{~mm}$. long, not very variable in length : bracts lanceolate or linear-lanceolate : sepals ovate, rather acute: petals white, 4-6 mm. long, usually broader : mature heads bur-like, 4-6 $\mathrm{mm}$. in diameter : achenes $2.5-3 \mathrm{~mm}$. long; body cuneate; beak slender, fully $\frac{1}{2}$ as long as the body. [E. rostratus Engelm.]

In ditches and swamps, Illinois and Missouri, to Florida and Texas. Spring and summer.

\section{LOPHOTOCÁRPUS T. Durand.}

Annual or perennial acaulescent aquatic or marsh herbs. Scapes simple below the inflorescence. Flowers in several whorls of $2-3$ at the top of the scape; upper staminate; lower pistillate. Stamens 9-15, hypogynous : filaments flattened, inserted at the base of the receptacle. Pistils numerous on a convex receptacle. Style slender, oblique. Achenes crowded together, crested or winged, more or less completely enveloped by the calyx. Embryo horseshoe-shaped.

Petioles 0.5-1.5 dm. long: leaf-blades less than $4.5 \mathrm{~cm}$. broad : whorls of the inflorescence usually solitary : mature fruiting heads $7-8 \mathrm{~mm}$. in diameter.

Petioles 1.5-4 dm. long: leaf-blades over $4.5 \mathrm{~cm}$. broad: whorls of the inflorescence

$2-6$ : mature fruiting heads $10-15 \mathrm{~mm}$. in diameter.

1. L. depauperatus.

1. Lophotocarpus depauperàtus J. G. Smith. Leaves with petioles $0.5-1.5 \mathrm{dm}$. long ; blades oblong, elliptic, oval or ovate, sometimes sagittate or hastate, $1-2 \mathrm{~cm}$. wide or the small basal lobes spreading to a width of 3-4 cm. and acuminate : inflorescence of usually 1 whorl : mature fruiting heads $7-8 \mathrm{~mm}$. in diameter : achenes cuneate, about 1.7 $\mathrm{mm}$. long, each with a slender horizontal beak.

On margins of ponds, Wisconsin, Illinois, Missouri and the Indian Territory. Summer and fall.

2. Lophotocarpus calycinus (Engelm.) J. G. Smith. Leaves with petioles 1.5-4 $\mathrm{dm}$. long; blades hastate or sagittate, sometimes almost triangular or lunate, the basal lobes often longer than the middle one, spreading to a width of $5-30 \mathrm{~cm}$. and usually acuminate : inflorescence of 2-6 whorls: mature fruiting heads $10-15 \mathrm{~mm}$. in diameter: achenes cuneate, $2-2.5 \mathrm{~mm}$. long, each with a triangular horizontal beak. [Sagittaria calycina Engelm.]

In swamps or ponds, often submerged, South Dakota to Delaware, Louisiana and New Mexico. Summer.

\section{SAGITTÀrIA L.}

Perennial acaulescent marsh or aquatic herbs, either erect or floating. Rootstock irregularly thickened or tuber-bearing. Leaves various, usually differentiated into petioles and blades, or reduced to phyllodes. Scapes sometimes greatly elongated, usually simple below the inflorescence. Flowers monoecious or dioecious, in whorls of 3 near the top of the scape, those of the upper whorls usually staminate. Staminate flowers with many stamens : anthers 2-celled, opening by lateral slits : gynoecium wholly or partially suppressed. Pistillate flowers with many distinct carpels : androecium wholly or partially suppressed. Receptacle more or less convex. Achenes numerous, flattened, densely crowded in globular heads. ARrow-HEaD.

Sepals of the pistillate flowers reflexed or spreading, not accrescent.

Pedicels of the pistillate flowers much thickened, reflexed at maturity.

Filaments glabrous. Scapes simple.

Filaments about as long as the anthers: achenes with 3 undulate or slightly toothed crests. 
Filaments much longer than the anthers: achenes with 5-7 crenate or dentate crests.

Scapes branching.

Filaments pubescent.

Pedicels of the pistillate flowers slender, ascending, or wanting.

Leaf-blades entire or barely hastate, sometimes greatly reduced.

Pistillate flowers pedicelled.

Filaments dilated.

Pedicels of the pistillate flowers shorter than those of the staminate.

Pedicels of the pistillate flowers as long as those of the staminate or longer.

Leaves terete, mostly bladeless.

Filaments as long as the anthers: achenes $1 \mathrm{~mm}$. long, with low facial ridges.

Filaments shorter than the anthers: achenes $2 \mathrm{~mm}$. long, with several facial wings.

Leaves with more or less flattened blades.

Achenes oval or broadly oblong.

Achenes cuneate.

Beak large, horizontal at the top of the achene.

Beak minute, much below the top of the achene.

Bracts ovate, united to the middle.

Bracts lanceolate, nearly distinct.

Filaments slender, not dilated.

Filaments glabrous.

Bracts ovate, obtuse, united to about the middle: beak near the middle of one side of the achene.

Bracts lanceolate, acuminate, distinet or nearly so: beak horizontal at top of the achene.

Filaments pubescent.

Pistillate flowers sessile.

Leaf-blades mostly sagittate.

Basal lobes twice or thrice as long as the middle lobe.

Basal lobes shorter than the middle lobe.

Pedicels of the pistillate flowers much shorter than their bracts.

Pedicels of the pistillate flowers surpassing their bracts.

Filaments villous, not dilated : bracts and sepals viscid.

Filaments glabrous: bracts and sepals not viscid.

Beak of the achene erect, the tip sometimes recurved.

Lobes of the leaf-blades ovate, obtuse: achenes broadest at the top with 1 facial wing on each side.

Lobes of the leaf-blades linear or nearly so, acute: achene broadest at the middle with 2 facial wings on each side.

Beak of the achene lateral, horizontal or oblique.

Foliage. especially that of the inflorescence, glabious.

Sepals of the pistillate flowers erect, accrescent.

2. S. natans.

3. S. filiformis.

4. S. platyphylla.

5. S. macrocarpa.

6. S. isoetiformis.

7. S. teres.

8. S. cycloptera.

9. S. Mohrii.

10. S. graminea.

11. S Chapmanii.

12. S.'papillosa.

13. S. ambigua.

14. S. lancifolia.

15. S. rigida.

16. S. longiloba.

17. S. longirostra.

18. S. viscosa.

19. S. australis.

20. S. Engelmanniana.

21. S. latifolia.

22. S. pubescens.

23. S. Montevidensis.

1. Sagittaria subulàta (L.) Buch. Monoecious or sometimes wholly staminate. Leaves usually represented by rigid phyllodes $2-12 \mathrm{~cm}$. long, rarely normal ; blades linear to linear-lanceolate, $2-3 \mathrm{~cm}$. long, acutish, shorter than the petioles : scapes $5-15 \mathrm{~cm}$. tall, rarely surpassing the leaves: whorls of the raceme solitary or often 2 : bracts thin, 1-3 $\mathrm{mm}$. long : pedicels of pistillate heads $10-15 \mathrm{~mm}$. long: sepals ovate-lanceolate, obtuse : corollas $15 \mathrm{~mm}$. broad : achenes few, 1.5 to nearly $2 \mathrm{~mm}$. long, with short lateral beaks and 3 prominent but merely undulate or sparingly toothed crests.

In mud and tidal flats, New York to Florida and Alabama. Summer and fall.

2. Sagittaria nàtans Michx. Monoecious, commonly submerged. Petioles bladeless, or blades floating, elliptic, oblong or ovate-oblong, $1.5-5 \mathrm{~cm}$. long, rounded, subcordate or hastate-truncate at the base : phyllodes flattened, elongated : scape elongating to the surface of the water or rising above it, 1-10 dm. long: whorls of the inflorescence one or several : bracts thin, acuminate: mature fruiting heads $8 \mathrm{~mm}$. in diameter : achenes rather numerous, $2 \mathrm{~mm}$. long, with short upeurved beaks and 5-7 prominently dentate or crenate crests.

In fresh or brackish ponds, South Carolina to Florida. Summer and fall.

3. Sagittaria filifórmis J. G. Smith. Monoecious, submerged. Leaves wanting: phyllodes filiform from thicker bases, $1-6 \mathrm{dm}$. long, rarely as long as the scape : scapes slender, 6-12 dm. long, often branching from the lower whorls : bracts lanceolate, $3-5 \mathrm{~mm}$. long, acuminate : pedicels filiform, those of the lower whorls $1-4 \mathrm{~cm}$. long, ascending or erect: whorls remote, staminate except 1 or 2 flowers of the lower one: sepals ovate, 2-3 $\mathrm{mm}$. long, obtuse : corolla white, about $2 \mathrm{~cm}$. broad : mature fruiting heads $6-7 \mathrm{~mm}$. in diameter: achenes $1.5 \mathrm{~mm}$. long, with upcurved lateral beaks and about 6 crests.

In ponds, Florida and Alabama. Spring and summer.

4. Sagittaria platyphýlla (EngeIm.) J. G. Smith. Monoecious. Leaf-blades rather leathery, lanceolate, elliptic to ovate, $5-15 \mathrm{~cm}$. long, 5-7-nerved, acute or acuminate, gradually narrowed or subcordate at the base : scapes $2-5 \mathrm{dm}$. tall, usually overtopped by 
the leaves: whorls of the inflorescence $3-8$, the 2 or 3 lower ones pistillate : pedicels $1-2.5$ $\mathrm{cm}$. long : bracts broadly ovate, $3-8 \mathrm{~mm}$. long, scarious tipped : mature fruiting heads fully $1 \mathrm{~cm}$. in diameter : achenes obliquely obovate, $2 \mathrm{~mm}$. long, winged; beak horizontal.

In ponds and swamps, Missouri to Alabama and Texas. Spring to fall.

5. Sagittaria macrocárpa J. G. Smith. Monoecious. Leaves phyllode-like; blades linear or linear-lanceolate, $5-7 \mathrm{~cm}$. long, much shorter than the petioles : scapes 3-4 $\mathrm{dm}$. tall, overtopping the leaves: whorls of the inflorescence $3-5$, the lower pair, or only the lowest one, pistillate : pedicels about as long as the internodes except those of the pistillate flowers ; these much shorter : bracts obovate, $3 \mathrm{~mm}$. long, acute, united at the base: filaments dilated, pubescent : mature fruiting heads $10-12 \mathrm{~mm}$. in diameter : achenes obovate or oblong-ovate, $3 \mathrm{~mm}$. long, winged ; beak ascending.

On the margins of ponds, North Carolina and South Carolina. Spring to fall.

6. Sagittaria isoetifórmis J. G. Smith. Monoecious, delicate. Leaves terete throughout, or rarely with imperfect flattish blades: scapes 8-12 cm. tall, as long as the leaves or overtopping them : whorl of the inflorescence usually one : bracts ovate, $2-3 \mathrm{~mm}$. long, acute, united below : pedicels of pistillate flowers slender, 15-18 mm. long, those of the staminate flowers filiform, $2-3 \mathrm{~cm}$. long : sepals $2 \mathrm{~mm}$. long : corolla white, 12-15 mm. broad : filaments dilated, pubescent, about as long as the anthers : mature fruiting heads about $6 \mathrm{~mm}$. in diameter : achenes obovate, $1 \mathrm{~mm}$. long, with a prominent dorsal crest and low facial ridges; beak short, oblique.

On sandy margins of lakes, peninsular Florida. Spring and summer.

7. Sagittaria tères S. Wats. Monoecious, slender. Leaves usually reduced to terete attenuate nodose phyllodes 1-3 dm. long, or rarely developing narrow, imperfect blades at the top: scapes slender, $1 \tilde{j}-45 \mathrm{~cm}$. tall : bracts ovate, $3 \mathrm{~mm}$. long, obtuse : whorls of the inflorescence solitary or sometimes 3,1 or 2 pedicels of the lower whorls bearing pistillate flowers, $10-25 \mathrm{~mm}$. long, longer than those of staminate flowers : sepals about $3 \mathrm{~mm}$. long: corolla white, $12-15 \mathrm{~mm}$. broad : stamens often 12 : filaments dilated, pubescent, shorter than the anthers : mature fruiting heads $8-12 \mathrm{~mm}$. in diameter : achenes oval or oval-obovate, $2 \mathrm{~mm}$. long, with stout obliquely upcurved beaks, an uneven crest and several facial wings.

In shallow water, Massachusetts to South Carolina. Summer and fall.

8. Sagittaria cyclóptera (J. G. Smith) C. Mohr. Monoecious or dioecious. Leaves sometimes reduced to slender tapering phyllodes; blades linear or linear-lanceolate, 4-15 $\mathrm{cm}$. long, tapering to both ends, shorter than the petioles : scapes $2-8 \mathrm{dm}$. long: whorls of the inflorescence 3-15, or rarely solitary, several of the lower ones usually pistillate : bracts ovate, $3-5 \mathrm{~mm}$. long, acute, united at the base : filaments dilated, pubescent : mature fruiting heads barely $1 \mathrm{~cm}$. in diameter : achenes broadly oblong or oval, $1.5 \mathrm{~mm}$. long, winged, crested, with 2 facial wings on each side; beak short, ascending, rather lateral.

In swamps, South Carolina to Florida and Louisiana. Spring to fall.

9. Sagittaria Mòhrí J. G. Smith. Monoecious. Leaves $3-7 \mathrm{dm}$. tall ; blades linear to lanceolate, $5-15 \mathrm{~cm}$. long, acuminate, often poorly developed : scapes ascending, decumbent or declining, 3-angled : whorls of the inflorescence 6-8, the lower 3-4 pistillate, with pedicels somewhat longer than those of the staminate flowers : bracts thin, 3-4 mm. long, united to about the middle : sepals oblong, 2-3 mm. long, obtuse : corolla hardly $1 \mathrm{~cm}$. broad : mature fruiting heads subglobose, $6-8 \mathrm{~mm}$. in diameter : achenes cuneate, 2.5-3.5 mm. long, winged, with cuneate crests; beak horizontal.

In muddy ponds, southern Alabama. Summer.

10. Sagittaria gramínea Michx. Monoecious or dioecious. Leaf-blades linear, lanceolate or elliptic, $5-15 \mathrm{~cm}$. long, or leaves represented by phyllodes : scapes 1-6 dm. tall, shorter than the leaves or overtopping them : whorls of the inflorescence few and remote or sometimes numerous and rather approximate : pedicels variable, but those of staminate and pistillate flowers often equal in length : bracts ovate, 3-5 mm. long, acute, united to about the middle : filaments dilated, pubescent : mature fruiting heads less than $1 \mathrm{~cm}$. in diameter : achenes cuneate, $1.5 \mathrm{~mm}$. long, winged, with one facial wing or crest ; beak short, lateral, spreading.

In mud or ponds, Newfoundland to Saskatchewan, Florida and Texas. Summer and fall.

11. Sagittaria Chapmánil (J. G. Smith) C. Mohr. Monoecious or dioecious. Leaves often accompanied by phyllodes; blades linear or lanceolate, $15-20 \mathrm{~cm}$. long, acute, usually much shorter than the petioles : scapes 3-5 dm. long : whorls of the inflorescence often numerous : pedicels spreading or ascending, those of the pistillate heads $1.5-3$ $\mathrm{cm}$. long : bracts lanceolate, 6-12 mm. long, acute or acuminate, slightly united at the base : filaments dilated, pubescent : mature fruiting heads $5 \mathrm{~mm}$. in diameter: achenes cuneate, $1 \mathrm{~mm}$. long, wingless; beak short, lateral and above the middle of the body.

In ponds and marshes, Florida and Alabama. Spring to fall. 
12. Sagittaria papillòsa Buch. Monoecious. Leaf-blades linear or linear-lanceolate, $10-15 \mathrm{~cm}$. long, acute, as long as the petioles or shorter : scapes $3-5 \mathrm{dm}$. tall : whorls of the inflorescence $3-10$, the lower remote : pedicels of pistillate flowers $1-1.5 \mathrm{~cm}$. long: bracts ovate, 3-4 mm. long, densely granular-papillose, united to about the middle : sepals ovate, roughened like the bracts : corollas $2-3 \mathrm{~cm}$. broad : filaments not dilated, glabrous : mature fruiting heads subglobose, $6-10 \mathrm{~mm}$. in diameter : achenes cuneate, $1.5 \mathrm{~mm}$. long ; beak lateral and slightly above the middle of the body.

In shallow ponds, Louisiana and Texas. Spring to fall.

13. Sagittaria ambígua J. G. Smith. Monoecious. Leaves erect; blades lanceolate, $12-50 \mathrm{~cm}$. long, 5-nerved, shorter than the petioles: scapes $3-6 \mathrm{dm}$. tall, as long as the leaves or surpassing them: whorls numerous, commonly 8-15: pedicels mostly ascending, those of the pistillate heads longer than those of staminate ; bracts lanceolate, 10-15 $\mathrm{mm}$. long, united at the bases : filaments not dilated, glabrous : achenes oblong, slightly curved, $2 \mathrm{~mm}$. long, narrowly winged, prolonged into short horizontal beaks at the top.

In ponds, Kansas and Oklahoma. Summer.

14. Sagittaria lancif òlia L. Monoecious. Leaves 4-9 dm. tall ; blades leathery, broadly linear to elliptic, 3-6 dm. long, acute, commonly shorter than the petioles : scapes 6-20 dm. tall, usually branched: whorls of the inflorescence numerous: pedicels of the pistillate heads ascending, often shorter than those of the staminate : bracts ovate or ovatelanceolate, 1-2.5 cm. long, acute or acuminate: sepals obtuse : corollas 4-5 cm. broad; petals obovate : filaments not dilated, pubescent : mature fruiting heads fully $1 \mathrm{~cm}$. in diameter : achenes cuneate or obovate, $2-3 \mathrm{~mm}$. long, winged ; beak short, ascending.

In marshes, Delaware to Florida, Texas and tropical America. Spring and summer.

15. Sagittaria rígida Pursh. Monoecious. Leaf-blades $5-20 \mathrm{~cm}$. long, linear, lanceolate, elliptic or broadly ovate, 7-9-nerved, acute or cordate at the base, sometimes with 1 or 2 spreading or recurved basal lobes : scapes 1-8 dm. long, commonly shorter than the leaves, usually bent and sometimes branched at the lower whorl of the inflorescence : pedicels of the pistillate heads ( 1 or 2 lower whorls) barely $1 \mathrm{~cm}$. long: bracts ovate, obtuse, 4-8 $\mathrm{mm}$. long, united at the base : mature fruiting heads $8-15 \mathrm{~mm}$. in diameter, bristly by the protruding beaks of the achenes : achenes cuneate, $3-4 \mathrm{~mm}$. long, winged ; beak stout, ascending.

In swamps or running water, Quebec to Minnesota, New Jersey, Tennessee and Nebraska. Summer and fall.

16. Sagittaria longíloba Engelm. Monoecious, glabrous. Leaf-blades $10-18 \mathrm{~cm}$. long; terminal lobe linear to lanceolate; basal lobes linear or linear-lanceolate, twice or thrice as long as the terminal one, long-acuminate : scapes $3-15 \mathrm{dm}$. tall, rarely branched : whorls of the inflorescence 4-8, remote, 1-3 lower very fertile : pedicels slender, $15-35 \mathrm{~mm}$. long, spreading: bracts lanceolate, $6-8 \mathrm{~mm}$. long, acuminate : filaments not dilated, glabrous : mature fruiting heads $10-15 \mathrm{~mm}$. in diameter : achenes cuneate, $1 \mathrm{~mm}$. long; wings somewhat undulate; beak very short, lateral.

On margins of shallow ponds, Nebraska to Colorado, Texas and Mexico. Summer and fall.

17. Sagittaria longiróstra (Micheli) J. G. Smith. Monoecious, glabrous. Leafblades rather ample, $10-25 \mathrm{~cm}$. long; terminal lobe broadly ovate, abruptly pointed; basal lobes ovate or oblong-lanceolate, acute, about $\frac{1}{2}$ as long as the blade : scapes 4-8 dm. tall, sharply 6-angled : whorls of the inflorescence few, 1 or 2 lower ones usually pistillate: bracts triangular, $15-30 \mathrm{~mm}$. long, acuminate : pedicels of the lower whorls $5-10 \mathrm{~mm}$. long, ascending: mature fruiting heads spheroidal, $12-18 \mathrm{~mm}$. in diameter: achenes obovate, $4 \mathrm{~mm}$. long, the crest undulate; beak about $\frac{1}{2}$ as long as the body, curved; facial wings prominent.

On margins of ponds, New Jersey and Penusylvania to Tennessee. Summer.

18. Sagittaria viscòsa C. Mohr. Monoecious. Leaf-blades broadly ovate, $2-3.5 \mathrm{dm}$. long, rounded to the apiculate apex; basal lobes ovate, acute or acuminate, shorter than the middle lobe : scapes 5-8 dm. tall, overtopping the leaves : pedicels in 8-10 whorls, of nearly equal length throughout: bracts leathery, ovate-oblong, obtuse, papillose, rugose and viscid : sepals leathery, ovate-lanceolate, roughened and viscid like the bracts : corollas white, fully $1 \mathrm{~cm}$. broad : filaments not dilated, pubescent: achenes not seen.

In muddy plases and marshes, southern Alabama. Spring and summer.

19. Sagittaria austràlis (J. G. Smith) Small. Monoecious, slender. Leaf-blades oval or suborbicular, $8-10 \mathrm{~cm}$. long, abruptly pointed at the apex, ciliate; basal lobes ovate, barely $\frac{1}{2}$ as long as the blade, obtuse : scapes $4-5 \mathrm{dm}$. tall, pubescent about the nodes in the inflorescence, angled, overtopping the leaves : whorls of the inflorescence 4-6, remote : bracts lanceolate or ovate-lanceolate : pedicels of lower whorls 10-13 mm. long: achenes obovate, $3-3.5 \mathrm{~mm}$. long; crest undulate; beak curved over the top of the crest, $\frac{1}{2}$ 
as long as the body ; facial wings prominent, 1 on each side. [S. longirostra australis J. G. Smith.]

In low grounds, Alabama. Summer.

20. Sagittaria Engelmanniàna J. G. Smith. Slender, monoecious, glabrous. Leafblades narrow, 8-20 cm. long, shorter than the petioles; lobes linear, 1-5 mm. broad, the terminal and basal about equal in length : scapes about as tall as the leaves, $2-6 \mathrm{dm}$. long : whorls of inflorescence 5-6, remote: bracts lanceolate, $8-12 \mathrm{~mm}$. long: pedicels ascending, those of staminate flowers often longer than those of the pistillate : sepals ovate, $6-7$ $\mathrm{mm}$. long, acute : filaments not dilated, glabrous : mature fruiting heads subglobose, 12-14 $\mathrm{mm}$. in diameter : achenes obovate, $4 \mathrm{~mm}$. long; beak erect, ${ }_{4}^{\frac{1}{-1}} \frac{1}{3}$ as long as the body ; facial wings $1-3$.

In shallow water, Massachusetts to Florida. Summer.

21. Sagittaria latif òlia Willd. Monoecious or dioecious. Leaf-blades ample, sometimes broader than long, 15-40 cm. long, glabrous and rarely pubescent; basal lobes ovate or lanceolate, acute or acuminate : scape $3-6 \mathrm{dm}$. long, angled : bracts 1-5 cm. long, glabrous, acute or acuminate : whorls of the inflorescence mostly distant: pedicels variable, those bearing pistillate heads $2-5 \mathrm{~cm}$. long, or longer : filaments not dilated, glabrous: mature fruiting heads subglobose, $1.5-3 \mathrm{~cm}$. in diameter : achenes obovate, about $3 \mathrm{~mm}$. long, erect, undulate; beak ascending or recurved.

In swamps and shallow water, New Brunswick to British Columbia, Florida and Louisiana. Summer and fall.

22. Sagittaria pubéscens Muhl. Monoecious or dioecious, puberulent or hirsute. Leaf-blades oblong or broadly ovate, $8-25 \mathrm{~cm}$. long, usually abruptly pointed ; basal lobes ovate to lanceolate, about $\frac{1}{2}$ as long as the blade or longer : scapes $3-6 \mathrm{dm}$. tall : whorls of the inflorescence remote : pedicels variable in length, surpassing the bracts : bracts ovate or suborbicular, obtuse, $7-10 \mathrm{~mm}$. long: mature fruiting heads $8-15 \mathrm{~mm}$. in diameter: achenes somewhat anvil-shaped or resembling the head of a bird, $2-3 \mathrm{~mm}$. long; beak horizontal or somewhat declined.

In meadows or marshes, Ontario to Florida and Alabama. Summer and fall.

23. Sagittaria Montevidénsis Cham. \& Schlecht. Monoecious, robust. Leaf-blades sagittate, $1-5 \mathrm{dm}$. long, often as broad, glabrous above, sparingly scabrous on the nerves beneath; basal lobes acute or acuminate, more or less divergent, middle lobe acute : scapes sometimes $6-8 \mathrm{~cm}$. thick at the base, usually simple : whorls of the inflorescence several or numerous, 2-4 of the lower ones pistillate: bracts lanceolate, acuminate, united below : pedicels of staminate flowers slender, $2-3 \mathrm{~cm}$. long, surpassing those of pistillate flowers : sepals 10-15 mm. long, obtuse : petals white, obovate : filaments not dilated, glandularpubescent, longer than the anthers : mature fruiting heads $1.5-3 \mathrm{~cm}$. in diameter : achenes 2-3 mm. long, rhomboid-obovate, winged; beak slender, oblique ; faces flat. and fall.

In swamps, North Carolina to Alabama and California, naturalized from South America. Spring

\section{Order 4. HYDROCHARITÀLES.}

Floating or more or less emersed herbs, perennial by rootstocks or stolons. Leaves usually with dilated blades. Flowers monoecious or dioecious, arising from spathes. Perianth of 2 dissimilar series, or the corolla rarely wanting. Androecium of 3-12 stamens. Gynoecium of 3-15 united carpels. Ovary inferior, with several parietal placentae or severa]-celled. Endosperm wanting. Ovary 1-celled, with 3 , or rarely 2,4 or 5 parietal placentae : stigmas usually 3 .

Ovary 6-9-celled : stigmas 6-9.

Fam. 1. Elodeaceae.

Fam. 2. HYDROCHARITACEAE.

\section{Family 1. FLODEÀCEAe Dumort. Tape-grass Family.}

Floating or submerged sometimes acaulescent herbs, perennial by rootstocks or stolons. Leaves clustered or remote : blades short and broad or much elongated and ribbon-like. Flowers monoecious or dioecious, arising from a spathe or 1-3 bracts. Perianth regular, of 3 sepals and 3 petals, or the latter wanting, all more or less petaloid. Androecium of 3-12 stamens. Filaments distinct or monadelphous. Anthers 2-celled. Gynoecium a single pistil. Ovary inferior, 1-celled with 3 or rarely 2-5 parietal placentae. Ovules mostly numerous, orthotropous or anatropous. Fruit usually indehiscent, often becoming 
submerged and maturing under water. Seeds with a straight embryo, without endosperm.

Staminate flowers with 1-3 stamens.

Spathes of pistillate flowers sessile or nearly so, of 2-3 distinct bracts.

Spathes of pistillate flowers very long peduncled, of several more or less united bracts.

Staminate flowers with 9 stamens.

1. Halophila.

2. VAllisNeria. 3. Philotria.

\section{HALOPHILA Thouars.}

Marine herbs, with creeping rootstocks. Leaves opposite or whorled at the nodes, accompanied by stipule-like scales. Flowers dioecious, solitary in spathes, 2 or 3 distinct bracts arising between the leaves. Staminate flowers pedicelled: perianth of 3 rather herbaceous sepals. Stamens 3: anthers nearly sessile, extrorse. Pistillate flowers sessile in the spathes: perianth of 3 minute sepals. Ovary 1-celled, with 3 parietal placentae, long-beaked. Style 3-parted: branches filiform. Fruit included in the spathe. Seeds numerous. Embryo with spirally bent cotyledons.

1. Halophila Engelmánnii Aschers. Floating, glabrous. Rootstocks branched, with many nodes : stems $10 \mathrm{~cm}$. long, or shorter, commonly erect : leaves mainly whorled at the ends of the stem or its branches; blades linear, oblong or oblanceolate, $1-3 \mathrm{~cm}$. long, obtuse or acutish, sharply serrulate, 3-nerved, sessile : flowers and fruit not known.

In coves and ereeks, peninsular Florida. Spring to winter.

\section{VALLISNÈRIA L.}

Acaulescent submerged herbs, very delicate. Leaves basal : blades several-nerved, ribbon-like. Flowers dioecious. Staminate minute, numerous, crowded on a spadix enclosed in a spathe of 3 segments. Perianth of 3 sepals. Stamens 2 or 1-3. Pistillate flowers solitary at the ends of elongated cordi-like spiral scapes, subtended by a tubular 2-cleft spathe : petals 3, larger than the 3 green sepals. Ovary 1-celled, inferior, with 3 parietal placentae: stigmas 3, each 2-lobed. Fruit elongated, leathery, indehiscent.

1. Vallisneria spiràlis L. Stoloniferous, flaccid, glabrous: leaf-blades narrowly linear, 1-18 dm. long, entire or serrate below the apex : flowers inconspicuous; staminate basal, detached at maturity, floating and expanding on the surface; pistillate floating, attached to the base of plant by elongated filiform scapes, which after fertilization coil spirally and submerge the flower: spathes cylindric, 1-2 cm. long, subtending one flower, membranous : fruit cylindric, $3-15 \mathrm{~cm}$. long.

In ponds or flowing water, New Brunswick to Minnesota, Florida and Texas. Summer and fall. Eel-grass. Tape-grass.

\section{PHILÓTRIA Raf.}

Caulescent submerged herbs, with slender rootstocks and branching stems. Leaves numerous, opposite or whorled : blades 1-nerved. Flowers polygamous or dioecious, from a sessile 2-cleft spathe. Sepals 3. Petals 3, thin. Staminate flowers minute, with 9 stamens. Fertile flowers pistillate or perfect: stamens 3-6, sometimes sterile. Ovary 1-celled, with 3 parietal placentae. Stigmas apparently sessile, 2-lobed. Orules few. Fruit leathery, inhehiscent. [Elodea Michx., not Elodes Adans.] W ATER-weed.

Leaf-blades oblong, elliptic or ovate-oblong : calyx over $2.5 \mathrm{~mm}$. broad.

Leaf-blades narrowly linear or narrowly linear-lanceolate: calyx less than $2.5 \mathrm{~mm}$. broad.

1. P. Canadensis.

1. Philotria Canadénsis (Michx.) Britton. Aquatic, flaccid. Stems variable in length, 1-12 dm. long, forking: leaves opposite or in whorls of 3 or 4 above the base ; blades oblong, elliptic or ovate-oblong, 4-15 mm. long, entire or serrulate; whorls often approximate: flowers axillary ; staminate submerged, breaking off at maturity and floating on the surface they discharge the pollen near the pistillate flowers, these floating, attached to the plant by the elongated stalk, which varies from 3-30 cm. in length : spathes 10-18 $\mathrm{mm}$. long. [Elodea Canadensis Michx.]

In ponds and slow-flowing water, nearly throughout North America. Spring to fall.

3. Philotria minor (Engelm.) Small. Similar to P. Canadensis in habit, but more slender, with more branched stems and less densely crowded leaves. Leaf-blades narrowly linear or narrowly linear-lanceolate : pedicels hair-like : calyx $1.5-2 \mathrm{~mm}$. broad.

In ponds and streams, Minnesota to Tennessee, Missouri and Arkansas. Summer. 


\section{FAMILY 2. HYDROCHARITÀCEAE Aschers. Frog's-BIT FAMILY.}

Aquatic or mud-inhabiting herbs. Leaves clustered, usually with well developed blades. Flowers monoecious or dioecious, arising from spathes of distinct or united bracts. Perianth regular, superior, of 3 sepals and 3 petals. Androecium of 6-12 stamens. Filaments distinct or partially united. Gynoecium of 6-15 united carpels. Ovary inferior, usually 6-9-celled. Styles as many as the cavities of the ovary. Ovules numerous. Fruit usually indehiscent.

Leaf not differentiated into blade and petiole: flowers dioecious: stamens distinct: anthers nearly sessile.

Leaf differentiated into blade and petiole: flowers monoecious : stamens with united filaments.

1. Thalassia.

2. LIMNOBIUM.

\section{THALÁsSiA Banks.}

Marine herbs, with elongated rootstocks. Leaves several at a joint, sheathing at the base: blades linear, elongated. Scape arising from the cluster of leaves. Flowers dioecious, solitary in narrow spathes of two bracts : these united into a tube at the base. Staminate flowers longpedicelled : perianth of 3 petaloid sepals : stamens 6 : filaments very short : anthers opening laterally. Pistillate flower nearly sessile in the spathe, caducous : ovary 6-9-celled, beaked. Fruit stalked, rugose or nearly echinate, opening by many valves. Seeds numerous.

1. Thalassia testùdinum Koenig \& Sims. Submersed, glabrous. Rootstocks creeping, elongated : stems short, arising from the nodes of the rootstock : leaves $2-5$, sheathing the stem; blades linear, strap-like, 0.5-3 dm. long, obtuse, withering-persistent : scapes solitary, central : fruit globose or oval, echinate-pubescent, slightly pointed.

In shallow water, along the coast of peninsular Florida. Also in the West Indies.

\section{LIMNÓBIUM L. C. Rich.}

Aquatic herbs usually floating and producing pendent roots and stolons. Leaves clustered : petioles elongated : blades broad, several-nerved. Flowers monoecious, from spathes of 2 membranous bracts. Perianth white : sepals 3 : petals 3 , narrower than the sepals. Staminate flowers 2-4 in a spathe, usually with 6-12 stamens : filaments united into a column, bearing the anthers at different heights. Pistillate flowers with 3-6 abortive stamens, a 6-9-celled ovary with several central placentae : stigmas as many as the cavities in the ovary, each 2-parted. Fruit a many-celled berry.

1. Limnobium Spóngia (Bosc) L. C. Rich. Acaulescent, stoloniferous. Leaves basal ; petioles erect or ascending, $5-25 \mathrm{~cm}$. long: blades ovate to suborbicular or reniform, $2-5 \mathrm{~cm}$. broad, obtuse, entire, truncate or cordate at the base; petioles tapering to the blade : flowers monoecious ; staminate on scapes $8-10 \mathrm{~cm}$. long; pistillate on shorter and stouter scapes, these recurving at maturity : berry nodding, oval, $1-1.5 \mathrm{~cm}$. long.

In shallow water or mud, Ontario to Illinois and Missouri, to Florida and Louisiana. Frog's-BIT.

\section{Order 5. POÀLES.}

Mostly perennial caulescent or acaulescent plants, commonly known as GRASSEs and SEDGES. Stems (culms) simple or branched, sometimes conspicuously jointed. Leaves alternate, mostly sheathing at the base : blades usually narrow and elongated, entire or nearly so. Flowers variously disposed in a simple or compound inflorescence, perfect, or rarely monoecious or dioecious, incomplete, inconspicuous, in the axils of chaffy bracts or scales (glumes). Fruit a caryopis (grain) or an achene.

Leaves 2-ranked, their sheaths with ununited margins : stems mostly hollow : fruit a grain (caryopsis). Leares 3-ranked, their sheaths with united margins : stems solid : fruit an achene. Fam. 1. POACERAE.

\section{Family 1. PoÀcéat R. Br. ${ }^{1}$ Grass Family.}

Annual or perennial herbs, rarely shrubs or trees, sometimes monoecious or dioecious, varying much in habit. Stems (culms) usually hollow, the nodes closed. Leaves alternate, 2-ranked, sheathing, the sheaths generally open to the base on the side opposite to the blade; a scarious or cartilaginous ring

\footnotetext{
${ }^{1}$ Contributed by Mr. George V. Nash.
} 
(ligule), naked or sometimes hairy, rarely wanting, occurs at the sheath-orifice. Inflorescence of spikes, racemes, or panicles, composed of spikelets, these consisting of 2-many 2-ranked imbricated bracts (scales), usually the lower 2, and occasionally the succeeding 2-4 scales also empty, rarely all the scales flowerbearing. One or more of the upper scales, except sometimes the terminal one, bearing an axillary flower surrounded by a bract-like organ (palet), which is placed opposite to the scale and with its back to the axis (rachilla) of the spikelet, usually 2-nerved or 2-keeled and awnless, rarely 1-nerved or awned; the palet is sometimes present without the flower and vice versa; the rachilla is often thickened and appears as a hard projection (callus) at the base of the scale. Flowers perfect, staminate, or pistillate, subtended by 1-3 minute scales (lodicules). Stamens 1-6, rarely more, usually 3. Anthers 2 celled, versatile. Ovary 1-celled, 1-ovuled. Styles 1-3, commonly 2, distinct or more or less united, rarely wanting. Stigmas hairy or plumose. Fruit a seed-like grain (caryopsis), sometimes nut-like. Endosperm starchy. [Gramineae Juss.]

A. Spikelets falling from the pedicel entire (see also nos. 58, 61, 62,68 and 76 of section B), naked, or enclosed in bristles or a bur-like involucre, or immersed in the internodes of a readily disarticulating rachis, 1-flowered, or if 2-flowered the lower flower staminate; no upper empty scales: rachilla not extending beyond the uppermost scale.

Spikelets round or somewhat dorsally compressed; empty scales manifest : hilum punctiform.

Flowering scale and palet hyaline, thin, much more delicate in structure than the thick-membranous to coriaceous empty scales.

Spikelets unisexual, the pistillate borne in the lower, the staminate in the upper, part of the same spike.

Spikelets in pairs, one sessile, the other pedicellate, the former perfect, the latter sometimes perfect, more commonly with a staminate flower, often empty or reduced to one or two scales, or occasionally wanting; both spikelets pedicellate in nos. 2 and 6 .

Flowering scale, at least that of the perfect flower, similar in texture to the empty scales, or frequently thicker and firmer, never hyaline and thin.

Flowering scale and palet membranous.

Inflorescence spicate: spikelets deciduous singly or in groups, the first scale usually larger than the rest.

Inflorescence paniculate: spikelets deciduous singly from the ultimate branches, the first scale usually smaller or narrower than the rest.

Flowering scale and palet chartaceous, cartilaginous, or coriaceous, very different in color and appearance from the remaining scales.

Spikelets much compressed laterally; empty scales none or rudimentary: hilum linear.

TRIBE I. MAYDEAE.

TRIBE II. ANDROPOGONEAE

TRIBE III. ZOYSIEAE.

TRIBE IV. TRISTEGINEAE.

Tribe V. PANICEAE.

TRIBE VI. ORYZEAE.

B. Spikelets with the empty scales persistent, the rachilla hence articulated above them (below them in nos. 58,61, 62, 68 and 76 and the spikelet falling entire), 1-many-flowered; frequently the upper scales are empty : rachilla often produced beyond the uppermost scale.

Stems herbaceous, hence annual: leaf-blade sessile, not articulated with the sheath.

Spikelets borne in open or spike-like panicles or racemes, usually upon distinct and often long pedicels.

Spikelets 1-flowered.

Empty scales 4 : palet 1-nerved.

Empty scales 2 (rarely 1): palet 2-nerved.

Spikelets 2-many-flowered.

Flowering scales usually shorter than the empty ones, the awn dorsal and usually bent.

Flowering scales usually longer than the empty ones. the awn terminal and straight, rarely dorsal, sometimes wanting.

Spikelets in two rows:

On one side of the continuous axis, forming one-sided spikes or racemes.

On opposite sides of an axis which is often articulated, forming equilateral spikes.

Stems, at least near the base, woody, hence perennial: leaf-blade

TRIBE VII. PHALARIDEAE:

TrIBE VIII. AGROSTIDEAE.

Tribe IX. AVENEAE.

Tribe XI. FESTUCEAE.

TRIBE X. CHLORIDEAE.

TRIBE XII. HORDEAE.

with a petiole-like base which is articulated with the sheath. TriBE XIII. BAMBUSEAE.

TRIBE I. MAYDEAE.

Fertile spikelets imbedded in the internodes of the thick rachis.

1. Tripsacum. 
TRIBE II. ANDROPOGONEAE.

A. Internodes of the rachis not thickened nor excavated for the reception of the spikelets.

Spikelets alike, perfect.

Axis of the racemes continuous, not articulated.

Axis of the racemes articulated.

Spikelets not alike:

All pedicellate, the long-pedicellate one perfect, the short-pedicellate one staminate.

Sessile and pedicellate, the former perfect, the latter empty, staminate or wanting.

First empty scale of the sessile spikelet balsam-bearing.

First empty scale of the spikelet not balsam-bearing.

a. Sessile spikelets alike throughout the inflorescence.

Racemes singly disposed : apex of the rachis-internodes a translucent cup-shaped, entire or irregularly toothed, appendage. Racemes disposed in pairs or more: apex of the rachis-internodes not appendaged.

Rachis-internodes and pedicels sulcate, the median portion translucent, the margins thickened.

Rachis-internodes and pedicels not sulcate. Some or all of the racemes sessile. All of the racemes more or less pedunculate. Sessile spikelets dorsally compressed.

Pedicellate spikelets wanting.

Pedicellate spikelets present and usually staminate. Sessile spikelets rounded or laterally compressed.

Racemes with many internodes: awns none.

Racemes with usually but one internode: awns long.

b. Lower spikelets differing from the others.

B. Internodes of the rachis much thickened and excavated to receive the spikelets.

First scale of the spikelet flat or convex.

First scale of the spikelet globose.

TRIBE III. ZOYSIEAE.

Second empty scale naked.

on the back.

Second empty scale with hooked spines on the back.

\section{TRIBE IV. TRISTEGINEAE.}

Inflorescence a panicle, the spikelets long-awned.

TRIBE V. PANICEAE.

A. Spikelets all perfect.

a. Spikelets not sunken in the rachis.

1. Spikelets naked, not involucrate.

Empty scale 1 .

Empty scales more than 1.

Empty scales 2.

Lower empty scale with a thickened ring-like callus.

Lower empty scale unappendaged.

Spikelets in one-sided racemes or spikes.

Flowering scale with its opening turned from the rachis. Spikelets ovate to orbicular, usually obtuse, rarely acute. Spikelets lanceolate, acute to acuminate.

Flowering scale with its opening turned toward the rachis. Spikelets in panicles:

Fertile.

Sterile: fertile spikelets on short subterranean branches.

Empty scales 3

Palet of the third scale not enlarged.

Second empty scale not saccate at the base.

Spikelets acute to obtuse, their empty scales not markedly exceeding the flowering ones.

Spikelets sessile or nearly so, singly disposed : flowering scale with the opening toward the rachis.

Spikelets more or less distinctly pedicellate, usually in pairs or more; flowering scale with the opening turned from the rachis.

Empty scales not awned.

Spikelets in very slender one-sided racemes which are usually whorled or approximate.

Spikelets in panicles or panicled racemes, the latter never whorled, commonly distant.

Spikelets lanceolate, acuminate, long-hairy.

Spikelets orbicular or lanceolate, if the latter then glabrous.

Spikelets in pairs in one-sided racemes: first scale of the short-pedicelled spikelet turned to one side and often much longer than the corresponding scale in the other spikelet.

Spikelets not in one-sided racemes, or if thus arranged, the first scale of the spikelets central.
2. IMPERATA.
3. ERIANTHUS.

6. TraChYPOGON.

7. Elionurus.

8. SCHIZACHYRIUM.

10. AMPHILOPSIS.

9. ANDROPOGON.

12. SORGHASTRUM.

11. Sorghum.

13. Vetiveria.

14. RAPHIS.

15. Heteropogon.

4. Manisuris.

5. HACKELOCHLOA.

16. Hilaria.

17. NAZIA.

18. LimNodeA.

19. Reimaria.

25. ERiochloA.

20. Paspalum.

27. SYNTHERISMA.

22. ANASTROPHUS.

23. Anthaenantia.

24. AMPHICARPON.

26. Brachiaria.

\section{SYNTHERISMA.}

28. TRIChachne.

21. Dimorphostachys.

31. Panicum. 
Empty scales awned or awn-pointed.

Stems creeping : leaf-blades short and broad : racemes or clusters usually of few spikelets.

Stems erect: leaf-blades long and narrow: racemes usually of many spikelets.

Spikelets and their empty scales long-acuminate, the latter not varying much in length and more than twice as long as the fourth scale.

Second empty scale much enlarged, many-nerved, saccate at the base.

Palet of the third scale much enlarged when mature, forcing open the spikelet.

2. Spikelets involucrate.

Involucre of numerous bristles.

Bristles persistent: spikelets deciduous.

Bristles not plumose.

Bristles plumose.

Bristles deciduous with the spikelets.

Bristles rigid, thickened at the base.

Bristles delicate, not thickened at the base, plumose.

Involucre of two spine-bearing valves.

b. Spikelets sunken in one side of the flat rachis.

B. Spikelets monoecious: leaf-blades with a petiole-like base at the junction with the sheath.

30. Oplismenus.

29. ECHINOCHLOA.

32. Phanopyrum.

33. SACCIOLEPIS.

34. Steinchisma.

35. Chaetochloa.

39. Penichllatia.

37. CENCHROPSIS.

38. Pennisetum.

36. CenChRUS.

40. Stenotaphrum.

41. OLyRA.

42. HYDROCHLOA.

43. Pharus.

46. ZiZANIA.

44. Luziola.

45. ZiZANIOPSIS.

47. ORYZA.

48. Homalocenchrus.

Empty scales present, manifest.

Empty scales wanting, or rarely present as minute rudiments.

TRIBE VII. PHALARIDEAE.

Third and fourth scales empty :

Awnless.

Awned upon the back.

Third and fourth scales enclosing staminate flowers.

49. Phalaris.

50. ANTHOXANTHUM.

5i. SAVASTANA.

\section{Tribe VIII. AGROSTIDEAE.}

A. Flowering scale indurated when mature and very closely embracing the grain, or at least firmer than the empty scales.

Rachilla not extending beyond the palet.

Flowering scale 3-awned.

Flowering scale 1-awned.

Awn untwisted :

Stout: spikelets large.

Slender : spikelets small.

Awn twisted.

Rachilla extending beyond the palet.

B. Flowering scale usually hyaline or membranous at maturity, at least more delicate than the empty ones: grain loosely enclosed.

Inflorescence a spike.

Rachilla of the spikelets articulated above the empty scales which are therefore persistent.

Rachilla of the spikelets articulated below the empty scales, hence deciduous entire.

Inflorescence an open or spike-like panicle.

Grain not permanently enclosed in the flowering scale and palet: pericarp opening readily when mature.

Grain permanently enclosed in the flowering scale and palet: pericarp adherent.

Spikelets readily falling off entire when mature.

Spikelets with the empty scales at least persistent.

Palet 1-nerved and 1-keeled: stamen 1.

Palet 2-nerved and 2-keeled : stamens 3.

Empty scales saccate at the base.

Empty scales not saccate at the base.

Flowering scale with long hairs at the base.

Flowering scale and palet thin-membranous.

Flowering scale and palet chartaceous.

Flowering scale 5-nerved.

Flowering scale 1-nerved.

Flowering scales naked at the base.

Inflorescence an elongated narrow panicle.

Inflorescence an open, or short and spike-like panicle.

52. Aristida.

53. ORtachne.

55. Muhlenbergia.

54. STIPA.

56. Brachyelytrum.
57. Phleum.

58. Alopecurus.

59. Sporobolus.

61. Polypogon.

62. Cinna.

64. Gastridium.

65. Calamagrostis.

66. A mMophila.

67. Camimovilfa.

60. EPICAMIPES

63. Agrostis, 
Tribe IX. AVENEAE.

Spikelets readily deciduous as a whole.

Spikelets with the empty scales persistent, the flowering scales deciduous.

Spikelets 2-flowered : rachilla not prolonged.

Spikelets 2-many-flowered: rachilla extending beyond the upper flower.

Flowering scale awned below the teeth.

Flowers all perfect.

Grain free, unfurrowed: spikelets less than $1 \mathrm{~cm}$. long.

Flowering scales erose-toothed or shortly 2-lobed at the apex.

Flowering scales cleft or 2-toothed, the teeth extending into awns.

Grain furrowed, adherent to the scale: spikelets exceeding $1 \mathrm{~cm}$. in length.

Flowers different, the upper perfect, the lower staminate and with its scale strongly awned.

Flowering scales awned between their usually awned teeth.

TRIBE X. CHLORIDEAE.

A. Spikelets with perfect flowers.

Spikelets deciduous as a whole.

Spikelets with at least the empty scales persistent.

Spikelets with one perfect flower.

No scales above the flowering scale.

Spikes 2-6, digitate.

Spikes numerous, arranged along a common axis.

1-several scales above the flower.

Empty scales 4.

Empty scales 2 .

Spikes in whorls or closely approximate.

Flowering scales with a single awn or awnless.

Second empty scale acute : awn of flowering scales usually long.

Second empty scale truncate or 2-toothed : flowering scales awnless or awn-pointed.

Flowering scales with three awns.

Spikes scattered.

Spikelets scattered or distant.

Spikelets crowded.

Spikes generally 4 or less, rarely as many as 8 , long : spikelets numerous, exceeding 12 .

Spikes often numerous, short: spikelets few, less than 12 Rachis of the spikes with manifest internodes

Spikelets broad, crowded; internodes of the rachis short: rachilla terminated by a 3-awned scale, or sometimes reduced to 3 weak awns.

Spikelets very narrow, scattered : internodes of the rachis at least $1 / 2$ as long as the spikelets: rachilla terminated by 3 stout awns.

Rachis with the internodes so short that the spikelets appear clustered.

Spikelets with $2-3$ perfect flowers.

Spikes commonly digitate; spikelets crowded.

Spikes with terminal spikelets.

Spikes with the rachis extending beyond the spikelets in a manifest point.

Spikes distant: spikelets alternate.

Spikelets small, numerous and crowded: scales thin

Spikelets large, few and distant: scales firm and thick.

B. Spikelets dioecious, those of the two sexes very dissimilar.

Tribe XI. FESTUCEAE.

Flowering scales many-cleft into awn-like divisions.

Flowering scales entire, or at most 2-lobed.

Hairs on the rachilla or flowering scale very long and enclosing the latter : tall reed-like grasses.

Flowering scales hairy : rachilla glabrous.

Flowering scales glabrous : rachilla hairy.

Hairs, if any, on the rachilla or flowering scales shorter than the scale: grasses of lower stature.

Stigmas barbellate, on elongated styles.

Spikelets dioecious, single, concealed in the heath-like leaves. Spikelets perfect, commonly in 3's, in the axils of stiff spinescent leaves. Stigmas plumose, sessile or on a short style.

Flowering scale 1-3-nerved, or rarely with faint additional intermediate nerves.

Flowering scales membranous : seed not beaked nor exserted from the scale.

Lateral nerves of the flowering scale pilose.

Internodes of the rachilla long, the deeply 2-lobed flowering scales attached by a long pointed callus.

Internodes of the rachilla and the blunt callus of the flowering scale short.

Inflorescence simple or compound, contracted or open, the spikelets on pedicels of varying length.
68. Holcus,

69. AIRA.

70. Deschampsia.

71. TRISETUM.

72. Avena.

73. ARRHENATHERUM. 74. DANTHONIA.

76. SPARTINA.

75. CAPRIOLA.

82. SCHEDONNARDUS.

77. Campulosus.

78. CHLORIS.

79. Eustachys.

80. TRICHLORIS

81. GYMNOPOGON.

83. Bouteloua

84. ATHEROPOGON.

85. TRIATHERA.

86. POLYODON.

87. Eleusine.

88. Dactyloctenium.

89. LEPTOCHLOA.

90. ACAMPTOCLADOS, 91. Bulbilis.

92. PAPPOPHORUM.

95. ARUNDO.

96. Phragmites.

93. MONANTHOCHLOE.

94. Munroa.

99. TRIPLASIS 
Inflorescence a short congested raceme: leaf-blades with thick conspicuous cartilaginous margins.

Inflorescence a contracted or open panicle: leaf-blades not cartilaginous on the margins.

Inflorescence composed of long branches along which the appressed spikelets are arranged on short pedicels, or sometimes only a one-sided raceme.

Lateral nerves of the flowering scale glabrous.

Callus of the flowering scales copiously pubescent with long hairs.

Panicle contracted : flowering scales broadly oval, rounded at the apex.

Panicle open and diffuse: flowering scales lanceolate and

Callus of the flowering scales glabrous.

Second empty scale similar to the first.

Rachilla of the spikelet continuous : palets often persistent.

Rachilla of the spikelet articulated.

Spikelets very small and numerous, less than $3 \mathrm{~mm}$. long, usually several-many-flowered.
Spikelets large, about $6 \mathrm{~mm}$. long, 2-3-flowered. ERAGrostis.

Second empty scale very dissimilar to the first, broad and rounded at the summit.

98. ERIONEURON.

97. TRIDENS.

101. Diplachne.

102. Rhомbolytrum.

100. REDFIELDiA.

103. Eragrostis.

105. Koeleria.

104. Eatonia.

Flowering scale coriaceous in fruit: seed beaked and exserted from the scale.

Flowering scales 5-many-nerved.

Spikelets with two or more of the upper scales empty, broad and enfolding each other.

Spikelets with the upper scales flower-bearing, or smaller and empty.

Empty basal scales 3-6.

Empty basal scales 2.

Spikelets dioecious.

Spikelets perfect :

Borne in fascicles which are arranged in a glomerate or interrupted panicle.

Borne in panicles or racemes, but not in fascicles.

Stigmas inserted at or near the apex of the ovary.

Flowering scales with the nerves parallel.

Flowering scales with the lateral nerves converging above toward the midnerve.

Flowering scales strongly keeled on the back, pubescent on some or all of the nerves: hilum

punctiform.
Flowering scales rounded on the back, at least below: hilum linear.

107. KORYCARPUS.

106. MeLiCA.

108. UNIOLA.

109. Distichlis.

110. Dactylis.

112. Panicularia.

111. PoA.

113. Festuca.

Stigmas plainly inserted below the apex of the ovary. 114. Bromus.

TRIBE XII. HORDEAE.

Spikelets singly arranged at the rachis nodes.

Spikelets with the flowering scales with their backs to the rachis; empty

Spikelets with the flowering scales with their sides to the rachis: empty scales 2.

Dpikelets $2-6$ at each rachis node :

1-flowered.

2-many-flowered.

Empty scales usually as long as the flowering ones.

Rachis of the spike articulated, its internodes readily separating at the joints: empty scales 2-many-parted or cleft.

Rachis of the spike continuous : empty scales entire.

Empty scales wanting or minute.

TRIBE XIII. BAMBUSEAE.

Shrubs or trees with the leaf-blades usually articulated with the sheaths.

115. Lolium.

116. Agropyron.

117. HORDEUM.

118. SITANION.

119. ELYMUS.

120. Hystrix.

121. Arundinaria.

\section{TRÍPSACUM L.}

Tall perennial monoecious grasses, with stout rootstocks, usually broad flat leaf-blades and spicate inflorescence. Spikes articulated, elongated. Staminate spikelets 2-flowered, in pairs at each joint of the upper portion of the axis, of 4 scales, the outer 2 empty, coriaceous and shining, the inner 2 thinner, each enclosing a hyaline palet and a flower consisting of 3 stamens. Pistillate spikelets 1 -flowered, in excavations in the lower internodes of the rachis, the outer scale very hard, thick and shining, concealing the more delicate remaining scales, the fourth scale enclosing a flower with a slender style. Stigmas 2, exserted. Grain enclosed in the appressed outer scale and the internode.

Spikes in pairs or more, rarely single, terminal and axillary: leaf-blades $1-2 \mathrm{~cm}$. broad.

Spike single, terminal, none axillary : leaf-blades $8 \mathrm{~mm}$. broad or less.

1. T. dactyloides.

2. T. Floridanum. 
1. Tripsacum dactyloides L. Glabrous, or on the summit of the sheaths and the upper surface of the leaves more or less hirsute. Stems 1-2.5 m. tall, from stout rootstocks; blades $6 \mathrm{dm}$. long or less, $1-4 \mathrm{~cm}$. wide: spikes terminating the stem and its branches, single, or at the summit of the stem in 2's-4's, 1-3 dm. long, the lower $\frac{1}{4}-\frac{1}{2}$ pistillate, the remainder staminate, the margins of the excavations in the pistillate portion ciliate, the sinus at the base with long hairs: pistillate spikelets $7-10 \mathrm{~mm}$. long, orbicularovate: staminate spikelets $7-10 \mathrm{~mm}$. long, $1.5-2 \mathrm{~mm}$. broad, oblong, the outer 2 scales glabrous or puberulent.

In swamps or along streams, Rhode Island to Kansas, Florida, Texas, and Mexico. Summer and fall. Gama Grass.

2. Tripsacum Floridànum Porter. Similar to the preceding species, but much more slender. Stems from stout rootstocks, $6-10 \mathrm{dm}$. tall : leaf-blades long and narrow, usually 5-8 mm. wide: spikes rather slender, $1.5-2 \mathrm{dm}$. long, single, terminal, never axillary.

In moist or wet places, peninsular Florida and the Keys to Texas. Spring and summer.

\section{IMPERÀTA Cyr.}

Perennial grasses, with long leaf-blades and long terminal cylindric dense and spikelike panicles. Spikelets 1 -flowered, rarely 2 -flowered, narrow, in pairs, unequally pedicellate. Scales 4, thin, hyaline, awnless, the outer 2 empty, pilose, the third scale glabrous, empty or rarely enclosing a palet and staminate flower, the fourth scale glabrous, subtending a perfect flower and its 2-nerved palet which is truncate and toothed at the apex. Stamens 1 or 2 . Styles distinct. Stigmas plumose.

1. Imperata Brasiliénsis Trin. Stems tufted, $3-8 \mathrm{dm}$. tall, slender : leaf-sheaths smooth and glabrous; blades $3 \mathrm{dm}$. long or less, $3-8 \mathrm{~mm}$. wide, smooth beneath, hirsute above near the base : panicle $6-15 \mathrm{~cm}$. long, $1.5-3 \mathrm{~cm}$. broad, oblong, its branches $1.5-4$ $\mathrm{cm}$. long, ascending : spikelets about $4 \mathrm{~mm}$. long, the one about equalling, the other about twice as long as its pedicel, the outer 2 scales and the callus densely clothed with hairs, these, as well as those at the summit of the rachis internodes, more than twice as long as the spikelets.

In dry soil, southern peninsular Florida. Also in tropical America. Spring and summer. BrAZILIAN BLADY-GRASS.

\section{ERIÁNTHUS Michx.}

Tall perennial grasses, with frequently robust stems arising from thick rootstocks, and with flat leaf-blades and perfect flowers in open or contracted terminal panicles. Spikelets usually with a basal ring of long hairs, or rarely naked, in pairs at each joint of the articulated and often hairy rachis. Scales 4, the outer 2 indurated, frequently hairy, the remainder hyaline, the fourth scale often 2-toothed at the apex, bearing an awn which is straight, spiral, or more or less contorted ; palet small, hyaline. Stamens 3. Styles distinct, elongated. Stigmas plumose. Plume Grass. Beard Grass.

Spikelets with a basal ring of hairs at least $1 / 2$ its length, the outer 2 scales long-

pilose or becoming glabrous.

Panicle pale, rarely tinged with purple, the basal hairs much exceeding the usually yellowish white spikelet.

Exserted portion of the awn loosely coiled, the included part tightly spiral.

Exserted portion of the awn straight, the included portion rarely slightly twisted.

Panicle dark, often tinged with purple, the basal hairs?from:shorter than to exceeding the yellowish brown or dark brown spikelet.

Exserted portion of the awn straight.

Spikelets $6 \mathrm{~mm}$. long or less, equalling or shorter than the basal hairs.

Panicle dense and compact, its branches short and erect; basal hairs about as long as the spikelet.

Panicle loose and open, its branches long and ascending; basal hairs much exceeding the spikelet.

Internodes of the branches commonly about as long as the spikelets which are about $2 / 3$ as long as the basal hairs.

Lower internodes of the elongated branches much exceeding the spikelets which are about $1 / 2$ as long as the basal hairs. Spikelets $8 \mathrm{~mm}$. long or more, exceeding the basal hairs.

Exserted portion of the awn contorted or loosely spiral.

Spikelets $7.5 \mathrm{~mm}$. long or less; summit of the stem and panicle-axis glabrous or sparingly appressed-hirsute.

Spikelets 8-9 mm. long; summit of the stem and panicle-axis densely appressed-hirsute.

Spikelet naked at the base or with a few short hairs, the outer 2 scales strongly appressed-hispid.

1. E. alopecuroides.

2. E. Tracyi.
3. E. compactus.

4. E. saccharoides.

5. E. laxus.

6. E. brevibarbis.

7. E. contortus.

8. E. Smallii.

9. E. strictus. 
1. Erianthus alopecuroides (L. ) EII. Stems $1.5-3 \mathrm{~m}$. tall, the apex, the panicle-axis, and often also the nodes, pubescent with long silky appressed hairs. Leaf-sheaths glabrous ; blades $1.5-7 \mathrm{dm}$. long, $5-25 \mathrm{~mm}$. broad, hirsute above near the base: panicle $2-3$. $\mathrm{dm}$. long, $5-10 \mathrm{~cm}$. broad, oblong, its branches erect-ascending, the larger $4-11 \mathrm{~cm}$. long : spikelets rather crowded, about $\frac{2}{3}$ as long as the basal hairs and $\frac{1}{2}$ again as long as the internodes; 2 outer seales about $6 \mathrm{~mm}$. long, pilose with hairs less than $1 \frac{1}{2}$ times as long as the scales ; fourth scale 2-toothed at the apex, the teeth acuminate, the awn 12-16 mm. long, the included portion a tightly spiral column, the remainder loosely coiled.

In damp soil, North Carolina, Kentucky and Missouri, to Georgia and Alabama. Fall.-A form, $E$. alopecuroides hirsùtus Nash, differs from the species in having the sheaths, at least the lower ones, and the lower surface of the leaf-blades appressed-hirsute. In similar situations, Florida.

2. Erlanthus Tràcyi Nash. Stems 2-4 m. tall, the summit and nodes together with the panicle-axis and top of the otherwise glabrous sheaths appressed-pubescent with long silky hairs. Leaf-sheaths shorter than the internodes; blades $5 \mathrm{dm}$. long or more, 1.5-3 cm. broad, very rough, pilose above at the base: panicle 3-5 dm. long, 8-12 cm. wide, oblong, its pubescent branches erect-ascending, the larger 1-1.5 dm. long: spikelets crowded, less than $\frac{1}{2}$ as long as the basal hairs and $\frac{1}{2}$ again as long as the internodes; 2 outer scales 5-6 mm. long, pilose with hairs twice as long as the scale ; fourth scale entire or somewhat 2-toothed at the apex, the awn $1.5-2 \mathrm{~cm}$. long, straight or slightly flexuous.

In moist open places, Florida and Mississippi. Fall.

3. Erianthus compáctus Nash. Stems 1-2 m. tall, the summit and nodes together with the panicle-axis and top of the otherwise glabrous sheaths appressed-pubescent with long silky hairs. Leaf-sheaths shorter than the internodes; blades 1.5-7 dm. long, 6-12 $\mathrm{mm}$. wide, rough on both surfaces, more or less appressed-hirsute beneath, also above near the base: panicle 1-2 dm. long, 4-6 $\mathrm{cm}$. wide, oblong, its branches erect-ascending, the larger 3-5 $\mathrm{cm}$. long: spikelets crowded, about equalling the basal hairs, and usually over twice as long as the internodes; 2 outer seales $5-6 \mathrm{~mm}$. long, pilose with long hairs ; fourth scale slightly if at all toothed at the apex, the awn straight or slightly flexuous, $1-2 \mathrm{~cm}$. long.

In swamps, New Jersey to North Carolina and Tennessee. Fall.

4. Erianthus saccharoides Michx. Stems $1.5-3 \mathrm{~m}$. tall, the summit and nodes together with the panicle-axis and top of the otherwise glabrous sheaths appressed-pubescent with long silky hairs. Leaf-sheaths shorter than the internodes; blades 1.5-7 dm. long, 6-25 mm. wide, usually rough and more or less hirsute on both surfaces : panicle 1.5-4 dm. long, 5-15 cm. wide, oblong, its branches ascending, the larger $7-15 \mathrm{~cm}$. long: spikelets rather loosely disposed, about $\frac{2}{3}$ as long as the basal hairs and a little exceeding the internodes ; 2 outer seales 4-6 mm. long, pilose with long hairs ; fourth seale slightly if at all toothed at the apex, the awn straight or slightly flexuous, $1.5-2.5 \mathrm{~cm}$. long.

In moist soil, New Jersey to Florida and Louisiana. Summer and fall.

5. Erianthus láxus Nash. Stems $2-3 \mathrm{~m}$. tall, pubescent, especially at the nodes, with appressed hairs, those at the apex and on the panicle-axis long and copious. Leafsheaths, particularly the lower ones, densely hirsute, especially at the ends; blades 2-5 dm. long, 6-12 mm. wide, hirsute on both surfaces, the upper surface becoming glabrous : panicle $4-5 \mathrm{dm}$. long, $1 \mathrm{dm}$. wide or less, its elongated and ascending branches lax and flexuous, the larger $2-2.5 \mathrm{dm}$. long : spikelets loosely disposed, $\frac{1}{2}$ as long as the basal hairs and much exceeded by the internodes, especially by the lower ones; 2 outer scales 4-5 $\mathrm{mm}$. long, pilose with long hairs ; fourth scale entire or shortly 2-toothed at the apex, the awn straight or slightly flexuous, about $2 \mathrm{~cm}$. long.

In swamps, peninsular Florida. Fall.

6. Erianthus brevibárbis Michx. Stems 1-1.5 m. tall, the nodes pubescent with readily deciduous hairs, the summit and panicle-axis glabrous. Leaf-sheaths rough, the summit appressed-hirsute ; blades 1.5-4 dm. long, 6-10 mm. wide, rough : panicle 2-3 $\mathrm{dn}$. long, about $3 \mathrm{~cm}$. wide, its branches erect, the larger $2-7 \mathrm{~cm}$. long : spikelets crowded, exceeding the basal hairs and a little less than twice as long as the internodes ; 2 outer scales $8-9 \mathrm{~mm}$. long, sparingly pilose; fourth scale usually entire at the apex, the awn straight, $1.5-2.5 \mathrm{~cm}$. long.

In moist soil, Delaware to North Carolina and Louisiana. Fall.

7. Erianthus contórtus EII. Stems 1-2 m. tall, the nodes often pubescent with readily deciduous hairs, the summit and panicle-axis glabrous, or sparingly appressedpubescent. Leaf-sheaths smooth or rough; blades $1.5-8 \mathrm{dm}$. long, 5-20 mm. wide, smoothish or rough : panicle $1.5-3 \mathrm{dm}$. long, 3-5 $\mathrm{cm}$. wide, its branches erect, the larger 4-7 $\mathrm{cm}$. long: spikelets crowded, exceeding the basal hairs and about $\frac{1}{2}$ again as long as the internodes ; 2 outer scales 7-7.5 mm. long, at first more or less pilose with long hairs ; fourth scale 2-toothed at the apex, the awn 1.5-2 $\mathrm{cm}$. long, the included portion often a little spiral at the base, the remainder loosely spiral.

In pine woods, Delaware to Florida and Mississippi. Fall. 
8. Erianthus Smállii Nash. Stems $1.5-2.5 \mathrm{~m}$. tall, the nodes pubescent with readily deciduous hairs, the summit and the panicle-axis copiously appressed-pubescent with long silky hairs. Leaf-sheaths usually sparingly hirsute at the apex, otherwise glabrous ; blades 1.5-7 dm. long, 6-20 mm. wide, rough on both surfaces: panicle 2-4 dm. long, 4-6 cm. wide, its branches erect, the larger $7-10 \mathrm{~cm}$. long : spikelets crowded, about equalling the basal hairs and $\frac{1}{2}$ again as long as the internodes ; 2 outer scales $8-9 \mathrm{~mm}$. long, pilose with long hairs; fourth scale 2-toothed at the apex, the teeth long and subulate, the awn 2-2.5 cm. long, the included portion long and tightly spiral, the remainder loosely spiral.

In low grounds, Tennessee to Georgia, Florida and Mississippi. Fall.

9. Erianthus stríctus Baldw. Stems 1-2 m. tall, the nodes usually pubescent with readily deciduous hairs, the summit and the panicle-axis glabrous. Leaf-sheaths glabrous ; blades 2-7 dm. long, 5-10 mm. wide, rough on the margins but otherwise smooth : panicle $2-4 \mathrm{dm}$. long, $1-2 \mathrm{~cm}$. wide, its branches appressed, the larger $5-8 \mathrm{~cm}$. long: spikelets crowded, about $\frac{1}{2}$ again as long as the internodes, the basal hairs wanting or sparse and less than $\frac{1}{4}$ as long as the spikelet; 2 outer scales $8-10 \mathrm{~mm}$. long, strongly appressed-hispid ; fourth scale entire or shortly 2 -toothed at the apex, the awn $1.5-2 \mathrm{~cm}$. long, straight.

In moist soil, Tennessee to Florida and Texas. Fall.

\section{MANISÙRIS L.}

Perennial, often tall grasses, sometimes with rootstocks, narrow flat leaf-blades, and cylindric articulated terminal and axillary spikes. Spikelets in pairs at each joint, in excavations in the rachis, one sessile and containing a perfect flower, the other pedicellate and either bearing a staminate flower, or empty. Scales of the sessile spikelet 4, the outermost thick and coriaceous, sometimes more or less rugose or pitted, concealing, together with the pedicel of the other spikelet, the remaining scales and the excavation in the rachis; second scale chartaceous, the third and fourth scales hyaline, the former empty or infolding a staminate flower, the latter enclosing a thinly hyaline palet and perfect flower. Scales of the pedicellate spikelet 4 or fewer. Stamens 3. Styles distinct. [Rottboellia L. f.] RAT-TAIL Grass.

Stems from horizontal rootstocks, round; sheaths round, narrow.

Stems tufted, much flattened, at least below ; rootstocks wanting; sheaths much compressed, broad, keeled.

First scale of the sessile spikelet transversely wrinkled (rarely smooth).

Wrinkles short, but little elevated, tubercle-like, sometimes entirely wanting.
Wrinkles long, often extending completely across the scale, much elevated.

Leaf-blades rather short and broad, especially those of the upper sheaths, $6-10 \mathrm{~mm}$. wide at the base : rachis of the racemes glabrous.

Leaf-blades elongated and narrow, even those of the upper sheaths, $6 \mathrm{~mm}$. wide at the base or less : rachis of the racemes puberulent.

First scale of the sessile spikelet pitted.

1. M. cylindrica.

2. M. tuberculosa.

3. M. Chapmanii.

4. M. rugosa.

5. M. tessellata.

1. Manisuris cylíndrica (Michx.) Kuntze. Stems from creeping rootstocks, round, 3-10 dm. tall, slender: leaf-sheaths round, narrow; blades $3 \mathrm{dm}$. long or less, 1-3 mm. wide : racemes finally exserted, 1-2 dm. long, straight or curved, the rachis barely if at all contracted at the nodes : sessile spikelet $4.5-5 \mathrm{~mm}$. long, about equalling the internode, the first scale more or less pitted in longitudinal lines, or rarely unpitted, each pit often containing a subulate hair; pedicellate spikelet reduced to 1 or 2 short scales, the pedicel linear, shorter than the sessile spikelet and curved around its margin. [Rottboellia cylindrica (Michx.) Chapm.]

In sandy soil, Georgia and Florida to Texas; also in Missouri and the Indian Territory. Summer.

2. Manisuris tuberculòsa Nash. Stems tufted, much compressed, $8-12 \mathrm{dm}$. tall, stout: leaf-sheaths much flattened, broad, keeled; blades $3 \mathrm{dm}$. long or less, 3-7 mm. wide : racemes finally exserted, 6-10 cm. long, straight, the rachis barely if at all contracted at the nodes: sessile spikelet about $4 \mathrm{~mm}$. long, about equalling the internode, the first scale transversely wrinkled, or very rarely without wrinkles, the wrinkles short, tuberclelike, irregularly disposed; pedicellate spikelet reduced to 1 or 2 short scales about $\frac{1}{2}$ the length of the linear pedicel which is a little shorter than the sessile spikelet and curved around its margin.

On lake shores, peninsular Florida. Summer.

3. Manisuris Chapmánii (Hack.) Nash. Stems tufted, 6-15 dm. tall, much compressed : leaf-sheaths much flattened, broad throughout; blades usually less than $2.5 \mathrm{dm}$. long, $6-10 \mathrm{~mm}$. wide, those of the inflorescence generally very short and broad : racemes commonly $4-5 \mathrm{~cm}$. long, occasionally longer, little compressed, exserted or a little included at the base, the rachis glabrous, the internodes and pedicels usually flat, not much depressed on the back: sessile spikelet $4-5 \mathrm{~mm}$. long, usually exceeding the stout inter- 
node; pedicellate spikelet smaller and of 2 scales, or sometimes staminate and as long as the linear pedicel.

In swampy places, Florida. Fall.

4. Manisuris rugòsa (Nutt.) Kuntze. Stems tufted, much compressed, 7-12 dm. tall, stout: leaf-sheaths much flattened, broad, keeled; blades $4 \mathrm{dm}$. long or less, $6 \mathrm{~mm}$. wide or less : racemes exserted or somewhat included at the base, $5-8 \mathrm{~cm}$. long, straight or a little curved, the rachis internodes usually much contracted at the base and puberulent : sessile spikelet $3.5-4.5 \mathrm{~mm}$. long, about equalling or a little exceeding the internodes, the first scale strongly transversely wrinkled, the wrinkles much elevated and often extending across the entire width of the scale, the longitudinal ridges usually rather prominent, often 2 -toothed at the obtuse apex; pedicellate spikelet of 2 scales, $\frac{2}{3}$ as long as the clavate puberulent pedicel or less. [Rottboellia rugosa Nutt. Rottboellia corrugata Baldw.]

In wet places, Delaware and Maryland to Florida and Texas. Summer and fall.

5. Manisuris tessellàta (Steud.) Seribn. Stems tufted, much compressed, $8-12 \mathrm{dm}$. tall, stout: leaf-sheaths much flattened, broad, keeled; blades $4 \mathrm{dm}$. long or less, 3-8 $\mathrm{mm}$. wide: racemes finally exserted, 6-12 $\mathrm{cm}$. long, straight, the rachis barely if at all contracted at the nodes: sessile spikelet about $5 \mathrm{~mm}$. long, a little exceeding the internode, the first scale deeply pitted, the pits quadrangular: pedicellate spikelet of 1 or 2 scales, about $\frac{1}{2}$ as long as the straight linear pedicel which is shorter than the sessile spikelet. [Rottboellia corrugata Chapm., not Baldw.]

In low pine lands, Alabama to Louisiana. Summer and fall.

\section{HACKELÓCHLOA Kuntze.}

Annual grasses, with branching stems, flat leaf-blades and terminal and axillary short spikes which are sometimes partially included in the sheaths. Spikelets in pairs in excavations at the rachis-joints, one sessile, 1-flowered, the other pedicellate, flowerless. Scales of the sessile spikelet 4, awnless, the outermost empty, firm, globose, pitted, covering the excavation in the rachis, the second small, concave, thin, somewhat rigid, the third empty, the fourth small, thin, hyaline, enclosing a perfect flower and sometimes also a minute palet. Stamens 3. Styles distinct. Stigmas plumose. [Manisuris Sw., not L.]

1. Hackelochloa granulàris (L.) Kuntze. Stems tufted, $2-10 \mathrm{dm}$. tall, finally much branched: leaf-sheaths papillose-hirsute; blades $1.5 \mathrm{dm}$. long or less, $3-15 \mathrm{~mm}$. wide, papillose-hirsute on both surfaces, ciliate on the margins : racemes $1-2 \mathrm{~cm}$. long, the peduncles hirsute: sessile spikelet about $1 \mathrm{~mm}$. in diameter; pedicellate spikelet about 2 mm. long, sterile, consisting of 2 scales. [Manisuris granularis Sw.]

In cultivated and waste places, Georgia and Florida to Arizona. Also in all tropical regions. Summer and fall. LIZARD-TAIL GRASS.

\section{TRACHYPÒGON Nees.}

Tall perennial grasses, with long narrow leaf-blades and spike-like terminal racemes. Spikelets 1-flowered, one almost sessile and staminate, or if perfect, sterile, the other pedicellate and enclosing a perfect flower. Scales usually 4 ; the first scale rigid, awnless, enclosing the rest, the second somewhat resembling the first but smaller and thinner, the third scale very thin and hyaline; fourth scale in the sessile spikelets very thinly hyaline, awnless, in the pedicellate spikelet very narrowly hyaline at the base, and produced into a very long contorted awn which is geniculate above. Palet minute or wanting. Stamens 3. Styles distinct. Stigmas plumose.

1. Trachypogon secúnaus (Presl) Nash. Stems tufted, $8-10 \mathrm{dm}$. tall, simple, the nodes barbed : leaf-blades erect, 1-3 dm. long, about $3 \mathrm{~mm}$. wide, hirsute on the upper surface : racemes 1-2 dm. long, the rachis glabrous : short-pedicellate spikelet about $7 \mathrm{~mm}$. long, the long-pedicellate one about $9 \mathrm{~mm}$. in length, the first scale of both copiously pubescent with rather long ascending hairs, the awn of the latter 4-6 $\mathrm{cm}$. long, twisted at the base and geniculate, pubescent below with long nearly erect hairs which become much shorter toward the summit. [Heteropogon secundus Presl.]

In dry soil, Texas to Arizona, south to Mexico. Summer and fall.

\section{ELIONÙRUS H. \& B.}

Tall and branched, or low and tufted grasses, with often elongated leaves, and terminal spikes. Spikelets in pairs in excavations at the rachis-nodes; one sessile, 1-flowered, or rarely 2 -flowered; the other pedicellate, sometimes enclosing a flower. Scales 4 , awnless, 
the outermost one larger than the rest, membranous, exhaling a balsam-odor when fresh or when soaked in water, second scale shorter, thinner, somewhat rigid, acute, the third scale empty, or rarely in the sessile spikelets infolding a staminate flower, the fourth scale very thinly hyaline, in the sessile spikelets enclosing a perfect flower, in the pedicellate spikelets either empty or enclosing a staminate flower; palet minute or wanting. Stamens 3. Styles distinct. Stigmas plumose.

1. Elionurus tripsacoìdes H. \& B. Stems $6-15 \mathrm{dm}$. tall, from a rootstock, branched above : leaf-blades $5 \mathrm{dm}$. long or less, involute above the base when dry and about 0.8 $\mathrm{mm}$. in diameter, $3-5 \mathrm{~mm}$. wide at the base, hirsute above near the base: racemes finally exserted, $7-14 \mathrm{~cm}$. long, the rachis-internodes pilose excepting the inner surface : sessile spikelet 6.5-8 mm. long, about twice as long as the rachis-internode ; pedicellate spikelet $5-6 \mathrm{~mm}$. long, reaching or extending a little beyond the apex of the sessile spikelet, the pedicel pilose, excepting the inner surface.

In low pine lands, Florida to Texas. Also in Mexico and Sóuth America. Summer and fall.

\section{SCHIZACHÝRIUM Nees.}

Annual or perennial grasses, tufted, or from rootstocks, with flat or involute leaf-blades, and spike-like racemes, singly disposed, terminating the stem or its branches. Spikelets in pairs at each node of the articulated and frequently hairy rachis, one sessile, the other pedicellate. Sessile spikelet of 4 scales, the outer 2 indurated, sometimes pubescent, the remainder of the scales hyaline, the fourth scale entire or 2-toothed at the apex, bearing a straight, contorted or spiral awn; palet small, hyaline. Pedicellate spikelet sterile, of 1 or 2 scales, or wanting. Stamens 1-3. Styles distinct. Stigmas plumose. Beard Grass. Internodes of the racemes glabrous, or merely shortly appressed-pubescent on

the back, the racemes hence appearing naked.

Internodes as well as the first scale of the sessile spikelet glabrous.

Sessile spikelet 5-6 mm. long; pedicel stout, oblong-elliptic, the outer margin ciliate its entire length.

Sessile spikelet $4 \mathrm{~mm}$. long; pedicel slender, linear, the outer margin ciliate only at the apex.

Internodes as well as the first scale of the sessile spikelet appressed-pubescent.

Internodes of the racemes and the pedicels long-ciliate on the margins, the inner or usually both surfaces glabrous, the racemes hence appearing hairy.

Leaf-blades flat and broad; rachis-internodes and pedicels glabrous on the back, or the former rarely sparsely pilose at the summit, the marginal hairs much shorter than the respective organs.

Stems tufted, no stolons.

Sheaths and leaf-blades glabrous or sometimes sparingly pubescent. Spikelets 5-7 mm. long.

Spikelets $10 \mathrm{~mm}$. long.

Sheaths and leaf-blades densely long-villous.

Stems not tufted, stoloniferous, rootstocks long and slender.

Pedicellate spikelet staminate: lower sheaths numerous, crowded, the blades spreading.

Pedicellate spikelet sterile: lower sheaths few, not crowded, the blades erect.

Sessile spikelet 6-7 mm. long, the first scale strongly tuberculateroughened; pedicellate spikelet of a single scale, about $3, \mathrm{~mm}$. long, single-awned.

Sessile spikelet 9-10 mm. long, the first scale smooth or nearly so ; pedicellate spikelet of 2 scales, $6-8 \mathrm{~mm}$. long, the first scale 3awned.

Leaf-blades involute, filiform; rachis-internodes and pedicels strongly pilose on the back, the marginal and dorsal hairs much longer than the respective members.

1. S. semiberbe.

2. S. tenerum.

3. S. oligostachyum.

4. S. scoparium.

5. S. acuminatum.

6. S. villosissimum.

7. S. maritimum.

8. S. stoloniferum.

9. S. triaristatum.

10. S. gracile.

1. Schizachyrium semibérbe Nees. Smooth and glabrous. Stems tufted, 6-12 dm. tall, the branches in 1's or 2's : leaf-blades $3 \mathrm{dm}$. long or less, $2-5 \mathrm{~mm}$. wide : racemes single, 5-8 cm. long, partially included at the base, the rachis-internodes with a dense ring of short hairs at the base, thick, channeled on the inner surface : sessile spikelet 5-6 $\mathrm{mm}$. long, the first scale rounded on the back, roughened, acuminate, the awn of the fourth scale 12-15 mm. long, geniculate, tightly spiral at the base, the column exserted ; pedicellate spikelet consisting of a single hispidulous scale about $3 \mathrm{~mm}$. long with an equally long awn, the pedicel stout, oblong-elliptic, ciliate on the outer margin, shorter than the internode. [Andropogon semiberbis (Nees) Kunth.]

In dry rocky or sandy ground, southern peninsular Florida. Also tropical America. Summer.

2. Schizachyrium ténerum Nees. Smooth and glabrous. Stems tufted, slender, often weak and decumbent, 4-10 dm. long, the branches in 1's or 2's : leaf-blades $2 \mathrm{dm}$. long or less, $0.5-2 \mathrm{~mm}$. wide, the lower ones often sparingly hirsute above near the base : racemes single, $3-6 \mathrm{~cm}$. long, the rachis-internodes with a ring of hairs at the base, stout, 
channeled on the inner surface : sessile spikelet about $4 \mathrm{~mm}$. long, the first scale somewhat rounded on the back, acute, the awn of the fourth scale 7-10 $\mathrm{mm}$. long, geniculate, tightly spiral at the base, the column exserted; pedicellate spikelet consisting of a single scale, 4-5 mm. long, awnless or awn-pointed, the pedicel linear, not stout, pilose on the outer side near the summit, usually equalling or a little exceeding the internode. [Andropogon tener (Nees) Kunth.]

In dry ground, South Carolina to Florida and southern Texas. Also in tropical America. Fall.

3. Schizachyrium oligostáchyum (Chapm.) Nash. Smooth and glabrous, sometimes glaucous. Stems $9-15 \mathrm{dm}$. tall, the branches in 1's or 2's : leaf-blades $2 \mathrm{dm}$. long or less, $4 \mathrm{~mm}$. wide or less : racemes single, usually partially included at the base, $6-10 \mathrm{~cm}$. long: sessile spikelet about $6 \mathrm{~mm}$. long, about as long as or a little exceeding the hirsute rachis-internode, the first scale hirsute, the geniculate awn of the fourth scale 10-12 min. long, closely spiral at the base, the column considerably exserted; pedicellate spikelet 4-5 mm. long, the first scale glabrous, bearing an awn about $2 \mathrm{~mm}$. long. [Andropogon oligostachyus Chapm.]

In dry sandy soil, Florida. Fall.

4. Schizachyrium scopàrium (Michx.) Nash. Green or purplish, sometimes glaucous. Stems tufted, 4.5-15 dm. tall, the branches in 1's-4's : leaf-sheaths usually glabrous, sometimes more or less hirsute; blades $5 \mathrm{dm}$. long or less, $8 \mathrm{~mm}$. wide or less, commonly roughened, and frequently somewhat hirsute above near the base : racemes single, 3-6 $\mathrm{cm}$. long, the hairs on the rachis-internodes and pedicels grayish white : sessile spikelet $5-7 \mathrm{~mm}$. long, usually about twice as long as the internode, the first scale generally more or less tuberculate-roughened, the awn of the fourth scale geniculate, 8-15 mm. long, closely spiral at the base, the column exserted ; pedicellate spikelet 2-4.5 $\mathrm{mm}$. long, the first scale usually glabrous, tipped with an awn generally $1 \mathrm{~mm}$. long or less, the pedicel considerally shorter than the sessile spikelet. [Andropogon scoparius Michx.]

In dry sandy soil, New Brunswick to Alberta, Florida and Texas. Summer and Fall. Broom Grass.

5. Schizachyrium acuminàtum Nash. Stems tufted, 7-10 dm. tall, the branches in 1's-3's : leaf-sheaths generally rough toward the summit, compressed, keeled; blades $2 \mathrm{dm}$. long or less, $5 \mathrm{~mm}$. wide or less, rough : racemes single, finally exserted, $3-6 \mathrm{~cm}$. long, the hairs of the rachis-internodes and pedicels grayish white: sessile spikelet $1 \mathrm{~cm}$. long, about twice the length of the internode, the awn about $1.5 \mathrm{~cm}$. long, geniculate; pedicellate spikelet consisting of 2 scales, the first 4-5 $\mathrm{mm}$. long, strongly hispidulous and bearing an awn $2 \mathrm{~mm}$. long or less, the pedicel about $\frac{2}{3}$ as long as the sessile spikelet.

In dry soil, Mississippi. Fall.

6. Schizachyrium villosíssimum (Kearn.) Nash. Leaf-sheaths, and blades on both surfaces, densely villous. Stems tufted, $8-10 \mathrm{dm}$. tall, rather stout : leaf-blades $3.5 \mathrm{dm}$. long or less, 3-5 mm. wide, erect, rather firm : racemes single, about $3 \mathrm{~cm}$. long, exserted from the spathes which are more or less villous: sessile spikelet about $6.5 \mathrm{~mm}$. long, the first scale tuberculate-roughened, acuminate, the awn of the fourth scale usually geniculate and more or less contorted, 10-13 mm. long, tightly spiral at the base, the column exserted ; pedicellate spikelet consisting of a single scale about $2 \mathrm{~mm}$. long with an awn 1-2 mm. long, the pedicel recurved, at least when dry, shorter than the sessile spikelet, pilose above the middle with white hairs, glabrous below. [Andropogon scoparius villosissimus Kearn.]

In dry sandy soil, Mississippi. Fall.

7. Schizachyrium marítimum (Chapm.) Nash. Smooth and glabrous, glaucous. Stems 4-6 dm. tall : leaf-sheaths compressed, keeled, the lower ones crowded and overlapping; blades $1 \mathrm{dm}$. long or less, $4 \mathrm{~mm}$. broad or less, widely spreading: racemes single, usually partially included at the base, $3-4 \mathrm{~cm}$. long, rather stout, the terminal hairs of the internodes of the rachis 5-7 mm. long: sessile spikelet 8-9 mm. long, about twice as long as the internodes, the awn twisted at the base, geniculate, 9-13 mm. long; pedicellate spikelet 5-7 mm. long, awnless, consisting of four scales, the outer two acuminate and usually awn-pointed, the fourth scale enclosing a staminate flower, the pedicel about $\frac{2}{3}$ as long as the sessile spikelet. [Andropogon maritimus Chapm.]

Along the seacoast, western Florida to Mississippi. Fall.

8. Schizachyrium stoloníferum Nash. Stems 6-10 dm. tall, stoloniferous: leafsheaths keeled, more or less hirsute on the margins near the summit; blades $2 \mathrm{dm}$. long or less, $2-5 \mathrm{~mm}$. wide, smooth beneath, rough above and hirsute near the base: racemes single, 3-4 cm. long: sessile spikelet $6-7 \mathrm{~mm}$. long, acuminate, about twice as long as the rachis-internode, the first scale strongly tuberculate-roughened, the awn of the fourth scale geniculate, more or less contorted, 8-10 mm. long, spiral at the base, the column not exserted; pedicellate spikelet of a single scale about $3 \mathrm{~mm}$. long, hispidulous, bearing an awn shorter than itself.

In sandy soil, western Florida. Fall. 
9. Schizachyrium triaristàtum Nash. Stems 6-8 dm. tall, stoloniferous: leafsheaths keeled, more or less hirsute on the margins near the summit; blades $1.5 \mathrm{dm}$. long or less, $3-5 \mathrm{~mm}$. wide, hirsute above near the base: racemes single, $3-5 \mathrm{~cm}$. long : sessile spikelet $9-10 \mathrm{~mm}$. Jong, acuminate, more than twice as long as the rachis-internode, the first scale smooth or nearly so, the awn of the fourth scale $12-15 \mathrm{~mm}$. long, geniculate, more or less contorted, spiral at the base, the column not exserted; pedicellate spikelet of 2 scales, 6-8 $\mathrm{mm}$. long, the first scale hispidulous, 3-awned.

In sand, Florida. Fall.

10. Schizachyrium grácile (Spreng.) Nash. Smooth and glabrous. Stems densely tufted, slender, rigid, 3-6 dm. tall ; leaf-blades $2 \mathrm{dm}$. long or less, very slender, involute, $0.5 \mathrm{~mm}$. in diameter or less : racemes long-exserted, single, $3-5 \mathrm{~cm}$. long, silvery white : sessile spikelet $5-6 \mathrm{~mm}$. long, about $\frac{1}{2}$ again as long as the internode, the awn geniculate, 13-20 mm. long, tightly spiral to the bend, loosely so above, the column much exserted : pedicellate spikelet consisting of a single scale, 1-2.5 mm. long, short-awned, the pedicel about as long as or a little shorter than the sessile spikelet. [Andropogon gracilis Spreng.]

In dry pine woods, southern peninsular Florida ; also in the West Indies. Summer.

\section{ANDROPÒGON L.}

Perennial grasses, tufted or from elongated rootstocks, with flat or involute leaf-blades, and spike-like racemes, disposed in pairs or sometimes in 3's or more, terminating the stem or its branches, and often protruding from the side of a membranous spathe-like sheath. Spikelets sometimes with a ring of short hairs at the base, in pairs at each node of the articulated and frequently hairy rachis, one sessile, the other pedicellate. Sessile spikelet of 4 scales, the outer 2 indurated, often pubescent, the remainder of the scales usually hyaline, the fourth scale entire or 2-toothed at the apex, bearing a straight contorted or spiral awn, or sometimes awnless ; palet small, hyaline. Pedicellate spikelet usually sterile of 1 or 2 scales, sometimes of four scales and enclosing a staminate or more rarely a perfect flower, or frequently entirely wanting, the first scale rarely short-awned. Stamens 1-3. Styles distinet. Stigmas plumose. Beard Grass. Broom Grass. Sand Grass.

A. Pedicellate spikelet sterile, consisting of 1 or 2 scales, much smaller than the sessile one.

a. Stamen 1.

1. Racemes usually equalling or a little shorter than the spathes, rarely somewhat exceeding them (considerably exserted in some forms of no. 2), the common peduncle thus concealed.

Inflorescence oblong to oval or obovate, the branches many times divided, the lower ones elongated, forming 1 or more corymbiform masses; upper stem-leaves usually equalling or exceeding the inflorescence.

Spathes smooth; apex of the common peduncle of the racemes glabrous.

Spathes very rough; apex of the common peduncle of the racemes hispidulous.

Inflorescence long and narrow, commonly linear, the branches not much divided nor the lower ones excessively elongated, hence forming no corymbiform masses; upper stem-leaves usually shorter than the inflorescence.

Racemes in pairs (very rarely in 3's or 4's).

Sheaths not glabrous.

Sheaths hirsute on the margins, the upper surface of the leafblades also hirsute near the base; hairs on the summit of the internodes of the racemes rather sparse, and about twice their length,

Sheaths, especially those of the innovations and their blades, densely appressed-hirsute; hairs on the summit of the internodes of the racemes copious and about three times their length.

Sheaths glabrous.

Leaf-blades tuberculate-hirsute above toward the base; hairs of the racemes dense, the spikelets therefore obscurely visible.

Leaf-blades not hirsute above; hairs of the racemes rather scant, the spikelets therefore plainly visible.

Branches of the inflorescence several times divided : spathes $2-3 \mathrm{~cm}$. long.

Branches of the inflorescence simple: spathes 4-7 cm. long. Stems slender; basal leaf-blades narrow, $2 \mathrm{~mm}$. wide or less, usually long and flexuous.

Stems stout; basal leaf-blades broad and rigid, 3-6 mm. wide.

Racemes in 4's (rarely in 2's or 3's); sheaths, at least the lower ones,

1. A. glomeratus.

2. A. corymbosus.

3. A. Virginicus.

4. A. longiberbis.

5. A. Tracyi.

6. A. capillipes.

7. A. perangustatus.

8. A. glaucopsis.

densely hirsute. 
Spathes narrow, long-acuminate, much exceeding the slender racemes : sessile spikelet $3-4 \mathrm{~mm}$. long, lanceolate.

Spathes broad, acuminate, equalling or shorter than the stout racemes : sessile spikelet about $4.5 \mathrm{~mm}$. long, broadly lanceolate.

2. Racemes, at least some of them, entirely exserted from the spathes. the 9. A. tetrastachyus

10. A. Mohrii. common peduncle thus visible.

Sheaths at the summit of the stem and also sometimes at the upper nodes much enlarged, crowded and imbricated.

All the flowering stems with enlarged upper sheaths; lower sheaths shorter than the internodes, hence distant.

Basal sheaths and those of the innovations glabrous; enlarged sheaths in 2's or 3's, $3 \mathrm{~mm}$. wide or less.

Basal sheaths and those of the innovations densely hirsute; enlarged sheaths in 4's or more, 4-6 mm. wide.

Only some of the flowering stems with enlarged upper sheaths; lower sheaths much exceeding the internodes, hence overlapping.

Sheaths not enlarged.

Spathes exceeding $10 \mathrm{~cm}$. in length : racemes long and lax, the internodes much exceeding the spikelets.

Spathes less than $8 \mathrm{~cm}$. long: racemes short and stout, the internodes equalling or shorter than the spikelets.

Inflorescence much branched, branches much divided; sheaths glabrous.

Racemes $1-2 \mathrm{~cm}$. long, the spikelets about twice as long as the

11. A. gracilior.

12. A. Elliottii.

13. A. campyloracheus.

13. A. campyloracheus. rachis-internodes.

Racemes 3-4 cm. long, the spikelets equalling or little exceeding the rachis-internodes.

Inflorescence not much branched, the branches little or not at all divided.

Sheaths glabrous; racemes silvery white.

Sheaths hirsute; racemes brown.

14. A. brachystachyus.

15. A. Floridanus.

16. A. subtenuis.

17. A. arctatus.

b. Stamens 3 .

First scale of the sessile spikelet appressed-hispid between the keels, rather thin: sheaths sometimes pubescent.

First scale nerveless between the keels, or if intermediate nerves occur, not running the entire length of the scale: terminal hairs of the internodes about twice their length.

First scale with 2 or 3 nerves between the keels, the nerves running the entire length of the scale: terminal hairs of the internodes about equalling them.

First scale of the sessile spikelet glabrous and shining between the keels, firm: sheaths glabrous, and, with their blades, glaucous.

B. Pedicellate spikelet as large as the sessile, or larger, consisting of 4 scales and a staminate or rarely perfect flower.

Stems tufted, no rootstocks.

Rachis-internodes of the racemes smooth : pedicellate spikelet staminate.

Outer 2 scales of the sessile spikelet more or less hispidulous all over: hairs on the internodes usually $2 \mathrm{~mm}$. long or less.

Outer 2 scales of the spikelet glabrous, excepting the nerves and also toward the summit of the first scale : hairs on the internodes $3-4$ $\mathrm{mm}$. long, usually yellow.

Rachis-internodes of the racemes strongly hispidulous: pedicellate spikelet perfect.

Stems from long horizontal rootstocks.

1. Andropogon glomeràtus (Walt.) B.S.P. Stems 5-15 dm. tall, commonly stout, the branches repeatedly and fastigiately branched, the lower ones somewhat elongated but considerably shorter than the stem, thus forming a large oblong glomerate panicle: leaf-blades $4 \mathrm{dm}$. long or less, $7 \mathrm{~mm}$. wide or less, rough : spathes $2.5-3 \mathrm{~cm}$. long, equalling or somewhat exceeding the racemes, smooth and glabrous, fastigiately crowded at the summit of the stem and ends of the branches : racemes in pairs, $1-2 \mathrm{~cm}$. long: sessile spikelet 3-4 mm. long, the awn 10-15 mm. long, straight; pedicellate spikelet wanting, or present as a subulate rudimentary scale. [A. macrourus Michx.]

In low ground, Florida to Texas, New Mexico and Mexico. Fall.-A form with the racemes usually more or less exserted from the apex of the narrow spathes which are tightly enrolled on the common peduncle of the racemes, is known as A. glomeratus tenuispatheus Nash.

2. Andropogon corymbòsus (Chapm.) Nash. Stems 4-10 dm. tall, rather stout, from a little exceeding to twice as long as the basal leaves, the branches much divided, the lower ones elongated and nearly equalling the upper, thus forming a corymbiform panicle : leaf-sheaths keeled, those at the base much compressed and equitant, rough, often more or less papillose-hirsute, especially the shorter and crowded ones of the inflorescence ; stem-leaves with blades $3 \mathrm{dm}$. long or less, $5 \mathrm{~mm}$. wide or less, rough : spathes very rough, narrow, tightly enrolled around the common peduncle of the raceme which is densely hispidulous toward the summit and rather stout : racemes in pairs, more or less exserted from the summit of the spathes, $2-3 \mathrm{~cm}$. long: sessile spikelet 4-5 mm. long, the awn $12-13$ $\mathrm{mm}$. long, straight or nearly so ; pedicellate spikelet usually present as a subulate scale 1-2 mm. long. [A. macrourus var. corymbosus Chapm.]

In wet soil, District of Columbia to Florida and Mississippi. Fall.-A form differing from the type in having the spathes generally about equalling the racemes and few if any of them narrow and inrolled on the peduncles is known as A. corymbosus abbreviatus (Hack.) Nash. It ranges as far north as Long Island, N. Y. 
3. Andropogon Virgínicus L. Stems tufted, $5-10 \mathrm{dm}$. tall, the branches in 1 's -3 's : leaf-sheaths, at least the lower ones, more or less tuberculate-hirsute on the margins with long usually lax hairs ; blades $4 \mathrm{dm}$. long or less, $2-5 \mathrm{~mm}$. wide, rough or roughish, hirsute on the upper surface near the base : spathes $3-5 \mathrm{~cm}$. long, extending beyond the racemes : racemes generally in pairs, rarely in 3 's or 4's, 2-3 cm. long: sessile spikelet 3-4 mm. long, twice to $\frac{1}{2}$ again as long as the internode, the awn straight, 10-15 mm. long; pedicellate spikelet wanting, or rarely present as a minute scale, the pedicel exceeding the sessile spikelet.

In dry or moist soil, Massachusetts to Pennsylvania, Illinois, Florida and Texas. Fall.

4. Andropogon longibérbis Hack. Stems tufted, 5-10 dm. tall, the branches in 1's-3's : leaf-sheaths, especially those on the innovations, appressed-hirsute, shorter than the internodes; blades $5 \mathrm{dm}$. long or less, $7 \mathrm{~mm}$. wide or less, those on the innovations densely appressed-hirsute, those on the stem more or less so beneath, rough above: spathes $3-5 \mathrm{~cm}$. long, usually considerably exceeding the racemes, commonly brown: racemes in pairs, 3-4 cm. long, stout: sessile spikelet $4-4.5 \mathrm{~mm}$. long, about twice as long as the rather stout rachis-internode, the awn straight or nearly so, 12-16 mm. long; pedicellate spikelet a subulate scale, or wanting, the pedicel rather stout and a little exceeding the sessile spikelet.

In dry pine lands, eastern and peninsular Florida. Spring and summer.

5. Andropogon Tràcyi Nash. Stems $5-8 \mathrm{dm}$. tall, the branches in 1's or 2's : leafsheaths smooth and glabrous; blades $2 \mathrm{dm}$. long or less, 1-2.5 mm. wide, smooth beneath, rough above and hirsute toward the base : spathes $4-5 \mathrm{~cm}$. long, rather broad, from slightly shorter to exceeding the racemes: racemes in pairs, 3-4 cm. long, rather stout : sessile spikelet $5 \mathrm{~mm}$. long, about twice as long as the stout internode which is densely clothed with silvery white hairs a little more than $1 \frac{1}{2}$ times as long as the spikelet, the awn 1.5-2 cm. long, sometimes a little spiral at the base ; pedicellate spikelet wanting, or present as a minute rudimentary scale, the pedicel exceeding the sessile spikelet.

In dry soil, Alabama and Mississippi. Fall.

6. Andropogon capillipes Nash. Smooth and glabrous, glaucous. Stems 8-12 dm. tall : leaf-sheaths on the branches and summit of the stem much narrower than the spathes, shorter than the peduncles which are usually in 3's and around which the sheaths are tightly enrolled, the peduncles usually manifestly exserted; blades $2 \mathrm{dm}$. long or less, 1-2.5 mm. wide, erect: spathes $2-3 \mathrm{~cm}$. long, exceeding the racemes: racemes $1.5-2 \mathrm{~cm}$. long: sessile spikelet $3-3.5 \mathrm{~mm}$. long, about twice as long as the internode, the awn straight, 11-13 mm. long: pedicellate spikelet wanting, or present as a minute rudimentary scale, the pedicel as long as or a little exceeding the sessile spikelet.

In dry soil, North Carolina to Florida. Fall.

7. Andropogon perangustàtus Nash. Smooth and glabrous, the basal leaves narrow and flexuous, about $\frac{1}{2}$ as long as the plant. Stems 2-8 dm. tall, slender, the branches usually single, sometimes in pairs : leaf-blades $3 \mathrm{dm}$. long or less, 1-2 mm. wide: spathes 4-5 cm. long, extending beyond the summit of the racemes which are in pairs, $2.5-4 \mathrm{~cm}$. long : sessile spikelet $3.5-4 \mathrm{~mm}$. long, twice to $\frac{1}{2}$ again as long as the internode, the awn 12-18 mm. long; pedicellate spikelet wanting or rarely present as a minute scale, the pedicel exceeding the sessile spikelet. [A. Virginicus var. stenophyllus Hack., not A. stenophyllus R. \& S.]

In dry soil, Florida to Mississippi. Fall.

8. Andropogon glaucópsís (Ell.) Nash. Glaucous, grayish green. Stems 6-10 dm. tall, rigid, rather stout, the branches in 1's-2's, usually considerably above the middle : leaf-sheaths smooth and glabrous, keeled, the lower ones compressed; blades erect, $2 \mathrm{dm}$. long or less, $2.5-6 \mathrm{~mm}$. wide, smooth and glabrous beneath, roughened above with a minute pubescence, the basal ones from $\frac{1}{3}-\frac{1}{2}$ as long as the stems : spathes 4-6 cm. long, equalling or usually a little exceeding the racemes : racemes in pairs, $3-4.5 \mathrm{~cm}$. long : sessile spikelet 4.5-5 mm. long, long-acuminate, from equalling to nearly twice as long as the internode, the awn 1.5-2 cm. long, straight; pedicellate spikelet wanting, or present as a rudimentary scale, the pedicel exceeding the sessile spikelet. [A. macrourus var. glaucopsis Ell.]

In dry soil, North Carolina to Florida and Mississippi. Fall.

9. Andropogon tetrastáchyus Ell. Stems tufted, 8-15 dm. tall : leaf-sheaths densely villous, at least the lower ones, with dark hairs; blades $4 \mathrm{dm}$. long or less, 2-4 $\mathrm{mm}$. wide, the lower ones villous on both surfaces toward the base : spathes $3-4$, rarely 6 , $\mathrm{cm}$. long, extending beyond the racemes: racemes usually in 4's, sometimes fewer, 3-4 $\mathrm{cm}$. long: sessile spikelet $3-4 \mathrm{~mm}$. long, twice to $\frac{1}{2}$ again as long as the internode, the awn straight, $1.5-2 \mathrm{~cm}$. long; pedicellate spikelet wanting, or rarely present as a minute 
scale, the pedicel considerably exceeding the sessile spikelet. [A. Virginicus var. tetrastachyus (Ell.) Hack.]

In dry or moist soil, South Carolina to Florida and Alabama. Fall.

10. Andropogon Mòhrii Hack. Stems 8-12 dm. tall: leaf-sheaths densely appressed-hirsute ; blades $3 \mathrm{dm}$. long or less, $5 \mathrm{~mm}$. wide or less, densely appressed-hirsute : spathes 4-5 cm. long, equalling or a little shorter than the racemes: racemes in 4's, 3-4 $\mathrm{cm}$. long, rather stout, the hairs at the summit of the rachis-internodes $\frac{1}{2}$ again as long as the spikelets: sessile spikelet about $4.5 \mathrm{~mm}$. long, about twice as long as the internode, the awn straight or nearly so, slightly if at all twisted at the base, $2-2.5 \mathrm{~cm}$. long ; pedicellate spikelet wanting, or sometimes present as a small subulate scale, the pedicel usually a little shorter than the sessile spikelet.

In low pine lands, western Florida to Louisiana. Fall.

11. Andropogon gracílior (Hack.) Nash. Stems tufted, slender, 3-7 dm. tall, 2-3 times as long as the basal leaves, the lower branches single : leaf-sheaths glabrous, shorter than the internodes, the terminal ones more or less enlarged, $5-7 \mathrm{~cm}$. long, $2-3 \mathrm{~mm}$. wide ; stem-leaves with blades $1.5 \mathrm{dm}$. long or less, 1-2 $\mathrm{mm}$. wide, smooth beneath, rough above and sparingly hirsute near the base : racemes in pairs, slender, about $3 \mathrm{~cm}$. long, exserted, or slightly included at the base : sessile spikelet $3.5-4 \mathrm{~mm}$. long, equalling or somewhat exceeding the internode, the awn geniculate, $1.3-2 \mathrm{~cm}$. long, loosely spiral at the base, the column exserted; pedicellate spikelet a minute rudimentary scale, the pedicel usually about $\frac{1}{2}$ again as long as the sessile spikelet.

In dry or moist places, Florida to Alabama; also in Tennessee. Fall.

12. Andropogon Ellióttii Chapm. Stems tufted, 5-8 dm. tall, rather stout, 2-3 times as long as the basal leaves : leaf-sheaths shorter than the internodes, the lower ones and those of the innovations densely appressed-hirsute, those of the inflorescence much enlarged and densely crowded at the summit and also sometimes at the nodes below, 8-11 cm. long, 3-6 $\mathrm{mm}$. wide; blades $2 \mathrm{dm}$. long or less, $2-5 \mathrm{~mm}$. wide, usually smooth beneath, rough above and hirsute near the base : racemes in pairs, slender, $3-4 \mathrm{~cm}$. long, the longer one at each node exserted, the rest concealed in the spathes: sessile spikelet $4.5-5 \mathrm{~mm}$. long, equalling or somewhat exceeding the internode, the awn geniculate, $1.5-2.3 \mathrm{~cm}$. long, usually spiral at the base, the column much exserted; pedicellate spikelet a minute rudimentary scale, the pedicel usually about $\frac{1}{2}$ again as long as the sessile spikelet.

In dry sandy soil, South Carolina and Tennessee to Florida and Mississippi. Fall.

13. Andropogon campylorácheus Nash. Stems densely tufted, 4-8 dm. tall, the terminal internode much elongated and slender, the branches single : leaf-sheaths much exceeding the internodes, overlapping, those on the stem 13-17 cm. long, sparingly hirsute, those on the innovations densely hirsute with ascending hairs, the terminal one very narrow and tightly embracing the stem, the upper sheaths on some of the stems much enlarged and producing smaller spathes in their axils with concealed racemes; blades erect, $2 \mathrm{dm}$. long or less, $2-3 \mathrm{~mm}$. broad, smooth beneath, hirsute above near the base : racemes in 2's-4's, flexuous, $5-10 \mathrm{~cm}$. long: sessile spikelet $5 \mathrm{~mm}$. long, usually much exceeded by the internode, the terminal hairs of which are $8-10 \mathrm{~mm}$. long, the awn more or less contorted, 1.5-2 cm. long, barely if at all twisted at the base ; pedicellate spikelet wanting, or present as a minute rudimentary scale, the pedicel much exceeding the sessile spikelet.

In dry sandy soil, southern peninsular Florida and Mississippi. Fall.

14. Andropogon brachystáchyus Chapm. Stems tufted, $6-15 \mathrm{dm}$. tall, the branches in 1's-3's and usually pilose just below the nodes: leaf-sheaths smooth and glabrous; blades erect, $3 \mathrm{dm}$. long or less, 3-4 mm. wide, smooth beneath, on the upper surface rough and hirsute near the base : racemes in pairs, shortly exserted, or partly included at the base, 1-2 $\mathrm{cm}$. long : sessile spikelet $3-4.5 \mathrm{~mm}$. long, about twice as long as the internode, the first scale pubescent between the keels, the awn of the fourth scale straight or nearly so, 6-9 mm. long; pedicellate spikelet consisting of a single scale, the pedicel shorter than the sessile spikelet.

In moist pine lands, Florida. Summer and fall.

15. Andropogon Floridànus Scribn. Stems tufted, $5-16 \mathrm{dm}$. tall, the branches in 1's-3's : leaf-sheaths roughish, usually shorter than the internodes; blades $5 \mathrm{dm}$. long or less, $1 \mathrm{~cm}$. wide or less, rough : racemes in pairs, occasionally in 3 's or 4's, 3-4 cm. long, exserted, or partly included at the base : sessile spikelet $3.5-4 \mathrm{~mm}$. long, equalling or a little longer than the internode, the awn straight, 8-12 $\mathrm{mm}$. long; pedicellate spikelet wanting or present as a small scale, the pedicel exceeding the sessile spikelet.

In dry pine lands, peninsular Florida. Summer and fall.

16. Andropogon subténuis Nash. Stems 3-6 dm. tall, slender, the branches single : leaf-sheaths smooth and glabrous; blades $1.5 \mathrm{dm}$. long or less, 1-2 mm. wide, smooth 
beneath, rough above and somewhat hirsute near the base : racemes in pairs, exserted, or a little included in the narrow spathes, $2-3 \mathrm{~cm}$. long: sessile spikelet $3-4 \mathrm{~mm}$. long, exceeding the internode, the awn 1-1.5 cm. long, more or less contorted, slightly twisted at the base ; pedicellate spikelet wanting, or a minute rudimentary scale, the pedicel considerably exceeding the sessile spikelet.

In sandy soil, Florida to Mississippi. Fall.

17. Andropogon arctàtus Chapm. Stems $1-1.5 \mathrm{~m}$. tall, branched toward the summit, the branches in 1's-3's : leaf-sheaths, at least the lower ones, more or less densely appressed-hirsute at the summit ; blades erect, $3 \mathrm{dm}$. long or less, $5 \mathrm{~mm}$. wide or less, the upper surface rough, the lower usually densely appressed-hirsute toward the base : racemes in pairs, rarely in 3's or 4's, rather stout, dark gray, $2.5-4 \mathrm{~cm}$. long, long-exserted : sessile spikelet 5-6 $\mathrm{mm}$. long, about twice as long as the internode, the awn more or less contorted, 1-1.5 cm. long; pedicellate spikelet usually present, consisting of a single scale, the pedicel considerably shorter than the sessile spikelet.

In low pine lands, Florida. Fall.

18. Andropogon argyraèus Schult. Stems tufted, $8-12 \mathrm{dm}$. tall, about twice as long as the basal leaves, the branches in 1's-3's: leaf-sheaths smooth or rough, glabrous or hirsute; blades $3 \mathrm{dm}$. long or less, $3 \mathrm{~mm}$. wide or less, rough : racemes in pairs, rather stout, silvery gray, $3-5 \mathrm{~cm}$. long, long-exserted, the hairs on the summit of the internodes $1 \frac{1}{2}-2$ times their length : sessile spikelet $5-6 \mathrm{~mm}$. long, about twice as long as the internode, the first scale appressed-pubescent between the nerves, acuminate from about the lower third, nerveless between the keels and usually deeply depressed, the awn more or less contorted, $1.5-2.5 \mathrm{~cm}$. long; pedicellate spikelet of a single scale, 1-3 mm. long, the pedicel usually a little shorter than the sessile spikelet.

In dry soil, Delaware and Maryland to Florida, and Texas; also in Indian Territory and Missouri, and probably southward to the Gulf. Fall. SILvER BEARD.

19. Andropogon Cabanísii Hack. Stems 6-10 dm. tall, the branches in 1's or 2's : leaf-sheaths smooth or a little roughened; blades $2.5 \mathrm{dm}$. long or less, $2-4 \mathrm{~mm}$. broad, smooth beneath, rough above: racemes in pairs, 4-7 cm. long, grayish, the hairs at the apex of the internodes as long as or a little exceeding them, rather scant: sessile spikelet 6-7 mm. long, broadly lanceolate, tapering from the middle, about twice as long as the internode, the first scale strongly hispidulous and 2-3-nerved between the keels, the nerves running the entire length of the scale; pedicellate spikelet of a single hispidulous scale $3-3.5 \mathrm{~mm}$. long, the pedicel about $\frac{2}{3}$ as long as the sessile spikelet.

In dry soil, Pennsylvania (according to Hackel) and Florida. Summer.

20. Andropogon Scribneriànus Nash. Glaucous. Stems tufted, $3-10 \mathrm{dm}$. tall, twice as long as the basal leaves, rather sparsely branched above : leaf-sheaths shorter than the internodes, smooth and glabrous; blades $1 \mathrm{dm}$. long or less, $2.5 \mathrm{~mm}$. wide or less, the upper surface minutely pubescent and also often hirsute near the base : racemes in pairs, stout, long-exserted, 4-7 cm. long, bright silvery white, the hairs on the internodes copious, those at the summit about twice the length of the internodes: sessile spikelet $5-6 \mathrm{~mm}$. long, about twice as long as the internode, the first scale narrowed from about the middle, glabrous and shining between the keels, the internerve flat or nearly so, the awn of the fourth scale more or less contorted and bent, somewhat twisted below, 1-1.5 cm. long; pedicellate spikelet wanting, or present as a small scale $1.5 \mathrm{~mm}$. long or less, the pedicel equalling or a little shorter than the sessile spikelet.

In dry pine lands, Georgia and Florida. Spring and summer.

21. Andropogon furcàtus Muhl. Stems $1-2 \mathrm{~m}$. tall : leaf-sheaths glabrous or sometimes slightly hirsute; blades $6 \mathrm{dm}$. long or less, $12 \mathrm{~mm}$. wide or less, smooth beneath and glabrous or rarely a little hirsute, more or less roughened above and hirsute at the base : racemes in 2's-6's, 5-10 cm. long, stout, long-exserted, the hairs of the internodes and pedicels grayish white, 1-2 mm. long: sessile spikelet 7-10 mm. long, the outer 2 scales more or less hispidulous, the awn 7-15 mm. long, geniculate, twisted at the base ; pedicellate spikelet as large as or a little smaller than the sessile, staminate, awnless. fall.

In dry or moist soil, Maine and Ontario to Manitoba, Florida, Kansas and Texas. Summer and

22. Andropogon chrysocòmus Nash. Stems 7-15 dm. tall, the branches in 1's-3's: leaf-sheaths smooth and glabrous; blades $3 \mathrm{dm}$. long or less, $7 \mathrm{~mm}$. wide or less, smooth beneath, a little roughened above : racemes in 2's-4's, 5-9 cm. long, stout, longexserted, the hairs of the internodes and pedicels about $3 \mathrm{~mm}$. long, usually yellow : sessile spikelet about $1 \mathrm{~cm}$. long, with a basal ring of short hairs, the outer 2 scales hispid on the nerves, the awn of the fourth scale twisted at the base, geniculate, 10-12 $\mathrm{mm}$. long ; pedicellate spikelet awnless.

In dry soil, Kansas to Texas. Summer and fall. 
23. Andropogon Tennesseénsis Scribn. Stems 1-1.5 m. tall, stout, the branches in 1's or 2's: leaf-sheaths, at least the lower ones, hirsute toward the summit ; blades 6 $\mathrm{dm}$. long or less, 6-12 mm. wide, rough, the lower surface sometimes hirsute, and also the upper surface near the base : racemes in 2's-4's, 5-8 cm. long: sessile spikelet about 8.5 $\mathrm{mm}$. long, broadly lanceolate, twice as long as the hispidulous internode, the outer 2 scales strongly hispidulous, the awn of the fourth scale geniculate, about $1.5 \mathrm{~cm}$. long, twisted below, the column a little exserted ; pedicellate spikelet $8-10 \mathrm{~mm}$. long, of 4 scales, perfect, the outer 2 scales strongly hispidulous, the first often short-awned, the hispidulous pedicel less than $\frac{1}{2}$ as long as the sessile spikelet.

In dry soil, Tennessee and Mississippi. Fall.

24. Andropogon geminàtus Hack. Smooth and glabrous, glaucous. Stems 6-10 dm. tall, from long rootstocks : leaf-blades erect, rigid, long-acuminate, $3 \mathrm{dm}$. long or less, $9 \mathrm{~mm}$. wide or less : racemes in pairs, finally exserted, $3-5 \mathrm{~cm}$. long, rather slender, the hairs on the rachis-internodes and the pedicels grayish or yellowish white: sessile spikelet 6-8 $\mathrm{mm}$. long, the awn not twisted below, geniculate, $5-7 \mathrm{~mm}$. long; pedicellate spikelet about the same length, awnless.

In dry soil, Texas. Summer.

\section{AMPHILÒPHIS Nash.}

Perennial grasses, with usually flat leaf-blades and showy often silvery white panicles, the axis short, making the panicle appear fan-like, or elongated with the branches scattered. Racemes usually numerous, the internodes with manifestly thickened margins, the median portion thin and translucent, the pedicels of the same construction, the margins ciliate with usually long hairs. Sessile spikelets, of 4 scales, the first one 2-keeled, the second 1-keeled, the third and fourth scales hyaline, the latter very narrow, stipe-like, somewhat thickened, gradually merging into a usually geniculate contorted or spiral awn, or the awn rarely wanting. Pedicellate spikelets staminate and similar to the sessile, or sterile and smaller than them. Stamens 3. Styles distinct. Stigmas plumose.

First scale of the sessile spikelet not pitted on the back.

Axis of the panicle elongated, the branches scattered, the panicle hence linear to oblong; stem-nodes naked.

Sessile spikelets $3 \mathrm{~mm}$. long, the awn wanting or rarely present and then but short and not twisted.

Sessile spikelets $4 \mathrm{~mm}$. long, the awn long and geniculate, spiral at the base.

Axis of the panicle short, the branches congested, the panicle hence fan-like, oval or obovate; stem-nodes densely barbed.

First scale of the sessile spikelet with a deep pit-like impression on the back.

1. A. exaristatus.

2. A. Torreyanus.

3. A. barbinodis.

4. A. perforat us.

1. Amphilophis exaristàtus Nash. Smooth and glabrous. Stems 6-8 dm. tall, rather slender : leaf-blades $2 \mathrm{dm}$. long or less, 3-6 mm. wide, rough toward the apex : panicle 10-13 cm. long, $2-2.5 \mathrm{~cm}$. wide, oblong, its axis $8-10 \mathrm{~cm}$. long, the branches much divided, the ultimate divisions (racemes) $1-2 \mathrm{~cm}$. long, the terminal hairs $2-3$ times as long as the rachis-internodes: sessile spikelet $3 \mathrm{~mm}$. long, about $\frac{1}{2}$ again as long as the internode, the fourth scale almost wanting, or present as a mere rudiment, very rarely short-awned; pedicellate spikelet of a single scale, $2-3 \mathrm{~mm}$. long, the pedicel considerably shorter than the sessile spikelet. [Andropogon saccharoides submuticus Vasey, not A. submuticus Steud.]

In dry soil, Texas. Summer.

2. Amphilophis Torreyànus (Steud.) Nash. Smooth and glabrous, glaucous. Stems $5-10 \mathrm{dm}$. tall, simple or somewhat branched : leaf-blades 1-5 dm. long or less, 3-7 mm. wide, rough above : panicle $4-10 \mathrm{~cm}$. long, 7-20 mm. wide, linear to oblong, its axis 2-7 $\mathrm{cm}$. long, the longer branches somewhat divided, the ultimate divisions (racemes) $1-4 \mathrm{~cm}$. long, the terminal hairs $1 \frac{1}{2}-2$ times as long as the internodes: sessile spikelet $4 \mathrm{~mm}$. long, about $\frac{1}{2}$ again as long as the internode, the awn geniculate, more or less contorted, 10-15 $\mathrm{mm}$. long, spiral at the base, the column much exserted; pedicellate spikelet consisting of a single scale, $2-3 \mathrm{~mm}$. long, the pedicel shorter than the sessile spikelet.

In dry soil, Kansas to Arizona, Texas and Mexico. Summer.

3. Amphilophis barbinòdis (Lag.) Nash. Stems tufted, 5-10 dm. tall, simple or somewhat branched, the nodes densely barbed with silvery hairs: leaf-sheaths and their blades smooth and glabrous, the latter $2 \mathrm{dm}$. long or less, $2-8 \mathrm{~mm}$. wide, rough : panicle broadly oblong, ovate, oval or obovate, $5-12 \mathrm{~cm}$. long, finally exserted, its axis $2-5 \mathrm{~cm}$. long: racemes $2-15,3-5 \mathrm{~cm}$. long, the terminal hairs twice as long as the internodes: sessile spikelet $5-6 \mathrm{~mm}$. long, about $\frac{1}{2}$ again as long as the internode, the geniculate awn 2-3 cm. long, spiral at the base, the column much exserted ; pedicellate spikelet of a single awnless scale, 4-5 mm. long, the pedicel considerably shorter than the sessile spikelet.

In moist or rocky ground, central Texas to Arizona and Mexico. Summer and fall. 
4. Amphilophis perforàtus (Hack.) Nash. Stems tufted, $8-10 \mathrm{dm}$. tall, the nodes barbed: leaf-sheaths and blades smooth and glabrous, or the latter with the upper surface pubescent with long scattered hairs ; blades $2 \mathrm{dm}$. long or less, $2-4 \mathrm{~mm}$. wide : panicle 6-8 cm. long, fan-shaped, much exserted : racemes 5-8, 5-6 cm. long, the terminal hairs about as long as the internodes: sessile spikelet $5-5.5 \mathrm{~mm}$. long, the first scale with a deep depression on the back above the middle, the fourth scale with a geniculate awn 2-2.5 $\mathrm{cm}$. long, the column tightly spiral and much exserted; pedicellate spikelet of a single awnless seale about $3 \mathrm{~mm}$. long.

In dry soil, Texas and Mexico. Fall.

\section{SÓRGHUM Pers.}

Tall grasses, with usually broad flat leaf-blades and large terminal panicles, its primary branches verticillate. Spikelets of 4 scales, in pairs, or in 3's at the end of the branches, one sessile and perfect, the rest pedicellate and staminate, dorsally compressed, pubescent or glabrous. Sessile spikelets with the outer 2 scales indurated, the third and fourth hyaline, the latter awned or awnless. Pedicellate spikelets with the outer 2 scales firm-membranous, or rarely reduced to 1 or 2 scales and sterile. Lodicules ciliate. Stamens 3. Styles distinct. Stigmas plumose.

1. Sorghum Halepènse (L.) Pers. Smooth and glabrous. Stems 5-15 dm. tall, from a long rootstock : leaf-blades $5 \mathrm{dm}$. long or less, $0.5-3 \mathrm{~cm}$. wide : panicle $1.5-5 \mathrm{dm}$. long, oblong to oval, its branches ascending, the longer ones 7-14 cm. long : sessile spikelet $4.5-5.5 \mathrm{~mm}$. long, ovate, the outer 2 scales densely appressed-pubescent with silky hairs and indurated at maturity, the first scale 3 -toothed at the apex, the readily deciduous awn of the fourth scale $1-1.5 \mathrm{~cm}$. long, geniculate, spiral below, the column much exserted; pedicellate spikelet $5-7 \mathrm{~mm}$. long, lanceolate, the 2 outer scales sparingly pubescent.

In fields and waste places, Pennsylvania to Kansas, Florida and Texas. Summer and fall. JOHNSON-GRASS.

\section{SORGHÁSTRUM Nash.}

Usually tall perennial grasses, with flat leaf-blades and terminal panicles with the primary branches usually solitary and branched from the base, hence appearing as if whorled. Sessile spikelets dorsally compressed, of 4 scales, the outer 2 indurated, often hairy, the third and fourth scales hyaline, the latter long-awned, the awn spiral at the base. Pedicellate spikelets wanting, or very rarely present as a minute rudiment, usually only the hairy pedicels present, a single one at the side of each sessile spikelet, or 2, one on each side, at the end of the branches. Lodicules glabrous. Stamens 3. Styles distinct.

Stigmas plumose.

Awn but once bent, 1-1.5 cm. long, the closely spiral portion but little exserted beyond the scales.

Awn twice bent, $2-3 \mathrm{~cm}$. long, the closely spiral portion extending to the second bend and much exserted beyond the scales.

Branches of the panicle much exceeding the internodes of the axis, the ultimate divisions of its branches straight.

Branches of the one-sided panicle shorter than the internodes of the axis, the ultimate divisions of the branches much curved, the spikelets hence reflexed.

1. Sorghastrum nùtans (L.) Nash. Stems 1-2.5 m. tall : leaf-sheaths usually smooth and glabrous, or the lowermost ones sometimes pubescent; blades $6 \mathrm{dm}$. long or less, $13 \mathrm{~mm}$. wide or less, very rough : panicle $2-5 \mathrm{dm}$. long, loose, the apex usually nodding, its branches erect or nearly so, at least the lower ones much exceeding the internodes of the axis, 7-10 cm. long, the ultimate divisions straight : spikelet $6-8 \mathrm{~mm}$. long, lanceolate, the 2 outer scales golden brown and indurated at maturity, the first one densely pubescent with long erect hairs, the awn of the fourth scale geniculate, 1-1.5 $\mathrm{cm}$. long, closely spiral to the bend, thence loosely twisted, the column more or less exserted; pedicel from $\frac{1}{2}-\frac{2}{3}$ as long as the spikelet. [Sorghum avenaceum (Michx.) Chapm.]

In dry or moist soil, Ontario to Manitoba, Rhode Island, Florida, Texas and Arizona. Late summer and fall. INDIAN GRAss.

2. Sorghastrum Linnaeànum (Hack.) Nash. Stems 1-1.5 m. tall : leaf-sheaths smooth and glabrous; blades $4 \mathrm{dm}$. long or less, $1 \mathrm{~cm}$. wide or less, very rough : panicle 1.5-3 dm. long, the apex usually nodding, its branches erect or nearly so, at least the lower ones much exceeding the internodes of the axis, 6-8 cm. long, the ultimate divisions straight : spikelet $5.5-7.5 \mathrm{~mm}$. long, lanceolate, the 2 outer scales blackish brown and indurated at maturity, the first one densely pubescent with long erect hairs, the awn of the 
fourth scale twice bent, $2-3 \mathrm{~cm}$. long, closely spiral to the second bend, thence loosely twisted, the column very much exserted; pedicel from $\frac{2}{3}$ as long as the spikelet to nearly equalling it. [Sorghum nutans Chapm.]

In dry soil, South Carolina and Tennessee to Florida and Mississippi. Fall.

3. Sorghastrum secúndum (Ell.) Nash.. Stems 8-14 dm. tall : leaf-sheaths smooth and glabrous; blades $6 \mathrm{dm}$. long or less, $7 \mathrm{~mm}$. wide or less, smooth beneath, rough above, often involute: panicle 2-4 dm. long, one-sided, its branches erect or nearly so, rarely exceeding $4 \mathrm{~cm}$. in length, usually shorter than the internodes of the axis, the ultimate divisions much curved, making the spikelets reflexed: spikelet $6-8 \mathrm{~mm}$. long, lanceolate, the 2 outer scales golden brown and indurated at maturity, the first one pubescent with long erect hairs, the awn of the fourth scale twice bent, $2.5-3 \mathrm{~cm}$. long, closely spiral to the second bend, thence loosely twisted, the column very much exserted; pedicel from $\frac{1}{2}-\frac{2}{3}$ as long as the spikelet. [Sorghum secundum (Ell.) Chapm.]

In dry sandy soil, Georgia and Florida. Fall. WILD OATs.

\section{VETIVÈRIA Thouars.}

Tall grasses with simple stems, narrow leaf-blades and terminal panicles with the branches usually much articulated and disposed in dense whorls. Spikelets in pairs, narrow, acute, of 4 scales, the one sessile and perfect, the other pedicellate and staminate. Sessile spikelets usually somewhat laterally compressed, the first scale coriaceous or chartaceous, the margin inflexed or involute, the second awned or awnless, the third and fourth scales hyaline, the latter entire or shortly 2-toothed, mucronate or awned from between the teeth. Pedicellate spikelets usually awnless, rarely awned. Stames 3. Styles distinct. Stigmas plumose.

1. Vetiverla zizanioìes (L.) Nash. Stems $2 \mathrm{~m}$. tall or more : sheaths smooth and glabrous; blades $9 \mathrm{dm}$. long or less, 4-10 mm. wide : panicle $2-3 \mathrm{dm}$. long, its slender ascending or nearly erect branches in dense whorls and readily disarticulating at the nodes : sessile spikelet about $4 \mathrm{~mm}$. long, about as long as the internode, the first scale minutely tuberculate-roughened, 2-keeled, the keels muricate, the second scale 1-keeled, the keel muricate, the fourth scale awnless or short-awned, the awn not exserted beyond the 2 outer scales ; pedicellate spikelet about as long as or a little shorter than the sessile, the 2 outer scales sparingly muricate.

Cultivated and escaping into fields in Louisiana. Fall.

\section{RHÀPHIS Lour.}

Perennial or rarely annual "grasses, with narrow leaf-blades and terminal panicles, whose branches usually bear clusters of 3 spikelets, or very rarely more, at the end, one spikelet sessile and perfect, the other 2 staminate or sterile and pedicellate. Sessile spikelets usually somewhat laterally compressed, of 4 scales, the first scale broadly involute, the second somewhat distinctly keeled, and usually awned, the third and fourth scales hyaline, the latter usually awned. Pedicellate spikelets dorsally compressed, awnless or awned. Stamens 3. Styles distinct. Stigmas plumose.

1. Rhaphis pauciflòrus (Chapm.) Nash. Annual. Stems 6-12 dm. tall, simple or somewhat branched: leaf-blades $2 \mathrm{dm}$. long or less, 2-10 $\mathrm{mm}$. wide, papillose-hirsute above : panicle 2-3 dm. long, its branches erect or ascending, slender, the lower in whorls of $2-5$, rarely divided, the longer, exclusive of the spikelets and awn, $5-8 \mathrm{~cm}$. long: sessile spikelet about $15 \mathrm{~mm}$. long, including the 6-7 $\mathrm{mm}$. long and densely pubescent callus, cylindric or slightly laterally compressed, the first and second scales dark brown, shining and coriaceous at maturity, hispidulous at the apex, the fourth scale emitting a flexuous more or less contorted usually geniculate awn 14-16 $\mathrm{cm}$. long; pedicellate spikelet 10-12 $\mathrm{mm}$. long, on slender pedicels about reaching the apex of the sessile spikelet, empty or containing a staminate flower. [Sorghum pauciflorum Chapm.]

In dry sandy soil, eastern and peninsular Florida. Also in Cuba. Fall.

\section{HETEROPÒgON Pers.}

Annual or perennial grasses, sometimes tall, with narrow leaf-blades and compressed sheaths, and terminal solitary dense racemes. Spikelets 1-flowered, in pairs at the rachisnodes, one sessile and fertile, the other pedicellate, containing a staminate flower, or empty. Scales of the sessile spikelets 4 , the outermost empty, firm, convolute, awnless, the second also empty, thinner, keeled, the third scale very thinly hyaline, likewise empty, the 
fourth scale, enclosing a pistillate flower, small and hyaline and bearing a long rigid contorted and geniculate awn; palet small and hyaline, or wanting. Pedicellate spikelet awnless, the outermost scale thinner than the corresponding one in the sessile spikelet. Stamens 3. Styles distinct. Stigmas plumose.

Upper sheaths tuberculate along the keel and the first scale of the pedicellate spikelet on the midnerve, the latter $1.5 \mathrm{~cm}$. long or more and glabrous.

Upper sheaths and the first scale of the pedicellate spikelet smooth all over, the

latter $1 \mathrm{~cm}$. long or less, papillose-hispid toward the summit and near the margins.

1. H. melanocarpus.

1. Heteropogon melanocárpus (Muhl.) Ell. Annual. Stems 4-15 dm. tall, much branched above : upper leaf-sheaths at least tuberculate on the keel; blades $5 \mathrm{dm}$. long or less, 3-12 $\mathrm{mm}$. wide : racemes 3-6 $\mathrm{cm}$. long, exserted, or included at the base, the peduncles pilose with ascending hairs, the internodes between the upper spikelets densely pubescent with long chestnut-brown hairs : sessile spikelet $5-6 \mathrm{~mm}$. long, the awn 9-15 cm. long ; pedicellate spikelet $15-22 \mathrm{~mm}$. long, sterile or staminate, the first scale long-acuminate, tuberculate on the midnerve. [H. acuminatus Trin.]

In cultivated grounds. South Carolina to Florida, Texas, Arizona and Mexico. Also in tropical America. Summer and fall.

2. Heteropogon contórtus (L.) Beauv. Perennial. Stems $2-8 \mathrm{dm}$. tall, rather sparingly branched above : leaf-sheaths smooth, even on the keel; blades $2 \mathrm{dm}$. long or less, 3-7 mm. wide : racemes 4-6 $\mathrm{cm}$. long, exserted, or included at the base, the peduncles hispidulous, the internodes between the upper spikelets densely pubescent with long nearly appressed chestnut-brown hairs : sessile spikelet $5-6 \mathrm{~mm}$. long, the awn $4.5-8 \mathrm{~cm}$. long; pedicellate spikelet about $1 \mathrm{~cm}$. long, sterile or staminate, the first scale acute, papillosehispid toward the summit and near the margins with long hairs.

In dry soil, southern and western Texas to Arizona and Mexico. Widely distributed in the warmer parts of all countries. Spring to fall.

\section{HILÀRIA H.B.K.}

Stoloniferous grasses, decumbent and branching at the base, with flat or convolute leaf-blades and spicate inflorescence. Spiklets in sessile deciduous crowded clusters of 3, the empty scales resembling an involucre, the central spikelet 1 -flowered, the flower pistillate or perfect, the lateral spikelets 2 -flowered, the flowers staminate. Scales 4 , the 2 outer empty, rigid, thin or indurated, the first the larger and varying much in shape, entire or 2-cleft at the toothed or lacerate apex, awnless, or bearing an awn between the lobes, the second scale narrower, often keeled, entire or 2-toothed at the apex, awnless, mucronate, or short-awned ; third and fourth scales thin-membranous, entire or toothed at the apex, each in the lateral spikelets enclosing a palet and a flower, in the central spikelet the third scale is empty. Stamens 3. Styles a little united at the base. Stigmas shortly plumose. Outer scales of the spikelet linear or oblong, the nerves parallel, some of them awned. 1 . H. Texana. Outer scales of the spikelet cuneate, the nerves strongly diverging above, awnless.

1. H. Texana.

1. Hilaria Texàna (Vasey) Nash. Creeping by arched stolons. Stems 1-2.5 dm. tall : basal leaves numerous ; blades $1-5 \mathrm{~cm}$. long and about $2 \mathrm{~mm}$. wide, very rough, pubescent, the upper surface densely so with short hairs, the lower surface with a few long hairs : spike 2-3 cm. long, of 4-8 spikelets, which are 4-5.5 mm. long, each cluster naked at the base.

On hills and plains, central Texas to Arizona. Spring and summer. Creeping Mesquite.

2. Hilaria mùtica (Buckl.) Benth. Stems rigid, 2-6 dm. tall, from rootstocks : leafblades erect, firm, $1 \mathrm{dm}$. long or less, $2-4 \mathrm{~mm}$. wide : spike $4-6 \mathrm{~cm}$. long : spikelets many, crowded, usually overlapping, 6-7 mm. long.

On plains and prairies, Texas to Arizona. Also in Mexico. Summer and fall. Black Grams.

\section{NÀZIA Adans.}

An annual grass, with flat leaf-blades and racemose or spike-like inflorescence. Spikelets articulated below the empty scales, 1-flowered, solitary, or in clusters of 3-5. Scales 2 or 3, the first small, or sometimes wanting, the second firm, with its nerves dorsally armed with hooked prickles, the third scale membranous, subtending a hyaline palet and a perfect flower. Stamens 3. Styles short, distinct. 'Stigmas moderately long, plumose.

1. Nazia alièna (Spreng.) Scribn. Tufted. Stems finally prostrate and rooting and branching at the lower nodes, 1-3 dm. tall: leaf-blades ciliate on the margin : spike 4-10 $\mathrm{cm}$. long: spikelets about $2.5 \mathrm{~mm}$. long.

On dry hillsides, Texas to Arizona. Also in Central and South America, and the West Indies. Spring and fall. 
18. LIMNÒdEA L. H. Dewey.

Somewhat branched tufted grasses, with the stems usually decumbent at the base, narrow flat leaf-blades, and narrow slender elongated contracted panicles. Spikelets 1-flowered, narrow, scattered on the panicle branches. Scales 3 , the 2 outer empty, about equal in length, hispidulous or pilose, the nerves inconspicuous, the third scale scarcely shorter, thin, the apex shortly 2-toothed or 2-cleft, with an elongated slender genieulate or flexuous awn, which is a little twisted at the base, arising from between the teeth, the scale enclosing a somewhat shorter 2-keeled narrow hyaline palet and a perfect flower. Stamens 3 . Styles short, distinct. Stigmas shortly pilose. [Thurberia Benth., not A. Gray.]

1. Limnodea Arkansàna (Nutt.) L. H. Dewey. Stems tufted, $2-4 \mathrm{dm}$. tall : leafsheaths glabrous or more or less hirsute ; blades erect, $3-12 \mathrm{~cm}$. long, $2-8 \mathrm{~mm}$. wide, more or less pubescent on both surfaces : panicle narrow, often partially included at the base, 7-17 cm. long: spikelets $3.5-4 \mathrm{~mm}$. long, the 2 outer scales tuberculate-hispidulous, the awn of the third scale geniculate, spiral at the base, $8-10 \mathrm{~mm}$. long. [Thurberia Arkansana (Nutt.) Benth.]

In dry soil, Florida, Arkansas and Texas. Spring.-A form known as L. Arkansana pilòsa (Trin.) Nash (Sclerachne pilosa Trin.) is like the preceding, but the two outer scales are densely hirsute. It occurs in Louisiana and Texas.

\section{REIMÀriA Fluegge.}

Perennial grasses, usually diffusely branching, with ascending stems, and the inflorescence composed of 2 or more secund racemes. Spikelets 1-flowered, awnless, acuminate, subsessile, alternately disposed in 2 rows on a narrow or somewhat dilated rachis. Scales 2 , the first empty, membranous, 3-5-nerved, acute, the second scarcely shorter and enclosing the slightly shorter palet and a perfect flower. Stamens 2. Styles distinct to the base. Stigmas long-plumose.

1. Reimaria oligostáchya Munro. Smooth and glabrous. Stems compressed, 4-8 dm. long: leaf-sheaths compressed; blades erect or ascending, 5-15 cm. long, 2-4 mm. wide : racemes one-sided, in pairs at the summit of the stem, or sometimes with an additional one a short distance below, $5-7 \mathrm{~cm}$. long: spikelets broadly lanceolate, about $5 \mathrm{~mm}$. long, about twice as long as the rachis-internodes, the first scale 9-nerved, the four nerves on each side close together and rather distant from the midnerve.

Along shores and in ditches, Florida. Summer.

\section{PÁSPALUM L.}

Usually perennial grasses with flat leaf-blades and an inflorescence composed of one or more unilateral racemes, arranged singly, in pairs, or in panicles. Spikelets 1-flowered, obtuse, or rarely short-acuminate, nearly sessile or short-pedicelled, alternately disposed, singly or in pairs, in 2 rows on one side of a narrow and usually winged rachis. Scales 3 , rarely 4 , the 2 outer, rarely 3 , empty, membranous, usually equal in length, the flowering scales glabrous and shining, more or less convex, with its back turned toward the rachis, at length indurated, enfolding a shorter palet of similar texture and a perfect flower. Stamens 3. Styles distinct to the base, often elongated. Stigmas plumose.

A. Rachis dilated, its broad margins membranous and at maturity inrolled on the spikelets.

Rachis long-acuminate, extending beyond the spikelets which are 1.5 $\mathrm{mm}$. long or less.

Rachis acute, not extended; spikelets about $2 \mathrm{~mm}$. long or more.

B. Rachis more or less winged, rarely wingless, its margins not membranous nor enclosing the spikelets.

a. Stems with 1-several raceme-bearing naked branches from the uppermost sheath.

1. Leaf-blades glabrous on the lower surface, or the midnerve sometimes pubescent.

*Blades conspicuously ciliate.

Uppermost sheath with the margins glabrous.

Spikelets glabrous, or nearly so, rounded at the apex. Spikelets densely pubescent, obtusely apiculate at the apex.

Uppermost sheath with the overlapping margin prominently ciliate.

Spikelets orbicular, hence as broad as long, straw-color.

Spikelets broadly obovate to oval, longer than broad, green.

Spikelets densely pubescent, $2 \mathrm{~mm}$. long, the leaves scattered along the stem.

1. P. mucromatum.

2. P. membranaceum.

3. P. blepharophyllum.

4. P. propinquım.

5. P. stramineum.

6. P. Chapmanii. 
Spikelets glabrous :

$2 \mathrm{~mm}$. long: leaves scattered along the stem.

$1.5 \mathrm{~mm}$. long: leaves crowded at the base of the stem:

Upper surface of the blades glabrous ; marginal hairs less than $1 \mathrm{~mm}$. long.

Upper surface of the leaves pubescent with short hairs; marginal hairs about $2 \mathrm{~mm}$. long.

**Blades naked on the margins, or rarely with a few scattered hairs. Racemes 1-3.

Uppermost sheath pubescent on the overlapping margin.

Leaf-blades lanceolate; spikelets orbicular-obovate, the first and second scales strongly pubescent.

Leaf-blades linear, rigid, long and narrow; spikelets oval, the first scale sparingly pubescent.

Uppermost sheath glabrous on the margin.

Spikelets glabrous.

Spikelets with the first scale pubescent.

Leaf-blades linear, narrow, becoming involute; spikelets elliptic.

Leaf-blades linear-lanceolate, broad, flat; spikelets

Racemes 6-12. broadly obovate.

2. Leaf-blades very pubescent on both surfaces.

Stem long-hirsute below the raceme; basal sheaths glabrous or nearly so.

Stem glabrous throughout; basal sheaths usually hirsute.

Spikelets 1-1.5 mm. long.

Stems slender; blades narrow and scattered.

Stems stout; blades broad, crowded at the base; pubescence very long and copious.

Spikelets 2-2.25 mm. long.

Raceme on the main stem 1 , or sometimes 2 together; spikelets glabrous; leaf-blades not thick.

Racemes on the main stem 2 or 3 ; spikelets usually more or less pubescent; leaf-blades thick.

b. Stems simple, no raceme-bearing branches from the uppermost sheath.

1. Racemes 2-several, scattered, never in pairs.

*Stems tufted.

†Spikelets rounded or obtuse at the apex, not ciliate on the margins.

SSpikelets convex on one side.

Spikelets $3 \mathrm{~mm}$. long or less.

Spikelets singly disposed.

Spikelets oval, $1 / 2$ as thick as broad or more, the outer scales firm.

Spikelets $2 \mathrm{~mm}$. long, the flowering scale deep seal brown at maturity.

Spikelets $2.5 \mathrm{~mm}$. long, the flowering scale yellowish white at maturity.

Leaf-sheaths glabrous.

Blades short; racemes usually 2 or 3 .

Blades elongated ; racemes usually 3-5.

Leaf-sheaths hirsute, at least on the margins.

Blades short, glabrous on the lower surface.

Sheaths hirsute only on the margins, or the basal ones sometimes sparingly so on the surface.

Sheaths broad and much compressed, densely hirsute all over with very long weak hairs.

Blades elongated, more or less hirsute on both surfaces.

Spikelets circular or nearly so, about $1 / 3$ as thick as broad, the outer scales very thin.

Spikelets in pairs.

Mature flowering scale white or yellowish.

Spikelets $2 \mathrm{~mm}$. long or less; stems slender.

Spikelets obovate, $1.5 \mathrm{~mm}$. long, pubescent with spreading glandular-tipped hairs.

Spikelets elliptic, $2 \mathrm{~mm}$. long, sparsely pubescent with long appressed hairs.

Spikelets 2.5-3 mm. long; stems usually stout. Spikelets pubescent.

Spikelets glabrous.

Stems rooting at the lower nodes; blades thin, long; racemes $4-8$.

Stems not rooting at the lower nodes; blades firm, short; racemes 3 , rarely 4 .

Mature flowering scale deep seal brown.

Rachis broadly winged, wider than the spikelets which are about $2 \mathrm{~mm}$. long.

Rachis narrowly winged, much narrower than the spikelets which are $2.5-3 \mathrm{~mm}$. long.

Spikelets more than $3 \mathrm{~mm}$. long.

Racemes long and strictly erect, or short and ascending.

Leaf-blades short; racemes short and ascending.

Sheaths glabrous or nearly so.

Sheaths densely hirsute.

7. P. ciliatifolium.

8. P. Kentuckiense.

9. P. longepedunculatum.

10. P. Eggertii.

11. P. rigidifolium.

12. P. epile.

13. P. elatum.

14. P. latifolium.

15. P. gracillimum.

16. P. pubescens.

18. P. setaceum.

19. P. villosissimum.

17. P. Muhlenbergii.

20. P. dasyphyllum.

21. P. scrobiculatum

22. P. laeve

23. P. angustifolium.

24. P. australe.

25. P. longipilum.

26. P. praelongum.

27. $P$. circulare.

28. P. Simpsonii.

29. P. Blodgettii.

30. P. Hallii.

31. P. laeviglumis.

32. P. geminum.

33. P. Boscianum.

34. P. plicatulum.

35. P. difforme.

36. P. altissimum. 
Leaf-blades elongated; racemes long and erect.

Sheaths glabrous

Sheaths densely hirsute.

Racemes finally widely spreading.

Sheaths glabrous; blades glabrous or ciliate with short hairs.

Sheaths densely hirsute; blades ciliate with long hairs.

z?Spikelets flat, barely if at all convex on one side.

Spikelets pubescent.

Spikelets glabrous.

Sheaths, excepting the exterior basal ones, glabrous, or the lower sometimes pubescent at the summit.

Stems and sheaths much compressed, the former rather slender.

Spikelets elliptic.

Spikelets orbicular or nearly so.

Leaf-blades glabrous.

Spikelets $2-2.5 \mathrm{~mm}$. long.

Spikelets $3 \mathrm{~mm}$. long.

Leaf-blades hirsute:

On the upper surface only : spikelets circular or nearly so.

On both surfaces, strongly so on the lower: spikelets broadly obovate.

Stems and sheaths not much compressed, the former stout.

Sheaths densely hirsute.

†TSpikelets acute, ciliate with very long hairs.

Spikelets about $2.5 \mathrm{~mm}$. long ; racemes numerous (usually 10 or more).

Spikelets 3.5-4 mm. long ; racemes few to several (usually less than 8).

**Stem single, from a long scaly rootstock.

Scales of the rootstock appressed-pubescent: rachis of the racemes not winged, the spikelets scattered.

Scales of the rootstock glabrous: rachis of the racemes winged, the spikelets crowded.

2. Racemes in pairs at the summit of the stem, rarely in 3's or with another raceme below.

Stems tufted : racemes long and slender, the spikelets about $1.5 \mathrm{~mm}$. long.

Stems from long rootstocks : racemes short and stout, the spikelets exceeding $2 \mathrm{~mm}$. long.

Spikelets ovate, $2.5-3 \mathrm{~mm}$. long, pubescent; midnerve of the second scale present.

Spikelets ovate-lanceolate, $3-4 \mathrm{~mm}$. long, glabrous; midnerve of the rugose second scale suppressed.

37. P. glabratum.

38. P. Floridanum.

39. P. giganteum.

40. P. longicilium.

41. P. Buckleyanum.

42. P. lividum.

43. P. praecox.

44. P. glaberrimum.

45. P. tardum.

46. P. Kearneyi.

47. P. amplum.

48. P. Curtisianum.

49. P. Vaseyanum.

50. P. dilatatum.

51. P. bifidum.

52. P. solitarium.

53. P. conjugatum.

54. P. distichum.

55. P. vaginatum.

1. Paspalum mucronàtum Muhl. Stems 1.5-8 dm. long, compressed, from a floating or creeping base, branched : leaf-sheaths loose or inflated, glabrous or hirsute ; blades 8-30 cm. long, 6-25 mm. wide, acuminate, rough : racemes $20-100$, scattered, or sometimes apparently whorled, 1-8 cm. long, slender, spreading, the rachis extending in an acuminate point beyond the spikelets, the wings membranous and nearly enclosing the spikelets at maturity : spikelets singly disposed in two rows, elliptic, 1.2-1.5 mm. long and about $0.6 \mathrm{~mm}$. wide, pubescent. [P. fluitans Kunth.] Fall.

In water, Virginia to southern Illinois, Missouri, Florida and Texas. Also in tropical America.

2. Paspalum membranàceum Walt. Stems sometimes $6-8 \mathrm{dm}$. long, compressed, creeping at the base, much branched : leaf-sheaths compressed, loose; blades $3-8 \mathrm{~cm}$. long, 4-6 mm. wide, smooth : racemes $3-7$, erect, $2-3 \mathrm{~cm}$. long, the rachis not extending beyond the spikelets, the wings broad and nearly enclosing the spikelets at maturity: spikelets singly disposed in two rows, $2-2.3 \mathrm{~mm}$. long and $1.3-1.5 \mathrm{~mm}$. wide, oval, glabrous. [P. Walterianum Schult. $]$

In moist or wet soil, New Jersey and Delaware to southern Ohio, Florida and Texas. Fall.

3. Paspalum blepharophýllum Nash. Stems tufted, 4-8 dm. tall : leaf-sheaths glabrous, even on the margins ; blades linear-lanceolate to lanceolate, glabrous on both surfaces, ciliate on the margins, $2.5 \mathrm{dm}$. long or less, $8-16 \mathrm{~mm}$. wide : racemes usually single, commonly 6-8 cm. long, sometimes longer : spikelets in pairs, $2 \mathrm{~mm}$. long and 1.3-1.6 mm. wide, broadly obovate or oval, the first scale 3 -nerved, usually pubescent with short hairs, the second seale 3-nerved, or sometimes 2-nerved by the suppression of the midnerve, glabrous.

In sandy soil, Florida to Louisiana. Spring and summer.

4. Paspalum propínquum Nash. Stems tufted, 8-10 dm. tall : basal leaf-sheaths pubescent, the remaining ones glabrous; blades glabrous on both surfaces, ciliate on the margins with stiff hairs, linear, erect or nearly so, $5-20 \mathrm{~cm}$. long, $5-10 \mathrm{~mm}$. wide : racemes rather slender, 8-12 cm. long, in 1's or 2's : spikelets in pairs, on shorter pubescent pedi- 
cels, oval, about $1.8 \mathrm{~mm}$. long and $1.5 \mathrm{~mm}$. wide, obtusely apiculate at the apex, the outer 2 scales densely pubescent with short spreading glandular-tipped hairs, the first scale 3nerved, the second usually 2 -nerved by the suppression of the midnerve.

In dry sandy soil, peninsular Florida. Summer.

5. Paspalum stramíneum Nash. Foliage light yellowish green, the spikelets, and sometimes also the sheaths, pale straw color. Stems tufted, $2-8 \mathrm{dm}$. tall : basal leaf-sheaths softly and densely pubescent, the remaining sheaths glabrous, excepting on the margins; blades erect or nearly so, firm, linear to lanceolate, long-ciliate on the margins, otherwise glabrous except usually on the midnerve beneath, $5-25 \mathrm{~cm}$. long, $5-10 \mathrm{~mm}$. wide : racemes 4-10 $\mathrm{cm}$. long, on the main stem usually 2 , rarely 1 or 3 , single on the branches : spikelets in pairs, on shorter pubescent pedicels, orbicular, $2 \mathrm{~mm}$. in diameter, the first scale 3 -nerved, pubescent with short spreading glandular-tipped hairs, the second scale glabrous or nearly so, 2-nerved, the midnerve suppressed.

In sandy places and fields, Nebraska, Kansas and the Indian Territory. Summer and fall.

6. Paspalum Chapmánii Nash. Stems tufted, $8-10 \mathrm{dm}$. tall : basal leaf-sheaths pubescent, the remaining ones glabrous except on the margins; blades glabrous on both surfaces, the margins ciliate, lanceolate to linear-lanceolate, rather thin, $7-20 \mathrm{~cm}$. long, 7-14 mm. wide : racemes $10-12 \mathrm{~cm}$. long, rather slender, usually in 2's on the main stem, single on the branches: spikelets in pairs on shorter pubescent pedicels, oval, $2.2 \mathrm{~mm}$. long and about $1.8 \mathrm{~mm}$. broad, the 2 outer scales densely pubescent with short spreading glandular-tipped hairs, 3-nerved, or the second often 2-nerved by the suppression of the midverve.

In dry sandy soil, Florida. Summer.

7. Paspalum ciliatifòlium Michx. Stems tufted, erect, 4-8 dm. tall, smooth and glabrous : leaf-sheaths ciliate on the overlapping margin, otherwise glabrous; blades 5-25 cm. long, 6-15 mm. wide, smooth and glabrous on both surfaces, the margins conspicuously ciliate with long hairs: racemes single, or sometimes in 2's, $5-11 \mathrm{~cm}$. long: spikelets in pairs, 1.8-2.1 mm. long and $1.5-1.8 \mathrm{~mm}$. broad, oval to broadly obovate, the 2 outer scales 3-nerved or the second one rarely 2 -nerved by the suppression of the midnerve, both the scales glabrous.

In sandy or rocky soil, District of Coiumbia to Alabama and Mississippi. Summer and fall.

8. Paspalum Kentuckiénse Nash. Stems tufted, $2-5 \mathrm{dm}$. tall, slender: leaf-sheaths ciliate on the overlapping margin, otherwise glabrous; blades erect, lanceolate, $6 \mathrm{~cm}$. long or less, 4-10 mm. wide, glabrous on both surfaces, ciliate on the margins with hairs less than $1 \mathrm{~mm}$. long: racemes single or in pairs, $2-5 \mathrm{~cm}$. long: spikelets about $1.6 \mathrm{~mm}$. long and about $1.3 \mathrm{~mm}$. wide, the scales glabrous, the first scale 3-nerved, the second one usually 2 -nerved by the suppression of the midnerve.

In dry soil, Kentucky and Tennessee. Summer.

9. Paspalum longepedunculàtum Le Conte. Stems tufted, 2.5-8 dm. tall, smooth and glabrous : leaf-sheaths glabrous excepting on the pilose margins, crowded towards the base of the stem : blades $2.5-9 \mathrm{~cm}$. long, rarely a little longer, 4-9 $\mathrm{mm}$. broad, smooth and glabrous below, pubescent above with short appressed hairs, conspicuously ciliate on the margins, the hairs about $2 \mathrm{~mm}$. long: racemes in 1's or 2's, $2.5-8 \mathrm{~cm}$. long: spikelets in pairs, 1.5-1.8 mm. long, 1-1.2 mm. wide, broadly obovate, glabrous, the first scale 3-nerved, the second 2-nerved by the suppression of the midnerve which is rarely present.

In sandy or rocky soil, Georgia and Florida. Summer and fall.

10. Paspalum Eggértii Nash. Stems tufted, 3-5 dm. tall : basal leaf-sheaths pubescent, the remainder ciliate on the overlapping margin but otherwise glabrous ; blades lanceolate, glabrous on both surfaces and on the margins, $10 \mathrm{~cm}$. long or less, 4-8 $\mathrm{mm}$. wide : racemes single or in pairs, 4-6 cm. long : spikelets in pairs, a little exceeding $2 \mathrm{~mm}$. long and about $1.5 \mathrm{~mm}$. wide, oval, the first scale strongly pubescent with short spreading hairs, 3 -nerved, the second scale usually 2-nerved by the suppression of the midnerve, sparingly pubescent with similar hairs.

On sandy ridges, Arkansas. Fall.

11. Paspalum rigidifòlium Nash. Stems tufted, erect, $3-8 \mathrm{dm}$. tall, smooth and glabrous : basal leaf-sheaths softly pilose with rather long spreading hairs, the remaining ones glabrous ; blades erect or ascending, rigid, linear, glabrous, $7-20 \mathrm{~cm}$. long, 3-7 mm. wide : racemes single, or rarely in 2's, 6-13 cm. long: spikelets in pairs, on shorter glabrous or nearly glabrous pedicels, $2.3-2.5 \mathrm{~mm}$. long, $1.7-2 \mathrm{~mm}$. wide, oval or broadly obovate, the first scale more or less pubescent with spreading hairs, 5-nerved, the second scale glabrous, 5-nerved, or sometimes 4-nerved by the suppression of the midnerve.

In dry sandy soil, peninsular Florida. Spring.

12. Paspalum épile Nash. Whole plant glabrous. Stems 6-8 dm. tall : leafblades thick, firm, linear-lanceolate, $2 \mathrm{dm}$. long or less, $7-10 \mathrm{~mm}$. wide : racemes single or 
in pairs, $6-10 \mathrm{~cm}$. long: spikelets in pairs, $2 \mathrm{~mm}$. long and about $1.5 \mathrm{~mm}$. wide, broadly obovate, the first scale 3 -nerved, the second one generally 2 -nerved by the suppression of the midnerve.

In sand, Key West, Florida. Spring to fall.

13. Paspalum elàtum L. C. Rich. Stems 6-8 dm. tall: leaf-sheaths glabrous; blades $3 \mathrm{dm}$. long or less, $2-6 \mathrm{~mm}$. wide, densely pubescent with long hairs above at the very base, otherwise glabrous : racemes in 3's, 10-13 cm. long : spikelets on hispidulous pedicels, elliptic, about $2.2 \mathrm{~mm}$. long and $1.3 \mathrm{~mm}$. wide, the 2 outer scales 3 -nerved, the first scale pubescent with long appressed hairs, the second one glabrous.

In sandy soil, Key West, Florida. Also in tropical America. Spring to fall.

14. Paspalum latifòlium Le Conte. Stems tufted, $6-8 \mathrm{dm}$. tall : leaf-sheaths smooth and glabrous, or the basal ones a little pubescent; blades $1.5-3 \mathrm{dm}$. long, or the uppermost often shorter, 1-2 cm. wide, rather thin, lanceolate to linear-lanceolate, glabrous, or some of them occasionally with a few scattered hairs on the margins near the base : racemes on the main stem usually in pairs, rarely single, those on the branches single, $6-12 \mathrm{~cm}$. long: spikelets in pairs, on shorter puberulent pedicels, about $2 \mathrm{~mm}$. long and 1.5-1.7 mm. wide, broadly obovate, the first scale 3-nerved, pubescent with short spreading hairs, the second scale 3-nerved, or rarely 5-nerved, glabrous.

In dry usually shady places, Georgia and Florida. Spring and summer.

15. Paspalum gracíllimum Nash. Stems slender, $4-6 \mathrm{dm}$. tall : leaf-sheaths smooth and glabrous : blades (the upper ones) $1.5 \mathrm{dm}$. long or less, $2-7 \mathrm{~mm}$. wide, flat, a ring of long hairs just above the ligule, otherwise glabrous : racemes $6-10$, usually alternate, widely spreading, slender, $3-7 \mathrm{~cm}$. long: spikelets in pairs, obovate, $1.4 \mathrm{~mm}$. long and 0.9 $\mathrm{mm}$. wide, the 2 outer scales 3 -nerved, the first scale pubescent with short glandular-tipped hairs, the second scale glabrous, the third scale about $\frac{1}{2}$ as thick as broad.

In sandy soil, Key West, Florida. Spring to fall.

16. Paspalum pubéscens Muhl. Stems tufted, 4-8 dm. tall, long-hirsute below the racemes: leaf-sheaths glabrous, or sometimes pubescent on the margins or toward the apex, the basal ones sometimes pubescent all over; blades 4-23 cm. long, 3-6 mm. wide, rarely broader, densely pubescent on both surfaces with long spreading rather stiff hairs arising from papillae, if ciliate on the margins the hairs short : racemes usually 1, rarely 2 on the main stem, generally straight, or sometimes a little curved, 6-12 cm. long, rarely shorter : spikelets in pairs, glabrous, on shorter puberulent pedicels, about $2 \mathrm{~mm}$. long and 1.5-1.8 $\mathrm{mm}$. wide, broadly obovate, the 2 outer scales 3 -nerved, or the second 2 -nerved by the suppression of the midnerve, the flowering scale triangular in cross-section, the angles rounded, about two-thirds as thick as broad.

In fields, New York and New Jersey to Pennsylvania, District of Columbia and Tennessee. Summer and fall.

17. Paspalum Muhlenbérgii Nash. Stems tufted, at first erect, finally reclining, 4-8 dm. tall, smooth and glabrous : leaf-sheaths generally pubescent all over with long hairs or sometimes only on the margins; blades $0.5-2 \mathrm{dm}$. long, rarely longer, usually 7-11 mm. wide, or sometimes narrower, ciliate on the margins with usually long hairs, more or less pubescent on both surfaces with long hairs : racemes in 1's or 2's, straight or curved, $5-10 \mathrm{~cm}$. long: spikelets in pairs, glabrous, on shorter puberulent pedicels, about $2 \mathrm{~mm}$. long and $1.8 \mathrm{~mm}$. wide, oval or broadly obovate, the 2 outer scales 3 -nerved, or the second rarely 2-nerved by the suppression of the midnerve, the flowering scale triangular in eross-section, the angles rounded, about $\frac{1}{2}$ as thick as broad.

In fields or in sandy or stony ground, Massachusetts to Missouri and the Indian Territory, South Carolina, Georgia and Mississippi. Late summer and fall.

18. Paspalum setàceum Michx. Stems tufted, slender, $2-7 \mathrm{dm}$. tall : basal leafsheaths densely pubescent with long hairs, the upper ones only on the margins; blades $3-14 \mathrm{~cm}$. long, rarely somewhat longer, usually $2.5-5 \mathrm{~mm}$. wide, sometimes a little broader, linear, strict and erect or ascending, densely pubescent on both surfaces with long hairs : racemes single, slender, 4-8 $\mathrm{cm}$. long, sometimes a little longer : spikelets either single or in pairs, on shorter puberulent pedicels, about $1.5 \mathrm{~mm}$. long and about $1.3 \mathrm{~mm}$. wide, broadly obovate, the first scale 3-nerved, pubescent with spreading glandular-tipped hairs, the second scale 2-nerved, the midnerve rarely, if ever, present, glabrous or occasionally pubescent.

In dry sandy soil, southeastern New York to Florida, west to Mississippi. Summer and fall.

19. Paspalum villosíssimum Nash. Plant yellowish gray-green. Stems tufted, erect, 4-10 dm. tall : leaf-sheaths crowded at the base of the stem, very densely pubescent, as well as both surfaces of the blades, with very long white spreading hairs; blades erect or ascending, thick, lanceolate, $2 \mathrm{dm}$. long or less, $6-10 \mathrm{~mm}$. broad : racemes single or in 
pairs, 5-9 $\mathrm{cm}$. long : spikelets in pairs, on shorter puberulent pedicels, about $1.8 \mathrm{~mm}$. long and about $1.5 \mathrm{~mm}$. wide, broadly obovate, the 2 outer scales densely pubescent with spreading glandular-tipped hairs, the first scale 3-nerved, the second 2-nerved, or the midnerve very rarely present.

In dry sandy soil, peninsular Florida. Summer.

20. Paspalum dasyphýllum Ell. Plant yellowish green. Stems tufted, stout, 2-6 dm. tall : leaf-sheaths, as well as both surfaces of the blades, densely pubescent with long yellowish spreading hairs; blades erect or ascending, thick, lanceolate, $2 \mathrm{dm}$. long or less, usually 1-2 $\mathrm{cm}$. broad, sometimes a little narrower: racemes on the main stem in 2's or 3 's, those on the branches single, 4-10 $\mathrm{cm}$. long : spikelets in pairs, on shorter puberulent pedicels, $2-2.2 \mathrm{~mm}$. long and about $1.8 \mathrm{~mm}$. wide, broadly obovate, the first scale usually more or less pubescent with spreading glandular-tipped hairs, 3-nerved, the second scale glabrous, usually 2-nerved or sometimes 3-nerved.

In dry usually sandy places, South Carolina to Florida; also in Missouri. Summer.

21. Paspalum scrobiculàtum L. Glabrous. Stems densely tufted, $2-6 \mathrm{dm}$. tall : leaf-blades erect, flat, $1 \mathrm{dm}$. long or less, $2-5 \mathrm{~mm}$. wide, those on the innovations longer : racemes $2-5$, erect or nearly so, $2-4 \mathrm{~cm}$. long: spikelets singly disposed, oval, about $2 \mathrm{~mm}$. long and 1.5-1.75 mm. wide, glabrous, the outer scales 5-nerved, the lateral nerves approximate and distant from the midnerve, the third scale deep seal brown when mature, scrobiculate.

In sandy soil, Florida. Also in tropical countries. Summer and fall. Ditch Millet.

22. Paspalum laève Michx. Stems tufted, 3-6 dm. tall : leaf-sheaths compressed, glabrous; blades short, those on the stem usually less than $1.5 \mathrm{dm}$. long, 5-8 mm. wide, pubescent above near the base : racemes 2 or 3 , spreading, $4-8 \mathrm{~cm}$. long: spikelets singly disposed, glabrous, oval, 2.5-3 $\mathrm{mm}$. long, 2-2.5 mm. wide, the 2 outer scales 3-nerved.

In fields, District of Columbia to Kentucky, Georgia, Arkansas and Texas. Summer.

23. Paspalum angustifòlfum Le Conte. Stems tufted, 6-12 dm. tall : leaf-sheaths compressed, glabrous; blades long, the larger 2-4 dm. long, less than $1 \mathrm{~cm}$. wide, glabrous, or the upper surface sometimes sparingly hirsute near the base : racemes $3-5$, spreading, usually $6-10 \mathrm{~cm}$. long, sometimes shorter : spikelets singly disposed, oval, $3-3.5 \mathrm{~mm}$. long and about $2.5 \mathrm{~mm}$. wide, glabrous, the 2 outer scales 3 -nerved. and fall.

In fields, District of Columbia to northern Florida, Louisiana, Kansas and Missouri. Summer

24. Paspalum austràle Nash. Stems tufted, 4-7 dm. tall : leaf-sheaths usually hirsute only on the margins; blades erect, short, generally $1.5 \mathrm{dm}$. long or less, $5-10 \mathrm{~mm}$. wide, strongly ribbed, rather thick, firm, glabrous beneath or nearly so, hirsute above : racemes $2-5$, usually 2 or 3 , finally spreading, commonly $5 \mathrm{~cm}$. long or less, sometimes longer : spikelets singly disposed, oval, 2.7-3 mm. long and about $2 \mathrm{~mm}$. wide, the 2 outer scales 3-nerved, glabrous.

On grassy flats and banks, Virginia to Florida and Alabama. Summer and fall.

25. Paspalum longípilum Nash. Stems tufted, compressed : leaf-sheaths much compressed, keeled, the lower ones strongly hirsute with very long hairs: blades erect, firm, stiff, folded when dry, $2 \mathrm{dm}$. long or less, 6-12 $\mathrm{mm}$. wide, glabrous beneath, densely hirsute above with very long hairs : racemes 2 or 3 , spreading or ascending, usually 4-6 cm. long, sometimes longer: spikelets singly disposed, oval, about $3 \mathrm{~mm}$. long and a little exceeding $2 \mathrm{~mm}$. broad, the 2 outer scales glabrous, 5 -nerved, the lateral nerves close together and near the margin.

In moist or wet soil, peninsular Florida. Spring and summer.

26. Paspalum praelóngum Nash. Stems tufted, 5-10 dm. tall : leaf-sheaths usually hirsute all over; blades long, usually exceeding $1.5 \mathrm{dm}$., sometimes $3 \mathrm{dm}$. long, 5-10 mm. wide, thin, lax, hirsute on both surfaces : racemes $2-4$, usually 3 or 4 , finally spreading, $5-10 \mathrm{~cm}$. long: spikelets singly disposed, oval, $2.5-2.8 \mathrm{~mm}$. long and about $2 \mathrm{~mm}$. wide, the 2 outer scales 3 -nerved, glabrous.

In moist or dry soil, District of Columbia to Georgia, Alabama and Missouri. Summer and fall.

27. Paspalum circulàre Nash. Stems tufted, 4-8 dm. tall : leaf-sheaths hirsute with long hairs, compressed; blades $2 \mathrm{dm}$. long or less, $5-8 \mathrm{~mm}$. wide, glabrous beneath or hirsute along the midnerve, the upper surface hirsute with long hairs: racemes 2-4, spreading or ascending, 4-6 $\mathrm{cm}$. long : spikelets singly disposed, glabrous, orbicular, about $2.5 \mathrm{~mm}$. in diameter, the 2 outer scales thin, finely but distinctly striate.

In fields and meadows, New York to North Carolina; also in Missouri Summer and fall.

28. Paspalum Simpsònii Nash. Stems tufted, slender, 4-8 dm. tall: basal leafsheaths hirsute, the rest glabrous ; blades lanceolate, 4-10 cm. long, 3-10 mm. wide, glabrous on both surfaces, ciliate on the margins below the middle : racemes $3-5$, spreading, 
$2-7 \mathrm{~cm}$. long: spikelets in pairs, obovate, $1.3-1.5 \mathrm{~mm}$. long and about $0.8 \mathrm{~mm}$. broad, the 2 outer scales 3 -nerved, densely pubescent with short glandular-tipped hairs.

In rocky pine woods, No-name Key and Key West, Florida. Spring and summer.

29. Paspalum Blodgéttii Chapm. Smooth and glabrous. Stems densely tufted, slender, 3-6 dm. tall : leaf-blades 5-15 $\mathrm{cm}$. long, 3-7 mm. wide, narrowed at both ends : racemes erect, $2-6,1.5-6 \mathrm{~cm}$. long, slender, the rachis flat, winged, about $0.5 \mathrm{~mm}$. broad, about $\frac{1}{2}$ as wide as the spikelets : spikelets in pairs, $1.5-2 \mathrm{~mm}$. long, about $1 \mathrm{~mm}$. broad, elliptic to obovate, the 2 outer scales papillose-pubescent with appressed hairs, 3 -nerved.

On coral soil or shell mounds, Florida. Also in Cuba. Spring and fall.

30 Paspalum Hállii Vasey \& Scribn. Stems 4-10 dm. long, finally prostrate and rooting toward the base, the nodes pubescent: leaf-sheaths more or less hirsute on one margin, the exterior basal ones hirsute all over; blades $3 \mathrm{dm}$. long or less, 1-1.5 cm. wide, glabrous on both surfaces : racemes $2-4$, usually ascending, the lower ones $5-10 \mathrm{~cm}$. long : spikelets in pairs, broadly obovate, $2.5-3 \mathrm{~mm}$. long and about $2 \mathrm{~mm}$. broad, the 2 outer scales 3-nerved, the first scale strongly hirsute, the second one glabrous.

In moist soil, Louisiana and Texas. Spring.

31. Paspalum laeviglùmis Scribn. Stems 5-15 dm. long, finally prostrate and rooting toward the base, the nodes pubescent : sheaths more or less hirsute on one margin, otherwise glabrous; leaf-blades 1-4 dm. long, 1-2 cm. wide, glabrous on both surfaces: racemes 4-7, spreading or ascending, the lower ones usually 5-10 $\mathrm{cm}$. long: spikelets in pairs, oval to broadly obovate, $2.7-3 \mathrm{~mm}$. long, $1.8-2 \mathrm{~mm}$. broad, glabrous, the first scale 3-5-nerved, the second scale 5-7-nerved.

In moist places, Tennessee to the Indian Territory, Mississippi and Texas. Summer and fall.

32. Paspalum géminum Nash. Stems $5-7 \mathrm{dm}$. tall : leaf-sheaths compressed, keeled, glabrous, or the basal ones pubescent; blades erect, firm, thick, $2 \mathrm{dm}$. long or less, 6-10 $\mathrm{mm}$. wide, glabrous beneath, hirsute above near the base with long hairs : racemes about 3 , sometimes more, spreading or ascending, $4-6 \mathrm{~cm}$. long : spikelets in pairs, elliptic, 3-3.3 mm. long and about $2 \mathrm{~mm}$. wide, glabrous, the 2 outer scales 3 -nerved.

In fields and orchards, Florida. Spring and summer.

33. Paspalum Bosclànum Fluegge. Stems $5-12 \mathrm{dm}$. long, compressed, finally branched, often decumbent at the base and rooting at the lower nodes : leaf-sheaths compressed, smooth and glabrous, or the basal ones papillose-hirsute; blades $4-30 \mathrm{~cm}$. long, 3-10 mm. wide, smooth or roughish, papillose-hirsute above near the base : racemes 2-13, spreading or ascending, 4-9 $\mathrm{cm}$. long, the rachis straight, $2-2.5 \mathrm{~mm}$. wide, broadly winged : spikelets in pairs and often so crowded as to appear in four rows, frequently redbrown, broadly obovate, $2-2.3 \mathrm{~mm}$. long, $1.5-1.8 \mathrm{~mm}$. broad, the 2 outer scales smooth and glabrous, the first 5-nerved, the second 3-nerved, the flowering scale faintly pitted in close longitudinal lines, deep brown at maturity. [P. purpurascens Ell.]

In meadows and moist places, North Carolina to Florida and Mississippi. Summer and fall.

34. Paspalum plicàtulum Michx. Stems tufted, flattened, 4-8 dm. tall : leafsheaths compressed, smooth and glabrous; blades usually folded, at least when dry, more or less long-hairy above, erect, rather stiff, $2 \mathrm{dm}$. long or less, $2-5 \mathrm{~mm}$. wide : racemes $3-7$, rarely fewer, spreading or ascending, $3-7 \mathrm{~cm}$. long: spikelets brown at maturity, elliptic, 2.5-3 mm. long and about $1.8 \mathrm{~mm}$. wide, the first scale 5-nerved, the lateral nerves approximate, more or less pubescent with appressed hairs, the second scale glabrous, 3 -nerved, the margins usually more or less transversely plicate, the third scale seal-brown at maturity.

In dry, usually sandy soil, Georgia and Florida to Texas. Also in Mexico, South America and the West Indies. Spring to fall.

35. Paspalum diffórme Le Conte. Stems 5-10 dm. tall, rather stout, leafy below, not tufted: leaf-sheaths somewhat compressed, the external basal ones, as well as sometimes the summit of the others, papillose-hirsute; blades erect or nearly so, commonly less than $1.5 \mathrm{dm}$. long, 6-10 mm. wide, flat, glabrous or hirsute above and sometimes more or less so below : racemes 2 or 3 , ascending, short, commonly $4-6 \mathrm{~cm}$. long : spikelets usually singly disposed, or rarely some of the central ones in pairs, 3-3.5 mm. long and abont $2.6 \mathrm{~mm}$. broad, the 2 outer scales 3-nerved, glabrous.

In low grounds, Georgia and Florida. Summer.

36. Paspalum altíssimum LeConte. Stems usually $5-8 \mathrm{dm}$. tall, rarely taller, slender: leaf-sheaths hirsute with rather short hairs; blades short-hirsute on both surfaces, commonly less than $2 \mathrm{dm}$. long, 3-6 mm. wide : racemes generally in pairs, 5-8 $\mathrm{cm}$. long, ascending : spikelets usually singly disposed, sometimes in pairs, about $3.5 \mathrm{~mm}$. long and $2.5 \mathrm{~mm}$. wide, the 2 outer scales glabrous, 3-nerved.

In dry pine lands, Alabama and Mississippi. Fall. 
37. Paspalum glabràtum (Engelm.) C. Mohr. Whole plant often glaucous. Stems usually 1-2 m. tall, stout, leafy : leaf-sheaths glabrous, or sometimes sparingly pubescent, the external basal ones sometimes hirsute; blades glabrous on the lower surface, the upper surface glabrous or more or less hirsute, the lower blades 3-7 dm. long, 6-15 $\mathrm{mm}$. wide : racemes usually $3-6$, sometimes 2 , erect or nearly so, the lower ones commonly $1-1.5 \mathrm{dm}$. long, occasionally shorter or longer: spikelets singly disposed or in pairs, 3.5-4.5 mm. long, $2.75-3.5 \mathrm{~mm}$. wide, the 2 outer scales glabrous, 3-nerved.

In low ground, Maryland to Kansas, Georgia and Texas. Summer and fall.

38. Paspalum Floridànum Michx. Stems 9-12 dm. tall, rather stout, leafy : leafsheaths densely hirsute with long hairs; blades densely hirsute above and usually also on the lower surface, the lower ones 3-6 dm. long, 6-10 $\mathrm{mm}$. wide: racemes commonly 2 or 3 , rarely 4 , erect, the lower ones usually $8-12 \mathrm{~cm}$. long: spikelets usually singly disposed, 3.5-4 mm. long, $2.5-3 \mathrm{~mm}$. wide, the 2 outer scales 3 -nerved, glabrous.

In low ground, South Carolina to Florida, west to Texas. Summer and fall.

39. Paspalum gigantèum Baldw. Stems tufted, 1-1.5 m. tall, stout: leaf-sheaths glabrous ; blades erect, glabrous on both surfaces, if ciliate on the margins the hairs short, the lower leaves $2-3 \mathrm{dm}$. long, $1.5-2 \mathrm{~cm}$. wide: racemes $3-5$, finally widely spreading, 1-1.5 dm. long: spikelets in pairs, about $3.25 \mathrm{~mm}$. long and $2.5 \mathrm{~mm}$. wide, the 2 outer scales glabrous, 3-nerved.

In ditches and swamps, Florida. Summer.

40. Paspalum longicílium Nash. Stems tufted, ascending, stout, 6-12 dm. tall : lower leaf-sheaths densely papillose-hirsute with long shaggy hairs ; blades glabrous on both surfaces, the margins ciliate with very long hairs, the lower blades $2-4 \mathrm{dm}$. long, 1-2 cm. wide : racemes ascending, the lower ones 8-17 $\mathrm{cm}$. long : spikelets usually singly disposed, $3-3.3 \mathrm{~mm}$. long and $2-2.3 \mathrm{~mm}$. wide, the 2 outer scales glabrous, 3-nerved.

In clay soil in ditches, central peninsular Florida. Summer.

41. Paspalum Buckleyànum Vasey. Stems erect, 6-8 dm. tall: leaf-sheaths smooth and glabrous; blades 4-20 $\mathrm{cm}$. long, 2-4 mm. wide, rough above, smooth beneath : racemes erect, $2-4,5-7 \mathrm{~cm}$. long, the rachis straight, broadly winged, $1.5-2 \mathrm{~mm}$. wide: spikelets in pairs, often so crowded as to appear as if in 4 rows, $3 \mathrm{~mm}$. long, about $1.5 \mathrm{~mm}$. broad, elliptic, the 2 outer scales 3 -nerved, densely appressed-pubescent, the flowering scale yellowish at maturity, faintly pitted in fine longitudinal lines.

In low grounds, Texas. Summer and fall.

42. Paspalum lívidum Trin. Stems 6-10 dm. tall: leaf-sheaths compressed, keeled, smooth, glabrous, except on the margins ; blades $3 \mathrm{dm}$. long or less, $\mathbf{3 - 5} \mathrm{mm}$. wide, more or less pubescent on the upper surface : racemes $3-7$, erect or ascending, $2.5-5 \mathrm{~cm}$. long, the rachis often setiferous on the margins : spikelets bright green, in pairs, elliptic, acute or acutish, about $2.5 \mathrm{~mm}$. long and $1.5 \mathrm{~mm}$. wide, the 2 outer scales 3-nerved, glabrous, the third scale yellowish white, only slightly convex in cross-section.

In wet places, Texas. Also in Mexico and South America. Summer.

43. Paspalum praècox Walt. Stems tufted, compressed, 6-12 dm. tall : leaf-sheaths compressed, the lower ones purple, the exterior basal ones hirsute, the remainder glabrous ; blades $2 \mathrm{dm}$. long or less, 4-6 mm. wide, glabrous : racemes usually $4 \cdot 6$, rarely more or fewer, ascending, 2-5 cm. long : spikelets in pairs, lenticular, nearly flat on the inner side, yellowish green, orbicular to oval, $2.2-2.6 \mathrm{~mm}$. long, $1.8-2.2 \mathrm{~mm}$. wide, the 2 outer scales glabrous, 3-nerved, the third scale striately roughened with conspicuous papillae.

In moist or wet places, South Carolina to Florida and Texas. In spring and early summer; sometimes also in the late fall.

44. Paspalum glabérrimum Nash. Glabrous. Stems single, about $1 \mathrm{~m}$. tall, erect, compressed : leaf-sheaths compressed; blades erect, long-acuminate, the larger 3-4 dm. long, $5-8 \mathrm{~mm}$. wide, the upper blade very short or wanting : racemes 3 or 4 , ascending, the lower 4-7 cm. long: spikelets nearly circular, barely if at all convex on one side, $3 \mathrm{~mm}$. long, light green, the 2 outer scales 3-nerved.

In low pine lands, southern peninsular Florida. Summer.

45. Paspalum tárdum Nash. Stems not tufted, compressed, usually $6-13 \mathrm{dm}$. tall : leaf-sheaths compressed, the outer basal ones densely papillose-hirsute with long hairs, the remainder similarly pubescent with very long hairs at the apex; blades $1.5-2.5 \mathrm{dm}$. long, 3-6 mm. wide, glabrous beneath, hirsute above toward the base, especially near the base where the hairs are very dense and long: racemes usually 3 or 4 , sometimes only 2 , spreading or ascending, commonly 3-6 $\mathrm{cm}$. long, sometimes shorter : spikelets singly or in pairs, orbicular or nearly so, $2.2-2.5 \mathrm{~mm}$. in diameter, the 2 outer scales 3-nerved, glabrous, the third scale striately roughened with conspicuous papillae.

In wet ground, Florida to Mississippi. Summer and fall. 
46. Paspalum Kearneỳi Nash. Stems single, slender, $8-10 \mathrm{dm}$. tall, compressed : leaf-sheaths compressed, the external basal ones hirsute, as well as sometimes the summit of some of the others; blades erect, elongated, densely hirsute on both surfaces, longacuminate, the lower ones $2-3 \mathrm{dm}$. long, 4-5 $\mathrm{mm}$. wide : racemes about 3 , spreading, 3-4 $\mathrm{cm}$. long : spikelets broadly obovate, $2.8 \mathrm{~mm}$. long and about $2 \mathrm{~mm}$. wide, barely if at all convex on one side, light green, the 2 outer scales 3 -nerved.

In dry soil, Mississippi. Fall.

47. Paspalum ámplum Nash. Stems tufted, stout, $1-1.5 \mathrm{~m}$. tall, round or but little compressed: leaf-sheaths a little flattened, the outer basal ones hirsute below, the remainder glabrous, excepting a tuft of long hairs at the apex ; blades 2-5 dm. long, 5-10 $\mathrm{mm}$. wide, glabrous beneath, pubescent above with short appressed hairs and near the base with very long ones: racemes usually $6-8$, erect or ascending, the lower ones commonly $8-15 \mathrm{~cm}$. long: spikelets orbicular to oval, about $3 \mathrm{~mm}$. long and $2.5-3 \mathrm{~mm}$. Wide, the third scale strongly roughened with conspicuous papillae.

In wet ground, Florida to Mississippi. Summer.

48. Paspalum Curtisiànum Steud. Stems stout, $8-10 \mathrm{dm}$. tall: leaf-sheaths densely papillose-hirsute with long ascending hairs ; blades $1.5-4 \mathrm{dm}$. long, $5-7 \mathrm{~mm}$. wide, strongly papillose-hirsute, especially above, with long hairs: racemes $5-10$, finally spreading, 3-8 cm. long: spikelets single or in pairs, lenticular, $2.5-3 \mathrm{~mm}$. in diameter, the 2 outer scales glabrous, 3-nerved, the third scale striately roughened with conspicuous papillae.

In wet places, South Carolina to Florida and Mississippi. Summer.

49. Paspalum Vaseyànum Scribn. Stems 1-1.5 m. tall, stout : lower leaf-sheaths densely papillose-hispid with ascending hairs ; blades $4 \mathrm{dm}$. long or less, $8-12 \mathrm{~mm}$. wide, hirsute above at the very base, otherwise glabrous : racemes erect, 10-20, the lower 8-12 $\mathrm{cm}$. long: spikelets in pairs, acute, $2.3-2.5 \mathrm{~mm}$. long and about $1.4 \mathrm{~mm}$. wide, the 2 outer scales 3 -nerved, acute, pilose on the margins with very long hairs, the surface, especially that of the first scale, pubescent with shorter hairs.

In fields, Alabama to Texas. Summer and fall.

50. Paspalum dilatàtum Poir. Smooth and glabrous. Stems 5-17 dm. tall, somewhat compressed : leaf-blades $3 \mathrm{dm}$. long or less, 3-12 $\mathrm{mm}$. wide : racemes $5-10 \mathrm{~cm}$. long, erect or ascending, the rachis broadly winged, $1.2-1.5 \mathrm{~mm}$. wide, straight: spikelets in pairs, so densely crowded as to appear as if in 4 rows, $3-3.3 \mathrm{~mm}$. long, $2-2.2 \mathrm{~mm}$. broad, nearly orbicular, apiculate, much compressed dorsally, the 2 outer scales 5-7-nerved, the first scale ciliate on the margins with very long lax hairs, the second sparingly ciliate with much shorter hairs, the flowering scale white at maturity, orbicular.

In meadows and moist places, Georgia and Florida to Louisiana. Summer and fall.

51. Paspalum bífidum (A. Bertol.) Nash. Glaucous. Stems $7-13 \mathrm{dm}$. tall, single, from a stout scaly rootstock, its scales strongly appressed-hirsute: leaves mostly at the base of the stem ; sheaths, at least the external basal ones, papillose-hirsute; blades $3 \mathrm{dm}$. long or less, generally $5-10 \mathrm{~mm}$. wide, narrowed at both ends, glabrous or but sparingly hirsute beneath, strongly hirsute above toward the base : racemes usually 2 or 3 , sometimes more or only $1,7-15 \mathrm{~cm}$. long, erect, the rachis triangular, slender, the lateral margins not winged: spikelets in rather distant pairs, oval, $3.5-4 \mathrm{~mm}$. long and about $2.5 \mathrm{~mm}$. broad; scales usually 3 (sometimes 4 and the first one minute), the first scale 7 -nerved, the second one 5-nerved. [P. racemulosum Nutt.]

In dry pine lands or on wooded hillsides, North Carolina to Florida and Louisiana. Fall.

52. Paspalum solitàrium Nash. Rootstock long and stout, scaly, the scales glabrous. Stems single, rigid, $6-10 \mathrm{dm}$. tall (rarely shorter) : leaf-sheaths sometimes pubescent on the exterior margin ; blades elongated, stiff, the larger ones often 3-6 dm. long, involute, at least when dry, long-acuminate, glabrous : raceme 1 , or rarely 2 racemes, 1-2 $\mathrm{dm}$. long, erect : spikelets crowded in pairs on hispid pedicels, glabrous, $3 \mathrm{~mm}$. long and about $1.5 \mathrm{~mm}$. wide, elliptic, the 3 outer scales 3 -nerved. [P. monostachyum Vasey, not Walp.]

In wet soil, southern Florida and Texas. Fall.

53. Paspalum conjugàtum Berg. Smooth and glabrous. Stems compressed, 2-9 dm. tall, finally decumbent at the base and rooting at the lower nodes: leaf-blades 4-16 $\mathrm{cm}$. long, 4-12 mm. wide : racemes in pairs, slender, often curved, spreading or ascending, $5-12 \mathrm{~cm}$. long, the rachis straight, or flexuous toward the apex, $0.6-0.8 \mathrm{~mm}$. broad : spikelets crowded, much compressed dorsally, singly disposed, $1.5 \mathrm{~mm}$. long, $1-1.2 \mathrm{~mm}$. broad, apiculate, the 2 outer scales 2-nerved, the nerves marginal, the first scale ciliate on the margins with very long lax hairs, the third scale smooth, white.

In wet places, Louisiana and Texas. Common in all tropical countries. Summer. 
54. Paspalum dístichum L. Stems 1-6 dm. tall, from a long stout rootstock: leaf-sheaths compressed, keeled, usually crowded and overlapping, especially at the base and on the innovations, glabrous, or more or less hairy on the margins; blades commonly less than $1 \mathrm{dm}$. long, $3-6 \mathrm{~mm}$. wide, generally glabrous : racemes terminal, in pairs, ascending, $2-5 \mathrm{~cm}$. long: spikelets singly disposed, ovate, $2.5-3 \mathrm{~mm}$. long, acute, the 2 outer scales firm, 5 -nerved, rarely 7 -nerved, the first scale glabrous, the second appressedpubescent, the third apiculate, strongly pubescent at the apex.

In sandy soil, on the seashore or along rivers, Virginia to Missouri, Florida and Texas, and on the Pacific coast. Also in tropical America. Summer and fall.

55. Paspalum vaginàtum $\mathrm{Sw}$. Stems $2-6 \mathrm{dm}$. tall. from a long stout rootstock : leaf-sheaths compressed, keeled, usually crowded and overlapping, at least at the base and on the innovations, glabrous ; blades folded, or involute when dry, $1.5 \mathrm{dm}$. long or less, 2-4 mm. wide, glabrous, or sparingly hairy above at the very base : racemes terminal, usually in pairs, rarely more or but a single one, erect or ascending, 3-7 cm. long : spikelets singly disposed, ovate-lanceolate, acute, $3-4 \mathrm{~mm}$. long, the 2 outer scales glabrous, thin, the first scale 4-nerved, the lateral nerves approximate at the margin, the midnerve suppressed, the second scale 5-nerved, the lateral nerves rather near together, the third scale glabrous at the apex or with 2 or 3 hairs.

Along the seashore, Florida to Texas. Also in the West Indies. Summer and fall.

\section{DIMORPHOSTÁCHYS Fourn.}

Perennial grasses with simple or somewhat branched stems, flat leaf-blades and one-sided racemes. Spikelets borne in pairs, the one short-, the other longer-pedicelled, the former with the first scale turned to one side and often much longer than the corresponding scale in the other spikelet. Scales 4 , the outer 3 membranous; fourth scale indurated in fruit, with its opening turned away from the rachis, and enclosing a palet of similar texture and a perfect flower. Stamens 3. Styles long, distinet. Stigmas plumose.

Spikelets $2.3-2.5 \mathrm{~mm}$. long: leaf-blades usually short, with naked margins. Spikelets $2.8-3 \mathrm{~mm}$. long: leaf-blades with ciliate margins.

1. Dimorphostachys Drummóndii Fourn. Stems tufted, 3-7 dm. tall, rather slender, glabrous: leaf-sheaths glabrous excepting the ciliate margins; blades erect, glabrous, or sometimes with a few scattered hairs on the surface, generally $1.5 \mathrm{dm}$. long or less, occasionally longer, $1-1.5 \mathrm{~cm}$. broad : racemes $2-4,4-9 \mathrm{~cm}$. long: spikelets in pairs, 2.3-2.5 mm. long and about $1.5 \mathrm{~mm}$. broad, obovate or elliptic; scales 4 (rarely 3 ), the first and second scales rather strongly pubescent, the first scale very small, nerveless, the second and third scales 5-nerved, the latter glabrous. [Paspalum Drummondii (Fourn.) Vasey.]

In low grounds, Texas and Mexico. Summer and fall.

2. Dimorphostachys ciliffera Nash. Stems tufted, glabrous, or sometimes papillosehirsute toward the base, $7-11 \mathrm{dm}$. tall : leaf-sheaths ciliate, otherwise glabrous, or the lower ones papillose-hirsute; blades erect or nearly so, the larger ones $2-3 \mathrm{dm}$. long and $1-1.5 \mathrm{~cm}$. wide, ciliate on the margins, sparingly pubescent on the surface with scattered hairs : racemes 2 or 3, finally spreading, 7-9 cm. long: spikelets crowded in pairs, 2.8-3 $\mathrm{mm}$. long and about $1.8 \mathrm{~mm}$. broad; scales 4 , the glabrous first scale very small or occasionally $\frac{1}{2}$ as long as the spikelet and acuminate, nerveless, or in the latter case 1-nerved, the second and third scales 5-nerved, the former glabrous, the latter sparingly pubescent with short appressed hairs.

In moist soil, southern peninsular Florida. Fall.

\section{ANÁSTROPHUS Schlecht.}

Perennial grasses, with compressed stems and sheaths, the stems creeping at the base, the inflorescence consisting of 2-several (rarely 1) unilateral more or less spreading spikes. Spikelets articulated below the empty scales, 1-flowered, singly and alternately disposed in 2 rows on one side of a narrow rachis, appressed, narrow, sessile, acute or acuminate. Scales 3 , the 2 outer empty, membranous, the third one firmer, glabrous and shining, at length indurated, with its back turned away from the rachis, enfolding a shorter palet of similar texture and a perfect flower. Stamens 3. Styles distinct. Stigmas plumose.

Spikelets 4-6 mm. long.

Spikelets 2-2.5 mm. long:

Ovate: lower leaf-blades 8-12 mm. wide.

Elliptic : lower leaf-blades rarely exceeding $6 \mathrm{~mm}$. in width.

1. A. paspaloides. 1. Anastrophus paspaloides (Michx.) Nash. Perennial, with creeping stolons Stems flattened, 2-8 dm. tall : leaf-sheaths compressed and, like the blades, pubescent or 
glabrous ; blades commonly $2 \mathrm{dm}$. long or less, 5-12 mm. wide : spikes 4-13 $\mathrm{cm}$. long, usually a pair at the summit of the stem, sometimes with an additional one a short distance below : spikelets 4-6 mm. long. [Paspalum furcatum Fluegge.]

In dry sandy soil, Virginia to Florida, Arkansas and Texas. Spring to fall.

2. Anastrophus platycaùlis (Poir.) Nash. Stolons stout and creeping. Stems flattened, 2-4 dm. tall : leaves glabrous or pubescent; sheaths compressed; blades $1.5 \mathrm{dm}$. long or less, 8-12 mm. wide: spikes a pair, or sometimes with an additional one below : spikelets about $2.25 \mathrm{~mm}$. long, ovate, very acute, pubescent.

In dry sandy soil, Florida. Summer and fall.

3. Anastrophus compréssus (Sw.) Schlecht. Stolons numerous and creeping. Stems 3-8 dm. tall, slender, flattened : leaves glabrous ; sheaths compressed; blades sometimes $3 \mathrm{dm}$. long, usually shorter, 4-8 $\mathrm{mm}$. wide: spikes in pairs, or with an additiona] third one below, slender, $4-10 \mathrm{~cm}$. long: spikelets about $2 \mathrm{~mm}$. long, elliptic, pubescent.

In dry sandy soil, Virginia to Florida and Texas. Also in tropical America. Summer and fall.

\section{ANTHAENÁNTIA Beauv.}

Erect perennial grasses, with numerous spikelets arranged in a narrow or contracted panicle. Spikelets 1-2-flowered, ovate, sometimes shortly acuminate. Scales 3 , the 2 outer equal, or nearly so, membranous, densely silky-pilose externally, empty, or the second one enclosing a palet and sometimes also a staminate flower, the third scale equalling or a little shorter than the second, membranous, finally somewhat rigid or slightly indurated, enclosing a shorter palet and a perfect flower. Stamens 3. Styles distinct. Stigmas penicillate-plumose.

Leaf-blades linear, the lower ones $3-4 \mathrm{~mm}$. wide : plant often purple or purplish. Leaf-blades narrowed toward the summit, the lower ones 5-10 mm. wide: plant green. $\quad$ 1. A. rufa.

1. Anthaenantia rùfa (Ell.) Schult. Smooth and glabrous, often purple. Stems 4-10 dm. tall, from a running rootstock : leaf-sheaths shorter than the internodes; blades erect, linear, obtuse, $2-5 \mathrm{~mm}$. wide, those at the base and on the innovations 2-4 dm. long, those on the stem $2 \mathrm{dm}$. long or less : panicle contracted, $8-20 \mathrm{~cm}$. long, 1-2 cm. broad: spikelets numerous, 3.5-4 $\mathrm{mm}$. long, the first and second scales about equal in length, 5 -nerved, the hairs about $1 \mathrm{~mm}$. long, the second enclosing a palet and often also a staminate flower, the third scale as long as or a little shorter than the others.

In moist pine lands, South Carolina to' Florida. Fall.-A form, A. rufa scàbra Nash, differing from the above in having the sheaths and blades scabrous, occurs in similar situations in South Carolina, but mainly from Alabama to Louisiana. Fall.

2. Anthaenantia villòsa (Michx.) Beauv. Smooth and glabrous, green. Stems $5-15 \mathrm{dm}$. tall, from a running rootstock: leaf-sheaths shorter than the internodes ; blades erect, narrowed toward the apex, acute or somewhat obtuse, $3 \mathrm{dm}$. long or less, $1 \mathrm{~cm}$. wide or less : panicle contracted, $8-20 \mathrm{~cm}$. long, 1-2 $\mathrm{cm}$. broad : spikelets $3-4 \mathrm{~mm}$. long, the 2 outer scales 5 -nerved, the hairs about $0.6 \mathrm{~mm}$. long, the first scale equalling or a little shorter than the second which encloses a palet and sometimes also a staminate flower, the third scale about equalling the second.

In dry pine lands, South Carolina to Florida and Texas. Summer and fall.

\section{AMPHICÁRPON Raf.}

Tufted grasses, with flat leaf-blades and 1-flowered spikelets of two kinds; one borne in terminal panicles, articulated below the empty scales and readily deciduous, lanceolate, not ripening fruit; the other solitary, larger, becoming ovoid and turgid, terminating subterranean stems, and maturing fruit. Scales 3 , the third subtending a palet and perfect flower; the scales of the aërial spikelets green, membranous; those of the subterranean spikelets much firmer in texture, white or yellowish, becoming indurated and enclosing the grain. Stamens 3. Styles distinct. Stigmas penicillate-plumose.

Stems not from rootstocks : leaf-blades papiliose-hispid.

Stems from long running rootstocks : leaf-blades glabrous.

1. A. Amphicarpon. 2. A. Floridanum.

1. Amphicarpon Amphicárpon (Pursh) Nash. Stems tufted, the aërial 3-8 dm. tall, naked above and bearing a terminal contracted panicle $3-20 \mathrm{~cm}$. long, the spikelets numerous, elliptic, 4-5 mm. long; subterranean stems slender, $1.5-10 \mathrm{~cm}$. long, bracted at the base, with a single terminal spikelet: leaf-sheaths and blades papillose-hispid with spreading hairs, the latter erect, $15 \mathrm{~cm}$. long or less, $1.5 \mathrm{~cm}$. wide or less, lanceolate. $[A$. Purshii Kunth.]

In sandy soil, New Jersey to Georgia (according to Chapman). Fall. 
2. Amphicarpon Floridànum Chapm. Stems tufted, from a long stout rootstock, the aërial 3-8 dm. tall, naked above and bearing a terminal contracted panicle $3-23 \mathrm{~cm}$. long, the lanceolate spikelets numerous, 6-7 mm. long; subterranean stems $3-15 \mathrm{~cm}$. long, scaly at the base, with a single terminal spikelet: leaf-sheaths papillose-hispid at the summit and along the margins, or sometimes the lower ones all over; blades erect or ascending, glabrous on both surfaces, or sparingly pubescent above, $2 \mathrm{dm}$. long or less, 1 cm. wide or less, lanceolate.

In dry sandy soil, Florida. Summer and fall.

25. ERIÓCHLOA H.B.K.

Perennial grasses, with flat leaf-blades and an inflorescence composed of spike-like onesided racemes which are racemosely arranged. Spikelets with an annular callus at the base, articulated below the callus, 1 -flowered, imbricated, arranged in 2 rows on a flat rachis, acute or acuminate. Scales 3, the two outer membranous, empty, acute or acuminate, the third scale glabrous and shining, shorter, at length indurated, awn-pointed or short-awned at the apex, enclosing a palet of similar texture and a perfect flower. Stamens 3. Styles distinct. Stigmas plumose.

Flowering scale $3 / 4$ as long as the spikelet or more, the awn a mere point or apiculation.

Hairs at the apex of the pedicels none, or few and short.

Rachis of the inflorescence and racemes puberulent or with a few scattered long hairs.

Rachis of the inflorescence and racemes densely pilose with long hairs.

Hairs at the apex of the pedicels many, more than $1 / 2$ as long as the spikelet.

Flowering scale usually about $2 / 3$ as long as the spikelet, the awn $1 / 3-1 / 2$ as long as the scale.

1. E. longifolia.

2. E. mollis.

3. E. sericea.

4. E. punctata.

1. Eriochloa longifòlia Vasey. Stems tufted, 4-8 dm. tall : leaf-sheaths glabrous ; blades erect or ascending, $4 \mathrm{dm}$. long or less, 2-4 mm. wide, smooth : inflorescence 6-20 $\mathrm{cm}$. long, its axis puberulent or with a few scattered long hairs : racemes erect, $2-4 \mathrm{~cm}$. long, puberulent: spikelets $8-16$, ovate-lanceolate, about $5 \mathrm{~mm}$. long, on puberulent pedicels, the 2 outer scales appressed-pubescent with long hairs, 5-nerved, acute or obtuse ; third scale about $3.5 \mathrm{~mm}$. long, coarsely transverse-rugose, about $\frac{3}{4}$ as long as the spikelet, apiculate, or with a short awn less than $1 \mathrm{~mm}$. long.

In sandy soil, southern peninsular Florida. Spring.

2. Eriochloa móllis (Michx.) Kunth. Stems single, 7-15 dm. tall, densely and softly pubescent at and near the nodes : leaf-sheaths glabrous or softly pubescent with short ascending hairs; blades 1-4.5 dm. long, 4-15 $\mathrm{mm}$. wide, smooth and glabrous : inflorescence $1.5-4 \mathrm{dm}$. long, its axis densely pilose with somewhat ascending hairs : racemes erect or nearly so, 8-20, 3-15 cm. long, the rachis densely pilose with somewhat ascending hairs : spikelets $12-40,5-5.5 \mathrm{~mm}$. long, ovate, acute, on pilose pedicels, the 2 outer scales appressedpubescent with long hairs, 5-nerved, acute ; third scale about $3.5 \mathrm{~mm}$. long, rather finely transverse-rugose, apiculate, or with a very short awn. [Panicum molle Michx.]

In low pine lands, South Carolina to Florida. Summer.

3. Eriochloa serícea Munro. Stems tufted, 4-10 dm. tall, softly pubescent at and near the nodes : leaf-sheaths usually softly pubescent; blades glabrous or pubescent, $4 \mathrm{~mm}$. broad or less, those on the innovations 1-3 dm. long, those on the stem 3-20 $\mathrm{cm}$. long: inflorescence 1-2 dm. long, its axis pubescent with short ascending hairs; racemes appressed, 5-9, 1-4 cm. long, the rachis pubescent with short ascending hairs: spikelets 10-24, 4.5-5.5 mm. long, ovate, acutish, on pedicels which are densely hispid at the apex with hairs more than $\frac{1}{2}$ as long as the spikelet, the 2 outer scales pubescent with rather long hairs, acute or obtuse ; third scale $3-3.5 \mathrm{~mm}$. long, transversely rugose, apiculate.

In dry soil, Texas and the Indian Territory to New Mexico. Summer.

4. Eriochloa punctàta (L.) Hamilt. Stems tufted, 2-8 dm. tall, finally much branched, the nodes puberulent: leaf-sheaths and blades glabrous or pubescent, the latter 2-30 cm. long, 3-10 mm. wide : inflorescence $6-20 \mathrm{~cm}$. long, its axis pubescent with short ascending or nearly appressed hairs : racemes erect or nearly so, 4-20, 1.5-4 cm. long, the rachis with short ascending hairs : spikelets $10-30,4.5-5.5 \mathrm{~mm}$. long, lanceolate, acuminate, on appressed-pubescent pedicels, the 2 outer scales appressed-pubescent with long hairs, acuminate; third scale transversely rugose, from $\frac{1}{2}-\frac{2}{3}$ as long as the spikelet, about $2.5 \mathrm{~mm}$. long, exclusive of the hispid awn which is $\frac{1}{2}$ as long as the scale or more.

On plains or prairies, Kansas to Texas. Summer and fall. Everlasting Grass.

26. BRACHIÀrIA Ledeb.

Grasses with flat leaves and the spikelets borne in 2 rows in one-sided spikes. Spikelets of 4 scales, the outer 3 membranous, the fourth scale chartaceous, indurated in fruit, trans- 
versely rugose, and enclosing a similar palet and a perfect flower, its opening turned toward the rachis. Stamens 3. Styles distinct. Stigmas plumose.

1. Brachiaria platyphýlla (Munro) Nash. Stems at first erect, finally prostrate and rooting at the lower nodes, 4-6 dm. long: leaf-sheaths pubescent, commonly overlapping ; blades flat, $5-10 \mathrm{~cm}$. long, 7-12 mm. wide, lanceolate : spikes $2-5$, rather distant, 3-6 cm. long, the rachis broadly winged : spikelets ovate, glabrous, about $4 \mathrm{~mm}$. long.

In wet woods, Louisiana and Texas. Summer and fall.

\section{SYNTHERISMA Walt.}

Annual grasses, with flat leaf-blades and an inflorescence composed of spike-like racemes which are disposed in whorls, or scattered and approximate, at the summit of the stems. Spikelets narrow, acute, in 2's or 3's on one side of the flat and winged or triangular rachis, one of the spikelets generally longer pedicelled than the rest. Scales 3 or 4 , the 3 outer membranous, the first small or wanting, the fourth scale chartaceous, glabrous and shining, at length indurated, enclosing a palet of similar texture and a perfect flower. Stamens 3. Styles distinct. Stigmas plumose. [Digitaria Scop., not Heist.] Crab Grass.

Rachis of the racemes with the angles naked, not winged: first scale wanting or sometimes present as an inconspicuous rudiment.

Second and third scales pubescent with appressed glandular tipped hairs : stems simple or sparingly branched at the base; nodes 5 or fewer.

Racemes usually short, $2-10 \mathrm{~cm}$. long: spikelets less than $2 \mathrm{~mm}$. long.

Racemes usually exceeding $10 \mathrm{~cm}$. in length, rarely shorter: spikelets 2.25 $\mathrm{mm}$. long or more.

Pubescence on the sheaths spreading: racemes commonly more than 5.

Pubescence on the sheaths appressed or nearly so: racemes commonly less than 4.

Second and third scales glabrous.

Hairs on the sheaths appressed or nearly so: nodes 5 or fewer.

Second scale $1 / 2$ as long as the spikelet or less, rounded or truncate at the apex.

Second scale more than $1 / 2$ as long as the spikelet, sparingly pilose at the

Hairs on the sheaths widely spreading: nodes numerous.

Rachis of the racemes with the lateral angles broadly winged, thus making it

appear flat: first scale usually present, or generally wanting in nos. 7 and 8 .

Pedicels terete or sometimes obscurely angled, sparingly if at all hispidulous.

Sheaths and leaf-blades strongly papillose-hirsute: rachis of the racemes $0.8 \mathrm{~mm}$. wide or less; second scale $1 / /$ as long as the spikelets or less.

Sheaths and leaf-blades glabrous: rachis of the racemes $1 \mathrm{~mm}$. wide or more; second scale nearly as long as the spikelet.

Pedicels sharply 3-angled, the angles strongly hispidulous.

Sheaths strongly papiliose-hirsute: racemes commonly more than 3.

Racemes very slender, the rachis usually less than $0.5 \mathrm{~mm}$. wide: spikelets $1 / 5$ as wide as long, acuminate: fourth scale greenish when mature.

Racemes stouter, the rachis usually exceeding $0.7 \mathrm{~mm}$. wide: spikelets $1 / 4$ as wide as long or more, acute: fourth scale yellowish white when mature.

Spikelets usually less than $3 \mathrm{~mm}$. long, the second scale $1 / 2$ as long as the spikelet or less, the third scale with the first and second nerves on each side hispid above the middle.

Spikelets commonly more than $3 \mathrm{~mm}$, long, the second scale more than $1 / 2$ as long as the spikelet, the third scale with the nerves smooth.

Sheaths glabrous or nearly so: spikelets about $4 \mathrm{~mm}$. long: racemes 2 .

1. S. filiforme.

2. S. villosum.

3. S. leucocomum.

4. S. gracillimum.

5. S. Bakeri.

6. S. Simpsonii.

7. S. serotinum.

8. S. humijusum.

9. S. setosum.

10. S. sanguinale.

11. S. fimbriatum.

12. S. barbatum.

1. Syntherisma filifórme (L.) Nash. Stems $1.5-7 \mathrm{dm}$. tall : leaf-sheaths papillose-hirsute, or the uppermost one glabrous ; blades $3-20 \mathrm{~cm}$. long, 1-4 mm. wide, erect, usually glabrous below, papillose-hirsute above toward the base : axis of the inflorescence 1-3 cm. long: racemes $2-5,2-10 \mathrm{~cm}$. long, erect or ascending, alternate : spikelets about $1.8 \mathrm{~mm}$. long, $0.75 \mathrm{~mm}$. wide, elliptic, acute, in pairs ; first scale wanting, the second and third scales appressed-pubescent with long glandular-tipped hairs, the former 3-nerved and about $\frac{3}{4}$ as long as the 7 -nerved third scale, the fourth scale slightly exceeding the third, deep chestnut brown when mature, striate. [Panicum filiforme L.]

In dry sandy soil, Massachusetts to Michigan, North Carolina and the Indian Territory. Summer.

2. Syntherisma villòsum Walt. Stems densely tufted, 6-14 dm. tall : lower leafsheaths papillose-hirsute, the uppermost one sometimes glabrous; blades $7-25 \mathrm{~cm}$. long, $3-6 \mathrm{~mm}$. wide, erect or nearly so, smooth beneath, rough above, the lower surface more or less papillose-hirsute, the upper leaves glabrous: axis of the inflorescence $3-9 \mathrm{~cm}$. long; racemes $2-8$, usually more than 5 , generally $12-15 \mathrm{~cm}$. long, erect or ascending, alternate : spikelets $2.5 \mathrm{~mm}$. long, about $0.8 \mathrm{~mm}$. wide, elliptic, acute, usually in 3 's, the first scale wanting, the second and third scales appressed-pubescent with long glandular-tipped hairs, 
the second scale 3-nerved, a little shorter than the 7 -nerved third, the fourth scale slightly exceeding the third, deep chestnut brown when mature, striate, apiculate.

In sandy soil, Illinois to the Indian Territory, Georgia and Texas. Summer.

3. Syntherisma leucocòmum Nash. Stems $1 \mathrm{~m}$. tall or less : leaf-sheaths coarsely striate, the lower one densely hirsute with nearly appressed hairs ; blades erect, often invoIute when dry, smooth beneath, rough above, those on the stem 1.5-2.5 dm. long, those on the innovations 1-4 dm. long: axis of the inflorescence 4-6 cm. long; racemes 2-4, 2-2.5 dm. long, erect or nearly so, alternate : spikelets $2.25-2.5 \mathrm{~mm}$. long, $0.8 \mathrm{~mm}$. wide, elliptic, acute, usually in 3 's ; first scale wanting, the second and third scales appressedpubescent with very long glandular-tipped hairs, the second scale about as long as the fourth, 3-nerved, the third scale a little longer than the fourth, 7-nerved, the fourth scale brown at maturity, striate, apiculate.

In high pine lands, Florida. Summer.

4. Syntherisma gracíllimum (Scribn.) Nash. Stems tufted, $6-8 \mathrm{dm}$. tall, the innovations mostly about $\frac{1}{2}$ as long: lower leaf-sheaths somewhat hirsute with ascending-ap. pressed hairs ; blades $2 \mathrm{~mm}$. wide or less, smooth beneath, rough above, those on the innovations 3-4 dm. long; axis of the inflorescence $3-6 \mathrm{~cm}$. long; racemes 2 , or rarely 3 , about $3 \mathrm{dm}$. long, erect : spikelets slightly exceeding $2 \mathrm{~mm}$. long, about $0.8 \mathrm{~mm}$. broad, elliptic, acute, usually in 3 's, irregularly scattered; scales glabrous, the first wanting, the second 3-nerved, usually about $\frac{1}{4}$ as long as the spikelet, the third scale 5-nerved, slightly shorter than the spikelet, the fourth scale deep seal brown when mature, conspicuously striate, obtusely angled on the back, apiculate.

In high pine lands, Florida. Summer.

5. Syntherisma Bàkeri Nash. Stems tufted, $1 \mathrm{~m}$. tall or less: lower leaf-sheaths densely hirsute with ascending hairs; blades $2 \mathrm{~mm}$. wide or less, involute when dry, smooth, densely pubescent above at the base, those on the innovations $2-4 \mathrm{dm}$. long, those on the stem 1-2.5 dm. long: axis of the inflorescence 4-7 $\mathrm{cm}$. long; racemes usually 3 , 14-22 $\mathrm{cm}$. long, densely long-pilose at the base : spikelets about $2.25 \mathrm{~mm}$. long, $0.8 \mathrm{~mm}$. wide, elliptic, usually in 3's; scales glabrous, excepting the sparsely pilose apex of the second, the first one wanting, the second about $\frac{4}{5}$ as long as the spikelet, acute or acutish, 3 -nerved, the third a little shorter than the fourth which is deep chestnut brown when mature, elliptic, obtusely apiculate and rather faintly striate.

In dry sandy soil, Florida. S' mmer.

6. Syntherisma Simpsònii (Vasey) Nash. Stems $8-12 \mathrm{dm}$. long, finally branched, prostrate at the base and rooting at the lower nodes : leaf-sheaths copiously papillose-hirsute with spreading hairs ; blades 7-30 cm. long, $5 \mathrm{~mm}$. wide or less, papillose-hirsute on both surfaces : axis of the inflorescence 4-6 $\mathrm{cm}$. long ; racemes $6-8,10-13 \mathrm{~cm}$. long, erect or ascending, usually scattered: spikelets a little exceeding $3 \mathrm{~mm}$. long, about $1 \mathrm{~mm}$. wide, elliptic-lanceolate, acute, in pairs ; scales glabrous, the first one usually wanting, the second and third about equal in length, the former 5-, the latter 7-nerved, the fourth a little shorter than the third, elliptic, acute, yellowish white, finely striate.

In moist saline soil, Florida. Summer.

7. Syntherisma serótinum Walt. Stems 2-5 dm. long, finally branched, prostrate at the base and rooting at the lower nodes : leaf-sheaths, especially the lower ones, papillose-hirsute with spreading hairs ; blades $1.5-10 \mathrm{~cm}$. long, 3-10 mm. wide, ascending, pubescent on both surfaces : axis of the panicle 1-2 cm. long; racemes 2-6, 2.5-10 cm. long, ascending, usually alternate : spikelets about $1.5 \mathrm{~mm}$. long, about $0.6 \mathrm{~mm}$. wide, elliptic, acute, usually in pairs ; first scale wanting, the second and third appressed-pubescent with Iong hairs, the second one about $\frac{1}{3}$ as long as the spikelet, 3-nerved, the fourth a little longer than the third, white, ovate-lanceolate, acute. [Panicum serotinum Trin.]

In low open grounds, Delaware to Florida and Mississippi. Summer.

8. Syntherisma humifùsum (Pers.) Rydb. Stems $2-5 \mathrm{dm}$. long, finally branched, prostrate and forming large mats : leaf-sheaths glabrous; blades $1.5-15 \mathrm{~cm}$. long, 2.5-6 mm. wide, erect or nearly so, smooth and glabrous on both surfaces : axis of the inflorescence $1-3 \mathrm{~cm}$. long; racemes $2-5,2-8 \mathrm{~cm}$. long, finally widely spreading, alternate : spikelets slightly exceeding $2 \mathrm{~mm}$. long, about $1 \mathrm{~mm}$. wide, elliptic, acutish, usually in pairs ; first scale usually wanting, the second and third appressed-pubescent, the 3-nerved second about equalling the 7 -nerved third, the fourth one a little longer than the third, deep chestnut brown when mature, striate, acute. [Panicum glabrum Gaud.]

In waste places and fields, Ontario to Kansas, Florida and Louisiana.-A form, S. humifusum Mississippiénse (Gattinger) Nash, differs from the above in having usually longer racemes and the first scale of the spikelet generally present. Cedar barrens, Nashville, Tenn. Summer.

9. Syntherisma setòsum (Desv.) Nash. Stems tufted, 4-10 dm. tall, finally branched, decumbent at the base and rooting at the lower nodes: leaf-sheaths, excepting the upper- 
most one, densely papillose-hirsute with spreading hairs; blades $2-12 \mathrm{~cm}$. long, $2-7 \mathrm{~mm}$. wide, papillose-hirsute on both surfaces: axis of the inflorescence $4 \mathrm{~cm}$. long or less; racemes 4-13, 4-13 cm. long, finally widely spreading, usually in a whorl at the base and the remainder alternate or approximately in pairs : spikelets about $2.5 \mathrm{~mm}$. long, about $0.5 \mathrm{~mm}$. wide, lanceolate, acuminate, in pairs, occasionally with a delicate basal bristle ; first scale minute, glabrous, the second and third scales appressed-pubescent, the second 3 -nerved, about $\frac{1}{2}$ as long as the spikelet, the third 7 -nerved, noticeably longer than the fourth one which is slightly less than $2 \mathrm{~mm}$. long, elliptic, greenish when mature.

In dry sandy soil, Florida. Also in the West Indies and South America. Summer.

10. Syntherisma sanguinàle (L.) Dulac. Stems $1 \mathrm{~m}$. long or less, finally branched, prostrate at the base and rooting at the lower nodes: lower leaf-sheaths densely papillosehirsute ; blades 4-20 cm. long, 4-10 mm. wide, more or less papillose-hirsute on both surfaces : axis of the inflorescence $1 \mathrm{~cm}$. long or less; racemes $3-10,5-18 \mathrm{~cm}$. long, usually erect or ascending, commonly digitate: spikelets $2.5-3 \mathrm{~mm}$. long, about $0.8 \mathrm{~mm}$. wide, elliptic-lanceolate, acute, in pairs ; first scale small, glabrous, the second and third appressedpubescent, the second about $\frac{1}{2}$ as long as the spikelet, ovate-lanceolate, 3-nerved, the third about as long as the flowering one, 7 -nerved, the first and second nerves on each side hispid above the middle, fourth scale yellowish white when mature, acutely apiculate, ellipticlanceolate. [Panicum sanguinale L.]

In cultivated places, nearly throughout North America. Introduced. Spring to fall.

11. Syntherisma fimbriàtum (Link) Nash. Stems $8 \mathrm{dm}$. long or less, finally branched, prostrate at the base and rooting at the lower nodes: lower leaf-sheaths densely papillose-hirsute with spreading hairs; blades 2-8 cm. long, 5-10 mm. wide, erect or ascending, both surfaces glabrous or more or less pubescent : axis of the inflorescence $2 \mathrm{~cm}$. or less long ; racemes 2-9, 2-12 cm. long, erect or ascending, alternate, in pairs or whorls : spikelets $3-3.5 \mathrm{~mm}$. long, about $0.8 \mathrm{~mm}$. wide, lanceolate, very acute, in pairs ; first scale small, glabrous, the second and third appressed-pubescent with long hairs, the second one $\frac{3}{5}$ to $\frac{4}{5}$ as long as the spikelet, lanceolate-cuneate, 3-nerved, the third slightly exceeding the flowering scale, 7 -nerved, the pubescence usually becoming widely spreading, the fourth one lanceolate, very acute, yellowish white at maturity.

In dry sandy soil, District of Columbia to Florida and Texas. Introduced. Summer.

12. Syntherisma barbàtum (Willd.) Nash. Stems $5 \mathrm{dm}$. long or less, branching, often rooting at the lower nodes : leaf-sheaths glabrous; blades lanceolate, $3 \mathrm{~cm}$. long or less, 3-5 mm. wide, glabrous on both surfaces, sparsely ciliate at the base : racemes in pairs, 4-6 cm. long, erect or ascending : spikelets $3.5-4 \mathrm{~mm}$. long, slightly exceeding 1 $\mathrm{mm}$. wide, lanceolate, acute, in pairs; first scale small, glabrous, the second and third appressed-pubescent with very long hairs, the second one about $\frac{4}{5}$ as long as the spikelet, lanceolate-cuneate, 3-nerved, the third 7-nerved and in the long-pedicelled spikelet the pubescence of two kinds; fourth scale yellowish white at maturity, elliptic-lanceolate, acuminate.

In sandy soil, Mississippi. Introduced. Summer.

\section{TRICHÁCHNE Nees.}

Perennial grasses, with flat leaf-blades, usually tufted stems and narrow or contracted panicles, usually densely hairy. Spikelets numerous, articulated below the empty scales, 1-flowered, lanceolate, acute or acuminate. Scales 4 , the outer 3 membranous, empty, the second and usually also the much shorter first densely silky-pilose or long-ciliate on the margins, often acuminate, and sometimes with a short bristle at the apex, the fourth scale shorter, chartaceous, glabrous and shining, finally indurated, enclosing a shorter palet of similar texture and a perfect flower. Stamens 3. Styles distinct. Stigmas plumose.

Panicle tawny white : spikelets $4-5 \mathrm{~mm}$. long, lanceolate.

Panicle silvery white: spikelets about $3 \mathrm{~mm}$. long, ovate-lanceolate.

1. T. insulare.

2. $T$. saccharatum.

1. Trichachne insulàre (L.) Nash. Stems 1-1.5 dm. tall, stout, finally more or less branched : leaf-sheaths usually glabrous, or sometimes papillose-hirsute; blades ascending, sometimes drooping, 1-3 dm. long, generally 5-20 $\mathrm{mm}$. wide : panicle tawny white, usually 2-3 dm. long, 1-2 cm. wide : spikelets 4-5 mm. long, long-acuninate, the hairs less copious than in the following species. [Panicum leucophaeum H.B.K.]

In cultivated ground, on banks, and in coral soil, Florida and southern Texas. Also in tropical countries. Spring to fall.

2. Trichachne saccharàtum (Buckl.) Nash. Stems 4-8 dm. tall, finally somewhat branched : leaf-sheaths glabrous, or sometimes papillose-hirsute ; blades erect or ascending, generally less than $1.5 \mathrm{dm}$. long and usually less than $5 \mathrm{~mm}$. wide : panieles silvery white, 
1-2 dm. long, usually $1.5 \mathrm{~cm}$. wide or less : spikelets ovate-lanceolate, acute, $3-3.5 \mathrm{~mm}$. long, the silvery white hairs very long and copious, extending much beyond the apex of the spikelet.

On dry hillsides, Texas to Colorado. Also in Mexico. Summer.

\section{ECHINÓCHLOA Beauv.}

Often tall grasses, with flat leaf-blades, the inflorescence composed of several to many unilateral more or less spreading spike-like racemes. Spikelets 1-2-flowered, lanceolate to ovate or orbicular-ovate, crowded in small clusters or racemes in 2 rows on one side of the flat rachis. Scales 4, the 3 outer membranous, spiny-hirsute or hispid externally, the first much shorter than the spikelet, often awn-pointed, the second and third awn-pointed or awned (rarely awnless), the latter bearing the longer awn and rarely enclosing a palet and sometimes also a staminate flower; fourth scale chartaceous, glabrous and shining, at length indurated, acute or acuminate, enclosing a shorter palet of similar texture and a perfect flower. Stamens 3. Styles distinct. Stigmas plumose.

Leaf-sheaths glabrous.

Awn of the third scale not exceeding 4 times the length of the spikelet, sometimes very short or almost wanting.

Spikelets $2.5-3 \mathrm{~mm}$. long : lower racemes rarely exceeding the rachis-internodes.

Spikelets $4 \mathrm{~mm}$. long; the lower racemes much exceeding the rachis-internodes.

Awn of the third scale 8-15 times the length of the spikelet.

Leaf-sheaths, at least the lower ones, densely papillose-hispid.

1. E. colona.

2. E. Crus-galli.

3. E. longearistata.

4. E. Walteri.

1. Echinochloa colòna (L.) Link. Stems tufted, 1-8 dm. tall, often decumbent and rooting at the lower nodes : leaf-sheaths glabrous, compressed; blades flat, $2-17 \mathrm{~cm}$. long, 2-8 $\mathrm{mm}$. wide: inflorescence composed of 3-18 one-sided more or less spreading racemes, $6-30 \mathrm{~mm}$. long: spikelets single, in pairs, or in 3's in 2 rows, obovate, pointed, hispid on the nerves, 2.5-3 mm. in length, the fourth scale cuspidate. [Panicum colonum L.]

In fields and along roadsides, Virginia to Florida, Texas and Mexico. Common in all tropical countries. Spring to fall. Jungle RICE.

2. Echinochloa Crùs-gálli (L.) Beauv. Stems 6-12 dm. tall : leaf-sheaths glabrous ; blades 1.5-6 dm. long, 6-25 mm. wide, glabrous, smooth or rough : panicle of 5-15 erect or ascending branches, or the lower ones spreading or reflexed and sometimes $6-8 \mathrm{~cm}$. long: spikelets ovate, densely crowded in 2-4 rows on one side of the rachis, about $4 \mathrm{~mm}$. long, exclusive of the awn, hispidulous, hispid on the nerves, the second and third scales more or less awned, the fourth abruptly pointed. [Panicum Crus-galli L.]

In cultivated and waste places throughout North America, excepting the extreme north, and widely distributed as a weed in all cultivated areas. Introduced from Europe. Summer and fall. BARNYARD GRASS.

3. Echinochloa longearistàta Nash. Stems 1-2 m. tall, stout: leaf-sheaths glabrous; blades flat, rough on the upper surface, smooth beneath, 6-12 dm. long, 2-4 cm. wide or more : panicle 4-6 dm. long, its branches ascending : spikelets ovate, $3.5-4 \mathrm{~mm}$. long, acuminate, hispidulous, the nerves strongly hispid, the awn of the third scale usually 8-15 times as long as the spikelet.

In wet ground, South Carolina to Louisiana. Summer.

4. Echinochloa Wálteri (Pursh) Nash. Stems 9-18 dm. tall, stout : leaf-sheaths, at least the lower ones, papillose-hispid; blades $3 \mathrm{dm}$. long or more, 1-2.5 $\mathrm{cm}$. wide, very rough above : panicle of 10-40 ascending or spreading branches : spikelets ovate-lanceolate, densely crowded in 2-4 rows on one side of the rachis, 3-4 mm. long, exclusive of the awns, hispidulous, hispid on the nerves, the second and third scales very long-awned, the fourth scale ovate-lanceolate, acuminate.

In marshes and ditches, usually near salt-water, New York to Florida. Summer and fall.

\section{OPLÍSMENUS Beauv.}

Perennial grasses, often decumbent and branched at the base, with broad flat leafblades and inflorescence composed of spikes, bearing on the lower side scattered clusters of a few spikelets. Spikelets 1-flowered. Scales 4 , the 3 outer membranous, the first and second empty, awned, the first equalling or somewhat shorter than the spikelet, the third scale usually awned, empty, or enclosing a small palet, the fourth one shorter than the others, obtuse, awnless, chartaceous, finally indurate, enclosing a shorter palet of similar texture and a perfect flower. Stamens 3. Styles distinct to the base. Stigmas plumose.

Oplismenus setàrius (Lam.) R. \& S. Stems prostrate, rooting at the nodes: leafblades ovate to ovate-lanceolate, acuminate, $1.5-6 \mathrm{~cm}$. long: panicle $2-8 \mathrm{~cm}$. long, its short 
branches erect to spreading: spikelets, exclusive of the awns, $2.5-3 \mathrm{~mm}$. long, the longer awns $6-8 \mathrm{~mm}$. long.

In low woods and swamps, Georgia to Texas. Also in tropical America. Summer and fall.

\section{PÁNICUM L.}

Annual or perennial grasses, varying much in habit, with elongated or flat and broad leaf-blades, and the spikelets in open or contracted panicles. Spikelets 1-2-flowered, lanceolate, oblong, ovate to obovate or globose, obtuse to acute or acuminate. Scales 4 , the 3 outer membranous, the first and second empty, the first usually much shorter than the spikelet, sometimes minute, the third one empty or enclosing a shorter hyaline palet and often also a staminate flower; fourth scale shorter and usually more obtuse than the others, chartaceous, glabrous and shining, at length indurated, enclosing a palet of similar texture and a perfect flower. Stamens 3. Styles distinct. Stigmas plumose.

Herbs, varying in habit.

Spikelets disposed singly or in pairs in one-sided racemes, the pedicels short.

Spikelets arranged in panicles but not disposed in one-sided racemes, the pedicels short or long.

Basal leaf-blades long and narrow, similar to those of the stem : no rosulate tufts of leaves in the fall: spikelets lanceolate to ovate, usually the former, acute to acuminate, rarely obtuse.

Spikelets manifestly tuberculate.

Spikelets not tuberculate.

Basal leaf-sheaths round or but little flattened, not keeled.

Fourth scale smooth.

Annuals or perennials, if the latter no rootstocks or stolons. Perennial by long rootstocks or stolons.

Rootstocks and stolons naked or with a few large scales : sandbinders.

Rootstocks, at least when young, and stolons covered with numerous small broad acute scales.

Fourth scale transversely rugose.

Basal leaf-sheaths much compressed, broad, keeled, often equitant.

Basal leaf-blades commonly unlike those of the stem, ovate to ovate-
lanceolate: perennial by rosulate tufts which form in the fall at the

base of the stems: spikelets elliptic to spherical, usually obtuse, some-

times acute, never acuminate.

Much branched shrubs, with broad leaf-blades: spikelets large and turgid, the outer scales woolly-tipped.

I. PASPALOIDEA.

II. VERRUCOSA.

III. CAPILLARIA.

IV. HALOPHILA.

V. VIRGATA.

VI. MAXIMA.

VII. AGROSTOIDEA.

VIII. DICHOTOMA.

IX. LATIFOLIA.

\section{PASPALOIDEA.}

Fourth scale of the spikelet smooth.

Spikelets not ciliate with long hairs, the first scale $1 / 2$ as long as the spike-

let or less, excepting in no. 2.

Terrestrial grasses.

Stems prostrate: leaf-blades short, ovate-lanceolate, spreading.

Stems erect: leaf-blades long and relatively narrow.

Spikelets obtuse, turgid, the first scale very large, rounded at the apex, more than $1 / 2$ as long as the spikelet.

Spikelets acute, the first scale small, acute at the apex, less than $1 / 2$ as long as the spikelet.

Aquatic grasses.

Spikelets singly disposed, about $3 \mathrm{~mm}$. long, the first scale rounded or truncate at the apex.

Spikelets in pairs, about $2 \mathrm{~mm}$. long, the first scale acute at the sum-

Spikelets ciliate with numerous very long hairs, the first'scale narrow and acuminate, nearly as long as the spikelet.

Fourth scale transversely rugose: usually the outer scales of some or all of the spikelets with anastomosing veinlets.

Branches of the panicle terminated by a spikelet, no extension beyond them.

Spikelets $2.5-3 \mathrm{~mm}$. long, broadly obovoid, obtuse or acutish, anastomosing veinlets numerous and prominent.

Spikelets 4-6 mm. long, acute or acuminate, oval, anastomosing veinlets few and faint.

Spikelets about $4 \mathrm{~mm}$. long, the first scale less than $1 / 2$ their length. Spikelets 5-6 mm. long, the first scale more than $1 / 2$ their length.

Branches of the panicle extending beyond the spikelets in an awn-like projection.

First scale of the spikelet 1-nerved, or sometimes with a faint lateral nerve on each side.

First scale of the spikelet 5-nerved.

Spikelets $2.5 \mathrm{~mm}$. long : leaf-blades usually short.

Spikelets $3.5 \mathrm{~mm}$. long : leaf-blades usually elongated.

1. P. prostratum.

2. P. obtusum.

3. P. malle.

4. P. paspaloides.

5. P. digitarioides.

6. P. ciliatissimum.

7. P. fuscum.

8. P. fasciculatum.

9. P. Texanum.

10. P. Chapmanii.

11. P. ramisetum.

12. P. Reverchonii.

\section{VERRUCOSA.}


Annuals.

\section{CAPILLARIA.}

spikelets $3 \mathrm{~mm}$. long or less, lanceolate or elliptic.

Leaf-sheaths pubescent.

Stems stout: panicle usually included at the base, its many branches repeatedly divided and bearing numerous spikelets.

Stems slender: panicle exserted, its few branches but little divided relatively and bearing comparatively few spikelets.

Spikelets $2 \mathrm{~mm}$. long, acute.

Spikelets lanceolate, about $0.6 \mathrm{~mm}$. wide.

Spikelets elliptic, about $0.8 \mathrm{~mm}$. wide.

Spikelets $3 \mathrm{~mm}$. long, acuminate.

Leaf-sheaths glabrous.

First scale about $1 / 4$ as long as the spikelet.

First scale more than $1 / 2$ as long as the spikelet.

Spikelets ovate, the panicle branches ascending: leaf-blades 1.5 dm. long or less.

Spikelets lanceolate, the panicle branches very long and widespreading: leaf-blades $2.5-4 \mathrm{dm}$. long.

Spikelets $5 \mathrm{~mm}$. long, ovate.

Perennials.

Spikelets less than $4 \mathrm{~mm}$. long.

Pedicels usually not exceeding four times the length of the spikelets, often shorter than them.

Stems densely tufted, stiff and wiry, slender.

Panicle branches appressed.

Panicle branches at maturity spreading.

Stems single or not much tufted, stout, not rigid and wiry.

Spikelets ovate, the panicle branches ascending: leaf-blades 1.5 dm. long or less.

Spikelets lanceolate, the panicle branches very long and widely spreading : leaf-blades $2.5-4 \mathrm{dm}$. long.

Pedicels usually many times exceeding the spikelets.

Spikelets 5-6 mm. long, acuminate.

\section{HALOPHILA.}

Spikelets less than $3 \mathrm{~mm}$. long, obtuse or acutish.

Panicle dense, the spikelets crowded, the first scale of the spikelet acute, about $1 / 2$ as long as the spikelet.

Panicle long and narrow, loose, the spikelets rather scattered, the first scale of the spikelet truncate, about $1 / 4$ as long as the spikelet.

Spikelets 5-6 mm. long, acuminate.

Stems tall, simple: panicle usually ample.

$$
\text { V. VIRGATA. }
$$

VI. MAXIMA.

Tall stout grasses, with large leaves and ample panicles.

\section{AGROSTOIDEA.}

Innovations intravaginal, hence stems tufted; spikelet not oblique to the pedicel, the apex straight, hence equilateral.

Fourth scale of the spikelet sessile.

Ligule membranous.

Panicle ovate, its branches at maturity widely spreading.

Panicle oblong, its branches erect.

Ligule a ring of long hairs.

Leaf-sheaths naked at the apex : panicle branches rigid and spreading at maturity.

Leaf-sheaths pubescent with long hairs at the apex on the outside : panicle branches long and slender, erect, flexuous.

Fourth scale of the spikelet with a distinct slender stipe.

Innovations extravaginal, the long stolons stout and scaly: spikelet oblique to the pedicel, the apex decidedly curved, hence inequilateral.

\section{DICHOTOMA.}

A. Leaf-blades on the stem long and narrow, linear, narrowed at both ends, very different from the early basal ones.

a. Leaf-blades erect.

Stems 8-14 dm. tall, stout.

Stems less than $6 \mathrm{dm}$. tall, not stout.

Primary leaf-blades of the stem usually less than $4 \mathrm{~mm}$. wide, from 25-50 times as long as broad.

Stems simple, finally with very short spikelet-bearing basal stems concealed in the leaves: spikelets $2 \mathrm{~mm}$. long or more.

Spikelets obtuse, the outer scales as long as or but little shorter than the fourth scale.

Spikelets 2-2.5 mm. long, pubescent.

Spikelets $3 \mathrm{~mm}$. long, with a few scattered hairs near the base.

Spikelets acute, glabrous, the outer scales manifestly exceeding the fourth scale.

Stems finally branching at the nodes, no short basal stems : spikelets $1.5 \mathrm{~mm}$. long or less.

Primary leaf-blades of the stem exceeding $4 \mathrm{~mm}$. wide, often more than $1 \mathrm{~cm}$. in width, 20 times as long as broad or less.

15. P. crpillare.

16. P. Philadelphicum.

17. P. Gattingeri.

18. P. flexile.

19. P. proliferum.

23. P. Hallii.

24. P. filipes.

20. P. miliaceum.

21. P. stenodes.

22. P. diffusum.

23. P. Hallii.

24. P. filipes.

25. P. cognatum.

26. P. capillarioides.

27. P. halophilum.

28. P. repens.

29. P. amarum.

30. P. virgatum.

31. P. maximum.

32. P. agrostoides.

33. $P$. condensum.

34. P. Combsii.

35. P. pseudanceps.

36. P. stipitatum.

37. P. rostratum.

105. P. scabriusculum.

38. P. linearifolium.

39. P. perlongum.

40. P. depauperatum.

41. P. glabrifolium. 
Stems simple, or sometimes sparingly branched at the nodes: plants usually bright green: hairs on the leaf-sheaths reflexed.

Spikelets 1.7-2 mm. long : leaf-blades usually pubescent, sometimes nearly glabrous, commonly ciliate on the margins.

Spikelets about $2.5 \mathrm{~mm}$. long : leaf-blades glabrous, excepting sometimes a few hairs on the margin.

Stems at length repeatedly dichotomous-branched, forming dense mats : plants grayish green : hairs on the leaf-sheaths, if any, ascending or appressed.

Whole plant, excepting the spikelets, glabrous or nearly so, or the sheaths and blades sometimes pubescent.

Spikelets broadly obovoid, about $2 \mathrm{~mm}$. long. Spikelets obovoid, 2.5-3.5 mm. long.

Whole plant, including the upper part of the stem, densely villous.

b. Leaf-blades widely spreading.

B. Leaf-blades of the main stem differing from the above, usually lanceolate

to ovate-lanceolate, sometimes short and linear.

Stems simple, or rarely a little branched at the lower nodes, forming dense tufts.

Leaf-sheaths hirsute.

Spikelets less than $1.5 \mathrm{~mm}$. long.

Spikelets exceeding $1.5 \mathrm{~mm}$. long.

Leaf-sheaths glabrous, excepting the ciliate margin; blades strongly and beautifully ciliate on the margins, otherwise glabrous.

Spikelets about $1.5 \mathrm{~mm}$. long, glabrous.

Spikelets 1.8-2 mm. long, pubescent.

Stems finally branching at the upper nodes (sometimes remaining simple in number 89 ), often repeatedly branching.

* Middle leaf-blades of the main stem less than $1.5 \mathrm{~cm}$. in width, usually less than $1 \mathrm{~cm}$. wide, the base rounded or truncate, sometimes in the broadest ones cordate.

$\dagger$ Leaf-sheaths glabrous or puberulent, the lower ones sometimes with a few scattered long hairs, the margins often ciliate.

Stem nearly naked above the base, a single leaf above the middle of the stem.

Stems leafy.

Nodes barbed.

Spikelets glabrous :

A little less than $2 \mathrm{~mm}$. long.

About $2.5 \mathrm{~mm}$. long.

Spikelets pubescent.

Nodes naked.

Spikelets glabrous.

Spikelets less than $1.5 \mathrm{~mm}$. long.

Stems densely tufted, less than $3 \mathrm{dm}$. tall, finally much-branched and prostrate and forming large mats : spikelets about $1 \mathrm{~mm}$. long.

Stems exceeding $6 \mathrm{dm}$. tall: spikelets about $1.3 \mathrm{~mm}$. long.

Spikelets 1.5-2 mm. long.

Leaf-blades ciliate with long hairs, at least for the lower half

Leaf-blades not ciliate.

Primary leaf-blades of the stem large, 9-12 $\mathrm{cm}$. long.

Primary leaf-blades of the stem small, rarely exceeding $6 \mathrm{~cm}$. long.

Leaf-blades widely spreading, thin.

Stems remaining erect, branching at the middle, the late state assuming the form of a little tree.

Stems becoming prostrate, branching their whole length.

Leaf-blades erect:

Thin : stems finally much-branched and prostrate.

Ligule membranous, $0.25 \mathrm{~mm}$. long to almost wanting: spikelets elliptic.

Ligule of erect hairs about $1 \mathrm{~mm}$. long: spikelets obovoid.

Firm, the basal ones thick and much broader than the upper.

Spikelets $2.5-3 \mathrm{~mm}$. long :

Elliptic: stems finally much-branched and prostrate.

Broadly obovoid: stems erect.

46. P. laxiflorum.

45. P. pyriforme.

47. $P$. neuranthum.

48. P. angustifolium.

49. P. consanguineum.

107. P. equilaterale.

42. P. strigosum.

46. P. laxiflorum.

43. P. polycaulon.

44. P. ciliatum.

66. P. nudicaule.

57. P. barbulatum.

58. P. nemopanthum.

59. P. Mattamuskeetense.

68. P. Baldvinii.

78. P. octonodum.

52. P. Nashianum.

56. P. Yadkinense.

55. P. dichotomum.

62. P. lucidum.

62. P. lucidum.

63. P. curtivaginum.

51. P. Roanokense.

65. P. sphagnicola.

116. P. pernervosum.

spikelets pubescent.

Spikelets less than $2 \mathrm{~mm}$. long.

Leaf-blades ciliate for at least $1 / 2$ their length.

Panicle ovoid: spikelets few, $1.75 \mathrm{~mm}$. long: leafblades small.

Panicle oblong: spikelets numerous, $1.3 \mathrm{~mm}$, long: leaf-blades large.

Leaf-blades naked on the margins, or sometimes with

52. P. Nashianum.

91. P. erectifolium. 
Spikelets less than $1 \mathrm{~mm}$. long.

Spikelets 1-2 mm. long.

Ligule $0.5 \mathrm{~mm}$. long to almost wanting.

Blades of the primary stem-leaves, the larger ones, $8-15 \mathrm{~mm}$. wide.

Spikelets $1.3 \mathrm{~mm}$. long: basal leaf-blades equalling or larger than those on the stem which are usually $5-7$ in number.

Spikelets $1.5 \mathrm{~mm}$. long or more : basal leafblades smaller than those on the stem which usually number 4 or less.

Upper surface of the blades very rough.

Upper surface of the blades smooth: stems much-branched: sheaths inflated.

Blades of the primary stem-leaves, the larger ones, rarely exceeding $6 \mathrm{~mm}$. wide :

With a broad cartilaginous white muchthickened margin.

Upper portion of the stem naked. the 2 leaves below the middle.

Stems leafy almost to the panicle: leaves usually 3 .

With no conspicuous white margin.

Leaf-blades glabrous on both surfaces. Spikelets barely exceeding $1 \mathrm{~mm}$. long, obovoid: primary leafblades $5-7 \mathrm{~cm}$. long.

Spikelets $1.5 \mathrm{~mm}$. long, elliptic : primary leaf-blades usually less than $5 \mathrm{~cm}$. long.

Leaf-blades pubescent, at least below. Stems very slender, weak: stemleaves light green, thin, spreading, usually less than $2 \mathrm{~cm}$. long. Upper surface of the blades pubescent with very long weak hairs.

Upper surface of the blades glabrous.

Stem stouter: stem-leaves grayish green, firm, $2-3 \mathrm{~cm}$. long.

Ligule of hairs $2-4 \mathrm{~mm}$. long.

Leaf-blades glabrous on the lower surface.

Plant bright green : panicle broadly ovoid, its branches spreading.

Plant grayish green, the leaves purplish: panicle oblong, its branches ascending or nearly erect.

Leaf-blades pubescent beneath with short hairs.

Stems slender, glabrous.

Plant bright green : sheath margin ciliate with long hairs.

Plant grayish green: sheath margin naked.

Stems rather stout, the lower portion densely pubescent with long nearly ereet hairs.

33. Spikelets exceeding $2 \mathrm{~mm}$. in length.

Primary leaf-blades elongated, broadly linear, often $2 \mathrm{dm}$. long and $1.5 \mathrm{~cm}$. wide, spreading.

Primary leaf-blades lanceolate:

Rounded or truncate at the base.

Margins ciliate, at least for the lower half.

Margins naked, or sometimes with a few hairs at the very base.

Leaf-blades spreading : first scale $1 / 2$ as long as the spikelet, acute.

Stems puberulent: primary leaf-blades less than $4 \mathrm{~cm}$. long: plant usually purplish.

Stems glabrous: primary leaf-blades $5-7$ $\mathrm{cm}$. long: plant usually green.

Leaf-blades erect : first scale $1 / 4-1 / 3$ as long as the spikelet, rounded at the apex.

Cordate at the clasping base.

Leaf-blades glabrous. sometimes ciliate on the margins.

Stems puberulent: blades naked on the margin.

Stems glabrous : blades ciliate on the margin. Leaf-blades pubescent.

t+ Leaf-sheaths pubescent with long hairs.

Spikelets very strongly and sharply nerved, acute: leaf-blades elongated, broadiy linear or linear-lanceolate, the larger ones often $2 \mathrm{dm}$. long and $1 \mathrm{~cm}$. wide.

67. P. Wrightianum.

89. P. sphaerocaipon.

90. P. inflatum.

73. P. albomarginatum.

74. P. trifolium.

71. P. gracilicaule.

72. P. flavovirens.

70. P. Cuthbertii.

69. P. ensifolium.

75. P. glabrissimum.

81. P. nitidum.

77. P. paucipilum.

81. P. nitidum.

76. P. longiligulatum.

80. P. parvispiculum.

107. P. equilaterale.

52. P. Nashianum.

53. P. patentifolium.

101. P. epilifolium.

54. P. Webberianum.

108. P. Ashei.

111. P. commutatum.

109. P. ovale.

105. P. scabriusculum. 
Spikelets and leaf-blades not as above, the former obtuse.

Spikelets glabrous, or with a few scattered hairs.

Spikelets $3 \mathrm{~mm}$. long.

Leaf-sheaths, at least the lower ones and those on the branches, densely papillose-hispid.

Lower leaf-sheaths with scattered papillae from some of which arise hairs.

Spikelets not exceeding $1.5 \mathrm{~mm}$. long.

Leaf-blades pubescent with long weak hairs.

Leaf-blades glabrous, or if pubescent the hairs few and very short.

Spikelets densely pubescent.

Leaf-blades glabrous on both surfaces, or the lower surface sometimes with a few scattered long hairs.

Spikelets $2 \mathrm{~mm}$. long or less.

Leaf-blades oblong-lanceolate, broadest at the middle: spikelets about $1.5 \mathrm{~mm}$. long.

Leaf-blades broadest below the middle, long-acuminate: spikelets a little less than $2 \mathrm{~mm}$. long.

Spikelets about $3 \mathrm{~mm}$. long :

Broadly obovoid, turgid.

Elliptic, not turgid.

Leaf-blades pubescent on one or both surfaces.

Spikelets but little exceeding $1.5 \mathrm{~mm}$. long or less.

Lower surface of the leaf-blades softly pubescent with usually short hairs,sometimes intermixed with a few stiff ones.

Spikelets about $1 \mathrm{~mm}$. long.

Spikelets about $1.5 \mathrm{~mm}$. long.

Upper surface of the leaf-blades glabrous or nearly so, or at first with a few scattered hairs.

Leaf-blades conspicuously ciliate on the margin with long hairs.

Leaf-blades naked on the margin, or sometimes with a few scattered hairs.

Upper surface of the leaf-blades strongly pubescent, sometimes with long stiff hairs.

Stems low, slender, usually $2 \mathrm{dm}$. tall or less.

Stems tall, stout, $4 \mathrm{dm}$. high or more.

Spikelets obovoid, $1.5 \mathrm{~mm}$. long: pubescence on the lower surface of the leafblades short.

Spikelets elliptic, about $1.75 \mathrm{~mm}$. long: pubescence on the lower surface of the leaf-blades longer and villous.

Lower surface of the leaf-blades as well as the upper surface pubescent with long usually stiff hairs.

Spikelets $2 \mathrm{~mm}$. long or more.

Pubescence on the lower surface of the leaf-blades of long stiff spreading hairs.

Pubescence on the leaf-sheaths and stems appressed or ascending.

Pubescence on the sheaths and stems widely spreading.

Spikelets about $2 \mathrm{~mm}$. long, obovoid.

Hairs on the upper surface of the leaf-blades similar to those on the lower surface.

Hairs on the upper surface of the leaf-blades much longer than those of the lower surface.

Spikelets 2.5-2.75 mm. long, elliptic.

Spikelets purplish.

Spikelets yellow.

Pubescence on the lower surface of the leaf-blades of either soft and short or appressed hairs.

Upper surface of the leaf-blades glabrous, or at least the pubescence much more scanty than on the lower surface.

Stems pubescent below with long stiff appressed

or nearly appressed hairs.

Leaf-blades naked on the margins :

Exceeding $1 \mathrm{~cm}$. in width : spikelets about $4 \mathrm{~mm}$. long.

Less than $1 \mathrm{~cm}$. in width: spikelets $3 \mathrm{~mm}$. long or less. Spikelets 2-2.5 $\mathrm{mm}$. long. Spikelets $3 \mathrm{~mm}$. long.

Leaf-blades ciliate on the margin with long hairs.

Stems villous below.

Both surfaces of the leaf-blades pubescent with short hairs.

Stems glabrous or nearly so.

Stems strongly pubescent.

Pubescence minutely villous, or of long and stiff ascending or appressed hairs.

118. P. Scribnerianum.

104. P. Helleri.

61. P. Earlei.

64. P. curtifolium.

88. P. Lindheimeri.

50. P. arenicola.

118. P. Scribnerianum.

104. P. Helleri.

79. P. leucothrix.

83. P. ciliosum.

82. P. Tennesseense.

86. P. filiculme.

84. P. lanuginosum.

85. P. Thurowii.

87. P. unciphyllum.

93. P. chrysopsidifolium.

94. P. pseudopubescens.

95. P. Atlanticum.

96. P. villosissimum.

97. P. xanthospermum.

\section{P. Ravenelii. \\ 98. P.Commonsianum. \\ 99. P. strictifolium.}

100. P. ciliiferum.

117. P. oligosanthes.

60. P. annulum. 
Plant green: stems slender: leaf-blades rather sparingly pubescent.

Plant purplish: stems stout: leaf-blades densely pubescent.

Pubescence of widely spreading hairs.

Stems, as well as the leaf-sheaths, densely velvety pubescent, usually $6-8 \mathrm{dm}$. tall.

Stems, as well as the leaf-sheaths, papillose-pubescent with rather stiff long hairs, usually less than $4 \mathrm{dm}$. tall.

** Middle leaf-blades of the main stem more than $1.5 \mathrm{~cm}$. wide, sometimes $3-4 \mathrm{~cm}$. in width, the base cordate and clasping.

spikelets $3 \mathrm{~mm}$. long or less.

Leaf-blades glabrous, or sometimes ciliate on the margins.

Spikelets $1.5 \mathrm{~mm}$. long.

Spikelets $2-3 \mathrm{~mm}$. long.

Leaf-sheaths glabrous, or sometimes ciliate on the margin.

Basal leaf-blades smaller than those of the stem. Stems erect, even in the late state, sparingly branched: spikelets obtuse or acutish.

Stems finally much-branched and prostrate, forming large mats: spikelets very acute.

Basal leaf-blades usually very long, larger than those of the stem:

Their margin naked.

Their margin ciliate with long hairs.

Leaf-sheaths, at least the lower ones and those of the branches, densely papillose-hispid.

Leaf-blades pubescent :

Ovate-lanceolate: stems pubescent with short ascending hairs.

Linear: stems densely velvety pubescent with spreading hairs.

Spikelets exceeding $3 \mathrm{~mm}$. long.

Pubescence on the stem and leaf-sheaths, if any, of soft weak hairs.

Nodes naked: leaf-blades usually ciliate on the margin.

Nodes densely barbed with spreading hairs: leaf-blades usually naked on the margins.

Lower surface of the leaf-blades paler, glabrous.

Lower surface of the leaf-blades pubescent, as are also the sheaths and stems.

Pubescence on the stem and leaf-sheaths of coarse rigid hairs arising from manifest papillae.

102. P. pedicellatum.

103. P. malacon.

106. P. scoparium.

115. P. malocophyllum.

92. P. polyanthes.

111. P. commutatum.

110. P. Manatense.

113. P. Joorii.

112. P. mutabile.

114. P. clandestinum.

109. P. ovale.

106. P. scoparium.

120. P. macrocarpon.

121. P. Porterianum.

122. P. pubifolium.

119. P. Ravenelii.

123. P. latifolium.

IX. LATIFOLIA.

Tropical plants represented in our range by a single species.

1. Panicum prostràtum Lam. Stems prostrate and creeping, leafy, branching, the summit ascending : leaf-blades ovate, glabrous or pubescent, ciliate on the margin near the cordate-clasping base, usually $1-3 \mathrm{~cm}$. long, sometimes larger : racemes 4-6, ascending, one-sided, $1.5-2.5 \mathrm{~cm}$. long : spikelets about $2 \mathrm{~mm}$. Iong, elliptic, glabrous, acute, the first scale broader than long, truncate at the apex, the fourth scale transversely rugose.

Along roadsides, Louisiana. Introduced from tropical countries. Summer and fall.

2. Panicum obtùsum H.B.K. Glabrous. Stems erect, simple, or branching at the base, 3-6 dm. tall : leaf-blades usually erect, long-acuminate, $6-22 \mathrm{~cm}$. long, 2-6 mm. wide: panicle linear, $5-15 \mathrm{~cm}$. long, its branches appressed, one-sided : spikelets about $3 \mathrm{~mm}$. long, crowded, oval or obovoid, obtuse, turgid, in pairs, the one short- the other long-pedicelled, glabrous, the first scale shorter than the rest, 5-nerved.

In dry usually sandy places, Kansas and Colorado to Texas and Arizona. Also in Mexico. Summer and fall.

3. Panicum mólle Sw. Sterile stems 1-2 m. long, rooting at the nodes, the fertile stems erect, $6-10 \mathrm{dm}$. tall or more, the nodes densely barbed : leaf-sheaths often overlapping, papillose-hirsute : blades 1-3 dm. long, glabrous or pubescent, $7-15 \mathrm{~mm}$. wide : panicle 1.5-2 dm. long, its branches spreading or ascending : spikelets about $3 \mathrm{~mm}$. long, glabrous. and fall.

In fields and along roadsides, Florida to Texas. Introduced from tropical America. Summer

4. Panicum paspaloìdes Pers. Aquatic. Stems 6-12 dm. long, usually clothed with sheaths below : leaves glabrous; blades $2.5 \mathrm{dm}$. long or less, $6-10 \mathrm{~mm}$. wide : racemes $10-20$, one-sided, the rachis broadly winged, appressed, $2-3.5 \mathrm{~cm}$. long : spikelets about 2.5 $\mathrm{mm}$. long, ovate, acute, glabrous, singly disposed in 2 rows, the first scale broader than long and clasping the spikelet at its base, truncate at the apex, the fourth scale transversely wrinkled.

In shallow water, southern Florida and Texas. Also in tropical America, Asia and Australia Spring to fall. WATER GRASS. 
5. Panicum digitarioìdes Carpenter. Aquatic. Stems from stout rootstocks, 6-12 dm. tall or more : leaves glabrous ; blades $3 \mathrm{dm}$. long or less, 6-12 mm. wide : racemes 6-20, appressed, one-sided, 4-10 $\mathrm{cm}$. long, the rachis barely if at all winged : spikelets in pairs, the one short- the other longer-pedicelled, about $2.5 \mathrm{~mm}$. long, the scales prominently nerved, the first scale ovate, acute, the fourth scale smooth.

In shallow water, Delaware to Florida and Texas. Spring and summer.

6. Panicum cillatíssimum Buckl. Perennial. Stems slender, branched at the base and barbed at the nodes, 2-6 dm. long: leaf-sheaths pubescent ; blades $4-9 \mathrm{~cm}$. long, 3-5 $\mathrm{mm}$. wide, flat, sparingly pubescent beneath and usually long-ciliate on the margin near the base : panicle 4-6 $\mathrm{cm}$. long, its branches erect : spikelets about $4 \mathrm{~mm}$. long, ovoid, the first scale deltoid-cuneate, but little shorter than the spikelet, glabrous, the second scale pubescent, the hairs near the margin very long, the third scale pubescent near the margin with very long hairs.

In low grounds, southern Texas. Spring and summer. Indian Wheat. Carpet Grass.

7. Panicum fúscum Sw. Annual. Stems tufted, finally branching at the base and often rooting at the lower nodes, glabrous, $3-8 \mathrm{dm}$. long: leaf-sheaths glabrous, pubescent ; blades $2.5 \mathrm{dm}$. long or less, $8-20 \mathrm{~mm}$. wide, glabrous or pubescent : panicle 1-2 dm. long, its branches ascending or nearly erect: spikelets usually borne in pairs on one side of the branches on frequently bristle-bearing pedicels, brown or green, $2.5-3 \mathrm{~mm}$. long, broadly obovoid, turgid, glabrous, obtuse, the second and third seales with anastomosing veinlets, the fourth scale transversely rugose.

In various situations, southern Florida and Texas. Also in tropical America. Spring to fall.

8. Panicum fasciculàtum Sw. Annual. Stems 4-6 dm. tall, glabrous, branching below : leaf-sheaths glabrous; blades $2 \mathrm{dm}$. long or less, $1.5-2 \mathrm{~cm}$. wide, glabrous : panicle 1-2 dm. long, its branches ascending or nearly erect: spikelets usually borne in pairs on one side of the branches, green, glabrous or pubescent, oval, abruptly acuminate, about $4 \mathrm{~mm}$. long, the second and third scales with a few anastomosing veinlets, the fourth scale transversely rugose.

In sandy soil, Key West. Also in the West Indies. Spring to fall.

9. Panicum Texànum Buckl. A softly pubescent annual. Stems $3-8 \mathrm{dm}$. tall, leafy, often branched at the base : leaf-blades erect, lanceolate, acuminate, commonly 1-2 dm. long, 1-2 cm. wide : racemes usually $6-12$, erect, one-sided, $3-8 \mathrm{~cm}$. long, the rachis wingless : spikelets in pairs, 5-6 mm. long, ovate, acute, pubescent, one short- the other longerpedicelled, the pedicels bristly, the first scale more than $\frac{1}{2}$ as long as the spikelet, ovate, acute, the fourth scale transversely rugose.

On plains and prairies, Texas. Summer and fall. Texas Millet.

10. Panicum Chapmánil Vasey. Glabrous or nearly so. Stems 3-6 dm. tall, slender, sometimes branched below : leaf-blades $3 \mathrm{dm}$. long or less, 4-6 mm. wide, longacuminate : inflorescence $1.5-2.5 \mathrm{dm}$. long, composed of appressed one-sided racemes, the lower ones $3-5 \mathrm{~cm}$. long, the rachis terminating in an awn-like point : spikelets nearly sessile, $2 \mathrm{~mm}$. long, singly disposed in 2 rows, broadly obovoid, glabrous, the fourth scale finely transversely rugose when mature.

In sandy soil, Florida keys. Summer.

11. Panicum ramisetum Scribn. Glabrous. Stems from a stout rootstock, 2-6 dm. tall, simple : leaf-blades ascending, 4-12 $\mathrm{cm}$. long, 2-4 mm. wide : panicle narrow, 4-10 cm. long, its short branches appressed and terminating in an awn-like projection : spikelets about $2.5 \mathrm{~mm}$. long, the fourth scale transversely rugose. [P. subspicatum Vasey, not Desv.]

In sandy places, southern Texas. Spring and summer.

12. Panicum Reverchònii Vasey. Glabrous. Stems from a stout rootstock, 2-4 $\mathrm{dm}$. tall, simple : leaf-blades erect, usually involute in drying, 1-2 dm. long, 2-4 $\mathrm{mm}$. wide : panicle narrow, 6-12 cm. long, its short branches appressed and terminating in an awn-like projection: spikelets $3.5 \mathrm{~mm}$. long, glabrous, the fourth scale finely and transversely rugose at maturity.

On sandy plains, Texas. Spring and summer.

13. Panicum verrucòsum Muhl. Stems erect or decumbent, slender, generally much branched at the base : leaf-sheaths glabrous; blades $5-18 \mathrm{~cm}$. long, $2-8 \mathrm{~mm}$. wide, erect or ascending, glabrous : panicle $7-30 \mathrm{~cm}$. long, its lower branches $5-15 \mathrm{~cm}$. long, naked below : spikelets about $1.5 \mathrm{~mm}$. long, elliptic, acutish.

In moist or wet soil, Massachusetts to Florida and Louisiana. Spring to fall.

14. Panicum brachyánthum Steud. Glabrous. Stems at first erect, finally prostrate at the base and branching, and rooting at the lower nodes, sometimes $1 \mathrm{~m}$. long: leaf-sheaths shorter than the internodes; blades erect or nearly so, usually $1.5 \mathrm{dm}$. long or less, $2-3 \mathrm{~mm}$. 
wide, linear: panicle $6-14 \mathrm{~cm}$. long, its branches very long, naked below, erect to widely spreading : spikelets at the end of the branches, $3-4 \mathrm{~mm}$. long and $1.5-1.8 \mathrm{~mm}$. wide, elliptic, acute, densely papillose-hirsute with ascending hairs. [P. sparsiflorum Vasey.]

In wet soil, the Indian Territory to Mississippi and Texas. Fall.

15. Panicum capillàre L. Stems $3-6 \mathrm{dm}$. tall, simple, or branched near the base, stout: leaf-sheaths usually purplish, papillose-hirsute; blades $1.5-8 \mathrm{dm}$. long, 6-16 mm. wide, pubescent: primary panicle $2-3.5 \mathrm{dm}$. long, the larger branches $1.5-2.5 \mathrm{dm}$. long, the lateral panicles smaller: spikelets very numerous, $2-2.5 \mathrm{~mm}$. long, lanceolate, acuminate, glabrous.

In dry soil, and common in cultivated ground as a weed, Nova Scotia to Minnesota, Florida and Texas. Summer and fall. Witch Grass. Tumble WeED.

16. Panicum Philadélphicum Bernh. Stems erect, $2-6 \mathrm{dm}$. tall, slender, somewhat branched at the base: leaf-sheaths hirsute; blades $5-10 \mathrm{~cm}$. long, 2-6 mm. wide, erect, pubescent : panicle 10-23 cm. long, its lower branches spreading or ascending : spikelets about $1.5 \mathrm{~mm}$. long, elliptic, acute, glabrous.

In dry woods and thickets, New Brunswick to Georgia and Missouri. Summer and fall.

17. Panicum Gattíngeri Nash. Annual. Stems commonly slender, finally branched and often prostrate at the base, 3-6 dm. long: leaf-sheaths papillose-hirsute; blades 1.5 $\mathrm{dm}$. long or less, 4-8 mm. wide, pubescent, erect: primary panicle $1-1.5 \mathrm{dm}$. long, its branches ascending, the larger ones usually $5-7 \mathrm{~cm}$. long, the lateral panicles smaller: spikelets about $2 \mathrm{~mm}$. long, elliptic, acute, glabrous.

In poor soil, Connecticut and New Jersey to North Carolina and Tennessee; also in Missouri. Fall.

18. Panicum fléxile (Gattinger) Scribn. Stems erect, $1.5-4.5 \mathrm{dm}$. tall, slender: leaf-sheaths papillose-hirsute ; blades $10-23 \mathrm{~cm}$. long, 4-6 $\mathrm{mm}$. wide, erect, long-acuminate, pubescent : panicle $1-2.5 \mathrm{dm}$. long: spikelets about $3 \mathrm{~mm}$. long, much shorter than the pedicels, acuminate, glabrous.

In moist or dry soil, Pennsylvania to Tennessee and Missouri. Summer and fall.

19. Panicum prolíferum Lam. Stems at first erect, $3-6 \mathrm{dm}$. tall, simple, later decumbent, 1-1.5 m. long, branched at all the upper nodes: leaf-sheaths loose, glabrous, somewhat flattened ; blades 1.5-6 dm. long, 4-20 mm. wide, long-acuminate: panicle pyramidal, 1-4 dm. long : spikelets $2-3 \mathrm{~mm}$. long, lanceolate, acute, glabrous.

In wet soil, Maine to Pennsylvania, Nebraska, Florida and Texas. Summer and fall.

20. Panicum miliàceum L. Stems erect or decumbent, rather stout, $3 \mathrm{dm}$. tall or more: leaf-sheaths papillose-hirsute; blades 1-2.5 dm. long, 8-25 mm. wide, pubescent: panicle rather dense, $1-2.5 \mathrm{dm}$. long, its branches erect or ascending : spikelets $5 \mathrm{~mm}$. long, acuminate, glabrous.

In waste places, Maine to Delaware, Pennsylvania, and Georgia, and in Nebraska. Introduced from the old World. Summer and fall. MiLLET.

21. Panicum stenòdes Griseb. Glabrous, or the lower leaf-sheaths sometimes pubescent. Stems tufted, wiry, erect, $3-8 \mathrm{dm}$. tall, finally branched : leaf-blades erect, involute when dry, $1.5 \mathrm{dm}$. long or less, $1-1.5 \mathrm{~mm}$. wide : panicle narrow, $3-15 \mathrm{~cm}$. long, its branches erect, the pedicels often with a few bristles at the base : spikelets about 2.5 $\mathrm{mm}$. long, lanceolate, acute, glabrous.

In moist and sandy pine lands, Florida to Texas. Also in the West Indies. Spring to fall.

22. Panicum diffùsum Sw. Glabrous. Stems tufted, erect, $2-4 \mathrm{dm}$. tall, rather slender: leaf-blades linear, narrowed toward the base, long-acuminate, $2.5 \mathrm{dm}$. long or less, 3-4 mm. wide, erect: panicle $8-15 \mathrm{~cm}$. long, its branches ascending : spikelets glabrous, lanceolate, acute, about $2 \mathrm{~mm}$. long.

In sandy soil, southern Texas and Mexico. Spring to fall.

23. Panicum Hállii Vasey. Stems tufted, branching from the base, glabrous : leafsheaths glabrous ; blades erect, linear, long-acuminate, 5-15 cm. long, 2-4 mm. wide, glabrous : panicle 1-2 dm. long, its branches long and ascending : spikelets about $2.5 \mathrm{~mm}$. long, ovoid, acute, glabrous.

In dry soil, Texas. Spring and summer.

24. Panicum fílipes Scribn. Glabrous. Stems erect, $8-10 \mathrm{dm}$. tall : leaf-blades linear, long-acuminate, lighter above, $3-4 \mathrm{dm}$. long, $5-8 \mathrm{~mm}$. wide : panicle $1.5-2.5 \mathrm{dm}$. long, effuse, its slender branches spreading: spikelets glabrous, ovate-lanceolate, about $2.5 \mathrm{~mm}$. long, acute, the first scale large and acute, a little more than $\frac{1}{2}$ as long as the spikelet.

In dry soil, southern Texas. Spring and summer.

25. Panicum cognàtum Schult. Stems tufted, $3-6 \mathrm{dm}$. long, at first erect, finally prostrate and branched at the base, glabrous: leaf-sheaths usually longer than the internodes, glabrous, or more or less pubescent with very long weak hairs; blades erect, linear 
to linear-lanceolate, glabrous, or sometimes pubescent, the primary ones $3-8 \mathrm{~cm}$. long, 4-7 $\mathrm{mm}$. wide, those on the branches smaller : panicle at first included at the base, finally exserted, as broad as or broader than long, the branches very long and finally spreading: spikelets on pedicels many times their length, elliptic, $2.5-3 \mathrm{~mm}$. long and about $0.8 \mathrm{~mm}$. wide, glabrous or pubescent. [P. autumnale Bosc. $]$

In dry places, South Carolina to Minnesota, Florida, Texas and Arizona. Spring and fall.

26. Panicum capillarioides Vasey. Perennial. Stems tufted, erect, or geniculate at the base, pubescent with spreading hairs, at least below : leaf-blades erect or ascending, linear, glabrous, or sparingly pubescent, $2 \mathrm{dm}$. long or less, $3-5 \mathrm{~mm}$. wide : panicle 1-1.5 $\mathrm{dm}$. long, its branches long and ascending: spikelets lanceolate, acuminate, $6 \mathrm{~mm}$. long, glabrous.

In dry soil, southern Texas. Summer.

27. Panicum halóphilum Nash. Stems from a long stout rootstock, $1.5-4 \mathrm{dm}$. tall : leaves numerous, crowded at the base of the stem ; sheaths overlapping, the margins sometimes ciliate; blades spreading, lanceolate, usually $2-6 \mathrm{~cm}$. long, sometimes longer, 3-8 $\mathrm{mm}$. wide : panicle dense, $2-9 \mathrm{~cm}$. long, its branches ascending: spikelets crowded, glabrous, about $2.5 \mathrm{~mm}$. long, the first scale $\frac{1}{2}$ as long as the spikelet, or nearly so, the apex acute at a broad angle, apiculate.

In sand along the seashore, Mississippi. Also in Mexico. Spring to fall.

28. Panicum rèpens $\mathrm{L}$. Stems $3-8 \mathrm{dm}$. tall, from long stout rootstocks : leaf-sheaths overlapping, at least at the base, the lower ones at first densely hirsute, later sometimes glabrate ; blades erect to spreading, $1.5 \mathrm{dm}$. long or less, 3-6 mm. wide : panicle $6-15 \mathrm{~cm}$. long, narrow and confined, slender, its branches erect or ascending : spikelets yellowish or green, glabrous, $2.5 \mathrm{~mm}$. long, the first scale about $\frac{1}{4}$ as long as the spikelet, truncate at the apex.

In sand along the seashore, Alabama, Mississippi, and California. Of wide geographic distribution. Summer and fall.

29. Panicum amàrum Ell. Smooth and glabrous, glaucous. Stems arising from long branching rootstocks, 3-9 dm. tall : leaf-sheaths overlapping ; blades $1.5-3 \mathrm{dm}$. long, 6-12 $\mathrm{mm}$. wide, long-acuminate, thick and leathery, involute on the margins, at least toward the apex : panicle linear, less than $3 \mathrm{dm}$. long, its branches erect : spikelets $5-6 \mathrm{~mm}$ long.

On sea beaches, New Hampshire to Florida. Fall.

30. Panicum virgàtum L. Glabrous. Stems erect from a stout rootstock, 9-15 dm. tall : leaf-blades elongated, $3 \mathrm{dm}$. long or more, $6-12 \mathrm{~mm}$. wide, flat, glabrous or pubescent : panicle $1.5-5 \mathrm{dm}$. long, its branches widely spreading or sometimes nearly erect : spikelets ovate, acuminate, 4-4.5 $\mathrm{mm}$. long, glabrous.

In moist or dry soil, Maine and Ontario to Minnesota, Florida and Texas. Summer and fall. A variety, known as P. virgatum breviramosum Nash, with short spreading branches and smaller spikelets, occurs in eastern Georgia. SwITCH Grass.

31. Panicum máximum Jacq. Stem 1-2 m. tall or more, leafy : leaf-sheaths overlapping, glabrous, or tuberculate-pubescent ; blades 2-8 dm. long or more, 1-4 cm. wide, glabrous : panicle 3-6 dm. long, its branches erect or nearly so, very long : spikelets glabrous, 3-4 $\mathrm{mm}$. long, the fourth scale transversely rugose.

In fields and along roadsides, Georgia and Florida to Texas. Introduced from tropical America. Summer and fall.

32. Panicum agrostoìdes Muhl. Stems 4-8 dm. tall, much branched, compressed : leaf-blades $3 \mathrm{dm}$. long or more, $4-8 \mathrm{~mm}$. wide: panicle pyramidal, 1-3 dm. long, its branches spreading: spikelets $1.5-2 \mathrm{~mm}$. long, acute, straight.

In wet ground, Maine to Missouri, Florida and Texas. Summer and fall.

33. Panicum condénsum Nash. Stems $6-10 \mathrm{dm}$. tall, branched, the lateral panicles often much exserted : leaf-blades 2-4 dm. long, 6-8 mm. wide, erect : panicle dense, 1-2 dm. long, contracted, its branches erect: spikelets numerous, about $2 \mathrm{~mm}$. long, glabrous, acute.

In ditches and wet places, South Carolina to Florida. Fall.

34. Panicum Còmbsii Scribn. \& Ball. Glabrous. Stems tufted, erect, slender, finally branched, 4-6 dm. tall : leaf-sheaths compressed, keeled ; blades erect, linear, acuminate, $5-15 \mathrm{~cm}$. long, $2-3 \mathrm{~mm}$. wide : panicle about $1 \mathrm{dm}$. long, its branches finally spreading : spikelets $3 \mathrm{~mm}$. long, lanceolate, acute.

In damp or wet woods, Florida. Summer and fall.

35. Panicum psendánceps Nash. Glabrous. Stems tufted, 3-7 dm. tall, erect, slender, compressed, finally branching at each node : leaf-sheaths compressed and keeled, an external tuft of long hairs on each side at the apex; ligule a ring of hairs $2-3 \mathrm{~mm}$. long; blades 1-3 dm. long, 2-4 mm. wide, somewhat pilose on the upper surface near the 
base : panicle narrow, 1-2 dm. long, its slender branches erect : spikelets numerous, about $2.5 \mathrm{~mm}$. long, lanceolate, often with 1-3 bristles at the base, glabrous.

In pine lands, southern peninsular Florida. Summer and fall.

36. Panicum stipitàtum Nash. Stems erect, $9-15 \mathrm{dm}$. tall, much branched : leafblades $3 \mathrm{dm}$. long or more, 4-8 mm. wide, acuminate, rough : panicle pyramidal, $1-3 \mathrm{dm}$. long, its primary branches spreading or ascending: spikelets about $2.5 \mathrm{~mm}$. long, acuminate, the fourth scale on a delicate stalk about $0.5 \mathrm{~mm}$. long.

In moist soil, New Jersey and Pennsylvania to Kentucky, Tennessee and Georgia. Summer and fall.

37. Panicum rostràtum Muhl. Stems erect, $4-15 \mathrm{dm}$. tall, branched : leaf-sheaths glabrous, or pubescent ; blades $3 \mathrm{dm}$. long or more, $4-10 \mathrm{~mm}$. wide : panicles $1.5-3 \mathrm{dm}$. long, its branches erect to spreading: spikelets $2.5-3.5 \mathrm{~mm}$. long, lanceolate, acuminate, curved at the apex.

In moist soil, southern New York and New Jersey to Missouri and the Indian Territory, Florida and Texas. Summer and fall.

38. Panicum linearifòlium Scribn. Stems tufted, slender, erect, glabrous, simple, $1.5-4 \mathrm{dm}$. tall : leaf-sheaths glabrous or hirsute; blades glabrous or pubescent, elongated, $7-25 \mathrm{~cm}$. long, 2-4 mm. wide, the uppermost blade the longest and often extending beyond the panicle : primary panicle loose and open, 4-10 $\mathrm{cm}$. long, its branches ascending : spikelets 2-2.5 mm. long, obtuse or acutish, pubescent with spreading hairs.

In dry soil, especially on hillsides, New York and New Jersey to Missouri and the Indian Territory. Summer and fall.

39. Panicum perlóngum Nash. A tufted pubescent perennial. Stems $2-4 \mathrm{dm}$. tall, simple, glabrous, or sparingly pubescent, the nodes barbed, finally with short basal stems : leaves 1 or 2 ; sheaths hirsute with long ascending hairs; blades elongated, linear, erect, papillose-hispid beneath, $2-3 \mathrm{~mm}$. wide, the upper blade commonly $8-14 \mathrm{~cm}$. long : panicle much exserted, generally extending beyond the apex of the upper leaf-blade, 4-6 $\mathrm{cm}$. long, its branches erect or erect-ascending : spikelets about $3.25 \mathrm{~mm}$. long and 1.5-1.75 $\mathrm{mm}$. wide, pubescent with a few scattered long hairs. mer.

On prairies and in dry soil, Illinois to South Dakota and the Indian Territory. Spring and sum-

40. Panicum depauperàtum Muhl. Stems erect, $3 \mathrm{dm}$. tall or less, simple : leafsheaths glabrous to hirsute; blades $8-15 \mathrm{~cm}$. long, elongated, 1-4 mm. wide, the upper one sometimes much exceeding the panicle : primary panicle much exserted, $2-8 \mathrm{~cm}$. long, usually linear, its branches erect or nearly so : spikelets $3-4 \mathrm{~mm}$. long, glabrous, acute.

In dry places, Maine to Minnesota, Florida and Texas. Summer and fall.

41. Panicum glabrifolium Nash. Glabrous and shining. Stems tufted, $1.5-4 \mathrm{dm}$. tall, erect, rigid, slender, leafy, finally much branched : leaf-sheaths with a tuft of hairs on each margin at the apex; blades narrowly linear, erect, rigid, thickish, long-acuminate, narrowed toward the base, those on the shoots $1.5 \mathrm{dm}$. long or less, $3-4 \mathrm{~mm}$. wide, those on the flowering stems 3-9 $\mathrm{cm}$. long, 1-3 mm. wide : panicle ovate, $4-6 \mathrm{~cm}$. long, its branches spreading or somewhat ascending : spikelets $1.3-1.5 \mathrm{~mm}$. long and $0.7 \mathrm{~mm}$. wide, obovoid.

In low pine lands, Florida. Summer.

42. Panicum strigòsum Muhl. A tufted densely papillose-hirsute perennial, the pubescence spreading. Stems 2-4 dm. tall, simple : leaves 2 or 3 ; sheaths much shorter than the internodes ; blades erect, lanceolate, $2-7 \mathrm{~cm}$. long, 3-10 mm. wide : panicle much exserted, $5-8 \mathrm{~cm}$. long, broadly ovate, its branches spreading or somewhat ascending: spikelets $1.3-1.5 \mathrm{~mm}$. long and about $0.8 \mathrm{~mm}$. wide, oval, glabrous.

In dry or moist pine lands, North Carolina and Tennessee to Florida. Spring and summer.

43. Panlcum polycaùlon Nash. Yellowish green. Stems tufted, naked above, 2 dm. tall or less, erect, simple, finally branched : leaf-sheaths ciliate on the margin ; blades erect or ascending, narrowly oblong-lanceolate, $2-7 \mathrm{~cm}$. long, $2-8 \mathrm{~mm}$. wide, ciliate on the margin : panicle broadly ovate, $3 \mathrm{~cm}$. long or less, its branches spreading or ascending, the main axis and generally the branches sparingly pilose : spikelets about $1.5 \mathrm{~mm}$. long and $0.8 \mathrm{~mm}$. wide, obovoid, obtuse, glabrous.

In low pine lands, Florida to Mississippi. Also in Cuba. Summer.

44. Panicum ciliàtum Ell. Stems tufted, 1-2.5 dm. tall, simple, glabrous, the axis of the panicle and its branches hirsute : leaves usually 2 ; sheaths shorter than the internodes; blades spreading or ascending, glabrous on both surfaces, conspicuously ciliate on the margins, acute at the apex, somewhat cordate at the base, narrowly elliptic, linear or lanceolate, usually $2-6 \mathrm{~cm}$. long and $5-10 \mathrm{~mm}$. wide, rarely larger : panicle $3-5 \mathrm{~cm}$. long, broadly ovate, its branches ascending: spikelets $1.8-2 \mathrm{~mm}$. long and about $1 \mathrm{~mm}$. wide, elliptic, pubescent with short spreading hairs, rarely nearly glabrous, the first scale about $\frac{1}{2}$ as long as the spikelet.

In sandy soil, North Carolina to Florida and Mississippi. Spring and summer. 
45. Panícum pyriforme Nash. Stems densely tufted, 3-4 dm. tall, rather slender, glabrous, rather weak, finally much branched : leaves usually 2 , or sometimes 3 ; sheaths densely papillose-hirsute with long reflexed hairs; blades thin, lax, glabrous on both surfaces, long-acuminate, narrowed to the barely rounded base, the primary ones 1-2 dm. long, 8-12 mm. wide: panicle ample, loose and open, 6-11 $\mathrm{cm}$. long, its branches widely spreading: spikelets rather few, about $2.5 \mathrm{~mm}$. long and $1.5 \mathrm{~mm}$. wide, broadly obovoid, densely pubescent with long hairs.

In clay or sandy soil, peninsular Florida. Spring and summer.

46. Panicum laxiflòrum Lam. Stems tufted, erect, simple, $2-4 \mathrm{dm}$. tall, pubescent or glabrous: leaf-sheaths hirsute with reflexed hairs; blades 6-13 $\mathrm{cm}$. long, 4-10 $\mathrm{mm}$. wide, erect, glabrous or pubescent, ciliate on the margin : panicle $5-10 \mathrm{~cm}$. long, its axis and erect or spreading branches sometimes hirsute : spikelets about $2 \mathrm{~mm}$. long, elliptic or narrowly obovoid, strongly pubescent.

In moist or dry soil, Virginia to Kentucky and Florida. Summer.

47. Panicum neuránthum Griseb. A tufted usually glabrous perennial, or sometimes the sheaths and lower part of the stem ascending-hirsute. Stems erect, $3-6 \mathrm{dm}$. tall, finally dichotomously much-branched : primary leaves $4-6$; sheaths usually much shorter than the internodes ; blades erect, firm, thickish, the primary ones $3-10 \mathrm{~cm}$. long, $2-5 \mathrm{~mm}$. wide, long-acuminate, those on the branches much smaller and usually involute: primary panicle much exserted, narrow, $5-8 \mathrm{~cm}$. long, its branches erect or nearly so, sometimes spreading in age : spikelets $1.75-2 \mathrm{~mm}$. long and about $1 \mathrm{~mm}$. wide, turgid, broadly obovoid, pubescent with short spreading hairs. [P. ovinum Scribn. \& Smith.]

In dry or moist sandy soil, Virginia to Florida, Texas and the Indian Territory. Also in Cuba. Spring to fall.

48. Panicum angustifòlium Ell. Stems tufted, 3-6 dm. tall, finally profusely branched, glabrous, or sometimes pubescent toward the base : primary leaves usually 4 or 5 ; sheaths glabrous, or the lower ones sometimes pubescent ; blades erect, linear-lanceolate, acuminate, glabrous, or the lower ones sometimes pubescent below, ciliate on the margin near the base, 5-12 $\mathrm{cm}$. long, 3-6 mm. wide, those on the branches much smaller, crowded, usually involute : primary panicle broadly ovate, long-exserted, 6-9 $\mathrm{cm}$. long, its branches spreading, glabrous, the secondary panicles much smaller, simple or nearly so: spikelets obovoid, $2.5-3.5 \mathrm{~mm}$. long and 1.3-1.6 mm. broad, strongly nerved, densely pubescent with spreading hairs. [P. arenicoloides Ashe. P. orthophyllum Ashe.]

In dry sandy soil, Maryland to Florida and Texas. Spring to fall.

49. Panicum consanguíneum Kunth. A densely villous tufted perennial. Stems $3-7 \mathrm{dm}$. tall, finally much branched, the nodes barbed with spreading hairs : primary leaves usually about 5 ; sheaths shorter than the internodes; blades erect, linear-lanceolate, the primary ones $4-8 \mathrm{~cm}$. long, $3-10 \mathrm{~mm}$. wide, those on the branches much smaller : primary panicle 4-8 cm. long, oval, its branches ascending : spikelets $2.5 \mathrm{~mm}$. long and about 1.3 $\mathrm{mm}$. wide, broadly obovoid, densely pubescent with spreading hairs.

In dry sandy soil, North Carolina to Florida and Texas. Spring and summer.

50. Panicum arenícola Ashe. Stems tufted, erect, usually from an ascending base, 2-4 dm. tall, finally branched, pubescent below with long ascending or nearly erect hairs, minutely pubescent above : leaves 4 or 5, confined to the lower two-thirds of the stem ; sheaths, at least the lower ones, hispid with ascending hairs ; blades erect, firm, stiff, inclined to become involute in drying, acuminate from below the middle, the lower ones sparingly hispid beneath, 2-6 $\mathrm{cm}$. long, 2-6 $\mathrm{mm}$. wide: panicle.long-exserted, broadly ovate, $2-5 \mathrm{~cm}$. long, its branches widely spreading: spikelets a little less than $2 \mathrm{~mm}$. long and about $1.2 \mathrm{~mm}$. wide, broadly obovoid, pubescent with very short spreading hairs.

In dry soil, North Carolina to Mississippi, Summer.

51. Panicum Roanokénse Ashe. Glabrous. Stems tufted, erect, $3-5 \mathrm{dm}$. tall, finally branched : leaves 3 or 4 ; blades erect, rather firm, 3-8 $\mathrm{cm}$. long, 3-5 $\mathrm{mm}$. wide : panicle $5-7 \mathrm{~cm}$. long, its branches ascending: spikelets glabrous, $2 \mathrm{~mm}$. long and $1 \mathrm{~mm}$. wide, elliptic.

In dry soil, North Carolina. Summer.

52. Panicum Nashiànum Seribn. Stems tufted, glabrous or puberulent, slender, 1.5-4 dm. tall, finally much branched : leaf-blades erect or ascending, lanceolate, acuminate, glabrous or puberulent beneath, ciliate, at least at the base, $2-5 \mathrm{~cm}$. long, $2-5 \mathrm{~mm}$. wide, the blades on the branches smaller: primary panicle $2.5-5 \mathrm{~cm}$. long, its branches widely spreading : spikelets about $2 \mathrm{~mm}$. long, obovoid, glabrous to densely pubescent with short spreading hairs. [P. pauciciliatum Ashe.]

In pine lands, Virginia to Florida and Mississippi. Spring and summer.

53. Fanicum patentif òlium Nash. A nearly glabrous purplish tufted perennial. Stems erect or nearly so, 2-4 dm. tall, puberulent, Slender, finally much branched : leaves 2-4, 
rather distant; sheaths minutely pubescent, especially at the apex on the margins ; blades widely spreading, firm, lanceolate, $2.5-4 \mathrm{~cm}$. long, $2-4 \mathrm{~mm}$. wide, puberulent at the very base on the upper surface : panicle 4-6 cm. long, broadly ovoid, its axis and spreading branches puberulent: spikelets about $2.5 \mathrm{~mm}$. long and $1.3 \mathrm{~mm}$. wide, pubescent with spreading hairs, the first scale $\frac{1}{2}$ as long as the spikelet.

In dry sandy soil, peninsular Florida. Spring.

54. Panicum Webberiànum Nash. Stems tufted, 2-4 dm. tall, erect or ascending, rigid, branched : leaf-sheaths ciliate on the margin ; blades lanceolate, 4-9 cm. long, 7-14 $\mathrm{mm}$. wide, sparsely ciliate at the base, usually erect: panicle ovate, 6-9 cm. Iong, its branches spreading: spikelets elliptic or obovoid, $2.5 \mathrm{~mm}$. long and about $1.3 \mathrm{~mm}$. wide, the apex of the fourth scale minutely pubescent. [P. Onslowense Ashe.]

In pine lands, North Carolina to Florida. Spring and summer.

55. Panicum dichótomum L. Light green, glabrous, or the lower nodes sometimes barbed. Stems tufted, slender, $2-6 \mathrm{dm}$. tall, rarely taller, finally much branched about the middle : primary leaves 4 or 5 ; sheaths shorter than the internodes; blades widely spreading, linear-lanceolate, the primary ones $4-8 \mathrm{~cm}$. long, usually $4-8 \mathrm{~mm}$. wide, rarely wider, those on the branches much smaller, often involute: panicle $4-8 \mathrm{~cm}$. long, broadly ovate, its branches usually ascending: spikelets rather few, 1.75-2 mm. long and 0.8-1 mm. wide, elliptic, glabrous.

In dry soil, Connecticut and southern New York to Ohio, Georgia and Texas. Summer.

56. Panicum Yadkinénse Ashe. A glabrous perennial. Stems single, $8-10 \mathrm{dm}$. tall, finally somewhat branched: leaves 5 or 6 ; sheaths much shorter than the internodes, white-spotted ; blades ascending, lanceolate, acuminate, narrowed toward the base, the primary ones 8-12 $\mathrm{cm}$. long, 8-12 mm. wide : panicle $8-12 \mathrm{~cm}$. long, broadly ovate or oval, its branches long, ascending : spikelets about $2.3 \mathrm{~mm}$. long and $1 \mathrm{~mm}$. wide, elliptic, acute, glabrous.

In dry or sandy soil, Maryland to Georgia. Summer.

57. Panicum barbulàtum Michx. Glabrous. Stems densely tufted, at first erect, finally much branched and decumbent, the nodes strongly barbed with silky somewhat reflexed hairs : primary leaves 5-7; sheaths shorter than the internodes, ciliate on the overlapping margin ; primary leaf-blades spreading, sometimes somewhat reflexed, usually $6-10$ $\mathrm{cm}$. long, rarely shorter or longer, $8-15 \mathrm{~mm}$. wide, lanceolate, the blades on the branches much smaller : panicle finally much exserted, 7-11 cm. long, oval, its branches ascending : spikelets $1.5-1.8 \mathrm{~mm}$. long and about $0.8 \mathrm{~mm}$. broad, elliptic, glabrous, or rarely minutely and sparingly pubescent. [P. nitidum var. barbulatum (Michx.) Wood.]

In wet places, New York to Illinois, Florida and Mississippi. Summer.

58. Panicum nemopánthum Ashe. A tufted nearly glabrous perennial with barbed nodes. Stems 3-5 dm. tall, erect : leaves 3 or 4 ; lowermost sheaths sometimes pubescent, the uppermost often longer than the internodes; blades spreading or ascending, lanceolate, long-ciliate toward the somewhat narrowed base, 7-10 cm. long, 5-6 mm. wide, longacuminate : panicle $7-10 \mathrm{~cm}$. long, broader than long, its branches wide-spreading, lax and drooping : spikelets about $2.5 \mathrm{~mm}$. long, a little exceeding $1 \mathrm{~mm}$. broad, elliptic, glabrous.

In woods, North Carolina. Spring.

59. Panicum Mattamuskeeténse Ashe. A tall sometimes tufted perennial with barbed nodes. Stems $6-12 \mathrm{dm}$. tall, finally much branched : leaves 6 or 7 ; sheaths much shorter than the internodes, usually considerably less than $\frac{1}{2}$ as long, ciliate on the margins, all but the lower ones glabrous ; blades spreading, 3-8 cm. long, 3-10 mm. wide, the lowermost pubescent on both surfaces: panicle 6-10 dm. long, ovate: spikelets $2-2.5 \mathrm{~mm}$. long and about $1 \mathrm{~mm}$. wide, elliptic, pubescent with short spreading hairs.

In wet places, North Carolina. Summer.

60. Panicum ánnulum Ashe. Stems 4-7 dm. tall, glabrous or sparingly pubescent, finally branched, the nodes densely barbed with spreading hairs: leaves 4 or 5 ; sheaths softly pubescent or sometimes the upper ones glabrous; blades erect or nearly so, softly pubescent on both surfaces, or the upper ones sometimes glabrous : panicle 4-10 $\mathrm{cm}$. long, its branches erect-ascending or ascending, rarely spreading: spikelets usually numerous, $1.8-2 \mathrm{~mm}$. long and about $0.8 \mathrm{~mm}$. wide, elliptic, strongly pubescent with spreading hairs.

In dry rocky woods, Maryland to Georgia and Mississippi. Spring and summer.

61. Panicum Eárlei Nash. Stems densely tufted, slender, 1-1.5 dm. tall, usually with a few long weak scattered hairs below, finally branched, the nodes rather sparingly barbed : leaves about 3 ; sheaths rather sparsely hirsute with long hairs; blades ascending, lanceolate, rather sparingly hirsute on both surfaces with long spreading hairs, 1-3 cm. long, 2-6 $\mathrm{mm}$. wide : panicle $2-3 \mathrm{~cm}$. long, broadly ovate, its smooth branches spreading: spikelets about $1.3 \mathrm{~mm}$. long, $0.7 \mathrm{~mm}$. wide, elliptic, glabrous. [P. austromontanum Ashe.]

In sandy soil, Tennessee and Alabama. Spring and summer. 
62. Panicum lùcidum Ashe. Stems tufted, $2-8 \mathrm{dm}$. long, slender, glabrous, weak, at first erect or ascending, simple, later prostrate and much branched: leaves $3-5$; sheaths much shorter than the internodes, eiliate on the margin ; blades thin, glabrous, the primary ones usually erect, 3-6 $\mathrm{cm}$. long, 3-6 mm. wide, those on the branches much smaller, generally $3 \mathrm{~cm}$. long or less and $1.5-3 \mathrm{~mm}$. wide, spreading to erect: primary panicle ovoid, 3-7 cm. long, its branches spreading or somewhat ascending: spikelets glabrous, 1.5-2 $\mathrm{mm}$. long and $0.6-0.75 \mathrm{~mm}$. wide, elliptic.

In wet shady places, usually sphagnum swamps, New Jersey and Maryland to Florida and Mississippi. Summer and fall.

63. Panicum curtivaginum Ashe. Stems tufted, 6-8 dm. long, slender, weak, glabrous, finally branched: leaves 4 or 5 ; sheaths much shorter than the internodes, sometimes sparingly ciliate on the margin; blades erect, glabrous, the primary ones linear, usually $3-6 \mathrm{~cm}$. long, rarely larger, $3-5 \mathrm{~mm}$. wide: panicle 4-8 $\mathrm{cm}$. long, ovoid, its branches ascending : spikelets $2 \mathrm{~mm}$. long and about $1 \mathrm{~mm}$. wide, elliptic, glabrous.

In sandy soil, Mississippi. Spring and summer.

64. Panicum curtifòlium Nash. A nearly glabrous tufted perennial. Stems 2-3 dm. tall, finally much branched: leaves 3 or 4 ; sheaths usually about $\frac{1}{3}$ as long as the internodes, sparsely pubescent with long weak spreading hairs; blades widely spreading, lanceolate, a few long hairs on the upper surface near the base, the primary blades $1.5-3 \mathrm{~cm}$. long, 3-5 mm. wide: panicle $2-4 \mathrm{~cm}$. long, broadly ovoid, its branches widely spreading : spikelets about $1.5 \mathrm{~mm}$. long and about $0.75 \mathrm{~mm}$. wide, elliptic, glabrous.

In sandy soil, Mississippi. Spring and summer.

65. Panicum sphagnícola Nash. Grayish green. Stems 6-10 dm. long, at first simple, finally repeatedly and dichotomously branched, the branches very divergent: leafblades glabrous, thick, lanceolate, the primary ones 5-8 $\mathrm{cm}$. long, 4-10 $\mathrm{mm}$. wide, those on the branches $2.5 \mathrm{~cm}$. long or less, $1-3 \mathrm{~mm}$. wide, appressed : primary panicle about 5 $\mathrm{cm}$. long, its branches spreading, 1.25-2.5 cm. long, the secondary panicles about $1.25 \mathrm{~cm}$. long, raceme-like : spikelets $2.5 \mathrm{~mm}$. long and $1 \mathrm{~mm}$. wide, few and appressed, glabrous or sparingly pubescent.

In sphagnum swamps, northern Florida. Summer.

66. Panicum nudicaùle Vasey. Glabrous. Stems $5-6 \mathrm{dm}$. tall : leaves 3 , the lower 2 approximate and near the base of the stem, the other distant, above the middle of the stem ; blades erect, firm, lanceolate, $2.5-7 \mathrm{~cm}$. long, 3-8 mm. wide : panicle 4-7 cm. long, broadly ovate, its branches ascending or spreading: spikelets $3 \mathrm{~mm}$. long and $1 \mathrm{~mm}$. wide, elliptic, acute, glabrous.

In swamps, western Florida. Spring and summer.

67. Panicum Wrightiànum Scribn. Stems tufted, 3-4 dm. long, puberulent, slender, at first erect, finally much branched and forming broad mats : leaves $5-7$; sheaths minutely pubescent with spreading hairs, ciliate on the margins ; blades minutely and softly pubescent on the lower surface, the upper surface pubescent with longer hairs, the primary blades $2-4.5 \mathrm{~cm}$. long, $2-4 \mathrm{~mm}$. wide, those on the branches much smaller : primary panicle 3-5 cm. long, ovoid, its branches ascending: spikelets a little less than $1 \mathrm{~mm}$. long and about $0.4 \mathrm{~mm}$. wide, elliptic, pubescent.

In sandy soil, North Carolina to Florida and Mississippi. Also in Cuba. Summer and fall.

68. Panicum Baldwínii Nutt. Glabrous or nearly so. Stems densely tufted, slender, 1-2 dm. tall, rarely longer, sometimes a little puberulent, erect, finally mueh branched and ascending or prostrate : leaves on the primary stem 2 , or sometimes 3 ; sheaths less than $\frac{1}{2}$ as long as the internodes; blades erect or ascending, lanceolate, rough on the margins, the primary ones $1-3 \mathrm{~cm}$. long, 1-3 mm. wide : primary panicle $1.5-4 \mathrm{~cm}$. long, broadly ovoid, its branches widely spreading: spikelets $1 \mathrm{~mm}$. long and about $0.7 \mathrm{~mm}$. broad, oval, or somewhat broadly ovoid, glabrous.

In dry sandy soil, southern Georgia and Florida, Spring and summer.

69. Panicum ensifòlium Baldw. A slender much tufted glabrous perennial. Stems 1-3 dm. tall, finally somewhat branched : leaves 2 or 3 ; sheaths very short, several times shorter than the internodes; blades widely spreading, lanceolate, usually less than $2 \mathrm{~cm}$. long, rarely larger, 1-3 mm. wide, densely puberulent on the lower surface, the basal blades markedly larger and more erect: panicle small, ovate, $1-2 \mathrm{~cm}$. long, occasionally larger, its branches usually ascending: spikelets about $1.3 \mathrm{~mm}$. long and about $0.6 \mathrm{~mm}$. wide, elliptic, pubescent with spreading hairs. [P. nitidum var. ensifolium (Baldw.) Chapm.]

In sphagnum bogs, North Carolina to Florida and Mississippi. Spring and summer.

70. Panicum Cuthbértii Ashe. Stems tufted, slender, weak, $2-3 \mathrm{dm}$. tall, glabrous, finally much branched : primary leaves 3 or 4 ; leaf-sheaths short, ciliate on the margin, much shorter than the internodes; blades densely pubescent beneath, more sparsely so 
above, with rather long hairs, the primary ones spreading, 1-3 cm. long, $1.5-3 \mathrm{~mm}$. wide : panicle $1.5-3 \mathrm{~cm}$. long, ovate, its branches spreading: spikelets elliptic, about $1.3 \mathrm{~mm}$. long and $0.5 \mathrm{~mm}$. wide, pubescent.

In wet places, South Carolina to Florida. Spring and summer.

71. Panicum gracilicaùle Nash. Glabrous. Stems tufted, erect, slender, $1-3 \mathrm{dm}$. tall : leaves 3 or 4 ; sheaths shorter than the blades; blades erect, linear, acuminate, 3-7 cm. long, 3-8 mm. wide: panicle $3-6 \mathrm{~cm}$. long, ovoid, its branches ascending: spikelets about $1.1 \mathrm{~mm}$. long and $0.7 \mathrm{~mm}$. wide, obovoid, pubescent with spreading hairs.

In sandy soil along brooks, Sand Mountain, Alabama. Summer.

72. Panicum flavóvirens Nash. A glabrous tufted light green perennial. Stems 2-3 dm. tall, slender, finally much branched : leaves 2 or 3 ; sheaths very short, the lower ones ciliate on the margin, the exterior basal ones pubescent all over; blades thin, erect, smooth or nearly so on the margins, linear-lanceolate, the primary ones $2.5-4 \mathrm{~cm}$. long, 2.5 $-4 \mathrm{~mm}$. wide, usually minutely pubescent on the lower surface between the nerves : panicle 3-4 cm. long, broadly ovate, its branches spreading : spikelets $1.5 \mathrm{~mm}$. long and $0.7 \mathrm{~mm}$. wide, elliptic, densely pubescent with spreading hairs, the first scale about $\frac{1}{2}$ as long as the spikelet.

In swampy woods, Florida. Summer.

73. Panicum albomarginàtum Nash. Glabrous, excepting the spikelets. Stems densely tufted, $2-4 \mathrm{dm}$. tall, finally branched toward the base, the upper part of the stem naked: leaves usually 2 ; sheaths on the primary stems much shorter than the internodes ; blades erect, thick, stiff, lanceolate, with a prominent wide thickened white margin, usually $1.5-4 \mathrm{~cm}$. long, rarely longer, $2-7 \mathrm{~mm}$. wide : panicle $2-4 \mathrm{~cm}$. long, broadly ovate : spikelets elliptic, about $1.3 \mathrm{~mm}$. long and $0.7 \mathrm{~mm}$. wide, pubescent with short spreading hairs.

In low pine lands, peninsular Florida. Spring and summer.

74. Panicum trifòlium Nash. A nearly glabrous tufted perennial. Stems slender, 2-4 dm. tall, finally a little branched : leaves 3 , rarely 4 , the uppermost one much above the middle of the stem and generally but a little below the panicle; sheaths often but $\frac{1}{4}$ as long as the internodes; blades erect or nearly so, firm, lanceolate, the margins thickened and cartilaginous, $1.5-6 \mathrm{~cm}$. long, $1.5-5 \mathrm{~mm}$. wide : panicle $2.5-6 \mathrm{~cm}$. long, broadly ovoid, its branches ascending : spikelets $1.5 \mathrm{~mm}$. long and about $0.7 \mathrm{~mm}$. wide, ellipsoid, densely pubescent with short spreading hairs.

In sandy soil, North Carolina to northern Florida and Mississippi. Spring and summer.

75. Panicum glabríssimum Ashe. Stems tufted, rather slender, $3-4 \mathrm{dm}$. tall, finally somewhat branched : leaves about 3 , distant ; sheaths less than $\frac{1}{2}$ as long as the internodes; blades erect or ascending, pubescent on the lower surface with short hairs, $1.5-35 \mathrm{~cm}$. long, 2-3 mm. wide : panicle long-exserted, 3-5 cm. long, ovate, its branches ascending : spikelets $1.5 \mathrm{~mm}$. long and a little less than $1 \mathrm{~mm}$. wide, oval, pubescent with spreading hairs.

In dry soil, North Carolina. Summer.

76. Panicum longiligulàtum Nash. A tufted nearly glabrous perennial. Stems 4-5 dm. tall, slender, finally branched, the branches fasciculately much divided and forming dense masses at their ends : leaves 4 or 5 ; sheaths minutely pubescent between the prominent nerves; ligule of erect silky hairs about $3 \mathrm{~mm}$. long; blades ascending, lanceolate, obscurely and minutely pubescent on the lower surface, the primary ones $2.5-3 \mathrm{~cm}$. long, about $3 \mathrm{~mm}$. wide : panicle $5-6 \mathrm{~cm}$. long, oval, its branches spreading : spikelets about 1.3 mm. long and $0.8 \mathrm{~mm}$. wide, oval, densely pubescent with spreading hairs.

In dry sandy soil, western Florida. Summer.

77. Panicum paucípilum Nash. A tufted nearly glabrous perennial. Stems 6-10 dm. tall, finally somewhat branched : leaves 5-8; sheaths with the exterior margin ciliate toward the summit; blades erect or ascending, thickish, rather firm, sometimes minutely puberulent on the lower surface, usually with a few hair-bearing papillae at the base, the lower and larger primary ones $6-9 \mathrm{~cm}$. long, 5-7 mm. wide : panicle 5-10 $\mathrm{cm}$. long, rather dense, its branches erect-ascending or erect: spikelets numerous, about $1.4 \mathrm{~mm}$. long and $0.8 \mathrm{~mm}$. wide, oval, pubescent with spreading hairs, the first scale about $\frac{1}{3}$ as long as the spikelet.

In wet soil, southern New Jersey to Florida and Mississippi. Summer.

78. Panicum octonòdum J. G. Smith. Glabrous. Stems erect, $7-11 \mathrm{dm}$. tall, finally branched: leaves $6-8$; sheaths much shorter than the internodes ; blades erect, firm, 4-11 cm. long, 4-8 mm. wide, lanceolate : panicle 9-13 cm. long, oblong, dense, 2-4 cm. wide, its branches erect or erect-ascending: spikelets $1.3 \mathrm{~mm}$. long and about $0.8 \mathrm{~mm}$. wide, oval, glabrous.

In wet places, New Jersey to Alabama and Texas. Spring and summer. 
79. Panicum leucòthrix Nash. A villous densely tufted perennial. Stems 3-6 dm. tall, erect, finally much branched : primary leaves $3-5$; sheaths usually less than $\frac{1}{2}$ as long as the internodes, the pubescence ascending; blades erect, rather firm, lanceolate, densely and softly pubescent on the lower surface with short spreading hairs, glabrous above, 3-5 $\mathrm{cm}$. long, 4-6 $\mathrm{mm}$. wide : primary panicle usually $3-5 \mathrm{~cm}$. long, rarely larger or smaller, broadly ovate, its branches ascending : spikelets about $1.2 \mathrm{~mm}$. long and about $0.6 \mathrm{~mm}$. wide, oval, pubescent with short spreading hairs.

In usually dry sandy soil, southern New Jersey to Florida and Texas. Spring and summer.

80. Panicum parvispículum Nash. A much tufted perennial. Stems glabrous, or more or less appressed-pubescent below, erect, finally branched: leaves 4 or 5 ; sheaths shorter than the internodes, glabrous, or the lower ones more or less pubescent; blades erect or ascending, firm, lanceolate, acuminate, the primary ones $3-10 \mathrm{~cm}$. long, 2-7 $\mathrm{mm}$. wide, minutely but densely pubescent on the lower surface : panicle $6-10 \mathrm{~cm}$. long, broadly ovate, its branches ascending: spikelets $1.3 \mathrm{~mm}$. long and about $0.8 \mathrm{~mm}$. wide, oval, densely pubescent with spreading hairs.

In dry soil, North Carolina to Florida and Mississippi. Spring and summer.

81. Panicum nítidum Lam. Stems tufted, 4-8 dm. tall, glabrous, finally much branched : leaves 4 or 5 ; sheaths glabrous, ciliate on the margin with long hairs; blades erect, glabrous, or the lower surface sometimes minutely pubescent with short hairs, ciliate at the base, the primary ones $2-8 \mathrm{~cm}$. long, 3-8 $\mathrm{mm}$. wide, lanceolate, firm, the blades on the branches much smaller : panicle $3-8 \mathrm{~cm}$. long, broadly ovoid, its branches ascending : spikelets about $1.5 \mathrm{~mm}$. long and $0.8 \mathrm{~mm}$. wide, obovoid, densely pubescent with short spreading hairs.

In dry soil, New York to Georgia. Summer.

82. Panicum Tennesseénse Ashe. Stems tufted, 4-6 dm. tall, rather weak and ascending, papillose-hirsute with long spreading hairs, finally much branched and prostrate and forming broad mats: leaves 4 or 5 ; sheaths densely papillose-hirsute with long spreading hairs; blades ascending, lanceolate, the lower surface densely and softly pubescent with short hairs, the upper surface with scattered hairs and those at the base very long, the primary blades $4-10 \mathrm{~cm}$. long, $5-10 \mathrm{~mm}$. wide, those on the branches much shorter and spreading with the upper surface nearly glabrous: panicle 7-10 $\mathrm{cm}$. long, ovoid, its branches ascending : spikelets $1.7-2 \mathrm{~mm}$. long, $0.8-0.9 \mathrm{~mm}$. wide, elliptic or obovoid, strongly pubescent with long spreading hairs. [P. Wilmingtomense Ashe.]

In woods, New York and Illinois to Tennessee and Florida. Summer and fall.

83. Panicum ciliòsum Nash. Stems tufted, 3-5 dm. tall, papillose-hirsute with spreading hairs, finally much branched: leaves 4 or 5 ; sheaths densely hirsute with spreading hairs, hirsute on the margins ; blades erect or ascending, narrowed toward the base, ciliate on the margins, glabrous above, the lower surface densely pubescent between the nerves with short spreading hairs : panicle about $8 \mathrm{~cm}$. long, broadly ovoid, its axis pubescent with short hairs, the branches spreading : spikelets a trifle less than $2 \mathrm{~mm}$. long and about $0.9 \mathrm{~mm}$. wide, elliptic, strongly pubescent with rather long spreading hairs.

In dry soil, Mississippi. Summer and fall.

84. Panicum lanuginòsum Ell. Stems and leaves villous with spreading hairs, those on the blades and upper part of the stems shorter. Stems leafy, tufted, $3-8 \mathrm{dm}$. tall, erect, finally branched, a smooth ring below each barbed node: leaf-blades erect, lanceolate, 4-13 cm. long, 4-9 mm. wide : panicle ovoid, 4-10 cm. long, the axis pubescent, the branches ascending : spikelets numerous, broadly obovoid, about $1.5 \mathrm{~mm}$. long and $0.8 \mathrm{~mm}$. wide, densely pubescent with spreading hairs.

In dry sandy soil, southern New Jersey to Florida and Alabama. Summer.

85. Panicum Thuròwii Scribn. \& Smith. Stems tufted, 4-6 dm. tall, at first erect and simple, finally branched, papillose-hirsute below with long hairs, the pubescence above softer : leaves 4 or 5 ; sheaths densely papillose-hirsute with long spreading hairs; blades erect or ascending, densely long-villous on the lower surface, the upper surface pubescent with long stiff spreading hairs, or sometimes nearly glabrous: panicle $6-9 \mathrm{~cm}$. long, broadly ovoid, its branches ascending: spikelets about $1.8 \mathrm{~mm}$. long and $0.8 \mathrm{~mm}$. wide, elliptic, pubescent with spreading hairs.

In dry soil, Texas. Summer.

86. Panicum filicúlme Ashe. Stems densely tufted, slender, finally much branched, 2-3 dm. tall, minutely pubescent above : leaf-sheaths strongly hirsute with very long hairs; blades erect, the primary ones $1.5-3 \mathrm{~cm}$. long, 2-4 mm. wide, papillose-pubescent on both surfaces, or sometimes glabrous beneath, the hairs on the upper surface exceedingly long and copions: primary panicle long-exserted, $2-3 \mathrm{~cm}$. long: spikelets broadly obovoir to 
elliptic, 1.5 mm. long, pubescent. [P. Albemarlense Ashe. P. microphyllum Ashe. P. subvillosum Ashe.]

In dry soil, New Jersey to Georgia. Summer.

87. Panicum unciphýllum Trin. Stems at first erect and simple, later profusely branched and leaning or ascending, glabrous or pubescent: leaf-sheaths hirsute, often papillose ; blades hirsute, especially beneath, erect or spreading, those on the main stem $5-8 \mathrm{~cm}$. long, those on the branches much shorter : primary panicle less than $8 \mathrm{~cm}$. long, ovoid, its branches ascending, the lateral panicles much smaller: spikelets hardly $2 \mathrm{~mm}$. long, pubescent. [P. pubescens A. Gray, not. Lam.]

In dry soil, common, Maine and Quebec to British Columbia, Georgia, the Indian Territory and Arizona. Summer.

88. Panicum Lindheìmeri Nash. A nearly glabrous perennial. Stems $3-5 \mathrm{dm}$. tall, finally much branched: primary leaves $5-7$; sheaths shorter than the internodes, ciliate on the margin, usually sparingly tuberculate-hirsute; blades ascending, lanceolate, acute, smooth on both surfaces, usually $2-7 \mathrm{~cm}$. long, sometimes longer, 4-10 mm. wide: primary panicle $3-5 \mathrm{~cm}$. long, broadly ovate or oval, its branches spreading: spikelets about $1.5 \mathrm{~mm}$. long and about $0.8 \mathrm{~mm}$. wide, broadly obovoid, pubescent with spreading hairs.

In dry soil, Georgia to Texas and the Indian Territory. Spring and summer.

89. Panicum sphaerocárpon Ell. Stems generally erect, simple or somewhat branched at the base, $2.5-6 \mathrm{dm}$. tall, glabrous : leaf-sheaths usually shorter than the internodes, glabrous, the margins ciliate; blades $5-10 \mathrm{~cm}$. long, 4-14 mm. wide, rough above, smooth beneath, the margins cartilaginous and minutely serrulate, ciliate toward the base: panicle ovoid, $5-10 \mathrm{~cm}$. long : spikelets less than $2 \mathrm{~mm}$. long, nearly spherical, or a little longer than thick, obtuse. fall.

In dry soil, southern Ontario, New York and Missouri to Florida, Texas and Mexico. Summer and

90. Panicum inflàtum Scribn. \& Smith. Stems $3-4 \mathrm{dm}$. tall, branched, finally prostrate and rooting at the lower nodes : sheaths compressed, inflated, very loosely embracing the stem, strongly striate, marked with white tubercles, ciliate on the margin; blades ascending, lanceolate, ciliate at the base, 3-7 cm. long, 7-10 mm. wide,"flat, acuminate into an obtuse point : panicle much exserted, $6-8 \mathrm{~cm}$. long, oval, its branches ascending: spikelets oval, $1.3 \mathrm{~mm}$. long and about $0.9 \mathrm{~mm}$. wide, minutely and sparsely pubescent. [P. Mississippiense Ashe.]

In sandy soil, Mississippi. Fall.

91. Panicum erectif òlium Nash. A nearly glabrous tufted perennial. Stems erect, 5-7 dm. tall, finally sparingly branched, the branches erect: primary leaves usually 5-7; sheaths usually about $\frac{1}{2}$ as long as the internodes, ciliate on the margins ; blades erect, firm, ciliate on the margins toward the base, lanceolate, acuminate, 5-10 cm. long, 5-13 $\mathrm{mm}$. wide : panicle elliptic, $8-12 \mathrm{~cm}$. long, its branches erect-ascending : spikelets numerous, 1-1.3 mm. long and $0.6-0.8 \mathrm{~mm}$. wide, elliptic to oval, pubescent with spreading hairs. [P. Floridanum Chapm.]

In wet soil or swamps, Florida to Mississippi. Spring and summer.

92. Panicum polyánthes Schult. Stems generally erect, 6-9 dm. tall, simple, glabrous: leaf-sheaths glabrous, longer than the internodes; blades 1-2 dm. long, 1-2.5 $\mathrm{cm}$. wide, long-acuminate, smooth, cordate-clasping and sparingly ciliate at the base: panicle 7-20 cm. long, ovoid to oblong, its branches slender, ascending: spikelets $1.5 \mathrm{~mm}$. long, obovoid to nearly spherical, numerous, puberulent. [P. microcarpon Muhl.]

In woods and along thickets, southern New York and Pennsylvania to Michigan, Florida, Louisiana, Nebraska and Texas. Summer and fall.

93. Panicum chrysopsídıfòlium Nash. Stems tufted, $2.5-5 \mathrm{dm}$. tall, stout, finally branched, strongly pubescent below with long stiff nearly appressed hairs, the upper portion sparingly pubescent : leaves 5 or 6 ; sheaths papillose-hirsute with ascending hairs ; blades lanceolate, acuminate, 3-12 cm. long, 3-10 mm. wide, thick, firm, rather sparingly papillose-hirsute on both surfaces with long spreading stiff hairs: panicle $5-7 \mathrm{~cm}$. long, broadly ovoid, its branches spreading: spikelets about $2 \mathrm{~mm}$. long and $1.2 \mathrm{~mm}$. wide, broadly obovoid, coarsely and strongly nerved, pubescent with short spreading hairs.

In dry sandy soil, middle Florida. Spring.

94. Panicum pseudopubéscens Nash. A densely tufted pubescent perennial. Stems 2-4 dm. tall, hirsute with ascending hairs, finally branched, the nodes barbed: leaves usually 3 ; sheaths densely hirsute with spreading hairs; blades erect, rather firm, lanceolate, 4-10 cm. long, 3-11 mm. wide, densely hispid on the lower surface with spreading hairs, the upper surface with long stout hairs at the base : panicle $5-9 \mathrm{~cm}$. long, broadly ovoid, its branches ascending or spreading: spikelets $2.25-2.5 \mathrm{~mm}$. long and $1-1.2 \mathrm{~mm}$. wide, obovoid, densely pubescent with spreading hairs.

In sandy soil, Alabama. Spring and summer. 
95. Panicum Atlánticum Nash. Densely papillose-hirsute, the hairs on the sheaths and upper surface of the leaf-blades exceedingly long. Stems tufted, erect, often from an ascending base, $3-5 \mathrm{dm}$. tall, finally branched, the nodes barbed with spreading hairs : sheaths shorter than the internodes; blades erect, lanceolate, rather firm, the primary ones usually 6-8 $\mathrm{cm}$. long, rarely longer or shorter, 4-8 $\mathrm{mm}$. wide: panicle 5-7 $\mathrm{cm}$. long, broadly òvoid, its branches ascending : spikelets barely exceeding $2 \mathrm{~mm}$. long and about 1.2 $\mathrm{mm}$. wide, broadly obovoid, pubescent with spreading hairs.

In dry soil, southeastern New York to Georgia and Mississippi. Summer.

96. Panicum villosíssimum Nash. Whole plant densely pubescent with long spreading hairs. Stems 3-6 dm. tall, erect or ascending, the nodes barbed : leaf-blades linear-lanceolate, $5-10 \mathrm{~cm}$. long, 4-9 $\mathrm{mm}$. wide, erect, yellowish green : panicle longexserted, broadly ovate, $6-10 \mathrm{~cm}$. long, its branches spreading or ascending, sometimes flexuous, the lower ones $3-6 \mathrm{~cm}$. long: spikelets elliptic, $2.5 \mathrm{~mm}$. long and about 1.25 $\mathrm{mm}$. wide, obtuse or acutish, pubescent.

In alluvial soil, Georgia. Spring and summer.

97. Panicum xanthospérmum Scribn. \& Mohr. Stems tufted, 1-2 dm. tall, hirsute, finally branched : leaf-sheaths hirsute; blades $3-6 \mathrm{~cm}$. long, 5-8 $\mathrm{mm}$. wide, lanceolate, pubescent on both surfaces with long rather stiff spreading hairs, those on the upper surface the longer: panicle $3-4 \mathrm{~cm}$. long, its branches ascending: spikelets yellowish, about 2.3 $\mathrm{mm}$. long and $1 \mathrm{~mm}$. wide, elliptic, pubescent with long weak hairs.

In dry sandy soil, Aiabama. Spring and fall.

98. Panicum Commonsiànum Ashe. Stems tufted, 3-5 dm. tall, finally branched, pubescent below with long nearly appressed hairs, the upper portion glabrous or puberulent, the nodes bearded with spreading hairs : primary leaves usually 2 or 3 ; sheaths, at least the lower ones, pubescent with nearly appressed hairs; blades erect, lanceolate, strigose on the lower surface, the upper surface glabrous or with some long spreading hairs toward the base, the primary ones $4-8 \mathrm{~cm}$. long, 3-6 mm. wide: panicle 4-8 $\mathrm{cm}$. long, ovate, its branches spreading or ascending: spikelets $2.5 \mathrm{~mm}$. long and about $1.3 \mathrm{~mm}$. wide, obovoid, pubescent with spreading hairs, the first scale about $\frac{1}{2}$ as long as the spikelet.

In dry sandy soil near the coast, New Jersey and Delaware. Spring and summer.

99. Panicum strictifòlium Nash. Stems tufted, $2.5-5 \mathrm{dm}$. tall, strongly pubescent toward the base with long soft hairs, puberulent toward the summit, finally much branched : leaves 3 or 4 ; sheaths much shorter than the internodes, the lower ones densely pubescent with long soft appressed hairs ; blades erect or nearly so, rather firm, narrowly lanceolate, the upper surface often with a few long scattered hairs, the primary blades $4-7 \mathrm{~cm}$. long, $3-5 \mathrm{~mm}$. wide : panicle $5-7 \mathrm{~cm}$. long, broadly ovoid, its axis and spreading branches minutely pubescent: spikelets obovoid, $3 \mathrm{~mm}$. long and about $1.5 \mathrm{~mm}$. wide, densely pubescent with rather long spreading hairs.

In dry sandy soil, peninsular Florida. Spring and summer.

100. Panicum ciliiferum Nash. Stems tufted, $2-5 \mathrm{dm}$. tall, finally much branched, densely hirsute below with long nearly erect hairs, sparsely pubescent above: primary leaves usually 3 , sometimes 2 ; sheaths densely hirsute with long ascending hairs ; blades erect or ascending, lanceolate, the upper surface glabrous or sometimes with some long erect hairs near the base, the lower surface strongly strigose, ciliate with long hairs, the primary ones $3-8 \mathrm{~cm}$. long, $4-10 \mathrm{~mm}$. wide: primary panicle ample, $6-11 \mathrm{~cm}$. long, broadly oval, its branches spreading or ascending : spikelets about $2.75 \mathrm{~mm}$. long and 1-1.2 $\mathrm{mm}$. wide, elliptic, pubescent with long spreading hairs.

In dry sandy soil, peninsular Florida. Spring and summer.

101. Panicum epilifòlium Nash. A glabrous tufted perennial. Stems $2-3.5 \mathrm{dm}$. tall : leaves 2 or 3 ; sheaths minutely pubescent at the apex, ciliate on both margins with long slender hairs; blades widely spreading, linear-lanceolate, 4-7 cm. long, 5-7 mm. wide, minutely pubescent on the upper surface between the nerves : panicle $5-7 \mathrm{~cm}$. long, ovate, its branches spreading or ascending: spikelets $3 \mathrm{~mm}$. long and about $1.5 \mathrm{~mm}$. wide, oval, obtusely apiculate, densely pubescent with short spreading hairs, the first scale about $\frac{1}{2}$ as long as the spikelet.

In dry sandy soil, peninsular Florida. Spring.

102. Panicum pedicellàtum Vasey. A pubescent perennial. Stems $3-4 \mathrm{dm}$. tall, pubescent with short ascending hairs, finally branched : leaves 4 or 5 ; sheaths shorter than the internodes, pubescent between the nerves with short hairs, ciliate on the margins with long hairs; blades erect or nearly so, linear-lanceolate, pubescent on both surfaces with rather short spreading hairs, usually ciliate at or toward the base, the primary ones 4-9 cm. long, 2.5-4 mm. wide, those on the branches smaller : panicle 3-4 cm. long, narrow, its branches erect-ascending: spikelets $4 \mathrm{~mm}$. long and $1.5 \mathrm{~mm}$. wide, the scales 
rather distantly inserted on the rachilla, the first scale about $\frac{1}{2}$ as long as the spikelet, the second and third scales densely pubescent with short spreading hairs.

In dry ground, Texas. Spring and summer.

103. Panicum málacon Nash. A densely tufted usually purplish perennial, with the stem and sheaths strongly hirsute with ascending or nearly erect hairs. Stems,3-5 dm. tall, finally much branched : sheaths shorter than the internodes ; blades erect, acuminate, softly pubescent on both surfaces with short hairs : panicle 7-10 $\mathrm{cm}$. long, oval, its branches ascending : spikelets $3.5 \mathrm{~mm}$. long and about $1.5 \mathrm{~mm}$. broad, obovoid, densely pubescent with rather long spreading hairs, the first scale fully $\frac{1}{2}$ as long as the spikelet and 5 -nerved.

In dry sandy soil, peninsular Florida. Spring.

104. Panicum Hélleri Nash. Stems tufted, $2-4 \mathrm{dm}$. tall, finally branched, appressedpubescent below with long hairs, the nodes sparingly barbed : leaves 5 ; sheaths ciliate on the exterior margin, bearing between the prominent nerves scattered papillae from which sometimes arise stiff hairs, the internerves of all but the upper sheaths minutely pubescent ; blades broadly lanceolate, thin, sparsely ciliate at the rounded base, the primary ones 6-8 $\mathrm{cm}$. long, 6-12 $\mathrm{mm}$. wide : panicle usually included at the base, $6-8 \mathrm{~cm}$. long, its branches ascending : spikelets $3.25-3.5 \mathrm{~mm}$. long and about $1.5 \mathrm{~mm}$. wide, ellipsoid or somewhat obovoid, pubescent toward the base with a few scattered hairs.

On stony wooded hillsides, southern Texas. Spring.

105. Panicum scabriúsculum Ell. Stems glabrous or pubescent, $8-14 \mathrm{dm}$. long, erect, sometimes rooting at the lower nodes, finally branched : leaves $6-8$; sheaths glabrous or pubescent ; blades erect or ascending, linear-lanceolate, glabrous, 1-2 dm. long, 8-12 mm. wide: panicle 1-2 dm. long, broadly ovoid, its branches spreading or ascending: spikelets lanceolate, glabrous, $2-2.3 \mathrm{~mm}$. long and $1 \mathrm{~mm}$. broad, ovate to ovate-lanceolate, acute, the nerves of the flowering scale very prominent.

In swampy places and ponds, Virginia to Florida and Texas. Spring and summer.

106. Panicum scopàrium Lam. Stems erect, 6-12 dm. tall, simple, finally much branched above, villous : leaf-sheaths villous ; blades softly pubescent, those on the main stem $10-18 \mathrm{~cm}$. long, 10-16 mm. wide, distant, those on the branches $2.5-6.5 \mathrm{~cm}$. long, 4-10 $\mathrm{mm}$. wide, crowded : primary panicle $7-15 \mathrm{~cm}$. long, ovoid, its branches ascending, the secondary panicles much smaller : spikelets ovoid to oval, about $2.5 \mathrm{~nm}$. long, pubescent. [P. viscidum Ell.]

In moist soil, New Jersey to Indiana, the Indian Territory, Florida and Texas. Summer.

107. Panicum equilateràle Scribn. A tufted nearly glabrous perennial. Stems 4-8 dm. tall, finally branched, the branchlets crowded at the end of the branches : primary leaves 4 or 5 ; sheaths ciliate on the margins, shorter than the internodes: primary blades spreading, elongated, linear to linear-lanceolate, $8-18 \mathrm{~cm}$. long, 7-15 mm. wide, those on the branches much smaller but similar in shape : primary panicle $7-9 \mathrm{~cm}$. long, broadly ovate, its branches somewhat ascending : spikelets about $3.5 \mathrm{~mm}$. long and about $1.3 \mathrm{~mm}$. wide, elliptic, somewhat acute, pubescent with short spreading hairs.

In dry soil, peninsular Florida. Summer.

108. Panicum Áshei G. Pearson. Stems tufted, $2-4 \mathrm{dm}$. tall, erect, usually sparingly branched, rarely much branched and prostrate, puberulent: leaves 3 or 4 ; sheaths usually less than $\frac{1}{2}$ as long as the internodes, ciliate on the overlapping margin; blades usually erect or ascending, sometimes spreading, lanceolate, sparsely ciliate at the base with long hairs, usually 5-8 cm. long, rarely longer, 6-10 mm. wide, occasionally broader, a little cordate at the base, the upper blades about the same length, the lower ones shorter, the early basal blades ciliate : panicle $5-7 \mathrm{~cm}$. long, its branches ascending : spikelets about $2.3 \mathrm{~mm}$. long and about $1 \mathrm{~mm}$. wide, elliptic, pubescent with rather long ascending hairs.

In dry woods, southern Connecticut and New York to Tennessee and Georgia; also in Missouri Summer.

109. Panicum ovàle Ell. Stems tufted, $3-7 \mathrm{dm}$. tall, villous, finally somewhat branched, the branches divergent: primary leaves usually $3-5$; sheaths shorter than the internodes, softly pubescent, ciliate on the margin ; upper blades ovate-lanceolate, crowded and clasping at the base, pubescent on both surfaces, ciliate on the margins, the primary ones $5-10 \mathrm{~cm}$. long, 1-2.5 cm. wide : primary panicle 7-12 cm. long, oval, its branches ascending : spikelets $2.5-3 \mathrm{~mm}$. long and about $1 \mathrm{~mm}$. wide, rarely larger, pubescent with spreading hairs. [P. commelinaefolium Ashe. P. Currani Ashe.]

In dry soil, North Carolina to Florida and Louisiana. Spring and summer.

110. Panicum Manaténse Nash. Stems $2-4 \mathrm{dm}$. long, finally decumbent and much branched : leaf-sheaths ciliate on the margin; blades erect or nearly so, lanceolate, 3-9 
cm. long, 7-15 mm. wide, sparsely ciliate at the base : panicle $4-6 \mathrm{~cm}$. long, its branches ascending : spikelets elliptic, about $3 \mathrm{~mm}$. long and $1.3 \mathrm{~mm}$. wide, very acute, strongly pubescent with spreading hairs.

In hammock land, southern peninsular Florida. Summer.

111. Panicum commutàtum R. \& S. Stems tufted, glabrous, erect, $3-6 \mathrm{dm}$. tall, finally rather sparingly branched : leaves 3 or 4 ; sheaths glabrous, ciliate on the margin; blades ciliate on the margin, otherwise glabrous, cordate and clasping at the base, those on the stem larger than the basal ones, 5-12 cm. long, 1-2 cm. wide, ovate-lanceolate : panicle $5-10 \mathrm{~cm}$. long, broadly ovoid, its branches spreading or ascending: spikelets $2.5-3 \mathrm{~mm}$. long and about $1 \mathrm{~mm}$. wide, elliptic, obtuse or acutish, pubescent.

In dry places, New York to Tennessee, Missouri, Florida and Texas. Summer.

112. Panicum mutábile Scribn. \& Smith. Stems 4-8 dm. tall, tufted, glabrous, at first erect, finally prostrate and much branched : leaves 3 or 4 ; sheaths glabrous, excepting the ciliate margin ; blades glabrous, cordate and clasping at the base, ovate-lanceolate, the basal ones larger than those on the stem and conspicuously ciliate with long hairs, the stem-leaves with blades $6-12 \mathrm{~cm}$. long and usually $1-2 \mathrm{~cm}$. wide : panicle $1-1.5 \mathrm{dm}$. long, broadly ovoid, its branches ascending: spikelets about $3 \mathrm{~mm}$. long and 1-1.2 $\mathrm{mm}$. wịde, pubescent.

In sandy soil, North Carolina to Florida and Mississippi. Summer and fall.

113. Panicum Joórii Vasey. Stems tufted, glabrous, at first erect, finally prostrate and much branched: leaves 3 or 4 ; sheaths glabrous, excepting the ciliate margin ; blades ovate-lanceolate, cordate and clasping at the base, glabrous, those on the stem, which are smaller than the basal ones, 5-10 cm. long, 1-2 $\mathrm{cm}$. wide : panicle $6-10 \mathrm{~cm}$. long, ovoid, its branches ascending : spikelets 2.5-3 $\mathrm{mm}$. long and 1-1.2 $\mathrm{mm}$. wide, obtuse or sometimes acutish, pubescent.

In sandy soil, Florida to Louisiana. Spring to fall.

114. Panicum clandestinum L. Stems tufted, 6-14 dm. tall, glabrous, or sometimes papillose-hirsute below, finally much branched, the branches clothed with the densely papillose-hispid overlapping leaf-sheaths : primary leaves usually $5-7$, their sheaths shorter than the internodes, ciliate on the exterior margin, at least the lower ones strongly papillosehispid with spreading hairs; blades spreading or ascending, glabrous on both surfaces, ciliate at the cordate and clasping base, the primary ones 1-2 dm. long, $1.5-2.5 \mathrm{~cm}$. wide, acuminate, lanceolate, those on the branches ovate-lanceolate and usually less than $1 \mathrm{dm}$. long: primary panicle long-exserted, $9-12 \mathrm{~cm}$. long, rarely larger, broadly ovate, its branches ascending, the later panicles wholly or partially concealed in the sheaths : spikelets $2.7-3 \mathrm{~mm}$. long and about $1.3 \mathrm{~mm}$. wide, elliptic, pubescent with spreading hairs.

In moist or wet places, Rhode Island and southern New York to Florida. Summer and fall.

115. Panicum malacophýllum Nash. A perennial with the stems and sheaths papillose-hirsute with long spreading hairs and the nodes barbed. Stems $3-4 \mathrm{dm}$. tall, finally somewhat branched above : leaves 4 or 5 ; sheaths about $\frac{1}{2}$ as long as the internodes; blades ascending, lanceolate, softly pubescent on both surfaces, $5-7 \mathrm{~cm}$. long, 5-7 mm. wide : panicle 4-5 $\mathrm{cm}$. long, its axis and spreading branches densely hirsute with spreading hairs: spikelets $3 \mathrm{~mm}$. long and about $1.5 \mathrm{~mm}$. wide, broadly oval or obovoid, densely hirsute with long spreading hairs.

In dry soil, Tennessee and the Indian Territory. Spring.

116. Panicum pernervòsum Nash. A glabrous perennial. Stems $3-5 \mathrm{dm}$. tall, finally branched: leaves 3 or 4 ; sheaths ciliate on the exterior margin; blades erect or ascending, narrowed toward the hase, the larger ones 5-10 $\mathrm{cm}$. long, 5-9 mm. wide, ciliate toward the base with a few long hairs, the lower ones usually pubescent on the lower surface, ciliate for $\frac{2}{3}$ their length : panicle $7-12 \mathrm{~cm}$. long, its branches ascending: spikelets 3 $\mathrm{mm}$. long and $1.8 \mathrm{~mm}$. wide, broadly oval, turgid, glabrous.

In woods, eastern Texas. Spring.

117. Panicum oligosánthes Schult. Stems tufted, erect, $3-8 \mathrm{dm}$. tall, villous, finally fasciculately branched : leaves 4 or 5 ; sheaths, at least the lower ones and th ose on the branches, papillose-hispid, ciliate on the margin ; blades erect or ascending, $5-10 \mathrm{~cm}$. long, 5-10 mm. wide, lanceolate, softly and densely pubescent on the lower surface, the upper surface glabrous, or with a few long hairs at the base: primary panicle $6-8 \mathrm{~cm}$. long, its branches ascending : spikelets about $3.5 \mathrm{~mm}$. long and $1.7 \mathrm{~mm}$. broad, oval, pubescent. [P. pauciftorum Ell., not R. Br.]

In dry soil, Virginia to Georgia and Mississippi. Summer and fall.

118. Panicum Scribneriànum Nash. Stems tufted, erect, $1.5-6 \mathrm{dm}$. tall, simple, finally dichotomously branched above, sparingly pubescent or glabrous: leaf-sheaths strongly papillose-hispid; blades 5-10 $\mathrm{cm}$. long, 6-12 $\mathrm{mm}$. wide, spreading, glabrous : 
primary panicle ovoid, $4-8 \mathrm{~cm}$. long, its branches spreading : spikelets turgid, obovoid, about $3 \mathrm{~mm}$. long, glabrous, or sometimes pubescent with short spreading hairs.

In dry soil, Vermont, Massachusetts and New Jersey to Minnesota, British Columbia, Missouri, the Indian Territory and Arizona. Spring and summer.

119. Panicum Ravenélii Scribn. \& Mer. Stems tufted, erect, 4-6 dm. tall, finally branched, papillose-hirsute below with ascending hairs, the pubescence above softer: leaves 3 or 4 ; sheaths densely papillose-hirsute with ascending hairs; blades erect or ascending, glabrous above, densely and softly pubescent below, broadly lanceolate, 8-12 cm. long, 1-2 cm. wide, cordate at the clasping base : panicle $8-10 \mathrm{~cm}$. long, its branches ascending: spikelets about $4 \mathrm{~mm}$. long and $1.8 \mathrm{~mm}$. wide, obovoid, pubescent with rather weak hairs. [P. scoparium Ell., not Lam.]

In woods, District of Columbia to Florida and Louisiana. Summer and fall.

120. Panicum macrocárpon Le Conte. Stems 3-9 dm. tall, erect, simple, or somewhat branched above, the nodes, at least the upper ones, naked: leaf-sheaths glabrous, ciliate; blades 7-18 $\mathrm{cm}$. long, 2-4 cm. wide, cordate-clasping at the base, acuminate, glabrous on both surfaces, ciliate : panicle $8-15 \mathrm{~cm}$. long, usually long-exserted, rarely included, its branches more or less ascending: spikelets 3-4 mm. long, turgid, oval to obovoid, pubescent.

In woods or on dry hillsides, New Hampshire to North Carolina, Iowa and Kansas. Summer.

121. Panicum Porteriànum Nash. Stems tufted, erect, the upper part, including the panicle axis, and sometimes also the lower portion, pubescent with short hairs, or sometimes glabrous, finally branching, the nodes densely barbed with long spreading hairs : leaves 4-6; sheaths ciliate on the margin, otherwise glabrous, or sometimes the lower ones softly pubescent; blades ovate-lanceolate, cordate and clasping at the base, paler on the lower surface, glabrous, or the upper surface sometimes sparsely pubescent, $6-12 \mathrm{~cm}$. long, the larger ones $2-4 \mathrm{~cm}$. wide : panicle $6-12 \mathrm{~cm}$. long, its branches ascending : spikelets 4-6 mm. long, 1.5-2 mm. wide, the scales distant, pubescent with long weak hairs. $[P$. latifolium Chapm., in part, not L.]

In rocky woods, New York to Florida and Texas. Summer.

122. Panicum pubifòlium Nash. A softly pubescent densely tufted perennial. Stems 3-7 dm. tall, pubescent with soft weak spreading hairs, finally branched, the nodes densely barbed with long hairs : leaves $3-5$; sheaths ciliate on the margins, densely pubescent, at least all but the uppermost, with spreading weak usually long hairs; blades spreading or ascending, ovate-lanceolate to ovate, acuminate, gradually narrowed to the rounded cordateclasping base, pubescent on both surfaces with short spreading hairs, the upper primary blades $7-11 \mathrm{~cm}$. long and $2-3 \mathrm{~cm}$. broad, the lower smaller : primary panicle usually but little exserted, sometimes included at the base, $7-11 \mathrm{~cm}$. long, its axis, as well as the branches, densely pubescent with short soft spreading hairs, the branches spreading or ascending : spikelets $4-5 \mathrm{~mm}$. long and about $1.6 \mathrm{~mm}$. broad, narrowly obovoid, the scales distant, strongly pubescent with long spreading hairs. [P. latifolium Chapm., in part, not L.]

In rocky woods, New York to Missouri, Florida and Mississippi. Summer and fall.

123. Panicum latif òlium $\mathrm{L}$. An intricately much branched shrub, sometimes 2-3 m. tall. Leaves crowded and numerous; sheaths overlapping, ciliate on the margin ; blades spreading or ascending, glabrous, acuminate, the larger ones $8-10 \mathrm{~cm}$. long, 13-35 $\mathbf{m m}$. wide, those on the ultimate divisions considerably smaller: panicle $1 \mathrm{dm}$. long or less, its branches spreading or ascending: spikelets turgid, 4-5 $\mathrm{mm}$. long, the scales tipped with woolly hairs, the first scale very broad, clasping the base of the spikelet. $[P$. divaricatum L.]

In dry soil, southern peninsular Florida. Spring to fall. Syall CaNE.

\section{PHANOPỲRUM Nash.}

Tall grasses with long flat linear or lanceolate leaf-blades which are cordate and clasping at the base, and ample panicles with the spikelets arranged in pairs or in short branchlets on one side of its branches. Spikelets on rather short pedicels, acuminate ; scales 4, acuminate, strongly nerved, the first seale $\frac{2}{3}$ as long as the spikelet or more, a little shorter than or equalling the third, the second scale considerably exceeding the third, the fourth scale less than $\frac{1}{2}$ as long as the spikelet, chartaceous, indurated in fruit. Stamens 3 . Styles long and slender, free to the base. Stigmas plumose.

1. Phanopyrum gymnocàrpon (Ell.) Nash. A glabrous perennial. Stems leafy, 6-12 dm. tall : leaf-blades $4 \mathrm{dm}$. long or less, 1-4 $\mathrm{cm}$. wide : panicle 1-2 dm. long, its branches long and ascending : spikelets $5-6 \mathrm{~mm}$. long. [Panicum gymnocarpon Ell.]

In moist places, Georgia and Florida to Texas. Summer and fall. 


\section{SACCIÓLEPIS Nash.}

Perennials with flat leaf-blades and contracted dense panicles. Spikelets numerous. Scales 4 , the 3 outer membranous; 2 outer scales empty, the first scale small and narrow, the second one large and broad, 11-nerved, saccate and gibbous at the base, the third scale enclosing a palet and staminate flower, the fourth scale chartaceous, finally indurated, about $\frac{1}{2}$ as long as the second scale, enclosing a palet of similar texture and a perfect flower. Stamens 3. Styles distinct. Stigmas plumose.

1. Sacciolepis gíbba (Ell.) Nash. Stems erect or ascending, usually rooting at the lower nodes, finally dichotomously branched, $3-20 \mathrm{dm}$. long: leaf-sheaths papillose-hirsute, at least the lower ones; blades lanceolate, spreading or ascending, long-acuminate, sometimes hirsute on one or both surfaces, 4-20 cm. long, 4-22 mm. wide : panicle contracted, 6-30 $\mathrm{cm}$. long, $1.5-2 \mathrm{~cm}$. wide: spikelets $4-5 \mathrm{~mm}$. long, ovate-lanceolate. [Panicum gibbum Ell.]

In swamps and low grounds, Virginia to Tennessee, Missouri, Florida and Louisiana, chiefly along the coast. Also in Cuba. Summer and fall.

\section{STEINCHÍsMA Raf.}

Perennial tufted grasses, with erect stems, flat leaf-blades and loose open panicles. Spikelets 1-flowered, the 3 outer scales membranous, the third scale bearing in its axil a much enlarged and inflated papery palet which exceeds in length the fourth scale; first scale short, the second one about as long as the spikelet; fourth scale indurated in fruit and enclosing a palet of similar texture and a perfect flower. Styles long, united only at the base. Stigmas plumose.

1. Steinchisma hìans (Ell.) Nash. Glabrous. Stems erect, $3-8 \mathrm{dm}$. tall, sometimes creeping at the base : leaf-blades $7-13 \mathrm{~cm}$. long, $2-6 \mathrm{~mm}$. wide, acuminate, usually erect: panicle 7-20 cm. long, its branches few, generally spreading: spikelets about $2 \mathrm{~mm}$. long. [Panicum hians Ell.]

In moist ground, North Carolina to Missouri, Florida and Texas. Summer and fall.

\section{CHAETÓCHLOA Scribn.}

Annual or perennial grasses, with usually flat, sometimes complanate, leaf-blades and dense terminal cylindric spike-like or narrowly thyrsoid panicles. Spikelets with one or a cluster of 2-several sterile barbed bristle-like persistent branches. Scales 4, the 3 outer membranous, the first often very short and together with the larger second one empty, the third scale frequently longer than the second, empty, or rarely enclosing a palet and also sometimes a staminate flower, the fourth scale usually shorter than the spikelet, chartaceous, glabrous, shining, often transversely rugose, finally indurated, obtuse, enclosing a shorter palet of similar texture and a perfect flower. Stamens 3. Styles distinct, elongated. Stigmas plumose. [Setaria Beauv., not Achar.] Foxtail. Foxtall Grass.

Inflorescence with the spikelets racemosely arranged : bristles 5-16 at the base of each spikelet, involucrate.

Annual; bristles tawny orange.

Perennial, from branching rootstocks : bristles green, yellowish green or

purple.
Inflorescence stout: bristles usually exceeding twice the length of the spikelet.

Rootstocks slender: leaf-blades elongated.

Second scale of the spikelet 5-7-nerved: leaf-blades sometimes with a few scattered hairs near the base on the upper surface. Second scale of the spikelet 3-nerved: leaf-blades glabrous. Rootstocks stout: leaf-blades short, thick and firm, grayish green.

Inflorescence slender: bristles once or twice as long as the spikelet. Leaf-blades linear-lanceolate, short.

Leaf-blades linear, elongated.

Inflorescence with the spikelets in clusters or on branches : bristles 1-3 at the base of each spikelet, not involucrate.

Bristles downwardly barbed.

Bristles upwardly barbed.

a. Second scale of the spikelet as long as the flowering scale or very nearly so. * Panicle thick, dense, its branches crowded.

Flowering scale dull, papery when mature, often finely transversely rugose : plants usually less than $1.5 \mathrm{~m}$. tall.

Panicle usually $1 \mathrm{~cm}$. thick or less : bristles commonly green : spikelets about $2 \mathrm{~mm}$. long.

1. C. glauca.

\section{C. imberbis. \\ 3. C. versicolor. \\ 4. C. occidentalis. \\ 5. C. purpurascens. \\ 6. C. gracilis.}

7. C. verticillata. 
Panicle usually 1-3 cm. thick: bristles usually purple: spikelets $2.5-3 \mathrm{~mm}$. long.

Flowering scale shining, very hard in fruit, smooth: plants usually 2-4 m. tall.

** Panicle slender, loose, narrow, often interrupted below.

Spikelets about $3 \mathrm{~mm}$. long.

Spikelets about $2 \mathrm{~mm}$. long.

b. Second scale manifestly shorter than the flowering scale.

Spikelets less than $3 \mathrm{~mm}$. long.

Panicle loose, often interrupted below, usually narrowed at the summit. Spikelets elliptic to ovate.

Panicle long-attenuate at the apex.

Panicle narrowed at the apex, but not long-attenuate.

Leaf-blades $1 \mathrm{~cm}$. wide or less : stems usually slender. Leaf-blades $1.5-2 \mathrm{~cm}$. wide: stems usually stout. Spikelets hemispheric.

Panicle dense, of the same diameter throughout.

Flowering scale very coarsely undulate-rugose : panicles with many bristles.

Flowering scale finely transverse-rugose: panicles with rather few bristles.

Spikelets $3 \mathrm{~mm}$. long or more.

Panicle dense, of equal diameter throughout, $1 \mathrm{~cm}$. thick or less, exclusive of the bristles.

Panicle loose, narrowed at the summit, $2-4 \mathrm{~cm}$. in diameter, exclusive of the bristles.

Leaf-blades 1-2 cm. wide, glabrous.

Leaf-blades $6-8 \mathrm{~mm}$. wide, pubescent on both surfaces with spreading hairs.

9. C. Italica.

10. C. magna.

15. C. villosissima.

16. C. Grisebachii.

\section{C. caudata.}

16. C. Grisebachii.

17. C. polystachya.

13. C. macrostachya.

11. C. corrugata.

12. C. composita.

12. C. composita.

14. C. macrosperma.

15. C. villosissima.

1. Chaetochloa glaùca (L.) Scribn. Annual. Stems tufted, $3-12 \mathrm{dm}$. tall, branching at the base : leaf-sheaths glabrous, loose, compressed ; blades $1.5 \mathrm{dm}$. long or less, 4-8 $\mathrm{mm}$. wide, glaucous, at least the lower ones pilose near the base on the upper surface : racemes dense, about $1 \mathrm{~cm}$. in diameter, the rachis pubescent, $2-10 \mathrm{~cm}$. long: spikelets broadly ovoid, $3 \mathrm{~mm}$. long and $2 \mathrm{~mm}$. wide, the acute flowering scale striate, coarsely transversely rugose. [Setaria glauca Beauv.]

In cultivated grounds and waste places nearly throughout North America. Naturalized from Europe. Summerand fall.

2. Chaetochloa imbérbis (Poir.) Scribn. Perennial. Stems tufted, $3-7 \mathrm{dm}$. tall, from rootstocks, slender, compressed, rough below the raceme : leaf-sheaths glabrous, compressed ; blades 1-3 dm. long, 3-7 mm. wide, the upper surface often with a few long hairs at the base : racemes dense, spike-like, $2-5 \mathrm{~cm}$. long, nearly $1 \mathrm{~cm}$. in diameter, exclusive of the bristles, the rachis pubescent: bristles $5-10 \mathrm{~mm}$. long: spikelets ovoid, acute, 2-2.5 $\mathrm{mm}$. long, the flowering scale acute, striate, finely transversely rugose. [Setaria laevigata Chapm. in part.]

In moist soil, New Jersey, Kansas and Missouri to Florida and Texas. Also in tropical America. Spring to fall.

3 Chaetochloa versícolor Bicknell. Perennial. Stems $6-12 \mathrm{dm}$. long, ascending : leaf-sheaths compressed, keeled, smooth and glabrous; blades long and narrow, 1-3.5 dm. long, 2-6 mm. wide, pale green or glaucous, glabrous: spike-like raceme long-exserted, rather slender, $2-7 \mathrm{~cm}$. long, about $1.5 \mathrm{~cm}$. in diameter : bristles in two nearly equal clusters of 5 each, very slender, $6-10 \mathrm{~mm}$. long: spikelets usually single, about $2.5 \mathrm{~mm}$. long and $1.25 \mathrm{~mm}$. wide, the first and second scales 3-nerved, the fourth scale purple-tipped. [Panicum laevigatum Ell., not Lam. Setaria laevigata Chapm. in part.]

Along borders of salt or brackish marshes, Massachusetts to Florida. Summer and fall.

4. Chaetochloa occidentàlis Nash. Perennial. Stems from a stout branching rootstock, 3-8 dm. tall : leaf-sheaths compressed, keeled, smooth and glabrous ; blades erect, firm, $1.5 \mathrm{dm}$. long or less, $5-7 \mathrm{~mm}$. wide, glabrous : spike-like racemes $3-5 \mathrm{~cm}$. long, $1: 5-$ $2 \mathrm{~cm}$. in diameter : bristles green: spikelets a little less than $3 \mathrm{~mm}$. long, the flowering scale strongly transversely rugose, elliptic.

In meadows, Kansas and the Indian Territory. Summer.

5. Chaetochloa purpuráscens (H.B.K.) Scribn. \& Mer. Perennial. Stems 1-6 dm. tall, slender, branching, from rootstocks : leaf-sheaths loose, striate, glabrous ; blades $5-10 \mathrm{~cm}$. long, 4-6 mm. wide, rough on both surfaces: racemes $1-5 \mathrm{~cm}$. long, about $5 \mathrm{~mm}$. in diameter, the rachis pubescent : bristles $5-10,3-8 \mathrm{~mm}$. long, often barely exceeding the spikelets : spikelets ovoid, acute, $2 \mathrm{~mm}$. long, the flowering scale acute, transversely rugose.

In dry places, Texas. Also in tropical America. Spring to fall.

6. Chaetochloa grácilis (H.B.K.) Scribn. \& Mer. Perennial. Stems erect, 3-7 dm. tall, slender, cylindric, simple, or somewhat branched at the base : leaf-sheaths loose, glabrous ; blades involute-setaceous, $2 \mathrm{dm}$. long or less, $1-3 \mathrm{~mm}$. wide : racemes dense, 2$6 \mathrm{~cm}$. long, 3-5 mm. in diameter: bristles $5-8$, very short, equalling or twice as long as 
the spikelet: spikelets $2 \mathrm{~mm}$. long, ovoid, acute, the flowering scale acute, abruptly apiculate, transversely rugose. [Setaria imberbis Chapm.]

In sandy soil, Texas, and adventive eastward. Also in tropical America. Spring to fall.

7. Chaetochloa verticillàta (L.) Scribn. Annual. Stems 3-6 dm. tall, erect or ascending : leaf-sheaths loose, the margin ciliate above ; blades $7-18 \mathrm{~cm}$. long, 6-12 mm. wide, flat, rough on both sides : panicle spike-like : bristles 1-3, stout, flexuous, 3-6 mm. long: spikelets narrowly elliptic-ovate, acute, $2-2.5 \mathrm{~mm}$. long, the flowering scale about 2 $\mathrm{mm}$. long, rounded at the shortly apiculate apex, smooth, or with very fine transverse wrinkles below the middle. [Setaria verticillata Beauv.]

In waste places, fields and along roadsides, throughout the United States. A cosmopolitan weed. Introduced from Europe. Summer and fall.

8. Chaetochloa víridis (L.) Scribn. Annual. Stems tufted, usually much branched at the base, compressed, $2-9 \mathrm{dm}$. tall : leaf-sheaths compressed, loose, ciliate on the margin ; blades $3 \mathrm{dm}$. long or less, 4-10 mm. wide : spike-like panicles $2-10 \mathrm{~cm}$. long, about $1 \mathrm{~cm}$. in diameter, exclusive of the bristles, green, the rachis villous: bristles $1-1.5 \mathrm{~cm}$. long: spikelets about $2 \mathrm{~mm}$. long, elliptic, the flowering scale elliptic, rounded at the apex, finely and faintly transversely rugose below the middle or merely striate and pitted. [Setaria viridis Beauv.]

In cultivated grounds and waste places nearly throughout North America. Introduced from Europe. Summer and fall.

9. Chaetochloa Itálica (L.) Scribn. Annual. Stems simple, or branched at the base : leaf-sheaths loose, glabrous, ciliate on the nargin ; blades long-acuminate, 2-4 dm. long, $1.5-3 \mathrm{~cm}$. wide, rough : panicles dense, cylindric, $8-20 \mathrm{~cm}$. long, $2-3 \mathrm{~cm}$. in diameter, obtuse or truncate at both ends, the rachis densely villous : bristles $1-3,3-10 \mathrm{~mm}$. long, often shorter than the spikelets or nearly wanting : spikelets elliptic, $2.5-3 \mathrm{~mm}$. long.

In fields and waste places, Quebec and Minnesota to Florida and Texas. Widely cultivated and very variable. Introduced from Europe or Asia. The variety C. Italica Germánica (Mill.) Scribn. differs in being smaller and more slender, and in having a smaller narrower panicle which is usually tapering at the base. Italian MiLlet. Hungarian Grass.

10. Chaetochloa mágna (Griseb.) Scribn. Stems stout, erect, 1-4 m. tall, branching at the base : leaf-sheaths glabrous, compressed; blades 3-6 dm. long, 1-3 cm. wide, rough : panicle usually interrupted below, $1-3.5 \mathrm{dm}$. long, $2-5 \mathrm{~cm}$. in diameter; bristles 1-3, green, 8-11 mm. long: spikelets elliptic, acute, $2 \mathrm{~mm}$. long. [Setaria magna Griseb.]

In swamps or even in shallow water, Delaware to Florida, Louisiana, and Texas. Also in tropical America. Summer and fall.

11. Chaetochloa corrugàta (Ell.) Scribn. Annual. Stems tufted, 5-10 dm. tall, compressed, much branched at the base, sometimes rooting at the lower nodes: leaf-sheaths very loose, compressed, keeled ; blades 1-3 dm. long, 3-6 mm. wide, rough, narrowed toward buth ends : panicle $5-15 \mathrm{~cm}$. long, $5-15 \mathrm{~mm}$. in diameter, exclusive of the bristles : bristles solitary or rarely 2 at each spikelet, $5-15 \mathrm{~mm}$. long: spikelets ovoid, acute, about $2 \mathrm{~mm}$. long, the fourth scale very strongly transversely and coarsely undulate-rugose. [Setaria corrugata Schult.]

In fields and waste places, Georgia and Florida. Summer and fall. The variety $C$. corrugata parviftorra (Poir.) Scribn. \& Mer. is a more slender and short form with shorter leaf-blades and panicles. In similar situations, South Carolina to Florida. Also in the West Indies. Spring to fall.

12. Chaetochloa compósita (H.B.K.) Scribn. Perennial. Stems tufted, 3-10 dm. tall, much branched from the base, usually pubescent : leaf-sheaths compressed, mostly glabrous ; blades linear, flat, $1-3 \mathrm{dm}$. long, $2-5 \mathrm{~mm}$. wide, glaucous, usually rough : panicle pale green, $5-15 \mathrm{~cm}$. long, $5-15 \mathrm{~mm}$. in diameter, exclusive of the bristles : bristles single, rarely in pairs, green, flexuous, $5-15 \mathrm{~mm}$. long: spikelets narrowly ovoid, $2-3 \mathrm{~mm}$. long, the flowering scale narrowly ovoid, acute.

In dry soil, Colorada to Arizona and Texas. Also in tropical America. Summer and fall.

13. Chaetochloa macrostáchya (H.B.K.) Scribn. \& Mer. Perennial. Stems erect or ascending, 6-12 dm. tall, rather stout, compressed : leaf-sheaths loose, glabrous or nearly so ; blades linear-lanceolate, rigid, $1.5-5 \mathrm{dm}$. long, 1-1.5 $\mathrm{cm}$. wide, usually rough, genererally with a few long white hairs near the base: panicle pale green, strict, usually tapering at the apex, 1-3 dm. long, 1-2 $\mathrm{cm}$. in diameter : bristles single or in pairs, slender, flexuous, 1-2 $\mathrm{cm}$. long: spikelets ovoid-globose, about $2 \mathrm{~mm}$. long, acute, the flowering scale strongly convex, apiculate, transversly undulate-rugose.

In dry soil, Texas. Also in tropical America. Spring to fall.

14. Chaetochloa macrospérma Scribn. \& Mer. Perennial. Stems stout, 6-12 dm. tall, glabrous : leaf-sheaths compressed, glabrous, the margins ciliate ; blades linear-lanceolate, 1-3 dm. long, 1-2 cm. wide, rough or smooth : panicle $1-2.5 \mathrm{dm}$. long, $2-4 \mathrm{~cm}$. in diameter, exclusive of the bristles: bristles single, $1.5-3 \mathrm{~cm}$. long, green : spikelets nar- 
rowly ovoid, acute, $3 \mathrm{~mm}$. long, the flowering scale acute, narrowly ovoid, finely transversely rugose.

On shell islands or keys, or sometimes in old fields, southern Florida and Texas. Summer to fall.

15. Chaetochloa villosíssima Seribn. \& Mer. Perennial. Stems branching at the base, 4-10 dm. tall, compressed, glabrous: leaf-sheaths loose, compressed, rough above, nearly smooth below, densely villous above; blades linear, $1.5-3 \mathrm{dm}$. long, $6-8 \mathrm{~mm}$. wide, tapering toward the base, pubescent on both surfaces with white spreading hairs : panicle about $2 \mathrm{dm}$. long, $2-3 \mathrm{~cm}$. in diameter, tapering to the apex : bristles single, green, 1.5-2.5 $\mathrm{cm}$. long : spikelets ovate-lanceolate, acute, $2.5-3 \mathrm{~mm}$. long, the flowering scale abruptly short-apiculate at the incurved tip, rather finely transversely rugose below and punctate above.

In dry soil, Texas. Spring and summer.

16. Chaetochloa Grisebáchii (Fourn.) Scribn. Annual. Stems $1.5-8 \mathrm{dm}$. tall, branching at the base, slender, glabrous : leaf-sheaths loose, compressed, sparingly strigose, the margins ciliate; blades lanceolate, slightly narrowed at the cordate base, $5-10 \mathrm{~cm}$. long, 5-10 mm. wide, rough and sparingly short-pubescent: bristles single or in pairs, widely spreading, purple or sometimes green, 5-15 mm. long: spikelets ovoid, $2 \mathrm{~mm}$. long, acute, the flowering scale nearly $2 \mathrm{~mm}$. long, ovoid, acute, very finely transversely rugose below.

In dry soil, Texas to Arizona. Also in Mexico. Spring to fall.

17. Chaetochloa polystáchya (Scheele) Scribn. \& Mer. Perennial. Stems stout, 6-12 dm. tall, branching at the base, glabrous : leaf-sheaths glabrous or sparingly pubescent, the margins ciliate : blades $1.5-3 \mathrm{dm}$. long, $1.5-2 \mathrm{~cm}$. wide, abruptly narrowed at the base, rough, the lower ones sometimes strigose: panicle lax, pale green, $1.5-3 \mathrm{dm}$. long, $1.5-3 \mathrm{~cm}$. in diameter : bristles single, $8-12 \mathrm{~mm}$. long, green, slender, flexuous : spikelets narrowly ovoid, acute, $2 \mathrm{~mm}$. long, the flowering scale narrowly ovoid, acute, transversely undulate-rugose at the base.

In dry soil, Texas. Summer and fall.

18. Chaetochloa caudàta (Lam.) Scribn. Annual. Stems $3-6 \mathrm{dm}$. tall, much branched from the base, glabrous, slender: leaf-sheaths pubescent, ciliate on the margin ; blades linear, 1-3 dm. long, 3-5 mm. wide, pubescent, filiform-attenuate at the apex: panicle 5-15 $\mathrm{cm}$. long, attenuate, the rachis slender and flexuous, pilose : bristles single, flexuous, 4-10 mm. long: spikelets ovoid, acute, the flowering scale ovoid, acute, shortapiculate, transversely undulate-rugose below.

In dry soil, New Jersey to Florida and Alabama. Also in tropical America. Spring to fall.

\section{CÉNCHRUS L.}

Annual or perennial grasses, with flat, convolute or complanate leaf-blades and terminal spikes. Spikelets 2-6, in an ovate or globose involucre, consisting of two thick hard valves which are exteriorly armed with stout spines and sometimes also with basal bristles which are thickened at the base, the involucres articulated to the rachis and readily deciduous, carrying the persistent spikelets with them. Scales 4, awnless, the first and second empty, the first small or minute, the third equalling or longer than the second, enclosing a palet and also sometimes a staminate flower, the fourth scale chartaceous, firmer, enclosing a palet of similar texture and a perfect flower. Stamens 3. Styles often connate at the very base. Stigmas plumose. Bur Grass. Sand Bur. Sand Spur. Cockspur.

Involucre armed at the base :

With shorter generally reflexed spines, the base of the involucre glabrous: in-

volueres containing 2 spikelets.

Involucre pubescent:

Usually less than $5 \mathrm{~mm}$. broad. $\quad$ 1. C. tribuloides.

$6-8 \mathrm{~mm}$. broad.

Involuere glabrous.

With erect barbed bristles, the base of the involucre villous: involucres containing $4-6$ spikelets.

Involucre naked at the base.

2. C. macrocephalus.

3. C. gracillimus.

4. C. echinatus.

5. C. incertus.

1. Cenchrus tribuloides L. Stems at first erect, later prostrate and forming mats, 2-6 dm. long, branching : leaf-sheaths compressed ; blades 6-12 $\mathrm{cm}$. long, 4-8 mm. wide, smooth or rough, usually flat: spikes $3-6 \mathrm{~cm}$. long: involueres $6-20,3-5 \mathrm{~mm}$. broad, enclosing 2 spikelets, pubescent, the spines $3-4 \mathrm{~mm}$. long: spikelets $6-7 \mathrm{~mm}$. long, usually not exserted beyond the involucre.

In dry sandy places, Massachusetts, Ontario, Minnesota and Nebraska to Florida, Texas and Mexico. Very variable. Spring to fall. 
2. Cenchrus macrocéphalus (Doell) Scribn. Stems at first erect or ascending, later becoming prostrate and branched and forming mats, 3-6 dm. long: leaf-sheaths very loose, glabrous, compressed ; blades flat or complanate, smooth and glabrous, $1 \mathrm{dm}$. long or less, 4-8 mm. wide : spikes stout, $3-5 \mathrm{~cm}$. long: involucres $5-12,6-8 \mathrm{~mm}$. broad, enclosing 2 spikelets, pubescent, the spines usually $5-8 \mathrm{~mm}$. long : spikelets not exserted beyond the involuere.

Along the seashore, New Jersey to Mississippi. Summer and fall.

3. Cenchrus gracíllimus Nash. Stems erect or ascending, 3-6 dm. tall, simple, or sometimes sparingly branched above, slender: leaf-sheaths but little inflated ; blades complanate, $5-8 \mathrm{~cm}$. long, about $2 \mathrm{~mm}$. wide, acuminate : spikes finally long-exserted, $3-5 \mathrm{~cm}$. long, bearing 3-6 distant purplish involucres which are glabrous and with a deeply furrowed and glabrous base, the spines purple, $5-6 \mathrm{~mm}$. long: spikelets about $8 \mathrm{~mm}$. long, exserted beyond the involucre from $\frac{1}{3}-\frac{1}{2}$ their length.

In dry sand in the high pine land region, peninsular Florida. Spring and summer.

4. Cenchrus echinàtus L. Stems finally prostrate and rooting at the nodes, branched: leaf-sheaths loose; blades 1-4 dm. long, 5-15 mm. wide, smooth or rough, flat: spikes 4-12 cm. long, finally more or less exserted : involucres 20-50, densely crowded, containing 4-6 spikelets, glabrous, green to purplish, pubescent, villous at the base, the spines 3-4 mm. long, the bristles at the base numerous, slender, distinetly barbed for their whole length : spikelets $6-7 \mathrm{~mm}$. long, exserted from the involucre.

In sandy places, North Carolina to Florida and Texas. Also in tropical America. Spring to fall.

5. Cenchrus incértus M. A. Curtis. Stems at first erect or ascending, finally prostrate and rooting at the lower nodes, 3-6 dm. long: leaf-sheaths compressed, inflated; blades glabrous, flat, $4-15 \mathrm{~cm}$. long, $3-5 \mathrm{~mm}$. wide : spikes usually exserted, $3-6 \mathrm{~cm}$. long: involucres 8-20, containing 2 spikelets, pubescent, ovoid, glabrous at the base, the spines about $3 \mathrm{~mm}$. long, very broad at the base, eiliate : spikelets $5 \mathrm{~mm}$. long, exserted from the involucre.

In dry sandy places, South Carolina to Florida and Texas. Summer and fall.

\section{CENCHRÓPSIS Nash.}

Perennial grasses, with long rootstocks, flat leaf-blades and terminal spicate inflorescence. Spikelets single, subtended by an involucre consisting of 1 or 2 outer rows of barbed bristles which are thickened at the base, and 1 or 2 inner rows of barbed spines 2-4 times as long as the bristles and about equalling the spikelet, the involucre articulated to the rachis and readily deciduous. Scales 4 , the first and second empty, the first about onehalf as long as the spikelet, the third scale longer than the second, enclosing a palet onehalf its length or less, the fourth scale chartaceous, firmer, enfolding a palet of similar texture and a perfect flower. Stamens 3. Styles often connate at the very base.

1. Cenchropsis myosuroìdes (H.B.K.) Nash. Stems 6-14 dm. tall, from a stout rootstock, simple, or branched above : leaf-sheaths glabrous; blades glabrous, $1-3 \mathrm{dm}$. long, 3-8 $\mathrm{mm}$. wide: spikes 5-20 cm. long, included at the base or exserted : involucres numerous, consisting of 1-2 rows of barbed spines as long as the single spikelet, and subtended by $1-2$ rows of barbed bristles $\frac{1}{4}-\frac{1}{2}$ as long: spikelets about $5 \mathrm{~mm}$. long. [Cenchrus. myosuroides H.B.K.]

In dry sandy places, Georgia and Florida. Also in tropical America. Spring to fall.

\section{PENNISÈTUM Pers.}

Annual or perennial, often branched, grasses, with flat leaf-blades and terminal dense cylindric spikes. Spikelets in 1's-3's, 1-2-flowered, subtended by an involucre consisting of numerous slender bristles which are not thickened at the base, all the bristles, or at least the middle ones, plumose. Scales 4, rarely 3, the 2 outer empty, the first small or minute, rarely wanting, the second often as long as the spikelet, the third scale empty or enclosing a palet and a staminate flower, the fourth scale firmer, shorter, enfolding a palet of similar texture and a perfect flower. Stamens 3. Styles usually distinct. Stigmas plumose.

1. Pennisetum setòsum (Sw.) Pers. Stems $1-1.5 \mathrm{~m}$. tall, simple or branched : leafsheaths glabrous, keeled; blades $3 \mathrm{dm}$. long or less, $6-13 \mathrm{~mm}$. wide, long-acuminate, the upper surface toward the base pubescent with long spreading stout hairs: spikes dense, eylindric, 1-3 dm. long, 1-1.5 cm. in diameter: bristles of two kinds, the outer short and slender, merely hispidulous, about as long as or shorter than the spikelet, the inner much 
longer, stouter, beautifully plumose below: spikelets very numerous, densely crowded, about $4 \mathrm{~mm}$. long.

In damp places, southern peninsular Florida. Also in tropical America. Summer and fall. Mission GRASs.

\section{PENICILLÀrIA Beauv.}

Tall grasses, with flat leaf-blades and dense cylindric panicles. Spikelets in pairs on a short pedicel, surrounded by bristles, persistent ; bristles little if at all exceeding the spikelets, the outer ones short and merely hispidulous, the inner ones plumose. Scales 4 , the 3 outer membranous, the fourth scale shorter, firmer, enclosing a palet of similar texture and a perfect flower. Stamens 3. Styles usually distinct. Stigmas plumose.

1. Penicillaria spicàta (L.) Willd. Stems erect, $1 \mathrm{~m}$. tall or more, densely and softly pubescent below the inflorescence, leafy : leaf-sheaths strongly ciliate on the margins with long hairs; blades $4 \mathrm{dm}$. long or less, $6-10 \mathrm{~mm}$. wide, long-acuminate : panicles $1-3 \mathrm{dm}$. long, eylindric, $1-1.5 \mathrm{~cm}$. in diameter: outer bristles shorter than the spikelet, numerous, slender, merely hispidulous, the inner ones stouter, few, about equalling the spikelet in length, plumose: spikelets about $4 \mathrm{~mm}$. long.

In fields and waste places, and along roadsides, Alabama and Mississippi. Summer and fall.

\section{STENOTÁPHRUM Trin.}

Perennial grasses, ereeping and branching at the base, with compressed stem, flat or convolute leaf-blades, and a terminal spike or spike-like panicle. Spikelets acute or acuminate, 2- (rarely 1-) flowered, in 2's-4's in short spikes which are embedded in the alternate notches on one side of the broad and compressed rachis. Scales 4, rarely 3 , the 2 outer empty, the first small, rarely wanting, the second equalling or a little shorter than the spikelet, the third scale similar to the second, enclosing a palet and a staminate flower, rarely empty, the fourth scale more rigid than the others, enfolding a palet of similar texture and a perfect flower. Stamens 3. Styles distinct. Stigmas plumose.

1. Stenotaphrum secundàtum (Walt.) Kuntze. Stems compressed, prostrate and rooting at the lower nodes: leaf-sheaths compressed, glabrous, keeled; blades flat, or folded when dry, linear, rounded at the apex, usually less than $1 \mathrm{dm}$. long, sometimes longer, 4-10 mm. wide : spikelets $5-10 \mathrm{~mm}$. long, immersed in one side of a broad compressed rachis, $3.5-5 \mathrm{~mm}$. long.

In sandy soil, South Carolina to Florida and Texas. Also in tropical America. Spring to fall. ShORE Grass.

\section{OLỲRA L.}

Usually tall grasses, with broad flat leaf-blades, which are contracted into a petiolelike base, and terminal or axillary panicles. Spikelets unisexual, monoecious : staminate spikelets arranged along the panicle branches below the summit; scale 1, usually awned ; palet as long as the scale, 2-nerved; stamens 3. Pistillate spikelets terminating the main branches of the panicle, much larger than the staminate; empty scales 2, usually awned, membranous, the third scale chartaceous, indurated in fruit ; styles 2 , united at the base.

1. Olyra latifolla L. Stems finally branched: leaf-blades contracted at their junction with the sheath into a petiole-like base, oblong to broadly lanceolate, rather abruptly acuminate, the primary ones $1.5 \mathrm{dm}$. long or less, $2-4 \mathrm{~cm}$. wide : panicle triangular or ovate, its branches spreading or ascending : staminate spikelets lanceolate, 4-5 mm. long, exclusive of the awn: pistillate spikelets ovoid, acuminate, $8-10 \mathrm{~mm}$. long, exclusive of the awn.

In dry places, southern peninsular Florida. Also in tropical America. Summer.

\section{HYDRÓCHLOA Beauv.}

Slender branching monoecious aquatic grasses, usually floating, sometimes creeping, with narrow flat leaf-blades and spicate inflorescence. Spikelets small, of two kinds, the staminate in a slender short terminal spike, the pistillate in few-flowered spikes in the upper leaf-axils, the spikes but little exserted from the sheaths. Scales 2, a little unequal, membranous, concave, awnless, palet wanting. Stamens 6 . Styles short, distinct, somewhat laterally attached to the apex of the ovary. Stigmas elongated, shortly plumose. 
1. Hydrochloa flùitans (Michx.) Nash. Floating or creeping. Stems $1 \mathrm{~m}$. long or less, slender, much branched : leaf-sheaths sparingly pilose at the summit; blades $1-4 \mathrm{~cm}$. long, $1.5-4 \mathrm{~mm}$. wide: staminate spikelets $4.5-5 \mathrm{~mm}$. long: stamens about $3 \mathrm{~mm}$. long: pistillate spikelets about $2.5 \mathrm{~mm}$. long.

In water or on muddy banks, North Carolina to Florida. Summer and fall.

\section{PHÀRUS L.}

Monoecious, usually tall, grasses, with ample panicles and large oblique long-petiolate feather-veined leaf-blades with numerous veinlets, the petioles twisted, hence reversing the leaf. Spikelets articulated below the scales, of two kinds, in pairs upon the branches of the panicle, one sessile, pistillate, the other much smaller, pedicellate, staminate. Scales 3 ; in the staminate spikelets membranous, somewhat broadened, the 2 outer empty, the first a little shorter, the second longer than the flowering scale; the third scale enclosing a flower but no palet; in the pistillate spikelets the outer two scales membranous, empty, many-nerved, subequal, the third scale much longer than the others, narrow, at length indurated, nearly closed by the involute margins, enfolding a 2-toothed membranous palet which is convolute around the flower. Stamens 6. Styles filiform, elongated, united to near the apex. Stigmas papillose.

1. Pharus latifòlia L. A leafy perennial. Stems $6-10 \mathrm{dm}$. tall : leaf-sheaths longer than the internodes, concealing the stems ; petiole-like base of the blades $1-5 \mathrm{~cm}$. long; blades oblanceolate to elliptic, acute, commonly 1-2 dm. long, 3-4 cm. wide : panicle 1-2 $\mathrm{dm}$. long, its branches finally widely spreading : sessile spikelet about $9 \mathrm{~mm}$. long, the empty scales brown, acute, the flowering scale about twice as long as the empty ones, cylindric, about $1.5 \mathrm{~mm}$. in diameter, densely pubescent with spreading glandular-tipped hairs, abruptly acute at the naked apex; pistillate spikelet $3-5 \mathrm{~mm}$. long, the apex about reaching the summit of the sessile spikelet.

In hammocks, near Orange Lake, Florida. Summer.

\section{LUzíora Juss.}

Creeping monoecious marsh or aquatic grasses, with flat leaf-blades and open terminal or lateral panicles. Spikelets small, articulated below the scales, 1-flowered, the staminate and smaller pistillate in separate panicles. Scales 2, awnless; in the staminate spikelet thin-membranous, the first empty, broader but scarcely shorter than the second which encloses a flower but no palet; in the pistillate spikelet membranous, the first scale striately many-nerved, broader than the second which encloses a flower. Stamens 6-18. Styles short, distinct. Stigmas plumose with simple hairs.

Staminate and pistillate spikelets borne in panicles on different stems : pistillate spikelets less than $3 \mathrm{~mm}$. long.

Staminate and pistillate spikelets borne in separate panicles on the same stem: pistillate spikelets about $4 \mathrm{~mm}$. long.

\section{L. Peruviana.}

1. Luziola Peruviàna Pers. Stems finally branching and rooting at the lower nodes, $4 \mathrm{dm}$. long or less : leaf-blades elongated and narrow : staminate panicles $3-6 \mathrm{~cm}$. long, the branches erect, the spikelets about $6 \mathrm{~mm}$. long : pistillate panicles 4-6 $\mathrm{cm}$. long, the branches spreading or ascending, the spikelets $2-2.5 \mathrm{~mm}$. long.

In ditches and in wet usually grassy places, Louisiana. Summer and fall.

2. Luziola Alabaménsis Chapm. Stems finally branching and rooting at the lower nodes, 1-3 dm. long: leaf-blades elongated and narrow, usually much exceeding the panicles : panicles $3-8 \mathrm{~cm}$. long, often included below in the upper leaf-sheath, the branches commonly ascending or erect : staminate spikelets $5-6 \mathrm{~mm}$. long : pistillate spikelets about $4 \mathrm{~mm}$. long.

In wet places, Alabama and Mississippi. Summer and fall.

\section{ZIZANIÓPsis Doell \& Aschers.}

Tall robust perennial monoecious aquatic grasses, with creeping rootstocks, long flat leaf-blades and ample terminal panicles. Spikelets with a more or less prominent cartilaginous ring at the base, 1-flowered, narrow, articulated below the scales, flattened, of 2 kinds, the staminate at the base of, the pistillate terminating, the branches of the narrow panicle. Seales 2, membranous, concave, acute, the first empty, awned in the pistillate spikelets, a little broader than the scarcely shorter awnless second scale which encloses a flower but no palet. Stamens 6. Styles united. Stigmas plumose with short hairs. 
1. Zizaniopsis miliàcea (Michx.) Doell \& Aschers. Stems 1-4 m. tall, from a long and creeping rootstock: leaf-sheaths smooth and glabrous; blades $3-10 \mathrm{dm}$. long, 1-3 $\mathrm{cm}$. wide, usually smooth and glabrous: panicle $2.5-6 \mathrm{dm}$. long: staminate spikelets 7-8 $\mathrm{mm}$. long, more or less awned: pistillate spikelets $5-6 \mathrm{~mm}$. long, the awn 2-6 $\mathrm{mm}$. long.

In swamps, Georgia and Ohio to Florida and Texas. Summer. Water Millet. Marsh Millet.

\section{ZIZÀNIA L.}

Tall robust annual monoecious aquatic grasses, with broad flat leaf-blades and ample terminal panicles. Spikelets of two kinds, articulated below the scales, 1-flowered, each with a more or less prominent cartilaginous ring at the base, narrow, the staminate readily deciduous, on the more or less spreading lower branches, the pistillate tardily deciduous, on the erect or appressed upper branches of the panicle. Scales 2, the first empty, the second enclosing a flower but no palet: scales of the staminate spikelets membranous, concave, acute or awn-pointed; those of the pistillate spikelets linear, firmer, involute, the first long-awned, longer than the awn-pointed second. Stamens 6. Styles nearly distinct. Stigmas plumose with short hairs.

1. Zizania aquática L. Annual. Stems 1-3 m. tall : leaf-sheaths smooth and glabrous; blades $1.5-8 \mathrm{dm}$. long, $5-25 \mathrm{~mm}$. broad, usually rough : panicle $2-3 \mathrm{dm}$. long: staminate spikelets $7-8 \mathrm{~mm}$. long: pistillate spikelets $12-20 \mathrm{~mm}$. long, the awn $2.5-5 \mathrm{~cm}$. long.

In swamps and along creeks and rivers, New Brunswick to Manitoba, Florida, Louisiana and Texas. Summer and Fall. indian Rice. Wild Rice. Reeds. Water OAts. Marsh Rice.

\section{ORỲZA L.}

Swamp grasses, with flat leaf-blades and terminal narrow panicles, the branches of which are slender, erect and somewhat flexuous. Spikelets much compressed, articulated below the empty scales, 1 -flowered. Scales 4 , the 2 outer empty, very small, scale-like or bristle-form, the 2 inner compressed-keeled, somewhat rigid, the first a little the larger, empty, awned or awnless, the keel often narrowly winged or muricate, the second scarcely shorter, narrower, short-awned or awnless, the keel not winged, naked, enclosing a perfect flower but no palet. Stamens 6. Styles short, scarcely united at the base. Stigmas plumose with short hairs.

1. Oryza sativa $\mathrm{L}$. Stems $5-10 \mathrm{dm}$. tall or more, simple : leaf-blades usually rough : panicle 1-3 dm. long, its branches erect : spikelets $8-10 \mathrm{~mm}$. long, oblong, hispid, sometimes awned.

In ditches and water, Virginia to Florida and Texas. Extensively cultivated. Native of tropical Asia. Summer and fall. RICE. RICE Grass. CUt GRASs.

\section{8. homalocéNChrus Mieg.}

Grasses of wet situations, with flat leaf-blades and usually open, rarely contracted, terminal panicles, the branches of which are slender. Spikelets often with a cartilaginous ring at the base, articulated below the scales, compressed, 1-flowered. Scales 2, compressedkeeled, somewhat rigid, awnless, the first scale empty, usually ciliate on the keel, broader than the second which encloses a perfect flower but no palet. Stamens 1-6. Styles short or slender, distinct. Stigmas plumose with branched hairs. [Leersia Sw., not Hedw.]

Spikelets oblong to elliptic, their width less than $1 / 2$ their length.

Spikelets glabrous, $2 \mathrm{~mm}$. long or less: stamen 1 : stems densely tufted, erect.

Spikelets aculeate on the keels, hispidulous on the surface, $2.5 \mathrm{~mm}$. long or more :

stamens 2 or more : stems decumbent at the base.

Panicle-branches singly disposed, few, usually less than 8 . $\begin{array}{ll}\text { Panicle-branches elongated, each with a long naked base; stamens } 2 . & \text { 2. H. Virginicus. } \\ \text { Panicle-branches short, spikelet-bearing to the base; stamens } 6 & 3 . \text { Hexandrus. }\end{array}$

Panicle-branches, at least the lower ones, in whorls or approximately in pairs, numerous, usually exceeding 15 .

Spikelets broadly oval to nearly orbicular, their width more than $1 / 2$ their length.

1. H. monandrus.

4. H. oryzoides.

4. H. oryzoides.
5. H. lenticularis.

1. Homalocenchrus monándrus (Sw. ) Kuntze. Stems densely tufted, 4-6 dm. tall : leaf-sheaths smooth and glabrous ; blades erect, $4-15 \mathrm{~cm}$. long, $2-5 \mathrm{~mm}$. wide, roughish : panicle 7-13 cm. long, its branches ascending, slender, $3-4 \mathrm{~cm}$. long : spikelets $1.75-2 \mathrm{~mm}$. long, about $1 \mathrm{~mm}$. broad, smooth and glabrous : stamen 1.

In dry soil, extreme southern parts of Florida and Texas. Also in tropical America. Spring. 
2. Homalocenchrus Virgínicus (Willd.) Britton. Stems 6-13 dm. tall, slender, pubescent at the nodes, finally much branched : leaves rough ; blades erect or ascending, 3$20 \mathrm{~cm}$. long, $2-11 \mathrm{~mm}$. wide : panicle $6-20 \mathrm{~cm}$. long, its branches finally spreading, slender, 4-9 $\mathrm{cm}$. long, single at the nodes : spikelets $2.5-3.5 \mathrm{~mm}$. long, 1-1.3 mm. broad, aculeate on the keels, hispidulous on the surface : stamens 2.

In moist places and low woods, Maine and Ontario to Dakota, Florida and Texas. Spring to fall. WhITE GRASS.

3. Homalocenchrus hexándrus (Sw.) Kuntze. Stems slender, weak, 6-10 dm. long, rooting at the lower nodes : leaves exceedingly rough ; blades flat, erect, $3-15 \mathrm{~cm}$. long, 3-6 mm. wide : panicle 4-8 cm. long, its branches ascending, $1.5-4 \mathrm{~cm}$. long: spikelet 4-4.5 mm. long, $1.25-1.5 \mathrm{~mm}$. broad, the keels strongly aculeate, the hairs increasing in length toward the apex, the surface of the scales hispidulous : stamens 6 .

In water, North Carolina to Florida and Texas. Also in tropical America. Spring and summer.

4. Homalocenchrus oryzoides (L.) Poll. Stems $8-15 \mathrm{dm}$. tall, often rooting at the lower nodes : leaves very rough ; blades $6-20 \mathrm{~cm}$. long, 5-13 $\mathrm{mm}$. wide, ascending: panicle 1-2 dm. long, often partially included at the base, its branches ascending or spreading, the longer 6-10 cm. long : spikelets $4-4.5 \mathrm{~mm}$. long, about $1.5 \mathrm{~mm}$. broad, the keels aculeate, the surface hispidulous: stamens 3 .

In wet places and swamps, Nova Scotia and Ontario to Washington, Florida, Texas and California. Also in Europe and Asia. Summer and fall. RICE CUT Grass.

5. Homalocenchrus lenticulàris (Michx.) Scribn. Stems 2-12 dm. tall : leaves rough ; blades $8-30 \mathrm{~cm}$. long, $8-20 \mathrm{~mm}$. wide : panicle $6-20 \mathrm{~cm}$. long, its branches spreading, 2-8 cm. long : spikelets $4.5-5 \mathrm{~mm}$. long, $3-3.5 \mathrm{~mm}$. broad, keels strongly aculeate, the surface glabrous or sparingly hispidulous : stamens 2 .

In marshes and wet places, Virginia to Florida, and from Illinois and Missouri to Louisiana. Summer and fall. CATCH-FLY GRASS.

\section{PHÁLARIS L}

Annual or perennial grasses, with flat leaf-blades and terminal panicles which are cylindric and spike-like, capitate, or densely thyrsoid and somewhat interrupted. Spikelets articulated above the empty scales, compressed, 1-flowered, crowded. Scales 5, the 2 lower persistent, larger than the rest, thin-paleaceous, compressed-keeled, the keel usually more or less winged, sometimes wingless, awnless, third and fourth scales shorter, very thin and narrowly lanceolate, sometimes reduced to bristles, or rarely one of them wanting; a fifth scale chartaceous, at length indurated, awnless, sometimes pointed, obscurely 3-5-nerved, the midnerve sometimes obsolete, enclosing a faintly 2-nerved palet of similar texture and a perfect flower. Stamens 3. Styles distinct. Stigmas plumose.

Outer scales of the spikelet not winged.

Outer scales of the spikelet manifestly winged.

Third and fourth scales of the spikelet very small, the blade barely if at all manifest.

Spikelets about $4 \mathrm{~mm}$. long: panicle ovoid or oval to oblong, if the latter exceeding $1 \mathrm{~cm}$. in diameter.

Spikelets $5-6 \mathrm{~mm}$. long: panicle linear cylindric, less than $1 \mathrm{~cm}$ in diameter. ${ }_{3}$. P. Carolinian

Third and fourth scales large, the blade broad and manifest.

1. P. arundinacea.

1. Phalaris arundinàcea $\mathrm{L}$. Stems erect, $6-15 \mathrm{dm}$. tall : leaf-blades $1-2.5 \mathrm{dm}$. long, $6-14 \mathrm{~mm}$. wide, smooth or rough : panicle $7-20 \mathrm{~cm}$. long, its branches erect or ascending : spikelets 5-6 mm. long.

In moist or wet soil, Nova Scotia and British Columbia to Maryland, Tennessee, Kansas, Arizona and California. Summer and fall.

2. Phalaris Caroliniàna Walt. Stems $3-12 \mathrm{dm}$. tall, erect, or sometimes decumbent at the base : leaf-blades $5-15 \mathrm{~cm}$. long, 4-10 $\mathrm{mm}$. wide, smooth or rough : panicle 1-10 $\mathrm{cm}$. long, ovoid, oval to oblong: spikelets $5-6 \mathrm{~mm}$. long.

In moist soil, South Carolina, Missouri and southern California to Florida and Texas. Summer.

3. Phalaris angústa Nees. Stenis erect, $8-14 \mathrm{dm}$. tall : leaf-blades rough, $2 \mathrm{dm}$. long or less, 5-10 mm. wide, acuminate : panicle $6-10 \mathrm{~cm}$. long, cylindric, less than $1 \mathrm{~cm}$. in diameter: spikelets about $4 \mathrm{~mm}$. long.

In moist soil, South Carolina and Louisiana. Spring and summer.

4. Phalaris Canariénsis L. Stems $3-9 \mathrm{dm}$. tall, erect: leaf-blades 5-30 cm. long, 4-12 mm. wide, very rough: panicle ovoid or oblong, 1.5-4 cm. long, 1-2 cm. in diameter: spikelets $6-8 \mathrm{~mm}$. long.

In waste places, Nova Scotia and Ontario to Georgia and Nebraska. Naturalized from Europe. Summer. CANARY GRASS. 


\section{ANTHOXÁNTHUM L.}

Erect aromatic annual or perennial grasses, with flat leaf-blades and terminal usually dense spike-like panicles. Spikelets articulated above the empty scales, 1 -flowered, narrow, a little compressed, crowded. Scales 5, the 2 outer persistent, empty, acute, mucronate, or short-awned, the second longer than the others, the third and fourth scales much shorter, empty, narrow, keeled, awned at the middle or near the base, the fifth scale shorter than the remainder, hyaline, obtuse, awnless, enclosing a 1-nerved palet and a perfect flower. Stamens 2. Styles distinct. Stigmas elongated, plumose.

1. Anthoxanthum odoràtum L. Stems 3-6 dm. tall, erect, tufted : leaf-blades 1-15 cm. long, 2-6 mm. wide: panicle $2-6 \mathrm{~cm}$. long: spikelets $8 \mathrm{~mm}$. long.

In fields and meadows throughout nearly the whole of North America. Naturalized from Europe. Summer. SweEt Vernal Grass.

\section{SAVASTANA Schrank.}

Aromatic perennial grasses, with flat leaf-blades and contracted or open panicles. Spikelets 3-flowered, the terminal flower perfect, the others staminate. Scales 5; first and second nearly equal ; third and fourth a little shorter, awned or awnless, enclosing a palet and stamens; fifth scale, often with a short awn, enclosing a palet and a perfect flower. Stamens in the staminate flowers 3, in the perfect 2. Styles distinct. Stigmas plumose.

1. Savastana odoràta (L.) Scribn. Stems $3-6 \mathrm{dm}$. tall, simple : leaf-blades glabrous ; blades on the innovations 1-3 dm. long, 2-6 mm. wide, those on the stem 1-5 $\mathrm{cm}$. long, broad : panicle $5-10 \mathrm{~cm}$. long, its branches usually spreading, naked at the base : spikelets 4-6 $\mathrm{mm}$. long.

In moist or wet places, Newfoundland and New Brunswick to British Columbia, and in or near the mountains to North Carolina (according to Chapman), Arizona and Mexico, and Oregon. Spring and summer. VANILIA Grass. HoLy Grass.

\section{ARÍstidA L.}

Tufted grasses, with narrow and often convolute or setaceous leaf-blades and contracted or open panicles, which are sometimes nearly racemose: Spikelets 1-flowered, narrow. Scales 3 , the outer 2 membranous, persistent, empty, narrow, keeled, awnless, usually longer than the third scale which is of firmer texture, narrow, rigid, strongly convolute about the 2-nerved palet and the perfect flower, often with a prominent callus at the base, 3-awned from the apex, the generally spreading awns glabrous to plumose, the central awn commonly flexuous, coiled, or bent, the lateral awns often shorter, occasionally very short and erect, the 3 awns sometimes more or less connate at the base and the column thus produced articulated to the scale. Stamens 3. Styles distinct. Stigmas plumose. Poverty Grass. Wire Grass.

A. Awns not articulated to the scale.

Central awn coiled at the base.

First scale usually equalling or sometimes slightly shorter than the second scale which is generally $7-9 \mathrm{~mm}$. long.

First scale much shorter than the second (often but little more than $1 / 2$ as long) which is $10-15 \mathrm{~mm}$. long.

Lateral awns short, straight and erect, 1-2 mm. long, the central awn usually more than five times their length, its straight portion 5-8 mm. long.

Lateral awns more or less spreading, usually a little spiral at the base, the central awn from $1 / 2$ again to twice their length, its straight portion from $10-15 \mathrm{~mm}$. long.

Central awn not coiled at the base.

a. Panicle narrow, linear to oblong, the branches generally short (or the lower ones in No. 24 commonly elongated and ascending), usually erect or ascending, sometimes spreading.

Central awn and sometimes the lateral ones also strongly reflexed, the bend semicireular.

Stems simple or neariy so: spikelets many, the first scale 1-nerved, or sometimes with an additional faint nerve on each side.

Spikelets less than $1 \mathrm{~cm}$. long, the first scale strongly hispidulous, the lateral awns of the flowering scale much more slender than the central awn.

Spikelets more than $1 \mathrm{~cm}$. long, the first scale glabrous, the lateral awns about as stout as the central one.

Stems much branched: spikelets few, the first scale 5-7-nerved.

Central awn from erect to spreading with no semicireular bend at the base.

* First scale much shorter than the second, usually about $1 / 2$ as long.

1. A. dichotoma.

\section{A. Curtissii.}

3. A. basiramea.

4. A. simpliciflora.

5. A. Mohrii.

6. A. ramosissima. 
Spikelets crowded, 4-6 on the short panicle-branches which are spikelet-bearing to the base or nearly so.

Spikelets not crowded, usually 1-3, or if more numerous the branches of the panicle, or their divisions, with a long naked base.

Flowering scale not twisted at the summit.

Second scale of the spikelet $1.5 \mathrm{~cm}$. long or less, usually equalling or slightly exceeding the flowering scale

Panicle simple or nearly so ; branches bearing 1 spikelet, or the longer sometimes 2 spikelets: stems commonly naked above.

Branches appressed, the longer, exclusive of the spikelets, usually $1 \mathrm{~cm}$. long or less.

Branches spreading or ascending, sometimes flexuous, the longer, exclusive of the spikelets, usually $1.5-3$ $\mathrm{cm}$. long.

Panicle compound; branches bearing 2 or more spikelets : stems usually leafy.

Stems stout: panicle branches straight.

Stems slender: panicle branches filiform, flexuous. Second scale of the spikelet $12-15 \mathrm{~mm}$. long, the awns of the flowering scale commonly $3-4.5 \mathrm{~cm}$. long. Second scale of the spikelet usually less than $1 \mathrm{~cm}$. long, the awns of the flowering scale generally $2 \mathrm{~cm}$. long or less, rarely longer.

Second scale of the spikelet $2 \mathrm{~cm}$. long or more, from $1 / 2$ again as

long as to nearly twice the length of the flowering scale. Flowering scale twisted at the summit.

Spikelets few and scattered: flowering scale without a long beak, much shorter than the second scale, the awns interlacingly coiled at the base.

Spikelets many and crowded: flowering scale with a long beak, equalling or exceeding the second scale, the awns not coiled at the base.

** First scale a little shorter than or exceeding the second.

Flowering scale not twisted.

Spikelets exceeding $2 \mathrm{~cm}$. long : first scale 5-7-nerved

Spikelets less than $1.5 \mathrm{~cm}$. long: first scale 1-3-nerved.

Sheaths glabrous, or pubescent only at the apex.

Leaves, at least the lower ones and those on the innovations, with the base of the strongly involute blades densely villous.

Leaves with the base of the flat blades at least not villous.

First scale of the spikelet 1-nerved.

First scale glabrous: stems single or few in a tuft.

First scale hispidulous : stems densely tufted.

First scale generally shorter than or equalling the second.

Annual : flowering scale equalling or exceeding at least the body of the second scale.

Flowering scale 5-6 mm. long, its central awn usually $6-10 \mathrm{~mm}$. long.

Flowering scale $7-9 \mathrm{~mm}$. long, its central awn exceeding $15 \mathrm{~mm}$. in length.

Perennial : flowering scale manifestly shorter than the second scale.

First scale usually exceeding the second.

First scale of the spikelet strongly 2-3-nerved.

Sheaths, at least the lower ones, densely woolly pubescent.

Flowering scale twisted above for the greater part of its length.

b. Panicle diffuse and open, the branches elongated and widely spread-

ing, with a long naked base.

B. Awns united at the base into a spiral column which is articulated to the scale. Column conspicuous, $6 \mathrm{~mm}$. long or more.

Column inconspicuous, $2 \mathrm{~mm}$. long or less.

7. A. fasciculata.

8. A. Fendleriana.

9. A. subuniflora.

10. A. Wrightii.

11. A. purpurea.

12. A. micrantha.

13. A. longiseta.

14. A. gyrans.

15. A. Reverchonii.

16. A. oligantha.

17. A. stricta

18. A. condensata.

19. A. gracilis.

20. A. intermedia.

21. A. Chapmaniana.

22. A. purpurascens.

23. A. palustris.

24. A. lanosa.

25. A. spiciformis.

26. A. patula.

27. A. tuberculosa.

28. A. desmantha.

1. Aristida dichótoma Michx. Stems densely tufted, slender, 2-6 dm. tall, finally branching: leaf-blades erect, $2-9 \mathrm{~cm}$. long, $1.5 \mathrm{~mm}$. wide or less, sparingly pilose above toward the base: panicle $3.5-7 \mathrm{~cm}$. long, the branches short or erect : spikelets $7-9 \mathrm{~mm}$. long, the 2 outer scales about equal in length, or the first a little the shorter, usually awnpointed, the flowering scale 5-7 $\mathrm{mm}$. long, the lateral awns very short, erect, the central awn spreading, spiral at the base, the straight portion 2-5 $\mathrm{mm}$. long, rarely longer.

In dry sandy soil, Maine to Ontario, Missouri and the Indian Territory, Florida and Texas. Summer and fall. PoverTy Grass.

2. Aristida Curtíssil (A. Gray) Nash. Stems tufted, $2-5 \mathrm{dm}$. tall, branching : leafblades 4-16 $\mathrm{cm}$. long, 1-2 mm. wide, sometimes sparsely pilose above near the base : panicle 5-9 $\mathrm{cm}$. long, the branches erect: spikelets generally 10-12 $\mathrm{mm}$. long, rarely longer, the first scale much shorter than the second which usually about equals the flowering one, rarely somewhat exceeding it, the flowering scale 7-11 mm. long, the lateral awns very short, 1-2 mm. long, straight and erect, usually less than $\frac{1}{5}$ as long as the central awn which has the straight portion $5-8 \mathrm{~mm}$. long.

In dry soil, Missouri and Kansas to the Indian Territory ; also in Virginia. Fall. 
3. Aristida basiràmea Engelm. Stems tufted, rather slender, $2-6 \mathrm{dm}$. tall, branching: leaf-blades $3-15 \mathrm{~cm}$. long, $1.5 \mathrm{~mm}$. wide or less, sometimes sparsely pilose above at the base : panicle 3-9 $\mathrm{cm}$. long, the branches erect : spikelets $10-15 \mathrm{~mm}$. long, the first scale much shorter than the second, the flowering scale 7-11 mm. long, considerably shorter than the second, the lateral awns more or less spreading, usually a little spiral at the base, $\frac{1}{2}-\frac{2}{3}$ as long as the central awn which is strongly spiral at the base and with the straight portion 10-18 $\mathrm{mm}$. long.

In dry fields, Manitoba to Illinois, Nebraska and the Indian Territory. Summer and fall.

4. Aristida simpliciflòra Chapm. Stems tufted, 4-6 dm. tall, slender, simple or sparingly branched : leaf-blades $3.5-15 \mathrm{~cm}$. long, 1-1.5 mm. wide, flat: panicle 1-2 dm. long, its branches short and appressed : spikelets 8-9 mm. long, crowded, the 2 outer scales 1-nerved, about equal or the first a little the shorter, the flowering scale 5-6 mm. long, the central awn 12-15 mm. long, strongly reflexed, the lateral awns ascending, about $\frac{2}{3}$ as long and much more slender than the central awn.

In low pine woods, Florida. Fall.

5. Aristida Mòhrii Nash. Stems 5-7 dm. tall, simple: leaf-blades $5-12 \mathrm{~cm}$. long, 1-1.5 mm. wide, those on the innovations hirsute above : panicles $1.5-3 \mathrm{dm}$. long, simple : spikelets 10-12 mm. long, on very short pedicels, appressed, scattered, the 2 outer scales 1-nerved, the first equalling or often a little exceeding the second, the flowering scale 8-9 $\mathrm{mm}$. long, the awns of equal thickness, all strongly reflexed, the central one 15-18 mm. long, the lateral ones a little shorter.

On dry sandy pine ridges, Alabama. Fall.

6. Aristida ramosíssima Engelm. Stems tufted, 2-4 dm. tall, slender, branched : leaf-blades 4-15 cm. long, 1-1.5 mm. wide, flat: panicle 6-10 $\mathrm{cm}$. long, simple, the branches very short and bearing a single usually ascending spikelet : spikelets $1.6-2.2 \mathrm{~cm}$. long, the 2 outer scales usually awned, the first scale 5-7-nerved, shorter than the 3-nerved second, the flowering scale $15-18 \mathrm{~mm}$. long, the central awn strongly reflexed, $2-3 \mathrm{~cm}$. long, the lateral awns rigid, erect, 1-2 $\mathrm{mm}$. long.

In dry ground, Illinois and Missouri to the Indian Territory. Late summer and fall.

7. Aristida fasciculàta Torr. Stems tufted, $5-8 \mathrm{dm}$. tall, branched : leaf-blades $6-12$ cm. long, 1-2 mm. wide: panicle 7-20 cm. long, its branches short, in fascicles of 2-4, erect or nearly so : spikelets $9-10 \mathrm{~mm}$. long, crowded, the 2 outer scales 1 -nerved, the first one $\frac{1}{2}-\frac{2}{3}$ as long as the second, the flowering scale $8-12 \mathrm{~mm}$. long, hispidulous on the keel, the callus densely pilose, the awns ascending, the central one 10-17 mm. long, the lateral awns $\frac{2}{3}-\frac{4}{5}$ as long.

In dry soil, Kansas to California, Texas, Mexico and New Mexico. Fall.

8. Aristida Fendleriàna Steud. Stems densely tufted, $1.5-2.5 \mathrm{dm}$. tall, erect, rigid, simple: leaf-sheaths smooth, confined to the base of the stem, a tuft of hairs on each side at the apex ; blades involute, at least when dry, often curved, $0.5 \mathrm{~mm}$. in diameter, those on the stem usually $2,1.5-5 \mathrm{~cm}$. long, the basal longer: panicle $7-10 \mathrm{~cm}$. long, strict, its branehes short and appressed and usually bearing but a single spikelet, rarely exceeding $1.5 \mathrm{~cm}$. long, or sometimes the lower ones with 2 spikelets : spikelets $12-15 \mathrm{~mm}$. long, the 2 onter scales 1-nerved, the first scale about $\frac{1}{2}$ as long as the second, the flowering scale 9-12 $\mathrm{mm}$. long, equalling or a little shorter than the second scale, the awns ascending, the central one $2-3.5 \mathrm{~cm}$. long, the lateral ones a little shorter.

In dry sandy soil, South Dakota to Utah, Texas and New Mexico. Summer and fall.

9. Aristida subuniflòra Nash. Stems densely tufted, 2.5-3.5 dm. tall, erect, simple: leaf-sheaths usually confined to the base of the stem; blades involute, at least when dry, usually straight, sometimes curved, those on the stem usually $2,2-4.5 \mathrm{~cm}$. long, the basal longer: panicle 6-13 $\mathrm{cm}$. long, its branches more or less spreading, the larger ones 2-3 cm. long, bearing 1 or 2 spikelets : spikelets $1.5-2 \mathrm{~cm}$. long, the 2 outer scales 1-nerved, the first about $\frac{1}{2}$ as long as the second, the flowering scale $13-15 \mathrm{~mm}$. long, usually a little shorter than the second scale, the awns ascending, the central one 3-5 cm. long, the lateral awns a little shorter.

In dry sandy soil, central Texas to New Mexico. Spring and summer.

10. Aristida Wrìghtii Nash. Stems tufted, $3.5-5 \mathrm{dm}$. tall, simple, leafy: leafblades involute, at least when dry, those on the stem usually 3 or $4,3-20 \mathrm{~cm}$. long, often curved, as are the commonly longer basal ones: panicle 1-2 dm. long, its branches more or less spreading, the longer usually bearing 2-4 spikelets : spikelets $12-15 \mathrm{~mm}$. long, the 2 outer scales 1 -nerved, the first scale about $\frac{1}{2}$ as long as the second, the flowering scale 10-12 mm. long, usually a little shorter than the second scale, the awns ascending, the central one $2.5-3 \mathrm{~cm}$. long, the lateral awns a little shorter.

In dry sandy soil, Kansas to Texas and New Mexico. Summer and fall. 
11. Aristida purpùrea Nutt. Stems tufted, $2-4 \mathrm{dm}$. tall, slender, simple, leafy : leaf-blades involute, at least when dry, often curved, those on the stem 2-5, 4-12 cm. long: panicle 1-2 dm. long, its branches spreading or ascending, filiform, flexuous, often with a long naked base : spikelets $12-15 \mathrm{~mm}$. long, the 2 outer scales 1 -nerved, frequently awned, the first about $\frac{1}{2}$ as long as the second, the flowering scale about $1 \mathrm{~cm}$. long, a little shorter than the second scale, the awns ascending, the central one about $3-5 \mathrm{~cm}$. long, the lateral awns a little shorter.

In dry sandy soil, Arkansas and Louisiana, to New Mexico. Spring and summer.

12. Aristida micrántha (Vasey) Nash. Stems tufted, $2-4 \mathrm{dm}$. tall, slender, simple : leaf-blades 4-15 cm. long, involute, at least when dry : panicle 8-12 cm. long, its branches filiform, flexuous, spreading or ascending: spikelets 2-4 on the longer branches, the 2 outer scales 1-nerved, the second one $8-10 \mathrm{~mm}$. long, the flowering scale $6-8 \mathrm{~mm}$. long, the awns ascending or nearly erect, the central awn $1.5-2 \mathrm{~cm}$. long, ra rely longer, the lateral awns a little shorter.

In dry soil, Texas. Summer.

13. Aristida longisèta Steud. Stems tufted, $2-4 \mathrm{dm}$. tall, simple : leaf-blades $3-10$ $\mathrm{cm}$. long, involute, at least when dry : panicle 1-2 dm. long, its branches usually ascending, bearing generally 1 spikelet, or in the longer branches sometimes 2 spikelets : spikelets $2-2.5 \mathrm{~cm}$. long, the 2 outer scales 1 -nerved, the first one about $\frac{1}{2}$ as long as the second, the flowering scale $12-16 \mathrm{~mm}$. long, occasionally a little shorter, from a little over $\frac{1}{2} \frac{2}{3}$ as long as the second scale, the awns ascending, the central one 6-11 cm. long, the lateral ones equalling it or a little shorter.

In dry sandy soil, Montana and Washington to Nebraska, Texas and Mexico. Summer and fall.

14. Aristida gỳrans Chapm. Stems $3-4 \mathrm{dm}$. tall, slender, simple : leaf-blades $6-12 \mathrm{~cm}$. long, involute, about $0.5 \mathrm{~mm}$. in diameter : panicle about $12 \mathrm{~cm}$. long, slender, its few branches short and appressed : spikelets $10-11 \mathrm{~mm}$. long, the 2 outer scales 1-nerved, the first one shorter than the second, the flowering scale about $6 \mathrm{~mm}$. long, including the $1.5 \mathrm{~mm}$. long callus, the apex a little twisted, the awns ascending, loosely twisted together at the base, the central awn about $12 \mathrm{~mm}$. long, the lateral ones a little shorter.

In sand, Keys of Caximbas Bay, southern Florida ; also in Cuba. Summer and fall.

15. Aristida Reverchònii Vasey. Stems tufted, $2-4 \mathrm{dm}$. tall, simple: leaf-blades $2-12 \mathrm{~cm}$. long, involute, about $0.5 \mathrm{~mm}$. in diameter : panicle $1-1.5 \mathrm{dm}$. long, its branches usually short and appressed, rarely long and somewhat spreading : spikelets on short pedicels, the 2 outer scales 1-nerved, the first one much shorter than the second which is 8-10 $\mathrm{mm}$. long, the flowering scale 9-11 $\mathrm{mm}$. long, usually hispidulous, with a long slender more or less twisted summit, a little exceeding the second scale, the awns ascending, the central one 1.5-2.5 cm. long, the lateral ones a little shorter.

In dry soil, the Indian Territory and Texas. Spring and summer.

16. Aristida oligántha Michx. Stems tufted, $2-6 \mathrm{dm}$. tall, branching: leaf-sheaths shorter than the internodes, smooth and glabrous; blades $0.5-2 \mathrm{dm}$. long, 1-2 mm. wide : panicle 1-2 dm. long, simple, its branches very short and bearing a single spreading spikelet : spikelets $2-3 \mathrm{~cm}$. long, the 2 outer scales usually awned, the first 5-7-nerved, from a little shorter than the second to a little exceeding it, $1.5-2 \mathrm{~cm}$. long, the awns ascending, the central one $3.5-7 \mathrm{~cm}$. long, the lateral ones a little shorter.

In dry usually sterile soil, New Jersey to Nebraska, Mississippi and Texas. Summer and fall.

17. Aristida strícta Michx. Stems densely tufted, 5-10 dm. tall, simple: leafsheaths, the lower ones and especially those on the innovations, villous at the apex ; blades involute, even when fresh, $0.5-3 \mathrm{dm}$. long, about $0.7 \mathrm{~mm}$. in diameter, the lower ones and those on the innovations densely villous at the base : panicle 1-3 dm. long, the short appressed branches in alternate fascicles of 2 or $3:$ spikelets $10-11 \mathrm{~mm}$. long, the 2 outer scales 1-nerved, usually awn-pointed, the first shorter than the second, the flowering scale 7-9 mm. long, glabrous or sparingly hispidulous toward the summit, the awns more or less spreading, the central one 11-17 $\mathrm{mm}$. long, the lateral ones from $\frac{3}{4}$ to nearly as long.

In dry sandy soil, Virginia (according to $\mathrm{S}$. Watson) to Florida. Spring to fall.

18. Aristida condensàta Chapm. Stems single or few in a cluster, $6-10 \mathrm{dm}$. tall, simple : leaf-sheaths confined to the lower part of the stem, overlapping, glabrous or sparingly pubescent; blades $2-3 \mathrm{dm}$. long, flat when fresh, $2-3 \mathrm{~mm}$. wide at the base from which they gradually taper to a long slender acumination : panicles $2-5.5 \mathrm{dm}$. long, usually densely spikelet-bearing, its branches erect or nearly so, the longer from 3-13 dm. long, the spikelets crowded and overlapping: spikelets $8.5-10 \mathrm{~mm}$. long, the 2 outer scales 1-nerved, glabrous, the first equalling or very little shorter than the second, the flowering scale about $7 \mathrm{~mm}$. long including the $1 \mathrm{~mm}$. long and densely pilose callus, glabrous, the awns spreading, the central one $10-14 \mathrm{~mm}$. long, the lateral ones from 2 as long as to nearly equalling it. [A. Combsii Scribn. \& Ball.]

In dry sandy soil, Florida. Fall. 
19. Aristida grácilis Ell. Stems densely tufted, $1.5-6 \mathrm{dm}$. tall, slender, finally more or less branched : leaf-sheaths equalling or shorter than the internodes, glabrous, or the lower ones sparingly pubescent ; blades $3-12 \mathrm{~cm}$. long, $1 \mathrm{~mm}$. wide or less, erect, flat: panicle $5-15 \mathrm{~cm}$. long, its short branches appressed: spikelets $5-7 \mathrm{~mm}$. long, the 2 outer scales 1-nerved, usually awn-pointed, the first equalling or a little shorter than the second, sparingly hispidulous, the flowering scale $5-6 \mathrm{~mm}$. long, frequently barred or spotted with black, more or less hispidulous, especially on the keel, the central awn spreading, 6-10 $\mathrm{mm}$. long, rarely longer, the lateral awns erect, 1-3 mm. long, occasionally longer.

In dry soil, Vermont to Illinois, Kansas, Florida and Texas. Summer and fall.

20. Aristida intermedia Scribn. \& Ball. Stems slender, finally branching, 3-8 dm. tall : leaf-sheaths glabrous or sparsely hirsute; blades $5-15 \mathrm{~cm}$. long, $2 \mathrm{~mm}$. wide or less, erect, involute : panicle $2-4 \mathrm{dm}$. long, slender, its branches appressed : spikelets 8-10 $\mathrm{mm}$. long, the empty scales manifestly awned, about equal, the flowering scale strongly hispidulous above the middle, equalling or exceeding the empty scales, the awns spreading, the middle one $15-25 \mathrm{~mm}$. long, the lateral ones shorter.

In sandy soil, Iowa to Mississippi and Texas. Summer and fall.

21. Aristida Chapmaniàna Nash. Stems densely tufted, $7-10 \mathrm{dm}$. tall, finally more or less branched : leaf-blades 1-2 dm. long, $1.5-2.5 \mathrm{~mm}$. broad, flat, long-acuminate : panicle 2-4 dm. long, the branches short and appressed : spikelets 6-8 $\mathrm{mm}$. long, rather crowded on the branches, the 2 outer scales 1-nerved, or the first rarely with faint lateral nerves, the first one shorter than the second, usually strongly hispidulous, the flowering scale about $5 \mathrm{~mm}$. long, glabrous or sparingly hispidulous on the upper part of the keel, the central awn widely spreading, at right angles to the scale, $1.8-2.5 \mathrm{~cm}$. long, the lateral awns erect, usually a little more than $\frac{1}{2}$ as long as the central awn, rarely shorter.

In dry sandy soil, North Carolina to Florida and Mississippi. Fall.

22. Aristida purpuráscens Poir. Stems tufted, $3-8 \mathrm{dm}$. tall, usually simple, or occasionally branched : leaf-sheaths smooth and glabrous, or the lower ones sometimes pubescent ; blades $0.5-2 \mathrm{dm}$. long, 1-2 mm. wide, flat, long-acuminate : panicle $1.5-3 \mathrm{dm}$. long, its branches appressed and usually short: spikelets $9-12 \mathrm{~mm}$. long, rarely a little smaller, usually crowded, the 2 outer scales 1-nerved, sometimes awn-pointed, the first one usually exceeding the second, occasionally equalling it, hispidulous, the flowering scale 6-8 mm. long, glabrous or sparingly hispidulous, the awns more or less spreading, especially the central one which is $1.5-2.5 \mathrm{~cm}$. long, the lateral awns from $\frac{2}{3}$ as long to nearly equalling it.

In dry soil, Massachusetts to Minnesota, Florida and Texas. Fall.

23. Aristida palústris (Chapm.) Vasey. Stems densely tufted, $8-12 \mathrm{dm}$. tall, firm and hard at the base : leaf-blades $2-4 \mathrm{dm}$. long, $2-3 \mathrm{~mm}$. wide : panicle $2-5 \mathrm{dm}$. long, its branches closely appressed, the longer $5-7 \mathrm{~cm}$. long: spikelets $10-12 \mathrm{~mm}$. long, the first scale prominently 2-3-nerved, strongly hispidulous, from a little shorter than to slightly exceeding the second, the flowering scale $8-9 \mathrm{~mm}$. long, smooth and glabrous, the callus fully $1 \mathrm{~mm}$. long, sparsely pilose, the central awn widely spreading, $1.5-3 \mathrm{~cm}$. long, the lateral awns erect or nearly so, from $\frac{2}{3}$ as long as to nearly equalling it.

In swamps and wet places, Florida to Louisiana. Late summer and fall.

24. Aristida lanòsa Muhl. Stems $8-14 \mathrm{dm}$. tall, simple, rather stout : leaf-sheaths confined to the lower part of the stem, densely woolly pubescent; blades $3-5 \mathrm{dm}$. long, 2-7 $\mathrm{mm}$. wide, flat : panicle 4-6 dm. long, its axis villous at the nodes, its lower branches distant, ascending, $8-12 \mathrm{~cm}$. long: spikelets $12-17 \mathrm{~mm}$. long, the 2 outer scales 1 -nerved, the first much exceeding the second, the flowering scale $8-10 \mathrm{~mm}$. long, the central awn widely spreading, $1.5-2.5 \mathrm{~cm}$. long, the lateral awns erect or ascending, about $\frac{1}{2}$ as long.

In dry thickets, Delaware to Florida, and Texas. Fall.

25. Aristida spiciformis Ell. Stems tufted, 4-10 dm. tall, simple: leaf-sheaths overlapping on the lower part of the stem ; blades 1-3 dm. long, flat, or involute when dry, 3-5 mm. wide: panicle 12-20 cm. long, oblong, very dense : spikelets densely erowded, the 2 outer scales 1-nerved, the first scale about $\frac{1}{2}$ as long as the second which is about $1 \mathrm{~cm}$. long, the former with an awn longer than its body, the latter bearing an awn of about equal length, the flowering scale, exclusive of the awns and including the $2 \mathrm{~mm}$. long callus, about $6 \mathrm{~mm}$. long, the awns united below into a twisted flexuous column $1.5-2.5 \mathrm{~cm}$. long, the free portion of the awns spreading or ascending, the central awn $2.5-3.5 \mathrm{~cm}$. long, the lateral ones a little shorter.

In moist or flat pine lands, South Carolina to Florida. Summer and fall.

26. Aristida pátula Chapm. Stems tufted, 1-1.5 m. tall, simple, the leaves confined to the lower part of the stem : leaf-sheaths overlapping, smooth, usually with a pubescent 
ring at the summit ; blades 2-6 dm. long, 3-5 mm. wide, flat, glabrous, smooth, even on the margins : panicle 4-6 dm. long, its branches widely spreading, rough, divided, the larger ones 2-3 dm. long: spikelets on short pedicels, the 2 outer scales 1-nerved, more or less awned, the first one 11-14 $\mathrm{mm}$. long, usually exceeding the second, rarely equalling or a little shorter than it, the flowering scale $1-1.5 \mathrm{~cm}$. long, smooth and glabrous, the awns erect or nearly so, the central one $2-3 \mathrm{~cm}$. long, the lateral ones $\frac{1}{3}-\frac{2}{5}$ as long.

In dry sandy soil, peninsular Florida. Summer and fall.

27. Aristida tuberculòsa Nutt. Stems tufted, $2-5 \mathrm{dm}$. tall, branched : leaf-sheaths shorter than the internodes, the lower ones pubescent ; blades $8-20 \mathrm{~cm}$. long, $1.5-2.5 \mathrm{~mm}$. wide, flat: panicle 1-2 dm. long, its branches erect or ascending, the larger ones $6-10 \mathrm{~cm}$. long: spikelets on short pedicels, the 2 outer scales 1-nerved, awn-pointed, the body of the first shorter than that of the second which, exclusive of the awn, is about $2 \mathrm{~cm}$. long, the flowering scale, exclusive of the awns and including the $2-3 \mathrm{~mm}$. long callus, $12-15 \mathrm{~mm}$. long, the awns united at the base into a spiral column $6-20 \mathrm{~mm}$. long which is articulated to the scale, the free portion finally reflexed and sometimes coiled at the base, the central awn $3.5-5 \mathrm{~cm}$. long, the lateral ones a little shorter.

In sandy soil, especially along sea beaches, Massachusetts to Georgia; also in the interior in Minnesota, Wisconsin and Illinois. Summer and fall.

28. Aristida desmántha Trin. \& Rupr. Stems $4-8 \mathrm{dm}$. tall, branching : lower leafsheaths pubescent; blades $6-30 \mathrm{~cm}$. long, $1.5-2 \mathrm{~mm}$. wide, flat, or involute when dry : panicle 1.5-2 dm. long, its branches erect or nearly so, the lower ones 6-8 $\mathrm{cm}$. long : spikelets on short pedicels, the 2 outer scales awned, 1-nerved, the first one sometimes with 2 or 3 lateral nerves on each side, the first usually equalling or shorter than the second which is 12-14 mm. long, exclusive of the awn, rarely exceeding it, the flowering scale, exclusive of the awns, $8-10 \mathrm{~mm}$. long, the awns united at the base into a usually spiral column $2 \mathrm{~mm}$. long or less which is articulated to the scale, the free portion finally reflexed and usually coiled at the base, the central awn $2.5-3 \mathrm{~cm}$. long, the lateral ones a little shorter.

In dry soil, the Indian Territory and Texas. Summer.

\section{ORTÁCHNE Nees.}

Tall usually slender grasses, with flat or involute leaf-blades and terminal panicles. Spikelets 1-flowered : empty scales narrow, acuminate, usually awn-pointed : flowering scale narrow, merging into the single terminal awn. Stamens 3. Styles distinet. Stigmas plumose.

1. Ortachne Floridàna (Chapm.) Nash. Stems 6-10 dm. tall, simple: leaf-blades $2-3 \mathrm{dm}$. long, involute, at least when dry, about $1 \mathrm{~mm}$. in diameter : panicle $2-3 \mathrm{dm}$. long, its branches ascending, the larger ones $8-14 \mathrm{~cm}$. long: spikelets 9-11 $\mathrm{mm}$. long, the 2 outer scales 1-3-nerved, the first from a little shorter than to somewhat exceeding the second, the flowering scale $1.5-2 \mathrm{~cm}$. long, compressed, curved at the summit, gradually tapering into the single awn which is $14-18 \mathrm{~mm}$. long. [Aristida Floridana (Chapm.) Vasey.]

In dry places, Key West, Florida. Spring to fall.

\section{STIPA L.}

Tufted grasses, with convolute or flat leaf-blades and terminal contracted or open, often slender, panicles. Spikelets narrow, 1-flowered, usually few and large, or sometimes smaller and numerous. Scales 3, the 2 outer empty, persistent, narrow, keeled, acute, rarely awned, the third scale tightly convolute about the 2-nerved or 2-keeled palet and the perfect flower, rigid, narrow, the apex usually attenuated into a more or less geniculate awn (or rarely 2-toothed or shortly 2-cleft, with the awn strict and arising between the teeth) which is often spiral or twisted at the base, and generally deciduous at the articulation to the scale, rarely not articulated and persistent. Stamens 3 , or rarely fewer, the anthers very often barbellate at the apex. Styles short, distinct. Stigmas plumose.

Flowering scale abruptly contracted above into a smooth cylindric appendage over

$1 \mathrm{~mm}$. long and hairy at the apex.

Flowering scale not thus appendaged :

About $1 \mathrm{~cm}$. long: empty scales $8-12 \mathrm{~mm}$. long.

Exceeding $1.5 \mathrm{~cm}$. in length: empty scales $1.5 \mathrm{~cm}$. long or more.

\section{S. leucotricha.}

2. S. avenacea.

1. Stipa leucotricha Trin. Stems tufted, $3-5 \mathrm{dm}$. tall, erect: leaf-sheaths glabrous, or sparingly pubescent, the upper one often enclosing the base of the panicle ; blades rather sparingly pubescent with short spreading hairs, $2 \mathrm{dm}$. long or less, $2-3 \mathrm{~mm}$. wide : panicle 1-1.5 dm. long, its branches erect: spikelets $15-18 \mathrm{~mm}$. long, exclusive of the awn; 
empty scales green, acuminate; flowering scale about $1 \mathrm{~cm}$. long, usually strongly papillose-roughened, the callus about $4 \mathrm{~mm}$. long and strongly pubescent with white appressed hairs the awn 6-8 $\mathrm{cm}$. long, spiral and very pubescent at the base, usually twice bent.

In dry soil, Texas. Spring and summer.

2. Stipa avenàcea L. Stems $3-8 \mathrm{dm}$. tall : leaf-blades involute-filiform, the basal $\frac{1}{3}-\frac{1}{2}$ as long as the stem, those on the stem $7-13 \mathrm{~cm}$. long: panicle 1-2 dm. long, loose, its branches lax and finally spreading: empty scales of the spikelet $8-12 \mathrm{~mm}$. long; flowering scale shorter, black, hairy at the base, and with a ring of short hairs at the top, the awn 4-7 cm. long, bent, loosely spiral below.

In dry woods, Rhode Island to Florida, mostly near the coast ; also in western Ontario and Wisconsin. BLACK OAT GRASS.

3. Stipa avenaceoides Nash. Stems 6-12 dm. tall, tufted, erect, slender: leafsheaths glabrous; blades involute-setaceous, glabrous, the basal ones about $3 \mathrm{dm}$. long, those on the stem $2.5-12 \mathrm{~cm}$. long: panicle simple, 1-2.5 dm. long, finally long-exserted, its branches $2.5-8 \mathrm{~cm}$. long: spikelets few ; empty scales purple at the base, acuminate, $15-22 \mathrm{~mm}$. long; flowering scale glabrous, excepting the hairy apex, 1.5-2 cm. long, including the callus which is $6-8 \mathrm{~mm}$. long and covered with appressed brown hairs, the awn $7-10 \mathrm{~cm}$. long, pubescent below, spiral at the base, twice bent.

In dry sandy soil, peninsular Florida. Spring and summer.

\section{MUHLENBÉRGIA Schreb.}

Perennial or rarely annual grasses, various in habit, with flat or often involute leafblades, and terminal contracted or open panicles, which are often slender, densely thyrsoid, or almost spike-like, or diffuse with long capillary branches. Spikelets 1-flowered, small. Scales 3 (or rarely 4 ), the outer 2 empty, persistent, membranous or hyaline, from minute to almost equalling the third scale, keeled, acute, mucronate or rarely short-awned, the second occasionally 3 -toothed, the third scale somewhat rigid, convolute about the 2-keeled hyaline palet and the perfect flower, at the apex entire or rarely 2-toothed, obtuse, acute, mucronate to long-awned, the awn very often capillary, a fourth awned scale very rarely present. Stamens usually 3, rarely fewer. Styles distinct. Stigmas plumose.

Panicle contracted, its branches erect or nearly so: spikelets on short pedicels.

Empty scales at least $1 / 2$ as long as the spikelet.

Flowering scale not awned, but sometimes awn-pointed.

Empty scales not awned, about $1 / 2$ as long as the flowering scale, acute.

Empty scales long-acuminate, awn-pointed or awned.

Empty scales about as long as the flowering scale, sharp-pointed, about $3 \mathrm{~mm}$. long.

Empty scales exceeding the flowering scale, usually twice as long, awned, about $5 \mathrm{~mm}$. long.

Flowering scale long-awned, the awn usually twice as long as the scale. Empty scales about equalling the flowering scale. Empty scales $1 / 2^{-2} / 3$ as long as the flowering scale.

Empty scales minute, the first one often wanting.

Panicle open, its filiform branches spreading or ascending: spikelets on very long capillary pedicels.

Stems erect, simple.

Empty scales awnless, or awn-pointed :

Awn of the flowering scale very short, rarely nearly equalling it in length. Awn of the flowering scale very long, often several times its length.

Empty scales long-awned, the awns usually many times as long as the scale.

Stems much branched and prostrate.

1. M. sobolifera.

2. M. Mexicana.

3. M. racemosa.

4. M. sylvatica.

5. M. tenuiflora

6. M. diffusa.

1. Muhlenbergia sobolífera (Muhl.) Trin. Stems 3-9 dm. tall, erect, slender, simple, or sparingly branched above : leaf-blades rough, those on the stem 1-1.5 dm. long, $2-6 \mathrm{~mm}$. wide, those on the branches $2-8 \mathrm{~cm}$. long and about $2 \mathrm{~mm}$. wide : panicle $7-15$ cm. long, slender: empty scales about $1 \mathrm{~mm}$. long, the flowering one obtuse, scabrous, the midnerve usually excurrent as a short tip.

In rocky woods, New Hampshire and Massachusetts to Minnesota, Virginia, Tennessee and the Indian Territory. Summer and fall.

2. Muhlenbergia Mexicàna (L. ) Trin. Stems 6-12 dm. long, erect, or often prostrate, much branched : leaf-blades rough, those on the stem 1-1.5 dm. long, 2-6 mm. wide, the branch blades smaller : panicle $5-15 \mathrm{~cm}$. long, contracted : spikelets $2.5-3 \mathrm{~mm}$. long, the outer scales somewhat unequal, acuminate or short-awned, rough, especially on the keel, the third scale acuminate, rough.

In swamps and borders of fields, New Brunswick to western Ontario, North Carolina, Tennessee, Nebraska and the Indian Territory. Summer and fall.

3. Muhlenbergia racemòsa (Michx.) B.S.P. Stems $3-9 \mathrm{dm}$. tall, erect, usually much branched : leaf-blades $5-13 \mathrm{~cm}$. long, $2-6 \mathrm{~mm}$. wide, rough : panicle 5-12 $\mathrm{cm}$. long, 
usually dense and interrupted : spikelets much crowded, the empty scales acuminate, 4-6 $\mathrm{mm}$. long, including the awn, the flowering scale $\frac{1}{2}-\frac{2}{3}$ as long, acuminate, the strongly scabrous midnerve excurrent as a short point. [M. glomerata Trin.]

In wet places, Newfoundland to British Columbia, New Jersey, North Carolina, Missouri, and New Mexico. Summer and fall.

4. Muhlenbergia sylvática Torr. Stems $3-9 \mathrm{dm}$. tall, erect, branched : leaf-blades 5-18 cm. long, 2-6 mm. wide, rough : panicle 7-18 $\mathrm{cm}$. long, somewhat lax : empty seales of the spikelet $2.5-3 \mathrm{~mm}$. long, awn-pointed, rough, the third scale equalling or somewhat exceeding the outer ones, very rough, attenuate into a slender awn 2-4 times its length.

In moist woods and along streams, New Brunswick to Ontario, Minnesota, North Carolina, Tennessee, Nebraska and the Indian Territory. Summer and fall.

5. Muhlenbergia tenuiflòra (Willd.) B.S.P. Stems 6-9 dm. tall, erect, slender, simple or sparingly branched : leaf-blades $6-18 \mathrm{~cm}$. long, $2-8 \mathrm{~mm}$. wide, narrowed toward the base, acuminate, rough : panicle 1-2.5 dm. long, slender: empty scales of the spikelet unequal, $\frac{1}{2}-\frac{2}{3}$ the length of the flowering scale, awn-pointed, rough, the flowering one 2.5-3 mm. long, rough, bearing an awn 2-4 times its length. [M. Wildenovii Trin.]

In rocky woods, Massachusetts to southern Ontaria, Minnesota, Alabama and Texas. Summer and fall.

6. Muhlenbergia diffùsa Willd. Stems 3-9 dm. long, decumbent, or often prostrate or creeping and ascending, very slender, diffusely branched : leaf-blades 4-9 $\mathrm{cm}$. long, 1-4 $\mathrm{mm}$. wide, rough : panicle $5-20 \mathrm{~cm}$. long, slender, somewhat lax : empty scales of the spikelet minute, the lower one often wanting, the flowering scale, exclusive of the awn, about $2 \mathrm{~mm}$. long, very rough, especially on the nerves, the awn 1-4 $\mathrm{mm}$. long.

On dry hills and in woods, Maine and southern Ontario to Minnesota, Florida, Kansas and Texas. Summer and fall.

7. Muhlenbergia trichópodes (Ell.) Chapm. Stems tufted, wiry, $7-10 \mathrm{dm}$. tall : leaf-blades long and narrow, stiff, often involute when dry: panicle 2-4 dm. long, its branches erect: spikelets, exclusive of the awn, 3.5-4.5 mm. long, the empty scales acuminate, shorter than the flowering scale, sometimes awn-pointed, the flowering one bearing a short awn $2 \mathrm{~mm}$. long or less.

In pine lands, North Carolina to Florida and Texas. Summer and fall.

8. Muhlenbergia capillàris (Lam.) Trin. Stems erect, wiry, tufted, $5-12 \mathrm{dm}$. tall : leaf-blades long and narrow, often involute when dry, $1-3 \mathrm{~mm}$. wide : panicle $1.5-4 \mathrm{dm}$. long, its branches spreading or ascending: spikelets, exclusive of the awn, 3.5-4 mm. long, lanceolate, acuminate, the empty scales usually $\frac{1}{2}$ as long as the spikelet or less, commonly bearing a short awn, the flowering scale bearing an awn longer than its body, sometimes 2 em. long. [M. caespitosa Chapm.]

In dry soil and pine lands, Massachusetts, New Jersey and Missouri to Florida, the Indian Territory and Texas. Also in Cuba. Fall.

9. Muhlenbergia fílipes M. A. Curtis. Stems tufted, erect, wiry, $5-10 \mathrm{dm}$. tall : leaf-blades long and narrow, involute, at least when dry, 1-2 mm. wide : panicle $2-3 \mathrm{dm}$. long, often included at the base, its long branches spreading or ascending : spikelets, exclusive of the awns, 4-5 mm. long, lanceolate, acuminate, the empty scales $\frac{1}{2}$ as long as the spikelet or less, bearing a long awn, that on the second scale, and also often that on the first, frequently much exceeding the spikelet.

In sands on the seashore and in pine lands, North Carolina to Florida and Mississippi. Fall.

10. Muhlenbergia Pòrteri Scribn. Stems $2-6 \mathrm{dm}$. long, much branched and prostrate : leaf-blades $3-6 \mathrm{~cm}$. long, $1-2 \mathrm{~mm}$. wide, flat, acuminate, linear : panicles $8-10 \mathrm{~cm}$. long, the branches widely spreading, rather stiff: spikelets, exclusive of the awn, 3-4 mm. long, the empty scales acuminate, shorter than the spikelet, the flowering one bearing an awn 5-10 $\mathrm{mm}$. long.

On hills and plains, central Texas to southern California. Summer and fall.

\section{BRACHYÉLYTRUM Beauv.}

Tall perennial grasses, with rather broad flat leaf-blades and a terminal narrow panicle, its branches few, erect and filiform. Spikelets 1-flowered, narrow, the rachilla produced beyond the flower into a long glabrous stipe which sometimes bears a small scale at its apex. Scales 3 (or rarely 4 ), the 2 outer empty, persistent, very small, the first minute, sometimes almost wanting, the third scale elongated, rather rigid, acuminate into a long erect awn and enclosing a somewhat short dorsally sulcate 2-nerved palet of similar texture and a perfect flower, a fourth scale sometimes terminating the rachilla-prolongation. Stamens 2. Styles short, distinct. Stigmas elongated, plumose. 
1. Brachyelytrum eréctum (Schreb.) Beauv. Stems $3-9 \mathrm{dm}$. tall, pubescent at and near the nodes: leaf-sheaths villous, especially at the throat; blades $5-13 \mathrm{~cm}$. long, $6-18$ $\mathrm{mm}$. wide, rough : panicle $5-15 \mathrm{~cm}$. long, slender, its branches erect or appressed : empty scales of the spikelet unequal, the upper one less than $\frac{1}{3}$ as long as the flowering scale, the lower minute or wanting, the flowering scale, exclusive of the awn, 9-12 mm. long, rough, the awn erect, $2-2.5 \mathrm{~cm}$. long. [B. aristatum R. \& S.]

In moist places or woods, Newfoundland and Ontario to Minnesota, Georgia and Kansas. Summer.

\section{PHLÈUM L.}

Annual or perennial grasses, with flat leaf-blades and terminal, often long-pedunculate, dense spike-like panicles, which are from elongated, narrow and cylindric, to short, oblong or nearly ovoid. Spikelets crowded, 1-flowered, compressed. Scales 3, the 2 outer empty, persistent, membranous, compressed-keeled, obliquely truncate at the summit, awned, the third scale much shorter, hyaline, truncate and denticulate at the apex, enclosing a narrower palet of similar texture and a perfect flower. Stamens 3. Styles distinct, rather long. Stigmas plumose.

1. Phleum praténse L. Stems $3-12 \mathrm{dm}$. tall, erect, simple: leaf-blades $7-23 \mathrm{~cm}$. long, 4-6 mm. wide, smooth or rough : spike usually elongated, cylindric, $3-18 \mathrm{~cm}$. long, $5-8 \mathrm{~mm}$. in diameter: empty scales of the spikelet, exclusive of the awn, $2.5 \mathrm{~mm}$. long, ciliate on the keel, the awn less than $\frac{1}{2}$ their length.

In fields and meadows nearly throughout North America. Widely cultivated. Also in Europe and Asia. Summer. Tiмотну.

\section{ALOPECÙRUS L.}

Annual or perennial grasses, erect, or decumbent at the base, with flat and lax or rather rigid or convolute leaf-blades, and dense terminal spike-like cylindric panicles. Spikelets articulated below the empty scales, readily deciduous, 1-flowered, compressed, crowded. Scales 3 , the 2 outer empty, acute, sometimes short-awned, usually more or less united at the base, compressed-keeled, the keel ciliolate or somewhat winged, the third scale broad, hyaline, obtuse, bearing a short awn or point on the back, the margins sometimes united into a short tube at the base, enclosing a perfect flower and sometimes also a hyaline keeled palet. Stamens 3. Styles distinct, or rarely more or less united at the base. Stigmas elongated, somewhat plumose with short hairs. FoxтAIL. Empty scales of the spikelet united for $1 / 2$ their length, glabrous to hispid on the keel.

Empty scales of the spikelet united for $1 / 4$ their length or less, long-ciliate on the

keel.

1. A. agrestis.

2. A. geniculatus.

1. Alopecurus agréstis $\mathrm{L}$. Stems $3-6 \mathrm{dm}$. tall, erect, simple : leaf-blades $4-18 \mathrm{~cm}$. long, 2-6 mm. wide, rough, especially above : spike $4-10 \mathrm{~cm}$. long, 4-8 mm. in diameter : empty scales of the spikelet narrowly winged, $4-5 \mathrm{~mm}$. long, the flowering scale equalling or slightly exceeding the empty ones, smooth and glabrous, the awn inserted near the base and about twice its length, bent.

In waste places and on ballast, southern New York, New Jersey, and Mississippi. Summer.

2. Alopecurus geniculàtus $\mathrm{L}$. Stems $1.5-4.5 \mathrm{dm}$. tall, erect, or sometimes decumbent at the base : leaf-blades 2-15 $\mathrm{cm}$. long, 1-4 mm. wide, rough, especially above : spike 2-8 $\mathrm{cm}$. long, $4-8 \mathrm{~mm}$. in diameter : empty scales of the spikelet $2-2.5 \mathrm{~mm}$. long, obtuse or subacute, glabrous, excepting the lateral nerves and strongly ciliate keel, the flowering scale somewhat shorter, obtuse, the awn inserted at or below the middle, equalling or exceeding it.

In wet soil, Newfoundland to British Columbia, Florida, Tennessee, Arizona, and California. Also in Europe and Asia. Summer and fall.

\section{SPORÓBOLUS R. Br.}

Perennial or rarely annual grasses, varying much in habit, with flat or convolute leafblades and terminal panicles, which are contracted, sometimes cylindric and spike-like, often elongated, or open and diffuse. Spikelets small, sometimes minute, 1-flowered, or very rarely $2-4$-flowered. Scales 3 , rarely 4-6, membranous, acute or obtuse, rarely awnpointed or short-awned, the 2 outer empty, the first shorter than the second, the remaining scale or scales longer or about equalling the second scale, enclosing a perfect flower, and a 2-nerved, often deeply 2-cleft or 2-parted, palet which is equal in length to, or a little shorter than, the scale, rarely awned and exceeding it. Stamens 2 or 3 . Styles short, distinet. Stigmas plumose. RUSH Grass. 
Plants with no long rootstocks : stems tufted or single.

Leaf-sheaths glabrous.

Upper leaf-sheaths enclosing panicles which are usually concealed, or sometimes partially protruding: terminal panicle contracted, narrow.

Annual.

Perennial.

Flowering scale appressed-pubescent below with long hairs.

Palet long-acuminate, sometimes almost awned, much exceeding the scale.

Palet merely acute, about equalling the scale, rarely a little exceeding it.

Flowering scale glabrous.

Stems slender: panicle very slender, usually less than $5 \mathrm{~mm}$. broad : spikelets $4 \mathrm{~mm}$. long or less.

Spikelets $3 \mathrm{~mm}$. long.

Spikelets $4 \mathrm{~mm}$. long.

Stems stout : panicle broader, usually $1 \mathrm{~cm}$. wide : spikelets $5-6 \mathrm{~mm}$. long.

Upper leaf-sheaths not enclosing panicles.

Panicle usually loose and open, its branches spreading or ascending, or if erect the panicle not elongated.

Spikelets $2 \mathrm{~mm}$. long or less.

Panicle branches verticillate, at least the lower ones. Larger leaf-blades rarely exceeding $5 \mathrm{~cm}$. in length. Larger leaf-blades $1 \mathrm{dm}$. long or more.

Panicle branches scattered.

Spikelets $3 \mathrm{~mm}$. long or more.

Panicle branches verticillate.

Panicle branches scattered.

Empty scales very unequal, the first subulate, the second very broad.

Empty scales approximating each other in shape, the first lanceolate.

Basal leaf-blades $1.5 \mathrm{~mm}$. wide or less.

Basal leaf-blades $3 \mathrm{~mm}$. wide or more.

Panicle narrow and elongated, spike-like.

Leaf-sheaths with a tuft of long spreading hairs on each side of the apex.

Plants with long rootstocks.

Panicle loose and open : rootstocks slender.

Panicle contracted, spike-like: rootstocks stout: sand-binders.

1. S. vaginaeflorus.

2. S. asper.

3. S. canovirens.

4. S. attenuatus.

5. S. Drummondii.

6. S. longifolius.

1. Sporobolus vaginaeflòrus (Torr.) Wood Stems 2-6 dm tall, erect, slender : leaf-blades $2 \mathrm{~mm}$. wide or less, attenuate and slender above, the lower ones elongated, the upper $2-8 \mathrm{~cm}$. long : terminal panicle $2-5 \mathrm{~cm}$. long : spikelets $3.5-4.5 \mathrm{~mm}$. long, the scales acuminate, the flowering one appressed-pubescent with long hairs. [S. vaginaeflorus var. minor Scribn.]

In dry soil, Massachusetts and New York to Nebraska, Georgia and Florida. Summer and fall.

2. Sporobolus ásper (Michx. ) Kunth. Stems 6-12 dm. tall, erect : leaf-blades 7-35 cm. long, 2-4 mm. wide, attenuate into a long slender involute tip: panicle $5-13 \mathrm{~cm}$. long: spikelets $6-8 \mathrm{~mm}$. long, the empty scales unequal, acute, the flowering scale appressed-pubescent below, much longer than the second one and much exceeded by the long-acuminate palet.

In dry soil, New York to Illinois, Florida and Texas. Summer and fall.

3. Sporobolus canóvirens Nash. Stems $3-10 \mathrm{dm}$. tall, erect: leaf-blades $2.5 \mathrm{dm}$. long or less, $1-3 \mathrm{~mm}$. wide, attenuate and filiform above : panicle $5-13 \mathrm{~cm}$. long: spikelets $5-6 \mathrm{~mm}$. long, the scales acuminate, the empty ones unequal, the flowering scale appressedpubescent below with long hairs, about equalling or a little exceeded by the acute palet.

In dry sandy soil, Tennessee to Missouri, Kansas, Mississippi and Texas. Summer and fall.

4. Sporobolus attenuàtus Nash. Stems tufted, slender, 5-7 dm. tall, erect: leafblades $4 \mathrm{dm}$. long or less, 1-2 $\mathrm{mm}$. wide at the base, the upper portion filiform : panicle 5-7 cm. long, very slender: spikelets $3 \mathrm{~mm}$. long, the scales acuminate, the empty ones unequal, the second a little shorter than the glabrous flowering one which about equals the acute palet.

In dry soil, Mississippi. Fall.

5. Sporobolus Drummóndii (Trin.) Vasey. Stems $5-10 \mathrm{dm}$. tall, erect, slender : leaf-blades $3 \mathrm{dm}$. long or less, 1-3 mm. wide, attenuate and filiform at the apex: panicle $1-1.5 \mathrm{dm}$. long, slender: spikelets about $4 \mathrm{~mm}$. long, the empty scales acute, the first a little shorter than the second, the flowering scale glabrous, acute or obtusish, longer than the second one and about equalling the acutish palet.

In dry soil, Louisiana and Texas. Summer.

6. Sporobolus longifòlius (Torr.) Wood. Stems 4-12 dm. tall, stout, erect : leafblades $5 \mathrm{dm}$. long or less, $2-5 \mathrm{~mm}$. wide: panicle 2-3 dm. long, usually more or less included in the upper leaf-sheath, sometimes entirely so : spikelets 5-6 mm. long, the scales obtuse, the first about $\frac{2}{3}$ as long as the second, the flowering scale glabrous, considerably exceeding the second one, about equalling the palet or a little shorter or longer than it.

In dry soil, Massachusetts to Iowa, Kansas and Arkansas. Fall. 
7. Sporobolus argùtus (Nees) Kunth. Stems $3 \mathrm{dm}$. tall or less, erect, or sometimes decumbent at the base : leaf-blades $2-5 \mathrm{~cm}$. long, 2-4 mm. wide, acuminate : panicle 4-8 $\mathrm{cm}$. long, its branches at first appressed, finally widely spreading: spikelets $1.5-1.8 \mathrm{~mm}$. long.

On prairies, Kansas and Colorado to Louisiana and Texas. Also in Mexico and the West Indies. Summer and fall.

8. Sporobolus Domingénsis (Trin.) Kunth. Stems 3-5 dm. tall, erect : leaf-blades $2 \mathrm{dm}$. long or less, $3-5 \mathrm{~mm}$. wide, long-acuminate : panicle $8-15 \mathrm{~cm}$. long, its branches at first erect, finally spreading: spikelets about $2 \mathrm{~mm}$. long.

In moist often brackish places, southern peninsular Florida. Also in Mexico and the West Indies. Summer.

9. Sporobolus ejúncidus Nash. Stems tufted, $3-6 \mathrm{dm}$. tall, erect, slender: leafblades filiform or setaceous, the basal numerous, $1.5-3 \mathrm{dm}$. long, those on the stem few, $2.5-8 \mathrm{~cm}$. long : panicle $7-18 \mathrm{~cm}$. long, open, its branches finally widely spreading : spikelets $2.5-3 \mathrm{~mm}$. long, purple, the empty scales very unequal, the first $\frac{1}{4}-\frac{1}{3}$ as long as the second, the flowering scale equalling the second and the obtuse palet. [S. junceus (Michx.) Kunth.]

In dry sandy soil, Virginia to Florida and Texas. Spring to fall.

10. Sporobolus heterólepis A. Gray. Stems $3-10 \mathrm{dm}$. tall, erect: leaf-blades involute-setaceous, the basal ones about $\frac{3}{4}$ as long as the stem, sometimes equalling it, those on the stem shorter: panicle 7-25 cm. long, its branches erect or ascending: spikelets 4-5.5 mm. long, the empty scales unequal, acuminate, the lower subulate, about $\frac{1}{2}$ as long as the broad second one, sometimes awn-pointed, the flowering scale obtuse or acute, exceeded by the second or occasionally equalling it.

In dry soil, Quebec to Assiniboia, Pennsylvania, Arkansas and Nebraska. Summer and fall.

11. Sporobolus Curtíssii (Vasey) Small. Stems tufted, 4-8 dm. tall, slender, erect, wiry : leaf-blades erect, $2.5 \mathrm{dm}$. long or less, $1-1.5 \mathrm{~mm}$. wide, stiff, often involute: panicle 1.5-2 dm. long, its branches ascending: spikelets 5-6 $\mathrm{mm}$. long, the scales acute, the empty ones unequal, the second equalling or somewhat shorter than the flowering one.

In sandy soil, Georgia, Florida and Alabama. Summer and fall.

12. Sporobolus Floridànus Chapm. Stems 6-12 dm. tall, erect, stout: leaf-blades broad, flat, $4 \mathrm{dm}$. long or less, $4-5 \mathrm{~mm}$. wide, linear, abruptly acute : panicle 2-4 dm. long, oblong, its branches ascending or erect-ascending : spikelets $4.5-5 \mathrm{~mm}$. long, the empty scales acute, unequal, the second a little shorter than or about equalling the flowering scale which is acute or obtusish and about as long as the palet.

In sandy soil, Georgia and northern Florida. Fall.

13. Sporobolus Buckleỳi Vasey. Stems $5-8 \mathrm{dm}$. tall, erect: leaf-blades $3 \mathrm{dm}$. long or less, $3-7 \mathrm{~mm}$. wide, flat, narrowed toward the base, long-acuminate above: panicle $1.5-2.5 \mathrm{dm}$. long, its branches at first erect, finally ascending : spikelets $1.5 \mathrm{~mm}$. long, the seales very acute.

In valleys, southern Texas. Also in Mexico. Summer.

14. Sporobolus cryptándrus (Torr.) A. Gray. Stems 4-12 dm. tall, erect : leafsheaths with a dense tuft of long hairs on each side at the apex : blades $7-15 \mathrm{~cm}$. long, 2-4 $\mathrm{mm}$. wide, flat, long-acuminate: panicle $1.5-2.5 \mathrm{dm}$. long, its branches spreading or ascending : spikelets $2-2.5 \mathrm{~mm}$. long, the scales acute.

In sandy soil, along the coast of New England and of the Great Lakes, to North Dakota, and in the interior in Missouri and Texas. Also in Mexico. Summer and fall.

15. Sporobolus Índicus (L. ) R. Br. Stems $3-12 \mathrm{dm}$. tall, erect, tufted : leaf-blades $2-6 \mathrm{~mm}$. wide, attenuate into a long slender points, the basal ones $2-3 \mathrm{dm}$. long: panicle 1-4 dm. long, usually much elongated, narrow, dense, spike-like: spikelets 1.5-2 mm. long.

In fields and waste places, Virginia to Florida, Arkansas and California. Naturalized from tropical regions. Summer and fall.

16. Sporobolus asperffollius Nees \& Meyen. Stems 1.5-5 dm. tall, erect, decumbent and branching at the base, from a slender rootstock: leaf-sheaths short, crowded and overlapping; blades numerous, $2-9 \mathrm{~cm}$. long, $2-3 \mathrm{~mm}$. wide, very rough above : panicle 7-20 cm. Iong, included at the base, rarely entirely exserted, the capillary branches spreading or ascending: spikelets sometimes 2-3-flowered, $1.5 \mathrm{~mm}$. long.

In dry soil, Assiniboia and British Columbia to Missouri, Texas and southern California. Also in Mexico. Summer and fall.

17. Sporobolus Virgínicus (L.) Kunth. Stems $1.5-6 \mathrm{dm}$. tall, erect, from a stout rootstock: leaf-sheaths numerous, short, overlapping, crowded on the lower part of the stem ; blades $2.5-20 \mathrm{~cm}$. long, $4 \mathrm{~mm}$. wide or less at the base, distichous, long-acuminate, 
involute on the margins and at the summit : panicle $2.5-8 \mathrm{~cm}$. long, 4-10 mm. wide, dense and spike-like: spikelets $2-2.5 \mathrm{~mm}$. long.

On sandy shores, Virginia to Florida and Texas. Also in tropical America. Summer and fall.

\section{EPICÁMPES Presl.}

Tall perennial grasses, with usually stout stems, flat leaf-blades, and contracted dense panicles. Spikelets 1-flowered ; empty scales about equal, very nearly as long as to somewhat exceeding the thinner flowering scale which is frequently awned, the awn inserted just below the apex. Stamens 3. Styles distinct, short. Stigmas plumose.

1. Epicampes lígulàta Scribn. Stems $8-12 \mathrm{dm}$. tall, stout: ligule pronounced, 1-2 cm. long; blades $5 \mathrm{dm}$. long or less, $3-5 \mathrm{~mm}$. wide, usually folded : panicle $2.5-4 \mathrm{dm}$. long, $1.5-3 \mathrm{~cm}$. wide : spikelets about $2.5 \mathrm{~mm}$. long.

In dry soil, central Texas to Arizona. Also in Mexico. Summer and fall.

\section{POLYPÒGON Desf.}

Annual or perennial grasses, with usually decumbent or rarely erect stems, flat leafblades, and terminal panicles, generally very dense, which are cylindric and spike-like, or sometimes broader and more lax. Spikelets articulated below the empty scales, crowded, 1-flowered. Scales 3, the 2 outer empty, about equal in length, each terminating in an erect slender awn, the third scale smaller, thinner, often hyaline, enclosing a smaller palet and a perfect flower, entire, emarginate, or 2-toothed, awned or awn-pointed, when entire the awn terminal, otherwise dorsal, the awn slender, either long with a twisted base and geniculate at the middle, or short and erect, sometimes reduced to a mere point. Stamens 1-3. Styles short, distinct. Stigmas plumose. BEard Grass.

Panicle silky : awn of the empty scales of the spikelet 2-3 times as long as the scale.

Panicle dull, often interrupted : awn of the empty scales of the spikelet about as long as the scale.

1. P. Monspeliensis.

2. P. littoralis.

1. Polypogon Monspeliénsis (L.) Desf. Stems $6 \mathrm{dm}$. tall or less, erect, from a usually decumbent base : leaf-blades $4-15 \mathrm{~cm}$. long, 3-6 mm. wide, rough: panicle 2-10 cm. long, dense and spike-like: spikelets crowded, the empty scales about $2 \mathrm{~mm}$. long, obtuse, slightly bifid, rough, bearing a bent awn 4-6 $\mathrm{mm}$. long, the flowering scale much shorter, erose-truncate, hyaline, bearing a delicate awn about $0.5 \mathrm{~mm}$. long, inserted below the apex.

In waste places, New Hampshire to South Carolina, and very common in western North America from British Columbia to Mexico. Naturalized from Europe. Summer and fall.

2. Polypogon littoràlís Sm. Stems tufted, 1.5-9 dm. tall, erect: leaf-blades erect, $1.5 \mathrm{dm}$. long or less, $3-8 \mathrm{~mm}$. wide : panicle $3-15 \mathrm{~cm}$. long, 6-40 $\mathrm{mm}$. wide : spikelets, exclusive of the awns, about $2 \mathrm{~mm}$. long.

In wet places, Louisiana; and from British Columbia to California. Naturalized from the old World. Summer.

\section{CÍNNA L.}

Tall perennial grasses, with flat leaf-blades and long terminal contracted or open panicles, often nodding, its branches slender and usually drooping. Spikelets numerous, flattened, 1-flowered, the rachilla articulated below the empty scales. Scales 3 , the 2 outer empty, persistent, keeled, acute, the third one similar in texture, stalked, bearing just below the somewhat obtuse apex a short awn or awn-like point, the scale enclosing a slightly smaller 1-nerved keeled palet, the keel minutely ciliate, and a perfect flower.

Stamen 1. Styles short, distinct. Stigmas plumose. Reed Grass.

Panicle contracted at maturity, its filiform branches erect, often drooping : spike-

lets $4-5 \mathrm{~mm}$. long, the first scale much shorter than the second.

Panicle open, its capillary branches flexuous and drooping: spikelets $3 \mathrm{~mm}$. long,

the first scale about equalling the second.

1. C. arundinacea.

1. Cinna arundinàcea $\mathrm{L}$. Stems $6-15 \mathrm{dm}$. tall : leaf-blades $1.5-3 \mathrm{dm}$. long, 4-14 $\mathrm{mm}$. wide, rough : panicle $1.5-3 \mathrm{dm}$. long, usually contracted, sometimes purple : scales of the spikelet acute, rough, the flowering scale slightly exceeded or equalled by the second, usually bearing an awn about $0.5 \mathrm{~mm}$. long from the 2-toothed apex.

In moist woods and swamps, Newfoundland to the Northwest Territory, North Carolina, Louisiana, Missouri and Texas. Summer and fall.

2. Cinna latifòlia (Trev.) Griseb. Stems 6-12 dm. tall : leaf-blades 1-2.5 dm. long, 4-12 mm. wide, rough : panicle $1-2.5 \mathrm{dm}$. long, the capillary branches generally spreading 
and flexuous: scales of the spikelet rough, strongly hispid on the keel, the flowering one usually exceeded by the second and bearing a rough awn 1-2 $\mathrm{mm}$. long from the 2-toothed apex. [C. arundinacea var. pendula A. Gray.]

In damp woods, Newfoundland to New Jersey and British Columbia, and in the Alleghanies to North Carolina, and in the Rockies to Colorado and Utah. Also in northern Europe. Summer and fall.

\section{AGRÓstis L.}

Annual or perennial usually tufted grasses, with flat or setaceous leaf-blades and terminal often slender contracted or open panicles with numerous branches. Spikelets very numerous, small, 1-flowered, the rachilla articulated above the empty scales. Scales 3 , the 2 outer empty, persistent, membranous, keeled, acute, awnless, the third one shorter, thin-hyaline, awnless, or sometimes bearing a slender dorsal often geniculate awn, enclosing a perfect flower and frequently also a short very thin hyaline palet rarely more than $\frac{1}{2}$ as long as the scale, sometimes minute or wanting. Stamens usually 3 . Styles distinct, very short. Stigmas plumose. Bent Grass.

Palet of the spikelet conspicuous, at least $1 / 3$ as Iong as the scale.

Panicle open, its branches long and at least some of them naked below: spikelets hispidulous on the keel only.

Panicle dense and contracted, its branches short and ascending or erect, spikelet-bearing to the very base: spikelets strongly hispidulous all over.

Palet inconspicuous, minute, or wanting.

Flowering scale awnless, or very rarely bearing a short awn.

Stems weak, usually decumbent and often prostrate at the base: leaf-blades lax: panicle oblong, the spikelets $1.5-2 \mathrm{~mm}$. long.

Stems, and usually also the leaf-blades, erect.

Branches of the panicle capillary, elongated, commonly dividing above the middle.

Spikelets $1.5-2 \mathrm{~mm}$. long : leaf-blades short.

Spikelets 2.5-3 mm. long : leaf-blades elongated.

Branches of the panicle not elongated, dividing at or below the middle. Spikelets about $2 \mathrm{~mm}$. long : a grass of low elevations.

Spikelets $2.5-3 \mathrm{~mm}$. long : a high mountain grass.

Flowering scale awned.

Awn glabrous, rigid, usually bent, less than twice as long as the spikelet. Branches of the panicle generally ascending: spikelets $2 \mathrm{~mm}$. long. Branches of the panicle usually spreading: spikelets $2.5-3 \mathrm{~mm}$. long.

1. A. alba.

2. A. verticillata.

\section{A. perennans.}

4. A. hyemalis.
5. A. altissima.

6. A. Scribneriana.

7. A. Novae-Angliae.

8. A. canina.

9. A. rubra.

Awn very finely filiform, barbellate, at least twice as long as the spikelet. 10 . A. Elliottiana.
1. Agrostis álba L. Stems $2-8 \mathrm{dm}$. tall, erect, or decumbent at the base, often stoloniferous : leaf-blades 5-20 cm. long, 2-6 mm. wide, rough or smooth : panicle 5-23 $\mathrm{cm}$. long, usually open, or sometimes contracted after flowering, green or purplish : spikelets 2-2.5 mm. long, the empty scales about equal, acute, hispidulous on the keel.

In fields and meadows, nearly throughout North America. Summer. RED-Top.

2. Agrostis verticillàta Vill. Stems tufted, $8 \mathrm{dm}$. tall or less : leaf-blades erect, linear to lanceolate, $1.5 \mathrm{dm}$. long or less, flat, very rough, $2-8 \mathrm{~mm}$. wide: panicle 4-12 cm. long, dense, often interrupted, its short branches ascending or erect, densely spikeletbearing to the base : spikelets $1.5-2 \mathrm{~mm}$. long, the empty scales strongly hispidulous.

In moist places, Texas to Arizona. Also in Mexico. Spring to fall.

3. Agrostis perénnans (Walt.) Tuckerm. Stems 3-8 dm. long from a decumbent or prostrate base, weak, slender, simple, or sparingly branched above: leaf-blades 5-15 em. long, 2-4 mm. wide, lax, rough : panicle 1-2 dm. long, open, oblong, its branches widely spreading, the branchlets and pedicels divergent: spikelets $1.5-2 \mathrm{~mm}$. long, the empty scales hispidulous on the keel. and fall.

In woods, New Hampshire and Massachusetts to Ohio, Kentucky and North Carolina. Summer

4. Agrostis hyemàlis (Walt.) B.S.P. Stems 3-6 dm. tall, slender : leaf-blades 5-13 cm. long, 1-3 mm. wide, usually erect, roughish : panicle $1.5-6 \mathrm{dm}$. long, usually purplish, the very rough capillary branches ascending or spreading, often drooping, the lower ones 7-15 $\mathrm{cm}$. long: spikelets $1.5-2 \mathrm{~mm}$. long. [A. scabra Willd.]

In dry or moist soil, throughout nearly the whole of North America. Summer.

5. Agrostls altíssima (Walt.) Tuckerm. Stems $6-12 \mathrm{dm}$. tall, erect: leaf-blades elongated, $1.5-3 \mathrm{dm}$. long, 2-3 mm. wide, rough : panicle $2-2.5 \mathrm{dm}$. long, its branches ascending or erect, the lower $5-10 \mathrm{~cm}$. long, spikelet-bearing at the end : spikelets $2.5-3$ $\mathrm{mm}$. long, occasionally bearing a short awn. [A. elata Trin.]

In sandy swamps, New Jersey to Florida and Alabama. Summer and fall.

6. Agrostis Scribneriàna Nash. Stems 3-9 dm. tall, erect, tufted, rather slender : leaf-blades 1-2.5 dm. long, 2-6 mm. wide, rough : panicle $1-2.5 \mathrm{dm}$. long, its ascending branches $3.5-8 \mathrm{~cm}$. long: spikelets about $2 \mathrm{~mm}$. long, on appressed pedicels. [Agrostis intermedia Scribn., not Balb.]

In dry soil, Massachusetts to New York, Tennessee and Missouri. Summer and fall. 
7. Agrostis Nòvae-Ángliae Tuckerm. Stems $2-4 \mathrm{dm}$. tall, erect, tufted : leaf-blades $2.5-9 \mathrm{~cm}$. long, $2 \mathrm{~mm}$. wide or less, erect, generally involute, rough : panicle 1-2 dm. long, open, the branches spreading or ascending : spikelets $2.5-3 \mathrm{~mm}$. long, very hispidulous on the keel.

In dry soil, Newfoundland and on the high mountains of New England, New York and North Carolina. Summer.

8. Agrostis canìna L. Stems $3-6 \mathrm{dm}$. tall, erect, slender : leaf-blades $2 . \tilde{\partial}-8 \mathrm{~cm}$. long, $2 \mathrm{~mm}$. wide or less, rough : panicle $5-18 \mathrm{~cm}$. long, contracted in fruit, its branches slender, naked below, ascending or spreading in flower: spikelets $2 \mathrm{~mm}$. long, on ap. pressed pedicels, the flowering scale with an awn 2-4 mm. long inserted just above the middle.

In meadows, Newfoundland and Alaska to Pennsylvania and Tennessee. Naturalized from Europe in the South. Summer and fall.

9. Agrostis rùbra L. Stems $1.5-6 \mathrm{dm}$. tall, erect: leaf-blades $5-10 \mathrm{~cm}$. long, 1-3 $\mathrm{mm}$. wide : panicle $6-13 \mathrm{~cm}$. long, open, the branches usually widely spreading and more or less flexuous, rarely erect : spikelets $2.5-3 \mathrm{~mm}$. long, the flowering scale bearing a generally bent awn 4-5 $\mathrm{mm}$. long and inserted below the middle.

In dry or wet soil, summits of the highest mountains in New England, New York and North Carolina. Summer.

10. Agrostis Elliottiàna Schult. Stems 1-4 dm. tall, erect, slender, tufted : leafblades 1-5 cm. long, $2 \mathrm{~mm}$. wide or less, rough : panicle $5-13 \mathrm{~cm}$. long, usually narrow, sometimes open, the branches slender, naked below, erect or ascending : spikelets $1.5 \mathrm{~mm}$. long, the third scale bearing a very finely filiform flexuous barbellate awn 2-4 times its length, inserted just below the apex. [Agrostis arachnoides Ell.]

In dry soil, South Carolina to Kentucky, Florida and Texas. Spring and summer.

\section{GASTRÍDIUM Beauv.}

Tufted annual grasses, with flat leaf-blades and spike-like dense cylindric shining panicles. Spikelets numerous, crowded, 1-flowered, the rachilla articulated above the empty scales and extending beyond the flower. Scales 3 , the 2 outer empty, unequal, persistent, narrow, keeled above, acute, sometimes short-awned, the third scale much shorter, thinly hyaline, broad, denticulate at the truncate apex, awnless, or sometimes bearing an awn below the apex, enclosing a narrow somewhat shorter palet and a perfect flower. Stamens 3. Styles short, distinct. Stigmas plumose.

1. Gastridium lendígerum (L.) Gaud. Stems $1.5-5 \mathrm{dm}$. tall, erect, or decumbent at the base, often branched : leaf-blades erect, $1 \mathrm{dm}$. long or less, $2-4 \mathrm{~mm}$. wide: panicle 3-13 cm. long, dense, 5-13 mm. in diameter : spikelets, exclusive of the awn, 3-4 mm. Iong.

In dry places, Texas. Also in Oregon and California. Naturalized from Europe. Summer.

\section{CALAMAgróstis Adans.}

Erect usually perennial grasses, with generally flat, sometimes involute leaf-blades, and terminal contracted or open panicles. Spikelets numerous, 1-flowered, commonly small, the rachilla usually prolonged beyond the flower, the prolongation either pilose throughout, the usual state, or with a terminal tuft of long hairs. Scales 3 , the 2 outer empty, persistent, narrow, keeled, acute or acuminate, the third scale much shorter than the others, very thickly hyaline, with a basal ring of hairs which are from one-half as long as the scale to somewhat exceeding it, rarely very short or almost wanting, bearing a usually delicate dorsal awn which is rarely twisted at the base, and enclosing a small narrow thinly hyaline palet and a perfect flower. Stamens 3. Styles short, distinct. Stigmas plumose.

Prolongation of the rachilla of the spikelet hairy throughout: spikelets $3-4 \mathrm{~mm}$. long. $\quad$ 1. C. Canadensis. Prolongation of the rachilla of the spikelet hairy at the summit: spikelets 6-8 mm. long. 2. C. cinnoides.

1. Calamagrostis Canadénsis (Michx.) Beauv. Stems 6-15 dm. tall, smooth or somewhat rough : leaf-blades 1-3 dm. long or more, $2-8 \mathrm{~mm}$. wide, rough : panicle 1-2 $\mathrm{dm}$. long, open, usually purplish, its branches spreading or ascending, naked at the base : spikelets 3-3.5 mm. long; flowering scale with a delicate awn, the basal hairs equalling or a little shorter than the scale.

In swamps and wet soil, Prince Edward Island to British Columbia, New Jersey, Ohio, Iowa, Utah and Oregon.-Represented in our area, on the high mountains of North Carolina, by $C$. Canadensis acuminata Vasey, which differs in having the panicle usually smaller, denser and darker purple, and in the larger spikelets which are $3.5-4 \mathrm{~mm}$. long and with the scales more pointed. Summer. 
2. Calamagrostis cinnoides (Muhl.) Scribn. Stems 9-15 dm. tall. erect: leafblades 1-3 dm. long or more, 4-10 $\mathrm{mm}$. wide, rough : panicle 7-18 $\mathrm{cm}$. long, contracted, its branches erect: spikelets $6-8 \mathrm{~mm}$. long, the scales very hispidulous, the outer ones about equal, acuminate and awn-pointed, the flowering scale obtuse, the basal hairs from $\frac{1}{2}-\frac{2}{3}$ its length, the awn stout, exceeding or equalling the scale. [C. Nuttalliana Stend.]

In moist soil, New Hampshire and Massachusetts to Pennsylvania and Georgia. Summer.

\section{AMMÓPHILA Host.}

Tall perennial grasses, with flat leaf-blades, which are often convolute above, and dense spike-like panicles. Spikelets 1-flowered, the rachilla prolonged beyond the flower and hairy. Scales 3, rigid, chartaceous, acute, keeled ; flowering scale 5-nerved, with a ring of short hairs at the base. Stamens 3. Styles distinct. Stigmas plumose.

1. Ammophila arenàuia (L.) Link. Stems 6-12 dm. tall, erect, rigid, stout, arising from a long branching rootstock : leaf-blades $1.5-3 \mathrm{dm}$. long or more, rigid, attenuated into a long slender involute point, rough above : panicle 1-3 dm. long, $1-1.5 \mathrm{~cm}$. in diameter : spikelets 10-12 mm. long, the scales hispidulous, the flowering scale usually with the rudiment of an awn just below the apex. [Calamagrostis arenaria (L.) Roth.]

In sands along the seacoast, New Brunswick to North Carolina, and inland along the shores of the Great Lakes. Summer and fall. SEA SAND REED.

\section{CALAMOVÍLFA Hack.}

Tall perennial grasses, with horizontal rootstocks, elongated narrow flat leaf-blades, involute at the apex, and contracted or open panicles. Spikelets flattened, 1-flowered, crowded, the rachilla articulated above the empty scales and not prolonged beyond the flower. Scales 3, rigid, chartaceous, awnless, keeled, 1-nerved, the 2 outer empty, unequal, persistent, the third scale with a ring of long hairs at the base, enclosing a 2-keeled palet and a perfect flower. Stamens 3. Styles distinct. Stigmas plumose. Reed Grass.

1. Calamovilfa Curtíssii Vasey. Stems $8-12 \mathrm{dm}$. tall, erect : leaf-blades $4 \mathrm{dm}$. long or less, $2-3 \mathrm{~mm}$. wide : panicle $1.5-3 \mathrm{dm}$. long, narrow, $1.5-2 \mathrm{~cm}$. in diameter, its branches erect: spikelets about $5 \mathrm{~mm}$. long. [Calamagrostis Curtissii Vasey.]

In dry or moist pine lands along the Indian River, Florida. Summer.

\section{HóLCUS L.}

Annual or perennial grasses, with usually flat leaf-blades and terminal spike-like contracted or open often interrupted panicles. Spikelets crowded, 2-flowered, the lower flower perfect, the upper one staminate, the rachilla articulated below the empty scales. Scales 4 , the 2 outer empty, keeled, the first 1-nerved, acute, the second broader, 3-nerved, acute or short-awned, the third and fourth scales shorter than the second, membranous, at length rigid, enclosing flowers, the former awnless, the latter bearing a slender dorsal awn which is often hooked when dry; palet narrow, 2-keeled. Stamens 3. Styles distinct. Stigmas plumose. Velvet Grass.

1. Holcus lanàtus L. Softly and densely pubescent. Stems 4-9 dm. tall, erect, tufted : leaf-blades $2.5-15 \mathrm{~cm}$. long, 4-12 mm. wide: spikelets $4 \mathrm{~mm}$. long, the empty scales white-villous, the upper one awn-pointed, the flowering scales $2 \mathrm{~mm}$. long, glabrous, shining, the upper one 2-toothed and bearing a finally hooked awn just below the apex.

In meadows, fields and waste places, Nova Scotia to Ontario, Illinois, North Carolina and Tennessee. Also on the Pacific Coast. Naturalized from Europe. Summer. Velvet Grass.

\section{AIrRA L.}

Mostly annual grasses, with narrow leaf-blades and contracted or open panicles. Spikelets small, 2-flowered, both flowers perfect. Scales 4, the lower 2 empty, thin-membranous, acute, subequal, persistent, the flowering scales usually close together on the rachilla, hyaline, mucronate or 2-toothed, bearing a delicate awn inserted just below the middle. Stamens 3. Stigmas plumose. HaIr Grass.

1. Aira caryophýllea L. Glabrous throughout. Stems $1-2.5 \mathrm{dm}$. tall, erect, from an annual root, slender : leaf-blades $1-5 \mathrm{~cm}$. long, involute-setaceous : panicle silvery, shining, 2-10 cm. long, open, its branches spreading or ascending: spikelets 2-2.5 mm. long, the empty scales acute, the flowering scales very acute, 2 -toothed, $2 \mathrm{~mm}$. long, bearing an awn 3-4 $\mathrm{mm}$. long.

In fields and waste places, Massachusetts to North Carolina. Also on the Pacific Coast. Naturalized from Europe. Spring and summer. 


\section{DESCHÁMPSIA Beauv.}

Perennial grasses, with narrow convolute or flat leaf-blades and terminal contracted or open panicles. Spikelets 2 -flowered, the rachilla articulated above the empty scales and prolonged beyond the flowers. Scales 4 , the 2 outer empty, persistent, keeled, acute, membranous, usually somewhat shining, the flowering scales thin-membranous, almost hyaline, entire or toothed, acute, obtuse, or truncate and denticulate at the apex, each bearing a slender dorsal straight or geniculate awn which is twisted at the base ; palet narrow, 2nerved. Stamens 3. Styles distinct. Stigmas plumose. Hair Grass.

Flowering scales about $2.5 \mathrm{~mm}$. long, erose-truncate: leaf-blades flat. Flowering scales about $4 \mathrm{~mm}$. long, acute or obtuse : leaf-blades involute.

1. D. caespitosa. 2. D. flexuosa.

1. Deschampsia caespitòsa (L. ) Beauv. Stems tufted, 6-12 dm. tall, erect: leafblades flat, $2-3 \mathrm{~mm}$. wide, rough above, the basal ones numerous, $\frac{1}{4}-\frac{1}{2}$ as long as the stem, those on the stem 5-15 $\mathrm{cm}$. long : panicle open, 7-23 $\mathrm{cm}$. long, its branches spreading or ascending, naked at the base : spikelets $3.5-4 \mathrm{~mm}$. long, the flowering scales about $2.5 \mathrm{~mm}$. long, erose-truncate at the apex, the awns somewhat shorter or a little longer than the scale.

In wet soil, Newfoundland to Alaska, New Jersey, Illinois, Minnesota and in the mountains to North Carolina, New Mexico and California. Also in Europe and Asia. Summer.

2. Deschampsia flexuòsa (L.) Trin. Stems tufted, 3-8 dm. tall, erect, slender : leaf-blades involute-setaceous, rough above, the basal very numerous, $\frac{1}{5}$ as long as the stem or less, those on the stem 2-8 cm. long: panicle open, 5-20 $\mathrm{cm}$. long, the branches spreading to nearly erect, naked at the base, flexuous : spikelets $4.5-5 \mathrm{~mm}$. long, the flowering scales about $4 \mathrm{~mm}$. long, acutely toothed at the apex, the awns bent and twisted, much exceeding the scale.

In dry soil, Greenland and Newfoundland to Ontario, Michigan, North Carolina and Tennessee. Also in Europe. Summer.

\section{TRISETUM Pers.}

Annual or perennial tufted grasses, with flat leaf-blades and terminal spike-like contracted or open panicles. Spikelets usually 2-flowered, rarely 3-6-flowered, the flowers perfect, or the upper one staminate, the rachilla glabrous or pilose, articulated between the flowering scales and prolonged beyond them. Scales 4 , rarely $5-8$, keeled, the 2 outer empty, membranous, unequal, acute, entire at the apex, awnless, persistent, the flowering scales usually shorter, sometimes longer, 2-toothed at the apex, the teeth acuminate and often terminating in a bristle or slender awn, awned, or the lower flowering scale rarely awnless, the awn often twisted, inserted below the apex and arising between the teeth ; palet hyaline, 2-toothed. Stamens 3. Styles distinct. Stigmas plumose. False OAt.

Flowering scales each bearing a long awn.

Empty scales shining, 1-nerved, or the second one 3-nerved.

Panicle spike-like, dense, its branches short and appressed.

Panicle loose and open, its branches she

Empty scales not shining, very strongly nerved, the first 3-nerved, the second 5-nerved.

Awn of the flowering scales inserted about $1 / 4$ way below the apex : teeth of the flowering scales cuneate.

Awn of the flowering scales inserted about the middle: teeth of the flowering scales subulate.

Lower flowering scale not bearing a long awn, a remnant sometimes-present.

Second empty scale less than $3 \mathrm{~mm}$. long: awn of the flowering scales $1-2 \mathrm{~mm}$. long.

Second empty scale $4-5 \mathrm{~mm}$. long: awn of the flowering scales exceeding 3 $\mathrm{mm}$. in length.

Empty scales dissimilar, the first much narrower than the second, 1-nerved, or sometimes 3-nerved at the base: leaf-blades $1 \mathrm{dm}$. long or less.

Empty scales similar, the first about as broad as the second, strongly 3nerved : leaf-blades 1.5-2 dm. long.

3. T. Hallii

4. T. interruptum.

5. T. aristatum.

6. T. Pennsylvanicum.

7. T. Ludovicianum.

1. Trisetum subspicàtum (L.) Beauv. Softly pubescent or glabrous in some or all of its parts. Stems 1-6 dm. tall, erect: leaf-blades 2-10 cm. long, 1-4 mm. wide : panicle spike-like, 2-13 cm. long, oval to oblong, sometimes interrupted below : spikelets 2-3flowered, the empty scales hispidulous on the keel, the second one about $5 \mathrm{~mm}$. long, the flowering scales 4-5 $\mathrm{mm}$. long, acuminate, hispidulous, each bearing a long bent and somewhat twisted awn. [T. molle Kunth.]

In dry or rocky places, Labrador to Alaska, and in the mountains to North Carolina, New Mexico and California. Also in Europe and Asia. Summer and fall.

2. Trisetum flavéscens (L.) R. \& S. Stems 4-8 dm. tall, erect, glabrous : leafsheaths pubescent ; blades $4-13 \mathrm{~cm}$. long, 2-6 mm. wide, rough : panicle open, $5-13 \mathrm{~cm}$. 
long, its branches ascending or erect, somewhat flexuous, naked below : spikelets 3-4flowered, the first empty scale about $\frac{1}{2}$ as long as the second which is about $5 \mathrm{~mm}$. long, the flowering scales 5-6 mm. long, hispidulous, each bearing a long, bent and twisted awn.

In waste places and fields, Missouri, Kansas and Mississippi. Naturalized from Europe or Asia. Summer.

3. Trisetum Eállii Scribn. Stems tufted, 1.5-5 dm. tall, slender: leaf-blades 3-13 cm. long, 2-3 mm. wide, rough, flat, or somewhat involute : panicle contracted, 3-15 cm. long, its branches erect or nearly so: spikelets $4-5 \mathrm{~mm}$. long, exclusive of the awns, the first scale much narrower and almost as long as the second.

On prairies, Texas. Spring.

4. Trisetum interrúptum Buckl. Stems tufted, $5 \mathrm{dm}$. tall or less, slender: leafsheaths glabrous or pubescent; blades flat or involute, rough, $8 \mathrm{~cm}$. long or less, 1-2 mm. wide : panicle 4-13 $\mathrm{cm}$. long, its branches erect or nearly so: spikelets 4-5 mm. long, exclusive of the awns, the first scale narrower than the second but about as long.

In dry soil, Texas. Spring.

5. Trisetum aristàtum (Scribn. \& Mer.) Nash. Stems 4-6 dm. tall, erect, slender : leaf-blades $1.5 \mathrm{dm}$. long or less, 1-2 mm. wide, roughish : panicle slender, 1.5-2.5 $\mathrm{dm}$. long, its branches erect or nearly so, the larger ones $6-8 \mathrm{~cm}$. long: spikelets of 4 or 5 scales, 4.5-5 mm. long, exclusive of the awns, the first scale linear, several times narrower than the broad second scale.

In moist or dry soil, North Carolina. Summer.

6. Trisetum Pennsylvánicum (L. ) B.S.P. Stems 3-9 dm. tall, erect, slender and often weak: leaf-sheaths sometimes rough; blades $1 \mathrm{dm}$. long or less, 1-4 mm. wide, rough : panicle $6-15 \mathrm{~cm}$. long, its branches erect or ascending: spikelets of four scales, the empty ones about equal, the first a little shorter than the second, the flowering scales 4-5 mm. long, the second one hispidulous or nearly glabrous. [ $T$. palustre Torr.]

In swamps and wet meadows, New York to Virginia, Tennessee and Florida. Spring and summer.

7. Trisetum Ludoviciànum Vasey. Stems 6-9 dm. long, weak : leaf-blades flat, the larger ones 1.5-2 dm. long, 4-6 mm. wide, rough : panicle $1.5-2.5 \mathrm{dm}$. long, its branches erect or nearly so : spikelets usually of 4 scales, the first a little shorter than the second, the second flowering scale strongly hispidulous.

In wet places, Louisiana. Spring.

\section{AVÈNA L.}

Annual or perennial grasses, varying in habit, with usually flat leaf-blades and terminal contracted or open panicles. Spikelets generally large, erect or pendulous, usually 2several-flowered, rarely 1 -flowered, the rachilla articulated between the fertile flowers, the lower flowers perfect, the upper ones often staminate or wanting. Scales 4-several, rarely 3 , the 2 outer empty, membranous, exceeding or shorter than the flowering scales, persistent ; the flowering scales 5-9-nerved, rounded on the back, the apex frequently shortly 2toothed, the scales enclosing perfect flowers and bearing a dorsal twisted geniculate awn, the upper empty ones or those infolding staminate flowers awnless; palet 2-cleft or 2toothed, narrow. Stamens 3. Styles distinct. Grain deeply furrowed, usually pubescent.

1. Avena sativa L. Annual. Stems $8-15 \mathrm{dm}$. tall : leaf-blades flat, $2.5 \mathrm{dm}$. long or less, $5-10 \mathrm{~mm}$. wide or more : panicle usually $1.5-4 \mathrm{dm}$. long, its branches erect or ascending: empty scales of the spikelet $2-3 \mathrm{~cm}$. long, acuminate, the flowering ones shorter, awned or awnless.

In fields and waste places, escaped from cultivation nearly every where in civilized Nort h America Summer. Оат.

\section{ARRHENATHÈRUM Beauv.}

Tall perennial grasses, with flat leaf-blades and terminal open or contracted panicles. Spikelets 2-flowered, the lower flower staminate, the upper one perfect or pistillate, the rachilla articulated above the empty scales and prolonged beyond the flowers. Scales 4 , the 2 outer empty, persistent, thin-membranous, keeled, the flowering scales more rigid, somewhat toothed at the apex, the lower one bearing near the base a long dorsal twisted and geniculate awn, the upper scale awnless, or short-awned below the apex ; palet 2-keeled, hyaline, narrow. Stamens 3. Styles short, distinct. Stigmas plumose. Grain hardly suleate.

1. Arrhenatherum elàtius (L.) Beauv. Stems 6-12 dm. tall, erect: leaf-blades 6-30 $\mathrm{cm}$. long, $2-8 \mathrm{~mm}$. wide, rough : panicle $1-3 \mathrm{dm}$. long, its branches ereet : empty 
seales of the spikelet unequal, the first shorter than the second which is about $8 \mathrm{~mm}$. long, the flowering scales about $8 \mathrm{~mm}$. long. [A. avenaceum Beauv.]

In fields and waste places, Maine and Ontario to Georgia, Tennessee and Nebraska. Also on the Pacific Coast. Naturalized from Europe. Summer. OAT GRAss.

\section{DANTHÒNIA DC.}

Usually perennial grasses, various in habit, with flat or convolute leaf-blades and terminal dense and contracted or open diffuse panicles. Spikelets 3-many-flowered, the flowers perfect or the upper ones staminate, the rachilla pilose, articulated between the scales and prolonged beyond them. Scales 5-many, the 2 outer empty, persistent, usually extending beyond the flowering scales, rarely shorter, keeled, acute or acuminate, the flowering scales rounded on the back, the margins often ciliate, 2-toothed at the apex, the teeth often awned, with an awn arising between the teeth which is more or less flattened and very often twisted at the base and frequently geniculate, the remaining scales often small and enclosing a palet only, or empty; palet obtuse or 2-toothed, 2-keeled, hyaline. Stamens 3. Styles distinct. Stigmas plumose. WiLd OAT Grass.

Empty scales of the spikelet $1.25 \mathrm{~cm}$. long or less : leaf-sheaths glabrous, or sometimes sparingly pubescent at the base.

Teeth of the flowering scale about $1 \mathrm{~mm}$. long, acute : leaf-blades of the stem short: panicle contracted.

Teeth of the flowering scale $2-3 \mathrm{~mm}$. long, awned: leaf-blades of the stem elongated : panicle usually open.

Empty scales more than $1.25 \mathrm{~cm}$. long.

Leaf-sheaths and flowering scales villous.

Leaf-sheaths glabrous: flowering scales pilose on the margins.

1. D. spicata.

2. D. compressa.

3. D. sericea.

4 D. epilis.

1. Danthonia spicàta (L.) Beauv. Stems $3-8 \mathrm{dm}$. tall, erect, nearly round : leafsheaths glabrous, or often sparingly pubescent below ; blades rough, $2 \mathrm{~mm}$. wide or less, usually involute, the lower ones $1-1.5 \mathrm{dm}$. long: panicle $2-5 \mathrm{~cm}$. long, its branches, as well as the pedicels, erect or ascending : spikelets 5-8-flowered, the empty scales 8-10 mm. long, the flowering scales broadly oblong, sparingly appressed-pubescent with silky hairs.

In dry soil, Newfoundland, Quebec and North Dakota to North Carolina, Kansas and Louisiana. Summer and fall.

2. Danthonia compréssa Austin. Stems $4-9 \mathrm{dm}$. tall, flattened, erect: leaf-blades $2 \mathrm{~mm}$. wide or less, the lower ones $1.5-2 \mathrm{dm}$. long : panicle open, $6-10 \mathrm{~cm}$. long, the lower branches usually spreading : spikelets 5-10-flowered, the empty scales 10-12 mm. long, the flowering scales oblong, with a ring of short hairs at the base, appressed-pubescent with silky hairs.

In woods, Maine and Vermont to North Carolina and Tennessee. Summer and fall.

3. Danthonia serícea Nutt. Stems 4-9 dm. tall : leaf-sheaths villous; blades rough and more or less villous, $2-3 \mathrm{~mm}$. wide, the basal ones usually flexuous, those on the stem $2-10 \mathrm{~cm}$. long, erect : panicle $6-12 \mathrm{~cm}$. long, contracted, the branches erect or ascending : spikelets 4-10-flowered, the empty scales 14-16 mm. long, the flowering scales oblong, strongly pubescent with long silky hairs, the teeth $2-3 \mathrm{~mm}$. long, acuminate, awned.

In dry sandy soil, Massachusetts to New Jersey and Florida. Spring and summer.

4. Danthonia épilis Scribn. Stems tufted, erect, 4-7 dm. tall, slightly roughened just below the panicle and puberulent below the brown nodes : leaf-blades 2-4 mm. wide, erect, those on the sterile shoots $1.5 \mathrm{dm}$. long or more, those on the stem $5-10 \mathrm{~cm}$. long: panicle $5-8 \mathrm{~cm}$. long, contracted : spikelets $5-10$-flowered, the empty scales acuminate, the flowering ones $5-6 \mathrm{~mm}$. long to the base of the teeth, pilose on the margins below and sometimes sparingly so on the midnerve at the base, the teeth, including the awn, 2-3 mm. long. [D. glabra Nash, not Philippi.]

In swamps, southern New Jersey to Georgia. Spring and summer.

\section{CAPRIOLA Adans.}

Perennial usually stoloniferous grasses, the stems as well as the stolons often creeping, with flat usually short leaf-blades and spicate inflorescence, the spikes terminal. Spikelets 1 -flowered, small, sessile, alternate in 2 rows on one side of the continuous rachis. Scales 3 , the 2 outer empty, persistent, thin, keeled, acute or obtuse, awnless, the flowering scale membranous, broader, its keel ciliate, awnless, enclosing a 2-keeled hyaline palet and a perfect flower. Stamens 3. Styles distinct. Stigmas plumose. [Cynodon L. C. Rich.]

1. Capriola Dáctylon (L.) Kuntze. Stems 1-3 dm. tall, erect, from long creeping and branching rootstocks: leaf-sheaths glabrous or somewhat pubescent, crowded at the 
base of the stems and along the stolons; blades $2.5-5 \mathrm{~cm}$. long, $2-4 \mathrm{~mm}$. wide, flat, rigid, rough above : spikes 4 or 5 , digitate, $1-5 \mathrm{~cm}$. long : spikelets $2 \mathrm{~mm}$. long, the outer scales hispid on the keel. [Cynodon Dactylon (L.) Pers.]

In fields and waste places, southern New York to Pennsylvania, Tennessee, Florida and Texas. Naturalized from Europe. Summer and fall. BERMUdA Grass.

\section{SPARTINA Schreb.}

Often tall grasses, with flat or convolute leaf-blades and spicate inflorescence, the spikes one-sided, the rachis extending beyond the spikelets. Spikelets 1-flowered, sessile or nearly so, much crowded and imbricated in 2 rows. Scales 3 , firm-membranous, the 2 outer empty, narrow, very unequal, keeled, the flowering scale equalling or a little longer and broader than the second scale; palet thin or almost hyaline, enclosing a perfect flower, obscurely 2-nerved, scarcely included in the scale which it often slightly exceeds. Stamens 3. Styles elongated. Stigmas 2, thread-like, papillose or shortly plumose. Marsh Grass. Second scale long-awned.

1. S. cynosuroides. Second scale awnless.

First scale strongly hispid on the keel.

Leaf-blades wide $(1-2.5 \mathrm{~cm}$.), flat.

Leaf-blades narrow $(6 \mathrm{~mm}$. or less) involute, at least when dry.

First scale less than $1 / 2$ as long as the second: spikes usually few, erect or ascending.

First scale about $3 / 4$ as long as the second : spikes numerous, appressed.

First scale not hispid on the keel.

2. S. polystachya.

3. S. patens.

4. S. junciformis.

5. S. stricta.

1. Spartina cynosuroìdes (L.) Willd. Stems 6-18 dm. tall: leaf-blades $3 \mathrm{dm}$. long or more, $6-14 \mathrm{~mm}$. wide, attenuate into long slender tips: spikes 5-30, ascending or erect, 5-13 cm. long: spikelets strongly imbricated, 12-14 $\mathrm{mm}$. long, the empty scales strongly hispid on the keel.

In swamps and streams of brackish or fresh water, Nova Scotia to Assiniboia, New Jersey and Texas. Summer and fall.

2. Spartina polystáchya (Michx. ) Ell. Stems 1-3 m. tall, stout : leaf-blades $3 \mathrm{dm}$. long or more, 1-2.5 cm. wide, flat, attenuate into long slender tips: spikes 20-50, ascending, 5-10 $\mathrm{cm}$. long: spikelets much imbricated, 8-10 $\mathrm{mm}$. long, the empty scales strongly hispid on the keel.

In salt and brackish marshes, New Jersey to Florida. Summer and fall. White Rush. SAldt REED GRASs.

3. Spartina pàtens (Ait.) Muhl. Stems $3-9 \mathrm{dm}$. tall, usually from a branching and decumbent base : leaf-blades $1.5-3 \mathrm{dm}$. long, $2-4 \mathrm{~mm}$. wide, involute, attenuate into long tips: spikes $2-10,2.5-5 \mathrm{~cm}$. long, usually ascending : spikelets $6-8 \mathrm{~mm}$. long, the empty scales hispid on the keel. [S. juncea Willd.]

On salt meadows, Newfoundland and Nova Scotia to Florida and Texas. Summer and fall. SALT MEADOW Grass. White RUSH.

4. Spartina juncifórmis Engelm. \& Gray. Stems tufted, stout, rigid, 3-10 dm. tall : leaf-sheaths thick, hard, the lower ones shining; blades involute, $5 \mathrm{dm}$. long or less : panicle 1-2 dm. long, narrow, strict, its branches $3-4 \mathrm{~cm}$. long: spikelets about $7 \mathrm{~mm}$. long, the first scale at least $\frac{3}{4}$ as long as the third scale.

In sandy or alluvial soil, Florida to Texas. Summer and fall.

5. Spartina strícta (Ait.) Roth. Stems 3-10 dm. tall, erect, usually stout: leafblades $5 \mathrm{dm}$. long or less : panicle 1-3 dm. long, its branches appressed, 4-10 $\mathrm{cm}$. long : spikelets 1-1.5 cm. long, glabrous or appressed-pubescent. [S. glabra Muhl.]

In salt or brackish marshes, Maine to Florida, Texas and California. Summer and fall.

\section{CAMPULòsus Desv.}

Often tall perennial grasses, with narrow flat or convolute leaf-blades and usually a terminal straight or curved dense spike. Spikes rarely 2 or 3 . Spikelets 1-2-flowered, if the latter the upper flower staminate, sessile, crowded in 2 rows. Scales 6 or 7 , the lower 4 empty, the first small, keeled, awnless, the second larger than the others, membranous or rigid, acute or 2-cleft, generally bearing near the middle a dorsal often stout and usually horizontal awn, or the awn sometimes reduced to a tubercle, the third, fourth and fifth scales awned, more delicate than the second, the 2 former empty or enclosing palets, the fifth scale enclosing a palet and a perfect flower, the remaining scales narrow, empty or enclosing palets, the first also rarely a staminate flower. Stamens 3. Styles distinct. Stigmas plumose. Toothache Grass. 
Spikes stout, the spikelets at right-angles to the rachis: second scale with a row of glands each side of the midnerve.

Spikes slender, the spikelets diverging from the rachis: second scale without glands.

1. C. aromaticus.

1. Campulosus aromáticus (Walt.) Scribn. Stems $9-12 \mathrm{dm}$. tall, erect : leaf-blades $1.5 \mathrm{dm}$. long or less, $2-4 \mathrm{~mm}$. wide, flat or involute : spikes 5-10 $\mathrm{cm}$. long: spikelets about $6 \mathrm{~mm}$. long. Plant pungent to the taste. [Ctenium Americanum Spreng.]

In moist soil in pine lands, Virginia to Florida and Mississippi. Summer and fall.

2. Campulosus Chapadénsis Trin. Stems slender, $6-10 \mathrm{dm}$. tall : leaf-blades flat, $2 \mathrm{dm}$. long or less, $1-3 \mathrm{~mm}$. wide : spikes slender, $5-15 \mathrm{~cm}$. long: spikelets $5-6 \mathrm{~mm}$. long, exclusive of the awns.

In pine woods, Florida. Also in Brazil. Summer and fall.

\section{CHLÒRIS Sw.}

Usually perennial grasses, with flat leaf-blades and spicate inflorescence, the spikes verticillate or approximate. Spikelets 1-flowered, sessile, crowded in 2 rows, the rachilla prolonged beyond the flower. Scales usually 4 , sometimes 5 , or occasionally more, the 2 lower empty, persistent, unequal, keeled, narrow, acute or acuminate, awnless or rarely awn-pointed, the third scale acute, usually long awned, rarely nearly awnless, enclosing a perfect flower and a folded 2 -keeled palet, the remaining scale or scales commonly empty and usually awned. Stamens 3. Styles distinct. Stigmas plumose.

Spikes slender, usually naked at the base or with a few scattered spikelets.

Midnerve of the third scale not pilose, but hispidulous above the middle.

Nerves of the third scale all pilose.

Apex of the elliptic fourth scale acute.

A pex of the obovate-cuneate fourth scale obliquely truncate.

Spikes stout, spikelet-bearing to the base.

Hairs on the nerves of the third scale short, $0.5 \mathrm{~mm}$. long or less, not manifest, nor extending beyond the apex of the scale.

Fourth scale obovate-cuneate, 3-nerved, $0.6 \mathrm{~mm}$. wide, the apex unequally rounded.

Fourth scale obcuneate or triangular, 5-nerved, $1 \mathrm{~mm}$. broad or a little more.

Fourth scale broadly triangular, 7-nerved, wider than long.

Hairs on the lateral nerves of the third scale long, $1 \mathrm{~mm}$. long or more, manifest and decidedly extending beyond the apex of the scale.

Scales 6: hairs on the lateral nerves of the third scale about equal in length. Hairs exceeding the apex of the scale, about $1 \mathrm{~mm}$. long: fourth scale $1 \mathrm{~mm}$. wide: upier surface of the leaves glabrous.

Hairs much exceeding the apex of the scale, $2-3 \mathrm{~mm}$. long: fourth scale 0.5

$\mathrm{mm}$. wide: upper surface of the leaves near the base usually long-hairy.
Scales 7-9, the upper ones much reduced; hairs on the lateral nerves of the third scale unequal in length, those at the summit much longer.
1. C. Nealleyi.
2. C. tenuispica.
3. C. verticillata.

4. C. brevispica.

5. C. la'isguamea.

6. C. cu ullata.

\section{C. Texana.}

8. C. barbata.

9. C. Prieuri.

1. Chloris Nealleỳi Nash. Stems 3-6 dm. tall : leaf-blades $2.5-15 \mathrm{~cm}$. long, 3-5 mm. wide, rough above : spikes 5-8, 10-18 $\mathrm{cm}$. long: spikelets, exclusive of the awns, about $4 \mathrm{~mm}$. long: scales 4 ; outer empty scales acuminate; third scale, exclusive of the awn, $4 \mathrm{~mm}$. long, in side view equilateral and $0.8 \mathrm{~mm}$. wide, acute, the internerves rough, the lateral nerves pilose above the middle, the awn $6-9 \mathrm{~mm}$. long; fourth scale $2-2.5 \mathrm{~mm}$. long, in side view elliptic and about $0.5 \mathrm{~mm}$. wide, the apex acute, the awn 4-5 $\mathrm{mm}$. long.

In dry soil, Texas. Summer.

2. Chloris tenuispìca Nash. Stems $2-4 \mathrm{dm}$. tall : leaf-blades $4-15 \mathrm{~cm}$. long, $2-3$ $\mathrm{mm}$. wide, abruptly acute, rough above and on the margins : axis of the inflorescence 2 $\mathrm{cm}$. long or less : spikes $10-12,6-10 \mathrm{~cm}$. long, spreading, very slender, in about 2 whorls : spikelets, exclusive of the awns, about $3 \mathrm{~mm}$. long: scales 4 or 5 ; outer empty ones narrow, acuminate, awn-pointed ; third scale about $3 \mathrm{~mm}$. long, in side view elliptic and 0.7 $\mathrm{mm}$. wide, the nerves pilose, the awn 4-6 mm. long; fourth scale nearly glabrous, smaller than the third, $1.75-2 \mathrm{~mm}$. long, acute at the apex, the awn $2.5-4 \mathrm{~mm}$. long; fifth scale smaller.

In dry soil, Texas. Summer.

3. Chloris verticillàta Nutt. Stems $2-5 \mathrm{dm}$. tall : leaf-blades $1.5-18 \mathrm{~cm}$. long, $2-4$ $\mathrm{mm}$. broad, rough above and on the margins, obtuse : axis of the inflorescence $0.5-5 \mathrm{~cm}$. long : spikes 8-21, spreading, 5-15 cm. long, in 1-4 whorls, or the upper ones scattered or approximate: spikelets, exclusive of the awns, about $3 \mathrm{~mm}$. long: scales 4 ; outer empty ones acuminate, awn-pointed; third scale $2.5-2.75 \mathrm{~mm}$. long, in side view nearly equilateral and $0.8 \mathrm{~mm}$. wide, the nerves pilose, the awn $5-8 \mathrm{~mm}$. long; fourth scale $1.5-2 \mathrm{~mm}$. long, in side view obovate-cuneate and about $0.75 \mathrm{~mm}$. wide, the apex obliquely truncate, the awn 4-5 mm. long.

In sandy soil, Arkansas to Kansas and Texas. Summer. 
4. Chloris brevispìca Nash. Stems 1-2 dm. tall : leaf-blades 1-6 cm. long, 1-3 mm. wide, rough above and on the margins : spikes $6-10$, finally spreading, $2.5-4.5 \mathrm{~cm}$. long : spikelets, exclusive of the awns, about $2.8 \mathrm{~mm}$. long: scales 4 ; outer empty ones lanceolate, acute; third scale $2.5 \mathrm{~mm}$. long, in side view elliptic and about $0.75 \mathrm{~mm}$. wide, the nerves pilose, the hairs about $0.5 \mathrm{~mm}$. long, the awn about $2 \mathrm{~mm}$. long; fourth scale obovate-cuneate, about $1.5 \mathrm{~mm}$. long, in side view about $0.6 \mathrm{~mm}$. wide, the apex unequally rounded, the awn 1.4-1.8 mm. long.

In sandy soil, Texas. Summer.

5. Chloris latisquàmea Nash. Stems 2-6 dm. tall : leaf-blades $1-10 \mathrm{~cm}$. long, 2-4 $\mathrm{mm}$. wide, obtuse, rough : axis of the inflorescence $1.5 \mathrm{~cm}$. long or less : spikes 10-16, 3-7 $\mathrm{cm}$. long, finally widely spreading: spikelets, exclusive of the awns, $2.3-2.8 \mathrm{~mm}$. long: scales 4 ; outer empty ones acute; third scale 2.2-2.7 mm. long, in side view elliptic and $0.8-0.9 \mathrm{~mm}$. wide, the nerves pilose, the awn $1.5-3 \mathrm{~mm}$. long; fourth scale $1.5-1.7 \mathrm{~mm}$. long, in side view obcuneate or triangular and 1-1.2 mm. broad, 3-nerved, the lateral nerves much curved, branching at the middle, thus making the scale appear 5 -nerved at the truncate apex, $0.5 \mathrm{~mm}$. wide, the awn $1.5-2 \mathrm{~mm}$. long.

In dry ground and on shady river banks, Texas. Summer.

6. Chloris cucullàta Bisch. Stems $2-7 \mathrm{dm}$. tall : leaf-blades $2-15 \mathrm{~cm}$. long, $3 \mathrm{~mm}$. wide or less, very rough : spikes $6-15,2-4 \mathrm{~cm}$. long, spreading : spikelets, exclusive of the awns, about $2 \mathrm{~mm}$. long, triangular, about as broad as long: scales 4 ; first scale acute, the second broader above the middle; third scale $1.7-2 \mathrm{~mm}$. long, in side view elliptic and about $0.9 \mathrm{~mm}$. wide, obtuse, the lateral nerves densely pilose with short hairs about 0.4 $\mathrm{mm}$. long, the midnerve sparingly so, the awn 0.5-1 $\mathrm{mm}$. long ; fourth scale about $1 \mathrm{~mm}$. long, in side view broadly triangular and $1.3 \mathrm{~mm}$. broad, the lateral nerves branching twice, making the scale appear 7 -nerved above, the awn $0.2-0.3 \mathrm{~mm}$. long.

In sandy soil, Texas. Fall.

7. Chloris Texàna (Vasey) Nash. Stems $2.5-6 \mathrm{dm}$. tall : leaf-blades $6-20 \mathrm{~cm}$. long, 3-6 $\mathrm{mm}$. wide, rough on the margins and toward the apex on the lower surface: spikes 3-6, 4-8 cm. long: spikelets, exclusive of the awns, about $2.8 \mathrm{~mm}$. long: scales 6 ; outer empty ones very acute, pointed ; third scale about $2.7 \mathrm{~mm}$. long, in side view inequilateral and $1 \mathrm{~mm}$. broad, the nerves pilose with hairs about $1 \mathrm{~mm}$. Iong, the awn about $1.5 \mathrm{~mm}$. long; fourth scale $1.7 \mathrm{~mm}$. long, in side view obovate-cuneate and $1 \mathrm{~mm}$. wide at the truncate and obscurely crenulate apex, 3-nerved, the awn 1-1.25 $\mathrm{mm}$. long; fifth scale 1 $\mathrm{mm}$. long; sixth scale about $0.5 \mathrm{~mm}$. long.

In low land, southern Texas. Summer.

8. Chloris barbàta (L.) Nash. Stems $5-10 \mathrm{dm}$. tall : leaf-blades $6 \mathrm{dm}$. long or less, $1 \mathrm{~cm}$. wide or less, attenuate into long slender tips, smooth: spikes 6-25, flexuous and spreading, $5-15 \mathrm{~cm}$. long: spikelets, exclusive of the awns, about $3 \mathrm{~mm}$. long: scales 6 ; outer empty ones acuminate ; third scale abont $2.25 \mathrm{~mm}$. long, in side view elliptic and about $0.75 \mathrm{~mm}$. wide, the nerves pilose, the midnerve-hairs about $0.5 \mathrm{~mm}$. long, the remainder of irregular length, 2-3 mm. long, the awn 3-4 mm. long; fourth scale about 1.3 $\mathrm{mm}$. long, in side view obovate-elliptic and about $0.5 \mathrm{~mm}$. wide, obliquely truncate at the crenulate apex, the awn $2.5-3 \mathrm{~mm}$. long; fifth and sixth scales smaller.

In sand or moist places, southern peninsular Florida. Also in the West Indies and South America. Summer.

9. Chloris Prieùri Kunth. Stems 4-10 dm. tall : leaf-blades $1.5 \mathrm{dm}$. long or less, 3-6 $\mathrm{mm}$. wide, rough above and on the margins : spikes $4-15,6-9 \mathrm{~cm}$. long, erect: spikelets, exclusive of the awns, about $4 \mathrm{~mm}$. long : scales 7-9, the upper ones much reduced; outer empty scales acuminate, awn-pointed ; third scale, exclusive of the awn, 3-3.5 mm. long, in side view narrowly oblong and about $0.5 \mathrm{~mm}$. wide, acute, a row of dark glands on each side of the glabrous midnerve, the lateral nerves glabrous below the middle, pilose above, the awn 8-13 $\mathrm{mm}$. long, the palet gland-bearing between the nerves.

Introduced at Wilmington, North Carolina, and on ballast at Mobile, Alabama. Summer.

\section{EUSTÁCHYS Desv.}

Perennial grasses, with flat or folded usually obtuse leaf-blades and spicate inflorescence, the spikes single, in pairs, or 3-many and digitate. Spikelets usually 1-flowered, rarely 2-flowered, if the latter the upper flower staminate, sessile, erowded in 2 rows. Scales 4 , rarely 5 , the 2 lower empty, persistent, unequal, keeled, the first generally acute, the second oblong, truncate or 2-lobed at the apex, short-awned, the remaining scales awnless, mucronate, or short-awned, firmer than the empty scales, the third scale enclosing a perfect flower and a palet, the fourth scale empty, or rarely enclosing a staminate flower, 
the fifth scale, when present, empty, similar in texture to the fourth. Stamens 3. Styles distinct. Stigmas plumose.

Spikelets $2 \mathrm{~mm}$. long: third and fourth scales awnless, or the former sometimes with a mere dorsal projection.

Spikes usually 4-6, rarely more: second scale of the spikelet manifestly 2 -toothed at the apex : leaf-blades usually $3-7 \mathrm{~mm}$. wide.

Spikes 10-25: second scale of the spikelet truncate at the apex : leaf-blades usually $1 \mathrm{~cm}$. wide or more.

Spikelets $3 \mathrm{~mm}$. long or more : third and fourth scales awned.

Spikes usually 1 or 2 , rarely 3 : third scale of the spikelet over $3 \mathrm{~mm}$. long.

Spikes 4-6: third scale of the spikelet less than $3 \mathrm{~mm}$. long.

1. E. petraea.

2. E. glauca.

3. E. Floridana.

4. E. neglecta.

1. Eustachys petraèa (Sw.) Desv. Stems $3-11 \mathrm{dm}$. tall : leaf-blades $3 \mathrm{dm}$. long or less, $10 \mathrm{~mm}$. wide or less, smooth : spikes $3-11$, usually $4-6$, erect, 4-11 $\mathrm{cm}$. long : spikelets about $2 \mathrm{~mm}$. long: scales 4 , the second, exclusive of the awn, $1.5-1.75 \mathrm{~mm}$. long, 2-toothed at the apex, the teeth triangular, acute or obtusish, the awn about $0.5 \mathrm{~mm}$. long; third scale about $2 \mathrm{~mm}$. long, in side view elliptic and about $1 \mathrm{~mm}$. wide, the nerve-hair about $0.3 \mathrm{~mm}$. long, the awn short or wanting ; fourth scale $1.3-1.5 \mathrm{~mm}$. long, in side view obovate-elliptic, $0.5-0.7 \mathrm{~mm}$. wide, rounded at the apex, awnless. [Chloris petraea Sw.]

In dry sandy soil. usually along the coast, North Carolina to Florida and Texas. Also in tropical America. In Florida it occurs in the heart of the peninsula, 50 miles from the coast. Summer.

2. Eustachys glaùca Chapm. Stems $6-15 \mathrm{dm}$. tall : leaf-blades $2.5 \mathrm{dm}$. long or less, $1.5 \mathrm{~cm}$. wide or less, smooth : axis of the inflorescence $2.5 \mathrm{~cm}$. long or less : spikes 10-25, $6-15 \mathrm{~cm}$. long: spikelets about $2 \mathrm{~mm}$. long: scales 4 ; second scale, exclusive of the awn, $1.5 \mathrm{~mm}$. long, in side view about $0.3 \mathrm{~mm}$. wide, minutely and irregularly toothed at the truncate apex, the awn about $0.3 \mathrm{~mm}$. long; third scale $1.75-2 \mathrm{~mm}$. long, in side view ovate and $0.8-0.9 \mathrm{~mm}$. wide, obtuse at the awnless apex, the nerves hispid above the middle; fourth scale about $1.3 \mathrm{~mm}$. long, in side view oblong and about $0.5 \mathrm{~mm}$. wide, rounded-truncate at the awnless apex. [Chloris glauca (Chapm.) Vasey.]

In brackish marshes and about cypress swamps, Florida. Summer.

3. Eustachys Floridàna Chapm. Stems 4-10 dm. tall: leaf-blades smooth, the early basal ones $1-3 \mathrm{dm}$. long, 4-8 $\mathrm{mm}$. wide, those on the stem $2-7 \mathrm{~cm}$. long, $5 \mathrm{~mm}$. wide or less : spikes 1-3, erect, $5-10 \mathrm{~cm}$. long : spikelets, exclusive of the awns, $3-3.5 \mathrm{~mm}$. long : scales 4 , the second about $2.5 \mathrm{~mm}$. long, exclusive of the awn, unequally 2-lobed at the apex, the lobes rounded and minutely and irregularly toothed, the awn $0.7-1 \mathrm{~mm}$. long ; third scale $3-3.5 \mathrm{~mm}$. long, in side view elliptic and 1-1.2 mm. wide, the nerve-hairs about $0.5 \mathrm{~mm}$. long, the awn $0.5-0.7 \mathrm{~mm}$. long; fourth scale smaller, the awn less than $0.5 \mathrm{~mm}$. long. [Chloris Floridana (Chapm.) Vasey.]

In dry sandy soil, southern Georgia and northern Florida. Summer.

4. Eustachys neglécta Nash. Stems 7-12 dm. tall: leaf-blades $2 \mathrm{dm}$. long or less, $9 \mathrm{~mm}$. wide or less, smooth : spikes $4-6$, erect, $8-15 \mathrm{~cm}$. long : spikelets, exclusive of the awns, about $3 \mathrm{~mm}$. long: scales 4 , rarely 5 ; second scale, exclusive of the awn, about $2.5 \mathrm{~mm}$. long, 2-lobed at the apex, the lobes obtuse and minutely and irregularly toothed, the awn about $1 \mathrm{~mm}$. long; third scale $2.5-2.8 \mathrm{~mm}$. long, in side view about $1 \mathrm{~mm}$. wide, the nerve-hairs about $0.7 \mathrm{~mm}$. long, the awn $1 \mathrm{~mm}$. long; fourth scale $1.5-2 \mathrm{~mm}$. long, in side view obovate-elliptic, about $0.75 \mathrm{~mm}$. wide, the awn less than $1 \mathrm{~mm}$. long; fifth scale smaller.

In dry sandy soil, eastern and peninsular Florida. Summer.

\section{TRICHLÒRIS Fourn.}

Tall grasses, with flat leaf-blades and usually numerous slender spikes which are closely approximate or subverticillate. Spikelets sessile, densely crowded in 2 rows on one side of the continuous rachis, 1-, rarely 2-3-flowered, the rachilla extending beyond the flowers as a scale-bearing appendage. Scales usually 3 , sometimes more, the 2 outer empty, small, persistent, membranous, the first usually very narrow, acute, awnless, the second shortawned, the flowering scale or scales 3-awned, the awns long and nearly equal or the lateral much shorter, the remaining scales empty or sometimes reduced to mere awns; palet hyaline, 2-keeled near the margins. Stamens 3. Styles distinct. Stigmas plumose.

1. Trichloris pluriflòra Fourn. Stems erect, 4-12 dm. tall : leaf-blades flat, $3 \mathrm{dm}$. long or less, 5-10 mm. wide : spikes 5 or more, 5-15 cm. long, slender : spikelets, exclusive of the awns, about $4 \mathrm{~mm}$. long, the awn of the flowering scales 2-3 times their length.

In dry soil, central and western Texas. Also in Mexico. Spring and summer.

\section{GYMNOPÒgON Beauv.}

Usually perennial grasses, with flat, generally short, rarely long, leaf-blades and an inflorescence composed of numerous long slender spikes which are alternately arranged or 
the lower ones subverticillate. Spikelets 1-flowered, narrow, sessile or nearly so, scattered, appressed, the rachilla glabrous and prolonged beyond the flower, bearing at its apex a small usually awned scale. Scales 4 , the 2 lower empty, persistent, narrow, acute, or the second short-awned, the third scale somewhat broader, shortly 2-toothed at the apex, bearing a straight awn, and enclosing a narrow 2-keeled palet and a perfect flower ; fourth scale empty, awned, the body often much reduced. Stamens 3. Styles distinct. Stigmas plumose.

Spikes spikelet-bearing their whole length: awn longer than the flowering scale.

1. G. ambiguus. Spikes spikelet-bearing only above the middle: awn shorter than the flowering scale. 2. G. brevifolius.

1. Gymnopogon ambíguus (Michx.) B.S.P. Stems 3-5 dm. tall, erect, or decumbent at the base : leaf-sheaths with a villous ring at the summit, crowded at the base of the stem; blades 2-10 $\mathrm{cm}$. long, 4-12 mm. wide, lanceolate, crowded at the base, spreading: spikes slender, the lower ones finally widely spreading, 1-2 dm. long: spikelets, exclusive of the awn, 4-5 mm. long, the awn of the flowering scale 4-6 mm. long. [G. racemosus Beauv.]

In dry sandy soil, southern New Jersey to Missouri, Florida and Texas. Summer and fall.

2. Gymnopogon brevifòlius Trin. Stems 3-6 dm. long, decumbent at the base, slender : leaf-sheaths sometimes crowded at the middle of the stem; blades $2-5 \mathrm{~cm}$. long, 2-8 mm. wide, lanceolate, usually spreading : spikes very slender, the lower ones finally widely spreading and 1-1.5 dm. long: spikelets, exclusive of the awn, $3 \mathrm{~mm}$. long, the flowering scale short-awned.

In dry soil, New Jersey to Florida and Mississippi. Summer and fall.

\section{SCHEDONNÁRDUS Steud.}

Annual grasses, with narrow almost subulate leaf-blades and an inflorescence consisting of numerous long slender spikes arranged in an open panicle. Spikelets 1-flowered, acuminate, scattered, appressed, sessile and alternate on opposite sides of the rachis. Scales 3 , membranous, the 2 lower empty, persistent, narrow, acuminate, somewhat unequal, the third scale longer, at length rigid, enclosing a narrow shorter palet and a perfect flower. Stamens 3. Styles distinct. Stigmas plumose.

1. Schedonnardus paniculàtus (Nutt.) Trelease. Stems $2-5 \mathrm{dm}$. tall, slender, erect, rigid, branched at the base: leaf-sheaths crowded at the base of the stem, compressed; blades $2-5 \mathrm{~cm}$. long, $2 \mathrm{~mm}$. wide or less, usually erect, flat: spikes numerous, widely spreading, alternate, rigid, the lower ones $5-10 \mathrm{~cm}$. long: spikelets $2.5-3 \mathrm{~mm}$. long, appressed, alternate.

In dry soil, Manitoba and Assiniboia to Illinois, Texas and New Mexico. Summer and fall.

\section{BOUTELOÙA Lag.}

Annual or perennial grasses, with narrow flat or convolute leaf-blades, and an inflorescence composed of few scattered one-sided, often more or less curved, many-flowered sessile spikes with the rachis sometimes conspicuously prolonged beyond the spikelets. Spikelets numerous, 1-2-flowered, the lower flower perfect, the upper one when present staminate or sterile, crowded in 2 rows. Scales 3 or more, the 2 lower empty, narrow, acute, unequal, keeled, the third one enclosing a narrow hyaline palet and a perfect flower, usually thinner and broader, 3-nerved, the nerves excurrent from the lobes or teeth as short projections or awns or protruding between the lobes, the small empty scales terminating the rachilla 1-3,3-awned. Stamens 3. Styles distinct. Stigmas plumose. Mesquite Grass.

A wns terminating the lobes of the flowering scale.

Stems glabrous.

Rachilla of the spikelet with a dense tuft of long hairs at the apex.

Rachilla glabrous.

Seeond empty scale with large hair-bearing tubercles on one or both sides of the midnerve.

Second empty scale glabrous and free of tubercles.

Flowering scale pubescent with long ascending silky hairs.

Flowering scale glabrous, or sometimes with a few hairs at the base.

Stems densely villous below.

A wns arising between the lobes of the flowering scale.

1. B. oligostachya.

2. B. hirsuta.

3. B. Burkei.

4. B. trifida.

5. B. eriopoda.

6. B. microstachys.

1. Bouteloua oligostáchya (Nutt.) Torr. Stems $1.5-5 \mathrm{dm}$. tall, erect : leaf-blades $2-10 \mathrm{~cm}$. long, $2 \mathrm{~mm}$. wide or less, involute, at least at the long slender point : spikes 1-3, $2.5-5 \mathrm{~cm}$. long, the rachis ending in a short inconspicuous tip : spikelets about $6 \mathrm{~mm}$. long, the rachilla with a tuft of leng hairs under the rudimentary scales and awns.

On prairies, Manitoba to Alberta, Wisconsin and Texas. Also in Mexico. Summer and fall. 
2. Bouteloua hirsùta Lag. Stems erect, $1.5-5 \mathrm{dm}$. tall : leaf-blades mostly at the base of the stem, $2-13 \mathrm{~cm}$. long, $2 \mathrm{~mm}$. wide or less, erect or ascending, flat, rough, sparingly papillose-hirsute near the base, especially on the margins : spikes 1-4, 1-5 cm. long, erect or ascending, the rachis extending beyond the spikelet in a conspicuous point: spikelets $5-6 \mathrm{~mm}$. long.

In dry soil, especially on prairies, Illinois to North Dakota, Texas and Arizona, and in southern peninsular Florida. Summer and fall.

3. Bouteloua Búrkei Scribn. Perennial. Stems tufted, $3 \mathrm{dm}$. tall or less : leafblades spreading, often involute, $1-3 \mathrm{~cm}$. long, about $1 \mathrm{~mm}$. wide, stiff : spikes 3-6, erect, 1-2 $\mathrm{cm}$. long: spikelets diverging from the rachis, about $2.5 \mathrm{~mm}$. long, exclusive of the awns.

In dry soil, central and western Texas. Also in Mexico. Spring and summer.

4. Bouteloua trífida Thurb. Perennial. Stems tufted, $3 \mathrm{dm}$. high or less : leafblades spreading, often involute, $4 \mathrm{dm}$. long or less, about $1 \mathrm{~mm}$. wide: spikes 3-6, erect, $1.5-3 \mathrm{~cm}$. long: spikelets diverging from the rachis, $3-4 \mathrm{~mm}$. long, exclusive of the awns.

In dry soil, central Texas to New Mexico. Also in Mexico. Spring and summer.

5. Bouteloua eriópoda Torr. Perennial. Stems tufted, $3-6 \mathrm{dm}$. tall, at least the lower internodes densely villous : leaf-blades $1.5 \mathrm{dm}$. long or less, 1-2 mm. wide, usually attenuated into a long slender point, erect : spikes $2-5$, erect, $2-5 \mathrm{~cm}$. long: spikelets diverging from the rachis, $6-8 \mathrm{~mm}$. long, exclusive of the awns.

In dry soil, central Texas to Arizona. Summer and fall.

6. Bouteloua microstáchys Fourn. Annual. Stems tufted, erect or ascending, slender, 1-3 dm. tall, sometimes branching: leaf-blades spreading or ascending, flat, 1-7 cm. long, 1-2 mm. wide : spikes $2-7$, usually curved, ascending, $1.5-3 \mathrm{~cm}$. long : spikelets diverging from the rachis, $2-3 \mathrm{~mm}$. long, exclusive of the awns, the flowering scale strongly pubescent, the rachilla with a terminal tuft of hairs.

In dry soil, southern Texas to southern California. Also in Mexico. Summer and fall.

\section{ATHEROPÒGON Muhl.}

Perennial grasses, with narrow flat leaf-blades and an inflorescence composed of numerous scattered short few-flowered spikes. Spikelets 1-flowered, sessile, crowded in 2 rows, imbricated, the rachilla extending beyond the flower, its summit bearing scales or awns. Scales 3 or more, the 2 lower empty, unequal, narrow, acute, keeled, the third scale thinner and broader, 3-toothed at the apex, the teeth more or less awned, enclosing a narrow hyaline 2-toothed palet and a perfect flower, the small upper scales empty, awned. Stamens 3. Styles distinct. Stigmas plumose.

1. Atheropogon curtipéndulus (Michx.) Fourn. Stems $3-9 \mathrm{dm}$. tall, tufted : leafblades $5-30 \mathrm{~cm}$. long, $4 \mathrm{~mm}$. wide or less, flat or involute, rough : spikes $6-16 \mathrm{~mm}$. long, widely spreading or reflexed : spikelets $4-12$, diverging from the rachis, $7-10 \mathrm{~mm}$. long. [Bouteloua racemosa Lag.]

In dry soil, Ontario to Manitoba, New Jersey, Kentucky, Georgia (according to Feay and Chapman) and Texas. Also in Mexico. Summer and fall.

\section{TRIATHÈRA Desv.}

Annual or perennial grasses, with flat or involute leaf-blades and slender nanicles composed of short slender one-sided spikes. Spikelets narrow, appressed, the rachilla terminating in 3 stout awns. Scales 3, long-acuminate, the 2 outer empty, unequal, the flowering scale 3 -toothed at the apex, the teeth usually awned. Stamens 3. Styles distinct. Stigmas plumose.

1. Triathera aristidoides (H.B.K. ) Nash. Stems slender, 1-4 dm. tall, wiry, finally somewhat branched : leaf-blades 2-10 $\mathrm{cm}$. long, 1-2 $\mathrm{mm}$. wide, flat, or sometimes involute : panicle slender, $4-10 \mathrm{~cm}$. long, consisting of $5-20$ spreading spikes $1-1.5 \mathrm{~cm}$. long, their bases strongly appressed-pubescent with long silky hairs : spikelets $2-3$ in each spike.

In dry places, central Texas to southern California. Also in Mexico. Summer and fall.

\section{FOLYÒDON H.B.K.}

Perennial grasses, with flat or involute leaf-blades, and short spikes arranged in slender panicles. Spikelets 1-flowered, appearing clustered by reason of the very short internodes of the rachis. Scales 5 or 6 : the 2 outer empty, narrow, acuminate ; third scale 3 -awned, enclosing a perfect flower; remaining scales empty, the lower 3 -awned, the uppermost usually reduced to 1-3 awns. Stamens 3. Styles 2, slender, distinct, distantly inserted. Stigmas plumose. 
1. Polyodon Texànus (S. Wats.) Nash. Stems tufted, wiry, erect, slender, 1-4 dm. tall : leaf-blades $2 \mathrm{dm}$. long or less, 1-2 mm. wide, often involute : panicle 3-6 $\mathrm{cm}$. long, of 5-8 short spreading spikes which are 9-12 $\mathrm{mm}$. long: spikelets 2-4 in each spike. [Bouteloua Texana S. Wats.]

In dry soil, the Indian Territory and Texas. Spring and summer.

\section{ELEUSINE Gaertn.}

Annual, or perennial and creeping, grasses, with flat leaf-blades, and an inflorescence composed of normally several spikes arranged digitately or approximately with sometimes an additional single spike below. Spikelets numerous, much crowded, imbricated, sessile, alternate in 2 rows, several-flowered, the flowers perfect, or the upper ones staminate. Scales several, obtuse or acute, flattened, keeled, thin, the 2 lower empty, a little shorter than the others, the remaining scales usually more obtuse, each of the lower ones enclosing a scarcely shorter compressed 2 -keeled palet and a flower, the terminal scales empty. Stamens 3. Styles distinct. Stigmas plumose.

1. Eleusine Índica (L.) Gaertn. Stems $1.5-6 \mathrm{dm}$. tall, erect, or decumbent at the base : leaf-sheaths loose, overlapping, often short and crowded at the base of the stem; blades 7-30 $\mathrm{cm}$. long, 2-6 mm. wide: spikes $2-10$, whorled, or approximate at the summit of the stem, or sometimes with 1 or 2 distant ones, $2-8 \mathrm{~cm}$. long : spikelets $3-4 \mathrm{~mm}$. long, 3-6-flowered.

In waste places, fields and dooryards nearly throughout North America. Naturalized from the old World. Summer and fall. WIREGrass. YARD Grass. Crab Grass. Dog Grass. Crow-Foot.

\section{DACTYLOCTÉNIUM Willd.}

Annual grasses, with flat leaf-blades and an inflorescence consisting of one-sided spikes terminally arranged in pairs or digitate. Spikelets numerous, crowded, imbricated, sessile, alternate in 2 rows, several-flowered, the flowers perfect or the upper ones staminate. Scales several, acute and mucronate-pointed, or the second awned, thin, flattened, keeled, the 2 lower empty, the remaining scales broader, each of the lower ones enclosing a scarcely shorter compressed 2-keeled palet and a flower, the upper scales empty. Stamens 3. Styles distinct. Stigmas plumose.

1. Dactyloctenium Aegýptium (L. ) Willd. Stems $1.5-6 \mathrm{dm}$. tall, usually decumbent and extensively creeping at the base : leaf-sheaths loose, overlapping, often crowded ; blades $1.5 \mathrm{dm}$. long or less, $2-6 \mathrm{~mm}$. wide, ciliate toward the base : spikes in pairs, or 3-5 and digitate, 1-5 cm. long: spikelets 3-5-flowered. [Eleusine Aegyptia Pers.]

In cultivated ground and waste places, southern New York, Pennsylvania and Virginia to Illinois, California and Florida. Also widely distributed in tropical America. Naturalized from Asia or Africa. Summer and fall. EgYptian Grass.

\section{LEPTÓCHLOA Beauv.}

Often tall grasses, with flat or convolute leaf-blades, and an inflorescence consisting of very many long slender spikes arranged in a panicle, rarely approximate at the summit of the stem. Spikelets small, close, or rarely scattered, 2-several-flowered, rarely 1-flowered, flattened, sessile, alternate in 2 rows. Scales 3 -several, keeled, obtuse, acute, or shortly awned, the 2 lower empty, a little unequal, usually shorter than the spikelet, or in the 1-flowered spikelets exceeding the third scale, the remaining scales more obtuse or sometimes bearing a slender awn, each of the lower enclosing a prominently 2-keeled palet and a flower, the upper empty. Stamens 3. Styles distinet. Stigmas plumose.

Spikes very slender, $1 \mathrm{~mm}$. broad or less: empty scales generally about the same

length, the first from nearly equalling to exceeding the first flowering scale.

Flowering scales $1.5 \mathrm{~mm}$. long, the pubescence on the nerves long and copious.

Flowering scales less than $1 \mathrm{~mm}$. long, the pubescence on the nerves short and scant.

Spikes stouter, $2 \mathrm{~mm}$. wide or more: empty scales usually very unequal, the first much shorter than the first flowering scale.

Inflorescence generally loose and open, the branches elongated and more or less spreading, usually in whorls or sometimes opposite or alternate.

Upper surface of the leaf-blades glabrous : scales of the spikelet usually 7-8, the flowering ones awnless, or sometimes the first and rarely the second short-awned.

Upper surface of the leaf-blades hirsute toward the base: scales of the spikelet usually 5-6, the flowering ones all awned, the awn of the first more than $1 / 2$ as long as the body.

Inflorescence long and narrow, the branches commonly short, erect or nearly so, crowded and disposed in dense alternate fascicles.

1. L. mucronata.

2. L. attenuata.
3. L. virgata.

4. L. Domingensis. 
Sheaths smooth or nearly so: Howering scales $1.75 \mathrm{~mm}$. long, broad, obtuse, the nerves densely pilose excepting at the summit.

Sheaths very rough: flowering scales $2.5 \mathrm{~mm}$. long, narrow, acute, the nerves pilose below the middle.

5. L. Nealleyi.

6. L. scabra.

1. Leptochloa mucronàta (Michx.) Kunth. Stems $3-12 \mathrm{dm}$. tall, finally branching : leaf-sheaths, at least the lower ones, generally more or less hirsute ; blades $6-25 \mathrm{~cm}$. long, $1 \mathrm{~cm}$. wide or less, rough : inflorescence $1.5-5 \mathrm{dm}$. long, usually included at the base : spikes slender, commonly elongated, ascending, $5-15 \mathrm{~cm}$. long: spikelets $2.5-3 \mathrm{~mm}$. long: scales usually 5 ; the 2 outer empty, acute, equal, or the first somewhat shorter than the second, the first commonly a little shorter than the first flowering scale, rarely somewhat exceeding it ; flowering scales about $1.5 \mathrm{~mm}$. long, rounded at the emarginate apex, the nerves pilose, excepting at the apex, the hairs copious and long.

In fields, Virginia to Florida and California. Summer.

2. Leptochloa attenuàta Nutt. Stems tufted, $2-6 \mathrm{dm}$. tall, finally branching : leafsheaths more or less hirsute ; blades $4-20 \mathrm{~cm}$. long, 3-8 mm. wide, rough, sparingly hirsute above : inflorescence 1.5-2 dm. long, usually included at the base : spikes slender, spreading or ascending, 4-10 cm. long : spikelets $1.6-2 \mathrm{~mm}$. long : scales 5 or 6 ; the 2 outer empty, subulate, acuminate, awn-pointed, generally about equal, or the first shorter than the second which reaches the apex of the second flowering scale; flowering scales a little less than $1 \mathrm{~mm}$. long, rounded at the apex, the nerve-hairs scant and very short.

In low sandy bottoms, Illinois to the Indian Territory. Fall.

3. Leptochloa virgàta (L.) Beauv. Stems $2-10 \mathrm{dm}$. tall : leaf-sheaths glabrous; blades $5-30 \mathrm{~cm}$. long, 5-15 mm. wide, often rough above : inflorescence 1-2.5 $\mathrm{dm}$. long, exserted : spikes numerous, erect or ascending, usually in whorls, sometimes scattered or in pairs, 3-12 $\mathrm{cm}$. long, rather stout : spikelets $3.5-4 \mathrm{~mm}$. long: scales $6-9$; the 2 outer empty, broad, acute; flowering scales $2-2.5 \mathrm{~mm}$. long, the midnerve glabrous, sometimes excurrent in a short point or awn, the lateral nerves pubescent for the upper two-thirds.

In sandy soil, Texas. Also in Mexico, South America and the West Indies. Summer.

4. Leptochloa Domingénsis (Jacq.) Trin. Stems $2-10 \mathrm{dm}$. tall, finally branching : leaf-sheaths glabrous or sparingly hirsute ; blades 1-3 dm. long, $1 \mathrm{~cm}$. wide or less, sometimes rough beneath, hirsute above : inflorescence 1-2 dm. long, its axis smooth : spikes erect or somewhat ascending, usually numerous, the lower ones $3-10 \mathrm{~cm}$. long : spikelets, exclusive of the awns, $2-3 \mathrm{~mm}$. long: scales 4 or 5 ; the 2 outer empty unequal, acute, shorter than the spikelet; flowering scales $1.75-2.25 \mathrm{~mm}$. long, acute, internerves glabrous or appressed-pubescent, the lateral nerves pilose for part way above the middle, the midnerve hispidulous above the middle and extending into an awn $\frac{1}{2}$ to fully as long as the body.

In sand, peninsular Florida and southern Texas. Also in tropical America. Summer.

5. Leptochloa Nealleỳi Vasey. Stems 4-10 dm. tall : leaf-sheaths smooth and glabrous ; blades 4-20 $\mathrm{cm}$. long, $2-4 \mathrm{~mm}$. wide, roughish ; inflorescence $1.5-3.5 \mathrm{dm}$. long, included at the base : spikes very numerous, short and stout, $2-5 \mathrm{~cm}$. long, appressed : spikelets crowded, about $3 \mathrm{~mm}$. long: scales 5 or 6 ; the 2 outer empty, broad, obtuse, the first about $\frac{1}{2}$ as long as the second which is $\frac{1}{2}$ as long as the spikelet or less ; flowering scales 1.75 $\mathrm{mm}$. long, rounded at the apex, the midnerve sometimes excurrent, the nerves pilose, excepting at the apex, with long hairs.

In low land, central and southern Texas. Summer.

6. Leptochloa scàbra Nees. Rough throughout. Stems $1 \mathrm{~m}$. tall or less: leafsheaths glabrous; blades $2-4 \mathrm{dm}$. long, $1 \mathrm{~cm}$. wide or less : inflorescence $2-4 \mathrm{dm}$. long, included at the base: spikes very numerous, erect-ascending, sometimes curved, the lower ones $5-8 \mathrm{~cm}$. long: spikelets $3.5-4 \mathrm{~mm}$. long: scales usually 6 ; the 2 outer empty, acute, the first $\frac{1}{2}$ as long as the second which is less than $\frac{1}{2}$ as long as the spikelet; flowering scales about $2.5 \mathrm{~mm}$. long, acute, the nerves pilose below the middle, the midnerve also hispidulous above the middle and usually excurrent in a short awn.

In ditches and fields, Louisiana. Probably introduced. Fall.

\section{ACAMPTOCLÀdOS Nash.}

Perennial tufted grasses, with stiff stems, flat or involute leaf-blades and a panicle composed of scattered and distant widely spreading rigid branches. Spikelets scattered and distinct, singly disposed in two rows, sessile, 4-6-flowered. Scales 6-8, firm : the 2 lower empty, acuminate, about equal, the first 1-nerved, the second usually 3-nerved; flowering scales very acute, becoming harder in fruit, 3-nerved, the nerves glabrous, the lateral nerves vanishing at the margin below the apex ; palet compressed, its 2 nerves ciliolate, gibbous at the base. Stamens 3. Styles distinct. Stigmas plumose. 
1. Acamptoclados sessilispicus (Buckl.) Nash. Stems $2-14 \mathrm{dm}$. tall, erect, simple: leaf-sheaths crowded at the base of the stem, hairy at the summit; blades $5-15 \mathrm{~cm}$. long, 1.5-3 mm. wide, rough above: panicle 1-4 dm. long, its branches stout and rigid: spikelets 4-6-flowered, the flowering seales $4 \mathrm{~mm}$. long. [Eragrostis sessilispica Buckl.]

On prairies, Kansas to Texas. Summer and fall.

\section{BúLBILIS Raf.}

Perennial creeping stoloniferous grasses, with narrow flat leaf-blades and the inflorescence of two forms, one staminate, consisting of one-sided spikes approximate at the summit of long-exserted stems, the other pistillate, on short stems, composed of small spikelike clusters barely exserted from the sheath. Spikelets dioecious, sessile, very unlike. Staminate spikelets 2-3-flowered, crowded in 2 rows on one side of the short flattened spikes; scales 4 or 5 , membranous; stamens 3 . Pistillate spikelets 1 -flowered, the larger scales united at the base and involucre-like ; scales 3 , the 2 outer empty, the first membranous, usually small, sometimes similar to the second which is the largest, firm, concave at the base, 3-lobed at the apex, the flowering scale narrow, nearly hyaline, enclosing a broad convolute 2-nerved palet and a flower. Styles distinct, long. Stigmas elongated, short-plumose.

1. Bulbilis dactyloìdes (Nutt.) Raf. Stoloniferous. Staminate stems $1-3 \mathrm{dm}$. tall, erect, slender, naked above : pistillate stems 1-8 $\mathrm{cm}$. long, much exceeded by the leaves: leaf-blades $2 \mathrm{~mm}$. wide or less, papillose-hirsute, those on the staminate stems $2-10 \mathrm{~cm}$. long, erect, those on the stolons and pistillate stems $2.5 \mathrm{~cm}$. long or less and spreading : staminate spikes 2 or 3 , approximate, the $2-3$-flowered spikelets $4-5 \mathrm{~mm}$. long, flattened: pistillate spikelets ovoid, the outer scales indurated.

On plains and prairies, Minnesota to North Dakota, Arkansas and Texas. Also in Mexico. Summer. Buffalo Grass.

\section{PAPPÓPHORUM Schreb.}

Perennial tufted grasses, with narrow leaf-blades and dense spike-like panicles. Spikelets usually 1-2-flowered, narrow. Scales usually 4-6; the 2 lower empty, acute, carinate ; flowering scales firm, divided into many awn-like lobes. Stamens 3 . Styles short, distinct. Stigmas plumose.

1. Pappophorum apértum Munro. Stems tufted, $5-10 \mathrm{dm}$. tall, erect, rather stiff, finally somewhat branched : leaf-sheaths pubescent at the summit on the outside; blades $3 \mathrm{dm}$. long or less, usually involute: panicle 1-2 dm. long, narrow, its branches erect: spikelets 7-8 mm. long, including the awns, the flowering scales pubescent on the margins and keel for $\frac{1}{2}$ their length.

In dry soil, central Texas to Arizona. Also in Mexico. Spring and summer.

\section{MONANThóchLÖ̈ Engelm.}

Perennial creeping or stoloniferous monoecious grasses, with short rigid convolute often curved leaf-blades crowded at the nodes, and an inconspicuous inflorescence concealed among the leaves. Spikelets unisexual, the staminate hardly differing from the pistillate, 2 -flowered, rarely 3 -flowered, usually sessile and in pairs, or stipitate and single, in the leaf fascicle;, the rachilla continuous and prolonged beyond the flower and sometimes bearing a short terminal scale. Seales 4 or 5 , the 2 outer empty, somewhat resembling the floral leaves, distichous, membranous and sheathing at the base, linear, rigid and spreading above, many-nerved, the remaining scales membranous, firmly hyaline, obtuse or denticulate, enclosing a 2-nerved convolute palet and a flower. Stamens 3. Styles distinct, long. Stigmas elongated, shortly barbellate-plumose.

1. Monanthochloë littoràlis Engelm. Branches densely tufted from creeping stems, 1-5 dm. tall, stiff, wiry : leaf-blades crowded on short branches, widely spreading, $1.5 \mathrm{~cm}$. long or less, stiff, often curved.

In sand along the seacoast, southern Florida and southern Texas and Lower California. Spring and summer.

\section{MUNRÒA Torr.}

Low annual tufted grasses, with many rigid and often creeping dichotomously or fasciculately branched stem, short rigid spinescent leaves which are crowded at the nodes or at 
the summit of the branches, and an inconspicuous inflorescence which is almost concealed in the leaf-fascicles. Spikelets few, usually 3 -flowered, almost sessile, in small elusters in the axils of the floral leaves. Scales several, the 2 outer empty, persistent, narrow, acute, hyaline, nerveless, the remaining ones 3-nerved, larger, entire, retuse, or 3-cleft at the apex, the central nerve or all of them excurrent in a short tip, each of the lower scales enclosing a narrow folded hyaline 2-keeled palet and a perfect flower, the upper scales empty, similar to the flowering ones but smaller and narrower or sometimes with one reduced to 3 awns. Stamens 3. Styles elongated. Stigmas loosely and shortly plumose.

1. Munroa squarròsa (Nutt.) Torr. Stems 5-20 dm. long, tufted, erect to prostrate, much branched : leaf-sheaths short, crowded at the nodes and ends of the branches; blades $2.5 \mathrm{~cm}$. long or less, $1-2 \mathrm{~mm}$. wide, rigid, spreading, rough, pungently pointed : spikelets 2-5-flowered ; flowering scales 3-toothed, the teeth short-pointed or awned.

On dry plains, South Dakota to Alberta, Nebraska, Texas and Arizona. Summer and fall.

\section{ARÚNDO L.}

Tall perennial grasses, with thick stout somewhat woody stems, broad flat leaf-blades and dense panicles. Spikelets 2-many-flowered, the rachilla-internodes glabrous. Scales 4-many ; empty scales narrow ; flowering scales broader, 3-nerved, hairy on the back. Stamens 3. Styles distinct. Stigmas plumose.

1. Arundo Dònax L. Stems stout, erect, $3-6 \mathrm{~m}$. tall : leaf-blades often $5 \mathrm{dm}$. long or more and sometimes $4-5 \mathrm{~cm}$. wide : panicle $5-8 \mathrm{dm}$. long, oblong : spikelets numerous, crowded.

Occasionally escaped from cultivation in the southern United States. Native of the tropical and warmer regions of both hemispheres. Summer.

\section{PHRAGMİTES Trin.}

Tall perennial grasses, with flat usually broad leaf-blades and ample terminal panicles. Spikelets 2-several-flowered, the lower flower staminate, the remainder perfect, the rachilla articulated between the flowers and covered with long silky hairs which surround the fertile scales. Scales 4 -several, glabrous, thin, narrow, acute, keeled, the 2 outer empty, the first much shorter than the second, the remaining scales long-acuminate, the lowest one enclosing a staminate flower, the remainder of the scales narrower and each containing a perfect flower or the upper sometimes empty ; palet hyaline, much shorter than the scale, 2-keeled. Stamens 3. Styles distinct, short. Stigmas plumose.

1. Phragmites Phragmìtes (L.) Karst. Stems 1-5 dm. tall, stout, erect, from long rootstocks : leaf-sheaths loose, overlapping; blades 1.5-3 dm. long or more, 1-5 cm. wide, flat: panicle ample, 1.5-3 dm. long or more, its branches ascending: spikelets crowded, the flowering scales 10-12 mm. long, long-acuminate. [P. communis Trin.]

In swamps and wet places in almost all parts of North America north of Mexico. Also in Europe and Asia. Summer and fall. CoMmon REED.

\section{TRIDENS R. \& S.}

Usually perennial grasses, with flat or involute leaf-blades and the inflorescence composed of open or contracted and sometimes spike-like panicles. Spikelets 3-many-flowered, the flowers perfect or the upper ones staminate. Scales 5-many, membranous, sometimes firmer, the 2 lower empty, keeled, obtuse to acuminate, usually shorter than the rest, sometimes longer: flowering scales 3-nerved, the midnerve or all the nerves excurrent, the midnerve and the lateral nerves or the margins pilose, the apex entire or shortly 2-toothed, the teeth obtuse to acute, the callus short and obtuse; palet shorter than the scale, compressed, 2-keeled. Stamens 3. Styles short, distinct. Stigmas plumose.

A. Panicle open, the branches long and more or less spreading.

Lateral nerves of the flowering scale vanishing at the margin, not excurrent. Spikelets 4-5 mm. long, the nerves of the palet not abruptly gibbous below the middle.

Spikelets 8-10 mm. long, nerves of the palet abruptly and strongly gibbous below the middle.

Lateral nerves manifestly exeurrent in short projections.

Spikelets oval, more than $1 / 2$ as broad as long

Spikelets 7-9-flowered, $5 \mathrm{~mm}$. long: palet rounded at the decidedly apiculate apex, the nerves ciliolate, the internerve broadly ovate-oval.

Spikelets 4-6-flowered, 6-7 mm. long: palet obtuse at the apex, the nerves ciliate, the internerve elliptic or nearly so.

Spikelets elliptic to linear-oblong, less than $1 / 2$ as broad as long.

1. T. eragrostoides.

2. T. Texanus.

\section{T. ambiguus.}

4. T. Langloisii.

5. T. seslerioides. 
B. Panicle narrow, often spike-like, its branches erect or appressed.

Second empty scale 1-nerved.

Lateral nerves excurrent in short projections, the nerve-hairs less than 1 mm. long.

Panicle exceeding $1.5 \mathrm{dm}$. in length: spikelets not turgid, the paletnerves not gibbous at the base.

Sheaths, at least the basal, villous; spikelets loosely arranged, the empty scales broad, $1 / 2$ as long as the spikelet or less.

Sheaths glabrous: spikelets crowded, the empty scales narrow and often equalling or exceeding the flowering scales.

Panicle less than $1 \mathrm{dm}$. long: spikelets turgid, the palet-nerves abruptly and strongly gibbous at the base.

Lateral nerves of the flowering scale vanishing below the apex : nerve-hairs about $1.5 \mathrm{~mm}$. long.

Second empty scale 3-5-nerved.

Spikelets 8-10-flowered, 10-14 $\mathrm{mm}$. long, the hairs on the margins and midnerve of the flowering scales copious.

Spikelets 3-5-flowered, $5-8 \mathrm{~mm}$. long, the hairs on the margins and midnerve of the flowering scales scanty,

6. T. Drummondii.

7. T. strictus.

8. T. congestus.

9. T. muticus.

10. T. elongatus.

11. T, Buckleyanus.

1. Tridens eragrostoides (Vasey \& Scribn.) Nash. Stems tufted, 3-12 dm. tall, smooth : leaf-sheaths overlapping, rough ; blades erect or ascending, 2-3 dm. long, 4-7 $\mathrm{mm}$. wide, long-acuminate, rough : panicle loose and open, $1.5-3 \mathrm{dm}$. long, its rough branches ascending, the larger $3-12 \mathrm{~cm}$. long: spikelets loosely arranged, $7-10$-flowered, 4-5 mm. long, $2.5 \mathrm{~mm}$. broad, ovate; empty scales 1-nerved, acuminate, hispid on the keel, the first much narrower than the second; flowering scales about $2.5 \mathrm{~mm}$. long, oval and about $1.5 \mathrm{~mm}$. wide when spread out, the apex rounded or nearly truncate, denticulate, the hairs on their margins and midnerve about $0.2 \mathrm{~mm}$. long, the midnerve usually excurrent, the lateral nerves vanishing at the margin. [Triodia eragrostoides Vasey \& Scribn.]

On hillsides, southern Florida and Texas. Also in Mexico. Summer and fall.

2. Tridens Texànus (Thurb. ) Nash. Stems tufted, $2-7 \mathrm{dm}$. tall, more or less hirsute toward the base: stem-leaves 2 or 3 ; sheaths glabrous to sparingly hirsute, pilose at the summit ; blades $3 \mathrm{dm}$. long or less, $2-4 \mathrm{~mm}$. wide, long-acuminate, often more or less hirsute : panicle loose and open, 6-17 $\mathrm{cm}$. long, its branches at length spreading, the lower 2-7 cm. long: spikelets loosely disposed, 8-11-flowered, $8-10 \mathrm{~mm}$. long, oblong to narrowly ovate; empty scales rather broad, 1-nerved, acute; flowering scales about $3.5 \mathrm{~mm}$. long, oval and about $2.5 \mathrm{~mm}$. broad when spread out, the apex obtusely 2-toothed, their nervehairs about $0.7 \mathrm{~mm}$. long, the lateral nerves barely if at all excurrent, the midnerve shortly so ; palet with the ciliolate nerves gibbous below the middle. [Triodia Texana Thurb.]

On hills and in valleys, Louisiana to Arizona and northern Mexico. Summer.

3. Tridens ambíguus (Ell.) Schult. Stems $5-9 \mathrm{dm}$. tall, smooth : leaf-sheaths smooth and glabrous; blades $0.5-3 \mathrm{dm}$. long, 1-3 mm. wide : panicle loose and open, $8-20 \mathrm{~cm}$. long, its branches ascending, the larger 4-10 cm. long : spikelets loosely arranged, 7-9-flowered, about $5 \mathrm{~mm}$. long, 2.5-3 mm. wide, oval; empty scales rather broad, acute, 1-nerved; flowering seales $3-3.5 \mathrm{~mm}$. long, oval and about $2 \mathrm{~mm}$. broad when spread out, their nerve-hairs about $0.7 \mathrm{~mm}$. long, the lateral nerves slightly excurrent, and the midnerve in an awn about $0.3 \mathrm{~mm}$. long; palet ciliolate on the nerves, the internerve broadly ovateoval, the rounded apex decidedly apiculate. [Triodia ambigua (Ell.) Vasey.]

In dry pine lands, South Carolina to Florida. Summer and fall,

4. Tridens Langloìsii Nash. Stems $5-15 \mathrm{dm}$. tall, smooth : leaf-sheaths glabrous, or pilose at the summit ; blades minutely pubescent above, the basal $2-4 \mathrm{dm}$. long, $2.5-5 \mathrm{~mm}$. wide, those on the stem shorter and narrower : panicle narrow, 1-2 dm. long, about $2 \mathrm{~cm}$. broad, its branches erect or nearly so, the larger $6-10 \mathrm{~cm}$. long : spikelets loosely arranged, 4-6-flowered, 6-7 mm. long, 3-4 mm. wide ; empty scales rather broad, acute, 1-nerved or the second rarely 3 -nerved; flowering scales about $4 \mathrm{~mm}$. long, elliptic and $2.25 \mathrm{~mm}$. wide when spread out, their nerve-hairs about $0.5 \mathrm{~mm}$. long, the apex minutely 2-toothed, the nerves excurrent in short tips; palet ciliate on the nerves, the apex obtuse, the internerve elliptic or elliptic-ovate.

In pine lands, western Florida to Texas. Summer and fall.

5. Tridens seslerioides (Michx.) Nash. Stems tufted, $5-16 \mathrm{dm}$. tall, smooth : stem-leaves 2-6; sheaths smooth, villous at the summit, those at the base crowded, the remainder shorter than the internodes; blades elongated, the basal and lower ones 2-6 dm. long, 5-15 mm. wide, the uppermost one 6-20 $\mathrm{cm}$. long, long-acuminate, smooth ; panicle loose and open, 1.5-4 dm. long, its branches from nearly erect to spreading, drooping at the end, the lower from 7-25 cm. long, the axils more or less villous : spikelets usually numerous, 5-8-flowered, 7-10 mm. long, elliptic to linear-oblong; empty scales rather broad, acute, 1-nerved; flowering scales about $4 \mathrm{~mm}$. long, their nerve-hairs about $0.7 \mathrm{~mm}$. long, the apex 2-toothed between the excurrent nerves. [Triodia cuprea Jacq.]

In dry soil, New York to Illinois, Kansas, Florida and Texas. Summer and fall.- T. seslerioides Chapmanii (Small) Nash, differs from the species in its smaller panicle with more rigid branches and more densely villous axils, and in the more acute teeth of the flowering scale. It occurs in Georgia, and from Texas to Oklahoma and the Indian Territory. RED-TOP. 
6. Tridens Drummóndii (Scribn. \& Kearn.) Nash. Stems 8-12 dm. tall from a scaly rootstock, smooth : basal leaf-sheaths erowded, villous, the upper ones glabrous or nearly so; blades of the basal leaves elongated, $2-4 \mathrm{dm}$. long, about $5 \mathrm{~mm}$. wide; blade of the uppermost stem-leaf $3 \mathrm{~cm}$. long or less : panicle narrow, spike-like, $1.5-2 \mathrm{dm}$. long, its branches short and appressed : spikelets rather loosely arranged, 3-5-flowered, 8-10 $\mathrm{mm}$. long; empty scales broad, 1-nerved, short-awned at the shortly 2-toothed apex; flowering scales firm, $5-6 \mathrm{~mm}$. long, elliptic-ovate when spread out, their nerve-hairs about $0.8 \mathrm{~mm}$. long, the apex 2-lobed, the nerves excurrent as projections. [Triodia Drummondii Scribn. \& Kearn.]

In dry soil or in low pine lands, South Carolina to Mississippi and Florida. Fall.

7. Tridens stríctus (Nutt.) Nash. Stems $5-15 \mathrm{dm}$. tall, smooth : leaf-sheaths smooth ; blades erect or ascending, $4 \mathrm{dm}$. long or less, $2-7 \mathrm{~mm}$. wide, long-acuminate, smooth except on the margins : panicle narrow, spike-like, $1.5-3 \mathrm{dm}$. long, $1-1.5 \mathrm{~cm}$. broad, its branches short and appressed : spikelets crowded, 6-10-flowered, 5-6 mm. long; empty scales narrow, 1-nerved, acuminate, usually exceeding the flowering scales; flowering scales 3.5-4 mm. long, $1.5 \mathrm{~mm}$. broad and elliptic when spread out, their nerve-hairs about $0.8 \mathrm{~mm}$. long, the lateral nerves usually slightly excurrent, the midnerve extended into a short awn 0.25-0.5 mm. long. [Tirodia stricta (Nutt.) Vasey.]

In moist soil and meadows, Kansas to Mississippi and Texas. Summer and fall.

8. Tridens congéstus (L. H. Dewey) Nash. Stems tufted, 1-7 dm. tall, smooth : leaf-sheaths shorter than the internodes, smooth; blades ascending, 5-20 cm. long, 2-5 $\mathrm{mm}$. wide, long-acuminate, smooth beneath, roughish above : panicle dense, $3-8 \mathrm{~cm}$. long, 1-1.5 cm. broad, its branches short and erect: spikelets nearly sessile, crowded, turgid, 8-15-flowered, 8-12 $\mathrm{mm}$. long, about $4 \mathrm{~mm}$. broad, ovate to oblong; empty scales broad, 1-nerved, acute ; flowering scales about $5 \mathrm{~mm}$. long, orbicular when spread out, their nervehairs about $0.8 \mathrm{~mm}$. long, the midnerve and often also the lateral nerves excurrent in short projections; palet-nerves hispid and saccate at the base. [Triodia congesta L. H. Dewey.]

In dry soil, Texas. Spring to fall.

9. Tridens mùticus (Torr.) Nash. Stems tufted, 2-5 dm. tall, roughened: leafsheaths glabrous or papillose-hirsute; blades erect or ascending, $2-12 \mathrm{~cm}$. long, $3 \mathrm{~mm}$. wide or less, often involute when dry, rough : panicle narrow, 6-15 $\mathrm{cm}$. long, its branches appressed : spikelets 6-9-flowered, 10-12 mm. long, lanceolate ; empty scales 1-nerved ; flowering scales 4-5 mm. long, obscurely and irregularly lobed at the obtuse or rounded apex, the hairs on their margins and midnerve about $1.5 \mathrm{~mm}$. long, the lateral nerves vanishing below the apex, the midnerve also, or the latter continued to the apex, or rarely excurrent as a short projection. [Tricuspis mutica Torr.]

On dry hills, Texas to Arizona and northern Mexico. Spring to fall.

10. Tridens elongàtus (Buckl.) Nash. Stems tufted, $3-9 \mathrm{dm}$. tall, very rough : leafsheaths longer than the internodes, rough ; blades erect or ascending, 4-25 cm. long, $3 \mathrm{~mm}$. broad or less, long-acuminate, rough : panicle narrow, $12-25 \mathrm{~cm}$. long, its branches appressed : spikelets 8-10-flowered, $10-14 \mathrm{~mm}$. long, 3-4 mm. wide, elliptic ; first empty scale 1-nerved, the second 3-5-nerved ; flowering scales 5-6 mm. long, the apex obtuse or minutely 2-toothed, their hairs on the margins and midnerve about $1 \mathrm{~mm}$. long, the lateral nerves vanishing below the apex, the midnerve excurrent as a short projection.

On plains or prairies, Colorado to Texas and Arizona. Summer and fall.

11. Tridens Buckleyànus (Vasey) Nash. Stems 6-8 dm. tall, very rough, as are the sheaths: leaf-blades $0.5-2 \mathrm{dm}$. long, $1-2.5 \mathrm{~mm}$. wide, involute when dry, rough on both surfaces : panicle narrow, slender, 1.5 -2.5 dm. long, its main axis and appressed branches rough, the larger ones $3-5 \mathrm{~cm}$. long : spikelets loosely disposed, 3-5-flowered, 5-8 $\mathrm{mm}$. long, 1.5-2 $\mathrm{mm}$. wide, narrowly elliptic; empty scales narrow, acuminate, the first 1-nerved, the second 3-nerved; flowering scales about $5 \mathrm{~mm}$. long, elliptic and about $2 \mathrm{~mm}$. wide when spread out, the apex minutely 2 -toothed, the midnerve sometimes excurrent in a short tip between the teeth, the lateral nerves vanishing just below the apex, the hairs on the margins and midnerve scanty, about $0.4 \mathrm{~mm}$. long. [Triodia Buckleyana Vasey.]

In dry soil, southern Texas. Summer and fall.

\section{ERIONEÙRON Nash.}

Perennial tufted grasses, with thick linear leaf-blades having thickened white margins, and dense contracted almost capitate panicles. Spikelets several-many-flowered: empty basal scales 2, narrow, acuminate : flowering scales broad, 3-nerved, pubescent on the nerves below, and sometimes also on the body of the scale at the base, with long silky 
white hairs, the apex acuminate, entire or slightly 2-toothed, the awn terminal or arising between the minute teeth. Stamens 3. Styles short, distinct.

1. Erioneuron pilòsum (Buckl.) Nash. Stems densely tufted, 0.4-3 dm. tall, naked above: leaf-sheaths sparingly pilose at the summit; blades erect, folded, linear, obtuse or abruptly acutish at the apex, thick, with broad white serrulate margins, papillose-hirsute, especially beneath, the basal numerous, $2-8 \mathrm{~cm}$. long, those on the stem usually $3 \mathrm{~cm}$. long or less : panicle racemose or nearly so, $1-3 \mathrm{~cm}$. long: spikelets $3-8$, crowded, 1-1.5 em. long, about $5 \mathrm{~mm}$. broad, the empty scales acuminate, 1-nerved, the flowering scales, exclusive of the awn, 5.5-6 mm. long, acuminate, entire or slightly toothed at the apex, the internerves pilose at the base, the nerves pilose on the lower $\frac{1}{3}$ and the midnerve also above the middle, the longer hairs about $2 \mathrm{~mm}$. long, the awn 1-1.5 $\mathrm{mm}$. long.

In dry gravelly soil, Kansas and Colorado to Texas and Arizona. Summer.

\section{TRIPIÀSIS Beauv.}

Perennial grasses, with very narrow flat or convolute leaf-blades and terminal contracted or open somewhat branched panicles. Spikelets shortly pedicellate, 2-6-flowered, the flowers perfect or the upper staminate, the glabrous rachilla articulated between the flowers, the internodes long. Scales 4-8, membranous, the 2 lower empty, keeled, acute shorter than the rest, the flowering scales distant on the rachilla, dorsally rounded at the base, 3-nerved, the lateral nerves pilose, deeply 2-lobed at the apex, the lobes obtuse, acute or acuminate, each with a glabrous or pubescent awn arising between the lobes, the callus long and subulate; palet shorter than the scale, compressed, 2-keeled, the keels long-ciliate.

Stamens 3. Styles short, distinct. Stigmas plumose.

Flowering scale $1 / 3$ as broad as long or more, with a shorter straight awn $3 \mathrm{~mm}$. long or less.

Lobes of the flowering scale rounded or truncate at the irregularly and minutely toothed apex; awn less than $2 \mathrm{~mm}$. long.

Lobes of the flowering scale acute or acutish at the apex; awn $2.5-3 \mathrm{~mm}$. long. Flowering scale $1 / 5$ as broad as long, its lobes acuminate, pointed, the awn longer than the scale, $6 \mathrm{~mm}$. in length or more, recurved, at least when dry.

1. T. purpurea. 2. T. intermedia.

3. T. Americana.

1. Triplasis purpùrea (Walt.) Chapm. Stems tufted, $2-8 \mathrm{dm}$. tall : leaf-sheaths rough; blades $15 \mathrm{~cm}$. long or less, $1-3 \mathrm{~mm}$. wide, rough : panicle finally exserted, its branches in 1's or 2's, $4 \mathrm{~cm}$. Iong or less : spikelets on short hispidulous pedicels : scales 4 or 5 ; the 2 outer empty, acuminate; flowering seales about $4 \mathrm{~mm}$. long, $1.75 \mathrm{~mm}$. wide when spread out, divided about $\frac{1}{4}$ way down, the lobes rounded or truncate at the irregularly and minutely toothed apex, the awn equalling or a little exceeding the lobes, pilose on the lower half, less than $2 \mathrm{~mm}$. long, straight. [T. sparsiflora Chapm.]

In sandy soil, usually along the coast, Ontario to Florida and Texas. Also along the Great Lakes and from Missouri and Nebraska southward. Summer. SAND GRAss.

2. Triplasis intermédia Nash. Stems densely tufted, 4-8 dm. tall, slender: leafsheaths very rough, papillose-hirsute toward the base with long ascending hairs; blades $13 \mathrm{~cm}$. long or less, involute when dry, rough, hirsute above : panicle finally exserted, its branches in 1's-3's, pubescent at the base, rough, the larger ones $2-4 \mathrm{~cm}$. long: spikelets on short pubescent pedicels, $8-10 \mathrm{~mm}$. long; scales 5 or 6 ; the 2 outer empty, acuminate ; flowering scales $4.5 \mathrm{~mm}$. Iong and $1.5 \mathrm{~mm}$. wide when spread out, divided from $\frac{1}{4}-\frac{1}{2}$ their length, the lobes acute to somewhat obtuse, the awn 2.5-3 mm. long, straight, much exceeding the scale.

In dry sandy soil, southern peninsular Florida. Summer.

3. Triplasis Americàna Beauv. Stems tufted, $3-8 \mathrm{dm}$. tall, slender, puberulent: leaf-sheaths smooth; blades $15 \mathrm{~cm}$. long or less, less than $2 \mathrm{~mm}$. wide, smooth, the upper surface minutely pubescent : panicle finally exserted, its branches single or in pairs, $3 \mathrm{~cm}$. long or less : spikelets on short hispidulous pedicels; scales 4 or 5 ; the 2 outer empty, acuminate; flowering scales about $5 \mathrm{~mm}$. long and $1 \mathrm{~mm}$. broad when spread out, divided to the middle, the lobes subulate, acuminate, pointed, the awn much exceeding the scale, usually reflexed, at least when dry, pilose for about $\frac{2}{3}$ its length, 6-8 $\mathrm{mm}$. long.

In dry sandy soil along the coast, North Carolina to Florida and Texas. Summer.

100. REDFIÈLDIA Vasey.

Tall perennial grasses, with long narrow leaf-blades and a terminal ample diffuse panicle, its branches long and capillary. Spikelets numerous, 1-3-flowered, the flowers perfect. Scales 3-5, acute, the 2 outer empty, about equal in length, the remaining scales compressed-keeled, larger, each furnished with a basal ring of hairs, 3-nerved, the middle 
nerve often excurrent as a short tip ; palet shorter than the scale, 2-nerved. Stamens 3. Styles long, distinct. Stigmas short, plumose.

1. Redfieldia flexuòsa (Thurb.) Vasey. Stems $1 \mathrm{~m}$. tall or less, from a stout rootstock : leaf-blades elongated, 2-6 dm. long, 2-4 mm. wide, smooth : panicle loose and open, 1.5-5 $\mathrm{dm}$. long, its branches spreading or ascending, the larger 7-15 $\mathrm{cm}$. long, their divisions spreading and more or less flexuous : spikelets $5-6 \mathrm{~mm}$. long, on slender spreading pedicels ; scales 4-7; the 2 outer empty, acuminate; flowering scales 5-6 $\mathrm{mm}$. long, acuminate, the callus densely pilose with long hairs.

On prairies, Nebraska and Wyoming to the Indian Territory and Colorado. Summer and fall.

\section{DIPLÁCHNE Beauv.}

Tufted often tall grasses, with narrow flat leaf-blades and an inflorescence usually composed of numerous long slender spikes or racemes (rarely reduced to one and terminal), racemosely arranged on a long axis. Spikelets linear, sessile or nearly so, often scattered along and appressed to the rachis, many-flowered, the flowers perfect or the upper ones staminate. Scales many, membranous, the 2 lower empty, persistent, keeled, acute, unequal, the remaining scales larger, the apex often 2-toothed and mucronate or short-awned between the teeth; palet shorter than the scale, hyaline, 2-nerved or 2-keeled. Stamens 3. Styles distinct. Stigmas plumose.

Inflorescence of a single raceme.
Inflorescence of 5-many racemes.

1. D. spicata.

Flowering scales entire or shortly and acutely 2-toothed at the apex, usually awned or awn-tipped.

Palet pilose on the infolded margins.

A wn less than $1 / 3$ as long as the body of the flowering scale.

Spikelets 4-8 $\mathrm{mm}$. long, the flowering scales acute or obtuse at the 2toothed apex, the lateral nerves often excurrent.

Spikelets 10-12 mm. long, the flowering scales acuminate at the usually entire apex, the lateral nerves rarely excurrent.

A wn $1 / 2$ as long as the body of the flowering scale or more.

Palet not pilose on the infolded margins.

Flowering scales usually awnless, 2-toothed at the apex, the teeth broad and rounded.

2. D. fascicularis.

3. D. acuminata.

4. D. procumbens.

5. D. Halei.

6. D. dubia.

1. Diplachne spicàta Doell. Stems densely tufted, 1-2 dm. tall, naked above, twice as long as the innovations or more: leaf-sheaths short, more or less pilose at the apex ; blades erect, sparingly pilose, $0.5 \mathrm{~mm}$. wide, involute, those on the stem $3 \mathrm{~cm}$. long or less, those on the innovations longer: inflorescence of • a single raceme, 4-10 cm. long: spikelets 7-8 $\mathrm{mm}$. long; scales 8-10, the lower empty ones rather narrow, the flowering scales, exclusive of the awn, about $3 \mathrm{~mm}$. long, the nerves glabrous, the lateral ones vanishing below the apex, the midnerve excurrent in an awn $0.75-1.5 \mathrm{~mm}$. long, the apex 2-toothed, a tuft of long hairs on the rachilla at the base of the palet.

Among rocks, central Texas to Mexico. Summer and fall.

2. Diplachne fasciculàris (Lam.) Beauv. Stems tufted, finally branched, $3-8 \mathrm{dm}$. tall, somewhat exceeding the innovations to twice their length : lower leaf-sheaths often rough; blades erect, 1-2 dm. long, $3 \mathrm{~mm}$. wide or less : involute when dry, rough, the uppermost one often equalling or exceeding the inflorescence : inflorescence usually partially included at the base, its 8 or more racemes erect or erect-ascending, the larger ones 4-8 cm. long: spikelets $6-8 \mathrm{~mm}$. long; scales $10-12$, the lower empty ones acute, the flowering scales, exclusive of the awn, 3-4 mm. long, the apex commonly 2-toothed, the nerves pilose below the middle, the lateral nerves usually slightly excurrent, the midnerve extending into an awn $1 \mathrm{~mm}$. long or less.

Along the coast, Florida to Texas, and in the Mississippi Valley to Missouri. Summer and fall.

3. Diplachne acuminàta Nash. Stems tufted, 3-6 dm. tall, finally branched : leafsheaths rough at the summit ; blades erect, 1-3 dm. long, $4.5 \mathrm{~mm}$. wide or less, usually involute when dry, very rough, uppermost one generally exceeding the inflorescence : inflorescence partly included at the base, the exserted portion $2.5 \mathrm{dm}$. long or less, its branches and the main axis rough, the former erect or ascending, the larger $0.7-1.5 \mathrm{dm}$. long: spikelets 10-12 mm. long; scales 8-11, the lower empty ones acuminate, the flowering scales 6-7 mm. long, acuminate at the entire or occasionally slightly 2-toothed apex, the lateral nerves rarely slightly excurrent, the midnerve extending into an awn $0.75-1.3$ $\mathrm{mm}$. long, the lateral nerves pilose below the middle, the midnerve rarely slightly so at the base.

In wet or moist soil, Nebraska and Colorado to Arkansas. Summer.

4. Diplachne procúmbens (Muhl.) Nash. Stems tufted, finally branched, 2-4 dm. tall : leaf-sheaths smooth ; blades erect, $8-20 \mathrm{~cm}$. long, $4 \mathrm{~mm}$. wide or less, involute when 
dry, the uppermost one much exceeding the inflorescence: inflorescence included at the base, the exserted portion $12 \mathrm{~cm}$. long or less, its branches erect, the larger $5-7 \mathrm{~cm}$. long: spikelets about $1 \mathrm{~cm}$. long; scales $8-10$, the lower empty ones acuminate, usually awned or awn-pointed, the flowering scales, exclusive of the awn, $4.5-5 \mathrm{~mm}$. long, acuminate at the 2-toothed apex, the nerves pilose below the middle, the lateral ones usually slightly excurrent, the awn $\frac{1}{2}$ as long as the scale-body or more. [Leptochloa polystachya Chapm.]

In brackish marshes, New York to South Carolina. Summer and fall.

5. Diplachne Hàlei Nash. Stems 6-10 dm. tall, finally branched: leaf-sheaths smooth ; blades erect or ascending, 1.5-4 dm. long, 6-12 mm. wide, flat, very rough : inflorescence finally exserted, 2-3 dm. long, 4-10 $\mathrm{cm}$. wide, its numerous branches ascending, 4-7 cm. long: spikelets 4-6 mm. long, about $2 \mathrm{~mm}$. wide; scales $7-10$, the lower empty ones rough, the first scale acute, the second obtuse, the flowering scales about $3 \mathrm{~mm}$. long, slightly and usually obtusely 2 -toothed at the obtuse apex, the lateral nerves pilose toward the base, not excurrent, the midnerve glabrous or pilose toward the base, excurrent in an awn $0.2 \mathrm{~mm}$. long or less.

In marshes, Louisiana to Texas. Summer and fall.

6. Diplachne dùbia (H.B.K.) Benth. Stems tufted, 3-10 dm. tall, simple : leafsheaths smooth ; blades erect, smooth or rough, $2-8 \mathrm{~mm}$. wide, the uppermost one $1.5-8$ cm. long, the lower $1.5-4 \mathrm{dm}$. long: inflorescence usually finally exserted, 1-2 dm. long, the 5-20 racemes erect to spreading, the larger 5-11 $\mathrm{cm}$. long: spikelets $5-9 \mathrm{~mm}$. Iong ; scales $5-10$, the lower empty ones acuminate, the flowering scales about $4.5 \mathrm{~mm}$. long, oblong, rough at the 2 -lobed apex, the lobes rounded at the summit, the nerves glabrous, the lateral ones vanishing considerably below the apex of the lobes, the midnerve at the cleft or rarely extending into a short awn, the nargins of the scale pilose below the middle.

In woods and rocky places, Florida to Texas, Arizona and Mexien, summer and fall.

\section{RHOMBÓLYTRUM Link.}

Perennial grasses, with usually flat leaf-blades and a narrow contracted spike-like panicle. Spikelets numerous, several-flowered. Scales several ; 2 lower empty, 1-nerved ; flowering scales broad, rounded at the summit, 3-nerved, the nerves glabrous, the lateral ones disappearing below the margin, the midnerve at the margin or sometimes excurren as a short projection. Stamens 3 . Styles short, distinet. Stigmas plumose.

1. Rhombolytrum albéscens (Munro) Nash. Stems $2.6 \mathrm{dm}$. tall : leaf-sheaths shorter than the internodes; blades ascending, 0.5-2 dm. long, 2-5 mm. wide, smooth : panicle contracted, spike-like, $6-15 \mathrm{~cm}$. long, $8-15 \mathrm{~mm}$. broad, its branches short and appressed : spikelets $4.5-5 \mathrm{~mm}$. long, about $2.5 \mathrm{~mm}$. wide, oval; scales $8-10$, the 2 outer empty ones rather broad, 1-nerved, the flowering scales about $3 \mathrm{~mm}$. long, nearly orbicular when spread out, rounded at the erose and sometimes acuminately 2-toothed apex, 3nerved, the nerves glabrous, the lateral ones vanishing below the margin, the midnerve at the margin or sometimes excurrent as a short projection.

In dry gravelly soil, Texas to Arizona. Summer.

\section{ERAGRóstrs Beauv.}

Low or tall annual or perennial tufted rarely dioecious grasses, the stems sometimes prostrate or creeping, with flat or convolute leaf-blades and open or contracted panicles. Spikelets numerous, arranged singly or in fascieles, 2-many-flowered, the flowers perfect or unisexual. Scales 4-many, membranous, compressed, keeled, the 2 lower empty, unequal, the remaining scales larger, 3-nerved, obtuse or acute at the apex; palet shorter than the scale, prominently 2 -nerved or 2 -keeled, often incurved and persistent on the rachilla after the fall of the scale. Stamens 2 or 3 . Styles distinct, short. Stigmas plumose.

A. Stems not creeping: flowers perfect.

a. Palet of the spikelets glabrous on the keels or merely hispidulous.

* Annuals.

Spikelets 2-5-flowered.

Pedicels and branches of the panicle short: stems usually branched above.

Pedicels and branches of the diffuse panicle long and capillary : stems branched only at the base.

Stems slender, rarely equalling $5 \mathrm{dm}$. in height : leaf-blades usually $1.5 \mathrm{dm}$. long or less.

Stems stout, 8-12 dm. tall : leaf-blades elongated, 4-6 dm. long.

Spikelets more than 5-flowered.

Panicle narrow, elongated, 2.5-5 dm. long, its branches erect or nearly so: spikelets crowded.

1. E. Frankii.

2. E. capillaris.

3. E. hirsuta.

4. E. glomerata. 
Panicle open, usually less than $2.5 \mathrm{dm}$. long, its branches spreading or ascending: spikelets not crowded.

Spikelets $1.5 \mathrm{~mm}$. wide or less : palets remaining attached to the continuous rachis for some time after the flowering scales have fallen.

Flowering scales thin, usually bright purplish, the lateral nerves faint or wanting: spikelets about $1 \mathrm{~mm}$. wide.

Flowering scales firm, usually dull purple or green, the lateral nerves very prominent: spikelets about $1.5 \mathrm{~mm}$. wide.

Spikelets more than $2 \mathrm{~mm}$. wide: palets falling with the flowering ** Perennials. scales and the internodes of the rachis.

5. E. pilosa.

6. E. Purshii.

7. E. major.

Spikelets scattered on long branches.

Branches of the open panicle spreading or ascending, rather stiff.

Lateral nerves of the flowering scales faint.

Lateral nerves of the flowering scale very prominent.

Spikelets short-pedicelled, the pedicel $1 \mathrm{~mm}$. long or less.

Spikelets on pedicels which are often as long as or much exceeding the spikelet.

Pedicels usually less than twice as long as the spikelet. Margins of the flowering scales convex above the middle, the scales hence merely acute.

Margins of the flowering scales straight or concave above the middle, the scales hence acuminate.

Pedicels many times longer than the spikelets.

Branches of the narrow and elongated panicle long and flexuous, erect or nearly so.

Spikelets crowded and clustered on short branches :

Linear-lanceolate, $2 \mathrm{~mm}$. wide or less.

Oblong to oval, exceeding $3 \mathrm{~mm}$. in width.

Flowering scales $3-4 \mathrm{~mm}$. long, acute, firm.

Flowering scales $5 \mathrm{~mm}$. long, acuminate, thin and papery.

b. Palets of the spikelets beautifully and conspicuously ciliate with long hairs.

Panicle contracted, spike-like, the branches short and appressed.

Panicle open, its branches spreading.

B. Stems creeping, rooting at the nodes.

Flowering scales less than $2 \mathrm{~mm}$. long, glabrous.

Flowering scales $3-4 \mathrm{~mm}$. long, pubescent.

8. E. lugens

9. E. curtipediccllata.

10. E. pectinacea.

11. E. refracta.

12. E. Elliottii.

13. E. trichodes.

14. E. simplex.

15. E. secundiflora. 16. E. Beyrichii.

17. E. ciliaris.

18. E. plumosa.

19. E. hypnoides.

20. E. capitata.

1 Eragrostis Fránkii Steud. Stems 1.5-4 dm. tall, tufted, erect, often decumbent at the base, branching: leaf-blades $5-13 \mathrm{~cm}$. long, $2-4 \mathrm{~mm}$. wide, rough above : panicle $5-15$ $\mathrm{cm}$. long, open, its branches ascending: spikelets ovate, $2-3 \mathrm{~mm}$. long, $3-5$-flowered, the flowering scales acute, the lower ones $1.5 \mathrm{~mm}$. long, their lateral nerves obscure.

In moist places, Connecticut to Minnesota, Mississippi, Louisiana and Kansas. Fall.

2. Eragrostis captllàris (L.) Nees. Stems $2-5 \mathrm{dm}$. tall, slender, erect, finally branching at the base : leaf-blades $7-25 \mathrm{~cm}$. long, 2-4 mm. wide: panicle diffuse, 1-4 dm. long, its capillary branches spreading or ascending: spikelets ovate, $2-3 \mathrm{~mm}$. long, 2-4flowered, the flowering scales acute, $1.5 \mathrm{~mm}$. long, their lateral nerves obscure.

In dry places, Rhode Island and New York to Missouri, Georgia and Texas. Summer and fall.

3. Eragrostis hirsùta (Michx.) Nash. Stems densely tufted, rather stout, 7-13 dm. tall : leaf-sheaths, at least the lower ones, strongly papillose-hispid, each with a tuft of hairs at the apex ; blades, the lower leaves, 4-6 dm. long, less than $1 \mathrm{~cm}$. wide, long-acuminate, flat : panicle 5-8 dm. long, diffuse, its long branches finally widely spreading: spikelets $3-5$-flowered, $3-4 \mathrm{~mm}$. long, the flowering scales $2-2.5 \mathrm{~mm}$. long.

In dry fields, thickets and woodlands, South Carolina to Florida, the Indian Territory and Texas. Summer and fall.

4. Eragrostis glomeràta (Walt.) L. H. Dewey. Stems erect, rather stout, 2.5-8 $\mathrm{dm}$. tall : leaf-sheaths glabrous ; blades rough, $2 \mathrm{dm}$. long or less, less than $1 \mathrm{~cm}$. wide, long-acuminate: panicle narrow, contracted, $1-5 \mathrm{dm}$. long, its branches erect or nearly so : spikelets 5-10-flowered, $2.5-3.5 \mathrm{~mm}$. long, the flowering scales about $1 \mathrm{~mm}$. long. $[E$. conferta Trin.]

In damp or wet places, South Carolina to Florida, Louisiana, Arkansas and Texas. Also in Mexico. Summer and fall.

5. Eragrostis pllòsa (L.) Beauv. Stems tufted, 1.5-5 dm. tall, erect, slender, branched : leaf-blades $2-13 \mathrm{~cm}$. long, $2 \mathrm{~mm}$. wide or less : panicle $5-15 \mathrm{~cm}$. long, its branches finally spreading, often hairy in the axils : spikelets 5-12-flowered, $3-6 \mathrm{~mm}$. long, about $1 \mathrm{~mm}$. wide, the flowering scales acute, the lower ones $1.5 \mathrm{~mm}$. long, thin, the lateral nerves faint or wanting.

In cultivated ground or waste places, southern New England to Illinois, Kansas, Florida and Texas. Naturalized from Europe. Summer and fall.

6. Eragrostis Púrshii Schrad. Stems 1.5-5 dm. tall, tufted, finally much-branched : leaf-blades 3-9 $\mathrm{cm}$. long, $2 \mathrm{~mm}$. wide or less : panicle 7-20 $\mathrm{cm}$. long, open, its branches spreading, naked in the axils : spikelets 5-15-flowered, $3-8 \mathrm{~mm}$. long, about $1.5 \mathrm{~mm}$. wide, the flowering scales acute, firm, the lower ones $1.5 \mathrm{~mm}$. long, the lateral nerves prominent.

In dry places, throughout the United States and extending into Ontario. Summer and fall. 
7. Eragrostis màjor Host. Ill-scented. Stems $1.5-6 \mathrm{dm}$. tall, at first erect, finally decumbent and much branched : leaf-blades $5-18 \mathrm{~cm}$. long, 2-6 mm. wide, flat: panicle $5-15 \mathrm{~cm}$. long, its branches spreading or ascending: spikelets $8-35$-flowered, $5-16 \mathrm{~mm}$. long and about $3 \mathrm{~mm}$. wide, flat, the flowering scales obtuse, $2-2.5 \mathrm{~mm}$. long, the lateral nerves prominent. [E. megastachya Link.]

In cultivated and waste places, nearly throughout North America. Naturalized from Europe. Summer and fall. SKUNK GRAss.

8. Eragrostis lùgens Nees. Stems tufted, slender, 2-3 dm. tall : leaf-sheaths, at least the lower ones, papillose-hirsute with long spreading hairs ; blades erect, papillosehirsute with long spreading hairs, $3-9 \mathrm{~cm}$. long, 1.5 $3 \mathrm{~mm}$. wide : panicle 1-2 dm. long, its branches long and ascending: spikelets 3-7-flowered, $3.5-4.5 \mathrm{~mm}$. long, $1.3 \mathrm{~mm}$. wide.

In dry soil, southern peninsular Florida. Also in Mexico and South America. Spring and summer.

9. Eragrostis curtipedicellàta Buckl. Stems 1.5-9 dm. tall, erect, rigid : leafsheaths overlapping, pilose at the summit; blades $5-20 \mathrm{~cm}$. long, $2-4 \mathrm{~mm}$. wide, rough above: panicle 1-3 dm. long, the branches widely spreading: spikelets 5-12-flowered, 3-6 mm. long, the flowering scales about $1.75 \mathrm{~mm}$. long, the lateral nerves prominent.

on prairies, Kansas to Texas. Summer and fall.

10. Eragrostis pectinàcea (Michx.) Steud. Stems $3-8 \mathrm{dm}$. tall, rigid : leaf-sheaths overlapping, glabrous or pubescent, the upper one often enclosing the base of the panicle ; blades 1-3 dm. long, 4-8 $\mathrm{mm}$. wide, rough above : panicle $1.5-6 \mathrm{dm}$. long, purple or purplish, its branches widely spreading or the lower ones reflexed, strongly bearded in the axils : spikelets $5-15$-flowered, $3-8 \mathrm{~mm}$. long, the flowering scales about $1.75 \mathrm{~mm}$. long, their lateral nerves very prominent.

In dry usually sterile soil, New Hampshire to South Dakota, Florida and Texas. Summer and fall.

11. Eragrostís refrácta (Muhl.) Scribn. Stems 3-9 dm. tall, slender : leaf-sheaths overlapping, glabrous ; blades 1-3 dm. long, $2-4 \mathrm{~mm}$. wide, rough above and villous toward the base : panicle 2-5 dm. long, its slender branches finally widely spreading, the axils often bearded: spikelets 6-25-flowered, 5-12 mm. long, the flowering scales acuminite, 1.5-2 $\mathrm{mm}$. long, the lateral nerves prominent. [E. campestris Trin.]

In moist soil, Delaware and Maryland to:Florida and Texas. Summer and fall.

12. Eragrostls Ellióttii S. Wats. Stems tufted, firm, erect, 4-10 dm. tall : leafsheaths glabrous; blades $4 \mathrm{dm}$. long or less, 3-5 mm. wide, smooth beneath, rough above, long-acuminate: panicle diffuse, $2-5 \mathrm{dm}$. long, its long slender branches finally widely spreading or ascending: spikelets $6-13$-flowered, $5-10 \mathrm{~mm}$. long, the flowering scales 1.75-2 mm. long, the lateral nerves prominent. [E. nitida Ell.]

In dry soil, South Carolina to Florida and Louisiana. Fall.

13. Eragrostis trichòdes (Nutt.) Nash. Stems $6-12 \mathrm{dm}$. tall : leaf-sheaths overlapping, pilose at the throat; blades $1.5-7 \mathrm{dm}$. long, $2-4 \mathrm{~mm}$. wide, attenuate into long slender tips : panicle $2-7 \mathrm{dm}$. long, narrow and elongated, the branches capillary, the lower axils sometimes bearded : spikelets usually pale, or sometimes purple-tinged, 3-10-flowered, $5-9 \mathrm{~mm}$. long, the flowering scales acute, the lower ones $2.5-3 \mathrm{~mm}$. long, their lateral nerves manifest.

In dry sandy soil, Ohio and Illinois to Nebraska, Arkansas and Texas. Summer and fall:

14. Eragrostis símplex Scribn. Stems densely tufted, ascending, $2-5 \mathrm{dm}$. tall, rather stiff : leaf-sheaths and blades usually sparsely pubescent, the latter erect or ascending, 7-10 cm. long and 2-4 mm. wide: panicle 1-2 dm. long, its branches stiff and widely spreading, usually $2-4 \mathrm{~cm}$. long: spikelets $12-40$-flowered, $5-17 \mathrm{~mm}$. long, 1.6-2 mm. wide. [E. Brownei Chapm., not Nees.]

In waste places and in ditches, Florida. Summer and fall.

15. Eragrostis secundiflòra Presl. Stems tufted, 1-9 dm. tall : leaf-blades $3 \mathrm{dm}$. long or less, $2-4 \mathrm{~mm}$. wide : panicle $4-15 \mathrm{~cm}$. long, its branches short and erect : spikelets crowded and clustered, 12-20-flowered, 6-14 mm. long, 3-4 mm. wide. [E. oxylepis Torr.]

In sandy soil, Missouri and Kansas to Mississippi and Texas. Also in Mexico. Summer and fall.

16. Eragrostis Beyríchii J. G. Smith. Stems tufted, 1-5 dm. tall : leaf-blades $2 \mathrm{dm}$. long or less, 1-2 mm. wide, involute when dry: panicle $3-20 \mathrm{~cm}$. long, its branches short and erect: spikelets crowded and clustered, 12-42-flowered, usually 1-2 cm. long and about $5 \mathrm{~mm}$. wide, the flowering scales about $4 \mathrm{~mm}$. long, acuminate, in side view cuneate.

In sandy places, Texas. Also in Mexico. Summer.

17. Eragrostis ciliàris (L.) Link. Annual. Stems densely tufted, erect or ascending, slender, $1.5-4 \mathrm{dm}$. tall, often branching : leaf-sheaths usually ciliate on the margin and with a tuft of long hairs at the apex ; blades flat, ascending, $2-8 \mathrm{~cm}$. long, 2-4 mm. wide : panicle spike-like, often interrupted below, $3-10 \mathrm{~cm}$. long, its branches short and 
appressed : spikelets $6-16$-flowered, the nerves of the palet long-ciliate, the hairs exceeding $0.5 \mathrm{~mm}$. in length.

In waste places and cultivated ground, Georgia and Florida to Mississippi. Widely distributed in tronical America. Summer and fall.

18. Eragrostis plumòsa Link. Annual. Stems densely tufted, ascending, slender, 1-4 dm. tall : leaf-sheaths usually ciliate on the margin and with a tuft of hairs at the apex ; blades flat, spreading or ascending, 2-10 $\mathrm{cm}$. long, 2-4 mm. wide: panicle open, usually diffuse, oblong, 4-16 cm. long, its branches spreading or ascending: spikelets 4-8-flowered, the nerves of the palet ciliate with hairs about $0.2 \mathrm{~mm}$. long.

In cultivated ground and waste places, southern Georgia and Florida. Widely distributed in tropical regions. Spring to fall.

19. Eragrostis hypnoìdes (Lam.) B.S.P. Stems $2-5 \mathrm{dm}$. long, slender, creeping and rooting at the nodes, branched : leaf-blades pubescent above, sometimes also below, erect to spreading, commonly $1-4 \mathrm{~cm}$. long, 1-2 mm. wide, flat, or sometimes involute : panicle 1.5-5 cm. long: spikelets 10-35-flowered, 4-16 mm. long, the flowering scales 1.5-2 mm. long, glabrous, those of the pistillate spikelets more sharply acute than those of the staminate. [E. reptans Nees.]

Along shores, usually in sand or gravel, Vermont and Ontario to Oregon, Florida and Texas. Also in tropical America. Summer and fall.

20. Eragrostis capitàta (Nutt.) Nash. Stems branching and creeping, rooting at the nodes which send up branches $6-10 \mathrm{~cm}$. long: leaf-sheaths, at least those on the branches, pubescent : blades spreading or ascending, 1-3 cm. long, 1.5-3 mm. wide, flat, lanceolate, pubescent : panicle $2-3 \mathrm{~cm}$. long, nearly or quite as broad, oval : spikelets crowded, clustered, 12-30-flowered, 6-14 mm. long. [Poa capitata Nutt.]

In sandy, usually wet soil, Arkansas and Louisiana to Nebraska, New Mexico and Texas. Also in Mexico. Summer.

\section{EATÒNIA Raf.}

Tufted perennial grasses, with flat or convolute leaf-blades and usually narrow and contracted, or sometimes open panicles. Spikelets numerous, 2-3-flowered, shining. Soales 4 or 5 , membranous, the 2 outer empty, the first very narrow, 1 -nerved, acuminate, the second much broader, obovate when spread out, obtuse, truncate, and sometimes apiculate at the apex, 3-nerved, the remaining scales narrower, obtuse or somewhat acute; palet narrow, 2-nerved. Stamens 3. Styles distinct, short. Stigmas plumose.

Empty scales usually unequal, the first commonly shorter and not more than $1 / 5$

as wide as the second.

Second scale obovate in side view, rounded at the summit.

Leaf-sheaths, blades and stems glabrous.

Leaf-sheaths, and often the blades and stems softly pubescent.

Second scale oblanceolate in side view, acute or acutish at the apex.

Basal leaf-blades long, slender, involute, at least when dry, usually equalling or sometimes exceeding the stems.

Basal leaf-blades short, broad, flat, many times shorter than the stems. Spikelets $3-3.5 \mathrm{~mm}$. long. Spikelets $4-5 \mathrm{~mm}$. long.

Empty scales usually equal, the first at least $1 / 3$ as broad as the second.

Leaf-sheaths and blades softly pubescent.

Leaf-sheaths and blades glabrous.

1. E. obtusata.

2. E. pubescens.

3. E. filiformis.

4. E. Pennsylvanica.

5. E. longiflora.

6. E. nitida.

7. E. glabra.

1. Eatonia obtusàta (Michx.) A. Gray. Stems 3-8 dm. tall, often stout : leafsheaths and blades usually rough, the latter flat, $2.5-23 \mathrm{~cm}$. long, 1-5 mm. wide, rarely wider : panicle $5-15 \mathrm{~cm}$. long, dense and usually spike-like, strict, sometimes purple, its branches erect : spikelets crowded, $2.5-3 \mathrm{~mm}$. long.

In dry soil, Massachusetts and Ontario to Assiniboia, Florida and Arizona. Summer.

2. Eatonia pubéscens Scribn. \& Mer. A tufted perennial, with the leaf-sheaths, back of the ligule and lower part of the stem softly and densely pubescent. Stems 3-8 dm. tall : leaf-blades 5-18 cm. long, 3-6 mm. wide, glabrous, or often softly pubescent : panicle $5-20 \mathrm{~cm}$. long : spikelets $2.5-3.5 \mathrm{~mm}$. long.

In dry soil, Pennsylvania to Georgia and Texas. Spring and summer.

3. Eatonia filifórmis (Chapm.) Vasey. Stems densely tufted, slender, 2.5-8 dm. tall : leaf-blades narrow, slender, involute, at least when dry, the stem-blades 2, usually less than $6 \mathrm{~cm}$. long : panicle $6-12 \mathrm{~cm}$. long, slender, often nodding at the apex : spikelets $3.5-4 \mathrm{~mm}$. long.

In dry soil, South Carolina and Tennessee to Florida and Texas. Spring.

4. Eatonia Pennsylvánica (DC.) A. Gray. Stems 3-9 dm. tall : leaf-blades 6-18 cm. long, $2-6 \mathrm{~mm}$. wide, rough : panicle $7-18 \mathrm{~cm}$. long, often nodding at the summit, lax : spikelets $3-3.5 \mathrm{~mm}$. long, the flowering scales narrow, acute.

In hilly woods or moist soil, New Brunswick to British Columbia, Georgia and Texas. Summer. 
5. Eatonia longiflòra (Vasey) Beal. Stems tufted, stout, 6-10 dm. tall : leaf-blades rough, lax, 5-20 $\mathrm{cm}$. long, 4-8 $\mathrm{mm}$. wide : panicle loose, lax, nodding at the apex, 1-2.5 $\mathrm{dm}$. long, its branches long, slender and erect : spikelets $4-5 \mathrm{~mm}$. long.

In dry soil, Louisiana and Texas. Spring.

6. Eatonia nítida (Spreng.) Nash. Stems tufted, slender, 3-6 dm. tall : leafsheaths pubescent; blades $1-8 \mathrm{~cm}$. long, $2 \mathrm{~mm}$. wide or less, usually pubescent: panicle $5-15 \mathrm{~cm}$. long, lax, its branches spreading at flowering time, finally erect: spikelets $3 \mathrm{~mm}$. long. [E. Dudleyi Vasey.]

In dry woods, Connecticut to Ontario, Georgia and Alabama. Spring and summer.

7. Eatonia glàbra Nash. Stems densely tufted, slender, $3-7 \mathrm{dm}$. tall : leaf-sheaths glabrous ; blades rough, flat, $2-7 \mathrm{~cm}$. long, $1.5-3 \mathrm{~mm}$. wide : panicle $7-15 \mathrm{~cm}$. long, slender, nodding at the summit: spikelets $3-4 \mathrm{~mm}$. long.

In woods, southern New York to Tennessee. Spring and summer.

\section{KOELÈRIA Pers.}

Annual or perennial tufted grasses, with narrow flat or involute leaf-blades and usually dense contracted or spike-like cylindric, rarely elongated and interrupted panicles. Spikelets numerous, crowded, 2-5-flowered, the flowers perfect or the upper ones staminate. Scales 4-7, membranous, the 2 lower empty, narrow, unequal, the flowering scales similar to the second, obtuse or acute at the summit, awnless, sometimes mucronate or short-awned at or just below the apex, the upper scales gradually smaller, the upper 1 or 2 often empty ; palet hyaline, 2-keeled, 2-toothed. Stamens 3. Styles very short. Stigmas plumose.

1. Koeleria cristàta (L.) Pers. Stems tufted, erect, rigid, often pubescent just below the panicle, $3-8 \mathrm{dm}$. tall : leaf-sheaths smooth or rough, sometimes pubescent; blades 2-30 cm. long, 1-3 mm. wide, erect, flat or involute, sometimes hirsute : panicle 2-18 cm. long, pale green, shining, usually contracted or spike-like, its branches generally erect: spikelets 2-5-flowered, 4-6 mm. long, the scales acute, the flowering scales 3-4 $\mathrm{mm}$. long.

In dry sandy soil, especially on prairies, Ontario to British Columbia, Pennsylvania, Nebraska. Texas and Arizona. Also in Europe and Asia. Summer and fall.

\section{MÉLICA L.}

Perennial grasses, with flat or convolute leaf-blades and contracted or open panicles which are sometimes almost racemose. Spikelets few-many, erect or nodding, 1-severalflowered, the flowers perfect or the upper ones staminate. Scales 3-several, the 2 lower empty, membranous or hyaline, obtuse or acutish, unequal in length, the flowering scales larger, membranous, the lateral nerves vanishing at the broad hyaline margin, acute or obtuse at the apex, the remaining scales empty, gradually smaller, convolute and involving each other and forming a clavate to obovoid mass ; palet shorter than the scale, 2-keeled. Stamens 3. Styles distinct. Stigmas plumose. Melic Grass.

Second scale much shorter than the 3 -5-flowered spikelet.

Spikelets few : branches of the panicle spreading or ascending.

Spikelets usually numerous : branches of the panicle erect. Second scale nearly equalling the 2 -flowered spikelet.

1. M. diffusa.

2. M. parviflora.

3. M. mutica.

1. Melica diffùsa Pursh. Stems 4-12 dm. tall, erect, tufted : leaf-blades 1-2 dm. long, 4-8 mm. wide, rough : panicle $1.5-2 \mathrm{dm}$. long, open, its branches spreading or ascending : spikelets usually numerous, about 3 -flowered, 9-11 $\mathrm{mm}$. long, nodding, on slender pubescent pedicels, the flowering scales 7-9 mm. long, acute or obtuse, hispidulous.

In rich soil, Pennsylvania to Missouri, Virginia, Kentucky and Texas. Spring and summer.

2. Melica parviflòra (Porter) Scribn. Stems 4-8 dm. tall, erect, rough : leafblades 1-2.5 dm. long, 2-4 mm. wide, rough: panicle 1-2 dm. long, contracted, its branches erect : spikelets few, 4-5-flowered, 10-13 mm. long, nodding, on slender strongly pubescent pedicels, the flowering scales $7-8 \mathrm{~mm}$. long, acutish, hispidulous.

On prairies, Kansas and Colorado to Arizona and Texas. Summer.

3. Melica mùtica Walt. Stems $3-9 \mathrm{dm}$. tall, erect, commonly slender : leaf-sheaths rough; blades $1-2.5 \mathrm{dm}$. long, 2-10 mm. wide, rough : panicle $1-2.5 \mathrm{dm}$. long, narrow, its branches spreading or ascending: spikelets $7-9 \mathrm{~mm}$. long, about 2-flowered, nodding, on flexuous pubescent pedicels, the flowering scales $6-8 \mathrm{~mm}$. long, usually very obtuse. In rích soil, Pennsylvania to Wisconsin, Colorado and Texas. Summer.

\section{KORYCÁRPUS Zea.}

Perennial grasses, with long flat leaf-blades and elongated narrow panicles. Spikelets few, erect, narrow, 3-5-flowered, the rachilla fragile and articulated between the perfect 
flowers. Scales 5-7, the 2 lower empty, the first narrow, acute, the second longer and broader, keeled, acuminate or mucronate, the flowering scales broader, rounded on the back, acuminate or mucronate, at length coriaceous and shining, the remaining scales empty, gradually narrower, involving each other; palet thin, 2-keeled. Stamens 2, or rarely solitary in each flower. Styles short, distinct. Stigmas plumose.

1. Korycarpus diándrus (Michx.) Kuntze. Stems 4-12 dm. tall, erect, rough below the panicle: leaf-sheaths overlapping, confined to the lower part of the stem, sometimes pubescent; blades $2-6 \mathrm{dm}$. long, 1-2 $\mathrm{cm}$. wide, commonly rough : panicle, often reduced to a raceme, 5-20 cm. long, its branches erect: spikelets $12-16 \mathrm{~mm}$. long, 3-5flowered, the flowering scales abruptly acuminate. [Diarrhena Americana Beauv.]

In rich woods, Ohio to Kansas, Georgia, Tennessee and the Indian Territory. Summer and fall.

\section{UNİOLA L.}

Usually tall perennial grasses, with flat or convolute leaf-blades and contracted or open panicles, the branches sometimes nodding. Spikelets many, erect, or sometimes nodding, laterally compressed, 2-edged, 3-many-flowered, the flowers perfect or the upper ones staminate. Scales 6-many, compressed-keeled, sometimes winged, the lower 3-6 empty, gradually enlarging, the flowering scales many-nerved, similar to the upper ones of the lower empty scales but larger, the remaining scales, if any, empty ; palet somewhat rigid, 2-keeled, the keels narrowly winged. Stamens 1-3. Styles distinct. Stigmas plumose.

Stamen 1: not strand grasses.

Inflorescence long and very slender, usually nodding at the apex.

Leaf-sheaths glabrous.

Leaf-sheaths, at least the lower ones, strongly hirsute.

Inflorescence not long and slender.

Spikelets less than $2 \mathrm{~cm}$. long, the scales less than 10.

Small empty scales at the base of the spikelet 3 : flowering scales ascending, longer than the acute palet: inflorescence usually with long spreading branches.

Small empty scales at the base of the spikelet 4 or 5 : flowering scales widely spreading, equalled or exceeded by the long-acuminate palet: inflorescence with short branches.

Spikelets $2.5-4 \mathrm{~cm}$. long, oval to ovate, the scales $10-20$. Stamens 3: strand grass.

1. U. laxa.

2. U. longifolia.

\section{U. nitida.}

4. U. ornithoryncha.

5. U. latifolia.

6. U. paniculata.

1. Uniola láxa (L.) B.S.P. Stems 4-12 dm. tall, erect, slender : leaf-blades 1-4 $\mathrm{dm}$. long, 2-6 $\mathrm{mm}$. wide, usually erect, each attenuate into a long tip : panicle slender, 1-3 dm. long, erect, strict, or nodding at the summit, its branches erect : spikelets about $6 \mathrm{~mm}$. long, 3-6-flowered, the flowering scales 4-5 mm. long, acuminate, spreading in fruit. [U. gracilis Michx.]

In sandy soil, Long Island to Pennsylvania, Kentucky, Florida and Texas. Summer and fall.

2. Uniola longifolia Scribn. Stems tufted, $8-12 \mathrm{dm}$. tall : leaf-sheaths, at least the lower ones, densely hirsute; blades flat, $3 \mathrm{dm}$. long or less, narrowed at both ends, 6-12 $\mathrm{mm}$. wide : panicle $2-4.5 \mathrm{dm}$. long, its branches short and appressed, or the lower ones sometimes long and ascending : spikelets 3-4-flowered, usually about $6 \mathrm{~mm}$. long, the flowering scales about $5 \mathrm{~mm}$. long.

In dry usually sandy soil, Tennessee to Florida and Louisiana. Summer and fall.

3. Uniola nítida Baldw. Stems 6-15 dm. tall : leaf-blades $2 \mathrm{dm}$. long or less, 4-8 $\mathrm{mm}$. wide: panicle $1-1.5 \mathrm{dm}$. long, its branches spreading or ascending, the larger ones 4-6 cm. long, or sometimes reduced to a raceme : spikelets $1-1.5 \mathrm{~cm}$. long.

In low woods, Georgia and Florida to Louisiana. Spring and summer.

4. Uniola ornithorhýncha Nees. Stems $2.5-6 \mathrm{dm}$. tall, slender : leaf-blades flat, 6-12 cm. long, 4-7 mm. wide: panicle 4-8 $\mathrm{cm}$. long, its branches short and ascending, sometimes bearing but a single spikelet: spikelets crowded, $8-10 \mathrm{~mm}$. long, broader than long, the flowering scales long-acuminate.

In low woods, Mississippi and Louisiana. Summer and fall.

5. Uniola latifòlia Michx. Stems 6-15 dm. tall, erect : leaf-blades $1-2.5 \mathrm{dm}$. long, 6-25 mm. wide, flat, the base often ciliate : panicle lax, 1.5-2.5 dm. Iong, its long branches filiform and pendulous : spikelets many-flowered, oval to ovate, much flattened, $2.5-4 \mathrm{~cm}$. long, on long capillary pendulous pedicels, the flowering scales 9-12 $\mathrm{mm}$. long, ciliatehispid on the winged keel.

In moist places, Pennsylvania to Illinois, Kansas, Florida and Texas. Summer and fall.

6. Uniola panículàta $\mathrm{L}$. Stems $1-2.5 \mathrm{~m}$. tall, erect : leaf-blades $3 \mathrm{dm}$. long or more, about $6 \mathrm{~mm}$. wide, involute, at least when dry, attenuate into long slender tips: panicle 2-3 dm. long or more, its branches erect or ascending, strict, rigid: spikelets 
many-flowered, ovate to oval when mature, $12-25 \mathrm{~mm}$. long, the flowering scales $8-10 \mathrm{~mm}$. long and hispidulous on the keel.

In sands along the seacoast, Virginia to Florida and Texas. Also in the West Indies and South America. Fall. SEA OATS.

\section{DISTÍchLIS Raf.}

Perennial dioecious grasses, with rigid creeping or decumbent stems concealed by the overlapping leaf-sheaths, stiff flat or convolute leaf-blades, and contracted panicles. Spikelets many-flowered, unisexual, more numerous in the staminate than in the pistillate panicles, the rachilla continuous in the staminate, articulated in the pistillate spikelets. Scales many, acute, keeled, the 2 lower empty, narrow, the flowering scales longer and broader, firm-membranous or nearly coriaceous; palet compressed, 2-keeled, the keels sometimes narrowly winged. Stamens 3. Styles thickened at the contiguous but distinct bases, moderately long. Stigmas plumose.

1. Distichlis spicàta (L. ) Greene. Stems 1-6 dm. long, erect, or often decumbent at the base, from a long rootstock: leaf-sheaths overlapping and often crowded; blades $1-15 \mathrm{~cm}$. long, $2-4 \mathrm{~mm}$. wide, flat or involute : panicle dense and spike-like, $2-6 \mathrm{~cm}$. long, its branches erect : spikelets 8-18 $\mathrm{mm}$. long, 6-16-flowered, pale green, the flowering scales 3-5 mm. long, acute or acuminate. [D. maritima Raf.]

On salt meadows along the Atlantic coast from Maine to Florida and Texas, on the Pacific Coast, and in saline soil throughout the interior. Summer. SPIKE Grass.

\section{DÁCTYLIS L.}

Perennial usually tall grasses, with flat leaf-blades and open or contracted panicles. Spikelets in head-like clusters which are unilaterally arranged and crowded at the ends of the branches, 3-5-flowered, the flowers perfect or the upper ones staminate. Scales 5-7, keeled, the 2 lower empty, unequal, mucronate, the second the larger, the flowering scales larger, more rigid, the keel ciliate and excurrent as a mucro or short awn; palet nearly as long as the scale, 2-keeled. Stamens 3. Styles distinct. Stigmas plumose.

1. Dactylis glomeràta L. Stems $6-12 \mathrm{dm}$. tall, tufted, erect: leaf-sheaths smooth or rough ; blades $7-23 \mathrm{~cm}$. long, 2-6 mm. wide, flat, rough : panicle $7-20 \mathrm{~cm}$. long, its branches spreading or ascending in flower, erect in fruit : spikelets in dense capitate clusters, 3-5-flowered, the flowering scales 4-6 mm. long, rough, pointed or short-awned, ciliate on the keel.

In fields, meadows and waste places, New Brunswick to Manitoba, Georgia and Colorado. Naturalized from Europe. Summer. ORC̈HARD Grass.

\section{PÒA L.}

Annual or perennial grasses, rarely dioecious, with flat leaf-blades and open sometimes contracted panicles, the branches often drooping. Spikelets 2-6-flowered, the flowers perfect, or rarely unisexual, the glabrous or rarely somewhat pilose rachilla articulated between the flowers. Scales 4-8, membranous, keeled, acute or obtuse, awnless, the 2 lower empty, persistent, the flowering scales usually longer, frequently pubescent on the callus and the midnerve and marginal nerves, the hairs often long and curled; palet shorter than the scale, 2-nerved or 2-keeled. Stamens 3. Styles short, distinct. Stigmas plumose. Mradow Grass. Spear Grass. Blue Grass.

Annuals or biennials: stems densely tufted, low, usually less than $3 \mathrm{dm}$. long.

Flowering scales distinct]y 5 -nerved, not webby at the base.

Flowering scales 3-nerved or sometimes with a pair of obscure additional nerves, webby at the base.

Perennials : stems usually exceeding $3 \mathrm{dm}$. in height.

A. Plants green, with no long rootstocks.

a. Flowering seales with long crimped hairs at the base.

Flowering scales with only the midnerve pubescent.

Flowering scales $2.5 \mathrm{~mm}$. long, the midnerve sparsely pubescent : plant yeliowish green.

Flowering scales $3.5 \mathrm{~mm}$. long, the midnerve densely pubescent : plant green.

Flowering scales with the midnerve and lateral nerves pubescent.

* Panicle open, its branches spreading: spikelets not crowded.

Midnerve of the flowering scale pubescent only below the middle. Flowering scales about $3 \mathrm{~mm}$. long: basal leaves usually relatively short.

Flowering scales $4-5 \mathrm{~mm}$. long: basal leaves very long, often equalling the stem in length or nearly as long.

1. P. annua.

2. P. Chapmaniana.
3. P. trivialis.

4. P. alsodes.
5. P. pratensis.

6. P. brevifolia. 
Midnerve of the flowering scale pubescent the whole length, or nearly so.

Flowering scales about $2.5 \mathrm{~mm}$. long, obtuse.

Flowering scales about $4 \mathrm{~mm}$. long, acute.

** Panicle contracted, its branches erect or nearly so : spikelets crowded.

Flowering scales strongly pubescent at the base with very long crimped hairs, the midnerve and lateral nerves pubescent.

Flowering scales with fewer crimped hairs at the base, the nerves all glabrous.

b. Flowering scales with no crimped hairs at the base.

Panicle loose and open, its branches long and widely spreading and spikelet-bearing only above the middle.

Panicle contracted, its branches short and erect or nearly so, spikeletbearing to the base or nearly so.

B. Plants dull bluish green, with long stout often branching rootstocks : stem much compressed.

7. P. sylvestris.

8. P. Wolfii.

9. P. arachnifera.

10. P. glabrescens.

11. P. autumnalis.

12. P. pratericola

13. P. compressa.

1. Poa ánnua L. Stems $5-30 \mathrm{~cm}$. tall, erect, or decumbent at the base : leaf-sheaths loose, usually overlapping; blades $1-10 \mathrm{~cm}$. long, $1.5-3 \mathrm{~mm}$. wide : panicle $1-10 \mathrm{~cm}$. long, its branches spreading: spikelets $3-5$-flowered, $3-5 \mathrm{~mm}$. long, the flowering scales $2.5-3$ mm. long.

In waste and cultivated places nearly throughout North America. Naturalized from Europe. Native also of Asia. Spring to fall.

2. Poa Chapmaniàna Scribn. Stems $7-15 \mathrm{~cm}$. tall, erect, rigid : leaf-sheaths tight, mostly at the base of the stem; blades $1-2.5 \mathrm{~cm}$. long, $2 \mathrm{~mm}$. wide or less : panicle $2.5-5$ $\mathrm{cm}$. long: spikelets $3-7$-flowered, $2.5-3 \mathrm{~mm}$. long, the flowering scales obtuse, webbed at the base and sometimes with hairs on the more prominent nerves. [P. cristata Chapm., not Walt.]

In dry soil, Kentucky and Tennessee to Georgia, Florida and Alabama. Spring.

3. Poa triviàlis L. Stems $3-9 \mathrm{dm}$. tall, usually decumbent at the base : leaf-sheaths very rough ; blades $5-18 \mathrm{~cm}$. long, 2-4 mm. wide, rough : panicle 1-1.5 dm. long : spikelets 2-3-tlowered, $3 \mathrm{~mm}$. long, the scales acute, the flowering scales $2-3 \mathrm{~mm}$. long, 5 -nerved, the intermediate nerves prominent.

In meadows and waste places, New Brunswick to Michigan and Georgia. Naturalized from Europe. Summer.

4. Poa alsòdes A. Gray. Stems $2-8 \mathrm{dm}$. tall: leaf-blades usually rough, $2-4 \mathrm{~mm}$. wide, those on the stem $5-20 \mathrm{~cm}$. long, the basal ones longer : panicle $8-20 \mathrm{~cm}$. long, its branches spikelet-bearing at the ends : spikelets $2-3$-flowered, about $5 \mathrm{~mm}$. long, the flowering scales acute, about $4 \mathrm{~mm}$. long, the intermediate nerves very faint.

In woods and thickets, Nova Scotia to Ontario, Minnesota, North Carolina and Tennessee. Spring and summer.

5. Poa praténsis L. Stems $3-12 \mathrm{dm}$. tall : leaf-blades smooth or rough, 1-6 mm. wide, those on the stem $5-15 \mathrm{~cm}$. long, the basal much longer : panicle $6-20 \mathrm{~cm}$. long, usually pyramidal : spikelets $3-5$-flowered, $4-5 \mathrm{~mm}$. long, the scales acute, the flowering scales $3 \mathrm{~mm}$. long, 5 -nerved.

In meadows, fields and woods, almost throughout North America. Widely cultivated for hay. Also in Europe and Asia. Summer. KENTUCKY BLUE Grass. JUNE Grass.

6. Poa brevifòlia Muhl. Stems 3-9 dm. tall, erect: leaf-blades smooth beneath, rough above, $2-4 \mathrm{~mm}$. wide, abruptly acute, those on the stem $1-10 \mathrm{~cm}$. long, the uppermost sometimes almost wanting: panicle $6-13 \mathrm{~cm}$. long, its branches widely spreading or often reflexed, spikelet-bearing at the ends : spikelets $3-6$-flowered, $5-7 \mathrm{~mm}$. long, the flowering scales $4-5 \mathrm{~mm}$. long, obtuse, the intermediate nerves prominent. summer.

In rocky woods, southeastern New York to Illinois, North Carolina and Tennessee. Spring and

7. Poa sylvéstris A. Gray. Stems $3-9 \mathrm{dm}$. tall, slender : leaf-blades smooth beneath, rough above, $2-6 \mathrm{~mm}$. wide, those on the stem 4-15 $\mathrm{cm}$. long, the basal much longer: panicle $7-18 \mathrm{~cm}$. long, the branches spreading or ascending, sometimes reflexed when old, spikelet-bearing at the ends : spikelets $2-4$-flowered, $2-4 \mathrm{~mm}$. long, the flowering scales about $2.5 \mathrm{~mm}$. long, obtuse.

In thickets and meadows, New York to Wisconsin, Nebraska, Georgia and Louisiana. Summer.

8. Poa Wólfii Scribn. Stems tufted, $3-9 \mathrm{dm}$. tall : leaf-blades rather lax, flat, 2-3 $\mathrm{mm}$. wide, those on the stem 5-10 $\mathrm{cm}$. long, the basal ones longer : panicle $7-15 \mathrm{~cm}$. long, its branches long and lax, drooping, spikelet-bearing toward the end: spikelets 2-4-flowered, $5-6 \mathrm{~mm}$. long, the acute flowering scales about $4 \mathrm{~mm}$. long, strongly pubescent on the midnerve and the lateral nerves, the intermediate nerves very prominent.

In moist soil, Illinois, Tennessee and Kansas. Summer.

9. Poa arachnífera Torr. Stems tufted, 3-9 dm. tall : leaf-blades erect, usually folded when dry, smooth beneath, rough above, 4-23 $\mathrm{cm}$. long, 3-6 mm. wide, abruptly acute : panicle dense and contracted, sometimes interrupted below, 7-16 cm. long, its 
branches erect or nearly so: spikelets numerous, 4-7-flowered, the scales acuminate, the flowering scales $4-5 \mathrm{~mm}$. long.

On prairies, Kansas to New Mexico, Louisiana and Texas. Also introduced into Florida. Spring.

10. Poa glabréscens Nash. Stems tufted, $2-5 \mathrm{dm}$. tall : leaf-blades erect, $1.5 \mathrm{dm}$. long or less, $2-5 \mathrm{~mm}$. wide, rough above : panicle $4-15 \mathrm{~cm}$. long, 1-3 cm. wide : spikelets 5-9-flowered, the flowering scales 4-5 mm. long.

On prairies, Indian Territory and Texas. Spring.

11. Poa autumnàlís Muhl. Stems 3-9 dm. tall : leaf-blades $2 \mathrm{~mm}$. wide or less, smooth beneath, rough above, those on the stem $4-15 \mathrm{~cm}$. long, the basal much longer: panicle $7-22 \mathrm{~cm}$. long, the branches long and slender and spikelet-bearing at the ends: spikelets 3-5-flowered, 5-6 mm. long, the flowering scales rounded or retuse at the apex, 3-4 mm. long, pubescent on the lower part of the internerves. [P. flexuosa Muhl.]

In woods, New Jersey and Pennsylvania to Kentucky, Florida and Texas. Spring and summer.

12. Poa praterícola Rydb. \& Nash. Stems $3-6 \mathrm{dm}$. tall, erect, rigid : leaf-sheaths usually overlapping; ligule $2-4 \mathrm{~mm}$. long, acute; blades smooth beneath, rough above, 1-2 mm. wide, flat or folded, pungently pointed, those on the stem $1-2.5 \mathrm{~cm}$. long, erect, the basal ones $7-15 \mathrm{~cm}$. long: panicle contracted, $5-13 \mathrm{~cm}$. long, the branches erect: spikelets 4-7-flowered, 5-7 mm. long, the flowering scales 3-4 mm. long, erose-truncate at the apex, strongly silky-pubescent on the nerves for $\frac{1}{2}$ their length, the internerves pubescent below, the intermediate nerves very obscure.

In meadows and low grounds, Northwest Territory to Kansas, the Indian Territory and Arizona. Spring and summer.

13. Poa compréssa $\mathrm{L}$. Stems $1.5-6 \mathrm{dm}$. tall, decumbent at the base, from long branching rootstocks, much flattened : leaf-sheaths loose, flattened; blades $2-10 \mathrm{~cm}$. long, about $2 \mathrm{~mm}$. wide: panicle usually contracted, the branches erect or ascending : spikelets 3-9-flowered, 3-6 $\mathrm{mm}$. long, the flowering scales 2-2.5 $\mathrm{mm}$. long, obscurely 3-nerved.

In cultivated grounds, waste piaces and woods, almost throughout North America. Naturalized from Europe, at least in some places. Also a native of Asia. Summer. Canadian Blue Grass.

\section{PANICULÀria Fabr.}

Usually perennial, rarely annual, sometimes aquatic grasses, with commonly flat leafblades and open or contracted panicles, the branches sometimes drooping. Spikelets usually numerous, ovate to linear, few-many-flowered, the glabrous rachilla articulated between the perfect flowers, the upper flowers sometimes imperfect. Scales few-many, awnless, the 2 lower empty, obtuse or acute, unequal, the flowering scales longer, obtuse to truncate and denticulate, rarely acute or acuminate at the more or less hyaline apex, convex on the back but not keeled, usually prominently nerved, the nerves vanishing at the hyaline margin; palet 2-keeled, equalling or shorter than, rarely exceeding, the scale. Stamens 3. Style short, distinct. Stigmas plumose. [Glyceria R. Br.] Manna Grass.

Spikelets ovate or oblong, $8 \mathrm{~mm}$. long or less.

Flowering scales very broad, obscurely or at least not sharply nerved.

Flowering seales narrow, sharply and distinctly 7 -nerved.

Panicle elongated, its branches erect or appressed.

Panicle not elongated, its branches usually spreading or ascending, sometimes drooping.

Flowering scales about $1.5-2 \mathrm{~mm}$. long, obtuse or rounded at the apex. Spikelets $2-3 \mathrm{~mm}$. long or less: branches of the panicle often drooping. Spikelets 4-6 mm. long: branches of the panicle ascending or spreading. Flowering scales 2.5-3 nim. long, truncate and denticulate at the apex. Spikelets linear, $12 \mathrm{~mm}$. long or more.

Flowering scales $4-5 \mathrm{~mm}$. long, obtuse, equalling or exceeding the obtuse palet. Flowering scales $6-8 \mathrm{~mm}$. long, acute, much shorter than the acuminate palet.

1. P. obtusa.

2. P. elongata.

3. P. nervata.

4. P. Americana.

5. P. pallida.

6. P. fluitans.

7. P. acutiflora.

1. Panicularia obtùsa (Muhl.) Kuntze, Stems 3-9 dm. tall, erect, stout, rigid : leaf-sheaths strongly striate, the lower overlapping; blades $1.5-4 \mathrm{dm}$. long, 4-8 mm. wide, usually stiff, erect or ascending, rough above: panicle 7-20 cm. long, contracted, dense, the branches erect: spikelets 3-7-flowered, 4-6 $\mathrm{mm}$. long, the flowering scales $3 \mathrm{~mm}$. long.

In swamps, New Brunswick to New York, Delaware, Maryland and North Carolina. Summer.

2. Panicularia elongàta (Torr.) Kuntze. Stems $6-9 \mathrm{dm}$. tall : leaf-blades lax, $1.5-3$ $\mathrm{dm}$. long, 3-6 $\mathrm{mm}$. wide, long-acuminate, rough above: panicle elongated, contracted, usually nodding at the summit, $1.5-3 \mathrm{dm}$. long, the branches erect or appressed : spikelets 3-4-flowered, 3-4 mm. long, the flowering scales about $2 \mathrm{~mm}$. long, obtuse or acutish.

In wet woods and swamps, Newfoundland to Quebec, Minnesota, Kentucky and North Carolina. Summer and fall.

3. Panicularia nervàta (Willd.) Kuntze. Stems $3-9 \mathrm{dm}$. tall : leaf-sheaths usually rough; blades $1.5-3 \mathrm{dm}$. long, 4-10 $\mathrm{mm}$. wide, rough above: panicle 7-20 $\mathrm{cm}$. long, often 
purple, the branches spreading, ascending, or often drooping : spikelets 3-7-flowered, 2-3 $\mathrm{mm}$. long, the flowering scales about $1.5 \mathrm{~mm}$. long, obtuse or rounded.

In wet places, Newfoundland to British Columbia, Florida, Texas and Mexico. Summer and fall.

4. Panicularia Americàna (Torr.) MacM. Stems 9-15 dm. tall : leaf-sheaths loose, sometimes rough ; blades $2-3 \mathrm{dm}$. long or more, $6-16 \mathrm{~mm}$. wide, rough above : panicle $2-4$ $\mathrm{dm}$. long, the lower branches 1-2 dm. long: spikelets 4-7-flowered, 4-6 mm. long, the flowering scales about $2 \mathrm{~mm}$. long.

In wet soil, New Brunswick to Alaska, Tennessee, Colorado and Nevada. Summer.

5. Panicularia pállida (Torr.) Kuntze. Pale green. Stems 3-9 dm. long, assurgent : leaf-blades $5-15 \mathrm{~cm}$. long, 2-4 mm. wide, rough above: panicle $4-18 \mathrm{~cm}$. long, its branches spreading or ascending: spikelets 4-8-flowered, $5-7 \mathrm{~mm}$. long, the flowering scales 2.5-3 mm. long, truncate and denticulate at the apex.

In shallow water, New Brunswick to Ontario, Virginia, Tennessee and Indiana. Summer.

6. Panícularia flùitans (L.) Kuntze. Stems 1-1.5 m. long, flattened, usually stout, often rooting from the lower nodes: leaf-sheaths loose, usually overlapping; blades 1-3 $\mathrm{dm}$. long or more, $4-12 \mathrm{~mm}$. wide, rough, often floating: panicle $2-4.5 \mathrm{dm}$. long, its branches finally ascending: spikelets $7-13$-flowered, $2-2.5 \mathrm{~cm}$. long, the flowering scales 4-5 mm. long, thick, oblong, rounded or truncate at the erose apex, hispidulous.

In wet places or in water, Newfoundland to British Columbia, North Carolina, Kentucky, Iowa and California. Summer and fall.

7. Panicularia acutiflòra (Torr.) Kuntze. Stems $3-6 \mathrm{dm}$. tall, flattened, erect from a decumbent base : leaf-sheaths loose, smooth; blades 7-15 $\mathrm{cm}$. long, 4-6 $\mathrm{mm}$. wide, rough above: panicle $1.5-3 \mathrm{dm}$. long, its branches erect or appressed : spikelets 5-12flowered, $2.5-4.5 \mathrm{~cm}$. long, the flowering scales $6-8 \mathrm{~mm}$. long, lanceolate, acute, smooth.

In wet places, Maine to southern New York, Ohio and Tennessee. Summer.

\section{FESTÙCA L.}

Usually perennial, rarely annual, tufted grasses, with flat or convolute sometimes setaceous leaf-blades and contracted often spike-like or open panicles which are sometimes nearly racemose. Spikelets 2 -several-flowered, the flowers perfect or the upper ones staminate, the rachilla articulated between the flowers. Scales 4 -several, membranous, the 2 lower empty, unequal, acute, keeled, the flowering scales rounded on the back, at least below, acute or rarely obtuse, usually more or less awned, occasionally awnless, the remaining scales if any, empty; palet a little shorter than the scale, 2-keeled. Stamens 1-3. Styles very short, distinct, terminal or nearly so. Stigmas plumose. Frescue Grass.

Annuals: stamens 1 or 2.

First empty scale less than $1 / 2$ as long as the second, usually very small.

First empty scale more than $1 / 2$ as long as the second.

Flowering scales not hirsute.

Spikelets 3-4-flowered; flowering scales glabrous or nearly so, appressed to the rachilla.

Spikelets 6-13-flowered; flowering scales usually strongly hispidulous, decidedly diverging from the rachilla.

Flowering scales appressed-hirsute.

Perennials: stamens 3.

Leaf-blades very narrow, $2 \mathrm{~mm}$. wide or less, involute or folded.

Plants without rootstocks: flowering scales awnless.

Plants with long rootstocks: flowering scales short-awned.

Leaf-blades $3 \mathrm{~mm}$. wide or more, flat.

Panicle open, its branches at maturity ascending or spreading : spikelets usually less than 6 -flowered.

Panicle-branches elongated, spikelet-bearing toward the end.

Panicle-branches not elongated, spikelet-bearing from the middle or below it. Flowering scales obtuse, 4-5 mm. long. Flowering scales acute, 6-7 $\mathrm{mm}$. long.

1. F. Myuros.

2. F. parviflora.

3. F. octoflora.

4. F. sciurea.

5. F. capillata.

6. F. rubra.

7. F. nutans.

8. F. obtusa.

9. F. Texana.

Panicle contracted, its branches erect or appressed : spikelets often 10-flowered. 10 . $F$. elatior.

1. Festuca Myùros L. Stems 3-6 dm. tall, erect: leaf-blades 5-13 cm. long, subulate, involute, erect : panicle usually one-sided, 1-3 dm. long, spike-like, its branches appressed : spikelets 3-6-flowered, the flowering scales, exclusive of the awn, 4-6 mm. long, narrow, acuminate into an awn much longer than itself. Summer.

In waste places and fields, New Hampshire to New Jersey and Florida. Naturalized from Europe.

2. Festuca parviflòra Ell. Stems $3-5 \mathrm{dm}$. tall, slender : leaf-blades $5-10 \mathrm{~cm}$. long, about $1 \mathrm{~mm}$. wide : panicle very slender, 1-2 dm. long, its branches appressed : spikelets 3-4-flowered, the flowering scales 4-5 mm. long, exclusive of the awn which is of equal length or somewhat longer.

In dry soil, South Carolina to Florida and Texas. Spring and summer. 
3. Festuca octoflòra Walt. Stems 1-5 dm. tall, erect, slender, rigid : leaf-blades 4-8 cm. long, involute, bristle-form : panicle or raceme often one-sided, $2.5-15 \mathrm{~cm}$. long, contracted, its branches erect, or nearly so : spikelets 6-13-flowered, $6-10 \mathrm{~mm}$. long, the flowering scales, exclusive of the awn, 3-5 mm. long, usually very rough, acuminate into an awn nearly as long as itself or shorter, or sometimes awnless. [F. tenella Willd.] summer.

In dry sandy usually sterile soil, Quebec to British Columbia, Florida, Texas and California.

4. Festuca sciùrea Nutt. Stems 1-5 dm. tall, slender: leaf-blades $5 \mathrm{~cm}$. long or less, less than $1 \mathrm{~mm}$. wide : panicle slender, $4-15 \mathrm{~cm}$. long, its branches erect or appressed : spikelets 3-5-flowered, the flowering scales about $3 \mathrm{~mm}$. long, exclusive of the awn which is $2-3$ times as long as the scale.

In dry soil, Florida to the Indian Territory and Texas. Spring and summer.

5. Festuca capillàta Lam. Stems densely tufted, erect, $1.5-4 \mathrm{dm}$. tall, slender, glaucous : leaf-sheaths confined to the base of the stem; blades filiform, the basal ones from $\frac{1}{3}-\frac{1}{2}$ as long as the stems, the stem-blades $2.5-4 \mathrm{~cm}$. long: panicle contracted, $1-5 \mathrm{~cm}$. long, its branches erect: spikelets 4-5-flowered, 4-5 mm. long, the flowering scales about 2.5 $\mathrm{mm}$. long, acute.

In fields and along roadsides, Maine, New York and Mississippi. Introduced from Europe. Summer.

6. Festuca rùbra L. Stems $4-8 \mathrm{dm}$. tall, erect : basal leaf-blades involute-filiform, $7-15 \mathrm{~cm}$. long, those on the stem shorter, erect, flat, or involute in drying, minutely pubescent above : panicle $5-13 \mathrm{~cm}$. long, sometimes reddish : spikelets $3-10$-flowered, 8-12 $\mathrm{mm}$. long, the flowering scales about $6 \mathrm{~mm}$. long, bearing an awn less than its own length.

In meadows and fields, Labrador to Alaska, and in the mountains to Virginia, Tennessee and Colorado. Also in Europe and Asia. Summer.

7. Festuca nùtans Willd. Stems $6-9 \mathrm{dm}$. tall, slender : leaf-blades $1-3 \mathrm{dm}$. long, 4-6 mm. wide, flat, rough above : panicle 1-2.5 dm. long, the lower branches $6-13 \mathrm{~cm}$. long: spikelets lanceolate, 3-5-flowered, $5-6 \mathrm{~mm}$. long, the flowering scales $3-4 \mathrm{~mm}$. long. In rocky woods, Nova Scotia to Ontario, Nebraska, Florida and Texas. Summer.

8. Festuca obtùsa Spreng. Stems 6-12 dm. tall : leaf-blades $1-2.5 \mathrm{dm}$. long, 2-6 $\mathrm{mm}$. wide, rough above : panicle $7-18 \mathrm{~cm}$. long, the lower branches $4-9 \mathrm{~cm}$. long : spikelets broadly obovate when mature, $3-6$-flowered, $5-6 \mathrm{~mm}$. long, the flowering scales 4-5 mm. long.

In woods and thickets, Pennsylvania and Illinois to Kansas, Georgia, Mississippi and Texas. Summer.

9. Festuca Texàna Vasey. Stems 4-8 dm. tall : leaf-blades $5-15 \mathrm{~cm}$. long, $3-5 \mathrm{~mm}$. wide : panicle 1-2 dm. long, its branches stiff and widely spreading, the lower ones usually in pairs : spikelets 2-4-flowered, the flowering scales glabrous, acute, sometimes short-awned.

In shady places, Oklahoma and Texas. Spring.

10. Festuca elàtior L. Stems $6-15 \mathrm{dm}$. tall : leaf-blades 1-4 dm. long, 4-8 mm. wide, rough above: panicle 1-4 dm. long, often nodding at the top, simple to very compound : spikelets $5-10$-flowered, $9-12 \mathrm{~mm}$. long, the flowering scales acute or short-pointed, $5-6 \mathrm{~mm}$. long, indistinetly 5 -nerved.

In waste places and fields, Nova Scotia to Ontario, North Carolina, Tennessee and Kansas. Naturalized from Europe. Summer.

\section{BRÒMUs L.}

Annual or perennial grasses, with usually closed leaf-sheaths, flat blades and contracted or open sometimes almost racemose panicles, the branches often nodding. Spikelets usually large, often drooping, few-many-flowered, the flowers perfect or the upper ones imperfect. Scales few-many, membranous, the 2 lower empty, persistent, narrow, unequal, acute or the second sometimes short-awned; flowering scales longer and often broader, rounded on the back, at least below, usually awned, rarely awnless, the straight or rarely recurved awn dorsal and inserted just below the 2-toothed or shortly 2-cleft apex; palet shorter than the scale, 2-keeled. Stamens 3, rarely fewer. Ovary crowned by a villous appendage, at the base of which arise the very short but distinct styles. Stigmas plumose. Brome Grass.

Chess. Cheat.

A. Lower empty scale 1-nerved, the upper 3-nerved.

Annuals: stems usually less than $6 \mathrm{dm}$. tall: awn longer than the flowering scale. Spikelets numerous, several on each panicle-branch : flowering scales 8-12 mm. long, appressed-hirsute.

Spikelets few, 1 or sometimes 2 on each panicle-branch : flowering scales 12-16 mm. long, sparıngly hispidulous.

Perennials: stems usually exceeding $6 \mathrm{dm}$. in height : awn shorter than the flowering scale or wanting.

1. B. tectorum.

2. B. sterilis. 
Flowering scales awnless, or merely awn-pointed.

Flowering scales with distinet awns.

Flowering scales glabrous, or pubescent on the margins.

Flowering scales densely pubescent all over the back.

B. Lower empty scale 3-nerved, the upper 5-9-nerved.

Flowering scales rounded on the back, at least below.

Leaf-sheaths glabrous: nerves of the turgid fruiting scales obscure.

Leaf-sheaths softly and densely pubescent with reflexed hairs: nerves of the flowering scales prominent.

Flowering scales compressed, keeled.

3. B. inermis.

4. B. ciliatus.

5. B. purgans.

6. B. secalinus.

7. B. racemosus

8. B. unioloides.

1. Bromus tectòrum L. Stems $1.5-6 \mathrm{dm}$. tall, erect : leaf-sheaths, at least the lower ones, softly pubescent ; blades $2.5-10 \mathrm{~cm}$. long, 2-4 mm. wide, softly pubescent : panicle $5-15 \mathrm{~cm}$. long, the branches slender and drooping: spikelets numerous, 5-8-flowered, on capillary recurved pedicels, the flowering scales $8-12 \mathrm{~mm}$. long, acuminate, usually rough or hirsute, the awn 1-1.5 $\mathrm{mm}$. long.

In fields and waste places, Massachusetts to Indiana, Colorado, Washington, Virginia and Mississippi. Naturalized from Europe. Spring and summer.

2. Bromus stérilis L. Stems $3-6 \mathrm{dm}$. tall : leaf-sheaths sometimes pubescent ; blades 7-23 cm. long, 2-6 mm. wide, commonly pubescent : panicle 1-2.5 dm. long, its branches usually widely spreading, stiff: spikelets few, 5-10-flowered, spreading or pendulous, the flowering scales 7-nerved, hispidulous on the nerves, the awn $1.5-2.5 \mathrm{~cm}$. long.

In waste places and on ballast. Locally naturalized from Europe. Summer.

3. Bromus inérmis Leyss. Stems tufted, $8-12 \mathrm{dm}$. tall : leaf-sheaths glabrous ; blades 1.5-2.5 dm. long, 4--6 mm. wide, glabrous: panicle $1.5-2.5 \mathrm{dm}$. long, oblong, its branches ascending: spikelets $2-2.5 \mathrm{~cm}$. long, about $5 \mathrm{~mm}$. wide, oblong, erect, the flowering scales 10-12 $\mathrm{mm}$. long.

In fields and waste places, escaping from cultivation, especially in the West. Summer.

4. Bromus ciliàtus L. Stems 7-12 dm. tall : leaf-sheaths retrorsely short-pilose or almost glabrous ; blades lax, 2.5-4 dm. long and about $1 \mathrm{~cm}$. wide, sparsely pubescent, or sometimes nearly glabrous : panicle $1.5-3 \mathrm{dm}$. long, the lower branches drooping: spikelets 5-9-flowered, 15-22 mm. long, the flowering scales 10-12 $\mathrm{mm}$. long, pubescent on each side for about $\frac{3}{4}$ the length, the awn straight, slender, $3-5 \mathrm{~mm}$. long.

In woods, Newfoundland to New York, Minnesota and Manitoba.-The variety B. ciliatus laeviglùmis Scribn. differs mainly in having the flowering scales glabrous, or with a few hairs at the base. Ontario, Maine and North Carolina. Summer.

5. Bromus púrgans L. Stems $7-15 \mathrm{dm}$. tall : leaf-sheaths usually coarsely retrorsely pubescent; blades $1.5-3 \mathrm{dm}$. long, 5-15 mm. wide, glabrous, or pubescent on the nerves above: panicle lax, nodding, 1.5 -3 dm. long: spikelets 7-11-flowered, $2-2.5 \mathrm{~cm}$. long, the flowering scales 10-12 mm. long, pubescent all over the back, the awn straight, $4-6 \mathrm{~mm}$. long.

In woods, Canada and New England to Wyoming, Florida and Texas. Summer.

6. Bromus secálinus L. Stems $3-9 \mathrm{dm}$. tall : leaf-sheath commonly glabrous; blades 5-23 cm. long, 2-6 mm. wide, sometimes hairy : panicle 5-10 $\mathrm{cm}$. long, its branches ascending or drooping : spikelets turgid when in fruit, 6-10-flowered, the flowering scales $6-8 \mathrm{~mm}$. long, rough toward the apex, awnless, or bearing a straight awn $8 \mathrm{~mm}$. long or less between the obtuse short teeth. Summer.

In fields and waste places almost throughout temperate North America. Naturalized from Europe

7. Bromus racemòsus $L$. Stems $3-7 \mathrm{dm}$. tall, commonly puberulent just below the panicle: leaf-sheaths, at least the lower ones, rather densely pubescent; blades 7-14 cm. long, pubescent, or sometimes glabrous above : panicle usually simple, sometimes compound: spikelets $1.5-2 \mathrm{~cm}$. long, generally nodding in fruit, acute, 5-9-flowered, the flowering scales elliptic, 6-8 $\mathrm{mm}$. long, smooth or rough, the awn $5-8 \mathrm{~mm}$. long, arising just below the apex.

In waste places, Cape Breton Island and Maine to Pennsylvania and Delaware.-The variety $B$. racemosus commutatus (Schrad.) Hook. has the spikelets 2-2.5 $\mathrm{cm}$. long, and somewhat broader flowering scales and the panicle larger. In similar situations and generally distributed throughout the East as far south as Tennessee. Summer.

8. Bromus unioloìdes (Willd.) H.B.K. Annual. Stems 5-10 dm. tall : leafsheaths commonly pubescent, or sometimes glabrous; blades rough, sometimes sparingly pubescent : panicle usually long and narrow, $1.5-5 \mathrm{dm}$. long: spikelets $2-3.5 \mathrm{~cm}$. long, 7-11-flowered, the flowering seales thick, firm, 12-16 mm. long, each commonly with a short stout awn.

In waste places, Alabama to Texas and California. Also in Mexico.-The variety B. unioloides Haenkeanus (Presl.) Shear, differs in its smaller size, and almost simple panicle with smaller spikelets. In similar situations, Florida to Texas and California. Spring and summer. 


\section{LÒLIUM L.}

Annual or perennial grasses, with flat leaf-blades and terminal simple usually elongated spikes. Spikelets with the edge (backs of the scales) to the rachis, scattered, erect, alternate, sessile and solitary in the rachis excavations, compressed, several-many-flowered, the flowers perfect or the upper ones imperfect, the rachilla articulated between the flowers. Scales rigid, rounded on the back, obtuse to acuminate, awned or awnless, the nerves connivent above or confluent into the awn, the lower scale of the lateral spikelets and the 2 lower scales of the terminal spikelet empty, narrow, longer than the remaining scales, thin flowering scales short, imbricated; palet shorter than the scale, 2-keeled. Stamens 3. Styles distinct, very short. Stigmas plumose. Darnel. Rye Grass.

Empty scale shorter than the spikelet.

Flowering scales awnless.

Flowering scales awned.

Empty scale equalling or extending beyond the flowering scales.

1. L. perenne.

2. L. Italicum.

3. L. temulentum.

1. Lolium perénne L. Stems $1.5-8 \mathrm{dm}$. tall : leaf-blades $5-13 \mathrm{~cm}$. long, $2-4 \mathrm{~mm}$. wide: spike $7-20 \mathrm{~cm}$. long: spikelets 5-10-flowered, $8-12 \mathrm{~mm}$. long, the empty scale strongly nerved, the flowering scales $4-6 \mathrm{~mm}$. long, acuminate, awnless.

In waste places and cultivated ground, almost throughout the northern United States. Naturalized from Europe. Summer.

2. Lolium Itálicum A. Br. Stems $6-10 \mathrm{dm}$. tall : leaf-sheaths glabrous; blades 1-2 dm. long, 3-7 mm. wide: spikes 2-3 dm. long: spikelets $20-30,1.5-2 \mathrm{~cm}$. long, the flowering scales bearing an awn equalling or a little shorter than the body.

In fields and waste places, sparingly introduced. Naturalized from Europe. Summer.

3. Lolium temuléntum L. Stems 6-12 dm. tall : leaf-blades 1-2.5 dm. long, 2-6 mm. wide, rough above: spike $1-3 \mathrm{dm}$. long: spikelets $4-8$-flowered, $1-2 \mathrm{~cm}$. long, the empty scale strongly nerved, the flowering scales awned or awnless.

In waste places and cultivated ground, New Brunswick to Michigan, Georgia and Kansas. Summer

\section{AGROPY̌RON J. Gaertn.}

Annual or perennial grasses, with flat or convolute leaf-blades and terminal usually rigid 2-4-sided spikes. Spikelets compressed, with the side (edge of the scales) toward the continuous or rarely articulated, rachis, sessile, alternate, single in the rachis excavations, appressed or oblique to the rachis, several-many-flowered, the flowers perfect or the upper ones imperfect, the rachilla articulated between the flowers. Scales several-many, the 2 lower empty, the flowering ones broader, rigid, rounded on the back, obtuse to acuminate, awned or awnless, the nerves connivent at the apex or confluent into the awn, the remaining scales if any empty ; palet shorter than the scale, 2-keeled, the keels usually ciliate. Stamens 3. Styles very short, distinct. Stigmas plumose. Wheat Grass.

Spikelets much compressed, lanceolate to ovate, ascending. Spikelets nearly terete, linear, erect.

1. A. occidentale. 2. A. repens.

1. Agropyron occidentàle Scribn. Pale green, glaucous. Stems 4-12 dm. tall, from a slender creeping rootstock : leaf-blades erect, 5-20 cm. long, 4-8 mm. wide, rough above, smooth beneath, becoming involute when dry : spike strict, $1-2 \mathrm{dm}$. long :spikelets crowded, diverging from the rachis, $1.25-2.5 \mathrm{~cm}$. long, 6-12-flowered, the empty scales acuminate, awn-pointed, hispidulous on the keel, the flowering scales 10-12 mm. long, acute, sometimes awn-pointed, glabrous or sparingly pubescent.

On prairies and high plains, Manitoba and Minnesota to Oregon, Missouri and Texas. Summer.

2. Agropyron rèpens (L.) Beauv. Stems 3-12 dm. tall, from a long rootstock : leaf-blades 7-30 cm. long, 2-10 mm. wide, smooth beneath, hirsute above: spike 5-20 cm. long, strict : spikelets 3-7-flowered, the empty scales strongly 5-7-nerved, usually acute or awn-pointed, sometimes obtuse, the flowering scales glabrous, acute or short-awned.

In fields and waste places, almost throughout North America. Naturalized from Europe. Summer and fall. Covch Grass. Quitch Grass.

\section{HÓRDEUM L.}

Annual, rarely perennial, grasses, with flat leaf-blades and terminal cylindric usually dense spikes which are often concealed by the long awns. Spikelets in alternate 3's (rarely in 2's) at each node of the articulated rachis, sessile or short-pedicelled, the lateral often much reduced, 1-flowered, the flower perfect, or in the lateral spikelets often imper- 
fect or wanting, the rachilla extending beyond the flowers as a long slender bristle or sometimes bearing a narrow terminal scale. Scales 3 or 4 , the 2 lower empty, awn-like, subulate, lanceolate, or narrowly linear, rigid, persistent, the empty scales at each rachisnode forming an apparent involucre and falling with the readily deciduous rachis joints, the flowering scales lanceolate, rounded on the back, the nerves confluent into a straight or divergent awn, or in the lateral spikelets awnless and sometimes much reduced; palet shorter than the scale, 2-keeled. Stamens 3. Styles very short, distinct. Barley.

Each cluster of spikelets with all the empty scales bristle-like.

Each cluster with four of the empty scales dilated above the base.

1. H. nodosum.

2. H. pusillum.

1. Hordeum nodòsum L. Stems $1.5-6 \mathrm{dm}$. tall, erect, or sometimes decumbent : leaf-blades 4-13 cm. long, 2-6 mm. wide, flat, rough : spike $2.5-9 \mathrm{~cm}$. long : spikelets usually in 3's, the flowering scale of the central spikelet $6.8 \mathrm{~mm}$. long, exclusive of the awn which is $6-12 \mathrm{~mm}$. long, the corresponding scale in the lateral spikelets much smaller and short-stalked. [H. pratense Huds. ]

In meadows and waste places, Indiana to Minnesota, British Columbia, Alaska, Georgia, Texas and California. Also in Europe and Asia. Summer.

2. Hordeum pusíllum Nutt. Stems 1-4 dm. tall, erect, or decumbent at the base : leaf-blades 1-8 cm. long, 1-4 mm. wide, erect, rough above : spike $2.5-8 \mathrm{~cm}$. long : spikelets usually in 3's, the scales awned, the empty ones rough, the flowering ones smooth, that of the central spikelet 6-8 mm. long, short-awned, the corresponding scale in the lateral spikelets smaller and very short-stalked.

In dry soil, Ontario to British Columbia, Nebraska, Arkansas, Texas and California ; also sparingly introduced into the southeastern United States. Summer.

\section{SITÀNION Raf.}

Erect perennial grasses, with flat or involute leaf-blades and a terminal dense cylindric spike which is covered with long spreading awns. Spikelets many, sessile, alternate, at each joint of the articulated rachis, 1-5-flowered. Scales 3-7, the 2 lower empty, rarely entire, usually 2-many-cleft, the divisions linear and long-awned, the awns spreading, the flowering scales broader, acute, entire and long-awned, or 2-toothed and the teeth sometimes short-awned; palet shorter than the scale, 2-keeled. Stamens 3. Styles very short, distinct.

1. Sitanion longifòlium J. G. Smith. Stems 3-5 dm. tall, stout, glaucous : leafblades of the innovations $1.5-3 \mathrm{dm}$. long, involute, often as long as the stems, those on the stem 1-2 dm. long, 1-4 mm. wide : spike 1-1.5 dm. long, rather loosely flowered, its base inclosed in the upper sheath : spikelets 2 , or sometimes 3 , at each node, the empty scales subulate-setaceous, divaricate, $6-8 \mathrm{~cm}$. long; flowering scales $8-11 \mathrm{~mm}$. long, rough, each tipped with a stout rough awn $5-6.5 \mathrm{~cm}$. long.

In dry soil, Nebraska to Wyoming, Texas and Nevada. Summer.

\section{9. ÉLYMUS L.}

Usually tall perennial grasses, with flat or convolute often rigid leaf-blades and a terminal cylindric dense spike which is sometimes interrupted and usually covered with long awns. Spikelets numerous, sessile, crowded, usually in alternate pairs, sometimes in 3 's or more, at each node of the continuous rachis, 2-several-flowered (rarely 1-flowered). Seales 4-several (rarely 3), the 2 lower empty, rigid, ảwn-like, subulate, or linear, persistent, awn-pointed or awned, those at each node forming an apparent involucre, the flowering scales shorter, oblong to lanceolate, rounded on the back, obtuse or acute, usually awned, rarely awnless, the remaining scales if any smaller and empty ; palet shorter than the scale, 2-keeled. Stamens 3. Styles very short, distinct. Stigmas plumose. LYME Grass. Will Rye.

Empty scales narrowly awl-shaped : spike slender.

Empty scales linear-lanceolate to linear: spike stout.

Flowering scales glabrous.

Flowering scales appressed-pubescent, usually densely so.

Empty scales linear, thick, firm, each bearing generally an awn much shorter than the body,

Empty scales narrowly lanceolate, rather thin, each bearing commonly an awn equalling or exceeding the body.

Spike rather loosely flowered, nodding at the summit, usually longexserted.

Spike densely flowered, compact, strict, usually included at the base.

1. E. striatus.

2. E. Virginicus.

3. E. hirsutiglumis.

4. E. Canadensis.

5. E. robustus. 
1. Elymus striatus Willd. Stems $3-9 \mathrm{dm}$. tall : leaf-sheaths glabrous or hirsute ; blades 1-2.5 dm. long, 4-10 $\mathrm{mm}$. wide, pubescent above : spike $6-12 \mathrm{~cm}$. long, often nodding, slender : spikelets 1-3-flowered, the empty scales $2-2.5 \mathrm{~cm}$. long, including the slender rough awn, 1-3-nerved, the nerves, and often the whole scale, rough, hispid or hirsute, the flowering scales about $6 \mathrm{~mm}$. long, hispid or hispidulous, each bearing a slender awn $1.5-3 \mathrm{~cm}$. long.

In woods and on banks, Maine and Ontario to Tennessee, Nebraska and Kansas. Summer.

2. Elymus Virgínicus L. Stems 6-9 dm. tall : leaf-sheaths sometimes pubescent, the uppermost usually inflated and enclosing the base of the spike : blades $1-3.5 \mathrm{dm}$. long, 4-16 mm. wide, rough : spike $5-18 \mathrm{~cm}$. long, broad, stout, upright ; spikelets $2-3$-flowered, the empty scales very thick and rigid, lanceolate, $1.5-2.5 \mathrm{~cm}$. long, including the short awn, 5-7-nerved, the flowering scales $6-8 \mathrm{~mm}$. long, each bearing a rough awn 4-18 $\mathrm{mm}$. long, or rarely awnless.

In moist soil, especially along streams, Nova Scotia and New Brunswick to Manitoba, Florida and Texas. Summer.

3. Elymus hirsutiglùmis Scribn. \& Sm. Stems 3-9 dm. tall, erect: leaf-sheaths longer than the internodes, the uppermost often inflated and enclosing the base of the spike ; blades 2-3 dm. long, 8-18 mm. wide, very rough on both surfaces : spike 6-15 $\mathrm{cm}$. long, stout, the rachis pubescent: spikelets crowded in pairs, 2-5-flowered, the empty scales linear, 10-12 mm. long, thick, 3-5-nerved, the nerves hirsute, each acuminate into an awn as long as or shorter than the body of the scale, the flowering scales lanceolate, $8-10 \mathrm{~mm}$. long, each acuminate into a rough awn $12-16 \mathrm{~mm}$. long.

On river banks, Maine to North Carolina, Illinois and Nebraska. Summer.

4. Elymus Canadénsis L. Stems 6-15 dm. tall : leaf-blades 1-3 dm. long or more, 4-20 mm. wide, rough, sometimes glaucous: spike $1-3 \mathrm{dm}$. long, nodding, its peduncle usually much exserted: spikelets 3-5-flowered, the empty scales awl-shaped, rigid, 3-5nerved, 16-32 mm. long, including the slender rough long awn, the flowering scales 8-14 $\mathrm{mm}$. long, nearly glabrous to hirsute and each bearing a slender rough awn $2-5 \mathrm{~cm}$. long. Summer.

On river banks, Nova Scotia and New Brunswick to Alberta, Georgia, Texas and New Mexico.

5. Elymus robústus Scribn. \& Sm. Stems $9-12$ dm. tall, erect, stout: leaf-blades firm, rough on both surfaces, 1-4 dm. long, $8-20 \mathrm{~mm}$. wide : spike usually partially included at the base, stout, strict, 1-2.5 dm. long, compact : spikelets numerous, crowded, in 2's-4's, 3-4-flowered, the empty scales 10-12 $\mathrm{mm}$. long, each bearing an awn about twice as long, the flowering scales lanceolate, $10-12 \mathrm{~mm}$. long, from sparsely to densely appressedpubescent, each bearing an awn $3-4.5 \mathrm{~cm}$. long.

On river banks, Illinois to Arkansas, Montana and Kansas. Summer.

\section{HÝSTRIX Moench.}

Usually tall grasses, with simple stems, flat leaf-blades and terminal spikes. Spikelets numerous, at length spreading, 2-several-flowered, usually in pairs, rarely in 3's, sessile, the clusters alternate on opposite sides of the continuous rachis, the rachilla articulated below the flowering scales. Scales 2 -several, the 2 lower empty, subulate, wanting in all but the lowest spikelets, the flowering scales lanceolate, rigid, convolute, rounded on the back, the nerves confluent into the long awn; palet somewhat shorter than the scale, 2keeled. Stamens 3. Styles very short, distinct. Stigmas plumose. Grain oblong, adherent to the palet when dry.

1. Hystrix Hýstrix (L. Millsp. Stems 6-12 dm. tall : leaf-blades 1-2.5 dm. long, 6-12 mm. wide, rough above : spike $7-18 \mathrm{~cm}$. long : spikelets at length widely spreading, 8-12 mm. long, exclusive of the awn, readily deciduous, the empty scales present only sometimes in the lowest spikelets, the flowering scales 8-12 mm. long, each acuminate into an awn about $2.5 \mathrm{~cm}$. long. [Asprella Hystrix (L.) Willd.]

In rocky woods, New Brunswick to Ontario and Minnesota, Georgia, Illinois and Nebraska. Summer. BOTTLE-BRUSH.

\section{ARUNDINÁRIA Michx.}

Tall shrubs, or rarely trees, with simple or branched stems, flat short-petioled leafblades which are articulated to the sheath, and racemose or paniculate inflorescence. Spikelets large, compressed, 2-many-flowered. Scales 3-many, the 2 lower empty, unequal, the first smaller or sometimes wanting, the flowering scales longer, membranous, manynerved, at the apex obtuse, acuminate or with a short awn or mucronate; palet scarcely 
shorter than the scale, prominently 2-keeled. Lodicules 3. Stamens 3. Styles 2 or 3 , somewhat united at the base. Stigmas long, loosely plumose.

Spikelets borne on radical shoots of the year : stems $4 \mathrm{~m}$. tall or less. Spikelets borne on the old stems which are $5 \mathrm{~m}$. tall or more.

1. A. tecta.

2. A. macrosperma.

1. Arundinaria técta (Walt.) Muhl. Stems 1-4 m. tall, erect, shrubby, branching at the summit : leaf-sheaths smooth or rough, ciliate on the margin ; ligule bristly ; blades lanceolate, 8-20 $\mathrm{cm}$. long, 8-24 mm. wide, flat, more or less pubescent beneath, glabrous above: inflorescence borne on short leafless stems : spikelets 7-10-flowered, $2.5-4 \mathrm{~cm}$. long, on pedicels $2.5 \mathrm{~cm}$. long or less, the first scale sometimes wanting, the flowering scales 1-2 $\mathrm{cm}$. long, acute or acuminate, glabrous or pubescent.

In swamps and moist soil, Maryland to Indiana, Missouri, Florida and Texas. Spring and summer. This and the following species flower only at intervals of several or many years. REED.

2. Arundinaria macrospérma Michx. Stems woody, $5-9 \mathrm{~m}$. tall, finally branched above : leaf-sheaths ciliate on the margin ; blades lanceolate, $3 \mathrm{dm}$. long or less, the larger $2-3 \mathrm{~cm}$. wide, those on the ultimate divisions smaller and crowded at the summit of the branches : spikelets $3.5-6 \mathrm{~cm}$. long, on slender more or less leafy branches, the flowering scales glabrous and pubescent, acuminate.

Along river banks and swamps, forming "cane brakes," Virginia to Florida and Louisiana, and along the Mississippi River and its tributaries as far north as Kentucky, Tennessee and Missouri. Spring and summer. CANE. CANE REeD.

\section{FAmily 2. CYPERÀCEAE J. St. Hil.1 Sedge Family.}

Grass-like or rush-like caulescent or scapose herbs, many species perennial by long rootstocks. Stems or scapes (culms) slender, solid or rarely hollow, triangular, quadrangular, terete or flattened. Leaves 3-ranked, with closed sheaths: blades narrow. Flowers perfect or imperfect, arranged in spikelets, one (rarely 2) in the axil of each scale (glume, bract), the spikelets solitary or clustered, 1-many-flowered. Scales 2-ranked or spirally imbricated, persistent or deciduous. Perianth hypogynous, composed of bristles, or scale-like parts, rarely calyx-like, or entirely wanting. Androecium of 1-3 stamens, or rarely more. Filaments slender or filiform. Anthers 2-celled. Gynoecium of 2-3 united carpels. Ovary 1-celled. Styles or stigmas 2-3, the former often more or less united. Ovule anatropous, erect. Fruit a lenticular, plano-convex, or 3-angled achene. Endosperm mealy. Embryo minute.

Flowers of the spikelets, or at least one of them, perfect.

Scales of the spikelets enclosing a bractlet or a pair of bractlets.

Bractlets 2, convolute around the ovary.

Bractlet solitary, minute, posterior.

Scales of the spikelets not enclosing bractlets.

Spikelets perfect or mainly so, rarely of 2 scales and 1 flower, or if polygamous, plants with'leaves not densely imbricated on the stems (Kyllinga).

Scales of the spikelets 2-ranked.

Perianth present, the members bristle-like.

Perianth wanting.

Spikelets with 2-several perfect flowers : scales several-many.

Spikelets with 1 perfect flower: scales $2-4$

Scales of the spikelets spirally imbricated all around.

Base of the style not at all or only slightly thickened, deciduous.

Perianth-parts conspicuously elongated.

Perianth-parts not conspicuously elongated.

Scales pubescent: perianth of bristles and dilated scales.

Scales glabrous : perianth of bristles only or none.

Base of the style manifestly swollen, persistent as a tubercle on the achene, or deciduous.

Perianth present.

Spikelets in compound umbels, 1-flowered.

Spikelets solitary, several-many-flowered.

Perianth wanting.

Achene not surmounted by a tubercle.

Achene surmounted by a tubercle.

Spikelets in umbels or cymes, without an imbricated involucre. Spikelets in a terminal umbel: base of the style persistent. Spikelets in terminal and axillary compound cymes: most of the style persistent.

Spikelets in heads subtended by an imbricated involucre.

Spikelets polygamous, or rarely of 4 scales and only 1 flower.

Scales of the spikelets 2-ranked.

Scales of the spikelets of spirally imbricated scales. Perianth present.

1. LIPOCARPHA.

2. HEMICA RPHA.

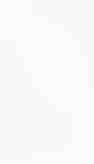

3. Dulichium.

4. Cyperus.

5. KYLLINGA.

6. ERIOPHORUM.

7. Fuirena.

8. SCIRPUS.

9. WEBSTERIA

10. Eleocharis.

11. Fimbristylis.

12. Stenophyllus.

13. Psilocarya.

14. Dichromena.

15. Abildgandia.

16. SCHOENUS.

${ }^{1}$ Prepared with the assistance of Dr. Nathaniẻl Lord Britton. 
Perianth wanting.

Stigmas 3: style deciduous. Inflorescence paniculate:

Inflorescence capitate :

Stigmas 2: style persistent.

Flowers monoecious or dioecious.

Achenes not enclosed in a utricle (perigynium):

Achenes enclosed in a utricle (perigynium):
17. Cladium.
18. REMIREA.
19. RYNCHOSPORA.
20. SCLERIA.
21. CAREX.

\section{IIPOCÁRPHA R. Br.}

Low annual slender herbs, with tufted scapes, and terete many-flowered spikelets in a terminal head, subtended by an involucre of 1-several bracts. Scales firm, spirally imbricated, all fertile or several of the lower ones empty, at length deciduous, each enclosing 2 bractlets which are convolute around the ovary. Flowers perfect. Perianth wanting. Stamens 1-2. Style deciduous, its base not swollen. Stigmas 2-3. Achene plano-convex or 3-angled.

1. Lipocarpha maculàta (Michx.) Torr. Glabrous. Scape grooved, compressed, smooth, longer than the narrowly linear somewhat channeled leaf-blades, $7-25 \mathrm{~cm}$. tall: bracts of the involucre 2-4: spikelets ovoid-oblong, obtuse, $5-6 \mathrm{~mm}$. long, $2 \mathrm{~mm}$. thick, in a terminal capitate cluster: scales rhombic or lanceolate, acute, curved, the sides nearly white, or flecked with reddish brown spots : exterior bractlet convolute around the achene, nerved, hyaline : stamen 1: achene oblong, yellowish, contracted at the base.

In wet or moist soil, eastern Virginia to Florida. Also adventive farther north. Summer and fall.

\section{HEMICÁRPHA Nees \& Arn.}

Low tufted mostly annual caulescent herbs, with erect or spreading, almost filiform stems and leaves, and terete small terminal capitate or solitary spikelets subtended by an involucre of 1-3 bracts. Scales spirally imbricated, deciduous, each subtending perfect flowers and a single posterior bractlet. Perianth wanting. Stamens 1-3. Style deciduous, not swollen at the base. Stigmas 2. Achene oblong, turgid or lenticular.

1. Hemicarpha micrántha (Vahl) Britton. Annual, glabrous. Stems compressed, grooved, 2-10 $\mathrm{cm}$. long, mostly longer than the setaceous smooth leaf-blades: spikelets ovoid, many-flowered, obtuse, about $2 \mathrm{~mm}$. long: involucral bracts usually much exceeding the spikelets : scales of the spikelets brown, obovate, each with a short blunt spreading or recurved tip : stamen 1 : achene obovoid-oblong, obtuse, mucronulate, little compressed, light brown.

In moist, sandy soil, Rhode Island to Pennsylvania, Iowa and Nebraska, Florida, Texas and Mexico. Summer and fall. -A variety ranging from Kansas to Texas, $H$. micrantha aristulata Coville, has pale cuneate-obovate scales each tapering into a squarrose awn about as long as the body.

\section{DULÍCHIUM L. C. Rich.}

Tall perennial herbs, with terete hollow, conspicuously jointed stems, leafy to the top, the lower leaves reduced to sheaths. Spikes axillary, peduncled, simple or compound. Spikelets 2 ranked, flat, linear, falling away from the axis at maturity (?), many-flowered. Scales 2-ranked, carinate, conduplicate, decurrent on the joint below. Flowers perfect. Perianth of 6-9 retrorsely barbed bristles. Stamens 3. Style persistent as a beak on the summit of the achenes. Stigmas 2. Achenes linear-oblong.

1. Dulichium arundinàceum (L.) Britton. Stems stout, $3-10 \mathrm{dm}$. tall, erect: leaves numerous : blades flat, $2-8 \mathrm{~cm}$. long, 4-8 $\mathrm{mm}$. wide, spreading or ascending, the lower sheaths bladeless, brown toward their summits: peduncles 4-25 mm. long: spikelets narrowly linear, spreading, 1-2.5 cm. long, about $2 \mathrm{~mm}$. wide, 6-12-flowered; scale lanceolate, acuminate, strongly several-nerved, appressed, brownish : bristles rigid, longer than the achene: style long-exserted, persistent. [D. spathaceum (L.) Pers.]

In wet or muddy places, Nova 'Scotia to Ontario, Minnesota and Nebraska, Florida and Texas. Summer and fall.

\section{CYPËUS L.}

Annual or perennial scapose herbs. Leaves basal: blades narrow. Scapes, in our species simple, triangular, and with one or more bracts at the summit forming an involucre to the simple or compound, umbellate or capitate inflorescence. Rays of the umbel sheathed at the base, usually very unequal, one or more of the heads or spikes commonly sessile. Spikelets flat or nearly terete, the scales falling away from the rachis as they ma- 
ture or persistent and the spikelets falling away from the axis of the head or spike with the scales attached. Scales concave, conduplicate or keeled, 2-ranked, all flower-bearing or the lower ones empty. Flowers perfect. Perianth none. Stamens 1-3. Style deciduous from the summit of the achene. Stigmas 2-3. Achene destitute of a tubercle. Style-branches or stigmas 2: achene lenticular.

Achene laterally compressed.

Superficial cells of the achene oblong.

Superficial cells of the achene quadrate.

1. C. flavescens.

Achenes oblong, linear or narrowly obovoid : plants relatively low. Scales of the spikelets blunt.

Spikelets several in each umbel.

Scales membranous, dull: style-branches or stigmas much exserted.

Scales subcoriaceous, shining : style-branches or stigmas included or scarcely exserted.

Spikelets 8-20 mm. long, dark green to brown.

Spikelets 5-8 mm. long, yellowish green or straw-colored. Spikelet solitary, appearing lateral.

Scales of the spikelets acute or mucronate.

Scales merely acute.

Achene narrowly obovoid.

Achene linear to linear-oblong.

Scales ovate: umbel subcapitate.

Scales oblong-lanceolate: umbel-rays usually developed. Scales $2-2.5 \mathrm{~mm}$. long, chestnut-brown, shining.

Scales $1.5 \mathrm{~mm}$. long, gray-brown or straw-colored, dull. Scales sharply mucronate.

Achenes broadly obovoid to orbicular: plants relatively tall.

Achenes obovoid, nearly as long as the scales.

Achenes obovoid-orbicular, much shorter than the scales.

Achene dorsally compressed.

Spikelets few, appearing lateral : one involucral bract long and erect.

Spikelets numerous, capitate: involucral bracts several and spreading.

Stvle-branches or stigmas 3 : achene trigonous.

A. Scales falling away from the persistent rachis of the flattened spikelets.

a. Wings of the rachis, if any, permanently attached to it.

Scales tipped with recurved awns: low annuals.

Achene $1 \mathrm{~mm}$. long, narrowly obovoid : scales light brown.

Achene $0.5 \mathrm{~mm}$. long, broadly obovoid: scales chestnut-brown.

Scales obtuse, acute or acuminate, not awn-tipped.

Wings of the rachis none, or very narrow.

Scales of the spikelets appressed, closely contiguous.

Stamens 3 or 1 : scales ovate, oblong or lanceolate.

Stamens 3: spikelets linear to linear-oblong.

Leaves not viscid.

Scales acuminate: plants annual.

Scales obtuse or mucronate: plants perennial.

Scales obtuse: achene obovoid. Scales mucronate : achene oblong. Leaves viscid.

Stamen 1: spikelets ovate to lanceolate.

Scale-tips recurved.

Annual: achene broadly oblong.

Perennial: achene narrowly oblong or elliptic.

Scale-tips straight or very nearly so: plants perennial,

Spikelets lanceolate to oblong-lanceolate.

Achene linear-oblong, stipitate.

Achene ovoid, not stipitate.

Spikelets ovate, elongating in fruit.

2. C. diandrus.

3. C. rivularis.

4. C. helvus.

5. C. bipartitus.
6. C. Nuttallii.
7. C. microdontus.
8. C. Gatesii.
'9. C. polystachyus.
10. C. pumilus.
11. C. flavicomus.
12. C. Hochstetteri.
13. C. laevigatus.
14. C. Careyi.

15. C. inflexus.

16. C. squarrosus.

Leaves, at least at the base, strongly transverse-veined between the nerves.

Leaf-blades 6-12 $\mathrm{mm}$. wide: spikelets $6-14 \mathrm{~mm}$. long.

Leaf-blades 2-6 mm. wide : spikelets 4-6 mm. long. Leaves not transversely veined between the nerves. Spikelets yellow, blunt.

Spikelets red or reddish brown, acute.

Stamens 2: scales nearly orbicular or obovate, mucronulate.

Scales of the spikelets not appressed, distant.

Spikelets linear-filiform, spicate.

Spikelets merely linear or oblong-linear, densely capitate.

Wings of the rachis distinet.

Scapes not transversely septate, 3 -angled.

Leaves reduced to pointed sheaths.

Leaves with elongated linear blades.

Scales mucronate.

Scales not mucronate.

Spikelets $3-4 \mathrm{~mm}$. wide.

Spikelets 1.5-2 mm. wide.

Scales wholly or partially purple-brown : achene linear oblong.

Scales tightly appressed throughout.

Scales with free tips.

Scales straw-colored: achene obovoid.

Scapes transversely septate, terete.

25. C. virens.

17. C. compressus.

18. C. Buckleyi.

19. C. Bushii.

21. C. acuminatus.

22. C. cyrtolepis.

23. C. Drummondii.

24. C. ochraceus.

26. C. pseudovegetus.

27. C. Surinamensis.

28. C. reflexus.

29. C. Iria.

30. C. distans.

31. C. cephalanthus.

32. C. Haspan.

33. C. dentatus.

34. C. multiradiatus.

35. C. rotundus.

36. C. Hallii.

37. C. esculentus.

38. C. articulatus. 
b. Wings of the rachis separating from it as interior scales: annuals.

Spikes loose, or if dense not narrowly cylindric: spikelets $6-25 \mathrm{~mm}$. long. Spikelets crowded: scales loose.

Spikelets not crowded: scales closely appressed.

Spikes very dense, cylindric : spikelets $3-5 \mathrm{~mm}$. long.

B. Rachis of the spikelets deciduous.

Rachis breaking up into 1-fruited joints : spikelets nearly terete.

Spikes solitary: scapes filiform: plants perennial.

Spikes umbellate or capitate-congested: scapes stout to slender: plants annual.

Scales of the spikelets distant: achene linear-oblong.

Scales of the spikelets manifestly imbricated: achene obovoid. Spikelets relatively loosely spicate.

Spikes dull brown: scales thin, not tightly appressed.

Spikes yellowish or grayish brown : scales firm, appressed.

Spikelets densely congested into $1-4$ heads.

Inflorescence umbellate: spikes disposed at the ends of the 2-4 rays of the umbel.

Inflorescence capitate: spikes collected into a terminal congested cluster.

Rachis deciduous above the lower pair of scales : plants perennial by hard corm-like tubers.

Achene narrowly linear-oblong, $2 \frac{1}{2}-4$ times as long as thick.

Spikelets distinctly flattened, several-many-flowered.

spikelets in dense globular heads.

Spikelets loosely spicate or relatively so.

Spikelets chestnut-brown.

Spikelets yellow to yellow-brown.

Scales appressed.

Scales loose, somewhat spreading.

Spikelets nearly terete to a little fiattened, 1 -few-flowered. Spikelets loosely spicate.

Spikelets 1-2 cm. long: achene about $3 \mathrm{~mm}$. long.

Spikelets less than $1 \mathrm{~cm}$. long: achene $1.5 \mathrm{~mm}$. long.

Spikelets capitate or capitate-spicate.

Spikelets all reflexed: scapes almost always rough.

Spikelets spreading or only the lower ones reflexed: scapes smooth.

Spikes or heads dense, cylindric to globose.

Spikes globose.

Spikes cylindric to oval or obovoid.

Spikelets 3-7 mm. long : spikes obovoid or cylindric. Spikes obovoid: lower spikelets reflexed. Spikes cylindric.

Spikes $0.5-2 \mathrm{~cm}$. long, simple.

Spikelets 3-4 mm. long, 1-2-flowered.

Spikelets 5-7 mm. long. 3-4-flowered.

Spikes $1.5-3.5 \mathrm{~cm}$. long, usually compound. Spikelets 8-10 mm. long: spikes oval.

Spikelets loosely spicate or capitate.

Spikelets 8-12 mm. long, subulate.

Spikelets $3-5 \mathrm{~mm}$. long, not subulate.

Achene oblong to obovoid, not more than twice as long as thick.

Spikelets with 1-4 achenes.

Rachis wingless or narrowly winged.

Umbel simple or head solitary : leaf-blades relatively narrow. Spikelets loosely spicate.

Spikelets densely spicate or capitate.

Heads ovoid to cylindric.

Heads globose to subglobose.

Heads dark brown: scales mucronulate.

Heads green or greenish brown: scales not mueronulate.

Achene $2 \mathrm{~mm}$. Iong: scales about $2 \mathrm{~mm}$. long.

Achene $1 \mathrm{~mm}$. long: scales less than $2 \mathrm{~mm}$. long.

Umbel compound: leaf-blades relatively broad.

Rachis-wings broad, membranous.

Scales firm, not appressed.

Scales thin, closely appressed.

Spikelets with 5-10 achenes.

Heads sessile, or on rays less than $2 \mathrm{~cm}$. long.

Heads terminating rays $2-7 \mathrm{~cm}$. long.

39. C. erythrorhizos.

40. C. digitalus.

41. C. Halei.

42. C. Floridanus.

43. C. Engelmannii.

44. C. speciosus.

45. C. ferax.

46. C. Eggersii.

47. C. oxycarioides.

48. C. Martindalei.

49. C. setigerus.

50. C. strigosus.

51. C. stenolepis.

52. C. refractus.

53. C. dissitiflorus.

54. C. retrofractus.

55. C. ovularis.

56. C. retrorsus.

57. C. cylindricus.

58. C. Plankii.

59. C. cylindrostachys.

60. C. Lancastriensis.

61. C. uniflorus.

62. C. subuniflorus.

63. C. tetragonus.

64. C. flavus

65. C. fuligineus.

66. C. filiculmis.

67. C. Blodgettii.

68. C. ligularis.

69. C. Grayi.

70. C. Echinatus.

71. C. brunneus

72. C. Ottonis.

1. Cyperus flavéscens L. Annual, yellowish green. Leaf-blades $2-3 \mathrm{~mm}$. wide, smooth, the longer usually exceeding the inflorescence: scapes very slender, tufted, 7-30 $\mathrm{cm}$. tall : spikelets in 3's-6's, linear, subacute, yellow, many-flowered, flat, 8-18 $\mathrm{mm}$. long, 3-4 mm. broad ; the clusters terminal and sessile, or on 1-4 short rays : scales ovate, obtuse, 1-nerved, appressed, twice as long as the achene: stigmas $2:$ achenes orbicular-obovoid, black, obtuse, shining, the superficial cells oblong.

In marshy soil, Maine to Michigan, Florida and Mexico. Also in the Old World. Summer and fall.

2. Cyperus diándrus Torr. Annual, deep green. Leaf-blades about $2 \mathrm{~mm}$. wide: scapes tufted, slender, $5-40 \mathrm{~cm}$. tall : bracts of the involucre usually $3:$ spikelets $8-18$ mm. long, linear-oblong, acute, flat, many-flowered; the clusters sessile and terminal or at 
the ends of 1-3 rays : scales ovate, green, brown, or with brown margins, obtuse, 1-nerved, appressed, membranous, dull : stigmas or style-branches 2 , much exserted: achenes lenticular, oblong, gray, not shining, $\frac{1}{2}$ as long as the scale, its superficial cells quadrate and about as long as wide, as in the eleven following species.

In marshy places, New Brunswick to Minnesota, South Carolina and Kansas. Summer and fall.

3. Cyperus rivulàris Kunth. Similar to the next preceding species. Scapes slender, tufted : umbel usually simple: spikelets linear or linear-oblong, acutish, $8-20 \mathrm{~mm}$. long: scales dark green or brown, or with brown margins, appressed, firm, rather coriaceous, shining, obtuse : stigmas or style-branches 2, scarcely exserted: achenes oblong or oblongobovoid, lenticular, somewhat pointed, dull.

In wet soil, especially along streams and ponds, Maine to Ontario, Michigan, Nebraska, North Carolina and Missouri. Summer and fall.

4. Cyperus hélvus Liebm. Annual. Leaves generally 2 or 4 ; blades $1-3 \mathrm{~mm}$. wide, smooth : scapes tufted, $1-7 \mathrm{dm}$. tall, as long as the leaves or longer: bracts of the involucre narrower than the leaf-blades, surpassing the umbel, the longer ones $5-20 \mathrm{~cm}$. long: umbel capitate, or 2-4 rays becoming 1-3 $\mathrm{cm}$. long: spikelets few, linear to linearlanceolate, 5-8 mm. long, acutish: scales straw-colored or yellowish green, ovate, obtuse, 2 $\mathrm{mm}$. long, deciduous at maturity, 2-keeled on the back: styles 2, well united: achenes lenticular, oval or oval-obovoid, $1 \mathrm{~mm}$. long, brown, dull, barely $\frac{1}{2}$ as long as the scale.

In ditches and moist grounds, Louisiana and Texas; also through the tropics to eastern South America and in the West Indies. Spring to fall.

5. Cyperus bipartitus Torr. Annual. Leaves usually 2 at the base of the the scape ; blades setaceous or filiform : scapes $5-15 \mathrm{~cm}$. tall : bracts of the involucre solitary or 2, but only one well developed and erect: spikelet ovate-oblong, $5-7 \mathrm{~mm}$. long, rather obtuse, about 14-flowered : scales ovate, obtuse, somewhat coriaceous, closely imbricated : styles 2, nearly distinct : achenes lenticular, obovoid, fully $1 \mathrm{~mm}$. long, obtuse.

In sandy soil, near New Orleans, Louisiana. Summer.

6. Cyperus Nuttállii Eddy. Annual. Scapes slender, tufted, equalling or longer than the leaves: bracts of the involucre $3-5$, spreading, the larger often $12 \mathrm{~cm}$. long: umbel 3-7-rayed: spikelets rather loosely clustered, linear, very acute, flat, spreading, 1-3 cm. long, 2-3 mm. wide: scales yellowish brown except the green keel, oblong, acute : stigmas 2, somewhat exserted : achenes lenticular, narrowly obovoid, obtuse or truncate, dull, light brown, $\frac{1}{3}$ to $\frac{1}{2}$ as long as the scale.

In salt marshes, or drifting sand, coast of Maine to Florida and Mississippi. Summer and fall.

7. Cyperus microdóntus Torr. Annual. Leaf-blades about $2 \mathrm{~mm}$. wide: scapes very slender, tufted, sometimes $0.5-1 \mathrm{dm}$. high : bracts of the involucre much elongated : umbel commonly simple, sessile, subcapitate : spikelets linear, acute, $6-18 \mathrm{~mm}$. long, less than $2 \mathrm{~mm}$. wide, yellowish brown: scales ovate, barely $2 \mathrm{~mm}$. long, acute, thin becoming rather lax: stigmas 2, much exserted: achenes lenticular, linear-oblong, short-pointed, light brown, $\frac{1}{2}$ as long as the scale.

In wet soil, on or near the coast, Virginia and North Carolina. Summer and fall.

8. Cyperus Gatèsii Torr. Annual, bright green. Leaves often $3-6$; blades 1-4 mm. wide, or sometimes narrower or even filiform, not firm: scapes slender, tufted, 1-4 dm. tall, often surpassing the leaves : bracts of the involucre $3-5$, surpassing the umbel, the longer ones usually $10-20 \mathrm{~cm}$. long: umbel with $3-8$ rays $1-5 \mathrm{~cm}$. long, or rarely nearly capitate : spikelets few, linear or linear-lanceolate, $6-15 \mathrm{~mm}$. long, acute : scales light chestnut-brown, oblong-lanceolate, $2-2.5 \mathrm{~mm}$. long, shining, striate, deciduous at maturity: achenes oblong, fully $1 \mathrm{~mm}$. long, grayish, abruptly apiculate, fully $\frac{1}{2}$ as long as the scale.

In springy places and low grounds, Virginia to Florida and Texas. Spring to fall.

9. Cyperus polystáchyus Rottb. Annual, pale green. Leaves usually 4-8; blades narrowly linear, $2-4 \mathrm{~mm}$. wide, smooth like the scape : scapes tufted, slender, 1-9 dm. tall, generally surpassing the leaves : bracts of the involucre $3-5$, much longer than the umbel, nearly equal in length, or one or two sometimes 1-2 dm. long: umbel capitate or some of the rays becoming 1-3 cm. long: spikelets numerous, linear-lanceolate, $6-20 \mathrm{~mm}$. long, acute, 15-25-flowered: scales $1.5 \mathrm{~mm}$. long, gray-brown or straw-colored, acute, dull, deciduous at maturity : achenes lenticular, oblong, $1.2 \mathrm{~mm}$. long, dull, about twice as long as thick, grayish.

In ditches and low grounds, Florida to Louisiana, and in tropical America. Spring to fall.

10. Cyperus pùmilus L. Annual, pale green. Leaves often $3-4$; blades gradually narrowed to the apex : scapes densely tufted, slender, 1-3 dm. tall, or sometimes shorter, mostly as long as the leaves or longer: bracts of the involucre usually 3 or 4, 1 or 2 of them much longer than the others, the longest one often $10 \mathrm{~cm}$. in length: umbel much shorter than the involucre, with 3-9 rays, 1-6 $\mathrm{cm}$. long and a sessile cluster of spikes, or sometimes all spikes sessile : spikelets linear, 4-8 $\mathrm{mm}$. long, relatively few in a spike, 15- 
25-flowered: scales silvery green, $1.5 \mathrm{~mm}$. long, 3-toothed at the apex, the middle tooth longest and acuminate, thus forming a sharp mucro, with broad scarious margins : achenes about $0.5 \mathrm{~mm}$. long, obovoid, truncate at the top, barely $\frac{1}{2}$ as long as the scale.

In sandy soil, Florida and Alabama. Common in the tropics. Summer.

11. Cyperus flavícomus Michx. Annual. Leaves 4-6 mm. wide : scapes $3-10 \mathrm{dm}$. tall : bracts of the involucre 3-8, the longer ones much exceeding the inflorescence : umbels few-several-rayed, often compound ; primary rays 1-6 $\mathrm{cm}$. long : spikelets numerous, usually densely clustered, linear, acute, $8-20 \mathrm{~cm}$. long, $2-3 \mathrm{~mm}$. wide, flat, many-flowered, spreading : scales oblong, obtuse, thin, dull yellowish brown : stigmas 2, little exserted : achenes obovoid, lenticular, black, mucronate, not shining, nearly as long as the scales and often persistent on the rachis after these have fallen away.

In wet or moist sandy soil, Virginia to Florida and Louisiana. Summer and fall.

12. Cyperus Hochstétteri Nees. Annual, bright green. Leaves mostly 2 or 3 ; blades $2-4 \mathrm{~mm}$. wide, smooth like the scape: scapes tufted, relatively stout, 1.5-6 dm. tall, mostly overtopping the leaves : bracts of the involucre $3-5$, all, or only the longer ones surpassing the umbel, longer ones $10-20 \mathrm{~cm}$. long: umbel with 2-5 rays, 1-10 $\mathrm{cm}$. long and one or more spikes sessile in the involucre: spikelets linear or linear-lanceolate, 1-4 $\mathrm{cm}$. long, 12-54-flowered: scales broadly ovate, deep chestnut color, $2 \mathrm{~mm}$. long, rather blunt: achenes lenticular, obliquely obovoid-orbicular, $1.5 \mathrm{~mm}$. long, about $\frac{1}{2}$ as long as the scale, apiculate, deep brown.

In low grounds, Louisiana, Texas and New Mexico. Also in the tropics. Spring to fall.

13. Cyperus laevigàtus L. Perennial, light green, resembling species of Scirpus. Leaves reduced to several colored scales at the base of the scape, the upper ones sometimes prolonged into short blades: scapes tufted from horizontal rootstocks, $0.5-4 \mathrm{dm}$. tall, smooth: spikelets few, usually $3-6$ in a head at the top of the scape, subtended by the single conspicuous erect involucral bract, oblong-ovate to linear, 6-15 mm. long, rather obtuse, mostly 16-30-flowered : scales deltoid-ovate, blunt, nearly $2 \mathrm{~mm}$. long, deep chestnut-brown and lustrous or merely variegated with chestnut, deciduous at maturity : achenes $1.5 \mathrm{~mm}$. to nearly $2 \mathrm{~mm}$. long, elliptic or obovoid-elliptic, minutely pointed.

In sandy soil, South Carolina and California. Also circumtropical. Spring to fall.

14. Cyperus Careỳi Britton. Annual, pale green. Leaves several; blades 1-1.5 mm. wide, keeled : scapes tufted, slender, less than $1 \mathrm{dm}$. tall, surpassed by some of the leaves, densely leafy at the base : bracts of the involucre usually 3 , surpassing the umbel, 2-8 cm. long: umbel capitate, about $1 \mathrm{~cm}$. broad, sessile: spikelets crowded, numerous, oblong or ovate-oblong, $3-4 \mathrm{~mm}$. long : scales silvery or whitish, about $2 \mathrm{~mm}$. long, broadly ovate, abruptly pointed, delicately ribbed : stigmas 2 : achene lenticular, oblong.

In sand, middle Florida. Summer.

15. Cyperus infléxus Muhl. Annual, fragrant in drying. Leaf-blades $2 \mathrm{~mm}$. wide or less : scapes slender or almost filiform, tufted, about equalled by the leaves : bracts of the involucre 2-3, exceeding the umbel: umbel sessile, capitate, or 1-3-rayed: spikelets linear-oblong, 6-10-flowered, 4-6 mm. long: scales light brown, lanceolate, rather firm, strongly several-nerved, each tapering into a long, recurved awn : stigmas 3 : achene 3angled, narrowly obovoid, $1 \mathrm{~mm}$. long, obtuse, mucronulate, brown, dull.

In wet, sandy soil, Vermont to the Northwest Territory, Oregon, Florida, Texas, California and Mexico. Summer.

16. Cyperus squarròsus L. Annual, bright green, licorice-scented. Leaves few ; blades mostly $1 \mathrm{~mm}$. wide or narrower, curved, revolute : scapes tufted, $2-15 \mathrm{~cm}$. tall, slender, overtopped by some of the leaves : bracts of the involucre usually 3 or 4 , surpassing the umbel, rarely $10 \mathrm{~cm}$. long: umbel of $2-5$ rays with one or more spikes sessile in the involucre, or sometimes all the spikes collected in a head : spikelets linear, $5-10 \mathrm{~mm}$. long, few in a spike, many-flowered: scales light chestnut-colored, nearly $2 \mathrm{~mm}$. long, the recurved spreading awn-like tip nearly as long as the body: achenes 3 -angled, broadly obovoid, $0.5 \mathrm{~mm}$. long, brown, minutely apiculate.

In sandy soil, Georgia and Florida to Texas and California. Also in the West Indies and tropics of the Old World.

17. Cyperus compréssus L. Annual. Leaves light green; blades about $2 \mathrm{~mm}$. wide: scapes slender, erect or reclining, smooth, $7-25 \mathrm{~cm}$. long: bracts of the involucre $2-3$, the longer exceeding the spikelets: umbel capitate or with $2-3$ short rays : spikelets narrowly lanceolate, acute, $8-20 \mathrm{~mm}$. long, 3-4 mm. wide, very flat, many-flowered : scales light green with a yellow band on each side, ovate, acuminate, firm, keeled, several-nerved : stigmas 3: achene sharply 3 -angled, obovoid, obtuse, dull brown, about $\frac{1}{3}$ as long as the scale.

In fields, Maryland to Florida, Missouri and Texas. Also in tropical America and the Old World. Summer and fall. 
18. Cyperus Buckleỳi Britton. Perennial, bright green. Leaves several at the base of the scape ; blades $2-7 \mathrm{~mm}$. wide, curling in age : scapes sometimes tufted, $3-15 \mathrm{dm}$. tall, overtopping the leaves, often conspicuously elongated : bracts of the involucre usually $3-5,10-20 \mathrm{~cm}$. long or the smaller ones shorter : umbel of 3-8 rays varying from 1-12 cm. in length and one or more spikes sessile in the involucre: spikelets linear, 8-12 $\mathrm{mm}$. long, rather lax : scales light or dark chestnut, rhombic-ovate, $3 \mathrm{~mm}$. long, obtuse, with several prominent ribs, not crowded, spreading and deciduous in age : achenes 3 -angled, obovoid, $2 \mathrm{~mm}$. long, brown.

In river valleys, the Indian Territory and Texas to adjacent Mexico. Summer and fall.

19. Cyperus Búshii Britton. Perennial by tuber-like corms. Leaves shorter than the scape, $4 \mathrm{~mm}$. wide or less, smooth, not viscid: scapes slender, smooth, 3-6 dm. tall: bracts of the involucre 3-5, the longer much exceeding the umbel : umbel simple, 1-5-rayed, the rays mostly short, or spikes congested into a single cluster: spikelets loosely capitate, linear, compressed, acute, 8-16 mm. long, 11-15-flowered : scales firm, shining, oblong, mucronate, strongly about 11-nerved: stigmas 3 : achene oblong, about $2 \mathrm{~mm}$. long, nearly twice as long as thick, 3-angled, pale brown, apiculate, $\frac{2}{3}$ as long as the scale.

In sandy soil, Minnesota and Wisconsin to Nebraska and the Indian Territory. Summer.

20. Cyperus élegans L. Perennial, pale green. Leaves several at the base of the scape, viscid; blades mostly $2-4 \mathrm{~mm}$. broad, involute above the loose, striate sheaths: scapes tufted, $2-7 \mathrm{dm}$. tall, sometimes equalled by the leaves or overtopped by them: bracts of the involucre $3-5$, very unequal, some $5 \mathrm{~cm}$. long, others often $30 \mathrm{~cm}$. long : umbel simple or compound, usually of $3-6$ rays, $1-8 \mathrm{~cm}$. long, with one or more spikes sessile in the involucre : spikelets linear-oblong, 6-12 mm. long, crowded : scales light tancolored, rhombic-ovate, $3 \mathrm{~mm}$. long, ascending, scabrous on the back, with more or less spreading short awn-like tips : achenes 3 -angled, obovoid, fully $1.5 \mathrm{~mm}$. long including the curved subulate beak.

In sandy soil, Florida to Texas and New Mexico. Also in tropical America. Spring to fall.

21. Cyperus acuminàtus Torr. \& Hook. Annual. Leaves light green; blades usually less than $2 \mathrm{~mm}$. wide : scapes very slender, tufted, $7-40 \mathrm{~cm}$. tall : bracts of the involucre much elongated : umbel 1-4-rayed, simple, rays short : spikelets flat, ovate-oblong, obtuse, 4-8 mm. long, many-flowered, densely capitate : scales oblong, pale green, 3-nerved, coarsely cellular, conduplicate, each with a short sharp more or less recurved tip : stigmas 3 : achenes sharply 3 -angled, gray, broadly oblong, narrowed at each end, little over 0.5 $\mathrm{mm}$. long, about $\frac{1}{2}$ as long as the scales.

In moist soil, Illinois to Iowa, Oregon, Louisiana, Texas and California. Summer and fall.

22. Cyperus cyrtólepis Torr. \& Hook. Perennial, bright green. Leaves mostly overtopped by the scape; blades $3-4 \mathrm{~mm}$. long, more or less revolute : scapes usually tufted, slender, 1-5 dm. long, smooth : bracts of the involucre 3-5, the longer ones surpassing the umbel, spreading : umbel capitate, or of 3-6 rays and some spikes sessile in the involucre, often compound : spikelets oblong or ovate-oblong, 5-7 mm. long, gray or yellowish, 1624-flowered: scales ovate, barely $2 \mathrm{~mm}$. long, acute, scarious-margined, with short recurved spreading tips: achenes 3-angled, elliptic or narrowly oblong, about $1 \mathrm{~mm}$. long, acnte or slightly pinched at both ends, rather lustrous.

In swampy grounds, Arkansas to Arizona and Texas. Spring to fall.

23. Cyperus Drummóndii Torr. \& Hook. Perennial. Leaves much shorter than the scape ; blades $4-6 \mathrm{~mm}$. wide : scapes $8-12 \mathrm{dm}$. tall, its angles very sharp, or almost winged, scabrous : bracts of the involucre usually 2 , surpassing the umbel : umbel capitate or congested, or with several more or less elongated rays, of many $(40-50)$ spikelets : spikelets lanceolate to oblong-lanceolate, 20-30-flowered, 6-12 mm. long, yellowish : scales lanceolate, very closely imbricated, acute : achenes 3 -angled, linear-oblong, above the slender stipe.

On plains or prairies, Texas. Summer.

24. Cyperus ochràceus Vahl. Perennial, bright or yellowish green. Leaves overtopped by the scape ; blades mostly 2-6 mm. long, smooth : scapes solitary or tufted, relatively slender, 2-12 dm. tall, smooth : bracts of the involucres mostly $3-5$, the longer ones much surpassing the umbel, spreading : umbel mostly compound, of 5-10 rays of various lengths, rarely over $15 \mathrm{~cm}$. lung, and one or more spikes sessile in the involucre: spikelets linear-oblong to linear-lanceolate, $5-12 \mathrm{~mm}$. long, 25-35-flowered : scales ovate, $2 \mathrm{~mm}$. long, rather blunt : achenes ovoid, slightly pinched at both ends, not stipitate.

In sandy soil, Alabama to Texas. Also in the West Indies and Mexico. Spring to fall.

25. Cyperus vírens Michx. Perennial, pale green. Leaves elongated ; blades 6-12 $\mathrm{mm}$. wide, striate : scapes stout, often tufted, 5-15 dm. tall, overtopping the leaves, smooth, naked above : bracts of the involucre $3-7$, variable in length, the longer surpassing the 
umbel, sometimes becoming $6 \mathrm{dm}$. long: umbel mostly compound, of 3-12 rays varying from $1-20 \mathrm{~cm}$. in length, with 1 or more spikes sessile in the involucre: spikelets numerous, ovate, 6-14 mm. long, acutish, many-flowered : scales oblong-ovate, fully $2 \mathrm{~mm}$. long, red-brown, pinched at the ends.

In sandy soil, North Carolina to Florida, and California, and in Mexico and Central America. Spring to fall.

26. Cyperus pseudovégetus Steud. Perennial by thickened tuber-like joints of the rootstocks. Leaf-blades $2-6 \mathrm{~mm}$. wide, smooth, nodulose, the midvein prominent: scapes rather stout, $3-13 \mathrm{dm}$. high, often equalled by the leaves : bracts of the involucre 4-6, spreading: umbel several-rayed, compound : spikelets ovate, flat, many-flowered, light green, densely capitate, 4-6 mm. long: scales keeled, conduplicate, 1-nerved, curved, acute : stigmas 3 : achene linear, 3-angled, slightly stalked. [C. calcaratus Nees.]

In marshes, Delaware to Kansas, Florida and Texas. Summer and fall.

27. Cyperus Surinaménsis Rottb. Perennial, pale green. Leaves overtopped by the scape; blades mostly $1.5-4 \mathrm{~mm}$. wide, usually rough along the margins : scapes slender, solitary or tufted, $2-12 \mathrm{dm}$. tall, naked and rough above: bracts of the involucre usually $3-5$, one or all longer than the rays of the umbel, rough-margined : umbels mostly compound, of generally 8-12 rays of various lengths, several spikes sessile or clustered in the involucre : spikelets oblong or linear-oblong, 5-12 mm. long, yellow, blunt, 40-50flowered, sometimes densely clustered: scales ovate, nearly $1.5 \mathrm{~mm}$. long, deciduous in age : achenes 3 -angled, oblong, about $0.8 \mathrm{~mm}$. long, brown, pinched at both ends.

In sandy swamps, Florida to Texas, and throughout tropical America. Spring to fall.

28. Cyperus refléxus Vahl. Perennial, bright green. Leaves overtopped by the scape; blades 1-4 mm. broad, smooth : scapes often tufted, slender, 1-7 dm. tall, smooth : bracts of the involucre 3-5, one or more surpassing the umbel, often compound, of 2-5rays and one or more spikes sessile in the involucre or capitate: spikelets ovate or ovatelanceolate, 4-6 mm. long, red or reddish brown, 20-25-flowered; scales ovate, about 1.5 $\mathrm{mm}$. long, acute, imbricated : achenes 3 -angled, elliptic, barely $1 \mathrm{~mm}$. long, pinched at the base, short-beaked.

In sandy soil, Texas. Also in tropical America. Spring to fall.

29. Cyperus İria L. Annual, bright green. Leaves mostly overtopped by the scape ; blades 2-4 mm. wide, revolute, striate : scapes erect, sometimes tufted, $2-5 \mathrm{dm}$. tall, smooth : bracts of the involucre usually 5 , the longer ones surpassing the umbel, curved : umbel of 5-9 rays of various lengths, compound : spikelets narrowly oblong, 5-10 $\mathrm{mm}$. long, yellowish or brownish, numerous, 12-26-flowered, rather lax : scales obovate or nearly orbicular, fully $1 \mathrm{~mm}$. long, thin, mucronulate, deciduous at maturity: achenes sharply 3 -angled, oblong-obovoid, about $1 \mathrm{~mm}$. long, reddish, minutely apiculate, slightly surpassing the scales.

In swamps mostly near the coast and rice fields, North Carolina to Florida and Texas. Naturalized from the tropics. Spring to fall.

30. Cyperus dístans $L$. Perennial, bright green. Leaves often overtopping the scape; blades 5-12 mm. wide, striate : scapes $3-15 \mathrm{dm}$. tall, erect, smooth, not jointed: bracts of the involucre 5 , the longer ones surpassing the umbel, ascending, spreading: umbels compound, of several slender rays and one or more spikes sessile in the involucre: spikelets numerous, very slender, linear-filiform, 1-2.5 cm. long, chestnut-colored, spicate and rather loosely disposed : scales oblong, fully $2 \mathrm{~mm}$. long, blunt, sharply keeled : achenes 3 -angled, narrowly oblong-obovoid, $1.5 \mathrm{~mm}$. long, abruptly pointed.

In swampy grounds or wet woods, North Carolina and Georgia. Widely distributed in the tropics. Spring to fall.

31 Cyperus cephalánthus Torr. \& Hook. Perennial, bright green. Leaves overtopped by the scape ; blades mostly $5-8 \mathrm{~mm}$. wide, rough on the margins and the nerves beneath: scapes erect, $6-15 \mathrm{dm}$. tall, rough on the angles near the top : bracts of the involucre often 4 or 5, several much elongated and surpassing the umbel, drooping in age : umbel of 4-7 rays and one or more spikes sessile in the involuere : spikelets linear or oblonglinear, numerous and densely capitate, $6-10 \mathrm{~mm}$. long, light chestnut-colored, scales ovalelliptic, $3 \mathrm{~mm}$. long, acute, with several sharp ribs along the back, loosely imbricated, deciduous: achenes 3-angled, elliptic or obovoid-elliptic, barely $1.5 \mathrm{~mm}$. long, rather abruptly pointed.

In low grounds, Louisiana and Texas. Spring to fall.

32. Cyperus Háspan L. Perennial by short rootstocks. Leaves reduced to membranous acuminate sheaths : scapes weak, tufted, $3-10 \mathrm{dm}$. high : bracts of the involucre about 2, usually less than $2 \mathrm{~mm}$. wide : umbel simple or compound, the longer rays $2-5$ cm. long : spikelets few, capitate, linear, acute, many-flowered, 6-12 mm. Iong, about 1 mm. wide : scales oblong or oblong-lanceolate, reddish brown, acute, mucronulate, keeled, 
3-nerved: rachis winged: stigmas 3 : achene 3 -angled, broadly obovoid, $0.5-0.7 \mathrm{~mm}$. long, obtuse, nearly white, much shorter than the scale.

In swamps and sandy bogs, Virginia to Florida and Texas, mostly near the coast. Also in tropical America and in the warmer parts of Europe, Asia and Australia. Summer and fall.

33. Cyperus dentàtus Torr. Perennial by scaly rootstocks which sometimes bear small tubers. Leaves keeled; blades $2-4 \mathrm{~mm}$. wide: scapes rather stiff, $2-5 \mathrm{dm}$. tall : bracts of the involucre $3-4,1$ or 2 usually exceeding the inflorescence: umbel somewhat compound ; longer rays $2.5-7.5 \mathrm{~cm}$. long : spikelets linear, very flat, many-flowered, mostly blunt, 10-20 $\mathrm{mm}$. long, nearly $4 \mathrm{~mm}$. wide: scales light reddish brown, ovate-lanceolate, thin, keeled, 5-7-nerved, mucronate, separating from the rachis when mature, their tips spreading, causing the spikelet to appear toothed : stigmas 3 , exserted : achene 3 -angled, obovoid, about $0.8 \mathrm{~mm}$. long, obtuse, mucronate, light brown, much shorter than the scale. Scales of the spikelets often modified into tufts of small leaf-like bracts.

In sandy swamps and on river shores, Maine to northern New York, South Carolina and West Virginia. Summer and fall.

34. Cyperus multiradiàtus (Torr.) Mohr. Perennial, yellowish green. Leaves overtopped by the scape ; blades firm, $2-5 \mathrm{~mm}$. broad, smooth : scapes solitary, $2-4 \mathrm{dm}$. tall, smooth : bracts of the involucre 3-5, one or more of them surpassing the umbel, ascending : umbel of 5-10 rays, all of different lengths : spikelets linear or linear-lanceolate, $1-2.5 \mathrm{~cm}$. long, 3-4 mm. wide, yellow, 30-70-flowered, numerous: scales ovate, fully $2 \mathrm{~mm}$. long, merely acute, scarious margined, minutely hooded at the apex, closely imbricated, faintly 7-nerved, pesistent: achenes 3 -angled, broadly ovoid, $0.8 \mathrm{~mm}$. long, lustrous, brown. [C. dentatus $\beta$ ? multiradiatus Torr. C. LeContei Torr.]

In sand, Florida to Louisiana. Spring to fall.

35. Cyperus rotúndus L. Perennial by scaly tuber-bearing rootstocks. Leaf-blades 3-6 mm. wide: scapes rather stout, 1-5 dm. high, usually longer than the leaves : bracts of the involucre 3-5: umbel 3-8-rayed, the longer rays $5-11 \mathrm{~cm}$. long: spikelets linear, clustered, few in each cluster, acute, $8-20 \mathrm{~mm}$. long, $2-3 \mathrm{~mm}$. wide : scales dark purplebrown or with green margins and center, ovate, acute, appressed, about 3-nerved on the keel : stigmas 3, exserted : achene 3 -angled, linear-oblong, about $1 \mathrm{~mm}$. long, about $\frac{1}{2}$ as long as the scale.

In fields, Virginia to Florida. Kansas and Texas. Also in tropical America, and widely distributed in the Old World. Summer and fall.

36. Cyperus Hállii Britton. Perennial by scaly rootstocks. Leaves with blades about 4-6 mm. wide: scapes rather stout, 6-9 dm. tall, about equalled by the leaves: involucral bracts $3-6$, the longer much exceeding the inflorescence : umbel compound, its longer rays $7-10 \mathrm{~cm}$. long, the raylets sometimes $2.5 \mathrm{~cm}$. long: spikelets numerous, loosely clustered, linear, 7-15-flowered, 10-16 mm. long, 2-3 mm. wide: involucels setaceous: scales ovate, acute, strongly 7-9-nerved, dark reddish brown or with lighter margins, their tips not appressed: stigmas 3 , much exserted: achene linear-oblong, $1.5 \mathrm{~mm}$. long, 3angled, about $\frac{1}{2}$ as long as the scale.

On plains and prairies, Kansas and the Indian Territory to Texas. Summer and fall.

37. Cyperus esculéntus L. Perennial by scaly tuber-bearing rootstocks. Leaves light green; blades $4-8 \mathrm{~mm}$. wide, the midvein prominent : scapes usually stout, $3-8 \mathrm{dm}$. tall, commonly shorter than the leaves : bracts of the involucre $3-6$, the longer much exceeding the inflorecence: umbel 4-10-rayed, often compound: spikelets numerous in loose spikes, straw-color or yellowish brown, flat, spreading, 1-2.5 cm. long, about $3 \mathrm{~mm}$. wide, many-flowered: scales ovate-oblong, rather acute, 3-5-nerved: rachis narrowly winged: stigmas 3 : achene obovoid, fully $1 \mathrm{~mm}$. long, obtuse, 3 -angled.

In moist fields, New Brunswick to Minnesota, Nebraska. Florida and Texas. Also on the Pacific coast from California to Alaska, in tropical America, and widely distributed in the Old World. Sometimes a troublesome weed. Summer and fall.-A form with very slender spikelets about $2 \mathrm{~mm}$. wide or narrower, is C. esculentus angustispicatus Britton; it ranges from Massachusetts and Missouri to South Carolina. Chufa.

38. Cyperus articulàtus L. Perennial, pale green. Leaves reduced to a few scales at the base of the scape or sometimes with a few well developed blades: scapes erect, $8-20 \mathrm{dm}$. tall, transversely septate, terete, smooth : bracts of the involucre mostly 3 , ovate or linear-lanceolate, much shorter than the umbel, erect or nearly so: umbel of 4-10 slender, curved rays, compound: spikelets slender, narrowly linear, $2-5 \mathrm{~cm}$. long, or sometimes shorter, deep straw-colored, not crowded, 30-50-flowered : scales elliptic or ovate, fully $3 \mathrm{~mm}$. long, acutish or rather blunt, faintly ribbed, closely imbricated : achenes 3 -angled, oblong or cuneate-oblong, fully $1 \mathrm{~mm}$. long, somewhat lustrous, pinched at the apex.

In sandy swamps, South Carolina to Florida and Texas. Throughout the tropics. Spring to fall.

39. Cyperus erythrorhìzos Muhl. Annual. Leaf-blades $3-8 \mathrm{~mm}$. wide, roughmargined: scapes tufted, stout or slender, $7-50 \mathrm{~cm}$. tall : bracts of the involucre $3-7$, some 
of them 3-5 times as long as the inflorescence: umbel mostly compound : spikelets linear, rather acute, 6-25 mm. long, less than $2 \mathrm{~mm}$. wide, compressed, many-flowered, crowded in oblong, nearly or quite sessile spikes: scales bright chestnut-brown, oblong-lanceolate, mucronulate, loose : stigmas 3 : achene sharply 3-angled, oblong, about $1 \mathrm{~mm}$. long, pointed at both ends, pale, $\frac{1}{2}$ as long as the scale.

In wet soil, southern Ontario to Massachusetts, Nebraska, Kansas, Florida, Texas and California. Summer and fall.

40. Cyperus digitàtus Roxb. Annual, yellowish green. Leaves sometimes overtopping the scape ; blades $4-15 \mathrm{~mm}$. wide, sometimes with rough margins and nerved beneath : scapes commonly solitary, 3-12 dm. tall, 3-angled, smooth : bracts of the involucre $6-10$, the longer ones surpassing the umbel : umbel compound, of 5-8 more or less elongated rays, and one or more spikes sessile in the involucre: spikes about $1 \mathrm{~cm}$. thick: spikelets laxly disposed, linear-subulate, $6-10 \mathrm{~mm}$. long, chestnut-colored, 10-15-flowered, numerous : scales broadly oblong, about $2 \mathrm{~mm}$. long, closely appressed, abruptly pointed or cuspidate, with pale hyaline margins: achenes 3-angled, fully $1 \mathrm{~mm}$. long, elliptic or oblong, pale brown. [C. erythrorhizos var. erectus Britton.]

In low grounds or swamps, Texas and Mexico. Spring to fall.

41. Cyperus Hàlei Torr. Annual. Leaf-blades 6-8 mm. wide, very rough-margined : scapes stout, $6-10 \mathrm{dm}$. tall, about equalled by the leaves: bracts of the involucre 5-8, much elongated : umbel compound, several-rayed : spikes cylindric, sessile or very nearly so, exceedingly dense, $1-2.5 \mathrm{~cm}$. long: spikelets very numerous, linear, $3-5 \mathrm{~mm}$. long, $1 \mathrm{~mm}$. wide, spreading : scales brown, keeled, indistinctly 5 -nerved, oblong, mucronulate: stigmas 3 : achene 3 -angled, about $1 \mathrm{~mm}$. long.

In swamps, south Missouri to Tennessee, Louisiana and Florida. Summer and fall.

42. Cyperus Floridànus Britton. Perennial, bright green. Leaves mostly reduced to a few basal scales and several filiform blades: scapes tufted, erect or reclining, 1-7 dm. long, filiform or wiry : bracts of the involucre 2, one about as long as the inflorescence, the other longer : umbel capitate, sessile : spikelets linear-subulate, 6-10 $\mathrm{mm}$. long, crowded, chestnut brown : scales broadly oblong, fully $2 \mathrm{~mm}$. long, blunt, closely imbricated, ribbed on the back, very firm : achenes 3 -angled, oblong or nearly so, about $1.5 \mathrm{~mm}$. long, dark brown, dull.

In sand, southern Florida and the West Indies. Spring to fall.

43. Cyperus Engelmánnii Steud. Annual. Leaves elongated; blades 4-6 mm. wide, flaccid, roughish on the margins : scapes slender, $15-75 \mathrm{~cm}$. tall : bracts of the involucre 4-6, the longer exceeding the umbel : umbel often compound, the spikelets often densely crowded, very commonly linear, subterete, 1-2.5 cm. long, 5-15-flowered : rachis narrowly winged: scales greenish brown, oblong, obtuse, thin, faintly 3-5-nerved on the back, distant, the successive ones on each side of the spikelet separated by a space of about $\frac{1}{2}$ their length : stigmas 3 : achene linear-oblong, 3-angled, $\frac{2}{3}$ as long as the scale, about 2 mm. long.

In wet soil, Massachusetts to southern Ontario, Wisconsin, New Jersey and Missouri. Summer and fall.

44. Cyperus speciòsus Vahl. Annual. Leaf-blades rough-margined, 3-5 mm. wide, the midvein prominent: scapes usually tufted, $10-40 \mathrm{~cm}$. tall, reddish toward the base : bracts of the involucre much exceeding the umbel : umbel 3-7-rayed, the primary rays 2-15 cm. long: involucels narrow : spikes dull brown: spikelets subterete, very narrowly linear, 8-25 mm. long, less than $2 \mathrm{~mm}$. thick, 10-30-flowered, falling away from the axis at maturity : scales dull brown, thin, not tightly appressed, ovate, obtuse, faintly 3-5nerved on the back : rachis-wings broad, clasping the achene, persistent: stigmas 3, slightly exserted : achene obovoid, barely $1.5 \mathrm{~mm}$. long, pale, 3-angled, about $\frac{1}{2}$ as long as the scale.

In marshes, eastern Massachusetts and Rhode Island to Ohio, Minnesota, Florida, Texas and California. Summer and fall.-A variety with reddish spreading or slightly recurved scales, is $C$. speciosus ferruginéscens (Boeckl.) Britton; its range is from Missouri to Texas and New Mexico. Another variety with about the same range, C. speciosus parvus (Boeckl.) Britton, has scapes 2-7 $\mathrm{cm}$. high, a very simple umbel and generally a single cluster of short spikelets.

45. Cyperus fèrax Vahl. Annual, closely related to the next preceding species, but with smooth-margined, shorter and broader leaf-blades : bracts of the involucre sometimes but little exceeding the inflorescence : urnbel often compact, the rays mostly short : spikes yellowish or grayish brown : spikelets linear, subterete, $10-20$-flowered, $16-25 \mathrm{~mm}$. long, about $2 \mathrm{~mm}$. thick: scales ovate-oblong, appressed, imbricated, obtuse, rather firm, green and 7-9-nerved on the back, yellowish on the sides: stigmas $3:$ rachis broadly winged: achene 3 -angled, narrowly obovoid, obtuse, about $1-1.5 \mathrm{~mm}$. long.

In wet soil, Missouri to California, and widely distributed in tropical America. Summer and fall. 
46. Cyperus Eggérsii Boeckl. Annual, pale or bright green. Leaves commonly overtopping the scape, rough-margined: scapes 3-9 dm. tall, smooth : bracts of the involucre mostly 5, somewhat broader than the leaf-blades, much surpassing the umbel : umbel of 2-4 rays 1-3 cm. long, compound: spikes several to many : spikelets greenish brown, 4-7 $\mathrm{mm}$. long, very brittle: scales blunt, less than $2 \mathrm{~mm}$. long: achenes oblong, fully $1 \mathrm{~mm}$. long, abruptly pointed at the apex, pinched at the base, straight, brown.

In low grounds, southern Texas. Also in tropical America. Spring to fall.

47. Cyperus oxycarioìdes Britton. Annual, bright green. Leaves mostly overtopped by the scapes; blades $3-8 \mathrm{~mm}$. wide, roughish on the margins: scapes $5-12 \mathrm{dm}$. tall, 3-angled, smooth : bracts of the involucre usually 5, several much longer than the umbel, spreading: umbel capitate, the spikes congested into a dense terminal cluster : spikelets linear-subulate, numerous, light green-brown, 6-10 mm. long, brittle, 8-12-flowered, densely crowded: scales oval-oblong, about $2 \mathrm{~mm}$. long, blunt, delicately ribbed, closely imbricated : achenes 3-angled, oblong-obovoid, $1.5 \mathrm{~mm}$. long, pale brown, slightly curved.

In sandy swamps, southern Texas and Central America. Spring to fall.

48. Cyperus Martindàlei Britton. Perenial, bright green. Leaves overtopped by the scape; blades filiform by the revolute margins, smooth : seapes tufted, erect, $2-7 \mathrm{dm}$. tall, 3-angled, smooth: bracts of the involucre 3-5, slender like the leaf-blades, several much elongated: umbel eapitate, or with 1-3 slender rays: spikes globular, $1-2 \mathrm{~cm}$. in diameter: spikelets linear or linear-subulate, 6-10 $\mathrm{mm}$. long, yellowish green, densely crowded: scales broadly oblong, $2-2.5 \mathrm{~mm}$. long, prominently ribbed, often becoming eroded at the apex, spreading at maturity : achenes 3 -angled, oblong, $2 \mathrm{~mm}$. long or nearly so, brown, dull.

In sand, Georgia to Florida and Louisiana. Spring to fall.

49. Cyperus setígerus Torr. \& Hook. Perennial, bright green. Leaves overtopped by the scape ; blades $4-10 \mathrm{~mm}$. wide, rough at least on the margins: scapes erect, $6-12 \mathrm{dm}$. tall, smooth : bracts of the involucre $3-5$, with scabrous margins, the longer ones much surpassing the umbels, spreading : umbels of usually 6-9 slender smooth or scabrous rays, and one or more spikes sessile in the involucre: spikelets linear, $1-2.5 \mathrm{~cm}$. long, chestnut-brown, rather numerous: scales lanceolate, $3-4 \mathrm{~mm}$. long, acute, rather closely imbricated, ribbed on the back : achenes 3 -angled, oblong-prismatic, $1.5 \mathrm{~mm}$. long, pinched at the apex.

In low grounds, Texas and New Mexico. Spring to fall.

50. Cyperus strigòsus $\mathrm{L}$. Perennial by basal tuber-like corms. Leaves rough-margined, 4-6 mm. wide : scapes rather stout, 3-9 dm. tall : the longer bracts of the involucre much exceeding the umbel : umbel several-rayed, some of the primary rays often 10-15 cm. long, their sheaths terminating in two bristles : involucels setaceous : heads oblong or ovoid : spikelets flat, linear, $8-19 \mathrm{~mm}$. long, $2 \mathrm{~mm}$. wide or less, 7-15-flowered : scales strawcolored, oblong-lanceolate, subacute, strongly several-nerved, appressed : stigmas 3 : achenes linear-oblong, 3 -angled, about $2 \mathrm{~mm}$. long, acute, about $\frac{1}{3}$ as long as the scale.

In moist meadows, swamps or along streams, Maine to Ontario, Minnesota, Nebraska, Florida and Texas. Summer and fall.--Several varieties have been described: C. strigosus robuistior Kunth, has a compound umbel and large spikelets $16-25 \mathrm{~mm}$. long with 10-25 flowers; it occurs with the type; $C$. strigosus capitatus Boeckl., has the umbel simple or nearly simple, and the spikelets 8-14 $\mathrm{mm}$. long, densely crowded in subglobose heads; its range is like that of the type; C. strigosus compositus Britton, has a compound umbel and spikelets $8-13 \mathrm{~mm}$. long, with only 4 or 5 flowers; it ranges from New York to Iowa and Alabama. C. strigosus gracilis Britton, is very slender, with leaves overtopped by the scape, umbel of 1-3 short rays, bearing few linear spreading spikelets; it is confined to Arkansas and Texas : and $C$. strigosus elongattus (Torr.) Britton, has much elongated rays bearing single capitate clusters, North Carolina and Texas.

51. Cyperus stenólepis Torr. Perennial, bright green. Leaves overtopped by the scapes ; blades $8-16 \mathrm{~mm}$. wide, very rough on the margins, pale beneath : scapes erect, 5-12 dm. tall, smooth, 3-angled : bracts of the involucre 3-6, the longer ones much surpassing the umbel, spreading : umbel simple or compound, of 6-9 rays of various lengths and one or more spikes sessile in the involucre : spikelets numerous, linear, $15-20 \mathrm{~mm}$. long, bright straw-colored, 5-12-flowered : seales linear or linear-lanceolate, 4-5 mm. long, prominently ribbed and deciduous at maturity, loose and somewhat spreading : achenes 3 -angled, oblong-prismatic, about $2 \mathrm{~mm}$. long, brown, abruptly pointed at the apex, pinched at the base.

In swamps or low grounds, North Carolina to Florida and Texas. Summer and fall.

52. Cyperus refráctus Engelm. Perennial by tuber-like corms. Leaf-blades 5-8 $\mathrm{mm}$. wide, rough-margined, elongated : scapes stout, smooth, 3-9 dm. tall : umbel 6-13rayed, usually compound, the longer rays sometimes $20 \mathrm{~cm}$. long, their sheaths terminating in 1 or 2 short teeth : involucels setaceous : raylets filiform : spikelets very narrowly linear, loosely spicate, acute, $1-2 \mathrm{~cm}$. long, $1 \mathrm{~mm}$. thick, 3-6-flowered, the upper spreading, the lower reflexed: scales yellowish green, oblong-lanceolate, obtuse, closely appressed, 9-11- 
nerved, thin : stigmas 3 , much exserted : achenes narrowly linear, about $3 \mathrm{~mm}$. long, obtuse, apiculate, about 5 times as long as thick, and $\frac{1}{2}$ as long as the scale.

In dry fields or woods, New Jersey to North Carolina and Missouri. Summer and fall.

53. Cyperus dissitiflòrus Torr. Perennial, bright green. Leaves somewhat overtop ping the scape, smooth or nearly so: scapes sometimes sparingly tufted, very slender, 3 -angled, smooth : bracts of the involucre mostly 4-6, the longer ones surpassing the umbel: umbel of $3-5$ slender rays and one or more spikes sessile in the involucre: spikelets linear-subulate, slender, $5-8 \mathrm{~mm}$. long, spreading, 5-7-flowered, chestnut-colored, acute, not crowded, flattened: scales ovate to oblong, $2.5-3 \mathrm{~mm}$. long, acute, closely imbricated: achenes 3-angled, oblong-prismatic or slightly broadened upward, $1.5 \mathrm{~mm}$. long, abruptly pointed.

In sand, Florida to Texas. Spring to fall.

54. Cỵperus retrofráctus (L.) Torr. Perennial by tuber-like corms. Leaf-blades 3-5 mm. wide: scapes usually rough-puberulent, at least above, mostly longer than the puberulent leaves : bracts of the involucre 4-7, the longer not greatly exceeding the umbel, sometimes shorter: umbel simple: rays $5-15 \mathrm{~cm}$. long, their sheaths 2-toothed : heads oblong or obovoid: spikelets linear-subulate, $6-12 \mathrm{~mm}$. long, about $1 \mathrm{~mm}$. thick, 1-2flowered, all soon strongly reflexed: flowering scales lanceolate, acute, the upper one subulate, all strongly several-nerved: stigmas 3 : achenes linear, $1.5-2 \mathrm{~mm}$. long, 3angled, obtuse, apiculate, $\frac{2}{3}$ as long as the scale.

In sandy soil, southern New Jersey to Florida, Kentucky, Arkansas and Texas. Summer and fall.

55. Cyperus ovulàris (Michx.) Torr. Perennial by hard tuber-like corms. Leaves smooth ; blades 4-6 mm. wide : scape usually strict, smooth, 2-8 dm. tall, longer than the leaves : longer bracts of the involucre much exceeding the umbel : umbel simple, few-rayed; sheath of the rays truncate or slightly toothed : spikes globose, $8-14 \mathrm{~mm}$. in diameter, very dense, the spikelets radiating in all directions : spikelets 4-7 mm. long, usually 3 -flowered: scales ovate or ovate-lanceolate, obtuse or subacute, green, strongly several-nerved : stigmas 3 : achenes linear-oblong, 3-angled, about $1.5 \mathrm{~mm}$. long, 1-3 times as long as thick.

In dry fields and on hills, southern New York to Florida, Illinois, Kansas and Texas.-C. ovularis sphaèricus Boeckl., differs in its usually smaller heads, the spikelets more subulate, reddish brown. Arkansas to Texas. Summer and fall.

56. Cyperus retrórsus Chapm. Perennial, pale green. Leaves overtopped by the scape; blades $3-5 \mathrm{~mm}$. wide, sometimes with rough margins and nerves beneath : scapes erect, 4-7 dm. tall, smooth : bracts of the involucre 7-10, mostly surpassing the umbel : umbel simple, of usually 8 slender rays : spikes narrowly obovoid, $1-1.5 \mathrm{~cm}$. long: spikelets densely crowded, subulate, $3 \mathrm{~mm}$. long, the lower ones becoming reflexed : scales oblong or nearly so, 2.5-3 mm. long, ribbed, closely appressed : achenes 3-angled, oblongprismatic, nearly $2 \mathrm{~mm}$. long, light brown. [C. retroversus Chapm.]

On the sandy shore of Caximbas Bay, Florida. Spring to winter.

57. Cyperus cylíndricus (Ell.) Britton. Perennial by hard corms. Leaf-blades 2-3 mm. wide : scapes smooth, usually tufted, 1-5 dm. tall, longer than the leaves: longer bracts of the involucre much exceeding the umbel : umbel simple, the rays short, or the longer 2-7 cm. long, the sheaths 2-toothed: spikes very dense, cylindric, 5-15 mm. long, 4-8 mm. in diameter, simple : spikelets 3-4 mm. long, flattish, 1-2-flowered, spreading or the lower reflexed : scales green, oblong: rachis winged : stigmas $3:$ achenes linear-oblong about $1.5 \mathrm{~mm}$. long, 3-angled, granular, apiculate, slightly more than $\frac{1}{2}$ as long as the scale,

In sandy soil and on the sea shore, southern New York to Florida and Texas. Summer and fall.

58. Cyperus Plánkii Britton. Similar to $C$. cylindricus in habit, but stouter. Leafblades mostly $2.5-4 \mathrm{~mm}$. wide, smooth : scapes solitary or sparingly tufted, $3-10 \mathrm{dm}$. tall, smooth, often surpassing the leaves : bracts of the involucre broader than the leaf-blades, sometimes 6-7 mm. broad, the longer ones surpassing the umbel : umbel simple, of 4-10 rays, the larger $5-15 \mathrm{~cm}$. long, mostly ascending: spikes very dense, cylindric, $15-20 \mathrm{~mm}$. long, 10-15 mm. in diameter, green : spikelets 5-7 mm. long, 3-4 flowered : scales ribbed: rachis winged : stigmas 3 : açhenes linear-oblong, $1.5 \mathrm{~mm}$. long, 3-angled, coarsely granular, apiculate.

On plains and prairies, Oklahoma, the Indian Territory and Texas. Spring to fall.

59. Cyperus cylindrostáchys Boeckl. Perennial, pale green. Leaves overtopped by the scape ; blades 4-8 mm. wide, smooth : scapes often sparingly tufted, $3-15 \mathrm{dm}$. tall, 3 -angled, smooth : bracts of the involucre 5-8, the longer ones much surpassing the umbel: umbel simple or compound, of 6-12 slender rays and one or more spikes sessile in the involucre: spikes cylindric, $1.5-3.5 \mathrm{~cm}$. long, mostly less than $1 \mathrm{~cm}$. thick, usually compound : spikelets subulate, 4-5 mm. long, grayish brown or tinged with yellow, numerous, densely crowded, spreading or recurved : scales oblong or nearly so, $2.5-3 \mathrm{~mm}$. long, blunt, 
finely ribbed, closely imbricated : achenes 3-angled, oblong-prismatic, nearly $2 \mathrm{~mm}$. long, abruptly pointed.

In sand, Florida to Texas. Spring to fall.

60. Cyperus Lancastriénsis Porter. Perennial by ovoid or oblong corms. Leafblades 4-6 mm. wide : scapes slender, smooth, mostly longer than the leaves, $3-8 \mathrm{dm}$. tall : bracts of the involucre $4-7$, the longer much exceeding the inflorescence : umbel simple, 5-9-rayed, the longer rays $5-10 \mathrm{~cm}$. long, their sheaths nearly truncate: spikes oval, obtuse, 1-2.5 cm. long: spikelets densely clustered, $8-10 \mathrm{~mm}$. long, linear, nearly terete, 2-4-flowered, the lower reflexed, the middle ones spreading, all separating from the axis at maturity : scales green, strongly several-nerved, the flowering ones lanceolate, subacute: stigmas 3 : achenes linear, obtuse, $2.5-3 \mathrm{~mm}$. long, apiculate, $2-3$ times as long as thick, $\frac{2}{3}$ as long as the scale.

In dry fields, New Jersey and Pennsylvania to Virginia and Alabama. Summer and fall.

61. Cyperus uniflòrus Torr. \& Hook. Perennial, bright green. Leaves overtopped by the scape; blades $2-4 \mathrm{~mm}$. wide, smooth: scapes often tufted, slender, $1-7 \mathrm{dm}$. tall, smooth : bracts of the involucre 4-7, the longer ones surpassing the umbel : umbel simple, of 3-6 slender rays and one or more spikes sessile in the involucre: spikes oval or ovoid, $1.5-2 \mathrm{~cm}$. long: spikelets spreading in all directions, usually curved, subulate, $8-12 \mathrm{~mm}$. long, gray-green, attenuate, never densely crowded : scales various, narrow, lower merely acute, upper more or less awn-tipped, closely imbricated: achenes 3-angled, oblong or slightly broadest above the middle, $2.5 \mathrm{~mm}$. long, brown.

In sandy swamps or low grounds, Arkansas and the Indian Territory to Texas, New Mexico and Mexico. Spring to fall.

62. Cyperus subuniflòrus Britton. Similar to the next preceding species in habit, but more slender and smaller throughout. Umbels with fewer rays: spikes globular or ovoid-globose, $6-10 \mathrm{~mm}$. long: spikelets more or less spreading, 3-5 mm. long, without conspicuous subulate tips, little if at all curved : achenes 3-angled, oblong, about $2 \mathrm{~mm}$. long, abruptly pointed.

In dry soil, the Indian Territory, Texas and Mexico. Spring to fall.

63. Cyperus tetrágonus Ell. Perennial, bright green. Leaves mostly overtopped by the scape ; blades $4-10 \mathrm{~mm}$. broad, smooth or nearly so: scape often solitary, erect, 3-8 dm. tall, smooth : bracts of the involucre 8-10, the longer ones surpassing the umbel, ascending, spreading: umbel mostly compound, of 6-12 slender erect or ascending rays and one or more spikes sessile in the involucre : spikelets linear-oblong, plump, 4-6 mm. long, acute, chestnut-colored, 4-6-flowered, spreading or the lower reflexed : scales oblong, fully $3 \mathrm{~mm}$. long, 9-11-nerved, closely imbricated : achenes oblong or elliptic, 3-angled, $2 \mathrm{~mm}$. long, chestnut-colored, dull.

In sandy soil, near the coast, North Carolina to Florida and Texas. Spring to fall.

64. Cyperus flàvus (Vahl) Nees. Perennial, bright green. Leaves overtopped by the scape ; blades $2-6 \mathrm{~mm}$. wide, smooth : scapes often tufted, 1-6 dm. tall, smooth : bracts of the involucre mostly 4-6, the longer ones surpassing the umbel : umbel capitate, of 3-6 sessile cylindric spikes, $1-2 \mathrm{~cm}$. long, or occasionally with $2-3$ short rays: spikelets densely crowded, $3-5 \mathrm{~mm}$. long, spreading, chestnut-colored : scales ovate to oblong, 2-2.5 $\mathrm{mm}$. long, finely ribbed, often eroded at the apex, closely imbricated : achenes 3-angled, broadly elliptic to obovoid-elliptic, about $2 \mathrm{~mm}$. long, brown, dull.

In sand, Texas and tropical America. Spring to fall.

65. Cyperus fuliginèus Chapm. Perennial, deep green. Leaves overtopped by the scape; sheaths blackish; blades revolute, about as slender as the scape, smooth : scapes tufted, filiform, 1-4 dm. tall, smooth : bracts of the involucre 2 , one much shorter than the other: spikelets crowded in a head about $1 \mathrm{~cm}$. in diameter, linear-oblong, 4-7 mm. long, dark brown, 8-12-flowered, often apparently lateral : scales oval or ovate, barely 2 $\mathrm{mm}$. long, mucronulate, several-ribbed : achenes 3-angled, oblong-obovoid, barely $1.5 \mathrm{~mm}$. long, dark brown, dull.

In sand, Key West, Florida. Spring to winter.

66. Cyperus filicúlmis Vahl. Perennial by hard oblong corms. Leaf-blades $2-4 \mathrm{~mm}$. wide, keeled : scape smooth, slender, or almost filiform, ascending or reclined, $1.5-4.5 \mathrm{dm}$. long, usually longer than the rough-margined leaves : spikelets densely clustered in 1-7 globose heads, linear, acute, 5-11-flowered, subterete or compressed, 5-12 mm. long, $2 \mathrm{~mm}$. wide or less : scales ovate, acute or obtuse, pale green, strongly 7-11-nerved, appressed : stigmas 3 : achenes oblong or obovoid, fully $2 \mathrm{~mm}$. long, 3-angłed, obtuse, apiculate, dull gray, $\frac{2}{3}$ as long as the scale, about twice as long as thick.

In dry fields and on hills, New Hampshire to Ontario, Minnesota, Nebraska, Florida, Kansas, Texas and northern Mexico. Spring and summer. 
67. Cyperus Blodgéttii Torr. Perennial, bright green. Leaves overtopped by the scapes; blades 2-4 mm. wide, smooth : scapes tufted, 1-3 dm. tall, 3 -angled, smooth : bracts of the involucre 3 or sometimes 2 very small additional ones present, the longer ones surpassing the umbel : umbel capitate or with one to three short rays: spikes $10-15 \mathrm{~mm}$. in diameter : spikelets $20-40$, oblong or linear-oblong, $6-8 \mathrm{~mm}$. long, densely crowded, 1-10flowered: scales oval to ovate, less than $2 \mathrm{~mm}$. long, mostly 9-nerved, rather obtuse : achenes 3-angled, oblong, about $1 \mathrm{~mm}$. long, brown, dull.

In sand, Key West, Florida. Spring to winter.

68. Cyperus ligulàris L. Perennial, glaucous. Leaves sometimes overtopping the scape ; sheath colored at the base ; blades 6-20 mm. broad, serrulate, somewhat revolute: scapes erect, 5-12 dm. tall, 3-angled, smooth : bracts of the involucre $3-6$, several much elongated : umbel compound, of 6-many short rays, often rather dense, or the rays rarely elongated: spikes cylindric or oblong, 1-2 $\mathrm{cm}$. long: spikelets 4-6 $\mathrm{mm}$. long, gray to brown, densely crowded, spreading ; scales oval, $2.5-3 \mathrm{~mm}$. long, blunt, closely imbricated delicately ribbed : achenes 3 -angled, elliptic or slightly broadest above the middle, $1.5 \mathrm{~mm}$. long, dark brown, dull.

In sand or swamps, Florida. Also in the tropies of both hemispheres. Spring to winter.

69. Cyperus Graỳi Torr. Perennial by thick, hard oblong or ovoid corms. Leaves shorter than the scape, bright green; blades $2 \mathrm{~mm}$. wide or less : scapes tufted, ascending or reclined, stiff, smooth, very slender, $15-50 \mathrm{~cm}$. long: bracts of the involucre 4-8: umbel 4-10-rayed, simple, the longer rays 7-10 cm. long: sheaths of the rays truncate or nearly so : spikelets $5-10 \mathrm{~mm}$. long, loosely capitate, compressed, linear, rigid, spreading : scales green, ovate, obtuse or subacute, strongly 13-15-nerved, rather widely spreading when old: joints of the rachis broadly winged: stigmas 3 : achene oblong or oblongobovoid, barely $2 \mathrm{~mm}$. long, obtuse, apiculate.

In sands of the sea shore and in pine lands, New Hampshire to Florida. Summer and fall.

70. Cyperus echinàtus (Ell.) Wood. Perennial by tuber-like corms. Leaves pale green ; blades 3-4 mm. wide : scape slender, smooth, erect, mostly longer than the leaves: bracts of the involucre 5-10, the longer usually much exceeding the umbel : umbel 6-13rayed : rays filiform, their sheaths short, mucronate : spikelets $4-8 \mathrm{~mm}$. long, linear, flat, capitate in globose heads : scales thin, pale green, appressed, ovate-lanceolate, acute, 9-13nerved, with narrow scarious margins: joints of the rachis broadly winged: stigmas 3 : achene oblong-obovoid, $2 \mathrm{~mm}$. long, about twice as long as thick.

In dry or sandy soil, North Carolina to Missouri, Florida and Texas. Summer.

71. Cyperus brúnneus Sw. Perennial, bright green. Leaves overtopped by the scape ; blades 2-7 mm. wide, smooth, sometimes involute : scapes erect, usually solitary, 3-7 dm. tall, 3-angled, smooth : bracts of the involucre often 4-5, all of them or the longer ones surpassing the umbel, spreading: umbel compound, capitate, or 3-5 of the rays becoming $1-5 \mathrm{~cm}$. long: spikelets linear or linear-lanceolate, $10-15 \mathrm{~mm}$. long, chestnutcolored, densely crowded : scales oval or ovate-oval, nearly $3 \mathrm{~mm}$. long, often apiculate, conspicuously ribbed : achenes 3-angled, elliptic-obovoid, fully $1.5 \mathrm{~mm}$. long, dark-brown, granular.

In sand, Florida. Also in tropical America. Spring to fall.

72. Cyperus Ottònis Boeckl. Perennial, bright green. Leaves mostly overtopping the scape; blades $4-12 \mathrm{~mm}$. wide, with rough margins : scapes $3-12 \mathrm{dm}$. tall, 3 -angled, smooth : bracts of the involucre usually 5 or 6 , several conspicuously elongated: umbel compound, of 4-8 rays and 1 or more spikes sessile in the involucre: spikelets linear, 1-1.5 cm. long, chestnut-colored, numerous, often crowded, 10-16-flowered: scales oblong or nearly so, fully $3 \mathrm{~mm}$. long, acute, many-ribbed on the back, rather loosely imbricated : achenes 3 -angled, oblong-obovoid, fully $1.5 \mathrm{~mm}$. long, dark brown, dull.

In wet sand, Florida and the West Indies. Spring to fall.

\section{KYLLÍNGA Rottb.}

Annual or perennial sedges, with slender triangular scapes bearing 2 or more bracts at the summit which form an involucre to the strictly sessile simple or compound, dense head of spikelets. Spikelets numerous, compressed, each with 1 perfect flower, falling away from the axis of the head at maturity, consisting of only 3 or 4 scales, the 1 or 2 lower ones small and empty, the middle one fertile, the upper empty or staminate. Scales 2ranked, keeled. Perianth none. Stamens 1-3. Style deciduous from the summit of the achene. Stigmas 2-3. Aंchene lenticular or 3-angled.

Upper scales of the spikelets with scabrous or ciliate keels.

Involuere with all the bracts spreading: upper scales of the spikelet scabrous.

Involucre with one bract erect: upper scales of the spikelet serrulate-ciliate.

Upper scales of the spikelet with smooth keels.

1. K. pumila.

2. K. brevifolia.

3. $K$. odorata. 
1. Kyllinga pùmila Michx. Annual. Leaves light green; blades roughish on the margins, usually less than $2 \mathrm{~mm}$. wide: scapes densely tufted, filiform, erect or reclined, $3-40 \mathrm{~cm}$. long, mostly longer than the leaves: bracts of the involucre $3-5$, elongated, spreading or reflexed : head oblong or ovoid-oblong, 6-7 mm. long, simple or commonly with 1 or 2 smaller ones at the base: spikelets about $3 \mathrm{~mm}$. long, flat, 1-flowered, the 2 empty lower scales more or less persistent on the rachis after the fall of the rest of the spikelet: scales ovate, acuminate or acute, thin, about 7 -nerved: stigmas 2 : achene lenticular, obtuse.

In moist or wet soil, Virginia to Illinois, Missouri, Florida, Texas and Mexico. Summer and fall.

2. Kyllinga brevifòlia L. Perennial, pale green. Leaves mostly shorter than the scape; blades 1-2.5 mm. wide, smooth : scapes very slender or filiform, 1-3 dm. tall, smooth : bracts of the involucre 3, one erect, the others spreading: spikes solitary, globose or ovoid, $5-10 \mathrm{~mm}$. long, greenish, commonly inclined : spikelets oblong-ovoid, $2-3 \mathrm{~mm}$. long, acuminate : scales various, the 2 outer minute, the third and fourth ovate, with recurved tips and serrulate-ciliate keels: achenes lenticular, orbicular-obovoid, about 1 mm. long.

In low grounds or springy places, Georgia and Florida to Texas. Also in tropical America. Spring to fall.

3. Kyllinga odoràta Vahl. Annual or biennial, pale green. Leaves mostly shorter than the scape ; blades usually $2-4 \mathrm{~mm}$. broad, smooth : scapes tufted, 1-3 dm. tall, smooth : bracts of the involucre 4-5, becoming reflexed: spikes whitish, 1-3, ovoid to cylindric, $8-15 \mathrm{~mm}$. long: spikelets $3 \mathrm{~mm}$. long, oblong-ovoid, 1-flowered or imperfectly 2 -flowered: scales various, the two lower ones barely $\frac{1}{2}$ as long as the ovate smooth third and fourth scale, the fifth enclosed in the fourth scale, larger than the first and second : achenes lenticular, obovoid, fully $1 \mathrm{~mm}$. long.

In wet soil and along roadsides, Georgia and Florida to Mississippi. Summer and fall. Throughout tropical America. Spring to fall.

\section{ERIÓPHORUM L.}

Bog herbs, perennial by rootstocks. Stems erect, triangular or nearly terete. Leaves with linear blades, or 1 or 2 of the upper ones reduced to bladeless sheaths. Spikelets terminal, solitary, capitate or in umbels, subtended by an involucre or 1-several bracts, or naked. Scales spirally imbricated, usually all fertile. Flowers perfect. Perianth of 6 or numerous filiform smooth soft bristles, which are white or brown, straight or crisped, and exserted much beyond the scales at maturity. Stamens 1-3. Style deciduous. Stigmas 3. Achene 3-angled, oblong, ellipsoid or obovoid. CotTon-Grass.

Spikelets umbellate: achenes obovoid, obtuse. Spikelets capitate: achenes linear-oblong, acute.

1. E. polystachyon. 2. E. Virginicum.

1. Eriophorum polystáchyon L. Stems stiff, smooth, obtusely triangular above, 4-9 dm. tall, all the sheaths blade-bearing: leaf-blades flat, 3-8 mm. wide, each tapering to a channeled rigid tip : bracts of the involucre $2-4$, the longer ones commonly equalling or exceeding the inflorescence: spikelets $3-12$, drooping, in a terminal umbel ; rays filiform, smooth or rough: scales ovate-lanceolate, acute or acuminate, purple-green or brown : perianth bristles numerous, bright white, about $2.5 \mathrm{~cm}$. long, 4-5 times as long as the scale : achene obovoid, obtuse, light brown.

In bogs, Newfoundland to Alaska, to New Jersey, the mountains of Georgia, and Nebraska. Also in Europe and Asia. Summer. HARE's-TAIL.

2. Eriophorum Virgínicum L. Stems stiff, obtusely triangular above, smooth, 4-11 dm. tall, rather leafy : leaf-blades narrowly linear, flat, $2-5 \mathrm{~mm}$. wide, channeled toward the apex : bracts of the involucre $2-4$, spreading or deflexed, $5-15 \mathrm{~cm}$. long: spikelets several or numerous in a dense terminal capitate cluster, erect or the outer spreading : scales ovate, acute, brown with a green center, about 5 -nerved : perianth bristles numerous, dingy brown, about 3 times as long as the scale : achene linear-oblong, acute, apiculate, light brown.

In bogs, Newfoundland to Manitoba, Florida and Nebraska. Summer and fall.

\section{FUIRÈNA Rottb.}

Perennial herbs, with triangular stems and many-flowered terete spikelets in terminal and axillary clusters, or rarely solitary. Scales spirally imbricated, awned, the 1 or 2 lower commonly empty. Flowers perfect. Perianth of 3 ovate, oblong or cordate-ovate, stalked, often awned sepals, usually alternating with as many downwardly barbed bristles. 
Stamens 3. Style not swollen at the base, deciduous. Stigmas3. Achene stalked or nearly sessile, sharply 3 -angled, acute or mucronate, smooth.

Leaves reduced to sheaths without blades, except sometimes near the top of the stem. Stems $2-6 \mathrm{dm}$. long: upper sheaths with barely any blades: achenes fully $1 \mathrm{~mm}$. long.

Stems 8-13 dm. long: upper sheaths with narrow blades: achenes barely $1 \mathrm{~mm}$. long.

Leaves with well-developed blades.

Awn at the apex of the sepal, or wanting.

Awn arising from the back of the sepal below its apex.

2. F. longa.

1. Fuirena scirpoìdea Michx. Rootstocks elongated : stems widely tufted, slender, 2-6 dm. tall, simple : leaves reduced to several sheaths $1-2 \mathrm{~cm}$. long, with oblique margins : bracts of the involucre $2-6 \mathrm{~mm}$. long, appressed to the spike, acute or cuspidate: spikelets sessile, solitary or 2 or 3 together, oblong or ovoid-oblong, 5-12 $\mathrm{mm}$. long, sessile: scales broadened upward, abruptly pointed, each with an erect awn, several-ribbed : sepals 3 ; blades oblong to oval-oblong, about as long as the stalks : perianth bristles hispid, longer than the stalks of the sepals : achenes 3-angled, oval-rhombic, constricted at both ends, fully $1 \mathrm{~mm}$. long.

In low sandy places, Georgia and Florida to Louisiana. Spring to fall.

2. Fuirena lónga Chapm. Rootstocks slender: stems loosely tufted, very slender, $8-15 \mathrm{dm}$. long, declining or reclining: leaves various, reduced to acute or acuminate sheaths $2.5-3 \mathrm{~cm}$. long on the lower part of the stem, near the top of the stem with very narrow blades as long as the sheaths or slightly longer : bracts of the involucre 8-16 mm. long, acuminate : spikelets oblong-ovoid, $2-4$ together, $10-15 \mathrm{~mm}$. long: scales pubescent, with awns about as long as the obovate body : sepals with ovate or suborbicular blades : perianth bristles slightly hispid : achenes 3 -angled, obovoid or oval, barely $1 \mathrm{~mm}$. long.

In low pine lands, western Florida. Summer and fall.

3. Fuirena squarròsa Michx. Rootstock short, sometimes tuber-bearing: stems tufted, glabrous or nearly so, $5-50 \mathrm{~cm}$. tall : leaf-blades flat, nearly or quite glabrous; the lower sheaths sometimes pubescent: spikelets sessile, solitary or 2-10 together in capitate clusters, ovoid or ovoid-oblong, 6-12 mm. long, about $5 \mathrm{~mm}$. in diameter : scales ovate or oblong, brown, pubescent, mostly obtuse, 3-nerved, each tipped with a stout, spreading or recurved awn nearly as long as the body : sepals 3 ; blades oblong, long-stalked, usually narrowed at both ends, the awn downwardly barbed or sometimes smooth : perianth-bristles mostly longer than the achene.

In wet meadows and marshes, Massachusetts to Florida and Louisiana, mostly near the coast. Also in Michigan and Nebraska Summer and fall.-A variety, F. squarrosa hispida (Ell.) Chapm. with retrorsely barbed bristles reaching to the middle of the achene or its tip, rhomboidal or deltoid-ovate, truncate or cordate scales, each tapering into a short thick unbarbed awn or tip, ranges from New York to Florida and Texas. Another variety, F. squarrosa brevisèta Coville, with smooth perianth-bristles not exceeding the stipe of the achene; oval or suborbicular scales rounded at the apex and with a minute apiculation, ranges from North Carolina to Florida and Texas.

4. Fuirena símplex Vahl. Similar to the preceding species in habit. Stems $1-5 \mathrm{dm}$. tall, glabrous : leaf-blades flat, glabrous or ciliate: scales numerous, each tipped with a spreading or reflexed awn : sepals 3 ; blades ovate-oblong, obtuse and usually notched at the apex, the awn smooth or downwardly barbed : perianth-bristles retrorsely hispid, equalling or exceeding the sessile or short-stalked achene.

In moist soil, Nebraska to Texas and Mexico. Summer and fall.-A form from the valley of the lower Rio Grande, Texas, larger throughout and with spikelets $2 \mathrm{~cm}$. long is $F$. simplex macrostáchya.
(Britton) Coville.

\section{SCÍRPUS L.}

Annual or perennial very small or very large caulescent or scapose herbs, the leaves sometimes reduced to basal sheaths. Spikelets terete or somewhat flattened, solitary, capitate, spicate or umbellate, subtended by an involucre of 1-several bracts, or the involucre wanting in some species. Scales spirally imbricated, the 1-3 lower sometimes empty. Flowers perfect. Perianth of 1-6 slender or rigid, barbed, pubescent or smooth bristles, or rarely none. Stamens 2-3. Style not swollen at the base, wholly deciduous from the achene, or its base persistent as a subulate tip. Stigmas 2-3. Achene triangular, lenticular or plano-convex. Bulrush. Club-rush.

Involucre of a single bract, or wanting.

Spikelets solitary, or rarely 2 in No. 5 , terminal.

Involucre wanting.

Involucre present, of a single bract.

Perianth-bristles present: scales not keeled.

Scapes terete: upper sheath with a subulate blade: perianth-bristles

1. S. nanus.

2. S. caespitosus. 
Scapes triangular: upper sheath with a linear blade: perianth-bristles upwardly barbed.

Perianth-bristles wanting: scales keeled.

Spikelets normaily more than 1 , usually several or numerous, often apparently lateral.

Spikelets few, 1-12, appearing lateral.

Scapes not sharply 3-angled: plants annual.

Achene strongly transverse-rugose: perianth-bristles wanting.

Achene smooth or very slightly roughened : perianth-bristles 4-6.

Scapes sharply 3-angled : plants perennial by rootstocks.

Spikelets acute: scales awned : involucral bract much surpassing the inflorescence.

Spikelets obtuse: scales mucronate : involucral bract only slightly surpassing the inflorescence.

Spikelets several or numerous, in umbels or umbel-like clusters.

Scapes sharply 3-angled: leaves with blades about as long as the scape.

Scapes terete: leaves reduced to mere sheaths.

Perianth-bristles down wardly barbed : achene gray, abruptly mucronate.

Perianth-bristles short-plumose below: achene nearly white, narrowed above.

Involucre of 2 or more bracts with flat blades.

Spikelets not in dense globular heads.

Spikelets few to several, capitate to umbellate, relatively large.

Spikelets in simple clusters : achenes obovoid-oblong, pale brown.

Spikelets in often compound clusters: achenes orbicular-obovoid, dark brown.

Spikelets very numerous, in compound umbels or umbelled heads, relatively small.

Perianth-bristles downwardly barbed, or wanting : spikelets in umbelled heads.

Perianth-bristles present.

Perianth-bristles equalling or slightly exceeding the achene: leafblades $6-16 \mathrm{~mm}$. wide.

Spikelets 3-8 in each head : scales obtuse : perianth-bristles barbed throughout.

Spikelets 8-20 in each head: scales acute: perianth-bristles not barbed below.

Perianth-bristles twice as long as the achene: leaf-blades 4-6 mm. wide.

Perianth-bristles wanting.

Perianth-bristles smooth or slightly pubescent : umbel mostly decompound.

Perianth-bristles shorter than the scales or scarcely exceeding them. Perianth-bristles about as long as the achene: scales rather acute.

Inflorescence merely terminal: spikelets $1 \mathrm{~mm}$. thick: achenes not papillose.

Inflorescence terminal and lateral: spikelets 2-3 $\mathrm{mm}$. thick achenes papillose.

Perianth-bristles much longer than the achene: scales mucronate.

Perianth-bristles much exsertedibeyond the scales at maturity Spikelets sessile, in small heads.

Spikelets, at least some of them, distinctly peduncled.

Spikelets very numerous in one or several dense globular heads.

3. S. Clintonii.

4. S. carinatus.

5. S. Hallii.

6. S. debilis.

7. S. Americanus.

8. S. Olneyi.

9. S. cylindricus.

10. S. lacustris.

11. S. Californicus.

12. S. campestris.

13. S. robustus.

14. S. sylvaticus.

15. S. atrovirens.

16. S. polyphyllus. 17. S. Georgianus.

18. S. divaricatus.

19. S. fontinalis.

20. S. lineatus.

21. S. cyperinus.

22. S. Eriophorum.

23. S. Cubensis.

1. Scirpus nànus Spreng. Annual. Roots fibrous: scapes filiform, flattened, grooved, tufted, erect or ascending, 2-5 cm. high, each bearing a scarious bladeless sheath near the base : spikelets solitary, terminal, ovoid-oblong, rather acute, 3-8-flowered, 2-3 $\mathrm{mm}$. long, not subtended by a bract : scales ovate or lanceolate, pale green, the lower obtuse, the upper subacute : perianth-bristles about 6 , downwardly barbed, longer than the achene : stigmas 3 : achenes oblong, $1 \mathrm{~mm}$. long, 3-angled, pale, pointed at each end.

In muddy places in salt marshes, Cape Breton Island to Florida and Texas and about salt springs in New York and Michigan. Also on the Pacific coast of North America and on the coasts of Europe. Summer and fall.

2. Scirpus caespitòsus L. Perennial. Scapes smooth, terete, densely tufted, light green, erect or ascending, almost filiform, wiry, 10-40 cm. long : basal sheaths numerous, membranous, imbricated, acuminate, the upper one bearing a short very narrow blade : spikelet solitary, terminal, few-flowered, ovoid-oblong, about $4 \mathrm{~mm}$. long, subtended by a subulate involucral bract of about its own length : scales yellowish brown, ovate, obtuse or subacute, deciduous: perianth-bristles 6 , smooth, longer than the achene: stigmas 3 : achenes oblong, $1.5 \mathrm{~mm}$. long, 3-angled, smooth, brown, acute.

In bogs and on moist rocks, Greenland to Alaska, south to the mountains of New England, the Adirondacks, western New York, Illinois, Minnesota and British Columbia, in the Rocky Mountains to Colorado, and on the higher summits of the southern Alleghenies. Also in Europe and Asia. Summer.

3. Scirpus Clintònii A. Gray. Perennial. Scapes tufted, triangular, very slender, erect, 10-40 cm. tall, roughish on the angles : lower sheaths imbricated, one or more of them bearing short subulate blades, the upper one bearing a flat, narrowly linear blade shorter than the stem : spikelet solitary, terminal, ovoid, few-flowered, 3-4 mm. long, subtended by a subulate involucral bract: scales ovate, pale brown, acute : perianth-bristles $3-6$, filiform, upwardly barbed, as long as the achene or longer : stigmas $3:$ achenes oblong, 1.5 to nearly $2 \mathrm{~mm}$. long, sharply 3 -angied, brown, sinooth, obtuse.

In dry fields and thickets, New Brunswick to Michigan and North Carolina. Local. Summer. 
4. Scirpus carinàtus (H. \& A.) A. Gray. Annual, bright green. Scapes tufted, $0.5-2 \mathrm{dm}$. tall, bristle-like, smooth : leaves solitary at the base of each scape, bristle-like : bracts of the involucre 1-3 cm. long, erect : spikelets solitary, ovoid, about $4 \mathrm{~mm}$. long, apparently lateral, 6-8-flowered: scales ovate to reniform, acuminate, loosely imbricated, keeled, rather persistent : stigmas 3 : achenes 3 -angled, oval, $1.5 \mathrm{~mm}$. long, brown, granular. [Isolepis carinata H. \& A.]

In low grounds, Tennessee to the Indian Territory, California, Alabama and Texas. Spring.

5. Scirpus Hállil A. Gray. Annual. Scapes very slender, smooth, tufted, obtusely triangular, erect, striate, 1-3 dm. tall : lower sheaths oblique, and acuminate or mucronate, the upper one commonly bearing a filiform blade $1-6 \mathrm{~cm}$. long : spikelets capitate in clusters of 1-7, oblong-cylindric, obtuse, many-flowered, 6-12 $\mathrm{mm}$. long, about $2 \mathrm{~mm}$. thick, appearing lateral by the extension of the solitary involucral bract: scales ovate-lanceolate, light greenish brown, acuminate, keeled, cuspidate : perianth-bristles wanting: achenes obovoid-orbicular or slightly broader than high, black, plano-convex, mucronulate, transversely wrinkled, about $1 \mathrm{~mm}$. in diameter.

In wet soil, Massachusetts to Florida, Illinois, Colorado, Texas and Mexico. Summer and fall.

6. Scirpus débilis Pursh. Annual, smooth : scapes slender, terete or nearly so, tufted, 1.5-5 dm. high : sheaths obliquely truncate, the upper ones rarely bearing a short subulate blade : spikelets capitate, in clusters of 1-12, ovoid-oblong, subacute, many-flowered, appearing lateral, the involucral bracts narrowly linear, $3-10 \mathrm{~cm}$. long, erect or divergent : scales light yellowish brown with a green midvein, broadly ovate, obtuse, or acute : perianth-bristles 4-6, downwardly barbed, about as long as the achene : stigmas 2 or rarely 3 : achenes plano-convex, broadly obovoid or orbicular, $1.5-2 \mathrm{~mm}$. long, smooth or slightly roughened, dark brown, shining, obtuse, mucronulate.

In wet soil, Maine to Ontario, Minnesota, Georgia, Alabama and Nebraska. Summer.

7. Scirpus Americànus Pers. Perennial by long rootstocks. Scapes sharply triangular, erect, stiff, 3-11 dm. tall : leaves 1-3; blades linear, keeled, shorter than the scape : spikelets oblong-ovoid, acute, 8-12 $\mathrm{mm}$. long, capitate in clusters of 2-7, appearing as if lateral : involucral bract slender, $3-10 \mathrm{~cm}$. long : scales broadly ovate, brown, often emarginate or sharply 2-cleft at the apex, the midvein extended into a subulate awn sometimes $2 \mathrm{~mm}$. long, the margins scarious : perianth-bristles 2-6, downwardly barbed, shorter than or equalling the achene : achenes obovoid, plano-convex, about $2.5 \mathrm{~mm}$. long, smooth, dark-brown, mucronate.

In fresh water and brackish swamps, nearly throughout North America. Summer.

8. Scirpus Olneỳi A. Gray. Similar to the next preceding species. Scapes stout, sharply 3-angled, with concave sides, $0.5-2 \mathrm{~m}$. tall : leaves 1-3, 2-13 cm. long, or represented by mere sheaths: spikelets capitate in dense clusters of 5-12, oblong or ovoid-oblong, obtuse, $5-8 \mathrm{~mm}$. long, the involucral bract short, stout, erect, 1-3 cm. long: scales oval or orbicular, dark brown with a green midvein, emarginate or mucronulate, glabrous : perianth-bristles usually 6 , slightly shorter than or equalling the achene, downwardly barbed : stigmas 2 : achenes obovoid, about $2.5 \mathrm{~mm}$. long, plano-convex, brown, mucronate.

In salt marshes, Massachusetts to Florida, Texas, Mexico and California, extending along the Pacific coast to Oregon. Also in Arkansas. Summer and fall.

9. Scirpus cylíndricus (Torr.) Britton. Perennial by stout rootstocks. Scapes stout, 3-angled above, 1-2 m. high, the linear nodulose keeled dark green leaves nearly or quite as long: involucral bract 1-2.5 dm. long, erect : spikelets in an apparently lateral umbel, drooping, oblong-cylindric, acutish, $1-2 \mathrm{~cm}$. long, primary rays of the umbel subtended by 1 or more subulate-linear bracts : scales ovate or ovate-lanceolate, pale-brown, acute, mucronulate: perianth-bristles 6 , stout, rigid, about as long as the achene, serrate: stigmas 3 : achenes obovoid, $3 \mathrm{~mm}$. long, excluding the beak, 3-angled, light brown, smooth, abruptly subulate-pointed.

In ponds and swamps, Maryland to Florida and Lousiana. Summer and fall.

10. Scirpus lacústris L. Perennial by rootstocks. Scapes stout, terete, smooth, erect, $1-3 \mathrm{~m}$. tall, sometimes $2 \mathrm{~cm}$. in diameter, sheathed below : involucral bract solitary, erect, shorter than the umbel: umbel compound, appearing lateral, its primary rays 3-10 cm. long: bracts linear-lanceolate: spikelets becoming oblong-cylindric, in mostly capitate clusters of $2-5$, sessile or some of them peduncled, $5-16 \mathrm{~mm}$. long, 3-4 mm. in diameter : scales ovate or oblong, each with a strong midvein which is sometimes excurrent: perianth-bristles 4-6, downwardly barbed, equalling or longer than the achene : stigmas 2 : achenes plano-convex, obovoid, $2-2.5 \mathrm{~mm}$. long, gray, abruptly mucronate, dull.

In ponds and swamps, nearly throughout North America. Also in the Old World. Summer and fall. Cat-tail Flag. 
11. Scirpus Califórnicus (C. A. Meyer) Britton. Perennial, similar to the next preceding species. Leaves reduced to basal sheaths : involucral bracts short, stoutly subulate : umbel compound : spikelets $6-10 \mathrm{~mm}$. long, acute, peduncled or some of them sessile : scales brown, ovate, awn-pointed : perianth-bristles shorter than or equalling the achene, short-plumose below : stigmas 2 : achene obovoid, $2 \mathrm{~mm}$. long, plano-convex, nearly white, narrowed above into a short tip, contracted at the base.

In swamps, Florida to Louisiana, northern Mexico and California, and widely distributed in tropical America. Summer.

12. Scirpus campéstris Britton. Perennial. Stems smooth, sharply triangular, 3-5 dm. tall. Leaves usually pale green ; blades smooth, $2-4 \mathrm{~mm}$. wide : bracts of the involucre 2 or 3 , the longer much exceeding the inflorescence : spikelets $3-10$, in a dense terminal simple head, oblong-cylindric, $1.5-2.5 \mathrm{~cm}$. long, $5-8 \mathrm{~mm}$. thick : scales ovate, pale brown, 2toothed at the apex, the midvein excurrent into an ascending or spreading awn : perianthbristles 1-3, much shorter than the achene, or none : stigmas 2 : achenes lenticular, obovoid or oblong-ovoid, $3-3.5 \mathrm{~mm}$. long, mucronulate, yellow-brown, their surface strongly cellular-reticulated.

On wet prairies and plains, Manitoba and Minnesota to the Indian Territory, Nevada and Mexico. Spring and summer.

13. Scirpus robústus Pursh. Perennial by rootstocks. Stem stout, stiff, 3 -angled, with flat sides, smooth, 5-14 dm. tall : leaves dark green; blades smooth, 5-10 mm. wide : involucral bracts 2-4, elongated, similar to the leaf-blades: spikelets ovoid-oblong, stout, $1.5-2.5 \mathrm{~cm}$. long, $8-10 \mathrm{~mm}$. in diameter, 6-20 together in a dense terminal cluster: scales ovate, brown, puberulent, thin, the midvein excurrent into an, at length, reflexed awn 3-5 $\mathrm{mm}$. long: perianth-bristles 1-6, fragile, shorter than the achene, or none : stigmas 3 : achenes 3-3.5 mm. long, compressed, flat on the face, convex or with a low ridge on the back, obovoid-orbicular, dark brown.

In salt marshes, Nova Scotia to Florida and Texas. Summer and fall.

14. Scirpus sylváticus L. Perennial by long rootstocks. Stems triangular, stout, smooth, 1-2 m. tall, often overtopped by the upper leaves : leaf-blades $1-1.6 \mathrm{~cm}$. wide, rough on the margins : bracts of the involucre $5-8$, the larger often $3 \mathrm{dm}$. long or more : umbel terminal, very large, sometimes $2 \mathrm{dm}$. broad, about 3 times compound, the spikelets ovoid or ovoid-oblong, 3-5 mm. long, in capitate clusters at the ends of the raylets : bractlets of the involucels small, linear or lanceolate : scales ovate-oblong, obtuse, brown with a green center : perianth-bristles 6 , downwardly harbed, slightly exceeding the achene : stigmas 3 : achenes oblong, fully $1 \mathrm{~mm}$. long, 3 -angled, obtuse, nearly white, mucronulate.

In swamps, New Hampshire to North Carolina and Georgia. Also in Europe. Summer and fall.

15. Scirpus atróvirens Muhl. Perennial by rootstocks. Stems triangular, rather slender, leafy, 5-12 dm. high : leaf-blades elongated, nodulose, dark green, 6-12 mm. wide, one or two of them usually exceeding the inflorescence : spikelets ovoid-oblong, acute, densely capitate at the ends of the rays or raylets : involucels short : scales greenish brown, oblong, acute, the midvein excurrent : perianth-bristles usually 6 , downwardly barbed above, naked below, about as long as the achene : stigmas $3:$ achenes oblong-obovoid, $1 \mathrm{~mm}$. long, 3-angled, pale brown, dull.

In swamps, Nova Scotia to Manitoba, Georgia and Louisiana. Summer.

16. Scirpus polyphýllus Vahl. Perennial by rootstocks. Stems slender, sharply triangular, 3-11 dm. tall, very leafy : leaves 3-ranked ; blades $4-6 \mathrm{~mm}$. wide, rough-margined : bracts of the involucre $3-6$, the longer commonly somewhat exceeding the inflorescence : spikelets ovoid, about $3 \mathrm{~mm}$. long, capitate at the ends of the raylets : scales ovate, bright brown, mostly obtuse, mucronulate: perianth-bristles 6 , downwardly barbed above the middle, twice as long as the achene : stigmas 3 : achenes obovoid, fully $1 \mathrm{~mm}$. long, 3angled, with a broad face and narrower sides, short-pointed, dull.

In swamps, wet woods and meadows, Massachusetts to Minnesota, Georgia, Alabama and Arkansas. Summer and fall.

17. Scirpus Georgiànus Harper. Perennial by rootstocks. Stems terete or nearly so, 4-12 dm. tall : leaf-blades smooth, about $2 \mathrm{dm}$. long, and $1 \mathrm{~cm}$. wide, or the upper ones smaller : bracts of the involucre mostly 3 , the largest surpassing the inflorescence : umbel thrice compound : spikelets green, about $3 \mathrm{~mm}$. long, 10-15-flowered, 5-10 in heads : scales orbicular-ovate, about $1.5 \mathrm{~mm}$. long, the toothed awns spreading at the tips, the midrib green, with a whitish keel : perianth-bristles wanting : achenes broadly oblong, about 0.8 $\mathrm{mm}$. long, short-beaked.

In alluvial soil, middle Georgia. Spring and summer.

18. Scirpus divaricàtus Ell. Stems obtusely triangular, rather slender, 6-11 dm. tall : leaf-blades 4-8 $\mathrm{mm}$. wide, rough-margined: umbel decompound, the primary rays 
very slender, sometimes $1.5 \mathrm{dm}$. long, spreading or drooping : spikelets mostly solitary at the ends of the raylets, $6-12 \mathrm{~mm}$. long, $1 \mathrm{~mm}$. thick : scales ovate, greenish brown : perianth-bristles 6 , flexuous, shorter than the scales : stigmas 3 : achenes 3 -angled, not papilillose, nearly white, not shining.

In swamps, Virginia and Kentucky to Missouri, Florida and Louisiana. Summer.

19. Scirpus fontinalis Harper. Related to $S$. divaricatus and S. lineatus; differing from both of these species by its curved stem and lateral umbels, from the former by its thicker spikelets and papillose achenes and from the latter by its merely acute scales and shorter perianth-bristles.

On margins of pools, Leslie, Georgia. Summer.

20. Sclrpus lineàtus Michx. Perennial by stout rootstocks. Stems triangular, 3-10 $\mathrm{dm}$. high : leaf-blades 4-8 mm. wide, flat, rough-margined : umbels decompound, the rays very slender, becoming pendulous : spikelets mostly solitary at the ends of the raylets, $6-10$ $\mathrm{mm}$. long, about $2 \mathrm{~mm}$. thick : scales ovate or oblong, reddish brown and each with a green midvein : perianth-bristles 6 , weak, smooth, entangled, much longer than the achene : stigmas 3 : achenes oblong or oblong-obovoid, $1 \mathrm{~mm}$. long, pale brown, 3-angled, short-beaked.

In swamps and wet meadows, New Hampshire to Ontario, Oregon, Georgia and Texas. Summer.

21. Scirpus cyperìnus (L.) Kunth. Perennial. Stems smooth, stiff, $6-20 \mathrm{dm}$. tall : leaves elongated ; blades 3-6 mm. wide, rough-margined : bracts of the involucre $3-6$, the longer much exceeding the inflorescence : umbel terminal, compound, the rays at length somewhat drooping : spikelets ovoid-oblong, 3-5 mm. long, in capitate clusters of 3-15 at the ends of the raylets : scales ovate or lanceolate : perianth-bristles 6 , entangled, smouth, much longer than the achene, much exserted beyond the scales, and grayish brown at maturity : stigmas 3 : achenes 3 -angled, barely $1 \mathrm{~mm}$. long, beaked, nearly white.

In swamps, Newfoundland to Ontario, Virginia and Tennessee. Summer and fall.

22. Scirpus Erióphorum Michx. Similar to the next preceding species in habit. Involucre more ferruginous at the base : umbel with laxer branches, the rays elongated and drooping at the ends : spikelets ovoid or oblong-ovoid, 3.5-6 mm. mostly $4.5 \mathrm{~mm}$. long, more deeply colored, at least some of them distinctly peduncled.

In low grounds or swamps, New York to Arkansas, Florida and Texas. Summer and fall.

23. Scirpus Cubénsis Poepp. \& Kunth. Perennial, glabrous. Scapes sometimes tufted, 2-7 dm. tall, sharply 3-angled : leaves basal; blades 3-5 mm. wide : bracts of the involucre mostly $3-5$, spreading : spikelets crowded into 1 or several very dense subglobose heads, about 12-flowered, 3-5 mm. long: scales firm, 13-nerved, each with a short spreading tip, commonly ciliate along the keel : perianth-bristles wanting: stigmas 2 : achenes elliptic or slightly broadest below the middle, $2-2.5 \mathrm{~mm}$. long, tapering into a slender beak.

In swamps, Alabama and Louisiana. Also in the West Indies, eastern South America and Africa. Summer and fall.

\section{WEBSTìrIA S. Hart Wright.}

Perennial caulescent aquatic herbs, with repeatedly branching stems. Leaves clustered, capillary. Umbel decompound. Bracts of the involucres similar to the leaves. Spikelets 1-flowered, peduncled : scales 2 to each spikelet, the lower one sterile. Flowers perfect. Perianth of 6-10 commonly barbed nearly white bristles. Stamens 3 . Style slender, deciduous above the base : stigmas 2 . Achene lenticular, minutely pitted in lines.

1. Websteria submérsa (Sauv.) Britton. Submersed, glabrous. Stems 3-12 dm. long, with internodes $8-25 \mathrm{~cm}$. long, sheathed, the branches topped by decompound umbels : spikelets 8-12 mm. long: scales acuminate, the lower one 3-nerved within, empty, the upper 1-nerved, with reddish brown margins : perianth-bristles tortuous : achenes lenticular, obovoid or oval, about $1.5 \mathrm{~mm}$. long, each tipped with the base of the style. [Scirpus submersus Sauv. Websteria limnophila S. Hart Wright.]

In lakes and ponds, peninsular Florida. Also in Cuba. Spring to winter.

\section{FLEÓCEARIS R. Br.}

Annual or perennial scapose herbs. Leaves reduced to sheaths, or the lowest very rarely blade-bearing. Scapes simple, triangular, quadrangular, terete, flattened or grooved. Spikelets solitary, terminal, erect, several-many-flowered, not subtended by an involucre or rarely by 2 small bracts. Scales concave, spirally imbricated. Perianth of 1-12 bristles, usually retrorsely barbed, wanting in some species. Stamens 2-3. Stigmas 2 and achene lenticular or biconvex, or when 3 , the achene 3 -angled, but sometimes with very obtuse 
angles and appearing turgid. Base of the style presistent on the summit of the achene, forming a tubercle. SPIKE RUSH.

Spikelet scarcely or not at all thicker than the scape: scales mostly leathery.

Bristles 6 , as long as the achene or shorter: scapes relatively stout.

Scapes terete, at least above: achenes not cancellate.

Achenes transversely ridged: scapes nodose-septate.

Achenes copiously pitted: scapes continuous. Scapes sharply 4-angled: achenes cancellate.

Bristles 7 , longer than the achene: scapes relatively slender.

Spikelet 6-8-flowered: achenes about $2 \mathrm{~mm}$. long, deeply pitted : scapes 3angled.

Spikelet 12-20-flowered: achenes about $1 \mathrm{~mm}$. long, faintly pitted: scapes terete.

Spikelet manifestly thicker than the scape: scales mostly membranous.

Style-branches or stigmas 2: achene lenticular or biconvex.

Upper sheath scarious, hyaline: plants perennial by slender rootstocks.

Achenes about $0.5 \mathrm{~mm}$. long.

Scales pale green or rarely white: perianth-bristles longer than the achene.

Scales brown: perianth-bristles shorter than the achene.

Achenes about $1 \mathrm{~mm}$. long.

Scapes $2-10 \mathrm{~cm}$. long: perianth-bristles longer than the achene.

Scapes $10-35 \mathrm{~cm}$. long: perianth-bristles as long as the achene.

Upper sheath truncate, oblique or toothed, not scarious.

Annuals with fibrous roots.

Scapes capillary: spikelets with 1-4 achenes.

Scapes slender: spikelets with several to many achenes.

Achenes black.

Perianth-bristles 2-4, pale: achenes $0.5 \mathrm{~mm}$. long : scapes $2-9 \mathrm{~cm}$. tall.

Perianth-bristles 5-8, brown: achenes $1 \mathrm{~mm}$. long: scapes 5-25 cm. tall.

Achenes pale brown to white.

Scapes filiform: achene white.

Scapes slender: achenes pale brown. Scales of the spikelets obtuse.

Perianth-bristles longer than the achene: spikelets ovoid.

Perianth-bristles not longer than the achene, often short or wanting: spikelets cylindric. Scales of the spikelets acute.

Perennials with horizontal rootstocks.

Scapes nodose-septate.

Scapes continuous.

Scales pale green or straw-colored: scape relatively stout.

Scales brown or dark green: scapes slender or filiform.

Achenes $1.5 \mathrm{~mm}$, long: tubercle conic.

Achenes $1 \mathrm{~mm}$. long or less: tubercle depressed.

Style-branches or stigmas 3: achene 3-angled/or turgid.

Achene cancellate.

Achene longitudinally ribbed.

Achene not longitudinally ribbed.

Scapes filiform: spikelets with 1-4 achenes.

Scapes slender: spikelets with many achenes.

Spikelets linear-oblong, often proliferous.

Spikelets ovoid to conic-ovoid, not proliferous.

Tubercle conic, smaller than the achene.

Tubercle cap-like, as large as the achene or larger.

Achene smooth. papillose. or irregularly ridged-reticulated.

Scapes capillary or filiform.

spikelets terete or nearly so, 6-2- flowered.

Spikelets oblong, 3-6 mm. long.

Spikelets ovoid, $2-3 \mathrm{~mm}$. long.

Spikelets flattened. 2-6-flowered, often proliferous.

Achene obovoid: tubercle deltoid or depressed.

Achene oblong : tubercle abruptly subulate-tipped.

E. interstincta

2. E. cellulosa.

3. E. mutata.

4. E. Robbinsii.

5. E. elongata.

6. E. ochreata.

7. E. praticola.

8. E. olivacea.

9. E. maculosa.

10. E. capillacea.

11. E. atropurpurea.

12. E. capitata.

13. E. bicolor.

14. E. obtusa.

15. E. Engelmannii.

16. E. lanceolata.

17. E. nodulosa.

18. E. macrostachya.

19. E. glaucescens.

20. E. Ravenelii.

21. E. acicularis.

22. E. Chaetaria.

23. E. vivipara.

24. E. tortilis.

25. E. tuberculosa.

26. E. Torreyana.

27. E. microcarpa.

28. E. prolifera.

29. E. Baldwinii.

Scapes slender or stout.

Tubercle plainly distinguishable from the achene.

Spikelets ovoid to oblong: achene not constricted at the neck.

Achenes smooth.

Tubercle flat, covering the top of the black achene.

Tubercle ovoid-conic, acute, contracted at the base.

Achenes papillose or irregularly ridged-reticulated.

Achenes with the 3 angles ribbed.

Achenes obtusely 3-angled.

Scapes slender to nearly filiform: scales obtuse.

Bristles 2-4, shorter than the achene: achene strongly papillose to reticulated.

Bristles 6 , the longer as long as the achene: achene faintly reticulated.

Scapes flattened: scales acute.

Spikelets linear-cylindric: achene constricted at the neck.

Tubercle long-conic, scarcely distinguishable from the achene.

30. E. melanocarpa.

31. E. albida.

32. E. tricostata.

33. E. tenuis.

34. E. arenicola.

35. E. acuminata.

36. E. cylindrica.

37. E. rostellata.

1. Eleocharis interstíncta $(\mathrm{Vahl})$ R. \& S. Perennial by stout rootstocks. Scapes terete, hollow, nodose-septate, 4-9 dm. tall, the sterile ones sharp-pointed : sheaths mem- 
branous, the lower sometimes bearing short blades : spikelet terete, cylindric, many-flowered, rather acute, $2.5-4 \mathrm{~cm}$. long, $4 \mathrm{~mm}$. in diameter, not thicker than the scape : scales ovate, orbicular or obovate, obtuse or the upper ones acute, narrowly scarious-margined, faintly many-nerved, persistent : perianth-bristles 6 , rigid, retrorsely barbed, as long as the body of the achene, or shorter : stigmas 3 , exserted : achenes obovoid, $1.5 \mathrm{~mm}$. long, brown, shining, with minute transverse ridges, convex on one side, very obtusely angled on the other, 2 or 3 times as long as the conic acute black broad-based tubercle. [E. equisetoides (Ell.) Torr.] fall.

In water, Massachusetts to Michigan, Florida and Mexico. Also in the West Indies. Summer and

2. Eleocharls cellulòsa Torr. Perennial by horizontal rootstocks. Scapes obscurely 3 -angled and invested by discolored sheaths at the base, terete above, $3-7 \mathrm{dm}$. tall, continuous : spikelet cylindric, $1.5-3 \mathrm{~cm}$. long, 3-5 mm. thick: scales broadly oborate, with white hyaline margins, appressed, rounded at the apex, minutely nerved : perianth-bristles 6 , slightly unequal, nearly smooth : stigmas $3:$ achenes broadly obovoid, copiously pitted, 1.5-2 mm. long excluding the tubercle, about as long as the bristles; tubercle finally deltoid, about $\frac{1}{2}$ as broad as the widest part of the achene.

In marshes near the coast, Florida to Texas. Also in the West Indies. Summer and fall.

3. Eleocharis mutàta (L.) R. \& S. Perennial by stout rootstocks. Scapes sharply 4-angled, stout, not nodose, 6-12 dm. tall: sheaths purplish brown or green, sometimes bearing short blades : spikelet terete, cylindric, $2-5 \mathrm{~cm}$. long, $4 \mathrm{~mm}$. in diameter, manyflowered, about as thick as the scape : scales broadly ovate or obovate, obtuse or the upper rather acute, scarious-margined, faintly many-nerved, persistent : perianth-bristles about 6 , rigid, retrorsely barbed, about as long as the achenes: stigmas $3:$ achenes obovoid, $2.5 \mathrm{~mm}$. long, biconvex or slightly angled on the back, minutely cancellate, about twice as long as the conic acute tubercle which is truncate or contracted at the base.

In ponds, streams and swamps, southern Ontario to New Jersey, Michigan, Alabama, Missouri, Texas and Guatemala. Also in the West Indies and South America. Summer and fall.

4. Eleocharis Robbínsil Oakes. Perennial by slender rootstocks. Scapes slender, 3-angled, 1-6 dm. long, sometimes producing numerous filiform flaccid, sterile branches from the base : sheaths appressed, obliquely-truncate; spikelet subulate, few-flowered, not thicker than the scape, $1-2 \mathrm{~cm}$. long, $2 \mathrm{~mm}$. in diameter : scales lanceolate or oblonglanceolate, strongly concave, faintly several-nerved, persistently clasping the rachis, narrowly scarious-margined : stigmas 3 : perianth-bristles 7, equalling the achene and tubercle, retrorsely barbed : achenes obovoid, $2 \mathrm{~mm}$. long, light brown, deeply pitted, biconvex or obtusely angled on the back, twice as long as the conic-subulate flattened tubercle, which has a raised ring around the base.

In shallow water, New Brunswick to Michigan and Florida. Summer and fall.

5. Eleocharis elongàta Chapm. Perennial from very slender rootstocks. Scapes slender, tufted, chiefly submerged, 3-10 dm. long, terete, accompanied by phyllode-like filiform sterile ones, tender : spikelet cylindric, 1-2 cm. long, $2-2.5 \mathrm{~mm}$. thick, 12-20flowered, acute : scales relatively distant, oblong-ovate, obtuse, prominently ribbed, with a green back and brown margins : perianth-bristles 7, plumose : achenes obovoid, faintly pitted, biconvex or slightly 3 -angled, about $1 \mathrm{~mm}$. long; tubercle minute.

In still water, Florida and Texas. Summer.

6. Eleocharis ochreàta (Nees) Steud. Perennial by slender rootstocks. Scapes very slender, or filiform, pale-green, 3-angled, $0.5-2.5 \mathrm{dm}$. tall : upper sheath with a white, hyaline, scarious limb: spikelet subacute, $2-3$ times as thick as the scape, about $4 \mathrm{~mm}$. long, 2-3 mm. in diameter, several-flowered : scales pale green, oblong-lanceolate, obtuse or the upper acute, hyaline, each with a faint midvein : perianth-bristles about 6 , slender, retrorsely barbed, somewhat longer than the achene: stigmas $2:$ achenes $0.7-1 \mathrm{~mm}$. long, lenticular, obovoid, smooth, brown, 2-4 times as long as the conic acute tubercle.

In wet soil, Virginia to Florida and Mississippi. Also in tropical America. Summer and fall.

7. Eleocharis pratícola Britton. Annual, relatively small. Scapes slender, tufted, $6 \mathrm{~cm}$. tall or less : spikelet ovoid or oblong-ovoid, about $2 \mathrm{~mm}$. long: scales brown, lanceolate or oblong-lanceolate, lax in age : perianth-bristles $5-7$, retrorsely barbed, shorter than the achene: stigmas 2: achenes obovoid, about $0.5 \mathrm{~mm}$. long, dark brown, shining, the tubercle very small.

In low places, Osceola County, Florida. Spring.

8. Eleocharis olivàcea Torr. Perennial by running rootstocks, often tufted and matted. Scapes very slender, bright green, erect or reclining, flattened, $2-10 \mathrm{~cm}$. long: upper sheath with a white hyaline limb: spikelet ovoid, much thicker than the scape, several-many-flowered, about $4 \mathrm{~mm}$. long, $2 \mathrm{~mm}$. in diameter : scales ovate, acute, reddish brown, each with a green midvein and narrow scarious margins : perianth-bristles 6-8, 
slender, retrorsely barbed, longer than the achene and tubercle : stigmas 2 : achenes obovoid, like those of $E$. ochreata, but twice as large, 3-4 times the length of the conic acute tubercle. In wet soil, Maine to southern Ontario, Pennsylvania, and South Carolina. Summer and fall.

9. Eleocharis maculòsa (Vahl) R. Br. Perennial by slender rootstocks. Scapes tufted, 1-3.5 dm. long, slender : spikelet ovoid, 5-12 $\mathrm{mm}$. long, rather blunt, dense, purplebrown : scales ovate or oblong-ovate, scarious-margined, rather persistent : perianth-bristles $7-8$, retrorsely scabrous, brown or rusty, as long as the achene : stigmas $2:$ achenes obovoid, about $1 \mathrm{~mm}$. long, chestnut-brown, shining, the tubercle abruptly pointed, pale.

In wet ground, Texas. Also in Central and South America. Spring to fall.

10. Eleocharis capillàcea Kunth. Annual, diminutive. Scapes tufted, capillary, $2-5 \mathrm{~cm}$. long, sligntly 4 -angled : spikelet linear-cylindric, $2-3 \mathrm{~mm}$. long, with 1-4 achenes, deep brown or reddish : scales few, nearly oblong or oblong-lanceolate, the 2 lower mostly including the spikelet: perianth-bristles $4-6$, about as long as the achene, retrorsely scabrous : stigmas 2: achenes lenticular, about $0.5 \mathrm{~mm}$. long, exclusive of the slender conic tubercle, brown.

A bout pine-land ponds and in wet sand, North Carolina to Florida. Also in Central and South America. Spring to fall.

11. Eleocharis atropurpùrea (Retz) Kunth. Annual with fibrous roots. Scapes tufted, very slender, $2-9 \mathrm{~cm}$. high : upper sheath 1-toothed : spikelet ovoid, many-flowered, subacute, 3-4 mm. long, $2 \mathrm{~mm}$. in diameter, or less : scales minute, ovate-oblong, persistent, purple-brown except the midvein and very narrow scarious margins : perianth-bristles $2-4$, fragile, pale, minutely downwardly hispid, about as long as the achene : stigmas 2 : achenes jet black, shining, $0.5 \mathrm{~mm}$. long, smooth, lenticular; tubercle conic, minute, depressed but rather acute, constricted at the base.

In moist soil. Iowa, Nebraska and eastern Colorado to Central America, east to Florida ; widely distributed in tropical America. Summer and fall.

12. Eleocharis capitàta (L.) R. Br. Annual with fibrous roots. Scapes densely tufted, nearly terete, almost filiform, 0.5-2.5 dm. tall : upper sheath 1-toothed: spikelet ovoid, obtuse, much thicker than the scape, 3-5 $\mathrm{mm}$. long, $2-3 \mathrm{~mm}$. thick, many-flowered : scales broadly ovate, obtuse, firm, brown except the greenish midvein, narrowly scariousmargined, persistent: perianth-bristles 5-8, slender, downwardly hispid, as long as the achene : stigmas 2 : achenes obovoid, jet black, smooth, shining, $1 \mathrm{~mm}$. long; tubercle depressed, apiculate, constricted at the base, very much shorter than the achene.

In moist soil, Maryland to Indiana, Florida and Texas. Also in the tropies. Summer and fall.

13. Eleocharis bícolor Chapm. Annual, pale green. Scapes tufted, filiform, 0.3-2 $\mathrm{dm}$. long, sometimes procumbent, 4-angled : spikelet ovoid, $2-3 \mathrm{~mm}$. long, rather blunt, 8-12-flowered: scales ovate, obtuse, thin, loosely imbricated, with whitish margins and keel : perianth-bristles 3 , fugacious : achenes lenticular, obovoid, $0.5 \mathrm{~mm}$. long, papillose, about twice as long as the bristles ; tubercle broadly conic, about $\frac{1}{3}$ as long as the body of the achene.

In sandy soil, near the coast, Florida. Summer.

14. Eleocharis obtùsa Schult. Annual with fibrous roots. Scapes tufted, relatively stout, rather deep green, nearly terete, mostly erect, $0.5-5 \mathrm{dm}$. tall : upper sheath 1toothed : spikelet ovoid or oblong-ovoid, obtuse, many-flowered, 3-13 mm. long, 3-5 mm. in diameter: scales thin, obovate, oblong-obovate or oblong-orbicular, obtuse, brown, each with a broad green midvein and scarious margins : perianth-bristles $6-8$, deciduous, usually longer than the achene: stigmas 2: achenes pale brown, shining, lenticular, obovoid-oblong, smooth, $1 \mathrm{~mm}$. long or more; tubercle deltoid, acute, compressed, scarcely constricted at the base, about $\frac{1}{4}$ as long as the achene.

In wet soil, New Brunswick to Ontario, British Columbia, Florida, Texas and Oregon. $-\mathrm{A}$ form with more slender generally decumbent or spreading scapes, smaller fewer-flowered spikelets with more spreading scales and a smaller achene, is E. obtusa jejuna Fernald. Summer and fall.

15. Eleocharis Engelmánnii Steud. Annual, quite similar to the next preceding species, but scapes commonly taller, sometimes $5 \mathrm{dm}$. high. Upper sheath obliquely truncate or 1-toothed : spikelet cylindric, obtuse or rather acute, 4-16 $\mathrm{mm}$. long, 2-3 $\mathrm{mm}$. in diameter, many-flowered : scales pale brown with a green midvein and narrow scarious margins, ovate, obtuse, deciduous: perianth-bristles about 6 , not longer than the achene or very short or wanting : stigmas 2 : achenes obovoid or cuneate-obovoid, fully $1 \mathrm{~mm}$, long, brown, smooth, lenticular; tubercle broad, low, covering the top of the achene, less than $\frac{1}{4}$ its length.

In wet soil, Massachusetts to Virginia. Indiana, Arkansas, Texas and California.-The form without perianth-bristles, or mere rudiments, and generally stouter scapes, is E. Engelmannii detónsa A. Gray. Summer and fall.

16. Eleocharis lanceolàta Fernald. Annual, bright green. Scapes tufted, slender or nearly filiform, 1-2.5 dm. tall : spikelet lanceolate in outline, $5-9 \mathrm{~cm}$. long, about 2 or $3 \mathrm{~mm}$. thick, rather acute : scales pale, hyaline except green ribs, acute, rather appressed : 
perianth-bristles overtopping the body of the achene : achenes broadly obovoid, fully $1 \mathrm{~mm}$. long; tubercle about $\frac{1}{2}$ as high as the body of the achene.

In moist soil, Arkansas to Texas. Summer and fall.

17. Eleocharis nodulòsa ( Roth) Schult. Perennial by horizontal rootstocks. Scapes closely tufted, relatively stout, $3-10 \mathrm{dm}$. tall, copiously nodose-septate, invested at the base by more or less discolored sheaths, constricted below the summit : spikelet conic-cylindric, acute, 1-2 cm. long, 4-6 mm. thick : scales closely imbricated, oblong-lanceolate, of ten constricted below the apex, 3-4 mm. long, scarious-margined : perianth-bristles very variable in length: achenes obovoid, pinched at the base, about $1 \mathrm{~mm}$. long, plump ; tubercle deltoid, about $\frac{1}{2}$ the width of the body of the achene.

In swamps, Florida to Louisiana and Arizona. Also in tropical America. Spring to fall.

18. Eleocharis macrostáchya Britton. Perennial by relatively short rootstocks, pale green or straw-colored. Scapes tufted, 2.5-12 dm. long, stout: spikelet narrowly cylindric or linear-lanceolate in outline, $1-2.5 \mathrm{~cm}$. long, many-flowered, acute : scales oblong-ovate to lanceolate, often rather acute, pale green or straw-colored with darker ribs: perianth-bristles 5-6, as long as the achene or somewhat shorter, retrorsely barbed, or sometimes very short: stigmas 2 : achenes lenticular, obovoid, about $1.5 \mathrm{~mm}$. long, excluding the small cap-like tubercle, lemon-yellow.

In low grounds, Arkansas to Nevada, Louisiana, Texas and Arizona. Spring to fall.

19. Eleocharis glaucéscens (Willd.) Schult. Perennial by horizontal rootstocks. Scapes tufted, slender, 1-9 dm. long, bright or deep green : spikelet oblong or oblong-lanceolate, $0.5-1.5 \mathrm{~cm}$. long, acute or rather obtuse: scales brown or dark green, blunt or acute in age : perianth-bristles usually 4, about as long as the achene or shorter or nearly wanting: stigmas 2 : achenes lenticular, obovoid, about $1.5 \mathrm{~mm}$. long, excluding the narrow conic tubercle, brown.

In swamps or meadows, Ontario to Minnesota, Nebraska, Florida and Texas. Spring to fall.

20. Eleocharis Ravenélii Britton. Perennial, bright green. Scapes tufted, 3-5 $\mathrm{dm}$. long, slender: spikelet lanceolate or oblong-lanceolate in outline, 8-11 $\mathrm{mm}$. long, acute: scales oblong to oblong-lanceolate, rather blunt, scarious-margined, brown on either side of the prominent midrib: perianth-bristles 4-5, somewhat shorter than the achene: stigmas 2 : achenes biconvex, plump, $1 \mathrm{~mm}$. long or less, narrowly obovoid, somewhat constricted at the top, smooth or nearly so ; tubercle depressed.

In sandy soil, southern Texas. Spring.

21. Eleocharis aciculàris (L.) R. \& S. Perennial by filiform stolons or rootstocks. Scapes tufted, finely filiform or setaceous, obscurely 4 -angled and grooved, weak, erect or reclining, $5-20 \mathrm{~cm}$. long: sheaths truncate : spikelet compressed, narrowly orate or linearoblong, acute, broader than the scape, 3-10-flowered, 3-10 mm. long, $1 \mathrm{~mm}$. wide: scales oblong, obtuse, or the upper subacute, thin, pale green, usually with a narrow brown band on each side of the midvein, deciduous, many of them commonly sterile : perianth-bristles $3-4$, fragile, fugacious, shorter than the achene: stigmas 3 : achenes obovoid-oblong, 0.5 $\mathrm{mm}$. long, pale, obscurely 3 -angled with a rib on each angle and 6-9 lower intermediate ribs connected by fine ridges; tubercle conic, acute, $\frac{1}{4}$ as long as the achene.

In wet soil, throughout North America, except the extreme north. Also in Europe and Asia. Summer and fall. - A variety, E. acicularis radicans (Poir.) Britton, is distinguished by its relatively stout scapes and thicker spikelets. Texas, California and Central America.

22. Eleocharis Chaetària R. \& S. Perennial or annual. Scapes tufted, $2-20 \mathrm{~cm}$. long, curved, filiform or wire-like, smooth, barely constricted at the summit, with a green sheath at the base : spikelet erect, oblong or ovoid-oblong, 2-3 mm. long, 1-4-flowered, flattened : scales in 2 or 3 rows, thin, barely discolored : perianth-bristles 6 , about as long as the achene, sometimes much reduced : stigmas 3 : achenes 3 -angled, obovoid, barely 1 $\mathrm{mm}$. long; tubercle pyramidal, shorter than the body of the achene.

In sandy soil or low grounds, southern Alabama. Also in the West Indies and most tropical and warm-temperate regions. Spring to fall.

23. Eleocharis vivipara Kunth. Perennial by horizontal rootstocks, pale green. Scapes very numerous, tufted, very slender, $1-3 \mathrm{dm}$. long, not rigid, sometimes spreading, barely constricted at the summit : spikelet linear-oblong, 4-7 mm. long, acutish, often sparingly proliferous : scales oblong or ovate-oblong, blunt, scarious-margined, closely imbricated, somewhat discolored : perianth-bristles 6 , barbed, unequal in length : achenes obovoid, nearly white, 3 -angled, plump, about $1 \mathrm{~mm}$. long, finely cancellate; tubercle deltoid, or depressed, shorter than the body of the achene.

In low grounds and on shores, South Carolina to Florida and Texas. Summer and fall.

24. Eleocharis tórtilis (Link) Schult. Annual. Scapes tufted, filiform, sharply 3angled, pale green, erect or reclining, twisting when old, 3-4 dm. long : sheaths obliquely truncate, 1-toothed : spikelet ovoid or oblong, rather acute, several-flowered, 4-6 mm. long, about $2 \mathrm{~mm}$. thick, much thicker than the scape : scales firm, pale, ovate, mostly obtuse: 
perianth-bristles 4-6, rigid, retrorsely barbed, about equalling the achene and tubercle : stigmas 3 : achenes obovoid, nearly $1.5 \mathrm{~mm}$. long, obscurely 3 -angled, strongly reticulated; tubercle cap-like or conic, truncate at the base, $\frac{1}{4}-\frac{1}{2}$ as long as the achene.

In wet soil, near the coast, New Jersey to Florida and Texas. Summer and fall.

25. Eleocharis tuberculòsa (Michx.) R. \& S. Annual. Scapes tufted, slightly compressed, very slender, rather stiff, striate, bright green, 2-5 dm. tall : upper sheath obliquely truncate or 1-toothed : spikelet ovoid to conic-ovoid, many-flowered, 6-12 mm. long, nearly $4 \mathrm{~mm}$. in diameter: scales broadly ovate, obtuse, pale greenish brown with darker midveins, broadly scarious-margined, firm, tardily deciduous: perianth-bristles 6, rigid, downwardly or rarely upwardly barbed, about as long as the achene and tubercle: stigmas 3 : achenes obovoid, $1.5 \mathrm{~mm}$. long, pale, 3-angled, strongly reticulated ; tubercle cap-like or conic, as large as the achene or larger. and fall.

In wet soil, mostly near the coast, Massachusetts to Pennsylvania, Florida and Texas. Summer

26. Eleocharis Torreyàna Boeckl. Annual. Scapes filiform, densely tufted, somewhat 4 -sided, erect or reclining, sometimes proliferous by developing secondary scapes in the axils of the spikelet, sometimes rooting at the summit, $2-20 \mathrm{~cm}$. long: upper sheath obliquely truncate: spikelet oblong, subacute, terete or nearly so, many-flowered, 3-6 $\mathrm{mm}$. long: scales ovate, acute, brownish red with green midveins and lighter margins, early deciduous except the lowest, which is commonly larger than the others, persistent and bract-like: perianth-bristles 3-6, slender, shorter than the achene or equalling it: stigmas 3 : achenes white, 3 -angled, obovoid, smooth, $0.7-0.8 \mathrm{~mm}$. long, constricted at the base; tubercle conic-pyramidal, minute.

In wet sandy soil, southern New Jersey to Florida and Texas, mostly near the coast. Also in Cuba. Spring and summer.

27. Eleocharis microcárpa Torr. Annual, bright green. Scapes tufted, finely filiform, or capillary, 5-20 cm. tall, smooth, barely constricted at the summit, spikelet oblong, 2-3 mm. long, few-flowered, acute: scales oblong to ovate, blunt or rather acute, pale or with brownish patches on either side of the midrib: perianth-bristles $3-5$, very slender, about $\frac{2}{3}$ as long as the achene : stigmas $3:$ achenes grayish white, 3 -angled, obovoid, $0.5-0.7 \mathrm{~mm}$. long, smooth or nearly so ; tubercle minute, pointed.

In wet soil, Florida to Louisiana. Also in Cuba. Spring to fall.

28. Eleocharis prolífera Torr. Annual, sometimes aquatic, bright green. Scapes numerous, tufted, filiform, diffuse, or floating, flattened, 1-6 dm. long, or rarely shorter : spikes conic, 4-8 $\mathrm{mm}$. long, rarely fruiting, acute, proliferous or rooting: scales oblong or oval, whitish, obtuse, thin : perianth-bristles barbed, stout, variable in length : achenes 3 -angled, obovoid, nearly $1 \mathrm{~mm}$. long, surpassing the bristles; tubercle deltoid, or depressed.

In and about ponds and ditches, North Carolina to Florida and Lousiana. Spring to fall.

29. Eleocharis Baldwínii (Torr.) Chapm. Perennial by slender rootstocks. Scapes filiform, tufted, diffusely spreading, 0.5-2 dm. long, grooved : spikelet oblong, 4-6 mm. long, flattened, 3-5-flowered, commonly rooting and proliferous: scales 2-ranked, 4-6, lanceolate, blunt or acutish, delicately nerved: perianth-bristles 4-6, unequal: achenes 3 -angled, oblong, $1 \mathrm{~mm}$. long, as long as the longer bristles; tubercle 3 -angled, abruptly subulate-tipped, about $\frac{1}{3}$ as long as the body of the achene.

In sandy swamps, Georgia and Florida. Spring to fall.

30. Eleocharis melanocárpa Torr. Perennial by short rootstocks. Scapes flattened, striate, tufted, slender, erect, 2-5 dm. tall : upper sheath truncate, 1-toothed : spikelet oblong or cylindric-oblong, obtuse, 6-12 mm. long, 3-4 mm. in diameter, many-flowered, thicker than the scape: scales ovate, obtuse, brown, with lighter midveins and scarious margins : perianth-bristles 3 or 4 , fragile, downwardly hispid, equalling or longer than the achene, fugacious or perhaps sometimes wanting; stigmas 3 : achenes 3 -angled, obpyramidal, fully $1 \mathrm{~mm}$. long, black, smooth; tubercle depressed, covering the summit of the achene, light brown, pointed in the middle.

In wet sandy soil, eastern Massachusetts and Rhode Island to Florida, near the coast. Also in the West Indies. Summer and fall.

31. Eleocharis álbida Torr. Annual. Roots fibrous: scapes very slender, tufted, nearly terete, striate, erect, 1-2 dm. tall : upper sheath very oblique and toothed on one side : spikelet ovoid-globose or oblong, obtuse, 4-8 $\mathrm{mm}$. long, 3-4 $\mathrm{mm}$. in diameter, manyflowered, thicker than the scape: scales pale green or nearly white, rather firm, ovate, obtuse, deciduous : perianth-bristles about 6, downwardly barbed, persistent, as long as the achene: stigmas 3 : achenes broadly obovoid, fully $1 \mathrm{~mm}$. long, nearly black when ripe, 3-angled, smooth ; tubercle ovoid-conic, contracted or truncate at the base, about $\frac{1}{4}$ as long as the achene.

In wet soil, Maryland to Florida, Texas and Mexico, near the coast. Spring and summer.-E. albida Berlandièri (Clarke) Britton, a variety native of southeastern Texas, is stouter, has longer spikelets and the tubercle is more beak-like. 
32. Eleocharis tricostàta Torr. Perennial by short rootstocks. Scapes very slender, erect, compressed, striate, 3-6 dm. tall : upper sheath obliquely truncate, toothed on one side : spikelet oblong, becoming oblong-cylindric, obtuse, many-flowered, $10-18 \mathrm{~mm}$. long, 2-3 mm. in diameter: scales ovate, thin, deciduous, obtuse, brown with green midveins and scarious margins : perianth-bristles none: stigmas 3 : achenes obovoid, $0.8-1 \mathrm{~mm}$. long, 3 -angled, brown, dull, papillose, with the three angles strongly ribbed; tubercle conic, acute, light brown, constricted at the base, minute, very much shorter than the achene.

In wet soil, southern New York to Florida. Summer and fall.

33. Eleocharis ténuis (Willd.) Schult. Perennial by rootstocks. Scapes tufted, filiform, mostly erect, 4-angled with concave sides, 2-4 dm. tall : upper sheath obliquely truncate, toothed an one side : spikelet narrowly oblong, mostly acute, many-flowered, thicker than the scape, $6-10 \mathrm{~mm}$. long, about $2 \mathrm{~mm}$. in diameter : involucral bract 1 : scales thin, obovate or ovate-oblong, obtuse, the midvein greenish, the margins scarious : perianth-bristles $2-4$, shorter than the achene, fugacious or wanting: stigmas 3 : achenes obovoid, about $1 \mathrm{~mm}$. long, obtusely 3 -angled, yellow to brown, irregularly ridged-reticulated or papillose, more or less persistent on the rachis of the spikelet after the scales have fallen ; tubercle conic, short, acute.

In wet soil, Cape Breton Island to Ontario, Manitoba, Florida and Texas. Spring and summer.

34. Eleocharis arenícola Torr. Perennial by horizontal rootstocks. Scapes very slender, tufted, 1.5-4-5 dm. tall, grooved, mostly erect : spikelets oblong to ovoid-oblong, 4-12 mm. long, 2.5-3.5 mm. thick, many-flowered : scales oblong or ovate, thin, blunt, each with a brown apex and whitish margins : perianth-bristles 6 , persistent, the longer as long as the achene : achenes 3 -angled, about $1 \mathrm{~mm}$. long, oblong-obovoid or obovoid, faintly reticulated ; tubercle thick, deltoid.

On sandy shores and in swamps, South Carolina to Florida and Texas. Spring to fall.

35. Eleocharis acuminàta (Muhl.) Nees. Perennial by stout rootstocks, similar to the next preceding species but stouter. Scapes flattened, striate, slender but rather stiff, tufted, 2-5 dm. tall : upper sheath truncate, sometimes slightly 1-toothed: spikelet ovoid or oblong, obtuse, thicker than the scape, many-flowered, 6-12 $\mathrm{mm}$. long: scales oblong or ovate-lanceolate, acute, purple-brown with greenish midveins and hyaline white margins, deciduous : perianth-bristles 1-5, shorter than or equalling the achene, fugacious, or wanting: stigmas 3 , exserted: achenes obovoid, $1.5 \mathrm{~mm}$. long, obtusely 3 -angled, light yellowish brown, papillose, much longer than the depressed conic acute tubercle, persistent on the rachis as in E. tenuis.

In wet soil, Anticosti to Manitoba, Georgia, Louisiana and Nebraska. Summer.

36. Eleocharis cylíndrica Buckl. Perennial by slender rootstocks. Scapes very slender, tufted: spikelets linear-cylindric, or slightly flattened, 1-2 cm. long, about $3 \mathrm{~mm}$. thick, acutish, many-flowered : scales various, the lower ovate and blunt, the upper ovate or oblong-lanceolate and acute, with whitish hyaline margins : perianth-bristles wanting : achenes obovoid, fully $0.5 \mathrm{~mm}$. long, yellowish, constricted at the ends but especially under the acute tubercle.

In sandy soil, Texas. Summer and fall.

37. Eleocharis rostellàta Torr. Perennial by a short caudex. Scapes slender, wiry, the fertile ones erect or ascending, the sterile reclining aud rooting at the summit, grooved, 3-15 dm. long: upper sheath truncate: spikelet oblong, narrowed at both ends, thicker than the scape, 10-20-flowered, 6-12 mm. long, about $2 \mathrm{~mm}$. in diameter: scales ovate, obtuse or the upper acute, green with somewhat darker midveins : perianth-bristles 4-8, retrorsely barbed, longer than the achene and tubercle: stigmas 3: achenes oblong-obovoid, $1.5 \mathrm{~mm}$. long, obtusely 3 -angled, their surface finely reticulated; tubercle conicsubulate, about $\frac{1}{2}$ as long as the achene or shorter, capping its summit, partly or entirely falling away at maturity.

In marshes and wet meadows, New Hampshire to Vermont and western New York, British Columbia, Florida, Texas, Mexico and California. Also in Cuba. Summer and fall.

\section{FIMBRÍSTYLIS Vahl.}

Annual or perennial scapose herbs. Spikelets umbellate or capitate, terete, several to many-flowered, subtended by a 1-many-leaved involucre, their scales spirally imbricated all around, mostly deciduous, all fertile. Perianth none. Stamens 1-3. Style pubescent or glabrous, its base usually much enlarged, but falling away from the summit of the achene at maturity. Stigmas 2-3. Achenes lenticular, biconvex, or 3-angled, reticulated, cancellate, or longitudinally ribbed or striate. The plants flower mainly in summer and fall. 
Style-branches or stigmas 2: achenes lenticular.

Spikelets peduncled, forming umbels, or solitary and sessile.

Perennial : leaf-blades strongly involute.

Bracts of the involucre shorter than the spikelets.

Bracts of the involucre or some of them longer than the spikelets.

Base of the style swollen.

Scales coriaceous, shining.

Scales thinner, dull.

Base of the style not swollen.

Annual : leaf-blades flat or nearly so.

Spikelets several, sessile, forming a terminal head.

Scales acuminate: achenes obovoid.

Scales subulate-tipped : achenes oblong-cylindric.

Style-branches or stigmas 3: achenes 3-angled.

Spikelets narrow, or if relatively thick, in simple umbels.

Umbel mostly simple: spikelets ovoid or oval, blunt: achenes distinctly reticulated.

Umbel mostly compound: spikelets linear-oblong, acute : achenes smooth or indistinctly reticulated.

Spikelets globular or about as thick as long, in decompound umbels.

1. F. schoenoides.

2. F. spadicea.

3. F. castanea.

4. F. Drummondii.

5. F. laxa.

6. F. Vahlii.

7. F. perpusilla.

8. F. Frankii.

9. F. autumnalis.

10. F. miliacea.

1. Fimbristylis schoenoìdes Vahl. Perennial, glabrous. Leaves erect or nearly so: blades attenuate from the slightly dilated bsaes, involute : scapes more or less densely tufted, 1-4 dm. tall, mostly overtopping the leaves, smooth : bracts of the involucre shorter than the spikelets, inconspicuous : spikelets solitary, or 2 or 3 together forming an umbel, and the earliest one sessile, ovoid or conic-ovoid, 5-12 mm. long, 3-4 mm. thick, pale brown: scales rather blunt, firm: stigmas 2 : achenes lenticular, broadly obovoid, barely 1.E mm. long, lustrous, whitish, not pointed.

In low grounds, Florida. Also in tropical Asia.

2. Fimbristylis spadícea (L.) Vahl. Perennial by a thickened base, glabrous. Leaves few : blades about $2 \mathrm{~mm}$. wide when unrolled, their sheaths dark brown : scapes stiff, slender, 3-angled, wiry, tall, usually longer than the strongly involute, rigid leaves : bracts of the involucre 3-6, erect: umbel several-rayed, the rays nearly erect, $5-15 \mathrm{~cm}$. long: central spikelets of the umbels and umbellets sessile, the others pedicelled: spikelets ovoid or ovoid-cylindric, acute, $5-12 \mathrm{~mm}$. long, about $2 \mathrm{~mm}$. in diameter: scales oval, obovate, or orbicular, obtuse or subacute, coriaceous, glabrous, shining, dark brown with green midribs : stigmas 2 : achenes lenticular, obovoid, $1.5 \mathrm{~mm}$. long, brown. America.

In marshes and shallow water, Virginia to Florida, near the coast. Widely distributed in tropical

3. Fimbristylis castànea (Michx.) Vahl. Perennial by a thick base. Leaves few ; blades involute, less than $2 \mathrm{~mm}$. wide, their sheaths green and more or less pubescent: scapes slender, 3 -angled, $2-5 \mathrm{dm}$. tall, usually exceeding the leaves : bracts of the involucre $2-4$, short : umbel simple or compound, the rays $1-5 \mathrm{~cm}$. long: the central spikelets sessile: spikelets oblong, 6-10 mm. long, 2-3 mm. in diameter : scales thin, brown with lighter midveins, broadly oblong or nearly orbicular, dull, puberulent, obtuse or mucronate: stigmas 2 : achenes obovoid or oblong, about $1.5 \mathrm{~mm}$. long, biconvex, pale brown, that of the prairie plant is shorter and less tapering to the base.

On salt meadows, southern New York to Florida and Louisiana. Also in wet soil in the interior from Ontario, Michigan and Illinois to Kansas and Texas, and in tropical America.-A variety with copiously pubescent leaves and scapes, is F. castanea pubèrula (Michx.) Britton. It ranges from Georgia and Florida to Texas.

4. Fimbristylis Drummóndii (Torr. \& Hook.) Britton. Perennial, glabrous. Leaves rather stiff; blades attenuate from the slightly dilated base, convex beneath, scarcely $2 \mathrm{~mm}$. wide : scapes erect, somewhat tufted, about $9 \mathrm{dm}$. tall, twice as long as the leaves, smooth, deeply channeled on one side: bracts of the involucre $2-3$, shorter than the inflorescence : umbel compound, with 4-6 curved rays $2-5 \mathrm{~cm}$. long : spikelets oblongovate, about $12 \mathrm{~mm}$. long, 3-5 mm. broad, pale brown, acute : scales mucronulate, rigid, slightly keeled near the apex : style not thickened at the base : stigmas 2 : achenes lenticular, obovoid, about $1.5 \mathrm{~mm}$. long, apiculate at the apex. [Isolepis Drummondii Torr. \& Hook.]

In low grounds, Texas.

5. Fimbristylis láxa Vahl. Annual, glabrous or sparingly ciliate. Leaves pale green; blades flat, about $1 \mathrm{~mm}$. wide: scapes slender, flattened, striate, densely tufted, erect or ascending, $5-40 \mathrm{~cm}$. long, usually longer than the leaves : bracts of the involucre 3-5: umbel simple or slightly compound, the central spikelets sessile : spikelets ovoid or ovoid-oblong, 6-12 $\mathrm{mm}$. long, about $2 \mathrm{~mm}$. in diameter : scales ovate, thin, pale greenish brown, subacute or mucronulate : stigmas 2: achenes biconvex, obovoid, fully $1 \mathrm{~mm}$. long, brown, longitudinally ribbed, the ribs tubercled and connected by very fine cross lines.

In moist soil, southern Pennsylvania to Missouri, Florida and Texas. Also in tropical America.

6. Fimbristylis Vàhlii (Lam.) Link. Annual. Leaves setaceous or almost filiform, rough : scapes very slender, densely tufted, compressed, striate, $2-10 \mathrm{~cm}$. high, longer than or equalling the leaves: bracts of the involucre $3-5$, erect, much exceeding the simple 
capitate cluster of 3-8 spikelets: spikelets oblong-cylindric, obtuse, 4-8 mm. long, about $1 \mathrm{~mm}$. thick, many-flowered : scales lanceolate, pale greenish brown, acuminate : stigmas 2 : achenes obovoid, about $0.5 \mathrm{~mm}$. long, biconvex, yellowish white, cancellate.

In moist soil, Msssouri to Texas, North Carolina and Florida.

7. Fimbristylis perpusílla Harper. Annual. Leaves few, basal, filiform, rather shorter than the scapes : scapes in small prostrate radiating tufts, 1-3 cm. long: bracts of the involucre few, mostly less than $1 \mathrm{~cm}$. long: spikelets globular, 1-2 mm. in diameter, sessile or nearly so during anthesis : scales green or yellowish, each tapering into a loosel y spreading awn: stamen 1 : stigmas 2 : achene oblong-cylindric, about $0.5 \mathrm{~mm}$. long.

In pine-land ponds, near Leslie, Georgia. Fall.

8. Fimbristylis Fránkii Steud. Annual, lower than the next following species, the leaves often shorter. Umbel mostly simple, the spikelets, or most of them, capitate and sessile, ovoid or oval, blunt, the heads sometimes appearing almost sessile at the base : achenes $0.5 \mathrm{~mm}$. long, distinctly reticulated.

In mud or wet sand, New Hampshire to Missouri, Tennessee and Louisiana.

9. Fimbristylis autumnàlis (L.) R. \& S. Annual. Leaves glabrous ; blades narrowly linear, flat, 1-2 mm. wide: scapes very slender, densely tufted, flat, $7-40 \mathrm{~cm}$. long, usually much exceeding the leaves : bracts of the involucre $2-3$, usually all shorter than the umbel : umbel compound or decompound, the primary rays 4-10 $\mathrm{mm}$. long, the secondary filiform : spikelets linear-oblong, acute, $6-40 \mathrm{~mm}$. long, $1 \mathrm{~mm}$. thick or less : scales ovate-lanceolate, subacute, strongly mucronate, greenish brown, the midvein prominent : stigmas 3 : achenes obovoid, about $0.5 \mathrm{~mm}$. long, nearly white, 3 -angled with a ridge on each angle, smooth or indistinctly reticulated, sometimes roughened.

In moist soil, Maine to Michigan, Florida, Louisiana and Texas. Also in tropical America. Summer and fall.

10. Fimbristylis miliàcea Vahl. Annual (always?), glabrous. Leaves rather tender ; blades ensiform, long-attenuate : scapes weak, often loosely tufted, $1.5-6 \mathrm{dm}$. tall, mostly overtopping the leaves, smooth : bracts of the involucre shorter than the inflorescence: umbel erect, decompound, its peduncles often filiform : spikelets several or numerous, ovoid or globular, 2-3 mm. long, blunt, pale brown : scales blunt, with broad midnerves : stigmas 3 : achenes 3 -angled, obovoid, less than $1 \mathrm{~mm}$. long, minutely roughened, pale.

In bogs and ditches, Florida. Widely distributed in the tropics. Spring to fall.

\section{STENOPHÝLLUS Raf.}

Mostly annual herbs, with slender erect scapes. Leaves basal : blades narrowly linear or filiform, the sheaths ciliate or pubescent. Spikelets umbellate, capitate or solitary, subtended by an involucre of 1-several bracts, their scales spirally imbricated, mostly deciduous. Flowers perfect. Perianth none. Stamens 2 or 3 . Style glabrous, its base much swollen and persistent as a tubercle of the achene as in Eleocharis. Stigmas 2-3. Achene 3 -angled, turgid or lenticular.

Spikelets in open umbels or sometimes solitary.

Leaf-blades serrulate-ciliate: umbel not contracted: spikelets 5 -8-flowered.

Umbel simple: scales of the spikelets obtuse : achene transversely wrinkled.

Umbel compound : scales of the spikelets acute: achene minutely papillose.

Leaf-blades smooth and glabrous : umbel contracted : spikelets 10-15-flowered.

Spikelets clustered in terminal heads.

Bracts of the involucre with entire bases.

Scales mucronate: involucral bracts few, short.

Scales subulate-tipped: bracts very long, much exceeding the heads.

Bracts of the involuere with fimbriate bases.

1. S. capillaris.

2. S. ciliatifolius.

3. S. coarctatus.

4. S. Floridanus.

5. S. Stenophyllus. 6. S. Warei.

1. Stenophyllus capillàris (L.) Britton. Leaves roughish, much shorter than the scape, their sheaths more or less pubescent with long hairs : scapes filiform, densely tufted, erect, grooved, smooth, $5-25 \mathrm{~cm}$. tall : involucral bracts $1-3$, setaceous : spikelets narrowly oblong, somewhat 4-sided, 5-8 $\mathrm{mm}$. long, less than $2 \mathrm{~mm}$. thick, several in a terminal umbel, or in depauperate forms solitary : scales oblong, obtuse or emarginate, puberulent, dark brown with green keels : stigmas 3 : achenes yellow-brown, narrowed at the base, very obtuse or truncate at the summit, nearly $1 \mathrm{~mm}$. long, transversely wrinkled; tubercle minute, depressed. [Isolepis capillaris (L.) R. \& S.]

In dry or moist soil, throughout North America, except the extreme north. Also in'tropical America. Summer and fall.

2. Stenophyllus ciliatifolius (Ell.) C. Mohr. Leaves erect; blades bristle-like or linear-filiform, channeled, serrulate-ciliate: scapes tufted, very slender, $10-30 \mathrm{~cm}$. tall, often slightly scabrous near the top : bracts of the involucre 2-3, similar to the leaves but shorter, one about as long as the umbel, the others very short : spikelets numerous in a terminal compound umbel, linear-oblong, 2-4 mm. long, acute, 6-12-flowered : scales broad, brown-margined, keeled, abruptly pointed, often ciliate toward the apex : achenes 3-angled, 
obovoid, less than $1 \mathrm{~mm}$. long, bluish, minutely papillose. [Isolepis ciliatifolia (Ell.) Torr].

In pine lands, North Carolina to Florida and Alabama. Spring to fall.

3. Stenophyllus coarctàtus (Ell.) Britton. Leaves few ; blades bristle-like, glabrous or nearly so; sheaths bearded at the mouth : scapes tufted, filiform, about $30 \mathrm{~cm}$. long, arching, smooth : bracts of the involucre several, only one as long as the umbel or slightly longer : spikelets several, linear-oblong, about $6 \mathrm{~mm}$. long, sessile or short-peduncled, $10-$ 15-flowered : scales ovate, acutish, with reddish margins, ciliate near the apex : achenes unequally 3 -angled, the inner face broadest, about $1 \mathrm{~mm}$. long, minutely papillose ; tubercle a minute black tip. [ Isolepis coarctata (Ell.) Torr.]

In dry sandy soil, Georgia and Florida. Summer and fall.

4. Stenophyllus Floridànus Britton. Leaves much surpassed by the scapes; blades filiform, erect, $\frac{1}{2}$ as long as the scapes or shorter; sheaths ciliate : scapes tufted, filiform, 10-20 cm. tall : spikelets linear or nearly so, 4-8 $\mathrm{mm}$. long, about $1 \mathrm{~mm}$. thick, acute, rich brown, 4-10 sessile in dense terminal heads: scales ovate-lanceolate, about $1 \mathrm{~mm}$. long, keeled, each prolonged into a minute slightly spreading tip : achenes 3 -angled, broadly obovoid, pale.

In high pine lands, southern Georgia and Florida. Summer. WATER-GRAss.

5. Stenophyllus Stenophýllus (Ell.) Britton. Leaves numerous, overtopped by the scape ; blades filiform or bristle-like, erect, bristly-ciliate : scapes densely tufted, 5-20 $\mathrm{cm}$. tall, scabrous at least above : bracts of the involucre several, 3 or 4 much longer than the rest, ciliate like the leaf-blades, the dilated bases never fimbriate : spikelets 4-8, sessile in dense terminal heads, about 5-7 mm. long, 6-10-flowered : scales variable in length, loosely imbricated, hispid on the 3-nerved keel, produced into a cuspidate tip : achenes 3angled, obovoid, about $1 \mathrm{~mm}$. long, bluish white, transversely wrinkled; tubercle minute, persistent. [Isolepis stenophylla (Ell.) Torr.]

In dry sandy soil, North Carolina to Florida and Louisiana. Spring to fall.

6. Stenophyllus Wàrei (Torr.) Britton. Leaves shorter than the scape ; blades bristle-like, channeled; sheaths pectinately fringed at the mouth. Scapes densely tufted, $20-40 \mathrm{~cm}$. tall, filiform, slightly flattened, smooth and glabrous: bracts of the involucre 3-4, about twice as long as the head, rigid, the broadly dilated bases fimbriate: spikelets 8-15 in a compact head, ovoid, 6-7 $\mathrm{mm}$. long, 10-15-flowered: scales broad, mucronate, ciliate-pubescent without : achenes 3 -angled, obovoid, white, obscurely wrinkled; tubercle minute, dark-colored. [Isolepis Warei Torr.]

In dry sand, Florida. Spring to fall.

\section{PSILOCÁRYA Torr.}

Annual herbs, with fibrous roots, slender stems and ovoid or oblong, many-flowered terete spikelets in terminal and axillary, mostly compound umbels, the rays and raylets bracted at the base. Scales of the spikelets spirally imbricated, all fertile, deciduous. Flowers perfect. Perianth none. Stamens 1 or 2. Style enlarged at the base. Stigmas 2. Achene lenticular or biconvex, smooth or transversely wrinkled, capped by the persistent base of the style (tubercle), or nearly the whole style persistent as a beak.

Scales of the spikelets acute or acuminate: tubercle less than $1 / 2$ as long as the achene.

Scales of the spikelets blunt: tubercle over $1 / 2$ as long as the achene.

1. P. nitens.

2. $P$. corymbiformis.

1. Psilocarya nitens (Vahl) Wood. Stems tufted, slightly angled, $7-40 \mathrm{~cm}$. tall : leaves sometimes overtopping the stem, sheathing at the base; blades narrowly linear, about $2 \mathrm{~mm}$. wide, smooth, the midvein prominent: umbels mostly loose : spikelets ovoid, 4-6 mm. long, rather less than $2 \mathrm{~mm}$. in diameter: scales brown, broadly ovate, thin, 1nerved, obtuse, acute or apiculate : achenes lenticular, nearly orbicular, nearly $1.5 \mathrm{~mm}$. long, light brown, strongly transversely wrinkled; tubercle shorter than the achene-body, subacute, 2-lobed at the base.

In wet soil, near the coast, Long Island and Delaware to Florida and Texas. Summer and fall.

2. Psilocarya corymbifórmis Benth. Stems solitary or sparingly tufted, 2-7 dm. tall, topped like the branches by a corymb : leaves several, mostly overtopped by the stems; blades more or less involute above the sheath, $2-6 \mathrm{~cm}$. broad, attenuate : spikelets in lax corymbs, oblong-ovoid, $6-10 \mathrm{~mm}$. long, fully $2 \mathrm{~mm}$. thick: scales brownish, narrowly ovate or ovate-lanceolate, thinner than in the preceding, blunt: achenes lenticular, suborbicular, $0.5 \mathrm{~mm}$. long, including the slightly decurrent tubercle, this nearly as long as the body of the achene.

In low pine lands, Georgia and Florida to Louisiana. Also in the West Indies. Spring to fall. 


\section{DICHRÓMENA Michx.}

Leafy-stemmed sedges, perennial by rootstocks, the spikelets crowded in a terminal head involucrate by several bracts, which are often white at the base. Spikelets compressed, several-many-flowered. Scales spirally imbricated all around, several of them with imperfect flowers, or empty. Perianth none. Stamens 3. Style subulate. Stigmas 2, very slender. Achene lenticular, transversely rugose, crowned with the broad persistent base of the style (tubercle). The plants bloom from spring to fall. White-top.

Involucre of 2 bracts : achenes barely $1 \mathrm{~mm}$. long.

Involucre of $4-10$ bracts : achenes over $1 \mathrm{~mm}$. long.

Bracts of the involucre 4-6, linear: tubercle truncate on top of the achene.

Leaves filiform above the dilated base: achenes dark ; tubercle low, blunt.

Leaves linear above the dilated base: achenes pale; tubercle long, acute.

Bracts of the involucre 7-10, lanceolate: tubercle decurrent on the sides of the achene.

- 1. D. nivea.

1. Dichromena nívea Boeckl. Stems tufted, 1-3 dm. tall, very slender nearly terete, smooth : leaves mostly shorter than the stems ; blades very narrowly linear or linear-filiform : bracts of the involucre 2, very unequal, slender beyond the white dilated bases: head less than $1 \mathrm{~cm}$. in diameter, pearly white, erect: spikelets ovate, 3-4 mm. long, crowded: scales smooth, notched at the apex, closely imbricated : achenes lenticular, plump, obovoid, barely $1 \mathrm{~mm}$. long, short-beaked, with prominently wrinkled sides.

In wet soil and low grounds, Arkansas and Texas.

2. Dichromena Floridénsis Britton. Stems copiously tufted, $2-4 \mathrm{dm}$. tall, smooth, slender : leaves numerous; blades involute-filiform, smooth : bracts of the involucre 4-6, slenderly attenuate : heads about $1 \mathrm{~cm}$. in diameter : spikelets oblong : scales pale : achenes obovoid, slightly over $1 \mathrm{~mm}$. long, dark brown, finely wrinkled, the tubercle nearly truncate on the top of the achene-body.

In low pine lands, southern Florida.

3. Dichromena coloràta (L.) A. S. Hitchcock. Stem slender, rather sharply triangular, 3-6 dm. tall. Leaf-blades narrowly linear, much shorter than the stem : bracts of the involucre 4-6, reflexed when mature, yellowish white at the base : head globose, 1-2 cm. in diameter: spikelets narrowly oblong, acute : scales membranous, lanceolate, nearly white, 1-nerved, subacute : achenes obovoid, a little over $1 \mathrm{~mm}$. long, excluding the tubercle, pale brown, compressed, nearly truncate at the summit, there covered by the tubercle which is not decurrent on its edges. [D. leucocephala Michx.]

In moist sandy soil, pine lands, New Jersey to Florida and Texas. Also in tropical America.

4. Dichromena latifolia Baldw. Similar to the next preceding species but the stem stouter, obtusely triangular or nearly terete. Leaf-blades lanceolate or linear-lanceolate, tapering gradually to a long acuminate apex from a broad base, 3-8 $\mathrm{mm}$. wide, sometimes overtopping the stem, but the lowest much shorter : bracts of the involucre $7-10$, strongly reflexed when old : head globose, 1-2 $\mathrm{cm}$. in diameter : spikelets oblong, subacute : scales ovate-lanceolate, nearly white, rather obtuse : achenes nearly orbicular in outline, a little over $1 \mathrm{~mm}$. long, excluding the tubercle, pale brown, faintly wrinkled transversely and longitudinally so as to appear reticulated ; the tubercle decurrent on its margins.

In wet pine lands, Virginia to Florida and Texas.

\section{ABILDGAàrdIA Vahl.}

Perennial, or sometimes annual, acaulescent herbs. Leaves basal : blades narrow, commonly involute : scapes tufted, jointless, simple. Involucre of a single small bract. Spikelets solitary or several in terminal umbels or clusters, several to many-flowered : scales imbricated in 2 rows, or in 3 rows by the twisting of the rachis, keeled, decurrent, deciduous. Perianth wanting. Stamens 1-3. Style pubescent, with a swollen base, deciduous. Stigmas 3 . Achenes 3 -angled, broadest above the middle, warty, pale.

1. Abildgaardia monostáchya (L.) Vahl. Perennial, glabrous. Leaves firm, shorter than the scape ; blades nearly filiform above the discolored bases, slightly involute, sharp-pointed : scapes tufted, very slender or filiform, 1-4 dm. tall, erect, smooth : bracts of the involucre much shorter than the spikelets, inconspicuous : spikelet solitary or sometimes 2 together, flattened, ovoid or conic, $1-1.5 \mathrm{~cm}$. long, pale : scales in 2 rows, acute or mucronulate, with broad white margins : stigmas 3 : achenes slightly pear-shaped, 2-2.5 $\mathrm{mm}$. long, constricted near the base, copiously warty, yellowish white, often apiculate.

In sandy or rocky soil, peninsular Florida and the Keys. Also in the tropics. Spring to fall.

\section{SCHOÈNUS L.}

Perennial rush-like herbs, with tufted rigid scapes. Leaves basal; sheath dark-col- 
ored ; blades resembling the scapes, half-terete. Spikes in a terminal cluster, 1-8-flowered, subtended by an involucre of 1-2 bracts. Spikelets crowded, often dark-colored : scales imbricated in 2 rows, the lower ones empty, the upper flower-bearing. Perianth of 3-6 scabrous or plumose hi istles. Stamens 3. Style barely enlarged at the base, almost wholly deciduous. Stigmas 3. Achene 3-angled, without a tubercle. [Chaetospora R. Br.]

1. Schoenus nígricans L. Foliage glabrous. Leaves basal; sheaths dark brown or almost black at the base; blades overtopped by the scape, erect, rigid, pungent : scapes tufted, 2-6 dm. tall : bracts of the involucre 2, the lower one surpassing the infloreseence : head about $1 \mathrm{~cm}$. long, dark chestnut-colored : spikelets flattened, 6-8-flowered, narrowed upward: scales ovate or lanceolate-ovate, firm, keeled : perianth-bristles 6 , unequal, somewhat plumose: achenes oval, white and polished, about $2 \mathrm{~mm}$. long, surpassed by the bristles. [Chaetospora nigricans (L.) Kunth.]

In damp sandy soil, Florida to Texas and California. Also in the Old World.

\section{CLÀDIUUM P. Br.}

Perennial leafy herbs, similar to the Rynchosporae in habit. Spikelets oblong or fusiform, few-flowered, variously clustered. Scales imbricated all around, the lower empty, the middle ones mostly subtending imperfect flowers, the upper usually fertile. Perianth none. Stamens 2, or sometimes 3 . Style deciduous from the summit of the achene. Stigmas 2-3. Achene ovoid to globose, smooth or longitudinally striate : tubercle none.

Leaf-blades about $2 \mathrm{~mm}$. wide: umbels small : achene truncate at the base.

Leaf-blades 6-20 mm. wide: umbels large, panicled : achene narrowed to the base.

1. C. mariscoides. 2. C. effusum.

1. Cladium mariscoìdes (Muhl.) Torr. Stems 3-9 dm. tall, slender, rather stiff, obscurely 3 -angled, smooth : leaves about $2 \mathrm{~mm}$. wide, concave, with long compressed tips, nearly smooth : umbels 2 or 3, compound, small : spikelets oblong, narrowed at both ends, acute, $5 \mathrm{~mm}$. long, capitate on the raylets : scales chestnut-brown, ovate or ovate-lanceolate, acute ; upper scale subtending a perfect flower with 2 stamens and a filiform style and 3 stigmas, the next lower one with 2 stamens and an abortive ovary : achene ovoid, acute, finely longitudinally striate, about $2 \mathrm{~mm}$. long.

In marshes, Nova Scotia to Minnesota, Florida and Kentucky. Pond Rush. Twig Rush.

2. Cladium effùsum (Sw.) Torr. Stems stout, $1.5-3 \mathrm{~m}$. high, obtusely 3 -angled: leaves very long, glabrous, $6-20 \mathrm{~mm}$. wide, the margins spinulose-serrulate : umbels several or numerous, decompound, forming a large panicle: spikelets mostly $2-5$ together at the ends of the raylets, narrowly ovoid, acute, $4-5 \mathrm{~mm}$. long; uppermost scale subtending a perfect flower : stamens 2 : achene ovoid, abruptly sharp-pointed, wrinkled, narrowed to the base, $2 \mathrm{~mm}$. long.

In water, Virginia to Florida and Texas. Also in the West Indies. SAW-Grass.

\section{REMIREA Aubl.}

Perennial sometimes caulescent herbs, with horizontal rootstocks. Stems more or less tufted, relatively low. Leaves imbricated : blades narrow, rigid. Involucre with numerous bracts, the outer spreading. Flowers perfect. Spikelets numerous, crowded into a single terminal head, sessile, 1-flowered. Scales about 4, imbricated, the lower one empty. Stamens 3. Perianth wanting. Style barely enlarged below, the base continuous with the ovary. Stigmas 3. Achenes 3-angled, tightly enclosed in the inner scales. TuFt-Grass.

1. Remirea maritima Aubl. Foliage glabrous, bright green. Stems erect, $0.5-3$ dm. tall, densely leafy, simple : leaves numerous; blades linear or linear-lanceolate, $2-10$ cm. long, attenuate, slightly involute, smooth: bracts of the involucre resembling the leaves : spike $1-1.5 \mathrm{~cm}$. long, ovoid, sometimes compound: spikelets $3-5 \mathrm{~mm}$. long: achenes narrowly oblong, $2.5-3 \mathrm{~mm}$. long, often curved, apiculate, rather granular.

On sandy beaches, peninsular Florida. Also widely distributed in the tropics. Spring to fall.

\section{RYNCHÓSPORA Vahl.}

Caulescent herbs, mostly perennial by rootstocks, with 3 -angled or terete stems, narrow, flat, or involute leaf-blades, and ovoid oblong or fusiform, variously clustered spikelets. Scales thin, 1-nerved, imbricated all around, usually mucronate by the excurrent midvein, the lower empty. Upper flowers imperfect, the lower perfect. Perianth of 1-24 (mostly 6) upwardly or downwardly barbed or scabrous bristles, or wanting in some species. Stamens commonly 3. Stigmas 2, rarely wholly united. Achene lenticular or swollen, not 3-angled, smooth, cancellate or transversely wrinkled, capped with the persistent base of the style (tubercle), or in some species by the whole style. BEAK Rush. 
Style long, its branches much shorter than the united lower part.

Spikelets in 1-4 dense globose heads.

Achene truncate, tipped by a subulate tubercle, ciliate.

Achene obovoid, tipped by a conic tubercle, not ciliate.

Spikelets in panicled clusters : achene capped by a stout tubercle.

Mature spikelets about $1 \mathrm{~cm}$. long: tubercle slightly longer than the achene. Mature spikelets much over $1 \mathrm{~cm}$. long: tubercle several times longer than the achene.

Style short, its branches as long as the united part or longer.

Perianth-bristles none or very short.

Achene transversely wrinkled.

Achene smooth or reticulated.

Achene reticulated, $0.5-0.7 \mathrm{~mm}$. long: spikelets loosely corymbose.

Achene smooth, 1.5-2 mm. long: spikelets corymbose-capitate.

Stem-leaves with blades $0.7 \mathrm{~mm}$. wide or less : spikelets $3-4 \mathrm{~mm}$. long. Stem-leaves with blades $1.5-2.5 \mathrm{~mm}$. wide : spikelets $4-6 \mathrm{~mm}$. long.

Perianth-bristles present and usually well developed.

Bristles plumose: achene wrinkled.

Spikelets solitary or 2-4 together. $6-8 \mathrm{~mm}$. long.

Spikelets numerous, clustered, $2.5-4 \mathrm{~mm}$. long.

Perianth-bristles plumose nearly or quite to the top.

Stems slender, $1.5-3.5 \mathrm{dm}$. tall : spikelets small

Stems stout, 3-6 dm tall: spikelets large.

Perianth-bristles plumose below the middle or only near the base.

Bristles not plumose.

Bristles retrorsely barbed.

Scales pale green or white: perianth-bristles 9-24.

Scales brown: perianth-bristles 6 .

Spikelets few to numerous in rather loose, often panicled clusters.

Spikelets numerous, in 2-4 dense globose heads.

Spikelets 5-6 mm. long: achene $2.5 \mathrm{~mm}$. long.

Spikelets 3-3.5 mm. long: achene $1.5 \mathrm{~mm}$. long.

Bristles upwardly barbed.

Achene smooth or cancellate, not transversely wrinkled. Achene smooth.

Tubercle of the achene ciliate to serrulate.

Leaf-blades flat.

Leaf-blades channeled, involute, filiform or nearly so. Achene linear-oblong: perianth-bristles much overtopping the tubercle.

Achene obovoid: perianth-bristles not longer than the achene and tubercle, or scarcely so. Achene $1 \mathrm{~mm}$. long or less, light brown. Achene 1.5-2 mm. long, dark brown.

Tubercle of the achene smooth or merely granular.

Perianth-bristles as long as the achene or longer.

Leaf-blades $0.5-2 \mathrm{~mm}$. wide.

Perianth-bristles about as long as the achene. Perianth-bristles much longer than the achene.

Leaf-blades 2-7 mm. wide.

Perianth-bristles much shorter than the achene, sometimes very short.

Leaf-blades $0.5-3 \mathrm{~mm}$. wide : spikelets $2-5 \mathrm{~mm}$. long. Leaf-blades narrowly linear : spikelets $2-3 \mathrm{~mm}$. long. Leaf-blades bristle-like, filiform: spikelets $4-5 \mathrm{~mm}$. long.

Leaf-blades 4-10 mm. wide : spikelets $6-8 \mathrm{~mm}$. long.

Achene cancellate.

Leaf-blades broadly linear, blunt or merely acute : achene $\mathbf{1 . 5}$ $\mathrm{mm}$. long.

Leaf-blades narrowly linear, attenuate.

Achenes $2.5 \mathrm{~mm}$. long, equalling or shorter than the bristles.

Achenes $1.5 \mathrm{~mm}$. long, much longer than the bristles.

Achene transversely wrinkled.

Perianth-bristles shorter than the achene.

Leaf-blades and stems filiform : spikelets filiform-pedicelled.

Leaf-blades not filiform, flat or involute: spikelets sessile or short-pedicelled.

Leaf-blades involute.

Achene flat, $1.5 \mathrm{~mm}$. long, continuous with the tubercle.

Achene strongly biconvex, $2 \mathrm{~mm}$. long, constricted under the tubercle.

Leaf-blades flat.

Achene biconvex. not constricted under the tubercle.

Achene $1 \mathrm{~mm}$. long : tubercle depressed, wider than high. Achene $1.5 \mathrm{~mm}$. long: tubercle conic, about as high as wide.

Achene compressed, constricted under the tubercle.

Perianth-bristles as long as the achene or longer.

A. Spikelets ovoid to globular, $2-4 \mathrm{~mm}$. long.

a. Achene not stipitate.

* Tubercle setose.

† Spikelets 1-3-flowered.

Perianth-bristles not longer than the achene and tubercle.

Perianth-bristles longer than the achene and tubercle. Achene broadly or orbicular-obovoid. Achene narrowly obovoid.

1. R. Tracyi.

2. R. solitaria.

3. R. Indianolensis.

4. R. corniculata.

5. R. pusilla.

6. $R$. divergens.

7. R. Charmanii.

8. R. pallida.

9. $R$. oligantha.

10. R. plumosa.

11. $R$. intermedia.

12. R. semiplumosa.

13. R. alba.

14. R. glomerata.

15. R. axillaris.

16. $R$. microcephala

17. R. fuscoides.

18. R. Curtissii.

19. R. filifolia.

20. $R$. leptorhyncha.

21. $R$, distans.

22 . $R$. gracilenta.

23. $R$. Baldwinii.

24. $R$. fascicularis.

25. R. brachychaeta.

26. $R$. dodecandra.

27. $R$. ciliata.

28. R. Grayi.

29. R. Plankii.

30. $R$. rariflora.

31. R. Torreyana.

32. R. Earlei.

33. R. perplexa.

34. R. cymosa.

35. $R$. compressa.
36. R. patula.

37. R. caduca.

38. R. mixta. 
† Spikelets 5-10-flowered.

**'Tuberele not setose.

Tubercle conic or triangular, acute, $1 / 4-1 / 2$ as long as the achene.

Achene about $2 \mathrm{~mm}$. long.

Achene 1-1.25 mm. long.

Perianth-bristles not longer than the achene or but little longer.

Spikelets elustered : tubercle bluntish.

Spikelets filiform-pedicelled: tubercle sharppointed.

Perianth-bristles as long as the achene and tubercle or longer.

Tubercle depressed, rounded, less than $1 / 4$ as long as the achene.

39. $R$. prolifera.

40. R. punctata.

41. R. microcarpa.

42. R. decurrens.

43. R. schoenoides.

44. R. miliacea. b. Achene constricted at the base into a stipe: tubercle setose. 45 . R. stipitata. B. Spikelets fusiform to lanceolate, 4-6 mm. long.

Leaf-blades filiform: achene obovoid : tubercle smooth.

Leaf-blades not filiform: achene linear-oblong or oblanceolate: tubercle setose.

46. R. stenophylla.

47. R. inexpansa.

1. Rynchospora Tràcyi Britton. Perennial, bright green. Stems tufted, $5-12 \mathrm{dm}$. tall, nearly terete: leaves elongated ; blades channeled, 4-8 $\mathrm{mm}$. wide, straight, erect or ascending : spikelets densely aggregated into 1-6 globose heads 1-2 cm. in diameter, lanceolate in outline, 5-6 mm. long, acuminate, pale: scales often 9 , the fourth one fertile: perianth-bristles 6, very slender: achenes flat, obovoid or cuneate-obovoid, 2.5 mm. long excluding the tubercle, minutely wrinkled, ciliate, surpassed by the bristles : tubercle subulate, fully twice as long as the achene. [Ceratoschoenus capitatus Chapm., not R. capitata R. \& S.]

In pine-land ponds, Georgia and Florida to Mississippi. Spring to fall.

2. Rynchospora solitària R. M. Harper. Perennial or perhaps annual, light green. Stems solitary, 6-8 dm. tall, flattened: leaves few ; blades about $2 \mathrm{~mm}$. wide, the lower ones about $\frac{1}{2}$ as long as the stem ; upper stem-leaves 1 or 2 : spikelets narrowly lanceolate, 5-6 mm. long, 1-flowered, aggregated into a single dense terminal head 12-15 mm. in diameter: bracts filiform, slightly exceeding the inflorescence : perianth-bristles 6 , fragile, equalling the achene, upwardly barbed: achenes obovoid, plump, $1.5 \mathrm{~mm}$. long, faintly pitted, not ciliate, capped by a triangular tubercle of about $\frac{1}{3}$ its length.

In moist pine lands, southern Georgia. Summer and fall.

3. Rynchospora Indianolénsis Small. Perennial, bright green. Stems 3-angled, $5-12 \mathrm{dm}$. tall : leaves sheathing the base of the stem; blades $4-8 \mathrm{~mm}$. broad, with smooth margins: spikelets rather numerous, about $1 \mathrm{~cm}$. long, aggregated into several dense panicled clusters $2-3 \mathrm{~cm}$. broad: scales oval, broadly acuminate, deciduous : perianthbristles surpassing the achene, persistent: achenes flattened and with impressed sides, about $4 \mathrm{~mm}$. long, each capped by a tubercle nearly $5 \mathrm{~mm}$. long.

On damp prairies, Indianola, Texas. Spring.

4. Rynchospora corniculàta (Lam.) A. Gray. Perennial. Stems smooth, 1-2 mm. tall : leaf-blades flat, $1.5-4.5 \mathrm{dm}$. long, $6-16 \mathrm{~mm}$. wide, rough-margined : umbels sometimes $2-5 \mathrm{dm}$. broad: spikelets spindle-shaped, much over $1 \mathrm{~cm}$. long when mature, clustered at the ends of the rays and raylets : primary rays sometimes $15 \mathrm{~cm}$. long: scales lanceolate, thin, acute, light brown : perianth-bristles about 6 , rigid, upwardly scabrous : style subulate from a broad base 2-4 times longer than the achene, upwardly scabrous, $1-2.5 \mathrm{~cm}$. long, much exserted beyond the scales when mature : achenes obovoid, flat, $4 \mathrm{~mm}$. long, dark brown, smooth.

In swamps, Delaware to Florida, Ohio, Missouri and Texas. Summer and fall.-A variety with perianth-bristles about twice as long as the achene and congested inflorescence is $R$. corniculata macrostáchya (Torr.) Britton; it extends north as far as Massachusetts.

5. Rynchospora pusílla M. A. Curtis. Perennial, bright green. Stems densely tufted, $0.5-3 \mathrm{dm}$. tall, filiform : leaves resembling the stems but more slender and curved : spikelets in 1-3 separate clusters, elliptic-ovoid, about $2 \mathrm{~mm}$. long, often 3-flowered : scales broadly ovate to suborbicular: perianth-bristles wanting: achenes whitish, flat, lenticular, oblong-obovoid or cuneate-obovoid, about $1 \mathrm{~mm}$. long, transversely wrinkled, not pinched at the base, each with an almost free tubercle.

About pine-land swamps, Florida to Texas. Also in the West Indies. Sp ring and summer.

6. Rynchospora divérgens M. A. Curtis. Perennial, bright green. Stems densely tufted, filiform or wiry, 1-4 dm. tall : leaves resembling the stems but more slender, curved : spikelets elliptic to ovoid-elliptic, $3-3.5 \mathrm{~mm}$. long, acute, in loose or rarely somewhat contracted corymbs: scales broadly elliptic or broadly ovate: perianth-bristles wanting: 
achenes plump-lenticular, orbicular-obovoid, pale, 0.5-0.8 mm. long, reticulated, pinched at the base, each with a depressed sessile tubercle.

In moist pine lands, South Carolina to Florida. Also in the Bahamas and the West Indies. Spring and summer.

7. Rynchospora Chapmánii M. A. Curtis. Perennial, pale green. Stems densely tufted, 2-6 dm. tall, filiform : leaves resembling the stem but more slender : spikelets aggregated into a solitary terminal cluster $1-1.5 \mathrm{~cm}$. broad, spindle-shaped, $3-4 \mathrm{~mm}$. long, whitish, 1-flowered: scales 5, acuminate or awn-tipped, the upper one fertile : perianthbristles wanting: achenes lenticular, oval, barely $1.5 \mathrm{~mm}$. long, smooth and shining, each with a depressed-deltoid tubercle $\frac{1}{5}-\frac{1}{4}$ as long as the achene.

In low pine lands, South Carolina to Florida and Louisiana. Spring to fall.

8. Rynchospora pállida M. A. Curtis. Rootstocks slender : stems triangular, 3-6 dm. tall : leaves various, the lower reduced to scales; blades $1-2.5 \mathrm{~mm}$. wide, nearly smooth : spikelets numerous, spindle-shaped, 4-6 mm. long, aggregated in a compound terminal head, or occasionally also in a cluster from the upper axil : bracts with subulate blades: scales pale greenish brown, lanceolate, acuminate : perianth-bristles minute and early deciduous, or wanting : stigmas 2 : achenes lenticular, obovoid-oblong, smooth, brown, shining, $2 \mathrm{~mm}$. long, or nearly so, each with a minute depressed tubercle.

In pine-land bogs, New Jersey to North Carolina. Summer and fall.

9. Rynchospora oligántha A. Gray. Rootstocks short: stems almost thread-like, leafy toward the base, $1.5-4 \mathrm{dm}$. tall : leaves few; blades filiform: spikelets solitary or 2-4 together, terminal, narrowly oblong, acute, $6-8 \mathrm{~mm}$. long, subtended by 1 or 2 filiform bracts: scales ovate, pale brown, acute, cuspidate: perianth-bristles usually 6 , densely plumose below the middle: stigmas 2 : achenes obovoid, $2 \mathrm{~mm}$. long or nearly so, obtuse, pale brown, dull, transversely wrinkled; tubercle with a flat depressed border and a flattened conic acute projection.

In wet sandy soil, Delaware to Florida and Texas. Summer.

10. Rynchospora plumòsa Ell. Perennial, bright green. Stems tufted, 1.5-3.5 dm. tall, slender and wiry : leaves few ; blades filiform, curving in age : spikelets oblongovoid, 2.5-3.5 mm. long, in 3 or 4 lax clusters at the top of the stem : scales broadly ovate or oval : perianth-bristles 6 , plumose nearly or quite to the top : achenes orbicular-obovoid, nearly $2 \mathrm{~mm}$. long, including the depressed conic glabrous tubercle, strongly wrinkled.

In dry pine lands, South Carolina to Florida and Louisiana. Spring to fall.

11. Rynchospora intermédia (Chapm.) Britton. Perennial, bright green. Stems tufted, 3-7 dm. tall, stout: leaves numerous at the base of the stem; blades 1-2 mm. broad, more or less involute, with roughish margins: spikelets 3-4 $\mathrm{mm}$. long, in 4-6 clusters, forming a more or less interrupted terminal spike-like inflorescence: perianthbristles plumose nearly or quite to the top: achenes obovoid, transversely wrinkled, more or less grooved, fully $2 \mathrm{~mm}$. long; tubercle depressed, conic, pubescent. [R. plumosa var. intermedia Chapm.]

In pine lands, Florida. Spring to fall.

12. Rynchospora semiplumòsa A. Gray. Perennial, bright green. Stems tufted, $2.5-7 \mathrm{dm}$. tall, rather rigid: leaves rather numerous at the base of the stem; blades $1.5-2.5 \mathrm{~mm}$. wide, often with roughish margins : spikelets crowded into a solitary terminal head, or with an additional cluster farther down the stem : perianth-bristles plumose below the middle or only near the base : achenes globose-obovoid, wrinkled, $1.5 \mathrm{~mm}$. long ; tubercle broadly conic, glabrous.

In pine lands, Georgia and Florida to Louisiana and Texas. Spring to fall.

13. Rynchospora álba (L.) Vahl. Pale green. Rootstocks short: stems slender or filiform, glabrous, $1.5-5 \mathrm{dm}$. tall : leaves bristle-like or slender, $0.5-1 \mathrm{~mm}$. wide, shorter than the stem : spikelets in 1-4 dense corymbose clusters, narrowly oblong, acute at both ends, 4-6 mm. long: scales ovate or ovate-lanceolate, white or pale green, acute : perianthbristles $9-15$, downwardly barbed, slender, about as long as the achene and tubercle: achenes obovoid-oblong, fully $1.5 \mathrm{~mm}$. long, smooth, pale brown, lenticular ; tubercle lanceolate, flat, $\frac{1}{2}$ as long as the achene.

In bogs, Newfoundland to Alaska, Florida, Kentucky, Minnesota and Oregon. Also in northern Europe and Asia. Summer.-A variety ranging from Georgia and Florida to Texas, with stouter stems, $15-24$ bristles and clusters of spikelets sometimes $3 \mathrm{~cm}$. broad, is $R$. alba macra Clarke.

14. Rynchospora glomeràta (L.) Vahl. Deep green. Rootstocks slender: stems smooth, 3-10 dm. high: leaves shorter than the stem ; blades flat. $2-4 \mathrm{~mm}$. wide, roughmargined: spikelets in 3-7 corymbose-capitate axillary clusters, oblong, narrowed at both ends, 3-4 mm. long: scales lanceolate, dark brown: perianth-bristles 6 , downwardly 
barbed: achenes obovoid, above the slender base, lenticular, about $1.5 \mathrm{~mm}$. long, smooth, dark brown ; tubercle subulate, about as long as the achene.

In moist soil, Maine to Ontario, Michigan, Florida and Texas. Summer and fall.-A relatively stout variety, with stems $1-1.5 \mathrm{~mm}$. tall, wider leaf-blades, numerous spikelets in compound clusters and achenes $2 \mathrm{~mm}$. long, is R.glomerata paniculata (A. Gray) Chapm.; it ranges from Maryland to Florida and Louisiana. A relatively slender form, with stems only $6-9$ dm. tall, and few distant simple peduncled clusters is $R$. glomerata leptocárpa Chapm.; it ranges from South Carolina to Florida and Alabama. A third variety, $R$. glomerata discutiens Clarke, has smooth bristles or these barbed only near the apex, and a known range from New Jersey to North Carolina.

15. Rynchospora axillàris (Lam.) Britton. Perennial. Stems stout, $5-10 \mathrm{dm}$. tall : leaf-blades nearly flat, keeled, 2-3 mm. wide: spikelets spindle-shaped, $5-6 \mathrm{~mm}$. long, numerous, in several short-peduncled axillary and terminal dense globose heads sometimes $2 \mathrm{~cm}$. in diameter: scales dark brown, ovate-oblong, acute: perianth-bristles 6 , downwardly barbed: achenes broadly obovoid above the contracted base, $2.5 \mathrm{~mm}$. long, brown, smooth, lenticular ; tubercle subulate, about as long as the achene.

In swamps, Long Island to Florida and Louisiana. Summer and fall.

16. Rynchospora microcéphala Britton. Perennial, deep green. Stems tufted, slender, 3-14 dm. tall, smooth : leaves overtopped by the stem; blades linear-filiform, involute, smooth : spikelets numerous, 3-3.5 mm. long, crowded into 2-4 short-peduncled compact globose heads about $1 \mathrm{~cm}$. in diameter or smaller: scales acuminate, smooth, chestnut-colored : perianth-bristles 6 , downwardly barbed : achenes lenticular, obovoid, $1.5 \mathrm{~mm}$. long, smooth, margined; tubercle shorter than the achene, subulate-lanceolate. [R. axillaris var. microcephala Britton.]

In swamps or low grounds, New Jersey to Florida and Louisiana. Spring to fall.

17. Rynchospora fuscoìdes Boeckl. Perennial, bright green. Stems tufted, 1.5-7 dm. tall, slender: leaves several, chiefly at the base of the stem; blades flat, smooth: spikelets $2-2.5 \mathrm{~mm}$. long, in small often geminate terminal clusters and on robust plants with an additional one lower down the stem : perianth-bristles 6 , barbed upward : achenes lenticular, smooth, about $2 \mathrm{~mm}$. long excluding the subulate conic ciliate tubercle, mostly surpassed by the bristles.

In low pine lands, Florida to Texas. Also in Cuba. Spring to fall.

18. Rynchospora Curtíssii Britton. Stems filiform, glabrous, 1-2 dm. tall : leaves few ; blades filiform, less than $0.5 \mathrm{~mm}$. wide, much shorter than the stem : spikelets few or solitary, in 1-3 loose clusters, oblong, acute at both ends, 4-6 $\mathrm{mm}$. long: scales ovateoblong, chestnut-brown, keeled, mucronate: perianth-bristles 6, slender, downwardly barbed, much overtopping the achene : achenes linear-oblong, nearly $1.5 \mathrm{~mm}$. long, light brown, smooth, lenticular; tubercle compressed, lanceolate, ciliate, dark brown, fully $\frac{1}{2}$ as long as the achene.

In bogs, Milton, Florida. Summer.

19. Rynchospora filifòlia Torr. Perennial, bright green. Stem tufted, $1.5-6 \mathrm{dm}$. tall, nearly terete, filiform or very slender : leaves numerous at the base of the stem; blades filiform or bristle-like : spikelets aggregated into 2-4 capitate clusters, lanceolate in outline, 3-3.5 mm. long: perianth-bristles barbed upward, rather rigid, not longer than the achene and tubercle or scarcely so: achenes lenticular, obovoid, margined, smooth and shining, light brown, less than $1 \mathrm{~mm}$. long; tubercle flat, ciliate, triangular.

About pine-land ponds, North Carolina to Florida and Texas. Spring to fall.

20. Rynchospora leptorhýncha C. Wright. Perennial, bright green. Stems tufted, slender, 3-6 dm. tall : leaves erect; blades involute, filiform or linear-filiform, curved, smooth: spikelets lanceolate in outline, about $5 \mathrm{~mm}$. long, acute, several together in 2 or 3 rather loose capitate clusters: perianth-bristles 6 , not longer than the achene and tubercle or scarcely so: achenes orbicular-obovoid or obovoid-oval, 1.5-2 mm. long, smooth, each capped by a lanceolate ciliate dark brown tubercle.

In grassy pine woods, Florida and Cuba. Spring to fall.

21. Rynchospora dístans (Michx.) Vahl. Perennial, pale green. Stems tufted, slender, $3-7 \mathrm{dm}$. tall : leaves several at the base of the stem; blades filiform or nearly so by the involute margins : spikelets ovoid, about $3 \mathrm{~mm}$. long, several together in terminal and axillary clusters : perianth-bristles mostly 6 , usually upwardly barbed, about as long as the achene : achenes oval or oblong-oval, $1.5-2 \mathrm{~mm}$. long, excluding the broad conic smooth tubercle.

In pine lands, South Carolina to Florida. Spring to fall.

22. Rynchospora gracilénta A. Gray. Stems slender or filiform, smooth, 3-5 dm. tall : leaf-blades flat or becoming involute in drying, rather less than $2 \mathrm{~mm}$. wide, shorter than the stem : spikelets narrowly ovoid, acute, $4 \mathrm{~mm}$. long, few, in 1-4 loose clusters, the lower clusters filiform stalked: scales ovate, brown: perianth-bristles 6, upwardly 
barbed, much longer than the achene: achenes broadly oval or nearly orbicular, $1.5 \mathrm{~mm}$. to nearly $2 \mathrm{~mm}$. long, dark brown, lenticular, dull, smooth; tubercle narrowly subulate, flat, widened at the base, pale, smooth, about as long as the achene.

In pine-land swamps, New Jersey to Florida and Texas. Summer.

23. Rynchospora Baldwínii A. Gray. Perennial, bright green. Stems somewhat tufted, stout, 6-12 dm. tall, sharply 3-angled : leaves several or numerous at the base of the stem, commonly over $1 \mathrm{dm}$. long; blades $2-7 \mathrm{~mm}$. wide, attenuate, smooth or nearly so, more or less glaucous : spikelets ovoid or elliptic-ovoid, $5-6 \mathrm{~mm}$. long, chestnut-colored, aggregated into 1-3 loosely capitate clusters: perianth-bristles 12-14, upwardly barbed, fully as long as the achene: achenes oval or orbicular-oval, minutely granular, fully $2 \mathrm{~mm}$. long, excluding the triangular-conic smooth tubercle.

In low pine lands, North Carolina to Georgia and Florida. Spring to fall.

24. Rynchospora fasciculàris (Michx.) Vahl. Perennial, light green. Stems sparingly tufted, 6-12 dm. tall, obscurely 3 -angled : leaves several at the base of the stem ; blades $1.5-3 \mathrm{~mm}$. broad from a dilated base, or rarely slightly wider, more or less involute: spikelets about $2-3 \mathrm{~mm}$. long, acuminate, lanceolate in outline, aggregated in $2-5$ remote sometimes compound clusters: perianth-bristles much shorter than the achene, upwardly barbed : achenes lenticular, oval or orbicular-oval, $2 \mathrm{~mm}$. long excluding the triangular smooth much flattened tubercle.

In low pine lands, South Carolina to Florida and Louisiana. Spring to fall.

25. Rynchospora brachychaèta Sauv. Perennial, pale green. Stems tufted, very slender or nearly filiform, spreading or procumbent, 2-4 dm. long: leaves several at the base of the stem ; blades involute, thus bristle-like or filiform : spikelets ovoid, about 4-5 $\mathrm{mm}$. long, usually few together in a small terminal cluster : perianth-bristles 3-6, upwardly barbed, much shorter than the achene: achenes lenticular, suborbicular, fully $2 \mathrm{~mm}$. long including the triangular tubercle, granular, dark brown, twice or thrice as long as the bristles.

In low pine lands, North Carolina to Florida. Also in Cuba. Spring to fall.

26. Rynchospora dođecándra Baldw. Perennial, yellowish green. Stems somewhat tufted, 5-12 dm. tall, 3-angled: leaves crowded at the base of the stem; blades 4-10 $\mathrm{mm}$. wide, rather rigid, smooth : spikelets ovoid, $6-8 \mathrm{~mm}$. long, several in 4-6 rather open corymbs: perianth-bristles 6-10, upwardly barbed, shorter than the achene : achenes lenticular, orbicular-obovoid or oval, smooth, 3-4 mm. long excluding the depressed nipplelike tubercle which is surrounded by a collar-like base, the body barely twice as long as the bristles. [R. megalocarpa A. Gray.]

In dry sand, North Carolina to Florida and Mississippi. Spring to fall.

27. Rynchospora ciliàta (Michx.) Vahl. Perennial, light green. Stems not densely tufted, 3-8 dm. tall, bluntly 3-angled, smooth: leaves often numerous at the base of the stem, mostly less than $1 \mathrm{dm}$. long; blades broadly linear, $5-8 \mathrm{~mm}$. wide, ciliate, glaucous, blunt or merely acute : spikelets narrowly ovoid or lanceolate in outline, 5-6 mm. long, usually aggregated into a solitary terminal capitate cluster : perianth-bristles $6, \frac{1}{3}$ as long as the achene : achenes lenticular, cancellate, oval or orbicular-oval, $1.5 \mathrm{~mm}$. long ; tubercle rather depressed, conic.

In low pine lands, North Carolina to Florida and Mississippi. Spring to fall.

28. Rynchospora Graỳi Kunth. Perennial, light green. Stems often solitary, 3-7 dm. tall, relatively slender : leaves several or numerous at the base of the stem; blades narrowly linear, $1.5-3 \mathrm{~mm}$. long, smooth, attenuate : spikelets ovoid, $5-6 \mathrm{~mm}$. long, light chestnut-colored, aggregated into usually 2-4 capitate clusters : perianth-bristles 6 , as long as the achene and tubercle : achenes lenticular, plump, cancellate, obovoid, or broadly oblong, 2-5 mm. long, dark brown; tubercle depressed-conic, overtopped by the bristles.

In dry pine lands, North Carolina to Florida and Texas. Spring to fall.

29. Rynchospora Plánkii Britton. Perennial, bright green. Stems more or less tufted, 1.5-4 dm. tall, slender: leaves mainly basal; blades narrowly linear, attenuate, 1.5-4 mm. wide, smooth, flat or nearly so: spikelets ovoid, $2.5-3 \mathrm{~mm}$. long, chestnut-colored, acute or acuminate, aggregated into 1 or few clusters: perianth-bristles 6 , much shorter than the achene, often about $\frac{1}{2}$ as long: achenes obovoid or orbicular-obovoid, about 1.5 $\mathrm{mm}$. long, cancellate, brown, each surmounted by a depressed tubercle with a collar-like base.

On plains and prairies, Arkansas and Texas. Spring and summer.

30. Rynchospora rariflòra Ell. Perennial, bright green. Stems densely tufted, $2-5 \mathrm{dm}$. long, sometimes reclining, filiform, smooth: leaves involute-filiform or bristlelike, smooth: spikelets elliptic or ovoid, few in 2 or 3 lax filiform-peduncled corymbs: perianth-bristles 6 , fragile, shorter than the achene : achenes lenticular, obovoid or broadly 
elliptic, fully $1.5 \mathrm{~mm}$. long, strongly transversely wrinkled, about twice as long as the bristles; tubercle low-conic.

In grassy pine lands, North Carolina to Florida and Texas. Spring to fall.

31. Ryachospora Torreyàna A. Gray. Stems terete or obscurely 3-angled, smooth, slender, 4-9 dm. tall : leaf-blades involute, the lower $3-4 \mathrm{~mm}$. wide at the base, elongated, the upper bristle-like, distant: spikelets ovoid, $3 \mathrm{~mm}$. long, peduncled, numerous in 1-4 loose distant clusters: scales brown, ovate, mucronate : perianth-bristles 6 , upwardly barbed : achenes flat, oblong-obovate, transversely wrinkled; tubercle flat, conic, ${ }_{4}^{\frac{1}{3}}-\frac{1}{3}$ as long as the achene and continuous with it.

In wet pine lands, New Jersey to South Carolina. Summer.

32. Rynchospora Eàrlei Britton. Perennial, light green. Stems 3-8 dm. tall, smooth : leaves mainly at the base of the stem ; blades narrowly linear, $1.5-3 \mathrm{~mm}$. broad, smooth : spikelets ovoid, 3.5-4 mm. long, acute, 2-6 in several cymose clusters on relatively stout peduncles: scales red, acute or apicnlate: perianth-bristles 6 , shorter than the achene: achenes strongly biconvex, broadly obovoid, $2 \mathrm{~mm}$. long, transversely wrinkled, reddish brown, constricted under the much depressed or nearly flat tubercle.

In pine woods, Marshallville, Georgia. Summer.

33. Rynchospora perpléxa Britton. Perennial, deep green. Stems slender, 5-11 dm. tall, often tufted: leaves mostly at the base of the stem ; blades narrowly linear, flat, 1-2.5 mm. wide, usually much elongated, smooth : spikelets ovoid or orbicular-ovoid, about $2 \mathrm{~mm}$. long, in a terminal and 1 or several axillary lax or rarely slightly congested corymbs on very slender peduncles: scales brown, blunt or merely acute: perianth-bristles 6 , shorter than the achene: achenes biconvex, not constricted under the tubercle, about $1 \mathrm{~mm}$. long; tubercle depressed, wider than high.

In swamps and hammocks, North Carolina to Florida. Summer.

34. Rynchospora cymòsa Ell. Light green. Stems tufted, 3 -angled, smooth, 3-8 dm. tall : leaf-blades flat, narrowly linear, grass-like, $3-4 \mathrm{~mm}$. wide or the basal ones broader : bracts setaceous : spikelets ovoid-oblong, acute, $3 \mathrm{~mm}$. long, sessile or nearly so, capitate in 2's-7's on the ultimate branches of the axillary and terminal clusters: scales dark brown, broadly ovate: perianth-bristles 6 , upwardly barbed, shorter than the achene: achenes broadly obovoid or oblong-obovoid, lenticular, $1.5 \mathrm{~mm}$. long, transversely wrinkled ; tubercle conic, about as high as wide, $\frac{1}{4}-\frac{1}{3}$ as long as the achene.

In moist soil, New Jersey to Kentueky, Missouri, Florida and Texas. Also in Cuba. Summer.-A variety with stems 1.5-3.5 dm. tall, corymbs of few ovoid-globose dark brown spikelets and more deeply wrinkled achenes $1 \mathrm{~mm}$. long, is R. cymosa globulàris Chapm.; it ranges from Florida to Louisiana.

35. Rynchospora compréssa Carey. Perennial, pale green. Stems tufted, 6-12 dm. tall, 3-angled : leaves several at the base of the stem; blades rather rigid, $3-5 \mathrm{~mm}$. broad, smooth or nearly so: spikelets ovoid, $2-2.5 \mathrm{~mm}$. long, numerous, in $3-5$ peduncled corymbs: perianth-bristles 6 , shorter than the achene: achenes lenticular, flat, $2 \mathrm{~mm}$. long, coarsely transversely wrinkled, rhombic-obovoid, topped by a low conic tubercle with a collar-like base, about twice as long as the bristles, contracted under the tubercle.

About pine-land ponds, Florida and Alabama. Spring to fall.

36. Rynchospora pátula A. Gray. Perennial, bright green. Stems somewhat tufted, 6-12 dm. tall, smooth, quite slender : leaves mainly on the lower part of the stem; blades narrowly linear, 2-6 mm. wide, smooth: spikelets ovoid, 3-3.5 mm. long, 1-3flowered, acute, many in terminal and axillary slender-peduncled compound corymbs : scales brown, deciduous : perianth-bristles not longer than the achene and tubercle : achenes lenticular, obovoid or orbicular-obovoid, barely $1.5 \mathrm{~mm}$. long, transversely wrinkled; tubercle setose, surpassing the perianth-bristles.

In sandy pine woods and swamps, North Carolina to Florida. Spring to fall.

37. Rynchospora cadùca Ell. Perennial, bright green. Stems often loosely tufted, 8-15 dm. tall, sharply 3-angled: leaves elongated; blades $4-10 \mathrm{~mm}$. wide, attenuate, rough-margined : spikelets ovoid, about $4 \mathrm{~mm}$. long, numerous in 4-6 compound corymbs : perianth-bristles 6 , longer than the achene and tubercle: achenes lenticular, orbicularobovoid, about $1.5 \mathrm{~mm}$. long, finely transversely wrinkled, surpassed by the slender bristles ; tubercle setose, conic.

In swamps and on shaded banks, North Carolina to Arkansas, Florida and Texas. Spring to fall.

38. Rynchospora míxta Britton. Perennial, pale or light green. Stems loosely tufted, 3-angled: leaves mostly at the base of the stem; blades $3-7 \mathrm{~mm}$. wide, slightly rough on the margins: spikelets 1-3-flowered, lanceolate in outline, $3.5-4 \mathrm{~mm}$. long, acute, in slender-peduncled lax corymbs : scales few, ereet : perianth-bristles 6 , longer than the achene and tubercle : achenes lenticular, narrowly obovoid, less than $1.5 \mathrm{~mm}$. long, transversely wrinkled, about $\frac{1}{2}$ as long as the slender bristles; tubercle depressed-conic, setose. In river swamps and low pine lands, Georgia and Florida. Spring to fall. 
39. Rynchospora prolífera Small. Perennial, bright green. Stems tufted, slender, 4-10 dm. tall, weak, smooth : leaf-blades elongated, $2-5 \mathrm{~mm}$. wide, pale green : spikelets numerous, in open corymbs, on filiform peduncles, flat, oblong-ovoid, 6-8 mm. long, acute, 5-10-flowered: scales very thin, spreading, early deciduous: perianth-bristles 6, fully as long as the achene and tubercle: achenes lenticular, obovoid to suborbicular, slightly transversely wrinkled, reddish brown, fully $1-1.5 \mathrm{~mm}$. long, persistent on the finally naked rachis; tubercle conic, setose.

In pine woods and sandy places, North Carolina to Florida and Mississippi. Summer.

40. Rynchospora punctàta Ell. Perennial, pale green. Stems tufted, $3-7 \mathrm{dm}$. tall, 3 -angled, slender: leaves several at the base of the stem; blades $2-4 \mathrm{~mm}$. wide, slightly channeled, rough-margined: spikelets in several small clusters near the top of the stem, 3-4 mm. long, acute : perianth-bristles 6 , longer than the achene and tubercle : achenes lenticular, obovoid, barely $2 \mathrm{~mm}$. long, prominently transversely wrinkled, surpassed by the bristles; tubercle triangular, smooth.

In pine lands, South Carolina and Georgia. Spring to fall.

41. Rynchospora microcárpa Baldw. Perennial, bright green. Stems tufted, $5-10 \mathrm{dm}$. tall, smooth : leaves mostly at the base of the stem; blades channeled, $1.5-4 \mathrm{~mm}$. wide, attenuate: spikelets ovoid, $2-3 \mathrm{~mm}$. long, numerous in 4-6 compound corymbs: perianth-bristles 5 or 6 , not longer than the achene or but little longer : achenes lenticular, broadly or orbicular-obovoid, barely $1 \mathrm{~mm}$. long, strongly transversely wrinkled, about as long as the bristles or surpassing them; tubercle bluntish, rather depressed.

on pond margins in pine lands, North Carolina to Florida and Texas. Also in the Bahamas. Spring to fall.

42. Rynchospora decúrrens Chapm. Perennial, pale green. Stems often loosely tufted, 6-12 dm. tall, arching above: leaves mostly numerous at the base of the stem; blades conspicuously elongated, lax, 2-4 mm. broad, glaucescent, smooth : spikelets ovoid, 2-2.5 mm. long, filiform-peduncled, in 5-6 remote spreading or drooping lax corymbs: perianth-bristles 6 : achenes lenticular, narrowly obovoid or cuneate-obovoid, about $1 \mathrm{~mm}$. long, transversely wrinkled, as long as the bristles or longer, each with the triangular sharp-pointed tubercle decurrent some distance on its sides.

On muddy banks, western Florida. Summer.

43. Rynchospora schoenoìdes (Ell.) Britton. Perennial, bright green. Stems loosely tufted, 3-angled, 6-12 dm. tall : leaves elongated, sometimes numerous at the base of the stem; blades smooth, or roughish on the margins: spikelets ovoid, $2.5-3 \mathrm{~mm}$. long, numerous, in 3-5 compound more or less lax corymbs: perianth-bristles 6 , as long as the achene and tubercle or longer: achenes lenticular, oval, strongly transversely wrinkled, fully $1 \mathrm{~mm}$. long; tubercle smooth.

About pine-land pools, North Carolina to Florida and Louisiana. Spring to fall.

44. Rynchospora miliàcea (Lam.) A. Gray. Perennial, light green. Stems loosely tufted, 3-angled, 6-15 dm. tall: leaves often numerous at the base of the stem; blades elongated, 3-8 mm. long, smooth : spikelets numerous, ovoid, $2.5-3 \mathrm{~mm}$. long, peduncled, in 6-8 open spreading corymbs : scales deciduous : perianth-bristles 6 : achenes $2-4$ in each spikelet, lenticular, obovoid or oval, fully $1 \mathrm{~mm}$. or rarely nearly $1.5 \mathrm{~mm}$. long, pale, transversely wrinkled, about as long as the bristles, persistent; tubercle smooth, depressedconic.

In bogs and miry localities, Florida to Louisiana, and in the West Indies. Spring to fall.

45. Rynchospora stipitàta Chapm. Perennial, bright green. Stems tufted, $8-10 \mathrm{dm}$. tall, arching above, 3-angled : leaves numerous at the base of the stem; blades conspicuously elongated, 4-10 $\mathrm{mm}$. wide, smooth: spikelets 7-8 $\mathrm{mm}$. long, narrowly ovoid, numerous, in 4-5 compound drooping corymbs: perianth-bristles 6 , upwardly barbed: achenes lenticular, 1-3 in a spikelet, orbicular-obovoid, stalked, the body about $1.5 \mathrm{~mm}$. long, finely transversely wrinkled, less than $\frac{1}{2}$ as long as the bristles; tubercle depressed, setose.

In river swamps, Florida. Spring to fall.

46. Rynchospora stenophýlla Chapm. Perennial, bright green. Stems tufted, 2-4 dm. tall, wiry-filiform : leaves resembling the stems but more slender, smooth : spikelets lanceolate in outline, 4-5 mm. long, acute, relatively few, (5-7), in 1-3 lax, erect corymbs: perianth-bristles 6: achenes lenticular, obovoid or obovoid-oblong, transversely wrinkled, $1.5 \mathrm{~mm}$. long excluding the conic smooth tubercle whose summit the perianth-bristles barely equal.

In grassy pine lands, Florida and Alabama. Spring to fall,

47. Rynchospora inexpánsa (Michx.) Vahl. Rootstocks slender. Stems slender, 3-angled, 5-9 dm. tall : leaves smooth; blades $2 \mathrm{~mm}$. wide or less, flat, the lower elon- 
gated, the upper more slender, remote : spikelets fusiform, acute at both ends, about 6 $\mathrm{mm}$. long, numerous in 1-4 narrow finally drooping panicles: scales brown, lanceolate, acuminate: perianth-bristles 6 , upwardly hispid, very slender, about twice as long as the achene: achenes linear-oblong or oblanceolate, $2 \mathrm{~mm}$. long, transversely wrinkled; tuberele flat, triangular-subulate, $\frac{1}{2}$ as long as the achene-body, setose.

In moist soil, Virginia to Florida and Louisiana. Summer.

\section{SCLÈrIA Berg.}

Mostly perennial caulescent herbs. Spikelets small, clustered in terminal, or terminal and axillary fascicles, or sometimes interruptedly glomerate-spicate. Flowers monoecious. Fertile spikelets 1-flowered. Staminate spikelets many-flowered. Scales imbricated, the 1-3 lower and sometimes also the upper ones of the pistillate spikelets empty. Perianth none. Stamens 1-3. Style slender or sometimes swollen at the base, deciduous. Stigmas 3. Ovary supported by a disk (hypogynium), or this wanting. Achenes globose or ovoid, obtuse, crustaceous or bony, white in our species. NUT RUSH.

Inflorescence of 1 or several terminal or lateral clusters.

Inflorescence a single terminal cluster : hypogynium wanting.

Achenes 2-3 mm. long, obtuse, with 2 pits in each side of the 3-angled base.

Achenes $4 \mathrm{~mm}$. long, acute, without pits.

Inflorescence of terminal and axillary clusters.

Achene smooth.

Hypogynium present, 3-angled : leaf-blades 3-9 $\mathrm{mm}$. wide.

Hypogynium covered with a rough white crust.

Hypogynium supporting 8 or 9 tubercles.

Hypogynium wanting : leaf-blades $1.5-2.5 \mathrm{~mm}$. wide.

Achene reticulated, ridged or papillose.

Achene reticulated or irregularly ridged.

Hypogynium 3-lobed, appressed to the base of the achene.

Clusters of spikelets sessile or nearly so: achene not hairy.

Lower clusters of spikelets filiform-peduncled : achene hairy. Achene regularly reticulated

Achene irregularly rugose-reticulated to nearly smooth.

Clusters of spikelets drooping.

Clusters of spikelets rigid, mostly erect.

Hypogyniums supporting 6 tubercles arranged in pairs.

Achene papillose.

Hypogynium supporting 3 entire emarginate or 2-lobed tubercles. Plant pubescent: bracts very ciliate: achene $3 \mathrm{~mm}$. long. Plant glabrous throughout: achene $2 \mathrm{~mm}$. long.

Hypogynium supporting 6 distinct tubercles.

Inflorescence interruptedly glomerate-spicate.

Achene with short transverse ridges or somewhat reticulated : plant annual.

Achene smooth : plant perennial.

1, S. gracilis.

2. S. Baldwinii.

3. S. triglomerata.

4. S. oligantha.

5. S. lithosperma.

6. S. reticularis.

7. S. trichopoda.

8. S. Torreyana.

9. S. hemitaphra.

10. S. Curtissii.

11. S. ciliata.

12. S. glabra.

13. S. pauciflora.

14. S. verticillata.

15. S. hirtella.

1. Scleria grácilis Ell. Perennial. Stems tufted, very slender or sometimes filiform, 2-4 dm. tall, smooth : leaves few, shorter than the stem; blades involute, filiform, smooth, simulating the stem : spikelets in a single terminal cluster : scales glabrous : achenes ovoid, $2-3 \mathrm{~mm}$. long, obtuse, shining or dull, distinctly ribbed lengthwise, with 2 pits on each side of the triangular base : hypogynium wanting.

In low pine lands, South Carolina to Florida and Texas. Also in Cuba. Summer.

2. Scleria Baldwínii Steud. Perennial. Stems relatively stout, $3-10 \mathrm{dm}$. tall, smooth, at least below, often rough above : leaves few ; blades linear, $2-5 \mathrm{~mm}$. broad, or sometimes narrower, smooth or somewhat scabrous : spikelets in a single terminal cluster : scales glabrous: achenes ovoid, about $4 \mathrm{~mm}$. long, smooth and even, dull, apiculate, obscurely triangular, without pits at the triangular base; hypogynium wanting.

In pine-land swamps. Florida to Texas.-A form with longitudinally ribbed achenes, growing from Georgia and Florida to Texas, is S. Baldwinii costäta Britton. Summer,

3. Scleria triglomeràta Michx. Perennial. Stems 3-angled, 4-10 dm. tall : leaves few, but often conspicuous ; blades flat, glabrous or nearly so, 3-9 mm. wide, the upper attenuate, rarely exceeding the stem : flower clusters terminal, and usually also 1 or 2 smaller ones from the axils : achenes ovoid or ovoid-globose, above the hypogynium, obtuse, bony, obscurely 3-angled, smooth, bright white, shining, about $2 \mathrm{~mm}$. high; hypogynium low, obtusely triangular, papillose-crustaceous. and fail.

In meadows, thickets and dry sand, Vermont to Wisconsin, Florida, Texas and Kansas. Summer

4. Scleria oligántha Michx. Perennial. Stems slender, erect, sharply 3-angled, nearly smooth, 4-9 dm. tall : leaves sometimes numerous in the tufts; blades smooth or slightly rough at the apex, 4-6 mm. wide, the lower short, acute, the upper elongated : clusters terminal, usually also 1 or 2 axillary and filiform-stalked: bracts slightly ciliate 
or glabrous : achenes ovoid above the hypogynium, obtuse but sometimes pointed, bright white, smooth, shining; hypogynium a narrow obtusely triangular border supporting 8 or 9 small tubercles under the achene-body.

In moist soil, near the coast, Virginia to Florida and Texas. Summer.

5. Scleria lithospérma (L.) Sw. Perennial. Stems slender, 3-6 dm. long, smooth : leaves quite numerous; blades narrowly linear, $1.5-2.5 \mathrm{~mm}$. wide, with scabrous-ciliate margins and keel; sheaths eiliate at the throat: spikelets in 2-4 distant interrupted spikes, the lower with leaf-like bracts, the upper with bristle-like bracts: scales lanceolate, acuminate, rough at the apex: achenes ;obovoid or oblong, about $1.5 \mathrm{~mm}$. long, smooth and glossy, without pores; hypogynium wanting. [S. filformis Sw.]

In low pine lands, southern peninsular Florida. Also in nearly all tropical regions.

6. Scleria reticulàris Michx. Perennial. Stems slender, erect, $3-6 \mathrm{dm}$. tall : leaves few ; blades narrowly linear, glabrous or nearly so, 2-3 mm. wide, not overtopping the stem : spikelets in a terminal cluster and 1-3 remote axillary sessile or nearly sessile clusters: bracts glabrous : achenes globose, dull white when mature, reticulated, $1 \mathrm{~mm}$. in diameter, glabrous; hypogynium 3-lobed, its lobes appressed to the base of the achene.

In moist meadows, Massachusetts to Missouri and Florida. Also in Cuba. Summer and fall.

7. Scleria trichópoda C. Wright. Perennial. Stems tufted, often spreading, 2-7 $\mathrm{mm}$. long, smooth : leaves often quite numerous in the tufts ; blades linear, $2-4.5 \mathrm{~mm}$. wide, usually with cartilaginous marginal ribs, rather abruptly pointed : clusters of spikelets 1$3 \mathrm{~cm}$. long, the axillary ones filiform-peduncled : bracts glabrous : stigmas $3:$ achenes globose or slightly depressed above the 3-lobed appressed hy pogynium, 2-2.5 mm. in diameter, regularly reticulated, somewhat pubescent.

In low grounds and pine lands, New Jersey to Missouri, Florida, Texas and Mexico. Also in the West Indies. Spring to fall.

8. Scleria Torreyàna Walp. Perennial. Stems weak, spreading or diffuse, nearly or quite smooth, 3-6 dm. long, relatively stout : leaves often few ; blades linear, nearly flat, glabrous, $3-8 \mathrm{~mm}$. wide, not exceeding the stem : spikelets in a loose terminal cluster, and 1-3 filiform-stalked drooping axillary ones : bracts glabrous : achenes globose above the 3lobed appressed hypogynium, somewhat pointed, $2-2.5 \mathrm{~mm}$. in diameter, irregularly rugose-reticulated with low ridges, the ridges pubescent, and connected by shorter ones.

In moist soil, southern New Jersey to Florida and Texas. Summer.

9. Scleria hemitáphra Steud. Perennial. Stems slender, $1.5-8 \mathrm{dm}$. long, more or less tufted, glabrous or nearly so: leaves shorter than the stem ; blades flat, 1-4 mm. broad, attenuate : clusters of spikelets $2-4 \mathrm{~cm}$. long or rarely smaller, rigid, or mostly erect, the bracts and scales conspicuous : stigmas 3 : achenes globular above the 3-lobed appressed hypogynium, $1.5-2 \mathrm{~mm}$. in diameter, irregularly rugose-reticulated, abruptly pointed, minutely pubescent.

In wet places or sandy swamps, Florida to Mississippi. Also in the West Indies, Mexico and Central America. Bummer and fall.

10. Scleria Curtíssii Britton. Perennial. Stems relatively slender, $1.5-4.5 \mathrm{dm}$. long, weak, glabrous or nearly so, loosely tufted on stout roostocks : leaves quite numerous in the tufts; blades very narrowly linear, 1-2 mm. wide, smooth, attenuate, often not much thicker than the stem : clusters of spikelets few-flowered, the axillary ones, when present, slender-peduncled : scales scarious-margined : bracts ciliate : stigmas 3 : achenes globular or slightly depressed above the hypogynium, reticulated, $1.5-2 \mathrm{~mm}$. in diameter, glabrous, shining, abruptly pointed ; hypogynium supporting 6 tubercles arranged in pairs. In pine lands, near Jacksonville, Florida. Summer and fall.

11. Scleria ciliàta Michx. Perennial. Stems slender or relatively stout, 3-6 dm. tall, pubescent especially on the angles above: leaves few or sometimes numerous at the base of the stem ; blades narrowly linear, very variable in width, sometimes pubescent, often glabrous; sheaths pubescent : spikelets generally in clusters with conspicuously ciliate bracts : achenes subglobose or globose-ovoid, $3 \mathrm{~mm}$. long, acute, roughened by unequal projections or short ridges, those near the base longer and deflected; hypogynium a narrow obtusely 3 -angled border supporting 3 entire or 2 -lobed tubercles. ' [S. Elliottii Chapm.]

In pine lands, Virginia to Missouri, Florida and Texas. Also in the West Indies. Spring and summer.

12. Scleria glàbra (Chapm.) Britton. Perennial. Stems, like the rest of the foliage, glabrous, relatively slender, $2.5-9 \mathrm{dm}$. long, loosely tufted from horizontal rootstocks : leaves few ; blades often about as thick as the stem, sometimes 2-3 mm. wide : clusters of spikelets small and few-flowered : bracts and scales glabrous : stigmas 3 : achenes globular, or globose-ovoid above the hypogynium, about $2 \mathrm{~mm}$. long, papillose : hypogynium supporting 3 entire or 2-lobed tubercles. [S. pauciflora var. glabra Chapm.]

In pine lands, North Carolina to Florida and Alabama. Also in the West Indies. Spring to fall, 
13. Scleria pauciflòra Muhl. Perennial, pubescent. Stems slender, erect, usually tufted, $2-5 \mathrm{dm}$. tall : leaves commonly numerous in the tufts ; blades narrowly linear, less than $2 \mathrm{~mm}$. wide, the upper elongated and often overtopping the stem, their sheaths often densely puberulent and pubescent : spikelets in a small terminal cluster and in 1 or 2 axillary ones : achenes globular, $1.5-2 \mathrm{~mm}$. in diameter, papillose, the lower: papillae elongated and reflexed : hypogynium a narrow obtusely triangular border supporting 6 distinct tubercles.

In dry soil, New Hampshire to Missouri, Florida and Texas. Also in Cuba. Summer and fall.

14. Scleria verticillàta Muhl. Annual. Stems very slender or filiform, smooth or nearly so, erect, 1-5 dm. tall : leaves numerous in the tufts ; blades very narrowly linear, 0.5-1 mm. wide, erect, weak, shorter than the stem : spikelets in several separated clusters: bracts bristle-like: scales glabrous : achenes globose, fully $1 \mathrm{~mm}$. in diameter, with short transverse ridges or somewhat reticulated: hypogynium none. Plant, especially the roots, fragrant in drying.

In moist meadows, eastern Massachusetts to Ontario and Michigan, Florida, Texas and Mexico. Also in the West Indies. Summer and fall.

15. Scleria hirtélla Sw. Perennial. Stems slender, 1-6 dm. long, smooth or nearly so : leaves extending well up on the stem; blades linear, mostly $2-4 \mathrm{~mm}$. wide, like the sheaths, pubescent : spikelets in 4-8 sessile sometimes nodding clusters: scales various; those of staminate flowers pointless; those of pistillate flowers broader, cuspidate, glabrous : achenes sulglobose, 1-1.5 mm. in diameter, pointed, smooth, slightly pinched at the triangular base, each side of which is furnished with 5-7 minute pores : hypogynium wanting.

In low pine lands, South Carolina to Florida and Louisiana. Also in tropical America. Summer.

\section{CÀrEX L.}

Grass-like herbs, perennial by rootstocks. Stems or scapes mostly 3-angled and tufted. Leaves 3-ranked. Bracts elongated or very short, subtending the spikes, or wanting. Flowers monoecious or dioecious, solitary in the axils of small bracts (scales). Spikes either wholly pistillate, wholly staminate, or bearing both staminate and pistillate flowers (androgynous). Perianth wanting. Staminate flowers of 3 stamens : filaments filiform. Pistillate flowers of a single pistil with a style and 2 or 3 stigmas, borne on a very short axis in the axil of a sac-like bractlet or second bract called the perigynium (utricle), which completely encloses the achene. Achene 3-angled, lenticular or plano-convex. SEDGE.

A. Staminate flowers numerous, in one or more terminal spikes, which are sometimes pistillate at the base or summit, or the spike solitary and the staminate flowers terminal or basal, rarely dioecious: stigmas mostly 3 and the achene 3-angled or swollen (stigmas 2 and the achene lenticular or compressed in nos. 29-30). EUCAREX.

* Perigynia mostly long-beaked, 3-20 mm. long, often inflated, the beak usually as long as the body or longer (short-beaked in no. 20): pistillate spikes mostly large, globose, ovoid, oblong or cylindric.

Perigynia membranous or papery.

Perigynia ovoid, conic, each with a narrowed base, or subulate, tapering into the beak.

Teeth of the perigynium-beak slender, short or none, not stiff nor awned. Teeth of the perigynium-beak lanceolate or subulate. Teeth of the perigynium-beak short or almost wanting.

Teeth of the perigynium-beak stiff, setaceous or awned.

Perigynia obovoid, very:abruptly contracted into the beak: spikes exceedingly dense

Perigynia firm, hard or leathery.

I. LUPULINAE.

II. VESICARIAE.

III. PSEUDOCYPERINAE.

\section{SQUARROSAE.}

V. PALUDOSAE.

** Perigynia short-beaked or beakless, little or not at all inflated, 1-5 mm. iong, the beak commonly not more than $1 / 2$ as long as the body (long-beaked in no. 27): spikes small and oblong or globose; or elongated, linear or narrowly cylindric.

† Spikes 2 or more, the staminate one always uppermost, sometimes partly pistillate.

(8) Pistillate spike or spikes many-flowered, mostly $2.5 \mathrm{~cm}$. long or more (or shorter in nos. 28,37 , $39,40,44,51-54)$, linear, narrowly cylindric or oblong.

Perigynium with a straight short beak (long-beaked in no. 27 ; nearly beakless in no. 21), firm or leathery in texture : pistillate spikes erect: stigmas 3.

Uppermost spike staminate from the base to about the middle.

Uppermost spike entirely staminate, or occasionally pistillate at the base.

Perigynia papillose; beak very short, nearly or quite entire.

Perigynia pubescent (sometimes glabrous in no. 24 ); beak sharply 2 -toothed.

\section{SHORTIANAE.}

VII. ANOMALAE.

VIII. HIRTAE.

Perigynium beakless or very short-beaked (see no. 21), and with orifice nearly or quite entire, thin in texture, not inflated, closely investing the achene: pistillate spikes erect or drooping, often brown or purple: stigmas often 2.

Pistillate spikes erect or somewhat spreading. Terminal spike staminate below: stigmas 3 . Terminal spike staminate throughout: stigmas 2.
IX. ATRATAE.

X. RIGIDAE. 
Pistillate spikes drooping. mostly on slender peduncles (erect in no. 35 ).

Pistillate spikes $0.6-7.5 \mathrm{~cm}$. long: stigmas $3(2$ in no. 30$)$. Pistillate spikes linear: scales shorter than the perigynia.

Pistillate spikes globose, oblong or cylindric: scales as long as the perigynia, or longer.

Pistillate spikes 2.5-10 cm. long: scales 1-8 times as long as the perigynia.

Perigynium tapering to a distinct beak (nearly or quite beakless in nos. 37-41), membranous in texture (firm in no. 50), inflated or loosely investing the achene; pistillate spikes mostly drooping, often narrowly linear.

Terminal spike staminate below, pistillate above: beak of the perigynium short or none.

Spikes all erect or nearly so.

Pistillate spikes drooping or spreading (erect or little spreading in no. 42).

Terminal spike entirely staminate, or sometimes pistillate at the base.

Leaves pubescent.

Leaves glabrous.

Perigynia manifestly beaked, nerved or nerveless: pistillate spikes drooping.

Perigynia beakless or minutely beaked, finely many-striate: spikes erect or nearly so.

¿६ Pistillate spikes small, few-many-flowered, mostly 6-25 $\mathrm{mm}$. long (sometimes longer in no.60). (See also nos. $28,37,39,40,44,51-54$.)

Perigynia glabrous.

Pistillate spikes many-flowered, 6-25 mm. long, usually dense.

Pistillate spikes few-several-flowered, often loose.

Scales of the spike normal, neither elongated nor leaf-like.

Leaf-blades 2-36 mm. wide: bracts leaf-like, usually large.

Perigynia finely many-striate.

Perigynia with few or many, mostly strong, nerves.

Leaf-blades and stems mostly capillary : bracts mere bladeless sheaths.

Scales of the spikes elongated, leaf-like.

Perigynia pubescent.

Perigynia mostly rounded.

Perigynia conspicuously 3 -angled.

†† Spikes solitary, sometimes dioecious.

Leaf-blades $2-5 \mathrm{~cm}$. wide, leathery.

Leaf-blades $0.5-6 \mathrm{~mm}$. wide, not leathery.

Staminate and pistillate flowers on different scapes.

Staminate and pistillate flowers in the same spike.

Scales of the spikes elongated, leaf-like.

Scales of the spikes short, normal.

Perigynia obtuse : swamp species.

Perigynia beaked: prairie species.
XI. PRASINAE.

XII. PENDULINAE.

XIII. CRYPTOCARPAE.

XIV. VIRESCENTES.

XV. GRACILLIMAE.

XVI. FLEXILES.

XVII. DEBILES.

XVIII. GRISEAE.

XIX. GRANULARES.

XX. OLIGOCARPAE.

XXI. LAXIFLORAE.

XXII. DIGITATAE.

XXVII. PHYLLOSTACHYAE,

XXIII. MONTANAE.

XXIV. TRIQUETRAE.

XXV. PHYSOCEPHALAE.

XXVI. SCIRPINAE.

XXVII. PHYLLOSTACHYAE.

XXVIII. LEPTOCEPHALAE. XXIX. FILIFOLIAE.

B. Staminate flowers few, at the summits or bases of the always sessile spikes, or sometimes forming whole spikes, or variously intermixed with the pistillate: stigmas always 2: achene lenticular, compressed, ellipsoid or plano-convex. VIGNEA.

Staminate flowers at the summit of the spike.

Spikes yellowish or brown at maturity, in compound or pan-

icled clusters.

Perigynia strongly several-nerved, especially on the outer face.

Perigy ria nerveless or faintly nerved.

Spikes green or greenish when mature, aggregated or separated, in simple clusters.

Staminate flowers at the bases of the spikes, variously intermingled with the pistillate in the spikes, or occasionally forming whole spikes.

Perigynia wingless, the inner face flat.

Perigynia with narrow or broad marginal wings, the inner face concave.

XXX. VULPINAE.

XXXI. MULTIFLORAE.

XXXII. MUHLENBERgIANAE.

XXXIII. ELONGATAE.

XXXIV. OVALES.

\section{LUPULINAE.}

A. Pistillate spikes ovoid or globose, relatively few-flowered. Perigynia subulate, reflexed when mature. Perigynia conic or ovoid, not reflexed.

Plants yellow or yellowish: perigynia little inflated.

Plants green: perigynia well inflated.

Perigynia $6-8 \mathrm{~mm}$. long.

Perigynia $12-20 \mathrm{~mm}$. long.

1. C. Collinsii.

2. C.folliculata.

3. C. Elliottii. 
Leaf-blades 4-6 mm. wide: spikes loosely flowered. Leaf-blades $6-10 \mathrm{~mm}$. wide: spikes dense.

B. Pistillate spikes oblong or cylindric, densely many-flowered. Pistillate spikes oblong: achenes longer than thick.

Perigynia strongly several-nerved, shining: leaf-blades $2-4 \mathrm{~mm}$. wide. Perigynia many-nerved, dull : leaf-blades $4-10 \mathrm{~mm}$. wide. Pistillate spikes cylindric: achenes not longer than thick.

\section{VESICARIAE.}

Scales acute, acuminate or smooth-awned, or the lower slightly roughened. Spikes few-several-flowered: perigynia little inflated, gradually beaked. Spikes many-flowered : perigynia much inflated, abruptly beaked. Scales tapering into rough awns.

Spikes stout-cylindric, about $12 \mathrm{~mm}$. thick : perigynium tapering into a beak.

Spikes narrowly cylindric, $6-8 \mathrm{~mm}$. thick: perigynium abruptly narrowed into a beak.

\section{PSEUDOCYPERINAE.}

Pistillate spikes oblong-cylindric, $1-3 \mathrm{~cm}$. long : perigynia ascending.

Pistillate spikes narrowly eylindric, $3-7 \mathrm{~cm}$. long: perigynia reflexed.

\section{SQUARROSAE.}

Scales linear-subulate, longer than the perigynia.

Scales lanceolate, $1 / 2$ as long as the perigynia.

Spikes 1-3, subglobose or oval, staminate below: achenes linear-oblong.

Spikes $2-6$, oblong-cylindric, usually staminate at both ends : achenes ovoid.

\section{PALUDOSAE.}

Leaves bright green, not glaucous: teeth of the perigynium-beak slender, conspicuous.

Leaves pale green, glaucous: teeth of the perigynium-beak short.

\section{SHORTIANAE.}

A single species in our range.

\section{ANOMALAE.}

Perigynia ovoid, longer than the scales.

Perigynia short-obovate, about equalling the serrate-awned scales.

\section{HIRTAE.}

Staminate spike or spikes sessile or nearly so.

Staminate spike or spikes distinctly stalked.

Leaves glabrous : native species.

Leaf-blades flat, or their margins slightly revolute.

Scales only $1 / 2$ as long as the perigynia : coast species.

Scales as long as the perigynia or only slightly shorter: Alleghenian species.

Leaf-blades strongly revolute, $2 \mathrm{~mm}$, wide or narrower.

Leaves, at least their sheaths, pubescent: naturalized species.

A single species in our range.

IX. ATRATAE.

A single species in our range.

\section{RIGIDAE.}

\section{PRASINAE.}

Perigynia twisted toward the top: scales purple-brown.

Perigynia straight: scales green.

A single species in our range.

\section{PENDULINAE}

\section{CRYPTOCARPAE.}

Perigynia nerveless or faintly nerved, much shorter than the scales. Perigynia obovoid, obtuse.

Perigynia oblong or elliptic, acute.

Perigynia strongly several-nerved, about equalling the scales in length. Spikes erect. Spikes drooping, filiform-stalked.

Perigynia densely pubescent.

XIV. VIRESCENTES.

Pistillate spikes oblong-cylindric, $8-20 \mathrm{~mm}$. long: perigynia oval or ovoid, few-nerved.

Pistillate spikes narrowly cylindric, $12-36 \mathrm{~mm}$. long: perigynia oblong, strongly many-nerved.

Perigynia glabrous or nearly so, at least when mature.

Spikes 5-7 $\mathrm{mm}$. thick: perigynia imbricated, flattened: top of the achene not bent.

Spikes $3-4 \mathrm{~mm}$. thick : perigynia not imbricated, swollen: top of the achene bent or tipped with a bent style.
4. C. intumescens.

5. C. Asa-Grayi.

6. C. Louisianica.

7. C. lupulina.

8. C. grandis.

9. C. turgescens.

10. C. buillata.

11. C. lurida.

12. C. Baileyi.

13. C. hystricina.

14. C. comosa.

15. C. Frankii.

16. C. squarrosa.

17. C. typhinoides.

18. C. trichocarpa.

19. C. riparia.

20. C. Shortiana.

21. C. scabrata.

22. C. Joorii.

23. C. vestita.

24. C. Walteriana.

25. C. lanuginosa

26. C. filiformis.

27. C. hirta.

28. C. fusca.

29. C. stricta.

30. c. torta

31. C. prasina.

32. C. littoralis.

33. C. crinita

34. C. gymandra

35. C. macrokolea.

36. C. verrucosa.

37. C. virescens.

38. C. costellata.

39. C. triceps.

40. C. Caroliniana. 


\section{GRACILLIMAE.}

Perigynia 2-4 mm. long, slightly swollen : spikes linear or linear-cylindric. Plants glabrous : perigynia obtuse.

Plants with pubescent sheaths: perigynia pointed at both ends. Perigynia $2 \mathrm{~mm}$. long: spikes erect or somewhat spreading. Perigynia $4 \mathrm{~mm}$. long: spikes drooping, at least when mature.

Perigynia 4-5 mm. long, manifestly swollen: spikes oblong or oblongcylindric.

A single species in our range.

\section{FLEXILES.}

\section{DEBILES.}

Perigynia membranous, few-nerved : pistillate spikes slender.

Leaf-blades 1-3 mm. wide: scales as long as the perigynia or nearly so. Leaf-blades $3-8 \mathrm{~mm}$. wide: scales about $1 / 2$ as long as the perigynia.

Perigynia glabrous, or merely puberulent, beaked.

Perigynia $6 \mathrm{~mm}$. long, the beak short.

Perigynia 8-10 mm. long, the beak subulate.

Perigynia pubescent, pointed, scarcely beaked.

Perigynia leathery, strongly many-nerved: spikes stouter.

\section{GRISEAE.}

Leaves slightly or not at all glaucous.

Perigynia little longer or shorter than the scales.

Pistillate spikes dense, usually many-flowered : leaf-blades 4-6 mm. wide, soft, spreading.

Pistillate spikes loosely several-flowered: leaf-blades $2-4 \mathrm{~mm}$. wide, mostly erect, rigid.

Perigynia twice or thrice longer than the scales.

Leaves, or the whole plant, very glaucous.

\section{GRANULARES.}

Bracts elongated, mostly overtopping the spikes : perigynia strongly manynerved.

Bracts short, rarely overtopping the spikes: perigynia finely few-nerved.

Leaf-blades 4-5 mm. wide: pistillate spikes long-peduncled.

Leaf-blades $2-4 \mathrm{~mm}$. wide: pistillate spikes short-peduncled.

\section{OLIGOCARPAE.}

Perigynia narrowed at both ends, beakless.

Perigynia with short entire beaks.

\section{LAXIFLORAE.}

Plants not at all glaucous, or very slightly so.

Beak of the perigynium slender, straight.

Beak of the perigynium bent, short or wanting.

Leaf-blades mostly narrow, 2-12 $\mathrm{mm}$. wide.

Scales, at least the upper ones, obtuse.

Bracts elongated: spikes loosely flowered: stems and scapes slender.

Bracts short: spikes densely flowered: stems and scapes stout. Scales acute, cuspidate, acuminate or awned.

Perigynia obtusely 3-angled.

Perigynia obovoid, $2.5-3 \mathrm{~mm}$. long, the beak short, blunt, bent. Perigynia elliptic to oblong, 3-5 $\mathrm{mm}$. long, the beak sharp. Perigynia narrowly oblong, $4-5 \mathrm{~mm}$. long, the beak oblique. Perigynia elliptic, $3-4 \mathrm{~mm}$. long, the beak nearly straight.

Perigynia sharply 3-angled.

Spikes drooping or spreading : leaf-blades $2-4 \mathrm{~mm}$. wide : perigynia about as broad as long.

Spikes erect or nearly so: leaf-blades 4-12 mm. wide: perigynia about twice as long as broad.

Leaf-blades $12-36 \mathrm{~mm}$. broad.

Plants distinctly glaucous.

Pistillate spikes drooping from hair-like peduncles.

Pistillate spikes erect.

A single species in our range.

\section{DIGITATAE.}

\section{MONTANAE.}

Plants not stoloniferous.

Plants stoloniferous, the stolons sometimes short

Scapes, or some of them, longer than the leaves.

Plant dark green : staminate spike very prominent: perigynia broadly oval.

Plant light green : staminate spike shorter: perigynia oblong.

Scapes, or most of them, much shorter than the leaves.

Scales light green, with purple margins, or these never pale: perigynia oblong.

Scales green, or sparingly dark-blotched.

Seales black or with broad black-purple margins.

Scales green with lighter scarious margins : perigynia oval.
41. C. gracillima.

42. C. aestivalis.

43. C. oxylepis.

44. C. Davisii.

45. C. Cherokeensis.

46. C.juncea.

47. C. tenuis.

48. C. debilis

49. C. venusta.

50. C. oblita.

51. C. grisea.

52. C. amphibola.

53. C. flaccosperma

54. C. glaucodea.

55. C. granularis.

56. C. microdonta.

57. C. Crawei.

58. C. conoidea.

59. C. oligocarpa.

60. C. polymorpha.

61. C. tetanica.

62. C. Meadii.

63. C. laxiflora.

64. C. styloflexa.

65. C. striatula.

66. C. digitalis.

67. C. Austro-Caroliniana.

68. C. plantaginea.

69. C. laxiculmis.

70. C. ptychocarpa

71. C. Baltzellii.

72. C. pedicellata.

73. C. Pennsylvanica.

74. C. varia.

75. C. Floridana.

76. C. nigro-marginata. 
Perigynia barely $4 \mathrm{~mm}$. long, each with a long 2-toothed beak. Perigynia 5-6 mm. long, each with a short entire or nearly entire beak.

\section{TRIQUETRAE.}

Leaf-blades scabrous : perigynia ovoid, somewhat longer than the scales.

Leaf-blades pubescent : perigynia oblong or elliptic, about twice as long as the scales.

A single species in our range.

XXV. PHYSOCEPHALAE.

XXVI. SCIRPINAE.

A single species in our range.

XXVII. PHYLLOSTACHYAE.

Body of the perigynium oblong; beak flattened.

Body of the perigynium globose; beak subulate.

XXVIII. LEPTOCEPHALAE.

A single species in our range.

\section{FILIFOLIAE.}

A single species in our range.

XXX. VULPINAE.

Spikes crowded into an oblong panicle: beak of the perigynium as long as the body to twice as long.

Spikes in a large branching panicle: beak of the perigynium 2-3 times as long as the body.

\section{XXXI, MULTIFLORAE.}

Spikes very numerous in branched decompound clusters, small.

Spikes several or many in narrow simple or slightly compound clusters. Scales acuminate, euspidate or awned.

Perigynia $3-5 \mathrm{~mm}$. long.

Perigynia $2-3 \mathrm{~mm}$. long

Leaves as long as the stem or longer: perigynia dull yellow to brown.

Perigynia ovate, nerveless or faintly 1-3-nerved, $1.5 \mathrm{~mm}$. long.

Perigynia nearly orbicular, delicately nerved, fully $2 \mathrm{~mm}$. long.

Leaves shorter than the stem: perigynia bright yellow. Scales blunt, scarious-tipped.

\section{MUHLENBERGIANAE.}

Spikes separated or the upper approximate : perigynia mostly radiating or reflexed.

Leaf-blades 1-3 mm. wide.

Perigynia ovate-lanceolate or oblong-lanceolate, $2-3 \mathrm{~mm}$. long.

Perigynia stellately radiating or ascending.

Perigynia radiately spreading, mostly over $3 \mathrm{~mm}$. long, gradually narrowed to the apex.

Perigynia ascending, mostly less than $3 \mathrm{~mm}$. long, each abruptly narrowed into a beak.

Perigynia reflexed, at least when mature.

Perigynia narrowly lanceolate, $3-4 \mathrm{~mm}$. long.

Leaf-blades $5-9 \mathrm{~mm}$. wide.

Spikes all aggregated or the lower separated: perigynia spreading or as cending.

Perigynia $2 \mathrm{~mm}$. long or shorter, nerveless or faintly few-nerved.

Leaf-blades $2-3 \mathrm{~mm}$. wide: perigynia ovate.

Leaf-blades 1-2 mm. wide: perigynia orbicular-ovate.

Perigynia $3 \mathrm{~mm}$. long, strongly nerved or nerveless.

Bracts very short.

Bracts foliaceous, much exceeding the spikes.

\section{ELONGATAE.}

Perigynia radiately spreading or reflexed when mature.

Perigynium distinetly nerved on both faces; beak rough.

Perigynium lanceolate: beak more than $1 / 2$ as long as the body.

Perigynium ovate: beak about $1 / 2$ as long as the body, abrupt.

Perigynium faintly nerved only on the outer face; beak smoothish.

Perigynia appressed or ascending, at least not radiating.

Perigynia oval to ovate-oval, about $2 \mathrm{~mm}$. long.

Perigynia linear-lanceolate, 4-5 mm. long.

\section{OVALES.}

A. Perigynia much longer than broad

Perigynia lanceolate or ovate-lanceolate, $2-5$ times as long as wide. Spikes green-brown, blunt. Spikes bright brown, pointed.

Perigynia ovate, or if narrower not more than twice as long as wide.

a. Perigynia spreading or ascending.

Spikes longer than thick, narrowed at the base: perigynia ascending, slightly longer than the scales.

Spikes as thick as long or shorter, rounded at the base: perigynia spreading, much longer than the scales.
77. C. umbellata.

78. C.planostachys.

79. C. Chapmanii.

80. C. dasycarpa.

81. C. Fraseri.

82. C. picta.

83. C. Willdenovii.

84. C. Jamesii.

85. C. leptalea.

86. C. filifolia.

87. C. stipata.

88. C. Crus-Corvi.

89. C. decomposita.

90. C. gravida.

91. C. vulpinoidea.

92. C. triangularis.

93. C. xanthocarpa.

94. C. Sartwellii.

95. C. rosea.

96. C. radiata.

97. C. retroflexa.

98. C. Texensis.

99. C. sparganioides.

100. C. cephalophora.

101. C. Leavenworthii.

102. C. Muhtenbergii.

103. C. Arkansana.

104. C. sterilis.

105. C. Atlantica.

106. C. interior.

107. C. brunnescens.

108. C. bromoides.

109. C. tribuloides.

110. C. scoparia.

111. C. straminea.

112. C. mirabilis. 
b. Perigynia erect or appressed.

113. C. tenera.

B. Perigynia about as broad as long or broader than long.

Spikes green-brown.

Perigynia spreading or ascending, 3-3.5 mm. broad: achenes sessile.

Perigynia erect, 4-5 mm. broad: achenes stipitate.

Spikes silvery green, whitish, yellowish or rusty.

Spikes 15-20 mm. long: perigynia 8-10 mm. long.

Spikes $6-12 \mathrm{~mm}$. long: perigynia $3-6 \mathrm{~mm}$. long.

Perigynium-wing firm: achene sessile.

Mature spikes loose: perigynium long-beaked, the body broader than long.

Mature spikes dense : perigynium short-beaked, the body longer than broad.

Perigynium-wing membranous : achene stipitate.

114. C. festucacea.

115. C. alata.

116. C. Brittoniana.

117. C. reniformis.

118. C. albolutescens.

119. C. Bicknellii.

1. Carex Collínsii Nutt. Green. Stems and scapes slender, erect or reclining, 1.5 $-5 \mathrm{dm}$. long: leaf-blades narrow, the broader about $5 \mathrm{~mm}$. wide: staminate spike stalked : pistillate spikes $2-4$, distant, 2-8-flowered : bracts similar to the leaves: stigmas 3 : perigynia light green, scarcely inflated, subulate, $1-1.4 \mathrm{~cm}$. long, each tapering into an almost filiform beak, faintly many-nerved, strongly reflexed when mature, about 3 times as long as the lanceolate-acuminate persistent scale. [C. subulata Michx.]

In bogs, Rhode Island to eastern Pennsylvania and the mountians of Georgia. Summer.

2. Carex folliculàta L. Yellow or yellowish. Stems and scapes erect or reclining, 4-10 dm. long: leaf-blades often $12 \mathrm{~mm}$. wide: pistillate spikes 2-4, usually distant, all except the uppermost slender-stalked, the lower often nodding: bracts commonly overtopping the spikes: stigmas 3 : perigynia ovoid, slightly inflated, green, rather prominently many-nerved, $12-16 \mathrm{~mm}$. long, about $2 \mathrm{~mm}$. in diameter near the base, each tapering from below the middle into a slender 2-toothed beak, longer than the awned scarious-margined persistent scale, the teeth nearly erect.

In swamps and wet woods, Newfoundland to Michigan, North Carolina and West Virginia. Probably extends further south.-The smaller and more slender form, with larger and looser pistillate spikes, more slender scarcely inflated perigynia and shorter scales, is $C$. folliculata australlis Bailey ; it ranges from South Carolina to Louisiana and Florida. Spring to fall.

3. Carex Ellióttii Schw. \& Torr. Green. Stems and scapes $3-9 \mathrm{dm}$. tall, slender : leaves overtopped by the scape ; blades narrowly linear, conspicuously elongated, 2.5-3.5 $\mathrm{mm}$. wide : staminate spike slender, $1.5-2 \mathrm{~cm}$. long : pistillate spikes mostly 3 , subglobose or slightly elongated, $1-1.5 \mathrm{~cm}$. in diameter, 8-16-flowered, approximate, or the lower one remote and longer-peduncled : stigmas 3 : perigynia lanceolate in outline, $6-8 \mathrm{~mm}$. long, spreading, few-nerved, abont twice as long as the scale, each tapering into a smooth 2-cleft beak with erect teeth.

About boggy pine-land streams, North Carolina to Florida. Spring and summer.

4. Carex intuméscens Rudge. Deep green. Stems and scapes slender, 4-9 dm. high : leaf-blades elongated, roughish, 3-6 $\mathrm{mm}$. wide: bracts similar, overtopping the scape : staminate spike mostly long-stalked : pistillate spikes 1-3, sessile or short-stalked, globose or ovoid : scales narrowly lanceolate, acuminate or aristate, about $\frac{1}{2}$ as long as the perigynia : stigmas 3: perigynia 1-30, spreading or the upper erect, 12-20 $\mathrm{mm}$. long, much inflated, about $6 \mathrm{~mm}$. in diameter above the base, many-nerved, each tapering into a subulate 2-toothed beak, the teeth somewhat spreading.

In swamps and wet woods, Newfoundland to Manitoba, Florida and Louisiana. Spring to fall.

5. Carex Àsa-Graỳi Bailey. Deep green. Stems and scapes stout, 5-9 dm. tall : leafblades elongated, dark green, 6-9 mm. wide : bracts similar to the upper leaves, usually much overtopping the scape : staminate spike mostly long-stalked : pistillate spikes 1 or 2 , dense, about $2.5 \mathrm{~cm}$. in diameter: scales ovate or lanceolate, acuminate or cuspidate, scarious, about $\frac{1}{3}$ as long as the perigynia : stigmas 3 : perigynia $10-30$, ovoid, glabrous or pubescent, much inflated, many-nerved, about $8 \mathrm{~mm}$. in diameter, each tapering to a sharp 2-toothed beak. [C. Grayi Carey.]

In swamps and wet meadows, Vermont to Michigan, Georgia and Missouri. Summer and fall.

6. Carex Louisiánica Bailey. Stems and scapes slender, smooth or nearly so, 2-5 dm. tall : leaves roughish ; blades $2-4 \mathrm{~mm}$. wide, the upper overtopping the spikes : staminate spike long-stalked: pistillate spikes 1-3, oblong, about $2.5 \mathrm{~cm}$. long, $1.5-2 \mathrm{~cm}$. thick, erect, the lower slender-stalked, the upper nearly sessile : scales oblong-lanceolate, acuminate, about $\frac{1}{2}$ as long as the perigynia : stigmas 3 : perigynia ovoid, much inflated, smooth, strongly several-nerved, shining, 10-12 $\mathrm{mm}$. long, about $5 \mathrm{~mm}$. in diameter at the rounded base, each tapering into a long 2 -toothed beak, the small teeth slightly spreading.

[C. Halei Carey.]

In swamps, Missouri to Texas and Florida. Summer. 
7. Carex lupulina Muhl. Stems and scapes stout, $3-10 \mathrm{dm}$. tall : leaf-blades elongated, nodulose, 5-12 mm. wide, the upper ones, and the similar bracts much overtopping the scape: staminate spikes solitary or rarely several : pistillate spikes $2-5$, densely manyflowered, oblong, $2.5 \mathrm{~cm}$. long, often $3-6 \mathrm{~cm}$. in diameter : scales acuminate or aristate, $\frac{1}{3}$ as long as the perigynia : stigmas 3 : perigynia often short-stalked, much inflated, manynerved, 12-15 mm. long, about $3 \mathrm{~mm}$. in diameter above the base, each tapering from below the middle into a subulate 2-toothed beak.

In swamps and ditches, Hudson Bay to western Ontario, Iowa, Florida and Texas. Summer.

8. Carex grándis Bailey. Stems and scapes slender, 5-9 dm. high : leaves rather dark green; blades elongated, 8-12 mm. wide : bracts similar to the leaves, much overtopping the scape: staminate spike sometimes bearing perigynia at its base: pistillate spikes $3-5$, all stalked or the upper sessile, cylindric, $2-7.5 \mathrm{~cm}$. long : stigmas 3 : perigynia much swollen at the base, about $4 \mathrm{~mm}$. in diameter, $10-12 \mathrm{~mm}$. long, many-nerved, spreading at maturity, 3-4 times as long as the scarious lanceolate acuminate or aristate scale, each abruptly contracted into a subulate 2-toothed beak 2-3 times as long as the inflated portion. [C. gigantea Dewey.]

In swamps, Delaware to Kentucky and Missouri, Florida, Louisiana and Texas. Summer.

9. Carex turgéscens Torr. Stems and scapes $5-12 \mathrm{dm}$. tall, smooth : leaves overtopped by the scape ; blades narrowly linear, $2-4 \mathrm{~mm}$. wide : staminate spike $2.5-4 \mathrm{~cm}$. long : pistillate spikes mostly 2 , ovoid or cylindric-ovoid, $1.5-2 \mathrm{~cm}$. long, 8-12-flowered, approximate or when 3 , the lower one remote: stigmas $3:$ perigynia lanceolate in outline, 8-11 $\mathrm{mm}$. long, little inflated, strongly many-nerved, erect, spreading, about twice as long as the scales, each gradually tapering into a 2-cleft beak with erect teeth.

In and about pine-land swamps, North Carolina to Florida. Spring and summer.

10. Carex bullàta Schk. Stems and scapes slender, $3-6 \mathrm{dm}$. high, roughish : leaves and bracts very narrow and elongated; blades rarely more than $4 \mathrm{~mm}$. wide, rough-margined : staminate spikes mostly 2, long-stalked : pistillate spikes 1-3, light green, oblong or oblong-cylindric, many-flowered, 2-4 cm. long, 9-12 mm. in diameter : stigmas 3 : perigynia much inflated, ovoid, 5-6 mm. long, each abruptly contracted into a subulate rough 2-toothed beak, shining, strongly nerved, 2-3 times longer than the scale.

In swamps, New Hampshire to North Carolina. Summer.

11. Carex lùrida Wahl. Stem and scapes slender, $3-10 \mathrm{dm}$. tall : leaves elongated, rough; blades rarely more than $4 \mathrm{~mm}$. wide: staminate spike short-stalked: pistillate spikes 1-4, cylindric, $2-5 \mathrm{~cm}$. long, the upper sessile, the lower peduncled : perigynia inflated, ovoid, each tapering into a long subulate beak, ascending or the lower spreading, 8 $\mathrm{mm}$. long, thin, yellowish green, rather conspicuously nerved, longer than the rough-awned scale. [C. tentaculata Muhl.]

In swamps and wet meadows, Nova Scotia to Minnesota. Nebraska, Florida and Texas. Summer. -The form with brown pistillate spikes $1-2.5 \mathrm{~cm}$. long, all sessile or very nearly so, clustered at the summit, rather more loosely flowered, ranging from northern New York to Carolina and Tennessee, is Carex lurida fláccida Bailey.

12. Carex Baileỳi Britton. Stems and scapes erect or reclining, slender, minutely scrabous above, 2-5 dm. long: leaves roughish; blades elongated, 3-4 mm. wide: staminate spike short-peduncled : pistillate spikes 1-3, narrowly cylindric, very dense erect or ascending, $1.5-2.5 \mathrm{~cm}$. long, about $8 \mathrm{~mm}$. in diameter : perigynia inflated, ovoid, $5-6 \mathrm{~mm}$. long, ascending, each abruptly contracted into a subulate 2-toothed beak, prominently several-nerved.

In bogs, Vermont to Virginia and Tennessee. Summer.

13. Carex hystricina Muhl. Stems and scapes 3-5. dm. tall : leaf-blades 3-5 mm. wide : staminate spike slender-stalked : pistillate spikes 1-4, oblong-cylindric, dense, 1-3 $\mathrm{cm}$. long, about $9 \mathrm{~mm}$. in diameter, the lower slender-stalked and drooping: stigmas 3 : perigynia ascending, somewhat inflated, ovoid-conic, $5-6 \mathrm{~mm}$. long, strongly many-nerved, each tapering into a subulate 2-toothed beak, equalling or the upper longer than the narrow rough scales.

In swamps and low meadows, Nova Seotia to the Northwest Territory, Georgia and Nebraska. Summer.

14. Carex comòsa Boott. Stems and scapes commonly stout, $3-12 \mathrm{dm}$. tall : leafblades sometimes $12 \mathrm{~mm}$. wide: staminate spikes sometimes pistillate at the summit : pistillate spikes 2-6, all spreading or drooping, 3-7 cm. long, bristly, about $12 \mathrm{~mm}$. in diameter : scales mostly shorter than the perigynia, very rough : stigmas 3 : perigynia more slender, little inflated, strongly reflexed when mature, each tapering into a slender prominently 2toothed beak, the teeth subulate and recurved-spreading.

In swamps, Nova Scotia to Ontario, Washington, Georgia, Louisiana and California. Spring to fall. 
15. Carex Fránkii Kunth. Stems and seapes stout, smooth, leafy, $3-7$ dm. tall : leaves roughish ; blades elongated, $5-8 \mathrm{~mm}$. wide: staminate spike stalked: pistillate spikes 3-6, exceedingly dense, cylindric, ereet, 1-4 dm. long, about $8 \mathrm{~mm}$. in diameter, the upper nearly or quite sessile, the lower slender-stalked : scales linear-subulate, longer than the perigynia: stigmas 3: perigynia green, slightly inflated, about $2 \mathrm{~mm}$. in diameter, few-nerved, obovoid, with a depressed summit from which arises the subulate 2-toothed beak. [C. stenolepis Torr.]

In swamps and wet meadows, eastern Pennsylvania to Georgia, Missouri, Louisiana and Texas. Summer and fall.

16. Carex squarròsa L. Stems and scapes slender, rough above on the angles, 6-9 dm. tall : leaf-blades elongated, rarely more than $4 \mathrm{~mm}$. wide, rough-margined: spikes 1-3, erect, stalked, oblong or globose, exceedingly dense, rarely over $2.5 \mathrm{~cm}$. long, 1-2 cm. in diameter, the upper one club-shaped, staminate at the base or sometimes for $\frac{1}{2}$ its length or more: stigmas 3: perigynia yellowish green, becoming tawny, the lower reflexed, somewhat inflated but firm, obovoid, $2-3 \mathrm{~mm}$. in diameter, few-nerved, each abruptly narrowed into a subulate minutely 2 -toothed beak, twice as long as the lanceolate-acuminate or awn-tipped scale: achenes linear-oblong, each tapering into the stout style.

In swamps and bogs, Connecticut to Michigan, Nebraska, Georgia, LLouisiana and Arkansas. Summer and fall.

17. Carex typhinoides Schwein. Similar to the next preceding species, but darker green. Leaf-blades often $8-10 \mathrm{~mm}$. wide : spikes 2-6, cylindric, $2-5 \mathrm{~cm}$. long, $8-14 \mathrm{~mm}$. in diameter, often st:tminate at both ends, the terminal one commonly tapering to a conic summit : basal staminate flowers much less numerous: scales oblong-lanceolate, obtusish : stigmas 3: perigynia dull straw-color, ascending or the lower spreading or reflexed, inflated, each abruptly contracted into the slender 2-toothed beak, which is often upwardly bent: achenes ovoid-elliptic, sharply 3-angled, each tipped with the subulate style.

In swamps, Quebec to Iowa, Virginia, Louisiana and Missouri. Summer.

18. Carex trichocárpa Muhl. Stems and scapes usually stout and tall, smooth below, very rough above : leaf-blades elongated, rough-margined, $4-6 \mathrm{~mm}$. wide : staminate spikes $2-6$, long-stalked : pistillate spikes cylindric, densely flowered except at the base, $2-10 \mathrm{~cm}$. long, 1-1.6 cm. in diameter, the upper sessile or nearly so and erect, the lower slenderstalked: scales hyaline, acute or acuminate : stigmas $3:$ perigynia ovoid-conic, pubescent or glabrous, many-ribbed, $8-10 \mathrm{~mm}$. long, each tapering into a stout conspicuously 2toothed beak, the teeth somewhat spreading.

In marshes and wet meadows, Quebec to Michigan, Iowa, Georgia and Kansas. Summer.

19. Carex ripària Curtis. Stems and scapes smooth, or roughish above, $5-10 \mathrm{dm}$. tall : leaf-blades elongated, $6-12 \mathrm{~mm}$. wide, about equalling the scape : staminate spikes 1-5: pistillate spikes $2-5$, cylindric, $3-10 \mathrm{~cm}$. long, about $8 \mathrm{~mm}$, in diameter, the upper erect, sessile or nearly so, the lower stalked: scales lanceolate or oblanceolate, long-aristate or acute, the lower longer, the upper equalling or shorter than the perigynia: perigynia narrowly ovoid, firm, scarcely inflated, ascending, each tapering into a short 2-toothed beak, the teeth divergent.

In swamps, Newfoundland to James' Bay and Manitoba, Florida, Louisiana, Texas and Idaho. Also in Europe. Spring and summer.

20. Carex Shortiàna Dewey. Stems and scapes slender, rough above, $3-10 \mathrm{dm}$. tall, usually overtopped by the upper leaves : leaves roughish ; blades elongated, 4-5 mm. wide : bracts short, narrow, rarely much exceeding the spikes: spikes $3-7$, linear-cylindric, densely many-flowered, 1-3 cm. long, 3-4 mm. in diameter, erect, the lower stalked : stigmas 3: perigynia dark brown, compressed, 2-edged, orbicular or obovoid, nerveless, each abruptly minutely beaked, equalling or shorter than its scale, which is hyaline, scariousmargined, ovate or oblong-lanceolate, persistent, the orifice of the perigynium entire or very nearly so.

In moist meadows and thickets, Pennsylvania to Virginia, Iowa, Tennessee and the Indian Territory. Spring and summer.

21. Carex scabràta Schwein. Stems and scapes rough above, $3-10 \mathrm{dm}$. tall : leaves rough ; blades much elongated, $5-7 \mathrm{~mm}$. wide: bracts similar but narrower : staminate spike short-stalked : pistillate spikes 3-6, erect, the upper short-stalked, the lower sometimes spreading or drooping, all linear-cylindric, densely many-flowered, $2-5 \mathrm{~cm}$. long, $5-8 \mathrm{~mm}$. in diameter: scales lanceolate, acute or short-awned, prominently 1-nerved, shorter than the perigynia : perigynia greenish brown, ovoid, somewhat inflated, strongly several-nerved, papillose, each tipped by a short minutely 2-toothed or entire beak.

In moist woods and thickets, Maine to Ontario, Michigan, South Carolina and Tennessee. Spring and summer. 
22. Carex Joòrii Bailey. Stems and scapes about $6 \mathrm{dm}$. tall, scabrous, sharply angled : leaves surpassing the stem; blades narrowly linear, slightly keeled, with rough margins: bracts mostly setaceous, without sheaths, the lower 1 or 2 surpassing the subtended spikes: staminate spike terminal: pistillate spikes remote from the staminate, often 5 or 6 , dense, cylindric, $2.5-5 \mathrm{~cm}$. long, erect or slightly spreading, slender-peduncled: scales hyaline, the serrate awns about as long as the perigynia : perigynia darkcolored, short-obovoid, nearly terete, granular, strongly many-nerved, each abruptly contracted into a beak about $\frac{1}{2}$ as long as the body.

In the Comite swamp, Baton Rouge, Louisiana. Summer.

23. Carex vestita Willd. Stems and scapes strict and slender, 4-8 dm. tall, rough above : leaves not overtopping the scape ; blades $3-5 \mathrm{~mm}$. wide : bracts similar, but narrower, short, rough-ciliate: staminate spike usually solitary, almost sessile: pistillate spikes 1-5, oblong, 1-2 cm. long, 6-8 mm. in diameter, erect, commonly staminate at the summit, sessile, or the lower ones short-stalked: perigynia ovoid, densely pubescent, less than $2 \mathrm{~mm}$. in diameter, prominently few-ribbed, each tapering gradually into a short conic 2 -toothed whitish beak, slightly shorter than or equalling the ovate, acute, membranous scales.

In sandy woods, New Hampshire to:Pennsylvania and Georgia. Summer.

24. Carex Walteriàna Bailey. Stems and scapes slender, strict, usually rough above, 3-8 dm. tall : leaves not overtopping the scape; blades narrow, elongated, 2-4 $\mathrm{mm}$. wide, nodulose : lowest bract similar, the upper smaller, often almost filiform : staminate spikes 2-5, long-stalked: pistillate spikes 1 or 2 , when 2 the lower one remote from the upper, sessile or short-stalked, oblong-cylindric, erect, $2-4 \mathrm{~cm}$. long, about $8 \mathrm{~mm}$. in diameter, rather loosely many-flowered : scales ovate, acute, short-aristate or obtuse, membranous, $\frac{1}{2}$ the length of the perigynia: perigynia ovoid, purple-brown, many-nerved, slightly inflated, glabrous or pubescent, $3 \mathrm{~mm}$. in diameter, each tapering into a short 2-toothed beak. [C. striata Michx.]

In pine-land bogs, southern New Jersey to Florida. Spring and summer.

25. Carex lanuginòsa Michx. Stems and scapes slender, but usually rather stouter than those of C. filiformis, sharp-angled and rough above. Leaves and the lower bracts elongated ; blades not involute, 2-4 mm. wide, sometimes overtopping the scapes : staminate spikes 1-3, long-stalked, sometimes pistillate at the base : pistillate spikes 1-3, usually distant, sessile or the lower slender-stalked, cylindric, 5-6 mm. in diameter: scales acuminate or aristate.

In swamps and wet meadows, Nova Scotia to British Columbia, south to New Jersey, North Carolina (according to Torrey), Kansas, New Mexico and California. Summer.

26. Carex filifórmis $L$. Stems and scapes very slender, erect or reclining, smooth, obtusely angled, 5-9 dm. long. Leaf-blades very narrow, involute, about $2 \mathrm{~mm}$. wide, rough margined, not overtopping the scape : lower bracts similar to the leaves, upper bracts filiform : flowers occasionally dioecious : staminate spikes $1-3$, commonly 2 , stalked : pistillate spikes 1-3, cylindric, $1.5-2 \mathrm{~cm}$. long, about $6 \mathrm{~mm}$. in diameter, erect, sessile, or the lower distant and short-peduncled : scales ovate, membranous, acute or short-awned, shorter than or equalling the perigynia : perigynia green, ascending, oval, densely pubescent, faintly nerved, about $2 \mathrm{~mm}$. in diameter, each tapering into a short 2 -toothed beak.

In wet meadows and swamps, Newfoundland to British Columbia, New Jersey, Pennsylvania, In wet meadows and swamps, Newfoundland to British Columbia, New
South Carolina (according to Torrey) and Iowa. Also in Europe. Summer.

27. Carex hírta L. Stems and scapes rather slender, nearly smooth, $1.5-4 \mathrm{dm}$. tall : leaf-blades flat, pubescent, but mostly less densely so than the sheaths, $3-5 \mathrm{~mm}$. wide, the basal ones much elongated, the upper, and the similar bracts, shorter: staminate spikes 2 or 3 , stalked : pistillate spikes 2 or 3 , remote, erect, oblong-cylindric, $2-3 \mathrm{~cm}$. long, about 6 $\mathrm{mm}$. in diameter: scales lanceolate, aristate, 3-nerved, shorter than the perigynia: perigynia ovoid-oblong, green, densely pubescent, $2 \mathrm{~mm}$. in diameter, $4 \mathrm{~mm}$. long, few-ribbed, each tapering into a prominently 2-toothed beak, the teeth often as long as the beak.

In fields and waste places. Massachusetts to eastern New York, Pennsylvania and Tennessee. Naturalized or adventive from Europe. Summer and fall.

28. Carex fúsca All. Stems and scapes slender, stiff, sharp-angled, rough above, $3-9 \mathrm{dm}$. tall : leaves rough; blades erect, $2-4 \mathrm{~mm}$. wide : spikes $2-4$, oblong or cylindric, erect, all'sessile and close together, or the lowest sometimes distant and short-stalked, $8-37 \mathrm{~mm}$. long, about $8 \mathrm{~mm}$. in diameter, the terminal one staminate at the base or rarely throughout: scales ovate, awn-tipped, black or dark brown with a green midvein, longer than the perigynia : perigynia elliptic or obovate, flat, ascending, $2 \mathrm{~mm}$. long, light green, faintly few-nerved, beakless, the apex minutely 2-toothed. [C. Buxbaumii Wahl.]

In bogs, Newfoundland to Alaska, south to Georgia, Kentucky, Utah and California. Also in Europe. Spring and summer. 
29. Carex strícta Lam. Leaves rarely overtopping the scape; blades very roughmargined, 2-4 $\mathrm{mm}$. wide : sheaths becoming fibrillose : scapes slender, stiff, usually in dense clumps, sharply 3 -angled, rough above, $3-11 \mathrm{dm}$. tall : lower bract similar to the leaves: staminate spikes solitary or sometimes 2 , stalked : pistillate spikes 2-5, linear-cylindric, often staminate at the top, densely flowered, or loose at the base, $2-5 \mathrm{~cm}$. long, about $4 \mathrm{~mm}$. thick, sessile or the lower stalked: scales brown purple with green margins and midvein, oblong or lanceolate, appressed : stigmas 2 : perigynia ovate, elliptic, acute, faintly few-nerved, $2 \mathrm{~mm}$. long or less, minutely beaked, the orifice entire or nearly so.

In swamps. Newfoundland to Ontario, Nebraska, Georgia and Texas.-A form with 6-8 more densely flowered spikes, mostly obtuse, if not staminate at the apex and the lowest one at least subtended by a leaf-like bract, is $C$. stricta Emòryi (Dewey) Bailey. Texas. Summer and fall.

30. Carex tórta Boott. Leaf-blades about $4 \mathrm{~mm}$. wide; sheaths not fibrillose : scapes slender, smooth or slightly scabrous above, 4-10 dm. long: lower bract commonly foliaceous : staminate spikes 1-3, stalked: pistillate spikes 3-5, all but the upper spreading or drooping, linear, $2-7.5 \mathrm{~cm}$. long, about $4 \mathrm{~mm}$. in diameter, often loosely flowered toward the base : scales ovate, purple-brown and each with a green midvein, shorter and mostly narrower than the perigynia: stigmas 2: perigynia oblong or narrowly ovate, green, nerveless, narrowed and more or less twisted above, 2-3 $\mathrm{mm}$. long.

In marshes and wet thickets, Maine and Vermont to North Carolina and Missouri. Summer.

31. Carex prasina Wahl. Leaves light green; blades flaccid, roughish, 3-5 mm. wide : scapes slender, smooth or nearly so, reclining, 3-angled, 3-7 dm. long : lower bract similar to the leaves, commonly overtopping the spikes : staminate spike short-stalked, often pistillate at the summit : pistillate spikes 2 or 3 , linear-cylindric, drooping, the lower filiform-stalked, 2-6 cm. long, $4 \mathrm{~mm}$. in diameter, rather loosely many-flowered : scales ovate, acute, acuminate, or short-awned, pale green, shorter than the perigynia : stigmas 3: perigynia light green, lanceolate, obscurely nerved, each tapering into a slender, minutely 2-toothed beak. [C. miliacea Muhl.]

In meadows and moist thickets. Maine to Ontario, New Jersey and Pennsylvania, and in the Alleghenies to Georgia. Spring and summer.

32. Carex littoràlis Schwein. Leaves somewhat glaucous : blades $3-4 \mathrm{~mm}$. wide, smooth, the lower sheaths fibrillose: scapes smooth, 2-5 dm. tall, bracts not sheathing, the lower usually short and narrow : staminate spikes 1-3, usually rather long-stalked : pistillate spikes 2-4, drooping or the upper ascending, slender-stalked, linear-cylindric, $1-5 \mathrm{~cm}$. long, $6 \mathrm{~mm}$. in diameter, mostly staminate at the summit : scales brown-purple with lighter margins, obtuse, equalling or shorter than the perigynia : stigmas 3 : perigynia oblong, green, faintly few-nerved, $2-3 \mathrm{~mm}$. long, each tipped with a minute entire beak. [C. Barrattii Schwein.]

In pine-land swamps, Long Island and New Jersey to eastern Pennsylvania and North Carolina Spring and summer.

33. Carex crinita Lam. Stems and scapes 3 -angled, $5-13 \mathrm{dm}$. tall : leaves not glaucous ; blades rough-margined, $6-10 \mathrm{~mm}$. wide, the lowest very short and sheathing : staminate spikes 1 or 2 , stalked : pistillate spikes $3-5$, narrowly cylindric, $2-11 \mathrm{~cm}$. long, 6-8 $\mathrm{mm}$. in diameter, stalked, drooping : scales green, subulate, ciliate-scabrous, spreading, 2-6 times as long as the perigynia : stigmas 2 : perigynia obovoid, obtuse, about $2 \mathrm{~mm}$. long and nearly as thick, nerveless, each abruptly tipped by a short entire beak.

In swamps and wet woods, Nova Scotia and Ontario to Florida and Texas. Summer.

34. Carex gynándra Schwein. Similar to the next preceding species in habit. Leaves glabrous or the sheaths often finely pubescent, not glaucous; blades 6-12 mm. wide : pistillate spikes $2-10 \mathrm{~cm}$. long, narrowly cylindric : scales subulate, rough, ascending, 2-4 times as long as the perigynia : perigynia oblong or elliptic, faintly few-nerved or nerveless, compressed, slightly inflated, $3-4 \mathrm{~mm}$. long, and about $\frac{1}{2}$ as broad, each tapering to an acute entire orifice.

In swamps, Nova Scotia to New York, Florida and Louisiana. Summer.

35. Carex macrokòlea Steud. Stems and scapes stout, 5-11 dm. tall. Leaves glaucous; blades rough, $3-6 \mathrm{~mm}$. wide, tapering to very long narrow tips : lower bracts similar to the leaves : staminate spikes 1 or 2 , short-stalked: pistillate spikes 2-8, cylindric, $2-5 \mathrm{~cm}$. long, erect, sessile or the lower stalked : scales oblong, rough-awned, as long as the perigynia or longer : perigynia dark brown, 3 -angled, $3 \mathrm{~mm}$. long, several-nerved, each abruptly contracted into a short sharp beak.

In swamps, Missouri to Florida and Texas. Summer.

36. Carex verrucòsa Muhl. Stems and scapes slender, $1 \mathrm{~m}$. tall or less: leaves glaucous; blades smooth or very nearly so, $2-6 \mathrm{~mm}$. wide, long-attenuate: staminate spike 1 , stalked : pistillate spikes $1-6$, cylindric, $3-5 \mathrm{~cm}$. long, filiform-stalked and nod- 
ding, or the upper erect: perigynia 3-angled, somewhat swollen, abruptly sharp-beaked, 3-4 $\mathrm{mm}$. long, about as long as the ovate awned scales.

In wet soil, southeastern Virginia to Florida, Missouri and Mississippi. Summer.

37. Carex viréscens Muhl. Stems and scapes slender, rough above, $1.5-5 \mathrm{dm}$. tall: leaves light green, pubescent, especially the sheaths; blades narrowly linear-elongated : spikes $2-5$, short-stalked, erect or nearly so, $8-20 \mathrm{~mm}$. long, about $3 \mathrm{~mm}$. in diameter, the terminal one staminate below: scales oblong-ovate, cuspidate, slightly shorter than the perigynia: perigynia 3-sided, rather less than $2 \mathrm{~mm}$. long, green, beakless, the orifice entire.

In dry woods and thickets, Maine and Ontario to Michigan, North Carolina and Missouri. Summer.

38. Carex costellàta Britton. Similar to the next preceding species, but taller and more spreading. Leaves pubescent; blades broader: spikes $2-5$, rather loose, $3 \mathrm{~mm}$. in diameter, the terminal one staminate below, the lower one commonly filiform-stalked: scales ovate, shorter than the perigynia: perigynia narrowed at each end, $2 \mathrm{~mm}$. long, rather more than $1 \mathrm{~mm}$. thick. [C. costata Schwein., not Presl.]

In woods, Maine and Ontario to North Carolina. Summer.

39. Carex trìceps Michx. Stems and scapes rough above, $1.5-9 \mathrm{dm}$. long: leaves bright or light green, pubescent ; blades 2-4 mm. wide : spikes 2-5, dense, erect, sessile or very nearly so, 6-20 mm. long, usually clustered, the terminal one staminate at the base : scales ovate, or lànceolate-acuminate : perigynia oval or obovoid, flattened, not inflated, green or greenish brown, few-nerved, usually pubescent when young, when mature 1-2 $\mathrm{mm}$. long, the orifice minutely notched or entire: achene elliptic-obovoid, its summit not bent.

In woods, fields and swamps, Massachusetts to southern Ontario and Michigan, Florida and Texas. Spring and summer.

40. Carex Caroliniàna Schwein. Stems and scapes slender, rough above, $3-6 \mathrm{dm}$. tall : leaves rather dark green, glabrous except the sheaths; blades 2-3 mm. wide: spikes $2-4$, oblong, dense, sessile or nearly so, $8-12 \mathrm{~mm}$. long, clustered, the upper one staminate at the base: scale brown, ovate, mucronate: perigynia subglobose or obovoid, swollen, about $1 \mathrm{~mm}$. in diameter, nerveless or faintly nerved, brown, beakless : achenes pyriform, bent at the summit or tipped with the bent styles. [C. Smithii Porter.]

In meadows, New Jersey and Pennsylvania to North Carolina and Arkansas. Spring and summer.

41. Carex gracíllima Schwein. Stems and scapes roughish above, $3-10 \mathrm{dm}$. long: leaves dark green, glabrous; blades $3-6 \mathrm{~mm}$. wide, shorter than the scape : lower bract foliaceous: spikes $3-5,2-6 \mathrm{~cm}$. long, about $4 \mathrm{~mm}$. thick or sometimes much smaller, filiform-stalked and drooping, the upper one partly or wholly staminate : scales ovate-oblong, pale, $\frac{1}{2}$ as long as the perigynia: perigynia ovoid-oblong, obtuse, few-nerved, glabrous, $2 \mathrm{~mm}$. long.

In moist woods and meadows, Nova Scotia to Manitoba, North Carolina, Ohio and Mississippi. Spring and summer.

42. Carex aestivàlis M. A. Curtis. Stems and scapes slender or filiform, 2-5 dm. tall : leaf-blades flat, elongated, $2-3 \mathrm{~mm}$. wide, sheaths usually pubescent : spikes $3-5$, narrowly linear, erect or somewhat spreading, $2-5 \mathrm{~cm}$. long, about $3 \mathrm{~mm}$. thick, the terminal staminate at the base or also at the summit: scales ovate-oblong, the lower cuspidate or short-awned : perigynia oblong, 3-sided, few-nerved, $2 \mathrm{~mm}$. long, beakless, the orifice entire.

In mountain woods, Massachusetts and New York to Georgia. Summer.

43. Carex oxýlepis Torr. \& Hook. Stems and scapes slender, smooth, $2-6 \mathrm{dm}$. tall : leaves pubescent, especially the sheaths; blades $3-6 \mathrm{~mm}$. wide : spikes 4 or 5 , linear-cylindrie, $2-5 \mathrm{~cm}$. long, about $4 \mathrm{~mm}$. in diameter, filiform-stalked, the terminal one staminate at the base or sometimes wholly staminate: scales ovate-lanceolate, short-awned, shorter than the perigynia : perigynia oblong, 3-angled, pointed at both ends, less than $2 \mathrm{~mm}$. thick, several-nerved, the orifice entire.

In low grounds, Missouri to Tennessee, South Carolina, Florida and Texas. Spring.

44. Carex Davísii Schwein \& Torr. Similar to the next preceding species, stouter. Leaves pubescent ; blades $3-6 \mathrm{~mm}$. wide: lower bract foliaceous : spikes clustered, or the lower one distant, $6 \mathrm{~mm}$. in diameter, at length spreading or drooping, the terminal one staminate at the base: scales lanceolate or oval, long-awned, equalling or longer than the perigynia : perigynia much swollen, strongly several-nerved, 4-5 $\mathrm{mm}$. long, each with a short but conspicuously 2-toothed beak.

In moist thickets and meadows, Massachusetts to New York, Minnesota, Georgia, Kentucky, Kansas and the Indian Territory. Spring and summer. 
45. Carex Cherokeénsis Schwein. Stems and scapes $3-8 \mathrm{dm}$. tall, slender: leaves light green, overtopped by the scape; blades elongated, $2-5 \mathrm{~mm}$. wide, rough toward the apex : staminate spikes 5-15, cylindric, often 2 or 3 together, all nodding from filiform peduncles: perigynia oblong-ovoid, numerous, 4-5 mm. long, whitish green, slightly 3angled, each with a curved membranous orifice, surpassing the ovate or oblong acute whitish scale.

On river banks and about swamps, Georgia and Florida to Arkansas and Texas. Spring and summer.

46. Carex júncea Willd. Stems and scapes densely tufted, slender, $2-4 \mathrm{dm}$. tall : leaves deep green, as long as the scape or overtopped by it ; blades very narrowly linear, 1-1.5 mm. wide, smooth : staminate spike slender, 1-2 cm. long, peduncled : pistillate spikes 1-3, linear, 1-3 mm. long, 3-4 mm. thick, the lower one longer peduncled than the others : scales ovate or lanceolate, about as long as the perigynia or shorter : perigynia spindleshaped, about $5 \mathrm{~mm}$. long, 3-angled, each with a rough apex and an entire orifice.

On exposed mountain summits at very high altitudes, North Carolina and Tennessee. Summer.

47. Carex ténuis Rudge. Stems and scapes rough above, 1-9 dm. long. Leaves bright green; blades $3-5 \mathrm{~mm}$. wide: lower bracts similar to the leaves: staminate spike short-stalked : pistillate spikes $2-5$, linear, $3 \mathrm{~mm}$. thick, filiform-stalked and spreading or drooping: scales ovate or oblong, $\frac{1}{2}$ as long as the perigynia : perigynia spindle-shaped, glabrous or puberulent, faintly few-nerved, obtusely 3 -angled, $6 \mathrm{~mm}$. long, less than $2 \mathrm{~mm}$. thick, each tapering into a short 2 -toothed beak.

In woods, Newfoundland to Michigan, North Carolina and Kentucky. Spring and summer.

48. Carex débilis Michx. Stems and scapes $3-8 \mathrm{dm}$. tall, smooth : leaves deepgreen, overtopped by the scape : blades $3-6 \mathrm{~mm}$. wide, rough : staminate spike inconspicuous, 1-4 cm. long, slender: pistillate spikes $3-5$, linear, remote or approximate near the top of the scape, arching or drooping, 2-5 $\mathrm{cm}$. long, not compact : scales about $\frac{1}{2}$ as long as the perigynia : perigynia spindle-shaped, $8-10 \mathrm{~mm}$. long, glabrous, 3 -angled, pinched at the base, few-ribbed, each acuminate to a subulate 2-cleft beak, appressed to the rachis.

In pine lands, South Carolina to Florida and Louisjana. Summer.

49. Carex venústa Dewey. Stems and scapes slender, 6-12 dm. tall, smooth : leaves light green, overtopped by the scape; blades $3-8 \mathrm{~mm}$. wide, scabrous : staminate spike slender, $2-5 \mathrm{~cm}$. long: pistillate spikes $3-5$, linear, arching or drooping, $2.5-5 \mathrm{~cm}$. long, the upper often approximate, the lower remote: scales about $\frac{1}{2}$ as long as the perigynia: perigynia spindle-shaped, mostly 5-6 mm. long, acute at both ends, appressed to the rachis, closely pubescent, prominently few-ribbed.

In low pine woods, North Carolina to Florida. Spring and summer.

50. Carex oblita Steud. Stems and scapes sharply 3-angled, smooth or nearly so, 3-9 mm. long: leaves glabrous, shorter than the stem; blades 4-5 mm. wide: lower bract similar to the leaves : staminate spike solitary, filiform-stalked : pistillate spikes $3-5,2-6$ cm. long, about $5 \mathrm{~mm}$. thick, loosely flowered, slender-stalked, the lower distant, drooping: scales obtuse, about $\frac{1}{3}$ the length of the perigynia : perigynia 3 -angled, glabrous, 6 $\mathrm{mm}$. long, less than $2 \mathrm{~mm}$. thick, each tapering into a short 2 -toothed beak.

In bogs, central New York to New Jersey, North Carolina and Mississippi. Summer.

51. Carex grísea Wahl. Stems and scapes smooth or nearly so, $3-6 \mathrm{dm}$. long : leaves light green, sometimes slightly glaucous : bracts similar to the leaves, much overtopping the spikes: staminate spike sessile : pistillate spikes $3-5$, oblong, $8-25 \mathrm{~mm}$. long, about 4 $\mathrm{mm}$. thick, the lower slender-stalked and distant : scales cuspidate or awned: perigynia 5 $\mathrm{mm}$. long, $2 \mathrm{~mm}$. thick, beakless.

In woods and thickets, Maine to Ontario and Minnesota, North Carolina and Kansas. Spring and summer.

52. Carex amphíbola Steud. Stems and scapes slender, $3-5 \mathrm{dm}$. long : leaves bright green; blades 2-4 mm. wide : bracts similar to the leaves, erect, not over $2 \mathrm{~mm}$. wide, overtopping the spikes: staminate spike short: pistillate $2-4,1-2.5 \mathrm{~cm}$. long, less than 4 $\mathrm{mm}$. thick, loosely several-flowered, the lower on filiform stalks : scales awned, spreading : perigynia oblong or obovoid, firm, pointed, beakless, 3-angled, $4 \mathrm{~mm}$. long, about $2 \mathrm{~mm}$. thick. [C. grisea var. angustifolia Boott.]

In dry soil, New Jersey and Pennsylvania to Iowa, Florida and Texas. Spring.

53. Carex flaccospérma Dewey. Similar to Carex grisea and C. glaucodea in habit, slightly glaucous. Stems and scapes $3-6 \mathrm{dm}$. tall : leaves delicate; blades thin, the basal ones $6-12 \mathrm{~mm}$. wide: bracts leafy : staminate spike sessile or nearly so: pistillate spikes $2-4$, oblong, erect, the lower slender-stalked: scales broadly ovate, green, $\frac{1}{2}-\frac{1}{3}$ as long as the perigynia : perigynia oblong, 3 -angled, $5 \mathrm{~mm}$. long. Summer.

In low grounds or on shaded hillsides, southern Missouri to Texas, North Carolina and Florida 
54. Carex glaucòdea Tuckerm. Similar in habit to Carex grisea, but pale and very glaucous. Stems and scapes $1.5-5 \mathrm{dm}$. long: leaf-blades $4-8 \mathrm{~mm}$. wide : bracts foliaceous : staminate spike sessile: pistillate spikes 3-5, erect, densely flowered, the lower slenderstalked : perigynia oblong, 3-4 mm. long, beakless, nearly twice as long as the scales.

In open fields and meadows, Massachusetts to Pennsylvania, Illinois, Virginia and Arkansas. Spring and summer.

55. Carex granulàris Muhl. Stems and scapes slender, smooth or nearly so, 1.5-6 $\mathrm{dm}$. long : leaves slightly glaucous ; blades $3-6 \mathrm{~mm}$. wide, the basal shorter than the scape : bracts similar to the leaves: staminate spike sessile or short-stalked : pistillate spikes 3-5, erect or slightly spreading, 1-3 $\mathrm{cm}$. long, $4 \mathrm{~mm}$. thick, many-flowered, stalked or the upper sessile : scales ovate, acute or cuspidate: perigynia ovoid, strongly many-nerved, 2-3 mm. long, each with a short, bent or nearly straight beak.

In moist meadows, New Brunswick to Manitoba, Florida and Louisiana. Spring and summer.

56. Carex microdónta Torr. Stems and scapes 1.5-5 dm. tall, smooth: leaves overtopped by the scapes; blades linear, $4-5 \mathrm{~mm}$. wide, smooth : staminate spikes 1-3, 1-4 $\mathrm{cm}$. long: pistillate spikes 2-3, cylindric or oblong-cylindric, 1-3 cm. long, 4-5 mm. thick, long-peduncled, erect or arching, remote, the lower one usually near the base of the scape : scales hyaline, as long as the perigynia or shorter: perigynia ovoid or oval, about $3 \mathrm{~mm}$. long, yellowish green, abruptly pointed, finely few-ribbed.

On wet prairies, Mississippi and the Indian Territory to Texas. Spring and summer.

57. Carex Crà wei Dewey. Stems and scapes stiff, 7-40 cm. tall : leaves rather stiff ; blades $2-4 \mathrm{~mm}$. wide, shorter than the scape : bracts similar to the leaves : staminate spikes 1-3, long-stalked : pistillate spikes 1-4, cylindric, short-peduncled, erect, $1-2.5 \mathrm{~cm}$. long, 4-6 mm. thick, the lowest often borne near the base : scales obovate or oval, acute or cuspidate, shorter than the perigynia: perigynia ovoid, usually resinous-dotted, $2-3 \mathrm{~mm}$. long, each tapering into a short entire beak.

In meadows and on banks, Quebec to Manitoba, Pennsylvania, Tennessee and Nebraska. Spring and summer.

58. Carex conoidea Schk. Stems and scapes rather stiff, $2-5 \mathrm{dm}$. tall : leaf-blades 2-3 mm. wide : lower bracts similar to the leaves: staminate spike long-stalked : pistillate spikes 1-3, distant, erect, oblong, 1-2.5 $\mathrm{cm}$. long, $5 \mathrm{~mm}$. thick, the lower slender-stalked : scales broadly ovate, each contracted into a rough awn, the lower longer than the perigynia, the upper shorter than or equalling them: perigynia oblong, obtusely 3 -angled, acute, beakless, $2-3 \mathrm{~mm}$. long, about $1 \mathrm{~mm}$. thick, the orifice entire.

In meadows, Nova Scotia to Ontario, Rhode Island, New Jersey, the mountains of North Carolina (according to Chapman), Ohio and Iowa. Spring.

59. Carex oligocárpa Schk. Stems and scapes very slender or almost filiform, roughish, $2-5 \mathrm{dm}$. long : leaf-blades about $2 \mathrm{~mm}$. wide, soft : bracts sinilar to the leaves : staminate spike long-stalked or nearly sessile: pistillate spikes 2-4, erect or nearly so, distant, loosely few-flowered, 8-16 mm. long, less than $4 \mathrm{~mm}$. thick, the lower filiformstalked: scales ovate, each with a rough spreading awn: perigynia oblong, pale, 2-2.5 $\mathrm{mm}$. long, each narrowed into a short entire beak.

In dry woods and thickets, Vermont and Ontario to Michigan, Iowa, New Jersey, North Carolina, the Indian Territory and Kansas. Spring and summer.

60. Carex polymórpha Muhl. Rather dark green. Stems and scapes stiff, $2-6 \mathrm{dm}$. tall : leaf-blades 3-4 mm. wide, nearly erect : bracts usually little longer than the pistillate spike : staminate spikes 1 or 2, long-stalked: pistillate spikes commonly solitary, erect, short-stalked or sessile, $2-4 \mathrm{~cm}$. long, $8 \mathrm{~mm}$. thick: scales red-brown, somewhat shorter than the perigynia : perigynia ovoid-oblong, obscurely 3 -angled, fully $4 \mathrm{~mm}$. long and 2 $\mathrm{mm}$. in diameter, the beak more than $\frac{1}{2}$ as long as the body, the orifice oblique.

In swamps or wet meadows, Maine to New Jersey, Pennsylvania and North Carolina. Summer.

61. Carex tetánica Schk. Light green and glabrous. Stems and scapes slender, rough above, $2-5 \mathrm{dm}$. tall : leaf-blades $2-4 \mathrm{~mm}$. wide : bracts narrow, elongated : staminate spike stalked : pistillate spikes 2 or 3 , erect, distant, $2.5 \mathrm{~cm}$. long or less, or the lower filiform-stalked and drooping : scales ovate-oblong: perigynia oblong, many-nerved, about 3 $\mathrm{mm}$. long, the summit of each curved outward and tapering to an entire orifice, beakless.

In meadows and wet woods, Maine to Manitoba, North Carolina and Louisiana. Summer.

62. Carex Meaddil Dewey. Similar to the next preceding species. Stems and scapes stouter, very rough above, $3-4 \mathrm{dm}$. tall : bracts short, not overtopping the spikes : staminate spike long-stalked: pistillate spikes 1-3, oblong-cylindric, dense, $1-2.5 \mathrm{~cm}$. long, about $6 \mathrm{~mm}$. in diameter, erect, stalked or the upper one sessile : the lowest spike is sometimes borne on a very long stalk arising from the axil of one of the basal leaves : scales 
ovate, green with purple-brown margins: perigynia broadly oblong, many-nerved, $3 \mathrm{~mm}$. long, each tipped with a minute slightly bent beak.

In swamps and wet meadows, Rhode Island to Pennsylvania, Georgia, Michigan, Assiniboia, Nebraska and the Indian Territory. Spring and summer.

63. Carex laxiflòra Lam. Leaf-blades $3-6 \mathrm{~mm}$. wide, soft : scapes slender, roughish above, 1.5-6 dm. long: staminate spike usually stalked: pistillate spikes 2-4, distant, linear-cylindric, 3-4 mm. thick, all slender-stalked and spreading or drooping or the upper one erect and sessile: scales ovate with broad white scarious margins, acute, cuspidate or awned: perigynia obovoid, more or less oblique, $2.5-3 \mathrm{~mm}$. long, strongly many-nerved, each tapering into a short outwardly bent entire beak.

In meadows and thickets, Maine and Ontario to Minnesota, Florida, Alabama and the Indian Territory,--A form with cylindric mostly densely-flowered pistillate spikes, the upper one sessile or nearly so, erect and contiguous to the usually sessile staminate spike is C. laxiflora blanda (Dewey) Boott; its range is about the same as that of the type. Another form with glaucous or pale green foliage, basal leaves $5-10 \mathrm{~mm}$. wide, staminate spike usually stalked, loosely-flowered scattered pistillate spikes often $2.5 \mathrm{~cm}$. long or longer, and rather narrower perigynia is C. laxiflora patulifólia (Dewey) Carey; it ranges from Nova Scotia and Wisconsin to Tennessee and Alabama. Spring and summer.

64. Carex stylofléxa Buckl. Leaf-blades 3-6 mm. (wide, shorter than the scape : scapes slender, smooth, $2-5 \mathrm{dm}$. long: bracts short : staminate spike usually long-stalked : pistillate spikes 1-4, distant, loosely-flowered, less than $16 \mathrm{~mm}$. long, the lower drooping on filiform stalks : scales ovate or ovate-lancelate, acute, cuspidate or short-awned, shorter than the perigynia : perigynia narrowly oblong, 3-angled, many-nerved, 4-5 mm. long, 2 $\mathrm{mm}$. thick, the slender beak oblique.

In woods and thickets, New York to Florida, Louisiana and Texas. Spring and summer.

65. Carex striàtula Michx. Resembling C. laxiflora in habit, but usually stouter. Leaves numerous in the tufts ; blades linear, 5-12 mm. wide, or slightly narrower on the upper part of the stem : scapes copiously tufted, $2-5 \mathrm{dm}$. tall : bracts resembling the leaves but shorter: staminate spike mostly short-peduncled, sometimes raised high above the nearest pistillate spike: pistillate spikes mostly 2-4, loosely several-many-flowered, generally $1.5-3.5 \mathrm{~cm}$. long, the individual flowers often distinctly separated : scales very thin, abruptly pointed, somewhat shorter than the perigynia : perigynia elliptic, $3-4 \mathrm{~mm}$. long, the short beak nearly straight.

In woods, meadows and thickets, Ontario to Florida, Ohio and Mississippi. Spring and summer.

66. Carex digitàlis Willd. Leaves bright green ; blades $2-4 \mathrm{~mm}$. wide : scapes slender or almost filiform, usually reclining, $1-4.5 \mathrm{dm}$. long: staminate spike stalked : pistillate spikes 2-4, linear, loosely alternately flowered, $1-2.5 \mathrm{~cm}$. long, the lower filiform-stalked, spreading or drooping: scales acute, acuminate or short-awned: perigynia oblong, sharply triangular, many-nerved, $2 \mathrm{~mm}$. long, more than $1 \mathrm{~mm}$. thick, the short beak slightly oblique.

In woods and thickets, Maine and Ontario to Minnesota, Florida and Texas. Spring and summer.

67. Carex Aùstro-Caroliniàna Bailey. Leaves bright green, overtopped by the scape ; blades 3-6 mm. wide, with rough margins and nerves beneath : scapes tufted, very slender, 1.5-5 dm. long, smooth, staminate spike 1-1.5 cm. long, slender-peduncled : pistillate spikes 3-4, loosely 3-6-flowered, on arching hair-like peduncles, the lower one often near the base of the scape : scales shorter than the perigynia, mucronate, dark green : perigynia ovoid or oval, $3-3.5 \mathrm{~mm}$. long, 3-angled, each with a very short oblique tip, delicately ribbed, sparingly scabrous. [C. Caroliniana Buckl.]

On cliffs or rocky slopes, in the mountains, South Carolina and Tennessee. Spring.

68. Carex plantagínea Lam. Leaves rather dark green; blades $1-2.5 \mathrm{~cm}$. wide, persistent through the winter : scapes $1.5-5 \mathrm{dm}$. long: bracts short, usually with purplish clasping sheaths: staminate spike long-stalked, purple: pistillate spikes 3 or 4 , slenderstalked, $2.5 \mathrm{~cm}$. long or less : scales ovate, cuspidate : perigynia oblong, outwardly curved, many-nerved, $3 \mathrm{~mm}$. long.

In woods, New Brunswick and Ontario to Manitoba, North Carolina (according to Chapman) and Wisconsin. Spring and summer.

69. Carex laxicúlmis Schwein. Leaves blue-green and glaucous ; blades elongated, 6-10 mm. wide : scapes filiform, ascending or diffuse, $1.5-6 \mathrm{dm}$. long : bracts usually short : staminate spike long-stalked : pistillate spikes 2-4, oblong, 6-12 $\mathrm{mm}$. long, about $4 \mathrm{~mm}$. thick, drooping from long hair-like stalks or the upper short-stalked : perigynia ovoid-oblong, 3-angled, many-nerved, about $2 \mathrm{~mm}$. long, scarcely beaked, longer than the ovate green cuspidate or short-awned scales.

In woods and thickets, Maine to Ontario, Michigan, Rhode Island and North Carolina. Spring.

70. Carex ptychocárpa Steud. Leaves pale green and glaucous; blades 4-8 mm. wide : scapes very slender, smooth, $5-15 \mathrm{~cm}$. tall : bracts foliaceous : staminate spike small, 
sessile : pistillate spikes 2 or 3 , the lower one often slender-stalked and nearly basal, all erect, $8-16 \mathrm{~mm}$. long: scales ovate, obtuse, about $\frac{1}{2}$ as long as the perigynia : perigynia oblong, pale, 3-angled, many-nerved, $2 \mathrm{~mm}$. long, pointed at both ends, minutely straightbeaked, the orifice entire.

In moist woods and thickets, Massachusetts and New Jersey to Florida and Louisiana. Summer.

71. Carex Baltzéllii Chapm. Leaves glaueous, overtopping the scape ; blades 4-10 $\mathrm{mm}$. wide, very scabrous above : scapes $5-20 \mathrm{~cm}$. tall, smooth : staminate spike $1.5-3.5 \mathrm{~cm}$. long, rigid, often with few pistillate flowers at the base: pistillate spikes $3-6$, narrowly cylindric, 1-4 cm. long, 4-5 mm. thick, rather loosely several-many-flowered, all except the upper 1 or 2 , on long arching or recurved basal or nearly basal peduncles : scales obovate, about as long as the perigynia, mucronate, reddish brown : perigynia narrowly oblong-obovoid, about $4 \mathrm{~mm}$. long, abruptly short-pointed, pubescent.

In dry pine woods, middle Florida. Spring.

72. Carex pedicellàta (Dewey) Britton. Plants not stoloniferous. Leaves light green, shorter than the scapes; blades $2-4 \mathrm{~mm}$. wide : scapes slender, roughish above, $1.5-5$ $\mathrm{dm}$. long: lower bract $0.6-5 \mathrm{~cm}$. long: staminate spike short-stalked, $8-25 \mathrm{~mm}$. long: pistillate spikes 2-4, short-oblong, few-flowered : scales green, ovate, acute : perigynia oval or oblong, rather less than $2 \mathrm{~mm}$. long, pale, pubescent, each with a subulate 2-toothed beak $\frac{1}{4}$ the length of the body.

In dry soil, Nova Scotia to Minnesota, Georgia, Ohio and Nebraska. Spring and summer.

73. Carex Pennsylvánica Lam. Plants stoloniferous. Leaves dark or dull green ; blades 1-3 mm. wide or rarely narrower, the old sheaths persistent and fibrillose : scapes slender, 1.5-4 dm. tall : lower bract rarely over $1 \mathrm{~cm}$. long : staminate spike sessile or very short-stalked, 1-2.5 cm. long: pistillate spikes 1-3, short-oblong, few-flowered, sessile: scales ovate, purplish, acute or cuspidate: perigynia oval, about $2 \mathrm{~mm}$. long, pubescent, 1-ribbed on each side, each with a 2 -toothed beak about $\frac{1}{4}$ the length of the body.

In dry soil, New Brunswick to Manitoba and the Northwest Territory, to North Carolina, Georgia, Tennessee and Kansas. Spring.

74. Carex vària Muhl. Plants stoloniferous. Leaf-blades $1-2.5 \mathrm{~mm}$. wide, nearly always shorter than the scape: scapes filiform, erect or somewhat spreading, $1.5-5 \mathrm{dm}$. long: lower bract scale-like or subulate, rarely $2 \mathrm{~cm}$. long: staminate spike 4-8 $\mathrm{mm}$. long, sessile, usually rather prominent : pistillate spikes $2-4,4-6 \mathrm{~mm}$. long : scales ovate, green or purplish brown, acute : perigynia oblong, pubescent, abuut $2 \mathrm{~mm}$. long, narrowed at the base, each with a subulate minutely 2 -toothed beak commonly $\frac{1}{2}$ the length of the body.

In dry soil, Nova Scotia to Ontario, Manitoba, Georgia and Texas. Spring and summer.

75. Carex Floridàna Schwein. Plants stoloniferous. Leaves bright green, overtopping the inflorescence; blades $2-5 \mathrm{~mm}$. wide, rough-margined : scapes tufted, often very short: staminate spike $0.5-1 \mathrm{~cm}$. long, inconspicuous, not much surpassing the 1 or 2 accompanying sessile pistillate spikes, these less than $1 \mathrm{~cm}$. long, terminating filiform peduncles 1-2 dm. long: scales green or sparingly dark blotched: perigynia plano-convex, $3-3.5 \mathrm{~mm}$. long, glabrous, each with a stipe-like base and a curved subulate beak.

In light dry soil, Florida to Texas. Spring.

76. Carex nìgo-marginàta Schwein. Plants stoloniferous. Leaves bright green, much longer than the scapes; blades $2-4 \mathrm{~mm}$. wide, rather stiff: scapes filiform, $5-20 \mathrm{~cm}$. long : bracts short and subulate or wanting: staminate spike sessile, 4-6 mm. long: pistillate spikes 1-3, sessile, about $6 \mathrm{~mm}$. long: scales acute or cuspidate, black or with broad black-purple margins, rather longer than the perigynia: perigynia oblong, narrowed at the base into short stipes, pubescent or nearly glabrous, $2-3 \mathrm{~mm}$. long, each with a cylindricsubulate 2-toothed beak $\frac{1}{3}$ or $\frac{1}{4}$ as long as the body.

In dry soil, New York to North Carolina. Spring and summer.

77. Carex umbellàta Schk. Plants stoloniferous. Leaves light green, usually much exceeding the scapes; blades $1-3 \mathrm{~mm}$. wide, the old sheaths fibrillose: scapes tufted and matted, filiform, $5-15 \mathrm{~cm}$. long: staminate spike commonly conspicuous : pistillate spikes 1-3, filiform-stalked from the basal sheaths or 1 or 2 of them sessile or very nearly so at the base of the staminate spike, ovoid-oblong, 4-8 mm. long: scales acuminate or short-awned, about as long as the perigynia : perigynia oval, pubescent, 3 -angled, the body rather less than $2 \mathrm{~mm}$. long, tipped with a subulate 2 -toothed beak of nearly its length.

In dry soil, Nova Scotia to the Northwest Territory, New Jersey, the Indian Territory and Oregon. Spring and summer.

78. Carex planostáchys Kunze. Leaves bright green, approximate, overtopping the inflorescence; blades stiff, $0.5-3 \mathrm{dm}$. long, involute, scabrous: scapes tufted, very short: staminate spike solitary at the base of the uppermost pistillate spike, inconspicu- 
ous, sessile or nearly so: pistillate spikes 1 or 2 , loosely few-flowered at the summit of filiform mostly basal peduncles, $1-1.5 \mathrm{~cm}$. long : perigynia 3-angled, narrowly ovoid, $5-6 \mathrm{~mm}$. long, acute, glabrous or minutely tomentulose, many-nerved, each with a terete entire or nearly entire beak.

In dry soil, Texas and Mexico. Spring and fall.

79. Carex Chapmánii Sartw. Leaves bright green, glabrous, overtopped by the scape ; blades firm, channeled, $2-5 \mathrm{~mm}$. wide, roughish : scapes tufted, rigid, $2-7 \mathrm{dm}$. tall, glabrous : staminate spike $1-3 \mathrm{~cm}$. long, erect: pistillate spikes $2-3$, approximate at the top of the scape, oblong, $1-1.5 \mathrm{~cm}$. long, less than $1 \mathrm{~cm}$. thick, sessile : scales more than $\frac{1}{2}$ as long as the perigynia : perigynia 3-angled, narrowly ovoid, $4.5-5 \mathrm{~mm}$. long, many-ribbed, short-beaked, sparingly pubescent. [C. tenax Chapm.]

On dry sand ridges, South Carolina to Florida. Spring and summer.

80. Carex dasycárpa Muhl. Leaves pubescent, overtopped by the scape, blades 1.5-5 mm. broad, rough-margined: scapes tufted, $1.5-4 \mathrm{dm}$. tall, slender, glabrous or nearly so: staminate spike solitary, 1-2 cm. long, short-peduncled : pistillate spikes 2-3, oblong, 1-2 cm. long, 6-8 mm. thick, few-flowered, sessile, approximate: scales abruptly pointed, about $\frac{1}{2}$ as long as the perigynia : perigynia 3 -angled, elliptic, about $5 \mathrm{~mm}$. long, woolly, scarcely beaked, several-ribbed.

In sandy woods, South Carolina to Florida. Spring and summer.

81. Carex Fràseri Andr. Monoecious. Leaves glabrous, pale green ; blades 2-4 dm. long, flat, firm, spreading, finely many-nerved, and with their margins usually finely crumpled in drying, accompanied by clasping basal sheaths: scapes smooth, slender, reclining, 2.5-5 dm. long: spike solitary, bractless, terminal, androgynous, 1-2.5 cm. long, the pistillate portion dense, about $1.2 \mathrm{~cm}$. in diameter in fruit : scales ovate, obtuse, much shorter than the perigynia : perigynia ovoid, pale green, faintly many-nerved, fully $4 \mathrm{~mm}$. long, each with a short nearly truncate beak. Our largest-leaved species. summer.

In rich mountain woods, Virginia, West Virginia, Tennessee and North Carolina. Spring and

82. Carex pícta Steud. Dioecious. Leaves glabrous, light green ; blades $3-6 \mathrm{~mm}$. wide : scape slender, smooth, 1.5-3 dm. long : spike usually solitary, densely many-flowered, the staminate about $2.5 \mathrm{~cm}$. long, the pistillate narrowed at the base, $2-6 \mathrm{~cm}$. long, subtended by a short purple sheath : scales purple, shining, obovate, acute or cuspidate, longer and wider than the perigynia : perigynia strongly many-nerved, pubescent at least toward the obtuse summit, about $3 \mathrm{~mm}$. long. [C. Boottiana Benth.]

In woods, Indiana to Alabama and Louisiana. Summer.

83. Carex Willdenòvii Schk. Monoecious. Leaves glabrous and pale green, often $3 \mathrm{dm}$. long, much overtopping the spikes; blades $2-3 \mathrm{~mm}$. wide, the lowest reduced to sheaths: scapes $2-10 \mathrm{~cm}$. high : spikes $1-5$, androgynous, staminate above, pistillate below, or sometimes completely staminate, about $1.2 \mathrm{~cm}$. long, appearing nearly basal, one of them or more on long filiform stalks : scales lanceolate, acute, acuminate or awned, finely several-nerved, the lower 1 or 2 commonly bract-like: body of the perigynium oblong, smooth, 2-3 mm. long, narrowed into a 2-edged rough beak of about its own length.

In dry woods and thickets, Maine to Ohio, Michigan, Manitoba, Florida, Kentucky and Texas. Spring and summer.

84. Carex Jamèsii Schwein. Similar to the next preceding species, but the leafblades rather narrower, soft, spreading or ascending: spikes androgynous, the terminal staminate portion slender, the pistillate flowers only 1-4 and slightly separated : lower scales bract-like, foliaceous, the upper shorter and sometimes not exceeding the perigynia : body of the perigynium subglobose, $2 \mathrm{~mm}$. in diameter, abruptly tipped by a subulate rough beak of more than its own length.

In dry woods and thickets, southern Ontario and New York to Indiana, Iowa, District of Columbia, Tennessee and the Indian Territory. Spring.

85. Carex leptàlea Wahl. Leaves light green and glabrous ; blades not over 0.5 mm. wide : scapes filiform, smooth, $1.5-4.5 \mathrm{dm}$. long : spike solitary, terminal, androgynous, linear, 4-14 mm. long: stigmas 2 or 3: perigynia few, linear-oblong, about $3 \mathrm{~mm}$. long, light green, many-nerved, obtuse and beakless: scales membranous, the lowest sometimes attenuated into a subulate awn nearly as long as the spike. [C. polytrichoides Muhl.]

In bogs and swamps, Newfoundland to British Columbia, Florida, Louisiana, Texas, Colorado and Oregon. Summer.

86. Carex filifolia Nutt. Leaves pale green, glabrous, as long as the scape or shorter; blades filiform, rather stiff, about $0.5 \mathrm{~mm}$. wide, the sheaths persistent and ultimately fibrillose : scapes densely tufted, slender but stiff, $8-35 \mathrm{~cm}$. tall : spike solitary, erect, 6-30 $\mathrm{mm}$. long, staminate above; the pistillate portion about $4 \mathrm{~mm}$. in diameter: scales 
very broad, concave, with wide scarious margins, obtuse or cuspidate, about as long as the perigynia, but much broader : perigynia oval or obovoid-oval, $2 \mathrm{~mm}$. long, 3-angled, fewnerved or nearly nerveless, scabrous, or somewhat pubescent near the apex, each abruptly tipped by a short cylindric beak.

In dry soil, Manitoba to British Columbia, Texas and California. SI ring and summer.

87. Carex stipàta Muhl. Leaves bright green ; blades flat, 4-8 mm. wide : scapes smooth, sharply 3 -angled, $2-10 \mathrm{dm}$. tall : bracts bristle-form or wanting : spikes numerous, yellowish brown, in a terminal oblong cluster $3-10 \mathrm{~cm}$. long, the staminate flowers few, always terminal : scales ovate or lanceolate, acuminate, shorter than the perigynia : perigynia lanceolate, $4-5 \mathrm{~mm}$. long, each tapering into a rough flattened 2-toothed beak 1-2 times as long as the body.

In swamps and wet meadows, Newfoundland to Ontario, British Columbia, Florida, Tennessee, Missouri, New Mexico and California. Spring and summer.

88. Carex Crús-Córvi Shuttlw. Leaves pale green and glaucous; blades flat, 5-12 $\mathrm{mm}$. wide, rough-margined : scapes 3 -angled, rough above, $5-11 \mathrm{dm}$. tall, longer than the leaves: spikes yellowish brown, very numerous in a large compound branching panicle, 1-3 dm. long: scales ovate or lanceolate, thin, much shorter than the perigynia : perigynia elongated-lanceolate, about $8 \mathrm{~mm}$. long, each with a short hard base and a subulate rough 2-toothed beak.

In swamps, District of Columbia to Indiana, Minnesota, Florida, Louisiana and Texas. Spring and summer.

89. Carex decompósita Muhl. Leaves dark green, longer than the scape; blades 4-8 mm. wide, rough : scapes smooth, obtusely angled, or terete below, 4-9 dm. tall: spikes yellowish brown, very numerous in a decompound cluster, $5-13 \mathrm{~cm}$. long, the lower branches $2-5 \mathrm{~cm}$. long: bracts subulate, ciliate, or wanting: scales ovate, about equalling the perigynia : perigynia short-obovate, less than $2 \mathrm{~mm}$. long, hard, each abruptly tipped with a short slightly 2-toothed beak.

In swamps, New York to Ohio, Michigan, Florida and Louisiana. Spring and summer.

90. Carex grávida Bailey. Leaves light green ; blades flat, $3-6 \mathrm{~mm}$. wide : scapes 4-9 dm. tall, 3-angled, rough above : bracts usually very short : spikes several, in a dense heavy head 2-3.5 cm. long, pale, subglobose : scales acute, cuspidate or short-awned, about as long as the perigynia: perigynia flat, broadly ovate or suborbicular, 3-4 $\mathrm{mm}$. long, rounded at the base, each narrowed into a 2-toothed beak about $\frac{1}{3}$ as long as the body, several-nerved on the outer face or nerveless.

On plains and prairies, Illinois to South Dakota and the Indian Territory. Spring and summer.

91. Carex vulpinoidea Michx. Leaves often exceeding the scape ; blades $2-5 \mathrm{~mm}$. wide : scapes stiff, 3 -angled, rough above, $3-12 \mathrm{dm}$. tall : bracts bristle-like : spikes ovoidoblong, 4-8 $\mathrm{mm}$. long, very numerous in a cluster, 3-13 cm. long: scales lanceolate, acuminate or awned, about as long as the perigynia, but narrower : perigynia ovate, about $1.5 \mathrm{~mm}$. long, greenish brown, flat, several-nerved on the outer face, nerveless or faintly 1-3-nerved on the inner, each tipped with a lanceolate 2-toothed beak about $\frac{1}{2}$ as long as the body.

In swamps and meadows, New Brunswick to Manitoba, Florida, Louisiana and Texas. Summer.

92. Carex triangulàris Boeckl. Leaves bright green, overtopped by the scape; blades 2-6 mm. wide, somewhat scabrous, attenuate: scapes tufted, 3-8 dm. tall, stiff: spikes ovoid or globose, $5-8 \mathrm{~mm}$. long, dense, approximate, forming a compound spike $3-5 \mathrm{~cm}$. long, with short filiform bracts, fawn-brown at maturity : scales as long as the perigynia or shorter: perigynia nearly orbicular, conspicuously spreading, fully $2 \mathrm{~mm}$. long, shortpointed, delicately nerved.

On low prairies, the Indian Territory to Mississippi and Texas. Spring and early summer.

93. Carex xanthocárpa Bicknell. Leaves bright green; blades $3-6$ mm. wide : scapes rather stout, rough above, $3-14 \mathrm{dm}$. tall, much longer than the leaves : head usually dense : spikes numerous, ovoid, short : bracts mostly short and inconspicuous : scales acuminate, short-awned : perigynia bright yellow, plano-convex, ovate-elliptic, $2.5-3 \mathrm{~mm}$. long, each with a narrowed or cuneate base, and a short minutely 2 -toothed beak, nerveless, or obscurely few-nerved on the outer face.

In fields, Massachusetts to North Carolina and Iowa. Summer.

94. Carex Sartwéllii Dewey. Leaves light green; blades 2-4 mm. wide: scapes stiff, rough above, 3-angled, $3-9 \mathrm{dm}$. tall : bracts setaceous, usually small : spikes ovoid or. oblong, 4-8 mm. long, usually densely aggregated in a narrow cluster : scales ovate, pale brown, about equalling the perigynia : perigynia lanceolate, about $2 \mathrm{~mm}$. long, strongly several-nerved on both faces, each tapering into a short 2-toothed beak.

In swamps, Ontario to British Columbia, New York, Illinois, Michigan, Arkansas and Utah. Spring and summer. 
95. Carex ròsea Schk. Leaves soft; blades flat, $2 \mathrm{~mm}$. wide or less, shorter than the stem : scapes slender or filiform, rough above, $3-7 \mathrm{dm}$. long : lower bract 1-6 $\mathrm{cm}$. long : spikes 4-8, subglobose, 4-6 mm. in diameter, 5-15-flowered : scales ovate-oblong, white, $\frac{1}{2}$ as long as the perigynia : perigynia ovate-lanceolate, flattish, bright green, radiately spreading, nerveless, shining, mostly over $3 \mathrm{~mm}$. long, each gradually narrowed into a stout 2toothed beak, about $\frac{1}{4}$ the length of the body.

In woods and thickets, Newfoundland to Ontario, Manitoba, North Carolina, Missouri and Nebraska. Spring and summer.

96. Carex radiàta (Dewey) Small. Leaves numerous, sometimes equalling the scape in length; blades about $1 \mathrm{~mm}$. wide or less, weak : scapes filiform, numerous, more or less diffusely spreading : spikes scattered, 2-6-flowered : perigynia mostly less than $3 \mathrm{~mm}$. long, ascending, the broadly oblong-ovoid or obovoid body abruptly narrowed into the beak. [C. rosea var. radiata Dewey.]

In woods, Ontario to Maine, Georgia and Tennessee. Summer.

97. Carex retrofléxa Muhl. Leaves mostly shorter than the scape; blades about 1 mm. in width : scapes very slender, $2-5 \mathrm{dm}$. tall : lower bract bristle-form : spikes 4-8, subglobose, 4-9-flowered, the upper all close together: staminate flowers terminal or rarely variously intermixed with the pistillate: scales ovate, about $\frac{1}{2}$ as long as the perigynia: perigynia oblong-lanceolate, or ovate-lanceolate, radiating or reflexed at maturity, about $3 \mathrm{~mm}$. long, smooth, compressed, but not as flat as those of the preceding species, somewhat corky-thickened at the base, each tapering upwardly into a 2-toothed beak about $\frac{1}{3}$ the length of the body.

In woods and thickets, Massachusetts to Ontario, Arkansas, Florida and Texas. Spring and summer.

98. Carex Texénsis (Torr.) Bailey. Similar to the next preceding species. Leaves soft; blades about $1 \mathrm{~mm}$. wide, shorter than the scape : scapes very slender : lower bract commonly filiform: spikes 4-7, 4-10-flowered, all close together in a narrow head, or the lower separated: scales lanceolate or ovate, acute or acuminate, less than $\frac{1}{2}$ as long as the perigynia : perigynia narrowly lanceolate, green, nerveless, smooth, radiating or widely spreading, $3-4 \mathrm{~mm}$. long, the tapering beak about $\frac{1}{2}$ as long as the body.

In moist soil and thickets, southern Illinois (according to Bailey) to Alabama and Texas. Spring.

99. Carex sparganioides Muhl. Leaf-blades flat, 5-9 $\mathrm{mm}$. wide, the lower very short: sheaths white or pale : scapes rough, 3-angled, 5-9 dm. tall : spikes $6-12$, oblong or subglobose, $5-8 \mathrm{~mm}$. in diameter, the upper aggregated, the 2-4 lower ones commonly separated : scales ovate, acute or cuspidate, about $\frac{1}{2}$ as long as the perigynia : perigynia flat, ovate, $3 \mathrm{~mm}$. long, spreading or radiating, pale, narrowly wing-margined, usually fewnerved on the outer face, the rough 2-toothed beak $\frac{1}{4}-\frac{1}{3}$ the length of the body.

In woods and thickets, Massachusetts to Ontario, Michigan, Virginia, Kentucky and the Indian Territory. Summer.

100. Carex cephalóphora Muhl. Leaf-blades $2-4 \mathrm{~mm}$. wide: scapes slender, rough above, 2.5-6 dm. tall : bracts of the lower spikes bristle-form : spikes few, subglobose, clustered in a short-oblong head $8-16 \mathrm{~mm}$. long: scales ovate, rough-cuspidate or awned, equalling or a little shorter than the perigynia: perigynia broadly ovate, $2 \mathrm{~mm}$. long or less, pale, nerveless or very faintly few-nerved, each tipped with a 2-toothed beak about $\frac{1}{4}$ the length of the body.

In dry fields and on hills, Maine and Ontario to Manitoba, Florida, Missouri and Texas. Spring and summer.

101. Carex Leavenwórthii Dewey. Similar to the next preceding species but smaller. Leaves mostly shorter than the scape ; blades narrower, 1-3 mm. wide: scapes almost filiform, roughish, $1.5-4 \mathrm{dm}$. tall : bracts of the lower spikes bristle-form or wanting: spikes 4-7, densely crowded: scales ovate, acute or cuspidate, shorter and narrower than the perigynia: perigynia orbicular-ovate, rather less than $2 \mathrm{~mm}$. long and about as wide, each tipped with a very short 2 -toothed beak.

In meadows, Iowa to Mississippi, Arkansas and Texas. Spring.

102. Carex Muhlenbérgii Schk. Leaves usually shorter than the scape ; blades 2-4 $\mathrm{mm}$. wide, somewhat involute in drying: scapes slender, erect, 3 -angled, rough, at least above, 3-6 dm. tall : bracts bristle-form, very short : spikes 4-10, ovoid or subglobose, close together in an oblong head: scales ovate-lanceolate, rough-cuspidate or short-awned, narrower and mostly longer than the perigynia: perigynia broadly ovate-oval, $3 \mathrm{~mm}$. long, strongly nerved, on both faces, ascending, each with a short 2-toothed beak.

In dry fields and on hills, Maine and New Hampshire to Ontario, Minnesota, Florida and Texas. -A form with broader and longer leaf-blades, and nearly or quite nerveless perigynia is C. Muhlenbergii Xalapénsis (Kunth) Britton; it ranges from New York and Missouri to Texas and Mexico. Another form with globular spikes collected into denser heads, broader bracts and much broader and less prominently nerved perigynia, is C. Muhlenbergii austrinus Small [C. Muhlenbergii australis Olney] ; Arkansas, the Indian Territory and Texas. Spring and summer. 
103. Carex Arkansàna Bailey. Leaves approximate; blades narrowly linear, rather elongated, but usually shorter than the scape, $1.5-2.5 \mathrm{~mm}$. wide: scapes tufted, 1.5-6 dm. tall, smooth: bracts leaf-like, much longer than the inflorescence, the lower ones often $15 \mathrm{~cm}$. long, dilated at the base : spikes dense, 3-5, approximate or contiguous : scales about as long as the perigynia, awn-tipped: perigynia broadly ovate or triangularovate, $4 \mathrm{~mm}$. long, spreading, barely if at all nerved, each with a thick spongy base.

In bottoms, Arkansas to the Indian Territory. Spring.

104. Carex stérilis Willd. Leaves shorter than the scape; blades 1-2 mm. wide : scapes slender, $2-4.5 \mathrm{dm}$. tall, rough, at least above : spikes $3-5$, subglobose or shortoblong, about $5 \mathrm{~mm}$. thick: staminate flowers usually numerous at the bottom of the upper spike, or whole spikes occasionally staminate, or plants rarely quite dioecious : scales ovate, shorter than the perigynia : perigynia pale, lanceolate, compressed, spreading or reflexed when old, $3 \mathrm{~mm}$. long, $1 \mathrm{~mm}$. wide, several-nerved on both faces, each tapering into a sharp-edged 2-toothed rough beak more than $\frac{1}{2}$ as long as the body. [C. stellulata var. sterilis Chapm.]

In moist soil and wet woods, Newfoundland to British Columbia, Florida, Louisiana, Colorado and California. Variable.-A variety stouter in habit, sometimes $5 \mathrm{dm}$. tall, with $4-8$ very bristly pistillate spikes, more numerous flowers and rather larger perigynia is $C$. sterilis cephalantha Bailey; its range is similar to that of the type. Spring and summer.

105. Carex Atlántica Bailey. Similar to large forms of the next preceding species, but stouter. Leaves stiff; blades $2-3 \mathrm{~mm}$. wide, flat, or in drying somewhat involute: scapes rough above, 3-7 dm. tall : spikes 4-7, subglobose or short-cylindric, nearly $6 \mathrm{~mm}$. in diameter : scales shorter than the perigynia : perigynia broadly ovate, flat, sharp-margined, 2-3 mm. long, strongly several-nerved on the outer face, few-nerved on the inner, spreading or reflexed at maturity, each abruptly tipped with a stout rough 2 -toothed beak about $\frac{1}{3}$ as long as the body. [C. stellulata var. conferta Chapm.]

In swamps, Newfoundland to Florida. Summer.

106. Carex intèrior Bailey. Similar to C. sterilis in habit. Leaves shorter than the scape; blades about $1 \mathrm{~mm}$. wide: scapes slender, wiry, $2-6 \mathrm{dm}$. tall : spikes $2-4$, nearly globular, $4 \mathrm{~mm}$. in diameter : scales ovate, shorter than the perigynia : perigynia ovate or ovate-lanceolate, $2 \mathrm{~mm}$. long or less, faintly few-nerved on the outer face, nearly nerveless on the inner, thickened, spreading or reflexed when old, each tapering into a nearly smooth 2-toothed beak $\frac{1}{3}$ to $\frac{1}{2}$ as long as the body.

In wet soil, Maine to Minnesota, Florida and Kansas. Spring and summer.

107. Carex brunnéscens (Pers.) Poir. Leaves shorter than the scapes; blades 2 $\mathrm{mm}$. wide or less : scapes stiff, roughish above, $2-4.5 \mathrm{dm}$. tall : spikes 4-8, subglobose or short-oblong, few-flowered, rarely over $5 \mathrm{~mm}$. long: scales ovate, membranous, brownish : perigynia brown, oval or ovate-oval, about $2 \mathrm{~mm}$. long, each with a manifest beak about $\frac{1}{4}$ as long as the body. [C. canescens var. alpicola Wahl.]

In wet places, mostly at high altitudes, Labrador to British Columbia, New York and on the southern Alleghenies and Rocky Mountains. Also in Europe.-A variety with nearly filiform weak and often spreading scapes, 7-8-flowered spikes and spreading long-beaked perigynia, is $C$. brunnescens gracilior Britton; it is more common at lower altitudes. Summer.

108. Carex bromoides Schk. Leaves soft; blades $2 \mathrm{~mm}$. wide or less, flat : scapes slender, roughish above, $2-6 \mathrm{dm}$. long: bracts subulate or bristle-form, the lowest commonly elongated : spikes 3-7, narrowly oblong-cylindric, $8-16 \mathrm{~mm}$. long, erect or ascending, mostly close together, the staminate flowers either basal, basal and terminal, or forming whole spikes, the plants occasionally quite dioecious : scales oblong-lanceolate, green, acute or acuminate, shorter than the perigynia : perigynia linear-lanceolate, pale, strongly several-nerved, 4-5 mm. long, the inner face flat, the tapering rough 2 -toothed beak at least $\frac{1}{2}$ as long as the body.

In bogs and swamps, Nova Scotia to Ontario, Michigan, Florida and Louisiana. Summer.

109. Carex tribuloìdes Wahl. Stems and scapes 2-9 dm. tall, the latter roughish above : leaf-blades flat, $2-6 \mathrm{~mm}$. wide: lower bract bristle-form : spikes 6-20, oblong or topshaped, blunt, 6-12 mm. long: scales lanceolate, whitish, acute, about $\frac{1}{2}$ as long as the perigynia : perigynia lanceolate, greenish brown, flat, 4-5 mm. long, 1-2 mm. wide, several-nerved on both faces, each with a sharply 2-toothed rough wing-margined beak.

In meadows, New Brunswick to Manitoba, Florida and Arizona, Summer and fall.

110. Carex scopària Schk. Stems and scapes slender, $1.5-7.5 \mathrm{dm}$. tall, the latter roughish above: leaf-blades less than $3 \mathrm{~mm}$. wide : spikes $3-10$, oblong, narrowed at both ends, bright brown, 6-16 mm. long, usually aggregated into an ovoid head: scales thin, brown, acuminate or cuspidate, shorter than the perigynia : perigynia lanceolate, $4-6 \mathrm{~mm}$. long, rather less than $2 \mathrm{~mm}$. wide, narrowly wing-margined, several-nerved on both faces, each tapering into a ciliate 2-toothed beak.

In moist soil, Nova Scotia to Manitoba, Florida and Colorado. Summer. 
111. Carex stramínea Willd. Stems and scapes slender, $3-7.5 \mathrm{dm}$. tall, the latter roughish above, the top commonly nodding : leaves shorter than the scape; blades $2 \mathrm{~mm}$. wide or less, long-pointed : bracts short or the lower bristle-form and exceeding its spike : spikes 3-8, longer than thick, narrowed at the base, slightly obovoid, 4-5 mm. thick, yellowish brown or greenish : scales lanceolate, acute, about equalling the perigynia, but narrower : perigynia ascending, ovate, brown, about $3 \mathrm{~mm}$. long, strongly several-nerved on the outer face, fewer nerved on the inner, wing-margined, the tapering rough 2-toothed beak shorter than the body.

In dry fields, New Brunswick to Manitoba, North Carolina and the Indian Territory. Summer.

112. Carex mirábilis Dewey. Larger than the next preceding species. Stems and scapes slender, $5-13 \mathrm{dm}$. long : leaf-blades $2-5 \mathrm{~mm}$. wide : spikes larger, as thick as long or thicker, $6-8 \mathrm{~mm}$. in diameter, rather greener, rounded at the base : perigynia spreading, ovate-lanceolate, much longer than the scales, narrowly margined, the beak about as long as the body.

In dry soil, New Brunswick to Manitoba, Georgia and the Indian Territory. Summer.

113. Carex ténera Dewey. Stems and scapes $2-6 \mathrm{dm}$. tall, slender, the latter erect, or the summit nodding, roughish above: leaves shorter than the scape; blades usually less than $2 \mathrm{~mm}$. wide, tapering to a very long tip : spikes 4-6, oval, obtuse, greenish brown, 8-10 mm. long, commonly much contracted at the base : scales lanceolate, about as long as the perigynia, but much narrower : perigynia ovate to ovate-lanceolate, strongly severalnerved on both faces, wing-margined, the tapering rough beak more than $\frac{1}{2}$ as long as the body.

In wet soil, common along brackish marshes, Maine and Ontario to Virginia and Louisiana. Spring.

114. Carex festucàcea Willd. Stems and scapes $3-12 \mathrm{dm}$. tall, the latter nearly or quite smooth: leaves erect; blades $2-4 \mathrm{~mm}$. wide, shorter than the scape : spikes 3-8, green-brown, oblong or nearly globular, clustered, 4-8 $\mathrm{mm}$. in diameter : scales acute or rather obtuse : perigynia orbicular or very broadly ovate, broadly wing-margined, about 3 $\mathrm{mm}$. in diameter, several-nerved on both faces, the roughish beak about $\frac{1}{3}$ the length of the body.

In dry or moist soil, New Brunswick to Assiniboia, Florida and Kansas. Spring and summer.

115. Carex alàta Torr. Stems and scapes $3-10 \mathrm{dm}$. tall, the latter roughish above: leaves shorter than the scape; blades $2-4 \mathrm{~mm}$. wide : spikes oblong or oblong-conic, greenbrown, 10-16 mm. long, 8-10 mm. thick, usually little separated, bractless, or the lower one subtended by a short bract : scales lanceolate, acuminate, scarcely over $0.5 \mathrm{~mm}$. wide : perigynia orbicular or obovate-orbicular, very broadly winged, 4-5 $\mathrm{mm}$. in diameter, faintly few-nerved or almost nerveless, the short beak not more than $\frac{1}{4}$ as long as the body: achenes distinctly stipitate.

In moist soil, New Hampshire to Pennsylvania and Florida, mostly near the coast. Spring.

116. Carex Brittoniàna Bailey. Glabrous. Stems tufted, together with the scapes 4-6 dm. tall, rather stiff : leaves overtopped by the scape ; blades smooth or nearly so, 3-6 $\mathrm{mm}$. wide: spikes $3-5$, contiguous at the top of the scape, sessile, $1.5-2 \mathrm{~cm}$. in diameter, rusty or whitish-rusty, subtended by linear-filiform bracts: scales acute, shorter than the perigynia : perigynia numerous, crowded, $8-10 \mathrm{~mm}$. long, broadly winged, each contracted into a long toothed beak, the body rather broader than long.

On damp prairies, Texas. Spring and summer.

117. Carex renifórmis (Bailey) Small. Stems and scapes slender, $3-7 \mathrm{dm}$. tall, rough above : leaves several ; blades $1.5-3 \mathrm{~mm}$. wide, smooth or slightly rough-margined, overtopped by the scape : spikes 4-6, usually 5, approximate, longer than thick, $6-10 \mathrm{~mm}$. long, not dense at maturity, silvery green : bracts slender or filiform, usually longer than the spikes, the lower ones sometimes $2.5 \mathrm{~cm}$. long: scales ovate or ovate-lanceolate, much shorter than the perigynia, acute : perigynia ascending, 3-4 mm. long, the body, at least, broader than long, normally reniform or nearly so by the broad wing, the beak shorter than the body : achenes sessile. [C. straminea var. reniformis Bailey.]

In alluvial soil, Mississippi and Louisiana. Spring and summer.

118. Carex albolutéscens Schwein. Stems and scapes $3-5 \mathrm{dm}$. tall, stout: leaves shorter than the scape ; blades 2-4 mm. wide : bracts filiform or wanting: spikes $3-8$, oblong, usually narrowed at both ends, silvery green when young, becoming brownish, 8-12 $\mathrm{mm}$. long, clustered : scales lanceolate, acuminate: perigynia broadly ovate, not twice as long as wide, broadly winged, strongly nerved on both faces, about $4 \mathrm{~mm}$. long, the roughish beak about $\frac{1}{3}$ as long as the body: achenes sessile.

In wet soil, abundant along salt meadows, New Brunswick to Pennsylvania, Florida and Alabama. Spring and summer. 
119. Carex Bicknéllii Britton. Stems and scapes 5-10 dm. high, the latter rough above, much surpassing the leaves: leaves mostly nearly basal; blades $3-5 \mathrm{~mm}$. wide : bracts usually very short: spikes 3-7, ovoid, subglobose, or somewhat obovoid, 8-12 mm. long, silvery green or becoming yellowish: perigynia very broadly ovate, thin, severalnerved on the outer face, 4-6 $\mathrm{mm}$. long, the broad membranous wing $1 \mathrm{~mm}$. wide, the rough 2 -toothed beak $\frac{1}{4}-\frac{1}{2}$ as long as the body : achenes stipitate.

In dry soil, New York to Minnesota, the Indian Territory and Kansas. Summer.

\section{Order 6. ARECÀLES.}

Shrubs or trees, with erect or horizontal stems (caudices), growing by a single terminal bud. Leaves at the end of the stem: petioles with imbricated bases : blades plaited in the bud, fan-shaped or pinnate. Flowers perfect or polygamous, disposed on more or less compound axillary spadices. Perianth in 2 series, persistent. Calyx of 3 united or nearly distinct sepals. Corolla of 3 partially united or distinct petals. Androecium of mostly 6, or sometimes 9-12 stamens. Filaments dilated at the base and partially united. Anthers introrse. Gynoecium of 3 more or less united or distinct carpels. Ovules solitary in each carpel, erect, orthotropous or anatropous. Fruit usually a drupe, developed from 1 carpel, or sometimes a berry. Seeds often hollow. Endosperm horny or cartilaginous, rarely channelled, with the embryo near its surface.

\section{Family 1. AREC̀aCEAE Reichenb. Palm Family.}

Characters of the order. [Palmae.]

Leaf-blades fan-shaped.

Calyx and corolla united into a 6-lobed or truncate cup, or obsolete.

Endosperm even : drupe with white flesh.

Endosperm channeled: drupe with black flesh.

Calyx and corolla distinct and manifestly in 2 series.

Style or stigma basal on the drupe.

Style or stigma terminating the drupe.

Lobes of the corolla, or petals, valvate : flowers perfect: carpels free : stigmas sessile.

Lobes of the corolla, or petals, imbricated : flowers mostly polygamodioecious: carpels free only at the base: style slender.

Leaf-blades pinnate.

Drupe with style or stigmas nearly basal: stamens exserted : endosperm not enclosing a milky juice.

Drupe violet-blue: branches of the spadix erect or ascending.

Drupe orange-scarlet : branches of the spadix spreading.

Drupe with style or stigmas terminal: stamens included: endosperm hollow, enclosing a milky juice.

1. Thrinax.

2. Coccothrinax.

3. SABAL.

4. SERENOA.

5. RHAPIDOPHYLLUM.

6. ROYSTONEA.

7. PSEUdOPHOENIX.

8. Cocos.'

\section{THRINAX L.}

Unarmed trees, with solitary or tufted, often elongated stems. Leaf-blades orbicular or sometimes truncate at the base, many-cleft, the segments 2-cleft : rachis short or wanting: ligule free, erect, concave: petioles with smooth edges. Spadix elongated, clothed with tube-like sheaths, paniculately branched. Flowers perfect. Calyx and corolla united into a lobed or truncate cup, not accrescent. Stamens mostly 6 : filaments united at the base. Ovary 1-celled: style columnar: stigma concave or flat. Drupe globose, with a thin white flesh. Seed free, erect. Endosperm horny, even. Embryo lateral. The plants flower in the spring, and mature their fruit about six months later.

Flowers slender-pedicelled: sepals and petals united into an obscurely lobed or truncate cup: filaments subulate: stigma oblique.

Flowers on short disk-like pedicels : sepals and petals partially united, acute : filaments nearly triangular: stigma not oblique.

Trunk without a basal enlargement: spadix $3-6 \mathrm{dm}$. long: drupe $3-4 \mathrm{~mm}$. in diameter.

Trunk with a basal enlargement: spadix nearly $2 \mathrm{~m}$. long: drupe $5-6 \mathrm{~mm}$. in diameter.

1. T. Floridana.

2. T. microcarpa.

3. T. Keyensis.

1. Thrinax Floridàna Sarg. A slender tree, with a slightly tapering trunk becoming about $9 \mathrm{~m}$. tall, usually less than $15 . \mathrm{cm}$ in diameter and partially clothed with the persistent leaf-bases. Leaves ample; blades rather longer than broad, about 9-13 dm. in 
diameter, yellowish green and lustrous above, silvery white beneath, the segments numerous; ligules orange, about $18 \mathrm{~mm}$. long, long-pointed ; petioles $12-14 \mathrm{dm}$. long, $18 \mathrm{~mm}$. broad at the apex to $5-7 \mathrm{~cm}$. broad at the base: spadix about $1 \mathrm{~m}$. long; branches ivorywhite becoming yellow-green or orange in age: pedicels about $3 \mathrm{~mm}$. long, slender: flowers pungent-aromatic : perianth ivory-white : drupes spheroidal, $6-9 \mathrm{~mm}$. in diameter : seeds chestnut-brown, lustrous, the basal cavity extending nearly to the apex.

On sandy shores and coral ridges, southern peninsular Florida and the Keys.

2. Thrinax microcárpa Sarg. A tree sometimes $10 \mathrm{~m}$. tall, with a maximum trunk diameter of about $2.5 \mathrm{dm}$. Leaves ample; blades suborbicular, $1 \mathrm{~m}$. broad, or smaller, pale green above, silvery white beneath, more or less tomentose when young, the segments longer than the body; ligules suborbicular, $2-2.5 \mathrm{~cm}$. broad, concave ; petioles $10-15 \mathrm{~mm}$. broad near the apex : spadix relatively slender, $3-6 \mathrm{dm}$. long; branches curved upward above the middle : perianth white, jointed to a disk-like pedicel, about $3 \mathrm{~mm}$. long, with 6 low broad lobes : filaments triangular, exserted : drupes subglobose, $3-4 \mathrm{~mm}$. in diameter, white: seeds depressed.

In dry coral soil, southern peninsular Florida and the Keys.

3. Thrinax Keyénsis Sarg. A tree with a trunk about $8 \mathrm{~m}$. tall and $2.5-3 \mathrm{dm}$. in diameter raised on a base of matted roots sometimes about $1 \mathrm{~m}$. high. Leaves ample; blades rather longer than broad, about $1 \mathrm{~m}$. in diameter, lustrous and yellowish green above, bluish green and more or less densely pubescent with silvery white hairs beneath, the segments numerous, longer than the body ; ligules acute, about $2.5 \mathrm{~cm}$. long; petioles stout, about as long as the blades, $2.5 \mathrm{~cm}$. broad at the apex, about $10 \mathrm{~cm}$. broad near the base : spadix nearly $2 \mathrm{~m}$. long, incurved; branches orange : pedicels very short, disk-like : flowers faintly aromatic : perianth ivory-white: drupes subglobose, 5-6 mm. in diameter, the flesh thin : seeds chestnut-brown, the basal cavity extending only to the middle.

In sandy soil, Florida Keys.

\section{COCCOTHRINAX Sarg.}

Shrubs or trees, with very short or elongated stems and unarmed foliage. Leaves approximate: blades plaited, suborbicular, or truncate at the base, pale or silvery white beneath, rather thin, more or less deeply parted: ligule free, concave: petioles flattened. Spadices shorter than the petioles, paniculately branched. Spathes papery, 2-cleft. Flowers perfect, slender-pedicelled. Perianth cup-like, obscurely 6-lobed, deciduous. Stamens 9: filaments subulate, nearly distinct. Ovary 1-celled: stigma funnelform. Ovule solitary, anatropous. Drupe subglobose, raised on the thickened receptacle. Seed erect, depressed. Endosperm channeled. Embryo lateral. The plants flower chiefly in the spring.

Plants stemless or nearly so: leaf-blades 2-3 dm. broad: drupes 7-9 mm. in diameter. Plants with upright trunks 4-8 m. tall: leaf-blades 4-6 dm. broad: drupes 12-18 $\mathrm{mm}$. in diameter.

1. C. Garberi.

1. Coccothrinax Gárberi (Chapm.) Sarg. A shrub with a very short stem or none. Leaves erect or spreading; blades suborbicular, rather broader than long, 2-3 dm. in diameter, yellowish green and lustrous above, pale or whitish beneath, the segments many times longer than the body; ligules rounded, $5-8 \mathrm{~mm}$. long; petioles as long as the blades or shorter : spadix erect or ascending, 2-4 dm. long, with slender branches : pedicels 1-3 $\mathrm{mm}$. long : perianth whitish : drupes subglobose, $7-9 \mathrm{~mm}$. in diameter, deep purple: seeds brownish. [ [Thrinax Garberi Chapm.]

On dry coral ridges along Biscayne Bay, Florida.

2. Coccothrinax jucúnda Sarg. An unarmed tree reaching a height of 4-8 m. and a maximum trunk diameter of about $15 \mathrm{~cm}$. Leaves numerous; blades rather longer than broad, 4-6 dm. broad, thinnish, yellow-green and lustrous above, silvery white beneath, the segments longer than the body; ligules orange, crescent-shaped, 16-20 mm. broad; petioles slender, early drooping, rather longer than the blades: spadix about as long as the leaf-blades : peduncles flattened : spathes brittle, reddish brown : pedicels rigid, spreading, about $3 \mathrm{~mm}$. long : perianth white : drupe subglobose, $12-18 \mathrm{~mm}$. in diameter, violet or nearly black at maturity, lustrous, edible: seeds tawny brown. [Thrinax argentea Chapm., not R. \& S. ]

On dry coral ridges, southern peninsular Florida and the Keys.

\section{SABÁL Adans.}

Unarmed plants with subterranean, creeping or erect stems. Leaves ample : blades fanshaped, cordate or narrowed at the base, many-cleft, the segments 2-cleft at the apex, often 
filamentose: ligule partially united to the rachis: petioles concave above, sharp-edged. Spadix decompound, commonly drooping. Flowers perfect. Perianth white or green, glabrous, sessile, not accrescent. Calyx cup-shaped. Sepals 3, unequal. Petals 3 , nearly distinct, imbricated. Stamens 6 : filaments subulate or lanceolate, their dilated bases united and adnate to the corolla. Ovary 3-celled : style 3-angled : stigma truncate. Drupe usually developed from 1 carpel, with a membranous epicarp and a fleshy pericarp. Seed solitary, spheroidal, erect with a dark brown, shining testa. Endosperm horny. The plants flower chiefly during the spring and summer.

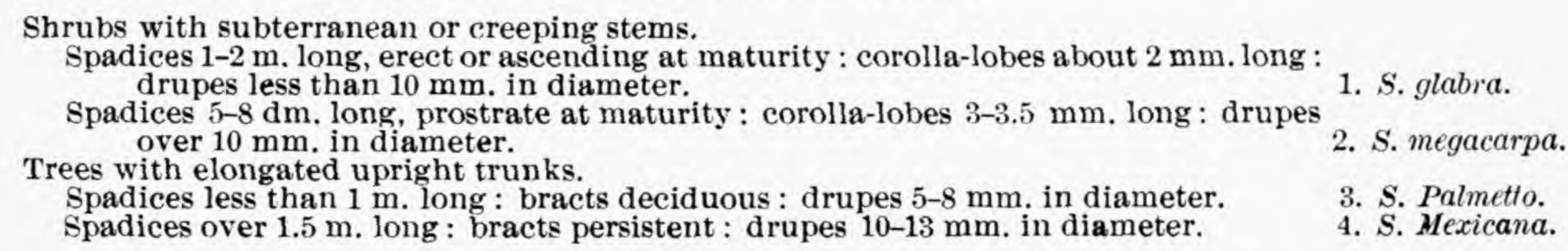

1. Sabal glabbra (Mill.) Sarg. A low shrub, with a subterranean stem several dm. long. Leaves clustered, 8-16 dm. tall ; blades suborbicular, 4-10 dm. in diameter, glaucous or pale green, the segments shallowly cleft at the apex, fully as long as the body of the leaf or shorter ; ligule 1-2 cm. long ; petioles shorter than the blades : spadices erect or ascending, 1-2 m. long, the ultimate branches slender, many-flowered: perianth whitish : calyx about $1 \mathrm{~mm}$. high : sepals acute or acutish : petals over twice as long as the calyx, oblong, concave: drupes subglobose, about $8 \mathrm{~mm}$. in diameter, black. $[S$. Adansonii Guerns.]

In low grounds along or near streams, South Carolina to Florida and Louisiana. Dwarf Palmetro. BLUE-STEM.

2. Sabal megacárpa (Chapm.) Small. A low shrub, with creeping elongated contorted stems. Leaves several, 8-14 dm. tall ; blades suborbicular, 4-8 dm. in diameter, the segments longer than the body, deeply cleft at the apex, filamentose; petioles longer than the blades, sharp-edged: spadices 5-8 dm. long, early erect or ascending, but prostrate at maturity, branching above : perianth yellowish white : calyx about $1.5 \mathrm{~mm}$. long: sepals broad : petals elliptic, $3-3.5 \mathrm{~mm}$. long, obtuse, 5 -nerved, concave : stamens about as long as the petals : drupes subglobose, $15-20 \mathrm{~mm}$. in diameter. [S. Etonia Swingle.]

In the scrub or coral sand, peninsular Florida SCRUb Palmetto.

3. Sabal Palmétto (Walt.) R. \& S. A tree ranging from 5 to $20 \mathrm{~m}$. in height, with a maximum trunk diameter of about $6 \mathrm{dm}$. Leaves widely spreading or drooping; blades often slightly broader than long, 1.5-2.5 m. in diameter, deep green and lustrous, the segments cleft, filamentose; ligule about $10 \mathrm{~cm}$. long; petioles stout, about as long as the blades: spadices 6-8 dm. long, more or less drooping; branches recurved, the ultimate divisions slender : flowers in the axils of acute deciduous bracts : sepals triangular, shorter than the perianth-tube: petals oblong or oblong-lanceolate, about as long as the subulate filaments : drupes subglobose, $5-8 \mathrm{~mm}$. in diameter.

On or near the coast, North Carolina to Florida. Palmetro. Cabbage Palmetto. Cabbage Tree.

4. Sabal Mexicàna Mart. A tree often $8-16 \mathrm{~m}$. tall, with a maximum trunk diameter of about $8 \mathrm{dm}$. Leaves ample; blades $1.5-2 \mathrm{~m}$. in diameter, lustrous, yellowish green, the segments often parted, filamentose; ligules about $15 \mathrm{~cm}$. long; petioles stout, as long as the blades or longer : spadices $2-2.5 \mathrm{~m}$. long, spreading or drooping; branches spreading, the ultimate divisions stout: flowers in the axils of scarious persistent bracts : sepals about as long as the perianth-tube, obtuse : petals oblong-lanceolate, acutish, about as long as the lanceolate filaments: drupes subglobose, 10-13 mm. in diameter, or 2-3-lobed.

In sandy soil, along the Rio Grande, Texas and northern Mexico.

\section{SERENÒA Hook.}

Armed trees, or low plants, with creeping or horizontal stems. Leaves clustered : blades fan-shaped, suborbicular, many-cleft, the segments narrow, 2-cleft at the apex, without a rachis: ligule short: petioles armed on the edges with rigid spine-like teeth. Spadix elongated, zigzag, pubescent. Flowers perfect, sessile, not accrescent, each subtended by a bract and 2 bractlets. Sepals partially united. Petals valvate, 2-keeled within. Stamens 6 : filaments filiform, adnate to the corolla below. Carpels 3 , free at the base, 3-angled, each narrowed into a slender style with a minute stigma. Drupe ovoid or globose, with a thin fleshy pericarp which is slightly fibrous within. Seed erect, solitary, 
slightly flattened on the ventral side. Endosperm solid. The plants flower chiefly in the spring and early summer.

shrub with creeping or horizontal stems : perianth 4-6 mm. long: drupe ovoid-obiong. 1. S. serrulata. Tree with a tall upright trunk : perianth about $1 \mathrm{~mm}$. long: drupe globose.

2. S. arborescens.

1. Serenoa serrulàta (Michx.) Hook. A shrub, with horizontal or creeping stems 1-2.5 m. long. Leaves erect or ascending; blades suborbicular, 3-7 dm. broad, rather stiff, light green, the segments cleft; petioles usually longer than the blades, armed with sharp spiny teeth : spadix erect or spreading, much shorter than the leaves, paniculately branched; branches tomentose : flowers fragrant, usually numerous : perianth ivory-white, sessile : calyx cup-shaped, about $1 \mathrm{~mm}$. high, shallowly lobed : petals about $3 \mathrm{~mm}$. long, oblong : drupe ovoid-oblong, $15-18 \mathrm{~mm}$. long, black : seeds subglobose.

In sandy soil, North Carolina and Arkansas to Florida and Texas. SAw PaLMETto.

2. Serenoa arboréscens Sarg. A tree, with one or several erect ascending or decumbent trunks $8-12 \mathrm{~m}$. tall and $6-10 \mathrm{~cm}$. thick. Leaves spreading in all directions ; blades half-orbicular, $5-6 \mathrm{dm}$. broad, yellowish green above, blue-green beneath, truncate at the base, the segments linear-lanceolote; ligule thin, short-pointed, with a red-brown deciduous margin ; petioles slender, rather shorter than the blades, armed with stout flattened orange teeth: spadix drooping, $1 \mathrm{~m}$. long or a little longer, its rachis flattened, paniculately branched; branches hoary-tomentose : flowers solitary or 2-3 in a cluster, sessile : perianth little over $1 \mathrm{~mm}$. long : sepals chestnut-brown, oblong, sometimes lacerate : petals yellowish green, nearly distinct, oblong-ovate, acute : filaments almost triangular : drupes globose, usually $8-9 \mathrm{~mm}$. in diameter, black, lustrous : seeds solitary, somewhat flattened at the base.

About margins of swamps, along the Chockoloskee River, southern peninsular Florida.

\section{RHAPIDOPHÝLLUM H. Wendl. \& Drude.}

Low armed shrubs or trees, with erect or creeping stems. Leaves ample: blades suborbicular, deeply and unequally cleft, silvery beneath, the segments entire or 2-cleft at the apex, without marginal filaments : rachis wanting : ligule very short, rounded : petioles 3-angled, woolly beneath, the edges denticulate. Spadix short, erect, flattened, the short branches densely flowered. Flowers perfect or polygamo-dioecious. Perianth yellow, not accrescent. Sepals broad gibbous at the base. Petals 3, broad, imbricated. Stamens 6. Carpels usually 3, distinct : stigmas nearly sessile, recurved. Drupes solitary, rarely 3 -lobed, with a fibrous pericarp. Seed spheroidal, erect. Endospern horny, somewhat channeled. Embryo dorsal.

1. Rhapidophyllum Hýstrix (Fraser) H. Wendl. A shrub with a proliferous erect or creeping stem 6-9 dm. long. Leaves about $1 \mathrm{~m}$. long, somewhat glaucous ; blades suborbicular, 5-7 dm. in diameter, the segments numerous, 2-4-toothed, scurfy beneath ; petioles triangular, rough-edged : sheaths of fibers interwoven in the stout spines : spadices 15-30 cm. long, short-peduncled : spathes often 4, woolly : perianth with ovate petals : drupe ovoid or oval-ovoid, 18-25 mm. long, red.

In shaded pine lands, South Carolina to Florida. Spring or early summer. Blue Palmetto. NeEdLe Palm.

\section{ROYSTÒNEA O. F. Cook.}

Tall unarmed trees, with erect, cylindric or spindle-shaped stems. Leaves with pinnate blades, the segments narrow, 2-cleft at the apex : rachis chaffy below : petioles dilated at the base: spadix pendulous, with slender drooping branches, shorter than the leaves. Flowers rather monoecious. Perianth white, sessile, the staminate often longer than the pistillate: sepals imbricated, unequal : petals valvate: stamens 6,9 or 12 , exserted : ovary rudimentary. Pistillate flowers with broader and more strongly imbricated sepals, broader petals, 6 scale-like staminodia and a 3-celled ovary. Drupe ovoid or obovoid, curved, with a fleshy-fibrous pericarp and a thin endocarp. Seed solitary, with a thin crustaceous testa. Endosperm horny, even. Embryo basal.

1. Roystonea règia (H.B.K.) O. F. Cook. A stately tree $20-30 \mathrm{~m}$. tall, with a trunk often 5-6 dm. in diameter, tapering from the middle to both ends and arising from an enlarged base. Leaves 3-4 m. long: blades pinnate, the segments numerous, approximate, $7-9 \mathrm{dm}$. long at the base of the blades, shorter above, acuminate, arising obliquely from the upper side of the rachis; petioles terete above, concave at the base : spadix 5-6 
dm. long: peduncles $2-2.5 \mathrm{~cm}$. thick, nearly terete; branches, except those bearing flowers, flattened above : perianth white; staminate $6-7 \mathrm{~mm}$. long, the sepals and petals oblong or ovate-oblong, acute or acutish ; pistillate perianth barely $\frac{1}{2}$ as long as the staminate, the sepals and petals triangular or ovate-triangular, slightly pinched below the apex : drupe oval-oblong or globose-oval, or sometimes slightly narrowed at the base, 12-14 $\mathrm{mm}$. long, violet-blue. [Oreodoxa regia H.B.K.]

In hammocks, southern peninsular Florida and the Keys, also in the West Indies and Central America. It flowers mainly in winter. ROYal PALM.

\section{PSEUDOPHOENIX H. Wendl.}

Unarmed trees, with enlarged bases and narrowly spindle-shaped trunks. Leaves arching, with pinnate blades, the segments numerous, narrow, longest and broadest about the middle of the blade, ascending: rachis concave above near the base, with gland-like excrescences along the sides: petioles relatively short, the margins thin, entire. Spadix much shorter than the leaves, pendulous, branched, glabrous, barely zigzag. Flowers monoecious: staminate not yet seen : pistillate with a 3-lobed cup-like calyx, 3 acute petals and 6 staminodia with imperfect anthers. Drupe subglobose or sometimes 2-3-lobed. bright-colored, with a thin mesocarp. Seed free, erect, slightly depressed. Endosperm uniform. Embryo basal.

1. Pseudophoenix Sargéntil H. Wendl. An unarmed tree, ranging from 6 to $8 \mathrm{~m}$. tall, with a maximum trunk diameter of about $3 \mathrm{dm}$. Leaves $1.5-2 \mathrm{~m}$. long; blades pinnate, the segments narrowly linear-lanceolate, acuminate, $4-4.5 \mathrm{dm}$. long at the middle of the blade, decreasing in size toward each end ; petioles strongly concave or nearly involute, $15-20 \mathrm{~cm}$. long : spadix slightly shorter than the leaves, becoming $6-7.5 \mathrm{dm}$. broad, yellowish green, the branches rather widely spreading, slightly flattened, the ultimate divisions rigid : pistillate flowers numerous : petals ovate or oblong-ovate, pinched under the acute or obtuse apex : drupe subglobose or 2-3-lobed, $12-20 \mathrm{~mm}$. broad, orange-scarlet, on pedicels $4-6 \mathrm{~mm}$. long.

In sandy soil, Elliott's and Long Keys, Florida.

\section{8. còcos L.}

Unarmed trees, with erect usually elongated stems. Leaves often ample : blades pinnate, the segments entire, toothed or cleft at the apex, 1-nerved, the rachis acute above, concave beneath. Spadix at length drooping. Flowers monoecious, white or yellowish : staminate with lanceolate or triangular valvate sepals, oblique valvate petals, 6 included stamens and a rudimentary ovary, or this wanting: pistillate flowers often larger than the staminate, accrescent, with thick imbricated sepals, included imbricated petals, an annular disk and a 3-celled ovary, in which 2 cavities are often imperfect. Drupe terete or 3 -angled, with a thick fibrous pericarp and a bony endocarp. Seed with a brown or reddish testa. Endosperm often hollow.

1. Cocos nucífera L. A stately tree often $12-30 \mathrm{~m}$. tall, with a trunk diameter varying from 2-6 dm. Leaves ample; blades pinnate, 3-5 m. long, short-petioled, the segments numerous, 5-7 dm. long, commonly 4-5 cm. broad: spadix 1-2 $\mathrm{m}$. long, the branches firm, 3-4 dm. long: perianth of staminate flowers fully $1 \mathrm{~cm}$. long : petals about twice as long as broad: pistillate perianth about $2.5 \mathrm{~cm}$. high, somewhat broader : drupe oval, or slightly broadest above or below the middle, obtusely 3 -angled, $2-3 \mathrm{dm}$. long, with a thick husk : stone with a wall $3-5 \mathrm{~mm}$. thick : endosperm hollow, enclosing a milky juice.

In sandy soil, peninsular Florida. Introduced. Also in all tropies. Coco PALM. Coco-NUt PALM.

\section{Order 7. ARÀLES.}

Perennial, frequently bog or aquatic herbs, or rarely trees ; in LEMNACEAE reduced to very small or minute floating thalloid plants. Leaves mainly basal : blades sword-like or expanded. Inflorescence a spadix, the complete or incomplete flowers wholly or partially covering the axis, sometimes subtended by or enclosed in a spathe, or in LEMNACEAE, with one or few flowers in propagative pouches on the margin of the plant-body. Perianth not readily separable into calyx and corolla, sometimes wanting. Fruit a berry or a utricle. 
Plants normal, with the flowers in a spadix, this sometimes subtended by or partly enclosd in a spathe.

Plants reduced to small floating thalloid structures, with one or few flowers. FAM. 2. LEMNACEAE.

\section{Family 1. ARÀCEAE Neck. Arum Family.}

Fleshy, mostly acaulescent herbs, with short or elongated rootstocks. Leaves basal : blades simple, sometimes divided. Flowers perfect, monoecious or dioecious, borne in a dense thick spadix, the staminate above the pistillate. Spadix subtended by or enclosed in a spathe. Perianth of 4-6 scale-like members, or wanting. Androecium often of 4-10 stamens. Filaments very short. Anthers 2-4-celled, with thick truncate connectives : sacs opening by dorsal slits or pores. Gynoecium of a single carpel or several united carpels. Ovary 1-several-celled. Stigma terminal, minute. Ovules 1-several in each cavity. Fruit a berry or utricle. Seeds with a smooth or sculptured testa.

Flowers monoecious or dioecious : perianth wanting.

Spadix free: pistillate flowers numerous.

Leaf-blades 3-many-divided: axis of the spadix naked above.

Lẹaf-blades palmately divided : spathe involute below, hooded above : spadix included, terete or obscurely angled.

Leaf-blades pedately divided: spathe convolute throughout: spadix exserted, more or less flattened or 2-edged.

Leaf-blades simple: axis of the spadix completely covered with flowers. Spadix adnate to the spathe: pistillate flower solitary.

Flowers perfect: perianth of several scale-like members.

Spadix surrounded by a spathe.

Spadix naked, merely subtended by a spathe.

Spadix terminating the club-shaped scape.

Spadix borne somewhat laterally on the leaf-like scape.

1. Arisaema.

2. MURICAUDA.

3. Peltandra.

4. PISTIA.

5. Spathyema.

6. ORontium.

7. Acorus.

\section{ARISAÈMA Mart.}

Scapose fleshy herbs, with acrid corms. Leaves basal, 1-3, erect: blades palmately 3-5-divided. Scapes erect, shorter than the leaves. Spadix free, bearing flowers on the lower part of its markedly differentiated fertile portion, the sterile portion club-shaped, included. Spathe cornucopia-like, convolute below, dilated above. Flowers destitute of a perianth, dioecious or monoecious: staminate of 4 nearly sessile 2-4-celled anthers, each opening by confluent slits at the apex. Pistillate flowers several, each with a 1-celled ovary. Stigmas peltate-capitate. Ovules 1-several, orthotropous. Fruits subglobose, red, in conspicuous heads. Endosperm copious. Jack-IN-the-Pulpit. Indian Turnip.

Leaf-segments 3 : spathe acuminate or acute.

Sterile part of the spadix 1-2 mm. thick: fruits 4-5 mm. in diameter.

Sterile part of the spadix 4-6 mm. thick: fruits $8-12 \mathrm{~mm}$. in diameter.

Dilated portion of the spathe mainly purple and brown, less than twice as long as broad, acute or short-acuminate.

Dilated portion of the spathe green, over twice as long as broad, long-acuminate. Leaf-segments 5 (the lateral ones sometimes more or less united): spathe abruptly short-pointed.

1. A. pusillum.

2. A. triphyllum.

3. A. acuminatum.

4. A. quinatum.

1. Arisaema pusíllum (Peck) Nash. Corm small, subglobose or spheroidal : leaves usually 2 , or 1 on staminate plants, $2-4 \mathrm{dm}$. tall ; petioles $5-18 \mathrm{~cm}$. long, or $7-10 \mathrm{~cm}$. in the case of the second leaf ; segments 3, thinnish, ovate to oblong or elliptic, acuminate, $5-12 \mathrm{~cm}$. long, green on both sides : scapes shorter than the petioles: spathe with the convolute portion $3-5 \mathrm{~cm}$. long, white without, red-brown within, the dilated part 5-6 $\mathrm{cm}$. long, acuminate, green without, dark red-brown within, or almost black: spadix slender, 1-2 $\mathrm{mm}$. thick; staminate $4-5 \mathrm{~cm}$. long; pistillate $5-6 \mathrm{~cm}$. long : anthers purple : fruits red, 1-5 $\mathrm{mm}$. in diameter.

In open swamps and deep woods, New York to Kentucky and Georgia. Late spring and summer.

2. Arisaema triphýllum (L.) Torr. Corm globose or spheroidal, sometimes 10 cm. in diameter : leaves usually 2 , sometimes solitary, 2-16 dm. tall ; segments 3 , ovate to elliptic or the middle one obovate, sessile, $8-30 \mathrm{~cm}$. long, acute or acuminate, erose, the lateral ones sometimes lobed at the base: scape erect, shorter than the petioles, simple: spathe with the lower portion white, the dilated portion often striped with purple, or brown and green, acuminate : spadix stout, 4-6 mm. thick; staminate 4-9 $\mathrm{cm}$. long; pistillate $5-10 \mathrm{~cm}$. long : fruits bright red, $10-12 \mathrm{~mm}$. in diameter. Spring.

In swamps or on shaded hillsides, Nova Scotia to Minnesota, Kansas, Florida and Louisiana.

3. Arisaema acuminàtum Small. Similar to A. triphyllum in habit, but much more slender and deliçate. Leaves 3-5 dm. tall ; segments lanceolate to elliptic or ovate-lanceo- 
late, acuminate, 7-12 cm. long, erose-ciliolate, bright green: spathe green throughout, the dilated portion deeper green than the convolute part, over twice as long as broad, long-acuminate.

In low rich woods, eastern and peninsular Florida. Spring.

4. Arisaema quinàtum (Nutt.) Schott. Corms often $3-7 \mathrm{~cm}$. in diameter: leaves 2 , or often solitary, quite large; segments 5 , erose, otherwise entire, the lateral ones sometimes partially united, or rarely only 3 , oval to elliptic, apiculate, glaucous beneath ; lateral nerves uniting and forming 2-3 marginal nerves: scapes about $\frac{1}{2}$ as long as the petioles: spathe $6-10 \mathrm{~cm}$. long, acute or acuminate: spadix $3-4 \mathrm{~mm}$. thick: fruits $6-7$ $\mathrm{mm}$. in diameter, red, crowded in a globose or oblong head. [A. polymorphum (Buckl.) Chapm. ] Spring.

In woods and rich soil, North Carolina and Tennessee to Georgia, Alabama and Mississippi.

\section{MURICAÙdA Small.}

Acaulescent herbs, with corms. Leaves basal, erect: blades several, pedately divided, the segments variable in size. Scape erect, overtopped by the leaves. Spadix more or less flattened or 2-edged, bearing flowers all over its slightly differentiated fertile portion, the sterile portion slender or filiform, long-exserted beyond the top of the spathe. Spathe convolute throughout, narrowed above. Flowers monoecious or dioecious : perianth wanting. Ovary turbinate. Ovules 6-8, bottle-shaped. Fruits in dense bright-colored heads. Endosperm present.

1. Muricauda Dracóntium (L.) Small. Foliage deep green. Leaves usually solitary, 3-10 dm. tall ; blades pedately divided, the segments $5-17$, oblong, oblanceolate or cuneate, 1-3 dm. long, abruptly pointed or acuminate, entire, or the lateral ones lobed: spathe white or greenish, 3-10 cm. long : spadix prolonged into a slender whip-like longexserted tip, 5-20 $\mathrm{cm}$. long, that of staminate plants, with the flowering part about as long as the tubular part of the "spathe; that of monoecious plants with the pistillate part near base of spadix : fruits bright red, 6-8 $\mathrm{mm}$. in diameter. [Arisaema Dracontium (L.) Schott.] RоOT.

In moist woods, Maine to Ontario, Minnesota, Florida and Texas. Spring. Green Dragon. Dragon

\section{PELTÁNDRA Raf.}

Swamp-inhabiting herbs. Leaves basal: blades shorter than the petioles, entire, sagittate or hastate. Scapes shorter than the leaves, at length recurved. Spathe green or petal-like, wholly convolute or expanding above, often undulate or crisped. Spadix covered by the monoecious flowers. Perianth wanting. Flowers inconspicuous: staminate uppermost, at first shield-like scales, in whose edges are imbedded 6-10 anthers, these opening by apical pores and finally nearly free: pistillate flowers merely 1-celled carpels surrounded by 4-5 scale-like staminodia. Ovules 1 or few, amphitropous. Fruits green or crimson, in heads surrounded by the leathery base of the spathe. Seeds 1-3, surrounded by a tenacious jelly. Endosperm wanting. Arrow-Arum.

Spathes convolute throughout, narrow, green : fruits green.
Spathes dilated and spreading above, mainly white: fruits crimson.

1. P. Virginica.

2. P. sagittaefolia.

1. Peltandra Virgínica (L.) Kunth. Foliage dark green. Leaves erect or ascending, 2-3 dm. tall, often numerous ; blades sagittate or hastate-sagittate, ovate or oblongovate in outline, 1-3 dm. long, acute or acuminate, undulate, the lateral nerves spreading: scapes about as long as the petioles, recurving and often immersing the fruit at maturity : spathe green, 8-20 cm. long, enveloping the spadix, elongated, pale and crisped along the edges : spadix tapering, shorter than the spathe, $\frac{1}{4}$ pistillate, $\frac{3}{4}$ staminate : fruits slightly angled, $1-1.5 \mathrm{~cm}$. in diameter, green. Staminate part of spadix and upper part of spathe decaying at maturity.

In swamps or shallow pools, Maine to Ontario, Michigan, Florida and Louisiana. Spring and summer.

2. Peltandra sagittaefòlia (Michx.) Morong. Foliage deep green. Leaves basal, 3-5 dm. tall, few ; blades sagittate, 1.5-2 dm. long, acute or acuminate, thinnish, the basal lobes about $\frac{1}{2}$ as long as the middle lobe, obtuse: scapes sometimes as long as the leaves : spathes white, or green merely at the base, $4-10 \mathrm{~cm}$. long, dilated above : spadix over $\frac{1}{2}$ as long as the spathe, $\frac{1}{2}$ pistillate, $\frac{1}{2}$ staminate : fruits irregularly globose, about $1 \mathrm{~cm}$. in diameter, crimson. [Peltandra alba Raf.]

In bogs or springy places, Virginia to Florida and Alabama. Spring and summer. 


\section{PÍstia L.}

Free-floating herbs, with fibrous roots. Stems jointed. Leaves clustered at the nodes: blades broadened upward, simple, entire. Spathes axillary, sessile or nearly so, tubular below, spreading above. Spadix adnate to the spathe. Flowers few, monoecious : pistillate solitary on lower part of spadix : staminate above, subtended by a cup-like involucre. Perianth wanting. Anthers 3-8-celled: sacs opening transversely. Ovary 1-celled. Ovules several, ascending, orthotropous.

1. Pístia Stratiòtes L. Foliage nearly glabrous. Roots furnished with numerous hair-like rootlets : stems elongating: leaves clustered ; blades cuneate or obovate-cuneate, 4-13 cm. long, rounded or notched at the apex, prominently nerved beneath : spathes white, or partially so, about $1.5 \mathrm{~cm}$. long, short-peduncled, villous, the lower part convolute, the upper part flat, ovate : spadix adnate to the spathe : pistil solitary.

In still water, Florida to Texas. Also throughout the tropics. Water Lettuce.

\section{SPATHYÈMA Raf.}

Swamp-inhabiting stinking herbs. Leaves basal: blades ample, cordate, leathery. Scapes erect, partly underground, very thick. Spathe shell-like, leathery, often variegated, slightly twisted at the apex. Spadix oblong or globose, completely enclosed in the spathe, short-stalked. Flowers perfect, covering the spadix. Perianth of 4 hooded members. Stamens 4 : anthers 2-celled; sacs opening lengthwise, extrorse. Ovary sunken in the spadix, 1-celled : style pyramidal, 4-sided: stigma minute. Ovule solitary, anatropous, suspended. Fruits immersed in the spadix, adnate to the accrescent fleshy perianth. Seed solitary, irregular. Endosperm wanting. [Symplocarpus Salisb.]

1. Spathyema foètida (L.) Raf. Foliage glabrous. Herbage garlic-scented : leafblades ample, 2-9 dm. long, oblong to ovate, obtuse, undulate, thick, truncate or subcordate at the base : petioles stout, shorter than the blades: scapes erect, mostly subterranean : spathe preceding the leaves, $8-15 \mathrm{~cm}$. long, ovoid, with a more or less curved beak, greenish or yellowish, mottled with purple: spadix subglobose, $2-2.5 \mathrm{~cm}$. becoming $10-15 \mathrm{~cm}$. in diameter at maturity : fruits spheroidal or globose, green : seeds subglobose, $9-15 \mathrm{~mm}$. thick. [Symplocarpus foetidus (L.) Nutt.]

In swamps or low grounds, Nova Scotia to Minnesota, Florida and Missouri. Winter or early spring. Skunk Cabbage. Midas' Ears.

\section{ORÓNTIUM L.}

Aquatic or swamp-inhabiting herbs, with deeply buried rootstocks. Leaves basal: blades flat. Scapes terete below, enlarged under the spadix. Spathe enclosing the spadix when young, persisting as a sheath-like bract at its base or deciduous. Spadix golden yellow, terminal, naked. Flowers perfect, covering the spadix. Perianth of 4-6 (6 below, 4 above), scale-like imbricated sepals. Filaments broader than the anthers, abruptly contracted above. Anther-sacs 2, spreading, opening by oblique valves. Ovary 1-celled, depressed, sunken in the spadix-axis. Ovule solitary, half-anatropous. Utricle green. Seed solitary. Endosperm wanting.

1. Orontium aquàticum L. Rootstock thick, uneven : leaf-blades thickish, oblong or elliptic, 1-3 dm. long, acute or apiculate, entire, gradually or abruptly narrowed at the base, sometimes lustrous, often inequilateral, petioled : scapes solitary or clustered, terete, or flattened below the spadix, 2-6 dm. long, or elongating and reclining at maturity : spathe bract-like, 4-10 cm. long, 2-keeled on the back, early falling away: spadix yellow, tapering upward, 2-6 $\mathrm{cm}$. long: utricles spheroidal. about $1 \mathrm{~cm}$. thick, few developing.

In swamps and shallow ponds, central Massachusetts to Florida and Louisiana. Spring. GoLdENCLUB. BOG TORCHES.

\section{7. ÁCORUS L.}

Swamp-inhabiting herbs, with elongated aromatic pungent rootstocks. Leaves basal : blades linear, sheathing each other and the base of the scape. Scapes erect, 3-angled, keeled on the back, channeled on the front, rather leaf-like. Spathe sword-like, apparently a prolongation of the scape. Spadix conic-cylindric, laterally attached, naked. Flowers perfect, crowded on the surface of the spadix-axis. Perianth of 6 concave membranous members. Filaments flattened. Anthers reniform or sagittate : sacs 2, con- 
fluent at maturity. Ovary 3-4-celled, oblong. Ovules 2-8, anatropous. Fruits gelatinous, 2-3-celled. Seeds several. Endosperm copious. Calamus. Sweet Flag.

1. Acorus Cálamus L. Rootstocks horizontal, pungent-aromatic: leaves several, 5-20 dm. tall ; blades linear, attenuate, sharp-edged, bright green : scape quite similar to the leaves, often narrower: spathe similar to the leaves, extending 2-8 dm. beyond the spadix, attenuate, erect: spadix elongated-conic, 3-8 $\mathrm{cm}$. long, yellowish, ascending or spreading, densely flowered : fruits 4-5 mm. long, lustrous.

In marshes and springy places, Nova Scotia to Minnesota, Florida and Texas. Spring and summer.

\section{FAmily 2. LEMNÀCEAE Dumort. Duckweed Family.}

Perennial floating herbs, consisting chiefly of very small, often minute, fleshy structures, representing modified stems, sometimes with 1 or several roots. Vegetative reproduction is accomplished by lateral branching. Propagative pouches 1 or 2 in each body. Flowers monoecious, one or two staminate and one pistillate, arising from a point in a propagative pouch. Staminate flowers consist of 1 stamen. Anthers 1-2-celled : sacs opening lengthwise or transversely. Pollen of minutely barbellate spherical grains. Pistillate flowers consist of 1 carpel, stigmatic at the apex. Ovules one or several. Fruit a utricle.

Plant-body much elongated or subglobose, not disk-like, rootless : propagative pouch solitary.

Plant-body very thick or subglobose.

Plant-body thin, tongue-like or saber-form.

Plant-body disk-like, with 1 root or several roots : propagative pouches 2.

Plant-body inconspicuously nerved: root solitary, without a fibro-vascular bundle. 3. LEMNA.

Plant-body conspicuously nerved : roots several, each with a fibro-vascular bundle. 4. SPIRodelA.

\section{WóLffia Horkel.}

Plant-body much thickened or subglobose, with the stipe attached beneath the propagative pouch near the margin. Propagative pouch funnelform, opening near the base of the plant-body. Spadix of 1 staminate and 1 pistillate flower bursting through the upper surface of the plant-body. Anther 1-celled. Ovule 1, orthotropous. Utriclesmooth.

Plant-body smooth, somewhat flattened above, gibbous beneath, brown-punctate. $\quad$ 1. W. punctata. Plant-body ellipsoidal or globose, with $2-3$ papules on dorsal surface, not punctate. 2 . W. Columbiana.

1. Wolffia punctàta Griseb. Plants solitary; body boat-like, elliptic to ovoid-oblong, $0.58-0.82 \mathrm{~mm}$. long, flat, or nearly so above, gradually rising at the apex, whole surface punctate with brown cells : tissue various; lower portion of the plant-body composed of larger cells than the upper. [W. Brasiliensis ;of Am. Auth., not of Wedd.]

In still or stagnant water, Ontario to Michigan, Illinois and Tennessee. Summer.

2. Wolffia Columbiàna Karst. Plants solitary ; body globose to ellipsoidal, 0.48$1 \mathrm{~mm}$. long, the upper surface convex, with a row of inconspicuous papillae only a small portion emersed, this with 1-10 stomata, not punctate : tissue of uniform large cells.

In lakes and pools, Massachusetts to Ontario, Minnesota, Florida and Louisiana. Spring to fall.

\section{WOLFFírLLA Hegelmaier.}

Plant-body thin, tongue-shaped or saber-form, with the stipe attached on the margin of the.propagative pouch. Roots wanting. Propagative pouch solitary, triangular, opening by a slit in the basal margin of the plant-body. Inflorescence and fruit unknown.

1. Wolffiella Floridàna (J. D. Smith) C. H. Thompson. Plants minute, solitary or usually several generations cohering, thus forming dense mats; body elongated, attenuate from the base to the slender apex, 5.5-8.5 mm. long, hollow except near the apex.

In still or stagnant water, Missouri to North Carolina, Georgia, Florida and Texas. Spring to fall.

\section{LÉMNA L.}

Plant-body disk-like, with 1-5 inconspicuous nerves, the stipe attached to the basal margin. Roots solitary, each with a blunt or pointed root-sheath. Propagative pouches 2, triangular, opening by slits in either margin of the basal part of the thallus. Spadix of 1 pistillate and 2 staminate flowers, arising from the propagative pouches. Anthers 2celled : sacs opening transversely. Ovary with 1 orthotropous and amphitropous ovule or 2-6 anatropous ovules. Utricle somewhat flattened, often ribbed. DucKwEED.

Plant-bodies long-stipitate, forming large submerged masses.

Plant-bodies sessile, or short-stipitate, fl
Plant-body symmetrical or nearly so.

Plant-body oblong-obovate: utricle lenticular.

1. L. trisulca..

2. L. minor. 
Plant-body elliptic or oblong: utricle elongated.

Plant-body unsymmetrical.

Plant-body thick, obliquely obovate, papillose on the median line.

Plant-body thin, oblong, smooth

Plant-body manifestly 3 -nerved : root-sheath with lateral appendages.

Plant-body obseurely 1-nerved: root-sheath without appendages.

6. L. cyclostasa.

1. Lemna trisúlca L. Plants prolific, often forming dens colonies of several generations. Root-sheath acute: plant-bodies both submerged and aërial, oblong to oblonglanceolate, often falcate, $5-10 \mathrm{~mm}$. long, acute, smooth, attenuate at the base or hastate when young : aërial plants smaller than the submerged and short-stalked, cavernous; submerged plants with twisted stipes: seeds prominently 12-15-ribbed.

Mostly in springs and flowing water, Nova Seotia to British Columbia, North Carolina, Alabama, New Mexico and California. Also in the eastern hemisphere. Summer.

2. Lemna minor L. Plants solitary or few in colonies, prolific. Root-sheath short, obtuse : plant-bodies thickish, elliptic, obovate or suborbicular, 2-4 mm. long, obscurely mostly 3-nerved, hollow, commonly keeled on the back and papillose on the midrib; apical papillae prominent : spathes cleft, finally ruptured: seeds uneven, 12-15-ribbed.

In ponds, lakes and stagnant water, Ontario to Vancouver Island, Florida and California. Summer.

3. Lemna mínima Philippi. Plants solitary or 2 , or sometimes 4 , in colonies. Rootsheath short, curved: plant-body oblong or elliptic, $1.5-3.9 \mathrm{~mm}$. long, rounded at the apex, sometimes slightly oblique, nearly nerveless, convex above, narrowly margined, cavernous in the central portion : seeds oblong, acute, $1.5 \mathrm{~mm}$. long, commonly 16-ribbed.

In still water, Wyoming to Georgia. Florida and California. Summer.

4. Lemna perpusílla Torr. Plants solitary or more commonly 2-6 in colonies. Root-sheath acute, $0.8-2 \mathrm{~mm}$. long: plant-body thick, obovate, usually obliquely so, unsymmetrical, 2-3.5 mm. long, obtuse, hollow, contracted at the base, 3-nerved, often papillose along the midrib and with a larger apical papilla : utricle ovoid or oblong, tipped with the eccentric style: seeds oblique in the utricle 12-16-ribbed.

In ponds and streams, Massachusetts to Minnesota, Nebraska and Florida. Spring to fall.

5. Lemna trinérvis (Austin) Small. Plants solitary or in colonies of 2 or 3 or rarely more. Root-sheath with lateral appendages : plant-body thin, oblong or nearly so, slightly unsymmetrical, little convex above, flat beneath, strongly 3-nerved, abruptly narrowed to the blunt apex, smooth: utricle tipped with the terminal style : seeds erect or nearly so in the utricle. [ $L$. perpusilla var. trinervis Austin.]

In still water, New Jersey to Missouri, Louisiana and the Indian Territory. Spring to fall.

6. Lemna cyclostàsa (Ell.) Chev. Plants solitary or usually 2-8 in colonies. Root-sheath rather elongated, without appendages: plant-body oblong or nearly so, 2.3$4.5 \mathrm{~mm}$. long, obtuse, hollow in the middle, often somewhat falcate, unsymmetrical at the base, obscurely 1-nerved : utricle tipped with the style : seeds 12-29-ribbed.

In ponds and rivers, Massachusetts to California, Florida, Mexico and South America. Summer.

\section{SPIRODÈLA Schleid.}

Plant-body disk-like, conspicuously several-nerved, with the stipe peltately attached back of and under the basal margin. Roots several slender, each with a sheath. Propagative ponches 2 , triangular, opening by slits in either margin of the basal portion of the plant-body. Spathe sac-like. Spadix of 1 pistillate and 2 staminate flowers arising from a propagative pouche. Anthers 2-celled : sacs opening lengthwise. Ovary with 1 amphitropous ovule or with 2 anatropous ovules. Utricle lenticular, with winged margins.

1. Spirodela polyrrhiza (L.) Schleid. Plants solitary or 2-5 in colonies, mostly sterile and perennial. Roots 4-16 ; sheaths $1.3-1.5 \mathrm{~mm}$. long, acute : plant-body obovate or suborbicular, $2.5-8 \mathrm{~mm}$. long, 5-15-nerved : spathe sac-like, opening at the upper end : pollen-grains globose to ellipsoidal, $0.18-0.23 \mathrm{~mm}$. in diameter, spinulose : utricle slightly winged : seeds somewhat flattened, smooth. [Lemna polyrrhiza L.]

In ponds or pools, Nova Scotia to British Columbia, Florida, Texas and California. Also in tropical America and the Old World. DUCK WEED.

\section{Order 8. XYRIDÀLES.}

Terrestrial, commonly bog-inhabiting herbs, or epiphytes (BRoMELIACEAE). Leaves often basal: blades prevailingly narrow. Inflorescence usually not a spadix, but often with a spathe-like bract or a spathe. Flowers mostly complete. Corolla regular or nearly so (except in some genera of CommelinaceaE, 
Pontederiaceae and Bromeliaceae). Gynoecium compound, superior or rarely inferior. Fruit a capsule or utricle, or baccate. Seed with mealy endosperm.

Ovary 1-celled, with parietal placentae: inflorescence without a spathe.

Caulescent moss-like herbs: flowers axillary to leaf-like bracts : sepals alike: styles wholly united.

Acaulescent rush-like herbs: flowers in terminal dense spikes : sepals of 2 forms, or 1 sepal wanting: styles partially united.

Ovary 2-3-celled, if incompletely so or if nearly 1-celled then the flowers in a spathe.

Flowers minute, monoecious or dioecious, in dense heads each seated in an imbricated involucre.

Flowers conspicuous or relatively so, perfect.

Terrestrial or aquatic plants: foliage not scurfy : stigmas united. Caly $\mathrm{x}$ and corolla free, of very different members: stamens free.

Calyx and corolla of quite similar members and partially united : stamens partially adnate to the perianth.

Epiphytes (our species), with scurfy foliage: stigmas 3.

Fam. 1. MAYACACEAE.

Fam. 2. XYRIDACEAE.

Fam. 3. Eriocaulaceae.

Fam. 4. Commelinaceae.

Fam. 5. Pontederiaceae. Fam. 6. Bromeliaceae.

\section{Family 1. mayacàceae Walp. Mayaca Family.}

Perennial caulescent moss-like marsh herbs. Leaves numerous : blades narrow, pellucid, flaccid, 1-nerved, entire below the notched apex. Flowers perfect, borne on axillary pedicels. Perianth regular, persistent. Sepals narrowed upward. Petals 3, white or purple, broadened upward. Androecium of 3 hypogynous stamens. Filaments filiform. Gynoecium 3-carpellary. Ovary 1-celled with 3 parietal placentae. Style filiform. Ovules orthrotopous. Capsule 3celled : valves 3 , with the placentae at the middle. Seeds rounded. Testa furrowed and pitted. Embryo at the top of the mealy endosperm.

\section{MAYÀCA Aubl.}

Characters of the family. The plants flower mainly from spring to fall.

Pedicels much longer than the leaves: capsule globular or ovoid.

Pedicels shorter than the leaves : capsule oblong.

1. M. Aubletii.

2. M. fluviatilis.

1. Mayaca Aublétii Michx. Stems tufted or matted, $2-20 \mathrm{~cm}$. long : leaves approximate or densely crowded; blades narrowly lanceolate or almost linear, $3-5 \mathrm{~mm}$. long, sharply notched at the apex : pedicels $8-20 \mathrm{~mm}$. long, surpassing the leaves : sepals about $4 \mathrm{~mm}$. long at maturity : capsules globular or ovoid, $4-4.5 \mathrm{~mm}$. long. [M. Michauxii Schott \& Endl. $]$

In springy places or on the margins of pools or streams, Virginia to Florida and Texas.

2. Mayaca fluviàtilis Aubl. Larger than M. Aubletii, the stems often $40 \mathrm{~cm}$. long: leaves very numerous, approximate; blades narrowly linear-lanceolate to linear-filiform, 4-12 mm. long, very flaccid: pedicels $2-5 \mathrm{~mm}$. long, shorter than the leaves : sepals 3-4 $\mathrm{mm}$. long: capsules oblong, 4-5 $\mathrm{mm}$. long.

In ponds, pools and streams, Georgia and Florida to Mississippi. Also in tropical America.

\section{Family 2. XYridàceate lindi. Yellow-eyed Grass Family.}

Annual or perennial scapose herbs. Leaves basal, mostly 2-ranked, swordlike. Scapes simple, terete or variously angled, or winged. Flowers perfect, subtended by crustaceous closely imbricated bracts, forming a compact terminal spike. Sepals 3, the two lateral firm, keeled and often appendaged, persistent, the third deciduous (or wanting). Corolla white or yellow, regular or nearly so. Petals 3, fugacious: blades spreading. Androecium of 3 stamens. Filaments usually alternating with 3 staminodia. Gynoecium 3-carpellary. Ovary 1-celled, sometimes incompletely 3 -celled, with 3 parietal placentae. Ovules numerous, orthotropous. Style unappendaged at the base (or appendaged). Stigmas 3. Fruit a 3-valved capsule. Seeds numerous.

\section{XỲRIS L.}

Characters of the family, omitting those in parentheses. Yellow-Eyed Grass.

A. Annual or biennial plants: leaves mainly shorter than the sheath of the scape. Keel of the lateral sepals smooth or erose-scabrous. Keel of the lateral sepals ciliate-fringed. 
B. Perennial plants: leaves mainly longer than the sheath of the scape. Sterile filaments bearded: leaf-blades flat.

Lateral sepals included.

Keel or wing of the lateral sepals ciliolate.

Lateral sepals winged, the wing partially ciliolate, not bearded. Sepal-wing narrow, narrower than the sepal-body. sepal-wing broad, broader than the sepal-body.

Lateral sepals keeled, the keel mainly ciliolate its entire length, bearded at the apex.

Keel or wing of the lateral sepals incised, erose-toothed or lacerate.

Keel or wing erose-toothed or incised.

Lateral sepals erested from below the middle or from the base to the apex.

Lateral sepals crested from above the middle to the apex.

Scape and leaves not scabro-puberulent.

Spikes ovoid, oval or globular, $5-15 \mathrm{~mm}$. long at maturity ; bracts in relatively few series.

Bracts loosely imbricated in few series, deciduous.

Bracts closely imbricated in several series, persistent.

Spikes oblong to conic-oblong, $16-23 \mathrm{~mm}$. long at maturity ; bracts numerous and in many series.

Scape and leaves scabro-puberulent all over.

3. X. ambigua.

4. X. stricta.

5. X. flexuosa.

7. X. Caroliniana.

8. X. communis.

9. X. elata.

10. X. scabrifolia.

Keel or wing lacerate.

Lateral sepals crested from about the middle, or below it, to the apex, the crest erect or nearly so.

Spikes ovoid, 11-15 mm. long ; bracts rounded at the apex.

Spike acute: lateral sepals with the wing narrow or obsolete near the base: leaves and scape smooth.

Spike obtuse: lateral sepals with the wing broad to the base, leaves and scape rough-margined.

Spikes oblong or cylindric, $15-30 \mathrm{~mm}$. long; bracts very broad and broadly truncate or nearly truncate at the apex.

Lateral sepals crested from the base to the apex, the crest spreading or partially recurved.

Lateral sepals partially exserted.

Plants not bulbous at the base, the leaf-bases not greatly dilated.

Leaves numerous ; blades mostly 1-2 mm. wide at maturity.

Leaves few ; blades mostly $5-10 \mathrm{~mm}$. wide at maturity.

Crest of the lateral sepals of very short erect segments : upper part of the scape smooth.

Crest of the lateral sepals of very long spreading segments: upper part of the scape rough.

Plants markedly bulbous at the base, the leaf-bases greatly dilated and persistent.

Corolla yellow : upper part of the scape, and the spike green.

Corolla white: upper part of the scape, and the spike glaucous or glaucescent.

Sterile filaments glabrous: leaves terete, filiform.

\section{X. difformis.}

12. $X$. serotina.

13. X. platylepis.

14. X. iridifolia.

15. X. Elliottii.

16. X. Smalliana.

17. X. fimbriata.

18. $X$. arenicola.

19. $X$. pallescens.

20. X. Baldwiniana.

1. Xyris brevif òlia Michx. Annual or biennial. Leaves narrowly linear, $2-8 \mathrm{~cm}$. long, clustered : scapes solitary or tufted, $8-30 \mathrm{~cm}$. tall, nearly terete, more or less spirally twisted : spikes subglobose, 4-6 $\mathrm{mm}$. long; bracts eroded : lateral sepals $3.5-4.5 \mathrm{~mm}$. long, the keel smooth or erose-scabrous : petals yellow; blades obovate, rounded at the apex.

In low pine lands, North Carolina to Florida. Spring.

2. Xyris flabellifórmis Chapm. Annual or biennial. Leaves linear or narrowly linear-lanceolate, $1-2.5 \mathrm{~cm}$. long, spreading in a fan-shaped manner, often curved : scapes very slender, $8-30 \mathrm{~cm}$. tall, spirally twisted, nearly terete below, slightly flattened above : spikes ovoid or oblong, 4-8 mm. long, usually acute ; bracts entire : lateral sepals 4-5 mm. long, the keel ciliate-fringed : corolla yellow.

In low pine lands, near the coast, Florida and Alabama to Mississippi. Spring.

3. Xyris ambígua Beyr. Perennial. Leaves linear, 1-4 dm. long, tapering from a rather broad base, commonly roughish on the edges : scapes usually solitary, 4-10 dm. tall, finely ridged, 2-edged above, the edges often rough : spikes ovoid or oblong-ovoid, 1.5-2.5 cm. long, often acute, compact; lateral sepals included, $5-8.5 \mathrm{~mm}$. long; wing ciliolate : corolla yellow.

In swamps or open pine lands, North Carolina to Florida and Texas. Summer and fall.

4. Xyris strícta Chapm. Perennial. Leaves linear or slightly tapering upward, 1-4 dm. long, quite narrow, smooth-edged, often discolored in drying: scapes often solitary, 4-10 dm. tall, 2-edged and margined above, the margins rough : spikes narrowly oblong or cylindric, $2-3.5 \mathrm{~cm}$. long, compact : lateral sepals $5.5-7 \mathrm{~mm}$. long, included; wing ciliolate the middle to the top : corolla yellow.

In ponds in pine lands, Florida to Mississippi. Summer and fall.

5. Xyris flexuòsa Muhl. Perennial. Leaves narrowly linear, $5-30 \mathrm{~cm}$. long, acute, straight or spirally twisted : scapes $2-6 \mathrm{dm}$. tall, more or less spirally twisted, nearly terete below, 2-edged above, smooth: spikes oval or subglobose, $5-10 \mathrm{~mm}$. long : lateral sepals margined, 4-5 mm. long; keel ciliolate and bearded at the apex : corolla yellow.

In swamps or wet soil, Maine to Minnesota, Georgia and Texas. Summer. 
6. Xyris neglécta Small. Perennial, slender. Leaves, few, linear, $3-10 \mathrm{~cm}$. long, acute, straight or slightly curved, rather erect : scapes solitary or commonly $2-4$ together, 1-4 dm. tall, spirally twisted, 10-ridged, the ridges in pairs, 2 on either side of a line connecting the 2 more prominent ridges : spikes ovoid, $4-9 \mathrm{~mm}$. long; bracts $3-5 \mathrm{~mm}$. long : lateral sepals $3-4 \mathrm{~mm}$. long; wing with erose-serrate crest from near the base to the apex : corolla bright yellow, $3 \mathrm{~mm}$. broad : petals irregularly arose.

In moist pine lands, Georgia and Florida to Mississippi. Summer and fall.

7. Xyris Caroliniàna Walt. Perennial. ILeaves linear, attenuate, smooth, the longer fully $\frac{1}{2}$ as long as the scapes: scapes erect, slender, 1-6 dm. tall, flattened and 2edged above, the edges smooth: spikes oval or ovoid, $5-9 \mathrm{~mm}$. long, obtuse ; bracts loosely imbricated in few series and splitting in age : lateral sepals $4-5 \mathrm{~mm}$. long; wing narrower than the sepal-body, incised-toothed or eroded beyond the middle : corolla yellow.

In swamps and shallow ponds, Vermont to Massachusetts, Florida and Louisiana. Summer.

8. Xyris commùnis Kunth. Perennial. Leaves linear, gradually attenuate, shorter than the scapes: scapes solitary or few together, $2-7 \mathrm{dm}$. tall, 2-edged above: spikes oval or globular, 8-15 mm. long; bracts closely imbricated in few series : lateral sepals 3-4 $\mathrm{mm}$. long, included; wing narrower than the sepal-body, erose- or incised-toothed above the middle : corolla yellow.

In bogs and swamps, Maryland to Florida and Louisiana. Summer. Also in tropical America.

9. Xyris elàta Chapm. Perennial. Leaves few, linear, $2-6 \mathrm{dm}$. long : scapes solitary or several together, 3-12 dm. tall, 2-edged above : spikes oblong or conic-oblong, 16$23 \mathrm{~mm}$. long; bracts numerous, closely imbricated in many series : lateral sepals $4-5 \mathrm{~mm}$. long, included; wing narrow, toothed above the middle : corolla yellow.

In swamps near the coast, Maryland to Florida and Louisiana. Summer.

10. Xyris scabrifolia Harper. Perennial. Leaves few, narrowly and elongated-linear, scabro-puberulent, 3-4 dm. long : scapes surpassing the leaves, and puberulent like them : spikes $1-1.5 \mathrm{~cm}$. long; bracts rather numerous, closely imbricated : lateral sepals about 5 mm. long; wing narrow, toothed above the middle.

In bogs, western Georgia. Summer.

11. Xyris diffórmis Chapm. Perennial. Leaves few, linear, 1-5 dm. long, smooth : scapes 2-5 dm. tall, mostly clustered, twisted, sharply 2-edged above, smooth : spikes ovoid, $12-18 \mathrm{~mm}$. long, acute, the bracts rounded: lateral sepals $4.5-6 \mathrm{~mm}$. long; wing narrow or obsolete near the base of the sepal, with a crest of fringe extending $\frac{1}{2}-\frac{1}{3}$ the length of the sepal from the tip : corolla yellow.

In swamps, Florida, Georgia and Alabama. Spring and summer.

12. Xyris serótina Chapm. Similar to $X$. difformis in habit. Leaves and scape rough-margined : spikes ovoid, $12-18 \mathrm{~mm}$. long, obtuse; bracts rounded : lateral sepals 4.5-5 mm. long; wing broad to the base of the sepal, with a fringed crest mainly above the middle: corolla yellow.

In pine-land swamps, western Florida. Summer and fall.

13. Xyris platýlepis Chapm. Perennial. Leaves linear, $2-6 \mathrm{dm}$. long : scapes erect, solitary or sometimes few together, 5-9 dm. tall, 2-ridged above, sometimes slightly roughened on the margins : spikes oblong or cylindric, $1.5-3 \mathrm{~cm}$. long; bracts very broad and broadly truncate or nearly so at the apex : lateral sepals $4.5-6 \mathrm{~mm}$. long; wing with a lacerate, crest above the middle : corolla yellow.

In low or swampy pine lands, South Carolina to Florida and Louisiana. Summer and fall.

14. Xyris iridifòlia Chapm. Perennial. Leaves linear, 5-8 dm. long, relatively broad: scapes $6-10 \mathrm{dm}$. tall, stout, nearly terete or 1-edged below, flattened and 2-edged above, the edges broad: spikes oblong or cylindric, $1.5-3.5 \mathrm{~cm}$. long; bracts rounded: lateral sepals 5-6 mm. long; wing narrow, incised-fimbriate its whole length; corolla yellow.

In shallow ponds, Georgia and Florida to Texas. Summer and fall.

15. Xyris Ellióttii Chapm. Perennial, lustrous. Leaves numerous, narrowly linear, grass-like, 3-10 $\mathrm{cm}$. long or longer, acute, often twisted : seapes solitary or clustered, 2-5 $\mathrm{dm}$. tall, twisted, 2-edged throughout, or only 1-edged below, roughish on the edges ; spikes oval or ellipsoidal ; bracts with thin eroded edges : lateral sepals 4-6.5 mm. long, exserted ; wing incised-lacerate above the middle or nearly entire below the terminal tuft or beard: corolla yellow.

In damp pine lands, South Carolina to Florida and Alabama. Summer.

16. Xyris Smalliàna Nash. Perennial, lustrous. Leaves linear, 3.5-7 dm. long, the lower half often purplish, striate : scapes $7-10 \mathrm{dm}$. tall, about twice as tall as the leaves, flattened, unequally 2-edged below the spikes, smooth : spikes ovoid or at maturity 
ellipsoidal, $1.5-2.5 \mathrm{~cm}$. long: lateral sepals conspicuously exserted, 5-8 mm. long ; wing crested with short erect segments from about the middle : corolla yellow.

In shallow water, Georgia to Florida and Louisiana. Summer.

17. Xyris fimbriàta Ell. Perennial, not lustrous. Leaves linear, 3-5 dm. long, smooth: scapes erect, solitary or tufted, 6-12 dm. tall, roughish, and 2-edged above : spikes ovoid to oblong, $1.5-2.5 \mathrm{~cm}$. long: lateral sepals exserted, $7-9 \mathrm{~mm}$. long, relatively broad; wing crested with long spreading segments from about the middle to the apex : corolla yellow.

In swamps or boggy places, New Jersey to Florida and Mississippi. Summer and fall.

18. Xyris arenícola Small. Perennial by bulb-like bases. Leaves linear, with dark dilated base, 1-4 dm. long, usually spirally twisted: scapes often tufted, $3-7 \mathrm{dm}$. tall, somewhat flattened above, spirally twisted or spiral : spikes cylindric or conic-oblong, 1.5$3 \mathrm{~cm}$. long, often acute : lateral sepals exserted, $8-12 \mathrm{~mm}$. long; fringe of the wing firm : corolla yellow. [X. torta Kunth, not J. E. Smith.]

In wet or dry sand, New Jersey and Arkansas, to Florida and Texas. Spring to fall.

19. Xyris palléscens (C. Mohr) Small. Perennial by bulb-like bases. Leaves few in a set accompanied by the persistent purple or brown bases of previous years, narrowly linear, 2-4 dm. long, spirally twisted : scapes solitary or few together, 3-6 dm. tall, spirally twisted, 2-edged above : spikes oblong or conic-oblong, 1-1.5 $\mathrm{cm}$. long : lateral sepals $6.5-9$ $\mathrm{mm}$. long, very delicate, narrow ; fringe of the wing delicate : corolla white.

In low pine lands, Georgia and Florida. Spring.

20. Xyris Baldwiniàna R. \& S. Perennial. Leaves numerous, filiform, terete, 0.5-2 dm. long, becoming twisted : scapes slender, 2-4 dm. tall, 1-angled or nearly terete, smooth : spikes ovoid or subglobose, 4-6 $\mathrm{mm}$. long, turbinate at the base: lateral sepals exserted, 4-6 mm. long, the upper half of the keel-wing serrate: sterile filaments glabrous.

In grassy or swampy pine lands, North Carolina to Florida and Texas. Summer and fall.

\section{Family 3. eriocaulàceae lindl. Pipewort Family.}

Perennial and perhaps rarely annual, mostly acaulescent bog or aquatic herbs. Leaves clustered, often very densely so. Scapes simple, subtended by sheathing bracts. Flowers monoecious (androgynous), or rarely dioecious, densely crowded in a terminal involucrate head; each flower is subtended by a minute bractlet. Perianth in 2 series (the inner rarely obsolete). Staminate flowers with 2-3 sepals, and 2-3 petals : stamens as many as the sepals or twice as many. Pistillate flowers with $2-3$ sepals and petals : ovary $2-3$-celled: styles 2-3. Ovules solitary in each cavity, orthotropous. Fruit a loculicidally 2-3-valved capsule. Seeds pendulous, each with a minute embryo at the apex of the mealy endosperm.

Stamens 2 or 3 , as many as the sepals : petals glandless.

Petals of the pistillate flowers obsolete.

Petals of the pistillate flowers resembling the sepals and united at the middle. Stamens $4-6$, twice as many as the sepals : petals each bearing a prominent gland.

1. LACHNOCAULON. 2. SYNGONANTHUS.

\section{LACHNOCAÙLON Kunth.}

Scapose herbs. Leaves basal : blades narrow, usually crowded. Scapes usually tufted, ridged. Flowers androgynous. Staminate flowers: sepals 3 ; petals obsolete; stamens 3 ; filaments united below, coalescent with a rudimentary corolla or pistil, this with 3 lobes at the top; anthers 1-celled. Pistillate flowers: sepals 3 ; petals obsolete; styles united below, the usually 3 divisions 2-cleft. Capsule delicate, 2-3-celled. Hairy Pipewort.

Scapes glabrous.

Gynoecium 3-carpellary : stigmas 3 : bracts of the involucre obtuse.

Heads dark brown or black, scarcely, if at all, pubescent: sepals obscurely pubescent near the apex.

Heads white or gray, woolly : sepals copiously ciliate.

Heads gray, globular at maturity: sepals about $1 \mathrm{~mm}$. long: anther as long as the filament.

Heads white, spheroidal at maturity : sepals about $1.5 \mathrm{~mm}$. long: anther shorter than the filament.

Gynoecium 2-carpellary : stigmas 2: bracts of the involucre acute. Scapes pubescent.

seeds smooth.

Seeds cancellate.

Bractlets and sepals of the pistillate flowers not ciliate.

Bractlets and sepals of the pistillate flowers ciliate.

Heads gray or brown-gray, $4 \mathrm{~mm}$. thick or less : seeds oval or ovoid, 0.5 mm. long.

Heads white, $5 \mathrm{~mm}$, thick or more : seeds oblong, $0.8 \mathrm{~mm}$. long.

1. L. Engleri.

\section{L. Floridanum.}

3. L. glabrum.

4. L. digynum.

5. L. Beyrichianum.

6. L. eciliatum.

7. L. minor.

8. L. anceps. 
1. Lachnocaulon Éngleri Ruhl. Leaf-blades 1-3 cm. long, linear-attenuate glabrous, firm : scapes $5-30 \mathrm{~cm}$. tall, $3-5$-ridged, twisted, glabrous : heads cylindric at maturity, 3-6 mm. long, dark brown or black : receptacle with slender-clavate hairs : bractlets obovate, minutely pubescent near the apex : sepals obovate, obtuse, minutely pubescent at the apex : ovary 3 -celled : stigmas 3 : seeds $0.5 \mathrm{~mm}$. long.

In damp sandy and springy places, Florida. Spring to fall.

2. Lachnocaulon Floridànum Small. Leaf-blades $2-4.5 \mathrm{~cm}$. long, linear, less attenuate than those of $L$. glabrum, sparingly ciliate, manifestly cellular at the base : scapes $3-11 \mathrm{~cm}$. tall, twisted, glabrous : heads globose, $3-3.5 \mathrm{~mm}$. long at maturity, dark gray : bractlets spatulate or obovate-spatulate, ciliate: sepals similar to the bractlets, ciliate : ovary 3-celled : seeds $0.5 \mathrm{~mm}$. long.

In low sandy places, peninsular Florida. Spring to fall.

3. Lachnocaulon glábrum Körn. Leaves spreading and ascending; blades linearattenuate, $4-5 \mathrm{~cm}$. long, glabrous : scape $15-30 \mathrm{~cm}$. tall, mostly 3-ridged, twisted, glabrous : heads white, spheroidal at maturity, $3-4 \mathrm{~mm}$. thick : bractlets and sepals ciliate : ovary 3 . celled : stigmas 3 .

In damp or wet sandy places, Florida. Spring to fall.

4. Lachnocaulon digỳnum Körn. Leaf-blades 8-15 mm. long, linear, glabrous : scapes $6-15 \mathrm{~cm}$. tall, glabrous : heads globular, about $2 \mathrm{~mm}$. in diameter, gray : bractlets spatulate, each with a nerve-like keel : sepals spatulate to obovate, obtuse, ciliate : ovary 2-celled.

In sandy soil, Alabama. Spring to fall.

5. Lachnocaulon Beyrichiànum Sporleder. Leaf-blades $1.5-5 \mathrm{~cm}$. long, very narrowly linear or linear-filiform, attenuate, sparingly ciliate or nearly glabrous: scapes 3-14 $\mathrm{cm}$. tall, sparingly hairy, very slender, more or less spiral : heads globular, becoming somewhat elongated, about $3 \mathrm{~mm}$. thick: bractlets spatulate, ciliate : sepals obovate to nearly spatulate, ciliate : ovary 3 -celled : seeds $0.5 \mathrm{~mm}$. long, smooth.

On sandy shores and in springy places, eastern and southern Georgia. Spring to fall.

6. Lachnocaulon eciliàtum Small. Leaf-blades $1-4.5 \mathrm{~cm}$. long, linear-attenuate, sparingly ciliate : scapes slender, $3-9 \mathrm{~cm}$. tall, pubescent : heads globular, $3-3.5 \mathrm{~mm}$. thick, gray : bractlets spatulate, not ciliate : sepals spatulate to oblanceolate, eciliate, those of the pistillate flowers wholly glabrous, those of the staminate minutely pubescent at the apex : seeds ovoid, cancellate.

On sandy shores, northwestern Florida. Spring to fall.

7. Lachnocaulon minus (Chapm.) Small. Leaf-blades $1-4 \mathrm{~cm}$. long, linear-attenuate, sparingly ciliate : scapes slender, $0.5-3 \mathrm{dm}$. tall, pubescent : heads globular to cylindric, 3-4 mm. thick, gray or brown-gray : bractlets and sepals ciliate with relatively short hairs : seeds oval or ovoid, $0.5 \mathrm{~mm}$. long, cancellate. [L. Michauxii var. minor, Chapm.]

In moist soil or often pond-margins, North Carolina to Florida. Spring to fall.

8. Lachnocaulon ánceps (Walt.) Morong. Leaf-blades $2-6 \mathrm{~cm}$. long, narrowly linear-attenuate, sparingly pubescent or glabrate : scapes $0.5 \mathrm{dm}$. tall, very slender, pubescent : heads spheroidal, $5 \mathrm{~mm}$. thick or more, white : bractlets and sepals ciliate with relatively long hairs: seeds oblong, $0.8 \mathrm{~mm}$. long.

In low or moist pine lands, Virginia to Florida. Spring to fall.

\section{SYNGONÁNTHUS Ruhl.}

Scapose herbs, with spongy tissues. Leaves basal, narrow, crowded. Scapes often tufted, each subtended by a sheathing bract at the base. Heads with an imbricated involucre of 3-4 series of bracts. Flowers androgynons. Staminate flowers with 2 or 3 distinct sepals and petals : stamens 2-3: filaments distinct; anthers 2-celled. Pistillate flowers with 2 or 3 distinct sepals and 2 or 3 petals united at the middle: style-branches 2-3, entire or each 2-cleft. Capsule 2-3-celled.

1. Syngonanthus flavídulus (Michx.) Ruhl. Leaf-blades filiform-linear or linearsubulate, $2-7 \mathrm{~cm}$. long, attenuate to a slender tip, floccose near the base, glabrate above : scapes 1-3 dm. tall, 5-angled, pubescent, very slender, or nearly filiform : heads 4-6 mm. thick : bracts of the involucre ovate-oval, obtuse, straw-colored, shining: perianth about $2.5 \mathrm{~mm}$. long, pale. [Paepalanthus flavidulus (Michx.) Kunth.]

In low pine lands, Virginia to Florida. Spring and summer.

\section{ERIOCAÙLON L.}

Herbs with spongy tissues. Leaves basal, attenuate, often with conspicuous crossnerves. Scapes simple, ridged, each subtended by a sheathing bract. Heads of various 
colors, woolly. Staminate flowers : sepals $2-3$; petals 2 or 3 , each furnished with a gland above the middle ; stamens usually 4-6; filaments distinct; anthers 2-celled. Pistillate flowers: sepals as in the staminate flowers: petals much reduced and narrow: stamens wanting: styles 2-3. Capsule thin-walled. Pipewort.

Sheath at the base of the scape surpassing the leaves, except in the case of submerged plants.

Petals linear: filaments ciliate.

Petals broader: filaments glabrous.

Receptacle silky-pubescent.

1. E. lineare.

Receptacle glabrous.

Heads about $3 \mathrm{~mm}$. in diameter: sepals of the staminate flowers merely glandular at the apex.

Heads $6-15 \mathrm{~mm}$. in diameter : sepals ciliate.

Bractlets acute: scapes 4-7-ridged: heads gray, less than $8 \mathrm{~mm}$. thick at maturity.

Bractlets obtuse: scapes 10-12-ridged: heads white, over $10 \mathrm{~mm}$. in diameter.

Sheath at the base of the scape surpassed by the leaves, or some of them.

Heads $10-16 \mathrm{~mm}$. thick: bractlets, sepals and petals ciliate: bractlets acute.

Heads 3-5 mm. thick: bractlets, sepals and petals glabrous : bractlets obtuse.

2. E. Texense.

3. E. Körnickianum.

4. E. septangulare.

5. E. compressum.

6. E. decangulare.

7. E. Ravenelii.

1. Eriocaulon lineàre Small. Leaves spreading; blades $2-5 \mathrm{~cm}$. long, alternate, curved, sparingly pubescent or almost glabrous : scapes deep green, very slender, 1-3 dm. tall, 3-5-ridged : sheath surpassing the leaves : heads somewhat depressed, $5-6 \mathrm{~mm}$. broad : bracts of the involucre rhombic, acute, pubescent near the tip : bractlets fimbriate-ciliate at the apex : sepals mainly spatulate: petals, at least those of the staminate flowers, linear, ciliate all around : filaments ciliate.

In wet woods, eastern Georgia. Spring and summer.

2. Eriocaulon Texénse Körn. Leaves spreading; blades very narrowly linearattenuate, $2-7 \mathrm{~cm}$. long, thin, glabrous, more or less involute : scapes straw-colored, very slender, 1-4 dm. tall, 5-6-ridged; sheath surpassing the leaves: heads globular, 4-5.5 $\mathrm{mm}$. broad : bracts of the involucre obovate, acute, glabrous : receptacle silky : bractlets oblong-cuneate to obovate, pubescent without and fimbriate-ciliate at the apex : sepals broadened upward, fimbriate at the apex : petals ovate or oval ciliate-fimbriate : filaments glabrous.

In wet soil, or moist pine lands, Florida and Texas, Summer.

3. Eriocaulon Körnickiànum Von Heurck \& Muell. Arg. Leaves spreading : blades $1.5-2.5 \mathrm{~cm}$. long, pellucid : scapes $10-15 \mathrm{~cm}$. tall, very slender, 2-3-ridged: sheath surpassing the leaves: heads about $3 \mathrm{~mm}$. in diameter: bracts of the involucre recurved at maturity : receptacle glabrous : sepals, at least those of the staminate flowers, glabrous but black glandular at the apex : petals pilose-ciliate above.

In low grounds, eastern Texas. Summer.

4. Eriocaulon septangulàre With. Leaves spreading; blades $2-6 \mathrm{~cm}$. long, or longer in submerged plants, permanently pellucid: scapes $3-40 \mathrm{dm}$. tall, 4-7-ridged : sheath surpassing the leaves : heads spheroidal, less than $8 \mathrm{~mm}$. thick : petals of the staminate flowers ovate or oval, ciliate all around : seeds oblong. fall.

In still water, Newfoundland to Minnesota, Florida and Texas. Also in Europe. Summer and

5. Eriocaulon compréssum Lam. Leaves ascending-spreading; blades 2-12 $\mathrm{cm}$. long, longitudinally striate and not pellucid at maturity, acute : scapes $2-10 \mathrm{dm}$. tall, 1012-ridged : sheath surpassing the leaves : heads spheroidal, over $10 \mathrm{~mm}$. thick : petals of the staminate flowers ciliate-fimbriate at the apex as above the middle: seeds oval.

In still water or swampy places, New Jersey to Florida and Texas. Spring to fall.

6. Eriocaulon decangulàre L. Leaves erect or ascending; blades $10-50 \mathrm{~cm}$. long, not pellucid but rather firm, finely many-striate, obtuse : scapes stout, $3-10 \mathrm{dm}$. tall, 10-14ridged : sheath surpassed by the leaves: heads globular, $10-16 \mathrm{~mm}$. thick: bracts of the involucre acute : bractlets, sepals and petals ciliate or pubescent on the back.

In swamps and low grounds, New Jersey and Pennsylvania to Florida and Texas. Spring to fall.

7. Eriocaulon Ravenélii Chapm. Leaves various, the smaller spreading, the larger ascending or erect; blades $2-13 \mathrm{~cm}$. long, pellucid, attenuate-acute : scapes very slender, 4-30 cm. tall, 5-6-ridged: sheath surpassed by the leaves: heads spheroidal, $3-5 \mathrm{~mm}$. thick : bracts of the involucre obtuse : bractlets, sepals and petals glabrous.

In wet soil, South Carolina to Florida. Summer and winter.

\section{FAmily 4. COMMELINÀCEAE Reichenb. SPIDERwort FAmily.}

Annual or mostly perennial succulent herbs, with fibrous or tuberous-thickened roots and erect or creeping stems. Leaves alternate, often with sheathing 
bases. Flowers perfect, solitary or several in variously suppressed cymes, arising from a spathe or involucre of often leaf-like bracts. Perianth in 2 series. Calyx of 3 distinct mostly persistent herbaceous sepals. Corolla often showy, regular or irregular, of 3 early withering or fugacious petals. Androecium of 5-6 hypogynous stamens, all of these perfect, or 2-3 sterile. Filaments slender. Anther-sacs mostly opening lengthwise. Gynoecium of 2-3 united carpels. Ovary superior, 2-3-celled. Styles united. Stigma sometimes obscurely 2-3lobed. Ovules solitary or several in each cavity, orthotropous. Fruit a loculicidally 2-3-valved capsule. Seeds sometimes suppressed in one cavity. Embryo pulley-shaped in the copious endosperm opposite the hilum.

Petals alike in shape: perfect stamens 6 or rarely 5.

Cymes elongated, scorpioid.

Cymes or eymules umbel-like or clustered.

Cymes or cymules subtended by small or minute bracts very unlike the leaves.

Inflorescence simple : filaments pubescent.

Inflorescence dichotomously compound: filaments glabrous.

Cymes subtended by an involucre of 1-3 bracts similar to the leaves.

Petals broad at the base and distinct : filaments free.

Petals with claws and coherent into a tube: filaments adnate to the petals.

Petals unequal in size and shape: perfect stamens 3 or rarely 2.

1. Tinantia.

2. Cuthbertia.

3. TRADESCANTElla.

4. Tradescantia.

5. Treleasea.

6. Commelina.

\section{TINÁNTIA Scheidw.}

Perennial herbs, with upright stems. Leaves alternate: blades flat, often quite ample. Peduncles terminal or sometimes in the upper axils. Involucre of leaf-like bracts. Cymes elongated, scorpioid. Sepals 3, nearly equal. Petals 3, nearly equal, showy. Stamens 6, all fertile: filaments filiform, pubescent. Capsule loculicidally 3-valved. Seeds in one row : testa rough or rugose.

1. Tinantia anómala (Torr.) Clarke. Stems weak, solitary or tufted, $2-7 \mathrm{dm}$. tall, glabrous: leaf-blades linear-spatulate below and narrowed into slender petioles, lanceolate or ovate-lanceolate above, 5-12 cm. long, acute or acuminate, glaucescent beneath, cordate, clasping at the base : pedicels $2-5 \mathrm{~mm}$. long : sepals oblong or oblong-lanceolate, 10-12 mm. long, acute: petals deep blue, obovate-elliptic, or obovate, longer than the sepals : filaments pubescent above: capsule oblong-oval, $6 \mathrm{~mm}$. long.

In rich soil and woods, Texas. Spring and summer.

\section{CUTHBÉRtia Small.}

Perennial herbs, with mostly tufted stems. Leaves alternate : blades very narrow and elongated. Cymes umbel-like, solitary at the ends of long peduncles, and subtended by very small bracts wholly unlike the leaves. Sepals 3 . Petals 3 , reddish, pink or rosepurple, distinct. Stamens 6: filaments pubescent. Capsule loculicidally 3-valved. Seed with a rough testa.

Leaf-blades mostly 1-3 mm. broad : corollas 1-2 $\mathrm{cm}$. broad : capsules subǵlobose. Leaf-blades mostly $5-8 \mathrm{~mm}$. broad : corollas $2-2.5 \mathrm{~cm}$. broad : capsules obovoid.

1. C. graminea. 2. C. rosea.

1. Cuthbertia gramínea Small. Stems erect, $0.5-2 \mathrm{dm}$. tall, densely tufted, sometimes 100 or more together, commonly simple, barely zigzag. Leaves quite numerous; blades narrowly linear or linear-filiform, 1-1.5 dm. long, or shorter above, mostly $1-3 \mathrm{~mm}$. broad, acute, mostly erect; sheaths ciliate: peduncles sometimes overtopping the leaves : cymes $3-15$-flowered, simple: pedicels slightly thickened at the apex, becoming about $10 \mathrm{~mm}$. long: sepals oblong-ovate or ovate, 4-5 mm. long, glabrous : corollas pink or rose-colored, 1-2 cm. broad: capsules subglobose, about $3 \mathrm{~mm}$. in diameter.

On sand hills or in sandy woods, Maryland and Missouri to Florida and Texas. Spring and summer

2. Cuthbertia ròsea (Vent.) Small. Stems erect or ascending, $2-6 \mathrm{dm}$. tall, sparingly tufted, or solitary, zigzag. Leaves relatively few ; blades linear, 1-3 dm. long, or shorter above, mostly 5-8 mm. broad, acute, spreading at maturity ; sheaths ciliate: peduncles $5-18 \mathrm{~cm}$. long: cymes $3-10$-flowered: pedicels $15 \mathrm{~mm}$. long, abruptly thickened at the apex : sepals ovate, becoming 4-5 mm. long, glabrous: corollas $2-2.5 \mathrm{~cm}$. broad, rosepurple : capsules obovoid, about $3 \mathrm{~mm}$. long. [Tradescantia rosea Vent.]

In sandy oak woods or pine lands, North Carolina to Georgia and Florida. Spring and summer.

3. TRADESCANTÉLLA Small.

Perennial herbs, with spreading or creeping stems. Leaves alternate: blades relatively short and broad. Cymes dichotomous, the cymules subtended by very small 
bracts wholly unlike the leaves. Sepals 3. Petals 3, white or colored, distinct. Stamens 6 : filaments glabrous. Capsule loculicidally 3 -valved. Seed with a rough testa.

1. Tradescantella Floridàna (S. Wats.) Small. Stems creeping, slender, more or less matted, flaccid, 1-3 dm. long: leaf-blades ovate or ovate-lanceolate, 1-2 cm. long, thinnish, acute, ciliolate; sheaths funnelform, minutely roughened, fringed with long white cilia : cymes solitary or 2 together, terminal, their peduncles $0.5-1.5 \mathrm{~cm}$. long, subtended by ovate or ovate-lanceolate bracts: pedicels filiform, 2-6 mm. long, villous or somewhat glandular : sepals ovate, about $2-3 \mathrm{~mm}$. long, acutish, purple, pubescent, ciliolate : petals white: filaments glabrous: anther-sacs contiguous : capsules oval, nearly 2 mm. long, glabrous. [Tradescantia Floridana S. Wats.]

In damp shady places, peninsular Florida. Thoughout the year.

\section{TRADESCÁNTIA L.}

Perennial caulescent herbs, sometimes with a mucila ginous sap. Leaves alternate: blades often elongated, usually narrow. Cymes umbel-like, terminal, subtended by an involucre of 1-3 (mostly 2), bracts similar to the leaves. Sepals 3 , distinct, nearly equal. Petals 3, showy, sessile, delicate. Stamens 6, all fertile, those opposite the petals sometimes shorter than the others: filaments filiform. Capsule loculicidally 3-valved, dry. Seeds 3-6, more or less sculptured. SPIDERwort.

Leaf-blades linear or linear-lanceolate, 12-50 times longer than broad, more or less

involutely folded.

Stems abbreviated, $1 \mathrm{~cm}$, to rarely $8 \mathrm{~cm}$. long: bracts mostly longer than the leaves.

Stems elongated, 10-100 $\mathrm{cm}$. long: bracts mostly shorter than the leaves.

Sheaths not imbricated at the base of the stem.

Stems glabrous, at least below the upper internodes: pubescence, when present on other parts, villous and silvery, or velvety.

Plants bright green : pedicels pilose or villous : sepals pilose or villous, becoming membranous.

Pedicels and sepals pilose with gland-tipped hairs.

Bracts usually much broader than the leaves near the sac-like bases.

Bracts usually narrower than the leaves, the base not conspicuously sac-like.

Pedicels and sepals villous with simple hairs.

Plants glaucous : pedicels glabrous or velvety : sepals often with a tuft of hairs at the apex, leathery.

Bracts of the involucre much longer than the cyme.

Pedicels glabrous : bases of the involucral bracts not sac-like.

Pedicels pubescent : bases of the involucral bracts conspicuously sac-like.

Bracts of the involucre shorter than the cyme.

Stems hirsute with brownish or whitish hairs.

Sheaths imbricated for $5-20 \mathrm{~cm}$, at the base of the stem.

Plants densely glandular: sepals linear-lanceolate or lanceolate-oblong, 8-10 mm. long.

Stems 1-3 dm. tall : leaf-blades 0.8-2 dm. long: Texas species.

Stems 4-5 dm. tall : leaf-blades 2-4 dm. long: Florida species.

Plant glabrous, except the villous sheaths at the base of the stem : sepals ovate or oblong, $7 \mathrm{~mm}$. long.

Leaf-blades ovate to lanceolate or narrowly lanceolate, 2-10 times longer than broad, flat.

Stems glabrous. or pubescent with very short hairs.

Leaf-blades 2-3 times longer than broad, $1-7 \mathrm{~cm}$. long.

Sepals pubescent chiefly toward the base: native Texan species.

Sepals pubescent chiefly toward the apex : introduced species.

Leaf-blades 5-10 times longer than broad, 10-25 $\mathrm{cm}$. long.

Slender: stems strict: cymes solitary and terminal or on corymbose branches: Alleghenian species.

Stout: stems zigzag: cymes terminal and sessile in the upper axils : cam-

pestrian species.
Stems clothed with long villous hairs.

1. T. brevicaulis

2. T. bracteata.

3. T. occidentalis.

4. T. Virginiana.

5. T. reflexa.

6. T. gigantea.

7. T. incarnata.

8. T. hirsuticaulis.

9. T. humilis.

10. T. longifolia.

11. T. foliosa.

1. Tradescantia brevicaùlis Raf. Stems usually clustered, erect, almost wanting, or 1-8 cm. tall, simple : leaf-blades linear or narrowly linear, $1.5-3 \mathrm{dm}$. long, flattish, acute or sometimes rather obtuse ; sheaths $1-2.5 \mathrm{~cm}$. long, villous, mostly imbricated: bracts 2, nearly equal, longer than the leaves: pedicels stoutish, $3.5-5.5 \mathrm{~cm}$. long, villous: cymes 5-15-flowered: sepals ovate or oblong-ovate, 10-11 mm. long, obtuse: corolla mostly purplish blue, about $2 \mathrm{~cm}$. broad: petals suborbicular, obtuse, delicately veined: mature capsule not seen.

On hillsides and in woods, Illinois to Missouri and Tennessee. Spring.

2. Tradescantia bracteàta Small. Stems rather stocky, often clustered, erect or ascending, 1-2 dm. tall or rarely somewhat taller, sometimes sparingly branched: leafblades broadly linear or linear-lanceolate, 1-2 dm. long, involutely folded, curred; 
sheaths 1-2 cm. long, conspicuously ribbed: bracts 2 , somewhat unequal, lanceolate, saccate at the base and broader than the leaves, sometimes sparingly ciliate near the base: sepals elliptic, slightly hooded, glandular-pilose like the pedicels: corolla deep blue or often red: petals orbicular-ovate, about $1.5 \mathrm{~cm}$. long: mature capsule not seen.

In valleys and along streams, Minnesota and South Dakota to Texas. Spring and summer.

3. Tradescantia occidentàlis Britton. Stems rarely solitary, slender, $3-8 \mathrm{dm}$. tall, often branched: leaf-blades linear, usually $2-3 \mathrm{dm}$. long, involutely folded, curved; sheaths 1-4 cm. long, conspicuously ribbed, rarely with a few cilia : bracts 2 , linear, slightly unequal: pedicels rather slender, 1-2 cm. long : sepals oblong or elliptic, apparently lanceolate from the involute edges, $8-10 \mathrm{~mm}$. long, glandular-pilose : petals blue or reddish, rather small, about $1 \mathrm{~cm}$. long, orbicular-obovate: capsules obovoid or oblong, 5-6 mm. long, glabrous except the puberulent apex: seeds oblong, nearly $3 \mathrm{~mm}$. long, pitted and ridged.

On sand hills or in stony grounds, Iowa to Texas and the Rocky Mountains. Summer.

4. Tradescantia Virginiàna L. Stems usually clustered, stout or stoutish, erect, 2 $\mathrm{dm}$. or mostly 3-4 dm. tall, nearly straight, simple : leaf-blades linear or linear-lanceolate, 1 or usually $2-7 \mathrm{dm}$. long, acuminate, more or less curved, nearly flat or involutely folded ; sheaths 1-3 cm. long, sometimes slightly ciliate: bracts 2, lanceolate or linear-lanceolate, nearly equal or very unequal, usually much smaller than the leaves: pedicels $2.5-5 \mathrm{~cm}$. long: sepals large, elliptic, ovate or ovate-lanceolate, 12-18 $\mathrm{mm}$. long, obtuse or acutish, villous with long non-glandular hairs, about twice as long as broad, becoming membranous: corolla dark blue or purplish or rarely white, about $3-4 \mathrm{~cm}$. broad: petals suborbicular, 1.4-2 cm. in diameter : capsules 5-7 mm. long, glabrous : seeds oblong, about $3 \mathrm{~mm}$. long.

On hillsides and along streams, New York to Illinois, North Carolina and Arkansas. Spring.

5. Tradescantia refléxa Raf. Stems often solitary, 4-9 dm. tall, nearly straight, commonly branched, glaucous or sometimes purplish : leaf-blades nearly linear, $2-5 \mathrm{dm}$. long, straight, or somewhat curved, long-attenuate, glaucous ; sheaths large, $1-3 \mathrm{~cm}$. long, glabrous or rarely slightly villous: bracts 2 , unequal, finally reflexed : cymes usually dense at maturity: pedicels slender, $2-2.5 \mathrm{~cm}$. long, crowded: sepals oblong or elliptic, apparently lanceolate from the involute edges, $8-10 \mathrm{~mm}$. long, hooded, mostly with a tuft of hairs at the apex, sometimes glabrate, 3-4 times as long as broad, leathery : corolla blue, 2-3 cm. broad : petals suborbicular: capsules ovoid or oblong, 5-6 mm. long, glabrous, constricted above the middle : seeds oblong, $3 \mathrm{~mm}$. long, with irregular transverse ridges.

In sandy or clay soil, in the Gulf States and from South Carolina to the Indian Territory and Texas; ascends the Mississippi Valley to Minnesota. Spring and summer.

6. Tradescantia gigantèa Rose. Stems tufted, erect, 6-10.5 dm. tall, stout, somewhat branched, glabrous and glaucous below: leaf-blades linear-oblong, $3 \mathrm{dm}$. long or shorter, glaucous, ciliate; sheaths glabrous: bracts of the involucre 2-3, narrowly linear beyond the sac-like bases, like the upper joint of the stem densely hairy with almost velvety pubescence: cymes with 50 or more flowers : pedicels $3-4 \mathrm{~cm}$. long, softly pubescent but not glandular: sepals oblong-ovate to oblong-lanceolate, about $10 \mathrm{~mm}$. long, acute, pubescent like the pedicels : corolla blue, pink or white.

On plains or prairies, Texas. Spring.

7. Tradescantia incarnàta Small. Stems stout, 3-7 dm. tall, sometimes branched above: leaf-blades narrowly lanceolate to almost linear, mostly $2-5 \mathrm{dm}$. long, undulate ; large sheaths ciliate with glandless hairs: bracts $2,1-2.5 \mathrm{~cm}$. long, shorter than the umbel: pedicels glabrous : sepals oblong to ovate, $6-8 \mathrm{~mm}$. long, one, at least, bearded at the apex : corolla bright red, about $2.5 \mathrm{~cm}$. broad : petals ovate, often acutish : capsules $5-6 \mathrm{~mm}$. long.

In sandy soil, Mississippi. Spring.

8. Tradescantia hirsuticaùlis Small. Stems, like all the foliage, hirsute throughout with long brownish or whitish hairs, or partially glabrous above, several together, erect or nearly so, 3-4 dm. tall, leafy throughout, simple or nearly simple : leaf-blades narrowly linear, 2-3 dm. long, more or less curved, involutely folded, less densely pubescent than the stem ; sheaths rather pale, $1-2.5 \mathrm{~cm}$. long, conspicuously ribbed : bracts 2 , linear, very unequal, somewhat smaller than the stem-leaves : pedicels slender, $2-2.5 \mathrm{~cm}$. long: sepals variable in the same flower, ovate or lanceolate, $9-15 \mathrm{~mm}$. long, rather villous and somewhat glandular : corolla $2.5-3 \mathrm{~cm}$. broad: petals suborbicular, pink-purple or bright blue, broader than long and undulate : mature capsules not seen.

In sandy places, Georgia, Alabama and Florida. Spring and early summer.

9. Tradescantia hùmilis Rose. Stems, like the rest of the foliage, scabrous-pubescent, finally branched at the base ; branches spreading, $3 \mathrm{dm}$. long or shorter : leaf-blades broadly linear or narrowly linear-lanceolate, $8-20 \mathrm{~cm}$. long, deep green ; sheaths imbricated at the base of the stem : cymes several-flowered : bracts of the involucre 2 or rarely 1 , quite sim- 
ilar to the leaves : pedicels 1-2 cm. long, glandular-pubescent : sepals lanceolate or oblonglanceolate, acute or acuminate, glandular-pubescent and with tufts of simple hairs near the apex : petals pale blue or pink, obtuse : capsules $5-6 \mathrm{~mm}$. long, pubescent.

On plains and prairies, Texas. Spring and summer.

10. Tradescantia longifòlia Small. Stems, like the rest of the foliage, glandular, usually solitary, erect or assurgent, 4-5 dm. tall, strict, sometimes sparingly branched above : leaf-blades brown-green, linear or nearly so, chiefly basal or confined to the lower part of the stem, $2-4 \mathrm{dm}$. long, even the lower ones surpassing or almost equalling the stem in length, gradually narrowed from near the base, flat, densely glandular like the stem ; sheaths $2-2.5$ cm. long, ciliate with long hairs, imbricated below: bracts 2, small, leaf-like or rarely almost wanting : pedicels stoutish, $1.5-2 \mathrm{~cm}$. long : sepals linear-lanceolate or linear-oblong, $1 \mathrm{~cm}$. long, obtuse : corolla deep blue, $2.5-3 \mathrm{~cm}$. broad : capsules oblong, 8-9 $\mathrm{mm}$. long, glandular: seeds oblong or ovoid, more or less flattened, gray, conspicuously marked with irregular transverse ridges.

In sandy pine lands, Florida. Spring and summer.

11. Tradescantia foliòsa Small. Stems often solitary, 4-7 dm. tall, simple or nearly so, very leafy near the base, glabrous or glabrate : leaf-blades narrowly linear, 2-6 $\mathrm{dm}$. long, nearly equalling or surpassing the stem, long-attenuate, crowded at the base ; sheaths large, often densely long-villous, imbricated and sheathing the stem for 1-2 dm., prominently ribbed : bracts 3 , unequal: pedicels slender, $1-1.5 \mathrm{~cm}$. long: cymes dense at maturity : sepals ovate or oblong, about $7 \mathrm{~mm}$. long, obtuse, two strongly hooded and with a tuft of hairs near the apex, one scarcely hooded and nearly glabrous at the apex : corolla blue, about $2 \mathrm{~cm}$. broad : capsules oblong, $5-6 \mathrm{~mm}$. long, glabrous : seeds irregular, 2-2.5 mm. long, not much longer than broad.

In clay soil, chiefly in hammocks, eastern and peninsular Florida. Spring.

12. Tradescantia micrántha Torr. Stems slender, sometimes creeping, 1-2 dm. long, spreading, leafy to the top: leaves few ; blades thickish, ovate to lanceolate, $1-3 \mathrm{~cm}$. long, acute, keeled beneath, often slightly reflexed, somewhat scabrous on the margins; sheaths $1-3 \mathrm{~mm}$. long, villous at the mouth : bracts 2 , or rarely solitary, leaf-like: cyme terminal, about 6 -flowered : pedicels $12-16 \mathrm{~mm}$. long, glabrous : buds acute : sepals nearly equal, greenish, $6 \mathrm{~mm}$. long, pubescent along the keel chiefly toward the base: petals bright pink, slightly longer than the sepals, orbicular or broadly ovate: filaments pubescent below : anther-sacs separated by a broad connective.

In rich soil, southern Texas. Spring to fall.

13. Tradescantia fluminénsis Vell. Stems ${ }^{\circ}$ more or less diffusely branched at the base, the branches spreading, or decumbent and creeping, 2-9 dm. long, often branched: leaves rather numerous; blades ovate or oblong-ovate, $2-6 \mathrm{~cm}$. long, acute or slightly acuminate, ciliolate, rounded or subcordate at the base; sheaths 4-6 mm. long, ciliate with villous hairs: cymes sessile, few-flowered: bracts 2, unequal, similar to the leaves but smaller: pedicels slender, $5-15 \mathrm{~mm}$. long, oblong-ovate, apparently narrower, minutely pubescent without and chiefly toward the apex : corolla white.

In sandy soil, North Carolina to Florida. Naturalized from South America. Spring to fall.

14. Tradescantia montàna Shuttl. Stems usually solitary, slender, $3-7 \mathrm{dm}$. tall, straight or nearly so, rarely sparingly branched above: leaf-blades narrowly lanceolate or linear-lanceolate, 1-3 dm. long, usually minutely pubescent, or rarely glabrate, acuminate, flat ; sheaths 1-2 cm. long, ciliate: bracts 2, lanceolate, one of which is at least one-half smaller than the other: pedicels slender, 1-1.2 cm. long: sepals ovate or oblong, sometimes apparently lanceolate from the involute edges, 5-6 $\mathrm{mm}$. long, pilose or villous, obtuse, hooded, often minutely glandular: corolla blue, $2-2.5 \mathrm{~cm}$. broad : petals suborbicular or orbicular-ovate : capsules oblong or oval, $5-6 \mathrm{~mm}$. long, glabrous, or pilose especially above the middle : seeds oval-oblong, $3 \mathrm{~mm}$. long, irregularly tuberculate and coarsely granular.

On sandy hillsides in the Allegheny Mountains from Virginia to North Carolina, Georgia and Alabama. Spring and summer.

15. Tradescantia pilòsa J. G. C. Lehm. Stems stout, 4-8 dm. tall, flexuous, often puberulent, leafy to the top, usually sparingly branched: leaf-blades lanceolate or sometimes rather narrowly lanceolate, 1-2.5 $\mathrm{cm}$. long, ciliate, inconspicuously ribbed : involucre of $2-3$ bracts similar to the leaves, one about twice as long as the others : pedicels normally slender, $1.5-2 \mathrm{~cm}$. long, villous-pilose, or often glabrate : cymes usually crowded at maturity : sepals ovate or oblong, about $7 \mathrm{~mm}$. long, apparently lanceolate from their involute edges, two strongly hooded, mostly villous-pilose: corolla pale blue or deep blue, large, $2.5-3 \mathrm{~cm}$. broad : petals ovate-orbicular, obtuse : capsules globose-oblong, $5 \mathrm{~mm}$. long, constricted at the middle, pilose at the summit : seeds oblong or ovoid, $2-3 \mathrm{~mm}$. long.

In thickets and on shaded hillsides, Ohio to Missouri, West Virginia, Alabama and TennesseeSpring and summer. 
16. Tradescantia comàta Small. Stems erect or ascending, 3-5 dm. tall, rarely sparingly branched, very villous: leaf-blades lanceolate or narrowly lanceolate, $1-3 \mathrm{dm}$. long, acute or short-acuminate, ciliate, villous on both surfaces or glabrate above, somewhat narrowed near the base; sheaths villous like the stem, $1-3 \mathrm{~cm}$. long: bracts 1-2, like the leaves but smaller : pedicels usually densely villous : sepals oblong or elliptic-oblong, 7-9 $\mathrm{mm}$. long, villous, acute or acutish : corolla blue, 1.5-2 cm. broad: capsules oblong, 4-5 mm. long, glabrous : seeds oblong, $3 \mathrm{~mm}$. long, tuberculate-ridged.

In the upper districts and mountains of Georgia. Summer.

\section{TRELEÀsea Rose.}

Perennial caulescent herbs, with tuberous-thickened roots. Leaves alternate: blades relatively broad and short. Cymes umbel-like, sessile in an involucre of bracts resembling the leaves. Sepals 3, concave. Petals 3, the claws cohering and forming a slender tube. Stamens 6 , all perfect, nearly equal : filaments pubescent, partially adnate to the petals. Capsule stalked. Seeds 2 in each cavity.

1. Treleasea brevifolia (Torr.) Rose. Stems often branched at the base, the branches prostrate or decumbent, $2-4 \mathrm{dm}$. long, leafy to the ends : leaves approximate; blades thick, oblong to ovate, $3-7.5 \mathrm{~cm}$. long, acute, glabrous except the scabrous-ciliate margins, glaucous; sheaths $1 \mathrm{~cm}$. long or shorter, ciliate: bracts 2 , similar to the leaves but smaller: cymes many-flowered : pedicels villous : sepals oblong, somewhat villous : corolla white, or pink : petals about $1 \mathrm{~cm}$. long, obovate beyond the claw : filaments pubescent, surpassing the petals : ovary villous at the top.

In rich soil, southern Texas and northern Mexico. Spring and summer.

\section{COMMELINA L.}

Annual or usually perennial herbs, with mostly spreading stems. Leaves alternate: blades thickish, entire, sheathing at the base. Involucre often peduncled, spathe-like, folded. Flowers irregular, few together in cymes. Sepals 3, unequal, the larger often partly united. Petals 3, commonly blue, 2 much larger than the third, showy. Stamens 3 or rarely 2: filaments filiform, glabrous, one usually incurved and with a larger anther than the rest. Sterile stamens 2-3, smaller than the fertile. Capsules 2-3-celled, hidden in the spathes. Seeds if 2, one above the other. DAY-Flower. Dew-Flower.

Spathes not united at the base.

Spathes acuminate: capsules 3-celled, 5 -seeded.

Spathes acute: capsules 2-celled, 4-seeded.

Spathes with the bases united.

All three cavities of the ovary with 2 ovules.

Spathes $1 \mathrm{~cm}$. long or shorter.

Spathes $2-3 \mathrm{~cm}$. long.

Sheaths at least the lower ones glabrous or nearly so: pubescence if present not hirsute.

Internodes or a portion below the sheaths pubescent or scabrous : rootstocks and roots abbreviated, the latter slender fusiform.

Internodes at least the lower ones smooth and glabrous : rootstocks and roots elongated, the latter cord-like.

Spathes pubescent, mainly at the base: sheaths neither pale nor loose and inflated.

Spathes pubescent throughout: sheaths pale, loose and inflated.

Sheaths usually more or less densely hirsute throughout.

Spathes pubescent with short hairs and with long hairs near the base or along the back.

Spathes 2-3 cm. long, acuminate, mainly longer than broad. Capsules 2-valved, the dorsal cavity indehiscent. Capsule 3-valved, all the cavities dehiscent.

Spathes $1-1.5 \mathrm{~cm}$. long, merely acute, mainly as broad as long. Spathes glabrous at least without long hairs near the base.

Ventral cavities of the ovary with 2 ovules, dorsal cavity with 1 ovule.

1. C. nudiflora.

2. C. communis.

3. C. Nashii.

4. C. Swingleana.

5. C. angustifolia. 6. .C. crispa.
7. C. Virginica.
8. C. erecta.
9. C. saxicola.
10. C. elegans.
11. C. hirtella.

1. Commelina nudiflòra L. Stems usually branched at the base ; branches spreading or decumbent and creeping, 3-10 dm. long, more or less diffuse : leaf-blades lanceolate or oblong-lanceolate, $3-10 \mathrm{~cm}$. long, acute, rounded at the base; sheaths sometimes ciliate or erose : peduncles 1-1.5 cm. long, usually with a line of hairs on the inner side: spathes 2-4 cm. long, often thrice as long as broad, acuminate, not united at the base : capsules 3celled, 7-8 mm. long, apiculate : seeds commonly 5 in each capsule, $3 \mathrm{~mm}$. long, granular.

In moist and waste ground, New Jersey to Missouri, Florida, Texas, and through tropical America to Paraguay. Spring to fall.

2. Commelina commùnis L. Stems erect, or diffusely branched from the base ; branches decumbent and creeping, 3-10 dm. long: leaf-blades lanceolate or oblong-lance- 
olate, 4-12 cm. long, acute or acuminate at the apex, acute or rounded at the base ; sheaths whitish, with green nerves, usually erose-ciliate : peduncles $1-3 \mathrm{~cm}$. long : spathes $2-4 \mathrm{~cm}$. long, acute, about twice as long as broad, not united at the base : capsules 2-celled, $6-7 \mathrm{~mm}$. long, apiculate : seeds 4 in each capsule, $3-3.5 \mathrm{~mm}$. long, tuberculate and pitted.

In waste places, New York to Pennsylvania, Georgia and Kentucky. Summer.

3. Commelina Náshii Small. Stems from cord-like spreading roots, erect or branched at the base; branches ascending or spreading, 2-4 dm. long, slender, glabrous except parts of the upper internodes: leaf-blades linear or nearly so, 4-8 cm. long, acuminate, somewhat crisped, glabrous above the base; sheaths $1 \mathrm{~cm}$. long or shorter, ribbed, ciliate: spathes $1 \mathrm{~cm}$. long or shorter, acute, closed at the truncate base, curved on the dorsal side, sharp-pointed : capsule about $4 \mathrm{~mm}$. long, prominently striate : seeds $2.5-3$ mim. long, smooth and glabrous.

In sandy soil, North Carolina to Florida and Mississippi. Summer and fall.

4. Commelina Swingleàna Nash. Stems erect or ascending from a cluster of descending, narrowly fusiform roots, 1-4 dm. long, simple or branched at the base and sometimes above, internodes or parts below the nodes pubescent or scabrous : leaf-blades linear to narrowly linear-lanceolate, $11-12 \mathrm{~cm}$. long, attenuate, glabrous or ciliate near the base ; sheaths somewhat inflated, 8-12 mm. long: peduncles 5-8 mm. long: spathes about $2 \mathrm{~cm}$. long, acuminate, somewhat falcate, closed at the base : corolla showy : larger petals deep blue, the blades reniform, about $12 \mathrm{~mm}$. long, $17 \mathrm{~mm}$. broad, the claws $3-4 \mathrm{~mm}$. long: capsules subglobose, $4-5 \mathrm{~mm}$. long, glabrous: seeds 3 in each capsule, $3-3.5 \mathrm{~mm}$. long, smooth, dark brown.

In pine lands, Florida. Spring to fall.

5. Commelina angustifòlia Michx. Stems erect or diffusely branched at the base, from cord-like roots, $2-8 \mathrm{dm}$. long, internodes, at least the lower ones, glabrous : leaf-blades linear or nearly so, sometimes narrowly linear, $3-12 \mathrm{~cm}$. long, attenuate, glabrous beyond the ciliate bases ; sheaths 1-2 cm. long, green or purplish, ribbed : spathes $2-2.5 \mathrm{~cm}$. long, acute or acuminate, pubescent mainly near the base : capsules $3-4 \mathrm{~mm}$. long, about as broad : seeds about $3 \mathrm{~mm}$. long, puberulent, otherwise smooth.

In sandy soil, North Carolina to Florida. Spring.

6. Commelina críspa Wooton. Stems finely villous, or glabrate below, branched at the base ; main branches ascending or spreading, 2-9 $\mathrm{dm}$. long, usually branched : leaf-blades lanceolate to linear-lanceolate, $3-8 \mathrm{~cm}$. long, acuminate, erisped, slightly contracted at the base ; sheaths thin, pale, $12-15 \mathrm{~mm}$. long, ciliate with a few bristle-like hairs : spathes $2-2.5 \mathrm{~cm}$. long, acute or acuminate, pubescent throughout, united at the base : sepals orbicular-elliptic: petals various, upper 2 bright blue, with slender claws $3-4 \mathrm{~mm}$. long, and broadly reniform blades $1-1.5 \mathrm{~cm}$. broad, delicately veined; third petal white, lanceolate, 2-3 mm. long: capsules 4-5 $\mathrm{mm}$. long, 2-celled, 2 cavities dehiscent, the third indehiscent : seeds smooth.

In sandy and rocky soil, Nebraska to Texas and New Mexico. Summer and fall.

7. Commelina Virgínica L. Stems branched ; branches spreading or decumbent, 2-9 $\mathrm{dm}$. long, pubescent, sometimes zigzag : leaf-blades lanceolate, often narrowly so, $3-10 \mathrm{~cm}$. long, mostly acuminate, often quite narrow at the base ; sheaths pale, 1.5-2 cm. long, often fringed at the top: peduncles $5-10 \mathrm{~mm}$. long: spathes $2-3 \mathrm{~cm}$. long, acuminate, mainly longer than broad: closed at the base: capsules 4-5 mm. long, glabrous, 2-valved, the dorsal cavity indehiscent : seeds $3-3.5 \mathrm{~mm}$. long.

In moist or dry sandy soil, New York to Nebraska, Florida and Texas. Summer to fall.

8. Commelina erécta $L$. Stems simple and erect or diffusely branched at the base, 1-8 dm. long, pubescent at least near the nodes : leaf-blades linear to linear-lanceolate, $6-12$ cm. long, acute or attenuate, more or less pubescent, sometimes hirsute ; sheaths somewhat hirsute and ciliate: peduncles $5-12 \mathrm{~mm}$. long: spathes $2-2.5 \mathrm{~cm}$. long, short-acuminate, nerved, closed at the base : capsules 3 -valved, all eavities dehiscent, 3-4 mm. long, about as broad : seeds 3 in each capsule, $3 \mathrm{~mm}$. long, puberulent. fall.

In rocky soil or banks, Pennsylvania to Florida and Texas and tropical America. Summer and

9. Commelina saxícola Small. Stems often branched at the base : branches spreading or decumbent, $2-8 \mathrm{dm}$. long, simple or again branched, pubescent below the nodes: leaves remote; blades lanceolate or linear-lanceolate, 4-10 $\mathrm{cm}$. long, acute, more or less pubescent, pale beneath : sheaths $1-15 \mathrm{~cm}$. long, pubescent, with a collar-like ciliate dilation at the top: pedicels $5-8 \mathrm{~mm}$. long, minutely pubescent : spathes about $1.5 \mathrm{~cm}$. long, nearly or quite as broad, finely pubescent, merely acute, nearly straight on the back : petals bright blue ; blades $2 \mathrm{~cm}$. broad, about $1.5 \mathrm{~cm}$. high, crisped, notched : capsules 4-5 mm. long: seeds $3 \mathrm{~mm}$. in diameter.

On rocks, especially granite, North Carolina and Georgia. Summer. 
10. Commelina élegans H.B.K. Stems erect or branching at the base ; branches decumbent, rooting at the nodes, $2-8 \mathrm{dm}$. long, with short or elongated puberulent internodes : leaf-blades lanceolate to elliptic or oblong-lanceolate, 4-10 cm. long, acute or acuminate, some often rounded at the base; sheaths $1-1.5 \mathrm{~cm}$. long, naked or sparingly ciliate on the spreading margin : spathes short-peduncled, glabrous, at least without long hairs at the base, 1.5-2 cm. long, acute: petals blue or white: capsules obovoid, $4 \mathrm{~mm}$. long, reticulated especially on the dorsal lobe: seeds 3 , smooth.

In sand, peninsular Florida and tropical Ameriea. Spring and fall.

11. Commelina hirtélla Vahl. Stems erect, ascending or reclining, $2-12 \mathrm{dm}$. tall, somewhat pubescent, more or less branched: leaf-blades lanceolate or oblong-lanceolate, 10-20 cm. long, acuminate, often roughish, narrowed into short petiole-like bases ; sheaths $1-2.5 \mathrm{~cm}$. long, fringed with brown hairs : peduncles very short: spathes usually clustered, triangular or triangular-ovate, $2-2.5 \mathrm{~cm}$. long, acute, united at the base, strongly nerved and cross-nerved : capsules 7-8 mm. long, smooth and shining: seeds 5 in each capsule, 4-6 mm. long, granular-puberulent.

In swamps and alluvial soil, New Jersey to Missouri, Florida and Texas. Summer and fall.

\section{Family 5. PONTEDeriadeEAE Dumort. Pickerel-Weed Family.}

Bog or aquatic herbs, with rootstocks. Leaves alternate, often clustered, sometimes mainly basal : blades ribbon-like or much dilated. Flowers perfect, more or less irregular, solitary or in spikes subtended by leaf-like spathes. Perianth corolla-like: members 6, partially united. Androecium of 3-6 stamens partially adnate to the perianth. Filaments filiform, or dilated at the base, or thickened about the middle. Gynoecium a compound pistil. Ovary 3-celled with axile placentae, or 1-celled by suppression. Stigma entire or minutely toothed. Ovules solitary or numerous, anatropous. Fruit a 1-celled 1-seeded utricle, or a many-seeded capsule. Endosperm mealy, copious, surrounding the central embryo.

Stamens 3, or rarely 1-4.

Stamens 6 .

Ovary 1-celled (by suppression): ovule and seed solitary : fruit indehiscent.

Ovary 3-celled : ovules and seeds numerous: fruit 3-valved.

1. Heteranthera.

2. Pontederia.

3. Piaropus.

\section{HETERANTHËA R. \& P.}

Herbs, with creeping or floating stems. Leaves alternate: blades broadened, or grass-like, often petioled, sometimes reduced to phyllodes. Spathes bract-like, 1-severalflowered. Perianth white, blue or yellow: members equal or nearly so, narrow, or dilated. Stamens 3, or rarely 1-4: filaments often unequal : anthers erect, introrse. Ovary 3-celled, sometimes incompletely so: style filiform. Ovules numerous, in 2 rows on each placenta. Capsule somewhat elongated, enclosed in the withered perianth. Seeds numerous, ribbed. [Schollera Schreb.]

Leaves not differentiated into blade and petiole, linear: perianth yellow.

Leaves differentiated into petiole and blade: perianth white or blue.

Leaf-blades longer than broad: spathes 1-flowered.

Leaf-blades broader than long: spathes 2-5-flowered.

1. H. dubia.

2. H. limosa.

3. H. reniformis.

1. Heteranthera dùbia (Jacq.) MacM. Stems floating or creeping, 2-9 dm. long, branched : leaves linear, more or less elongated, flat, acute, sheathing at the base: spadix 1-2-flowered : perianth light yellow, delicate; tube about $1 \mathrm{~mm}$. thick; lobes linear, 8-12 $\mathrm{mm}$. long: filaments dilated below : anthers linear-sagittate: seeds oblong or oval-oblong, $1.5 \mathrm{~mm}$. long, delicately ribbed. [H. graminea (Michx.) Vahl.]

In still water, Ontario to Oregon, Florida and Mexico. Summer and fall. WATER STAR-GRAss.

2. Heteranthera limòsa (Sw.) Willd. Stems 1-5 dm. long, branched, succulent : leaves often numerous ; petioles terete or nearly so, $3-20 \mathrm{~cm}$. long; blades ovate to oblongovate, 1-3 cm. long, obtuse, entire, rounded or subcordate at the base : phyllodes sometimes present: spathe 1-flowered: perianth white or blue; tube slender, $1.5-2 \mathrm{~cm}$. long; lobes linear, shorter than the tube: seeds delicately ribbed.

In shallow water or muddy places, Virginia to Missouri, Florida, Louisiana and tropical America. Spring to fall. MUD PLANTAin.

3. Heteranthera renifórmis R. \& P. Stems creeping in the mud, $0.5-4 \mathrm{dm}$. long, or more elongated : leaves few ; petioles $0.5-2 \mathrm{dm}$. long; blades reniform to orbicularreniform, $3-6 \mathrm{~cm}$. broad, entire, more or less deeply cordate : spathe 2-5-flowered: 
perianth white or pale blue; tube straight or slightly curved, 7-8 $\mathrm{mm}$. long; lobes shorter than the tube: anthers various, the 2 upper oval, the lower linear or nearly so and on a larger filament.

In shallow water or muddy places, Connecticut to Kansas, Louisiana, Texas and South America. Spring to fall. MUD Plantain.

\section{PONTEDÈRIA L.}

Herbs, with horizontal rootstocks. Stems simple, nearly naked. Leaves few : blades leathery, many-nerved. Spike subtended by a bract-like spathe, many-flowered. Flowers ephemeral. Perianth corolla-like, blue or white, 2-lipped; upper lip with 3 rather broad lobes; lower lip with 3 narrow lobes. Stamens 6, very unequally adnate to the perianthtube: filaments filiform : anthers introrse, nearly versatile. Ovary 3-celled, 2 of the cavities empty : style filiform, sometimes elongated. Utricle 1-celled, surrounded by the accrescent base of the perianth. Seed solitary.

1. Pontederia cordàta L. Foliage mostly glabrous. Stems $3-12 \mathrm{dm}$. tall, simple, or branching at the base: leaves erect; petioles elongated, sheathing at the base, those of the stem much shorter than those of the basal leaves; blades ovate to lanceolate, $10-20 \mathrm{~cm}$. long, obtuse, entire, cordate or somewhat sagittate at the base : spike minutely glandular: perianth bright blue or white, $10-15 \mathrm{~mm}$. long; tube curved; lobes oblong to linear, shorter than the tube, the middle one with two yellow spots near the base within : stamens and style colored like the perianth : seeds oblong-ovoid, $3 \mathrm{~mm}$. long.

On borders of streams, ponds and in swamps, Nova Scotia to Minnesota, Florida and Texas. Spring to fall. PtCK EREL-WeEd. WAMPEE.

\section{PIARÒPUS Raf.}

Herbs, with floating rootstocks copiously root-bearing at the nodes. Leaves clustered at the nodes, more or less emersed : petioles slender or inflated : blades commonly widely dilated. Flowers sessile, solitary, or in terminal spikes or racemes on scaly peduncles. Perianth showy : members 6 , in 2 series, united into a tube below, the limb oblique. Stamens 6 , irregularly adnate to the perianth, 3 included, 3 exserted : filaments sometimes flattened at the base. Ovary 3-celled : stigma terminal. Ovules numerous. Capsule included in the withering-persistent perianth, loculicidal. Seeds many-ribbed. [Eichornia Kunth.]

1. Piaropus crássipes (Mart.) Britton. Floating or rooting in the mud. Foliage glabrous below : leaves erect, or ascending; petioles elongated, wholly or partly inflated or sometimes gradually tapering from the base ; blades $3-8 \mathrm{~cm}$. in diameter, ovate to orbicular or nearly reniform, leathery : scapes $1-4 \mathrm{dm}$. tall, simple : spadix glandular-pubescent : perianth showy, bluish purple; tube curved, about $1.5-2 \mathrm{~cm}$. long; lobes suborbicular or obovate, longer than the tube, the upper one with a yellow center.

In slow streams and lakes, Florida, introduced and often troublesome, and tropical America. WATER HYACINTH. WAMPEE.

\section{Family 6. BRomeliàceat J. St. Hil. Pine-Apple Family.}

Epiphytic or rarely terrestrial rigid or pendent caulescent herbs, with scurfy foliage, or sometimes glabrous. Leaves various, sometimes mainly basal, filiform or with dilated blades, elongated, entire, or coarsely spiny-toothed. Flowers perfect, regular, solitary or usually in spikes, commonly subtended by conspicuous bracts. Perianth white or green, or of deeper colors. Sepals 3, distinct or partially united. Petals 3 , often narrowed into claws, distinct or partially united. Androecium of 3-6 stamens. Anthers introrse. Gynoecium a superior or inferior 3-celled pistil. Styles united. Stigmas 3 or 3-lobed. Ovules numerous in each cavity, anatropous. Fruit a berry or a 3 -valved capsule. Seeds stalked. Embryo minute at the base of the mealy endosperm.

Style filiform : stalk of the seed erect: seed erect, pointed.

Stems string-like, pendent : flowers solitary : inflorescence axillary : stamens 3-6. 1. DENDRoPoGoN.

Stems rigid, not pendent: flowers in spikes: inflorescence terminal : stamens 6 . 2 . TILLANDSIA.

Style wanting or nearly so: stalk of seed incurved: seed ascending, tipped by a

blunt coma.

3. Catopsis.

\section{DENDROPÒGON Raf.}

Delicate, chiefly epiphytes, with silvery-scurfy foliage. Stems string-like, branching, pendent, elongated. Leaves scattered, without distinction of blade and petiole, linear- 
filiform above the slightly dilated base. Flowers perfect, axillary, normally solitary. Sepals 3 , imbricated. Petals surpassing the sepals, yellow or greenish. Stamens 6 or rarely 3, included : filaments filiform. Style slender. Stigma 3-lobed. Capsule prismatic, finally septicidally 3 -valved.

1. Dendropogon usneoides (L.) Raf. Scurfy with silvery-gray scales. Stems string-like, spiral-zigzag, hanging in festoons 1-6 m. long, from the branches of trees: leaves scattered, slender, linear-filiform, $2.5-8 \mathrm{~cm}$. long, pubescent like the stem : flowers fragrant, especially at night: peduncles shorter than the leaves : sepals green, oblong or oblong-lanceolate, 5-7 mm. long, acute : petals linear-spatulate, about twice as long as the sepals, their spreading tips yellowish green : capsules linear, $15-30 \mathrm{~mm}$. long. [Tillandsia usneoides L. ]

On trees, mostly near the coast, Virginia to Florida, Texas and Central America. Long Moss, SPANish Moss. Florida Moss.

\section{TILLÁNDSIA L.}

Rigid epiphytes, or rarely terrestrial herbs. Stems firm, often scape-like. Leaves mainly basal, commonly crowded, mostly dilated or saccate at the base, tapering to the apex, entire or variously toothed. Flowers perfect in terminal simple or branched spikes. Sepals 3, firm, distinct. Petals 3, deciduous, with erect claws and narrow blades. Stamens 6 : filaments free. Style filiform. Stigmas spreading. Ovules ascending. Capsule oblong or narrowly prismatic, septicidally 3-valved. Seeds nearly erect from an erect stalk, which separates into delicate hairs, acute. Our species are all epiphytic. Air Plant.

Flowering stems scape-like, filiform or nearly so, with 1 or 2 inconspicuous sheathing scales.

Foliage clothed with a fuzzy scurf.

Flowering stems conspicuously leafy, their leaves smaller than the basal ones.

Basal leaves about as long as the stems or surpassing them.

Leaf-blades less than $2 \mathrm{~cm}$. broad at the base.

Leaves of the stems scurfy.

Leaf-blades abruptly contracted at the base, the dilated part very short. 3. T. tenuifolia.

Leaf-blades gradually contracted, the basal dilated part $1 / 4$ or $1 / 2$ as long as the leaf.

Leaves of the stems glabrous.

Leaf-blades more than $2 \mathrm{~cm}$. broad at the base.

Leaves dilated at the base but not bladder-like, erect or ascending, nearly straight.

Bracts ribbed : leaf-blades tender, flat or nearly so.

Bracts not ribbed : leaf-blades rigid, involute.

Leaves with bladder-like dilations at the base, diffusely spreading and twisted.

Dilated leaf-bases over $3.5 \mathrm{~cm}$. broad, not conspicuously ciliate: inflorescence usually compound.

Dilated leaf-bases less than $3.5 \mathrm{~cm}$. broad, conspicuously ciliate : inflorescence usually simple.

Basal leaves shorter than the stems.

Bracts and flowers erect or appressed to the rachis.

Leaves of the stem with long spreading or recurved tips.

Stems rarely $2 \mathrm{dm}$. tall : inflorescence simple.

2. T. Wilsonii.

Stems $4 \mathrm{dm}$. tall or taller: inflorescence branched,

Leaves of the stem merely clasping scales.

Bracts and flowers more or less strongly spreading.

4. T. juncea.

5. T. festucoides.

6. T. Valenzuelana.

7. T. fasciculata.

8. T. Balbisiana.

9. T. Baileyi.

10. T. circinata.

11. T. polystachya.

12. T. utriculata.

13. T. aloifolia.

1. Tillandsia recurvàta L. Rather slender. Foliage fuzzy-scurfy: stems tufted, $5-15 \mathrm{~cm}$. long, more or less branched, scape-like, with 1 or 2 inconspicuous long-sheathing scales : leaves 2-ranked, numerous ; blades setaceous-filiform from short dilated sheathing bases, these $3-4 \mathrm{~mm}$. broad : flowers usually 2 together : bracts lanceolate, $10-15 \mathrm{~mm}$. long: sepals lanceolate, 7-9 mm. long, acute : petals violet-blue, $12-14 \mathrm{~mm}$. long, each with a narrow claw and somewhat broader blade : capsules cylindric-prismatic, $2-2.5 \mathrm{~cm}$. long, more than twice as long as the bracts.

In swamps, Florida to Texas and Mexico, and in tropical America.

2. Tillandsia Wilsònii S. Wats. Dwarf. Foliage hoary with closely set small peltate brown-centered scales : stems slender, solitary, recurved, $2.5-10 \mathrm{~cm}$. long, with 2 bractlike leaves : basal leaves numerous, nearly terete, $2.5-10 \mathrm{~cm}$. long, attenuate from the elasping base, curved : flowers and fruit unknown.

On branches of Juniperus, Hernando County, Florida.

3. Tillandsia tenuifolia L. Rather slender, scurfy, sometimes reddish. Stems tufted, sometimes recurving, 2-3 dm. long, simple : leaves numerous, erect or ascending ; blades about as long as the stem or longer, abruptly contracted at the base, thence linearsubulate, the dilated base $8-12 \mathrm{~mm}$. long : spikes 4-7 $\mathrm{cm}$. long, continuous : bracts oblong or oblong-lanceolate, $1.5-2 \mathrm{~cm}$. long, abruptly pointed : sepals leathery, lanceolate, $10-12 \mathrm{~mm}$. 
long, keeled: petals blue, $2.5-2.7 \mathrm{~cm}$. long, acutish : capsules cylindric-prismatic, 18-20 mm. long. [T. setacea Sw. T. Bartramii Ell. $]$

In swamps and about rivers, Georgia and Florida. Also in tropical America.

4. Tillandsia júncea Le Conte. Stoutish. Foliage scurfy, green: stems $2-3 \mathrm{dm}$. long, clustered, usually simple : leaves numerous, more or less spreading or recurved ; blades as long as the stems or overtopping them, gradually contracted from a dilated somewhat saccate base, which is often $\frac{1}{4}-\frac{1}{2}$ as long as the leaf: spikes $3-10 \mathrm{~cm}$. long, continuous: bracts broadly oblong or ovate-oblong, $1.5-2 \mathrm{~cm}$. long, acute : sepals lanceolate, $2-2.5 \mathrm{~cm}$. long, acute: petals violet-blue, barely twice as long as the sepals : capsules cylindric-prismatic, 3-3.5 cm. long.

In river swamps, Florida.

5. Tillandsia festucoìdes Brongn. Partially scurfy. Stems tufted, $3-4 \mathrm{dm}$. tall, slender, simple or branched above : leaves numerous, more or less spreading; blades narrowly linear from a gradually contracted base, often fully as long as the stem, rather rigid, those of the stem not scurfy : spikes dense, $2-3.5 \mathrm{~cm}$. long: bracts contiguous, leathery, acute or slightly acuminate : sepals leathery, lanceolate, $15-18 \mathrm{~mm}$. long, glabrous : petals lilac, fully twice as long as the sepals : capsules prismatic-fusiform, $2-2.5 \mathrm{~cm}$. long, acute.

In and about river swamps, Florida, and in the West Indies.

6. Tillandsia Valenzuelàna A. Rich. Scurfy. Stems $2.5-5 \mathrm{dm}$. tall, usually branching above : leaves numerous, 2-3 dm. long; blades rather tender, flat or nearly so, lanceolate-subulate above the dilated but not saccate bases; those of the stems abruptly contracted about 1 or $2 \mathrm{~cm}$. above their bases and usually twisted: spikes many-flowered, narrow : bracts closely imbricated, ribbed : sepals narrowly elliptic or lanceolate, about 10 or $11 \mathrm{~mm}$. long, glabrous : petals about $2.7 \mathrm{~cm}$. long, often pale blue: capsules narrowly prismatic, about $3 \mathrm{~cm}$. long, about thrice as long as the sepals. [T. Houzeavii Morr.]

About river banks, Florida. Also in tropical America.

7. Tillandsia fasciculàta Sw. Scurfy. Stems 2-5 dm. long, solitary or tufted, usually branched above, stout, rarely slightly surpassing the lower leaves : leaves mainly basal, crowded, rigid ; blades erect or somewhat spreading, involute, attenuate from dilated somewhat saccate bases, these often $4-5 \mathrm{~cm}$. broad; stem-leaves sheathing by the broad bases, each contracted into a slender tip : bracts imbricated, in 2 ranks, broadly oblong or ovateoblong, $2-3 \mathrm{~cm}$. long, acute, or acuminate at the base of the spike, becoming lustrous, keeled: sepals parchment-like, lanceolate, $2.5-2.8 \mathrm{~cm}$. long, mucronulate: petals blue : capsules $2.5-3 \mathrm{~cm}$. long.

In swamps or low situations, Florida. Also in tropical America.

8. Tillandsia Balbisiàna Schult. Gray-scurfy. Stems solitary or tufted, $2-8 \mathrm{dm}$. tall, simple or branched above, sheathed throughout : leaves numerous ; blades, especially those of the basal leaves, fully as long as the stem, with large bladder-like dilations at the base, thence rather abruptly narrowed and more or less diffusely spreading and twisted : spikes continuous, compact and usually compound : bracts firm, $1.5-2 \mathrm{~cm}$. long, acute, often abruptly pointed: sepals linear-lanceolate, $15-17 \mathrm{~mm}$. long, acute : petals violet-blue, much longer than the sepals, often $4-5 \mathrm{~cm}$. long: capsules cylindric-prismatic, about $4 \mathrm{~cm}$. long.

In and about swamps, peninsular Florida. Also in tropical America.

9. Tillandsia Baileỳi Rose. Densely scurfy. Stems widely tufted, 1-3 dm. long, simple : leaves mainly basal ; blades elongated, strongly involute, those of basal leaves, often as long as the stem or nearly so, curved and twisted, the bases dilated and bladderlike at maturity, conspicuously ciliate; stem-leaves with sheathing bases: spikes simple, $3-10 \mathrm{~cm}$. long : bracts imbricated, acute, 2-ranked, about $2 \mathrm{~cm}$. long : sepals becoming 1.5 $\mathrm{cm}$. long, acute : petals purple, about $3 \mathrm{~cm}$. long; blades oblong-spatulate : capsules narrowly oblong, $2-2.5 \mathrm{~cm}$. long.

On trees, Cameron County, Texas.

10. Tillandsia circinàta Schlecht. Scurfy. Stems 1-2 dm. long, simple, usually curved, often tufted: leaves mostly basal and crowded; blades shorter than the stem, curved, attenuate from much dilated saccate bases $1.5-3 \mathrm{~cm}$. broad; stem-leaves with long spreading or recurved tips : bracts broadly oblong or lanceolate, $2-2.5 \mathrm{~cm}$. long, continuous, erect or appressed : sepals somewhat membranous, linear-lanceolate, 20-22 $\mathrm{mm}$. long, acute or acuminate: petals violet-blue, about $3-3.5 \mathrm{~cm}$. long: capsules cylindric-prismatic, $5-6 \mathrm{~cm}$. long, twice or thrice as long as the bracts.

In swamps, Florida. Also in tropical America.

11. Tillandsia polystáchya L. Glabrate. Stems stout, $2.5-4 \mathrm{dm}$. tall, simple or branched above : leaves numerous, shorter than the stem; blades linear or linear-filiform, and often recurving above the dilated somewhat saccate bases: spikes continuous, erect, 
5-40 cm. long: bracts ovate-oblong, boat-like, erect or appressed: sepals leathery, elliptic or linear-elliptic, 14-15 mm. long: petals nearly twice as long as the sepals, blue: capsules cylindric-prismatic, about $4 \mathrm{~cm}$. long, acute. [T. angustifolia Sw.]

In river swamps and hammocks, Florida. Also in tropical America.

12. Tillandsia utriculàta L. Deep green beneath the scurfy coating. Stems $3-10$ dm. long, simple or usually branched, curved: leaves numerous, mainly basal; blades shorter than the stem, nearly flat, attenuate from the dilated saccate imbricated bases; these $2-10 \mathrm{~cm}$. broad; stem-leaves wholly clasping, without spreading tips : rachis of the inflorescence zigzag : bracts oblong or ovate-oblong, $1.5-3 \mathrm{~cm}$. long: sepals deep green, oblong or elliptic-obovate, $15-20 \mathrm{~mm}$. long: petals erect, ivory-white or slightly creamcolored : capsules twice or thrice as long as the bracts. [T. flexuosa Sw.]

In hammocks, swamps or about the margins of ponds, Florida. Also in tropical America.

13. Tillandsia aloifòlia Hook. Pale-scurfy. Stems $3-8 \mathrm{dm}$. tall., slender, glabrous, usually branched above : leaves numerous, densely clustered at the base of the stem; blades rather gradually contracted into spreading or recurved tips : stem-leaves sheathing, much reduced, without spreading tips: spikes interrupted, rather few-flowered, the branches ascending or spreading : bracts and flowers more or less spreading, not at all appressed : sepals parchment-like, narrowly elliptic, $2-2.5 \mathrm{~cm}$. long, obtuse, prominently nerved : petals white, pink or purple : capsules cylindric, $5 \mathrm{~cm}$. long, acute.

Near the coast, commonly in hammocks, Florida. Also in tropical America.

\section{CATópsis Griseb}

Epiphytic caulescent herbs, with glabrate or scurfy foliage. Leaves mainly basal : blades tapering, entire, much reduced on the stem. Spikes straight or zigzag. Sepals 3, erect, imbricated. Petals 3, rarely twice as long as the sepals, distinct, or slightly coherent. Stamens 6, included: filaments narrow. Style wanting or nearly so: stigmas 3. Ovules numerous in each cavity. Capsule septicidal. Seeds ascending, on incurved stalks, each tipped by a blunt often several times folded tuft of hairs.

1. Catopsis Berteronlàna (Schult.) Mez. Perennial, light green. Stems 3-9 dm. long, simple or corymbosely branched above : leaves many, mainly crowded at the base of the stem, pale green, 1-4 dm. long; blades lanceolate or ovate at the base, attenuate, much shorter than the stem: bracts remote, ovate or oval, 4-8 $\mathrm{mm}$. long, obtuse : sepals oval or suborbicular, longer than the bractlets: petals white, oblong or ovate-oblong, about as long as the sepals or shorter, persistent : stamens shorter than the petals : capsules ovoid, 6-10 mm. long, exserted, abruptly pointed. [C. nutans Chapm., not Griseb.]

On trees, peninsular Florida, and in tropical America.

\section{Order 9. LILIÀLES.}

Relatively fleshy, or grass-like or sedge-like herbs, rarely vines or trees. Leaves various, mostly with flat blades, sometimes scale-like or terete. Flowers perfect, polygamous or dioecious, complete, regular, or in a few cases irregular. Perianth of 3 or 6 members, these more or less readily distinguishable into calyx and corolla, sometimes partially united. Gynoecium of 3 or rarely 2 united carpels. Ovary superior or nearly so. Fruit various, commonly a capsule or a berry, sometimes berry-like. Endosperm flesh or horny.

Styles present, distinct or united : stigmas terminal.

Styles distinct : capsule septicidal and rarely also loculicidal.

Styles united, often very short or obsolete during anthesis: capsule primarily loculicidal.

Sepals and petals chaffy.

Sepals and petals not chaffy.

Herbs with bulbs, corms or rootstocks. Plants with bulbs or corms.

Flowers in umbels, at first included in and later subtended by a scarious involucre.

Flowers solitary or racemose, without an involucre. Plants with elongated rootstocks.

Shrubby plants with woody caudices, or trees.

Styles wanting: : stigmas introrse, sometimes elongated.

Flowers perfect.

Gynoecium 3-carpellary : fruit a berry.

Gynoecium 2-carpellary : fruit a capsule.

Flowers dioecious.

Fam. 1. Melanthaceae.

Fam. 2. Juncaceae.

Fam. 3. Alliaceat.

Fam. 4. Liliaceak.

Fam. 5. CONVAllariaceae.

Fam. 6. DRACAENACEAE.

Fam. 7. Trilliaceae.

Fam. 8. RoX bURGHIACEAE.

Fam. 9. SMIlacaceaE. 


\section{Family 1. MELANThÀCEAE R. Br. BunCh-Flower Family.}

Perennial caulescent or scapose herbs, with elongated or bulb-like rootstocks. Leaves alternate, sometimes all basal: blades various, often much elongated. Flowers perfect, polygamous or dioecious, regular, in terminal spikes, racemes or panicles, or solitary. Perianth mostly inconspicuous : sepals and petals each 3 , distinct or nearly so. Androecium of 6 stamens, or rarely of 9-12. Filaments often adnate to the base of the sepals and petals. Anthers 2-celled and oblong or ovoid, or confluently 1-celled and cordate or reniform, usually versatile, extrorse, or rarely introrsely dehiscent. Gynoecium of 3 united carpels. Ovary 3-celled, superior or rarely slightly inferior. Styles 3, distinct. Ovules few or many in each cavity, anatropous or amphitropous. Fruit a septicidally 3-valved capsule or rarely also loculicidal. Seeds commonly appendaged. Embryo minute, in copious endosperm.

Anthers oblong or ovoid, 2-celled.

Anther-sacs introrsely dehiscent.

Bracts short: flowers subtended by 3 connate bractlets : stamens 6 : anthers erect.

Flowers in centripetal racemes : seeds unappendaged. 1 . TOFIELDIA.

Flowers in centrifugal panicles: seeds appendaged. 2 . TRIANTHA.

Bracts spathe-like: bractlets wanting: stamens 9-12: anthers versatile. $\quad 3$. PLEEA.

Anther-sacs extrorsely dehiscent.

$\begin{array}{ll}\text { Flowers perfect: capsule with } 6 \text { seeds : leaf-blades elongated, very slender. } & \text { 4. XEROPHYLLUM. } \\ \text { Flowers dioecious : capsule with many seeds: leaf-blades flattened. } & \text { 5. CHAMAELIRIUM. }\end{array}$

Anthers cordate or reniform, sometimes becoming peltate, confluently 1-celled.

Sepals and petals glandless.

Inflorescence racemose or spicate: flowers perfect.

Flowers in spikes or long spike-like racemes: styles short and stout.

Flowers in broad racemes: styles long and slender.

Filaments nearly as long as the sepals and petals: capsules broader than long. with widely spreading styles.

Filaments surpassing the sepals and petals: capsules much longer than broad, with erect styles.

Inflorescence paniculate: flowers polygamous.

Ovary wholly superior: hypanthium scarcely developed: sepals and petals obtuse.

Ovary inferior at the base: hypanthium manifestly developed: sepals and petals acuminate.

Sepals and petals with glands at or near the base.

Sepals and petals with a single gland each.

Flowers polygamous: rootstocks fibrous-coated.

Flowers perfect: rootstocks membranous-coated.

Sepals and petals with two glands each.

Sepals and petals barely clawed : flowers perfect : seeds wingless : plants glabrous.

Sepals and petals long-clawed: flowers polygamous : seeds winged: plants pubescent.

6. SCHOENOCAULON.

7. Chrosperma.

8. Tracyanthus.

9. Veratrum.

10. Stenanthium.

11. OCEANOROS.

12. TOXICOSCORDION.

13. ZYGADENUS.

14. melanthium.

\section{TOFIÈLDIA Huds.}

Perennial herbs, with glabrous foliage. Stems rigid, often scape-like. Leaves basal or mainly so : blades narrow, rather few. Flowers perfect, in erect terminal simple, centripetal recemes. Sepals and petals white or green, nearly equal, narrow, glandless, persistent. Stamens 6, hypogynous, at least the outer series: filaments filiform, sometimes slightly flattened. Ovules numerous in each cavity. Capsule 3-celled, 3-beaked, dehiscent to the base. Seeds unappendaged.

1. Tofieldia glàbra Nutt. Stems erect, $3-6 \mathrm{dm}$. tall : leaf-blades linear, 5-40 $\mathrm{cm}$. long or shorter above : racemes cylindric, $2-10 \mathrm{~cm}$. long, $1.5 \mathrm{~cm}$. thick : pedicels solitary, ascending, $2-4 \mathrm{~mm}$. long: sepals and petals white, oblong or ovate-oblong, 2-3 $\mathrm{mm}$. long, acute : capsules $3-3.5 \mathrm{~mm}$. long.

In low pine lands, North Carolina and South Carolina. Fall.

\section{TRIÁNTHA Nutt.}

Perennial herbs, with pubescent foliage. Stems nearly naked. Leaves mainly basal : blades narrow, flat. Flowers perfect, in erect narrow centrifugal panicles. Sepals and petals white or greenish, nearly equal, glandless, persistent. Stamens 6, mainly hypogynous: filaments slender. Ovules numerous in each cavity. Capsule 3-celled, dehiscent to the base or near it. Seeds with tail-like appendages at each end. 
1. Triantha glutinòsa (Michx.) Baker. Foliage viscid-pubescent. Stems erect, 1.5$5 \mathrm{dm}$. tall : leaf-blades linear, 5-20 $\mathrm{cm}$. long, or shorter above, acute : panicles cylindric, $2-4 \mathrm{~cm}$. long, soon somewhat interrupted : pedicels ascending, $3-10 \mathrm{~mm}$. long, often 3 or 4 together : sepals and petals whitish, oblong or spatulate-oblong, $2.5-4 \mathrm{~mm}$. long, obtuse, membranous : capsules oblong, 6-7 mm. long, about twice as long as the perianth.

In bogs, Newfoundland to Alaska, Maine, and in the Alleghenies to North Carolina, to Ohio, Wyoming and Oregon. Spring.

2. Triantha racemòsa (Walt.) Small. Pubescent like the preceding. Stems 3$9 \mathrm{dm}$. tall, simple : leaf-blades narrowly linear, $1-5 \mathrm{dm}$. long, firm, acuminate: panicles 2-10 cm. long, soon interrupted : pedicels ascending, 1-4 mm. long, often 3 together : sepals and petals whitish, narrowly oblong or oblong-spatulate, fully $3-4 \mathrm{~mm}$. long, firm : capsules oval, shorter than the perianth. [Tofieldia pubens (Michx.) Ait. f.]

In swamps and low ground, New Jersey to Florida and Louisiana. Spring to fall.

\section{PLEÈA Michx.}

Rigid herbs, with slender rootstocks. Stems upright. Leaves mainly basal : blades narrow, sword-like, striate. Flowers perfect, in simple racemes. Bracts spathe-like, clasping. Perianth white within : sepals and petals 6 , rigid, spreading, distinct, persistent. Stamens 9-12, shorter than the perianth : filaments slender : anthers introrse, versatile; sacs distinct at the base. Ovary 3-celled : styles 3, short. Ovules numerous in each cavity. Capsule leathery, separating into 3 carpels. Seeds bristle-tipped.

1. Pleea tenuifòlia Michx. Plant rush-like. Stems $3-8 \mathrm{dm}$. tall, simple, rather rigid : leaf-blades erect or ascending, narrowly linear, 1-2.5 dm. long, firm, attenuate, those of the stem few, similar but smaller : raceme 3-9-flowered, interrupted : bracts appressed, rigid, $1.5-2 \mathrm{~cm}$. long, acuminate, partially imbricated : perianth $2-2.5 \mathrm{~cm}$. broad : sepals and petals linear or linear-lanceolate, firm, acuminate : capsules erect, $6-9 \mathrm{~mm}$. long, as long as the perianth or nearly so.

In pine-land swamps, South Carolina to Florida. Fall.

\section{XEROPHÝLLUM Michx.}

Rigid herbs, with short woody rootstocks. Stems leafy, simple. Leaves numerous : blades sessile, slender, elongated, wire-like, spreading, rough-margined. Raceme simple, with ascending or erect pedicels. Flowers perfect. Perianth white or cream-colored: sepals and petals 5-7-nerved, glandless, persistent. Stamens 6, not surpassing the perianth : filaments subulate : anthers 2-celled ; sacs extrorsely dehiscing. Ovary 3-celled : styles 3, distinct. Ovules 2-4 in each cavity. Capsule little elongated, if at all, 3-celled, loculicidal and also septicidal. Seeds usually 6 , unappendaged or nearly so.

1. Xerophyllum asphodeloides (L.) Nutt. Rootstock large and very hard. Stems $6-15 \mathrm{dm}$. tall, rigid: leaves very numerous, densely crowded at the base of the stem; blades narrowly linear, rigid, $1-5 \mathrm{dm}$. long or much shorter above on the stem, long-attenuate : racemes usually many-flowered, $5-15 \mathrm{~cm}$. long, conic while in flower: pedicels slender, ascending or erect at maturity, $1.5-2 \mathrm{~cm}$. long: perianth white : sepals and petals ovate or oblong-ovate, 5-6 mm. long, obtuse : capsules oval-ovoid, 4-5 mm. long.

In pine lands, New Jersey to Florida and on mountain slopes and summits, North Carolina and Tennessee. Spring and summer. TURKEY-BEARD.

\section{ChAMAELÍrIUM Willd.}

Glabrous fleshy caulescent herbs, with bitter aromatic rootstocks. Leaf-blades various : basal broadened upward, the cauline narrowed upward or linear above, all thickish. Flowers dioecious. Racemes elongated, slender, simple, spike-like. Perianth white : sepals and petals narrow, 1-nerved, nearly equal, distinct. Stamens 6 , much reduced in pistillate flowers : filaments filiform: anthers 2-celled Ovary 3-celled. Ovules 6-12 in each cavity. Staminodia commonly 6 in the pistillate flowers. Capsule somewhat elongated, 3-sided, 3-celled. Seeds 6-12 in each cavity, winged, broadly so at each end. Blazing-Star. Devil's Bit.

Capsules oblong or ovoid-oblong, 7-10 mm. long.

Capsules obovoid or oblong-obovoid, 12-14 mm. long.

1. C. luteum.

2. C. obovale.

1. Chamaelirium lùteum (L.) A. Gray. Stems 2-12 dm. tall, those of staminate plants shorter than those of the pistillate, simple : leaves mainly basal; blades spatulate or oblong-spatulate, $5-20 \mathrm{~cm}$. long, tapering into broad petioles ; stem-leaves usually oblanceo- 
late to lanceolate or linear, few : racemes spike-like ; staminate usually continuous, 5-20 $\mathrm{cm}$. long, its tip nodding; pistillate stiff, interrupted, longer than the staminate : pedicels 1-5 mm. long: perianth (staminate) white: sepals and petals narrowly linear: capsules oblong-ovoid or oblong, 7-10 mm. long.

In open woods, Massachusetts to Optario, Michigan, Florida and Arkansas. Spring and summer.

2. Chamaelirium obovàle Small. Stems $6-11 \mathrm{dm}$. tall, leafy at the base and near the middle, somewhat zigzag : leaves various ; basal with spatulate blades ; cauline shorter, 4-15 cm. long, with oblanceolate to lanceolate or linear, acute or acuminate blades, erect or ascending: flowers manifestly larger than those of $C$. luteum : capsules obovoid or oblongobovoid, 12-14 mm. long, on stout club-shaped pedicels fully as long as the capsules or slightly shorter.

In open woods, New York to West Virginia and North Carolina. Spring.

\section{SCHOENOCAÙLON A. Gray.}

Scapose herbs, with fibrous-coated bulbs. Leaves basal: blades slender, elongated, channeled, firm. Scapes upright, simple. Flowers inconspicuous, in slender spikes or spike-like racemes. Bracts small. Perianth green, persistent : sepals and petals 6 , narrow, nearly equal, distinct, glandless. Stamens 6, hypogynous, surpassing the perianth : filaments elongating : anthers reniform, becoming peltate. Ovary 3-celled : styles very short. Ovules 4-8 in each cavity. Capsule 3-celled, septicidally separating into 3 carpels. Seeds often solitary in each cavity, slender, nearly terete.

Compact portion of the spike $5 \mathrm{~mm}$. thick : sepals oblong : capsules sessile.

1. S. dubium.

Compact portion of the raceme $10 \mathrm{~mm}$, thick : sepals linear: capsules pedicelled. 2. S. Drummondii.

1. Schoenocaulon dùbium (Michx.) Small. Leaf-blades narrowly linear, 1-6 dm. long, involute : scapes slender, 3-9 dm. tall : spikes slender, interrupted, $10-30 \mathrm{~cm}$. long : perianth greenish : sepals and petals oblong, 2-2.5 mm. long, leathery, obtuse, glabrous : filaments filiform : capsules conic, $8-10 \mathrm{~mm}$. long. [S. gracile A. Gray.]

In dry pine lands, Georgia and Florida. Spring.

2. Schoenocaulon Drummóndil A. Gray. Leaf-blades narrowly linear, $2-7 \mathrm{dm}$. long, curved, involute: scapes $3-9 \mathrm{~mm}$. tall : racemes spike-like, $5-15 \mathrm{~cm}$. long, becoming interrupted : perianth green : sepals and petals narrowly linear, $2-3 \mathrm{~mm}$. long, obtuse, inflexed at the apex : filaments clavate : capsules conic-ovoid, $10-12 \mathrm{~mm}$. long.

On prairies, Texas and adjacent Mexico. Spring and summer.

\section{CHROSPÉRMA Raf.}

Glabrous caulescent herbs, with bulb-like rootstocks. Leaves numerous at the base of the stem : blades elongated, spreading, those of the stem much shorter and fewer. Flowers perfect. Racemes thick, cylindric. Perianth white: sepals and petals broad, glandless. Stamens 6 : filaments subulate, acute, shorter than the sepals and petals : anthers 2-celled, broader than long. Ovary 3-celled, the carpels united to below the middle. Ovules few in each cavity. Capsule conspicuously 3-lobed, each carpel tipped with the spreading subulate style-base. Seeds 1-2 in each cavity, thick, reddish brown.

1. Chrosperma muscaetóxicum (Walt.) Kuntze. Foliage somewhat glaucous. Stems 3-12 dm. tall, nearly leafless : leaf-blades linear, strap-like, $3-6 \mathrm{dm}$. long, spreading ; stem-leaves few, narrow ; racemes cylindric, 5-15 cm. long, $3-6 \mathrm{~cm}$. thick, continuous : pedicels spreading or ascending, 1-2 cm. long, slightly thickened upward : perianth white, $8-10 \mathrm{~mm}$. broad : sepals suborbicular : petals slightly broadened above the middle : capsules broader than high, the carpels 4-6 mm. long, plump. [Amianthium muscaetoxicnm (Walt.) A. Gray.]

In sandy woods, Long Island to Tennessee, Florida and Arkansas. Spring and summer. FLYPOISON. CrOW-POISON.

\section{TRACYÁNTHUS Small.}

Glabrous caulescent herbs, with bulb-like rootstocks. Leaves alternate, mainly basal, few, the outer ones mere sheathing scales: blades very narrow and elongated, those of the stem successively shorter and scale-like below the inflorescence. Flowers perfect, in terminal simple racemes. Perianth white: sepals and petals broadened upward, glandless. Stamens 6 : filaments filiform, truncate, longer than the sepals and petals : anthers 2-celled. 
Ovary 3-celled, the carpels united to above the middle. Ovules several in each cavity. Capsule fluted, long and narrow, each carpel with a slender erect tip. Seeds few, narrow.

1. Tracyanthus angustifòlius (Michx.) Small. Foliage glabrous. Stems $5-10 \mathrm{dm}$. tall, simple, racemose at the top: leaf-blades narrowly linear, 1-7 dm. long, or shorter above, flat: racemes oblong-cylindric, $5-10 \mathrm{~cm}$. long: pedicels slender, $1-2 \mathrm{~cm}$. long: perianth white, sometimes turning purple: sepals and petals cuneate, or the oval or ovate sepals somewhat the broader, all 4-5 $\mathrm{mm}$. long, obtuse : capsule narrowly conic, somewhat lustrous, $15-20 \mathrm{~mm}$. long, the carpels with erect tips: seeds linear. [Amianthium angustifolium (Michx.) A. Gray. Zygadenus angustifolius (Michx.) S. Wats.]

In low grounds, North Carolina to Florida. Spring. Crow-Poison.

\section{VERÀTRUM L.}

Coarse caulescent pubescent herbs, with stout poisonous rootstocks. Leaves mainly cauline, often ample: blades plaited, sessile, or with short clasping petiole-like bases. Flowers polygamous or monoecious, numerous. Perianth greenish, yellow or purple: sepals and petals 6 , glandless or nearly so, adnate to the base of the ovary, clawless. Stamens 6 , inserted at the bases of the perianth-members : filaments filiform : anther-sacs confluent. Ovary 3-celled : styles 3, persistent. Ovules usually numerous. Capsule 3-lobed, septicidally 3 -valved. Seeds several in each cavity, flat, broadly winged.

Upper stem-leaves sessile or merely slightly clasping.

Pedicels more than twice as long as the subtending bracts.

Pedicels shorter than the subtending bracts or barely twice as long. Bracts shorter than the pedicels.

Bracts longer than the pedicels or about as long. Upper stem-leaves with sheathing bases.

1. V. parviflorum.

2. V. intermedium.

3. V. Woodii.

4. V. viride.

1. Veratrum parviflòrum Michx. Foliage thinly pubescent. Stems $6-15 \mathrm{dm}$. tall, slender, often reddish purple: leaves mostly near the base of the stem; blades oblong, elliptic or oval or rarely broadest above the middle, $1-3 \mathrm{dm}$. long, acute, narrowed into petiole-like bases: stem-leaves reduced to linear or narrowly linear-lanceolate blades: panicles $3-7 \mathrm{dm}$. long, loosely flowered, the branches slender, usually spreading: pedicels fully twice as long as the subtending bracts : perianth greenish or yellowish green, 10-12 $\mathrm{mm}$. broad: sepals and petals elliptic or spatulate, acute, narrowed to the base: capsules oblong-oval, 12-15 mm. long. [Melanthium parviflorum (Michx.) S. Wats.]

In open woods, on mountain slopes, Virginia to Georgia and Tennessee. Summer. Hellebore.

2. Veratrum intermédium Chapm. Foliage thinly pubescent. Stems $9-15 \mathrm{dm}$. tall: leaf-blades narrowly elliptic, $1-3 \mathrm{dm}$. long, acute, narrowed into sheathing petiole-like bases shorter than the blades: stem-leaves reduced to linear or linear-lanceolate blades : panicle ample, 5-8 dm. long, the branches ascending or curving upward: pedicels longer than the subtending bracts : perianth brown, $15-17 \mathrm{~mm}$. broad : sepals and petals elliptic-spatulate or oblong-spatulate, pubescent without : ovary hairy : capsule 3 -winged, fully $1 \mathrm{~cm}$. long.

In rich hammocks, Florida. Summer.

3. Veratrum Woòdii Robbins. Foliage pubescent, especially above. Stems 6-15 dm. tall : leaf-blades oblong-elliptic or oval, rarely slightly broadest above the middle, 1-3 dm. long, narrowed into sheathing petiole-like bases as long as the blades or shorter; stemleaves reduced to linear blades : panicle ample, $3-9 \mathrm{dm}$. long, the branches ascending : pedicles about as long as the bracts or shorter : perianth purple, $12-15 \mathrm{~mm}$. broad : sepals and petals spatulate or cuneate, obtuse, glabrous or nearly so : ovary pubescent when young : capsules oblong or oval, $12-15 \mathrm{~mm}$. long.

On dry hillsides and in woods, Indiana to Missouri and Arkansas. Summer. False Hellebore.

4. Veratrum vírdde Ait. Foliage pubescent. Stems 6-25 dm. tall, stout, more or less completely sheathed : leaf-blades broadly oval or on upper part of stem becoming elliptic or oblong, 1-3 dm. long, narrowed into sheathing bases : panicle ample, 2-6 dm. long, closely pubescent, many-flowered: pedicels shorter than the subtending bracts : perianth yellowish green, 2-2.5 cm. broad : sepals and petals oblong or oblong-elliptic, ciliate and serrulate : ovary glabrous : capsules $2-2.5 \mathrm{~cm}$. long, oblong or oblong-ovate.

In swamps and deep woods, Quebec to Alaska, Georgia, Tennessee, Minnesota and British Columbia. Spring and summer. INDIAN POKE. AMERICAN WHITE HELLEBORE.

\section{STENÁNTHIUM Kunth.}

Glabrous caulescent herbs, with bulb-like rootstocks. Leaves mainly basal : blades linear, elongated, somewhat keeled, few on the stem. Flowers polygamous, the upper ones of the raceme fertile, numerous in terminal panicles. Perianth white or greenish : sepals 
and petals narrow, acuminate, glandless, persistent. Stamens 6 : filaments shorter than the sepals and petals. Ovary 3-celled: styles 3, spreading or recurving at maturity. Ovules few in each cavity. Capsule oblong or ovoid, erect or reflexed, the carpels tipped by the recurving styles. Seeds about 4 in each cavity, angled.

Perianth usually white : capsules deflexed, about $8 \mathrm{~mm}$. long. Perianth usually green: capsules erect, fully $10 \mathrm{~mm}$, long.

1. S. gramineum.

2. S. robustum.

1. Stenanthium gramíneum (Ker) Morong. Stems 8-15 dm. tall, terete, rather slender, simple to the inflorescence : leaf-blades linear, curved, 2-6 dm. long, shorter above, acute, mostly less than $10 \mathrm{~mm}$. broad : branches of the panicles spreading or ascending : pedicels 1-3 mm. long: perianth white : sepals and petals lanceolate, $6-7 \mathrm{~mm}$. long, irregularly spreading, acuminate : capsules conic, about $8 \mathrm{~mm}$. long, deflexed. [Stenanthium angustifolium Kunth.]

In open woods, Virginia to Kentucky, Florida and Alabama. Summer and fall.

2. Stenanthium robústum S. Wats. Stems stout, $8-16 \mathrm{dm}$. tall, simple to the inflorescence: leaves rather numerous; blades linear, 2-7 dm. long, or shorter above, acute, lower ones usually over $10 \mathrm{~mm}$. broad : panicle many-flowered, the branches mostly numerous : perianth green : sepals and petals linear-lanceolate, $5-6 \mathrm{~mm}$. long, acuminate : capsules oblong-ovoid, fully $10 \mathrm{~mm}$. long, erect.

In swamps, Pennsylvania and Ohio to South Carolina and Tennessee. Summer and fall.

\section{OCEANÒROS Small.}

Glabrous caulescent herbs, with fibrous-coated bulb-like rootstocks. Leaves alternate, mainly basal or on the lower part of the stem, the outer ones bladeless fibrous sheathing scales: blades narrow and elongated, successively shorter above. Flowers in terminal panicles, polygamous, the lower ones of each raceme fertile. Perianth cream-colored or deeper yellow : sepals and petals with a thick yellow gland, broadest about the middle or above it. Stamens 6 : filaments filiform, shorter than the sepals and petals. Ovary 3-celled, the carpels united to the styles. Ovules several in each cavity. Capsule conic, erect, the carpels tipped by the erect or ascending styles. Seeds few in each cavity, winged at the apex.

1. Oceanoros leimanthoides (A. Gray) Small. Stems $5-12 \mathrm{dm}$. tall, paniculate at the top : leaf-blades linear, flattish, 1-6 dm. long, finely ribbed at maturity : panicle pyramidal, 1-3 dm. long, the branches ascending or spreading: pedicels much longer than the subtending bracts : perianth cream-colored or yellowish : sepals and petals oblong or oblong-obovate, 4-5 $\mathrm{mm}$. long, obtuse, the basal gland merging into the surrounding tissues : capsules conic, $8-9 \mathrm{~mm}$. long, much surpassing the perianth. [Zygadenus leimanthoides (A. Gray) S. Wats. ]

In wet soil near the coast, New Jersey to Georgia, and in the mountains of Virginia, North Carolina and Tennessee. Summer.

\section{TOXICOSCÓRDION Rydb.}

Glabrous caulescent herbs, with bulb-like rootstocks. Leaves alternate, mainly basal : blades narrow, more or less conduplicate. Flowers perfect, in terminal racemes or panicles. Perianth white or yellowish : sepals and petals 3 each, often clawed, each bearing an obovate or half-orbicular gland at or near the base of the blade. Stamens 6 : filaments commonly adnate to the base of the claws. Ovary 3-celled, wholly superior. Ovules numerous. Capsule 3-celled, 3-beaked, septicidal. Seeds numerous.

Sepals and petals without claws; gland obovate: filaments free.

Sepals and petals with claws; gland half-orbicular: filaments slightly adnate to the base

1. T. Nuttallii. of the claws.

2. T. Texense.

1. Toxicoscordion Nuttállii (A. Gray) Rydb. Stems $3-7 \mathrm{dm}$. tall, racemose or paniculate above : leaf-blades linear, $1-5 \mathrm{dm}$. long or shorter above, involute, more or less curved, the upper with sheaths: raceme or panicle narrow, $5-30 \mathrm{~cm}$. long, open at maturity : pedicels slender, longer than the subtending bracts: perianth whitish yellow : sepals and petals ovate-oval, clawless, obtuse or notched at the apex, 6-8 $\mathrm{mm}$. long, the glands obovate, merging into the surrounding tissues: capsules conic, 8-12 mm. long. [Zygadenus Nuttallii (A. Gray) S. Wats.]

On prairies, Kansas to Tennessee and Texas. Spring.

2. Toxicoscordion Texénse Rydb. Stems $3-4 \mathrm{dm}$. tall : leaf-blades narrowly linear, 1-3 dm. long, or the upper shorter, conduplicate and somewhat curved, the upper sheathless : 
raceme many-flowered : perianth yellow : sepals and petals about $5 \mathrm{~mm}$. long, subcordate, the sepals more broadly ovate than the petals, both with fleshy claws about $1 \mathrm{~mm}$. long, the glands distinct, half-orbicular, the upper edge free.

On plains or prairies, Texas. Spring.

\section{ZYGADÈnUS Michx.}

Showy caulescent herbs, with glabrous foliage and horizontal rootstocks. Leaves mainly basal : blades linear, elongated, more or less involute. Flowers perfect. Perianth white : sepals and petals furnished with 2 glands above the claw, distinct. Stamens 6, about as long as the perianth : filaments free and distinct. Ovary 3-celled : styles 3 , shorter than the ovary. Capsule somewhat elongated, 3-celled, dehiscent to the base. Seeds few or several in each cavity, angled.

1. Zygadenus glabérrimus Michx. Foliage glaucous. Stems $5-12 \mathrm{dm}$. tall, paniculate above : leaf-blades linear, 1-4 dm. long or shorter above, alternate, finely ribbed, attenuate, often approximate on the lower part of the stem : panicles 1-3 dm. long, the branches ascending : pedicels surpassing the bracts : perianth white : sepals and petals ovate to oblong or lanceolate, $1-1.5 \mathrm{~cm}$. long, acute or acuminate, with 2 glands near the base: filaments dilated at the base : capsules conic-ovoid, about $1 \mathrm{~cm}$. long, much shorter than the perianth.

In swamps near the coast, Virginia to Florida. Summer.

\section{MELÁNTHIUM L.}

Coarse caulescent herbs, with thick rootstocks. Leaves mainly basal: blades narrow, more or less elongated. Flowers monoecious or polygamous. Perianth white, creamcolored or greenish, or darker in age : sepals and petals various, clearly distinguishable into blade and claw, spreading, the blades with 2 conspicuous glands at the base. Stamens 6 : filaments shorter than the perianth. Ovary 3-celled, longer than broad, sessile : styles 3. Ovules numerous. Capsule 3-celled, 3-lobed, membranous. Seeds flat, winged. BunchFLOWER.

Blades of the sepals and petals suborbicular, undulate or crisped: leaf-blades manifestly broadest above the middle.

Blades of the sepals and petals oblong, entire: leaf-blades linear or nearly so.

Panicle narrow, elongated, central axis much surpassing the branches: flowers numerous: blades almost twice as long as the claws of the sepals and petals.

Panicle about as broad as long, central axis not surpassing the branches : flowers few : blades fully thrice as long as the claws of the sepals and petals.

1. M. latifolium.

2. M. Virginicum.

3. M. dispersum.

1. Melanthium latifòlium Desr. Foliage pubescent. Stems 5-10 dm. tall, leafy near the base; leaf-blades elongated, slightly broadest above the middle, 1-3 dm. long, acute or acuminate, narrowed into petiole-like bases; stem-leaves reduced to narrow sessile blades : panicles $2-6 \mathrm{dm}$. long, the branches ascending, middle axis continued beyond the branches : flowers fragrant : perianth whitish, $10-15 \mathrm{~mm}$. broad : sepals and petals spreading; blades suborbicular, more or less undulate or crisped, longer than the claws, each with 2 glands at the base: capsules broadest above or below the middle, $12-15 \mathrm{~mm}$. long.

In open woods and on hillsides, Connecticut to Pennsylvania and South Carolina. Summer.

2. Melanthium Virgínicum L. Foliage pubescent. Stems $7-15 \mathrm{dm}$. tall, leafy below the middle : leaf-blades linear, 1-4 dm. long or shorter above, attenuate, elongated : panicle narrow, 1-5 dm. long, many-flowered, the central axis much surpassing the ascending branches: pedicels as long as the perianth or longer: perianth greenish yellow, turning brown, 15-20 mm. broad : sepals and petals spreading; blades oblong, entire, about twice as long as the claws, each with 2 dark basal glands: capsules broadest near the middle, $10-15 \mathrm{~mm}$. long.

In swamps and meadows, Rhode Island to Minnesota, Florida and Texas. Summer.

3. Melanthium dispèrsum Small. Foliage glabrate below the inflorescence. Stems apparently $10-20 \mathrm{dm}$. tall, simple below the panicle, thence zigzag and scurfy-pubescent : leaf-blades narrowly linear, elongated, 3-8 dm. long, sheathing the stem for several $\mathrm{cm}$. : panicles ample, open, the branches zigzag, widely ascending, corymbosely arranged, the upper ones equalling or overtopping the central axis : bracts $3-10 \mathrm{~cm}$. long, obtuse : pedicels spreading, 8-12 $\mathrm{mm}$. long, rigid : perianth $12-15 \mathrm{~mm}$. broad : sepals and petals thickish ; blades oblong, obtuse, entire, several times longer than the claws, each with 2 dark glands at the base : capsules (barely mature) ovoid, 7-9 $\mathrm{mm}$. long.

In woods, Walton county, Florida. Summer. 


\section{FAmily 2. JUNCÀCEAE Vent. Rush Family.}

Perennial or sometimes annual often tufted herbs, usually grass-like in habit. Inflorescence paniculate, corymbose or umbel-like, compound, or rarely reduced to a single flower. Flowers sometimes collected into dense heads. Perianth regular, inconspicuous : parts (sepals and petals) 6, chaffy, often quite similar. Androecium of 3 or 6 , or rarely 4 or 5 , stamens. Anthers adnate, 2-celled : sacs introrse, opening by slits. Gynoecium of 3 united carpels. Ovary 1-3-celled. Stigmas 3. Ovules 3-many, anatropous. Fruit a loculicidal capsule, but sometimes breaking up irregularly. Seeds 3 -many, sometimes with caruncular or tail-like appendages.

Leaf-sheaths open: capsules 1- or 3-celled with axile or parietal placentae: seeds many. 1. JuNCUS. Leaf-sheaths closed : capsules 1-celled with basal placentae: seeds 3 .

2. JUNCOIDES.

\section{JÚNCUS L. ${ }^{1}$}

Caulescent or scapose often swamp-inhabiting herbs, with glabrous foliage. Leaves terete or flattened : sheaths with free margins. Flowers in often apparently lateral panicles or corymbs or heads, either singly and with 2 bractlets (prophylla) or when in heads each merely in the axil of a bract. Bracts usually entire. Stamens 6 or 3 . Ovary 1-celled or by the intrusion of the placentae 3-celled. Seeds often tailed, usually distinctly reticulated or ribbed. RusH.

Lowest bract of the inflorescence terete, not markedly channeled, erect, appearing like a continuation of the scape, the inflorescence thus appearing lateral.

Flowers bracteolate, inserted singly on the branches of the inflorescence.

Stamens 3 : sepals and petals about as long as the capsule: petals acute or acuminate: capsules of an obovoid type.

Stamens $6:$ sepals and petals about $1 / 2$ as long as the capsule: petals obtuse: capsules of an ovoid type.

Flowers not bracteolate, inserted in heads on the branches of the inflorescence.

Lowest bract of the inflorescence not appearing like a continuation of the scape

(or if so, markedly channeled along the inner side), the inflorescence therefore usually appearing terminal.

A. Leaf-blades with their flat surfaces facing the stem, or terete and channeled, not provided with node-like septa.

a. Flowers bibracteolate, inserted singly on the branches of the inflorescence, sometimes clustered, but never in true heads.

* Leaf-blades flat, but sometimes involute in drying so as to appear terete. (See also $J$. dichotomus below).

Annual : inflorescence, exclusive of its bracts, more than $1 / 3$ the height of the plant : anthers shorter than the filaments.

Perennial: inflorescence, exclusive of its bracts, less than $1 / 3$ the height of the plant (except sometimes in J. Georgianus, and the anthers then longer than the filaments).

Inflorescence 1-3-flowered : leaves with fimbriate auricles.

Inflorescence several-many-flowered : leaves with entire auricles. Plants caulescent : sepals and petals obtuse.

Plants scapose: sepals and petals acute or acuminate.

Auricles at the summit of the leaf-sheath membranous or scarious, whitish.

Auricles membranous, scarcely scarious, rarely if at all prolonged beyond the point of insertion.

Sepals and petals $2.5-4 \mathrm{~mm}$. long : capsule about as long as the perianth.

Flowers and fruit conspicuously secund: perianth 2.5-3.5 mm. long: anthers longer than the filaments : bract shorter than the inflorescence: capsules oval.

Flowers scarcely or not at all secund: perianth 3-4 $\mathrm{mm}$. long: anthers shorter than the filaments: bracts exceeding the inflorescence: capsules ovoid-oblong or oblong.

Sepalsandipetals $4-6 \mathrm{~mm}$. long : capsules shorter than the perianth.

Plants 4-7 dm. tall : anthers and style very short.

Plants 1-4 dm. tall: anthers linear, longer than the filaments : style often 1-1.5 mm. long.

Auricles scarious, markedly prolonged beyond the point of insertion.

Capsules oblong, about equalling the perianth, 3-celled : sepals and petals erect or appressed.

Capsules ovoid or oval, $3 / 4$ as long as the perianth or less, 1-celled: sepals and petals more or less spreading.

Auricles at the summit of the leaf-sheath cartilaginous, yellow to yellow brown.

1. J. effusus.

2. J. gymnocarpus.

3. J. Roemerianus.

4. J. bufonius.

5. J. trifidus.

6. J. Gerardi.

7. J. secundus.

8. J. interior.

9. J. Arizonicus.

10. J. Georgianus.

11. J. brachyphyllus.

12. J.tenuis.

13. J. Dudleyi. 
** Leaf-blades terete, channeled along the upper side.

Lowest bract less than 4 times the length of the inflorescence: capsule oblong or obovoid, with the ordinary dehiscence.

Lowest bract rarely less than 4 times the length of the inflorescence: capsule globose-ovoid, breaking up irregularly in age.

b. Flowers not bibracteolate, in true heads on the branches of the infiorescence.

Stems floating, creeping or diffusely spreading: capsule of a subulate type.

Stems erect or nearly so: capsule of an obovoid type.

Perianth at least $1 / 2$ longer than the capsule: anthers yellow.

Perianth equalling or barely exceeding the capsule: anthers reddish brown.

Petals lanceolate to ovate-lanceolate, setiform-acuminate at the apex. Petals obovate to oblong, broadly obtuse at the apex and sometimes slightly mucronate.

Heads of the inflorescence commonly $5-15$, usually 5 -10-flowered : plants mostly less than $5 \mathrm{dm}$. tall.

Heads of the inflorescence numerous, except in depauperate plants, usually 2-5-flowered : plants mostly over $5 \mathrm{dm}$, tall.

B. Leaf-blades either terete and not channeled, or flattened or compressed, with the flat surfaces not facing the stem.

Leaf-blades terete, the pith perforated with slender tubes: clusters of the inflorescence reduced to a single flower each.

Leaf-blades either terete, hollow, and provided with node-like septa, or flattened or compressed, or both: clusters of the inflorescence few-manyflowered.

Capsule truly subulate.

Stamens 6, one opposite each sepal and petal: rootstock slender, tuberbearing at intervals.

Stem stout: sepals longer than the petals : capsules barely exceeding the perianth, each with a beak 1-1.5 $\mathrm{mm}$. long.

Stem slender : sepals shorter than the petals : capsules conspicuously exserted from the perianth, each with a beak $1.5-2 \mathrm{~mm}$. long.

Stamens 3, none opposite the petals : rootstock not tuber-bearing, usually short and thickened throughout.

Uppermost leaf-sheath with an almost obsolete blade, this seldom exceeding 1 or $2 \mathrm{~cm}$. in length.

Uppermost leaf-sheath with a normal blade few to several $\mathrm{cm}$. in length.

Stamens as long as the petals, the anthers exserted between them. Stamens considerably shorter than the petals: anthers included.

Leaf-blades flattened and usually with incomplete septa: capsules markedly beaked, the valves in dehiscence curved outward in the middle, but united above by the beak.

Leaf-blades slightly compressed, the septa complete: capsules beakless, the valves separating throughout in dehiscence.

Capsule oblong to linear-lanceolate in outline, obtuse or acute at the apex, or sometimes mucronate, but not truly subulate.

Capsules $1 / 2-2 / 3$ as long as the perianth.

Capsules equalling the perianth in length or exceeding it.

Seeds $0.7-2.5 \mathrm{~mm}$. long, the body tapering at either end into a white tail of varying length.

Plant rigid throughout: stems 2-4 mm. in diameter : sepals and petals spinescent: capsules dark red, firm, exceeding the perianth by about $1 / 2$ their length.

Plant with none of its parts unusually stiff or hard: stems less than $2 \mathrm{~mm}$. in diameter, or the capsule not exserted from the perianth by more than $1 \mathrm{~mm}$.

Seeds $0.35-0.55 \mathrm{~mm}$. long, the body with a short, rather abrupt, papilla-like, usually dark-colored apiculation at either end.

Capsules nearly twice the length of the perianth, the two together $3.5-5 \mathrm{~mm}$. long.

Capsules equalling or sometimes about $1 / 3$ exceeding the perianth, the two together 2-3.5 $\mathrm{mm}$. long.

Perianth 2-2.5 mm. long.

Larger basal leaf-blades with more than 40 septa: capsule green or straw-colored : plants usually over $5 \mathrm{dm}$. tall. Larger basal leaf-blades with less than 40 septa: capsule dark brown above at maturity.

Perianth 2.5-3.5 mm. long, or if less the capsule straw-colored at maturity and the whole plant less than $5 \mathrm{dm}$. tall.

Sepals and petals $2.5-3.5 \mathrm{~mm}$. long: capsules ovoid-lanceolate in outline, broadly acute and mucronate, about as long as the perianth.

Sepals and petals 2-2.5 mm. long: capsules linear-lanceolate in outline, obtuse and merely apiculate, about $1 / 3 \mathrm{ex}$ ceeding the perianth.

14. J. dichotomus.

15. J. setaceus.

16. J. repens.

17. J. filipendulus

18. J. setosus.

19. J. marginatus.

20. J. aristulatus.

21. J. abortivus

22. J. Torreyi.

23. J. Texanus.

24. J. megacephalus.

25. J. scirpoides.

26. J. polycephalus.

27. J. validus.

28. J. brachycarpus.

29. J. trigonocarpus.

30. J. Canadensis.

31. J. diffusissimus.

32. J. robustus.

33. J. Elliottii.

34. J. acuminatus.

35. J. debilis.

1. Juncus effùsus L. Plants 5-12 dm. high, densely tufted. Leaves basal, reduced to filiform rudiments few $\mathrm{mm}$. long : inflorescence $2-10 \mathrm{~cm}$. high, occasionally congested ; its bract erect, appearing like a continuation of the scape, 5-25 $\mathrm{cm}$. long : perianth 2-3 $\mathrm{mm}$. long : sepals and petals lanceolate, acuminate : stamens 3 ; anthers shorter than the filaments : capsules obovoid or oblong-obovoid, about as long as the perianth, 3-celled, regularly debiscent.

In swamps and low grounds, nearly through the United States and southern British America. Also in Europe and Asia. Spring to fall. 
2. Juncus gymnocárpus Coville. Plants $3-8 \mathrm{dm}$. high. Scapes arising at intervals from a proliferous rootstock about $3 \mathrm{~mm}$. thick: leaf-sheaths basal, bladeless: inflorescence appearing lateral, $15-30 \mathrm{~mm}$. high, spreading, its bract 1-2.5 dm. long : flowers perfect : perianth rather less than $2 \mathrm{~mm}$. long: sepals and petals nearly equal, ovate or ovate-lanceolate: sepals apiculate, with firmer bodies than the obtuse petals : stamens 6 , nearly as long as the perianth ; anthers shorter than the filaments : capsules ovoid, 2-2.5 $\mathrm{mm}$. long, about twice as long as the perianth, prominently apiculate, shining, barely dehiscent.

In swamps, eastern Pennsylvania and northern Florida. Spring and summer.

3. Juncus Roemeriànus Scheele. Plants 5-12 dm. high. Scapes arising from scaly horizontal rootstocks $5-10 \mathrm{~mm}$. thick : leaf-sheaths basal, bearing erect blades resembling the stem and of about the same length : iuflorescence appearing lateral, $6-15 \mathrm{~cm}$. high, diffuse, its bract 10-25 cm. long: flowers usually dioecious : heads 2-6-flowered: perianth 2-3.5 mm. long: sepals linear-oblong, acuminate: petals shorter and blunt pointed : stamens 6 , or in pistillate plants reduced to staminodia : capsules brown, 3-celled, about as long as the perianth, narrowly obovoid, obtuse or truncate, mucronate : placenta thick and spongy, about $\frac{1}{3}$ as broad as the valve.

In brackish marshes, New Jersey to Florida and Texas. Spring.

4. Juncus bufònius L. Plants branching from the base, seldom over $20 \mathrm{~cm}$. high. Stems in robust plants with 1-2 leaves: leaf-blades $0.2-1 \mathrm{~mm}$. wide, in larger plants flat, in depauperate ones filiform-involute : inflorescence about $\frac{1}{2}$ the height of the plant : flowers inserted singly on its branches: sepals and petals 4-7 mm. long, lanceolate, acuminate: stamens usually 6 , seldom $\frac{1}{2}$ as long as the perianth; anthers shorter than the filaments : capsules 3-celled, about $\frac{2}{3}$ as long as the perianth, narrowly oblong, obtuse, mucronate : seeds broadly oblong with straight apiculations, $0.35-0.5 \mathrm{~mm}$. long, finely reticulated in 30-40 longitudinal rows, the areolae broader than long.

About dried-up pools and on roadsides, throughout North America, except the extreme north. Also cosmopolitan. Spring and summer.

5. Juncus trífidus $\mathrm{L}$. Plants densely tufted, $1-3 \mathrm{dm}$. high. Stems closely set on stout rootstocks, about $0.5 \mathrm{~mm}$. thick : basal leaves reduced to almost bladeless sheaths, the uppermost with a rudimentary blade and fimbriate auricles; stem-leaf solitary, just below the inflorescence, with a narrower flat or involute blade: inflorescence a cluster of 1-3 flowers, the lowest bract resembling the upper leaf, the succeeding one much smaller or obsolete: perianth dark brown, 2.5-3 mm. long : stamens 6 ; anthers about as long as the filaments : capsules leathery, about as long as the perianth, obovoid, with a mucronatearistate top : seeds few, narrowly obovoid, irregularly angled, minutely striate.

In sterile or stony soil, Greenland and Labrador, to the higher mountains of New England, New York and North Carolina. Also in northern Europe and Asia. Summer.

6. Juncus Gerárdi Lois. Plants copiously tufted, $2-6 \mathrm{dm}$. high, from horizontal rootstocks. Stems not bulbous-thickened at the base : basal leaves with loosely clasping auriculate sheaths, the blades mostly 1-2 dm. long, less than $2 \mathrm{~mm}$. wide, flat or involute in drying ; stem-leaves 1 or 2 , similar to the basal, but with shorter blades : inflorescence paniculate, often overtopped by the lowest bract: panicle erect: perianth about $2 \mathrm{~mm}$. long: sepals and petals oblong, obtuse, with green midribs and dark brown margins, or straw-colored in age : stamens 6 , barely exceeded by the perianth; anthers much longer than the filaments : capsules $\frac{1}{4}-\frac{1}{2}$ longer than the perianth, obovoid, 3 -celled, mucronate, dark brown, shining.

On salt meadows, Gulf of St. Lawrence to Virginia, and Florida (according to Engelmann), and about the Great Lakes. Also in Europe. Spring and summer.

7. Juncus secúndus Beauv. Plants tufted, 1-4 dm. high. Leaves basal, usually less than $\frac{1}{3}$ the height of the plant: inflorescence longer than its lowest bract, or only slightly exceeded by it, $3-8 \mathrm{~cm}$. high : flowers secund on the strongly ascending and usually somewhat incurved branches : perianth $2.5-3.5 \mathrm{~mm}$. long : sepals and petals lanceolate or broadly lanceolate, acute, equalling or barely exceeding the capsule and appressed to it for about $\frac{2}{3}$ their length: stamens 6 , about $\frac{1}{2}$ as long as the perianth ; anthers slightly longer than the filaments : capsule oval, 3 -sided above the middle, with straight sides and a truncate apex, completely 3-celled : seeds narrowly oblong to ovoid, obliquely tipped, $0.28-0.37 \mathrm{~mm}$. long.

In dry or sandy soil, Massachusetts and Pennsylvania to North Carolina. Spring and summer.

8. Juncus intèrior Wiegand. Plants $5-10 \mathrm{dm}$. high, light green. Leaves basal, several ; blades about $\frac{1}{3}$ the length of the scape, 1-1.25 mm. wide, sometimes involute : scapes grooved : inflorescence $3-10 \mathrm{~cm}$. long, many-flowered, the branches ascending: flowers scattered, rather distant : perianth straw-colored, 3-4 mm. long : sepals and petals 
nearly equal, lanceolate-subulate, slenderly acute or acuminate, appressed or erect, the petals margined to the apex : stamens $6, \frac{1}{2}$ as long as the perianth ; anthers much shorter than the filaments: capsules oblong or rarely ovoid-oblong, about as long as the perianth, obtuse or barely apiculate: seeds oblong, $0.35-0.50 \mathrm{~mm}$. long.

In dry woods or on prairies, Illinois to Wyoming, Tennessee, Mississippi and Arkansas. Spring and early summer.

9. Juncus Arizónicus Wiegand. Plants sparingly tufted, pale. Leaves basal ; bladies usually flat and $1 \mathrm{~mm}$. broad: scapes $4-7 \mathrm{dm}$. tall, twice as high as the leaves, coarsely grooved: inflorescence straw-colored, many-flowered: bracts resembling the leaves, exceeding the inflorescence: perianth about $5 \mathrm{~mm}$. long: sepals and petals lanceolate-subulate, nearly equal, rigid, very acute : anthers about equalling the filaments : capsules ovoid-oblong, much shorter than the perianth : seeds irregularly curved, $0.3-0.37$ $\mathrm{mm}$. long, the areolae in 12-14 transverse rows.

In dry soil, Texas, New Mexico and Arizona. Spring to fall.-A variety, more slender in habit and with nearly filiform leaf-blades; inflorescence $3-5 \mathrm{~cm}$. long; perianth about $4 \mathrm{~mm}$. long; capsule more ovoid and nearly equalling the perianth, is $J$. Arizonicus curtiflòrus Wiegand ; it occurs from eastern Texas to Arizona.

10. Juncus Georgiànus Coville. Plants densely tufted, 1-4 dm. high. Leaves basal ; sheaths minutely auriculate, commonly $2-4 \mathrm{~cm}$. long, or the innermost $8 \mathrm{~cm}$. long ; blades erect, striate on the back, $1 \mathrm{~mm}$. in width or less, sometimes involute when dry : inflorescence 5-10 cm. high : scapes barely exceeding $1 \mathrm{~mm}$. in diameter : lowest involucral bract not exceeding the panicle: flowers usually not more than 10 , inserted singly on the branches of the panicle, prophyllate: perianth 4-6 $\mathrm{mm}$. long: sepals and petals subulate-lanceolate : stamens $6, \frac{1}{2}-\frac{2}{3}$ the length of the perianth ; anthers $1.5-2 \mathrm{~mm}$. long and several times longer than the filaments: capsules about $\frac{3}{4}$ as long as the perianth, narrowly oblong-lanceolate in outline, obtuse or broadly acute, mucronate, 3-celled : seeds about $0.4-0.5 \mathrm{~mm}$. long, oblong, reticulated, the areolae linear and arranged transversely on the seed in about 16 longitudinal rows.

On granite, middle North Carolina and middle Georgia. Spring and summer.

11. Juncus brachyphýllus Wiegand. Plants stont, tufted, 4-5 dm. high. Leaves basal, $\frac{1}{4}-\frac{1}{3}$ the height of the scapes; sheaths blade-bearing except the lowest one; blades thickish, but flat, relatively broad, stiff and spreading: scapes stiff, slightly compressed, conspicuously grooved : inflorescence crowded, $2-6 \mathrm{~cm}$. long, straw colored, with ascending branches: bracts resembling the leaves, usually exceeding the inflorescence: perianth about $5 \mathrm{~mm}$. long: sepals and petals slightly unequal, subulate, very acute, narrowly scarious near the base, or the petals scarious all around: anthers nearly equalling the filaments : capsules narrowly oblong, obtuse or retuse, about equalling the perianth : seeds oblong, $0.5-0.55 \mathrm{~mm}$. long, strongly apiculate at both ends.

In low grounds, Arkansas and the Indian Territory to Idaho. Summer and fall.

12. Juncus ténuis Willd. Plants closely tufted, $2-7 \mathrm{dm}$. high. Leaves basal; blades flat, $0.5-1.5 \mathrm{~mm}$. wide, sometimes involute in drying: inflorescence rarely reaching $\frac{1}{4}$ the height of the plant: perianth $3.5-5 \mathrm{~mm}$. long: sepals and petals lanceolate, acuminate, more or less spreading : stamens 6 , about $\frac{1}{2}$ as long as the perianth ; anthers shorter than the filaments : capsules usually about $\frac{1}{4}$ shorter than the perianth, ovoid to obovoid, obtuse, mucronate, 3-celled : seeds $0.4-0.55 \mathrm{~mm}$. in lengtb, narrowly oblong, with oblique apiculations, reticulated in about 16 longitudinal rows, the areolae $2-3$ times broader than long.

In dry or moist soil, throughout the United States and southern British America. Spring and summer.-A variety, J. tenuis anthelatus Wiegand, with scapes 5-9 dm. tall, more numerous and looser leafsheaths, more diffuse inflorescence, a perianth $2.5-3.5 \mathrm{~mm}$. long or rarely longer, and a capsule not over $3 / 4$ the length of the perianth, occurs from Maine to Missouri, South Carolina and Texas.

13. Juncus Dudleỳi Wiegand. Plants $3-10 \mathrm{dm}$. high, pale green. Leaves basal ; blades about $\frac{1}{2}$ the length of the scapes or less, very narrowly linear but flat, frequently somewhat involute: scapes tufted, often relatively stout but wiry, striate-grooved: inflorescence $2-5 \mathrm{~cm}$. high, or rarely slightly larger, usually rather congested, considerably exceeded by its bract, few-flowered : perianth green or pale straw-colored, $4-5 \mathrm{~mm}$. long: sepals and petals firm, nearly equal, lanceolate-subulate, acute, more or less spreading, scarious-margined : stamens $\frac{1}{2}$ as long as the perianth; anthers slightly shorter than the filaments : capsules ovoid-oval, $\frac{3}{4}-\frac{7}{8}$ the length of the perianth, somewhat apiculate : seeds oblong, $0.37-0.45 \mathrm{~mm}$. long, apiculate at each end.

In damp soil and open places, Maine to Ontario, Saskatchewan, Washington, Pennsylvania, Tennessee and Mexico. Spring and summer.

14. Juncus dichótomus Ell. Plants tnfted, usually stout and stiff, $2-9 \mathrm{dm}$. high, purplish tinged toward the base : leaves basal, terete, channeled along the upper side, 
rarely flat: inflorescence and flowers as in J. tenuis but darker, sometimes smaller and frequently with more rigid parts : seeds oblong, obliquely apiculate, $0.36-0.45 \mathrm{~mm}$. long, with about 13 longitudinal ribs, the smooth areolae about as long as broad.

In dry or sandy soil, Massachusetts to Florida and Texas, mostly near the coast. Spring and summer.-When the leaves are expanded and flat this species can be separated from $J$. tenius by the purple base, darker flowers and the semi-cartilaginous auricles.

15. Juncus setàceus Rostk. Plants in dense tufts. Uppermost sheath usually bearing a terete blade similar to the stem, but channeled : other sheaths with minute filiform blades less than $1 \mathrm{~cm}$. in length: scapes spreading and at length recurved, 4-10 $\mathrm{dm}$. long: involucral bract appearing like a continuation of the stem, $10-30 \mathrm{~cm}$. long : inflorescence appearing lateral, $5 \mathrm{~cm}$. long or less: perianth $3-5 \mathrm{~mm}$. long: sepals and petals lanceolate, acuminate, rigid, widely divergent in fruit: stamens 6 ; anthers usually longer than the filaments: capsules globose-ovoid, shining, mucronate, 1 -celled, with intruded placentae, breaking irregularly in age : seeds subglobose, $0.5-0.7 \mathrm{~mm}$. long, reticulated in about 11 longitudinal rows, the areolae usually a little broader than long.

In marshes, usually near the coast, Delaware to Missouri, Florida and Texas. Spring and summer.

16. Juncus rèpens Michx. Plants stoloniferous. Stems tufted, compressed, commonly 1-2 mm. in width, 5-20 cm. high, or prostrate, often creeping, and sometimes attaining a length of more than $5 \mathrm{dm}$.: leaves with compressed sheaths $2 \mathrm{~cm}$. long or less, auriculate ; blades commonly 3-8 $\mathrm{cm}$. long and 1-2 $\mathrm{mm}$. broad, filiform-acuminate at the apex : heads $1-8,1$ or more often occurring also at the lower nodes, $5-10$-flowered : perianth 6-10 $\mathrm{mm}$. long: sepals subulate-lanceolate, keeled and about $\frac{1}{3}$ shorter than the otherwise similar petals: stamens $3, \frac{1}{2}-\frac{1}{3}$ the length of the perianth ; filaments several times longer than the yellow anthers: capsules subulate, but beakless, about as long as the sepals, 3-celled, the valves membranous and breaking away from the placental axis in dehiscence : seeds oblong, acute at both ends, $0.3-0.4 \mathrm{~mm}$. long, finely reticulated in 25-40 longitudinal rows, the areolae much broader than long.

In streams and swamps, Delaware to Florida and Texas. Also in Cuba and Lower California. Spring and summer.

17. Juncus filipéndulus Buckl. Plants 1-3 dm. high. Rootstock branching; branches hardly longer than broad, congested: stems tufted, $1 \mathrm{~mm}$. broad or less : basal leaves about $\frac{1}{2}$ the length of the stem ; blades 1-2.5 $\mathrm{mm}$. broad : inflorescence consisting of 1-5, commonly 2-3, heads each 4-7-flowered: perianth 4-6 mm. long: sepals and petals lanceolate, with hyaline margins and green midrib, acuminate into an aristate apex, the sepals slightly the shorter: stamens 3 , about $\frac{1}{2}$ as long as the perianth; anthers yellow, much shorter than the filaments: capsules about $\frac{1}{2}$ as long as the perianth, obovoid, retuse, mucronate, almost $3 \cdot$ celled : seeds $0.45-0.55 \mathrm{~mm}$. long, oblong, acute at both ends, with 14-18 prominent longitudinal costae (and often as many intermediate, much less conspicuous ones), the intermediate areas smooth, with an occasional transverse line.

In low grounds, Tennessee to Arkansas and southern Texas. Spring to fall.

18. Juncus setòsus (Coville) Small. Plants rather Joosely tufted, 3-7 dm. high, bright green. Stems not much thickened at the base: leaves with auriculate sheaths, sometimes quite numerous; blades $2-5 \mathrm{~mm}$. wide, nearly similar to those of $J$. marginatus: panicle $3-10 \mathrm{~cm}$. high, composed of $20-100$ heads, or smaller in depauperate forms : perianth 3-3.5 mm. long: sepals lanceolate-acuminate: petals slightly larger than the sepals, lanceolate to ovate-lanceolate, setiform-acuminate: stamens 3 , much shorter than the perianth; anthers and filaments about equal in length, the former reddish-brown: capsules oblong, about as long as the perianth, blunt. [J. marginatus var. setosus Coville.]

In woods and wet places, Nebraska to Louisiana, Arizona and Mexico. Spring and summer.

19. Juncus marginàtus Rostk. Plants tufted, mostly $1.5-5 \mathrm{dm}$. high, from branching rootstocks. Stems somewhat bulbous at the base : leaves with auriculate sheaths; biades 1-3 $\mathrm{mm}$. broad, 2-4 conspicuous veins in addition to the midrib : panicle $10 \mathrm{~cm}$. high or less, composed mostly of 5-10-flowered heads: perianth $2.5-3 \mathrm{~mm}$. long: sepals ovate, acute : petals slightly longer, obovate, broadly obtuse, hyaline-margined : stamens 3 , nearly as long as the perianth; anthers ovoid, reddish brown when dry, much shorter than the filaments: capsules equalling the perianth, obovoid, truncate or retuse.

In meadows or grassy places, Maine to Ontario and Nebraska, south to Florida. Summer.

20. Juncus aristulàtus Michx. Plants solitary or sparingly tufted, 6-12 dm. high or sometimes lower. Stems markedly bulbous-thickened at the base : leaves similar to those described under $J$. marginatus, but sometimes $5 \mathrm{~mm}$. broad : panicle $15 \mathrm{~cm}$. high or less, composed of numerous, usually 20-100 relatively small 2-5-flowered heads: perianth about $2.5 \mathrm{~mm}$. long: sepals acute or acuminate : petals oblong or obovate, obtuse, longer 
than the sepals : stamens as long as the perianth or longer; anthers much shorter than the filaments : capsules obovoid, about $2-2.5 \mathrm{~mm}$. long, truncate or depressed at the apex.

In moist soil or meadows, New York to Michigan, Florida, Texas and Mexico. Spring and summer. -A variety, $J$. aristulatus pinetorum Coville, has stems arising at intervals from thick woody tuberbearing rootstocks and persistent leaves with short blades; it occurs in sandy pine woods from North Carolina to Florida.

21. Juncus abortivus Chapm. Plants 3-6 dm. high, deep green. Stems slender, rising at intervals from suout elongated horizontal rootstocks: leaves few; blades terete, much shorter than the stems, the pith perforated with slender tubes, slightly nodose : panicle rather diffuse, the branches filiform : flowers scattered singly on the branches of the panicle: perianth $1.5-2 \mathrm{~mm}$. long: sepals firm, lanceolate, acute : petals firm, lanceolate, rather broader at the base than the sepals, blunt: capsule subulate, slightly surpassing the perianth. [J. pelocarpus var. crassicaudex Engelm.]

On grassy pond-margins, Florida. Summer and fall.

22. Juncus Torreỳi Coville. Plants $2-10 \mathrm{dm}$. high, not tufted. Rootstock slender, about $2 \mathrm{~mm}$. thick, tuberiform-thickened at intervals of a few centimeters, each tuber supporting a single stem : stems terete or slightly compressed, stout: leaf-blades terete, 1-2.5 mm. thick, abruptly divergent from the stem: inflorescence usually congested, only a few $\mathrm{cm}$. in length and consisting of from 1 to 6 heads, or occasionally $10 \mathrm{~cm}$. long and bearing 15-20 heads, exceeded by the involucral bract: heads $10-15 \mathrm{~mm}$. in diameter : perianth 4-5 $\mathrm{mm}$. long: sepals and petals subulate, the sepals longer than the petals : stamens about $\frac{1}{2}$ as long as the perianth : capsule subulate, 1-celled, its beak 1-1.5 mm. long, barely exceeding the perianth and holding the valves together throughout dehiscence : seeds $0.4-0.5 \mathrm{~mm}$. long, oblong, acute at both ends, reticulated in about 20 longitudinal rows, the areolae transversely plurilineolate.

In low grounds, New York to the Pacific and Gulf coasts. Summer and fall.

23. Juncus Texànus (Engelm.) Coville. Plants $2-6 \mathrm{dm}$. high. Rootstock slender, about $1 \mathrm{~mm}$. thick, tuberiform-thickened at intervals of a few centimeters: stems single, one for each tuber, terete, slender: leaf-blades slender, divergent, seldom over $1 \mathrm{~mm}$. thick : inflorescence $10 \mathrm{~cm}$. high or less, consisting of $2-15$ heads, about equalled by its lowest bract: heads 10-40-flowered, $12-15 \mathrm{~mm}$. thick: perianth $3.5-4.5 \mathrm{~mm}$. long: sepals and petals subulate, the sepals shorter than the petals : stamens $\frac{1}{2}-\frac{2}{3}$ as long as the perianth : capsules subulate, 1-celled, valves united above in dehiscence, the beak 1.5-2 mm. long: seeds broadly oblong or obovoid, acute at both ends, reticulated in about 20 longitudinal rows, the areolae transversely plurilineolate.

In low grounds, southern and eastern Texas. Spring to fall.

24. Juncus megacéphalus M. A. Curtis. Plants $3-10 \mathrm{dm}$. high. Stems tufted, from branching rootstocks, stout, 2-3-leaved : leaves with auricled sheaths; blades of the basal leaves $2 \mathrm{dm}$. long or less, those of the stem successively shorter, the uppermost rarely $2 \mathrm{~cm}$. in length : inflorescence $2.5 \mathrm{~cm}$. high or less, its lowest bract almost bladeless, the other scarious : panicle of $1-40$ heads : heads spherical, $8-12 \mathrm{~mm}$. in diameter : perianth 3-3.5 mm. long : sepals and petals subulate, the sepals longer than the petals: stamens $3, \frac{1}{2}-\frac{2}{3}$ the length of the petals ; anthers included, shorter that the filaments: capsule subulate, beaked, equalling the perianth, 3-sided, 1-ce!led : seeds oblong, 0.4-0.5 $\mathrm{mm}$. long, acute at either end, reticulated in 12-14 rows, the areolae smooth.

In sandy soil, North Carolina to Florida. Spring to fall.

25. Juncus scirpoides Lam. Plants 2-7 dm. high. Stems terete, clustered on short horizontal rootstocks, these $2-3 \mathrm{~mm}$. thick, and with a yearly growth of $1-2 \mathrm{~cm}$.: stemleaves 1-3; blades terete, $2 \mathrm{~mm}$. thick or less, usually less than $10 \mathrm{~cm}$. long, the septa perfect; basal leaves similar, but with longer blades: inflorescence strict or slightly spreading, reaching $15 \mathrm{~cm}$. in length, or sometimes only 1 or $2 \mathrm{~cm}$. long: heads $2-30$, either simple, globose, 8-11 mm. in diameter in fruit, or compound, lobed, and of slightly greater diameter : perianth $2.5-3.5 \mathrm{~mm}$. long : sepals and petals subulate, the petals somewhat the shorter: stamens equalling at least the petals; anthers exserted between the petals : capsules subulate, 1-celled, the long beak exceeding the perianth and holding the valves united above in dehiscence: seeds oblong, acute at both ends, 0.4-0.5 mm. in length, reticulated in about 20 longitudinal rows, the areolae smooth and nearly isodiametrical.

In sandy soil, New York to Florida, Louisiana and Texas. Summer and fall.

26. Juncus polycéphalus Michx. Plants about $10 \mathrm{dm}$. high. Stem stout, compressed, 2-4-leaved : leaves $50 \mathrm{~cm}$. long or less, the upper shorter ; blades flattened, $3-8$ $\mathrm{mm}$. broad, the septa incomplete : inflorescence $8-30 \mathrm{~cm}$. high, its bracts with nearly obsolete blades: heads globose, 7-10 mm. in diameter, $20-100$-flowered : perianth $3-4 \mathrm{~mm}$. 
long: sepals and petals subulate : stamens $3, \frac{1}{2}-\frac{3}{4}$ as long as the perianth ; anthers shorter than the filaments : capsule subulate, 1-celled, slightly exceeding the perianth, the valves in dehiscence remaining united by the slender beak, abruptly divergent below, the margins finally involute: seeds narrowly oblong, acute at either end, with nearly straight apiculations, $0.45-0.6 \mathrm{~mm}$. long, reticulated in about 13 longitudinal rows, the areolae smooth.

In sandy soil, North Carolina to Florida and Texas. Summer.

27. Juncus válidus Coville. Plants $4-10 \mathrm{dm}$. high. Stems stout, compressed, 1-3leaved : leaf-blades commonly 10-20 cm. long, merely compressed, 2-4 mm. wide, gradually acuminate above, the septa complete : inflorescence $8-35 \mathrm{~cm}$. high, its branches stiff and spreading, its bracts with nearly obsolete blades : heads globose, $12-15 \mathrm{~mm}$. in diameter in fruit: perianth 4-5 mm. long: sepals and petals subulate: stamens about $\frac{1}{2}$ as long as the perianth; anthers not exceeding the filaments : capsules subulate, often falcate, exceeding the perianth, 1-celled, the valves separating throughout in dehiscence, flat, their apices spreading : seeds broadly oval, broadly acute at both ends, $0.4-0.55 \mathrm{~mm}$. in length, not more than twice as long as broad, reticulated in about 20 longitudinal rows, the areolae smooth.

In sandy soil, Missouri to Mississippi and Texas. Summer and fall.

28. Juncus brachycárpus Engelm. Plants $2-9 \mathrm{dm}$. high, loosely tufted from horizontal rootstocks, which have a yearly growth of $1-5 \mathrm{~cm}$., a thickness of about $2.5 \mathrm{~mm}$., and bear 1-6 stems. Stems terete : stem-leaves 1-4; blades terete, $2 \mathrm{~mm}$. thick or less, seldom exceeding $15 \mathrm{~cm}$. in length, or the upper much shorter : inflorescence $10 \mathrm{~cm}$. in height, and with 20 heads, or reduced to a single one : perianth $3-3.5 \mathrm{~mm}$. long: sepals and petals subulate, the petals about $\frac{3}{4}$ as long as the sepals : stamens about $\frac{1}{2}$ as long as the perianth : capsules $\frac{1}{2}-\frac{2}{3}$ as long as the perianth, oblong, acute, mucronate, 1-celled, dehiscent through the mucro : seeds oblong, acute at both ends, $0.35-0.4 \mathrm{~mm}$. long, reticulated in about 18 longitudinal rows, the areolae smooth, nearly isodiametrical.

In sandy soil or low grounds, southern Ontario and the Mississippi Valley. Also from Maryland to North Carolina. Summer.

29. Juncus trigonocárpus Steud. Plants 6-12 dm. high, in tufts, from short congested rootstocks. Stems stout, $2.5-4 \mathrm{~mm}$. or $5 \mathrm{~mm}$. thick at the hase, much narrower above, terete or nearly so, 3-4-leaved : leaf-blades nearly as thick as the stem, commonly $15-40 \mathrm{~cm}$. long, or the upper shorter : infiorescence commonly $8-20 \mathrm{~cm}$. high, the bread th about $\frac{1}{2}$ the height, ordinarily much branched and with the clusters 2-4-flowered, sometimes Jessbranched and with the clusters 5-10-flowered : perianth 3-4 $\mathrm{mm}$. long: sepals and petals 3-5-nerved, lanceolate, narrowly acute, the sepals shorter than the petals: stamens 3, $\frac{2}{3}-\frac{3}{4}$ the length of the perianth; anthers shorter than the filaments : capsules lanceolate in outline, tapering to a narrow acute apex, dark red, about twice as long as the perianth, 1-celled above, the placentae toward the base intruded to the center : seeds tailed at either end, about $2 \mathrm{~mm}$. long including the tails. [J. caudatus Chapm.]

In low grounds and sandy bogs, South Carolina to Florida and Alabama. Summer and fall.

30. Juncus Canadénsis J. Gay. Plants 3-12 dm. high, stout. Stems 2-4-leaved, few in a tuft, from a branched rootstock : leaves various; basal usually decayed at flowering time; stem-leaves with large loose auriculate sheaths commonly 5-10 cm. long, and a stout erect blade usually $10-25 \mathrm{~cm}$. long : panicle $7-25 \mathrm{~cm}$. in height, the branches moderately spreading: heads usually crowded, top-shaped to hemispheric or globose, 5-40flowered : perianth 3-4 mm. long: sepals and petals narrowly lanceolate, acute, the petals longer than the sepals : stamens $3, \frac{1}{2}-\frac{2}{3}$ as long as the perianth; anthers much shorter than the filaments : capsule lanceolate, acute, mucronate, 3 -sided, 1-celled, reddish brown, exceeding the perianth by $1 \mathrm{~mm}$. or less : seeds $1 \mathrm{~mm}$. to nearly $2 \mathrm{~mm}$. long, tailed at either end, the body with a smooth shining coat, about 40 -striate.

In moist or wet soil, New Brunswick to Minnesota, Georgia and Louisiana. Summer and fall.-A form, J. Canadensis subcaudditus Engelm., has frequently weak and reclining slender stems 4-8 dm. long, few scattered heads and seeds with very short tails; it occurs from Rhode Island to Pennsylvania and Georgia.

31. Juncus diffusíssimus Buckl. Plants $3-6 \mathrm{dm}$. high. Rootstock short and inconspicuous: stems usually few in a tuft, slender, terete or slightly compressed, 2-4leaved : leaf-blades 10-20 $\mathrm{cm}$. long, 1-1.5 mm. thick : inflorescence diffusely branched, $10-20 \mathrm{~cm}$. high, much exceeding its lowest bract, the branches slender and widely spreading : heads 3-12 flowered : perianth $2.5-3.5 \mathrm{~mm}$. long: sepals and petals subulate, equal : stamens $\frac{1}{2}-\frac{2}{3}$ as long as the perianth : capsule linear-lanceolate, $4-5.5 \mathrm{~mm}$. in length, almost twice as long as the perianth, obtuse or broadly acute, short-mucronate, 1-celled, the valves separating through the apex in dehiscence : seeds oblong to obovoid, 0.4-0.5 $\mathrm{mm}$. long, acute at the base, abruptly apiculate at the apex, reticulated in about 16 rows, the areolae transversely plurilineolate.

In low grounds, Indiana and Kansas to Georgia and Texas. Spring and summer. 
32. Juncus robústus (Engelm.) Coville. Plants $6-10 \mathrm{dm}$. high. Rootstock short, inconspicuous: stems few in a tuft, nearly terete, $2-3 \mathrm{~mm}$. thick below, 1-2-leaved : leaf-blades erect, terete, conspicuously septate, $20-60 \mathrm{~cm}$. long, $2-3.5 \mathrm{~mm}$. thick, usually reaching the inflorescence: inflorescence $10-25 \mathrm{~cm}$. high, with moderately spreading branches and many (300-500) heads, its largest bract with the blade obsolete or sometimes $\frac{1}{2}$ as long as the inflorescence : heads $2-10$-flowered : perianth $2-3 \mathrm{~cm}$. long: sepals and petals nearly equal, lanceolate-subulate : stamens $\frac{1}{2}-\frac{2}{3}$ as long as the perianth : capsule 1-1 $\frac{1}{3}$ times as long as the perianth, light brown or almost stramineous at maturity, narrowly to broadly oblong, obtuse but short apiculate, 3 -angled when dry, 1-celled, the valves separate and involute after dehiscence: seeds as in $J$. acuminatus.

In low grounds, Illinois to Kansas, Louisiana and Texas. Summer.

33. Juncus Ellióttii Chapm. Plants $2-8 \mathrm{dm}$. high. Stems tufted, from branched congested rootstocks, 3-leaved, nearly terete : lower leaf-blades commonly 8-15 cm. long, or rarely reaching $25 \mathrm{~cm}$. high, or occasionally somewhat larger, with moderately spreading branches, and 5 or sometimes 50 heads, the blade of the lowest involucral bract usually obsolete, or rarely $4 \mathrm{~cm}$. long: heads $2-5$-flowered : perianth $2-2.5 \mathrm{~mm}$. long: sepals and petals equal, lanceolate and acute : stamens $\frac{1}{2}-\frac{3}{4}$ as long as the perianth; anthers shorter than the filaments: capsule oblong to narrowly oblong, chestnut-brown above and shining, broadly acute, equalling the perianth, 1-celled, the valves spreading and of ten involute when mature : seeds lanceolate-oblong, 0.35-0.45 in length, reticulated in about 12-14 rows, the areolae linear-oblong, and smooth, or marked with a single longitudinal line.

In bogs or ditches, North Carolina to Florida and Texas. A large form, J. Elliottii polyanthemus C. Mohr, has stems 6-8 dm. tall, flat long-acuminate leaves $25-35 \mathrm{~cm}$. long, and panicles with very numerous (100-200) 4-6-flowered heads ; it occurs in southern Alabama. Summer and fall.

34. Juncus acuminàtus Michx. Plants 2-8 dm. high. Rootstock short and inconspicuous: stems few or several in a tuft, terete or slightly compressed, 1-3-leaved : blades of the lower leaves 10-18 $\mathrm{cm}$. long, 1-2 mm. thick, the upper shorter : inflorescence c mmonly 5-15 cm. high, and with 5-50 heads, rarely larger, or reduced to a single head, its branches usually spreading or sometimes strict : heads 3-20-flowered, commonly 5-12flowered: perianth 2.5-3.5 mm. long: sepals and petals lanceolate-subulate, nearly equal : stamens about $\frac{1}{2}$ as long as the perianth : capsules ovoid-lanceolate, broadly acute, mucronate, 1-celled, equalling the perianth, light brown, the valves separating through the apex in dehiscence : seeds narrowly to broadly oblong, $0.4-0.55 \mathrm{~mm}$. in length, acute at both ends, reticulated in about 16-20 longitudinal rows, the areolae transversely plurilineolate.

In low grounds, Maine to Ontario, Minnesota, Georgia, Texas and Mexico. Also on our northwestern coast. Spring.

35. Juncus débilis A. Gray. Plants $2-4 \mathrm{dm}$. high or sometimes with weak procumbent stems, often densely tufted. Leaves with blades usually less than $\frac{1}{2}$ the height of the plant, more or less involute in age or in drying: panicle with ascending or diffuse branches : heads mostly 2-6-flowered : perianth $2-2.5 \mathrm{~mm}$. long: sepals and petals narrowly lanceolate, the petals broader at the base and less concave : stamens much over $\frac{1}{2}$ as long as the perianth : capsules linear-lanceolate in outline, about $\frac{1}{3}$ exceeding the perianth.

In wet places and sandy shores, New Jersey to Missouri, Florida, Mississippi and Arkansas. Spring and summer.

\section{JUNCOİES Adans.}

Perennial caulescent herbs, with glabrous or sparingly webby-pubescent foliage. Leaves with closed sheaths and grass-like blades. Inflorescence various, of ten congested. Flowers always subtended by bractlets, these usually lacerate or denticulate. Stamens 6 (in our species). Ovary 1-celled. Ovules 3, basal. Capsule sessile, 1-celled. Seeds 3, reticulated, sometimes carunculate but not distinctly tailed. [Luzula DC.] WooD-RUSH.

Peduncles terminated by 1 or rarely 2 flowers: capsule of an ovoid type. Peduncles terminated by compact spikes: capsule of an obovoid type.

Sepals and petals 3-4 mm. long: capsule much surpassed by the perianth.

Sepals and petals 2-2.5 mm. long: eapsule surpassing the perianth or about equalling it in length.

1. J. pilosum.

2. J. echinatum.

3. J. bulbosum.

1. Juncoides pilòsum (L.) Kuntze. Stems 1-3 dm. tall, 2-4-leaved : leaf-blades flat, 3-8 mm. wide, webby, especially when young, blunt and almost gland-like at the tip : inflorescence umbel-like, subtended by a bract $10-25 \mathrm{~mm}$. long: peduncles filiform, equal or nearly so, 1 -flowered or rarely 2 flowered : perianth $2.5-3 \mathrm{~mm}$. long: sepals and petals triangular-ovate, brown except the byaline margins, about twice as long as the 
toothed bractlets: capsules usually about $\frac{1}{4}$ longer than the perianth : seeds with a conspicuous hooked caruncle at the top. [Luzula Carolinae S. Wats.]

In woods, New Brunswick to Alaska, Georgia, Tennessee, Michigan and Oregon. Also in Europe and Asia. Spring.

2. Juncoides echinàtum Small. Base of the plants not bulblet-bearing. Foliage webby-pubescent: stems $2.5-5 \mathrm{dm}$. tall : inflorescence umbel-like, subtended by a leaflike bract: peduncles conspicuously unequal, each terminated by an oblong or a cylindric spike : sepals and petals lanceolate, 3-4 mm. long, greenish or pale brown, acuminate, soft and hyaline at the tip : capsules obovoid, 2.5-3 mm. long, manifestly longer than thick, much surpassed by the sepals and petals. [Luzula campestris Chapm. in part, not DC.]

In woodlands, North Carolina to Georgia and Alabama. Spring.

3. Juncoides bulbòsum (Wood) Small. Base of the plants accompanied by bulblets. Foliage almost glabrous or somewhat webby on the leaf-margins and at the tops of the sheaths : stems 1-4 dm. tall, usually lower than those of J. echinatum: inflorescence umbel-like, the peduncles very unequal at maturity : sepals and petals ovate-lanceolate or lanceolate, $2-2.5 \mathrm{~mm}$. loug, brownish, acuminate, neither manifestly soft nor hyaline at the apex : capsules broadly obovoid, or globose-obovoid, of ten nearly as thick as long, surpassing the sepals or sometimes about equalling them.

In woods, thickets and open sandy places, Virginia to Kansas, Georgia and Texas. Spring.

\section{FAmily 3. ALLIÀCEAE Batsch. Onion FAmily.}

Perennial mainly scapose herbs, with bulbs or corms. Leaves basal or more rarely cauline: blades narrow. Flowers in terminal umbels, which are at first enveloped in and finally subtended by a scarious involucre. Perianth sometimes conspicuous. Sepals and petals 3 each, quite similar in shape, usually membranous, distinct or partially united. Androecium of 6 stamens. Filaments usually distinct. Anthers 2-celled. Gynoecium of 3 united carpels. Ovary superior, 3-celled. Styles united. Ovules 1-several in each cavity. Fruit a loculicidal capsule, 3-lobed, sometimes crested.

Sepals and petals distinct or nearly so.

Ovules or seeds 1 or 2 in each cavity : plants with an onion-like odor.

Ovules 2 in each cavity: scape or stem accompanied by leaves.

Ovule 1 in each cavity : scape not accompanied by leaves.

Ovules or seeds several in each cavity : plants destitute of an onion-like odor. Sepals and petals united to about the middle.

1. Allium.

2. VALIDALLIUM.

3. NOTHOSCORDIUM.

4. ANDROSTEPHIUM.

\section{1. ÁLIIUM L.}

Characteristically odorous herbs, with solitary or clustered bulbs. Leaves basal or mainly so: blades narrow, sometimes hollow or keeled, several. Scapes or stems simple, often hollow. Flowers perfect, in terminal usually simple umbels subtended by $2-3$ thin bracts. Perianths of various colors, often white, pink, green or purple, persistent : sepals and petals distinct or nearly so. Stamens 6, adnate to the bases of the sepals and petals: filaments filiform or dilated, sometimes toothed : anthers opening introrsely. Ovary sessile or nearly so, more or less completely 3-celled: style filiform, jointed: stigma somewhat depressed. Ovules 2 in each cavity. Capsule membranous, loculicidal. OnIon. Garlic. Bulbs with membranous outer coats.

Umbels horizontal or nodding during anthesis.

Perianth campanulate, mostly white or pink : sepals acute.

Perianth urn-shaped, mostly deep purple : sepals obtuse or notched.

Umbels erect.

Caulescent : naturalized species.

Scapose: Texano-Mexican species.

Bulbs with fibrous outer coats.

Sepals and petals obtuse or notched : flowers mostly replaced by bulblets. Umbels simple.

Umbels 1-2-proliferous.

Sepals and petals acute or acuminate: flowers rarely replaced by bulblets. Ovary and valves of the capsule not crested.

Pedicels 16-25 mm. long.

Sepals and petais $5-7 \mathrm{~mm}$. long : bulbs mostly over $2 \mathrm{~cm}$. long.

Sepals and petals $4-5 \mathrm{~mm}$. long : bulbs mostly less than $1.5 \mathrm{~cm}$. long. Pedicels 8-12 mm. long.

Bulbs usually solitary; the outer coats with loosely woven fibers: sepals and petals $4-5 \mathrm{~mm}$. long.

Bulbs usually 2 together; the outer coats with tightly woven fibers : sepals and petals $6-7 \mathrm{~mm}$. long.

ovary and valves of the capsule crested.

1. A. cernuum.

2. A. Allegheniense.

3. A. vineale.

4. A. scaposum.

5. A. Canadense.

6. A. continuum.

7. A. mutabile.

8. A. microscordion.

9. A. arenicola.

10. A. Helleri.

11. A. Cuthbertii. 
1. Allium cérnuum Roth. Bulbs membranous-coated: leaves basal; blades erect or spreading, narrowly linear, 1-3 dm. long, nearly flat: scapes 2-6 dm. tall, 2-edged: umbel nodding, subtended by 2 deciduous bracts, several-many-flowered : pedicels slender, 1-2 or $3 \mathrm{~cm}$. long: perianth deep pink or purplish, ovoid-globose : sepals and petals ovate or ovate-oblong, 5-6 mm. long: filaments nearly filiform, commonly surpassing the perianth : capsules 4-5 $\mathrm{mm}$. long and a little broader.

In rocky hillsides, New York to Minnesota, British Columbia, North Carolina and Tennessee. Summer.

2. Allium Allegheniénse Small. Bulbs narrowly ovoid, $1-2.5 \mathrm{~cm}$. long, with membranous coats: leaves few, erect or ascending; blades narrowly linear, 2-3 dm. long, 2-4 $\mathrm{mm}$. broad : scapes $3-5 \mathrm{dm}$. tall, 2 -edged at least at maturity, commonly overtopping the leaves: umbel 12-40-flowered, nodding: pedicels $1.5-2.6 \mathrm{~cm}$. long, nearly filiform, becoming much thicker at maturity, pink or purple: perianth purple, often deeply so, mostly urn-shaped, 4-5 mm. high : sepals and petals oval or nearly so, the sepals obtuse or notched at the apex, manifestly shorter than the petals: capsules $4-5 \mathrm{~mm}$. high, with 2 large processes on each valve.

On cliffs or in rocky soil, Virginia to North Carolina, Tennessee and Georgia. Summer and fall.

3. Allium vineàle L. Bulbs with membranous outer coats : stems $3-9 \mathrm{dm}$. tall, leafy to about the middle : leaves mainly basal; blades linear, 1-4 dm. long, somewhat channeled, those of the stem 2-4, similar but shorter : umbel erect, subtended by 2 lanceolate acuminate bracts: pedicels few or very numerous, slender, $1-3 \mathrm{~cm}$. long, wholly or partly replaced by bulblets; these furnished with filiform appendages: perianth green, pink or purple : sepals and petals ovate and lanceolate, 4-5 mm. long, acute or obtusish : filaments about as long as the perianth or shorter, flattened, the 3 interior each furnished with 2 appendages: capsules 3-lobed, not surpassing the perianth.

In meadows and fields, Connecticut to Missouri and Georgia. Naturalized from Europe. Spring and summer. WILD GARLIC.

4. Allium scapòsum Benth. Bulbs ovoid, $1.5-3 \mathrm{~cm}$. long; outer coats with rectilinear reticulations: leaves 2-4, slender: scapes solitary or few together, 1-3 dm. tall, as long as the leaves or usually overtopping them : spathe 2-valved : umbel loose, few-flowered, erect: pedicels 1-1.5 cm. long: perianth white: sepals and petals lanceolate or oblonglanceolate, acuminate, $6-8 \mathrm{~mm}$. long, usually with red midnerves : stamens not surpassing the perianth : capsules $5-6 \mathrm{~mm}$. broad, the valves crestless.

On gravelly hillsides or in grassy places, Texas to Arizona and Mexico. Summer and fall.

5. Allium Canadénse L. Bulbs with fibrous outer coats : leaves basal; blades narrowly linear, $1-5 \mathrm{dm}$. long, rounded on the back : scapes $2-6 \mathrm{dm}$. tall, finely ridged in age : umbel subtended by 2 or 3 ovate membranous bracts, most of the flowers replaced by bulblets : pedicels few, slender: perianth pink or white: sepals and petals oblong-lanceolate, obtuse, 4-5 mm. long, or sometimes longer: filaments dilated at the base, entire, about as long as the perianth.

In meadows and fields, Maine to Minnesota, Florida and Louisiana. Spring. Meadow Garlic.

6. Allium contínuum Small. Bulbs with fibrous outer coats : leaves basal; blades narrowly linear, often shorter than the scape, early withering: scapes often tufted, 3-4 $\mathrm{dm}$. tall, topped by a head of ovoid or oblong-ovoid bulblets, subtended by an involucre of 3 reflexed acuminate bracts; bulblets sending out relatively stout scapes $1-2 \mathrm{dm}$. long: flowers few, accompanying the bulblets : pedicels slender, 1-3 cm. long: perianth pink, about $1 \mathrm{~cm}$. broad : sepals and petals lanceolate or almost linear, notched at the apex : filaments dilated below : capsules lobed, the valves not crested.

In and near the Ocmulgee river-swamps, Georgia. Spring.

7. Allium mutàbile Michx. Bulbs with conspicuously fibrous outer coats: leaves basal ; blades narrowly linear, 1-4 dm. long, channeled : scapes $2-5 \mathrm{dm}$. tall, usually surpassing the leaves: umbels erect, subtended by $2-3$ ovate to oblong long-acuminate bracts: pedicels often numerous, $1-2.5 \mathrm{~cm}$. long, slender : perianth white, pink or rosecolored: sepals and petals lanceolate or ovate-lanceolate, acute or acuminate, $5-7 \mathrm{~mm}$. long: filaments dilated at the base, shorter than the perianth : capsules surpassed by the perianth, the valves not crested.

In fields and dry soil, Virginia to Nebraska, Florida and Texas. Spring. WILd ONION.

8. Allium microscórdion Small. Bulbs ovoid, 1-1.5 cm. long, with fibrous outer coats: leaves basal; blades narrowly linear, $1-3.5 \mathrm{dm}$. long, becoming very slender: scapes solitary or tufted, $2-4 \mathrm{dm}$. tall, mostly larger than the leaves : umbels erect, 10-45flowered : pedicels slender, 18-23 mm. long: perianth pink : sepals and petals oblong to oblong-lanceolate, 4-5 mm. long, acute but slightly hooded at the apex : filaments lanceolate subulate at the tip, slightly coherent with the sepals and petals at the broad bases: capsules about $3 \mathrm{~mm}$. broad, the valves not crested.

On hillsides or in sandy soil, Alabama to Florida, Texas and Colorado. Spring. 
9. Allium arenícola Small. Bulbs nearly $1 \mathrm{~cm}$. long, usually solitary, with fibrous outer coats, the fibers loosely woven : leaves basal ; blades very narrowly linear, becoming almost filiform, about as long as the scape or shorter: scapes sometimes several together, 1-3 dm. tall, more or less curved: umbels erect, 10-30-flowered : pedicels 5-10 $\mathrm{mm}$. long, slender : perianth deep pink, not tubular : sepals and petals linear or narrowly linear-lanceolate, about 4-5 mm. long, acute or acuminate, very delicate : filaments dilated below : capsules lobed, the valves not crested.

In sandy soil, Arkansas, the Indian Territory, Mississippi and Texas. Spring.

10. Allium Hélleri Small. Bulbs ovoid, usually 2 together, with fibrous outer coats, but the fibers closely woven: Leaves basal; blades linear, 1-2 dm. long: scapes as long as the leaves or overtopping them, terete or nearly so: bracts $2-3$, ovate or ovate-lanceolate : umbel erect, few-or many-flowered : pedicels slender, $8-15 \mathrm{~mm}$. long, erect or ascending: perianth white or rose-colored, $6-7 \mathrm{~mm}$. long, tubular : sepals and petals oblonglanceolate to elliptic, rather blunt, relatively firm: filaments granular, barely dilated above the base : capsules $3-5 \mathrm{~mm}$. broad, included, the valves crestless.

On prairies, usually in dry soil, Nebraska to Colorado, Texas and Arizona. Spring.

11. Allium Cuthbértii Small. Bulbs ovoid, with coarse-fibrous outer coats: leaves basal; blades narrowly linear, 1-3 dm. long, slightly channeled : scapes usually solitary, mostly longer than the leaves: umbel erect, often 10-30-flowered, subtended by $2-3$ very delicate long-acuminate bracts: pedicels slender or filiform, $2-2.5 \mathrm{~cm}$. long: perianth white: sepals and petals linear-lanceolate, $6-9 \mathrm{~mm}$. long, acuminate, delicately striate : filaments subulate above a dilated base which is somewhat coherent with the sepals and petals : capsules $4-5 \mathrm{~mm}$. wide, the valves crested.

In sand, Georgia and Florida. Spring.

\section{VALIDÁLLIUM Śmall.}

Scapose herbs giving off a strong alliaceous odor, with clustered bulbs. Leaves basal, mostly 2-3: blades relatively broad, appearing before the scape, thickish. Scape simple. Flowers perfect, in a terminal umbel subtended by 2 bracts. Perianth white or pale, persistent: sepals and petals distinct or nearly so. Stamens $6:$ filaments slender : anthers opening introrsely. Ovary sessile, 3-celled : stigma depressed. Ovules solitary in each cavity. Capsule loculicidal, 3-lobed.

1. Validallium tricóccum (Ait.) Small. Bulbs clustered, with fleshy-membranous outer coats : leaves 2 , basal, vernal, disappearing before the flowers appear; blades oblong to oblong-elliptic, 1-3 dm. long, acute, tapering into petiole-like bases : scapes 1-4 dm. tall, often curved, terete: umbel erect, subtended by 2 bracts: pedicels numerous, $1-1.5 \mathrm{~cm}$. long, nearly straight: perianth white : sepals and petals oblong to oval, $6-7 \mathrm{~mm}$. long, obtuse : filaments subulate-lanceolate, about as long as the perianth : capsules 3-lobed, about $6 \mathrm{~mm}$. broad : seeds globose, about $3 \mathrm{~mm}$. in diameter, black, smooth and shining. [Allium tricoccum Ait.]

In moist woods and on hillsides, New Brunswick to Minnesota and Georgia. Summer.

\section{NOTHOSCÓRDIUM Kunth.}

Scapose herbs resembling Allium, but without the characteristic odor. Bulbs membranous coated. Leaves basal : blades narrow. Scape topped by a simple few-rayed umbel, this subtended by 2 bracts. Flowers perfect. Perianth yellow, greenish or white, withering but persistent: sepals and petals 6, narrow, 1-nerved, distinct or nearly so. Stamens 6, adnate to the base of the sepals and petals : filaments subulate or filiform : anthers narrow, opening introrsely. Ovary 3-celled : style filiform, jointed near the base : stigma capitate. Ovules several in each cavity. Capsule 3-celled or 3-lobed, loculicidal. Seeds black, angled, or flattened.

1. Nothoscordium biválve (L.) Britton. Bulbs 1-2 cm. long: leaves basal ; blades narrowly linear, 1-4 dm. long: scapes 1-4 dm. tall, commonly overtopping the leaves: umbel erect, subtended by several membranous acute or acuminate bracts, 3-15-flowered: pedicels slender, $2-5 \mathrm{~cm}$. long, straight : perianth white, delicate : sepals and petals oblonglanceolate or narrowly oblong, acute, $10-12 \mathrm{~mm}$. long: filaments shorter than the perianth : capsules obovoid or rarely broader than high, 4-6 $\mathrm{mm}$. long. [Allium striatum Jacq.]

In sandy soil, Virginia to Nebraska, Florida, Texas and Mexico. Spring. False Garlic. 


\section{ANDROSTÉPHIUM Torr.}

Scapose herbs, with membranous-coated corms. Leaves basal: blades narrow, elongated. Scape simple, topped by a several-rayed umbel, this subtended by several bracts. Flowers perfect, few, short-pedicelled. Perianth blue: sepals and petals 6 , about as long as the funnelform tube, united to about the middle. Stamens 6, adnate to the throat of the perianth-tube : filaments united to the middle or above it into a tube, this bearing toothlike lobes between the free parts of the filaments : anthers narrow, introrse. Ovary 3-celled : style filiform: stigma 3-grooved. Ovules several in each cavity. Capsule 3-angled, membranous, loculicidal. Seeds few, black, thick.

1. Androstephium coerùleum (Scheele) Greene. Bulbs ovoid, with thin outer coats: leaves basal; blades rather flat, linear, commonly overtopping the scape: scape solitary, 1-3 dm. tall, topped by a 2-6-rayed umbel : pedicels ascending, 1-3 cm. long, relatively stout : perianth lilac or violet, $2-3 \mathrm{~cm}$. long: sepals and petals oblong or oblonglanceolate, about as long as the tube, obtuse: anthers not surpassing the perianth : capsules over $1 \mathrm{~cm}$. long and broad: seeds flat, $4-6 \mathrm{~mm}$. broad. [A. violaceum Torr.]

On prairies and in light soil, Kansas to the Indian Territory and Texas. Spring.

\section{FAmily 4. LILIÀCEAE Adans. Lily Family.}

Perennial, mainly caulescent herbs, with bulbs or corms. Leaves alternate or whorled, basal or apparently basal : blades entire. Flowers solitary, or in terminal racemes, corymbs or panicles. Perianth commonly conspicuous or showy. Sepals and petals 3 each, quite similar, sometimes partially united. Androecium of 6 stamens. Filaments usually distinct. Anthers 2-celled. Gynoecium of 3 united earpels. Ovary superior, 3-celled. Styles united. Ovules 2-many in each cavity. Fruit a loculicidal capsule, globular or elongated, lobed or prismatic.

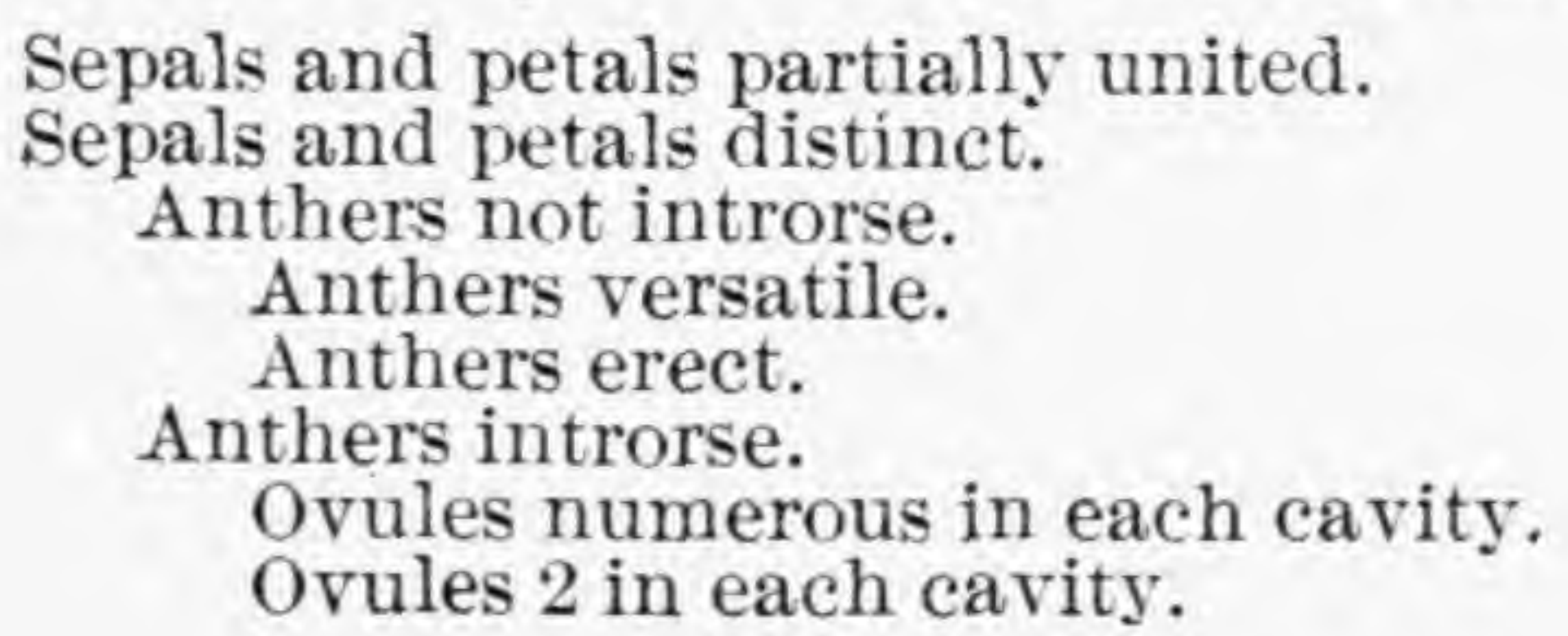

Sepals and petals partially united.

thers not introrse.

Ovules numerous in each cavity.

1. Hemerocallis.

2. LILIUM.

3. ERYthronium.

4. QUAMASIA.

5. OXYTRIA.

\section{HEMEROCÁLLIS L.}

Acaulescent herbs, with glabrous foliage and clustered coated bulbs. Leaves basal: blades linear, elongated, ascending or spreading, sometimes slightly involutely folded. Scapes simple below the inflorescence. Flowers perfect, in terminal clusters. Perianth mostly yellow or orange, funnelform ; lobes longer than the tube, recurving. Stamens 6, adnate to near the top of the perianth-tube : filaments shorter than the perianth : anthers narrow, opening introrsely. Ovary longer than broad, 3-celled : style declined : stigma small, capitate. Ovules numerous in each cavity. Capsule 3-celled, 3-angled, longitudinally 3-valved. Endosperm fleshy.

1. Hemerocallis fúlva L. Foliage glabrous, bright green. Leaves basal, often numerous ; blades linear, elongated, curved, acute: scapes 1-2 $\mathrm{m}$. tall, overtopping the leaves, often mottled : flowers 5-15, short-pedicelled, opening for about one day : perianth showy, tawny orange, 10-15 $\mathrm{cm}$. long; lobes spreading or recurved, the outer $3 \mathrm{flat}$, acutish, the inner 3 undulate, obtuse: stamens exserted, shorter than the style.

In thickets and meadows, New Brunswick and Ontario to North Carolina and Tennessee. Native of Europe and Asia. Summer. DAY LILY.

\section{LÍLIUM L.}

Caulescent herbs, with scaly bulbs. Leaves alternate or whorled: blades flat, entire, smooth, or with rough margins and nerves. Flowers perfect, erect or drooping. Perianth showy, variously colored, funnelform to campanulate: sepals and petals 3 each, distinct, straight or recurved, each with a nectar-bearing groove at the base within. Stamens 6 , slightly adnate to the sepals and petals : filaments subulate or filiform, shorter than the perianth: anthers narrow, versatile, opening lengthwise. Ovary 3-celled: style often club-shaped : stigma 3-lobed. Ovules numerous in each cavity. Capsule longer than broad, loculicidal. Seeds flat, horizontal, closely packed in 2 rows in each cavity. 
Flower or flowers erect: sepals and petals narrowed into elaws.

Leaves erect or nearly so, all alternate: sepals and petals long-acuminate.

Leaves spreading, some alternate: sepals and petals merely acute, or obtuse. Leaves mostly alternate: capsules cylindric, over $5 \mathrm{~cm}$. long.

Leaves mostly whorled : capsules obovoid, less than $5 \mathrm{~cm}$. long.

Flower or flowers horizontal or nodding: sepals and petals without claws.

Leaf-blades finely roughened on the margins and nerves beneath: sepals and petals not recurved.

Sepals and petals ereet, abruptly pointed: flowers horizontal.

Sepals and petals spreading at the middle, acuminate : flowers nodding.

Leaf-blades smooth: sepals and petals recurved.

Foliage green: leaf-blades broadest below the middle.

Foliage glaucous: leaf-blades broadest above the middle.

1. L. Catesbaei.

2. L. umbellatum.

3. L. Philadelphicum.

1. Lilium Catesbaèi Walt. Bulbs with narrow scales often prolonged into slender tips : stems 3-8 dm. tall, simple: leaves alternate, erect or nearly so; blades linear or narrowly linear-lanceolate, $3-12 \mathrm{~cm}$. long, fleshy : flowers solitary, erect : perianth mainly scarlet : sepals and petals 8-12 cm. long; blades lanceolate or elliptic-lanceolate, conspicuously acuminate, undulate, spotted with purple and yellow, longer than the involute claw : capsules oblong or obovoid-oblong, $1.5-2 \mathrm{~cm}$. long.

In low pine lands, North Carolina to Florida and Alabama. Summer.

2. Lilium umbellàtum Pursh. Bulbs with stout scales : stems $3-8 \mathrm{dm}$. tall, simple: leaves alternate or those under the inflorescence whorled; blades linear, 3-8 cm. long, ascending or spreading, pale beneath : flowers erect, solitary or 3 in a terminal whorl : perianth red, orange or yellow : sepals and petals $5-8 \mathrm{~cm}$. long; blades elliptic to oblong or ovate-lanceolate, acute or rather obtuse, narrowed into shorter claws : capsules cylindric, 7-10 cm. long.

In dry soil, Minnesota to Northwest Territory, Ohio, Arkansas and Colorado. Spring and summer.

3. Lilium Philadélphicum L. Bulbs with stout scales : stems $3-9 \mathrm{dm}$. tall, simple, at least below the inflorescence: leaves in whorls of 3's or 8's or alternate on the upper part of stem ; blades linear to narrowly elliptic, $3-10 \mathrm{~cm}$. long, acute or acuminate at both ends, rough-margined : flowers solitary, or rarely 4 in a whorl : perianth mainly reddish orange : sepals and petals 5-6 cm. long; blades oblong, elliptic or oval, spotted with purple below the middle, longer than the claws, obtuse or abruptly pointed: capsules obovoid, $2-4 \mathrm{~cm}$. long.

In open woods or rocky soil, Maine and Ontario to the mountains of North Carolina and West Virginia. Summer.

4. Lilium Graỳi S. Wats. Bulbs with many thick scales : stem 5-10 dm. tall, simple or topped by an umbel : leaves whorled in 3's-8's or scattered on the lower part of the stem ; blades lanceolate to oblong or elliptic-lanceolate, 4-12 $\mathrm{cm}$. long, acute or acuminate, slightly roughened on the edges, sessile, minutely roughened on the nerves beneath : flowers solitary or 3 at top of the stem, horizontal or nearly so: perianth mostly red : sepals and petals oblong-spatulate, $3.5-4.5 \mathrm{~cm}$. long, acute or abruptly pointed : capsules fig-shaped, 3-4 cm. long.

On high mountain peaks, Virginia, North Carolina and Tennessee. Summer.

5. Lilium Canadénse L. Bulbs stout, with numerous thick scales : stems $6-15 \mathrm{dm}$. tall, more or less branched above, strict or slightly zigzag: leaves in whorls of 4's-10's or scattered at the base or the top of stem; blades linear to oblong or elliptic-oblong, 5-15 $\mathrm{cm}$. long, acute or acuminate, roughened on the margins and nerves beneath : flowers solitary or as many as 16 : perianth red or yellowish, often variegated, usually spotted : sepals and petals broadest at or above the middle, $4.5-7.5 \mathrm{~cm}$. long: capsules oblong-prismatic, $3-5 \mathrm{~cm}$. long.

In meadows and swamps, Nova Scotia to Minnesota, Georgia, Alabama and Missouri. Summer. WILD YELLOW LILY.

6. Lilium supérbum L. Bulbs large, with thick scales : stems 9-25 dm. tall, strict, shining: leaves in whorls of 3's-8's or alternate on the upper part of the stem; blades elliptic, elliptic-lanceolate or nearly linear, $5-15 \mathrm{~cm}$. long, acuminate at both ends, smooth, without conspicuously anastomosing veins, sessile or nearly so : pedicels spreading : flowers showy, 3-40: perianth orange, red or orange-yellow, nodding: sepals and petals linear-lanceolate to oblong-lanceolate, $6-10 \mathrm{~cm}$. long, recurving from below the middle at maturity, usually spotted with purple : capsules oblong or obovoid-oblong, $3-5 \mathrm{~cm}$. long.

In swamps or meadows, Maine to Minnesota, Georgia and Tennessee. Summer. Turk's Cap Lily.

7. Lilium Caroliniànum Michx. Bulbs solitary or several together, with thick scales: foliage glabrous : stems $6-12 \mathrm{dm}$. tall, simple or topped by a 3 -rayed umbel : leaves in whorls of 3's-8's or scattered at the base or top of the stem, or often all scattered; blades obovate, elliptic-obovate or oblanceolate, 3-12 $\mathrm{cm}$. long, abruptly pointed or acuminate, gradually narrowed to the sessile base, 3-nerved: flowers nodding, fragrant: perianth 
orange-red, 4-8 cm. long, very showy : sepals and petals lanceolate or oblong-lanceolate, 8$10 \mathrm{~cm}$. long, spotted with purple, strongly recurved from below the middle, the tips often converging on the base of the perianth, the midrib winged beneath : capsules obovoid.

In open woods, Virginia to Florida and Louisiana. Summer.

\section{ERYTHRÒNIUM L.}

Low herbs, with deeply buried membranous-coated corms, sometimes producing offshoots. Stems chiefly underground, simple. Leaves 2 at the top of the stems and appearing basal : blades thickish, flat, spreading, sheathing at the base. Flowers perfect. Perianth often showy, nodding, solitary, or rarely several flowers together : sepals and petals narrow, each with a nectar-bearing groove at the base. Stamens 6 , hypogynous: filaments shorter than the perianth: anthers narrow, erect. Ovary 3-celled: style filiform or thickened upward, 3-lobed or 3-cleft at the apex. Ovules several or numerous in each cavity. Capsule slightly elongated, 3-celled, loculicidal. Seeds flattened. Dog's-тоотн Violet. New corms produced at the base of the old ones : sepals and petals erect or only slightly spreading.

New corms produced at the ends of offshoots: sepals and petals recurved.

Perianth white, pink or purplish within: styles united to above the middle, topped by 3 spreading stigmas.

Perianth yellow within: styles wholly united: stigma terminal.

1. E. mesachoreum.

1. Erythronium mesachòreum Knerr. Corms ovoid, $2-3 \mathrm{~cm}$. long, with large membranous coats, not producing offshoots but the new bulb forming at the base of the old one or within its coats. Leaves 2 ; blades oblong to linear-oblong, $8-18 \mathrm{~cm}$. long, deep green, not mottled, commonly involutely folded, narrowed into petiole-like bases: scapes 1-3 dm. tall, simple : perianth nodding : sepals and petals linear to linear-lanceolate, 2.5-4 cm. long, white, sometimes tinted with lavender, erect, barely spreading, not recurved : stigmas recurved : capsules obovoid, $2-3 \mathrm{~cm}$. long.

On prairies, Iowa to Nebraska, and the Indian Territory. Winter and early spring.

2. Erythronium álbidum Nutt. Corms ovoid, $1-2 \mathrm{~cm}$. long. Leaves apparently basal ; blades oblong to elliptic, $5-15 \mathrm{~cm}$. long, acute, mottled with light and dark green, or of only one shade of green, narrowed into petiole-like bases: scapes 1-3 dm. tall, overtopping the leaves, slender: perianth white, pink or purplish, nodding : sepals and petals linear or linear-lanceolate, $3-3.5 \mathrm{~cm}$. long, recurved, destitute of auricles : stigmas 3 , linear, 2-3 mm. long : capsules oblong or oblong-obovoid, 1-2 cm. long.

In thickets and on hillsides, Ontario to Minnesota, Georgia and Texas. Spring. $-A$ form from Waco, Texas, with the sepals and petals suffused with rose-purple or red is known as E. albidum colorìtum Sterns.

3. Erythronium Americànum Ker. Corms ovoid, 1-2.5 cm. long. Leaves apparently basal, usually 2 ; blades oblong to elliptic, 10-15 $\mathrm{cm}$. long, acute, commonly mottled above, lustrous on both sides, entire, sheathing at the base: scapes 1-3 dm. tall, simple: peduncles more or less glaucous, simple: perianth-members various, $3-3.5$ $\mathrm{cm}$. long ; sepals linear-lanceolate, glaucous without, greenish yellow within ; petals linearelliptic, pale yellow, the midvein green without, all spotted within below the middle: stigma terminal, slightly lobed: capsules broadly obovoid, or fig-shaped, $1-1.5 \mathrm{~cm}$. long.

In thickets and moist woods, Nova Scotia to Ontario, Minnesota, Florida and Arkansas. Spring.

\section{QUAMÀsIA Raf.}

Scapose herbs, with coated edible bulbs. Leaves basal: blades narrow, elongated. Scape solitary, simple. Raceme terminal, cylindric. Pedicels subtended by narrow bracts. Flowers perfect. Perianth white, blue or purple: sepals and petals 6, distinct, equal, 3-8-nerved. Stamens 6 , adnate to the base of perianth-members: filaments filiform: anthers narrow, versatile, introrse. Ovary 3-celled: style filiform: stigma 3-lobed. Ovules numerous in each cavity. Capsule about as broad as long, 3-angled, loculicidal. Seeds black, lustrous. [Camassia Lindl.]

1. Quamasia hyacínthina (Raf.) Britton. Bulbs ovoid or subglobose, $2-3 \mathrm{~cm}$. long : leaves basal ; blades narrowly linear, acuminate, 2-5 dm. long, entire: scapes 3-6 dm. tall, overtopping the leaves, wholly naked or rarely with 1 or 2 reduced leaves : racemes $8-20 \mathrm{~cm}$. long or longer at maturity, showy : pedicels spreading, $1-1.5 \mathrm{~cm}$. long: bracts slender, membranous: perianth blue or rarely white, about as long as the pedicel : sepals and petals oblong, sometimes narrowly so, obtuse, several-nerved : capsules 3-angled, 7-8 mm. long, broader than high. [Camassia Fraseri Torr.] CINTH.

In thickets and meadows, Pennsylvania to Minnesota, Georgia and Texas. Spring. WILD HyA- 


\section{OXÝTRIA Raf.}

Scapose herbs, with bulb-like corms. Leaves basal, often numerous : blades narrow, elongated. Flowers perfect, regular, in terminal racemes or panicles. Pedicels solitary. Perianth white or yellow: sepals and petals 3 each, distinct, 3-nerved, withering-persistent. Stamens 6: filaments adnate to the base of the sepals and petals : anthers versatile, introrsely dehiscing. Ovary sessile or nearly so, 3-celled : style filiform : stigma 3-lobed. Ovules 2 in each cavity, anatropous. Capsule not elongated, 3-angled, leathery, loculicidally 2 -valved. Seeds few, sometimes angled. Embryo straight, as long as the fleshy endosperm. [Schoenolirion Durand.]

Perianth bright yellow: bracts obtuse.

Perianth white or greenish white: bracts acute or acuminate.

Racemes mostly simple: bracts acute: seeds $2 \mathrm{~mm}$. long.

Racemes mostly panicled: bracts acuminate: seeds $4 \mathrm{~mm}$. long.

1. O. crocea.

2. O. Texana.

3. O. albiflora.

1. Oxytria cròcea (Michx.) Raf. Leaves basal, erect or ascending ; blades narrowly linear, $2-4 \mathrm{dm}$. long, attenuate : scapes often tufted, scarcely taller than the leaves, simple below the racemes, slender : racemes $3-10 \mathrm{~cm}$. long, simple: pedicels ascending, 5-13 mm. long: bracts obtuse : perianth bright yellow, about $1 \mathrm{~cm}$. broad : sepals and petals oblong or oblong-oblanceolate, rather obtuse : capsules 3-lobed, 4-5 mm. broad : seeds black, $3 \mathrm{~mm}$. long. [Schoenolirion croceum (Michx.) A. Gray.]

In sandy soil, Georgia and Florida to Louisiana. Spring.

2. Oxytria Texàna (Scheele) Pollard. Leaves basal; blades narrowly linear, 1-4 dm. long, attenuate: scapes erect, about as long as the longer leaves, simple below the inflorescence : racemes $5-10 \mathrm{~cm}$. long, mostly simple : pedicels ascending or spreading, 8-14 mm. long: perianth greenish white, about $1 \mathrm{~cm}$. broad : sepals and petals oblong, obtuse: capsules 3-lobed : seeds $2 \mathrm{~mm}$. long. [Schoenolirion Texanum (Scheele) A. Gray.]

On prairies, Louisiana and Texas. Spring.

3. Oxytria albiflòra (Raf.) Pollard. Leaves basal ; blades narrowly linear, 4-6 dm. long, gradually contracted from the base: scapes erect, somewhat longer than the leaves, paniculately branched above: pedicels ascending, $1-2.5 \mathrm{~cm}$. long, ascending: perianth white, $10-12 \mathrm{~mm}$. broad : sepals and petals broadly oblong or oval, obtuse, 5 -nerved : capsules 3-lobed, 5-6 mm. broad : seeds $4 \mathrm{~mm}$. long. [Schoenolirion Elliottii Feay.]

In low pine lands, Georgia and Florida. Spring.

\section{FAmily 5. CONVALLARIÀCEAE Link. Lrly-OF-The-VAlley Family.}

Perennial scapose or caulescent herbs, with rootstocks; never with bulbs or corms. Leaves alternate, sometimes all basal, sometimes reduced to scales. Flowers perfect, regular, in terminal umbel-like clusters, racemes, panicles, or solitary, or sometimes 1 or several in the axils. Perianth inferior: sepals and petals 2 or 3 each, distinct or partially united. Androecium of 6 hypogynous stamens. Filaments partly adnate to the perianth. Gynoecium of 2-3 united carpels. Ovary 2 or 3-celled, superior. Styles mostly united. Stigma 2 or 3lobed. Ovules 2-several, anatropous or amphitropous. Fruit a fleshy berry, or rarely a tardily dehiscent capsule. Seeds few or numerous. Embryo surrounded by copious endosperm.

Leaves reduced to scales: branchlets very numerous, filiform.

Leaves normal : stems or scapes simple or sparingly branched.

Sepals and petals distinet.

Plants scapose: leaves basal.

Plants caulescent: leaves cauline.

Flowers in terminal racemes or panicles.

Sepals and petals 3 each : stamens 6 . Sepals and petals 2 each: stamens 4 .

Flowers axillary or opposite the leaves, solitary, or few in the clusters.

Fruit a berry : filaments mostly longer than the anthers.

Flowers axillary: filaments slender: anthers acute.

Flowers terminal : filaments dilated: anthers obtuse.

Fruit a capsule: filaments mostly shorter than the anthers.

Sepals and petals with 2 ridges on either side of a deep nectary : capsules obovoid or turbinate, 3-lobed.

Sepals and petals without ridges or nectary : capsules elliptic or oval, 3 -winged.

Sepals and petals partially united into a tube.

Flowers axillary: perianth tubular: anthers sagittate.

Flowers in terminal racemes: perianth campanulate: anthers oblong.

1. Asparagus.

2. Clintonia.

3. VAGNERA.

4. UNIFOLIUM.

5. Streptopus.

6. Disporum.

7. Uvularia.

8. OAKESIELLA.

9. Salomonia.

10. Convallaria. 


\section{ASPÁRAgUS L.}

Caulescent herbs, with elongated rootstocks. Stems first arising as simple scaly stalks ( these often edible), finally branched. Leaves all reduced to scales. Branchlets filiform to linear or ovate, often clustered in the axils of the scale-like leaves. Flowers solitary in the axils, or sometimes in racemes or umbels. Perianth nodding: sepals and petals alike, distinet or slightly united at the base. Stamens 6, inserted at the base of the perianth: filaments usually filiform: anthers introrse. Ovary 3-celled: stigmas 3 . Ovules 2 in each cavity. Berry drooping, pulpy. Seeds few or solitary, often black.

1. Asparagus officinàlis L. Rootstocks much branched. Foliage glabrous, glaucescent: stems at first stout, with broad scales, edible, becoming 4-20 dm. tall, widely branching, conspicuous on account of the numerous thread-like branchlets clustered in the axils of minute scales : flowers mostly solitary at the nodes, drooping from recurved pedicels : perianth greenish, 4-6 $\mathrm{mm}$. long: sepals and petals linear, obtuse, erect, or with spreading tips : stamens shorter than the perianth : berries subglobose, red, $6-8 \mathrm{~mm}$. in diameter.

In waste places and salt marshes, New Brunswick to Georgia and Louisiana. Naturalized from Europe. Spring to fall. Asparagus.

\section{CLINTÒNIA Raf.}

Scapose herbs, with horizontal rootstocks and pubescent foliage. Leaves normal, basal: blades flat, thickish, the petiole-like bases sheathing. Scape solitary, simple. Flowers in terminal umbels, or rarely solitary or racemose. Perianth erect or drooping: sepals and petals equal or nearly so, distinct, deciduous. Stamens 6, inserted at the base of the perianth : filaments filiform: anther-sacs opening laterally, or nearly so. Ovary 2 or 3 -celled, sessile : stigma slightly 2 - or 3 -lobed. Ovules 2 -several in each cavity. Berry not drooping. Seeds 2-many, rounded or angled.

Perianth greenish yellow : sepals and petals over $1 \mathrm{~cm}$. long : flowers nodding : berries blue.

Perianth

Perianth white: sepals and petals less than $1 \mathrm{~cm}$. long: flowers erect: berries black. 2. C. umbellulata.

1. Clintonia boreàlis (Ait.) Raf. Foliage deep green. Leaf-blades oblong, elliptic or oval, 1-3 dm. long, ovate or abruptly pointed, ciliate, sheathing at the base: scapes erect, surpassing the leaves, pubescent above: flowers sometimes in racemes: perianth greenish yellow, $1.5-2 \mathrm{~cm}$. long, nodding: sepals and petals linear or linear-lanceolate, $1.5-2 \mathrm{~cm}$. long, pubescent without : berries oval or subglobose, $8-9 \mathrm{~mm}$. in diameter, blue.

In deep woods, Newfoundland to Minnesota, North Carolina and Wisconsin. Spring.

2. Clintonía umbellulàta (Michx.) Torr. Foliage bright green. Leaf-blades oblong, oblong-spatulate or elliptic, 1-3 dm. long, acute or abruptly pointed, ciliate, sheathing at the base : scapes erect, as long as the leaves or $1.5 \mathrm{dm}$. longer, rarely bearing a leaf-like scale, pubescent, especially above: umbel 5-15-flowered : pedicels ascending or upcurved, 1-3 cm. long: perianth white, spotted with green or purple : sepals and petals elliptic to oval, about $5 \mathrm{~mm}$. long: berries subglobose, $5-7 \mathrm{~mm}$. in diameter, black.

In woods and on hillsides, New York to Georgia and Alabama. Spring.

\section{VÁGNERA Adans.}

Caulescent herbs, with elongated rootstocks. Leaves cauline: blades thickish, severalnerved. Flowers in terminal racemes or panicles. Perianth white or greenish white: sepals and petals 3 each, equal, distinct or nearly so. Stamens 6 , often conspicuous : filaments filiform, or slightly flattened, inserted at the base of the perianth : anthers introrse. Ovary sessile, 3-celled : stigma 3-grooved or 3-lobed. Ovules 2 in each cavity. Berry subglobose, sometimes mottled. Seeds 1-2, with a thin testa. [ Smilacina Desf.] WILD SPIKENARD.

Sepals and petals broadly linear: filaments inflated, about as long as the perianth. Sepals and petals narrowly linear: filaments flat, twice as long as the perianth.

1. V. racemosa. 2. V. australis.

1. Vagnera racemòsa (L.) Morong. Stems erect or ascending, 3-9 dm. tall, more or less zigzag, slightly angled : leaf-blades oblong, oblong-lanceolate or elliptic, $5-20 \mathrm{~cm}$. long, acute or acuminate, several-nerved, sessile : panicles $3-10 \mathrm{~cm}$. long, not, very dense, the branches usually pubescent: perianth white, about $4 \mathrm{~mm}$. broad, glabrous or nearly so : sepals and petals broadly linear : filaments about as long as the sepals and petals, in- 
flated: berries subglobose, 4-6 mm. in diameter, red and spotted with purple, aromatic.

In woods and on banks, Nova Scotia to British Columbia, south to Georgia, Missouri and Arizona. Spring and summer.

2. Vagnera austràlis Rydb. Similar to $V$. racemosa in habit, but more slender. Leaf-blades relatively narrower, markedly acuminate, prominently 3-nerved, the other lateral nerves less prominent: panicles loosely flowered, the branches glabrous: perianth white, about $3 \mathrm{~mm}$. broad : sepals and petals narrowly linear: filaments twice as long as the sepals and petals, flat.

In woods or on hillsides, Georgia and Alabama. Spring.

\section{UNIFÓLIUM Adans.}

Caulescent herbs, with slender rootstocks. Leaves few: blades thickish, severalnerved. Flowers in terminal racemes. Perianth white: sepals and petals 4, distinct, spreading. Stamens 4, hypogynous : filaments filiform, or slightly flattened : anthers versatile, introrse. Ovary sessile or nearly so, 2-celled: stigmas 2 . Ovules 2 in each cavity. Berry subglobose, pulpy. Seeds 1-2. Embryo shorter than the horny endosperm. [Maianthemum Wigg.]

1. Unifolium Canadénse (Desf.) Greene. Foliage finely pubescent or glabrous. Stems erect, $5-15 \mathrm{~cm}$. tall, commonly zigzag: leaves 2 or commonly 3 ; blades ovate to lanceolate, $2-8 \mathrm{~cm}$. long, acute or somewhat acuminate, usually truncate or subcordate at the base, sessile or short-petioled: racemes $2-5 \mathrm{~cm}$. long, not dense: pedicels $2-8 \mathrm{~mm}$. long: perianth white, about $5 \mathrm{~mm}$. broad: sepals and petals oblong or oblong-lanceolate, acute: berries subglobose, $4 \mathrm{~mm}$. in diameter, pale, red-speckled. [Smilacina bifolia Chapm., not Ker.]

In damp woods and thickets, Newfoundland to the Northwest Territory, North Carolina and South Dakota. Spring and summer. TWO-LEAVED SOLOMON's SEAL.

\section{STRÉPtOPUS Michx.}

Caulescent herbs, with horizontal rootstocks. Leaf-blades thinnish, sessile or clasping. Flowers solitary, or 2 together, nodding from extra-axillary peduncles. Perianth greenish or purplish: sepals and petals 3 each, separate, with spreading or recurved tips, the petals keeled. Stamens 6, hypogynous : filaments flattened, very short : anthers sagittate, opening nearly laterally. Ovary 3-celled: stigma entire or 3-lobed. Ovules in two rows in each cavity. Berry red, oval or subglobose. Seeds numerous.

Leaf-blades green, sessile: perianth rose or purple: anthers 2-pointed.

1. S. roseus.

Leaf-blades glaucous beneath, clasping: perianth greenish white: anthers 1-pointed. 2. S. amplexifolius.

1. Streptopus ròseus Michx. Foliage pubescent. Rootstocks stout, with numerous roots : stems $3-9 \mathrm{dm}$. tall, forking, somewhat pubescent above: leaf-blades oblong to oblongovate or ovate, $5-12 \mathrm{~cm}$. long, acuminate, ciliolate, many-nerved, sessile : peduncles 1-2.5 $\mathrm{cm}$. long, pubescent, usually 1 -flowered: perianth rose or purple, 8-12 $\mathrm{mm}$. long: sepals and petals narrowly lanceolate, acuminate, the tips more or less strongly recurved : anthers 2-horned : stigmas 3 : berries globose or oval-globose, 10-12 $\mathrm{mm}$. long.

In deep woods, Labrador and Alaska to the mountains of Georgia, Michigan and Oregon. Spring and summer.

2. Streptopus amplexifòlius (L.) DC. Foliage glancous. Rootstocks horizontal, with numerous roots : stems $3-12 \mathrm{dm}$. tall, forking, usually from below the middle, glabrous or nearly so: leaf-blades oblong to oblong-lanceolate or ovate-lanceolate, 5-12 $\mathrm{cm}$. long, acuminate, thin, becoming green above, clasping, pale beneath : peduncles curved, $2-5 \mathrm{~cm}$. long, 1-2-flowered : pedicels much shorter than the peduncles : perianth greenish white, 10-12 mm. long: sepals and petals narrowly lanceolate, acuminate, more or less recurved : anthers subulate-tipped : stigma entire, slightly dilated : berries oval, $10-15 \mathrm{~mm}$. long.

In woods, Labrador and Alaska, to the mountains of North Carolina, Ohio and New Mexico. Spring and summer.

\section{DÍSPORUM Salisb.}

Caulescent herbs, with elongated rootstocks and pubescent foliage. Leaf-blades thinnish, sessile or clasping, somewhat inequilateral. Flowers solitary or in terminal simple clusters, drooping. Perianth whitish or greenish yellow : sepals and petals 3 each, narrow, distinct, deciduous. Stamens 6 , hypogynous : filaments filiform, or somewhat flattened: anthers narrow, extrorse, shorter than the filaments. Ovary 3-celled: stigma 
entire or 3-cleft. Ovules 2 or several in each cavity. Berry thick, juicy, usually highly colored. [Prosartes D. Don.]

Sepals and petals yellowish, finely dotted with black. Sepals and petals greenish, not dotted with black.

1. D. maculatum.

2. D. lanuginosum.

1. Disporum maculàtum (Buckl.) Britton. Foliage lanuginous, thinly so in some parts. Rootstocks slender : stems $2-6 \mathrm{dm}$. tall, forking above, scaly below : leaf-blades ovate-lanceolate or oblong-ovate, $3-6 \mathrm{~cm}$. long, ciliate, acute or acuminate, sessile : pedicels 5-10 $\mathrm{mm}$. long: perianth yellowish, 1.5-2 cm. long, nodding : sepals and petals narrowly lanceolate or linear-lanceolate, acuminate, dotted with black, delicate.

In woods on the mountains, North Carolina to Georgia and Tennessee. Spring and summer.

2. Disporum lanuginòsum (Michx.) Nichols. Foliage tomentulose. Rootstock elongated : stems 3-9 dm. tall, widely forking, glabrous below : leaf-blades oblong, lanceolate-oblong or ovate-lanceolate, $5-12 \mathrm{~cm}$. long, acuminate, ciliolate, prominently 3-5nerved at maturity, sessile: pedicels solitary or 2-3 together, 2-3 $\mathrm{cm}$. long: perianth drooping, greenish yellow, 14-20 $\mathrm{mm}$. long, glabrous : sepals and petals linear-lanceolate, each with more or less of a claw, acuminate : berries oval, 10-14 mm. long, red.

In woods, Ontario and New York, to the mountains of Georgia and Alabama. Spring.

\section{UVULÄIA L.}

Slightly fleshy herbs, with short rootstocks and fibrous roots. Stems terete, forking, often with several scales at the base. Leaves mainly cauline: blades perfoliate, membranous, smooth-margined. Flowers terminal. Perianth drooping, conspicuous: sepals and petals 3 each, distinct, each furnished with a deep nectary at the base and 2 callous ridges along its sides. Stamens 6, included: filaments free: anthers elongated, erect. Ovary 3-celled, 3-angled : styles united to about the middle : stigmas 3. Ovules several in each cavity. Capsule obovoid or turbinate, truncate or notched at the apex, 3 -lobed. Seeds 1-3 in each cavity, subglobose, about half covered with a thin pale aril.

Sepals and petals papillose within. Sepals and petals smooth within.

1. U. perfoliata.

2. U. grandiflora.

1. Uvularia perfoliàta L. Foliage glaucescent. Stems 1-8 dm. tall, forking above: leaf-blades thinnish, oblong to oval or broadest above the middle, $3-15 \mathrm{~cm}$. long, green above, acute or abruptly pointed, perfoliate, rounded or subcordate: pedicels $5-25 \mathrm{~mm}$. long, terminating the branches : perianth pale yellow, $2-2.5 \mathrm{~cm}$. long: sepals and petals linear or slightly broadened upward, more or less densely granular-papillose within : anthers with acute connectives: capsules turbinate or obovate-turbinate, $1 \mathrm{~cm}$. long, truncate or lobed at the apex.

In rich woods and thickets, Quebec and Ontario to Florida and Mississippi. Spring.

2. Uvularia grandiflòra J. E. Smith. Foliage usually puberulent when young. Stems $2-8 \mathrm{dm}$. tall, forking above: leaf-blades oblong to oblong-lanceolate, perfoliate, $5-15 \mathrm{~cm}$. long, more or less pubescent beneath or glabrate in age : pedicels $1-4 \mathrm{~cm}$. long, terminating the branches: perianth lemon-yellow, 3-4 $\mathrm{cm}$. long, drooping: sepals and petals linear-oblong or linear, acute or acuminate, smooth on both sides or nearly so : anthers with blunt connectives: capsules about $1 \mathrm{~cm}$. long, truncate or rounded at the apex, 3-lobed.

In rich woods and thickets, Quebec to Minnesota, Georgia and Tennessee. Spring.

\section{OAKesí́lla Small.}

Firm-fleshy herbs, with slender elongated rootstocks and angled stems. Leaf-blades sessile, leathery, with scabrous margins. Flowers 1 or 2, opposite to the leaves. Perianth drooping: sepals and petals 3 each, narrow, without ridges or nectaries within, nearly erect. Stamens included : filaments flattened : anthers elongated. Ovary 3-celled : styles partially united. Ovules several in each cavity. Capsule elliptic or oval, acutish at each end, slightly stalked, tardily dehiscent. Seeds subglobose, each with a swollen spongy raphe. [Oakesia S. Wats., not Tuckerm.]

Foliage puberulent.

Foliage glabrous.

Sepals and petals acuminate: anthers with acute connectives.

Sepals and petals obtuse : anthers with obtuse connectives. 
1. Oakesiella pubérula (Michx.) Small. Foliage deep green. Stems 1-5 dm. tall, sparingly forked, minutely rough-pubescent, at least about the nodes: leaf-blades thickish, oblong to oval, $3-8 \mathrm{~cm}$. long, acute or abruptly pointed at the apex, rough-margined, rounded or subcordate at the base, sessile : pedicels 1-2 $\mathrm{cm}$. long: perianth light yellow, $2-2.5 \mathrm{~cm}$. long: sepals and petals linear or nearly so: capsules oval or elliptic, $2.5 \mathrm{~cm}$. long, the angles acute. [Uvularia puberula Michx.]

In woods on mountain slopes, Virginia and West Virginia, to middle Georgia. Spring.

2. Oakesiella Floridàna (Chapm.) Small. Foliage glabrous. Stems 1-2 dm. tall, simple or sparingly forked, slender: leaf-blades oblong, $3-8 \mathrm{~cm}$. long, acute at both ends, green above, glaucous beneath, sessile: pedicels about $1 \mathrm{~cm}$. long, very slender: perianth pale yellow, $1.5-2 \mathrm{~cm}$. long, nodding : sepals and petals linear or linear-lanceolate, acuminate : anthers with acute connectives: capsules not seen. [Uvularia Floridana Chapm.]

In low woods, Florida and Alabama. Spring.

3. Oakesiella sessilifòlia (L.) Small. Foliage glabrous. Stems 1-4 dm. tall, simple or forking above: leaf-blades elliptic, 3-8 $\mathrm{cm}$. long, acute at both ends, sessile, pale beneath, rough-margined : perianth greenish yellow, $1.5-2 \mathrm{~cm}$. long: sepals and petals linear or linear-lanceolate, smooth, obtuse: anthers with obtuse connectives: capsules oval, about $2.5 \mathrm{~cm}$. long, stalked. [Uvularia sessilifolia L.]

In woods and thickets, New Brunswick to Minnesota, Georgia, Alabama and Arkansas. Spring.

\section{SALOMÒNIA Heist.}

Caulescent herbs, with jointed rootstocks. Leaf-blades thickish, sessile. Flowers solitary or several together on axillary peduncles. Perianth drooping, greenish or pink, the lobes erect or nearly so, shorter than the tube. Stamens 6 , included : filaments adnate to the perianth-tube for one-half their length or more : anthers sagittate, introrse. Ovary 3-celled : stigma eapitate or slightly 3-lobed. Ovules 2-6 in each cavity. Berry subglobose, drooping, dark blue or nearly black. Seeds more or less flattened, with horny endosperm. [Polygonatum Adans.] Solomon's SEAL.

Leaf-blades pubescent beneath: filaments rough, adnate to the perianth for about $3 / 4$ its length. 1. S. biflora.

Leaf-blades glabrous : filaments smooth, adnate to the perianth for about $1 / 2 \mathrm{its}$ length.

2. S. commutata.

1 Salomonia biflòra (Walt.) Britton. Foliage glaucescent. Rootstocks horizontal : stems erect or arching, 2-9 dm. tall, simple: leaf-blades oval, elliptic, or oblonglanceolate, 4-10 cm. long, finely pubescent beneath, acutish to acuminate : peduncles 1-4flowered, often 2-flowered: pedicels slender, longer than the peduncles or sometimes shorter: perianth whitish or greenish, $8-12 \mathrm{~mm}$. long, drooping : filaments adnate to the perianth-tube for about $\frac{3}{4}$ its length, granular : berries subglobose, $6-8 \mathrm{~mm}$. in diameter.

In woods and on banks, Nêw Brunswick to Michigan, Florida and West Virginia. Spring and summer.

2. Salomonia commutàta (R. \& S.) Britton. 'Foliage glabrous. Rootstocks horizontal : stems erect or arching, 3-25 dm. tall, often zigzag above : leaf-blades oblong, oblong-lanceolate to oval or oval-ovate, $5-15 \mathrm{~cm}$. long, acute or rather obtuse: peduncles recurving, 1-8-flowered: pedicels often shorter than the peduncles: perianth white or greenish, 10-20 $\mathrm{mm}$. long, drooping: filaments smooth, adnate to the perianth for about $\frac{1}{2}$ its length: berries subglobose, 8-12 mm. in diameter. [Polygonatum giganteum Dietr.]

In woods and on banks, Ontario and Manitoba, to Georgia, Louisiana, New Mexico and Utah. Spring and summer.

\section{CONVALLÀRIA L.}

Low herbs, with elongated horizontal rootstocks. Leaves 2 or 3 : blades thick, deep green, narrowed into sheathing bases. Flowers fragrant, nodding, in a one-sided raceme. Perianth white, globose-campanulate: lobes 6 , recurved. Stamens 6 , included : filaments short, adnate to the lower part of the perianth-tube : anthers short, introrse. Ovary 3celled : style slender, 3-grooved: stigma capitate or slightly 3-lobed. Ovules several in each cavity. Berry subglobose, pulpy. Seeds several, rounded, with horny endosperm.

1. Convallaria majàlis L. Foliage glabrous. Leaves basal, 2 or 3 , erect or spreading; blades oblong to elliptic, 1-3 dm. long, usually acute, or often somewhat acuminate : scapes erect or slightly inclining, $1.5-4 \mathrm{dm}$. tall, shorter than the leaves, glabrous : racemes onesided, $2-10 \mathrm{~cm}$. long : pedicels curved, $5-10 \mathrm{~mm}$. long, more or less recurved: perianth white, campanulate, nodding, $5-7 \mathrm{~mm}$. long, the lobes ovate or triangular-ovate, as long as the tube or shorter: berries globose, about $1 \mathrm{~cm}$. in diameter or less, reddish.

In mountain woods, Virginia and Tennessee to South Carolina. Spring. LiLY-of-THE-VAlley. 


\section{FAMILy 6. DRACAENÀCEAE Link. YuCCA FAMily.}

Shrubby plants or trees, with woody caudices which are generally copiously leafy. Leaves alternate : blades narrow, firm or rigid, sometimes with marginal filaments, often finely toothed. Flowers in racemes or panicles terminating scapes or scape-like stems. Perianth usually not colored. Sepals and petals 3 each, but little dissimilar. Androecium of 6 stamens. Filaments distinct, sometimes partially adnate to the perianth. Anthers 2-celled. Gynoecium of 3 united carpels. Ovary superior, 1-3-celled. Styles united, sometimes very short or obsolete during anthesis, but manifest in fruit. Ovules 2-severai, or many in each cavity. Fruit a primarily loculicidal capsule, or berry-like and indehiscent.

Flowers perfect.

Flowers dioecious or polygamo-dioecious.

Flowers polygamo-dioecious, in open panicles : ovary 3-celled : stamens included.

Flowers dioecious, in dense panicles: ovary 1-celled: stamens exserted.
1. YUCCA.

2. Nolina.

3. Dasylimion.

\section{YÚCCA L.}

Large scapose or caulescent plants, with short or elongated, sometimes horizontal, rootstocks. Leaves firm or rarely thinnish : blades rather narrow, rigidly pointed, commonly furnished with thread-like fibers along the edges, serrulate or entire. Flowers in terminal racemes or panicles. Perianth usually white, drooping, subglobose to campanulate : sepals and petals distinct or slightly united at the base. Stamens 6, hypogynous: filaments enlarged above, shorter than the perianth. Ovary 3-celled, or imperfectly 6-celled or 1celled : style columnar or tumid. Ovules numerous in each cavity. Capsule dehiscent, or berry-like and indehiscent. Seeds flattened or turgid.

Fruit an erect, dry dehiscent capsule.

Leaf-blades with several marginal fibers.

Style columnar, white.

Leaves with blades of a lanceolate or spatulate type, marked with gray or brown near the marginal fibers.

Leaf-blades short-attenuate : capsule evenly narrowed to the apex, the carpels evenly convex.

Leaf-blades long-attenuate: capsule truncately narrowed to the apex, the carpels uneven or angulate.

Leaves with blades of a linear type, white-margined.

Leaves pliable, grass-like, mostly recurved : sepals oblong or elliptic. Leaves rigid, stiffly spreading: sepals oval or oval-ovate.

1. Y. filamentosa.

2. Y. flaccida.

3. Y. tenuistyla.

4. Y. constrictá.

Style turgid, green.

Flowers in racemes or almost sessile panicles.

Leaves rigid, stiffly spreading.

Leaves pliable, erect or laxly spreading.

Flowers in long-stalked panicles.

Leaf-blades with markedly horny rough-serrulate yellow or brown margins.

Fruit a drooping pulpy indehiscent berry-like capsule, or erect in $Y$, recurvifolia.

Seeds thin, slightly margined : endosperm not ruminated.

Leaves rigid, stiffly erect or spreading: capsule 6-ribbed : seeds lustrous.

Leaves pliable, recurving: capsule 6-winged: seeds dull.

Seeds turgid, essentially marginless: endosperm ruminated.

Ovary stalked : fruit with a purple pulp and coreless : leaves horny and denticulate on the border.

Ovary sessile: fruit with a greenish or yellowish pulp and a papery core: leaves more or less filiferous.

5. Y. glauca.

6. Y. Arkansana.

7. Y. Louisianensis.

8. Y. rupicola.

9. Y. gloriosa.

10. Y. recurvifolia.

11. $Y$, aloifolia.

12. Y. Treculeana.

1. Yucca filamentòsa L. Caudex short : leaves firm, 3-6 dm. long, stiffly erect or spreading, mostly over $2-5 \mathrm{~cm}$. wide, constricted above the base, abruptly acute or sometimes rather attenuate, the marginal fibers relatively coarse and curly: flowering stalk $1.5-4 \mathrm{~m}$. tall : panicle-branches usually glabrous : perianth white or cream-colored : sepals and petals $4-5 \mathrm{~cm}$. long: capsules $5-6 \mathrm{~cm}$. long, the carpels even in ripening: seeds lustrous, about $7 \mathrm{~mm}$. long.

In dry or sandy soil, North Carolina to Florida and Mississippi. Spring and summer.

2. Yucca fláccida Haw. Similar to Y. filamentosa in habit, but less rigid. Leaves elongated, 1-4 cm. wide, long-attenuate, pliable, the outer ones recurved, all with long straight marginal fibers : panicle-branches pubescent : sepals and petals relatively broad: capsules 6-7 cm. long, the carpels irregularly flattened in patches while ripening, constricted near the middle at maturity: seeds dull, $8-10 \mathrm{~mm}$. long. summer.

On dry or stony slopes, in and near the mountains, North Carolina to Alabama. Spring and 
3. Yucca tenuistỳla Trelease. Caudex short: leaves pliable, mostly recurved and $5 \mathrm{dm}$. long, $1-1.5 \mathrm{~cm}$. wide, long-attenuate, white-margined, with slender marginal fibers: flowering stem about $1 \mathrm{~m}$. tall: panicle-branches glabrous or merely puberulent: sepals and petals relatively narrow : capsules $5-6 \mathrm{~cm}$. long : seeds $8-10 \mathrm{~mm}$. long.

In dry soil, northeastern Texas. Summer.

4. Yucca constrícta Buckl. Caudex short, or several dm. long: leaves firm, spreading, 4-6 cm. long, about $1 \mathrm{~cm}$. broad, attenuate, white-margined, with fine marginal fibers : flowering stem 1-1.5 m. tall : panicle rather broad: perianth globular, the sepals and petals relatively broad : capsules $4.5-5.5 \mathrm{~cm}$. long : seeds about $9 \mathrm{~mm}$. long.

On plains, southwestern Kansas, southward to the Rio Grande. Spring and summer.

5. Yucca glaùca Nutt. Caudex short or somewhat elongate, prostrate and crawling: leaves firm, commonly $1 \mathrm{~m}$. long, 6-12 mm. wide, mostly ascending, white-margined, sparingly filiferous: flowering stem 1-2 m. tall, simple or with an occasional branch near the caudex, flower-bearing nearly to the base: raceme glabrous: perianth greenish white: sepals and petals acute : capsules $6-7 \mathrm{~cm}$. long, roughened : seeds lustrous, 11-13 $\mathrm{mm}$. long.

On plains, South Dakota and Wyoming to Missouri, Texas and New Mexico. Summer.

6. Yucca Arkansàna Trelease. Similar to $Y$. tenuistyla in habit, but leaves rather broader : flowering stem about $1 \mathrm{~m}$. tall, simple or with a few branches near the caudex, flower-bearing nearly to the base : perianth greenish white : sepals and petals obtuse : capsules $5-6 \mathrm{~cm}$. long, smooth : seeds dull, about $10 \mathrm{~mm}$. long.

On prairies, Arkansas and the Indian Territory to eastern Texas. Summer.

7. Yucca Louisianénsis Trelease. Caudex short: leaves pliable, 5-7 cm. long, 1 $\mathrm{cm}$. to rarely $4 \mathrm{~cm}$. wide, white-margined, sparingly filiferous : flowering stem 1-2 m. tall, the panicle mostly shorter than the unbranched portion: perianth white, campanulate: capsules $4-5 \mathrm{~cm}$. long, irregularly angled while maturing like that of $Y$. flaccida: seeds 6-10 $\mathrm{mm}$. long.

In dry soil, the Indian Territory to Louisiana. Spring and summer.

8. Yucca rupícola Scheele. Caudex short : leaves usually firm or relatively so, 3-5 dm. long, 2.5-3 cm. wide, glaucous, often twisted, the serrulate margin early becoming brown : flowering stem 1-2 $\mathrm{m}$. tall, the panicle usually shorter than the unbranched portion, glabrous: perianth white or greenish, globular: sepals and petals acute, 3.5-4 $\mathrm{cm}$. long : capsules about $6 \mathrm{~cm}$. long, thin-walled: seeds dull, 7-9 mm. long.

In dry soil, southern Texas. Spring and summer.

9. Yucca gloriòsa L. Caudex tall, usually simple : leaves numerous, nearly linear, from a constricted base, $3-5 \mathrm{dm}$. long, rigidly pointed, smooth throughout : panicles showy, conic, 5-10 dm. long: perianth white, 4-5 cm. long: sepals and petals lanceolate or oblong-lanceolate, acute : capsules leathery, nodding, nearly oblong, constricted at or near the middle, indehiscent, 5-6 cm. long : seeds lustrous, 6-7 mm. long.

On the coast, North Carolina to Florida. Spring. SPANish Bayonet.

10. Yucca recurvifòlia Salisb. Caudex commonly 1-2 m. tall, branching: leaves numerous, recurving, smooth-margined or eventually so: panicle narrow, but little raised above the leaves : capsules erect, $5-7 \mathrm{~cm}$. long, indehiscent, the 6 ribs winged : seeds dull, $7-8 \mathrm{~mm}$. long.

In sand, coast of Georgia, Alabama and Mississippi. Spring and summer.

11. Yucca aloifolia L. Caudex $10-25 \mathrm{dm}$. tall, commonly branching : leaves numerous, spreading above, deflexed below and falling from the lower part of the caudex, 3-9 $\mathrm{dm}$. long, rigidly pointed, scabrous-margined, more or less constricted between the middle and the dilated base: panicle ample, showy, conic, 3-6 dm. long: perianth white, often tinged with purple, 4-6 cm. long : sepals and petals oblong to elliptic : capsules pulpy, oblong, indehiscent, nodding, 7-9 cm. long.

In sandy soil, North Carolina to Florida and Louisiana. Spring and summer.

12. Yucca Treculeàna Carr. Caudex $18-75 \mathrm{dm}$. high, usually branching above : leaves numerous, 7-13 dm. long, rigid, straight, entire : panicles showy, 6-12 dm. long, many-flowered : perianth cream-white : sepals and petals ovate or ovate-lanceolate, 4-6.5 $\mathrm{cm}$. long, acute or acuminate: capsules berry-like, nodding, indehiscent, 7-10 cm. long, beaked.

In sandy or dry soil, southern Texas and adjacent Mexico. Spring and summer. 


\section{NOLìna Michx.}

Coarse herbs, with woody caudices. Leaves crowded on the caudex : blades rigid, narrow, elongated, curved, entire or serrulate, keeled. Flowering stems often widely branching. Flowers polygamo-dioecious, in open panicles. Perianth white, witheringpersistent : sepals and petals distinct, 1-nerved. Stamens 6, reduced to staminodia in the pistillate flowers : filaments thickish, shorter than the perianth. Ovary 3-celled, abortive in staminate flowers: style obsolete or very short during anthesis. Ovules 2 in each cavity, erect. Capsule dry, 3-winged, tardily and irregularly opening. Seeds often solitary, thick.

Capsules fully as long as broad, not notched at the ends, or barely so at the apex. 1. N. Georgiana. Capsules manifestly broader than long, notched at the ends.

Capsules $10 \mathrm{~mm}$. broad: perianth about $10 \mathrm{~mm}$. broad : Floridian species.

2. N. Brittomiana.

Capsules $5 \mathrm{~mm}$. broad: perianth 4-5 mm. broad: Texano-New Mexican species. 3 . N. Lindheimeriana,

1. Nolina Georgiàna Michx. Flowering stem scape-like, 5-15 dm. tall : leaves numerous; blades linear, rigid, 2-7 dm. long, widely spreading, those of the flowering stem much reduced, nearly erect : panicle more or less elongated, rather loosely flowered: perianth 4-5 $\mathrm{mm}$. broad : sepals and petals oblong to oblong-lanceolate : capsules suborbicular or obovoid-orbicular, 6-8 mm. long, 3-winged, barely notched at the apex.

In dry pine lands, South Carolina, Georgia and Florida. Spring.

2. Nolina Brittoniàna Nash. Flowering stem 10-20 dm. tall : leaves 40-70, forming a dense mat about the base of the plant; blades linear, strap-like, recurved and prostrate, 1-2 m. long, scabrous-margined, attenuate to a slender apex : panicle oblong or ovoid in outline: perianth nearly $10 \mathrm{~mm}$. broad: sepals and petals elliptic or elliptic-obovate, glandular at the apex : capsules broader than high, $10 \mathrm{~mm}$. broad, on recurved pedicels, notched at the base and the apex.

In dry pine lands, Florida. Spring.

3. Nolina Lindheimeriàna (Scheele) S. Wats. Flowering stem 10-18 dm. tall, often proliferously branched : leaves numerous, narrowly linear, 3-9 dm. or $15 \mathrm{dm}$. long, thinnish, serrulate, more or less strongly concave : perianth 4-5 mm. broad: sepals and petals oblong-lanceolate, obtusish : capsules $5 \mathrm{~mm}$. broad, much broader than long, notched at both ends.

In stony places, Texas and New Mexico. Spring.

\section{DASYLÍRION Zucc.}

Coarse herbs, with woody caudices. Leaves numerous, crowded on the caudex : blades narrow and elongated, rigid, spiny-margined. Flowering stems narrowly branched above. Flowers dioecious, in close narrow panicles. Perianth white, withering-persistent : sepals and petals distinct. Stamens 6, reduced to staminodia in pistillate flowers : filaments thickish, longer than the sepals and petals. Ovary 1-celled : stigmas 3. Ovules 3, erect. Fruit dry-leathery, 3-winged, indehiscent or nearly so. Seed solitary.

1. Dasylirion Texànum Scheele. Caudex 1-4 dm. long, densely leafy : flowering stem 20-35 dm. tall : leaves spreading; blades linear, 5-12 $\mathrm{cm}$. long, attenuate, armed with hooked spines and denticulate between them: panicle narrow, 5-9. dm. long, conspicnously bracted : bracts ovate or ovate-lanceolate, acuminate, membranous, often surpassing the branches of the panicle during anthesis: perianth $2 \mathrm{~mm}$. long; sepals ovate, often toothed; petals narrower, more nearly entire: capsules oval or ellptic, 6-7 mm. long.

In stony soil or on prairies, Texas. Spring and summer.

\section{Family 7. TRILLIÀceat Lindl. Trillium Family.}

Perennial caulescent or scapose herbs, with rootstocks, and rather fleshy tissues. Leaves in a whorl about the middle of the stem, or basal and wanting on the mature plant. Bracts in a whorl subtending the inflorescence at the top of the peduncle or scape, usually leaf-like. Flowers perfect, solitary, or in terminal umbel-like clusters. Perianth of 3 distinct sepals and 3 petals. Androecium of 6 short stamens. Anthers 2-celled. Gynoecium of 3 united carpels. Ovary 3-celled. Stigmas 3. Ovules several in each cavity. Fruit a 3-celled, 3-lobed or 3-angled berry. 
Flowers several in an umbel-like cluster: sepals and petals nearly alike: flowering stem with a whorl of leaves and a whorl of bracts.

Flower solitary : sepals and petals very different: flowering stem (scape) with only a whorl of leaf-like bracts.

1. MEDEOla.

2. Trillium.

\section{MEDÈOLA L.}

Caulescent herbs, with elongated brittle rootstocks and loosely woolly foliage. Leaves several in a whorl, flat, thinnish. Bracts few in a whorl, high above the leaves, subtending the simple flower-cluster. Pedicels slender, more or less declined. Sepals and petals quite similar. Anthers shorter than the filaments. Stigmas recurved. Berries pulpy. The plants flower in the spring.

1. Medeola Virgínica L. Foliage sparingly woolly. Rootstock horizontal, several cm. long: stems 2-9 dm. tall, naked except for a whorl of leaves about the middle and a whorl of bracts at the top of the peduncle, simple : leaves 4-10; blades elliptic, spatulate or obovate, $5-15 \mathrm{~cm}$. long, acuminate, sessile : bracts similar to the leaves but fewer, smaller and rather broader in proportion to their length : pedicels $2-15$ in the umbel, slender, $2-3 \mathrm{~cm}$. long, declined in flower, erect or ascending at maturity : perianth greenish, $1.5-2 \mathrm{~cm}$. broad : sepals and petals oblong to oval : berries subglobose or depressed, $8-15 \mathrm{~mm}$. in diameter, dark purple.

In woods and on banks, Nova Scotia to Minnesota, Florida and Alabama. INDIAN CUCUMber-Root.

\section{TRÍLLIUM L.}

Scapose fleshy herbs, with short or elongated corm-like rootstocks. Scapes surmounted by a whorl of 3 netted-veined bracts. Flower solitary, sessile or pedicelled, the pedicels erect, recurved or declined. Sepals 3, herbaceous, persistent. Petals 3, early withering or deciduous, white, pink, purple, brown or yellow. Filaments mainly shorter than the narrow anthers. Berry ovoid or subglobose, 3-6-lobed or 3-6-angled. The plants flower in the spring and mature their fruit in the summer. Wake-robin. Birth-Root. BessRоOT.

Flower sessile.

Petals neither narrowed into claws nor claw-like bases, of one color throughout.

Petals broadly spatulate, one usually apiculate: anthers less than $10 \mathrm{~mm}$. long.

Petals not broadly spatulate, not apiculate: anthers over $10 \mathrm{~mm}$. long.

Scape rough-pubescent near the top: bracts with pubescent veins beneath.

Scape erect: bracts raised above the ground: petals $2-3 \mathrm{~cm}$. long: anther-sacs $15-18 \mathrm{~mm}$. long; connective not much prolonged.

Scape decumbent: bracts lying flat on the ground: petals 4-7 $\mathrm{cm}$. long: anther-sacs 8-10 mm. long; connective much prolonged. Scape and bracts smooth and glabrous.

Bracts 4-8 cm. long, with blades of an oval or suborbicular type.

Bracts 10-20 cm. long, with blades of an ovate-lanceolate or ovate-orbicular type.

Petals purple: anthers with purple connectives.

Blades of the bracts typically twice as long as broad, and conspicuously mottled: filaments less than $2 \mathrm{~mm}$. long.

Blades of the bracts typically as broad as long, and not mottled : filaments over $2 \mathrm{~mm}$. long.

Petals yellow : anthers with yellow or greenish connectives.

Petals narrowed into claws or claw-like bases which often differ in color from the blades.

Bracts not narrowed at the base: petals with linear or linear-oblong blades. Scapes rough-pubescent above.

Bracts acuminate: petals thin, mainly purple or red.

Bracts obtuse or merely acute: petals thick, green.

Scapes smooth and glabrous.

Bracts with ovate blades: anthers straight: filaments $\frac{1}{3}-\frac{1}{5}$ as long as the anthers.

Bracts with lanceolate or elliptic blades: anthers curved : filaments about as long as the anthers.

Bracts narrowed into petiole-like bases : petals with ovate, elliptic or obovate blades.

1. T. discolor.

2. T. stamineum.

3. T. decumbens.

4. T. sessile.

5. T. Underwoodii.

6. T. Hugeri.

7. T. luteum.

8. T. viridescens.

9. T. viride.

10. T. Ludovicianum.

11. T. lanceolatum.

12. T. recurvatum.

Flower pedicelled.

A. Bracts not narrowed into petiole-like bases.

a. Pedicel erect or rarely declined, if declined usually several times longer than the sepals.

Bracts with lanceolate or oblong-lanceolate blades, 3-4 cm. long.

Bracts with broadly rhombic or rhombic-ovate or oval blades, $6-16 \mathrm{~cm}$. in diameter.

* Petals ovate or lanceolate, slightly longer than the sepals.

+ Filaments stout, much shorter than the anthers.

13. T. pusillum. 
Petals purple or purplish brown: stamens with purple filaments and connectives: ovary purple.

Petals white or pinkish : stamens with pink or reddish filaments and connectives: ovary pink or red.

it Filaments slender, as long as the anthers or nearly so.

** Petals oblanceolate or obovate-oblanceolate, much longer than the sepals.

b. Pedicel recurved or declined, shorter or slightly longer than the sepals. Bracts rhombic or orbicular-1 hombic: filaments $1 / 2$ as long as the anthers. Bracts oval or elliptic: filaments longer than the anthers.

B. Bracts narrowed into petiole-like bases.

14. T. erectum.

15. T. album.

16. T. Vaseyi.

17. T. grandiflorum.

18. T. cernuum.

19. T. stylosum.

20. T. undulatum.

1. Trillium díscolor Wray. Scapes 1-2dm. tall, smooth : bracts 3 ; blades oval, $6-7$ $\mathrm{cm}$. long, obtuse, or short-acuminate, 3-5-nerved, mottled, rounded at the base : flower sessile : sepals oblong or oblong-lanceolate, $2 \mathrm{~cm}$. long, obtuse or acute, spreading: petals broadly spatulate, greenish, sessile, rounded, and one usually apiculate at the apex : stamens less than $\frac{1}{2}$ as long as the petals, the filaments nearly wanting : berry not seen.

In pine woods, North and South Carolina and Georgia.

2. Trillium stamíneum Harbison. Scapes sometimes clustered, 1-3 dm. tall, pubescent near the top : bracts 3 ; blades ovate-lanceolate to broadly ovate, $5-8 \mathrm{~cm}$. long, acute or acuminate, mottled and usually somewhat pubescent on the veins beneath, sessile : flower sessile, fetid: sepals broadly lanceolate to elliptic, 2-3 cm. long, deeply purpletinged, spreading or finally reflexed : petals lanceolate, dark purple, widely spreading and somewhat twisted, somewhat narrower than the sepals: stamens $\frac{1}{2}-\frac{2}{3}$ as long as the petals : anthers stout, 15-18 mm. long, dark purple, straight: filaments very short, colored like the anthers : stigmas slender : berry ovoid, about $1 \mathrm{~cm}$. in diameter, pale purple.

In rocky woods, Georgia, Alabama and Mississippi.

3. Trillium decúmbens Harbison. Scapes solitary or sometimes clustered, $4-10 \mathrm{~cm}$. long, rough-pubescent at the summit : bracts 3 ; blades ovate, broadly ovate or suborbicular, 4-8 cm. long, 3-6 cm. wide, acute or obtuse, rounded at the base, sessile, usually pubescent on the nerves beneath, mottled: flower sessile : sepals lanceolate, occasionally somewhat broadly so, $2-3 \mathrm{~cm}$. long, acute, purplish at the base, green above : petals linear or linear-lanceolate, $4-7 \mathrm{~cm}$. long, acute, erect, purple : stamens $\frac{1}{5}-\frac{1}{4}$ as long as the petals: filaments very short, the connective much prolonged beyond the anther-sacs: stigmas short: berry ovoid, about $1 \mathrm{~cm}$. in diameter, prominently and sharply angled, the angles in pairs.

In rocky woods, northeastern Alabama.

4. Trillium séssile $\mathrm{L}$. Scapes solitary or clustered, 1-2 dm. tall, slender : bracts 3 : blades oval or suborbicular, 4-8 $\mathrm{cm}$. long, rounded at the base, sessile, not mottled : flower sessile : sepals lanceolate, $2-3 \mathrm{~cm}$. long, acute or acutish : petals narrowly elliptic, sessile, acutish, purple: stamens about $\frac{1}{2}$ as long as the petals : filaments dilated at the base, $\frac{1}{3}-\frac{1}{4}$ shorter than the anthers: stigmas elongated : berry broadly ovoid, 1-1.5 $\mathrm{cm}$. long.

In woods, Pennsylvania to Minnesota, Florida and Mississippi.

5. Trillium Underwoòdii Small. Scapes solitary or clustered, 1-3 dm. tall, stout : bracts 3 ; blades lanceolate to ovate-lanceolate, 10-18 cm. long, acute or short-acuminate, with a velvety luster, mottled with three shades of green, sessile : flower often muskscented : sepals lanceolate, $4.5-5.5 \mathrm{~cm}$. long, green or purplish green : petals lanceolate, elliptic or oblanceolate, $5.5-8.5 \mathrm{~cm}$. long, sessile, acute or obtuse, erect, purple : stamens $\frac{1}{4}-\frac{1}{3}$ as long as the petals : filaments less than $2 \mathrm{~mm}$. long: anthers $1-1.5 \mathrm{~cm}$. long, subsessile : stigmas recurved : berry ovoid, $1.5-2 \mathrm{~cm}$. long.

In woods and fields, North Carolina to Tennessee, Florida and Alabama.

6. Trillium Hùgeri Small. Scapes relatively stout, 1-2.5 dm. tall : bracts 3 ; blades suborbicular to broadly ovate, 10-14 $\mathrm{cm}$. long, abruptly pointed, bright green, typically not mottled : flowers sessile, musk-scented : sepals oblong to oblong-lanceolate, 4-5.5 $\mathrm{cm}$. long, green : petals oblong-lanceolate to spatulate, purple, somewhat longer than the sepals : filaments over $2 \mathrm{~mm}$. long: anthers 1-2 $\mathrm{cm}$. long : berry broadly ovoid.

In rich woods, North Carolina and Tennessee to Florida. Spring.

7. Trillium lùteum (Muhl.) Harbison. Scapes 1.5-3 dm. tall, purplish at the base : bracts 3 ; blades orbicular to orbicular-ovate, 1-2 dm. long, acuminate or abruptly pointed, rarely slightly mottled, rounded or abruptly contracted at the base : flower sessile, lemonscented: sepals lanceolate, sometimes narrowly so, 4-5 cm. long, acute or acutish, green : petals lanceolate, to oblong-elliptic, 6-8 cm. long, acute or acutish, bright yellow or lemonyellow : stamens about $\frac{1}{4}$ as long as the petals : anthers $1.5-2 \mathrm{~cm}$. long, nearly sessile : berry ovoid, $1.5-2 \mathrm{~cm}$. long.

In woods and on hillsides, North Carolina and Tennessee to Georgia. 
8. Trillium viridéscens Nutt. Scapes 4-6 dm. tall, rather slender, more or less pubescent under the bracts : bracts 3 ; blades ovate, orbicular-ovate or elliptic, 1-1.5 dm. long, acuminate, often abruptly so, 5-nerved, sessile : flower sessile : sepals narrowly linearlanceolate or almost linear, 4-5 $\mathrm{cm}$. long, acute, green : petals conspicuously narrow ; claws $1.5-2 \mathrm{~cm}$. long, purple or red; blades narrowly linear-lanceolate or almost linear, fully twice as long as the claws : filaments $2.5-5 \mathrm{~mm}$. long: anthers $12-15 \mathrm{~mm}$. long.

On hillsides and in rich copses, Kansas and Arkansas.

9. Trillium víride Beck. Scapes solitary, or several together, 1-2 dm. tall, purple, rough-pubescent near the top, or glabrous at maturity : bracts 3 ; blades oblong to ovate or rarely suborbicular, $5-11 \mathrm{~cm}$. long, acute or obtusish, 3-5-nerved, usually blotched, more or less pubescent on the nerves beneath, sometimes abruptly short-attenuate at the base : flower sessile : sepals linear or linear-lanceolate, $2-4 \mathrm{~cm}$. long, bright green : petals 2-4.5 $\mathrm{cm}$. long, surpassing the sepals; blades linear or linear-elliptic, light green or purplish green ; claws colored like the blades : stamens about $\frac{1}{3}$ as long as the petals: filaments flattened, $2-3 \mathrm{~mm}$. long: anthers $1.5-2 \mathrm{~cm}$. long : berry not seen.

In woods and glades, Missouri to North Carolina, Alabama and Mississippi.

10. Trillium Ludoviciànum Harbison. Scapes $0.8-2 \mathrm{dm}$. tall, smooth and glabrous : bracts 3 ; blades ovate, to broadly ovate, $5-8 \mathrm{~cm}$. long, sometimes obtuse, mottled, sessile : flower sessile: sepals lanceolate to broadly lanceolate, $2-3.5 \mathrm{~cm}$. long, acute or obtuse, tinged with purple at the base, spreading or finally reflexed: petals with linear or linearlanceolate blades, 3-6 cm. long, scarcely as broad as the sepals but longer, purple, or greenish above a purple base, spreading: anthers straight or slightly recurved, 12-18 mm. long; filaments about $4 \mathrm{~mm}$. long: berry ovoid, about $1 \mathrm{~cm}$. in diameter, pale purple.

In low rich woods, Louisiana and Mississippi.

11. Trillium lanceolàtum Boykin. Scapes 1-4 dm. tall, slender, purplish, smooth, sometimes curved : bracts 3 ; blades lanceolate or elliptic, $7-9 \mathrm{~cm}$. long, acute or acutish, more or less constricted at the base, sessile : flower sessile : sepals linear or linear-lanceolate, 2-2.5 cm. long, acute, green, spreading : petals clawed, 3-3.5 cm. long; blades linear or linear-oblong, acute; claws about twice as long as the blades : filaments about as long as the more or less incurved anthers : berry not seen.

In moist woodlands and river bottoms, Georgia to Alabama and Louisiana.

12. Trillium recurvàtum Beck. Scapes $1-4 \mathrm{dm}$. tall, smooth: bracts spreading; blades ovate-lanceolate, oval or suborbicular, $5-9 \mathrm{~cm}$. long, rounded or subcordate at the base or rarely attenuate, often mottled, the petiole-like bases much shorter than the blades : flower sessile, purple : sepals lanceolate, $2-3 \mathrm{~cm}$. long, acute, finally deflexed : petals clawed; blades ovate, obovate or elliptic, usually acute, about twice longer than the claws : filaments about $\frac{1}{2}$ or $\frac{1}{3}$ as long as the more or less incurved anthers: berry not seen.

In woods, Ohio to Minnesota, Mississippi and Arkansas.

13. Trillium pusíllum Michx. Scapes slender, 1-2 dm. tall, smooth: bracts 3 ; blades oblong or lanceolate, 3-4 cm. long, obtuse, 3-nerved, sessile : pedicel erect, $1 \mathrm{~cm}$. long: sepals lanceolate or oblong-lanceolate, about $1.5 \mathrm{~cm}$. long, obtuse, spreading : petals linear-oblong or lanceolate, somewhat longer than the sepals, pink, acutish : filaments about $\frac{1}{2}$ as long as the anthers: berry less than $1 \mathrm{~cm}$. high.

In pine lands, North Carolina and South Carolina.

14. Trillium eréctum L. Scapes solitary or clustered, 3-6 dm. tall, smooth : bracts 3 ; blades rhombic, often broader than long, 6-16 cm. in diameter, acuminate at the apex, more or less cuneate at the base, sessile : flower ill-scented : pedicel $3-10 \mathrm{~cm}$. long, erect or declined : sepals oblong or lanceolate, acuminate, $2-3.5 \mathrm{~cm}$. long, spreading : petals lanceolate or ovate-lanceolate, surpassing the sepals, brown-purple: filaments stout, 3-4 mm. long: berry about $2 \mathrm{~cm}$. long, purple or nearly black, 6-angled.

In woods, Nova Scotia to Manitoba, North Carolina and the mountains of Georgia, Alabama and Missouri. BETH.

15. Trillium álbum (Michx.) Small. Similar to T. erectum in habit, but flowers smaller : petals white or pinkish, less inclined to be acuminate, or sometimes obtuse : filaments pink or reddish : anthers often 8-11 mm. long, with pale connectives colored like the filaments : ovary pink or red : berry about as large as that of the next preceding species but not as deeply colored. [ $T$. rhomboideum var. album Michx.]

In woods, North Carolina, Tennessee and Georgia.

16. Trillium Vaseỳi Harbison. Scapes erect, $3-6 \mathrm{dm}$. tall : bracts 3 ; blades oval to broadly rhombic, $10-20 \mathrm{~cm}$. broad, sometimes broader than long, slightly acuminate : flower often with a rose-like fragrance : pedicel 4-8 $\mathrm{cm}$. long, declined : sepals lanceolate, 4-6 cm. long, acuminate, more or less involute above the middle: petals ovate or 
orbicular-ovate, 4-6 $\mathrm{cm}$. long, crimson or purple-brown : filaments slender, 7-11 $\mathrm{mm}$. long : anthers as long as the filaments or slightly longer.

In woods or on open mountain slopes, North Carolina, Tennessee and Georgia.

17. Trillium grandiflòrum (Michx.) Salisb. Scapes $2-5 \mathrm{dm}$. tall, smooth : bracts 3 ; blades oval or rhombic-oval, 6-14 cm. long, acuminate, 5-nerved, more or less cuneate at the sessile sometimes constricted base : flower showy : pedicel $5-8 \mathrm{~cm}$. long, erect or ascending : sepals lanceolate, $2.5-5 \mathrm{~cm}$. long, acute : petals oblanceolate, or obovate-oblanceolate, much longer than the sepals, white, pink or rarely green, ascending, crisped : berry subglobose, 2-2.5 $\mathrm{cm}$. in diameter, becoming black.

In woods and on hillsides, Quebec to Minnesota, Florida and Missouri.

18. Trillium cérnuum L. Scapes $2-6 \mathrm{dm}$. tall, smooth : bracts 3 ; blades rhombic, 6-12 cm. long, sometimes broader than long, acuminate at the apex, more or less cuneately narrowed at the sessile or constricted base : pedicel $1-2.5 \mathrm{~cm}$. long, reflexed : sepals oblonglanceolate or ovate-lanceolate, $2-2.5 \mathrm{~cm}$. long, curled back : petals white or pink, elliptic, oval or ovate, a little longer than the sepals, acute, revolute, white or pink : filaments $\frac{1}{2}$ as long as the anthers : berry ovoid, 1.5-2 cm. high, drooping, red-purple.

In rich woods, Nova Scotia to Minnesota, Georgia and Missouri.

19. Trillium stylòsum Nutt. Scapes $2-5 \mathrm{dm}$. tall, purple below, mottled above: bracts 3 ; blades elliptic or oval, $5-15 \mathrm{~cm}$. long, acute or acuminate, rarely mottled, 5nerved, constricted at the base : pedicel spreading or deflexed, 2-5 $\mathrm{cm}$. long: sepals linear or linear-lanceolate or sometimes spatulate-oblong, 2-4 $\mathrm{cm}$. long, more or less curled or reflexed : petals oblong or oblong-lanceolate, $3-6 \mathrm{~cm}$. long, pink or rose-color, obtuse or abruptly pointed, crisped, recurved; filaments longer than the bright yellow recurved anthers : berry globose-ovoid, $1-1.5 \mathrm{~cm}$. long.

In woods, North Carolina and Tennessee to Georgia and Alabama.

20. Trillium undulàtum Willd. Scapes $2-5 \mathrm{dm}$. tall : bracts 3 ; blades ovate, $6-20$ cm. long, acuminate, rounded above the petiole-like bases : pedicel erect, $2-6 \mathrm{~cm}$. long : sepals lanceolate or oblong-lanceolate, $1.5-2.5 \mathrm{~cm}$. long, acute, spreading : petals oblong or oval, varying to obovate, much longer than the sepals, white striped with purple, especially at the base : filaments about as long as the anthers: berry broadly ovoid, $2 \mathrm{~cm}$. long, bright red.

In damp woods and bogs, Nova Scotia to Wisconsin, Georgia and Missouri.

\section{Family 8. ROXBURGhiÀCEAE Wallich. Roxburghia Family.}

Perennial herbs or shrubs, sometimes with twining stems. Leaves alternate : blades with palmately parallel nerves. Flowers perfect, in axillary racemes. Perianth regular, green or more highly colored. Sepals and petals distinct, or partially united. Androecium of 4 hypogynous stamens. Filaments stout, distinct or united at the base. Anthers 2-celled, introrse. Gynoecium a single pistil of 2 united carpels. Ovary 1-celled, free or adherent to the perianth below with a parietal placenta. Stigmas sessile. Ovules few or numerous, anatropous. Fruit a 2-valved capsule. Seeds erect on or pendulous from hairy or fibrillose funicles. Embryo slender or minute, in fleshy endosperm.

\section{CROÒMIA Torr.}

Herbs, with slender creeping or horizontal rootstocks. Stems sheathed at the base. Leaves 4-6, near the top of the stem : blades 5-9-nerved. Flowers 1 or 2 on axillary peduncles. Perianth nodding, slender-pedicelled : sepals and petals 2 each, partially united, persistent. Stamens 4: filaments stout, nearly erect, unappendaged: anthers oblique. Ovary sessile : style wanting : stigma 2-lobed. Ovules 4-6, pendulous. Capsule finally 2-valved, constricted near the apex. Seeds 2-4, or sometimes solitary. Embryo minute.

1. Croomia pauciflòra (Nutt.) Torr. Foliage glabrous. Stems 1-4 dm. tall, simple, naked below except for a few scales near the base, leafy above; leaves approximate; blades oblong or oblong-ovate, $5-15 \mathrm{~cm}$. long, acute or slightly acuminate, often somewhat crisped, cordate : petioles $\frac{1}{3}$ as long as the blades or shorter : peduncles curved, as long as the petioles or longer: pedicels $2-10 \mathrm{~mm}$. long, filiform: perianth greenish or tinged with 
purple within, with a slender stipe-like base: sepals and petals $3-5 \mathrm{~mm}$. long, ovate, spreading or reflexed : capsule somewhat berry-like, ovoid, 3-6 $\mathrm{mm}$. long.

In woods, Georgia to Florida and Alabama. Spring.

\section{Family 9. SMiladìceae Vent. Smilax Family.}

Perennial vines, with herbaceous or woody, smooth or armed stems. Leaves alternate : blades several-nerved and netted-veined, commonly punctate or lineolate, articulated to the petioles, sometimes persistent : petiole persistent, commonly bearing a pair of elongated appendages. Flowers dioecious, in axillary peduncled umbels. Perianth regular, usually green, that of the staminate flower larger than that of the pistillate. Sepals and petals 3 each, with spreading tips. Androecium of 6 stamens. Filaments distinct, inserted at the base of the perianth, flattened. Anthers 2-celled, introrse, attached at the base. Gynoecium of 3 united carpels, with the cavities opposite the petals. Stigmas 3, sessile. Ovules 1 or 2 in each cavity, orthotropous or half-anatropous. Fruit a berry. Seeds 1-6, with horny endosperm. Embryo remote from the hilum.

Stems herbaceous, annual, unarmed : ovules 2 in each ovary-cavity. Stems woody, perennial, prickly: ovule solitary in each ovary-cavity.

1. NemExia.

2. Smilax.

\section{NEMÉXIA Raf.}

Unarmed vines, with knotted or tuberous rootstocks and annual stems. Leaf-blades membranous, broad, sometimes hastate. Umbels on long and slender peduncles. Pedicels inserted in small pits in a conic or globose receptacle. Stamens 6 , more or less reduced in pistillate flowers. Ovary 3-celled, wanting in staminate flowers. Ovules 2 in each cavity. Berry blue-black, with 3 bands of stengthening tissue running through the pulp and connected at the base and the apex. Smilax. The plants flower in the spring or rarely in early summer.

Plants without tendrils: stem erect, relatively short, simple: leaves approximate at the top of the stem. Leaf-blades pubescent beneath, thin during anthesis: anthers shorter than the filaments.

Sepals of the staminate flowers obovate or oblanceolate: leaf-blades acute or short-acuminate: berries not glaucous.

Sepals of the staminate flowers oblong: leaf-blades broadly rounded and obtuse or abruptly pointed at the apex : berries glaucous

Leaf-blades wholly glabrous and glaucous beneath, thick during anthesis: anthers longer than the filaments.

Plants furnished with tendrils: stems elongated, climbing.

Leaf-blades pubess:ent beneath.

Peduncles fully twice as long as the subtending bracts, which are wholly different from the leaves.

Peduncles shorter than the subtending bracts or slightly longer: leaves and bracts alike.

Leaf-blades ovate or elliptic-ovate: peduncles stout : sepals and petals of the staminate flowers about $5 \mathrm{~mm}$. long.

Leaf-blades triangular-ovate: peduncles filiform: sepals and petals of the staminate flowers $2.5 \mathrm{~mm}$. long.

Leaf-blades glabrous beneath.

Peduncles becoming much longer than the subtending bracts : leaf-blades prominently 7-9-nerved.

Peduncles shorter than the subtending bracts or slightly longer: leaf-blades prominently 5-nerved.

1. N. ecirrhata.

2. N. Hugeri.

3. N. Biltmoreana.

4. N. diversifolia.

5. N. pulverulenta.

6. N. tenuis.

7. N. herbacea.

8. N. tamnifolia.

1. Nemexia ecirrhàta (Engelm.) Small. Stems $3-6 \mathrm{dm}$. tall : leaf-blades ovate, 8-12 cm. long, acute or short-acuminate, pubescent beneath, but not especially so on the ribs and the veins, prominently ribbed in age : sepals of the staminate flowers obovate or oblanceolate, 4-5 mm. long: berries globular, purple-black, 9-11 $\mathrm{mm}$. in diameter.

In woods, Minnesota to the Indian Territory, lllinois and Arkansas.

2. Nemexia Hùgeri Small. Stems 2-5 dm. tall : leaf-hlades oblong-oval, 9-14 cm. long, broadly rounded and obtuse or abruptly pointed at the apex, pubescent beneath, especially on the ribs and the veins, prominently ribbed in age: sepals of the staminate flowers oblong, 3-4 mm. long: berries globular, glaucous, $8-10 \mathrm{~mm}$. in diameter.

In woods, Tennessee to North Carolina, Georgia and Alabama. 
3. Nemexia Biltmoreàna Small. Stems $2.5-6 \mathrm{dm}$. tall : leaf-blades ovate, $6-12 \mathrm{~cm}$. long, wholly glabrous, and glaucous beneath, thick even during anthesis : sepals of the staminate flowers oblong or ovate-oblong, $2.5-4 \mathrm{~mm}$. long, ciliolate at the apex.

On hillsides and in woods, about Biltmore, North Carolina.

4. Nemexia diversifòlia Small. Stems 1-3 m. long, climbing : leaves numerous ; blades ovate or oval-ovate, $3-5 \mathrm{~cm}$. long, terminating in abrupt slightly twisted tips, dark green above, pale and minutely pubescent on the nerves and veins beneath, prominently 3-nerved, truncate or subcordate at the base : blades of the bracts subtending the peduncles, lanceolate, acuminate, somewhat smaller than those of the leaves : tendrils filiform, developed at the majority of the leaves : peduncles stout, twice or thrice as long as the bracts : pedicels (pistillate) 20-25, 8-10 mm. long, slightly thickened upward : berries subglobose, about $5 \mathrm{~mm}$. in diameter. [Smilax diversifolia Small.]

In river swamps, middle Georgia.

5. Nemexia pulverulénta (Michx. ) Small. Stems elongated, climbing, often stout, leaves numerous; blades ample, ovate to elliptic-ovate, $8-15 \mathrm{~cm}$. long, short-acuminate, usually 9-nerved, cordate at the base: peduncles as long as the petioles or longer: pedicels $5-12 \mathrm{~mm}$. long: perianth greenish : sepals and petals about $5 \mathrm{~mm}$. long, acutish, those of the staminate flowers oblong-ovate: filaments about twice as long as the anthers or shorter : berries subglobose, $8-10 \mathrm{~mm}$. in diameter. [Snilax pulverulenta Michx.]

In alluvial soil, Ontario to Wisconsin, North Carolina and Missouri.

6. Nemexia ténuis Small. Stems elongated, commonly simple, slender, glabrous: leaves rather few ; blades thin, triangular-ovate, $5-9 \mathrm{~cm}$. long, acuminate, coarsely erosedenticulate, 5-nerved, with an inconspicuous sprinkling of minute hairs beneath, truncate at the base ; tendrils few, sometimes developed from the sheaths of the upper leaves, filiform: peduncles as long as the subtending bracts or longer, nearly filiform : pedicels (staminate) 15-25, 6-8 mm. long : sepals and petals greenish, oblong or linear-oblong, 2.5 mm. long : filaments barely twice as long as the anthers. [Smilax tenuis Small.]

In sandy woods, Louisiana.

7. Nemexia herbàcea (L.) Small. Stems elongated, climbing, glabrous : leaves numerous; blades ovate, triangular-lanceolate to lanceolate, essentially alike throughout the plant, 4-8 cm. long, short-acuminate, 7-9-nerved, rounded or truncate at the base : bracts subtending the peduncles like the leaves : peduncles much surpassing the subtending bracts at maturity : flowers carrion-scented : sepals and petals greenish, oblong or broadened upward, acutish: filaments twice or thrice as long as the anthers: berries subglobose, bluish black, $6-8 \mathrm{~mm}$. in diameter.

In woods and thickets, New Brunswick to Manitoba, Florida and Louisiana. CArrion-FLower.

8. Nemexia tamnifólia (Michx.) Small. Stems erect or reclining, terete or obtusely angled, commonly simple : leaf-blades thickish, 5-7-nerved, ovate-hastate or linear-lanceolate, 5-12 cm. long, more or less constricted at or about the middle, green on both sides, truncate or cordate at the base, the basal lobes rounded; peduncles solitary or 3 from the same axil, shorter than the subtending bracts or surpassing them at maturity : umbels 1030-flowered : pedicels 4-6 $\mathrm{mm}$. long: sepals and petals greenish, those of the staminate flowers slightly pubescent, those of the pistillate often glabrous, oblong, $2 \mathrm{~mm}$. long, rather obtuse : berries subglobose, 4-6 $\mathrm{mm}$. in diameter, black, 1-3-seeded.

In thickets and marshy grounds, New Jersey and Pennsylvania to South Carolina and Tennessee.

\section{SMİLAX L.}

Prickle-armed vines, with elongated often tuberous rootstocks and perennial stems. Leaf-blades leathery, entire or lobed : petioles present, furnished with coiling appendages. Umbels on short, often stout peduncles. Pedicels usually accompanied by bractlets. Stamens 6 , reduced in the pistillate flowers. Ovary 3-celled, wanting or abortive in staminate flowers, 2 of the cavities sometimes suppressed. Ovule 1 in each cavity. Berry red, blue or black, with 3 bands of strengthening tissue connected at the base and the top. Catbrier. Greenbrier. Horsebrier. Smilax.

A. Peduncles of pistillate plants much longer than the subtending petioles.

Leaf-blades glaucous beneath.

Blades of the leaves, or bracts subtending the peduncles, little longer than broad: berries about $8 \mathrm{~mm}$. in diameter.

Blades of the leaves, or bracts subtending the peduncles, twice or thrice as long as broad : berries about $10 \mathrm{~mm}$. in diameter.

Leaf-blades green on both sides.

Leaf-blades broader than long.

1. S. glauca.

Leaf-blades longer than broad.

2. S. cinnamomifolia.

3. S. renifolia. 
Peduncles of pistillate plants fully twice or four times as long as the petioles during anthesis.

Peduncles fully twice as long as the petioles in fruit: spines on lower part of stem numerous, bristle-like.

Peduncles 3-4 times as long as the petioles in fruit : spines few, stout and rigid or almost wanting.

Peduncles of pistillate plants barely twice as long as the petioles.

B. Peduncles of pistillate plants shorter than the petioles or barely surpassing them. Leaf-blades entire or merely erose.

Leaf-blades neither aurieled nor dilated at the base.

Foliage glabrous.

Bracts subtending the peduncles with blades rounded or cordate at the base.

Branches and lower leaf-surfaces not glaucous. Berries black or bluish black. Berries red.

Branches and lower leaf-surfaces glaucous.

Bracts subtending the peduncles with blades acute, acuminate, or cuneate at the base.

Berries red : leaf-blades mostly 5-7-nerved. Leaf-blades with lustrous upper surface: berries 4-6 $\mathrm{mm}$. in diameter.

Leaf-blades with dull upper surface : berries $6-10 \mathrm{~mm}$. in diameter.

Berries black : leaf-blades mostly 3-nerved.

Leaf-blades over twice as long as broad : berries 4-6 $\mathrm{mm}$. long. Leaf-blades never twice as long as broad : berries 6-8 $\mathrm{mm}$. long. Foliage pubescent.

Leaf-blades more or less strongly auricled at the base.

7. S. rotundifolia.

8. S. Walteri.

9. S. Smallii.

4. S. hispidn.

5. S. Psendo-China. 6. S. Bona-nox.

eaf-blades spiny-toothed.

10. S. lanceolata.

11. S. Morongii.

12. S. laurifolia.

13. S. lata.

14. S. pumila.

15. S. Beyrichii.

16. S. Havanensis.

1. Smilax glaùca Walt. Stems terete, high-climbing, armed with straight or slightly curved spines, the branches angled, commonly unarmed : leaf-blades broadly ovate, $3-15 \mathrm{~cm}$. long, abruptly pointed or cuspidate, entire, glaucous beneath, $5-7$-nerved, rounded or cordate at the base ; petioles 6-12 mm. long: peduncles 1-3 $\mathrm{cm}$. long: pedicels 6-12, 4-8 $\mathrm{mm}$. long: sepals and petals greenish, linear-oblong or slightly broadened upward, 4 $\mathrm{mm}$. long: anthers mostly shorter than the filaments : berries subglobose, mostly $6-8 \mathrm{~mm}$. in diameter, bluish black, lustrous under the glaucous coating.

In sandy soil, Massachusetts to Kansas, Florida and Texas. Spring and early summer.

2. Smilax cinnamomifòlia Small. Stems high-climbing, sometimes 10-15 m. long, sparingly armed with slender spines : leaf-blades lanceolate or ovate-lanceolate, those on vigorous shoots ample, normally $7-10 \mathrm{~cm}$. long, acute or apiculate, entire, glaucous beneath, cuneate to truncate at the base : stipular sheath about $\frac{1}{2}$ as long as the petiole, usually with tendrils: peduncles much longer than the petioles, slender, sometimes $4-5 \mathrm{~cm}$. long at maturity : pedicels 5-10, 6-12 $\mathrm{mm}$. long: sepals and petals greenish, linear-oblong or slightly broadened upward, $4 \mathrm{~mm}$. long: anthers mostly longer than the filaments : berries subglobose, about $10 \mathrm{~mm}$. in diameter, bluish black, lustrous under the glaucous coating.

In woods and rich soil, Alabama and western Florida to Arkansas and Texas. Spring.

3. Smilax renifolia Small. Stems elongated, climbing high over shrubs and trees, more or less distinctly angled : leaves numerous ; blades reniform or deltoid-reniform, 3-7 $\mathrm{cm}$. long, resembling those of Cercis, rounded and mucronate at the apex, entire, mostly broader than long, subcordate at the base ; petioles 5-10 mm. long : stipular sheath fully $\frac{1}{2}$ as long as the petiole, usually furnished with tendrils : peduncles of pistillate plants $10-20$ $\mathrm{mm}$. long, flattened, much longer than the petioles: pedicels $16-25,2-3 \mathrm{~mm}$. long: sepals and petals $2 \mathrm{~mm}$. long, acutish : berries black, subglobose.

Along streams, southern Texas. Spring.

4. Smilax híspida Muhl. Stems terete, 1-5 m. long, usually thickly armed, especially below, with slender, straight unequal bristle-like spines; branches more or less angled, sometimes unarmed : leaves numerous; stipular sheath with broad, denticulate margins, $\frac{1}{3}-\frac{1}{2}$ the length of the petiole; blades thinnish, broadly ovate or elliptic-ovate, $5-15 \mathrm{~cm}$. long, abruptly pointed or cuspidate at the apex, 7-9-nerved, lineolate, usually erose-denticulate on the margins and nerves beneath, green on both sides, obtuse or subcordate at the base or cuneate to the petioles : peduncles $2-5 \mathrm{~cm}$. long, flattened : pedicels $10-26$, slender, 4-8 $\mathrm{mm}$. long: receptacle barely $2 \mathrm{~mm}$. in diameter: sepals and petals greenish yellow, those of the staminate flowers $4 \mathrm{~mm}$. long: berries globose, about $6 \mathrm{~mm}$. in diameter, often 5 or 6 together, bluish black.

In thickets, in low or high rocky soil, Ontario to Minnesota, Nebraska, North Carolina, Louisiana and Texas. Spring and summer. HaGBrier.

5. Smilax Pseùdo-Chìna L. Stems terete, often with few stout spines below; branches angled, sparingly armed, if at all : leaves various; stipular sheath $\frac{1}{3}-\frac{1}{2}$ the length of the petiole ; blades firm or leathery at maturity, persistent, ovate or suborbicular, so me- 
times 2-lobed at the base, acute or cuspidate at the apex, green on both sides, lineolate, commonly bristly-toothed on the margins and nerves beneath, 7-9-nerved, or in the case of broad leaves 11-nerved, obtuse or cordate at the base : peduncles $2.5-8 \mathrm{~cm}$. long, flattened: pedicels $12-40,6-8 \mathrm{~mm}$. long : receptacle irregular, $2-4 \mathrm{~mm}$. in diameter : sepals and petals dark green, various, those of staminate flowers about $5 \mathrm{~mm}$. long, those of pistillate flowers much shorter: berries globose, 4-6 mm. in diameter, often 8-16 together, black, 1-3seeded.

In dry soil, Maryland to Nebraska, Florida and Texas. Spring to fall. Bamboo. China-brier.

6. Smilax Bòna-nóx L. Stems high-climbing; branches angled, often square, like the stem, armed with stout or slender spines, or naked: leaves various; stipular sheath $\frac{1}{3}-\frac{1}{2}$ as long as the petiole, with usually denticulate margins; blades often persistent, mostly leathery, broadly ovate to hastate or fiddle-shaped, $3-12 \mathrm{~cm}$. long, acute or cuspidate at the apex, pellucid-punctate and lineolate, 5-9-nerved, smooth or erose-spiny on the margins and nerves beneath, obtuse, truncate or cordate at the base: peduncles slender, $1.5-3 \mathrm{~cm}$. long, flattened : pedicels $15-45,4-8 \mathrm{~mm}$. long: receptacle subglobose, $2-2.5 \mathrm{~mm}$. in diameter: sepals and petals deep green, various, those of staminate flowers $4-5 \mathrm{~mm}$. long, about twice as long as those of pistillate flowers : berries subglobase, 4-6 mm. in diameter, 8-20 together, black, 1-seeded.

In thickets, Massachusetts to Kansas, Florida and Texas. Spring and summer. Stretchbrrry.

7. Smilax rotundifòlia L. Stems $2-6 \mathrm{~m}$. long, like the more or less sharply angled branches, armed with sharp prickles : leaves various; blades ovate to suborbicular, 3-15 $\mathrm{cm}$. long, mostly acute or cuspidate at the apex, entire or nearly so, more or less roughened on the nerves beneath, rounded or cordate at the base, leathery in age, punctate : peduncles 6-12 mm. long, flattened : pedicels 6-25, 2-8 $\mathrm{mm}$. long: sepals and petals greenish yellow, 3-4 mm. long or $5 \mathrm{~mm}$. in pistillate flowers, oblong, acute, often pubescent at the apex, sometimes ciliolate : berries subglobose, about $6 \mathrm{~mm}$. in diameter, 1 -3-seeded, bluish black.

In thickets and woods, Ontario to Minnesota, Florida and Texas. Spring. Fruit ripening the first year.-A more slender state with dark green foliage, thinnish lanceolate to oblong-lanceolate, acuminate, conspicuously erose-denticulate, mainly 3-nerved, lustrous leaf-blades $6-10 \mathrm{~cm}$. long, and subglobose berries 5-6 mm. in diameter, S. rotundifolia crenulata Small \& Heller, occurs in mountain woods, Virginia to Georgia and Alabama. Spring and summer.

8. Smilax Wálteri Pursh. Stems trailing or climbing over shrubs, angled, armed near the base ; branches usually unarmed, often square : leaves alternate : stipular sheath $\frac{1}{4}-\frac{1}{3}$ as long as the petiole, often with denticulate margins; blades ovate to lanceolate, 5-12 $\mathrm{cm}$. long, cuspidate at the apex, smooth-margined, 5-7-nerved, sparingly lineolate, cordate, rounded or abruptly pointed at the base : peduncles flattened, 4-10 mm. long: pedicels 6-15, 4-6 mm. long : receptacle depressed-globose, $3 \mathrm{~mm}$. broad : bractlets acuminate : sepals and petals greenish, linear or linear-lanceolate, those of staminate flowers $6-8 \mathrm{~mm}$. long, about twice as long as those of the pistillate flowers : berries globose, $6-8 \mathrm{~mm}$. in diameter, coral-red, 2-3-seeded.

In swamps and pine lands, New Jersey and Tennessee, to Florida and Louisiana. Spring.

9. Smilax Smállii Morong. Stems prostrate, or high-climbing, 2-8 m. long, terete, striate, glaucous, usually, like the branches, unarmed, sometimes with few short spines below : leaves evergreen, uniform; petioles 4-10 $\mathrm{mm}$. long, the stipular sheath about $\frac{2}{3}$ as long, with membranous, smooth-edged margins ; blades light green, ovate to oblong-ovate, $2.5-5 \mathrm{~cm}$. long, abruptly narrowed into obtuse tips, lustrous above, glaucous beneath, sparsely lineolate, 5-nerved : peduncles barely surpassing the petioles, twisted, stout, pedicels $2-8 \mathrm{~mm}$. long, very unequal : receptacle subglobose, $2-2.5 \mathrm{~mm}$. in diameter : bractlets triangular: sepals and petals yellowish green, recurving, those of the staminate flowers narrowly lanceolate, about $4 \mathrm{~mm}$. long: mature fruit not seen.

On granite slopes or in sandy woods, Stone Mountain, Georgia. Summer.

10. Smilax lanceolàta L. Stems often $10 \mathrm{~m}$. long, high-climbing, like the branches, terete, usually unarmed except near the base; branchlets slightly angled, spreading: leaves numerous, bright green ; petioles $2-4 \mathrm{~mm}$. long, their sheaths about $\frac{1}{2}$ as long, with entire or ciliolate margins ; blades thinnish, lanceolate or ovate-lanceolate, $5-8 \mathrm{~cm}$. long, acute or acuminate, lustrous above, lineolate, 5-7-nerved, smooth-nargined, acute at the base, dull green beneath: peduncles $6-16 \mathrm{~mm}$. long, stout-angled : pedicels 8-40, 4-14 $\mathrm{mm}$. long : receptacle subglobose or conic, $2-4 \mathrm{~mm}$. long: sepals and petals (staminate) light green, slightly broadened upward, about $4 \mathrm{~mm}$. long, acute : filaments longer than the anthers : berries subglobose, 4-6 mm. in diameter, often 4-10 together, dark red, mostly 2-seeded.

In pine lands and dry woods, Virginia and Arkansas to Florida and Texas. Spring and summer. Fruit ripening the first year. 
11. Smilax Moróngii Small. Stems high-climbing, terete, branched; branches more or less angled, slightly zigzag : leaves numerous; petioles 4-8 $\mathrm{mm}$. long, stout, their sheaths $\frac{1}{4}-\frac{1}{2}$ their length, sometimes ciliolate; blades leathery, elliptic, $5-10 \mathrm{~cm}$. long, abruptly acute or cuspidate at the apex, smooth-margined, often rounded at the base, minutely pellucid-punctate : peduncles $12-16 \mathrm{~mm}$. long, stout, angled, becoming flattened : pedicels 6-8 $\mathrm{mm}$. long : berries subglobose, 6-10 $\mathrm{mm}$. in diameter, often 4-6, red, 3-seeded. [S. megacarpa Morong, not A. DC.]

In pine lands, Duval County, Florida.

12. Smilax laurif òlia L. Stems high-climbing, terete, armed with strong, straight spines; branches angled, unarmed : leaves evergreen, numerous: stipular sheath $\frac{1}{3}-\frac{1}{2}$ as long as the petiole, smooth or ciliolate ; blades leathery, elliptic, oblong or oblong-lanceolate or rarely linear, $5-15 \mathrm{~cm}$. long, acute or cuspidate at the apex, somewhat lustrous above, 3-nerved, smooth margined, minutely pellucid-punctate, acute at the base : peduncles 4-20 mm. long, usually shorter than the petioles, angled: pedicels 6-30, often 4-6 $\mathrm{mm}$. long: receptacle subglobose, $2-4 \mathrm{~mm}$. in diameter : sepals and petals oblong, those of staminate flowers 5-6 mm. long, those of pistillate flowers shorter : berries ovoid or globoseovoid, 4-6 mm. long, often 8-12, commonly white during the first year, becoming black, mostly 1-seeded.

In swamps and moist thickets, New Jersey to Arkansas, Florida and Texas. Spring to fall. Fruit ripening the second year.

13. Smllax làta Small. Stems branching, glabrous, of ten climbing to the tops of trees, commonly armed; branches often unarmed; branchlets zigzag: leaves numerous ; blades suborbicular to oblong, obovate to ovate, not twice as long as broad at maturity, cuspidate and sometimes retuse at the apex, not at all or barely auricled at the base, somewhat reticulated, dull in age : peduncles as long as the petioles or slightly longer : pedicels 4-8 $\mathrm{mm}$. long at maturity : sepals and petals greenish, various, those of staminate flowers 4-5 mm. long, those of pistillate flowers broader, $2-2.5 \mathrm{~mm}$. long: berries subglobose, 6-8 $\mathrm{mm}$. in diameter, black.

In or near hammocks, peninsular Florida and the Keys. Spring.

14. Smilax pùmila Walt. Stems terete, weak, trailing or reclining, $3-10 \mathrm{dm}$. long, unarmed, simple or sparingly branched, clothed with a soft, of ten fuzzy, pubescence : leaves quite numerous; stipular sheath $\frac{1}{4}-\frac{1}{2}$ as long as the petiole and pubescent like it and the tendrils; blades thinnish, ovate-oval or oblong, 5-10 cm. long, acute, or mucronate at the apex, often white-pubescent beneath, glabrous and lustrous or sparingly pubescent above, pellucid-punctate and sometimes lineolate, 3-5-nerved, cordate at the base ; peduncles 4-16 mm. long, pubescent : pedicels $6-30$, about $2 \mathrm{~mm}$. long: receptacle globose, $2-3$ $\mathrm{mm}$. broad, hairy : sepals and petals yellowish green, oblong or oblong-lanceolate, those of staminate flowers $2-3 \mathrm{~mm}$. long, those of pistillate flowers shorter, all delicate, recurved : berries ovoid, 5-8 $\mathrm{mm}$. long, pointed, red, each with one yellow seed.

In dry pine lands, South Carolina to Florida and Louisiana. Fall. Fruit ripening the second year.

15. Smilax Beyríchii Kunth. Stems trailing or climbing over trees, terete or obscurely angled below; branches angled, often square, zigzag, armed like the stem with stout, scattered spines, or naked : leaves various, numerous; stipular sheath $\frac{1}{2}$ as long as the petiole, with glabrous,or ciliolate margins ; blades leathery, lustrous on both sides, 2-10 cm. long, ovate, oblong or fiddle-shaped, more or less strongly auricled or dilated at the base, prominently reticulated, abruptly pointed or mucronate, with a thick marginal nerve: peduncles stout, fully as long as the petioles or shorter: pedicels 7-40, 4-8 mm. long, at maturity straight: receptacle $2.5-3 \mathrm{~mm}$. in diameter : flowers fragrant: sepals and petals yellowish green, various, those of the staminate flowers linear or nearly so, about $5 \mathrm{~mm}$. long, those of pistillate flowers oval or oblong, 2-2.5 mm. long : berries subglobose, 3-6 mm. in diameter, black, 1-3-seeded. [S. auriculata Walt.?] first year.

In pine lands, North Carolina to Florida and Alabama. Spring and summer. Fruit ripening the

16. Smilax Havanénsis Jacq. Stems trailing or high-climbing, angled, usually armed with small stout hooked prickles, zigzag : leaves numerous : stipular sheath equalling the petiole, smooth-margined or ciliolate to bristly; blades firm, orbicular-ovate to ovate-elliptic or oblong, $2.5-5 \mathrm{~cm}$. long, 3-7-nerved, mucronate and sometimes notched as well, spiny-toothed on the nerves beneath and the callous-nerved margins, narrowed, rounded or subcordate at the base, reticulated: peduncles stout, about as long as the petioles, angled : pedicels 4-30, 1-2 $\mathrm{mm}$. long: receptacle depressed, 2-6 mm. broad: sepals and petals oblong, those of staminate flowers $1.5 \mathrm{~mm}$. long, those of pistillate 1 $\mathrm{mm}$. long : berries subglobose, $4-6 \mathrm{~mm}$. in diameter.

In pine woods and on coral rock, southern peninsular Florida and the Keys. Also in the West Indies and Mexico. Spring. 


\section{Order 10. AMARYLLIDÀLES.}

Perennial herbs, or vines. Leaves various : blades very narrow to widely dilated. Flowers perfect or dioecious, complete, regular or irregular. Perianth of 6 parts, sometimes readily distinguishable into calyx and corolla, the members distinct or partially united. Androecium of 3-6 stamens. Gynoecium compound, the ovary wholly inferior or half-inferior. Fruit capsular or baccate. Endosperm horny or fleshy.

Stamens 6.

Upright herbs : Howers perfect.

Twining vines: flowers dioecious. Stamens 3.

Filaments opposite the sepals.

Filaments opposite the petals.

Fam. 1. LeUCOJACEAE.

Fam. 2. TAMACEAE.

Fam. 3. IxIACEAE.

Fam. 4. HAEMODORACEAE.

\section{Family 1. LeUCoJaceat Batsch. Amaryllis Family.}

Perennial herbaceous, often watery or fleshy herbs, with bulbs or corms, or sometimes with fibrous roots. Leaves basal: blades simple, usually narrow, parallel-nerved, sheathing at the base. Flowers perfect, regular or irregular, sometimes solitary. Perianth epigynous, coralloid, deciduous or withering and and persistent. Sepals and petals 3 each, united into a tube below. Androecium of 6 stamens inserted on an epigynous disk, or at the throat of the tube opposite the sepals and petals. Filaments sometimes dilated, and more or less united at the base or connected by a crown. Anthers introrse. Gynoecium a single compound pistil. Ovary inferior, 3-celled or very rarely nearly 1-celled, the cavities opposite the sepals. Styles united. Stigma entire or 3-lobed. Ovules numerous, anatropous, pendulous or rarely ascending. Fruit a 3-celled capsule or berry. Seeds globose, flattened or angled, with a thin crustaceous testa which is sometimes produced into a wing, or thick and fleshy, variable in color. Endosperm fleshy. Embryo axile, nearly straight. [Amaryllidaceae Lindl. 7

Perennial from corms or elongated rootstocks.

Ovary and capsule one-half-inferior.

Flowers in racemes or spikes: perianth granular; lobes relatively short, converging, erect or somewhat spreading : stamens included.

Flowers in dichotomous cymes: perianth woolly; lobes relatively long and widely spreading: stamens exserted.

Ovary and capsule wholly inferior.

Inflorescence umbel-like : capsule circumscissile.

Inflorescence spicate, racemose or paniculate: capsules 3-valved.

Plants with bulbs, dying down annually : leaf-blades neither spiny-toothed nor spine-tipped.

Plants with caudices, long-persistent : leaf-blades spiny-toothed and spinetipped.

Perennial from bulbs.

1. Aletris.

2. LOPHIOLA.

3. HYPOXIS.

4. Manfreda.

5. Agave.

Filaments distinct.

Scapes 1-flowered.

Perianth-tube very short or the sepals and petals distinct: anthers versatile. 6. ATAMosco.

Perianth-tube elongated: anthers erect. 7 . COOPERIA.

Scapes 2-6-flowered. $\quad 8$. CRINUM.

Filaments connected by a cup-like or funnelform crown. 9. HYMENOCALLIS.

\section{1. ÁLETRIS L.}

Caulescent herbs, with hard rootstocks and simple scape-like stems. Leaves mainly basal : blades flat, spreading, reduced to slender scales on the stem. Raceme elongated, interrupted, terminal. Flowers perfect. Perianth white to yellow, campanulate, cylindric or obovoid, granular, 6-lobed. Stamens 6 : filaments partially adnate to the perianth tube, short : anthers introrse, acute. Ovary 3-celled, half-inferior. Ovules anatropous, numerous in each cavity. Capsule 3-celled, enclosed in the persistent perianth, loculicidal. Seeds numerous, ribbed. Endosperm fleshy. Colic-root. Star-grass.

Perianth cylindric or campanulate: filaments adnate to near the base of the perianth-lobes.

Perianth campanulate. 5-7 mm. long: lobes erect.
Perianth cylindric or constricted above the middle, 7-10 mm. long: lobes spreading.

Perianth yellow : capsule gradually narrowed into a beak $1 / 2$ as long as the body.
Perianth

Perianth white: capsule abruptly narrowed into a beak as long as the body.

Perianth obovoid : filaments adnate to a little above the middle of the perianth.

1. A. aurea.

2. A. lutea.

3. A. farinosa.

4. A. obovata. 
1. Aletris aùrea Walt. Stems $3-8 \mathrm{dm}$. tall : basal leaves often yellow ; blades oblong to elliptic, $3-8 \mathrm{~cm}$. long, acute or acuminate: raceme $10-40 \mathrm{~cm}$. long : perianth campanulate, yellow, 5-7 mm. long; lobes triangular, broader than long, erect, thicktipped : style very short: capsules ovoid, $5 \mathrm{~mm}$. long, very short-beaked.

In sandy pine woods, Virginia to Florida and Texas. Spring and summer.

2. Aletris lùtea Small. Stems 3-9 dm. tall : leaf-blades linear to linear-lanceolate, or sometimes broadest above the middle, 4-12 $\mathrm{cm}$. long, acuminate, entire, dilated at the base : raceme 4-20 $\mathrm{cm}$. long : perianth yellow, cylindric or contracted above the middle, 8-9 mm. long ; lobes triangular, erect, spreading: style elongated : capsules conic-ovoid, each gradually narrowed into a beak about $\frac{1}{2}$ as long as the body.

In low pine lands, Florida to Louisiana. Spring and summer.

3. Aletris farinòsa L. Stems $3-10 \mathrm{dm}$. tall : leaf-blades green, narrowly oblong, elliptic or broadly linear and elongated, $5-30 \mathrm{~cm}$. long, acute or acuminate, persistent : raceme 11-30 cm. long, or elongating in fruit: perianth white or light cream-colored, cylindric, sometimes constricted above the middle, 7-9 $\mathrm{mm}$. long ; lobes ovate, spreading: style elongated: capsules ovoid, each abruptly narrowed into a slender beak about as long as the body.

In sandy soil, Maine to Ontario, Minnesota, Florida and Louisiana. Spring and summer. AloE.

4. Aletris obovàta Nash. Stems $5-7 \mathrm{dm}$. tall, striately ridged : basal leaves crowded ; blades narrowly elliptic to obovate-oblanceolate, 6-8 cm. long, 9-11-nerved, the margins translucent : racemes slender, 2-4 dm. long: perianth white, obovoid, 5-6 mm. long ; lobes ovate, converging: filaments adnate to a little above the middle of the perianth: style very short.

In pine lands, Jacksonsville, Florida. Spring and summer.

\section{LOPHİOLA Ker.}

Caulescent herbs, with slender rootstocks and more or less pubescent foliage. Leaves mostly basal : blades narrow, entire. Flowers in terminal dichotomous cymes. Perianth yellowish, persistent, pubescent: sepals and petals 3 each, relatively long, nearly equal. Stamens 6 : filaments adnate to the base of the perianth : anthers not versatile. Ovary 3-celled, half-inferior : style subulate, partly seperated at maturity. Ovules numerous, in 2 rows in each cavity. Capsule ovoid, loculicidally 5 -valved at the apex. Seeds ribbed.

1. Lophiola Americàna (Pursh) Wood. Foliage glabrous below, woolly above. Stems $5-8 \mathrm{dm}$. tall, terete, corymbose above : leaves equitant ; blades linear, much shorter than the stem, glabrous or nearly so, the upper reduced to narrow scales : cymes dichotomous: perianth yellow and glabrous within except a tuft of hairs near the base : sepals and petals linear-lanceolate, 4-5 mm. long, acute, woolly without : capsules $2 \mathrm{~mm}$. long, included in the perianth, about as long as the persistent style. [Lophiola aurea Ker.]

In pine lands, New Jersey to Florida. Spring and summer.

\section{HYPÓXIs L. ${ }^{1}$}

Acaulescent herbs, with corm-like rootstocks and usually pubescent foliage. Leaves basal : blades narrow, grass-like. Scapes solitary or tufted, terete or flattened. Flowers solitary or in umbel-like clusters. Perianth often yellow within, withering-persistent: members 6 , equal or nearly so. Stamens 6 : filaments short, adnate to the base of the perianth : anthers erect. Ovary 3-celled: stigmas 3. Ovules numerous, in 2 rows in each cavity. Capsule subglobose or elongated, circumscissile. Seeds laterally short-beaked. Star-grass. Star of Bethlehem.

Leaf-blades filiform or narrowly linear, less than $2 \mathrm{~mm}$. broad.

Leaves conspicuously sheathed at the base.

Leaves only slightly sheathed at the base.

Leaf-blades linear, more than $2 \mathrm{~mm}$. broad.

Leaves glabrous.

Leaves more or less pubescent.

Plants densely clustered.

Plants usually solitary.

1. H. juncea.

2. H. mierantha.

3. H. Curtissii.

4. H. grandis.

5. H. hirsuta.

${ }^{1}$ Contributed by Dr. J. N. Rose and Mr. C. L. Pollard. 
1. Hypoxis jùncea Smith. Leaf-blades linear-filiform, 1-3 dm. long, glabrous above, curved : scapes solitary or 2-3 together, wiry-filiform, 1-2-flowered, usually overtopped by the leaves, decumbent or procumbent at maturity : bracts subulate : perianth $2-2.5 \mathrm{~cm}$. broad : sepals and petals pubescent without, oblong-lanceolate or elliptic-lanceolate, acute, yellow within : capsules $4-6 \mathrm{~mm}$. long, topped with the erect sepals and petals : seeds $0.8 \mathrm{~mm}$. in diameter, granular.

In pine lands, Georgia to Mississippi and Florida. Spring.

2. Hypoxis micrántha Pollard. Corm globose, $5-8 \mathrm{~mm}$. in diameter : plant about $1 \mathrm{dm}$. high : leaf-blades very narrowly linear $(1 \mathrm{~mm}$. to nearly $2 \mathrm{~mm}$. wide), channeled, hirsute with copious slender spreading hairs, the base only slightly sheathing: scapes very short (3-7 cm.), 2-flowered: perianth when expanded about $6 \mathrm{~mm}$. broad: sepals and petals, and anthers, similar to those of $H$. juncea, but relatively more narrow.

In wet woods, Carteret County, North Carolina. Spring and summer.

3. Hypoxis Curtíssii Rose. Corm small : leaf-blades glabrous, linear, much elongated, 3-5 dm. long, $10-20 \mathrm{~mm}$. broad, weak and spreading: scapes rather short, 2-flowered : pedicels slender, erect: bracts elongated : sepals and petals (in fruit) erect, narrow, 6-8 $\mathrm{mm}$. long: capsules oblong, $6 \mathrm{~mm}$. long, many-seeded.

In sandy soil, northern Florida. Spring and summer.

4. Hypoxis grándis Pollard. Plants clustered, 3-4 dm. high, a number growing from a single large corm : leaf-blades linear, with a maximum width of $7 \mathrm{~mm}$., sparsely hirsute, prominently $3-5$-nerved, their lower portions expanded into broad membranous sheaths: scapes rather stout, equalling or somewhat shorter than the leaves, 5-9-flowered: perianth 1-2 cm. broad, densely hirsute without.

In clay soil, southern Alabama. Spring and summer.

5. Hypoxis hirsùta (L.) Coville. Plants usually solitary : leaf-blades linear, 1-4 $\mathrm{dm}$. long, often slightly involute, attenuate, the midrib impressed above, forming a keel beneath : scapes solitary or several together, $0.3-5 \mathrm{dm}$. tall, simple below, usually umbellately branched above : pedicels $1-2.5 \mathrm{~cm}$. long, subtended by linear-subulate bracts: perianth pubescent without : sepals and petals oblong or elliptic, 6-7 $\mathrm{mm}$. long, yellow within, greenish without: capsules globose or obovoid, 4-5 mm. long: seeds oblong or subglobose, $1.5 \mathrm{~mm}$. in diameter, black, minutely granular-papillose. [H. erecta L.]

In dry or sandy soil, Maine to Ontario, Assiniboia, Florida and Texas. Spring to fall.

\section{MANFRÈDA Salisb. ${ }^{1}$}

Fleshy herbs, the plants arising annually from bulbs borne on more or less thickened rootstocks, and dying down annually. Leaves mainly basal : blades neither spiny-edged nor spine-tipped. Flowers in narrow terminal spikes or racemes. Perianth rather inconspicuous : sepals and petals partially united, the lobes nearly equal. Stamens 6 : filaments more or less adnate to the perianth-tube : anthers versatile. Ovary 3-celled : style slender. Ovules in 2 rows in each cavity. Capsule 3-celled. Seeds flattened. False Aloz.

Filaments adnate to the base of the perianth-tube.

Capsules longer than broad: leaves green.

Capsules broader than long: leaves purple-blotched.

Filaments adnate to near the top of the perianth-tube.

Stamens much longer than the perianth-lobes : stigmatic lobes rounded: capsules much longer than broad.

Stamens about as long as the perianth-lobes: stigmatic lobes notched: capsules about as broad as long.

1. M. Virginica.

2. M. tigrina.

3. M. variegata.

4. M. maculosa.

1. Manfreda Virgínica (L.) Salisb. Basal leaves 6-15; blades lanceolete, oblong or oblong-spatulate, 1-3 dm. long, 3-5 cm. broad, herbaceous-tipped, obscurely and rather irregularly serrulate, not mottled: stem 8-18 dm. tall, simple : bracts as long as the ovaries or shorter: raceme loosely flowered: perianth greenish or brownish yellow ; tube narrowly funnelform; lobes linear-oblong, 10-12 mm. long: filaments narrowly clavate, adnate to the base of the perianth-tube : anthers $12 \mathrm{~mm}$. long : capsules 15-20 mm. long, longer than broad : seeds 4-6 mm. long.

In sandy soil, Maryland to Missouri, Florida and Texas. Spring and summer.

2. Manfreda tigrìna (Engelm.) Small. Basal leaves several ; blades lanceolate or oblong-lanceolate, $3-5 \mathrm{dm}$.- long, 5-7 $\mathrm{cm}$. broad, acute or cuspidate, with herbaceous tips, mottled with green and purple: stem 10-25 dm. tall, simple : raceme several-flowered:

${ }^{1}$ Revised by Dr. J. N. Rose. 
perianth greenish or tinged with brown; tube funnelform; lobes larger than those of the preceding species : filaments adnate to the base of the perianth-tube : capsules depressed, $16-18 \mathrm{~mm}$. broad : seeds $8-10 \mathrm{~mm}$. broad. [Agave Virginica var. tigrina Engelm.]

In sandy soil, near Blufiton, South Carolina. Also reported from Missouri. Spring.

3. Manfreda variegàta (Jacobi) Rose. Basal leaves few ; blades mainly lanceolate, 3-4 dm. long, green spotted with brown, finely toothed, the teeth obscure, curved upward : stem $9-15 \mathrm{dm}$. tall, loosely flowered : perianth greenish brown, glaucous, $3-3.8 \mathrm{~cm}$. long; lobes narrow, about as long as the tube, or somewhat longer: stamens about $5 \mathrm{~cm}$. long, much exserted ; filaments adnate to a point about $\frac{2}{3}$ or $\frac{3}{4}$ from the base of the perianthtube : anthers $8 \mathrm{~mm}$. long : capsules oblong, 15-22 $\mathrm{mm}$. long, cuspidate.

In dry soil, on prairies, lower Rio Grande Valley, Texas and adjacent Mexico. Spring. Huaco.

4. Manfreda maculòsa (Hook.) Rose. Basal leaves few ; blades narrowly lanceolate, 1.5-3 dm. long, recurved, concave throughout, attenuate, glaucous, generally spotted with dark green or brown; margins more or less transparent and furnished with small unequal cartilaginous teeth: sten $9-12 \mathrm{dm}$. tall : spikes $2-3 \mathrm{dm}$. long, loosely flowered : perianth white to purplish green, $3-5 \mathrm{~cm}$. long; lobes oblong, 10-18 $\mathrm{mm}$. long, shorter than the tube: stamens slightly exserted; filaments adnate up to the bases of the perianthlobes : anthers 9-16 mm. long: capsules oval or globose-oval, $2-2.5 \mathrm{~cm}$. long, slightly pointed.

- In thickets or dry soil, southern Texas. spring.

\section{AGÀVE L.}

Fleshy or partially woody plants, occasionally very tall, with more or less elongated caudices. Leaves crowded on the caudex, persisting for several or many years : blades very thick, armed with spiny teeth, sometimes horny-margined, spine-tipped. Flowers succulent, paniculate. Perianth of various colors, withering-persistent : sepals and petals partly united : lobes equal or nearly so. Stamens 6 : filaments more or less adnate to the perianth-tube, flattened or filiform: anthers versatile. Ovary 3-celled: style slender. Ovules numerous, in 2 rows in each cavity. Capsule 3-celled, various in shape, thickwalled. Seeds numerous, black, flattened. The plants flower usually after a long period of growth, some only once, others occasionally. American Aloe. Century-plant.

Leaves with repand edges, the teeth prominent.

1. A. Americana.

Leaves not repand, the teeth wanting or minute.

Caulescent : lobes of the perianth longer than the tube. Leaves entire or obsoletely toothed.

Leaves with many minute teeth.

Acaulescent: lobes of the perianth shorter than the tube.

2. A. sisalana.

3. A. decipiens.

4. A. neglecta.

1. Agave Americàna L. Foliage glabrous. Leaves basal; blades oblanceolate to spatulate, 10-20 dm. long, glaucous, more or less curved; terminal spine $3.5-5 \mathrm{~cm}$. long, brown ; marginal teeth deltoid-cuspidate, brown, unequal : scape erect, 8-12 m. tall, paniculate above : perianth yellowish, 75-90 $\mathrm{mm}$. long, erect or ascending ; lobes yellowish, 25-30 mm. long, much longer than the tube : filaments adnate to above the middle of the perianth-tube, twice as long as the perianth-lobes : anthers $1-1.5 \mathrm{~cm}$. long: capsules $5 \mathrm{~cm}$. long.

In sandy or dry soil, Florida and Texas, naturalized from Central America.

2. Agave sisalàna (Engelm.) Perrine. Foliage glabrous. Leaves mainly basal ; blades 12-18 dm. long, broadest at the middle or above it, thence attenuate, keeled at the more or less narrowed base ; terminal spine reddish brown, terete, $1-2 \mathrm{~cm}$. long, often twisted; margins entire or sometimes with a few unequal teeth : scape erect, $45-90 \mathrm{dm}$. tall : panicle $20-45 \mathrm{dm}$. high, showy : perianth $55-65 \mathrm{~mm}$. long, greenish ; lobes shorter than the tube, obtuse : filaments adnate $\frac{2}{3}$ the distance from base of the perianth-tube, the free portion 55-60 mm. long: anthers $2 \mathrm{~cm}$. long: capsules about $5 \mathrm{~cm}$. long.

In sandy soil, peninsular Florida and the Keys. Also in the West Indies and Central America.

3. Agave decípiens Baker. Foliage glabrous. Leaves mainly basal ; blades spreading or recurved at maturity, $10-25 \mathrm{dm}$. long, constricted and thickened above the dilated base, broadest about the middle, thence tapering to the apex; terminal spine 1-1.5 cm. long, brown ; margins uneven, armed with small very close-set often recurved teeth : scape erect, 50-60 dm. tall : panicle $25-30 \mathrm{dm}$. high, loosely branched : perianth greenish yellow, about $75 \mathrm{~mm}$. long; lobes $16-17 \mathrm{~mm}$. long, about twice as long as the funnelform tube : filaments adnate to the middle of the perianth-tube, $33-37 \mathrm{~mm}$. long.

In sand, peninsular Florida and the Keys. 
4. Agave neglécta Small. Foliage glabrous. Leaves basal ; blades glaucous, ascending or spreading when young, becoming numerous, short and recurved at maturity, 15-28 dm. long, thick at the base, broadest at the middle, thence tapering to the apex; terminal spine brown, with a short narrow channel ; margins armed with minute close-set teeth : scape erect, $13 \mathrm{~m}$. tall : panicle about $30 \mathrm{dm}$. high : perianth yellowish green, 55 $\mathrm{mm}$. long ; lobes about $23 \mathrm{~mm}$. long : filaments adnate to about the middle of the tube, exserted.

In sand or sandy soil, peninsular Florida.

\section{AtAmósco Adans.}

Acaulescent herbs, with coated bulbs and glabrous foliage. Leaves basal : blades narrowly linear, flat or channeled. Scape fleshy, 1-flowered. Perianth white, pink, purple or yellow : tube funnelform: lobes 6, equal, more or less spreading. Stamens 6, equal or nearly so: filaments adnate to the throat of the perianth-tube : anthers versatile. Ovary 3-celled : style filiform, 3-lobed at top, or stigma nearly capitate. Ovules numerous, in two rows in each cavity. Capsule 3-celled, subglobose or depressed, more or less 3lobed, loculicidally 3-valved. Seeds black or nearly so, usually flattened. [Zephyranthes Herb.] Atamasco Lily. Stagger Grass. Amarylits.
Perianth white, pink or purplish.
Spathe entire, about $1 / 2$ as long as the perianth.
Spathe 2-cleft, barely $1 / 3$ as long as the perianth.
Leaf-blades half-terete, with rounded margins.
Leaf-blades concave, with sharp margins.
Perianth yellow.
Spathe surpassing the pedicel.
Spathe about equalling the perianth : stigma 3-parted.
Spathe about equalling the top of the ovary : stigma 3 -lobed.
Spathe much shorter than the pedicel.
1. A. Simpsonii.
2. A. Tieatiae.
3. A. Atama:co.

1. Atamosco Simpsònii (Chapm.) Greene. Bulbs ovoid, $2.5-3 \mathrm{~cm}$. in diameter, with brown coats : leaves basal, erect or nearly so; blades linear, $3-5 \mathrm{dm}$. long, $2-4 \mathrm{~mm}$. broad, overtopping the scape, channeled, narrower above : scapes erect, solitary or 3 together, stout, $2-2.5 \mathrm{dm}$. tall, flattened : spathe cylindric, $2-3 \mathrm{~cm}$. long, oblique at the entire opening: perianth pale pink, about $5-5.5 \mathrm{~cm}$. long, about twice as long as the spathe ; lobes oblong-obovate, apiculate: capsules about $1 \mathrm{~cm}$. high.

In low pine lands, peninsular Florida. Spring and summer.

2. Atamosco Treàtiae (S. Wats.) Greene. Bulbs $1-1.5 \mathrm{~cm}$. in diameter: leaves basal; blades linear, 1-4 dm. long, less than $3 \mathrm{~mm}$. wide, half-terete, not lustrous, with rounded margins: scapes erect, $1-3.5 \mathrm{dm}$. tall, terete: peduncle $6-18 \mathrm{~mm}$. long: spathe membranous, surpassing the ovary : perianth white, turning pink, $6-8 \mathrm{~cm}$. high ; lobes slightly broadened upward, much longer than the tube, apiculate: capsules depressed, about $1 \mathrm{~cm}$. broad.

In pine lands, Florida. Spring.

3. Atamosco Atamásco (L.) Greene. Bulbs ovoid, $2-2.5 \mathrm{~cm}$. long. Leaves basal ; blades fleshy, linear, $1.5-4 \mathrm{~cm}$. long, lustrous, blunt, as long as the scape or longer: scapes erect, terete : spathe surpassing the ovary, 2-cleft : perianth white or light purple, $5-8 \mathrm{~cm}$. high ; lobes lanceolate to ovate-lanceolate, longer than the tube: stamens included : capsules broader than long, $1 \mathrm{~cm}$. high.

In low grounds, Pennsylvania to Florida and Alabama. Spring. EAster LiLy.

4. Atamosco longifolia (Hemsl.) Small. Bulbs ovoid, $2-2.5 \mathrm{~cm}$. long, the neck $3.5-5 \mathrm{~cm}$. long : leaves basal, erect or ascending; blades linear, 1.5-2.5 dm. long, 1-2 mm. wide, often nearly filiform: scape solitary, $7.5-15 \mathrm{~cm}$. tall, terete: spathe nearly equalling the perianth : perianth yellow, $2-2.5 \mathrm{~cm}$. long; lobes oblong or broadened upward, acute or abruptly pointed : capsules subglobose or slightly depressed, about $1 \mathrm{~cm}$. in diameter. [Zephyranthes longifolia Hemsl.]

In dry soil, Texas to Arizona and Mexico.

5. Atamosco pulchélla (J. G. Smith) Greene. Bulbs subglobose, 1-2 cm. in diameter, with dark brown coats, the neck $3-4 \mathrm{~cm}$. long. Leaves basal, 3-4; blades linear, 1.5-2.5 $\mathrm{dm}$. long, 1-2 mm. broad : scape erect, slender, 1.5-2 dm. tall : flower solitary, erect, appearing with the leaves: spathe $2-2.5 \mathrm{~cm}$. long, entire at the apex, tubular for $\frac{1}{2}$ its length, slightly surpassing the pedicel : perianth about $2 \mathrm{~cm}$. long, light yellow; lobes oblanceolate, acute; tube $5 \mathrm{~mm}$. long : stamens about $\frac{1}{2}$ as long as the perianth-lobes inserted at the throat of the tube : style as long as the stamens.

In sandy soil, Corpus Christi, Texas. Summer. 
6. Atamosco Texàna (Herb.) Greene. Bulbs subglobose, about $2 \mathrm{~cm}$. in diameter, neck $2.5-3.5 \mathrm{~cm}$. long: leaves basal, $3-4$; blades narrowly linear, $5-10 \mathrm{~cm}$. long, usually 3-4 together: scape very slender, 1-2 dm. tall, terete : spathe much surpassing the ovary, about $2.5 \mathrm{~cm}$. long: perianth yellow, somewhat coppery and striped with purple without, $25 \mathrm{~cm}$. long; lobes cuneate, acute, about $6 \mathrm{~mm}$. wide: capsules about $1 \mathrm{~cm}$. broad, depressed.

On prairies, Texas. Summer.

\section{COOPÈRIA Herb.}

Acaulescent herbs, with coated bulbs and glabrous foliage. Leaves basal: blades very narrow, grass-like. Scape erect, simple, 1-flowered, often shorter than the leaves. Perianth subtended by a bract-like spathe, salverform: tube elongated-cylindric or slightly dilated at the top: lobes 6 , spreading above. Stamens 6 : filaments adnate to the throat of the perianth-tube : anthers narrow, erect, not versatile. Ovary 3-celled: style filiform: stigma slightly 3-lobed. Ovules numerous in 2 rows in each cavity. Capsule depressed, 3-lobed, loculicidally 3-valved. Seeds numerous, black. Prairie Lily.

Neck of the bulb less than $4 \mathrm{~cm}$. long: perianth-tube over $7 \mathrm{~cm}$. long: ovary sessile. 1. C. Drummondii. Neck of the bulb over $5 \mathrm{~cm}$. long: perianth-tube less than $5 \mathrm{~cm}$. long: ovary stalked. 2. C. pedunculata.

1. Cooperia Drummóndii Herb. Bulbs subglobose, $2.5 \mathrm{~cm}$. in diameter; neck short: leaves basal ; blades narrowly linear, erect, 1-3 dm. long: scape $1.5-3 \mathrm{dm}$. long, fragile, terete : perianth whitish ; tube very slender, $7-13 \mathrm{~cm}$. long; lobes ovate, elliptic or oval, 1-2 cm. long, acute : ovary sessile : capsule about $1 \mathrm{~cm}$. in diameter.

On prairies, Texas to New Mexico and adjacent Mexico.

2. Cooperia pedunculàta Herb. Bulbs subglobose, mostly $2.5-3 \mathrm{~cm}$. in diameter ; neck $5-7.5 \mathrm{~cm}$. long : leaves basal ; blades narrowly linear, $1-3 \mathrm{dm}$. long, $2-5 \mathrm{~mm}$. broad : scape 1-2 dm. long, simple : perianth whitish; tube slender, $3.5-4 \mathrm{~cm}$. long, slightly dilated above; lobes about as long as the tube, oval or broadest a little above or below the middle : ovary short-pedicelled: capsules about as large as those of the preceding species.

On prairies, Texas. Spring.

\section{CRINUM L.}

Succulent acaulescent herbs, with large bulbs. Leaves basal, persistent : blades linear or slightly broadened upward, spreading or arching. Scape erect, often solitary, topped by an umbel of 2-6 flowers. Spathe 2-valved, broad. Perianth white, showy : tube elongated: lobes narrowed upward. Stamens 6, exserted : filaments distinct, filiform, elongated: anthers linear, versatile. Ovary 3-celled: style slender, elongated: stigma entire. Capsule bursting and exposing the green corm-like seeds.

1. Crinum Americànum L. Bulb $7 \cdot 5-10 \mathrm{~cm}$. in diameter, with a short neck: leaves basal; blades linear, 6-12 dm. long, strap-like, arching, denticulate : scape erect, 3-7 dm. tall, surmounted by 2-4 flowers : perianth showy ; lobes white, linear or linearlanceolate, $5-12 \mathrm{~cm}$. long, acute ; tube green, as long as the lobes or longer.

In river swamps, Georgia to Florida, Louisiana and Texas. Spring and summer.

\section{HYMENOCÁLLIS Salisb. ${ }^{1}$}

Acaulescent fleshy herbs, with coated bulbs. Leaves basal : blades linear or nearly so, often strap-like. Scape terminated by a single flower or an umbel, with membranous bracts. Perianth showy : tube elongated, slender : lobes narrow, nearly equal, spreading. Stamens 6 : filaments adnate to the perianth-tube, above which they are connected by a thin cup-like or saucer-shaped crown : anthers narrow, versatile. Ovary 3-celled : style filiform, exserted : stigma nearly entire. Ovules 1 or 2 in each cavity. Capsule thick, rather fleshy. Seeds green and fleshy, 1 or 2 in each cavity. SPIDER Lily.

Perianth-tube $13 \mathrm{~cm}$. long or more.

Perianth-tube $10 \mathrm{~cm}$. long or less.

A. Scapes terminated by several flowers : bulbs $3-10 \mathrm{~cm}$. in diameter or more.

Leaf-blades $4.5 \mathrm{~cm}$. broad or more.

Leaf-blades $3.5 \mathrm{~cm}$. broad or less.

a. Leaves green; blades $18-24 \mathrm{~mm}$. broad.

Staminal erown $4.5 \mathrm{~cm}$. broad or more: species Carolina-Floridian. Staminal crown less than $4.5 \mathrm{~cm}$. broad : species Texan.

1. H. Caymanensis.

2. H. Caribaea.

3. $H$. rotatum.

4. H. Galvestonensis.

${ }^{1}$ Contributed by Dr. J. N. Rose. 
b. Leaves glaucous ; blades 24-35 mm. broad.

B. Scapes terminated by a single flower : bulbs $1-2.5 \mathrm{~cm}$. in diameter.

Perianth-tube over $7 \mathrm{~cm}$. long: staminal crown with free tips between the filaments.

Perianth-tube less than $5 \mathrm{~cm}$. long: staminal crown truncate between the filaments.

6. H. Palmeri.

7. H. humilis. .

1. Hymenocallis Caymanénsis Herb. Bulb large, with a short neck: leaf-blades linear-oblong, 3-8 dm. long, 6-8 cm. broad, obtuse, tapering somewhat towards the base : flowers 6-12 together at the top of the scape : perianth-tube $13-15 \mathrm{~cm}$. long; lobes $10 \mathrm{~cm}$. long: staminal crown funnel-shaped, $2.5 \mathrm{~cm}$. long: ovules 2 in each cavity.

In sand or sandy soil, Florida and the West Indies.

2. Hymenocallis Caribaèa (L.) Herb. Bulb subglobose, 7-10 cm. in diameter : leaf-blades linear-oblong, about $4 \mathrm{dm}$. long, $4.5 \mathrm{~cm}$. broad or more, scarcely tapering either way, acute : scape acutely angled : flowers $6-12$ together, terminating the scape : perianthtube $5-10 \mathrm{~cm}$. long ; lobes $7-9 \mathrm{~cm}$. long: ovules 2 in each cavity.

In sand or sandy soil, Florida and the West Indies.

3. Hymenocallis rotàtum (Ker.) Herb. Bulb ovoid, 4-5 cm. in diameter, with a prolonged neck and copious stolons : leaf-blades linear, 3-5 dm. long, less than $2.5 \mathrm{~cm}$. broad, bright green : flowers 2-6 together, terminating the scape : perianth-tube $7.5-10 \mathrm{~cm}$. long; lobes linear, about as long as the tube: staminal crown about $2.5 \mathrm{~cm}$. long, very rotate : ovules 2 in each cavity.

In low places or sandy soil, North Carolina to Florida.

4. Hymenocallis Galvestonénsis Baker. Bulb relatively large : leaf-blades linear, 4-6 dm. long, 2-2.4 cm. broad : scape 3-4 dm. tall : flowers 4-6 together, terminating the scape : perianth-tube $4-9 \mathrm{~cm}$. long; lobes $6.5 \mathrm{~cm}$. long.

In damp places, eastern Texas.

5. Hymenocallis occidentàlis Kunth. Bulbs large: leaf-blades strap-shaped, glaucous, $3-5 \mathrm{dm}$. long, $2.4-3.5 \mathrm{~cm}$. broad : flowers $3-6$, terminating the scape : perianthtube $6-10 \mathrm{~cm}$. long; lobes linear, about as long as the tube: staminal crown $25-32 \mathrm{~mm}$. long.

In moist soil or shaded hillsides, South Carolina to Missouri, Georgia and Mississippi.

6. Hymenocallis Pálmeri S. Wats. Bulb narrowly oblong, 8-24 mm. in diameter : leaf-blades linear, $5 \mathrm{dm}$. long or less, $6-10 \mathrm{~mm}$. wide: scapes $1.5-2.6 \mathrm{dm}$. tall : flower solitary : perianth-tube $7.5-10 \mathrm{dm}$. long; lobes nearly as long as the tube : staminal crown funnel-shaped, $3-4 \mathrm{~cm}$. long, with acuminate tips between the filaments.

In sand or sandy soil, Florida.

7. Hymenocallis hùmilis $\mathrm{S}$. Wats. Bulb about $1.8 \mathrm{~cm}$. in diameter: leaf-blades linear, 10-15 cm. long, about $4 \mathrm{~mm}$. wide : scape shorter than the leaves: flower solitary : perianth-tube about $3 \mathrm{~cm}$. long, dilated at the top; lobes linear, $5 \mathrm{~cm}$. long: staminate crown broadly funnel-shaped, $16 \mathrm{~mm}$. long, truncate between the filaments.

In sand or sandy soil, Florida.

\section{Family 2. TAMÀCEAE S. F. Gray. Yam Family.}

Perennial herbaceous or somewhat woody vines, with tuberous or knotted rootstocks. Stems twining, unarmed. Leaves often opposite or whorled near the base of the stem, alternate above : blades simple, several-nerved and nettedveined, petioled. Flowers regular, perfect, monoecious or dioecious, in axillary spikes, racemes or panicles. Perianth calyx-like: sepals and petals 3 each, partially united. Androecium of 3-6 stamens at the base of the perianthlobes. Gynoecium of 3 united carpels. Ovary 3-celled, inferior. Styles as many as cavities in the ovary. Stigmas small. Ovules 1-2 in each cavity. Fruit a 3-winged 3-valved capsule, or berry-like. Embryo small, in the fleshy or almost cartilaginous endosperm. [Dioscoreaceae Lindl.]

\section{DIOSCORÈA L.}

Herbaceous twining vines, with fleshy or woody rootstocks. Leaves alternate, at least above: blades often broadest below the middle and cordate : petioles enlarged at the base. Flowers mostly dioecious or monoecious, in spikes, recemes or panicles. Sepals and petals 3 each, partially united. Staminate flowers with 3-6 stamens at the base of the limb of the perianth and occasionally with a rudimentary ovary: sepals and petals deciduous. Pistil- 
late flowers with a persistent perianth. Ovary inferior: styles $3:$ stigmas entire. Ovules 2 or rarely one in each cavity, pendulous, anatropous or amphitropous. Capsule broadly 3 -winged, opening through the wings. Seeds flat, membranous-winged.

1. Dioscorea villòsa $L$. Rootstocks knotted, $1-3 \mathrm{~cm}$. thick : stems twining, $1-5 \mathrm{~m}$. long, more or less branched : leaves sometimes whorled below ; blades thinnish, ovate or oblong-ovate, 6-15 $\mathrm{cm}$. long, acuminate, entire, bright green above, pale and somewhat pubescent beneath, cordate, usually 9-11-nerved; petioles slender, as long as the blades or shorter: staminate flowers $3 \mathrm{~mm}$. broad, whitish, in delicate panicles: sepals and petals ovate or oblong; tube very short: pistillate flowers in simple racemes: hypanthium early elongated : capsules $1.5-2.5 \mathrm{~cm}$. long, broadly 3 -winged, persistent, becoming lustrous and dry at maturity : seeds 1-2 in each cavity, broadly thin-winged.

In thickets, Ontario to Rhode Island and Minnesota, Florida and Texas. Summer. YAM. WILD YAM-ROOT.

\section{FAmily 3. IXIÀCEAE Ecklon. Iris FAmily.}

Perennial, mostly caulescent herbs, with bulb-like or elongated rootstocks. Leaves equitant, 2-ranked, commonly elongated. Flowers perfect, regular or irregular, solitary or in clusters from spathe-like bracts. Perianth often highly colored: sepals and petals nearly equal or often very different, withering-persistent or fugacious, distinct, or united below. Androecium of 3 stamens, adnate to the perianth opposite the sepals. Filaments filiform, distinct or partially united. Anthers 2-celled, extrorse. Gynoecium of 3 united carpels. Ovary inferior, 3-celled. Styles distinct, entire or parted, sometimes petal-like. Ovules numerous, anatropous, on central placentae. Fruit a loculicidally 3-valved capsule. Seeds numerous in 1 or 2 rows in each cavity. Embryo straight in the fleshy or horny endosperm.

Styles alternate with the stamens.

Styles 2-cleft or 2-parted.

Styles entire or stigmas merely emarginate.

Rootstocks bulb-like.

Rootstocks not bulb-like, often elongated.

Filaments distinct: seeds drupe-like.

Filaments wholly or partially united : seeds dry.

Styles opposite or arching over the stamens.

Styles slender: filaments united into a tube.

Styles petal-like : filaments distinct.

1. Nemastylis.

2. Calydorea.

3. Gemmingia.

4. SISYRINCHIUM.

5. Herbertia.

6. IRIS.

\section{NEMÁSTYLIS Nutt.}

Caulescent herbs, with coated bulb-like rootstocks. Stems terete. Leaves alternate : blades narrow, elongated, folded. Flowers solitary or several together from two herbaceous bracts, fugacious. Perianth usually showy : lobes 6 , nearly equal. Stamens 3 : filaments more or less united. Ovary 3-celled : styles alternate with the stamens, each parted into 2 filiform segments: stigmas terminal. Ovules numerous. Capsule somewhat elongated, loculicidally 3 -valved at the apex.

Leaves or some of them overtopping the inflorescence: perianth-lobes broadest below the middle.

Leaves not overtopping the inflorescence: perianth-lobes broadest above the middle. $2 . \mathrm{N}$. coelestina.

1. Nemastylis acùta (Bart.) Herb. Foliage bright green. Stems 1-6 dm. tall, simple or sparingly forked: leaf-blades linear, 1-3.5 dm. long, some at least overtopping the inflorescence: flowers 2-3 from a spathe: bracts unequal, the outer shorter: perianth light blue or purple, 4-5 cm. broad; lobes slightly unequal, broadest below the middle: capsule turbinate or obovoid-turbinate, 10-15 mm. high.

On prairies, Tennessee to Kansas, Louisiana and Texas. Spring.

2. Nemastylis coelestina (Bart.) Nutt. Foliage deep green. Stems $3-6 \mathrm{dm}$. tall, somewhat zigzag: leaf-blades linear, 1-4 dm. long, or more reduced above, none overtopping the inflorescence: flowers commonly solitary in the spathes: bracts lanceolate or linear-lanceolate, the outer shorter : perianth bright blue, about $4 \mathrm{~cm}$. broad ; lobes nearly equal, broadest above the middle: capsule oblong-prismatic, $2-2.5 \mathrm{~cm}$. long, obtusely 3-angled.

On prairies or in pine woods, Georgia to Florida and Texas. Spring and summer.

\section{CALYDÒREA Herb.}

Caulescent herbs, with coated bulb-like rootstocks. Leaves mainly basal : blades narrow, sometimes nearly filiform. Flowers usually few from the terminal solitary spathe. 
Perianth showy: lobes 6 , equal or nearly so, distinct or slightly united at the base, somewhat spreading. Stamens adnate to the base of the perianth : filaments distinct : anthers narrow. Ovary 3-celled: styles partially united, the free portions club-shaped or the stigmas notched at the apex. Ovules numerous in each cavity. Capsule slightly elongated. Seeds several, even or angled.

1. Calydorea Texàna (Herb.) Baker. Bulbs brown, flask-shaped. Foliage bright green : stems 1-3 dm. tall, simple or sparingly forked, barely strict, terete : leaves few, erect or nearly so ; blades linear and grass-like ; basal often longer than the stem, but barely overtopping the inflorescence : those of the stem few and shorter: spathes cylindric, 3-5 $\mathrm{cm}$. long, the outer bract shorter than the inner, rather delicate : perianth bright blue, about $5 \mathrm{~cm}$. broad; lobes cuneate-obovate, $2.5 \mathrm{~cm}$. long; style-branches shorter than the anthers.

On prairies, Texas. Spring.

\section{GEMMÍNGIA Fabr.}

Caulescent herbs, with horizontal rootstocks. Leaves alternate : blades folded, sheathing the stems. Flowers in terminal, small bracted clusters, these disposed in corymbs. Perianth usually mottled : lobes 6 , nearly equal, united to the top of the ovary, or slightly beyond it, withering but persistent. Stamens 3: filaments distinct, adnate to the bases of the perianth-lobes: anthers elongated. Ovary 3-celled: styles undivided, very slender, alternate with the stamens. Ovules numerous. Capsule fig-shaped, loculicidally 3-valved to the base : valves reflexed. Seeds exposed as a mass resembling a blackberry, persistent on a central axis. [Belamcandu Adans.]

1. Gemmingia Chinénsis (L.) Kuntze. Foliage bright green, sometimes glaucescent. Stems 3-12 dm. tall, leafy below, nearly naked above: leaf-blades 1-5 dm. long, acute or acuminate, upper faces united above the middle: bracts similar to the leaves but much smaller, their faces not united : perianth pink to reddish, $3-5 \mathrm{~cm}$. broad; lobes oblong or elliptic, more gradually narrowed at the base than at the apex, persistent as a coil on top of the fruit: capsules oblong-turbinate, $2-2.5 \mathrm{~cm}$. long : seeds black and shining, disposed in a mass resembling a blackberry.

Along roadsides and on banks, New York to Missouri, Georgia and Alabama. Summer. BLAckBERRY LILY.

\section{SISYRÍNCHIUM L. ${ }^{1}$}

Perennial scapose usually tufted grass-like herbs, with distinct or obsolete rootstocks and fibrous roots. Leaves basal : blades linear : scapes 2 -edged or 2 -winged, when branched each node furnished with a bract resembling a leaf-blade: flowers in terminal clusters arising from spathes of mostly 2 bracts each. Perianth blue, white or yellow : lobes spreading. Stamens 3; filaments united to the top or nearly so: anthers clustered. Ovary 3celled : style-branches filiform, alternate with the anthers, or styles mostly wholly united : ovules few to many in each cavity of the ovary. Capsule subglobose or depressed or longer than thick, globular or angled, readily opening near the apex. Seeds smooth or pitted. Blue-Eyed Grass.

A. Scapes simple and terminated by the sessile or nearly sessile spathe or spathes, or rarely some in the tufts with 1 or 2 terminal peduncles.

a. Tufts of plants normally with simple scapes only.

Filaments distinct above: both bracts of the spathe foliaceous : plants $3-8 \mathrm{~cm}$. tall.

Filaments completely united : inner bract of the spathe not foliaceous : plants $10-50 \mathrm{~cm}$. tall.

* Spathe not subtended by an accessory outer bract: tufts of plants not densely fibrillose at the base.

Spathe solitary or normally so.

Outer bract of the spathe with its edges distinetly united at the base: bracts smooth.

Capsules 4-6 mm. high: leaf-blades and scapes mostly 1.5$2.5 \mathrm{~mm}$. wide.

Capsules 2-4 mm. high : leaf-blades and scapes mostly $0.5-$ $1.5 \mathrm{~mm}$. wide.

Outer bract of the spathe with completely free edges.

Bracts usually roughish: capsules pale, $2-4 \mathrm{~mm}$. high : pedicels scarcely exserted.

Bracts smooth: capsules dark, 4-6 mm. high: pedicels flexuously exserted.

1. S. exile.

2. S. angustifolium.

3. S. mucronatum.

4. S. campestre.

5. S. sagittiferum.

${ }^{1}$ Contributed by Mr. E. P. Bicknell. 
Spathes 2 together, or rarely 3 .

Plants smooth (rarely with the bracts obscurely roughened in nos. 6 and 8 ): leaf-blades mostly $1.5-3 \mathrm{~mm}$. wide.

Plants drying green : capsules pale, $2-3 \mathrm{~mm}$. high.

Plants drying dark : capsules dark, 4-6 mm. high.

Plants more or less scabrous (sometimes smooth in no. 8), not drying dark: leaf-blades mostly 1-2 mm. wide.

Spathes mostly green: outer bract of the second spathe slender-prolonged: perianth pale blue.

Spathes mostly red-purple: outer bract of the second spathe as long as the inner: perianth deep violet-blue.

* Spathe subtended by an accessory outer slender bract: tufts of

plants densely fibrillose at the base.

b. Tufts of plants with both simple and branched scapes, the latter being terminated by 1 or 2 peduncles.

Scapes wiry, nearly terete: spathes green, mostly narrow and almost terete at the base.

Scapes flattened, distinctly winged : spathes mostly purplish, flattened.

Plants drying dark: leaf-blades rather thin: bracts of the spathe smooth.

Plants not drying dark : leaf-blades rather stiff : bracts rough.

B. Scapes branched or bearing 2 or more terminal peduncles.

Tufts of plants densely fibrous at the base.

Plants drying very dark.

Leaves and scapes smooth.

Bracteal leaf conspicuously elongated; leaf-blades 2-4 $\mathrm{mm}$. wide, finely cross-rugulose.

Bracteal leaf short and narrow: leaf-blades 1-2 mm. wide, not rugulose.

Leaves and scapes more or less roughened on the sides: interior scales much shorter than the bracts of the spathe.

Plants pale and glaucous, or not very dark when dry.

Scapes slender, often flexuous, ciliolate-serrulate: plants rather bright or deep green: peduncles very short or subfascicled.

Scapes rather stiff or stout: plants pale or glaucous : peduncles slender, not fascicled.

Scapes flattened and wing-margined or broadly winged.

Leaf-blades and scapes mostly manifestly serrulate: peduncles usually 5-10 cm. long: staminal column 4-5 mm. high.

Leaf-blades and scapes mostly smooth-edged: peduncles $2-5$ $\mathrm{cm}$. long: staminal column $2-4 \mathrm{~mm}$. high.

Scapes subterete or narrowly margined.

Leaves numerous; blades elongated, becoming flexuous, 2-4 $\mathrm{mm}$. wide: plants flowering from February to March.

Leaves few; blades more slender and much narrower and shorter: plants smaller, flowering from June to August.

Tufts of plants without fibers, or not densely fibrous at the base.

a. Plants more or less stiffly erect or erect-ascending ; scapes not usually branched below the middle: peduncles usually shorter than the scape proper: species, except $S$. graminoides, not occurring west of the Mississippi River, as far as known.

Plants drying very dark (except no. 26).

Scapes and leaf-blades mostly $2-4 \mathrm{~mm}$. wide or more : pedicels finally much spreading or recurved.

Inflorescence not repeatedly dichotomous.

Capsule thick-walled: bracts of the spathe closely striatenerved, $2-2.5 \mathrm{~cm}$. long.

Capsule thin-walled: bracts of the spathe not closely striate-nerved, the inner one $2 \mathrm{~cm}$. long or less.

Perianth about $10 \mathrm{~mm}$. long or more. Capsules $2.5-4 \mathrm{~mm}$. high, on recurved pedicels : seeds few in each cavity.

Capsules 3-6 mm. high, on spreading pedicels.

Interior scales much shorter than the bracts of the spathe: seeds numerous.

Interior scales often equalling the bracts of the spathe: seeds $2-3$ in each cavity.

Perianth 5-8 mm. long: capsules $1.5-3 \mathrm{~mm}$. long: seeds $2-3$ in each cavity.

Inflorescence more or less dichotomous from successive nodes : perianth about $5 \mathrm{~mm}$. long, white or perhaps also blue.

Scapes and leaf-blades mostly 1-2 mm. wide: pedicels erect or nearly so.

Leaves and scapes mostly smooth-edged, the scapes becoming widely flexuous: peduncles very slender, $5-12 \mathrm{~cm}$. long.

Leaves and scapes serrulate, erect: peduncles $3-7 \mathrm{~cm}$. long.

Plants pale or bright green, not drying very dark.

Roots thickened and clustered, becoming $1.5 \mathrm{~mm}$. thick or more : Florida species, the plants becoming $50-80 \mathrm{~cm}$. tall.

Leaves very long, equalling the tufts; blades $1.5-2.5 \mathrm{~mm}$. wide : capsules thin-walled, subglobose, $5-6 \mathrm{~mm}$. high.

Leaves shorter than the scapes; blades becoming 3-4 mm. wide: capsules thick-walled, broadly oblong, $2.5-5 \mathrm{~mm}$. high.

Roots less clustered, not thickened, usually slender and fibrous : plants mostly $15-50 \mathrm{~cm}$. tall.

6. S. albidum.

5. S. sagittiferum.

7. S. scabrellum.

8. S. Asheanum.

9. S. capillare.

10. S. biforme.

11. S. intermedium.

12. S. versicolor.

13. S. xerophyllum.

14. S. fuscatum.

15. S. incrustatum.

16. S. rufipes.

17. S. fibrosum.

18. S. tortum.

19. S. Floridanum.

20. S. Nashii.

21. S. solstitiale.

22. S. recurvatum.

23. S. graminoides.

24. S. membranaceum.

25. S. tenellum.

26. S. dichotomum.

27. S. flagellum.

28. S. Miamiense.

29. S. longifolium.

30. S. corymbosum. 
Inflorescence scant, with 1 or sometimes 2 nodes, each bearing 1 or 2 peduncles.

Plants mostly over $30 \mathrm{~cm}$. tall, when lower very delicate and slender. Leaves much shorter than the straight wing-flattened scapes: capsules $2-4 \mathrm{~mm}$. long.

Leaves equalling the flexuous subterete scapes: capsules 4-6 $\mathrm{mm}$. high.

Plants 15-30 cm. tall, somewhat stiff or rigid.

Perianth becoming $15 \mathrm{~mm}$. long: staminal column 5 $\mathrm{mm}$. high : bracts of the spathe finely puncticulatedotted.

Perianth about $10 \mathrm{~mm}$. long: staminal column $4 \mathrm{~mm}$. high or less : bracts of the spathe not dotted.

Inflorescence more contracted and compound, mostly with 2-4 nodes each bearing $2-4$ peduncles.

Scapes $1.5-3 \mathrm{~mm}$. wide: perianth over $10 \mathrm{~mm}$. long, the sepals and petals slenderly aristulate.

Scapes 1-1.5 mm. wide : perianth less than $10 \mathrm{~mm}$. long, the sepals and petals short aristulate.

b. Plants in finally depressed assurgent or weakly diffuse tufts.

Perianth less than $6 \mathrm{~mm}$. long: capsules oblong: plants branched and leafy-bracted from the base.

Perianth over $8 \mathrm{~mm}$. long: capsules subglobose.

Leaf-blades 5-7 mm. wide: scape broadly thin-winged.

Leaf-blades $0.5-3 \mathrm{~mm}$. wide : scape narrowly margined.

Plants in depressed or ascending more or less rosulate tufts : scapes stiff, the outer ones geniculate below.

Perianth reddish purple: capsules pale, about $3 \mathrm{~mm}$. high : plants not discoloring when dry.

Perianth blue: capsules dark, becoming $6 \mathrm{~mm}$. high : plants dark when dry.

Plants in weakly diffuse finally spreading or reclining tufts.

Leaf-blades extremely slender, $1 \mathrm{~mm}$. wide or less : peduncles much shorter than the scapes: plants pale and glaucescent.

Leaf-blades 1-3 mm. wide: peduncles very slender, mostly as long as the scapes or nearly so: plants deep green, drying dark.

c. Plants erect: species trans-Mississippian, or essentially so.

Sides of the leaf-blades and the scapes scabrellous: pedicels slenderly flexuous.

Sides of the leaf-blades and the scapes smooth (except sometimes in no. 49): pedicels not widely flexuous.

Plants tall and stiff, becoming $50 \mathrm{~cm}$. high: peduncles terminal, very long and slender: capsules 6-7 $\mathrm{mm}$. high or more.

Plants lower, from $5 \mathrm{~cm}$. to rarely over $30 \mathrm{~cm}$. tall : terminal peduncles never elongated : capsules less than $5 \mathrm{~mm}$. high.

Plants very stiff and glaucous: scapes and leaf-blades $1.5-4$ $\mathrm{mm}$. wide, their edges normally rough-serrulate.

Plants never very rigid and glaucous: scapes and leaf-blades not strongly serrulate when over $2 \mathrm{~mm}$. wide.

Bracts of the spathe closely and delicately many-nerved: plants $5-30 \mathrm{~cm}$. tall.

Leaf-blades mostly over $2 \mathrm{~mm}$. wide: plants $15-30 \mathrm{~cm}$. tall.

Foliage glaucous to glaucesent : perianth light blue: pedicels exserted.

Foliage green to glaucescent: perianth deep bluepurple: pedicels scarcely exserted.

Leaf-blades mostly less than $2 \mathrm{~mm}$. wide: plants $5-20$ em. tall.

Plants bright or light green, becoming darkened when dry, the tufts mostly loose and open. Scapes rigid, somewhat curved: perianth bright blue: ovary glabrous.

Scapes straight, not rigid : perianth deep purpleblue or pale blue : ovary puberulent.

Leaves shorter than the scapes: flowers deep purple-blue: staminal column $1 / 2$ the length of the perianth or less.

Leaves equalling the scapes: perianth pale blue: staminal column $1 / 2$ the length of the perianth or more.

Plants pale and glaucescent, not becoming dark when dry, relatively small and closely tufted.

Leaf-blades $1-2 \mathrm{~mm}$. wide: perianth pale violetblue : staminal column $4-6 \mathrm{~mm}$. high : ovary puberulent to glabrate.

Leaf-blades about $0.5 \mathrm{~mm}$. wide: perianth bright purplish blue: staminal column $3 \mathrm{~mm}$. high :

Bracts of the spathe thickened, strongly rather few-nerved,
then glabrous. the spathes becoming somewhat thickeried.

31. S. Atlanticum.

32. S. flexile.

33. S. violaceum.

34. S. nanum.

35. S. Tracyi.

36. S. scoparium.

37. S. minus.

38. S. colubriferum.

39. S. rosulatum.

40. S. Helleri.

41. S. implicatum.

42. S. flaccidum.

43. S. pruinosum.

44. S. longipedunculatum.

45. S. ensigerum.

46. S. varians.

47. S. amoenum.

48. S. Brayi.

49. S. fureatum.

50. S, Langloisii.

51. S. Bushii.

52. S. Canbyi.

53. S. Texanum. 
1. Sisyrinchium éxile Bicknell. Plants in diminutive tufts $3-8 \mathrm{~cm}$. high. Foliage glaucescent: larger leaves equalling or surpassing the scapes; blades $0.75-1.5 \mathrm{~mm}$. wide, firm, weakly few-nerved: scapes $1.5-6.5 \mathrm{~cm}$. tall, less than $1 \mathrm{~mm}$. wide, narrowly margined, the edges smooth: spathes sometimes larger than the scapes, the bracts foliaceous, very unequal, the outer one $2-2.8 \mathrm{~cm}$. long: interior scales less than $\frac{1}{2}$ the length of the inner bract: flowers few, on hair-like pedicels spreading or recurved from about midway in the spathe: perianth very small and delicate, about $5 \mathrm{~mm}$. long, pale yellowish and bluish: sepals and petals short-aristulate : staminal column $1.5-2 \mathrm{~mm}$. high, its base dilated and puberulent.

On sandy sea shores, Galveston, Texas. Late winter and early spring.

2. Sisyrinchium angustifòlium Mill. Plants tufted, 1-4 dm. tall or more, more or less glaucous. Leaf-blades $1-3 \mathrm{~mm}$. wide, usually serrulate roughened : scapes twice longer than the leaves, about as wide, wing-margined : spathes mostly green, sometimes purplish, the outer bract $2-6 \mathrm{~cm}$. long, clasping for $2-6 \mathrm{~mm}$. at its base, much larger than the inner one : pedicels stiff and nearly erect: perianth violet-blue, 10-12 $\mathrm{mm}$. long: staminal column 4-6 mm. high : eapsules 4-6 mm. high, oblong-globose : seeds dark brown, 1-1.5 $\mathrm{mm}$. long, obovoid-oblong, with shallow pits, or nearly smooth.

In moist or dry soil, Newfoundland to Saskatchewan, New Jersey, North Carolina and Colorado. Spring and summer.

3. Sisyrinchium mucronàtum Michx. Plants in close tufts, $1-4.5 \mathrm{dm}$. tall, dull green or glaucescent. Leaves numerous; blades from nearly filiform to $1.5 \mathrm{~mm}$. wide : scapes twice as long as the leaves or sometimes equalled by them and of about the same width, merely margined or narrowly winged, smooth or denticulate-roughened : spathes bright red-purple or rarely green, the bracts thin, smooth, the outer one $2-6 \mathrm{~cm}$. long, united-clasping for 1-4 mm. at the base, the inner emerging gradually from the outer one, $1-1.5 \mathrm{~cm}$. long : pedicels slender, somewhat spreading : perianth deep purple-blue or sometimes white, $6-14 \mathrm{~mm}$. long: capsules $2-4 \mathrm{~mm}$. high, pale, thin-walled : seeds black, about 1 $\mathrm{mm}$. long, subglobose, pitted. Spring.

In meadows and grassy places, or sometimes in dry soil, Ontario and Michigan to North Carolina.

4. Sisyrinchium campéstre Bicknell. Plants closely tufted, 1-3 dm. tall, glaucescent or glaucous. Leaf-blades mostly 1-1.5 mm. wide, smooth-edged : scapes twice as long as the leaves or sometimes surpassed by them, 1-1.5 $\mathrm{mm}$. wide, narrowly wing-margined, the sides often obscurely scabrous : spathes dull purple to green, the bracts commonly roughish all over or canescently scabrous-puberulent, or sometimes glabrous, the outer one 2.5-4.5 $\mathrm{mm}$. long, its edges free to the extreme base, the inner bract $1.2-2 \mathrm{~cm}$. long, somewhat abruptly emerging from the outer one : pedicels nearly erect : perianth pale blue or white, 8-14 mm. long: capsules pale, 2-4 mm. high : seeds 1-1.25 mm. long, obovoid-globose, faintly pitted.

On plains, prairies and in meadows and open woods, Wisconsin to North Dakota, Louisiana and New Mexico. Spring.-A variety from Kansas and Oklahoma, $S$. campestre Kansanum Bicknell, is stouter, has larger flowers, broader leaf-blades, more winged scapes and larger spathes, the slenderly prolonged outer bract being $2.5-6.5 \mathrm{~cm}$. long.

5. Sisyrinchium sagittíferum Bicknell. Plants thinly tufted, 1-3 dm. tall, fibrillose at the base, drying dark. Roots clustered and becoming much thickened : leaf-blades rather thin, but firm, 0.5-3 mm. wide, striate-nerved, the edges smooth or serrulate: scapes about as long as the leaves, very slender, 0.5-1.5 mm. wide, wing-margined, mostly denticulate-roughened : spathes erect, often 2 together, the outer bract slenderly attenuate, $1.5-7 \mathrm{~cm}$. long, its margins free to the base, the inner bract $1-1.7 \mathrm{~cm}$. long, rather broad below, mostly scarious and obtuse at the apex: pedicels hair-like, flexuously exserted : perianth violet or white, $8-10 \mathrm{~mm}$. long: capsules dark, subglobose, 4-6 $\mathrm{mm}$. high, on finally spreading or recurved pedicels.

In dry woods, Louisiana and Texas. Early spring.

6. Sisyrinchium álbidum Raf. Plants more or less tufted, 1.5-4.5 dm. tall, green or glaucous. Leaf-blades mostly $1.5 \mathrm{~mm}$. wide $(0.5-3.5 \mathrm{~mm}$. $)$, usually smooth-edged, sometimes serrulate: scapes about twice as tall as the leaves, mostly $1.5 \mathrm{~mm}$. wide, often very flat, the thin wings mostly serrulate or hispidulous on the margins: spathes 2 together, the primary bract $2.5-7 \mathrm{~cm}$. long, much surpassing the others, foliaceous or slenderly attenuate, the edges distinct to the base : perianth 8-12 mm. long, elear white or violet-blue: capsules pale, broadly subglobose, $2-3 \mathrm{~mm}$. long, thick-walled: seeds $0.75-1 \mathrm{~mm}$. in diameter, black, distinctly pitted.

In dry or moist soil, or in meadows, Michigan and Missouri to North Carolina, Alabama and Louisiana. Spring.

7. Sisyrinchium scabréllum Bicknell. Plants closely tufted, $2.5-4 \mathrm{dm}$. tall, slightly fibrillose at the base, dull pale green or glaucescent. Leaves stiffly erect, purple-tinged at 
the base; blades 1-2 mm. wide, cuspidate-acute, usually scabrous or even canescently incrustate with minute white setulose papillae, sometimes less so or quite smooth above: scapes slender, but stiff, about $\frac{1}{4}$ longer than the leaves, 1-2 $\mathrm{mm}$. wide, flattened, usually roughened like the leaves, at least below, the wing-margins with rough edges: spathes 2 or rarely 3 together, mostly green, the bracts more or less roughened, the primary bract stiff and elongated, $3.5-11.5 \mathrm{~cm}$. long, usually smooth or nearly so above, the inferior outer bract attenuate, often slenderly prolonged, $1.2-3.8 \mathrm{~cm}$. long, surpassing the inner bracts : pedicels loosely erect or flexuously much exserted : perianth pale blue, $8-12 \mathrm{~mm}$. long.

On hillsides or in woods, North Carolina. Spring.

8. Sisyrinchium Asheànum Bicknell. Similar to S. scabrellum, but lower and more slender, with the leaves and bracts slightly if at all roughened. Leaf-blades $0.5-1.5 \mathrm{~mm}$. wide, tapering to a hardened acute or obtuse tip : scapes $1.5-3 \mathrm{dm}$. tall, about $1 \mathrm{~mm}$. wide : spathes mostly red-purple, the primary bract $2-6 \mathrm{~cm}$. long, those of the spathes proper 1-1.6 $\mathrm{cm}$. long; first (outer) bract of the outer spathe mostly not longer than the inner one or even shorter: perianth rather smaller than that of the preceding species, deep violet-blue.

In wet meadows, North Carolina. Spring.

9. Sisyrinchium capillàre Bicknell. Plants extremely slender and delicate, 2-4.5 dm. tall, in thin tufts, closely fibrillose at the base, glaucescent, drying a dull olive-green. Leaves almost filiform, $0.5 \mathrm{~mm}$. wide or less, attenutate, often developing hardened tips, like the spathes often dull purple at the base: scapes $\frac{1}{2}-\frac{1}{3}$ again higher than the leaves which they resemble, smooth, firm-margined : spathes mostly in pairs, sometimes solitary or 3 together, sessile and subtended by an elongated $(2-8.5 \mathrm{~cm}$.) slender, accessory bract : bracts of the spathe nearly equal, $10-13 \mathrm{~mm}$. long, narrowly acute or aculeate : flowers on slenderly exserted finally spreading pedicels : perianth light violet-blue, $6-8 \mathrm{~mm}$. long : capsules pale, subglobose, $2-3 \mathrm{~mm}$. high : seeds $0.75 \mathrm{~mm}$. in diameter, distinctly alveolate.

In flat sandy woods, North Carolina to Florida. Spring.

10. Sisyrinchium bifórme Bicknell. Plants in scant tufts, 20-40 cm. high, pale green and glaucescent. Roots stout and simple: leaf-blades $1-1.5 \mathrm{~mm}$. wide, very acute, prominently close-nerved, the edges smooth: scapes often twice the height of the leaves, and as stiff, narrow, simple or with 1-3 terminal peduncles, sinuous or straight, subterete, the smooth margins sometimes almost obsolete: peduncles $5-7 \mathrm{~cm}$. long, longer than the erect bracteal leaf : spathes narrow, often subterete at the base, $1.5-3 \mathrm{~cm}$. long, the bracts stiff, cuspidate-acute, the inner one mostly longer than the outer, flattened-navicular, with an incurved apex : interior scales crowded, nearly equalling the bracts : pedicels erect, slightly exserted : capsules dark brown, 5-7 mm. high, broadly oblong, many-seeded : seeds 1-1.25 $\mathrm{mm}$. in diameter, coarsely pitted.

In dry soil, San Felipe, Texas. Spring.

11. Sisyrinchium intermédium Bicknell. Plants tufted 1.5-3.5 dm. tall, dull green, turning dark in drying. Leaves erect; blades $1.5-2.5 \mathrm{~mm}$. wide, attenuate, and cuspidate-acute, thin and grass-like, the edges serrulate to smooth : scapes mostly twice as long as the leaves, straight, frail, $1-2.5 \mathrm{~mm}$. wide, the thin wings fine-serrulate: peduncles $1-2,3-7 \mathrm{~cm}$. long : spathes mostly purple, narrow, rather sharply 2 -edged, the sides margined below by the ascending wings of the scape or peduncle, the bracts thin, glabrous, the outer one $2-6 \mathrm{~cm}$. long, on simple scapes prolonged beyond the inner 1-4 cm., the edges not united below ; inner bracts 1.5-2 $\mathrm{cm}$. long: perianth pale-blue, $8-14 \mathrm{~mm}$. long : ovary glabrous : capsules dark, thin-walled, about $4 \mathrm{~mm}$. high, on slender flexuously spreading pedicels.

In sandy soil, New Jersey to North Carolina. Late spring.

12. Sisyrinchium versícolor Bicknell. Plants tufted, becoming $3.5 \mathrm{dm}$. tall, pale green or glaucous, not drying dark. Leaves rather stiff, rose-pink at the base; blades $1.5-3 \mathrm{~mm}$. wide, close-striate, the edges like those of the scape mostly serrulate-roughened : scapes 1-2.5 mm. wide, simple or frequently developing an erect bracteal leaf and 2 peduncles: spathes mostly purple-tinged, their bracts like the bracteal leaf roughened all over, with minute papillae, often prominently striate, the outer bract $2.5-5 \mathrm{~cm}$. long, much prolonged beyond the inner or little surpassing it when the scape is branched, the margins not united below, the inner bract $17-20 \mathrm{~mm}$. long: perianth pale blue, $10-12 \mathrm{~mm}$. long: capsules pale, about $3 \mathrm{~mm}$. in diameter, on delicate slenderly exserted pedicels.

In sandy soil, District of Columbia to North Carolina and Georgia. Spring.

13. Sisyrinchium xerophýllum Greene. Plants tufted, coarsely brown-fibrose at the base, dull green, glaucescent, drying dark brown. Leaves stiff, becoming flexuous, often longer than the scapes; blades $2-4 \mathrm{~mm}$. wide, elosely striate, transversely rugulose or granulose between the nerves, the edges obscurely roughened to smooth : scapes $2-3 \mathrm{~mm}$. wide, winged, above passing into the primary bract which subtends the lateral appearing cluster of 2-6 short-peduncled spathes : peduncles $2-6 \mathrm{~cm}$. or even $10 \mathrm{~cm}$. long, slightly 
curved : spathes 14-19 mm. long, sometimes slightly purplish: bracts firm-herbaceous, conspicuously hyaline-margined, nearly equal, somewhat keeled, acuminate : interior scales exserted at maturity : flowers 8-12 together: perianth violet-blue, $12 \mathrm{~mm}$. long or more : capsules 4-6 mm. high, on spreading or recurved pedicels : seeds rugulose, becoming fully $1 \mathrm{~mm}$. in diameter.

In dry sandy soil, peninsular Florida. Early spring.

14. Sisyrinchium fuscàtum Bicknell. Plants thinly tufted, rather stiff, $15-50 \mathrm{~cm}$. high, more or less fibrose at base, dull green and glaucescent, drying dark. Leaves firmly erect, becoming flexuous, long and slender ; blades $0.5-2.5 \mathrm{~mm}$. wide, close striate, the edges smooth or roughened: scapes straight and slender, longer than the leaves, 0.75-2 $\mathrm{mm}$. wide, narrowly winged: bracteal leaf narrow, erect, shorter than the peduncles: peduncles 2, approximate, subterete, short and erect, $2-6 \mathrm{~cm}$. long: spathes narrow, $1.5-1.8$ $\mathrm{cm}$. long, the subequal bracts firmly herbaceous, striate, cuspidate-acuminate: interior scales much shorter than the bracts: flowers blue, on erect exserted pedicels: perianth about $10 \mathrm{~mm}$. long, the narrow sepals and petals prominently veined : capsules $2.5-4 \mathrm{~mm}$. high, broadly subglobose, drying dark.

In sandy soil, western Florida to Mississippi. Spring.

15. Sisyrinchium incrustàtum Bicknell. Plants thinly tufted, $2.5-5 \mathrm{dm}$. tall, coarsely fibrose at the base, dull green and glaucescent, drying dark. Leaves erect; blades 1.5-3.5 mm. wide, aculeate-tipped, rather thin but firm, striate, harshly rugulose-scabrous to densely incrustate-roughened with pale papillae, the edges ciliolate-serrulate: scapes often sinuously curved, $1.5-3 \mathrm{~mm}$. wide, roughened like the leaves; nodes $1-2$, the lower one bearing an often much elongated bracteal leaf and 2-3 peduncles, the upper one terminating an outcurved prolongation of the scape 4-9 $\mathrm{cm}$. long, with a shorter bracteal leaf and peduncle: spathes $1.5-2.5 \mathrm{~cm}$. long, the nearly equal bracts acute to slenderly attenuate : interior scales shorter than the bracts : perianth violet-blue, about $8 \mathrm{~mm}$. long: capsules subglobose, dark, 3-4 mm. in diameter, on slightly exserted nearly erect pedicels : seeds finely pitted, $1-1.5 \mathrm{~mm}$. in diameter.

In moist sandy soil or open grassy woods, North Carolina. Summer.

16. Sisyrinchium rùfipes Bicknell. Plants thinly tufted, often very slender, 1.5-3 $\mathrm{dm}$. tall, with rufous or brown fibers at the base, rather bright green and glaucescent, partly turning a dull brownish green. Leaves becoming flexuous; blades 1-2.5 mm. wide, often granular-scabrous between the close nerves, the margins finely sharp-serrulate : scapes about as tall as the leaves, slender and often flexuous, about $1 \mathrm{~mm}$. wide, narrowly margined, the edges closely ciliolate-serrulate, bearing an erect slender bracteal leaf subtending a cluster of $2-3$ short-peduncled or merely stipitate spathes and sometimes also a short branch : spathes about $12 \mathrm{~mm}$. long, the bracts somewhat divergent : flowers $2-5$, on hairlike flexuous pedicels: perianth blue, about $8 \mathrm{~mm}$. long: anthers relatively large: capsules about $3 \mathrm{~mm}$. high.

On sand hills, North Carolina to Georgia. Early spring.

17. Sisyrinchium fibròsum Bicknell. Plants loosely tufted, $2-3 \mathrm{dm}$. tall, fibrouscoated at the base, pale and glaucescent, often yellowish green. Leaves firm; blades somewhat striate-nerved, mostly $2-3 \mathrm{~mm}$. wide, or some of them even $5 \mathrm{~mm}$. wide, the edges usually serrulate: scapes longer than the leaves, $2-3 \mathrm{~mm}$. wide, broadly winged, the edges mostly serrulate or even ciliolate; nodes $1-2$, each furnished with a foliaceous bracteal leaf which subtends 2 or 3 more or less diverging peduncles : peduncles $4-8 \mathrm{~cm}$. long: spathes $15-20 \mathrm{~mm}$. long, the bracts nearly equal, varying from herbaceous attenuate to scarious-obtuse and mucronulate : interior scales about $\frac{1}{2}$ the length of the bracts : flowers on delicate loosely erect slightly exserted pedicels : perianth pale violet-blue, $8-10 \mathrm{~mm}$. long: staminal column 4-5 mm. high : capsules pale and thick-walled, broadly ovoid, $3-4 \mathrm{~mm}$. high : seeds rugulose, $1 \mathrm{~mm}$. in diameter. [S. Carolinianum Bicknell, not Klatt.]

In woods or fields, North Carolina to Florida and Mississippi. Spring.

18. Sisyrinchium tórtum Bicknell. Plants thinly tufted, $1.5-3 \mathrm{dm}$. tall, pale and glaucous, coarsely fibrous at the base. Leaves erect, the longer ones nearly equalling the seapes; blades firm, $1.5-3 \mathrm{~mm}$. wide, finally close-striate, faintly vermiculate-rugulose between the nerves, the edges smooth or obscurely roughened: scapes usually one to four times spirally twisted, as wide as the leaf-blades, wing-flattened, usually with but one node: bracteal leaf short, broad-based, equalling the 2 peduncles or shorter: spathes 10-16 mm. long, usually abruptly broader and thicker than the peduncles, becoming $3 \mathrm{~mm}$. wide, the bracts nearly equal, rather thin and membranous : interior scales shorter than the bracts : flowers on loosely erect finally exserted pedicels : perianth pale blue, 8-10 $\mathrm{mm}$. long: staminal column short, 2-4 mm. high.

In sandy soil, Florida and Mississippi. Early spring. 
19. Sisyrinchium Floridànum Bicknell. Plants tufted, $2.5-5 \mathrm{dm}$. tall, densely fibrillose at the base, dull green and glaucescent. Leaves numerous, often equalling the scapes, becoming flexuous, thickish ; blades usually $2-3 \mathrm{~mm}$. wide, attenuate to the slender nearly terete apex, smooth-edged : scapes narrowly firm margined, $2-3 \mathrm{~mm}$. wide, smooth-edged: bracteal leaf shorter than the 2 or 3 usually erect very slender peduncles one of which is sometimes topped by 3 shorter peduncles: spathes green or slightly purplish, $15-20 \mathrm{~mm}$. long, the bracts nearly equal, mostly attenuate and acute : interior scales about equalling the bracts or slightly exserted : flowers on slender exserted pedicels : perianth pale blue, about $10 \mathrm{~mm}$. long: capsules pale, subglobose, $3-4 \mathrm{~mm}$. high.

In sand, peninsular Florida. Late winter and early spring.

20. Sisyrinchium Náshii Bicknell. Resembling S. Floridanum, but much more slender and delicate, and smaller throughout, flowering in midsummer instead of late winter and early spring. Leaves few ; blades $0.5-2 \mathrm{~mm}$. wide, less elosely and strongly striate than in the next preceding species, and frequently denticulate, especially toward the scarcely terete apex : scapes few, about twice as tall as the leaves, mostly $1 \mathrm{~mm}$. wide or less, like the leaves sometimes obscurely roughened with minute papillae, the very narrow margins usually minutely denticulate: bracteal leaf almost setaceously slender, much shorter than the almost filiform peduncles: spathes narrow, $13-15 \mathrm{~mm}$. long, the bracts mostly thinner and less sharply pointed than in S. Floridanum, the inner one frequently surpassing the outer and scarious obtuse at the apex : perianth smaller than that of $\dot{S}$. Floridanum: capsules $2-3 \mathrm{~mm}$. in diameter, on slenderly exserted pedicels $17-22 \mathrm{~mm}$. long: seeds finely rugulose-pitted.

In dry sandy soil, low pine land, peninsular Florida. Summer.

21. Sisyrinchium solstitiàle Bicknell. Plants thinly tufted, chaffy and slightly fibrillose at the base, 2-4.6 dm. tall or taller, pale green or glaucescent, becoming brownish green when dry. Leaves erect; blades very straight, becoming $4 \mathrm{~mm}$. wide, narrowed to the stiff acicular apex, striate-nerved and minutely rugulose, minutely serrulate, becoming smooth: scapes about twice as tall as the leaves, once or twice spirally twisted, becoming $3 \mathrm{~mm}$. wide, the firm wings hyaline-margined and obscurely serrulate, becoming smooth: inflorescence elongated, with 3 rather remote nodes each with a foliaceous bract and 2 peduncles or the lower one with a slender branch: spathes dull green, 20-25 mm. long, the bracts stiff, nearly equal, the outer one narrowly acuminate : interior scales finally equalling the bracts : perianth blue, about $12 \mathrm{~mm}$. long : flowers on slightly exserted pedicels.

In high pine lands, peninsular Florida. Summer.

22. Sisyrinchium recurvàtum Bicknell. Plants dull green, turning brownish when dry, 1.5-2.5 dm. high. Leaves about $\frac{3}{4}$ the height of the tufts ; blades $1.5-2.5 \mathrm{~mm}$. wide, erect but rather thin, not closely nerved, the edges smooth or nearly so: scapes wingmargined, sometimes obscurely serrulate, the single node supporting a short erect bracteal leaf and 2-3 peduncles 5-11 $\mathrm{cm}$. long: spathes 17-20 $\mathrm{mm}$. long, the inner bract mostly longer than the very acute outer one and apiculate from a scarious-obtuse apex : interior scales equalling the bracts or nearly so : flowers blue-purple, about $10 \mathrm{~mm}$. long: capsules on much exserted and recurved pedicels, subglobose or obovoid, dark brown, 2.5-4 mm. high : seeds $1 \mathrm{~mm}$. in diameter or less, close-pitted.

In sand, Longboat Key, Florida. Early spring.

23. Sisyrinchtum graminoìdes Bicknell. Plants often not tufted, $1.5-6 \mathrm{dm}$. high, rather bright green, turning dark when dry. Leaves thin and grass-like, $\frac{1}{2}-\frac{3}{4}$ the height of the scape ; blades 1.5-6 mm. wide, the edges like those of the scape minutely serrulate: scapes thin, wing-flattened, as broad as the leaf-blades, mostly forking into two peduncles $5-20 \mathrm{~cm}$. long, subtended by a conspicuous bracteal leaf : spathes green, flat, the subequal or unequal bracts acute or acuminate, $15-20 \mathrm{~mm}$. long, the interior scales much shorter : perianth blue, $10 \mathrm{~mm}$. long : capsules thin-walled, subglobose, 3-6 $\mathrm{mm}$. high, on slender spreading pedicels : seeds numerous, about $1 \mathrm{~mm}$. in diameter, globose, pitted.

In grassy places and low meadows, Newfoundland to Minnesota. Florida and Texas. Spring and summer.

24. Sisyrinchium membranàceum Bicknell. Plants loosely erect or assurgent, in thin tufts, $20-25 \mathrm{~cm}$. high, scarcely glaucescent, drying brownish green. Leaves half the height of the stem or more; blades $1.5-3.5 \mathrm{~mm}$. wide, thin and membranous, prominently few-nerved, mostly serrulate-roughened, cuspidate-acute : scapes similar to the leaves, broadly thin-winged, mostly with 1 node bearing a short bracteal leaf $2-6 \mathrm{~cm}$. long and two slender peduncles $4-10 \mathrm{~cm}$. long: bracts of the spathe subequal, cuspidate-acute, thin and delicately veined, mostly about $1.5 \mathrm{~cm}$. long : interior scales often equalling the bracts : perianth violet-blue: sepals and petals rather firm and membranous, $10-12 \mathrm{~mm}$. long: capsules dark, subglobose, $3.5 \mathrm{~mm}$. high, on slenderly exserted pedicels : seeds only $2-3$ in each cavity.

In sand, Jackson County, Florida. Spring. 
25. Sisyrinchium tenéllum Bicknell. Plants loosely tufted, $1.5-3 \mathrm{dm}$. tall, dull green, drying dark. Leaves usually openly erect; blades soft, very thin, 1-3 mm. or even $4 \mathrm{~mm}$. wide, distinctly few-nerved, mostly smooth-edged : scapes as long as the leaves or longer, weakly erect, $1-3.5 \mathrm{~mm}$. wide, mostly with broad thin wings, usually with a single node: bracteal leaf erect, usually long and narrow, mostly surpassing the 2 slender peduncles: peduncles $3-12 \mathrm{~cm}$. long: spathes green, narrow, often deflected, the bracts membranous, weakly or obscurely few-nerved, slenderly attenuate and very acute, the outer one usually somewhat prolonged, $12-25 \mathrm{~mm}$. long: interior scales $\frac{1}{2}$ the length of the spathes or less : flowers $3-5$ : perianth violet-blue, $5-8 \mathrm{~mm}$. long: capsules $1.5-3 \mathrm{~mm}$. high, on capillary exserted pedicels : seeds $2-3$ in each cavity, rough, $0.75 \mathrm{~mm}$. in diameter.

In moist soil, Georgia and Alabama. Late spring.

26. Sisyrinchium dichótomum Bicknell. Plants yellowish green and glaucescent, not drying dark, in thin tufts 3-4 dm. high. Leaves half the height of the plant or more, blades $2-6 \mathrm{~mm}$. wide, thin but firm, openly nerved, the edges serrulate to smooth : scapes broadly thin-winged, more or less dichotomously branched mostly above the middle, from 2-4 successive nodes: bracteal leaves prominent: lower peduncles sometimes over $10 \mathrm{~cm}$. long, the uppermost only $3-5 \mathrm{~cm}$. long, often curved : spathes green, small and narrow, the inner bract $8-15 \mathrm{~mm}$. long, the outer one mostly surpassing it, both thin and slendertipped: perianth very small, white, about $5 \mathrm{~mm}$. long: staminal column $2-3 \mathrm{~mm}$. high : capsules pale, thin-walled, subglobose, about $3 \mathrm{~mm}$. high, on slender flexuously exserted pedicels : seeds only 1-2 in each cavity, large, 1.5-2 mm. in diameter, becoming smooth or nearly so.

In woods, Rutherford County, North Carolina. Spring.

27. Sisyrinchium flagéllum Bicknell. Plants very slender and flexuous, 1-3.2 dm. high, slightly glaucescent, drying dark. Leaves as long as the scapes or shorter; blades narrow and flexuous, $0.5-3 \mathrm{~mm}$. wide, few-striate, smooth-edged : scapes $0.75-1.5 \mathrm{~mm}$. $\mathrm{mm}$. wide, narrowly margined, smooth-edged, often flexuous and geniculate at the nodes: nodes 1-2, when two remote, supporting narrow bracteal leaves and 1-3 very slender peduncles $5-12 \mathrm{~cm}$. long: spathes often deflected, $1.5-2 \mathrm{~cm}$. long, the bracts subequal or the inner one longer, and often scarious-margined to the apex, the outer one narrowly acuminate: interior scales much shorter than the bracts : capsules on erect slightly exserted pedicels, subglobose, dark, about $4 \mathrm{~mm}$. high : seeds globose, finely alveolate, about $1 \mathrm{~mm}$. in diameter.

In sand, southern and western peninsular Florida. Also in Cuba. Late winter and early spring.

28. Sisyrinchium Miamiénse Bicknell. Plants dull green and glaucescent, drying dark, $2 \mathrm{dm}$. tall or more. Leaves about $\frac{3}{4}$ the height of the plant; blades 1-1.5 mm. wide, striate-nerved, serrulate: scapes of the width of the leaves, wing-margined, denticulate-serrulate, bearing $2-3$ erect peduncles at the top and sometimes an ascending branch lower down: peduncles $3-7 \mathrm{~cm}$. long: spathes $1.3-1.5 \mathrm{~cm}$. long, the outer bracts stiffly acute, slightly longer than the scarious-obtuse inner one: perianth blue, mediumsized : capsules on exserted pedicels, dark, obovoid, $3-5 \mathrm{~mm}$. high : seeds subglobose, 1-1.25 mm. in diameter, faintly rugulose-pitted.

In sand, eastern peninsular Florida. Early spring.

29. Sisyrinchium longifòlium Bicknell. Plants tall and slender, in thin erect tufts $5-8 \mathrm{dm}$. high, yellowish green and glaucescent. Roots thickened and clustered: leaves very long, about equalling the scapes, erect, becoming flexuous; blades $1.5-2.5 \mathrm{~mm}$. wide, thickish, closely striate-nerved, mostly smooth-edged, attenuate to the subterete apex, 1.5-2.5 $\mathrm{mm}$. wide: scapes narrowly firm-margined, with 1 or 2 nodes high up, each supporting a short stiff bracteal leaf and a cluster of 3-5 slender, unequal peduncles $5-10 \mathrm{~cm}$. long: spathes narrow, $18-22 \mathrm{~mm}$. long, the bracts subequal, stiffly attenuate, very acute : interior seales crowded, sometimes exceeding the bracts : pedicels slightly exserted: perianth very pale blue, $12 \mathrm{~mm}$. long, or more : capsules light brown, thin-walled, subglobose, 5-6 mm. high, the valves developing lateral nerves.

In sand, Manatee, Florida. Spring.

30. Sisyrinchium corymbòsum Bicknell. Plants $3-7.5 \mathrm{dm}$. tall, in scant tufts, pale dull green and glaucescent, the roots coarse and woody. Leaves stiff and thickish, 3-4 $\mathrm{dm}$. long; blades striate-nerved, 1.5-3 mm. wide, mostly smooth-edged : scapes $1.5-4 \mathrm{~mm}$. wide, firmly wing-margined, stifly long-branched above into an erectly subcorymbose several times compound inflorescence or the inflorescence scant and little branched in weak plants : bracteal leaves often purplish, the upper ones reduced : branches and slender peduncles $7-14 \mathrm{~cm}$. long : spathes small, $12-15 \mathrm{~mm}$. long, the subequal bracts thin and membranous, delicately close-nerved, acute or subulate: interion scales much shorter than the bracts: flowers numerous on exserted pedicels : perianth blue, 8-12 $\mathrm{mm}$. long: capsules 
broadly oblong, $2.5-5 \mathrm{~mm}$. high, dark and thick-walled : seeds globose, $1 \mathrm{~mm}$. in diameter, faintly pitted or almost smooth.

In sand or sandy soil, Florida and Alabama. Spring.

31. Sisyrinchium Atlánticum Bicknell. Plants tufted, pale and glaucous, 2-6 dm. tall. Leaves commonly much shorter than the scapes, firm; blades like the scapes mostly $1 \mathrm{~mm}$. wide or less and smooth-edged : scapes wiry and narrowly firm-margined : nodes 1 or 2 bearing narrow bracteal leaves and usually two slender peduncles: spathes often purplish, 10-16 mm. long, the subequal bracts thin, the outer one acute, the inner mostly scarious-obtuse, longer than the interior scales : perianth violet-blue, $8-10 \mathrm{~mm}$. long: capsules oblong to subglobose, dark, thick-walled, 2-4 mm. high, on erect little exserted pedicels : seeds numerous, $0.5-1 \mathrm{~mm}$. in diameter, finely wrinkled-pitted to nearly smooth.

In salt marshes or in sandy soil, mostly near the coast, Maine to Florida.

32. Sisyrinchium fléxile Bicknell. Plants tall and very slender, becoming $5 \mathrm{dm}$. tall or more, pale green but scarcely glaucous. Leaves long, the longer ones equalling the scapes, stiff, becoming flexuous; blades about $1.5 \mathrm{~mm}$. wide, closely few-striate, very smooth, the tips finally hardened: scapes flexuous, subterete and narrowly firm-margined: nodes 1 or 2 , bearing narrow bracteal leaves and nearly terete peduncles $3-7 \mathrm{~cm}$. long, mostly in pairs : spathes $1.5 \mathrm{~cm}$. long or more, narrow, subterete at the base, the stiff, subequal bracts closely striate, their tips acute or narrowly scarious-obtuse : capsules brown, rather thick-walled, broadly oblong, 4-6 mm. high on erect somewhat exserted pedicels : seeds numerous, $0.5-1$ $\mathrm{mm}$. in diameter, alveolate.

Along the coast, Mississippi. Spring.

33. Sisyrinchium violàceum Bicknell. Plants light green, drying yellowish and brownish, the roots rather thick. Leaves erect or firmly ascending, mostly $\frac{1}{2}$ the height of the scapes or less ; blades 1-2.5 mm. wide, strongly nerved: scapes $1.5-2.0 \mathrm{dm}$. high or finally $3.5 \mathrm{dm}$. high, 1-2 mm. wide, stiff, narrowly firm-margined, the edges smooth: peduncles terminal, $2-3$, unequal, $4-8 \mathrm{~cm}$. long, the bracteal leaf short and stiffly erect: spathes $1.5-3.0 \mathrm{~cm}$. long, the bracts subequal, firmly nerved and finely puncticulate, acute or the inner one obtuse : flowers pale violet, rather large, on pedicels subequal with the bracts : perianth 1-1.5 $\mathrm{cm}$. long : staminal column $5 \mathrm{~mm}$. high or more : capsules dark, thick-walled, ovoid-subglobose, $2-3 \mathrm{~mm}$. high : seeds few, $1 \mathrm{~mm}$. in diameter or more, rugulose-pitted.

In woods, Walton County, Florida. Summer.

34. Sisyrinchium nànum Bicknell. Plants low and stiff, $1.2 \mathrm{dm}$. tall or more, pale and glaucous, not fibrose at the base. Leaves sometimes equalling the scapes; blades 1-2 $\mathrm{mm}$. wide, close-striate: scapes stiff, with firm narrow margins, the edges smooth: peduncles one or more, short: spathes about $1.5 \mathrm{~cm}$. long, the bracts closely striate, the outer bract acute, sometimes shorter than the scarious-obtuse inner one : flowers on slightly exserted pedicels : perianth bright violet-blue, about $10 \mathrm{~mm}$. long: staminal column $4 \mathrm{~mm}$. high or less.

Along the coast, Mississippi. Late spring and early summer.

35. Sisyrinchium Tràcyi Bicknell. Plants slightly glaucescent, discoloring somewhat when dry, rather stout, stiff, 3.5-7 dm. high. Leaves $\frac{3}{4}$ the height of the plant or more; blades 1-3 mm. wide, close-striate: scapes rigid, often curved, narrowly firm-margined, like the leaves very smooth and as wide: inflorescence stiff and often contracted, from 2 nodes, the lower one often bearing 1 or 2 short branches: peduncles mostly in clusters of 3 's-4's, slender, stiff, approximate, the upper 3-5 cm. long: lower bracteal leaf elongated : bracts of the spathe strongly close-striate, subequal, $15-22 \mathrm{~mm}$. long, the outer one often abruptly short-acuminate, the inner mostly scarious-obtuse: flowers on scarcely exserted pedicels: perianth violet-blue, $10-12 \mathrm{~mm}$. long, with long-aristulate sepals and petals: staminal column $5-6 \mathrm{~cm}$. high.

In sandy soil, southern Mississippi. Spring.

36. Sisyrinchium scopàrium Bicknell. Plants pale and glaucous, in close tufts $1.5-5 \mathrm{dm}$. high. Leaves very slender, equalling the shorter scapes; blades 1-1.75 mm. wide, the edges mostly smooth: scapes narrowly wing-margined: inflorescence sometimes scant but often appearing dense from the numerous clustered scapes, mostly arising from 2 nodes each bearing a short bracteal leaf and 2-3 somewhat diverging usually short peduncles: spathes $1.2-1.8 \mathrm{~cm}$. long, the subequal bracts striate-nerved, acuminate: perianth violet-blue, 8-10 $\mathrm{mm}$. long: staminal column about $4 \mathrm{~mm}$. high : capsules clustered on pedicels about equal with the bracts, dark, thick-walled, remaining slightly puberulent at maturity, $2-5 \mathrm{~mm}$. high : seeds $1 \mathrm{~mm}$. in diameter, flnely pitted.

On or near the coast, Mississippi. Spring. 
37. Sisyrinchium mìnus Engelm \& Gray. Plants ascending, in loose tufts, deep green, usually turning very dark when dry; blades thin, delicately nerved, $2-7 \mathrm{~cm}$. long, 1-4 mm. wide, the edges roughened: scapes $0.5-2.5 \mathrm{dm}$. long, branched and leafy from near the base, margined or narrowly winged, the nodes 2-6, the branches and peduncles more or less diverging or outcurved : peduncles $4-6 \mathrm{~cm}$. long, the ultimate ones a diverging pair, or solitary : spathes flattened, the bracts very unequal, the larger outer one foliaceous, $1.3-3.5 \mathrm{~cm}$. long: flowers on hair-like slightly exserted pedicels : perianth very small, 5-6 mm. long, reddish purple or yellowish white : capsules light brown, corrugated, oblong, $3-5 \mathrm{~mm}$. high : seeds very small, $0.5-0.75$ in diameter, strongly pitted.

In damp soil or low prairies, central and eastern Texas to Louisiana. Spring.

38. Sisyrinchium colubríferum Bicknell. Plants suberect or spreading, in firm, leafy tufts $2 \mathrm{dm}$. tall or more, dull green, turning brownish, mostly purplish at the nodes. Leaf-blades broad and thin, $5-7 \mathrm{~mm}$. wide, the edges mostly smooth : scapes numerous, branched from near the often outcurved base, the internodes and often compound branches more or less stiffly sinuous, broadly thin-winged, $2-5 \mathrm{~mm}$. wide, the edges denticulate-serrulate: peduncles in clusters of $3-4$, mostly curved, $5-10 \mathrm{~cm}$. long: bracts of the spathe thin, closely many-nerved, acuminate, the outer one a little the longer: flowers on somewhat exserted pedicels : perianth light violet-blue, about $10 \mathrm{~mm}$. long: staminal column short, $4 \mathrm{~mm}$. high : capsules on somewhat spreading pedicels, $4 \mathrm{~mm}$. high or more; the valves distinctly 3 -nerved.

In sandy soil, eastern Texas. Spring.

39. Sisyrinchium rosulàtum Bicknell. Plants ascending or prostrate in small rosulate tufts or larger plants becoming $2 \mathrm{dm}$. high, pale green, not drying dark : leaves $2-8$ $\mathrm{cm}$. long; blades 1-2 mm. wide, the margins serrulate: scapes often branched from near the base and geniculate, the nodes 2 or more, each supporting mostly two peduncles: peduncles mostly long and slender, $2-10 \mathrm{~cm}$. long, often more broadly margined than the scape : spathes relatively large, about $2 \mathrm{~cm}$. long, the bracts foliaceous, equal or unequal : perianth reddish purple, rather small : capsules broadly globose, on capillary flexuously spreading pedicels, pale but purplish tinged, $2.5-3.5 \mathrm{~mm}$. high the valves without lateral nerves : seeds numerous, very small, $0.5-0.75 \mathrm{~mm}$. in diameter, finely alveolate.

In sandy soil, Mobile, Alabama and Charleston, South Carolina. Spring.

40. Sisyrinchium Hélleri Bicknell. Plants 0.8-2 dm. tall, spreading or suberect in stiff, loosely many-stemmed tufts, glaucescent, turning dark. Leaves about $\frac{1}{2}$ the length of the scapes; blades 1-2 mm. wide, thin, mostly smooth-edged : scapes 1-1.5 mm. wide, mostly geniculate at the 1 or 2 nodes, narrowly firm-margined, the edges smooth or denticulate : peduncles 2-4, more or less unequal and diverging, $3-9 \mathrm{~cm}$. long, sometimes twice the length of the scapes, longer than the bracteal leaves: spathes $1.5-1.8 \mathrm{~cm}$. long, the bracts closely fine-striate, acuminate, the inner one usually the longer : flowers on erect pedicels equalling or much surpassing the bracts : perianth deep blue, $10 \mathrm{~mm}$. long or more: capsules on spreading or recurved pedicels, dark, subglobose or obovoid, 4-7 mm. high, the valves not 3-nerved: seeds rather large, 2-5 in each cavity.

On the coast, southeastern Texas. Spring.

41. Sisyrinchium implicàtum Bicknell. Plants densely tufted, the numerous slender scapes mostly curved or ascending in a loose entanglement, pale dull green and glaucescent. Leaf-blades $0.5-1 \mathrm{~mm}$. wide, few-nerved : scapes $15-20 \mathrm{~cm}$. long, longer than the leaves, less than $1 \mathrm{~mm}$. wide, firm but frail, narrowly margined, the edges smooth or denticulate, geniculate above at the single node which supports a pair of short capillary peduncles 2-4 cm. long, subequal with their slender bracteal leaf : spathes very small, $1.0-$ $1.5 \mathrm{~cm}$. long, the subequal bracts close-nerved, slenderly acute or the inner one scariousobtuse and apiculate : flowers small on hair-like slightly exserted pedicels : perianth delicate, pale blue, about $8 \mathrm{~mm}$. long: staminal column 4-5 mm. high.

In wet bottoms, Calhoun County, Mississippi. Spring.

42. Sisyrinchium fláccidum Bicknell. Plants forming many-scaped finally diffuse or spreading tufts, 1-2 dm. high, rather deep green, turning dark when dry. Leaves frèquently as long as the scapes; blades thin and lax, delicately nerved, 1-3 mm. wide, the edges smooth: bracteal leaves elongated: scapes weak, $0.5-1.5 \mathrm{~mm}$. wide, two-edged or narrowly thin-winged, the edges mostly smooth : nodes mostly 2 : peduncles very straight and slender, "4-9 cm. long: spathes narrow, the thin bracts delicately many-nerved, narrowly acuminate or acute, $13-20 \mathrm{~mm}$. long, the outer one often the longer: perianth deep purple-blue, $8-10 \mathrm{~mm}$. long : ovary glabrous.

on prairies, eastern Texas. Spring.

43. Sisyrinchium pruinòsum Bicknell. Plants glaucescent, not darkening when dry, $1.5-2.5 \mathrm{dm}$. high, the sides of the scapes, leaf-blades and bracts closely roughened all 
over with minute whitish points. Leaves about $\frac{3}{4}$ the height of the plant; blades 1-3.5 $\mathrm{mm}$. wide, rather thin, the edges smooth : scapes $1-2.5 \mathrm{~mm}$. wide, sometimes rather broadly thin-winged ; nodes 1-2, the first one usually low on the scape: peduncles 2-3 together, straight and slender, $5-12 \mathrm{~cm}$. long, surpassing the bracteal leaves, sometimes longer than the main scape: spathes narrow, the bracts slenderly sharp-attenuate, delicately manynerved, the usually longer outer one $1.5-3 \mathrm{~cm}$. long : flowers on hair-like, flexuously much exserted and recurved pedicels: perianth violet-blue, with a broad pale yellow center, 10 $\mathrm{mm}$. long or more : ovary glabrous.

In woods and on prairies, Dallas, Texas. Spring.

44. Sisyrinchium longipedunculàtum Bicknell. Plants pale green and glaucescent, about $5 \mathrm{dm}$. tall, the roots rather few and coarse. Leaves dry and stiff, over half the height of the plant; blades $2-4 \mathrm{~mm}$. wide, firmly close-nerved, slenderly attenuate, the sharp edges close-serrulate: scapes few or solitary, $2.5 \mathrm{~mm}$. wide, stiff, the wing-margins sharp-serrulate : bracteal leaf much shorter than the 2 very long slender peduncles which are sometimes $1.8 \mathrm{dm}$. long: spathes about $2.6 \mathrm{~cm}$. long, very narrow, almost subterete, the stiff, obscurely nerved nearly equal bracts cuspidate-acute: capsules pale brown, on nearly erect, slightly exserted pedicels, large, obovoid-oblong, becoming $7.5 \mathrm{~mm}$. high: seeds 1.5-2 mm. in longer diameter, at length smooth and somewhat shining.

In dry soil, Gaudaloupe Mountains, and probably further east, Texas. Spring.

45. Sisyrinchium ensígerum Bicknell. Plants stiff and pale glaucous-green, drying pale, 1-4 dm. high. Leaf-blades $1.5-4 \mathrm{~mm}$. wide, often ensiform and outcurved, firmly close-nerved, the edges usually serrulate: scapes rigid, erect or outcurved, sometimes branched, $1.5-3.5 \mathrm{~mm}$. wide, the firm wing-margins rough-serrulate: peduncles $2-4$ together, short or long, stout or slender : spathes mostly $2-2.5 \mathrm{~cm}$. long, but sometimes much longer, the outer bract even $4.5 \mathrm{~cm}$. long, broadly flattened or narrow, the stiff thickish bracts strongly nerved, mostly attenuate: flowers on pedicels equalling or longer than the bracts : perianth pale violet-blue, $1-1.5 \mathrm{~cm}$. long: staminal column about $5 \mathrm{~mm}$. high : ovary puberulent: capsules pale and rather thick-walled, 4.5-5 mm. high.

On prairies, south-central to northwestern Texas. Spring.

46. Sisyrinchlum várians Bicknell. Plants erect or ascending, $1.5-3 \mathrm{dm}$. tall, light green and glaucescent, often discoloring somewhat when dry. Leaves rather thin and soft to firm ; blades $1.5-4 \mathrm{~mm}$. wide, the nerves evident, the edges smooth: bracteal leaves often much elongated : scapes $1.5-3 \mathrm{~mm}$. wide, narrowly winged, the edges smooth to denticulate ; nodes 1-3: peduncles 2-3 together: spathes mostly narrow, the somewhat unequal bracts finely many-nerved, the longer outer one $2-3 \mathrm{~cm}$. long or sometimes more, narrowly acute or more foliaceous and somewhat incurved : flowers on slightly exserted pedicels : perianth light-blue, $8-13 \mathrm{~mm}$. long : staminal column $4-5 \mathrm{~mm}$. high : ovary glabrous.

On prairies, central and eastern Texas and the Indian Territory. Spring.

47. Sisyrinchium amoènum Bicknell. Plants erect in many-scaped tufts, becoming $3 \mathrm{dm}$. tall, or more, yellowish green and glaucescent, brownish green when dry, the spathes mostly purplish. Leaves of ten equalling the scrapes, not rigid ; blades $1-3 \mathrm{~mm}$. wide, fine-nerved, the edges smooth: scapes narrowly winged, 1-2 $\mathrm{mm}$. wide, the edges mostly smooth, usually two-branched from about the middle, each branch bearing 2-4 shorter peduncles: lower bracteal leaf elongated: peduncles mostly short and somewhat curved : spathes $15-18 \mathrm{~mm}$. long, the bracts subequal, short-attenuate, finely close-nerved, the interior scales little shorter: flowers rather large: perianth deep purple-blue, about 12 $\mathrm{mm}$. long on an erect pedicel equalling the bracts : staminal column $5 \mathrm{~mm}$. high : ovary glabrous.

On prairies, eastern Texas. Spring.

48. Sisyrinchium Braỳi Bicknell. Plants stiff, erectly ascending, about $1.5 \mathrm{dm}$. tall, much darkened when dry. Leaves nearly equalling the scape, firm; blades often curved, 1-2 mm. wide, smooth or minutely denticulate : scapes often outcurved below, 1-1.5 mm. wide, narrowly margined, the edges cartilaginous and denticulate; nodes 1 or 2 , the lower mostly below the middle: peduncles solitary or 2-4 together, stiff and slender, $3-8 \mathrm{~cm}$. long: spathes narrowly oblong, about $1.5 \mathrm{~cm}$. long, the subequal bracts firmly membranous and finely many-nerved, very acute, the interior scales but little shorter : flowers on erect pedicels subequal with the bracts : perianth bright-blue, about $10 \mathrm{~mm}$. long : ovary glabrous : capsules apparently very small, the valves 3-nerved.

On prairies, eastern Texas. Spring.

49. Sisyrinchium furcàtum Bicknell. Plant forming close many-scaped tufts, $10-20$ $\mathrm{cm}$. high, bright yellowish green, turning duller or brownish, the spathes and nodes usually purplish. Leaf-blades $0.5-2 \mathrm{~mm}$. wide, closely striate-nerved, the edges mostly smooth, 
the sides below, as well as the scapes and bracts, sometimes incrustate-roughened : scapes 0.5$1.5 \mathrm{~mm}$. wide, narrowly thin-winged or margined : peduncles $2-3$, slender, 4-6 $\mathrm{cm}$. long: spathes mostly $1.5-2 \mathrm{~cm}$. long, the bracts membranous and delicately nerved, acute or acuminate, equal, or the outer one longer: interior scales $\frac{1}{2}$ the length of the bracts: flowers on erect mostly not exserted pedicels: perianth deep purple-blue, 10-12 mm. long: staminal column 4-5 mm. high, usually less than $\frac{1}{2}$ the length of the perianth : ovary densely glandular puberulent or tomentulose.

On prairies, Arkansas to Mississippi and Texas. Spring.

50. Sisyrinchium Langloìsii Greene. Plants ascending or erect, in loose tufts, 6$25 \mathrm{~cm}$. tall, dull green turning dark. Leaves often equalling the scapes; blades from almost capillary to over $1 \mathrm{~mm}$. wide, firm, the edges smooth: scapes very slender, the narrow margins smooth to denticulate, the node often low down or nearly basal, bearing 2-3 extremely slender peduncles 4-9 $\mathrm{cm}$. long: spathes narrow, about $1.5 \mathrm{~cm}$. long, the bracts rather stiff and firmly close-nerved, narrowly attenuate, equal, or the outer one sometimes longer : flowers on hair-like, slenderly exserted pedicels : perianth pale blue, less than 10 $\mathrm{mm}$. long: staminal column 4-5 $\mathrm{mm}$. high, usually over $\frac{1}{2}$ the length of the perianth: ovary sparsely puberulent.

On prairies, Louisiana and Texas. Spring.

51. Sisyrinchium Búshii Bicknell. Plants erect, or at length spreading or depressed, in small tufts $6-15 \mathrm{~cm}$. tall, pale and glaucescent. Leaves shorter than or equalling the scapes; blades 1.5-2 mm. wide, firmly close-nerved, the edges smooth or denticulate : scapes sometimes geniculate at the first node, 1-2 mm. wide, the firm margins denticulate : nodes 1-2, the first one often low down, bearing 2-4 peduncles: spathes 12-20 $\mathrm{mm}$. long, the bracts equal or either one slightly the longer, closely nerved, acute or the inner obtuse, the interior scales scarcely shorter : flowers on well exserted often recurved pedicels : perianth pale violet-blue, $8-12 \mathrm{~mm}$. long: ovary puberulent to glabrate.

In dry soil, the Indian Territory and Texas. Spring.

52. Sisyrinchium Cánbyi Bicknell. Plants diminutive, 4-6 $\mathrm{cm}$. tall, in tufts of several stiffly ascending scapes, dull glaucescent green. Leaf-blades mostly only $0.5 \mathrm{~mm}$. wide, prominently nerved, the edges, as are those of scapes and peduncles, finely cartilaginous-denticulate: scapes very narrow, mostly branched about the middle into two slightly curved peduncles $1.5-2.5 \mathrm{~cm}$. long with a subequal bracteal leaf : spathes narrowly oblong, the acute or obtuse bracts close-nerved, 10-12 $\mathrm{mm}$. long, the outer one often linear-attenuate : interior scales nearly equalling the bracts : flowers on exserted pedicels : perianth 6-8 $\mathrm{mm}$. long, bright purplish blue : staminal column $3 \mathrm{~mm}$. high : ovary glabrous.

On prairies, eastern Texas. Early spring.

53. Sisyrinchium Texànum Bicknell. Plants $1.2-2.5 \mathrm{dm}$. tall, dull green and glaucescent, mostly discolored when dry. Leaves usually equalling the scapes ; blades 1-2.5 $\mathrm{cm}$. wide, close-striate, the edges mostly smooth : scapes narrow-margined, smooth-edged or denticulate, 1-2 mm. wide; node mostly one, supporting an erect bracteal leaf mostly longer than the 2-3 diverging peduncles : peduncles slender, 5-12 cm. long: spathes rather short and broad-based, becoming pale and somewhat turgid on the sides, the bracts stiff, strongly few-nerved, subequal or the attenuate or acute outer one longer: inner bract usually very obtuse and scarious at the apex, about $1.5 \mathrm{~cm}$. long: interior scales nearly as long: flowers on erect, slightly exserted pedicels : perianth light violet-blue, $10-15 \mathrm{~mm}$. long: ovary glabrate or nearly so : capsules dark, thick-walled, 3-5 $\mathrm{mm}$. high, the valves usually apiculate and bearing submarginal nerves.

On prairies, eastern Texas and Louisiana. Spring.

\section{HERBÉRtia Sweet.}

Caulescent herbs, with coated bulb-like rootstocks. Leaves few : blades narrow, elongated, slightly folded. Flowers several in the solitary, terminal spathe. Perianth showy, long-pediceled : members 6 , distinct ; sepals 3 , more or less spreading ; petals 3 , much smaller. Stamens 3 : filaments united into a tube which is adnate to the perianth : anthers narrow, sessile on the tube. Ovary 3-celled : styles partially united, the distinct portions 2-cleft, opposite the anthers. Ovules numerous in each cavity. Capsule exserted, slightly elongated, loculicidally 3-valved. Seeds rather numerous, angled.

Perianth blue: sepals obovate: petals oblanceolate.

Perianth purple: sepals oblanceolate: petals obovate.

1. H. Diummondiana. 2. H. Watsonii.

1. Herbertia Drummondiàna Herb. Stems 1-3 dm. tall, simple or forked : leaves mainly basal, erect, often 4 ; blades linear, about equalling the top of the stem : spathes. 
3-5 cm. long: perianth blue, $4-5 \mathrm{~cm}$. broad, fugacious : sepals obovate, with white and violet-spotted claws : petals oblanceolate, acute : filament-tube $4 \mathrm{~mm}$. long, blue : capsules oblong-cavate, $2-2.5 \mathrm{~cm}$. long.

On prairies, Texas. Spring.

2. Herbertia Watsònii Baker. Stems 1-2 dm. tall : leaves mainly basal, usually $1-2$; blades sheathing at the base: spathe about $3 \mathrm{~cm}$. long: perianth purple, about $5 \mathrm{~cm}$. broad : sepals oblanceolate, about $2.5 \mathrm{~cm}$. long: petals obovate, $6 \mathrm{~mm}$. long: filaments united nearly to the top, $6 \mathrm{~mm}$. long.

On damp prairies, Texas. Spring.

\section{6. İRIS L.}

Herbs, with creeping or horizontal, sometimes tuber-bearing rootstocks. Leaves equitant : blades sword-shaped. Flowers solitary or in terminal panicles. Perianth more or less highly colored, usually showy : tube narrow below : lobes various, the 3 outer dilated, spreading or recurved, the 3 inner smaller, often erect, sometimes nearly as large as the outer. Stamens 3: filaments adnate to the bases of the outer perianth-lobes : anthers narrow. Ovary 3 -celled : styles petal-like, arching over the stamens, adnate to the ovary at the base : stigmas under the usually two-lobed style-tips. Ovules numerous. Capsule somewhat elongated, 3-6-angled or 3-6-lobed. Seeds in 1 or 2 rows in each cavity, vertically flattened. Flag. Blue Flag. Fleur-de-lis.

Stems usually less than $1 \mathrm{dm}$. tall, covered by the leaves: outer and inner perianth-lobes nearly equal.

Leaves linear : outer perianth-lobes crestless : angles of capsule obtuse.

Leaves more or less broadened near the middle: outer perianth-lobes crested: angles of capsule acute.

Stems usually over $3 \mathrm{dm}$. tall, leafy : outer perianth-lobes larger than the inner.

Perianth reddish brown or red.

Perianth blue or lilac variegated with white, green or yellow or rarely white. Leaves less than $1 \mathrm{~cm}$. broad.

Flower usually solitary: blades of outer perianth-lobes suborbicular or ovate, blue variegated with yellow and purple.

Flowers usually several: blades of outer perianth-lobes cuneate or obovate, blue variegated with white.

Leaves more than $1 \mathrm{~cm}$, broad.

Seeds in 1 row in each cavity.

Seeds in 2 rows in each cavity.

Flowers and capsules pedicelled.

Flowers and capsules sessile or nearly so.

1. I. verna.

2. I. cristata.

3. I. fulva.

4. I. tripetala.

5. I. prismatica.

6. I. Caroliniana.

7. I. versicolor.

8. I. hexagona.

1. Iris vérna L. Rootstocks creeping. Foliage bright green : leaves overtopping the flowers; blades linear, in age elongating to $3-4 \mathrm{dm}$. and becoming grass-like, attenuate : perianth violet-blue or rarely white, violet-scented; tube barely as long as the bracts ; lobes spatulate or cuneate-obovate, crestless, about as long as the slender tube : capsules prismatic, 12-15 mm. long, 3-angled, the angles obtuse.

In open woods and on dry slopes, Pennsylvania to southern Georgia, Kentucky and Alabama. Spring. VIOLET IRIS.

2. Iris cristàta Ait. Rootstocks creeping, slender. Foliage bright green : leaves (longer ones) overtopping the flowers; blades linear or usually broadest about the middle, more or less curved, acuminate : scapes somewhat flattened, bearing 1 or 3 flowers: perianth bright or pale blue ; tube surpassing the bracts ; lobes spreading, obovate or spatulate, the outer ones crested, longer than the inner, much shorter than the nearly filiform tube : capsules oblong-oval, 15-18 mm. long, 3-angled, the angles acute.

On banks or hillsides in open woods, Maryland to Ohio, Missouri, Georgia and Tennessee. Spring. Crested Iris,

3. Iris fúlva Ker. Rootstocks stout. Foliage pale-green or glaucescent : stems erect, 3-9 dm. tall, simple or branched, 1-angled below : leaves rarely overtopping the stem; blades narrowly-linear, sword-shaped: flowers solitary or 2 together: perianth reddish brown or red variegated with blue or green ; tube surpassed by the bracts; lobes crestless, 3-5 cm. long; blades oblong to ovate-oblong, glabrous : appendages of the stigmas toothed : capsules oblong, $2.5-3 \mathrm{~cm}$. long, obtusely 6-angled. [I. cuprea Pursh.]

In swamps, Kentucky to Illinois, Missouri, Georgia and Texas. Spring.

4. Iris tripétala Walt. Rootstocks horizontal. Foliage glaucous : stems $3-7 \mathrm{dm}$. tall, simple or nearly so, rather slender: leaves shorter than the stem; blades narrowly linear, less than $1 \mathrm{~cm}$. broad : flower usually solitary : perianth blue, variegated with yellow and purple ; tube about as long as the bracts; lobes various, crestless, the inner cuneate, short, the outer showy ; blades ovate or suborbicular, $3-4 \mathrm{~cm}$. long, narrowed into claws of nearly 
equal length : appendages of the stigmas slightly toothed : capsules oval, $3-3.5 \mathrm{~cm}$. long, 3-angled.

In low pine lands, North Carolina to Florida. Spring and summer.

5. Iris prismática Pursh. Rootstocks rather slender. Foliage bright green : stems slender, 3-9 dm. tall, often zigzag, simple: leaves not overtopping the stem; blades narrowly linear, grass-like, $2-3$ on the stem, the rest basal, less than $1 \mathrm{~cm}$. broad : flowers solitary or 2 together : perianth blue, variegated mainly with white; tube much surpassing the bracts; lobes about $4 \mathrm{~cm}$. long, crestless, spatulate, longer than the tube : appendages of the stigmas toothed : capsule oblong, $2.5-4 \mathrm{~cm}$. long, acute at both ends, 3-angled, the angles acute : seeds in one row in each cavity. [I. Virginica Muhl., not L.] IOLE.

In swamps or low grounds, New Brunswick to Pennsylvania and Georgia. Spring. Blue GLaD-

6. Iris Caroliniàna S. Wats. Rootstocks stout. Foliage bright green : stems 5-9 dm. tall, simple or branched: leaves equalling or surpassing the stem; blades linear, thinnish, somewhat glaucous beneath : perianth lilac, variegated with yellow, purple and brown ; tube 11-13 mm. long, broadened upward ; lobes various, the inner narrowly spatulate, nearly erect, the outer broadly spatulate, much longer, spreading or recurved, $8-10 \mathrm{~cm}$. long : appendages of the stigma toothed : capsules oblong, $3-5 \mathrm{~cm}$. long, obtusely 3 -angled : seeds in 1 row in each cavity.

In swamps, Virginia to Florida. Spring.

7. Iris versícolor L. Rootstocks stout. Foliage somewhat glaucous: stems $8-10$ dm. tall, simple or branched: leaves shorter than the stem, often numerous; blades linear, sword-shaped, acuminate, glaucous on both sides, thickish : perianth showy, blue or lilac, variagated with white, yellow or purple ; tube 10-15 mm. long, slightly dilated upward ; lobes various, the outer much longer than the inner, 7-9 $\mathrm{cm}$. long; blades spatulate to ovate, obtuse : appendages of the stigmas eroded : capsules oblong-prismatic, $3-4 \mathrm{~cm}$. long, obtusely 3 -angled : seeds in 2 rows in each cavity.

In swamps or on river banks, Newfoundland to Manitoba, Florida and Arkansas. Spring to fall.

8. Iris hexágona Walt. Rootstocks stout. Foliage not glaucous : stems $3-9 \mathrm{dm}$. tall, zigzag above, simple or sometimes branched : leaves sometimes as long as the stem : blades linear, sword-shaped, attenuate, thickish : flowers sessile or nearly so: perianth violetblue, variegated with white, yellow and purple; tube usually shorter than the bracts; lobes usually 8-9 $\mathrm{cm}$. long, spatulate, or blades ovate : appendages of the stigmas eroded: capsules prismatic, sessile or nearly so, $2.5-3.5 \mathrm{~cm}$. long: seeds in 2 rows in each cavity.

In swamps, South Carolina to Missouri, Florida and Texas. Spring

\section{FAMILY 4. HAEMOdoRÀCEAE R. Br. Bloodwort FAMILY.}

Perennial caulescent herbs, with rootstocks. Leaves alternate, often mainly basal : blades narrow, somewhat elongated. Flowers perfect, in terminal spikes, cymes or panicles. Perianth usually pubescent: sepals and petals 3 each, more or less united, persistent. Androecium of 3 stamens opposite the petals. Filaments slender, distinct. Anthers often narrow. Gynoecium of 3 united carpels. Ovary wholly or partially 3-celled or rarely 1-celled. Styles united. Stigma nearly entire or 3-ridged. Ovules few, half-anatropous. Fruit a loculicidally 3 -valved capsule. Seeds few or rarely many. Endosperm fleshy, surrounding the small embryo.

\section{GYROTHÈCA Salisb.}

Herbs, with short rootstocks, these like the roots, highly colored. Stems simple to the inflorescence, glabrous below. Leaves mainly basal, equitant: blades narrow, elongated, not overtopping the stem. Flowers in terminal, cymose corymbs. Perianth yellowish, pubescent without: sepals 3, smaller than the petals. Stamens 3, surpassing the perianth : filaments filiform: anthers versatile. Ovary 3-celled, inferior: styles slender, declined. Ovules few in each cavity, on fleshy placentae. Capsule subglobose, 3-celled, 3 -valved, enclosed in the persistent perianth. Seeds usually 6 in each cavity, peltate. [Lachnanthes Ell.]

1. Gyrotheca tinctòria (Walt.) Salisb. Rootstock red : stems $3-9 \mathrm{dm}$. tall, glabrous below, closely pubescent and corymbosely branched above: leaf-blades linear, somewhat shorter than the stem, attenuate, those on the stem gradually reduced: inflorescence woolly, 
round-topped: perianth 10-12 $\mathrm{mm}$. long, woolly without, yellow and glabrous within : sepals linear, about as long as the hypanthium ; petals about $\frac{1}{4}$ longer than the sepals, narrowly oblong, involute, obtuse : capsules subglobose, $5-6 \mathrm{~mm}$. in diameter : seeds angled. [Lachnanthes tinctoria (Walt.) Ell.]

In swamps and wet pine lands, Massachusetts to Florida. Spring to fall. RED-Root.

\section{Order 11. SCITAMINÀLES.}

Large herbs, commonly perennial by rootstocks or tubers, or rarely annual. Leaves sometimes all basal, with ample blades. Flowers very irregular. Perianth often brightly colored. Gynoecium compound. Ovary inferior. Fruit a capsule or utricle. Endosperm present.

Caulescent plants : fruit capsular, 3-celled : embryo straight. Scapose plants : fruit utricular, 1-celled : embryo hooked.

\section{Family 1. CANNÀCEAE Link. Canna FAmily.}

Perennial herbs, with erect stems. Leaves alternate : blades thick : petioles sheathing the stem. Flowers perfect, in terminal racemes or spike-like racemes. Perianth usually showy, double. Sepals 3 , imbricated, erect. Petals 3 , more or less united below into a tube and adnate to the corolloid androecium. Filaments petal-like, the 3 exterior nearly equal, sterile, the 2 interior more or less united, but only one filament anther-bearing. Anther marginal. Gynoecium of 3 united carpels. Ovary 3-celled, inferior, with parietal placentae. Style petal-like. Stigma marginal. Ovules numerous. Fruit a 3-celled loculicidally 3 -valved capsule with a papillose or bristly coat. Seeds with a membranous or somewhat fleshy testa. Embryo often central, sometimes flattened. Endosperm horny.

\section{CÁNNA L.}

Characters of the family. INDIAN-SHOT.

Petals lanceolate, $3-3.5 \mathrm{~cm}$. long. Petals obovate, $5-8 \mathrm{~cm}$. long.

1. C. Indica.

2. C. flaccida.

1. Canna Índica L. Stems $8-16 \mathrm{dm}$. tall, commonly simple, slender : leaf-blades oblong, elliptic-oblong or elliptic-ovate, $2-4 \mathrm{dm}$. long, acute or slightly acuminate, entire, rounded at the base; petioles sheathing : spikes few-flowered : sepals oblong, $3-4 \mathrm{~cm}$. long, acute: petals pale green or yellowish green, lanceolate, $3-3.5 \mathrm{~cm}$. long : filaments bright red: lip reddish yellow, spotted with red.

On river banks, Mississippi and Texas. Naturalized from the tropies. Summer.

2. Canna fláccida Roscoe. Stems 4-18 dm. tall, stout, commonly simple: leafblades leathery, narrowly elliptic to oblong-elliptic or sometimes broadest above or below the middle : spikes few-flowered : sepals 3 , linear or oblong, $2.5-3 \mathrm{~cm}$. long, acute : petals yellow, obovate, $5-8 \mathrm{~cm}$. long, rather large : capsule oblong, 4-6 $\mathrm{cm}$. long, densely bristly : seeds subglobose, about $5 \mathrm{~mm}$. in diameter, coarsely reticulated except a small portion.

In swamps near the coast, South Carolina to Florida. Spring to fall.

\section{Family 2. MARANTÀCEAE Lindl. Arrowroot Family.}

Tall scapose herbs, mostly perennial by short or elongated rootstocks. Leaves alternate, commonly ample: blades leathery, pinnately-nerved : petioles sheathing. Flowers perfect or sometimes polygamous, in terminal spikes, racemes or panicles, two commonly arising from a 2-valved, spathe-like organ of 2 bracts. Gynoecium of united carpels. Ovary 1-3-celled, inferior. Style slender, curved. Ovule 1 in each cavity, anatropous. Fruit a 1-3-celled utricle or a utricle-like capsule. Seed solitary in each cavity, covered by the thin coat. Embryo central or nearly so.

\section{THÀLIA L.}

Acaulescent herbs, with tall scapes, simple below the inflorescence. Leaves basal: blades ample: petioles elongated, sheathing at the base. Flowers in terminal panicles, not 
showy. Perianth colored, double : sepals 3, equal, distinet: petals 3 , distinct, somewhat coherent at the base. Staminodia partially united, one broader than the rest, crested : anther 1-celled. Ovary mainly 1-celled, with 2 small additional cavities : style spiral, adnate to the stamen-tube at the base : stigma 2-lipped, with lower lip pendulous, appendaged on the back. Capsule utricle-like. Seed solitary, erect. Embryo hooked, in hard endosperm.

Nodes of the inflorescence beardless.

1. T. dealbata.

Nodes of the inflorescence bearded.

Branches of the inflorescence erect or ascending : internodes 2-3 mm. long : outer bractlets $1-1.2 \mathrm{~cm}$. long.

Branches of the inflorescence spreading or drooping: internodes $5-8 \mathrm{~mm}$ long: outer bractlets $2-2.5 \mathrm{~cm}$. long.

2. T. barbata.

3. T. divaricata.

1. Thalia dealbàta Roscoe. Plant white-powdery above. Leaves basal; petioles elongated, sheathing at the base; blades oblong-ovate or oblong-lanceolate, 2-5 dm. long, acute or acuminate, entire, rounded at the base : scapes erect, 10-20 dm. tall, paniculately branched above, the branches surpassing the bracts; nodes not bearded; internodes 1-2 $\mathrm{mm}$. long: bractlets ovate, the outer $2-15 \mathrm{~mm}$. long, the inner smaller : perianth mainly purple, about $1.5 \mathrm{~cm}$. long: capsules globose-oval, $1 \mathrm{~cm}$. long.

In swamps, South Carolina and Missouri to Florida and Texas. Summer.

2. Thalia barbàta Small. Plant white-powdery. Leaves 2-ranked; petioles reedlike, 3-8 dm. long, sheathing below ; blades leathery, narrowly ovate to oblong-lanceolate, 2-4 dm. long, acute or somewhat acuminate: scapes reed-like, 9-18 dm. tall, sparingly branched above, the branches erect or ascending, short; nodes bearded; internodes powdery, 2-3 mm. long: bractlets ovate, unequal, the outer 1-1.2 cm. long: perianth purple: capsules oblong-oval, about $1 \mathrm{~cm}$. long.

In ponds and swamps, South Carolina to Florida and Texas. Spring to fall.

3. Thalla divaricàta Chapm. Plant green below the inflorescence. Leaves 2-ranked; blades lanceolate or broadly lanceolate, 2-6 dm. long, somewhat acuminate, with many lateral nerves, rounded or truncate at the base: petioles much longer than the blades: scapes erect, 9-30 dm. tall, widely branching above, the branches spreading or drooping, elongated : nodes of the rachis bearded; internodes $5-8 \mathrm{~mm}$. long, often pubescent : bractlets lanceolate or oblong-ovate, the outer $2-2.5 \mathrm{~cm}$. long, the inner smaller : perianth purple : capsules oval-oblong, 8-10 mm. long.

In ponds and low grounds, Florida. Fall.

\section{Order 12. ORCHIDÀLES.}

Terrestrial, aquatic or epiphytic herbs, sometimes with climbing stems. Leaves commonly of a fleshy texture, often reduced to scales. Flowers mostly perfect and complete, very irregular, or regular in BURMAnNIACEA. Perianth often highly colored and showy, its parts in 3's or 6's. Gynoecium compound. Ovary inferior. Seeds numerous, minute. Endosperm wanting.

Flowers regular: stamens and pistil distinct.

Flowers irregular : stamens and pistil united into a column.

FAM. 1. BURMANNIACEAE. FAM. 2. ORCHIDACEAE.

\section{FAmily 1. BURMANNIÀCEAE Blume. BurmanNia Family.}

Slight or relatively small caulescent herbs, with fibrous roots. Leaves mainly basal, often few, mostly reduced to scales on the stems. Flowers regular, perfect, solitary or in terminal racemes or clusters. Perianth colored, of 3 sepals and 3 petals, partially united. Stamens 3 or 6 , included. Filaments usually seated high on a tube. Anthers 2-celled: sacs opening transversely. Gynoecium of 3 united carpels. Ovary inferior, 1-3-celled, with three central or parietal placentae. Styles united. Stigmas 3, sometimes almost wholly united into one. Ovules numerous on each placenta. Fruit a terete, or 3-angled or 3-winged capsule. Seeds minute, somewhat elongated.

Hypanthium 3-angled or 3-winged : ovary 3-celled : capsule 3-valved from the apex or irregularly rupturing.

Hypanthium terete: ovary 1-celled : capsule 3-valved from the base.

1. BuRManNia.

2. APTERIA.

\section{BURMÁNNIA L.}

Annual herbs, with firm erect very slender scape-like stems. Leaves mainly basal. early deciduous, grass-like or these wanting, those of the stem merely alternate scales, 
Flowers spreading or erect. Perianth colored: lobes unequal, the outer longer than the inner. Hypanthium strongly 3-angled or 3-winged. Stamens 3, opposite the inner perianth-lobes : filaments very short : anthers with connective prolonged beyond the sacs and 2-cleft. Ovary 3-celled with 3 central 2 -lobed placentae : stigma 3-lobed or capitate. Capsule 3-celled, crowned with the persistent perianth-lobes, opening by lateral ruptures or 3 valves at the apex.

Flowers 1-several, often 2, in a terminal raceme : hypanthium broadly 3-winged. Flowers several in a terminal cluster: hypanthium 3-angled.

1. B. biflora.

2. B. capitata.

1. Burmannia biflòra L. Stems slender, $5-15 \mathrm{~cm}$. tall, simple or sparingly branched : leaves reduced to scales, these 1-3 mm. long, scattered : flowers 1 or often 2 at the end of a branch, sometimes nearly sessile : perianth blue, $3-4 \mathrm{~mm}$. long; lobes various, the outer ovate or triangular, the inner much smaller, nearly linear, incurved: hypanthium broadly 3-winged : capsules 4-5 mm. long, surrounded by the 3-winged hypanthium.

In grassy swamps or on margins of ponds, Virginia to Florida and Louisiana. Spring to fall.

2. Burmannia capitàta (Walt.) Mart. Stems nearly filiform, 5-20 cm. tall, simple, sometimes almost naked : leaves reduced to scales, these subulate, 1-5 mm. long, acute, scattered : flowers several in a terminal cluster, crowded : perianth white or pale blue, 3-4 mm. long; outer lobes triangular or deltoid, the margins involute ; inner lobes obsolete : hypanthium 3-angled, wingless : anthers with 2-horned connective : stigmas 2-lobed, flattened, hollow : capsules oblong, 2-3 mm. long : seeds minute.

In low pine lands, North Carolina to Florida and Louisiana. Spring to fall.

\section{APTÉrIA Nutt.}

Perennial herbs, with weak slender scape-like stems. Leaves reduced to scales on the stems. Flowers racemose, nodding. Perianth colored, delicate : lobes unequal, the inner smaller than the outer. Stamens 3: filaments very short, flattened and dilated at the apex : anthers 2-celled, adhering to the stigmas. Hypanthium terete. Ovary inferior, 1-celled, with 3, 2-winged parietal placentae : stigmas 3, capitate. Ovules numerous on each placenta. Capsule terete, 3-valved from the base, the valves clinging to the top of the persistent placentae. Seeds numerous, the loose testa reticulated.

1. Apteria aphýlla (Nutt.) Barnhart. Stems erect or decumbent, $5-20 \mathrm{~cm}$. long, purple, simple or sparingly branched: leaves scale-like, 1-2 $\mathrm{mm}$. long, scattered : pedicels slender, 5-15 mm. long, curved : perianth white or purple, nodding, 10-15 mm. long; lobes acute, shorter than the tube, the 3 inner smaller than the outer: stamens and style included : capsules oval or globose-obovoid, $5-8 \mathrm{~mm}$. long: seeds about $0.3 \mathrm{~mm}$. long. [Lobelia aphylla Nutt. A. setacea Nutt.]

In deep swampy woods, Georgia to Florida and Louisiana. Summer and fall.

\section{FAMILy 2. ORChidàceae Lindl. ORChid Family.}

Perennial herbs, commonly succulent, with tuberous or fibrous roots, corms, bulbs or elongated rootstocks. Stems or scapes usually simple, at least below the inflorescence. Leaves basal or cauline, various, often reduced to scales, mostly sheathing at the base. Flowers perfect, irregular, solitary or disposed in a simple or compound inflorescence. Perianth inconspicuous or showy, usually of 2 series. Sepals 3, alike, or nearly so. Petals 3 , of 2 kinds, the 2 lateral ("petals") similar, and the middle one ("lip") usually very different from the other petals, often prolonged below into a spur, sometimes inferior by the torsion of the pedicel or ovary. Androecium irregular, of one or more stamens, adnate to the style, forming an asymmetrical column. Anther 1, or rarely 2 anthers, often 2-celled, containing 2-8 waxy or powdery pollinia; these pollen-masses usually stalked, united by elastic threads and often attached at the base to a viscid gland. Gynoecium of 3 united carpels. Ovary inferior, 1-celled, twisted. Style commonly terminating in a beak at the base of the anther, or between its sacs. Stigma a viscid surface facing the lip beneath the beak or between the anther-sacs. Ovules numerous, on 3 placentae, anatropous. Fruit a 3-valved capsule. Seeds numerous, very small, each with a loose reticulated testa. Endosperm wanting. Embryo fleshy. 
Anthers 2: lip a Iarge inflated sac.

Caulescent : leaves several : lip with a rounded opening : sterile stamen glabrous: stigma broadest at the base.

Scapose: leaves 2 , basal : lip with a fissure down the front : sterile stamen glandular-pubescent: stigma broadest at the apex.

Anther solitary : lip various.

Anther adnate to the column, erect, persistent.

Lip with a tubular spur at the base : anther adnate to the apex of the column : sacs separate.

Glands of the stigma enclosed in a pouch.

Glands of the stigma not enclosed in a pouch.

Stigmas without appendages.

Lip entire or merely notched at the apex.

Stems normally leafy : anther-sacs parallel or nearly so.

Valves of the anther dilated at the base, enclosing the glands.

Valves of the anther not dilated: glands surrounded by a thin membrane.

Stems scape-like, with 1 or 2 basal leaves and several scale-like leaves above: anther-sacs divergent.

Lip cut-toothed or fringed.

Stigmas with appendages.

Anther-bases with long slender appendages.

Lip 3-parted : stigmas erect.

Lip entire: stigmas drooping.

Anther-bases without appendages.

Lip spurless, or if with a spur, this merely sac-like: anther adnate to the back of the column; sacs approximate.

Pollen masses 2.

Lip flat, at least not saccate.

Stems with alternate leaves, these often more or less reduced to scales : lip neither cleft nor parted.

Lip without a spur: stem-leaves partially or wholly reduced to scales.

Lateral sepals and column not decurrent on the ovary: foliage bright green.

Lip merely adherent to the column or free and not embracing it: stigma 2-cleft : lip with callosities at the base.

Lip adnate to the column and embracing it: stigma entire, pointed : lip without callosities.

Lateral sepals and column conspicuously decurrent on the ovary : foliage yellowish green.

Lip with a sac-like spur: stem leaves not reduced to scales.

Stems with two opposite leaves : lip 2-cleft or 2-parted. Lip sac-like.

Pollen masses 4.

Anther attached to the apex of the column like a lid, deciduous.

Pollen in loose powdery masses.

Erect herbs with terminal spikes or racemes, or a solitary flower.

Scapose : leaves basal, sometimes mere scales.

Leaves basal, sheathing the scape: bracts alternate: column winged at the apex.

Leaves none or mere basal scales: bracts leaf-like, whorled at the top of the scape.

Caulescent: leaves usually solitary or rarely several.

Column club-shaped or very short, wingless: pollen-masses 2 or 2-parted.

Flowers normally solitary, terminal : lip crested.

Flowers axillary, forming few-many-flowered racemes: lip not crested.

Column elongated.

Column very short.

Column dilated above, petal-like: pollen-masses 4 .

Vines with axillary racemes.

Pollen in waxy masses.

Pollen-masses without either elastic connecting tissue or stalks.

Stems furnished with normal leaves.

Leaves sheathing the scape to near the middle: column minute, 2-toothed at the apex.

Leaves barely sheathing the scape: column elongated, incurved, margined above.

Stems furnished with clasping or sheathing scales.

Rootstocks coral-like : lip with a short spur adnate to the ovary : proper leaf none.

Rootstocks corm-like : lip spurless : proper leaf solitary, but absent during anthesis.

Pollen-masses with elastic connecting tissue and stalks.

Lip with a slender free spur: scapes naked or nearly so: pollenmasses 2 or 4 .

Terrestrial plants : pollen-masses 4.

Epiphytic plants: pollen-masses 2.

Lip spurless or the short spur adnate to the ovary.

Lip or its claw markedly adnate to the column.

Lip or its claw not adnate to the column.

A. Flower-stalk terminal.

Pollen-masses 4: plant epiphytic, with large leaves near the base : inflorescence branched.

1. Cypripedium.

2. Fissipes.

3. GALEORCHIS.

5. Coeloglossum.

6. Lysias.

7. BLEPHARIgLOTtIS.

8. HABENARIA.

9. HABENELLA.

10. GYMNADENIOPSIS.
11. Gy ROSTACHYS.

12. BEADLEA.

13. STENORHYNCHUS.

14. Physurus.

15. Listerd.

16. Peramium.

17. Ponthieva.
18. Limodorum.

19. Isotria.

20. Pogonia.

21. TRIPHORA.

22. EPIPACTIS.

23. Arethusa.

24. VANILLA.

25. ACHROANTHES.

26. LEPTORCHIS.

27. Corallorhiza.

28. Aplectrum.

29. Tipularia.

30. DENDROPHYLAX.

31. EPIDENDRUM.

32. Polystachya. 
Pollen-masses 8: plant terrestrial, the leaves all scale-like : inflorescence simple.

B. Flower-stalk lateral.

Column without a foot: lip sessile.

Column with a foot.

Lip sessile, the base truncate or cuneate : foot of the column dilated or abruptly narrowed at the base.

Lip crestless, deeply three-lobed, the lateral lobes widely spreading: foot of the column concave and grooved, not dilated, the margins thick.

Lip with a crest of nipple-like papillae, shallowly three-lobed: foot of the column flat, thin and dilated, the margins thin.

Lip contracted into a claw: foot of the column slender.

33. Hexalectris.

34. Bletia.

(1)

35. Triorchos.

36. Platypus.

37. CyRTOPODIUM.

\section{CYPRIPÈDIUM L.}

Caulescent often scented herbs, with very long fibrous roots and glandular-pubescent foliage. Leaves alternate: blades several-nerved, plaited. Flowers solitary or several, near the top of the stem, drooping. Perianth showy. Sepals 3, distinct, or 2 usually united under the lip, often twisted. Lateral petals 2, spreading. Lip conspicuous, horizontal, an inflated sac with a rounded orifice. Column declined, glabrous, bearing a sessile or stalked anther on each side and a petaloid sterile stamen above which covers the top of the style. Stamens appressed, the free tips directed forward, surpassing the anthers: sterile stamen longer than broad, glabrous. Pollen pulpy or granular, without glands or tails. Stigma terminal, broadest at the base. Capsule ribbed. The plants flower in the spring. LADIES' SLIPPER.

Lip longer than the sepals and lateral petals.

Lip as long as the sepals and lateral petals or shorter.

Lip bright yellow, 1.5-3 cm. long: stigma acute.

Lip pale yellow, $3.5-5 \mathrm{~cm}$. long : stigma obtuse.

1. C. reginae.

2. C. parviflorum.

3. C. hirsutum.

1. Cypripedium reginae Walt. Foliage villous-hirsute. Stems erect or ascending, 3-6 dm. tall, leafy to the top, usually stout: leaf-blades oval or elliptic, $8-20 \mathrm{~cm}$. long, acute, with large sheathing bases: flowers solitary or 2-3 at the top of the stem: sepals white, oblong to oval : lateral petals white, lanceolate, barely as long as the sepals : lip inflated, 2.5-4 cm. long, with purple and white stripes, shorter than the sepals and petals : capsule oblong, 3-4 cm. long, excluding the stipe-like base. [C. spectabile Salisb.]

In swamps and woods, Nova Scotia to Ontario, Minnesota and Georgia. Moccasin Flower.

2. Cypripedium parviflòrum Salisb. Foliage glandular-villous. Stems erect or ascending, 3-6 dm. tall, often zigzag, commonly tufted: leaf-blades elliptic to oval, $8-15 \mathrm{~cm}$. long, acute or acuminate, glabrate : bracts similar to the leaves but smaller : perianth yellow, somewhat drooping: sepals lanceolate or oblong-lanceolate, $2.5-3 \mathrm{~cm}$. long: lateral petals longer and narrower than the sepals: lip inflated, bladder-like, $15-3 \mathrm{~cm}$. long, light yellow, shorter than the sepals and petals : capsule $2-3 \mathrm{~cm}$. long. Washington,

In woods and on hillsides, Newfoundland to British Columbia, middle Georgia, Missouri and

3. Cypripedium hirsùtum Mill. Foliage glandular-pubescent or glabrate. Stems erect or ascending, 3-7 dm. tall, simple, tufted : leaf-blades oblong or elliptic, $8-15 \mathrm{~cm}$. long, acute or acuminate, sheathing at the base : bract similar to the leaves : perianth yellow, drooping or horizontal : sepals ovate-lanceolate or oblong-ovate : lateral petals linear or attenuate, longer than the sepals, twisted or curled : lip inflated, bladder-like, 3.5-5 $\mathrm{cm}$. long, pale yellow, veined with purple : capsule elliptic, $3.5-4 \mathrm{~mm}$. long. [Cypripedium pubescens Willd.]

In woods and on shaded banks, Nova Scotia to Ontario, Minnesota, the mountains of Georgia, and Nebraska. GOLDEN SLIPPFr.

\section{FíssIPEs Small.}

Acaulescent herbs, with fleshy-fibrous roots and glandular-pubescent foliage. Leaves 2, basal : blades ample, plaited, spreading. Scape simple. Flower usually solitary at the top of the scape. Perianth irregular. Sepals greenish, narrowed upward. Lateral petals about as long as the sepals, linear, greenish. Lip drooping, showy, a large inflated sac with a closed fissure down its whole length in front. Column declined, glandular-pubescent, bearing a sessile anther on each side, and a rhomboidal glandular-pubescent sterile stamen above. Stamens spreading, the free tips at right angles to the column. Pollen granular, without glands or tails. Stigma broadest at the apex. Capsule ascending.

1. Flssipes acaùlis (Ait.) Small. Foliage glandular-pubescent. Stem wanting: leaf-blades sheathing the lower part of the scape, usually 2, oblong-elliptic or oval, 1-3 
dm. long, usually accompanied by a scale : scapes erect, 1-5 dm. tall, simple, bearing 1 or rarely 2 flowers at the top : bracts linear to lanceolate, $3-6 \mathrm{~cm}$. long : sepals oblong to lanceolate, 3-4 cm. long, acute or rather obtuse: lateral petals narrower and longer than the sepals, acute : lip showy, obovoid, 4-6 mm. long, surpassing the other perianth-members, pink with darker venation, or white, upper part crested within with long white hairs : capsule oblong, 3.5-4 cm. long, slightly curved. [Cypripedium acaule Ait.]

In sandy woods and sphagnous bogs, Newfoundland to Minnesota, North Carolina and Tennessee. Spring. MocCasin Flower. PURPle Slipper.

\section{GALEÓRCHIS Rydb.}

Acaulescent fleshy herbs, with short roostocks and several coarse fleshy roots. Leaves 2, basal, thick and succulent. Flowers in terminal spikes. Perianth showy, ringent. Sepals nearly equal, united above, converging. Lateral petals converging similar to the sepals and somewhat adnate to them. Lip united to the base of the column, with a short spur below. Column short, barely extending beyond the base of the lip. Anther 2-celled : sacs contiguous, slightly divergent. Pollen-masses granulose, 1 in each sac produced into a slender tail, this attached to a small gland. Style terminating in a knob-like projection under the anther. Stigma hollow, between the anther-sacs. Glands enclosed in a pouch. Capsule slightly elongated, beakless.

1. Galeorchis spectábilis (L.) Rydb. Roots thick, clustered : leaf-blades usually 2, preceded by 1 or 2 clasping scales, oblong-elliptic, elliptic or oval, sometimes slightly broadest above the middle, obtuse, narrowed into sheathing petiole-like bases : scapes stout, 1-3 dm. tall : spike 3-12-flowered : bracts oblong or lanceolate, commonly surpassing the perianth : perianth violet-purple or white : spur obtuse, fully $1.5 \mathrm{~cm}$. long : column violet on the back : capsules angled, $2-2.5 \mathrm{~cm}$. long. [Orchis spectabilis L.]

In woods, New Brunswick to Ontario, Minnesota, Georgia, Kentucky and Nebraska. Spring. SHOWY ORCHIS.

\section{PERULÀria Lindl.}

Caulescent herbs, with thick fibrous clustered roots. Leaves alternate : blades entire. Flowers relatively small in elongated spikes. Bracts narrow, elongated. Perianth yellowish or greenish. Sepals and lateral petals spreading, relatively broad. Lip lanceolate, with a tooth on each side near the base, and a median tubercle. Spur slender, straight, shorter than the ovary but longer than the lip. Anthers with horizontal valves opening upward, dilated at the base, thus forming an oblong cavity enclosing the orbicular incurved gland. Pollen-masses granulose, each produced at the base into a tail.

1. Perularia flàva (L.) Rydb. Roots clustered, elongated, stems $3-6 \mathrm{dm}$. tall : leafblades elliptic, oblong or lanceolate, 1-3 dm. long, or shorter above, with clasping bases : spikes elongated : bracts surpassing the perianth: perianth greenish or yellowish green : sepals ovate or orbicular-ovate, obtuse : lateral petals similar to the sepals but rather shorter, crisped: lip somewhat longer than the petals, erose or crenulate, with 2 lateral projections and a medium basal callosity: spur sac-like, surpassing the lip, obtuse : capsules oblong, 8-10 mm. long. [Habenaria flava (L.) A. Gray.]

In low grounds, Ontario to Minnesota, Florida and Louisiana. Summer.

\section{COELOGLÓsSUM Hartman.}

Caulescent herbs, with biennial 2-branched tubers. Leaves alternate : blades entire. Flowers perfect, in elongated spikes. Bracts leaf-like, relatively long. Perianth greenish. Sepals free, converging, thus forming a hood. Lateral petals narrow. Lip obtuse, 2-3-toothed at the apex. Spur sac-like, obtuse, much shorter than the lip. Column short. Pollen-masses with long tails: glands small, barely wider than the tail of the pollinia, surrounded by a thin membrane.

1. Coeloglossum bracteàta (Willd.) Parl. Roots coarse, or even tuber-like : stems 2-6 dm. tall : leaf-blades oblong-ovate to oblong-elliptic or oblong-lanceolate, 1-1.5 dm. long or shorter above, varying from acute to obtuse: spikes loosely flowered, 5-15 cm. long: bracts linear-lanceolate, $1.5-4 \mathrm{~cm}$. long, surpassing the perianth : perianth green or greenish : sepals ovate-lanceolate, $5-6 \mathrm{~mm}$. long : lateral petals very narrow, or filiform : lip oblong-spatulate, 6-8 mm. long, 2-3-toothed or lobed at the apex : spur club-shaped : capsules oblong, 8-10 mm. long. [Platanthera bracteata (Willd.) Torr.]

In meadows or woods, New Brunswick to British Columbia, North Carolina and Nebraska. Spring. 


\section{LÝSIAS Salisb.}

Caulescent herbs, with fleshy roots or tubers. Stems often scape-like. Leaves mainly basal : blades broad, or those of the stems very narrow or scale-like. Flowers in elongated racemes or spikes. Perianth white or greenish. Sepals free, large, spreading. Lateral petals relatively small and narrow. Lip entire, narrow. Spur slender, usually longer than the ovary. Anthers with diverging sacs whose beak-like bases project forward. Pollen-mass with its stalk laterally affixed to the back of the orbicular gland. Stigma without appendages at the beak. Capsule usually broadened upward, stalked.

1. Lysias orbiculàta (Pursh) Rydb. Roots coarse : stems scape-like, $3-9 \mathrm{dm}$. tall, strict : leaves mainly basal, usually 2 ; blades flat on the ground, orbicular to oval, 1-3 $\mathrm{dm}$. long, undulate, lustrous, silvery beneath : those of the stem lanceolate or linear scales : raceme elongated, conspicuous, rather loose: perianth greenish white: sepals various, the upper one suborbicular or reniform, the lateral scythe-shaped, $8-10 \mathrm{~mm}$. long : lateral petals smaller than the sepals, reflexed : lip slender, curved, $1.5-3 \mathrm{~cm}$. long, entire, obtuse : spur surpassing the ovary, $2.5-4 \mathrm{~cm}$. long, curved : capsules oblong, about $1.5 \mathrm{~cm}$. long. [Platanthera orbiculata (Pursh) Lindl.]

In rich or deep woods, Newfoundland to British Columbia, Georgia and Minnesota. Summer.

\section{BLEPHARIGLÓTTIS Raf.}

Caulescent herbs, with fleshy or tuberous roots. Leaves alternate: blades entire. Flowers several or numerous in terminal spikes. Bracts sometimes leaf-like. Perianth white, yellow, purple or violet-purple. Sepals spre ading or reflexed. Laterals petals various. Lip fringed or 3-parted and toothed or laciniate. Spur longer than the lip. Anthers with widely separated and usually diverging sacs, their narrow beak-like bases supported on the arms of the stigma, strongly projecting forward and upward. Gland naked. Pollen-masses granular. Fringed Orchis. Showy Orchis.

Lip not 3-lobed; body narrow, not dilated upward.

Spur about $1 / 2$ as long as the ovary.

Spur as long as the ovary or much longer.

Perianth white.

Spur about as long as the ovary. Spur about twice as long as the ovary.

Perianth yellow or orange.

Lip with spreading fringe : petals linear or oblong-linear.

Lip with drooping fringe except;2 tufts at the base : petals cuneate or fanshaped.

Lip 3-lobed; body of the lobes, at least the terminal one, dilated upward.

Lobes of the lip incised or erose.

Lobes of the lip fringed.

Body of each lobe $1 \mathrm{~mm}$. broad or narrower, slightly broadened.

Body of each lobe markedly fan-shaped.

Perianth white: fringe $1 / 2$ as long as the lobes.

Perianth lilac: fringe shorter.

Lip 1-1.5 cm. broad.

Lip 2-2.5 cm. broad.

1. B. cristata.

2. B. Blephariglottis.

3. B. conspicua.

4. B, ciliaris.

5. B. Chapmanii.

6. B. peramoena.

7. B. lacera.

8. B. leucophaea.

9. B. psycodes.

10. B. grandiflora.

1. Blephariglottis cristàta (Michx.) Raf. Roots clustered, coarse or narrowly fusiform : stems 2-6 dm. tall : leaf-blades linear to linear-lanceolate, $5-20 \mathrm{~cm}$. long, shorter and passing into the bracts above : spike oblong, 5-10 $\mathrm{cm}$. long, rather dense : sepals orbicular-ovate, about $3 \mathrm{~mm}$. long : lateral petals narrower, pectinate : lip 8-9 mm. long, deeply fringed ; segments as long as the body or longer : spur slender, 4-6 mm. long, about $\frac{1}{2}$ as long as the ovary: capsules less than $1 \mathrm{~cm}$. long. [Platanthera cristata (Michx.) Lindl.]

In swamps, New Jersey to Florida and Louisiana. Summer.

2. Blephariglottis Blephariglóttis (Willd.) Rydb. Roots coarse : stems 3-9 dm. tall : leaf-blades linear-oblong or oblong-lanceolate, 1-2.5 $\mathrm{cm}$. long or shorter above : spike showy, 3-10 cm. long, rather loosely flowered : perianth white : sepals suborbicular to orbicular-obovate, 6-7 mm. long, obtuse : lateral petals smaller than the sepals, toothed or fringed at the apex : lip 6-8 mm. long, sparsely or copiously fringed : spur $1-2.5 \mathrm{~cm}$. long, about as long as the ovary. [Platanthera blephariglottis (Willd.) Hook.]

In swamps and low woods, Newfoundland to Minnesota and Florida. Summer.

3. Blephariglottis conspicua (Nash) Small. Roots coarse or tuberous-thickened : stems 4-8 dm. tall, often slightly zigzag : leaf-blades broadly linear to linear-lanceolate, 1-4 dm. long, or shorter above, acute: spike ovoid or oblong, 6-12 cm. long, showy : perianth white : sepals suborbicular, $6-7 \mathrm{~mm}$. broad : lateral petals oblanceolate or linear, 
about $5 \mathrm{~mm}$. long, entire or toothed at the apex : lip narrowly oblong, $12-15 \mathrm{~mm}$. long, narrowed into a short claw ; blade rather copiously fringed : spur curved, $4-5 \mathrm{~cm}$. long, about twice as long as the ovary. [Habenaria conspicua Nash.]

In bogs, Florida. Summer.

4. Blephariglottis ciliàris (L.) Rydb. Roots coarse and cord-like or tuberous : stems 3-8 dm. tall : leaf-blades oblong to lanceolate, $10-20 \mathrm{~cm}$. long, or smaller above, often acute : spike showy, 3-10 $\mathrm{cm}$. long, 3-8 cm. thick : perianth bright orange : sepals orbicular-obovate, 6-8 mm. long, entire : lateral petals smaller, linear or oblong-linear, usually toothed : lip 10-15 mm. long, copiously fringed from below the middle, the fringe spreading : spur slender, 1.5-2.5 cm. long: capsules 10-12 mm. long, each tapering to a beak. [Platanthera ciliaris (L.) Lindl.]

In woods and meadows, Ontario to Michigan, Florida and Texas. Summer.

5. Blephariglottis Chapmánii Small. Roots coarse : stems 6-10 dm. tall : leaves few ; blades broadly linear to linear-lanceolate, 1-2 dm. long or shorter above, acute, the lower ones with clasping bases, the upper reduced to sessile bracts : spikes cylindric, about $1 \mathrm{dm}$. long, $4 \mathrm{~cm}$. thick, many-flowered : perianth deep orange : sepals about $4 \mathrm{~mm}$. long, the lateral suborbicular, the other concave, often notched at the apex : lateral petals fan-shaped, $3.5-4 \mathrm{~mm}$. long, pectinate-fringed : lip about $1 \mathrm{~cm}$. long, the body linear, with a terminal drooping fringe of 6-8 simple or forking hair-like appendages and 2 basal staghorn-like forking appendages : spur as long as the ovary or longer.

In pine woods, Apalachicola, Florida. Summer.

6. Blephariglottis peramoèna (A. Gray) Rydb. Roots coarse, often tapering : stems 3-9 dm. tall, strict : leaf-blades oblong to lanceolate, $8-20 \mathrm{~cm}$. long or much smaller above : spike showy, oblong, 4-15 $\mathrm{cm}$. long, 5-8 $\mathrm{cm}$. thick : perianth violet-purple : sepals orbicular-ovate or suborbicular, 6-8 $\mathrm{mm}$. long or the upper smaller : lateral petals smaller than the sepals, orbicular-obovate, entire or erose, contracted into claws : lip 15-20 mm. long, 3-parted, the lobes fan-shaped or cuneate, incised or erose-toothed, the middle lobe usually notched at the apex : spur slender, about as long as the ovary : capsules usually 12-15 mm. long. [Platanthera peramoena A. Gray.]

In meadows, New Jersey to Illinois, North Carolina and Tennessee. Summer.

7. Blephariglottis lácera (Michx.) Rydb. Roots coarse or tuberous-thickened : stems 3-9 dm. tall, strict : leaf-blades oblong to lanceolate, 8-20 cm. long or shorter above, ascending : spike elongated, 5-30 cm. long, 3-4 cm. thick : perianth greenish yellow, conspicuous : sepals ovate or suborbicular, 5-6 mm. long, obtuse : lateral petals linear, about as long as the sepals, obtuse : lip 3-parted, the lobes with bodies $1 \mathrm{~mm}$. broad or narrower, deeply cleft into a fringe of a few filiform segments : spur somewhat club-shaped, 14-16 mm. long: capsules oblong or clavate, about $1 \mathrm{~cm}$. long. [Platanthera lacera (Michx.) A. Gray.]

In swamps and open woods, Nova Scotia to Minnesota, Georgia and Missouri. Summer.

8. Blephariglottis leucophaèa (Nutt.) Rydb. Roots coarse : stems 3-8 dm. tall, relatively stout : leaf-blades oblong to oblong-lanceolate, 8-20 cm. long or shorter above, ascending : spike ovoid or broadly oblong, 5-12 cm. long, relatively few-flowered : flowers fragrant : perianth white : sepals broadly ovate or oval, 6-10 $\mathrm{mm}$. long, very thin : lateral petals obovate or spatulate, 6-8 mm. long, erose-toothed : lip 3-parted, 12-16 mm. long, the lobes cuneate, divided to about the middle; segments forming a fringe : spur much longer than the ovary, $2.5-4 \mathrm{~cm}$. long.

On moist prairies, New York to Minnesota, Kentucky and Arkansas. Summer.

9. Blephariglottis psycòdes (L.) Rydb. Roots coarse : stems 3-10 dm. tall : leafblades oval, elliptic or oblong-lanceolate, $5-25 \mathrm{~cm}$. long, or the upper ones smaller : spike $5-15 \mathrm{~cm}$. long, several-many-flowered : flowers fragrant : perianth lilac or rarely white : sepals ovate, about $8 \mathrm{~mm}$. long, obtuse, the upper one narrower than the lateral ones: lateral petals oblong or oblanceolate, with a few teeth on the upper side : lip 3-parted, 8-12 mm. wide, the lobes fan-shaped, well fringed : spur about $15 \mathrm{~mm}$. long, slightly clubshaped near the apex. [Platanthera psycodes (L.) A. Gray.] Summer.

In wet woods, meadows and swamps, Newfoundland to Minnesota, North Carolina and Indiana.

10. Blephariglottls grandiflòra (Bigel.) Rydb. Roots coarse : stems 3-15 dm. tall, relatively stout : leaf-blades oblong-obovate, oblong or lanceolate, $\mathbf{1 - 3} \mathrm{dm}$. long, or shorter above, erect or ascending : spike showy, 8-40 cm. long, copiously flowered: perianth lilac-purple or white, very showy : sepals ovate or oval, 5-8 $\mathrm{mm}$. long : lateral petals oblong or oblanceolate, somewhat toothed : lip 3-parted, 2-2.5 cm. broad, the lobes fanshaped, fringed : spur $2-3 \mathrm{~cm}$. long : capsules oblong or nearly so, over $1 \mathrm{~cm}$. long. [ $\mathrm{Pla}$ tanthera fimbriata (Willd.) Lindl.]

In rich woods and meadows, New Brunswick to Ontario, Michigan and North Carolina. Summer. 


\section{HABENÀria Willd.}

Caulescent herbs, with cord-like or tuberous roots. Leaves alternate, sheathing at the base. Flowers in terminal spikes. Perianth of various colors, or white, often conspicuous. Sepals equal or nearly so, distinct or cohering at the base, the lateral 2 usually spreading. Lateral petals unequally 2-parted. Lip drooping or spreading, with a more or less conspicuous spur at the base, mostly 3-parted. Column very short: anther 2-celled : sacs elevated, each with a slender appendage at the base. Pollen-masses coarsely granular with short tails. Stigma erect, with narrow appendages. Glands naked. Capsule more or less elongated, angled or ribbed.

Spur about as long as the ovary.

Bracts not surpassing the flowers: spikes few-flowered.

Leaves basal or nearly so: spur club-shaped.

Leaves scattered along the stem : spur filiform.

Bracts surpassing the flowers: spikes many-flowered.

1. H. distans.

2. Huttallii.

3. H. repens.

Spur much longer than the ovary.

Middle sepal less than $10 \mathrm{~mm}$. long: spur less than $6 \mathrm{~cm}$. long.

Leaves largest at the base of the stem, those of the stem broadest near the base: middle sepal suborbicular.

Leaves largest about the middle of the stem, those of the stem broadest at the middle: middle sepal ovate.

Middle sepal over $10 \mathrm{~mm}$. long : spur over $10 \mathrm{~cm}$. long.

4. H. Simpsonii.

5. H. quinqueseta 6. H. Habenaria.

1. Habenarla dístans Griseb. Roots coarse or tuber-like : stems scape-like, $2-3 \mathbf{d m}$. tall, slender : leaves several at the base of the stem; blades oblong or elliptic, or slightly broadest above the middle, 4-15 $\mathrm{cm}$. long, acute or abruptly acuminate ; stem-leaves mostly reduced to partly sheathing scales : spike few-flowered, lax : bracts surpassing the ovaries : sepals oval or broadly ovate, 5-6 mm. long : lateral petals 2-parted, the upper segment narrowly oblong, the lower linear : lip 6-8 mm. long, 3-parted ; segments linear, spreading : spur club-shaped, about as long as the ovary.

In low pine lands, Florida.

2. Habenaria Nuttállí Small. Roots cord-like, relatively slender : stem 2-4 dm. tall, leafy, rather slender: leaf-blades broadly linear to linear-lanceolate, $5-20 \mathrm{~cm}$. long, or shorter above, acute or acuminate, erect or ascending, sheathing at the base: spike 6-12 cm. long, rather few-flowered, narrow: bracts lanceolate, shorter than the flowers : middle sepal $4 \mathrm{~mm}$. long, suborbicular, broader than long, notched at the apex ; lateral sepals $5 \mathrm{~mm}$. long: lateral petals $4-5 \mathrm{~mm}$. long, the narrower segment longer than the broader one : lip 3-parted ; middle segment $4 \mathrm{~mm}$. long; lateral segments $\frac{1}{4}-\frac{1}{3}$ longer : spur filiform, about as long as the ovary : capsules oblong-prismatic, a little over $1 \mathrm{~cm}$. long.

In swamps, Florida to Louisiana.

3. Habenaria rèpens Nutt. Roots fibrous : stems $3-6 \mathrm{dm}$. tall, usually stoutish : leafblades oblong-lanceolate, to linear-lanceolate, $5-30 \mathrm{~cm}$. long, acute or acuminate, 3-nerved, sheathing at the base: spike 10-30 cm. long, closely many-flowered: bracts lanceolate or linear-lanceolate, surpassing the flowers : perianth greenish : sepals various, the middle one ovate-orbicular, $5 \mathrm{~mm}$. long, the lateral oblong, slightly curved, $6 \mathrm{~mm}$. long: lateral petals with the broader segments, $5 \mathrm{~mm}$. long, slender segment $\frac{1}{4}$ longer : lip 3-parted ; middle segment $5 \mathrm{~mm}$. long; lateral $\frac{1}{3}$ longer and more slender than the middle one : spur filiform, about as long as the ovary.

In swamps or low grounds, Florida to Louisiana.

4. Habenaria Simpsònti Small. Roots cord-like, sometimes accompanied by tubers : stems 2-4 dm. tall, conspicuously leafy to the middle : leaves mainly on the lower half of the stem, and there sheathing it ; blades ovate or sometimes oval-oblong, 3-10 cm. long, acute or acutish, spreading, clasping, those above the middle of the stem much smaller than the rest and more remote : bracts ovate or ovate-lanceolate, acuminate : middle sepal suborbicular, $7 \mathrm{~mm}$. long; lateral sepals $9 \mathrm{~mm}$. long: lateral petals with the larger segments oblong, $6 \mathrm{~mm}$. long, curved, the other segment filiform, spreading, fully twice as long : lip 5-parted; middle segment linear, $10 \mathrm{~mm}$. long ; lateral segments about $\frac{1}{3}$ longer : spur about twice as long as the ovary.

In dry hammocks, near Manatee, Florida.

5. Habenaria quinquesèta (Michx.) C. Mohr. Roots fibrous : stems 2-5 dm. tall, leafy to the inflorescence: leaves largest about the middle of the stem; blades oblong to oblong-lanceolate, 4-10 $\mathrm{cm}$. long, or shorter above, broadest about the middle: spike $8-15 \mathrm{~cm}$. long, rather few-flowered : perianth white : sepals various; the middle one ovate : 8-9 $\mathrm{mm}$. long, obtuse : lateral petals with the broader segment 9-10 mm. long, the narrower one nearly twice as long : lip 3-parted; middle segment linear, 12-13 mm. long : lateral segments filiform, about $\frac{1}{2}$ longer : spur about twice as long as the ovary. [Habenaria Michauxii Nutt.]

In sandy or gravelly soil, South Carolina to Florida and Louisiana. 
6. Habenaria Habenària (L.) Small. Roots fibrous, often accompanied by a tuber : stems rather slender, 3-6 dm. tall : leaves chiefly on the lower part of the stem ; blades oblong or lanceolate, $5-15 \mathrm{~cm}$. long, acute, entire, sheathing at the base, those above the middle of the stem much smaller: spike loosely few-flowered : bracts ovate-lanceolate to lanceolate, acuminate: middle sepal oval or orbicular-oval, 12-14 mm. long, obtuse: lateral sepals oblong or slightly narrowed upward: lateral petals with the broader segment $8-10 \mathrm{~mm}$. long, the other segment filiform, fully twice as long: lip 3-parted, the middle segment about $2 \mathrm{~cm}$. long; lateral segments $\frac{1}{3}-\frac{1}{4}$ longer: spur conspicuous, 11-12 cm. long. [H. macroceratitis (Sw.) Willd.]

In sandy soil, peninsular Florida and tropical America.

\section{HABENÉLLA Small.}

Caulescent herbs, with large tuber-like roots. Leaves alternate, several : blades spreading beyond the sheathing bases, extending well towards the inflorescence. Spike severalflowered. Perianth rather inconspicuous. Sepals 3, the upper one about as broad as long, boat-shaped, the 2 lateral concave, inequilateral. Lateral petals nearly oblong, much smaller than the sepals. Lip entire, narrow. Anther with filiform appendages at the base of each sac. Stigma drooping, with 2 short appendages on each side. Glands naked. Capsule rather elongated.

1. Habenella Gárberi (Porter) Small. Roots tuber-like, several : stems 3-6 dm. tall, leafy throughout : leaves only slightly reduced above ; blades oblong to oblong-lanceolate, 6-10 cm. long, acute, with clasping bases : spike $8-15 \mathrm{~cm}$. long, loosely flowered : bracts lanceolate or linear-lanceolate : perianth greenısh yellow, not showy : sepals broadly ovate or oval, 4-5 mm. long: lateral petals narrower than the sepals, oblong or nearly so: lip longer than the petals, entire, linear from a broad base, obtuse : spur slender, 12-18 $\mathrm{mm}$. long, as long as the ovary or longer. [Habenaria Garberi Porter.]

In hammocks, peninsular Florida. Fall or winter.

\section{GYMNADENIÓPSIS Rydb.}

Caulescent herbs, with fibrous or somewhat tuberous roots. Leaves alternate: blades entire. Flowers in relatively stout spikes. Bracts inconspicuous. Perianth white, pink, greenish or orange-yellow. Sepals free, spreading. Lateral petals usually smaller than the sepals. Lip entire or 3-toothed at the apex. Spur much longer than the lip. Anthers with parallel and approximate sacs and naked contiguous glands. Pollen-masses granular, with short tails. Stigma with 2-3 oblong or club-shaped appendages at the beak.

Lip 3-toothed at the apex : spur club-shaped.

Lip entire or crenulate: spur filiform.

Perianth white or pink: ovary not twisted, shorter than the spur.

Perianth yellow or orange-yellow: ovary twisted, longer than the spur.

1. G. clavellata.

2. G. nivea.

3. G. integra.

1. Gymnadenlopsis clavellàta (Michx.) Rydb. Roots coarse, clustered : stems 1$5 \mathrm{dm}$. tall, relatively slender, naked above: leaves reduced to scales, except 1 or rarely 2 , these near the middle of the stem or below it ; blades oblong or oblong-oblanceolate, 5 $12 \mathrm{~cm}$. long, obtuse or acute, ascending: spike $2-5 \mathrm{~cm}$. long, few-flowered: perianth greenish or whitish : sepals ovate or broadly oval, $2-2.5 \mathrm{~mm}$. long, obtuse : lateral petals quite similar to the sepals : lip 3-4 mm. long, 3-toothed at the apex : spur club-shaped, longer than the ovary : capsules oblong, 7-8 mm. long. [Gymnadenia tridentata (Willd.) Lindl.]

In low grounds, Newfoundland to Minnesota, Florida and Louisiana. Summer. Frog-SPIKE.

2. Gymnadeniopsis nívea (Nutt.) Rydb. Roots tuber-like : stems usually slender, 2-5 dm. tall : leaves several on the lower part of the stem, the upper ones much reduced; blades linear or linear-oblong, 5-20 cm. long, or shorter above, and there attenuate : spike cylindric, $2-10 \mathrm{~cm}$. long : flowers not inverted : perianth white or pink : lateral sepals ovate, much dilated on the lower side at the base, 4-4.5 mm. long, other sepal ovate or oval, 3-4 mm. long: lateral petals smaller than the sepals, broadly linear or linearoblong, 3-3.5 mm. long: lip linear or gradually narrowed upward, 5-5.7 mm. long, with 2 teeth near the base : spur filiform, about $1 \mathrm{~cm}$. long, as long as the ovary or longer. [Gymnadenia nivea (Nutt.) Engelm. \& Gray.]

In pine lands and on wooded hillsides, Delaware to Florida and Mississippi. Summer.

3. Gymnadeniopsis íntegra (Nutt.) Rydb. Roots rather thick or even tuber-like : stems 3-6 dm. tall, rather naked above : leaf-blades broadly linear or linear-lanceolate, $5-20 \mathrm{~cm}$. long, much reduced above : spike oblong, $3-8 \mathrm{~cm}$. long: bracts about as long as the perianth or shorter : perianth orange or orange-yellow : sepals oval or obovate, $3-4$ $\mathrm{mm}$. long, obtuse : lateral petals often slightly larger than the sepals : lip oblong or ovate- 
oblong, longer than the petals, erose or crenulate: spur straight, longer than the lip. [Gymnadenia flava (Nutt. ) Lindl.]

In pine-land swamps, New Jersey to Florida and Louisiana. Summer.

\section{GYROSTÁCHYS Pers.}

Herbs, with tuberous or fleshy-fibrous roots. Stems more or less completely clothed with the sheathing leaf-bases. Leaves alternate, sometimes mainly basal, those on the upper part of the stem reduced to sheathing scales. Flowers in terminal spiral spikes of 1-3 rows. Perianth not showy. Sepals distinct or coherent at the top or united to the nearly similar lateral petals. Lip concave, erect, sessile or contracted into a claw, bearing 2 callosities near the base. Column oblique from the top of the ovary, arched, merely adherent to the lip and often embraced by it. Anther erect, the back of the column without a lid. Pollen-masses one in each sac. Stigma prolonged into a beak and 2-cleft, covering the anther, stigmatic beneath. Capsules erect. [Spiranthes L. C. Rich.] Ladies' Tresses.

Flowers alternate, forming a one-sided spike by the twisting of the rachis.

Lip oblong or nearly so.

Leaves with blades at the base of the stem or near it, fugacious ; blades oblong, elliptic or ovate.

Lip white: root solitary.

Lip green in the middle: roots several.

Leaves with blades extending up the stem, persistent; blades linear.

Lateral sepals lanceolate.

Lateral sepals narrowly linear-lanceolate.

Lip laciniate near the tip.

Lip merely crisped or erose.

Bracts scarious-margined, ovate: lower leaves with very narrow elongated blades and narrow bases.

Bracts not scarious-margined, lanceolate or oblong-lanceolate : lower leaves with relatively short and broad blades and broad loose sheathing bases.

Lip ovate to rhombic.

Leaves with blades only 1 or 2, or none: Floridian species.

Leaves with blades $3-6$ : Texan species.

Flowers 2-ranked, forming a cylindric spike: rachis barely twisted.

Lip merely crisped at the apex, not lobed.

Lip oblong or nearly so.

Lip less than $5.5 \mathrm{~mm}$. long.

Lip over $6 \mathrm{~mm}$. long.

Lip with a cuneate base and 2 stout reflexed callosities.

Corolla white: spike blunt: the lower bracts shorter than the corollas.

1. G. simplex.

2. G. gracilis.

3. G. praecox.

4. G. laciniata.

5. G. linearis.

6. G. xyridifolia.

7. G. brevifolia.

8. G. Reverchonii.

Corolla yellowish: spike acute: the lower bracts longer than the corollas.

Lip with a truncate base and 2 small spreading callosities.

Lip with a dilated base or both base and apex dilated.

Upper part of the lip oblong at least not dilated.

Upper part of the lip dilated.

Leaf-blades linear: dilated upper portion of lip oval or suborbicular.

Leaf-blades broader: dilated upper portion of lip ovate.

Lip 3-lobed at the apex.

9. G. parviflora.

10. G. cernua.

11. G. ochroleuca.

12. G. plantaginea.

13. G. odorata.

14. G. vernalis.

15. G. constricta.

16. G. triloba.

1. Gyrostachys símplex (A. Gray) Kuntze. Root solitary, tuber-like: stems very slender, 1-3 dm. tall, furnished with few often deciduous scales: leaf-blades ovate or oblong, 1-3 cm. long, disappearing before flowering time : spike slender, $1-5 \mathrm{~cm}$. long, $5-8 \mathrm{~mm}$. thick, glabrous: perianth white, $2-3 \mathrm{~mm}$. long: lip broadly oblong, $2.5-3 \mathrm{~mm}$. long, crisped at the apex, with a short claw-like base and 2 basal nipple-like callosities: capsules 4-5 $\mathrm{mm}$. long.

In sandy soil, Massachusetts to Florida. Summer and fall.

2. Gyrostachys grácills (Bigel.) Kuntze. Roots coarse, clustered : stems scape-like, 2-6 dm. tall, glabrous or pubescent above, furnished with remote clasping scales: leafblades oblong, elliptic or ovate-lanceolate, $1.5-5 \mathrm{~cm}$. long, short-petioled : spike slender, $3-15 \mathrm{~cm}$. long, 8-10 mm. thick : perianth white, 4-5 $\mathrm{mm}$. long : lip shorter than the sepals, oblong, undulate or crenulate near the apex, green in the centre, otherwise hyaline and white, with 2 nipple-shaped callosities at the truncate base : capsules slightly curved, 4-5 mm. long. and fall.

In open woods and on slopes, Nova Scotia to Minnesota, Florida, Louisiana and Kansas. Summer

3. Gyrostachys praècox (Walt.) Kuntze. Roots tuberous, several : stems 2-8 dm. tall, leafy to the top: leaf-blades linear, attenuate from the narrow sheathing base, or sometimes slightly dilated toward the middle, $\tilde{0}-30 \mathrm{~cm}$. long, or reduced to sheathing scales above : spike spirally twisted, $3-10 \mathrm{~cm}$. long: bracts more or less imbricated: perianth whitish or yellowish, pubescent without, $6-8 \mathrm{~mm}$. long, curved and slightly nodding: 
lateral sepals lanceolate 5-6 $\mathrm{mm}$. long: lip 5-6 mm. long, cordate at the base, oblong, crisped and drooping above the middle or recurved at the tip ; callosities nipple-like, projecting backward : capsules $7-8 \mathrm{~mm}$. long, thick and club-shaped, curved.

In moist ground, New York to Florida and Louisiana. Summer.

4. Gyrostachys laciniàta Small. Nearly similar to G. praecox in habit, but more slender. Leaf-blades very narrowly linear: spike many-flowered : bracts ovate-lanceolate, long-acuminate, not scarious margined: lateral sepals linear-lanceolate, $6-7 \mathrm{~mm}$. long, acute : lip barely as long as the sepals, finely laciniate, especially along the edges near the tip : capsules oval-obovoid, $6-7 \mathrm{~mm}$. long.

In sand, Eustis, Florida. Spring.

5. Gyrostachys lineàris Rydb. Roots several, coarse fibers : stems slender, $4-5 \mathrm{dm}$. tall, glandular-pubescent above : leaves mainly on the lower part of the stem ; blades narrowly linear, 5-10 $\mathrm{cm}$. long, 2-4 mm. wide, mostly persistent: spike narrow, $4-10 \mathrm{~cm}$. long, 8-10 $\mathrm{mm}$. thick : bracts broadly ovate, scarious-margined, abruptly narrowed into the tip : perianth yellowish, about $8 \mathrm{~mm}$. long: lateral sepals free, linear-lanceolate, placed so as to leave a space between them and the upper one which converges with the petals: lip oblong, cordate at the base, less curved than in $G$. praecox: capsules 5-6 mm. long.

In meadows, New York to North Carolina. Summer.

6. Gyrostachys xyridifollia Small. Roots tuberous, several : stems erect, 2-5 dm. tall, simple, glabrous or nearly so below the inflorescence, leafy to the top: leaves mostly at the base of the stem ; blades linear, attenuate from the broad sheathing bases or sometimes slightly dilated toward the middle, $5-10 \mathrm{~cm}$. long, the largest of the lower ones barely reaching the middle of the stem : spike $3-15 \mathrm{~cm}$. long: bracts more or less imbricated, lanceolate to oblong-lanceolate : perianth whitish, pubescent without, 6-8 mm. long, curved and slightly nodding: lateral sepals linear-lanceolate, about $5 \mathrm{~mm}$. long: lip 5-6 $\mathrm{mm}$. long, cordate at the base, with a rhombic-orbicular base and oblong much crisped drooping or recurved tip; callosities nipple-like, projecting backward: capsules 7-8 mm. long, obovoid-clavate, curved.

In moist ground. Florida and Texas. Spring.

7. Gyrostachys brevifòlia (Chapm.) Kuntze. Roots often 3 together, coarse : stemslender, scape-like, 2-4 dm. tall, pubescent above, furnished with clasping scales : leafs blades linear or narrowly linear-spatulate, $2-5 \mathrm{~cm}$. long, early withering: spike 5-12 cm. long, 1-1.5 cm. thick, flowers in 1 row, more or less spiral : perianth white, 8-12 mm. long: lip ovate, 7-8 mm. long, undulate, curved at the apex, with 2 basal callosities.

In pine-land swamps, Florida. Fall.

8. Gyrostachys Reverchònii Small. Roots coarse : stems $3-6 \mathrm{dm}$. tall : leaf-blades various, those of the basal and lower stem-leaves linear or slightly broadened upwards, those of upper stem-leaves linear, 1-2 dm. long, acute or acuminate, reduced to sheathing bracts high up on the stem: spike long, about $1.5 \mathrm{~cm}$. thick: bracts often as long as the flowers : perianth whitish : lateral sepals free, acutish : lateral petals obtuse : lip rhombicovate, $6 \mathrm{~mm}$. long, obtuse, surpassed by the sepals and petals, slightly crisped near the apex ; callosities stout, slightly curved, pubescent at the base.

On damp prairies, Louisiana and Texas. Spring.

9. Gyrostachys parviflòra (Chapm.) Small. Roots 3-6 together, rather coarse : stems 2-4 dm. tall, minutely pubescent, especially above, commonly leafy to about the middle : leaf-blades linear to linear-oblong, $2-10 \mathrm{~cm}$. long, acute or rather obtuse, contracted above the dilated base, reduced to sheathing scales from about the middle of the stem to the inflorescence: spike $2.5-8 \mathrm{~cm}$. long: bracts lanceolate, acuminate, not surpassing the flowers : lateral sepals lanceolate from a somewhat dilated base, $5 \mathrm{~mm}$. long, acuminate, slightly undulate above : lip drooping, about $5 \mathrm{~mm}$. long, oblong or nearly so, not dilated at the base, slightly crisped above the middle, acutish ; callosities reflexed from the truncate-cordate base. [Spiranthes cernua var. parviflora Chapm.]

In rich oak woods, near Rome, Georgia. Fall.

10. Gyrostachys cèrnua (L.) Kuntze. Roots coarse, clustered : stems scape-like, 1-6 dm. tall, furnished with sheathing scales : leaf-blades linear or oblong, 5-30 cm. long, nearly sessile or narrowed into petioles : spike $5-15 \mathrm{~cm}$. long, $2-2.5 \mathrm{~cm}$. thick : flowers fragrant: perianth white, $8-10 \mathrm{~mm}$. long: lateral sepals free: lip oblong or slightly broader at the base, 7-9 mm. long, crenulate at the apex, cuneate at the base; callosities nipple-shaped, lateral on the base : capsules $6-8 \mathrm{~mm}$. long.

In meadows and swamps, Nova Scotia to Minnesota, Florida and Texas. Summer and fall. 
11. Gyrostachys ochroleùca Rydb. Roots similar to those of G. cernua: stem 3-5 dm. tall, densely pubescent above : leaves various ; basal with linear blades 1-2 dm. long, tapering to both ends and distinctly petioled ; lower stem-leaves similar, but mostly sessile; upper stem-leaves reduced to lanceolate scales: spike densely flowered, 5-15 cm. long, 15-20 mm. thick, usually acute: perianth yellow-green or ochroleucous, very fragrant, about $1 \mathrm{~cm}$. long: bracts lanceolate or ovate-lanceolate, acuminate, the lower ones generally longer than the perianth : lip rounded at the apex, with straight hairy nipple-shaped callosities.

On hillsides, New Hampshire to Pennsylvania and North Carolina. Spring and summer.

12. Gyrostachys plantagínea (Raf.) Britton. Roots clustered, coarse : stems 1-4 dm. tall : leaf-blades broadly linear or oblong, $5-15 \mathrm{~cm}$. long, reduced to sheathing scales above; petioles shorter than the blades: spike $2-10 \mathrm{~cm}$. long, $1-1.5 \mathrm{~cm}$. thick : perianth white, $6.5-7 \mathrm{~mm}$. long: lateral sepals free, narrowly lanceolate : lateral petals somewhat united with the upper sepals : lip yellow within, oblong, undulate, with a short claw ; callosities relatively small, spreading from the sides of the truncate base of the lip. [Spiranthes latifolia Torr.]

In woods and on shaded banks, New Brunswick to Minnesota, North Carolina and Michigan. Spring and summer.

13. Gyrostachys odoràta (Nutt.) Kuntze. Roots clustered, coarse : stems 2-6 dm. tall : leaf-blades oblong to oblong-lanceolate or sometimes narrowly linear-oblanceolate, 1-3 $\mathrm{dm}$. long or shorter above and reduced to scales, acute; petioles as long as the blades or shorter, margined : spike 1-1.5 dm. long, $2-2.5 \mathrm{~cm}$. thick : bracts acuminate, somewhat shorter than the fragrant flowers or longer : perianth yellowish white : lateral sepals free, like the lateral petals acute : lip nearly $1 \mathrm{~cm}$. long, the base broadly oval or suborbicular, the tip oblong, eroded and crisped, about as long as the base ; callosities slender, incurved, each more or less pubescent at the base.

On river banks, often in the water, Kentucky to North Carolina, Florida and Texas. Fall.

14. Gyrostachys vernàlis (Engelm. \& Gray) Small. Roots several, coarse : stems 3-5 dm. tall, slender, scape-like : leaf-blades linear, early disappearing, those above the middle of the stem reduced to sheathing scales: spike $5-12 \mathrm{~cm}$. long, about $1.5 \mathrm{~cm}$. thick : bracts lanceolate, somewhat shorter than the flowers, acuminate : perianth white or whitish : lip about as long as the sepals and lateral petals, $6-7 \mathrm{~mm}$. long, constricted about the middle, the base oblong, oval or rhombic-orbicular, the tip oval, suborbicular, crisped. [Spiranthes vernalis Engelm. \& Gray.]

In sandy woods, Alabama to Texas. Fall.

15. Gyrostachys constrícta Small. Roots very coarse: stems $3-4 \mathrm{~cm}$. tall, stout: leaf-blades linear or narrowly linear-spatulate, 1-2 dm. long, acute, narrowed into margined petioles or those higher up on the stem reduced to sheathing scales : spike $5-10 \mathrm{~cm}$. long, $2-2.5 \mathrm{~cm}$. thick, closely flowered : bracts lanceolate, as long as the flowers or shorter, acuminate : lip 7-10 mm. long, nearly as long as the sepals and lateral petals, constricted above the middle, the tip ovate or deltoid-ovate, much shorter than the base, the base ovate, with 2 more or less incurved basal callosities.

In marshes, Louisiana. Fall.

16. Gyrostachys tríloba Small. Roots several, cord-like: stems $3-5 \mathrm{dm}$. tall, slender, sometimes rather weak : leaf-blades oblong or elliptic-oblong, $3-8 \mathrm{~cm}$. long, acute, sheathing at the base; upper stem-leaves reduced to sheathing scales: spike 4-8 cm. long, about $1.5 \mathrm{~cm}$. thick : bracts lanceolate, acuminate, shorter than the flowers : lip oblong, 6 $\mathrm{mm}$. long, about equalling the sepals and lateral petals in length, recurved and 3-lobed at the tip, crisped throughout, cordate, with 2 basal callosities.

In sand, near Fort Meyer, Florida. Winter.

\section{BEÁDLEA Small.}

Herbs, with short coarse fibrous roots. Stem scape-like, solitary. Leaves various : those at the base of the stem normal, few ; blades broad, contracted into short petioles: those on the stem reduced to sheathing scales, rather remote. Flowers in a terminal fewflowered spike. Perianth inconspicuous. Sepals various, the lateral free, curved, the middle one adnate to the lateral petals : lip folded around the column and adnate to it, without callosities at the base. Anthers erect on the back of the column, ovoid, shorter and broader than the lanceolate entire pointed stigma. Capsules ascending or spreading.

1. Beadlea Stòreri (Chapm.) Small. Roots usually four, coarse fibers: stem 1-2 $\mathrm{dm}$. tall, pubescent above : leaves $3-4$, basal or nearly so; blades ovate, somewhat oblique, 
2-2.5 cm. long, acute or somewhat acuminate, entire, rounded at the base, those of the stem reduced to sheathing scales: petioles $\frac{1}{2}$ as long as the blades or shorter: spike $2-4 \mathrm{~cm}$. long, about 12-flowered : bracts lanceolate, acuminate, less than $1 \mathrm{~cm}$. long: perianth 3-4 mm. long, surpassing the bracts: lateral sepals obliquely lanceolate, about 3.5 $\mathrm{mm}$. long, acutish : lip about $4 \mathrm{~mm}$. long, the tip cuneate, not crisped, drooping, the base oval : column $\frac{2}{3}$ as long as the lip : anther ovate. [Spiranthes Storeri Chapm.]

On decaying vegetable matter in hammocks, near Enterprise, Florida. Spring.

\section{STENORHÝNCHUS L. C. Rich.}

Terrestrial herbs, with pale foliage. Stems leafy, or scaly, often stout. Leaves short or elongated, sheathing at the base, the lower ones early disappearing. Flowers perfect, in a large terminal spike. Bracts narrow, acuminate. Perianth white or pale. Sepals and petals narrow, decurrent on the ovary, forming a stout beak. Lateral sepals nearly free, the middle sepal adnate to the lateral petals. Lip erect, with a broad claw-like base and broad blade, destitute of callosities. Anther adnate to the back of the column, persistent. Pollen-mass 1 in each sac. Capsules erect, beaked on one side.

1. Stenorhynchus Jaliscànum (S. Wats.) Nash. Roots several, coarse, in a dense cluster. Foliage yellowish white: leaves mostly basal, those of the stem sheathing scales 2-4 cm. long : stems $3-7 \mathrm{dm}$. tall : bracts shorter than the flowers, acuminate : spike 5-20 cm. long, 4-6 cm. thick: perianth yellowish white : sepals and lateral petals $1.5-2 \mathrm{~cm}$. long, acute or acuminate : lip slightly shorter than the sepals or petals, the claw-like base obcuneate, densely pubescent along the edges, the blade triangular-lanceolate, acute, about as long as the base: capsules about $1.5 \mathrm{~cm}$. long. [Spiranthes Jaliscana S. Wats.]

In hammocks, peninsular Florida, and in Mexico. Spring.

\section{PHYSÙRUS L. C. Rich.}

Terrestrial herbs, with leafy stems. Leaves alternate: blades often membraneous, sometimes blotched. Flowers in terminal spikes, or spike-like racemes, with small bracts. Perianth inconspicuous. Sepals nearly equal, distinct, the 2 lateral spreading, the middle one erect. Lateral petals converging with the middle sepal or coherent with it. Lip dilated above, concave and prolonged into a spur at the base, sessile. Column very short. Anther erect on the column, conic. Pollen-masses 2, powdery, entire. Capsules erect.

1. Physurus quercetícola Lindl. Plants succulent: stems 1-3 dm. tall, leafy to the top : leaf-blades lanceolate to ovate-lanceolate or ovate, 1-6 cm. long, acute or obtuse on the lower part of the stem, rounded or truncate at the base ; petioles 5-10 mm. long, dilated into sheathing bases: upper leaf for two reduced to sheathing scales: raceme $1-5 \mathrm{~cm}$. long: bracts ovate-lanceolate, shorter than the flowers : perianth-members $3.5-4 \mathrm{~mm}$. long: lateral sepals linear or linear-lanceolate: lip with a dilated suborbicular dish-like claw and an orbicular-obovate blade, this notched or truncate and tipped by a drooping or recurved triangular tip : spur pouch-like, shorter than the ovary.

In shady pine lands, Florida and Louisiana. Spring to fall.

\section{LÍSTERA R. Br.}

Delicate herbs, with fleshy-fibrous roots. Leaves reduced to scales at the base of the stem and 2 opposite ones higher up (the latter perhaps more properly regarded as bracts subtending the inflorescence). Flowers in terminal racemes. Perianth inconspicuous. Sepals and lateral petals distinct, rather similar, reflexed. Lip erect or drooping, notched or sometimes elongated and deeply cleft. Anther erect, jointed to the back of the column, without a lid. Column wingless. Pollen-masses, 2 powdery, united to a minute gland. Capsules pedicelled, erect or drooping. TwIFole. Tway-BLAdE.

Lip wedge-shaped, about twice as long as the petals, notched at the apex : column $1.5 \mathrm{~mm}$. long.

Lip linear, 6-10 times longer than the petals, 2-parted : column $0.5 \mathrm{~mm}$. long.

1. L. Smallii.

1. Listera Smállii Wiegand. Foliage deep green. Stem 1-3 dm. tall, slender, glabrous or nearly so below, densely glandular-pubescent above : leaves 2, opposite, about the middle of the stem; blades reniform or ovate-reniform, $1-3 \mathrm{~cm}$. in diameter, apiculate or short-acuminate, glabrous above, more or less pubescent beneath, cordate or subcordate, sessile: racemes $2-10 \mathrm{~cm}$. long: perianth greenish: bracts lanceolate or ovate-lanceolate, 3-5 mm. long, acute: pedicels slender, $4-7 \mathrm{~mm}$. long, glabrate, or much less pubescent 
than the stem : sepals oblong or linear-oblong, about $3 \mathrm{~mm}$. long, obtuse or acutish, reflexed : lip wedge-shaped, 6-7 mm. long, with 2 prominent teeth on both sides near the base, sharply cleft to near the middle, the lobes rounded. [L. reniformis Small, not D. Don.] In damp thickets on the mountains, Pennsylvania to Virginia, North Carolina and Tennessee Spring and summer.

2. Listera austràlis Lindl. Foliage glabrous below the inflorescence. Stem 1-3 dm. tall : leaves opposite ; blades ovate or triangular-ovate, $1.5-2.5 \mathrm{~cm}$. long, acute, or apiculate, truncate or slightly cordate at the base : racemes $5-8 \mathrm{~cm}$. long, red-glandular: pedicels slender, 2-6 mm. long: bracts round, ovate, much shorter than the pedicels: perianth yellowish green : sepals broadly ovate, about $1 \mathrm{~mm}$. long: petals about as long as the sepals, rather narrower, striped with purple: lip 6-10 times longer than the petals, cleft to near the base; lobes narrowly linear or setaceous, with a small tooth in the sinus.

In wet soil, New York to South Carolina, Florida and Louisiana. Spring.

\section{PERÀMIUM Salisb.}

Caulescent herbs, with coarse fleshy-fibrous roots and usually glandular-pubescent foliage. Leaves mainly basal, and reduced to sheathing scales on the stem : blades commonly. blotehed. Flowers in terminal dense or loose spikes. Perianth inconspicuous, often white or pink. Sepals 3, the 2 lateral ones distinct, the upper one united with the lateral petals. Lip sessile, concave or sac-like, without callosities. Anther short-stalked on the column, erect or incumbent, without a lid. Pollen-masses 2, one in each sac, angular, attached to a small disk, this cohering with the stigma. Column straight, relatively small. Capsule erect or drooping. [Goodyera R. Br.] Rattlesnake Plantain. Spike one-sided, somewhat spirally twisted : lip ending in an oblong, recurved tip : stigma 2-toothed.

Spike cylindric: lip ending in an ovate, straight tip: stigma entire.

1. P. ophioides.

2. P. pubescens.

1. Peramium ophioìdes (Fernald) Rydb. Foliage glandular-pubescent. Stem very short, leafy : leaves approximate ; blades ovate to lanceolate-ovate, 1-2 cm. long, blotched with white, mostly along the cross nerves, abruptly contracted into sheathing petioles, glabrate : scapes erect, $1-2.5 \mathrm{dm}$. tall, simple, with several sheathing bracts, racemes spikelike, $6-10 \mathrm{~cm}$. long, one-sided : perianth whitish, 4-5 $\mathrm{mm}$. long: galea concave with a short recurved tip : lip saccate, with a recurved tip: capsules oblong, 6-8 mm. long. [Goodyera repens of Am. Auth., not R. Br.]

In damp woods, Nova Scotia to Alaska (?), North Carolina, Minnesota and Colorado. Summer.

2. Peramium pubéscens (Willd.) MacM. Foliage more or less pubescent. Stem very short, leafy : leaves approximate ; blades leathery, oblong, elliptic or ovate, $2-5 \mathrm{~cm}$. long, mottled with white, glabrate or glabrous, contracted into sheathing petioles : spikes cylindric, 5-15 cm. long, continuous : perianth white or pink, 4-5.5 mm. long: lateral sepals ovate: lip saccate, with a blunt tip : capsule oval, 7-9 $\mathrm{mm}$. long. [Goodyera pubescens (Willd.) R. Br.]

In woods, Newfoundland to Minnesota, Florida and Tennessee. Summer.

\section{PONTHIÈva $\mathrm{R}$. Br.}

Terrestrial caulescent herbs, with clustered roots and glabrous or pubescent foliage. Leaves mainly basal: blades thinnish. Flowers in terminal glandular-pubescent racemes. Perianth not showy. Sepals nearly equal, the lateral spreading, the middle one converging with the petals. Lateral petals nearly like the sepals, adnate to the middle of the column. Lip posterior, dilated above, concave, narrowed into a claw and adnate to the column below. Anther narrow, on the back of the column, stalked. Column 2-lobed, beaked. Pollen-masses 4, narrow, powdery. Capsules erect, beakless.

1. Ponthieva glandulòsa (Sims) R. Br. Roots coarse, elongated : stems scape-like, $2-5 \mathrm{dm}$. tall : leaves mainly near the base of the stem ; blades various, those of basal leaves oblong or elliptic, 4-12 cm. long, spreading; those of the stem reduced to sheathing scales, erect or nearly so : spike glandular-pubescent, $3-15 \mathrm{~cm}$. long : bracts linear-lanceolate, 5-10 mm. long: sepals ovate, oblique, 4-5 mm. long, acute : lateral petals larger than the sepals; blades about as broad as long, curved, acute, undulate, short-clawed : lip firm.

In open woods, North Carolina to Florida. Also in tropical America. Fall.

\section{LIMODÒRUM L.}

Scapose herb3, with corms arising from similar members of the previous year. Leaf solitary, appearing one year, followed the next year by a scape and 1 or 2 basal leaves. 
Flowers in a terminal spike or raceme. Perianth showy. Sepals and lateral petals similar or the latter narrower or broader, distinct, spreading. Lip spreading, dilated, stalked, bearded on the upper surface, with club-shaped hairs. Column elongated, incurved, 2winged above. Anther terminal, sessile, lid-like. Pollen-masses 2, one in each sac, loosely granular. Capsules erect. [Catopogon R. Br.] Grass-PINk.

Bracts as long as the ovaries or only slightly shorter.

Middle sepal and petals less than $1.5 \mathrm{~cm}$. long: petals acute.

Petals ovate: lip conspicuously mucronate.

Petals linear-lanceolate: lip barely mucronate.

Middle sepal and petals over $2 \mathrm{~cm}$. long: petals obtuse.

Bracts much shorter than the ovaries.

Blade of lip much broader than long: hairs of the crest decurrent on the claw.

Blade of lip barely broader than long: hairs of the crest not decurrent.

1. L. multiflorum.

2. L. pallidum.

3. L. Simpsonii.

4. L. tuberosum.

5. L. graminifolium.

1. Limodorum multiflòrum (Lindl.) Mohr. Leaves usually 2, basal, $8-15 \mathrm{~cm}$. long, sheathing at the base; blades linear, acuminate : scapes $2-4 \mathrm{dm}$. tall, slender, sometimes zigzag : spike continuous, 7-14-flowered: bracts about as long as the ovaries: perianth deep purple : lateral sepals obliquely ovate, $10-12 \mathrm{~mm}$. long : lateral petals ovate, acute: lip with a broadly cuneate blade, about $1 \mathrm{~cm}$. long, notched and mucronate at the apex, crested in the middle with a beard of slender hairs.

In low pine lands, peninsular Florida.

2. Limodorum pállidum (Chapm.) Mohr. Leaves solitary, basal, 1-3 dm. long; blades narrowly linear, attenuate, acute, accompanied by 1 or 2 sheathing scales at the base : scapes $2-5 \mathrm{dm}$. tall, slender : spike interrupted, $8-20$-flowered : perianth white tinged with purple : lateral sepals oblong or obovate, 11-13 mm. long, acuminate : lateral petals linear or linear-lanceolate, longer than the sepals, acute : lip with a cuneate-flabellate blade, 6-8 mm. long, barely mucronate, crested with purplish hairs : capsules oblong or oblongclavate, $1.5 \mathrm{~cm}$. long.

In low pine lands, North Carolina to Florida and Alabama. Spring.

3. Limodorum Simpsònii (Chapm.) Small. Leaves basal, usually solitary ; blades narrow, linear, 3-4 dm. long, erect, finely ribbed: scapes 5-7 dm. tall, slender, wandlike : spike few-flowered, soon interrupted: bracts about as long as the ovaries: perianth purple : lateral sepals obliquely oblong-ovate, fully $1.5 \mathrm{~cm}$. long, acuminate ; middle sepal oblong, about $2 \mathrm{~cm}$. long, acuminate : lateral petals oblong-ovate, $2.3-2.5 \mathrm{~cm}$. long, obtuse : lip about $1 \mathrm{~cm}$. long, densely bearded near the apex, the hairs club-shaped : column $1.2 \mathrm{~cm}$. long, curved.

In low pine lands, peninsular Florida. Spring and summer.

4. Limodorum tuberòsum L. Leaf usually solitary, basal; blades linear to narrowly oblong, 1-4 cm. long, acute : scape solitary, 2-9 dm. tall, straight or curved: spike 10-40 cm. long, 3-22-flowered, not dense : perianth pink-purple : bracts much shorter than the ovaries, acute: lateral sepals ovate-oblong, fully $1.5 \mathrm{~cm}$. long, oblique, acute : lateral petals lanceolate or oblong, surpassing the lateral sepals : lip fully $1.5 \mathrm{~cm}$. long, with a fan-shaped blade, erose or crenulate at the apex, crested with pink, yellow or orange hairs, these decurrent on the claw : capsule oblong, 2-2.5 cm. long. [Calopogon pulchellus R. Br.] mer.

In swamps and meadows, Newfoundland to Minnesota, Florida and Missouri. Spring and sum-

5. Limodorum graminifòlium (Ell.) Small. Leaf solitary, basal, but accompanied by 1 or 2 sheathing scales, 1-2 dm. long; blades narrowly linear, acute, often little broader than thick: scapes wire-like, $1.5-4 \mathrm{dm}$. tall : spike barely interrupted, 3-7flowered: bracts much shorter than the ovaries : perianth bright purple : lateral sepals elliptic-oblong, about $1 \mathrm{~cm}$. long, acuminate : lateral petals oblong, surpassing the lateral sepals, rather obtuse : lip with a broadly cuneate-obovate blade, barely broader than long, crested with yellow hairs; the claw glabrous. [Calopogon parviflorus Lindl.]

In low pine lands, North Carolina to Florida. Spring.

\section{ISÓTRIA Raf.}

Scapose herbs, with elongated fleshy-fibrous roots. Leaves reduced to several scales at the base of the scape. Scape solitary, topped by a whorl of several spreading leaf-like bracts. Flowers solitary or 2 together at the top of the scape, pedicelled. Perianth dusky purple or greenish, erect or ascending. Sepals narrow, nearly equal, sometimes much elongated. Lateral petals narrow, shorter than the sepals. Lip slightly 3-lobed, spurless, 
sessile, erect from the base of the column, crested. Anther terminal, stalked, with parallel sacs. Pollen-masses 2 in each sac, powdery-granular, without tails. Capsule erect, pedicelled.

1. Isotria verticillàta (Willd.) Raf. Foliage glabrous. Leaves wanting in the flowering plant or represented by several basal scales: scapes $2-4 \mathrm{dm}$. tall, topped by a whorl of 4-5 bracts : bracts thickish ; blades elliptic to oval or often broadest a little above the middle, abruptly acuminate, sessile : peduncles erect or ascending, shorter than the bracts : sepals linear or linear-filiform, $2.5-5 \mathrm{~cm}$. long, spreading: lateral petals linear, $1.5-2 \mathrm{~cm}$. long, erect, entire : lip nearly erect, 3 -lobed, crested, 1-1.5 cm. long : capsule oblong, 2-3 cm. long. [Pogonia verticillata (Willd.) Nutt.]

In woods, Ontario to Wisconsin, Florida and Alabama. Spring.

20. POGÒNIA Juss.

Caulescent herbs, with slender or cord-like roots and glabrous foliage. Leaves alternate, sometimes solitary on the stem, sessile, or the basal with long petioles. Flowers solitary or 2 at the top of the stem. Perianth commonly highly colored. Sepals distinct, erect or ascending. Petals distinct, the lateral ones about as long as the sepals or shorter. Lip erect from the base of the column, sometimes fringed, crested. Column club-shaped, elongated. Anther terminal and stalked on the back of the column : sacs parallel. Pollenmasses 2, one in each sac, powdery-granular, tailless. Stigma disk-like, below the anther. Capsule erect, ribbed.

Sepals and lateral petals about equal in length: lip bearded and crested. Sepals much longer than the lateral petals : lip merely crested.

1. P. ophioglossoides. 2. P. divaricata.

1. Pogonia ophioglossoìdes (L.) Ker. Roots fibrous, cord-like. Foliage green : stems $2-5 \mathrm{dm}$. tall: leaves basal and 1 or 2 on the stem; blades various, those of basal leaves oblong-elliptic, $8-13 \mathrm{~cm}$. long, pinched at the apex, tapering into a slender petiole longer than the blade; those of the stem oblong-lanceolate to elliptic, $3-8 \mathrm{~cm}$. long, clasping: bracts similar to the leaves, but smaller: flowers solitary or several at the top of the stem : perianth rose-colored, somewhat nodding: sepals linear-elliptic or oblong, $1.5-2 \mathrm{~cm}$. long, acute : lateral petals elliptic or oblong-cuneate, about as long as the sepals : lip spatulate or linear-spatulate, fimbriate, crested : capsules oblong, $1.5-2 \mathrm{~cm}$. long.

In swamps and meadows, Newfoundland to Ontario, Kansas, Florida and Alabama. Spring and summer.

2. Pogonia divaricàta (L.) R. Br. Roots fibrous, cord-like. Foliage glaucescent : stems 2-6 dm. tall, strict: leaves basal, and 1 or 2 on the stem : blades narrowly oblong or oblong-lanceolate, $5-15 \mathrm{~cm}$. long, obtuse or acutish, entire, sessile and partly clasping: bracts similar to the leaves but smaller : flowers normally solitary at the top of the stem : perianth deep pink or lilac : sepals linear or nearly so, $2.5-5 \mathrm{~cm}$. long : lateral petals oblong to narrowly elliptic or elliptic-oblanceolate, acuminate, shorter than the sepals : lip about as long as the petals, half-tubular, 3-lobed: capsule.

In moist soil, New Jersey to Florida and Alabama. Summer.

\section{TRIPHÒRA Nutt.}

Caulescent herbs, with fleshy tubers. Stem simple. Leaves alternate : blades thick, entire. Flowers axillary. Sepals and lateral petals free, ascending, nearly equal. Lip erect, neither crested nor spurred, 3-lobed, slightly clawed. Column elongated, clubshaped at the summit. Anther terminal, stalked on the back of the column, with parallel sacs. Pollen-masses 2, granular-powdery, 1 in each sac, without tails. Stigma a flattened disk below the anther. Capsules stalked, drooping. Nodding-cap.

1. Triphora trianthóphora (Sw.) Rydb. Roots tuberous: stems sometimes clustered, $5-30 \mathrm{~cm}$. high : leaf-blades, $2-10$, suborbicular to ovate, $5-20 \mathrm{~mm}$. long, clasping : flowers $2-7$ or sometimes solitary, axillary : perianth pedicelled, soon drooping, pale purple, $10-$ $16 \mathrm{~mm}$. long: sepals and lateral petals nearly equal, converging, obtuse, rather elliptic : lip 3-lobed, about as long as the lateral petals, narrowed into a short claw : capsules oval, 10-12 mm. long, drooping. [Pogonia pendula Lindl.]

In rich woods, Canada to Wisconsin and Kansas, south to Florida. Summer.

\section{EPIPÁCTIS R. Rr.}

Caulescent herbs, with fibrous roots. Leaves alternate: blades plaited, clasping or partly so. Flowers several in conspicuously bracted terminal racemes. Sepals and petals 
all free and separate. Lip free, concave below, constricted below the dilated and petal-like upper portion. Column short, erect. Anther erect, operculate, its sacs contiguous. Pollenmasses granulose, 2-parted, becoming attached to the glandular stigma-beak. Capsules oblong, beakless.

1. Epipactis gigantèa Dougl. Stems $3-12 \mathrm{dm}$. tall, simple, often slightly zigzag: leaf-blades lanceolate to ovate-lanceolate or ovate near the base of the stem, 1-1.5 dm. long, or shorter above, the lower ones clasping or sheathing the stem, the upper merely sessile: bracts similar to the leaves but much smaller : raceme pubescent : perianth greenish, purple-veined : sepals lanceolate to ovate-lanceolate, $12-18 \mathrm{~mm}$. long: lateral petals somewhat smaller than the sepals : lip about as long as the sepals, the concave portion with erect margins and callous-thickened nerves below, the upper portion ovate or lanceolate-ovate, entire : capsules oblong, $15-20 \mathrm{~mm}$. long.

In damp shaded places, British Columbia to California and Texas. Summer.

\section{ARETHÙSA L.}

Caulescent herbs, with corm-like rootstocks. Leaves mostly reduced to scales, one with a linear blade sometimes near the top of the stem. Flowers usually solitary and terminal. Sepals cohering at the base, converging and hooded. Lateral petals similar to the sepals. Lip broadly dilated, recurved, spreading above, crested on the inner face. Column narrow, coherent to the lip below, winged and dilated at the apex. Anther incumbent on the column : sacs approximate. Pollen-masses 4, two in each sac, powdery-granular. Capsule elongated, erect, angled or ribbed. RosE-LIP.

1. Arethusa bulbòsa L. Corm 1-2 cm. in diameter: stems scape-like, $1-3 \mathrm{dm}$. tall : leaves various, one basal with a linear blade, 1-1.5 dm. long, others mostly mere sheathing scales : flowers solitary or rarely 2 , subtended by 2 small unequal bracts : perianth showy, rose-purple, 3-6 mm. long, erect : sepals linear or oblong, 3-4 cm. long ; latteral ones curved : lateral petals often slightly shorter than the sepals: lip drooping, 2.5$3 \mathrm{~mm}$. long, dilated to the toothed or fringed apex, the face often blotched, bearded, crested with 3 white hairy lines : capsule $2-2.5 \mathrm{~cm}$. long, strongly 6 -ribbed.

In bogs, Newfoundland to Minnesota, the mountains of North Carolina, and Indiana. Spring.

\section{VANÍLLA $\mathrm{Sw}$.}

Vines climbing by aerial roots. Stems elongated, often with very long internodes. Leaves fleshy or leathery: blades sessile or slightly petioled, jointed at the base, rarely wanting. Flowers in axillary racemes. Perianth showy. Sepals and lateral petals nearly similar, distinct, spreading. Lip dilated above, adnate to the naked column. Anther large, hemispheric, or conic, incumbent. Pollen-masses rather granular. Capsule fleshy, often elongated, sometimes very fragrant, dehiscent, or indehiscent.

1. Vanilla planifòlia Andr. A vine climbing to a height of several $\mathrm{m}$. Stems terete, branching: leaf-blades leathery, oblong or elliptic-oblong, 10-18 cm. long, acute, sessile or nearly so : bracts ovate, acute: perianth green, $5-6 \mathrm{~cm}$. long, not showy : sepals linear-spatulate, slightly involute : lateral petals rather similar to the sepals but shorter and narrower, more delicate : lip shorter than the sepals; blade cornucopia-like, toothed, crested : column extending to the toothed portion of the lip : capsules cylindric, elongated, 1-2 dm. long, ver y fragrant when partially dry.

In forests, peninsular Florida and tropical America. Also widely cultivated.

\section{ACHROÁNTHES Raf.}

Caulescent herbs, with short corms. Leaves mostly reduced to scales, and one normally with an expanded blade and sheathing base. Flowers in a terminal raceme. Perianth white or greenish, not showy. Sepals distinct, spreading, the 2 lateral equal. Lateral petals very narrow or filiform, spreading. Lip broad, cordate or auricled at the base. Anther 2celled, erect or between the auricles of the lip. Pollen-masses 4, two in each sac, waxy, tailless and without glands, cohering at the apex. Column embraced by the lip. Capsule ribbed, beakless. [Microstylis Nutt.] The plants flower in the summer. AdDER's Mouth. 
1. Achroanthes unifòlia (Michx.) Raf. Leaves solitary or sometimes 2 ; blade oblong, ovate or oval, $2-6 \mathrm{~cm}$. long, obtuse or acutish, entire, with bases clasping the scape to about the middle: scapes 1-3 dm. tall, usually with a sheathing scale at the base: raceme erect, $2-10 \mathrm{~cm}$. long: pedicels very slender, spreading: perianth greenish : sepals oblong, about $1 \mathrm{~mm}$. long: lip 3-toothed at the apex : capsules oval or globose-oval, 5-6 $\mathrm{mm}$. long. [Microstylis ophioglossoides Nutt.]

In open woods and on banks, Newfoundland to Minnesota, Florida, Alabama and Missouri.

2. Achroanthes monophýlla (L.) Greene. Leaf solitary; blade oblong-elliptic to oval, 3-7 cm. long, obtuse, entire, narrowed into a long sheathing base: scape 1-2 dm. tall : raceme slender, $3-10 \mathrm{~cm}$. long, often continuous : pedicels ascending or erect, $1-4 \mathrm{~mm}$. long, or rarely shorter: sepals linear or nearly so, 1.5-2 mm. long, acute: lip ovate or nearly triangular, $2 \mathrm{~mm}$. long, acuminate, erose on the sides : capsules oval or oblong-oval, 4-5 mm. long, surpassing the pedicels in length.

In woods, Quebec to Minnesota, Pennsylvania and Texas.

3. Achroanthes Floridàna (Chapm.) Greene. Leaves 2, basal; blades ovate to oblong-ovate, $3-10 \mathrm{~cm}$. long, slightly pointed, rounded or subcordate at the base, thence prolonged into narrow sheaths : scapes 1-3 dm. tall : bracts oblong or oblong-lanceolate: pedicels surpassing the bracts : perianth greenish, $2-3 \mathrm{~mm}$. broad : sepals oblong, about 3 mm. long, spreading : lateral petals reflexed, twisted : lip cordate, abruptly pointed : capsules oblong-obovate, $6-7 \mathrm{~mm}$. long, about as long as the pedicels.

In low woods, Florida.

\section{LEPTÓRCHIS Thouars.}

Low scapose herbs, with short corms. Leaves $2-6$ at the base of the scape, spreading, commonly accompanied by several scales. Scape topped by a loosely-flowered raceme. Perianth greenish. Sepals 3, narrow. Lateral petals nearly filiform, about as long as the sepals. Lip flat, dilated, often bearing 2 tubercles above the base. Column elongated, incurved, thickened and margined above. Anther terminal, lid-like. Pollenmasses 4, two in each sac, waxy, each pair slightly united, without tails and glandless. Capsules erect or ascending. [Liparis L. C. Rich.] Twayblade.

Petals linear : lip 2.5-3.5 mm. broad : capsules oblong.

Petals filiform or linear-filiform : lip $9-12 \mathrm{~mm}$. broad: capsules clavate-oblong.

1. L. Loeselii.

2. L. liliifolia.

1. Leptorchis Loesèli1 (L.) MacM. Leaf-blades elliptic or elliptic-lanceolate, 5-17 $\mathrm{cm}$. long, acutish or obtuse, narrowed into petiole-like bases and with the lower part more or less involutely folded: scape $0.5-2 \mathrm{dm}$. tall, ridged : raceme $1.5-8 \mathrm{~cm}$. long, few-flowered : bracts minute, 1-2 $\mathrm{mm}$. long: pedicels erect or nearly so : sepals narrowly lanceolate, spreading: lateral petals linear, more or less reflexed : lip with a suborbicular blade $2.5-3.5 \mathrm{~mm}$. broad, abruptly pointed, rather shorter than the sepals and petals : capsules oblong, 10-14 mm. long.

On springy banks and in wet thickets, Nova Scotia to Saskatchewan, Maryland, Alabama and Missouri. Also in Europe. Spring and early summer.

2. Leptorchis liliifollia (L.) Kuntze. Leaf-blades relatively broad, ovate, oval or oblong-ovate, $5-15 \mathrm{~cm}$. long, obtuse or sometimes acute, narrowed into short sheathing bases: scape 1-3 dm. tall, often accompanied by one of the preceding year: raceme 3$15 \mathrm{~cm}$. long: bracts $1-3 \mathrm{~mm}$. long: pedicels ascending, thickened upward : sepals linear : lateral petals linear-filiform or filiform, sometimes surpassing the sepals : lip erect, about as long as the petals, $9-13 \mathrm{~mm}$. broad, cuneate or obovate-cuneate, apiculate: column dilated at the apex, incurved : capsules clavate-oblong, 12-18 mm. long.

In thickets and open woods, Maine to Minnesota, Georgia and Missouri. Spring and summer.

\section{CORALLORHİza R. Br.}

Saprophytic more or less colored herbs, with masses of coral-like branching roots. Stems sometimes clustered. Leaves reduced to sheathing scales. Flowers in terminal racemes. Perianth conspicuous but not showy. Sepals nearly equal, the two lateral united with the foot of the column forming a short spur, which is adnate to the top of the ovary. Lateral petals about as long as sepals, 1-3-nerved. Lip spreading or recurved, adherent to the base of the 2-edged or winged column, 1-2-ridged below. Anther terminal, lid-like. Pollen-masses 4, a pair in each sac, oblique, free, soft-waxy. Capsules spreading or drooping. Coral-root. Crawley-root.

A. Lip not 3-lobed, but often erose or finely toothed.

Sepals 1.5-2.5 mm. long : lip oblong or oval, 1.5-2. $5 \mathrm{~mm}$. long.

Sepals $2.5-10 \mathrm{~mm}$. long: lip obovate or suborbicular, $2 . \overline{-}-10 \mathrm{~mm}$. long.

Lip not notched, clawless : perianth $6-8 \mathrm{~mm}$. long: column narrowly winged.

$\mathrm{Lip}$ notched, clawed : perianth $12-14 \mathrm{~mm}$. long : column strongly winged.

1. C. mierantha.

2. C. odontorhiza. 3. C. Wisteriana. 
B. Lip 3-lobed, the lateral lobes spreading or directed forward. Spur obsolete : lip shallowy 3-lobed: capsules $8-10 \mathrm{~mm}$. long. Spur prominent : lip deeply 3-lobed : capsules $12-20 \mathrm{~mm}$. long.

4. C. Corallorhiza. 5. C. multiflora.

1. Corallorhiza micrántha Chapm. Foliage pale or greenish purple. Stems rigid, $8-15 \mathrm{~cm}$. tall : leaves reduced to 2 or 3 sheathing scales : raceme $2-4 \mathrm{dm}$. long, loosely 6-12-flowered : pedicels 1-2 mm. long, ascending : sepals linear-oblong, 1.5-2.5 mm. long: lateral petals oblong, shorter than the sepals: lip broadly oblong or oval, about as long as the petals, rounded at the apex, erose on the sides : capsules oval-obovoid, $6-7 \mathrm{~mm}$. long.

In woods, Florida. Summer and fall.

2. Corallorhiza odontorhìza (Willd.) Nutt. Foliage light or deep purple. Stems 1-3 dm. tall, sometimes zigzag: leaves reduced to several sheathing scales : racemes 4-10 cm. long, 6-20-flowered : sepals linear, or linear-spatulate, $2.5-3 \mathrm{~mm}$. long: lateral petals nearly similar, broader and barely shorter : lip obovate or oval-obovate, about as long as the petals, entire or erose, not notched, gradually contracted to the base : column with very narrow wings : capsules oval, $6-7 \mathrm{~mm}$. long.

In woods, Massachusetts to Michigan, Florida and Missouri. Summer.

3. Corallorhiza Wisteriàna Conrad. Foliage light to deep purple or brownish. Stems 2-3.5 dm. tall, strict or slightly zigzag: leaves reduced to several sheathing scales: racemes $3-10 \mathrm{~cm}$. long, 6-15-flowered: pedicels $2-3 \mathrm{~mm}$. long : sepals linear or linear-lanceolate: lateral petals nearly similar to the sepals: lip broadly oval or broadly obovate, 8-10 mm. long, white spotted with crimson, notched at the apex, truncately narrowed into a claw : column strongly 2-winged near the base: capsules elliptic-oblong or oblongobovoid, about $1 \mathrm{~cm}$. long, often drooping.

In woods, Massachusetts to Ohio, Florida and Texas. Winter and spring.

4. Corallorhiza Corallorhìza (L.) Karst. Foliage light purple. Stems 1-3 dm. tall : leaves reduced to 2 or 5 sheathing scales : raceme $2-10 \mathrm{~cm}$. long, loosely severalflowered : pedicels 1-4 mm. long: perianth dull purple: sepals linear or slightly broadened upward, 3-4 mm. long: lateral petals similar to the sepals or a little broader, shorter: lip oblong, shorter than the petals, with two small lateral teeth below the middle, notched or 3-toothed at the apex : capsules oblong or oblong-obovoid, 8-10 $\mathrm{mm}$. long. [Corallorhiza innata R. Br.].

In woods, Nova Scotia to Alaska, New Jersey, Wisconsin and Washington, and in the mountains to Georgia. Spring.

5. Corallorhiza multiflòra Nutt. Foliage deep purple. Stems $2-5 \mathrm{dm}$. tall, stout : leaves reduced to several sheathing scales : racemes $5-20 \mathrm{~cm}$. long, 9-30-flowered : perianth brownish purple: sepals linear or linear-oblong, 5-7 $\mathrm{mm}$. long: lateral petals oblong, shorter than the sepals: lip white, spotted and striped with purple, 3-lobed, crenulate: capsules oblong, 12-20 mm. long.

In woods, Nova Scotia to British Columbia, Florida, Missouri and California. Summer.

\section{APLÉCTRUM Nutt.}

Succulent herbs, from a chain of corms, one of these representing a season's growth. Stems scape-like, solitary. Leaves reduced to sessile scales on the stem, a solitary normal blade developed in the late summer or fall. Flowers in terminal racemes. Perianth darkcolored but conspicuous. Sepals and lateral petals rather similar, narrow. Lip broadened upward, slightly 3-ridged, narrowed into a claw at the base, spurless. Column free. Anther slightly below the summit of the column. Pollen masses 4, lenticular : capsules drooping. Adam-and-Eve. Putty-Root.

1. Aplectrum spicàtum (Walt.) B.S.P. Foliage glabrous. Leaf solitary, developed in the fall, erect; blade elliptic, 4-20 $\mathrm{cm}$. long, acute, commonly lasting until spring, narrowed into a winged petiole : scape beside the leaf, $2-6 \mathrm{dm}$. tall, usually with 3 scales : raceme $5-15 \mathrm{~cm}$. long: bracts longer than the pedicels : pedicels stout, shorter than the ovary: perianth brownish yellow mixed with purple: sepals linear to linearspatulate, about $1 \mathrm{~cm}$. long: lateral petals nearly like the sepals: lip shorter than the lateral petals, undulate-crenulate: column shorter than the lip, curved : capsules oblong, $2-2.5 \mathrm{~cm}$. long. [A. hiemale Nutt.]

In woods and stony soil, Ontario to the Saskatchewan and the mountains of Georgia, Missouri and California. Spring.

\section{TIPULÀrIA Nutt.}

Acaulescent herbs, with corms of several generations often connected by offsets. Leaf solitary, erect, appearing in fall or winter. Scape solitary, appearing in the summer, simple, topped by a loosely flowered bractless raceme. Flowers not showy. Perianth green. 
Sepals and lateral petals nearly similar, spreading. Lip 2-lobed, produced backward into a long slender spur. Column erect, very slightly winged, or wingless. Anther 2-celled, terminal, lid-like. Pollen-masses 4, waxy, 2 in each sac, each attached to a small transverse gland. Capsules drooping. Crane-Fly OrCHis.

1. Tipularia unifòlia (Muhl.) B.S.P. Foliage glabrous. Leaf solitary, developing in the fall and lasting till spring ; blade ovate or ovate-lanceolate, 4-9 cm. long, acute or acuminate, truncate or subcordate at the base, plaited, brown-spotted: scape erect, 3-6 dm. tall, simple : raceme $\frac{1}{2}$ as long as the rest of the scape or shorter : bracts none: pedicels spreading: sepals linear or oblong-linear, $6-8 \mathrm{~mm}$. long, rather obtuse : lip as long as the petals or shorter, 3-lobed, the middle lobe narrow : spur slender, thrice or four times as long as the petals : column shorter than the petals, often minutely pubescent at the top : capsules oblong, 10-12 mm. long. [T. discolor Nutt.]

In woods or on banks, Vermont to Michigan, Florida and Louisiana. Summer.

\section{DENDROPHYेLAX Reichenb. f.}

Epiphytic herbs, with dense clusters of roots. Leaves wanting or obsolete. Scape simple, slender. Flowers solitary at the top of the scape or few in a terminal raceme. Perianth often white. Sepals 3, nearly equal, spreading. Lateral petals nearly like the sepals. Lip erect, sessile, 3-lobed, the middle lobe 3-lobed, the lateral lobes angular, each prolonged at the base into a filiform spur. Column very short. Anthers 2-celled, terminal, lid-like, incumbent. Pollen-masses 2, waxy, unappendaged. Capsule beakless.

1. Dendrophylax Isindènii Benth. Epiphytic, with fleshy, cord-like roots 1-4 dm. long. Stem scape-like, 6-12 cm. long, slender, with several clasping scales : perianth showy : sepals linear or linear-lanceolate, $2.5-5 \mathrm{~cm}$. long: lateral petals similar to the sepals : lip ample, $3-5 \mathrm{~cm}$. long, the middle lobe with 2 linear-lanceolate attenuate spreading segments 5-10 cm. long: spur filiform, 10-15 cm. long: capsule oval or oblong-oval, stalked.

On palms, southern peninsular Florida. Also in Cuba.

\section{EPIDÉNDRUM L.}

Epiphytic herbs, clinging to the bark of trees. Leaves persistent. Flowering stems simple or branched, each terminated by a raceme or panicle. Sepals and lateral petals quite similar, and equal, mostly spreading. Lip dilated above : claw wholly or partially adnate to the column : blade entire or parted : spur none, or adnate to the ovary. Anther lid-like. Pollen-masses 4, stalked. Capsule somewhat elongated, ribbed. Tree Orchis. Flowering stems with one or several remote scales above the leaves.

Lip 3-lobed: sepals and lateral petals obtuse or abruptly pointed.

Column slightly margined: lip 3-lobed, the middle lobe not dilated.

Column 2-winged: lip 3-parted, the middle lobe dilated.

Lip entire: sepals and lateral petals attenuate or acuminate.

Lip orbicular-reniform : sepals $2-5 \mathrm{~cm}$. long: leaf-blades broadly linear.

Lip rhombic-obovate: sepals $10-11 \mathrm{~mm}$. long: leaf-blades narrowly spatulate. 4. E. erythronioides. Flowering stems completely sheathed by the leaf-bases.

Inflorescence spicate or racemose.

Sepals and lateral petals 5-7 mm. long : capsules $15-18 \mathrm{~mm}$. long.

Sepals and lateral petals $4-6 \mathrm{~cm}$. long : capsules $3-4 \mathrm{~cm}$. long.

Inflorescence umbel-like.

1. E. conopseum.

2. E Tampense.

3. E. cochleatum

1. Epidendrum conópseum Ait. Plants tufted, 5-20 cm. tall. Roots matted: leaves 1-3; blades leathery, oblong to oblong-lanceolate, 3-8 cm. long, sheathing at the base : flowering stems slender, $5-20 \mathrm{~cm}$. long, with a few remote scales : pedicels spreading, $5-10 \mathrm{~mm}$. long: perianth green, often tinged with purple : sepals spatulate or linearspatulate, 7-10 mm. long: lateral petals similar but usually narrower : lip with 2 callosities at the base of the blade, this 3-lobed, the lateral lobes crenulate, the terminal one notched at the apex : capsules oblong, $1.5-2 \mathrm{~cm}$. long.

On trees in river swamps and low grounds, South Carolina to Florida and Alabama. Summer.

2. Epidendrum Tampénse Lindl. Plants tufted, 1.5-6 dm. tall. Leaf-blades linear or linear-lanceolate, $8-20 \mathrm{~cm}$. long, leathery, typically 2 together: flowering stems slender, with several remote scales : sepals nearly $2 \mathrm{~cm}$. long, slightly broadened upward, lightly shaded with brown : lateral petals slightly shorter than the sepals, rather spatulate, of a deeper brown than the sepals : lip 1-1.5 $\mathrm{cm}$. long, the middle lobe orbicular or reniformorbicular, 7.5-8.5 mm. wide, crisped, with white edges and a rose-purple center, the lateral lobes erect, oblong-lanceolate, about $1 \mathrm{~cm}$. long, white streaked at the base with rosepurple : column 2-winged : capsules oblong, $2.5-3 \mathrm{~cm}$. long.

On trees, peninsular Florida and the Keys.

3. Epidendrum cochleàtum L. Plants 2-4 dm. tall. Leaves usually 2 ; blades leathery, broadly linear, $1.5-4 \mathrm{dm}$. long, acute : flowering stems stout, with 1 or several 
scales : bracts $5-10 \mathrm{~mm}$. long, lanceolate or ovate : sepals greenish, linear, $2-5 \mathrm{~cm}$. long, attenuate : lateral petals similar to the sepals : lip shorter than the petals, purple, entire ; blade orbicular-reniform, 2-2.5 cm. broad : capsules oblong, 3-3.5 cm. long.

In forests, peninsular Florida. Also in tropical America.

4. Epidendrum erythronioides Small. Plants tufted, 1-2 dm. tall. Leaves 3 at the base of the flowering stem, two of them with narrowly spatulate blades $6-12 \mathrm{~cm}$. long and scarcely sheathing, and one much smaller and sheathing the lower part of the flowering stem : bracts deciduous : perianth persistent : sepals broadly linear, or the lateral ones linear-elliptic, $10-11 \mathrm{~mm}$. long, acuminate : lateral petals similar to the lateral sepals : lip rhombic-obovate, slightly shorter than the lateral petals, 4-5 $\mathrm{mm}$. wide, entire : capsules elliptic or oval-elliptic, about $3 \mathrm{~cm}$. long, lustrous.

On trees, Key Largo, Florida. Summer and fall.

5. Epidendrum rígidum Jacq. Plants tufted, 1-4 dm. tall. Flowering stems completely sheathed by the leaf-bases: leaf-blades oblong, 4-8 cm. long, obtuse, leathery, approximate : bracts ovate, $1-1.5 \mathrm{~cm}$. long: perianth greenish : sepals oblong or ovate-oblong, 5-7 mm. long, acutish : lateral petals linear, about as long as the sepals : lip small ; blade deltoid-reniform, 2-2.5 mm. long, with 2 callosities near the base : column denticulate, adnate to the claw of the lip: capsules oblong or ovoid, 15-18 mm. long, beaked.

On trees, southern peninsular Florida. Also in tropical America.

6. Epidendrum noctúrnum L. Plants 3-7 dm. high. Stems sheathed by the leafbases : leaf-blades oblong to linear, $8-15 \mathrm{~cm}$. long, obtuse, spreading or ascending : perianth white or yellowish : sepals and lateral petals linear, attenuate, 4-6 $\mathrm{cm}$. long: lip 3-cleft, the lateral segments ovate-oblong, the terminal segment linear-setaceous, surpassing the lateral : capsules 3-4 cm. long, each narrowed into a beak at the apex and a stipe at the base. On trees, peninsular Florida. Also in tropical America.

7. Epidendrum umbellàtum Sw. Plants 1-3 dm. tall. Stems rather stout, sheathed by the leaf-blades, simple : leaves several ; blades leathery, oblong, 4-8 cm. long, obtuse, spreading : flowers in nearly sessile umbel-like clusters : bracts ovate or oblong-ovate, rather thin: perianth green : sepals oblong or a little broadened upward, about $1 \mathrm{~cm}$. long: lateral petals almost similar to the sepals but narrower or sometimes linear : lip orbicular-reniform, notched, obscurely 3-lobed : column straight: capsules about $1.5 \mathrm{~cm}$. long, constricted at the apex, each narrowed into a slender angled pedicel-like base.

In the everglades, peninsular Florida. Also in tropical America.

\section{POLYSTÁCHYA Hook.}

Caulescent herbs inhabiting trees. Stems scape-like above. Leaves few, 2-ranked, blades not plaited, sheathing at the base, reduced to sheathing scales above. Flowers in a terminal panicle. Perianth not showy. Sepals various, one narrow, two brcader, gibbous, converging. Lateral petals rather similar to the narrow sepal, but smaller, often much narrower. Lip sessile, jointed, abruptly bent at the base, 3-lobed. Anther free, lid-like. Pollen-masses 4, waxy, hemispheric, unappendaged. Capsules more or less elongated.

1. Polystachya minùta (Aubl.) Britton. Leaves sheathing the lower part of the stem ; blades leathery, oblong or broadly linear, 1-3 dm. long, the sheathing bases persistent. Flowering stems scape-like, 3-6 dm. long, paniculate above, with sheathing scales : perianth greenish yellow : sepals various, the middle one oblong or ovate-oblong, $4 \mathrm{~mm}$. long, obtuse, the 2 lateral obliquely ovate, acute, longer : lateral petals linear or slightly broadened upward, acute, much shorter than the sepals: lip obovate or cuneate, folded up against the lateral sepals, $4 \mathrm{~mm}$. long, hairy within, with 2 small incurved lateral lobes and a broad notched middle lobe : capsules usually $1 \mathrm{~cm}$. long. [P. luteola Hook.]

On trees, peninsular Florida. Also in tropical America.

\section{HEXALÉCTRIS Raf.}

Succulent herbs, with scaly coral-like rootstocks. Stems scape-like. Leaves reduced to sessile scales. Flowers few, in a loose terminal raceme. Sepals and lateral petals rather similar. Lip broadened upward, 3-lobed with several crested ridges, neither spurred nor gibbous. Column short, free, slightly incurved. Anther lid-like, at the apex of the column. Pollen-masses 8, aggregated in a cluster. Capsules drooping, on short pedicels.

1. Hexalectris aphýllus (Nutt.) Raf. Foliage glabrous. Stems 1-5 dm. tall, stout, scape-like : leaves (scales) sheathing or sessile : raceme $5-30 \mathrm{~cm}$. long, interrupted : perianth brownish purple, striped with lighter purple : sepals linear-oblong or elliptic, more or less curved, $1.5-2 \mathrm{~cm}$. long, acutish : lateral petals similar to the sepals but slightly shorter : 
lip colored like the petals, shorter than the sepals, 3-lobed, the lateral lobes barely crisped, the middle lobe suborbicular, crisped : capsules elliptic-oblong, $2-2.5 \mathrm{~cm}$. long.

In woods, Virginia to Missouri, Florida, Texas and Mexico. Summer.

\section{BLÈTIA R. \& P.}

Caulescent herbs, terrestrial, or inhabiting trees. Leaves few : blades elongated, firm, plaited. Flowers in terminal spikes or racemes. Sepals and lateral petals similar and nearly equal. Lip jointed, 5-lobed, hooded, without a spur, crested on the upper surface. Column elongated, free, half-terete. Anther fleshy, lid-like. Pollen-masses 8, each pair with a stalk. Capsules somewhat elongated, erect or drooping.

1. Bletia verecúnda Sw. Flowering stem lateral, $3-9 \mathrm{dm}$. tall, simple, with several remote short sheathing scales, sooner or later accompanied by a leafy shoot: leaves imbricated at the base : racemes elongated, simple : bracts very small, 1-4 mm. long : pedicels longer than the bracts : perianth showy, mainly deep pink or purplish : sepals oblong to oblong-ovate, 1-1.5 cm. long: lateral petals nearly oval, about as long as the sepals, concave, slightly wavy-margined : lip 1-1.5 $\mathrm{cm}$. long, recurved, the middle lobe crisped, notched, with $7-9$ crests, these running as ridges to the base, the lateral lobes broad and ear-like.

In low, pine lands, peninsular Florida. Also in the West Indies. Spring to fall.

\section{TRÍORCHOS Small \& Nash.}

Terrestrial herbs, with the flower-stalk lateral and distinct from the leafy stem. Leaves erect: blades several-ribbed, those of the flower-stalk reduced to almost bladeless sheaths: raceme with narrow elongated bracts. Perianth rather inconspicuous. Sepals and lateral petals oblong to elliptic, the lateral sepals slightly adnate to the foot of the column, the petals somewhat smaller than the sepals, not adnate to the column-foot. Lip crestless, 3-lobed, the lateral lobes widely spreading. Column with thick margins, the foot concave and grooved, not dilated. Capsules erect, ribbed.

1. Triorchos ecristàtus (Fernald) Small. Tubers several together, $2-2.5 \mathrm{~cm}$. in diameter: leaves mainly near the base of the stem; blades erect, nearly linear to narrowly linear-elliptic, $2-5 \mathrm{dm}$. long, acute, strongly 3 -ribbed, reduced to sheathing scales above: scape solitary, slender, 4-21 dm. tall : raceme simple, 6-12 $\mathrm{cm}$. long: pedicels 1-5 mm. long : bracts lanceolate to linear-lanceolate, the lower ones $3-5 \mathrm{~cm}$. long, surpassing the flowers : perianth brown : sepals oblong or nearly so, $8-10 \mathrm{~mm}$. long: lateral petals similar to the sepals : lip crestless, deeply 3 -lobed, the middle lobe $5-6 \mathrm{~mm}$. broad, suborbicular, crenulate, the lateral lobes slightly shorter than the middle one, oblong to obovate-oblong : capsules erect, elliptic to oblong-elliptic, about $2 \mathrm{~cm}$. long.

In dry pine lands, eastern and peninsular Florida. Spring and fall.

\section{PLÁTYPUS Small \& Nash.}

Terrestrial plants, with the flower-stalk lateral and distinct from the leafy stem. Leaves erect: blades flat, several-ribbed, those of the flower-stalk reduced to almost or wholly bladeless sheaths. Raceme elongated, rather inconspicuously bracted. Perianth relatively showy. Lateral sepals slightly broadened upward, adnate to and decurrent to the base of the dilated and forked foot of the column. Lateral petals shorter than the lateral sepals, only partially decurrent on the column-foot. Lip with a crest of nipple-like papillae, shallowly 3-lobed, the lateral lobes directed forward. Capsules ascending or spreading, ribbed.

1. Platypus papilliferus Small \& Nash. Stems 5-10 dm. tall, furnished with long sheathing scales: leaves (normal) developed sooner or later in a cluster beside the stem; blades firm, nearly linear or narrowly linear-elliptic, 2-5 dm. long, acuminate, severalribbed, sheathing at the base : racemes 1-3 dm. long, loosely flowered : bracts $3-6 \mathrm{~mm}$. long, about as long as the pedicels at maturity : perianth rather showy : sepals oblong or slightly broadened upward, acute, about $1.5 \mathrm{~cm}$. long: lateral petals barely as long as the sepals, but broader : lip fully $1.5 \mathrm{~cm}$. long, the middle lobe reniform or orbicular-reniform, 8-10 mm. broad, crisped, not notched, with nipple-like papillae, the lateral lobes rounded, with 2 crests between them: column fully $\frac{1}{2}$ as long as the lip.

In moist soil, everglades, peninsular Florida. 


\section{CYRTOPÒDIUM R. Br.}

Epiphytic herbs, with the flower-stalk lateral. Leaves borne on a stout club-like stem : blades elongated, ribbed, or those of the flower-stalks reduced, mainly to sheathing scales. Flowers several or numerous in a terminal panicle. Perianth showy. Sepals and lateral petals quite similar. Lip ample, the lateral lobes larger than the middle lobe, the claw jointed to the descending slender column-foot. Capsules drooping.

1. Cyrtopodium punctàtum Lindl. Flowering stems $8-15 \mathrm{dm}$. tall, branched above, furnished with large sheathing scales. Leaves partly drooping; blades firm, 3-7 dm. long, $2-3 \mathrm{~cm}$. wide, broadly linear, acuminate, dilated and sheathing at the base: bracts leaf-like, somewhat crisped : pedicels stout, $3-4 \mathrm{~cm}$. long at maturity : perianth showy, $3-3.5 \mathrm{~cm}$. broad: sepals oval or obovate, fully $1.5 \mathrm{~cm}$. long : lateral petals slightly longer than the sepals, thinner, somewhat crisped : lip much broader than long, rather butterfly-like, the middle lobe broadly reniform, beaded along the margins, more or less deeply notched, the lateral lobes larger, broader than long, with a broad crest between them, nearly even along the edge : capsules oblong, 6-10 cm. long, ribbed.

In dense hammocks, on trees, peninsular Florida. Spring to fall.

\section{SUBCLASS 2. DICOTYLEDÒNES.}

Stems exogenous, consisting of pith, wood and bark (endogenous in rare cases): pith of parenchymatous cells: wood in one or several layers surrounding the pith, traversed by medullary rays: bark covering the wood. Leaves various: blades mostly pinnately or palmately nerved, their bases, or the bases of the petioles articulated. Perianth and essential parts of the flower rarely in threes or sixes. Embryo with two cotyledons (rarely with only one, or probably none in Cuscuta). The first leaves (cotyledons) are opposite.

\section{Series 1. CHORIPÉTALAE.}

Petals separate and distinct from each other, or wanting. The series embraces most of the families formerly included in the Apetalas and the Polypetalae.

\section{Order 1. PIPERÀLES.}

Herbs of low or moist situations, usually with rootstocks, or shrubs, or rarely trees. Leaves normal : blades simple. Flowers perfect, or unisexual. Perianth wanting. Androecium of several stamens. Gynoecium of one or several distinct or united carpels. Fruit berry-like or somewhat capsular, or nut-like. Endosperm present.

Carpels distinct or nearly so, $3-4$ : ovules $2-8$ in each cavity. Carpels united to form a single pistil : ovule 1 in each cavity.

Fam. 1. SAURURACEAE. Fam. 2. Piperaceae.

\section{FAmily 1. SAURURÀCEAE Lindl. Lizard's-tail Family.}

Caulescent herbs, with submerged rootstocks. Leaves alternate, sometimes all basal; blades commonly thickish. Inflorescence terminal, spicate or racemose. Flowers perfect, incomplete, subtended by small bractlets. Perianth wanting. Androecium of 3-8 stamens. Filaments distinct, subulate, filiform or club-shaped, inserted under the ovary or adnate to its base. Anthers introrse. Gynoecium of 3-4 distinct carpels, or these united only at the base. Stigmas introrse. Ovules 2-8 in each cavity, ascending, orthotropous. Fruit dry or berry-like, usually with 1 seed in each carpel. Testa fleshy-leathery. Endosperm mealy or fleshy, with the minute embryo at the top.

\section{SAURÙRUS L.}

Marsh herbs, with horizontal rootstocks and erect jointed stems. Leaf-blades dilated : stipules sheathing, membranous. Flowers small, white, in slender terminal racemes with drooping tips, furnished with minute bractlets which are adnate to each pedicel or ovary. Filaments filiform or club-shaped, distinct : anther-sacs opening lengthwise. Pistils 3-4. Fruit of the 3-4 accrescent carpels which are distinct or nearly so, and veiny, opening lengthwise along the inner side. Seeds subglobose or ovoid. Endosperm mealy. 
1. Saururus cèrnuus L. Foliage dark green, glabrous, or glabrate below, the young parts and the inflorescence finely pubescent. Stems 3-12 dm. tall, erect from a swollen base, which gives off slender roots at the nodes, simple or branched above, angled : leafblades ovate or ovate-lanceolate, or sometimes slightly hastate, $8-15 \mathrm{~cm}$. long, acuminate, slightly wavy-margined, cordate and often slightly auricled at the base, commonly pubescent on the nerves ; petioles winged, often $\frac{1}{2}$ as long as the blades : racemes $1-2 \mathrm{dm}$. long, villous : filaments thickened upward, about $4 \mathrm{~mm}$. long : ovary glabrous : fruit depressed, $2.5-3 \mathrm{~mm}$. broad; carpels nearly distinct, very strongly wrinkled, brown: seed ovoidglobose, $0.7 \mathrm{~mm}$. long, shining and transversely wrinkled under an ash-colored coat.

In marshes and along streams, Ontario to Minnesota, Connecticut, Florida and Texas. Summer. LIZARD's-TAIL.

\section{Family 2. Piperàceat H.B.K. Pepper Family.}

Herbs, shrubs or trees, with tissues of a firm or a flimsy texture, often possessing spicy or aromatic properties. Leaves leathery, or fleshy, alternate, opposite or whorled: blades usually entire, often pellucid-punctate: stipules present or wanting. Flowers perfect or unisexual, in solitary or clustered spikes or rarely in racemes, subtended by cup-shaped or peltate bractlets. Perianth wanting. Androecium of $2-6$, or rarely 8 or 10 stamens inserted under the ovary. Filaments distinct, sometimes adnate to the base of the ovary. Anthers attached at the base, the 2 sacs often confluent. Gynoecium of 3 or rarely more united carpels. Ovary 1-celled, sessile or nearly so. Stigmas 3 or many in a brushlike mass. Ovule solitary, erect, orthotropous. Fruit drupaceous, indehiscent, with a fleshy or thin and almost dry pericarp. Seed solitary, with a membranous or leathery testa. Endosperm mealy, with the minute embryo at the top.

\section{PEPERÒMIA R. \& P.}

Annual or perennial caulescent herbs, with creeping often tuberous rootstocks. Leaves alternate, opposite or whorled : blades fleshy, often pellucid-punctate, sometimes very thin. Flowers perfect, minute, in dense or open slender spikes furnished with peltate bractlets. Stamens 2: filaments usually short: anthers transversely broadened, 2-valved, extrorse, the cavities confluent. Pistil solitary : stigmas forming a brush-like tuft. Fruit smail, often minute, with a thin pericarp. Seed shaped like the pericarp.

Leaf-blades thin, 3-nerved, 1-4 cm. long: spikes loosely flowered.

Leaf-blades leathery, 5-9-nerved, 6-12 cm. long: spikes densely flowered.

1. P. leptostachya.

2. P. magnoliaefolia.

1. Peperomía leptostáchya (Nutt.) Chapm. Foliage finely pubescent. Stems erect, 1-4 dm. tall, slender, closely jointed below, simple or branched above, fleshy : leaves opposite or whorled; blades 1-4 cm. long, thin, 3-nerved, the lower ones broadly cuneate, truncate or retuse at the apex, the upper ones varying from obovate to ovate, obtuse or acutish, all petioled : spikes very slender, $2-6 \mathrm{~cm}$. long, loosely-flowered ; bractlets peltate, $0.6-0.7 \mathrm{~mm}$. in diameter: stamens shorter than the ovary.

In woods and hammocks, peninsular and eastern Florida.

2. Peperomia magnoliaefòlia (Jacq.) C. DC. Foliage glabrous. Stem stout: leaves alternate; blades leathery, oval varying to ovate or obovate, or rarely broadly cuneate, 6-12 cm. long, truncate, obtuse or notched at the apex, entire, dull, on short, slightly winged petioles, 5-9-nerved : spikes slender, 5-10 $\mathrm{cm}$. long, densely flowered : bractlets peltate, $0.3-0.4 \mathrm{~mm}$. in diameter : stamens shorter than the ovary.

In rich woods and hammocks, peninsular Florida. Also in tropical America.

\section{Order 2. CASUARINÀLES.}

Shrubs or trees destitute of proper leaves, with loosely jointed angled branches. Leaves reduced to scales; these small, appressed or recurved, 4 or more in a whorl at a node, sometimes united into a sheathing base, the midrib decurrent on the branches. Flowers unisexual : staminate in slender cylindric or 4-angled terminal spikes, subtended by imbricated bracts, often with an anterior and posterior perianth-part, 1 stamen and a large anther with sacs opening lengthwise. Pistillate flowers in dense spikes or cones : perianth wanting : ovary 1-celled; styles slightly united at the base, the 2 branches slender. Ovules 1-2 
in a cavity, orthotropous or half-anatropous. Fruit a collection of winged achenes subtended by the accrescent bracts. Seed solitary, with a membranous testa. Embryo straight, with equal flat cotyledons.

\section{Family 1. CASUARINÀCEAE Lindl. Beefwood Family.}

Characters of the order.

\section{CASUARINA Adans.}

The only genus. BeEFwood.

1. Casuarina equisetifòlia Forst. A tree often $10 \mathrm{~m}$. high, with numerous very slender Equisetum-like branchlets. Scales (leaves) appressed, or the older ones recurved, 1-3 mm. long, acute, ciliate, 6-8 in a whorl at each node, their ribs decurrent as ridges on the branches and branchlets : staminate spikes slender, terminal, 1-4 cm. long; bracts appressed and imbricated: stamens exserted: pistillate spikes subglobose on lateral peduncles 1-2 $\mathrm{cm}$. long: fruiting heads globose or oblong, 1-2 cm. in diameter : seeds $2 \mathrm{~mm}$. long, pale, with the wing $5 \mathrm{~mm}$. long.

In sand, southern peninsular Florida and the Keys. Spring and summer. A native of the East, now widely distributed in the tropies.

\section{Order 3. JUGLANDÀLES.}

Monoecious aromatic very valuable timber trees, with a close or scaly resinous bark, and almost naked or scaly buds. Leaves alternate, exstipulate : blades pinnately compound, or rarely entire or toothed. Staminate flowers in lateral aments, arising from the twigs of the preceding or present year: perianth an irregularly 2-6-lobed calyx, which is sometimes united to a bract, or wanting : androecium of several rows of stamens inserted on the calyx ; filaments distinct ; anther-sacs opening lengthwise. Pistillate flowers solitary or clustered, terminal, consisting of an incompletely 2-4-celled ovary, subtended by an involucre composed of a more or less united bract and 2 lateral bractlets: calyx of 1 or several parts inserted on the ovary : style or stigmas terminal, the latter sometimes plumose : ovule solitary, orthotropous, erect. Fruit drupe-like, the hard or fibrous dehiscent or indehiscent husk enclosing a crustaceous or bony smooth or sculptured nut. Seed oily, with a membranous testa. Endosperm wanting. Embryo large, with fleshy wrinkled often 2-lobed cotyledons.

\section{FAmily 1. JUGLANDÀCEAE Lindl. WALnUt FAmily.}

\section{Characters of the order.}

Staminate aments stout, simple, sessile or short-stalked : husk indehiscent : nut sculptured. 1. JUGLANs. Staminate aments slender, branched, long-stalked : husk dehiscent: nut not sculptured.

2. HICORIA.

\section{JÙGLANS L.}

Trees often subglobose in outline, with durable and aromatic wood, watery sap, and a furrowed resinous bark. Pith in plates. Leaflets conduplicate in vernation: blades membranous. Staminate aments solitary, simple, arising from the branchlets of the preceding year, drooping : calyx 3-6-lobed : stamens in several rows : anthers glabrous, each surmounted by a conspicuous connective. Pistillate flowers solitary or several in terminal spike-like clusters on the twigs of the present year : sepals adnate to the ovary : ovary inferior : stigmas plumose, spreading. Fruit globose or oblong-cylindric, sometimes obscurely angled : husk indehiscent, glabrous or glandular-hirsute: nut deeply sculptured, thickwalled. Seed with 2-lobed cotyledons. The plants flower in the spring and mature their fruit in the fall.

Fruit elongated, viscid-pubescent: nut 4-angled, 2-celled below the middle: heart-wood light brown.

Fruit globose or subglobose, glabrous : nut not angled, 4-celled below the middle: 
Leaflets with lanceolate or narrowly-lanceolate blades: fruits 5-8 $\mathrm{cm}$. in diameter. 2. J. nigra. Leaflets with ovate or ovate-lanceolate blades : fruits about $2 \mathrm{~cm}$. in diameter.

3. J. rupestris.

1. Juglans cinèrea L. A tree, reaching a maximum height of about $30 \mathrm{~m}$., with a trunk diameter of $1 \mathrm{~m}$., the heart-wood pale, the bark light brown. Leaves $3-6 \mathrm{dm}$. long, with stout pubescent petioles; leaflets 11-17, the blades lanceolate or oblong-lanceolate or oblong, 6-12 cm. long, acute or acuminate at the apex, serrate, inequilateral at the base, sessile or short-stalked, viscid-pubescent, but at length glabrous above: staminate aments $6-15 \mathrm{~cm}$. long: anther with an apiculate appendage: fruits spicate, oblong, 8-12 $\mathrm{cm}$. long, usually acute, very viscid-pubescent : nut shaped like the husk, 1-celled above, 2-celled below the middle, the surface sculptured into thin brittle irregular longitudinal ridges.

In moist soil or rich woods, New Brunswick to North Dakota, Georgia, Alabama, Arkansas and Nebraska. ButTernut. White Walnut.

2. Juglans nìgra $\mathrm{L}$. A forest tree, reaching a maximum height of $50 \mathrm{~m}$. and a trunk diameter of $2.5 \mathrm{~m}$., producing a dark brown heart-wood, the bark dark brown, broken into broad ridges. Leaves 3-6 dm. long, with stout pubescent petioles; leaflets $15-23$ (the terminal one often suppressed), the blades $8-10 \mathrm{~cm}$. long, ovate or ovate-lanceolate, acute or acuminate, serrate, rounded or subcordate at the inequilateral base, sessile or nearly so, becoming glabrous above, pubescent beneath: staminate aments $5-10 \mathrm{~cm}$. long: anther tipped by the dilated connective : fruits globose or globose-ovoid, $5-8 \mathrm{~cm}$. long, rounded at the apex, glabrous: nut globose-ovoid, slightly flattened, sometimes broader than high, 2-celled above, 4-celled below the middle, the surface sculptured into thick irregular ridges.

In rich soil, Massachusetts to Ontario and Minnesota, Florida, Texas and Nebraska. WALnut. Black WaLNUT.

3. Juglans rupéstris Engelm. A small tree, sometimes reaching a height of $16 \mathrm{~m}$. and a trunk diameter of $1.5 \mathrm{~m}$., the bark pale, deeply furrowed. Leaves $2-3 \mathrm{dm}$. long, with slender pubescent petioles; leaflets $9-23$, the blades lanceolate or narrowly-lanceolate, acuminate, distantly serrate with appressed rather blunt teeth, often scythe-shaped, inequilateral, especially near the base, short-stalked, pubescent when young, usually becoming glabrous in age : staminate aments $5-10 \mathrm{~cm}$. long: anther tipped by the dilated connective: fruits globose, about $2 \mathrm{~cm}$. in diameter, solitary, or often 2 together, giabrous: nut subglobose, grooved, 4-celled below the middle.

In valleys, middle Texas to New Mexico and northern Mexico. WaLnut.

\section{HICÒRIA Raf.}

Trees, cylindric in outline, with hard and very tough wood, a watery sap, and a close or scaly bark. Pith solid. Leaflets involute in vernation: blades usually leathery. Staminate aments often branched, clustered on the twigs of the preceding year or at the base of the twigs of the present year, mostly long-stalked : calyx 3-lobed or rarely 2-lobed, subtended by an almost free bract; this longer than the calyx-lobes : stamens $3-10$, in several rows : anthers 2-celled, pubescent, each notched at the apex ; sacs opening lengthwise, with an inconspicuous connective. Pistillate flowers in spike-like clusters at the ends of the twigs of the present year: calyx of 1 sepal adnate on the ovary : ovary inferior : stigmas spreading. Fruit subglobose, obovoid or cylindric: husk becoming dry, 4-valved, splitting more or less readily to the middle or base, its angles sometimes winged : nut smooth, thin-walled or thick-walled, more or less flattened. Seed sweet or bitter. [Carya Nutt.] The plants flower in the spring and mature their fruit in the fall.

Cotyledons entire or merely notched at the apex : nuts terete or slightly flattened, smooth and even.

Leaflets $5-9$ : nuts with exceedingly thick shells.

Leaflets 9-15: nuts with thin shells.

Leaflets with stalked blades: nut terete: seed sweet.

Leaflets with sessile or nearly sessile blades : nuts flattened : seed bitter.

Cotyledons deeply 2-lobed : nuts markedly flattened, usually uneven.

Bud-scales valvate: lateral leaflets mostly falcate.

Leaflets 9-13, glabrous: nuts corrugated.

Leaflets 5-9, pubescent beneath : nuts smooth.

Bud-scales imbricated : lateral leaflets not falcate.

* Middle lobe of the staminate caly $x$, much larger than the lateral : husk of the fruit freely splitting to the base.

Bark close, but rough: foliage scurfy or pubescent.

Rachis of the leaves and staminate aments scurfy pubescent at least when young.

Rachis of the leaves and staminate aments densely hirsute.

Bark shaggy, separating in long plates: foliage glabrous or puberulent. $\dagger$ Leaflets 7-9: nuts pointed at both ends.

1. H. myristicaeformis.

2. H. Pecan.

3. H. Texana.

4. H. aquatica.

5. H. minima.

6. H. pallida.

7. H. alba.

8. H. laciniosa. 
$\dagger \dagger$ Leaflets 3-5: nuts rounded or notched at the base. Twigs and lower surface of the leaflets puberulent. Twigs and lower surface of the leaflets glabrous or glaucous.

** Middle lobe of the staminate calyx about equal to the lateral,

9. H. ovata.

10. H. Carolinae-septentriomalis. except in No. 12: husk of the fruit not freely splitting to the base.

Bark shaggy : fruit mostly subglobose : nut thin-shelled : seed sweet.

Bark close: fruit mostly obovoid: nut thick-shelled: seed bitter.

Foliage glabrous: staminate calyx with an elongated acute middle lobe : anther-sacs acute.

Foliage pubescent: staminate calyx with a short blunt middle lobe : anther-sacs obtuse.

11. H. microcarpa.

12. H. glabra.

13. H. villosa.

1. Hicoria myristicaefórmis (Michx. f.) Britton. A forest tree $20-35 \mathrm{~m}$. tall, with a trunk rarely $1 \mathrm{~m}$. in diameter. Bark scaly: bud-scales scurfy or tomentose: leaves 1-3 $\mathrm{dm}$. long; leaflets 5-9, the blades oblong or ovate-lanceolate to obovate, $5-12 \mathrm{~cm}$. long, acute or acuminate, rather coarsely serrate : staminate aments $6-10 \mathrm{~cm}$. long, pubescent with brown scurfy hairs : fruit elliptic or elliptic-obovoid, $2.5-3.5 \mathrm{~cm}$. long, prominently 4-ridged to the base, scurfy-pubescent : husk splitting to the base : nut apiculate at both ends, exceedingly hard, furrowed.

In low grounds or on hillsides, South Carolina and Arkansas to Alabama, Texas and Mexico.

2. Hicoria Pecán (Marsh.) Britton. A slender tree, reaching a height of about 50 m., with a maximum trunk diameter of about $2 \mathrm{~m}$. Bark somewhat roughened: foliage pubescent when young, nearly glabrous in age: bud-scales few, valvate: leaves $1.5-3 \mathrm{dm}$. long ; leaflets falcate, $11-15$, the blades oblong-lanceolate, $8-15 \mathrm{~cm}$. long, acuminate, shortstalked: staminate aments $12-15 \mathrm{~cm}$. long, sessile or nearly so near the ends of the twigs of the preceding season, or rarely on the twigs of the present season : fruit oblong, $3.5-5 \mathrm{~cm}$. long, with a thin, 4-valved husk: nut oblong-cylindric, terete or nearly so, acute, thinshelled, 2-celled at the base, the partitions very astringent, the seed very sweet.

In moist soil and along streams, Iowa to Kentucky and Texas. Also introduced into the eastern Gulf States. PECAN.

3. Hicoria Texàna LeConte. A small often bushy tree with a broad or rounded head, sometimes $26 \mathrm{~m}$. tall. Bark rough : leaves $2-4 \mathrm{dm}$. long; leaflets $9-13$, the blades firm, lanceolate to oblong-lanceolate, 8-15 $\mathrm{cm}$. long, somewhat acuminate, falcate, shallowly serrate, dark green above, paler beneath, sessile or nearly so : staminate aments slender, $5-11 \mathrm{~cm}$. long : fruit oblong: nut much flattened, oblong or ovoid-oblong, smooth, the seed very bitter.

In low grounds or river swamps, Texas.

4. Hicoria aquàtica (Michx. f.) Britton. A slender tree, sometimes $30 \mathrm{~m}$. tall, with a maximum trunk diameter of about $1 \mathrm{~m}$. Bark flaky : foliage pubescent, or glabrate in age: bud-scales valvate : leaves very numerous; leaflets $9-13$, the blades lanceolate, or the terminal one oblong, 5-15 cm. long, long-acuminate, more or less lustrous, all but the terminal one falcate : staminate aments in 3 's, arising from the shoots of the season or rarely on the twigs of the previous year, peduncled : fruit subglobose, but beaked, $2.5-3 \mathrm{~cm}$. thick, with a thin rigid, tardily 4-valved husk : nut 4-angled, slightly flattened, pointed, corrugated, thin-shelled, the seed very bitter.

In river swamps and wet woods, Virginia to Illinois, Florida and Texas. WATER Hickory.

5. Hicoria mínima (Marsh.) Britton. A slender tree, reaching a height of $30 \mathrm{~m}$. , with a maximum trunk diameter of about $1 \mathrm{~m}$. Bark close, with shallow furrows and flat ridges : foliage minutely pubescent or glabrate in age : bud-scales few, valvate : leaves 1.5-3 dm. long; leaflets 5-9, the blades lanceolate or oblong-lanceolate, acuminate, 8-15 $\mathrm{cm}$. long, sessile, all but the terminal one falcate : staminate aments in 3's, arising from the bases of the shoots of the season, or rarely on the twigs of the previous year, peduncled : fruit subglobose, $2.5-3 \mathrm{~cm}$. thick, slightly 6-ridged, with a thin, tardily 4-valved husk: nut slightly flattened, often larger than that of $H$. aquatica, short-pointed, thin-shelled, smooth, the seed intensely bitter. [Carya amara Nutt.]

In swamps and low woods, Quebec to Minnesota, Florida and Texas.

6. Hicoria pállida Ashe. A forest tree, with a very rough pale bark and purplebrown twigs. Buds acute, with 5-9 scales : leaves numerous, pale green ; leaflets 7-9, the blades lanceolate or ovate-lanceolate, long-acuminate, with numerous silvery scales beneath, glabrous or nearly so at maturity : rachis pubescent with stellate hairs at least when young: staminate aments slender, $8-12 \mathrm{~cm}$. long : caly $\mathrm{x}$ with the middle lobe longer than the lateral : fruit subglobose or oval to obovoid-pyriform, the husk rather thin, sometimes tardily splitting: nut flattened, whitish or pale.

In dry soil, Virginia to Tennessee, Florida and Alabama. 
7. Hicoria álba (L.) Britton. A forest tree, reaching a height of about $30 \mathrm{~m}$. and a maximum trunk diameter of nearly $1.5 \mathrm{~m}$. Bark rather close, in flat ridges: foliage tomentose : bud-scales imbricated : leaves ample; leaflets $7-9$, the blades oblong, oblonglanceolate, or the upper broadest above the middle, $8-13 \mathrm{~cm}$. long, short-acuminate, acute or rounded at the base, sessile: staminate aments in 3's, 10-15 cm. long, peduncled : fruit globose or globose-obovoid, 4-6 $\mathrm{cm}$. in diameter, the thick husk readily splitting to the base: nuts slightly flattened, acute, angled, thick-shelled, the seed sweet. [Carya tomentosa (Lam.) Nutt.]

In stony or rich soil, Massachusetts to Ontario and Nebraska, Florida and Texas.

8. Hicoria laciniòsa (Michx.) Sarg. A forest tree, reaching a height of $40 \mathrm{~m}$. and a maximum trunk diameter of about $1.5 \mathrm{~m}$. Bark separating in narrow plates : foliage densely puberulent when young: bud-scales imbricated : leaves ample; leaflets puberulent beneath in age, 7-9 or rarely 5, the blades oblong, oblong-lanceolate, or the upper broadest above the middle, acute or acuminate, $10-20 \mathrm{~cm}$. long: staminate aments in 3's, peduncled, arising from the base of the shoots of the year: fruit broadly oblong or oblong-obovoid, $5-8 \mathrm{~cm}$. long, with a thick husk which readily splits its entire length : nut broadly oblong, pointed at both ends, slightly flattened, the seed sweet. [Carya sulcata Nutt.]

In rich soil, New York to Iowa, Kansas, Pennsylvania, Tennessee and the Indian Territory. KINGNUT. BIG SHAG-BARK.

9. Hicoria ovàta (Mill.) Britton. A forest tree, reaching a height of $40 \mathrm{~m}$. and a maximum trunk diameter of $1.5 \mathrm{~m}$. Bark separating in large plates : foliage pubescent when young, glabrate in age: bud-scales imbricated: leaves deep green; leaflets 5 or rarely 7 , the blades oval or oblong-lanceolate, $10-15 \mathrm{~cm}$. long, acuminate, sessile: staminate aments in 3's, on the shoots of the season, peduncled : fruit subglobose, $3-5 \mathrm{~cm}$. thick, with a thick early 4-valved husk: nut slightly flattened, pointed, slightly angled, with a thin shell, the seed sweet. [Carya alba Nutt.]

In rich soil, Quebec to Minnesota, Kansas, Florida and Texas. Shell-bark Hickory. Shag-Bark.

10. Hicoria Carolìnae-septentrionàlis Ashe. A forest tree, $20-40 \mathrm{~m}$. tall, with a deep gray bark hanging in loose strips, and slender, smooth and glaucous, purplish brown twigs. Bud-scales 8-10, the inner much enlarged in unfolding : terminal bud ovoid-lanceolate, truncate : young foliage blackening in drying : leaves numerous, usually crowded at the ends of the branchlets; leaflets $3-5$, the blades lanceolate, sometimes narrowly so, $6-15 \mathrm{~cm}$. long, glabrous, ciliate, with few resinous globules: staminate aments glabrous: fruit subglobose, $1.5-3 \mathrm{~cm}$. in diameter, the husk early separating in 4 valves : nut white or brownish, flattened, angled, thin-shelled, cordate or subcordate at the top, the seed sweet.

In sandy or rocky woods or bottoms, Delaware to Kentucky, Georgia and Alabama.

11. Hicoria microcárpa (Nutt.) Britton. A forest tree, sometimes $25 \mathrm{~m}$. tall and rarely $1.5 \mathrm{~m}$. thick near the base. Bark separating into thin plates : foliage glabrous in age : bud-scales imbricated : leaves resembling those of $H$. ovata; leaflets $5-7$, the blades oval, oblong or ovate-lanceolate, acuminate at the apex, 6-14 cm. long, sometimes rounded at the base : staminate aments in 3 's, glabrous or nearly so, peduncled: fruit subglobose, $2-2.5 \mathrm{~cm}$. in diameter, the thin husk tardily splitting: nut slightly flattened, hardly angled, acute, thin-shelled, the seed sweet.

In rich woods, Massachusetts to Michigan, Missouri and Georgia.

12. Hicoria glàbra (Mill.) Britton. A forest tree, reaching a height of $60 \mathrm{~m}$, with a trunk diameter sometimes over $1.5 \mathrm{~m}$. Bark close, in flat ridges : foliage glabrous or nearly so: bud-scales imbricated : leaves $1.5-3 \mathrm{dm}$. long; leaflets $3-7$ or rarely $9,7-15$ $\mathrm{cm}$. long, the blades acuminate, often firm and lustrous, commonly oblong or oblong-lanceolate, usually acute at the base : staminate aments in 3's, peduncled, 6-10 cm. long: fruit subglobose to obovoid or pyriform, $3.5-5 \mathrm{~cm}$. long, with a thinnish, tardily separating husk : nut often brown, angled, acute, thick-shelled, the seed bitter and astringent.

In woods, Maine to Minnesota, Florida and Texas.- $\mathrm{A}$ form with larger hirsute leaflets and larger fruit is known as H. glabra hirsuta Ashe; it ranges from Virginia to Georgia. PIG-NUT Hickory.

13. Hicoria villòsa (Sarg.) Ashe. A small or medium-sized tree, with a deeply furrowed dark gray bark and glabrous or nearly glabrous, bright purple-brown twigs. Buds various, the lateral mostly short-stalked, all with $6-8$ scales, the outer scales with resinous globules: leaves 1-3 dm. long; leaflets 5-9, the blades oblong to oblong-oval, or slightly broadest above or below the middle, $8-12 \mathrm{~cm}$. long, covered beneath with silvery peltate scales and resinous globules, and usually pubescent: petioles and rachis pubescent: staminate aments 5-10 cm. long, pubescent : fruit obovoid or globose-obovoid, about $2.5 \mathrm{~cm}$. long, the husk partly splitting : nut brown, thick-shelled, angled : seed small.

In open woods, Missouri and Arkansas. 


\section{Order 4. LEITNERIÀLES.}

Dioecious shrubs or trees, with a watery sap, slightly furrowed bark and terete pithy branchlets. Leaves alternate: blades entire, leathery-membranous, elongated, the margins slightly thickened, undulate, deciduous: stipules wanting. Aments dioecious, appearing before the leaves: staminate with acuminate concave imbricated bracts inserted on a stout pubescent rachis : perianth wanting: stamens $3-12$, inserted on the receptacle-like stalk of the bract : filaments filiformsubulate, slightly dilated at the base, incurved: anthers introrse, notched at the apex. Pistillate aments mostly near the ends of the branchlets, the bracts like those of the staminate, but acute, subtending the minute perianth of gland-fringed scales. Gynoecium a single carpel. Ovary sessile or nearly so, 1-celled, oblique: style eccentric, constricted at the junction with the ovary : stigma introrse. Ovule solitary, ascending, half-anatropous. Fruit a collection of drupes each subtended by the little-changed bract. Embryo with cordate cotyledons.

\section{Family 1. LeitNeriàceae Drude. Corkwood Family.}

One genus in the southern and south-central United States. Its morphological characters associate it with MYRICACEAE, while its anatomy is nearer to that of the Hamamelidaceae.

Characters of the order.

\section{LEITNÈRIA Chapm.}

Leitneria Floridàna Chapm. A shrub or small tree, reaching a height of $7 \mathrm{~m}$. and a maximum trunk diameter of $14 \mathrm{~cm}$., with a gray bark and very light wood. Leaf-blade, narrowly elliptic, oblong or elliptic-lanceolate, or rarely oval, $10-20 \mathrm{~cm}$. long, mostly acutes sometimes obtuse or apiculate, becoming thickish, rugose, glabrous above except the midrib and lateral nerves, densely pubescent beneath; petioles $3-6 \mathrm{~cm}$. long, pubescent: staminate aments cylindric, 3-4 cm. long, pubescent, with triangular-ovate, acuminate bracts varying from 4-5 mm. in length : pistillate aments smaller than the staminate, their bracts ovate, acute, pubescent : ovary pubescent : stigma rather foliaceous : drupes elliptic, 15-17 mm. long, slightly compressed. The wood weighs about $12 \frac{1}{2}$ pounds to the cubic foot, being lighter than cork and probably the lightest wood known.

In swamps, southern Missouri to Texas and Florida. Spring.

\section{Order 5. MYRICÀLES.}

Dioecious or sometimes monoecious aromatic shrubs or small trees, commonly with a smooth bark. Leaves alternate, mostly without stipules: blades simple, resinous-dotted. Staminate flowers in elongated axillary aments, each consisting of 2-8 stamens on a bract. Filaments short, somewhat united at the base. Anthers extrorse. Pistillate flowers in short axillary aments. Gynoecium of 2 united carpels on a bract, subtended by two bractlets and surrounded by 2-8 short or elongated scales. Ovary 1-celled. Stigmas 2, filiform. Ovule solitary, erect, orthotropous. Fruit a nut, whose epicarp often excretes particles of wax. Seed solitary, with a thin-membranous testa. Embyro central.

\section{Family 1. Myricàceate Dumort. Bayberry Family.}

Characters of the order.

Leaf-blades pinnatifid; stipules present: scales surrounding the ovary 8, awl-shaped, conspicuous.

Leaf-blades entire or toothed ; stipules wanting : scales surrounding the ovary $2-4$, very] short, inconspicuous. 


\section{COMPTÒNIA Banks.}

Commonly monoecious aromatic shrubs. Leaves approximate: blades narrow, pinnatifid, rather thin. Staminate aments elongated, axillary. Stamens 3-6 on each bract : filaments shorter than the anthers : anthers erect. Pistillate aments axillary, subglobose, spiny. Ovary 1-celled, subtended by 2 bractlets and surrounded by 8 long persistent awlshaped scales: nut smooth, surrounded by a bur-like involucre formed by the accrescent scales of the flower.

1. Comptonia peregrìna (L.) Coulter. An aromatic finely pubescent shrub, 3-10 dm. tall, with erect or spreading branches. Leaves deciduous: blades linear-oblong or linear-lanceolate, 4-10 cm. long, acute or acutish, pinnately cleft into many oblique obtuse entire or sparingly toothed segments, minutely pubescent, especially beneath, shortpetioled: staminate aments narrowly-cylindric, $1-3 \mathrm{~cm}$. long, with triangular-reniform acuminate pubescent subcordate bracts which vary from $3-4 \mathrm{~mm}$. in length. Pistillate aments bur-like, their bracts reniform, the 8 scales surrounding the ovary awl-shaped: nut ovoid, $5 \mathrm{~mm}$. long, brown, shining, striate. [Comptonia asplenifolia (L.) Gaertn.]

On dry hillsides, Nova Scotia to Manitoba, Michigan, Indiana, Tennessee and North Carolina. Spring. SWEET FERN.

\section{MORÉLLA Lour.}

Mostly dioecious, sometimes evergreen, aromatic shrubs, or small trees. Leaves alternate : blades fleshy-leathery, often toothed, especially toward the apex. Staminate aments axillary, elongated. Stamens $2-8$ on a bract : filaments short, somewhat adherent at the base : anthers erect, 2-celled. Pistillate aments axillary, short, not spiny. Ovary solitary, 1-celled, subtended by $2-4$, or rarely more, short inconspicuous scales. Drupe-like nut with a fleshy epicarp which excretes granules of wax. WAX-MYRTLE. BAY-BERRY.

Shrub, 2-6 dm. tall, with woody horizontal underground stems (rootstocks).

Trees or shrubs, 1-12 m. tall, without rootstocks.

Drupes $2-3 \mathrm{~mm}$. in diameter.

Drupes 4-7 $\mathrm{mm}$. in diameter.

Leaf-blades dull above, toothed, usually pubescent and glandular beneath. 3. M. Carolinensis.

Leaf-blades lustrous above, entire, glabrous and dull green beneath.

1. M. pumila.

2. M. cerifera.

3. M. Carolinen
4. M. inodora.

1. Morella pùmila (Michx.) Small. A low much branched shrub, 2-6 dm. tall. spreading by horizontal rootstocks. Stems erect or ascending, often tufted : leaves numerous; blades leathery, varying from obovate to linear-spatulate, cuneately narrowed at the base, obtuse or acute at the apex, commonly toothed near the apex, glandular, mostly pubescent beneath, dark green above, sessile or nearly so : staminate aments $5-8 \mathrm{~mm}$. long, with reniform-flabellate bracts : pistillate aments much smaller, their bracts suborbicular, often broader than long: fruits globose, $3.5-4 \mathrm{~mm}$. in diameter. [Myrica cerifera $\gamma$ pumila Michx.]

In sandy barrens, Georgia and Florida. Flowers in winter or in early spring and fruits in the fall.

2. Morella cerifera (L.) Small. An evergreen shrub, or a small tree, reaching a maximum height of about $12 \mathrm{~m}$., with a maximum trunk diameter of $30 \mathrm{~cm}$. Stems usually ascending, often much curved, with a pale bark : leaf-blades oblanceolate or oblong-oblanceolate, $3-10 \mathrm{~cm}$. long, acute or acutish, entire or sharply and coarsely toothed, especially toward the apex, glandular, becoming glabrous, except the midnerve beneath, yellowishresinous, narrowed into slender petioles, which are usually less than $1 \mathrm{~cm}$. long: staminate aments about 1-1.5 cm. long, with reniform-flabellate bracts : pistillate aments shorter than the sterile, with broadly ovate bracts: fruits globose, about $2-3 \mathrm{~mm}$. in diameter : seeds oblong. [Myrica cerifera L.]

In sandy soil, Maryland and Arkansas to Florida and Texas. Spring.

3. Morella Carolinénsis (Mill.) Small. A shrub 1-3 m. tall, with little or no pubescence. Stems erect or ascending, more or less twisted, clothed with a pale smooth bark : leaf-blades elliptic, oblong, oblanceolate or obovate, 2-10 $\mathrm{cm}$. long, obtuse or sometimes acute, entire near the base, shallowly toothed toward the apex, glandular and sometimes pubescent beneath ; petioles usually $5 \mathrm{~mm}$. long, rarely about $1 \mathrm{~cm}$. long: staminate aments $1-1.5 \mathrm{~cm}$. long, their bracts mainly reniform-flabellate: pistillate aments much smaller than the staminate, with ovate, acute bracts: fruits globose, $4-5 \mathrm{~mm}$. in diameter: seers oblong. [Myrica Carolinensis Mill.]

In sandy soil, Nova Scotia to Florida and Alabama, chiefly near the coast, but also on the shores of Lake Erie, and in swamps inland. Spring.

4. Morella inodóra (Bartr.) Small. An evergreen shrub or small tree reaching a height of $6 \mathrm{~m}$., with a maximum trunk diameter of nearly $9 \mathrm{~cm}$. Stems often straight, clothed 
with a nearly white bark : leaf-blades leathery, oblong-obovate, elliptic-obovate, or sometimes spatulate, $4-8 \mathrm{~cm}$. long, obtuse, usually entire, lustrous above, bright green beneath ; petioles short, partially winged: staminate aments stout, 1-1.5 mm. long, their bracts orbicular-ovate, about as broad as high : pistillate aments elongated, slender, their bracts loosely imbricated, orbicular-ovate, broader than long : fruits globose, 5-7 mm. in diameter, often solitary: seeds oblong or oblong-ovoid. [Myrica inodora Bartr.]

About pine-land ponds and swamps, near the coast, Florida. Flowers during February and March.

\section{Order 6. SALICÀLES.}

Dioecious shrubs or trees, with soft weak wood and bitter bark. Leaves alternate, with or without stipules: blades simple, entire or toothed: inflorescence consisting of bracted aments. Flowers solitary in the axils of the bracts. Perianth (?) a gland or a cup-shaped disk. Staminate flowers of 2 or more stamens : anthers introrse, innate. Pistillate flowers similarly disposed. Gynoecium of 2 or rarely 4 united carpels. Ovary 1-celled with 2-4 parietal placentae: stigmas 2-4, more or less divided and sometimes raised on a short style. Ovules numerous. Fruit a dehiscent capsule. Seeds numerous, each bearing a coma. Endosperm wanting. Embryo straight.

\section{Family 1. SAlicàceat Lindl. ${ }^{1}$ Willow Family.}

\section{Characters of the order.}

Bracts incised : disk cup-shaped: stamens usually 10 or more, or rarely 7 or 8 : stigmas elongated and expanded: winter-buds with several scales.

Bracts entire : disk reduced to 1 or more axillary glands : stamens less than $10:$ stigmas short, not expanded: winter-buds with one scale each.

1. Populus.

2. SALIX.

\section{PÓPULUS L.}

Large trees, with furrowed bark and stout twigs terminated by scaly, often resinous buds. Leaf-blades palmately veined, usually coarsely toothed, or lobed; the relatively long petioles, sometimes laterally flattened, subtended by membranous, caducous stipules. Flowers in drooping lateral aments, adapted to anemophilous pollination : bracts membranous, lobed or fimbriate at the apex, usually caducous: disk cup-shaped, often oblique, entire, toothed or irregularly lobed, adnate to the pedicel of the flower. Stamens adnate to the disk: filaments distinct, glabrous : anthers purple or red. Ovary sessile in the disk, glabrous, or rarely villous: style short: stigmas dilated. Ovules anatropous. Capsule opening by 2-4 recurved valves. The plants flower in the spring and mature their fruit in the summer.

Petioles much flattened laterally.

Leaf-blades ovate or suborbicular.

Leaf-blades crenate-dentate: bracts usually surpassing the pistils.

Leaf-blades sinuate-dentate : bracts usually shorter than the pistils.

Leaf-blades deltoid or somewhat reniform.

Stamens 6-8: branches erect.

Stamens 50 or more: branches spreading.

Leaf-blades mostly longer than broad: disk very small and inconspicuous. 4. $P$. deltoides,

Leaf-blades mostly broader than long: disk large, usually conspicuous.

Leaf-blades truncate and slightly cordate at the base, with many relatively small teeth : pedicels mostly less than $4 \mathrm{~mm}$. long.

Leaf-blades more or less cuneately narrowed on the petiole, with few relatively large teeth: pedicels mostly over $5 \mathrm{~mm}$. long.

Petioles terete or channeled.

Leaf-blades glabrous or nearly so when mature, not lobed.

Stigmas dilated: leaf-blades acuminate: anthers about as broad as long: capsules less than $1 \mathrm{~cm}$. long.

Stigmas narrow: leaf-blades blunt: anthers about twice as long as broad : capsules over $1 \mathrm{~cm}$. long.

Leaf-blades persistently white-tomentose beneath, 3-5-lobed.

5. P. Fremontii.

6. P. Wislizeni.

1. P. tremuloides.

2. P. grandidentata.

3. P. dilatata.

7. P. candicans.

8. P. heterophylla.

9. P. alba.

1. Populus tremuloìdes Michx. A slender tree, reaching a maximum height of about $30 \mathrm{~m}$. and a trunk diameter of $1 \mathrm{~m}$., with glabrous foliage, except the ciliate margins

${ }^{1}$ Prepared with the assistance of Dr. W. W. Rowlee. 
of young leaves. Bark rather smooth : leaves numerous, very restless on account of the slender elongated petioles; blades ovate or orbicular-ovate, $3-8 \mathrm{~cm}$. long, or larger on young plants, crenate, rounded, truncate or subcordate at the base : staminate aments 4-6 $\mathrm{cm}$. long, 6-8 mm. thick: stamens about 10 : mature pistillate aments $8-10 \mathrm{~cm}$. long, about $1 \mathrm{~cm}$. thick : capsules conic, $5-8 \mathrm{~mm}$. long, papillose, 2-valved.

In dry or moist soil and in thickets, Newfoundland to Alaska, New Jersey, Tennessee and southward in the Rocky Mountains.

2. Populus grandtdentàta Michx. A forest tree of medium size, occasionally 20-25 m. high, with a trunk $7 \mathrm{dm}$. thick. Bark of the trunk irregularly fissured, that on young branches smooth and light gray: twigs soon glabrous: winter buds puberulent: leaves densely white-tomentose especially beneath when young, early glabrous; blades ovate, 6-10 cm. long, or $3 \mathrm{dm}$. long on young plants, short-acuminate, coarsely dentate, obtuse or truncate at the base; petioles laterally flattened, 4-6 cm. long; stipules linear, $1 \mathrm{~cm}$. long: staminate aments $4-10 \mathrm{~cm}$. long, about $1 \mathrm{~cm}$. thick: stamens $6-12$ : mature pistillate aments 8-12 cm. in length, somewhat pubescent: capsules conic, 4-7 mm. long, 2valved.

On dry uplands and in rich woods, Nova Scotia and Ontario to Minnesota, New Jersey and along the mountains to North Carolina and Tennessee.

3. Populus dilatàta Ait. An ornamental tree of very rapid growth, with a fastigiate top. Buds very resinous : leaves stiff ; blades deltoid or subrhomboid, crenate, or crenateserrate, short-acuminate, glabrous, firm, slender-petioled : staminate aments $2-5 \mathrm{~cm}$. long, cylindric, densely flowered: stamens 6-8; anthers purple : pistillate aments about as long as the staminate.

In fields and pastures, and about gardens, naturalized in the Atlantic States. Native of Europe.

4. Populus deltoides Marsh. A large tree, sometimes 45 meters high, with a trunk 2-3 meters in diameter, the foliage glabrous. Bark of trunk gray, deeply divided into interrupted longitudinal ridges in age : twigs olive-green, stout: winter buds resinous, ovoid, acute, $2 \mathrm{~cm}$. long, with $7-8$ brown scales : leaves numerous; blades broadly ovate to deltoid, abruptly acute or acuminate, coarsely serrate or crenate-serrate, truncate at the base ; petioles as long as the blades or shorter: staminate aments short-peduncled, 8-12 cm. long, $10-12 \mathrm{~mm}$. thick : mature pistillate aments $20-30 \mathrm{~cm}$. long; bracts scarious : stamens 60 or more : capsules ovoid, $8-10 \mathrm{~mm}$. long, acute, 2-4-valved, as long as the pedicels or shorter.

In moist soil, common along streams, Quebec to Manitoba, Florida and Tennessee.-A campestrian variety, with light yellow shining branches, broader leaf-blades with longer acuminations and coarser teeth is known as $P$. deltoides accidentalis Rydb.; it ranges from Saskatchewan and Alberta south to Kansas, Texas and New Mexico.

5. Populus Fremóntii S. Wats. A large tree, reaching a height of $30 \mathrm{~m}$. and a maximum trunk diameter of about $2 \mathrm{~m}$. Bark gray, more or less fissured : leaves numerous ; blades broadly deltoid or reniform-deltoid, $6-12 \mathrm{~cm}$. broad, with rather numerous, relatively fine crenate teeth, abruptly contracted into the slender petioles : aments raceme-like : the staminate 7-12 $\mathrm{cm}$. long, with pedicels $1.5-2 \mathrm{~cm}$. long: pistillate aments $8-11 \mathrm{~cm}$. long at maturity, copiously fruiting: capsules ovoid, 8-12 mm. long, often with 3 leathery valves.

\section{On river banks, Colorado to California, Texas, Mexico and Lower California.}

6. Populus Wislizèni (S. Wats.) Small. A tree, resembling P. Fremontii, but of more southern range. Bark cracked, often light gray : leaves numerous; blades deltoid or somewhat reniform, mostly less than $1 \mathrm{dm}$. broad, usually with abrupt entire acuminations and few relatively coarse crenate teeth, more or less cuneately-narrowed into the slender petioles from a broad rather truncate base : aments raceme-like : staminate mostly less than $1 \mathrm{dm}$. long, with pedicels less than $1.5 \mathrm{~cm}$. long : pistillate aments often becoming 1 $\mathrm{dm}$. long, with slender pedicels nearly $1 \mathrm{~cm}$. long: capsules ovoid, fully $1 \mathrm{~cm}$. long, usually 4-angled and 4-valved.

Along streams, southern Texas and the Rio Grande Valley.

7. Populus cándicans Ait. A large tree, reaching a height of $30 \mathrm{~m}$., with a maximum trunk diameter of about $2 \mathrm{~m}$., with spreading branches and scantily pubescent, very resinous fragrant buds. Leaves quite fleshy; blades broadly ovate, cordate, nearly or quite glabrous, $6-15 \mathrm{~cm}$. long, dark green above, pale beneath, except the margins and nerves, coarsely crenate with gland-tipped teeth: petioles generally pubescent : aments preceding the leaves: staminate $8-14 \mathrm{~cm}$. long, fully $1 \mathrm{~cm}$. thick : stamens $18-30$ : mature pistillate aments 10-15 cm. long, lax, much interrupted : stigmas with dilated lobes : capsules conic or ovoid, 8-11 mm. long, short-pedicelled, 2-valved.

In moist or dry soil, mostly escaped from cultivation, New Brunswick to Minnesota and Georgia.

8. Populus heterophýlla L. A tree $25-30 \mathrm{~m}$. high, with a maximum trunk diameter of $1 \mathrm{~m}$., but usually much smaller. Bark reddish brown, flaky : twigs hoary when 
young, soon glabrous or nearly so: winter buds broadly ovoid, less than $1 \mathrm{~cm}$. long: leaves numerous; blades broadly ovate, three-nerved, $10-15 \mathrm{~cm}$. long, or longer on young plants, usually acutish, crenate-serrate, sometimes floccose beneath, rounded to subcordate at the base, long-petioled : staminate aments $5-10 \mathrm{~cm}$. long, 18-25 mm. thick : stamens 12-20: stigmas with much thickened and dilated lobes : mature pistillate aments $3-10 \mathrm{~cm}$. long, raceme-like : capsules ovoid, $8-12 \mathrm{~mm}$. long, acute, on pedicels about $1 \mathrm{~cm}$. long.

In swamps or on river banks, Connecticut and Indiana to Arkansas, Georgia and Louisiana.

9. Populus álba L. A tree, with a maximum height of about $35 \mathrm{~m}$. and a trunk diameter of $1.5 \mathrm{~m}$. Bark light gray or whitish : buds and twigs tomentose : leaf-blades silvery white, tomentose beneath, deep green above, ovate or suborbicular, usually 3-5lobed, 5-10 $\mathrm{cm}$. long, rounded or cordate at the base; petioles shorter than the blades: staminate aments $3-5 \mathrm{~cm}$. long: anthers purple: pistillate aments about twice as long as the staminate: stigmas small and narrow.

In cultivated grounds and along roadsides, rather commonly established throughout eastern North America. Native of Europe and Asia.

\section{SALIX L.}

Trees and shrubs, with dark more or less flaky bark. Twigs slender and flexible : buds with a single scale each. Leaves alternate : blades pinnately veined, usually finely toothed, petioled or nearly sessile : stipules foliaceous or obsolete. Flowers in aments, pollination entomophilous. Aments usually dioecious : bracts entire, more or less clasping at the base, with one or more glands at the base of the flower. Stamens usually $2(1-7)$ : anthers yellow or reddish. Ovary more or less stipitate: stigmas often divided and filiform. Ovules anatropous. Capsules dehiscent at the apex into two valves. The plants flower in the early or late spring.

Capsules glabrous, at least at maturity.

Stamens 3-7: filaments pubescent at the base : bracts yellow, caducous.

Pedicels 3-5 times as long as the glands.

Leaf-blades green on both sides, but often paler beneath.

Leaf-blades 2-5 cm. long: bracts of staminate aments acute or acutish. $\quad$ 1. S. marginata.

Leaf-blades $6-15 \mathrm{~cm}$. long: bracts of staminate aments blunt.

Leaves with narrowly lanceolate blades.

Bracts of pistillate aments about $1 \mathrm{~mm}$. long: leaf-blades slenderpetioled.

Bracts of pistillate aments fully $2 \mathrm{~mm}$. long: leaf-blades shortpetioled.

Leaves with broadly lanceolate blades and slender petioles.

Leaf-blades glaucous or silvery pubescent beneath.

Pedicels about twice as long as the glands.

Stamens 2.

Filaments pubescent at the base : bracts caducous.

Pedicels 1-3 mm. long at maturity.

Styles wanting: leaves with linear or linear-lanceolate blades.

Leaf-blades finely and mostly permanently silky.

Leaf-blades glabrous, or sometimes coarsely silky when young.

Leaves with linear-lanceolate blades: bracts ovate or obovate, obtuse.

Leaves with narrowly linear blades: bracts lanceolate, acute. Styles manifest, but short: leaves with lanceolate blades.

Pedicels less than $1 \mathrm{~mm}$. long at maturity : stigmas sessile.

Branches erect or spreading: leaf-blades lanceolate.

Branches drooping: leaf-blades linear or linear-lanceolate.

Filaments glabrous : bracts persistent.

Leaf-blades less than 3 times as long as broad.

Leaf-blades fully 3 times as long as broad.

Bracts pale : leaf-blades green on both sides.

Bracts fuscous : leaf-blades glaucous beneath.

Capsules variously pubescent.

Filaments distinet.

Leaf-blades glabrous or sparingly pubescent beneath.

Leaves with linear, linear-lanceolate or lanceolate blades.

Filaments pubescent : capsules nearly glabrous at maturity.

Leaf-blades finely and mostly permanently silky.

Leaf-blades glabrate, often coarsely silky when young.

Leaves with linear-lanceolate blades: bracts ovate or obovate, obtuse.

Leaves with narrowly linear blades: bracts lanceolate, acute.

Filaments glabrous: capsules pubescent.

Leaves with oblong or oblong-lanceolate blades, or these sometimes broadest above the middle.

Leaf-blades densely pubescent beneath with white hairs.

Leaves with blades 2-5 cm. long: fruiting aments $1-1.5 \mathrm{~cm}$. long.

Leaves with blades $6-10 \mathrm{~cm}$. long: fruiting aments $2-3 \mathrm{~cm}$. long.

Filaments, and usually the anthers, united.

2. S. nigra.

4. S. longipes.

3. S. amygdaloides.

4. S. longipes.

5. S. fragilis.

\section{S. luteosericea.}

12. S. interior:

13. S. linearifolia.

5. S. fragilis.

6. S. alba.

7. S. Babylonica.

8. S. Floridana.

9. S. cordata.

10. S. Missouriensis.

11. S. luteosericea.

12. S. interior.

13. S. linearifolia.

14. S. petiolaris.

15. S. discolor.

16. S. tristis.

17. S. humilis.

18. S. purpurea. 
1. Salix marginàta Weimer. A spreading shrub or.small tree, with reddish, rather brittle twigs and glabrous or rarely permanently sparingly pubescent foliage. Leaf-blades oblong, lanceolate or ovate-lanceolate, or more rarely ovate to obovate, $2-5 \mathrm{~cm}$. long, mostly acute or blunt, serrulate, paler beneath than above, cuneate to truncate at the base, short-petioled : aments appearing with the leaves, the staminate $3-6 \mathrm{~cm}$. long; bracts densely pubescent: pistillate aments becoming 4-7 $\mathrm{cm}$. long, rather large: capsules ovoid-conic, 4-5 mm. long, glabrous, nearly twice as long as the pedicel at maturity.

On river banks and in swamps, North Carolina to Florida and Louisiana.

2. Salix nìgra Marsh. A tree, reaching a height of $40 \mathrm{~m}$., often $10-20 \mathrm{~m}$. high. Trunk sometimes $1 \mathrm{~m}$. thick : bark flaky : twigs brittle, brown, glabrous : leaf-blades narrowly lanceolate, $6-12 \mathrm{~cm}$. long, paler beneath than above, finely serrate, acute at both ends; petioles sparsely pubescent: staminate aments 4-6 cm. long, slightly less than 1 cm. thick, rather closely flowered, borne on short leafy branches; bracts ovate, white, finely pubescent : stamens $3-7$ : filaments hairy at the base: pistillate aments $4-8 \mathrm{~cm}$. long, or 10-12 $\mathrm{cm}$. in length and $1 \mathrm{~cm}$. thick at maturity ; bracts oblong, finely pubescent: stigmasnotched : capsules 4-5 times as long as the pedicels, which are not more than three times the length of the glands, borne rather closely on the rachis.

In low grounds and along river banks, New Brunswick to Ontario, California and Florida.-A variety with narrow falcate leaf-blades $4-6 \mathrm{~mm}$. wide and green on both sides, ranging from Massachusetts to Florida, is S. nigra falcàta (Pursh) Torr.

3. Salix amygdaloìdes Anders. A small tree reaching a height of $20 \mathrm{~m}$., with a trunk diameter of $6 \mathrm{dm}$. Bark scaly : leaf-blades broadly lanceolate, $8-12 \mathrm{~cm}$. long, about $2 \mathrm{~cm}$. wide, sharply serrulate, glabrous in age, dark green above, paler or glaucescent beneath; petioles slender, without glands, 6-15 $\mathrm{mm}$. long: aments appearing with the leaves, on short lateral branches, the staminate $3-5 \mathrm{~cm}$. long; bracts somewhat pubescent : pistillate aments becoming $6-10 \mathrm{~cm}$. long, lax : stigmas nearly sessile : capsules narrowly ovoid, about as long as the slender pedicels, acute, glabrous.

Along streams or lakes, Quebec to British Columbia, New York, Texas and New Mexico.

4. Salix lóngipes Anders. A shrub or small tree, rarely attaining a height of $10 \mathrm{~m}$. Bark deeply cross-checked, not flaky: twigs not brittle at the base, gray or gray-brown : leaf-blades narrowly lanceolate, $10-15 \mathrm{~cm}$. long, finely serrate, green above, glaucous and veiny beneath, more or less pubescent when young, becoming glabrous at maturity; petioles finely pubescent; stipules spinulosely denticulate: staminate aments 4-10 cm. long, often 1 $\mathrm{cm}$. thick ; bracts ovate, pale, finely ciliate : stamens $3-7$ or rarely more ; filaments united and villous at the base: pistillate aments $3-5 \mathrm{~cm}$. long, during anthesis on short leafy branches ; bracts white, oblong, sparsely pubescent, one-half as long as the ovary : stigmas minutely notched : capsules conic, 4-6 mm. long, 3-4 times as long as their pedicels. [ $S$. Wardi Bebb.]

In rocky and gravelly stream beds and along rivers, Maryland to Missouri, Florida and Texas.

5. Salix frágilis L. A tall and graceful tree, becoming $25 \mathrm{~m}$. high, with a maximum trunk diameter of $2 \mathrm{~m}$., the branches more divergent than in S. alba. Bark longitudinally furrowed but not exfoliating: twigs brittle at the base : leaf-blades lanceolate, green and glabrous, more or less glaucous beneath, 10-15 cm. long, 1-3 cm. wide, irregularly serrulate, acuminate; petioles glandular above : staminate aments on leafy branches, $2-5 \mathrm{~cm}$. long ; bracts oblong, obtuse, pubescent : stamens usually 2 , rarely 3 or 4 ; filaments free, pilose toward the base : pistillate aments becoming 7-12 cm. long, lax : capsules longconic, glabrous, on pedicels about twice as long as the glands.

Escaped from cultivation in the eastern United states. Native of Europe.

6. Salix álba L. A large tree of exceedingly rapid growth, often attaining a height of 20-30 m., often with a massive trunk 1-2.5 m. in diameter. Bark dark gray, longitudinally furrowed : twigs brown, olive-green, or yellow : leaf-blades narrowly lanceolate, more or less silky on both sides, pale or glaucous beneath, obscurely serrate, 5-12 cm. long, $1-2 \mathrm{~cm}$. wide ; petioles sometimes sparingly glandular : aments appearing with the leaves : stamens two ; filaments pilose below : pistillate aments $3-6 \mathrm{~cm}$. long: style short and thick : capsules ovoid, acute, rarely containing fertile seeds. The staminate tree is rare.

In low grounds and moist soil, naturalized in eastern North America, except the extreme north. Native of Europe and Asia.-The most common form is S. alba vitellina (L.) Koch, with glabrous leaves and twigs brilliant yellow especially in spring at which time the hue of the tree is very striking. Another variety, S. alba coerulea (J. E. Smith) Koch, with blue or bluish twigs, is commonly cultivated.

7. Salix Babylònica L. A large tree, sometimes $20 \mathrm{~m}$. high, with elongated graceful pendant branches. Leaf-blades narrowly lanceolate, $8-12 \mathrm{~cm}$. long, 10-19 mm. wide, serrulate, tapering at the base, acuminate at the apex, sometimes curling; petioles glandular above: aments appearing with the leaves, about $3 \mathrm{~cm}$. long; bracts ovate-lanceolate, 
obtusish, nearly glabrous : style yery short : stigmas lobed : capsules rarely containing fertile seeds, ovoid-conic.

Naturalized in eastern North America, except the extreme north. Native of Asia.

8. Salix Floridàna Chapm. A branching shrub $2-4 \mathrm{~m}$. tall, with sparingly pubescent twigs. Leaf-blades oblong or oblong-lanceolate, $5-8 \mathrm{~cm}$. long, acute, serrulate, glabrous, dark-green above, glaucous beneath, rounded or truncate at the base; petioles $4-10 \mathrm{~mm}$. long, pubescent: mature pistillate aments oblong-cylindric, $4-7 \mathrm{~cm}$. long, fully $2 \mathrm{~cm}$. thick, dense : capsules ovoid-conic, 6-8 mm. high, glabrous.

On rocky banks, middle and western Florida.

9. Salix cordàta Muhl. A shrub 1-5 m. high, often widely spreading from the base. Twigs stout, usually hairy: winter buds plano-convex, decidedly larger on the staminate than on the pistillate shoots: leaf-blades oblong-lanceolate, sharply serrate, tapering, rounded, or obscurely cordate at the base, green on both sides, usually silky when young, glabrous at maturity, not blackening in drying; stipules mostly large and conspicuous : aments very silky, appearing before the leaves, the staminate about $2 \mathrm{~cm}$. long: stamens 2 , with free filaments : pistillate aments $3-6 \mathrm{~cm}$. long, $1 \mathrm{~cm}$. thick : stigmas short and thick, usually two-lobed : capsules ovoid, acute.

In wet soil or on banks of streams, New Brunswick to British Columbia, North Carolina, Missouri and California,-A form with linear-lanceolate leaf-blades is, $S$. cordata angustàta (Pursh) Anders.

10. Salix Missouriénsis Bebb. A tree, reaching a height of $15 \mathrm{~m}$., with a trunk usually less than $5 \mathrm{dm}$. thick and gray scaly bark. Twigs pubescent or puberulent: leafblades lanceolate or sometimes oblanceolate, 7-15 cm. long, 1-3 cm. wide, acuminate, finely serrate with gland-tipped teeth, usually glaucous beneath: aments appearing before the leaves, the staminate $2.5-4 \mathrm{~cm}$. long, pubescent, the pistillate $7-10 \mathrm{~cm}$. long, silky: style very short : capsules narrowly ovoid.

On river banks, Missouri to Nebraska and the Indian Territory.

11. Salix luteoserícea Rydb. A branching shrub 1-6 m. high, occasionally monoecious, with grayish bark. Leaf-blades linear-lanceolate, or linear, $2-8 \mathrm{~cm}$. long, 2-6 $\mathrm{mm}$. wide, acute, entire or remotely denticulate, permanently yellowish silky : staminate aments $2-3 \mathrm{~cm}$. long; bracts obovate : pistillate aments $3-5 \mathrm{~cm}$. long; bracts broadly lanceolate : capsules elongated ovoid, 4-5 mm. long, soon glabrate.

On sand bars, Saskatchewan and British Columbia to Nebraska, the Indian Territory and Arizona.

12. Salix intèrior Rowlee. A low shrub, often forming thickets, or a slender tree 6-9 m. tall, with a trunk sometimes $3 \mathrm{dm}$. thick. Twigs brown to gray : buds plano-convex, obtuse, very small : leaf-blades linear-lanceolate or linear, ordinarily 6-10 cm. long, less than $1 \mathrm{~cm}$. wide, varying to much wider, especially on young shoots, remotely dentate, the teeth narrow and spinulose: aments on short lateral branches, which bear 4-6 leaves, loosely flowered, the staminate $2-4 \mathrm{~cm}$. long and 1-2 cm. thick; bracts usually glabrous or slightly hairy toward the base, narrowly oblong: filaments crisp-hairy below the middle : capsules sometimes nearly or quite glabrous, conic-ovoid, about $5 \mathrm{~mm}$. long.

Along streams and lakes, Quebec to the Northwest Territory, Virginia, Tennessee and Texas.

13. Salíx linearifòlia Rydb. A low branching shrub, with early glabrous foliage. Branchlets red : leaf-blades narrowly linear or viearly so, 4-10 cm. long, 2-4 mm. wide, remotely dentate; stipules minute, deciduous : aments terminating leafy branches, loosely flowered, the staminate about $3 \mathrm{~cm}$. long, the pistillate $3-4 \mathrm{~cm}$. long : bracts nearly glabrous, about as long as the pistils: capsules conic, $3-4 \mathrm{~mm}$. long, glabrous.

On sand bars, Saskatchewan to Minnesota, the Indian Territory and Colorado.

14. Salix petiolàris J. E. Smith. A shrub 2-4 m. tall, with erect or ascending slender branches. Leaf-blades lanceolate, 4-9 $\mathrm{cm}$. long, slightly silky when young, acuminate at both ends, serrulate with blunt cartilaginous teeth, short-petioled, remaining green in drying: aments unfolding before the leaves, the staminate, 1-2 cm. long, dense: pistillate aments loosely flowered, becoming $2-2.5 \mathrm{~cm}$. long: stigmas nearly sessile : capsules ovoidoblong below the tapering apex, 4-6 mm. long, about twice as long as the slender pedicels.

In swamps or low grounds, New Brunswick to the Northwest Territory and Tennessee. $-S$. petiolaris grácilis Anders. is a form with narrower leaf-blades and pedicels nearly as long as the capsules.

15. Salix díscolor Muhl. A shrub or small tree, becoming $7 \mathrm{~m}$. high. Trunk rarely $3 \mathrm{dm}$. thick, with dark bark : branches tough : buds large, glabrous, nearly black: leaf-blades oblong or oblong-lanceolate, $5-10 \mathrm{~cm}$. long, sometimes silky when young, becoming glabrous and rigid at maturity, dark-green above, glaucous-white beneath, entire or remotely serrate, slender-petioled; stipules conspicuous, acute : aments sessile, appearing before the leaves, large, cylindric, the staminate brilliant yellow at anthesis; bracts oblong, rounded, fringed with long white hairs : pistillate aments becoming $4-7 \mathrm{~cm}$. long : pedicels 
4-5 times as long as the glands : capsules conic, $5-10 \mathrm{~cm}$. long, slender-beaked, loosely disposed.

In swamps or on moist hillsides, Nova Scotia to Manitoba, North Carolina and Missourı.

16. Salix trístis Ait. A low diffuse and very leafy shrub, usually much less than $1 \mathrm{~m}$. high, with puberulent twigs. Leaf-blades oblanceolate, or linear-oblong, $2-5 \mathrm{~cm}$. long, entire or undulate, slightly revolute, hoary-white on both sides, becoming glabrous and greenish above ; petioles about $2 \mathrm{~mm}$. long or nearly wanting: aments expanding before the leaves, small, nearly globular during anthesis, the pistillate, at least, sometimes becoming 1.5 $\mathrm{cm}$. long: stigmas red, sessile or almost so : capsules ovoid below the slender beak, 5-6 $\mathrm{mm}$. long, tomentulose, with pedicels twice the length of the bracts.

In dry or barren soil, Nova Scotia? to Maine and Minnesota, Florida and Tennessee.

17. Salix hùmilis Marsh. A branching shrub 1-2.5 m. high, the twigs brown, more or less pubescent. Leaf-blades narrowly elliptic to oblanceolate, 6-10 $\mathrm{cm}$. long, green above, whitish and puberulent beneath, entire or sparingly denticulate, slightly revolute, acute at both ends or sometimes rounded at the apex, distinctly petioled ; stipules lunate, acute, obscurely toothed: aments expanding before the leaves at least twice as long as thick during anthesis, sessile, often drooping; bracts oblong, rounded at the apex, brown or black, clothed with long white hairs: style very short: stigmas thick: capsules narrowly conic, 7-8 $\mathrm{mm}$. long, beaked, silky, on pedicels equal to or slightly longer than the bracts.

In dry soil, Nova Scotia to Ontario and Nebraska, North Carolina and Tennessee.

18. Salix purpùrea L. A shrub or small tree, becoming $3.5 \mathrm{~m}$. tall, with glabrous slender flexible twigs. Bark smooth, very bitter: leaf-blades oblong to oblanceolate or spatulate, 4-7 cm. long, serrulate toward the apex, veiny, deep green above, paler beneath, short-petioled, sometimes appearing nearly opposite: aments densely flowered, $2-5 \mathrm{~cm}$. long, less than $1 \mathrm{~cm}$. thick, sessile, cylindric, often curved; bracts obtuse, black, hairy : staminate aments about $2 \mathrm{~cm}$. long, the flowers monandrous by the union of the filaments and anthers, these purple, turning black : pistillate aments sessile or nearly so, $3-5 \mathrm{~cm}$. long : capsules densely tomentose, ovoid-conic, obtuse, about $5 \mathrm{~mm}$. long.

Sparingly escaped from cultivation in the Atlantic States. Native of Europe.

\section{Order 7. FAGÀLES.}

Shrubs and trees, with hard wood and sometimes aromatic foliage. Leaves alternate: blades simple. Flowers monoecious or rarely dioecious, at least the staminate in aments, the pistillate sometimes surrounded by an involucre which becomes a bur or cup in fruit. Calyx usually present. Corolla wanting. Fruit a nut, or rarely a samara. Endosperm wanting. Embryo straight, with fleshy cotyledons.

Staminate and pistillate flowers in aments : fruit never with a bur or a cup.

Staminate flowers solitary in the axil of each bract, without a calyx : pistillate flowers with a calyx.

Staminate flowers $2-3$ together in the axil of each bract, each with a

calyx : pistillate flowers without a calyx.
Staminate flowers in aments : pistillate often solitary, the involucre becoming a bur or cup.

Fam. 1. CORYlaceae.

Fam. 2. Betulaceae.

Fam. 3. Fagaceae.

\section{Family 1. CORYLÀCEAE Mirbel. Hazel-nut Family.}

Monoecious shrubs or trees, with a close-grained wood and a scaly or smooth bark. Leaves alternate, deciduous : blades simple, mostly doubly toothed, with straight parallel lateral nerves : stipules free, deciduous or caducous. Staminate aments usually elongated, drooping, with each bract subtending a single flower without a calyx. Filaments distinct, forked at the apex. Anthers erect, the sacs separated. Pistillate aments short and stout, erect or ascending, their bracts imbricated, accrescent, foliaceous at maturity, each bearing 2-3 ovaries, with a calyx and an involucre formed by the union of a bractlet and 2 scales: styles filiform or subulate. Ovule solitary, pendulous, anatropous. Fruit of accrescent bracts, each subtending or enclosing 1 or 3 nuts. Seed solitary by suppression, with a membranous testa. 
Staminate flowers without bractlets: pistillate flowers numerous in elongated aments: nuts small, subtended by or inclosed in a bract.

Fruiting bracts flat, 3-lobed, the terminal lobe toothed.

Fruiting bracts bladder-like.

Staminate flowers with bractlets : pistillate flowers few, in heads : nuts large, in leaf-like involucres.

1. Carpinus.

2. OSTRYA.

3. Corylus.

\section{CARPINUS L.}

Trees or rarely shrubs, with a heavy close-grained wood and a pale smooth bark. Staminate aments relatively short, drooping, solitary. Stamens 3-20, inserted on a broad scale : filaments very short, branched at the summit: anther-sacs separate, pilose at the apex. Pistillate aments terminal, lax, ascending : bracts accrescent, leafy, 3-lobed : pistils 2 , at the base of a scale. Nut ovoid, flattened, sessile, ribbed, crowned by the remains of the calyx, the outer coat thin, membranous, the inner thicker, bony. Seed solitary, pendulous. The plants bloom in the spring. Hornbeam. Iron-wood. Blue Beech.

1. Carpinus Caroliniàna Walt. A shrub or small tree, with a maximum height of about $13 \mathrm{~m}$. and a trunk diameter of $8 \mathrm{dm}$. Bark blue-gray : leaf-blades thinnish, oblong, varying to ovate or ovate-lanceolate, or obovate, $3-14 \mathrm{~cm}$. long, acute or acuminate, rather finely and doubly serrate (the larger teeth sometimes flaring), glabrous above, more or less pubescent on the nerves beneath and tufted in the axils ; petioles slender, $3-17 \mathrm{~mm}$. long: staminate aments drooping, $2-5 \mathrm{~cm}$. long, their scales spreading, triangular-ovate, $3 \mathrm{~mm}$. long, acute, ciliate : anthers pubescent at the tips : pistillate aments inconspicuous, 1-1.5 $\mathrm{cm}$. long, their bracts lanceolate, 6-7 mm. long, acuminate, ciliate, accrescent : fruiting aments 3-10 cm. long, their bracts hastate, $2-3 \mathrm{~cm}$. long, the lobes entire or toothed, the lateral ones usually only on one side : nut ovoid, $5-6 \mathrm{~mm}$. long, slightly flattened, ribbed.

In moist woods and swampy places, Nova Scotia to Minnesota, Nebraska, Florida and Texas

\section{2. ÓSTRYA Scop.}

Trees, with a hard close-grained wood, a scaly bark and slender terete branches. Staminate aments clustered, drooping: bracts very broad, bearing 3-14 stamens, which are crowded on a receptacle without bractlets : filaments very short, forked at the tips : anthersacs pilose towards the ends, separated. Pistillate aments solitary and terminal on leafy branchlets : bractlets subtending 2 flowers : pistils surrounded by a pilose involucre : calyxlimb denticulate. Nut ovoid, flattened, obscurely ribbed, crowned by the remains of the calyx, with a double pericarp, the outer coat thin, membranous, the inner thicker, bony. The plants bloom in the spring. Lever-wood. Hop-Hornbeam. Iron-wood.

1. Ostrya Virginiàna (Mill.) Willd. A shrubor or tree, reaching a maximum height of $18 \mathrm{~m}$., with a trunk diameter of about $6 \mathrm{dm}$. Bark dry, scaly : leaf-blades oblong, elliptic or oval, varying towards ovate or obovate, $3-13 \mathrm{~cm}$. long, acute or acuminate, finely and doubly serrate, rounded, subcordate and inequilateral at the base, dark green and slightly pubescent or glabrate above, more densely pubescent beneath ; petioles 2-8 $\mathrm{mm}$. long: staminate aments drooping, $3-8 \mathrm{~cm}$. long: scales orbicular-obovate, $3.5 \mathrm{~mm}$. long, delicately nerved, ciliate, the acuminate apex colored: anthers villous at the top: pistillate aments shorter than the staminate, their scales lanceolate or ovate-lanceolate, 3 $\mathrm{mm}$. long, ciliate, the tip of the acumination colored, the bracts developing into pubescent nerved bladdery sacs, which are collected into a drooping oblong spike at maturity : nuts ovoid, 6-7 $\mathrm{mm}$. long, faintly ribbed.

In dry woods and on hillsides, Cape Breton Island to South Dakota, Florida and Texas.

\section{CÓRYLUS L.}

Shrubs or trees, with much branched stems. Staminate aments elongated, pendulous, solitary or clustered : bracts bearing 4-8 stamens which are inserted on a pilose receptacle, accompanied by 2 bractlets : filaments very short, forked at the top : 'anther-sacs pilose at the apex, separated. Pistillate aments inconspicuous, clustered at the tips of twigs of the season : each bract subtending an incompletely 2 -celled ovary and 2 bractlets : nuts as broad as long or nearly so, sometimes flattened, enclosed in an involucre formed of the nearly distinct or united bractlets. HAZEL-NUT. 
1. Corylus rostràta Ait. A low shrub 1-2 m. tall, with sparingly pubescent or glabrate twigs. Stems erect, much branched : leaf-blades thinnish, oval or oblong, tending to ovate or obovate, 4-12 cm. long, acute or acuminate, coarsely-serrate, and sharply serrulate, rounded or cordate at the base, slightly inequilateral, glabrous above, paler and sparingly pubescent beneath on the nerves or glabrate; petioles 4-15 $\mathrm{mm}$. long: staminate aments drooping, $2-5 \mathrm{~cm}$. long, their bracts rhomboidal-obovate, apiculate, ciliate : pistillate aments few-flowered; bractlets developing a long-beaked tubular involucre, which includes the nut in its base : nut ovoid, $1-1.5 \mathrm{~cm}$. long, flattened, longitudinally ribbed, usually exceeded twice by the slender beak of the involucre.

In thickets and open woods, Nova Scotia to South Dakota, Georgia and Kansas. Spring.

2. Corylus Americàna Walt. A shrub 1-3 m. tall, with pubescent twigs. Stems erect, often much branched : leaf-blades oval or suborbicular, tending towards ovate or obovate, $5-15 \mathrm{~cm}$. long, acute or short-acuminate, usually undulately-toothed and serrulate, rounded or cordate at the base, dark-green and glabrous above, paler and finely pubescent beneath ; petioles $5-10 \mathrm{~mm}$. long : staminate aments drooping, 6-10 $\mathrm{cm}$. long; bracts broadly oval or nearly so, $3 \mathrm{~mm}$. long, acuminate, the acuminate tips colored: pistillate aments densely few-flowered, their bractlets lobed at the apex, the lobes toothed : nut broadly ovoid, about $1.5 \mathrm{~cm}$. long, somewhat flattened, subtended by the accrescent, laciniate bractlets.

On hillsides and in thickets, Maine to Manitoba, Georgia and Kansas. Spring.

\section{Family 2. BETUlàceat Agardh. Birch Family.}

Monoecious trees or shrubs, with a compact wood, and an aromatic, resinous or astringent, smooth or shining bark which often separates into thin plates. Leaves alternate, deciduous: blades simple, with straight prominent parallel lateral nerves and 2 or several series of often sharp teeth. Staminate aments usually long and drooping with each bract subtending 2-3 flowers : calyx present : filaments sometimes simple : anther-sacs sometimes contiguous. Pistillate aments seldom drooping, their bracts thickened and woody: calyx wanting. Pistils usually 2-3 at the base of each bract: styles slender. Ovule pendulous, anatropous. Fruit a cone-like aggregate of the accrescent bracts, each of which subtends a nut. Seed solitary : testa membranous.

Stamens 2 : bracts of the mature pistillate aments membranous, 3 -lobed, deciduous with the nuts.

Stamens $4(3-6)$ : bracts of the mature pistillate aments thickened and woody, persistent. 1. BETULA.

\section{BÉTULA L.}

Shrubs or trees, with a resinous aromatic bark, and slender terete branchlets with transverse lenticels. Staminate aments elongated, pendulous. Calyx membranons, irregularly 4-lobed, or 2-lobed. Stamens 2, inserted at the base of the calyx : filaments very short, branched at the apex : anther-sacs separated. Pistillate aments erect, oblong or cylindric. dense : bracts elongated, 3-lobed, 3-flowered, accrescent, deciduous. Ovary naked, 2-celled, Nut minute, flattened, the outer coat thin, membranous, and produced into a wing, the inner crustaceous. Seed solitary, pendulous. The plants flower in the spring. Birch.

Fruiting aments peduncled.

Fruiting aments sessile at the ends of short branchlets.

Bark brown : leaf-blades shining above: mature bracts with 2 short divergent lateral lobes: nut with triangular-obovate wings.

Bark yellowish or silvery : leaf-blades dull above: mature bracts with 2 ascending lateral lobes: nut with orbicular-obovate wings.

1. B. nigra.

1. Betula nigra $L$. A tree, reaching a maximum height of $30 \mathrm{~m}$. and a trunk diameter of $1.5 \mathrm{~m}$. Trunk comparatively slender, its bark varying from brown at the base to a lustrous silvery or yellow above : leaves not aromatic; blades rhombic-ovate, $3-6 \mathrm{~cm}$. long, acute, finely serrate or cut into coarse teeth (the teeth serrate), abruptly narrowed into an entire, broadly cuneate base, glabrous or nearly so above, somewhat tomentose or pubescent on the nerves beneath; petioles pubescent, $0.5-2 \mathrm{~cm}$. long: staminate aments $6-8 \mathrm{~cm}$. long ; bracts suborbicular, cuneate at the base, often apiculate at the apex, $2 \mathrm{~mm}$. long, the bractlets rather reniform, erose : pistillate aments nearly $2 \mathrm{~cm}$. long, accrescent into eylindric cones $3-4 \mathrm{~cm}$. long ; bracts pubescent, 3-cleft, the lateral lobes about as long as the terminal one : nuts ovoid, $3.5 \mathrm{~mm}$. long, flattened, pilose at the apex, furnished with ciliate wings, which form a nearly reniform fruit twice as broad as long.

On banks of streams and in swamps, Massachusetts to Minnesota and Kansas, Florida and Texas. RIVER BIRCH. RED BIRCH. 
2. Betula lénta L. A forest tree reaching a maximum height of $25 \mathrm{~m}$. and a trunk diameter of $1.5 \mathrm{~m}$. Trunk clothed with a brown exfoliating aromatic bark : leaves aromatic; blades ovate, oblong-ovate or oblong-lanceolate, 4-12 $\mathrm{cm}$. long, acute or acuminate, finely doubly serrate, rounded or cordate at the base, dark-green and shining above, paler and silky on the nerves beneath; petioles $0.5-2 \mathrm{~cm}$. long, sometimes pubescent: staminate aments $\tilde{5}-10 \mathrm{~cm}$. long; bracts ovate, about $2.5 \mathrm{~cm}$. long, naked like the suborbicular bractlets: pistillate aments about $1.5 \mathrm{~cm}$. long, accrescent into cones $2-3 \mathrm{~cm}$. long, whose bracts are hastate or the lateral lobes ascending, glabrous or pubescent : nuts oval or obovoid, about 3 $\mathrm{mm}$. long, each furnished with a triangular-obovate wing.

In woods, Newfoundland to Minnesota, Tennessee and Florida. Sweet, Cherry or Black Birch.

3. Betula lùtea Michx. f. A forest tree, reaching a maximum height of about $30 \mathrm{~m}$. and a maximum trunk diameter of $2 \mathrm{~m}$. Trunk clothed with a yellowish or silvery slightly bitter and aromatic bark, which is close or separated in thin layers : leaves barely aromatic ; blades ovate or oblong-ovate, $5-10 \mathrm{~cm}$. long, usually acuminate at the apex, sharply and doubly serrate, rounded or cordate at the base, dull green and glabrous above, pubescent on the nerves beneath; petioles $0.5-1.5 \mathrm{~cm}$. long: staminate aments $5-10 \mathrm{~cm}$. long; bracts ovate or ovate-oval, about $2.5 \mathrm{~mm}$. long, obtuse, ciliate and colored at the apex like the reniform bractlets : pistillate aments about $1.5 \mathrm{~cm}$. long, accrescent into cones $2-4 \mathrm{~cm}$. long, their bracts 3-lobed, ciliate, ascending: nuts elliptic, $4 \mathrm{~mm}$. long, rather pointed at both ends, each furnished with an orbicular-obovate wing. BIRCH.

In woods, Newfoundland to Manitoba and the mountains of Georgia. Gray Birch. Yellow

\section{2. ÁLNUS L.}

Shrubs or trees, with a pale astringent bark, and terete branchlets. Staminate flowers in drooping aments. Calyx usually 4-lobed or irregularly 10-12-lobed. Stamens as many as the calyx-lobes and opposite them, or rarely half their number : anthers introrse. Pistillate flowers in ovoid or oblong, cone-like aments : bracts bearing 2 flowers, which are subtended by 2-4 minute bractlets, becoming woody and truncate or lobed at the apex, persistent. Ovary 2-celled, naked. Nut minute, flattened, winged or wingless, the outer coat thin-membranous, the inner thick-crustaceous. Seed solitary, filling the cavity of the nut.

Peduncles shorter than the mature fertile aments : nuts merely margined. Peduncles as long as the mature fertile aments or longer: nuts broadly winged.

1. A. rugosa.

2. A. Alnobetula.

1. Alnus rugòsa (Du Roi) K. Koch. A shrub or small tree reaching a height of about $13 \mathrm{~m}$. and a trunk diameter of $15 \mathrm{~cm}$. Stems clothed with a pale smooth bark, the twigs pubescent and slightly glutinous : leaf-blades thickish, obovate or oval, $4-10 \mathrm{~cm}$. long, obtuse or rarely acute at the apex, undulately toothed and irregularly serrulate, rounded or acutish at the base, glabrous on both surfaces, or either pubescent on the nerves beneath or the whole lower surface tomentose; petioles $0.5-15 \mathrm{~mm}$. long: staminate aments drooping, $8-12 \mathrm{~cm}$. long, appearing before the leaves; bracts orbicular-ovate, short acuminate, nearly $1.5 \mathrm{~mm}$. long, the bractlets suborbicular : pistillate aments very small, developing into oval or oblong cones 1.5-2 cm. long, their bracts flabellate, cuneate at the base, shallowly 3lobed: nuts suborbicular or rather ovoid, $1.5 \mathrm{~mm}$. long, flattened, furnished with sharp margins. [A. serrulata Willd.]

On banks of streams, in swamps and on hillsides, Maine to Minnesota, Florida and Texas. Winter and spring. SMOOTH ALDER.

2. Alnus Alnobétula (Ehrh.) K. Koch. A shrub ranging from less than $1 \mathrm{~m}$. to 3 $\mathrm{m}$. in height. Stems often diffusely branched, the twigs and young foliage glutinous and usually pubescent: leaf-blades oval or ovate, $3-9 \mathrm{~cm}$. long, rounded or acute at the apex, unevenly serrulate and sometimes incised-toothed, obtuse or cordate at the base, glabrous and dark green above, glutinous and more or less pubescent, especially on the nerves beneath ; petioles 5-25 mm. long: staminate aments $5-10 \mathrm{~cm}$. long, rather slender, usually appearing with the leaves: pistillate aments developing ovoid or oblong, long-peduncled cones, 1-2 $\mathrm{cm}$. long, their bracts flabellate, undulately-lobed at the top : nuts oblong or obovoid, $2 \mathrm{~mm}$. long, furnished with orbicular-obcordate wings. [A. viridis (Chaix.) DC.]

In stony soil, Arctic America to New York, Michigan and British America, and on open mountain tops in the Alleghenies to North Carolina. Also in Aretic Europe and Asia. Spring. MounTAIN ALDER.

\section{Family 3. Fagadefae Drude. Beech Family.}

Monoecious shrubs or trees, with a watery sap. Leaves alternate: blades simple, entire, toothed or lobed, sometimes persistent: stipules, if any, fugacious. Staminate flowers in elongated or head-like aments. Perianth of 4-7 
partially united parts. Stamens 4-20 : filaments distinct : anther-sacs opening lengthwise. Pistillate flowers solitary or several in short or elongated aments. Perianth of 4-8 partially united parts. Ovary 3-7-celled, adnate to the perianth : styles as many as there are cavities in the ovary, stigmatic at the tip, or along the side. Ovules 1-2 in each cavity, pendulous, anatropous, only 1 maturing. Fruit a 1-seeded nut with a leathery or bony exocarp, included in or seated in an accrescent scaly or spiny involucre. Testa membranous. Endosperm wanting.

Staminate aments globose, drooping on slender bracted peduncles: nuts 3-angled or 3-winged.

Staminate aments elongated, slender.

Staminate aments erect or ascending: nuts 1-3, included in a very spiny involucre.

Staminate aments drooping: nut seated in an involucre of imbricated scales.

1. FAGUS.

2. Castanea.

3. QUERCUS.

\section{FÀGUS L.}

Shrubs or trees with a close-grained wood, and a smooth pale bark. Leaf-blades leathery, usually dentate-serrate : stipules rarely persistent. Staminate aments globose, pendulous, peduncled: calyx campanulate 4-7-lobed; lobes imbricated: stamens 8-16, inserted on the base of the calyx ; filaments filiform ; anthers introrse. Pistillate flowers 2-4, in axillary peduncled accrescent involucres composed of densely imbricated scales : calyx-limb 4-5-lobed. Staminodia wanting. Ovary inferior, 3-celled : styles 3, filiform, stigmatose on the inner surface. Ovules 2 in each cavity. Mature involucre with fleshy spines, 4valved, entirely enclosing the nuts. Nuts 2-4, unequally 3 -angled or 3-winged, with a double pericarp, the outer coat leathery or crustaceous, the inner membranous. Cotyledons oily, plicate, epigaeous.

1. Fagus Amexicàna Sweet. A large forest tree, reaching a maximum height of about $40 \mathrm{~m}$., with a trunk diameter of $1.5 \mathrm{~m}$., clothed with a pale or bluish bark. Leaves rigid; blades leathery, ovate, oval or oblong-ovate, 5-14 cm. long, usually short-acuminate, rather distantly serrate, very silky when young, dark green, glabrous, dull or glossy above in age, paler and pubescent on the nerves beneath : staminate aments $1-1.5 \mathrm{~cm}$. in diameter, drooping : peduncles $2-4 \mathrm{~cm}$. long, pubescent : calyx $3-4 \mathrm{~mm}$. long; lobes ovate, obtuse, becoming acutish, about as long as the tube : filaments exserted : pistillate flowers usually 2 in each involucre : calyx silky; lobes erect, linear-lanceolate, acute : ripe involucre bur-like, ovoid, $1.5-2 \mathrm{~cm}$. long, short-peduncled, clothed with brown tomentum, the soft spines spreading or recurved : nut ovoid, $1-1.5 \mathrm{~cm}$. long, narrowly winged, finely pubescent, edible. [F. ferruginea Ait.]

Chiefly in deep damp woods, and on banks, Nova Scotia to Lake Huron, Florida and Texas. Flowers from March to May; matures its fruit in the fall. BEECH.

\section{CAStànea Adans.}

Shrubs or trees, with a very porous wood. Leaf-blades coarsely serrate or serratedentate with slender-tipped teeth. Staminate aments axillary, elongated, ill-scented, plumose, each bract subtending 3-7 flowers, accompanied by 2 bractlets. Calyx campanulate, 6-lobed. Stamens 10-20, inserted on an inconspicuous receptacle : anthers introrse, attached at the back. Pistillate aments axillary, above the staminate, bearing imbricated sessile or nearly sessile involucres, each containing 2-3 flowers. Calyx-limb campanulate, 6-lobed. Staminodia present. Ovary inferior, imperfectly 6 -celled: styles 6 . Ovules 2 in each cavity. Fruit maturing in one season, composed of the accrescent spiny 2-4-valved involucre, enclosing 1,2 or 3 nuts. Nut with a leathery-cartilaginous pericarp. Cotyledons large, fleshy, more or less furrowed.

Stems horizontal under the surface of the ground, the branches erect.

1. C. nana. Stems normal, erect or ascending.

Usually shrubby, sometimes a small tree : leaf-blades densely white-tomentose beneath. 2. C. pumila.

A large tree: leaf-blades glabrous on both surfaces.

3. C. dentata.

1. Castanea nàna Muhl. A low shrub, forming wide patches by the means of underground stems. Branches solitary or clustered, erect, $2-5 \mathrm{dm}$. tall, glabrous except the twigs: leaf-blades oblong or oblong-obovate, $5-15 \mathrm{~cm}$. long, obtuse or apiculate, sinuate-toothed, dark green above, clothed with a thin tawny or dirty-white tomentum beneath; lateral nerves in 12-14 pairs, at irregular intervals, sometimes branching, usually recurved at the ends ; petioles 1-4 mm. long: staminate aments $5-15 \mathrm{~cm}$. long, much interrupted, commonly 
bearing a few fertile flowers at the base : calyx-lobes broadly ovate : fruiting involucre burlike, $1-2 \mathrm{~cm}$. in diameter, the rigid spines comparatively few ; nut solitary, $1.5-2 \mathrm{~cm}$. long.

On sand hills and in barrens, Georgia and Florida to Louisiana. Early spring. CHINQUAPIN.

2. Castanea pùmila (L.) Mill. A shrub or tree, reaching a maximum height of 16 $\mathrm{m}$, with a trunk diameter of $1 \mathrm{~m}$. Trunk clothed with a smooth bark : leaf-blades oblong or obovate, acute or rounded at the apex, sinuate-toothed, glabrous above, densely whitetomentose beneath, the lateral nerves in 14-20 pairs, quite regularly disposed ; petioles 3-10 $\mathrm{mm}$. long : staminate aments more or less spreading, $5-20 \mathrm{~cm}$. long, continuous, sometimes bearing several fertile flowers at the base: calyx-lobes ovate or oblong, obtuse : fruiting involucre subglobose, $3-4 \mathrm{~cm}$. in diameter, the rigid spines densely disposed; nuts ovoid, $1-1.5 \mathrm{~cm}$. long, solitary or rarely 2 in a bur, shining, nearly terete.

In sandy soil, New Jersey to Indiana, Florida and Texas. May and June. ChINQUAPIN.

3. Castanea dentàta (Marsh.) Borkh. A forest tree, reaching a maximum height of about $30 \mathrm{~m}$., with a trunk diameter of about $4 \mathrm{~m}$. Trunk clothed with a longitudinally furrowed bark: leaf-blades narrowly elliptic, elliptic-lanceolate or oblong-lanceolate, rarely tending to oblanceolate, $10-30 \mathrm{~cm}$. long, acuminate, coarsely and sharply serrate, darkgreen and shining above, paler beneath, glabrous on both sides; petioles 1-2.5 $\mathrm{cm}$. long: staminate aments nearly continuous, $15-30 \mathrm{~cm}$. long, white : calyx-lobes ovate or oblong:ovate, obtuse: fruiting involucre globular, $5-7 \mathrm{~cm}$. in diameter, thickly beset with rigid spines; nuts 2,3 or 5 , or rarely 1 in a bur, ovoid, $2-2.5 \mathrm{~cm}$. long, nearly terete, or usually flattened, at least on one side, appressed-pubescent especially near the apex.

Chiefly in rich woods, Maine to Ontario and Michigan, Georgia and Alabama. June and July. Chestnut, American Chestnut.

\section{QUÉRCUS L.}

Shrubs or trees, sometimes evergreen, with a hard, coarse-grained wood, all pervaded by an astringent principle. Leaf-blades entire, toothed, or lobed, very variable in shape, leathery, or firm-membranous, the lateral nerves often prolonged into slender bristles. Staminate aments elongated, drooping, clustered. Calyx campanulate, 4-7-lobed, subtended by caducous bracts. Stamens 6-12: filaments filiform. Pistillate flowers solitary or several together. Calyx often urn-shaped. Ovary usually 3-celled. Styles short, usually 3. Ovules 2 in each cavity, but rarely more than 1 in each.pistil maturing. Fruit an acorn, consisting of a leathery 1 -seeded nut subtended by or nearly enclosed in the accrescent involucre (cup). Cotyledons half-terete. The plants flower in the spring and mature their fruit in the fall of the first or second year. There are many natural hybrids.

Leaf-blades or their lobes bristle-tipped : styles elongated : nuts often:pubescent within.

A. Fruit maturing the second season: main stems erect or ascending.

a. Leaves deciduous, sometimes slightly persistent in the far south.

Leaf-blades entire, little or not at all dilated at the apex, never lobed except on shoots, sometimes with 1 or few teeth near the apex.

Lower surface of the leaf-blades glabrous. Cup of the acorn very flat.

Leaf-blades acute, linear-oblong to narrowly elliptic or broadest slightly above or below the middle.

Leaf-blades blunt, oblong or euneate.

Cup of the acorn with a manifest and constricted base.

Lower surface of the leaf-blades pubescent.

Leaf-blades brown-tomentose beneath: cup of acorn hemispheric.

Leaf-blades gray-tomentose beneath : cup of acorn saucer-shaped.

Leaf-blades dilated near the apex, lobed to pinnatifid.

Leaf-blades broadened upward, 3-lobed near the apex, occasionally with several smaller lobes below.

Cup of the acorn sauzer-shaped or cup-shaped: leaf-blades spatulate, glabrous.

Acorns less than $10 \mathrm{~mm}$. long; cup deep saucer-shaped : leafblades thin.

Acorns over $15 \mathrm{~mm}$. long ; cup shallowly saucer-shaped : leafblades thick.

Cup of the acorn hemispheric : leaf-blades obovate, brown-tomentose beneath.

Leaf-blades pinnatifid or pinnately lobed.

* Leaf-blades green and glabrous on both sides.

$\dagger$ Cup of the acorn saucer-shaped.

Cup less than $18 \mathrm{~mm}$. wide.

Acorns or nuts little if at all longer than thick.

Petioles over $2 \mathrm{~cm}$. long: leaf-blades with 5-7 lobes.

Petioles less than $2 \mathrm{~cm}$. long : leaf-blades with 3-5 lobes. Acorns or nuts markedly longer than thick.

Cup over $18 \mathrm{~mm}$. wide.

Inner scales of the cup not inflexed.

Leaf-blades with acute narrow sinuses; lobes usually tapering to the apex.

1. Q. Phellos.

2. Q. hybrida.

3. Q. laurifolia.

4. Q. imbricaria.

5. Q. brevifolia.

6. Q. microcarya.

7. Q. nigra.

8. Q. Marylandica.
9. Q. palustris.

10. Q. Georgiana.

11. Q. Schneckii.

12. Q. rubra. 
Leaf-blades with rounded broad sinuses; lobes usually dilated near the apex.

Inner scales of the cup inflexed.

i† Cup of the acorn turbinate or hemispheric.

Acorns less than $15 \mathrm{~mm}$. long; cup hemispheric, less than 15 $\mathrm{mm}$. broad.

Acorns over $20 \mathrm{~mm}$. long; cup turbinate, over $15 \mathrm{~mm}$. broad.

** Leaf-blades pubescent beneath.

Cup of the acorn turbinate : leaf-blades brown- or rusty-pubescent beneath.

Cup of the acorn saucer-shaped : leaf-blades gray-or white-pubescent beneath.

Large trees: leaves with lanceolate lobes.

Leaf-blades rounded at the base; lobes $3-5$.

Leaf-blades cuneate or truncate at the base; lobes 5-13.

b. Leaves persistent.

Shrubs or small trees : leaves with triangular lobes.

B. Fruit maturing the first season : stems underground, the branches erect.

Leaf-blades, or their teeth or lobes without bristles (except on shoots): nuts often glabrous within.

Leaves persistent.

Stems underground, the branches upright.

Stems erect.

Leaf-blades prominently rugose-reticulated : cup of the acorn turbinate.

Leaf-blades not rugose-reticulated: cup of the acorn hemispheric (except in Q. fusiformis).

Leaf-blades entire (or sometimes spiny-toothed on shoots): nuts fusiform to ovoid, over $18 \mathrm{~mm}$. long and $9 \mathrm{~mm}$. thick.

Acorns less than twice as long as thick; cup hemispheric ; nut ovoid or oblong-ovoid.

Acorns over twice as long as thick; cup turbinate ; nut fusiform.

Leaf-blades sinuate-toothed: nuts cylindric or oblong-cylindric, less

Leaves deciduous. than $18 \mathrm{~mm}$. long and $9 \mathrm{~mm}$. thick.

Leaf-blades entire or sinuate-undulate or merely lobed at the apex.

Cup of the acorn saucer-shaped.

Leaf-blades pubescent beneath : cup thin and with a thin edge: nut of an obovoid type.

Leaf-blades glabrous : cup thick and with a thick corky edge : nut of an oblong or ovoid type.

Cup of the acorn hemispheric.

Young leaf-blades white beneath ; mature leaves glabrous, prominently lobed near the apex.

Young leaf-blades tawny beneath; mature leaves pubescent beneath, irregularly lobed or merely angulate.

Leaf-blades coarsely toothed or lobed.

Leaf-blades toothed or shallowly lobed.

Acorns sessile.

Shrubs or small trees : leaf-blades mostly broadest above the middle.

Cup saucer-shaped : margins of the leaf-blades irregular.

Leaf-blades pubescent beneath : cup thin and with thin edges: nut of an obovoid type.

Leaf-blades glabrous: cup thick and with a thick corky edge: nut of an oblong or ovoid type.

Cup hemispheric : margins of the leaf-blades regular.

Tall trees: leaf-blades mostly broadest below the middle.

Acorns peduncled.

Peduncles shorter than the petioles or about equalling them.

Bark close, dark-colored : leaf-blades gray-tomentose beneath.

Bark flaky, white: leaf-blades glabrous or white-tomentose beneath.

Leaf-blades leathery, densely pubescent beneath, with many

, lateral nerves and many relatively small teeth.

Leaf-blades membranous, glabrous, with few lateral nerves

and few large teeth.
Peduncles much longer than the petioles.

Leaf-blades prominently or deeply lobed.

Mature leaf-blades more or less pubescent beneath : cup fully $1 / 3$ as long as the nut.

Upper scales of the cup awned, forming a fringe around the nut.

Upper scales of the cup not awned.

Acorn broader than high; nut immersed in the cup or nearly so. 39. Q. lyrata.

Acorn longer than broad; nut about $1 / 2$ longer than the cup.

Leaf-blades obovate, gray or yellowish beneath, with 3-5ample dilated lobes.

Leaf-blades with rounded upper lobes: cup 11-14 mm. broad : nut $12-14 \mathrm{~mm}$. long.

Leaf-blades with truncate or emarginate upper lobes: cup $15-20 \mathrm{~mm}$. broad; nut $15-20 \mathrm{~mm}$. long.

Leaf-blades cuneate, brown or yellowish brown beneath, with 3-7 low never dilated lobes.

Mature leaf-blades glabrous and pale, or glaucous beneath: cup shallow.

11. Q. Schneckii.

13. Q. Catesbaei.

14. Q. Texana.

15. Q. coccinea.

16. Q. velutina.

17. Q. digitata.

18. Q. pagodaefolia.

19. Q. nana.

20. Q. myrtifolia.

21. Q. pumila.

22. Q. minima.

23. Q. geminata.

24. Q. Virginiana.

25. Q. fusiformis.

26. Q. undulata.

27. Q. Durandi.

28. Q. Laceyi.

29. Q. austrina.

30. Q. Chapmanii.

31. Q. breviloba.

28. Q. Laceyi.

32. Q. prinoides.

33. Q. acuminata.

34. Q. Prinus.

35. Q. Michauxii.

36. Q. Brayi.

57. Q. platanoides.

38. Q. macrocarpa.

40. Q. Margaretta.

41. Q. minor.

42. Q. Boyntonii.

43. Q. alba.

1. Quercus Phéllos L. A tree, reaching a maximum height of about $25 \mathrm{~m}$. and a trunk diameter of $1 \mathrm{~m}$., sometimes evergreen, the bark of the trunk nearly smooth. Leafblades linear-oblong or narrowly-elliptic, varying to lanceolate or oblanceolate, 4-10 cm. 
long, glabrous and shining on both sides or sparingly tomentose beneath and tufted in the axils of the nerves when young, acute and bristle-tipped at the apex, usually entire, except on young shoots; petioles $2-5 \mathrm{~mm}$. long: acorns sessile or nearly so ; cup saucer-shaped, $10-15 \mathrm{~mm}$. broad, the bracts appressed; nut subglobose, often depressed or globose-ovoid, about $1 \mathrm{~cm}$. long.

In sandy soil, Long Island to Missouri, Florida and Texas. Willow OAK.

2. Quercus hýbrida (Chapm.) Small. A large tree, sometimes $25 \mathrm{~m}$. tall, with a roughish bark and smooth ash-colored branchlets. Leaf-blades oblong to cuneate, 6-12 $\mathrm{cm}$. long, rounded or 3-lobed at the apex, or sometimes with an additional lobe on one side, dark green, glabrous on both sides at maturity, gradually or abruptly narrowed into the short petiole : acorn closely sessile, 10-12 mm. long; cup flat, saucer-shaped, 10-12 $\mathrm{mm}$. broad, with appressed scales; nut subglobose or ovoid-globose, fully thrice longer than the cup. [Q. aquatica var. hybrida Chapm.]

On sandy or rocky river shores, Georgia and Florida to Mississippi.

3. Quercus laurifòlia Michx. A tree, reaching a height of about $30 \mathrm{~m}$., with a trunk diameter of more than $1 \mathrm{~m}$, the bark of the trunk almost black. Leaf-blades oblong, varying to oval or obovate, 4-13 cm. long, entire or those on shoots unequally lobed, or pinnatifid, all bristle-tipped, slightly thickened and revolute along the margin, deep green and shining above, paler and finally glabrous beneath; petioles 1-3 mm. long : acorns short-stalked or subsessile; cup saucer-shaped, $10-15 \mathrm{~mm}$. broad, the scales appressed; nut ovoid or globose-ovoid, 1-1.5 cm. long.

On sandy banks and in swamps, chiefly near the coast, Virginia to Florida and Louisiana. LAUREL OAK.

4. Quercus imbricària Michx. A forest tree, rarely $30 \mathrm{~m}$. tall, with a maximum trunk diameter of about $1 \mathrm{~m}$, the bark of the trunk brown, fissured. Leaf-blades oblong, varying to lanceolate or oblanceolate, $6-20 \mathrm{~cm}$. long, bristle-tipped, entire, undulately toothed or rarely prominently 3 -toothed at the apex, deep green and shining above, softly tomentose beneath; petioles 0.5-2 cm. long: acorns short-peduncled; cup nearly hemispheric, $15-20 \mathrm{~mm}$. broad, the bracts appressed, obtuse ; nut ovoid or subglobose, 10-15 mm. long.

In dry woods, Pennsylvania to Michigan, Nebraska, Georgia and Arkansas. SHINGLE OAK.

5. Quercus brevifòlia (Lam.) Sarg. A tree, rarely $30 \mathrm{~m}$. high, with a maximum trunk diameter of $5 \mathrm{dm}$., the bark of the trunk gray and scaly. Leaf-blades oblong, varying to lanceolate or oblanceolate, $5-12 \mathrm{~cm}$. long, entire, undulate or rarely tocthed near the apex or shallowly lobed, pale green and shining above, gray-tomentose beneath; petioles 3-8 mm. long: acorns often nearly sessile; cup saucer-shaped, 10-15 $\mathrm{mm}$. broad, the bracts appressed ; nut oblong or subglobose, $1.5 \mathrm{~cm}$. high, often striate. [Q. cinerea Michx.]
[ OAK.

In sandy soil, chiefly on ridges, North Carolina to Florida and Texas. HigH-GRound Willow

6. Quercus microcárya Small. A shrub or small tree, sometimes $5 \mathrm{~m}$. tall, with very crooked branches and glabrous foliage. Leaf-blades thin, spatulate in outline, $5-10 \mathrm{~cm}$. long, undulate or shallowly lobed, gray-green above, yellowish green beneath, shortpetioled, the small bristles early deciduous: acorns sessile, less than $10 \mathrm{~mm}$. long; cup deep saucer-shaped, 6-7 mm. broad; nut globose-ovoid, often nearly one-half in the cup.

On granite rocks, Little Stone Mountain, Georgia.

7. Quercus nigra L. A tree, reaching a maximum height of $30 \mathrm{~m}$., with a trunk diameter of a little more than $1 \mathrm{~m}$., the bark of the trunk smooth. Leaf-blades firm, oblanceolate or spatulate in outline, $5-15 \mathrm{~cm}$. long, entire and sometimes with a dilated terminal lobe or 3 -lobed at the apex, those of the shoots often pinnatifid, bright green and glabrous on both surfaces, or somewhat tomentose beneath, the principal nerves ending in bristles; petioles 2-7 mm. long : acorns sessile or short-peduncled; cup saucer-shaped, $12-15 \mathrm{~mm}$. broad, the scales appressed ; nuts subglobose, 1-1.3 cm. long, pubescent. [Q. aquatica Walt.]

In sandy soil, along streams, Delaware to Missouri, Florida and Texas. WATER OAK.

8. Quercus Marylándica Muench. A forest tree, reaching a maximum height of about $20 \mathrm{~m}$., with a trunk diameter of $1 \mathrm{~m}$., the bark of the trunk very rough, black. Leafblades broadly or narrowly obovate, 3-5-lobed or with one much dilated terminal lobe, firm, deep green and shining above, brownish pubescent beneath, rounded or cordate at the base ; petioles about $0.5-1 \mathrm{~cm}$. long : acorns sessile or short-peduncled; cup depressed-hemispheric, $15-20 \mathrm{~mm}$. broad, constricted at the base, the scales obtuse, appressed; nuts subglobose or ovoid, 10-20 mm. long, usually one-half included in the cup. [Q. nigra Wang. not L.]

Chiefly in rocky soil, Long Island to Nebraska, Florida and Texas. BLACK JACK. BARREN OAK. JACK OAK. 
9. Quercus palústris Du Roi. A forest tree, reaching a maximum height of about $60 \mathrm{~m}$., with a trunk diameter of $1.5 \mathrm{~m}$., the trunk clothed with a brown rough bark, its lower branches often deflexed. Leaf-blades broadly oval, varying to ovate or obovate, $6-15 \mathrm{~cm}$. long, deeply pinnatifid into oblong, lanceolate or triangular lobes, glabrous on both sides except the tufted axils of the nerves beneath, shining above; petioles $3-5 \mathrm{~cm}$. long, or shorter on seedlings: acorns short-peduncled; cup saucer-shaped, 12-15 mm. long, finely pubescent, the scales appressed ; nut subglobose, 10-15 $\mathrm{mm}$. long.

In swamps and wet places, Massachusetts to Wisconsin, Florida and the Indian Territory. PIN OAK. SWAMP OAK.

10. Quercus Georgiàna M. A. Curtis. A bushy shrub or small tree, reaching a height of about $9 \mathrm{~m}$., with a trunk diameter of about $3 \mathrm{dm}$., the bark of the trunk dark, rough. Leaf-blades obovate or oblong in outline, pinnatifid into 3-5 triangular or ovate bristletipped lobes, glabrous and somewhat shining on both sides or the axils of the nerves beneath often tufted; petioles $0.5-1 \mathrm{~cm}$. long: acorns very short-peduncled or sessile ; cup saucer-shaped, 12-16 $\mathrm{mm}$. broad, sparingly tomentose, the scales appressed ; nut ovoid or nearly globose, 10-14 mm. long, usually striate.

On granite rock and in sandy soil, middle Georgia.

11. Quercus Schnéckii Britton. A shrub or forest tree, reaching a maximum height of $65 \mathrm{~m}$., with a trunk diameter of $2.5 \mathrm{~m}$., the trunk clothed with a reddish brown bark. Leafblades oval varying to obovate, $6-20 \mathrm{~cm}$. long, glabrous and shining above, paler beneath and tufted in the axils of the nerves, usually pinnately 5-7-lobed; lobes ascending, oblong or triangular, entire or several-toothed, the sinuses rounded, the lobes and teeth bristletipped; petioles slender, $2-5 \mathrm{~cm}$. long, or shorter in some Texas forms : acorns shortpeduncled or nearly sessile ; cup saucer-shaped, $20-30 \mathrm{~mm}$. broad, or smaller in arid regions, the scales appressed; nut ovoid, 1.5-2.5 cm. long. [Q. Texana Sarg., not Buckl.]

On plains and prairies, Iowa to Florida and Texas. SPANISH OAK.

12. Quercus rùbra L. A forest tree, reaching a maximum height of $50 \mathrm{~m}$., with a trunk diameter of $1.5 \mathrm{~m}$., the trunk clothed with a rough, close, often mottled bark. Leafblades oval, varying to ovate or obovate in outline, $10-20 \mathrm{~cm}$. long, dull or slightly shining above, pale and glabrous beneath, except the tufts of hairs in the axils of the nerves, 5-7-lobed, the lobes ascending, entire or usually with a few bristle-tipped teeth, the sinuses rounded; petioles $3-5 \mathrm{~cm}$. long: acorns short-stalked ; cup saucer-shaped, slightly tomentose, $25-35 \mathrm{~mm}$. broad, its base usually flat, its scales large, appressed, flat; nut ovoid, $2.5-3 \mathrm{~cm}$. long.

In woods, Nova Scotia and Ontario to Minnesota and Kansas, Florida and Texas. RED OAK. LEOPARD OAK.

13. Quercus Catesbaèi Michx. A small tree, sometimes reaching a height of $20 \mathrm{~m}$., with a trunk diameter of $1 \mathrm{~m}$., the trunk clothed with a thick furrowed blue-gray bark, which finally separates into small blocks. Leaf-blades oblong or ovate in outline, usually deeply pinnately-lobed, rather pale green and glabrous on both surfaces, except the tufted axils of the nerves beneath, the lobes oblong, ovate or usually lanceolate, often curved, entire, or with coarse bristle-tipped teeth towards the end; petioles about $0.5-1 \mathrm{~cm}$. long: acorns short-peduncled; cup saucer-shaped, about $25-30 \mathrm{~mm}$. broad, the scales broad, appressed, but not closely so ; nut ovoid, $2-2.5 \mathrm{~cm}$. long.

On sand ridges, North Carolina to Florida and Louisiana. TURKEY OAK.

14. Quercus Texàna Buckl. A small tree, with spreading branches. Leaves numerous; blades 5-10 $\mathrm{cm}$. long, with 3-7 triangular or ovate lobes, the terminal one much longer than the rest, broadly cuneate to truncate at the base ; petioles slender, 1-3 cm. long : acorns about $1.5 \mathrm{~cm}$. long, nearly sessile ; cup hemispheric, $9-11 \mathrm{~mm}$. broad ; nut oblong or ovoid-oblong, 8-10 mm. thick.

In dry or rocky soil, southern and western Texas.

15. Quercus coccínea Wang. A forest tree, reaching a height of about $50 \mathrm{~m}$., with a trunk diameter of $1.5 \mathrm{~m}$., the trunk clothed with an irregularly ridged bark. Leaf-blades oval, varying to oblong or obovate in outline, 1-2 dm. long, usually deep green and shining above, paler and glabrous beneath, or tufted in the axils of the nerves, 5-7-lobed, the lobes ascending or spreading, usually toothed, the teeth as well as the lobes bristle-tipped ; petioles 2-6 cm. long: acorns sessile or short-peduncled ; cup turbinate, $15-20 \mathrm{~mm}$. broad, more or less constricted at the base, the scales appressed ; nut ovoid or oblong-ovoid, mostly $1-2 \mathrm{~cm}$. long.

In dry soil, Maine to Ontario and Minnesota, Florida and Missouri. Scarlet OAK.

16. Quercus velutina Lam. A forest tree, reaching a height of $50 \mathrm{~m}$., with a trunk diameter of $1.5 \mathrm{~m}$., the bark dark brown, close or in low irregular ridges. Leaf-blades oval or obovate in outline, $10-30 \mathrm{~cm}$. long, pinnately lobed, glabrous and often shining 
above, usually rusty-pubescent beneath and tufted in the axils or sometimes glabrate, the lobes and their teeth bristle-tipped; petioles 1-6 $\mathrm{cm}$. long: acorns sessile or nearly so ; cup turbinate or hemispheric-turbinate, $20-25 \mathrm{~mm}$. broad, the scales coarse, appressed, nearly flat; nut globose-oblong or obovoid, $1.5-2.5 \mathrm{~cm}$. long, abruptly pointed. [Q. tinctoria Michx.]

In rocky or sandy soil, Maine to Ontario, Minnesota, Florida and Texas. BLACK OAK. QUercitron.

17. Quercus digitàta (Marsh.) Sudw. A forest tree, reaching a height of $40 \mathrm{~m}$. and a trunk diameter of $1.5 \mathrm{~m}$., the trunk clothed with a brown shallow-fissured bark. Leafblades ovate or oval in outline, pinnatifid above a rounded base into 3-7 flaring or scytheshaped lobes, glabrate above, finely and usually densely tomentose beneath with yellowish-gray hairs, the lobes (and their teeth when present) bristle-tipped, the terminal one often conspicuously elongated ; petioles $2-4 \mathrm{~cm}$. long : acorns short-peduncled ; cup saucershaped above a turbinate base, $15-18 \mathrm{~mm}$. broad, the scales lightly appressed, obtuse or truncate at the apex; nut subglobose, $1-1.5 \mathrm{~cm}$. long. [Q.falcata Michx.]

In sandy soil, New Jersey to Missouri, Florida and Texas. SPANish OAK. Red OAK.

18. Quercus pagodaefòlia (Ell.) Ashe. A tree, becoming $32 \mathrm{~m}$. tall, with a dark gray rough bark and spreading branches. Leaf-blades oval to oblong, $1.5-3 \mathrm{dm}$. long, broadly cuneate or nearly truncate at the base, dark green above, persistently white-tomentulose beneath, pinnately 5-13-lobed, the lobes lanceolate to narrowly triangular, mostly entire ; petioles $3-6 \mathrm{~cm}$. long : acorns sessile or nearly so ; cup shallow, with appressed scales ; nut subglobose, about $1 \mathrm{~cm}$. long, nearly one-half enclosed in the cup.

In river swamps or low grounds, Virginia and Indiana to Missouri and Georgia. SPANISH OAK.

19. Quercus nàna (Marsh.) Sarg. An intricately branched shrub, forming wide thickets, or sometimes a small tree reaching a height of $7 \mathrm{~m}$., with a trunk diameter of $2 \mathrm{dm}$., the stems clothed with a smooth gray or dark brown bark. Leaf-blades obovate or oval in outline, pinnatifid into triangular or ovate bristle-tipped lobes, deep green and shining above, white or pale gray-tomentose beneath ; petioles $1-2 \mathrm{~cm}$. long : acorns short-peduncled or nearly sessile, often clustered ; cup saucer-shaped, $15-18 \mathrm{~mm}$. broad, the scales appressed; nut ovoid, globose or depressed-globose, 10-15 mm. long, often striate. [Q. ilicifolia Wang.]

In sandy or rocky soil, Maine to Ohio, North Carolina and Kentucky. BeAr OAK. ScrUb OAK.

20. Quercus myrtifòlia Willd. A much branched evergreen shrub, or a small tree reaching a height of $6 \mathrm{~m}$., the trunk rarely $1 \mathrm{dm}$. in diameter, clothed with a smooth bark. Leaf-blades leathery, obovate or oval, $2-5 \mathrm{~cm}$. long, obtuse or apiculate, entire, or sinuatetoothed on the shoots, glabrous and shining above, paler and dull beneath; petioles 1-3 $\mathrm{mm}$. long: acorns sessile or nearly so ; cup saucer-shaped, 10-13 $\mathrm{mm}$. long, the scales closely appressed and imbricated ; nut ovoid or oblong-ovoid, 1-1.4 $\mathrm{cm}$. long, dark brown, often striate, pubescent at the apex.

On sand ridges, chiefly near the coast, South Carolina to Florida and Louisiana.

21. Quercus pùmila Walt. A low shrub, spreading extensively by the underground stems, the branches erect or ascending, 3-6 dm. tall or rarely $2 \mathrm{~m}$. tall. Leaf-blades thickish, narrowly oblong, varying to lanceolate or oblanceolate, $5-12 \mathrm{~cm}$. long, obtuse or acute, often slightly revolute, usually bright green and shining above, finely tomentose or glabrate beneath : acorns sessile or nearly so; cup saucer-shaped, sometimes varying towards hemispheric, 12-15 mm. broad, the scales relatively large, flat, appressed; nut ovoid, 10-15 mm. long.

On open sandy barrens, especially near the coast, North Carolina to Florida. RUNNING OAK.

22. Quercus mínima (Sarg.) Small. A low shrub, forming wide patches by the extensive spreading of its underground stems, the branches erect or ascending, less than $1 \mathrm{~m}$. tall, solitary or several together. Leaf-blades obovate or sometimes oblong or oblanceolate, $3-10 \mathrm{~cm}$. long, thickish, acute or apiculate, repand-toothed or the upper ones sometimes entire, those of the shoots often lobed, glabrous on both sides, or finely tomentose beneath; petioles 2-5 mm. long : acorns solitary or several at the end of a short peduncle; cup hemispheric, sometimes slightly constricted at the base, about $15 \mathrm{~mm}$. broad, the scales appressed, thickened on the back, except near the edge ; nut ovoid or elliptic, 15-18 mm. long, dark brown, glabrous. [Q. virens var. dentata Chapm.]

In sandy sterile pine lands, chiefly near the coast, Florida.

23. Quercus geminàta Small. A shrub, or rarely a small tree, $3-4 \mathrm{~m}$. tall, with a trunk diameter of $10-15 \mathrm{~cm}$., the bark pale or gray. Leaf-blades narrowly-oblong, elliptic or oblong-oblanceolate, $3-6 \mathrm{~cm}$. long, entire, obtuse or apiculate, strongly revolute, mostly gradually narrowed at the base, rugose-reticulated, glabrous and parchment-like above, finely tomentose beneath; petioles $2-6 \mathrm{~mm}$. long : acorns usually 2 at the end of the peduncle 
varying from 1-4 $\mathrm{cm}$. in length; cup turbinate, $10 \mathrm{~mm}$. broad, tomentose, its scales appressed, slightly thickened near the base, fringed at the edge ; nut ovoid or narrowly oval, 10-17 $\mathrm{mm}$. long, twice surpassing the cup.

In sandy soil, chiefly in the scrub, Florida to Mississippi. LIVE OAK.

24. Quercus Virginiàna Mill. A large evergreen tree, reaching a maximum height of about $30 \mathrm{~m}$. and a trunk diameter of about $2.5 \mathrm{~m}$., the trunk clothed with a pale-gray or white furrowed bark. Leaf-blades leathery, oblong or oval, varying to obovate or oblanceolate, 3-12 cm. long, obtuse or acutish, entire (except on shoots), more or less revolute, glabrous and often shining above, glabrous or sparingly pubescent beneath, never rugose; petioles $0.5-1 \mathrm{~cm}$. long: acorns solitary or spicate at the ends of the usually long peduncles ; cup hemispheric, often slightly constricted at the base, $15-20 \mathrm{~mm}$. broad, its scales appressed, the lower ones thickened on the back; nut ovoid or oblong-ovoid, $2-2.5 \mathrm{~cm}$. long, twice longer than the cup. [Q. virens Ait.]

In sandy soil chiefly near the coast, Virginia to Florida and Mexico, also in Cuba. Live OAK.

25. Quercus fusifórmis Small. A shrub $1.5-3 \mathrm{~m}$. tall, with slender or switch-like stems or branches. Leaves persistent; blades leathery, oblong or oblong-ovate, $3-5 \mathrm{~cm}$. long, entire or sparingly spiny-toothed on twigs, gray-green and lustrous above, paler and scurfy-tomentulose beneath, slightly revolute, rounded or truncate at the oblique base, short-petioled : acorns numerous, solitary or several on slender peduncles ; cup turbinate, 10-12 mm. high, gray; nut fusiform, $2-2.5 \mathrm{~cm}$. long, acute, conspicuously striate, thrice surpassing the cup.

On arid limestone and granite hills, central Texas. Lrve OAK.

26. Quercus undulàta Torr. A shrub or small tree, with slender often switch-like stems or branches. Leaves numerous, persistent; blades firm and leathery, oblong or slightly broadest above or below the middle, $2-5 \mathrm{~cm}$. long, sinuate-toothed, somewhat resembling those of Ilex opaca, light bluish or brownish green and lustrous above, dull, somewhat reticulated and obscurely puberulent beneath; petioles $2-6 \mathrm{~mm}$. long, puberulent : acorns sessile, $8-15 \mathrm{~mm}$. long ; cup hemispheric, $5-7 \mathrm{~mm}$. broad, not quite as high, with minute gray scales; nut cylindric or barrel-shaped, usually over twice as long as the cup, brown.

On escarpment hills, Colorado to Texas and Arizona. SwITCH OAK,

27. Quercus Durándi Buckl. A tree sometimes, becoming $16 \mathrm{~m}$. tall, with a trunk diameter of nearly $1 \mathrm{~m}$., but often much smaller, the bark pale or light gray and somewhat scaly. Leaves numerous; blades narrowly oblong varying to broadest above the middle or below it, 4-10 $\mathrm{cm}$. long, entire, or slightly 5-lobed near the blunt or slightly notched apex, rather leathery, pale green and lustrous above, very pale or whitish tomentulose beneath, gradually or abruptly narrowed at the base, short-petioled : acorns nearly sessile ; cup very shallow, thickish, the thin acute scales appressed, whitish tomentulose ; nut ovoid or somewhat depressed, about $1 \mathrm{~cm}$. long, only about $2 \mathrm{~mm}$. included in the cup.

In dry soil, often near streams, Alabama to eastern Texas.

28. Quercus Laceỳi Small. A shrub or small tree, becoming $6 \mathrm{~m}$. tall, with a rough deeply and irregularly grooved bark. Leaves numerous, rather tardily deciduous; blades oblong and with 3-5 shallow lobes, or oblong-obovate and more prominently 3-lobed below the apex, 4-8 cm. long, olive-green and with a waxy lustre above, grayish and slightly and minutely scurfy beneath, sometimes truncate or subcordate at the base, short-petioled: acorns sessile or nearly so ; cup shallowly saucer-shaped, 12-17 mm. broad, stout and corky, coarsely warty ; nut oblong to oblong-ovoid, 15-19 $\mathrm{mm}$. long, often depressed at the apex : seed very bitter.

On the summits of Caprina limestone hills, south-central Texas. Bastard Oak. Mountain OAK.

29. Quercus austrìna Small. A tree, reaching a height of $15 \mathrm{~m}$. and a trunk diameter of about $1 \mathrm{~m}$. with a roughish bark and smooth reddish glaucous twigs. Leaf-blades cuneate to oblong-cuneate, $5-15 \mathrm{~cm}$. long, with 3-5 blunt lobes above the middle, bright green but not lustrous above, white tomentulose but soon becoming glabrous and more or less glaucous beneath, short-petioled: staminate aments $5-7 \mathrm{~cm}$. long, slender: acorns $1.5-2 \mathrm{~cm}$. long.

On river banks, Georgia and Alabama.

30. Quercus Chapmánii Sarg. A rigid shrub, or a small tree, with a maximum height of $10 \mathrm{~m}$. and a trunk diameter of $3 \mathrm{dm}$., the trunk clothed with a dark bark which separates in irregular plates. Leaf-blades obovate or oblong, thickish, 5-10 cm. long, undulate or usually shallowly 3-lobed near the apex, or merely angulate, glabrous and lustrous above, sparingly pubescent beneath, more or less revolute, nearly sessile or short-petioled : acorns sessile or nearly so ; cup depressed-hemispheric, 15-20 mm. broad, its scales tuberculate- 
thickened except near the edge ; nut oblong or elliptic in outline, $15-25 \mathrm{~mm}$. long, about twice as long as the cup. [Q. obtusiloba var. parvifolia Chapm.]

In sandy barrens, chiefly near the coast, South Carolina to Florida.

31. Quercus brevíloba (Torr. ) Sarg. A shrub often forming thickets, or a small tree, the trunk clothed with a gray or silvery white bark which scales off in thin strips. Leafblades obovate or broadly oblanceolate, or spatulate, 4-12 cm. long, obtuse, shallowly lobed above, bluish green or deep-green and shining above, densely felty tomentose with grayish white hairs beneath, the lobes rounded: acorns sessile or nearly so ; cup saucer-shaped, with a thin edge 10-15 $\mathrm{mm}$. broad, tomentose, the scales appressed; nut slightly obovoid, 10-15 mm. long.

Chiefly in limestone soil, middle and southern Texas. SHIN OAK.

32. Quercus prinoìdes Willd. A shrub or small tree, with a slender trunk and a maximum height of about $5 \mathrm{~m}$., the bark pale. Leaf-blades obovate, oblanceolate or rarely nearly oblong, 5-15 cm. long, usually acute or short acuminate, coarsely toothed, cuneately narrowed or sometimes rounded at the base, glabrous and somewhat shining above, finely graytomentose beneath ; petioles $0.5-1.5 \mathrm{~cm}$. long : acorns sessile or nearly so ; cup hemispheric, 13-18 mm. broad, thin, its scales appressed, thickened on the back; nut oblong-ovoid, $15-25 \mathrm{~mm}$. long, more than twice as long as the cup.

In sandy or rocky places, Maine to Minnesota, North Carolina, Alabama and Texas. CHINQUapiN OAK. SCRUB ChESTNUT OAK.

33. Quercus acuminàta (Michx.) Honda. A handsome tree, reaching a maximum height of about $50 \mathrm{~m}$. and a maximum trunk diameter of $2.5 \mathrm{~m}$., the trunk clothed with a palegray or white scaly bark. Leaf-blades varying from lanceolate to oblong-lanceolate, $5-20 \mathrm{~cm}$. long, mostly acuminate at the apex, coarsely serrate, with flaring or rarely depressed teeth, glabrous and glossy above, glaucous, minutely pubescent or glabrate beneath ; petioles 1-3 cm. long : acorns sessile or nearly so ; cup hemispheric, about $15 \mathrm{~mm}$. broad, its scales thickened, especially near the base ; nut ovoid, about $15 \mathrm{~mm}$. long, about twice as long as the cup.

Chiefly in limestone soil, Vermont to Ontario, Minnesota, Florida and Texas. Chestnut or YelLOW OAK.

34. Quercus Prìnus L. A forest tree, reaching a maximum height of $30 \mathrm{~m}$. and a trunk diameter of $2 \mathrm{~m}$., the trunk clothed with a dark, hard, close, furrowed bark. Leafblades oblong to oval, varying to slightly broadest above or below the middle, $15-20 \mathrm{~cm}$. long, coarsely crenate-serrate, dark green, glabrous and barely shining above, finely graytomentulose beneath; petioles 1-3 cm. long: acorns short-peduncled; cup hemispheric, $12-35 \mathrm{~mm}$. broad, with appressed bracts; nut ovoid or oblong-ovoid, $25-35 \mathrm{~mm}$. long, with an edible but not very sweet seed.

In rocky woods, Maine and Ontario to Georgia and Alabama. Rock CHESTNuT OAK.

35. Quercus Michaùxii Nutt. A large tree, reaching a maximum height of $35 \mathrm{~m}$. and a trunk diameter of $2 \mathrm{~m}$., the trunk clothed with a white or ash-gray bark which separates in very thin plates. Leaf-blades obovate, varying to oblong, usually acute or short-acuminate, coarsely serrate, nearly glabrous and often shining above, finely tomentose beneath with white hairs; petioles $1-3 \mathrm{~cm}$. long: acorns peduncled; cup deep saucer-shaped or shallowly hemispheric, $25-35 \mathrm{~mm}$. broad, finely tomentose, the bracts broad, appressed, often keeled on the back; nut oblong or oblong-ovoid, 30-35 mm. long : seed sweet, edible.

In swamps and damp places, Delaware to Indiana, Missouri, Florida and Texas. Cow OAK. BASKET OAK.

36. Quercus Braỳi Small. A large tree, sometimes $18 \mathrm{~m}$. tall, or more, with a pale flaky bark. Leaves very numerous, deciduous; blades thin, cuneate, $10-20 \mathrm{~cm}$. long, abruptly acuminate at the apex, regularly and coarsely sinuate-toothed nearly to the base, glabrous, with relatively few regular and prominent lateral ribs, deep green above, slightly paler and rather olive-green beneath; petioles $1.5-2.5 \mathrm{~cm}$. long: acorns sessile or nearly so ; cup hemispheric, $20-25 \mathrm{~mm}$. broad, the lower scales somewhat warty on the back; nut oblong to ovoid, $25-30 \mathrm{~mm}$. long, about $1.5 \mathrm{~cm}$. thick : seed rather sweet.

In cañons. central Texas. WhITE OAK.

37. Quercus platanoìdes (Lam.) Sudw. A stately tree, reaching a maximum height of $36 \mathrm{~m}$. and a trunk diameter of $2.5 \mathrm{~m}$., the trunk clothed with a gray or whitish flaky bark. Leaf-blades obovate or oblong-obovate, $5-20 \mathrm{~cm}$. long, coarsely toothed or lobed, usually cuneately narrowed at the base, deep green and shining above, densely white-tomentose beneath, the teeth or lobes rounded; petioles 1-3 cm. long: acorns usually long-peduncled; cup saucer-shaped or depressed-hemispheric, $20-25 \mathrm{~mm}$. broad or rarely smaller, the bracts mostly appressed, much narrower at the edge than at the base; nut oblong or oblong-ovoid, 20-25 mm. or nearly $3 \mathrm{~cm}$. long. [Q. bicolor Willd.]

In swamps or moist places, Quebec to Maine, Iowa, Georgia, Arkansas and Missouri. SwaMP WHITE OAK. 
38. Quercus macrocárpa Michx. A large forest tree, reaching a maximum height of about $55 \mathrm{~m}$. and a trunk diameter of $2.5 \mathrm{~m}$., the trunk clothed with a brown or gray flaky bark. Leaf-blades thinnish, obovate or spatulate in outline, 1-3 dm. long, glabrous and shining above, with fine white or gray tomentum beneath, pinnatifid into mostly diverging lobes or sometimes crenate-sinuate, the terminal lobe largest and usually coarsely crenate ; petioles 1-3 cm. long : acorns on naked or leafy peduncles ; cup deeply hemispheric or subglobose, 3-5 cm. long, the lower scales tuberculate on the back, the upper ones prolonged into long thread-like tips; nut subglobose or broadly oblong, 3-5 cm. long, pubescent, especially towards the apex, often twice as long as the cup.

In rich woods, Nova Scotia to Manitoba, Georgia and Texas. Mossy-cup OAK. BUr OAK.

39. Quercus lyràta Walt. A handsome tree, reaching a maximum height of about $35 \mathrm{~m}$. and a trunk diameter of more than $1 \mathrm{~m}$., the trunk clothed with a brown or dark gray bark which separates in narrow scales. Leaf-blades rather thin, obovate or spatulate in outline, deep green, glabrous and shining above, white-tomentose or glabrate beneath, lyratepinnatifid ; petioles $0.5-2 \mathrm{~cm}$. long : acorns usually short-penduncled; cup hemispheric or depressed-globose, $2-4 \mathrm{~cm}$. broad, the scales thickened on the back, not prolonged into conspicuous tips along the edge; nut ovoid and exserted or depressed-globose, ovoid and nearly or completely included in the cup.

Mostly in swamps, New Jersey and Missouri to Florida and Texas. Swamp White OAK. Overcup OAK. SWaMp Post OAK.

40. Quercus Margarétta Ashe. A shrub, or a small tree, sometimes $10 \mathrm{~m}$. tall, with glabrous twigs, the bark very rough. Leaves numerous; blades oval or obovate in outline, 6-9 cm. long, undulate, sinuate or rather shallowly 3-5-lobed above the middle, smooth and mostly shining above, pale green or glaucous and more or less pubescent about the nerves beneath, short-petioled : acorns sessile or short-peduncled ; cup turbinate-hemispheric, 11-14 mm. broad, the lower scales much larger than the marginal; nut oblong to ovoid-oblong, 12-14 $\mathrm{mm}$. long, one-half or less included in the cup, pubescent at the beaked apex.

In pine lands or woods, Virginia to Florida and Alabama.

41. Quercus minor (Marsh.) Sarg. A forest tree, reaching a maximum height of 30 $\mathrm{m}$. and a trunk diameter of about $1.5 \mathrm{~m}$., the trunk clothed with a narrowly ridged bark. Leaf-blades thickish, broadly obovate in outline, 1-2 dm. long, or smaller in the Southwest, dark green, shining and sparingly pubescent or glabrate above, finely tomentose with gray or yellowish hairs beneath, pinnatifid into usually 5 rather broad diverging lobes; petioles $1-3 \mathrm{~cm}$. long: acorns often clustered; cup hemispheric, constricted at the base, $15-20 \mathrm{~mm}$. broad, the scales flat, often somewhat spreading; nut ovoid, $15-20 \mathrm{~mm}$. long, pubescent at the top, twice or thice as long as the cup.

In dry rocky soil, Massachusetts to Missouri, Kansas, Florida and Texas. Post OAK. Iron OAK.

42. Quercus Boyntònii Beadle. A shrub 1-5 m. tall, usually in large clumps, or occasionally with the aspect of a small tree, the trunk less than $1 \mathrm{dm}$. in diameter, the twigs clothed with a yellowish brown or brown tomentum, the bark of the main stems fissured and broken into irregular scales. Leaves deciduous ; blades obovate in outline, $5-9 \mathrm{~cm}$. long, with 3-5 small obtuse lobes above the middle or usually near the summit, often cuneately narrowed to the base, soon glabrous and lustrous above, permanently tomentose beneath : acorns sometimes short-peduncled; cup turbinate or cup-shaped, the closely imbricated acute or acutish scales densely tomentose; nut oval or ovoid, about $12 \mathrm{~mm}$. long, brown and striped, pale-pubescent at the apex, less than one-half enclosed in the cup.

In rocky soil, Georgia and Alabama. Spring.

43. Quercus álba L. A forest tree, reaching a maximum height of $45 \mathrm{~m}$. and a trunk diameter of $2.5 \mathrm{~m}$., the trunk clothed with a pale gray or white scaly or flaky bark. Leaf-blades obovate in outline, 1-2 dm. long, pale green above, glaucous beneath, finally glabrous, pinnatifid into $3-9$, or usually, 7 ascending lobes, these entire or shallowly lobed ; petioles 1-2 cm. long: acorns sometimes clustered; cup saucer-shaped or shallowly hemispheric, woody, 15-20 mm. broad, its bracts often tuberculate, except near the edge ; nut oblong-ovoid, 15-25 mm. long, surpassing the cup 3-4 times.

In woods, Maine to Ontario, Minnesota, Nebraska, Florida and Texas. WHITE OAK.

\section{Order 8. URTICÀLES.}

Shrubs or trees with a hard wood, or herbs. Leaves alternate, or in the case of herbs often opposite : blades simple, entire, toothed or divided. Flowers various, never in aments. Calyx present. Corolla wanting. Androecium often 
of as many stamens as there are sepals. Gynoecium of a single carpel or 2 united carpels. Fruit an achene, samara, drupe or syncarp. Endosperm usually scant or wanting.

Fruit an achene, the achenes sometimes in the accrescent sepals and disposed in a syncarp.

Flowers not on a receptacle: fruits not forming syncarps : sepals neither thick and juicy, nor enveloping the achenes.

Style or stigma 1, the latter sometimes tufted : ovule erect : filaments inflexed in the bud.

Styles or stigmas 2 : ovule pendulous : filaments erect in the bud. Fam. 1. URTICACEAE.

Flowers on the outside or inside of a receptacle: fruits forming syncarps : sepals accrescent, enveloping the achenes.

Fruit a samara or a drupe, sometimes nut-like.

Fam. 2. CanNabinaceat.

Fam. 3. Artocarpaceae. Fam. 4. Ulmaceae.

\section{Family 1. URTICACEAE Reichenb. Nettle Family.}

Herbs (or in the tropies, shrubs or trees), with pellucid and watery, or firm tissues, sometimes armed with stinging hairs. Leaves alternate or opposite : blades simple, entire, toothed or rarely lobed : stipules usually present. Flowers small, greenish, dioecious, monoecious or polygamous, in axillary, simple or compound, often congested cymes. Calyx of $2-5$ distinct or partially united equal or unequal sepals. Androecium of 2-5 stamens inserted at the base of the sepals or calyx lobes, reduced to staminodia in the pistillate flowers, or none. Filaments distinct, strongly inflexed in the bud. Anthers opening lengthwise. Gynoecium a single carpel. Ovary superior, 1-celled. Style or stigma solitary, terminal or becoming lateral, the stigma often tufted. Ovule erect or nearly so, orthotropous or half-amphitropous. Fruit an achene. Endosperm oily, sometimes nearly wanting. Embryo straight, with broad cotyledons.

Plants armed with stinging hairs.

Leaves opposite : staminate flowers with 4 sepals and 4 stamens : achenes equilateral : style terminal.

Leaves alternate: staminate flowers with 5 sepals and 5 stamens: achene oblique: style lateral.

Plants glabrous or at least destitute of stinging hairs.

Flower-clusters not involuerate: leaves mostly opposite.

Flower-clusters in axillary often clustered cymes: achene not included.

Flower-clusters spicate on slender mostly simple branches: achene included.

Flower-clusters involucrate: leaves alternate.

1. URTICA.

2. Urticastrum.

3. ADICEA.

4. BOEHMERIA.

5. Parietaria.

\section{URTİCA L.}

Annual or perennial often coarse herbs armed with stinging hairs. Leaves opposite : blades membranous, toothed or incised-lobed, mostly 5-7-nerved : stipules free. Flowers dioecious or monoecious, in axillary cymes which are panicled, or often much reduced, the staminate with 4 nearly distinct sepals, which are concave or hooded at the apex, 4 stamens and a rudimentary ovary. Pistillate flowers with a perianth of 4 nearly distinct sepals, two of them larger than those of the other pair, and an equilateral ovary : stigma tufted. Achene flattened, with a membranous or crustaceous pericarp, enveloped in the 2 accrescent sepals. Seed with its membranous testa and pericarp often adherent. NETTLE.

Annual: flower-clusters simple.

Leaf-blades incised-toothed, the upper ones but little reduced.

Leaf-blades crenate-dentate, the upper ones much reduced.

Perennial : flower-clusters compound.

Stems sparingly bristly.

$\begin{array}{lll}\text { Leaf-blades with coarse flaring teeth : sepals oval. } & \text { 3. U. Breweri. } \\ \text { Leaf-blades with rather fine ascending or incurved teeth : sepals orbicular. } & \text { 4. U. gracilis. }\end{array}$

Stems densely bristly.

1. $U$. urens.

2. U. chamaedryoides.

1. Urtica ùrens L. Annual, stoutish. Stems erect or ascending, 1-4 dm. tall, simple or branched, bristly with stinging hairs: leaf-blades thin, oval or ovate, $1-4 \mathrm{~cm}$. long, acute, glabrous or sparingly bristly, acute or truncate at the base, incised, the tooth-like segments ascending or spreading, entire or toothed; petioles slender, $\frac{1}{2}$ as long as the blades or much longer : flower-clusters shorter than the petioles or a little longer: sepals oval or broadly oblong, less than $1 \mathrm{~mm}$. long : achene ovoid, nearly $2 \mathrm{~mm}$. long, enveloped in the accrescent sepals.

In waste places, Newfoundland to New York and Florida. Also in California. Naturalized from Europe. Spring to fall.

2. Urtica chamaedryoìdes Pursh. Annual, slender. Stems solitary or tufted, ascending, weak, 1-10 dm. tall, sparingly armed with stinging bristle-like hairs other- 
wise glabrous, simple or branched at the base or above: leaf-blades thin, varying from suborbicular on the lower part of the stem, through ovate to lanceolate on the upper part of the stem, 1-4 cm. long, obtuse or acute, crenate-dentate, truncate or cordate at the base or the upper ones acutish ; petioles slender, $\frac{1}{3}-\frac{1}{2}$ as long as the blades : flower-clusters shorter than the petioles : sepals oblong or those of the pistillate flowers oval, less than $1 \mathrm{~mm}$. long, obtuse : achene ovoid, $1 \mathrm{~mm}$. long, enveloped in the 2 accrescent sepals.

In thickets, Kentucky to Arkansas, Florida and Texas. Spring and summer.

3. Urtica Brèweri S. Wats. Perennial, stout, finely pubescent with somewhat curled hairs or glabrate except scattered bristle-like hairs. Stems $4-12 \mathrm{dm}$. tall, often branched: leaf-blades thin, lanceolate to narrowly oblong, 7-20 cm. long, acuminate, coarsely serrate with somewhat flaring teeth, rounded or subcordate at the base; petioles about $\frac{1}{3}$ as long as the blades: panicles about as long as the petioles: sepals oval, $1 \mathrm{~mm}$. long, obtuse, densely hispid : achene ovoid, $1.2 \mathrm{~mm}$. long, enveloped in the 2 accrescent sepals.

On river banks, Wyoming to California, Texas and Mexico. Summer and fall.

4. Urtica grácilis Ait. Perennial, slender, sparingly pubescent with stinging hairs. Stems erect, 6-18 dm. tall, angled, simple or sparingly branched above : leaf-blades thin, lanceolate to ovate-lanceolate, $6-15 \mathrm{~cm}$. long, acuminate, rather coarsely serrate, the teeth often somewhat incurving, acute or obtuse at the base; petioles $\frac{1}{3}-\frac{1}{4}$ as long as the blade : panicles much longer than the petioles: sepals suborbicular, about $1 \mathrm{~mm}$. long, densely puberulent: achenes ovoid, $1.2 \mathrm{~mm}$. long, enveloped in the accrescent ovate sepals.

On river banks and along fences, Nova Scotia to British Columbia, North Carolina and Louisiana. Summer and fall.

5. Urtica dioìca $\mathrm{L}$. Perennial, stoutish, densely bristly with stinging hairs. Stems erect, $6-13 \mathrm{dm}$. tall, simple or branched : leaf-blades ovate to ovate-lanceolate, $3-12 \mathrm{dm}$. long, acute or short-acuminate, coarsely serrate or sometimes incised, cordate at the base ; petioles $\frac{1}{3}-\frac{1}{2}$ as long as the blades : panicles shorter than the petioles or about equalling them in length : sepals densely soft-pubescent, less than $1 \mathrm{~mm}$. long, the outer obovate, the inner spatulate : achene suborbicular, $1 \mathrm{~mm}$. long, enveloped in the accrescent depressed orbicular sepals.

In waste places, Nova Scotia to Minnesota, South Carolina and Missouri. Naturalized from Europe and Asia. Summer and fall.

\section{URTRIĆASTRUM Fabr.}

Perennial herbs (shrubs or trees in the tropics), armed with stinging hairs. Leaves alternate : blades often large and membranous, toothed : stipules distinct. Flowers monoecious or dioecious, mostly in axillary panicled or dichotomous cymes, the staminate with a perianth of 5 partially united sepals, 5 stamens, and a rudimentary ovary. Pistillate flowers with a perianth of 4 partially united somewhat unequal sepals and an oblique ovary: style subulate, becoming lateral. Achene oblique with a membranous or fleshy pericarp. Wood NetTle.

1. Urticastrum divaricàtum (L.) Kuntze. Foliage bright green, bristly with stinging hairs. Stems 2-12 dm. tall, often flexuous : leaves alternate ; blades thin, ovate, oblong or elliptic, 5-20 cm. long, acuminate, coarsely serrate or crenate-serrate, rounded or rarely acutish at the base, glabrous or bristly, especially on the nerves; petioles slender, $\frac{1}{2}$ as long as the blades or longer : panicles slender, spreading, the lower staminate, the upper pistillate : sepals oblong (in the staminate flowers) or suborbicular (in the pistillate), hyaline, or with hyaline margins : achene oblique, almost $3 \mathrm{~mm}$. in diameter, the style lateral, about twice as long as the 2 accrescent sepals. [Laportea C'anadensis Gaud.]

In thickets and rich woods, Nova Scotia to Minnesota, Florida and Kansas. Summer and fall.

\section{ADÍCEA Raf.}

Annual or perennial herbs, with pellucid watery tissues, destitute of stinging hairs. Leaves opposite : blades often 3-nerved or nearly nerveless, and transversely ridged or wrinkled, entire or toothed: stipules interpetiolar. Flowers monoecious or dioecious, in axillary panicled or congested cymes, the staminate with a perianth of 4 or rarely 2-3 partially united sepals, the tube often cup-like, 4 or rarely $2-3$ stamens and a rudimentary ovary. Pistillate flowers with a perianth of 3 partially united sepals and an equilateral ovary surrounded by 4 or rarely 2-3 staminodia : stigma tufted. Achene flattened, with a membranous pericarp. [Pilea Lindl.] Richweed. Clearweed.

Leaf-blades 2-10 mm. long, entire, transversely wrinkled or ridged.

Stems filiform : leaf-bladies suborbicular or broadly oval, $2-4 \mathrm{~mm}$. long.

Stems not filiform : leaf-blades elliptic or oblanceolate, 5-10 mm. long.

Leaf-blades $3-10 \mathrm{~cm}$. long, toothed, not transversely roughened.

1. A. herniarioides.

2. A. microphylla.

3. A. pumila. 
1. Adicea herniarioìdes ( $\mathrm{Sw}$.) Small. Annual, very slender, glabrous. Stems filiform, 3-10 cm. long, prostrate or decumbent, soft, pellucid, simple or branched : leaf-blades suborbicular to broadly oval, 2-4 mm. long, obtuse at the apex, entire, acute at the base, marked on the upper surface with pale transverse ridges; petioles filiform, somewhat shorter than the blades: flower-clusters very small, shorter than the petioles: sepals oblong, acutish : achene $0.4 \mathrm{~mm}$. long, oblong-ovoid, lenticular. [Pilea hernarioides (Sw.) Lindl.]

In dry woods and hammocks, Key West, Florida. Also in the West Indies.

2. Adicea microphýlla (Sw.) Kuntze. Annual or biennial, slender, glabrous. Stems erect or ascending, or sometimes creeping at the base, $5-20 \mathrm{~cm}$. long, fleshy, simple or mostly branched : leaf-blades elliptic or oblanceolate, $5-10 \mathrm{~mm}$. long, acute or acutish at the apex, entire, acuminate at the base, transversely wrinkled; petioles filiform, shorter than the blades: flower-clusters very small, shorter than the petioles: sepals ovate, very thin, acutish : achenes oblong, $0.4 \mathrm{~mm}$. long, lenticular. [Pilea microphylla (Sw.) Liebm.]

In rocky woods, western Florida. Also in the West Indies.

3. Adicea pùmila (L.) Raf. Annual, fleshy, glabrous or finely pubescent. Stems erect or decumbent, 1-7 dm. tall, obtusely angled, often branched, watery, pellucid : leafblades ovate to elliptic, 3-10 cm. long, usually short-acuminate, coarsely crenate-serrate, broadly cuneate at the base ; petioles as long as the blades or somewhat shorter: panicles spreading, shorter than the subtending petioles : sepals lanceolate, each of those of the pistillate flowers accompanied by a staminodium : achene ovoid, $2 \mathrm{~mm}$. long, acutish. [Pilea pumila (L.) A. Gray.]

In damp shaded places, New Brunswick to Minnesota, Florida and Louisiana. Summer and fall.

\section{BOEHMÈrIA Jacq.}

Herbs, shrubs or trees, more or less pubescent with stingless hairs. Leaves alternate or opposite: blades often 3-nerved, toothed or rarely lobed: stipules mostly free. Flowers monoecious or dioecious, in dense contiguous or distant clusters on slender branches : the staminate with a perianth of 4 or rarely 3-5 partially united sepals, 4 or rarely $3-5$ stamens and a rudimentary ovary. Pistillate flowers with a perianth of 2-4 united sepals and a sessile or stalked ovary : stigma elongated. Achene flattened, included, the pericarp somewhat crustaceous. FALSE NetTle.

Leaf-blades not white-pubescent beneath : native species.

Leaf-blades leathery, finely serrate; petioles much shorter than the blades. $B . s c a t$
Leaf-blades relatively thin, coarsely serrate; petioles as long as the blades or little shorter.

Main pair of lateral nerves arising at the base of the leaf-blade.

Main pair of lateral nerves arising some distance above the base of the leaf-blade.

Leaf-blades glabrous or merely puberulent and slightly pubescent about the nerves beneath : calyx glabrous or nearly so at maturity.

Leaf-blades velvety pubescent beneath : calyx copiously pubescent.

Leaf-blades white-pubescent beneath : introduced species.

3. B. decurrens.

4. B. austrina.

5. B. nivea.

1. Boehmeria scàbra (Porter) Small. Perennial, rough-pubescent or nearly glabrous. Stems 2-12 dm. tall, rarely branched, very leafy : leaf-blades leathery, firm, ovate or elliptic-ovate, $2-5 \mathrm{~cm}$. or rarely $10 \mathrm{~cm}$. long, acute or short-acuminate, finely serrate, cordate or rounded at the hase, short-petioled; petioles $1 \mathrm{~cm}$. or rarely $2 \mathrm{~cm}$. long: spikes continuous, dense: calyx $3.5 \mathrm{~mm}$. broad, the sepals ovate-lanceolate, strongly hooded at the apex: achenes suborbicular, sometimes broader than high, nearly $1.5 \mathrm{~mm}$. broad, pointed, quite oblique at the base. [Boehmeria cylindrica var. scabra Porter.]

In swamps, New York to Michigan, Kansas, Florida and Texas. Summer and fall.

2. Boehmeria cylíndrica (L.) Willd. Perennial, bright green, pubescent with rigid straight or hooked hairs or nearly glabrous. Stems $2-10 \mathrm{dm}$. tall, simple or branched above: leaf-blades thin, ovate to lanceolate, $3-12 \mathrm{~cm}$. long, acuminate, coarsely-serrate, rounded or obtuse at the base ; petioles slender, often nearly as long as the blades : flowerclusters dense, forming usually interrupted spikes on slender branches: calyx $3 \mathrm{~mm}$. broad : sepals ovate-lanceolate: achenes suborbicular, $1 \mathrm{~mm}$. broad, pointed, oblique at the base, ciliate.

In woods and low ground, Quebec to Minnesota, Florida and Kansas. Summer and fall.

3. Boehmeria decúrrens Small. Perennial, nearly glabrous at maturity, deep green. Stems 7-12 dm. tall, sometimes inconspicuously pubescent: leaf-blades thin, lanceolate to ovate-lanceolate, $10-18 \mathrm{~cm}$. long, acuminate, serrate or crenate-serrate, with scattered hairs on and about the nerves beneath, deeper green above, rounded or very slightly cordate at the base, the main pair of lateral nerves arising some distance above the base of the blade; petioles slender, nearly as long as the blades or somewhat shorter: flower-clusters 
disposed on elongated spike-like branches : calyx about $3 \mathrm{~mm}$. broad : sepals oblong, obtuse, sparingly pubescent or glabrate : achenes fully $1.5 \mathrm{~mm}$. broad.

In moist sandy soil, Florida. Summer and fall.

4. Boehmeria austrìna Small. Perennial, copiously but finely pubescent, dull green. Stems 5-9 dm. tall, closely pubescent: leaf-blades oblong to oblong-lanceolate, 9-14 cm. long, thickish, acute or acuminate, crenate-serrate, velvety pubescent beneath, glabrate and darker green above at maturity, cordate or rounded at the base, the main pair of lateral nerves arising some distance above the base of the blade; petioles relatively short, mostly somewhat shorter than the blade: flower-clusters separated, on elongated spike-like branches : calyx about $3 \mathrm{~mm}$. broad ; sepals ovate, acute or acutish, copiously pubescent.

In moist or sandy soil, Texas to Arizona. Summer and fall.

5. Boehmeria nivea (L.) Gaud. A shrub or shrubby plant. Stem and branches pubescent with more or less spreading hairs: leaves alternate ; blades broadly ovate, $8-15$ $\mathrm{cm}$. long, somewhat acuminate, dentate, rounded, truncate or subcordate at the base, the upper surface rough, the lower densely white-pubescent, long-petioled: flower-clusters axillary, green, those of the pistillate flowers loosely branched.

In waste places, South Carolina and Florida and about the large cities in the Gulf States. Introduced from eastern Asia. RAMIE.

\section{PARIETÀRIA L.}

Annual or perennial, often flimsy herbs, with simple diffusely branched sometimes pellucid stems. Leaves alternate : blades entire, 3-nerved. Involucres of 2-6 more or less united bracts. Flowers polygamous, in clustered axillary cymes, the staminate with a perianth of 4 , or rarely 3 more or less united sepals, 4 or rarely 3 stamens and a rudimentary ovary. Pistillate flowers with a perianth like that of the staminate, and a free ovary : stigma tufted. Achene nearly terete, included, with a crustaceous pericarp. Pellitory.

Leaf-blades of an ovate, rhombic or an oblong type, relatively long-petioled.

Bracts of the involucre linear or linear-lanceolate, acute : sepals lanceolate.

Bracts of the involucre oblong, sometimes narrowly so, obtuse : sepals ovate. Leaf-blades of a lanceolate type, relatively short-petioled.

1. P. Floridana.

2. P. obtusa.

3. P. Pennsylvanica.

1. Parietaria Floridàna Nutt. Annual, slender, finely but often densely puberulent. Stems ascending or spreading, 1-5 dm. long, often much branched : leaf-blades thin, numerous, usually ovate to subrhombic, $0.5-5 \mathrm{~cm}$. long, blunt at the apex or sometimes shortacuminate but obtuse, entire, mostly obtuse at the base; petioles filiform : flower-clusters in nearly all the axils: bracts of the involucre linear or linear-lanceolate, $4 \mathrm{~mm}$. long, acute : sepals lanceolate, thin, acute or acutish : achenes ovoid, $1 \mathrm{~mm}$. long, shining.

In damp shaded places, New Hampshire to California, Florida and Mexico. Summer.

2. Parietaria obtùsa Rydb. Similar to $P$. Floridana in habit. Stems usually branched at the base, the branches spreading, 0.5-2 dm. long, copiously but very finely villous: leaf-blades oblong to ovate-oblong, $0.5-2 \mathrm{~cm}$. long, scarcely or not at all constricted below the apex, obtuse : bracts of the involucre oblong or narrowly oblong, obtuse : sepals ovate, obtuse or rarely acutish.

In shaded places, Colorado and Utah to Texas and Arizona. Spring and summer.

3. Parietaria Pennsylvànica Muhl. Annual, slender, finely pubescent. Stems weak, ascending or reclining, 1-4 dm. long, simple or branched: leaf-blades thin and flimsy, lanceolate or elliptic or sometimes oval or ovate, $1-6 \mathrm{~cm}$. long, obtuse or acuminate at the apex, entire, acute or acuminate at the base ; petioles slender: flower-clusters sessile in all but the lower leaf-axils : bracts of the involucre linear, 4-5 mm. long: sepals oblong or lanceolate, acute : achenes oval, $1 \mathrm{~mm}$. long, shining, minutely apiculate.

Cn shaded banks and rocks, Ontario to British Columbia, Florida and Mexico. Summer.

\section{Family 2. CanNabinàceae lindl. Hop or Hemp Family.}

Annual or perennial, often coarsely pubescent herbs, with erect or twining stems. Leaves opposite or sometimes alternate: blades toothed, lobed or divided, membranous, petioled : stipules persistent. Flowers dioecious : staminate in panicled racemes, with 5 sepals, and 5 stamens, or fewer or more. Pistillate flowers in bracted spikes, with an entire perianth, and a gynoecium of 2 united carpels. Ovary 1-celled. Styles or stigmas 2, subulate. Ovule solitary, pendulous. Fruit an achene, subtended by and often enclosed in a bract: 
pericarp crustaceous. Endosperm fleshy. Embryo curved or coiled. The perianth is sometimes much reduced or obsolete.

Stems twining: leaf-blades usually 3-lobed : fruit a drooping cone with thin imbricated bracts.

Stems erect: leaf-blades 3-7-parted : fruit spicate on stiff branches.

1. Humulus.

2. CanNabis.

\section{HÙMULUS L.}

Perennial twining herbs, with coarse pubescence. Leaves opposite : blades serrate or 3-7-lobed : stipules free, persistent. Staminate flowers in panicled racemes, with a perianth of 5 imbricated sepals, and 5 stamens with short erect filaments. Pistillate flowers in ament-like drooping spikes, 2 together, subtended by a bract, with an entire scale-like perianth and a sessile 1-celled ovary. Achene a little flattened, subtended by a membranous bract. Embryo spirally coiled.

1. Humulus Lùpulus L. A prostrate or climbing vine roughly pubescent throughout with stiff recurved hairs. Stems 2-9 m. long, dextrorsely twining, angled : leaf-blades firm, orbicular or ovate in outline, 3-15 cm. in diameter, simply serrate or 3-7-lobed, the lobes serrate, cordate at the base; petioles about $\frac{1}{2}$ as long as the blades: panicles 1-2 $\mathrm{dm}$. long, open : sepals oblong varying to ovate or obovate, obtuse, pubescent, about $3 \mathrm{~mm}$. long: stamens surpassing the sepals: fruiting spikes $3-8 \mathrm{~cm}$. long, ovoid or cylindric; bracts membranous, suborbicular to oblong-ovate, obtuse, 1-2 cm. long : achenes subglobose, about 2-3 $\mathrm{mm}$. in diameter.

In thickets, Nova Scotia to Manitoba, Florida and Arizona. Escaped from cultivation. Native of Europe and Asia. Summer. Hop.

\section{CÁNNABIS L.}

Coarse pubescent annual herbs, with erect stems. Leaves alternate or opposite : blades digitately divided into 5-11 narrow, serrate, firm segments: stipules free, persistent. Staminate flowers in panicled racemes, with a perianth of 5 imbricated sepals, and 5 stamens with short erect filaments. Pistillate flowers solitary in the axils of leafy bracts, forming spikes, with an entire perianth subtending a sessile 1-celled ovary. Achene oval, slightly flattened. Embryo curved.

1. Cannabis sativa L. A coarse erect herb, with a very tough inner bark. Stems branched, 1.5-4 m. tall, rough pubescent, angled : leaf-blades divided into 5-11 linear or linear-lanceolate serrate acuminate segments varying from $4-15 \mathrm{~cm}$. long ; petioles 2-8 $\mathrm{cm}$. long: panicles about as long as the subtending leaves : calyx $4-5 \mathrm{~mm}$. broad : sepals oblong or oval, pubescent obtuse : stamens about as long as the sepals : spikes leafy-bracted, 1-2 cm. long : achenes oval-lenticular, 4-5 mm. long, variegated, enveloped in the persistent perianth.

In waste places. New Brunswick to Minnesota, Kansas, Georgia and Tennessee. Native of Asia and Europe. Summer. HEMP.

\section{Family 3. ARtocarpàceae Horan. Mulberry Family.}

Shrubs or trees, with a milky sap and often edible fruit. Leaves mostly alternate: blades entire, toothed or lobed : stipules deciduous. Flowers monoecious or dioecious, in ament-like spikes or heads, on the outside of a receptacle, or on the inside of a closed receptacle, the staminate with a perianth of 3-4 sepals, somewhat united at the base. Stamens $3-4$, inserted at the base of the perianth. Filaments inflexed, straightening out elastically. Pistillate flowers with a perianth of $3-5$, partially united sepals which enlarge and envelop the achene at maturity and a 1-2-celled ovary. Styles or stigmas single or 2. Ovule solitary. Fruit a syncarp or syconium. Achenes inclosed in the pulpy calyx. Endosperm fleshy, or wanting. Embryo curved.

Staminate and pistillate flowers on the outside of the receptacle.

Staminate and pistillate flowers in ament-like spikes.

Staminate flowers in ament-like racemes; pistillate flowers in heads.

Plants armed : leaf-blades entire.

Plants unarmed : leaf-blades serrate and often lobed.

Staminate and pistillate flowers on the inside of a closed receptacle.

1. Morus.

2. TOXYLON.

3. BROUSSONETIA.

4. FICUS.

\section{Mòrus L.}

Monoecious or dioecious shrubs or trees, with a thin scaly bark. Leaves alternate : blades entire or 3-lobed, serrate, membranous, or somewhat leathery, deciduous. Flowers 
pedunculate. The staminate in elongated cylindric, ament-like drooping spikes: sepals nearly equal: stamens 4, inserted opposite the sepals under the rudimentary ovary, exserted : filaments filiform : anthers introrse, with roundish connectives. Pistillate flowers in shorter, stouter and denser spikes: calyx with 4 sepals, the outer often much larger than the inner, accrescent and enclosing the fruit. Ovary sessile, 1-celled : style terminal, very short: stigmas linear, ascending. Ovules suspended, campylotropous. Syncarp more or less elongated, white or black. Achenes tipped by the persistent stigmas. Mulberry.

Leaf-blades glabrous beneath or sparingly pubescent on the nerves.

Leaf-blades $6-20 \mathrm{~cm}$. long, rather smooth above: species introduced.

Syncarp white or pinkish.

Syncarp black at maturity.

Leaf-blades $2-5 \mathrm{~cm}$. long, scabrous above : species Texano-Mexican. Leaf-blades softly pubescent beneath.

1. M. alba.

2. M. nigra.

3. M. microphylla.

4. M. rubra.

1. Morus álba L. A tree 5-12 m. tall, with a maximum trunk diameter of $1 \mathrm{~m}$., the twigs and young foliage sparingly pubescent. Leaf-blades ovate or oval-ovate, 6-15 $\mathrm{cm}$. long, acute or short-acuminate, singly or doubly serrate, sometimes lobed, rounded or cordate at the base, generally pubescent on and about the nerves beneath; petioles $\frac{1}{3}-\frac{1}{4}$ as long as the blades, puberulent: staminate spikes $1-2 \mathrm{~cm}$. long, mostly longer than the peduncle : pistillate spikes $0.5-1 \mathrm{~cm}$. long : syncarp subglobose or oval-oblong, $1-2 \mathrm{~cm}$. long, usually longer than the peduncle, white or pinkish.

In fields and waste places, Maine to Minnesota, Georgia and Texas. Naturalized from the old World. Spring and summer.

2. Morus nìgra L. A shrub or tree, ranging from $3-20 \mathrm{~m}$. high, with puberulent twigs and young foliage. Leaf-blades thin, ovate, 4-15 $\mathrm{cm}$. long, short-acuminate, serrate, undivided or 2-3-lobed, rounded or cordate at the base, becoming glabrous ; petioles $\frac{1}{4}-\frac{1}{2}$ as long as the blades : staminate spikes cylindric, $1-2 \mathrm{~cm}$. long, longer than the peduncles: pistillate spikes oval, $5-8 \mathrm{~mm}$. long, shorter than the pubescent peduncles : syncarp ovaloblong, 1-2 cm. long, the drupelets black when mature.

Along roadsides and in waste places, New York to Florida and Texas. Introduced from the old World. spring.

3. Morus microphýlla Buckl. A shrub or small tree $10 \mathrm{~m}$. tall, with a trunk $3-4$ $\mathrm{dm}$. in diameter. Leaf-blades ovate, oval or suborbicular, $2-5 \mathrm{~cm}$. long, short-acuminate, serrate with rather appressed teeth, rounded or subcordate at the base, scabrous, deep green, sparingly pubescent on the nerves beneath; petioles $0.5-1 \mathrm{~cm}$. long, puberulent: staminate spikes slender, $1-2 \mathrm{~cm}$. long, longer than the peduncles : pistillate spikes small, drooping : syncarp oval-oblong, $1-1.5 \mathrm{~cm}$. long, deep purple or nearly black.

On plains or prairies, Texas to Arizona, and in northern Mexico. Early spring.

4. Morus rùbra L. A tree, reaching a height of $20 \mathrm{~m}$. and a maximum trunk diameter of $2.5 \mathrm{~m}$. the bark separating in thin scales. Leaf-blades ovate or oval-ovate, 6-20 $\mathrm{cm}$. long, abruptly acuminate, serrate, rounded or cordate at the base, becoming glabrous above, softly pubescent beneath; petioles $\frac{1}{4}-\frac{1}{7}$ as long as the blades: staminate spikes slender, 4-8 cm. long, cylindric, much longer than the peduncles : pistillate spikes about $1 \mathrm{~cm}$. long, drooping : syncarp cylindric, $3-6 \mathrm{~cm}$. long, deep red or purplish, very juicy. Plants sometimes flower in the fall, especially in southern Florida.

In fields and woods, Vermont to Ontario, South Dakota, Florida and Texas. Spring and summer.

\section{TóXYLON Raf.}

Dioecious trees, with a furrowed bark, armed with axillary thorns. Leaves alternate : blades entire, leathery. Flowers green, pedunculate, on branchlets of the previous year, the staminate in globose racemes: calyx campanulate, the 4 sepals narrowed to a pubescent pedicel. Stamens 4, inserted opposite the sepals : filaments filiform, slightly flattened : anthers introrse, with a short connective. Fertile flowers in dense heads on the stout shoots of the year. Calyx narrowly campanulate, the 2 outer sepals much broader than the inner, persistent, accrescent. Ovary ovoid, 1-celled, sessile, flattened, included, prolonged into a long terminal filiform plumose stigma. Ovule suspended, anatropous. Achenes oblong, flattened, collected into a large globose syncarp. Osage Orange.

1. Toxylon pomiferum Raf. A shrub or tree $20 \mathrm{~m}$. high, with a maximum trunk diameter of nearly $1 \mathrm{~m}$., the foliage pubescent when young, glabrous at maturity. Branchlets zigzag : leaf-blades ovate, ovate-lanceolate or oblong-lanceolate, or rarely obovate, 4-30 $\mathrm{cm}$. long, acuminate, entire, rounded or subcordate at the base, dark green and lustrous above, dull and paler beneath; petioles about $\frac{1}{3}$ as long as the blades: racemes 1-2 cm. long, subglobose, shorter than the peduncles: sepals united to the middle, the lobes ovate, 
obtuse: stamens long-exserted: fruiting heads globose, $5-15 \mathrm{~cm}$. in diameter, goldenyellow. [Maclura aurantiaca Nutt.]

In fields or thickets, Virginia to Arkansas, Georgia and Texas. Late spring and summer.

\section{BROUSSONÉTIA L'Her.}

Wide-spreading trees, with a milky sap. Leaves alternate : blades undivided, or 3-5lobed, serrate, softly pubescent. Flowers dioecious, the staminate in elongated ament-like spikes, with a perianth of " 4 partially united valvate sepals, 4 stamens with filiform filaments, and a rudimentary ovary. Pistillate flowers in heads, with an ovoid or tube-like toothed perianth, a stalked included ovary with a single stigma. Ovule pendulous. Fruiting head peduncled, each achene protruding from the persistent perianth, with a rugose crustaceous endocarp. PAPer Mulberry.

1. Broussonetia papyrífera (I.) Vent. A Morus-like tree 4-15 m. tall, with hirsutetomentose twigs and foliage. Leaf-blades thinnish, ovate, serrate, undivided or 3-lobed, acuminate or acute at the apex, rounded or cordate at the base, scabrous above, tomentose beneath; petioles $\frac{1}{2}-\frac{1}{3}$ as long as the blades : racemes $2-5 \mathrm{~cm}$. long, cylindric, longer than the peduncles: mature heads globose, $2-3 \mathrm{~cm}$. in diameter.

In waste places or cultivated lands, New York to Missouri and Florida. Native of Asia. Spring.

\section{Fìcus $\mathrm{L}$.}

Monoecious or rarely dioecious shrubs, trees or climbing plants, with a thick milky sap and usually naked buds. Leaves alternate or rarely opposite : blades entire, toothed or lobed, leathery : stipules interpetiolar. Flowers in hollow receptacles. Staminate flowers nearly sessile : calyx of 2-6 partially united sepals, or sometimes wanting: stamens 1 or 2 , or rarely 3 : filaments short and stout, when more than one, united : anthers innate or adnate. Pistillate flowers short-stalked : sepals commonly fewer and narrower than in the staminate flowers, or rarely wanting. Ovary sessile, 1-celled, sometimes oblique : style lateral, elongated : stigma club-shaped, peltate or 2-lobed. Ovule suspended or horizontal, anatropous. Achenes immersed in the accrescent receptacle. FIG.

Leaf-blades lobed, very scabrous-pubescent.

Leaf-blades entire, smooth and glabrous.

Receptacles pedunculate.

Receptacles sessile.

1. F. Carica.

2. F. populina.

3. F. aurea.

1. Ficus Carica L. A shrub or small tree $2-5 \mathrm{~m}$. tall, the stems sometimes clustered. Leaf-blades very scabrous-pubescent, firm, leathery, suborbicular or oval in outline, truncate or cordate at the base, palmately 5-7-lobed; lobes coarsely toothed or again lobed; petioles densely pubescent, about $\frac{1}{2}$ as long as the blades : fruit obovoid, $2-8 \mathrm{~cm}$. long.

In fields, escaped from cultivation, Virginia to Tennessee, Florida and Texas. Spring.

2. Ficus populina Willd. A small tree, sometimes $15 \mathrm{~m}$. tall with a maximum trunk diameter of $5 \mathrm{dm}$. Leaf-blades leathery, ovate, oval or rarely obovate, $3-10 \mathrm{~cm}$. long, obtuse, acute or abruptly short-acuminate at the apex, entire, deep green, lustrous above, rounded or cordate at the base ; petioles $\frac{1}{3}-\frac{1}{2}$ as long as the blades : receptacle globose-obovoid, pedunculate : flowers intermixed with chaff-like scales: sepals united to about the middle, broader in the pistillate flowers than in the staminate : fruit subglobose, $2-2.5 \mathrm{~cm}$. in diameter. [F. brevifolia Nutt.]

In hammocks, peninsular Florida and the Keys. Also in the West Indies. Spring and summer.

3. Ficus aùrea Nutt. A tree, starting as a parasite on the trunks of other trees, producing aërial roots which on reaching the ground produce large trunks and propagate the tree over large areas, maximum height $20 \mathrm{~m}$. Leaf-blades leathery, oblong, oval or elliptic, 3-10 cm. long, acute or short-acuminate at both ends, entire, yellowish green, lustrous above, paler beneath, usually short-petioled : receptacles sessile or nearly so in the axils, depressed globose, often in pairs : flowers reddish, tinged with purple, intermixed with chaff-like scales: sepals united to the middle or only at the base, the lobes broad in the staminate flowers, narrow in the pistillate : fruit obovoid, $2 \mathrm{~cm}$. in diameter.

In hammocks, southern Florida and the Keys. Also in the Bahama Islands. Spring and summer.

\section{FAMily 4. ULMÀCEAE Mirbel. Elm Family.}

Sometimes evergreen shrubs or trees, with a watery sap and spreading or usually drooping terete angled or winged branches. Pubescence not stinging. 
Leaves alternate, often 2-ranked: blades simple, usually inequilateral, oblique at the base, commonly scabrous: stipules fugacious. Flowers inconspicuous, perfect, polygamous, or monoecious, in axillary or lateral cymes, racemes or clusters. Perianth a green or slightly colored calyx. Sepals $4-5$ or rarely $3-8$, more or less united at the base, imbricated. Androecium usually of as many stamens as there are sepals. Filaments inserted at the base of the perianth opposite the lobes, distinct. Anthers opening lengthwise. Gynoecium of 2 united carpels. Ovary 1-2-celled, free. Stigmas 2. Ovule solitary, pendulous, anatropous or amphitropous. Fruit a stalked samara or a drupe, or nut-like. Seed with a membranous testa. Endosperm wanting or scant. Embryo with flat or conduplicate cotyledons.

Fruit dry, a samara, or nut-like : embryo straight.

Flowers mostly perfect: fruit a samara winged all around.

Flowers polygamo-monoecious: fruit nut-like, bearing wart-like tubercles. Fruit a drupe: embryo with conduplicate cotyledons.

Flowers solitary or merely clustered in the axils : drupe solitary.

Flowers in dichotomous cymes: drupes cymosely disposed.

Stigmas 2-cleft : sepals of staminate flowers imbricated: plants armed.

Stigmas entire: sepals of staminate flowers valvate: plants unarmed.

1. Ulmus.

2. Planera.

3. Celtis.

4. Momisia.

5. TREMA.

\section{1. ÚLMUS L.}

Shrubs or trees, with a furrowed bark and flexuous branchlets which are sometimes furnished with corky wings. Leaves 2-ranked: blades oblique, straight-nerved, rigid, serrate, deciduous. Flowers perfect (American species), in axillary clusters or cymes, articulated to the pedicels which are furnished with 2 scales. Calyx campanulate, membranous, 4-9-lobed, usually 5-lobed. Stamens exserted: filaments filiform or slightly flattened : anthers extrorse, erect, emarginate at the apex, subcordate at the base. Ovary sessile or short-stalked, flattened, 1-celled or rarely 2-celled, surmounted by 2, often recurved, introrse stigmas. Samara suborbicular or oblong, its membranous wing subtended by the persistent calyx. Seed flattened. Elm.

Flowers and fruit autumnal, in the axils of the leaves.

Leaf-blades obtuse : fruit short-ciliate.

Leaf-blades acute or acuminate : fruit long-ciliate.

1. U. crassifolia.

2. U. serotina.

Flowers and fruit vernal, on the naked branches.

Leaf-blades smooth or roughened above: flowering pedicel longer than the calyx.

Branches with corky wings.

Branches without corky wings.

Leafy twigs purple, glabrous : samara ovate, the tips erect or nearly so.

Leafy twigs pubescent: samara oval or obovate, the tips converging.

Leaf-blades very scabrous-pubescent : flowering pedicel shorter than the calyx.

3. U. alata.

4. U. Floridana.

5. U. Americana.

6. U. fulva.

1. Ulmus craseifòlia Nutt. A tree, reaching a maximum height of $30 \mathrm{~m}$. and a trunk diameter of $1 \mathrm{~m}$, its twigs and lower leaf surfaces pubescent. Leaf-blades firm and leathery, inequilateral, usually oblong, elliptic or ovate, obtuse, finely and often doubly serrate, mostly rounded at the oblique base, very rough above, more or less pubescent beneath, short-petioled : flowers autumnal, in axillary clusters : pedicels very short : calyx campanulate-turbinate, the lobes oblong or linear-oblong: samara oval, undulate, 8-10 $\mathrm{mm}$. long, finely pubescent, produced into 2 short beaks : seed ovate.

On prairies and along rivers, Arkansas to Mississippi and Texas, and in northern Mexico. Flowers in the late summer and fall; matures its fruit in September and October.

2. Ulmus serótina Sarg. A tree, reaching a height of $16 \mathrm{~m}$., with a maximum trunk diameter of nearly $1 \mathrm{~m}$., the branches spreading or pendulous, often with $2-3$ corky wings, the buds acute, about $6 \mathrm{~mm}$. long. Leaf-blades oblong to oval or broadest above the middle, $5-8 \mathrm{~cm}$. long, firm, often relatively thin, lustrous and yellow-green above, coarsely toothed, with a prominent midnerve and about 20 pairs of lateral nerves; petioles mostly about $6 \mathrm{~mm}$. long: racemes $2-4 \mathrm{~cm}$. long, many-flowered : pedicels $2-4 \mathrm{~mm}$. long: calyx reddish brown, 2-3 mm. long: anthers yellow : samara oblong-elliptic, 10-12 mm. long, ciliate with silvery hairs.

On banks and bluffs, Tennessee, Georgia and Alabama. Fall; fruit ripen in November.

3. Ulmus aláta Michx. A tree, reaching a height of $20 \mathrm{~mm}$., with a trunk diameter of $1 \mathrm{~m}$., the branches corky-winged. Leaf-blades firm, usually narrowly-elliptic or ellipticoblong, rarely nearly oval or ovate-lanceolate, $2-10 \mathrm{~cm}$. long, acute or short-acuminate, doubly or triply serrate, equilateral or slightly inequilateral, obtuse or slightly cordate at the base, short-petioled: flowers in clustered racemes, vernal: pedicels 4-8 $\mathrm{mm}$. long: calyx campanulate, the lobes ovate or suborbicular : samara elliptic, $5-6 \mathrm{~mm}$. long, conspicu- 
ously fringed with cilia, and pubescent all over, prolonged into 2 slender hooked beaks : seeds ovate-lanceolate.

Chiefly along streams, Virginia to Kansas, Florida and Texas. Late winter and spring. WAHоo.

4. Ulmus Floridàna Chapm. A small tree, sometimes $20 \mathrm{~m}$. tall, with a maximum trunk diameter of about $1 \mathrm{~m}$., its mature leafy twigs purple, glabrous. Leaf-blades firm, leathery, oblong, oval or ovate or rarely ovate-lanceolate, 3-12 cm. long, acute or shortacuminate, doubly or triply serrate with appressed or incurved teeth, inequilateral, oblique at the base, glabrous, smooth or rough above, more or less pubescent beneath, shortpetioled : flowers vernal in somewhat clustered racemes : pedicels $1-1.5 \mathrm{~cm}$. long, glabrous : calyx campanulate, $3-4 \mathrm{~mm}$. long : samara ovate, $11-13 \mathrm{~mm}$. long, reticulated, ciliate, the tips erect or nearly so.

On river banks, North Carolina to Florida. Late winter and early spring.

5. Ulmus Americàna L. A forest tree, reaching a maximum height of about $40 \mathrm{~m}$., with a trunk diameter of 1-3 m., its mature leafy twigs pubescent. Leaf-blades oval or ovate, 5-10 cm. long, short-acuncinate, usually doubly serrate, with more or less incurved teeth, inequilateral, oblique at the base, sometimes cordate, glabrous or nearly smooth above, sparingly pubescent and prominently nerved beneath, short-petioled: flowers vernal, elustered : pedicels $1-1.3 \mathrm{~cm}$. long, glabrous: calyx campanulate, $2-3 \mathrm{~mm}$. long : samara oval or obovate, $10-12 \mathrm{~mm}$. long, reticulated, fringed, the tips strongly convergent : seeds central, oval or elliptic.

Along water courses, Newfoundland to Saskatchewan, Florida and Texas. Late winter and early spring. White or WATER ELM.

6. Ulmus fúlva Michx. A tree, becoming $25 \mathrm{~m}$. tall, with a trunk, diameter of less than $1 \mathrm{~m}$., the twigs and leaves scabrous pubescent : inner bark mucilaginous. Leaf-blades ovate, oval or obovate, or those on shoots lanceolate, acuminate, doubly or triply serrate, obliquely truncate or cordate at the base, scabrous-pubescent on both sides, short-petioled : flowers vernal, in dense clusters, nearly sessile or the pedicels 1-2 mm. long ; calyx campanulate, pubescent, $3 \mathrm{~mm}$. long, the lobes half-orbicular: samaras suborbicular, 14-17 $\mathrm{mm}$. in diameter, finely pubescent, with a slightly thickened margin not fringed with cilia : seeds oval, 5-6 mm. long. ELM.

On banks and in rocky soil, Quebec to North Dakota, Florida and Texas. Early spring. SLIPPERY

\section{PLÁNERA J. F. Gmel.}

Small trees, with a scaly bark and very slender somewhat flexuous branchlets. Leaves three-ranked : blades rather rigid, crenate-serrate with gland-tipped teeth, otherwise elmlike. Flowers polygamo-monoecious : staminate in clusters arising from the axils of the branchlets : pistillate (or perfect) solitary or several together in the axils of the leaves. Calyx campanulate, somewhat scarious, 4-5-lobed. Stamens 4-5, exserted : filaments filiform: anthers introrse, notched at the apex, cordate at the base. Ovary short-stalked, 1-celled, tuberculate, surmounted by two recurved introrse stigmas. Nut-like fruit dryleathery, covered with irregular elongated wart-like projections. Seed solitary, flattened, with a lustrous testa. Planer-Tree. Water Elm.

1. Planera aquàtica (Walt.) J. F. Gmel. A small tree 4-12 m. tall, with a maximum trunk diameter of about $6 \mathrm{dm}$. Bark smooth or scaly : leaf-blades ovate or ellipticovate, 3-8 cm. long, acute or obtuse, singly or doubly serrate or crenate-serrate, inequilateral, oblique at the base, finely reticulated and deep green above, glabrous or minutely pubescent and paler beneath, short-petioled : staminate flowers in clusters or clustered racemes : pistillate flowers solitary or several in an axil : pedicel longer than the calyx : calyx turbinate-campanulate, about $2 \mathrm{~mm}$. long, "the lobes ovate, obtuse : fruit ovoid, about $1 \mathrm{~cm}$. long, surpassing its pedicel in length, tuberculate-echinate with soft processes.

In river swamps, Indiana and Missouri to North Carolina, Florida and Texas. Early spring.

\section{CÉLtIS L.}

Unarmed shrubs or trees, with a thin smooth or extensively corky-ridged bark. Leaves 2-ranked : blades oblique, entire or serrate, membranous or somewhat leathery. Flowers polygamo-monoecious, or rarely monoecious, axillary, on the new branchlets : staminate solitary or clustered: pistillate solitary or a few together near the ends of the branchlets. Calyx 4-5-lobed, deciduous. Stamens 4-5 : filaments incurved : anthers extrorse, loosely attached just above the base. Ovary sessile, 1-celled, prolonged into two recurved stigmas. Drupe subglobose with a firm outer coat, the pulp scant and the stone bony, its surface smooth or rugose. Seed filling the cavity of the stone. The plants flower in the spring. Hackberry. Sugar-berry. 
Leaf-blades of an ovate type. ${ }^{1}$

Twigs glabrous.

Twigs puberulent.

Leaf-blades green beneath, glabrous or slightly pubescent.

Mature drupes 7-10 $\mathrm{mm}$. in diameter.

Leaf-blades barely reticulated: species of the middle and eastern United States.

Leaf-blades conspicuously reticulated: western species.

Mature drupes 5-7 $\mathrm{mm}$. in diameter.

Leaf-blades gray beneath and subtomentose.

Leaf-blades of a lanceolate type.

Leaf-blades entire or nearly so.

Leaf-blades sharply serrate.

1. Celtis occidentàlis $\mathrm{L}$. A tree, sometimes reaching a height of $40 \mathrm{~m}$, with a trunk diameter of $1 \mathrm{~m}$., the twigs glabrous. Leaf-blades ovate or rarely oblong-ovate, 5-15 cm. long, usually abruptly acuminate, sharply serrate except at the oblique, truncate or cordate base, smooth or nearly so above, short-petioled : drupes subglobose or globose, $7-10 \mathrm{~mm}$. in diameter, orange, purple or nearly black when mature.

- On river banks and in rich soil, Quebec to Manitoba, North Carolina, Alabama and Kansas.

2. Celtis crassifolia Lam. A shrub or tree, with puberulent twigs. Leaf-blades ovate, firm in texture, $3-12 \mathrm{~cm}$. long, acute or short-acuminate at the apex, of ten truncate or cordate at the base, usually serrate to near the apex, pubescent, scabrous on the upper surface, short-petioled : drupes $7-10 \mathrm{~mm}$. in diameter, red-purple or nearly black at maturity, oval or subglobose.

In dry or stony soil, New York to Kansas, South Carolina and Tennessee.

3. Celtis reticulàta Torr. A small tree $3-15 \mathrm{~m}$. tall, with pubescent twigs and foliage, the bark blue-gray, smooth or with high corky warts. Leaf-blades ovate, 3-7 cm. long, obtuse or acuminate, more or less revolute, entire or serrate, very scabrous above, pubescent and very prominently rugose-nerved beneath, truncate or cordate at the oblique base ; petioles 4-10 $\mathrm{mm}$. long, pubescent : drupes globose, 7-10 $\mathrm{mm}$. in diameter, orange-red.

In rocky places, southern Colorado to Texas and Arizona.

4. Celtis Georgiàna Small. A diffuse shrub or small tree, with slender, often pinnately arranged branches, the leafy twigs pubescent. Leaf-blades ovate, $2-5 \mathrm{~cm}$. long, acute or short-acuminate, entire or sharply serrate above the middle, inequilateral, rounded or truncate at the oblique base, scabrous and sometimes sparingly pubescent on the upper surface ; petioles short, pubescent : pedicels short, often not longer than the diameter of the fruit : drupes globose or subglobose, $5-7 \mathrm{~mm}$. in diameter, red-purple or tan-color.

In rocky places and along streams, Maryland and Missouri to Georgia, Florida and Alabama.

5. Celtis Hélleri Small. A much-branched wide-spreading tree, sometimes $10 \mathrm{~m}$. tall, with a maximum trunk diameter of $1.5 \mathrm{~m}$., the bark of the trunk and main branches with numerous corky warts. Leaves rather firm; blades ovate to oblong, $4-7 \mathrm{~cm}$. long, obtuse or acute, crenate-serrate, especially above the middle, rounded or subcordate at the base, deep green and scabrous-pubescent above, pale and tomentose beneath, slightly inequilateral, oblique at the base ; petioles stout, $3-4 \mathrm{~mm}$. long, tomentose : pedicels sparingly pubescent, curved, 1-1.5 cm. long: drupes subglobose, 7-9 dm. in diameter, light brown, translucent, smooth and shining: seeds globose, strongly 4-ribbed, prominently reticulated.

In dry grounds, southern Texas.

6. Celtis Mississippiénsis Bosc. A large tree, reaching a height of $30 \mathrm{~m}$., with a maximum trunk diameter of about $1 \mathrm{~m}$., the bark light gray, usually covered with high corky warts. Leaf-blades lanceolate, ovate-lanceolate or oblong-lanceolate, 6-12 cm. long, long-acuminate at the apex, entire or nearly so, rounded, truncate or subcordate at the oblique base, dark green and smooth above, pale beneath; petioles 4-10 mm. long : pedicels slender, 1-2 cm. long : drupes globose or globose-ovoid, $5-7 \mathrm{~mm}$. in diameter, purple-black or orange-red.

Mostly along streams, Indiana and Inlinois to Texas and Florida.

7. Celtis Smállii Beadle. A tree usually smaller than C. Mississippiensis. Leaf-blades thin, lanceolate or oblong-lanceolate, 5-10 cm. long, acuminate, sometimes with conspicuously elongated tips, sharply and irregularly serrate, wedge-shaped or rounded at the base, delicately but usually conspicuously veined, slender-petioled: pedicels slender, mostly longer than the petioles: drupes subglobose, $5-7 \mathrm{~mm}$. in diameter.

Sandy or rocky soil, North Carolina and Tennessee to Georgia and Alabama.

${ }^{1}$ Key and descriptions revised by Mr. C. D. Beadle. 


\section{Momisia F. G. Dietr.}

Spine-armed shrubs or small trees, with usually pubescent or scabrous foliage. Leafblades often leathery, variously toothed, nearly equilateral : stipules in the form of spines. Flowers polygamo-monoecious, at least the staminate in elongated axillary cymes. Calyx with 4-5 lobes, deciduous. Stamens 4-5, exserted: filaments longer than the extrorse anthers. Ovary sessile, 1-celled. Stigmas 2-cleft. Drupe oblong, ovoid or globose, sometimes slightly angled, with a more or less flattened, tuberculate or reticulated stone.

Leaf-blades nearly smooth : drupe $8-12 \mathrm{~mm}$. in diameter : stone with warty faces. Leaf-blades very scabrous : dupes $5-8 \mathrm{~mm}$. in diameter: stone with reticulated faces.

1. M. aculeata. 2. M. pallida.

1. Momisia aculeàta (Sw.) Kl. A spreading or often climbing shrub, 1-3 m. tall, with little or no pubescence, its branches and twigs with more or less recurved stipular spines. Leaf-blades ovate, oval or oblong-ovate, obtuse or acutish, nearly entire or coarsely crenate-serrate above the middle, rounded or cordate at the base, slightly inequilateral and sometimes oblique at the base, nearly smooth on both sides, short-petioled: flowers in cymes : pedicels $2-5 \mathrm{~mm}$. long: drupes globose-ovoid, $8-12 \mathrm{~mm}$. long, obscurely 4-angled : seeds obliquely oval, slightly flattened, warty. [Celtis aculeata Sw.]

In sandy soil, Florida Keys and the valley of the Rio Grande. Also in tropical America and the West Indies. Spring.

2. Momisia pállida (Torr.) Planch. A spreading shrub $2-4 \mathrm{~m}$. tall, with puberulent twigs and inflorescence, its branches armed with straight stipular spines. Leaf-blades ovate to oblong, $2-3.5 \mathrm{~cm}$. long, acute or apiculate, 3-nerved, nearly entire or coarsely toothed, slightly inequilateral, often oblique at the rounded or subcordate base, very scabrous on both sides, short-petioled : cymes $3-5$-flowered : pedicels $1-2 \mathrm{~mm}$. long, shorter than the petioles: drupes subglobose, $5-8 \mathrm{~mm}$. in diameter, yellow, orange or red, with an acid pulp: seeds oval or obovoid, 4-ribbed, reticulated. [Celtis pallida Torr.]

In sandy soil, Florida and Texas to northern Mexico. Spring.

\section{TRÈMA Lour.}

Tall shrubs or trees, unarmed, usually pubescent. Leaves alternate, often 2-ranked : blades toothed, 3-nerved at the base, equilateral or only slightly inequilateral, short-petioled : stipules lateral. Flowers mostly monoecious or polygamous, the perfect mostly fertile, in axillary cymes. Sepals of pistillate flowers induplicate-valvate, those of the perfect flowers slightly imbricated. Stamens 4-5. Ovary sessile. Stigmas 2, entire. Ovule pendulous. Drupe ovoid to globose.

1. Trema Floridàna Britton. A shrub or tree $6 \mathrm{~m}$. tall, with copiously pubescent foliage. Leaf-blades ovate, oblong-ovate or lanceolate, 4-10 cm. long, more or less acuminate, scabrous-pubescent above, softly pubescent beneath, finely serrate, rounded or cordate at the base : flowers greenish : drupes subglobose, yellow or orange.

In woods and hammocks, peninsular Florida and the Keys.

\section{Order 9. POLYGONÀLES.}

Herbs, shrubs, trees or vines. Leaves alternate, or sometimes opposite or whorled: blades mostly entire: stipules mostly present, usually as a sheath. Flowers perfect, monoecious, dioeeious or polygamous, in variously disposed clusters. Calyx inferior, of 2-6 more or less united sepals sometimes developing keels or wings, often corolloid. Androecium of 2-9 stamens. Filaments often dilated at the base. Anthers 2-celled, opening longitudinally. Gynoecium 2-3carpellary. Ovary superior, 1-celled. Styles 2 or 3, more or less united. Stigmas capitate or tufted, rarely 2-cleft. Ovule solitary, orthotropous. Fruit a lenticular or 3-angled achene, usually invested by the persistent calyx. Seed with horny or mealy endosperm. Embryo with incumbent or accumbent cotyledons. 


\title{
Family 1. POLYGONÀCEAE Lindl. Buckwheat Family.
}

\author{
Characters of the order.
}

Flowers or flower-clusters in involucres of partially united bracts: stamens 9 .

Flowers or flower-clusters not involucrate: stamens 4-8.

Hypanthium little or barely developed, at least not investing the achene.

Stigmas tufted.

Stigmas not tufted.

Internodes of the stem and branches partially adnate.

Inner sepals not fimbriate, often conspicuously accrescent.

Flowers polygamo-dioecious : filaments subulate: embryo axile.

Flowers perfect: filaments various, the inner dilated: embryolateral.

Inner sepals fimbriate, or in fruit-producing flowers all fimbriate, not accrescent.

Internodes of the stem and branches not adnate.

Leaf-blades jointed at the base : ocreae 2-lobed, becoming lacerate : filaments, at least the inner, dilated.

Leaf-blades not jointed at the base : ocreae various, not 2-lobed : filaments slender.

Ocreae cylindric, truncate.

Sepals 4 : calyx curved: stamens 4 .

Sepals 5 , if fewer, the stamens more than 5 : calyx not curved.

Ocreae oblique, more or less open on the side facing the leaf.

Herbs, various in habit, not vines: sepals neither keeled nor winged.

Racemes collected into terminal corymbs : embryo dividing the endosperm by an S-shaped curve: plants smooth.

Racemes not in terminal corymbs: embryo slender, at one side of the endosperm : plants prickle-armed.

Vines with twining stems: outer sepals winged or keeled.

Hypanthium well developed, enclosing the achene.

Hypanthium winged at maturity : stigmas 2-eleft.

Hypanthium not winged: stigmas not cleft.

1. Eriogonum.

2. RUMEX.

4. Gonopyrum.

5. Thysanella.

6. Polygonum.

7. TOVARA.

8. Persicaria.

9. FAGopyrum.

10. Tracaulon.

11. Tiniaria.

12. BRUNNICHIA.

13. Coccolobis.

\section{ERIÓGONUM Michx.}

Annual or perennial herbs or shrubby plants. Leaves basal or cauline, alternate, opposite or whorled: blades entire: ocreae wanting. Flowers perfect, or polygamomonoecious, the involucrate clusters variously disposed. Involucres varying from turbinate to almost cylindric, 5-8-loped. Calyx more or less colored, jointed to a short pedicel which is subtended by a minute bractlet. Sepals 6 , equal, or the outer ones larger. Stamens 9 : filaments filiform, often villous. Ovary 1-celled, very narrowly pyramidal : styles 3 : stigmas capitate. Achene 3-angled, more or less swollen at the base, invested by the accrescent calyx. Embryo axile or eccentric in the mealy endosperm.

Calyx narrowed into a stipe-like base.

Leaves whorled; blades relatively broad: inflorescence with leaf-like bracts.

Leaves alternate; blades relatively narrow : inflorescence naked.

Peduncles mostly over $1 \mathrm{~cm}$. long: calyx 6-10 mm. long: involucres over 5 mm. high.

Peduncles mostly less than $1 \mathrm{~cm}$. long: calyx 4-5 mm. long: involucres less than $5 \mathrm{~mm}$. high.

Calyx without a stipe-like base.

Annual: leaf-blades much longer than broad.

Outer sepals obovate, not cordate : achenes $1.5 \mathrm{~mm}$. long.

Outer sepals suborbicular, cordate : achenes $3 \mathrm{~mm}$. long.

Perennial by a shrubby caudex : leaf-blades as broad as long or nearly so.

1. E. tomentosum.

2. E. Floridanum.

3. E. longifolium.

4. E, annuum.

5. E. multiflorum.

6. E. tenellum.

1. Eriogonum tomentòsum Michx. Perennial by a gnarled rootstock, tomentose with brown or reddish hairs. Stems often clustered, 4-12 dm. tall, corymbosely branched above : basal leaves $5-15 \mathrm{~cm}$. long; blades oblong, oblanceolate or spatulate, long-petioled : stem-leaves in whorls of 3-5; blades ovate or obovate or sometimes oblanceolate, sessile or short-petioled, tomentose beneath : bracts usually elliptic or oval : involucres campanulate, about $4 \mathrm{~mm}$. high, sessile in a whorl of bractlets : calyx white, turbinate, 4-5 mm. long, becoming $10 \mathrm{~mm}$. long, at maturity : sepals tomentose without, the inner larger and thinner than the outer : filaments villous at the base : achenes 3 -angled, ovoid, $5 \mathrm{~mm}$. long, villous at the top. TONGUE.

In dry pine lands or on sand hills, South Carolina to Florida and Alabama. Spring to fall. Dog-

2. Eriogonum Floridànum Small. Perennial by a stout rootstock. Stems 6-10 dm. tall, branched above, densely scaly at the base : leaves rather numerous at the base of the stem, 1-2 dm. long; blades broadly or narrowly linear, narrowed to the base, but with little distinction into blade and petiole: peduncles mostly over $1 \mathrm{~cm}$. long: involucres 6-7 mm. high : calyx 6-10 mm. long, green : sepals linear-subulate, attenuate, involute, copiously pubescent without : achenes 3 -angled.

In sand or sandy soil, Florida. Summer and fall. 
3. Eriogonum longifòlium Nutt. Perennial by a thick rootst ock, pubescent. Stems 6-13 dm. tall, paniculately or corymbosely branched above, finely grooved : leaves mostly at the base of the stem; blades narrowly oblong or linear-oblong, 5-22 cm. long, silkystrigose above, tomentose beneath, obtuse or acutish, the upper ones sessile, the lower ones attenuate into winged petioles with dilated sheathing bases : peduncles mostly less than 1 $\mathrm{cm}$. long : involucres turbinate-campanulate, 4-5 mm. high : calyx herbaceous, 4-5 mm. long, densely silky with silvery hairs: sepals lanceolate or oblong-lanceolate: achene 3angled.

In sandy soil, southern Missouri to the Indian Territory and Texas. Spring to fall.

4. Eríogonum ánnuum Nutt. Annual, floccose-tomentose with white hairs. Stems erect, $3-9 \mathrm{dm}$. tall : leaf-blades narrowly oblong or oblanceolate, $2-7 \mathrm{~cm}$. long, acute or obtuse, flat or slightly revolute, or crisped, attenuate into short petioles : peduncles shorter than the stems or almost wanting, topped by a dichotomous compound cyme: involucres turbinate or turbinate-campanulate, $2-3 \mathrm{~mm}$. high, very short-stalked, densely whitetomentose; lobes 5, obtuse: calyx white or pink, 1-2 mm. long, glabrous, the outer sepals obovate, the inner narrower, all truncate or retuse at the apex, sometimes fiddleshaped : achenes 3 -angled, $1.5 \mathrm{~mm}$. long, with a globular base and a beak of equal length, the angles smooth.

In dry places, Nebraska to Texas, New Mexico and Chihuahua. Summer and fall.

5. Eriogonum multiflòrum Benth. Annual, woolly-tomentose with white hairs. Stems erect 3-10 dm. tall, leafy below, strict : leaf-blades lanceolate or oblong-lanceolate, 2-7 cm. long, acute or obtuse, undulate and often crisped, revolute, sessile and somewhat auricled: peduncles $2-30 \mathrm{~cm}$. long, each topped by a trichotomous cyme : involucres turbinate-campanulate, about $2 \mathrm{~mm}$. high, shorter than their stalks; lobes 5 , triangular: calyx white, 2-3 mm. long, glabrous: sepals very unequal, the outer suborbicular, retuse or notched at the apex, cordate at the base, the inner linear, shorter than the outer : achenes 3 -angled, about $3 \mathrm{~mm}$. long, subglobose below, each narrowed into an acute beak.

In dry soil, Arkansas to Louisiana and Texas. Summer and fall.

6. Eriogonum tenéllum Nutt. Perennial, usually scapose. Stems sometimes developed, 1-3 dm. long, leafy : leaves usually basal; blades ovate or suborbicular, 0.5-1.5 $\mathrm{cm}$. in diameter, obtuse or acutish, gradually or abruptly narrowed at the base, densely and softly tomentose on both surfaces; petioles longer than the blades or shorter: scapes often wand-like, 1-4 dm. tall, rather sparingly branched: involucres turbinate-campanulate, 3-4 mm. high, on more or less elongated stalks; lobes 5 , broad, often acutish : calyx white or pink, at length about $3 \mathrm{~mm}$. long, glabrous, the outer sepals obovate or suborbicular, retuse or notched at the apex, more or less spreading, the inner sepals linearoblong, erect, shorter than the outer: filaments slightly villous at the base : achenes 3angled, $2.5 \mathrm{~mm}$. long, globose at the base, each short-beaked.

In dry places, Colorado to Texas, New Mexico and Chihuahua. Summer and fall.

\section{RÙMEX L.}

Annual or usually perennial, caulescent herbs, with large roots. Leaves alternate: blades entire, flat, undulate or crisped, narrowed, or cordate or auricled at the base : ocreae thin, brittle. Flowers green, perfect, polygamo-monoecious or dioecious on pedicels which are jointed to and terminate short peduncles, in distant or contiguous whorls disposed in panicles. Sepals 6 , the 3 inner usually developing entire toothed or spiny wings one or each of which usually bear a callosity. Stamens 6 . Ovary sessile : styles $3:$ stigmas peltate, tufted. Achene 3-angled, usually invested by the accrescent calyx, its angles more or less margined. Dock. SoRREL.

Flowers dioecious : some or all of the leaves with hastate blades : plants sour.

Inner sepals not developing wings : achenes granular.

Inner sepals developing wings: aehenes smooth.

Flowers polygamo-monoecious : none of the leaves with hastate blades : plant not sour.

Sepal-wings entire, undulate or shallowly toothed.

Leaves flat or the margins sometimes slightly crisped, usually pale, the lower ones mostly narrow.

Pedicels together with the peduncles, or at least some in a cluster, longer than the wings.

Leaf-blades about twice as long as broad.

Leaf-blades several times longer than broad.

Pedicels together with the peduncles several times longer than the wings.

Pedicels together with the peduncles slightly longer than the wings.

1. R. Acetosella.

2. R. hastatulus:

3. R. fascicularis.

4. R. verticillatus.

5. R. salicifolius. 
Pedicels together with the peduncles shorter than the wings.

Sepal-wings longer than broad, 4-5 $\mathrm{mm}$. broad.

Sepal-wings blunt, with stout nerves : achenes acuminate.

Sepal-wings acutish, with slight nerves: achenes acute.

Sepal-wings broader than long, 1-1.2 mm. broad.

Leaves strongly crisped, the lower ones mostly large and broad, usually dark green.

Lower leaves narrowed at the base.

Lower leaves truncate or cordate at the base.

Stout plants, usually with dense contracted panicles in fruit.

Slender plants, with loose spreading panicles in fruit.

Each wing bearing a callosity : inflorescence leafy, at least the main axis.

Branches of the panicle naked: sepal-wings triangular.

Branches of the panicles leafy : sepal-wings oblong, fiddleshaped.

One wing only bearing a callosity: inflorescence not leafy.

Sepal-wings armed with spine-like teeth.

Tall plants : lower leaves cordate or truncate.

Sepal-wings armed with 5-10 teeth, two bearing callosities.

Sepal-wings armed with 3-5 teeth, one bearing a callosity.

Low plants : lower leaves abruptly or gradually narrowed at the base.

Pedicels abruptly enlarged near the calyx.

Pedicels dilated above, the margins revolute.

6. R. Langloisii.

7. $R$. altissimus.

8. R. spiralis.

9. R. hymenosepalus.

10. R. crispus.

\section{1. $R$. Berlandieri.}

12. $R$. conglomeratus.

13. $R$. sanguineus.
14. R. pulcher.
15. R. obtusifolius.
16. $R$. persicarioides.
17. R. bucephalophorus.

1. Rumex Acetosélla L. Perennial, slender, glabrous. Stems erect or nearly so, 1-6 dm. tall, one or several from a woody creeping or horizontal rootstock: leaf-blades hastate, $2.5-15 \mathrm{~cm}$. long, obtuse or acute, usually broadest above the middle, with two entire or 1-2-toothed auricles at the base, papillose, petioled, the uppermost merely linear : ocreae silvery, soon lacerate: flowers dioecious, in more or less whorled clusters: calyx green, $1 \mathrm{~mm}$. long: pedicels slender: stamens 6 , exserted: achenes ovoid, 3-angled, 1.5 $\mathrm{mm}$. long, granular, exceeding the presistent calyx, whose sepals are unchanged in fruit, the angles not margined.

In dry and rocky soil, throughout North America, except the extreme northern part. Spring to fall. SHEEP or FIELD SORREL.

2. Rumex hastátulus Baldw. Perennial, glabrous, rather strict. Stems $1.5-6 \mathrm{dm}$. tall, one or several from a woody base, erect, simple or branched : leaf-blades hastate, oblong or oblanceolate, $2.5-13 \mathrm{~cm}$. long, more or less strongly auricled at the base, acutish, petioled, or those of the cauline leaves linear, all papillose: ocreae silvery, at length lacerate: flowers dioecious in whorled clusters: calyx $1 \mathrm{~mm}$. long, green, winged in fruit: sepal-wings reniform, $4 \mathrm{~mm}$. long: pedicels as long as the wings or longer: achenes broadly oblong, 3-angled, $1.5 \mathrm{~mm}$. long, reddish, smooth and shining, invested by the sepal-wings, the angles margined. Spring.

On the coast or in sandy soil, southern New York to Florida, and on the plains, Kansas to Texas.

3. Rumex fasciculàris Small. Perennial by a small cluster of fusiform roots, of a dull and olive-green color. Stem lax and weak, 5-12 dm. long, decumbent, abruptly thickened at the base and slightly so at the nodes : leaf-blades mostly oblong, a few occasionally oblong-ovate or ovate, $8-15 \mathrm{~cm}$. long, of much the same size throughout, about twice as long as broild, mostly truncate or cordate at the base, drying thin: ocreae fugacious: panicles 1-2 dm. long, rather dense in fruit, the branches ascending: pedicels slender, narrowly clavate, deflexed in fruit, winged at the summit, longer than the sepal-wings, and much longer than the peduncles : sepal-wings broadly deltoid, 4.5-5.5 mm. long, undulate, strongly-nerved, each bearing a callosity: achenes pyramidal-ovoid, $3 \mathrm{~mm}$. long, the angles slightly margined.

About pools, peninsular Florida. Summer.

4. Rumex verticillàtus L. Perennial, rather bright green. Stem $9-15 \mathrm{dm}$. long, erect, ascending or somewhat decumbent, simple or nearly so, more or less flexuous when old: leaf-blades narrowly oblong, oblong-lanceolate or lanceolate, $5-30 \mathrm{~cm}$. long, acute or obtusish, more or less acuminate at the base, slightly papillose: panicle open, the branches rather erect, or spreading in fruit, the rather dense whorls separated below : pedicels stout, club-shaped, much longer than the very short peduncles: sepal-wings broadly deltoid, $4 \mathrm{~mm}$. long, more or less decurrent on the pedicel, $\frac{1}{5}-\frac{1}{3}$ as long as the pedicels and peduncles, each bearing a narrowly-ovoid callosity : achenes broadly ovoid, $3-3.5 \mathrm{~mm}$. long.

In swamps, Quebec to Iowa, Florida and Texas. Spring and summer.

5. Rumex salicifolius Weinm. Perennial, pale green. Stem $3-9 \mathrm{dm}$. tall, erect or decumbent, flexuous : leaf-blades narrowly lanceolate or linear-lanceolate, $3-20 \mathrm{~cm}$. long, or the lower ones sometimes oblong, acute or acuminate at both ends, or rarely obtuse: panicle open or dense, the branches erect or divergent, sometimes reflexed, the very dense whorls separated only below : pedicels much longer than the peduncles: sepal-wings 
triangular-ovate, $3 \mathrm{~mm}$. long, undulate or subdentate, slightly shorter than most of the pedicels and peduncles, each bearing a large ovoid callosity: achenes ovoid or oblongovoid, 2-2.5 $\mathrm{mm}$. long, the angles slightly margined.

In swamps, Labrador and British Columbia to Florida and Lower California. Also in Europe Spring to fall.

6. Rumex Langloìsii Small. Perennial, somewhat scurfy, dark green. Stem erect or ascending, 5-7 dm. tall, simple or with a few nearly erect branches, more or less flexuous : leaf-blades oblong or linear-oblong, 3-12 cm. long, acuminate or acutish, erosecrenulate, slightly crisped, rather prominently nerved, especially beneath: panicle usually dense at maturity: pedicels about $5 \mathrm{~mm}$. long, much longer than the very short peduncles, each enlarged toward the apex : sepal-wings leathery, deltoid, $4 \mathrm{~mm}$. long, blunt, the surface prominently nerved, each bearing a papillose callosity, which is $1 \mathrm{~mm}$. broad and $3 \mathrm{~mm}$. long: achenes ovoid, nearly $3 \mathrm{~mm}$. long, each abruptly contracted into a very short base, slightly acuminate at the apex, the angles slightly paler than the faces, margined.

In low grounds, southern Louisiana. Summer.

7. Rumex altíssimus Wood. Perennial, pale green. Stem 6-12 dm. tall, erect, simple or sparingly branched above: leaf-blades lanceolate, oblong-lanceolate or ovatelanceolate, or sometimes oblanceolate, $5-25 \mathrm{~cm}$. long, acute at the apex, thickish, acute or acuminate at the base: panicle rather open, the branches somewhat spreading or erect, the rather dense whorls only slightly separated in fruit: pedicels slender, much longer than the very short peduncles: sepal-wings triangular-cordate, 4-5 mm. long, about as long as the pedicels, usually only one producing a large ovoid callosity : achenes ovoid, $3 \mathrm{~mm}$. long.

In river bottoms, Massachusetts to Iowa, the District of Columbia and Texas. Spring and early summer.

8. Rumex spiràlis Small. Perennial, light green, somewhat glaucescent. Stem erect, 8-9 dm. tall, simple or sparingly branched above, slightly flexuous : leaf-blades lanceolate or oblong-lanceolate, 6-13 cm. long, acute or sometimes attenuate at the apex, the lower ones obtuse or truncate at the base, the upper acute or acuminate at the base, coriaceous, neither prominently nor conspicuously nerved: panicle nearly naked, the mature branches $5-12 \mathrm{~cm}$. long, rather erect, the terminal one usually about twice as long as the lateral ones, with dense, barely interrupted whorls: pedicels together with the peduncles varying from $2-4 \mathrm{~mm}$. in length, the joint below the middle: sepal-wings broadly ovate-cordate, broader than high, $1 \mathrm{~cm}$. long, 1-1.2 cm. broad, straw-colored, sometimes slightly constricted below the apex, prominently nerved, crenulate and undulate, each one bearing an oblong-ovoid callosity and strongly spirally twisted : achenes broadly oblong-ovoid, $3 \mathrm{~mm}$. long, short-pointed, the angles conspicuously margined.

On the margins of ponds, Texas. Spring.

9. Rumex hymenosépalus Torr. Perennial by a cluster of fusiform roots, light green, glaucescent. Stem erect, 3-9 dm. tall, simple or nearly so, often red, somewhat fleshy: leaf-blades fleshy, lanceolate or ovate-lanceolate, $5-25 \mathrm{~cm}$. long, varying from gradually acuminate to acute, undulate and somewhat crisped, the lower ones attenuate into thick petioles, the upper sessile: panicle somewhat leafy-bracted, dense in fruit, the branches erect, $5-20 \mathrm{~cm}$. long : pedicels about as long as the peduncles : sepal-wings ovatecordate, $1 \mathrm{~cm}$. long, acutish, obtuse or emarginate at the apex, about as long as the pedicels, none bearing callosities : achenes ovoid, $5-5.3 \mathrm{~mm}$. long, the angles more or less margined.

On dry plains, the Indian Territory to Texas, California, and Lower California. Summer.

10. Rumex críspus L. Perennial, dark green. Stem $3-9 \mathrm{dm}$. tall, erect, simple or sparingly branched above: lower leaves with oblong or oblong-lanceolate, long-petioled blades, 1.5-3 dm. long; upper leaves with mostly narrowly-oblong or lanceolate shortpetioled blades, $8-16 \mathrm{~cm}$. long ; all acute or obtuse, cordate or obtuse at the base, more or less papillose : panicle rather dense; the branches with contiguous whorls in fruit by the elongation of the pedicels and peduncles: pedicels much longer than the peduncles : sepalwings cordate, 3-4 mm. long, truncate or slightly notched at the base, erose-dentate, about $\frac{2}{3}$ as long as the pedicels, each bearing a callosity : achenes oblong-ovoid, $2 \mathrm{~mm}$. long.

Common throughout the United States and southern British America. Naturalized from Europe. Native also of Asia. Summer.

11. Rumex Berlandièri Meisn. Perennial, somewhat papillose, dark green. Stem erect or ascending, 6-12 dm. tall, rather stout, somewhat fleshy, simple or sparingly branched, usually reddish, strict, or flexuous above : leaf-blades oblanceolate or spatulate, 1-3 dm. long, obtuse or the upper ones sometimes acute, flat or sometimes crisped : panicle leafy-bracted, the branches nearly naked, ascending or erect, $3-20 \mathrm{~cm}$. long, the dense 
whorls usually separated, except towards the ends of the branches : pedicels rather stout, somewhat longer than the peduncles: sepal-wings triangular, $2.5-3.5 \mathrm{~mm}$. long, erose or somewhat toothed, acute, strongly nerved, about as long as the pedicels and peduncles, each bearing a narrowly-oblong callosity : achenes ovoid, $2.5 \mathrm{~mm}$. long, the angles margined.

In valleys, Texas to Arizona and Mexico. Summer.

12. Rumex conglomeràtus Murray. Perennial, pale green. Stem $3-9 \mathrm{dm}$. long, erect, simple or branched : leaf-blades ovate, oblong or lanceolate, $2.5-13 \mathrm{~cm}$. long, some slightly fiddle-shaped, acute, crenulate and slightly crisped, obtuse at the base : panicle loose and open even in fruit, the branches with leafy bracts, slender, ascending, the loose whorls much separated : pedicels much longer than the peduncles : sepal-wings oblong, fiddle-shaped, $3 \mathrm{~mm}$. long, dentate near the base, as long as the pedicels or slightly longer, each bearing a large oblong callosity : achenes ovoid, nearly $2 \mathrm{~mm}$. long, pointed.

In waste places, Virginia to South Carolina. Also in California. Naturalized from Europe. Spring and summer.

13. Rumex sanguíneus L. Perennial, glabrous. Stem $3-9 \mathrm{dm}$. long, erect, simple or branched: leaf-blades oblong, oblong-lanceolate or lanceolate, $2.5-16 \mathrm{~cm}$. long, the lower ones long-petioled, acute or obtuse at the apex, cordate at the base, the upper ones short-petioled, acute at the apex, obtuse at the base, all usually with red veins: panicle loose, the branches slender, spreading, without leafy bracts, the lax whorls separated : pedicels slender : sepal-wings oblong, $3 \mathrm{~mm}$. long, as long as the pedicels or somewhat shorter, only one bearing a spherical-oblong callosity : achenes broadly ovoid, nearly 2 $\mathrm{mm}$. long, sharp-pointed.

In waste places, New York to Virginia and Louisiana. Naturalized from Europe. Spring and summer.

14. Rumex púlcher L. Perennial, deep green. Stem 3-9 dm. long, erect or procumbent, rather diffusely branched: lower leaves with oblong, often fiddle-shaped, longpetioled blades $2.5-15 \mathrm{~cm}$. long, obtuse at the apex, cordate at the base, the upper ones oblong or oblong-lanceolate, $2.5-8 \mathrm{~cm}$. long, short-petioled, acutish, the uppermost acuminate at the base : petioles more or less pubescent : panicle loose, the branches spreading, without leafy bracts, the few-flowered whorls much separated: pedicels and peduncles about equal in length : sepal-wings ovate or oblong-ovate, $4 \mathrm{~mm}$. long, truneate at the base, about as long as the pedicels and peduncles, one larger than the rest or all three of different sizes, armed with 5-10 spine-like teeth, 2 of the wings bearing callosities : achenes pyramidal-ovoid, $2 \mathrm{~mm}$. long, pointed.

In dry ground along the coast from Virginia to Florida and Louisiana. Also on the Pacific slope and on ballast at various ports. Naturalized from Europe. Summer.

15. Rumex obtusifòlius L. Perennial, dark green. Stem 6-12 dm. tall, erect, simple or sparingly branched, more or less scurfy above : lower leaves with oblong-lanceolate long-petioled blades $1.5-4 \mathrm{dm}$. long, the upper ones lanceolate or oblong-lanceolate, $5-15 \mathrm{~cm}$. long, short-petioled, all cordate or obtuse at the base, obtuse or acute at the apex, more or less eroded and crisped: panicle rather open, the branches nearly erect, with contiguous or partially separated loose whorls: pedicels slender, somewhat longer than the peduncles : sepal-wings hastate, 4-5 $\mathrm{mm}$. long, fringed with 3-5 spreading spine-like teeth, somewhat shorter than the pedicels and peduncles, only one bearing an oblong callosity : achenes ovoid, $2 \mathrm{~mm}$. long, pointed, the angles slightly margined.

In waste places. Nova Scotia and New Brunswick to Oregon, Florida and Texas. Naturalized from Europe. Also a native of Asia. Summer.

16. Rumex persicarioìdes L. Annual, pubescent, pale green. Stem $3-9 \mathrm{dm}$. long, simple, erect, or diffusely branched, spreading and creeping, leafy : leaf-blades lanceolate, oblong, 2.5-30 cm. long, usually abruptly narrowed at the base, acute at the apex, undulate, more or less crisped : panicle simple or compound, open, or dense at maturity, the branches erect, leafy-bracted, the very dense whorls mostly separated : pedicels slender, abruptly enlarged at the calyx, much longer than the peduncles: sepal-wings oblong, 2 $\mathrm{mm}$. long, as long as the pedicels or slightly shorter, with 1-3 awn-like bristles on each side, each bearing an ovoid callosity : achenes oblong-ovoid, 1-2 mm. long, pointed, the angles slightly margined.

On sandy shores, New Brunswick to British Columbia, North Carolina, Kansas, New Mexico and California. Summer and fall.

17. Rumex bucephalóphorus L. Annual, glabrous, glaucescent. Stems usually branched at the base, the branches spreading, 1-2 dm. long, often conspicuously jointed : leaf-blades spatulate or oblanceolate, the upper ones sometimes lanceolate, 1-4 cm. long, acute or obtuse, entire, petioled : panicle terminal, simple, $1 \mathrm{dm}$. long, or shorter, contimuous, or at length interrupted : flowers several in a whorl: pedicels gradually di- 
lated toward the calyx where the edges are revolute, longer than the peduncles, somewhat scurfy : sepal-wings ovate, 1-2 $\mathrm{mm}$. long, reticulate with several transverse nerves, armed with several spreading spine-like teeth, each bearing a minute callosity: outer sepals reflexed or spreading, nearly as large as the wings: achenes oblong-ovoid, 1-3 mm. long, the angles slightly margined.

In waste places, Louisiana. Adventive from Europe.

\section{POLYGONÉLLA Michx.}

Rigid caulescent shrubby herbs. Stems erect or nearly so, conspicuously jointed, striate, the branches partially adnate to the internodes. Leaves alternate : blades narrow, or cuneate, rather leathery, jointed near the top of the ocreae. Ocreae cylindric. Flowers polygamo-dioecious, on solitary jointed pedicels. Ocreolae imbricated. Sepals 5, petaloid, usually white or rose, persistent, the 3 inner usually developing wings. Stamens 8 : filaments subulate. Ovary 3-angled : styles short: stigmas capitate. Ovule erect. Achenes 3-angled, invested by the accrescent calyx. Embryo nearly straight, axile. Jointweed.

Ocreae fringed with a few bristle-like cilia.

1. P. ciliata. Ocreae naked.

Leaf-blades 1-5 mm. broad : sepals 1-2 mm. long.

Achenes rhomboidal : leaves filiform-spatulate.

Achenes ovoid or oblong-ovoid: leaves with cuneate or spatulate blades. Stems branched above: outer sepals not reflexed. Stems diffusely branched at the base: outer sepals reflexed.

Leaf-blades $5-25 \mathrm{~mm}$. broad : sepals $2.5-3.5 \mathrm{~mm}$. long.

2. P. brachystachya.

3. P. gracilis.

4. P. polygama.

5. P. macrophylla.

1. Polygonella ciliàta Meisn. Annual, very slender, bright green. Stems erect, 6-9 dm. tall, branched throughout, the branches wiry, ascending: leaf-blades filiform, $2-4 \mathrm{~cm}$. long, often less than $1 \mathrm{~mm}$. wide, acute : ocreae nerved, slightly oblique, fringed with bristle-like yellowish cilia: racemes few, mostly terminal, $2-3 \mathrm{~cm}$. long: ocreolae funnelform, each prolonged into a sharp tip at the back: calyx nearly $3 \mathrm{~mm}$. broad, white or rose: sepals oblong, obtuse.

In sandy soil, near the Manatee River, Florida. Summer and fall.

2. Polygonella brachystáchya Meisn. Perennial, very slender. Stems branched, 2-6 dm. tall, the branches wiry, erect or ascending, nearly strict, the branchlets short : leafblades filiform-spatulate, $5-13 \mathrm{~mm}$. long, narrowed from the obtuse apex to the base : ocreae slightly oblique, nerved : racemes very short, about $1 \mathrm{~cm}$. long, disposed in elongated panicles: ocreolae obliquely funnelform, bluntly pointed at the back : pedicels as long as the peduncles : calyx about $2 \mathrm{~mm}$. broad : sepals oblong, truncate or rounded at the apex : sepal-wings orbicular-ovate, $2 \mathrm{~mm}$. long : achenes rhomboidal, nearly $2 \mathrm{~mm}$. long, brown, equally pointed at both ends.

In sand or sandy soil, peninsular Florida. Summer.

3. Polygonella grácilis (Nutt.) Meisn. Annual, very slender, glaucescent. Stems erect, 3-16 dm. tall, strict, branched, especially above, the branches usually filiform : leafblades spatulate, 1-4 cm. long, obtuse, sometimes prominently 3 -nerved, remote, commonly shorter than the internodes, sometimes persistent : ocreae very slightly oblique, strongly nerved : racemes slender, $2-8 \mathrm{~cm}$. long, disposed in an open panicle on the sterile plant, more contracted on the fertile: ocreolae funnelform, slightly oblique: pedicels much shorter than the peduncles: calyx $2.5 \mathrm{~mm}$. broad, white or pink : sepals nearly equal, oblong or oblong-obovate, rounded at the apex, all slightly accrescent, the inner ones more so than the outer: sepal-wings not conspicuous, ovate, $2.5-3 \mathrm{~mm}$. long: achenes oblong or oblong-ovoid, long-attenuate, $3.5 \mathrm{~mm}$. long, brown.

On sand hills, South Carolina to Florida and Louisiana. Fall.

4. Polygonella polýgama (Vent.) A. Gray. Perennial by a woody base, slender, glaucescent. Stems diffusely branched near the base, the branches spreading, 3-6 dm. long, wiry, more or less zigzag : leaf-blades wedge-shaped or spatulate, 1-3 cm. long, persistent, commonly longer than the internodes, clustered on the sterile branchlets, remote toward the ends of the branches, 3-nerved at the base : ocreae cylindric, oblique at the top : racemes $2-4 \mathrm{~cm}$. long, disposed in elongated or corymbose panicles : ocreolae obliquely funnelform, bluntly pointed at the back : pedicels as long as the peduncles : caly $\times 3-4 \mathrm{~mm}$. broad, white, rose or yellowish : sepals oblong or obovate-oblong, obtuse, the 3 inner developing wings : sepal-wings ovate or orbicular-ovate, $2 \mathrm{~mm}$. long: achenes ovoid, brown, $1.5 \mathrm{~mm}$. long, pointed at both ends but less so at the base.

In dry sandy soil near the coast, North Carolina to Florida. Summer and fall.

5. Polygonella macrophýlla Small. Perennial, stout, glaucous. Stems erect, $8 \mathrm{dm}$. tall, simple below, branched above : leaf-blades obovate or oblanceolate, $2-6 \mathrm{~cm}$. long or 
sometimes shorter on the branchlets, obtuse, 3-5-nerved, leathery, exceeding the internodes except on the upper part of the stem : ocreae cylindric, slightly oblique, not pointed, increasing in length toward the upper part of the stem : racemes very dense, $2-3 \mathrm{~cm}$. long, disposed in ovoid panicles: ocreolae funnelform, densely imbricated, slightly pointed: pedicels jointed at the middle : calyx purple or purplish, $2.5-3.5 \mathrm{~mm}$. long: outer sepals slightly accrescent : sepal-wings oblong, $4 \mathrm{~mm}$. long : achenes narrowly oblong, acuminate at both ends, $4 \mathrm{~mm}$. long, brown.

On sand hills, near the coast, Florida. Summer and fall.

\section{GONOPỲRUM F. \& M.}

Shrubby herbs, with rigid conspicuously jointed stems. Leaves alternate : blades narrow, often nearly terete, somewhat fleshy, jointed to the ocreae. Ocreae cylindric. Flowers perfect, on solitary jointed pedicels. Ocreolae numerous. Sepals 5, petaloid, persistent, unchanged at maturity or the 3 inner developing wings. Stamens 8 : filaments various, the 3 inner dilated at the base. Ovary 3-angled: styles 3, manifest: stigmas capitate. Achene 3-angled, mainly invested by the calyx. Embryo in the face of the mealy endosperm.

Annual: outer sepals not reflexed; inner sepals not becoming conspicuously larger than the outer.

Perennial : outer sepals reflexed; inner sepals developing large wings.

1. G. articulatum.

2. G. Americanum.

1. Gonopyrum articulàtum (L.) F. \& M. Annual, wiry, glaucous. Stems 1-3 dm. tall : leaf-blades linear or linear-subulate, $1-2.5 \mathrm{~cm}$. long, filiform on account of the revolute margins : ocreae slightly expanded at the summit : racemes many-flowered, $2.5-4 \mathrm{~cm}$. long, erect, panicled : ocreolae contiguous or imbricated : pedicels spreading or deflexed, longer than the peduncles: calyx pink : sepals erect or slightly spreading in fruit, none developing conspicuous wings : achenes narrowly ovoid, $2 \mathrm{~mm}$. long, pointed, brown, smooth and shining. [Polygonella articulata (L.) Meisn.]

On sandy shores along or near the Atlantic coast, Maine to Florida, and along the Great Lakes. Summer and fall.

2. Gonopyrum Americànum F. \& M. Perennial by a long root, glaucescent. Stems 5-12 dm. tall, somewhat flexuous, often sparingly branched : leaf-blades linear or linearspatulate, 1-3 cm. long, more or less clustered on short branches, obtuse and revolute at the apex : ocreae cylindric, slightly split on one side, scarious-margined : racemes $2.5-7.5$ $\mathrm{cm}$. long, disposed in compound panicles: ocreolae densely imbricated: pedicels rigid, divergent, terminating somewhat shorter peduncles: calyx white or pink, the 2 outer sepals reflexed in fruit, the 3 inner developing suborbicular wings: achenes elliptic-oblong, not quite $3 \mathrm{~mm}$. long, chestnut-brown, pointed at both ends, smooth and shining. [Polygonella ericoides Engelm. \& Gray ; P. Meisneriana Shuttl.]

In sandy soil, Missouri to Georgia, Alabama and Texas. Summer and fall.

\section{THYSANÉLLa A. Gray.}

Annual caulescent herbs. Stem erect, nearly strict, terete, the branches partially adnate to the internodes. Leaves alternate: blades narrow, sessile. Ocreae cylindric, oblique at the top, fringed with long bristles. Racemes rather dense, disposed in panicles, the upper ones fertile, the lower sterile. Flowers polygamo-monoecious, on club-shaped pedicels about as long as the peduncles. Ocreolae obliquely-funnelform, prolonged into long bristles. Sepals 5, unchanged in fruit, unequal, the 2 outer cordate, the 3 inner pectinate-fimbriate, or in fertile flowers all fimbriate. Stamens 8: filaments filiform, flattened and spirally twisted. Ovary 3-angled : styles 3, distinct or nearly so : stigmas capitate. Achene 3-angled. Embryo in an angle of the seed without the mealy endosperm.

1. Thysanella fimbriàta (Ell.) A. Gray. Glabrous. Stem erect, $1.5-6 \mathrm{dm}$. tall, nearly strict, paniculately branched above : leaf-blades narrowly linear, $2-6 \mathrm{~cm}$. long, acute, more or less distinctly 3-ribbed, inconspicuously jointed near the top of the ocreae : ocreae 5-13 mm. long: racemes 1-8 $\mathrm{cm}$. long: ocreolae imbricated : calyx white or pink, the outer sepals oblong-sagittate, cordate, the inner always fimbriate, or all fimbriate in fertile flowers: styles $\frac{1}{2}$ as long as the achene: achenes pyramidal-ovoid, 3-angled, 2 $\mathrm{mm}$. long, dark brown, long-pointed, smooth, shining, the angles more or less margined.

In dry pine lands, Georgia and Florida. Summer and fall. 


\section{POLÝGONUM L.}

Annual or perennial, often somewhat shrubby herbs, with terete, but usually ridged erect or prostrate stems. Leaves alternate : blades leathery or somewhat fleshy, sometimes with two lateral impressions, articulated to the ocreae. Ocreae lobed when young, at length lacerate, hyaline, never fringed. Inflorescence axillary, consisting of clusters bearing normally several flowers at each node throughout the plant or confined to the branches and branchlets. Calyx of 5-6 partially united sepals. Sepals mostly green with white or pink margins, 2 wholly interior, 2 wholly exterior and 1 with one edge exterior and one edge interior, the outer sometimes corrugated in age, but not winged. Stamens varying from 3 to 8 , often 5 or 6 , included : filaments, at least the inner ones, dilated. Styles 3 , usually distinct, sometimes very short. Achenes 3-angled, included or slightly exserted, brown or black, granular or smooth and shining. Endosperm horny. Cotyledons incumbent. The plants flower in the summer and fall, except in the extreme southern part of our range. KNotweed. Doorweed. Knotgrass.

Stems branched at the base, the branches prostrate.

Achenes exserted, chestnut-colored : calyx 5-7 mm. broad : sepals petaloid.

Achenes included, black or brown: calyx $2-3.5 \mathrm{~mm}$. broad : sepals not petaloid. Leaf-blades mostly acute : achenes not pinched at the apex.

Leaf-blades mostly obtuse : achenes pinched at the apex.

Stems erect or ascending, more or less diffusely branched above.

Fruits erect on the short stout pedicels.

Leaf-blades without lateral impressions parallel to the midrib. Styles manifest.

Leaves persistent: achenes granular and dull.

Leaves fugacious: achenes smooth and shining. Styles wanting or nearly so.

Leaf-blades with lateral impressions.

Fruits drooping from the slender reflexed or deflexed pedicels.

1. P. maritimum.

2. P. aviculare.

3. P. littorale.

1. Polygonum marítimum L. Perennial or sometimes annual, glaucous, somewhat fleshy. Stem branched from the base, the branches prostrate, $2-7 \mathrm{dm}$. long: leaf-blades ovate, oblong or linear-oblong, $0.5-3 \mathrm{~cm}$. long, generally equalling or exceeding the internodes of the stem and branches, obtuse, revolute, strongly nerved especially beneath, somewhat rugose above : ocreae $0.5-1.5 \mathrm{~cm}$. long, at length lacerate, bright and silvery, becoming brown at the base : clusters with 2 or 3 flowers : pedicels slender, 3-4 mm. long: calyx green about the base, $3 \mathrm{~mm}$. long: sepals obovate, petaloid, rather obtuse, white or pink with a green rib: stamens $8:$ achenes $3.5-4 \mathrm{~mm}$. long, ovoid, acute or acuminate, chestnut-colored, smooth and shining or minutely granular, conspicuously exserted.

Along the coast, Maine to Florida and Alabama. Also in Europe.

2. Polygonum aviculàre L. Annual or perennial, glabrous, dull green or bluish green. Stem usually branched from the base, the branches prostrate, 1-6 dm. long: leafblades oblong, linear-lanceolate or oblanceolate, $0.5-2 \mathrm{~cm}$. long, usually acute or sometimes rather obtuse, not conspicuously nerved : ocreae $4 \mathrm{~mm}$. long, silvery, becoming lacerate with age : clusters with from 2 to 5 flowers : pedicels slender, $1-2 \mathrm{~mm}$. long: sepals oblong, obtuse, with white or pink borders: stamens $5-8$ : achenes $2.5 \mathrm{~mm}$. long, ovoid, acute, dark brown, rounded at the base, rather pointed at the apex, granular and dull.

Common throughout North America except the extreme north. Also in Europe and Asia.

3. Polygonum littoràle Link. Annual or perennial, bright green, often glaucous. Stem diffusely branched from the woody base, the branches prostrate, $3-12 \mathrm{dm}$. long ; internodes often very short, especially at the ends or bases of branches; the whole plant sometimes dwarfed and reduced to a small, erect state less than $1 \mathrm{dm}$. tall : leaf-blades oblong, oblong-lanceolate or oblanceolate, $0.4-2 \mathrm{~cm}$. long, usually obtuse or sometimes acutish, conspicuously nerved, often crisped: ocreae 4-5 mm. long, silvery when young, at length lacerate and brownish : clusters often numerous, with from 2 to 6 flowers : calyx mostly green : sepals oblong, obtuse, with white borders, or sometimes red: stamens $8:$ achenes 2-2.5 mm. long, broadly ovoid, usually somewhat constricted and often conspicuously so below the summit, enlarged and rounded at the base, dark brown, more or less granular, mostly dull, sometimes shining. Europe.

In dry soil, New Brunswick to British Columbia, North Carolina, Illinois and California. Also in

4. Polygonum eréctum L. Annual, stout, green, or at length turning yellowish green. Stem erect, or ascending, with somewhat spreading branches, $2-6 \mathrm{dm}$. long : leafblades oval, oblong or obovate, $1-6 \mathrm{~cm}$. long, obtuse or acutish : ocreae $0.3-1 \mathrm{~cm}$. long, 
silvery when young, becoming lacerate and brown with age : clusters of several flowers: pedicels 2-2.5 mm. long: calyx greenish, $3 \mathrm{~mm}$. long: sepals oblong, obtuse, paler or whitish on the margins, the outer corrugated at maturity : stamens 6 or sometimes 5 : achenes $3 \mathrm{~mm}$. long, pyramidal-ovoid or broadly ovoid, dark brown, granular and dull.

In open grounds, Ontario to the Northwest Territory, Georgia, Texas and Colorado.

5. Polygonum campòrum Meisn. Perennial or sometimes annual, rarely glaucescent, turning brown or black in drying. Stem erect or ascending, 6-10 dm. long, sometimes much branched and straggling: leaf-blades varying from linear-lanceolate to oblong, 1-3 $\mathrm{cm}$. long, sometimes oblanceolate, obtuse or acute, fugacious or rarely somewhat persistent, conspicuously nerved beneath : ocreae 3-5 mm. long, two-lobed when very young, silvery, at length dark brown, soon becoming much lacerate and falling away : clusters severalflowered: pedicels slender, $2-3 \mathrm{~mm}$. long: calyx greenish, $3 \mathrm{~mm}$. long: sepals oblong: stamens 8 : achenes $3 \mathrm{~mm}$. long, broadly ovoid, black or dark brown, smooth and shining.

On plains or prairies, Nebraska to Louisiana and New Mexico. Also in South America.

6. Polygonum ramosíssimum Michx. Annual, somewhat scurfy, bright green or yellowish green. Stem erect or ascending, 1-3 dm. long, somewhat virgate, the branches ascending or spreading : leaf-blades lanceolate, oblong or linear-oblong, 0.7-4 cm. long, acuminate at both ends or acute at apex, persistent, nerves either prominent or indistinct on the lower surface : ocreae $0.5-1.5 \mathrm{~cm}$. long, very early becoming lacerate, silvery, or at length turning brown : clusters several-flowered : pedicels $1.5-2 \mathrm{~mm}$. long: calyx greenish or yellowish, about $3 \mathrm{~mm}$. long: sepals narrowly oblong: stamens 6 or fewer, sometimes only 3 : achenes $3 \mathrm{~mm}$. long, ovoid, pointed, mostly included or rarely slightly protruding beyond the calyx, black, somewhat granular, not shining.

In saline or sandy soil, Northwest Territory to California, New Mexico, Texas and Illinois. Also along the Atlantic Coast from Maine to New Jersey.

7. Polygonum ténue Michx. Annual. Stem erect, 1-3 dm. long, with scabrous and scurfy nodes, four-winged below the ocreae: leaf-blades linear or linear-lanceolate, 0.5-3 $\mathrm{cm}$. long, acuminate or cuspidate, with two lateral impressions appearing as ribs parallel to the midrib: ocreae $3-15 \mathrm{~mm}$. long, two-lobed, at length lacerate: clusters bearing several flowers, or sometimes only one flower at a node: pedicels stout, 1-1.5 mm. long: calyx green, $3 \mathrm{~mm}$. long, erect: sepals ovate, acutish, with whitish margins : stamens 8: achenes $3 \mathrm{~mm}$. long, ovoid, pointed, black, granular about the angles, the center of each face smooth and shining.

In dry or stony soil, Ontario to Minnesota, Georgia and Arkansas.

8. Polygonum Douglásii Greene. Annual, sometimes glaucescent. Stem erect, 2-4 dm. long, with more or less scabrous nodes : leaf-blades oblong or narrowly lanceolate, 1-5 cm. long, obtuse, acute or cuspidate, flat, at least without lateral impressions : ocreae 10-14 mm. long, two-lobed, at length lacerate : clusters several-flowered, or occasionally only a single flower at a node : pedicels $2-3 \mathrm{~mm}$. long, reflexed and at length deflexed: calyx 3-4 mm. long, drooping: sepals oblong, obtuse, with whitish or rose-colored margins and a dark rib in the middle : stamens 8 : achenes $3-4 \mathrm{~mm}$. long, oblong or rarely ovoid-oblong, black, smooth and shining.

In dry soil, Northwest Territory to California, New Mexico and Indian Territory, east through Ontario to Vermont and New York.

\section{TOVÀra Adans.}

Annual herbaceous plants, becoming somewhat woody below. Stem mostly erect, virgate, simple or virgately branched. Leaves alternate: blades membranous, short, acute at both ends, continuous with the ocreae. Ocreae cylindric, fringed with bristles. Flower-clusters not dense, remote. Racemes linear, very long and wand-like, conspicuously interrupted. Calyx more or less colored, somewhat curved. Sepals 4, the 2 lateral ones overlapping the others. Stamens 4, and alternating with the sepals, or 5, the fifth one opposite the lower sepal : filaments barely flattened, erect or slightly spreading. Styles 2, conspicuously exserted, recurved or curled. Achenes lenticular, strongly biconvex, brown or cream-colored, smooth and shining. Endosperm horny. Cotyledons accumbent.

1. Tovara Virginiàna (L.) Adans. Annual, sometimes strigose throughout. Stem erect or reclining, $3-13 \mathrm{dm}$. long, virgate, simple or virgately branched, especially above : leaf-blades ovate, elliptic-ovate or ovate-lanceolate, $3-16 \mathrm{~cm}$. long, acuminate, acute at the base; petioles 1-2.5 cm. long: ocreae cylindric, $0.5-1.5 \mathrm{~cm}$. long, fringed with short bristles : racemes 1-6 dm. long, naked, much interrupted, virgate : ocreolae funnelform, $2 \mathrm{~mm}$. long, fringed with short bristles : pedicels $3 \mathrm{~mm}$. long, somewhat reflexed, conspicuously articu- 
lated at the base of the calyx : calyx greenish or reddish, 4-5 mm. long, somewhat curved : sepals unequal : stamens 4-5: styles long-exserted, recurved and curled at the tips : achenes lenticular, 3.5-4 mm. long, ovoid-oblong, dark brown or cream-colored, smooth and shining. [Polygonum Virginianum L.]

In woods and thickets, Nova Seotia to Minnesota, Nebraska, Texas and Florida. Summer and fall.

\section{PERSICÀrIA Adans.}

Annual or perennial often pubescent or glandular caulescent herbs, various in habit, never twining nor climbing. Leaves alternate : blades entire, continuous with the ocreae, often glandular-punctate. Ocreae cylindric, mostly membranous, truncate, naked, ciliate or fringed with bristles. Racemes spike-like, varying from linear to ovoid, dense and erect, or few-flowered, lax and drooping. Ocreolae funnelform, naked, ciliate or fringed. Pedicels rather stout, articulated at the base of the calyx. Calyx more or less colored, varying from white and green to red, often glandular-punctate, investing the achene. Sepals mostly 5,2 wholly exterior, 2 wholly interior and 1 with one margin interior and the other exterior, none of them winged or keeled. Stamens varying from 4 to 8 , included or exserted : filaments not dilated, erect or nearly so. Styles mostly 2, sometimes 3, usually partially united, included or exserted: stigmas capitate. Achene mostly lenticular sometimes 3-angled and lenticular on the same plant, usually black, smooth or granular Endosperm horny. Cotyledons accumbent. The plants bloom in the summer and fall, or earlier in the southern part of the range. SMart WeEd.

Raceme usually solitary and terminal : plants aquatic.

Racemes several or numerous : plants mostly terrestrial.

Ocreae naked or fringed, not spreading at the top: cotyledons accumbent.

Ocreae truncate and naked at maturity.

Racemes erect.

Achenes strongly biconvex.

Achenes flat.

Style-branches conspicuously exserted.

Style-branches included.

Achene gibbous on one side, ovoid : leaf-blades linear or linearlanceolate.

Achene flat, orbicular or broader than high : leaf-blades lanceolate or broadly-lanceolate.

Racemes drooping, or with drooping tips.

Styles united only at the base.

Styles united to above the middle.

Ocreae fringed with bristles (except a variety of no. 15).

Racemes erect.

Flower-clusters contiguous or mainly so.

Achenes lenticular.

Ocreae with short inconspicuous bristles.

Racemes linear.

Racemes oblong.

Ocreae with long conspicuous bristles.

Achenes 3-angled.

Stems or ocreae glabrous or strigose: leaf-blades neither rounded nor cordate at the base.

Racemes oblong.

Ocreae inconspicuously fringed : achenes narrowly ovoid. Ocreae conspicuously fringed: achenes broadly ovoid.

Racemes linear.

Ocreolae conspicuously fringed.

Ocreolae inconspicuously fringed.

Leaf-blades mainly glabrous above : achenes pointed at the apex.

Leaf-blades strigose above: achenes pointed at both ends.

Stems or ocreae copiously hirsute : leaf-blades rounded or cordate at the base.

Flower-clusters mostly separated.

Racemes drooping.

Leaf-blades lanceolate or linear-lanceolate: achenes smooth and shining.

Leaf-blades ovate or ovate-lanceolate : achenes granular and dull.

Ocreae with spreading, fringed tops: cotyledons incumbent.

1. P. emersa.

2. P. Portoricensis.

3. P. longistyla.

4. P. Mexicana.

5. P. Pennsylvanica.

6. P. incarnata.

7. P. lapathifolia.

\section{P. segeta. \\ 9. P. persicarioides. \\ 10. P. Persicaria.}

1. Persicaria emérsa (Michx.) Small. Perennial, often strigose throughout. Stem more or less creeping in wet places, the distal end erect, 3-8 dm. long, mostly simple, leafy, enlarged at the nodes, lower parts becoming hollow : leaf-blades broadly-lanceolate or oblong-lanceolate, sometimes narrowly-lanceolate, $5-20 \mathrm{~cm}$. long, acute or acuminate at the apex, rounded, cordate or truncate at the base, the lateral nerves prominent, often forking: ocreae $2-3 \mathrm{~cm}$. long, the younger clasping the stem, eciliate : raceme narrow, 3-10 
cm. long, erect, dense : ocreolae funnelform, oblique, $2 \mathrm{~mm}$. long, fringed with short bristles: calyx dark rose-colored or sometimes pink, $4 \mathrm{~mm}$. long: stamens 5 , exserted: achenes lenticular, $3 \mathrm{~mm}$. long, broadly obovoid or orbicular, conspicuously biconvex, black, slightly granular but shining. [Polygonum emersum (Michx.) Britton.]

In wet places or lakes throughout North America from the Aretic regions to southern Mexico.

2. Persicaria Portoricénsis (Bertero) Small. Perennial, glabrous, but more or less scurfy throughout. Stem erect, at least from a decumbent base, $8-13 \mathrm{dm}$. long, enlarged at the nodes, often of a dark brown color : leaf-blades lanceolate or narrowly lanceolate, 3-25 cm. long, acuminate at both ends, very obscurely punctate, the midrib broad, the lateral nerves prominent or conspicuous beneath : ocreae $2-4 \mathrm{~cm}$. long, fringed with short bristles when young, at length eciliate, sometimes hispid : racemes linear, $2-11 \mathrm{~cm}$. long, erect, dense : ocreolae funnelform, about $3 \mathrm{~mm}$. long, oblique, with a membranous rim : calyx white or whitish, about $3 \mathrm{~mm}$. long: stamens 6 or sometimes 8 : styles somewhat exserted : achenes lenticular, $2.5 \mathrm{~mm}$. long, very broadly oblong or nearly orbicular, sometimes slightly obovoid and broader than high, strongly biconvex, black, smooth and shining or sometimes minutely granular. [Polygonum Portoricense Bertero.]

In swamps, southern Missouri to Texas and Florida. Also in the West Indies and South America, except the extreme south.

3. Persicaria longístyla Small. Annual or perennial, glabrous, except the upper branches and peduncles. Stem erect, 3-6 dm. long, branched throughout: leaf-blades lanceolate to narrowly lanceolate or sometimes ovate-lanceolate, $3-10 \mathrm{~cm}$. long, acuminate at both ends, undulate, ciliate, somewhat crisped; petioles $0.5-1.2 \mathrm{~cm}$. long: ocreae brittle, soon falling away: racemes cylindric, $2-8 \mathrm{~cm}$. long, fully $1 \mathrm{~cm}$. thick, manyflowered but not dense, conspicuous: ocreolae funnelform, 2-2.5 mm. long, their margins hyaline : calyx mostly lilac, $4 \mathrm{~mm}$. long: sepals oblong, obtuse : stamens varying from $6-8$ included: styles $3-3.5 \mathrm{~mm}$. long, united to below the middle, slender, conspicuously exserted : stigmas black: achenes lenticular, $2.5 \mathrm{~mm}$. long, broadly ovoid, long-pointed, slightly gibbous on the sides, dark brown or black, slightly granular, somewhat shining or dull. [Polygonum longistylum Small. ]

In low grounds, southern Missouri to Louisiana and New Mexico.

4. Persicaria Mexicàna Small. Annual, slender, pale green, glabrous to the upper branches. Stem erect, 4-7 dm. tall, more or less branched : leaf-blades varying from linear-lanceolate to linear, $3-12 \mathrm{~cm}$. long, firm, obscurely punctate, ciliate, inclined to be revolute, short-petioled : ocreae $0.5-1.5 \mathrm{~cm}$. long, thin, becoming loose, sparsely hispidulous or nearly glabrous, eciliate : inflorescence pubescent or glandular : racemes oblong, $1.5-3.5 \mathrm{~cm}$. long, erect, densely flowered: ocreolae funnelform, $3 \mathrm{~mm}$. long, very oblique, fringed with short bristles : calyx light rose-color, $2-3 \mathrm{~mm}$. long: stamens 6-8: achenes lenticular, 3-4 mm. long, ovoid or broadly ovoid, flat, but inconspicuously gibbous on one side, thick-tipped, dark brown or nearly black, mostly granular and dull. [Polygonum Mexicanum Small.]

In low grounds, southern Louisiana to southern Texas and Mexico.

5. Persicaria Pennsylvánica (L.) Small. Annual, deep green. Stem erect, 3-9 $\mathrm{dm}$. high, often much branched throughout: leaf-blades varying from narrowly to broadly lanceolate, 4-22 cm. long, acuminate and somewhat unsymmetrical at the base, glabrous or the upper ones occasionally glandular beneath, ciliate; petioles about $1 \mathrm{~cm}$. long: ocreae $1-1.5 \mathrm{~cm}$. long, rather thin, eciliate : inflorescence paniculate, glandular : racemes oblongcylindric, $2-5 \mathrm{~cm}$. long, erect, dense : ocreolae funnelform, $3 \mathrm{~mm}$. long, oblique : calyx pink or light purple, sometimes reddish, 3-4 mm. long: stamens 8 or fewer: achenes lenticular, flat or sometimes slightly biconcave, $3-3.5 \mathrm{~mm}$. long, mostly orbicular or broader than high, short-tipped, black, smooth and shining. [Polygonum Pennsylvanicum L.]

In dry soil, Nova Scotia to Minnesota, Nebraska and Florida. Also in Mexico.

6. Persicaria incarnàta (Ell.) Small. Annual, nearly glabrous throughout, light green. Stem erect, 6-10 dm. tall, almost simple or branched : leaf-blades lanceolate or narrowly-lanceolate, $5-20 \mathrm{~cm}$. long, acuminate at both ends, sparingly punctate and ciliate, short-petioled : ocreae 1-2 cm. long, loose, brittle, eciliate, or occasionally ciliolate when young: racemes linear, $3-8 \mathrm{~cm}$. long, drooping, dense : ocreolae funnelform, $2 \mathrm{~mm}$. long, oblique, cuspidate : calyx whitish, green or rose-colored, $2-3 \mathrm{~mm}$. long: stamens 6 : achenes lenticular, $2 \mathrm{~mm}$. long, ovoid or broadly oblong-ovoid, flat and biconcave, dark brown or black, smooth and shining. [Polygonum incarnatum Ell.]

On river banks, southern New England to Minnesota, Florida and Texas.

7. Persicaria lapathifòlia (L.) S. F. Gray. Annual, deep green. Stem mostly erect, 3-6 dm. tall, thickened at the nodes, the peduncles and pedicels more or less glandular : leaf- 
blades varying from broadly lanceolate to narrowly lanceolate, sometimes oblong-lanceolate, $5-20 \mathrm{~cm}$. long, attenuate to the apex from the broadest part, acuminate at the base, ciliate, inconspicuously but thickly punctate, the petiole and midrib slightly hispid, the latter and the lateral nerves prominent beneath : ocreae 1-2 $\mathrm{cm}$. long, striate or ribbed, brittle, slightly ciliate when young, at length eciliate: racemes linear, 2-8 $\mathrm{cm}$. long, mostly drooping, dense: ocreolae funnelform, $2 \mathrm{~mm}$. long, very oblique, acute: calyx fleshcolored or whitish, $2-2.5 \mathrm{~mm}$. long: stamens 6 : achenes lenticular, $2-2.5 \mathrm{~mm}$. long, very broadly oblong or broadly ovoid, biconcave, brownish or black, slightly granular but usually shining. [ Polygonum lapathifolium L.]

In waste places, throughout North America except the extreme north, Mexico, Central America and the West Indies. Apparently mainly introduced from Europe.

8. Persicaria ségeta (H.B.K.) Small. Perennial, pubescent or glandular about the inflorescence. Stem erect, 4-8 $\mathrm{dm}$. long, enlarged at the nodes: leaf-blades narrowly lanceolate, $6-16 \mathrm{~cm}$. long, acuminate at both ends, sometimes undulate and slightly crisped, glabrous, except occasional short stout hairs on the midrib, and the ciliate margin ; petioles about $1 \mathrm{~cm}$. long: ocreae $1-1.5 \mathrm{~cm}$. long, those on the lower part of the stem glabrous, the upper ones pubescent or glandular, fringed with short bristles: racemes erect, $2-4 \mathrm{~cm}$. long, cylindric, rather loosely flowered: ocreolae funnelform, 2-2.5 mm. long, oblique, coriaceous with a somewhat membranous edge: calyx 2-2.5 $\mathrm{mm}$. long: sepals oblong, obtuse : stamens 6 or 7 : achenes lenticular, $2.5 \mathrm{~mm}$. long, ovoid, usually somewhat plano-concave, rather long-tipped, dark brown, minutely granular, dull. [Polygonum segetum H.B.K.]

In low grounds, Louisiana, Mexico and the West Indies. Also in Colombia.

9. Persicaria persicarioìdes (H.B.K.) Small. Perennial, nearly glabrous or strigillose. Stem erect or decumbent and creeping, 3-7 dm. long : leaf-blades lanceolate or often linear-lanceolate, $3-20 \mathrm{~cm}$. long, acuminate at both ends, glabrous or pubescent with scattered hairs, especially on the midrib, ciliate, punctate, short-petioled or subsessile : ocreae 1-2 cm. long, glabrous or sparsely strigillose, inconspicuously fringed with short bristles : racemes erect, $2-6 \mathrm{~cm}$. long, narrowly oblong or linear, rather loosely flowered : ocreolae funnelform, oblique, $3 \mathrm{~mm}$. long, fringed with a few short bristles or naked, often glandular or scurfy about the summit : calyx $2-3 \mathrm{~mm}$. long, rose-color tinged with green: sepals oblong, obtuse : stamens 8 or fewer: achenes lenticular, biconvex and more or less gibbous, or 3-angled, 2.5-3 mm. long, narrowly ovoid or sometimes broadly oblong, rather long-tipped, black, somewhat granular but shining. [Polygonum persicarioides H.B.K.]

On plains or prairies, Nebraska, Texas, New Mexico and Mexico. Also in South America.

10. Persicaria Persicària (L. ) Small. Annual, glabrous or puberulent. Stem erect or sometimes spreading, 2-8 dm. long : leaf-blades varying from lanceolate to linear-lanceolate, 2-18 cm. long, acuminate at both ends, entire or sometimes eroded, often somewhat ciliate, conspicuously punctate, generally with a dark triangular or lunar spot in the middle: ocreae 1-1.5 cm. long, nearly glabrous or with short hairs on the ridges, usually conspicuously fringed with short bristles : racemes oblong or ovoid, $1-3 \mathrm{~cm}$. long, $0.5-1 \mathrm{~cm}$. thick, mostly erect, densely-flowered : ocreolae funnelform, 1.5-2 mm. long, oblique, smooth or nearly so, fringed with short bristles: calyx about $1.5 \mathrm{~mm}$. long, varying from pink to dark purple or sometimes red or greenish : sepals obtuse : stamens generally $6:$ achenes lenticular, biconvex, often gibbous, or 3-angled, $2-2.5 \mathrm{~mm}$. long, broadly ovoid, pointed, black, smooth and shining. [Polygonum Persicaria L.]

In waste places, throughout temperate and tropical North and South America. Naturalized from Europe. LADY's THuMB.

11. Persicaria Opelousàna (Ridd.) Small. Perennial, slender and rather strict. Stem erect or ascending, 3-9 dm. long, glabrous, becoming woody below : leaf-blades varying from linear-lanceolate to linear, 3-10 cm. long, glabrous or with a few stout hairs especially on or about the midrib, ciliate : ocreae $1-1.5 \mathrm{~cm}$. long, strigose, fringed with long bristles : racemes linear, $1.5-4 \mathrm{~cm}$. long, erect, not densely flowered : ocreolae funnelform, $2.5 \mathrm{~mm}$. long, slightly oblique, conspicuously fringed with long bristles: calyx 1-1.5 mm. long, white: sepals oblong, obtuse : stamens 8 or fewer : achenes 3-angled, or rarely 4angled, about $2 \mathrm{~mm}$. long, varying from broadly ovoid to obovoid, black, smooth and shining. [Polygonum Opelousanum Ridd.]

In swamps, southern Missouri and the Indian Territory to Louisiana, Texas and Mexico.

12. Persicaria hydropiperoìdes (Michx.) Small. Perennial, glabrous or sometimes slightly strigillose, often tinged with red throughout. Stem erect or the base decumbent and creeping, 3-9 dm. long: leaf-blades lanceolate or oblong-lanceolate, sometimes linearlanceolate, 4-13 cm. long, acute at both ends, ciliate, papillose on the lower surface, shortpetioled, the midrib clothed with short hairs: ocreae $1-1.8 \mathrm{~cm}$. long, strigose, fringed with 
long bristles : racemes narrowly cylindric or almost linear, $3-6 \mathrm{~cm}$. long, erect : ocreolae funnelform, 2.5-3 mm. long, oblique, fringed with short bristles: calyx about $2 \mathrm{~mm}$. long, flesh-colored or sometimes greenish : sepals oblong or obovate, obtuse or acutish, glandular: stamens 8 : achenes 3 -angled, about $3 \mathrm{~mm}$. long, ovoid or broadly oblong, pointed at the apex, black, smooth and shining. [Polygonum hydropiperoides Michx.]

In swamps, New Brunswick to California, Florida and Mexico. Also in Brazil.

13. Persicaria setàcea (Baldw.) Small. Perennial, more or less strigose throughout. Stem erect, 6-11 dm. long, sometimes becoming nearly glabrous, enlarged especially above the nodes: leaf-blades oblong-lanceolate or narrowly lanceolate, 4-18 cm. long, acuminate at both ends, strigose on both sides, or occasionally nearly glabrous, except the midrib and nerves beneath, ciliate, inconspicuously but closely punctate : ocreae 1-1.5 $\mathrm{cm}$. long, strigose, fringed with bristles often equalling the body in length : racemes erect, 1-6 cm. long, almost linear, loosely flowered : ocreolae funnelform, slightly oblique, $2-2.5$ $\mathrm{mm}$. long, fringed with bristles, some of the bristles exceeding them in length : calyx about $2 \mathrm{~mm}$. long, white or pink: sepals ovate-oblong, obtuse : stamens 8 : achenes 3 -angled, 2-3 mm. long, broadly oblong, obovoid or oblong-ovoid, somewhat rhomboidal, thicktipped at both ends, black, minutely granular and rather dull or slightly shining. [Polygonum setaceum Baldw.]

In swamps, Missouri and North Carolina to Texas, Louisiana and Florida.

14. Persicaria hirsùta (Walt.) Small. Perennial, conspicuously hirsute with reddish or brown hairs. Stem erect or decumbent and creeping, 3-9 dm. long, becoming woody below : leaf-blades lanceolate, $3-10 \mathrm{~cm}$. long, cordate or subcordate, acute at the apex, the upper ones acuminate, more or less hispid on both surfaces, ciliate, inconspicuously punctate: ocreae 1-1.5 $\mathrm{cm}$. long, very hispid, fringed with many but rather short bristles: racemes erect, $1.5-6 \mathrm{~cm}$. long, narrow or almost linear, rather loosely flowered, sometimes interrupted: ocreolae funnelform, oblique, $2 \mathrm{~mm}$. long, acute, fringed with a few bristles: calyx 2.5-3 mm. long, white: sepals oblong, obtuse : stamens 8 or fewer : achenes 3 -angled, $2 \mathrm{~mm}$. long, broadly obovoid or nearly oblong, short-tipped, black, smooth and shining. [Polygonum hirsutum Walt.]

In swamps or wet soil, Florida and Georgia. Spring to fall.-A more slender form with erect stems 2-4 dm. long, glabrous or sparingly strigose especially about the nodes, narrowly lanceolate, obtuse leafblades 3-6 $\mathrm{cm}$. long, $0.5-1 \mathrm{~cm}$. broad, glabrous except the midrib and a few straggling hairs on the upper and lower surfaces, P. hirsuta glabréscens (Meisn.) Small, [Polygonum hirsutum glabrescens Meisn.], has been collected at Lake Jamony and Tallahassee, Florida.

15. Persicaria punctàta (Ell.) Small. Annual or perennial, mostly glabrous throughout. Stem erect or ascending, rarely creeping, 3-11 dm. long: leaf-blades varying from lanceolate to narrowly lanceolate, often oblong-lanceolate, $2-16 \mathrm{~cm}$. long, acuminate at both ends, nearly glabrous, conspicuously punctate, often bearing a few short hairs on the midrib, ciliate: ocreae $1-1.5 \mathrm{~cm}$. long, glabrous or sometimes sparingly strigillose, fringed with rather long bristles : racemes linear, 1-6 cm. long, erect, somewhat interrupted below, loosely flowered : ocreolae funnelform, $2.5-3 \mathrm{~mm}$. long, fringed with a few short bristles, mostly imbricated : calyx greenish, about $2 \mathrm{~mm}$. ular : sepals oblong or ovate, obtuse, punctate : stamens 8 : achenes lenticular and slightly gibbous, or 3-angled, $2-2.5 \mathrm{~mm}$. long, broadly oblong, black, smooth and shining. [Pulygonum punctatum Ell.]

In low places or swamps, throughout America except the extreme north and south. Also in the West Indies. Spring to fall.-Very variable: $\imath$ The slender state $P$. punctata leptostachya (Meisn.) Small, has much-interrupted racemes and remote ocreolae. Two stout varieties are distinguished : $P$. punctata robuistior Small, inhabiting swamps on the eastern side of the American continent, has larger leaf-blades, and 3-angled achenes $3-4 \mathrm{~mm}$. long ; P. punctata eciliata Small, occurring in New Jersey, Tennessee and Mexico, has large leaves like the next preceding variety, naked ocreae, reddish purple inflorescence, and a 3 -angled achene about $3.5 \mathrm{~mm}$. long.

16. Persicaria mìnor (Huds.) Opiz. Annual, dull-green, scurfy throughout. Stem lax, diffuse, 3-5 dm. long, sometimes procumbent and creeping: leaf-blades varying from lanceolate to linear or sometimes oblong, $2-8 \mathrm{~cm}$. long, unsymmetrical and often scytheshaped, ciliate : ocreae $1 \mathrm{~cm}$. long, sparingly strigose and fringed with a few short bristles : racemes linear, 1-5 $\mathrm{cm}$. long, lax, few-flowered, more or less interrupted at the base: ocreolae funnelform, $3 \mathrm{~mm}$. long, somewhat oblique, fringed with short bristles: calyx greenish, $2.5-3 \mathrm{~mm}$. long: stamens 8 or fewer : achenes lenticular, nearly $2 \mathrm{~mm}$. long, broadly oblong, conspicuously biconvex or 3-angled and narrowly ovoid-oblong, black, smooth and shining. [Polygonum minus Huds.]

In low grounds, Louisiana. Also in Chili. Introduced from Europe.

17. Persicaria Hydropìper (L.) Opiz. Annual, glabrous, usually bright green. Stem erect or assurgent, $2-6 \mathrm{dm}$. long, lax, sometimes red or reddish : leaf-blades varying from ovate to oblong-lanceolate, sometimes lanceolate, $1.5-9 \mathrm{~cm}$. long, acute at both ends or 
often acuminate at the apex, ciliate, more or less papillose, undulate or slightly crisped, punctate, containing a very acrid juice : ocreae $0.5-1 \mathrm{~cm}$. long, fringed with long bristles, usually enlarged about the bases, often bearing one or two flowers within : racemes linear, 2-6 cm. long, drooping, much interrupted : ocreolae funnelform, $1.5-2 \mathrm{~mm}$. long : slightly oblique, fringed with a few short bristles: calyx greenish, 2.5-3 mm. long: sepals rather narrowly oblong, obtusish, glandular: stamens 4 or sometimes 6 : achenes lenticular, biconvex, slightly gibbous, or 3 -angled, $3 \mathrm{~mm}$. long, broadly oblong or ovoid, sometimes orbicular or even broader than high, short-tipped, dark brown, strongly granular and dull. [Polygonum Hydropiper L.]

Common in moist or waste places, almost throughout North America. Naturalized from Europe southward and eastward, said to be native in the north and west. WATER PEPPER.

18. Persicaria orientàlis (L.) Vilm. Annual, large, more or less hispid. Stem erect, 4-25 dm. tall, becoming woody below : leaf-blades ovate or broadly oblong, 6-25 $\mathrm{cm}$. long, acuminate, varying from acute to cordate at the base, ciliate, hispidulous on the midrib and its lateral branches on both surfaces; petioles $2-8 \mathrm{~cm}$. long, slightly winged: ocreae 1-3 cm. long, with a spreading border at the summit, ciliate : racemes varying from oblong to linear, 3-10 cm. long, drooping or sometimes suberect, often slightly interrupted near the base : ocreolae funnelform, 3-5 mm. long, very oblique, ciliate : calyx dark rosecolored, 4-4.5 mm. long: stamens 7 : achenes lenticular, $3 \mathrm{~mm}$. long, orbicular or broader than high, thickened laterally about the base, biconcave, minutely granular and rather dull. [Polygonum orientale L.]

In waste places, generally. Naturalized from India. Summer and fall. Prince's Feather.

\section{FAGOPỲRUM Gaertn.}

Annual caulescent smooth and usually glabrous herbs. Leaves alternate : blades entire, hastate or cordate : ocreae oblique, entire. Flowers perfect, white or whitish, several together on slender pedicels subtended by an ocreola. Racemes in cluster-like cymes or corymbs. Calyx corolloid, persistent and unchanged in fruit. Sepals about equal. Stamens 8: filaments filiform, glabrous. Ovary 3-angled: styles 3: stigmas capitate. Ovule erect. Achene 3-angled,its angles slightly margined or crested, its faces transversely striate. Embryo dividing the mealy endosperm by an S-shaped curve.

1. Fagopyrum Fagopỳrum (L.) Karst. Rather fleshy when young. Stem 1-9 dm. tall, erect, simple or branched, with a little pubescence about the nodes: leaf-blades hastate, $2.5-8 \mathrm{~cm}$. long, cordate, petioled, abruptly narrowed above the middle : ocreae brittle and fugacious: racemes many-flowered, erect or inclined to droop, continuing to flower after fruit is produced : calyx white or whitish : pedicel as long as the calyx, onehalf as long as the achene or shorter : achenes broadly ovoid, acute, $5 \mathrm{~mm}$. long, the faces pinnately-striate when mature, and slightly variegated, the angles acute, entire.

In waste places, about cultivated fields and along railroads, more or less persistent. Adventive from eastern Europe and western Asia. Summer. BUCKWHEAT.

\section{TRACAUULON Raf.}

Annual or sometimes perennial prickle-armed herbs, with reclining-climbing 4-angled stems. Leaves alternate: blades truncate, hastate or cordate, membranous, the petiole, midrib and principal nerves armed with small recurved prickles. Ocreae oblique, finely nerved, variously roughened about the base. Flowers in terminal and axillary spikelike racemes, these usually somewhat interrupted, or in capitate clusters. Sepals somewhat colored, 4-5, neither keeled nor winged, enveloping the achene. Stamens varying from 5 to 8 , included : filaments not dilated. Styles 2 or 3 , partially united, included. Achenes lenticular or 3-angled, variously colored, strongly biconvex or three-angled, smooth and shining. Endosperm horny. Cotyledons accumbent. The plants flower in the summer and fall, or earlier in the extreme south. TEAR-THUMB.

Leaf-blades sagittate or subsagittate: achenes 3-angled.

Inflorescence dichotomous: leaf-blades sessile or nearly so : achenes blunt-angled.

Inflorescence not dichotomous : leaf-blades manifestly petioled : achenes sharp-angled.

Leaf-blades hastate: achenes lenticular.

2. T. sagittatum.

1. Tracaulon Beyrichiànum (Cham. \& Schlecht.) Small. Perennial, somewhat wiry. Stem 5-10 dm. long, reclining, dichotomously branched, slightly enlarged at the nodes, 
rather sharply angled, the angles mostly armed with recurved prickles : leaf-blades linear or linear-lanceolate, subsagittate, $3-15 \mathrm{~cm}$. long, acute or acutish, subsessile, cordate and more or less clasping, almost glabrous on the upper surface, glabrous beneath except the midrib which is sometimes sparsely pubescent with prickle-like hairs, glandular-ciliate : ocreae 1-2 cm. long, somewhat obliquely opened and spreading at the summit, naked, very thin, fringed around the base with small recurved prickles: inflorescence dichotomous, more or less compound, the ultimate divisions ending in clusters or spicate racemes: peduncles glandular: racemes few-flowered : ocreolae $1 \mathrm{~mm}$. long, ciliate : calyx rosecolored, campanulate: sepals $2-3 \mathrm{~mm}$. long, ovate-oblong, obtuse: stamens 5 : achenes varying from broadly ovoid to obovoid, 3-angled, dark brown, smooth and shining, the angles obtuse. [Polygonum Beyrichianum Cham. \& Schlecht.]

In low ground, Louisiana to Texas, Mexico and Brazil. Also in the West Indies.

2. Tracaulon sagittàtum (L.) Small. Annual, bright green or parts tinged with red. Stem decumbent, ascending or reclining, 3-15 dm. long, four-angled and finely channeled, armed on the angles with, sharp recurved prickles, by which the plant climbs : leafblades lanceolate or oblong, sagittate, 1-12 cm. long, cordate, the lower ones long-petioled, the upper short-petioled, lighter green beneath than above, slightly roughened on the edge by small prickles : ocreae funnelform, very oblique, $0.5-1 \mathrm{~cm}$. long, acute, eciliate : ocreolae bract-like, lanceolate, $3-5 \mathrm{~mm}$. long: calyx white, green or red, $4 \mathrm{~mm}$. long: sepals oblong, obtuse : stamens 8 : achenes 3-angled, 3-3.5 mm. long, ovoid, sharp-tipped, black or brownish, smooth and shining. [Polygonum sagittatum L.]

In swamps, Newfoundland to Saskatchewan, Florida and Texas.

3. Tracaulon arif òlium (L.) Raf. Perennial or annual, bright green. Stem ascending and reclining, $2-9 \mathrm{dm}$. long, nearly simple or much branched, armed on the four angles with stout recurved prickles, the peduncles and pedicels glandular or pubescent: leaf-blades broadly hastate, $2-18 \mathrm{~cm}$. long, cordate or subcordate, pubescent or glabrous on the lower surface, the basal lobes acuminate : ocreae funnelform, oblique, $0.5-1 \mathrm{~cm}$. long, fringed at the summit with short bristles and at the base with short bristle-like prickles : racemes 1-2 cm. long, somewhat leafy, interrupted : ocreolae funnelform, oblique, $2 \mathrm{~mm}$. long : calyx greenish or rose-colored : sepals 4, oblong, obtuse : stamens 8 : achenes lenticular, $4 \mathrm{~mm}$. long, obovoid or oblong-ovoid, dark brown or variegated, very smooth and shining. [Polygonum arifolium $\mathrm{L}$.]

In swamps, New Brunswick to Minnesota and South Carolina.

\section{TINIARIA Reichenb.}

Annual or perennial often scurfy unarmed twining vines. Leaves alternate: blades membranous or leathery, cordate or hastate. Ocreae oblique, naked or fringed at the top or the base. Racemes loosely flowered, axillary or terminal, often paniculate, leafybracted or naked. Sepals 5, green, white or yellowish, 2 exterior, 2 interior and 1 with one edge interior and one edge exterior, this sepal and the two outer keeled or strongly and conspicuously winged. Pedicels slender, reflexed and articulated. Stamens 8, included : filaments short, converging. Styles 3, short or almost wanting, distinct or rarely united. Achenes 3-angled, dark brown or black, included, smooth and shining or granular and dull. Endosperm horny. Cotyledons accumbent. The plants flower in the summer and fall.

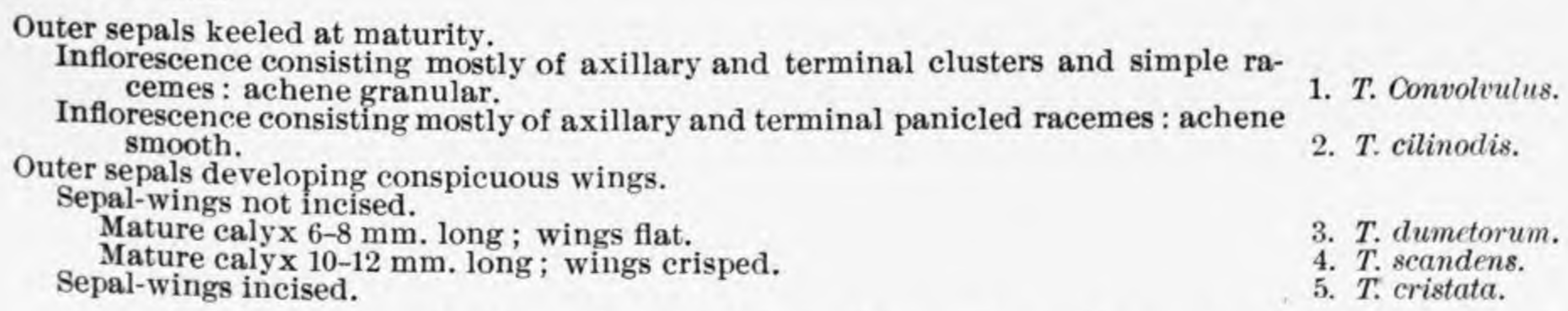

1. Tiniaria Gonvólvulus (L.) Webb. \& Moq. Annual, seurfy, dull green or pale green. Stem prostrate or twining, 1-12 dm. long, branched from near the base, the internodes of the older branches greatly elongating: leaf-blades broadly or narrowly ovate or ovate-sagittate, the uppermost nearly sagittate, $1.5-6 \mathrm{~cm}$. long, acuminate at the apex, cordate or truncate at the base, somewhat undulate and crisped : ocreae oblique, 2-4 mm. long, acute, rough on the edges: flowers several in a cluster: racemes simple, 1-6 cm. long, loosely flowered, interrupted : calyx green, at length $3.5-4 \mathrm{~mm}$. long, closely investing the fruit: sepals oblong, obtuse, the three outer ones keeled : stamens 8 : achenes 3-angled, 
$3.5 \mathrm{~mm}$. long, broadly obovoid or oblong-obovoid, short-tipped, black, granular. [Polygonum Convolvulus L. ]

Common throughout North|America, except the extreme north. Naturalized from Europe. BLACK BINDWEED.

2. Tiniaria cilinòdis (Michx.) Small. Annual or perennial, sparingly pubescent, of a reddish or reddish green tint. Stem prostrate or extensively twining, 6-25 dm. long: leaf-blades broadly ovate or ovate-lanceolate, $2-8 \mathrm{~cm}$. long, acute or acuminate, cordate or subcordate, sometimes inclined to be hastate, petioled, somewhat crisped, minutely ciliate, often prominently nerved on the lower surface: ocreae very oblique, 3-4 $\mathrm{mm}$. long, acutish, fringed with reflexed bristles at the base: racemes 1-10 $\mathrm{cm}$. long, loosely flowered, interrupted : calyx white, 3-4 mm. long: sepals 5, oblong or obovate, obtuse, the three outer ones keeled : stamens 6 or 8 : achenes 3 -angled, $3 \mathrm{~mm}$. long, broadly oblong or often nearly ovoid, black, very smooth and shining. [Polygonum cilinode Michx.]

In rocky places, Nova Scotia and New Brunswick to the Rocky Mountains, south to the Great Lake Region; also in and near the Allegheny Mountains.

3. Tiniaria dumetòrum (L.) Opiz. Perennial, bright green, somewhat scurfy. Stem weak, extensively twining, 6-40 dm. long, much branched : leaf-blades ovate-cordate, $2-7 \mathrm{~cm}$. long, acuminate, petioled or nearly sessile toward the ends of the branches : ocreae oblique, 3-4 mm. long, acute or obtusish, glabrous : racemes $3-8 \mathrm{~cm}$. long, usually numerous, loose, interrupted, bearing a few small leaf-like bracts: calyx yellowish green, at length $5 \mathrm{~mm}$. long: sepals obtuse, the three outer ones keeled and in fruit much enlarged and conspicuously winged: stamens 8 : achenes 3 -angled, $2-3 \mathrm{~mm}$. long, oblong, inclined to be pointed at both ends, black, smooth and shining. [Polygonum dumetorum L.]

In thickets, Missouri, Illinois and Tennessee. Also in Europe. False Buckwheat.

4. Tiniaria scándens (L.) Small. Perennial, more or less scurfy. Stem extensively twining, 1-10 m. long, often copiously branched, roughened on the ridges: leaf-blades ovate or oblong-ovate, 4-12 cm. long, cordate, acuminate, sparingly scabrous or eroded on the margins, papillose : ocreae oblique, $2-4 \mathrm{~mm}$. long, acute, rough on the ridges : racemes 3-24 cm. long, interrupted, bearing many large bracts : calyx greenish yellow, at length $1 \mathrm{~cm}$. long: sepals obtuse, the three outer ones keeled and conspicuously winged in fruit : stamens 8 : achenes 3-angled, 3.5-4.5 mm. long, oblong, often enlarged about the middle, rather blunt at both ends, black, smooth and shining. [Polygonum scandens L.]

In thickets, Nova Scotia to the Rocky Mountains, Florida and Louisiana. Hedge Buckwheat.

6. Tiniaria cristàta (Engelm. \& Gray) Small. Perennial, slender, very scurfy. Stem twining, 5-20 dm. long, more or less branched, somewhat twisted : leaf-blades ovate, triangular-ovate or triangular, 1-6 $\mathrm{cm}$. long, varying from cordate to truncate, acute or acuminate, obscurely eroded, short-petioled : ocreae 2-4 mm. long, hardly oblique : racemes axillary, 2-4 cm. long, loosely flowered, naked, interrupted : calyx greenish white, 4-5 mm. long, the three outer sepals keeled and winged in fruit, the wings more or less incised: stamens 8 : achenes 3 -angled, $2.5-3 \mathrm{~mm}$. long, oblong, black, smooth and shining. [Polygonum cristatum Engelm. \& Gray.]

In thickets or woods, New York to Georgia and Texas.

\section{BRUNNÍCHIA Banks.}

Perennial vines. Stems much elongated, climbing by tendrils arising from the ends of the branches. Leaves alternate: blades entire, truncate or cordate at the base: ocreae obsolete. Flowers perfect, $2-5$ in clusters subtended by narrow bracts, disposed in terminal panicled racemes. Pedicels slender, jointed near the base. Hypanthium much enlarged and leathery in fruit, winged on one side near the base and along the pedicel-like base, investing the achene. Sepals 5, spreading or converging when dry. Stamens 7-10, usually 8 : filaments filiform, slender, much dilated at the junction with the sepals. Ovary imperfectly 3-celled, 3-angled: styles 3: stigmas 2-cleft at the apex. Ovule pendulous. Achene 3 -angled, smooth. Seed irregularly 6-grooved. Embryo in one of the angles.

1. Brunnichia cirrhòsa Banks. A slender shrub, climbing over bushes and trees by means of terminal tendrils. Stems $2-8 \mathrm{~m}$. long, woody and tough : leaf-blades ovate or ovate-lanceolate, $3-15 \mathrm{~cm}$. long, acute or acuminate at the apex, truncate or subcordate at the base, petioled, slightly pubescent beneath : ocreae obsolete, sometimes represented by a ring of short hairs : racemes $3-15 \mathrm{~cm}$. long, naked or nearly so: hypanthium campanulate, 6-8 mm. long, greenish, winged along the base and pedicel-like base : sepals 5 , spreading or recurved, but converging at maturity when dry : stamens exserted : achenes oblong- 
ovoid, 3-angled, $6 \mathrm{~mm}$. long, smooth, closely invested by the accrescent and leathery hypanthium, which becomes nearly $3 \mathrm{~cm}$. long.

Along streams, Missouri to South Carolina, Georgia and the Gulf States. Spring and summer.

\section{COCCOLÒBIS P. Br.}

Evergreen shrubs or trees, with erect branched trunks, or rarely high-twining vines, clothed with a very thin bark. Leaves alternate: blades leathery, entire. Ocreae cylindric or funnelform, truncate, acuminate or lobed, membranous, often very small. Flowers perfect, green, on short jointed clustered pedicels subtended by small bracts, disposed in axillary or terminal, spike-like racemes. Sepals 5, herbaceous, nearly equal, little changed at maturity. Hypanthium accrescent, fleshy. Stamens 8: filaments slender, surmounting the hypanthium. Ovary free, 3-angled: styles 3. Ovule erect. Achene ovoid or globose, with a crustaceous or bony pericarp, invested by the accrescent hypanthium, to which it is sometimes more or less adherent. Seed 3-6-lobed, with a membranous testa. Embryo more or less eccentric in the channeled mealy endosperm, its cotyledons cordate.

Leaf-blades cordate at the base : drupe-like fruit $1.5-2 \mathrm{~cm}$. thick. Leaf-blades cuneate or rounded at the base: drupe-like fruit about $1 \mathrm{~cm}$. thick.

1. C. uvifera.

2. C. laurifolia.

1. Coccolobis uvífera (L.) Jacq. A shrub or small tree, $5 \mathrm{~m}$. tall or higher, with a short contorted trunk reaching a diameter of more than $1 \mathrm{~m}$. Branches forming a round head: leaf-blades suborbicular, often broader than long, 4-20 cm. in diameter, obtuse or retuse at the apex, undulate, cordate at the base, short-petioled: ocreae funnelform, less than $1 \mathrm{~cm}$. long, firm : racemes interrupted, $1-3 \mathrm{dm}$. long : hypanthium campanulate, 3-4 $\mathrm{mm}$. broad: sepals obovoid-orbicular, whitish, undulate : filaments subulate, red: fruiting racemes dense, resembling bunches of grapes, each drupe-like fruit subglobose, 1.5-2 $\mathrm{cm}$. in diameter, purple or greenish white, with an astringent juicy pulp and a broadly ovoid achene with a thin reddish pericarp.

Along the coast within the influence of the salt water, southern Florida and the Keys. Common on the Bahamas and in Bermuda, southern Central to northern South America. Throughout the year. SEA-GRAPE. SHORE-GRAPE.

2. Coccolobis laurifòlia Jacq. A tree, reaching a height of $20 \mathrm{~m}$. and a trunk diameter of $6 \mathrm{dm}$., the branches spreading. Leaf-blades oblong, ovate or obovate, $5-10 \mathrm{~cm}$. long, acute or rounded at the apex, entire, slightly revolute, bright green above, paler beneath, rounded or somewhat wedge-shaped at the base, short-petioled : ocreae less than $1 \mathrm{~cm}$. long, scarious : racemes terminal, $1 \mathrm{dm}$. or less in length, continuous : hypanthium campanulate, 4-5 mm. broad : sepals suborbicular, undulate: stamens 8 : filaments subulate, yellow : fruiting racemes interrupted, each drupe-like fruit globose-ovoid, dark red, $1 \mathrm{~cm}$. in length or longer, with an acid pulp and an ovoid achene with a hard brown pericarp.

Along the coast, southern Florida. Also in the Bahamas and northern South America. Fruit ripening in winter or spring.

\section{Order 10. CHENOPODIÀLES.}

Herbs, sometimes more or less shrubby, occasionally nearly leafless, with green, pale or highly colored foliage. Leaves alternate or opposite, sometimes reduced to scales. Flowers mostly perfect, sometimes monoecious or dioecious, variously disposed, occasionally much reduced. Calyx usually present, the sepals mainly separate. Corolla wanting or present, small and inconspicuous or relatively large and showy. Androecium of 1-several stamens. Gynoecium of a single carpel or several united carpels. Ovary 1-many-celled, sometimes 1celled by suppression. Styles mainly distinct. Ovules amphitropous or campylotropous. Fruit a utricle, achene, or berry, sometimes an anthocarp. Embryo curved, annular or coiled.

A. Fruit a utricle, achene or berry, sometimes an anthocarp, not valvate, or merely circumscissile.

a. Fruit various, not an anthocarp.

* Fruit utricular.

† Bracts not scarious: stipules wanting.

Stamens inserted at the base of the ovary or in the margin of a short hypanthium.

Stamens inserted on the margin of an hypanthium which ultimately exceeds the sepals in length.

Fam. 1. Chenopodiaceae.

Fam. 2. Scleranthaceaf. 
†† Bracts or stipules scarious.

Stipules wanting: sepals scarious.

Stipules present : sepals herbaceous or scarious-margined.

** Fruit baccate or an achene, or aggregate.

Fruit an achene or a berry : flowers not in cones.

Fruit aggregate: flowers in axillary cones.

b. Fruit an anthocarp, the achene surrounded by the calyx-tube.

B. Fruit a capsule dehiscent by apical or longitudinal valves.

Ovary several-celled : corolla wanting.

Ovary 1-celled : corolla mostly present.

Sepals 2: leaves mostly alternate.

Sepals 4 or 5 : leaves mostly opposite.

Sepals distinct: ovary sessile: petals not clawed.

Sepals united: ovary stipitate: petals clawed.

Fam. 3. Amaranthaceae.

Fam. 4. Corrigiolaceae.

Fam. 5. Petiveriaceak.

Fam. 6. Batidaceae.

Fam. 7. Allioniaceae.

Fam. 8. Tetragoniaceae.

Fam. 9. Portulacaceae.

Fam. 10. Alsinaceae.

Fam. 11. Caryophyllaceae.

\section{Family 1. Chenopodiàceat Dumort. Goosefoot Family.}

More or less fleshy often glandular annual or perennial mostly weedy plants, or rarely vines, but of considerable economic importance. Leaves alternate or opposite: blades entire or toothed, often much reduced: stipules wanting. Flowers terminal and axillary, often densely clustered, sometimes spicate, cymose or panicled, inconspicuous, herbaceous, sometimes subtended by bracts, sometimes naked. Calyx of 2,3, 4 or 5 persistent sepals. Androecium of as many stamens as there are sepals. Filaments distinct, rarely as long as the sepals opposite which and at whose bases they are inserted. Anthers introrse. Gynoecium of 2 or more united carpels. Ovary 1-celled, sometimes free, variable in shape. Styles 2-5, more or less united. Ovule solitary, amphitropous. Fruit a utricle. Seed solitary, often reniform, with mealy endosperm or this wanting. Embryo spiral in seeds without endosperm or curved or spiral around the endosperm when this is present.

Embryo annular or conduplicate, neither spiral nor coiled : endosperm copious (except in Salicornia).

Leaves normal: endosperm copious.

Fruit enclosed in the calyx, or equalled by the sepals or bractlets.

Flowers perfect or some of them pistillate: calyx fleshy or herbaceous.

Mature calyx without a horizontal wing.

Mature calyx with a broad horizontal wing.

Flowers dioecious or monoecious : pistillate flowers without a calyx : fruit enclosed in 2 bractlets.

Fruit much surpassing the calyx.

Leaves reduced to scales or mere ridges: endosperm wanting.

Embryo spirally coiled : endosperm wanting or scant.

Mature calyx wingless : leaf-blades not spine-tipped.

Mature calyx with a horizontal wing: leaf-blades spine-tipped.

1. Chenopodium. 2. CyCLOLOMA.

3. ATRIPlex.

4. CORISPERMUM.

5. SAlicorNia.

6. Dondia.

7. SALSOLA.

\section{CHENOPÒdIUM L.}

Annual or perennial herbs, with glabrous pubescent glandular or mealy-coated foliage, often pervaded by an aromatic or scented principle. Leaves alternate, various : blades entire, toothed or lobed. Flowers perfect or sometimes dioecious, small, in axillary or terminal congested spikes, with or without bracts. Sepals flat or keeled, persistent. Stamens 5 or fewer, hypogynous or somewhat perigynous : filaments filiform, sometimes united. Ovary usually depressed, 1-celled: styles or stigmas 2-5, the latter filiform or subulate. Utricle commonly enveloped in the accrescent calyx, containing a horizontal or vertical seed, with a crustaceous or leathery testa. Endosperm mealy. Embryo completely or partly annular. Goosefoot. Pigweed.

A. Embryo forming a complete ring: plants neither glandular nor aromatic.

Seed and pericarp firmly attached together.

Flowering branches longer than the accompanying leaves: mature sepals keeled.

Leaves with coarsely toothed blades.

Lower surface of the leaf-blades decidedly mealy: inflorescence dense.

Lower surface of the leaf-blades glabrous or glabrate: inflorescence lax.

Leaves with entire blades.

Flowering branches shorter than the accompanying leaves : mature sepals not keeled.

Seed and pericarp easily separable from one another.

a. Foliage and inflorescence pale and copiously mealy, even at maturity. Leaf-blades mainly linear, entire.

Leaf-blades mainly ovate, angulately lobed or toothed.

1. C. album.

2. C. viride.

3. C. Berlandieri.

4. C. murale.

5. C. leptophyllum.

6. C. albescens. 
b. Foliage and inflorescence green and glabrous at least at maturity.

B. Embryo horseshoe-shaped, forming an incomplete ring: plants glandular and aromatic.

Leaf-blades pinnately lobed.

Leaf-blades entire, undulate or coarsely toothed. Spikes conspicuously leafy-bracted.

Spikes nearly naked or minutely bracted.

\section{C. Boscianum.}

\section{C. Botrys.}

9. C. ambrosioides.

10. C. anthelminticum.

1. Chenopodium álbum L. Annual, pale green. Stems erect, 6-30 dm. tall, striate or grooved at maturity, normally widely branched, firm : leaf-blades ovate to lanceolate or linear-lanceolate, more or less rhombic, $2-8 \mathrm{~cm}$. long, acute or obtuse, sometimes 3-lobed, mostly serrate throughout the plant, cuneate at the base, slender-petioled : flower-clusters contiguous or interrupted, dense: sepals mealy, pale-margined, acute, keeled : utricle depressed, 2-2.5 mm. broad, enclosed in the calyx : seed horizontal, black, shining, adherent to the pericarp.

In waste places and thickets, throughout North America except the extreme north. Naturalized from Europe. Spring to fall. LAMB's QUARTERS.

2. Chenopodium víride L. Annual, bright green. Stems erect, 4-12 dn. tall, branched, ridged: leaf-blades ovate to lanceolate or linear-lanceolate, acute or slightly acuminate, entire at least above or usually coarsely toothed below the inflorescence, acute or cuneate at the base, glabrous on both sides or sparingly mealy beneath especially when young, slender-petioled : flower-clusters contiguous or interrupted, rather laxly disposed : sepals mealy-pubescent, acute, barely keeled : utricle depressed, $2-2.5 \mathrm{~mm}$. broad: seed about $1.5 \mathrm{~mm}$. broad, firmly attached to the pericarp.

In waste places, throughout North America except the extreme north. Naturalized from Europe. Spring to fall. LAMB'S QUARTERS.

3. Chenopodium Berlandièri Moq. Annual, sparingly mealy or glabrous in age. Stems erect, 3-9 dm. tall, commonly much branched, ridged : leaf-blades thinnish, lanceolate, oblong or ovate, often somewhat rhombic, $1.5-4 \mathrm{~cm}$. long, acute or cuspidate, entire or sinuate, often cuneate at the base ; petioles slender, nearly as long as the blades or much shorter: flower-clusters continuous or interrupted, often subglobose : sepals more or less densely mealy, ovate or oblong-ovate, rather obtuse, keeled : utricle depressed, 1.5-2 mm. broad, enclosed in the calyx : seed horizontal, firmly adherent to the pericarp.

In dry soil, Missouri to Texas and in Florida. Summer and fall.

4. Chenopodium muràle L. Annual, glabrous or barely mealy, deep green. Stems erect or decumbent, 1-6 dm. long, mostly widely branched : leaf-blades thinnish, rhombicovate, $2-8 \mathrm{~cm}$. long, acute, sinuate-dentate or incised-serrate, cuneate or nearly truncate at the base; petioles slender, as long as the blades or shorter : flower-clusters small, often separated at maturity : sepals slightly mealy, oblong or ovate-oblong, obtuse, not keeled : utricles depressed, 1.5-2 mm. broad, partly enclosd in the calyx : seed horizontal, firmly adherent to the pericarp, the edges sharp.

In waste places, Maine to British Columbia, Florida and Mexico, naturalized from Europe. Summer and fall.

5. Chenopodium leptophýllum (Moq.) Nutt. Annual, mealy-pubescent. Stems decumbent in age, $2-9 \mathrm{dm}$. long, more or less branched, striate or grooved at maturity : leaf-blades mainly linear, sometimes rather broadly so, $1-3.5 \mathrm{~cm}$. long, entire, or repand on the lower part of the stem, pale green above : flowers in contiguous or interrupted clusters : sepals mealy, oblong or nearly so, keeled, obtuse : utricle depressed, $1.5 \mathrm{~mm}$. broad, nearly enclosed in the calyx : seed horizontal, black, smooth and shining, free from the pericarp.

In sandy soil, Connecticut to New Jersey, also from Manitoba and the Northwest Territory to Missouri, Texas and Árizona. Summer and fall.

6. Chenopodium albéscens Small. Annual, pale green. Stems erect, 8-12 dm. tall, relatively stout, mealy when young, prominently pale-ridged : leaf-hlades mainly ovate, some of the upper ones narrower, $2-4 \mathrm{~cm}$. long, sharply acute or minutely bristle-tipped, nearly all angulately lobed or toothed, permanently mealy at least beneath, 3-nerved, cuneate at the base, slender-petioled : flower-clusters continuous or becoming interrupted, relatively slender, whitish : sepals mealy, ovate, barely keeled : utricle depressed, 1-1.5 $\mathrm{mm}$. broad, included : seed horizontal, black, shining, free from the pericarp.

In dry soil, Kerrville, Texas. Spring and summer.

7. Chenopodium Bosciànum Moq. Annual, light green. Stems erect, 3-9 dm. tall, striate, rather widely branched : leaf-blades thinnish, 1-3 cm. long, acute, entire, or sinuate near base of stem, green on both sides, cuneate at the base; petioles slender, about $\frac{1}{3}$ as long as the blades : racemes or panicles slender, loosely flowered : sepals herbaceous, oblong or oval, 1-1.5 mm. long, scarious-margined, flat or barely keeled at maturity: utricle depressed, about $1 \mathrm{~mm}$. broad, nearly enclosed in the calyx : seed horizontal, easily separable from the pericarp, black, shining.

In open woods and thickets, New York to Minnesota, Georgia and Texas. Summer. 
8. Chenopodium Bótrys L. Annual, glandular-pubescent and viseid, strong-scented. Stems erect, 1-6 dm. tall, simple or considerably branched, the branches commonly erect : leaf-blades 1-5 cm. long, oblong to ovate, irregularly pinnately lobed, entire or toothed, spreading; petioles as long as the blades or shorter : flower-clusters small, in axillary cymes : sepals pubescent, lanceolate or oblong-lanceolate, about $1 \mathrm{~mm}$. long, acute or somewhat acuminate: utricle depressed, $1.5 \mathrm{~mm}$. broad, enclosed in the calyx : seed horizontal or vertical, about $0.8 \mathrm{~mm}$. broad, firmly adherent to the pericarp.

In waste places and on banks, Nova Scotia to Oregon, south to Georgia and Mexico. Summer and fall. Jerusalem OAK.

9. Chenopodium ambrosioìdes L. Annual, glabrous or glandular-pubescent, heavy-scented. Stems erect or decumbent, $5-8 \mathrm{dm}$. long, more or less branched, grooved at maturity : leaf-blades oblong or oblong-lanceolate, $3-10 \mathrm{~cm}$. long, repand-dentate or undulate or even entire above : flower-clusters in short spikes, these usually surpassed by the accompanying leaves : sepals often yellowish, often 3 , rather obtuse : utricle less than $1 \mathrm{~mm}$. in diameter, enclosed in the calyx : seed horizontal or vertical, free, shining.

In waste places and thickets, Maine to California, Florida, Mexico and tropical America whence naturalized. Summer and fall. MEXICAN TEA.

10. Chenopodium anthelmínticum L. Annual or perennial, glandular-pubescent or glabrate, heavy-scented. Stems erect or spreading, 5-12 dm. long, ridged : leaf-blades lanceolate or oblong to ovate-lanceolate, $3-15 \mathrm{~cm}$. long, acute or acuminate, coarsely toothed or incised, cuneate-acuminate at the base, short-petioled: flower-clusters in more or less elongated interrupted spikes, these generally surpassing the accompanying leaves: sepals glabrous, acute or obtuse, contiguous : utricle about $1 \mathrm{~mm}$. in diameter, enclosed in the calyx : seed horizontal or vertical.

In waste places and thickets, Ontario to Wisconsin, New York, Florida, Texas and Mexico. Naturalized from Europe. Summer and fall. WORMSEED.

\section{CYCLOLÒMA Moq.}

Annual coarse herbs, with diffusely branched stems. Leaves alternate: blades flat, irregularly toothed. Flowers perfect or pistillate, disposed in panicled spikes, without bractlets. Sepals 5 , keeled, each appendaged at maturity by a horizontal wing. Stamens 5 : filaments about as long as the calyx. Ovary 1-celled, sessile, hairy : styles 2-3, partially united. Utricle depressed, wholly enclosed by the calyx or nearly so. Seed flat, horizontal. Embryo annular in the mealy endosperm.

1. Cycloloma atriplirifolium (Spreng.) Coulter. Annual, deep green, often becoming dark purple. Stems bushy-branched, 1.5-5 dm. tall, like the branches striate and angled: leaf-blades lanceolate or oblong, $2-8 \mathrm{~cm}$. long, acuminate, irregularly sinuatedentate with sharp teeth, narrowed into short petioles: spikes numerous, in open panicles: calyx sometimes pubescent, surrounded by a scarious erose wing: sepals triangular or ovate-triangular: utricle depressed, $2-3 \mathrm{~mm}$. broad, with an area exposed between the sepals as a 5 -rayed star.

On banks and along streams, Manitoba and the Northwest Territory, south to Indiana, Texas and Arizona. Summer.

\section{3. ÁTRIPLEX L.}

Annual or perennial herbs or low shrubs, with a scaly often silvery pubescence. Leaves alternate, or some opposite : blades often deltoid or hastate in outline, angularly toothed or sometimes entire. Flowers monoecious or dioecious, in axillary or terminal panicles, or congested axillary spikes, the staminate bractless : sepals $3-5:$ stamens $3-5$, inserted at the base of the calyx : filaments distinct or united: anthers 2-celled, opening lengthwise. Pistillate flowers subtended by two more or less united entire or toothed bracts, which are commonly crested, tubercled or winged on the back. Ovary 1-celled, tipped by the 2 subulate or filiform stigmas. Utricle wholly or partially surrounded by the accrescent bracts. Seed erect or nearly horizontal, with a membranous leathery or almost crustaceous testa. Endosperm mealy. Embryo annular. OrAche.

A. Annual.

Leaf-blades triangular-hastate or hastate-lanceolate in outline.

Leaf-blades oblong, oval or broadest above the middle.

Fruiting bracts united to above the middle.

Fruiting hracts united only at the base.

Styles exserted: fruiting bracts with equal teeth.

Styles included: fruiting bracts with the middle tooth longest.

1. A. hastata.

2. A. arenaria.

3. A, tuberculata.

4. A. cristata. 
B. Perennial.

Fruiting bracts spongy, wingless.

Fruiting bracts $8-12 \mathrm{~mm}$. long, the faces tubercled: leaves alternate; blades about $1 \mathrm{~cm}$. long.

Fruiting bracts $2 \mathrm{~mm}$. broad, the faces not tubercled : leaves opposite ; blades less than $1 \mathrm{~cm}$. long.

Fruiting bracts indurated, winged.

5. A. acanthocarpa.

6. A. oppositifolia. 7. A. canescens.

1. Atriplex hastàta L. Annual, somewhat scurfy or glabrate, the foliage light green or purplish. Stems erect or ascending, 3-8 dm. long, more or less branched, the branches often spreading : leaf-blades triangular in outline, triangular-hastate or hastate-lanceolate above, 2-8 $\mathrm{cm}$. long, acute or acuminate, entire or sparingly toothed, broadly cuneate, truncate or subcordate at the base, the basal lobes spreading; petioles much shorter than the blades : flower-clusters commonly separated: mature bracts ovate or triangular, 4-5 mm. long, toothed, the faces spiny.

In salt meadows and waste places mostly near the coast, New Brunswick to South Carolina. Summer and fall.

2. Atriplex arenària Nutt. Annual, pale or silvery with more or less dense scurf. Stems widely branched, often from the base, 1-5 $\mathrm{dm}$. long, the branches spreading or prostrate : leaf-blades oblong to oval, 1-4 cm. long, acute or mucronate, somewhat crisped, entire, short-petioled or sessile : mature bracts united to above the middle, $3-5 \mathrm{~mm}$. broad, fan-shaped, 3-toothed at the top, the faces tuberculate or spiny.

On sea beaches, Nova Scotia (?) to Florida and Alabama. Summer and fall.

3. Atriplex tuberculàta (Torr.) Coulter. Annual, scurfy-pubescent. Stems erect or ascending, 1-5 dm. tall, more or less branched: leaf-blades oblong-spatulate or oblongoblanceolate, $1.5-2 \mathrm{~cm}$. long, acute, entire or unevenly repand-dentate, narrowed into short petioles: flower-clusters inconspicuous: styles exserted : mature bracts broadly cuneate, 2.5-3 mm. long, united at the base, with coarse equal triangular teeth, the faces reticulated and crested with 2 rows of acute tubercles.

On hillsides, Texas. Spring and summer.

4. Atriplex cristàta H.B.K. Annual, green, but more or less scurfy. Stems erect or ascending, 3-6 dm. tall, rather diffusely branched, the branches ridged : leaf-blades oblong or nearly so, $1.5-3 \mathrm{~cm}$. long, acute or cuspidate, undulate or finely serrate-dentate or repand, short-petioled : flower-clusters continuous or often interrupted : styles included : mature bracts $2-3 \mathrm{~mm}$. broad, spiny toothed, the middle tooth longest, the faces with $2-4$ tubercles.

On sandy coasts, Florida. Spring to fall.

5. Atriplex acanthocárpa (Torr.) S. Wats. Perennial, appressed-scurfy. Stems erect, $3-7 \mathrm{dm}$. tall, branched, woody especially below : leaves alternate; blades oblong to oblong-lanceolate or almost ovate, commonly somewhat hastate, 1-4 cm. long, acutish, entire or sinuate, cuneately narrowed, short-petioled : flowers dioecious ; staminate in dense interrupted spikes or panicles; pistillate fewer in axillary clusters : mature bracts 8-12 $\mathrm{mm}$. long, united to the linear apex, spongy, the edges toothed, the faces appendaged with flattened tubercles.

In dry soil, Texas and adjacent Mexico. Summer and fall.

6. Atriplex oppositif òlia S. Wats. Perennial, somewhat scurfy. Stems erect, 1-4 $\mathrm{dm}$. tall, woody below, branched at the base and above : leaves mostly opposite; blades thick, oblong or oblong-lanceolate, $2-4 \mathrm{~mm}$. long, about equalling the nodes or surpassing them, acute, broadest at the base, sessile : flowers axillary: mature bracts suborbicular, $2 \mathrm{~mm}$. broad, radiately toothed, the faces 3-nerved, not appendaged.

In dry soil, Texas and adjacent Mexico. Summer and fall.

7. Atriplex canéscens (Pursh) James. Perennial, scurfy-pubescent. Stems erect or spreading, 2-6 dm. long, often copiously branched : leaf-blades oblong or oblanceolate to linear-oblong, $1.5-5 \mathrm{~cm}$. long, acute or slightly apiculate, entire, narrowed to the sessile or nearly sessile hase : flower-clusters axillary or in naked often interrupted spikes, monoecious or dioecious : mature bracts united to the apex, indurated, slightly flattened: wings 4-8 $\mathrm{mm}$. in diameter : seed $2 \mathrm{~mm}$. long or nearly so.

On prairies and hillsides, South Dakota to Nebraska, Texas and California. Spring and fall.

\section{CORISPÉRMUM L.}

Annual caulescent herbs, with glabrous or pubescent foliage. Stems more or less diffusely branched. Leaves alternate: blades narrow, entire, sessile. Flowers perfect, solitary in the axils of leaf-like bracts, without bractlets. Sepal 1, or sepals 2-3, unequal, scarious. Stamens $1-3$, or rarely 5 , hypogynous, one longer than the rest: filaments 
flattened. Ovary 1-celled, exserted : styles 2. Utricle more or less flattened. Seed vertical, adherent to the pericarp, with acute or winged edges. Endosperm fleshy, copious. Embryo annular.

1. Corispermum nítidum Kit. Foliage villous, or glabrous at maturity. Stems erect or decumbent, $2-6 \mathrm{dm}$. long, more or less strongly zigzag, often copiously branched : leaf-blades linear, commonly narrowly so, $1.5-5 \mathrm{~cm}$. long, cuspidate, entire, revolute, somewhat fleshy, sessile : bracts ovate or lanceolate, 4-8 $\mathrm{mm}$. long, acute or acuminate, imbricated, scarious-margined : utricle $2-2.5 \mathrm{~mm}$. long, winged : seed about $2 \mathrm{~mm}$. long.

In sandy soil, Aretic America to Washington, Texas and Arizona. Summer and fall. Bug-seEd.

\section{SALICÓRNIA L.}

Annual or perennial fleshy glabrous herbs, destitute of normal leaves. Branches opposite. Scales (leaves) opposite at the numerous nodes. Spikes cylindric. Flowers perfect or polygamous, 3-7 in cavities at the joints. Calyx fleshy, obpyramidal, with a truncate or 3-4-lobed border, becoming spongy at maturity, deciduous. Stamens 2 or rarely 1 : filaments filiform or subulate : anthers exserted, opening lengthwise. Ovary commonly ovoid : stigmas often subulate. Utricle oblong or ovoid, included in the spongy perianth, sunken in the rachis. Seed erect, flattened, with a thin-leathery testa. Endosperm wanting. Embryo conduplicate. Glasswort. Samphire.

Annual : stems erect.

Scales 1-2 mm. long, obtuse or merely acute : spikes $2-3 \mathrm{~mm}$. thick.

Scales 2-4 mm. long, mucronate: spikes $4-6 \mathrm{~mm}$. thick.

Perennial: stems decumbent or trailing.

1. S. herbacea.

2. S. Bigelovii.

1. Salicornia herbàcea L. Annual from slender roots. Foliage green, turning bright red in fall : stems erect, 1-6 dm. tall, much branched : scales 1-2 mm. long, obtuse or acutish, sometimes broader than long: spikes becoming 2-8 cm. long, 2-3 mm. thick, the joints 2-4 times longer than thick : utricle pubescent.

In salt marshes, Anticosti to Florida, and at salt springs and in saline soil in the interior. Also in Asia and Europe. Summer and fall.

2. Salicornia Bigelòvil Torr. Annual, robust. Foliage green, turning bright red in fall : stems erect, 1-4 dm. tall, branching, the branches erect or ascending : scales 2-4 mm. long, acuminate or rather mucronate: spikes becoming 1-7 cm. long, 4-6 mm. thick, the joints about as long as broad: utricle pubescent. [S. mucronata Bigel., not Lag.]

In salt marshes, Nova Scotia to Florida and Texas. Summer and fall.

3. Salicornia ambígua Michx. Perennial from woody rootstocks. Stems decumbent or trailing, 1-6 dm. long, branched, the branches erect or ascending, often numerous : scales often broader than high : spikes becoming $1-4 \mathrm{~cm}$. long, $3-4 \mathrm{~mm}$. thick, the joints about as thick as long.

In salt meadows and on beaches, Massachusetts to Florida and Texas. Summer and fall.

\section{DóNdia Adans.}

Annual or perennial herbs or shrubby plants, with fleshy tissues. Leaves alternate : blades thick to terete, narrow, entire. Flowers perfect or polygamous, solitary or clustered in the upper axils, accompanied by bractlets. Sepals 5, keeled or narrowly winged at maturity. Stamens 5: filaments short. Ovary 1-celled, rounded or flat at the top : styles often 2. Utricle surrounded by the calyx. Seed horizontal or vertical. Endosperm wanting or scant. Embryo coiled in a flat spiral.

Annual, herbaceous.

Perennial, shrubby.

Foliage, especially the stems and leaves, pubescent: leaf-blades and sepals acute.

Foliage glabrous : leaf-blades and sepals obtuse.

1. D. linearis.

2. D. multiflora.

3. D. conferta.

1. Dondia lineàris (Ell.) Millsp. Annual, glabrous. Stems prostrate or ascending, 1-9 dm. tall, at length diffusely branched, the branches erect or ascending: leaf-blades nearly terete, linear, 1-5 cm. long, shorter above, acute : flower-clusters 3-5 mm. thick : hypanthium fleshy : sepals oval or suborbicular, $1 \mathrm{~mm}$. long, scarious-margined, keeled at maturity or swollen : seed horizontal, $2 \mathrm{~mm}$. broad, reticulated. [Suaeda linearis (Ell.) Moq.] Along the coast, North Carolina to Florida and Texas. Spring and fall.

2. Dondia multiflòra (Torr.) Heller. Perennial, more or less shrubby. Stems erect, 5-9 dm. tall, the branches diffuse or spreading, leafy, tomentose: leaves numerous, pubescent : blades thick, linear, mostly less than $1 \mathrm{~cm}$. long, acute : flowers clustered in the 
axils: sepals acute : seed mostly vertical, barely $1 \mathrm{~mm}$. broad, obscurely tuberculate. [Suaeda fruticosa var. multiflora Torr.; suffruticosa S. Wats.]

On saline plains, Texas to southern California. Spring to fall.

3. Dondia conférta Small. Perennial, shrubby. Stems erect or ascending, 4-10 dm. long, the branches prostrate or spreading, forming dense tufts, glabrous : leaves numerous, glabrous; blades fleshy, oblong, mostly less than $1 \mathrm{~cm}$. long, obtuse : flowers solitary or clustered in the axils of the rather approximate leaves, especially numerous on the branchlets : sepals obtuse : seed about $1 \mathrm{~mm}$. broad.

Along the coast, Texas. Spring and summer.

\section{SALSOLA L.}

Annual or perennial herbs or shrubby plants. Stems bushy-branched. Leaves rigid : blades narrow, entire, spine-tipped. Flowers perfect, solitary or several together in the axils, accompanied by 2 bractlets. Sepals 5, appendaged with horizontal wings at maturity. Stamens 5, or rarely fewer : filaments subulate or narrowly linear. Ovary 1-celled, more or less depressed: styles 2. Utricle flattened, with a depressed or elevated top, enclosed in the calyx. Seed mostly erect. Testa membranous. Endosperm wanting. Embryo in the form of a spiral cone. Saltwort.

1. Salsola Kàli L. Annual, glabrous, or finely pubescent. Stems 2-6 dm. tall, erect or diffusely branched and spreading, the branches often striate and slightly ridged: leaves alternate ; blades subulate-lanceolate, 6-20 $\mathrm{mm}$. long, entire, somewhat revolute at maturity, the midrib prolonged into a rigid yellow-green spine: flowers solitary in the axils, inconspicuous: calyx leathery, the surface smooth, the wing nearly orbicular, 4-8 $\mathrm{mm}$. in diameter, erose or lacerate at maturity : sepals erect or ascending, about as long as the wings.

On sea beaches, Cape Breton Island to Florida and Mississippi. Also in Europe and Asia. Summer and fall.

\section{Family 2. SCLERANThÀCEAE Lindl. KNAWEL Family.}

Annual or biennial herbs, with firm forking stems. Leaves opposite, with united bases: blades subulate or narrow: stipules wanting. Flowers in small clustered cymes. Hypanthium well develcped, often exceeding the sepals in length at maturity. Calyx of 5 or rarely 4 persistent awnless sepals. Androecium of 1-10 included stamens inserted on the margin of the hypantbium. Gynoecium of 2 united carpels. Ovary 1-celled. Styles 2. Ovule solitary, pendulous from a basal funicle, amphitropous. Utricle included in the hypanthium. Seed solitary.

\section{Characters of the family.}

\section{SCLERÁNTHUS L.}

1. Scleranthus ánnuus L. Annual, slender, bright green. Stem more or less branched at the base, the branches ascending or decumbent, $0.5-3 \mathrm{dm}$. long, forking, pubescent with recurved hairs and somewhat viscid on one side: leaves opposite, with connate bases; blades linear-filiform, $0.5-1.5 \mathrm{~cm}$. long, acute, sessile, ciliate : flowers inconspicuous, short-pedicelled or nearly sessile : hypanthium together with the calyx about $3 \mathrm{~mm}$. long: sepals lanceolate or ovate-lanceolate, rather obtuse or acutish, hyaline-margined, slightly longer than the hypanthium during anthesis : utricle ovoid, nearly $1.5 \mathrm{~mm}$. long.

In waste places, Quebec and Ontario to Florida. Naturalized from Europe. Spring to fall. KNAWEL. German KNotgrass.

\section{Family 3. Amaranthàceaf J. St. Hil. Amaranth Family.}

Coarse and weedy, often diffuse, annual or perennial herbaceous plants, or sometimes shrubs or small trees. Leaves opposite or alternate, exstipulate: blades simple, entire or nearly so. Inflorescence terminal or axillary, often congested. Flowers rarely dioecious, inconspicuous, subtended by more or less imbricated scarious various-colored bracts. Calyx scarious, herbaceous or corolloid, consisting of $2-5$ equal or unequal sepals. Stamens 5 or fewer, distinct or monodelphous, hypogynous, opposite the sepals. Sterile stamens (staminodia) when 
present alternating with the fertile, lobed or toothed. Anthers introrse, 2-celled or sometimes 1-celled. Gynoecium of a single pistil. Ovary solitary, 1-celled, variable in shape, superior. Style terminal, sometimes almost wanting. Ovules solitary or numerous, attached to the base of the cavity, amphitropous. Fruit a membranous utricle or pyxidium, rarely a berry, 1-many-seeded. Seed lenticular or reniform, with a crustaceous testa. Embryo annular, often nearly surrounding the endosperm.

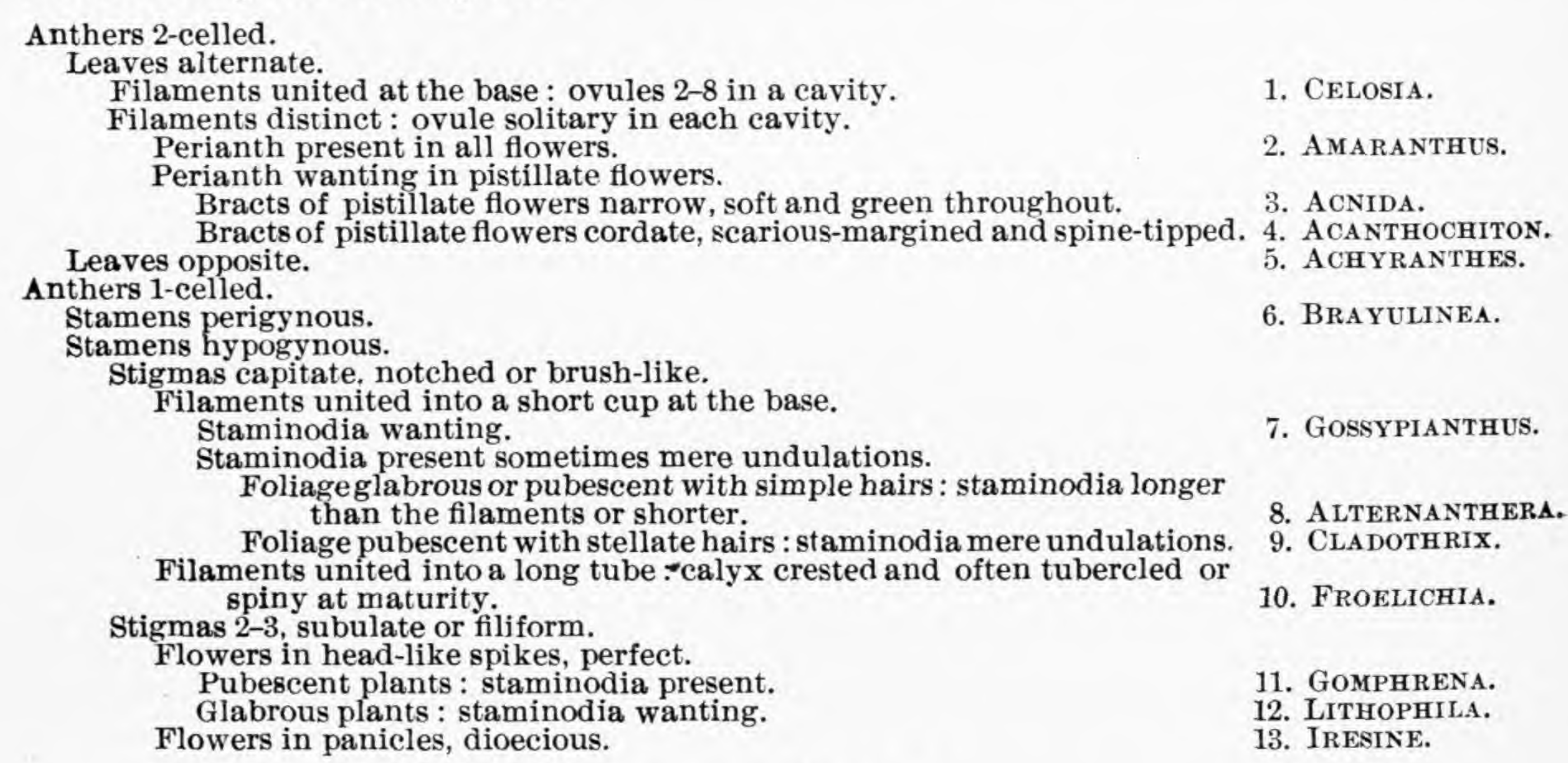

1. Celòsta L.

Annual herbs or shrubs, with upright or climbing stems. Leaves alternate: blades entire or rarely lobed. Flowers perfect, subtended by bracts, in dense terminal or axillary spikes. Sepals 5, scarious, striate. Stamens 5 : filaments united into a short tube at their bases: anthers 2-celled. Ovary 1-celled: styles or stigmas 2-3, the latter sometimes sessile. Ovules 2-8 in each cavity. Utricle included or exserted, circumscissile. Seeds often erect, shining.

1. Celosia paniculàta L. Perennial, glabrous. Stems fully $1 \mathrm{~m}$. long, more or less widely branched: leaf-blades ovate, deltoid-ovate or ovate-lanceolate, $1.5-7 \mathrm{~cm}$. long, acute or slightly acuminate, entire, abruptly narrowed or truncate at the base; petioles less than $\frac{1}{2}$ as long as the blades: spikes solitary or panicled, 1-3 cm. long: sepals oblong, acute, firm, 3.5-4 mm. long, much surpassing the bracts: utricle included: seed lenticnlar, about $1 \mathrm{~mm}$. long.

In sandy soil, Florida, Texas and Mexico.

\section{AMARÁNTHUUS L.}

Annual weedy herbs, with upright or diffusely branched and spreading stems, occasionally armed with spines. Leaves alternate : blades flat, pinnately nerved, entire or undulate, sometimes crisped. Flowers monoecious, polygamous or dioecious, in dense spikes or clusters, each subtended by mostly 3 more or less conspicuous green, red or purple bracts. Sepals 2-5, distinct. Stamens 2-5, distinct : anthers 2-celled, the sacs opening lengthwise. Ovary 1-celled : styles or stigmas 2-3. Ovule solitary. Utricle circumscissile, irregularly opening or indehiscent, 2-3-beaked. Seeds often lenticular and shining. Embryo annular. The plants flower in summer and fall or from spring to fall in the southern part of our range. Amaranth. Pigweed.

A. Sepals abruptly contracted into narrow claws,

Plants monoecious. Utricle indehiscent. Utricle circumscissile.

Plants dioecious.

Bracts scarious, acuminate, shorter than the sepals : stigmas usually 3. Bracts rigid, awn-tipped, longer than the sepals : stigmas usually 2.

1. A. Berlandieri.

2. A. polygonoides.

3. A. Greggii:

4. A. Palmeri. 
B. Sepals not abruptly contracted into claws.

Utricle circumscissile.

Flowers, at least the upper ones, in dense terminal spikes.

Stems unarmed, without spines at the leaf-axils.

Stamens 3.

Stamens 5.

Spikes strict: sepals mostly obtuse.

Spikes drooping: sepals mostly acute.

Stems furnished with a pair of spines at each leaf-axil.

Flowers in small axillary clusters usually surpassed by the leaves.

Sepals 4 or 5 : stems prostrate : seeds $1.5-2 \mathrm{~mm}$. long.

Sepals 3 : stems erect : seeds about $1 \mathrm{~mm}$. long.

Utricle indehiscent.

Flowers, at least the upper ones, in continuous or interrupted spikes. Utricle rugose : stems erect.

Utricle prominently 3-5-ribbed : stems spreading or decumbent.

Flowers in axillary clusters surpassed by the leaves.

Pedicels conspicuously thickened.

Pedicels not thickened.

Stems elongated.: seeds less than $1 \mathrm{~mm}$. long.

Stems abbreviated: seeds fully $2 \mathrm{~mm}$. long.

\section{A. Powellii. \\ 6. A. retroflexus. \\ 7. A. hybridus. \\ 8. A. spinosus. \\ 9. A. blitoides. \\ 10. A. albus.}

11. A. viridis.

12. A. deflexus.

13. A. crassipes.

14. A. emarginatus.

15. A. pumilus.

1. Amaranthus Berlanđiéri (Moq.) Uline \& Bray. Foliage deep green. Stems erect or ascending, 1.5-3 dm. tall, slender, branching from the base, pubescent : leaves crowded; blades oblong to oblong-lanceolate, 1.5-2.5 cm. long, obtuse or notched at the apex, entire, glabrous or glabrate, short-petioled: flowers crowded in small axillary clusters, monoecious : sepals delicate, about $2 \mathrm{~mm}$. long, 3-nerved, narrowed into claws: bracts about $\frac{1}{3}$ as long as the sepals: stamens 2: utricle included, indehiscent : seeds about $1 \mathrm{~mm}$. long, shining.

In valleys, Texas and adjacent Mexico.

2. Amaranthus polygonoides L. Foliage bright green. Stems branched at the base, the branches erect or spreading, 1-5 $\mathrm{cm}$. long, often slightly pubescent : leaf-blades rhombic, ovate or oval, 1-2 cm. long, obtuse or notched at the apex ; petioles longer than the blades or shorter, slender: flowers monoecious, in dense axillary clusters: bracts subulate : sepals (pistillate) about twice as long as the bracts, oblong-cuneate, with spreading tips, apiculate, white-margined : utricle included, circumscissile: seeds barely $1 \mathrm{~mm}$. long.

In sandy soil, Florida and the West Indies.

3. Amaranthus Gréggii S. Wats. Foliage glabrous or nearly so. Stems erect, or branched at the base, the branches ascending or spreading, 2-6 dm. long, commonly with short branches: leaves few ; blades rhombic-ovate to oblong, 1-3 cm. long, thickish, slightly scabrous, narrowed into short or slender petioles: spikes elongated, more or less leafy-bracted, somewhat interrupted below : flowers dioecious : bracts lanceolate, acuminate, scarious: sepals much longer than, the bracts, distinct, equal or nearly so, acute : stigmas usually 3 : utricle indehiscent.

In valleys, southern Texas near the mouth of the Rio Grande.

4. Amaranthus Pálmeri S. Wats. Foliage glabrous or nearly so. Stems erect, or branched at the base, the branches ascending or decumbent, 2-9 dm. tall, leafy : leaf-blades rhombic-oblong to rhombic-ovate, or almost lanceolate, $1.5-6 \mathrm{~cm}$. long, obtuse or mucronate ; petioles commonly as long as the blades : flowers dioecious : spikes conspicuously elongated, interrupted below, often leafy at the base: bracts conspicuous, rigid, awn-tipped: sepals much shorter than the bracts, nearly equal, commonly obtuse or retuse and apiculate : stigmas usually 2 : utricle indehiscent.

In valleys, Texas to California, south to Mexico.

5. Amaranthus Powéllii S. Wats. Foliage sparingly pubescent or glabrate. Stems erect, 4-7 dm. tall, sparingly branched : leaf-blades lanceolate to elliptic or ovate, 1.5-7 $\mathrm{cm}$. long, obtuse or acutish, narrowed into short or slender petioles : flowers polygamous : spikes 2.5-10 $\mathrm{cm}$. long, or those in the axils shorter: bracts subulate, 3-4 $\mathrm{mm}$. long, rigid : sepals shorter than the bracts, 5 , unequal, oblong, acute: stamens $3:$ utricle about as long as the calyx : seeds oblong-ovoid, fully $1 \mathrm{~mm}$. long, shining.

In valleys, Texas to Arizona and adjacent Mexico.

6. Amaranthus retrofléxus L. Foliage roughish pubescent, bright green. Stems erect or ascending, 3-30 dm. tall, more or less branched, not spine-armed : leaf blades ovate to ovate-lanceolate, or lanceolate near top of stem, often conspicuously rhombic, 5-15 $\mathrm{cm}$. long, undulate or crisped, cuneate at the base; petioles shorter than the blades: spikes dense, 1-6 cm. long, sessile : bracts subulate : sepals green, about $\frac{1}{2}$ as long as the bracts, oblong or oblong-spatulate, mucronate, scarious: stamens 5: utricle surpassed by the sepals, wrinkled, circumscissile : seeds fully $1 \mathrm{~mm}$. long. America.

In waste places and fields, North America, except the extreme north. Naturalized from tropica] 
7. Amaranthus hýbridus L. Foliage glabrous or sparingly pubescent, dark green or purplish. Stems erect or ascending, 5-25 dm. tall, more or less branched, not spinearmed : leaf-blades ovate to ovate-lanceolate or elliptic, 3-12 cm. long, acutish or somewhat acuminate, with prominent often hairy nerves beneath; petioles as long as the blades or shorter: spikes bristly, panicled, especially at the ends of the branches: bracts subulate : sepals about $\frac{1}{2}$ as long as the bracts, oblong, acute or cuspidate: stamens 5 : utricle surpassing the calyx, scarcely wrinkled, circumscissle : seeds fully $1 \mathrm{~mm}$. long.

In waste places or cultivated grounds, North America, except the extreme north. Naturalized from tropical America.

8. Amaranthus spinòsus L. Foliage glabrous or nearly so, dark green. Stems ascending or spreading, often diffusely branched, $2-12 \mathrm{dm}$. long, usually firm-fleshy : leafblades ovate, rhombic-ovate or lanceolate above, $1.5-8 \mathrm{~cm}$. long, entire, commonly cuneate at the base; petioles as long as the blades or shorter, with a pair of spines at the bases : spikes erect or nodding, closely flowered: bracts subulate-lanceolate : sepals $2 \mathrm{~mm}$. long, about as long as the bracts, oblong, mucronate, 1-nerved : stamens 5 : utricle nearly as long as the sepals, imperfectly circumscissile: seeds about $1 \mathrm{~mm}$. long.

In waste places and cultivated soil, Massachusetts to Kansas, Florida and Mexico. Naturalized from tropical America.

9. Amaranthus blitoìdes S. Wats. Foliage glabrous or nearly so, pale green. Stems branched at the base, the branches spreading or prostrate, 1-6 dm. long, commonly forming wide mats: leaf-blades spatulate to elliptic, 1-2 $\mathrm{cm}$. long, narrowed into slender petioles; these longer than the blades or usually shorter: flower-clusters axillary, surpassed by the leaves: bracts subulate-lanceolate : sepals $2.5-3 \mathrm{~mm}$. long, oblong or oblonglanceolate, acute or cuspidate : stamens 3 : utricle as long as the calyx or slightly longer, circumscissile : seeds $1.5-2 \mathrm{~mm}$. long.

In waste places and dry grounds. Maine to Minnesota, Utah, New Jersey, Texas and Arizona.-A variety with very slender branches, narrow leaf-blades and a red-topped utricle has been described as A. blitoides Reverchònii Uline and Bray. Central Texas.

10. Amaranthus álbus L. Foliage glabrous, pale green. Stems erect, becoming widely and diffusely branched, 1-6 $\mathrm{dm}$. tall, the branches ascending or spreading : leafblades spatulate, obovate or oblong, 1-3 cm. long, mucronate; petioles shorter than the blades: spikes much shorter than the leaves: Howers polygamous, in axillary clusters: bracts firm, awn-tipped : sepals 3 : stamens 3 : utricle surpassing the sepals, wrinkled, circumseissile : seeds about $1 \mathrm{~mm}$. long.

In waste places and cultivated grounds, North America generally. Naturalized from tropical America. TUMBLE WEED.

11. Am aranthus víridis L. Foliage deep green. Stems ereet, $2-9 \mathrm{dm}$. tall, more or less widely branched : leaf-blades ovate or rhombic, $2-6 \mathrm{~cm}$. long, obtuse or notched at the apex, more or less distinctly erose, cuneate at the base : petioles as long as the blades or shorter: spikes dense, or somewhat interrupted below : bracts inconspicuous : sepals 3, delicate, twice or thrice longer than the bracts: utricle surpassing the calyx, acutish, wrinkled, indehiscent : seeds fully $1 \mathrm{~mm}$. long, rather dull.

In waste places, locally in the Gulf States. Also widely distributed in the tropics.

12. Amaranthus defléxus L. Foliage glabrous, purplish green. Stems spreading or decumbent, rather succulent, more or less branched : leaves often numerous ; blades ovate, oval or oblong-lanceolate, 1-6 $\mathrm{cm}$. long, obtuse to notched at the apex, somewhat cuneately narrowed at the base; petioles about as long as the blades or longer on the lower part of the stem : flowers polygamous: spikes stont, 1-6 cm. long: sepals $2-3$, becoming $1.5 \mathrm{~mm}$. long, surpassing the bracts, oblong or spatulate-oblong, thin : utricle fully $2 \mathrm{~mm}$. long, 3-5-ribbed, surpassing the sepals : seeds fully $1 \mathrm{~mm}$. long.

In waste places, Massachusetts to Florida and Alabama. Widely distributed.

13. Amaranthus crássipes Schlecht. Foliage glabrate, deep green. Stem erect or decumbent, 1-6 dm. long, more or less branched, sometimes slightly fleshy : leaf-blades spatulate or ovate, $1-2.5 \mathrm{~cm}$. long, rounded or notched at the apex, cuneate at the base ; petioles longer than the blades or shorter : pedicels conspicuously thickened : bracts inconspicnous, keeled : sepals spatulate, surpassing the bracts, obtuse : utricle indehiscent, surpassed by the calyx, rough : seeds fully $1 \mathrm{~mm}$. long.

In waste places, peninsular Florida and the Keys. Also in tropical America.

14. Amaranthus emarginàtus Salzm. Foliage glabrous, deep green. Stems usually branched at the base, the branches elongated, decumbent or prostrate, 1-6 dm. long, often sparingly branched : leaf-blades rhombic-ovate, 1-2 cm. long, deeply emarginate, more or less cuneate at the base; petioles slender, twice as long as the blades or shorter: clusters not very densely flowered: pedicels not thickened : bracts inconspicuous : sepals $1.5-2 \mathrm{~mm}$. long, delicate, scarious : utricle scarious, indehiscent, smooth : seeds less than $1 \mathrm{~mm}$. long.

In waste places, Louisiana and Texas. 
15. Amaranthus pùmilus Raf. Foliage glabrous, fleshy, deep green. Stems branched at the hase, the branches spreading or prostrate, $5-20 \mathrm{~cm}$. long, usually abbreviated : leaf-blades suborbicular, rhombic or ovate, $1-1.5 \mathrm{~cm}$. long, rounded or notched at the apex, cuneate or truncate at the base ; petioles shorter than the blades: clusters fewflowered : bracts lanceolate or oblong: sepals surpassing the bracts, oblong, obtuse : utricle oblong, nearly twice as long as the sepals, indehiscent : seeds fully $2 \mathrm{~mm}$. long.

On sea beaches, Rhodge Island to South Carolina.

\section{ACNIDA L.}

Annual coarse herbs, with branching stems. Foliage usually glabrous. Leaves alternate : blades narrow, entire, pinnately nerved, petioled. Flowers dioecious, subtended by 1-3 bracts, in terminal or axillary, narrow continuous or interrupted spikes or short clusters. Staminate flowers with 5 scarious mucronate sepals surpassing the bracts and 5 stamens, the filaments distinct, subulate. Anthers 2-celled. Pistillate flowers destitute of a perianth, with a 1-celled ovary. Stigmas $2-5$, variable in length, papillose or plumose. Ovule solitary. Utricle either membranous and circumscissile or opening irregularly, or fleshy and indehiscent. Seed erect, smooth and shining. WATER-Hemp.

Utricle angled : species of the Atlantic coast region.

Utricle fleshy, becoming black at maturity.

Spikes leafy to the ends: utricles over $2 \mathrm{~mm}$. long.

Spikes naked above: utricles less than $2 \mathrm{~mm}$. long.

Utricle membranous, green at maturity.

Utricle not angled: species of the interior.

Utricle circumscissile.

Utricle indehiscent.

Flowers in elongated continuous or slightly interrupted spikes.

Flowers in more or less remote subglobose clusters.

1. A. cannabina.

2. A. australis.

3. A. Floridana.

4. A. tamariscina.

5. A. tuberculata.

6. A. concatenata.

1. Acnida cannábina L. Somewhat succulent. Stems erect, $3-30 \mathrm{dm}$. tall, usually much branched, the branches ascending: leaf-blades lanceolate, acuminate at both ends, but usually blunt at the apex, entire or slightly undulate, gradually narrowed at the base ; petioles shorter than the blades : flowers dioecious, the staminate in dense spikes 2-15 cm. long : sepals oblong-lanceolate to ovate-oblong : utricles obovoid or subglobose, 3-5-angled, $2-4 \mathrm{~mm}$. long, fleshy, black at maturity.

In salt and brackish marshes, ascending rivers to fresh water, Massachusetts to Florida. Summer.

2. Acnida austràlis A. Gray. Somewhat fleshy. Stems erect, $1.5-7 \mathrm{~m}$. tall, widely branching above: leaf-blades lanceolate to elliptic-lanceolate, 1-3 dm. long, attenuate to the slender apex, undulate, cuneate or somewhat acuminate at the base; petioles shorter than the blades: flowers dioecious, the staminate in slender spikes : spikes leafy-bracted at the base : utricles fleshy, ovoid, 1-1.5 mm. long, 3-angled.

In salt or brackish marshes, Florida to Mexico, and in the West Indies. Summer and fall.

3. Acnida Floridàna $S$. Wats. Glabrous. Stems erect or reclining, $5-14 \mathrm{dm}$. tall, simple and wand-like or sparingly branched, ridged in age: leaf-blades linear to narrowly lanceolate, $5-10 \mathrm{~cm}$. long, often rather blunt, remote or at least not numerous : spikes simple or nearly so, conspicuously elongated, interrupted: sepals surpassing the bracts, 1-2 mm. long: utricles membranous, angled, tuberculate, green at maturity.

In sandy soil, Florida. Fall.

4. Acnida tamaríscina (Nutt.) Wood. Glabrous or nearly so. Stems erect or ascending, 1-2 m. long, much branched: leaf-blades lanceolate or ovate-lanceolate, obtuse or notched at the apex, uneven along the edge, narrowed into slender petioles: spikes slender, interrupted near their bases, naked or with a few leaves at the base : bracts lanceolate, firmly tipped: sepals lanceolate, 1-nerved, subulate-tipped : utricles membranous, not angled, cireumscissile.

In swamps, Illinois to South Dakota, Louisiana and New Mexico. Summer and fall.

5. Acnida tuberculàta Moq. Glabrous. Stems erect, $5-30 \mathrm{dm}$. tall, usually much branched: leaf-blades lanceolate to elliptic or ovate, $5-30 \mathrm{~cm}$. long, obtuse or acutish, prominently nerved beneath: spikes in loose or finally dense panicles: bracts often preading : sepals acute or acuminate : utricles ovoid, indehiscent, tuberculate, not angled.

In swamps or sandy bottoms, Vermont to Manitoba, Louisiana and Nebraska. Summer and fall.

6. Acnida concatenàta Moq. Glabrous or nearly so. Stems weak, often decumbent, 2-12 dm. long, with rather short internodes : leaves $1.5-15 \mathrm{~cm}$. long; blades oblong to oblong-ovate, often apiculate, undulate, narrowed into slender petioles: flowers in dense clusters, varying from 1-2 cm. in diameter, remote, or contiguous only toward the ends of 
the branches : utricles indehiscent, slightly over $1 \mathrm{~mm}$. long : seed lenticular, less than 1 mm. long, shining. fall.

On river banks, or in moist soil, Manitoba to Wisconsin, Tennessee and Nebraska. Summer and

\section{ACANTHOCHİTON Torr.}

Annual herbs, with smooth and glabrous foliage. Leaves alterrate : blades elongated, entire, acuminate, spine-tipped, slender-petioled. Flowers dioecious, in axillary clusters. Staminate flowers bractless, with 5 acuminate sepals and 5 stamens. Filaments distinct. Anthers 2-celled. Pistillate flowers furnished with large rigid-tipped bracts. Perianth wanting. Ovary 1-celled. Styles 2-4. Ovule solitary, erect. Utricle flattened, membranous, circumscissile.

1. Acanthochiton Wrìghtii Torr. Foliage glabrous. Stems erect, $2-5 \mathrm{dm}$. tall, sparingly or rather freely branched, ridged: leaf-blades linear or nearly so, $2-8 \mathrm{~cm}$. long, minutely awn-tipped, prominently nerved beneath, erose or undulate, slender-petioled: bracts various, those of the staminate inflorescence inconspicuous, those of pistillate plants conspicuous, more or less interlocking, broadly cordate, 6-7 mm. long, awn-tipped, scariousmargined and with reticulated faces. to fall.

In and near the valley of the Rio Grande, Texas and New Mexico, and adjacent Mexico. Spring

\section{ACHYRÁNTHES L.}

Herbs or sometimes shrubby plants, with often conspicuously slender and elongated branches. Leaves opposite: blades simple, entire, petioled or sessile. Flowers perfect, in slender elongated often interrupted spikes, commonly deflexed. Calyx firm, often becoming very hard: sepals 4-5, narrow, nearly equal, acuminate or awn-tipped. Stamens 5 , or rarely fewer : filaments filiform-subulate: anthers 2-celled. Ovary 1-celled, somewhat flattened : style filiform : stigma capitate. Ovule solitary. Utricle included, membranous, indehiscent.

1. Achyranthes obtusifòlia Lam. Plant 4-12 dm. tall. Stems more or less extensively branched, finely pubescent, ridged: leaves mainly opposite, with clusters of smaller leaves or short branches in the axils; blades rhombic-ovate to obovate or cuneate, 1-3 cm. long, truncate or retuse at the apex, each with an abrupt tip, prominently nerved beneath, short-petioled : spikes virgate, $2-6 \mathrm{dm}$. long, mostly simple, somewhat interrupted below, finely hirsute : flowers deflexed, barely $4 \mathrm{~mm}$. long : sepals acute, glabrous or nearly so, rigid, surpassing the awn of the firm bract : utricle included, with a sharp rim at the top.

In sand, Key West and tropical America. Spring to fall.

\section{BRAYULINEA Small.}

Perennial pubescent herbs, with prostrate or decumbent stems. Leaves opposite: blades rather broad, entire. Flowers perfect, subtended by bracts, in axillary clusters. Sepals 5, pubescent. Stamens 5, perigynous: filaments broad and sometimes slightly united at the base, inserted at the base of the sepals: anthers 1-celled. Ovary 1-celled, flattened: style short: stigma notched. Ovule solitary. Utricle membranous, indehiscent. Seed smooth. [Guilleminea H.B.K., not Neck.]

1. Brayulinea dénsa.(Willd.) Small. Foliage lanuginose. Stems branched at the base, the branches spreading or prostrate, forking, often zigzag: leaf-blades spatulate, elliptic or oblong-spatulate, or oval-elliptic, $7-15 \mathrm{~mm}$. long, acute, glabrous or nearly so above, punctate, short-petioled, or sessile above : flowers minute, in clusters $5-10 \mathrm{~mm}$. in diameter : bracts nearly equal, silvery white, ovate and acute to oblong-ovate and obtuse, glabrous or nearly so: sepals about $1.5 \mathrm{~mm}$. long, oblong to ovate, acute, woolly at the base : utricle included. [Guilleminea densa (Willd.) Moq.]

On plains, Texas to New Mexico, south to Mexico and tropical America. Spring to fall.

\section{GOSSYPIÁNTHUS Hook.}

Perennial herbs, with woolly foliage and branching prostrate stems. Leaves mainly basal : blades entire, without rigid tips. Flowers perfect, subtended by hyaline bracts, in 
axillary clusters. Sepals 5, lanuginous, 3-nerved or nerveless. Stamens 5: filaments united into a short cup at the base, without staminodia between the 1-celled anthers. Ovary 1-celled, flattened : style short: stigma notched. Ovule solitary. Utricle membranous, indehiscent. Seed lenticular, shining.

Bracts ovate or ovate-lanceolate: sepals 3-nerved. Bracts suborbicular: sepals nerveless.

1. G. lanuginosus. 2. G. Sheldonii.

1. Gossypianthus lanuginòsus (Poir.) Moq. Foliage woolly. Stems branched at the base, the branches spreading or prostrate, $5-30 \mathrm{~cm}$. long, forking : leaves various ; basal prostrate, the blades spatulate or linear-spatulate, $2-7 \mathrm{~cm}$. long, acute or obtusish : stem-leaves opposite ; blades orbicular-obovate, ovate or lanceolate, 4-12 mm. long, acute or obtuse, sessile, often reflexed : clusters 5-10 mm. thick, more or less conspicuously woolly : bracts ovate to ovate-lanceolate, about $\frac{1}{2}$ as long as the calyx : sepals densely woolly, 2.5-3 mm. long, narrowly lanceolate, acuminate, 3-nerved, scarious-margined : utricle included.

On dry plains or prairies, the Indian Territory to Texas and adjacent Mexico. Summer and fall.

2. Gossypianthus Sheldònii (Uline \& Bray) Small. Similar to G. lanuginosus in habit, but much stouter and with more densely woolly foliage. Leaf-blades, at least some of them, broadly spatulate, leathery : bracts suborbicular : sepals 5-6.5 $\mathrm{mm}$. long, lanceolate.

In dry soil, near Cash Creek, Indian Territory. Summer.

\section{ALTERNÁNTHERA Forsk.}

Annual or perennial herbs, with decumbent or prostrate stems. Leaves opposite : blades narrow or broad, entire or nearly so, sessile or petioled. Flowers perfect, in sessile or peduncled head-like spikes; these usually white or silvery. Sepals 5, unequal, 2 more concave than the rest. Stamens 5, the filaments partially united into a cup-like tube: staminodia surpassing the filaments and 1-celled anthers or shorter. Ovary 1-celled : style variable in length : stigma capitate. Ovule solitary. Utricle flattened, indehiscent. Seeds lenticular, smooth. The plants flower from spring to fall, and also in winter in the southern part of our range. Our species are perennials.

Staminodia shorter than the filaments.

Stems pubescent: sepals awn-tipped : staminodia entire or nearly so.

Stems glabrous or nearly so: sepals not awn-tipped: staminodia copiously toothed.

Staminodia as long as the filaments or surpassing them.

Spikes sessile or nearly so: calyx sessile : sepals unequal in length.

Spikes long-peduncled : calyx pedicelled : sepals, at least 4, nearly equal.

Peduncles shorter than the leaves : sepals glabrous.

Leaf-blades linear to linear-oblanceolate, many times longer than broad : sepals $5-6 \mathrm{~mm}$. long.

Leaf-blades broadly ovate, a little longer than broad: sepals 3-3.5 mm. long.

Peduncles surpassing the leaves : sepals pubescent.

Stems minutely pubescent with appressed hairs: anthers on filaments equalling them in length.

Stems pubescent with ascending or spreading hairs : anthers sessile or nearly so.

1. A. repens.

2. A. paronychioides.

3. A. maritima.

4. A. philoxeroides.

5. A. Moquinii.

6. A. Floridana.

7. A. Brasiliana.

1. Alternanthera rèpens (L.) Kuntze. Plants pubescent. Stems branched at the base, the branches prostrate, 1-5 dm. long, forking, somewhat hirsute : leaves somewhat clustered; blades spatulate, oval, ovate or suborbicular, $8-20 \mathrm{~mm}$. long, often abruptly pointed or rather obtuse, narrowed into short petioles : flower-clusters axillary : sepals unequal, lanceolate, awn-tipped, the shorter one copiously pubescent with barbed hairs, all 1-nerved : staminodia nearly as long as the filaments, entire, at least above : utricle ovoid, included, furnished with a sharp wing below the apex.

In waste places and cultivated grounds, South Carolina to California and South America.

2. Alternanthera paronychioides St. Hil. Plants glabrate. Stems branched at the base, the branches prostrate or creeping, 1-4 dm. long, freely branching, glabrous or glabrate : leaf-blades spatulate or elliptic to oval, $0.5-2 \mathrm{~cm}$. long, acute or obtuse, entire, decidedly petioled : flower-clusters axillary, $1 \mathrm{~cm}$. thick or smaller: bracts lanceolate, acuminate : sepals pearly white, nearly equal, pubescent, not awn-tipped, merely acute : staminodia broad, about as long as the filaments, toothed to the apex : utricle flattened, obcordate.

In dry soil, North Carolina to Florida, Texas and tropical America.

3. Alternanthera marítima St. Hil. Plants glabrous, fleshy. Stems or the branches prostrate, $2-8 \mathrm{dm}$. long, angled, branched: leaf-blades leathery, cuneate to 
oblong or elliptic, 1.5-6 $\mathrm{cm}$. long, obtuse, commonly mucronate, entire, sessile or somewhat petioled: spikes dull straw-colored, 6-12 $\mathrm{mm}$. long, sessile, at maturity resembling the flower-clusters of Ephedra, leaving a conspicuous scar when detached: bracts ovate, keeled : calyx $\frac{1}{3}$ longer than the bracts : sepals rigid, ovate, acute and slightly awn-tipped, usually 5-nerved, glabrous : staminodia longer than the filaments, cleft or lacerate at the tip.

In sand, peninsular Florida and tropical America.

4. Alternanthera philoxeroìdes (Mart.) Griseb. Plants glabrous or nearly so. Stems or their branches prostrate or decumbent, freely creeping, the ascending portion often 1-5 dm. long, the upper internodes of ten a little hairy : leaf-blades somewhat fleshy, linear to linear-oblanceolate, $2-10 \mathrm{~cm}$. long, usually acute or mucronulate, entire, narrowed to the sessile base: spikes subglobose or cylindric, long-peduncled, silvery white: peduncles 2-7 $\mathrm{cm}$. long, glabrous or pubescent in lines : sepals $5-6 \mathrm{~mm}$. long, glabrous, unequal, 4-nerved, lanceolate, acute, firm : staminodia narrow, usually entire.

In waste places, South Carolina to Florida and Louisiana. Also in tropical America.

5. Alternanthera Moquínii Webb. Plants suggesting broad-leaved species of Allionia. Foliage glabrous or glabrate : stems erect or ascending, 3-8 dm. tall, sparingly forked: leaves about as long as the internodes; blades broadly ovate, 4-8 cm. long, acute or slightly acuminate, entire, abruptly narrowed or truncate at the base, short-petioled : spikes slenderpeduncled, ovoid, less than $1 \mathrm{~cm}$. long: peduncles shorter than the leaves : sepals 3-3.5 $\mathrm{mm}$. long, glabrous, mainly lanceolate, acute, surpassing the ovate, scarious-margined acuminate bracts : staminodia surpassing the anthers and the very short filaments, fringed at the apex : utricle included.

In sand, Key West, Florida. Also in tropical America.

6. Alternanthera Floridàna (Chapm.) Small. Plants slender. Pubescence minute, appressed : stems erect, $6-14 \mathrm{dm}$. tall, forking, the internodes elongated : leaves much shorter than the internodes; blades lanceolate to elliptic, 1.5-3 cm. long, acute or acuminate, entire, short-petioled or nearly sessile : spikes ovoid, about $1 \mathrm{~cm}$. long, silvery white : peduncles conspicuously elongated, many times longer than the leaves : sepals about $4 \mathrm{~mm}$. long, minutely pubescent, lanceolate or one of them broader, all acute, surpassing the bracts: staminodia longer than the narrowly elongated filaments : utricle with a toothed crown. [Telanthera Floridana Chapm.]

In sand, peninsular Florida and the Keys.

7. Alternanthera Brasiliàna (L.) Kuntze. Plants stoutish. Pubescence comparatively long and coarse : stems erect, $0.5-2 \mathrm{~m}$. tall, more or less forked, pubescent with ascending or spreading hairs : leaves commonly as long as the rather short internodes; blades lanceolate or oblong-lanceolate, $3-10 \mathrm{~cm}$. long, acuminate, entire, cuneate or somewhat rounded at the base, short-petioled: spikes slender-peduncled, ovoid to cylindric, 1-2.5 $\mathrm{cm}$. long: sepals 4-4.5 mm. long, lanceolate or oblong-lanceolate, acute, finely pubescent : anthers nearly sessile, or filaments very short: staminodia much surpassing the anthers: utricle with an entire crown.

In sand, peninsular Florida and tropical America.

\section{CLADÓthriX Nutt.}

Annual or perennial, diffusely branched herbs. Foliage pubescent with stellate hairs. Leaves mainly opposite: blades entire or merely undulate, short-petioled. Flowers perfect, subtended by 3 bracts, solitary or clustered in the axils. Sepals 5, equal, pubescent, thin. Hypanthium small or obsolete. Stamens 5, hypogynous : filaments united at their bases : anthers 1-celled. Ovary 1-celled, subglobose : style short: stigma capitate or 2lobed. Ovule solitary. Utricle subglobose, indehiscent.

Annual : stems or branches mostly prostrate or procumbent. Perennial: stems or branches erect or ascending.

1. C. lanuginosa.

2. C. suffruticosa.

1. Cladothrix lanuginòsa Nutt. Annual, lanuginose. Stems branched at the base, the branches procumbent or prostrate, 1-6 dm. long, forking, terete : leaves sometimes in 3 's at the joints, 2 smaller than the third; blades suborbicular, ovate or rhombic-ovate, obtuse or emarginate at the apex, entire, $0.5-2 \mathrm{~cm}$. long, rather prominently nerved beneath, more or less abruptly contracted and often oblique at the base : flowers usually in pairs : bractlets obtuse, pubescent : sepals twice as long as the bractlets, narrower, obtuse, glabrous, 1-nerved: utricle glabrous, included in the calyx.

In dry soil, Kansas to Texas, Arizona and Mexico. Spring to fall.

2. Cladothrix suffruticòsa (Torr.) S. Wats. Perennial, lanuginose. Stems erect or ascending, several from a woody base, forking, 1-1.5 dm. long, the branches ascending: 
leaves opposite, or alternate below ; blades suborbicular or ovate, $0.5-1 \mathrm{~cm}$. long, obtuse, entire, rounded or truncate at the often oblique base, short-petioled: flowers inconspicuous: bractlets shorter than the calyx : sepals oblong or oblong-lanceolate, a little over $2 \mathrm{~mm}$. long, obtuse or acutish, densely pubescent at least above the middle: utricle included.

In valleys, southern Texas. Spring to fall.

\section{FroELÍ́chia Moench.}

Annual or biennial herbs, with woolly or silky-pubescent foliage. Leaves opposite : blades entire or merely undulate, thickish, sessile, except for the petiole-like bases of some of the lower ones. Flowers perfect, inconspicuous, subtended by 3 bracts and occasionally furnished with bractlets, in dense spikes usually disposed in panicles. Sepals 5, woolly: tube longitudinally erested or tubercled at maturity. Stamens 5, included: filaments united into a tube : anthers 1-celled, situated between the projecting entire segments of the filament-tube. Ovary 1-celled : style short or wanting: stigmas capitate or brush-like. Utricle indehiscent, enclosed in the filament-tube.

Calyx-tube with lateral crests of distinct spines or tubercles at maturity.

Mature calyx-tube with tubercled faces: stems woolly.

Mature calyx-tube with spiny faces: stems minutely appressed-pubescent.

Calyx-tube with lateral crests of erose or toothed wings at maturity.

Calyx-wings deeply toothed : leaf-surfaces white or pale-pubescent beneath.

Stems puberulent at least above: one or both faces of the mature caly x-tube with 1 or 2 tubercle-like or spiny ridges.

Stems woolly: one or both faces of the mature calyx-tube with a basal spine.

Calyx-wings merely erose: leaf-surfaces tawny or coppery pubescent beneath.

1. F. gracilis.

2. F. Texana.

\section{F. Floridana.}

4. F. campestris.

5. F. Drummondii.

1. Froelichia grácilis Moq. Annual, slender. Stems usually branched at the base, the branches erect or ascending or rarely spreading, 2-3 dm. long, more than $\frac{1}{2}$ the length represented by the peduncle : leaves rather numerous, near the base of the plant, often clustered; blades linear to linear-oblong, 1-5 cm. long, acute, like the stems, white-woolly beneath : spikes 1-3 $\mathrm{cm}$. long: calyx-tube with crests of distinct spines, and tubercled faces at maturity.

In dry soil, Nebraska to Colorado, Texas and Arizona. Spring to fall.

2. Froelíchia Texàna $\mathrm{A}$. Br. Annual, stoutish. Stems erect or ascending, 4-12 dm. tall, simple or nearly so, at least above the base, pubescent with minute appressed hairs: leaves few, conspicuously remote; blades linear or nearly so, 2-12 $\mathrm{cm}$. long, often curved, acute or acuminate, appressed-woolly beneath, the upper sessile : spikes $0.5-2 \mathrm{~cm}$. long, sometimes black : calyx-tube with crests of distinct spines, and spiny faces at maturity.

In dry soil, Texas. Summer and fall.

3. Froelichia Floridàna (Nutt.) Moq. Annual, rather slender. Stems erect or ascending, 4-18 dm. tall, sometimes branched at the base, thence usually simple, puberulent : leaves few, conspicuously remote; blades linear or slightly broadest above or below the middle, 3-12 cm. long, acute, sessile or the lower ones narrowed into winged petioles, all pubescent with appressed hairs beneath or occasionally barely woolly : spikes 1-6 cm. long: calyx-tube with deeply toothed crests and 1 or 2 tubercle-like or spiny ridges on one or each face at maturity.

In sandy soil, Georgia and Florida. Spring to fall.

4. Froelichia campéstris Small. Annual or biennial, stoutish. Stems erect or branched near the base, the branches often ascending, 4-12 dm. tall, sometimes forking, woolly : leaves quite numerous, usually approximate; blades spatulate to oblong or broadly linear, acute or acutish, white-woolly beneath, entire, sessile or narrowed into broad petioles below: spikes $1-10 \mathrm{~cm}$. long, sometimes black: calyx-tube with rather shallowly toothed crests and a basal spine on one or each face at maturity.

In dry soil, Minnesota to Illinois, Colorado, Texas and Arizona. Spring to fall.

5. Froelichia Drummóndii Moq. Annual or biennial, stout. Stems erect or ascending, often branched at the base, the branches simple or forking, becoming floccose in age : leaves opposite, some often clustered in the axils of larger ones; blades elliptic, oblong or oblong-lanceolate, 6-12 cm. long, acute, with tawny or copper-colored pubescence beneath, narrowed into short petioles except the upper pairs: spikes stout, 1-6 cm. long: calyxtube with merely erose crests at maturity.

On prairies, Texas and Louisiana, and probably farther northand in the Mississippi Valley* Summer and fall. 


\section{GOMPHRÈNA L.}

Annual or perennial herbs, with stems mostly enlarged at the joints, and variously pubescent foliage. Leaves opposite: blades entire, sessile or short-petioled. Flowers perfect, usually in solitary and sessile clusters. Sepals 5, concave, mostly acute. Stamens 5 , included or exserted : filaments united into a tube : anthers in the sinuses of notched or cleft segments of the filament tube. Ovary 1-celled. Utricle more or less flattened. Globe Amaranth.

Stigmas short, sessile or nearly so. Stigmas filiform: style manifest.

1. G. Nealleyi.

2. G. decumbens.

1. Gomphrena Nealleỳi Coult. \& Fish. Perennial, villous. Stems erect or ascending, 1-3 dm. long, sparingly forked: leaf-blades oblong to oblong-spatulate, $2-3.5 \mathrm{~cm}$. long, mucronate, glabrate above, half-clasping at the base: peduncle slender, often about as long as the main stem : heads ovoid or cylindric-oblong to cylindric, $1-3 \mathrm{~cm}$. long, often rose-tinted, sessile, subtended by 2 leaf-like bracts : bracts of the head ovate, acute or acuminate, 2.5-3 mm. long, about $\frac{1}{2}$ as long as the keeled bractlets : sepals about $5 \mathrm{~mm}$. long, rigid at maturity, linear-lanceolate, densely woolly below, slightly surpassed by the bractlets, somewhat united at the base : stigmas 2, sessile or nearly so.

In sandy soil, Texas and adjacent Mexico.

2. Gomphrena decúmbens Jacq. Perennial, woolly or villous-woolly. Stems branched at the base, the branches procumbent, or ascending, 1-4 dm. long, more or less branched : leaf-blades oblong to spatulate-oblong, 2-4 cm. long, acutish or obtuse and mucronulate, entire, each narrowed into a petiole-like base which is partly clasping : peduncles mostly simple: heads subglobose to globose-cylindric, 1-2 $\mathrm{cm}$. long, pearly white or rose, subtended by 2 leaf-like bracts : bracts of the head ovate, acuminate, about $\frac{1}{2}$ as long as the narrower keeled and crested obtuse bractlets: sepals about as long as the bractlets, 1-nerved, the outer obtuse, glabrous, the interior villous, less obtuse : style slender.

In sandy soil, southern Texas and Mexico, and throughout tropical America.

\section{LITHOPHILA Sw.}

Perennial, rather fleshy herbs, with prostrate or creeping branches. Leaves opposite : blades narrow, entire, thickish, commonly sparingly pubescent at the base. Flowers perfect, in dense axillary or terminal sessile or peduncled heads. Calyx flattened. Sepals 5, firm, obtuse. Stamens 5, included : filaments united into a short tube at the base. Staminodia wanting. Anthers 1-celled. Ovary 1-celled, flattened : style very short: stigmas subulate. Ovule solitary. Utricle broad, rather leathery, indehiscent. [Philoxerus R. Br.]

1. Lithophila vermiculàris (L.) Uline. Perennial, glabrous, somewhat fleshy. Stems branched at the base, the branches spreading radially, prostrate, often creeping, 2-7 $\mathrm{dm}$. long, more or less ascending at the tips : leaf-blades half-terete, linear or club-shaped, 1-2.5 cm. long, acute or acutish, entire, sessile: heads subglobose to cylindric, 1-2 cm. long, sessile, silvery-white : bracts lanceolate, acute, glabrous : sepals surpassing the bracts, usually $3.5-4 \mathrm{~mm}$. long, flattened, obtuse, the 2 outer woolly at the base : stamens 5 : staminodia wanting: utricle included.

In sandy soil, Florida to Texas and in tropical America.

\section{IRESINE $\mathrm{R}$ : Br.}

Annual or perennial herbs, with tall upright stems. Leaves opposite : blades thin, pinnately nerved, entire, petioled. Flowers perfect, polygamous or dioecious, subtended by 3 bracts, in terminal panicles. Sepals 5, glabrous, or those of the pistillate flowers usually pubescent. Stamens 5 or fewer: filaments filiform, united at their bases : anthers 1-celled. Ovule solitary. Utricle subglobose, indehiscent. Blood-Leaf. Juba's Bush.

1. Iresine paniculàta (L.) Kuntze. Foliage glabrous. Stems erect, more or less widely branched, 6-12 dm. tall, ridged or angled, commonly swollen at the nodes : leafblades narrowly lanceolate to ovate, $5-10 \mathrm{~cm}$. long, acute or acuminate at both ends, entire, slender-petioled: panicles usually ample, rather narrow, nearly leafless at least above: spikes white or nearly so: calyx glabrous and with 5 stamens in the case of staminate flowers, woolly in the case of pistillate flowers : sepals 3-nerved.

In dry soil, Ohio to Florida and New Mexico. Also in tropical America. Summer and fall. 


\section{FAmily 4. CORRIGIOLÀCEAE Reichenb. Whitlow-wort Family.}

Herbs, with firm or rigid tissues and erect or creeping commonly tufted stems. Leaves opposite: blades often narrow, entire : stipules scarious, sometimes conspicuous, or rarely wanting. Flowers incomplete, perfect, in clustered or dichotomous cymes. Sepals 4-5, nearly distinct or partly united, white or green, persistent. Corolla wanting. Androecium of 4-5 stamens inserted at the base of the ovary. Filaments slender. Anthers short, 2-celled. Gynoecium of a single pistil. Ovary 1-celled, sessile. Styles wholly or partially united, sometimes very short. Ovule solitary. Fruit a utricle or an achene. Seed solitary : endosperm nearly surrounding the embryo. [Illecebraceae Lindl.]

Hypanthium wanting or very small : stamens inserted under the ovary at the sepal-bases.

Caly x sessile in a pair of bracts which simulate the sepals: sepals awned.
Calyx manifestly pedicelled : bracts simulating the leaves: sepals merely cuspi-

Calyx manifestly pedicelled : bracts simulating
date on the back, or the cusps wanting.

Styles relatively long: sepals cuspidate: radicle ascending.

Styles wanting or nearly so : sepals barely mucronate: radicle descending.

Hypanthium present, often about as long as the sepals, the stamens inserted near

its edge.

Flowers subtended by normal bracts.

Sepals merely concave: flower not urn-shaped: stems or branches simple below.

Sepals with small cusps back of the hoods: flower urn-shaped: stems or branches dichotomous throughout.

Flowers subtended by thick clamp-like involucels.

1. PARONYCHIA.

2. Anychiastrum.

3. ANYCHIA.

4. ODONTONYCHIA.

5. SIPHONYCHIA.

6. GIBBESIA.

\section{PARONÝCHIA Adans.}

Annual or perennial herbs, with stems often branching at the base. Leaves mostly opposite: blades narrow. Flowers in clustered or dichotomous cymes. Calyx persistent. Sepals 5, narrow, concave or hooded at the awn-tipped apex. Stamens 5, included : filaments inserted at the base of the ovary, alternating with 5 small staminodia. Styles partially united. Utricle included. Seed resupinate. The plants flower in the summer and fall. WHITLOW-WORT.

Annual or biennial : sepals dilated at the apex.

Leaf-blades fully $2 \mathrm{~mm}$. broad.

Leaf-blades less than $2 \mathrm{~mm}$. broad.

Foliage pubescent.

Caly x surpassing the bracts : awns spreading at maturity, much shorter than the sepals.

Calyx shorter than the bracts: awns erect or ascending, about as long as the sepals.

Foliage glabrous, sometimes slightly scabrous.

Perennial: sepals not dilated at the apex.

Calyx glabrous or merely puberulent.

Cymes strict, the branches erect or ascending : leaves scabrous.

Cymes open, the branches spreading: leaves smooth.

Calyx manifestly pubescent.

Calyx exserted beyond the bracts and stipules; awns spreading at maturity : species campestrian.

Calyx about $2.5 \mathrm{~mm}$. long: sepals lanceolate, gradually acuminate: cymes with ascending branches.

Calyx about $2 \mathrm{~mm}$. long: sepals oblong, abruptly acuminate: cymes with divaricate branches.

1. P."Drummondii.

2. P. chorizanthoides.

3. P. setacea.

4. P. Lindheimeri.

5. P. scoparia.

6. P. dichotoma.

alyx hidden in the bracts and stipules; awns erect : species Alleghenian.

7. P. Jamesii.

8. P. Wardi.

9. P. argyrocoma.

1. Paronychia Drummóndii T. \& G. Annual or biennial, stoutish, finely pubescent. Stem simple below, erect, 1-2 dm. tall, corymbosely branched above : leaf-blades thick, oblong or narrowly oblong-spatulate, $1-2 \mathrm{~cm}$. long, over $2 \mathrm{~mm}$. broad, acute, apiculate, ciliate, sessile; stipules lanceolate, long-acuminate, silvery : cymes dense : sepals cuneate, $1.5 \mathrm{~mm}$. long, with white hoods and short spreading cusps : stamens $\frac{1}{2}$ as long as the sepals.

In dry soil, southern Texas.

2. Paronychia chorizanthoìdes Small. Annual, slender, minutely pubescent. Stem erect, 1-2 dm. tall, forking from a point $3-8 \mathrm{~cm}$. above the base : leaf-blades linear-filiform, $0.8-2 \mathrm{~cm}$. long, less than $2 \mathrm{~mm}$. broad, acute, with a stout midrib, sessile; stipules lanceolate, silvery, acuminate : calyx sessile, $1.5 \mathrm{~mm}$. long, strigose at the base, finally urnshaped, the base much enlarged : sepals ovate or ovate-lanceolate, with a stout midrib, abruptly contracted into the ascending cusps which are about $\frac{1}{2}$ as long as the body at maturity. In dry soil, Texas.

3. Paronychia setàcea T. \& G. Annual, slender, finely pubescent. Stem erect, simple below, forking above, $0.5-1 \mathrm{dm}$. tall : leaf-blades linear-filiform, $0.5-1.5 \mathrm{~cm}$. long, 
acute, deciduous: calyx shorter than the bracts: sepals cuneate, $2 \mathrm{~mm}$. long (with the cusps), hooded above, the awn-like cusp nearly as long as the body of the sepal, ascending or diverging.

In dry soil, Texas.

4. Paronychia Lindheìmeri Engelm. Annual or biennial, slender, glabrous. Stem branched at the base, the branches erect or ascending, wiry, $0.5-2 \mathrm{dm}$. tall, forking above or throughout : leaf-blades nearly filiform, $0.5-1.5 \mathrm{~cm}$. long, acute, sessile; stipules narrowly lanceolate: cymes open: sepals oblong, 1.7-2 mm. long, slightly hooded, scabrous at the base, minutely cuspidate, the cusp more or less spreading.

In dry soil, Texas and New Mexico.

5. Paronychia scopària Small. Perennial, rather slender, minutely pubescent. Stem much branched at the base, the branches tufted, erect or ascending, 2-3 dm. tall, simple below, sparingly forked above, roughish : leaf-blades linear-filiform, $1-3 \mathrm{~cm}$. Iong, acute, grooved on either side of the midrib, serrulate-ciliate, especially near the apex, sessile; stipules linear-lanceolate, 1-1.5 cm. long, attenuate : branches of the cymes erect or strongly ascending: sepals linear-lanceolate, gradually narrowed to the apex, $3-3.5 \mathrm{~mm}$. long, firm, keeled, usually with a short lateral nerve on each side of the keel, hooded, each prolonged into a stout ascending cusp, which is $\frac{1}{3}$ to $\frac{1}{4}$ as long as the body : stamens half as long as the sepals.

In dry soil, Indian Territory and Texas.

6. Paronychia dichótoma (L.) Nutt. Perennial, slender, the foliage glabrate or nearly so. Stem branched at the base, the branches erect or ascending, tufted, 1-4 dm. tall, rigid, wire-like, forking above : leaf-blades linear-filiform, 1-4 cm. long, acute, smooth ; stipules linear-lanceolate, $8-13 \mathrm{~mm}$. long, long-attenuate, silvery: cymes open, manyflowered : sepals lanceolate, about $3 \mathrm{~mm}$. long, slightly hooded, the back produced into a short terminal cusp : stamens fully $\frac{1}{2}$ as long as the sepals.

In rocky soil, Maryland to North Carolina, Arkansas and Texas. NAILwort.

7. Paronychia Jamèsii T. \& G. Perennial, minutely pubescent. Stem usually much branched at the base, the branches tufted, erect or ascending, 0.5-2 dm. tall, forking above : leaf-blades linear-filiform, $0.5-2 \mathrm{~cm}$. long, acute, sessile; stipules silvery, linearlanceolate: cymes slightly open : calyx about $2.5 \mathrm{~mm}$. long: sepals lanceolate, gradually acuminate, hooded, each terminating in a short more or less spreading cusp : utricle ovoid, less than $1 \mathrm{~mm}$. in diameter.

In dry soil, Nebraska and Colorado to Texas, Arizona and Mexico.

8. Paronychia Wárdi Rydb. Perennial, puberulent or minutely pubescent. Stem much branched at the base, the branches quite slender: leaf-blades narrowly linear to linear-filiform, $0.7-2 \mathrm{~cm}$. long, acute, early deciduous or fugacious : cymes widely open, the branches diverging: calyx about $2 \mathrm{~mm}$. long: sepals oblong, abruptly acuminate: utricle somewhat smaller than that of the next preceding species.

In dry or stony soil, Kansas and Colorado to Texas and New Mexico.

9. Paronychia argyrocòma (Michx.) Nutt. Perennial, finely pubescent, conspicuous on account of the numerous silvery stipules. Stem branched at the base, the branches ascending or decumbent, tufted, 0.5-3 dm. long, simple or sparingly forked, the hairs recurved : leaf-blades linear or nearly so, 1-3 cm. long, acute, ciliolate, rather fleshy ; stipules lanceolate, 5-10 $\mathrm{mm}$. long, acuminate : flowers in congested cymes: sepals narrowly lanceolate, 4-5 mm. long, firm, long-attenuate, ciliate, the tips and edges hyaline: stamens about $\frac{1}{2}$ as long as the sepals : anthers dark green : utricle nearly oblong, about $1.5 \mathrm{~mm}$. long.

On cliffs, Maine and New Hampshire to Georgia and Tennessee.

\section{ANYCHIÁSTRUM Small.}

Annual or perennial mostly Anychia-like herbs, with finely pubescent or glabrous foliage. Stems branched at the base, the branches diffusely spreading or prostrate. Leaves opposite : blades narrow or as broad as long. Flowers in dichotomous cymes, inconspicuous. Bracts similar to the leaves. Calyx manifestly pedicelled. Sepals distinct or nearly so, merely cuspidate, erect. Stamens mostly 5 , inserted at the base of ovary. Styles relatively long, united to near the top. Utricle included. The plants flower during the summer and fall.

Annual or biennial : calyx pubescent.

Calyx becoming $2 \mathrm{~mm}$. long: sepals bristly pubescent.

Calyx becoming $1 \mathrm{~mm}$. long: sepals inconspicuously pubescent.

Perennial : calyx glabrous.

1. A. herniarioides.

2. A. Baldwinii.

3. A. riparium. 
1. Anychiastrum herniarioìdes (Michx.) Small. Annual or biennial, scabrouspubescent. Stems branched at the base, the branches spreading, 2-15 cm. long, forking, often numerous: leaves numerous; blades oblong to oval, 3-10 mm. long, mucronate, ciliate, sessile ; stipules acuminate : calyx bristly pubescent : sepals ovate, becoming 2 $\mathrm{mm}$. long, slightly hooded, minutely cuspidate : utricle conspicuously swelling the base of the calyx at maturity. [Paronychia herniarioides (Michx.) Nutt.]

In sandy soil, often on sand hills, North Carolina to Florida.

2. Anychiastrum Baldroinii (T. \& G.) Small. Annual or biennial, slender, minutely pubescent. Stems branched at the base, the branches prostrate, 1-4 dm. long, wiry, usually forked, sometimes filiform: leaves rather numerous; blades narrowly oblong or linear-elliptic, 8-20 mm. long, acute, ciliolate, sessile or nearly so ; stipules linear-lanceolate, 2-6 mm. long: sepals oval, about $1 \mathrm{~mm}$. long, slightly hooded, 3-ridged, ciliate, each abruptly narrowed into a short cusp: utricle equalling the sepals in length or slightly surpassing them. [Paronychia Baldwinii (T. \& G.) Chapm.]

In sandy soil, Georgia to Louisiana and Florida.

3. Anychiastrum ripàrium (Chapm.) Small. Perennial, very slender, glabrous or nearly so. Stems sparingly branched at the base, the branches prostrate, wire-like, 3-12 dm. long, widely forking; branchlets filiform: leaves few; blades oblong or linear-elliptic, 5-12 mm. long, acute, scarcely paler beneath than above, sessile; stipules short, soon lacerate : cymules open, terminating filiform branchlets : sepals ovate, about $1 \mathrm{~mm}$. long, slightly hooded, minutely cuspidate, glabrous : utricle obovoid, about as long as the sepals. [Paronychia riparia Chapm.]

In dry sand, along or near the Flint River, southwestern Georgia.

\section{ANÝCHIA Michx.}

Annual herbs, with slender forking stems. Leaves opposite : blades narrow or somewhat dilated. Flowers solitary or clustered in the forks. Calyx persistent. Sepals 5, greenish, distinct, barely mucronate on the back, nearly flat. Stamens 2-3, or rarely 5, included : filaments inserted at the base of the ovary. Styles very short : stigmas spreading. Utricle nearly as long as the calyx or exserted. Seed erect. The plants flower in the summer. Forked CHICKWEED.

Foliage glabrate : sepals oblong: utricle surpassing the calyx. Foliage pubescent : sepals ovate: utricle nearly as long as the calyx.

1. A. Canadensis.

2. A. dichotoma.

1. Anychia Canadénsis (L.) B.S.P. Annual, deep green, glabrous. Stems erect or ascending, $0.5-4 \mathrm{dm}$. tall, simple below, forking above, the branches filiform : leaf-blades thinnish, oblong to elliptic, $0.5-2 \mathrm{~cm}$. long, obtuse or acutish, short-petioled : cymes open : calyx nearly $1 \mathrm{~mm}$. long: sepals oblong, obtuse, slightly white-margined, hooded at the apex: utricle subglobose, slightly surpassing the calyx: seed lenticular, $1 \mathrm{~mm}$. broad. [A. dichotoma var. capillacea Torr.]

In open woods and on hillsides, Ontario to Minnesota, Massachusetts, Georgia and Arkansas.

2. Anychia dichótoma Michx. Annual, pale green, minutely pubescent. Stems erect or decumbent, $0.5-3 \mathrm{dm}$. long, forking, the branches often densely disposed, wiry : leafblades thickish, oblanceolate or linear-elliptic, $0.5-1.5 \mathrm{~cm}$. long, acute, sessile or nearly 8o: cymes rather dense: calyx $0.8-0.9 \mathrm{~mm}$. long: sepals ovate, acute, 3-ribbed, green, hooded at the apex : utricle obovoid, flat-topped, shorter than the calyx.

In dry soil, Maine to Minnesota, Florida, Alabama and Arkansas.

\section{ODONTONÝCHIA Small.}

Perennial caulescent herbs, with glaucous or finely pubescent foliage. Stems commonly tufted, erect or assurgent, corymbose above. Leaves opposite: blades somewhat fleshy, narrow. Flowers in dense terminal corymbose cymes. Calyx sessile, not urnshaped. Sepals 5, about as long as the hypanthium, erect, paler than the hypanthium. Stamens 5, included : filaments inserted on the margin of the hypanthium. Styles united to near the apex. Urticle included. The plants flower from spring to fall.

Foliage glaueous : hypanthium glabrous : sepals lanceolate or oblong-lanceolate. Foliage pubescent : hy panthium pubescent: sepals oblong or ovate-oblong.

1. O. erecta.

2. O. corymbosa.

1. Odontonychia erécta (Chapm.) Small. Perennial, stout, glaucous. Stem branched at the base, the branches tufted, erect, ascending or slightly decumbent, 1-4 dm. tall, usually simple below, forked above : leaf-blades linear, linear-oblanceolate, or the upper oblong, 1-3 cm. long, obtuse or acute, erect or ascending, sessile; stipules silvery, 
broadly lanceolate, about $\frac{1}{2}$ as long as the leaves: cymes corymbosely disposed : calyx 3 $\mathrm{mm}$. long. glabrous : sepals lanceolate or oblong-lanceolate, obtuse or acutish, slightly longer than the angled glabrous hypanthium : utricle about $1 \mathrm{~mm}$. in diameter. [Siphonychia erecta Chapm.]

In sand along the coast, Florida to Alabama.

2. Odontonychia corymbòsa Small. Perennial, stoutish, pubescent with recurved hairs. Stem branched at the base, the branches tufted, 1-3 dm. tall, erect or ascending, olivegreen or brownish, forking, especially above, ribbed, topped by the corymbosely disposed cymes : leaf-blades oblanceolate to oblong-oblanceolate, $0.5-1.5 \mathrm{~cm}$. long, acutish, ciliate, sessile; stipules ovate, silvery, long-acuminate: inflorescence silvery : calyx 2-2.2 mm. long: sepals oblong or ovate-oblong, white, longer than the pubescent hypanthium, obtuse, concave : utricle ovoid, $1 \mathrm{~mm}$. long. [Siphonychia corymbosa Small.]

In sand, Ship Island, Mississippi.

\section{SIPHONÝCHIA T. \& G.}

Annual or biennial herbs, with diffuse stems. Leaves opposite : blades fleshy, often deciduous. Flowers in rather dense dichotomous cymes. Calyx urn-shaped, sessile. Sepals 5, equalling the hypanthium, white-tipped, inflexed, obtuse or mucronate. Stamens 5, included: filaments inserted on the margin of the hypanthium. Styles mainly united. Utricle included. Seed resupinate. The plants flower from spring to fall.

Sepals narrowed to the apex: hypanthium broadly rounded at the base.

Sepals dilated at the apex: hypanthium narrowed at the base.

Hypanthium sparingly and inconspicuously pubescent: cymes many-flowered.

Hypanthium bristly pubescent: cymes few-flowered.

1. S. diffusa.

2. S. Americana.

3. S. pauciflora.

1. Siphonychia diffùsa Chapm. Annual, slender, minutely pubescent. Stems branched at the base, the branches wiry, spreading radially, prostrate, 1-6 dm. long, forking, the ultimate divisions ending in dense often rectangular cymes: leaf-blades oblanceolate or linear-oblanceolate, $0.5-1.5 \mathrm{~cm}$. long, acute, very hairy, sessile : hypanthium pubescent with hooked hairs at the base: flowers oblong-urceolate, $1.5 \mathrm{~mm}$. long: sepals ovate, slightly shorter than the hypanthium, white-margined, minutely cuspidate below the hooded apex : style included : utricle ovoid, less than $1 \mathrm{~mm}$. long.

In dry sandy soil, Florida to Alabama.

2. Siphonychia A mericàna (Nutt.) T. \& G.. Annual or biennial, slender, minutely pubescent. Stems branched at the base, the branches spreading radially, prostrate, $2-7$ dm. long, wiry, diffusely forking, pubescent in lines, the ultimate divisions ending in small dense cymes : leaf-blades linear-oblanceolate, or the upper spatulate, the basal much longer than the stem-leaves, $2-5 \mathrm{~cm}$. long, acute or acutish; stem-leaves $0.5-2 \mathrm{~cm}$. long, sessile : hypanthium inconspicuously pubescent with hooked hairs: flowers urn-shaped, 1.5-2 mm. long: sepals shorter than the hypanthium, the tips white, rounded, inflexed, minutely cuspidate on the back : style exserted : utricle ovoid, about $0.8 \mathrm{~mm}$. broad.

In sandy soil, South Carolina to Florida.

3. Siphonychia pauciflòra Small. Annual or biennial, minutely pubescent. Stems branched at the base, the branches spreading, prostrate, 1-6 dm. long, sparingly forked, the ultimate divisions ending in inconspicuous few-flowered cymes or the flowers sometimes solitary : leaf-blades spatulate to oblong-spatulate or linear-spatulate, $0.8-2 \mathrm{~cm}$. long, or shorter above, ciliolate : flowers urn-shaped, about $2 \mathrm{~mm}$. long : hypanthium bristly pubescent, narrowed at the base : sepals white or broadly white-margined, dilated at the apex, very minutely cuspidate on the back : style included : utricle $0.8 \mathrm{~mm}$. long.

In sand or sandy soil, Georgia and Florida.

\section{GIBBìsIA Small.}

Annual or biennial pubescent herbs. Stems erect, forking above, the ultimate divisions disposed in cymes. Leaves opposite: blades narrow. Cymes many-flowered, rather dense. Flowers inconspicuous, usually 3 together in an involucre and each one or only 2 of them seated in a hard clamp-like involucel. Hypanthium shorter than the sepals, ribbed. Calyx of 5 narrow erect sepals. Stamen on the margin of the hypanthium. Style long and slender.

1. Gibbesia Rugélii (Chapm.) Small. Foliage finely pubescent. Stem erect, rather slender, 1-5 dm. tall, forking, tinally diffuse : leaves few ; blades thickish, oblanceolate, or the upper linear-oblanceolate, 1-3 cm. long, acute, pubescent on both sides, ciliate, sessile : bracts linear-subulate, their stipules ovate, acutish or short-acuminate, denticulate : calyx 
$3 \mathrm{~mm}$. long, pubescent below the middle, erect in the whitish clamp-like involucel : sepals linear-subulate, acutish, erect, slightly involute: stamens included : style about equalling the sepals in length : utricle ovoid, tipped by the slender style : seed lenticular, about 1 mm. broad.

In sandy soil and on sand hills, southwestern Georgia and adjacent Florida. Summer and fall.

\section{Family 5. Petiveriàceat Link. Pokeweed Family.}

Shrubs, trees or shrubby herbs, often giving off an unpleasant odor. Leaves alternate: blades entire, or nearly so, often thickish. Inflorescence terminal or axillary, spicate or racemose. Flowers perfect or dioecious. Calyx of 4-5 equal or unequal, distinct or partially united imbricated sepals. Corolla wanting. Androecium of 4-8 stamens or rarely more. Filaments filiform or subulate, distinct or united. Anthers introrse. Gynoecium of a single carpel or of several united carpels. Ovary 1-several-celled, sessile. Stigmas various. Ovule solitary in each cavity, mostly erect. Fruit a berry or an achene. Seed usually erect, flattened. Testa membranous or crustaceous. Embryo curved around the mealy endosperm, or rarely straight. [Phytolaccaceae Lindl.]

Gynoecium of a single carpel : style single.

Fruit an achene: flowers in virgate spikes.

Fruit a berry : flowers in racemes.

Gynoecium of 2-many carpels: styles 2-many.

1. Petiveria.

2. RIVINA

3. Phytolacca.

\section{PETIVÈRIA L.}

Strong-scented shrubby plants, with erect stems. Leaves alternate : blades thickish, stipules small. Flowers perfect, in terminal wand-like spikes. Calyx herbaceous, shortpedicelled, the 4 sepals nearly equal, persistent and unchanged in fruit. Stamens 4-8: filaments filiform, unequal in length : anthers linear. Ovary 1-celled, elongated, flattened : stigma 2-lobed. Ovule amphitropous. Achene narrow, cuneate, surrounded by the persistent sepals, tipped with 1-6 subulate reflexed spines. Seed narrow, erect, with a membranous testa. Embryo nearly straight.

1. Petiveria alliàcea $\mathrm{L}$. An ill-smelling shrub $3-10 \mathrm{dm}$. tall with wand-like branches. Stems erect, closely pubescent : leaf-blades elliptic, elliptic-oblanceolate or obovate, 4-12 $\mathrm{cm}$. long, usually acute or abruptly acuminate, entire, undulate, sparingly pubescent on both sides or only hairy on the nerves, narrowed into short petioles : spikes virgate, 1-3 $\mathrm{dm}$. long, solitary or in pairs: calyx greenish or white, short-pedicelled: sepals linear, about $3 \mathrm{~mm}$. long, obtusish, spreading in flower, erect in fruit: stamens shorter than the sepals : achenes linear-cuneate, ribbed, about $6 \mathrm{~mm}$. long, twice as long as the persistent calyx, furnished with 1-6 reflexed spines at the apex, appressed to the rachis.

In woods and thickets, peninsular Florida. Common in tropical America. Summer.

\section{RIVÌNA L.}

Glabrous or pubescent shrubby herbs, with erect branching stems. Leaves alternate : blades entire, undulate, or erose-crenate, with small caducous stipules. Flowers perfect, in slender, axillary or rarely terminal racemes. Calyx corolloid. Sepals 4 , about equal, usually broadened upward, unchanged in fruit. Stamens 4 : filaments filiform: anthers erect. Ovary 1-celled, subglobose, flattened: style rather lateral, curved : stigma capitate or 2lobed. Ovules amphitropous. Berry subglobose, flattened, with a thin fleshy pericarp. Seed erect, lenticular, with a smooth or wrinkled crustaceous testa. Embryo bent around the scant mealy endosperm.

1. Rivina hùmilis L. A shrubby herb, 3-7 dm. tall, with spreading branches and closely pubescent foliage. Leaf-blades thickish, ovate to lanceolate or oblong, 3-15 cm. long, acute or usually acuminate, undulate, acutish at the base, or truncate; petioles about $\frac{1}{3}$ as long as the blades: racemes loosely flowered, $310 \mathrm{~cm}$. long, peduncled: calyx rosecolored, 5- $6 \mathrm{~mm}$. broad, pubescent without: sepals cuneate or linear-cuneate, spreading, obtuse, more or less eroded at the apex: stamens erect or ascending, shorter than the sepals: berries subglobose, somewhat flattened, $2-3.5 \mathrm{~mm}$. in diameter, mostly red.

In woods and thickets, Arkansas to Florida and Texas. Also a native of the tropics. Spring and summer. 


\section{PHYTOLÁCCA L.}

Large perennial herbs or shrubs, with erect or climbing stems and glabrous foliage, except in the inflorescence. Leaf-blades entire, thickish. Stipules wanting. Flowers perfect or rarely dioecious, in terminal racemes, which become lateral by the prolongation of the stems: pedicels bracted, angled. Calyx herbaceous or slightly colored. Sepals 4-5, imbricated, not accrescent. Stamens 5-25, inserted at the base of the ovary, reduced to staminodia in the pistillate flowers : filaments filiform or subulate: anthers opening lengthwise. Ovary depressed, sessile, of 5-12 more or less united carpels : styles 5-12, distinct. Ovules campylotropous. Berry depressed, pulpy. Seeds reniform, flattened, with a shining testa. Embryo bent around the mealy endosperm.

1. Phytolacca decándra L. Perennial from a very large poisonous root, glabrous, except the racemes, bright green. Stem stout, erect, 1-3 m. tall, more or less branched, green or magenta, its pith in transverse plates: leaf-blades ovate, oblong or elliptic, 1-3 $\mathrm{dm}$. long, acute or short-acuminate, undulate, rather abruptly narrowed into the petiole : racemes puberulent or glabrate, somewhat drooping, 1-2 cm. long: pedicels pink, about 1 $\mathrm{cm}$. long, subtended by narrow lanceolate bracts, bearing several narrow scales: calyx white or greenish, rather flat: sepals obovate, $3 \mathrm{~mm}$. long, obtuse, somewhat hooded at the apex : berries spheroidal, $7-10 \mathrm{~mm}$. broad, dark purple, filled with a crimson juice.

Common, Maine to Minnesota. Florida and Texas. Summer and fall. Poke. InkBerry. Scoke. PigeON-BERRY.

\section{Family 6. BATIdàceat Dammer. Batis Family.}

Maritime shrubs, with erect or prostrate branching stems. Leaves opposite, fleshy, half-terete, linear or club-shaped, entire, sessile, without stipules. Flowers small, dioecious, in axillary cones. Staminate cones with persistent imbricated scales each subtending a flower: calyx cup-shaped, 2-lobed: stamens 4-5, inserted at the base of the calyx : filaments thick, alternating with staminodia: anthers introrse, the sacs attached to each other above the middle. Pi-tillate cones peduncled, 4-12-flowered, the scales deciduous: calyx and corolla wanting: stamens and staminoidia wanting: ovary sessile, 4-celled, stigma sessile, cushion-like, somewhat 2-lobed. Ovule 1 in each cavity, erect, anatropous. Fruit a fleshy aggregate from the pistillate inflorescence, 4-seeded. Seeds erect, club-shaped, slightly curved. Testa membranous. Endosperm wanting. Embryo shaped like the seed, with large cotyledons.

\section{Characters of the family.}

\section{BÀTIS L.}

1. Batis marítima L. A glabrous pale green strong-scented shrub, with spreading or prostrate stems $0.5-1.5 \mathrm{~m}$. long. Branches angled, often erect : leaves fleshy, half terete, curved, 1-2.5 cm. long, acutish : spikes $5-10 \mathrm{~mm}$. long, ovoid; staminate sessile; pistillate on peduncles $2-5 \mathrm{~mm}$. long: bracts reniform or suborbicular, often apiculate: calyx shorter than the bract: stamens 4-5, exserted, longer than the staminodia whose blades are triangular: fruit oblong or obovoid, 1-2 cm. long, short-stalked, drooping.

In sand along the coast and in salt marshes, North Carolina to Florida and Texas and through the tropics to northern South America. Also in the West Indies. SALT-WoRT.

\section{Family 7. ALLioniàceate Reichenb. Four-o'clock Family.}

Herbs, shrubs or trees, with branching or dichotomous-forking stems. Leaves alternate or opposite, without stipules: blades simple, entire or repand. Inflorescence various. Flowers regular, perfect, or sometimes unisexual, often subtended by a conspicuous involucre. Calyx usually corolla-like, campanulate, trumpet-shaped or rotate, usually deciduous above the ovary. Corolla wanting. Androecium of 1-many stamens. Filaments filiform, distinct or united at the base, often unequal in length. Anthers 2-celled, opening by longitudinal cracks. Gynoecium of a single carpel. Ovary 1-celled, superior, but surrounded by the calyx-tube, sessile or short-stalked. Style slender. Stigma usually capitate. Ovule solitary, erect, campylotropous. Fruit an anthrocarp, indehiscent, fleshy, leathery or hard, angled, ribbed or grooved. Seed erect, with a hyaline testa, 
which is free from or adnate to the pericarp. Endosperm variable. Embryo straight or curved.

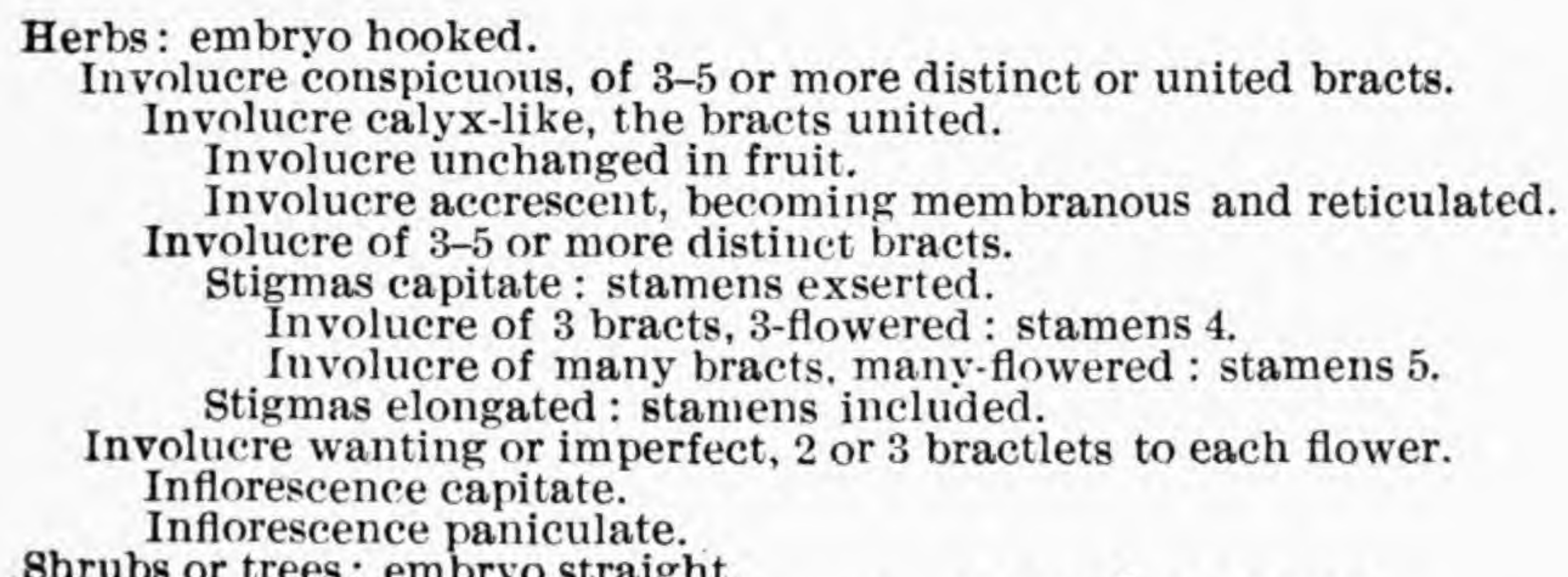

Shrubs or trees: embryo straight.

\section{MIRÁBILIS L.}

1. Mirabilis.

2. AliLionia.

3. WEDELIA.

4. NYCTAGINIA.

5. ABRoNia.

6. Acleisanthes.

7. BOERHAAVIA.

8. Pisonia.

Perennial glabrous or glandular herbs, with large tuberous-thickened roots and forking stems. Leaves opposite : blades somewhat fleshy, petioled, or the upper sessile. Flower solitary or many flowers in a 5-lobed calyx-like involucre. Calyx colored : tube elongated, constricted above the ovary : limb expanding, deciduous. Stamens 5-6, unequal in length : filaments filiform, very slender, incurved, united into a fleshy cup at the base. Style filiform. Fruit ribbed, leathery or parchment-like, glabrous or pubescent. Seed filling the pericarp to which the testa adheres. Endosperm mealy. Four-o' CLOCK.

Involucre 1-flowered.

Caly $\mathrm{x}$ 10-15 $\mathrm{cm}$. long ; tube long-tubular: plant viscid-pubescent.

Calyx $3-5 \mathrm{~cm}$. long; tube funnelform: plant not glandular.

Involucre $3-6$-flowered.

Calyx 4-6 $\mathrm{cm}$ long: involucre $1 \mathrm{~cm}$. long; lobes shorter than the tube.

Calyx 1.5-2 cm. long: involucre $1.5-2 \mathrm{~cm}$. long; lobes longer than the tube.

1. Mr. Wrightiana.

2. M. Jalapa.

3. M. multiflora.

4. M. coccinea.

1. Mirabilis Wrightiàna A. Gray. Foliage more or less viscid-pubescent. Stem erect, diffusely branched, 3-6 $\mathrm{dm}$. tall : leaf-blades ovate, acuminate, $4-10 \mathrm{~cm}$. long, glandular-pubescent on both sides, undulate, truncate or cordate at the base ; petioles less than $\frac{1}{2}$ as long as the blades : involucres campanulate, $8-9 \mathrm{~mm}$. high, densely glandular when young, 1-flowered; lobes lanceolate, acute: calyx tubular, trumpet-shaped, 10-15 cm. long, white or pink; lobes notched: stamens exserted : fruit ovoid, about $1 \mathrm{~cm}$. long, attenuate at the apex, pubescent, transversely wrinkled and longitudinally 5-ribbed.

Chiefly in valleys, Texas to Arizona. Spring to fall.

2. Mirabilis Jalápa L. Foliage deep green, glabrous or slightly pubescent. Stem erect, 3-7 dm. tall, much branched : leaf-blades ovate or sometimes as broad as long, longacuminate or short-acuminate, sometimes sparingly ciliate, entire, truncate or cordate at the base; petioles about $\frac{1}{2}$ as long as the blades: involucres campanulate, $7-8 \mathrm{~mm}$. high, pubescent, 1-flowered; lohes ovate-lanceolate, twice as long as the tube, acute, bristletipped: calyx trumpet-shaped, $3-5 \mathrm{~cm}$. long, deep red to purple or white, more or less blotched, the edge notched : stamens exserted: fruit ovoid, black, $8-10 \mathrm{~mm}$. long, wrinkledtuberculate, 5-ribbed.

On plains and prairies, Texas, through Mexico to Central and South America. Spring and summer.

3. Mirabilis multiflòra (Torr.) A. Gray. Foliage more or less pubescent. Stem diffusely branched, 3-7 dm. tall, the branches often stout : leaf-blades broadly ovate or deltoid, commonly as broad as long, $3-8 \mathrm{~cm}$. long, acutish or slightly acuminate, undulate, rounded or subcordate at the base; petioles less than $\frac{1}{2}$ as long as the blades: involucres campanulate, $1.5-2 \mathrm{~cm}$. long, usually 6 -flowered, minutely pubescent; lobes ovate, shorter than the tube, acute : calyx purplish or pink, 4-6 $\mathrm{cm}$. long, trumpet-shaped : fruit oval, 7-8 $\mathrm{mm}$. long, obtuse at each end, slightly ribbed.

In valleys, Colorado to Texas and California. Spring to fall.

4. Mirabilis coccínea (Torr.) Benth. \& Hook. Foliage nearly glabrous, except in the inflorescence, glaucous. Stems sometimes tufted, $2-5 \mathrm{dm}$. tall, forked, very finely striate : leaf-blades narrowly linear, 4-7 cm. long, acute, involute, ciliate or glabrate : involucres about $1 \mathrm{~cm}$. broad, pilose ; lobes ovate, acute or short-acuminate, usually 3 -flowered : calyx crimson, trumpet-shaped, $1.5-2 \mathrm{~cm}$. long, sparingly pubescent; tube gradually enlarged; lobes of its limb notched: stamens mostly 3 , about as long as the caly $\mathrm{x}$ : ovary pubescent, strongly ribbed : fruit oblong or slightly broadened upward, 5-6 mm. long, with rough or tuberculate prominent ridges.

On plains and prairies, southern Texas to New Mexico and Mexico. Spring. 


\section{ALLIÒNIA Loefl.}

Perennial glabrous or glandular herbs, with forking stems. Leaves opposite : blades fleshy, drying very brittle. Flowers 1-5 in an involucre, white, pink or scarlet. Involucre accrescent, usually conspicuously nerved, with 5 lobes. Calyx often oblique, campanulate or infundibuliform: tube constricted above the ovary: limb erect or spreading, plicate, deciduous. Stamens 2-5, unequal in length : filaments filiform, very slender, rolled in, united into a cup at the base. Style filiform. Fruit club-shaped to spindleshaped or obovoid, ribbed or terete, glabrous or pubescent. Seed shaped like the pericarp to which its testa adheres. Endosperm mealy. [Oxybaphus L'Her.] Umbrella-wort.

Fruit glabrous : involucres 2-3-flowered.

Fruit pubescent : involucres 3 -5-flowered.

Leaf-blades linear, oblong, lanceolate or ovate, sessile or only the lower ones with short petiole-like bases.

Involucres on solitary axillary peduncles.

Involucres in terminal cymes.

Stems glabrous, at least below, not hirsute, but often puberulent above.

Bracts of the inflorescence numerous, often conspicuously so: upper leaves much reduced and resembling the bracts.

Bracts of the inflorescence not numerous: upper leaves not conspicuously reduced.

Leaves with narrowly linear blades less than $5 \mathrm{~mm}$. broad.

Leaves with obovate to ovate, oblong or linear-lanceolate blades mostly over $5 \mathrm{~mm}$. broad.

Calyx pink: leaf-blades thick, blunt.

Caly $x$ white : leaf-blades thin, acute or acuminate.

Stems more or less hirsute as well as viscid.

1. A. Texensis,

2. A. decumbens.

3. A. bracteosa.

4. A. linearis.

5. A. lanceolata.

6. A. albida.

7. A. pilosa.

Leaf-blades cordate to broadly ovate-lanceolate, or rarely broadly lanceolate, distinctly petioled.

Leaves with ovate or ovate-lanceolate blades rounded or cuneate at the base. Stems usually copiously hirsute.

Stems glabrous or sometimes merely puberulent above.

Involucres less than $1 \mathrm{~cm}$. broad at maturity: leaf-blades mostly cuneate at the base.

Involucres over $1 \mathrm{~cm}$. broad at maturity : leaf-blades mostly rounded at the base.

Leaves, at least those on the lower part of the stem, with cordate blades.

\section{A. comata.}

9. A. oblongifolia.

10. A. floribunda.

11. A. nyctaginea.

1. Allionia Texénsis (Coulter) Small. Stems rather slender, glabrous, more or less branched, several dm. tall : leaf-blades ovate, $2-7 \mathrm{~cm}$. long, obtuse or rounded at the apex, undulate, rounded or subcordate at the base; petioles $\frac{1}{3}-\frac{1}{4}$ as long as the blades: involucres crisped, about $8 \mathrm{~mm}$. broad, 2-3-flowered; lobes broadly ovate, longer than the tube, acute, ciliate : calyx $2-3 \mathrm{~mm}$. broad, pubescent : fruit tuberculate along the ribs, glabrous. [A. corymbosa var. Texensis Coulter.]

In and near the valley of the Rio Grande, Texas. Summer and fall.

2. Allionia cecúmbens (Nutt.) Rydb. Foliage sparingly pubescent, at least when young. Stems decumbent or ascending, $2-8 \mathrm{dm}$. tall, simple and tufted, or sometimes branched above, the sides pubescent, or glabrous in age: leaf-blades oblong to linear-lanceolate, or rarely oblong-lanceolate, $2-11 \mathrm{~cm}$. long, thick, sometimes slightly acuminate, but rather blunt, ciliate, narrowly cuneate at the base, essentially sessile : involucres terminating solitary axillary peduncles, $1.5-2 \mathrm{~cm}$. wide; lobes acute or acutish or rarely rounded: calyx sparingly pubescent, about $3 \mathrm{~mm}$. hroad : fruit narrowly obovoid, 5-6 mm. long, with prominent ribs and tubercled faces.

In dry or sandy soil, Missouri to Mississippi and New Mexico. Spring and summer.

3. Allionia bracteòsa Rydb. Foliage, at least that of the upper parts and the inflorescence, viscid-puberulent. Stems erect or ascending, 4-13 dm. tall, with several or many ascending or spreading branches above : leaf-blades oblong to linear-lanceolate or linear, 3-9 $\mathrm{cm}$. long, blunt or acutish, thick, mostly ciliate, each narrowed to the essentially sessile base: involucres often numerous, disposed in terminal cymes, 10-14 mm. wide; lobes ovate, obtuse : calyx white or pale, about $10 \mathrm{~mm}$. broad: fruit oblongobovoid, 5-5.5 mm. long, prominently 8-ribbed, apiculate, constricted near the base.

In dry and rocky soil, South Dakota to Missouri and Alabama. Summer and fall.

4. Allionia lineàris Pursh. Foliage glabrous, or glandular-pubescent above. Stems slender, 3-15 dm. tall, terete, or 4-angled below : leaf-blades thick, linear, $2.5-10 \mathrm{~cm}$. long, acute, undulate, sessile, or the lower sometimes short-petioled : involucres becoming $1.5 \mathrm{~cm}$. broad; lobes broadly ovate, obtuse, about as long as the tube: calyx finely pubescent, campanulate, purple; lobes ovate : stamens and style exserted : fruit oblong-obovoid, $5 \mathrm{~mm}$. long, 5-ribbed, the faces tuberculate, pubescent.

In dry soil, Minnesota to Texas, Utah and Mexico. Spring and summer. 
5. Allionia lanceolàta Rydb. Foliage glabrous or nearly so to the inflorescence. Stems erect or ascending, 4-17 dn. tall, simple or sparingly branched above, or throughout, sometimes finely pubescent on the sides : leaf-blades lanceolate to linear-lanceolate, or rarely oblong to oblong-obovate, $3-15 \mathrm{~cm}$. long, thick, obtuse or blunt, even the narrow and more or less acuminate ones with blunt tips, slightly undulate or crisped, ciliolate, essentially sessile : involucres in terminal cymes, 1-1.5 cm. wide ; lobes rounded or acutish : calyx pink, about $10 \mathrm{~mm}$. broad: fruit obovoid, $4.5-5 \mathrm{~mm}$. long, with usually 4 broad ribs and finely tubercled faces.

On plains and prairies and in dry sandy soil, Minnesota to Tennessee, South Carolina, Alabama, Texas and Colorado. Summer and fall.

6. Allionia álbida Walt. Foliage glabrous, except the viscid-pubescent inflorescence and upper part of the stem. Stems 2-12 dm. tall, 4-angled below, enlarged at the nodes : leaf-blades lanceolate to oblong-lanceolate or oblong, 3-12 $\mathrm{cm}$. long, thin, acute or acuminate at the apex, attenuate to the petiole-like base, nearly sessile: involucres becoming $2 \mathrm{~cm}$. broad; lobes triangular, about as long as the tube: calyx pubescent, white; lobes ovate, shorter than the tube: stamens and style exserted : fruit obovoid, $5 \mathrm{~mm}$. long, with tufts of silvery hairs, the angles crested, the faces tuberculate. [Oxybaphus albidus (Walt. ) Chois.]

In dry soil, South Carolina and Georgia. Spring and summer.

7. Allionia pilòsa (Nutt.) Rydb. Foliage finely hirsute. Stems erect or somewhat spreading, 3-12 dm. tall, sometimes sparingly branched, more or less hirsute as well as visoid : leaf-blades oblong-ovate to lanceolate or narrowly lanceolate, $2-9 \mathrm{~cm}$. long, sometimes slightly acuminate but blunt, thick, often slightly crisped, cuneately narrowed at the base, essentially sessile: involucres in terminal cymes, $1.5-2 \mathrm{~cm}$. broad; lobes acute or acutish : calyx about $10 \mathrm{~mm}$. broad : fruit narrowly obovoid, $4.5-5.5 \mathrm{~mm}$. long, with usually 5 slender ridges and transversely rugose-tuberculate faces.

In dry or sandy soil, Wisconsin to South Dakota, Louisiana and Texas. Summer and fall.

8. Allionia comàta Small. Foliage hirsute or hirsute-pilose. Stems 3-6 dm. tall, angled, the hairs viscid, somew hat tangled : leaf-blades thick, ovate or broadly ovate, $2-5$ $\mathrm{cm}$. long, usually rounded at both ends or cordate at the base, undulate; petioles shorter than the blades: inflorescence viscid: involucres becoming fully $1 \mathrm{~cm}$. broad, copiously pubescent : calyx glabrous or nearly so, pale red, about $2 \mathrm{~cm}$. broad; lobes shorter than the tube: stamens and style exserted : fruit slightly broadened upward, minutely pubescent.

In dry soil, Nebraska to Texas and New Mexico. Summer.

9, Allionia oblongifòlia (A. Gray) Small. Foliage glabrous or nearly so. Stems erect, or ascending, 8-12 dm. tall, with elongated ascending branches: leaf-blades ovatelanceolate to broadly lanceolate, $3-7 \mathrm{~cm}$. long, acute, more or less crisped, glabrous or nearly so, cuneately or abruptly narrowed into the relatively slender petioles: involucres in open paniculate cymes, terminating slender peduncles $5-7 \mathrm{~mm}$. long, relatively small, less than $1 \mathrm{~cm}$. broad; lobes ovate or orbicular-ovate, obtuse or acutish : caly x white. [Oxybaphus nyctagineus $\gamma$ oblongifolius A. Gray.]

In river valleys, southern Texas. Summer.

10. Allionia floribúnda (Chois.) Rydb. Foliage glabrous below. Stems 3-9 dm. tall, stoutish, swollen at the nodes : leaf-blades ovate to lanceolate, $2-5 \mathrm{~cm}$. long, obtuse, acute or acuminate, entire, rounded or acutish at the base, short-petioled : inflorescence pubescent : involucres finally more than $1.5 \mathrm{~cm}$. broad, glabrate; lobes triangular, longer than the tube : calyx pubescent without, usually white : fruit obovoid, constricted near the base, $4 \mathrm{~mm}$. long, minutely pubescent, with stout prominent crested ridges.

In dry soil, Nebraska to Texas and New Mexico. Summer.

11. Allionia nyctagínea Michx. Foliage glabrous or minutely pubescent. Stems $3-10 \mathrm{dm}$. tall, stoutish, forking : leaf-blades triangular-ovate, $2-10 \mathrm{~cm}$. long, acute or acuminate, erose, obtuse or cordate at the base; petioles $1-2 \mathrm{~cm}$. long : inflorescence pubescent : involucres campanulate, $1.5 \mathrm{~cm}$. broad, pubescent; lobes ovate to triangular, shorter than the tube: calyx red, hairy without; lobes oblong to ovate, shorter than the tube: stamens 3-5, exserted: fruit linear-oblong to oblong-ovate, $4 \mathrm{~mm}$. long, pubescent, sharply but shallowly ridged, the faces minutely tuberculate.

In dry soil, Northwest Territory to Wisconsin, Louisiana and New Mexico. Spring and summer.

\section{WEDËLIA Loefl.}

Annual or perennial depressed pubescent herbs, with forking stems. Leaves opposite : blades unequal in size, inequilateral, entire, petioled. Flowers white or pink, 3 in each involucre. Involucres calyx-like, solitary in the axils, peduncled, the bracts unequal. Calyx membranous : tube oblique, constricted above the ovary : limb expanded, unequally 
4-lobed. Stamens 4, exserted: filaments very slender. Ovary 1-celled: style filiform: stigma capitate. Fruit leathery, with a firm margin-like wing, smooth on one side, with two rows of tubercles on the other. Seed filling the pericarp to which its testa adheres. Endosperm mealy.

1. Wedelia incarnàta L. Foliage viscid-pubescent. Stem more or less diffusely branched at the base, the branches prostrate, 1-5 dm. long, forking : leaf-blades thickish, ovate to oblong, 1-3 cm. long, obtuse or acute, undulate; petioles slender, those on the lower part of the plant often longer than the blades, those above shorter: bracts of the involucre oval or orbicular, 4-6 mm. long, concave, reticulated, ciliate : calyx rose to white, $5-6 \mathrm{~mm}$. long; lobes emarginate : stamens shorter than the calyx : fruit $3-4 \mathrm{~mm}$. long.

In valleys, Texas to Arizona and Mexico. Also through tropical America to South America. Spring to fall.

\section{NYCTAGÍNIA Chois.}

Annual depressed glandular-hirsute herbs, with forking stems. Leaves opposite: blades shallowly toothed, more or less triangular in outline, petioled. Flowers pink or red, many in the many-bracted involuere, which is not acerescent. Calyx slender : tube elongated, constricted above the ovary : limb spreading, 5-lobed, deciduous. Stamens 5, unequal in length : filaments very slender, pubescent, dilated and united below. Style very slender : stigma capitate. Fruit leathery, many-ribbed, top-shaped. Seed filling the pericarp to which it adheres. Endosperm mealy.

1. Nyctaginia capitàta Chois. Foliage viscid-pubescent. Stem erect or decumbent, 3-7 dm. long, simple or branched at the base, forking above: leaf-blades thick, ovate to triangular, usually acuminate, undulate, rounded, truncate or subcordate at the base, bracts of the involucre 8-12, linear-lanceolate, 10-20 mm. long, acuminate: flowers 8.15 in an involucre: calyx red, villous with glandular hairs without, $2.5-3 \mathrm{~cm}$. long : fruit turbinate, 5-6 mm. long, many-ribbed.

In dry soil, Texas and New Mexico to Mexico. Spring to fall.

\section{ABRÒNIA Juss.}

Annual or perennial viscid-pubescent herbs, with forking stems. Leaves opposite: blades unequal, thick, entire, petioled. Flowers usually numerous, in many-bracted involucres. Involucres not accrescent. Calyx colored: tube elongated, constricted above the ovary : limb spreading, 5-lobed, deciduous. Stamens 3-5, unequal in length: filaments very slender. Style filiform : stigma elongated. Fruit leathery, ribbed or winged. Seed filling the pericarp to which it adheres. Endosperm mealy.

Annual : fruit $2-2.5 \mathrm{~cm}$. broad, with $2-4$ suborbicular or oval wings. Perennial: fruit 5-6 mm. broad, obpyramidal, with 4 wing-like ridges.

1. A. cycloptera. 2. A. fragrans.

1. Abronia cyclóptera A. Gray. Annual, stoutish, glabrous below, viscid-pubescent above. Stem erect or ascending, 2-6 dm. long, sparingly branched : leaf-blades oblong, oval or ovate, obtuse or acutish at the apex, undulate, rounded or acutish at the base ; petioles as long as the blades or shorter : bracts of the involucre lanceolate or ovate-lanceolate, acute : flowers crowded in a head : calyx bright pink, about $2 \mathrm{~cm}$. long; tube gradually enlarged upward: fruit conspicuous, $2-2.5 \mathrm{~cm}$. broad, the $2-4$ thin membranous wings sharply nerved, completely surrounding the achene, suborbicular to oval in outline.

In dry places, Texas to New Mexico. Summer.

2. Abronia fràgrans Nutt. Perennial, viscid-pubescent. Stem erect or decumbent, 3-8 dm. long, more or less branched: leaf-blades oblong, oval or ovate, 5-10 cm. long, rounded at both ends or rarely acute; petioles as long as the blades or shorter: bracts of the involucre membranous, white, ovate to obovate: flowers fragrant, nocturnal, numerous in each involucre: caly $\mathrm{x}$ white, $1-2 \mathrm{~cm}$. long; tube gradually enlarged upward : fruit nearly $1 \mathrm{~cm}$. long, minutely pubescent, resembling the mature calyx of Physalis but inverted, 5-winged, the wings not prolonged over the top, coarsely wrinkled.

In dry soil, Montana to Nebraska, Texas and Mexico. Summer.

\section{ACLEISÁNThes A. Gray.}

Perennial pubescent herbs or shruoby plants, with forking stems. Leaves opposite, thick: blades unequal, entire, petioled. Flowers often solitary, subtended by minute bracts, axillary or terminal. Caly $\mathrm{x}$ white: tub? elongated, constricted above the ovary : 
limb spreading, 5-lobed. Stamens 2-5, unequal: filaments very slender, united into a cup at the base. Style filiform : stigma peltate. Fruit 5-angled or 5-ribbed, constricted under the apex. Seed filling the pericarp to which its testa adheres. Endosperm mealy.

Calyx-tube over $11 \mathrm{~cm}$. long : leaf-blades acuminate.

Caly $x$-tube less than $6 \mathrm{~cm}$. long: leaf-blades obtuse or merely acute.

Stems copiously scabrous-pubescent or puberulent: leaf-blades gradually or abruptly narrowed at the base.

Leaf-blades barely ciliolate: fruit about $4 \mathrm{~mm}$. thick, not ribbed.

Leaf-blades conspicuously ciliolate: fruit about $3 \mathrm{~mm}$. thick, strongly ribbed.

Stems smooth and glabrous, or nearly so: leaf-blades truncate or cordate at the base.

1. A. longiflora.

1. Acleisanthes longiflòra A. Gray. Stems more or less branched at the base, the branches slender, glabrous, trailing, 2-6 dm. long, forking: leaf-blades thickish, lanceolate to rhombic-lanceolate, $1-2.5 \mathrm{~cm}$. long, acute or acuminate at the apex, acute to rounded at the base, short-petioled : calyx white or nearly so, 12-15 cm. long : fruit 8-10 mm. long, with a constriction above the base and thence slightly narrowed.

In sandy soil, Texas and New Mexico. Spring to fall.

2. Acleisanthes crassifolia A. Gray. Stems stoutish, scabrous-pubescent, sparingly branched, several dm. long: leaf-blades thick, ovate, 1-3 cm. long, acute, undulate, mostly rounded at the base, scabrous on both sides; petioles $\frac{1}{2}$ as long as the blades or shorter: calyx white, 4-5 cm. long : fruit oblong-oval, 6-7 mm. long, obtusely 4-angled, not ribbed, densely scabrous-pubescent.

In dry soil, along and near the Rio Grande, Texas. Summer and fall.

3. Acleisanthes Wrightil (A. Gray) Benth. \& Hook. Stems branched at the base, the branches scabrous-pubescent, spreading, 1-5 dm. long, forking: leaf-blades thickish, ovate, oval or ovate-lanceolate, 1-4 cm. long, obtuse or acutish, undulate, acute or rounded at the base, nearly sessile, or petioles $\frac{1}{2}$ as long as the blades: calyx 4-5 cm. long: fruit 6-7 mm. long, strongly 5-ribbed, each rib ending in a knob.

On stony plains or prairies, southern Texas. Spring and summer,

4. Acleisanthes Berlandièri A. Gray. Stems slender, glabrous or puberulent near the nodes, more or less diffusely branched, the branches prostrate or spreading, 1-4 dm.long : leaf-blades deltoid-ovate, $1.5-6 \mathrm{~cm}$. long, about as broad, rounded and apiculate at the apex, truncate to cordate at the base, the petioles often as long as the blades: flowers fragrant : calyx white, $4-5 \mathrm{~cm}$. long.

In dry soil, southern Texas and northern Mexico. Summer and fall.

\section{BOERHAàvIA L.}

Slender, often diffuse, glabrous pubescent or glandular herbs, with forking stems. Leaves opposite : blades unequal, thickish, entire or undulately toothed. Flowers very small, variously disposed, subtended by minute bracts, on jointed pedicels. Calyx campanulate or funnelform : tube short or elongated: limb often spreading, 5-lobed, deciduous. Stamens 1-5, exserted : filaments very slender, united at the base. Ovary oblique : style filiform: stigma peltate. Fruit club-shaped to obovoid, 5-10-ribbed. Seed filling the pericarp to which it adheres.

Leaf-blades linear to lanceolate: calyx-limb rotate.

Stamens 3: calyx-limb 6-8 mm. broad.

Stamens 5: calyx-limb 12-14 mm. broad.

Leaf-blades deltoid or broadly oblong : caly $x$-limb campanulate.

Fruit rounded at the apex.

Fruit shallowly grooved.

Fruit deeply gronved.

Leaves with like-colored surfaces.

Leaves white beneath.

Fruit flat at the apex.

1. B. tenuifolia.

2. B. linearifolia.

3. B. decumbens.

4. B. hirsuta.

5. B. viscosa.

6. B. erecta.

1. Boerhaavia tenulfòlia A. Gray. Annual or biennial, very slender, glabrous below, glandular-pilose above. Stem more or less branched at the base, the branches prostrate or spreading, 4-10 dm. long, forking, wire-like, rigid : leaf-blades linear-lanceolate, 1-3 cm. long, acute, strongly revolute, glabrous or glabrate, sessile or nearly so: peduncles slender: calyx sparingly pubescent ; limb rotate, 6-8 $\mathrm{mm}$. broad : stamens 3 , exserted : fruit oblong-clavate, $3 \mathrm{~mm}$. long, glabrous, strongly $\tilde{o}$-ribbed, rounded at the apex.

In arid places, Texas. Spring to fall. 
2. Boerhaavia linearifòlia A. Gray. Perennial, slender, puberulent, hirsute and more or less glandular. Stem diffusely branched at the base, the branches erect or ascending, 3-9 dm. long: leaf-blades linear to lanceolate, $1-3 \mathrm{~cm}$. long, acute or acutish, usually revolute, rounded or subcordate at the oblique base, short-petioled : peduncles slender: calyx purple; tube glabrous or nearly so ; limb rotate, $12-14 \mathrm{~mm}$. broad : stamens 5 , exserted : fruit oblong-clavate, $3 \mathrm{~mm}$. long, 5-ribbed, rounded at the apex, glabrous.

In arid places, Texas and New Mexico to Mexico. Spring and summer.

3. Boerhaavia decúmbens Vahl. Perennial, glabrous or nearly so. Stem branched at the base, the branches decumbent, 4-11 dm. long: leaf-blades ovate, 2-4 cm. long, rounded at the apex, strongly undulate, ciliate, whitish beneath, rounded or subcordate at the base; petioles $\frac{1}{2}$ as long as the blades or shorter : peduncles filiform, loosely spreading : calyx purple; tube glandular; limb campanulate, nearly $1 \mathrm{~mm}$. high, glabrous or nearly so : stamens exserted: fruit club-shaped, about $3 \mathrm{~mm}$. long, 5-angled, glandular-pilose, obtuse at the apex.

In dry soil, Florida to Texas, New Mexico and Mexico. Spring to fall.

4. Boerhaavia hirsùta L. Annual or biennial, minutely pubescent and more or less hirsute above. Stem branched at the base, the branches diffusely spreading, 6-12 dm. long : leaf-blades ovate to oblong-ovate, $2-8 \mathrm{~cm}$. long, acute or obtuse, and mucronate, ciliate, undulate, both surfaces of almost the same color, the base rounded or truncate, or that of the upper ones acute; petioles $\frac{1}{2}$ as long as the blades or shorter: peduncles wire-like : calyx pink or purplish ; tube glandular-pubescent ; limb campanulate, $1.5 \mathrm{~mm}$. high, glabrous or sparingly pubescent: stamens exserted : fruit obpyramidal, $3 \mathrm{~mm}$. long, the ribs glandular, the top rounded. to fall.

In dry soil, peninsular Florida and southern Texas to Mexico. Also in tropical America. Spring

5. Boerhaavia viscòsa Lag. \& Rodr. Annual or biennial, stout, with viscid pilose hairs or puberulent. Stem widely branched at the base and throughout, the branches spreading in all directions : leaf-blades ovate to oblong, $2-4 \mathrm{~cm}$. long, obtuse or mucronate, or acute, undulate, rounded or obtuse at the base, whitish beneath, becoming glabrous; petioles $\frac{1}{2}$ as long as the blades or shorter : peduncles slender : calyx pink or purple-pink, glandular; limb campanulate, 1-1.5 mm. long : stamens 3, exserted : fruit club-shaped, 3-3.5 mm. long, acutish.

In sandy soil, peninsular Florida. Also in tropical America. Summer and fall.

6. Boerhaavia erécta L. Annual or perennial, roughish pubescent or glabrous. Stem simple below, erect or ascending, or branched at the base, the branches decumbent or spreading, 3-12 dm. long : leaf-blades ovate to deltoid-ovate, sometimes inequilateral, 2-8 $\mathrm{cm}$. long, acute or obtuse and apiculate, repand or undulate, varying from acute to cordate at the base, minutely black-dotted on the lower whitish surface ; petioles usually about $\frac{1}{2}$ as long as the blades or longer: peduncles filiform : flowers 2-6 in a cluster : calyx white to purple; tube glabrous; limb campanulate, $1-1.5 \mathrm{~mm}$. long, sparingly pubescent: stamens exserted : fruit obpyramidal, $3.5-4 \mathrm{~mm}$. long, 5-angled, the grooves transversely wrinkled, the top flat.

In dry soil, South Carolina to Texas, south to Florida and Mexico. Also in tropical America. Spring to fall.

\section{PISÒNIA L.}

Tropical shrubs or trees, with erect or partly climbing armed or unarmed stems. Leaves opposite or alternate, without stipules: blades entire. Flowers perfect, dioecious or rarely monoecious, small, green or yellow, in pedunculate compound cymes: pedicels bracteolate, subtended by small bractlets. Calyx campanulate, tubular or funnelform, accrescent: limb 5-lobed or 5-toothed, erect or spreading. Stamens 5-30, usually $5-8$, inserted on the base of the calyx or under the ovary : filaments filiform, distinct or united at the base, exserted, unequal : anthers introrse. Style stoutish, terminal or nearly so: stigma capitate, radiate or fimbriate. Fruit angled or ribbed, sometimes with rows of glands.

Fruit with 5 rows of glands.

Plant spiny : leaf-blades acute or short acuminate: fruit glandular from the base to the apex.

Plant unarmed : leaf-blades blunt or retuse: fruit glandular above the middle.

1. P. aculeata.

Fruit without glands.

Leaf-blades glabrous : fruit not constricted under the apex.

Leaf-blades copiously pubescent: fruit constricted under the apex.

2. $P$. rotundata.

3. P. obtusata.

4. P. Floridana.

1. Pisonia aculeàta L. A shrub, 1-2 m. tall, with widely spreading branches, spine-armed. Leaf-blades elliptic, oval or ovate, $2.5-5 \mathrm{~cm}$. long, acute or short acumi- 
nate, glabrous, short-petioled : cymes many-flowered, the divisions copiously pubescent : calyx yellow, that of the pistillate flowers with short ovate lobes: fruit club-shaped, $8-9 \mathrm{~mm}$. long, slender-pedicelled, 10-ridged, with 5 rows of glands from the base to the apex.

In hammocks, Florida Keys. Also in the West Indies.

2. Pisonia rotundàta Griseb. A shrub or small tree, with very irregular branches, unarmed. Leaf-blades oval, broadly obovate or oblong, $2.5-5 \mathrm{~cm}$. long, rounded or retuse at the apex, glabrous, rounded or rarely cuneate at the base, short-petioled : cymes manyflowered, the divisions glabrous or nearly so: calyx pinkish, that of the pistillate flowers with short ovate lobes : fruit club-shaped, $6-\overline{7} \mathrm{~mm}$. long, not ridged, with 5 rows of glands above the middle.

In woods, Florida Keys. Also in the West Indies.

3. Pisonia obtusàta Sw. A shrub or small tree, with smooth and glabrous foliage, more or less irregular branches, unarmed. Leaf-blades spatulate to oval, $2-4 \mathrm{~cm}$. long, blunt or notched at the apex, glabrous; petioles slender, relatively long (5-15 $\mathrm{mm}$.): cymes rather few-flowered : calyx pale, that of the pistillate flowers with ovate or lanceolate lobes : fruit oblong or elliptic, glandless, about 4-7 mm. long, 10-ribbed at the base.

In woods, peninsular Florida and the Keys. Also in the West Indies and tropical America.

4. Pisonia Floridàna Britton. A low shrub, with more or less gnarled branches, unarmed. Leaf-blades spatulate, $2-3 \mathrm{~cm}$. long, rounded at the apex, copiously pubescent, slender-petioled : cymes relatively few-flowered, the divisions finely pubescent : calyx pale, that of the pistillate flowers with ovate lobes: fruit narrowly urn-shaped, 6-7 $\mathrm{mm}$. long, somewhat constricted under the apex, delicately nerved.

Among lime rocks, Rock Key, Florida.

\section{Family 8. TETRAgOniÀceat Reichenb. Carpet-weed Family.}

Annual or perennial herbs, with a watery sap and usually succulent tissues. Stems often branched at the base, the branches radiating, sometimes creeping. Leaves mostly opposite or apparently whorled : blades simple. Flowers perfect, polygamous or unisexual, regular. Calyx of 4-5 sepals. Corolla wanting (in our genera). Androecium of 4-5 hypogynous or perigynous stamens or sometimes fewer or more numerous. Anthers 2-celled. Gynoecium of 2 or several united carpels. Ovary 2-many-celled or 1-celled by suppression, superior, or somewhat inferior. Styles or stigmas as many as there are cavities in the ovary. Ovules 1 or many. Fruit a circumscissile or loculicidal capsule, or rarely berrylike or nut-like. Seeds solitary or many. Endosperm copious. Embryo curved, near the surface.

Ovary superior.

Hypanthum wanting or nearly so: capsule loculicidal.

Stamens 3-5: seeds estrophiolate, with short straight funiculi.

Stamens 5-10: seeds strophiolate, with elongated coiled funiculi. Hypanthium manifest, cylindric, turbinate or campanulate: capsule circumscissile.
Stipules present : ovary 2-celled or 1-celled by suppression.

Sepals unappendaged: stamens $1-3$.

Sepals appendaged : stamens 5-10.

Ovary partly inferior.

1. Moliugo.

2. GLINUS.

3. CYPSELEA.

4. TRIANTHEMA.

5. SEsuvium.

6. Tetragonia.

\section{MOLLÙGO L.}

Annual herbs, with erect stems or radially spreading branches, and glabrous or pubescent foliage. Leaves basal and cauline, alternate or apparently whorled, with hyaline stipules. Flowers perfect, in axillary clusters, cymes or racemes, pedicelled, usually white. Sepals 5, with hyaline margins, persistent. Disk annular or wanting. Stamens 3 , opposite the angles of the ovary, or 5 and alternate with the sepals : filaments filiform or rather subulate. Ovary 3-5-celled, superior: styles 3, distinct: stigmas entire. Capsule subglobose or oblong, 3-5-valved. Seeds few or numerous, estrophiolate, with short straight funiculi : aril wanting or inconspicuous. INDIAN CHICKWEED.

Blades of the stem-leaves narrowly linear: seeds finely reticulated.

Blades of the stem-leaves broadened upward: seeds $3-5$-ribbed.

1. M. Cerviana.

2. M. verticillata.

1 Mollugo Cerviàna (L. ) Seringe. Foliage glabrous or nearly so. Stems filiform or nearly so, $520 \mathrm{~cm}$. tall, much branched, terete: leaves glaucous, various; basal in a more or less persistent whorl, spatulate; those of the stem narrowly linear or the upper ones reduced to scales: flowers in whorls on the lower part of the stem, in delicate panicles above : pedicels capillary : sepals oblong to ovate, fully $1 \mathrm{~mm}$. long at maturity, each 
with a green midnerve and a reticulation of green secondary nerves : capsule subglobose, $1.5-2 \mathrm{~mm}$. in diameter : seeds finely reticulated.

On wet or dry plains or prairies, Texas to California and Mexico. Also widely distributed in temperate and tropical regions. Spring to fall.

2. Mollugo verticillàta L. Foliage glabrous. Stems branched at the base, the branches slender, spreading radially, prostrate, 4-30 $\mathrm{cm}$. long, forking: leaves in apparent whorls of 4-8; blades unequal, narrowly or broadly spatulate, 1-3 cm. long, rounded or acute at the apex, entire, short-petioled : pedicels $3-8 \mathrm{~mm}$. long, reflexed in fruit : sepals oblong, $2 \mathrm{~mm}$. long, obtuse, with hyaline margins: stamens 3 , shorter than the sepals: styles 3 , the tips recurved : capsule oblong or oval, 4-5 $\mathrm{mm}$. long, surpassing the sepals : seeds red, $0.6 \mathrm{~mm}$. broad, shining.

In waste places and cultivated grounds, New Brunswick, Ontario and North Dakota to Florida. Texas and Mexico. Widely distributed. Spring to fall. CARPET-WEED.

\section{GLINUS L.}

Annual herbs, with forking branches and usually pubescent foliage. Leaves basal and cauline, whorled, often fleshy : blades unequal : stipules hyaline. Flowers perfect, sessile, clustered. Sepals 5, with hyaline borders, tomentose without. Stamens mostly 5-10: filaments filiform: anthers 2-celled. Ovary 3-5-celled, superior: styles very short or none: stigmas sometimes sessile. Ovules numerous. Capsule often included in the calyx, 3-5-valved. Seeds numerous, strophiolate, with elongated coiled funiculi: aril conspicuous.

1. Glinus lotoìdes Loefl. Foliage villous-pilose, especially when young. Stems stout, more or less diffusely branched at the base, the branches radially spreading, $0.5-3$ dm. long, forking : leaves apparently whorled; blades very unequal, suborbicular, often broader than long, rounded or apiculate; petioles shorter than the blades: flowers sessile or nearly so: sepals linear-lanceolate, $3-4 \mathrm{~mm}$. long, acuminate, pubescent, with hyaline margins : stamens 5 : stigmas sessile: capsule oblong-ovoid, $3 \mathrm{~mm}$. long, shorter than the sepals: seeds dull red, $0.6 \mathrm{~mm}$. broad, granular.

In waste places and cultivated soil, the Indian Territory and Arkansas. Summer. Naturalized from Europe.-A related species $G$. Cambessidèsii Fenzl., with a less robust habit, smaller flowers, 3-5 stamens and smooth seeds. occurring from Mexico and lower California to South America and in Cuba, has apparently been collected in Texas.

\section{CYPSELÈA Turp.}

Annual or probably perennial, rather diminutive herbs, with elongated roots. Leaves opposite, those of each pair unequal, with laciniate scarious stipules. Flowers axillary. Sepals 4-5, erect, green, unequal, unappendaged. Hypanthium campanulate. Stamens 1-3, alternate with the sepals: filaments shorter than the calyx. Ovary 2-celled, or 1-celled by suppression, superior: styles usually 2, erect. Ovules numerous. Capsule circumscissile. Seeds minute, estrophiolate, becoming detached from the straight funiculi which remain attached to the central placenta.

1. Cypselea humifusa Turp. Low, glabrous. Stems densely branched at the base, the branches prostrate, forming small mats $2-10 \mathrm{~cm}$. broad : leaf-blades oblong to oval, $3-9$ $\mathrm{mm}$. long, obtuse, pellucid-punctate, on short petioles with dilated hyaline bases; stipules becoming lacerate : flowers greenish, axillary, short-pedicelled : sepals 5 , ovate : stamens 3 or sometimes 1 or 2 , alternate with the sepals : capsule subglobose, $1.5-2 \mathrm{~mm}$. in diameter, apiculate.

In sandy pine lands, peninsular Florida and California. Introduced from the West Indies.

\section{TRIÁNTHEMA L.}

Annual or perennial herbs or shrubby plants, with a spreading habit. Stem commonly branched at the base. Leaves opposite, those of each pair unequal, with stipules* Flowers axillary. Sepals 5, petal-like, with horn-like appendages on the back below the apex. Stamens 5-6, or sometimes 10 : filaments alternating with sepals when of the same number. Ovary 2-celled, or 1-celled by suppression, superior, truncate: styles usually 2, sometimes eccentric. Ovules few. Capsule turbinate to cylindric, tardily circumscissile, often leathery or corky above, with usually 2 marginal crests partly or wholly surrounding the oblique concave top.

1. Trianthema Portulacástrum L. Perennial, fleshy, sometimes sparingly pubescent. Stems diffusely branched at the base, the branches often prostrate, $5-10 \mathrm{dm}$. long, 
torking, often matted: leaf-blades suborbicular to broadly obovate, $0.5-2 \mathrm{~cm}$. broad, rounded, notched or apiculate at the apex, contracted into petioles which are somewhat shorter than the blades, and clasping at the dilated bases: flowers sessile in the axils: sepals ovate-lanceolate, $2-5 \mathrm{~mm}$. long, purple within, acuminate : capsule $3.5-5 \mathrm{~mm}$. long, tipped by the persistent styles. [Trianthema monogyna L. ]

In sandy soil, peninsular Florida to Texas, Arizona, Lower California and Mexico. Also in the West Indies.

\section{SESÜVIUM L.}

Annual or perennial spreading herbs or shrubby plants, with fleshy tissues. Leaves opposite, succulent, without stipules. Flowers axillary. Sepals 5, usually with horn-like appendages on the back below the apex. Stamens 1-many, perigynous : filaments sometimes collected into groups. Ovary 3-5-celled, half-inferior. Styles 3-5, distinct, filiform. Ovules numerous. Fruit a circumscissile 3-5-valved capsule. Seeds several or many in each cavity. Sea Purslane.

Stamens 5.

Stamens numerous.

Caly $x$ 4-6 $\mathrm{mm}$. long: sepals broadly ovate-oblong.

Calyx 8-10 mm. long: sepals narrowly oblong.

1. S. maritimum.

2. S. sessile.

1. Sesuvium marítimum (Walt.) B.S.P. Annual, stout, fleshy, glabrous. Stems more or less branched at the base, the branches spreading or ascending, 0.5-4 dm. long, forking: leaf-blades spatulate or obovate, 1-2.5 cm. long, rounded or notched at the apex, short-petioled : flowers sessile in the axils, usually solitary, about $4 \mathrm{~mm}$. broad : sepals 5, lanceolate or oblong-lanceolate, hooded, the back prolonged into an appendage : stamens 5 , shorter than the ovary: capsule ovoid, $5 \mathrm{~mm}$. long: seeds $0.7 \mathrm{~mm}$. broad, shining. [Sesuivim pentandrum Ell.]

In sand on the coast, Long Island to Florida and Louisiana. Also in Cuba.

2. Sesuvium séssile Pers. Perennial, stout, fleshy, glabrous. Stems more or less diffusely branched at the base, the branches ascending or prostrate, $1-8 \mathrm{dm}$. long, forking: leaf-blades spatulate to spatulate-oblanceolate, 1-2.5 cm. long, obtuse or acutish, on stout winged petioles which are dilated into somewhat clasping bases : flowers short-pedicelled, solitary in the axils : sepals ovate-oblong, $8-10 \mathrm{~mm}$. long : stamens numerous : capsule oblong, $6 \mathrm{~mm}$. long: seeds $1 \mathrm{~mm}$. broad, smooth. Brazil.

On sandy beaches, river banks and saline plains, Kansas to California, Texas and Mexico, and in

3. Sesuvium Portulacástrum L. Perennial, fleshy, glabrous. Stems usually diffusely branched at the base, the branches prostrate, often creeping, forming patches $2 \mathrm{~m}$. broad : leaf-blades oblanceolate to oblong, 1.5-4 cm. long, acute or acutish, the bases clasping: flowers short-pedicelled, solitary in the axil: sepals broadly lanceolate, 7-10 mm. long, hooded, purple within, the back prolonged into an appendage: stamens numerous : capsule conic, 8-10 mm. long.

On muddy and sandy shores, along the coast, North Carolina to Florida, and in the West Indies, Bermuda and the tropies.

\section{TETRAGÒNIA L.}

Annual or perennial fleshy herbs or shrubby plants, with branching stems. Leaves mainly opposite, succulent. Flowers axillary to leaf-like bracts. Sepals mostly 4 , fleshy, erect or converging at maturity, obtuse. Corolla wanting. Stamens 1-many, perigynous : filaments, when numerous, somewhat collected into groups. Ovary 3-9-celled, half-inferior: styles 3-9, short, distinct. Ovule solitary in each cavity. Fruit indehiscent, a 4-6-horned nut. Seed solitary, pendent, pear-shaped, estrophiolate, with a horseshoeshaped embryo.

1. Tetragonia expánsa Murr. Annual, succulent, usually papillose. Stems branched at the base, the branches spreading or procumbent : leaf-blades ovate, $2-6 \mathrm{~cm}$. long, acutish or obtuse, entire, sometimes undulate, contracted into cuneate petioles: flowers nearly sessile : calyx yellowish green : sepals 4, spreading : ovary 5-9-celled : styles 5-9 : nuts cartilaginous, 8-12 mm. long, 4-6-horned, slightly flattened.

In waste places and old fields, peninsular Florida. Also in California. Introduced from eastern Asia and New Zealand. NEW ZEALAND SPINACH.

\section{Family 9. PORTUlacàceat Reichenb. Purslane Family.}

Succulent herbs or partly shrubby plants, with fibrous roots rootstocks or corms. Leaves alternate or opposite: blades terete or flat. Flowers perfect, 
regular, usually symmetrical. Perianth of two whorls. Calyx of 2 sepals. Corolla of 4 or 5 or rarely more hypogynous imbricated petals. Disk wanting. Androecium of as many hypogynous stamens as there are petals, or sometimes fewer, or more. Filaments slender. Anthers 2-celled, opening lengthwise. Gynoecium of several united carpels. Ovary 1-celled. Styles 2-5, distinct or united. Stigmas 2-5. Ovules 2-many, amphitropous. Fruit a membranous or crustaceous capsule, dehiscing usually by 3 valves, or circumscissile. Seeds 2-many, with the embryo curved or coiled around the mealy endosperm.

Ovary and capsule superior: capsule 3-valved.

Sepals deciduous : stamens more numerous than the sepals or petals : capsules many-seeded. ovary and capsule wholly or partially inferior : capsule circumscissile.

2. Ci.aytonia.

3. Portulaca.

\section{TALİNUM Adans.}

Perennial herbs or shrubby plants, with usually glabrous foliage. Stems very short or elongated, often surmounted by wire-like peduncles. Leaves fleshy, alternate or nearly opposite : blades flat or terete, entire: stipules wanting. Flowers axillary or variously disposed at the end of the scape, showy. Sepals 2, herbaceous deciduous. Petals 5 or more, early withering. Stamens usually more numerous than the petals: filaments filiform. Ovary superior : styles 3, more or less united. Ovules numerous in the cavity. Capsules 1celled, parchment-like, 3-valved. Seeds flattened, somewhat reniform, with a shining testa. Flowers axillary.

Leaves linear: stamens about 20 : peduncles wanting or very short.

Leaves broadest above or below the middle: stamens about 25 : peduncles about as long as the pedicels.

Flowers in terminal cymes, sometimes panicled.

Leaves terete: flowers in terminal cymes.

Capsules elliptic.

Capsules subglobose.

Petals 5, less than $8 \mathrm{~mm}$. long: stamens less than 25: capsules less than 6 mm. long.

Petals 8 -10, over $8 \mathrm{~mm}$. long: stamens over 25 : capsules over $6 \mathrm{~mm}$. long.

Leaves flat: flowers in panicled cymes.

1. T. lineare.

2. T. aurantiacum.

3. T. parviflorum.

4. T. teretifolium.

5. T. calycinum.

6. T. reflexum.

1. Talinum lineàre H.B.K. Foliage glabrous. Stems slender, erect or ascending, simple or branched, 1-4 dm. tall : leaf-blades flattish, linear, 2-7 cm. long, acute or acutish, sessile or nearly so : flowers axillary : corolla yellow, $2-3 \mathrm{~cm}$. broad : peduncles very short or wanting : pedicels 1-2 cm. long, curved in fruit: sepals ovate, $56 \mathrm{~mm}$. long, acute: stamens about 20 : capsule subglobose, 5-6 mm. long: seeds obovoid, $2 \mathrm{~mm}$. long. with curved ridges which are finely transverse-wrinkled.

In sandy soil, Texas and New Mexico to Mexico. Summer.

2. Talinum aurantìacum Engelm. Foliage glabrous or puberulent. Stems simple and erect or branched below, the branches spreading, 1-5 dm. long : leaf-blades flattish, linear-lanceolate to linear-oblanceolate, $2-7 \mathrm{~cm}$. long, sessile or nearly so : flowers axillary : corolla golden yellow to red, $2-2.3 \mathrm{~cm}$. broad : peduncles slender, as long as the pedicels or shorter, recurved in fruit: sepals ovate, acuminate, 3-keeled : stamens about 25 : filaments red : style orange : capsule subglobose, $6 \mathrm{~mm}$. long : seeds obovoid, $2 \mathrm{~mm}$. long, slightly curved, with curved ridges and minute transverse wrinkles.

In rocky soil and on prairies, Texas to New Mexico. Summer.

3. Talinum parviflòrum Nutt. Foliage glabrous. Stems slender, very short, loosely tufted : leaf-blades terete, $2-5 \mathrm{~cm}$. long, crowded : scapes solitary or tufted, wire-like, 1-2 $\mathrm{dm}$. tall, simple below, corymbosely branched above: peduncles very slender: bracts slightly prolonged backward: sepals ovate or ovate-lanceolate, shorter than the petals: corolla pink, 8-10 mm. broad : stamens 5 : capsule elliptic, 3-4 mm. long.

In rocky soil, Minnesota to Texas, New Mexico and Mexico. Summer.

4. Talinum teretifòlium Pursh. Foliage glabrous. Stems short, more or less tufted, ough : leaf-blades terete, crowded, $2-6 \mathrm{~cm}$. long, acute : peduncles very slender : bracts conspicuously prolonged backward : sepals elliptic or ovate, $3-4 \mathrm{~mm}$. long : corolla blue or purplish, 2-3 cm. broad : stamens usually $15-20$ : capsule subglobose, $4-5 \mathrm{~mm}$. in diameter : seeds $1 \mathrm{~mm}$. broad, minutely wrinkled.

In sandy soil or on rocks, Pennsylvania to Minnesota, Florida and Texas. Spring to fall.

5. Talinum calycinum Engelm. Foliage glabrous. Stems very short, more or less tufted : leaf-blades terete, $1-5 \mathrm{~cm}$. long, acute : scapes wire-like, erect or ascending, 5-20 $\mathrm{cm}$. tall, nearly simple or sparingly branched into a corymb above: peduncles very 
slender : sepals 2, ovate-orbicular, about $5 \mathrm{~mm}$. long, cuspidate : corolla pink, $2-3 \mathrm{~cm}$. broad : stamens 30 or more : capsule subglobose, $6-7 \mathrm{~mm}$. long.

In sandy soil, Arkansas to the Indian Territory, New Mexico, Texas and Mexico. Summer.

6. Talinum refléxum Cav. Foliage glabrous. Stems erect, 2-9 dm. tall, stout below, wire-like above, where they are branched: leaf-blades flat, spatulate to elliptic, 3-10 cm. long, short-acuminate, undulate, short-petioled : peduncles filiform, diverging: sepals ovate or oval, $2-2.5 \mathrm{~mm}$. long, concave : corolla rose to yellow, $6-8 \mathrm{~mm}$. broad : petals 5 , oblong to cuneate-oblong : stamens often 12-15: capsule subglobose, $5 \mathrm{~mm}$. in diameter : seeds about $1 \mathrm{~mm}$. long, minutely tuberculate. [Talinum patens Willd.]

On dry hillsides, Florida and Texas to New Mexico and Mexico. Spring to fall.-The form that produces procumbent branches, is T. reflexum sarmentòsum (Engelm.) Small [T. sarmentosum Engelm.].

\section{CLAYTÒNIA L.}

Annual or perennial fleshy herbs, sometimes with tuber-like corms and generally glabrous foliage. Stems more or less tufted, commonly simple. Leaves basal and cauline, alternate or opposite, various, without stipules. Flowers in terminal racemes or eymes. Sepals 2, herbaceous, persistent, distinct. Petals 5. Stamens 5, opposite the petals and adnate to their bases : filaments slender. Ovary free : styles 3 , mostly united : stigmas minute. Ovules few in a cavity. Capsule 1-celled, becoming membranous, 3-valved, often 3-angled. Seeds few, flattened, reniform. Spring Beauty. $\begin{array}{ll}\text { Leaves of an elliptic or oblong type, mostly less than } 7 \mathrm{~cm} \text {. long. } & \text { 1. C. Caroliniana. } \\ \text { Leaves of a linear type, mostly over } 7 \mathrm{~cm} \text {. long. } & \text { 2. Cirginica. }\end{array}$

1. Claytonia Caroliniàna Michx. Corm subglobose. Stems tufted, 0.5-2 dm. long, erect or spreading, simple : leaf-blades ovate to narrowly oblong, $2.5-7 \mathrm{~cm}$. long, obtuse or acutish, narrowed at the base into petioles: racemes $2-10 \mathrm{~cm}$. long: pedicels $1-4 \mathrm{~cm}$. long, inclined to one side : sepals ovate or oval to suborbicular, 6-9 $\mathrm{mm}$. long, obtuse : petals oblong, white to pink, 10-12 mm. long, obtuse, delicately veined : capsule oval, 3-4 mm. long, 3-angled : seeds lenticular, about $2 \mathrm{~mm}$. broad, black, smooth, shining.

In woods, chiefly on the mountains, Nova Scotia to the Northwest Territory, North Carolina, Tennessee and Missouri. Spring and early summer.

2. Claytonia Virgínica L. Corm globose or irregular. Stems more or less tufted, erect or spreading, $0.5-2.5 \mathrm{dm}$. long, simple : leaf-blades linear or nearly so, 7-12 cm. long, acute or acutish : racemes $0.5-1.5 \mathrm{dm}$. long, loosely flowered : pedicels $1-3 \mathrm{~cm}$. long, inclined to one side : sepals ovate, leathery, $5-7 \mathrm{~mm}$. long : petals oblong, $8-10 \mathrm{~mm}$. long, usually notched at the apex, white or pink, delicately veined : capsule globose-obovoid, 3 $\mathrm{mm}$. high, slightly 3 -angled : seeds lenticular, $2 \mathrm{~mm}$. broad, smooth, shining.

In woods, Nova Scotia to the Northwest Territory, Georgia and Texas. Spring.

\section{PORTULÀCA L.}

Annual or perennial fleshy herbs, with simple or diffusely branched stems. Leaves alternate or nearly opposite, flat to terete, furnished with scarious or bristle-like stipules. Flowers perfect, of various colors, sometimes subtended by an involucre. Sepals 2, deciduous. Petals 4-6, usually 5, fugacious. Stamens 8-many, inserted with the petals : filaments slender. Ovary partly or wholly inferior: styles 3-8, slender. Ovules numerous. Capsule 1-celled, membranous, opening by a cap. Seeds more or less flattened, reniform or cochleate, with a smooth or minutely tuberculate testa.

Leaf-blades terere or nearly so. more or less hairy in the axils.

Annual or usually so: lid of capsule ovoid or hemispheric. Corolla over $2 \mathrm{em}$. broad.

Corolla less than $1.5 \mathrm{~cm}$. broad.

Perennial or usually so: lid of eapsule depressed.

Leaf-blades flat, glabrous in the axils or nearly so.

Petals acute: capsule with a crown-like border near the mouth. Upper leaf-blades broadest below the middle. Upper leaf-blades broadest above the middle.

Petals notched: capsule without a crown-like border.

Stems or branches prostrate: sepals acute: styles $5-7$ : seeds granulate.

Stems or branches ascending : sepals obtuse: styles 3-4: seeds tuberculate.

1. P. grandiflora.

2. P. pilosa.

3. P. halimoides.

1. Portulaca grandiflòra Hook. Annual, bright green. Stems often branched at the base, the branches ascending or decumbent, $0.5-3 \mathrm{dm}$. long, more or less villous-pilose especially near the nodes : leaves somewhat clustered; blades terete, $1-2.5 \mathrm{~cm}$. long. blunt, with stout petioles about $1 \mathrm{~mm}$. long: flowers usually solitary : sepals 2 , ovate, $10-15 \mathrm{~mm}$. long, acute or slightly acuminate, one at least horned back of the apex: corolla pink, 
red, yellow or white, $2.5-5 \mathrm{~cm}$. broad: petals cuneate or obovate, notched at the apex: capsules $3-5 \mathrm{~mm}$. high.

In waste places and cultivated grounds, naturalized in eastern North America. Native of South America. Sun-PLANT.

2. Portulaca pilòsa L. Annual, more or less villous. Stems sparingly or diffusely branched, 0.5-2 dm. long, green, ascending, or the branches spreading : leaves numerous; blades nearly terete, linear-subulate, $1-2 \mathrm{~cm}$. long : flowers sessile : sepals narrowly oblong : corolla pink, $1.5-2 \mathrm{~cm}$. broad: petals ovate-oblong, obtuse or retuse: stamens $1 \tilde{0}-25$ : capsules 4-7 mm. high.

In dry soil, North Carolina to Arizona, Florida and Mexico. Also in the tropies. Spring to fall.

3. Portulaca halimoìdes L. Perennial or usually so, from a stout fleshy root. Stems erect or diffuse, corymbosely branched, the young branches copiously hairy : leaves few, the upper approximate; blades slightly flattened, 5-12 $\mathrm{mm}$. long, acute: flowers clustered : corolla yellow : stamens 8-12: capsules $2.5-3.5 \mathrm{~mm}$. high, the lid depressed, much shorter than the basal portion.

In sand, Florida Keys. Also in the West Indies. Spring to winter.

4. Portulaca coronàta Small. Annual, glabrous. Stems simple and erect or diffusely branched, like the branches, usually deep pink or magenta : leaves rather numerous, alternate; blades flat but thick, mostly $1-1.5 \mathrm{~cm}$. long, sessile, the lower ones usually oblanceolate, the upper oblong or oblong-lanceolate : flowers clustered at the ends of the clubshaped branches : sepals triangular, $2 \mathrm{~mm}$. long: corolla about $5 \mathrm{~mm}$. broad : petals ovate or oblong-ovate, $2 \mathrm{~mm}$. long, 5-7-nerved : stamens 11 or 12 : capsules hemispheric or turbinate-hemispheric, about $5 \mathrm{~mm}$. high, the lower portion surmounted by a free edge, the lid rather low, not crested.

In sand, Little Stone Mountain, Georgia. Fall.

5. Portulaca lanceolàta Engelm. Annual, glabrous. Stems erect, or branched and somewhat diffuse, green : leaves rather few ; blades flat, mostly 1-2 $\mathrm{cm}$. long, sessile, the lower spatulate and obtuse, the upper oblanceolate to oblong, often acute : flowers clustered at the ends of the branches : sepals ovate : corolla yellow, orange or reddish : petals spatulate or obovate: stamens 7-27: capsules with a turbinate base surmounted by a narrow crown, and a flattish lid.

On granite rocks, Texas to Arizona. Summer.

6. Portulaca oleràcea L. Annual, stout, fleshy. Stems usually branched at the base, the branches spreading radially, prostrate, 1-6 dm. long, forking: leaves fleshy ; blades cuneate or obovate, 1-3 cm. long, rounded at the apex : buds flattened, acute : flowers sessile, opening on sunny mornings : sepals rather acute, keeled : petals yellow : stamens 7-12: styles 5-6, slightly united : capsules 5-9 $\mathrm{mm}$. high.

In waste places, nearly throughout North America. Also in Central and South America and naturalized in the Old World. Spring to fall. Purslane. Pussley. DuCkweed.

7. Portulaca retùsa Engelm. Annual, stout, glabrous, similar to $P$. oleracea in habit, but rather more slender. Leaf-blades cuneate, $1-2.5 \mathrm{~cm}$. long, mostly retuse or emarginate at the apex : sepals rather obtuse, carinate-winged: petals smaller than those of $P$. oleracea : stamens about 15 : styles $3-4$, well united : capsules $5-6 \mathrm{~mm}$. high.

In sandy soil, Arkansas to Texas and New Mexico. Summer.

\section{Family 10. Alsinàceae Wahl. Chickweed Family.}

Annual or perennial herbs, sometimes shrubby at the base, with a watery sap. Stems often diffusely branched. Leaves opposite, with or without stipules: blades various, entire. Flowers mostly perfect, sometimes incomplete. Perianth usually of 2 series. Calyx of 4-5 persistent distinct or nearly distinct sepals. Corolla of 4-5 clawless petals, or wanting. Androecium of twice as many stamens as there are sepals or fewer. Filaments distinct or cohering below. Anthers introrse, opening lengthwise. Gynoecium of 2-5 united carpels. Ovary 1-celled or rarely 2-5-celled. Styles 2-5. Ovules several or many, amphitropous or campylotropous, on a central column. Fruit a capsule, opening by valves, these sometimes tooth-like. Embryo more or less curved in the endosperm, usually with incumbent cotyledons.

Styles partially united.

1. Loeflingia. Styles distinct.

A. Stipules present.

a. Leaves merely opposite by pairs.

Flowers in terminal elusters.

Flowers solitary in the axils.

2. Stipulicida.

3. TIssa. 
b. Leaves whorled.

Styles 5: stamens 5-10: capsules 5-valved. 4. Spergula.

Styles 3 : stamens $3-5$ : capsules 3 -valved. 5 . POLYCARPON.

B. Stipules wanting.

Petals entire, toothed or slightly notched.

Styles as many as the sepals.

Styles fewer than the sepals.

Petals toothed: flowers in umbel-like cymes.

Petals entire or emarginate: flowers in dichotomous or capitate cymes, or solitary.

Capsules opening by as many valves as there are styles.

Capsules opening by twice as many valves as there are styles.

Petals 2-cleft or 2-parted.

Capsules relatively short, ovoid or oblong.

Capsules relatively long, cylindric.

6. SAGINA.

7. Holosteum.

8. Alsinopsis.

9. Arenaria.

10. Alsine.

11. Cerastium.

\section{LOEFLÍNGIA L.}

Low annual herbs, with glandular foliage. Stems diffusely branched. Leaves opposite, subulate or bristle-like, with stipules. Flowers solitary or clustered in the axils, inconspicuous. Sepals 5, rigid, sometimes awn-tipped, keeled, the outer ones often with a tooth on each side. Petals 3-5, minute, or wanting. Stamens 3-5, perigynous : filaments longer than the anthers. Ovary 1-celled, triangular: styles partially united. Capsule shorter than the calyx, 3-valved. Seeds laterally attached, each with a slightly curved embryo and accumbent cotyledons.

1. Loeflingia Texàna Hook. Annual, glandular-pilose. Stem usually branched at the base, the branches ascending or decumbent, $0.5-1.5 \mathrm{dm}$. long, forking, with enlarged nodes: leaves firm, subulate, 4-8 mm. long, very sharp at the apex, spreading: flowers sessile, inconspicuous : sepals subulate-lanceolate, somewhat shorter than the leaves, long-attenuate, the 3 outer with a bristle-like tooth on either side, each terminating in a short bristle-like apex : petals much smaller than the sepals or wanting : capsules oblong, $3 \mathrm{~mm}$. long, 3 -angled : seeds $0.3 \mathrm{~mm}$. long.

In sandy soil, Nebraska to Texas. Spring.

\section{STIPULÍ́cida Michx.}

Slender perennial herbs, with scape-like stems. Leaves various: basal with normal blades: cauline reduced to scales: stipules pectinate or fringed. Flowers in terminal clusters. Sepals 5, scarious-margined, obtuse and often emarginate. Petals 5, broadened upward, persistent, often 2-toothed near the base. Stamens 3, opposite the inner sepals. Ovary 1-celled: styles 3. Capsule about as broad as long, 3-valved. Seeds numerous. Stems or branches filiform: flowers solitary or 2-3 in a cluster: petals constricted at the middle. Stems or branches wire-like: flowers $3-6$ in a cluster : petals spatulate. $\quad$ 1. S. filiformis.

1. Stipulicida filifórmis Nash. Stems branched at the base, the branches ascending or spreading, 1-2 dm. long, almost filiform, diffusely forked above: leaves basal, deciduous; blades suborbicular, acute, about $4 \mathrm{~mm}$. broad, shorter than the petioles: flowers solitary or 2-3 together, sessile or nearly so : sepals narrowly obovate, notched at the apex, about $1 \mathrm{~mm}$. long, hyaline-margined : petals linear-oblong, slightly longer than the sepals, constricted at the middle, notched at the apex, ciliate-toothed near the base : capsules subglobose, shorter than the sepals, obscurely 3-angled.

In sandy soil, peninsular Florida to Mississippi. Spring to fall.

2. Stipulicida setàcea Michx. Stems branched at the base, the branches wire-like, erect or ascending, 4-15 $\mathrm{cm}$. tall, forking: leaves mainly basal ; blades spatulate, elliptic or orbicular, 1-2 cm. long, obtuse or apiculate; petioles longer than the blades : stipules forming a bristly mass : bracts subulate, $1-4 \mathrm{~mm}$. long: pedicels very short or the lower flowers sessile : sepals oblong-obovate, $2 \mathrm{~mm}$. long, hyaline-margined : petals spatulate, slightly longer than the sepals : capsules subglobose, a little over $1 \mathrm{~mm}$. in diameter.

In pine lands, North Carolina to Florida and Mississippi. Spring.

\section{TÍssA Adans.}

Low annual, biennial or perennial herbs, with rather succulent tissues and diffusely branched stems. Leaves opposite, with small ones often clustered in the axils: blades narrow, with scarious stipules. Flowers in terminal racemose cymes. Sepals 5, persistent. 
Petals 5, or rarely fewer or wanting, pink or whitish, entire. Stamens 2 or often 10 : filaments slender. Ovary 1-celled: styles 3 or rarely 5. Capsule 3 -valved to the base, the valves alternate with the sepals, rarely 5 -valved. Seeds often margined, smooth or tuberculate. The plants flower from spring to fall. SAND SPURRY.

Species of sandy banks of the interior: plants scarcely fleshy.

Corolla much longer than the sepals.

Corolla wanting, or of 1-3 minute petals.

Species of maritime or saline habitats: plants decidedly fleshy.

1. T. bracteata.

2. T. gracilis,

1. Tissa bracteàta (Robinson) Small. Annual, slender, alnost glabrous or viscidpubescent. Ster. branched at the base, the branches wire-like, spreading or procumbent, 4-15 $\mathrm{cm}$. long, forking: leaves fleshy, linear-filiform, $0.5-2 \mathrm{~cm}$. long : pedicels filiform, 4-6 $\mathrm{mm}$. long : sepals ovate, about 2-3 mm. long, obtuse, hyaline-margined : corolla pink or whitish, 4.5-6.5 mm. broad : stamens usually 2 or 3 : eapsules ovoid, slightly longer than the sepals: seeds usually roughened, $0.5 \mathrm{~mm}$. broad. [Spergularia salsuginea var. bracteata Robinson.]

In sandy soil, Texas. Also from Washington to California.

2. Tissa gráctlis (S. Wats.) Britton. Annual, slender, glabrous. Stem diffusely branched at the base, the branches erect or spreading, 4-15 $\mathrm{cm}$. long, forking: leaves filiform, 3-10 $\mathrm{mm}$. long, acute; stipules deltoid: pedicels 4-7 $\mathrm{mm}$. long: sepals ovate or elliptic-ovate, $1.5-2 \mathrm{~mm}$. long, obtuse, hyaline-margined : corolla $2-2.5 \mathrm{~mm}$. broad : petals surpassing the sepals : capsules ovoid, $\frac{1}{3}-\frac{1}{2}$ longer than the sepals : seeds $0.4 \mathrm{~mm}$. thick, minutely roughened.

In sandy soil, Texas and southern California.

3. Tissa marìna (L.) Britton. Annual or biennial, stoutish, glabrous or pubescent. Stem branched at the base, the branches decumbent, 1-2 dm. long, forking: leaves fleshy, linear, 1-3 cm. long, sometimes fascicled; stipules ovate: pedicels slender, $0.5-1.5 \mathrm{~cm}$. long: sepals ovate to oblong-lanceolate, 4-6 $\mathrm{mm}$. long, obtuse, hyaline-margined : corolla pink or reddish, 2-4 mm. broad: capsules ovoid, slightly longer than the sepals or sometimes twice as long: seeds smooth or minutely roughened, each with a broad wing.

In sandy soil along the coast, New Brunswick to Florida and Texas. Also in saline soil in the interior and on the Pacific coast.

\section{SPÉRGULA L.}

Diffuse annual herbs, with somewhat succulent tissues. Leaves numerous, often apparently whorled and commonly clustered, thick, narrow, with stipules. Flowers in terminal cymes. Sepals 5, persistent. Petals 5, white, surpassing the sepals. Stamens 10, or rarely 5: filaments very short. Ovary 1-celled: styles 5. Capsule 5-valved, often surpassing the calyx, the valves opposite the sepals. Spurry. Corn Spurry.

1. Spergula arvénsis L. Foliage glabrous or pubescent. Stems more or less diffusely branched at the base, the branches usually simple below the wide-spreading terminal dichotomous cyme : leaves clustered, apparently whorled, linear-filiform, 1-3 cm. long : pedicels filiform, often deflexed in fruit : sepals oblong or oblong-ovate, $3.5-5 \mathrm{~mm}$. long, obtuse : petals equalling or slightly surpassing the sepals : capsules globose-ovoid, $6-7 \mathrm{~mm}$. long, surpassing the sepals : seeds slightly over $1 \mathrm{~mm}$. broad, minutely roughened, narrowly winged.

In fields and waste places, throughout eastern North America. Naturalized from Europe. Summer.

\section{POIYCÁRPON L.}

Low annual herbs, with branching stems. Leaves opposite or four in a whorl : blades flat. Flowers inconspicuous, in more or less compound cymes. Sepals 5, entire, keeled, scarious-margined. Petals 5, shorter than the sepals, sometimes emarginate. Stamens 3-5: filaments short. Ovary 1-celled: styles 2-3. Capsule 3-valved, often surpassed by the calyx. Seeds several, with the embryo merely curved.

1. Polycarpon tetraphýllum L. f. Foliage glabrous. Stems usually much branched at the base, the branches forking, 2-12 cm. long: leaves spatulate to oval, 0.5$1.5 \mathrm{~cm}$. long, obtuse or acutish, in whorls of 4 below, opposite above : pedicels 1-3 mm. long: sepals less than $1.5 \mathrm{~mm}$. long, hooded, the keel prolonged into a tip: petals shorter than the sepals, emarginate: capsules broadly ovoid, much shorter than the sepals : seeds $0.4 \mathrm{~mm}$. long.

In waste places and woods, South Carolina to Alabama, and in California. Also widely distributed in other parts of the world. Spring to fall. 


\section{SAGINA L.}

Low often matted annual or perennial herbs, with slender stems. Leaves opposite, subulate or filiform, without stipules. Flowers on more or less elongated axillary pedicels. Sepals 4-5, persistent. Petals 4-5, entire or notched, white or greenish, or wanting. Stamens usually 5, sometimes 3-10: filaments slender. Ovary 1-celled. Styles as many as there are sepals. Capsule 4-5-valved, the valves opposite the sepals. Seeds several or many. PEARLWORT.

Sepals and petals mostly 4 : petals much shorter than the sepals. Sepals and petals mostly 5: petals as long as the sepals or nearly so.

1. S. procumbens. 2. S. decumbens.

1. Sagina procúmbens L. Annual, slender, glabrous. Stem branched at the base, the branches prostrate, $2-12 \mathrm{~cm}$. long, simple or sparingly forked : leaves linear-filiform, $0.5-1.5 \mathrm{~cm}$. long: pedicels filiform, $1-2 \mathrm{~cm}$. long: sepals usually 4 , oval, $1.5-2 \mathrm{~mm}$. long, obtuse: petals 4 , much shorter than the sepals : stamens 4 : capsule ovoid, somewhat surpassing the sepals.

On sandy shores, Greenland to Labrador, Newfoundland, Michigan and North Carolina. Also in Europe, Asia, Mexico and South America. Spring and summer.

2. Sagina decúmbens (Ell.) T. \& G. Annual, slender, glabrous or nearly so. Stem more or less branched at the base, the branches erect or decumbent, $2-15 \mathrm{~cm}$. long, wiry or filiform, simple or forked: leaves linear-filiform, $0.5-1.5 \mathrm{~cm}$. long: pedicels filiform, erect or ascending, 1-2 $\mathrm{cm}$. long: sepals 5, oblong, about $1.5 \mathrm{~mm}$. long, obtuse : petals 5 , as long as the sepals or nearly so: stamens 10 : capsule elliptic-ovoid, about $3 \mathrm{~mm}$. long, nearly $\frac{1}{2}$ longer than the sepals.

In sandy soil, Massachusetts to Illinois, Missouri, Florida and Texas. Spring.

\section{HOLÓSTEUM L.}

Annual rather tender caulescent herbs, with sparingly leafy stems and relatively long peduncles. Leaves opposite : blades spreading or recurved. Flowers perfect, in terminal umbel-like cymes. Sepals 5, persistent. Petals 5, finely toothed or emarginate. Stamens 5 or 3 , erect or nearly so. Ovary 1-celled: styles 3. Capsule cylindric or ovoid-cylindric, surpassing the sepals, opening by 6 apical valves. Seeds flattened.

1. Holosteum umbellàtum L. Plant glabrous, or somewhat glandular-pubescent above and sparingly hairy below. Stems simple and erect or branched at the base, the branches more or less spreading, 0.8-4 dm. tall: leaves various, the basal with oblong or oblanceolate blades, the cauline with oblong to lanceolate entire sessile blades $1-3 \mathrm{~cm}$. long: umbel-like cyme 2-9-flowered: pedicels spreading in all directions, $1-3 \mathrm{~cm}$. long: petals white : capsules ovoid-cylindric, $5-6 \mathrm{~mm}$. long, about twice as long as the sepals.

In waste places and cultivated grounds, Pennsylvania, Delaware and Georgia. Spring. JAGGED CHICK WEED.

\section{ALSINÓPSIS Small.}

Annual or perennial herbs, commonly with tufted stems. Leaves opposite, sometimes clustered, without stipules : blades subulate or fleshy, or sometimes flat, but narrow. Flowers solitary in the axils or in terminal cymes. Sepals 5, often fleshy. Petals 5, white, entire or emarginate. Stamens usually 10: filaments slender. Ovary 1-celled : styles normally 3. Capsules somewhat longer than broad, opening by as many valves as there are styles. Seeds several or numerous. [Alsine Wahl., not L.]

Leaves herbaceous or fleshy.

Sepals not ribbed, scarcely nerved.

Mature sepals 4-5 mm. long.

Leaf-blades linear or linear-oblong.

Leaf-blades mostly less than $2 \mathrm{~mm}$. broad : sepals ovate or oval.

Leaf-blades mostly over $3 \mathrm{~mm}$. broad: sepals lanceolate.

Leaf-blades filiform to subulate.

Mature sepals $2-3 \mathrm{~mm}$. long.

Basal and lower stem-leaves mostly less than $1 \mathrm{~cm}$. long: upper stemleaves and bracts minute or subulate.

Basal and lower stem-leaves mostly over $1 \mathrm{~cm}$. long: upper stem-leaves and bracts linear.

Sepals strongly $3-5$-ribbed.

Leaves rigid, subulate or bristle-like.

Leaves elustered in the axils.

Sepals narrowly lanceolate, $5-6 \mathrm{~mm}$. long.

Sepals ovate to ovate-lanceolate, $3.5-4.5 \mathrm{~mm}$. long.

Leaves densely imbricated.

1. A. uniflora.

2. A. Nuttallii.

3. A. Groenlandica.

\section{A. brevifolia.}

5. A. glabra.

6. A. patula.

7. A. Texana.

8. A. stricta.

9. A. Caroliniana. 
1. Alsinopsis uniflòra (Walt.) Small. Annual, slender, glabrate. Stem weak, decumbent or ascending, 1-3 dm. tall, simple or sparingly branched : leaves few ; blades linear, 1-4 cm. long, acute, sessile : pedicels filiform, elongated, $2-8 \mathrm{~cm}$. long: flowers terminal and solitary on small plants, axillary and terminal on more robust plants: sepals lanceolate, 4-5 mm. long, acute, minutely pubescent: petals linear-cuneate, twice as long as the sepals, notched at the apex : capsules ovoid, slightly shorter than the sepals : seeds about $0.5 \mathrm{~mm}$. broad. [Stellaria uniflora Walt.]

In meadows or springy places, North Carolina to Alabama and Florida. Spring.

2. Alsinopsis Nuttállii (T.\&G.) Small. Annual, more or less densely glandularpilose. Stem simple or branched at the base, the branches erect or ascending, $0.5-2 \mathrm{dm}$. tall, often forking above : leaves few ; blades linear or linear-oblong, 1-3 cm. long, obtuse or acutish, sessile: pedicels $1-2 \mathrm{~cm}$. long: buds drooping: flowers $1-1.5 \mathrm{~cm}$. broad: sepals ovate or oval, about $5 \mathrm{~mm}$. long, obtuse, glandular-pilose and ciliate: petals oblongcuneate, deeply emarginate, delicately striate, each contracted into a short claw : capsules ovoid, 4-5 mm. long, slightly acuminate: seeds $1 \mathrm{~mm}$. broad. [Stellaria Nuttallii T. \& G.]

On moist prairies, Arkansas to Louisiana and Texas. Spring.

3. Alsinopsis Groenlándica (Retz.) Small. Annual or perennial, rather fleshy, glabrous. Stems tufted, $3-20 \mathrm{~cm}$. tall, erect or decumbent, sparingly forked : leaf-blades filiform to subulate, $0.3-1.5 \mathrm{~cm}$. long, the basal in a dense cluster, the cauline in several pairs : pedicels filiform, $0.5-1.5 \mathrm{~cm}$. long : sepals oblong or oblong-lanceolate, $3-4 \mathrm{~mm}$. long, obtuse, with scarious margins: petals obovate, about twice as long as the sepals, rounded or notched at the apex : capsules ovoid, or rarely subglobose or nearly oblong, 5-6 mm. long, obtuse : seeds nearly $1 \mathrm{~mm}$. broad. [Stellaria Groenlandica Retz.]

In rocky soil, Greenland to Maine and New Jersey. Also in the mountains of New York, Pennsylvania and North Carolina. Spring and summer.

4. Alsinopsis brevifòlia (Nutt.) Small. Annual, very slender, glabrous. Stems erect or ascending, often tufted, simple below or branched at the base, the branches often forked, wire-like, 2-12 cm. tall : leaves fleshy; the basal with linear-spatulate blades, $8-12 \mathrm{~mm}$. long; the stem-leaves with minute or subulate terete blades $2-6 \mathrm{~mm}$. long, acutish, sessile: pedicels very slender, $1-3 \mathrm{~cm}$. long: sepals ovate-lanceolate, $3 \mathrm{~mm}$. long, obtuse, hyaline-margined, forming a turbinate-campanulate calyx with a flat base: corolla white, about $8 \mathrm{~mm}$. broad : petals spatulate, $5 \mathrm{~mm}$. long, fluted, emarginate, yellowish at the base : capsules oblong or oblong-ovoid, $4 \mathrm{~mm}$. long, acuminate. [Arenaria brevifolia Nutt.]

On granite rocks, North Carolina to Georgia and Alabama. Spring.

5. Alsinopsis glàbra (Michx.) Small. Annual or perennial, slender, glabrous. Stems usually tufted, erect or ascending, 0.5-3 dm. tall, wire-like, forking, often bushy : leafblades narrowly linear or nearly filiform, $1-2.5 \mathrm{~cm}$. long, obtuse or acutish : pedicels filiform, 1-4 cm. long: sepals oblong or ovate-oblong, 2.5-3 mm. long, obtuse, hyaline-margined, nerveless : petals spatulate, about twice as long as the sepals : capsules ovoid, $3 \mathrm{~mm}$. long, slightly surpassing the sepals : seedsabout $1 \mathrm{~mm}$. broad. [Arenaria glabra Michx.]

In cliffs on the mountains of North Carolina and Tennessee. Summer.

6. Alsinopsís pátula (Michx.) Small. Annual, slender, often puberulent. Stems tufted, more or less branched at the base, the branches wire-like or filiform, $4-30 \mathrm{~cm}$. tall, forking: leaves fleshy; blades linear or filiform, 1-4 cm. long, spreading: pedicels slender, $0.5-4 \mathrm{~cm}$. long: sepals lanceolate, $3.5-5 \mathrm{~mm}$. long, acuminate, usually slightly glandular, with 3-5 hard rib-like nerves: petals white, about twice as long as the sepals, retuse or notched at the apex : capsules ovoid-oblong, about as long as the sepals, the valves obtuse : seeds about $0.5 \mathrm{~mm}$. broad, minutely tuberculate. [Arenaria patula Michx.]

In rocky woods, Minnesota to Alabama and Texas. Spring.

7. Alsinopsis Texàna (Robinson) Small. Perennial, slender, glabrous. Stems branched at the base, the branches tufted, forking above, often densely leafy below the middle: leaves firm; blades subulate, $0.5-1 \mathrm{~cm}$. long, straight or slightly curved : pedicels slender, $0.5-1.5 \mathrm{~cm}$. long: sepals narrowly lanceolate, $5-6 \mathrm{~mm}$. long, long-acuminate with 3 hard rib-like nerves: petals white, $6-8 \mathrm{~mm}$. long: capsules much shorter than the sepals : seeds $0.8 \mathrm{~mm}$. broad. [Arenaria stricta var. Texana Robinson.]

On rocky hillsides, Kansas to Texas. Spring and summer.

8. Alsinopsis strícta (Michx.) Small. Perennial, slender, glabrous. Stems diffusely branched at the base, the branches erect or ascending, or sometimes decumbent, 1-3 dm. long, simple or sparingly forked above, commonly leafy to the middle : leaves firm, often fascicled ; blades linear-subulate, $8-15 \mathrm{~cm}$. long, curved, sessile : pedicels filiform, $0.5-4$ $\mathrm{cm}$. long: sepals firm, ovate, $3.5-4.5 \mathrm{~mm}$. long, acuminate, 3-nerved : petals narrowly obovate, about twice as long as the sepals, rounded at the apex : capsules ovoid, about equalling the sepals in length: seeds $1 \mathrm{~mm}$. broad. [Arenaria stricta Mich x.]

On rocky hillsides or cliffs, Vermont to Minnesota and South Carolina. Spring and summer. 
9. Alsinopsis Caroliniàna (Walt.) Small. Perennial, tufted, slender. Stems much branched at the base, the branches ascending or decumbent, $0.5-3 \mathrm{dm}$. tall, very leafy below, glandular, often viscid and nearly naked above, the scape-like portion sparingly forking near the top: leaves firm ; blades linear-subulate, $0.5-1 \mathrm{~cm}$. long, acute, channeled above, sessile, imbricated on the luwer part of the branches: cymes few-flowered : pedicels slender, 1-5 cm. long : sepals ovate, $2.5 \mathrm{~mm}$. long, obtuse : petals oblanceolate, about thrice as long as the sepals, rounded at the apex : capsules ovoid, nearly twice as long as the sepals : seeds $0.5 \mathrm{~mm}$. broad. [Arenaila squarrosa Michx.]

On sand hills and in pine lands, New York to Florida. Spring and summer.

\section{ARENÁRIA L.}

Annual or perennial herbs, sometimes woody at the base, with more or less diffusely branched stems. Leaves opposite, sometimes clustered, without stipules : blades flattened or merely subulate or filiform. Flowers in open or capitate cymes or solitary in the axils. Sepals 5, often ribbed. Petals 5, white, entire or rarely notched, occasionally wanting. Stamens normally 10 : filaments slender. Ovary 1-celled: styles 3, or rarely 2-5. Capsule globose to oblong, opening by twice as many tooth-like valves as there are styles. Seeds numerous, sometimes flattened. SANDworT.

Plants annual.

Sepals pubescent: pedicels less than $13 \mathrm{~mm}$. long.

Sepals glabrous: pedicels over $13 \mathrm{~mm}$. long. Plants perennial.

1. A. serpyllifolia.

2. A. Benthamii.

3. A. lanuginosa.

1. Arenaria serpyllifòlía L. Annual, slender, puberulent and roughish, bright green. Stem diffusely branched, the branches spreading, 1-4 dm. long, at length wirelike: leaf-blades ovate or broadly elliptic, $2-6 \mathrm{~mm}$. long, short-acuminate, with very minute spine-like cilia, narrowed at the base, sessile or mainly so: sepals 5, lanceolate, 3-4 mm. long, acuminate, with broad hyaline margins and spine-like hairs on the back : petals oblong-ovate, $2 \mathrm{~mm}$. long, obtuse, white, shorter than the sepals, clawed : anthers lilac: capsules conic, $2.5-4 \mathrm{~mm}$. long, yellowish green, slightly constricted above the middle, the valves lanceolate.

In dry soil or waste places, throughout North America, except northern British America. Naturalized from Europe. Native also of Asia. Spring.

2. Arenaria Benthámii Fenzl. Annual, slender, bright green. Stems more or less branched at the base, the branches wire-like, erect or ascending, $0.5-1.5 \mathrm{dm}$. tall, forking, pubescent in lines: leaf-blades thickish, the lower ones spatulate or elliptic-spatulate, petioled, the upper ones oblong or elliptic, sessile, all acute, sparingly ciliate : pedicels filiform, $1.5-3 \mathrm{~cm}$. long: sepals ovate, $2.5 \mathrm{~mm}$. long, acutish : petals elliptic, nearly as long as the sepals, slightly acuminate at the apex : capsules ovoid, about $3 \mathrm{~mm}$. long, acutish : seeds reniform, about $0.6 \mathrm{~mm}$. broad, minutely tuberculate.

On rocky hillsides, Texas. Spring.

3. Arenaria lanuginòsa (Michx.) Rohrb. Perennial, slender, light green. Stems branched at the base, the branches spreading, prostrate, $3-13 \mathrm{dm}$. long, forking, more or less pubescent with hooked hairs: leaf-blades narrowly elliptic or linear-spatulite, 1-2 cm. long, acute, sessile or short-petioled : pedicels filiform, $1.5-4 \mathrm{~cm}$. long : sepals lanceolate, $2.5-3.5 \mathrm{~mm}$. long, acute : petals $1-5$, shorter than the sepals or none : capsules ovoid, about as long as the sepals : seeds $0.8 \mathrm{~mm}$. long, shining. [Arenaria diffusa Ell.]

In shaded situations, North Carolina to Texas and Florida. Spring to fall.

\section{ALSINE L.}

Annual or perennial herbs, with weak spreading stems. Leaves opposite: blades narrow or dilated. Flowers in more or less open cymes. Sepals 5 or 4 , not ribbed. Petals 5 or 4 , white, 2-cleft or 2-parted, rarely wanting. Stamens 10 or fewer, hypogynous : filaments slender. Ovary 1-celled: styles 3 or 4 , or rarely 5, usually opposite the sepals. Capsule relatively short, opening by twice as many valves as there are styles. Seeds flattened or globose. [Stellaria I.] Chickweed. Starwort. Stitchwort.

A. Corolla present.

a. Leaf-blades manifestly petioled.

Petals shorter than the sepals : sepals mostly over $3 \mathrm{~mm}$. long.

Petals longer than the sepals : sepals mostly less than $3 \mathrm{~mm}$. long. 
b. Leaf-blades, at least those of the upper leaves, sessile.

Seeds smooth.

Seeds rough.

Sepals obtuse: petals longer than the sepals.

B. Corolla wanting.

sepals acute or acuminate: petals about as long as the sepals.

4. A. longifolia.

5. A. pubera.

6. A. Tennesseensis.

7. A. fontinalis.

1. Alsíne aquática (L.) Britton. Perennial, stout. Stem erect or ascending, $2-6 \mathrm{dm}$. tall, angled, forking above, usually villous and more or less glandular above : leaves few ; blades ovate or oblong-ovate, sometimes ovate-lanceolate, $3-6 \mathrm{~mm}$. long, acute or acuminate at the apex, truncate or cordate at the base, the upper ones sessile, the lower ones petioled: pedicels $2-3 \mathrm{~cm}$. long, glandular-pilose like the calyx : sepals ovate, 4-5 mm. long, obtuse, scarious-margined : petals $1 \frac{1}{2}-2$ times as long as the sepals, 2-cleft, the segments linear: capsules slightly longer than the sepals: seeds tuberculate.

In woods and waste places, Ontario and British Columbia, and in the eastern states to Pennsylvania and Louisiana. Spring and summer.

2. Alsine medala L. Annual or sometimes perennial, glabrous or nearly so. Stem much branched, prostrate, sometimes creeping, 1-3 dm. long, forking: leaves opposite; blades ovate, $0.5-2 \mathrm{~cm}$. long, acute; petioles longer than the blades or shorter : flowers slender-pedicelled : sepals oblong-lanceolate, 3-4 mm. long, rather obtuse : petals shorter than the sepals, 2-parted nearly to the base, the segments linear-oblong, obtuse: stamens shorter than the petals : capsules elliptic or oval, about as long as the sepals : seeds flattened, about $1 \mathrm{~mm}$. broad.

In all situations throughout North America, except the extreme north, mainly naturalized from Europe. Almost universally distributed. Throughout the year. CHIOKWEED.

3. Alsine Baldwínii Small. Annual, slender, pubescent or nearly glabrous. Stem diffusely branched, the branches prostrate, 1-6 dm. long, forking : leaves usually numerous; blades ovate, semetimes as broad as long, $0.5-2 \mathrm{~cm}$. long, acute or acuminate, truncate or cordate ; petioles longer than the blades except those of the upper leaves : pedicels filiform, 1-3 cm. long: sepals ovate, $2-3 \mathrm{~mm}$. long : petals about twice as long as the sepals : capsules ovoid, surpassing the sepals : seeds $1 \mathrm{~mm}$. long, minutely tuberculate, especially on the edges. [Stellaria prostrata Baldw., not Alsine prostrata Forsk.]

In moist and shaded soil and rocky woods, Georgia to Texas and Florida. Also in Mexico. Spring.

4. Alsine longifolla (Muhl.) Britton. Annual or perennial, glabrous or nearly so. Stem commonly simple below the inflorescence, 1.5-4.5 dm. long, erect or reclining, sometimes rough-angled : leaves relatively few ; blades narrowly linear to narrowly linear-lanceolate, $1.5-7 \mathrm{~cm}$. long, or often reduced to scales at the base of the stem: cymes becoming widely branched: sepals lanceolate, about $3 \mathrm{~mm}$. long, acute, 3 -nerved: petals as long as the sepals or somewhat longer: capsules oblong-ovoid, abcut twice as long as the sepals : seeds smooth and shining.

In swamps and low meadows, Nova Scotia to Alaska, Maryland, Louisiana, the Rocky Mountain region and British Columbia. Spring and summer.

5. Alsine pùbera (Michx. ) Britton. Perennial, sparingly pilose or glabrate. Stem more or less diffusely branched at the base, the branches erect or decumbent, 1-3 dm. long, forking, accompanied later in the season by long sterile shoots bearing large leaves : leaf-blades ovate, oblong or elliptic, or the lower ones sometimes spatulate, 1-4 cm. long, or those on shoots $5-10 \mathrm{~cm}$. long, obtuse or acute, usually ciliate, sessile or nearly so: pedicels 1-3 cm. long: sepals ovate to oblong-lanceolate, $5-7 \mathrm{~mm}$. long, obtuse : petals slightly longer than the sepals, cleft to the middle or nearly to the base, the segments acutish : capsules globose-ovoid, $3-4 \mathrm{~mm}$. long, much shorter than the sepals : seeds nearly 1.5 mm. long.

In woods, Pennsylvania to Indiana, middle Georgia and Alabama. Spring.

6. Alsine Tennesseénsis (Mohr) Small. Perennial, bright green. Stem more or less branched at the base, the branches tufted, decumbent, 1-3 dm. long, pubescent in liness forked, the shoots bearing leaves somewhat larger than those of the main plant : leafblades ciliate, the lower ones with long petioles, oval or suborbicular, acute or shortacuminate, upper leaves short-petioled or sessile, elliptic or elliptic-lanceolate, 3-5 $\mathrm{cm}$. long: calyx over $2 \mathrm{~cm}$. broad, long-pedicelled : sepals lanceolate, $1 \mathrm{~cm}$. long, acuminate, the outer ones fringed with long cilia: petals about as long as the sepals, cleft to below the middle: capsules 4-5 mm. long. [A. pubera Tennesseensis Mohr.]

In rocky woods, Kentucky to Alabama. Spring.

7. Alsine fontinàlis (Short \& Peter) Britton. Annual, glabrous. Stem much branched, the branches spreading, 1-3 dm. long, forking : leaves few ; blades linear-spatulate, $0.5-2 \mathrm{~cm}$. long, obtusish, sessile: pedicels solitary, filiform, $1.5-3 \mathrm{~cm}$. long: sepals oblong or oblong-lanceolate, $2.5 \mathrm{~mm}$. long, acute, 3 -nerved : petals wanting : stamens 4-8: 
styles 3-4, very short : capsules ovoid, surpassing the persistent sepals : seeds about $0.8 \mathrm{~mm}$. broad.

On river banks, Kentucky and Tennessee. Spring.

\section{CERÁSTIUM L.}

Annual or perennial, often upright herbs, with pubescent and commonly viscid foliage. Leaves opposite : blades flat. Flowers in forking cymes. Sepals 5, or rarely 4. Petals as many as there are sepals, white, notched or 2-cleft, rarely wanting. Stamens 10 or fewer : filaments shorter than the petals. Ovary 1-celled: styles as many as there are sepals and opposite them, or rarely fewer. Capsule cylindric, often curved, opening by 10 or rarely 8 apical tooth-like valves. Mouse-Ear Chick Weed.

Segments of the capsule revolute at maturity.

1. C. Texanum. Segments of the capsule erect or spreading.

Petals shorter than the sepals or about equalling them in length.

Pedicels shorter than the sepals at maturity.

Pedicels longer than the sepals at maturity.

Leaf-blades less than $4 \mathrm{~mm}$. long: sepals $3-3.5 \mathrm{~mm}$. long : capsules $5-7$ $\mathrm{mm}$. long.

Leaf-blades over $4 \mathrm{~mm}$. long : sepals $5-6 \mathrm{~mm}$. long : capsules 7-10 mm. long.

Petals manifestly longer than the sepals.

Annual: foliage viscid: corollas 6-12 $\mathrm{mm}$. broad.

Pedicels several times longer than the sepals, abruptly bent.

Pedicels shorter than the sepals or but slightly longer, straight or nearly so.

Perennial: foliage glabrous or pubescent: corollas 17-21 mm. broad.

2. C. viscosum.

3. C. semidecandrum.

4. C. vulgatum.

5. C. longipedunculatum.

6. C. brachypodum.

7. C. arvense.

1. Cerastium Texànum Britton. Perennial, slender, sparingly pilose. Stem erect, 1.5-2 dm. tall, wire-like, forking above: leaf-blades spatulate, 2-4 pairs near the base of the stem, 8-15 mm. long, acute, pilose on both sides : sepals oblong-lanceolate, $4 \mathrm{~mm}$. long, obtuse or notched at the apex: petals white, oblanceolate, delicately nerved, notched at the apex, slightly longer than the sepals : stamens slightly shorter than the petals : capsules $5 \mathrm{~mm}$. long, the 10 valves with recurved tips : seeds $0.5 \mathrm{~mm}$. thick, sharply tubereulate, especially on the edges.

On hills, central Texas and Arizona.

2. Cerastium viscòsum L. Annual, viscid-villous, pale green. Stem branched at the base, the branches erect or decumbent, 1-4 dm. tall, simple below, forking above : leafblades varying from spatulate at the base of the stem to oval above, obtuse or rounded at the apex, sessile : pedicels usually shorter than the calyx : sepals oblong-lanceolate, 3-4 $\mathrm{mm}$. long, acute : petals white, elliptic-oblong, longer than the sepals, deeply notched, the segments acutish : stamens about $\frac{1}{2}$ as long as the petals : capsules $7-9 \mathrm{~mm}$. long, the valvetips ascending: seeds $0.6 \mathrm{~mm}$. broad.

In meadows and on hillsides, New Brunswick to Ontario, Florida and Texas. Spring. A native of Europe, now widely naturalized.

3. Cerastium semidecándrum L. Annual or biennial, slender, viscid-villous. Stem simple, or branched at the base, the branches erect or ascending, 0.5-1.5 dm. tall, forking above: leaf-blades oblong, elliptic or obovate, or the lower spatulate, $5-10 \mathrm{~cm}$. long, acute or obtuse, sessile : flowers in open or close cymes: pedicels finally longer than the calyx : sepals lanceolate, 3-3.5 mm. long, acuminate: petals oblong, deeply notched at the apex, about as long as the sepals : stamens often 5 : capsules $5-7 \mathrm{~mm}$. long, slightly curved : seeds $0.5 \mathrm{~mm}$, in diameter.

In waste places, New Jersey to North Carolina. Naturalized from Europe. Spring.

4. Cerastium vulgàtum L. Perennial, slender, pilose and somewhat elammy, dark green. Stem branched at the base, the branches erect or ascending, 1-5 dm. long, with enlarged nodes and spreading or recurved pubescence : leaf-blades oblong, narrowly elliptic or ovate, or the lower spatulate, $0.5-3.5 \mathrm{~cm}$. long, acute or obtuse, ciliate, sessile : cymes at length open : sepals lanceolate, obtuse, ciliate, ascending, 5-6 mm. long, pilose, with scarious margins : petals white, $5-6 \mathrm{~mm}$. long, narrowly obovate, cleft to above the middle : capsules narrowly ovoid, $7-10 \mathrm{~mm}$. long, fluted, the valves lanceolate, spreading: seeds brown, $0.5-1 \mathrm{~mm}$. in diameter.

Along roadsides and in woods, throughout North America, except the extreme north. Mainly naturalized from Europe. Widely distributed. Spring to fall.

5. Cerastium longipedunculàtum Muhl. Annual or biennial, clammy-villous or glabrate. Stem more or less branched at the base, the branches ascending or reclining, 1-5 dm. tall, simple or forked above : leaf-blades thinnish, the lower ones spatulate or oblanceolate, 2-8 cm. long, obtuse, the upper stem-leaves oblong, linear-oblong or lanceolate, 
1-6 cm. long, obtuse or acute, sessile: flowers in open cymes: pedicels finally bent or hooked at the apex, often conspicuously elongated : sepals oblong or oblong-lanceolate, 4-5 mm. long, acute: petals linear-oblong, notched at the apex, slightly longer than the sepals, very delicate : capsules slender, 9-13 mm. long, nodding, eurved upward : seeds $0.8 \mathrm{~mm}$. broad. [Cerastium nutans Raf.]

In woods, Nova Scotia to British Columbia, Florida and Mexico. Spring. Powder-Hors.

6. Cerastium brachýpodum (Engelm.) Robinson. Annual, slender, pale green. Stem simple or branched at the base, the branches erect or ascending, $0.5-1.5 \mathrm{dm}$. tall, simple or forked above: leaf-blades thickish, the lower ones oblanceolate or spatulate, the stemleaves oblanceolate, oblong or linear-oblong, 1-3 cm. long, acute or obtuse : flowers in open or sometimes congested cymes : sepals lanceolate, $3-4 \mathrm{~cm}$. long, acute or acuminate: petals longer than the sepals : capsules $5-8 \mathrm{~mm}$. long, about as long as the pedicels or slightly shorter: seeds $0.5 \mathrm{~mm}$. in diameter.

In dry soil, Illinois to South Dakota, Georgia, Texas, Arizona and Mexico. Spring and summer.The state with congested cymes and very slender capsules is, C. brachypodum compactum Robinson; it occurs from Nebraska to Texas.

7. Cerastium arvénse L. Perennial, slender, softly pubescent. Stem usually much branched at the base, often matted, the branches erect or ascending, 1-4 dm. tall, simple or sparingly forking above, often nearly naked: leaf-blades thick, the lower ones sometimes spatulate, or narrowly oblanceolate, the rest linear or linear-lanceolate, $3-5 \mathrm{~cm}$. long, acute, sessile : flowers in open cymes on erect elongating pedicels : sepals oblong-lanceolate, 4-5 mm. long, acutish : petals cuneate, fully twice as long as the sepals, deeply notched: capsules about equalling the sepals.

On dry or rocky hillsides, Labrador to Alaska, Georgia and California. Spring.

\section{Family 11. CARYOPHyLlàceaE Reichenb. Pink Family.}

Annual or perennial herbs, with a watery sap and usually erect stems enlarged at the nodes. Leaves opposite: blades commonly narrow, often with connate bases: stipules wanting. Flowers perfect, polygamous or rarely dioecious. Calyx of 4-5 united sepals forming a toothed tube. Corolla often showy, of 4-5 petals with narrow claws and blades at whose junction there usually exists a scale. Androecium of usually twice as many stamens as there are petals. Filaments usually distinct, inserted like the corolla and 1-celled ovary on the columnar prolongation of the receptacle. Gynoecium of a single compound pistil. Styles 2-5. Ovules numerous. Fruit a capsule opening by $2-5$ apical valves. Seeds many or rarely few, with the embryo straight in the endosperm or nearly so.

Calyx-tube with 5 ribs, nerved or nerveless.

Petals unappendaged.

Calyx-tube terete or nearly so, subtended by bractlets.

Calyx-tube 5-angled, without bractlets.

Petals appendaged at the base of the blade.

Calyx-tube with at least twice as many ribs as lobes.

Styles 3 or rarely 4 .

Styles 5 .

1. Dianthus.

2. VACCARIA.

3. SAPONARIA.

4. Silene.

5. Agrostema.

\section{DIÁNTHUS L.}

Perennial or rarely annual herbs, with rather stiff stems. Leaves opposite: blades usually narrow. Flowers perfect, solitary or in terminal cymes. Calyx sessile in an involucre of several bractlets : tube elongated, finely and equally striate: lobes 5 , relatively short. Petals 5, deeply colored, with long claws : blades toothed or eroded. Stamens 10. Ovary 1-celled, stalked: styles 2. Capsule opening by 4 or rarely 5 tooth-like valves. Seeds flattened. Embryo straight, eccentric. PINk.

1. Dianthus Armèria L. Annual, minutely pubescent. Stems erect, simple or usually branched at the base and above, 2-6 dm. tall : leaves linear, or the blades of the basal ones linear-spatulate, $3-8 \mathrm{~cm}$. long, obtuse or acutish, sessile, the cuneate bases sheathing the stem: flowers clustered at the ends of the branches : calyx pilose; tube cylindric, nearly $1.5 \mathrm{~cm}$. long, delicately striate; lobes lanceolate, acuminate, about $\frac{1}{3}$ as long as the tube: petals pink, often spotted with white; blades oblong, notched at the apex, crenate, about $\frac{1}{2}$ as long as the claws : capsules cylindric, about as long as the calyx, shortstalked : seeds $1.5 \mathrm{~mm}$. long, abruptly pointed.

In fields and on roadsides, Maine to Ontario and Iowa, south to Georgia. Naturalized from Europe. Summer. 


\section{VACCÀRIA Medic.}

Annual caulescent herbs, with glabrous and glaucous foliage. Leaves opposite : blades narrow, often thickish, entire, clasping. Flowers in dichotomous cymes. Calyx pedicelled, without an involucre of bractlets: tube somewhat inflated, 5-angled : lobes 5, very short. Petals 5, surpassing the calyx, without appendages, with claws. Stamens 10: filaments slender. Ovary 1-celled: styles 2. Capsule opening by 4 apical tooth-like valves. Seeds laterally attached. Embryo slightly curved.

1. Vaccaria Vaccària (L.) Britton. Foliage glaucous. Stems erect, $3-9 \mathrm{dm}$. tall, corymbose above: leaf-blades lanceolate to ovate-lanceolate or broadest above the middle on the lower part of the stem, acute, connate, entire : calyx oblong to ovoid, $1-1.5 \mathrm{~cm}$. long, 5 -angled, becoming 5 -winged at maturity : petals without appendages at the base of the erose rose-colored blades: capsules $5-10 \mathrm{~mm}$. long.

In fields and waste places, Ontario to British Columbia, Florida and Texas. Summer. Cow-Herb.

\section{SAPONÀRIA L.}

Annual or perennial caulescent herbs, often with elongated rootstocks. Leaves opposite: blades flat, mainly sessile. Flowers perfect, in close cymes. Calyx short-pedicelled : tube terete, somewhat elongated: lobes 5, relatively short. Petals 5, with long claws and notched blades. Stamens 10: filaments slender. Ovary 1-celled or incompletely 2-4-celled : styles 2. Capsules opening by 4 apical tooth-like valves.

1. Saponaria officinàlis L. Perennial, stout, nearly glabrous, bright green. Sten erect or usually decumbent, 3-9 dm. long, becoming woody below, enlarged at the nodes, simple or branched above, the internodes lengthening upwards: leaf-blades elliptic or lanceolate, leathery, 3-10 cm. long, obtuse or acute, ciliate, 3-nerved, sessile or nearly so : flowers often double, in terminal or axillary, more or less corymbed clusters : calyx cylindric, terete, $2-2.5 \mathrm{~cm}$. long, at length somewhat inflated; lobes triangular, acute or short-acuminate, whitish-margined: pedicels $0.5-1 \mathrm{~cm}$. long, bearing 2 scales: petals spatulate; blades $1.5 \mathrm{~cm}$. long, notched at the apex, shorter than the claws, each furnished with an appendage at the base : stamens exserted, their tips spreading: capsules shortstalked, conic, 1-1.5 cm. long, smooth and glabrous.

On river banks and roadsides, common in eastern North America. Naturalized from Europe. Summer and fall. BOUNCING BET. SOAPWORT. HEDGE PINK.

\section{SILÈNE L.}

Annual or perennial herbs, with simple or matted stems. Leaves opposite or whorled: blades usually flat, entire. Flowers perfect, often showy, in terminal cymes, or solitary. Calyx often pedicelled : tube more or less inflated, 10-many-nerved: lobes short, erect or spreading. Petals 5, usually red, pink or white: claws mostly appendaged at the top: blades variously cleft or divided, or rarely entire. Stamens 10. Ovary 1-celled or incompletely 2-4-celled: styles 3 , or rarely 4 . Capsule opening by 6 or rarely 3 apical tooth-like valves.

Annual or biennial.

Inflorescence simple.

Inflorescence branched.

Flowers in dichotomous racemes.

Flowers in dichotomous cymes.

Foliage pubescent: stem viscid.

Foliage glabrous, sometimes glutinous about the nodes of the stem.
Perennial.

Caly $\mathrm{x}$ inflated.

Leaves in whorls of 4's: petals laciniately cleft; appendages wanting.

Leaves opposite: petals 2-cleft; appendages present.

Calyx merely filled by the capsules.

Bla white or pink.

Blades of the petals erose.

Blades of the petals fringed or dichotomously cleft.

Stems with short rigid hairs : caly $x$ about $1 \mathrm{~cm}$. long.

Stems with villous pubescence: caly $\mathrm{x}$ about $2.5 \mathrm{~cm}$. long.

1. S. Anglica.

2. S. dichotoma.

Corolla scarlet or crimson.
* Petals 2-lobed.

Stems finely pubescent: upper stem-leaves with blades several times longer than broad.

Stems villous: upper stem-leares with blades usually less than twice as long as broad.

3. S. noctiflora.

4. S. antirrhina.

5. S. stellata.

6. S. alba.

7. S. Caroliniana.

8. S. ovata.

9. S. Baldwinit.

10. S. Virginica.

11. S. rotundifolia. 
** Petals entire or nearly so, sometimes merely erose. Foliage pubescent: leaf-blades lanceolate to ovate. Foliage glabrous : leaf-blades narrowly linear-oblong.

12. S. regia.

13. S. subciliata.

1. Silene Ánglica L. Annual, villous. Stems erect, 2-4 dm. tall, simple or branched: leaves opposite; blades spatulate or the upper linear, $1.5-3 \mathrm{~cm}$. long, obtuse, apiculate, sessile or the lower ones short-petioled : flowers racemose on the branches : pedicels shorter than the calyx : calyx furnished with long villous hairs; tube becoming oval, less than 1 $\mathrm{cm}$. long; lobes narrowly lanceolate, about $\frac{1}{4}$ as long as the tube : petals pink or crimson, with a paler edge ; blade notched: capsules oval, about $8 \mathrm{~mm}$. long: seeds about $1 \mathrm{~mm}$. broad.

In waste places, Maine and Ontario to South Carolina. Also on the Pacific slope. Spring and summer.

2. Silene dichótoma Ehrh. Annual or biennial, hirsute and viscid. Stems erect, 3-7 dm. tall, branching above : leaves opposite ; blades oblanceolate to lanceolate, $5-8 \mathrm{~cm}$. long, or the upper ones narrower and shorter: flowers in dichotomous racemes, often nodding during anthesis : calyx hirsute, 12-16 mm. long; tube cylindric, becoming ovoid, with simple green ribs; lobes ovate or ovate-lanceolate, acute : petals white or pink; blades obovate, 2-cleft : capsules about $1 \mathrm{~cm}$. long.

In fields and waste places, locally established in the United States. Summer.

3. Silene noctiflòra L. Annual, viscid-pubescent. Stems erect, 2-8 dm. long, simple or branched : leaf-blades thickish, the lower ones spatulate, $5-15 \mathrm{~cm}$. long, obtuse or acutish, those on the upper part of the stem elliptic, oblong or lanceolate, shorter than the lower ones: flowers fragrant: calyx glandular-pubescent; tube becoming ovoid or elliptic, 1-1.5 cm. long, with green ribs; lobes lanceolate, twice or thrice shorter than the tube, acute : petals with 2-cleft blades : capsules elliptic or elliptic-ovoid, $1.5-2 \mathrm{~cm}$. long, shining : seeds about $1 \mathrm{~mm}$. in diameter, minutely tuberculate.

In fields and waste places, New Brunswick to Manitoba, Florida and Missouri. Summer.

4. Silene antirrhìna L. Annual, glabrous or minutely papillose, with viscid patches on the upper internodes. Stems erect, $2-8 \mathrm{dm}$. tall, simple or much branched: leaf-blades linear to linear-oblong, or the lower ones elliptic, 2-8 $\mathrm{cm}$. long, acute or acutish, entire, sessile, ciliate, especially near the base : flowers inconspicuous : calyx glabrous, 7-9 mm. long; tube delicately ribbed; lobes triangular or ovate, $\frac{1}{4}-\frac{1}{5}$ as long as the tube : petals nearly linear, about $8 \mathrm{~mm}$. long, deeply notched at the apex, "the tips white or pink: stamens about as long as the calyx : capsules oblong to oval, slightly longer than the calyx, the tips of the valves spreading : seeds $0.7 \mathrm{~mm}$. broad, gray-black.

In fields and waste places, Maine to Ontario, British Columbia. Florida, Texas and Mexico. Summer.-A very slender state with globose calyx-tubes, occurring in Georgia and Florida, is known as $S$. antirrhina linària Wood. SLEEPY CATCHFLY.

5. Silene stellata (L.) Ait. f. Perennial by a stout rootstock, slender, pubescent with short recurved hairs or rarely glabrous, bright green. Stems solitary or several together, simple or branched above, very prominently enlarged at the nodes: leaves in whorls of 4 ; blades ovate or lanceolate, 4-12 cm. long, acuminate, ciliate, abruptly narrowed or rounded at the base, sessile : panicle 1-5 dm. Jong: caly x campanulate, $1-1.5 \mathrm{~cm}$. long, inflated above the middle; lobes broadly triangular or triangular-ovate, obtuse, $\frac{1}{3}$ as long as the tube, somewhat spreading: petals white, spatulate, about $2 \mathrm{~cm}$. long, laciniate, the segments often toothed at the tips : filaments nearly as long as the petals : capsules subglobose or ovoid-globose, smooth, shining, 6-7 mm. in diameter : seeds black, a little more than $1 \mathrm{~mm}$. in diameter.

In woods, Massachusetts to Minnesota, Georgia and Texas. Summer. Starry CaMPion.

6. Silene álba Muhl. Perennial, minutely pubescent or glabrate in age. Stems reclining, 3-8 dm. long, simple or branched : leaves opposite ; blades lanceolate or linearlanceolate, sometimes slightly broadest above the middle, 4-15 cm. long, acuminate, sometimes ciliate, sessile : flowers about $2 \mathrm{~cm}$. long : calyx viscid-pubescent, 1.5-1.8 cm. long ; tube cylindric ; lobes ovate, about $\frac{1}{4}$ as long as the tube, obtuse, with hyaline edges : petals white ; claws oblanceolate; blades broadly oval or suborbicular, shorter than the claws, notched at the apex, with 2 spurs at the base : stamens slightly exserted : capsules ovoid, about $1 \mathrm{~cm}$. long, each on a stout stalk 4-5 mm. long : seeds $1 \mathrm{~mm}$. broad, minutely tuberculate. [S. nivea Otth.]

On river banks, Pennsylvania to Minnesota, Maryland and Tennessee. Summer.

7. Sllene Caroliniàna Walt. Perennial, clammy-pubescent. Stems more or less densely tufted, $1-2.5 \mathrm{dm}$. tall, erect or spreading, simple or sparingly branched : leafblades oblanceolate, linear-oblanceolate or spatulate, or the upper ones lanceolate, $3-12 \mathrm{~cm}$. long, acute or apiculate, ciliate, the lower ones slender-petioled, the upper ones sessile or 
nearly so : calyx densely glandular, delicately ribbed; tube narrowly cylindric or inflated in age, $1.5-2 \mathrm{~cm}$. long; lobes ovate, about $3 \mathrm{~mm}$. long, with broad hyaline margins : petals white or deep pink, about $3 \mathrm{~cm}$. long; claws linear-filiform ; blades obovate, emarginate, undulate, about $\frac{1}{2}$ as long as the claws, with 2 scales at the base: capsules elliptic, less than $1 \mathrm{~cm}$. long, about equalling the short stalks in length. [S. Pennsylvanica Michx.]

In rocky woods and on banks, Maine to New York, Georgia and Kentucky. Spring. Wild Pink.

8. Silene ovata Pursh. Perennial, roughish with a short rigid pubescence. Stems erect, 5-12 dm. tall, simple or sparingly branched above : leaves opposite ; blades ovate to ovate-lanceolate or oblong-lanceolate, 4-15 cm. long, acuminate, 3-nerved, sessile, the lower ones cordate: flowers in a narrow panicle 1-3 dm. long: calyx about $1 \mathrm{~cm}$. long; tube cylindric or inflated and obovoid in age; lobes triangular or broadly lanceolate, acute, $\frac{1}{3}-\frac{1}{4}$ as long as the tube: petals white; blades fimbriate, without appendages : capsules narrowly ovoid, $8 \mathrm{~mm}$. long : seeds about $1 \mathrm{~mm}$. thick.

In woods on the mountains, North Carolina to Georgia and Alabama. Summer.

9. Silene Baldwíni Nutt. Perennial, villous. Stem erect or ascending, 1-4 dm. tall, simple or sparingly branched above, producing runners at the base : leaves opposite; blades 3-9 $\mathrm{cm}$. long, obtuse or acute, the lower ones spatulate, on winged petioles, those about the middle of the stem often oblong and the upper ones usually lanceolate or oblonglanceolate, sessile : calyx about $2.5 \mathrm{~cm}$. long; tube cylindric or barely inflated in age; lobes lanceolate, about $\frac{1}{4}$ as long as the tube : corolla $5 \mathrm{~cm}$. broad, white or pink : petals delicate ; blades fan-shaped, fimbriate, without appendages, nearly as long as the claws: stamens exserted.

In shady woods, Georgia and Florida. Spring.

10. Silene Virgínica L. Perennial, clammy-pubescent. Stems erect, solitary or several together, $2-5 \mathrm{dm}$. tall, simple or branched above : leaves opposite : blades thickish, the lower ones spatulate, $0.5-2 \mathrm{dm}$. long, acute or acutish; petioles winged, ciliate, the upper leaves passing through obovate, oblong or elliptic to lanceolate near the top of the stem, sessile : calyx densely glandular-pilose ; tube $1.5-2.5 \mathrm{~cm}$. long, delicately ribbed ; lobes triangular-ovate, $\frac{1}{3}-\frac{1}{4}$ as long as the tube : corolla crimson $2.5 \mathrm{~cm}$. broad : petals delicate ; blades linear or narrowly-oblong, notched at the apex, a little shorter than the claws : capsules oval, $1-1.5 \mathrm{~cm}$. long, several times longer than the stalk: seeds a little over $1 \mathrm{~mm}$. thick.

In dry woods and on hillsides, Ontario to Minnesota, New Jersey, middle Georgia, Alabama and Arkansas. Spring to fall. FIRE PINK.

11. Silene rotundifòlia Nutt. Perennial, clammy-villous. Stems weak, solitary or tufted, decumbent or reclining, 2-7 dm. long, simple or branched above : leaves opposite ; blades thinnish, the lower ones spatulate, 2-10 $\mathrm{cm}$. long, the upper stem-leaves oval, abruptly acuminate at each end, or the uppermost broadly ovate and cordate at the base : flowers few, showy: calyx-tube cylindric, somewhat inflated in age, $2-2.5 \mathrm{~cm}$. long; lobes ovate-lanceolate, about $\frac{1}{3}$ as long as the tube : petals bright scarlet ; blades oblong, deeply 2-cleft, the segments entire or toothed; claws longer than the blades : stamens exserted: capsules about $2 \mathrm{~cm}$. long.

On rocky banks, Ohio to Alabama and Georgia. Summer.

12. Silene règia Sims. Perennial, viscid-pubescent with short stiff hairs. Stems erect, solitary or several together, $1-1.5 \mathrm{~m}$. tall, strict, rigid, simple below : leaves opposite; blades thickish, lanceolate to ovate, or the lower ones linear-oblong, 4-8 cm. long, acute or acutish, ciliolate, sessile : flowers in strict panicles : calyx about $2 \mathrm{~cm}$. long; tube cylindric, with green ribs, somewhat inflated in age ; lobes ovate, $\frac{1}{6}-\frac{1}{8}$ as long as the tube : corolla $3 \mathrm{~cm}$. broad : petals scarlet, often notehed or laciniate : capsules oblong-conic, about $1.5 \mathrm{~cm}$. long.

In dry soil or rocky woods, Ohio to Missouri, Georgia and the Indian Territory. Summer.

13. Silene subciliàta Robinson. Perennial, glabrous. Stems erect, strict: leaves opposite, slightly fleshy, $3-5 \mathrm{~cm}$. long, narrowly linear-oblong, sparingly ciliate, terminating in blunt callous tips, narrowed into ciliate winged petioles : flowers in slender elongated racemes, the lower ones distant : calyx glabrous, about $2 \mathrm{~cm}$. long; tube cylindric : petals crimson; blades elliptic, entire, obtuse.

On prairies, Louisiana and Texas. Summer.

\section{AgROSTÉmMa L.}

Annual herbs, with upright stems. Leaves opposite: blades narrow, sessile. Flowers perfect, terminating elongated pedicels. Calyx woolly : tube becoming distended, 10ribbed : lobes narrowly linear, elongated. Corolla showy. Petals 5: blades shorter than 
the calyx-lobes, broadened upward, unappendaged. Stamens 10. Ovary 1-celled : styles 5 , alternating with the calyx-lobes. Capsule 1-celled, opening by tooth-like valves. Seeds black, the embryo eurved.

1. Agrostemma Githàgo L. Foliage pubescent with long appressed hairs. Stems erect, 2-9 dm. tall, branched, the branches erect or ascending: leaf-blades linear, 4-12 cm. long, acute, sessile : pedicels $0.5-2.5 \mathrm{dm}$. long : calyx pubescent like the stem; tube eylindric, 1.5-2 cm. long, 10-ribbed ; lobes linear, longer than the tube, acute: petals with obovate blades $2 \mathrm{~cm}$. long, rounded or notched at the apex, purple or magenta, paler at the base, indistinctly nerved, shorter than the calyx-lobes: seeds angular, $2 \mathrm{~mm}$. in diameter, spiny-tuberculate all over.

In fields, common in or about grain fields throughout North America. Naturalized from Europe. Summer. CORN COCKLe. CORN Rose.

\section{Order 11. RANALES.}

Herbs, shrubs or trees. Leaves normal, often of 2 forms on aquatic plants : blades simple or sometimes compound. Flowers perfect, monoecious or dioecious, variously disposed. Calyx and corolla of distinct and separate members. Androecium of usually hypogynous stamens, which are mostly more numerous than the sepals. Gynoecium of 1 or several, distinct or rarely more or less united, carpels. Ovary superior. Fruit various.
Stamens usually numerous, the anther-sacs opening by slits.
Land plants, except in CERATOPHYLLACEAE and some RANUNCULACEAE: leaf-blades not peltate.
Flowers perfect or monoecious, if dioecious on neither vines nor herbs with simple leaves. Plants with minute axillary monoecious flowers : anthers with horn-like appendages.

Plants with perfect or rarely dioecious flowers: anthers not with horn-like appendages.

Carpels 1 or more, distinct, at least at maturity. Sepals $2-15$ : petals about as many : plants if shrubby not with pulpy fruit: endosperm even. Sepals 5: petals $6:$ fruit pulpy: endosperm channeled.

Carpels more or less coherent or united into cone-like structures, or immersed in the pulpy receptacle. Sepals valvate. Sepals imbricated.

Flowers dioecious : vines with simple leaves.

Water plants: emersed or floating leaves with peltate blades.

Carpels several and distinet.

Carpels not in a fleshy receptacle: sepals and petals 3 or 4 each : stamens 3-18.

Carpels immersed in a fleshy receptacle: sepals and petals numerous : stamens indefinite.

Carpels united into a compound pistil.

Stamens few and definite, the anther-sacs opening by hinged valves, except in Podophyllum.

Fam. 1. Ceratophylclaeak.

Fam. 2. Ranunculaceae.

Fam. 3. ANonaceat.

Fam. 3. ANONACEAE.

Fam. 4. MAgNoliachae.

Fam. 5. Menisperyaceae.

Fam. 6. Cabombaceae.

Fam. 7. Nelumbonaceae. Fam. 8. NYMPHAEACEAE.

Fam. 9. Podophyllaceae.

\section{Family 1. CERATOPHyllàceat A. Gray. Hornwort Family.}

Aquatic perennial herbs, with submersed jointed branching stems. Leaves whorled: blades 2-cleft or finely dissected, the filiform segments forking. Flowers monoecious, inconspicuous, axillary, sessile. Caly x herbaceous. Sepals 6-12, narrow, rather valvate, toothed or cleft at the apex. Staminate flowers with 10-24 stamens crowded on a flat or convex receptacle : filaments very short : anthers opening by longitudinal cracks, the connective produced into an often 2-3-toothed fleshy appendage. Pistillate flowers without staminodia. Ovary 1-celled, sessile: style cylindric. Ovule solitary, anatropous, pendulous. Fruit nut-like, somewhat flattened, 1-celled, naked : pericarp leathery or crustaceous. Seed pendulous, with a membranous testa. Endosperm wanting. Embryo straight.

\section{CERATOPHÝLLUM L.}

Characters of the family. The plants flower mainly in the summer.

Achenes unarmed.

Achenes armed on the edges with spines.

Leaves 6-9 in a whorl; segments spiny-toothed: achenes with a spine on either side of the base.

Leaves $9-12$ in a whorl; segments bristly-toothed: achenes fringed with spines.

1. C. submersum.

3. C. echinatum. 
1. Ceratophyllum submérsum L. Stems $3-4 \mathrm{dm}$. long. Leaves flaccid, several in a whorl ; blades three to four times forking, the segments filiform, bristly-toothed : achenes oblong, slightly flattened, $4 \mathrm{~mm}$. long, unarmed, sparingly warty, the rounded edges unarmed.

In ponds, southern peninsular Florida.

2. Ceratophyllum demérsum L. Stems $3-12 \mathrm{dm}$. long, branching. Leaves rather rigid, 6-9 in a whorl, 1-2 cm. long; blades once or twice forking, the ultimate segments spiny-toothed : achenes oblong, slightly flattened, $5 \mathrm{~mm}$. long, each tipped with the persistent style and armed with a spreading spine on either side at the base.

In ponds and still water, throughout North America except the extreme north.

3. Ceratophyllum echinàtum A. Gray. Stems $2-5 \mathrm{dm}$. long, branching. Leaves flaccid, 9-12 in a whorl, $1.5-2.5 \mathrm{~cm}$. long; blades three to four times forking, the ultimate segments bristly-toothed: achenes oval, 5-6 mm. long, flattened, each tipped with the persistent style, the faces warty, the slightly winged edges fringed with spreading spines.

In slow streams and ponds, throughout the United States and southern British America.

\section{FAmily 2. RANUNCULÀCEAE Juss. Crowfoot FAmily.}

Annual or perennial herbs, or rarely climbing shrubs, with an acrid sap. Leaves alternate (except in the ClematideAE): blades simple or compound. stipules wanting, but the base of the petiole often clasping or sheathing. Pubescence, when present, composed of simple hairs. Calyx of 3-15, generally caducous often petal-like sepals, imbricated (except in the Clematideat). Corolla of about as many petals as there are sepals, occasionally more, or wanting. Flowers regular or irregular. Stamens several or numerous, hypogynous, their anthers innate. Carpels numerous, or rarely solitary, 1-celled, 1-manyovuled. Ovules anatropous. Fruit an achene, follicle or berry. Seed with endosperm.

Fruit a follicle or a berry : carpels with several ovules or with only 1 or 2 ovules in genera Nos. 1 and 4 .

Flowers regular.

Leaf-blades palmately nerved or palmately compound.

Petals wanting.

Carpels ripening into a head of red berries.

Carpels ripening into a head of dry follicles.

Petals present.

Leaf-blades pinnately or ternately compound or decompound.

Petals without spurs or wanting.

Fruit dry follicles.

Shrubs.

Herbs.

Low herbs, with solitary or few loosely panicled flowers. Carpels and follicles stalked.

Carpels and follicles sessile.

Tall herbs, with numerous flowers in strict, simple or branched racemes.

Fruit berry-like follicles.

Petals prolonged back ward into hollow spurs.

Flowers irregular.

Posterior sepals prolonged into a spur.

Posterior sepals more or less helmet-like.

Fruit an achene : carpels with a single ovule each.

Flowers, or their pedicels or peduncles, subtended by involucres.

Involucre close under the calyx; bracts entire.

Involucre remote from the calyx; bracts toothed, divided or compound.

Styles subulate: leaf-segments sessile.

Styles wanting: leaflets stalked.

Flowers not subtended by involucres.

Leaves opposite: sepals petal-like.

Petals wanting.

Stamens spreading : sepals spreading.

Sepals with scarcely any border: flowers dioecious or polygamodioecious.

Sepals with a wide border : flowers perfect.

Stamens erect: sepals more or less converging.

Petals present (in our species), smaller than the sepals.

Leaves alternate, sometimes all basal.

Sepals spurred.

Sepals spurless.

A. Leaf-blades entire, toothed, palmately lobed or dissected.

Petals wanting.

Petals present.

a. Blades of the petals with a nectariferous pit at the base.

Achenes transversely wrinkled : petals white.

Achenes not transversely wrinkled: petals yellow, at least

1. HYDRASTIS.

2. CALTha.

3. HELLEBORUs.

4. XANTHORRHIZA.

5. Coptis.

6. ISOPYRUM.

7. Cimicifuga.

8. ACTAEA.

9. Aquilegia.

10. Delphinium.

11. Aconitum.

12. Hepatica.

13. AnEMONE.

14. SYNDESMON. without.

15. Clematis

16. Viticella.

17. VIORNA.

18. Atragene.

19. Myosurus.

20. Trautvetteria.

21. Batrachitu. 
Achenes longitudinally ribbed.

Achenes smooth, papillose or spiny.

b. Blades of the petals without a nectariferous pit at the base.

B. Leaf-blades ternately decompound.

22. HALERPESTES.

23. Ranunculus.

24. A DONIS.

25. THALICTRUM.

\section{HYDRÁSTIS Ellis.}

Perennial herbs, with pubescent foliage and erect stems. Leaves few : blades palmately lobed, reniform. Flower terminal, solitary, greenish white. Sepals 3, petal-like, falling away at anthesis. Petals wanting. Stamens numerous: filaments white. Carpels numerous, each bearing two ovules near the middle, and in fruit forming a head of 1-2-seeded crimson berries, somewhat resembling a raspberry.

1. Hydrastis Canadénsis L. Rootstock thick, yellow. Stem erect, mostly 2-4 dm. high. Basal leaf with a long-petioled reniform blade $12-20 \mathrm{~cm}$. broad, palmately 5 -9-lobed, the lobes broad, acute, sharply and unequally serrate; cauline leaf borne at the summit of the stem : bract leaf-like, subtending the greenish white flower which is $8-10 \mathrm{~mm}$. broad when expanded : filaments widened, about $4 \mathrm{~mm}$. long: anthers oblong, obtuse : head of fruit ovoid, blunt, about $16 \mathrm{~mm}$. long, each fleshy carpel tipped with a short curved beak.

In woods and thickets, Connecticut to Vermont, Minnesota, Georgia and Missouri. Spring. Orange-Root. Golden SEAL.

\section{CÁLtha L.}

Perennial herbs, with succulent tissues. Leaves few, mostly basal : blades simple, entire or crenate, cordate or auriculate. Flowers yellow, white or pink. Sepals large, petal-like, deciduous. Petals wanting. Stamens numerous, obovoid. Carpels numerous or few, sessile, bearing ovules in two rows along the ventral suture, in fruit forming follicles.

1. Caltha palústris L. Foliage glabrous. Stem stout, hollow, often tufted, erect or ascending, 2-6 dm. high, branching and bearing several flowers : basal leaves with long and stout petioles; blades cordate or reniform, 5-18 $\mathrm{mm}$. wide, with a narrow sinus, entire, crenate or dentate, the upper ones shorter-petioled or sessile, nearly truncate at the base : flowers bright yellow, $2 . \tilde{0}-4 \mathrm{~cm}$. broad : sepals oval, obtuse : follicles $3-12$ or even more, compressed, 10-12 mm. long, slightly curved outward, many-seeded.

In swamps and meadows, Newfoundland and British America to the Rocky Mountains, South Carolina and Iowa. Spring. Marsh-Marigold. Meadow-Gowan.

\section{HELLÉBORUS L.}

Perennial herbs, with erect stems. Leaves large: blades palmately divided, the basal long-petioled, the upper sessile and sometimes much reduced. Flowers large, white, greenish or yellowish. Sepals 5, broad, petal-like, mainly persistent. Petals small, unguiculate, tubular. Stamens numerous. Carpels generally few, sessile, in fruit forming several-seeded capsules, which are dehiscent at the apex at maturity.

1. Helleborus víridis L. Foliage glabrous. Stem stout, erect, $3-6 \mathrm{dm}$. high : basal leaves with blades $2-3 \mathrm{dm}$. broad, on petioles $1.5-2.5 \mathrm{dm}$. long, palmately divided into $7-11$ oblong acute sharply serrate segments $7-10 \mathrm{~cm}$. long: bracts sessile, similar to the leaves, subtending the large drooping yellowish green flowers: sepals broadly oblong, obtuse, spreading, about $2.5 \mathrm{~cm}$. long: petals tubular, 2-lipped, $4 \mathrm{~mm}$. long: stamens widened : anthers oblong, obtuse : pods $15 \mathrm{~mm}$. long, each tipped with a slender beak onethird their length or longer.

In waste places, locally adventive from Europe in New York, New Jersey, Pennsylvania, Virginia and North Carolina. Spring. Green HeLlebore.

\section{XANTHORRHİZA L'Her.}

Low shrubby plants,"with yellow roots and rootstocks and brittle stems. Leaves approximate : blades pinnate or bipinnate. Flowers in compound racemes. Sepals 5, petal-like, deciduous. Petals 5, smaller than the sepals, clawed, concave, 2-lobed. Stamens 5 or 10, sessile, 2-ovuled, forming 1-seeded follicles at maturity by the suppression of one of the ovules.

1. Xanthorrhiza apiifolia L'Her. A weak shrub 2-6 dm. tall, with glabrate foliage and yellow and bitter bark, and long roots. Leaves clustered at the summit of the short stem; blades pinnate or sometimes bipinnate, 1-15 cm. long, slender-petioled; leaflets 
mostly 5 , thin, ovate or oblong, $2.5-7.5 \mathrm{~cm}$. long, incisely toothed, cleft or divided, acute, cuneate, shining, sessile : branches of the raceme or panicle slender, drooping, $5-7.5 \mathrm{~cm}$. long : flowers about $4 \mathrm{~mm}$. broad, pedicelled, solitary or 2 or 3 together, brownish purple : sepals ovate, acute : follicles 4-8, inflated, light yellow, 1 -seeded, diverging, curved at the apex, minutely beaked.

In woods and on rocky ledges, southwestern New York to western Florida and Alabama. Spring. Shrub Yellow-Root. Brook-FEATHER.

\section{CÓPtis Salisb.}

Low perennial scapose herbs, with slender rootstocks. Leaves basal : blades compound or divided, petioled. Scape slender. Sepals 5-7, petal-like, deciduous. Petals 5-6, white, small, linear, cucullate. Stamens numerous. Carpels stipitate, few, in fruit forming an umbel of follicles.

1. Coptis trifòlia (L.) Salisb. Foliage glabrous. Plants tufted, $7-15 \mathrm{~cm}$. high from slender or filiform yellow bitter rootstocks: leaves all basal, evergreen, with long, very slender petioles; blades reniform in outline, $2.5-5 \mathrm{~cm}$. broad, 3-divided, the segments broadly obovate-cuneate, obtuse, prominently nerved, crenate, or slightly lobed, dark green or shining above, paler beneath, the teeth mucronate: scape 1-flowered, slender: sepals oblong, obtuse : petals small, club-shaped: follicles $3-7$, about $6 \mathrm{~mm}$. long, borne on stipes of about their own length, spreading, each tipped with a beak $2-3 \mathrm{~mm}$. long.

In damp mossy woods and bogs, Newfoundland to Minnesota, British Columbia and Alaska, and in the Alleghenies to North Carolina. Spring and summer. GOLD-THREAD.

\section{ISOPỲRUM L.}

Slender perennial caulescent herbs, with glabrous foliage. Leaves basal and cauline: blades ternately decompound. Flowers solitary or panicled, white. Sepals 5-9, petal-like. deciduous. Petals 5, nectariform, or wanting. Stamens numerous. Carpels 2-20, sessile (stalked in a western species), forming a head of follicles in fruit, each with several ovules.

1. Isopyrum biternàtum (Raf.) T. \& G. Roots fibrous and sometimes tuberiferous. Stems slender, erect, paniculately branching above: basal leaves with long petioles; blades biternate, thin, the ultimate segments broadly obovate, obtuse, lobed or divided: upper leaves similar to the basal but sessile or with short petioles : flowers several, terminal or axillary, white, 1-2 $\mathrm{cm}$. broad : sepals 5, oblong or somewhat obovate, obtuse : petals wanting: stamens many : filaments slender, thickened above : carpels few : follicles widely spreading, ovate, $4 \mathrm{~mm}$. long, several-seeded, each tipped with a beak nearly one-half the length of the body. ANEMONE.

In moist woods and thickets, Ontario to Minnesota, Florida and Texas. Spring. Fatse RUE

\section{CIMICÍfUGA L.}

Perennial herbs, with stout poisonous rootstocks and tall erect stems. Leaves large, with decompound blades. Flowers white, in racemes. Sepals 2-5, petal-like, deciduous. Petals 1-8, small, clawed, 2-lobed, or wanting. Carpels 1-8, many-ovuled, sessile or stipitate. Stigma broad or minute. Follicles dry, dehiscent at maturity.

Carpels 1 or 2, sessile: seeds wholly or partially in 2 rows.

Filaments about $4 \mathrm{~mm}$. long : follicles $8-10 \mathrm{~mm}$. long : seeds chaffy

Filaments about $8 \mathrm{~mm}$. long: follicles $5-7 \mathrm{~mm}$. long: seeds smooth. Carpels 3 or 8 , stalked : seeds in 1 row.

1. C. rubifolia.

2. C. racemosa.

1. Cimicifuga rubifolia Kearney. Stems erect, 6-14 dm. tall, slender above the stout 4-angled base, terete above, with 1 or 2 leaves near the base. Leaves ample, the blades biternate, the lateral divisions 2 -foliolate, the terminal divisions mostly simple: leaflets broadly ovate or suborbicular, or broader than long, with irregular acute or acuminate lobes, sharply toothed, $12-20 \mathrm{~cm}$. broad, light green beneath, cordate at the base : panicle of $2-4$ slender racemes, the terminal one $15-30 \mathrm{~cm}$. long: pedicels $4-5 \mathrm{~mm}$. long at maturity, subtended by lanceolate-subulate bracts: sepals $4.5-5 \mathrm{~mm}$. long, fugacious, obtuse: petals wanting : filaments about $4 \mathrm{~mm}$. long, flattened : pistil sessile : follicles $8-10 \mathrm{~mm}$. long, becoming parchment-like, prominently nerved, each with a short blunt lateral beak : seeds usually 6 , lenticular, $3 \mathrm{~mm}$. long.

On wooded bluffs of the Tennessee River, near Knoxville, Tennessee. Fall.

2. Cimicifuga racemòsa (L.) Nutt. Stems slender, 1-2.5 m. high, leafy above. Leaf-blades ternate, the divisions pinnate and the secondary divisions often again compound : 
leaflets ovate or oblong, or the terminal one obovate, acute or sometimes obtusish at the apex, narrowed, truncate or the lower subcordate at the base, incised-toothed, cleft or divided, thickish, nearly glabrous : racemes compound, terminal, 1.5-6 dm. long, usually finely pubescent : pedicels bracted : flowers $12-14 \mathrm{~mm}$. broad, foetid : petals 4-8, 2-cleft : stamens very numerous : pistils solitary, or 2, sessile : stigma broad : follicles oval, 6-8 $\mathrm{mm}$. long, minutely beaked : seeds in 2 rows, smooth, flattened.

In woods, Maine and Ontario to Wiseonsin, middle Georgia and Missouri. Summer. BLACk Snakeroot. Black Cohosh. Star-lance. Rattle-wood.

3. Cimicifuga Americàna Michx. Stems slender, 1-2 m. high, leafy. Leaf-blades ternate, the divisions pinnate with many of the secondary divisions again compound : leaflets ovate or oblong, the terminal one generally cuneate, acute, thin, glabrate, all incisely toothed, cleft or divided, $2.5-7.5 \mathrm{~cm}$. long : racemes terminal, slender, compound, densely and finely pubescent, $3-6 \mathrm{dm}$. long : flowers pedicelled, $8-12 \mathrm{~mm}$. broad : pedicels minutely bracted: petals few, 2-lobed: stamens numerous: pistils $3-8$, stipitate : stigma minute: follicles inflated, membranous, $10 \mathrm{~mm}$. long, narrowed below, each tipped with a short oblique subulate beak: seeds in 1 row, flattened, chaffy.

In woods, Pennsylvania, and along the mountains to Georgia. Summer. American Bugbane.

\section{ACTAÈA L.}

Perennial herbs, with thick rootstocks and erect stems. Leaves basal and cauline: blades large, ternately compound. Flowers small, white, in terminal racemes. Sepals 3-5, petal-like. Petals 4-10, small, spatulate or narrow, clawed. Stamens numerous. Carpel solitary, many-ovuled. Stigma broad, sessile. Fruit a large, somewhat poisonous, berry-like follicle.

Pedicels slender, less than $1 \mathrm{~mm}$. thick: fruits red. Pedicels stout, over $1 \mathrm{~mm}$. thick; fruits white.

1. A. rubra. 2. A. alba.

1. Actaea rùbra (Ait.) Willd. Foliage pubescent or glabrate. Stems erect, fleshy, 3-6 dm. tall. Leaf-blades petioled or the upper sessile, ternate, the divisions pinnate with the lower terminal leaflets sometimes again compound; leaflets ovate or the terminal one obovate, toothed or somewhat cleft, the teeth mainly rounded or mucronate, or acutish : raceme ovoid: petals spatulate, shorter than the stamens : pedicels mainly slender, 10-14 $\mathrm{mm}$. long, less than $1 \mathrm{~mm}$. thick : fruits red, oval, 10-12 mm. long, many-seeded.

In woods, Nova Scotia to the Rocky Mountains, New Jersey, Pennsylvania and Tennessee. Most abundant northward. Spring. Red Baneberry.

2. Actaea álba (L.) Mill. Closely resembles the preceding species in habit and aspect. Leaflets generally more cut and the teeth and lobes acute or acuminate: raceme oblong: petals truncate at the apex : fruiting pedicels as thick as the peduncle, over 1 mm. thick and often red : fruits short-oval, white, often purplish at the tip.

In woods, Nova Scotia and Anticosti, west to British Columbia, south to the mountains of Georgia, and Missouri. White Baneberry. White CoHosh.

\section{AQUILÈGIA L.}

Perennial herbs, with erect often branching stems. Leaves basal and cauline : blades ternately decompound. Flowers commonly large, showy. Sepals 5, regular, petal-like, deciduous. Petals concave, produced backward between the sepals into hollow spurs. Stamens numerous, the inner ones reduced to staminodia. Carpels 5, sessile, many-ovuled, forming heads of follicles in fruit. CoLumbine.

Sepals ovate or oblong-ovate, $10-14 \mathrm{~mm}$. long: spurs 2-2.5 cm. long: follicles with spreading tips. 1. A. Canadensis.

Sepals lanceolate-ovate to lanceolate, $16-21 \mathrm{~mm}$. long : spurs $3-3.5 \mathrm{~cm}$. long: follicles with erect tips. $\begin{array}{ll}\text { Sepals lanceolate-ovate : follicles fully } 2 \mathrm{~cm} \text {. long. } & \text { 2. A. coccinea. }\end{array}$

Sepals lanceolate or oblong-lanceolate : follicles about $1.5 \mathrm{~cm}$. long.

3. A. australis.

1. Aquilegia Canadénsis L. Foliage glabrous or somewhat pubescent. Stems 3-6 $\mathrm{dm}$. high, branching. Lower and basal leaves with slender petioles; blades biternate, $10-15 \mathrm{~cm}$. broad, the ultimate leaflets cuneate, obtusely lobed and toothed, pale beneath : leaf-blades of the upper part of the stem lobed or divided: flowers nodding, less than 3 $\mathrm{cm}$. long, mainly scarlet or rarely white: sepals ovate or oblong-ovate, $10-15 \mathrm{~mm}$. long : spurs nearly straight, $2-2.5 \mathrm{~cm}$. long, thickened at the tip, gradually narrowed from near the base : stamens and styles long-exserted: head of fruit erect: follicles mainly $1.5-2 \mathrm{~cm}$. high, widely spreading at the top, each tipped with a filiform beak of about the same length. In rocky woods, Nova Scotia to the Northwest Territory, Georgia and Texas. Spring and summer. 
2. Aquilegia coccínea Small. Foliage light green. Stems solitary or tufted, 3-8 dm. tall, erect or ascending, usually branching above, commonly sparingly pubescent about the nodes: leaves larger than those of $A$. Canadensis, otherwise quite similar; leaflets suborbicular to cuneate in outline, with 3 main lobes or divisions, glaucous beneath, the segments incised or lobed: pedicels minutely glandular-pubescent: sepals ovate-lanceolate, acute or short-acuminate, $17-21 \mathrm{~mm}$. long, scarlet : corolla mainly scarlet : spurs $3-3.3 \mathrm{~cm}$. long, rather abruptly narrowed below the middle, the lamina yellow : styles not twice as long as the ovary: follicles straight, fully $2 \mathrm{~cm}$. long, each tipped with the erect style which is much shorter than the body.

On cliffs and in rocky woods, western Virginia to Nebraska and Alabama. Spring.

3. Aquilegia austràlis Small. Foliage pale green. Stems erect, usually solitary, 3-9 $\mathrm{dm}$. tall, branching above, finely pubescent, or glabrate in parts: leaves with slender petioles, except on the upper part of the stem; blades twice ternate ; leaflets thin, reniform, suborbicular or orbicular-obovate, 1-2 cm. long, glaucescent, especially beneath, crenately toothed or lobed, rounded or subcordate at the base : sepals erect, lanceolate or oblonglanceolate, acuminate, $16 \mathrm{~mm}$. long or less, scarlet: corolla mainly scarlet : spurs 3-3.5 $\mathrm{cm}$. Yong, rather abruptly narrowed below the middle: styles more than twice as long as the ovary : follicles about $1.5 \mathrm{~cm}$. long, the body about as long as the bristle-like style.

On limestone cliffs and bluffs, Florida and Texas. Spring.

\section{DELPHÍNIUM L.}

Annual or perennial herbs, with erect often branching stems. Leaves mostly cauline : blades palmately lobed or divided. Flowers in racemes or panicles, showy. Sepals 5, the posterior one prolonged into a spur. Petals 2 or 4 , small, the two posterior ones spurred, the lateral, when present, inconspicuous. Carpels few, sessile, many-ovuled, forming follicles at maturity.

Plants annual: carpel 1 : petals 2, united.

Follicles glabrous.

Follicles pubescent.

Plants perennial : carpels 3 : petals 4 , distinct.

Follieles erect : racemes elongated.

Leaf-segments narrow, the ultimate divisions linear or narrowly oblong. Bractlets some distance below the calyx. Spur about twice as long as the petals: sepals obovate. Spur thrice as long as the petals: sepals oblong.

Bractlets close under the calyx on the thickened end of the pedicel.

Sepals greenish or yellowish white: segments of the upper leaves oblong. 5. D. virescens. Sepals blue or bluish: segments of the upper leaves narrowly linear. Seeds strongly wing-margined. slightly rugnse-squamellate.

Seeds not wing-margined, strongly squamellate.
Leaf-segments relatively broad, the ultimate divisions lanceolate.

Follicles widely spreading: racemes short.

1. D. Consolida.

2. D. Ajacis.

3. D. albescens.

4. D. macroceratilis.

6. D. Carolinianum.

7. D. vimineum.

8. D. urceolatum.

9. D. tricorne.

1. Dels hinium Consólida L. Plant glabrous, or fomewhat pubescent. Stems erect, 3-8 dm. high, divaricately branched : leaf-blades short-petioled or sessile, all divided into narrowly linear cleft or toothed segments : racemes terminal, rather loose, $15-30 \mathrm{~cm}$. long: flowers short-pedicelled, blue or white, $2.5-3.5 \mathrm{~cm}$. long: spur slender, bent near the middle : petals 2 , united : follicles erect, glabrous, $8-10 \mathrm{~mm}$. long, each tipped with a short slender beak.

In waste places, New Jersey and Pennsylvania to Florida. Naturalized from Europe. Locally adventive or fugitive further north ward. Summer. FIELD LARKSPUR. KKIGHT's-8PUR. LARK-HEEL.

2. De phinium Ajàcis L. Similar to D. Consolida, but usually taller, commonly $5-12 \mathrm{dm}$. high. Leaves with shorter and more diverging segments : racemes longer, mostly $24 \mathrm{dm}$. long, more densely flowered: follicles 12-15 $\mathrm{mm}$. long, pubescent, each with a short stout beak.

In waste places. escaped from gardens mainly in the Atlantic States. Naturalized from Europe. Summer. GARDEN LARKSPUR.

3. Delphinium albéscens Rydb. Plant finely pubescent, at least above, and some what viscid, the roots woody.. Stems 3-15 dm. high: leaves variable; blades 5-15 dm. broad, repeatedly divided into linear segments or those of the lower leaves oblong : racemes simple, often becoming 5-6 dm. long: pedicels 1-2 cm. long, erect : bractlets 2-4 $\mathrm{mm}$. below the calyx or at maturity $68 \mathrm{~mm}$. below it: sepals white or nearly so, each with a blue - pot : spur twice a* long as the petals, nearly straight, usually horizontal : lateral petals bearded, 2-cleft, the lobes not diverging : follicles cylindric, pubescent, $15-20 \mathrm{~mm}$. long: seed sharply angled, $1.5-2 \mathrm{~mm}$. long, brown.

In drs ground, Manitoba to Minnesota, Illinois, Texas and Colorado. Summer. 
4. Delphinium macroceràtilis Rydb. Plants more or less pubescent with grayish hairs. Stems slender, 3-5 dm. tall, mostly simple : leaves few ; blades $3-6 \mathrm{~cm}$. broad, parted into 3-5 segments, these 2-3-cleft : racemes simple, many-flowered : pedicels erect, about $1 \mathrm{~cm}$. long, the linear bractlets $2-4 \mathrm{~mm}$. below the calyx : sepals white or the lower ones with a bluish spot, oblong, fully twice as long as the upper petals : spur slightly S-shaped, bluish, about thrice as long as the obliquely pointed upper petals : lateral petals much longer than the upper, bearded, 2-cleft : fruit unknown.

On prairies, Tom Greene County, Texas. Summer.

5. Delphinium viréscens Nutt. Plants somewhat pubescent. Stems erect, stout, 2-3 dm. tall : leaves few ; blades $2.5-3 \mathrm{~cm}$. broad, usually $3-5$-cleft or 3-5-parted : racemes few-flowered, simple: flowers greenish white: sepals oblong or nearly so: spur longer than the petals, nearly straight : petals various, the 2 lateral bearded, with a small appendage at the base of each claw, the 2 upper much smaller, concave : fruit not seen.

On plains, North Carolina, Georgia and Arkansas. Summer.

6. Delphinium Caroliniànum Walt. Plants slender, pubescent. Stems $3-6 \mathrm{dm}$. tall : leaf-blades deeply cleft into linear toothed or cleft segments: racemes terminal, 10-20 $\mathrm{cm}$. long: flowers pedicelled, deep blue, rarely varying to white, about $2.5 \mathrm{~cm}$. long, the spur slightly curved upward, usually horizontal, $15 \mathrm{~mm}$. long: follicles 3 , erect or slightly spreading, downy, 14-18 $\mathrm{mm}$. long, each tipped with a subulate beak: seeds 1.5 $\mathrm{mm}$. long, wing-margined, the faces slightly squamellate. [D. azureum Michx.]

On prairies and in open grounds, Virginia to Arkansas, Florida and Texas. Spring and summer.

7. Delphinium vimíneum D. Don. Plants mínutely pubescent. Stems erect, 5-7 dm. tall, simple : leaves several; blades 3-parted; segments entire, or mostly incised or cleft, the lateral ones more so than the middle ones, the ultimate segments acute : racemes elongated, few-flowered, interrupted : sepals deep blue, oblong or nearly so, 12-18 mm. long, somewhat crisped, obtuse: spur shorter than the sepals : fruit not seen.

On prairies, Texas. Spring.

8. Delphinium urceolàtum Jacq. Plants glabrous or sparingly hairy below, densely pubescent above. Stems slender, $0.5-2 \mathrm{~m}$. tall : leaves large, all but the upper with petioles; blades deeply 3-5-cleft, the divisions lanceolate or oblanceolate, cuneate, acuminate, cleft and toothed toward the apex, the upper ones reduced to linear or lanceolate bracts subtending the flowers: racemes dense, elongated, sometimes over $3 \mathrm{dm}$. in length: Iower pedicels about $2.5 \mathrm{~cm}$. long: flowers purple or blue, 16-20 $\mathrm{mm}$. Iong, downy-pubescent : spur nearly straight, $8 \mathrm{~mm}$. long: follicles 3 , erect, $8-10 \mathrm{~mm}$. long, pubescent, each tipped with a subulate beak. [D. exaltatum Ait.]

In woods, Pennsylvania to Minnesota, North Carolina, Alabama and Nebraska. Summer.

9. Delphinium tricórne Michx. Plants glabrous or pubescent, the roots tuberous. Stems stout, simple, 3-9 dm. tall : leaves with slender petioles; blades deeply 3-7-cleft or divided, the divisions linear or obovate, obtuse, entire, or again cleft and toothed : raceme loose, $10-15 \mathrm{~cm}$. long, mostly several-flowered: flowers $2.5-3.5 \mathrm{~cm}$. long, blue or white: spur generally slightly bent, ascending, $2-3 \mathrm{~cm}$. long: follicles 3 , widely spreading, $10-$ $12 \mathrm{~mm}$. long, each tipped with a short beak : seed-coat smooth, dark. spring.

In woods and thickets, Pennsylvania to Minnesota, and in the mountains to Georgia, and Arkansas.

\section{ACONìtuM L.}

Perennial herbs, with elongated erect ascending or trailing stems and poisonous roots. Leaves alternate: blades palmately lobed or divided. Flowers large, irregular, showy. Sepals 5, the posterior (upper) one larger, hooded or helmet-shaped. Petals 2-5, small, the 2 superior ones hooded, clawed, concealed in the helmet, the 3 posterior ones, when present, minute. Stamens numerous. Carpels 3-5, sessile, many-ovuled, forming follicles at maturity.

Flowers blue or purplish : hood helmet-shaped.

Flowers white or yellowish: hood oblong-conic.

1. A. uncinatum.

2. A. reclinatum.

1. Aconitum uncinàtum L. Stems slender, weak, 6-12 dm. long, ascending or climbing, leafy : leaf-blades thick, broader than long, 7-10 cm. wide, deeply 3-5-lobed or cleft, the lobes oblong or ovate-lanceolate, cleft or toothed, acute, glabrous or nearly so : panicle few-flowered, pubescent, the flowers clustered at the ends of its branches, blue or purplish, $2.5 \mathrm{~cm}$. broad or more : hood erect, obtusely conic, acute in front but scarcely beaked : follicles 12-14 $\mathrm{mm}$. long, subulate-beaked.

In woods, southern Pennsylvania and chiefly along the mountains to Georgia. Also in Wisconsin. Summer and fall. WILD MONKSHOOD. 
2. Aconitum reclinàtum A. Gray. Stems trailing, $0.5-2.5 \mathrm{~m}$. long: leaf-blades 3-7-cleft, all but the upper petioled, thin, the lower $15-20 \mathrm{~cm}$. broad, mainly obovate, acute, toothed and cleft toward the apex: panicle or raceme loose, pubescent : flowers white or yellowish, 16-20 mm. long: hood horizontal or nearly so, elongated-conic, with a straight short beak : follicles $10 \mathrm{~mm}$. long, each with a slender divergent beak.

In woods, Cheat Mountain, Virginia, and along the Alleghenies to Georgia. Summer. Trailing WOLFBANE.

\section{HEPÁtICA Scop.}

Perennial scapose herbs, with short often tufted rootstocks. Leaves basal: blades long-petioled, thick, 3-lobed, evergreen. Flowers white or purple, solitary on slender scapes. Involucre of 3 small sessile bracts close under the flower, simulating a calyx. Sepals membranous, petal-like. Petals wanting. Stamens all anther-bearing. Achenes short-beaked, pubescent.

Lobes of the leaf-blades and bracts of the involucres obtuse.

Lobes of the leaf-blades and bracts of the involucres acute.

1. H. Hepatica.

1. Hepatica Hepática (L.) Karst. Roots fibrous. Leaves basal ; blades longpetioled, reniform, $5-8 \mathrm{~cm}$. broad when mature, spreading on the ground, 3-lobed, the lobes sometimes toothed or again lobed, obtuse : scapes $1-1.5 \mathrm{dm}$. long, villous : involucre of 3 sessile obtuse oblong bracts immediately under the flower : calyx blue, purple or white, $12-20 \mathrm{~mm}$. broad : sepals oval or oblong, obtuse, longer than the stamens : achenes several, 4-5 mm. long, oblong, acute, hairy. [H. triloba Chaix.]

In woods, often in large tufts, Nova Scotia to Manitoba, northern Florida and Missouri. Also in Europe and Asia. Winter to spring. HEPatica. Liver-LEAF.

2. Hepatica acùta (Pursh) Britton. Plant closely resembling the preceding species but often larger; differing in that the lobes of the leaf-blades and the bracts of the involucres are acute or acutish. [H. acutiloba DC. $]$

In woods, Quebec to Minnesota and in the Alleghenies to Georgia, but rare or absent near the Atlantic coast. Spring. Hepatioa. Liver-leaf.

\section{ANEMÒNE L.}

Perennial herbs, with horizontal rootstocks and erect scapes. Leaves basal: blades lobed, divided or dissected, petioled. Bracts similar to leaves, forming an involucre remote from the flower. Sepals 4-20, petal-like. Petals wanting. Stamens numerous, shorter than the sepals. Carpels several or numerous. Achenes compressed, 1-seeded.

Achenes densely long-woolly.

Scapes simple, 1-flowered.

Involucre mostly above the middle of the scape : tips of the achenes not projecting beyond the wool. Involucre mostly below the middle of the scape : tips of the achenes project-
ing beyond the wool.

Scapes mostly branched, several-flowered.

Sepals greenish : head of fruit mostly over $1 \mathrm{~cm}$. thick: achenes with spreading styles.

Sepals clear white: head of fruit mostly less than $1 \mathrm{~cm}$. thick : achenes with appressed or ascending styles.

Achenes glabrate or finely pubescent, never woolly.

Divisions of the involucral bracts lobed or incised, membranous.

Divisions of the involucral bracts merely toothed, leathery at maturity.

1. A. decapetala.

2. A. Caroliniana.

3. A. Virginiana.

4. A. riparia.

5. A. quinquefolia.

6. A. trifolia.

1. Anemone decapétala Ard. Foliage finely pubescent. Root tuberous, oblong: leaves few ; blades 3-divided, the segments ovate or ovate-oblong, crenate or crenate-cleft : scape erect, 1-3 dm. tall, simple: bracts of the involucre very different from the leafblades, mostly above the middle of the scape, nearly sescile, once or twice palmately cleft, the segments linear, mostly entire : sepals 10-20, pink or greenish white: head of fruit cylindric, $2-3.5 \mathrm{~cm}$. long: achenes completely buried in the wool.

On plains and prairies, Alabama, Arkansas, Texas and the Great Plains, south through Mexico to Central America. Also in South America. Spring and summer.

2. Anemone Caroliniàna Walt. Foliage sparsely hairy. Leaves slender-petioled; blades 3-divided, the divisions variously lobed and parted: scapes 1-2.5 dm. high, arising from a tuber, 6-8 $\mathrm{mm}$. in diameter : bracts of the involucre sessile; blades cleft: flower erect, 18-36 mm. broad : sepals 6-20, linear-oblong, purple, varying to white: head of fruit oblong: achenes densely woolly but the tips projecting.

On open plains, Illinois to Wisconsin, Nebraska, Georgia and Texas. Spring.

3. Anemone Virginiàna L. Foliage hairy. Leaves with long petioles; blades broader than long, 3-parted, the divisions broadly cuneate-oblong, variously cleft and 
divided into acute serrate lobes: scapes 5-10 dm. high, stout, branching at the involuere, the lateral peduncles bearing secondary involucres: bracts of both primary and secondary involucres similar to the leaves, with petioles $2.5-5 \mathrm{~cm}$. long: sepals generally 5 , white or greenish, acute or obtuse : calyx $18.30 \mathrm{~mm}$. broad : head of fruit oblong, $18-25 \mathrm{~mm}$. long, mostly over $1 \mathrm{~cm}$. thick : achenes compressed, woolly, each tipped with the subulate style.

In woods or thickets, Nova Scotia to Kansas, Manitoba and the Canadian Rocky Mountains to middle Georgia. Summer.

4. Anemone ripària Fernald. Foliage glabrate or loosely pubescent, or silky above. Leaves several; blades thin, 3-divided, the divisions lanceolate to ovate, acuminate at the base, coarsely and sharply toothed, the lateral divisions deeply cleft on the lower side: scapes 3-9 dm. tall : bracts of the involucre 3 , quite similar to the leaves, subtending 1-5 peduncles : sepals thin, white, unequal, oval or obovate, $1.5-2 \mathrm{~cm}$. long, obtuse or rather acute: head of fruit short-cylindric, $1.5-2 \mathrm{~cm}$. long, barely $1 \mathrm{~cm}$. thick : achenes with appressed or ascending styles.

In rocky soil or on steep banks, New Brunswick to Quebec and along the mountains to North Carolina and Tennessee. Summer.

5. Anemone quinquefòlia L. Foliage nearly glabrous. Leaves basal; blades 5-divided, 4-11 cm. broad, appearing later than the scapes, the divisions oblong or ovate, more or less cuneate at the base: scapes erect, $1-2.5 \mathrm{dm}$. tall, slender, simple: bracts of the involucre 3, slender-petioled, 3-5-parted, the segments $1.5-3 \mathrm{~cm}$. long, acute, lobed or incised : flower solitary, $2-2.5 \mathrm{~cm}$. broad : sepals 4-9, white, or purplish without: head of fruit globose, inclined : achenes oblong, 4-5 mm. long, pubescent, the styles hooked. [A. nemorosa Michx., not L. ]

In low woods, Nova Scotia to the Rocky Mountains, middle Georgia and Alabama. Spring.

6. Anemone trifòlia L. Foliage nearly glabrous throughout. Leaves basal ; blades mostly 3-divided (sometimes 4-5-divided), long-petioled, dentate, often somewhat lobed: scapes erect, relatively stout, 1-4 dm. tall : involucral bracts 3 , stout; blades petioled, 3-parted, the divisions oblong-lanceolate, acute or acuminate at the apex, dentate, often coarsely so, $2.5-7.5 \mathrm{~cm}$. long : flower solitary, white, $2.5-4 \mathrm{~cm}$. broad when expanded: pedicel $2.510 \mathrm{~cm}$. long : sepals oblong: head of fruit globose, $10-12 \mathrm{~mm}$. in diameter : achenes 10-20, oblong, finely pubescent, each tipped with the hooked style.

In woods. southern Pennsylvania to Virginia and Georgia, chiefly in the mountains. Also in south-central Europe. Spring.

\section{SYNDÉSMON Hoffmg.}

Perennial herbs, the slender scapes from a cluster of tuberous-thickened roots. Leaves basal : blades 2-3-ternately compound. Bracts of the involucre similar to the leaves but sessile. Flowers large, terminal, umbellate, slender-pedicelled. Sepals white, thin, petal-like. Petals wanting. Stamens all anther-bearing. Stigma sessile, truncate. Achenes plump, deeply grooved. [Anemonella Spach.]

1. Syndesmon thalictroìdes (L.) Hoffmg. Foliage glabrous. Scapes arising in early spring from the cluster of tuberous roots, 1-2.5 dm. high : leaves basal, appearing and resembling those of Thalictrum; blades ternately-compound: hracts of the involucre similar to the leaf-blades, sessile; leaflets long-stalked : flowers $1-2.5 \mathrm{~cm}$. broad, perfect, umbellate, immediately above the involucre : sepals 5-10, white or pinkish, longer than the stamens : stigmas depressed-truncate, sessile: achenes sessile, pointed, 8-12 mm. long. [Anemonella thalictrnides ( L.) Spach.]

In woods, Ontarin and nearly throughout the eastern United States, westward to Kansas and Minnesota. Spring. Rue Anemone. Wind Rue.

\section{CLÉMATIS L.}

Vines, usually climbing over shrubs. Leaves opposite : blades 3-several-foliolate, the leaflets entire, toothed or incised. Flowers several or many in broad paniculate cymes, dioecious or polygamo-dioecious. Sepals relatively small but petaloid, without a border, thin, white or pale, spreading. Petals wanting. Stamens spreading: anthers short and blunt. Pistils several. Achenes 1-seeded, with silky or plumose styles.

Leaflets less than $4 \mathrm{~cm}$. long : styles 5-10 cm. long at maturity.

Leaflets nver $5 \mathrm{~cm}$. long: styles $2.5-4 \mathrm{~cm}$. long at maturity.

Leaf-blades inainly 3 - foliolate.

Leaf-blades mainly twice ternately compound.

1. C. Drummondit.

2. C. Virginiana.

3. C. Catesbyana.

1 Clematis Drummóndii T. \& G. A climbing or straggling vine, with cinereouspubescent foliage. Leaves numerous; blades mainly pinnately 5 -7-foliolate; leaflets 
$1.5-2.5 \mathrm{~cm}$. long, coarsely cleft or parted, the segments more or less flaring, acute or acuminate, sometimes toothed : peduncles mostly trichotomous, sometimes simple: flowers few : sepals 10-12 mm. long, slightly broadened upward, silky without: heads of fruit conspicuous : achenes $2-3 \mathrm{~mm}$. long : persistent styles very slender, $5-10 \mathrm{~cm}$. long, silky-plumose.

In dry soil, Texas to Arizona and Mexico. Spring and summer.

2. Clematis Virginiàna L. A long vine, climbing over bushes in low woodlands and along fences and water-courses. Leaves glabrous or nearly so ; blades 3 -foliolate or rarely 5 -foliolate; leaflets mostly broadly ovate, acute at the apex, toothed or lobed, sometimes slightly cordate: flowers white, in leafy-bracted panicles, polygamo-dioecious: calyx 15-30 mm. broad when expanded: sepals mainly oblong-spatulate: filaments glabrous : achenes very inequilateral : persistent styles plumose, $2.5 \mathrm{~cm}$. long or more.

In moist soil, Nova Scotia to Manitoba, Georgia and Kansas. Summer. Virgin's Bower.

3. Clematis Catesbyàna Pursh. A climbing vine several $\mathrm{m}$. long, with pubescent or occasionally glabrate foliage. Leaves numerous; blades mainly twice ternately compound; leaflets suborbicular, ovate or lanceolate, $2-5 \mathrm{~cm}$. long, acute or acuminate, 3-lobed, otherwise entire or sparingly toothed : flowers relatively few in a panicle: calyx 2-2.5 $\mathrm{cm}$. broad : sepals oblong or spatulate, $6-9 \mathrm{~mm}$. long, obtuse, pubescent : achenes barely inequilateral : persistent styles plumose.

In sand or sandy soil, South Carolina to Florida and Mississippi. Spring and summer.

\section{VITICÉLLA Dill.}

Climbing or reclining vines. Leaves opposite: blades several-foliolate, the leaflets entire, lobed or parted. Flowers perfect, solitary on short branches or few together. Sepals petal-like, spreading, each with a wide border on either side of the nerves, relatively large. Petals wanting. Stamens spreading: anthers long and narrow. Pistils several. Achenes 1-seeded, with elongated, often pubescent but rarely plumose styles.

1. Viticella Viticélla (L.) Small. A branching vine several $\mathrm{m}$. long, with minutely pubescent foliage : leaves numerous; leaflets thin, $2-5 \mathrm{~cm}$. long, acute or apiculate, entire, lobed or parted, mostly inequilateral : flowers showy, $4-8 \mathrm{~cm}$. broad: sepals thin, cuneate to cuneate-spatulate, spreading : achenes ovoid to elliptic-ovoid, $8-10 \mathrm{~mm}$. long, minutely pubescent, the styles relatively short, not plumose. [Clematis Viticella L.]

On rocky banks, Tennessee. Naturalized from Europe. Summer.

\section{VIÓRNA Reichenb.}

Climbing vines, or perennial herbs, with erect or ascending, more or less woody stems. Leaves opposite : blades slender-petioled, pinnately-compound, lobed or in some species entire. Sepals 4 or 5 , valvate in the bud, petal-like. Petals wanting. Stamens numerous, erect : anthers long and narrow. Pistils many. Achenes 1-seeded, with long persistent plumose, silky or naked styles.

Climbing or shrubby vines.

Sepals relatively thin: styles silky at maturity, not plumose, rarely glabrous.

Leaflets pinnately nerved: sepals recurved from near the middle.

Leaflets reticulated: sepais recurved at the tips.

Sepals leathery : styles plumose.

Foliage glandular.

Foliage glabrous. glaucous or simply pubescent.

Leaflets prominently and conspicuously reticulated.

Sepals dull purple, pubescent without.

Sepals carmine or scarlet, glabrous without.

Peduncles forking: calyx less than $2 \mathrm{~cm}$. long: sepals thin.

Peduncles simple: calyx over $2 \mathrm{~cm}$. long: sepals thick.

Leaflets not reticulated, sometimes with a few prominent nerves. Elongated vines.

Achenes oblong or elliptic: leaflets not glaucous beneath. Leaflets simple and usually entire. Sepals over $2.5 \mathrm{~cm}$. long: leaflets glabrous. Sepals less than $2.5 \mathrm{~cm}$, long: leaflets silky beneath. Leaflets, at least the lower ones. ternate or 3 -lobed. Achenes suborbicular : leaflets glaucous beneath. Shrubby or stocky vine.

Upright perennial herbs.

Leaf-blades reticulated, rounded or cordate at the base.

Calyx yellowish green: style erect; plumes brown at maturity.

Calyx purple: style horizontal; plumes white at maturity.

Leaf-blades not reticulated, mostly cuneately narrowed at the base.

1. V. crispa.

2. V. Simsii.

3. V. Gattingeri.

4. V. reticulata.

5. V. versicolor.

6. V. coceinea.

1. Viorna críspa (L.) Small. A climbing vine, $1 \mathrm{~m}$. long or much longer. Leafblades pinnate; leaflets mostly trifoliolate, the ultimate divisions entire or occasionally 
lobed, ovate to broadly lanceolate, glabrous and thin : flowers solitary, nodding, bluish purple, 18-36 mm. long: calyx cylindric below, but the sepals thin and widely spreading above, their margins undulate: filaments hairy : persistent styles silky, not plumose. [Clematis crispa L.]

In marshes, southeastern Virginia to Florida and Texas. Spring and summer.-The variety with linear or linear-lanceolate leaflets, is V. crispa. Wálteri (Pursh) Small, [Clematis Walteri Pursh]; it ranges from South Carolina and Florida to Texas.

2. Viorna Símsii (Sweet) Small. A climbing vine, with more or less puhescent branches. Leaf-blades pinnate; leaflets entire, lobed or trifoliolate, thick, reticulated, generally mucronate : flowers solitary : calyx campanulate, less than $2.5 \mathrm{~cm}$. long, purplish, pubescent : sepals with recurved margined tips : filaments hairy : persistent styles more or less pubescent, about $2.5 \mathrm{~cm}$. long. [Clematis Simsii Sweet.]

In low grounds, southern Indiana to Nebraska and Texas. Spring and summer.

3. Viorna Gattíngeri Small. A slender branching vine 1-3 m. long, climbing over rocks and bushes, the foliage copiously glandular. Leaves $1-1.5 \mathrm{dm}$. long ; blades pinnate ; petioles less glandular than the stem; leaflets membranous, lanceolate or broadly lanceolate, $1.5-5 \mathrm{~cm}$. long, pubescent on both sides as well as glandular, acute or slightly acuminate, ciliate: peduncles stoutish, $3-5 \mathrm{~cm}$. long: bracts ovate, 5-10 $\mathrm{mm}$. long: calyx purple, 10-13 mm. long: sepals felt-like, elliptic or elliptic-lanceolate, often recurved from the middle, crested near the edges below the apex, narrowed into recurved caudate tips: filaments pubescent : achenes ovate-oval or elliptic, 6-7 $\mathrm{mm}$. long, minutely pubescent, each face with an ovate or oval impression : persistent styles erect or nearly so, curved from below the middle, tawny green, $2-2.5 \mathrm{~cm}$. long, plumose. [Clematis Gattingeri Small.]

On the banks of the Cumberland River, near Nashville, Tennessee. Summer.

4. Viorna reticulàta (Walt.) Small. A branching vine several $\mathrm{m}$. long, with minutely pubescent or glabrate foliage. Leaves numerous; blades pinnately foliolate ; leaflets rather leathery, oblong, lanceolate, oval or suborbicular, $2-8 \mathrm{~cm}$. long, acute or apiculate, very prominently and conspicuously reticulated, entire or lobed : pedicels about as long as the peduncles : flowers nodding: calyx about $2 \mathrm{~cm}$. long, dull, canescent without : sepals felty, lanceolate : achenes elliptic, 5-6 mm. long, silky : persistent styles plumose, 4-5 cm. long. [Clematis reticulata Walt.]

In thickets and dry soil, South Carolina to Texas and Florida. Spring and summer.

5. Viorna versícolor Small. A branching vine 2-4 m. long, with glabrous and glaucous foliage or sometimes an indication of pubescence below the nodes. Leaves numerous; blades slender-petioled; leaflets firm, oblong to ovate-lanceolate, $2-7 \mathrm{~cm}$. long, apiculate, glaucescent and conspicuously reticulated above, conspicuously glaucous and prominently reticulated beneath : pedicels as long as the peduncles or longer : bracts ovate, $2-2.5 \mathrm{~cm}$. long, or the secondary ones smaller and nearly oblong : calyx purplish, about $1.5 \mathrm{~cm}$. long: sepals lanceolate, glabrous, slightly recurved at the tip : achenes pubescent : persistent styles plumose, $3.5-4.5 \mathrm{~cm}$. long, white or nearly so. [Clematis versicolor Small.]

On dry rocky ledges, Missouri and Arkansas. Summer.

6. Viorna coccínea (Engelm.) Small. A vine several $\mathrm{m}$. long, with branching stems. Leaves numerous ; blades mostly pinnate on sometimes tendril-like petioles; leaflets ovate to ovate-lanceolate or suborbicular, $4-6 \mathrm{~cm}$. long, acute, obtuse or even notched at the apex, entire or rarely lobed, glaucous and more or less prominently reticulated beneath, mostly truncate or subcordate at the base : flowers scarlet or purple-red, ovoid or globose-ovoid, about $2 \mathrm{~cm}$. long, nodding: sepals with spreading or recurved tips: achenes. mostly broader than long, 6-7 mm. wide, silky: persistent styles plumose, $3-5 \mathrm{~cm}$. long. [Clematis coccinea Engelm.]

In thickets and along streams, Texas. Spring.

7. Viorna oblìqua Small. A climbing vine, with elongated stems. Leaves with long petioles; leaflets thickish, ovate or ovate-lanceolate, $3-8 \mathrm{~cm}$. long, slightly acuminate, erose-denticulate and undulate, truncate at the inequilateral base, long-stalked : calyx conic, about $3 \mathrm{~cm}$. long, sparingly pubescent without : sepals lanceolate, recurved at the tip.

In pine lands, near St. Augustine, Florida.

8. Viorna fláccida Small. A slender vine, the stems climbing over bushes, angled, thinly pubescent or glabrous below, branched, enlarged below the nodes and there densely hairy like the branchlets and petioles. Leaves many ; leaflets thin, oblong, ovate or ovatelanceolate, 2-10 cm. long, slender-stalked, apiculate or rarely acuminate, densely silky beneath, sparingly so above or glabrate, entire or nearly so : bracts similar to the leaflets, but usually smaller and sessile or nearly so : peduncles usually slender, commonly in clusters of 3 's : calyx greenish to light lavender, about $1.5 \mathrm{~cm}$. long, nodding: sepals pubescent without like the lower surface of the leaflets, acutish, with very short tails : achenes rhom- 
boidal or nearly orbicular, stout, $6-7 \mathrm{~mm}$. long, more or less inequilateral, thick-margined : persistent styles plumose, 2.5-3 cm. long. [Clematis flaccida Small.]

In thickets, Kentucky and Tennessee. Spring.

9. Viorna Viórna (L.) Small. A vine, climbing to the height of $3 \mathrm{~m}$. or more. Leaves numerous, deep green ; blades mostly pinnate; leaflets glabrous, entire, lobed or 3 -foliolate, the uppermost and lowest leaves often entire : calyx ovoid-campanulate, purple : sepals exceedingly thick : flowers solitary, nodding : persistent styles plumose throughout, $2.5 \mathrm{~cm}$. long or more, brownish. [Clematis Viorna L.]

In woods, southern Pennsylvania to Ohio, West Virginia. Georgia and Alabama. Spring and summer. LEATHER-FLOWER. VASE-VINE.

10. Viorna glaucophýlla Small. A showy bright green vine, the stem rather slender, $2-5 \mathrm{~m}$. long, climbing over bushes and trees, nearly simple, dark red, furrowed, much enlarged at the nodes. Leaves ovate, $3-10 \mathrm{~cm}$. long, thickish, acute, often apiculate or acuminate, entire, 3-lobed or 3-foliolate, often with conspicuous white nerves above, prominently nerved and glaucous beneath, cordate or subcordate; bracts leaf-like with petioles 1 cm. long, the nerves gradually diverging from the midrib: calyx reddish purple, glossy, 2-2.5 cm. long, thick, conic-ovoid : sepals lanceolate, acuminate, the tips very slightly spreading : achenes suborbicular, 6-8 $\mathrm{mm}$. in diameter, puberulent, abruptly narrowed at both ends, each with an orbicular impression in the middle, sometimes slightly inequilateral : plumose style erect or slightly oblique, 5-6 cm. long, tawny, lustrous, the hairs spreading. [Clematis glaucophylla Small.]

In river valleys, Kentucky to North Carolina, Florida and Alabama. Spring and early summer.

11. Viorna Addísònii (Britton) Small. A shruby or stocky vine, $\dot{3}-10 \mathrm{dm}$. long, simple or often branched, glaucous and glabrous. Lower leaf-blades simple, entire or 1-4-lobed, obtuse, deep bluish green above, glaucous beneath, sessile, clasping, $5-10 \mathrm{~cm}$. long: upper leaf-blades pinnate, or sometimes simple, tendril-bearing; leaflets 2-4, ovate, sessile : flowers solitary, terminal and axillary, purplish, nodding : calyx ovoid, $18-30 \mathrm{~mm}$. long, contracted near the summit: sepals thick, lanceolate, acute, their tips recurved: stamens numerous, pubescent above : achenes flat, nearly orbicular, silky-pubescent : persistent styles $2.5-3 \mathrm{~cm}$. long, brown-plumose throughout. [Clematis Addisonii Britton.]

On river banks, Virginia to North Carolina and Tennessee. Spring.

12. Viorna ochroleùca (Ait.) Small. An erect plant, 3-6 dm. tall, sometimes woody at the base, with silky-hairy foliage. Leaf-blades sessile, ovate, obtuse, glabrous and reticulated above, silky beneath, entire or occasionally lobed, mucronate : flower terminal, nodding, $2 \mathrm{~cm}$. long: calyx cylindraceous, green : sepals thick, very silky without, their tips recurved : head of fruit erect : achenes scarcely oblique : persistent styles erect, yellowish brown, plumose throughout, $2.5-5 \mathrm{~cm}$. long. [Clematis ochroleuca Ait.]

In sandy soil, Staten Island, New York and Pennsylvania to Georgia. Spring.

13. Viorna ovata (Pursh) Small. Similar to the next preceding species in habit, the stems $2-6 \mathrm{dm}$. tall, pubescent when young, becoming nearly glabrous when old. Leafblades ovate, entire, $3-6 \mathrm{~cm}$. long, strongly reticulate-veined and nearly glabrous when mature : flowers solitary at the ends of the stem or branches: calyx purple, nodding, 2.5 $\mathrm{cm}$. long: achenes distinctly oblique : persistent styles nearly horizontal, plumose throughout, the plumes white or slightly dingy, 2.5-4 cm. long. [Clematis ovata Pursh.]

In dry soil, Kate's Mountain, West Virginia and apparently first collected on Negro's Head, a mountain of the Blue Ridge in South Carolina or Georgia. Spring.

14. Viorna Baldwínil (T. \& G.) Small. An erect, simple or sparingly branched plant, with a more or less woody base and glabrate foliage. Leaf-blades various, the lower ones linear to lanceolate or oblong, 3-10 cm. long, apiculate or rarely acute, sessile, the upper ones entire, or 3-cleft or 3-parted : peduncles 2-4 dm. long, strict : flower nodding, solitary : calyx $2-3 \mathrm{~cm}$. long, purple or paler, suggesting that of $V$. crispa: sepals linear-lanceolate, spreading or recurved from above the middle: head of fruit conspicuous : achenes elliptic or ovate-elliptic, more or less rhomboidal : persistent styles very plumose, 6-10 cm. long. [Clematis Baldwinii T. \& G.]

In pine lands or hammocks, peninsular Florida. Spring to fall. PINE Hyacinth.

\section{ATRÁGENE L.}

Perennial climbing vines, with glabrous or nearly glabrous foliage. Leaves opposite: blades petioled, compound. Flowers large, showy, peduncled, solitary in the axils or at the ends of the branches. Sepals very large, petal-like, mostly membranous and prominently veined. Petals small, spatulate. Stamens very numerous, erect, the outer filaments more or less petal-like. Styles very long, persistent, plumose at maturity. BeLL Rue. 
1. Atragene Americàna Sims. A trailing or partly climbing vine of rocky woodlands. Leaf-blades trifoliolate; leaflets thin, ovate, acute, toothed or entire, more or less deeply cordate ; petioles slender : flowers solitary, purplish blue, $5-10 \mathrm{~cm}$. broad when expanded : sepals 4, thin and translucent, strongly veined, silky along the margins and the veins : petals spatulate, $12-18 \mathrm{~mm}$. long: persistent styles plumose throughout. [Clematis verticillaris DC.] BOWER.

In dry soil, Hudson Bay to Manitoba, North Carolina and Minnesota. Spring. Purple Virain's

\section{MYOSÙRUS L.}

Diminutive annual acaulescent herbs, with fibrous roots. Leaves basal : blades linear, entire. Scapes 1-flowered, simple. Sepals 5 (rarely 6 or 7 ), long-spurred at the base. Petals 5 ( rarely 6 or 7 ) or wanting, when present greenish yellow, narrow; each claw with a nectariferous pit at its summit ; blades spreading. Stamens $5-25$, about equalling the sepals in length. Pistils numerous, borne on a central axis, which becomes greatly elongated in fruit. Ovule solitary, suspended. Achenes apiculate or aristate. Embryo minute.

1. Myosurus mínimus L. Foliage glabrous. Leaves all basal, $5-10 \mathrm{~cm}$. long, narrowly linear, blunt: scapes $2.5-15 \mathrm{~cm}$. high, at length surpassing the leaves : petals present, small : the elongated receptacle attaining the length of $2.5 \mathrm{~cm}$. or more : achenes glabrous, apiculate.

In moist places, southern Ontario to Illinois, Kentucky and Florida. Reported from the Pacific coast. Also in*entral Europe. Spring and summer. Mouse-TAIL.

\section{TRAUTVETTÉria F. \& M.}

Perennial herbs, with horizontal rootstocks and tall erect stems. Leaves mainly basal : blades ample, palmately lobed. Flowers white, corymbosely paniculate. Sepals 3-5, concave, caducous. Petals wanting. Carpels numerous, 1-ovuled. Achenes capitate, sharply angular, inflated, each tipped with the minute style. Embryo large.

1. Trautve teria Carolinénsis (Walt.) Vail. Foliage nearly glabrous, or rarely pubescent. Stems stout, 4-15 dm. high, branching: basal leaves with long petioles; blades $15-30 \mathrm{~cm}$. broad, deeply lobed, the lobes acute and sharply dentate : panicle ample, corymb-like : flowers 6-12 mm. broad, borne in cymose clusters at the ends of the branches: filaments slender, slightly widened: anthers oblong. ['Trautvetteria palmata F. \& M.]

In woods. southwestern Pennsylvania to Indiana and Missouri, but chiefly in the mountains of Virginia and Kentucky to Georgia, and in western Florida. Spring and summer. FALse BugBanE.

\section{BATrÁCHIUM S. F. Gray.}

Perennial aquatic or ditch herbs, with creeping or floating stems. Leaves alternate : blades dissected or palmately lobed, the segments of the submerged ones often filiform. Flowers solitary, rather small, borne on peduncles opposite the leaves. Sepals and petals usually 5. Petals white or sometimes yellowish at the base; each claw bearing a small pit. Stamens several or numerous. Achenes oblique, compressed, not margined, often nearly or quite beakless, transversely wrinkled.

Achenes with beaks about $1 \mathrm{~mm}$. long.

Achenes beakless or nearly so.

Leaf-segments $10-15 \mathrm{~mm}$. long, firm : blades scarcely collapsing when withdrawn from the water.

Leaf-segments $15-30 \mathrm{~mm}$. long, flaccid : blades collapsing when withdrawn from the water.

1. B. longirostre.

1. Batrachium longiróstre (Godr.) F. Schultz. Submerged. Foliage nearly glabrous : stems very leafy, several $\mathrm{dm}$. long: leaf-blades short-petioled, not flaccid, with very numerous segments about $15 \mathrm{~mm}$. long; stipules broad, pubescent : pedicels $2-4 \mathrm{~cm}$. long: petals broadly ovate, 5-7 mm. long: head of fruit globose, 3-4 mm. in diameter.

In ponds and streams, Ontario to Minnesota, Connecticut, Missouri and Mexico. Summer.

2. Batrachium trichophýllum (Chaix) Bossch. Submerged. Foliage glabrous : stems branching, usually $3 \mathrm{dm}$. long or longer: leaf-blades petioled, $3-5 \mathrm{~cm}$. long, flaccid ; stipules short and broad, hairy : flowers white, $12-18 \mathrm{~mm}$. broad, on stout peduncles 2.5-5 cm. long, blooming at the surface of the water: head of fruit globose, 4-5 mm. broad : receptacle hairy : achenes apiculate but beakless. [Ranunculus aquatilis var. trichophyllus (Chaix) A. Gray.]

In ponds and streams, Nova Scotia to British Columbia, North Carolina and California. Also in Europe and Asia. Summer.-A small state growing in the mud, with fleshy leaf-segments, is called $B$. trichophyllum caespitòsum. 
3. Batrachium fláccidum (Pers.) Rupr. Resembling the next preceding species. Leaves with larger and more slender petioles ; blades with very long flaccid segments, collapsing when withdrawn from the water.

In streams, Massachusetts to Washington, North Carolina and Lower California. Also in Europe, Asia and Africa. Spring to fall.

\section{HALERPÉSTES Greene.}

Perennial sometimes scapose herbs, with runners. Leaves mainly basal : blades crenate, dentate or lobed, long-petioled. Flowers small, yellowish, solitary or 2-7 together on scapes or scape-like peduncles. Sepals usually 5, spreading, tardily deciduous. Petals $5-12$, each bearing a small nectar-pit near the base. Stamens and pistils numerous. Head of fruit oblong, oval or subglobose. Achenes compressed, sometimes swollen, longitudinally striate, without a hard coat.

1. Halerpestes Cymbalària (Pursh) Greene. Foliage glabrous. Plants somewhat fleshy, spreading by runners. Leaves mostly basal; blades slender-petioled, ovate, cordate-oval or reniform, crenate, 4-18 $\mathrm{mm}$. long: flowers 1-7, about 6-8 $\mathrm{mm}$. broad, borne on scapes $2.5-15 \mathrm{~cm}$. long, these sometimes bearing one or more leaves toward the base : head of fruit oblong, 6-16 mm. long: achenes compressed, somewhat swollen, distinctly striate, minutely sharp-tipped.

On sandy shores, Labrador to New Jersey, west along the St. Lawrence River and the Great Lakes to Minnesota and the Northwest Territory, and in saline soil throughout the western half of the continent, extending into Mexico. Also in Asia and South America. Summer.

\section{RANÚNCULUS L.}

Annual or perennial herbs, with erect or creeping stems. Leaves alternate : blades simple, entire, lobed or divided, or dissected. Flowers solitary or variously disposed. Sepals mostly 5, deciduous. Petals as many as the sepals or more, or rarely fewer, yellow, white or red, conspicuous or minute, each provided with a nectariferous pit and a scale at the base of the blade. Carpels several or numerous, 1-ovuled. Achenes capitate or spicate, generally flattened, smooth, papillose or echinate, each tipped with a minute or an elongated style. Crow-Foot. Butrercup.

Aquatic plants: submerged leaves with dissected blades; floating leaves with lobed blades.

Terrestrial or mud plants: leaves with entire. toothed, lobed or divided blades.

1. R. delphinifolius.

Mud plants: leaves with entire or denticulate blades.

Annuals: achenes beakless.

Petals mostly $1-3$, pale yellow, barely $2 \mathrm{~mm}$. long: stamens $5-10$.

Head of fruit oblong or cylindric: achenes suborbicular, less than $1 \mathrm{~mm}$. long.

Head of fruit subglobose: achenes obovoid, fully $1 \mathrm{~mm}$. long.

Petals 5, bright yellow, over $2 \mathrm{~mm}$. long : stamens numerous.

Perennial: stems creeping: achenes with subulate beaks.

Terrestrial plants : leaves with all or some of the blades lobed or divided.

Basal leaves with all or some of the blades crenate.

Petals conspicuous, much longer than the sepals.

Petals inconspicuous, shorter than the sepals or about equalling them in length.

Styles very short.

Basal leaves with cordate blades: foliage glabrous or nearly so.

Basal leaves with truncate or cuneately narrowed blades : foliage pubescent.

Styles subulate, hooked, nearly $1 / 2$ as long as the achene-body.

Basal leaves with all blades lobed or divided.

A. Achenes smooth and glabrous.

Foliage glabrous: stem hollow: flowers relatively small.

Foliage more or less pubescent : stems not hollow: flowers relatively large.

Beaks of the achenes hooked.

Beaks of the achenes straight or slightly curved.

2. R. tener.

3. $R$. pusillus.

4. $R$. oblongifolius.

5. R. obtusiusculus.

6. R. Harveyi.

Achenes with beaks less than $1 / 2$ as long as the bodies.

Petals about as long as the sepals : head of fruit oblong or cylindric.

Petals much longer than the sepals : head of fruit subglobose. Achenes with beaks over $1 / 2$ as long as the bodies; beaks sometimes partially deciduous.

Carpels or achenes few.

Carpels or achenes numerous.

a. Corolla $2.5 \mathrm{~cm}$. broad or smaller : petals $5:$ head of fruit subglobose.

* Plants stoloniferous : foliage glabrous or nearly so.

7. R. abortivus.

8. R. micranthus.

9. R. Allegheniensis.

10. R. sceleratus.

11. $R$. recurvatus.

12. R. Pennsylvanicus. 13. R. bulbosus.

14. R. palmatus.

15. R. septentrionalis. 


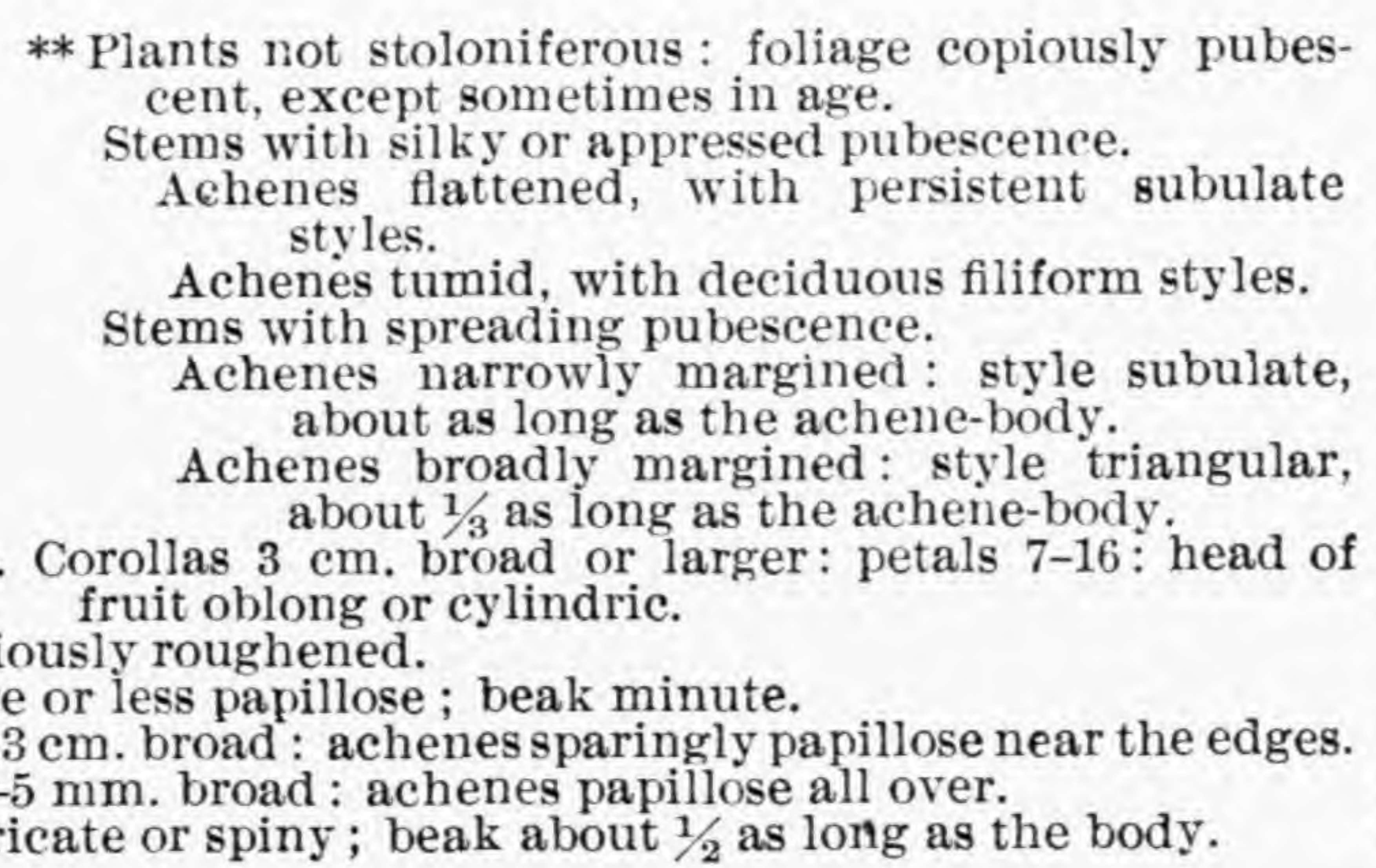

16. R. fascicularis.

17. R. apricus.

18. R. hispidus.

19. R. cuneiformis.

20. R. macranthus.

21. R. parvulus. 22. R. parviflorus.

23. R. muricatus.

1. Ranunculus delphinifòlius Torr. Aquatic or partly emersed. Foliage glabrous or pubescent : stems branching, sometimes several dm. long : submersed leaf-blades shortpetioled, $2.5-7.5 \mathrm{~cm}$. long, repeatedly divided into capillary segments; emersed leafblades $1.5-5 \mathrm{~cm}$. broad, petioled or the upper nearly sessile, 3-5-divided, the divisions cleft into linear or cuneate segments : corolla yellow, $18-36 \mathrm{~mm}$. broad : petals $5-8$, much longer than the sepals : head of fruit globose or oblong, 6-10 $\mathrm{mm}$. long: achenes less than $2 \mathrm{~mm}$. long, callous-margined, each tipped with a straight persistent beak $\frac{1}{2}$ its length or more. [Ranunculus multifidus Pursh, not Forsk.]

In ponds, Massachusetts and Ontario to Michigan, North Carolina and Missouri. Summer.

2. Ranunculus téner Mohr. Foliage glabrous. Stems ascending or erect, $0.5-6 \mathrm{dm}$. tall, more or less branched, often tufted, rarely rooting: basal leaves few; blades ovate to ovate-lanceolate, 1-2 cm. long, entire or undulate, slender-petioled ; stem-leaves conspicuously different from the basal, the blades oblong, lanceolate or linear, undulate, repand or denticulate: flowers inconspicuous, slender-pedicelled: petals 1-3 or rarely 5, yellow, 1-1.5 mm. long: stamens 5-10: head of fruit oblong-cylindric, $3-4 \mathrm{~mm}$. long: achenes suborbicular, lenticular but swollen, $0.6-0.8 \mathrm{~mm}$. long, slightly margined, the faces minutely tuberculate.

In low grounds, Alabama to Louisiana and Texas. Spring.

3. Ranunculus pusíllus Poir. Foliage glabrous. Stems slender, weak, branching, 1.5-3 dm. high: leaf-blades entire or denticulate, the lower oblong or ovate, on long petioles, the upper narrower, lanceolate or linear, short-petioled or sessile : corolla yellow, 4-6 mm. broad : petals few, often barely exceeding the sepals in length : stamens 1-10: head of fruit, globose, $4 \mathrm{~mm}$. broad: achenes fully $1 \mathrm{~mm}$. long, beakless, each merely tipped with the persistent style-base.

In marshes, southern New York and Pennsylvania, mostly near the coast, to Florida and through the Gulf States to Texas and Missouri. Spring and early summer.-The small form of the southern border of the United States with more prominently papillose achenes, is $R$. pusillus Lirudheimeri (Engelm.) A. Gray.

4. Ranunculus oblongifòlius Ell. Foliage glabrous or pubescent. Stems branched above, erect or ascending, 2-5 $\mathrm{dm}$. high : leaf-blades entire or denticulate, mainly oblong or oblong-lanceolate, $2-7.5 \mathrm{~cm}$. long, the lower on long petioles, the upper narrower, lanceolate or linear: corolla yellow, $10-12 \mathrm{~mm}$. broad : petals 5 , much exceeding the sepals : stamens numerous : head of fruit $4 \mathrm{~mm}$. broad : achenes beakless, each merely tipped with the style-base.

In swamps, Virginia to southern Illinois and Missouri, Florida and Texas. Spring and summer.

5. Ranunculus obtusiúsculus Raf. Foliage glabrous. Stems stout, hollow, 3-9 $\mathrm{dm}$. long, ascending, rooting from the lower nodes, sometimes nearly $2.5 \mathrm{~cm}$. thick at the base : leaf-blades linear or lanceolate, $8-15 \mathrm{~cm}$. long, denticulate or entire, all but the uppermost on broad petioles, each clasping the stem by a broad base : corolla yellow, 12$16 \mathrm{~mm}$. broad, or smaller : petals $5-7$, much exceeding the sepals : head of fruit globose or slightly elongated, 10-12 mm. in diameter : achenes compressed, $1 \mathrm{~mm}$. long, subulatebeaked, but the beak early deciduous. [Ranunculus ambigens $\mathrm{S}$. Wats.]

In marshes, Maine and Ontario to Minnesota, Georgia and Missouri. Summer.

6. Ranunculus Harveỳi (A. Gray) Britton. Foliage glabrous. Stems erect, slender, branched, 1.5-5 dm. tall : leaf-blades thin, those of basal and lower stem-leaves long-petioled, reniform or suborbicular, obtusely crenate or somewhat lobed, $1-2 \mathrm{~cm}$. wide, cordate, or some of them truncate at the base, those of the upper stem-leaves sessile or nearly so, deeply 3-cleft or 3-parted into linear or narrowly oblong entire or few-toothed obtuse segments : corolla bright yellow, $12-18 \mathrm{~mm}$. broad : petals 4-8, oblong, 4-5 times as 
long as the reflexed sepals : head of fruit globose, $4 \mathrm{~mm}$. in diameter : achenes oblique, compressed, each tipped with a minute straight style.

On dry hillsides, Missouri and Arkansas. Spring.

7. Ranunculus abortìvus L. Foliage glabrous or only sparingly pubescent. Stems erect or nearly so, $1.5-6 \mathrm{dm}$. high, branched. Basal leaves several ; blades long-petioled, bright green, thick, crenate or sometimes lobed, broadly ovate, obtuse, and generally cordate or reniform; blades of the cauline leaves sessile or nearly so, divided into oblong or linear somewhat cuneate lobes: corolla yellow, 4-6 mm. broad: petals oblong, shorter than the reflexed sepals: head of fruit globose, the receptacle short, pubescent: achenes 1-1.5 mm. long, each tipped with a minute curved beak.

In woods and moist grounds, Labrador and Nova Scotia to Manitoba, Florida, Arkansas and Colorado. Spring.

8. Ranunculus micránthus Nutt. Similar to $R$. abortivus but usually rather more slender, the foliage villous. Stems 1-5 dm. tall : leaf-blades relatively thin, dull green, those of basal leaves ovate or suborbicular, 3-lobed or crenate, narrowed, rounded or nearly truncate at the base; segments of the upper stem-leaves narrow, entire or sharply toothed: corolla pale yellow, about $6 \mathrm{~mm}$. broad: petals oblong or oval, 2-3 times as long as wide: head of fruit rather longer than thick, the receptacle linear, glabrous or very nearly so.

In rich woods, often on rocks, Massachusetts to Minnesota, Georgia and Arkansas. Spring.

9. Ranunculus Allegheniénsis Britton. Similar in aspect to $R$. abortivus and $R$. micranthus, the foliage glabrous. Stems widely branched, $2-6 \mathrm{dm}$. tall : basal leaves several ; blades reniform or suborbicular, 1-2.5 cm. wide, long-petioled, crenate or some of them lobed, the teeth and lobes subacute; blades of stem-leaves sessile or the lower petioled, divided nearly or quite to the base into linear, acute, entire, toothed or cleft segments : corolla about $6 \mathrm{~mm}$. broad : petals oblong, not exceeding the calyx, yellow, glandular : head of fruit globose, or globose-oblong, $4 \mathrm{~mm}$. in diameter : achenes slightly compressed and margined, each tipped with a subulate hooked or recurved style of about $\frac{1}{2}$ its length. Spring.

In open woods, eastern Massachusetts and in the mountains to North Carolina and Tennessee.

10. Ranunculus sceleràtus L. Foliage glabrous or nearly so. Stems stout, 1.5-6 dm. high, freely branching, hollow : basal leaves with thick, 3-5-lobed reniform or cordate blades, $2.5-5 \mathrm{~cm}$. broad, on long and broad petioles ; blades of the stem-leaves petioled or the upper sessile, deeply lobed or divided, the lobes obtuse, cuneate-oblong or linear, toothed or entire : flowers numerous : corolla yellow, $6-8 \mathrm{~mm}$. broad : petals about equalling the calyx in length: head of fruit oblong or cylindric, 8-12 $\mathrm{mm}$. long: achenes about $1 \mathrm{~mm}$. long, very numerous, merely apiculate.

In swamps and wet ditches, New Brunswick to Florida, abundant along the coast, and locally in the interior to Minnesota, preferring saline or alkaline situations. Also in Europe and Asia. Spring and summer.

11. Ranunculus recurvàtus Poir. Foliage usually hirsute. Stems erect, $1.5-6 \mathrm{dm}$. high, branching : leaf-blades all petioled, broadly reniform, $5-7.5 \mathrm{~cm}$. wide, deeply 3-cleft, the divisions broadly cuneate, acute, toothed and lobed: corolla light yellow, 8-18 mm. broad : petals shorter than or equalling the reflexed calyx : head of fruit globose, $12 \mathrm{~mm}$. wide: achenes compressed, margined, each tipped with a recurved hooked beak of $\frac{1}{2}$ its length.

In rich woods, Nova Scotia to Manitoba, Florida and Missouri. Spring.

12. Ranunculus Pennsylvánicus L. f. Foliage pilose-hispid. Stems erect, branching, 3-7 dm. high, leafy : leaf-blades thin, 3-divided, the divisions deeply 3-cleft, the lobes lanceolate, cuneate, acute, incised: corolla yellow, $6-8 \mathrm{~mm}$. wide : petals equalling the reflexed sepals or shorter: head of fruit oblong or cylindric, $6 \mathrm{~mm}$. thick, sometimes $14 \mathrm{~mm}$. long : receptacle hairy : achenes smooth, each tipped with a sharp beak one-third its length.

In wet open places, Nova Scotia to British Columbia and Georgia. Summer.

13. Ranunculus bulbòsus L. Foliage pubescent. Stems erect from a bulbousthickened base, $1.5-5 \mathrm{dm}$. high : leaf-blades petioled, 3-divided, the terminal division stalked, the lateral ones sessile or nearly so, all variously lobed and cleft : corolla bright yellow, about $2.5 \mathrm{~cm}$. broad: petals much longer than the reflexed sepals, obovate, rounded : head of fruit globose, 10-12 mm. broad : achenes compressed, very short-beaked.

In fields and on roadsides, quite common in most sections of North America. Naturalized from Europe. Spring.

14. Ranunculus palmàtus Ell. Foliage glabrate, strigillose or sparingly hirsute. Roots clustered, slightly thickened : stems usually several together, slender, becoming de- 
cumbent and producing runners $2-8 \mathrm{dm}$. long : leaves mainly basal ; blades long-petioled, various, merely lobed or 3-several-cleft or parted or divided, $2-10 \mathrm{~cm}$. broad, the segments bluntly or sharply toothed or incised; stem-leaves with narrow often entire segments: corolla yellow, about $12 \mathrm{~mm}$. broad: pedicels slender: petals oblong to oblong-obovate : achenes few, 5-6 mm. long, including the flat nearly straight beak, broadly margined.

In river swamps or low woods, South Carolina to Tennessee and Florida. Spring.

15. Ranunculus septentrionàlis Poir. Foliage glabrous or rarely pubescent. Roots simply fibrous : stems branching, 3-12 dm. long, the later branches procumbent and sometimes rooting at the nodes: leaves large; hlades petioled, 3-divided, the divisions mostly cuneate at the base, cleft into broad lobes; lower petioles occasionally a foot long: corolla $25 \mathrm{~cm}$. in diameter or more, bright yellow : petals obovate, twice the length of the spreading sepals: head of fruit globose or oval, $10-13 \mathrm{~mm}$. in diameter: achenes flat, strongly margined, subulate-beaked by the stout sword-shaped styles which are of nearly their length and often early deciduous.

In low grounds and mainly in swamps, New Brunswick to Manitoba, Georgia and Kentucky. spring and early summer.

16. Ranunculus fasciculàris Muhl. Foliage silky-pubescent. Roots thickened and clustered : stems low, 1-3 dm. tall, tufted : leaf-blades petioled, 3 -5-divided, the divisions stalked (especially the terminal one), deeply lobed and cleft, the lobes oblong or linear : corolla $2-2.5 \mathrm{~cm}$. broad : petals yellow, obovate, much longer than the spreading sepals, rounded, truncate, or even emarginate : head of fruit globose, mostly $8-10 \mathrm{~mm}$. in diameter : achenes flat, slightly margined, each beaked with the subulate persistent style which is nearly or quite the length of the body.

In woods, Ontario and New England to Manitoba, middle Georgia and Texas. Spring.

17. Ranunculus ápricus Greene. Foliage sparingly strigillose or barely hirsute. Roots clustered, slightly thickened : stems slender, erect or ascending, 2-3 dm. long, several together : leaves mainly basal, of 2 kinds; blades slender-petioled, merely toothed or slightly 3 -lobed, truncate at the base, others on longer petioles, several times larger, 3-divided and the terminal lobe mostly 3 -parted; stem-leaves few, with linear or linear-oblong, entire or sparingly toothed segments: flowers slender-pedicelled: corolla $1.5 \mathrm{~cm}$. broad: petals oblong or oblong-obovate, white or pale within, yellowish without : achenes numerous, turgid-lenticular, $2-2.5 \mathrm{~mm}$. long, narrowly margined, subulate-beaked.

In moist pine woods, the Indian Territory to Mississippi and Louisiana. Winter and spring.

18. Ranunculus híspidus Michx. Foliage densely villous-hirsute, especially when young, becoming less densely pubescent in age. Roots relatively slender: stems commonly several together, erect or decumbent, $2-6 \mathrm{dm}$. long: leaves mainly basal ; blades pinnately 3-5-divided, rather thin, the segments sharply cleft or lobed; upper stemleaves 3-lobed or 3-parted : corolla yellow, $1.2-3.5 \mathrm{~cm}$. broad : petals obovate or cuneate, about twice as long as the spreading sepals : head of fruit globular or oval-globose, 6-10 $\mathrm{mm}$. long : achenes lenticular, broadly oval, $3-4 \mathrm{~mm}$. long, the subulate beak about $\frac{1}{2}$ as long as the body.

In woods and thickets, Ontario to the Northwest Territory, Georgia and Arkansas. Spring.

19. Ranunculus cuneifórmis Small. Foliage hirsute below the inflorescence. Roots thickened, clustered: stems usually several together, 2-3 dm. tall, erect or ascending, rather slender: leaves mainly basal; blades, at least some of them, 2-divided into cuneate rather obtuse segments, $5-10 \mathrm{~cm}$. long, about as long as the petioles; upper stemleaves with 3-parted blades, the segments narrow, often incised: corolla yellow, about 1.5 $\mathrm{cm}$. broad : peduncles strigillose : head of fruit subglobose or ovoid-globose, about $1 \mathrm{~cm}$. long, the receptacle barely elongated : achenes $4 \mathrm{~mm}$. long, conspicuously winged, each with a triangular beak.

On prairies, Kerrville, Texas. Spring.

20. Ranunculus macránthus Scheele. Foliage hirsute. Stems erect or acending, 1-6 dm. tall, simple or sparingly branched: leaves mainly basal ; blades long-petioled, 1-divided into more or less cuneate, entire or toothed segments; upper stem-leaves with narrower and more sharply toothed segments: corolla yellow, $3-5 \mathrm{~cm}$. broad, rather showy : petals cuneate to obovate, or oblong, much longer than the reflexed sepals: head of fruit oblong to cylindric, $1-1.5 \mathrm{~cm}$. long, the receptacle elongated : achenes $2-5 \mathrm{~mm}$. long, exclusive of the flat slightly curved beak, narrowly margined.

On plains and prairies, Texas. Spring and summer.

21. Ranunculus párvulus L. Foliage hairy. Stems erect, $1.5-4 \mathrm{dm}$. high, branching: basal and lower stem-leaves long-petioled; blades about $5 \mathrm{~cm}$. broad and long, 3 -divided or 3-cleft, the divisions broadly ovate, cuneate, stalked, cleft and lobed; upper 
stem-leaves sessile or nearly so; blades deeply cleft into linear-oblong obtuse segments : corolla yellow, $2-2.5 \mathrm{~cm}$. broad: petals much exceeding the reflexed sepals in length : head of fruit ohlong, 4-6 $\mathrm{mm}$. thick : achenes flat, strongly margined, short-beaked, provided with a series of small tubercles or papillae which become more prominent in drying, or rarely nearly smooth.

In ballast grounds and waste places, New Brunswick to New York, Virginia and Georgia. Adventive from Europe. Summer.

22. Ranunculus parviflòrus L. Foliage villous. Stems slender, diffuse, branching from the base, $1.5-3 \mathrm{dm}$. high : basal leaves with long petioles; blades reniform or cordateorbicular, $2.5 \mathrm{~cm}$. broad or less, 3-cleft, the lobes broadly oval, obtuse, and toothed ; upper leaves with short petioles, or blades nearly sessile, 3-5-parted into linear-oblong lobes: corolla yellow, 2-4 mm. wide : petals not longer than the sepals : head of fruit globose, 4 $\mathrm{mm}$. broad: achenes flat, margined, densely papillose, $3 \mathrm{~mm}$. long, each tipped with a sharp beak of about one-fourth its length.

In waste places, Maryland and eastern Virginia to Florida, Arkansas and Texas, and in ballast grounds about the northern seaports. Naturalized from Europe. Also naturalized in Bermuda. Summer.

23. Ranunculus muricàtus L. Foliage glabrous or sparingly pubescent. Stems branched from the base, 3-6 dm. high. Lower and basal leaves with long broad petioles; blades reniform or cordate-orbicular, 2.5-5 $\mathrm{cm}$. wide, 3-lobed, cleft or crenate ; upper leaves with 3-divided cuneate short-petioled or sessile blades: corolla light yellow, 6-10 $\mathrm{mm}$. wide : petals exceeding the sepals in length : head of fruit globular, $10-12 \mathrm{~mm}$. wide : achenes flat, densely muricate and spiny on the sides, $4 \mathrm{~mm}$. long, each tipped with a stout slightly curved beak of one-half its length.

In waste places, eastern Virginia to Florida and Louisiana; naturalized or fugitive from Europe. Also on the Pacific Coast. Native also in Asia and naturalized in tropical America. Summer.

\section{ADÒNIs L.}

Annual or perennial herbs, with rather succulent tissues and erect stems. Leaves alternate: blades pinnately dissected into numerous linear segments. Flowers yellow or red, solitary, terminal. Petals 5-16, conspicuous. Carpels numerous, each with 1 ovule. Achenes capitate or spicate, tipped with the persistent styles.

1. Adonis ánnua L. Annual, glabrous. Stems erect, 2-6 dm. tall, branched : leaves several ; blades finely dissected, $2-5 \mathrm{~cm}$. long, the lower petioled, the upper sessile, the segments narrow, acute, toothed or incised : flowers orange or red, $18-36 \mathrm{~mm}$. broad, stoutpeduncled : sepals glabrous, deciduous : petals obovate or cuneate, darker at the base than above : achenes $3-5 \mathrm{~mm}$. long, crowded in a cylindric head $1-2 \mathrm{~cm}$. long. [ $A$. autumnalis $\mathrm{L}$.]

In waste places, widely cultivated and spontaneous in the eastern United States.

\section{THALÍCTRUM L.}

Perennial herbs, with erect or decumbent stems. Leaves alternate : blades ternately decompound, the segments entire, toothed or lobed : petioles with dilated bases. Flowers perfect, polygamous or dioecious, generally small, in panicles or racemes. Sepals greenish white, 4 or 5. Petals wanting. Stamens numerous, exserted. Carpels commonly few, one-seeded, ribbed or nerved, stipitate or nearly sessile. Meadow RUe. Main-of-theMist.

Flowers perfect : filaments petal-like.

Achenes curved along the upper edge, the body longer than the stipe.

Achenes straight along the upper edge. the body shorter than the stipe.

lowers dinecious or polygamous: filaments not petal-like.

Filaments subulate or filiform.

Flowers strictly dinecious: leaflets not waxy beneath.

Stamens less than 18.

Stems procumbent: Jeaflets $6-15 \mathrm{~mm}$. broad, not glaucous : achenes $3.5-4 \mathrm{~mm}$. long.

Stems erect or ascending : leaflets $2-7 \mathrm{~mm}$. broad, glaucous beneath : achenes $3-3.5 \mathrm{~mm}$. long.

Stamens more than 18.

Leaflets longer than broad.

Roots not vellow: petioles barely dilated at the base.

Roots bright yellow: petioles widely dilated at the base.

Leaflets broader than long.

Flowers polygamous : leaflets more or less glandular or waxy beneath.

Filaments spatulate, often broader than the ant hers.

Leaflets entire or nearly so: flowers nearly dioecious : achene-body $3-4$ $\mathrm{mm}$. loung.

Leaflets strongly lobed : flowers polygamous : achene-body 4-5 mm. long.

1. T. clavatum.

2. T. mirabile.

3. T. debile.

4. T. Texanum.

5. T. dioicum.

6. T. coriaceum.

7. T. caulophylloides.

8. T. purpurascens.

9. T. macrostylum.

10. T. polygamum. 
1. Thalictrum clavàtum DC. Foliage glabrous. Stems branching, $1.5-6 \mathrm{dm}$. high, nearly leafless : leaves mainly basal, $5-10 \mathrm{~cm}$. long, biternate ; leaflets thin, stalked, oval, ovate, or the terminal obovate-cuneate, with 3 main lobes and a few secondary ones, the margins not revolute: inflorescence cymose: flowers perfect: filaments spatulate and petal-like : anthers oblong, blunt: achenes spreading, rather scimitar-shaped, the body longer than the stipe, narrowed at each end, flattened, tipped with the minute stigma.

About mountain brooks, Virginia and West Virginia to Georgia and Alabama. Spring and early summer.

2. Thalictrum miràbile Small. Foliage glabrous, bright green. Stems erect, 1-3 dm. tall, wiry, dichotomously branched above: leaves various, the basal usually ternately compound, with petioles about $2 \mathrm{~cm}$. long; upper leaves gradually more simple and shorter-petioled; leaflets suborbicular or orbicular-reniform, $2-3 \mathrm{~cm}$. broad, very thin, delicately nerved, glaucescent beneath, broadly crenate or shallowly crenate-lobed, truncate or subcordate at the base, longer than the petioles : peduncles hair-like : flowers white: sepals spatulate or rhombic-spatulate, fully $1.5 \mathrm{~mm}$. long: filaments fully $2 \mathrm{~mm}$. long, petallike by an abrupt thickening about the middle: achenes spreading at right angles to the peduncle, the body plump, about $2 \mathrm{~mm}$. long, acute, not depressed along the upper side, shorter than the filiform stalk.

On sandstone bluffs, Little Mountain, northern Alabama. Spring.

3. Thalictrum débile Buckl. Foliage glabrous. Roots tuber-like, clustered : stems simple or sparingly branched, procumbent, 1-4 dm. long, slender: leaves delicate, with slender petioles; leaflets thin, suborbicular to obovate, $0.5-1.5 \mathrm{~cm}$. broad, more or less distinctly 3-lobed, the lobes entire or shallowy toothed: flowers dioecious, few, mostly in pairs, short-pedicelled : sepals cuneate or oblong-spatulate, $2-2.5 \mathrm{~mm}$. long: stamens 7-11 : filaments slender, shorter than the mucronulate anthers : achenes 1-6, oblong, sessile, 3.5-4 mm. long, prominently 6-8-ribbed.

In rich woods in the mountains, Georgia and Alabama. Spring.

4. Thalictrum Texànum (A. Gray) Small. Foliage glabrous, somewhat glaucous. Roots fusiform, clustered: stems often branched at the base, the branches wiry, erect or ascending, 1-3 dm. tall : leaves rather numerous, with filiform petioles; leaflets firm, cuneate to reniform, $2-7 \mathrm{~mm}$. broad, entire, cleft or lobed : flowers several, slender-pedicelled : achenes narrowly oblong, $3-3.5 \mathrm{~mm}$. long, prominently $6-8$-ribbed, slender-beaked. [T. debile var. Texanum A. Gray.]

On moist prairies, near Houston, Texas. Early spring.

5. Thalictrum dioìcum L. Foliage glabrous. Roots not yellow : stems erect, 3-6 dm. high, slender, leafy : leaves ample; blades 3-4-ternate; leaflets thin, pale beneath, orbicular or broader, often cordate and the terminal one somewhat cuneate, 5-9-lobed: flowers dioecious, greenish, drooping or spreading : panicle elongated, of numerous lateral corymbs or umbel-like corymbs : filaments longer than the sepals : anthers linear, blunt, longer than the filaments : stigma elongated: achenes ovoid or oval, sessile or minutely stipitate, with rounded ribs, much longer than the style.

In woods, Labrador and Anticosti to Saskatchewan, in the mountains to Georgia and Alabama, and Missouri. Spring.

6. Thalictrum coriàceum (Britton) Small. Foliage glabrous. Rootstocks and roots bright yellow : stems 1-1.5 m. high, striate, paniculately branched above : leaves ample ; blades 3-4-ternate, short-petioled, the lower petioles expanded at the base into broad stipule-like appendages; leaflets obovate or reniform-orbicular, rather leathery, nearly white beneath, usually deeply and sharply incised, the nerves prominent on the lower surface: flowers dioecious; staminate nearly white, the anthers linear, subulate-tipped, longer than the filiform filaments; pistillate flowers purple : achenes oblong-ovoid, subacute, stipitate, sharply ribbed, longer than the persistent style.

In open woods, mountains of southwestern Virginia to Kentucky, Tennessee and North Carolina. Spring and early summer.

7. Thalictrum caulophylloides Small. Foliage deep green, glabrous. Stems erect, 6-12 dm. tall : leaves 2-5 dm. long, spreading, with long petioles ; leaflets firm, broadly oval to suborbicular in outline, mainly broader than long, 4-9 $\mathrm{cm}$. in diameter, glaucous and prominently nerved beneath, cordate or truncate, 3-5-lobed above the middle, the lobes apiculate; petiolules slender, 5-30 $\mathrm{mm}$. long: pedicels $8-20 \mathrm{~mm}$. long, wire-like : achenes elliptic, $6 \mathrm{~mm}$. long, sharply ribbed, contracted into stipes $1.5-2 \mathrm{~mm}$. long, each tipped with the persistent club-shaped style.

on mountain slopes, Tennessee. Spring and summer. 
8. Thalictrum purpuráscens L. Foliage glandular-pubescent or glabrate. Stems stout, erect, 1-2 m. high, leafy, branching above, often purplish : leaves ample ; blades 3-4-ternate ; leaflets thick, oblong or obovate, dark green above, commonly waxy beneath, with revolute margins, and 3 main apical pointed lobes : panicle compound, leafy-bracted, $3 \mathrm{dm}$. long or more : flowers polygamous : filaments narrow, slightly widened above : anthers linear or linear-oblong, cuspidate : stigma linear, persistent : achenes ovoid, glabrous or pubescent, short-stipitate, with 6-8 longitudinal wings.

In copses and woodlands, Nova Scotia and Anticosti to Saskatchewan, Florida and Arizona. Spring and summer.

9. Thalictrum macrostỳlum (Shuttl.) Small \& Heller. Foliage glabrous. Stems slender, $0.5-1.5 \mathrm{~m}$. tall, striate-ridged: leaves few, the upper cauline, nearly sessile ; leaflets thick, conspicuously small, 5-9 mm. broad, entire or shallowly 2-3-lobed, pale green above, whitish beneath : flowers dioecious or nearly so, relatively numerous : filaments spatulate, about as long as the anthers : achenes oval, $4-5 \mathrm{~mm}$. long, numerous, often 12-24, or sometimes only a few maturing, in dense globose heads, somewhat grooved, each tipped with the stout style.

In meadows and lime sinks, North Carolina to Georgia and Florida. Spring.

10. Thalictrum polýgamum Muhl. Foliage pubescent or glabrous, never glandular. Stems stout, 1-3 m. high, branching, leafy : leaves ample; blades 3-4-ternate; leaflets moderately thick, light green above and paler beneath, oblong-obovate, or orbicular, with 3 main apical pointed or obtuse lobes: panicle compound, leafy-bracted, $3 \mathrm{dm}$. long or more : flowers polygamous, white : filaments broadened : anthers oblong, short: achenes ovoid, stipitate, 6-8-winged, glabrous or pubescent.

In open swamps, Labrador and Quebec to Ohio and Florida.

\section{Family 3. ANONÀCEAE DC. Custard-Apple Family.}

Shrubs or trees, possessing a light wood and an aromatic or strong-scented bark. Leaves alternate, without stipules: blades entire, commonly broadest above the middle. Inflorescence terminal, axillary or opposite the leaves. Flowers perfect or sometimes monoecious or dioecious. Calyx of 3 or rarely 2 distinct or united valvate or rarely imbricated sepals. Corolla of mostly 6 imbricated or valvate membranous or thick petals, in 2 series, the inner smaller, or rarely wanting. Androecium of numerous stamens usually crowded on a receptacle. Filaments very short, distinct. Anthers extrorse, surmounted by appendages. Gynoecium of few or numerous sessile, distinct or somewhat united carpels. Ovaries 1-celled. Style short, or wanting. Stigma rarely grooved or 2-lobed. Ovules anatropous, solitary or few, erect or ascending, or many and horizontal in 2 series. Fruit a more or less pulpy berry derived from one carpel or from the union of many carpels. Seeds flattened, with a parchment-like or crustaceous testa, naked or enclosed in an aril. Endosperm copious, ruminated. Embryo near the hilum.

Anther-sacs separated : petals imbricated : ovules numerous : fruit simple, from one pistil. 1. AsImiNa. Anther-sacs contiguous : petals valvate: ovule solitary : fruit compound, from the confluent pistils.

2. ANONA.

\section{ASÍMINA Adans.}

Ill-scented shrubs or trees. Leaves deciduous. Flowers perfect, white or purple, axillary on branchlets of the present or preceding year, solitary or in pairs. Sepals 3, valvate, much smaller than the petals. Petals 6 , imbricated, the outer spreading and of ten the larger. Receptacle subglobose. Anther-sacs separated, adnate to the back of the filaments, surmounted by the glandular tip of the connective. Carpels 3-15, distinct, on top of the receptacle. Ovary tipped by a curved style. Ovules numerous, in 2 series, horizontal. Berries simple, solitary or several together, more or less elongated. Seeds flattened, with a leathery-crustaceous testa, enclosed in a fleshy-membranous aril, imbedded in a yellowish pulp. Endosperm horny. Embryo with very short cotyledons.

A. Flowers terminal, or from the axils of the leaves of the season, appearing after the leaves.

a. Flowers axillary (except rare cases in no. 1), long-pedicelled: leaf-blades long and narrow, linear or oblanceolate.

Mature outer petais $3.5 \mathrm{~cm}$. long or longer, white or yellowish white at maturity.

Mature outer petals $3 \mathrm{~cm}$. long or shorter, deep black-purple at maturity. Petals oblanceolate or narrowly obovate. the outer $2-3 \mathrm{~cm}$. long. Petals oblong, all nearly alike, $6-8 \mathrm{~mm}$. long.

1. A. angustifolia.

2. A. pygmaea.

3. A. Rugelii. 
b. Flowers terminal, sessile or nearly so: leaf-blades short and broad, obovate or oval.

B. Flowers from the axils of the deciduous leaves of the preceding season, appear4. A. obovata. ing before the leaves.

Leaves leathery; blades reticulated: flowers yellowish white. 1 or 2 in an axil. Young leaves densely tomentose on both surfaces: mature outer petals 4-5 cm. long.

Young leaves sparingly tomentose, the upper surface soon glabrous : mature outer petals $2.5-4 \mathrm{~cm}$. long.

Leavesmembranous; blades not reticulated : flowers purple, solitary in the axils. A sh rub mostly less than $1.5 \mathrm{~m}$. tall : mature outer petals $1 \mathrm{~cm}$. long or shorter: fruit 3-4 cm. long.

A shrub or tree $3-12 \mathrm{~m}$. tall : mature outer petals $2 \mathrm{~cm}$. long or longer : fruit 7 $16 \mathrm{~cm}$. long.

5. A. speciosa.

6. A. reticulata.

7. A. parviflora.

8. A. triloba.

1. Asimina angustifòlia A. Gray. A shrub, 4-9 dm. tall. Stems branched at the base ; branches, except their twigs, glahrous, the old bark gray, the younger reddish : leafblades linear to oblanceolate or narrowly spatulate, $5-20 \mathrm{~cm}$. long, acute or obtuse at the apex, acute at the base, glabrous, reticulated, sessile or short-petioled: flowers solitary in the axils of the leaves, or rarely terminating the branches : pedicels glabrous or sparingly pubescent, 1-2 cm. long: sepals ovate, nearly glabrous, $1-1.5 \mathrm{~cm}$. long : outer petals oblong-. obovate or obovate, accrescent, $6 \mathrm{~cm}$. long, white or yellowish white even at maturity: berries oblong, 3-5 cm. long, acute. [A. pygmaea (Michx.) Dunal, not Anona pygmaea. Bartr.]

In sandy pine lands, Georgia and northern Florida. Spring. Fruit ripening in summer.

2. Asimina pygmaèa (Bartr.) A. Gray. A shrub, $2-6 \mathrm{dm}$. tall. Stems simple, or commonly branched at the base; branches arcuate, often nearly prostrate, reddish, often tomentose at the ends : leaves tomentose when young, especially beneath, at maturity usually erect, appearing as if secund; blades oblong-oblanceolate, or spatulate-obovate, 5-15 cm. long, rounded, obtuse or acutish at the apex, acute at the base, glabrous, reticulated, sessile or short-petioled : flowers solitary in the axils, often nodding: pedicels slender, $1-1.5 \mathrm{~cm}$. long, glabrous or somewhat tomentose, often recurved : sepals ovate, $7-10 \mathrm{~mm}$. long, tomentose when young, glabrate when old : petals greenish and slightly pubescent externally when young, becoming dull black-purple and glabrous, the outer narrowly obovate, $2-3 \mathrm{~cm}$. Jong at maturity, the inner smaller: fruit not seen.

In pine lands, eastern and peninsular Florida. Spring. Fruit ripening in summer.

3. Asimina Rugé ii Robinson. A low branching shrub. Stems zigzag, red, ferrugineous-tomentulose : leaves early glabrate; blades oblong, $2.5-4 \mathrm{~cm}$. long, rounded at the apex, firm-leathery, reticulated, abruptly contracted at the base, nearly sessile : flowers inconspicuous, short-pedicelled: petals oblong, $6-8 \mathrm{~mm}$. long, those of both series nearly similar, obtuse, leathery : carpels pubescent when young.

In sandy pine woods, peninsular Florida. Spring.

4. Asimina obovàta (Willd.) Nash. A shrub or small tree, 1-3 m. tall. Stems much branched, clothed with a grayish brown bark; branchlets, petioles and the lower surface of the leaves, especially the midrib and nerves, tomentose with bright red or brown hairs : leaf-blades obovate, or the smaller ones often oval, 4-10 cm. long, glabrous above; petioles 3-5 $\mathrm{mm}$. long : flowers sessile or nearly so, terminating the branchlets: sepals ovate to oval, 10-12 mm. long, tomentose when young, glabrate : petals vellowish white, glabrous, the outer obovate, $5-6 \mathrm{~cm}$. long at maturity, the inner smaller : fruit not seen.

In pine lands, peninsular Florida. Spring. Fruit ripening in summer.

5. Asimina speciòsa Nash. A shrub, 6-12 dm. tall. Stems clothed with a smooth gray bark; branchlets, as well as the peduncles and both surfaces of the young leaves densely tomentose with yellowish or tawny hairs : leaf-blades oblong, narrowly obovate or obovate, $7-14 \mathrm{~cm}$. long, leathery, reticulated, tomentose on both sides, sparingly so above at maturity; petioles 3-7 mm. long, densely tomentose : flowers sometimes accompanied by branchlets from the axils of the deciduous leaves of the preceding year : pedicels 7-18 $\mathrm{mm}$. long: sepals ovate, $6-8 \mathrm{~mm}$. long, tomentose : outer petals oval or obovate, 4-5 cm. long at maturity, much exceeding the inner ones, about six times as long as the sepals, pubescent, particularly on the outside near the base: berries glabrous. [A. grandiflora (Michx.) A. Gray, not Anona grandiflora Bartr.]

In pine lands, eastern Georgia and eastern Florida. Spring. Fruit ripening in summer.

6. Asímina retículàta Shuttl. A shrub, 5-10 dm. tall. Stems with a grayish brown or brown bark ; branchlets, lower surface of the young leaves, peduncles and the outer surfaces of the sepals and young petals densely tomentose with reddish brown hairs: leaves somewhat tomentose above when young ; blades leathery, narrowly oblong, or oblanceolate, sometimes cuneate, $25-9 \mathrm{~cm}$. long, glabrous, reticulated, the midrib and nerves prominent beneath ; petioles 1-2 mm. long: flower: on pedicels $5-8 \mathrm{~mm}$. long, arising from the axils of the deciduous leaves of the preceding year, each often accompanied by a branchlet: 
sepals ovate, $5-7 \mathrm{~mm}$. long: outer petals oval to obovate, $2.5-4 \mathrm{~cm}$. long at maturity, much exceeding the inner ones and about five times the length of the sepals, pubescent on the outside, especially toward the base : berries glabrous or nearly so. [A. cuneata Shuttlw.]

In pine lands, peninsular Florida. Spring. Fruit ripening in summer.

7. Asimina parviflòra (Michx.) Dunal. A shrub, $3-40 \mathrm{dm}$. tall. Stems with spreading branches, clothed with gray to reddish bark; branchlets, young leaves, particularly their lower surfaces, peduncles, and the outside of the young sepals and petals tomentose with bright reddish brown hairs : leaf-blades obovate to oblong-obovate, $6-17 \mathrm{~cm}$. long, acute at the apex or short-acuminate, narrowed at the base, thin, glabrous above, usually more or less tomentose beneath, especially on the midrib and veins; petioles tomentose, $6 \mathrm{~mm}$. long or shorter: flowers solitary from the axils of the deciduous leaves of the preceding year: pedicels $5 \mathrm{~mm}$. long: sepals ovate, $5-7 \mathrm{~mm}$. long: mature outer petals ovate to broadly oval, $7-10 \mathrm{~mm}$. long, less than twice the length of the sepals : berries oblong, about $3.5 \mathrm{~cm}$. long, sparingly pubescent.

In sandy soil in the low country and foothills, North Carolina to Alabama and Florida, Spring.

8. Asimina triloba (L.) Dunal. A shrub or tree, $3-12 \mathrm{~m}$. tall. Stems much branched, clothed with a dark gray bark; branchlets and leaves when young, peduncles, and exterior surfaces of the sepals and petals tomentose with reddish brown hairs: leaf-blades obovate or obovate-cuneate, 10-30 $\mathrm{cm}$. long, abruptly acuminate at the apex, usually acute, but sometimes rounded at the base, membranous, glabrous above, the midrib and primary nerves, usually pubescent; petioles $0.5-1 \mathrm{~cm}$. long, glabrous or sparingly pubescent: flowers in the axils of the deciduous leaves of the preceding year : pedicels often recurved, $8-15 \mathrm{~mm}$. long : sepals ovate or orbicular-ovate, $8-12 \mathrm{~mm}$. long : petals at first greenish, later purple and conspicuously nerved, the outer ones nearly orbicular, $2-2.5 \mathrm{~cm}$. long, more than twice the length of the sepals : berries oblong-cylindric, 7-16 cm. long, glaucous, turning yellow, becoming soft and edible : seeds brown, oblong, $2-2.5 \mathrm{~cm}$. long, flattened, obtuse at the apex and usually obliquely truncate at the base.

In rich moist soil and on river banks, northern New Jersey to western New York, southern Michigan, Nebraska, middle Florida and eastern Texas. Spring.

\section{ANÒNA L.}

Pungent-aromatic shrubs or trees. Leaves persistent: blades entire, leathery, often punctate. Flowers perfect, white or yellow, solitary, clustered or rarely racemose, terminal or lateral, nodding. Sepals 3, valvate, concave, somewhat united, deciduous. Petals mostly 6 , valvate, fleshy, concave, converging, 3 -angled at the apex, the outer ones larger, the inner sometimes wanting. Receptacle hemispheric. Anther-sacs contiguous, united to the back of the filament, surmounted by the truncate, sometimes glandular tip of the connective. Carpels numerous, on the top of the receptacle, distinct or united. Ovaries prolonged into a sessile or nearly sessile stigma. Ovule solitary, erect. Fruit compound, many-celled, smooth, scaly or muricate. Seeds flattened, with a brown leathery-crustaceous testa, enclosed in an aril. Embryo with rather long cotyledons. Custard-APPLE.

1. Anona glàbra L. A stout tree, $8-14 \mathrm{~m}$. tall, with a maximum trunk diameter of $5 \mathrm{dm}$., the branches spreading. Leaf-blades oblong or oval, $10-18 \mathrm{~cm}$. long, leathery, acute, or short-acuminate, rounded or abruptly narrowed at the base, dark green above, paler beneath ; petioles 1-2 cm. long: flowers nodding, yellow or dirty white : pedicels $1-3 \mathrm{~cm}$. long, enlarged at both ends: sepals 3, slightly united at the base, broader than long: petals 6 , fleshy, concave, $2-3.5 \mathrm{~cm}$. long, converging, those of the outer series marked with red within near the base, those of the inner series smaller and shorter: berry broadly ovoid, 6-12 cm. long, flattened and depressed at the base, rounded at the apex, yellow blotched with brown when mature, edible but insipid : seeds oblong, 1-2 cm. long, the thin aril surrounding the body.

In swamps and ponds, peninsular Florida and the keys. Also in West Indies.

\section{Family 4. magnoliàceae J. St. Hill. Magnolia Family.}

Shrubs, trees or vines, often conspicuous by their large leaves, with a soft wood and pale often aromatic bark. Leaves alternate, or sometimes apparently whorled at the ends of branches: blades often punctate, entire or lobed : stipules deciduous or wanting. Flowers commonly perfect or monoecious axillary or terminal, mostly large, showy, fragrant or ill-scented. Calyx of 3 petaloid, deciduous sepals or rarely more. Petals 5 or more, imbricated in 2 or more series. 
Androecium of numerous stamens or rarely of only 5. Filaments filiform or short and much flattened. Anthers introrse or extrorse, adnate. Gynoecium of usually numerous carpels in a whorl, or imbricated on an elongated receptacle, Ovaries 1-celled, narrowed into short, often recurved styles stigmatic on the inner side. Ovules 1 or 2 in each cavity, anatropous or amphitropous. Fruit a whorl or head of accrescent carpels, which become berries or follicles. Seeds 1-2, with a leathery or crustaceous testa, or an inner crustaceous and outer fleshy testa, sometimes drupe-like and pendulous on slender threads. Endosperm fleshy, oily, homogeneous. Embryo minute at one end of the endosperm.

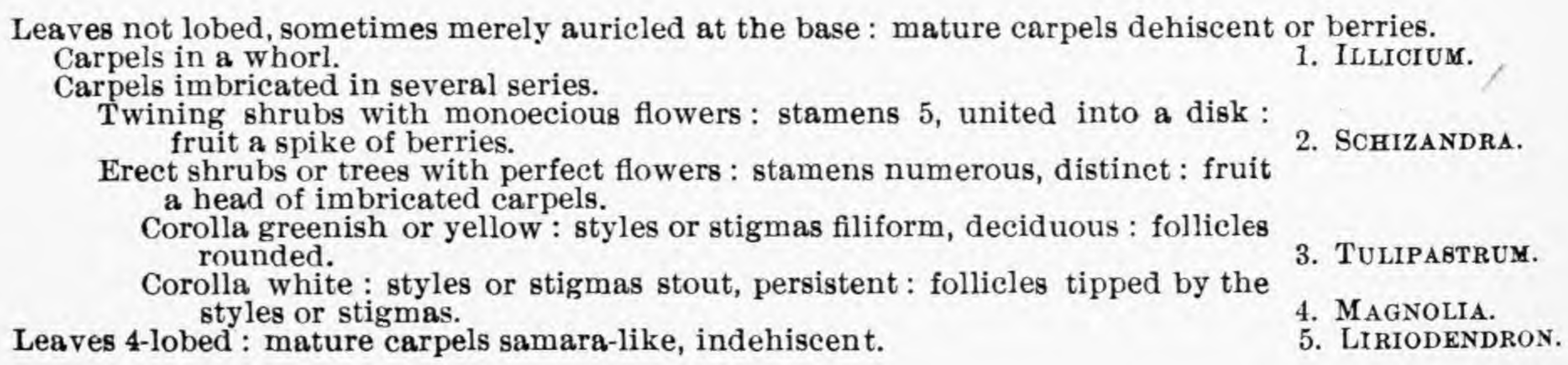

\section{ILLÍCIUM L.}

Glabrous aromatic evergreen shrubs or small trees. Leaves alternate, often crowded, without stipules : blades leathery, entire, minutely punctate. Flowers perfect, solitary on axillary peduncles. Sepals 3-6, petaloid, membranous, imbricated in 2 series, deciduous. Petals numerous, arranged in 3-several series, the inner ones gradually narrower, deciduous. Stamens numerous in several series. Carpels numerous (6-18), distinct, sessile, flattened, inserted in a whorl on a conic receptacle. Style recurved. Ovule solitary, ascending. Fruit a whorl of hard crustaceous drupe-like follicles at length dehiscing. Seed solitary, with a smooth shining testa Anise Tree. Star Anise.

Corolla $2 \mathrm{~cm}$. broad : petals 6-12: leaf-blades obtuse.

Corolla $2.5-3 \mathrm{~cm}$. broad : petals $20-30$ : leaf-blades acuminate.

1. I. parvifiorum.

2. I. Floridanum.

1. Illicium parviflòrum Michx. An erect glabrous shrub, 1-2 m. tall. Leaf-blades leathery, elliptic or oblong, 6-10 $\mathrm{cm}$. long, obtuse at both ends, more or less revolute, lustrous above, paler and dull beneath ; petioles 1-1.5 cm. long: peduncles 1-3 cm. long: sepals suborbicular, nearly $10 \mathrm{~mm}$. in diameter : corolla yellow, $2 \mathrm{~cm}$. broad : petals $6-12$, ovate or suborbicular, about as large as the sepals, obtuse : stamens usually as many as the petals.

Along the coast, Georgia and Florida. Spring.

2. Illicium Floridànum Ellis. A glabrous shrub, 2-3 m. tall. Leaf-blades leathery, slightly fleshy, elliptic or narrowly elliptic, $6-15 \mathrm{~cm}$. long, acute or acuminate at both ends, deep green above, paler beneath; petioles $1-2 \mathrm{~cm}$. long: peduncles $2-5 \mathrm{~cm}$. long : sepals ovate or oblong, over $1 \mathrm{~cm}$. long, obtuse, membranous : corolla $3-5 \mathrm{~cm}$. broad, purple, nodding : petals $20-30$, linear or nearly so, $1.5-2 \mathrm{~cm}$. long, acute, spreading : filaments enlarged upward, larger than the anthers: fruit $2.5-3 \mathrm{~cm}$. broad : carpels ovate, $1-1.5 \mathrm{~cm}$. long, acuminate : seeds oval, 5-6 mm. long, shining.

In swamps, Florida to Louisiana. Spring.

\section{SCHIZÁNDRA Michx.}

Glabrous or glabrate vines. Leaves deciduous, alternate, without stipules : blades membranous, entire or toothed, long-petioled, punctate. Flowers monoecious, white, yellow, or crimson, solitary on axillary peduncles. Sepals 5 or 6 , imbricated in 2 series, petaloid, with scarious edges, the outer smaller, deciduous. Petals 5 or 6 imbricated in 1-2 series, thickened at the narrowed base, deciduous. Stamens 5 : filaments very short, flat, united into a broad disk : anthers rather introrse : sacs widely separated. Carpels distinct, imbricated in several series on an elongated receptacle. Style very short. Ovules 2 in each cavity, pendulous. Fruit a spike of berries on a much elongated receptacle. Seeds 2 in berry, reniform, with a crustaceous testa. BAY-STAR Vine. 
1. Schizandra coccínea Michx. A slender high climbing shrub. Stem twining, several $\mathrm{m}$. long : leaf-blades membranous, oval, elliptic or ovate, 5-15 cm. long, short-acuminate, acute or obtuse, undulate or shallowly toothed, acute or subcordate at the base, glabrous or sparingly pubescent beneath; petioles slightly winged, about $\frac{1}{2}$ as long as the blades : peduncles 3-7 cm. long, naked: sepals oval or broadly ovate, $2-5 \mathrm{~cm}$. long, obtuse, erose : corollas $12-20 \mathrm{~cm}$. broad : petals obovate-cuneate, longer than the sepals, rounded or truncate at the apex, mostly crimson, each with a thickened claw : filaments united into a broad disk : carpels inserted on a cylindric receptacle, imbricated in several series : fruiting spike $4-7 \mathrm{~cm}$. long : berries oval, about $1 \mathrm{~cm}$. long, red.

In woods, South Carolina to Florida and Louisiana. Spring and summer.

\section{TULIPÁSTRUM Spach.}

Stately trees, often with much elongated trunks. Leaves alternate, not disposed in umbrella-like clusters, deciduous: blades membranous, relatively small, entire, slenderpetioled. Flowers perfect, erect, greenish, yellowish or canary-yellow, relatively small. Sepals green, deciduous. Petals much larger than the sepals, curved, commonly 6 or fewer. Stamens numerous: anthers introrse. Carpels several or numerous, glabrous, in many series. Styles or stigmas filiform, deciduous. Ovules 2 in each cavity. Fruit a relatively small narrow torulose cone, the carpels rounded. Seeds pendulous from the follicles. Cucumber-tree. Wauhoo. Elk-Wood.

Leaf-blades rhombic-obovate: flowers canary-yellow.

1. T. cordatum.

Leaf-blades elliptic or oval varying to ovate or rarely obovate: flowers greenish yellow. 2. T. acuminatum.

1. Tulipastrum cordàtum (Michx.) Small. A tree, reaching a height of $20 \mathrm{~m}$., with a trunk diameter of about $1 \mathrm{~m}$., the buds, shoots and young leaves silky-pubescent. Leafblades rhombic-ovate or rhombic-oval, 1-2 dm. long, usually acute, undulate, truncate or cordate at the base, sparingly pubescent on both surfaces; petioles 1-2 $\mathrm{cm}$. long : flowers campanulate, canary-yellow : sepals ovate or oblong-obvate, about $2 \mathrm{~cm}$. long, obtuse : petals obovate or obovate-oblanceolate, $4-5 \mathrm{~cm}$. long, rounded at the apex, more or less glaucous : fruit oblong, $2-5 \mathrm{~cm}$. long. [Magnolia cordata Michx.]

In woods, on the mountains, North Carolina to Georgia. Spring.

2. Tulipastrum acuminàtum (L.) Small. A forest tree, sometimes $30 \mathrm{~m}$. in height and $1.5 \mathrm{~m}$. in diameter, the bark furrowed. Leaf-blades elliptic or oval, varying to ovate or obovate, 1.5-3 dm. long, short-acuminate at the apex, undulate, acute or cordate at the base, silky when young, finally glabrous above, sparingly pubescent beneath ; petioles 2-4 cm. long : flowers campanulate, greenish or yellowish : sepals oblong or oblong-lanceolate, about $2 \mathrm{~cm}$. long, obtuse, spreading or reflexed: petals oblong or oblanceolate, $5-7 \mathrm{~cm}$. long, glaucous, obtuse : fruit oblong or nearly so, $4-6 \mathrm{~cm}$. long, often curved, often very irregular. [Magnolia acuminata L.]

In woods, Ontario to Illinois, Georgia and Arkansas. Spring.

\section{MAGNÒLIA L.}

Handsome, sometimes evergreen, trees or shrubs. Leaves alternate, or apparently whorled at the ends of branches : blades membranous or leathery, short-petioled, entire, occasionally auricled at the bas e: stipules membranous. Flowers perfect, white, often showy, fragrant or ill-scented, solitary at the ends of branches. Sepals 3, petaloid, spreading or reflexed, deciduous. Petals 6-12, imbricated in 2-4 series, slightly spreading, or erect and converging. Stamens numerous, imbricated in many series at the base of the receptacle ; filaments short and stout, the connective produced beyond the anthers: anthers introrse, adnate to the inner side of the filament. Carpels numerous, imbricated in many series on the elongated receptacle. Style persistent. Ovules 2 in each cavity, anatropous, pendulous or horizontal. Fruit a variously shaped cone of imbricated more or less united fleshy follicleś, these tipped by the style or stigma. Seeds 2 in each follicle, each with a pulpy scarlet testa, at length pendulous on a thread.

Leaf-blades thick-leathery, very thick, persistent, brown or rusty-tomentose beneath. 1. M. foetida.

Leaf-blades membranous, sometimes firm, usually deciduous, glabrous, glaucous or silky beneath.

Leaf-blades not auricled at the base.

Leaf-blades oblong, elliptic or oval, rarely broadest below the middle, $5-15 \mathrm{~cm}$. long, firm : fruit $3-5 \mathrm{~cm}$. long.

Leaf-blades elliptic-oblanceolate or obovate-oblanceolate, $2-6 \mathrm{dm}$. long, membranous : fruit $6-9 \mathrm{~cm}$. long. 
Leaf-blades auricled at the base.

Fruit oblong-conic: carpels with long curved beaks : leaf-blades pale green beneath.

Leaves elongated-obovate, gradually acute: stamens $9-13 \mathrm{~mm}$. long. $\quad 4$. M. Fraseri. Leaves rhombic-obovate, abruptly acute : stamens $4-6 \mathrm{~mm}$. long. ruit subglobose : carpels obtuse or acutish : leaf-blades very glaucous beneath.

5. M. pyramidata.

1. Magnolia foètida (L.) Sarg. A stately tree, reaching a maximum height of 20 m., with a trunk diameter of $2.5 \mathrm{~m}$., its twigs, petioles and buds red-tomentose. Leaves evergreen, firm and leathery ; blades elliptic, oval or oblanceolate, or rarely ovate, 1-3 $\mathrm{dm}$. long, obtuse or acute, glabrous and usually shining above (except the midrib), finely tomentose with brown or rusty hairs beneath, acute or rounded at the base; petioles stont, 1-3.5 cm. long: flowers creamy-white, broadly campanulate, lemon-scented, 1-2 dm. broad : petals with suborbicular or orbicular-obovate blades $5-10 \mathrm{~cm}$. in diameter, emarginate or notehed at the apex, contracted into broad claws : fruit oval, 8-12 cm. long : seeds obovoid or triangular-obovoid, $1.5-2 \mathrm{~cm}$. long, more or less flattened.

In hammocks and river swamps, North Carolina to Florida, Texas and Arkansas. Spring and summer. LaURel. Bull Bay.

2. Magnolia Virginiàna L. A shrub or slender tree, $2-2.5 \mathrm{~m}$. tall, the trunk rarely $1 \mathrm{~m}$. in diameter, the bark pale, smoothish. Leaves evergreen and firm ; blades oblong, elliptic or oval, sometimes broadest a little above or below the middle, 5-15 cm. long, acute or obtuse at the apex, undulate, acute or rounded at the base, not auricled, glabrous and deep green above, glaucous and more or less pubescent beneath; petioles $1-2 \mathrm{~cm}$. long: flowers globose-campanulate, white, fragrant, $3-8 \mathrm{~cm}$. broad : sepals oblong or obovate, 1.5-3.5 cm. long, rounded at the apex: petals elliptic, oblong, oval or obovate, longer than the sepals, rounded or obtuse at the apex, more or less distinctly clawed : fruit oval or ovoid, 3-5 cm. long, glabrous, dark red, the carpels acute : seeds flattened, obovoid, oval or suborbicular, 8-10 mm. long. [Magnolia glauca L.]

In swamps, Massachusetts to Florida and Texas, and locally inland. Spring and early summer. SWEET BAY.

3. Magnolia tripétala L. A small tree, reaching a maximum height of $14 \mathrm{~m}$. and a trunk diameter of about $4 \mathrm{dm}$., the bark pale. Leaf-blades elliptic-oblanceolate or obovatelanceolate, acute or apiculate at the apex, 2-7 dm. long, undulate, gradually narrowed to the base, not auricled, glabrous above, more or less densely tomentose beneath; petioles stout, $2-4 \mathrm{~cm}$. long: flowers creamy-white, unpleasantly scented : sepals oblong-oblanceolate $10-15 \mathrm{~cm}$. long, bright green, finally reflexed: petals 6-9, slightly longer than the sepals, erect or spreading, oblong-oblanceolate, concave, obtuse : fruit oblong, 8-12 cm. long, rose-color, the carpels prolonged into slender somewhat curved beaks : seeds obovoid, barely $1 \mathrm{~cm}$. long.

In woods, Pennsylvania to Georgia, Alabama and Arkansas. Spring. Umbrella-tree.

4. Magnolia Fràseri Walt. A slender tree, 5-15 m. tall, with a maximum trunk diameter of $0.5 \mathrm{~m}$., the trunk erect or ascending. Leaf-blades membranous, elongatedobovate to obovate-spatulate, $2-4 \mathrm{dm}$. long, acute or obtuse, sometimes slightly fan-shaped above the middle, undulate, auricled at the base, dark green above, pale or slightly glaucous beneath, glabrous; petioles $4-7 \mathrm{~cm}$. long : flowers white or creamy : sepals spreading or recurved, $\frac{1}{3}$ as long as the petals, rounded at the apex : petals elliptic or narrowly ovate, 5-12 cm. long, mostly obtuse, clawed : fruit oblong-conic, 7-12 cm. long, rose-color when mature : seeds elliptic or oval, nearly $1 \mathrm{~cm}$. long, the carpels yellow within, the long slender beak incurved.

Chiefly in the mountains, Virginia to Georgia and Alabama. Spring.

5. Magnolia pyramidàta Pursh. A small tree 4-10 m. tall, with a trunk diameter of about 1-2 dm. Leaf-blades membranous, 1-2 dm. long, rhombic-obovate, very abruptly acute at the apex, constricted near the base and dilated into diverging auricles, dark green above, pale or slightly glaucous beneath, glabrous; petioles $35 \mathrm{~cm}$. long : flowers white or creamy : sepals spreading or recurved: petals lanceolate, mostly acute, $5-8 \mathrm{~cm}$. long, clawed : fruit oblong, $6-8 \mathrm{~cm}$. long, rose-red at maturity, the carpels yellow within, the beak incurved.

In woods and on banks of streams, mostly in damp soil, Chattahoochie basin of Georgia, Alabama and Florida. Spring.

6. Magnolia macrophýlla Michx. A small tree, sometimes $15 \mathrm{~m}$. tall, with a maximum trunk diameter of about $5 \mathrm{dm}$., the bark pale. Leaf-blades obovate or oblong-oblanceolate, more or less rhombic, 3-9 dm. long, obtuse or short-acuminate, undulate, narrowed to the auricled base, deep green and glabrous above, glaucous beneath ; petioles stout, $5-15$ $\mathrm{cm}$. long, prolonged into the very prominent midrib : flowers creamy-white, fragrant, $2-3$ $\mathrm{dm}$. broad : sepals oblong or broadened upward, 10-15 $\mathrm{cm}$. long, rounded at the apex : 
petals fully twice as long as the sepals, obtuse : fruit subglobose, $6-10 \mathrm{~cm}$. long, rose-colored, the carpels obtuse or acutish : seeds flattened, obovoid, about $1 \mathrm{~cm}$. long.

In woods, Kentucky to Florida, Louisiana and Arkansas. Spring.

\section{LIRIODÉNDRON L.}

An elegant and stately tree, with spreading and drooping branches. Leaves alternate : blades leathery-membranous, deciduous, 4-lobed and notched at the apex, slender-petioled, the large stipules deciduous. Flowers perfect, greenish yellow, solitary at the ends of branches. Sepals 3, petioled, imbricated, reflexed. Petals 6, imbricated in 2 series, nearly erect. Stamens numerous, imbricated in several series, slightly shorter than the petals : filaments slender : anthers linear, extrorse, adnate to the outside of the filaments. Carpels numerous, closely imbricated on the slender receptacle forming a conic-fusiform spike. Ovaries 1-celled, prolonged into a winged style with a small recurved stigma at the end. Ovules 2 in each cavity, pendulous, anatropous. Fruit a cone formed of the accrescent indehiscent earpels. Seeds 1-2 in each carpel, with a thin leathery testa. Tulip-tree. White Poplar.

2. Lirlodendron Tulipífera L. A forest tree, reaching a maximum height of $60 \mathrm{~m}$. with a trunk diameter of $3 \mathrm{~m}$. Bark broken into large flat ridges : leaf-blades orbicular or depressed-orbicular in outline, 6-20 cm. in diameter, dark green above, paler beneath, truncate or notched at the apex, truncate or subcordate at the base, 4-lobed, the lobes entire or toothed ; petioles 5-10 $\mathrm{cm}$. long: flowers campanulate, $5-7 \mathrm{~cm}$. broad : sepals oblong or oblong-obovate, $4-5 \mathrm{~cm}$. long, rounded at the apex : petals oblong, oval or suborbicular, somewhat longer than the sepals, greenish yellow, often tinged with orange, narrowed into broad claws : fruit conic, $5-7 \mathrm{~cm}$. long, ?erect, persistent : mature carpels indehiscent, samara-like, $3-4 \mathrm{~cm}$. long.

In woods and swamps, Vermont to Rhode Island, Michigan, Missouri, Florida, Mississippi and Arkansas. Spring.

\section{Family 5. MENISPERMACEAE DC. Moonseed Family.}

Twining or trailing vines, either wholly or partly woody, with a watery bitter sap. Leaves alternate, without stipules: blades entire or palmately lobed, sometimes peltate. Flowers dioecious, or polygamous, in racemes, panicles or cymes. Calyx of 6 sepals, or these fewer or more. Corolla of 6 or more petals, or rarely wanting. Androecium of 6-12 stamens or rarely of many. Filaments distinct. Anthers 2-4-celled, opening lengthwise. Gynoecium of 3-6 distinct carpels or rarely more. Ovules solitary, amphitropous. Fruit berrylike drupes. Seeds with crescent-like or annular embryos. Endosperm scant.

\footnotetext{
Petals none : anthers 2-celled : stigma apical at maturity.

Petals present : anthers mostly 4-celled : stigma bent around to the base of the fruit.

Staminate flowers with 6 stamens : drupe red or purple.

Staminate flowers with 12-24 stamens : drupe black.
}

1. Calycocarpum.

2. Cebatha.

3. Menispermum.

\section{CALYOCÁRPUM Nutt.}

Perennial vines, with twining stems. Leaves alternate : blades palmately 3-5-lobed. Flowers dioecious, not showy, in slender raceme-like axillary panicles. Sepals 6, in 2 unequal series. Petals wanting. Stamens 12, imperfect in the pistillate flowers : filaments distinct. Carpels 3, erect. Ovary 1-celled, sessile: stigma radially cleft. Ovule solitary in each cavity. Drupes barely elongated, the flesh thin over a smooth laterally bowlshaped stone. Embryo curved, with flat cotyledons. CUP-SEED.

1. Calycocarpum Lyònii (Pursh) Nutt. A high climbing vine, with twining stems. Leaf-blades membranous, suborbicular in outline, $6-20 \mathrm{~cm}$. long, palmately 3-7-lobed, truncate to cordate at the base, the lobes acuminate; petioles as long as the blades or longer: flowers inconspicuous; staminate in elongated panicles; pistillate in shorter panicles: sepals 6, oblong, $2-2.5 \mathrm{~mm}$. long, obtuse : petals wanting : stamens shorter than the sepals : drupes subglobose or oval, about $2.5 \mathrm{~cm}$. long, black, the stone toothed along the edge of the cavity.

Along streams and in rich woods, Illinois to Kansas, Florida and Louisiana. Spring. 


\section{CÉBATHA Forsk.}

Perennial climbing plants, with slender twining stems. Leaves alternate: blades thickish, entire or angularly lobed, petioled, not peltate. Flowers dioecious or polygamous, in axillary cymes or panicles. Sepals 6 , in 2 series, the inner ones larger than the outer. Petals 6, in 2 series, smaller than the inner sepals, entire or cleft, concave or inrolled. Stamens 6, more or less reduced or wanting in the pistillate flowers : filaments distinct : anthers 4-celled. Carpels 3-6. Ovary 1-celled : style or stigma subulate, entire. Ovule solitary in each cavity. Drupes somewhat flattened, with a more or less reniform or horseshoe-shaped stone. Seed shaped like the stone. Embryo curved with flat narrow cotyledons. [ Cocculus DC.] CoRAL-BEAD.

Foliage glabrate or merely puberulent: petioles much shorter than the leaf-blades. Foliage tomentose: petioles nearly as long as the leaf-blades.

1. C. diversifolia. 2. C. Carolina.

1. Cebatha diversifòlia (DC.) Kuntze. A glabrous or almost glabrous vine, with elongated stems. Leaf-blades leathery, varying from almost linear to oblong-ovate or ovate, acute or obtuse, more or less revolute, rounded or subcordate at the base; petioles much shorter than the blades : flowers yellowish; staminate in leafy racemes; pistillate in naked racemes: sepals eroded, the 3 onter ovate, $1 \mathrm{~mm}$. long, the 3 inner broadly ovate, $2 \mathrm{~mm}$. long: petals ovate-oblong, about $1 \mathrm{~mm}$. long: drupe apparently purple, 6-7 $\mathrm{mm}$. long. [Cocculus diversifolius DC.]

In dry soil, Texas and Arizona to Mexico. Summer.

2. Cebatha Carolina (L.) Britton. A vine, with trailing or climbing stems $0.5-3 \mathrm{~m}$. long. Leaf-blades broadly-ovate or deltoid, 4-12 cm. long, entire or 3-5-lobed, tomentose beneath, deep green and glabrate above, rounded or cordate at the base ; petioles slender, somewhat shorter than the blades : flowers white ; staminate in compound racemes ; pistillate in simple racemes : sepals 6 , eroded, the 3 outer nearly oblong, $1 \mathrm{~mm}$. long, the 3 inner oval, $2 \mathrm{~mm}$. long: petals $1 \mathrm{~mm}$. long, eroded at the apex, auricled at the base: drupe red, 7-8 mm. broad. [Cocculus Carolinus (L.) DC.]

In woods, fields and thickets, Virginia to Kansas, Florida and Texas. Summer.

\section{MENISPÉRMUM L.}

Perennial slender twining vines, woody below, herbaceous above. Leaves alternate : blades membranous, peltate, often palmately lobed, petioled. Flowers dioecious, white, in axillary panicles. Sepals $4-8$, in 2 series. Petals $4-8$, in 2 series, shorter than the sepals. Stamens 12-24, or reduced to 6 staminodia in the pistillate flowers : filaments distinct: anthers 4-celled. Carpels 2-4. Ovary 1-celled, sessile: stigma dilated. Ovule solitary. Drupe somewhat flattened, with a broadly reniform crested stone. Seed horseshoe-shaped. Embryo curved, with narrow cotyledons. MOoN-SEED.

1. Menispermum Canadénse $L$. A finely pubescent vine, with twining stems $1-4 \mathrm{~m}$. long. Leaf-blades orbicular to reniform in outline, 5-20 cm. broad, entire or 3-7-lobed, subcordate or cordate at the base, peltate near the base, glabrate above, the lobes rounded or short-acuminate; petioles slightly shorter than the blades: flowers greenish white, in panicles: sepals oblong to oval, $1.5 \mathrm{~mm}$. long: petals clawed, somewhat fan-shaped, the edges of the blade involute : stamens twice as long as the sepals : fruiting panicle resembling a bunch of grapes: drupes bluish black, $1 \mathrm{~cm}$. in diameter.

In thickets and along fences, Quebec to Manitoba, Georgia and the Indian Territory. Summer.

\section{Family 6. CABombàceat A. Gray. Water-shield Family.}

Perennial aquatic caulescent herbs, with the foliage often mucilage-coated. Leaves alternate, opposite or whorled: blades various, those of submerged leaves often dissected, those of floating leaves peltate. Flowers perfect, inconspicuous. Perianth of 2 whorls. Sepals and petals 3 or rarely 4 each, persistent. Androecium of 3-18 hypogynous stamens. Filaments slender. Anthers usually extrorse. Gynoecium of 2-18 distinct carpels. Disk wanting. Ovary 1-celled. Stigma sessile or nearly so, blunt. Ovules 2, on the sides of the cavity or the dorsal suture, or when 3 , one near the ventral suture. Fruit several indehiscent nut-like carpels. Seeds 1-3, often 2. Embryo at the base of the fleshy endosperm. 
Leaf-blades dissected except the inconspicuous floating ones : petals auricled: carpels 2-4. Leaf-blades all entire: petals entire: carpels 4-18.

1. САВОмва.

2. BRASENiA.

\section{CABÓMBA Aubl.}

Weak, slender aquatic mucilage-coated herbs, with branching stems. Leaves of two forms : submerged opposite or whorled, divided into numerous filiform segments : floating with peltate blades. Flowers white or yellow, small, solitary on long axillary pedicels Sepals 3, petal-like. Petals 3, similar to the sepals, but auricled near the base. Stamens 6 , inserted with the petals: filaments subulate : anthers extrorse. Pistils 2-4, usually 3, inserted on a small receptacle: style short: stigma terminal, depressed. Ovules usually 3, pendulous. Fruit leathery, indehiscent. Seeds 1-3 in each carpel.

1. Cabomba Caroliniàna A. Gray. Perennial, bright green. Stems submersed, 1-2 $\mathrm{m}$. long, branched : leaves of two kinds ; submersed opposite or whorled, 4-7 cm. long; blades petioled, cut into repeatedly forking narrowly-linear or ffliform segments ; floating leaves with peltate linear-oblong blades, $1.5-2 \mathrm{~cm}$. long, the ends obtuse : flowers on pedicels $3-6 \mathrm{~cm}$. long, arising from the upper axils, about $1-1.5 \mathrm{~cm}$. broad : sepals and petals obovate, white or yellow at the base, or sometimes deep pink, truncate or retuse at the apex : stamens about $\frac{1}{2}$ as long as the petals: fruit a cluster of 3 flask-shaped carpels. summer.

In ponds and slow flowing water, Missouri to North Carolina, Florida and Texas. Spring and

\section{BRASENIA Schreb.}

Slender mucilage-coated perennial aquatic herbs, with long branching stems. Leaves mostly floating: blades peltate on elongated petioles, leathery. Flowers small, dull purple, solitary at the ends of long axillary pedicels : sepals 3 , colored within. Petals 3 , narrow, recurving. Stamens 12-18: filaments filiform or subulate. Pistils 4-8, distinct, inserted on a small receptacle. Style subulate. Ovules 2-3, pendulous. Fruit leathery, indehiscent. Seeds 1-2 in each fruit. WAter-SHIELD.

1. Brasenia purpùrea (Michx.) Casp. Rootstocks slender, the submersed foliage mucilage-coated. Leaf-blades on delicate petioles, leathery, centrally peltate, oval, oblong or elliptic, $5-12 \mathrm{~cm}$. long, rounded at each end, floating, bright green and shining above, often purple beneath : flowers purple, long-pedicelled: sepals linear or linearlanceolate, 1-1.5 cm. long, obtuse or acutish : petals like the sepals: stamens exserted: fruit $5-8 \mathrm{~mm}$. long, the body rounded, the beak angled. [Brasenia peltata Pursh.]

In ponds, lakes and slow streams, Nova Scotia to Manitoba, Florida and Texas. Summer. Also in Cuba and Central America, and on the Pacific slope.

\section{FAmily 7. NELUMBONÀCEAE Lindl. ${ }^{1}$ Lotus Family.}

Perennial aquatic herbs, with large creeping rootstocks. Leaves alternate : blades suborbicular, centrally peltate, concave, floating or emersed on long stout petioles. Scapes arising with the petioles, stout, each terminated by a single perfect showy flower. Sepals and petals similar, hypogynous, numerous, imbricated, inner larger and more highly colored than the outer, all deciduous. Androecium of numerous long hypogynous stamens. Anthers narrow, extrorse, the connective prolonged into an incurved appendage. Gynoecium of several carpels separately immersed in an obconic enlargement of the receptacle. Ovary 1-celled. Style very short. Stigma umbilicate. Ovules solitary or rarely 2, suspended. Fruit several nuts immersed in the accrescent receptacle. Seeds without endosperm. Embryo consisting of 2 thick cotyledonary bodies, enclosing a plumule of 2-3 developing leaves.

\section{NELÚmBo Adans.}

Characters of the family. Water Chinguapin. Duck Acorn.

1. Nelumbo lùtea (Willd.) Pers. Rootstock horizontal, stout. Foliage bright green. Emersed leaves with centrally peltate orbicular strongly ribbed blades, sometimes standing high above the water on stout petioles, or floating, the margins more or less turned upward: peduncles stout, 1-2 m. tall : flowers pale yellow, 1-2.5 dm. broad : petals obovate

\footnotetext{
${ }^{1}$ Originally spelled NeLUMBiace.e.
} 
to elliptic or elliptic-oblanceolate, concave, obtuse : appendages of the anthers 4-7 mm. long: fruit turbinate-hemispheric or nearly hemispheric, becoming hard, 7-10 $\mathrm{cm}$. broad: nuts subglobose, $10-12 \mathrm{~mm}$. in diameter.

In ponds and slow streams, locally, Ontario to Michigan, Florida and Texas. Summer.

\section{Family 8. NYMPHAEÀCEAE DC. WATER Lily Family.}

Perennial acaulescent herbs, with more or less elongated often tuber-bearing rootstocks. Leaves alternate: blades leathery or those of submersed leaves membranous and delicate, all with a sinus at the base, petioled. Flowers perfect, terminating elongated scapes. Sepals 4-6, often green. Petals numerous, usually passing into staminodia or stamens, decaying. Androecium of numerous stamens. Anthers introrse, adnate. Gynoecium of several carpels more or less united into a compound ovary. Stigmas united into a disk with radiating stigmatic lines. Ovules very numerous on the walls of the ovary. Fruit a leathery many-seeded berry. Seeds often shining, with the embryo enclosed in a sac at the base of the fleshy endosperm.

Petals small, filament-like: stamens hypogynous.

Petals as large as the sepals: stamens epigynous.

1. Nymphaea.

2. Castalia.

\section{NYMPHAìA L.}

Aquatic herbs, perennial by large horizontal rootstocks. Leaves numerous: blades long-petioled, with a sinus at the base; those erect or floating, leathery; those submersed membranous. Flowers yellow, erect at the ends of the elongated scapes. Sepals 5-6, leathery, concave. Petals 10-20, small, filament-like. Filaments flattened. Carpels several, united into a several-celled ovary: stigmas forming an 8-24-radiate disk. Ovules numerous, pendulous. Fruit leathery. [Nuphar Sibth. \& Smith.] SpatTer Dock. Bonnets.

Leaf-blades elongated, fully 5 times as long as the sinuses.

Leaf-blades ovate, oval or suborbicular, less than 4 times as long as the sinuses.

Leaf-blades manifestly longer than broad, ovate or oval or somewhat oblong. Stigmatic disk with lines terminating remote from the edge: leaf-blades oblong-ovate.

Stigmatic disk with lines terminating near the edge : leaf-blades ovate or oval.

Leaf-blades suborbicular.

1. N. sagittaefolia.

2. N. macrophylla.

3. N. advena.

4. N. orbiculata.

1. Nymphaea sagittaefòlia Walt. Perennial by thick rootstocks, the foliage glabrous. Leaves of two kinds, the submerged numerous, with membranous, crisped, lanceolate or ovate-lanceolate blades: emersed leaves leathery; blades narrowly ovate to almost linear, 1.5-4 dm. long, undulate, obtuse, the sinus open : flowers yellow, $2.5-3 \mathrm{~cm}$. in diameter: sepals 5 : stamens in 4-5 rows: stigmatic disk with 11-15 lines, crenate : berry ovoid, about $2.5 \mathrm{~cm}$. long, constricted into a neck.

In ponds and slow streams, southern Indiana and Illinois to North Carolina and Florida. Spring and summer.

2. Nymphaea macrophýlla Small. Perennial from very thick horizontal rootstocks, bright green. Foliage glabrous or nearly so : emersed leaves leathery ; petioles short, sometimes sparingly pubescent; blades oblong-ovate, 3-8 dm. long, obtuse, notched at the apex, 1-2.5 dm. broad at the middle, the sinus $\mathrm{V}$-shaped, or rarely closed : flowers erect, subglobose, $3-5 \mathrm{~cm}$. in diameter: sepals leathery, $2.5-3 \mathrm{~cm}$. long, concave : petals yellow, slightly longer than the sepals : stamens numerous: stigmatic disk becoming 3-3.5 $\mathrm{cm}$. broad, often deeply crenate, the coarse stigmatic lines not approaching the edge : berry ovoid, $3-4 \mathrm{~cm}$. high, coarsely ribbed above the middle : seeds subglobose, $5-6 \mathrm{~mm}$. in diameter.

In ponds, creeks and slow streams, Florida to Louisiana. Spring to fall.

3. Nymphaea ádvena Soland. Perennial by thick rootstocks, light green. Leaves glabrous or nearly so, of two kinds, the submerged with suborbicular membranous blades on short petioles; emersed with long petioles; blades leathery, erect or rarely floating, oval or nearly so, 1-3 dm. long, rounded or retuse at the apex, the sinus open or rarely closed : flowers yellow, erect on stout scapes, depressed-globose: sepals obovate, rounded at the apex: petals obovate, rarely tinged with purple: anthers and filaments about equal in length : stigmatic disk yellow or pale red, with 12-24 lines, which terminate near the 
edge : berry ovoid, $3-4 \mathrm{~cm}$. long, slightly constricted under the disk : seeds globose, about $4 \mathrm{~mm}$. in diameter, shining. [Nuphar advena (Soland.) R. Br.]

In ponds, pools and slow streams, New Brunswick to the Rocky Mountains, Georgia and Alabama. Spring to fall.

4. Nymphaea orbiculàta Small. Perennial by thick rootstocks, robust, pubescent, except the upper surface of the leaf-blades, bright green. Emersed leaves leathery ; blades orbicular, floating, 3-5 dm. in diameter, somewhat crisped, the lobes at the base often conspicuously overlapping, the upper surface very smooth, the lower surface pubescent with short shining silvery hairs, marked with numerous secondary nerves ; petioles variable in length, faintly striate, clothed with silky pubescence, like the lower surface of the leaf-blades : flowers about $6 \mathrm{~cm}$. in diameter: sepals oblong-obovate, $5 \mathrm{~cm}$. long, obtuse, somewhat eroded, faintly ribbed : stigmatic disk $2 \mathrm{~cm}$. in diameter : berry subglobose, 4-5 $\mathrm{cm}$. in diameter : seeds ovoid, 4-5 mm. long, ridged on one side.

In ponds, southern Georgia and Florida. Spring to fall.

\section{CASTÀLIA Salisb.}

Perennial aquatic succulent herbs, with stout branching horizontal rootstocks. Leaves peltate, cleft at the base, with elongated submersed petioles : blades floating. Flowers perfect, showy, white, yellow, pink or blue, solitary and floating at the end of elongated pedun. cles. Sepals 4. Petals numerous, imbricated in many series, grading into the epigynous stamens. Carpels several, united into a several-celled ovary. Stigmas terminal. Ovules numerous, pendulous. Berry with a leathery outer coat, maturing under water. Seeds immersed in a pulp, each surrounded by a membranous aril. Water Lily. Pond Lily.

Carpels combined only dorsally and ventrally.

Carpels combined into a many-celled ovary.

Corolla white or of a faint blue, pink or a violet tint, sometimes yellowish in the center.

Outer anthers appendaged : corolla of a blue or violet tint.

Outer anthers unappendaged : corolla white or pink-tinged.

Leaf-blades $0.5-1.5 \mathrm{dm}$. broad : corollas less than $17 \mathrm{~cm}$. broad.

Leaf-blades 2-6 dm. broad : corollas over $17 \mathrm{~cm}$. broad.

1. C. ampla. Corolla yellow.

2. C. elegans.

3. C. odorata.

4. C. reniformis.

5. C. flava.

1. Castalia ámpla (DC.) Small. Perennial by short, tuber-bearing rootstocks. Leaves with long petioles ; blades suborbicular or oval-orbicular, 1-2 dm. long, acute-dentate, glabrous, or pubescent beneath, reticulated on the lower surface, the sinus narrowly V-shaped or closed : flowers 7-12 cm. broad : sepals oblong or oblong-lanceolate, obtuse, green, without purple streaks : petals bright white, like the sepals in shape or varying to elliptic-lanceolate, obtuse or acutish : anthers tipped with the linear connective : berry subglobose, 2.5-3 cm. broad : seeds subglobose, $1 \mathrm{~mm}$. in diameter. [Nymphaea ampla DC.] to fall.

In lagoons, southern Texas and Mexico. Also in the West Indies and tropical America. Spring

2. Castalia élegans (Hook.) Greene. Perennial from short slender or stoutish rootstocks. Leaves with slender petioles ; blades floating, oval to suborbicular, 1.5-2 dm. long, obtuse, nearly entire or crenate-repand, glabrous, ribbed and coarsely reticulated beneath : flowers 6-8 cm. broad : sepals lanceolate or oblong, often purplish without and streaked with deep purple lines, obtuse : petals shaped like the sepals or sometimes elliptic, cream colored, the tips blue: anthers tipped with the oblong connective : berry depressed, 2-3.5 cm. broad : seeds subglobose, about 5-6 $\mathrm{mm}$. in diameter.

In ponds and lagoons, Texas to adjacent Mexico. Spring to fall.

3. Castalia odoràta (Dryand.) Woodv. \& Wood. Perennial by stout, simple or sparingly branched rootstocks. Leaves with slender petioles; blades floating, suborbicular or oval, 5-15 cm. long, rounded or notched at the apex, more or less conspicuously undulate, purple beneath ; sinus V-shaped or closed : flowers $7-15 \mathrm{~cm}$. broad, fragrant : sepals oblong or oblong-lanceolate, obtuse, green or purplish : petals white or pink, shaped like the sepals or elliptic: berry depressed-globose, $2.5-3 \mathrm{~cm}$. broad: seeds subglobose, $1.5 \mathrm{~mm}$. in diameter. [Nymphaea odorata Dryand.]

In ponds, lakes and slow rivers, Nova Scotia to Manitoba, Florida and Louisiana. Summer and fall.

4. Castalia renifórmis (Walt.) Nash. Perennial by very stout rootstocks destitute of tubers. Leaves with very thick petioles ; blades floating, suborbicular, $2-6 \mathrm{dm}$. broad, undulate, glabrous, sometimes purple beneath, the nerves prominent or impressed on the lower surface, the basal lobes acuminate ; sinus V-shaped or closed : flowers apple-scented, $18-25 \mathrm{~cm}$. broad : sepals green, oblong to oblong-lanceolate, sometimes scarious-margined: petals white, shaped like the sepals or varying to narrowly-elliptic.

In lakes and lagoons, Georgia and Florida. Spring to fall. 
5. Castalia flàva (Leitner) Greene. Perennial by a stout rootstock. Leaves with slender petioles ; blades floating, oval, suborbicular or sometimes slightly ovate, 6-20 cm. long, obtuse, more or less undulate, glabrous, bright green above, crimson or purple beneath, the nerves impressed beneath; sinus V-shaped or closed: flowers $6-10 \mathrm{~cm}$. broad : sepals lanceolate or oblong-lanceolate, obtuse or acutish, often reddish without: petals bright yellow, like the sepals in shape or varying to oblanceolate: berry subglobose, $2-2.5 \mathrm{~cm}$. broad : seeds subglobose. [ [Nymphaea flava Leitner.]

In lakes, lagoons and slow streams, Florida. Spring to fall.

\section{FAmily 9. PODOPHYLLACEAE DC. BARBERRy FAMILy.}

Perennial, sometimes acaulescent herbs or shrubs. Leaves alternate, sometimes all basal, with or without stipules: blades simple or compound, often petioled. Flowers perfect, regular, solitary or in racemes. Sepals and petals usually six, imbricated, in 2 series each (except the sepals in Jeffersonia), the petals opposite the sepals. Androecium of 6-18 stamens. Filaments sometimes flattened. Anthers extrorse, opening by valves, except in Podophyllum. Gynoecium, of a single carpel in our genera. Ovules 2-many, anatropous. Fruit a berry or capsule. Seeds with endosperm. Embryo straight or nearly so.

Herbs: leaves with simple or ternately compound blades.

Anthers opening lengthwise.

Anthers opening by valves hinged at the top.

Leaf-blades simple : seeds enclosed.

Flower solitary : stamens 8 : fruit a capsule.

Flowers several, cymose : stamens $6:$ fruit baccate.

Leaf-blades ternately compound: seed naked, drupe-like.

Shrubs: leaves with pinnately compound blades, sometimes 1-foliolate.

1. Podophyllum.

\section{PODOPHÝLLUM L.}

Strong-scented glabrous herbs, with elongated poisonous rootstocks. Flowering stems erect, simple below, bearing 2 flat peltate many-lobed leaves at the top. Flower white and showy, solitary, nodding on a short pedicel on the top of the stem. Sepals 6, petal-like. Petals 6-9, larger than the sepals. Stamens 6-18: filaments distinct: anthers opening lengthwise. Ovary 1-celled, sessile: stigma peltate, sessile. Ovules numerous. Berry large, many-seeded, edible. Seeds immersed in the pulp. May Apple. Indian Apple.

1. Podophyllum peltàtum L. Rootstock horizontal. Foliage glabrous, bright green : sterile stems simple, $2-4 \mathrm{dm}$. long, surmounted by a centrally peltate umbrellalike, 7-9-lobed leaf-blade $1-3 \mathrm{dm}$. broad, the lobes cuneate at the base, 2-3-cleft at the apex, the segments usually toothed: fertile stems erect, simple, $2-4 \mathrm{dm}$. long, surmounted by usually 2 petioled leaf-blades similar or nearly similar to that of the sterile stem, but attached at or near the margin : pedicel stout, $2-4 \mathrm{~cm}$. long, arising between the petioles : flower nodding: bractlets 3 , green, caducous: sepals 6 , fugacious: petals $6-9$, obovate, $2.5-4 \mathrm{~cm}$. long, wax-like, white : berry obliquely oblong or ovoid, $4-5 \mathrm{~cm}$. long, greenish yellow, tipped with the black remains of the style.

In woods and on hillsides, Quebec to Minnesota, Florida and Texas. Spring. WiLd MANDrake.

\section{JEFFERSÒNIA Bart.}

Acaulescent herbs with short rootstocks and glabrous foliage. Leaves basal : blades 2-parted, long-petioled. Flower perfect, white, solitary at the end of a long scape. Sepals 4, petal-like, deciduous. Petals 8, larger than the sepals. Stamens 8: filaments distinct: anthers opening by 2 valves. Ovary 1-celled: style wanting: stigma 2 -lobed. Ovules numerous, in many rows. Capsule leathery, broadest at the top, opening by a terminal lid. Seeds numerous, each with a fleshy cleft aril. TwIN-LEAF.

1. Jeffersonia diphýlla (L.) Pers. Foliage glabrous, more or less glaucous. Leaves basal, tufted; petioles erect, 1-3 dm. tall; blades 2-parted, the segments obliquely reniform, 5-10 cm. long, nearly entire or coarsely crenate, becoming deep green above, glaucous beneath : scapes erect, about equalling the petioles in length or a little longer at maturity, simple : sepals oblong-oblanceolate, $1.5-2 \mathrm{~cm}$. long, obtuse : petals white, similar to the sepals, often a little longer : capsule obovoid or obconic, $1.5-2 \mathrm{~cm}$. long, shortstalked, often somewhat curved at the base, opening by a transverse lid : seeds 4-7 mm. long, red.

In woods and thickets, Ontario and Wisconsin to Virginia and Tennessee. Spring. 


\section{DIPHYLLEIA Michx.}

Large herbs, with stout horizontal rootstocks and glabrous foliage. Leaves few : blades peltate, suborbicular in outline, palmately lobed, all basal except the two near the top of the stem. Flowers white, in terminal umbel-like cymes. Sepals 6, petal-like, deciduous. Petals 6, somewhat larger than the sepals. Stamens 6 : filaments distinct : anthers opening by two valves. Ovary 1-celled : stigma orbicular or nearly so or 2-lobed. Ovules numerous, in many rows. Berries oblique, pedicelled. Seeds $2-4$, erect, curved.

1. Diphylleia cymòsa Michx. Foliage bright green. Stem stout, erect, 6-12 dm. tall, simple below : leaves few, the basal with long erect petioles and nearly centrally peltate, membranous, 2-cleft, many-lobed blades, the lobes acuminate, finely toothed; cauline leaves similar but smaller, laterally peltate, shorter-petioled: cymes many-flowered: sepals 6 , obovate, white, nearly $1 \mathrm{~cm}$. long, undulate at the apex: petals 6 , similar to the sepals but usually a little longer: berries subglobose, 10-12 cm. in diameter, blue, with a bloom, sessile.

In and about mountain brooks, Virginia to Georgia. Spring. Umbrella-leaf.

\section{CAULOPHÝLLUM Michx.}

Caulescent herbs, with thick rootstocks. Leaves few: blades ternately compound, large, mostly basal, 2 usually near the top of the stem. Flowers perfect, greenish yellow in a terminal racemose cyme. Sepals 6, above 3-4 bractlets. Petals 6, gland-like, shorter than the sepals, hooded. Stamens 6 : filaments distinct : anthers opening by 2 valves. Ovary 1-celled: style short: stigma 1-sided. Ovules 2, erect. Capsule rupturing and withering before maturity. Seed globose, drupe-like, naked, on a stout stalk. Endosperm horny. Blue CoHosh.

1. Caulophyllum thalictroides (L.) Michx. Foliage glabrous, glaucous. Stem erect, $3-9 \mathrm{dm}$. tall, simple or branched above, sheathed at the base by several membranous scales : leaves usually 2, a large one at the first node of the stem and a smaller one subtending the panicle; blades triternately compound, the divisions ternate, their segments pinnate or ternate, the leaflets of various shapes, 2-3-lobed at the apex, rounded or cordate at the base: panicle 4-10 $\mathrm{cm}$. long, erect: flowers greenish or purplish : sepals 6 , oval to suborbicular, short-clawed, 5-6 mm. long: petals gland-like : seeds drupe-like, about $1 \mathrm{~cm}$. in diameter, dark blue, with more or less bloom, on short stalks $5-7 \mathrm{~mm}$. long.

In damp woods, New Brunswick to Minnesota, South Carolina, Tennessee and Nebraska. Spring.

\section{BERB́ERIS L.}

Unarmed or spiny shrubs, with a yellow wood. Leaves alternate, often clustered : blades firm or leathery, 1-foliolate or pinnate, more or less prominently spiny-toothed, often changed into forking spines. Flowers perfect, yellow, solitary or in peduncled racemes. Sepals 6 , accompanied by 2 or 3 bractlets, broad, the outer ones much smaller than the petaloid inner ones. Petals 6, commonly smaller than the sepals, imbricated in 2 rows, often with 2 glands near the base. Stamens 6 , irritable : filaments distinct : anthers opening by 2 valves. Ovary 1-celled, sessile: stigma peltate. Ovules few, erect or ascending. Berries pulpy, 1-few-seeded, rarely dry. Seeds with a crustaceous testa. Barberry.

Leaf-blades unifoliolate, deciduous : racemes drooping : berries scarlet. Leaf-blades pinnate, persistent: racemes erect : berries white.

1. B. Canadensis. 2. B. Swazeyi.

1. Berberis Canadénsis Mill. A glabrous spiny shrub, 0.5-2 m. tall, the branches angled. Leaves firm, clustered; leaflet 1 , the blade spatulate, oblong-spatulate, or rarely oval, $2-8 \mathrm{~cm}$. long, obtuse or apiculate, spiny-serrate : racemes drooping, 6-10-flowered, $2-6 \mathrm{~cm}$. long: flowers yellow, about $8-11 \mathrm{~mm}$. broad : sepals oval, mostly 4-5 mm. long: petals $2-3 \mathrm{~mm}$. long, notched at the apex, eroded, narrowed into stout claws, with 2 oblong orange-colored glands near the base : berries oval or subglobose, $6-8 \mathrm{~mm}$. long, scarlet.

On hillsides, in the mountains from Virginia to Georgia. Also in Missouri. Spring.

2. Berberis Swazeỳi Buckl. An evergreen shrub, 6-9 dm. tall with erect or spreading branches. Leaves pinnate, $0.5-1 \mathrm{dm}$. long, leaflets $7-9$, the blades leathery, oval to oblong, 1-2 cm. long, with 5-11 spine-like teeth, finely reticulated : bracts foliaceous, but 
rather small, ovate to suborbicular : berries subglobose, white, and transluscent with a reddish tinge, 10-12 mm. in diameter, of a pleasant taste, but slightly acid.

On limestone hills, central Texas. Spring.

\section{Order 12. PAPAVERÀLES.}

Herbs or rarely shrubs or trees, often with pungent properties or colored juices. Leaves various, usually normal : blades often dissected. Flowers perfect, sometimes irregular. Calyx and corolla present, the members distinct and separate. Androecium of several hypogynous stamens. Gynoecium of 2 or several united carpels. Ovary superior. Fruit capsular or baccate.

Sepals 2 , or very rarely 3 or 4 : endosperm present.

Flowers regular: stamens 8 or numerous : juice usually milky or colored. Fam. 1. PAPAVERACEAE.

Flowers irregular: stamens 6: juice usually watery. Fam. 2. Fumariaceat.

Sepals 4-8: endosperm wanting.

Capsules 2-celled: stamens 6, tetradynamous.

Capsules 1-celled: stamens when 6 not tetradynamous.

Gynoecium 2-carpellary : leaves with simple or palmately compound blades.

Gynoecium 3-carpellary : leaves with pinnately compound blades.

Fam. 3. BRassidaceae.

Fam. 4. CAPPARIDACEAE. Fam. 5. Moringaceak.

\section{Family 1. PAPAVERÀCEAE Juss. Poppy Family.}

Annual or perennial caulescent or acaulescent herbs, or rarely shrubby plants, with usually a colored sap and narcotic or acrid properties. Leaves alternate or sometimes opposite or whorled, without stipules: blades entire, toothed or divided. Flowers perfect, regular, variously disposed. Calyx of 2 or rarely 3 caducous sepals. Corolla of 4,8, 12 or rarely more deciduous petals. Androecium usually of many stamens. Filaments distinct, sometimes dilated. Anthers innate. Gynoecium of 2-several carpels united into a 1-celled ovary with parietal placentae. Ovules numerous, anatropous. Fruit a depressed or elongated capsule. Seeds often numerous, each with a very small embryo at the base of the fleshy or oily endosperm.

Acaulescent herbs: petals 8-12, not crumpled in the bud : stigmas over the valves of the capsule.

Caulescent herbs: petals 4-6, mostly crumpled : stigmas over the placentae.

Capsule splitting to the base.

Capsule pubescent.

Capsule glabrous.

Stigma mitre-shaped, with a deflexed or spreading base on each side: capsule leathery, 2-celled by a spongy partition.

Stigma simple: capsules membranous, 1-celled.

Capsule dehiscent at the top or only to the middle.

Leaf-blades unarmed.

Leaf-blades spiny-toothed.

1. SANGUiNARIA.

2. STYLOPHORUM.

3. Glaucium.

4. CHELIDONIUM.

5. PAPAVER.

6. ARGEMONE.

\section{SANGUINÀRIA L.}

Perennial acaulescent herbs, with thick horizontal rootstocks containing a red juice. Leaves basal : blades petioled, 5-7-lobed: scape erect, 1-flowered, simple. Flowers white, showy. Sepals 2. Petals $8-12$, in 2 or 3 series, flat. Stamens numerous : filaments distinct. Ovary slightly elongated : stigmas 2, over the valves of the capsule. Capsule elongated, short-stalked, 2-valved, the valves completely separating from the persistent placenta. Seeds numerous, crested, the testa smooth. Endosperm oily. Embryo minute.

1. Sanguinaria Canadénsis L. Foliage glabrous. Leaves 1 or 2 , basal ; blades thickish, orbicular or reniform in outline, $6-25 \mathrm{~cm}$. broad, 5-9-lobed, cordate, more or less glaucous, especially beneath, the lobes repand or again lobed; petioles stout, 2-3 times longer than the blades: scape finally overtopped by the leaves: corolla white, 4-6 cm. broad : petals 8-12, oblong, elliptic or rarely oval, thin, obtuse : capsule narrow, fusiform, acuminate at both ends, $3-5 \mathrm{~cm}$. long.

In woods, Nova Scotia to Manitoba, Fiorida and Arkansas. Spring. Bloodroot. Puocoon.

\section{STYLÓPHORUM Nutt.}

Perennial caulescent herbs, with an orange-yellow juice. Leaves mainly alternate, the basal with pinnatifid blades, the cauline with lobed or dissected blades. Flowers perfect, yellow or red, long-peduncled, solitary or clustered. Sepals 2, pubescent. Petals 4, decidu- 
ous. Stamens numerous: filaments slender. Ovary with 3-4 nerviform placentae : style manifest, the dilated tip 2-4-lobed: stigmas black: ovules numerous. Capsule elongated, often stalked, bristly. Seeds numerous, crested : scrobiculate-reticulated. Endosperm oily. Embryo minute, basal. Celandine Poppy. Yellow Poppy.

1. Stylophorum diphýllum (Michx.) Nutt. Foliage glaucous, sparingly pubescent. Stem 2-5 dm. tall, often simple: leaves basal and cauline, 1-2.5 dm. long; blades petioled, 2-pinnatifid, the segments broadened upward, lobed or crenate-undulate : flowers 2-4 at the top of the stem : sepals 2 , hirsute : corolla deep yellow, $2-3 \mathrm{~cm}$. broad : petals obovate, rounded at the apex : capsule ovoid or oval, about $2-5 \mathrm{~cm}$. long, hirsute, acute at each end.

In low woods, Pennsylvania to Wisconsin, Tennessee and Missouri. Spring.

\section{CHELIDÒNIUM L.}

Biennial or perennial caulescent herbs, with a yellow sap, and erect branching stems. Leaves alternate : blades pinnately dissected, pubescent. Flowers perfect, yellow, numerous. Sepals 2. Petals 4, relatively small, very deciduous. Stamens numerous : filaments slender. Ovary 1-celled with 2 placentae: styles 2, distinct : stigmas barely dilated, 2-lobed. Ovules numerous, inserted on the 2 nerviform placentae. Capsule narrow, 2 -valved, the valves separating to the base. Seeds numerous, crested, the testa shining. Endosperm oily. Embryo minute.

1. Chelidonium màjus L. Foliage bright green, sparingly pubescent below. Stem erect, 2-7 dm. tall, branching, succulent : leaf-blades pinnatifid or bipinnatifid, 1-3 dm. long, the segments with rounded lobes or teeth, the lower petioles elongated, the upper ones very short: cymes peduncled : pedicels 1-5 $\mathrm{cm}$. long: sepals 2 , boat-shaped, about 7 $\mathrm{mm}$. long, villous below the apex : petals 4, yellow, suborbicular, rounded or emarginate at the apex : filaments clavate, a little more than $\frac{1}{2}$ as long as the petals : capsules slender, 3-5 cm. long, constricted between the seeds.

In waste places, common in eastern North America. Naturalized from Europe. Spring to fall. Rock Poppy. CELANDINe.

\section{PAPÀVER L.}

Annual or perennial glaucous or pubescent herbs, with milky sap, and erect, usually branched stems. Leaves alternate, sometimes mainly basal : blades usually lobed or dissected. Buds drooping. Flowers perfect, showy, variously colored, on elongated peduncles. Sepals 2 or rarely 3 . Petals 4 or rarely 6 , broadened upward. Stamens numerous : filaments slender. Ovary with 4-20 septiform placentae : stigmas united into a disk-like or variously shaped crown-like body. Ovules numerous. Capsule subglobose to oblong, opening by 4-20 pores or cracks under the stigma. Seeds naked, crestless. PopPy.

Plants hirsute: leaf-blades pinnately divided : capsule oblong-obovoid. Plants glaucous: leaf-blades lobed: capsule subglobose.

1. P. dubium.

1. Papaver dùbium L. Annual, slender, hirsute. Stem erect, often branched at the base and above, $2-7 \mathrm{dm}$. tall : leaf-blades pinnately divided, the divisions entire, toothed, or pinnatifid, the ultimate segments acute : flowers scarlet, $5-7 \mathrm{~cm}$. broad, on long slender stalks : sepals oblong or oval, about $1.5 \mathrm{~cm}$. long: petals undulate or crisped : filaments filiform : capsule oblong-obovoid, $1.5-2 \mathrm{~cm}$. long, glabrous.

In fields and waste places, Pennsylvania to North Carolina and Tennessee. Summer. Naturalized from Europe.

2. Papaver somniferum L. Annual, stoutish, glabrous, glaucous. Stem erect, 3-10 dm. tall, simple or sparingly branched : leaf-blades oblong to ovate, $6-20 \mathrm{~cm}$. long, incurved, lobed and toothed, the lobes toothed, sessile, the cordate base clasping: flowers long-stalked, white to purple, often variegated, 4-10 $\mathrm{cm}$. broad : petals about as broad as long, undulate : filaments somewhat club-shaped: capsule subglobose or slightly narrower above the middle, $2-3 \mathrm{~cm}$. long, glabrous.

In waste places, naturalized or adventive in the eastern United States. Native of the Mediterranean region. OPIUM POPPY. GARDEN POPPY.

\section{ARGEMÒNE L.}

Annual or biennial herbs, with glaucous foliage and a yellow sap. Stems erect, branching. Leaves alternate : blades sessile or clasping, incised, pinnatfid, the segments tipped with bristle-like spines. Buds erect. Flowers perfect, showy, white or yellow. Sepals $2-3$, hooded or horned. Petals $4-6$, broadened upward. Stamens numerous: filaments 
slender. Ovary with 4-6 nerviform placentae: stigma sessile, depressed, the lobes spreading or recurved. Ovules numerous. Capsule slightly elongated, opening at the top by 4-6 valves. Seeds numerous, subglobose, pitted, not crested. Endosperm oily. Embryo minute, basal. Prickly Poppy.

Inflorescence and capsules spineless.

Inflorescence and capsules spine-armed.

Corolla yellow: leaf-blades blotched.

Corolla white: leaf-blades not blotched or sometimes slightly so.

Stems unarmed or spiny, but not hispid-pubescent.

Horns of the sepals erect or nearly so, the terminal spine 1-1.5 mm. long: flowers manifestly pedicelled.

Horns of the sepals diverging, the terminal spine $2-4 \mathrm{~mm}$. long : flowers sessile or nearly so.

Horns of the sepals smooth and glabrous. Plants tall : capsule-valves veiny all over. Horns of the sepals bristly.

Stems hispid-pubescent as well as spine-armed.

1. A. leiocarpa.

2. A. Mexicana.

3. A. alba.

4. A. intermedia.

5. A. delicatula.

6. A. platyceras.

1. Argemone leiocárpa Greene. Resembling A. Mexicana but more glaucous, devoid of spines except on the margins of the leaf-blades, which are rather more copiously spinescent : calyx unarmed : petals yellow, $3-4 \mathrm{~cm}$. long : capsules smooth and glabrous, $3-4 \mathrm{~cm}$. long.

In sand, southern peninsular Florida and the Keys. Spring to fall.

2. Argemone Mexicàna L. Foliage glaucous. Stems $3-9 \mathrm{dm}$. tall, more or less spiny: leaves 10-25 $\mathrm{cm}$. long; blades runcinate-pinnatifid, blotched, spiny-toothed and commonly spiny along the midrib, sessile and clasping: flowers sessile or nearly so : sepals acuminate and bristle-tipped : corolla yellow, 2.5-7 $\mathrm{cm}$. broad : capsules oblong, 2.5-3 em. long, spine-armed.

In waste places, New Jersey and Pennsylvania to Florida and Texas. Naturalized from tropical America. Spring to fall. Mexican Poppy. Thorn Apple.

3. Argemone álba Lestib. Foliage pale or somewhat glaucous, spine-armed. Stems rather stout, $3-5 \mathrm{dm}$. tall, not pubescent : leaves $3-15 \mathrm{~cm}$. long; blades pinnately lobed or pinnatifid, sometimes whitish along the veins, the midrib slightly prickly : flowers pedicelled : sepals $1.5-2 \mathrm{~cm}$. long, the horns erect or nearly so, the terminal spine $1-1.5 \mathrm{~mm}$. long, distinctly flattened : corolla white, $7-10 \mathrm{~cm}$. broad : capsules oval or oblong, 2.5-4 $\mathrm{cm}$. long.

In dry or sandy soil, Missouri to Florida and Texas. Spring and summer.

4. Argemone intermédia Sweet. Quite similar to $A$. alba. Stems more prickly, 3-10 dm. tall : leaves 4-16 long ; blades pinnately toothed or pinnatifid : flowers sessile : sepals $2-2.5 \mathrm{~cm}$. long, the horns diverging, the terminal spine $2-4 \mathrm{~mm}$. long, scarcely flattened : corolla white, $6-9 \mathrm{~cm}$. broad : capsules cylindric or oblong cylindric, $3-4 \mathrm{~cm}$. long.

On plains, South Dakota to Idaho, Texas and Mexico. Spring and summer.

5. Argemone delícátula Small. Foliage conspicuously spiny. Stems 1-3 dm. tall, sometimes sparingly branched : leaves $5-15 \mathrm{~cm}$. long : leaves pinnatifid or bipinnatifid, the spines of the lobes spreading in all directions : flowers short-pedicelled : sepals about $2 \mathrm{~cm}$. long, the smooth and glabrous horns diverging, the terminal spine $2-4 \mathrm{~mm}$. long: corolla white, $6-9 \mathrm{~cm}$. broad : capsules oblong-obovoid, $1.5-2 \mathrm{~cm}$. long.

In dry soil, Texas. Spring.

6. Argemone platýceras Link \& Otto. Foliage usually conspicuously spiny : stems 3-11 dm. tall, mostly branched, often almost completely covered with spines : leaves 4-14 $\mathrm{cm}$. long; blades pinnately lobed or pinnatifid : flowers sessile or nearly so : sepals $2-2.5$ long, spiny, the horns bristly at the base : corolla white, 6-9 $\mathrm{cm}$. broad : capsules oblong or ovoid-oblong, $2.5-3.5 \mathrm{~cm}$. long, completely covered with spines.

On plains and prairies, Texas to California and Mexico. Spring and summer.

7. Argemone híspida A. Gray. Foliage usually copiously spine-armed. Stems 3-8 dm. tall, hispid-pubescent as well as spine-armed : leaves $5-9 \mathrm{~cm}$. long, often numerous ; blades pinnatifid or 2-pinnatifid : flowers short-pedicelled: sepals $2-3 \mathrm{~cm}$. long, the horns triangular-lanceolate, more or less bristly and hispid : corolla white, $7-10 \mathrm{~cm}$. broad : capsules oblong or oblong-conic, $2.5-3.5 \mathrm{~cm}$. long.

On plains or prairies, Kansas to California, Texas and New Mexico. Spring to fall.

\section{FAMILY 2. FUMARIÀCEAE DC. FUMitory FAMILY.}

Annual or perennial acaulescent or caulescent herbs with a watery sap, sometimes with corms. Leaves alternate, often all basal: blades compound, usually rather finely dissected, very delicate. Flowers perfect, irregular, often 
in racemes, panicles or cymes. Calyx of 2 scale-like sepals. Corolla of 4 petals : outer (lateral) spreading above, both or one saccate or spurred at the base: inner smaller, thickened at the tips, enclosing the stigma. Androecium of 6 stamens. Filaments diadelphous : anthers various, middle one 2-celled, lateral 1-celled. Gynoecium of 2 carpels united into a single pistil. Ovary 1-celled, with 2 perietal placentae. Stigma flattened contrary to the placentae, 2-lobed or 2-horned. Ovules amphitropous or anatropous, numerous or rarely solitary. Fruit a silique-like capsule or rarely indehiscent. Seeds with a minute embryo in fleshy endosperm.

Each of the 2 outer petals spurred at the base.

Petals permanently united and enclosing the capsule: seeds crestless: vines.

Petals lightly united, deciduous : seeds mostly erested : acaulescent herbs.

One of the 2 outer petals spurred at the base.

Ovules several or many : fruit an elongated capsule.

Ovule solitary : fruit a glabrous nutlet.

1. Adlumia.

2. Bicudulla.

3. CAPNOIDEg.

4. Fumaria.

\section{ADLÙmIA Raf.}

Biennial or perennial tender climbing vines. Stems slender and elongated. Leaves alternate : blades decompound, very delicate. Flowers perfect, irregular, white or pink, in terminal racemes or panicles or these opposite the leaves. Sepals 2. Petals 4, permanently united into a tube and enclosing the fruit, the two outer swollen below. Stamens 6 , in 2 groups opposite the outer petals : filaments monadelphous below, diadelphous above. Ovary elongated : style filiform: stigma 2-lobed. Capsule in the remains of the corolla, opening by 2 valves. Seeds crestless.

1. Adlumia fungòsa (Ait.) Greene. A delicate vine climbing over various objects by the tendril-like petioles. Stem slender, several meters long: leaf-blades decompound, the primary divisions slender-stalked, the secondary divisions stouter-stalked, the ultimate segments very thin, entire or lobed : cymes many-flowered, often dense : pedicels filiform, $0.5-1 \mathrm{~cm}$. long: sepals scale-like: corolla $15-18 \mathrm{~mm}$. long, pink or whitish : petals 4 , the 2 outer with rounded bases and spreading or converging tips, the two inner with suborbicular blades about $1.5 \mathrm{~mm}$. broad: capsule slender, $1.5-2 \mathrm{~cm}$. long, few-seeded. [ $A$. cirrhosa Raf.]

In woods, New Brunswick to Michigan, Kansas and North Carolina. Summer and fall. ALlEGHeNy Vine. Climbing Fumitory.

2. BICUCÚLLA Adans.

Perennial acaulescent herbs, with horizontal, granular or tuberous rootstocks. Leaves basal: blades long-petioled, ternately divided and many-cleft, their texture delicate. Scapes erect, simple, or branched above, naked. Flowers of various colors, perfect, irregular, in terminal racemes or panicles. Sepals 2, scale-like. Petals 4, the two outer spurred at the base, loosely united, deciduous, the tips often spreading, the 2 inner crested, clawed, their tips cohering. Stamens 6 , in 2 groups opposite the outer petals : filaments more or less diadelphous at the base. Ovary with two placentae : style filiform : stigma 2-4-lobed. Capsules elongated, opening by two valves. Seeds 10-20 in each capsule crested. [Diclytra Borck. Dicentra Bernh.] Dutchman's Breeches.

\footnotetext{
Racemes simple.

Rootstocks with yellow tubers : spurs rounded : inner petals conspicuously crested. 1. B. Canadensis.

Rootstocks without tubers : spurs spreading: inner petals minutely crested. $\quad 2$. B. Cucullaria. Racemes compound.

2. B. Cucullario.
3. B. eximia.
}

1. Bicuculla Canadénsis (Goldie) Millsp. Rootstocks slender, bearing numerous pea-like tubers. Foliage bright green : leaves basal ; petioles 1-2 dm. long; blades ternately compound, the divisions delicately dissected, the ultimate segments linear or nearly so : scapes erect, $2-3 \mathrm{dm}$. long, usually overtopping the leaves, simple : racemes $2-7 \mathrm{~cm}$. long, 2-10-flowered : pedicels 5-10 mm. long: corolla $1.5-2 \mathrm{~cm}$. long, greenish white or purplish tinged: petals 4 , the outer produced into rounded sacs, the bases of which are much shorter than the upper part, the apex hooded and recurved, the inner petals with claws as long as the blades, their crests crisped, conspicuous.

In rich woods, Nova Scotia to Minnesota, North Carolina and Missouri. Spring. SQuirrel Corn.

2. Bicuculla Cucullària (L.) Millsp. Rootstocks bulb-like. Foliage often glaucescent : leaves basal, nearly similar to those of the preceding species : scapes erect, $1-3 \mathrm{dm}$. tall, usually overtopped by the leaves: racemes $3-10 \mathrm{~cm}$. long, 4-12-flowered: pedicels 
5-12 mm. long: corolla white or pale pink : petals 4 , the 2 outer produced at the base into horn-like spreading spurs, which are about as long as the other part, the apex hooded and reflexed, the inner petals with claws as long as the blades, their inconspicuous crests hardly crisped.

In woods and on banks, Nova Seotia to Minnesota, Nebraska and Georgia. Spring. Soldier's Cap.

3. Bicuculla exímia (Ker.) Millsp. Rootstocks scaly. Foliage dark green : leaves basal ; blades $2-4 \mathrm{dm}$. broad, the ultimate segments oblong or ovate : scapes erect or ascending, 3-6 dm. tall, longer or shorter than the leaves: panicles $5-12 \mathrm{~cm}$. long, rather lax, several-many-flowered : corolla deep pink: petals 4 , the 2 outer produced into rounded sacs at the base, the boat-like tops spreading, the 2 inner petals cohering at the apex, the blades auricled at the base, longer than the claws, their crests crisped.

In woods and on cliffs, western New York and in and near the Alleghenies to Georgia. Summer. BLEEDING-HEART.

\section{CAPNOIDES Adans.}

Annual or biennial caulescent herbs, with erect or prostrate, usually branched, sometimes diffuse, stems. Leaves alternate : blades bipinnately dissected, commonly delicate in texture. Flowers perfect, irregular, white, pink or yellow, in terminal or lateral racemes. Sepals 2, usually scale-like. Petals 4, distinct, the 2 outer dissimilar, the one flat, the other more or less spurred at the base, the 2 inner narrower than the outer, often cohering at the apex, keeled or winged. Stamens 6, in two groups opposite the exterior petals : filaments united above the middle. Ovary narrow, with 2 placentae : style filiform : stigma dilated or lobed. Ovules numerous or several. Capsule silique-like, sometimes torulose. Seeds crested. [Corydalis Vent.]

Corolla pink or purple, yellow at the tip. Corolla yellow.

Corolla less than $12 \mathrm{~mm}$. long.

Capsules ascending: seeds with blunt margins.

Capsules drooping or spreading : seeds with acute winged margins.

1. C. sempervirens.

Colla over $12 \mathrm{~mm}$. long.

Hood or sac of the outer petals with a wing-like crest. Capsules copiously covered with transparent vesicles. Capsules smooth; sometimes glaucous.

Spur nearly as long as the corolla-body: pods strongly curved.

Spur abnut $1 / 4$ as long as the corolla-body : pods straight or nearly so.

Hood or sac of the outer petals merely keeled.

Spur $1 / 2$ as long as the body of the corolla : capsules spreading or drooping. Spur about as long as the body of the corolla : capsules ascending.

2. C. micranthum.

3. C. flavulum.

4. C. crystallinum.

5. C. curvisiliquum.

6. C. Halei.

7. C. aureum.

8. C. montanum.

1. Capnoides sempérvirens (L.) Borck. Annual or biennial, glaucous, glabrous. Stems erect, finally much branched, $3-12 \mathrm{dm}$. tall, the branches ascending : leaves 3-25 cm. long; blades pinnately decompound, the ultimate segments obovate or cuneate: panicles open, few-flowered: bracts variable, the lower ones dissected like the leaves, the upper entire : pedicels $5-10 \mathrm{~mm}$. long: corolla pink, tinged with yellow at the tip, $1.5 \mathrm{~cm}$. long, the spur much shorter than the body of the corolla: capsules slender, $3-4 \mathrm{~cm}$. long, smooth : seeds shining, finely reticulated. [Corydalis glauca Pursh.]

In rocky places, Nova Scotia to Alaska, British Columbia and Minnesota and along the mountains to Georgia. Spring and summer.

2. Capnoides micránthum (Engelm.) Britton. Annual, very slender, glabrous. Stems 1-3 dm. long, more or less branched, the branches weak : leaves delicate, sometimes glaucescent, the ultimate segments lobed or toothed: racemes or panicles $1-8 \mathrm{~cm}$. long: flowers sometimes cleistogamous, short-pedicelled : corolla pale yellow, less than $1 \mathrm{~cm}$. long, the spur much shorter than the body of the corolla, the crest small, entire : capsules ascending, 1-2 cm. long, torulose, smooth : seeds smooth or nearly so, shining, the edges obtuse.

In woods, Minnesota to Missouri, Virginia and Florida. Spring.

3. Capnoides flávulum (Raf.) Kuntze. Annual, slender, glabrous, bright green. Stem 1-5 dm. long, erect or ascending, sometimes diffusely branched, the branches spreading : leaves delicate; blades finely dissected, the ultimate segments toothed or lobed, the divisions acute : racemes few-flowered : bracts elliptic or ovate, acute or acuminate : corolla yellow, $1 \mathrm{~cm}$. long or slightly longer, the spur rounded, much shorter than the body of the corolla, the crest toothed: capsules drooping, $1.5-2.5 \mathrm{~cm}$. long, torulose, smooth: seeds sharpmargined, finely reticulated, shining.

In rocky woods, Ontario to Minnesota, Virginia, Louisiana and Kansas. Spring.

4. Capnoides crystallìnum (T. \& G.) Kuntze. Annual or biennial, stoutish, bright green. Stem usually branched at the base : branches tufted, erect or ascending, 2-4 dm. tall, simple or branched above : leaves relatively few ; blades finely dissected, the ultimate 
segments narrowly oblong or cuneate: racemes spike-like, $3-10 \mathrm{~cm}$. long : bracts ovate to lanceolate, acuminate : corolla bright yellow, $1.5-2 \mathrm{~cm}$. long, the spur usually a little shorter than the rest of the corolla : crest large, toothed : capsules $1.5-2 \mathrm{~cm}$. long, erect, or ascending, densely granular : seeds shining, minutely tuberculate-reticulated.

In dry soil, Missouri to Arkansas, the Indian Territory and Texas. Spring and summer.

5. Capnoides curvisiliquum (Engelm.) Kuntze. Annual, stoutish, the foliage glaucescent. Stems erect or ascending, simple or branched chiefly at the base: leaves delicate ; blades dissected into mostly cuneate segments : racemes spike-like, $3-10 \mathrm{~cm}$. long: pedicels stoutish, 2-6 mm. long: bracts ovate : corolla bright yellow, $1.5 \mathrm{~cm}$. long, the spur about as long as the rest of the corolla, straight: capsules $2-3 \mathrm{~cm}$. long, 4-angled, curved upward : seeds turgid, finely muriculate, shining, sharp-margined.

In dry soil, Kansas to Texas. Spring.

6. Capnoides Hàlei Small. Annual, glabrous, bright green. Stems branched at the base, the branches spreading or ascending, 1-3 dm. long, simple or sparingly branched: leaves glaucescent beneath, the lower ones with petioles longer than the blades, the upper ones sessile, all dissected; segments rather coarse, acute : racemes erect, peduncled, 2-5 cm. long: bracts ovate to elliptic, acuminate : pedicels $2-5 \mathrm{~mm}$. long, stout : corolla yellow, about $1.5 \mathrm{~cm}$. long, the spur obtuse, much shorter than the body, the outer petals with thin incised-toothed crests: capsules stoutish, $2 \mathrm{~cm}$. long, straight, erect or nearly so, on short, almost erect pedicels.

In dry soil, Florida to Louisiana. Spring.

7. Capnoides aùreum (Willd.) Kuntze. Annual, glabrous. Stems diffusely branching, the branches $1.5-3 \mathrm{~cm}$. tall, sometimes decumbent: leaves often numerous ; blades rather finely dissected : racemes relatively short, few-flowered : pedicels slender, $3-6 \mathrm{~mm}$. long : corolla golden yellow, 11-13 mm. long; the spur barely $\frac{1}{2}$ as long as the body, slightly decurved, the hood or sac merely keeled: capsules spreading or drooping, hardly $10 \mathrm{~mm}$. long, torulose, terete : seeds 10-12, plump, shining but obscurely reticulated, obtuse along the margin.

In woods or on rocky banks, Nova Scotia to Yukon Territory and Texas. Spring.

8. Capnoides montànum (Engelm.) Britton. Annual, slender, bright green. Stems branched, sometimes diffusely so, the branches erect or ascending: leaves dissected, 5-13 $\mathrm{cm}$. long; blades rather finely dissected, the ultimate segments narrow: racemes $2-8 \mathrm{~cm}$. long, sometimes dense: bracts oval or ovate: pedicels spreading, $2-6 \mathrm{~mm}$. long: corolla bright yellow, about $1.5 \mathrm{~cm}$. long, the spur straight, as long as the body of the corolla or longer: capsules stout, slightly curved, $2-3 \mathrm{~cm}$. long, smooth, slightly torulose : seeds smooth and shining, slightly acute along the margin.

In dry soil, South Dakota to Montana, Texas, Utah and Arizona. Spring and summer.

\section{FUMARIA L.}

Annual glaucous herbs, with delicate foliage. Stems ereet, prostrate or climbing, sometimes diffusely branched. Leaves alternate: blades finely dissected. Flowers perfect, irregular, white or pink, in terminal or lateral racemes. Sepals 2, scale-like. Petals 4, the 2 outer dissimilar, the one flat the other spurred at the base, the 2 inner narrower, often cohering at the apex. Stamens 6 , in 2 groups opposite the outer petals. Ovary as broad as long, with 2 nerviform placentae, one of which is sterile and the other with 1 ovule at the base: style filiform, topped by a slender stigma. Nut subglobose, 1-seeded. Seed not crested. Fumitory.

1. Fumaria officinàlis L. Foliage glabrous. Stem slender, usually much branched at the base, the branches ascending or spreading, 2-10 dm. long, simple or branched : leafblades dissected, the ultimate segments linear or nearly so: racemes slender, $2-10 \mathrm{~cm}$. long, axillary or terminal : pedicels $2-4 \mathrm{~mm}$. long : corolla purplish or flesh-colored, with crimson at the tip, 6-8 mm. long, the spur somewhat shorter than the body of the corolla : nuts slightly flattened, $2-2.5 \mathrm{~mm}$. broad, roughened, emarginate at the apex.

In waste places, Nova Scotia to Florida and Texas and less abundant in the interior. Adventive from Europe. Summer.

\section{Family 3. BRAssicàceat Lindl. Mustard Family.}

Annual or perennial sometimes acaulescent herbs, or shrubby plants, with an acrid watery sap. Leaves alternate : blades entire, toothed or dissected. Flowers perfect, regular (except sometimes in Streptanthus), in spikes or racemes, or sometimes corymbose. Calyx of 4 mostly erect or appressed sepals, the inner pair lateral, similar to the outer, or more saccate at the base. Corolla of 4 variously 
colored hypogynous petals in a single series, or wanting, the spreading blades forming a cross. Androecium of 6 (or rarely 2 or 4 ) didynamous stamens, the 2 outer ones lateral, opposite the inner sepals, the other 4 longer, almost opposite the petals. Filaments often dilated or toothed towards the base. Anthers mostly 2-celled, opening lengthwise. Receptacle with honey glands. Gynoecium of 2 lateral united carpels. Ovary 2-celled, or rarely 1-celled, or falsely severalcelled, superior cavities sometimes superposed. Style simple or wanting. Stigma terminal, depressed or 2-lobed. Ovules horizontal or pendulous, or when solitary erect. Fruit capsular, elongated (silique) or relatively short and broad (silicle), valved, or rarely indehiscent, terete, angled or variously flattened. Seeds without endosperm. Embryo usually curved. Cotyledons accumbent, incumbent or conduplicate. [Cruciferae B. Juss.]

Pods not stipitate.

Pods flattened or compressed contrary to the narrow partition.

Pods didymous, separating from the partition as 2 plump nutlets.

Pods flat, regularly dehiscent.

Pods cuneate, winglesś.

Pods orbicular to elliptic or obovate, wing-margined at least at the apex.

Pods orbicular or obovate: seeds 1 or 2 .

Pods elliptic-oblong: seeds several.

Pods neither compressed nor flattened contrary to the partition.

Pods terete or prismatic.

Pods regularly dehiscent.

Length of pod less than twice the width.

Seeds flat : plants pubescent with mostly branched hairs.

Pods globular, the valves nerveless : cotyledons accumbent.

Pods pyriform, the valves 1-nerved: cotyledons incumbent.

Seeds turgid: plants pubescent with simple hairs, or glabrous.

Length of pod over twice the width.

Pods merely tipped with the short style, or style wanting, not beaked.

Pods terete or nearly so.

Seeds in 2 rows in each cavity of the pod.

Seeds in 1 row in each cavity of the pod.

Leaf-blades pinnatifid or coarsely toothed.

Outer sepals not horned: corollas yellow or white. Outer sepals horned: corollas violet or purple.

Leaf-blades entire or slightly toothed. Stigmas discoid, barely lobed.

Pods 4-sided or 4-angled. Stigmas manifestly 2-lobed.

Corolla white.

Corolla yellow.

Seeds flat: leaf-blades pinnatifid.

Seeds plump: leaf-blades entire or toothed.

Pods markedly beaked.

Beak flat and sword-like.

Beak conic.

Pods with transverse partitions, separating into joints.

Pods flattened or compressed parallel to the broad partition.

Pods suborbicular or oval.

Pods oblong to narrowly linear.

Valves of the pods nerveless.

Seeds wingless.

Seeds in 2 rows in each cavity.

Seeds in 1 row in each cavity.

Scapose, with 2-4 leaf-like bracts subtending the peduncle: embryo with unequal cotyledons.

Caulescent, with alternate leaves : embryo with equal cotyledons.

Seeds winged.
Valves of the pods nerved.

Anthers not sagittate.

Leaf-blades entire or merely toothed.

Pods oval, oblong to broadly linear.

Pods narrowly linear to linear-filiform.

Leaf-blades finely dissected.

5. Lesquerella.

6. Camelina.

7. RORIPA.

1. Coronopus.

2. Bursa.

3. LEPIDIUM.

4. SYNTHLIPSIS.

\section{RORIPA.}

8. Sisymbrium.

9. IODANTHUS.

10. THELYPODIUM.

11. Hesperis.

12. Stenophragma.

13. BARBAREA.

14. ERysimum.

15. SINAPIS.

16. BRASSICA.

17. CAKILE.

18. Koniga.

19. Draba.

20. Dentaria.

21. Cardamine.

22. LEAVENWORTHIA.

Anthers sagittate.

Petals with blades much wider than the claws : calyx not cam-

panulate.
Petals with narrow blades scarcely wider than the claws: calyx campanulate.

Pods stipitate.

Leaf-blades pinnatisect : pods oblong: seeds in 2 rows in each cavity.

Leaf-blades entire: pods narrowly linear: seeds in 1 row in each cavity.

\section{DRABA. \\ 23. Arabis. \\ 24. SOPHIA.}

25. STREPTANTHUS.

26. EukLisia.

27. SELENIA.

28. WAREA.

\section{CORÓNOPUS Gaertn.}

Annual or biennial caulescent herbs. Stems branched at the base, the branches diffusely spreading. Leaves alternate: blades entire or pinnatifid. Flowers perfect, in small 
lateral racemes. Sepals 4, spreading, equal. Corolla white to purple, the 4 petals larger than the sepals. Stamens often 2 or 4 . Ovary sessile : style wanting : stigma barely lobed. Ovule usually solitary. Silicle laterally flattened, didymous, the valves crested, rugose or coarsely wrinkled. Seed solitary. Cotyledons incumbent or conduplicate. [Senebiera Poir.] Wart Cresss. Swine Cress.

Capsules finely wrinkled, crestless.

Capsules tuberculate-wrinkled, crested.

1. C. didymus.

2. C. Coronopus.

1. Coronopus dídymus (L.) J. E. Smith. Sparingly pubescent. Branches ascending or prostrate, $1-4 \mathrm{dm}$. long: basal leaves $3-10 \mathrm{~cm}$. long, with margined petioles and 1-2pinnatifid blades: stem-leaves similar to the basal but shorter and with much shorter petioles, or sessile : racemes $1-5 \mathrm{~cm}$. long : pedicels spreading, 1-2 $\mathrm{mm}$. long : sepals ovate to oblong-ovate, about $0.5 \mathrm{~mm}$. long: petals white, less than twice as long as the sepals : pods didymous, $2-2.5 \mathrm{~mm}$. broad, notehed, finely wrinkled. [Senebiera pinnatifida DC.]

In waste places, Newfoundland to Missouri, California, Florida and Texas. Naturalized northward. Spring and summer.

2. Coronopus Corónopus (L.) Karst. Fleshy, usually glabrous. Branches ascending or spreading, $0.5-3 \mathrm{dm}$. long: basal leaves 4-12 $\mathrm{cm}$. long, with margined petioles and pinnately-parted blades, the segments long and narrow : stem-leaves similar but smaller and with shorter petioles : racemes $0.5-3 \mathrm{~cm}$. long: pedicels $1-1.5 \mathrm{~mm}$. long : sepals oblong or oval, nearly $1 \mathrm{~mm}$. long: petals white, barely twice as long as the sepals : pods not didymous, $3.5-4 \mathrm{~mm}$. broad, apiculate, tuberculate-wrinkled.

In waste places, New Brunswick to Florida and Texas. Also on the Pacific coast. Naturalized from Europe. Spring to fall.

\section{BÚRSA Weber.}

Annual caulescent herbs, with glabrous or pubescent foliage. Leaves alternate, often mainly basal : blades entire, lobed, or pinnatifid. Flowers perfect, in elongated racemes. Sepals 4, spreading, equal. Corolla white, the petals much longer than the sepals. Ovary sessile: style short: stigma capitate. Ovules numerous. Silicles strongly flattened contrary to the narrow septum, cuneate or obcordate, more or less deeply notched at the apex, the valves boat-shaped. Seeds numerous in each cavity, marginless. Cotyledons accumbent. [Capsella Medic.] Shepherd's Purse.

1. Bursa Búrsa-pastòris (L.) Britton. Annual, more or less pubescent below, glabrous above. Stems 3-9 dm. tall, simple, or usually branching above: leaves mainly basal ; petioles short; blades pinnately lobed or pinnatifid, rarely dentate or entire, 3-15 cm. long: stem-leaves few, linear or lanceolate, auricled at the base : pedicels spreading or ascending, 1-1.5 cm. long: sepals ovate or oval-oblong, about $1.5 \mathrm{~mm}$. long: petals white, spatulate, about twice as long as the sepals : pods triangular-cuneate or cuneate, 5$8 \mathrm{~mm}$. long, emarginate at the apex : seeds $10-12$ in each cavity.

In all situations, common nearly throughout North America. Naturalized from Europe and now widely distributed over the globe. Spring to winter.

\section{LEPÍDIUM L.}

Annual or biennial caulescent herbs. Leaves alternate : blades entire, lobed, incised or pinnatifid, sometimes clasping the stem. Flowers perfect, in racemes or panicles. Sepals 4, equal. Corollas white or greenish, the 4 petals small, or wanting. Stamens usually fewer than 6. Ovary sessile: style slender, or wanting: stigma emarginate. Ovule solitary, pendulous. Silicles oblong to orbicular, transversely flattened, sometimes margined. Seed solitary in each cavity. Cotyledons incumbent or rarely accumbent. Peppergrass.

Cotyledons accumbent.

Cotyledons incumbent.

Capsules about $3 \mathrm{~mm}$. broad : petals conspicuous.

Capsules about $2 \mathrm{~mm}$. broad: petals wanting or obsolete.

Pods as broad as long: pedicels glabrous or finely hirsute. Pedicels and pods glabrous. Pedicels and pods finely hirsute.

Pods markedly longer than broad: pedicels puberulent.

1. L. Virginicum.

2. L. medium.

3. L. apetalum.

4. L. austrinum.

5. L. interior.

1. Lepidium Virginicum L. Annual or biennial, more or less puberulent. Stems 2-9 dm. tall, simple or widely branched: basal leaves spatulate or oblanceolate; blades pinnatifid, the segments toothed or incised, the terminal one much longer than the others; stem-leaves narrow, erect or ascending, sharply toothed or incised : pedicels finally spread- 
ing, 3-4 mm. long : sepals oblong, about $1 \mathrm{~mm}$. long, obtuse : petals white, spatulate, slightly longer than the sepals : silicles suborbicular or oval-orbicular, 3-4 mm. broad, margined above, notched at the apex.

In all situations, Quebec to Minnesota, Kansas, Florida, Texas and Mexico. Naturalized in Europe. Spring and fall.

2. Lepidium mèdium Greene. Annual, glabrous or nearly so. Stems 1-5 dm. tall, simple, or more or less branched: basal leaves $2-8 \mathrm{~cm}$. long: blades coarsely toothed or rarely 1-2-pinnatifid: stem-leaves narrow, more or less distinctly toothed or those of the branches entire: pedicels ascending, finally $2-3 \mathrm{~mm}$. long: petals conspicuous, bright white : pods suborbicular, about $3 \mathrm{~mm}$. broad, notched at the apex.

In dry soil, Idaho to Vancouver Island, Texas and California. Spring and summer.

3. Lepidium apétalum Willd. Annual or perhaps more persistent, glabrous or puberulent, odorless. Stems 2-7 dm. tall, more or less branched : basal leaves and sometimes the lower stem-leaves with pinnatifid blades: upper stem-leaves narrow, incised to entire, erect or ascending: pedicels erect or nearly so during anthesis, thereafter becoming 2-3 $\mathrm{mm}$. long, curving out making the fruiting raceme much thicker than the top: petals minute and inconspicuous or obsolete : pods suborbicular, about $2 \mathrm{~mm}$. broad, notched at the apex.

In dry soil and waste places, Maine to the Northwest Territory, California, New York and Texas. Spring to fall.

4. Lepidium austrìnum Small. Annual or biennial, finely hirsute all over, at least during anthesis. Stems 1-3 dm. tall, branched above and sometimes also at the base: basal leaves spatulate, early deciduous: stem-leaves with spatulate or oblanceolate blades $1.5-5 \mathrm{~cm}$. long : pedicels ascending during anthesis, spreading at maturity, becoming 2-3 $\mathrm{mm}$. long: petals minute or wanting: pods suborbicular, $2 \mathrm{~mm}$. broad or slightly more, finely hirsute.

In plains and prairies, Texas. Spring.

5. Lepidium oblóngum Small. Annual or biennial, minutely pubescent. Stems usually much branched at the base, the branches radially spreading, more or less decumbent, 0.5-2 dm. long, usually branched: leaves rather numerous ; blades pinnatifid, 1-2 $\mathrm{cm}$. long, the segments mostly $5-7$, quite narrow, acute : pedicels puberulent : petals wanting or obsolete : pods oblong or oval, about $3 \mathrm{~mm}$. long, slightly winged at the apex.

In dry ground, near Sapulpa, Indian Territory. Spring and summer.

\section{SYNTHLÍPSIS A. Gray.}

Annual caulescent herbs, with grayish pubescent foliage. Leaves alternate: blades sinuate or pinnatifid, sometimes petioled. Flowers perfect, in loose racemes. Sepals oblong, spreading during anthesis. Petals surpassing the sepals, with flat blades and short claws. Stamens 6: filaments unappendaged. Ovary 2-celled: style slender: stigma entire. Ovules several. Pods relatively short, strongly compressed, on ascending or reflexed pedicels, the valves merely keeled. Seeds neither winged nor margined, about 10 in each cavity. Cotyledons accumbent.

1. Synthlipsis Berlandièri A. Gray. Foliage finely stellate-tomentose. Stems branched at the base, the branches spreading, simple or branched : basal leaves $3-8 \mathrm{~cm}$. long, with short petioles and pinnatifid blades; stem-leaves sessile, oblong, oblanceolate or oval, dentate or sinuate-pinnatifid, $1-2.5 \mathrm{~cm}$. long, acute: pedicels finally recurved, 1-1.5 $\mathrm{cm}$. long: sepals oblong-lanceolate, $3 \mathrm{~mm}$. long: petals yellow to purple, about twice as long as the sepals : pods suborbicular, about 6 or $7 \mathrm{~mm}$. broad, reticulated, glabrous, usually deflexed.

On plains and prairies, southern Texas. Spring.-The variety with hirsute stems is S. Berlandieri hispida S. Wats. Spring.

\section{LESQUERÉLLA S. Wats.}

Annual or perennial scapose or caulescent herbs, with stellate pubescence. Leaves alternate, sometimes mainly basal : blades entire or undulate. Flowers perfect, in racemes or panicles. Sepals 4, equal, or 2 saccate at the base. Corolla usually yellow or yellowish, the 4 petals surpassing the sepals, entire. Stamens 6 . Ovary sessile or stalked : style slender : stigma capitate or 2-lohed. Ovules few. Silicles oblong or globose, inflated, the valves nerveless : septum nerved from the apex to the middle. Seeds flattened, sometimes narrow-margined. Cotyledons accumbent. BLADDER-POD. 
Filaments more or less dilated below: foliage hispidly stellate.

Seeds margined : filaments strongly dilated at the base.

Capsules flattened, pubescent.

Capsules subglobose, glabrous.

Filaments gradually dilated : style less than $2 \mathrm{~mm}$. long at maturity.

Filaments abruptly dilated : style over $2 \mathrm{~mm}$. long at maturity.

Seeds without margins: filaments slightly dilated.

Capsules pubescent: filaments dilated for $1 / 2$ their length.

Capsules glabrous : filaments dilated for $1 / 3$ their length.

Filaments very slender or linear-subulate: foliage compactly canescent or scalystellate.

Ovaries and capsules pubescent.

Cavities of the ovary with 2 ovules: pods $2 \mathrm{~mm}$. in diameter.

Cavities of the ovart with 4-6 ovules: pods $3-5 \mathrm{~mm}$. in diameter.

Ovaries and capsules glabrous.

Capsules oblong or pear-shaped.

Capsules oblong : pedicels ascending : style about as long as the capsule.

Capsules pyriform: pedicels spreading: style much shorter than the capsule.

Capsules subglobose.

Capsules pendent from recurved pedicels.

Corollas white or pink : ovules 6 in a cavity : style one-half as long as the capsule.

Corollas yellow : ovules $2-4$ in a cavity : style as long as the capsule

Capsules erect, or nearly so, from ascending often curved pedicels. Annuals.

Stem-leaves with pinnatifid-dentate blades.

Stem-leaves entire or merely repand blades.

Ovules 4-8 in each cavity of the ovary.

Pods $2-3 \mathrm{~mm}$. in diameter.

Pods stipitate.

Pods sessile.

Pods $4-5 \mathrm{~mm}$. in diameter.

Ovules 2 in each cavity of the ovary.

Biennials or perennials.

Capsules $6 \mathrm{~mm}$. long.

Capsules 4-5 mm. long.

1. L. Lescurii.

2. L. grandiflora.

3. L. auriculata.

4. L. lasiocarpa.

5. L. densiflora.

6. L. globosa.

7. L. Berlandieri.

8. L. repanda.

9. L. Nuttallii.

10. L. pallida.

11. L. recurvata.

12. L. Lindheimeri.

13. L. gracilis.

14. L. sessilis.

15. L. polyantha.

16. L. angustifolia.

17. L. Engelmannii.

18. L. argyrea.

1. Lesquerella Lescúrii (A. Gray) S. Wats. Annual, roughish with stellate hairs. Stems branched at the base ; branches erect, ascending or decumbent, 1-3 dm. long, simple or branched : basal-leaves longer than the cauline: stem-leaves oblong-oval or oblongovate, 1-4 cm. long, repand-dentate, sessile and clasping by the auricled bases: pedicels ascending, 5-10 mm. long: sepals $2-2.5 \mathrm{~mm}$. long: petals yellow, broadly spatulate, 4-6 $\mathrm{mm}$. long: pods oval or ovoid, $4-5 \mathrm{~mm}$. long, flattened, pubescent, the style about $\frac{1}{2}$ as long as the body.

On hillsides, near Nashville, Tennessee. Early spring.

2. Lesquerella grandiflòra (Hook.) S. Wats. Annual, thinly pubescent or somewhat hispid. Stems branched at the base ; branches erect or ascending, 1-4 dm. long, commonly simple : basal leaves oblanceolate, deeply sinuate or pinnatifid: stem-leaves shorter than the basal; blades oblanceolate, oblong or oblong-oblanceolate, $1-3.5 \mathrm{~cm}$. long, entire or sinuate, sessile and somewhat clasping : pedicels ascending or spreading, $1-1.5 \mathrm{~cm}$. long: sepals oblong to oblong-lanceolate, $3-4 \mathrm{~mm}$. long : petals obovate, twice or thrice as long as the sepals: pods subglobose, $5 \mathrm{~mm}$. in diameter, glabrous.

On plains or prairies, Texas. Spring.

3. Lesquerella auriculàta (Engelm. \& Gray) S. Wats. Annual, hirsute. Stems simple and erect or usually branched at the base ; branches ascending or decumbent, 1-3 $\mathrm{dm}$. long, commonly simple: basal leaves oblanceolate, repand, $2-5 \mathrm{~cm}$. long: stemleaves with oblong or oblong-lanceolate blades, 1-3 dm. long, entire or repand, sessile, clasping by the auricled bases : pedicels ascending, $1-1.5 \mathrm{~cm}$. long: sepals oblong to oblong-lanceolate, 4-5 $\mathrm{mm}$. long: petals yellow, narrowly obovate, about twice as long as the sepals : pods subglobose, $5-6 \mathrm{~mm}$. in diameter, glabrous, narrowed at the base, the style $\frac{1}{2}$ as long as the body.

On dry prairies, Texas. Winter and spring.

4. Lesquerella lasiocárpa (Hook. ) S. Wats. Annual, finely hispid. Stems branched at the base; branches ascending or spreading, 1-7 dm. long, simple or branched : basal leaves oblanceolate in outline: blades pinnatifid, $3-8 \mathrm{~cm}$. long, the segments entire or toothed : stem-leaves oblong or oval, 1-3 cm. long, pinnatifid or coarsely toothed, sessile, not auricled : pedicels spreading or slightly recurved, $1-1.5 \mathrm{~cm}$. long : petals obovate, about 6 $\mathrm{mm}$. long: filaments slightly dilated below the middle : pods spheroidal, $5-6.5 \mathrm{~mm}$. long, the style $\frac{1}{2}$ as long.

In.valleys, Texas and adjacent Mexico. Spring.

5. Lesquerella densiflòra (A. Gray) S. Wats. Annual, more or less densely canescent. Stems branched at the base; branches erect or ascending, 1-3 dm. long, often 
simple: leaf-blades spatulate to lanceolate or oblong, entire or repand, the lower with petioles, the upper sessile: corymbs rather densely flowered: pedicels finally $6-10 \mathrm{~mm}$. long, ascending: sepals lanceolate or linear-lanceolate, 4-4.5 mm. long: petals broadly spatulate, about twice as long as the sepals : filaments slightly dilated for $\frac{1}{3}$ their length : pods subglobose, $4 \mathrm{~mm}$. in diameter, rather crowded, glabrous.

In valleys and dry soil, central Texas. Spring.

6. Lesquerella globòsa (Desv.) S. Wats. Annual or biennial, densely pubescent with fine stellate hairs. Stems erect, or usually branched at the base, with ascending branches. 2-4 dm. tall, more or less branched: basal leaves with oblong or obovate-oblong blades 1.5-4 cm. long: stem-leaves oblanceolate, narrowly oblong or linear, 1-2 cm. long, sessile or nearly so, rarely undulate-repand : racemes elongating, sometimes paniculate : pedicels finally spreading, $5-10 \mathrm{~mm}$. long, very slender: sepals ovate-oblong or oblong, about 3 . $\mathrm{mm}$. long : petals yellow, spatulate, about twice as long as the sepals : cavities of the ovary with 2 ovules: pods subglobose, $2 \mathrm{~mm}$. in diameter, glabrous, the style much longer than the body.

On open banks, Wisconsin to Kentucky and Tennessee. Early spring.

7. Lesquerella Berlandièri (A. Gray) S. Wats. Annual or biennial, rather sparsely pubescent. Stems usually branched; branches slender, 1-3 dm. long: basal leaves with lyrate-pinnatifid blades several $\mathrm{cm}$. long: stem-leaves few ; blades oblanceolate, oblong-lanceolate or ovate, shorter than those of the basal leaves, repand, petioled : petals spatulate, about $6 \mathrm{~mm}$. long: cavities of the ovary with 4-6 ovules : pods globose or ellipsoidal, 3-5. $\mathrm{mm}$. in diameter, the style longer than the body.

On plains and prairies, along or near the Rio Grande, Mexico, not yet definitely known from the Texan side.

8. Lesquerella repánda (Nutt.) S. Wats. Annual, finely scurfy-pubescent. Stems simple or sparingly branched, $2-3 \mathrm{dm}$. long, often spreading : leaves various; basal with lyrately pinnatifid blades $5 \mathrm{~cm}$. long: stem-leaves spatulate to linear-spatulate, entire: racemes several-many-flowered : pedicels ascending, $1.5-2 \mathrm{~cm}$. long : petals spatulate, about $6 \mathrm{~mm}$. long: pods oblong, 4-5 mm. long, glabrous, acutish, slightly narrowed to the very short stipe, the style about as long as the body.

On the banks of the Red River, Arkansas. Spring.

9. Lesquerella Nuttállii (A. Gray) S. Wats. Annual, quite similar to L. repanda. Basal leaves and flowers unknown: racemes many-flowered, elongating: pedicels spreading, 1-2 cm. long: pods $5 \mathrm{~mm}$. long, erect, pyriform, slightly constricted above the abrupily contracted base, short-stalked, glabrous, the style 2-4 mm. long.

On prairies near the Red River, Arkansas. Spring.

10. Lesquerella pállida (T. \& G.) S. Wats. Annual, rather thinly scurfy-pubescent. Stems branching; branches erect or spreading, $2-3 \mathrm{dm}$. long : leaves mainly with oblanceolate repand blades $1-3.5 \mathrm{~cm}$. long: pedicels recurving, about $1 \mathrm{~cm}$. long: sepals $1-1.5 \mathrm{~mm}$. long: petals white or pink, spatulate, $1 \mathrm{~mm}$. long: cavities of the ovary with 6 ovules : pods subglobose, nodding, $4 \mathrm{~mm}$. in diameter, short-stalked, the style about $2 \mathrm{~mm}$. long.

On prairies, eastern Texas. Spring.

11. Lesquerella recurvàta (Engelm.) S. Wats. Annual, slender, thinly pubescent. Stems branched at the base; branches ascending or spreading, 0.5-3 dm. long, often branched : leaf-blades varying from spatulate to obovate or linear, $0.5-3 \mathrm{~cm}$. long, acutish, entire, the lower ones with petioles sometimes as long as the blades : pedicels recurving, about $1 \mathrm{~cm}$. long: sepals oblong, $2-3 \mathrm{~mm}$. long: petals yellow, spatulate, 4-6 mm. long: cavities of the ovary with 2-4 ovules: pods subglobose, $2.5-3 \mathrm{~mm}$. thick, not stipitate, glabrous.

In light soil, Texas. Spring.

12. Lesquerella Lindheìmeri (A. Gray) S. Wats. Annual, finely but densely pubescent with stellate hairs. Stems branched at the base; branches ascending, 1-3 dm. long, simple or branched : leaf-blades varying from oblanceolate to lanceolate, $2-6 \mathrm{~cm}$. long, more or less prominently repand: pedicels finally spreading, 10-12 mm. long: sepals oblong, 3-3.5 mm. long, obtuse : petals yellow, obovate, spatulate, about twice as long as the sepals : cavities of the ovary with $6-8$ ovules : pods subglobose, $3-4 \mathrm{~mm}$. long, barely stipitate.

In light soil, Texas. Spring.

13. Lesquerella grácilis (Hook.) S. Wats. Annual, sparsely pubescent with stellate hairs. Stems branched at the base ; branches erect or ascending, sometimes spreading, 1-3 $\mathrm{dm}$. long, simple or branching : leaf-blades linear or oblanceolate, 1-3 cm. long, entire or repand: pedicels ascending or spreading, 1-2 cm. long: sepals oblong, 3-3.5 mm. long : 
petals yellow, spatulate, about twice as long as the sepals : cavities of the ovary with 4-6 ovules: pods subglobose, $2-2.5 \mathrm{~mm}$. in diameter, stipitate, glabrous.

On prairies, Nebraska to Texas. Spring.

14. Lesquerella séssilis (S. Wats.) Small. Quite similar to L. gracilis, but usually larger and with more densely pubescent foliage. Leaves erect or ascending; blades undulate or repand, more or less silvery or lustrous beneath : pods globular, $2.5-3 \mathrm{~mm}$. in diameter, sessile. [L. gracilis var. sessilis S. Wats.]

On plains or prairies, Texas Summer.

15. Lesquerella polyántha Schlecht. Annual, more or less densely stellate-pubescent. Stems branched at the base ; branches ascending or spreading, 1-4 dm. long, simple or branched : basal leaves $1.5-5 \mathrm{~cm}$. long, with lanceolate or oblanceolate lyrate blades and short petioles : stem-leaves with oblanceolate or oblong, or linear or rarely spatulate, obtuse or acutish, entire or undulate blades: pedicels finally spreading or recurving, $8-20 \mathrm{~mm}$. long: sepals oblong, $2.5-3.5 \mathrm{~mm}$. long: petals yellow, spatulate, about twice as long as the sepals : cavities of the ovary with $6-8$ ovules : pods subglobose, 4-5 $\mathrm{mm}$. in diameter, stipitate, glabrous.

On plains and prairies, Texas and the Indian Territory. Spring.

16. Lesquerella angustifòlia (Nutt.) S. Wats. Annual, finely scaly-pubescent. Stems simple or branched, $2-3 \mathrm{dm}$. long, slender: leaves various; basal with lyrate-pinnatifid blades $1.5-4.5 \mathrm{~cm}$. long: stem-leaves shorter, narrowly linear, racemes few-severalflowered : pedicels slender, ascending or spreading or almost wanting: sepals $3.5-4 \mathrm{~mm}$. long : petals yellow, spatulate, $5 \mathrm{~mm}$. long : cavities of the ovary with 2 ovules : pods subglobose, 4-5 mm. in diameter, glabrous, the style shorter than the body.

On prairies, near the Red River, Arkansas. Spring.

17. Lesquerella Engelmánnii (A. Gray) S. Wats. Biennial or perennial, densely pubescent with stellate hairs. Stems branched at the base ; branches erect or ascending, 2-4 dm. tall, simple or branched : basal leaves $2-6 \mathrm{~cm}$. long; blades linear-spatulate or narrowly oblanceolate, obtuse ; petioles sometimes as long as the blades : pedicels spreading or ascending, fully $1 \mathrm{~cm}$. long at maturity : sepals about $6 \mathrm{~mm}$. long: petals yellow, broadly spatulate, $6-12 \mathrm{~mm}$. long: cavities of the ovary with $6-8$ ovules : pods almost 6 $\mathrm{mm}$. long, barely stipitate, the style as long as the body or longer.

In dry soil, Kansas to Colorado and Texas. Spring.

18. Lesquerella argyrèa (A. Gray) S. Wats. Biennial or perennial, more or less densely stellate-pubescent. Stems usually much branched at the base; branches decumbent or prostrate, 1-4 dm. long : basal leaves $1.5-3 \mathrm{~cm}$. long; blades elliptic, or linearelliptic, entire or repand; petioles shorter than the blades: stem-leaves similar to the basal but with shorter petioles or oblanceolate: pedicels finally spreading, $8-12 \mathrm{~mm}$. long, more or less curved : sepals linear-oblong, 3-4 mm. long: petals yellow, turning purple, nearly twice as long as the sepals: cavities of the ovary with 6-10 ovules : pods subglobose, $3 \mathrm{~mm}$. broad, not stalked, the style as long as the body or shorter. Spring.

In dry soil, Texas, between the Colorado River and the Rio Grande. Also in adjacent Mexico.

\section{CAMÉlina Crantz.}

Annual caulescent herbs, with glabrous foliage, or pubescent with branching hairs. Stems erect, terete. Leaves alternate : blades entire or toothed, often clasping, the lower ones sometimes pinnatifid. Flowers perfect, in elongated racemes. Sepals 4, equal. Corolla yellowish or greenish, the 4 petals longer than the sepals. Stamens 6 . Ovary sessile: style slender : stigma capitate. Ovules few or numerous. Silicles short, inflated, nearly terete or flattened, the valves 1-nerved. Seeds in 2 rows in each cavity, marginless. Cotyledons incumbent. False Flax.

Plant pubescent : silicles 4-6 mm. long.

Plant glabrous or nearly so: silicles $6-8 \mathrm{~mm}$. long.

1. C. microcarpa.

2. C. sativa.

1. Camelina microcárpa Andrz. Foliage pubescent, at least below. Stems erect, simple or with a few elongated branches : leaves few ; blades lanceolate, $1.5-7 \mathrm{~cm}$. long, sessile, auricled or the lower ones narrowed at the base, acute or acuminate : pedicels slender, spreading : racemes elongating, often $2-3 \mathrm{dm}$. long: silicles slightly flattened, $4-6 \mathrm{~mm}$. long, broader above the middle, strongly margined.

In fields and waste places, Rhode Island to Idaho and British Columbia, West Virginia, Tennessee and Kansas. Spring. 
2. Camelina sativa (L.) Crantz. Foliage glabrous or nearly so. Stems erect, 3-9 dm. tall, simple or branching above: basal leaves spatulate or oblanceolate, undulate, or repand: stem-leaves with sagittate-lanceolate blades $2-7 \mathrm{~cm}$. long, acutish, entire, sessile, clasping by the auricled bases : pedicels ascending, 1-1.5 $\mathrm{cm}$. long, enlarged at the apex : sepals oblong, $2.5-3 \mathrm{~mm}$. long: petals yellowish, nearly twice as long as the sepals : silicles pyriform, 6-8 mm. long, somewhat flattened, each tipped with the acute style, the sutures margined.

In fields and waste places, southern British America and the eastern United States. Naturalized from Europe. Spring.

\section{RORİPA Scop.}

Aquatic or terrestrial herbs, with erect or creeping stems and glabrous or pubescent foliage, the hairs simple. Leaves alternate: blades toothed, lobed or pinnately dissected. Flowers perfect, in terminal or axillary racemes. Sepals 4, equal, spreading during anthesis. Corolla yellow or white: petals 4 (or rarely wanting), usually small, without very manifest claws. Stamens 1-6. Ovary sessile: styles stout or slender: stigmas 2-lobed. Pods of various lengths, terete or nearly so, rarely didymous, the valves commonly 1-nerved. Seeds in 2 rows, turgid. Cotyledons accumbent. [Nasturtium R. Br.] Water-cress. Sturshum.

Corolla white.

Blades of all leaves similar: sepals $2-2.5 \mathrm{~mm}$. long: pods fully $1 \mathrm{~cm}$. long.

Blades of submersed leaves unlike those of emersed leaves : sepals $3 \mathrm{~mm}$. long: pods less than $1 \mathrm{~cm}$. long.

Corolla yellow.

Annual or perennial from fibrous roots: petals mostly shorter than the sepals. Flowers and pods sessile or nearly so.

Leaf-blades bipinnatifid : style $2 \mathrm{~mm}$. long : pods $4-7 \mathrm{~mm}$. long.

Leaf-blades pinnatifid : style almost wanting: pods $3-4 \mathrm{~mm}$. long.

Flowers and pods manifestly pedicelled. Stems upright : pedicels $4-8 \mathrm{~mm}$. long.

Pods subglobose or oval, shorter than the pedicels : stem pubescent.

Pods linear or narrowly oblong, as long as the pedicels or longer : stem glabrous or nearly so.

Stems diffuse : pedicels $2-4 \mathrm{~mm}$. long.

Pods subglobose, about $2 \mathrm{~mm}$. in diameter.

Pods oblong, 4-8 $\mathrm{mm}$. long.

Perennial by creeping or horizontal stems : petals mostly surpassing the sepals. Leaf-blades pinnatifid: style slender.

Leaf-blades pinnately parted: style short and stout.

1. R. Nasturtium.

2. R. Americana.

3. R. Walteri.

4. $R$, sessiliflora.

5. R. hispida.

6. $R$. palustris.

7. R. sphaerocarpa.

8. R. obtusa.

9. R. sinuata.

10. K. sylvestris.

1. Roripa Nastúrtium (L.) Rusby. Perennial, aquatic, glabrous. Stems floating, or decumbent and creeping, 1-6 dm. long, simple or branched: leaves alternate ; blades unequally pinnate, $2-15 \mathrm{~cm}$. long; leaf-segments $3-9$, irregular, obtuse, the lateral ones sometimes much reduced, the terminal one larger, usually truncate or cordate at the base : racemes elongating in fruit: pedicels finally spreading, $5-15 \mathrm{~mm}$. long: sepals oblong, $2-2.5 \mathrm{~mm}$. long, obtuse : petals white, about twice as long as the sepals : pods linear, 1-2.5 $\mathrm{cm}$. long, nearly terete, more or less strongly curved upward. [Nasturtium officinale $\mathrm{R}$. Br.]

In swampy places or in brooks, Nova Scotia to Idaho, Georgia and Texas. Naturalized from Europe. Spring to fall. WATER-CREsS.

2. Roripa Americàna (A. Gray) Britton. Perennial, aquatic, glabrous or nearly so. Stems 3-8 dm. long, zigzag, branching above : leaves alternate ; submersed with finely pinnately dissected blades, readily deciduous ; emersed, oblong-elliptic or linear-oblong, 3-10 $\mathrm{cm}$. long, undulate, serrate or pinnatifid : pedicels spreading, 5-15 mm. long, slender : sepals oblong, $3 \mathrm{~mm}$. long, obtuse : petals white, about twice as long as the sepals: pods oblong or oval-oblong, 5-6 mm. long, nearly 1-celled. [Nasturtium lacustre A. Gray.]

In ponds or in sluggish streams, Quebee to Minnesota, Florida and Louisiana. Summer.

3. Roripa Wálteri (Ell.) Mohr. Annual or biennial, glabrous. Stems more or less diffusely branched at the base ; branches ascending or spreading, 1-4 dm. long, branched : leaves basal and cauline, $2-10 \mathrm{~cm}$. long; blades bipinnatifid, the segments of various shapes : racemes elongating in fruit: pedicels spreading or ascending, $1-5 \mathrm{~mm}$. long: sepals about $1 \mathrm{~mm}$. long: petals slightly longer than the sepals : pods oblong, 8-15 mm. long, slightly curved, erect or ascending. [Nasturtium tanacetifolium (Walt.) Hook.] Spring.

In low ground and ditches, South Carolina to Florida, the Indian Territory, Texas and Mexico.

4. Roripa sessiliflòra (Nutt.) A. S. Hitchcock. Annual or biennial, glabrous. Stems erect, $2-6 \mathrm{dm}$. tall, branching above : leaves alternate; blades lanceolate or ovate to obovate or oblanceolate, $3-15 \mathrm{~cm}$. long, obtuse, coarsely toothed, lobed or pinnatifid, the lower ones petioled, the upper often sessile: racemes elongating: pedicels mostly 1-2 
$\mathrm{mm}$. long : sepals oblong or nearly so, obtuse, $1 \mathrm{~mm}$. long: petals yellow, about twice as long as the sepals : pods oblong, $6-14 \mathrm{~mm}$. long, ascending or spreading.

In damp places or on shaded banks, Iowa to Kansas, Tennessee, Florida and Texas. Spring and summer.

5. Roripa híspida (Desv.) Britton. Annual or biennial, with more or less densely hirsute or hispid foliage. Leaves alternate ; blades oblong, elliptic, or oblanceolate in outline, $2-18 \mathrm{~cm}$. long, pinnatifid or rarely only shallowly toothed, the lobes repand or toothed, or the large terminal one again lobed : racemes elongating : pedicels $2-2.5 \mathrm{~mm}$. long, finally spreading: pods subglobose to oval, $2-3 \mathrm{~mm}$. long, shorter than the pedicels.

In damp soil, New Brunswick to British Columbia, Florida and New Mexico. Summer.

6. Roripa palústris (L. ) Bess. Annual or biennial, glabrous or minutely pubescent. Leaves alternate ; blades oblong, linear-oblong or oblanceolate, $2-20 \mathrm{~cm}$. long, pinnatifid, or the upper repand or coarsely toothed, the lower ones petioled and upper ones sessile or nearly so, the lobes more or less deeply toothed : racemes elongating at maturity : pedicels finally spreading, 2-6 mm. long: pods linear, or narrowly oblong, longer than the pedicels or about equalling them in length, more or less strongly curved.

In swampy soil, throughout North America, except the extreme north. Spring and summer. Also in Europe.

7. Roripa sphaerocárpa (A. Gray) Britton. Annual or perennial, glabrous. Stems erect or decumbent and rooting at the lower nodes, 1-4 dm. long: leaves alternate, 3-8 $\mathrm{cm}$. long; blades thinnish, the lower incised or lyrate-pinnatifid, the upper undulate or shallowly toothed, all obtuse : pedicels slender, 2-6 $\mathrm{mm}$. long, recurving: sepals oblong or oblong-ovate, barely $1 \mathrm{~mm}$. long: petals yellow, somewhat longer than the sepals : pods subglobose, about $2 \mathrm{~mm}$. in diameter, nodding.

In low grounds, 'Illinois to Kansas, California and Texas. Summer.

8. Roripa obtùsa (Nutt.) Britton. Annual or biennial, glabrous. Stems 2-5 dm. long, nearly simple and erect or diffusely branched : leaves alternate; blades oblong to oblanceolate, pinnatifid or pinnately-divided, 3-15 $\mathrm{cm}$. long, petioled, the segments angular, variously toothed or lobed, the terminal one largest : pedicels $1-3 \mathrm{~mm}$. long, erect or ascending: sepals about $1 \mathrm{~mm}$. long: petals yellow, somewhat surpassing the sepals: pods oblong, 4-8 $\mathrm{mm}$. long, erect or ascending.

In low grounds or on wet banks, Michigan to Vancouver Island and Texas. Spring and summer.

9. Roripa sinuàta (Nutt.) A. S. Hitchcock. Perennial, pale green, glabrous or nearly so. Stems procumbent or prostrate or sometimes decumbent, $2-6 \mathrm{dm}$. long, diffusely branched : leaves numerous; blades oblanceolate, oblong or lanceolate in outline, pinnatifid, the segments nearly equal, entire or sparingly toothed : pedicels slender, spreading, 4-10 $\mathrm{mm}$. long: sepals $2.5-3 \mathrm{~mm}$. long: petals yellow, $4.5-6 \mathrm{~mm}$. long: style slender: pods linear to oblong, 6-10 $\mathrm{mm}$. long, curved, acute at both ends.

On banks, Saskatchewan to Minnesota, Arkansas, New Mexico and Oregon. Summer.

10. Roripa sylvéstris (L. ) Bess. Perennial, glabrous. Stems ascending or decumbent, $2-7 \mathrm{~cm}$. long, sometimes ereeping at the base, more or less branched : leaves alternate, 4-15 cm. long; blades often ovate or oblong in outline, pinnately divided, the segments distant, entire or toothed : pedicels 4-10 mm. long, spreading: sepals oblong, 1-1.5 mm. long, obtuse : petals bright yellow : style short and thick : pods linear, nearly terete, 8$15 \mathrm{~mm}$. long.

In waste places and moist soil, Massachusetts to Ohio, Virginia and Alabama. Summer to fall. Naturalized from Europe.

\section{SISÝMBRIUM L.}

Annual or biennial herbs, with erect branching stems. Leaves alternate, sometimes mainly basal : blades entire, lobed or pinnatifid. Flowers perfect, in racemes. Sepals 4. Corolla white, pink or yellow : petals 4 , usually with claws. Stamens 6 : filaments unappendaged. Ovary sessile: style short or wanting: stigma sometimes 2-lobed. Ovules numerous. Pods elongated, nearly terete, often constricted between the seeds. Seeds in 1 row in each cavity, marginless. Cotyledons incumbent. Hedge Mustard.

1. Sisymbrium officinàle (L.) Scop. Annual, glabrous or sparingly pubescent. Stems 3-12 dm. tall, branched above, the branches widely spreading : leaves variable, 2-20 $\mathrm{cm}$. long; blades runcinate-pinnatifid, the segments 5-13, irregular, entire, toothed or lobed, the terminal one largest; petioles sometimes as long as the blades at the base of the plant, decreasing in length above : pedicels 1-2 $\mathrm{mm}$. long, erect or appressed : sepals oblong, $1.5-2 \mathrm{~mm}$. long : petals yellow, spatulate, about twice as long as the sepals : pods slender, 10-15 mm. long, each narrowed into a slender beak.

In waste places, throughout cultivated North America. Naturalized from Europe. Spring to fall. 


\section{IODÁNTHUS T. \& G.}

Perennial herbs, with erect branching stems and glabrous foliage. Leaves alternate: blades toothed or lyrate-pinnatifid, with auricled bases. Flowers perfect, in terminal panicles or in axillary racemes or panicles. Sepals 4, equal or nearly so, the lateral pairs more or less appendaged near the apex. Corollas white or violet, the 4 petals with long claws. Stamens 6, strongly tetradynamous. Ovary sessile : stigma nearly capitate, sessile. Ovules numerous. Pods elongated, linear-cylindric, slightly constricted between the seeds, the valves stiff, nerveless. Seeds in 1 row in each cavity, marginless. Cotyledons accumbent. Purple Rocket.

1. Iodanthus pinnatífidus (Michx.) Steud. Stems $3-10 \mathrm{dm}$. tall, branching above : leaves variable, $3-20 \mathrm{~cm}$. long; blades of the lower ones often pinnatifid, with several basal segments and a large terminal segment which is distinctly toothed or incised, the teeth flaring; blades of the upper leaves elliptic, oblong or ovate-lanceolate, dentate or incised ; petioles broadly winged, clasping, often surpassing the blades on the lower part of the stem, thence gradually reduced and very short above : pedicels finally $5-10 \mathrm{~mm}$. long, spreading : sepals oblong, about $3 \mathrm{~mm}$. long: petals white or violet, spatulate, nearly thrice as long as the sepals, even their claws surpassing them: pods elongated, $3-4 \mathrm{~cm}$. long, spreading. [I. hesperioides T. \& G. ]

On river banks, Pennsylvania to Minnesota, Tennessee, Louisiana and Texas. Spring.

\section{THELYPÒDIUM Endl.}

Annual or mostly biennial caulescent herbs. Leaves alternate: blades often sagittate or clasping at the base. Flowers in relatively dense racemes. Sepals somewhat spreading during anthesis, rather short. Corolla white, purple or rarely yellow. Petals flat, sometimes with well-expanded blades. Stamens 6 , exserted : filaments slender : anthers narrow, sagittate at the base, curved or coiled. Ovary mostly sessile : stigma orbicular or 2-lobed. Pods usually spreading, slender, terete or nearly so, often torulose.

1. Thelypodium Vaseỳi Coulter. Stems branched near the base, the branches several dm. tall, slender, glabrous, glaucous : stem-leaves several ; blades obovate or oblongobovate, thin, repand-dentate, each narrowed to a clasping base : corolla white, inconspicuous : petals about $3 \mathrm{~mm}$. long: pods in loose racemes, very slender, about $5 \mathrm{~cm}$. long, almost erect, terminating pedicels $6-8 \mathrm{~mm}$. long.

In dry soil, southern Texas. Spring and summer.

\section{HÉSPERIS L.}

Biennial or perennial herbs, the foliage pubescent with simple or forked hairs, sometimes glandular. Stems erect, usually branched. Leaves alternate : blades entire or toothed, or rarely lyrate. Flowers perfect, in racemes or panicles, sometimes fragrant. Sepals 4, erect, equal or 2 gibbous at the base. Corolla white to purple, the 4 petals with claws. Stamens 6. Ovary sessile : stigma 2-lobed, the lobes erect. Ovules numerous. Pods elongated, nearly terete or 4-angled, keeled. Seeds in 1 row in each cavity, marginless and wingless. Cotyledons incumbent. Rocket.

1. Hesperis matronàlís L. Biennial or perennial, roughish pubescent. Stems erect, 3-12 dm. tall, simple or sparingly branched above : leaves $2-15 \mathrm{~cm}$. long; blades of the lower ones elliptic-oblanceolate, those of the upper oblong or ovate-lanceolate, acute or acuminate, denticulate or rarely slightly pinnatifid; petioles about $\frac{1}{3}$ as long as the blades at the base of the plant, very short above: pedicels stout, ascending, finally 10-15 mm. long: sepals oblong, 5-6 mm. long, rounded at the apex: petals white, pink or purple, about thrice as long as the sepals; blades suborbicular or obovate; claws longer than the blades: pods elongated, 5-10 $\mathrm{cm}$. long, spreading or ascending, swollen about the seeds.

In fields and waste places, Massachusetts to Iowa and North Carolina. Spring and summer.

\section{STENOPHRÁGMA Celak.}

Annual or perennial herbs, more or less densely pubescent with branching hairs. Leaves alternate, sometimes mainly basal : blades entire, toothed or pinnatifid. Flowers perfect, in racemes. Sepals 4 . Corolla white : petals 4 , surpassing the sepals. Stamens 
6. Ovary sessile : style short: stigma 2 lobed. Ovules numerous. Pods slender, slightly angled, the valves nerveless. Seeds in one row in each cavity, or sometimes in two rows. Cotyledons incumbent. Wall Cress. Mouse-ear Cress.

1. Stenophragma Thaliàna (L.) Celak. Annual, slender. Stems erect, $0.3-5 \mathrm{dm}$. tall, branched throughout or sometimes simple, glabrous above, pubescent with stiff short hairs near the base: leaves mainly basal, 1-5 $\mathrm{cm}$. long; blades oblong, elliptic or oblanceolate, obtuse, entire or shallowy-toothed; petioles as long as the blades or shorter; stem-leaves similar to the basal but narrower and sessile : pedicels very slender, 4-8 $\mathrm{mm}$. long, spreading or ascending: sepals oblong, $1 \mathrm{~mm}$. long, obtuse: petals white, twice as long as the sepals : pods linear-filiform, 1-1.5 cm. long, spreading or ascending. [Sisymbrium Thaliana (L.) Gay.]

In sandy soil and waste places, Ontario to Minnesota, Massachusetts, Georgia and Missouri. Spring.

\section{BARBARغ̀A R. Br.}

Biennial or perennial herbs, with upright angled stems. Leaves alternate: blades thickish, lyrate-pinnatifid. Flowers perfect, in racemes or panicles. Sepals 4, equal, erect or nearly so. Corolla yellow, the 4 petals with claws. Stamens 6 . Ovary sessile: style short : stigma 2-lobed or nearly capitate. Ovules numerous. Pods elongated, 4-angled, the valves ribbed or keeled. Seeds in 1 row in each cavity, flattish, marginless. Cotyledons accumbent. Scurvy-grass. Wintrer Cress. Rocket.

Capsules slender-pedicelled, obtusely 4-angled : leaf-segments 3-9.

Capsules spreading or ascending.

Capsules erect and appressed.

Capsules stout-pedicelled, acutely 4-angled : leaf-segments 9-17.

1. B. Barbarea.

2. B. stricta.

1. Barbarea Barbarèa (L.) MacM. Glabrous or nearly so. Stems $2-7 \mathrm{dm}$. tall, more or less freely branched : leaves numerous ; those near the base of the stem with pinnatifid blades $5-15 \mathrm{~cm}$. long, the terminal segments much larger than the several lateral ones, mostly repand ; upper leaves mostly sessile or clasping, toothed or incised : racemes many-flowered, elongating : corolla bright yellow, $6-8 \mathrm{~mm}$. broad : petals about twice as long as the narrow sepals : pods spreading or ascending, $2-2.5 \mathrm{~cm}$. long, obscurely 4 angled. [Barbarea vulgaris R. Br.]

In fields and waste places, Labrador to New York and middle Georgia ; also locally in the interior and on the Pacific coast. Spring.

2. Barbarea strícta Andrz. Glabrous. Stems $2-6 \mathrm{dm}$. tall, simple below or branched at the base and above : leaves alternate, $5-15 \mathrm{~cm}$. long; blades oblong to oblanceolate in outline, pinnatifid, the segments $3-8$, entire or repand, the terminal one much larger than the lateral ones: pedicels erect, $2-5 \mathrm{~mm}$. long : sepals oblong or oblong-lanceolate, $3.5-4 \mathrm{~mm}$. long, obtuse: petals yellow, spatulate, twice as long as the sepals : pods slender, obtusely 4 -angled, $2-2.5 \mathrm{~cm}$. long, erect or appressed against the rachis.

In waste places and fields, Quebec to the Northwest Territory, Florida and Nebraska. Spring.

3. Barbarea praècox (J. E. Smith) R. Br. Glabrous or nearly so. Stems usually branched at the base, the branches erect or ascending, 1-6 dm. tall, simple or branched: leaves alternate, $2-15 \mathrm{~cm}$. long; blades pinnatifid, the segments $9-17$, variable in shape, more or less strongly toothed, the terminal one much larger than the rest; petioles often ciliate : pedicels $2-5 \mathrm{~mm}$. long, spreading or ascending, very stout : sepals oblong to oblonglanceolate, $3-3.5 \mathrm{~mm}$. long, obtuse : petals yellow, spatulate, at least twice as long as the sepals : pods stoutish, $3.5-8 \mathrm{~cm}$. long, ascending or spreading, sharply 4-angled, not much thicker than the pedicels.

In fields and waste places, New York to Washington, Florida and California. Spring.

\section{ERÝSIMUM L.}

Annual or biennial herbs, the foliage usually pubescent with forked hairs. Stems erect, often branching. Leaves alternate : blades entire, toothed or lobed. Flowers perfect, in terminal racemes. Sepals 4, erect, equal, 2 gibbous at the base. Corolla yellow, the petals 4, with spreading blades. Stamens 6 : filaments free and unappendaged. Ovary sessile: style short or elongated: stigma 2-lobed. Ovules numerous. Pods elongated, flattish, nearly terete or 4 -angled, the valves often keeled by a strong nerve. Seeds in 1 row in each cavity, marginless, or margined at the top. Cotyledons incumbent or nearly accumbent. 
1. Erysimum cheiranthoìdes L. Minutely strigillose. Stems erect, 1-7 dm. tall, simple or much branched : leaf-blades lanceolate to linear or rarely oblong, $2-10 \mathrm{~cm}$. long, acute or obtuse at the apex, entire or repand-dentate, tapering at the base, the lower ones with short petioles : racemes slender, elongating: pedicels 5-12 mm. long, ascending or slightly reflexed : sepals oblong, $2 \mathrm{~mm}$. long: petals yellow, twice as long as the sepals: pods linear, 1-2 $\mathrm{cm}$. long, glabrous, erect, ascending or spreading.

In dry soil or on river banks, Newfoundland to Alaska, North Carolina and Tennessee. Summer. WORMSEED MUSTARD.

2. Erysimum Arkansànum Nutt. More or less densely scabrous and canescent with 2 3-pronged hairs. Stems erect, 6-10 dm. tall, simple or branched : leaf-blades lanceolate, linear or oblong, 3-15 cm. long, entire, repand or the lower ones sometimes pinnatifid: pedicels spreading or ascending, stout, finally $5-10 \mathrm{~mm}$. long : sepals linear-oblong, 10-12 mm. long, rather thin : petals orange-yellow; blades suborbicular or obovate, 9-11 mm. in diameter; claws longer than the blades: pods elongated, spreading or ascending, 4sided, $8-10 \mathrm{~cm}$. long, scabrous.

In dry soil or on prairies, Ohio to Illinois and Texas. Spring.

\section{SINÀPIS L.}

Annual or biennial caulescent herbs, with rough-pubescent foliage. Leaves alternate : blades lobed or pinnatifid. Flowers perfect, in racemes or panicles. Sepals spreading. Corolla mostly yellow, the 4 petals surpassing the sepals. Stamens 6: filaments not toothed. Ovary sessile: style persistent. Ovules numerous. Pods elongated, nearly terete, constricted between the seeds, often hispid, each prolonged into a sword-like beak, which sometimes contains one seed. Seeds thick or subglobose, marginless and wingless. Cotyledons conduplicate. White Mustard.

1. Sinapis álba $L$. Pubescent with rigid spreading hairs. Stems $3-7 \mathrm{dm}$. tall, branched: leaves variable, the basal with obovate pinnatifid blades and long petioles, the upper stem-leaves with narrow, oblong to lanceolate, pinnatifid or coarsely-toothed blades and shorter petioles, or those near the top of the stem sessile : pedicels ascending or spreading, stout, $5-10 \mathrm{~mm}$. long: sepals $4-5 \mathrm{~mm}$. long: petals yellow, much longer than the sepals : pods hispid, the body $8-15 \mathrm{~mm}$. long, constricted below the seeds, the beak flat, as long as the body or longer.

In waste places, cultivated North America. Adventive from Europe and Asia. Summer.

\section{BRÁSSICA L.}

Annual biennial or perennial caulescent herbs, with glabrous glaucous or pubescent foliage. Leaves alternate : blades lobed or pinnatifid, or the upper ones nearly entire. Flowers perfect, in racemes. Sepals 4, sometimes equal at the base. Corollas bright yellow or white, the four petals manifestly clawed. Stamens 6 : filaments free, unappendaged. Ovary sessile : style persistent: stigma truncate or 2-lobed. Ovules numerous. Pods elongated, terete or 4-angled, each prolonged into a conic indehiscent beak, the valves 1-3-nerved. Seeds in one row in each cavity, often subglobose, marginless. Cotyledons conduplicate.

Upper leaf-blades merely sessile.

Pods erect or appressed, short-beaked, less than $2 \mathrm{~cm}$. long : pedicels appressed.

Pods more or less spreading, long-beaked, over $2 \mathrm{~cm}$. long : pedicels not appressed. Stem glabrous, more or less glaucous: pedicels over $6 \mathrm{~mm}$. long at maturity. Stem hispid: pedicels less than $5 \mathrm{~mm}$. long at maturity. Upper leaf-blades clasping.

1. B. nigra.

2. B. juncea.

3. B. arvensis.

4. B. campestris.

1. Brassica nìgra (L.) Koch. Glabrous or sparingly pubescent. Stems 1-2 m. tall, usually widely branched: leaves $5-20 \mathrm{~cm}$. long; blades more or less deeply lyrate-pinnatifid, petioled, the segments $3-5$, various, the terminal one largest, or the upper leaves simply toothed or entire, narrow : racemes slender: pedicels slender, 2-4 mm. long, erect: sepals narrowly oblong, $4 \mathrm{~mm}$. long : petals bright yellow, about twice as long as the sepals ; blades broadened upward; claws slender, longer than the blades : pods erect or appressed, 1-1.5 cm. long, somewhat constricted between the seeds, each abruptly constricted into a slender beak. [Sinapis nigra L.]

In waste places and fields, southern British America and the United States. Naturalized from Europe. Summer and fall. Black Mustard. 
2. Brassica júncea (L.) Cosson. Glabrous, more or less glaucous. Stems 3-17 dm. tall, usually sparingly branched : leaves $5-17 \mathrm{~cm}$. long or shorter on the upper part of the plant; blades oblong to oval on the lower part of the plant, narrower above, all coarsely toothed or lyrate-pinnatifid, none of them clasping: racemes elongated : pedicels $6.5-10$ $\mathrm{mm}$. long, not appressed : sepals narrow, $3.5-4.5 \mathrm{~mm}$. long: petals yellow, fully twice as long as the sepals : pods slender, $2.5-4.5 \mathrm{~cm}$. long, the subulate beak about $\frac{1}{3}$ or $\frac{1}{4}$ as long as the body.

In waste places, New Hampshire to Michigan, Kansas and Georgia. Adventive or naturalized from Asia. Spring and summer.

3. Brassica arvénsís (L.) B.S.P. Hispid. Stems 3-6 dm. tall, more or less branched above: basal and lower leaves coarsely toothed or lyrate-pinnatifid, the terminal segment several times longer than the others; upper leaves ovate, lanceolate, or obovate, coarse-toothed, sessile or nearly so, not clasping: pedicels ascending or erect, 3-5 mm. long: sepals spreading, oblong, 5-6 $\mathrm{mm}$. long, obtuse : petals yellow, spatulate, twice as long as the sepals: pods slender, $2-3.5 \mathrm{~cm}$. long, the body slightly constricted between the seeds, the beak nearly $\frac{1}{2}$ as long as the body, sometimes 1-seeded, the valves strongly nerved. [Sinapis arvensis L.]

In waste places and fields, throughout North America, except the extreme north. Adventive from Europe. Spring to fall. CHARLOCK. WiLd Mustard.

4. Brassica campéstris L. Glabrous, more or less glaucous. Stems $3-6 \mathrm{dm}$. tall, simple or widely branching: lower leaves 1-3 dm. long, with short petioles and lyrate-pinnatifid blades; upper leaves shorter than the lower, sessile, clasping, entire or toothed: racemes elongating : pedicels ascending, 1-2 cm. long : sepals oblong, 3-5 cm. long : petals bright yellow, twice or thrice longer than the sepals : pods slender, terete, $3-7 \mathrm{~cm}$. long, each narrowed into a beak often $1 \mathrm{~cm}$. long: seeds dark brown.

In waste places and cultivated grounds, southern British America and the United States. Adventive from Europe. Spring to fall. TURNIP.

\section{CAKILE Gaertn.}

Annual chiefly maritime fleshy caulescent herbs, with glabrous foliage. Leaves alternate: blades entire or pinnatifid. Flowers perfect, in racemes. Sepals erect, somewhat gibbous at the base. Corolla white to purple, the 4 petals surpassing the sepals. Stamens 6 : filaments not toothed. Ovary sessile: style wanting: stigma entire. Ovule solitary. Pods indehiscent, 2-jointed, the joints 1-celled, 1-seeded, or the lower joint 2-seeded. Cotyledons accumbent. The plants flower from spring to fall, or throughout the year in the South. Sea Rocket.

Lower joint of the pod 2-seeded.

Upper joint of the pod coarsely 8-ridged, over $1 \mathrm{~cm}$. long.

Upper joint of the pod delicately 4-ridged, less than $1 \mathrm{~cm}$. long.

Lower joint of the pod 1-seeded.

Upper joint of the pod slender, slightly, if at all, thicker than the lower.

Upper joint of the pod swollen, markedly thicker than the lower.

Pod without lateral projections at the node, the upper joint not constricted.

Pod with a 4-ridged upper joint.

Pod with a 6-10-ridged upper joint.

Facial ridges of the upper joint 8 , sharp.

Facial ridges of the upper joint 6 or 10 , rounded. Upper joint 6-ridged. Upper joint 10-ridged.

1. C. geniculata.

2. C. fusiformis.

3. C. Americana.

4. C. edentula.

5. C. Harperi.

6. C. Chapmanii.

7. C. Cubensis.

Pod with 2 lateral projections at the node, the upper joint much constricted. 8. C. Cakile.

1. Cakile geniculàta (Robinson) Millsp. Stout, glabrous. Stem branched and more or less spreading, 1-4 dm. long: leaves 3-7 cm. long; blades oblanceolate or linearoblanceolate, entire, or with a few coarse rounded teeth, tapering into short petioles : racemes becoming 1-2 dm. long, the rachis strongly geniculate : pedicels very stout, spreading or somewhat ascending, 3-6 mm. long : sepals narrowly oblong, $2.5-3 \mathrm{~mm}$. long, obtuse : pods stout, about $2.5 \mathrm{~cm}$. long; lower joint narrowly turbinate, with a prominent border at the top ; upper joint lanceolate or oblong-lanceolate in outline, usually curved, twice as long as the lower one, both joints prominently 8-ribbed.

In sand, on the coast of Texas.

2. Cakile fusifórmis Greene. Not especially fleshy. Stems erect or branched and spreading, 3-7 dm. long, of rather firm tissues : leaves $5-15 \mathrm{~cm}$. long; blades ovate in outline, laciniate-pinnatifid, obtuse, the segments linear, ascending or spreading; petioles shorter than the blades : racemes greatly elongating, finally $2-4 \mathrm{dm}$. in length : pedicels ascending, 1-4 mm. long: sepals linear-oblong, $3.5-4 \mathrm{~mm}$. long, obtuse : pods slender, $1.5-2.5 \mathrm{~cm}$. long; lower joint turbinate to cylindric-turbinate; upper joint subulate or lanceolatesubulate, longer than the lower, delicately 4-ridged, the lower joint nearly terete.

In sand, Florida Keys to Mississippi. Also in Cuba. 
3. Cakile Americàna Nutt. Rather stout. Stem simple or branched throughout, zigzag : leaves $2.5-7 \mathrm{~cm}$. long; blades oblanceolate to spatulate, toothed near the apex, or sometimes slightly incised : racemes somewhat elongating at maturity : pedicels ascending, $3-6 \mathrm{~mm}$. long: sepals $3-4 \mathrm{~mm}$. long : pods relatively slender, $1.5-2 \mathrm{~cm}$. long; lower joint oblong-clavate, 4-angled and with delicate facial ridges; upper joint fusiform, slenderbeaked, 8-angled by the prominent facial ridges, thin-walled, larger than the lower joint.

In sand on the Atlantic coast, Connecticut to South Carolina; also along the Great Lakes.

4. Cakile edéntula (Bigel.) Hook. Fleshy. Stems erect or decumbent, 1-3 dm. long, more or less diffusely branched, the branches spreading below, ascending or erect above: leaves succulent; blades oblanceolate or oblong-lanceolate, or rarely obovate, 2-15 $\mathrm{cm}$. long, obtuse, coarsely toothed or lobed : pedicels stout, ascending, 1-5 mm. long: sepals oblong, about $4 \mathrm{~mm}$. long: petals light purple; claws slender, longer than the blades: pods 1.5-2 cm. long; lower joint oblong or obovoid, 4-angled or 4-ribbed; upper joint ovoid or oblong-ovoid, usually longer than the lower, 4-angled near the base, more or less flattened above, the apex truncate or retuse.

In sand, chiefly on beaches, Labrador to Florida, and along the Great Lakes to Minnesota. Also in California.

5. Cakile Hárperi Small. Similar to C. edentula in habit, but often more robust. Leaves succulent; blades spatulate to oblanceolate, $3-11 \mathrm{~cm}$. long, crenate or incised-crenate : pedicels very stout, $1-2 \mathrm{~mm}$, or rarely $3 \mathrm{~mm}$. long : sepals $2-2.5 \mathrm{~mm}$. long : pods 2-2.5 $\mathrm{cm}$. long; lower joint slightly broadened upward, finely several-ridged ; upper joint oblongconic, often twice as long as the lower one, the faces with 8 sharp ridges.

On sandy beaches, South Carolina to Florida.

6. Cakile Chapmànii Millsp. Fleshy. Stems more or less branched, ascending or prostrate, $2-7 \mathrm{dm}$. long, the branches spreading: leaves $2-10 \mathrm{~cm}$. long; blades oblong or oblanceolate, obtuse, undulate or sometimes coarsely-toothed, mostly longer than the petioles: pedicels ascending or spreading, rather stout, 4-6 $\mathrm{mm}$. long: sepals narrowly oblong, $3.5-4 \mathrm{~mm}$. long: petals pale purple ; blades cuneate-obovate : pods $1.5-2 \mathrm{~cm}$. long; lower joint enlarged upward, sometimes globular, nearly terete ; upper joint fusiform-lanceolate, acuminate and acute, 6-ridged, $\frac{1}{3}$ longer than the lower one. [C. maritima var. aequalis Chapm., not L'Her. $]$

In drifting sand, Florida to Mississippi. BEACH-SAP.

7. Cakile Cubénsis Kunth. Relatively slender. Stem widely branched : leaves few ; blades oblanceolate to broadly linear, $3-8 \mathrm{~cm}$. long or longer, entire or crenate to dentate : pedicels 1-2 mm. long: pods quite slender, about $1.8 \mathrm{~cm}$. long; lower joint nearly terete, obconic to turbinate : upper joint conic or ovoid-conic, mostly over $1 \mathrm{~cm}$. long, 10-ridged, not constricted at the base.

In sand, Florida Keys. Also in the West Indies and Central America.

8. Cakile Cakile (L.) Karst. Stem spreading : leaves with pinnatifid blades, the segments linear: pods about $2 \mathrm{~cm}$. long, lower joint dilated at the top, flattened; upper joint mitre-like, about $1.5 \mathrm{~cm}$. long, constricted near the base, with broad ridges and a slender beak.

About seaports, New Jersey and North Carolina. Adventive from Europe.

\section{KÒNIGA ${ }^{1}$ Adans.}

Annual or perennial caulescent herbs or shrubs, the foliage pubescent with branched hairs. Stems erect or decumbent. Leaves alternate : blades entire, narrow. Flowers perfect, in racemes or panicles. Sepals 4. Corolla white: petals 4, entire, with claws, surpassing the sepals. Stamens 5 : filaments with two small glands at the base. Ovary sessile : style slender. Ovule usually solitary in each cavity. Silicles flat, ovate to suborbicular. Seed solitary. Cotyledons accumbent. Sweet Alyssum.

1. Koniga marítima (L.) R. Br. Annual, pubescent with minute appressed hairs. Stems usually branched at the base, the branches ascending or decumbent, more or less forked: basal leaves oblanceolate; stem-leaves narrowly oblanceolate, linear or linear-lanceolate, 1-5 cm. long, acute, entire, sessile : flowers fragrant : pedicels spreading, or ascending, 6$8 \mathrm{~mm}$. long: sepals oblong or ovate, $1-1.5 \mathrm{~mm}$. long, obtuse : petals white, broadly spatulate, twice or thrice longer than the sepals: pods oval to suborbicular, 2-3 mm. long, acute. [Alyssum maritimum (L.) Lam.]

In waste places, southern British America and the United States generally. Summer. Naturalized from Europe.

${ }^{1}$ Originally spelled Konig; latinized by R. Brown in 1826. 


\section{DRABA L.}

Low annual or perennial scapose or caulescent herbs, often clothed with stellate pubescence. Leaves alternate or basal : blades entire or toothed. Flowers perfect, in racemes. Sepals 4, equal. Corolla white or yellow, sometimes pink or purple: petals 4, longer than the sepals. Stamens 6. Ovary sessile : style short or elongated: stigma capitate. Ovules 2 -several in each cavity. Silicles elliptic to linear, flat : valves nerveless. Seeds in 1 row in each cavity. Cotyledons usually accumbent. Whitlow Grass.

Annuals or often winter-annuals : pods not spirally twisted : petals about twice as long as the sepals.

Petals 2-cleft.

Petals entire, erose or emarginate.

Leaf-blades entire.

Pods glabrous.

Pods pubescent.

Leaf-blades toothed.

Pods $5-15 \mathrm{~mm}$. long: sepals $2 \mathrm{~mm}$. long.

Pods linear, oblong-linear or narrowly oblong.

Racemes elongated : pods over $7 \mathrm{~mm}$. long.

Racemes umbel-like or corymbose: pods less than $7 \mathrm{~mm}$. long. Pods elliptic.

Pods 2-3 mm. long: sepals barely $1 \mathrm{~mm}$. long.

Perennial : pods spirally twisted: petals thrice as long as the sepals.

1. D. verna.

2. D. Caroliniana

3. D. micrantha.

1. Draba vérna L. Annual, acaulescent, bright green. Leaves basal ; blades spatulate, oblanceolate or narrowly oblong, $5-15 \mathrm{~mm}$. long, obtuse or acute, entire or with several teeth near the apex, pubescent with stellate hairs : scapes erect or ascending, usually branched at the base, glabrous : pedicels filiform, ascending, $0.5-2 \mathrm{~cm}$. long : sepals oblong or oval, $1 \mathrm{~mm}$. long, obtuse : petals white, cuneate, 2-cleft, twice as long as the sepals : pods elliptic or oblong-elliptic, or sometimes oval, 5-9 $\mathrm{mm}$. long.

In fields and waste places, widely distributed in southern British America and the United States. Winter and spring.

2. Draba Caroliniàna Walt. Annual, more or less hispid, especially below. Leaves approximate; blades oblong, obovate, spatulate or suborbicular, $0.5-1.5 \mathrm{~cm}$. long, obtuse, entire, or with several shallow teeth : scapes erect or ascending, often glabrous above, 2-10 $\mathrm{cm}$. long: pedicels ascending or spreading, 1-8 mm. long: sepals oblong, 2-2.5 mm. long, obtuse : petals white, spatulate-obovate, rounded or emarginate at the apex, about twice as long as the sepals : pods linear, $7-18 \mathrm{~mm}$. long, glabrous.

In sandy soil and on rocks, Massachusetts to Minnesota, Georgia and Arkansas, Spring.

3. Draba micrántha Nutt. Similar to $D$. Caroliniana in habit, but commonly more branched at the base. Leaves mostly at the base of the plant; blades spatulate to cuneate or oblong, entire : scapes erect or spreading, longer than the stems : racemes abbreviated : pedicels $2-4 \mathrm{~mm}$. long : sepals ovate or oblong-ovate : petals white, about as large as those of $D$. Caroliniana, or those of the later flowers much smaller or obsolete : pods linear, 12-18 $\mathrm{mm}$. long, often slightly curved, pubescent.

In sandy soil, Illinois to Washington, Texas and California. Spring.

4. Draba cuneifolia Nutt. Annual, pubescent with stellate hairs. Stems 1-10 cm. long, simple or branched : leaves approximate; blades cuneate, obovate or the lower sometimes spatulate, 1-3 cm. long, obtuse or acutish, entire or coarsely toothed above : peduncles erect or spreading, 3-20 cm. long: pedicels finally $2-7 \mathrm{~mm}$. long, spreading or somewhat ascending : sepals oblong, $2 \mathrm{~mm}$. long, obtuse": petals white, broadly spatulate, with a broad sinus at the apex: pods linear-oblong, $8-15 \mathrm{~mm}$. long, minutely pubescent with simple hairs.

In fields and on cliffs, Illinois to California, Florida and Texas. Spring.

5. Draba Hélleri Small. Annual, dwarf, scabrous-pubescent or merely puberulent above. Leaves mainly basal, rather crowded ; blades spatulate to oblong, 4-11 mm. long, slightly toothed, acute or acutish : scapes spreading or ascending, 1-4 cm. long, usually 4-8 together, rough puberulent to the top : racemes abbreviated or congested : pedicels ascending or spreading, 1-3 mm. long, puberulent like the scape : sepals oblong or ovateoblong, about $1 \mathrm{~mm}$. long: petals white : pods narrowly oblong, 2-6 mm. long, minutely pubescent.

In dry or sandy soil, near Corpus Christi, Texas. Spring.

6. Draba platycárpa T. \& G. Annual, finely pubescent all over. Leaves on the lower part of the plant, but not crowded ; blades 1-2 $\mathrm{cm}$. long, those of the basal and lower cauline leaves cuneate to oblong, those of the upper cauline oblong-lanceolate to lanceolate, acute or acutish, all more or less serrate, usually rather coarsely so : scapes slender, longer 
than the stems, simple or branched, $5-25 \mathrm{~cm}$. high : racemes elongated : pedicels spreading or somewhat ascending, 4-9 $\mathrm{mm}$. long: sepals oblong, about $1.5 \mathrm{~mm}$. long: petals white : pods elliptic, $6-7.5 \mathrm{~mm}$. long, finely pubescent.

In dry soil, Texas to Arizona. Spring.

7. Draba brachycárpa Nutt. Annual, thinly pubescent with stellate hairs. Stems simple or usually branched at the base ; branches erect or ascending, 2-20 cm. long, leafy to the racemes : leaves $5-15 \mathrm{~mm}$. long; blades oblong or oblong-lanceolate, or the basal with ovate to obovate blades : racemes narrow, 1-10 $\mathrm{cm}$. long, pedicels 1-3 mm. long, ascending or nearly divaricate : sepals oval or oblong, less than $1 \mathrm{~mm}$. long: petals white, longer than the sepals or wanting: pods oblong, about as long as the pedicels, glabrous, acute.

In fields and dry soil, Virginia to Missouri, Georgia and Texas. Spring.

8. Draba ramosíssima Desv. Perennial, more or less densely pubescent with stellate hairs. Stems decumbent or creeping, the branches erect, 1-3 dm. tall, simple below, corymbose above : leaves mainly basal ; blades narrowly oblong, oblanceolate or cuneate-oblanceolate, 1-4 cm. long, acute, remotely dentate with spreading teeth : racemes in terminal corymbs : pedicels ascending, $5-10 \mathrm{~mm}$. long : sepals oblong-lanceolate, $3 \mathrm{~mm}$. long, obtuse : petals white, spatulate, about thrice as long as the sepals, rounded at the apex : pods narrowly oblong, 5-12 $\mathrm{mm}$. long, spirally twisted at maturity, acuminate.

On cliffs or rocky banks, Virginia to Kentucky, North Carolina and Tennessee. Spring.

\section{DENTÀRIA L.}

Erect scapose herbs, perennial by horizontal rootstocks. Leaves basal. Bracts usually similar to the leaves, opposite or 3 or 4 in a whorl or approximate above the middle of the scape : blades palmately cleft or 3-divided, the segments toothed or incised. Flowers perfect, in terminal racemes or corymbs. Sepals 4, equal at the base. Corolla white or purple : petals with spreading blades and slender claws. Stamens 6. Ovary sessile : style slender : stigma entire or rarely 2 -lobed. Ovules numerous. Pods elongated, flattish or nearly terete, the valves nerveless, or with a faint midnerve, elastically dehiscent from the base. Seeds in 1 row in each cavity, not margined, somewhat flattened. Cotyledons accumbent. The plants flower in the spring. ToOTHWORT.

Blades of basal and stem-leaves similar.

Leaf-segments linear.

Leaf-segments 1-2-parted.

Leaf-segments entire, toothed or merely incised.

Leaf-segments not linear.

Rootstocks tuberous, moniliform, not scaly : leaf-segments laciniate.

Rootstocks elongated, continuous, scaly : leaf-segments toothed or incised.

Leaf-segments incised, with narrow, very acute, often flaring teeth.

Leaf-segments not incised, with broad, blunt or merely mucronate teeth. Blades of basal and stem-leaves very dissimilar.

1. D. multifida.

2. D. furcata.

3. D. laciniata.

4. D. incisa.

5. D. diphylla.

6. D. heterophylla.

1. Dentaria multífida Muhl. Rootstocks continuous. Foliage glabrous or nearly so : leaves nearly 3 -foliolate, with long petioles and once or twice pinnately parted segments, the ultimate segments linear, entire or sparingly toothed : scapes erect, $2-3 \mathrm{dm}$. tall, simple : bracts 2, with short petioles, and blades similar to those of the leaves: pedicels ascending, 1.5-2 cm. long: sepals oblong, 5-6 mm. long, obtuse : petals white, almost twice as long as the sepals : pods slender, ascending, $3 \mathrm{~cm}$. long, long-beaked.

In rocky woods, North Carolina to Tennessee, Georgia and Alabama.

2. Dentaria furcàta Small. Rootstocks moniliform. Foliage sometimes pubescent: leaves with long petioles and 3 linear entire toothed or merely incised segments: scapes erect, $2-3 \mathrm{dm}$. tall, simple : bracts 3 , the blades similar to those of the leaves : pedicels $1-2.5$ $\mathrm{cm}$. long: sepals oblong to oblong-lanceolate, $5-6 \mathrm{~mm}$. long: petals pink or whitish, 12-14 $\mathrm{mm}$. long: pods narrowly fusiform, fully $3 \mathrm{~cm}$. long, the slender beak nearly $1 \mathrm{~cm}$. long.

In moist or rich woods, Ohio to Tennessee and Alabama.

3. Dentaria laciniàta Muhl. Rootstocks jointed. Foliage glabrous or sometimes finely pubescent: leaves with long petioles and 3 linear-lanceolate or oblong coarsely serrate or incised segments : scapes erect, $1-3.5 \mathrm{dm}$. tall : bracts 3 , the blades similar to those of the leaves : pedicels ascending, stout, $1-2 \mathrm{~cm}$. long : sepals oblong, 5-6 mm. long, obtuse: petals pink or purple, twice or thrice as long as the sepals : pods slender, $3-5 \mathrm{~cm}$. long, long-beaked.

In woods, Quebec to Minnesota, Florida and Louisiana. PEPPER-Root.

4. Dentaria incìsa Small. Rootstocks continuous, scaly. Foliage glabrous : leaves with long petioles and 3 ovate or lanceolate segments conspicuously incised with narrow 
more or less flaring acute teeth : scapes erect, $2-3 \mathrm{dm}$. tall : bracts 3 , with blades similar to those of the leaves: pedicels ascending, $1-1.5 \mathrm{~cm}$. long, or longer at maturity : sepals oblong, 5-6 mm. long, obtuse : petals about twice as long as the sepals : pods not seen.

In open woods, Tennessee. Spring.

5. Dentaria diphýlla Michx. Rootstocks continuous. Foliage glabrous : leaves with long petioles and 3 ovate or lanceolate crenate-serrate segments: scapes erect, 1-3 dm. tall: bracts 2 , with blades similar to those of the leaves: pedicels $2-3 \mathrm{~cm}$. long, ascending: sepals oblong, 5-6 mm. long, obtuse : petals white, twice as long as the sepals : pods slender, $2-3 \mathrm{~cm}$. long.

In rich woods and damp soil, Nova Scotia to Minnesota, South Carolina and Kentucky. Spring.

6. Dentaria heterophýlla Nutt. Rootstocks jointed. Foliage glabrous or sparingly pubescent: leaves with long petioles and ovate or obovate coarsely crenate or lobed segments, the teeth or lobes mucronulate: scapes $2-3 \mathrm{dm}$. tall : bracts usually 2 , with blades very unlike those of the leaves, divided into linear or linear-lanceolate entire or serrate segments: pedicels ascending, $2-2.5 \mathrm{~cm}$. long: sepals oblong, about $5 \mathrm{lmm}$. long, obtuse : petals light purple, twice as long as the sepals : pods slender, about $2.5 \mathrm{~cm}$. long, narrowed at each end, beaked.

In woods, New Jersey and Pennsylvania to Georgia and Tennessee. Spring.

\section{CARDAMİNE L.}

Annual or perennial herbs, with erect or weak and creeping stems. Leaves alternate : blades entire or pinnately dissected. Flowers perfect, in racemes or panicles. Sepals 4, equal or nearly so. Corolla white or pink, or purple : petals 4, narrowed into claws. Stamens 6 or rarely 4 . Ovary sessile : style short or elongated : stigma capitate or 2-lobed. Ovules numerous. Pod elongated, narrow, flattened, often erect, the valves nerveless or nearly so, elastically opening at maturity. Seeds in 1 row, not margined. Cotyledons accumbent, one sometimes overlapping the radicle. Bitter Cress.

Leaf-blades entire or undulate.

Stems erect from a tuberous base.

stems decumbent from a creeping base.

Leaf-blades, at least those of cauline leaves, pinnately divided.

Basal leaves with entire or repand blades.

Stems decumbent: sepals $1-1.5 \mathrm{~mm}$. long: petals $2-3 \mathrm{~mm}$. long: pods 2-2.5 cm. long.

Stems erect: sepals $3-3.5 \mathrm{~mm}$. long: petals $6-9 \mathrm{~mm}$. long : pods $3-3.5 \mathrm{~cm}$. long.

Basal leaves with pinnately divided blades.

Stems leafy.

Pods spreading or ascending, over $1 \mathrm{~mm}$. broad.

Pods erect, less than $1 \mathrm{~mm}$. broad.

Corolla $3 \mathrm{~mm}$. wide or narrower.

Corolla $4 \mathrm{~mm}$. wide or broader.

Sepals about $1 \mathrm{~mm}$. long.

Sepals about $2 \mathrm{~mm}$. long.

Stems scape-like : leaves basal or mainly so.

1. C. bulbosa.

2. C. rotundifolia.

3. C. curvisiliqua.

4. C. Clematitis.

5. C. flexuosa.

6. C. parviflora.

7. C. arenicola.

8. C. Pennsylvanica.

9. C. hirsuta.

1. Cardamine bulbòsa (Schreb.) B.S.P. Perennial by tuberous rootstocks, glabrous. Stems erect, $1-5 \mathrm{dm}$. tall, simple or branching above, destitute of runners : leaves few ; basal and lower stem-leaves with suborbicular, often cordate, entire or angled blades and long petioles; upper leaves sessile or nearly so, with more or less elongated entire angled or coarsely toothed blades : pedicels ascending, 1-2 cm. long: sepals oblong, 2.5$3.5 \mathrm{~mm}$. long, obtuse : petals white or pink, about thrice as long as the sepals or sometimes four times longer : pods slender, linear, $2.5 \mathrm{~cm}$. long. [Cardamine rhomboidea DC.]

In swampy meadows and low grounds, Nova Scotia to Minnesota, Florida and Texas. Spring.

2. Cardamine rotundifòlia Michx. Annual or perennial, glabrous. Stems weak, ascending, or prostrate and creeping, $1-4 \mathrm{dm}$. long, prodncing runners : leaves few ; blades ovate, oval or suborbicular, $1-4 \mathrm{~cm}$. long, entire, undulate or angled, rarely accompanied by two small lateral segments, petioled : pedicels ascending, 1-2.5 cm. long, slender : sepals oblong, $2 \mathrm{~mm}$. long, obtuse : petals white, about 4 times as long as the sepals: pods slender, linear, $2-3 \mathrm{~cm}$. long, beaked.

In springy places, New Jersey to Ohio, North Carolina and Kentucky. Spring and summer.

3. Cardamine curvisíliqua Shuttl. Perennial, aquatic, glabrous. Stems weak, decumbent, 3-8 dm. long, creeping, branching: leaves various, the lower ones simple, with suborbicular blades and long petioles, the upper ones pinnate; segments $3-7$, oval or obovate, 1-3 $\mathrm{cm}$. long, undulate or slightly lobed, attenuate at the base : raceme elongating, with a zigzag rachis: pedicels ascending or spreading, $5-10 \mathrm{~mm}$. long: sepals oblong, $1-1.5 \mathrm{~mm}$. long, obtuse: petals white, $2-3 \mathrm{~mm}$. long: pods slender, $2-2.3 \mathrm{~cm}$. long, nearly terete, curving upward.

In springs and slow streams, Florida. Spring to fall. 
4. Cardamiue Clematìtis Shuttl. Perennial by elongated rootstocks, glabrous, dark green. Stems erect, $1-3 \mathrm{dm}$. tall, often tufted, simple or rarely sparingly branched above : leaves various, the lower ones with entire suborbicular or reniform more or less angular blades, or sometimes 3-foliolate; upper leaves entire or nearly 3 -foliolate, the segments various: pedicels ascending, 5-12 mm. long: sepals oblong or ovate-oblong, 3-3.5 mm. long, obtuse: petals white, twice or thrice as long as the sepals: pods slender, narrowly linear, $3-3.5 \mathrm{~cm}$. long, beaked, ascending.

In springy places at high altitudes, Virginia to North Carolina and Alabama. Spring and summer.

5. Cardamine flexuòsa With. Annual or perennial, glabrous, dark green. Stems ascending or spreading, often weak, 1-4 dm. long, leafy, simple or usually branching: leaf-blades pinnately divided or pinnatifid, 1-7 cm. long, the segments broadest above the middle, the terminal one cuneate or cordate at the base : pedicels spreading or ascending, $5-10 \mathrm{~mm}$. long: sepals oblong, 1.5-2 mm. long: petals white, about twice as long as the sepals : pods narrowly linear, $1.5-2 \mathrm{~cm}$. long, slightly flattened, ascending or irregularly spreading, beaked.

In mountain swamps and woods, Maine to Michigan and North Carolina. Also in Europe and Asia. Spring and summer.

6. Cardamine parviflòra L. Annual, slender, glabrous or sparingly pubescent. Stems erect, 0.5-3 dm. tall, often zigzag, more or less branched, sometimes nearly filiform : leaves few ; blades 1-5 cm. long, pinnate, the segments narrow, broadest above the middle, the terminal one sometimes suborbicular: pedicels ascending, 4-10 mm. long: sepals oblong, $1 \mathrm{~mm}$. long, scarious-margined, obtuse : corolla barely $3 \mathrm{~mm}$. broad: petals white, about twice as long as the sepals : pods narrowly linear, $1.5-2.5 \mathrm{~cm}$. long, short-beaked.

In dry soil and on rocky banks, Quebec to Oregon, southward on the mountains to Georgia. Also in Europe and Asia. Spring.

7. Cardamine arenícola Britton. Annual, glabrous. Stems usually much branched at the base, the branches erect or ascending, 1-3 dm. tall, leafly to the inflorescence: leafblades pinnately divided, 1-4 cm. long, the segments linear or linear-oblong, obtuse or acutish, entire or with 1-2 small teeth: pedicels ascending, 4-6 $\mathrm{mm}$. long: sepals oblong, about $1 \mathrm{~mm}$. long: corolla fully $4 \mathrm{~mm}$. broad: petals white, nearly twice as long as the sepals, obtuse : pods slender, linear, $2 \mathrm{~cm}$. long, erect.

In moist, usually sandy soil, Connecticut to Kentucky, Florida and Tennessee. Spring.

8. Cardamine Pennsylvánica Muhl. Annual, fleshy, glabrous or nearly so. Stems erect, $2-10 \mathrm{dm}$. tall, more or less branched, leafy, the branches ascending : leaves variable ; blades $4-15 \mathrm{~cm}$. long, pinnate, the segments undulate, toothed or lobed, the terminal one much the largest, more or less cuneate at the base: pedicels 4-10 $\mathrm{mm}$. long, ascending : sepals oblong, about $2 \mathrm{~mm}$. long, obtuse : corolla fully $4 \mathrm{~mm}$. broad: petals white, about twice as long as the sepals : pods linear-filiform, ascending, $2-2.5 \mathrm{~cm}$. long, beaked.

In swamps and low grounds, Newfoundland to Minnesota, Florida and Missouri. Spring.

9. Cardamine hirsùta L. Annual, slender, more or less densely pubescent. Stems erect, $0.5-2.5 \mathrm{dm}$. long, simple or branched throughout: leaves mainly basal, 1-6 cm. long; blades pinnate, the segments broadest above the middle, entire or slightly lobed, the terminal one cuneate or subcordate at the base : pedicels erect or ascending, 4-8 mm. long: sepals oblong, 1-1.5 mm. long, obtuse, usually pubescent at the apex : petals white, about twice as long as the sepals : pods narrowly linear, $2-2.5 \mathrm{~cm}$. long, erect, not beaked.

In dry or moist soil, Massachusetts to Michigan, North Carolina and Georgia. Also in Europe and Asia. Spring.

\section{LEAVENWÓRthia Torr.}

Low annual or biennial herbs, with scape-like, often tufted, stems and glabrous foliage, or the pubescence, if present, of simple hairs. Leaves mainly basal : blades lyrate-pinnatifid. Flowers perfect, solitary or a few in racemes. Sepals 4, narrow, equal at the base. Corolla white, yellow or purplish : petals 4 , broadened upward. Stamens 6 : filaments few, unappendaged. Ovary short-stalked: style slender: stigma 2-lobed. Ovules numerous or few. Pods elongated, somewhat inflated, often contracted between the seeds, the valves nerveless. Seeds flattened, in 1 row in each cavity, winged. Embryo straight or nearly so. Cotyledons as broad as long. The plants flower in the spring.

Cotyledons orbicular, cordate : radicle straight.

1. L. aurea.

Cotyledons, oval : radicle oblique.

Capsules not constricted between the seeds.

Petals with white or purplish blades: styles less than $3 \mathrm{~mm}$. long.

Petals with yellow blades: style over $3 \mathrm{~mm}$. long.

Capsules constricted between the seeds. 
1. Leavenworthla aùrea Torr. Foliage glabrous. Stems erect or decumbent, 4-15 cm. long, often branched at the base : leaves mainly basal, a few on the stems; blades divided into 5-9 angular-toothed segments, the terminal one largest: pedicels $1-4 \mathrm{~cm}$. long, ascending, often curved : sepals oblong, 3.5-4 mm. long, obtuse : petals yellow, or purplish with a yellow base, twice as long as the sepals, narrowly cuneate, retuse at the apex: pods linear-oblong, not torulose, $1.5-2 \mathrm{~cm}$. long, each tipped with a slender style 1-2 mm. long: seeds.4-14: cotyledons orbicular, cordate ; radicle straight.

On rocks, Arkansas to Tennessee, south to Alabama and Texas.

2. Leavenworthia uniflòra (Michx.) Britton. Foliage glabrous or nearly so. Stems $2-15 \mathrm{~cm}$. long, erect or ascending, simple or sparingly branched : leaves mainly basal, 2-10 cm. long; blades divided into 5-17 unequal toothed or angular segments, the terminal one "larger than the rest: pedicels $2-15 \mathrm{~cm}$. long, erect or ascending : sepals oblong, obtuse: petals white or purplish, with a yellow base, cuneate-oblanceolate, retuse at the apex: pods linear-oblong, $2.5-3.5 \mathrm{~cm}$. long, each tipped with a stout style $1 \mathrm{~mm}$. long: seeds 4-18: cotyledons oval; radicle oblique. [L. Michauxii Torr.]

In dry soil, Indiana to Missouri, Tennessee and Alabama.

3. Leavenworthia stylòsa A. Gray. Foliage glabrous. Stems $2-12 \mathrm{~cm}$. long, ascending or prostrate : leaves mainly basal, $2-8 \mathrm{~cm}$. long ; blades divided into $3-7$ entire or angular segments, the terminal one much larger than the rest: pedicels ascending, 4-10 $\mathrm{cm}$. long: sepals oblong, about $5 \mathrm{~mm}$. long, obtuse : petals yellow, emarginate, about twice as long as the sepals : pods oblong, 4-8 mm. long, each tipped with a slender style 4-6 $\mathrm{mm}$. long, not torulose : seeds 6-8: cotyledons oval; radicle oblique.

In cedar woods, Tennessee.

4. Leavenworthia torulòsa A. Gray. Foliage glabrous. Stems 2-15 cm. long, erect or ascending, sometimes almost wanting : leaves mainly basal, $2-10 \mathrm{~cm}$. long; blades pinnately-divided into entire angled or lobed segments, sometimes represented by a large terminal segment and two small lateral ones: pedicels erect or ascending, 4-10 cm. long: sepals narrowly oblong, $5 \mathrm{~mm}$. long, obtuse : petals purplish, with a yellow base, nearly twice as long as the sepals, emarginate: pods linear, 2-3 cm. long, conspicuously constricted below between the seeds, each tipped with a slender style 2-3 mm. long: seeds 4-14: cotyledons oval; radicle oblique.

In wet soil, cedar barrens, Kentucky and Tennessee.

\section{3. ÁRABIS $L$.}

Annual or perennial herbs, with glabrous or glaucous foliage, or pubescent with forking or stellate, or rarely simple hairs. Leaves alternate, sometimes mainly basal : blades entire, toothed or pinnatifid. Flowers perfect, in terminal or axillary racemes. Sepals 4 , equal or nearly so, sometimes saccate at the base. Corolla white, pink, purple or yellowish : petals 4, entire or emarginate, often with claws. Stamens 6 : filaments free, unappendaged. Ovary sessile : stigma capitate or 2-lobed. Ovules numerous. Pods elongated, flat, the valves sometimes nerved or keeled, not dehiscent. Seeds in 1 row in each cavity, marginless, margined or winged. Cotyledons accumbent or incumbent. Rock Cress.

Basal leaves with pinnatifid blades.

Sepals 1-2 mm. long: seeds winged.

Pods $2-2.5 \mathrm{~cm}$. long, the valves obscurely nerved at the base: seeds narrowly winged.

Pods $5-7.5 \mathrm{~cm}$ long the

.

Basal als 2-2.5 mm. long: seeds wingless.

Seeds wingless.

Seeds winged or margined.

3. A. lyrata.

Capsules erect or nearly so, sometimes appressed.

Corollas over $7 \mathrm{~mm}$. broad : capsules not appressed : style $1 \mathrm{~mm}$. long. $\quad$ 5. A. patens.

Corollas less than $7 \mathrm{~mm}$. broad: capsules appressed: stigma sessile.

Capsules recurved.

Plants glabrous, glaucous : pods 1-2 mm. wide.

Plants pubescent, at least below : pods $2.5-3.5 \mathrm{~mm}$. wide.

6. A. hirsuta.

7. A. laevigata.

8. A. Canadensis.

1. Arabis Virgínica (L.) Trelease. Annual or biennial, sparingly hirsute or nearly glabrous. Stems usually branched at the base, the branches ascending or decumbent, 1-4 dm. long, simple or branched : basal and stem-leaves quite similar, 2-7 cm. long; petioles much shorter than the blades, margined; blades deeply pinnatifid into uniform entire or 1-2-toothed nearly oblong or linear segments : pedicels finally spreading or ascending, 3-6 mm. long: sepals narrowly oblong, $1 \mathrm{~mm}$. long, obtuse : petals white : pods linear, $2-2.5 \mathrm{~cm}$. long, straight, ascending or somewhat spreading: seeds in 1 row, winged.

[A. Ludoviciana (Hook.) C. A. Meyer.]

In sandy or rocky soil, Virginia to Missouri, Florida and Texas. Spring. 
2. Arabis petiolàris A. Gray. Annual or biennial, glabrous, or sparingly pubescent with reflexed simple hairs. Stems erect, 4-9 dm. tall, simple or branched above : basal leaves few, 12-20 cm. long, with somewhat lyrate-pinnatifid blades ; segments 5-7, sinuate : stem-leaves various; blades all petioled, lower ones pinnatifid or hastately lobed, upper entire or merely sinuate : pedicels becoming $6-10 \mathrm{~mm}$. long: petals purplish : pods ascending, 5-7.5 $\mathrm{cm}$. long, 3-4 mm. broad, slender-beaked, the valves 1-nerved below the middle : seeds broadly winged.

On plains or prairies, Texas, mainly between the Colorado River and the Rio Grande. Spring.

3. Arabis lyràta L. Biennial or perennial, glabrous, or pubescent near the base. Stems solitary or tufted, erect or ascending, 1-4 dm. tall, often diffusely branched : basal leaves 1-4 cm. long, with short margined petioles; blades spatulate or oblanceolate in outline, lyrate-pinnatifid: stem-leaves 1-3 cm. long, linear and entire or some of the lower ones broader and irregularly toothed: pedicels ascending, 5-10 mm. long: sepals oblong, 2-2.5 mm. long, obtuse : petals white, twice or thrice as long as the sepals : pods narrowly linear, $2-3 \mathrm{~cm}$. long, ascending, straight or slightly curved : seeds in 1 row, wingless.

On cliffs and in sandy soil, Ontario to Manitoba, North Carolina and Missouri. Spring.

4. Arabis dentàta T. \& G. Biennial, pubescent with fine rigid stellate hairs. Stems erect, 2-6 dm. tall, branching from the base, the branches ascending or decumbent: basal leaves spatulate, $5-12 \mathrm{~cm}$. long; petioles winged, shorter than the remotely dentate blades : stem-leaves quite numerous; blades sessile, clasping, more finely toothed than the basal, usually oblanceolate to oblong : pedicels $1-3 \mathrm{~mm}$. long, finally spreading: sepals oblong, $1.5 \mathrm{~mm}$. long, obtuse: petals white, nearly twice as long as the sepals : pods linear, $2-2.5 \mathrm{~cm}$. long, straight, spreading: seeds in 1 row, marginless.

In moist soil, New York to Minnesota, Virginia (?), Tennessee and Missouri. Spring.

5. Arabis pàtens Sulliv. Biennial, more or less densely hirsute with simple or branched hairs, or rarely glabrous above. Stems solitary or loosely tufted, 3-7 dm. tall, simple or sometimes sparingly branched : basal leaves $3-10 \mathrm{~cm}$. long; blades oblanceolate, spatulate or obovate, on winged petioles : stem-leaves shorter than the basal ; blades oblanceolate or obovate to ovate or lanceolate, sessile, serrate or dentate like the basal, but the teeth usually more prominent : pedicels finally spreading, $1-2.5 \mathrm{~cm}$. long : sepals oblong, 4-5 mm. long, obtuse, scarious-margined : petals white, twice as long as the sepals : pods narrowly linear, spreading or erect-spreading, $2.5-4 \mathrm{~cm}$. long : seeds in 1 row, narrowly winged.

On river banks, Pennsylvania to Minnesota, Alabama and Missouri. Spring and summer.

6. Arabis hirsúta (L.) Scop. Biennial, finely hirsute throughout with simple or forking hairs. Stems erect, $2-9 \mathrm{dm}$. tall, simple or nearly so, sometimes branched at the base : basal leaves 2-4 cm. long, with short winged petioles, and obovate, elliptic or spatulate repand or shallowly dentate blades : stem-leaves 1-6 cm. long; blades sessile, clasping by the auricled bases, oblong to lanceolate, or rarely linear, nearly entire, or dentate : pedicels erect or nearly so, finally 4-12 mm. long: sepals oblong, $2.5-3 \mathrm{~mm}$. long, obtuse : petals greenish white, or nearly white, about twice as long as the sepals : pods narrowly linear, $2.5-3 \mathrm{~cm}$. long, erect or appressed : seeds in one row, narrowly margined.

In rocky or poor soil, Newfoundland to British Columbia, Georgia and California. Also in Europe and Asia. Spring to fall.

7. Arabis laevigàta (Muhl.) Poir. Biennial, glaucous. Stems erect, $3-10 \mathrm{dm}$. tall, simple, or virgately branched above : basal leaves with varying petioles and spatulate or obovate dentate blades: stem-leaves $3-15 \mathrm{~cm}$. long; blades oblong, lanceolate or linear, entire or coarsely toothed, sessile, clasping by the strongly auricled bases: pedicels ascending, finally spreading, $8-10 \mathrm{~mm}$. long : sepals narrowly oblong, about $5 \mathrm{~mm}$. long, obtuse : petals white or greenish white, about twice as long as the sepals: pods narrowly linear, $6-10 \mathrm{~cm}$. long, partially drooping: seeds in 1 row, broadly winged.

In rocky soil, Quebec to Minnesota, Georgia and Arkansas. Spring.

8. Arabis Canadénsis L. Annual or biennial, more or less pubescent. Stems erect, 2-9 dm. tail, simple, or virgately branched above: basal or lower leaves with short petioles and toothed or lyrate-pinnatifid blades: upper stem-leaves $3-12 \mathrm{~cm}$. long; blades thin, lanceolate or oblanceolate, nearly entire or shallowly toothed, acute : pedicels spreading or recurved at maturity, 5-12 $\mathrm{mm}$. long: sepals oblong, $4 \mathrm{~mm}$. long, obtuse : petals greenish white, about twice as long as the sepals: pods scythe-shaped, narrowly linear, $5-7 \mathrm{~cm}$. long, drooping : seeds in 1 row, winged.

In rocky woods, Ontario to Minnesota, middle Georgia and Texas. Spring and summer.

24. SÒPHIA Adans.

Annual or perennial caulescent herbs or shrubby plants, more or less densely pubescent with short branched hairs. Leaves alternate: blades 2-pinnatifid, or finely dissected. 
Flowers perfect, in elongating racemes. Sepals 4, narrow, early deciduous. Corolla yellow or yellowish, the 4 petals slightly longer than the sepals. Ovary sessile : style short : stigma minute. Ovules numerous. Pods linear or narrowly oblong, flattish, the valves 1-nerved. Seeds in 1 or 2 rows in each cavity. Cotyledons incumbent. Tansy MusTARD. The plants flower mainly in the spring and summer.

Pods narrowly linear, $1.5-2.5 \mathrm{~cm}$. long, $1 \mathrm{~mm}$. wide, curved upward.

Pods oblong or linear-oblong, 5-14 mm. long, 1-2 mm. wide, straight or nearly so.

Foliage densely canescent : pedicels horizontal : pods ascending.

Foliage glabrate or sparingly canescent.

Pedicels and pods horizontal.

Pedicels ascending: pods nearly erect.

Pods mostly shorter than the pedicels.

Pods mostly longer than the pedicels.

1. S. Sophia.

2. S. pinnata.

3. S. millefolia.

4. S. intermedia.

5. S. brevipes.

1. Sophia Sòphia (L.) Britton. Foliage minutely hoary-canescent. Stems 3-7.5 dm. tall, usually much branched: leaves $3-14 \mathrm{~cm}$. long; blades 2-3-pinnatifid into narrowly linear or oblong-linear segments : flowers numerous : pedicels slender, 12-16 mm. long, ascending, glabrous or nearly so : pods narrowly linear, $1.5-2.5 \mathrm{~cm}$. long, curved upward: seeds in 1 row in each cavity.

In waste places, New Brunswick to Ontario, Nebraska, New York and about the northern sea-ports. Naturalized from Europe. FLAXWEED.

2. Sophia pinnàta (Walt.) Britton. Annual, canescent with pale hairs and sometimes glandular. Stems erect, 2-6 dm. tall, simple, or branched above, the branches ascending: leaves with short petioles and 2-pinnatifid blades, the segments oblong: racemes elongating, sometimes paniculate : pedicels slender, spreading, $8-15 \mathrm{~mm}$. long: sepals oblong, about $1 \mathrm{~mm}$. long: petals spatulate, equalling or somewhat surpassing the sepals: pedicels horizontal, 10-14 mm. long: pods oblong, straight, $6-8 \mathrm{~mm}$. long, glabrous, ascending : seeds in 2 rows in each cavity. [Sisymbrium canescens Nutt.]

In dry soil, Virginia to Florida and Texas.

3. Sophia millefòlia Rydb. Rather taller and less leafy than $S$. pinnata and nearly glabrous. Leaves 2-9 $\mathrm{cm}$. long; blades oval or oblong-oval in outline, very thin, less dissected : pedicels $12-20 \mathrm{~mm}$. long: pods club-shaped, less than $1 \mathrm{~cm}$. long, with a very short style: seeds in 2 rows in each cavity. [S. myriophylla Rydb., not Sisymbrium myriophyllum DC.]

In dry soil, Kentucky to Texas.

4. Sophia intermédia Rydb. Annual, nearly glabrous or thinly stellate-pubescent and glandular. Stems erect, 2-7 dm. tall, more or less branched above: leaves with short petioles and pinnate or bipinnatifid blades : segments linear or oblong : racemes elongating, simple or branched: pedicels filiform, $10-20 \mathrm{~mm}$. long, widely ascending: sepals oblong, $1-2 \mathrm{~cm}$. long at maturity : petals sometimes nearly twice as long as the sepals : pods linearoblong, straight, 8-15 mm. long, acute, glabrous or nearly so, erect or nearly so : seeds in 1 row in each cavity. fornia.

In dry soil, Minnesota to the Northwest Territory, British Columbia, Tennessee, Texas and Cali-

5. Sophia brévipes (Nutt.) Rydb. Foliage minutely canescent or puberulent. Stems 5-6 dm. tall : leaves $2-7 \mathrm{~cm}$. long; blades pinnately divided into 5-7 segments, these pinnatifid, with obtuse lobes : pedicels erect-appressed, $3-8 \mathrm{~mm}$. long, mostly shorter than the pods : pods erect or nearly so, linear, $8-10 \mathrm{~mm}$. long, about $1 \mathrm{~mm}$. wide : seeds in 1 row in each cavity. [Sisymbrium canescens $\xi$ brevipes Nutt.]

In dry soil, Minnesota to British Columbia and Texas.

\section{STREPTÁNTHUS Nutt.}

Annual or biennial caulescent herbs, with often glaucous foliage. Leaves alternate: blades entire or toothed or rarely pinnatifid, the cauline sagittate and clasping at the base. Flowers perfect, in terminal racemes. Calyx not campanulate. Sepals often purplish, barely saccate at the base. Petals purple or white or rarely yellowish, with narrow claws and broad well developed blades. Stamens 6 : filaments of the longer pairs sometimes united below : anthers sagittate. Ovary sessile on the enlarged receptacle. Ovules several or numerous. Pods oblong to narrowly linear, flattened. Seeds flattened, margined or winged. Cotyledons accumbent.

Flower-stalks with conspicuous scales.

Flower-stalks without scales or these minute.

Pedicels naked: pods $10-13.5 \mathrm{~cm}$. long, $2 \mathrm{~mm}$. wide.

Pedicels often with minute scales: pods $5-7.5 \mathrm{~cm}$ long, $4-5 \mathrm{~mm}$. wide.

1. S. bracteatus.

2. S. maculatus.

3. S. platycarpus. 
1. Streptanthus bracteàtus A. Gray. Foliage glabrous. Stems $3-9 \mathrm{dm}$. tall, simple, or branching above: basal and lower stem-leaves with short petioles and blades varying from entire to lyrate-pinnatifid; upper stem leaves ovate or oblong, 2-10 cm. long, entire, clasping : pedicels ascending, 5-10 mm. long, the scales ovate, cordate : sepals oblong-ovate, about $8 \mathrm{~mm}$. long: pods $10-15 \mathrm{~cm}$. long, $4 \mathrm{~mm}$. broad, spreading, tipped with the broad stigma : seeds oblong, broadly winged.

In dry soil, southwestern Texas. Spring.

2. Streptanthus maculàtus Nutt. Foliage glabrous, glaucous. Stems 2-6 dm. tall, often simple : leaves various, the cauline with oblong, elliptic or ovate entire blades, sessile, deeply cordate and clasping: pedicels 4-9 $\mathrm{mm}$. long, naked : sepals purplish : pods slender, 10-15 cm. long, straight or curved, erect or ascending, beaked : seeds oblong, winged.

On plains and prairies, Arkansas and Texas. Spring.

3. Streptanthus platycárpus A. Gray. Foliage glabrous. Stems $2-6 \mathrm{dm}$. tall, branching from near the base : basal and lower stem-leaves lyrate-pinnatifid ; upper stemleaves lanceolate to ovate-oblong, $2-8 \mathrm{~cm}$. long, entire, or pinnatifid, sessile, clasping: pedicels stout, ascending, finally about $1 \mathrm{~cm}$. long, often with minute scales : sepals purplish, oblong-lanceolate, $8-10 \mathrm{~mm}$. long: pods linear, ascending, $5-8 \mathrm{~cm}$. long, 4-5 mm. broad : seeds winged, suborbicular.

In valleys, Texas to Sonora. Spring.

\section{EUKLìsia Rydb.}

Annual or biennial mainly glabrous herbs. Leaves alternate, sometimes mostly basal : blades various, entire, toothed or pinnatifid, those of the cauline sometimes clasping at the base. Flowers perfect, in terminal racemes. Calyx campanulate. Sepals mainly purple, with somewhat thickened spreading tips, the outer pair at least, strongly saccate at the base. Petals white or purple, the blade scarcely wider than the claw. Stamens 6 : filaments slender : anthers sagittate. Ovary sessile. Ovules several. Pods narrow. Seeds flattened, mostly winged. Cotyledons accumbent.

1. Euklisia hyacinthoìdes (Hook.) Small. Foliage glabrous. Stems $3-12 \mathrm{dm}$. tall, simple or sparingly branched: leaves several ; blades linear to linear-lanceolate, $3-15 \mathrm{~cm}$. long, acute, entire, or slightly toothed, half-clasping: pedicels ascending, $3-5 \mathrm{~mm}$. long : sepals linear, about $8 \mathrm{~mm}$. long, acute, saccate : pods $2.5-10 \mathrm{~cm}$. long, $2 \mathrm{~mm}$. wide, ascending, beaked: seeds oblong, winged. [Streptanthus hyacinthoides Hook.]

On plảins or prairies, the Indian Territory and Texas. Spring.

\section{SELÈNIA Nutt.}

Low annual caulescent herbs, with glabrous foliage. Stems often branching at the base. Leaves alternate: blades pinnatisect, the segments entire or toothed. Flowers perfect, in loose racemes. Sepals 4, spreading, equal or nearly so, somewhat sulcate at the base. Corolla yellow, the four petals erect, narrowed into claws. Stamens 6, accompanied by 10 hypogynous glands. Ovary sessile or nearly so : style slender : stigma capitate. Ovules several. Pods flat, oblong, or elliptic, abruptly narrowed at each end, stipitate, the thin valves with a nerve. Seeds in two rows in each cavity, orbicular, margined or broadly winged. Cotyledons accumbent.

Pedicels erect or ascending : capsules oblong, the style-beak about $4 \mathrm{~mm}$. long. Pedicels spreading: capsules elliptic, the style-beak 8-12 $\mathrm{mm}$. long.

1. S. aurea.

2. S. aperta.

1. Selenia aùrea Nutt. Foliage bright green. Stems with erect or ascending branches $5-20 \mathrm{~cm}$. long: leaves conspicuous; blades narrow, $2.5-7 \mathrm{~cm}$. long, pinnatisect, the segments entire or with 1 or 2 coarse teeth : racemes several-flowered : bracts similar to the leaves, but smaller : pedicels erect or ascending, 1-2.5 cm. long: sepals narrow, unappendaged : petals yellow, about twice as long as the sepals : pods oblong, $12-20 \mathrm{~mm}$. long, 4-6 mm. wide, each tipped with a very slender style-beak about $4 \mathrm{~mm}$. long.

On wet plains and prairies, Missouri to Kansas and Texas. Spring.

2. Selenia apérta (S. Wats.) Small. Similar to S. aurea in habit. Racemes with divaricate pedicels at maturity : pods elliptic, usually broadly so, 12-16 $\mathrm{mm}$. long, the - slender style-beak 8-12 mm. long. [S. aurea var. aperta S. Wats.]

On plains or prairies, Texas. Spring. 


\section{WÀréa Nutt.}

Annual glabrous herbs, with branching stems. Leaves alternate, without stipules: blades entire, sessile, obtuse, retuse or rarely acutish. Flowers white, rose or purple, perfect, in terminal naked corymbose racemes. Sepals 4, spatulate, imbricated, often petaloid. Receptacle dilated, with a pair of glands before the shorter stamens. Petals 4, the blades broad, abruptly narrowed into long slender claws which are granular-toothed, serrulate or pectinate-fimbriate. Stamens 6, exserted: filaments filiform, more or less spreading : anthers curved or coiled. Ovary elongated, 2-celled, shorter than its stipe : style wanting : stigma emarginate. Ovules numerous, in one row in each cavity. Pods narrowly linear, long-stalked, curved, spreading and somewhat pendulous, flattened, the two valves each one-ribbed and delicately nerved, the septum nerveless. Seeds numerous, pendulous, on slender funiculi, flattened, not margined. Embryo conduplicate, with narrow thick incumbent or oblique and nearly accumbent cotyledons.

Leaf-blades cuneately narrowed at the base: claws of the petals pectinate-fimbriate. Leaf-blades rounded or auricled at the base.

Leaves not auricled at the base : claws of the petals granular-toothed.

Leaves auricled and clasping: claws of the petals serrulate.

1. W. cuneifolia.

2. W. sessilifolia. 1. Warea cuneifòlia (Muhl.) Nutt. Plant scarcely glaucescent. Stems 3-7 dm. tall, branched above, the branches ascending : leaf-blades obovate, oblanceolate, or linearoblong, 1-4 cm. long, obtuse or retuse, entire, cuneately narrowed at the base : racemes dense, 1-3 cm. long: pedicels filiform, spreading: sepals spatulate, $3-4 \mathrm{~mm}$. long, faintly ribbed : petals white or purplish; blades suborbicular, about $2 \mathrm{~mm}$. in diameter, crisped, undulate, delicately nerved, subcordate; claws dilated towards the base, pectinate-fimbriate : anthers curled when dry : stalk of the ovary shorter than the claws of the petals : pods linear-filiform, $3.5-4 \mathrm{~cm}$. long, slightly curved : seeds oblong, $1 \mathrm{~mm}$. long.

On sand hills, near the coast, Georgia to Florida. Summer to winter.

2. Warea sessilifòlia Nash. Plant glaucescent. Stems $3-6 \mathrm{dm}$. tall, branched, sometimes diffusely so, the branches wiry, ascending or spreading: leaf-blades ovate or ovate-lanceolate, 1-2 $\mathrm{cm}$. long, erect or ascending, obtuse, entire, sessile, not auricled: racemes dense, $1-3 \mathrm{~cm}$. long: pedicels filiform, $6-10 \mathrm{~mm}$. long : sepals spatulate, $7-8 \mathrm{~mm}$. long, faintly ribbed, purple below, greenish near the apex : petals deep purple; blades orbicular-ovate, about $5 \mathrm{~mm}$. long, abruptly narrowed into filiform claws which are 5-6 mm. long and granular-toothed, especially the lower half : filaments purple except the ends, $1.5 \mathrm{~cm}$. long : anthers linear, $2 \mathrm{~mm}$. long, coiled when dry : stalk of the ovary as long as or longer than the petals : pods (rather immature) filiform, slightly curved, $2 \mathrm{~cm}$. long.

On sand hills, western Florida. Summer to winter.

3. Warea amplexifòlia (Nutt.) Small. Plant glaucous above. Stem $3-7 \mathrm{dm}$. tall, simple or branched above, the branches very slender : leaf-blades ovate, $1-3 \mathrm{~cm}$. long, acutish, entire, ascending or spreading, sessile, auricled at the base, clasping: racemes rather dense, $1-1.5 \mathrm{~cm}$. long: sepals spatulate, about $6 \mathrm{~mm}$. long: petals purplish ; blades orbicularovate, about $4 \mathrm{~mm}$. long, each abruptly narrowed into a filiform claw which is about $5 \mathrm{~mm}$, long and serrulate: anthers coiled when dry, $1 \mathrm{~mm}$. long: stalk of the ovary shorter than the petals : pods nearly similar to those of the next preceding species.

On sand hills, eastern Florida. Summer to winter.

\section{Family 4. Capparidàceat lindl. Caper Family.}

Annual or perennial caulescent, often viscid, usually pungent herbs, or sometimes shrubs or trees, with a bitter nauseous and sometimes poisonous principle. Leaves alternate, or rarely opposite: blades simple or palmately compound : stipules wanting or represented by spines. Inflorescence terminal, usually racemose. Flowers perfect, regular or irregular, white, yellow or purple, in terminal racemes or rarely solitary. Sepals usually 4, distinct or more or less united, imbricated, or rarely valvate. Receptacle depressed or elongated. Petals 4 or rarely more, or sometimes wanting, often unequal, mostly narrowed into slender claws. Androecium of 6 stamens or more. Filaments distinct or united at the base and sometimes adnate to the stalk of the ovary. Anthers introrse, attached at or near the base. Gynoecium 2-carpellary. Ovary free, sessile to longstalked, 1-celled, commonly elongated, with 2 parietal placentae. Style wanting or filiform, terminal. Stigma depressed or acute. Ovules numerous, in 2 rows on each placenta. Fruit a 1-celled, often stalked, capsule or berry. Seeds 
usually numerous, conduplicately bent, with a membranous leathery or crustaceous testa. Endosperm wanting. Embryo bent, with flat or convolute cotyledons.

Herbs or herbaceous plants : fruit a 2-valved capsule.

Receptacle neither elevated nor elongated, with or without an appendage.

Appendage present: filaments distinct.

Appendage tubular: petals with laciniate or dissected blades.

Appendage solid : petals entire or notched at the apex.

Petals very unequal, barely clawed : capsules with deciduous valves. Petals nearly equal, long-clawed : capsules opening near the apex.

1. Cristatella.

A ppendage wanting: filaments united below and adnate to the stalk of the ovary. 4. PEDICELLARIA. Receptacle elevated or elongated.

Appendage wanting: petals sessile: capsule thicker than broad.

Appendage present: petals short-clawed: capsule broader than thick.

Shrubs or trees: fruit baccate, or a pulpy capsule, sometimes opening irregularly.

5. Cleomella.

6. Cleome.

7. CAPPARIS.

\section{CRISTAtÉLLA Nutt.}

Slender viscid-glandular herbs. Leaves alternate, without stipules : blades palmately 3 -foliolate : leaflets narrow, entire. Flowers small, irregular, white or yellow, in terminal leafy-bracted racemes. Sepals 4, united at the base, deciduous. Receptacle developed between the posterior petal and ovary into a tubular appendage (gland) as long as the anterior petals. Petals 4, hypogynous : blades strikingly unequal, more or less fan-shaped and cuneately narrowed into slender claws, of 2 forms, the anterior small, dissected into 5-9 narrow lobes which are 2-3-cleft at the apex, the posterior larger, toothed or laciniate at the apex. Stamens 6-14, declined: filaments filiform, unequal (when more than 6), distinct: anthers sagittate. Ovary elongated, somewhat declined, short-stalked: style slender, short: stigma blunt. Capsule elongated, silique-like, slightly flattened, with 2 reticulated valves. Seeds numerous, conduplicate.

Blades of large petals about $3 \mathrm{~mm}$. long: mature stipe only slightly longer than the gland. 1. C. Jamesii. Blades of large petals about $6 \mathrm{~mm}$. long: mature stipe twice as long as the gland.

2. C. erosa.

1. Cristatella Jamèsii T. \& G. Foliage glandular-pilose. Stems 1-4 dm. tall, simple, or branching above: leaf-blades 3-foliolate; petioles much shorter than the leaflets ; leaflets 1-2.5 cm. long, with linear obtuse entire, more or less revolute, nearly sessile blades: racemes $3-8 \mathrm{~cm}$. long: bracts mostly like the leaves but smaller: sepals oblong, about $2 \mathrm{~mm}$. long, obtuse: petals 4 ; claws shorter than the blades; blades various, the 2 upper with incised, the 2 lower laciniate at the apex : capsules linear, $1.5-2.5 \mathrm{~cm}$. long, densely glandular, much longer than the pedicels.

In sandy soil, Nebraska to Louisiana and Texas. Spring to fall.

2. Cristatella eròsa Nutt. Foliage glandular-pubescent. Stems 2-6 dm. tall, simple below, branching above : leaf-blades 3 -foliolate ; petioles shorter than the leaflets, swollen at the base ; leaflets 1-2 cm. long, with linear obtuse or acutish, entire, often shortpetioluled blades: racemes $2-10 \mathrm{~cm}$. long: bracts like the leaves but smaller: sepals oblong, 3-3.5 mm. long, obtuse : petals 4, the 2 upper with claws, longer than the manyparted blades : capsules linear, $2.5-3 \mathrm{~mm}$. long, about twice as long as the pedicels.

In dry or sandy soil, Arkansas to the Indian Territory and Texas. Spring and summer.

\section{ALDENÉLLA Greene.}

Annual caulescent herbs, with somewhat glandular foliage. Leaves alternate, without stipules : blades 3 -foliolate : leaflets with very narrow blades. Flowers irregular, in terminal racemes. Sepals 4, imbricated, reflexed. Receptacle developed into a solid gland on the upper side. Petals 4, very unequal, those of the smaller pair scarcely $\frac{1}{2}$ as large as those of the larger pair, entire, spreading, barely clawed. Stamens 9-11; filaments unequal, slightly declined: anthers introrse. Ovary elongated, short-stipitate : style declined and curved : stigma capitate. Capsule elongated, very narrow, silique-like, the two valves readily deciduous. Seeds numerous, conduplicate.

1. Aldenella tenuifòlia (T. \& G.) Greene. Foliage glandular. Stems 2-8 dm. tall, branching, often diffusely so: leaf-blades 3 -foliolate; petioles filiform ; leaflets with linearfiliform entire blades somewhat longer than the petioles: racemes $0.5-2.5 \mathrm{dm}$. long: bracts like the leaves, or the upper ones 1-foliolate: sepals oblong to oblong-ovate, $2-2.5 \mathrm{~mm}$. long, acute: petals white, oval to ovate, 6-8 $\mathrm{mm}$. long, entire, unequal, the claws very short: stamens usually 9-11; filaments filiform-clavate: capsules linear, 4-6 cm. long, sharp-pointed, short-stipitate, several times longer than the pedicels : seeds $0.6 \mathrm{~mm}$. broad, minutely wrinkled. [Polanisia tenuifolia T. \& G.]

In sandy soil, Georgia and Florida. Spring to fall. 


\section{POLANÍsia Raf.}

Annual often clammy-glandular fetid herbs, with erect stems. Leaves alternate, without stipules: blades simple or 3 -foliolate, the upper ones often reduced. Flowers somewhat irregular, in terminal bracted racemes. Sepals 4, imbricated, spreading, sometimes purplish, deciduous. Receptacle inconspicuous, developed into a solid gland on the upper side. Petals 4, hypogynous, deciduous : blades imbricated in aestivation, entire or notched at the apex, narrowed into very slender claws, turned toward the appendage on the receptacle. Stamens 12-32 : filaments filiform, purple, more or less declined, the outer ones shorter : anthers introrse. Ovary elongated, viscid-glandular, sessile or short-stalked : style filiform, deciduous: stigma depressed. Capsule elongated, silique-like, flattened, sessile, 2-valved at the apex. Seeds numerous, conduplicate. Clammy-weed.

Stamens slightly longer than the petals.

Stamens much surpassing the petals.

Petals $10 \mathrm{~mm}$. long or shorter: filaments $10-12 \mathrm{~mm}$. long.

Petals $12 \mathrm{~mm}$. long or longer : filaments $30-50 \mathrm{~mm}$. long.

1. P. graveolens.

2. P. trachysperma.

3. P. uniglandulosa.

1. Polanisia gravèolens Raf. Heavy-scented, clammy-pubescent. Stems 1-8 dm. tall, branching, rarely spreading: leaf-blades 3 -foliolate; petioles about as long as the terminal leaflet, slender; leaflets $1.5-3.5 \mathrm{~cm}$. long, the blades elliptic to oblong or obovate, obtuse or acutish, entire, nearly sessile: racemes 1-3 dm. long : lower bracts 3foliolate, upper bracts 1 -foliolate : sepals oblong, $3 \mathrm{~mm}$. long, abruptly acuminate : petals white to pink, 4-5 mm. long; claws shorter than the suborbicular blades, which are notched at the apex : stamens hardly longer than the petals : capsules linear-oblong, 3-5 $\mathrm{cm}$. long, erect: seeds $2 \mathrm{~mm}$. broad, minutely roughened.

On gravelly or sandy shores, Quebec to the Northwest Territory, New York, Tennessee and Colorado. Summer.

2. Polanisia trachyspérma T. \& G. Stout, clammy-pubescent. Stems simple or branching: leaf-blades 3-foliolate ; petioles longer than the leaflets, stoutish ; leaflets 1-4 $\mathrm{cm}$. long, the blades elliptic, oval or obovate, obtuse or acutish, entire, sessile: racemes 3-10 mm. long: bracts 1 -foliolate, ovate, $0.5-1 \mathrm{~cm}$. long: sepals lanceolate, $5 \mathrm{~mm}$. long, ciliate, acuminate : petals $4,8-10 \mathrm{~mm}$. long ; claws as long as the notched blades or longer: stamens long-exserted : capsules erect, linear, 4-6 cm. long, about twice as long as the pedicels : seeds $2 \mathrm{~mm}$. broad, pitted and wrinkled all over.

In dry soil, Iowa to British Columbia, Texas, Arizona and Nevada. Summer and fall,

3. Polanisia uniglandulòsa (Cav.) DC. Foliage clammy-pubescent. Stems erect, 2-7 dm. tall, simple or branching: leaf-blades 3 -foliolate; petioles about as long as the leaflets or longer; leaflets $1-3 \mathrm{~cm}$. long, the blades elliptic, oval, ovate or obovate, obtuse or acutish, entire, sessile or nearly sessile: racemes $0.5-3 \mathrm{dm}$. long: bracts chiefly 1-foliolate, ovate: sepals lanceolate, about $5 \mathrm{~mm}$. long, acuminate, glandular and eiliate : petals 4 , about $1 \mathrm{~cm}$. long; claws longer than the obovate or cuneate notched blades: stamens conspicuously exserted : capsules linear-oblong, erect, $3-7 \mathrm{~cm}$. long, hardly stipitate, about twice as long as the pedicels : seeds $2 \mathrm{~mm}$. broad, minutely wrinkled.

In dry soil, along the Rio Grande, Texas and Mexico. Spring to fall.

\section{PEDICELLÀrIA Schrank.}

Glabrous pubescent or glandular herbs. Leaves alternate, without stipules: blades palmately|3-7-foliolate, commonly petioled. Flowers nearly regular, white or purplish, in terminal leafy-bracted racemes. Sepals 4, spreading, deciduous. Receptacle depressedhemispheric. Petals 4, hypogynous, often imbricated, entire or crenulate, narrowed into slender claws, inserted under the receptacle. Stamens 6 : filaments filiform, distinct above, united below and adnate to the stalk of the ovary for at least $\frac{1}{2}$ its length. Ovary longstalked: style wanting: stigma depressed. Ovules numerous. Capsule elongated, siliquelike, somewhat flattened, its stalk apparently jointed at the junction of the filaments. Seeds conduplicate, with a rugose or tuberculate testa. [Gynandropsis DC.]

1. Pedicellaria pentaphýlla (L.) Schrank. Annual, bright green, clammy-pubescent. Stem 5-10 dm. tall, branching: leaf-blades palmately 3-5-foliolate ; petioles longer than the leaflets; leaflets $2-6 \mathrm{~cm}$. long, the blades oval to obovate, acute or short-acuminate, serrulate : racemes 1-4 dm. long: bracts suborbicular, oval or broadly obovate: sepals lanceolate, 4-5 mm. long, acuminate : petals white or pink, 5-10 mm. long: blades suborbicular, longer than the claws : capsules linear, 4-6 cm. long, surpassing the glandular pedicel in length : seeds 1-5 mm. broad, coarsely rugose and muricate. [Gynandropsis pentaphylla (L.) DC.]

In waste places. Georgia and Florida to Louisiana. Naturalized from tropical America, but originally from the Old World. Summer. 


\section{CLEOMÉlLa DC.}

Glabrous herbs, with odd-shaped capsules. Leaves alternate, without stipules : blades 3-foliolate, petioled: leaflets narrow, usually petiolulate. Flowers small, yellow, regular or nearly so, in terminal leafy-bracted racemes. Sepals 4 , thin, distinct, imbricated, deciduous. Receptacle elongated, without an appendage. Petals 4, hypogynous, entire, sessile, deciduous. Stamens 6, inserted on the top of the receptacle : filaments filiform, equal, distinct. Ovary ovoid, 1-celled, long-stalked : style wanting : stigma blunt. Ovules 4-8, usually 2 above the middle of each placenta, amphitropous, becoming campylotropous. Capsule short, thicker than broad, inflated, long-stalked, with 2 helmet-like valves. Seeds usually 2 on each placenta, pendulous, conduplicate, the crustaceous testa rugose.

1. Cleomella angustif òlia Torr. Annual, slender, glabrous. Stem 2-7 dm. tall, branching, often reddish : leaves alternate; blades 3 -foliolate; petioles shorter than the leaflets; leaflets $1-4 \mathrm{~cm}$. long, with entire, acute or apiculate blades: racemes $3-10 \mathrm{~cm}$. long: bracts unifoliolate, linear : sepals ovate, $2 \mathrm{~mm}$. long, acuminate : petals oblong, obtuse, concave : filaments shorter than the petals or equalling them in length: anthers acute, about $8 \mathrm{~mm}$. broad: capsule rhomboidal, commonly broader than long, the two valves conic or cap-like, the stipe shorter than the pedicel : seeds $3 \mathrm{~mm}$. long, papillose.

In dry soil, Nebraska to Colorado, Texas and New Mexico. Summer.

\section{CLEÒME L.}

Glabrous or glandular herbs, sometimes slightly woody. Leaves alternate: blades palmately 3-7-foliolate, or rarely simple, petioled. Flowers nearly regular, solitary or in terminal leafy-bracted racemes, white, yellow or purple. Sepals 4, valvate, nearly distinct or more or less united, sometimes rather persistent. Receptacle elevated, with an appendage opposite the upper sepal. Petals 4, hypogynous, nearly equal, narrowed into short claws, convolutely imbricated. Stamens 6 or rarely 4 , inserted on top of the receptacle : filaments filiform, distinct, unequal, more or less declined. Ovary 1-celled, more or less stalked : style wanting or nearly so : stigma blunt. Ovules numerous, campylotropous. Capsule elongated, silique-like, flattened, 2-valved. Seeds usually numerous, pendulous, conduplicate.

1. Cleome spinòsa L. Annual, bright green, clammy-pubescent. Stem erect, 3-9 dm. tall, simple or branched: leaves alternate; blades palmately $5-7$-foliolate; petioles longer than the leaflets, commonly with stipular spines; leaflets with elliptic to obovate or rarely oblanceolate blades $2-10 \mathrm{~cm}$. long, acute or acuminate at both ends, entire, sessile: racemes 1-3 dm. long, leafy below, bracted above: bracts ovate to lanceolate, truncate to cordate at the base: sepals linear-lanceolate, $5-10 \mathrm{~mm}$. long: petals purple or rarely white, $2.5-3.5 \mathrm{~cm}$. long; blades suborbicular to oval, shorter than the claws: stamens 2-3 times longer than the blades: capsule linear, 6-10 cm. long, usually about as long as the stipe, much longer than the pedicel : seeds pale, finely reticulated.

In waste places, New Jersey to Illinois, south to Florida and Texas. Summer. SPIDER FLower.

\section{CÁPPARIS L.}

Glabrous pubescent or scurfy shrubs or trees, with an acrid often pungent watery sap. Stems erect, climbing or prostrate. Leaves alternate, or rarely opposite, very rarely wanting: blades simple, entire, menbranous or leathery: stipules bristle-like or spiny. Flowers white, regular or irregular, axillary or nearly so, sometimes in terminal cymes or racemes. Sepals 4 or rarely 5 , distinct or united at the base, valvate or imbricated, naked or with a gland or ligule within. Petals 4 or rarely more, imbricated, inserted on the base of the short unappendaged receptacle. Stamens numerous, inserted on the receptacle, in several series: filaments filiform, distinct. Ovary 1-4-celled, long-stalked, with 2 parietal placentae : style wanting : stigma depressed. Berry or capsule more or less'elongated, staked, indehiscent or rarely opening irregularly. Seeds usually numerous, reniform, immersed in a pulp, with a leathery or crustaceous testa.

Foliage glabrous : leaf-blades reticulated: sepals imbricated: capsule glabrous. 1. C. cynophallophora. Foliage densely scaly : leaf-blades not reticulated : sepals valvate: capsule scaly. 2. C. Jamaicensis.

1. Capparis cynophallóphora L. A glabrous shrub or small tree sometimes several m. tall. Leaf-blades oblong or oblong-cuneate, $5-8 \mathrm{~cm}$. long, abruptly pointed, obtuse or notched at the apex, entire, reticulated on both sides ; petioles stout, $2-6 \mathrm{~mm}$. long: flowers white, $5.5-7.5 \mathrm{~cm}$. broad, few in a eluster : sepals suborbicular, 6-8 $\mathrm{mm}$. in diameter, 
imbricated : petals $1.5-2 \mathrm{~cm}$. long : stamens numerous, $5-6 \mathrm{~cm}$. long, naked : fruit linear, 10-20 cm. long, flat, knotty, short-pedicelled, 2-3 times longer than the stipe, glabrous.

Along the coast, peninsular Florida and the Keys.

2. Capparis Jamaicénsis Jacq. A shrub or small tree, sometimes $7 \mathrm{~m}$. tall, the twigs, lower leaf-surfaces and inflorescence densely scaly. Leaf-blades elliptic, oblong or oval, 4-10 $\mathrm{cm}$. long, obtuse or notched at the apex, usually shining above, entire, acute at the base ; petioles stout, $8-12 \mathrm{~mm}$. long: flowers white, about $3 \mathrm{~cm}$. broad, usually 2 at the end of a flattened peduncle: sepals lanceolate to ovate-lanceolate, $8-10 \mathrm{~mm}$. long, acutish : petals about $1 \mathrm{~cm}$. long: stamens 16-32; filaments villous near the base: fruit slender, 2-3 dm. long, on a stout angled pedicel 3-5 times longer than the stipe, scaly.

On the coast, peninsular Florida and the Keys.

\section{Family 5. Moringàceate Dumort. Horseradish Tree Family.}

Trees, with a gummy bark. Leaves alternate, deciduous: blades 2-3-pinnate, the divisions and leaflets opposite, the latter entire, freely deciduous : stipules wanting or mere glands. Flowers perfect, slightly irregular, in axillary panicles. Calyx of 5 unequal imbricated reflexed-spreading sepals on the edge of the short cup-like hypanthium. Corolla of 5 petals resembling the sepals, the lower petal reflexed, the upper one more or less erect. Andreocium of 5 stamens inserted on the margin of the hypanthium and 5 staminodia. Filaments distinct. Anthers 1-celled, opening lengthwise. Gynoecium 3-carpellary, stalked. Ovary 1-celled, with 3 parietal placentae. Styles united. Stigma minute. Ovules numerous, anatropous, pendulous, in two series on each placenta. Capsule elongated, 3-6-angled, somewhat torulose, beaked, 3-valved. Seeds relatively large, 3-winged or wingless. Endosperm wanting. Embryo straight with large halfglobose cotyledons and a very small radicle.

\section{MORÍNGA Juss.}

Characters of the family. Horseradish Tree.

1. Moringa Morínga (L. ) Small. A tree 3-9 m. tall. Leaves $3-6 \mathrm{dm}$. lung ; blades 23-pinnate, the leaflets cuneate to oval or oblong, mostly 1-2 cm. long, entire, obtuse : panicles several, many-flowered : sepals linear to linear-oblong, 9-13 mm. long, reflexed: petals slightly larger than the sepals, white or nearly so: capsules $2.5-3.5 \mathrm{dm}$. long, 3-angled : seeds 3-winged, $2.5-3 \mathrm{~cm}$. long, the body fully $1 \mathrm{~cm}$. long. [Guilandina Moringa L.] ern Asia.

In sandy soil, southern peninsular Florida. Introduced from the West Indies. Native of south-

\section{Order 13. SARRACENIÀLES.}

Insectivorous, usually scapose, herbs, with viscid-fluid secreting tissues. Leaves various, filiform, or with dilated sometimes sensitive blades, or hollow. Flowers usually perfect and regular. Androecium of few or many stamens. Gynoecium of 2-5 united carpels. Ovary 1-celled, with several parietal or basal placentae, or 3-5-celled. Fruit capsular. Endosperm fleshy.

Ovary 1-celled, with a basal placenta or parietal placentae, not surmounted by a peltate disk : leaves with filiform or dilated blades.

Styles distinet: stigmas 2-lobed: placentae parietal: stamens 4-8,usually 5. Fam. 1. DroseraceAE.

Styles united: stigmas pinnatifid : placentae basal : stamens 10-20.

Ovary $3-5$-celled, with central placentae, surmounted by a peltate disk :
leaves with hollow blades. Fam. 2. DionaEaceae.

Fam. 3. Sarraceniaceae.

\section{FAmily 1. DROSERÀCEAE S. F. Gray. Sundew Family.}

Biennial or perennial often acaulescent herbs, with glandular-pubescent foliage, exuding a viscid secretion. Leaves alternate, often all basal, circinate in the bud, merely filiform, or with broad blades, conspicuously ciliate. Flowers perfect, often in spikes or racemes. Calyx of 4-8 imbricated persistent sepals. Corolla of 4-8 convolute hypogynous usually distinct petals. Androecium of usually 5 perigynous or hypognous stamens. Filaments distinct. Anthers usually versatile. Disk wanting. Gynoecium a compound pistil. Ovary 1-celled with 3-5 parietal placentae, or 2-3-celled, free or nearly so. Styles $2-5$, entire or cleft. Ovules numerous, anatropous. Fruit usually a 1-celled capsule, loculicidally $3-5 \cdot$ valved. Seeds several or numerous. 


\section{DRÒSERA L.}

Perennial sometimes scapose herbs, with elongated or corm-like rootstocks, the pubescence glandular. Leaves alternate, usually basal : blades varying from filiform to peltate, circinate in vernation: stipules a scarious dilation at the base of the petiole or wanting. Sepals 4-8, withering. Petals 4-8, white or pink, broadened upward. Stamens 4-8: filaments subulate or filiform : anthers extrorse. Ovary 1-celled, superior, sessile: styles 2-5, distinct. Capsule 2-5-valved. Seeds minute, the testa loose, reticulated. SundEw.

Leaf-blades suborbicular or broader than long.

Leaf-blades filiform, linear, spatulate or cuneate.

1. D. rotundifolia.

Corolla white or pink : leaves with dilated blades.

Leaf-blades cuneate, usually longer than the petioles : scapes glandular-pubescent.

Leaf-blades spatulate, usually shorter than the petioles: scapes glabrous. Leaf-blades broadly spatulate: corolla pink.

Leaf-blades linear-spatulate: corolla white.

Corolla purple (rarely white): leaves with filiform blades.

2. D. brevifolia.

3. D. capillaris.

4. D. intermedia.

5. D. filiformis.

1. Drosera rotundifòlia L. Annual, or perennial by short rootstocks. Leaves basal, 2-4 cm. long; blades suborbicular, much shorter than the flat glandular-pilose petioles: scapes erect, solitary or tufted, glabrous, $5-30 \mathrm{~cm}$. tall. wiry, few-many-flowered : sepals oblong, 4-5 mm. long, obtuse : corolla white, $5-6 \mathrm{~mm}$. broad : petals white, expanding in sunshine, somewhat longer than the sepals : capsule about $5 \mathrm{~mm}$. long : seeds slender-fusiform, $1.5 \mathrm{~mm}$. long, with a loose wrinkled testa, acute at both ends.

In bogs or wet sandy swamps, Labrador to Alaska, Florida, Alabama and California. Also in Europe and Asia. Summer.

2. Drosera brevifòlia Pursh. Biennial, or perennial by short rootstocks, glandularpilose. Leaves basal, flimsy, $1-1.5 \mathrm{~cm}$. long; blades cuneate, mostly longer than the petioles: scapes erect, solitary or several together, 5-15 cm. tall, 2-6-flowered, glandularpilose : sepals oblong, $3-10 \mathrm{~mm}$. long, acute, united below : coralla white, $1.5 \mathrm{~cm}$. broad : capsule about as long as the calyx : seeds oblong, $0.3 \mathrm{~mm}$. long, minutely tuberculate all over.

In damp sandy pine lands, North Carolina to Florida. Spring.

3. Drosera capillàris Poir. Biennial, or perennial by short rootstocks. Leaves basal, 3-6 cm. long; blades spatulate, much shorter than the slender, elongated, glabrous petioles: scapes erect, 5-40 $\mathrm{cm}$. tall, wiry, solitary or several together, glabrous, 5-20flowered : sepals oblong, 3-4 mm. long, obtuse : corolla pink, 8-9 mm. broad : capsule surpassing the calyx : seeds oval, $0.5 \mathrm{~mm}$. long, minutely tuberculate all over.

In and about ponds, South Carolina to Florida. Spring.

4. Drosera intermédia Hayne. Perennial by elongated rootstocks. Leaves slender, 2-6 cm. long; blades spatulate, much shorter than the slender glabrous petioles: scapes usually decumbent, wiry, $5-20 \mathrm{~cm}$. tall, 6-14-flowered, glabrous : sepals oblong, about 4 $\mathrm{mm}$. long, obtuse, united at the base : corolla white, 10-12 mm. broad : capsule obovoid, 4-4.5 mm. long: seeds oblong, with a close roughened testa.

In sandy swamps or ponds, Anticosti to Manitoba, south to Florida and Louisiana. Also in the West Indies and Europe. Summer.

5. Drosera filifórmis Raf. Perennial by short rootstocks. Leaves basal, filiform, without distinction between blade and petiole, 1-4 dm. long, conspicuously glandularvillous throughout, erect : scapes erect, solitary or several together, 1-6 dm. tall, glabrous, few-many-flowered : sepals 5 , oblong to oval, about $4 \mathrm{~mm}$. long, united below, glandular-pubescent like the pedicels, which are longer or shorter than the calyx : corolla bright purple or rarely white, $2.5-3 \mathrm{~cm}$. broad : petals 5 , cuneate-obovate, erose at the apex : capsules oblong-ovoid, about $5 \mathrm{~mm}$. high : seeds $0.6 \mathrm{~mm}$. long, oblong, papillose. summer.

In wet pine lands or sandy swamps, Massachusetts to Florida, chiefly near the coast. Spring and

\section{Family 2. Dionaeàceat Lindl. Venus' Flytrap Family.}

Perennial glabrous herbs, with corymbosely branched scapes. Leaves basal, with dilated petioles and short 2 -lobed blades with coarsely ciliate margins and irritable, the two lobes folding together when stimulated. Sepals 5, spreading. Petals 5, hypogynous, white, the broad tip eroded. Androecium of 10-20, often 15 , stamens, inserted with the petals: filaments filiform, united at the base: anthers extrorse. Gynoecium of 5 united carpels. Ovary sessile, 1-celled, nearly superior: styles united: stigmas 5, pinnatifid. Ovules on a basal placenta. Capsule sessile, opening irregularly. Seeds numerous, with a smooth shining testa. 


\section{DIONAÈA Ellis.}

\section{Characters of the family. Flytrap. Venus' Flytrap.}

1. Dionaea muscípula Ellis. Foliage deep green. Leaves thickish, 4-8 cm. long ; petioles spatulate or obovate, naked; blades suborbicular in outline, cordate at the base, notched at the apex, $1.5-2.5 \mathrm{~cm}$. broad, fringed with long bristles : scape erect, $1-3 \mathrm{dm}$. tall, simple below, sometimes branched above : cymes 8-10-flowered : pedicels stout, 1-2 $\mathrm{cm}$. long: sepals ovate or elliptic-ovate, 7-9 mm. long, acute, serrulate : petals cuneate, 11-13 mm. long, truncate and erose at the apex : stamens hardly $\frac{1}{2}$ as long as the petals: capsule broadly ovoid, $3-4 \mathrm{~mm}$. high.

In sandy bogs, near the coast, eastern North Carolina and South Carolina. Spring.

\section{Family 3. SARRACeniàceat la Pylaie. Pitcher-plant Family.}

Perennial acaulescent herbs, inhabitants of bogs and swamps, living to some extent on decaying organic matter which has fallen into their leaves. Leaves basal, in the form of variously shaped trumpets or pitchers, often highly colored. Flowers perfect, solitary or rarely several at the end of a scape. Perianth of 2 series. Calyx of 5 persistent sepals, subtended by 3 bracts. Corolla of 5 hypogynous colored deciduous petals. Androecium of numerous hypogynous stamens. Filaments very short. Anthers introrse. Gynoecium a compound pistil. Ovary 3-5-celled, superior. Styles united into a 5-angled peltate covering. Ovules numerous, anatropous. Fruit a 5-valved capsule with placentae projecting into each cavity. Seeds numerous, minute.

\section{SARRACÈNIA L.}

Marsh herbs, with horizontal rootstocks. Leaves basal, erect or procumbent, hollow, often variegated, winged or margined on one side, sticky and pubescent within with deflexed hairs. Scapes erect, naked, 1-flowered. Flowers often showy, nodding, of various colors. Sepals 5, leathery, spreading, persistent. Petals 5, usually broadest above the middle, converging or drooping, deciduous. Stamens numerous. Styles united into a five-angled umbrella-like body, the projections from the angles recurved, introrsely stigmatose. Capsule very much wrinkled or echinate-papillose, locudicidally 5-valved. Seeds anatropous, with a reticulated coat. Pitcher-Plant. Side-saddle Flower. Trumpet-LEAF.

Petals maroon or reddish brown, rarely varying to yellowish green.

Leaves decumbent or ascending, with broad ventral wings.

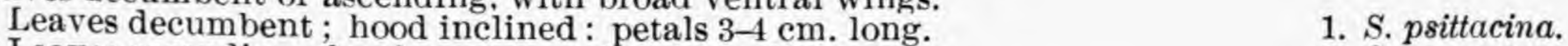

$\begin{array}{ll}\text { Leaves ascending; hood erect: petals } 4-5 \mathrm{~cm} \text {. long. } & \text { 2. S. purpurea. }\end{array}$

Leaves erect with ventral margins.

Hood acute or acuminate, the margin entire: sepals $2-2.5 \mathrm{~cm}$. long: petals $3-4 \mathrm{~cm}$. long.

Hood rounded, the margin wavy : sepals $5-6 \mathrm{~cm}$. long : petals 5-7 cm. long. Petals yellow.

Hond of the leaf erect, not conspicuously reticulate-variegated without.

Capsules with processes much less than $0.5 \mathrm{~mm}$. high : seeds over $2 \mathrm{~mm}$. long, not verrucose.

Capsules with processes $0.5 \mathrm{~mm}$. high : seeds less than $2 \mathrm{~mm}$. long, verrucose. 6. S. Catesbaei.

列

1. Sarracenia psittacina Michx. Leaves $0.5-1.5 \mathrm{dm}$. long, decumbent, in a basal rosette, variegated, especially above, with white spots and purple veins; tube club-shaped, with a broad half-obovate wing, contracted at the orifice; hood strongly incurved, inflated, subglobose : scapes erect, $2-4 \mathrm{dm}$. tall : flowers $3-5 \mathrm{~cm}$. broad : sepals ovate, 2-2.5 $\mathrm{cm}$. long, obtuse : petals oblanceolate or spatulate, $3-4 \mathrm{dm}$. long, rounded or retuse at the apex : style-disk about $3.5 \mathrm{~cm}$. broad, the lobes 2-cleft : capsule 10-14 mm. in diameter.

In pine-land swamps, Georgia to Florida and Alabama. Spring.

2. Sarracenia purpùrea L. Leaves $1-2 \mathrm{dm}$. long, ascending, in a basal rosette, often variegated with purple; tube inflated, with a half-obovate or half-oblanceolate wing, the orifice not contracted; hood reniform, often notched at the apex, erect or nearly so: scapes erect, $2-4 \mathrm{dm}$. tall : flowers $5-6 \mathrm{~cm}$. broad : sepals ovate, about $3 \mathrm{~cm}$. long. obtuse : petals fiddle-shaped, 4-5 cm. long, obtuse, purple: style-disk $3-4 \mathrm{~cm}$. broad, the lobes notched : capsule about $1.5 \mathrm{~cm}$. broad.

In sphagnous swamps, Labrador and Newfoundland to the Rocky Mountains, south to Florida and Alabama. Spring. SIDE-SADDLE FLOWER. 
3. Sarracenia rùbra Walt. Leaves erect, tubular or trumpet-shaped, $1-3 \mathrm{dm}$. long, or sometimes slightly longer, narrowly winged, hardly expanded at the throat, the slenderest in the genus, slightly paler above, and, like the ovate acute or acuminate finally erect hood, faintly reticulated with purple: scapes erect, longer than the leaves: flowers $3-5 \mathrm{~cm}$. broad : sepals ovate, $2-2.5 \mathrm{~cm}$. long, obtuse : petals $3-4 \mathrm{~cm}$. long, reddish purple, with obovate blades : style-disk $3-3.5 \mathrm{~cm}$. broad, the lobes notched at the apex : capsules about $1.5 \mathrm{~cm}$. in diameter.

In swamps, away from the coast, North Carolina to Georgia and Alabama. Spring.

4. Sarracenia Drummóndii Croom. Leaves erect, elongated, narrowly trumpetshaped, 4-12 dm. long, slightly winged, the upper part gradually expanding, white, reticulated with purple, like the erect ovate or suborbicular hood, whose margins are undulate above and recurved below, the edges of the trumpet revolute: scapes erect, scarcely longer than the leaves : flowers $7-10 \mathrm{~cm}$. broad : sepals ovate, $5-6 \mathrm{~cm}$. long, obtuse : petals fiddleshaped, $5-7 \mathrm{~cm}$. long, purple : style-disk $5-6 \mathrm{~cm}$. broad, the lobes 2 -cleft : capsule $2.5-3.5$ cm. in diameter.

In sandy bogs, southwestern Georgia and Florida. Spring.

5. Sarracenia flàva L. Leaves erect, elongated, trumpet-shaped, $5-9 \mathrm{dm}$. tall, gradually expanding above, the edges revolute, the upper part of the trumpet as well as the suborbicular apiculate hood which is $8-12 \mathrm{~cm}$. broad, often bright yellow, more or less reticulated with reddish or purple veins : scape about as long as the leaves : flowers 10-12 cm. broad : sepals widest at the middle, 4-5 cm. long, rounded at the broad apex : petals yellow, much thinner than the sepals, $7-10 \mathrm{~cm}$. long ; blades obovate, obtuse, abruptly narrowed to the oblong claw, scarcely widened at the base : style-disk 7-9 $\mathrm{cm}$. broad, the lobes 2-cleft at the apex : capsule about $2 \mathrm{~cm}$. in diameter.

In pine-land swamps, and in meadows near the mountains, Virginia to Florida. Spring Watches. Trumpets.

6. Sarracenia Catesbaèi Ell. Leaves erect, rather slender, narrowly trumpetshaped, $2-5 \mathrm{dm}$. long, slightly expanding above; hood ovate, with relatively straight inconspicuous veins, these much less branched than those of $S$. flava: scapes about as tall as the leaves : sepals widest near the base, tapering to the narrow but blunt apex, resembling the petals in texture: petals greenish yellow, $5-6 \mathrm{~cm}$. long, fiddle-shaped; blades rhombic-ovate, the abruptly widened basal portion nearly $2 \mathrm{~cm}$. long, rhombic-obovate : capsule similar to those of $C$. flava, but with longer processes.

In swamps, South Carolina to Georgia and Alabama. Spring.

7 Sarracenia mìnor Walt. Leaves erect, 2-4 dm. long, narrowly trumpet-shaped, gradually expanding from the base, variegated at and near the top with green and purple veins and white or yellowish scar-like blotches; hood ovate, arching, incurved over the orifice of the trumpet : scapes erect, shorter than the leaves or slightly longer: flowers $4-6 \mathrm{~cm}$. broad : sepals ovate, about $2.5 \mathrm{~cm}$. long, obtuse : petals narrowly fiddle-shaped, about $4 \mathrm{~cm}$. long, rounded at the apex: style-disk $2.5-3 \mathrm{~cm}$. broad, the lobes notched: capsule $1.5 \mathrm{~cm}$. broad. [S. variolaris Michx.]

In pine-land swamps and low woods, North Carolina to Florida and Alabama. Spring.

\section{Order 14. ROSÀLES.}

Herbs, shrubs or trees, rarely wholly aquatic plants, or vines. Leaves with simple or compound blades. Flowers mostly perfect. Calyx and corolla present and sometimes irregular, or the latter occasionally, or both rarely wanting. Sepals distinct or partially united, commonly confluent with the hypanthium. Androecium of several mostly epigynous or perigynous stamens. Gynoecium of 1 or several distinct or united carpels. Fruit various. Aquatic alga-like fleshy herbs, with spathe-like involucres : perianth usually wanting.

Terrestrial or swamp plants, without spathe-like involucres: perianth

Fam. 1. Podostemaceae.

present.

A. Endosperm present, usually copious and fleshy : stipules mostly wanting.

a. Herbs.

* Carpels as many as the sepals: stamens as many as the sepals or twice as many.

Plants succulent : carpels distinct or united at the base, opening lengthwise.

Plants not succulent: carpels united to the middle, circumscissile.

Fam. 2. Sedackat.

Fam. 3. Penthoraceae. 
** Carpels fewer than the sepals.

Staminodia present: carpels 3 or 4 , wholly united into a 1-celled gynoecium.

Staminodia wanting: carpels mostly 2, distinct or partially united.

b. Shrubs or trees.

Leaves opposite.

Leaves alternate.

Fruit a 2-celled capsule.

Capsule thin-walled, almost free from the hypanthium.

Capsule woody or thick-walled, manifestly adnate to the

Fruit a 1-celled berry.

B. Endosperm wanting or scant (copious in Opulaster in ROSACEAE): stipules mostly present.

Flowers monoecious, in dense capitate clusters.

Flowers perfeet,or if monoecious or dioecious, not in capitate clusters. Flowers regular.

Carpels several or numerous, or if solitary becoming an achene. Carpels distinct, rarely adnate to the hypanthium: fruit achenes or follicles.

Sepals and petals 5 : leaves mostly alternate.

Sepals and petals numerous : leaves opposite.

Carpels united, enclosed by the hypanthium and adnate to it : fruit a pome.

Carpel solitary, not becoming an achene.

Ovary with 2 ovules: leaf-blades simple : fruit a drupe.

Ovary with several ovules: leaf-blades 2-3-pinnate : fruit! a legume.

Petals valvate in the bud.

Petals imbricated in the bud, Gleditsia and Gymnocladus in CASSIACEAE.

Flowers irregular (nearly or quite regular in Gleditsia and Gymnocladus in CASSIACEAE.)

Fruit indehiscent, armed with barbed spines : leaf-blades|simple: stipules wanting.

Fruit a legume or loment: leaf-blades compound: stipules usually present.

Upper petal enclosed by the lateral ones in the bud.

Upper petal enclosing the lateral ones in the bud.

Fam. 4. Parnassiaceae.

Fam. 5. SAXIFragaceaE.

Fam. 6. Escalloniaceae.

Fam. 7. Iteaceae.

Fam. 8. Altingiaceae.

Fam. 9. Grossulariaceae.

Fam. 10. Platanaceae.

Fam. 11. Rosacear.

Fam. 12. Calycanthaceae.

Fam. 13. Malaceae.

Fam. 14. Amygdalaceae.

Fam. 15. Mimosaceae.

Fam. 16. Cassiacear.

Fam. 17. Krameriaceae.

Fam. 16. Cassiacene.

Fam. 18. FABACEAE.

\section{Family 1. PODOSTEMÀCEAE Lindl. River-Weed Family.}

Annual aquatic herbs, with poorly differentiated vegetative organs, commonly resembling the thallus of an alga or hepatic. Leaves alternate: blades often divided. Flowers usually perfect, incomplete, subtended by a spathe-like involucre. Perianth wanting, or when present of 3-5 membranous sepals. Androecium of 2 or sometimes many hypogynous stamens. Anthers 2-celled, opening lengthwise. Gynoecium of 2 or 3 united carpels. Ovary 2-3-celled. Styles 2 or 3, short. Ovules several or numerous, anatropous. Fruit a 2-3-celled ribbed capsule. Seeds often numerous. Endosperm wanting. Embryo straight.

\section{PODOSTÈmon Michx.}

Fresh-water caulescent herbs, various in habit, usually resembling algae. Leaves alternate: blades divided or dissected. Flowers inconspicuous, sessile or nearly so in the spathe-like involucre. Perianth wanting. Stamens 2: filaments united to near the top. Staminodia 2, slender. (Ovary 2-celled. Stigmas 2, narrow, nearly erect. Capsule longer than thick, 2-valved, 6-10-ribbed. Seeds very small.

Flower solitary : capsules oval. 8-ribbed: leaf-segments flattened. $\quad$ 1. P. Ceratophyllum. Flowers 2 or 3 together: capsules oblong, 10-ribbed : leaf-segments almost capillary. 2. P. abrotanoides.

1. Podostemon Ceratophýllum Michx. Plants olive green, glabrous. Stems 0.5-2 dm. long, attached to stones in running water by disk-like expansions: leaves rigid; blades divided into many narrow segments, the base sheathing the stem : flowers solitary, slender-pedicelled, about $1.5 \mathrm{~mm}$. broad, bursting from the spathes : united filaments much onger than the ovary : capsules oval, $2.5 \mathrm{~mm}$. long, obtuse at both ends, 8-ribbed.

In running water, on rocks, Ontario to Minnesota, New York, Georgia, Alabama and Kentucky. Summer and fall.

2. Podostemon abrotanoides Nutt. Similar to the preceding species in habit, but larger, the stems sometimes becoming 6 or $7 \mathrm{dm}$. long. Leaves often numerous: blades much divided into almost capillary segments : flowers 2 or 3 together, short-pedicelled : capsules oblong, 10-ribbed.

On gravelly river bottoms, Georgia and Florida to Mississippi. Summer. 
Family 2. Sedàceae Neck. Orpine Family.

Herbs or somewhat shrubby plants, various in habit, with mostly succulent tissues. Leaves alternate, opposite or whorled, without stipules : blades thick. Flowers perfect or dioecious, solitary, or usually in cymes. Perianth usually of 2 series. Calyx of 4 or 5 persistent sepals, or rarely fewer or more. Corolla of as many imbricated, sometimes united petals as there are sepals, or wanting. Androecium of as many stamens as there are petals, or twice as many. Anthers opening lengthwise. Receptacle with a scale at the base of each carpel. Gynoecium of as many distinct or partially united carpels as there are sepals. Styles terminal. Ovules in 2 rows along the ventral suture. Fruit membranous or leathery follicles, opening along the ventral suture. Seeds minute, numerous. Endosperm fleshy. Embryo terete. [Crassulaceae DC.]

Sepals and petals distinct or nearly so: calyx not inflated.

Stamens as many as the sepals.

Stamens twice as many as the sepals.

Carpels distinet.

Carpels partially united.

Sepals and petals united : caly $x$ inflated.

1. Tillaea.

2. SEDUM.

3. DIAMORPHA.

4. BRYOPHYLLUM.

\section{TILLAغ̀A L.}

Low fleshy usually mud-inhabiting glabrous caulescent herbs. Leaves opposite, terete or flattish, entire. Flowers white or reddish, solitary in the axils, or in simple axillary or terminal cymes. Sepals 3-5, united below. Petals 3-5, distinct, or united at the base. Stamens 3-5: filaments filiform: scales 3-5, narrow, or obsolete. Carpels 3-5, distinct. Ovary 1-celled: styles subulate or wanting: stigmas minute. Ovules several or rarely 1 in each cavity. Follicles 3-5, distinct.

Flowers sessile or nearly so : corolla greenish : follicles with 8-10 seeds. Flowers manifestly pedicelled : corolla reddish : follicles with 12-20 seeds.

1. T. aquatica.

2. T. Drummondii.

1. Tillaea aquática $L$. Stems simple or widely branching, $2-7 \mathrm{~cm}$. long, sometimes creeping : leaves opposite and connate, linear-oblong, 4-6 $\mathrm{mm}$. long, acutish or obtuse : flowers solitary and sessile in the axils or nearly so : corolla greenish, about $1 \mathrm{~mm}$. broad : petals about twice as long as the sepals: follicles ovoid, surpassing the calyx : seeds 8-10 in each follicle. [T. simplex Nutt.]

On muddy banks, Nova Scotia to Massachusetts, Maryland and Alabama. Summer.

2. Tillaea Drummóndii T. \& G. Stems usually much branched at the base, the branches 1-3 cm. long, often rooting at the lower nodes, mostly forking above: leaves linear-oblong or spatulate, $2-4 \mathrm{~mm}$. long, obtuse, the bases connate : flowers mostly solitary in the axils : pedicels finally as long as the leaves : sepals ovate, $0.5 \mathrm{~mm}$. long, rather obtuse : petals reddish, twice as long as the sepals: follicles $1 \mathrm{~mm}$. long, obtuse : seeds oval, 12-20 in each follicle.

On muddy shores of ponds, Washington to Colorado, Louisiana, Texas and Mexico. Spring to fall.

\section{SÈDUM L.}

Fleshy commonly glabrous caulescent herbs or rarely shrubby plants. Stems solitary, or often tufted. Leaves alternate, opposite or whorled: blades flat or terete, entire or toothed. Flowers perfect or dioecious, white, yellow, pink or blue, in terminal or axillary cymes or rarely solitary. Sepals 4 or 5 , distinct. Petals 4 or 5 or rarely more, distinct. Stamens 8-10, or rarely more : filaments subulate or filiform, often adnate to the petals. Carpels 4 or 5 , distinct or nearly so. Ovary 1-celled: styles subulate : stigmas minute. Ovules usually numerous in each cavity. Follicles 4 or 5, erect or spreading.

Stem-leaves with terete or nearly terete blades.

Corolla yellow.

Corolla white, pink or purple.

Corolla purple.

Corolla white or pink.

Stem-leaves with flat blades.

Relatively low plants with decumbent or creeping stems. Corolla less than $13 \mathrm{~mm}$. broad : follicles $2.5-4.5 \mathrm{~mm}$. long : bracts linear. Corolla over $13 \mathrm{~mm}$. long: follicles $5.5-8 \mathrm{~mm}$. long : bracts oblong.

Relatively tall plants with erect stems.

Leal-blades toothed : flowers in dichotomous or corymb-like cymes. Flowers perfect: sepals and petals 5 : corolla white or pink. Flowers dioecious: sepals and petals 4 or rarely 5 : corolla purple.

Leaf-blades entire : flowers in spike-like, raceme-like or panicle-like cymes.

1. S. Nuttallianum.

2. S. pulchellum.

3. S. pusillum.

4. S. Nevii.

5. S. ternatum.

6. S. telephioides.

7. S. Roanense.

8. S. Texanum. 
1. Sedum Nuttalliànum Raf. Annual, slender, glabrous. Stems $3-5 \mathrm{~cm}$. tall, often branched at the base or above: leaves scattered; blades nearly terete, obtuse, 3-9 mm. long, sessile: branches of the eymes 3-5, 1-6 cm. long: flowers rather few : sepals oblongovate, nearly $2 \mathrm{~mm}$. long, obtuse : petals yellow, broadly lanceolate, $3 \mathrm{~mm}$. long, acutish : follicles $3.5 \mathrm{~mm}$. long, diverging, each tipped with the subulate style.

In dry soil, Missouri to Arkansas and Texas. Spring.

2. Sedum pulchéllum Michx. Annual or perennial, bright green. Stems usually branched at the base, the branches $5-30 \mathrm{~cm}$. tall, leafy above : leaves numerous; blades terete or nearly so, linear, 1-2 cm. long, obtuse : branches of the cymes $2-6 \mathrm{~cm}$. long: flowers numerous : sepals linear or linear-oblong, $2-2.5 \mathrm{~mm}$. long, obtuse : petals deep or pale purple, oblong, hardly twice as long as the sepals: stamens 8 or those of the central flowers sometimes 10 : follicles slender, about $5 \mathrm{~mm}$. long, tapering into the subulate styles.

On rocks, Virginia to Missouri, Georgia and Texas. Spring and summer.

3. Seđum pusíllum Michx. Annual, glabrous, pale green. Stems $2-10 \mathrm{~cm}$. tall, simple or branched, the branches corymbose : leaves alternate; blades nearly terete, 2-6 $\mathrm{mm}$. long, obtuse, sessile : cymes open, the branches 1-3 cm. long : flowers several : sepals 5 , broader than long: petals white or pink, ovate, $2.5 \mathrm{~mm}$. long, obtuse often hooded at the apex : stamens 8 : follicles spreading, $4 \mathrm{~mm}$. long, acute.

On granite rocks, South Carolina and Georgia. Spring.

4. Sedum Nèvii A. Gray. Perennial, pale green, forming wide mats. Stems decumbent, 2-14 cm. long, very leafy, simple or branched, the flowering stems longer than the sterile ones: leaves alternate; blades club-shaped or spatulate, $5-15 \mathrm{~mm}$. long, obtuse : flowers several, about $1 \mathrm{~cm}$. broad: branches of the cyme usually $2-6 \mathrm{~cm}$. long: sepals linear-lanceolate, acutish: petals white, lanceolate, acute, as long as the sepals or slightly longer : stamens 8 , shorter than the petals : anthers purple-brown: follicles slender, 2.5$4.5 \mathrm{~mm}$. long, each terminating in the bristle-like style.

On banks in woods, Virginia to Alabama. Spring.

5. Sedum ternàtum Michx. Perennial, matted, bright green. Stems decumbent, $3-15 \mathrm{~cm}$. long, often creeping, branching below : leaves mostly in whorls of 3's, those on sterile branches crowded, those on fertile branches distant; blades varying from spatulate to suborbicular, sessile or nearly so: flowers perfect: branches of the cymes $3-10 \mathrm{~cm}$. long, spreading or recurved: sepals linear, $4 \mathrm{~mm}$. long, obtuse : petals white, oblonglanceolate, about $7 \mathrm{~mm}$. long, obtuse : stamens 8 , or in the central flowers 10 : follicles diverging, 5.5-8 $\mathrm{mm}$. long, each tipped with the subulate style.

On rocks or shady banks, New York to Indiana and in or near the mountains to Georgia and Tennessee. Spring.

6. Sedum telephioides Michx. Perennial, stout, glaucous. Stems sometimes tufted, 1-4 dm. tall, simple below, corymbosely branched above : leaves not approximate ; blades oval to ovate, $2-7 \mathrm{~cm}$. long, coarsely toothed or nearly entire, the lower ones usually short-petioled, the upper ones sessile : cymes terminal, corymbose: flowers several, not crowded : sepals linear-lanceolate, nearly $3 \mathrm{~mm}$. long, acute : petals white or pink, oblong, about $5 \mathrm{~mm}$. long, acute: stamens 10 : follicles $3.5-4 \mathrm{~mm}$. long, erect, slender-beaked.

On dry rocks, western New York to Indiana, Maryland and Georgia. Summer.

7. Sedum Roanénse Britton. Perennial, stout, deep green. Stems tufted, 1-4 dm. tall, simple : leaves approximate; blades elliptic, narrowly cuneate or almost linear, 1-3.5 $\mathrm{cm}$. long, acutish or obtuse, entire or nearly so, sessile : flowers dioecious, in dense terminal cymes, purple, the staminate with 8 or rarely 10 stamens, the pistillate with 4-5 carpels: sepals 4 or rarely 5 , linear, about $1 \mathrm{~mm}$. long, obtuse: petals oblong-linear, $3 \mathrm{~mm}$. long, obtuse : follicles nearly erect, $8-12 \mathrm{~mm}$. long, the tips slightly spreading. [S. Rhodiola Chapm., not DC.]

On cliffs, Roan Mountain, North Carolina. Spring and summer.

8. Sedum Texànum J. G. Smith. Perennial, glabrous. Stems 1.5-2 dm. tall, sparingly branched from near the base: leaves few, alternate; blades fleshy, obovate to ovate or ovate-lanceolate, $2-2.5 \mathrm{~cm}$. long, entire, acute or acuminate, or some of them blunt, sessile: flowers in spike-like, raceme-like or panicle-like cymes, the individual flowers or the flower-clusters remote: sepals 5, oblong, acute : petals 5, pinkish yellow, $3-3.5 \mathrm{~mm}$. long, often slightly broadened upward, thickened and apiculate at the apex: follicles inflated, subulate-tipped.

In chapparal, Corpus Christi, Texas. Summer and fall.

3. DIAMÓRPHA Nutt.

Low, annual or biennial herbs. Stens usually highly colored, branched. Leaves alternate or scattered, nearly terete, sessile. Flowers perfect, pink or pinkish, in corymbose 
cymes. Sepals 4. Petals 4, distinct. Stamens 8, inserted at the base of the petals : filaments filiform : anthers dark-colored. Scales minute, suborbicular. Carpels 4, united below the middle. Ovary 1-celled : styles subulate, short: stigmas minute. Ovules numerous in each carpel, crowded on axile placentae. Follicles 4, the tips spreading at maturity.

1. Diamorpha cymòsa (Nutt.) Britton. Plants glabrous, reddish throughout. Stems 2-10 cm. tall, simple or branched at the base or above : leaves nearly terete, $2-5$ $\mathrm{mm}$. long, obtuse, ascending, sometimes incurved, sessile : pedicels $1-1.5 \mathrm{~mm}$. long: sepals triangular, acute or acutish, slightly spreading: petals oblong-ovate, boat-shaped, nearly 3 $\mathrm{mm}$. long, obtuse : stamens shorter than the petals: anthers black: follicles $1.5-2 \mathrm{~mm}$. long, with curved or hooked tips. [D. pusilla Nutt.]

On rocks, chiefly granite, North Carolina and Tennessee to middle Georgia and Alabama. Spring.

\section{BRYOPHÝLLUM Salisb.}

Upright herbs, with a shrubby base and fleshy tissues. Leaves opposite : blades simple or pinnately compound; leaflets mostly toothed. Flowers perfect, often showy, nodding, in cymes or panicles which are opposite the branches. Sepals 4, united into an often inflated calyx. Corolla nearly campanulate, or urn-shaped, the narrow limb with 4 spreading lobes. Stamens 8 , in 2 rows, adnate to about the middle of the corolla-tube: filaments filiform : anthers mostly exserted. Glands of the disk 4, oblong. Carpels 4, distinct or partially united. Ovules many in each cavity. Follicles 4. Seeds numerous.

1. Bryophyllum pinnàtum (Lam.) S. Kurz. Perennial, glabrous. Stems $4-15$ dm. tall, more or less widely branched : leaf-blades often pinnately compound, 1-3 dm. long; leaflets oblong, oval or elliptic, obtuse, crenate, the terminal one several times longer than the lateral ones: panicles 1-4 dm. long, conspicuous: calyx bladder-like when growing, finally oblong-campanulate, $3-3.5 \mathrm{~cm}$. long, glabrous : corolla reddish, twice as long as the calyx or shorter; lobes lanceolate or narrowly ovate, acute. [B. calycinum Salisb.]

In waste places, Florida. Introduced from tropical America.

\section{Family 3. Penthoràceae Rydb. Virginia Stonecrop family.}

Perennial herbs, with relatively firm tissues and erect stems. Leaves alternate; blades thinnish, serrate. Flowers perfect, greenish, in terminal cymes, secund on the branches. Sepals 5. Petals 5, inconspicuous, or wanting. Stamens 10, hypogynous: filaments filiform. Scales wanting. Carpels 5, united to about the middle: styles very short, abruptly pointed, diverging: stigmas capitate. Ovules numerous in each carpel, on axile placentae. Follicles united into a 5-celled, 5-lobed depressed circumscissile capsule with wide-spreading or recurved persistent styles.

\section{PENTHÒRUM L.}

Characters of the family. Ditch or Virginia Stonecrop.

1. Penthorum sedoides L. Foliage bright green, glabrous, or glandular pubescent above. Stems 1-6 dm. tall, simple or branched above, terete below, angled above: leafblades narrowly elliptic to elliptic-lanceolate, $3-15 \mathrm{~cm}$. long, acuminate at both ends, serrate ; petioles $0.5-2 \mathrm{~cm}$. long: branches of the cymes $2-8 \mathrm{~cm}$. long, spreading: flowers greenish white, $4 \mathrm{~mm}$. broad : sepals ovate, $1.5 \mathrm{~mm}$. long, acute : petals generally wanting : capsule depressed, $4-5 \mathrm{~mm}$. broad, each lobe tipped with a stout slightly recurved style.

In swamps and wet soil, New Brunswick to Minnesota, Florida and Texas. Summer.

\section{Family 4. Parnassiàceae Dumort. Grass-of-Parnassus Family.}

Acaulescent herbs, with glabrous foliage. Leaves basal : blades leathery, entire : petioles usually elongated, erect, dilated at the base. Scapes usually solitary, simple, each bearing a bract. Flowers perfect, white or pale yellow, solitary. Perianth in 2 series. Calyx persistent : sepals 5, imbricated. Corolla of 5 variously shaped imbricated entire or fimbriate, often conspicuously nerved, deciduous petals. Androecium of 5 hypogynous or perigynous stamens alternating with entire or tufted staminodia. Filaments subulate. Anthers introrse. Gynoecium of 3 or 4 united carpels. Ovary 1-celled, superior or half- 
inferior, with 3 or 4 parietal placentae. Styles very short. Stigmas 3-4, over the placentae. Ovules anatropous, numerous. Capsule membranous, 1-celled, loculicidally 3-4-valved at the apex. Seeds numerous, winged, the testa loose. Endosperm wanting. Embryo straight, terete.

\section{PARNÁSSIA L.}

Characters of the family. Grass-of-Parnassus.

Leaf-blades longer than broad: petals sessile. Leaf-blades broader than long: petals with claws.

1. $P$, grandifolia. 2. P. asarifolia.

1. Parnassia grandifòlia DC. Leaf-blades suborbicular to ovate, rounded or obtuse at the apex, narrowed or cordate at the base, entire; petioles as long as the blades or longer: scapes erect, solitary or several together, $3-6 \mathrm{dm}$. tall, with a bract at the middle or much below it: sepals reflexed, ovate, obtuse, striped : petals white or cream-colored with dark parallel nerves and dark reticulated veins on either side near the base, oval to elliptic, 2-2.5 cm. long, sessile : staminodia $3-5$ in each set, filiform, about $1 \mathrm{~cm}$. long, twice longer than the stamens : filaments recurved at maturity : capsule oval, 1-1.5 mm. long.

In wet soil, Virginia to Missouri, Florida and Louisiana. Summer and fall.

2. Parnassia asarifolia Vent. Leaf-blades reniform to orbicular-reniform, $5-10 \mathrm{~cm}$. broad, rounded at the apex, entire, cordate at the base, deeper green above than beneath; petioles somewhat longer than the blades or much longer : scapes erect, solitary or tufted, 2-4 dm. tall, bearing a clasping bract below the middle : sepals ovate or oblong, 4-5 mm. long, obtuse : petals cream-colored striped with green, $1.5-2 \mathrm{~cm}$. long, the blades broadly ovate to suborbicular, obtuse or notched at the apex; claws about $\frac{1}{2}$ as long as the blades or shorter : staminodia 3 in each set : stamens about as long as the staminodia : capsule ovoid, $6-10 \mathrm{~cm}$. long.

In wet mountain brooks, Virginia to middle Georgia. Summer and fall.

\section{Family 5. SAXIFRAGÀCeae Dumort. Saxifrage Family.}

Caulescent or acaulescent herbs, with glabrous or variously pubescent foliage. Leaves alternate or opposite : blades often thick. Flowers perfect or polygamo-dioecious, solitary, racemose, paniculate or cymose. Perianth usually of 2 series. Calyx of 5 , or rarely 4 or more sepals, usually persistent. Corolla of usually 4-5 distinct petals, or wanting. Disk normally present. Androecium of as many or twice as many epigynous or perigynous stamens as there are petals, or in apetalous species as many or twice as many as there are sepals. Filaments distinct, thickest below the middle or above it. Gynoecium of 1 or several distinct or united carpels. Styles as many as there are carpels, or cavities in the ovary. Ovules numerous, anatropous. Fruit a capsule or follicle. Seeds commonly numerous, with copious fleshy endosperm. Embryo terete.

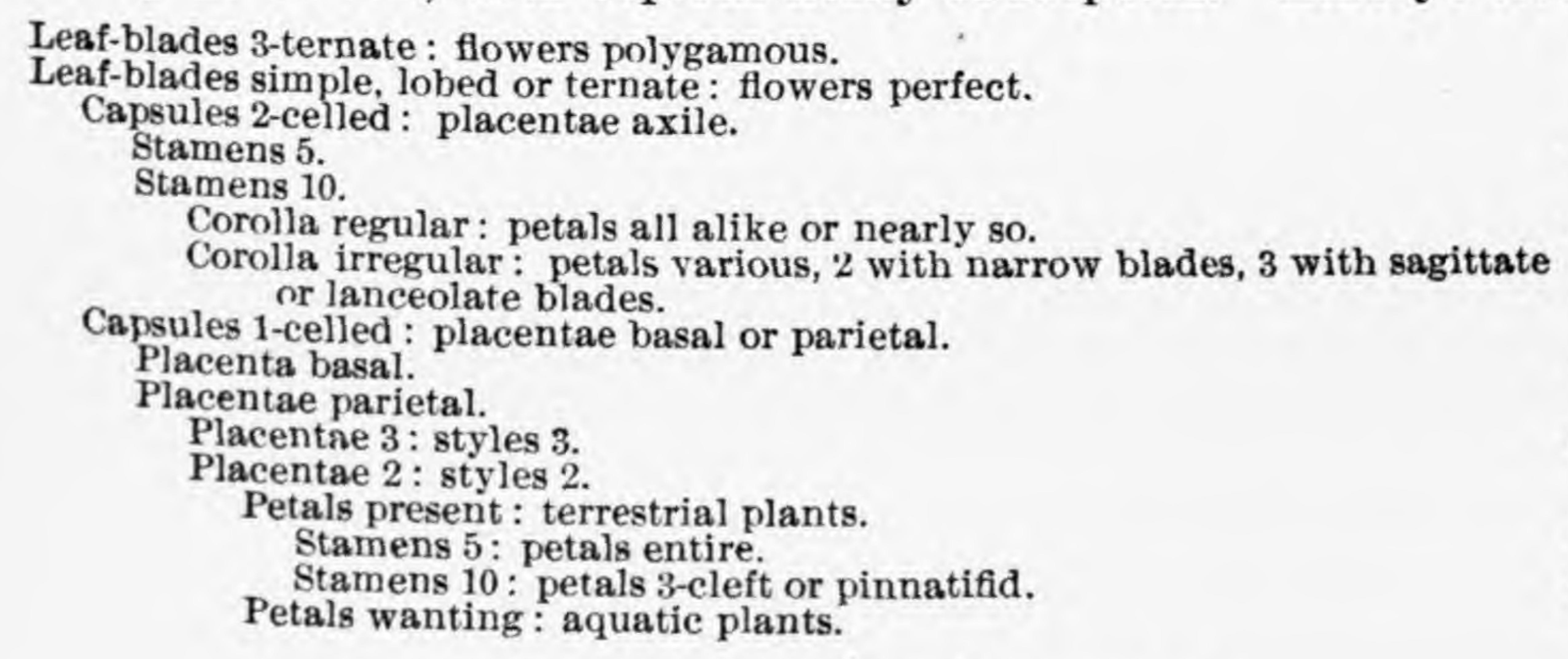

1. Astilbe.

2. THEROFON.

3. Micranthes.

4. Spatularia.

5. THARELLA.

6. LEPUROPETALON.

7. HEUCHERA.

8. Mitelia.

9. CHRYsospleniUM.

\section{ASTÍLBE Hamilt.}

Perennial caulescent herbs, resembling Aruncus. Leaves alternate : blades thrice compound, petioled; leaflets toothed. Flowers usually polygamo-dioecious, in terminal panicled spikes or racemes. Sepals 5 , or rarely 4 , imbricated. Petals 5 , or rarely 4 , or wanting, narrow, inserted at the base of the calyx. Stamens 10, inserted with the petals : 
filaments elongated: anthers cordate. Ovary partly inferior. Carpels 2-3, more or less united. Ovules numerous in each cavity, on axile placentae. Fruit of $2-3$ carpels. Seeds small, usually numerous. Testa membranous. FALSE GOAT's-BEARD.

Leaflets sharply toothed or lobed : fruit $4 \mathrm{~mm}$, high.

Leaflets crenately toothed or lobed: fruit $3 \mathrm{~mm}$. high.

1. A. biternata.

2. A. crenatilobata.

1. Astilbe biternàta (Vent.) Britton. Foliage bright green. Stem 1-2 m. tall, branching or sometimes simple : leaves ample; blades mostly thrice ternate, longer than the petioles; leaflets acuminate, sharply serrate or incised, often lobed, cordate at the base, the lateral ones oblong to ovate, the terminal ones oval to suborbicular in outline, sharply 3-lobed, all sparingly pubescent beneath : panicle 1-3 dm. long, finely glandular-pilose: sepals ovate, less than $1 \mathrm{~mm}$. long, obtuse: petals narrowly spatulate, $2-3.5 \mathrm{~mm}$. long, shorter or wanting in the perfect flowers: fruit oblong-ovoid, $4 \mathrm{~mm}$. high, the follicles distinct. [A. decandra D. Don.]

In rich woods in and near the mountains, Virginia to Tennessee, and Georgia. Spring.

2. Astilbe crenatilobàta (Britton) Small. Foliage deep green. Stem about $1 \mathrm{~m}$. tall, more or less branched : leaves ample; blades thrice ternate; petioles usually shorter than the blades; leaflets thin, crenately toothed or lobed, the teeth or lobes apiculate, the lateral leaflets ovate or oval, cordate at the base, the terminal leaflet, ovate or suborbicular in outline, usually 3 -lobed, cordate or acute at the base: fruit ovoid, $3 \mathrm{~mm}$. high, the follicles distinct. [A. decandra crenatilobata Britton.]

In deep woods, North Carolina. Summer.

\section{THÉROFON Raf.}

Perennial caulescent herbs, with glandular-pubescent foliage. Leaves alternate, chiefly basal : blades suborbicular, toothed, lobed or cleft, petioled, with narrow sometimes cleft stipules. Flowers perfect, white, in terminal panicles or corymbose cymes. Sepals 5, valvate. Petals 5, surpassing the sepals, deciduous. Stamens 5, inserted near the sepals. Ovary 2-3-celled, partly inferior: styles 2-3, short. Ovules numerous, borne on axile placentae. Capsule urn-shaped or subglobose, erect or drooping, opening between the styles. Seeds minute, numerous, the coat somewhat punctate. [Boykinia Nutt.]

1. Therofon aconitifòlium (Nutt.) Millsp. Stem erect, $2-10 \mathrm{dm}$. tall, simple below : leaves alternate; blades suborbicular or reniform in outline, 4-18 $\mathrm{cm}$. broad, palmately 5 -7-lobed, the lobes incised-serrate or lobed, the segments acute; petioles glandular-pilose, the lower ones longer than the blades, the upper shorter: bracts leaf-like, incised : corymb glandular-pubescent : sepals 5, triangular-ovate or broadly lanceolate, acute, glandularciliate, longer than the hypanthium during anthesis : corolla white, $5-7 \mathrm{~mm}$. broad : petals 3-3.5 mm. long, eroded ; blades oval, narrowed into short claws : capsules $3-4 \mathrm{~mm}$. long, adnate to the hypanthium up to the distinct beaks : seeds $0.5 \mathrm{~mm}$. long, black.

In and along streams chiefly on mountain slopes, Virginia to North Carolina, Tennessee and Georgia. Spring and summer.

\section{MiCrÁNTHES Haw.}

Perennial scapose herbs, with short rootstocks and glabrous or glandular-pubescent foliage. Leaves basal: blades thick, entire or variously toothed, mostly petioled. Flowers perfect, in terminal panicled or head-like cymes. Sepals 5. Corolla regular: petals 5, equal or nearly so, scarcely clawed. Stamens 10: filaments subulate or clubshaped. Carpels normally 2, slightly united below: styles erect or recurved. Ovules numerous. Follicles 2, more or less narrowed above, often diverging. Seeds variously roughened. Saxifrage. Mountain Lettuce.

Filaments subulate or filiform-subulate.

Sepals $1.5-4.5 \mathrm{~mm}$. long: petals oblong, elliptic, oval or suborbicular.

Petals oblong, oval or suborbicular, wholly white.

Petals over twice as long as wide, much longer than the sepals : pedicels pubescent.

Petals less than twice as long as wide, slightly surpassing the sepals: pedicels glabrous.

Petals lanceolate, each with 2 yellow spots.

Sepals $1 \mathrm{~mm}$. long: petals elliptic.

Filaments club-shaped.

Petals with 2 yellow spots, ovate or oblong-ovate: follicles 4-6 $\mathrm{mm}$. long.

Petals white throughout, oblong: follicles $7-8 \mathrm{~mm}$. long.

1. M. Virginiensis.

2. M. Texana.

3. M. Tennesseensis.

4. M. Careyana.

5. M. Grayana.

6. M. micranthidifolia. 
1. Micranthes Virginiénsis (Michx.) Small. Foliage pubescent. Leaf-blades 2-20 $\mathrm{cm}$. long, ovate to obovate or spatulate, crenate or crenate-dentate, obtuse, each narrowed into a winged petiole shorter or longer than the blade: scapes solitary or tufted, 1-4 dm. tall, strict: branches of the inflorescence much elongated at maturity : sepals as long as the hypanthium, $1.5 \mathrm{~mm}$. long, triangular, or triangular-ovate, sometimes nearly lancelate, each terminating in a black gland: corolla white, $5-8 \mathrm{~mm}$. broad : petals nearly equal, $3.5-6 \mathrm{~mm}$. long, oblong or nearly so: filaments subulate: follicles distinct or nearly so, 4-5 mm. long, inflated. [Saxifraga Virginiensis Michx.]

On banks and rocks, New Brunswick to Minnesota, middle Georgia and Tennessee. Spring.

2. Micranthes Texàna (Buckl.) Small. Resembling S. Virginiensis, but glabrous, at least the inflorescence. Leaf-blades $1-2.5 \mathrm{~cm}$. long, ovate or obovate, obtuse, entire or shallowly toothed, sessile or short-petioled: scapes $0.5-1.5 \mathrm{dm}$. tall, sparingly branched above: branches of the inflorescence terminating in congested eymules: sepals oblong to ovate, slightly shorter than the hypanthium : corolla white, 4-6 $\mathrm{mm}$. broad : petals nearly equal, 2-3 mm. long, suborbicular or obovate : filaments subulate : follicles united at the base, 3-4 $\mathrm{mm}$. high, slightly surpassing the sepals, the style-beaks not diverging. [Saxifraga Texana Buckl.]

On hillsides, Texas. Spring.

3. Micranthes Tennesseénsis Small. Leaf-blades ovate or sometimes suborbicular, 2-6 $\mathrm{cm}$. long, obtuse or rounded at the apex, but usually terminated by a tooth, coarsely crenate-dentate, abruptly narrowed at the base; petiole winged, longer or shorter than the blade: scapes erect or assurgent, 1-2.5 dm. tall: branches of the panicles subtended by linear or spatulate bracts: cymules open: sepals triangular-ovate, $1-1.5 \mathrm{~mm}$. long, acute, spreading, longer than the hypanthium : corolla white, $8-9 \mathrm{~mm}$. broad : petals lanceolate, $3.5-4 \mathrm{~mm}$. long, obtuse or slightly notched at the apex, sessile, or nearly so, each with 2 yellow spots and 2 lateral nerves which arise below the middle and converge at the apex : filaments subulate, slightly longer than the sepals : follicles somewhat inflated, $4 \mathrm{~mm}$. long, distinct, each terminating in a slender divergent style-beak. [Saxifraga Tennessensis Small.]

On rocky bluffs of the Tennessee River, Knoxville, Tennessee. Spring.

4. Micranthes Careyàna (A. Gray) Small. Leaf-blades broadly ovate or orbicular-ovate, $1-4 \mathrm{~cm}$. long, obtuse, crenate, truncate or subcordate at the base; petioles slender, equalling the blades or thrice exceeding them in length: scapes erect, $1-2 \mathrm{dm}$. tall, slender, paniculately branched above: pedicels filiform : sepals ovate, obtuse, spreading: corollas white, $5-6 \mathrm{~mm}$. broad : petals twice longer than the sepals, elliptic, faintly bimaculate, rather cuneately narrowed at the base: filaments filiform-subulate: follicles distinct or nearly so, $3-3.5 \mathrm{~mm}$. long, widely spreading, each terminating in a slender style-beak. [Saxifraga Careyana A. Gray.]

On cliffs of high mountains, North Carolina and Tennessee. Spring.

5. Micranthes Grayàna (Britton) Small. Leaf-blades $2-12 \mathrm{~cm}$. long, oblong, oval or orbicular, crenate with mucronate teeth, truncate at the base or narrowed into winged petioles which are usually shorter than the blades: scapes erect, $2-5 \mathrm{dm}$. tall, paniculately branched, the branches widely spreading : sepals oblong or ovate-oblong, $2-2.5 \mathrm{~mm}$. long, reflexed, obtuse, twice longer than the hypanthium: corolla white, $7-9$ $\mathrm{mm}$. broad: petals 5 , the blades ovate or oblong-ovate, $3-3.5 \mathrm{~mm}$. long, obtuse, strongly bimaculate, contracted into stout claws: filaments club-shaped : follicles 4-6 mm. long, united at the base, at length widely diverging: seeds oblong, 0.7-1 mm. long, strongly papillose in lines. [Saxifraga Grayana Britton. S. Caroliniana A. Gray, not Schleich.]

On banks and cliffs in the mountains of Virginia and North Carolina. Summer.

6. Micranthes micranthidifòlia (Haw.) Small. Leaf-blades oblong or oblanceolate, 1-3 dm. long, coarsely dentate, crenate or sometimes serrate, narrowed into broad winged petioles: scapes erect, $2-9 \mathrm{dm}$. tall, usually solitary, paniculately branched, the branches subtended by leaf-like bracts : pedicels slender or filiform : sepals oblong-lanceolate, obtuse, much longer than the hypanthium, reflexed : corolla white, $6-7 \mathrm{~mm}$. broad: petals oblong, surpassing the calyx : filaments club-shaped, longer than the petals : follicles 7-8 mm. long, united at the base, each terminating in a slender style-beak : seeds oblongelliptic, $1 \mathrm{~mm}$. long, longitudinally ribbed. [Saxifraga erosa Pursh.]

In mountain brooks and swamps, Pennsylvania to Georgia and Tennessee. Spring and summer.

\section{SPATULÀria Haw.}

Perennial scapose herbs, with short rootstocks and glandular-pubescent foliage. Leaves basal : blades narrow, broadened upward, coarsely or incisely toothed, with petiolelike bases. Flowers perfect, in spreading panicles. Sepals 5, slightly united, recurved at 
maturity. Corolla irregular: petals 5, various, 2 narrow, tapering into slender claws, 3 with short claws and sagittate or lanceolate blades. Stamens 10 : filaments filiform: anthers small. Carpels 2, partially united : styles diverging at maturity. Ovules numerous. Follicles rather plump, with diverging tips. Seeds with longitudinal striations.

1. Spatularia Michaùxil (Britton) Small. Foliage glandular-villous. Leaf-blades oblanceolate or oblong-spatulate, 3-30 $\mathrm{cm}$. long, coarsely dentate-serrate, each narrowed into a winged petiole-like base as long as the blade or commonly shorter: scapes erect, 2-9 dm. tall, usually flexuous, paniculately branched above : flowers irregular, white, 7-9 $\mathrm{mm}$. broad : sepals oblong, rather acute, reflexed: petals various, 2 spatulate, 1-nerved, with long slender claws, 3 lanceolate or sagittate, 3-nerved, bimaculate, all thrice longer than the sepals : filaments filiform : follicles $5-6 \mathrm{~mm}$. long, united for about $\frac{1}{3}$ their length, the tips widely diverging : seeds oblong, $1 \mathrm{~mm}$. long, with longitudinal papillose ridges. [Saxifraga leucanthemifolia Michx., not Le Peyr.]

On cliffs and steep banks in the mountains, Virginia to Georgia and Tennessee. Summer.

\section{TIARÉLLA L.}

Perennial scapose herbs, with horizontal rootstocks. Leaves chiefly basal: blades simple or 3-foliolate, long-petioled : petioles with small adnate stipules. Flowers perfect, in simple or branched terminal racemes. Sepals 5, persistent. Petals 5, entire, white. Stamens 10 : filaments elongated. Ovary 1-celled, flattened, 2-lobed at the apex, partly inferior: styles 2. Ovules numerous, borne on basal placentae. Capsules flattened, 1celled, opening by 2 unequal valves between the styles. Seeds numerous, at the base of the capsule, smooth. False Mitrewort.

Leaf-blades 3-6 cm. in diameter, the terminal lobes longer than the others: sepals $2.5 \mathrm{~mm}$. long: petals with elliptic blades: capsules $7-8 \mathrm{~mm}$. long.

Leaf-blades $15-20 \mathrm{~cm}$. in diameter, the terminal lobes not longer than the others: sepals

$2 \mathrm{~mm}$, long: petals with lanceolate blades: capsules 8-10 $\mathrm{mm}$. long.

1. T. cordifolia.

2. T. macrophylla.

1. Tiarella cordifòlia L. Leaf-blades $3-6 \mathrm{~cm}$. broad, ovate to suborbicular in outline, 3-5-lobed, sparingly pubescent on both sides, cordate, the lobes becoming rounded, crenate with mucronulate teeth, the terminal one much larger than the others ; petioles erect or nearly so, retrorsely pubescent, much longer than the blades: scapes erect, solitary or tufted, 1-3 dm. tall : raceme 3-20 cm. long: pedicels $5-10 \mathrm{~mm}$. long, subtended by minute bracts : hypanthium minutely glandular-pilose : sepals oblong-spatulate to obovate, $2.5 \mathrm{~cm}$. long, obtuse : petals $3 \mathrm{~mm}$. long: blades narrowly elliptic, acuminate at the apex, narrowed into short claws : filaments club-shaped : capsule slender-beaked, the valves striate, the larger one $7-8 \mathrm{~mm}$. long: seeds $1-1.3 \mathrm{~mm}$. long.

In woods, Nova Scotia to Minnesota and Indiana, and along the mountains to Georgia and Alabama. Spring.

2. Tiarella macrophýlla Small. Leaf-blades $15-20 \mathrm{~cm}$. broad, 5-lobed, glabrous, except a few hairs on the nerves beneath, deeply cordate, the lobes acute or acuminate, lobed again and coarsely toothed, the terminal lobe not longer than the others; petioles glabrous, longer than the blades: scapes erect, $2-4 \mathrm{dm}$. tall : raceme $1.5-3 \mathrm{dm}$. long : pedicels $5-10 \mathrm{~mm}$. long, solitary or several together, subtended by linear bracts : hypanthium minutely glandular-pilose : sepals oblong or oblong-ovate, $2 \mathrm{~mm}$. long, obtuse : petals white, $2.5 \mathrm{~mm}$. long; blades lanceolate, acuminate, narrowed into short claws : filaments clubshaped : capsules short-beaked, the larger valve $8-10 \mathrm{~mm}$. long: seeds about $1 \mathrm{~mm}$. long.

In woods, in or near the mountains, North Carolina. Spring.

\section{LEPUROPÉTALON Ell.}

Diminutive annual caulescent herbs. Leaves alternate: blades broadened upward, entire. Flowers perfect, solitary and terminal. Sepals 5. Petals 5, white, minute, broadened upward. Stamens 5 : filaments very short. Carpels 3, united. Ovary 1-celled, with 3 parietal placentae: styles 3 . Ovules numerous. Capsule 1-celled, opening by 3 valves at the apex. Seeds numerous.

1. Lepuropetalon spathulàtum (Muhl.) Ell. Glabrous, 0.5-1.5 cm. tall. Stems angled, branching from the base, the branches tufted : leaf-blades spatulate, $2-6 \mathrm{~mm}$. long, obtuse, entire, sessile : flowers terminal, solitary, $1.5-2 \mathrm{~mm}$. broad : sepals ovate, obtuse, persistent: petals spatulate, longer than the sepals: filaments much shorter than the sepals : anthers yellow : seeds numerous, oval, $0.3 \mathrm{~mm}$. long, punctate.

In clay soil, South Carolina and Georgia. Spring. 


\section{HEÙCHERA L.}

Perennial, mostly scapose herbs, with horizontal rootstocks and pubescent or glandular foliage. Leaves chiefly basal: blades thickish, coarsely toothed or lobed, longpetioled : petioles with adnate stipules. Flowers perfect, in rather narrow panicled cymes. Sepals 5, unequal, imbricated. Petals 5, or very rarely wanting, inserted at the top of the hypanthium, entire. Stamens 5, inserted with the petals: filaments slender. Ovary mostly inferior, 1-celled: styles 2, elongated. Ovules numerous, borne on 2 parietal placentae. Capsule 2-beaked, 2-valved at the top between the styles. Seeds numerous with a muricate or hispidulous testa. Alum-root. Rock Geranium.

Flowering stems with 1-3 or rarely 4-5 leaves.

Stamens slightly, if at all exceeding the petals: hypanthium decidedly turbinate at maturity.

Leaf-blades with rounded lobes and crenate teeth: petals spatulate, 2-2.5 mm. long, obtuse.

Leaf-blades with sharp lobes and very sharp teeth : petals oblanceolate, 2.5-3 mm. long, acute.

Stamens about twice as long as the petals: hypanthium campanulate during anthesis or slightly turbinate at maturity.

Stems and petioles glabrous or puberulent: hypanthium and calyx $3-4 \mathrm{~mm}$. long during anthesis.

Stems and petioles villous: hy panthium and calyx $2 \mathrm{~mm}$. long during anthesis. Flowering stems scape-like : leaves reduced to scales.

Flowers small: hypanthium and calyx $2-5 \mathrm{~mm}$. long during anthesis, slightly oblique.

Petioles and stems hirsute or villous, rarely glabrate.

Leaf-blades deeply lobed, the lobes acute.

Leaves with ovate or suborbicular blades, the lobes triangular.

Petioles sparingly pubescent or glabrate at maturity : pedicels ${ }^{3}$ less pubescent than the hypanthium: middle lobe of the leaf-blade relatively narrow.

Petioles densely and shaggy pubescent : pedicels more pubescent than the hy panthium : middle lobe of the leaf-blade relatively broad. Leaves with broadly reniform blades, the lobes broadly ovate.

Leaf-blades shallowly lobed, the lobes obtuse.

Hypanthium and caly $x$ about $2 \mathrm{~mm}$. long during anthesis : petals white.

Hypanthium and calyx 4-5 mm. long during anthesis: petals greenish or purple.

Petioles glabrous or puberulent : stems rarely slightly hirsute.

Petals spatulate to oblong, shorter than the sepals.

Hypanthium fully $1 \mathrm{~mm}$. long during anthesis, this together with the calyx becoming 4-5 mm. long.

Hypanthium barely $1 \mathrm{~mm}$. long during anthesis, this together with the

caly $x$ becoming $3 \mathrm{~mm}$. long.
Petals oblanceolate, $\mathrm{twice}$ as long as the sepals.

Flowers large : hypanthium and calyx 6-10 mm. long during anthesis, decidedly oblique.

1. H. pubescens.

2. H. aceroides.

3. H. Curtisii.

4. H. crinita.

\section{H. villosa.}

6. H. macrorhiza.

4. H. crinita.

7. H. parviflora.

8. H. hirsuticaulis.

\section{H. Americana.}

10. H. calycosa. 11. H. lancipetala.

12. H. longiflora.

1. Heuchera pubéscens Pursh. Stems erect, $3-10 \mathrm{dm}$. tall, usually bearing several leaves, densely glandular-pubescent, at least above: leaf-blades suborbicular, varying from orbicular-ovate to orbicular-reniform, $5-10 \mathrm{~cm}$. broad, ciliate, 5-7-lobed, sparingly pubescent on both sides, or glabrous, the lobes rounded, crenate: panicle 1-4 dm. long, lax : flowering hypanthium campanulate, slightly oblique, together with the calyx 5-6 mm. long, minutely glandular: sepals ovate to ovate-oblong, obtuse : petals firm, spatulate, $2-2.5 \mathrm{~mm}$. long, entire, slightly exceeding the sepals, eroded, obtuse : stamens slightly if at all exserted.

In woods, Pennsylvania to North Carolina and Tennessee. Spring and summer.

2. Heuchera aceroìdes Rydb. Similar to $H$. pubescens in habit. Leaf-blades ovate, sharply lobed, the lobes dentate or serrate-dentate with very sharp teeth: flowering hypanthium long-campanulate, very oblique, together with the caly x 6-8 mm. long: sepals oblong: petals delicate, oblanceolate, $2.5-3.5 \mathrm{~mm}$. long, manifestly surpassing the sepals, acute, eroded : stamens included.

On hillsides, near Asheville, North Carolina. Spring.

3. Heuchera Curtísii T. \& G. Stems erect, $5-10 \mathrm{dm}$. tall, glabrous below, puberulent above: basal leaves with suborbicular or reniform blades $3-8 \mathrm{~cm}$. broad, with rounded lobes and crenate, sometimes hispidulous above, ciliate: stem-leaves with orbicular or broadly ovate blades and acuminate teeth : panicle open, with diverging branches: hypanthium puberulent: sepals oblong, 1.5-2 mm. long, obtuse: petals purple, spatulate, scarcely surpassing the sepals, puberulent.

In rich woods, Virginia and North Carolina. Spring and early summer.-The variety in which the stem bears $3-5$ leaves with cordate crenate blades and terminates in a narrow panicle, and whose corolla consists of minute petals is $H$. Curtisii crendita Rydb

4. Heuchera crinita Rydb. Stems stout, 5-8 dm. tall, with several scales or 1-3 leaves, like the petioles villous with brownish hairs. Leaves mainly basal; blades suborbicular and more or less reniform, $9-22 \mathrm{~cm}$. broad, glabrous or sparingly hispidulous 
above, more or less pubescent beneath, especially on the nerves : hypanthium campanulate, nearly regular, strigose-villous: sepals ovate or oval-ovate, $1 \mathrm{~mm}$. long, obtuse: petals spatulate, pinkish, slightly longer than the sepals: stamens conspicuously exserted.

In rocky soil, Virginia to Illinois and Tennessee. Summer.

5. Heuchera villòsa Michx. Foliage quite glabrous or villous. Rootstocks relatively slender: stems erect, usually tufted, 2-4 dm. tall, naked or bearing a few scales: leaf-blades $5-10 \mathrm{~cm}$. broad, suborbicular or orbicular-ovate in outline, slightly ciliate, acitely 7-9-lobed, the surfaces sparingly pubescent, or bristly on the nerves beneath, the lobes toothed; petioles loosely villous or nearly glabrous: pedicels as long as the flower or longer: hypanthium and calyx $3-4 \mathrm{~mm}$. long at maturity, slightly hairy: sepals ovate : petals linear-spatulate, $2-2.5 \mathrm{~mm}$. long, about twice as long as the sepals, white or nearly so: stamens much exserted : capsule much exceeding the calyx.

On cliffs and rocks, in and near the mountains, Virginia and West Virginia to Georgia and Tennessee. Summer and fail.

6. Heuchera macrorhìza Small. Foliage often copiously villous. Rootstocks stout, woody, 1-3 dm. long, scaly : stems erect or nearly so, $2-5 \mathrm{dm}$. tall, naked or with several scales, surpassing the leaves : leaves basal; petioles $1-3 \mathrm{dm}$. tall, densely villous ; blades suborbicular in outline, 8-20 $\mathrm{cm}$. in diameter, shallowly 5-9-lobed (lobes much broader than long), sharply, closely and irregularly dentate with apiculate teeth pubescent on both sides, sparingly so above, densely ciliate, cordate: panicles $5-12 \mathrm{~cm}$. long, nearly cylindric: hypanthium and calyx densely pubescent, $2-2.5 \mathrm{~mm}$. long at maturity: sepals oblong or ovate-oblong: petals linear with a filiform base, fully twice as long as the sepals: capsule about equalling the calyx at maturity.

On river bluffs, Kentucky and Tennessee. Summer.

7. Heuchera parviflòra Bartl. Foliage rather bright green to hoary. Stems erect, solitary or tufted, pubescent like the petioles, $1-6 \mathrm{dm}$. tall, sometimes bearing small scales: leaf-blades orbicular-reniform or reniform, 5-14 $\mathrm{cm}$. broad, shallowly 5-9-lobed, the lobes crenate, the surfaces sparingly pubescent to densely hoary; petioles slender, longer than the blades, glandular-hirsute to villous-lanate: hypanthium campanulate, nearly $2 \mathrm{~mm}$. long, beset with scattered soft hairs : petals linear-spatulate, about $2.5 \mathrm{~mm}$. long, thrice longer than the ovate sepals: stamens conspicuously exserted. [H. Rugelii Shuttlw. ]

On cliffs or in rocky places, Kentucky to Missouri, North Carolina, middle Georgia and Alabama. Summer and fall.

8. Heuchera hirsuticaùlis (Wheelock) Rydb. Foliage hirsute. Stems stout, 5-6 dm. tall, like the nerves of the leaf-blades thickly beset with spreading whitish or yellowish hairs: leaves mainly basal ; blades suborbicular or reniform, 2.5-10 $\mathrm{cm}$. broad, with 5-7 obtuse crenate-apiculate ciliate lobes, glaucous above, pale green beneath, the sinus broad and deep; petioles mostly longer than the blades, pubescent like the stems : paniclebranches spreading: hypanthium about $4 \mathrm{~mm}$. long, campanulate, minutely glandular: sepals somewhat unequal, obtuse, about as long as the hypanthium : petals spatulate, greenish or pinkish, not surpassing the sepals, minutely glandular : seeds about $0.5 \mathrm{~mm}$. long.

On shaded banks, Indiana and Missouri to Louisiana. Spring.

9. Heuchera Americàna L. Foliage sparingly glandular-pubescent or nearly glabrous. Stems erect, $3-8 \mathrm{dm}$. tall, naked or with a few small scales, glandular-pubescent: leaves basal ; blades ovate to suborbicular, $5-10 \mathrm{~cm}$. broad, cordate, $7-9$-lobed, glabrous or with a few scattered hairs on both surfaces, the lobes rounded, crenate; petioles pubescent like the stem : panicles $1-3 \mathrm{dm}$. long: hypanthium broadly campanulate, fully $1 \mathrm{~mm}$. long during anthesis : sepals ovate, obtuse: petals spatulate, clawed, about $2 \mathrm{~mm}$. long, about equalling the sepals, entire : stamens much exserted.

In woods or rocky soil, Ontario to Minnesota, Georgia and Louisiana. Spring and summer.

10. Heuchera calycòsa Small. Resembling $H$. Americana, but more slender. Stems and petioles more or less puberulent : leaf-blades ovate or orbicular-ovate, $5-10 \mathrm{~cm}$. long, shallowly lobed, ciliate and pubescent near the margins: pedicels very slender: hypanthium turbinate, barely $1 \mathrm{~mm}$. long during anthesis: sepals broadly ovate, about $2 \mathrm{~mm}$. long, rounded at the apex: petals oblong or spatulate-oblong, much surpassed by the sepals, acute or apiculate, entire.

In mountain woods, Georgia and Alabama. Spring.

11. Heuchera lancipétala Rydb. Foliage sparingly glandular-hirsute. Stems stout, 5-7 dm. high, naked or nearly so : leaf-blades orbicular-reniform, 4-8 cm. broad, glabrous except the ciliate margins and the nerves beneath: panicle narrower and more simple than that of $H$. Americana: hypanthium open-campanulate beyond the turbinate base, oblanceolate, whitish or pinkish : stamens about twice as long as the petals.

In woods, Kentucky and Tennessee. Spring and summer. 
12. Heuchera longiflòra Rydb. Foliage nearly glabrous except the leaf-blades. Stem 4-6 dm. tall, glandular-puberulent above, sometimes with a few scales : leaf-blades reniform or orbicular-reniform, $5-8 \mathrm{~cm}$. broad, merely ciliate: hypanthium oblique, deeply campanulate, glandular-puberulent, gibbous on the shorter side: sepals oblong, obtuse : petals spatulate, with slender claws, purple at the apex, yellowish at the base, about equalling the sepals: stamens included.

On hillsides, Kentucky and Tennessee. Spring.

\section{MITÉLLA L.}

Perennial herbs, with slender rootstocks. Stems scape-like. Leaves chiefly basal, with adnate stipules: blades membranous, toothed or lobed, long-petioled. Flowers white or greenish, in slender, interrupted, often secund racemes. Calyx persistent. Sepals 5, spreading, valvate. Petals 5, 3-cleft or pinnatifid, the segments hair-like. Stamens 10 : filaments short: anthers reniform or cordate. Ovary superior, 1-celled: styles 2, short: stigmas capitate. Ovules numerous, borne on parietal placentae. Capsule 1-celled, 2-valved. Seeds numerous with a smooth and shining testa. Mitrewort.

1. Mitella diphýlla L. Leaves basal ; blades thin, ovate to orbicular-ovate in outline, 3-5-lobed, 3-8 $\mathrm{cm}$. broad, sparingly pubescent on both sides, cordate, the lobes erenate, obtuse, except the terminal one ; petioles erect or nearly so, pubescent with retrorse hairs, much longer than the blades: scapes solitary or several together, $2-4 \mathrm{dm}$. tall, simple, 2-bracted above the middle: bracts opposite, ovate, crenate or 3-lobed, sessile, smaller than the leaves: inflorescence finely glandular-pubescent : raceme $4-15 \mathrm{~cm}$. long: pedicels 1-2 $\mathrm{mm}$. long: hypanthium campanulate, $3 \mathrm{~mm}$. broad : sepals ovate, about as long as the hypanthium, obtuse: petals $2.5-3 \mathrm{~mm}$. long, pinnatifid, the segments subulate: capsule flattened, broader than high, minutely pubescent, 2-beaked, 2-valved at the apex.

In woods, Quebec to Minnesota, North Carolina and Missouri. Spring. BisHoP's CAP.

\section{CHRYSOSPLÈNIUM L.}

Annual or perennial, often fleshy, diminutive herbs. Stems erect or creeping. Leaves alternate or opposite, without stipules : blades crenate or lobed. Flowers green, axillary or terminal, solitary or several together. Calyx persistent. Sepals 4 or 5 , imbricated. Petals wanting. Stamens 8-10 or rarely 4, inserted on the margin of the epigynous disk : filaments short. Ovary inferior, 1-celled, 2-3-lobed above: styles 2, recurved. Ovules numerous, borne on 2 or rarely 3 parietal placentae. Capsule membranous, unequally 2-lobed above. Seeds with a smooth or papillose, sometimes pubescent testa. GroLdeN SAXIFRAGE. WATER-CARPET.

1. Chrysosplenium Americànum Schwein. Perennial, glabrous, bright green. Stems prostrate or decumbent, $2-20 \mathrm{~cm}$. long, creeping : leaves mainly opposite ; blades suborbicular to orbicular-reniform, $0.5-1.5 \mathrm{~cm}$. broad, crenate or nearly entire, commonly truncate at the base; petioles much shorter than the blades: flowers axillary, about $3 \mathrm{~mm}$. broad, yellowish, sometimes tinged with purple: sepals 4 , ovate, becoming reniform, obtuse : petals wanting: stamens erect, commonly 4 : anthers orange-red : capsule $3 \mathrm{~mm}$. high, with two inflated lobes each tipped by a divergent beak: seeds $0.7 \mathrm{~mm}$. broad, minutely pubescent.

In brooks or wet shady places, Nova Scotia to Saskatchewan, Ohio and on or near the mountains to Georgia. Spring.

\section{Family 6. FSCALLONIÀCEAE Dumort. Hydrangea Family. .}

Shrubs or trees, or sometimes vines. Leaves mostly opposite : blades simple, often toothed. Flowers commonly perfect, in raceme-like or panicled cymes. Calyx of mostly 4-10 small sepals surmounting the often ribbed hypanthium, in sterile flowers often conspicuously enlarged. Corolla of 4-10 petals valvate or convolute in the bud. Androecium of 8-many stamens. Filaments subulate or linear. Gynoecium of 2-5 united carpels. Styles rarely united. Ovules numerous, anatropous. Fruit capsular, sometimes opening through the sides. Seeds numerous.

Upright shrubs : styles distinct or rarely united : capsules 3-5-celled.

Vines : styles united: capsules 5-10-celled.

1. HYDRANgea.

2. Philadelphus. 3. DeCUMARia. 


\section{HYDRÁNGEA L.}

Shrubs or trees. Leaves opposite, without stipules : blades entire, toothed, or lobed. Flowers perfect, except a few conspicuous ones around the edge of the corymb or thyrse. Sepals united into a truncate or 4-5-toothed border, or in sterile flowers of 4-5 spreading petal-like lobes. Petals 4-5, valvate. Stamens 8-10, inserted at the base of an epigynous disk : filaments filiform. Ovary inferior, completely or partially 2-4-celled : styles 2-4, distinct or slightly united at the base. Ovules numerous, borne on axile placentae. Capsule 2-4-celled, membranous, opening at the top between the styles. Seeds numerous, minute. Testa membranous, reticulated. The plants flower during the spring and summer.

Leaf-blades merely toothed : inflorescence corymbose.

Leaf-blades glabrous or inconspicuously pubescent beneath.

Leaf-blades conspicuously and copiously pubescent beneath. Leaf-blades membranous, light gray beneath.

Leaf-blades leathery, bright white beneath. Leaf-blades deeply lobed : inflorescence thyrsoid.

1. H. arborescens.

2. H. cinerea.

3. H. radiata.

4. H. quercifolia.

1. Hydrangea arboréscens L. A branching, sometimes straggling shrub 1-3 m. tall. Leaf-blades ovate, oval or elliptic, 0.5-2 dm. long, short-acuminate, serrate, acute, rounded or cordate at the base, glabrous or sometimes minutely pubescent beneath; petioles shorter than the blades: corymbs $5-20 \mathrm{~cm}$. broad, usually with few sterile ray-flowers or these wanting, commonly pubescent: hypanthium campanulate, $1-1.5 \mathrm{~mm}$. broad : sepals minute, triangular: petals deciduous, concave, ovate, abont $1 \mathrm{~mm}$. long: stamens conspicuously exserted : stigmas reddish : capsules $2 \mathrm{~mm}$. broad, 8-ribbed, broader than high, each tipped with the 2 spreading styles.

In woods or along streams, New York to Iowa, Florida and Louisiana.

2. Hydrangea cinèrea Small. A spreading shrub, 1-2 $\mathrm{m}$. tall, with deep green foliage. Leaf-blades thinnish, oval, elliptic, narrowly ovate or orbicular-ovate, $6-15 \mathrm{~cm}$. long, acuminate, serrate, obtuse, rounded or cordate at the base, bright green above, graytomentose and not reticulated beneath; petioles somewhat more than one-half as long as the blades or shorter: corymbs $5-15 \mathrm{~cm}$. broad, rather round-topped : sterile ray-flowers commonly present: hypanthium campanulate, ribbed : sepals triangular, acute: petals 5 , ovate, boat-shaped, $1.5 \mathrm{~mm}$. long, hooded at the apex : stamens conspicuously exserted: capsules urn-shaped, about $2 \mathrm{~mm}$. in diameter, usually higher than broad, strongly ribbed, each tipped with the $2-3$ spreading styles.

On the slopes of the Alleghenies, North Carolina, Tennessee, Georgia and Alabama.

3. Hydrangea radiàta Walt. A branching shrub, 1-2.5 m. tall. Leaf-blades leathery, ovate, varying to oval or ovate-lanceolate, $6-12 \mathrm{~cm}$. long, acuminate, serrate or crenateserrate, acute, rounded or subcordate at the base, bright green and glabrous above, densely silvery white-tomentose and reticulated beneath; petioles about $\frac{1}{2}$ as long as the blades or shorter : corymb round-topped, 4-12 $\mathrm{cm}$. broad: sterile flowers always present: hypanthium urn-shaped, ribbed: sepals triangular or usually somewhat acuminate: petals 5 , ovate, concave, nearly $1 \mathrm{~mm}$. long, apiculate : stamens much exserted: capsules urnshaped, $2 \mathrm{~mm}$. broad, strongly ribbed, shorter than their pedicels, each tipped with the 2 spreading swollen styles.

On rocky slopes, North and South Carolina.

4. Hydrangea quercifòlia Bartr. A stout shrub, 1-2 m. tall, with densely tomentose twigs and branches. Leaf-blades oval or suborbicular in outline, usually 5-lobed, 6-20 $\mathrm{cm}$. long, tomentose beneath, the lobes serrate and often slightly lobed; petioles $\frac{1}{3}-\frac{1}{5}$ as long as the blades : panicles 1-2 dm. long: sterile flowers numerous, white, turning purple : hypanthium urn-shaped, longer than the pedicel: sepals ovate, about $\frac{1}{3}$ as long as the hypanthium: petals 5, oblong, $1.5 \mathrm{~mm}$. long, slightly concave : stamens conspicuously exserted : capsules urn-shaped, $2.5 \mathrm{~mm}$. in diameter, ribbed, each tipped with the spreading much enlarged styles.

On river banks, middle Georgia to Florida and Mississippi. Gray-BEard. Old Man's-Beard.

\section{PHILADÉLPHUS L. ${ }^{1}$}

Shrubs, with branching stems. Leaves opposite, deciduous: blades simple, petioled: stipules wanting. Flowers solitary, corymbose or racemose, either terminal or axillary. Hypanthium turbinate, adnate with the ovary. Sepals 4 or 5 , persistent. Corolla white or cream-colored. Petals 4 or 5, obovate or rounded, convolute in the bud. Stamens numerous, inserted on the disk : filaments slender. Styles 3-5, united, at least at the base :

${ }^{1}$ Contributed by Mr. C. D. Beadle. 
stigmas distinct or united. Capsule 3-5-celled, at maturity loculicidally dehiscent by as many valves. Seeds very numerous, the membranous testa prolonged at the ends. Syringa. Mock Orange.

Stigmas distinct.

Flowers solitary or few, never more than five: bark of last year's shoots brown, exfoliating.

Pedicels and hypanthium glabrous.

Base of the capsule attenuate to the pedicel, the point of union obscure.

Leaf-blades ovate or oval, the borders entire or with minute distant teeth : sepals acute.

Leaf-blades ovate-lanceolate or elliptic, the borders with sharp remote teeth : sepals acuminate.

Base of the capsule abruptly contracted, the pedicel sharply differentiated. Pedicels, hypanthium and exterior surface of the sepals pubescent.

Flowers racemose, numerous: bark of last year's shoots gray or ochre-color, not exfoliating.

Leaf-blades pubescent on the lower surface : hypanthium and sepals pubescent.

Leaf-blades glabrous or nearly so: hypanthium and exterior surface of the sepals glabrous.

Stigmas united.

1. P. inodorus.

2. P. grandiflorus.

3. P. gloriosus.

4. P. floridus.

5. P. latifolius.

6. P. intectus.

7. P. hirsutus.

1. Philadelphus inodòrus L. A shrub $2-3 \mathrm{~m}$. high, the bark of the shoots brown, exfoliating. Leaf-blades ovate, broadly ovate or oval, acute at the apex, rounded or slightly narrowed at the base, $3-10 \mathrm{~cm}$. long, $1.5-5 \mathrm{~cm}$. broad, glabrate or with short appressed hairs either scattered or more copious, especially on the lower surface, prominently 3-nerved, entire or with minute distant teeth : sepals acute : corolla $3-4 \mathrm{~cm}$. wide.

On banks of streams and moist woods, North Carolina to Mississippi and Tennessee. Spring.-A form, possibly specifically distinct, $P$. inodorus strigòsus Beadle, may be recognized by the thick covering of appressed rather stiff hairs on the lower surface of the leaves and frequently on the exterior of the sepals.

2. Philadelphus grandiflòrus Willd. A shrub 2-3 m. tall, the bark of the shoots brown, exfoliating. Leaf-blades ovate-lanceolate or elliptic, acuminate, sharply dentate, either rounded or narrowed at the base, 4-12 $\mathrm{cm}$. long, $1.5-4 \mathrm{~cm}$. broad, glabrate or with short appressed pubescence, 3-nerved : sepals acuminate: corolla 4-5 cm. wide : capsule attenuate to the pedicel.

On banks of streams and moist rocky slopes, Virginia to Florida, mainly along the mountains. Spring. $-P$. laxus Schrad., similar to the last, but with much narrower leaf-blades more densely appressed pubescent on the lower surface, and smaller and usually solitary flowers, is unknown to the writer in a wild state, although apparently of eastern American origin.

3. Philadelphus gloriòsus Beadle. A shrub 2-3 m. high, the bark of the previous season's growth dark brown, exfoliating. Leaf-blades ovate or elliptic, acute at the apex, either rounded or narrowed at the base, 4-10 $\mathrm{cm}$. long, $1.5-5 \mathrm{~cm}$. broad, glabrate or with short appressed hairs, remotely dentate, 3-nerved : hypanthium and sepals glabrous : corolla 3-4 cm. broad: stigmas distinct : capsules abruptly contracted at the base, about $1 \mathrm{~cm}$. long.

On rocky banks of the Coosa River, northwestern Georgia. Spring.

4. Philadelphus flòridus Beadle. A shrub 2-3 m. high, the bark of last year's shoots dark brown, exfoliating. Leaf-blades oval or elliptic, acute, remotely toothed, either rounded or narrowed at the base, 4-10 $\mathrm{cm}$. long, 2-5 $\mathrm{cm}$. broad, sparsely pubescent on the lower surface, glabrate above, prominently 3-nerved : pedicels, hypanthium and exterior surface of the acuminate sepals appressed pubescent : corolla $3-4 \mathrm{~cm}$. broad : stigmas not united.

On rocky slopes and banks of streams, Floyd County, Georgia. Spring.

5. Philadelphus latif ollius Schrad. A shrub 2-3 m. high, the bark of the shoots gray or yellowish, not exfoliating. Leaf-blades broadly ovate or elliptic, acute at the apex, rounded or contracted at the base, 3-10 $\mathrm{cm}$. long, 2-7 cm. wide, mostly dentate, softly and densely pubescent on the lower surface, glabrate or glabrous above, 3-5-nerved: flowers racemose, the lower pair axillary: pedicels, hypanthium and exterior of the sepals pubescent : corolla $3-4 \mathrm{~cm}$. wide : stigmas not united.

On rocky banks of streams, especially near Nashville, Tennessee. Spring.-P. pubescens Loisel., resembling the last but with brown bark and more numerous flowers, the lower two or three pairs of which are axillary, is unknown in a wild state, but usually regarded of eastern American origin.

6. Philadelphus intéctus Beadle. A shrub 2-3 m. tall, the bark of the shoots gray or ochre-color, not exfoliating. Leaf-blades ovate, oval or elliptic, acute or acuminate at the apex, either rounded or narrowed at the base, $3-12 \mathrm{~cm}$. long, $1-5 \mathrm{~cm}$. broad, glabrous or glabrate on both surfaces, prominently 3-nerved, either entire or remotely dentate: flowers racemose, the lower pair axillary : pedicels, hypanthium and exterior of the sepals glabrous : corolla $3-4 \mathrm{~cm}$. wide : stigmas distinct.

On bluffs of the Cumberland River, below Nashville, Tennessee. Spring.

7. Philadelphus hirsùtus Nutt. A shrub 1-2.5 m. tall, the bark of the previous season's growth brown, exfoliating. Leaf-blades ovate or ovate-acuminate, either rounded 
or narrowed at the base, gray-pubescent on the lower surface, appressed pubescent or eventually glabrate or glabrous above, $3-8 \mathrm{~cm}$. long, $1-4 \mathrm{~cm}$. broad, dentate, prominently 3-nerved : flowers solitary or in twos and threes: pedicels, hypanthium and sepals pubescent : corolla $2-3 \mathrm{~cm}$. wide : stigmas united. Spring.

On rocky slopes and banks of streams, North Carolina and Tennessee to Georgia and Alabama.

\section{DECUMÀrIA L.}

Climbing evergreen shrubby vines, with terete stems. Leaves opposite, without stipules: blades thick, entire or sparingly toothed. Flowers white, in terminal corymbose panicles. Calyx 7-10-toothed. Petals 7-10, narrow, valvate. Stamens 20-30, inserted under the edge of the disk: filaments subulate. Ovary 5-10-celled, inferior: style thick, 5-10-ribbed: stigma capitate, 5-10-lobed. Ovules numerous, pendulous. Capsule turbinate, many-ribbed, opening between the ribs. Seeds narrowly club-shaped, pendulous. Testa thin, reticulated.

1. Decumaria bárbara L. A vine, with climbing stems $1-10 \mathrm{~cm}$. thick which attach themselves by rootlets. Leaf-blades leathery, elliptic or oval, varying to ovate or rarely to obovate, $5-10 \mathrm{~cm}$. long, usually acute or abruptly short-acuminate, more or less strongly toothed above the middle, acute to subcordate at the base, glossy, sometimes slightly pubescent on the nerves beneath; petioles $\frac{1}{3}-\frac{1}{5}$ as long as the blades: corymb $5-10 \mathrm{~cm}$. broad, round-topped : hypanthium campanulate to turbinate, about $2 \mathrm{~mm}$. broad: sepals triangular, acute : petals oblong to linear-oblong, 3-4 $\mathrm{mm}$. long, concave, obtuse, shorter than the petals: capsules urn-shaped, 6-8 $\mathrm{mm}$. long, strongly ribbed, surrounded above the middle by the persistent calyx-limb, the clusters pendent : seeds very numerous, $2 \mathrm{~mm}$. long.

On river banks and in low woods, Virginia to Louisiana and Florida. Spring.

\section{Family 7. ITEÀCeae Agardh. Virginia Willow Family.}

Shrubs or trees with upright stems. Leaves alternate: blades simple, toothed, the teeth sometimes glandular-tipped: stipules wanting. Flowers perfect, white, in simple terminal narrow racemes or axillary panicles. $\mathrm{Hy}-$ panthium turbinate, or campanulate. Sepals 5, erect. Petals 5, narrow, valvate, the tips inflexed. Stamens 5, inserted under the edge of an epigynous disk. Filaments slender. Anthers oblong. Gynoecium of 2 carpels united to the apex or near it. Ovary superior or nearly so, elongated, 2-celled. Styles united, a groove showing the line of union. Stigmas capitate. Ovules numerous, in two rows on the placenta. Capsule elongated, 2-grooved lengthwise, opening septicidally by 2 valves. Seeds flattened, with the testa produced at both ends, and copious endosperm.

\section{1. İTEA L.}

Characters of the family. Virginia Willow.

1. Itea Virginica L. A straggling shrub, 1-3 m. tall, with pubescent twigs and racemes. Leaf-blades elliptic to oval or obovate, 5-14 cm. long, acute or short-acuminate, bristly-serrate, usually acute at the base, glabrous above, often sparingly pubescent beneath; petioles $0.5-1 \mathrm{~cm}$. long: racemes terminal, $3-15 \mathrm{~cm}$. long: pedicels $1.5-3 \mathrm{~cm}$. long: hypanthium broadly campanulate, $2-2.5 \mathrm{~mm}$. broad: sepals lanceolate, about 1 $\mathrm{mm}$. long, acute : petals linear or linear-lanceolate, $4 \mathrm{~mm}$. long, erect or finally spreading, acutish : stamens finally as long as the petals : capsules narrow, 6-8 mm. long, seated in the hypanthium, pubescent, 2-grooved.

In or near swamps, New Jersey and eastern Pennsylvania to Florida and Louisiana. Spring.

\section{Family 8. ALtingiàceae Hayne. Witch Hazel Family.}

Shrubs or trees, the bark often aromatic and sometimes exuding a fragrant balsam. Stem or branches occasionally furnished with corky wings. Leaves alternate: blades simple, entire, toothed or lobed. Flowers perfect, or often polygamous or monoecious, in terminal or axillary spikes, clusters or heads. Perianth of 1 or 2 series, or wanting. Calyx of 4 or 5 imbricated sepals. Corolla of 4 or 5 , elongated or strap-shaped, valvate petals inserted at the base of the sepals, sometimes wanting. Androecium various: stamens twice as many as 
the petals, and one-half of them sterile, or numerous and the petals wanting. Filaments distinct, dilated at the base. Anthers introrse. Gynoecium of 2 partially united carpels which cohere to the base of the calyx. Styles 2, distinct. Stigmas simple. Ovules solitary and suspended or several and horizontal. Fruit a capsule, often opening elastically. Testa shining. Embryo straight in the fleshy cartilaginous or bony endosperm. [Hamamelidaceae Lindl.]

Calyx or calyx and corolla present: ovule solitary in each cavity, suspended.

Petals wanting: stamens about 24 : filaments club-shaped, elongated.

Petals 4, ribbon-shaped: stamens 4 : staminodia 4 : filaments short.

1. Fothergilla.

aly $\mathrm{x}$ and corolla wanting: ovules several or numerous, horizontal.

2. HAMAMELIS.

3. LIQUiDAMBAR.

\section{FOTHERGÍLLA L.}

Low monoecious shrubs, with erect or underground stems. Leaves alternate: blades membranous or leathery, more or less coarsely toothed, short-petioled, deciduous. Flowers white, fragrant, appearing before the leaves or with them, in terminal bracted spikes. Hypanthium campanulate. Calyx truncate or obscurely 5-7-lobed. Petals wanting. Stamens numerous, inserted in 1 row, very conspicuous : filaments clavate-filiform. Ovary 2-3-celled, partly inferior: styles 2-3, subulate-filiform. Ovule 1 in each cavity. Capsule 2-3-lobed, 2-3-valved at the apex. Seed solitary in each cavity. Testa bony. The plants flower in the spring. DWARF ALDER.

Flowers appearing before the leaves: leaf-blades stellate-pubescent above: filaments mostly less than

$10 \mathrm{~mm}$. long: capsules $6-10 \mathrm{~mm}$. long.

Leaf-blades cordate at the base, about as broad as long, toothed from below the middle to the apex.

Leaf-blades cuneate or rounded at the base, much longer than broad, toothed only near the apex.

Flowers appearing with the leaves: leaf-blades glabrate above : flaments mostly over

$11 \mathrm{~mm}$. long: capsules 11-13 mm. long.

1. F. parvifolia.

2. F. Carolina.

1. Fothergilla parvifòlia Kearney. A low shrub, forming patches by underground stems, its twigs, leaves and inflorescence canescent. Branches 3-6 dm. tall, simple below, branched above: leaf-blades leathery, suborbicular or oval, $2-6 \mathrm{~cm}$. long, coarsely crenate above the middle, dull green and stellate-pubescent above, canescent beneath when mature, cordate at the base, short-petioled : flowers appearing before the leaves: spikes $2-3 \mathrm{~cm}$. long, dense: hypanthium canescent : filaments 6-7 mm. long: eapsules about 6-8 mm. long, turbinate at the base, acute at the apex.

In sandy oak or pine lands, in the low country, North Carolina to Florida.

2. Fothergilla Carolìna (L.) Britton. A low shrub, with erect branching stems, its twigs and petioles finely pubescent. Stems becoming stout near the base: leaf-blades usually leathery, oblong, or nearly so, undulate or sharply toothed near the apex, paler and more densely pubescent beneath than above, varying from cuneate to rounded at the base, short-petioled: flowers appearing before the leaves: spikes 1-4 cm. long, dense: hypanthium very densely pubescent : filaments $8-10 \mathrm{~mm}$. long: eapsules $8-10 \mathrm{~mm}$. long.

In dry soil, Virginia to Georgia.

3. Fothergilla màjor Lodd. A tall shrub, its twigs, petioles and peduncles downy. Stems erect, much branched : leaf-blades membranous, suborbicular, oval or obovate, 6-8 $\mathrm{cm}$. long, coarsely crenate above the middle, cuneate or subcordate at the base, bright green on both sides, glabrous above, paler beneath, and pubescent on the nerves; petioles 5-10 $\mathrm{mm}$. long: flowers appearing with the leaves: spikes 4-7 $\mathrm{mm}$. long, dense above looser below : hypanthium downy : filaments 11-15 mm. long: capsules 11-13 mm. long

On mountain slopes, North and South Carolina to Alabama.

\section{HAMAMELIS L.}

Slightly aromatic shrubs or small trees, with a scaly bark and flexuous terete branchlets. Leaves alternate: blades simple, slightly leathery, crenate, inequilateral at the base : stipules acute, deciduous. Flowers perfect or polygamous, appearing in fall or winter, in terminal 3-flowered clusters, on short lateral bracted peduncles, each flower subtended by bractlets. Hypanthium campanulate, persistent. Sepals 4, reflexed. Petals 4, ribbon-like, persistent, or wanting in fertile flowers. Stamens 4 , opposite the sepals, alternating with 4 strap-shaped staminodia : filaments subulate, each prolonged into a stout connective, shorter than the calyx : anther-sacs separated by the connective, opening by persistent valves attached on the outer edge. Ovary of 2, 1-celled carpels united at the base : styles 2, subulate : stigma terminal, minute. Ovules 1-2 in each cavity, suspended. Cap- 
sule woody, 2-beaked, opening loculicidally by two valves at the top and elastically discharging the seeds. Seeds solitary in each cavity, elongated, with a crustaceous shining testa. Endosperm fleshy. Witch Hazel. Witch Elm.

1. Hamamelis Virginiàna L. A shrub or small tree, reaching a maximum height of $10 \mathrm{~m}$., with a trunk diameter of about $1 \mathrm{dm}$. Leaf-blades rather leathery, suborbicular, oval, elliptic or obovate, 4-15 cm. long, acute or obtuse, coarsely crenate, truncate or cordate at the very oblique base, glabrous or sometimes pubescent above, more or less pubescent beneath : sepals triangular, spreading or recurved : petals linear, strap-like, bright yellow, more or less crisped, much exserted : stamens included : filaments subulate : ovary villous : capsules ovoid or subglobose, $12-15 \mathrm{~cm}$. long, densely tomentulose : seeds oblong or elliptic, 7-9 mm. long, beetle-like, nearly black, smooth and shining.

In low woods or on moist hillsides, New Brunswick and Nova Scotia to Ontario and Nebraska, south to Florida and Texas. Flowers in the fall and matures its fruit during the next summer.

\section{LIQUIDÁMBAR L.}

Usually monoecious trees, with a balsamic sap, a soft scaly bark, terete and often corkywinged branchlets. Leaves alternate : blades palmately lobed, thickish, long-petioled, the lobes glandular-serrate: stipules acute, caducous. Flowers monoecious or rarely perfect, in peduncled heads subtended by 4 deciduous bracts. Perianth wanting. Staminate flowers in terminal racemed heads: stamens numerous, accompanied by numerous minute scales: filaments slender, shorter than the anthers. Pistillate flowers in solitary long-peduncled axillary heads : staminodia 4. Ovary of 2 united 1-celled carpels, partly immersed in the receptacle, surmounted by 2 stout styles, stigmatose on the inner faces. Ovules numerous, pendulous, anatropous. Capsules armed with the accrescent, incurved, horn-like styles, united into a globose head, septicidally 2 -valved at the apex. Seeds 1 or 2 , flattened, with a crustaceous testa which is produced into an obovate wing. Endosperm fleshy.

1. Liquidambar Styraciflua L. A forest tree, reaching a maximum height of $45 \mathrm{~m}$. and a trunk diameter of $1.5 \mathrm{~m}$. Bark with broad ridges and deep fissures, the branchlets often corky-winged : leaf-blades suborbicular in outline, palmately 5-lobed, deep green, shining and glabrous, except the nerves beneath, truncate or subcordate at the base, the lobes triangular or lanceolate, serrate, more or less acuminate; petioles slender, about as long as the blades: flowers monoecious, in globose clusters, the staminate heads racemose, the pistillate heads solitary on long dropping peduncles : fruiting heads globose, $3-4 \mathrm{~cm}$. in diameter, the bodies of the capsules somewhat longer than the horns.

In low woods, Connecticut to Missouri, Florida and Texas. Flowers in spring, matures its fruit in the summer. Sweet GUM. Red Gum. Bilsted. Star-leaved Gum. Alligator-tree.

\section{FAmily 9. GROSSULARIÀCEAE Dumort. Gooseberry Family.}

Smooth or spiny shrubs, sometimes copiously furnished with resin glands. Leaves few or numerous and clustered : blades usually lobed or cleft: stipules, if present, adnate to the petiole. Flowers sometimes imperfect, of various colors, solitary in the axils or in loose axillary racemes. Perianth of 2 series. Hypanthium oblong or subglobose. Calyx of 4 or 5 sepals. Corolla 4 or 5 scale-like petals inserted at the base of the calyx. Androecium of 4 or 5 stamens inserted with the petals. Filaments variable in length. Gynoecium a compound pistil. Ovary inferior, 1-celled or very rarely 3 or 4-celled. Styles mostly united or 2-lobed. Ovules usually numerous, borne in 2 or more rows on 2 parietal placentae. Fruit a globose or oblong berry crowned by the more or less persistent calyx, pulpy within. Seeds somewhat angled. Testa gelatinous without, crustaceous within. Endosperm fleshy. Embryo terete, at the base of the endosperm.

1. RìBES L.

Characters of the family. Gooseberry. Currant. The plants flower in the spring.

Plants usually armed with firm spines: peduncles 1-3-flowered. (Gooseberries.)

A. Calyx-lobes longer than the limb: berry smooth and glabrous.

Hypanthium glandular-pubescent: petals lanceolate, with 2 lateral teeth.

Hypanthium glabrous : petals cuneate or spatulate, toothless.

Filaments pubescent : spines slender and relatively long: bark reddish or purplish.

Filaments glabrous: spines stout or short: bark gray.

Filaments slightly longer than the sepals: species Alleghenian.

Filaments conspicuously longer than the sepals : species campestrian.

1. R. curvatum.

2. R. gracile.

3. $R$. rotundifolium. 4. R. Missouriense. 
B. Calyx-lobes shorter than the limb: berry prickly.

Plants unarmed: racemes many-flowered, or more than 3-flowered. (Currants.) Sepals distinct to the top of the ovary.

Foliage viscid with glandular-pubescence: bracts longer than the pedicels. Inflorescence only glandular-pubescent: bracts shorter than the pedicels.

Sepals united for at least $1 \mathrm{~cm}$.

1. Ribes curvàtum Small. A diffusely branched glabrate shrub, $5-8 \mathrm{dm}$. tall, armed with subulate spines $4-6 \mathrm{~mm}$. long, the stem with a loose exfoliating bark, the branches purplish, the recurved or drooping branchlets reddish. Leaf-blades suborbicular, $1-2 \mathrm{~cm}$. in diameter, 3-lobed, the lobes toothed, the terminal lobe often mucronate; petioles slender, as long as the blade or shorter, usually somewhat villous: peduncles 7-8 mm. long, mostly 1-flowered: pedicels twisted, nearly as long as the peduncles, subtended by two 3-lobed ciliate bractlets : hypanthium glandular-pubescent : sepals linear or linear-spatulate, $6 \mathrm{~mm}$. long, whitish, reflexed and recurved, the edges hyaline, obtuse : petals lanceolate, $1.5 \mathrm{~mm}$. long, white, obtuse with lateral teeth and one or two nerves: stamens conspicuous, $7 \mathrm{~mm}$. long, erect: filaments villous : berry globose, $6-8 \mathrm{~mm}$. in diameter, crowned by the persistent stamens.

In dry or stony soil, Georgia and Alabama.

2. Ribes grácile Michx. A rather rigid shrub, 1-1.5 m. tall, armed with slender spines, the shoots sometimes densely clothed with prickles, the bark reddish or purplish. Leaf-blades 2-4 cm. broad (often larger on the shoots), more or less pubescent, 3-5-lobed, the lobes rounded, toothed, the teeth obtuse or rarely acute; petioles villous, shorter than the blades: peduncles usually 3 -flowered, about as long as the pedicels: bracts ovate, glandular-ciliate : hypanthium glabrous: sepals linear-spatulate, $2 \frac{1}{2}-3$ times longer than the hypanthium : petals obovate or spatulate, about $2 \mathrm{~mm}$. long: filaments pubescent: style exserted : berries globose, 1-1.5 cm. in diameter.

In dry or rocky soil, Illinois to Kansas, Tennessee, Louisiana and Texas.

3. Ribes rotundifolium Michx. A straggling shrub, 1-2 m. tall, clothed with a reddish or purple bark, the spines $5-10 \mathrm{~mm}$. long, the young shoots without prickles. Leafblades $2-3.5 \mathrm{~cm}$. in diameter, glabrate or finely pubescent, especially on the nerves beneath, 3-5-lobed, toothed; petioles slender, more or less villous, much shorter than the blades : peduncles mostly 1-2-flowered, longer than the pedicels : hypanthium glabrous : sepals linear-spatulate, obtuse : petals cuneate, 1.5-2 $\mathrm{mm}$. long, undulate, at length crisped : filaments glabrous : berries globose, $8-10 \mathrm{~mm}$. in diameter, reddish purple.

In rocky woods, on or near the mountains, Massachusetts to New York and North Carolina.

4. Ribes Missouriénse Nutt. A spreading shrub, with short branches clothed with a gray shreddy bark, the spines stout, $8-15 \mathrm{~mm}$. long, young shoots with numerous prickles. Leaf-blades $2-6 \mathrm{~cm}$. in diameter, more or less pubescent, especially when young ; petioles stout, usually shorter than the blades: hypanthium glabrous : sepals narrowly oblong or oblong-spatulate : petals cuneate, $2-2.5 \mathrm{~mm}$. long: filaments glabrous : berries 10-15 mm. in diameter, purple.

In thickets and on river banks, Pennsylvania to Minnesota, South Dakota, Kansas and Tennessee.

5. Ribes Cynósbati L. A straggling shrub, 1-2 m. tall, with spine-armed and often prickly stems. Leaf-blades $3-5 \mathrm{~cm}$. in diameter, pubescent when young, mostly glabrate in age, 3-5-lobed, the lobes rounded or the terminal one acute, crenate; petioles somewhat shorter than the blades, villous with simple or glandular hairs: peduncles and pedicels of about the same length: bracts suborbicular, glandular-toothed: hypanthium glabrous: sepals oblong, 'obtuse: petals minute, reniform, about $0.5 \mathrm{~mm}$. high : filaments subulate, about $\frac{1}{2}$ as long as the anthers : berries globose, about $1-1.5 \mathrm{~cm}$. in diameter, armed with stout prickles.

In rocky woods and on hillsides, New Brunswick to Manitoba, Alabama and Missouri. Dogberry.

6. Ribes resinòsum Pursh. A shrub about $1 \mathrm{~m}$. tall, with clammy glandular-pubescent foliage and inflorescence. Leaf-blades thickish, 3-5-lobed, cordate at the base, the lobes rounded or obtuse, crenate toothed; petioles stout, shorter than the blades, furnished with broad stipules which are early deciduous : racemes ascending, many-flowered : bracts oblong: flowers short-pediceled.

In woods, southern Alleghenies, probably in North Carolina. Not recently collected.

7. Ribes prostràtum L'Her. A low shrub, with spreading decumbent stems, the inflorescence glandular-pubescent. Leaf-blades $5-12 \mathrm{~cm}$. broad, sparingly pubescent when young, finally glabrate, ciliate, dark green above, paler beneath, cordate, angularly 5lobed, the lobes acute, serrate or serrate-crenate; petioles finely pubescent, often about as long as the blades, the dilated stipules fringed : racemes $6-14 \mathrm{~cm}$. long, spreading, longpeduncled : pedicels $5-10 \mathrm{~mm}$. long, subtended by ovate bracts 1-1.5 mm. long: hypanthium bristly and densely glandular-pubescent: sepals rhomboidal-obovate, sometimes 
constricted at the middle, about $3 \mathrm{~mm}$. long, spreading: petals cuneate, about $1 \mathrm{~mm}$. long: stamens shorter than the sepals : berries globose, $5-8 \mathrm{~mm}$. in diameter.

In deep woods, common on the mountains, Labrador to the Northwest Territory south to North Carolina, Michigan and Colorado. FETID CURRANT.

8. Ribes aùreum Pursh. A glabrous or glabrate shrub, 1-4 m. tall, with bright green or glaucous foliage. Leaf-blades firm, 2-6 $\mathrm{cm}$. broad, 3-5-lobed, rounded, truncate or rarely subcordate at the base, the lobes slightly toothed near the apex; petioles glabrous or puberulent, shorter than the blades : racemes $1-5 \mathrm{~cm}$. long, drooping, few-manyflowered: pedicels $5-10 \mathrm{~mm}$. long, subtended by somewhat leafy bracts: hypanthium elongated, 1.2-2 cm. long: sepals oblong-obovoid, rounded at the apex, spreading or recurved: petals spatulate-obovate, $3 \mathrm{~mm}$. long, eroded, erect: stamens shorter than the petals, erect: filaments shorter than the anthers: berries globose, smooth, $8-12 \mathrm{~mm}$. in diameter, varying from yellow to black.

In valleys, Northwest Territory to Minnesota, Texas and California. Cultivated eastward. BuFFalo, Golden or Missouri Currant.

\section{Family 10. PLATANÀCEAE Lindl. Plane-tree Family.}

Handsome trees, with a watery sap and a thin pale smooth exfoliating bark. Leaves alternate: blades membranous-leathery, palmately lobed: petioles subtended by thin, entire or toothed, sheathing stipules. Flowers monoecious, minute, inserted on globose receptacles, in dense pedunculate solitary, spicate or racemose heads. Perianth much reduced. Staminate heads red: calyx of 3-6 scale-like sepals : corolla of 3-6 scale-like petals, longer than the sepals : stamens as many as the sepals and opposite them ; filaments nearly obsolete: anthers elongated, each surmounted by a large connective. Pistillate heads green : calyx of $3-6$, or usually 4 sepals : corolla of $3-6$, or usually 4 rounded petals : carpels as many as the sepals, 1 -celled, mingled with staminodia which are pilose at the apex, surrounded by long-jointed persistent hairs : style terminal, stigmatose to below the middle on the ventral suture. Ovules solitary or rarely 2, horizontal, orthotropous : fruit an elongated achene, surrounded by rigid hairs, with a thin leathery pericarp, crowded in dense globose heads. Seed pendulous, elongated, with a thin membranous testa. Endosperm fleshy. Embryo straight in the axis of the endosperm.

\section{PLÁtTANUS L.}

Characters of the family. Plane-tree. Button-wood. Button-ball.

1. Platanus occidentàlis L. A forest tree, reaching a height of $55 \mathrm{~m}$., with a trunk diameter of $3 \mathrm{~m}$. Bark thin, pale, scaly : leaves conspicuous; blades suborbicular in outline, 3-5-lobed, 10-20 cm. in diameter, becoming glabrous, except the woolly-pubescent nerves beneath, truncate or cordate at the base, the lobes more or less prominently toothed, the teeth acuminate: petioles $\frac{1}{2}$ or $\frac{1}{3}$ as long as the blades, pale, tomentose: fruiting heads globose, $2-4 \mathrm{~cm}$. in diameter, solitary at the ends of, or rarely spicate on, slender drooping tomentose or glabrate peduncles which vary from $8-15 \mathrm{~cm}$. in length.

Along streams and in moist woods, Maine to Ontario and Nebraska. Florida and Texas. Spring.

\section{Family 11. ROSÀCEAE Juss. Rose Family.}

Herbs, shrubs or trees, or rarely vines, various in habit. Leaves mostly alternate: blades simple or compound: stipules often present, sometimes conspicuous. Flowers perfect, or rarely dioecious, variously disposed. Calyx of 5 or rarely 4-9 sepals, surmounting the more or less highly developed hypanthium, often accompanied by as many scale-like bractlets. Corolla of as many distinct petals as there are sepals, or wanting. Androecium of 1 or more series of stamens. Filaments distinct. Anthers 2-celled. Gynoecium of 1 or many carpels, on a depressed or elongated receptacle. Ovary 1-celled or imperfectly 2-celled. Style terminal, lateral or basal. Ovules 1, 2 or several in each cavity. Fruit various, mostly follicles, drupelets or achenes, these sometimes raised on a conspicuously accrescent receptacle. Endosperm wanting or rarely present.

A. Fruit not enclosed in a depressed or hollow hypanthium.

a. Pistils few, rarely more than 5 , maturing into 2-4-seeded follicles.

Follicles opening along both sutures: seeds shining.

Follicles opening along one suture: seeds dull or granular.

* Pistils alternating with the sepals. 
Flowers perfect: shrubs with simple leaf-blades.

Flowers dioecious : herbs with 2-3-pinnate leaf-blades. ** Pistils opposite the sepals.

b. Pistils numerous or rarely few, maturing into achenes or 1-2-seeded drupelets.

Pistils ripening into drupelets crowded on a receptacle.

Receptacle flat: ovary pubescent above : drupelets crowned by a hairy cushion.

Receptacle convex or conic : ovary glabrous : drupelets glabrous.

Pistils ripening into achenes.

Style deciduous.

Style basal.

Style lateral.

Achenes pubescent: low shrubs.

Achenes glabrous : herbs.

Receptacle pulpy, edible: petals white.

Receptacle neither pulpy nor edible: petals yellow.

Style terminal nearly so.

Pistils numerous : ovules pendulous: plants caulescent.

Pistils 2-6: ovules erect: plants acaulescent.

Style persistent on the achene.

Pistils numerous.

Styles jointed, the upper part deciduous.

Styles not jointed.

Pistils 5-15, at maturity resembling follicles, but indehiscent.

B. Fruit consisting of several achenes enclosed in the persistent hypanthium.

Achenes 1-4 within the dry hypanthium.

Shrubs : leaf-blades simpie, merely toothed.

Herbs: leaf-blades pinnate, or digitately lobed or divided.

Receptacle accompanied by 4-5 bractlets.

Receptacle without bractlets.

Receptacle bearing hooked prickles : petals 5 .

Receptacle without prickles: petals wanting.

Achenes numerous, within the fleshy hypanthium.
2. Spiraea.

3. Aruncus.

4. Porteranthus.

5. RUBACER.

6. Rubus.

7. Drymocallis.

8. SibBaldiopsis.

9. Fragaria.

10. Duchesnea.

11. Potentilla.

12. WALDSTEINIA.

13. GEUM.

14. Sieversia.

15. ULMARIA.

16. Neviusia.

17. Alchemilla.

18. Agrimonia.

19. SANGUISORBA.

20. Rosa.

\section{OPULÁSTER Medic.}

Wide-branching shrubs. Leaves alternate: blades simple, palmately lobed. Flowers perfect, white, in terminal corymbs. Hypanthium campanulate, or flattened in age. Sepals 5, persistent. Petals 5, spreading. Stamens numerous, 20-40. Disk clothing the hypanthium. Pistils 1-5, short-stalked: stigmas capitate. Ovules several. Follicles 1-5, inflated, opening along both sutures. Seeds thick, 2-4 in each cavity, shining. Testa crustaceous. Endosperm copious. Ninebark.

Leaf-blades densely stellate-pubescent.

Leaf-blades glabrous or sometimes slightly pubescent with simple hairs.

Follicles 2-4, pubescent.

Follieles mostly 5, glabrous.

1. O. stellatus.

2. . intermedius.

1. Opulaster stellàtus Rydb. A low branching shrub, with decidedly pubescent foliage, the hairs mostly branched. Leaf-blades ovate to orbicular-ovate, 1-4 cm. long, slightly lobed and crenate, stellate-pubescent on both sides, especially so beneath, rounded at the apex or merely obtuse : inflorescence densely stellate-pubescent : follicles mostly 4, pubescent, about $5 \mathrm{~mm}$. long. [Spiraea opulifolia var. ferruginea Nutt.]

In sand or sandy soil, Georgia and Florida. Spring.

2. Opulaster intermédius Rydb. A much branched shrub, 1-1.5 m. tall, with sparingly pubescent foliage. Leaf-blades orbicular or broadly ovate, $2-6 \mathrm{~cm}$. long, bluntly lobed and crenate, rounded or subcordate at the base : pedicels, hypanthium and calyx finely pubescent : follicles 3 or 4 , or rarely 2 , pubescent, united below, $6-7 \mathrm{~mm}$. long, rounded or obtuse at the apex.

On river banks, South Dakota to Illinois, Alabama and Colorado. Spring.

3. Opulaster opulifòlius (L.) Kuntze. A shrub, 1-3 m. tall, with wide-spreading or recurving branches, and glabrous or nearly glabrous foliage. Leaf-blades ovate to suborbicular, $3-8 \mathrm{~cm}$. long, acutely 3 -lobed, with unequally serrate margins, broadly cuneate to cordate at the base : corymbs $3-6 \mathrm{~cm}$. broad: hypanthium glabrous or nearly so: follicles 5, glabrous, shining, inflated, 8-10 mm. long, acute. [Physocarpus opulifolius (L.) Maxim.]

In rocky soil and on river banks, Quebec to Kentucky and Georgia. Spring and summer.

\section{SPIRAÈA L.}

Shrubs or perennial herbs, usually with branching stems. Leaves alternate: blades simple, often lobed : stipules present. Flowers perfect, in terminal or axillary corymbs or panicles. Hypanthium turbinate, campanulate or urn-shaped. Sepals 4 or 5 , erect or reflexed. Petals 4 or 5, imbricated. Stamens 20-60. Pistils usually 5, or sometimes 1-18, 
sessile or short-stalked : styles terminal : stigmas capitate or disk-like. Ovules 2-many in each cavity. Follicles 5, or rarely more or fewer, not inflated, opening along one suture. Seeds 1-10, narrow. Testa dull. Endosperm wanting, or very scant.

Flowers in terminal panicles.

Foliage glabrous or nearly so: panicle broad: follicles glabrous.

Foliage tomentose(except upper leaf-surfaces): panicle narrow: follicles tomentose. Flowers in terminal corymbs.

Leaf-blades 3-4 times as long as broad: sepals triangular.

Leaf-blades as broad as long or twice as long as broad: sepals triangular-ovate.

1. S. salicifolia.

2. S. tomentosa.

3. S. Virginiana.

4. S. corymbosa.

1. Splraea salicifòlia L. An erect glabrous or nearly glabrous shrub, 3-12 dm. tall, with reddish branching stems. Leaf-blades thinnish, oval, elliptic or narrowly oblong, or often ranging from obovate to oblanceolate, $2-8 \mathrm{~cm}$. long, sharply serrate, except the more or less cuneate base: panicle broad, densely flowered, 5-20 cm. long: hypanthium campanulate, $2 \mathrm{~mm}$. broad, shorter than the pedicel : sepals triangular, rather obtuse, spreading : petals white or pinkish, suborbicular to deltoid-orbicular, $2 \mathrm{~mm}$. long: follicles $3 \mathrm{~mm}$. high, glabrous, the tips recurved.

In swamps and low grounds, Newfoundland to the Rocky Mountains, Georgia and Missouri. Also in northern Europe and Asia. Summer. MEAdow-sweet. MEadow QueEn.

2. Spiraea tomentòsa L. An erect shrub, $3-12 \mathrm{dm}$. tall, with tomentose folliage, the stem simple or nearly so, cobwebby below, closely tawny-pubescent above. Leaf-blades leathery, oblong or oval, varying to ovate or oblong-ovate, $1.5-7 \mathrm{~cm}$. long, sharply serrate except at the cuneate or rounded base, glabrous above, white- or tawny-tomentose beneath : panicles narrow, densely flowered, 5-30 cm. long : hypanthium campanulate, $1.8 \mathrm{~mm}$. broad, longer than the pedicel : sepals triangular, recurved: petals pink, purple or rarely white, orbicular-ovate, 1-1.5 mm. in diameter: follicles 2-2.5 mm. high, pubescent, the tips spreading.

In swamps and damp soil, Nova Scotia to Manitoba, northern Georgia and Kansas. Summer. HARDHACK. STEEPLE-BUSH.

3. Spiraea Virginiàna Britton. A straggling glabrous shrub, with a much branched stem and wide-spreading often wand-like branches. Leaf-blades thinnish, cuneate, oblanceolate or elliptic, or rarely lanceolate, $2-6 \mathrm{~cm}$. long, acute or rounded at the apex, undulate, serrate above the middle, glaucous beneath, cuneate or rarely rounded at the base : corymbs 3-9 $\mathrm{cm}$. broad, naked or leafy-bracted : hypanthium turbinate or campanulate-turbinate, $2 \mathrm{~mm}$. broad: sepals triangular, spreading: petals white, suborbicular, more than $2 \mathrm{~mm}$. in diameter, crisped : follicles about $2 \mathrm{~mm}$. high, glabrous.

On rocky banks, in the mountains, West Virginia to Tenrfessee. Spring and summer.

4. Spiraea corymbòsa Raf. An erect glabrous or glabrate shrub, with erect simple or little branched dark red stems. Leaf-blades thinnish, oval, elliptic or suborbicular, varying to ovate or obovate, $2-10 \mathrm{~cm}$. long, sharply or coarsely-serrate above the middle, with sharp or mucronate teeth or rarely slightly lobed, rounded or subcordate at the base or rarely acute: corymbs $5-15 \mathrm{~cm}$. broad, naked or leafy-bracted: hypanthium broadlycampanulate, $2 \mathrm{~mm}$. broad : sepals triangular-ovate, spreading : petals white, suborbicular, nearly $1.5 \mathrm{~mm}$. in diameter, more or less curled back : follicles erect, $1.5 \mathrm{~mm}$. high, glabrous.

On rocky banks or in poor soil, in the mountains, New Jersey to Georgia. Spring to summer.

\section{ARÚNCUS Adans.}

Large perennial herbs, with erect terete sparingly branched stems. Leaves alternate : blades twice or thrice pinnately compound: leaflets many, the blades toothed, membranous : stipules minute or none. Flowers dioecious, in slender panicled many-flowered racemes. Hypanthium persistent, spreading in age. Sepals mostly 5, narrowed upward. Petals usually 5, narrow. Stamens numerous. Pistils commonly 3, alternating with the sepals: stigma terminal. Ovules several. Follicles mostly 3 , finally deflexed. Seeds 2 in each cavity. Testa dull. Goat's-Beard.

1. Aruncus Arúncus (L.) Karst. Foliage bright green, glabrous. Stems erect, 1-2 m. tall : leaflets numerous, the blades ovate, oval or oblong, 4-10 cm. long, acuminate, finely and unequally serrate and incised, acutish to subcordate at the base : racemes slender, in plume-like panicles varying from $1-5 \mathrm{dm}$. in length : pedicels less than $1 \mathrm{~mm}$. in length : sepals ovate, about as long as the hypanthium : petals cuneate or obovate, $1 \mathrm{~mm}$. long, obtuse: filaments glabrous: follicles deflexed, $2-2.5 \mathrm{~mm}$. long, glabrous, the tips spreading. [Spiraea Aruncus L.]

In woods or clearings. Pennsylvania to Iowa, northern Georgia and Missouri. Also in northern Europe and Asia. Spring and summer. 


\section{PORTERÁNTHUS Britton.}

Perennial herbs, with erect, simple or sparingly branched stems. Leaves alternate : blades 3-parted or 3-foliolate, subtended by narrow or leaf-like stipules: leaflets toothed or incised. Flowers perfect, in loose terminal panicles. Hypanthium campanulate or cylindric, longer than the 5 sepals. Petals 5, narrow, convolute in the bud, slightly unequal. Stamens 10-20: filaments very short. Pistils 5, opposite the sepals: styles slender. Ovules 2-4, ascending from the base of the cavities. Follicles 5, leathery, partially included. Seeds 1-4, in each follicle. Testa leathery. Endosperm striate. The plants flower in the spring and summer. [Gillenia Moench.]

Lower leaflets serrate: stipules subulate or linear-lanceolate, entire or nearly so. Lower leaflets incised-pinnatifid: stipules leaf-like, incised or serrate.

1. P. trifoliatus.

2. P. stipulatus.

1. Porteranthus trifoliàtus (L. ) Britton. Stems erect, $3-12 \mathrm{dm}$. tall, usually somewhat branched: stipules subulate or linear-lanceolate: leaflets 3 , the blades elliptic or oblong, varying to lanceolate or oblanceolate, or rarely obovate, acute or acuminate at the apex, irregularly serrate and incised or lobed, acute or obtuse at the more or less oblique base : panicles open : sepals glandular-ciliate, lanceolate, acuminate, longer than the elongated ribbed hypanthium : petals linear-elliptic, about 1-5 cm. long, acuminate : follicles glabrous, 5-6 mm. long.

In woods and on hillsides or river banks, New York to Michigan, middle Georgia and Missouri. INDIAN PHYSIC. BOWMAN's-ROOT.

2. Porteranthus stipulàtus (Muhl.) Britton. Stems erect, 1-12 dm. tall, simple below, sparingly branched above: stipules leaf-like, serrate or incised: leaflets 3 , the blades elliptic or narrowly-elliptic, varying to lanceolate, 4-10 $\mathrm{cm}$. long, acuminate, the lower ones incised-pinnatifid, the upper irregularly but sharply serrate: panicles fewflowered: sepals ovate, glandular-ciliate, acute, longer than the tubular-campanulate hypanthium: petals narrowly-elliptic, $1-1.5 \mathrm{~cm}$. long: follicles glabrous, $6-7 \mathrm{~mm}$. long. IPECAC.

In rich woods, New York to Missouri and the Indian Territory, Georgia and Alabama. AmERICAN

\section{RUBÀCER Rydb.}

Perennial caulescent herbaceous shrubs, with more or less glandular-pubescent foliage. Leaves alternate: blades simple, prominently lobed and toothed, petioled. Flowers perfect, in terminal corymbs or racemes. Hypanthium flat. Sepals 5, not accompanied by bractlets, with long-acuminate tips. Corolla showy. Petals rose-purple or white, not clawed, deciduous. Stamens numerous. Pistils numerous, on a flat receptacle. Ovary pubescent above : style terminal, but to one side of the center, filiform. Drupelets rather dry, each furnished with a cushion of hairs covering the top and part of the dorsal side.

1. Rubacer odoràtum (L.) Small. An erect, unarmed, branching shrub, 1-2 m. tall, the foliage more or less densely glandular-pubescent and clammy. Leaf-blades simple, 0.5-3 dm. broad, 3-5-lobed, cordate, the lobes irregularly serrate, sometimes angled, acuminate ; petioles shorter than the blades : flowers showy : sepals ovate or oblong-ovate, with a slender terminal appendage longer than the body, tomentose within: petals rose-purple, or rarely white, suborbicular, $1.5-2 \mathrm{~cm}$. broad, undulate: fruit depressed-hemispheric, red, 1.5-2 cm. broad, rather dry, and insipid. [Rubus odoratus L.]

In woods or on rocky banks, Nova Scotia to Michigan, Georgia and Alabama. Spring to summer.

\section{RÙBUS L.'}

Perennial herbs or shrubs, with erect or trailing stems, often bristly or armed with prickles. Leaves alternate : blades usually lobed or 3-7-foliolate : stipules adnate to the petiole. Flowers perfect or dioecious, solitary or disposed in corymbs, racemes or panicles. Hypanthium persistent, broad. Sepals 5, not augmented by bractlets. Petals 5, sessile or short-clawed, deciduous. Stamens numerous : filaments filiform. Pistils usually numerous on a convex or conic receptacle. Ovary glabrous : styles slender, glabrous, nearly terminal. Ovules 2 in each cavity, pendulous. Drupelets destitute of hairy cushions, crowded together. Seed pendulous, the testa membranous. Raspberry. Blackberry.

\footnotetext{
'Prepared with the assistance of Dr. Per Axel Rydberg.
} 
Fruit falling away from the dry receptacle: petals erect. (Raspberries.)

Stems prickly, glaucous : fruit purple-black or black.

Stems bristly, not glaucous : fruit light red.

Fruit persistent on a fleshy receptacle: petals spreading. (Blackberries.)

Stems erect, ascending or recurved.

Leaf-blades white-woolly beneath.

Leaf-blades not white-woolly beneath.

Branches of the inflorescence and the petioles distinctly glandular-pubescent.

Fruit broadly oval or nearly spherical, very juicy.

Fruit narrowly oblong or thimble-shaped, comparatively dry.

Branches of the inflorescence and petioles villous, strigose or nearly glabrous, scarcely glandular.

Pubescence copious in the inflorescence.

Terminal leaflet $1 / 2$ longer than the lateral ones, oblong or oblongovate.

Terminal leaflet slightly longer than the lateral ones, obovate to rhombic.

Prickles of the stem flattened only at the base, straight or slightly curved.

Prickles of the stem much flattened throughout, strongiy hooked.

Pubescence sparse in the inflorescence.

Plants low, almost herbaceous, weakly prickly.

Plants tall and shrubby.

Plants strongly prickly.

Leaflets pubescent beneath, doubly serrate. Leaflets glabrous beneath, singly serrate.

Plants unarmed or with few weak prickles.

Stems trailing, creeping or decumbent.

Leaflets thin, membranous: leaves deciduous.

Stems merely prickly.

Inflorescence usually several-many-flowered.

Corolla generally over $3 \mathrm{~cm}$. broad: inflorescence usually glanduliferous: terminal leaflets of the shoots rounded at the base.

Leaflets simply serrate.

Leaflets doubly serrate.

Corolla generally less than $3 \mathrm{~cm}$. broad : inflorescence not glanduliferous : terminal leaflets of the shoots cuneate or obtuse at the base.

Terminal leaflet $1 / 2$ longer than the lateral ones, oblong or oblongovate, acute.

Terminal leaflet slightly longer than the lateral ones, ovate, acuminate.

Leaflets mostly acute or acuminate, glabrous or somewhat pubescent beneath: peduncles slightly villous.

Leaflets mostly obtuse, tomentulose beneath: peduncles densely tomentulose or tomentose.

Inflorescence usually 1-2-flowered.

Lateral leaflets cuneate at the base, glabrous.

Leaflets sharply serrate with triangular teeth.

Leaflets erenate-serrate with ovate teeth.

Lateral leaflets rounded at the base, pubescent beneath.

Stems bristly and prickly, sometimes merely bristly.

Flowering branches and petioles bristly or glabrous : terminal leaflets cuneate.

Flowering branches and petioles prickly : terminal leaflets oblong-elliptic.

Leaflets leathery : leaves persistent, evergreen.

Corolla 1-1.5 cm. broad.

Corolla $2-3.5 \mathrm{~cm}$. broad.

Flowering branches usually simple and 1-flowered.

Flowering branches usually corymbosely branched and several-flowered.

Pedicels not bristly under the hypanthium : stems with recurved prickles.

Pedicels densely bristly under the hypanthium : stems with straight prickles and numerous bristles.

1. $R$. occidentalis.

2. R. strigosus.

3. R. cuneifolius.

4. R. nigrobaccus.

5. R. Allegheniensis.

6. R. ostryifolius.

7. R. frondosus.

8. R. floridus.

9. R. Randii.

10. R. argutus.

11. $R$. betulifolius.

12. $R$. Canadensis.

13. $R$. invisus.

14. $R$. roribaccus.

\section{R. ostryifolius.}

15. R. procumbens.

16. R. rhodophyllis.

17. R. subuniflorus.

18. R. Enslenii.

19. R. Baileyanus.

20. R. hispidus.

21. R. carpinifolius.

20. $R$. hispidus.

22. R. trivialis.

23. R. persistens.

24. $R$. rubrisetus.

1. Rubus occidentàlis L. A straggling shrub, with cane-like glaucous pricklearmed branches 1-3 m. long, curved, sometimes rooting at the end. Leaves pinnately 3foliolate, or rarely 5 -foliolate: blades of the leaflets ovate to obovate, $2-8 \mathrm{~cm}$. long, acute or acuminate, incised-serrate, sometimes lobed, cuneate or subcordate at the base : flowers not showy, in terminal corymbs : sepals oblong-ovate or ovate-lanceolate, 5-6 mm. long, acuminate : petals white, spatulate or cuneate-spatulate, 4-5 mm. long, obtuse : fruit depressed-hemispheric, black or purple-black, 8-12 $\mathrm{mm}$. broad.

On the borders of woods and in rocky thickets, Quebec to Ontario, northern Georgia, Alabama and Missouri. Spring. BlaCK RASPBERry. BLACK-CAP.

2. Rubus strigòsus Michx. A branching shrub, 1-2 m. tall, with curved branches and more or less densely bristly foliage. Leaves pinnately 3 -5-foliolate : blades of the leaflets ovate to oblong-ovate or ovate-lanceolate, rarely elliptic, $2-8 \mathrm{~cm}$. long, acute or acuminate, slightly serrate, sometimes slightly lobed, glabrous above or nearly so, whitetomentose beneath, usually rounded at the base: flowers in loose racemes or panicles : 
hypanthium bristly : sepals lanceolate, acuminate, $5-6 \mathrm{~mm}$. long, spreading : petals white, cuneate or oblanceolate, about $5 \mathrm{~mm}$. long, ascending, obtuse : fruit high-hemispheric, light red, or rarely white, $8-10 \mathrm{~mm}$. broad.

In rocky soil, Newfoundland to Labrador and British Columbia, North Carolina and New Mexico. Spring and summer. RED RASPBERRY.

3. Rubus cuneifolius Pursh. An erect much-branched armed shrub, 0.5-1 m. tall. Leaves 3 -foliolate, or those on the shoots 5 -foliolate, with stout prickly petioles: blades of the leaflets leathery, acute or abruptly acuminate, glabrous or nearly so and rugose above, densely tomentose beneath, sharply serrate, the terminal one cuneate : flowers usually few, in terminal corymbs: hypanthium woolly : sepals ovate or oval, about $4 \mathrm{~mm}$. long: petals white or pink, cuneate : fruit oblong, $1.5-2.5 \mathrm{~cm}$. long, black or nearly so, sweet.

In sandy soil, Connecticut to Missouri, Florida and Lousiana. Spring and summer.

4. Rubus nigrobáccus Bailey. A straggling branched shrub, with glandular-pilose young foliage, armed with recurved prickles, the stems 1-3 m. long, angled in age. Leaves 3 -foliolate, or sometimes 5 -foliolate : blades of the leaflets thickish, ovate, oval or obovate, $5-11 \mathrm{~cm}$. long, acute or acuminate, coarsely and unequally serrate, softly pubescent at least beneath : flowers in terminal or axillary racemes : hypanthium glandular : sepals ellipticlanceolate, 6-7 mm. long, acuminate : petals white or pink, 1-2 cm. long, obovate to suborbicular: fruit oval to globose-oval, $12-25 \mathrm{~mm}$. long, black, juicy. [R. villosus A. Gray, not Ait. $]$

In dry soil, chiefly in thickets, New England to Florida and Arkansas. Spring.

5. Rubus Allegheniénsis Porter. Resembling $R$. nigrobaccus, but with more densely glandular foliage, the stems rather more slender, erect or spreading, 6-25 dm. long, copiously prickly, red or purple. Leaves 3-5-foliolate : blades of the leaflets relatively narrow, ovatelanceolate to ovate, elliptic, oblong or oval : corolla $2.5-3 \mathrm{~cm}$. broad : fruit cylindric, 16-28 mm. long, much less juicy than that of related species but of a peculiar spicy flavor.

In dry, usually stony soil, Ontario to New York and North Carolina. Spring and early summer.

6. Rubus ostryifòlius Rydb. An ascending or depressed shrub, with brownish purple stems 6-12 dm. long, armed with stout prickles, these broad and flat at the base, the young foliage villous. Leaves 5-foliolate: blades of the leaflets oblong or ovate-oblong, 4-8 cm. long, rather simply serrate, glabrate or slightly pubescent above, finely villous beneath : inflorescence villous and somewhat prickly : corymbs 1-5-flowered: sepals ovate, with short subulate tips : corolla $1-2 \mathrm{~cm}$. broad : fruit hemispheric, less than $1 \mathrm{~cm}$. high, black, rather dry.

Along or near the coast, New Jersey to North Carolina, Florida and Louisiana. Spring and summer.

7. Rubus frondòsus Bigel. An erect or spreading shrub, with closely pubescent foliage, armed with straight or slightly curved prickles, the stems $0.5-2 \mathrm{~m}$. long. Leaves 3or rarely 5 -foliolate: blades of the leaflets elliptic to oval, varying to ovate or obovate, $1.5-6 \mathrm{~cm}$. long, usually acute or acuminate, sharply but rather finely serrate and incised: flowers in terminal leafly-bracted racemes: petals white or pinkish, obovate to oblongcuneate, $1-1.5 \mathrm{~cm}$. long: fruit oblong-cylindric, $1-1.5 \mathrm{~cm}$. long, fleshy. $[R$. villosus var. frondosus Torr.]

In dry or rocky soil, Prince Edward's Island to Michigan and North Carolina. Spring and summer.

8. Rubus flóridus Tratt. Similar to $R$. frondosus in habit, the stem armed with flat hooked prickles. Leaves 3-foliolate : blades of the leaflets ovate, obovate or rhombic, 3-6 $\mathrm{cm}$. long, acute or slightly acuminate, coarsely and mostly doubly serrate, silky-villous when young, glabrate in age, except the nerves beneath : inflorescence silky-villous, the corymbs several-flowered : corolla $3-3.5 \mathrm{~cm}$. broad.

In thickets, Georgia and Florida. Spring.

9. Rubus Rándii (Bailey) Rydb. A low and diffuse shrub, with almost glabrous foliage, the stems 5-6 dm. long, with few weak prickles or commonly unarmed and chiefly herbaceous. Leaves 3 -foliolate, or 5 -foliolate on the shoots : blades of the leaflets thin, ovate to ovate-lanceolate, long-acuminate, sharply and doubly serrate, the terminal one slenderstalked : inflorescence bristly, but not glandular, elongated : flowers numerous: corolla $1.5-2.5 \mathrm{~cm}$. broad : fruit globose-hemispheric, less than $1 \mathrm{~cm}$. long.

In woods and thickets, Maine to the Lake Superior region and North Carolina. Spring and summer .

10. Rubus argùtus Link. Resembling $R$. Randii, but stems 1-2 m. long, purple, angled, armed with stout slightly recurved prickles. Leaves various, those of flowering branches relatively small and the upper ones often 1-foliolate: inflorescence corymbose, short, many-flowered : corolla $2-3 \mathrm{~cm}$. broad : petals oval or obovate : fruit hemispheric, about $1 \mathrm{~cm}$. high.

In dry soil, Prince Edward's Island to Georgia and Alabama. Spring and early summer. 
11. Rubus betulifòlius Small. Resembling $R$. ostryifolius in habit, the foliage glabrous or nearly so, the stem, branches and petioles armed with flat recurved prickles. Leaves 3 -foliolate: blades of the leaflets oblong to oval, the terminal one $4-10 \mathrm{~cm}$. long, usually much longer than the lateral ones, all rather coarsely and mostly simply serrate, sometimes slightly puberulent on the veins beneath, smooth and somewhat shining above: flowering branches slightly strigillose when young: corolla $2.5-3 \mathrm{~cm}$. broad : fruit rounded-oblong, 10-12 mm. long, black.

In thickets, Georgia and Alabama. Spring.

12. Rubus Canadénsis L. An unarmed or slightly prickly shrub, with ascending or spreading wand-like stems, and branches 1-4 m. long, the foliage glabrous, or the shoots scurfy pubescent. Leaves pedately 5 -foliolate or rarely 3 -foliolate: blades of the leaflets thin, oval, elliptic or ovate, sometimes obovate, usually glabrons, acuminate, sharply serrate: flowers in large leafy-bracted racemes : petals white or pink, $1.5-2.5 \mathrm{~cm}$. long: fruit cylindric-oblong, $1.5-2.5 \mathrm{~cm}$. long, black, juicy.

In woods and thickets, mountains of New England to Georgia and Alabama. Spring to fall.

13. Rubus invìsus Bailey. A low shrub, with stout ascending or decumbent terete stems armed with straight slightly reflexed prickles. Leaves glabrous or nearly so, those of shoots 5-foliolate, those of flowering branches 3-foliolate: blades of the leaflets broadly ovate to oblong or oval, $2-8 \mathrm{~cm}$. long, acuminate, especially on sterile shoots : corymbs few-flowered, with rather elongated pedicels : sepals with slender tips : fruit globose-oblong, $1-1.5 \mathrm{~cm}$. long.

In dry soil, New York to Kansas and Alabama. Summer.

14. Rubus roribáccus (Bailey) Rydb. A stocky shrub, with terete stems 1-2 m. long, armed with straight weak prickles, the young foliage glandular-villous. Leaves resembling those of $R$. invisus, but the blades of the leaflets less acuminate, sharply doubly serrate, thinner and lighter green: inflorescence many-flowered, leafy-bracted: sepals with a lanceolate base, foliaceous : corolla $3-5 \mathrm{~cm}$. broad : petals usually broadly obovate : fruit globose-oblong, $1-1.5 \mathrm{~cm}$. long.

In thickets, Pennsylvania to Virginia and North Carolina. Spring and summer.

15. Rubus procúmbens Muhl. A trailing shrub, with prickle-armed or nearly naked stems 1-3 m. long, the foliage thinly pubescent, the branches erect or ascending, 1-3 $\mathrm{dm}$. tall. Leaves often clustered, with bristly or prickly petioles, 3-7-foliolate : blades of the leaflets elliptic-oval, suborbicular or sometimes ovate or cuneate, $2-8 \mathrm{~cm}$. long, sharply dentate-serrate and often incised, usually acute or acuminate : flowers solitary or few in loose racemes : petals white or pink, obovate or cuneate, fully $10 \mathrm{~mm}$. long, rounded or retuse at the apex : fruit suborbicular to oval, $2-2.5 \mathrm{~cm}$. long, black, very sweet and juicy. [R. Canadensis T. \& G., not L.]

In dry open soil, Ontario to Minnesota, North Carolina, Louisiana and the Indian Territory. Spring. DEWBERRY.

16. Rubus rhodophýllus Rydb. Resembling $R$. procumbens in habit, but with much shorter branches and denser tomentuiose or tomentose pubescence, the stems armed with rather weak slightly recurved prickles flattened only at the base. Leaves 3-foliolate: blades of the leaflets broadly ovate to obovate, rather finely and mostly simply serrate, $1-3 \mathrm{~cm}$. long, generally obtuse, closely tomentulose beneath, slightly silky above or glabrate at maturity : corolla about $2.5 \mathrm{~cm}$. broad.

In dry soil or fields, Mississippi and Alabama. Spring.

17. Rubus subuniflòrus Rydb. Resembling $R$. procumbens but early glabrate or glabrous throughout, with very weak prickles. Branches very slender: flowers mostly solitary on long axillary peduncles at maturity fully as long as the leaves: corolla white, $3-4 \mathrm{~cm}$. broad : fruit globose-hemispheric, $1 \mathrm{~cm}$. long or shorter, of few large drupelets. [R. villosus Ait., not Thunb.]

In dry or sandy soil, near the coast, Maine to South Carolina. Spring and summer.

18. Rubus Enslénii Walt. A slender trailing vine, with glabrous foliage, sparingly armed with reflexed prickles. Leaves $2-4 \mathrm{~cm}$. long: blades of the leaflets obovate-cuneate, or the terminal one rhombic-cuneate, crenate-dentate or crenate-serrate above the entire base, usually acute : flowers solitary or 2 together: sepals narrowly ovate, mucronate : corolla $2.5-3 \mathrm{~cm}$. broad : fruit $1-1.5 \mathrm{~cm}$. long, of few drupelets.

In open woods, Kansas to Alabama and Mississippi. Spring.

19. Rubus Baileyànus Britton. A prickle-armed shrub, with ascending or trailing stems 3-15 dm. long, the foliage more or less pubescent or glabrate in age. Leaves 3foliolate, or the upper ones usually simple : blades of the leaflets elliptic to suborbicular varying to ovate or obovate, often acute or acuminate, sharply serrate or incised, commonly 
cuneate or obovate-cuneate, $1.5-2 \mathrm{~cm}$. long: fruit subglobose, or oval, $1-1.5 \mathrm{~cm}$. high, rather dry, black.

In dry woods or rocky soil, Maine to New York and Georgia. Spring.

20. Rubus híspidus L. A slender bristly or prickly shrub, with trailing stems, the branches erect or ascending, 1-3 dm. tall. Leaves relatively few, mostly 3 -foliolate : blades of the leaflets rather leathery, 1-4 cm. long, usually obtuse at the apex, unequally serrate, the terminal one narrowly or broadly cuneate, the lateral ones oval or suborbicular varying to ovate or obovate : flowers solitary, or a few in corymbs : petals white or pinkish, spatulate to cuneate-obovate, $5-8 \mathrm{~mm}$. long: fruit of few drupelets about $1 \mathrm{~cm}$. in diameter, black, sour. summer.

In woods, thickets or damp places, Nova Scotia to Minnesota, Georgia and Kansas. Spring and

21. Rubus carpinifòlius Rydb. A slender trailing shrubby vine, with bristly and weak-prickly stems, the flowering branches $2-3 \mathrm{dm}$. long, armed with flatter and more recurved prickles than the stem, the lower leaves 5 -foliolate, the upper 3 -foliolate: blades of the leaflets very thin, the terminal one oblong to elliptic-oblong, 4-6 cm. long, somewhat longer than the lateral ones, the lateral ones ovate to cuneate, all glabrous, rather coarsely and mostly doubly serrate with ovate teeth : inflorescence few-flowered, the peduncles elongated : corolla about $2.5 \mathrm{~cm}$. broad : fruit oblong, about $1.5 \mathrm{~cm}$. long.

In dry soil, Arkansas and Louisiana. Spring.

22. Rubus triviàlis Michx. An evergreen trailing or procumbent shrub, with prickle-armed and more or less bristly stems 1-2 $\mathrm{m}$. long, the flowering branches erect, usually $2-10 \mathrm{~cm}$. tall, the prickles hooked. Leaves often numerous, 3-foliolate or rarely 5foliolate : blades of the leaflets thickish, elliptic or oval, or sometimes ovate-lanceolate, sharply serrate, the terminal one often cuneate at the base: flowers usually solitary : sepals ovate to oval or lanceolate : petals white, broadly or narrowly obovate, 10-12 mm. long: fruit oblong, $2.5 \mathrm{~cm}$. long, black, sweet and juicy.

In sandy soil, Virginia south to Florida and Texas. Spring.

23. Rubus persístens Rydb. Similar to $R$. trivialis in habit, but the flowering branches more leafy and terminated by several-flowered corymbs, the stems prickle-armed, the prickles somew hat flattened and more or less recurved. Leaves 3-foliolate: blades of the leaflets thickish, the terminal ones cuneate, oblong-obovate or oblong-lanceolate, 1.5-4 cm. long, all glabrous or sparingly pubescent about the veins beneath, serrate or slightly incised-serrate: flowering branches armed like the stem, terminated by several-flowered corymbs : corolla $2-2.5 \mathrm{~cm}$. broad : fruit oblong.

In sandy soil, South Carolina to Florida and Mississippi. Spring.

24. Rubus rubrisètus Rydb. An evergreen shrub, the stems trailing, 6-12 dm. long, prickly and densely clothed with red or purplish bristles. Leaves 5 -foliolate or on flowering branches sometimes 3 -foliolate: blades of the leaflets thick, obovate or oval, 2-6 $\mathrm{cm}$. long, acute or acuminate, smooth and shining, dentate with broad teeth : inflorescence bristly and prickly : flowers 3-7 in each corymb: sepals ovate, with short subulate tips: corolla $1.5-2.5 \mathrm{~cm}$. wide.

In sandy soil, Missouri to Louisiana. Winter and spring.

\section{DRYMOCÁLIIS Fourr.}

Perennial caulescent herbs, with villous or viscid foliage. Leaves alternate: blades pinnate. Flowers in irregular cymes. Hypanthium nearly flat. Sepals 5, accompanied by bractlets. Corolla yellow or white. Petals not notched. Stamens 20-30, in 5 clusters on the thickened margin of the 5-angled disk around the hemispneric receptacle. Pistils numerous: style basal, usually thickened near the middle. Seed orthotropous, ascending from its attachment near the base of the style.

1. Drymocallis argùta (Pursh) Rydb. Stems stout, 3-10 dm. tall, glandular and villous. Basal leaves with pinnately $7-11$-foliolate blades; leaflets ovate, oval or rhombic, obtuse and sharply incised-serrate, the terminal one cuneate at the base: stem-leaves much reduced: flowers in dense cymes: sepals ovate, acute: corolla white, 10-18 mm. broad : achenes glabrous. Summer.

On dry or rocky hills, New Brunswick to the Rocky Mountain region, Tennessee and Kansas.

\section{SIBBALDIÓPSIS Rydb.}

Low perennial caulescent shrubby plants, with horizontal rootstocks and short caudices. Leaves alternate: blades 3 -foliolate, petioled : leaflets leathery, the blades broadened up- 
ward. Flowers in terminal corymbs. Hypanthium persistent, rather flat. Sepals 5, nearly as broad as long. Bractlets 5, narrower than the sepals. Petals 5, white, sessile, without claws. Stamens about 20, in 3 series : filaments filiform. Receptacle hemispheric. Pistils numerous. Styles slender, lateral. Stigma truncate. Ovule ascending, amphitropous. Achenes turgid, pubescent.

1. Sibbaldiopsis tridentàta (Soland.) Rydb. Foliage pubescent, bright green. Caudices decumbent, scaly below, sometimes creeping: leaves often clustered; stipules lanceolate, $5-10 \mathrm{~mm}$. long; leaflets 3 , the blades 1-3 cm. long, cuneate or obovate-cuneate, 3 -toothed at the apex, appressed-pubescent : peduncles $0.5-3 \mathrm{dm}$. tall, topped by fewflowered corymbose cymes : bractlets mostly oblong : sepals triangular-ovate or ovate, acute, surpassing the bractlets : corolla white, about $1 \mathrm{~cm}$. broad : petals obovate or elliptic-obovate, fully twice as long as the sepals.

In rocky soil, Greenland to Manitoba, New Jersey and along the mountains to northern Georgia. spring and summer.

\section{FRAGÁRIA L.}

Perennial acaulescent often stoloniferous herbs, the foliage usually silky or villous. Leaves basal, with long petioles: blades 3 -foliolate. Scapes simple or branched above. Flowers polygamo-dioecious, in terminal cymes. Hypanthium persistent, turbinate. Sepals 5 , spreading or reflexed, valvate, accompanied by 5 bractlets. Petals 5 , white, or rarely reddish, short-clawed. Stamens about 20, in 3 series. Pistils numerous, glabrous, inserted on a conic or hemispheric accrescent receptacle : style lateral, rather persistent : stigma capitate. Ovule solitary, ascending. Achenes crustaceous, numerous, imbedded in or seated on the more or less elongated fleshy receptacle. STrawberry.

Leaflets sessile or nearly so: achenes superficial.

Leaflets stalked: achenes in pits.

1. F. Americana.

2. F. Virginiana.

1. Fragaria Americàna (Porter) Britton. Rootstock rather slender. Runners long and slender : leaves erect; petioles $5-10 \mathrm{~cm}$. long, silky or glabrate; leaflets 3 , the blades rhombic-obovate, $3-8 \mathrm{~cm}$. long, mostly acute, sharply and deeply serrate, the lateral pair oblique : scapes slender, mostly less than $1.5 \mathrm{dm}$. tall, silky or the hairs finally spreading: corolla white, $1-1.5 \mathrm{~cm}$. broad : fruit conic-ovoid, 1-1.5 $\mathrm{cm}$. long, red : achenes superficial.

In woods and thickets, Newfoundland to North Carolina and New Mexico. Spring.

2. Fragaria Virginiàna Duchesne. Rootstock thick. Runners long and stout; leaves mostly erect; petioles $2-30 \mathrm{~cm}$. long, villous ; leaflets 3 , the blades rather thick, obovate to oblong, 3-10 cm. long, coarsely toothed, obtuse, deep green, glabrate in age, not glaucous : scape erect, stout, $1.5-5 \mathrm{dm}$. long, but usually less than $2 \mathrm{dm}$, villous : sepals and bractlets lanceolate, acute or acuminate : corolla $1.5-2.5 \mathrm{~cm}$. broad: petals obovate, about twice as long as the sepals : fruit hemispheric, $1-1.5 \mathrm{~cm}$. long : achenes in pits.

In dry soil, Prince Edward's Island to Minnesota, Georgia and the Indian Territory. Spring.-A smaller form 3-8 cm. high, with more copiously pubescent foliage, leaflets $2-4 \mathrm{~cm}$. long, almost sessile and broader, and the sepals more acuminate, is $F$. Virginiana australis Rydb.

\section{DUCHÉsNeA J. E. Smith.}

Perennial caulescent herbs, with trailing, often creeping branches. Leaves alternate : blades 3 -foliolate, petioled. Flowers perfect, pedicelled, axillary. Hypanthium flattish. Sepals 5 , accompanied by as many toothed or incised bractlets, which are longer than the sepals. Petals 5, yellow, fugaceous. Stamens numerous. Pistils numerous, inserted on a depressed-hemispheric receptacle: style lateral. Ovule solitary, ascending. Achenes crustaceous, seated on the dry receptacle. Yellow or INdian StrawberRy.

1. Duchesnea Índica (Andr.) Focke. Stem usually branched at the base, the branches hirsute or silky with partially appressed hairs, prostrate or ascending, 1-9 dm. long, often creeping: leaflets 3 , the blades ovate to obovate, $1-4 \mathrm{~cm}$. long, crenate or serrate-crenate, the terminal one cuneate at the base, the lateral ones inequilateral, their nerves prominent beneath : peduncles as long as the subtending bracts or longer : flower solitary : sepals ovate-lanceolate, $6-8 \mathrm{~mm}$. long, abruptly acuminate : bractlets $3-5$-toothed : corolla $1.6-2 \mathrm{~cm}$. broad : petals 5 , yellow, obovate, truncate or retuse at the apex : fruit ovoid or subglobose, 8-10 mm. in diameter. [Fragaria Indica Andr.]

In waste places, New York to Florida and Alabama. Naturalized from India. Spring to fall. 


\section{POTENTILLA L.}

Herbs or shrubby plants, with erect or creeping stems. Leaves alternate : blades pinnately or digitately divided. Flowers perfect, in terminal corymbose cymes or solitary and axillary to leaf-like bracts. Calyx erect or drooping. Sepals usually 5, persistent. Bractlets 5. Petals usually 5, white, yellow, red or purple, mostly sessile. Stamens mostly 20, (5-30) in 2 or 3 series. Receptacle hemispheric or conic. Pistils mostly numerous : style terminal. Ovule pendulous, anatropous. Achenes smooth or wrinkled. Cinqueforl.

Flowers axillary to the leaf-like bracts : stems creeping or spreading: perennials. Stems silky-villous: first flower at the second node of the stem or a succeeding node.

Stems silky-strigillose : first flower at the first node of the stem.

Flowers in terminal cymes : stems erect or ascending: annuals or biennials.

Upper leaf-blades digitately 3-7-foliolate.

Corolla $10 \mathrm{~mm}$. broad: stamens 20 : petals as long as the sepals.

Corolla $5 \mathrm{~mm}$. broad : stamens $5-8$ : petals much shorter than the sepals.

Upper leaf-blades pinnately 3-11-foliolate.

\section{P. Canadensis.}

2. P. pumila.

3. P. Monspeliensis.

4. P. pentandra.

5. P. paradoxa.

1. Potentilla Canadénsis L. Perennial, bright green. Stems branched at the base, the branches 3-6 dm. long, becoming decumbent or prostrate, silky-villous : basal leaves few ; petioles 4-6 $\mathrm{cm}$. long, silky ; blades digitately 5 -foliolate, or 3 -foliolate with the lateral leaflets nearly divided; blades of the leaflets obovate or cuneate-oblong, 2-4 cm. long, coarsely and usually doubly serrate : stem-leaves similar to the basal but with shorter petioles : flowers solitary in the axils : pedicels $3-10 \mathrm{~cm}$. long: sepals ovate or lanceolate, about as long as the lanceolate bractlets : corolla yellow, 10-12 mm. broad : petals obcordate, about $\frac{1}{3}$ longer than the sepals : achenes with a few transverse wrinkles.

In dry soil, Maine to Quebec, Minnesota, northern Georgia and the Indian Territory. Spring and summer--A larger form with more elongated branches, more appressed pubescence and glabrate larger leaflets 5-6 cm. long, is P. Canadensis simplex (Michx.) T. \& G.

2. Potentilla pùmila Poir. Perennial, pale green. Stems erect, less than $1.5 \mathrm{dm}$. tall, producing elongated runner-like densely silky-strigillose branches: basal leaves few; petioles 2-4 cm. long, pubescent like the stem ; blades digitately 5 -foliolate: blades of the leaflets obovate, about $2 \mathrm{~cm}$. long, coarsely serrate : stem-leaves similar to the basal, but with shorter petioles: flowers solitary in the axils, the first one accompanying the first stem-leaf: pedicels $3-5 \mathrm{~cm}$. long: sepals lanceolate, about as long as the similar bractlets : corolla yellow, $6-10 \mathrm{~mm}$. broad : petals obcordate, little surpassing the sepals.

In dry woods, New England to North Carolina and Georgia. Spring.

3. Potentilla Monspeliénsis L. Annual or biennial. Stems solitary or several together, 3-8 dm. tall, branched above, hirsute: leaf-blades digitately 3 -foliolate (or the lower ones in robust plants digitately or pinnately 5-foliolate): stipules ovate, 1-4 cm. long, toothed; blades of the leaflets obovate, $3-10 \mathrm{~cm}$. long, serrate with broad teeth : hypanthium hirsute, becoming $1 \mathrm{~cm}$. broad : sepals oblong-lanceolate, acute, about as long as the similar bractlets : corolla light yellow, about $1 \mathrm{~cm}$. broad: petals obovate, almost as long as the sepals: stamens 20.

In dry soil and cultivated grounds, Labrador to Alaska, Georgia, Texas and Mexico. Spring and summer. Also in Europe and Asia.-The form with oblong leaflets and fine pubescence, rarely with some longer hairs, is P. Monspeliensis Norvègica (L.) Rydb.

4. Potentilla pentándra Engelm. Annual or biennial. Stems 3-7 dm. tall, hirsute, much branched above: blades of the basal and lower stem-leaves 3 -foliolate, with the lower pair of leaflets parted so as to simulate a 5 -foliolate blade, slender-petioled; blades of the leaflets oblanceolate or oblong, $3-5 \mathrm{~cm}$. long, obtuse, incised-dentate : cyme flat-topped : sepals ovate, acute : corolla pale yellow, less than $5 \mathrm{~mm}$. broad: petals spatulate, much surpassed by the sepals : stamens 5-8.

On prairies, Manitoba to Missouri, Kansas and Arkansas. Summer.

5. Potentilla parađóxa Nutt. Annual or biennial. Stems 3-8 dm. tall, softly pubescent, rather much branched: blades of the lower leaves pinnately 7-11-foliolate; blades of the leaflets obovate or oval, $1.5-2.5 \mathrm{~cm}$. long, obtuse, sparingly pubescent: cymes loose : sepals ovate, acute : corolla $7-8 \mathrm{~mm}$. broad : petals obovate-cuneate, about as long as the sepals : stamens about 20 .

On river banks or in low grounds, New York to Ontario, Oregon, Tennessee and Mexico. Summer.

\section{WALDSTEINIA Willd.}

Perennial acaulescent herbs, resembling Fragariae, with horizontal rootstocks. Leaves basal, with long petioles : blades simple, 3-5-lobed or 3-5-foliolate, the lobes or leaflets with toothed or incised blades: stipules membranous. Scapes erect, branched above. Flowers perfect, in terminal corymbs. Hypanthium turbinate. Sepals 5, valvate, often 
augmented by 5 bractlets. Petals 5, surpassing the sepals. Stamens numerous, in several series on the throat of the receptacle: filaments distinet, rigid. Pistils 2-6, on a short pubescent receptacle: style nearly terminal, filiform, glabrous. Ovule 1 in each cavity, ascending. Achenes 2-6, oblique, dry or somewhat fleshy. Barren Strawberry.

\section{Leaf-blades 3-lobed.}

Leaf-blades 3-foliolate.

Petals as long as the sepals or shorter:

Petals twice as long as the sepals or longer.
1. W. lobata.

2. W. parviflora.

3. W. fragarioides.

1. Waldsteinia lobàta (Baldw.) T. \& G. Foliage slightly bristly with delicate spreading hairs. Leaves 1-2 dm. tall; petioles longer than the blades, slender; blades suborbicular in outline, $2.5-6 \mathrm{~cm}$. in diameter, cordate, 3-lobed, the lobes crenate with mucronulate teeth: scapes filiform, about as long as the leaves, simple or corymbosely branched above: sepals triangular-lanceolate, acute, somewhat longer than the hypanthium: petals narrowly oblong or narrowly elliptic, as long as the sepals or shorter: achenes usually 2 , densely pubescent.

On the banks of the Flint and the Chattahoochee Rivers, southwestern Georgia. Spring.

2. Waldsteinia parviflòra Small. Foliage glabrous or villous-hirsute. Leaves 1-3 dm. tall; petioles much longer than the blades, usually less pubescent than the scapes; blades compound : leaflets 3 , the blades cuneate, obovate or broadly rhomboidal, 2-8 $\mathrm{cm}$. long, coarsely and irregularly crenate or lobed: scapes solitary or several together, commonly shorter than the leaves, more or less extensively corymbosely branched: sepals triangular-lanceolate or lanceolate-acuminate, often shorter than the hypanthium : petals linear-oblong or narrowly elliptic, as long as the sepals or slightly shorter.

In woods or shaded places, Pennsylvania to North Carolina, Tennessee and Georgia. Spring.

3. Waldsteinia fragarioides (Michx.) Tratt. Foliage glabrous or with few spreading hairs. Leaves basal, $0.5-3 \mathrm{dm}$. tall; petioles as long as the blades or longer; blades compound : leaflets 3 , the blades $2-4 \mathrm{~cm}$. long, broadly cuneate or obovate, or sometimes suborbicular in outline, crenate, crenate-lobed or incised : scapes solitary or tufted, shorter than or mostly longer than the leaves, simple or corymbosely branched above: bracts lanceolate to ovate: sepals ovate to ovate-triangular, longer than the hypanthium, acute or acutish : petals bright yellow, ovate or oval, $8-10 \mathrm{~mm}$. long, twice as long as the sepals or longer.

In woods or on shaded banks, Ontario (?) to New York, New Jersey, Virginia and Georgia. Spring.

\section{GEेUM L.}

Perennial herbs, with horizontal rootstocks and upright stems. Leaves alternate, sometimes all basal: blades 3 -foliolate or pinnately divided, the divisions alternate, the terminal one larger than the rest. Flowers of various colors, solitary or in corymbs or cymes. Hypanthium turbinate to hemispheric. Sepals 5, valvate or imbricated, usually augmented by as many bractlets. Petals 5, longer than the sepals. Stamens numerous, in several series : filaments distinct. Pistils numerous, inserted on a short or elongated receptacle: style filiform, jointed, more or less angled : stigma minute. Ovule 1 in each cavity, ascending. Achenes dry, sessile or short-stalked. Avens.

Heads of achenes sessile: sepals accompanied by bractlets.

Corolla yellow or cream-yellow.

Corolla white.

Plant glabrate or softly pilose : receptacle glabrous.

Plant hirsute: receptacle bristly.

Petals shorter than the sepals : achene-body $2.5-3 \mathrm{~mm}$. long.

Petals as long as the sepals or longer: achene-body $3.5-4.5 \mathrm{~mm}$. long. Heads of achenes stalked : sepals not accompanied by bractlets.

1. G. flavum.

2. G. Canadense.

3. G. Virginianum.

4. G. geniculatum.

5. G, vernum.

1. Geum flàvum (Porter) Bicknell. Foliage dingy green. Stems 3-12 dm. tall. hirsute below, corymbosely branched above : leaf-blades variable, those of the basal and lower stem-leaves usually pinnately divided (rarely only lobed), the divisions toothed or incised, the terminal one much larger than the rest; upper stem-leaves with less divided and shorter-petioled blades: sepals lanceolate, entire, reflexed : petals yellow or creamyellow, oblong or oblong-cuneate, $3-4 \mathrm{~cm}$. long, usually shorter than the sepals: achenebody about $3 \mathrm{~mm}$. long, with a few bristles especially above the middle.

In woods and on banks, New York to North Carolina. Spring and summer.

2. Geum Canadénse Jacq. Foliage bright green. Stems $3-9 \mathrm{dm}$. tall, finely pubescent or glabrate, corymbosely branched above : leaf-blades variable; those of the basal leaves lobed, 3-divided or pinnate, the divisions toothed, lobed or incised; stem-leaves similar, but the upper with less divided and with shorter petioled blades: hypanthium 
glabrous or finely canescent: sepals lanceolate, longer than the hypanthium, reflexed: petals white, obovate to suborbicular, as long as the sepals, or shorter: fruiting heads 8-11 mm. long: achene-body $2.5-3 \mathrm{~mm}$. long, bristly above the middle. [G. album Gmel.]

On banks and in shaded soil, Nova Scotia to Minnesota, Georgia and Missouri. Spring and summer.

3. Geum Virgtniànum L. Stems more or less densely pubescent with retrorse hairs, 3-9 dm. tall, branched above : leaves variable, the basal with long petioles and lobed, 3divided, or pinnate blades, the divisions lobed or incised; stem-leaves with short-petioled or sessile 3-5-lobed or parted blades: hypanthium hirsute: sepals lanceolate, acuminate: petals white, obovate or cuneate, shorter than the sepals : fruiting heads $12-16 \mathrm{~mm}$. long: achene-body $2.5-3 \mathrm{~mm}$. long, sparingly pubescent near the apex.

In thickets or low places, New Brunswick to Minnesota, North Carolina and Missouri. Spring and summer.

4. Geum geniculàtum Michx. Stems hirsute, the hairs sometimes retrorse, 5-9 dm. tall, corymbosely branched above: leaves various, the basal with long petioles; blades toothed or 3-divided, the divisions $5-8 \mathrm{~cm}$. long, coarsely toothed; the stem-leaves similar, but with shorter petioles, the terminal segment of the upper ones often acuminate: peduncles densely pubescent : sepals lanceolate, acuminate: petals white, conspicuously nerved, as long as the sepals or longer : achene-body $3.5-4.5 \mathrm{~mm}$. long, tawny, bristly near the edges.

On high mountain slopes, North Carolina. Summer.

5. Geum vérnum (Raf.) T. \& G. Stems branched at the base, the branches decumbent or ascending, 2-9 dm. long, glabrous or finely pubescent : leaves mainly basal, 5-20 cm. long, very variable, with long petioles; basal with both lobed and pinnate blades, the segments incised ; stem-leaves similar to the pinnate basal ones, but shorter-petioled : peduncles commonly glabrous: sepals ovate or triangular-ovate, reflexed: petals broadly cuneate, about as long as the sepals : fruiting heads $7-9 \mathrm{~mm}$. in diameter : achene-body 3 $\mathrm{mm}$. long, glabrous or nearly so.

In shaded ground and thickets, Ontario to New Jersey, Tennessee and Texas. Spring.

\section{SIEVìrsia R. Br.}

Low perennial caulescent herbs, but the stems often scape-like. Leaves mainly basal : blades odd-pinnate. Flowers solitary, or few in cymes. Hypanthium hemispheric or obconic. Sepals 5, generally accompanied by 5 bractlets. Corolla yellow or purplish. Petals 5. Stamens numerous. Carpels numerous on a hemispheric receptacle. Style terminal, not jointed, pubescent or plumose, generally elongating at maturity, persistent. Seed basal, erect.

1. Siervesia radiàta (Michx.) Greene. Foliage hirsute. Stems erect, 1-6 dm. tall, simple below, corymbosely branched above, often tufted : leaves of two kinds, the basal with lyrate-pinnate blades, and long petioles, the terminal division suborbicular to reniform, 4-15 cm. broad, unequally toothed, obscurely 5-7-lobed, and crisped, cordate; lateral leaflets small or wanting; stem-leaves with sessile orbicular or cuneate, many-cleft or incised blades $2-6 \mathrm{~cm}$. long: hypanthium broadly turbinate, $7-9 \mathrm{~mm}$. broad : sepals triangular or lanceolate, acuminate, longer than the hypanthium : bractlets linear or nearly so: corolla $3-4 \mathrm{~cm}$. broad: petals deep yellow, broadly and deeply obcordate: styles straight: achene-body 3-4 mm. long, pubescent. [Geum radiatum Michx.]

In rocky soil, on the summits of high mountains, North Carolina and Tennessee. Summer

\section{ULMÀrIA Hill.}

Perennial herbs, with erect stems. Leaves alternate : blades pinnate, petioled : leaflets variously toothed or lobed. Flowers perfect, white, pink or purple, in terminal corymbose cymes. Sepals 5. Petals 5, clawed. Stamens numerous, inserted on the concave or flat disk : filaments club-shaped. Pistils 5-15, often 10, distinct: style short. Ovules 2 in each cavity, pendulous. Fruit capsular, indehiscent. Seed usually solitary, pendulous.

1. Ulmaria rùbra Hill. Foliage deep green. Stems 5-24 dm. tall, usually branched : leaf-blades pinnate, petioled, the lower ones $3-9 \mathrm{dm}$. long, the upper successively shorter; stipules leaf-like, serrate : leaflets glabrous above, pubescent heneath, the lateral ones opposite, the blades palmately $3-5$-lobed, the terminal one larger, 7-9-lobed, its segments sharply serrate : corymbs compound, 1-sided : hypanthium glabrous : sepals almost half-orbicular, reflexed: petals suborbicular, pink to purple, 2-3 mm. in diameter : follicles 6-7 mm. high, club-shaped, curved below. [Spiraea lobata Gronov.]

In swamps and low grounds, Pennsylvania to Michigan and Iowa, Georgia and Kentucky. Spring and summer. QUeEN of THE Prairie. 


\section{NEVIÙSIA A. Gray.}

Shrus, with spreading terete branches. Leaves alternate : blades membranous, simple, doubly serrate : stipules slender. Flowers perfect, white, solitary or in open clusters. Hypanthium bractless, flattish. Sepals 5, petal-like, imbricated, spreading, incised-serrate, persistent. Petals wanting. Stamens numerous, persistent, in several series: filaments glabrous. Pistils 2-4, sessile. Style nearly terminal, stigmatose on the inner side. Ovules solitary in each cavity, pendulous. Achenes drupe-like, with a thin fleshy epicarp and a crustaceous endocarp.

1. Neviusia Alabaménsis A. Gray. A branching shrub 6-15 dm. tall, with minutely pubescent young foliage. Leaves numerous; blades ovate to ovate-lanceolate, $2-7 \mathrm{~cm}$. long, acute or acuminate, doubly serrate, rounded or subcordate at the base, sparingly pubescent on both sides or glabrous in age; petioles $3-8 \mathrm{~mm}$. long: pedicels slender, 1.5-2 cm. long: hypanthium minutely pubescent without: sepals leaf-like, obovate or oblong-cuneate, $8-12 \mathrm{~mm}$. long, sharply serrate above the middle : petals wanting: filaments filiform-clavate, longer than the sepals.

On cliffs, near Tuscaloosa and on Sand Mountain, Alabama. Summer.

\section{ALCHEMÍLLA L.}

Annual or perennial caulescent herbs. Leaves alternate : blades digitately lobed or compound, petioled : stipules a dilation of the base of the petiole. Flowers perfect, small, in open or congested cymes. Hypanthium urn-shaped. Sepals 4-5, valvate, augmented by 4-5 bractlets. Disk often almost closing the throat of the hypanthium. Petals wanting. Stamens 1-4: filaments very short, distinct. Pistils 1-4, sessile or short-stalked : style lateral or basal, glabrous: stigma capitate. Ovule solitary, ascending. Achenes 1-4, included.

1. Alchemilla arvénsís (L.) Scop. Annual, strigillose or somewhat villous. Stems simple and erect or usually branched at the base, the branches ascending, 2-15 $\mathrm{mm}$. long: leaf-blades 3-parted, 4-10 mm. long, the segments cuneate, 2-4-cleft, the lobes obtuse : stipules leaf-like, cleft or rarely nearly entire : flowers in sessile axillary clusters : calyx greenish, $2-3 \mathrm{~mm}$. broad : sepals shorter than the hypanthium, ovate, obtuse or obtusish.

In sandy fields, Virginia to Tennessee, North Carolina and middle Georgia. Naturalized from Europe. Also on the Pacific slope and in Nova Scotia. Early spring.

\section{AGRIMÒNIA L. ${ }^{1}$}

Perennial pubescent and often glandular herbs, with erect stems. Roots sometimes tuberous. Leaves alternate, with leaf-like stipules: blades unequally pinnate, the rachis often bearing interposed small leaflets between the larger ones. Flowers perfect, in wandlike racemes. Hypanthium persistent, campanulate or turbinate, more or less distinctly grooved, armed above with hooked bristles. Sepals 5, converging. Petals yellow, 5, longer than the sepals. Stamens 5-15, in one series : filaments distinct. Pistils 2, sessile, included: style slender: stigmas 2-lobed. Ovule solitary, pendulous. Achenes 1 or 2, included in the hardened accrescent hypanthium. Seed pendulous. Agrimony.

Leaflets incised-toothed, the teeth few, salient or recurved.

1. A. incisa.

Leaflets serrate, dentate or crenulate, the teeth several or many.

Lower surfaces of the leaves, and racemes softly and closely pubescent.

Roots not tuberous-thickened : leaves mostly with over 11 narrow leaflets.

Roots tuberous-thickened: leaves mostly with less than 9 broader leaflets. Leaflets $3-5$.

Leaflets $5-9$ or rarely more.

Lower surfaces of the leaves, and racemes glabrous or with loosely spreading hairs.

Roots tuberous-thickened : fruit $2.5-3.5 \mathrm{~mm}$. high, hemispheric, with few ascending bristles.

Roots not tuberous-thickened : fruit $6-12 \mathrm{~mm}$. high, turbinate, with many radiating bristles.

2. A. parviflora.

3. A. pumila.

4. A. mollis.

5. A. striata.

6. A. hirsuta.

1. Agrimonia incisa T. \& G. Stems shaggy-villous below the inflorescence, 3-11 dm. tall, simple or branching above, the branches ascending: leaves 5-16 cm. long; stipules incised-laciniate; leaflets $7-11$ or fewer in the upper leaves, the blades firm, cuneate, obovate or oblong-obovate, coarsely incised, the teeth salient or recurved, a main pair and 1 or 2 smaller pairs of small leaflets on the rachis in each interval : racemes in-

${ }^{1}$ Revised by Mr. E. P. Bicknell. 
terrupted, 1-4 dm. long: corolla 4-5 mm. broad : hypanthium granular : fruit $4 \mathrm{~mm}$. long the body campanulate, with hooked ascending or erect bristles.

In dry pine woods, North Carolina to Florida and Alabama. Summer.

2. Agrimonia parviflòra Soland. Roots fibrous. Stems $5-18 \mathrm{dm}$. tall, usually shaggy-pubescent below the racemes, often widely branched above : leaves numerous, 1-3 dm. long, stipules (excepting the lower ones) clasping, incised ; leaflets 11-19 or rarely 27, the blades narrowly elliptic to oblong, varying to lanceolate or oblanceolate, $2.5-10 \mathrm{~cm}$. long, acute or acuminate at both ends, serrate, often coarsely so, accompanied by 4-5 small pairs or fewer in each interval: racemes many-flowered, $2-7 \mathrm{dm}$. long, erect or spreading: hypanthium ribbed: sepals oblong-ovate, acute : corolla 6-10 $\mathrm{mm}$. broad: petals pale yellow : fruit spreading or drooping, 2-4 $\mathrm{mm}$. long, the body varying from subglobose to turbinate, the bristles hooked, the outer reflexed, the inner erect and longer.

In damp thickets and on borders of woods, New York to Missouri, middle Georgia and Mississippi. Summer.

3. Agrimonia pùmila Muhl. Roots tuberous-thickened. Stems pubescent with spreading hairs, 2-6 dm. tall, slender, prolonged into wand-like, simple or sparingly branched racemes: leaves mostly on the lower part of the stem, 3-8 cm. long (the upper ones much reduced and often 2-foliolate) ; stipules clasping, incised; leaflets mostly 3-5, the blades oval to elliptic or the terminal one cuneate, $2.5-3 \mathrm{~cm}$. long, crenate or crenatedentate, the interposed leaflets few and small : racemes much interrupted, 1-5 dm. long: hypanthium campanulate: corolla $4-6 \mathrm{~mm}$. broad: petals yellow : fruit turbinate or turbinate-campanulate, $4 \mathrm{~mm}$. long, the hooked bristles erect and ascending.

In open woods, Pennsylvania to Kentucky, Florida and Louisiana. Summer.

4. Agrimonia móllis (T. \& G.) Britton. Roots tuberous-thickened, elongated. Stems loosely tomentose and somewhat villous, $3-18 \mathrm{dm}$. tall, sparingly branched, or sometimes in robust plants widely branched : leaves $10-15 \mathrm{~cm}$. long or sometimes $3 \mathrm{dm}$. long, rather numerous ; stipules varying from lanceolate and entire to broad and incised ; leaflets $5-9$, usually 5 , the blades firm, oblong, elliptic or oval, varying to ovate or obovate, $3-7.5$ $\mathrm{cm}$. long, coarsely crenate or serrate-crenate, cuneate at the base, at least as to the terminal one, sometimes rounded : racemes interrupted, wand-like, 1-4 dm. long : hypanthium ribbed : corolla $6-10 \mathrm{~mm}$. broad : petals deep yellow : fruit turbinate, sometimes broadly so, 4-5 mm. long, the hooked bristles erect or ascending. [A. Eupatoria var. mollis T. \& G. ]'

In woods and on hillsides. Connecticut to Michigan, Kansas and Georgia. Summer and fall-A variety, A. mollis Bicknéllii Kearney, is smaller and less branched, has 7-13 oblong or narrowly oblong broadly serrate-dentate leaflets, the terminal one often cleft or lobed at the base, and fruit with longer and more spreading bristles; it ranges from Connecticut to North Carolina and Tennessee.

5. Agrimonia striàta Michx. Roots tuberous-thickened, elongated. Stems nearly glabrous to loosely pubescent with spreading hairs, $2-15 \mathrm{dm}$. tall, simple or delicately branched above : leaves 5-20 cm. long; stipules lanceolate or broader, more or less deeply incised ; leaflets $3-9$, usually 5 , the blades thinnish, obovate, oval or elliptic, 3-8 cm. long, coarsely crenate-serrate or crenate, usually cuneately narrowed at the base, accompanied by few small interposed leaflets: racemes simple or compound, 7-15 cm. long, slender : hypanthium granular, hemispheric : sepals oblong-ovate, obtuse, canescent within at the apex : corolla 4-6 mm. broad : fruit 2.5-3.5 mm. long, spreading on recurved, the body hemispheric, the hooked bristles erect or ascending, equalling the terminal process or shorter.

In shaded soil or on wooded hillsides, Connecticut to Missouri and Georgia. Summer and fall.

6. Agrimonia hirsùta (Muhl.) Bicknell. Roots fibrous. Stems more or less pubescent with spreading hairs, 5-15 dm. tall, usually branching above, the branches ascending, zigzag: leaves $5-30 \mathrm{~cm}$. long; stipules often $2-3 \mathrm{~cm}$. long, coarsely incised, the margins of each pair often overlapping; leaflets $5-9$, usually 7 , the blades rather thin, elliptic to oval, sometimes varying to obovate, $2-12 \mathrm{~cm}$. long, coarsely serrate or serrate-crenate, cuneate at the base or sometimes rounded, accompanied by 3 pairs of interposed leaflets or sometimes fewer : racemes simple or mostly branched, 1-4 dm. long: hypanthium granular, turbinate: sepals ovate, acuminate : corolla $8-12 \mathrm{~mm}$. broad : petals 5 , bright yellow, oblong or obovate : fruit 6-12 mm. long, the body strongly fluted, the hooked bristles spreading.

In thickets and open woods, New Brunswick to Minnesota and North Carolins. Summer.

\section{SANGUISÓRBA L.}

Perennial or rarely annual caulescent herbs. Leaves alternate, furnished with conspicuous stipules : blades unequally pinnate, petioled : leaflets with serrate blades. Flowers perfect or polygamo-dioecious, in dense peduncled spikes or heads. Hypanthium very small, constricted at the throat. Sepals 4, imbricated, petal-like, deciduous. Petals wanting. 
Stamens 4, or numerous : filaments elongated. Pistils solitary or 2-3, included: style filiform : stigma brush-like. Ovule solitary, pendulous. Achenes mostly solitary, leathery, included in the dry angled or variously roughened hypanthium.

1. Sanguisorba Canadénsis L. Perennial, glabrous or sparingly pubescent. Stems 3-18 dm. tall, simple or somewhat branched above : leaf-blades pinnate, those on the lower part of the stem 2-6 dm. long, long-petioled with 7-15 leaflets, the upper ones gradually reduced ; stipules leaf-like, inequilateral : blades of the leaflets oblong, varying to ovateoblong, or oblong-lanceolate, $1.5-8 \mathrm{~cm}$. long, sharply serrate, rounded or cordate at the base, petioluled : spikes cylindric, $3-15 \mathrm{~cm}$. long : calyx corolloid, white, 3-4 mm. broad : sepals oblong or cuneate, acute or mucronate at the apex, spreading : filaments club-shaped. [Poterium Canadense (L.) A. Gray.]

In swamps and low grounds, Newfoundland to Michigan and Georgia. Summer and fall.

\section{RÒsA L.}

Usually prickly shrubs, with erect trailing or climbing stems. Leaves alternate : blades unequally pinnate or rarely 2 -foliolate: stipules adnate to the petioles. Flowers solitary or in corymbs, showy, white, pink, yellow or red, fragrant. Hypanthium accrescent, urn-shaped. Sepals usually 5, imbricated, sometimes leaf-like, deciduous or persistent. Petals usually 5 , spreading, deciduous. Stamens numerous, inserted near the edge of the disk : filaments filiform. Pistils numerous, distinct, sessile at the base of the hypanthium : styles lateral, distinct or united above. Ovule solitary, pendulous. Achenes numerous, corky to bony in texture, included in the berry-like accrescent hypanthium. Rose. Styles cohering and forming a column, exserted. Styles distinct, included.

Sepals persistent.

Hypanthium densely silky, subtended by an involucre of bracts: sepals merely acuminate.

Hypanthium glabrous or nearly so, not subtended by bracts: sepals with somewhat dilated tips.

Infrastipular spines usually wanting.

Leaflets 3-9, often resinous, the blades obtuse at the base : flowers solitary : sepals erect.

Leaflets $7-11$, not resinous, the blades narrowed at the base: flowers corymbed : sepals spreading.

Infrastipular spines present.

1. R. setigera.

\section{R. bracteata.}

3. R. Engelmannii.

4. R. Arkansana.

5. R. Woodsii.

Sepals deciduous.

Deciduous-leaved : leaflets normally 5-13: stems erect or ascending: hypanthium often pubescent or glandular.

Leaflets with serrulate or finely serrate blades.

Blades of the leaflets lanceolate, leathery.

Blades of the leaflets elliptic to oblanceolate, membranous.

Leaflets with coarsely serrate blades.

Fruit subglobose.

Leaflets 7-11: hypanthium hispid.

Leaflets 5-7: hypanthium glandular-pubescent.

Fruit oval to narrowly ovoid.

Blades of the leaflets doubly serrate.

Blades of the leaflets simply serrate.

Evergreen: leaflets normally $3:$ stems climbing or trailing: hypanthium spinescent.

1. Rosa setígera Michx. A climbing or reclining shrub, with glabrous or glandularpubescent young foliage. Stems $2-5 \mathrm{~m}$. long, armed with recurved prickles : leaves 5-10 cm. long; leaflets $3-5$, the blades elliptic or oval, varying to ovate or obovate, $2-8 \mathrm{~cm}$. long, acute or somewhat acuminate, serrate, often lustrous above : flowers showy, a few in terminal corymbs : hypanthium glandular-pubescent, often glaucous: sepals lanceolate, acuminate, reflexed at maturity, deciduous : corolla red, 4-6 $\mathrm{cm}$. broad : petals obcordate : styles cohering : fruit subglobose, 5-10 mm. in diameter, red.

In thickets and low ground, Ontario to Wisconsin, West Virginia, Florida and Texas. Spring and ummer. Prairie or Climbing Rose.

2. Rosa bracteàta Wendl. An evergreen spreading shrub, with deep green foliage. Stems and branches diffuse, 2-6 m. long, armed with recurved prickles: leaves numerous, 3-6 cm. long ; leaflets 5-11, the blades leathery, obovate, cuneate or oval, 1-2 cm. long, retuse, truncate or apiculate at the apex, serrate, lustrous above, glabrous or minutely pubescent beneath : flowers showy, solitary or a few together: sepals elliptic or triangularlanceolate, acuminate, reflexed at maturity: corolla cream-colored or yellow, 4-8 $\mathrm{cm}$. broad : petals retuse or notched at the apex : styles distinct : fruit $1.5-2 \mathrm{~cm}$. thick.

In waste places or in pine woods, Virginia to Florida and Mississippi. Spring and summer. Naturalized from China.

3. Rosa Engelmánnili S. Wats.

A bushy shrub 2-5 dm. tall. Stems very slender, 
sparingly branched, closely armed with straight prickles: leaves $4-11 \mathrm{~cm}$. long; stipules relatively broad; leaflets $5-9$, the blades oval or oval-lanceolate, $3-5 \mathrm{~cm}$. long, obtuse, sharply and doubly serrate, very thin, pale beneath, more or less copiously resinous-pubescent : flowers normally solitary : sepals lanceolate, acuminate or somewhat dilated above, entire or with few teeth : corolla $6-7 \mathrm{~cm}$. broad : fruit about $2 \mathrm{~cm}$. long, elongated, with a conic base and manifest neck.

In open woods, Michigan to South Dakota, Texas and Colorado. Summer.

4. Rosa Arkansàna Porter. A branching shrub 3-6 dm. tall. Stems and branches more or less densely armed with bristle-like prickles : leaves $5-10 \mathrm{~cm}$. long, often numerous; stipules rather narrow ; leaflets $7-11$, the blades oval, obovate or cuneate, 1-2.5 $\mathrm{cm}$. long, rounded at the apex, simply serrate, sometimes tomentose beneath: flowers in terminal corymbs, rarely solitary : hypanthium glaucous : sepals lanceolate, acuninate, glandular without, tomentose within, spreading or reflexed at maturity, persistent : corolla 4-5 $\mathrm{cm}$. broad : styles distinct : fruit subglobose, red, 10-12 mm. long, glabrous.

On prairies, Minnesota to Colorado, Missouri, Texas and New Mexico. Spring and summer.

5. Rosa Woòdsii Lindl. A bushy shrub 3-10 dm. tall. Stems with slender, mostly straight, prickles, or unarmed above : leaves $3-10 \mathrm{~cm}$. long; stipules entire, rather broad; leaflets 5-9, the blades oval or obovate, 1-2 $\mathrm{cm}$. long, rather obtuse, simply serrate, cuneate or narrowed at the base, somewhat glabrous beneath : sepals erect at maturity: corolla 3-5 $\mathrm{cm}$. broad : fruit globose or ovoid-globose, $8-10 \mathrm{~mm}$. high, glabrous and sometimes glaucous.

On prairies, Minnesota to the Northwest Territory, Missouri, Texas and New Mexico. Summer.

6. Rosa lancifòlia Small. A branching shrub 1-2 m. tall. Stems and branches terete, armed with short, stout, straight prickles: leaves $5-8 \mathrm{~cm}$. long; leaflets $3-7$, the blades leathery, lanceolate or oblong-lanceolate, $2-6 \mathrm{~cm}$. long, acute or slightly acuminate, finely serrate, glabrous, somewhat lustrous above, the lateral ones sessile : flowers clustered: hypanthium somewhat glandular-pubescent: sepals narrowly linear-lanceolate, slightly dilated at the apex, often with 1 or 2 lateral teeth : fruit somewhat depressed.

About cypress swamps, central peninsular Florida. Spring and summer.

7. Rosa Carolìna L. A bushy shrub 1-3 m. tall. Stems and branches armed with rather stout recurved prickles : leaves $6-14 \mathrm{~cm}$. long; leaflets 5-9, commonly 7 , the blades membranous, elliptic to elliptic-obovate or oblanceolate, $2.5-7 \mathrm{~cm}$. long, acute or obtuse at the apex, finely serrate, glabrous or pubescent beneath : flowers in terminal corymbs, or rarely solitary: hypanthium glandular: sepals lanceolate or linear-lanceolate, acuminate, often dilated at the apex, rarely lobed, spreading or reflexed at maturity, deciduous : style distinct : fruit subglobose or depressed, 7-9 mm. in diameter, red, more or less glandular.

In swamps and low situations, Quebec to Minnesota, Florida and Mississippi. Spring and summer.

8. Rosa foliòsa Nutt. A branching shrub, about $1 \mathrm{~m}$. tall. Stems and branches armed with straight or slightly curved prickles: leaves $3-7 \mathrm{~cm}$. long; leaflets $7-11$, the blades firm, usually acute, serrate, glabrous or nearly so : flowers solitary, or a few in corymbs : hypanthium hispid : sepals lanceolate, acuminate, glandular-pubescent, often lobed, spreading at maturity, deciduous : corolla $3-4 \mathrm{~cm}$. broad : styles distinct : fruit subglobose, 8-10 $\mathrm{mm}$. in diameter, red, glabrous or nearly so.

On plains or prairies, Arkansas and the Indian Territory to Texas. Spring and summer.

9. Rosa hùmilis Marsh. A bushy shrub 2-24 dm. tall. Stems and branches armed with straight prickles : leaves $5-15 \mathrm{~cm}$. long; leaflets $5-7$, usually 5 , the blades rather leathery, elliptic, oval or ovate-lanceolate, or sometimes cuneate, $1.5-5 \mathrm{~cm}$. long, acute or rarely rounded at the apex, serrate, sometimes pubescent beneath : flowers solitary, or few in corymbs: hypanthium more or less densely glandular-pubescent: sepals lanceolate, acuminate, dilated or lobed above, spreading deciduous : corolla $4-6 \mathrm{~cm}$. broad : styles distinct : fruit subglobose or depressed, $12-15 \mathrm{~mm}$. in diameter, red.

In dry soil, Ontario to Wisconsin, Georgia and Louisiana. Spring and summer.

10. Rosa rubiginòsa L. A straggling aromatic shrub. Stems and branches often wand-like, $1-3 \mathrm{~m}$. long, armed with recurved prickles : leaves $2-8 \mathrm{~cm}$. long; leaflets $5-7$, the blades elliptic, oval or suborbicular, sometimes varying to ovate or obovate, $1.5-3 \mathrm{~cm}$. long, acute or obtuse at both ends, sharply serrate, resinous beneath : flowers solitary, or few in corymbs: hypanthium glabrous or bristly : sepals lanceolate, with an acuminate pinnatifid apex : corolla white or pink : styles distinct : fruit oval to narrowly ovoid, $1-2 \mathrm{~cm}$. long, deep red, shining.

In waste places, Nova Scotia and Ontario, Georgia and Tennessee. Spring and summer. Naturalized from Europe. SW EETBRIER.

11. Rosa canina L. A straggling shrub. Stems and branches 1-3 m. long, armed with slightly curved prickles : leaves $5-8 \mathrm{~cm}$. long ; leaflets $5-7$, the blades usually ovate or oval, 1-3 cm. long, often obtuse at both ends, sometimes acuminate at the apex, serrate, glabrous or slightly pubescent beneath : flowers solitary, or a very few in corymbs : sepals lanceolate or oblong-lanceolate, acuminate, lobed near the apex, reflexed at maturity, 
deciduous : corolla pink, often 4-5 cm. broad : styles distinct : fruit ovoid, 1-2 cm. long, dark red, glabrous or nearly so.

In waste places, Nova Scotia to New Jersey and Tennessee. Spring and summer. Naturalized from Europe. DOG Rose.

12. Rosa Cherokeénsis Donn. An evergreen shrub. Stems and branches trailing or climbing, 2-4 m. long, armed with short recurved prickles : leaf-blades mostly 3 -foliolate : leaflets $2-8 \mathrm{~cm}$. long, the blades leathery, elliptic to elliptic-lanceolate, acute or slightly acuminate, finely serrate, glabrous, lustrous : flowers solitary : hypanthium bristly : sepals leaf-like, dilated into a blade above, entire or toothed, reflexed at maturity : corolla white, 4-6 cm. broad or sometimes larger : styles distinct: fruit obovoid, $1.5-2 \mathrm{~cm}$. broad, contracted into a stipe-like base.

In waste places and along roadsides, Georgia to Florida and Texas. Spring and summer.

\section{Family 12. CALYCANThàCEAE Lindl. Strawberry-shrub Family.}

Slender shrubs, with an aromatic bark. Leaves opposite: blades usually entire : stipules wanting. Flowers perfect, terminal, purplish or yellow, fragrant. Receptacle cup-like, short-peduncled. Calyx of numerous sepals, imbricated in many series. Corolla of petals similar to the sepals and inserted like them on the edge of the receptacle. Androecium of numerous stamens inserted on the receptacle, the outer 5-12 fertile, the rest reduced to staminodia. Gynoecium of numerous distinct carpels borne on the inside of the hypanthium. Ovary 1celled, sessile : style simple, filiform : stigma simple, terminal. Ovules solitary or 2, one above the other, anatropous. Fruit capsular, including few or many achenes each with a crustaceous pericarp. Seed erect, solitary. Testa membranous. Endosperm wanting. Embryo straight, with convolute cotyledons.

\section{BUTNÈrIA Duham.}

Aromatic shrubs, with opposite branches. Leaves opposite : blades glabrous, but usually scabrous above, often glaucous or pubescent beneath. Flowers brownish purple, usually strawberry-scented, terminal. Sepals in several series, imbricated. Petals like the sepals, inserted in several series on the edge of the receptacle. Stamens numerous, in many series, the outer 12 fertile, the rest reduced to staminodia. Capsular fruit nodding leathery. The plants flower in the spring and early summer. Strawberry-SHRUb. Leaf-blades not tomentose beneath.

Lower surface of the leaf-blades glabrous, not glaucous.

Lower surface of the leaf-blades glaucous.

Leaf-blades tomentose beneath.

Blades of the leaves of an ovate type, obtuse or subcordate at the base.

Blades of the leaves of an elliptic or oval type, acute or acuminate at the base.

1. B. nana.

2. B. fertilis.

(1) fler no

3. B. Mohrii.

4. B. florida.

1. Butneria nàna (Loisel.) Small. An aromatic shrub 1-3 m. tall, with little or no pubescence. Leaf-blades membranous, oblong-lanceolate, elliptic or oval, $7-16 \mathrm{~cm}$. long, acuminate, deep-green and more or less scabrous above, slightly lighter green and glabrous beneath ; petioles glabrous or sparingly pubescent, $0.5-1 \mathrm{~cm}$. long : flowers brownish purple, short-peduncled, fragrant or inodorous: sepals and petals linear or linear-oblanceolate, $0.5-3 \mathrm{~cm}$. long, acute, sparingly pubescent: capsule oblong-obovoid, glabrous or sparingly pubescent, $4-6 \mathrm{~cm}$. long : seeds oblong, 10-12 mm. long, not flattened, sparingly hirsute.

Along streams, chiefly in or near the mountains, Pennsylvania to Georgia and Alabama.

2. Butneria fértilis (Walt.) Kearney. An aromatic shrub 1-3 m. tall, with almost glabrous foliage. Leaf-blades thin but rather firm, oblong-elliptic, elliptic or oval, 7-20 cm. long, mostly long-acuminate, bright green and scabrous above, smooth and glaucous beneath, acutish or rounded at the base; petioles sparingly pubescent, $0.5-1.5 \mathrm{~cm}$. long:
flowers short-peduncled, purple, fragrant: sepals and petals pubescent, linear or nearly so, flowers short-peduncled, purple, fragrant: sepals and petals pubescent, linear or nearly so,
acute or acuminate, $1.5-2.5 \mathrm{~cm}$. long: capsule irregularly obovoid, glaucescent, $4-6 \mathrm{~cm}$. long : seeds oblong, 12-14 mm. long, slightly flattened, sparingly hirsute.

In woods and along streams, in the mountains, Virginia to Kentucky, Georgia and Alabama.

3. Butneria Móhrii Small. A branching shrub, 1-2 m. tall, with pubescent twigs and leaves. Leaf-blades firm, oblong-obovate to broadly ovate, $6-20 \mathrm{~cm}$. long, pubescent on both sides when young, when mature, bright green and scabrous above, tomentose beneath, acuminate at the apex, rounded or subcordate at the base; petioles stout, pubescent, 8-10 mm. long: flowers purple, stout-peduncled : sepals and petals pubescent, linear to 
linear-oblanceolate, acute or acuminate, $2-3 \mathrm{~cm}$. long, often with green tips: capsule unknown.

On rocky ridges and mountains, southern Tennessee and northern Alabama.

4. Butneria flórida (L.) Kearney. An aromatic shrub $0.5-3 \mathrm{~m}$. tall, with pubescent twigs and leaves. Leaf-blades firm, elliptic or oval, 4-14 cm. long, short-acuminate at both ends or rarely obtuse at the apex, entire or rarely lobed, pubescent on both sides when young, when mature dark green and very scabrous above, tomentose beneath ; petioles pubescent, $0.5-1 \mathrm{~cm}$. long: flowers short-peduncled, dull purple, fragrant : sepals and petals pubescent, linear-oblanceolate or oblanceolate, $1.5-2 \mathrm{~cm}$. long, acutish : capsule oblong-obovoid, 4-6 cm. long, finely tomentose, ribbed : seeds obovoid, $1 \mathrm{~cm}$. long, more or less hirsute.

On hillsides and along streams, Virginia to Florida and Alabama.

\section{Family 13. MALÀCEAE Small. ${ }^{1}$ Apple Family.}

Trees or shrubs, with upright stems. Leaves alternate : blades pinnately veined or pinnate, petioled, the small deciduous stipules free from the petiole. Flowers regular, perfect, racemed, cymose or solitary. Calyx superior. Sepals mostly 5. Hypanthium adnate to the ovary. Petals mostly 5, usually clawed. Stamens numerous or rarely few, distinct. Anthers small, 2-celled : sacs longitudinally dehiscent. Ovary 1-5-celled, usually 5-celled, composed of 1-5 wholly or partly united carpels. Ovules 1-2 (rarely several) in each carpel, anatropous, ascending. Styles 1-5. Stigma small. Fruit a more or less fleshy pome, consisting of the thickened hypanthium, enclosing the bony, papery or leathery carpels. Endosperm wanting. Cotyledons fleshy. [Pomaceae L.]

Carpels papery or leathery at maturity.

Leaf-blades pinnately compound.

Leaf-blades simple, entire, toothed or lobed.

Cavities of the ovary (carpels) as many as the styles.

Flesh of the pome with grit-cells.

Flesh of the pome without grit-cells.

Cymes simple.

Cymes compound.

Cavities of the ovary becoming twice as many as the styles.

Carpels bony at maturity.

ovules solitary in each carpel, or, if 2, dissimilar.

Ovules 2 in each carpel, alike.

1. Sorbus.

2. Pyrus.

3. MALUS.

4. Aronia.

5. AMELANCHIER.

6. Crataegus.

7. Cotoneaster.

\section{SÓRBUS L.}

Trees or shrubs, with alternate pinnate leaves: leaflets several, the blades toothed : stipules deciduous. Flowers perfect, regular, white, in terminal compound cymes. Hypanthium urn-shaped, not bracteolate. Sepals 5. Petals 5, spreading, with short claws. Stamens 8. Ovary inferior. Styles usually 3, distinct: stigmas truncate. Ovules 2 in each cavity. Fruit a small red berry-like pome, its carpels not cartilaginous.

1. Sorbus Americàna Marsh. A small tree, with smooth bark, reaching a maximum height of about $9 \mathrm{~m}$. and a trunk diameter of $5 \mathrm{dm}$. Leaf-buds acute : leaf-blades petioled; leaflets 11-17, the blades lanceolate, long-acuminate, glabrous on both sides or slightly pubescent when young, bright green above, generally paler beneath, 3.5-10 cm. long, sharply serrate with mucronate teeth : cymes densely compound, $8-15 \mathrm{~cm}$. broad : corolla 4-6 $\mathrm{mm}$. broad : pomes globose, bright red, 4-6 $\mathrm{mm}$. in diameter.

In low woods or moist ground, New foundland to Manitoba, south, especially along the mountains, to North Carolina, and Michigan. Spring and summer. MOUNTAIN AsH.

\section{PỲRUS L.}

Trees, or some species shrubs, with simple petioled leaf-blades. Flowers large, showy, in simple terminal cymes. Hypanthium urn-shaped. Sepals 5, acute. Petals 5, white or pink, rounded, with short claws. Stamens usually numerous. Styles mostly 5, distinct, or united only at the very base. Ovules 2 in each cavity. Carpels cartilaginous or leathery. Fruit a pome, usually pear-shaped, its flesh abounding in grit-cells. Pear.

1. Pyrus commùnis $\mathrm{L}$. A tree, sometimes $17 \mathrm{~m}$. high, with a trunk $2-6 \mathrm{dm}$. in diameter, or commonly much smaller, the branches usually thorny. Leaf-blades ovate,

${ }^{1}$ Contributed, except the genus Crataegus, by Dr. Nathaniel Lord Britton. 
elliptic or obovate, finely serrulate or entire, slender-petioled, 3-8 cm. long, downy and ciliate when young, becoming glabrous or nearly so when old, the apex acute or acuminate, the base usually rounded; petioles sometimes as long as the blades or longer: cymes fewseveral-flowered, borne at the ends of short twigs of the preceding year: pedicels 1.8-5 cm. long, at first downy : sepals about as long as the hypanthium : corolla white, $2.5 \mathrm{~cm}$. broad : styles distinct to the base : pome, in the wild form, seldom over $5 \mathrm{~cm}$. long, in the numerous cultivated forms often much larger.

In thickets and woods, Maine to New York and Florida. Escaped from cultivation. Native of Europe and Asia. Spring.

\section{MÀLUS Juss.}

Trees or shrubs, with alternate leaves, their blades toothed or lobed. Flowers showy in simple terminal cymes. Hypanthium urn-shaped or campanulate. Sepals 5. Petals 5 , pink or white, rounded, with claws. Styles 2-5, usually united at the base. Ovules 2 in each cavity. Carpels papery or leathery. Fruit a pome, usually depressed-globose, mostly hollowed at the base, its flesh not containing grit-cells. APPLE. CRAB APPLE.

Leaf-blades glabrous at least at maturity.

Leaf-blades oblong or lanceolate : styles nearly distinct.

Leaf-blades ovate: styles manifestly united at the base.

Leaf-blades persistently pubescent, often tomentose beneath.

Leaf-blades gradually or abruptly narrowed at the base: pomes less than $4.5 \mathrm{~cm}$. thick. Pediceis slender, over $2.5 \mathrm{~cm}$. long. Pedicels stout, less than $2.5 \mathrm{~cm}$. long.

Leaf-blades rounded or subcordate at the base : pomes over $4.5 \mathrm{~cm}$. thick.

1. M. angustifolia.

2. M. coronaria.

1. Malu 3 angustlfòlía (Ait.) Michx. A small tree, sometimes $6 \mathrm{~m}$. high, with the trunk $3 \mathrm{dm}$. in diameter. Leaf-blades oblong, or lanceolate, thick, shining and dark green above, dentate or often entire, rather obtuse or acute at the apex, narrowed at the base, $2.5-5 \mathrm{~cm}$. long: cymes few-Howered : pedicels $2.5-4 \mathrm{~cm}$. long, slender: flowers fragrant: corolla pink, mostly less than $2.5 \mathrm{~cm}$. broad: styles nearly separate : pome about $2.5 \mathrm{~cm}$. in diameter.

In thickets, New Jersey to Illinois, Kansas, Florida and Louisiana. Early spring.

2. Malus coronària (L.) Mill. A small tree, sometimes reaching a height of $7 \mathrm{~m}$. and a trunk diameter of $3 \mathrm{dm}$. Leaf-blades petioled, ovate to triangular-ovate, sparingly pubescent beneath along the veins when young, glabrous when old, sharply serrate and often somewhat lobed, acute or acutish at the apex, rounded or cordate at the base, 2.5$7.5 \mathrm{~cm}$. long: flowers very fragrant : pedicels $1.5-2.5 \mathrm{~cm}$. long, glabrous : corolla rosecolored, $2.5-5 \mathrm{~cm}$. broad: pome globose or depressed, $2.5-3.5 \mathrm{~cm}$. in diameter, greenish yellow, fragrant, very acid.

In thickets, Ontario to Michigan, New Jersey and South Carolina. Early spring.

3. Malus Ioénsis (Wood) Britton. A small tree, resembling Malus coronaria. Leafblades simple, firm, white-pubescent beneath, at length glabrous above, obtuse at the apex, mostly narrowed at the base, ovate, oval or oblong, dentate, crenate or with a few rounded
lobes, $2.5-5 \mathrm{~cm}$. long, or on young shoots much larger; petioles pubescent, $1.7-3.5 \mathrm{~cm}$. long: flowers much like those of $M$. coronaria: pedicels pubescent, slender, $2.6-3.5 \mathrm{~cm}$. long.

In woods, Minnesota and Wisconsin to Kentucky, Louisiana and the Indian Territory. Spring.

4. Malus Soulárdi (Bailey) Britton. A small upright stout-growing tree, resembling the two preceding species. Leaf-blades ovate, elliptic or obovate, mostly obtuse or truncate at the apex, narrowed or rounded at the base, rugose and densely tomentose beneath, irregularly crenate-dentate or sometimes few-lobed; petioles $2.5 \mathrm{~cm}$. long or less, tomentose : flowers smaller than those of $M$. coronaria: cymes dense : pedicels stout, white-tomentose, 12-24 mm. long: pome $2.5-6 \mathrm{~cm}$. in diameter.

In woods, Minnesota to Missouri and Texas. Spring.

5 Malus Màlus (L.) Britton. A tree with spreading branches, the trunk sometimes reaching a diameter of $1 \mathrm{~m}$. in cultivation. Leaf-blades petioled, broadly ovate or oval, obtuse or abruptly pointed at the apex, rounded or slightly cordate at the base, $2.5-7.5 \mathrm{~cm}$. long, dentate or nearly entire, glabrous or nearly so above, pubescent and often woolly beneath, especially when young: pedicels generally tomentose, $2.5-5 \mathrm{~cm}$. long: calyx tomentose : corolla pink or white, $3.5-7.5 \mathrm{~cm}$. broad : fruit depressed-globose or elongated, hollowed at the base, $3.5-7.5 \mathrm{~cm}$. in diameter.

In woods and thickets, frequent in southern New York, New Jersey and Pennsylvania, south to Georgia. Our common apple, introduced from Europe and escaped from cultivation. Native also of western Asia. Spring. 


\section{Arònia Pers.}

Shrubs, with alternate simple leaves: blades petioled, finely serrate, the upper side of the midrib glandular, the narrow stipules early deciduous. Flowers small, in terminal compound cymes. Hypanthium urn-shaped. Sepals 5. Petals 5, white or pink, concave, spreading. Stamens numerous. Styles 3-5, united at the base. Ovary woolly. Pome small, globose or somewhat top-shaped, its carpels rather leathery. CHokeberry.

Cymes and lower surfaces of the leaf-blades woolly : fruit red or purple-black.

Fruit broadly pyriform, bright red.

Fruit oval or globose. purple-black.

Cymes and surfaces of the leaf-blades glabrous : fruit black or purplish.

1. A. arbutifolia.

2. A. atropurpurea.

3. A. nigra.

1. Aronia arbutifòlia (L. f. ) Ell. A branching shrub, sometimes reaching a height of $3.5 \mathrm{~m}$., but usually lower. Leaf-blades oval, oblong or obovate, obtuse or abruptly short-pointed at the apex, narrowed or somewhat cuneate at the base, $2.5-7.5 \mathrm{~cm}$. long, serrulate-crenulate, glabrous above, generally densely tomentose beneath : cymes terminal, but at length overtopped by the young sterile shoots, compound : hypanthium and pedicels tomentose : corolla white or purplish tinged, $8-12 \mathrm{~mm}$. broad : pome $4-6 \mathrm{~mm}$. in diameter, broadly pyriform, and bright red when mature, long persistent. [Pyrus arbutifolia L.f.]

In swamps and wet woods, Nova Scotia to Minnesota, Florida and Louisiana. Spring.

2. Aronia atropurpùrea Britton. A branching shrub, reaching a height of $4 \mathrm{~m}$. Leaf-blades quite similar to those of the preceding species, tomentose beneath: cymes tomentose : flowers quite similar to those of A. arbutifolia: pome oval to globose, $6-10 \mathrm{~mm}$. long, purple-black.

In low grounds or wet soil, Nova Scotia to Florida. Spring.

3. Aronia nigra (Willd.) Britton. A shrub resembling the preceding species, but larger, sometimes $5 \mathrm{~m}$. tall. Leaf-blades obovate or oval, obtuse, acute, or abruptly acuminate at the apex, narrowed or cuneate at the base, short-petioled, crenulate, dark green above, paler beneath, glabrous or nearly so on both surfaces: flowers similar to those of the preceding species : hypanthium and pedicels nearly glabrous : fruit globose or oval, nearly black, or purplish black, 6-8 $\mathrm{mm}$. in diameter.

In swamps or low woods, or in dryer soil, Nova Scotia to Ontario, Florida and Michigan. Spring

\section{AMELÁNCHIER Medic.}

Shrubs or trees, the branches unarmed. Leaves alternate: blades simple, petioled, serrate or entire. Flowers racemose or rarely solitary, white. Hypanthium campanulate, more or less adnate to the ovary. Sepals 5, narrow, reflexed, persistent. Petals 5. Stamens 8 , inserted on the throat of the hypanthium: filaments subulate. Styles $2-5$, connate, pubescent at the base. Ovary wholly or partly inferior, the cavities becoming twice as many as the styles. Ovule one in each cavity, erect. Pome small, berry-like, 4-10-celled. Testa of the seeds cartilaginous. June-berry. Service-berry. May Cherry.

Leaf-blades acute or acuminate at the apex: top of the ovary glabrous or nearly so.

Leaf-blades ovate or ovate-lanceolate, rounded or cordate at the base, glabrous at maturity.

Leaf-blades oblong, oval, ovate or obovate, rarely subcordate at the base: densely white-woolly beneath at least when young.

Leaf-blades rounded, obtuse or merely abruptly pointed at the apex: top of the ovary woolly.

Low shrub, 3-6 dm. tall : petals 4-8 mm. long.

Tree or tall shrub: petals $10-16 \mathrm{~mm}$. long.

1. A. Canadensis.

2. A. Botryapium.

3. A. spicata.

4. A. rotundifolia.

1. Amelanchier Canadénsis (L.) Medic. A tree, sometimes reaching the height of $17 \mathrm{~mm}$., with a trunk diameter of $6 \mathrm{dm}$. but usually lower, seldom over $8 \mathrm{~m}$. high. Leafblades ovate or oval, acute or acuminate at the apex, rounded or cordate at the base, sharply and finely serrate, sometimes sparingly pubescent when young, soon entirely glabrous, $2.5-7.5 \mathrm{~cm}$. long, or larger on young shoots : racemes spreading or drooping: pedicels long, slender : bracts silky, purplish, deciduous : petals linear, linear-spatulate or linear-oblong, 12-18 $\mathrm{mm}$. long, 3-4 times the length of the nearly or quite glabrous calyx and hypanthium : pome globose, red or purple, sweet, about $6 \mathrm{~mm}$. high.

In dry woodlands, Newfoundland to Ontario, Florida and Louisiana. Early spring.

2. Amelanchier Botryàpium (L. f.) DC. A shrub or small tree, sometimes $9 \mathrm{~m}$. high, the foliage and inflorescence densely white-woolly when young, often nearly or quite glabrous when old. Leaf-blades oval, oblong, elliptic or obovate, acute at the apex, rounded, or sometimes narrowed or subcordate at the base, finely and sharply serrate nearly all around: racemes short, usually rather dense: pedicels short, seldom over $2-5 \mathrm{~cm}$. 
long: hypanthium usually densely white-woolly : petals spatulate or linear-spatulate, 6-14 $\mathrm{mm}$. long, 2-3 times as long as the sepals : pome globose, $6-8 \mathrm{~mm}$. in diameter.

In swamps and moist soil, New Brunswick to Manitoba, Florida and Louisiana. Spring.

3. Amelanchier spicàta (Lam.) Dec. A shrub usually $3-6 \mathrm{dm}$. tall, the foliage and inflorescence glabrous at maturity. Leaf-blades oval or broadly elliptic, $2-4 \mathrm{~cm}$. long, serrulate or dentate-serrate, sometimes toothed only above the middle, rounded at both ends, or sometimes abruptly pointed at the apex, or subcordate at the base : racemes 4-10flowered : pedicels $1-2.5 \mathrm{~cm}$. long: sepals nearly triangular: petals $4-8 \mathrm{~mm}$. long: pomes about $6 \mathrm{~mm}$. in diameter.

In rocky places, New York to North Carolina. Spring.

4. Amelanchier rotundifòlia (Michx.) Roem. A tall shrub, or a small tree, glabrous throughout, at least at maturity. Leaf-blades broadly oval, ovate or suborbicular, 4-8 cm. long, obtuse or rounded at both ends, or sometimes abruptly pointed at the apex or often cordate, serrate, the teeth often incurved : racemes several-flowered: pedicels 2-4 cm. long: sepals lanceolate: petals $10-16 \mathrm{~mm}$. long: pomes $6-8 \mathrm{~mm}$. in diameter.

In woods and thickets, New Brunswick to Minnesota and North Carolina.

\section{CRATAÈGUS L. ${ }^{1}$}

Small trees or shrubs, usually armed with thorns or spines. Leaves alternate : blades simple, petioled. Flowers terminal, cymose or corymbose. Hypanthium cup-shaped or campanulate, adnate to the carpels. Sepals 5, reflexed after anthesis. Corolla white or pink. Petals 5, spreading, rounded, inserted on the margin of the disk in the throat of the hypanthium. Stamens 5-25, inserted in 1-3 rows on the edge of the hypanthium : filaments slender, incurved : anthers oblong or suborbicular, white, yellow, pink or purple. Ovary inferior, or its summit free, composed of 1-5 carpels : styles $1-5$, not united, persistent: stigmas terminal. Pome globose, pyriform or oval, yellow, orange-red, blue or black, containing 1-5 bony carpels, each usually 1-seeded. Seed erect, the testa membranous. Haw. The plants bloom in the spring.

Lateral or ventral faces of the nutlets grooved or hollowed.

I. TOMENTOSAE.

Lateral or ventral faces of the fertile nutlets plane or plano-convex.

Hypostyle short and broad, upwardly and dorsally extended over the apex of the nutlets.

Fruit small, bright scarlet at maturity.

Fruit about $1 \mathrm{~cm}$. in diameter, blue at maturity.

Hypostyle confined to the ventral or lateral surfaces of the nutlets, abruptly terminated at the apex.

a. Corymbs simple, 2-5-flowered, glabrous, expanding in February and early March : fruit globose, red or orange-red, ripening from May to July.

b. Corymbs compound, many-flowered, usually glabrous (pilose in nos. 13 and 16), stamens normally 20 : fruit red or yellow, less than $1 \mathrm{~cm}$. in diameter.

c. Corymbs simple, 3-7-flowered, glabrous or sparsely pubescent : stamens 10: fruit globose, red.

d. Corymbs few-many-flowered, glabrous or pubescent : stamens 20 : fruit globose or oval, red or yellow.

e. Corymbs 4-10-flowered, glabrous : stamens 10 : fruit glabrous, at maturity red, red and yellow or clear yellow, the flesh firm: leaf-blades broadly ovate, oval or obovate, those of the shoots frequently deltoid-ovate, eventually glabrous.

f. Corymbs 4-10-flowered, glabrous or very nearly so: stamens 20 : fruit glabrous, $15 \mathrm{~mm}$. in diameter or less, at maturity yellow, orange, green or red, the flesh firm : leaf-blades glabrous when grown, ovate, lanceolate, elliptic or sometimes obovate, serrate and shallowly incised (deeply incised in no. 40$)$.

g. Corymbs similar to those of the next preceding section : fruit small, oval, subpyriform or globose : leaf-blades deeply and acutely incised or with numerous serrate rounded lobe-like incisions.

h. Corymbs 1-, 2- or 3-flowered, or frequently 5-7-flowered, the pedicels and hypanthium either glabrous, pubescent or tomentose: fruit glabrous, yellow, green, orange or red, the flesh usually soft, and pleasant to the taste: leaf-blades various in outline, serrate, crenate, dentate or entire, pubescent or glabrous: branches often pendulous.

II. CORDATAE.

III. BREVISPINAE.

\section{AESTIVALES. \\ V. VIRIDES. \\ VI. SILVICOLAE.}

VII. PUNCTATAE.

VIII. BOYNTONIANAE.

IX. SARGENTIANAE.

X. PULCHERRIMAE.

${ }^{1}$ Contributed by Mr. C. D. Beadle.-The treatment of the genus here presented is based only on the material at the Biltmore Herbarium, supplemented by brief notes taken at several of the leading herbaria. C. D. B. 
Stamens 10.

Stamens more than 10.

Flowers produced in few-flowered, mostly 5-7-flowered corymbs : pedicels and hypanthium pubescent or glabrous (densely white-tomentose in no. 78): leaf-blades serrate, dentate or crenate, pubescent or glabrous : branches spreading or ascending or occasionally drooping as in the VISENDAE.

Leaf-blades sharply serrate and pointed.

Leaf-blades serrate or coarsely and irregularly dentate.

Leaf-blades crenate.

Leaf-blades finely dentate or glandular-dentate, usually with several tooth-like lobes.

Flowers produced in few-flowered, mostly 3-5-flowered corymbs: pedicels and hypanthium tomentose or pubescent (glabrous or nearly so in the ATTRITAE): leaf-blades dentate, crenate or entire, or occasionally serrate as in the SENTAE, either tomentose, pubescent or glabrous : branches mostly drooping.

Mature fruit globose, subglobose or oval.

Fruit averaging $1 \mathrm{~cm}$. in diameter or more.

Leaf-borders glandular, entire, dentate or crenate. often with blunt or sharp tooth-like lobes.

Inflorescence tomentose or pubescent.

Mature leaves densely tomentose beneath.

Mature leaves less tomentose, sometimes merely pubescent or glabrous.

Leaf-blades entire or nearly so.

Leaf-blades toothed, often lobed.

Inflorescence glabrous or with a few weak hairs.

Leaf-borders serrate or serrate-dentate and incisely lobed.

Fruit averaging less than $1 \mathrm{~cm}$. in diameter.

Mature fruit pyriform.

Fruits $1.5-2 \mathrm{~cm}$. long, over $1 \mathrm{~cm}$. thick.

Fruits smaller.

Flowers solitary, 2 or 3 together (usually more in no. 132): pedicels and hypanthium glabrous or pubescent: leaves small; blades cuneate or spatulate, or sometimes with abruptly contracted bases : spines usually numerous : sepals narrow.

i. Corymbs with a single flower each, or 2 or 3 flowers, or occasionally more: sepals long and usually conspicuously incised : fruit globose or pyriform, at maturity red, yellow or greenish, the flesh firm: leaves relatively small; blades spatulate, elliptic or ovate: spines usually numerous, long and slender.

j. Corymbs several-many-flowered, tomentose or pubescent : stamens 10-20: fruit pubescent, at maturity red, orange or yellowish: leaf-blades tomentose or pubescent at least beneath and on the petioles.

Margins of the petioles without glands : corymbs compound, many-flowered.

Margins of the petioles glandular or bearing stalked glands. Sepals about $5 \mathrm{~mm}$. long.

Sepals 7-10 mm. long.

Corymbs 2-5-flowered.

Corymbs many-flowered.

k. Corymbs 5-12-flowered, glabrous : stamens 5-20: fruit glabrous, at maturity red, dull greenish red or scarlet, usually pruinose, the flesh firm or succulent: leaves glabrous when fully grown (slightly scabrous or roughened in no. 158): blades serrate and incised, those of leaves of the shoots truncate or cordate at the base.

Flesh of the mature fruit firm.

Flesh of the mature fruit succulent.

1. Corymbs several-many-flowered, pubescent or glabrous : stamens 7-20: fruit red, green and red or yellow, the flesh firm or succulent : leaf-blades mostly shining, obovate, spatulate, oval or elliptic, glabrous or nearly so when fully grown: branches frequently armed with numerous large spines, or occasionally unarmed.

Corymbs more or less pubescent, at least during anthesis.

Corymbs glabrous.

I. TOMENTOSAE.
XI. EUFLAVAE.

XII. IGNAVAE.

XIII. SORORIAE.

XIV. SEGNES.

XV. VISENDAE.

XVI, MICHAUXIANAE.

XVII. INTEGRAE.

XVIII. DENTATAE.

XIX. ATTRITAE.

XX. SENTAE.

XXI. ANISOPHYLLAE.

XXII. COLONICAE. XXIII. RECURVAE.

XXIV. LEPIDAE.

XXV. UNIFLORAE.

XXVI. MOLLES.

XXVII. BILTMOREANAE.

XXVIII. TRIFLORAE.

XXIX. HARBISONIANAE.

XXX. PRUINOSAE.

XXXI. TENUIFOLIAE.

XXXII. BERBERIFOLIAE. XXXIII. CRUS-GALLI.
Corymbs densely pubescent.

Fruit dull red, oval or pyriform.

Fruit bright red, globose or subglobose.

Corymbs glabrous or glabrate.
1. C. tomentosa.

2. C. Chapmanii.

3. C. neofluvialis.

\section{CORDATAE.}

Leaf-blades broadly ovate, cordate, truncate or abruptly contracted at the base. Inflorescence glabrous.

Inflorescence villose-pubescent.

Leaf-blades spatulate or oblanceolate, narrowed or cuneate at the base.

4. C. cordata.

5. C. apiifolia.

6. C. spathulata. 
A single species in our range.

\section{BREVISPINAE.}

\section{AESTIVALES.}

Shoots, petioles and lower surfaces of the leaves rufous tomentose.

Shoots, petioles and leaves glabrous or nearly so.

Leaf-blades with abruptly contracted bases.

Leaf-blades with cuneate or narrowed bases.

7. C. brachyacantha.

8. C. aestivalis.

9. C. maleoides.

10. C. luculenta.

\section{VIRIDES.}

Ripe fruit red, or at least with ruddy cheeks.

Leaf-blades ovate-lanceolate, elliptic or obovate, either narrowed or contracted at the base.

Leaf-blades coarsely and irregularly serrate, often with blunt or acute shallow lobes.

Leaf-blades ample, $2-4 \mathrm{~cm}$. wide.

Leaf-blades (exclusive of those on the shoots) $1-2 \mathrm{~cm}$. wide : twigs very

Leaf-blades all sharply serrate and incisely lobed.

Inflorescence pilose-pubescent: terminal leaves of the shoots with broadly ovate blades, broad, rounded or truncate at the base.

Inflorescence glabrous: terminal leaves of the shoots with broadly ovate blades, mostly broad, rounded at the base.

Leaf-blades all broadly ovate or oval, rounded and very abruptly contracted at the base: fruit yellowish green flushed with red, 7-9 mm. in diameter. Ripe fruit bright canary yellow.

\section{SILVICOLAE.}

Inflorescence and young shoots glabrous.

Inflorescence and young shoots sparsely pubescent.

11. C. viridis.

12. C. paludosa.

13. C. subviridis.

14. C. interior.

15. C. vulsa.

16. C. Brazoria.

17. C. silvicola.

18. C. aemula.

19. C. punctata.

20. C. collina.

21. C. rigens.

22. C. amnicola.

23. C. ingens.

24. C. penita.

25. C. Margaretta.

26. C. Boyntonii.

27. C. Buckleyi.

28. C. communis.

29. C. straminea.

30. C. rubella.

31. C. Sargentii.

32. C. pallens.

33. C. austrina.

34. C. gilva.

35. C. contrita.

36. C. venusta.

37. C. inanis.

38. C. eximia.

39. C. tecta.

40. C. ancisa.

41. C. alma.

42. C. pinetorum.

43. C. macilenta.

44. C. mendosa. 


\section{PULCHERRIMAE.}

Fruit oval at maturity, the flesh attenuate with the pedicels.

Anthers dark: leaf-blades elongated.

Fruit $6-8 \mathrm{~mm}$. long.

Fruit 10-12 mm. long.

Anthers light: leaf-blades short.

- Fruit globose or nearly so, the flesh not attenuate with the pedicel.

Leaves more than $2 \mathrm{~cm}$. wide.

Leaf-blades conspicuously elongated, $5-8 \mathrm{~cm}$. long.

Leaf-blades shorter.

Pomes depressed-globose: leaves $3-5 \mathrm{~cm}$. broad.

Pomes not depressed: leaves narrower.

Anthers dark purple.

Anthers pale purple.

Leaf-borders with round, usually sharp-pointed lobes.

Leaf-borders with acute lobes.

Leaves (exclusive of those on the shoots) mostly less than $2 \mathrm{~cm}$. wide.

45. C. pulcherrima.

46. C. abstrusa.

47. C. lenis.

48. C. incilis.

49. C. illustris.

50. C. opima.

51. C. assimilis.

52. C. robur.

53. C. concinna.

Fruit pyriform or globular-pyriform.

\section{EUFLAVAE.}

Leaf-blades dentate or crenate-dentate.

Leaf-blades very sharply serrate and incisely lobed.

Fruit globose.

Leaf-blades serrate : anthers purple.

Leaf-blades dentate or crenate-dentate: anthers yellow.

54. C. flava.

55. C. Allegheniensis.

56. C. frugiferens.

57. C. aprica.

XII. IGNAVAE.

Inflorescence glabrous or with a few weak hairs.

Fruit subglobose or oval.

Spines $2-3.5 \mathrm{~cm}$. long: anthers purple.

Spines $3.5-5 \mathrm{~cm}$. long: anthers yellow.

Fruit pyriform.

Inflorescence decidedly pubescent.

XIII. SORORIAE.

Leaf-blades longer than broad.

Anthers yellow, white or cream color.

Fruit about $1 \mathrm{~cm}$. in diameter or more.

Fruit yellow and red, or orange-red with ruddy cheeks.

Fruit deep or bright red.

Pedicels short, pubescent, at least at flowering time.

Pedicels $1 \mathrm{~cm}$. or more long, white-tomentose.

Fruit $5-8 \mathrm{~mm}$. in diameter.

Anthers purple or purplish.

Inflorescence pubescent or slightly tomentose: leaf-blades suborbicular. slightly pointed.

Cavity 3-4 mm. wide: pomes 9-12 $\mathrm{mm}$. in diameter.

Cavity 4-6 mm. wide: pomes $12-15 \mathrm{~mm}$. in diameter.

Inflorescence glabrous : leaf-blades more elongated, acutely pointed and with several tooth-like lobes.

Leaf-blades broader than long.

A single species in our range.

XIV. SEGNES,

XV. VISENDAE.

58. C. ignava.

59. C. impar.

60. C. agrestina

61. C. extraria.

62. C. sororia.

63. C. galbana.

64. C. abdita.

65. C. exilis.

66. C. consanguinea. 67. C. valida.

68. C. limata.

69. C. mira.

70. C. segnis.

71. C. visenda.

72. C. sodalis.

73. C. furtiva.

74. C. arrogans.

75. $C$ egregia.

Fruit red or scarlet, anthers very small, bright purple.

Fruit orange-red.

Leaf-blades with large blunt or rounded lobes.

Leaf-blades with numerous small, tooth-like lobes.

Branches drooping.

Anthers pink or pale purple: inflorescence pubescent.

Leaf-blades glandular-dentate and with tooth-like lobes.

Leaf-blades dentate and cleft.

Anthers white: inflorescence densely white-woolly.

Branches spreading or ascending.

Inflorescence pubescent.

Inflorescence glabrous.

\section{MICHAUXIANAE.}

Leaf-blades abruptly contracted at the base.

Leaf-blades with long cuneate bases.

\section{INTEGRAE.}

Fruit red.

Anthers light yellow: caly $x$ deciduous.

Anthers pale purple: calyx persistent.

Fruit yellow, orange or orange-red, the cheeks often flushed.

a. Pubescence of the corymbs copious but thin.

Fruit subglobose, the flesh attenuate with the pedicel.

Fruit depressed globose, the flesh depressed about the pedicel.

76. C. tristis.

77. C. quaexita.

78. C. egens.

79. C. annosa.

80. C. calva.

81. C. Michanxii.

82. C. lanata.

83. C. integra.

84. C. adunca.

85. C. constans,

86. C. panda. 
b. Pubescence of the corymbs densely white-woolly.

Vernal leaves bright green : pedicels at maturity $1 \mathrm{~cm}$. long or more.

Mature leaf-blades subcoriaceous, conspicuously margined with black glands.

Mature leaf-blades thinner, not very glandular.

Vernal leaves gray-green: pedicels very short.

87. C. dapsilis.

88. C. dolosa.

89. C. rava.

\section{DENTATAE.}

Fruit red at maturity.

Corolla $2-2.5 \mathrm{~cm}$. broad : sepals $6-8 \mathrm{~mm}$. long.

Pomes oval. $1.5-2 \mathrm{~cm}$. long: anthers yellow.

Pomes subglobose, $1-1.5 \mathrm{~cm}$. thick: anthers pale purple.

Corolla smaller: sepals shorter.

Inflorescence densely woolly : leaf-blades contracted at the base.

Inflorescence pubescent: leaf-blades cuneate.

Fruit yellow, orange or orange-red, the cheeks often red.

Pedicels clothed with white spreading hairs: flowers $2-2.5 \mathrm{~cm}$. wide.

Leaf-blades sharply dentate, mostly pointed.

Leaf-blades crenate-dentate, mostly obtuse

Pedicels white-woolly.

Anthers very small, less than $1 \mathrm{~mm}$. long.

Leaf margins very glandular: petioles short.

Leaf margins slightly glandular: petioles long.

Anthers larger : flowers $2-2.5 \mathrm{~cm}$. broad.

Nutlets $6-7 \mathrm{~mm}$. long.

Nutlets $7-9 \mathrm{~mm}$. long.

XIX. ATTRITAE.

Spines 1-2 cm. long: leaves very irregularly and coarsely dentate.

Spines longer: leaves finely serrate-dentate.

XX. SENTAE.

Leaf-blades with long cuneate bases.

Fruit red.

Fruit orange with ruddy cheeks.

Leaf-blades suborbicular with rounded or abruptly contracted bases.

\section{ANISOPHYLLAE.}

Fruit orange, often with flushed cheeks.

Fruit red or reddish.

Vernal leaves slightly pubescent or glabrate.

Leaf-blades subentire.

Leaf-blades lobed and toothed.

Vernal leaves scurfy-tomentose.

Anthers yellow : fruit globose or subglobose.

Leaf-blades conspicuously lobed, toothed and crisped.

Leaf-blades subentire or with shallow lobes and teeth.

Anthers white: fruit subglobose or oval.

\section{COLONICAE.}

Leaf-blades entire or nearly so, gland-margined.

Leaf-blades dentate, glands less conspicuous.

\section{RECURVAE.}

Leaf-blades (exclusive of those on the shoots) less than $2 \mathrm{~cm}$. wide.

Fruit red.

Fruit yellow, orange or orange red, cheeked or splotched with red.

Prevailing leaves with the blades abruptly contracted at the base.

Fruit $8-12 \mathrm{~mm}$. thick: spines mostly $1-2 \mathrm{~cm}$. long.

Leaf-blades conspicuously dentate and glandular.

Leaf-blades subentire, the glands less conspicuous.

Blades obovate or suborbicular.

Blades much more elongated.

Fruit smaller: spines numerous, $1.5-3.5 \mathrm{~cm}$. long.

Prevailing leaves with the blades cuneate at the base, or with longwinged petioles.

Leaf-blades acute or very sharply pointed, toothed or lobed.

Leaf-blades abruptly pointed or obtuse, either toothed, lobed or entire.

Mature leaves more than $1 \mathrm{~cm}$. wide.

Vernal leaves long, conspicuously overreaching the flowers.

Petioles mostly short, never as long as the blades.

Nutlets 6-7 mm. long.

Nutlets $7-9 \mathrm{~mm}$. long.

Petioles mostly elongated, sometimes as long as the blades.

Flowers large : sepals $4-5 \mathrm{~mm}$. long.

Flowers small: sepals very small.

Vernal leaves less than $2 \mathrm{~cm}$. long, the petioles white-woolly.

Mature leaves less than $1 \mathrm{~cm}$. wide.

Some or all of the leaves (exclusive of those on the shoots) $2 \mathrm{~cm}$. wide.

Pubescence of the inflorescence copious but thin.

Pubescence of the inflorescence densely white-woolly.

111. C. colonica.

112. C. vicana.

90. C. Alabamensis.

91. C. fortis.

92. C. compitalis.

93. C. insidiosa.

94. C. florens.

95. C. clara.

96. C. pulla.

97. C. inops.

98. C. amica.

99. C. Ravenelii.

100. C. attrita.

101. C. teres.

102. C. senta.

103. C. Cullasagensis.

104. C. dispar.

105. C. anisophylla.

106. C. frugalis.

107. C. viaria.

108. C. cirrata.

109. C. arguta.

110. C. laxa.

113. C. recurva.

114. C. rimosa.

115. C. inopina.

116. C. villaris.

117. C. curva.

118. C. resima.

119. C. lassa.

120. C. adusta.

121. C. illudens.

122. C. versita.

123. C. incana.

124. C. crocea.

125. C. audens.

126. $C$. meridiana. 
XXIV. LEPIDAE.

Spines less than $3 \mathrm{~cm}$. long.

Fruit globose at maturity.

Inflorescence tomentose : leaf-blades abruptly contracted below.

Inflorescence glabrous: leaf-blades cuneate or spatulate.

Fruit pyriform or nearly so.

Leaf-blades crenate.

Leaf-blades dentate or lobed.

Spines long and slender.

Fruit globose.

Fruit pyriform or nearly so.

Sepals 3-4 mm. long: corymbs few-several-flowered.

Sepals 4-6 mm. long: flowers solitary or in 2's and 3's.

Leaf-blades toothed: pedicels and shoots soon becoming glabrous.

Leaf-blades finely toothed and lobed: pedicels and shoots tomentose.

127. C. lepida.

128. C. lacrimata.

129. C. condigna.

130. C. geniculata.

131. C. pexa.

132. C. Yadkinensis.

133. C. munda.

134. C. invicta.

\section{UNIFLORAE.}

Mature fruit globose or nearly so.

Leaf-blades obovate or cuneate, mostly obtuse.

Fruit yellow, orange or greenish yellow.

Fruit red.

Leaf-blades oval, ovate or elliptic, mostly acute.

Leaves frequently lobed or incised: fruit red at maturity.

Leaves (exclusive of those on the shoots) not lobed; fruit yellow, orange or greenish yellow.

Mature fruit pyriform.

Leaf-blades prevailingly oval, ovate or elliptic.

Leaf-blades prevailingly obovate or cuneate.

Sepals broad and incised.

Sepals narrow, entire or serrulate.

XXVI. MOLLES.

Hypanthium tomentose or pubescent.

Corolla at least $2 \mathrm{~cm}$. broad : fruit not depressed globose.

Anthers yellow.

Fruit subglobose, ripening in August or September.

Fruit oblong or obovoid, ripening in October.

Anthers dark red or purplish.

Corolla about $15 \mathrm{~mm}$. broad: fruit depressed globose.

Hypanthium glabrous.

Anthers yellow: leaf-blades finely serrate.

Anthers red or purple: leaf-blades coarsely serrate.

135. C. uniflora.

136. C. armentalis.

137. C. Vailiae.

138. C. Raleighensis.

139. C. bisulcata.

140. C. gregalis.

141. C. Earlei.

\section{BILTMOREANAE.}

Stamens normally 10: fruit yellow or orange, often cheeked red.

Stamens normally 20 : fruit red or ruddy.

\section{TRIFLORAE.}

Stamens normally 20: leaf-blades ovate, obovate or elliptic.

Stamens normally 10 : leaf-blades broadly oval or round-ovate.

150. C. triflora.

151. C. austromontana.

\section{HARBISONIANAE.}

Corymbs compound, many-flowered.

Corymbs 3-10-flowered, subsimple.

152. C. Harbisonii.

153. C. Ashei.

\section{XXX, PRUINOSAE.}

Fruit globose, subglobose or oval.

Stamens normally 20.

Fruit angled, conspicuously swollen below the middle. Anthers white or light yellow.

Anthers purple or purplish.

Fruit neither angled nor swollen below the middle.

Anthers purple or purplish.

Stamens 10 .

Fruit pyriform.

ers white or pale yellow.

143. C. Arkansana.

144. C. Texana.

145. C. gravida.

146. C. cibaria.

147. C. lacera.

148. C. Biltmoreana.

149. C. Craytomii.

154. C. rustica.

155. C. arcana.

156. C. Georgiana.

157. C. callida.

158. C. iracunda.

159. C. vicinalis.

XXXI; TENUIFOLIAE.

Fruit $10-18 \mathrm{~mm}$. thick at maturity, subglobose, oblong or oval.

Stamens normally 20.

Stamens normally 10 .

Fruit $6-8 \mathrm{~mm}$. thick at maturity, subglobose or oval.

Stamens normally 20 .

Stamens fewer.

160. C. basilica.

161. C. macrosperma.

162. C. nubicola.

163. C. Roanensis. 
Fruit globose or very nearly so.

Stamens 15-20.

Mature fruit $1 \mathrm{~cm}$. or more in diameter.

Ripe fruit yellow, orange, orange-red or green, often with red cheeks. Corymbs and shoots densely hirsute or pubescent. Corymbs and shoots finely pubescent. Ripe fruit red or scarlet.

Mature fruit smaller.

Anthers yellow or nearly white.

Pedicels and branches of the corymbs long and flexuous. Pedicels short. the corymbs congested. Anthers purple or purplish.

Stamens fewer.

Mature fruit $1 \mathrm{~cm}$. or more in diameter. Corymbs and shoots densely hirsute or pubescent. Corymbs sparsely pubescent: the shoots glabrous or nearly so.

Mature fruit smaller. Nutlets $1-3$.

Nutlets $3-5$.

Fruit oval or oblong.

Stamens normally 20.

Stamens fewer.

Mature fruit yellow, orange or orange-red, often with red cheeks. Spines few or wanting: fruit succulent, yellow. Spines numerous : fruit hard, ruddy on the cheeks.

Mature fruit red.

\section{CRUS-GALLI.}

164. C. berberifolia.

165. C. editu.

166. C. fera.

167. C. Mohrii.

168. C. edura.

169. C. tersa.

170. C. tetrica.

171. C. arta.

172. C. torva.

173. C. denaria.

174. C. crocina.

175. C. albicera.

176. C. sinistra.

177. C. signata.

Stamens 7-12.

Fruit subglobose or oval.

Anthers rose-color or purplish.

Inflorescence of ample spreading corymbs: fruit $8-13 \mathrm{~mm}$. broad. Inflorescence of small short corymbs: fruit 5-8 mm. broad.

Anthers yellow or nearly white.

Leaf-blades oval, broadly oval or elliptic. Leaf-blades obovate or cuneiform.

Fruit globose, 5-8 mm. in diameter.

Ripe fruit bright, shining red : spines slender, 1-4 cm. long.

Ripe fruit pruinose, dull red: spines stout, $3-5 \mathrm{~cm}$. long.

Stamens more numerous.

Anthers light yellow.

Anthers bright rose-color.

178. C. Crus-Galli.

179. C. macra.

180. C. regalis.

181. C. algens.

182. C. pyracanthoides.

183. C. armata.

184. C. arborea.

185. C. Bushii.

1. Crataegus tomentòsa L. A tree $5-7 \mathrm{~m}$. in height, or frequently a large shrub with several stems, the bark fissured and scaly ashy gray or dark brown. Leaf-blades $5 \cdot 10$ $\mathrm{cm}$. long, 3-6 cm. wide, oval, ovate or oblong-ovate, acute or occasionally rounded at the apex, narrowed at the base into broad margined petioles, serrate or serrate-dentate and incisely lobed, slightly scabrous or eventually smooth above, pubescent, especially along the veins below : corymbs compound, many-flowered, pubescent : corolla 10-14 mm. broad : stamens normally 20 , the anthers purplish: pedicels, hypanthium and the lanceolate sepals pubescent : fruit oval or pyriform, $10-15 \mathrm{~mm}$. long, dull red : nutlets $2-3$, the ventral or lateral faces grooved or hollowed.

In low rich soil, usually near watercourses, Ontario to North Carolina, Michigan and Missouri.

2. Crataegus Chapmánii (Beadle) Ashe. A tree $4-6 \mathrm{~m}$. high, or more frequently a large shrub with several stems, the bark fissured and scaly, ashy gray or brown. Leafblades 5-10 cm. long, 3-6 cm. wide, broadly ovate, oval or oblong-ovate, acute or occasionally rounded at the apex, narrowed at the base into margined petioles, serrate or serratedentate, incisely lobed, eventually glabrous or glabrate above, below varying from sparingly to densely pubescent, especially along the veins : corymbs compound, many-flowered, pubescent : corolla about $15 \mathrm{~mm}$. wide : stamens about 20 , the anthers purplish : pedicels, hypanthium and the lanceolate sepals pubescent: fruit globose or subglobose, 8-10 mm. long, bright red : nutlets 2-3, the ventral or lateral faces grooved or hollowed.

In low, rich soil and on banks of streams, Virginia to Georgia, Tennessee and Texas.

3. Crataegus neofluviàlis Ashe. A small tree, or a large much-branched shrub, 3-5 m. tall, with gray scaly bark. Leaf-blades obovate, elliptic or rhombic-ovate, 4-8 cm. long, $1.5-5 \mathrm{~cm}$. broad, pointed at the apex, below narrowed into margined petioles, sharply and often doubly serrate and incisely lobed, glabrous above, sparingly pubescent or glabrate beneath: corymbs compound, many-flowered, glabrous or very nearly so: corolla 12-15 mm. broad : stamens normally 20 , the small anthers rose-color or purplish : pedicels, hypanthium and lanceolate usually incised glandular sepals glabrous or the former with a few weak hairs: fruit globose, $6-10 \mathrm{~mm}$. in diameter, red, green and red, or orange with red cheeks, the flesh thin and firm: nutlets $3-5$, the lateral faces grooved or hollowed.

On banks of streams in the mountains of Virginia, North Carolina and Tennessee. 
4. Crataegus cordàta (Mill.) Ait. A tree $5-10 \mathrm{~m}$. tall, with grayish brown scaly bark, or more often a large spreading shrub. Leaf-blades $2-7 \mathrm{~cm}$. long, broadly ovate, serrate and incisely 3-7-lobed, acute at the apex, truncate or cordate at the base, glabrous : corymbs compound, many-flowered, glabrous : pedicels and hypanthium glabrous : sepals short, triangular, hairy on the margins : stamens 20 : fruit depressed-globose, 4-6 $\mathrm{mm}$. in diameter, bright red or scarlet : nutlets $3-5$, the hypostyle upwardly and dorsally extended over the apex.

In moist rich soil and on banks of streams, Virginia to Georgia, Illinois, Missouri and Tennessee.

5. Crataegus apiifòlia (Marsh.) Michx. A shrub, or a small tree, 2-6 m. tall, with smooth gray bark, usually with several crooked stems. Leaf-blades broadly ovate or orbicular, 2-4 cm. long, $2-4 \mathrm{~cm}$. wide, acute at the apex, mostly truncate or cordate at the base, pubescent, at least when young, pinnately and deeply 5-7-cleft, the lobes sharply serrate : corymbs subsimple, 3-10-flowered : pedicels and hypanthium pilose-pubescent : sepals lanceolate, usually glandular-serrate and colored at the tips: corolla $10-12 \mathrm{~mm}$. broad : stamens about 20, the anthers pink or purplish : fruit oblong or oval, 4-7 mm. long, scarlet: nutlets 1-3, the hypostyle upwardly and dorsally extended over the apex.

In low rich soil, swamps and on banks, Virginia to Florida, Missouri and Texas. PArsley Haw.

6. Crataegus spathulàta Michx. A shrub or small tree, sometimes 6-8 m. tall, with gray or brown smooth or minutely scaly bark and usually several stems. Leaf-blades spatulate or oblanceolate, $1-4 \mathrm{~cm}$. long, 5-20 mm. wide, narrowed into winged petioles, obtuse or subacute at the apex, the borders crenate or crenate-serrate and frequently incisely 2-3-lobed, glabrous or very nearly so, shining above : corymbs compound, manyflowered, glabrous: pedicels, hypanthium and short triangular sepals glabrous: corolla 7-10 mm. broad : stamens about 20 : fruit globose, red at maturity, 4-6 mm. in diameter : nutlets $3-5$, the hypostyle upwardly and dorsally extended over the apex.

In moist rich soil and on banks of streams, Virginia to Florida, Missouri and Texas.

7. Crataegus brachyacántha Engelm. \& Sarg. A tree $10-15 \mathrm{~m}$. tall, with dark brown rough scaly bark. Leaf-blades oblong-lanceolate, elliptic or ovate, 1-5 cm. long, 5-20 mm. wide, crenate-serrate, glabrous when fully grown, acute or sometimes blunt at the apex, contracted at the base, shining above: corymbs many-flowered, compound, glabrous: pedicels, hypanthium and the exterior surface of the short triangular sepals, glabrous : corolla 10-12 mm. broad : stamens 15-20: fruit subglobose, at maturity bright blue with a glaucous bloom: nutlets $3-5$, the hypostyle dorsally extended over the apex.

In moist soil and on borders of swamps and streams, Louisiana and Texas.

8. Crataegus aestivàlis (Walt.) T. \& G. A tree 5-9 m. tall, or a large shrub with several stems, the bark dark reddish brown, fissured and scaly. Leaf-blades elliptic, oblong, oblong-cuneate or obovate, $2-7 \mathrm{~cm}$. long, $1.5-3 \mathrm{~cm}$. wide, either acute or rounded at the apex, narrowed or contracted below into winged petioles, dentate, sinuate or crenateserrate, tomentose with a pale or rufous covering when voung, becoming in age glabrate or glabrous above, below rufous-tomentose, especially along the midrib and veins: corymbs 2-5-flowered, simple : pedicels and hypanthium glabrous : sepals triangular, usually colored near the tips, minutely serrate or entire: stamens about 20 , the anthers purple: fruit depressed-globose, red at maturity, punctate, $12-15 \mathrm{~mm}$. in diameter : nutlets $3-5$, the hypostyle confined to the lateral faces and terminated at the ventral apex.

In shallow ponds in the pine lands and on low banks of streams, South Carolina to Texas and Arkansas. MAY HAW.

9. Crataegus maleoìdes Sarg. A small tree 4-5 m. tall, or more frequently a large shrub with several stems. Leaf-blades oval, obovate or nearly orbicular, those of the shoots usually ovate, $1.5-5 \mathrm{~cm}$. long, $1-4 \mathrm{~cm}$. broad, glabrous or with tufts of hairs in the axils of the veins beneath, acute or rounded at the apex, narrowed or contracted below into short winged petioles, serrate, and at least on the shoots shallowly incised : corymbs simple, 3-5-flowered : pedicels and hypanthium glabrous: sepals lanceolate, usually colored : stamens $15-20$, the anthers purple : fruit subglobose or slightly oval, at maturity red, 8-12 $\mathrm{mm}$. thick : nutlets $3-5$, the hypostyle confined to the lateral surfaces.

In wet or moist soil bordering streams, Volusia County, Florida.

10. Crataegus luculénta Sarg. A slender tree 4-5 m. tall, with ashy gray or dark reddish brown bark. Leaf-blades spatulate or cuneiform, frequently ovate or obovate on the shoots, $2-4 \mathrm{~cm}$. long, 1-3 cm. broad or larger on vigorous branches, cuneate or contracted at the base into margined petioles, acute or bluntly pointed at the apex, irregularly serrate and incised, glabrous when fully grown, or with tufts of pale hairs in the axils of the principal veins beneath : corymbs $2-5$-flowered, simple: pedicels, hypanthium and lanceolate sepals glabrous : corolla $15-18 \mathrm{~mm}$. broad: stamens $15-20$, the anthers purple : fruit globose or subglobose, $8-10 \mathrm{~mm}$. in diameter, orange-red when ripe : nutlets $3-5,4-6$ $\mathrm{mm}$. long, the hypostyle $3-4 \mathrm{~mm}$. long.

In swampy woods, Volusia County, Florida. 
11. Crataegus víridis L. A tree often $6-10 \mathrm{~m}$. tall, with gray or reddish brown fissured and frequently exfoliating bark. Leaf-blades ovate-lanceolate, elliptic or oblongobovate, rarely ovate, $2-7 \mathrm{~cm}$. long, $2-4 \mathrm{~cm}$. wide, or larger on the shoots, acute or bluntly pointed at the apex, narrowed or abruptly contracted at the base, irregularly serrate and often with acute or blunt shallow lobes, glabrous or with tufts of pale hairs in the axils of the veins beneath : corymbs compound, many-flowered, glabrous : corolla 10-14 mm. wide: stamens normally 20 : fruit globose or subglobose, $4-7 \mathrm{~mm}$. in diameter, red or orange-red when ripe: nutlets usually 5 , the hypostyle three-fourths as long as the ventral angle.

In low grounds and moist woods, Virginia and North Carolina to Florida, Texas and Missouri.

12. Crataegus paludòsa Sarg. A small tree 4-5 m. tall, with gray or reddish brown bark, or more frequently a large shrub with several stems and spiny branches. Leafblades oval, elliptic, obovate or oblanceolate, or on the shoots ovate, $2-4 \mathrm{~cm}$. long, 7-30 mm. wide, mostly acute at the apex, cuneate, contracted or on the shoots rounded at the base, glabrous or with tufts of pale hairs in the axils of the veins beneath, serrate, occasionally cleft or incised, especially on vigorous shoots: corymbs several-many-flowered : stamens about 20 , the anthers purple : fruit subglobose or short-oval, $5-8 \mathrm{~mm}$. in diameter, red or orange-red at maturity : nutlets $3-5$, the hypostyle three-fourths the length of the ventral angle.

In low grounds and on banks of streams, Volusia County, Florida.

13. Crataegus subvíridis Beadle. A tree $6-8 \mathrm{~m}$. tall, with gray bark. Leaf-blades ovate, obovate or oval, 2.5-6 cm. long, 1-4 cm. wide, or larger on the shoots, acute or acuminate, rarely rounded at the apex, contracted or narrowed at the base, or on the shoots rounded and truncate, glabrous or glabrate when fully grown, the borders serrate and incisely lobed : corymbs compound, many-flowered, pilose-pubescent : pedicels and hypanthium sparsely pilose : sepals narrowly lanceolate, entire or minutely serrate, pubescent on the inner surface, at least at flowering time : corolla $12-15 \mathrm{~mm}$. wide: stamens normally 20 : fruit globose, $5-7 \mathrm{~mm}$. in diameter : nutlets $3-5$, about $5 \mathrm{~mm}$. long, the hypostyle three-fourths as long as the nutlet.

In low woods and on banks of streams, Chattahoochee, Florida.

14. Crataegus intérior Beadle. A small tree about $5 \mathrm{~m}$. tall, with dark gray flaky bark. Leaf-blades ovate, ovate-lanceolate or oblong, 2-6 cm. long, 1-4 cm. wide, glabrous or glabrate when old, acute or acuminate at the apex, rounded or abruptly contracted at the base, the borders serrate and deeply incised; petioles margined, slightly hairy on the upper surface, at least when young : corymbs compound, many-flowered, glabrous : pedicels, hypanthium and exterior surface of the sepals glabrous : corolla about $15 \mathrm{~mm}$. wide : stamens usually 20, the anthers yellow : fruit globose, bright red at maturity, 7-8 mm. wide : nutlets $3-5$, about $5 \mathrm{~mm}$. long, the hypostyle occupying about two-thirds of the ventral angle.

In flat woods, near Chattanooga, Tennessee.

15. Crataegus vúlsa Beadle. A tree 4-6 m. high, with a trunk 1-2 dm. in diameter, clothed with gray or brownish fissured bark. Leaf-blades ovate, oval or round-ovate, 1.5-7 cm. long, 1-6 cm. broad, glabrous or with a few hairs along the veins and in their axils, sharply and irregularly serrate and incised, acute at the apex, either rounded or abruptly narrowed at the base into margined petioles : corymbs glabrous, compound, $3-10$ flowered : pedicels, hypanthium and exterior surface of the nearly or quite entire sepals glabrous: corolla about $15 \mathrm{~mm}$. wide: stamens normally 20 , the anthers pale yellow or nearly white: fruit globose, $7-9 \mathrm{~mm}$. in diameter, at maturity yellow-green flushed with red : nutlets $3-5$, about $5.5 \mathrm{~mm}$. long. Georgia.

In flat woods and on banks of streams, northeastern Alabama to Floyd County, northwestern

16. Crataegus Brazòria Sarg. A tree about $6 \mathrm{~m}$. tall, with a trunk $1.5 \mathrm{dm}$. in diameter and ashy gray scaly bark. Leaf-blades 4-6 cm. long, 2-3.5 cm. wide, oval or obovate, acute or acuminate at the apex, cuneate or narrowed, or on vigorous shoots rounded at the base, coarsely serrate above the middle, glabrous when fully grown; petioles winged, pubescent, at least when young: corymbs compound, many-flowered, pilose : pedicels, hypanthium and the lanceolate-acuminate sepals pilose-pubescent: corolla about 16 mm. wide: stamens 20 , the small anthers dark red : fruit subglobose or short oval, when ripe $6-7 \mathrm{~mm}$. in diameter, bright canary-yellow : nutlets usually 5 , about $6 \mathrm{~mm}$. long.

In the valley of the Brazos River, Brazoria, Texas.

17. Crataegus silvícola Beadle. A tree 6-10 m. tall and sometimes with a trunk 2 $\mathrm{dm}$. in diameter covered with a close or slightly fissured and scaly bark. Leaf-blades ovate, round ovate, or on vigorous shoots deltoid, $2-7 \mathrm{~cm}$. long, $2-6 \mathrm{~cm}$. wide, glabrous at 
maturity, acute at the apex, rounded or narrowed, or occasionally truncate or subcordate at the base, sharply serrate and incisely lobed ; petioles $5-30 \mathrm{~mm}$. long, usually glandular : corymbs simple, 3-7-flowered : pedicels, hypanthium and lanceolate sepals glabrous : corolla about $15 \mathrm{~mm}$. wide: stamens 10 , the anthers purple: fruit globose, when ripe $10-11 \mathrm{~mm}$. in diameter, red or rarely greenish with red cheek, the flesh firm: nutlets $3-5$, about $6 \mathrm{~mm}$. long, the hypostyle about three-fourths as long as the ventral angle.

In flat woods, northern Alabama and northwestern Georgia.

18. Crataegus aèmula Beadle. A shrub or small tree $3-5 \mathrm{~m}$. tall, with dark gray, either smooth or scaly bark. Leaf-blades broadly ovate, oval or suborbicular, $3-5 \mathrm{~cm}$. long, $1.5-4 \mathrm{~cm}$. wide, acute at the apex, rounded or contracted at the base, the borders serrate and incised, glabrous or glabrate at maturity; petioles 5-15 mm. long, glandular : corymbs subsimple, 5-10-flowered : pedicels and hypanthium sparsely pubescent: sepals lanceolate, about $4 \mathrm{~mm}$. long, glandular-serrate or pectinately-glandular: corolla 14-18 $\mathrm{mm}$. wide: stamens 10 , the anthers purple: fruit globose or subglobose, $10-13 \mathrm{~mm}$. in diameter, at maturity red, the flesh firm: nutlets $3-5,5-7 \mathrm{~mm}$. long, the hypostyle about two-thirds as long as the ventral angle.

In low woods and uplands, northwestern Georgia to Mississippi.

19. Crataegus punctàta Jacq. A tree occasionally $9 \mathrm{~m}$. tall, with dark gray or reddish brown scaly bark or oftener a large shrub with spreading branches. Leaf-blades obovate, $3-7 \mathrm{~cm}$. long, $1.5-5 \mathrm{~cm}$. broad, either obtuse or pointed at the apex, cuneate or more abruptly contracted at the base, irregularly and usually doubly serrate and incised, when fully grown glabrous on the upper surface, the prominent midrib and ascending veins deeply impressed, pubescent below : corymbs compound, many-flowered, pilosepubescent : pedicels and hypanthium pilose : sepals linear or linear-lanceolate, $5-7 \mathrm{~mm}$. long, pubescent : corolla about $2 \mathrm{~cm}$. wide : stamens 20 , the anthers purplish : fruit subglobose or oval, 1-2 cm. broad, red or yellow when ripe: nutlets $2-3$, about 7-9 $\mathrm{mm}$. long, the hypostyle about $5 \mathrm{~mm}$. long.

On hillsides and in rocky soil, Quebec to.Wisconsin, the mountains of North Carolina and Tennessee.

20. Crataegus collina Chapm. A small tree 4-6 m. tall, with dark gray scaly bark, Leaf-blades obovate or oval, $2.5-7 \mathrm{~cm}$. long, $2-5 \mathrm{~cm}$. wide, or some larger on leading shoots. acute at the apex, narrowed or contracted at the base into margined glandless or minutely, glandular petioles, glabrous or glabrate when fully grown, the borders serrate and frequently incised : corymbs subsimple or compound, pubescent : pedicels and hypanthium pubescent : sepals lanceolate, pubescent and glandular : corolla $15-20 \mathrm{~mm}$. broad : stamens normally 20 , the anthers light yellow or nearly white : fruit globose, about $1 \mathrm{~cm}$. in diameter, dull red at maturity, the flesh firm: nutlets $3-5$, about $7 \mathrm{~mm}$. long, the hypostyle about 4-5 mm. long. [ [C. collicola Ashe.]

In woods and on borders of fields and streams, Virginia to Georgia and Alabama, westward to Tennessee and Missouri.

21. Crataegus rígens Beadle. A small tree 4-6 m. tall, with dark gray scaly bark, or more frequently a large much-branched shrub with one or several stems. Leaf-blades obovate, broadly oval or occasionally nearly round, $2-5 \mathrm{~cm}$. long, $1.5-4 \mathrm{~cm}$. wide, mostly pointed at the apex, contracted or narrowed at the base into margined glandular petioles, glabrous or glabrate when fully grown, the borders sharply and irregularly serrate and occasionally shallowly incised, especially on leading shoots: corymbs simple or subsimple : pedicels and hypanthium pubescent : sepals lanceolate, pubescent, glandular: stamens 20 , the anthers nearly white: fruit subglobose or slightly pyriform, 9-12 $\mathrm{mm}$. thick, red when fully ripe, ripening about a month earlier than that of C. collina, the flesh firm : nutlets 35 , about $8 \mathrm{~mm}$. long, the hypostyle occupying two-thirds of the ventral angle.

In woods and on banks of streams, Georgia and Alabama.

22. Crataegus amnícola Beadle. A tree occasionally $8 \mathrm{~m}$. tall, with dark gray or reddish brown scaly bark and a diameter of trunk of 2-3 dm. Leaf-blades obovate, oval or ovate, $2-6 \mathrm{~cm}$. long, $1.5-4 \mathrm{~cm}$. wide, acute at the apex, contracted or narrowed at the base into margined, glandless or sparingly glandular petioles, glabrous or nearly so when fully grown, the borders sharply and irregularly serrate and incised : corymbs compound, many-flowered, pubescent : pedicels and hypanthium pubescent: sepals 4-5 mm. long, glandular or pectinately glandular: corolla about $15 \mathrm{~mm}$. wide : stamens 20 , the anthers nearly white: fruit subglobose, $7-10 \mathrm{~mm}$. in diameter, red at maturity, the flesh firm : nutlets $3-5$, about $6 \mathrm{~mm}$. long, the hypostyle two-thirds the length of the ventral angle.

In moist grounds and on banks of streams, eastern Tennessee and adjacent stations in Georgia 23. Crataegus íngens Beadle. A tree $5-8 \mathrm{~m}$. tall, with dark gray or brownish scaly
bark. Leaf-blades obovate, oval or ovate, $2.5-7 \mathrm{~cm}$. long, $1.5-5 \mathrm{~cm}$. broad, glabrate at maturity, or with some pubescence along the midrib and principal veins beneath, mostly 
pointed at the apex, contracted at the base into winged petioles $1-2 \mathrm{~cm}$. long, the borders serrate or crenate-serrate and shallowly lobed or incised : corymbs compound, many-flowered, pubescent : pedicels and hypanthium pubescent : sepals linear-lanceolate, glandular: corolla $10-13 \mathrm{~mm}$. wide : stamens normally 20 , the anthers bright purple: fruit globose or subglobose, 7-9 mm. wide, red when fully ripe, the flesh firm : nutlets $3-5$, about $6 \mathrm{~mm}$. long, the hypostyle three-fourths as long as the ventral angle.

In moist woods and on banks of streams, southeastern Tennessee and adjacent Georgia.

24. Crataegus penita Beadle. A tree 4-6 m. tall, with brownish gray bark and a wide-spreading crown, the twigs sparsely pubescent or eventually glabrous. Leaf-blades broadly obovate, oval or ovate, $2.5-6 \mathrm{~cm}$. long, $2-5 \mathrm{~cm}$. wide, glabrous or nearly so, acute at the apex, contracted or rounded at the base, the borders serrate and shallowly incised: petioles $5-20 \mathrm{~mm}$. long, slightly pubescent, at least when young : corymbs compound, usually many-flowered, glabrous or glabrate: pedicels and hypanthium glabrous or bearing a few weak hairs: sepals triangular-lanceolate, glandular-serrate or entire : corolla 15-18 $\mathrm{mm}$. wide: stamens about 20 , the anthers faintly pink or almost white: fruit globose or depressed-globose, $810 \mathrm{~mm}$. wide, at maturity red, with firm flesh : nutlets $3-5$, about 6 nm. long, the hypostyle occupying two-thirds of the ventral angle.

In low woods and on banks of streams, southeastern Tennessee.

25. Crataegus Margarétta Ashe. A small tree 4-5 m. tall, or more freqently a large shrub, with ascending or spreading branches. Leaf-blades obovate, broadly rhombic or nearly orbicular, sometimes broader than long, 3-4 cm. long, $2.5-5 \mathrm{~cm}$. wide, glabrous at maturity, acute or bluntly terminated at the apex, narrowed or abruptly contracted at the base, the borders serrate and shallowly incised, especially above the middle; petioles 1-2.5 $\mathrm{cm}$. long, slightly margined: corymbs glabrate, 5-12-flowered : pedicels and hypanthium glabrous or with scattering, weak hairs : sepals triangular, entire or slightly serrate : corolla 14-17 mm. wide: stamens 15-20, about the length of the styles: fruit globose, 8-10 mm. in diameter, ruddy when ripe, the flesh firm : nutlets usually $2-3$, about $5-6 \mathrm{~mm}$. long, the lateral or ventral faces nearly plane, the hypostyle $3-3.5 \mathrm{~mm}$. long.

In woods and on banks of streams, Missouri to Tennessee.

26. Crataegus Boyntònii Beadle. A tree about $6 \mathrm{~m}$. tall, with dark gray or brownish smooth or sometimes scaly bark, or oftener a large branching shrub $2-4 \mathrm{~m}$. in height. Leaf-blades broadly ovate or oval, $2.5-6 \mathrm{~cm}$. long, 2-5 $\mathrm{cm}$. wide, glabrous when fully grown, acute at the apex, rounded or narrowed at the base and prolonged into margined, glandular petioles 1-2.5 cm. long, or on leading shoots deltoid-ovate with truncate, subcordate or even cordate bases, the borders serrate and incised: corymbs short, 4-10-flowered: pedicels and hypanthium glabrous : sepals 4-6 $\mathrm{mm}$. long, entire or serrate near the tip, without glands below the middle: corolla $15-20 \mathrm{~mm}$. wide: stamens 10 , the anthers yellow : fruit globose or depressed-globose, $10-15 \mathrm{~mm}$. wide, at maturity yellow-green flushed with red : nutlets $3-5$, about $7 \mathrm{~mm}$. long, 4-5 $\mathrm{mm}$. measured dorso-ventrally, the hypostyle about $4 \mathrm{~mm}$. long.

In woods and on banks of streams at elevations between 400 and $900 \mathrm{~m}$. in the mountains of North Carolina and Tennessee.

27. Craetagus Buckleỳi Beadle. A tree sometimes $8 \mathrm{~m}$. tall, with dark gray, hrown or nearly black fissured scaly bark, or more often a large much-branched shrub with one or more stems. Leaf-blades $1.5-5 \mathrm{~cm}$. long, $1-5 \mathrm{~cm}$. wide, or even larger on vigorous shoots, ovate or round ovate, acute at the apex, rounded or narrowed at the base into margined and glandular petioles, serrate and incisely lobed, glabrous when fully grown : corymbs 3-7-flowered: pedicels and hypanthium glabrous: sepals 3-5 $\mathrm{mm}$. long, glandular-serrate and with stalked glands below the middle : corolla $15-20 \mathrm{~mm}$. wide : stamens normally 10 , the anthers purplish : fruit subglobose, usually angled, at maturity red or russet-red, 8-12 $\mathrm{mm}$. in diameter : nutlets $3-5,7.5-9 \mathrm{~mm}$. long, 4-5 mm. thick from back to inner angle, the hypostyle about $3 \mathrm{~mm}$. long.

In woods and on banks in the mountains, Virginia to North Carolina and Tennessee.

28. Crataegus commùnis Beadle. A shrub 1-2 m. tall, frequently growing in clumps or patches of considerable area. Leaf-blades ovate, oval or broadly oval, $2-5.5 \mathrm{~cm}$. long, 1.5-4 cm. wide, acutely or bluntly pointed at the apex, rounded or contracted at the base into margined petioles 5-20 mm. long, glabrous when fully grown, the borders serrate and incised : corymbs simple, 2-5-flowered : pedicels and hypanthium glabrous : sepals triangular-lanceolate, serrate and glandular: corolla $15-20 \mathrm{~mm}$. wide: stamens 10 , the anthers pale purple or nearly white : fruit globose or subglobose, $9-13 \mathrm{~mm}$. in diameter, red when ripe, the flesh firm : nutlets $3-5,6-7 \mathrm{~mm}$. long, the hypostyle about $3 \mathrm{~mm}$. long.

On the limestone formation in the Cumberland Mountains. Tennessee.

29. Crataegus stramínea Beadle. A shrub 1-3 m. tall, frequently growing in large patches. Leaf-blades oval, ovate or round-ovate, $2-6 \mathrm{~cm}$. long, $1.5-6 \mathrm{~cm}$. broad, acute at 
the apex, abruptly contracted or rounded, or on vigorous shoots truncate or subcordate at the base, serrate and acutely incised, glabrous in age ; petioles winged, $7-35 \mathrm{~mm}$. long, bearing several or many glands: corymbs 3-6-flowered : pedicels and hypanthium glabrous: sepals 4-6 mm. long, glandular-serrate or with a few stalked glands below the middle : corolla $1520 \mathrm{~mm}$. wide: stamens 10, the anthers purplish : fruit more or less pyriform, 9-11 mm. wide, at maturity yellow or greenish yellow, the flesh firm: nutlets $3-5,7-8 \mathrm{~mm}$. long, 3-4 mm. deep, the hypostyle $3-3.5 \mathrm{~mm}$. long.

In woods, especially in the mountains, northern Alabama and easstern Tennessee.

30. Crataegus rubélla Beadle. A shrub 1-4 m. tall, clothed with gray or reddish brown, smooth or sometimes fissured and scaly bark. Leaf-blades oval, ovate or obovate, 2-7 cm. long, 1.5-4.5 $\mathrm{cm}$. wide, glabrous at maturity, acute at the apex, narrowed or contracted at the base, the borders sharply serrate and incised ; petioles $1-2.5 \mathrm{~cm}$. long, margined, sparingly glandular: corymbs simple, 3-6-flowered : pedicels and hypanthium glabrous: sepals 4-6 mm. long, glandular-serrate : corolla $15-20 \mathrm{~mm}$. wide : stamens 10 , the anthers light purple: fruit more or less pyriform, 10-12 mm. wide, at maturity red, the flesh firm : nutlets $2-5$, about $6.5 \mathrm{~mm}$. long, $3-4 \mathrm{~mm}$. deep, the hypostyle about $4 \mathrm{~mm}$. long.

In woods, especially in the mountains, northern Alabama to eastern Tennessee and western North Carolina.

31. Crataegus Sargéntii Beadle. A tree sometimes $7 \mathrm{~m}$. tall, with ashy gray or brownish smooth or scaly bark, or more frequently a large shrub with one or more stems. Leaf-blades glabrous at maturity, ovate, ovate-lanceolate or round-ovate, $2-9 \mathrm{~cm}$. long, 1-6 $\mathrm{cm}$. wide, or occasionally larger on leading shoots, acute at the apex, rounded or abruptly contracted at the base into a margined or winged petiole $5-35 \mathrm{~mm}$. long, the borders irregularly serrate and incised : corymbs 3-5-flowered : sepals $6-9 \mathrm{~mm}$. long, like the pedicels and hypanthium, glabrous or with a few weak hairs : corolla $17-20 \mathrm{~mm}$. wide : stamens 20 , the anthers pale purple: fruit globose or subglobose, $10-13 \mathrm{~mm}$. broad, at maturity yellow or orange-yellow flushed with red, the flesh thin and firm: nutlets 3-5, 7-9 mm. long, 4-6 mm. thick measured dorso-ventrally, the hypostyle $3-4 \mathrm{~mm}$. long.

In rocky woods and on bluffs, northern Alabama and adjacent Georgia and Temnessee.

32. Crataegus pállens Beadle. A tree 5-7 m. tall,.with scaly dark gray bark, or a much-branched shrub with one or more stems. Leaf-blades $2-5 \mathrm{~cm}$. long, $1.5-5 \mathrm{~cm}$. wide, ovate, round-ovate or occasionally obovate in outline, acute at the apex, contracted at the base into margined and glandular petioles, glabrous when fully grown, the borders serrate and incisely lobed: corymbs simple, 5-7-flowered: pedicels and hypanthium glabrous: sepals 3-5 mm. long, glandular-serrate, glabrous on the outer surface: stamens about 20 , the anthers purple : fruit subglobose or oval, $8-15 \mathrm{~mm}$. wide, yellow or. greenish yellow when ripe : nutlets usually $3,7-9 \mathrm{~mm}$. long, $3.5-5 \mathrm{~mm}$. thick, the hypostyle $4-5 \mathrm{~mm}$. long.

In upland woods, Buncombe County, North Carolina.

33. Crataegus austrìna Beadle. A small tree 4-6 $\mathrm{m}$. tall, with dark gray or brownish scaly bark, or oftener a large shrub with one or more stems. Leaf-blades ovate, oval or oblong-oval, $2-5 \mathrm{~cm}$. long, 1-4 cm. wide, or larger on leading shoots, glabrous, pointed at the apex, rounded or contracted at the base, or on the shoots truncate, the borders serrate and incised ; petioles margined, 5-15 $\mathrm{mm}$. long: corymbs simple, 5-8-flowered : pedicels and hypanthium glabrous : sepals $3-4 \mathrm{~mm}$. long, glandular-serrate : corolla $15-18 \mathrm{~mm}$. wide: stamens normally 20 , the anthers small, bright purple: fruit globose, about $1 \mathrm{~cm}$. in diameter, green or greenish yellow at maturity, the flesh firm : nutlets 3-5, about $7 \mathrm{~mm}$. long, the hypostyle $4 \mathrm{~mm}$. long.

In woods, near Greenville, Alabama.

34. Crataegus gilva Beadle. A shrub 1-4 m. tall, with dark gray scaly bark and spreading branches. Leaf-blades elliptic, ovate or ovate-lanceolate, $3-7 \mathrm{~cm}$. long, $1.5-5$ $\mathrm{cm}$. wide, acute or acuminate at the apex, narrowed or contracted at the base, glabrous when fully grown, the borders serrate and incised; petioles $1-2.5 \mathrm{~cm}$. long, margined, often clandular: corymbs glandular-bracteate, 3-7-flowered : pedicels and hypanthium glabrous: sepals about $4 \mathrm{~mm}$. long, glandular-serrate : corolla $15-20 \mathrm{~mm}$. wide: stamens 20 , the anthers pale purple : fruit subglobose or short-pyriform, $6-8 \mathrm{~mm}$. wide, at maturity yellow or greenish yellow, rarely with a flushed cheek, the flesh firm : nutlets 3-5, about $5 \mathrm{~mm}$. long, the hypostyle about $2 \mathrm{~mm}$. long.

In rocky woods, Marshall County, Alabama.

35. Crataegus contrita Beadle. A tree sometimes 6-7 m. tall, with ashy gray or brownish scaly bark, or more frequently a large shrub with spreading branches. Leafblades ovate, oval or oblong, rarely short-obovate or suborbicular, $2-5 \mathrm{~cm}$. long, $1.5-5 \mathrm{~cm}$. broad, glabrous at maturity, acute or bluntly terminated at the apex, rounded or contracted 
at the base, the borders serrate and incised ; petioles 5-20 $\mathrm{mm}$. long, margined : corymbs simple, glandular-bracteate, 3-7-flowered : pedicels and hypanthium glabrous : sepals 3-5 $\mathrm{mm}$. long, glandular-serrate : corolla $12-17 \mathrm{~mm}$. wide : stamens 20 , the anthers dark purple : fruit subglobose, 7-9 mm. in diameter, at maturity yellow-green or orange, often with ruddy cheek, the flesh firm : nutlets $2-3$, rarely $3-5$, about $6 \mathrm{~mm}$. long, the hypostyle occupying a trifle more than half of the ventral angle.

In dry woods and uplands, southwestern Georgia and adjacent Florida.

36. Crataegus venùsta Beadle. A tree seldom more than $8 \mathrm{~m}$. tall, with ashy gray or light brown, fissured and scaly bark, or more frequently a large branching shrub. Leafblades obovate or ovate, occasionally round-ovate on leading shoots, $2-8 \mathrm{~cm}$. long, 1-6 cm. wide, acute at the apex, rounded or narrowed at the base into narrowly winged and remotely glandular petioles $7-40 \mathrm{~mm}$. long, the borders irregularly or doubly serrate and incised : corymbs 3-6-flowered : pedicels and hypanthium glabrous : sepals 4-6 mm. long, glandular-serrate or pectinately-glandular below the middle: corolla $2-2.5 \mathrm{~cm}$. wide: stamens 20 , the anthers nearly yellow : fruit oval or slightly so, 9-13 $\mathrm{mm}$. wide, at maturity dull red to greenish red, or, when more exposed, bright red, the flesh firm : nutlets 3-5, $7-9 \mathrm{~mm}$. long, the hypostyle occupying about half of the ventral angle.

On Red Mountain, near Birmingham, Alabama.

37. Crataegus inànis Beadle. A shrub 2-4 m. tall, with dark gray or brownish black smooth or scaly bark. Leaf-blades ovate, broadly ovate or oval, or suborbicular in outline, $2-5 \mathrm{~cm}$. long, $1.5-5 \mathrm{~cm}$. broad, glabrous at maturity, acute or short pointed at the apex, rounded or abruptly contracted at the base, the borders serrate and incised ; petioles $1-2 \mathrm{~cm}$. long, winged: corymbs $3-6$-flowered: pedicels and hypanthium glabrous : sepals 3-4 mm. long, serrate and glandular near the apex : corolla 14-18 mm. wide: stamens normally 20, the anthers yellow : fruit short oval or slightly pyriform, 6-8 mm. wide, red or ruddy at maturity, the flesh firm : nutlets $3-5$, abont $6 \mathrm{~mm}$. long, the hypostyle occupying about half of the ventral angle.

In rocky woods and glades, Marshall County, Alabama.

38. Crataegus exímia Beadle. A shrub 2-4 m. tall, with dark gray scaly bark and spreading branches which sometimes bear spines fully $7 \mathrm{~cm}$. long. Leaf-blades ovate or ovate-lanceolate, $3-8 \mathrm{~cm}$. long, 2-6 cm. wide, glabrous at maturity, acute or acuminate at the apex, rounded or contracted, or on leading shoots sometimes truncate at the base, the borders serrate and incised; petioles 1-3 cm. long, margined, remotely glandular : corymbs simple, glandular-bracteate, 3-6-flowered : pedicels 1-2 cm. long, glabrous, as is the hypanthium: sepals $5-6 \mathrm{~mm}$. long, glandular-serrate : corolla $2-2.5 \mathrm{~cm}$. wide: stamens 20 , the anthers yellow : fruit globose, $8-12 \mathrm{~mm}$. wide, at maturity red, the flesh firm : nutlets 3-5, 6-7 mm. long, the hypostyle about $3 \mathrm{~mm}$. long.

In rocky woods and glades, Sand Mountain, Alabama.

39. Crataegus técta Beadle. A shrub 2-5 m. tall, with dark ashy gray scaly bark. Leaf-blades $2-6 \mathrm{~cm}$. long, $1.5-6 \mathrm{~cm}$. broad, ovate or round-ovate, acute at the apex, rounded or contracted at the base into margined gland-bearing petioles, sharply and irregularly serrate and incised, glabrous or with a few hairs at the time of unfolding: corymbs 3-6-flowered, simple: pedicels and hypanthium glabrous : sepals $3-4 \mathrm{~mm}$. long, serrate or nearly entire: stamens usually 20 , the anthers light purple : fruit globose or subglobose, red at maturity, $10-13 \mathrm{~mm}$. in diameter : nutlets $3-5,6-7 \mathrm{~mm}$. long, 3.5-4.5 $\mathrm{mm}$. deep, the hypostyle $2-3 \mathrm{~mm}$. long.

In rocky woodlands, Marshall County, Alabama.

40. Crataegus ancisa Beadle. A small tree 4-5 m. tall, with dark gray scaly bark, or more frequently a much-branched shrub with ascending or spreading branches. Leafblades ovate or oval, $2.5-6 \mathrm{~cm}$. long, $1.5-5 \mathrm{~cm}$. wide, glabrous at maturity, acute at the apex, contracted or rounded, or on leading shoots truncate at the base, the borders serrate and deeply incised: petioles 1-3 cm. long, margined, remotely glandular: corymbs simple glandular-bracteate, 3-6-flowered : pedicels and hypanthium glabrous : sepals 3-4 mm. long, glandular-serrate: corolla $15-20 \mathrm{~mm}$. wide : stamens 20 , the anthers pale purple: fruit globose or subglobose, $10-12 \mathrm{~mm}$. in diameter, at maturity red or ruddy, the flesh firm : nutlets $3-5,6-7 \mathrm{~mm}$. long, the hypostyle occupying about two-thirds of the ventral angle.

On hillsides and in upland woods, Mississippi and Alabama.

41. Crataegus álma Beadle. A shrub 2-4 m. tall, with dark gray, either smooth or scaly bark. Leaf-blades ovate, oval or obovate, $2-6 \mathrm{~cm}$. long, $1.5-4 \mathrm{~cm}$. wide, pointed at the apex, rounded, contraeted or narrowed at the base, the borders serrate and incised ; petioles 1-2 cm. long, margined : corymbs glabrous, glandular-bracteate, 3-7-flowered : pedicels and hypanthium glabrous: sepals glandular-serrate or subentire, about $4 \mathrm{~mm}$. 
long: corolla 15-20 mm. wide: fruit subglobose, 10-12 mm. in diameter, red when fully ripe, the flesh firm : nutlets $3-5,7-8 \mathrm{~mm}$. long, the hypostyle about half the length of the nutlet.

On gravelly hills, near Meridian, Mississippi.

42. Crataegus pinetòrum Beadle. A shrub 1-5 m. tall, frequently with severaI stems, clothed with dark gray, either smooth or scaly bark. Leaf-blades ovate, oval or obovate, 2-6 cm. long, $1.5-5 \mathrm{~cm}$. wide, glabrous when fully grown, acute at the apex, narrowed or rounded at the base, the borders serrate and incised; petioles 1-2.5 cm. long, margined, sparsely glandular: corymbs simple, glandular-bracteate, 3-6-flowered : pedicels 1-2 $\mathrm{cm}$. long, glabrous : hypanthium glabrous : sepals $3-5 \mathrm{~mm}$. long, glandular-serrate : corolla 14-18 mm. wide : stamens 20 , the anthers pale purple: fruit subglobose, 7-10 mm. wide, at maturity red or ruddy, the flesh thin and firm : nutlets 2-3, sometimes 5 , about $6 \mathrm{~mm}$. long, 3-4 $\mathrm{mm}$. deep, the hypostyle about half the length of the nutlet.

In dry or rocky woods, Marshall County, Alabama.

43. Crataegus macilénta Beadle. A shrub 3-5 m. tall, with dark gray smooth or scaly bark. Leaf-blades ovate, oval or obovate, $2-6 \mathrm{~cm}$. long, $2-5 \mathrm{~cm}$. wide, glabrous at maturity, acute at the apex, rounded or contracted at the base, the borders serrate and incised; petioles $1-2.5 \mathrm{~cm}$. long, margined, usually bearing a few small glands : corymbs simple, 3-7-flowered : pedicels $5-10 \mathrm{~mm}$. long, glabrous, as is the hypanthium : sepals about $4 \mathrm{~mm}$. long, glandular-serrate : corolla $15-18 \mathrm{~mm}$. wide : stamens 20 , the anthers dark purple : fruit globose or subglobose, $7-9 \mathrm{~mm}$. in diameter, red when fully ripe, the flesh firm : nutlets $3-5,5-6 \mathrm{~mm}$. long, the hypostyle a little less than half the length of the ventral angle.

In rocky woods and glades, Marshall County, Alabama.

44. Crataegus mendòsa Beadle. A shrub or small tree 3-6 m. tall, with dark gray scaly bark and spreading or ascending branches. Leaf-blades oval, ovate or elliptic, occasionally ovate-lanceolate or slightly oblanceolate, $3-6 \mathrm{~cm}$. long, $1.5-4.5 \mathrm{~cm}$. wide, glabrous at maturity, bluntly pointed or even rounded at the apex, rounded or contracted at the base, the borders serrate, rarely very shallowly and bluntly incised; petioles 1-3.5 cm. long, winged, remotely glandular: corymbs $3-6$-flowered: pedicels $1 \mathrm{~cm}$. long, or less glabrous, as is the hypanthium: sepals $3-4 \mathrm{~mm}$. long, glandular-serrate : corolla 15-18 mm. wide: stamens about 20 , the anthers very faintly tinged with purple: fruit globose or subglobose, $8-10 \mathrm{~mm}$. in diameter, red at maturity, the flesh firm : nutlets $3-5,5-6 \mathrm{~mm}$. long, $3-4 \mathrm{~mm}$. deep, the hypostyle about $3 \mathrm{~mm}$. long.

In rocky woods and glades, Marshall County, Alabama.

45. Crataegus pulchérrima Ashe. A small tree 4-6 m. tall, with dark rough or scaly bark, or oftener a large shrub with one or several stems. Leaf-blades ovate, oval or slightly obovate, $2-5 \mathrm{~cm}$. long, $1.5-4 \mathrm{~cm}$. wide, glabrous at maturity, mostly acute at the apex, narrowed or contracted, or on leading shoots rounded or truncate at the base, the borders serrate and deeply incised or 3-7-lobed; petioles slender, 5-20 $\mathrm{mm}$. long, margined : corymbs simple, glandular-bracteate, 3-7-flowered : pedicels and hypanthium glabrous: sepals 3-4 mm. long, entire or glandular-serrate : corolla $15-18 \mathrm{~mm}$. wide : stamens 20 , the anthers dark purple: fruit oval, 5-7 mm. thick, 6-8 $\mathrm{mm}$. long, at maturity yellowgreen, sometimes with flushed cheeks, the flesh thin and firm: nutlets usually 2-3, rarely more, 4-5 mm. long, the hypostyle about half the length of the ventral angle.

In woods and on banks, southwestern Georgia and adjacent Florida.

46. Crataegus abstrùsa Beadle. A shrub or small tree 2-5 m. tall, with gray or brownish scaly bark. Leaf-blades oval, ovate, obovate or orbicular, 2-4.5 cm. long, $1.5-3.5 \mathrm{~cm}$. broad, glabrous, obtuse or slightly pointed at the apex, contracted at the base, borders serrate and with shallow rounded, lobe-like incisions ; petioles 5-20 mm. long, margined, remotely glandular : corymbs glandular-bracteate, simple, 3-7-flowered : pedicels $5-12 \mathrm{~mm}$. long, glabrous, as is the hypanthium : sepals triangular-lanceolate, $3-4 \mathrm{~mm}$. long, serrate or entire : corolla $15-20 \mathrm{~mm}$. wide: stamens 20 , the anthers dark purple: fruit oval or short-pyriform, $7-9 \mathrm{~mm}$. thick, $10-12 \mathrm{~mm}$. long: the flesh firm : nutlets usually $2-3$, rarely more, about $6 \mathrm{~mm}$. long, the hypostyle occupying about half of the ventral angle.

In woods, usually in sandy soil, Tallahassee, Florida. 47. Crataegus lènis Beadle. A shrub or small tree 2-6 m. tall, with dark gray or
brownish scaly bark, frequently with several stems. Leaf-blades ovate, oval or suborbicular, $1.5-5 \mathrm{~cm}$. long, $1.5-5 \mathrm{~cm}$. wide, glabrous, mostly pointed at the apex, rounded or contracted, or on leading shoots truncate or subcordate at the base, the borders serrate and incisely lobed; petioles 7-20 mm. long, margined, remotely glandular: corymbs simple, glandular-bracteate, $3-7$-flowered : pedicels and hypanthium glabrous : sepals triangular- 
lanceolate, serrate or nearly entire : corolla $15-18 \mathrm{~mm}$. wide: stamens 20 , the anthers nearly yellow : fruit oval or subpyriform, $6-8 \mathrm{~mm}$. thick, $8-11 \mathrm{~mm}$. long, at maturity red or ruddy, the flesh firm : nutlets $2-3$, rarely more, $5-6 \mathrm{~mm}$. long, the hypostyle about half as long.

On wooded slopes, near Greenville, Alabama.

48. Crataegus incilis Beadle. A tree $5-7 \mathrm{~m}$. tall, with a trunk sometimes $1.5 \mathrm{dm}$. in diameter, or often a large shrub with one or several stems. Leaf-blades ovate, ovateoblong or oval, $2-7 \mathrm{~cm}$. long, 1-5.5 cm. wide, glabrous, acute at the apex, narrowed or abruptly contracted at the base, or those of the shoots rounded or truncate, the borders irregularly serrate, incisely $6-10$-lobed or cleft : corymbs 5-10-flowered, subsimple : pedicels and hypanthium glabrous : sepals $3-4 \mathrm{~mm}$. long, usually serrate near the summit : corolla 14-18 $\mathrm{mm}$. wide: stamens about 20 , the anthers purple : fruit globose, $5-9 \mathrm{~mm}$. in diameter, at maturity red or red and green, the flesh firm: nutlets $3-5,5-6 \mathrm{~mm}$. long, the hypostyle about half the length of the ventral angle.

On borders of swamps and in low grounds, usually in clay soil, Evergreen, Alabama.

49. Crataegus illústris Beadle. A small tree or shrub $3-6 \mathrm{~m}$. tall, with scaly rough bark of a dark gray or brownish color. Leaf-blades broadly ovate or oval, $3-5 \mathrm{~cm}$. long, $2.5-5 \mathrm{~cm}$. broad, glabrous, acute or obtusely pointed at the apex, rounded at the base, the borders serrate and mostly with rounded, lobe-like incisions; petioles $1-2.5 \mathrm{~cm}$. long, margined : corymbs simple, $3-6$-flowered : pedicels glabrous, $7-13 \mathrm{~mm}$. long : hypanthium glabrous: sepals triangular-lanceolate, about $3 \mathrm{~mm}$. long, serrate or nearly entire : corolla 14-18 mm. wide: stamens 20, the anthers dark purple: fruit depressed-globose, about 1 $\mathrm{cm}$. in diameter, the flesh firm : nutlets $3-5,6-7 \mathrm{~mm}$. long, the hypostyle about half as long.

On gravelly hills, near Meridian, Mississippi.

50. Crataegus ópima Beadle. A tree 4-7 m. tall, sometimes with a trunk $2 \mathrm{dm}$. in diameter, clothed with ashy gray scaly bark, or frequently a much-branched shrub with one or more stems. Leaf-blades oval, ovate or orbicular, $2-5 \mathrm{~cm}$. long, $1.5-5 \mathrm{~cm}$. broad, glabrous when fully grown, acute at the apex, contracted, or on leading shoots rounded or subtruncate at the base, the borders serrate and incisely lobed : corymbs simple, bracteate, 3-7-flowered : pedicels and hypanthium glabrous : sepals $2-3.5 \mathrm{~mm}$. long, entire or sparingly glandular-serrate : corolla $14-18 \mathrm{~mm}$. wide : stamens 20 , the anthers dark purple: fruit globose, $5-8 \mathrm{~mm}$. in diameter, at maturity bright red, the flesh firm : nutlets $3-5$, $3.5-4.5 \mathrm{~mm}$. long, $2.5-3 \mathrm{~mm}$. deep, the hypostyle about $2 \mathrm{~mm}$. long.

In low woods and moist soil, Greenville, Alabama.

51. Crataegus assímilis Beadle. A small tree or large shrub $3-6 \mathrm{~m}$. tall, with dark gray or brownish scaly bark. Leaf-blades ovate or oval, $2-5 \mathrm{~cm}$. long, $1.5-4 \mathrm{~cm}$. wide, glabrous, acute at the apex, contracted or rounded at the base, the borders serrate and with rounded, lobe-like incisions; petioles 7-20 mm. long, margined : corymbs simple, 3-6flowered: pedicels and hypanthium glabrous : sepals triangular-lanceolate, 3-4 mm. long, serrate or nearly entire : corolla $15-18 \mathrm{~mm}$. wide : stamens 20 , the anthers pale purple: fruit globose, $7-9 \mathrm{~mm}$. wide, the flesh firm: nutlets $3-5$, about $6 \mathrm{~mm}$. long, the hypostyle occupying a trifle more than half the ventral angle.

On hills and in dry woods, near Chattahoochee, Florida.

52. Crataegus ròbur Beadle. A tree, sometimes 7-8 m. tall, with a trunk 1-1.5 dm. in diameter, clothed with gray or brownish scaly bark, or more often a large shrub with one or more stems. Leaf-blades ovate, oval or short obovate, $3-6 \mathrm{~cm}$. long, $1.5-4 \mathrm{~cm}$. broad, or wider on leading shoots, glabrous, acute at the apex, narrowed or contracted, or on vigorous shoots rounded or subtruncate at the base, the borders serrate and incisely lobed or acutely cleft : corymbs simple or subsimple, 3-10-flowered, glandular-bracteate : pedicels 1-2 cm. long, like the hypanthium, glabrous: sepals lanceolate, 3-4 mm. long, entire or sparingly serrate : corolla $15-18 \mathrm{~mm}$. wide : stamens 20 , the anthers pale purple: fruit subglobose, $7-9 \mathrm{~mm}$. wide, the flesh firm : nutlets $3-5,5-6 \mathrm{~mm}$. long, the hypostyle about $4 \mathrm{~mm}$. long.

In woods and on borders of fields, Tallahassee, Florida.

53. Crataegus concínna Beadle. A shrub 2-4 m. tall, with dark gray scaly bark. Leaf-blades ovate-lanceolate, oblong or elliptic, those of the shoots ovate, $2-5 \mathrm{~cm}$. long, 7 $\mathrm{mm} .-2 \mathrm{~cm}$. wide or on the shoots $3-4 \mathrm{~cm}$. wide, glabrous, acute or bluntly pointed at the apex, narrowed or contracted or on leading shoots, rounded at the base, the borders serrate and more or less incised, the lobes or incisions rounded or on the larger leaves, acutely notched : corymbs simple, glandular-bracteate, 3-6-flowered : pedicels and hypanthium glabrous: sepals triangular-lanceolate, mostly serrate, $3-4 \mathrm{~mm}$. long: corolla $15-18 \mathrm{~mm}$. wide : stamens 20 , the anthers purple : fruit subglobose, $7-8 \mathrm{~mm}$. thick, the flesh firm : nutlets $3-5$, about $5 \mathrm{~mm}$. long, the hypostyle about half the length of the ventral angle.

In woods and about borders of swamps, western Florida. 
54. Crataegus flàva Ait. A tree sometimes $8 \mathrm{~m}$. tall, with spreading or ascending branches and scaly bark. Leaf-blades oval, ovate or obovate, 2-5.5 cm. long, 1.5-4 $\mathrm{cm}$. wide, glabrous at maturity, pointed at the apex, narrowed or contracted, or on leading shoots rounded and abruptly prolonged at the base into margined or winged glandular petioles $5-15 \mathrm{~mm}$. long, the borders crenate-serrate or dentate and shallowly incised: corymbs simple or subsimple, 3-7-flowered : pedicels $5-15 \mathrm{~mm}$. long, pubescent, at least at flowering time: hypanthium glabrous or nearly so: sepals 5-6 mm. long, glandular, pubescent on the inner surface : corolla $15-18 \mathrm{~mm}$. wide: stamens 10 , the anthers purplish: styles $3-5$ : fruit pyriform, $8-12 \mathrm{~mm}$. thick, $12-16 \mathrm{~mm}$. long, at maturity yellow or yellow-green, the flesh firm : nutlets $3-5,7.5-9 \mathrm{~mm}$. long, the hypostyle $5-6 \mathrm{~mm}$. long.

Commonly eultivated in Europe and doubtless of east American origin. The description is based on specimens from the Kew gardens.

55. Crataegus Allegheniénsis Beadle. A small tree or large shrub 2-5 m. tall, with gray or brownish, sealy or rough bark and spreading or ascending branches. Leafblades ovate, oval or nearly orbicular, 1-6 cm. long, $1.5-6 \mathrm{~cm}$. broad, glabrous in age, acute at the apex, abruptly narrowed or rounded, or on leading shoots truncate or subcordate at the base, the borders sharply serrate and incisely lobed ; petioles $5-20 \mathrm{~mm}$. long, margined, glandular : corymbs simple, 3-6-flowered : pedicels 1-2 cm. long, glabrous as is the hypanthium : sepals 4-6 mm. long, glandular-serrate: stamens 10 , the anthers purple : fruit globular-pyriform, 9-14 $\mathrm{mm}$. long, 8-12 $\mathrm{mm}$. broad, at maturity red, the flesh soft : nutlets $2-5$, usually $3-4,5-7 \mathrm{~mm}$. long, about $3 \mathrm{~mm}$. deep, the hypostyle 4-5 $\mathrm{mm}$. long.

In woods and on rocky exposures, Lookout Mountain, northeastern Alabama.

56. Crataegus frugíferens Beadle. A shrub or small tree 1-5 m. tall, with dark gray rough or scaly bark. Leaf-blades obovate, oval or round-ovate, 1-6 cm. long, 1.5-6 $\mathrm{cm}$. wide, glabrous or glabrate in age, mostly acute at the apex, rounded or abruptly contracted at the base into petioles $5-20 \mathrm{~mm}$. long, the borders sharply and irregularly serrate and incised : corymbs simple, 3-5-flowered: pedicels $7-15 \mathrm{~mm}$. long, bearing a few weak hairs : hypanthium glabrous : sepals about $4 \mathrm{~mm}$. long, sparingly glandular-serrate or entire: stamens 10, the anthers purple : fruit globose or subglobose, 9-13 mm. in diameter, at maturity red, the flesh yellow or orange: nutlets $3-5,7-8 \mathrm{~mm}$. long, 4-5 mm. deep, the hypostyle 5-6 mm. long.

In sandy or rocky soil, northern and upper central Alabama.

57. Crataegus áprica Beadle. A small tree or shrub 3-7 m. tall, with dark gray or nearly black, rough or scaly bark. Leaf-blades obovate, rhombic-ovate or orbicular, $1.5-5 \mathrm{~cm}$. long, $1-5 \mathrm{~cm}$. broad, glabrous at maturity, acute at the apex, usually narrowed but sometimes rounded at the base, the borders dentate or crenate-dentate, more or less toothed or lobed above the middle, or on leading shoots deeply lobed even to below the middle ; petioles 7-20 mm. long, margined and, like the base of the blade, bearing numerous black glands : corymbs 3-6-flowered, simple : pedicels $1-2 \mathrm{~cm}$. long, pilose-pubescent : hypanthium sparingly pilose, at least near the base : sepals $3-5 \mathrm{~mm}$. long, glandular-serrate or pectinately-glandular: stamens 10 , the anthers yellow : fruit globose, 9-14 mm. in diameter, at maturity red or orange-red, the flesh thick, orange-yellow : nutlets $3-5$, about $7 \mathrm{~mm}$. long, 3-4 mm. deep, the hypostyle about $5 \mathrm{~mm}$. long.

On sunny exposures in the mountains, western North Carolina and adjacent Tennessee to Georgia.

58. Crataegus ignàva Beadle. A small tree $3-4 \mathrm{~m}$. tall, with gray or brownish scaly bark, or more frequently a much-branched shrub with two or more stems. Leafblades obovate, ovate or round-ovate, $2-5 \mathrm{~cm}$. long, 1-3 cm. wide, glabrous or with a few hairs along the midrib and principal veins, acute at the apex, wedge-shaped or more abruptly contracted at the base, the margins sharply serrate and incised ; petioles 5-15 mm. long, margined, glandular: corymbs simple, glandular-bracteate, 3-5-flowered : pedicels glabrous or with a few weak hairs : hypanthium glabrous : sepals $4.5-5 \mathrm{~mm}$. long, serrate or glandular-serrate : stamens 20 , the anthers purplish : fruit subglobose, $8-12 \mathrm{~mm}$. in diameter, at maturity red or orange-red, the flesh soft : nutlets $3-5,6-7 \mathrm{~mm}$. long, $3 \mathrm{~mm}$. deep, the hypostyle about $3 \mathrm{~mm}$. long.

In woods and on rocky bluffs, Lookout and Sand Mountains, Alabama and adjacent stations in northwestern Georgia.

59. Crataegus ímpar Beadle. A large shrub 2-4 m. tall, with many stems and spreading or ascending branches clothed with dark gray or brownish, rough or scaly bark. Leaf-blades obovate or oval, or on leading shoots broadly ovate, $2-5 \mathrm{~cm}$. long, $1.5-4$ $\mathrm{cm}$. broad, glabrous when fully grown, acute at the apex, narrowed or contracted, or on the shoots sometimes rounded at the base, the borders sharply serrate and incised; petioles 7-20 mm. long, margined, remotely glandular : corymbs simple, 3-6-flowered : pedicels and hypanthium glabrous or with several weak hairs : sepals 4-5 $\mathrm{mm}$. long, serrate : corolla 15-18 mm. wide : stamens varying in number, usually 12-15, the anthers nearly yellow : 
fruit oval, $10-13 \mathrm{~mm}$. thick, red at maturity : nutlets mostly $2-3,8-10 \mathrm{~mm}$. long, 4-5 mm. deep, the hypostyle about half the length of the nutlet.

On hillsides in clay soil, northwestern Georgia.

60. Crataegus agrestina Beadle. A small tree 4-5 m. tall, with dark gray or brownish bark and spreading branches, or a shrub with one or more stems. Leaf-blades ovate, oval or obovate, $2-5 \mathrm{~cm}$. long, $1-3.5 \mathrm{~cm}$. wide, glabrous at maturity, acute at the apex, narrowed or contracted at the base, the borders sharply serrate and incised; petioles 5-20 mm. long, margined : corymbs simple, glandular-bracteate, 3-5-flowered: pedicels 5-10 mm. long, sparsely pubescent: hypanthium glabrous or with a few weak hairs at the base : sepals 3-4 mm. long, glandular: corolla $15-18 \mathrm{~mm}$. wide : stamens about 20 , the anthers nearly yellow: fruit pyriform, 7-9 mm. thick, 9-12 mm. long, red at maturity, nutlets mostly $2-3,5-6 \mathrm{~mm}$. long, the hypostyle a trifle less than half the length of the nutlet.

In woods and about margins of swamps, southern Alabama.

61. Crataegus extrària Beadle. A large shrub 2-4 m. tall, with spreading or ascending branches, and dark gray or brownish, rough or scaly bark. Leaf-blades oval, obovate, or on leading shoots ovate or suborbicular, $2-5 \mathrm{~cm}$. long, $1.5-4 \mathrm{~cm}$. wide, glabrous, acute at the apex, narrowed or contracted, or on the shoots rounded at the base, the borders sharply serrate and incised : corymbs simple, 3-5-flowered, glandular-bracteate : pedicels and hyanthium pilose-pubescent: sepals $4-5 \mathrm{~mm}$. long, usually glandular-serrate : corolla 16-20 mm. wide : stamens usually $12-15$, the anthers pale purple : fruit subglobose or oval, 9-12 mm. thick, red at maturity : nutlets mostly $2-3,8-10 \mathrm{~mm}$. long, 4-5 mm. deep, the hypostyles 4-5 mm. long.

On hillsides, mostly in red clay soil, northwestern Georgia.

62. Crataegus soròria Beadle. A tree $5-7 \mathrm{~m}$. tall, with dark gray or brownish black, rough or scaly bark, or more often a large much-branched shrub with spreading or ascending branches. Leaf-blades 1-4.5 $\mathrm{cm}$. long, 1-4 cm. wide, or larger on leading shootsglabrous in age, obovate, round-ovate or nearly orbicular, or on the vigorous shoots fre, quently broader than long, acute or sometimes scarcely pointed at the apex, abruptly con, tracted or narrowed, or on the shoots truncate at the base, the borders irregularly serratedentate; petioles 5-15 mm. long, margined, glandular: corymbs simple, 3-6-floweredglandular-bracteate : pedicels $5-15 \mathrm{~mm}$. long, sparsely pubescent: hypanthium glabrous or with a few weak hairs: sepals about $6 \mathrm{~mm}$. long, glandular-serrate: stamens 20 , the anthers nearly yellow : fruit globose, $12-18 \mathrm{~mm}$. in diameter, at maturity red or red and yellow, the flesh thick and succulent: nutlets mostly 3, 7-9 mm. long, 4-5 mm. thick, the hypostyle about $5 \mathrm{~mm}$. long.

On wooded hills and rocky exposures, northwestern Georgia and adjacent Alabama.

63. Crataegus galbàna Beadle. A small tree 5-6 m. tall, with a short trunk sometimes 1-1.5 dm. in diameter, clothed with dark gray or brownish black bark, or more frequently a large shrub with one or more stems. Leaf-blades oval, obovate or round-ovate, 1-4 cm. long, 1-3 cm. wide, glabrous at maturity, acute or rounded at the apex, rounded or contracted at the base, the margins irregularly dentate: corymbs simple, 1-5-flowered : pedicels short, like the hypanthium, pubescent : sepals 3-5 mm. long, serrate and glandular : corolla 15-20 mm. wide: stamens 20 , the anthers light yellow or nearly white: fruit globose, $9-13 \mathrm{~mm}$. in diameter, at maturity red, the flesh orange-yellow, succulent : nutlets $3-5$, about $8 \mathrm{~mm}$. long, $3.5-4.5 \mathrm{~mm}$. deep, the hypostyle about half the length of the ventral angle.

In woods and on borders of swamps, River Junction, Florida.

64. Crataegus ábdita Beadle. A shrub or small tree 3-6 m. tall, with dark ashy gray or brownish bark. Leaf-blades obovate, oval or suborbicular, or on leading shoots sometimes broadly ovate, $1.5-3.5 \mathrm{~cm}$. long, 1-3 cm. wide, glabrous or glabrate at maturity, rounded or abruptly pointed at the apex, narrowed or contracted, or occasionally rounded at the base, the margins irregularly dentate: corymbs simple, 3-5-flowered : pedicels mostly $10-15 \mathrm{~mm}$. long, like the hypanthium, white tomentose : sepals $5-6 \mathrm{~mm}$. long, serrate and glandular: corolla $15-20 \mathrm{~mm}$. wide : fruit globose, $10-15 \mathrm{~mm}$. in diameter, at maturity red, the flesh orange or orange-yellow, succulent: nutlets $3-5,7-9 \mathrm{~mm}$. long, $3.5-5 \mathrm{~mm}$. deep, the hypostyle 5-6 $\mathrm{mm}$. long.

In woods, mostly in sandy soil, River Junction, Florida.

65. Crataegus éxilis Beadle. A large shrub or small tree $3-6 \mathrm{~m}$. tall, with dark gray or brownish, rough or scaly bark. Leaf-blades obovate, oval or elliptic, or on the shoots rhombic-ovate, $1.5-4 \mathrm{~cm}$. long, 1-3.5 cm. wide, glabrous at maturity, acute or abruptly pointed at the apex, cuneate or contracted, rarely rounded at the base, the borders serrate 
nutely glandular : corymbs simple or subsimple, 3-7-flowered : pedicels and hypanthium pilose-pubescent: sepals 3-4 mm. long, lanceolate, serrate or entire, glandular: corolla about $15 \mathrm{~mm}$. wide : stamens 20 , the anthers pale yellow : fruit globose or subglobose, 5-7 $\mathrm{mm}$. wide, at maturity red or ruddy, the flesh thin : nutlets $3-5,4-5 \mathrm{~mm}$. long, the hypostyle about $3 \mathrm{~mm}$. long.

In sandy soil and on banks of streams, southwestern Georgia.

66. Crataegus consanguínea Beadle. A tree 5-7 m. tall, with a trunk 1-2 dm. in diameter, clothed with ashy gray or brownish black, scaly bark, or often a large shrub with one or more stems. Leaf-blades obovate, round-ovate or nearly orbicular, $1-4.5 \mathrm{~cm}$. long, 1-4 $\mathrm{cm}$. broad, or larger on the shoots, glabrous at maturity, acute or abruptly pointed at the apex, contracted or rounded at the hase, the margins serrate or serrate-dentate and shallowly incised; petioles 1-2 $\mathrm{cm}$. long, margined, glandular : corymbs simple, 1-5flowered: pedicels and hypanthium pubescent : sepals $4-5 \mathrm{~mm}$. long, glandular : corolla about $2 \mathrm{~cm}$. wide: stamens 20 , the anthers purplish : fruit globose, $9-12 \mathrm{~mm}$. broad, at maturity red or orange flushed with red, the flesh succulent : nutlets $3-5,7-8 \mathrm{~mm}$. long, the hypostyle 4-5 $\mathrm{mm}$. long.

In woods, mostly in sandy soil, Tallahassee, Florida, westward to the Apalachicola River.

67. Crataegus válida Beadle. A large shrub or small tree $2-5 \mathrm{~m}$. tall, with gray or brownish, rough or scaly bark and spreading or ascending branches. Leaf-blades obovate, oval or orbicular, $2-5 \mathrm{~cm}$. long, $1.5-5 \mathrm{~cm}$. broad, or larger and broader than long on the shoots, glabrous or very nearly so at maturity, rounded or abruptly pointed at the apex, contracted or rounded, or on strong shoots truncate or subcordate at the base, the margins irregularly dentate; petioles 5-15 mm. long, margined, glandular : corymbs 3-5-flowered : pedicels and hypanthium sparsely pilose-pubescent : sepals $3-4 \mathrm{~mm}$. long, $1.5-2 \mathrm{~mm}$. wide, serrate, glandular : corolla $15-20 \mathrm{~mm}$. wide : stamens 20 , the anthers purple : fruit subglobose, $12-15 \mathrm{~mm}$. thick, the cavity 4-6 mm. wide : nutlets $3-5,8-9 \mathrm{~mm}$. long, 4-5 mm. deep, the hypostyle about $5 \mathrm{~mm}$. long.

On hills and rocky exposures, northwestern Georgia.

68. Crataegus limàta Beadle. A large shrub or small tree $2-5 \mathrm{~m}$. tall, with one or more stems clothed with dark gray or brownish, rough or scaly bark. Leaf-blades ovate, elliptic, obovate or suborbicular, $2-4.5 \mathrm{~cm}$. long, $1.5-3.5 \mathrm{~cm}$. broad, acute or abruptly pointed at the apex, contracted or rounded at the base, the borders finely serrate and incised or with tooth-like lobes; petioles $5-15 \mathrm{~mm}$. long, margined, glandular : corymbs simple, glandular-bracteate, 3-5-flowered : pedicels and hypanthium glabrous: sepals lanceolate, 4-6 mm. long, serrate, glandular: stamens 20 , the anthers purplish : fruit globose, $10-13 \mathrm{~mm}$. in diameter, at maturity red, the flesh orange-yellow, succulent : nutlets $3-5$, about $6 \mathrm{~mm}$. long and $3 \mathrm{~mm}$. deep, the hypostyle a little more than half the length of the ventral angle.

On hills and in dry woods, western and northwestern Georgia.

69. Crataegus mìra Beadle. A large shrub 2-3 m. tall, with one or more stems clothed with dark gray, rough or scaly bark. Leaf-blades orbicular or very broadly ovate, mostly broader than long, $2-4 \mathrm{~cm}$. long, $2-5.5 \mathrm{~cm}$. broad, glabrous when fully grown, abruptly pointed at the apex, rounded or contracted, or on leading shoots, truncate or cordate at the base, the borders dentate or serrate-dentate and incised or with tooth-like lobes; petioles 4-12 mm. long, margined, glandular : corymbs simple, 3-6-flowered : pedicels and hypanthium sparingly pilose : sepals 4-6 mm. long, serrate, glandular : corolla 16-20 mm. wide : stamens varying, but usually $12-17$, the anthers nearly yellow : fruit subglobose, 10-12 mm. in diameter: nutlets $3-5$, about $8 \mathrm{~mm}$. long, the hypostyle $4-5 \mathrm{~mm}$. long.

On hills and in upland woods, northwestern Georgia.

70. Crataegus ségnis Beadle. A tree $5-7 \mathrm{~m}$. tall, with very rough dark colored bark. Leaf-blades obovate, oval or nearly orbicular, $2-4 \mathrm{~cm}$. long, 1-3.5 cm. wide, glabrous at maturity, acute or abruptly pointed at the apex, contracted or rounded at the base, the margins crenate or crenate-dentate ; petioles $5 \mathrm{~mm} .-2 \mathrm{~cm}$. long: margined, glandular : corymbs simple, 3-7-flowered : pedicels $5 \mathrm{~mm} .-1 \mathrm{~cm}$. long, sparingly pilose, as is the hypanthium: sepals $3-5 \mathrm{~mm}$. long, serrate, glandular: corolla 12-16 mm. wide: stamens normally 20 : fruit globose, $8-12 \mathrm{~mm}$. in diameter, red at maturity : nutlets $3-5$, 6-7 mm. long, 3.5-4.5 mm. deep, the hypostyle 4-5 mm. long.

In clay soil, Greenville, Alabama.

71. Crataegus visénda Beadle. A tree sometimes $10 \mathrm{~m}$. tall, with a trunk 2.5-3 $\mathrm{dm}$. in diameter, clothed with dark gray or brownish rough bark. Leaf-blades ovate, obovate or orbicular, $2-4 \mathrm{~cm}$. long, $1-3.5 \mathrm{~cm}$. broad, glabrous in age, acute or abruptly pointed or occasionally rounded at the apex, contracted at the base, the borders finely dentate and usually with several acute tooth-like lobes; petioles 5-15 mm. long, margined, 
glandular : corymbs simple, 3-6-flowered : pedicels and hypanthium pubescent : sepals 4-5 $\mathrm{mm}$. long, glandular, serrate : corolla $16-20 \mathrm{~mm}$. broad : stamens 20 , the anthers pale purple: fruit pyriform, 10-12 mm. thick, 12-15 mm. long, at maturity orange, diffused or cheeked with red, the flesh yellow or orange-yellow, soft: nutlets $3-5$, mostly $3,7-8.5$ $\mathrm{mm}$. long, the hypostyle two-thirds as long as the ventral angle.

In sandy soil, near Bristol, Florida.

72. Crataegus sodàlis Beadle. A small tree or large shrub $3-5 \mathrm{~m}$. tall, often with two or more stems, with dark gray or brownish black rough bark, and somewhat recurved branches. Leaf-blades obovate, oval or orbicular, $1.5-2.5 \mathrm{~cm}$. long, $8 \mathrm{~mm} .-2.5 \mathrm{~cm}$. wide, or larger on leading shoots, pubescent or glabrate, rounded or abruptly pointed at the apex, rounded or contracted, or on leading shoots, truncate at the base, the borders minutely dentate and glandular, frequently with small tooth-like projections, especially on the larger leaves; petioles 5-15 mm. long, pubescent, glandular : corymbs simple, 3-5flowered : pedicels $5 \mathrm{~mm} .-1 \mathrm{~cm}$. long, pilose-pubescent: hypanthium pubescent : sepals 3-4.5 mm. long, linear-lanceolate, glandular, serrate: stamens normally 20 : fruit pyriform, 8-12 mm. thick, $12-15 \mathrm{~mm}$. long, at maturity orange-red, the flesh orange-yellow, soft : nutlets mostly 3 , about $8 \mathrm{~mm}$. long, the hypostyle $5-6 \mathrm{~mm}$. long.

In dry woods and on gravelly ridges, Girard, Alabama.

73. Crataegus furtìva Beadle. A large shrub 2-4 m. tall, with dark rough bark and drooping branches. Leaf-blades obovate, or on leading shoots broadly ovate, 1-3 cm. long, $7 \mathrm{~mm} .-3 \mathrm{~cm}$. wide, glabrate in age, narrowed or contracted at the base, pointed at the apex, the margins finely dentate or glandular, usually with a few short tooth-like lobes ; petioles $5 \mathrm{~mm} .-2 \mathrm{~cm}$. long, pubescent, winged, glandular : corymbs simple, fewflowered : pedicels $5 \mathrm{~mm} .-1 \mathrm{~cm}$. long, pubescent or tomentose-pubescent, as is the hypanthium : sepals $3-4.5 \mathrm{~mm}$. long, glandular, mostly serrate: stamens normally 20 : fruit pyriform, $7-12 \mathrm{~mm}$. thick, $12-15 \mathrm{~mm}$. long, at maturity orange, usually flushed with red, the flesh orange-yellow, soft: nutlets mostly $2-4,6-7 \mathrm{~mm}$. long, the hypostyle about $4 \mathrm{~mm}$. long.

In sandy soil, near Albany, Georgia.

74. Crataegus árrogans Beadle. A tree 4-5 m. tall, with dark, rough bark and somewhat drooping branches. Leaf-blades oval, elliptic, obovate or cuneate, or on leading shoots nearly orbicular, $1-3.5 \mathrm{~cm}$. long, $7 \mathrm{~mm} .-3 \mathrm{~cm}$. broad, glabrous or glabrate at maturity, acute or abruptly pointed at the apex, contracted or narrowed, or on the shoots rounded at the base, the borders finely dentate or glandular, usually with several short acute tooth-like projections or lobes; petioles $3-10 \mathrm{~mm}$. long, margined, glandular: corymbs simple, few-flowered : pedicels and hypanthium pubescent: sepals $3-4 \mathrm{~mm}$. long, glandular, mostly serrate: stamens 20, the anthers small, bright purple: fruit short-oval or slightly pyriform, 9-12 mm. thick, 11-13 mm. long, red at maturity, the flesh orangeyellow, soft : nutlets mostly $3-4$, about $8 \mathrm{~mm}$. long, the hypostyle about $5 \mathrm{~mm}$. long.

In woods and on ridges, east-central Alabama and northwestern Georgia.

75. Crataegus egrègia Beadle. A small tree 4-6 m. tall, with dark and very rough bark. Leaf-blades ovate, oval or obovate, $1.5-3.5 \mathrm{~cm}$. long, $7 \mathrm{~mm} .-3 \mathrm{~cm}$. broad, glabrous at maturity, acute at the apex, narrowed or contracted at the base, the borders glandular, broken by several large, shallow, blunt or rounded lobes; petioles 5-15 mm. long, margined, glandular : flowers produced in simple few-flowered corymbs : pedicels and hypanthium sparsely pilose-pubescent: sepals about $3 \mathrm{~mm}$. long, entire or sparingly serrate, glandular: stamens $15-20$ : fruit subglobose, $10-12 \mathrm{~mm}$. in diameter, at maturity yellow or orange, sometimes flushed with red, the flesh orange-yellow, soft : nutlets $3-5$, about 8 $\mathrm{mm}$. long, 4-5 $\mathrm{mm}$. deep, the hypostyle about $5 \mathrm{~mm}$. long.

In sandy soil, Bristol, Florida.

76. Crataegus trístis Beadle. A large shrub or small tree 3-7 m. tall, with dark rough or rimose bark and drooping branches. Leaf-blades obovate, cuneate or broadly oval or suborbicular, $1.5-4 \mathrm{~cm}$. long, $1-4 \mathrm{~cm}$. wide, glabrate or pubescent along the midrib and in the axils of the veins beneath, pointed or rounded at the apex, narrowed or contracted or on leading shoots sometimes rounded at the base, the margins dentate and glandular; petioles $5 \mathrm{~mm} .-2 \mathrm{~cm}$. long, margined, pubescent, glandular : corymbs simple, glandular-bracteate, $3-5$-flowered : pedicels and hypanthium pubescent : sepals $4-5 \mathrm{~mm}$. long, glandular-serrate: corolla $16-20 \mathrm{~mm}$. wide : stamens 20 , the anthers pink: fruit oval or short oval, 10-12 mm. thick, red or orange-red at maturity, the flesh soft : nutlets $3-5,8-9 \mathrm{~mm}$. long, the hypostyle $6-7 \mathrm{~mm}$. long.

On wooded slopes, northwestern Georgia.

77. Crataegus quaesita Beadle. A tree occasionally $5-7 \mathrm{~m}$. tall, with a short trunk 1-1.5 dm. in diameter, clothed with ashy gray or brownish black rough bark, the branches 
drooping, or oftener a large shrub with one or more stems. Leaf-blades obovate or cuneiform, $1.5-5 \mathrm{~cm}$. long, 1-3 cm. wide, or larger on leading shoots, glabrous or glabrate at maturity, abruptly pointed at the apex, cuneate or more abruptly contracted at the base, the borders dentate, serrate-dentate or crenate-dentate and with tooth-like lobes; petioles $5 \mathrm{~mm} .-2 \mathrm{~cm}$. long, margined, glandular: corymbs simple, 3-5-flowered: pedicels and hypanthium pubescent: sepals $3.5-5 \mathrm{~mm}$. long, glandular-serrate: corolla $15-20 \mathrm{~mm}$. wide: stamens 20 , the anthers light purple : fruit subglobose, $8-11 \mathrm{~mm}$. in diameter, at maturity orange-red, often with deeper colored cheeks, the flesh soft : nutlets $3-5$, about 7 $\mathrm{mm}$. long, the hypostyle occupying about two-thirds of the ventral angle.

On sandy uplands, Apalachicola River basin, Florida.

78. Crataegus égens Beadle. A tree 4-7 m. tall, with a trunk sometimes $2 \mathrm{dm}$. in diameter, covered with dark rough bark, the branches crooked and recurved. Leaf-blades obovate, cuneate or spatulate, 1-3 cm. long, $5 \mathrm{~mm} .-2.5 \mathrm{~cm}$. wide, glabrate at maturity, abruptly pointed at the apex, narrowed or contracted at the base, the borders dentate, glandular and with tooth-like lobes above the middle ; petioles $3-15 \mathrm{~mm}$. long, glandular : corymbs simple, 2-4-flowered or flowers solitary : pedicels and hypanthium densely whitewoolly : sepals $3-4 \mathrm{~mm}$. long, glandular-serrate : corolla $14-18 \mathrm{~mm}$. wide: stamens 20 , the anthers almost white : fruit subglobose or slightly oval, $9-11 \mathrm{~mm}$. thick, at maturity orange-red with ruddy cheeks, the flesh succulent: nutlets $3-5$, about $7 \mathrm{~mm}$. long, the hypostyle about $5 \mathrm{~mm}$. long.

In sandy soil, near Bristol, Florida.

79. Crataegus annòsa Beadle. A tree sometimes $8 \mathrm{~m}$. tall, with a trunk $3 \mathrm{dm}$. in diameter elothed with dark rough or rimose bark, and spreading or ascending branches. Leaf-blades obovate, oval or oblanceolate, or on leading shoots orbicular, $2-4.5 \mathrm{~cm}$. long, $1-4 \mathrm{~cm}$. wide, mostly pointed at the apex, cuneate or more abruptly contracted or on strong shoots rounded at the base, glabrous or glabrate at maturity, the borders dentate and glandular, mostly with several sharp, tooth-like lobes; petioles $5 \mathrm{~mm} .-2 \mathrm{~cm}$. long, glandular, margined: corymbs simple, glandular-bracteate, 3-5-flowered: pedicels and hypanthium pubescent : sepals $3-4.5 \mathrm{~mm}$. long, serrate, glandular: corolla $15-20 \mathrm{~mm}$. wide : stamens 20 , the anthers nearly white : fruit subglobose or oval, $10-12 \mathrm{~mm}$. in diameter, orange-red or red and orange when ripe, the flesh soft : nutlets $3-5,7-8 \mathrm{~mm}$. long, the hypostyle occupying about two-thirds of the ventral angle.

In woods and on hills, east-central Alabama.

80. Crataegus cálva Beadle. A shrub 2-4 m. tall, with rough bark and ascending or spreading branches. Leaf-blades obovate, oval or elliptic, $1.5-3 \mathrm{~cm}$. long, $7 \mathrm{~mm} .-2 \mathrm{~cm}$. broad, glabrous when fully grown, mostly pointed at the apex, narrowed or contracted, or occasionally rounded at the base, the borders dentate, glandular and usually with several tooth-like lobes; petioles 5-15 mm. long, margined, glandular: corymbs simple, 3-5flowered : pedicels and hypanthium glabrous : sepals $3-4 \mathrm{~mm}$. long, entire or glandularserrate : corolla 16-18 mm. wide: stamens 20 , the anthers light yellow or nearly white : fruit globose, $7-10 \mathrm{~mm}$. in diameter, at maturity yellow or orange-red, the cheeks often bright red : nutlets $3-5,5-6 \mathrm{~mm}$. long, the hypostyle about $4 \mathrm{~mm}$. long.

In woods and on ridges, Ozark, Alabama.

81. Crataegus Michaùxii Pers. A small tree or large shrub 2-5 m. tall, with dark rough or rimose bark and crooked and drooping branches. Leaf-blades obovate, spatulate or suborbicular, $1-4 \mathrm{~cm}$. long, $5 \mathrm{~mm} .-4 \mathrm{~cm}$. wide, tomentose, at least on the lower surface, pointed or rounded at the apex, abruptly contracted at the base, the borders glandular, usually broken above the middle, especially on leading shoots, by one or several small lobes ; petioles 3-15 mm. long, margined, glandular, tomentose : corymbs 2-3-flowered, or flowers solitary : pedicels and hypanthium densely white-woolly : sepals 4-5 mm. long, almost linear, glandular, serrate: stamens 20 : fruit subglobose, $8-12 \mathrm{~mm}$. thick, red or ruddy at maturity : nutlets $3-5$, about $7 \mathrm{~mm}$. long, the hypostyle $5-6 \mathrm{~mm}$. long.

In dry woods and sandy barrens, North Carolina to Georgia.

82. Crataegus lanàta Beadle. A large shrub or small tree $2-5 \mathrm{~m}$. tall, with dark rough or rimose bark and drooping branches. Leaf-blades cuneate, 2-4 cm. long, $7 \mathrm{~mm}$.$2 \mathrm{~cm}$. wide, or on leading shoots often larger and broader than long, tomentose at least on the lower surface, mostly pointed at the apex, cuneate at the base, the borders glandular and usually broken by one or more short point-like lobes; petioles $5-15 \mathrm{~mm}$. long, winged, glandular, tomentose : corymbs simple, mostly 2-4-flowered : pedicels and hypanthium densely tomentose: sepals $4-5 \mathrm{~mm}$. long, narrowly lanceolate or almost linear, glandular, serrate : stamens 20 , the anther light yellow or nearly white : fruit globose, $8-11 \mathrm{~mm}$. in $\mathrm{mm}$. in diameter : nutlets $3-5,6-7 \mathrm{~mm}$. long, the hypostyle about $5 \mathrm{~mm}$. long.

In rocky woods and sandy soil, northern Georgia to western North Carolina. 
83. Crataegus intègra (Nash) Beadle. A small tree 4-5 m. tall, with a trunk 1-2 $\mathrm{dm}$. in diameter, ashy gray or dark rough bark and drooping branches. Leaf-blades obovate or cuneate, $1.5-4 . \mathrm{cm}$. long, $7 \mathrm{~mm} .-2.5 \mathrm{~cm}$. wide, pubescent on the lower surface, pointed or occasionally rounded at the apex, contracted or narrowed at the base, the margins glandular, bluntly or undulately lobed ; petioles $5 \mathrm{~mm} .-2 \mathrm{~cm}$. long, margined, glandular, pubescent : corymbs simple, 3-5-flowered : pedicels and hypanthium densely whitetomentose : sepals 4-5 mm. long, glandular-serrate : corolla $15-20 \mathrm{~mm}$. wide : stamens 20 , the anthers light yellow : fruit globose, $10-15 \mathrm{~mm}$. in diameter, at maturity red, the flesh soft : nutlets $3-5$, about $8 \mathrm{~mm}$. long, the hypostyle 5-6 mm. long.

In sandy woods and old fields, central peninsular Florida.

84. Crataegus adúnca Beadle. A large shrub or small tree 2-5 m. tall, with ashy gray or dark scaly or rough bark. Leaf-blades obovate, $2-3 \mathrm{~cm}$. long, $7 \mathrm{~mm} .-2.5 \mathrm{~cm}$. wide, or larger on leading shoots, glabrous or glabrate at maturity, abruptly pointed or rounded at the apex and with a small tooth-like point, contracted or narrowed at the base, the borders minutely dentate or nearly entire, glandular, sometimes with shallow toothlike lobes ; petioles 5-15 mm. long, margined, glandular: corymbs simple, 3-5-flowered: pedicels and hypanthium tomentose-pubescent : sepals 4-5 mm. long, serrate, glandular: corolla $15-20 \mathrm{~mm}$. wide : stamens 20 , the anthers pale purple : fruit globose, $12-15 \mathrm{~mm}$. in diameter, red at maturity, the flesh orange, soft : nutlets $3-5,7-8 \mathrm{~mm}$. long, the hypostyle 4-5 mm. long.

In sandy woods, about Tallahassee, Florida.

85. Craetagus cónstans Beadle. A shrub 2-4 m. tall, with dark gray scaly or rough bark and crooked recurved branches. Leaf-blades obovate or cuneate, $1.5-4 \mathrm{~cm}$. long, $7 \mathrm{~mm} .-3 \mathrm{~cm}$. wide, glabrate or pubescent, abruptly pointed at the apex, narrowed or contracted at the base, the borders glandular, minutely dentate or entire ; petioles $5 \mathrm{~mm} .-2 \mathrm{~cm}$. long, margined, glandular, pubescent : corymbs simple, 3-5-flowered : pedicels 1-2.5 cm. long, like the hypanthium, pubescent: sepals 4-5 mm. long, serrate, glandular : corolla $16-20 \mathrm{~mm}$. wide : stamens 20 , the anthers nearly yellow : fruit subglobose or slightly pyriform, $10-12 \mathrm{~mm}$. thiek, orange-red at maturity, the flesh soft : nutlets $3-5$, about $7 \mathrm{~mm}$. long, the hypostyle about $5 \mathrm{~mm}$. long.

In woods, mostly in sandy soil, Columbus, Mississippi.

86. Crataegus pánda Beadle. A tree sometimes $6-7 \mathrm{~m}$. tall, with dark rough bark and crooked recurved branches. Leaf-blades obovate or cuneate, 2-4 cm. long, 1-2.5 cm. wide, or broader on leading shoots, glabrous or glabrate at maturity, pointed or rounded and with an abrupt sharp point at the apex, contracted or narrowed at the base, the borders nearly entire, glandular; petioles $5-15 \mathrm{~mm}$. long, margined, glandular : corymbs simple, 3-5-flowered: pedicels and hypanthium pubescent : sepals 4-5 mm. long, serrate, glandular: corolla $15-20 \mathrm{~mm}$. wide : stamens 20 , the anthers almost white: fruit globose or depressed globose, 10-15 mm. in diameter, at maturity orange-yellow, often tinged or cheeked with red, the flesh orange-yellow, soft : nutlets $3-5$, about $7 \mathrm{~mm}$. long, the hypostyle about $5 \mathrm{~mm}$. long.

In dry sandy soil, about Tallahassee, Florida.

87. Crataegus dápsilis Beadle. A shrub or small tree $2-5 \mathrm{~m}$. tall, with ashy gray rough bark and drooping or recurved branches. Leaf-blades obovate or cuneate, $1.5-4$ $\mathrm{cm}$. long, $7 \mathrm{~mm} .-2.5 \mathrm{~cm}$. wide, or larger on the shoots, more or less pubescent at maturity, especially on the lower surface along the midrib and in the axils of the veins, rounded or slightly and abruptly pointed at the apex, contracted or narrowed, or on leading shoots sometimes rounded at the base, the borders entire, glandular; petioles 5-15 mm. long, margined, glandular : corymbs 2-4-flowered or flowers solitary : pedicels and hypanthium densely white-tomentose : sepals 4-5 mm. long, glandular, slightly serrate : corolla 15-20 $\mathrm{mm}$. wide : stamens 20 , the anthers light yellow : fruit globose or subglobose, $10-15 \mathrm{~mm}$. in diameter, yellow or orange, cheeked with red, the flesh soft : nutlets $3-5,8-9 \mathrm{~mm}$. long, the hypostyle 5-6 mm. long.

In sandy soil, central peninsular Florida.

88. Crataegus dolòsa Beadle. A shrub or small tree $2-6 \mathrm{~m}$. tall, with ashy gray rough or scaly bark. Leaf-blades obovate, or on leading shoots, broadly ovate or orbicular, $1.5-4 \mathrm{~cm}$. long, 1-3 cm. wide, or broader on the shoots, glabrous or nearly so at maturity, rounded or abruptly pointed at the apex, contracted or narrowed, or on vigorous shoots rounded at the base, the borders minutely dentate or nearly entire; petioles $5 \mathrm{~mm} .-2 \mathrm{~cm}$. long, margined, glandular: corymbs simple, 3-5-flowered : pedicels and hypanthium tomentose: sepals 4-5 mm. long, serrate, glandular: corolla $18-20 \mathrm{~mm}$. wide : stamens 20 , the anthers light yellow or nearly white : fruit subglobose or short oval, 9-12 mm. thick, yellow or orange at maturity, sometimes with flushed cheeks : nutlets $3-5,7-8 \mathrm{~mm}$. long, the hypostyle about $5 \mathrm{~mm}$. long.

In dry woods, Abbeville, Alabama. 
89. Crataegus ràva Beadle. A shrub or small tree $2-5 \mathrm{~m}$. tall, with ashy gray rough or scaly bark and crooked, slightly drooping branches. Leaf-blades obovate, cuneate or spatulate, $1-3 \mathrm{~cm}$. long, $7 \mathrm{~mm} .-2.5 \mathrm{~cm}$. wide, pubescent or glabrate at maturity, rounded and mostly with a short abrupt point at the apex, narrowed or contracted at the base, the borders glandular and nearly entire; petioles 5-15 mm. long, margined, glandular: corymbs 2-4-flowered or flowers solitary : pedicels very short, like the hypanthium densely tomentose : sepals 4-5 mm. long, serrate, glandular : corolla 15-20 mm. wide : stamens 20 , the anthers light yellow or almost white : fruit globose or subglobose, 10-12 mm. in diameter, when ripe yellow or orange-yellow cheeked or splotched with red, the flesh soft: nutlets $3-5$, about $7 \mathrm{~mm}$. long, the hypostyle about $5 \mathrm{~mm}$. long.

In open woods, mostly in sandy soil, Tallahassee, Florida.

90. Crataegus Alabaménsis Beadle. A tree 4-6 m. tall, or more often a large branching shrub with one or more stems, clothed with rough dark gray or brownish black bark, the branches pendulous. Leaf-blades obovate or obovate-cuneiform, $1.5-5 \mathrm{~cm}$. long, $1-3.5 \mathrm{~cm}$. wide, pubescent on the lower surface at maturity, especially along the midrib and principal veins, rounded at the apex and often with a short, abrupt point, or occasionally abruptly contracted into an acute tip, narrowed or contracted at the base, the borders irregularly dentate; petioles $7 \mathrm{~mm} .-2.5 \mathrm{~cm}$. long, margined, glandular: corymbs simple or subsimple, 3-9-flowered : pedicels and hypanthium tomentose-pubescent: sepals 6-8 mm. long, serrate, glandular : corolla $2-2.5 \mathrm{~cm}$. broad: stamens 20 , the anthers yellow : fruit oval, $1.5-2 \mathrm{~cm}$. long, $1-1.5 \mathrm{~cm}$. wide, red when fully ripe, the flesh soft : nutlets mostly 2-3, 8-10 $\mathrm{mm}$. long, 3-4 $\mathrm{mm}$. deep, the hypostyle 6-7 $\mathrm{mm}$. long.

In open woods and clearings, mostly in clay soil, Montgomery, Alabama.

91. Crataegus fórtis Beadle. A large shrub or occasionally a small tree 2-5 m. tall, with ashy gray or brownish, rough or scaly bark. Leaf-blades obovate or obovate-cuneiform, 2-4 cm. long, 1-3 cm. wide, or broader on leading shoots, glabrate at maturity, rounded or abruptly pointed at the apex, narrowed or contracted at the base, the borders dentate; petioles 5-15 mm. long, margined, glandular: corymbs simple, 3-5-flowered : pedicels and hypanthium tomentose-pubescent : sepals 6-8 mm. long, serrate, glandular: corolla $2-2.5 \mathrm{~cm}$. wide: stamens 20 , the anthers pale purple : fruit subglobose or shortoval, $10-15 \mathrm{~mm}$. thick, red at maturity, the flesh soft : nutlets $3-5$, about $8 \mathrm{~mm}$. long, the hypostyle about three-fourths the length of the ventral angle.

In sandy woods bordering the Tombigbee River, northeastern Mississippi.

92. Crataegus compitàlis Beadle. A small tree, or oftener a large shrub, 2-5 m. tall, with dark gray or brownish rough bark and recurved branches. Leaf-blades obovate or obovate-cuneiform, $2-4 \mathrm{~cm}$. long, $1-3 \mathrm{~cm}$. wide, nearly or quite glabrous in age, rounded or with a small abrupt point at the apex, usually contracted at the base, the Borders dentate or serrate-dentate; petioles $5-15 \mathrm{~mm}$. long, margined, glandular: corymbs simple, 3-5-flowered: pedicels and hypanthium densely tomentose: sepals 4-5 $\mathrm{mm}$. long, serrate, glandular : corolla $15-18 \mathrm{~mm}$. wide : stamens 20 , the anthers light yellow or nearly white: fruit subglobose or oval, 10-13 mm. thick, red when fully ripe, the flesh soft : nutlets $3-5$, 8-9 $\mathrm{mm}$. long, the hypostyle 6-7 mm. long.

On roadsides, near Gainesville, Florida.

93. Crataegus insidiòsa Beadle. A large shrub, or a small tree 4-7 m. tall, with dark gray or brownish, rough or rimose bark and crooked, recurved branches. Leaf-blades cuneate, 2-4 cm. long, 1-2 cm. wide, or broader on leading shoots, pubescent or glabrate at maturity, blunt or abruptly pointed, or sometimes shallowly lobed at the apex, wedgeshaped at the base, the borders glandular and dentate near the apex; petioles $5 \mathrm{~mm} .-2 \mathrm{~cm}$. long, margined glandular: corymbs mostly 2-4-flowered, simple or flowers solitary: pedicels and hypanthium pubescent : sepals $4-5 \mathrm{~mm}$. long, glandular, usually serrate : corolla $16-20 \mathrm{~mm}$. wide : stamens 20 , the anthers light yellow or almost white : fruit oval or subglobose, $9-12 \mathrm{~mm}$. thick, at maturity red, the flesh soft : nutlets $3-5,7-8 \mathrm{~mm}$. long, the hypostyle about $5 \mathrm{~mm}$. long.

In dry woods and on slopes, southeastern Alabama and western Georgia.

94. Crataegus flórens Beadle. A small tree, or a large shrub 3-6 m. tall, with dark rimose bark and crooked, recurved branches. Leaf-blades obovate, oblong-cuneate or on leading shoots suborbicular, $2-5.5 \mathrm{~cm}$. long, $1-3 \mathrm{~cm}$. wide, or broader on the shoots, pubescent or glabrate in age, pointed or rounded at the apex, narrowed or contracted at the base, the borders dentate or serrate-dentate; petioles $5 \mathrm{~mm} .-2 \mathrm{~cm}$. long, margined, glandular: corymbs simple or subsimple, 3-6-flowered : pedicels and hypanthium pilose-pubescent : sepals $6-8 \mathrm{~mm}$. long, glandular-serrate : corolla $2-2.5 \mathrm{~cm}$. wide: stamens 20 , the anthers light yellow : fruit subglobose, $10-15 \mathrm{~mm}$. thick, orange-red at maturity, the flesh soft: nutlets $3-5$, about $8 \mathrm{~mm}$. long, the hypostyle $5-6 \mathrm{~mm}$. long.

On sandy flats along the Tombigbee River, eastern Mississippi. 
95. Crataegus clàra Beadle. A small tree 4-6 m. tall, with dark gray or brownish rough bark, or oftener a large much-branched shrub. Leaf-blades obovate or obovatecuneate, $2-4 \mathrm{~cm}$. long, 1-2 cm. broad, or larger on vigorous shoots, shining above, slightly pubescent below, even in age, rounded or pointed at the apex, narrowed or sometimes more abruptly contracted at the base, the borders dentate or crenate-dentate ; petioles 5-15 $\mathrm{mm}$. long, margined, glandular : corymbs simple, 3-5-flowered : pedicels and hypanthium pubescent : sepals 4-5 mm. long, serrate, glandular: corolla $15-18 \mathrm{~mm}$. wide : stamens 20 , the anthers faintly tinged with purple: fruit globose, 9-12 $\mathrm{mm}$. in diameter, orange-red when ripe : nutlets $3-5$, about $7 \mathrm{~mm}$. long, the hypostyle about $5 \mathrm{~mm}$. long.

In sandy soil in oak woods, Apalachicola River basin, Florida.

96. Crataegus púlla Beadle. A large shrub, or a small tree $3-5 \mathrm{~m}$. tall, with dark rimose bark and pendulous branches. Leaf-blades obovate, cuneate, elliptic or on leading shoots suborbicular, $1.5-3 \mathrm{~cm}$. long, $7 \mathrm{~mm} .-3 \mathrm{~cm}$. wide, pubescent, either pointed, rounded or lobed at the apex, narrowed or contracted, or on the shoots rounded at the base, the border dentate, glandular; petioles 5-12 mm. long, pubescent, margined, glandular: corymbs simple, 2-5-flowered : pedicels and hypanthium tomentose : sepals 4-6 mm. long, glandular-serrate : corolla 14-17 mm. wide : stamens 20 , the anthers light yellow : fruit subglobose or oval, $9-12 \mathrm{~mm}$. thick, $10-14 \mathrm{~mm}$. long, at maturity yellow or orange-yellow flushed with red, the flesh soft: nutlets $3-5$, about $8 \mathrm{~mm}$. long, the hypostyle occupying about three-fourths of the ventral angle.

In sandy soil along the Tombigbee River, eastern Mississippi.

97. Crataegus ínops Beadle. A small tree sometimes $6-7 \mathrm{~m}$. tall, with a trunk 2 $\mathrm{dm}$. in diameter, clothed with rough or rimose bark. Leaf-blades cuneate, $1.5-3.5 \mathrm{~cm}$. long, $7 \mathrm{~mm} .-2.5 \mathrm{~cm}$. wide, or broader on leading shoots, pubescent on the lower surface, especially along the midrib and principal veins, rounded, abruptly pointed or lobed at the apex, wedge-shaped or more abruptly contracted at the base, the margins dentate above the middle; petioles $5 \mathrm{~mm} .-2.5 \mathrm{~cm}$. long, pubescent, margined, glandular: corymbs simple, 3-5-flowered : pedicels and hypanthium tomentose : sepals 3-4 mm. long, serrate, glandular : corolla 18-20 mm. wide: stamens 20 , the anthers light yellow or nearly white : fruit globose, $10-14 \mathrm{~mm}$. in diameter, at maturity orange, flushed or diffused with red, the flesh soft: nutlets $3-5$, about $7 \mathrm{~mm}$. long, the hypostyle about $5 \mathrm{~mm}$. long.

In sandy oak woods, southeastern Alabama.

98. Crataegus amica Beadle. A small tree, or a large shrub $3-6 \mathrm{~m}$. tall, with dark rough or rimose bark and recurved branches. Leaf-blades cuneate or oblong-cuneiform, or on leading shoots broadly ovate, $1.5-3.5 \mathrm{~cm}$. long, $7 \mathrm{~mm} .-2.5 \mathrm{~cm}$. broad, or wider on the shoots, mostly pointed or lobed at the apex, narrowed or contracted at the base, the borders glandular, dentate above the middle; petioles $5 \mathrm{~mm} .-2.5 \mathrm{~cm}$. long, margined, glandular: corymbs simple, $3-5$-flowered : pedicels and hypanthium densely tomentose : sepals about $5 \mathrm{~mm}$. long, glandular-serrate : corolla about $2 \mathrm{~cm}$. wide: stamens 20 , the anthers light yellow : fruit subglobose, $10-13 \mathrm{~mm}$. thick, at maturity orange blotched or cheeked with red, the flesh soft : nutlets $3-5,6-7 \mathrm{~mm}$. long, the hypostyle occupying three-fourths of the ventral angle.

In sandy woods and on borders of roads, Ocala, Florida.

99. Crataegus Ravenélii Sarg. A shrub, or a small tree 2-8 m. tall, with ashy gray or brownish rough bark. Leaf-blades obovate or spatulate, $1.5-3.5 \mathrm{~cm}$. long, $1-3 \mathrm{~cm}$. wide, glabrate at maturity or with some pubescence persistent along the midrib and in the axils of the principal veins beneath, either rounded or pointed at the apex, narrowed or contracted at the base, the margins dentate or serrate-dentate, the teeth glandular; petioles $5-15 \mathrm{~mm}$. long, margined, glandular : corymbs simple, 3-7-flowered : pedicels and hypanthium tomentose : sepals 4-5 mm. long, serrate, glandular : corolla $16-20 \mathrm{~mm}$. wide : stamens 20 , the anthers pale yellow : fruit globose or subglobose, 10-12 mm. in diameter, orange-red at maturity : nutlets $3-5,7-9 \mathrm{~mm}$. long, the hypostyle about three-fourths the length of the ventral angle.

In woods and on slopes, South Carolina and Georgia.

100. Crataegus attrita Beadle. A shrub, or a small tree 2-5 m. tall, with dark rough or rimose bark and recurved branches. Leaf-blades cuneate or obovate-cuneiform, $2-3.5 \mathrm{~cm}$. long, $7 \mathrm{~mm} .-3 \mathrm{~cm}$. broad, glabrous or glabrate at maturity, blunt or sharppointed at the apex, narrowed or contracted at the base, the margins coarsely and irregularly dentate ; petioles $5 \mathrm{~mm} .-2 \mathrm{~cm}$. long, pubescent, margined, glandular: corymbs 2-3flowered or flowers solitary : pedicels and hypanthium bearing a few weak hairs : sepals about $5 \mathrm{~mm}$. long, glandular-serrate or nearly entire : corolla $20-22 \mathrm{~mm}$. wide : stamens 20 , the anthers light yellow or nearly white : fruit subglobose, $10-14 \mathrm{~mm}$. thick, at maturity yellow, splashed with red, the flesh soft : nutlets $3-5,7-9 \mathrm{~mm}$. long, the hypostyle two-thirds as long as the ventral angle.

In sandy upland woods, southeastern Alabama. 
101. Crataegus téres Beadle. A tree 5-6 m. tall, or more often a large muchbranched shrub with one or more stems, clothed with dark ashy gray or brownish black rough bark. Leaf-blades obovate or broadly cuneiform, or on leading shoots broadly obovate or oval, $2-5 \mathrm{~cm}$. long, 1-4 cm. wide, smooth and shining at maturity, either rounded or with a short, abrupt point or even truncate at the apex, cuneate or more abruptly contracted at the base, the margins dentate or serrate-dentate; petioles $5 \mathrm{~mm} .-1.5 \mathrm{~cm}$. long, margined, glandular : corymbs subsimple or compound, 3-10-flowered : pedicels and hypanthium glabrous or with a few weak hairs : sepals $4.5-6 \mathrm{~mm}$. long, glandular-serrate : corolla about $15 \mathrm{~mm}$. wide : stamens 20 , the anthers light yellow : fruit oblong, 1-1.5 cm. long, $8 \mathrm{~mm} .-1 \mathrm{~cm}$. thick, red at maturity, the flesh soft: nutlets usually $2-3,8-9 \mathrm{~mm}$. long, $3-4 \mathrm{~mm}$. deep, the hypostyle about $4 \mathrm{~mm}$. long.

In pine woods, near Montgomery, Alabama.

102. Crataegus sénta Beadle. A small tree 5-6 m. tall, or more frequently a large shrub with one or more stems, clothed with dark gray or brownish black rough bark, the branches recurved. Leaf-blades obovate, obovate-cuneiform, or on leading shoots roundovate, or nearly orbicular, $2-5 \mathrm{~cm}$. long, $7 \mathrm{~mm} .-5 \mathrm{~cm}$. wide, glabrate at maturity, either pointed or lobed at the apex, wedge-shaped or more abruptly contracted at the base, the borders irregularly and deeply dentate or serrate-dentate; petioles $5 \mathrm{~mm} .-2.5 \mathrm{~cm}$. long, margined, glandular : corymbs simple, $3-6$-flowered : pedicels and hypanthium tomentose : sepals 4-6 mm. long, glandular-serrate, pubescent : corolla $15-20 \mathrm{~mm}$. wide: stamens 20 : fruit globose, 10-14 mm. in diameter, red at maturity : nutlets 3-5, 7-9 mm. long, 4-5 mm. deep, the hypostyle 4-5 mm. long.

In woods and on dry hills, North Carolina.

103. Crataegus Cullasagénsis Ashe. A small tree 4-7 m. tall, with dark rough bark and drooping branches. Leaf-blades obovate or elliptic or on leading shoots ovate, 2-4 cm. long, $7 \mathrm{~mm} .-3 \mathrm{~cm}$. wide, pubescent on the lower surface, especially along the midrib and in the axils of the veins, or glabrate in age, acute or rounded at the apex, cuneate or contracted at the base, the borders serrate or serrate-dentate, 3-5-notched or lobed above the middle ; petioles $5 \mathrm{~mm} .-2 \mathrm{~cm}$. long, winged, glandular : corymbs simple, $3-6$-flowered : pedicels and hypanthium pubescent : sepals 4-6 $\mathrm{mm}$. long, glandular-serrate : stamens 20 : fruit subglobose or short-oblong, $10-14 \mathrm{~mm}$. thick, at maturity orange or orange-red with ruddy cheeks : nutlets $3-5,6-7 \mathrm{~mm}$. long, the lateral faces plane.

In dry woods and on slopes, Macon County, North Carolina.

104. Crataegus díspar Beadle. A small tree, with drooping branches sometimes 6 m. tall, with furrowed dark gray or nearly black bark, or more frequently a shrub with one or several stems. Leaf-blades obovate or orbicular, sometimes on vigorous twigs broader than long, 1.5-1 $\mathrm{cm}$. long, 1-4 $\mathrm{cm}$. wide, rounded or short pointed at the apex, either rounded or narrowed at the base into glandular, tomentose pedicels, densely tomentose when young, becoming glabrate on the upper surface, below permanently tomentose, especially on the midrib and prominent veins, the borders sharply and irregularly serrate and incisely lobed, especially above the middle: corymbs densely white-tomentose, 3-7-flowered : pedicels, hypanthium and sepals tomentose or pubescent: stamens about 20 : fruit subglobose or oval, $8-12 \mathrm{~mm}$. long, $7-10 \mathrm{~mm}$. wide, red when fully ripe : nutlets $3-5,6-7 \mathrm{~mm}$. long, smooth or slightly ridged on the back, the hypostyle about $5 \mathrm{~mm}$. long.

In sandy soil, South Carolina and Georgia, near Aiken and Augusta.

105. Crataegus anisnphýlla Beadle. A large shrub, or a tree sometimes $6 \mathrm{~m}$. tall, with a short trunk 1.5-2 dm. in diameter, clothed with dark brown rough or rimose bark, the branches drooping. Leaf-blades spatulate or cuneate, $2-4 \mathrm{~cm}$. long, $5 \mathrm{~mm} .-1.5 \mathrm{~cm}$. wide, or a little broader on the shoots, glabrous in age, rounded, pointed or lobed at the apex, wedge-shaped at the base; petioles $5 \mathrm{~mm} .-3 \mathrm{~cm}$. long, winged, remotely glandular : corymbs simple, 2-4-flowered or flowers solitary : pedicels and hypanthium tomentose : sepals $3-4 \mathrm{~mm}$. long, glandular-serrate : corolla about $15 \mathrm{~mm}$. wide: stamens about 20 , the anthers yellow : fruit globose or subglobose, 6-8 mm. in diameter, orange flushed or cheeked with red when fully ripe, the flesh soft : nutlets $3-5,4.5-5.5 \mathrm{~mm}$. long, the hypostyle about $3 \mathrm{~mm}$. long.

In sandy soil and on banks of the St. Johns River, northeastern Florida.

106. Crataegus frugàlis Beadle. A small tree, or a large shrub $3-5 \mathrm{~m}$. tall, with dark rough bark and slightly drooping branches. Leaf-blades cuneate or obovate-cuneate, $1.5-3.5 \mathrm{~cm}$. long, $7 \mathrm{~mm} .-2 \mathrm{~cm}$. wide, or broader on leading shoots, glabrous or glabrate in age, rounded or with a short abrupt point at the apex, wedge-shaped or more abruptly contracted at the base, the borders glandular, dentate or nearly entire; petioles $5 \mathrm{~mm} .-2 \mathrm{~cm}$. long, winged, glandular: corymbs simple, $3-5$-flowered : pedicels and hypanthium tomentose: sepals 3-4 mm. long, glandular-serrate or nearly entire: corolla 12-17 mm. wide: 
stamens 20 , the anthers yellow : fruit subglobose, 7-9 mm. thick, red at maturity : nutlets $3-5,5-6 \mathrm{~mm}$. long, the hypostyle $3-4 \mathrm{~mm}$. long.

On banks of the Flint River, near Albany, Georgia.

107. Crataegus viàtia Beadle. A large shrub, or a small tree $2-5 \mathrm{~m}$. tall, with dark rough bark and drooping branches. Leaf-blades spatulate, cuneate or obovatecuneiform, $1.5-3.5 \mathrm{~cm}$. long, 1-2 cm. wide, glabrate or pubescent along the midrib and in the axils of the principal veins beneath at maturity, pointed or lobed at the apex, wedgeshaped or more abruptly contracted at the base, the borders dentate, glandular, and usually shallowly lobed above the middle ; petioles $7 \mathrm{~mm} .-2 \mathrm{~cm}$. long, winged, glandular : corymbs simple, 2-4-flowered or flowers solitary : pedicels and hypanthium tomentose : sepals 3-4 mm. long, glandular-serrate or nearly entire : corolla $10-13 \mathrm{~mm}$. wide: stamens 20 , the anthers yellow : fruit globose, $7-9 \mathrm{~mm}$. in diameter, red at maturity : nutlets $3-5,6-7 \mathrm{~mm}$. long, the hypostyle $4-5 \mathrm{~mm}$. long.

In sandy soil, northeastern Florida.

108. Crataegus cirràta Beadle. A large shrub, or frequently arborescent, 2-6 m. tall, with dark rough bark and crooked drooping branches. Leaf-hlades spatulate, cuneate or obovate-cuneiform, variously curled and crisped, $1.5-2.5 \mathrm{~cm}$. long, $7 \mathrm{~mm} .-2 \mathrm{~cm}$. wide, or broader on leading shoots, pubescent, pointed or lobed at the apex, narrowed or contracted at the base, the borders dentate, glandular, lobed above the middle; petioles $5 \mathrm{~mm} .-2 \mathrm{~cm}$. long, pubescent, margined, glandular : corymbs simple, $3-5$-flowered : pedicels and hypanthium tomentose : sepals $4-5 \mathrm{~mm}$. long, serrate, glandular : corolla about $15 \mathrm{~mm}$. wide: stamens 20, the anthers light yellow: fruit globose or subglobose, 7-9 $\mathrm{mm}$. in diameter, red at maturity : nutlets $3-5$, about $6 \mathrm{~mm}$. long, the hypostyle about two-thirds as long as the ventral angle.

On gravelly hills at Girard, Alabama.

109. Crataegus argùta Beadle. A small tree, or a large shrub 2-6 m. tall, with dark rough bark and drooping branches. Leaf-blades cuneate or obovate-cuneiform, 1.5-3 $\mathrm{cm}$. long, $8 \mathrm{~mm} .-2.5 \mathrm{~cm}$. wide, pubescent, at least on the lower surface at maturity, rounded or abruptly short-pointed at the apex, wedge-shaped or more abruptly contracted at the base, the borders dentate, glandular, or shallowly lobed, especially above the middle; petioles $5 \mathrm{~mm} .-2 \mathrm{~cm}$. long, winged, glandular : corymbs simple, 3-5-flowered : pedicels and hypanthium tomentose : sepals 4-5 mm. long, glandular-serrate : corolla about $15 \mathrm{~mm}$. wide: stamens 20 , the anthers yellow : fruit globose when fully ripe, $7-9 \mathrm{~mm}$. in diameter, red, nutlets $3-5$, about $6 \mathrm{~mm}$. long, the hypostyle $4 \mathrm{~mm}$. long.

In dry woods and on slopes, east-central Alabama and southwestern Georgia.

110. Crataegus láxa Beadle. A small tree, or a large shrub 3-6 m. tall, with dark gray or brownish black rough bark. Leaf-blades cuneate or obovate-cuneiform, $1.5-5 \mathrm{~cm}$. long, $7 \mathrm{~mm} .-3 \mathrm{~cm}$. wide, or broader on leading shoots, pubescent, rounded, abruptly pointed or lobed at the apex, narrowed or contracted at the base, the borders dentate, glandular; petioles $7 \mathrm{~mm} .-2.5 \mathrm{~cm}$. long, winged, glandular, pubescent : corymbs simple, 3-5-flowered : pedicels and hypanthium tomentose : sepals 3.5-5 mm. long, serrate, glandular: corolla 14-18 mm. wide : stamens 20 , the anthers white : fruit subglobose or shortoval, 7-9 mm. thick, 9-11 mm. long, red at maturity : nutlets $3-5$, about $7 \mathrm{~mm}$. long, the hypostyle 4-5 mm. long.

In dry woods and on ridges, east-central Alabama.

111. Crataegus colónica Beadle. A small tree, or a large shrub 3-6 m. tall, with ashy gray rough or rimose bark and drooping branches. Leaf-blades cuneate or obovate-cuneiform, 1-3 cm. long, $7 \mathrm{~mm} .-3.5 \mathrm{~cm}$. wide, glabrate in age or pubescent on the lower surface, especially along the midrib and in the axils of the prominent veins, rounded or abruptly pointed at the apex, narrowed or contracted at the base, the borders glandular, usually dentate or shallowly-lobed above the middle; petioles 5-20 mm. long, margined, glandular: corymbs simple, mostly 2-4-flowered : pedicels and hypanthium tomentose: sepals 3-4.5 mm. long, serrate, glandular : stamens 20 : fruit pyriform, 10-13 mm. thick, $1.5-2 \mathrm{~cm}$. long, orange-red at maturity, the flesh soft : nutlets $3-5$, about $8 \mathrm{~mm}$. long, the hypostyle about $5 \mathrm{~mm}$. long.

On bluff's of the May River, Beaufort County, South Carolina.

112. Crataegus vicàna Beadle. A large shrub, or a small tree $2-4 \mathrm{~m}$. tall, with ashy gray or brownish, rough or rimose bark and drooping branches. Leaf-blades cuneate or oblong- or obovate-cuneiform, $1.5-3.5 \mathrm{~cm}$. long, $7 \mathrm{~mm} .-2 \mathrm{~cm}$. wide, or on leading shoots sometimes $4.5 \mathrm{~cm}$. wide, glabrate or somewhat pubescent beneath at maturity, either pointed or rounded, occasionally truncate at the apex, narrowed or contracted at the base, the margins dentate or shallowly lobed near the apex; petioles $7 \mathrm{~mm} .-2.5 \mathrm{~cm}$. long, margined, glandular : corymbs simple, $3-5$-flowered : pedicels and hypanthium tomentose : 
sepals 4-5 mm. long, glandular-serrate : corolla $15-20 \mathrm{~mm}$. wide : stamens 20 , the anthers light yellow: fruit pyriform or oblong-pyriform, 10-14 mm. thick, about $1.5 \mathrm{~cm}$. long, yellow or orange at maturity, blotched or cheeked with red, the flesh soft : nutlets mostly 3, 8-10 $\mathrm{mm}$. long, the hypostyle 6-7 $\mathrm{mm}$. long.

In sandy soil, Tavares, Florida.

113. Crataegus recúrva Beadle. A shrub, or a small tree $3-5 \mathrm{~m}$. tall, with ashy gray or brownish, rough or rimose bark and pendulous branches. Leaf-blades cuneate or spatulate or on leading shoots obovate-cuneiform, $1.5-3 \mathrm{~cm}$. long, 5-15 mm. wide, or broader on the shoots, glabrous or glabrate at maturity, wedge-shaped or more abruptly contracted at the base, pointed or rounded at the apex, the margins glandular, dentate or lobed; petioles 5-15 mm. long, margined, glandular: corymbs simple, 2-3-flowered or flowers solitary: pedicels and hypanthium tomentose : sepals 4-5 $\mathrm{mm}$. long, glandularserrate : corolla $12-15 \mathrm{~mm}$. wide : stamens about 20 , the anthers light yellow : fruit pyriform or short-pyriform, $7-9 \mathrm{~mm}$. thick, red at maturity, the flesh soft : nutlets $3-5,6-7$ $\mathrm{mm}$. long, the hypostyle about $5 \mathrm{~mm}$. long.

In sandy soil, Ocala, Florida.

114. Crataegus simòsa Beadle. A small tree, or a large shrub 2-4 m. tall, with rimose bark and slender drooping branches. Leaf-blades cuneate, spatulate or oblongcuneiform, 1-2.5 cm. long, $7 \mathrm{~mm} .-2 \mathrm{~cm}$. wide, or broader on leading shoots, glabrate or pubescent on the lower surface, especially along the midrib and in the axils of the principal veins, usually abruptly contracted, but occasionally wedge-shaped at the base, either rounded, abruptly pointed or lobed at the apex, the borders glandular, dentate above the middle; petioles $5 \mathrm{~mm} .-2 \mathrm{~cm}$. long, margined, glandular: corymbs simple, 3-4-flowered, or flowers solitary : pedicels and hypanthium tomentose : sepals 3-4 mm. long, glandularserrate : corolla $12-15 \mathrm{~mm}$. wide : stamens 20 , the anthers light yellow : fruit short-pyriform, 9-12 mm. thick, at maturity yellow or orange-yellow flushed or cheeked with red, the flesh soft : nutlets $3-5,6-7 \mathrm{~mm}$. long, the hypostyle 4-5 $\mathrm{mm}$. long, $1.5-2 \mathrm{~mm}$. wide on each side of the ventral angle.

In sandy soil, Citra, Florida.

115. Crataegus inopina Beadle. A small tree, or a large shrub 3-5 m. tall, with dark rough or rimose hark and recurved branches. Leaf-blades obovate-cuneiform, sometimes suborbicular, $1.5-2.5 \mathrm{~cm}$. long, 1-2 cm. wide, or larger on leading shoots, glabrate at maturity or with some pubescence on the lower surface and in the axils of the large veins, usually abruptly contracted, but occasionally wedge-shaped at the base, either rounded, pointed or lobed at the apex, the borders entire or denticulate; petioles $5 \mathrm{~mm} .-2 \mathrm{~cm}$. long, margined, glandular, mostly scurfy-tomentose : corymbs simple, 2-4-flowered, or flowers solitary : pedicels and hypanthium tomentose: sepals $3-4.5 \mathrm{~mm}$. long, glandular-serrate : corolla $12-15 \mathrm{~mm}$. wide : stamens 20 , the anthers light yellow or almost white : fruit pyriform, 8-11 mm. thick, 12-14 mm. long, at maturity yellow or orange-yellow, sometimes cheeked with red, the flesh soft : nutlets $3-5,6-7 \mathrm{~mm}$. long, the hypostyle $4-5 \mathrm{~mm}$. long.

In sandy soil, Ocala, Florida.

116. Crataegus villàris Beadle. A small tree, or a large shrub 3-5 m. tall, with dark rough or rimose bark and drooping branches. Leaf-blades cuneate or oblong-cuneiform, $1.5-3.5 \mathrm{~cm}$. long, $5 \mathrm{~mm} .-2 \mathrm{~cm}$. wide or broader on leading shoots, glabrous or glabrate at maturity, usually abruptly contracted, but occasionally wedge-shaped at the base, rounded or abruptly pointed at the apex, the borders glandular, entire or nearly so ; petioles $5 \mathrm{~mm}$.$2 \mathrm{~cm}$. long, margined, glandular : corymbs simple, 2-4-flowered, or flowers solitary : pedicels and hypanthium tomentose : sepals $3-4 \mathrm{~mm}$. long, glandular-serrate : corolla 12-16 $\mathrm{mm}$. wide : fruit pyriform, 8-11 mm. thick, at maturity yellow or orange-yellow, cheeked or flushed with red, the flesh soft : nutlets mostly $3-4,6-7 \mathrm{~mm}$. long, the hypostyle 4-5. mm. long.

In sandy soil, Citra, Florida.

117. Crataegus cúrva Beadle. A shrub, or a very small tree $2-4 \mathrm{~m}$. tall, usually with several trunks clothed with dark rough bark, and crooked, drooping, very spiny branches. Leaf-blades obovate or obovate-cuneiform, 1-2 cm. long, $5 \mathrm{~mm}$. $-2 \mathrm{~cm}$. wide, glabrate at maturity or with some conspicuous pubescence along the midrib and in the axils of the prominent veins beneath, rounded or abruptly pointed at the apex, abruptly contracted at the base, the borders subentire or denticulate and shallowly lobed; petioles 5-15 $\mathrm{mm}$. long, margined, glandular : corymbs simple, 2-4-flowered, or flowers solitary : pedicels and hypanthium tomentose : sepals $3-4 \mathrm{~mm}$. long, serrate, glandular : corolla 12-15 mm. wide : stamens 20 , the anthers light yellow : fruit pyriform, 6-9 mm. thick, at maturity orange-red or orange with red cheeks, the flesh very thin : nutlets usually $3-4,6-7$ $\mathrm{mm}$. long, the hypostyle 4-5 mm. long, $2-2.5 \mathrm{~mm}$. wide near the top of each lateral surface.

In sandy soil, notheastern Florida. 
118. Crataegus resima Beadle. A small tree, or a large shrub, 2-4 m. tall, with rough bark and drooping branches. Leaf-blades cuneate or spatulate, 1-2.5 cm. long, $7 \mathrm{~mm} .-1.5 \mathrm{~cm}$. wide, pubescent or glabrate, pointed or variously lobed at the apex, wedgeshaped at the base, the border glandular, dentate or irregularly notched above the middle ; petioles $5 \mathrm{~mm} .-2 \mathrm{~cm}$. long, winged, glandular : corymbs simple, $2-5$-flowered : pedicels and hypanthium tomentose : sepals $3-4 \mathrm{~mm}$. long, glandular-serrate : corolla about $12 \mathrm{~mm}$. wide: stamens 20 , the anthers pale yellow : fruit pyriform, $9-11 \mathrm{~mm}$. thick, at maturity orange-yellow, blotched with red, the flesh soft: nutlets mostly 3 , about $7 \mathrm{~mm}$. long, the hypostyle 4-5 mm. long, 1.5-2 mm. wide on each lateral surface.

In open woods and fieids, mostly in sandy soil, Albany, Georgia.

119. Crataegus lássa Beadle. A large much-branched shrub, or a small tree sometimes $5 \mathrm{~m}$. tall, with ashy gray or brownish rough bark and drooping branches. Leafblades cuneiform, $1.5-3 \mathrm{~cm}$. long, $7 \mathrm{~mm} .-2 \mathrm{~cm}$. wide, or on leading shoots much dilated or frequently broader than long and with rounded bases, glabrate in age, or with some pubescence persistent along the midrib and in the axils of the prominent veins, rounded at the apex and with a short abrupt point or nearly truncate with one or more short points or shallow lobes, the borders roughened with black glands; petioles $7 \mathrm{~mm} .-2 \mathrm{~cm}$. long, margined, glandular, pubescent: corymbs simple, 2-5-flowered : pedicels and hypanthium tomentose : sepals about $5 \mathrm{~mm}$. long, glandular-serrate : corolla $15-18 \mathrm{~mm}$. wide : stamens 20 , the anthers yellow : fruit pyriform, $8-10 \mathrm{~mm}$. wide, $10-13 \mathrm{~mm}$. long, at maturity orangered, the flesh soft : nutlets 3-5, 6-7 mm. long, the hypostyle 4-5 $\mathrm{mm}$. long.

In sandy oak barrens, near Selma, Alabama.

120. Crataegus adústa Beadle. A large shrub, or a small tree $2-5 \mathrm{~m}$. tall, with dark gray or brownish rough bark and drooping branches. Leaf-blades cuneiform, 1.5-3 $\mathrm{cm}$. long, $7 \mathrm{~mm} .-2 \mathrm{~cm}$. wide or larger and obovate-cuneiform on the leading shoots, glabrate at maturity, rounded or with a short, abrupt point at the apex, the borders glandular, subentire, or dentate near the apex; petioles $5-15 \mathrm{~mm}$. long, margined, glandular : corymbs simple, 2-4-flowered or flowers solitary: pedicels and hypanthium tomentose : sepals 3-5 mm. long, glandular-serrate : corolla 14-18 mm. wide: stamens 20 , the anthers almost white : fruit short-pyriform, $9-11 \mathrm{~mm}$. thick, at maturity orange-red, usually spotted and streaked with red, the flesh soft: nutlets $3-5$, about $8 \mathrm{~mm}$. long, the hypostyle $5-6 \mathrm{~mm}$. long.

In sandy woods, Gainesville, Florida.

121. Crataegus illùdens Beadle. A small tree, or a large shrub with dark gray or brownish rough bark and drooping branches. Leaf-blades cuneiform, $1.5-3.5 \mathrm{~cm}$. long, 7 $\mathrm{mm} .-2 \mathrm{~cm}$. wide, or broader on vigorous shoots, glabrous or glabrate at maturity, rounded, pointed or lobed at the apex, the borders entire or denticulate, glandular, sometimes lobed above the middle, especially on leading shoots ; petioles $7 \mathrm{~mm} .-3 \mathrm{~cm}$. long, winged, glandular: corymbs 2-4-flowered, or flowers occasionally solitary: pedicels and hypanthium tomentose : sepals $3.5-5 \mathrm{~mm}$. long, glandular-serrate : corolla $14-18 \mathrm{~mm}$. wide : fruit pyriform, 8-11 mm. thick, yellow at maturity, the flesh soft : nutlets mostly 3 , about $7 \mathrm{~mm}$. long, the hypostyle about $5 \mathrm{~mm}$. long.

In sandy soil, Citra, Florida.

122. Crataegus versùta Beadle. A shrub, or a small tree 3-6 m. tall, with dark rough bark and drooping branches. Leaf-blades cuneiform, $1-3 \mathrm{~cm}$. long, $5 \mathrm{~mm} .-2 \mathrm{~cm}$. wide, or broader on leading shoots, pubescent or tomentose at maturity, at least on the lower surface along the midrib and in the axils of the principal veins, rounded, pointed or lobed at the apex, the borders glandular, dentate or lobed above the middle; petioles 5 mm. $-3 \mathrm{~cm}$. long, winged, glandular, pubescent : corymbs simple, 2-4-flowered, or flowers solitary : pedicels and hypanthium tomentose : sepals $2-3 \mathrm{~mm}$. long, glandular : corolla 10-12 mm. wide : stamens 20 , the anthers light yellow : fruit short-pyriform, 6-9 mm. thick, at maturity orange or greenish yellow with ruddy cheeks : nutlets $3-5$, about $6 \mathrm{~mm}$. long, the hypostyle $3-4 \mathrm{~mm}$. long.

In woods and on banks, southwestern Georgia.

123. Crataegus incàna Beadle. A large shrub 2-4 m. tall, with dark gray or brownish, rough or scaly bark and crooked recurved branches. Leaf-blades cuneate or obovatecuneate, 1-2.5 cm. long, $7 \mathrm{~mm} .-2 \mathrm{~cm}$. wide, pubescent, abruptly pointed or rounded at the apex, wedge-shaped or more abruptly contracted at the base, the margins glandular, subentire or shallowly lobed; petioles $5-15 \mathrm{~mm}$. long, margined, densely white-tomentose when young, glandular: corymbs simple, 2-4-flowered, or flowers solitary : pedicels and hypanthium densely white-tomentose : sepals 4-5 mm. long, glandular: corolla about 15 $\mathrm{mm}$. wide : stamens 20 , the anthers nearly white : fruit pyriform, 8-9 mm. thick, at maturity orange-yellow, flushed or cheeked with red : nutlets $3-5$, about $7 \mathrm{~mm}$. long, the hypostyle about $5 \mathrm{~mm}$. long.

In sandy oak woods, Apalachicola River basin, Florida. 
124. Crataegus cròcea Beadle. A small tree, or a large shrub 3-6 m. tall, with dark rough bark and slender drooping branches. Leaf-blades cuneiform, 1-2.5 cm. long, 5-15 mm. wide, or broader on leading shoots, at maturity smooth above, more or less pubescent beneath, especially along the midrib, either pointed or rounded at the apex, the borders glandular, denticulate above the middle ; petioles $7 \mathrm{~mm} .-2 \mathrm{~cm}$. long, margined, glandular, pubescent or glabrate: corymbs simple, 2-4-flowered, or flowers solitary : pedicels and hypanthium tomentose : sepals 3-4 mm. long, glandular-serrate: corolla $15 \mathrm{~mm}$. wide: stamens 15-20, the anthers nearly white: fruit pyriform, $9-12 \mathrm{~mm}$. thick, at maturity yellow or orange-yellow, rarely cheeked with russet-red, the flesh soft : nutlets 3-5, about 6 $\mathrm{mm}$. long, the hypostyle $4-5 \mathrm{~mm}$. long.

In sandy soil, Citra, Florida.

125. Crataegus aùdens Beadle. A large shrub, or a small tree, with dark gray or brownish rough or scaly bark. Leaf-blades obovate or obovate-cuneiform, $1.5-3.5 \mathrm{~cm}$. long, $1-3.5 \mathrm{~cm}$. wide, at maturity glabrate and shining on the upper surface, pubescent beneath especially along the midrib and principal veins, abruptly pointed, rounded or lobed at the apex, contracted or narrowed at the base, the margins dentate and shallowly lobed; petioles 5-15 mm. long, margined, glandular, pubescent: corymbs simple, 2-5-flowered, or flowers occasionally solitary : pedicels and hypanthium pubescent : sepals 4-5 $\mathrm{mm}$. long, glandularserrate : corolla $15-16 \mathrm{~mm}$. wide : stamens 20 , the anthers almost white : fruit pyriform, 9-12 mm. thick, at maturity orange-yellow, flushed or cheeked with red, the flesh soft: nutlets mostly $3,7-8 \mathrm{~mm}$. long, the hypostyle $4-5 \mathrm{~mm}$. long.

On dry hills, near Chattahoochee, Florida.

126. Crataegus meridiàna Beadle. A small tree, or a large shrub 3-7 $\mathrm{m}$. tall, with dark rough or rimose bark and recurved branches. Leaf-blades cuneate, obovatecuneiform, or on vigorous shoots broader than long, $2-3 \mathrm{~cm}$. long, $7 \mathrm{~mm} .-3 \mathrm{~cm}$. wide, at maturity glabrate above, more or less pubescent beneath, especially along the midrib and the axils of the prominent veins, abruptly pointed or lobed at the apex, narrowed or contracted at the base, the borders dentate, glandular, shallowly lobed above the middle; petioles $7 \mathrm{~mm} .-3 \mathrm{~cm}$. long, winged, glandular, pubescent : corymbs simple, $3-5$-flowered: pedicels and hypanthium tomentose: sepals $5-6 \mathrm{~mm}$. long, glandular serrate: corolla 18-20 mm. wide: stamens 20 , the anthers light yellow or nearly white : fruit pyriform, 7-9 mm. thick, 12-15 mm. long, at maturity orange-yellow, sometimes flushed or streaked with red, the flesh soft : nutlets $3-5$, about $6 \mathrm{~mm}$. long, the hypostyle about $4 \mathrm{~mm}$. long.

In sandy oak woods, southeastern Alabama.

127. Crataegus lépida Beadle. A small very spiny shrub, seldom more than 1-1.5 $\mathrm{m}$. tall, with drooping branches. Leaf-blades obovate, round-ovate, suborbicular or spatulate, $5 \mathrm{~mm} .-2 \mathrm{~cm}$. long, $4 \mathrm{~mm} .-2 \mathrm{~cm}$. wide, at maturity glabrous and lustrous above, more or less pubescent beneath, especially along the principal veins and in their axils, rounded, truncate or short-pointed at the apex, abruptly contracted at the base, or sometimes cuneate, the margins denticulate or crenate-dentate, glandular; petioles $2 \mathrm{~mm} .-1 \mathrm{~cm}$. long, margined, glandular : corymbs 2-3-flowered, or flowers solitary : pedicels and hypanpanthium tomentose: sepals $2-3 \mathrm{~mm}$. long, glandular-serrate : stamens 20 ; fruit subglobose, $7-11 \mathrm{~mm}$. in diameter, at maturity orange or orange-red : nutlets $3-5,6-7 \mathrm{~mm}$. long, 3-4 $\mathrm{mm}$. deep, the hypostyle 4-5 $\mathrm{mm}$. long.

In sandy soil and open woods, southeastern Georgia and northeastern Florida.

128. Crataegus lacrimàta Small. A small tree, sometimes 4-5 m. tall, or more frequently a large shrub with several stems clothed with ashy gray often scaly bark, the branches drooping. Leaf-blades cuneate-spatulate, 1-2.5 cm. long, 7-15 mm. wide, or broader on vigorous leading shoots, glabrous in age, rounded, truncate or pointed at the apex, wedge-shaped at the base, the borders dentate above the middle, glandular; petioles 5-15 mm. long, pubescent, glandular : corymbs simple, 2-4-flowered, or flowers solitary : pedicels and hypanthium glabrous : sepals $2.5-3 \mathrm{~mm}$. long, entire or nearly so, glabrous : stamens 20, the anthers light yellow : fruit globose, or subglobose, at maturity yellow or orange, mostly with ruddy cheeks, the flesh soft : nutlets $3-5,5-6 \mathrm{~mm}$. long, the hypostyle occupying about two-thirds of the ventral angle.

In sandy woods and on borders of streams, western Florida.

129. Crataegus condígna Beadle. A large shrub, with one or more stems, or sometimes a small tree $5 \mathrm{~m}$. tall, with ashy gray or brownish scaly bark. Leaf-blades cuneate, obovate-cuneate or on vigorous shoots broadly obovate, $1-3 \mathrm{~cm}$. long, $7 \mathrm{~mm} .-2.5 \mathrm{~cm}$. broad, glabrate in age, rounded or abruptly pointed at the apex, wedge-shaped or more abruptly narrowed at the base, the borders crenate or crenate-dentate; petioles $3 \mathrm{~mm} .-1$ $\mathrm{cm}$. long: corymbs simple, mostly 2-3-flowered, or flowers solitary : pedicels and hypanthium tomentose : sepals $3.5-5 \mathrm{~mm}$. long, serrate, glandular : corolla about $16 \mathrm{~mm}$. wide : stamens 20 , the anthers almost white : fruit pyriform or nearly so, $7-9 \mathrm{~mm}$. wide, 8-11 
$\mathrm{mm}$. long, at maturity yellow-green or orange, flushed with red : nutlets $3-5,5-6 \mathrm{~mm}$. long, about $4 \mathrm{~mm}$. deep, the hypostyle about $4 \mathrm{~mm}$. long.

In sandy soil, southwestern Georgia and adjacent Florida.

130. Crataegus geniculàta Ashe. A shrub 1-4 m. tall, with dark rimose bark and drooping branches. Leaf-blades cuneate or spatulate, or on vigorous shoots obovate, 1-3. $\mathrm{cm}$. long, $5 \mathrm{~mm} .-2 \mathrm{~cm}$. wide, in age glabrate or pubescent on both surfaces, especially along the midrib and principal veins beneath, rounded or pointed at the apex, wedgeshaped or more abruptly contracted at the base, the borders dentate and often broken by shallow lobes; petioles 5-15 mm. long, glandular: corymbs 2-3-flowered or flowers solitary : pedicels and hypanthium tomentose : sepals $4-5 \mathrm{~mm}$. long, glandular-serrate : stamens 20 : fruit pyriform, $7-12 \mathrm{~mm}$. thick, $8-14 \mathrm{~mm}$. long, at maturity yellow or orange, blotched or cheeked with red : nutlets $3-5,5-6 \mathrm{~mm}$. long, the hypostyle about $4 \mathrm{~mm}$. long.

On dry hills, middle North Carolina.

131. Crataegus péxa Beadle. A shrub 1-3 m. tall, with spiny branches. Leafblades cuneate or spatulate, 1-2 $\mathrm{cm}$. long, 7-15 $\mathrm{mm}$. wide, or larger on vigorous shoots, and varying from obovate to broadly ovate, frequently broader than long, pubescent, rounded, pointed or lobed at the apex, wedge-shaped or more abruptly contracted at the base, the margins dentate or crenate ; petioles very short, 1-10 mm. long, glandular, pubescent : corymbs 2-3-flowered, or flowers solitary : pedicels and hypanthium tomentose : sepals about $4 \mathrm{~mm}$. long, glandular-serrate : corolla $10-15 \mathrm{~mm}$. wide : stamens about 20 : fruit globose, $7-9 \mathrm{~mm}$. in diameter : nutlets $3-5$, about $6 \mathrm{~mm}$. long, the hypostyle about 4 $\mathrm{mm}$. long.

In dry woods and on ridges, Rowan County, North Carolina.

132. Crataegus Yadkinénsis Ashe. A shrub, or a small tree $3-7 \mathrm{~m}$. tall, with ashy gray or brownish bark. Leaf-blades obovate, spatulate or cuneiform, $1.5-3 \mathrm{~cm}$. long, 7 mm. $-2 \mathrm{~cm}$. wide, or on vigorous shoots larger and suborbicular in ontline with rounded or truncate bases, either rounded or short-pointed at the apex, narrowed or contracted at the base, the borders denticulate, glandular, often shallowy lobed above the middle; petioles $3 \mathrm{~mm} .-1 \mathrm{~cm}$. long, pubescent, glandular: corymbs mostly 2-5-flowered: pedicels and hypanthium pilose-pubescent : sepals $3-4 \mathrm{~mm}$. long, glandular-serrate : corolla 12-15 mm. wide : stamens about 20 : fruit pyriform or nearly so, 7-10 mm. thick, at maturity red or orange-red : nutlets $3-5$, about $6 \mathrm{~mm}$. long, the hypostyle occupying about three-fourths of the ventral angle.

In dry woods and on ridges, Rowan County, North Carolina.

133. Crataegus múnda Beadle. A small shrub, 1-1.5 m. tall, with spiny, drooping branches. Leaf-blades obovate, spatulate or cuneate, $1-2 \mathrm{~cm}$. long, $4 \mathrm{~mm} .-1.5 \mathrm{~cm}$. wide, glabrate in age, rounded or abruptly pointed at the apex, narrowed or contracted at the base, the borders dentate, glandular; petioles very short, 2-7 $\mathrm{mm}$. long, glabrous or with a few hairs at maturity : corymbs 2 or 3 -flowered, or flowers solitary : pedicels and hypanthium pubescent : sepals $3.5-5 \mathrm{~mm}$. long, serrate or glandular-serrate : stamens normally 20 : fruit pyriform, 7-9 mm. thick, $9-12 \mathrm{~mm}$. long : nutlets $3-5$, about $7 \mathrm{~mm}$. long, $3-4$ $\mathrm{mm}$. deep, the hypostyle about $5 \mathrm{~mm}$. long.

In sandy pine lands, South Carolina and Georgia.

134. Crataegus invícta Beadle. A shrub 1-1.5 m. tall, with zigzag, recurved and very spiny branches. Leaf-blades cuneate or spatulate, or on vigorous shoots obovate or broadly ovate, $5 \mathrm{~mm} .-2 \mathrm{~cm}$. long, $3 \mathrm{~mm} .-1 \mathrm{~cm}$. broad, or wider on the shoots, glabrate or slightly pubescent above, pubescent, especially along the veins beneath, either rounded, pointed or shallowly lobed at the apex, wedge-shaped at the base, the borders dentate, glandular; petioles very short, 2-7 mm. long, pubescent, glandular : corymbs 2- or 3-flowered, or flowers solitary: pedicels and hypanthium tomentose : sepals $3-4.5 \mathrm{~mm}$. long, glandular-serrate : stamens normally 20 : fruit pyriform, 6-8 mm. wide, $8-11 \mathrm{~mm}$. long: nutlets $3-5$, about $7 \mathrm{~mm}$. long, 3-4 mm. deep, the hypostyle about $6 \mathrm{~mm}$. long.

In sandy soil, southeastern Georgia.

135. Crataegus uniflòra Muench. A shrub 1-3m. tall. Leaf-blades obovate or oblong-cuneiform, $1.5-4 \mathrm{~cm}$. long, $7 \mathrm{~mm} .-2 \mathrm{cr}$. wide, glossy on the upper surface, pubescent beneath, especially along the midrib and principal veins, mostly obtuse at the apex, wedgeshaped or contracted at the base, the borders crenate or crenate-serrate; petioles very short, pubescent : flowers mostly solitary : pedicels and hypanthium hirsute-tomentose: sepals lanceolate, deeply incised, glandular, 6-9 mm. long : corolla 10-15 mm. wide : stamens 20 , the anthers almost white : fruit globose, 10-14 mm. in diameter, yellow or greenish yellow at maturity : nutlets $3-5$, about $7 \mathrm{~mm}$. long, the hypostyle about $5 \mathrm{~mm}$. long.

In woods and on slopes, or in old fields and sandy flats, southern New York to Florida and Louisiana. 
136. Crataegus armentàlis Beadle. A shrub 3 dm. $-1 \mathrm{~m}$. tall, usually forming small clumps or covering patches of considerable area. Leaf-blades cuneate or spatulate, 1-2 $\mathrm{cm}$. long, 5-15 mm. wide, slightly pubescent at maturity, rounded or pointed at the apex, wedge-shaped at the base, the borders serrate; petioles very short, pubescent: corymbs 2-3-flowered, or flowers solitary: pedicels and hypanthium densely hirsute-tomentose : sepals narrowly lanceolate, $5-7 \mathrm{~mm}$. long, serrate, glandular : corolla $10-15 \mathrm{~mm}$. wide : stamens 20, anthers pale yellow or nearly white: fruit globose, about $1 \mathrm{~cm}$. in diameter, red at maturity, nutlets $3-5$, about $6 \mathrm{~mm}$. long, the hypostyle $4-5 \mathrm{~mm}$. long.

In shallow soil in rocky glades. Marshall County, Alabama.

137. Crataegus Vaìiae Britton. A shrub 1-4 m. tall. Leaf-blades mostly oval or ovate, $1.5-4 \mathrm{~cm}$. long, 1-3 cm. wide, often lobed, at maturity smooth and shining above, pubescent below, especially along the midrib and principal veins, mostly pointed at the apex, contracted at the base, the borders serrate ; petioles $3-10 \mathrm{~mm}$. long: corymbs 2-6flowered : pedicels and hypanthium hirsute-tomentose : sepals $5-8 \mathrm{~mm}$. long, deeply incised, glandular : corolla $10-15 \mathrm{~mm}$. wide : stamens 20 , the anthers almost white : fruit globose, $8-10 \mathrm{~mm}$. in diameter, red at maturity: nutlets $3-5$, about $6 \mathrm{~mm}$. long, the hypostyle about $4 \mathrm{~mm}$. long.

In woods and thickets, Virginia and North Carolina.

138. Cratıegus Raleighénsis Ashe. A shrub 1-4 m. tall. Leaf-blades prevailingly oval, ovate or elliptic, $1.5-4 \mathrm{~cm}$. long, 1-3 $\mathrm{cm}$. wide, more or less pubescent, especially along the veins beneath, usually pointed but sometimes rounded at the apex, wedge-shaped or more abrustly contracted, or occasionally, especially on vigorous shoots, almost rounded at the base, the borders sharply serrate; petioles 3-10 $\mathrm{mm}$. long, margined : corymbs simple, 2-4-flowered, or flowers solitary: pedicels and hypanthium hirsute-pubescent : sepals 5-8 mm. long, incised: stamens 20: fruit globose, 8-10 mm. in diameter, at maturity yellow or greenish yellow : nutlets $3-5,6-7 \mathrm{~mm}$. long, the hypostyle about $5 \mathrm{~mm}$. long.

On dry hills and in old fields, North Carolina to Georgia.

139. Crataegus bisulcàta Ashe. A shrub 1-3 m. tall. Leaf-blades prevailingly ovate, oval or elliptic, $1.5-3 \mathrm{~cm}$. long, $1-3 \mathrm{~cm}$. wide, at maturity smooth and lustrous on the upper surface, glabrate or pubescent beneath, acute or obtuse at the apex, rounded or contracted at the base, the borders sharply and coarsely serrate and incisely lobed; petioles $3 \mathrm{~mm} .-1 \mathrm{~cm}$. long, margined, pubescent: corymbs simple, 2-4-flowered, or flowers solitary : pedicels and hypanthium hirsute-pubescent : sepals 5-8 $\mathrm{mm}$. long, serrate : stamens 20 : fruit pyriform, $9-10 \mathrm{~mm}$. thick, at maturity yellow, orange or greenish yellow : nutlets $3-5$, about $7 \mathrm{~mm}$. long, the hypostyle about two-thirds the length of the ventral angle.

In woods and fields, North Carolina to Stone Mountain, Georgia.

140. Crataegus gregàlis Beadle. A shrub 1-3 m. tall. Leaf-blades prevailingly obovate or oblong-cuneiform, $1.5-3.5 \mathrm{~cm}$. long, $7 \mathrm{~mm} .-2 \mathrm{~cm}$. wide, or broader on leading shoots, pubescent on the lower surface at maturity, mostly rounded but occasionally pointed at the apex, wedge-shaped at the base, the borders crenate or bluntly serrate; petioles very short, pubescent : corymbs 2-3-flowered, or flowers solitary : pedicels and hypanthium densely hirsute-pubescent : sepals 5-6 mm. long, incised: corolla about $15 \mathrm{~mm}$. wide : stamens 20 , the anthers nearly white : fruit pyriform, 10-16 mm. thick, 12-15 mm. long, at maturity red or ruddy : nutlets $3-5$, about $7 \mathrm{~mm}$. long, the hypostyle about $5 \mathrm{~mm}$. long.

In sandy flats of the French Broad River, western North Carolina.

141. Crataegus Eàrlei Ashe. A shrub 1-3 m. tall. Leaf-blades cuneate or obovateor oblong-cuneiform, $1-2.5 \mathrm{~cm}$. long, 5-15 mm. wide, or broader on leading shoots, pubescent on the lower surface at maturity, especially along the midrib and veins, either rounded or pointed at the apex, wedge-shaped at the base, the borders serrate, at least above the middle; petioles 1-10 mm. long, pubescent : corymbs 2-3-flowered, or flowers solitary : pedicels and hypanthium tomentose : sepals narrow, 5-7 mm. long, serrate or entire : corolla about $15 \mathrm{~mm}$. wide : stamens 20 , the anthers nearly white : fruit pyriform, 7-9 mm. wide, $8-11 \mathrm{~mm}$. long: nutlets $3-5,5-7 \mathrm{~mm}$. long, the hypostyle occupying about three-fourths of the ventral angle.

On dry hills and in sandy soil, Alabama to Florida.

142. Crataegus móllis (T. \& G.) Scheele. A tree 6-10 m. tall, with dark gray or brownish fissured and scaly bark. Leaf-blades broadly ovate, 4-9 $\mathrm{cm}$. long, $2.5-8 \mathrm{~cm}$. broad, or even larger on leading shoots, at maturity softly pubescent or tomentose on the lower surface, glabrous or slightly pubescent above, acute at the apex, rounded, truncate, or cordate at the base, the borders sharply serrate and incisely lobed; petioles $1-5 \mathrm{~cm}$. long, pubescent: corymbs compound, densely tomentose, many-flowered : pedicels and 
hypanthium tomentose : sepals $5-7 \mathrm{~mm}$. long, serrate, glandular, tomentose : corolla 2-2.5 cm. wide : stamens 20 , the anthers pale yellow : fruit subglobose, $13-18 \mathrm{~mm}$. thick, eventually bright red, ripening in August and early September : nutlets 3-5, 7-8 $\mathrm{mm}$. long, the hypostyle about $5 \mathrm{~mm}$. long.

Mostly in rich soil, Michigan to middle Tennessee and Missouri.

143. Crataegus Arkansàna Sarg. A tree 5-7 m. tall, with gray scaly bark. Leafblades oval or oblong-ovate, $4-10 \mathrm{~cm}$. long, $2.5-8 \mathrm{~cm}$. wide, at maturity glabrous on the upper surface, glabrate beneath or with some pubescence along the midrib and in the axils of the veins, acute at the apex, broadly cuneate or rounded at the base, sharply serrate and usually incised above the middle into $6-8$ short acute lobes ; petioles $1.5-4 \mathrm{~cm}$. long, winged above, ultimately glabrous or glabrate : corymbs compound, many-flowered, villous: pedicels and hypanthium villous-tomentose : sepals $4 \div 5 \mathrm{~mm}$. long, incised, glandular : corolla $2-2.5 \mathrm{~cm}$. wide : stamens 20 , the anthers pale yellow : fruit oblong or obovoid, 13-18 mm. thick, at maturity bright crimson, the flesh thick and dry: nutlets $3-5$, about $7 \mathrm{~mm}$. long, the hypostyle about $5 \mathrm{~mm}$ long.

Mostly in rich soil, southern Arkansas.

144. Crataegus Texàna Buckl. A tree, sometimes $10 \mathrm{~m}$. tall, with a trunk $3 \mathrm{dm}$. in diameter clothed with scaly bark. Leaf-blades broadly ovate, $5-10 \mathrm{~cm}$. long, $3-7.5 \mathrm{~cm}$. wide, at maturity lustrous on the upper surface, pubescent or tomentose beneath, especially along the midrib and principal veins, acute or sometimes rounded at the apex, cuneate or on leading shoots truncate at the base, the borders coarsely serrate and usually incisely 8-10-lobed; petioles 1-3 cm. long, winged above, tomentose or glabrate: corymbs compound, many-flowered, tomentose : pedicels and hypanthium tomentose : sepals 5-8 mm. long, incised, glandular, villous-tomentose : corolla about $2 \mathrm{~cm}$. wide: stamens 20 , the anthers dark red : fruit short oblong or obovate, $12-18 \mathrm{~mm}$. thick, at maturity bright scarlet, the flesh thick, soft : nutlets usually 5, 7-9 mm. long, slightly grooved on the back.

In rich bottom lands, central and western Texas.

145. Crataegus grávida Beadle. A wide-spreading tree, sometimes $6-7 \mathrm{~m}$. tall, with a trunk $2 \mathrm{dm}$. in diameter covered with dark brown scaly bark. Leaf-blades broadly ovate, 4-9 $\mathrm{cm}$. long, 3-8 $\mathrm{cm}$. wide, at maturity lustrous on the upper surface, pubescent beneath, mostly acute at the apex, rounded, truncate or cordate at the base, the borders serrate and shallowly incised; petioles $1.5-3 \mathrm{~cm}$. long, pubescent : corymbs compact, subsimple or compound, hirsute-tomentose, many-flowered : pedicels and hypanthium hirsutetomentose : sepals $3-5 \mathrm{~mm}$. long, glandular-serrate : corolla about $15 \mathrm{~mm}$. wide : stamens about 20 : fruit depressed-globose, $12-15 \mathrm{~mm}$. in diameter, red at maturity : nutlets mostly 5 , about $8 \mathrm{~mm}$. long, the hypostyle $4-5 \mathrm{~mm}$. long.

On hills, near Nashville, Tennessee.

146. Crataegus cibària Beadle. A shrub or small tree 3-6 m. tall, with dark gray scaly bark. Leaf-blades ovate, broadly ovate or oval, $3-9 \mathrm{~cm}$. long, $2-7 \mathrm{~cm}$. wide, at maturity glabrous above, pubescent along the midrib and principal veins beneath, acute or acuminate at the apex, rounded or contracted at the base, the margins sharply serrate and incised; petioles 1-4 cm. long, pubescent : corymbs ample, many-flowered, pubescent: pedicels pubescent : hypanthium glabrous : sepals 5-6 $\mathrm{mm}$. long, incised, glandular: corolla $2 \mathrm{~cm}$. broad or more: stamens 20 , the anthers light yellow: fruit short-oblong or obovate, $10-14 \mathrm{~mm}$. wide, $12-15 \mathrm{~mm}$. long, at maturity red, the flesh soft and edible : nutlets $3-5$, about $8 \mathrm{~mm}$. long, the hypostyle about $5 \mathrm{~mm}$. long.

On hills, near Nashville, Tennessee.

147. Crataegus lácera Sarg. A tree $6-8 \mathrm{~m}$. tall, with a trunk sometimes $1 \mathrm{dm}$. in diameter, clothed with gray or brownish scaly bark. Leaf-blades ovate or rhombic, or on leading shoots broadly ovate, $2.5-9 \mathrm{~cm}$. long, $2-8 \mathrm{~cm}$. wide, glabrous at maturity, acute at
the apex, broadly cuneate or on leading shoots subtruncate at the base, the margins coarsely serrate and incised; petioles $1-4 \mathrm{~cm}$. long, margined, ultimately nearly glabrous : corymbs compound, sparingly villous, many-flowered : pedicels sparingly villous: hypanthium glabrous: sepals linear-lanceolate, 4-5 mm. long, serrate, glandular: corolla $15 \mathrm{~mm}$. wide : stamens 20 , anthers rose-color : fruit oblong, $7-10 \mathrm{~mm}$. thick, $10-13 \mathrm{~mm}$. long, at maturity bright red : nutlets $3-5$, about $8 \mathrm{~mm}$. long, the hypostyle $5-6 \mathrm{~mm}$. long.

In low woods, near Fulton, Arkansas.

148. Crataegus Biltmoreàna Beadle. A shrub 1-5 m. tall, with gray or reddish brown scaly bark. Leaf-blades ovate or round-ovate, $2-7 \mathrm{~cm}$. long, $2-6 \mathrm{~cm}$. wide, pubescent on both surfaces, acute at the apex, contracted, rounded, or on leading shoots truncate at the base, the margins serrate and incised ; petioles 1-3 cm. long, margined, glandular : corymbs simple, pubescent, 3-7-flowered : pedicels and hypanthium pubescent: sepals 
about $5 \mathrm{~mm}$. long, glandular: corolla $2-2.5 \mathrm{~cm}$. wide: stamens 10 , the anthers pale yellow : fruit subglobose, $10-15 \mathrm{~mm}$. thick, $10-12 \mathrm{~mm}$. long, at maturity yellow, greenish yellow or orange, often cheeked with red : nutlets $3-5,5-7 \mathrm{~mm}$. long, 3-5 $\mathrm{mm}$. deep, the hypostyle about $4 \mathrm{~mm}$. long.

In dry or rocky woodlands, Pennsylvania to South Carolina and Tennessee.

149. Crataegus Craytònii Beadle. A shrub 1-2 m. tall, with dark gray or brownish scaly bark. Leaf-blades ovate, oblong-ovate or oval, 3-7 cm. long, 2-5 cm. broad, pubescent, acute at the apex, rounded or contracted at the base, the borders serrate and incised ; petioles 1-2.5 cm. long, margined, glandular, pubescent: corymbs simple, 3-7-flowered : pedicels and hypanthium pubescent : sepals 4-5 mm. long, glandular-serrate : corolla about $2 \mathrm{~cm}$. wide: stamens 20 , the anthers light yellow : fruit oblong or obovate, 9-12 mm. thick, $10-14 \mathrm{~mm}$. long, at maturity red or ruddy : nutlets $3-5$, about $8 \mathrm{~mm}$. long, the hypostyle $3-4 \mathrm{~mm}$. long.

On bluffs along the French Broad River, western North Carolina.

150. Crataegus tıiflòra Chapm. A large shrub, or a small tree $2-7 \mathrm{~m}$. tall. Leafblades ovate, elliptic or slightly obovate, $2-7 \mathrm{~cm}$. long, $1-5 \mathrm{~cm}$. wide, or on leading shoots even larger, pubescent, acute at the apex, rounded or abruptly contracted at the base, the borders serrate and often with short acute lobes; petioles $8 \mathrm{~mm} .-3 \mathrm{~cm}$. long, margined, glandular, pubescent : corymbs mostly 3 -flowered : pedicels and hypanthium hirsute-pubescent : sepals 7-9 mm. long, pubescent, glandular, serrate : corolla $2.5-3 \mathrm{~cm}$. wide : stamens 20 , the anthers pale yellow : fruit globose, $12-15 \mathrm{~mm}$. in diameter, pubescent, red at maturity : nutlets $3-5,7-9 \mathrm{~mm}$. long, about $5 \mathrm{~mm}$. deep, the hypostyle $5-6 \mathrm{~mm}$. long.

On rocky banks, northwestern Georgia and Alabama.

151. Crataegus austromontàna Beadle. A straggling shrub 1-4 m. tall. Leafblades broadly oval or round-ovate, $3-9 \mathrm{~cm}$. long, $2.5-7.5 \mathrm{~cm}$. wide, pubescent, acute at the apex, contracted, rounded or truncate at the base, the borders serrate and often with short, acute lobes ; petioles 1-4 cm. long, margined, glandular, pubescent : corymbs simple, 2-5(mostly 3-) flowered : pedicels and hypanthium hirsute-pubescent : sepals 6-10 mm. long, serrate, glandular, pubescent : corolla $2.5 \mathrm{~cm}$. wide : stamens 10, the anthers light-yellow: fruit globose, $12-15 \mathrm{~mm}$. in diameter, bright red at maturity, pubescent, the flesh soft : nutlets $3-5,8-10 \mathrm{~mm}$. long, 4-5 $\mathrm{mm}$. deep, the hypostyle about $5 \mathrm{~mm}$. long.

In rocky woods and on banks, Alabama and Tennessee.

152. Crataegus Harbisònii Beadle. A tree $5-8 \mathrm{~m}$. tall, with ashy gray or brownish black bark. Leaf-blades obovate, oval or broadly ovate, $2.5-10 \mathrm{~cm}$. long, 2-9 cm. wide, pubescent, acute at the apex, narrowed, contracted or rounded at the base, the borders serrate and incised; petioles $6 \mathrm{~mm} .-2 \mathrm{~cm}$. long, margined, glandular, pubescent : corymbs broad, pubescent or pilose, compound : pedicels and hypanthium pilose-pubescent : sepals lanceolate, 4-6 mm. long, serrate, glandular: corolla about $2 \mathrm{~cm}$. wide : stamens 20 , the anthers light yellow : fruit globose, $10-13 \mathrm{~mm}$. in diameter, red at maturity : nutlets $3-5$, about $8 \mathrm{~mm}$. long, 4-5 mm. deep, the hypostyle 5-6 mm. long.

On limestone hills and ridges, near Nashville, Tennessee.

153. Crataegus Áshei Beadle. A large branching shrub, or a small tree 3-6 m. tall, with light gray or brownish scaly bark. Leaf-blades ovate, round-ovate or occasionally obovate, $2.5-7 \mathrm{~cm}$. long, $2-6 \mathrm{~cm}$. wide, at maturity pubescent on the lower surface, especially along the midrib and veins, rounded or acute at the apex, abruptly contracted or broadly wedge-shaped at the base, the borders serrate ; petioles $5 \mathrm{~mm} .-2 \mathrm{~cm}$. long, margined, pubescent, glandular : corymbs subsimple or branched, 3-10-flowered : pedicels and hypanthium pilose-pubescent : sepals $7-10 \mathrm{~mm}$. long, serrate, glandular : corolla about 2 cm. wide: stamens 20, the anthers light yellow : fruit subglobose or short-oval, 10-14 mm. thick, red at maturity : nutlets $3-5$, about $8 \mathrm{~mm}$. long, the hypostyle about $5 \mathrm{~mm}$. long.

In abandoned fields and woodlands, generally in clay soil, Montgomery County, Alabama.

154. Crataegus rústica Beadle. A large shrub, or a small tree 2-6 m. tall, sometimes with a trunk $2 \mathrm{dm}$. in diameter clothed with dark gray or brownish black scaly bark. Leaf-blades ovate, or oval, $2-5 \mathrm{~cm}$. long, $1.5-5 \mathrm{~cm}$. wide, glabrous when fully grown, acute at the apex, rounded, narrowed, or on leading shoots truncate or cordate at the base, the borders serrate and incisely lobed; petioles $1.5-3 \mathrm{~cm}$. long, glabrous: corymbs simple, 3-9-flowered: pedicels and hypanthium glabrous: sepals $3-4 \mathrm{~mm}$. long, mostly entire: corolla $15-18 \mathrm{~mm}$. wide: stamens 20 , the anthers light yellow : fruit subglobose, $7-11 \mathrm{~mm}$. thick, obtusely angled and conspicuously swollen below the middle, at maturity dull red, or red and green, the flesh firm : nutlets $3-5$, about $7 \mathrm{~mm}$. long, the hypostyle about $4 \mathrm{~mm}$.
long.

In old fields and woodlands, near Biltmore, North Carolina. 
155. Crataegus arcàna Beadle. A shrub or small tree 2-6 m. tall, with a short trunk sometimes $2 \mathrm{dm}$. in diameter, clothed with dark gray or brownish black scaly bark. Leaf-blades ovate or oval, $2.5-6 \mathrm{~cm}$. long, 2-7 cm. wide, glabrous when fully grown, acute or acuminate at the apex, rounded or contracted, or on leading shoots truncate or subcordate at the base, the borders sharply serrate and incised; petioles $1-3 \mathrm{~cm}$. long, glabrous: corymbs simple or subsimple, 4-10-flowered: pedicels and hypanthium glabrous: sepals 4-5 mm. long: corolla $16-20 \mathrm{~mm}$. wide : stamens 20 , the anthers light purple : fruit subglobose, $8-12 \mathrm{~mm}$. thick, obtusely angled and conspicuously swollen below the middle, at maturity red or ruddy, the flesh firm: nutlets $3-5,6-7 \mathrm{~mm}$. long, the hypostyle about half the length of the ventral angle.

In woods and old fields near Biltmore, North Carolina.

156. Crataegus Georgiàna Sarg. A tree sometimes $8-10 \mathrm{~m}$. tall, with a trunk $3 \mathrm{dm}$. in diameter, covered with dark gray or brownish scaly bark. Leaf-blades ovate, 3.5-5.5 cm. long, 2.5-3.5 cm. wide, or larger on leading shoots, glabrous when fully grown, acute or acuminate at the apex, contracted or rounded at the base, the borders serrate and with short acute lobes; petioles $1.5-3 \mathrm{~cm}$. long, glabrous : corymbs subsimple or compound, 5-10-flowered : pedicels and hypanthium glabrous : sepals $3-5 \mathrm{~mm}$. long, entire or obscurely serrate : corolla about $20 \mathrm{~mm}$. wide : stamens 20 , the anthers purplish': fruit globose, $10-13$ $\mathrm{mm}$. in diameter, at maturity dull russet-green, the flesh firm : nutlets $3-5,6-7 \mathrm{~mm}$. long.

In low woods and meadows, near Rome, Georgia.

157. Crataegus cállida Beadle. A shrub or small tree $2-5 \mathrm{~m}$. tall, the trunk or stems covered with dark gray or brownish scaly bark. Leaf-blades ovate, $2-7 \mathrm{~cm}$. long, $2-6 \mathrm{~cm}$. wide, glabrous, acute or acuminate at the apex, rounded, truncate or subcordate at the base, the borders serrate and with several pairs or short point-like lobes; petioles 1-3 $\mathrm{cm}$. long, glabrous : corymbs subsimple or compound, 5-10-flowered : pedicels and hypanthium glabrous : sepals $3-5 \mathrm{~mm}$. long, mostly entire : corolla about $20 \mathrm{~mm}$. wide : stamens 20 , the anthers very pale yellow or almost white: fruit depressed-globose, $8-10 \mathrm{~mm}$. wide : at maturity red or green and red often with russet surfaces, the flesh firm : nutlets $3-5$, about $7 \mathrm{~mm}$. long, the hypostyle occupying about two-thirds of the ventral angle.

In flat woods, northeastern Alabama.

158. Crataegus iracùnda Beadle. A large shrub, or a slender tree $2-5 \mathrm{~m}$. tall, with ashy gray, either smooth or scaly bark. Leaf-blades ovate or deltoid, $1.5-6 \mathrm{~cm}$. long, 1-6 $\mathrm{cm}$. wide, scabrous above, glabrous beneath, acute or acuminate at the apex, truncate, cor. date or occasionally broadly cuneate at the base, the borders sharply serrate and incised; petioles $7 \mathrm{~mm} .-2 \mathrm{~cm}$. long, glabrous, glandular: corymb simple, 3-7-flowered : pedicels and hypanthium glabrous: sepals $3-4 \mathrm{~mm}$. long, entire or glandular-serrate : corolla about $15 \mathrm{~mm}$. wide : stamens 10 , the anthers purple : fruit subglobose, $8-10 \mathrm{~mm}$. thick, at maturity red or red and green, the flesh firm : nutlets $3-5$, about $6 \mathrm{~mm}$. long, the hypostyle 3-4 mm. long.

In flat woods, northwestern Georgia.

159. Crataegus vicinàlis Beadle. A large shrub, or a small tree $3-6 \mathrm{~m}$. tall, with dark gray or brownish scaly bark. Leaf-blades ovate, $2-5 \mathrm{~cm}$. long, $1.5-4 \mathrm{~cm}$. wide, glabrous, acute or acuminate at the apex, rounded, truncate or cordate, or sometimes broadly cuneate at the base, the margins serrate and with short, acute lobes; petioles $7 \mathrm{~mm} .-2 \mathrm{~cm}$. long, glabrous : corymbs simple, 3-7-flowered: pedicels and hypanthium glabrous : sepals 2-4 mm. long, entire or serrate: corolla 14-16 mm. wide: stamens 20 , the anthers white or cream-color : fruit pyriform, $7-9 \mathrm{~mm}$. thick, $9-12 \mathrm{~mm}$. long, at maturity red or ruddy, the flesh firm : nutlets $3-5,6.5-7.5 \mathrm{~mm}$. long, the hypostyle about $5 \mathrm{~mm}$. long.

In woods and on slopes, southeastern Tennessee and Georgia.

160. Crataegus basílica Beadle. A shrub or small tree 4-7 m. tall, with dark gray or brownish scaly bark. Leaf-blades ovate, $3-7 \mathrm{~cm}$. long, $2.5-6.5 \mathrm{~cm}$. wide, glabrous, acute or acuminate at the apex, broadly cuneate, rounded or truncate at the base, the borders serrate and with several pairs of short, acute lobes; petioles 1-3 cm. long, glabrous : corymbs subsimple or compound, glabrous, 5-15-flowered : pedicels and hypanthium glabrous : sepals 4-5 mm. long, entire or serrate: corolla $14-17 \mathrm{~mm}$. wide : stamens $15-20$, the anthers purple : fruit subglobose, $12-15 \mathrm{~mm}$. thick, at maturity red or pruinose-red, the flesh soft : nutlets $3-5,7-8 \mathrm{~mm}$. long, the hypostyle about $5 \mathrm{~mm}$. long.

In woods and on slopes in the mountains, western North Carolina.

161. Crataegus macrospérma Ashe. A shrub or small tree 3-7 m. tall, with dark gray or brownish scaly bark. Leaf-blades ovate or oval, $2.5-6 \mathrm{~cm}$. long, $2-5 \mathrm{~cm}$. wide, glabrous, acute at the apex, rounded, truncate or cordate at the base, sharply serrate and with several pairs of short, acute lobes ; petioles 1-3 $\mathrm{cm}$. long, glabrous : corymbs simple or subsimple, 4-9-flowered : pedicels and hypanthium glabrous: sepals 3-5 mm. long, serrate 
or entire : corolla 14-17 mm. wide : stamens normally 10 , the anthers purple : fruit shortoblong or obovate, $9-15 \mathrm{~mm}$. thick, red at maturity, the flesh soft : nutlets $3-5,6-7 \mathrm{~mm}$. long, the hypostyle $5-6 \mathrm{~mm}$. long.

Mountains of North Carolina, Tennessee, Georgia and Alabama.

162. Crataegus nubícola Beadle. A shrub 1-3 m. tall, with ashy gray scaly bark. Leaf-blades ovate, $2-5 \mathrm{~cm}$. long, $2-5 \mathrm{~cm}$. wide, glabrous, acute at the apex, rounded or truncate at the base, the borders sharply serrate and with 3-5 pairs of short acute lobes ; petioles 1-2.5 $\mathrm{cm}$. long, glabrous: corymbs subsimple or compound, 5-10-flowered, glabrous : pedicels and hypanthium glabrous : sepals $4-5 \mathrm{~mm}$. long, entire or slightly serrate : stamens 20 : fruit subglobose, $7-9 \mathrm{~mm}$. thick, red at maturity : nutlets $3-5,6-7 \mathrm{~mm}$. long, the hypostyle $5-6 \mathrm{~mm}$. long.

On the high mountains of western North Carolina, at elevations above $1750 \mathrm{~m}$.

163. Crataegus Roanénsis Ashe. A shrub or small tree $2-6 \mathrm{~m}$. tall, with ashy gray scaly bark. Leaf-blades ovate, $2.5-6 \mathrm{~cm}$. long, $2-6 \mathrm{~cm}$. wide, glabrous, acute at the apex, rounded, truncate or cordate at the base, the margins serrate and with 3-5 pairs of short acute lobes; petioles 1-3 cm. long, glabrous : corymbs subsimple or compound, glabrous : pedicels and hypanthium glabrous: sepals $3.5-5 \mathrm{~mm}$. long, entire or slightly serrate : corolla 14-16 mm. wide : stamens normally 10, the anthers purple : fruit oblong, 7-9 mm. wide, 9-11 mm. long, at maturity red, pruinose, the flesh soft : nutlets $2-5,6-8 \mathrm{~mm}$. long, the hypostyle $5-6 \mathrm{~mm}$. long.

On the high mountains of western North Carolina and eastern Tennessee, mostly above $1400 \mathrm{~m}$ elevation.

164. Crataegus berberifòlia T. \& G. A tree, sometimes attaining a height of $8 \mathrm{~m}$., with dark gray scaly bark. Leaf-blades oblong-cuneiform or spatulate, 2-6 cm. long, 1-2.5 $\mathrm{cm}$. wide, or on leading shoots obovate-cuneate and frequently $3.5 \mathrm{~cm}$. wide, at maturity dark green or scabrous or eventually smooth above, pale or even whitened and pubescent beneath, especially along the midrib and principal veins, rounded or obtuse at the apex, gradually or sometimes abruptly contracted at the base, the borders serrate above the middle ; petioles 2-12 $\mathrm{mm}$. long, pubescent, at least when young : corymbs compound or subsimple, ample, densely hirsute: pedicels and hypanthium hirsute-pubescent : sepals 3.5-5 $\mathrm{mm}$. long, serrate or entire : corolla $10-15 \mathrm{~mm}$. wide : stamens $16-20$, the anthers yellow : fruit subglobose, $10-13 \mathrm{~mm}$. thick, at maturity yellow or orange with flushed cheeks : nutlets mostly $2-3$, about $7 \mathrm{~mm}$. long, the hypostyle about $5 \mathrm{~mm}$. long.

In woods and open grounds, southern Louisiana.

165. Crataegus edita Sarg. A tree sometimes $12 \mathrm{~m}$. tall, with a trunk $4 \mathrm{dm}$. in diameter covered with dark scaly bark. Leaf-blades oblong-obovate or oval, 3-5 cm. long, $1.5-2.5 \mathrm{~cm}$. wide, or on leading shoots longer and broader, at maturity glabrous or glabrate on the upper surface, usually with some persistent pubescence beneath, especially along the midrib, acute at the apex, gradually narrowed or slightly contracted at the base, the borders serrate above the middle; petioles $5-15 \mathrm{~mm}$. long, margined : corymbs few-flowered, compound, slightly villose : pedicels and hypanthium villose : sepals $3-4 \mathrm{~mm}$. long, entire or obscurely serrate : corolla $12-16 \mathrm{~mm}$. wide : stamens 20 , the anthers rose colored : fruit short oblong, about $1 \mathrm{~cm}$. thick, at maturity dull green tinged with red, the flesh thin and firm : nutlets $2-3,6-7 \mathrm{~mm}$. long, the hypostyle $4-5 \mathrm{~m}$. long.

In low grounds and on hills, Louisiana and Texas.

166. Crataegus féra Beadle. A tree 5-7 m. tall, with a trunk sometimes $2 \mathrm{dm}$. in diameter, covered with dark gray or brownish scaly bark. Leaf-blades oblong or obovatecuneiform, $2.5-5 \mathrm{~cm}$. long, $1.5-3 \mathrm{~cm}$. wide, at maturity dark green, lustrous and slightly scabrous on the upper surface, pale or whitened beneath and with some persistent pubescence, especially along the midrib, rounded or obtuse or rarely nearly truncate at the apex, gradually narrowed or sometimes contracted at the base, the borders serrate above the middle ; petioles 5-15 mm. long, margined : corymbs pilose-pubescent, compound, ample : pedicels and hypanthium pilose-pubescent, or the latter pubescent only at the base: sepals $3-4.5 \mathrm{~mm}$. long, entire or serrate : corolla $12-15 \mathrm{~mm}$. wide : stamens $16-20$, the anthers yellow or cream-color : fruit globose or subglobose, about $1 \mathrm{~cm}$. wide, at maturity bright red or scarlet : nutlets mostly $2-3$, about $6 \mathrm{~mm}$. long, the hypostyle about $4 \mathrm{~mm}$. long.

In low woods, southern Louisiana.

167. Crataegus Móhri Beadle. A tree, sometimes $10 \mathrm{~m}$. tall, but oftener a large shrub or very small tree clothed with dark gray or brownish scaly bark. Leaf-blades obovate-cuneiform, oval or elliptic, or on leading shoots broadly oval or suborbicular, 2-5 $\mathrm{cm}$. long, $1.5-4 \mathrm{~cm}$. wide, glabrous in age, or with traces of pubescence in the axils of the veins beneath, acute or rounded at the apex, contracted or gradually narrowed at the base, the margins serrate to near the base ; petioles $7 \mathrm{~mm} .-2 \mathrm{~cm}$. long, margined : corymbs more 
or less pilose, compound, many-flowered : pedicels $8 \mathrm{~mm} .-2.5 \mathrm{~cm}$. long, pilose or glabrous : hypanthium usually glabrous : sepals $2-5 \mathrm{~mm}$. long, entire or slightly glandular-serrate : corolla about $15 \mathrm{~mm}$. wide: stamens 20 , the anthers light yellow : fruit globose, 7-9 mm. in diameter, at maturity red or greenish red, frequently with black spots and blotches: nutlets $3-5,5-7 \mathrm{~mm}$. long, the hypostyle occupying about two-thirds of the ventral angle.

In woods and fields, northwestern Georgia to Alabama, Mississippi and Tennessee.

168. Crataegus edùra Beadle. A tree sometimes $7-8 \mathrm{~m}$. tall, with a trunk $2 \mathrm{dm}$. in diameter covered with ashy gray or brownish scaly bark. Leaf-blades cuneate or oblong- or obovate-cuneiform, $2.5-6 \mathrm{~cm}$. long, $1-3 \mathrm{~cm}$. wide, at maturity glabrate or slightly scabrous on the upper surface, usually with some pubescence along the midrib beneath, mostly rounded or obtuse, but occasionally acute at the apex, cuneate at the base, the borders serrate or crenate-serrate above the middle; petioles $2-10 \mathrm{~mm}$. long, pubescent, at least when young : corymbs small, congested, compound, 5-12-flowered: pedicels sparingly pilose : hypanthium glabrous or with a few hairs at the base : sepals 3-4.5 mm. long, entire or slightly serrate : corolla $10-14 \mathrm{~mm}$. wide : stamens $16-20$, the anthers light yellow or almost white : fruit subglobose, $8-9 \mathrm{~mm}$. thick, at maturity orange-yellow with red or ruddy cheeks : nutlets mostly $2-3,6-7 \mathrm{~mm}$. long, the hypostyle about two-thirds the length of the nutlet.

In upland woods, southern Louisiana.

169. Crataegus térsa Beadle. A tree 4-6 m. tall, with dark gray or brownish scaly bark. Leaf-blades oblong- or obovate-cuneiform, $2-6 \mathrm{~cm}$. long, $1-4.5 \mathrm{~cm}$. wide, at maturity lustrous and glabrous or slightly scabrons on the upper surface, more or less pubescent beneath, rounded or obtuse, or on leading shoots slightly pointed at the apex, wedge-shaped or more abruptly contracted at the base, the borders serrate or crenate-serrate above the middle ; petioles 5-15 mm. long, margined, pubescent, at least when young: corymbs compound, many-flowered, pilose-pubescent: pedicels and hypanthium pilose-pubescent : corolla $15-18 \mathrm{~mm}$. wide : stamens 18-20, the anthers purplish : fruit subglobose, 8-9 mm. thick, ruddy at maturity : nutlets mostly $2-3$, about $6 \mathrm{~mm}$. long, the hypostyle about $4 \mathrm{~mm}$. long.

In upland woods, southern Louisiana.

170. Crataegus tétrica Beadle. A large shrub, or a small tree 4-7 m. tall, with a short trunk 1-2 dm. in diameter covered with dark brown scaly bark. Leaf-blades oval or obovate, $2.5-6 \mathrm{~cm}$. long, $1.5-4.5 \mathrm{~cm}$. wide, bright green and glabrous or glabrate on the upper surface, pale and pubescent beneath, especially along the midrib and principal veins, rounded or on vigorous shoots pointed at the apex, abruptly contracted or narrowed at the base, the borders serrate above the middle or sometimes nearly to the base; petioles $5 \mathrm{~mm}$. $-1 \mathrm{~cm}$. long, margined, pubescent : corymbs compound, hirsute or pilose-pubescent, 10-20-flowered: pedicels and hypanthium pilose-pubescent: sepals about $4 \mathrm{~mm}$. long, entire or nearly so: stamens normally 10 , the anthers purplish : fruit globose, about $1 \mathrm{~cm}$. in diameter, red or yellow-green with red cheeks : nutlets mostly in pairs, 6-8 $\mathrm{mm}$. long, 3-4 $\mathrm{mm}$. deep, the hypostyle 4-5 $\mathrm{mm}$. long.

On limestone hills, middle Tennessee.

171. Crataegus árta Beadle. A large shrub, or a small tree $3-4 \mathrm{~m}$. tall, the trunk or main stems clothed with dark gray or brownish scaly bark. Leaf-blades cuneate, obo. vate- or oblong-cuneiform, rarely elliptic, 2-4 cm. long, 1-2 cm. wide, or larger on leading shoots, glabrous or with a few hairs along the midrib, especially on the upper surface, rounded or pointed at the apex, wedge-shaped or more abruptly contracted at the base, the borders serrate above the middle; petioles 2-10 mm. long, sparingly pubescent when young, mainly on the upper surface and margins : corymbs narrow, close, 4-8-flowered: pedicels 4-10 mm. long, more or less pubescent : hypanthium glabrous or with a few hairs near the base: corolla $15 \mathrm{~mm}$. wide : stamens normally 10 , the anthers purplish : fruit subglobose or short ovoid, about $1 \mathrm{~cm}$. thick, at maturity yellow-green or orange with red cheeks : nutlets mostly $2-3,7-8 \mathrm{~mm}$. long, the hypostyle $4-5 \mathrm{~mm}$. long.

On limestone hills, middle Tennessee.

172. Crataegus tórva Beadle. A large shrub, or a small tree 3-4 m. tall, with dark gray or brownish scaly bark. Leaf-blades obovate, elliptic or cuneiform, or on leading shoots sometimes oval, $2-5 \mathrm{~cm}$. long, 1-3 cm. wide, or larger on the shoots, glabrous or
glabrate at maturity, either pointed or rounded at the apex, wedge-shaped or more abruptly contracted at the base, the borders serrate above the middle : corymbs compound, manyflowered, more or less pilose-pubescent: pedicels and hypanthium pilose or glabrate: sepals $3-4 \mathrm{~mm}$. long, entire or sparingly serrate: corolla about $15 \mathrm{~mm}$. wide : stamens
$7-10$, the anthers purplish : fruit subglobose, $7-9 \mathrm{~mm}$. in diameter : nutlets mostly $2-3$, 6-7 mm. long, the hypostyle about two-thirds as long as the ventral angle.

In woods and on hills, Georgia and Alabama. 
173. Crataegus denària Beadle. A tree $5-7 \mathrm{~m}$. tall, with a trunk sometimes $2 \mathrm{dm}$. in diameter covered with dark gray or brownish scaly bark. Leaf-blades oval, oblongobovate or elliptic, or on leading shoots broadly oval, ovate or obovate, $2.5-6 \mathrm{~cm}$. long, 1-4 cm. wide, glabrous at maturity, mostly pointed at the apex, contracted or narrowed at the base, the borders serrate; petioles $5 \mathrm{~mm} .-2 \mathrm{~cm}$. long, margined, glabrous or with a few hairs on the upper side, especially when young: corymbs compound, many-flowered, more or less pilose : pedicels and hypanthium sparingly pilose or glabrous : sepals 4-6 $\mathrm{mm}$. long, entire or slightly serrate : corolla $13-16 \mathrm{~mm}$. wide : stamens normally 10 : fruit globose or subglobose, $6-9 \mathrm{~mm}$. thick, the flesh thin and firm : nutlets $3-5,5-6 \mathrm{~mm}$. long, the hypostyle about two-thirds as long as the ventral angle.

On banks of streams, eastern Mississippi.

174. Crataegus crocina Beadle. A tree 4-6 m. tall, with a short trunk covered with ashy gray or brownish black scaly bark. Leaf-blades oblong or obovate-cuneiform, 2-5.5 cm. long, 1-3 cm. wide, glabrous or glabrate on the upper surface at maturity, pale or whitened and pubescent beneath, especially along the midrib and principal veins, either rounded or pointed at the apex, cuneate at the base, the borders serrate, except near the base ; petioles $5-15 \mathrm{~mm}$. long, margined, pubescent, at least when young: corymbs subsimple or compound, few- or many-flowered : pedicels and hypanthium pilose-pubescent : sepals $3.5-5 \mathrm{~mm}$. long, entire or slightly serrate : corolla $12-16 \mathrm{~mm}$. wide : stamens normally 20, the anthers yellow : fruit oval or oblong, 8-11 mm. thick, ripening in October, yellow at maturity : nutlets 2 , about $7 \mathrm{~mm}$. long, the hypostyle $4-5 \mathrm{~mm}$. long.

In low woods, southern Louisiana.

175. Crataegus albícera Beadle. A tree sometimes $7-8 \mathrm{~m}$. tall, with a trunk $2 \mathrm{dm}$. in diameter clothed with dark gray or brownish scaly bark. Leaf-blades oval, elliptic or oblong, sometimes obovate- or oblong-cuneiform, $2-6 \mathrm{~cm}$. long, 1-4 cm. wide, at maturity dark green and glabrate on the upper surface, pale or whitened and pubescent beneath, the pubescence dense and more persistent along the midrib and principal veins, mostly pointed at the apex, contracted or narrowed at the base, the borders serrate, mostly above the middle ; petioles 2-10 mm. long, pubescent : corymbs hirsute-pubescent, compound : pedicels and hypanthium hirsute-pubescent : sepals $3-4 \mathrm{~mm}$. long, slightly serrate or entire : stamens 10-14, the anthers purple: fruit oblong, 8-12 mm. thick, 10-14 mm. long, ripening in August, at maturity pale yellow, the flesh soft and edible: nutlets solitary or in pairs, about $7 \mathrm{~mm}$. long, the hypostyle about $4 \mathrm{~mm}$. long.

In open, rich woods, southern Louisiana.

176. Crataegus sínistra Beadle. A small tree, or a large much-branched shrub 3-5 $\mathrm{m}$. tall, with one or more stems clothed with dark gray or brownish black scaly bark. Leaf-blades obovate, oval or elliptic, $2-5 \mathrm{~cm}$. long, $8 \mathrm{~mm} .-3 \mathrm{~cm}$. wide, glabrous or glabrate in age on the upper surface, pubescent beneath, especially along the midrib and principal veins, mostly rounded but occasionally pointed at the apex, wedge-shaped or more abruptly contracted at the base, the borders serrate above the middle, or rarely entire ; petioles 3-7 mm. long, margined, pubescent : corymbs compound, pilose-pubescent, 7-15-flowered : pedicels and hypanthium pilose-pubescent : sepals $3-4 \mathrm{~mm}$. long, mostly entire: stamens normally 10 , the anthers purple : fruit oval, 9-12 mm. long, 6-8 $\mathrm{mm}$. thick, at maturity reddish, red and green or with yellowish surfaces where not exposed and brownish red cheeks, the flesh thin and firm: nutlets 1-2, 7-8 mm. long, the hypostyle about $4 \mathrm{~mm}$. long.

On limestone hills, middle Tennessee.

177. Crataegus signàta Beadle. A tree 5-6 m. tall, or frequently a large muchbranched shrub with one or more stems. Leaf-blades obovate or obovate-cuneiform, or occasionally oval on leading shoots, $2-4 \mathrm{~cm}$. long, $1.5-3 \mathrm{~cm}$. wide, pubescent, either rounded or pointed at the apex, wedge-shaped or contracted at the base, the borders sharply serrate especially above the middle, or on the shoots more sharply serrate and frequently incised ; petioles $3-15 \mathrm{~mm}$. long, margined, pubescent, glandular : corymbs pilose-pubescent, compound: pedicels and hypanthium pubescent: sepals 4-6 mm. long, glandular-serrate : stamens normally 10 : fruit oval or oblong, 9-14 mm. long, $7-10 \mathrm{~mm}$. wide, red at maturity, more or less pruinose, punctate: nutlets $3-5,7-8 \mathrm{~mm}$. long, $3-4 \mathrm{~mm}$. deep, the hypostyle 4-5 mm. long.

In open, mostly dry copses, southern Alabama.

178. Crataegus Crús-Gálli L. A tree sometimes $8-9 \mathrm{~m}$. tall, with a trunk $3-4 \mathrm{dm}$. in diameter, covered with dark gray or brownish scaly bark. Leaf-blades obovate or oblanceolate, $2-5 \mathrm{~cm}$. long, 1-3 cm. wide, or on leading shoots frequently oval and of greater size, glabrous, obtuse or pointed at the apex, cuneate at the base, the borders sharply serrate above the middle; petioles 5-15 mm. long, margined : corymbs compound, 
glabrous, many-flowered: pedicels and hypanthium glabrous: sepals $3.5-5 \mathrm{~mm}$. long, linear-lanceolate: corolla $12-14 \mathrm{~mm}$. wide: stamens about 10 , the anthers rose-color or purplish : fruit oval or oblong, $8-13 \mathrm{~mm}$. thick, dull red at maturity; nutlets mostly 2, about $8 \mathrm{~mm}$. long, the hypostyle about $5 \mathrm{~mm}$. long.

In woods and thickets. Canada and New England to North Carolina and Missouri.

179. Crataegus mácra Beadle. A small tree, or a large spreading shrub 2-5 m. tall, with one or more stems covered with dark gray or brownish scaly bark. Leaf-blades cuneate or oblong- or obovate-cuneiform, 2-5 cm. long, $8 \mathrm{~mm} .-2 \mathrm{~cm}$. wide, glabrous, rounded or pointed at the apex, cuneate at the base, the borders serrate above the middle; petioles 3-10 $\mathrm{mm}$. long, margined : corymbs small, short, compound, glabrous : pedicels and hypanthium glabrous: sepals $3-4.5 \mathrm{~mm}$. long, mostly entire : corolla about $12 \mathrm{~mm}$. wide: stamens about 10 , the anthers purplish : fruit subglobose or oval, $5-8 \mathrm{~mm}$. broad, red at maturity : nutlets $1-3,6-7 \mathrm{~mm}$. long, the hypostyle $3-4 \mathrm{~mm}$. long.

In flat woods, northwestern Georgia.

180. Crataegus regàlis Beadle. A tree, sometimes $10 \mathrm{~m}$. tall, with a trunk $2-3 \mathrm{dm}$. in diameter covered with ashy gray or brownish scaly bark. Leaf-blades oval, broadly oval or elliptic, $3-8 \mathrm{~cm}$. long, $1.5-5 \mathrm{~cm}$. wide, glabrous, acute or acuminate at the apex, contracted or broadly cuneate at the base, the borders serrate, and on leading shoots often incised ; petioles 5-15 mm. long, margined : corymbs glabrous, compound, many-flowered : pedicels and hypanthium glabrous: sepals $4-5 \mathrm{~mm}$. long, linear-lanceolate, entire or remotely serrate : corolla $12-14 \mathrm{~mm}$. wide : stamens about 10 , the anthers yellow : fruit oblong, about $8 \mathrm{~mm}$. thick and $1 \mathrm{~cm}$. long: nutlets mostly 2-3, 7-8 $\mathrm{mm}$. long, the hypostyle 5-6 mm. long.

In low woods, northwestern Georgia and northern Alabama.

181. Crataegus álgens Beadle. A large shrub, or a small tree $2-5 \mathrm{~m}$. tall, the trunk clothed with dark gray or brownish black scaly bark. Leaf-blades obovate- or oblong-cuneiform, sometimes broadly obovate or elliptic, $2-6 \mathrm{~cm}$. long, $1.5-4 \mathrm{~cm}$. wide, glabrous, either rounded or pointed at the apex, wedge-shaped or more abruptly contracted at the base, the borders serrate, at least above the middle; petioles $5-15 \mathrm{~mm}$. long, margined : corymbs compound, glabrous, many-flowered: pedicels and hypanthium glabrous; sepals 4-5.5 mm. long, entire or remotely serrate : corolla $12-14 \mathrm{~mm}$. wide: stamens about 10 , the anthers yellow : fruit subglobose or somewhat ovoid, 8-10 mm. thick, dull red at maturity : nutlets mostly $1-2,7-8 \mathrm{~mm}$. long, the hypostyle about $5 \mathrm{~mm}$. long.

In woods and fields, North Carolina to Georgia, Alabama and Tennessee.

182. Crataegus pyracanthoides Beadle. A shrub, or a small tree $2-5 \mathrm{~m}$. tall, with ashy gray or brownish smooth or scaly bark. Leaf-blades obovate, oblanceolate or elliptic, $1.5-5 \mathrm{~cm}$. long, $7 \mathrm{~mm} .-3 \mathrm{~cm}$. wide, glabrous, acute or rounded at the apex, cuneate at the base, the margins serrate above the middle; petioles $2-10 \mathrm{~mm}$. long, margined : corymbs compound, glabrous, many-flowered : pedicels and hypanthium glabrous : sepals $2.5-4 \mathrm{~cm}$. long, entire or remotely serrate : stamens $7-12$, the anthers purplish : fruit globose or nearly so, $5-8 \mathrm{~mm}$. in diameter, bright red at maturity : nutlets mostly $2,5-6 \mathrm{~mm}$. long, the hypostyle about half the length of the nutlet.

Banks of the Chipola River, near Marianna, Florida.

183. Crataegus armàta Beadle. A shrub, or a small tree $2-5 \mathrm{~m}$. tall, with ashy gray or brownish scaly bark. Leaf-blades oblong- or obovate-cuneiform, $2-4 \mathrm{~cm}$. long, 1-2 cm. wide, or on leading shoots oval, $2.5-3.5 \mathrm{~cm}$. wide, glabrous, rounded, mucronate or even acute at the apex, wedge-shaped, or more abruptly contracted at the base, the margins serrate above the middle, or occasionally subentire ; petioles 5-10 mm. long, margined : corymbs compound, glabrous, many-flowered : pedicels and hypanthium glabrous : sepals 2.5-4 mm. long, entire or slightly serrate: stamens 7-10: fruit globose or nearly so, 5-8 mm. wide, dull red, pruinose : nutlets $1-2,6-7 \mathrm{~mm}$. long, the hypostyle $3-4 \mathrm{~mm}$. long.

On limestone hills, middle Tennessee and northern Alabama.

184. Crataegus arbòrea Beadle. A tree, sometimes 8-10 m. tall, with a trunk 2-3 $\mathrm{dm}$. in diameter covered with dark gray fissured exfoliating bark. Leaf-blades obovatecuneiform or oblanceolate, $2-6 \mathrm{~cm}$. long, $12 \mathrm{~mm} .-4 \mathrm{~cm}$. wide, glabrous, rounded or pointed at the apex, wedge-shaped at the base, the margins serrate except at the base or below the middle; petioles 5-15 mm. long, margined : corymbs glabrous, compound, many-flowered: pedicels and hypanthium glabrous : sepals $2.5-4 \mathrm{~mm}$. long, mostly entire : corolla 12-15 $\mathrm{mm}$. wide : stamens about 20 , the anthers light yellow : fruit globose or subglobose, $6-9$ $\mathrm{mm}$. thick, red or ruddy at maturity : nutlets mostly 2 , about $7 \mathrm{~mm}$. long, the hypostyle 4-5 mm. long.

In pine woods, mostly in clay soil, Montgomery, Alabama, 
185. Crataegus Búshil Sarg. A large shrub, or a small tree 4-7 m. tall, with a trunk sometimes $2-2.5 \mathrm{dm}$. in diameter covered with dark brown fissured and scaly bark. Leaf-blades obovate or elliptic, or on leading shoots sometimes suborbicular, $2-7 \mathrm{~cm}$. long, $1-3.5 \mathrm{~cm}$. wide, glabrous or glabrate in age, either rounded or pointed at the apex, wedgeshaped or more abruptly contracted at the base, the margins serrate above the middle ; petioles 5-15 mm. long, eventually glabrous : corymbs broad, compound, glabrous, manyflowered : pedicels and hypanthium glabrous : sepals 4-5 $\mathrm{mm}$. long, mostly entire : corolla 2-2.5 mm. wide: stamens 20 , the anthers bright rose-color : fruit oblong, 7-10 $\mathrm{mm}$. long, at maturity green tinged with dull red, the flesh thin and firm: nutlets 2-3, about $6 \mathrm{~mm}$. long.

Upland woods, Fulton, Arkansas.

\section{COTONEÁSTER Medic.}

Shrubs, with much branched stems. Leaves alternate, stipulate: blades simple. Flowers in corymb-like cymes or rarely solitary. Sepals 5, persistent. Corolla white. Petals 5, scarcely clawed. Stamens numerous. Ovary 2-5-celled, the carpels more or less distinct above : styles 2-5. Ovules 2 in each cavity or carpel, erect. Pome ovoid, globose or turbinate, the carpels bony at maturity.

1. Cotoneaster Pyracántha (L.) Spach. An evergreen shrub, 1-2.5 m. tall, with slender spines, 1-2.5 cm. long. Leaves persistent; blades oval or slightly oblanceolate, $2-5 \mathrm{~cm}$. long, obtuse, crenulate, glabrous, short-petioled : cymes many-flowered : pedicels and hypanthium pubescent: sepals ovate : corolla about $6 \mathrm{~mm}$. broad : pomes depressedglobose, about $4 \mathrm{~mm}$. high, scarlet, bitter.

In thickets and cultivated grounds, Pennsylvania to Tennessee and Alabama. Naturalized from Europe and Asia. Spring.

\section{Family 14. amygdalàceae Reichenb. Plum Family.}

Shrubs or trees more or less manifestly imbued with prussic acid, with a smooth or flaky bark which often exudes gum. Leaves alternate, deciduous or persistent, with deciduous stipules: blades various, simple, leathery or membranous, mostly toothed. Flowers perfect, in clusters, corymbs or racemes. Calyx of 5 sepals, inferior, deciduous. Corolla of 5 distinct petals inserted on the hypanthium. Disk annular. Androecium of numerous stamens inserted with the petals. Anthers 2-celled. Gynoecium of a single carpel or rarely of 2 or 3 carpels. Ovary 1-celled. Style simple. Stigmas truncate or peltate. Ovules 2, pendulous. Fruit a drupe. Seed solitary. Endosperm wanting. Embryo with fleshy cotyledons.

Style basal : ovules erect.

Style terminal: ovules pendulous.

Drupe with a pulpy exocarp: leaves deciduous : flowers in clusters or terminal racemes.

Calyx sessile or nearly so: stone coarsely wrinkled and pitted.

Calyx manifestly pedicelled: stone neither wrinkled nor grooved.

Flowers in corymbs from scaly buds of the branches of the preceding year, before the leaves.

Flowers in racemes terminating branches of the year, after the leaves.

Drupe with a dry exocarp: leaves persistent: flowers in axillary racemes.

1. Chrysobalanus.

\section{ChRYSOBÁtuanUs L.}

Shrubs or trees, with erect or underground stems. Leaves alternate: blades simple, leathery, often lustrous. Flowers perfect, white or greenish, in cymes, pedicelled. Hypanthium campanulate or turbinate. Sepals 5, nearly equal, imbricated. Petals 5, deciduous. Stamens numerous, sometimes 15 , inserted with the petals : filaments distinct or united at the base, glabrous or pubescent. Ovary inferior, 1-celled, sessile : style basal, filiform. Ovules 2, erect. Drupe pulpy, often edible, the stone 5-6-ridged. Seeds solitary.

Leaf-blades several times longer than broad : inflorescence terminal : filaments and ovary glabrous. Leaf-blades as long as broad or nearly so: inflorescence axillary : filaments and
ovary pubescent. 1. C. oblongifolius.

2. C. Icaco.

1. Chrysobalanus oblongifolius Michx. A low shrub, forming wide patches by the spreading of underground stems, the branches erect, 1-3 dm. tall, simple or sparingly branched. Leaf-blades oblanceolate to oblong, or cuneate, $3-12 \mathrm{~cm}$. long, subulate-tipped, 
glabrous, lustrous on both sides, but paler above, undulate, short-petioled, the nerves prominent: corymbs or panicles minutely pubescent: hypanthium campanulate, $3 \mathrm{~mm}$. broad : sepals triangular-ovate or triangular, rather obtuse, shorter than the hypanthium. petals oblong or oblong-obovate, $2.5-3 \mathrm{~mm}$. long, obtuse, whitish green, pubescent within near the base : filaments and ovary glabrous: drupe ovoid to obovoid, $2.5-3.5 \mathrm{~cm}$. long.

In dry sandy pine lands. Georgia to Florida and Mississippi. Ground OAK. Gopher ApPLE.

2. Chrysobalanus Icàco L. An erect shrub 1-10 m. tall. Leaf-blades leathery, broadly obovate, oval or suborbicular, $3-8 \mathrm{~cm}$. long, glabrous, somewhat lustrous, truncate or notched at apex, entire, usually broadly cuneate at the base, short-petioled: panicles axillary, few-flowered: hypanthium turbinate, 4-5 mm. broad: sepals ovate or oblongovate, obtuse or abruptly pointed: petals spatulate, $5-6 \mathrm{~mm}$. long, rounded at the apex, white : filaments and ovary villous : drupe globular or oval, $3-4 \mathrm{~cm}$. in diameter,yellow, purple or black.

In sandy soil, southern peninsular Florida. Also in the West Indies and tropical America. Gopher Plum. COCOA Plum.

\section{AMÝGDALUS L.}

Shrubs or trees pervaded with prussic acid. Leaves alternate : blades simple, toothed, conduplicate. Flowers perfect, from scaly buds of the preceding year, appearing before the leaves, pedicelled. Sepals 5. Corolla white or pink. Petals 5, spreading. Stamens 20-30 : filaments slender, distinct. Ovary 1-celled, sessile : style simple. Ovules 2, pendulous. Drupe subglobose or oval, with a fleshy velvety-pubescent exocarp and_a bony wrinkled and pitted endocarp (stone). Seed solitary. РeAch.

1. Amygdalus Pérsica L. A tree several m. high, with glabrous almond-scented foliage. Leaves numerous; blades thinnish, narrowly elliptic or lanceolate or rarely oblong-obovate, bright green, shining above, sharply serrate, acuminate at both ends or acute at the base; petioles $0.5-1 \mathrm{~cm}$. long: flowers few or numerous, fragrant : petals pink, 8-20 $\mathrm{mm}$. long, rounded : filaments usually colored like the petals : drupe subglobose, $4-10 \mathrm{~cm}$. in diameter, grooved on one side, soft-velvety : stone elliptic or ovoid-elliptic, pointed especially at one end, coarsely wrinkled and pitted.

In waste places and cultivated grounds, throughout the United States. Spring; fruit ripening in summer and fall. Originally from western Asia.

\section{PRÙNUS L.}

Low shrubs or lofty trees, slightly if at all pervaded with prussic acid, sometimes armed with thorns. Leaves alternate, deciduous : blades thin or leathery, simple, usually toothed. Flowers perfect, white or pink, solitary, in cluster-like corymbs from scaly buds. Sepals 5, deciduous, imbricated. Petals 5, imbricated, spreading, inserted in the throat of the hypanthium. Stamens 15-30, inserted with the petals: filaments filiform, distinct. Ovary sessile, 1-celled : style simple, terminal : stigma truncate or peltate. Ovules 2, side by side, pendulous. Drupe with a pulpy exocarp, often glaucous : stone bony, smooth, more or less flattened, indehiscent. Seed solitary. Testa membranous. The plants flower in the spring.

Drupe velvety.

Leaf-blades 1-2 cm. long, entire or with glandless teeth : sepals not glandular-toothed.

Leaf-blades $2-2.5 \mathrm{~cm}$. long, conspicuously glandular-toothed : sepals glandulartoothed.

Drupe glabrous.

Inflorescence corymbose: drupes 4-7 $\mathrm{mm}$. in diameter.

Inflorescence umbel-like : drupes 8-30 $\mathrm{mm}$. in diameter.

Leaves conduplicate in vernation.

Low shrubs: corolla about $1 \mathrm{~cm}$. broad : leaf-blades appressed-serrate :

drupes mostly less than $10 \mathrm{~mm}$. in diameter.
Large trees : corolla $1.5-3 \mathrm{~cm}$. broad : leaf-blades sharply serrate : drupes mostly over $10 \mathrm{~mm}$. in diameter.

Drupe sour: leaves glabrous.

Drupe sweet: leaves pubescent.

1. P. minutiflora.

2. P. glandulosa.

3. P. Pennsylvanica.

es convolute in vernation.

A. Drupe purple with a bloom (variously colored in $P$. tarda), mostly less than $15 \mathrm{~mm}$. thick.

Drupe globose : stone globular : leaves glabrous.

Drupe oblong or oval : stone manifestly elongated : leaves pubescent. Twigs glabrous.

Stone acute at the base: drupe purple: species of the Gulf States east of the Mississippi River.

Stone rounded at the base: drupe variously colored : species of the Gulf States west of the Mississippi River.

4. P. cuneata.

5. P. Cerasus.

6. P. Avium.

7. P. umbellata.

8. P. mitis.

9. P. tarda. 
Twigs closely pubescent.

Corolla 6-8 $\mathrm{mm}$. broad : drupe $8-10 \mathrm{~mm}$. long.

Corolla 14-20 mm. broad: drupe 12-15 mm. long.

B. Drupe red or orange, without bloom, mostly over $20 \mathrm{~mm}$. thick.

Sepals glandular-ciliate or glandular-serrate or merely ciliate.

Sepals ciliate or glandular-ciliate, otherwise glabrous: leaf-blades minutely toothed.

Leaf-blades with acuminate tips, serrate : drupe $15-20 \mathrm{~mm}$. long.

Leaf-blades obtuse or merely acute, serrulate: drupe $20-26 \mathrm{~mm}$. long.

Sepals ciliate with simple hairs : drupe thick-skinned. Sepals ciliate with glandular hairs : drupe thin-skinned.

Sepals glandular-serrate, pubescent, at least within: leaf-blades rather coarsely toothed.

Sepals pubescent on both sides.

Sepals pubescent within.

Sepals entire, not glandular-ciliate.

10. $P$. normalis.

11. $P$. injucunda.

12. $P$. rivularis.

13. P. Watsonii.

14. P. angustifolia.

15. P. hortulana.

16. P. nigra.

17. P. Americana.

1. Prunus minutiflòra Engelm. A low rigid intricately-branched shrub $3-7 \mathrm{dm}$. tall. Leaf-blades leathery, obovate or cuneate, 1-2 $\mathrm{cm}$. long, clustered on shortened branches, rounded or obtuse at the apex, entire or coarsely toothed with glandless teeth, minutely pubescent beneath or glabrous, cuneately narrowed into short petioles : flowers usually solitary, very short-pedicelled : sepals not glandular-toothed : drupes ovoid or globose-ovoid, 8-12 $\mathrm{mm}$. long, velvety.

On prairies, Texas.

2. Prunus glandulòsa Hook. A low diffuse, somewhat thorny shrub, with zigzag branches. Leaf-blades oblong or oblong-elliptic, $2-2.5 \mathrm{~cm}$. long, obtuse at the apex, serrate with gland-tipped spreading teeth, rather acute at the base, pubescent on both sides, short-petioled: clusters usually 2-flowered, or the flowers sometimes solitary : pedicels mostly less than $1 \mathrm{~cm}$. long, finely pubescent: sepals oblong, about as long as the hypanthium, conspicuously glandular-toothed : petals obovate, much longer than the sepals : drupes subglobose, velvety.

On prairies, Texas.

3. Prunus Pennsylvánica L. f. A small tree, with a smooth aromatic bark and glabrous foliage. Leaf-blades thinnish, oblong-elliptic to nearly oval or lanceolate, 8-15 $\mathrm{cm}$. long, acuminate at the apex, doubly serrate, acute or rounded at the base; petioles slender, 1-1.5 cm. long: flowers in lateral sometimes peduncled clusters: pedicels slender, $1-2.5 \mathrm{~cm}$. long or $3 \mathrm{~cm}$. long at maturity : corolla 10-12 mm. broad : drupes globose, 4-7 mm. in diameter, red, without bloom, with thin sour flesh : stone subglobose, or slightly elongated.

In rocky or open woods, Newfoundland to the Rocky Mountain region, south to Georgia. WILD Red Cherry. Pin or Pigeon ChERry.

4. Prunus cuneàta Raf. A low spreading shrub $3-12 \mathrm{dm}$. tall, with glabrous foliage. Leaf-blades firm, oblong, oval or somewhat obovate, $3-8 \mathrm{~cm}$. long, sometimes acute at both ends, cuneate at the base, bright green above, glaucous beneath, rather coarsely serrate with appressed teeth; petioles $8-20 \mathrm{~mm}$. long: flowers in clusters appearing with the leaves : pedicels $1-1.5 \mathrm{~cm}$. long: corolla about $1 \mathrm{~cm}$. broad, white or nearly so: drupes subglobose, 8-10 mm. in diameter.

In moist, sometimes rocky soil or meadows, New Hampshire to Wisconsin, Minnesota and North Carolina. DWARF ChERrY.

5. Prunus Cérasus L. A relatively small tree. Leaf-blades ovate, oval-ovate or ovate-lanceolate, 4-11 cm. long, abruptly acute or acuminate, serrate-dentate, glabrous, resinous when young: flowers in lateral clusters from scaly buds : pedicels about $3 \mathrm{~cm}$. long during anthesis : corolla $1.5-2.5 \mathrm{~cm}$. broad : drupes nearly globose, 8-10 $\mathrm{mm}$. in diameter, or larger in cultivation, sour, red or black, without bloom : stone subglobose.

In woods and thickets, New York to Pennsylvania and Georgia, escaped from cultivation. Native of Europe. SOUR CHERRY.

6. Prunus Àvium L. A tree becoming $23 \mathrm{~m}$. high. Leaf-blades ovate to oval or oval-ovate, $5-10 \mathrm{~cm}$. long, abruptly short-acuminate, serrate, pubescent beneath, sometimes only on the nerves : flowers in lateral clusters from scaly buds : pedicels slender, $25-36 \mathrm{~mm}$. long during anthesis: corolla $2.5-3 \mathrm{~cm}$. broad : drupes subglobose, 8-10 mm. in diameter, sweet, without bloom: stone globular.

In open woods and thickets, Connecticut to Pennsylvania and Georgia. Escaped from cultivation. Native of Europe. SWEET CHERRY.

7. Prunus umbellàta Ell. A low shrub or small tree, sometimes $6 \mathrm{~m}$. tall, with a slender, erect or ascending trunk. Leaf-blades thinnish, oblong, elliptic or nearly oval, sometimes broadest above or below the middle, short-acuminate, or merely acute, serrate, rounded or acute at the base, glabrous on both sides or sparingly pubescent beneath, on short slender petioles: flowers expanding before the leaves, in lateral clusters: pelicels 
usually $1.5-2 \mathrm{~cm}$. long or longer at maturity : sepals pubescent within : drupes globose or nearly so, $12-15 \mathrm{~mm}$. in diameter, nearly black beneath the bloom when mature, with an acid flesh : stone plump, acute at both ends.

About river swamps and hammocks, South Carolina to Florida, Louisiana and Arkansas. HoG Plum. Black Sloe. Bullace Plum.

8. Prunus mitis Beadle. A shrub or small tree, 4-8 m. tall, seldom spiny, with dark gray or reddish brown bark and glabrous shining twigs. Leaf-blades $2-9 \mathrm{~cm}$. long, elliptic, oblong-lanceolate or rarely ovate or obovate, acute or acuminate, sharply serrate, narrowed or rounded at the base, finely pubescent on both surfaces and especially along the prominent midrib and veins beneath, biglandular at the base, or on the short pubescent petioles : hypanthium glabrous, at least the lower portion: sepals triangular, subacute, pubescent outside, densely so on the inner surface : drupe oblong, $10-14 \mathrm{~mm}$. long, dark purple with a glaucous bloom : stone ovoid or oval, slightly compressed, about $1 \mathrm{~cm}$. long, pointed at both ends and especially at the apex, crested on one margin.

In dry soíl, Georgia and Alabama.

9. Prunus tárda Sarg. A tree often becoming $8 \mathrm{~m}$. tall and $6 \mathrm{dm}$. in diameter at the base, with wide-spreading branches, the slender branchlets lustrous. Leaf-blades firm, oblong to obovate, $3.5-7.5 \mathrm{~cm}$. long, acute or acuminate at the apex, finely serrate with minutely glandular teeth, becoming glabrous above, more or less pubescent beneath along the yellow midrib and its branches, gradually narrowed and rounded or cuneate at the base; petioles densely pubescent : flowers 2 or 3 together: pedicels glabrous, $2 \mathrm{~cm}$. long or shorter: sepals acute, entire, pubescent on both surfaces : corolla 10-14 mm. broad: drupe broadly oblong to subglobose, 8-12 $\mathrm{mm}$. long, yellow, purple, red, blue or black, somewhat acid: stone slightly flattened, acute and apiculate at the apex, rounded at the base.

In open woods and thickets, Arkansas to Louisiana and Texas.

10. Prunus normàlis (T. \& G.) Small. A shrub $3-13 \mathrm{dm}$. tall, with spreading unarmed branches and densely pubescent young foliage. Leaf-blades thick, oblong to elliptic, 2-3 cm. long, obtuse or merely acute at each end, sharply serrate with appressed teeth, sparingly pubescent above, densely tomentose and prominently nerved beneath, shortpetioled : flowers in lateral elusters preceding the leaves : pedicels slender, $9-15 \mathrm{~cm}$. long: sepals ovate or ovate-lanceolate, finely pubescent, obtuse : corolla 6-8 mm. broad : drupes globose-oval, 8-10 mm. long: stone suborbicular, slightly flattened.

In dry or sandy soil, Kansas to Tennessee and Texas. Sow Plum.

11. Prunus injucúnda Small. A shrub or tree of a somewhat straggling habit, $5-8 \mathrm{~m}$. high, with a maximum trunk diameter of $2 \mathrm{dm}$., seldom spiny, clothed with a dull darkgray bark which on the younger branches is covered with fine pubescence of a velvety texture. Leaf-blades $2-6 \mathrm{~cm}$. long, 1-3 cm. broad, oval or obovate, acute or somewhat acuminate, finely but sharply serrate with apiculate teeth, acute or acuminate at the base, conspicuously and densely pubescent beneath, inconspicuously pubescent and slightly rugose above, the midrib very prominent, its lateral branches less so ; petioles $0.5-1 \mathrm{~cm}$. long, pubescent : drupe oblong, 12-15 mm. iong, dark purple, clothed with a lighter bloom : stone ovoid, 8-10 mm. long, much compressed, pointed at both ends, crested, and grooved on each side of the crest, also grooved on the opposite side.

In sandy soil in the granite districts, Georgia and Alabama. Hog PluM.

12. Prunus rivulàris Scheele. A shrub 1-2 m. tall, with shining, glabrous, somewhat angled branchlets. Leaf-blades oblong or oblong-ovate, long-acuminate, serrate, glabrous above, sparingly pubescent beneath, short-petioled : clusters with usually 2 or 5 flowers, or flowers sometimes solitary : pedicels $9-13 \mathrm{~mm}$. long : sepals lanceolate, sparingly pubescent : corolla mostly $12-13 \mathrm{~mm}$. broad : drupes subglobose, 15-20 mm. long, brightred, shining.

In river valleys, Texas.

13. Prunus Watsònii Sarg. A sparingly spiny shrub $2-3.5 \mathrm{~m}$. tall, with glabrous 'foliage. Leaf-blades thickish, oblong or oblong-lanceolate, $2-5 \mathrm{~cm}$. long, acute at the apex, crenulate-serrate, acute or rounded at the base, lustrous above, pale and dull beneath ; peti-
oles slender, wiry, $1-1.5 \mathrm{~cm}$. long : clusters few-flowered : pedicels $8-12 \mathrm{~mm}$. long, red : sepals ciliate, but without glands: corolla $10-12 \mathrm{~mm}$. broad, pure white : drupes subglobose or
somewhat elongated, $20-22 \mathrm{~mm}$. long, orange-red, without bloom, the flesh yellow : stone oval, slightly pitted, abruptly flattened near the apex.

In sandy soil, Nebraska to Arkansas. SAND PLUM.

14. Prunus angustif òlia Marsh. A sparingly spiny shrub or small tree, sometimes $8 \mathrm{~m}$. tall, with a slender trunk, often forming thickets. Leaf-blades rather thin, oblong to oblong-lanceolate, $3-10 \mathrm{~cm}$. long, acute or slightly acuminate at the apex, serrulate, acute or rounded at the base, short-petioled : flowers in lateral clusters, appearing before the leaves : 
pedicels about $1 \mathrm{~cm}$. long : corolla white or creamy, 10-15 mm. broad : drupes oval-globose, 22-26 mm. long, red or yellowish, with a slight bloom : stone ovoid, hardly flattened, acute, one of the rounded edges slightly grooved.

In dry soil or thickets, New Jersey to Florida, Alabama and the lower Mississippi Valley. CHICK ASAW PLUM.

15. Prunus hortulàna Bailey. A small tree resembling $P$. Americana and $P$. nigra in habit, with a thin bark and spreading branches. Leaf-blades ovate to ovate-lanceolate or oval, 10-15 cm. long, long-acuminate, glandular-serrate; petioles less than $2.5 \mathrm{~cm}$. long, usually with 2 or several glands near the blade: flowers in lateral clusters preceding the leaves: pedicels 1-2 cm. long: sepals glandular-serrate : corolla $1.5-2 \mathrm{~cm}$. broad : drupes subglobose or oval-globose, $20-23 \mathrm{~mm}$. long, bright red, with a thin skin : stone somewhat swollen, roughened, neither margined nor crested.

In thickets and woods, Illinois and Tennessee to Alabama, Arkansas and Texas.-A variety with thick, dull, coarsely serrulate sometimes oblanceolate leaf-blades prominently nerved beneath, and a smooth stone is P. hortulana Mineri Bailey; it occurs in Tennessee, Illinois and Missouri. WILD GoosE PLUM.

16. Prunus nìgra Ait. A small tree, rarely $10 \mathrm{~m}$. tall, with a trunk sometimes $3 \mathrm{dm}$. thick. Leaf-blades firm, elliptic to oval, 6-12 cm. long, acuminate at the apex, sharply and mostly doubly serrate, obtuse or rounded at the base, bright green and glabrous above, usually sparingly pubescent beneath; petioles $1-2 \mathrm{~cm}$. long, with two red glands near the blade : flowers 3-5 in lateral clusters : pedicels 1-2 cm. long : sepals glandular-serrate : corolla about $3 \mathrm{~cm}$. broad : drupes oval or subglobose, $2.5-3 \mathrm{~cm}$. long, orange-red, with a slight bloom and thick skin : stone oval, flattened, acutely crested on the ventral edge.

In woods or clearings, Newfoundland to Wisconsin, Alberta and Georgia. HoRse Plum.

17. Prunus Americàna Marsh. A small, somewhat spiny tree, sometimes $10 \mathrm{~m}$. tall, with a maximum trunk diameter of about $3 \mathrm{dm}$. Leaf-blades firm, elliptic to oval, or oval-obovate, $4-10 \mathrm{~cm}$. long, acuminate, sharply singly or doubly serrate, pubescent beneath especially near the nerves, acute or rounded at the slightly inequilateral base; petioles $0.5-2 \mathrm{~cm}$. long, usually glandless : flowers $2-5$ in lateral clusters appearing before the leaves : pedicels 1-2 cm. long : sepals entire : corolla $1.5-2.5 \mathrm{~cm}$. broad : drupes subglobose or barely elongated, $18-25 \mathrm{~mm}$. long, with a tough skin and sometimes a slight bloom : stone ovoid or oval, flattened, not crested along the ventral suture.

In woods and thickets, New York to Montana, Florida and Colorado. WILD Yellow Plum. RED PLUM.-The variety with copiously pubescent leaves and twigs, is $P$. Americana lanḋta Sudw.; it occurs mainly in the Gulf States west of the Mississippi River and in the contiguous states.

\section{PÀDUS Borckh.}

Shrubs or trees, manifestly pervaded with prussic acid. Leaves alternate, deciduous : blades various, simple, usually toothed, petioled. Flowers perfect, in racemes terminating in leafy branches of the season, following the leaves, pedicelled. Hypanthium often campanulate. Sepals 5, short. Petals5, white, imbricated, inserted in the throat of the hypanthium. Stamens 15-30, inserted with the petals: filaments slender, distinct. Ovary sessile, 1-celled. Style simple. Ovules 2, pendulous. Drupe with a pulpy exocarp, not glaucous, indehiscent : stone nearly as thick as broad, bony. Seed solitary.

Sepals deciduous: leaf-blades mostly serrulate with very slender teeth.

1. P. Virginiana.

Young

Young shoots, raceme-rachis and pedicels glabrous.

Sepals deltoid, slightly broader than long : leaf-blades delicately reticulated.

Younals ovate, longer than broad: leaf-blades not reticulated.

oung shoots, raceme-rachis and pedicels pubescent.

Leaf-blades finely and rather sparingly pubescent beneath (except along the midrib), becoming glabrate and glaucous with age.

Drupe red : leaf-blades prevailingly obovate, blunt.

Drupe purple : leaf-blades ovate, oblong or elliptic, acute or acuminate.

Leaf-blades densely and permanently clothed with tawny or rufous tomentum, not glaucous.

2. P. eximia.

3. P. serotina.

1. Padus Virginiàna (L.) Roem. A shrub or small tree, sometimes $12 \mathrm{~m}$. tall, with spreading or drooping branches and a very bitter bark. Leaf-blades thinnish, oval or obovate, 5-10 cm long, short-acuminate at the apex, sharply serrate, usually rounded at the base, glabrous or nearly so on both sides; petioles $1-2 \mathrm{~cm}$. long, slender: racemes rather lax, 8-15 $\mathrm{cm}$. long: sepals reflexed : corolla $8-10 \mathrm{~mm}$. broad : drupes globose, $8-10 \mathrm{~mm}$. in diameter, red or almost black, or rarely yellow, very astringent. [Prunus Virginiana L.] In rocky soil or on river banks, Newfoundland to Manitoba and British Columbia, south to Georgia, Texas and colorado. Spring. CHOKE CHERRY. WILD CHERRY.

2. Padus exímia Small. A tree becoming $26 \mathrm{~m}$. tall, with loosely spreading branches and glabrous twigs. Leaf-blades relatively thin, mainly ovate, varying to oblong, oblong- 
lanceolate or oval, 3-8 cm. long, obtuse or slightly acuminate but blunt, glabrous, serrate with appressed teeth, bright green above, pale green beneath, slender-petioled : racemes drooping, 5-7 $\mathrm{cm}$. long, glabrous : pedicels 4-8 $\mathrm{mm}$. long, thickened upward : sepals deltoid, slightly broader than long : corolla $10-12 \mathrm{~mm}$. broad : petals orbicular-ovate : drupes globular, 8-10 mm. in diameter, purple, sweet. [Prunus eximia Small.]

In river valleys, Texas. Spring.

3. Padus serótina (Ehrh.) Agardh. A forest tree, reaching a height of $35 \mathrm{~m}$., with a maximum trunk diameter of nearly $2 \mathrm{~m}$., the bark aromatic and bitter. Leaf-blades firm, oblong or elliptic, varying to obovate, or lanceolate, $5-15 \mathrm{~cm}$ long, acuminate or acute at both ends, or rounded at the base, finely serrate with callous teeth, glabrous or nearly so ; petioles 1-1.5 $\mathrm{cm}$. long: racemes often dense : pedicels less than $1 \mathrm{~cm}$. long: sepals ovate, longer than broad : corolla $8-10 \mathrm{~mm}$. broad : drupes globose, $8-10 \mathrm{~mm}$. in diameter, dark purple or nearly black, sweet but slightly astringent.

In woods or clearings, Ontario to North Dakota, Florida and Texas. Spring and early summer.-A variety with ample leathery coarsely serrate leaf-blades pale or whitish beneath, stout, fewflowered, diverging racemes and pubescent sepals and filaments, is P. serotina neomontàna (Sudw.) Small, [Prunus serotina neomontana Sudw.]; it is confined to high summits in the southern Alleghenies. WILD Cherry. Black Cherry. Rum Cherry.

4. Padus Cuthbértii Small. A tree $6 \mathrm{~m}$. tall and sometimes $1.5 \mathrm{dm}$. in diameter near the base, with tomentose twigs. Leaf-blades leathery, normally obovate, varying to oval or fiddle-shaped, 4-9 cm. long, blunt or notched at the apex, shallowy serrate, not markedly biglandular at the often cuneate base, dull green above, pale or glaucesent beneath, the midrib and petioles copiously tomentose and the lateral veins slightly so: racemes $5-8 \mathrm{~cm}$. long, terminating short leafy branches, the rachis and pedicels pubescent like the twigs: pedicels clavate, $3-5 \mathrm{~mm}$. long during anthesis, becoming 8-11 $\mathrm{mm}$. long: sepals broader than long, obtuse, shorter than the hypanthium : petals suborbicular, about $2 \mathrm{~mm}$. in diameter, crisped : drupes subglobose, $8-9 \mathrm{~mm}$. in diameter, red. [Prunus Cuthbertii Small.]

In rich or sandy woods, Georgia. Spring.

5. Padus Alabaménsis (C. Mohr) Small. A tree rarely over $10 \mathrm{~m}$. tall, with a maximum trunk diameter of about $1-5 \mathrm{dm}$., the bark rough. Leaf-blades leathery or thick, ovate, oblong to elliptic, 6-12 cm. long, short-acuminate but sometimes obtuse at the apex, serrate with blunt appressed gland-tipped teeth, paler beneath than above and finely pubescent with simple or forked hairs, rounded or slightly narrowed at the base : racemes $10-15 \mathrm{~cm}$. long, spreading, peduncled, the rachis and peduncles, like the calyx, pubescent.

On mountain slopes, Alabama and Georgia. Spring.

6. Padus austràlis Beadle. A tree $10-20 \mathrm{~m}$. tall, the trunk sometimes $3-4 \mathrm{dm}$. in diameter near the base. Leaf.blades obovate, oval or elliptic, 4-10 cm. long, 2-6 cm. wide, abruptly and rather bluntly pointed at the apex, or occasionally obtuse, either rounded or obtusely narrowed at the base, finely serrate, dark green and glabrous above, densely and permanently clothed on the lower surface with tawny or rufous tomentum, not not at all glaucous; petioles $1 \mathrm{~cm}$. iong or less, tomentose : raceme-rachis and pedicels, like the young shoots, pubescent : drupes globose, $5-8 \mathrm{~mm}$. in diameter, purple.

In clay soil, Evergreen, Alabama. Spring.

\section{LAUROCÉRASUS Reichenb.}

Shrubs or trees manifestly pervaded with prussic acid. Leaves alternate, persistent: blades leathery, simple, entire or remotely toothed. Flowers perfect, in racemes from the axils of the persistent leaves. Hypanthium white. Sepals 5, various, deciduous. Petals 5, white, deciduous. Stamens 15-30: filaments slender, distinct. Ovary sessile, 1-celled: style simple. Ovules 2, pendulous. . Drupe subglobose or slightly elongated, with a dry exocarp, not glaucous, the stone turgid. Seed solitary.

Drupe subglobose : petals larger than the sepals.

Drupe oblong or oval: petals smaller than the sepals.

1. L. sphaerocarpa.

2. L. Caroliniana.

1. Laurocerasus sphaerocárpa (Sw.) Roem. A small evergreen tree, sometimes $12 \mathrm{~m}$. tall, with glabrous foliage. Leaf-blades leathery, lustrous, elliptic, $5-10 \mathrm{~cm}$. long, entire, acuminate at the apex, acute or rounded at the base; petioles slender, about $1 \mathrm{~cm}$. long: racemes shorter than the leaves, rather dense: pedicels slender, 4-8 mm. long, subtended by early deciduous bracts : sepals acute, laciniate, deciduous : petals much larger than the sepals, reflexed at maturity, yellowish near the base within: drupes subglobose, apiculate, 8-12 $\mathrm{mm}$. in diameter, orange: stone subglobose.

In sandy soil, southern peninsular Florida, also in the West Indies and Brazil. Fall, fruit ripening in the spring or summer. 
2. Laurocerasus Caroliniàna (Mill.) Roem. An evergreen tree, sometimes $12 \mathrm{~m}$. tall, with a slender trunk rarely over 3 decimeters thick. Leaf-blades leathery, narrowly elliptic to oblong-lanceolate, sometimes remotely toothed, acuminate at both ends or acute at the base, slightly revolute, lustrous above, dull beneath ; petioles $5-8 \mathrm{~mm}$. long: racemes shorter than the leaves, rather dense : pedicels club-shaped, $2-4 \mathrm{~mm}$. long, subtended by early deciduous scarious acute bracts : sepals suborbicular, reflexed, deciduous : petals boat-shaped, fully $1 \mathrm{~mm}$. long, erect, smaller then the sepals: drupes oblong or oval, 10$13 \mathrm{~mm}$. long, abruptly pointed, black, lustrous : stone ovoid.

In river valleys and near the coast, North Carolina to Florida and Texas. Winter and spring, fruit persistent for a year.

\section{Family 15. Mimosaceat Reichenb. Mimosa Family.}

Herbs, shrubs or trees, with erect or prostrate stems. Leaves alternate : blades usually compound, commonly 2-3-pinnate: stipules various, sometimes spine-like. Flowers mostly perfect, sometimes polygamous, relatively small. Calyx of 3-6 valvate partially united sepals. Corolla regular, of 3-6 distinct or partially united valvate petals. Androecium of as many stamens as there are petals or twice as many, or numerous, usually conspicuously exserted. Filaments distinct or monadelphous. Gynoecium of a single carpel. Ovary superior, 1-celled. Style simple. Ovules several or numerous. Fruit a legume (pod). Seeds with thick cotyledons. Endosperm wanting.

Stamens numerous, more than 10.

Filaments partially united into a tube.

Valves of the pod not separating from the continuous margin.

Pods with woody or thick-leathery valves.

Leaves with 4 leaflets, or if more, few and relatively large: spikes head-like: ovary stipitate: pods contorted, with thick-leathery valves.

Leaves with many relatively small leaflets: spikes elongated : ovary sessile : pods straight or merely curved. with woody valves,

Pods with membranous or thin-leathery very flat valves.

Ovary stipitate: calyx very short and different from the corolla in texture.

Ovary sessile: calyx simulating the corolla, but much shorter, and

Valves of the pod separating from the continuous margin.

Filaments distinet, or the inner ones sometimes slightly united at the base.

Ovary stipitate: petals distinct or united, commonly only to below the mid-

dle: pods flat, dry. the seeds not in two distinct rows.

Ovary sessile: petals united into a tubular-funnelform, shallowly lobed co-

rolla: pods nearly terete or broader than high, pulpy within, the seeds

in two separate rows.
Stamens as many as the petals or the corolla-lobes or twice as many.

Anthers without glandular appendages at the top.

Valves of the pod not separating from the continuous margin.

Shrubs or trees: seeds transverse in the pod.

Herbs: seeds lengthwise or oblique in the pod.

Valves of the pod separating from the continuous margin. Pods slightly, if at all, flattened, 4 -angled or with a broad margin, beaked,

Pods flat, jointed, not beaked.

Anthers, at least in the bud, topped by glandular appendages.

Herbs: pods flat and thin, twice or thrice longer than broad.

Shrubs or trees: pods relatively thick, many times longer than broad. Pods straight or merely curved, somewhat constricted between the seeds,

Pods tightly coiled into a spiral, in bunch-like clusters.

1. Pithecolobium.

2. SIDEROCA RPOS.

3. Havardia.

4. Albizzia.

5. Lysiloma,

6. Acacia.

7. Vachellia.

8. LeUCAENa.

9. Acuan.

10. Morongia.

11. Mimosa.

12. Neptunia.

13. Prosopis.

14. STROMBOCARPA.

\section{PITHECOLÒBIUM Mart.}

Shrubs or trees, usually armed. Leaves with 2-pinnate blades: leaflets few, often 4. Flowers perfect or rarely polygamous, in head-like spikes. Calyx 5-6-lobed. Corolla of 5-6 partially united petals. Stamens numerous, long-exserted : filaments often well united. Ovary short-stalked. Ovules several or numerous. Pods narrow, contorted, often with mealy or pulpy partitions within, 2-valved, but not elastically so, sometimes tardily so. Seeds partially enclosed in highly colored arils. The plants often flower throughout the year. Catsclaw.

Leaflets with leathery blades: petioles shorter than the petiolules: ovary pubescent. 1. P. Guadalupense. Leaflets with membranous blades: petioles longer than the petiolules : ovary glabrous. 
1. Pithecolobium Guadalupé 1se (Desv.) Chapm. An unarmed shrub 1-2 m. tall. Leaflets 4 , the blades obliquely obovate or oblong-obovate, $2-4 \mathrm{~cm}$. long, leathery, mucronate, undulate, delicately nerved, lustrous above; petioles shorter than the petiolules: heads yellow: peduncles solitary on the axils, $4-8 \mathrm{~cm}$. long, surpassing the subtending bracts : calyx campanulate, pubescent, the triangular lobes shorter than the tube : corolla pubescent: stamens 3-4 times longer than the corolla, crisped : ovary pubescent: pods $5-10 \mathrm{~cm}$. long, contorted.

In sand, Florida keys. Also in the West Indies.

2. Pithecolobium Únguis-Càti (L.) Benth. An armed or unarmed straggling shrub or small tree, sometimes $8 \mathrm{~m}$. tall. Leaflets 4 , the blades thinnish, obliquely obovate or oval, rounded or mucronate at the apex, delicately reticulated; petioles slender, mostly much longer than the petiolules: heads in terminal axillary panicles: calyx turbinatecampanulate, glabrous, the triangular lobes much shorter than the tube: corolla glabrous or nearly so: stamens about twice as long as the corolla : pods $8-12 \mathrm{~cm}$. long, contorted.

In sand, southern peninsular Florida and the Keys, also in the West Indies and tropical America.

\section{SIDEROCÁRPOS Small.}

Trees, with spreading branches and zigzag twigs. Leaves alternate, but often clustered : blades 2-pinnate, with 4-6 pinnae: leaflets relatively few. Flowers mostly perfect, in cylindric spikes. Calyx campanulate, 5-lobed, very different from the corolla. Corolla 5-lobed, the lobes longer than the tube. Stamens numerous: filaments united below. Ovary sessile : style filiform. Ovules numerous. Pods stout and turgid, very tardily dehiscent, the valves woody, enclosing a soft tissue which separates the seeds from each other. Seeds transverse, on straight funicles. TExan EBony.

1. Siderocarpos flexicaùlis (Benth.) Small. An evergreen shrub or tree, reaching a height of $10 \mathrm{~m}$., armed with short spines. Leaves with 4-6 pinnae; leaflets $6-8$, the blades oblong, oval or obovate, $5-10 \mathrm{~mm}$ : long, usually obtuse, delicately reticulated beneath : peduncles 1-1.5 cm. long : spikes eylindric, 2-4 cm. long, often clustered in the axils : calyx campanulate, about $0.5 \mathrm{~mm}$. high : corolla 4-5 times longer than the calyx, the lobes longer than the tube : pods narrowly oblong, $1-1.5 \mathrm{dm}$. long, thick and turgid, slightly curved, sessile. [Pithecolobium flexicaule (Benth.) Coulter.]

On bluffs, Texas and Mexico. Summer.

\section{HAVÁRDIA Small.}

Small evergreen trees, sometimes shrubby, armed with stipular spines. Leaves alternate: blades 2-pinnate, with 6-10 pinnae: leaflets numerous (20-40 in each pinna), relatively small. Flowers perfect, in head-like spikes. Calyx quite short, 5-lobed, very different from the corolla in shape and texture. Corolla 5-lobed, the lobes shorter than the tube. Stamens numerous: filaments united below. Ovary stipitate: style filiform. Ovules several. Pods flat, readily dehiscent, with membranous or thin-leathery valves. Seeds few. Huajillo.

1. Havardia brevifòlia (Benth.) Small. An evergreen shrub or small tree, sometimes $10 \mathrm{~m}$. tall, armed with short spines. Leaves with 6-10 pinnae; leaflets $20-40$, the blades oblong or narrowly oblong, 3-7 mm. long, obtuse or acutish, reticulated beneath : panicles $5-10 \mathrm{~cm}$. long: peduncles $1-1.5 \mathrm{~cm}$. long : heads subglobose, about $2 \mathrm{~cm}$. in diameter : corolla 6-8 times longer than the caly $x$, the ovate lobes shorter than the tube : stamens between twice and thrice longer than the corolla: pods linear-oblong, flat, 7-10 $\mathrm{cm}$. long, acuminate at the apex, stipitate. [Pithecolobium brevifolium Benth.]

In valleys, southern Texas and northern Mexico.

\section{ALBízzia Durazz.}

Unarmed shrubs or trees, with wide spreading branches. Leaves alternate, blades 2pinnate : leaflets small, numerous, their glands, as well as the petiolar glands, more or less conspicuous. Flowers perfect, or polygamous, in peduncled, sometimes panicled, capitate spikes. Calyx tubular to campanulate, 5-lobed. Corolla funnelform, the lobes often shorter than the tube. Stamens numerous, exserted: filaments united at the base of the corolla-tube and sometimes adnate to it. Ovary often short-stalked. Pods linear, flattish, 2-valved, the valves not separating from the margins, or indehiscent 
1. Albizzia Julibríssin Durazz. An unarmed shrub or tree, reaching a height of $10 \mathrm{~m}$. Bark scaly : leaves $2-4 \mathrm{dm}$. long, with $16-24$ pinnae; leaflets $50-70$, the blades oblong, inequilateral, acute : heads showy, pink, 4-6 cm. in diameter : corolla pink, 3-4 times longer than the calyx; lobes ovate: stamens $33.5 \mathrm{~cm}$. long: pod broadly linear, $10-15 \mathrm{~cm}$. long, acuminate at both ends, sometimes slightly constricted between the seeds.

In sandy soil and woods, Virginia to Florida and Louisiana. Naturalized from Asia. Spring and summer.

\section{IYSILÒMA Benth.}

Unarmed shrubs or trees, with slender branches. Leaves alternate: blades pinnate : each petiole often bearing a large gland : leaflets small and in many pairs, or large and in few pairs. Flowers often polygamous, subtended by 3 -lobed bractlets, in globose or cylindric long-peduncled heads. Calyx campanulate, 5-lobed. Petals united into a 5-lobed corolla. Stamens numerous : filaments united at the base. Ovary sessile or short-stalked : style filiform. Ovules several, anatropous. Pods flat, linear or oblong, straight or falcate, somewhat membranous. Seeds flattened, transverse. WiLd TAMARIND.

1. Lysiloma latisiliqua (L.) Benth. An unarmed tree $5-16 \mathrm{~m}$. tall, with widespreading branches. Leaves 8-14 cm. long, with 4-8 pinnae; leaflets $20-40$, the blades oblong or oblong-lanceolate, $8-11 \mathrm{~mm}$. long, acute : heads about $1 \mathrm{~cm}$. in diameter, white : pods oblong, $8-15 \mathrm{~cm}$. long, flat, undulate, each with a stipe $2-4 \mathrm{~cm}$. long.

In sandy soil, Florida Keys and the West Indies. Spring.

\section{ACÀCIA Adans.}

Shrubs or trees, or rarely herbs, usually armed. Leaves normal or sometimes reduced to phyllodes: blades usually 2-pinnate, the pinnae numerous : leaflets often very numerous. Flowers perfect or polygamous, in globose or cylindric spikes on axillary peduncles. Calyx mostly campanulate, 4-5-lobed, or wanting. Petals 4-5, distinct or somewhat united. Stamens numerous : filaments distinct, or the inner somewhat united at the base. Ovary often stalked. Ovules 2-many. Pod flat, straight or curved, 2-valved or indehiscent.

Leaflets of each pinna mostly more than 20 .

Pods over $15 \mathrm{~mm}$. broad : the ultimate divisions of the leaf-rachis puberulent.

Pods less than $10 \mathrm{~mm}$. broad: the ultimate divisions of the leaf-rachis glabrous or with few long hairs.

Leaflets of each pinna $40-100$, acute.

Leaflets of each pinna $20-34$, blunt.

Leaflets of each pinna mostly less than 20.

Flo,vers in head-like spikes.

Pods less than $8 \mathrm{~mm}$. broad, constricted between the seeds : leaflets less than $1 \mathrm{~mm}$. broad.

Pods over $15 \mathrm{~mm}$. broad, not constricted between the seeds: leaflets over 2 $\mathrm{mm}$. broad.

Flowers in elongated spikes or racemes.

Pods over $10 \mathrm{~mm}$. broad.

Flowers slender-pedicelled.

Flowers sessile or nearly so.

Pods less than $10 \mathrm{~mm}$. broad.

1. A. Berlandieri.

2. A. filicioides.

3. A. cuspidata.

4. A. constricta.

5. A. Roemeriana.

6. A. Wrightii.

7. A. Greggii.

1. Acacia Berlandièri Benth. A shrub, clothed with ashy pubescence, unarmed or with few spines. Leaves $10-15 \mathrm{~cm}$. long, with 10-18 pinnae; leaflets 50-90, the blades linear-oblong, 4-6 mm. long, oblique, prominently nerved, acute or acutish : spikes globose, slightly over $1 \mathrm{~cm}$. thick : pods flat, linear, $10-15 \mathrm{~cm}$. long, $18-20 \mathrm{~mm}$. broad, usually straight, obtuse or apiculate at the apex, each narrowed into a stipe at the base, the valves velvety-tomentose, firm.

On dry bluffs, southern Texas and Mexico. spring.

2. Acacia filicioides (Cav.) Trelease. An unarmed shrub, with more or less densely hirsute foliage, stems angled. Leaves $5-15 \mathrm{~cm}$. long, with 8-30 pinnae or sometimes fewer; leaflets very numerous, the blades oblong or narrowly oblong, $4-5 \mathrm{~mm}$. long : spikes globose, about $1 \mathrm{~cm}$. thick, on hirsute peduncles $1-2 \mathrm{~cm}$. long : pods linear-oblong, $3-4 \mathrm{~cm}$. long, 6-9 mm. wide. [A. filicina Willd.] On prairies and in sandy soil, Missouri and Kansas to Texas, Arizona and Mexico, also in Florida,
Spring, fruit ripe in summer.-The wholly or partially glabrous form, sometimes occurring in Texas and

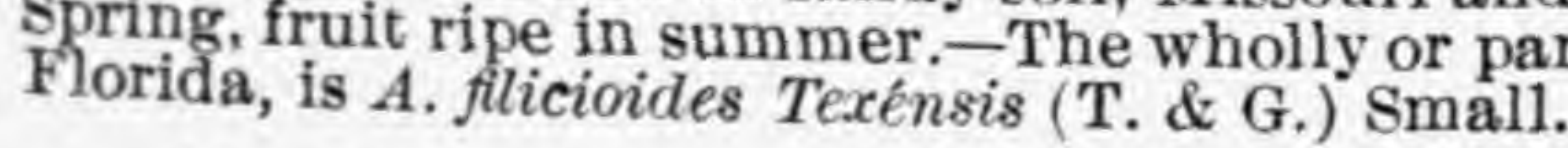

3. Acacia cuspidàta Schlecht. A low shrub, with sparingly pubescent foliage. Leaves $2.5-7 \mathrm{~cm}$. long, with 4-10 pinnae, the rachis and its divisions with few scattered hairs; leaflets $20-34$, or rarely some of the pinnae with fewer, the blades thick, linear- 
oblong, 2.5-5 mm. long, mostly blunt: spikes globose, about $1.5 \mathrm{~cm}$. in diameter, the peduncle pubescent like the subtending rachis : pods broadly linear, $3-6 \mathrm{~cm}$. long, 6-8 mm. wide, delicately veined, abruptly acuminate.

In dry soil, Texas to Arizona. Spring and summer.

4. Acacia constrícta Benth. A shrub, armed with spreading straight or slightly curved spines, the foliage often sticky. Leaves $3-6 \mathrm{~cm}$. long, with $4-14$ pinnae ; leaflets 12-20, the blades oblong, 1.5-2 mm. long, obtuse, nerveless: spikes globose, 8-10 mm. thick, on pubescent peduncles 1-2 $\mathrm{cm}$. long: pods elongated, linear, constricted between the seeds, glabrous, $5-13 \mathrm{~cm}$. long, each narrowed into a stipe.

In dry soil, southern Texas to New Mexico, and adjacent Mexico. Spring.

5. Acacia Roemeriàna Schlecht. A stout shrub, with spreading branches, armed with stout prickle-like spines. Leaves $3-10 \mathrm{~cm}$. long, with 4-6 pinnae ; leaflets $8-16$, the blades oblong, oval or cuneate, $8-10 \mathrm{~mm}$. long, oblique, apiculate or retuse at the apex, prominently nerved : spikes globose, $8-10 \mathrm{~mm}$. thick, on glabrous peduncles $1-2 \mathrm{~cm}$. long: pods flat, oblong or linear-oblong, $5-15 \mathrm{~cm}$. long, slightly curved, each narrowed into a stipe, the valves prominently nerved near the edges.

In dry soil, southern Texas, New Mexico and Mexico. Spring.

6. Acacia Wrìghtii Benth. A shrub or small tree, with streaked branchlets armed with short prickles. Leaves numerous, $2-3.5 \mathrm{~cm}$. long, usually with 4-6 pinnae; leaflets 6-12, the blades oblong to obovate, 5-7 mm. long, often minutely pointed, prominently nerved beneath : racemes cylindric, $2-3 \mathrm{~cm}$. long, not very dense : flowers slender-pedicelled : pods $8-11 \mathrm{~cm}$. long, $2-2.5 \mathrm{~cm}$. broad, curved, often irregularly undulate along the margins.

In dry soil, Texas, New Mexico and adjacent Mexico. Spring and summer. Texas Catsclaw.

7. Acacia Gréggii A. Gray. A shrub or small tree, commonly armed with short curved prickle-like spines. Leaves $2.5-5 \mathrm{~cm}$. long, with 2-6 pinnae; leaflets 8-14, the blades firm, oblique, oblong to cuneate, 4-6 mm. long, apiculate, obtuse or truncate at the apex, prominently nerved : spikes long-peduncled, $2-4 \mathrm{~cm}$. long : pods flat, linear-oblong, 8-12 cm. long, sometimes glaucous, irregularly constricted between the seeds.

In dry or rocky soil, Texas and Mexico. Spring and summer. Devil's Claws. Paradise Flower. Catsclaw.

8 Acacia amentàcea DC. A glabrous shrub, with zigzag branches, armed with straight or slightly curved pale spines $1-2 \mathrm{~cm}$. long. Leaves 1-2 $\mathrm{cm}$. long, with 2 pinnae; leaflets 4-8, the blades firm, obliquely oblong or obovate, 4-6 mm. long, truncate or retuse at the apex, prominently nerved : racemes oblong, 1-2 $\mathrm{cm}$. long: pods linear, flat, $6-10$ cm. long, curved, constricted between the seeds, usually acuminate at the apex, each attenuate at the base into a stipe.

On hillsides, from the Guadalupe River to the Pecos, south to Mexico. Spring.

\section{VACHÉLLIA Wight \& Arn.}

Shrubs or small trees, with spreading branches and straight spines. Leaves alternate : blades 2-pinnate, with 8-16 pinnae : leaflets numerous (20-50 in each pinna), relatively small. Flowers polygamous, in globular spikes. Calyx simulating the corolla hut only about $\frac{1}{2}$ as long, shallowly 5-lobed. Corolla tubular-funnelform, shallowly 5-6-lobed, the lobes as broad as high. Stamens very numerous : filaments distinct. Ovary sessile : style filiform. Pod stout, turgid, nearly terete or usually broader than high, scarcely dehiscent, filled with a pulp which separates the two rows of seeds and the individual seeds from each other. Huisache. Cassie.

1. Vachellia Farnesiàna (L.) Wight \& Arn. A shrub or small tree, with spreading branches and straight spines 5-15 mm. long. Leaves 1-2.5 cm. long, with 8-16 pinnae; leaflets $20-50$, the blades linear-oblong, 2-4 mm. long, rather obtuse : spikes
globose, 8-12 mm. in diameter, on pubescent peduncles $1-2 \mathrm{~cm}$. long : pods cylindric, 3$7.5 \mathrm{~cm}$. long, straight or slightly curved, often slightly constricted between the seeds. [Acacia Farnesiana (L.) Willd.]

On plains and prairies, southern Texas and Mexico, also naturalized in Florida. Spring, fruit ripe in summer. YELLOW OPOPANAX.

\section{LEUCAÈnA Benth.}

Evergreen shrubs or trees, usually unarmed. Leaves alternate: blades pinnate; petioles often furnished with a gland, the leaflets subtended by setaceous stipels: leaflets 
oblique, small and in many pairs or large and in few pairs : flowers mostly perfect, sessile, in dense heads. Calyx 5-lobed. Corolla of 5 distinet petals. Stamens 10, exserted. Ovary stalked. Style filiform. Ovules numerous. Pods broadly linear, flat. Seeds crosswise in the pod.

Leaves with 14-18 pairs of pinnae: branches tomentose : leaflets less than $1.5 \mathrm{~mm}$. broad.

Leaves with 2-10 pairs of pinnae: branches glabrous or glabrate: leaflets over 1.5 . L. pulverulenta.

Leaflets 12-16, mostly less than twice as long as broad: pods with leathery valves. 3 . L. retusa.

1. Leucaena pulverulénta Benth. A small tree, sometimes $18 \mathrm{~m}$. tall, with finely pubescent inflorescence. Leaves 1-2 dm. long, with 28-36 pinnae; leaflets $60-120$, the blades narrowly oblong, acute: peduncles often clustered, 1-3.5 $\mathrm{cm}$. long: heads globose, 1-1.5 $\mathrm{cm}$. in diameter : calyx campanulate, $1-1.5 \mathrm{~mm}$. high ; lobes obtuse : petals linearspatulate, about thrice as long as the calyx, pubescent near the tip: stamens hardly twice as long as the petals : pods linear, $10-20 \mathrm{~cm}$. long.

In rich boil, southern Texas and Mexico. Spring.

2. Leucaena glaùca (L.) Benth. A small tree, sometimes $10 \mathrm{~m}$. tall, with spreading branches and tomentose twigs. Leaves 1-3 dm. long, with 6-20 pinnae ; leaflets 20-40, the blades narrowly oblong to lanceolate, oblique, 6-12 mm. long, acute : peduncles tomentose, 1-4 cm. long: heads globose, $1-3 \mathrm{~cm}$. in diameter: calyx obconic, $1 \mathrm{~mm}$. long, subtended by peltate bracts; lobes obtuse : petals linear-oblong or linear-spatulate, erect, more than twice as long as the calyx, pubescent: stamens nearly thrice as long as the petals: pods linear, $10-15 \mathrm{~cm}$. long, acute or acuminate at both ends.

In sandy or rocky soil, Florida to Texas and Mexico. A native of tropical America, now widely distributed in all tropical regions. Spring.

3. Leucaena retùsa Benth. A shrub, with tomentose twigs. Leaves 1-2 cm. long, with 4-10 pinnae; leaflets 12-16, the blades leathery, oblique, obovate or ovate to oval or oblong, 1-3 cm. long, prominently nerved, usually apiculate : peduncles 5-8 $\mathrm{cm}$. long: heads globose, about $2 \mathrm{~cm}$. in diameter : calyx obconic, $3-3.5 \mathrm{~mm}$. long : pods linear, $15-25 \mathrm{~cm}$. long, acute or acuminate at both ends.

On plains and prairies, southern Texas and New Mexico. Spring.

\section{9. ÁCUAN Medic.}

Perennial unarmed herbs or somewhat shrubby plants. Leaves with 2-pinnate blades : leaflets numerous. Flowers in peduncled greenish or whitish head-like spikes, perfect, or the lower ones staminate or neutral, and sometimes apetalous. Calyx 5-lobed. Corolla of 5 distinct or slightly united petals. Stamens 5-10, exserted : filaments distinct or nearly so. Ovary nearly sessile. Ovules numerous. Pods very narrow or oblong, unarmed, 2valved. Seeds lengthwise or oblique in the pod. [Desmanthus Willd.]

Stamens 5.

Pods 4-6 mm. wide, in compact heads : peduncles longer than the pods.

Pods $2 \mathrm{~mm}$. wide, in loose clusters: peduncles shorter than the pods. Stamens 10.

Leaves mostly with 8-12 pinnae.

Stems glabrous or nearly so: peduncles $1-2 \mathrm{~cm}$. long.

Stems velvety pubescent : peduncles $2.5-5 \mathrm{~cm}$. long.

Leaves mostly with 2-6 pinnae.

Peduncles $1-2.5 \mathrm{~cm}$. long.

Leaf-rachis and its branches glabrous: leaflets not ciliate.

Leaf-rachis and its branches pubescent : leaflets ciliate.

eduncles 4-12 cm. long.

Pinnae mostly with 12-18 leaflets : leaflets glaucous beneath, glabrous or nearly 8o: pods $3 \mathrm{~mm}$. wide.

Pinnae mostly with $20-28$ leaflets : leaflets ciliate and pubescent beneath: pods $2 \mathrm{~mm}$. wide.

1. A. Illinoensis.

2. A. leptoloba.

3. A. Jamesii.

4. A. velutina.

5. A. depressa.

6. A. acuminata.

7. A. reticulata.

8. A. fallax.

1. Acuan Illinoénsis (Michx.) Kuntze. Stems erect or ascending, 3-10 dm. tall, sparingly branched, glabrous or nearly so: leaves with $20-28$ pinnae; leaflets numerous, the blades linear-oblong, $2.5-3.5 \mathrm{~mm}$. long, acute, not reticulated : peduncles $2.5-8 \mathrm{~cm}$. long, usually shorter than the subtending bracts: spikes less than $1 \mathrm{~cm}$. in diameter : pods oblong, numerous, $1.5-2 \mathrm{~cm}$. long, curved and slightly spirally twisted, in heads $2-3 \mathrm{~cm}$. in diameter. [Desmanthus brachylobus (Willd.) Benth.] summer.

In dry soil, and on river banks, Minnesota to Tennessee, Florida, Colorado and Texas. Spring and

2. Acuan leptóloba (T. \& G.) Kuntze. Stems ascending, 3-10 dm. tall, sparingly branched, with scabrous angles: leaves with 10-20 pinnae; leaflets numerous, the blades 
linear-lanceolate to linear-oblong, 2-5 mm. long, acute, not reticulated : peduncles 1.5-2 $\mathrm{cm}$. long, shorter than the subtending leaves: spikes smaller than those of A. Illinoensis: pods few, linear, $5-8 \mathrm{~cm}$. long, straight or nearly so, acuminate at the apex.

On prairies, Kansas to Texas. Summer.

3. Acuan Jamèsii (T. \& G.) Kuntze. Stems branched at the base, the branches spreading, 1-5 dm. long, glabrous or nearly so: leaves with 4-12, usually 8-10 pinnae ; leaflets $16-28$, the blades oblong, 3-5 mm. long, not reticulated, more or less strongly apiculate: peduncles 1-2 cm. long, much shorter than the subtending bracts : spikes about 1 $\mathrm{cm}$. in diameter : pods linear, $3.5-8 \mathrm{~cm}$. long, slightly curved, acuminate at the apex.

In dry soil, the Indian Territory to Texas and Arizona. Spring and summer.

4. Acuan velutina (Scheele) Kuntze. Stems branched at the base, the branches ascending or prostrate, $2-6 \mathrm{dm}$. long, finely canescent : leaves with $4-12$ or usually $8-10$ pinnae ; leaflets numerous, the blades oblong, 2-5 $\mathrm{mm}$. long, obtuse or acutish, not reticulated: peduncles $2.5-6.5 \mathrm{~cm}$. long, shorter than the subtending leaves or longer: spikes about $1.5 \mathrm{~cm}$. in diameter : pods linear, $2-6 \mathrm{~cm}$. long, straight or nearly so, acuminate at both ends.

In dry soil, southern and western Texas. Spring and summer.

5. Acuan depréssa (Willd.) Kuntze. Stems branched at the base, the branches prostrate, 3-8 dm. long, glabrous or nearly so : leaves with $2-8$ pinnae ; leaflets numerous, the blades narrowly oblong, 2-5 $\mathrm{mm}$. long, obtuse or acutish, not reticulated : peduncles as long as the subtending bracts or shorter : pods linear, 4-6 $\mathrm{mm}$. long, acuminate, straight.

In sandy soil, near the coast, Florida to Texas and Mexico. Spring and summer.

6. Acuan acuminata (Benth.) Kuntze. Stems branched at the base, the branches spreading or prostrate, sparingly pubescent: leaves with 4-8 pinnae; leaflets 14-20, the blades oblong, 2-4 mm. long, acute, not reticulated, ciliate : peduncles $1-1.5 \mathrm{~cm}$. long, shorter than the subtending bracts : pods linear, 3-4 cm. long, slightly curved, acuminate.

In dry soil, southern Texas. Spring and summer.

7. Acuan reticulàta (Benth.) Kuntze. Stems branched at the base, the branches ascending or prostrate, $2-8 \mathrm{dm}$. long, sparingly pubescent : leaves with $4-8$, usually 6 pinnae : leaflets $8-20$, the blades oblong to obovate, $3-5 \mathrm{~mm}$. long, very oblique at the base, prominently reticulated, acute or acutish : peduncles elongated, 7-10 $\mathrm{cm}$. long, surpassing the subtending bracts : spikes few-flowered, $1.5-2 \mathrm{~cm}$. in diameter : pods linear, straight, 4-6 $\mathrm{cm}$. long, acuminate.

In dry soil, southern Texas. Spring and summer.

8. Acuan fállax Small. Stems branched at the base, the branches spreading or prostrate, 1-2 dm. long, finely canescent, angled. Leaves with 4-8 pinnae : leaflets mostly 20-28, the blades oblong, slightly inequilateral, $3-5 \mathrm{~mm}$. long, rather obscurely reticulated, acutish : peduncles elongated, 3-7 $\mathrm{cm}$. long, surpassing the subtending bracts : spikes about $1 \mathrm{~cm}$. in diameter : pods linear, $3-4 \mathrm{~cm}$. long, slightly curved, acute.

In dry soil, San Diego, Texas. Spring and summer.

\section{MORÓNGIA Britton. ${ }^{1}$}

Perennial herbs, or shrubby plants, mostly with spreading or prostrate prickle-armed stems. Leaves usually sensitive : blades 2-pinnate : leaflets numerous, relatively small : stipels setaceous. Flowers perfect or polygamous, in axillary head-like spikes. Calyx 4-5-lobed. Corolla of 4-5 petals united to about the middle. Stamens 8-10, exserted: filaments distinct or nearly so. Ovary nearly sessile. Ovules numerous. Pods narrow, prickly all over, 4 -angled, or with broad margins, finally 4 -valved by the valves separating from the margins. [Schrankia Willd., not Medic.]

Leaflets prominently nerved beneath.

Leaflets scarcely, if at all, nerved.

Sides and margins of the pods with similar or nearly similar prickles.

Sides and margins of the pods with conspicuously dissimilar prickles.

Pods scarcely flattened, the sides with long and broad prickles, the margins nearly unarmed; beak $10-15 \mathrm{~mm}$. long.

Pods markedly flattened, the sides with very fine prickles, the margins with stouter prickles; beak $4-5 \mathrm{~mm}$. long.

1. M. uncinata.

2. M. angustata.

1. Morongia uncinàta (Willd.) Britton. Stems armed with recurved prickles, 3-15 $\mathrm{dm}$. long: leaves with 6-12 pinnae; leaflets many, the blades oblong, 3-7 $\mathrm{mm}$. long,

${ }^{1}$ A Mexican species, Morongia aculeata, has been reported from Texas, but I have not yet been able to examine authentic or satisfactory specimens. Species additional to those here recognized have been described by Michaux and Chapman. 
apiculate or slightly acuminate, strongly nerved beneath : peduncles armed with slender prickles : pods $3-15 \mathrm{~cm}$. long, beaked, densely prickly or sometimes sparingly so.

In dry soil, Virginia to Florida and South Dakota to Arkansas, Texas and the Gulf of Mexico. spring and summer.

2. Morongia angustàta (T. \& G.) Britton. Stems sparingly armed with recurved prickles, the angles not conspicuously paler than the rest of the stem, 3-15 dm. long, simple or sparingly branched: leaves with 6-16 pinnae; leaflets many, the blades narrowly oblong, $1.5-7 \mathrm{~mm}$. long, scarcely or not at all nerved; peduncles armed like the stem : pods $5-15 \mathrm{~cm}$. long, beaked, densely or sparingly prickly.

In dry soil, Virginia to Tennessee, Texas and Florida. Spring and summer.

3. Morongia làtidens Small. Stems usually bright green, $3-10 \mathrm{dm}$. long, with conspicuously pale and sharp angles and still paler prickles : leaves with 4 pinnae or rarely some of them with only 2 pinnae; leaflets many, the blades thick, oblong, $3-8 \mathrm{~mm}$. long, apiculate, not nerved: peduncles much stouter than the petioles, with few pale prickles: pods stout, 3-7 cm. long, the sides with broad prickles, the broad margins scarcely or only slightly armed; beak $1-1.5 \mathrm{~cm}$. long.

In dry soil, Kenedy, Carnes County, Texas. Spring and summer.

4. Morongia Roemeriàna (Scheele) Heller. Stems armed with very small prickles, 3-12 dm. long, prominently but not conspicuously angled: leaves with 4-8 pinnae; leaflets many, the blades oblong, 4-5.5 mm. long, apiculate, not nerved, more or less ciliate : peduncles much stouter than the petioles, and armed like them, and with numerous smaller bristles crowded near the apex: pods flattened, $3.5-4.5 \mathrm{~cm}$. long, the sides with very fine prickles, the margins with stouter prickles; beak 4-5 $\mathrm{mm}$. long.

In stony soil, southern Texas. Spring.

\section{MIMÒsA L.}

Shrubby plants or trees, or rarely herbs, usually thorny or prickly. Leaves often sensitive, with 2-pinnate blades : leaflets four or numerous. Flowers perfect or polygamous, in axillary, white or colored head-like or cylindric spikes. Calyx mostly 4-5-lobed, sometimes obsolete. Corolla of usually 4-5 well united petals. Stamens 4-10, exserted : filaments distinct. Ovary sessile or nearly so. Ovules 2-several. Pods flat, sometimes conspicuously jointed, often prickle-armed, the valves separating from the persistent margins.

Stamens as many as the corolla-lobes.

Stamens twice as many as the corolla-lobes.

Shrubs or trees with hard wood.

Branchlets and petioles or their divisions glabrous.

Leaves usually with 2 pinnae|; leaflets $6-10$, the blades oval or orbicularoval, 2-4 mm. long: pods armed.

Leaves usually with 4-6 pinnae; leaflets usually 12 , the blades oblong or oblong-obovate, 4-6 mm. long: pods unarmed or nearly so.

Branches and petioles or their divisions puberulent or pubescent.

Leaves with $2-4$ or rarely 6 pinnae; leaflets $4-12$.

Herbs or undershrubs or pinnae; leaflets numerous.

Climbindershrubs or soft-woody climbing shrubs.

Climbing: foliage tomentose or puberulent: leaflets with blades less than twice as long as broad.

Prostrate and creeping or erect: foliage strigose or strigillose: leaflets with blades over twice as long as broad.

Erect or ascending : peduncles becoming 1-2 $\mathrm{cm}$. long : pods 8-15-seeded.

Prostrate: peduncles becoming $5-20 \mathrm{~cm}$. long: pods 2-4-seeded.

1. M. pudica.

1. Mimosa pùdica L. Herbaceous or somewhat shrubby, several dm. tall, the stems usually branched, more or less hirsute with downy hairs. Leaves with 1 or 2 approximate pairs of pinnae : peduncles 1-4 cm. long: pods often densely clustered, 1-2 $\mathrm{cm}$. long, the valves glabrous, the margins armed with spreading bristles.

In waste places, about the cities of the Gulf States. Naturalized from tropical America.

2. Mimosa boreàlis A. Gray. A glabrous armed shrub usually over $1 \mathrm{~m}$. tall, with the spines beside the axils. Leaves inconspicuous, usually with 2 pinnae; leaflets $6-10$, the blades oval, or orbicular-oval, $2-4 \mathrm{~mm}$. long, thick, glaucescent : peduncles slender, $12-18 \mathrm{~mm}$. long: pods $2.5-5 \mathrm{~cm}$. long, usually armed on one or both margins, deeply constricted, the segments often 4.

In dry soil, the Indian Territory and Texas.

3. Mimosa fràgrans A. Gray. A glabrous armed shrub, usually less than $1 \mathrm{~m}$. tall, with the spines beside the axils. Stems much branched : leaves mostly with 2-6 pinnae; leaflets $10-16$, the blades oblong to oblong-obovate, $4-6 \mathrm{~mm}$. long, usually obtuse, promi- 
nently nerved: peduncles surpassing the subtending bracts : pods linear, $3-6 \mathrm{~cm}$. long, curved, mostly unarmed, the segments often 5-8.

In dry soil, Texas and New Mexico.

4. Mimosa Texàna (A. Gray) Small. A low rigidly branched shrub, with finely pubescent or puberulent foliage, armed with subaxillary spines, the branches zigzag. Leaves inconspicuous, with 4-6 approximate pinnae, or rarely only a pair, the rachis pubescent ; leaflets usually $8-14$, the blades oblong, $2-4 \mathrm{~mm}$. long, veiny, ciliolate : peduncles becoming 1-2 cm. long: pods broadly linear, 2-3 cm. long, not constricted between the seeds, but well armed around the margin.

On plains and prairies, Texas to New Mexico and adjacent Mexico.

5. Mimosa Lindheimeri A. Gray. A puberulent shrub or small tree, armed with flattened spines beside and slightly below the axils, the branches zigzag. Leaves numerous, with 8-12 pinnae ; leaflets 16-24, the blades oblong, 2-3 $\mathrm{mm}$. long: peduncles shorter than the subtending bracts : spikes globose, fully $1 \mathrm{~cm}$. in diameter : pods linear, curved, 2-4 cm. long, 3-4-jointed, glabrous, the margins armed with recurved prickles.

In dry soil, western and southern Texas.

6. Mimosa malacophýlla A. Gray. A shrubby climber, with stems and branches 1-5 mm. long, armed with recurved prickles, tomentose. Leaves numerous, with 8-14 pinnae; leaflets relatively few, the blades oval to obovate, $6-16 \mathrm{~mm}$. long, more or less oblique, rounded or apiculate at the apex : peduncles $1-1.5 \mathrm{~cm}$. long: spikes oblong, 1.5 $\mathrm{cm}$. long, white or yellowish: pods broadly linear, $5-7 \mathrm{~cm}$. long, curved, 6-8-jointed, glabrous, veiny.

In dry soil, Texas to New Mexico and Nuevo Leon.-The form with merely puberulent stems and branches and rather larger glabrous leaflets is M. malacophylla glabräta Benth.

7. Mimosa Berlandièri A. Gray. A sparingly strigose upright shrub, with sparingly prickle-armed branches. Leaves 3-6 cm. long, with 8-12 pinnae; leaflets numerous, 40-80, the blades linear or linear-oblong, 4-5 $\mathrm{mm}$. long, acute : peduncles shorter than the subtending bracts : spikes oblong or ovoid, 12-14 mm. long: pods linear-oblong, slightly curved, 4-9 $\mathrm{cm}$. long, with 8-15 joints, rough-pubescent, each narrowed into a short stipe.

In low ground, southern Texas to San Luis Potosi.

8. Mimosa strigillòsa T. \& G. A perennial herb, with radially prostrate often creeping branches, the foliage more or less densely pubescent with rigid strigose hairs : leaves numerous, with 10-16 pinnae ; leaflets $20-28$, the blades oblong or linear-oblong, 4-6 mm. long, obtuse or acutish, reticulated : peduncles surpassing the leaves : spikes pink, oblong, $1.5-2.5 \mathrm{~cm}$. long : pods oblong or oval, 1-3 cm. long, 1-4-jointed, hispid, very oblique at the apex.

On river banks and in moist soil, chiefly near the coast, Florida to Texas.

\section{NEPTÙNIA Lour.}

Perennial herbs or shrubby plants, with unarmed prostrate or diffuse stems, or sometimes floating. Leaves with 2-pinnate blades: leaflets relatively small. Flowers perfect or polygamous, in head-like or cylindric spikes on solitary axillary peduncles. Calyx 5 -lobed. Corolla of 5 distinct or partially united petals. Stamens 10, or rarely 5, exserted : filaments distinct. Ovary stipitate. Ovules several. Pod relatively broad, flat, oblique, 2-valved.

Spikes about 50 -flowered, oblong-cylindric.

1. N. lutea.

Spikes about 20-flowered, ovoid or oval.

Bracts and calyx-lobes ciliolate.

Pinnae 4-6: leaflets merely ciliolate.

Pinnae 6-10: leaflets ciliolate and pubescent beneath.

Bracts and calyx-lobes not ciliolate.

1. Neptunia lùtea (Leavenw.) Benth. Stems branched at the base, the branches prostrate, $5-15 \mathrm{dm}$. long, somewhat shaggy pubescent, usually branching: leaves with 6-10 pinnae ; leaflets 18-34, the blades crowded, oblong, apiculate, ciliate, prominently nerved beneath : stipules ovate-lanceolate: peduncles finally longer than the subtending bracts : spikes oblong, $1-2 \mathrm{~cm}$. long, usually nodding: pods oblong, $2-4 \mathrm{~cm}$. long, flat, abruptly pointed, contracted into a rather slender stipe often $8 \mathrm{~mm}$. long: seeds 3-9.

In moist or clay mer.-A Texan form with nearly or quite glabrous branches and peduncles is $N$. lutea ténuis (Benth.)
Robinson.

2. Neptunia pubéscens Benth. Stems branched at the base, the branches $2-4 \mathrm{dm}$. long, spreading or trailing, sparingly pubescent: leaves usually with 4-6 pinnae; leaf- 
lets 30-70, the blades oblong, 3-4 mm. long, obtuse or acutish, merely ciliolate, not prominently nerved : stipules ovate: peduncles commonly shorter than the subtending bracts or longer at maturity: spikes globose or nearly so, about $1 \mathrm{~cm}$. in diameter: pods oblong, 2-3 cm. long, narrowed into stipes only $2-4 \mathrm{~mm}$. long.

In dry soil, southern Texas and tropical America. Spring to fall.

3. Neptunia Lindheimeri Robinson. Stems branched at the base, the branches diffuse, persistently pubescent, several $\mathrm{dm}$. long: leaves with 6-10 pinnae, leaflets 30-60, the blades conspicuously ciliate and pubescent on the lower surface, blunt or mucronulate : peduncles becoming $2.5-6.5 \mathrm{~cm}$. long: pods oblong and cuneate at the base, $2.5-3.8 \mathrm{~cm}$. long, permanently pubescent, the stipes 4-5 mm. long: seeds $3-10$.

- On prairies, Texas. Spring and summer.

4. Neptunia Floridàna Small. Stems several from large roots, ascending or spreading, 3-7 dm. long, sparingly pubescent or glabrate, commonly branching, more or less roughish pubescent: leaves rather numerous, with $3-5$ pairs of pinnae: stipules lanceolate, acuminate; leaflets numerous, the blades oblong or narrowly oblong, 4-5.5 $\mathrm{mm}$. long, often mucronulate, ciliate, prominently 3-nerved, sesile: peduncles slender, much longer than the subtending leaves: spikes oval or oblong, $1-1.5 \mathrm{~cm}$. long: pods oblong, 2.5-3.5 $\mathrm{cm}$. long, apiculate, rather lustrous, glabrous, the stipe 2-4 $\mathrm{mm}$. long: seeds 5-10.

In sand, Florida to Louisiana. Spring to fall.

\section{PROSÒPIS L.}

Shrubs or trees, often armed with axillary spines. Leaves alternate : blades 2-pinnate, with four pinnae : leaflets narrow, relatively few. Flowers perfect, in green or yellowish cylindric spikes. Calyx 5-lobed, sessile. Corolla of 5 distinct or slightly united petals. Stamens 10 : filaments distinct. Ovary often stipitate. Ovules numerous. Pods in lax clusters, flattened, straight or slightly curved, indehiscent, the interior tissues more or less spongy.

1. Prosopis glandulòsa Torr. A shrub or tree sometimes $15 \mathrm{~m}$. tall, usually with zigzag branches, mostly armed with thorn-like spines. Leaves with 2-4 pinnae, longpetioled; leaflets $12-60$, the blades linear or nearly so, $1.5-4 \mathrm{~cm}$. long, obtuse or acutish : peduncles $5-10 \mathrm{~mm}$. long : spikes $4-8 \mathrm{~cm}$. long: calyx campanulate, about $1 \mathrm{~mm}$. high; lobes triangular, slightly shorter than the tube : petals erect, linear or nearly so, 4-5 times longer than the calyx, acute, pubescent within: stamens hardly twice as long as the petals: ovary pubescent: pods linear, 1-2 dm. long, straight or nearly so : seeds oblong.

In plains or prairies, Kansas to Texas, Arizona and Mexico.

\section{STROMBOCÁrPA A. Gray.}

Shrubs or trees, with axillary spines. Leaves alternate: blades 2-pinnate, shortpetioled or sessile, with few pinnae : leaflets relatively few. Flowers perfect, in cylindric or globular spikes. Calyx 5-lobed, campanulate or turbinate. Corolla of 5 distinct or slightly united petals. Stamens 10 : filaments distinct. Ovules numerous. Pods in dense clusters, each tightly coiled into a spiral, woody without, pulpy within.

1. Strombocarpa cineréscens A. Gray. A low shrub, armed with slender spines. Leaves with 2-4 pinnae, sessile or short-petioled; leaflets 10-20, the blades crowded, 1.5-3 $\mathrm{mm}$. long, obtuse, reticulated: peduncles $1-3 \mathrm{~cm}$. long : heads globose, $1-1.5 \mathrm{~cm}$. in diameter : calyx turbinate, nearly $2 \mathrm{~mm}$. high : petals linear, fully twice as long as the calyx : pods $1.5-4 \mathrm{~cm}$. long, spirally twisted into a cylinder 5-7 mm. thick.

In moist soil, along or near the lower Rio Grande, southern Texas and Mexico.

\section{Family 16. CASSiàcEAE Link. Senna Family.}

Trees, shrubs or herbs, sometimes prickle-armed. Leaves alternate, usually with stipules: blades simple or compound. Flowers mostly perfect, sometimes polygamous, monoecious or dioecious, variously disposed, regular or irregular. Calyx of 5 more or less united sepals. Corolla of usually 5 petals, imbricated, the upper one enclosed by the lateral ones in the bud. Androecium of 10 stamens or fewer. Filaments distinct or united. Gynoecium of a single carpel. Ovary 1-celled, sometimes stipitate. Style terminal. Ovules 1-many. Fruit a legume, 2-valved or indehiscent. Seeds with or without endosperm. 
Corolla apparently papilionaceous : leaves with 1-folioliate blades.

Corolla more or less irregular, sometimes nearly regular: leaves with pinnately compound blades.

Leaves with simply pinnate blades.

Corolla essentially regular, the 5 petals nearly equal : calyx-lobes obtuse.

Corolla very irregular, one of the lateral petals (standard) and the lowest petal large, the other 3 petals often greatly reduced: calyx-lobes acuminate.

Leaves with 2-pinnate blades.

Flowers dioecious or polygamous.

Flower with a very small receptacle: stamens surpassing the petals: nod leathers.

Flower with a long receptacle: stamens shorter than the petals: pod woody.

Flowers perfect.

Leaf with a very short petiole which ends in a spine, each division with a long flat phyllode-like rachis.

Leaf with a relatively long petiole, the rachises of the divisions not phyllode-like. Shrubs or trees.

Calyx-lobes valvate.

Armed shrubs or trees: leaf-divisions with few leaflets.

Unarmed trees: leaf-divisions with very many leaflets.

Calyx-lobes imbricated.

Pods smooth.

Herbs.

Pods prickle-armed.

1. Cercis.

2. CASSIA.

3. Chamaecrista.

4. Gleditsia.

5. Gymnocladus.

6. Parkinsonia.

7. CERCIDIUM.

8. DELONIX.

9. Poinciana.

10. Guilandina.

11. Hoffma NSEgGia.

\section{CÉRCIS L.}

Unarmed shrubs or small trees, with a scaly bark. Leaves alternate, deciduous, 1foliolate : leaflet with a simple entire long-petioled blade. Flowers perfect, in axillary clusters or racemes on the branchlets of a previous year. Sepals united into a campanulate 5-lobed calyx which is swollen on one side and lined with a thin disk in the bottom. Corolla pink or rose : petals 5 , nearly equal, clawed : standard smallest : wings obliquely truncate : keel-petals somewhat auricled on one side. Stamens 10, in 2 rows : filaments distinct, conspicuously enlarged and pilose below the middle, those opposite the petals shorter: anthers versatile, opening lengthwise. Ovary short-stipitate, oblique. Ovules anatropous. Pods narrow, very flat, leathery, 2-valved, the ventral suture with 2 narrow wings. Seeds flat, transverse, with a reddish brown crustaceous testa. Endosperm horny. The plants flower in the spring. RED-BUd. JudAs-TreE.

Blades of the leaflets not acuminate: pods sessile or nearly so.

Blades of the leaflets manifestly acuminate: pods manifestly stipitate.

1. C. occidentalis.

2. C. Canadensis.

1. Cercis occidentàlis Torr. A slender small tree, sometimes $12 \mathrm{~m}$. tall, with glabrous foliage. Blades of the leaflets suborbicular varying to reniform, $4-12 \mathrm{~cm}$. in diameter, rounded or obtuse at the apex, cordate, fustrous above; petioles stout, much shorter than the blades: pedicels $1.5-2 \mathrm{~cm}$. long, or sometimes shorter: calyx 3-4 mm. long; lobes acute or acutish, much shorter than the tube : corolla similar to that of the following species : pods linear-oblong, 6-9 $\mathrm{cm}$. long, acuminate at both ends, sessile or nearly so.

In valleys, Texas and northern Mexico. Spring.

2. Cercis Canadénsis L. A shrub or small tree rarely $15 \mathrm{~mm}$. tall, with glabrous or sometimes pubescent foliage. Blades of the leaflets suborbicular in outline varying to broadly ovate or reniform, $6-12 \mathrm{~cm}$. in diameter, acuminate at the apex, somewhat lustrous above, truncate or cordate at the base; petioles shorter than the blades: pedicels slender, $0.5-1.5 \mathrm{~cm}$. long: calyx $3-4 \mathrm{~mm}$. high; lobes rounded, shorter then the tube : corolla pink-purple; standard with an oval blade, 7-8 mm. long; keel petals concave, about $1 \mathrm{~cm}$. long: pods linear-oblong, $5-10 \mathrm{~cm}$. long, acuminate at both ends, short-stipitate, often glaucous.

In rich soil, Ontario to Minnesota, New Jersey, Florida and Texas. Spring.

\section{CÁSSIA L. 1}

Herbs, shrubs or trees, various in habit, with evenly pinnate leaves, and mostly yellow flowers in terminal or axillary panicles or racemes. Petiole often with one or several glands borne near the base or between the leaflets. Calyx-lobes 5, obtuse, somewhat leathery. Petals 5, spreading, nearly equal, imbricated. Stamens 5 or 10 , all perfect or the 3 upper ones reduced to staminodia : filaments unequal : anthers opening by apical

${ }^{1}$ Contributed by Mr. Charles Louis Pollard. 
pores. Ovules numerous. Pods turgid or somewhat compressed, often elongated. Seeds transverse or parallel with the septa. Senna.

Leaf-blades 2-foliolate.

Peduncles 1-flowered.

Peduncles 2-several-flowered.

Gland conical, situated between the lowermost leaflets.

Gland setaceous, below the lowermost leaflets.

Leaf-blades 4-20-foliolate or rarely 2 -foliolate.

Pod less than $5 \mathrm{~cm}$. in length.

Pod more than $5 \mathrm{~cm}$. in length.

Petiolar gland at base of rachis.

Stipules filiform.

Leaf-blades 8-12-foliolate.

Leaf-blades 12-20-foliolate.

Stipules linear, foliaceous.

Petiolar gland between the lowermost pair of leaflets.
Leaflets with obovate blades.

Leaflets with elliptic blades.

Peduncles 2-flowered.

Peduncles several-flowered.

1. C. pumilio.

2. C. Roemeriana.

3. C. bauhinioides.

4. C. Lindheimeriana.

1. Cassia pumilio A. Gray. Plant $8-15 \mathrm{~cm}$. tall, the stems and leaves sparsely pubescent. Stems tufted from a long, branching rootstock : leaflets 2 , the blades linear, or the earlier obovate, $3-3.5 \mathrm{~cm}$. long, $2 \mathrm{~cm}$. wide, slightly shorter than the elongated rhachis ; petiolar gland slender, setaceous, situated between the lowermost pair of leaflets: stipules acute, linear, membranaceous, persistent : flowers solitary on elongated axillary peduncles : calyx persistent ; lobes slightly shorter than petals : pods turgid, oblong, finely pubescent, $1.5 \mathrm{~cm}$. long, $7 \mathrm{~mm}$. wide.

On dry mesas, Texas and New Mexico to Mexico.

2. Cassia Roemeriàna Scheele. Plant erect, villous, 4-5 dm. tall. Stems numerous, from a thick rootstock : leaflets 2 , densely pubescent, the blades lance-linear, $3-6 \mathrm{~cm}$. long, $7-12 \mathrm{~mm}$. wide, asymmetrical at the base, borne on a somewhat elongated rhachis: stipules filiform, persistent : peduncles 2 -4-flowered, forming terminal corymbose racemes : calyx-lobes ovate, membranaceous : petals strongly veined : pods nearly straight, turgid, mucronate, dehiscent along both sutures, $2.5-3 \mathrm{~cm}$. long.

On mesas, Texas and New Mexico to Mexico.

3. Cassia bauhinioides A. Gray. Plant 3-4 dm. tall. Stem somewhat branching, densely pubescent, pilose or even tomentose: leaflets 2 , the blades oblong-ovate, very asymmetrical at the base, canescent beneath, 2-3 cm. long, 1-1.5 cm. wide: stipules filiform, persistent : peduncles 2 -flowered, forming corymbs at the ends of the branches: calyx-lobes thin, membranaceous, elliptic : pods villous, compressed, straight or subfalcate, acute, dehiscent along both sutures, $3-5 \mathrm{~cm}$. long.

On mesas, western Texas to Arizona and Mexico.

4. Cassia Lindheimeriàna Scheele. Plant erect, $0.5-1 \mathrm{~m}$. tall. Stems branching, silky-pubescent : leaflets $8-12$, the blades asymmetrical, oval or elliptical, acute or mucronate, canescent beneath, $2.7-3 \mathrm{~cm}$. long, $1.5 \mathrm{~cm}$. wide: petiolar gland setaceous, situated between the next to the lowermost pair of leaflets: stipules linear, membranaceous: racemes loosely many-flowered, becoming corymbose at the ends of the branches: calyxlobes ovate-lanceolate, striate: pods straight, acute, apparently indehiscent, nearly glabrous, very much compressed, $5 \mathrm{~cm}$. long, $5 \mathrm{~mm}$. wide.

In dry ground, Texas to Arizona and Mexico.

5. Cassia occidentàlis L. Plant annual, $0.5-1.5 \mathrm{~m}$. tall, herbaceous, glabrous : leaflets 8-12, the blades lanceolate, becoming lance-elliptic, subglaucous beneath, $3.6-5 \mathrm{~cm}$. long, 1-2 cm. wide : petiolar glands 2, sessile, conical, between the lowermost pair of leaflets : stipules filiform, caducous : flowers large, in closely-crowded axillary racemes : calyx-lobes rather short, oval or lance-ovate: pods linear, turgid, slightly compressed, glabrous, straight, or arcuate, with the septa externally prominent, $11 \mathrm{~cm}$. long, $6 \mathrm{~mm}$. wide: seeds numerous, transverse. In waste grounds, Virginia and Indiana to Florida and Mexico. Adventive or naturalized from
tropical America.

6. Cassia Marylándica L. Plant perennial, 1-2 m. tall, branching, herbaceous, glabrous : leaflets $12-20$, the blades acute-elliptical, submucronate, glaucous beneath, slightly asymmetrical at the base, $4-\overline{0} \mathrm{~cm}$. long, about $1.4 \mathrm{~cm}$. wide: petiolar gland obconical, stipitate, situated a short distance above base of rhachis : stipules filiform, ciliate, caducous: racemes short, many-flowered : calyx-lobes oval, more or less petal-like: pods falcate, flat, linear, somewhat hispid, with undulate margins, 10-12 cm. long, $6 \mathrm{~mm}$. wide: seeds numerous, transverse.

In moist or alluvial soil, Connecticut to Florida, Nebraska, Kansas and Louisiana. 
7. Cassia ligustrìna L. Plant perennial, 1-2 m. tall, herbaceous, glabrous. Stem grooved : leaflets 12-16, the blades lanceolate, glabrous, $4-4.2 \mathrm{~cm}$. long, about $1 \mathrm{~cm}$. wide : petiolar gland at base of rachis, elongated, stipitate: stipules linear, membranaceous, caducous: racemes few-flowered, forming a corymbose panicle: calyx-lobes oval, membranaceous, shorter than the petals : pods flat, glabrous, with slightly sinuate margins, 8 cm. wide: seeds parallel with the valves.

In swamps or woods, peninsular Florida. Also in the West Indies and tropical America.

8. Cassia Tòra L. Plant annual, $0.5-1.5 \mathrm{~m}$. tall. Stem glabrous, herbaceous : leaflets 4-6, the blades glabrous or pubescent beneath, obovate-elliptical or wedge-obovate, very slightly cuspidate, the terminal pair much the largest, all symmetrical or nearly so at the base, $3-5 \mathrm{~cm}$. long, about $2.5 \mathrm{~cm}$. wide: petiolar glands slender, elongated, situated between the lowermost pair of leaflets: stipules persistent: racemes loose, few-flowered : flowers large: calyx-lobes oval, membranaceous: pods elongated, linear, acute, falcate, more or less tetragonal, glabrous, $16-18 \mathrm{~cm}$. long, $3 \mathrm{~mm}$. wide : seeds numerous, large, quadrate.

In waste grounds, Virginia to Indiana, Florida and Arkansas. Also in Cuba and tropical America.

9. Cassia biflòra L. Plant shrubby. Stems branching freely, glabrous or pilose: leaflets 4-10, the blades usually pubescent or canescent beneath, sometimes glabrous, oblong-elliptical, acute or obtuse at apex, $4 \mathrm{~cm}$. long, about $1.6 \mathrm{~cm}$. wide: petiolar gland stipitate, slender, acute, situated between lowermost pair of leaflets : stipules linear, membranaceous, caducous: peduncles 2 -flowered, in close terminal racemes: flowers large: calyx-lobes oblong-elliptical, as long as the petals : pods falcate, narrowly linear, $9 \mathrm{~cm}$. long, $5 \mathrm{~mm}$. wide.

An occasional escape in Florida. Abundant in the West Indies and Mexico.

10. Cassia Bahaménsis Mill. Plant shrubby, tall. Stems often simple, glabrous or somewhat pilose : leaflets $6-10$, the blades subcoriaceous, ovate or acutely elliptical, submucronate, $3.5-5 \mathrm{~cm}$. long, $1.6 \mathrm{~cm}$. wide: petiolar gland orbicular, depressed, varying in position from between lowermost pair of leaflets to near base of rachis : stipules linear, caducous: flowers corymbose-paniculate : sepals petal-like: pods linear, flat, with lateral depressions between the seeds, $9 \mathrm{~cm}$. long, $5 \mathrm{~mm}$. wide.

In dry soil, Florida. Also in the Bahamas.

\section{CHAMAECRÍSTA Moench. ${ }^{1}$}

Herbs or shrubs, with pinnate leaves and axillary or supra-axillary flowers or flowerclusters. Rachis of the leaf bearing one or rarely two glands near the base. Flowers solitary or clustered, each borne on a twisted pedicel. Calyx-lobes 5, acuminate, membranaceous. Corolla irregular. Petals 5, one of the lateral ones (banner) and the lowermost petal (one of the wings) largest, the remaining three petals often greatly reduced. Stamens 10, all perfect, or occasionally some of them reduced to staminodia: anthers irregular in size, opening by apical pores: filaments short. Pods linear, flat, promptly dehiscent at maturity, the valves very elastic. Seeds compressed, ovoid or quadrate, oblique. Sensitive Pea. Sensitive Plant.

Corolla large, exceeding $1 \mathrm{~cm}$. in diameter: petals only moderately unequal.

Plants shrubby or woody, at least at the base.

Leaflets few, 3-8 pairs.

Leaflets numerous, $10-24$ pairs.

Plants erect: leaf-blades 20-40-foliolate. Leaflets $5 \mathrm{~mm}$. long.

Leaflets $1 \mathrm{~cm}$. long.

Leaves cinereous-pubescent.

Leaves glabrous.

Plant prostrate or decumbent : leaf-blades 18-24-foliolate.

Plants annual, herbaceous.

Petiolar gland oblong, depressed-truncate: species northern.

Petiolar gland orbicular : species all southern.

Plant robust, strongly hirsute.

Plants of low stature, glabrate or only slightly pubescent.

Gland crateriform.

Gland discoid.

Corolla $2-3 \mathrm{~cm}$. broad.

Plant low and spreading: leaflets scattered on the rachis. Plant erect: leaflets crowded on the rachis. Corolla 1-1.5 $\mathrm{cm}$. broad.

Corolla small, less than $1 \mathrm{~cm}$. in diameter, one petal much larger than the remaining four.

a. Plants copiously hirsute.

1. C. grammica.

2. C. Mississippiensis.

3. C. cinerea.

4. C. brachiata.

5. C. procumbens.

6. C. fasciculata.

7. C. robusta.

8. C. bellula.

9. C. chamaecristotdes. 10. C. littoralis. 11. C. Tracyi.

\footnotetext{
${ }^{1}$ Contributed by Mr. Charles Louis Pollard.
} 
Leaf-blades 40-54-foliolate.

Leaf-blades 16-24-foliolate.

b. Plants glabrate or merely puberulent.

Leaflets 20-25 pairs, the blades narrowly linear.

Leaflets 6-14 pairs, the blades broadly linear.
12. C. aspera.

13. C. Simpsonii.

14. C. multipinnata.

15. C. nictitans.

1. Chamaecrista grámmica (Spreng.) Pollard. Plant erect, branching. Stem herbaceous or suffruticose at base, densely pubescent: leaflets 6-16, the blades elliptical or subobovate, mucronate, subcoriaceous, canescent beneath, $1 \mathrm{~cm}$. long, $3 \mathrm{~mm}$. wide: petiolar gland obsolescent, sessile, compressed : stipules aculeate : peduncles 1-flowered: flowers large: pods pubescent, linear, mucronate, 3-4 cm. long, $4 \mathrm{~mm}$. wide: seeds few.

In sand, Florida Keys. Also in Cuba.

2. Chamaecrista Mississippiénsis Pollard. Plant decumbent, branching, suffruticose. Stem glabrous : leaflets 18-28, the blades subcoriaceous, pubescent, small, elliptical or obovate, mucronate, basally asymmetrical, $5 \mathrm{~mm}$. long, $1-1.5 \mathrm{~mm}$. wide : petiolar gland minute, cupuliform, sessile : stipules linear, membranaceous, persistent : peduncles $1 \mathrm{~cm}$. long, axillary, 1-flowered: flowers large: calyx-lobes lance-linear, slightly pubescent, not surpassing the petals : pods linear, sparsely pubescent, $2.5 \mathrm{~cm}$. long, $4 \mathrm{~mm}$. wide : seeds 4 or 5 , ovoid, rather large.

In sandy soil, Alabama and Mississippi.

3. Chamaecrista cinèrea (Cham. \& Schlecht.) Pollard. Plant suffruticose. Stem branching, puberulent: leaflets $20-40$, clothed with cinereous pubescence, the blades narrow, linear-falcate, acute, $1 \mathrm{~cm}$. long, $2 \mathrm{~mm}$. wide : petiolar gland small, cupuliform, stipitate: stipules filiform or linear: peduncles 1-2-flowered, rather short, axillary or supra-axillary : flowers large : pods linear, pilose or sparsely pubescent, prostrate, somewhat elongated, $5-5.5 \mathrm{~cm}$. long, $5 \mathrm{~mm}$. wide.

In dry ground, Texas and Mexico.

4. Chamaecrista brachiàta Pollard. Plant $1 \mathrm{~m}$. high or less. Stem tough, freely branching, glabrate : leaflets 20-28, the blades linear, glabrous on both surfaces, the midvein somewhat excentric, the obtuse apex tipped with a slender cusp: petiolar gland very much depressed, discoid : stipules lanceolate, acuminate, striate, and strongly persistent : flowers large, $3 \mathrm{~cm}$. in diameter, the broad yellow petals considerably exceeding the lanceolate scarious calyx-lobes : pods linear, $6-7 \mathrm{~cm}$. long, quite glabrous when mature : seeds quadrate, oblong, compressed on both sides.

In sandy pine lands, peninsular Florida.

5. Chamaecrista procúmbens (L.) Greene. Plant prostrate. Stem branching from a fruticose base : leaflets $18-24$, pubescent, the blades very small, linear, acutely subfalcate, $5 \mathrm{~mm}$. long, $1 \mathrm{~mm}$. wide, on a stout rachis: petiolar gland minute: stipules cordate, foliaceous : peduncles rather long, 1-flowered, axillary : flower large : pods linear, puberulent, somewhat crisped, with prominent sutural margins, $3.5 \mathrm{~cm}$. long, $4 \mathrm{~mm}$. wide.

In dry soil, Texas and Mexico.

6. Chamaecrista fasciculàta (Michx.) Greene. Plant erect or spreading. Stem herbaceous, glabrous : leaflets 16-28, the blades oblong-elliptical, acute or mucronate, 1.5 $\mathrm{cm}$. long, $3 \mathrm{~cm}$. wide : petiolar gland sessile, compressed, truncate: stipules lance-linear, membranaceous : peduncles numerous, supra-axillary, 3-5-flowered : flowers large : sepals membranaceous, lanceolate, equalling or exceeding the petals: pods elongated-linear, subrostrate, pubescent, $5 \mathrm{~cm}$. long, $5 \mathrm{~mm}$. wide : seeds numerous.

In fields and meadows, Maine to Minnesota, Kansas, Florida and Mexico.

7. Chamaecrista robústa Pollard. Plant erect, 1-2 m. tall. Stem branching, herbaceous, densely pubescent, stout : leaflets glabrate, 20-30, blades elliptical, obtuse, finely cuspidate, $2 \mathrm{~cm}$. long, $5-6 \mathrm{~mm}$. wide, occasionally an odd one terminating the rachis: petiolar gland orbicular, truncate, compressed, sessile: stipules foliaceous, broadly lanceolate : peduncles 1-3-flowered, supra-axillary : flowers large and conspicuous: calyx-lobes small, membranaceous, lanceolate, only half as long as the petals: pods narrow, linear, pubescent, $4 \mathrm{~cm}$. long, $5 \mathrm{~mm}$. wide.

In upland regions, Kentucky to northern Alabama and Louisiana.

8. Chamaecrista béllula Pollard. Plant slender, erect, 3-4 dm. high, the branches ascending. Stems and rachises puberulent : leaflets 10-20, the blades linear-elliptical, glabrous, 6-10 mm. long, of thin texture, minutely apiculate, the midvein rather excentric, not prominent : petiolar gland crateriform, subsessile : stipules linear, acuminate, membranaceous, striate: peduncles 1-flowered, almost always bibracteolate, supra-axillary: corolla $2 \mathrm{~cm}$. broad : calyx-lobes linear, attenuate, nearly equalling the obovate petals : pods $6-7 \mathrm{~cm}$. long, linear, puberulent : seeds ovoid, compressed, oblique.

In sand, St. Vincent, Florida. 
9. Chamaecrista chamaecristoìdes (Collad.) Greene. Plant low and spreading, but not prostrate. Stems divaricately much branched, obscurely strigose-pubescent: leaflets 12-24, scattered, linear-elliptical, glabrous, $9 \mathrm{~mm}$. long, 2 to $3 \mathrm{~mm}$. broad: petiolar gland small, circular, sessile, depressed : flowers solitary on filiform mostly supra-axillary peduncles: calyx-lobes linear, scarious, strongly ciliate : petals large, obovate, much exceeding the sepals, $1.5 \mathrm{~cm}$. long, $1.5 \mathrm{~cm}$. broad : pods not seen. [Cassia depressa Pollard.]

In dry ground, Missouri to Florida.

10. Chamaecrista littoràlis Pollard. Plant erect. Stem diffusely branching, the branchlets and younger shoots finely puberulent : leaflets $12-24$, the blades elliptic, prominently cuspidate, $5-8 \mathrm{~mm}$. long, midvein more or less excentric : stipules persistent, lanceolate, sharply attenuate, 3-5-nerved, the margin usually hispidulous: petiolar gland cupuliform, practically sessile : flowers about $2-2.5 \mathrm{~cm}$. wide, on slender solitary peduncles $1-1.5 \mathrm{~cm}$. long: petals exceeding the linear-lanceolate scarious calyx-lobes : pods densely pubescent, not at all falcate, $4-5 \mathrm{~cm}$. long: seeds quadrate, compressed, dark brown.

Near the coast, Mississippi and Louisiana.

11. Chamaecıista Tràcyi Pollard. Plant erect, herbaceous. Stem freely branching, the branches inclined to be lax and spreading, like the rest of the foliage densely clothed with a slight glandular pubescence : leaflets 8-18, the leaflets oblong or elliptical, very small, 5-8 mm. long: petiolar gland cupuliform, sessile near the base of the rachis: stipules setaceous : flowers solitary, on slender axillary or supra-axillary peduncles as long as the leaves or longer, upcurved in fruit: calyx-lobes narrowly linear, acuminate, about equalling the petals : corolla $1-1.5 \mathrm{~cm}$. wide : pods pubescent, $4 \mathrm{~cm}$. long, rather moderately rostrate.

In sandy soil, Koshtaw, Mississippi.

12. Chamaecrista áspera (Muhl.) Greene. Plant tall, erect, herbaceous. Stem hispid with fulvous hairs: leaflets $40-54$, the blades glabrous, narrowly linear, acuminate, $1 \mathrm{~cm}$. long, $1.5 \mathrm{~mm}$. wide : petiolar gland slender, erect, elongated : stipules linear, membranaceous, striated: peduncles 2-3-flowered, supra-axillary, very short: flowers rather larger than in $C$. nictitans, usually in pairs : pod hispid, somewhat obtusely linear, $2.8 \mathrm{~cm}$. long, $6 \mathrm{~mm}$. wide : seeds few, oblique.

In waste ground, Georgia to Florida.-A variety from Alabama, with hoary-pubescent leaflets, is Chamaecrista aspera Móhrii Pollard.

13. Chamaecrista Simpsònii Pollard. Plant low, branching from a fruticose base. Stem more or less puberulent : leaflets $16-24$, the blades glabrous or nearly so, small, narrowly linear, $5 \mathrm{~mm}$. long, $1 \mathrm{~mm}$. wide, each tipped with a black rigid acuminate tip: petiolar gland minute, stipitate, obconical : stipules foliaceous, tipped with rigid acuminate tips similar to those on leaflets : flowers sessile or subsessile, somewhat supra-axillary, 5-8 mm. broad : calyx-lobes lanceolate, membranaceous, equalling the petals : pods flat, linear, hirsute, subrostrate, $2 \mathrm{~cm}$. long, $4-5 \mathrm{~mm}$. wide: seeds few.

In sand, Big Pine and No Name Keys, Florida.

14. Chamaecrista multipinnàta (Pollard) Greene. Plant slender, tall, erect, more or less branched. Stem pubescent : leaflets 40-50, the blades $10 \mathrm{~mm}$. long, $1.5 \mathrm{~mm}$. wide, glabrous, narrowly linear, cuspidate: petiolar gland minute, depressed-cupuliform, substipitate : stipules long-acuminate, striate, foliaceous: flowers scattered, sessile, the corolla quite irregular, its small yellow petals not much exceeding the narrow, scariousedged sepals : pods linear, compressed, pubescent or even hirsute, dorsally and ventrally dehiscent, elastic, 2 to $2.5 \mathrm{~cm}$. long: seeds 4 to 6 .

In sandy woods, Georgia and Florida to Louisiana.-The low diffusely spreading form is Chamaecrista multipinnata Náshii (Pollard) Greene.

15. Chamaecrista níctitans (L. Moench. Plant low, herbaceous. Stems branching and spreading freely : leaflets glabrous, $12-28$, the blades linear-elliptical, acute or mucronate, 1-1.4 cm. long, 2-3 mm. wide: petiolar gland urceolate, subsessile : stipules inconspicuous, subsessile : pods pubescent, submembranaceous, acute, $3.5 \mathrm{~cm}$. long, $6 \mathrm{~mm}$. wide: seeds few.

In woods and fields, New England, Kansas, Georgia and Louisiana.

\section{GLEDÍtsia L.}

Trees, usually armed with simple or branched thorns, the bark pale, often smooth. Leaves equally bipinnate or some of them merely pinnate, with stipules: leaflets small, numerous, often crenulate. Flowers small, polygamous, greenish, clustered or in axillary or lateral racemes or panicles. Calyx-lobes $3-5$, nearly equal, surmounting the campanu- 
late-turbinate tube. Petals 3-5, nearly equal. Receptacle very small. Stamens 6-10, longer than the petals : filaments distinct: anthers uniform in size, opening lengthwise, Pod elliptic or elongated, flattened, more or less curved and twisted, indehiscent or tardily dehiscent, the valves leathery. Seerls flattened. The plants flower in the spring. Honey Locust.

Ovary glabrous: pods oval or elliptic, 1-seeded, or rarely 2-seeded.

Ovary pubescent: pods linear or oblong-linear, many-seeded.

Trees unarmed: pods 10-13 cm. long, not twisted, not pulpy within.

Trees usually armed: pods 20-30 cm. long, twisted, pulpy within.

1. G. aquatica.

2. G. Texana.

3. G. triacanthos.

1. Gleditsia aquática Marsh. A tree sometimes $20 \mathrm{~m}$. tall, armed with simple or branching thorns. Bark dull gray : leaves numerous : leaflets 12-18, the blades leathery, oblong to ovate or oblong-lanceolate, $2-4.5 \mathrm{~cm}$. long, obtuse or retuse at the apex, obtuse at the base, crenate, lustrous above, paler beneath : staminate racemes $5-8 \mathrm{~cm}$. long, loosely flowered: calyx-lobes lanceolate to oblong-lanceolate, obtuse, sparingly pubescent : petals oblong or oval-oblong, rather longer than the calyx-lobes: pods oval or elliptic, oblique, $3-5 \mathrm{~cm}$. long, abruptly acuminate at both ends : seed solitary, or rarely 2 seeds in a pod.

In swamps, Indiana and Missouri to South Carolina, Florida and Louisiana. WATER Locust.

2. Gleditsia Texàna Sarg. A tree becoming $30-36 \mathrm{~m}$. tall, unarmed. Bark pale, smooth : leaves numerous: leaflets $12-22$, the blades mainly oblong-ovate, $1.2-2.5$ $\mathrm{cm}$. long, obtuse or acute, and apiculate at the apex, firm, crenulate-serrate, deep green and lustrous above, pale beneath, obliquely rounded at the base: staminate racemes slender, 7-10 $\mathrm{cm}$. long: calyx-lobes ovate, acute, villous: petals slightly longer than the calyx-lobes : stamens exserted : pods linear-oblong, flat, 10-13 cm. long, straight, puberulous, chestnut-brown : seeds several, oval, lustrous.

In dry bottom lands, valley of the Brazos River, Texas.

3. Gleditsia triacánthos L. A tree often $40 \mathrm{~m}$. tall, usually armed with branching thorns. Bark pale : leaves numerous: leaflets $12-28$, the blades firm, ovate-lanceolate varying to elliptic, $1-2.5 \mathrm{~cm}$. long, inequilateral, crenulate, obtuse at both ends, like the rachis often pubescent beneath : staminate racemes solitary or clustered, short-peduncled, $3-12 \mathrm{~cm}$. long: calyx-lobes unequal, narrowly oblong to lanceolate: petals greenish, oval to oblong-oval, considerably longer than the calyx-lobes: pods elongated, linear, $20-30$ $\mathrm{cm}$. long, somewhat curved and twisted, black, lustrous : seeds numerous.

In rich woods, Ontario to Kansas, Florida and Texas.

\section{GYMNÓCLADUS Lam.}

Unarmed trees, clothed with a rough deeply furrowed bark, the branches stout, pithy. Leaves alternate, unequally bipinnate, deciduous. Leaflets opposite or nearly so, the blades entire, membranous. Flowers polygamous, regular, in terminal racemes or thirsoid panicles. Calyx-lobes 5, narrow, equal, erect or somewhat spreading, surmounting the long tube. Corolla greenish white. Petals 5, inserted on the edge of the disk, rather longer than the calyx-lobes. Stamens 10: filaments subulate, pubescent, those opposite the petals often shorter: anthers introrse, opening lengthwise. Ovules numerous, pendulous, anatropous. Pod oblong, flattened, slightly curved, woody. Seeds more or less flattened, on slender funiculi. Kentucky Coffee-TREe.

1. Gymnocladus dioìca (L.) Koch. A forest tree sometimes $33 \mathrm{~m}$. tall, with a deeply furrowed bark. Leaves with 5-9 pinnae: leaflets in 3-7 pairs and terminal ones present or absent, the blades ovate or oval, $2-7 \mathrm{~cm}$. long, acuminate at the apex, entire, rounded at the base, short-stalked : panicles $1-3 \mathrm{dm}$. long, the pistillate larger than the staminate : calyx pubescent within and without; tube nearly cylindric, about $1 \mathrm{~cm}$. long; lobes linear-lanceolate, $5-6 \mathrm{~mm}$. long: corolla nearly white : petals oblong, slightly longer than the calyx-lobes: pods oblong, 1-2 dm. long, flat, curved, thick: seeds lenticular, nearly $2 \mathrm{~cm}$. broad.

In rich woods, Ontario to Minnesota, Nebraska, Tennessee and the Indian Territory. Spring.

\section{PARKINSÒNIA L.}

Shrubs or trees, clothed with a thin smooth bark and armed with simple or 3-branched thorns. Leaves alternate, or fascicled : petioles very short, with $2-4$ branches on which are borne many pairs of small leaflets. Flowers in slender axillary solitary or fascicled racemes. Calyx-lobes unequal, valvate or imbricated. Corolla bright yellow. Petals 5, 
with comparatively large blades, somewhat unequal, the standard larger than the rest and bearing a gland at its base, all spreading. Stamens 10 : filaments distinct, villous below the middle, those opposite the petals shorter: anthers opening lengthwise. Pods narrow, leathery, tapering to both ends, tortulose. Seeds oblong, lengthwise, with a crustaceous brown testa. Endosperm horny.

1. Parkinsonia aculeàta L. A shrub or small tree sometimes $9 \mathrm{~m}$. tall, with zigzag thorny branches. Leaves elongated, 2-4 dm. long, slender, the rachis winged; leaflets numerous, more or less distant, the blades linear to linear-oblanceolate, 1-10 mm. long, inequilateral, on slender petiolules : racemes slender, $1-1.5 \mathrm{~cm}$. long : calyx glabrous; tube very short; lobes oblong, reflexed, surpassing the tube: petals yellow, $1-1.5 \mathrm{~cm}$. long; blades suborbicular or oval, longer than the claws: stamens and ovary pubescent: pods narrow, 5-10 cm. long, contracted between the seeds, acuminate at both ends : seeds oblong.

In sandy soil, Florida to Texas, California and Mexico. Also in tropical America. Spring.

\section{CERCÍDIUM Tulasne.}

Shrubs or trees, with spine-armed more or less tortuous branches. Leaves bipinnate, relatively small. Leaflets few to each pinna, small. Flowers in short, often clustered, racemes. Calyx-lobes 5, slightly unequal, valvate. Corolla yellow. Petals 5, with broad imbricated blades. Stamens 10, slightly declined : filaments distinct, pubescent near the base : anthers opening lengthwise. Pods flattened, narrow, 2-valved. Seeds several.

Ovary and pod pubescent: pods $5-6 \mathrm{~mm}$. broad. Ovary and pod glabrous : pods $10-12 \mathrm{~mm}$. broad.

1. C. Texanum. 2. C. floridum.

1. Cercidium Texànum A. Gray. A thorny shrub 6-15 dm. tall, with rigid zigzag, often intricate, branches. Leaves early deciduous : leaflets 2-4, the blades leathery, oblongobovate, 4-6 mm. long, rounded or retuse at the apex, sessile: flowers solitary in the axils or racemose at the ends of the branchlets: calyx-lobes ovate-lanceolate, or lanceolate, reflexed : corolla yellow, $1.5-2 \mathrm{~cm}$. broad : petals spreading, slightly crisped, the standard with a suborbicular blade, the others with obovate blades: pods flat, linear, $3-5 \mathrm{~cm}$. long, pubescent, slightly constricted between the seeds.

On mesas, along and near the Rio Grande, Texas. Spring.

2. Cercidium flóridum Benth. A thorny tree 4-6 m. tall, with a crooked trunk becoming $2.5 \mathrm{dm}$. thick and a wide top. Leaves deciduous : leaflets 4-6, the blades obovate or oblong-obovate, 4-6 mm. long, obtuse or slightly emarginate, minutely puberulent and sometimes slightly glandular, nearly sessile: flowers in lax racemes: calyx-lobes oblong, reflexed, deciduous : corolla golden-yellow, nearly $2 \mathrm{~cm}$. broad : petals spreading, undulate, the standard with a reniform-obicular blade, the others with obovate-orbicular blades : ovary glabrous : pods flat, narrow, 4-6 $\mathrm{cm}$. long, glabrous.

On dry gravelly mesas, southern Texas and Mexico. Spring.

\section{DELònIX Raf.}

Trees, with spreading branches, unarmed. Leaves bipinnate, with several or many pinnae. Leaflets relatively small, numerous. Flowers in corymbose racemes. Calyxlobes 5 , nearly equal, valvate, much longer than the tube. Corolla showy, red or orange. Petals 5, with broad imbricated blades. Stamens 10, declined : filaments distinct : anthers opening lengthwise. Pod somewhat flattened, elongated, often solid between the seed, 2-valved. Seeds several.

1. Delonix règia (Boj.) Raf. A shrub or tree becoming $5 \mathrm{~m}$. tall, with a widesprearing top. Leaves spreading, the larger with 20-50 pinnae : leaflets numerous, the blades linear oblong, 4-10 mm. long, 2-4 mm. wide: pedicels stout: corolla red or orange : petals $5-7 \mathrm{~cm}$. long, the blades undulate and crisped. [Poinciana regia Boj.]

In sandy soil, southern peninsular Florida and the Keys. Also in the tropies generally.

\section{POINCIÀNA L.}

Shrubs or trees, smooth or prickle-armed. Leaves abruptly bipinnate, with several or many pinnae. Leaflets few or many to each pinna, entire. Flowers in racemes or panicles. Bracts wanting or caducous. Calyx-lobes 5, petaloid, imbricated, the lower lobe largest, overlapping the rest. Corolla often highly colored. Petals 5, unequal. Stamens 10 : filaments distinct : anthers opening lengthwise. Pods rather narrow, unarmed, straight or nearly so, wingless. 
Leaflets $6-12 \mathrm{~mm}$. long: pedicels $1-1.5 \mathrm{~cm}$. long: petals $1-1.5 \mathrm{~cm}$. long. Leaflets $15-25 \mathrm{~mm}$. long: pedicels $4-9 \mathrm{~cm}$. long: petals $2-3 \mathrm{~cm}$. long.

1. P. pauciflora.

2. P. pulcherrima.

1. Poinciana pauciflòra (Griseb.) Small. A slender shrub, 1-2 m. tall. Leaves spreading with 8-12 pinnae : leaflets relatively few, the blades oblong, sometimes broadly so, to obovate, $6-12 \mathrm{~mm}$. long, $3.5-5.5 \mathrm{~mm}$. wide : pedicels $1-1.5 \mathrm{~cm}$. long : corolla yellow : petals 1-1.5 cm. long, the blades slightly crisped : pods oblong or elliptic-oblong, 2-3.5 cm. long. [Caesalpinia pauciflora (Griseb.) Benth. \& Hook.]

In sandy soil, Florida Keys. Also in the West Indies.

2. Poinciana pulchérrima L. A prickle-armed shrub or tree becoming $4 \mathrm{~m}$. tall. Leaves spreading, the larger with 6-18 pinnae : leaflets relatively few, the blades oblong to cuneate, 15-25 mm. long, 5-11 mm. wide : pedicels 4-9 cm. long : corolla orange-red or rarely yellow : petals $2-3 \mathrm{~cm}$. long, the blades crisped : pods broadly linear or slightly broadened upward, 9-13 cm. long. [Caesalpinia pulcherrima (L.) Sw.]

In sandy soil, southern peninsular Florida and the Keys. Also in the tropies generally.

\section{GUILANDINA L.}

Shrubs, with stout but weak stems, armed with recurved prickles. Leaves abruptly bipinnate, with several pinnae. Leaflets 10-16 to each pinna, pellucid-punctate. Flowers in racemes or panicles. Bracts narrow, deciduous. Calyx-lobes 5, imbricated, longer than the tube. Corolla yellow. Petals 5, nearly equal. Stamens 10: filaments pubescent near the base : anthers opening lengthwise. Pods little longer than broad, flattened, pricklearmed, 2-valved, 1-few-seeded. Seeds slightly flattened.

Leaves with foliaceous stipules: seeds gray or lead-colored.

Leaves without stipules: seeds yellow.

1. G. Crista.

2. G. major.

1. Guilandina Crísta (L.) Small. A straggling or sprawling shrub, armed with hooked prickles, the foliage finely pubescent. Leaves $2-5 \mathrm{dm}$. long, the leaflets numerous, the blades ovate to oblong-ovate or nearly oblong, mucronulate, $1.5-3.5 \mathrm{~cm}$. long, rounded, truncate or subcordate at the base: stipules foliaceous : racemes or panicles 1-4 dm. long : bracts surpassing the pedicels, recurved: corolla dull yellow, 1-1.5 $\mathrm{cm}$. broad : pods oval or oval-oblong, $5-7 \mathrm{~cm}$. long, prickly all over, obliquely short-beaked : seeds gray or leadcolored. [Caesalpinia Crista L. Guilandina Bonduc L. G. Bonducella L.]

In pine lands and hammocks, peninsular Florida and the Keys. Also in the tropies generally.

2. Guilandina màjor (DC.) Small. Similar to G. Crista in habit. Leaves without stipules: leaflets with relatively large blades which vary from $4-8 \mathrm{~cm}$. in length : seeds yellow. [G. Bonduc L., not L. Sp. Pl. Ed. 1. G. Bonduc var. majus DC.]

In sandy soil, peninsular Florida and the Keys. Also widely distributed in the tropics.

\section{HOFFMANSÉGGIA Cav.}

Herbs, sometimes a little woody at the base, the stem usually branched at the base. Leaves bipinnate. Leaflets several to many, often glandular-punctate. Flowers racemose. Calyx-lobes 5, nearly equal, much longer than the tube. Corolla yellow or yellowish. Petals 5, imbricated. Stamens 10, slightly declined : filaments distinct, often glandular at the base : anthers opening lengthwise. Pods flat, narrow and more or less curved, or broad and straight or slightly curved along the upper edge, few-seeded. The plants flower mainly in the spring.

Leaflets not glandular-punctate: pods long and narrow, strongly falcate.

Petals with long claws, the claw of the standard thick and dilated: style clavate.

Petals with very short claws, the standard essentially sessile: style cylindric.

Branches glabrous : filaments glandular: pods about $2 \mathrm{~cm}$. long.

Branches pubescent : filaments glandless : pods about $1.5 \mathrm{~cm}$. long.
Leaflets glandular-punctate or prominently veined : pods broad and short, not falcate.

Leaflets approximate, not veiny, obtuse.

Leaflets separated, prominently veined, acute.

1. H. Falcaria.

2. H. Drummondii. 3. H. Texensis.

1. Hoffmanseggia Falcària Cav. Stem usually branched at the base, the branches erect or ascending, $5-30 \mathrm{~cm}$. tall, often pubescent and sometimes puberulent, simple or sparingly branched : leaves with 5-9 pinnae : leaflets usually 10-20, the blades mainly oblong, 4-6 mm. long, obtuse, not glandular-punctate: calyx glandular-pubescent ; lobes linear to linear-oblong, $7-8 \mathrm{~mm}$. long : corolla $1.5-2 \mathrm{~cm}$. broad: pods linear, $3-4 \mathrm{~cm}$. long, curved.

On plains and prairies, Kansas to California and Texas. Also in Central and South America. 
2. Hoffmanseggia Drummóndii T. \& G. Stem branched at the base, the branches more or less spreading, 10-20 cm. long, glabrous, much branched : leaves with 3 pinnae; leaflets usually 8-12, the blades oblong-cuneate or nearly oblong, 1.5-2.5 mm. long, obtuse, not glandular-punctate: calyx glabrous or nearly so, except the ciliate margins of the lobes; lobes narrowly oblong to linear-lanceolate, $3.5-4.5 \mathrm{~mm}$. long: corolla 1-1.2 $\mathrm{cm}$. broad: pods narrow, about $2 \mathrm{~cm}$. long.

On plains or prairies, southern Texas.

3. Hoffmanseggia Texénsis E. M. Fisher. Stem branched at the base, the branches intricately branched, $15-30 \mathrm{~cm}$. long, their gray bark finely pubescent: leaves with 3 pinnae: leaflets $6-10$, the blades mainly oblong, 1-2 mm. long: calyx finely pubescent or nearly glabrous; lobes narrow, $2-2.5 \mathrm{~mm}$. long: corolla mainly less than $1 \mathrm{~cm}$. broad: pod narrow, about $1 \mathrm{~cm}$. long.

In rocky soil, southern Texas.

4. Hoffmanseggia Jamèsii T. \& G. Stem branched at the base, the branches erect or ascending, $10-35 \mathrm{~cm}$. long, finely pubescent and more or less glandular: leaves with 5-7 pinnae: leaflets approximate, $10-20$, the blades oblong to ovate-oblong, 3-5 mm. long, obtuse, glandular-punctate : calyx strigillose; lobes narrowly oblong or linear-oblong, 7-9 $\mathrm{mm}$. long: corolla $10-12 \mathrm{~mm}$. wide : pods about $2 \mathrm{~cm}$. long, nearly $1 \mathrm{~cm}$. wide, glandular, slightly curved along the upper edge.

On plains and prairies, Kansas to Texas and New Mexico.

5. Hoffmanseggia caudàta A. Gray. Stem often branched at the base, the branches ascending, $10-30 \mathrm{~cm}$. long, glabrous: leaves with 7-9 pinnae : leaflets separated, $8-22$, the blades suborbicular to ovate, $2-5 \mathrm{~mm}$. long, acute, prominently veined : calyx puberulent; lobes oval to ovate, $5-6 \mathrm{~mm}$. long: corolla about $1.5 \mathrm{~cm}$. wide : pods about $2 \mathrm{~cm}$. long, 1 cm. wide, glandular.

On plains, southern Texas.

\section{Family 17. KRAmeriàceae Dumort. Krameria Family.}

Shrubs or perennial herbs, generally with prostrate or spreading rigid branching stems and silky pubescent foliage. Leaves alternate, without stipules: blades entire or trifoliate, relatively small. Flowers perfect, irregular. Calyx of 4-5 petal-like unequal sepals, deciduous. Corolla of 4-5 petals, shorter than the sepals, the posterior with long claws, thin, their claws often united, the 2 anterior thick, sessile. Androecium of 3-4 stamens. Filaments united at the base or as far as the middle. Anthers 2-celled : sacs opening by terminal pores. Gynoecium of a single carpel. Ovary 1-celled or apparently 2-celled by the intrusion of the placentae. Style simple. Stigma truncate or acute. Ovules 2, collateral, pendulous, anatropous. Fruit indehiscent, woody, 1-celled, armed. Seed usually solitary. Endosperm wanting. Embryo with thick cotyledons including the radicle.

\section{Characters of the family.}

\section{KRAMìrIA Loefl.}

Herbs : branches prostrate or decumbent.

Shrubs: branches diffusely spreading.

Plants canescent or somewhat tomentose. Spines on the fruit barbed.

Spines on the fruit not barbed.

Plants silky-strigillose.

1. Krameria secundiflòra DC. Herbaceous, from a stout underground stem, foliage strigose. Stems ascending or spreading, 1-4 dm. long, branching: leaf-blades oblanceolate, linear-oblong or narrowly linear, $1-3 \mathrm{~cm}$. long, tipped with small spines, sessile : peduncles $2-3 \mathrm{~cm}$. long, slender, 1 -llowered : pedicels much shorter than the pemm. long, acute : petals 5 , the 3 upper with united claws : stamens 4 , monadelphous : fruit subglobose, 7-9 mm. in diameter, the stout spines retrorsely scabrous.

In sandy soil, Kansas to Florida, New Mexico and Mexico. Spring.

2. Krameria canéscens A. Gray. Shrubby, tomentose-canescent. Stems spreading: leaf-blades linear-lanceolate to linear, $0.5-2 \mathrm{~cm}$. long, acute, sessile, straight or curved by 2 bracts : flowers axillary : sepals lanceolate, nearly $1 \mathrm{~cm}$. long, the smaller one some 
times linear, acute: fruit subglobose, $7-8 \mathrm{~mm}$. thick, silvery-canescent, spiny, its spines barbed at the apex.

In dry soil, Texas to California and Mexico. Spring.

3. Krameria ramosíssima (A. Gray) S. Wats. Shrubby, spiny, canescent. Stems erect, $2-7 \mathrm{dm}$. tall, rigidly much branched; branches spreading: leaf-blades linear, or linear-lanceolate, $2-5 \mathrm{~mm}$. long, often clustered in the axils, obtuse, sessile : peduncles 3-6 $\mathrm{mm}$. long: pedicels about as long as the peduncles, subtended by 2 bracts : sepals lanceolate or ovate-lanceolate, $6-8 \mathrm{~mm}$. long : petals light maroon : fruit ovoid, 6-7 mm. long, silky, the slender spines unarmed.

In dry soil, Texas, New Mexico and adjacent Mexico. Spring.

4. Krameria parvifòlia Benth. Shrubby, silky-pubescent and somewhat glandular. Stem erect, 2-7 dm. tall, rigid, diffusely branched ; branches spreading, sometimes spiny : leaves linear or nearly so, $0.5-1.5 \mathrm{~cm}$. long, the lower ones obtuse, the upper spine-tipped, sessile : peduncles 4-8 $\mathrm{mm}$. long: pedicels longer than the peduncles, subtended by 2 bracts: sepals 7-9 mm. long, strigose and often slightly glandular: fruit subglobose, cordate, 7-9 mm. long, the slender spines retrorsely barbed their whole length.

In dry soil, Texas to California and Mexico. Spring.

\section{Family 18. Fabàceate Reichenb. Pea Family.}

Herbs, shrubs, vines or trees of vast and varied economic importance. Leaves alternate: blades mostly compound, sometimes 1-foliolate, or probably simple, occasionally perfoliate. Flowers perfect, or rarely polygamo-dioecious, solitary or variously disposed in a simple or co spound inflorescence, irregular. Calyx of 4 or 5 partially united sepals, sometimes 2-lipped. Corolla papilionaceous, hypogynous or perigynous. Petals 5, distinct or somewhat united, usually separable into $3 \mathrm{kinds}$; a broadened upper one surrounding the rest in the bud (standard), 2 lateral ones (wings), and 2 united or cohering ones (keel). Androecium of 10 or sometimes 9 or rarely 5 stamens. Filaments monadelphous, diadelphous or occasionally distinct. Gynoecium of a single carpel. Ovary superior, 1-celled or 2-several-celled by cross partitions. Styles entire. Stigma terminal, oblique or lateral. Ovules 1 or many, anatropous or amphitropous. Fruit capsular, a 2-valved or indehiscent legume, or a loment. Seeds usually destitute of endosperm. Embryo with thick cotyledons. [Papilionaceae L.]
[Pollo

Stamens 10 : filaments distinct.

Leaf-blades pinnate.

Leaf-blades digitately 3 -foliolate, 1 -foliolate or simple.

Stamens 10 or fewer : filaments monadelphous or diadelphous.
Leaves destitute of tendrils.

Herbs, shrubs, trees or woody vines.

Fruit 2-valved or indehiscent, not a loment.

Foliage not glandular-dotted (except in Glycyrrhiza).

Anthers of 2 kinds : filaments monadelphous.

the middle.

Leaf-blades 3-foliolate. Leaflets toothed. Leaflets entire.

Leaf-blades pinnately several-many-foliolate or rarely 1-foliolate. Pods dehiscent.

Foliage Pods indehiscent.

Froliage glandular-dotted. Fruit a loment. Herbaceous vines or herbs. Leaves bearing tendrils.

TRIBE I. SOPHOREAE.

Inflorescence racemose : pods moniliform.

TRIBE I. SOPHOREAE.

TRIBE II. PODALYRIEAE.

Inflorescence paniculate: pods flattened.

Tribe III. GenisteaE.

TRIBE IV. TRIFOLIEAE. TRIBE V. LOTEAE.

Tribe VI. GALEGEAE. TRIBE VII. DALBERGIEAE. Tribe VIII. PSORALEAE. TRIBE IX. HEDYSAREAE. TRIBE $X$. PHASEOLEAE. Tribe XI. VICIEAE.

\section{Tribe II. PODALYRIEAE.}

Ovary sessile or nearly so: pods flat.

Ovary manifestly stalked: pods inflated or turgid.

1. SOPHORA.

2. Cladrastis.

Tribe III. GENISTEAE.

Stipules at least the upper ones decurrent : pods inflated.

Stipules not decurrent: peds flat. 38

3. THERMOPSIS.

4. BAptisia. 
TRIBE IV. TRIFOLIEAE.

Pods curved or coiled.

Pods straight.

Pod-valves leathery.

Pod-valves membranous.

Tribe V. LOTEAE.

One genus within our range.

Tribe VI. GALEGEAE.

7. Medicago.

8. Melilotus.

9. TRIFOliUM.

10. Lotus.

11. INDIGOFERA.

12. Cracca.

13. Bradleia.

14. RoBINIA.

15. Coursetia.

Leaf-blades equally pinnate.

Pods wingless, more or less compressed.

Pods several-many-seeded, with thick margins, not in a bladdery envelope.

Standard broad and longer than the keel petals: calyx with acute or acuminate lobes.

Standard narrow and shorter than the keel petals : calyx with broad, low lobes.

Pods 2-seeded, the margins thin : seeds remaining in the bladdery inner part of the pod when the valves fall away.

Pods 4-sided and 4-winged.

Standard with the blades relatively narrow, commonly erect.

Pod 2-celled, with a perfect partition.

Pod fleshy, indehiscent.

Pod membranous, leathery or woody, dehiscent.

Pod ovoid to oblong, rarely almost didymous, terete or vertically flattened, leathery or woody.

Pod linear, somewhat laterally flattened, membranous.

Pod 1-celled, the partition, if any, rudimentary :

Lower suture strongly intruded or sometimes both sutures inflexed.

Both sutures inflexed, each valve of the pod almost circular in crosssection.

Upper suture prominent, the pod obcordate in cross-section.

Neither suture intruded.

Pod membranous, inflated : calyx campanulate : corolla mainly ochroleucous.

Pod woody, not inflated : calyx cylindric : corolla mainly purple.

TRIBE VII. DALBERGIEAE.

Leaf-blades normally 1-foliolate: pods suborbicular, 1-seeded.

Leaf-blades pinnately several-foliolate: pods linear, several-seeded.

TRIBE VIII. PSORALEAE.

Leaf-blades digitately 3-5-foliolate or pinnately 3-foliolate.

Leaf-blades mainly pinnately 5 -many-foliolate.

Stamens 9 or 10 .

Corolla of a single petal (standard).

Corolla of 5 petals.

Corolla with all petals free and distinct.

Corolla with claws of all petals adnate to the filament tube.

Stamens 5.

Spikes not subtended by an involucre: calyx-lobes narrow, shorter than the tube.

Spikes subtended by an imbricated involucre: calyx-lobes bristle-like, longer than the tube.

TRIBE IX. HEDYSAREAE.

Corolla yellow.

Flowers perfect.

Leaf-blades unequally pinnate: stamens diadelphous (5 and 5 ).

Leaf-blades equally pinnate : stamens monadelphous.

Flowers monoecious, at least some of them sterile, others fertile.

Anthers of 2 kinds.

Anthers alike.

Corolla white, blue, violet or purple.

Leaflets stipellate: loments of several joints.

Leaflets not stipellate: loments of 1-2 joints.

16. Sesban.

17. AgATI.

18. GLotTidium.

19. Daubentonia.

20. GEOPRUMNON.

21. Astragalus.

22. Hamosa.

23. HoLCOPHACOS.

24. TIUM.

25. PhaCA.

26. XYlophacos.

27. DAlbergia.

28. ICHTHYOMETHIA.

29. Psoralea.

30. Amorpha.

31. EYSENHARDTIA.

32. Parosela.

33. Petalostemon.

34. KunNistera.

35. AESCHYNOMENE.

36. ZORNIA.

37. Stylosanthes.

38. Chapmania.

39. MеiвомLA.

40. LESPEDEZA.

Tribe X. PHASEOLEAE.

A. Keel of the corolla neither curved nor coiled.

a. Style glabrous or sparingly pubescent below.

* Standard not spurred at the base.

tCorolla yellow.

F Flowers 1 or 2 , or 3 together, axillary to the leaf-like bracts.

41. Pitcheria. 
3. Flowers in terminal or axillary clusters or racemes.

† Corolia blue, purple, white or scarlet.

Pods terete, torulose : corolla scarlet.

Pods flattened, not torulose : corolla blue, purple or white.

Calyx subtended by 2 bractlets.

Standard and the filament opposite partially adnate.

Standard and the filament opposite free from each other.

Caly without bractlets.

b. Style bearded along the inner side.

B. Keel of the corolla coiled or curved.

Keel spirally twisted.

Leaflets not stipellate 5 or more.

Leaflets stipellate 3 .

Keel incurved.

Inflorescence capitate.

Pods flattened.

Pods nearly terete.

Inflorescence racemose.

Tribe XI. VICIEAE.

42. Dolicholus.

43. Erythrina.

44. Dioclea.

45. GaLACTEA.

46. Falcata.

47. BRADBURYA.

48. Clitoria.

49. Apios.

50. Phaseolus.

51. STROPHOSTYLES.

52. Vigna.

53. Canavalia.

Style terete, with a tuft of hairs at the apex.

Style flattened, pubescent along the inner side.

54. VICIA.

55. LATHYRUS.

\section{SOPHÒRA L.}

Unarmed shrubs or trees, or rarely perennial herbs. Leaves alternate, deciduous or persistent, with minute deciduous stipules: blades unequally pinnate: leaflets opposite, sometimes with bristle-like stipels. Flowers perfect, in terminal or axillary racemes. Calyx pedicelled: tube campanulate, often oblique: lobes 5 . Corolla white, yellow or violet. Petals 5, with claws, all of which are about equal in length : standard with a suborbicular blade notched at the apex, truncate or subcordate at the base : wings oblongspatulate, slightly oblique, the blade auricled or truncate at the base : keel-petals much like the wings. Stamens 10 . Filaments distinct or nearly so : anthers versatile. Ovary narrow, short-stalked. Style subulate, incurved. Pod nearly terete, moniliform fleshy, leathery or woody, indehiscent or tardily dehiscent. Seeds globose, each in a separate cavity.

Perennial herbs.

Shrubs or trees.

Calyx less than $4 \mathrm{~mm}$. long.

Calyx over $4 \mathrm{~mm}$. long.

Leaflets smooth: racemes elongated, mostly over $20 \mathrm{~cm}$. long.

Leaflets reticulated : racemes thick, usually less than $10 \mathrm{~cm}$. long.

1. S. sericea.

2. S. affinis.

3. S. tomentosa.

4. S. secundiflora.

hair. Sophora serícea Nutt. Herbaceous, pubescent with silvery or silky appressed leaflet Stems branching at the base, the branches $1-3 \mathrm{dm}$. tall : leaves $3-8 \mathrm{~cm}$. long ; leaflets $7-25$, the blades oblong, elliptic, or obovate, 5-12 mm. long, obtuse or notched at the apex : racemes $3-12 \mathrm{~cm}$. long, peduncled : calyx oblong, 7-9 $\mathrm{mm}$. long; tube oblique at the base; lobes ovate, obtuse, much shorter than the tube: corolla white; standard with a dilated blade about $1 \mathrm{~cm}$. broad : keel-petals $13-16 \mathrm{~mm}$. long : pods leathery, $2.5-5$ $\mathrm{cm}$. long, becoming hard, constricted between the seeds.

On prairies, Nebraska to Colorado, Texas and Arizona. Spring and summer.

2. Sophora affinis T. \& G. An almost glabrous shrub or small tree sometimes $6 \mathbf{m}$. tall, with spreading branches. Leaves 1-2 dm. long; leaflets firm, 13-15, the blades elliptic or oval, $1-4 \mathrm{~cm}$. long, mucronate, somewhat lustrous above : racemes slender, 5-15 $\mathrm{cm}$. long, ascending: pedicels 1-10 mm. long: calyx campanulate, less than $4 \mathrm{~mm}$. long, shallowly 5-lobed : corolla white or pink; petals all with short claws; standard with a suborbicular blade $1-1.5 \mathrm{~cm}$. broad; other petals with oblong-ovate blades : pods $3-8 \mathrm{~cm}$. long, pubescent, more or less strongly constricted between the seeds.

On limestone prairies, Arkansas to Texas. Spring and summer.

3. Sophora tomentòsa L. A shrub 1-3 m. tall, with tomentose foliage. Leaves 1-2 dm. long; leaflets 11-17, the blades leathery, oblong, oblong-obovate or oval, inequilateral, becoming glabrous and revolute : racemes elongating, 1-4 $\mathrm{dm}$. long: pedicels 5-10 $\mathrm{mm}$. long: calyx oblong or oblong-funnelform, 5-8 mm. long, constricted at the base, the edge undulate or indistinctly 5-lobed : corolla yellow; standard with an ovate blade fully $1 \mathrm{~cm}$. broad, and over $1.5 \mathrm{~cm}$. long : keel-petals $20 \mathrm{~mm}$. long : pods $5-10 \mathrm{~cm}$. long, strongly constricted between the seeds, long-stalked.

Along or near the coast, peninsular Florida and the Keys. Spring to fall.

4. Sophora secundiflòra (Ortega) DC. A shrub or small tree sometimes $10 \mathrm{~m}$. tall, with upright branches. Leaves 1-1.5 dm. long; leaflets leathery, 7-13, the blades oblong 
to oblong-oblanceolate or oval, 2-5 cm. long, mucronate or notched at the apex, reticulated and lustrous above : racemes $5-12 \mathrm{~cm}$. long, densely flowered : pedicels 5-15 $\mathrm{mm}$. long: calyx campanulate, $8-10 \mathrm{~mm}$. long; tube oblique, turbinate at the base; lobes unequal, the 2 upper ones mostly united, the lower ovate to triangular : corolla violet; standard with a suborbicular or ovate crisped notched blade $1-1.5 \mathrm{~cm}$. long; other petals with oblong-obovate blades : pods $5-10 \mathrm{~cm}$. long, 3-4-seeded, constricted between the seeds.

Along limestone bluffs, Texas to New Mexico and Mexico. Spring and summer.

\section{CLADRÁSTIS Raf.}

Small trees, with watery sap and yellow wood. Leaves alternate, without stipules, deciduous : blades unequally pinnate : petioles stout, enlarged at the base : leaflets mostly alternate, with entire blades. Flowers perfect, in elongated terminal thirsoid panicles: calyx nearly tubular, somewhat oblique, puberulent : lobes 5 , short and broad. Corolla white : petals 5 , all with claws of about the same length : standard with an oblong-orbicular blade, somewhat emarginate, undulate: wings with an oblong straight auricled blade, this blotched with yellow: keel-petals distinct, much like the wings. Stamens 10 : filaments distinct, glabrous. Ovary narrow, stalked, villous. Style subulate, slightly incurved. Pod linear, flattened, glabrous, short-stalked, tardily dehiscing, slightly thickened at the margins. Seeds oblong, flattened. YELLOW-wood.

1. Cladrastis lùtea (Michx.) Koch. A tree reaching a height of $17 \mathrm{~m}$., with a smooth bark and almost glabrous foliage. Leaves 2-4 dm. long; leaflets with membranous, oval to oblong or ovate or even suborbicular blades, or the terminal one sometimes cuneate, somewhat acuminate at the apex, the nerves and short stalk more or less pubescent: panicles loosely many-flowered, 1-5 dm. long: pedicels $1-2.5 \mathrm{~cm}$. long: calyx tubularcampanulate, the base of the tube oblique and turbinate: lobes rounded, much shorter than the tube : corolla white : petals more or less crisped : pods linear-oblong, acute at each end, 4-8 cm. long, short-stalked. [C. tinctoria Raf.]

In rich soil, Kentucky to Tennessee and North Carolina. Spring and summer.

\section{THERMÓPSIS R. Br.}

Perennial caulescent herbs, with horizontal rootstocks. Leaves alternate, with leaflike stipules: blades digitately 3 -foliolate: leaflets nearly equal, with entire membranous blades. Flowers perfect, in terminal or lateral racemes. Calyx pedicelled : lobes nearly equal or the 2 upper wholly united. Corolla yellow or rarely purple: standard with a broad spreading blade, the sides reflexed : wing-petals with oblong blades: keel as long as the wings or longer. Stamens 10, distinct. Anthers nearly alike. Ovary sessile or nearly so, narrow. Style slightly incurved. Ovules numerous. Pod narrow, often linear, flat, 2-valved.

Stems branched above the base: pods glabrous or nearly so.

Peduncles and pedicels closely pubescent: calyx-tube pubescent.

Lower calyx-lobes triangular, much shorter than the tube.

Lower calyx-lobes lanceolate, as long as the tube. Peduncles and pedicels glabrous or sparingly pubescent : calyx-tube glabrous.
Stems simple above the base : pods woolly.

1. T. mollis.

2. T. Hugeri.

3. T. fraxinifolia.

4. T. Caroliniana.

1. Thermopsis móllis (Michx.) M. A. Curtis. Foliage pubescent with minute appressed hairs. Stems 3-9 dm. tall, branching: stipules oblong-lanceolate : leaflets 3 , the blades oblanceolate to elliptic, notched or acute at the apex, acute at the base: racemes erect, 1-3 dm. long, loosely flowered : pedicels 7-15 mm. long, subtended by lanceolate or oblong-lanceolate bracts : calyx campanulate; lobes triangular, acute, $\frac{1}{3}$ as long as the tube : corolla yellow : pods linear, 5-10 cm. long, slightly curved.

In dry soil, Virginia to North Carolina and Alabama. Spring and summer.

2. Thermopsis Hùgeri Small. Foliage minutely pubescent, but little changed in drying. Stems 3-6 dm. tall, branching : stipules lanceolate or linear-lanceolate, $1.5-2 \mathrm{~cm}$. long, acute : leaflets 3 , the blades elliptic, somewhat acuminate at both ends or those of the lower leaves oblanceolate, $5-6 \mathrm{~cm}$. long, somewhat lustrous above, the minute pubescence often abundant at the conspicuous nerves : racemes about $1 \mathrm{dm}$. long, few-flowered : pedicels $46 \mathrm{~mm}$. long, with bracts similar to the stipules: calyx campanulate, $6-7 \mathrm{~mm}$. long; lobes, except the upper one, lanceolate-acuminate, about as long as the tube: corolla bright yellow ; standard with a suborbicular notched blade about $12 \mathrm{~mm}$. in diameter; wings nearly $2 \mathrm{~cm}$. long, their blades almost oblong; keel-petals similar to the wings, but oblongobovate. [Baptisia Hugeri Small.]

On mountain slopes, North Carolina and Georgia. Spring. 
3. Thermopsis fraxinifòlia (Nutt.) M. A. Curtis. Foliage glabrous or nearly so. Stems 3-9 dm. tall, widely branching: stipules linear to linear-lanceolate : leaflets 3 , the blades oblanceolate to elliptic, oval or lanceolate, obtuse or acute, often mucronulate: racemes 1-3 dm. long, loosely flowered : pedicels $1-1.5 \mathrm{~cm}$. long, subtended by linear or lanceolate bracts : calyx campanulate; lobes acuminate, less than $\frac{1}{3}$ as long as the tube : corolla yellow; keel-petals 12-15 mm. long; standard with a suborbicular notched blade fully $1 \mathrm{~cm}$. broad : pods linear, $5-10 \mathrm{~cm}$. long, long-acuminate.

On dry mountain sides, North Carolina to Georgia. Spring and summer.

4. Thermopsis Caroliniàna M. A. Curtis. Foliage glabrous or nearly so. Stems 6-15 dm. tall, wand-like, more or less zigzag : stipules oblong, ovate or oblong, obtuse, clasping : leaflets 3 , the blades oblanceolate to oblong-elliptic, 3-10 cm. long, obtuse or mucronulate, more or less pubescent beneath : racemes terminal, 1-3 dm. long, erect, lanuginous : pedicels stout, 1-3 mm. long, subtended by broad acute bracts : calyx campanulate, 7-8 $\mathrm{mm}$. long; lobes triangular, less than $\frac{1}{3}$ as long as the tube : corolla yellow ; keel-petals 15-20 mm. long; standard with a reniform-orbicular notched blade fully $1 \mathrm{~cm}$. broad: pods linear, 4-6 cm. long, tomentose, slender-beaked.

On river banks, North Carolina to Tennessee and Georgia. Spring.

\section{BAPTísia Vent.}

Perennial herbs, with large rootstocks and erect stems. Leaves alternate. Blades digitately 3 -foliolate or sometimes simple: leaflets with entire blades commonly broadest above the middle. Flowers perfect, in terminal or lateral, simple or branched racemes or axillary. Calyx pedicelled : lobes nearly equal or the 2 upper wholly united. Corolla white, cream -colored, yellow or blue: standard broad, spreading, the sides reflexed : wings oblong or broadened upward: keel slightly curved, about as long as the wings. Stamens 10, distinct : anthers similar. Ovary stipitate. Style slightly incurved. Ovules several or numerous. Pod cylindric or subglobose, more or less inflated, stalked. WILD INDIGO.

Leaf-blades simple, rarely lobed : stipules wanting.

Leaves with perfoliate blades: inflorescence axillary.

Leaves with merely sessile blades : inflorescence racemose.

Leaf-blades 3-foliolate: stipules present.

Upper leaflets and stipules more or less united : stipules persistent.

Upper leaflets, like the rest, distinct: stipules mostly deciduous or fugacious.

Flower-stalk distinguished into peduncle and pedicel. Foliage glabrous or minutely pubescent.

Calyx-lobes triangular, about as long as the tube.

Calyx-lobes spatulate, several times longer than the tube.

Foliage copiously hirsute.

Flower-stalk not distinguished into peduncle and pedicel.

Racemes terminal, often leafy bracted at least to the base. Corolla less than $1.5 \mathrm{~cm}$. long.

Pods with oval or oblong bodies gradually beaked.

Pods with globular bodies abruptly beaked.

Corolla over $1.5 \mathrm{~cm}$. long.

Terminal leaflets broadest above the middle.

Leaflets 5-6 times as long as broad.

Leaflets about twice as long as broad.

Terminal leaflets broadest at the middle, more or less distinctly rhombic.

Racemes opposite leaves, naked or with small bracts.

Corolla yellow.

Pods subglobose, with thick and hard walls.

Pods more or less elongated, with thin walls.

Pods conspicuously acuminate.

Pods blunt and apiculate or abruptly pointed.

Stipules persistent.

Stipules deciduous.

Corollas over $1.5 \mathrm{~cm}$. long: pods about $2 \mathrm{~cm}$. thick.

Corollas less than $1.5 \mathrm{~cm}$. long: pods less than $1 \mathrm{~cm}$. thick.

Corolla of various colors, not yellow.

A. Corolla white or cream-colored.

Racemes naked, or with minute or obsolute bracts.

Corolla less than $1.5 \mathrm{~cm}$. long.

Racemes mostly longer than the peduncles: pedicels"glabrous : lower calyx-lobes triangular : corolla less than $1.5 \mathrm{~cm}$. long.

Racemes mostly shorter than the peduncles: pedicels pubescent : lower calyx-lobes orate : corolla over $1.5 \mathrm{~cm}$. long.

Corolla over $1.5 \mathrm{~cm}$. long.

1. B. perfoliata.

2. B. simplicifolia.

3. B. microphylla.

4. B. LeContei.

5. B. calycosa

6. B. hirsuta.

7. B. tinctoria

8. B. Gibbesii.

9. B. lanceolata.

10. B. Nuttalliana.

11. B. elliptica.

12. B. sphaerocarpa.

13. B. villosa."

14. B. sulphurea.

15. B. megacarpa.

16. P. Serenae.

cemes with manifest, sometimes almost leaf-like, bracts.

a. Pedicels mainly less than $1.5 \mathrm{~cm}$. long.

17. B. alba.

18. B. albescens.

19. B. leucantha. 
Raceme-rachis and pedicles pubescent with spreading hairs : bracts mostly larger than the pedicels : species Georgian.

Raceme-rachis and pedicels pubescent with appressed hairs : bracts mostly shorter than the pedicels : species Texan.

b. Pedicels over $1.5 \mathrm{~cm}$. long.

Foliage glabrous except sometimes the ciliate leaflets and the interior of the calyx.

Stems glaucous: leaflets glabrous: calyx glabrous within. B. Corolla blue.

Stems glabrous : leaflets ciliate : calyx pubescent within. Foliage copiously or manifestly pubescent.

20. B. bracteata.

21. B, Bushii.

22. B. cuneata.

23. B. laevicaulis.

24. B. leucophaea.

25. B. australis.

1. Baptisia perfoliàta (L.) R. Br. Foliage glabrous, more or less glaucous. Stems 3-9 dm. tall, widely branching : leaves simple; blades entire, leathery, perfoliate, orbicular or oblong-oval, $5-10 \mathrm{~cm}$. long, rounded at each end, finely reticulated : flowers axillary : pedicels 5-10 mm. long, ascending : calyx campanulate, 6-7 mm. long; lobes ovate, nearly as long as the tube: corolla yellow; standard with a suborbicular notched blade; keelpetals 11-13 mm. long : pods oval or oblong-oval, $1-1.5 \mathrm{~cm}$. long, short-stipitate, constricted at both ends.

On sand hills, Georgia and South Carolina. Spring.

2. Baptisia simplicifolia Croom. Foliage glabrous. Stems erect or ascending, 3-9 $\mathrm{dm}$. tall, more or less branched, zigzag : leaves simple; blades entire, firm, ovate to oval, $3-10 \mathrm{~cm}$. long, obtuse or notched, lustrous above, sessile : racemes $1-3 \mathrm{dm}$. long: pedicels slender, $5-10 \mathrm{~mm}$. long, subtended by oblong or oval bracts : calyx campanulate, $5 \mathrm{~mm}$. long; lobes ovate or oblong-ovate, about as long as the tube : corolla yellow ; standard with a broadly obcordate blade; wings and keel-petals oblong, about $1.5 \mathrm{~cm}$ long : pods about $1.5 \mathrm{~cm}$. long, oval, constricted at both ends.

In dry pine or oak lands, Florida. Summer.

3. Baptisia microphýlla Nutt. Foliage glabrous, green when dried. Stems $3-9 \mathrm{dm}$. tall, widely branched : leaves 3 -foliolate or the upper ones simple and entire: stipules ovate, variable in size, partially or wholly united with the leaf-blades: leaflets 3 , blades obovate, cuneate or broadly spatulate, $1-3 \mathrm{~cm}$. long, rounded at the apex or apiculate: flowers axillary, sometimes racemose at the ends of the branches : pedicels $8-10 \mathrm{~cm}$. long: calyx campanulate, $5-6 \mathrm{~mm}$. long; lobes triangular, shorter than the tube : corolla yellow ; standard much shorter than the other petals, with a blade about $1 \mathrm{~cm}$. broad: pods subglobose or oval, $1-1.5 \mathrm{~cm}$. long, stipitate, constricted at both ends.

On sand hills, South Carolina to Florida and Alabama. Spring and summer.

4. Baptisia LeCóntei T. \& G. Foliage strigillose, green when dried. Stems 3-7 dm. tall, much branched, zigzag : leaflets 3 , the blades oblanceolate to cuneate, $1-4 \mathrm{~cm}$. long, obtuse or apiculate: raceme-like panicles numerous, loosely flowered: peduncles slender, 1-3 cm. long, subtended by ovate or ovate-lanceolate acuminate bracts : pedicels shorter than the peduncles subtended by lanceolate bractlets: caly $x$ campanulate, $5-6 \mathrm{~mm}$. long; lobes triangular, about as long as the tube : corolla yellow; standard with a blade about $1 \mathrm{~cm}$. broad : pods slender-beaked, the body ovoid or oval, 1-1.2 $\mathrm{cm}$. long, stipitate.

In sandy soil, Georgia and Florida. Spring.

5. Baptisia calycòsa Canby. Foliage glabrous or nearly so, turning dark in drying. Stems 4-11 dm. tall, much branched : stipules linear or linear-lanceolate : leaflets 3, the blades firm, cuneate to spatulate, $1-3.5 \mathrm{~cm}$. long, retuse or apiculate : racemes numerous, 5-15 cm. long: peduncles slender, $1-4 \mathrm{~cm}$. long, subtended by oblong or oblonglanceolate bracts : pedicels much shorter than the peduncles, subtended by bractlets similar to the bracts : calyx glabrous; tube campanulate; lobes leaf-like, spatulate, several times longer than the tube : corolla yellow, hardly surpassing the calyx-lobes: pods longer than the calyx or shorter, the body ovoid, $1.5-2 \mathrm{~cm}$. long, beaked.

In sandy pine lands, eastern Florida. Spring.

6. Baptisia hirsùta Small. Foliage hirsute. Stems several dm. tall, much branched, stoutish : stipules oblanceolate or oblong-elliptic : leaflets 3 , the blades oblanceolate, spatulate or cuneate, 1-2 cm. long, obtuse or apiculate, conspicuously ciliate : peduncles 1-1.5 cm. long, shorter than their oblong-elliptic or lanceolate bracts: pedicels $1-2 \mathrm{~mm}$. long, subtended by bractlets which are narrower than the bracts : calyx hirsute; tube campanulate; lobes leaf-like, longer than the tube, oblong-spatulate, acute: corolla yellow, distinctly surpassing the calyx-lobes.

In dry pine woods, northwestern Florida. Spring.

7. Baptisia tinctòria (L. ) R. Br. Foliage glabrous, usually turning black in drying. Stems 3-12 dm. tall, much branched: leaflets 3 , the blades obovate or spatulate-cuneate, 
$1-3 \mathrm{~cm}$. long, rounded or retuse at the apex, delicately nerved beneath : racemes numerous, few-flowered : pedicels $5-8 \mathrm{~mm}$. long : calyx campanulate, about $3 \mathrm{~mm}$. long; lower lobes triangular, acuminate, shorter than the tube : corolla yellow; keel-petals less than $1.5 \mathrm{~cm}$. in length ; standard with a blade $1 \mathrm{~cm}$. broad or less : pods oval or oblong, long-stipitate, 9-12 mm. long, exclusive of the slender beak.

In dry soil, Maine to Ontario, Minnesota, Florida and Louisiana. Spring to fall.

8. Baptisia Gibbèsii Small. Similar to B. tinctoria in habit, glaucous. Stem often diffusely branched: leaflets 3 , the blades cuneate to spatulate-cuneate, $1-1.5 \mathrm{~cm}$. or rarely $2 \mathrm{~cm}$. long, rounded or emarginate at the apex, revolute especially near the base or throughout in age : racemes few-flowered : pedicels $1-4 \mathrm{~mm}$. long : caly x campanulate, $2.5-3$ $\mathrm{mm}$. long; lower lobes triangular, acute, much shorter than the tube: corolla yellow ; keelpetals $10-12 \mathrm{~mm}$. long; standard with a suborbicular blade about $1 \mathrm{~cm}$. broad : pods globular, sometimes depressed-globose, slender-stipitate, the body 6-7 $\mathrm{mm}$. long, exclusive of the subulate beak.

In sandy soil, eastern South Carolina. Spring and summer.

9. Baptisia lanceolàta Walt. Foliage pubescent when young, glabrate in age. Stems 3-9 dm. tall, widely branching : leaflets 3, the blades firm, oblanceolate to linearoblanceolate, 4-10 $\mathrm{cm}$. long, rounded or notched at the apex, scarcely lustrous above, reticulated, tapering to the base: flowers axillary, usually approximate at the ends of the branches: pedicels 4-5 $\mathrm{mm}$. long: calyx campanulate, $7-8 \mathrm{~mm}$. long; lower lobes rather triangular, shorter than the tube: corolla dull yellow, over $2 \mathrm{~cm}$. long; standard with a reniform blade about $2 \mathrm{~cm}$. broad: pods leathery, the body ovoid, $2-2.5 \mathrm{~cm}$. long, sparingly pubescent, long-beaked, stipitate.

In sandy pine lands, North Carolina to Florida. Spring.

10. Baptisia Nuttalliàna Small. Foliage more or less densely pubescent. Stems 4-11 dm. tall, branching: leaflets 3 , the blades firm, cuneate or obovate-cuneate, $2-6$ $\mathrm{cm}$. long, rounded or notched at the apex, reticulated : flowers in terminal racemes : pedicels 1-3 mm. long: calyx campanulate, 8-10 mm. long, silky ; lower lobes triangular or triangular-lanceolate, shorter than the tube : corolla yellow; keel-petals fully $15 \mathrm{~mm}$. long; standard with a reniform blade $1.2-1.8 \mathrm{~cm}$. broad : pods oval, firm, the body $1-1.7 \mathrm{~cm}$. long, long-stipitate, pubescent, the beak fully $\frac{1}{2}$ as long as the body. [B. confusa Pollard \& Ball.]

In dry soil, Arkansas to Louisiana, Texas and adjacent Mexico. Spring and summer.

11. Baptisia ellíptica Small. Foliage glabrous or minutely pubescent. Stems 3-9 dm. tall, sometimes zigzag, branching: leaflets 3 , variable, the blades of the lower ones oblanceolate, those of the upper leaves elliptic or sometimes broadened slightly above the middle, or below it, rounded or notched at the apex, rarely acute, lustrous above, mostly tapering to both ends, especially to the base, reticulated: flowers solitary in the upper axils or approximate at the ends of the branches, sometimes in terminal racemes : pedicels 5-10 mm. long : caly x campanulate, 6-8 mm. high; lower lobes triangular, shorter than the tube : corolla yellow, about $2 \mathrm{~cm}$. long; standard with a nearly reniform blade notched at the apex, truncate or cordate at the base: pods firm, the body $1.5-2 \mathrm{~cm}$. Iong, slenderbeaked, strigillose, long-stipitate.

In dry pine lands, Florida. spring.

12. Baptisia sphaerocárpa Nutt. Foliage glabrous or parts of it sparingly pubescent when young. Stems $3-10 \mathrm{dm}$. tall, solitary or several together, branching : leaflets 3 , firm, the blades elliptic to elliptic-oblanceolate, obtuse or retuse at the apex : racemes opposite the leaves, elongated, 1-4 dm. long, loosely flowered : pedicels 3-8 mm. long, subtended by minute bracts : calyx campanulate; 6-8 mm. high; lower lobes lanceolatereniform blade fully $1 \mathrm{~cm}$. broad : pods woody, the body broadly oval or subglobose, $1.5-2$ $\mathrm{cm}$. long, glabrous, stipitate, abruptly short-beaked.

In dry soil, Arkansas and Texas. Spring and summer.

13. Baptisia villòsa (Walt.) Ell. Foliage minutely pubescent or glabrate in age, turning black in drying. Stems stout, $5-8 \mathrm{dm}$. tall, branching: leaflets 3 , firm, the blades elliptic to elliptic-oblanceolate or obovate, obtuse or notched at the apex, reticulated, lustrous above : racemes 2-4 dm. long, erect or spreading: pedicels strigillose, $5-8 \mathrm{~cm}$. long: calyx campanulate, about $1 \mathrm{~cm}$. long; lobes triangular to ovate, $\frac{1}{2}$ as long as the tube : corolla yellow, over $2 \mathrm{~cm}$. long; standard with a blade $2 \mathrm{~cm}$. broad : pods firm, the body oblong-ovoid, $3-3.5 \mathrm{~cm}$. long, conspicuously slender-beaked, long-stipitate.

In sandy soil, North Carolina. Spring.

14. Baptisia sulphùrea Engelm. Foliage glabrous. Stem 5-12 dm. tall, with spreading branches, the branches glaucous : leaves few ; petioles mostly 5-10 mm. long : 
leaflets 3 , the blades obovate or oblong-obovate, sometimes slightly rhombic, obtuse or notched at the apex: stipules lanceolate, mostly shorter than the petioles, rather persistent : racemes $1-2 \mathrm{dm}$. long, few-flowered : pedicels $2-4 \mathrm{~mm}$. long: bracts deciduous : calyx longer than the pedicel, $7-8 \mathrm{~mm}$. long; lobes triangular, acute, shorter than the tube, pubescent within : corolla sulphur-yellow, $2 \mathrm{~cm}$. long; standard with a crisped blade : pods subglobose, $1.5-2 \mathrm{~cm}$. in diameter, the stipe surpassing the calyx.

On prairies, the Indian Territory. Spring.

15. Baptisia megacárpa Chapm. Foliage mainly glabrous, unchanged in drying. Stems 5-9 dns. tall, with spreading branches: leaflets 3 , the blades thinnish, elliptic to ovate,or obovate-elliptic, 4-8 cm. long, minutely pubescent or glaucous beneath, usually obtuse at the apex, acute or short-acuminate at the base : racemes 1-1.5 dm. long, shortpeduncled : pedicels $8-10 \mathrm{~mm}$ long: calyx campanulate, stout, $1 \mathrm{~cm}$. long ; lobes, except the upper one, triangular or triangular-ovate, acute: corolla pale yellow, $2 \mathrm{~cm}$. long; standard with a blade nearly $1.5 \mathrm{~cm}$. broad : pods fragile, the body bladder-like, oval or ovoid, about $4 \mathrm{~cm}$. long, about $2 \mathrm{~cm}$. thick, slender-pointed, the stipe as long as the calyx.

In rich or sandy soil, Georgia and Florida. Spring.

16. Baptisla Sérenae M. A. Curtis. Foliage glabrous, light green. Stems $3-7 \mathrm{dm}$. tall, widely branched : leaflets 3 , the blades obovate to spatulate-oblanceolate, slightly revolute, $1.5-4 \mathrm{~cm}$. long, unchanged in drying: racemes terminal, 1 main one $3-4 \mathrm{dm}$. long, and the other smaller ones terminating the branches: pedicels $5-10 \mathrm{~mm}$. long : calyx campanulate, $4 \mathrm{~mm}$. long; lobes, except the upper one, triangular, acute : corolla bright yellow, less than $1.5 \mathrm{~cm}$. long: pods firm, the body oblong, $1.5-2 \mathrm{~cm}$. long, beaked, longstipitate.

On sand hills, South Carolina and Georgia. Spring.

17. Baptisia álba (L.) R. Br. Foliage glabrous, light green, unchanged in drying. Stems 3-9 dm. tall, with spreading branches: leaflets 3 , the blades thickish, oblanceolateoblong, 2-7 cm. long, mostly obtuse or mucronulate : racemes various, one erect and elongated, 3-5 dm. long, others terminating the branches and shorter : pedicels slender, 8-10 $\mathrm{mm}$. long: caly x campanulate, $5-7 \mathrm{~mm}$. long; lobes triangular or ovate-triangular, much shorter than the tube: corolla white, less than $1.5 \mathrm{~cm}$. long : pods oblong, $2-2.5 \mathrm{~cm}$. long, short-beaked, the stipe surpassing the calyx.

In rich soil, Ontario to Minnesota to Florida and Texas. Spring and summer.

18. Baptisia albéscens Small. Foliage finely pubescent with more or less glandular hairs. Stems $0.5-1.5 \mathrm{~m}$. tall, somewhat branched, the branches zigzag : leaflets 3 , the blades oblong to oblanceolate, $2-6 \mathrm{~cm}$. long, mostly obtuse or retuse, often becoming glabrous above, much longer than the petiole: racemes 1-2 dm. long, mostly shorter than the peduncles: pedicels $5-8 \mathrm{~mm}$. long, more densely pubescent than the rachis: calyx $5-6 \mathrm{~mm}$. long; lobes much shorter than the tube, the lower ones ovate: corolla white or creamcolored, fully $1.5 \mathrm{~cm}$. long: pods $2.5-3 \mathrm{~cm}$. long, thicker than those of $B$. alba.

In sandy woods, North Carolina and Tennessee to Georgia and Alabama. Spring.

19. Baptisia leucántha T. \& G. Foliage glabrous, glaucous, blackening in drying. Stems 4-10 dm. tall, widely branching: leaflets 3 , the blades thickish, oblong-oblanceolate to ovate or cuneate, $2-5 \mathrm{~cm}$. long, mostly obtuse or retuse, undulate: racemes elongated, $2-5 \mathrm{dm}$. long, short-peduncled: pedicels $3-10 \mathrm{~mm}$. long: calyx campanulate, $7-9 \mathrm{~mm}$. high, nearly as broad ; lobes, except the upper one, triangular, acute or acutish, sinuses V-shaped : corolla white, $2 \mathrm{~cm}$. long ; standard with a suborbicular blade about 1.5 $\mathrm{mm}$. broad : pods firm, the body oblong, $2-3 \mathrm{~cm}$. long, the stipe as long as the calyx.

On river banks, Ontario to Minnesota, North Carolina, Florida and Texas. Spring and summer.

20. Baptisia bracteàta Muhl. Foliage softly pubescent with loose hairs, turning black in drying. Stems $3-6 \mathrm{dm}$. high, with widely spreading branches: stipules lanceolong, obtuse or notched at the apex, barely reticulated, acuminate at the base : racemes 1-2 dm. long, short-peduncled, declined : pedicels 1-1.5 cm. long, subtended by lanceolate acuminate bracts : calyx loosely pubescent, glabrate, $8-9 \mathrm{~mm}$. long; lobes lanceolate, acuminate, nearly as long as the tube : corolla cream-colored, $2-2.5 \mathrm{~cm}$. long; standard with an orbicular-reniform blade $1.5-1.7 \mathrm{~cm}$. broad: pods firm, the body elliptic, 4-5 $\mathrm{cm}$. long, slender-beaked, the stipe as long as the calyx.

In dry rich soil, middle Georgia. Spring.

21. Baptisia Búshii Small. Foliage pale green, pubescent, at least the younger parts, with appressed hairs, not turning black in drying. Stems several dm. tall, widely branched : stipules ovate-lanceolate to lanceolate; leaflets 3 , blades thickish, oblanceolate to 
erect or ascending: pedicels 5-9 $\mathrm{mm}$. long, appressed-pubescent : bracts ovate to ovatelanceolate, mostly shorter than the pedicels: calyx appressed-pubescent; lobes lanceolate, acute, nearly as long as the tube : corolla cream-yellow, about $2 \mathrm{~cm}$. long; standard with a suborbicular blade $14-16 \mathrm{~mm}$. broad.

On prairies, eastern Texas. Spring.

22. Baptisia cuneàta Small. Foliage glabrous, slightly discolored in drying. Stems 3-5 dm. tall, sparingly branched : stipules lanceolate: leaflets 3 , the blades leathery, cuneate, sometimes slightly cuneate-rhomboidal, $3-6 \mathrm{~cm}$. long, often mucronulate, barely reticulated : racemes about $1 \mathrm{dm}$. long, slender, short-peduncled : pedicels slender, $1.5-2.5 \mathrm{~cm}$. long: bracts lanceolate or ovate-lanceolate, acuminate, deciduous : calyx campanulate, nearly 1 $\mathrm{cm}$. long, glabrous within ; lobes, except the upper one, ovate, acute : corolla pale creamcolored ; standard broader than high, nearly $2 \mathrm{~cm}$. broad, notched, abruptly narrowed into the claw ; wings and keel-petals with blades $2 \mathrm{~cm}$. long: pods spreading, the body about 2 $\mathrm{cm}$. long, long-stipitate and long-beaked.

In sand, along or near the coast, Texas. Spring.

23. Baptista laevicaùlis (A. Gray) Small. Foliage nearly glabrous, turning blackish in drying. Stems 3-7 dm. tall, branching: leaflets 3 , the blades leathery, obovate or cuneate-obovate, 4-8 $\mathrm{cm}$. long, mucronulate to retuse at the apex, delicately reticulated : racemes somewhat declined, 1-3 dm. long, 1 -sided : pedicels $3-6 \mathrm{~cm}$. long, subtended by ovate or oblong-lanceolate acute bracts : calyx pubescent within, $1 \mathrm{~cm}$. long, prominently nerved; lobes, except the upper one, lanceolate or ovate-lanceolate, about as long as the tube: corolla cream-yellow ; standard orbicular-ovate, $2 \mathrm{~cm}$. in diameter, deeply cleft, rather abruptly narrowed into the short claw; wings and keel-petals with blades over $2 \mathrm{~cm}$. long: pods firm, the body oval, $3-4 \mathrm{~cm}$. long, with a slender curved beak and a' stipe at least as long as the calyx.

On prairies, Louisiana and Texas. Spring and fall.

24. Baptisia leucophaèa Nutt. Foliage villous. Stems $3-8 \mathrm{dm}$. tall, widely branching: leaflets 3 , the blades leathery, oblong, oblanceolate or linear-oblong, $3-10 \mathrm{~cm}$. long, obtuse or retuse at the apex, strongly reticulated : racemes 1-2 dm. long, one-sided : pedicels $1-3 \mathrm{~cm}$. long, subtended by lanceolate or ovate-lanceolate acute or acuminate bracts : caly $\mathbf{x}$ strigillose ; tube campanulate, $7-8 \mathrm{~mm}$. long; lobes except the upper one, triangular, much shorter than the tube : corolla white or cream-colored ; keel-petals 20-25 mm. long; standard with an orbicular blade fully $2 \mathrm{~cm}$. broad : pods rather firm, the body ovoid or oval, 4-5 $\mathrm{cm}$. long, slender-beaked, short-stipitate.

On prairies, Michigan to Minnesota, Louisiana and Texas. Spring.

25. Baptisia austràlis (L.) R. Br. Foliage glabrous, more or less glaucous, turning black in drying. Stems 6-12 $\mathrm{dm}$. tall, widely branched : stipules usually lanceolate : leaflets 3 , the blades leathery, cuneate to oblanceolate or oblong-oblanceolate, $4-8 \mathrm{~cm}$. long, obtuse, notched or mucronulate : racemes stout, 1-3 dm. long: pedicels stout, 5-10 $\mathrm{mm}$. long: bracts lanceolate or oblong-lanceolate : calyx campanulate, $1 \mathrm{~cm}$. long; lobes triangular or ovate, much shorter than the tube : corolla indigo-blue; keel-petals $25-30$ $\mathrm{mm}$. long; standard with a reniform-orbicular blade about $2 \mathrm{~cm}$. broad: pods ascending, the body oblong, 3-4 cm. long, short-beaked, the stipe surpassing the body.

In rich soil, Pennsylvania to Kansas, Alabama and Texas. Spring.

\section{CROTALÀria l.}

Annual or perennial herbs, or shrubby plants, with erect or procumbent stems. Leaves alternate, often with decurrent stipules : blades compound, sometimes 1-foliolate : leaflets $3-7$, or 1 , with entire blades. Flowers perfect, solitary or in terminal racemes. Calyx pedicelled : lobes 5 , often nearly distinct, the 2 upper and the 3 lower often partially united into lips. Corolla yellow or rarely blue : standard with a dilated blade: keel-petals scythe-shaped or angled. Stamens monadelphous : anthers alternately small and versatile and larger and erect. Ovary terminating in a curved style. Ovules 2-many. Pod globular to cylindric, 2-valved, sometimes leathery. Seeds becoming loose in the pod at maturity. RATTLE-Box.

A. Leaves with 1-foliolate blades.

a. Standard with a blade much less than $2 \mathrm{~cm}$. broad: blades of the upper leaf-

lets of a linear-oblong or lanceolate type: stipules more or less decurrent.

Leaflets with orbicular or oval blades predominating.

Stems and peduncles with relatively long, loose or spreading hairs.

Leaflets with peduncles with short appressed hairs.

* Stems and peduncles with loose or spreading hairs: lower and upper leaves 
with slightly different blades.

** Stems and peduncles with short appressed hairs: lower and upper leaves with very different blades.

a. Standard with a blade nearly or quite $2 \mathrm{~cm}$. broad: blades of the upper leaves

of a spatulate or oblanceolate type: stipules not decurrent.

Bracts minute, caducous.

Bracts ovate, cordate, persistent.

B. Leaves with 3-foliolate blades.

Plants annual: keel-petals over $1 \mathrm{~cm}$. long : pods $2.5-3.5 \mathrm{~mm}$. long.

Plants perennial : keel-petals less than $1 \mathrm{~cm}$. long: pods $1-1.5 \mathrm{~cm}$. long.

3. C. sagittalis.

4. C. Purshii.

5. C. retusa.

6. C. spectabilis.

7. C. incana.

8. C. pumila.

1. Crotalaria rotundifòlia (Walt.) Poir. Perennial, conspicuously pubescent. Stems tufted, often densely so, more or less spreading, 1-4 dm. long, like the peduncles pubescent with loose or spreading hairs : leaves alternate; leaflets solitary, the blades entire, mostly orbicular or obovate near the base of the plant, oval, oval-ovate or broadly oblong above, obtuse or mucronulate, hairy on both sides, sometimes glaucescent beneath, short-petioled: calyx pubescent with relatively long loose hairs; lobes of the lower lip about $10 \mathrm{~cm}$. long, slenderly acuminate : corolla yellow : standard with a blade $9-12 \mathrm{~mm}$. broad : pods oblong, $2-3 \mathrm{~cm}$. long.

In dry or sandy soil, Virginia to Florida and Mississippi. Spring to fall.

2. Crotalaria marítima Chapm. Perennial, similar to $C$. rotundifolia in habit, but slightly smaller and inconspicuously pubescent. Stems pubescent with short appressed hairs: leaves alternate; leaflets solitary, the blades entire, suborbicular to oval on the lower part of the stems, somewhat narrower above, obtuse or acutish, sparingly pubescent, short-petioled: stipules mostly decurrent but narrow: calyx pubescent with short closely appressed hairs; lobes of the lower lip mostly less than $10 \mathrm{~mm}$. long, slightly acuminate : corolla smaller than that of $C$. rotundifolia: pods $1.5-2.5 \mathrm{~cm}$. long.

In pine lands, Florida to Mississippi. Spring and summer.

3. Crotalaria sagittàlis L. Annual, or perennial southward, conspicuously pubescent. Stems more or less tufted, 1-5 dm. tall, erect or ascending, often branched above, like the peduncles with loose or spreading hairs: leaflets solitary, the blades oblong to lanceolate or linear-lanceolate, $2-6 \mathrm{~cm}$. long, often abruptly acute, sessile or nearly so: stipules decurrent, usually broad and conspicuous: calyx rather shaggy-pubescent; lobes of the lower lip $10 \mathrm{~mm}$. long or nearly so, somewhat acuminate : corolla yellow; standard with a blade $6-11 \mathrm{~mm}$. broad: pods $2.5-4 \mathrm{~cm}$. long.

In dry soil, New England to Minnesota, Florida and Texas. Spring to fall.

4. Crotalaria Púrshii DC. Perennial, similar to C. sagittalis in habit, but rather fleshy and inconspicuously pubescent. Stems more or less tufted, 1-5 dm. long, often branched, like the peduncles with short appressed hairs: leaflets solitary, the blades various, those of the lower leaves spatulate or oblanceolate, those of the upper ones linear, often narrowly so and much elongated, sometimes $12 \mathrm{~cm}$. long, but usually shorter: stipules mostly decurrent, narrow : calyx pubescent with appressed hairs; lobes of the lower lip commonly over $10 \mathrm{~mm}$. long, slenderly acuminate : corolla yellow; standard with a blade $9-13 \mathrm{~mm}$. broad : pods $2-3 \mathrm{~cm}$. long.

In grassy pine lands or sandy soil, Georgia and Florida to Louisiana. Spring to fall.

5. Crotalaria retùsa $\mathrm{L}$. Annual, stout. Stems $4-9 \mathrm{dm}$. tall, more or less branched, finely and softly pubescent: leaflets solitary, the blades cuneate to oblanceolate, $3-9.5 \mathrm{~cm}$. long, rounded or retuse at the apex, often glabrous above, more or less pubescent beneath, short-petioled : stipules minute : racemes conspicuous, several-many-flowered : pedicels $5-10 \mathrm{~mm}$. long, subtended by minute caducous bracts : calyx finely pubescent; lobes of the upper lip triangular-lanceolate, those of the lower lip lanceolate: corolla relatively large, yellow ; standard with a blade usually about $20 \mathrm{~mm}$. broad : pods $3-5 \mathrm{~cm}$. long, spreading or drooping.

In sand or sandy soil, peninsular Florida and the Keys. Also in tropical America.

6. Crotalaria spectàbiliss Roth. Similar to C. retusa but rather larger. Stems 5-18 dm. tall, leafy, pale-pubescent : leaflets solitary, the blades dark green above, pale beneath, often minutely bristle-tipped : stipules small but broad: flowers nearly similar to those of $C$. retusa, but commonly slightly smaller: pedicels clavate, subtended by ovate-cordate acuminate bracts.

In sand or sandy soil, Key West, Florida. Also in tropical America.

7. Crotalaria incàna L. Annual, minutely pubescent. Stems more or less branched, $5-13 \mathrm{dm}$. tall : leaves often numerous; leaflets 3 , the blades oval to obovate, $1-3.5 \mathrm{~cm}$. long, rounded or truncate at the apex, sometimes glabrous: the terminal one usually shorter than the petiole: calyx becoming 10-12 $\mathrm{mm}$. long: corolla greenish yellow; standard over $10 \mathrm{~mm}$. long : pods $2.5-4 \mathrm{~cm}$. long.

In sand or sandy soil, peninsular Florida and the Keys to Texas. Also in tropical America. 
8. Crotalaria pùmila Ortega. Perennial, minutely pubescent or glabrate. Stems several together, often branched throughout, 1-9 dm. long, decumbent: leaves numerous : leaflets 3 , the blades cuneate to oblong-cuneate, $0.5-1.5 \mathrm{~cm}$. long, mostly emarginate, the terminal one longer than the petiole: calyx becoming 4 or $5 \mathrm{~mm}$. long : corolla yellowish ; standard less than $10 \mathrm{~mm}$. long: pods $1-1.5 \mathrm{~cm}$. long.

In sand, peninsular Florida and the Keys. Also in tropical America.

\section{LUPİNUS L.}

Annual or perennial herbs or shrubby plants, with erect or prostrate stems. Leaves alternate, with stipules at the base of the petioles: blades 1-foliolate, or usually digitately 5 -15-foliolate or rarely 3 -foliolate. Flowers perfect, in terminal racemes. Calyx 2lipped, the upper lip of 2 partially united sepals, the lower lip of 3 partially or wholly united sepals. Corolla of various colors : standard broad with recurved margins : wings more or less curved: keel scythe-shaped. Stamens monadelphous. Anthers alternately small and versatile. Style curved. Ovules 2-many. Pod flattened, 2-valved. Lupine.

Leaf-blades palmately several-foliolate.

Leaflets $7-11$ : plants perennial.

Leaflets 5: plants annual or biennial.

Leaflets with cuneate, truncate blades: corollas $1 \mathrm{~cm}$. long or shorter.

Leaflets oblanceolate, elliptic or obovate-oblanceolate blades, not truncate : corolla $1 \mathrm{~cm}$. long or longer.

Leaf-blades 1 -foliolate.

Biennial : corolla mainly blue.

Perennial : corolla mainly red.

1. L. perennis.

2. L. subcarnosus.

3. L. Texensis.

4. L. diffusus.

5. L. villosus.

1. Lupinus perénnis L. Perennial, more or less pubescent. Stems solitary or several together, ascending or erect, 2-6 dm. long, simple or sparingly branched : leaves spreading; petioles usually longer than the blades; leaflets $7-11$, the blades oblanceolate to elliptic, $1.5-5 \mathrm{~cm}$. long, obtuse or mucronate: raceme $0.5-3 \mathrm{dm}$. long: calyx $6-8 \mathrm{~mm}$. long: corolla blue or rarely white to pink; standard with a blade $12-15 \mathrm{~mm}$. broad : pods narrowly oblong, $3-3.5 \mathrm{~cm}$. long, pubescent, beaked.

In sandy soil, Maine to Minnesota, Florida, Louisiana and Missouri. Spring.

2. Lupinus subcarnòsus Hook. Annual or biennial, somewhat villous. Stems branched at the base, the branches ascending or decumbent, 1-3 dm. long, mostly simple : leaves rather numerous; petioles mostly longer than the blades, pubescent like the branches ; leaflets 5 , the blades cuneate, $2-4 \mathrm{~cm}$. long, truncate, mucronulate : racemes often overtopping the leaves, $4-8 \mathrm{~cm}$. long : pedicels $2-6 \mathrm{~mm}$. long: calyx $5-6 \mathrm{~mm}$. long, densely silky-villous : corolla purplish blue, $1 \mathrm{~cm}$. long or shorter.

On prairies, Texas. Spring.

3. Lupinus Texénsís Hook. Annual or biennial, silky-strigillose. Stems branched at the base or near it, the branches a-cending or decumbent, 1-3 dm. long, sometimes sparingly branched: leaves rather numerous; petioles mostly longer than the blades; leaflets often 5 , the blades elliptic to oblanceolate or obovate-oblanceolate, $1.5-4 \mathrm{~cm}$. long, acute or acutish, sometimes merely apiculate or obtuse : racemes $5-15 \mathrm{~cm}$. long, often rather many-flowered: pedicels 4-10 mm. long: calyx 7-8 mm. long, silky strigose : corolla purplish, $1 \mathrm{~cm}$. long or slightly longer; standard with a pale blotch in the center: pods linear, $3-4 \mathrm{~cm}$. long.

In prairies or in sand, Texas. Spring.

4. Lupinus diffùsus Nutt. Perennial, densely silky. Stems several or many from the base, 1-6 dm. long, erect or prostrate : leaves 1-foliolate; blade oblanceolate, oblong or obovate, 4-10 cm. long, mucronate, longer than the petiole or shorter : racemes $0.5-3 \mathrm{dm}$. long: pedicels about 1-5 mm. long: calyx 8-12 mm. long : corolla blue; standard with a purple blotch in center : pods oblong, $3-4 \mathrm{~cm}$. long, woolly.

In dry pine lands, North Carolina to Florida. Spring.

5. Lupinus villòsus Willd. Biennial, densely villous. Stems solitary or several from the base, 3-6 dm. long, ascending or prostrate: leaves 1 -foliolate; blade lanceolate to oblanceolate, 4-15 cm. long, usually acute and apiculate, longer than the petioles or shorter: racemes 1-4 dm. long: pedicels about $2-5 \mathrm{~mm}$. long: calyx 8-12 $\mathrm{mm}$. long: corolla pale red; standard with a purple blotch in center: pods oblong, 2-4 cm. long, densely woolly.

In dry pine lands, South Carolina to Florida. Spring. 


\section{MEDICÀGO L.}

Herbs or shrubby plants, with erect or prostrate stems. Leaves alternate: blades pinnately 3 -foliolate : leaflets commonly toothed by the prominent excurrent lateral nerves. Flowers perfect, in elongated or head-like peduncled racemes. Calyx pedicelled: lobes slender, nearly equal. Corolla yellow or violet: standard with an oblong or obovate nearly sessile blade : wings nearly oblong: keel obtuse, shorter than the wings. Stamens 10, diadelphous, the one opposite the standard, distinct. Anthers all alike. Ovary sessile or short-stalked. Style subulate. Stigma oblique. Ovules numerous or rarely solitary. Pod curved or spirally coiled, often spiny, usually reticulated, indehiscent. Medic.

Pods unarmed, 1-seeded.

Pods prickle-armed, several-seeded.

Pods loosely coiled, not furrowed on the edge between the prickles.

Pods tightly coiled, furrowed on the edge between the prickles.
1. M. Lupulina.

2. M. denticulata. 3. M. Arabica.

1. Medicago lupulina L. Foliage strigillose. Stems branching at the base, the branches spreading, prostrate, $2-7 \mathrm{~cm}$. long; leaflets 3 , the blades obovate or rhomboidal, $0.5-1.5 \mathrm{~cm}$. long, usually retuse and mucronate at the apex, denticulate, sessile or shortstalked : petioles variable in length : peduncles slender, 2-10 $\mathrm{cm}$. long : racemes subglobose or ovoid in flower, oblong-cylindric in fruit : calyx-tube turbinate: corolla bright yellow, $2-3 \mathrm{~mm}$. long: pods spirally twisted, about $3 \mathrm{~mm}$. long, black, reticulated, glabrous or nearly so, unarmed, 1-seeded.

In waste places throughout North America except the extreme north. Spring to winter. Widely naturalized in temperate regions, from Europe and Asia.

2. Medicago denticulàta Willd. Foliage glabrous or sparingly pubescent. Stems branched at the base, the branches radially spreading, ascending or procumbent, 1-4 dm. long : leaflets 3 , the blades obovate, cuneate or oval, $0.5-1.5 \mathrm{~cm}$. long, denticulate, rounded, retuse or notched at the apex : petioles variable in length: peduncles $0.5-2 \mathrm{~cm}$. long: calyx often sparingly pubescent : corolla yellow, about $5 \mathrm{~mm}$. long: pods loosely twisted into 2-3 coils, flat, $5-8 \mathrm{~mm}$. broad, reticulated, the edges armed with 1-2 rows of curved prickles.

In waste places, especially near seaports, Nova Scotia to Florida and Texas. Summer. Naturalized from Europe and Asia.

3. Medicago Arábica All. Foliage glabrous or pubescent with a few spreading hairs. Stems branched at the base, the branches prostrate or ascending: leaflets 3 , the blades broadly cuneate or obovate, $1-2.5 \mathrm{~cm}$. long, denticulate, usually blotched in the center, rounded or notched at the apex : petioles commonly longer than the leaflets: peduncles 1-2 $\mathrm{cm}$. long: calyx often sparingly pubescent : corolla yellow, about $5 \mathrm{~mm}$. long: pods closely twisted into $3-4$ coils, $6-9 \mathrm{~mm}$. broad, reticulated, the edges armed with curved prickles.

In waste places, New Brunswick to Georgia and Louisiana. Summer. Introduced from Europe.

\section{MELILÒTUS Juss.}

Annual or biennial caulescent herbs, with fragrant herbage. Leaves alternate, with thin stipules: blades pinnately 3 -foliolate : leaflets much longer than broad, the nerves excurrent into teeth. Flowers perfect, in elongated narrow racemes. Calyx pedicelled: lobes 5, nearly equal. Corolla yellow or white, deciduous : petals free from the filaments : standard rather abruptly contracted at the base of the blade, nearly sessile : wings narrower than the standard, cohering with the shorter obtuse keel-petals. Stamens diadelphous. Ovary sessile or short-stalked. Style filiform. Stigma terminal. Ovules few. Pod straight, short and thick, often subglobose, indehiscent or nearly so. SwEET Clover.

\section{Corolla 2-2.5 mm. long.}

Corolla $5-6 \mathrm{~mm}$. long.

Corolla yellow: standard and wing-petals about equal in length.

Corolla white: standard surpassing the wing petals.

1. M. Indica.

1. Melilotus Índica (L.) All. Foliage minutely pubescent when young. Stems erect or spreading, 2-7 dm. long, sometimes copiously branched : leaflets 3 , the blades oblong, oval, cuneate or obovate, $0.5-2 \mathrm{~cm}$. long, retuse to rounded at the apex, serrate: racemes slender, 1-2 cm. long: calyx campanulate; lobes longer or shorter than the tube which is scarious in the sinuses: corolla yellow, about $2-2.5 \mathrm{~mm}$. long; standard with a blade 1-1.5 mm. broad : pods oval or subglobose, $2 \mathrm{~mm}$. long, wrinkled.

In waste places, about seaports, on the Atlantic and Pacific coasts and sometimes in the interior. Introduced from Europe. Spring to fall. 
2. Melilotus officinàlis (L.) Lam. Foliage glabrous, or twigs sparingly pubescent. Stems erect or spreading, 3-10 dm. long, more or less branched : leaflets 3 , the blades narrowly oblong, oblanceolate or oval, 1-3 cm. long, rounded or truncate at the apex, sharply serrate, bright green above : racemes 1-12 $\mathrm{cm}$. long : flowers sometimes secund : calyx campanulate; lobes shorter than the tube : corolla yellow, $5-6 \mathrm{~mm}$. long; standard and wing-petals about equal in length: pods about $4 \mathrm{~mm}$. long, reticulate-wrinkled, slightly pubescent.

In waste places about cities, throughout the United States and southern British America. Naturalized from Europe and Asia. Spring to fall.

3. Melilotus álba Desv. Foliage glabrous, or twigs pubescent. Stems erect, 3-12 dm. tall, widely branching: leaflets 3 , the blades linear-oblong, oblanceolate or elliptic, 1-3 cm. long, obtuse or truncate at the apex or sometimes emarginate, serrate, longer or shorter than the petiole : racemes wand-like, elongated : flowers often secund: calyx campanulate, pubescent; lobes usually shorter than the tube : corolla white, 4-5 mm. long; standard surpassing the wing-petals : pods oval, $3-3.5 \mathrm{~mm}$. long, rugose, glabrous.

In waste places about cities, throughout the United States and southern British America. Introduced from Europe and Asia. Spring to fall.

\section{TRIFÒLIUM L.}

Annual or perennial herbs, with erect or creeping stems. Leaves alternate : petioles variable in length : blades digitately 3 -foliolate or rarely 5-7-foliolate: leaflets entire or toothed. Flowers perfect, disposed in abbreviated or elongated racemes, often in heads. Calyx pedicelled : lobes 5, slender, nearly equal, or broad and the upper 2 united. Corolla of various colors, often white, pink or purple : standard straight or recurved : wings narrow, longer than the obtuse keel. Stamens 10, diadelphous ( 9 and 1$)$ or the 10 th filament sometimes united to about the middle. Anthers all alike. Ovary sessile or stalked. Ovules few. Pod flattish or terete, included in the persistent corolla. Seeds few or solitary. CLOver.

Corolla yellow.

Terminal leaflet longer-stalked than the rest.

Racemes 8-12-flowered, much less than $1 \mathrm{~cm}$. long.

Racemes $20-40$-flowered, about $1 \mathrm{~cm}$. long.

Terminal leaflet not longer-stalked than the rest.

Corolla white, pink or purple.

Flowers not reflexed at maturity.

Racemes cylindric, peduncled : calyx plumose-pubescent.

Racemes subglobose, sessile : calyx glabrous or sparingly pubescent.

Flowers reflexed at maturity.

Racemes over $2 \mathrm{~cm}$. broad: cleistogamous flowers always wanting. Annual or biennial : foliage pubescent. Perennial: foliage glabrous.

Racemes less than $2 \mathrm{~cm}$. broad: cleistogamous flowers sometimes present.

Calyx nearly as long as the corolla. Calyx-lobes about as broad as long. Calyx-lobes subulate.

Calyx barely $1 / 2$ as long as the corolla. Stems creeping.

Racemes 6-12-flowered : creeping stems with cleistogamous flowers. Racemes many-flowered: cleistogamous flowers wanting. Leaflets prominently nerved, spinulose-serrate : terminal leaflet no longer stalked than the lateral.

Leaflets not prominently nerved, serrulate: terminal leaflets longer stalked than the lateral.

Stems erect or ascending.

1. T. dubium.

2. T. procumbens.

3. T. agrarium.

4. T. arvense.

5. T. pratense.

6. T. reflexum.

7. T. stoloniferum.

8. T. Bejariense.

9. T. Carolinianum.

10. T. amphianthum.

11. T. saxicola.

12. T. repens.

13. T. hybridum.

1. Trifolium dùbium Sibth. Foliage glabrous, strigillose or pilose. Stems usually branched at the base, the branches spreading or ascending, $0.3-5 \mathrm{dm}$. long: leaflets 3 , the blades cuneate to obovate, $4-8 \mathrm{~mm}$. long, rounded, truncate or notched at the apex, denticulate, the terminal one longer-stalked than the rest: peduncles surpassing the subtending leaves : heads rather loosely 8-12-flowered : calyx glabrous; tube campanulate ; lobes lanceolate or subulate-lanceolate, the longer surpassing the tube in length : corolla pale yellow turning brown; standard involutely folded, surpassing the wing-petals.

In waste places and open grounds, New England to British Columbia, Florida and Texas. Naturalized from Europe. Spring and summer.

2. Trifolium procúmbens L. Foliage more or less densely pilose or strigillose. Stems erect and simple or usually branched at the base, the branches decumbent or prostrate, 1-7 dm. long: leaflets 3 , the blades cuneate or obovate, $6-12 \mathrm{~mm}$. long, rounded or notched at the apex, denticulate: racemes 20-40-flowered: peduncles surpassing the subtending leaves : calyx usually sparingly pubescent ; tube campanulate; lobes lanceolate or 
subulate-lanceolate, the longer ones exceeding the tube in length : corolla yellow, 3-4 mm. long; standard with a suborbicular blade, surpassing the wing-petals.

In fields and waste places, throughout the United States and southern British America. Naturalized from Europe. Spring to fall.

3. Trifolium agràrium L. Foliage bright green. Stems more or less diffusely branched, often from the base, the branches $2-8 \mathrm{dm}$. long, ascending or reclining, strigillose : leaves numerous, petioles shorter than the leaflets on the upper part of the branches; stipules somewhat acuminate: leaflets 3 , the blades broadest above the middle, the terminal one no longer-stalked than the lateral, all denticulate: peduncles becoming 1-5 $\mathrm{cm}$. long, finely pubescent : racemes oblong or oval, $12-20 \mathrm{~mm}$. long, densely many-flowered : calyx $3.5-4$ $\mathrm{mm}$. long, short-pedicelled; lobes linear-subulate, longer than the ribbed tube: corolla deep yellow, 4-5 mm. long, becoming reflexed, turning brown in age.

In fields and waste places, Nova Scotia to Ontario, Iowa and Georgia. Naturalized from Europe. Spring and summer.

4. Trifolium arvénse L. Annual, villous-lanuginose. Stems erect, 1-4 dm. tall, usually branched throughout: leaflets 3 , the blades linear to oblanceolate, $1-2.5 \mathrm{~cm}$. long, notched or truncate at the apex, often mucronate, entire or slightly two-toothed : peduncles surpassing the subtending leaves : heads dense, oblong or cylindric, $1-3 \mathrm{~cm}$. long : calyx gray; tube finally ovoid; lobes subulate, longer than the tube: corolla whitish, surpassed by the calyx lobes: standard somewhat longer than the wing-petals.

Along roadsides, in dry fields and on banks, throughout eastern North America. Naturalized from Europe and Asia. Summer.

5. Trifolium praténse L. Perennial, more or less densely pubescent. Stems commonly branched at the base, the branches erect or ascending, 2-7 dm. long: leaflets 3 , the blades oblong, elliptic or oval, varying to ovate or obovate, 1-4 cm. long, rounded or notched at the apex, sometimes apiculate, denticulate, often blotched : peduncles commonly shorter than the subtending leaves: heads subglobose to ovoid, $2.5-3 \mathrm{~cm}$. thick : calyx villous; tube long-campanulate; lobes filiform, the longer ones often surpassing the tube : corolla red, purple or white, nearly $1.5 \mathrm{~cm}$. long; standard elongated, surpassing the wing-petals.

In fields, meadows and cultivated grounds, throughout the United States and southern British America. Widely cultivated and naturalized from Europe. Spring to fall.

6. Trifolium refléxum L. Annual or biennial, more or less densely villous or downy, destitute of runners. Stems simple and erect or usually branched at the base, the branches ascending or spreading, 1-5 $\mathrm{dm}$. long: leaflets 3 , the blades oblong, elliptic-obovate to suborbicular, $1.5-3 \mathrm{~cm}$. long, rounded or emarginate at the apex, often mucronate, denticulate: peduncles longer or shorter than the subtending leaves: calyx often glabrous; tube campanulate, very short; lobes lanceolate-subulate, much longer than the tube: corolla $6-10 \mathrm{~mm}$. long; standard red or purple, surpassing the white keel and wingpetals.

In waste places, fields, dry woods and meadows, Ontario to Nebraska, Florida and Texas. Spring.

7. Trifolium stoloniferum Muhl. Perennial, glabrous, producing runners at the base. Stems simple and erect or branched at the base, the branches widely spreading, 1-3 $\mathrm{dm}$. long: leaflets 3 , the blades obovate, broadly cuneate or nearly orbicular, $1-3 \mathrm{~cm}$. in diameter, rounded or notched at the apex, denticulate : peduncles surpassing the subtending leaves: calyx ribbed; tube campanulate; lobes subulate, twice or thrice as long as the tube: corolla white tinged with purple, $8-12 \mathrm{~mm}$. long; standard involutely folded, surpassing the wing-petals.

In open woods and on prairies, Ohio to Nebraska, Tennessee and Missouri. Spring and summer.

8. Trifolium Bejariénse Moric. Annual, sparingly pubescent. Stems erect, or branched at the base, the branches ascending or decumbent, 1-2 dm. long, simple or branching above: leaflets 3 , the blades obovate or cuneate, $5-10 \mathrm{~mm}$. long, rounded or emarginate at the apex, denticulate : peduncles several times longer than the subtending leaves : heads many-flowered, $1.5-2 \mathrm{~cm}$. thick : calyx reticulated, 2 -lipped; tube campanulate; lobes unequal, the upper one nearly distinct, the rest shorter than the tube : corolla pale, becoming brown, somewhat longer than the caly $\mathrm{x}$; standard and wing-petals toothed, the former surpassing the latter.

On prairies, Texas. Spring.

9. Trifolium Caroliniànum Michx. Perennial, slender, pubescent. Stems usually branched at the base, the branches ascending or decumbent, 1-3 dm. long, often sparingly branched above: leaves with slender petioles: leaflets 3 , the blades obovate or cuneate, 5-12 mm. long, rounded or emarginate at the apex, denticulate, acute at the base : peduncles usually many times longer than the subtending leaves: calyx pilose, reticulated; 
tube campanulate; lobes lanceolate to linear-lanceolate, longer than the tube: corolla white, pink or tinged with purple ; standard acute, surpassing the wing-petals.

In sandy soil or waste places, or on rocks, Pennsylvania to Florida and Texas. Spring to fall.

10. Trifolium amphiánthum T. \& G. Perennial, stoloniferous, glabrous or nearly so. Stems branched at the base, the branches prostrate, creeping, $2-16 \mathrm{~cm}$. long, simple or branched: leaves clustered at the nodes : leaflets 3 , the blades broadly cuneate-obovate, 5-10 $\mathrm{mm}$. long, emarginate, undulate or denticulate: peduncles overtopping the leaves, slender : heads rather few-flowered : calyx nerved; tube campanulate; lobes lanceolate or subulate-lanceolate, about as long as the tube : corolla bright purple, $8-10 \mathrm{~mm}$. long ; standard somewhat longer than the wing-petals: pods mainly solitary from fertile flowers usually borne at the lower nodes.

On prairies, Louisiana and Texas. Spring.

11. Trifolium saxícola Small. Perennial, glabrous. Stems branched at the base, the branches prostrate, creeping, 0.5-2 dm. long, rigid : leaflets 3 , the blades cuneate or obdeltoid, 3-8 mm. long, firm, usually truncate or retuse at the apex, spiny-serrate; secondary nerves close, straight: peduncles stout, surpassing the subtending leaves : calyx glabrous, about $3 \mathrm{~mm}$. long; tube narrowly campanulate, prominently ribbed ; lobes subulate-lanceolate, shorter than the tube : corolla white, 5-7 mm. long; standard erose at the apex, surpassing the wing-petals.

On granite rocks, Stone Mountain, Georgia. Summer.

12. Trifolium rèpens $\mathrm{L}$. Perennial, glabrous or sparingly pubescent. Stems more or less densely branched at the base, the branches prostate, creeping, $1-4 \mathrm{dm}$. long: leaflets 3 , the blades obovate or orbicular-obovate or oval, 1-1.5 cm. long, rounded or notched at the apex, denticulate: peduncles elongated, erect or ascending, $5-20 \mathrm{~cm}$. long: calyx glabrous ; tube campanulate, ribbed ; lobes lanceolate or at maturity triangular-lanceolate, shorter than the tube : corolla usually white, $6-10 \mathrm{~mm}$. long; standard much longer than the wing-petals and the keel.

In all situations, throughout North America except the extreme north and south. Naturalized, wholly or perhaps only partially from Europe. Widely distributed. Spring to winter.

13. Trifolium hýbridum L. Perennial, glabrous or nearly so. Stems branched at the base, the branches erect or ascending or spreading, $2-8 \mathrm{dm}$. long, more or less branched : leaflets 3 , the blades oval to oblong varying to ovate or obovate, or sometimes suborbicular, rounded or notched at the apex, denticulate, the teeth often spine-like: peduncles usually surpassing the subtending leaves: heads rather dense: calyx often sparingly pubescent ; tube campanulate; lobes subulate-lanceolate, surpassing the tube in length : corolla pink or rarely nearly white: standard longer than the wing-petals.

In various situations, Nova Scotia to Idaho, Georgia and Missouri. Spring to fall.

\section{LÒTUS L.}

Annual or perennial herbs or shrubs, with glabrous or silky-pubescent foliage. Leaves alternate: blades 1-foliolate or pinnately 3 -foliolate, petioled: leaflets with entire blades. Flowers perfect, solitary in the axils or clustered. Calyx pedicelled : lobes nearly equal, often shorter than the tube. Corolla yellow, white or reddish : standard broad, clawed: wings narrow, about as long as the incurved obtuse keel. Stamens 10, diadelphous $(9$ and 1$)$ : filament opposite the standard free. Anthers all alike. Ovary sessile. Style glabrous, incurved or inflexed. Ovules 1 or several. Pod narrow, flattish or nearly terete, 2-valved, straight or curved. Seeds 1 or several. [Hosackia Dougl.]

Stem leaves persistent: leaflets oblong to ovate: branches villous.

Stem leaves fugacious: leaflets linear: branches glabrous or glabrate.

1. L. Americana.

2. L. Helleri.

1. Lotus Americànus (Nutt.) Bisch. Foliage more or less densely villous or glabrate. Stems 2-6 dm. tall, branching : leaves 3-foliolate, or the upper sometimes 1-foliolate, the lower with short petioles, the upper sessile: leaflets mostly 3 , the blades oblong or elliptic varying to lanceolate, $0.8-2.5 \mathrm{~cm}$. long, acute or sharply acuminate, inequilateral : peduncles 1-flowered, bearing a bractlet at the top: calyx copiously pubescent; tube turbinate; lobes narrowly linear, over twice as long as the tube: corolla 6-7 mm. long, pink; standard striped with purple: pods linear, 2.5-3 cm. long, straight, acute. In dry soil, Minnesota to Texas and New Mexico. Summer.

2. Lotus Hélleri Britton. Foliage glabrous or finely pubescent. Stems 2-6 dm. tall, usually much and regularly branched : leaves 3 -foliolate or the upper ones 1-foliolate : leaflets mostly 3 , the blades linear or linear-oblong, $5-15 \mathrm{~mm}$. long, acute: peduncles 
axillary, 1-flowered, bracted at the top : calyx usually sparingly pubescent; tube turbinatecampanulate ; lobes narrowly linear, hardly twice as long as the tube : corolla pink, 6-7 $\mathrm{mm}$. long; standard very faintly if at all veined : pods linear, $2-3 \mathrm{~mm}$. long, straight, acute.

In dry soil and open pine woods, North Carolina. Summer.

\section{INDIGÒFERA L.}

Perennial herbs or shrubs, with erect or prostrate stems. Foliage often more or less densely clothed with simple 2-horned or forking hairs. Leaves alternate : blades unequally pinnate, or sometimes 3 -foliolate or rarely 1 -foliolate : leaflets with entire blades. Flowers perfect, in axillary spikes or racemes. Calyx-lobes oblique, nearly equal or the upper shorter. Corolla often pink or purple: standard broad; blade sessile or clawed, persistent : wings somewhat elongated, slightly cohering with the more or less inflated erect keel and deciduous like it. Stamens 10, usually monadelphous, or one partially distinct. Anthers alike. Ovary sessile or nearly so. Style glabrous. Ovules numerous or rarely few or solitary. Pod linear to subglobose, angled or turgid. Seeds subglobose or flattened, separated from each other. INDIGio-PLANT.

Racemes surpassing the subtending leaf-like bracts.

Pods about $1 \mathrm{~cm}$. long or shorter, oblong.

Pods 1.5-3 cm. long, linear.

Pods curved.

Pods straight.

Standard 8-10 mm, long: racemes many-flowered : campestrian species. Standard 5-6 mm. long: racemes few-flowered : Floridian species.

Racemes shorter than the subtending leaf-like bracts.

Pods straight or nearly so, over $2 \mathrm{~cm}$. long.

Pods strongly curved, less than $2 \mathrm{~cm}$. long.

Leaflets copiously pubescent above.

Leaflets glabrous above or nearly so.

1. I. Caroliniana.

2. I. subulata.

3. I. leptosepala.

4. I. miniata.

5. I. tinctoria.

6. I. Lindheimeriana.

7. I. Anil.

1. Indigofera Caroliniàna Walt. Foliage minutely strigillose. Stems erect, $1-2 \mathrm{~m}$. tall, widely branched: leaflets $9-15$, the blades oblong, oval or oblanceolate, thinnish, $1-2.5 \mathrm{~cm}$. long, mucronate, slender-stalked : racemes surpassing the leaf-like bracts : calyx densely strigillose; lobes triangular, acute, shorter than the tube : corolla yellowish brown; standard 5-6 mm. long, surpassed by the other petals: pods oblong, 5-10 $\mathrm{mm}$. long, acute at each end, drooping on short reflexed pedicels.

In dry pine lands, North Carolina to Florida." Spring and summer.

2. Indigofera subulàta Vahl. Foliage sparingly strigillose. Stems branched at the base, the branches spreading or decumbent, $2-6 \mathrm{dm}$. long, more or less branched : leaflets $3-5$, the blades oval or oblong to obovate, $0.5-1.5 \mathrm{~cm}$. long, mucronulate, short-stalked: racemes surpassing the leaf-like bracts : calyx pubescent; lobes subulate, much longer than the tube: corolla pale, often pinkish ; standard 4-5 mm. long: pods linear, $3-4 \mathrm{~cm}$. long, acute, slightly curved.

In sand, Florida Keys. Throughout the year.

3. Indigofera leptosépala Nutt. Foliage strigillose. Stems more or less branched at the base, the branches decumbent, 3-10 dm. long, simple or branching: leaflets 7-9, the blades oblong-obovate to cuneate, 1-2 cm. long, mucronate, sessile or nearly so: racemes surpassing the leaf-like bracts: pedicels stout, 1-1.5 mm. long, finally recurved : calyx strigillose; lobes subulate, much longer than the tube : corolla pale scarlet; standard 8-10 mm. long : pods linear, $3-3.5 \mathrm{~cm}$. long, not torulose, straight.

In dry soil, Kansas to Georgia and Florida, Texas and Mexico. Spring to fall.

4. Indigofera miniàta Ortega. Foliage densely strigillose with whitish hairs, consequently pale. Stems more or less freely branched at the base, the branches spreading or procumbent: leaflets firm, 5-9, the blades linear-oblong to narrowly oblanceolate, $0.5-1$ cm. long, acute, short-stalked : racemes surpassing the leaf-like bracts: calyx closely pubescent; lobes lanceolate-subulate, longer than the tube : corolla pinkish or reddish;
standard 5-6 mm. long: pods oblong-linear, $1.5-2 \mathrm{~cm}$. long, acute, not torulose, straight. In sand, southern peninsular Florida and the Keys. Throughout the year.

5. Indigofera tinctòria L. Foliage strigillose. Stems erect, 1-2 m. tall, branching: leaflets 7-11, the blades oblong, oval or obovate, 1-2.5 $\mathrm{cm}$. long, mucronulate: racemes shorter than the leaf-like bracts : pedicels $1-1.5 \mathrm{~cm}$. long, finally recurved : calyx pubescent; lobes subulate, the lower ones surpassing the tube in length : corolla rose or purplish ; standard, 4-5 mm. long: pods linear, $2.5-3 \mathrm{~cm}$. long, straight or slightly curved, torulose.

In waste places, North Carolina to Florida and Louisiana. Introduced from Asia. Summer. 
6. Indigofera Lindheimeriàna Scheele. Foliage densely strigillose with whitish hairs, consequently pale. Stems erect, 1-2 m. tall, more or less branched : leaflets firm, 7-15, the blades oblong or oval varying to cuneate, 1-2 cm. long, mucronate, short-petioluled : racemes shorter than the leaf-like bracts : pedicels about $1 \mathrm{~mm}$. long, finally recurved : calyx densely strigillose; lobes subulate-lanceolate, as long as the tube or longer: corolla 6-7 mm. long: pods linear, about $2 \mathrm{~cm}$. long, curved, beaked, thickened at each suture.

In dry soil, Texas and adjacent Mexico. Spring to fall.

7. Indigofera Ànil L. Foliage strigillose. Stems erect, 1-2m. tall, angular, sparingly branched : leaflets $7-15$, the blades oblong, oblanceolate or obovate, $1-3 \mathrm{~cm}$. long, mucronate, acute at the base, glabrous or glabrate above : racemes shorter than the leaf-like bracts : pedicels about $1 \mathrm{~mm}$. long, finally recurved: calyx densely pubescent ; lobes about as long as the tube : corolla $3.5-4.5 \mathrm{~mm}$. long: pods stout, $12-15 \mathrm{~mm}$. long, curved, thickened at the sutures. to fall.

In waste places, North Carolina to Florida and Louisiana. Introduced from the tropics. Spring

\section{CRÁCCA L.}

Perennial herbs or shrubby plants, with long tough roots and usually pubescent foliage. Stems erect or prostrate, often branched at the base. Leaves alternate : blades unequally pinnate: leaflets numerous, or rarely few, with entire blades. Flowers perfect, in axillary lateral or terminal racemes. Calyx pedicelled: lobes nearly equal or the 2 upper united and shorter than the lower. Corolla white, pink, purple or red : petals clawed : standard suborbicular: wings oblique, lightly adhering to the incurved keel. Stamens diadelphous or monadelphous. Anthers alike. Ovary sessile. Ovules numerous or rarely few. Pod elongated, flat, 2-valved. Seeds variegated. [Tephrosia Pers.] The plants flower in summer, or from spring to fall in the South. Cat-Gut. Goat's Rue.

Stem monopodial : flowers in terminal or axillary sessile racemes.

Calyx-lobes ovate to lanceolate: plants pale- or gray-pubescent.

Calyx-lobes ovate, the upper shorter than the tube.

Calyx-lobes lanceolate, the upper longer than the tube.

Leaflets with oblong or elliptic blades: stems and raceme pubescent with short hairs.

Leaflets with linear-lanceolate or linear-oblong blades: stems and raceme woolly or villous.

Calyx-lobes very slender, often nearly setaceous : plants tawny-pubescent.

Stems sympodial: flowers in peduncled racemes which terminate the main axis at nne or more nodes.

Flowers relatively smail : standard less than $10 \mathrm{~mm}$. long.

Flowers relatively large: standard $10 \mathrm{~mm}$. long or longer.

Petioles longer than the leaflets.

Leaflets with linear to oblong or cuneate blades : pods about $4 \mathrm{~mm}$. wide. Leaflets with narrowly linear blades, slenderly acute.

Leaflets with oblong or cuneate blades, truncate or abruptly pointed.

Leaflets with obovate or suborbicular blades : pods $6 \mathrm{~mm}$. wide or wider. Petioles shorter than the leaflets.

Racemes many-flowered, the middle nodes bearing 3-4 flowers.

Racemes few-flowered, the flowers single or in pairs at the nodes. Stem, at least the lower part, clothed with a tawny spreading pubescence.

Leaflets with oblong or obovate blades, the terminal one nearly similar to the rest.

Leaflets with linear blades, the terminal one conspicuously elongated.

Stem clothed with an appressed or somewhat tomentose often lustrous pubescence, or nearly glabrous.

Leaves manifestly petioled, not prostrate.

Leaflets mostly $11-17$, relatively small.

Leaflets mostly $7-11$, relatively large.

Stems or branches prostrate : peduncles strigillose.

Stems or branches assurgent: peduncles hirsute.

Leaves sessile or nearly so, prostrate.

Calyx-lobes longer than the tube: leaflets $6-13 \mathrm{~mm}$. long: pods $3 \mathrm{~cm}$. long or more.

Calyx-lobes shorter than the tube: leaflets mostly $13-30 \mathrm{~mm}$. long: pods $2 \mathrm{~cm}$. long or less.

1. C. latidens.

2. C. Virginiana.

3. C. holosericea.

4. C. Rugelii.

5. C. purpurea.

6. C. gracillima.

7. C. ambigua.

8. C. Lindheimeri.

9. C. onobrychoides.

10. C. spicata.

11. C. Rexuosa.

12. C. hispidula.

13. C. Floridana.

14. C. Smallii.

15. C. chrysophylla.

16. C. Chapmanii.

1. Cracca làtidens Small. Root exceedingly long $(7-12 \mathrm{dm}$. $)$ from elongated rootstocks. Foliage finely and quite closely pubescent with pale hairs: stems often tufted, $2-5 \mathrm{dm}$. tall, finely ridged : leaves linear-oblong or narrowly oblong in outline, $5-9 \mathrm{~cm}$. long; leaflets 19-37, the blades of the lateral ones mainly oblong, sometimes oblongcuneate, 9-17 cm. long, mucronate, those of each leaf quite uniform in size : raceme fewflowered : calyx strigillose; lobes ovate, rather abruptly pointed, the upper ones shorter 
than the tube : corolla nearly similar to that of $C$. Virginiana; standard sparingly pubescent without.

In sand, peninsular Florida.

2. Cracca Virginiàna L. Root long, tougb. Foliage villous-hirsute or canescent throughout : stems woody at the base, tufted, simple, erect or ascending, 3-6 dm. tall, angled and striate: leaves elliptic or linear-oblong in outline, $6-10 \mathrm{~cm}$. long or longer, nearly sessile ; stipules caducous ; leaflets 11-21, the blades of the lateral ones 1-3 cm. long, mainly oblong or elliptic, obtuse or acutish, apiculate, glabrous or nearly so above, silky-villous beneath, often becoming glabrate with age: racemes often many-flowered: calyx silky-villous; lobes lanceolate, long-pointed, longer than the tube : corolla creamcolored, tinged with purple or pink; standard copiously pubescent without : pods $3-5 \mathrm{~cm}$. long, straight or somewhat curved, villous.

In dry sandy soil, Ontario to Manitoba, Florida, Texas and Mexico. Devil's Shoe-string.

3. Cracca holoserícea (Nutt.) Small. Foliage pale green, densely pubescent. Stems branched at the base, the branches tufted, $2-4 \mathrm{dm}$. tall, villous-hirsute : leaves mostly $8-12 \mathrm{~cm}$. long; leaflets 15-25, the blades of the lateral ones linear-oblong or linear-lanceolate, except the more or less cuneate terminal one, 1-2.5 cm. long, apiculate, conspicuously and densely silky: racemes terminal, sessile; rachis like the pedicels which sometimes become $1 \mathrm{~cm}$. long, densely villous-hirsute: calyx pubescent like the pedicels; lobes narrow, acuminate : corolla nearly $2 \mathrm{~cm}$. long : pods linear, curved, 4-6 cm. long.

On prairies, Arkansas and Louisiana and probably in Wisconsin and Illinois.

4. Cracca Rugèlii (Shuttleworth) Small. Root woody. Stem branched at the base: the several branches decumbent or assurgent, finely pubescent with bronze-colored hairs, leaves nearly oblong in outline; stipules 4-6 $\mathrm{mm}$. long, persistent; leaflets $3-11$, the blades of the lateral ones obovate, $8-17 \mathrm{~mm}$. long, retuse and mucronulate, finely appressedpubescent and yellowish green above, much paler or even gray and prominently veiny beneath : raceme terminating the stem, sometimes much reduced and represented by pairs of flowers in the upper axils: calyx tawny-villous; lobes very slender, nearly equal: corolla probably purple at maturity : pods about $3-8 \mathrm{~cm}$. long, somewhat falcate, tomentulose.

In pine woods, along the Manatee River, peninsular Florida.

5. Cracca purpùrea L. Root elongated, slender. Foliage strigillose or glabrate : stems erect or ascending, 1-6 dm. long, branched, the branches spreading : leaves oblong or linear-oblong in outline, $0.6-1 \mathrm{dm}$. long; petioles $1-3 \mathrm{~cm}$. long: stipules setaceous : leaflets $7-17$, the blades of the lateral ones linear, linear-oblong or oblong-cuneate, $2-5 \mathrm{~cm}$. long, obtuse or acute at both ends, apiculate, sometimes glaucous beneath: peduncles 2-sided: pedicel slightly longer than the calyx : calyx finely pubescent: lobes slender, as long as the tube : corolla white, turning purple, 6-10 $\mathrm{mm}$. long; standard minutely pubescent : pods linear, slightly falcate, $3-5 \mathrm{~cm}$. long, strigillose or glabrate.

In sandy soil, Florida to Arizona and Mexico. Also in eastern Central and South America to Brazil.

6. Cracca gracíllima (Robinson) Heller. Root relatively slender. Foliage glabrate or minutely pubescent : stems prostrate, very slender, 3-6 dm. long, diffusely branching, the branches flexuous : leaves linear-oblong in outline ; stipules $3-7 \mathrm{~mm}$. long, setaceous, persisting ; petioles $3-9 \mathrm{~cm}$. long; leatlets 5-17, the blades of the lateral ones linear, 1-3 cm. long, acute at each end, minutely pubescent beneath : peduncles $5-10 \mathrm{~cm}$. long: pedicels $7-10 \mathrm{~cm}$. long: bracts setaceous, persisting: caly $\mathrm{x}$ quite long-pedicelled; lobes lanceolatesubulate, about the length of the tube : corolla purplish, $8-12 \mathrm{~mm}$. long; standard pubescent : pods $3 \mathrm{~cm}$. long or longer, $4 \mathrm{~mm}$. wide, minutely hirsute, somewhat inflated at maturity.

In pine lands, near Eau Gallie, Indian River, southern Florida.

7. Cracca ambígua (M. A. Curtis) Kuntze. Root woody, elongated. Foliage hirsute with short spreading, somewhat viscid hairs : stems trailing or assurgent, 3-4 dm. long or longer, often purplish, dichotomously branching, straggling, angled : leaves 7-15 $\mathrm{cm}$. long, remote, linear-oblong in outline ; stipules $5-7 \mathrm{~mm}$. long, lanceolate, persisting; petioles $3-8 \mathrm{~cm}$. long; leaflets leathery, $7-11$, the blades of the lateral ones linear-oblong to cuneate-oblong or obovate, $2-14 \mathrm{~cm}$. long, acutish or mostly obtuse-apiculate, glabrous and yellowish green above, appressed-hirsute with whitish hairs and the nerves often turning reddish or purplish beneath: peduncles $1-1.5 \mathrm{~cm}$. long, ancipital : calyx lobes subulate, as long as the tube : corolla $10-13 \mathrm{~mm}$. long; standard pubescent : pods $4 \mathrm{~cm}$. long or more, $4 \mathrm{~mm}$. wide, nearly straight.

In high pine lands, dry soil. North Carolina to Florda and Mississippi. 
8. Cracca Lindheìmeri (A. Gray) Kuntze. Root tuberous and woody. Foliage cinereous-pubescent or sericeous : stems prostrate or ascending, 6-12 dm. long, rather stout, flexous, branching, spreading, more or less strongly angled : leaves oblong, linear-oblong, or obovate-oblong in outline; stipules somewhat persisting; leaflets $9-17$, the blades of the lateral ones obovate or suborbicular, $2-3 \mathrm{~cm}$. long, apiculate, pubescent above, densely sericeous or velvety-pubescent beneath : racemes loosely many-flowered: peduncle 1-2 dm. long: calyx sericeous; lobes acuminate, about the length of the tube : corolla redpurple, standard pubescent: pods $3-4 \mathrm{~cm}$. long, undulate, densely velvety-pubescent, tawny or yellowish.

In dry soil, Texas and New Mexico to northern Mexico.

9. Cracca onobrychoìdes (Nutt.) Kuntze. Root long. Foliage pilose with spreading rusty hairs. Stems erect, several dm. long, rather stout, simple or branching, flexuous, striate and angled above ; leaves oblong or linear-oblong in outline, 1-1.6 dm. long ; stipules 8-12 $\mathrm{mm}$. long, often persisting; petioles 1-3 cm. long; leaflets $13-23$, the blades of the lateral ones often retuse, apiculate, pubescent or glabrate above, more or less closely silkypilose beneath : peduncles rusty-villous or rarely glabrate: bracts $5 \mathrm{~mm}$. long, subulate, mostly caducous : pedicels slightly longer than the bracts: flowers 2 or several together, often the whole length of the peduncles : calyx more or less pubescent ; the upper lobes shorter than the tube, the lower one subulate, longer : corolla white turning to pale scarlet; standard pubescent on the outer surface, green toward the middle : pods $3-5 \mathrm{~cm}$. long, 5 $\mathrm{mm}$. wide, linear, acute, somewhat falcate, spreading, puberulent.

In dry soil, Arkansas and the Indian Territory to Alabama and Texas.

10. Cracca spicàta (Walt.) Kuntze. Root elongated. Foliage villous or villoushirsute : stems decumbent or ascending, 3-15 dm. long, simple or diffusely branched, angled, spreading, flexuous, often glabrate in age : leaves oblong or linear-oblong in outline, $0.5-1.5 \mathrm{dm}$. long; stipules more or less persistent, $5-10 \mathrm{~mm}$. long ; leaflets $5-15$, the blades of the lateral ones oval, oblong or cuneate-oblong, (terminal one mostly obovate), 1-2.5 $\mathrm{cm}$. long, often reflexed, mucronulate, more or less densely silky above : peduncles 2-edged, 1-3 dm. long: pedicels remote, few, or clustered near the top of the peduncle: bracts subulate, 5-10 mm. long: calyx-lobes subulate, slightly longer than the tube, copiously villous: corolla white, fading purple, $1-1.5 \mathrm{~cm}$. long; standard fully $1 \mathrm{~cm}$. long: pods linear, 3-5 cm. long, acute, rather straight.

In dry soil, Virginia to Tennessee, Florida and Mississippi.

11. Cracca flexuòsa (Chapm.) Heller. Root relatively slender. Foliage pubescent with somewhat spreading hairs or partially glabrate: stems slender, 2-6 dm. long, or longer, zigzag, sometimes almost glabrous, more or less spreading: Peaves few, $4-11 \mathrm{~cm}$. long; leaflets $3-17$, the blades of the lateral ones linear or nearly so, spreading or deflexed, delicately veined beneath, acute or short-acuminate, that of the terminal one conspicuously longer than those of the lateral: calyx-lobes lanceolate-subulate, longer than the tube, sparingly villous : corolla becoming purplish; standard about $1 \mathrm{~cm}$. long.

In dry or sandy soil, Florida and Alabama.

12. Cracca hispídula (Michx.) Kuntze. Root more or less fusiform. Foliage minutely appressed-pubescent or glabrate : stems 1-3 dm. long or longer, decumbent or assurgent, dichotomously branching, straggling, angled : leaves $3-6 \mathrm{~cm}$. long, linear-oblong in outline, with short petioles $5-10 \mathrm{~mm}$. long or the upper ones often sessile; leaflets $7-13$, the blades of the lateral ones elliptic, oval-oblong, or linear-oblong, $0.8-2 \mathrm{~cm}$. long, acutish, or sometimes obtuse, apiculate, reflexed, glabrous above, the nerves often turning purplish beneath : peduncles ancipital, $5-10 \mathrm{~cm}$. long : bracts $2-5 \mathrm{~mm}$. long, setaceous : calyx-lobes acute, as long as the tube : corolla white, turning pink, 10-12 mm. long; standard minutely pubescent : pods about $4 \mathrm{~cm}$. long, 4-6 $\mathrm{mm}$. wide, straightish or slightly falcate, minutely hispid.

In sandy soil and low pine lands, Virginia to Florida and Louisiana.

13. Cracca Floridàna Vail. Root relatively short, stout, woody. Foliage pubescent and somewhat viscid : stems spreading, prostrate, $2-6 \mathrm{dm}$. long or longer, dichotomously branching, angled above, clothed with a short appressed or spreading often somewhat viscid pubescence : leaves $4-10 \mathrm{~cm}$. long, oblong or rarely linear-oblong in outline; stipules 3-5 mm. long, subulate, often persisting; petioles 1-2.5 cm. long; leaflets 9-13, the blades of the lateral ones oblong or oblong-obovate, obtuse or truncate at the apex, apiculate, 1.5-3 cm. long, glabrous and yellowish green above, lighter, strigose with whitish hairs and the veins turning reddish beneath : peduncles $7-20 \mathrm{~cm}$. long, appressedpubescent : pedicels 5-8 mm. long, solitary or geminate : corolla becoming purple, 1-1.5 cm. long; standard finely pubescent: pods $3-4 \mathrm{~cm}$. long, $4 \mathrm{~mm}$. wide, erect, straight, strigillose.

In pine lands, Florida to Louisiana. 
14. Cracca Smállii Vail. Root elongated. Foliage pubescent throughout and somewhat viscid : stems branched from the base, the branches 4-6 dm. long, spreading, assurgent, flexuous, more or less angled ; leaves oblong-obovate in outline, 6-12 cm. long; stipules subulate, caducous ; petioles $1 \mathrm{~cm}$. long; leaflets $3-11$, the blades of the lateral ones oblongobovate, 1-3 cm. long, glabrous and yellowish green above, strigose with whitish hairs and becoming somewhat purplish beneath, truncate at the apex, apiculate : peduncles $8-15 \mathrm{~cm}$. long, hirsute: bracts 5-7 $\mathrm{mm}$. long: pedicels remote, each longer than its calyx : calyxlobes lanceolate, acuminate : corolla $1 \mathrm{~cm}$. long; standard minutely pubescent : pods $3.5-4$ $\mathrm{cm}$. long, about $4 \mathrm{~mm}$. wide, straightish, strigillose.

In dry or poor blackjack thickets, Georgia and Florida.

15. Cracca chrysophýlla (Pursh) Kuntze. Root woody, elongated. Foliage pubescent with more or less lustrous hairs. Stems prostrate, 3-10 dm. long, dichotomously branched : leaves oval in outline, $3-5 \mathrm{~cm}$. long, with very short petioles, or sessile ; stipules subulate, caducous ; leaflets leathery, 3-7 or rarely 1 , the blades of the lateral ones cuneateobovate, $1.3-3 \mathrm{~cm}$. long, obtuse or often retuse, sometimes apiculate, the terminal one conspicuously larger than the rest: peduncles two-sided, 4-6 $\mathrm{cm}$. long: pedicel shorter than the calyx or a little longer: calyx-lobes lanceolate or lanceolate-subulate, longer than the tube : corolla becoming purple; standard fully $1 \mathrm{~cm}$. long: pods $3-5 \mathrm{~cm}$. long, nearly straight, erect or spreading.

In sandy pine lands, Georgia to Florida and Mississippi.

16. Cracca Chapmánii (Vail) Small. Similar to C. chrysophylla in habit, but much smaller. Stems prostrate, $2 \mathrm{dm}$. long or longer, slender : leaves $1.5-3 \mathrm{~cm}$. long ; leaflets $5-7$, the blades of the lateral ones oblong to obovate, 6-12 $\mathrm{mm}$. long, rounded, truncate or retuse at the apex and often apiculate, resembling those of Stylosanthes riparia: peduncles about as long as the leaves or longer: calyx-lobes triangular, shorter than the tube: corolla becoming purple ; standard about $1 \mathrm{~cm}$. long : pods $2 \mathrm{~cm}$. long or less.

In sandy soil, Florida and Alabama to Louisiana.

\section{BRADLEìA Adans.}

Perennial vines, with climbing woody stems. Leaves alternate: blades unequally pinnate: leaflets often subtended by stipels, the blades entire. Flowers perfect, in terminal racemes. Calyx slightly 2-lipped, the 2 upper lobes partially united and shorter than the 3 lower. Corolla blue, purple or rarely white: standard broad, abruptly contracted into a claw with 2 appendages at the top: wings somewhat curved: keel incurved, obtuse. Stamens diadelphous. Anthers alike. Ovary stalked. Style inflexed. Ovules numerous. Pod elongated, 2-valved, flat, constricted between the seeds. [Wistarna Nutt.] Wisteria.

Racemes $4-10 \mathrm{~cm}$. long : calyx-lobes shorter than the tube.

Racemes 20-30 cm. long: calyx-lobes as long as the tube or the lower ones longer.

1. B. frutescens

2. B. macrostachys.

1. Bradleia frutéscens (L.) Britton. A slender vine becoming $12 \mathrm{~m}$. long. Leaves 1-2 dm. long : leaflets $9-15$, the blades oblong to ovate or lanceolate, $1.5-6 \mathrm{~cm}$. long, acute or slightly acuminate at the apex, acute or obtuse at the base : racemes ovoid to oblong, 4-10 cm. long, the rachis and pedicels lanuginous : calyx pubescent with appressed hairs, 6-7 mm. long: corolla lilac-purple, 15-18 $\mathrm{mm}$. long; standard with a suborbicular blade which has 2 incurved auricles at the base; wing-petals oblique, with a slender and short auricle on either side the claw : pods linear, $\overline{5}-10 \mathrm{~cm}$. long, flat.

In thickets and low grounds, climbing over trees, Virginia to Florida. Spring.

2. Bradleia macrostáchys (T. \& G.) Small. A stout climbing vine 1-8 m. long. Stems becoming $2-3 \mathrm{~cm}$. thick: leaves $2-3 \mathrm{dm}$. long or rarely shorter : leaflets usually 9 , the blades ovate or oval-ovate to elliptic or elliptic-lanceolate, $3-7 \mathrm{~cm}$. long, acuminate, ciliate, rounded or cordate at the base : racemes $2-3 \mathrm{dm}$. long, drooping, the rachis and pedicels densely hirsute and glandular : calyx pubescent like the pedicels; lobes lanceolate or narrowly lanceolate, acuminate, the lateral ones about as long as the tube and the lowest one much longer : corolla lilac-purple or light blue; standard with a short claw and suborbicular blade rather broader than high, about $1.5 \mathrm{~cm}$. in diameter : wing-petals $1.5 \mathrm{~cm}$. long, the subulate-linear spur about as long as the claw : pods $7-12 \mathrm{~cm}$. long,
reddish brown, rather obtuse : seeds oblong or cylindric-oblong, black, lustrous.

In swamps, Missouri to Tennessee and Arkansas. Spring. 


\section{ROBÍNIA L. ${ }^{1}$}

Shrubs or trees, with glabrous, glandular or bristly foliage, sometimes armed with spine-like stipules, the foliage not grandular-dotted. Winter buds naked, in the petiolebases. Leaves alternate: blades unequally pinnate: leaflets opposite or nearly so, the blades entire. Flowers perfect, in axillary or rarely terminal racemes. Calyx pedicelled : lobes 5 , acute, the 2 upper more united than the rest and often shorter. Corolla white, pink or purplish : standard with a broad reflexed blade, naked within : wings curved, free : keel-petals incurved, united below. Stamens 10, diadelphous; the free filament sometimes united to the middle of the tube. Anthers alike or those opposite the petals smaller. Ovary stalked. Style subulate. Ovules several. Pod narrow, flat, short-stalked, glabrous, bristly or prickly. Seeds oblique, with a thin crustaceous testa. Locust.

Pods smooth and glabrous: corolla white.

Pods prickly, hispid, bristly or glandular: corolla pink or purplish.

Peduncles not hispid.

Twigs, and often the petioles and pedicels, viscid.

Twigs and peduncles not viscid.

Leaves, twigs and peduncles glabrous.

Leaves and branches of the inflorescence pubescent.
Peduncles hispid.

Twigs hispid.

Twigs merely pubescent.

1. R. Pseudacacia.

1. Robinia Pseudacàcia L. A tree 6-35 m. tall, with firm brown furrowed bark, hard and very durable wood, especially in contact with the soil, horizontal or spreading branches, and short twigs, forming an oval or irregular crown. Foliage and inflorescence glabrous, or soon becoming so : stipules spiny on vigorous shoots : leaflets $9-19$, the blades thin, 2.5-4.5 cm. long, elliptic or ovate : racemes drooping, dense, 10-25-flowered, 1-2 $\mathrm{dm}$. long: corolla $15-20 \mathrm{~mm}$. long, white, except a yellow spot on the standard : pods glabrous, flat, $5-10 \mathrm{~cm}$. long, $10-15 \mathrm{~mm}$. wide, 3-10-seeded.

Native from Pennsylvania to Iowa, Georgia and the Indian Territory. Also naturalized in northeastern North America. Spring.

2. Robinia viscòsa Vent. A shrub, or exceptionally a small tree $3-8 \mathrm{~m}$. tall, with rough dark gray bark, and spreading branches forming a round crown, or in cultivation much larger. Twigs, pods, and often petioles and peduncles glandular-viscid : foliage and inflorescence glabrate or appressed-pubescent: stipules small, setaceous, exceptionally spiny on vigorous shoots : leaflets 11-27, the blades thick and firm, ovate, oblong or elliptic, 2.5-4 cm. long: racemes $5-8 \mathrm{~cm}$. long, 6-15-flowered, ascending : corolla $15-22 \mathrm{~mm}$. long, pink : pod flat, $5-8 \mathrm{~cm}$. long, often contracted between the seeds, sparingly glandularhispid, 2-7-seeded.

In dry rocky woods, middle North Carolina to Alabama. Local. Often escaped from cultivation in the Atlantic States. Spring.

3. Robinia Boyntònii Ashe. A large shrub 2-3.5 m. tall, with ascending branches. Twigs glabrous or at first minutely pubescent : stipular spines none : leaves 1-1.5 dm. long; leaflets $7-13$, the blades oblong or elliptic, $1.8-2.5 \mathrm{~cm}$. long, soon glabrous : racemes loosely 8-12-flowered : corolla rose-purple or pink, with white, about $18 \mathrm{~mm}$. long; standard with the blade abruptly contracted into the claw : peduncles ascending or spreading: pods slender, hispid.

On mountain slopes, usually at high elevations, North Carolina and Tennessee to Georgia and Alabama. Very local. Spring.

4. Robinia Ellióttil (Chapm.) Ashe. A shrub 6-15 dm. tall. Stem ereet, virgate, with few short, stout branches near the summit, the twigs, especially when young, white or grayish canescent: stipular spines short and stout: leaves 10-14 cm. long; leaflets $11-15$, the blades elliptic, $1.5-2.8 \mathrm{~cm}$. long: calyx, peduncles and pedicels canescent: corolla rose-purple or purple and white : pods linear, hispid.

Chiefly near the coast, North Carolina to Georgia. Local. Late spring.

5. Robinia híspida L. A straggling shrub $3-10 \mathrm{dm}$. tall, often branching from the base. Twigs, stem, peduncles, and often petioles and calyx, densely bristly hispid, or occasionally nearly smooth : stipular spines short, often present : leaves 1-2 dm. long; leaflets $7-11$, rarely 13 , the blades oblong to nearly orbicular, $1.8-3.5 \mathrm{~cm}$. long, glabrate : racemes 3-5-flowered : corolla about $25 \mathrm{~mm}$. long, purple or red-purple: pods $5-8 \mathrm{~cm}$. long, stout, few-seeded, densely hispid, and often glandular-hispid, with purple bristles.

In and near the mountains, Virginia and Kentucky to Georgia and Alabama. Spring and early summer.

${ }^{1}$ Contributed by Mr. W. W. Ashe. 
6. Robinia nàna (Ell.) Spach. A shrub 2-4.5 dm. tall, with a generally simple stem. Stem, peduncles and petioles more or less hispid, or nearly smooth, the young twigs and foliage often sparingly pubescent, soon glabrate: leaves 1-1.5 dm. long; leaflets 9-15, the blades elliptic or ovate, acute at the apex, rounded or acute at the base : racemes 3-6-flowered : corolla 16-20 mm. long, purple with white : pods oblong, bristlyhispid, but not as much so as that of the next preceding species.

In dry sandy soil, at low altitudes, North and South Carolina. Local. Spring.

\section{COURSÈTIA DC.}

Shrubs or trees, with pubescent foliage. Leaves equally or unequally pinnate: leaflets several, with very small stipels, the blades entire. Flowers perfect, solitary in the axils (in our species). Calyx pedicelled: lobes 5, nearly equal, the 2 upper strongly united. Corolla colored, sometimes showy : standard reflexed, with an orbicular or reniform blade : wings free : keel-petals incurved. Stamens 10, diadelphous or monadelphous to about the middle. Anthers all alike. Ovary sessile. Style incurved, pubescent along the inner side. Stigma capitate. Ovules several. Pod narrow, 2-valved, marginless.

1. Coursetia axillàris Coult. \& Rose. A much branched shrub or small tree, reaching a height of several $\mathrm{m}$., with finely pubescent young foliage. Branchlets somewhat zigzag: leaves clustered, 1-2 $\mathrm{cm}$. long: leaflets 7-11, the blades obovate or oblong-obovate, except the orbicular or oval lower pair, bright green, reticulated, entire, minutely pubescent beneath : flowers axillary, solitary : pedicels becoming $5-10 \mathrm{~mm}$. long: calyx strigillose, 4-5 $\mathrm{mm}$. long; tube campanulate ; lobes triangular-lanceolate or lanceolate, acute, longer than the tube : corolla barely $1 \mathrm{~cm}$. long; standard reflexed, the blade about $12 \mathrm{~mm}$. broad: pods linear, $3-3.5 \mathrm{~cm}$. long, glabrous, much constricted between the seeds, each narrowed into a broad stipe.

In dry soil, San Diego, Texas. Spring.

\section{SÉSBAN Adans.}

Herbs or shrubs, with upright stems. Leaves alternate, equally pinnate, with fugacious stipules: leaflets numerous, the blades entire. Flowers perfect, few in axillary racemes. Calyx pedicelled : lobes 5 , nearly equal. Corolla white, yellow, red or purple: standard broad, erect or reflexed : wings curved : keel-petals blunt. Stamens diadelphous (9 and 1): anthers alike or nearly so. Ovary often stalked. Style glabrous, incurved. Ovules numerous. Pod elongated, flat, narrow, neither 4-angled, nor winged, septate between the seeds, more or less torulose, dehiscent, the walls united. Seeds numerous. [Sesbania Scop.]

1. Sesban macrocárpa Muhl. Annual, glabrous, often glaucous. Stems 1-4 m. tall, widely branching: leaves pinnate; leaflets $20-70$, the blades oblong, $1-2.5 \mathrm{~cm}$. long, mucronulate: racemes shorter than the leaves : pedicels 5-10 mm. long: calyx membranous; lobes triangular, acuminate, shorter than the campanulate tube : corolla yellow : petals often spotted with purple; standard with a suborbicular blade $15-20 \mathrm{~mm}$. in diameter : pods elongated, $1.5-3 \mathrm{dm}$. long, slightly curved, the edges thickened, the sides constricted between the seeds.

In moist soil, Pennsylvania to Missouri, Florida, Texas and Central America. Spring to fall.

\section{AGÁTI Adans.}

Trees, usually of rapid growth and short-lived. Leaves alternate, with lanceolate stipules: blades equally pinnate : leaflets numerous, the blades entire. Flowers perfect, 2-4 in axillary racemes. Calyx pedicelled: tube campanulate, nearly truncate or 2lipped. Corolla ample: standard with an ovate to oblong blade: wings surpassing the standard: keel-petals curved, acuminate but obtuse, distinct at the base and the apex. Stamens 10, diadelphous (9 and 1), the sheath auricled at the base. Ovary short-stalked. Style subulate. Ovules several. Pod elongated, rather slender, flattened, wingless, more or less torulose, stipitate. Seeds several, separated by partitions.

1. Agati grandiflòra (L.) Desv. A small tree, with finely pubescent foliage or finally nearly glabrous. Leaves $1-3 \mathrm{dm}$. long, narrowly oblong in outline : leaflets numerous, the blades oblong or linear-oblong, $2-4 \mathrm{~cm}$. long, mostly truncate or retuse at the apex : racemes mostly $2-4$-flowered: calyx $2-2.5 \mathrm{~cm}$. long, the lobes broadly triangular, 
much shorter than the tube : corolla pinkish or red, or almost white, $6-10 \mathrm{~cm}$. long: pods narrowly elongated-linear, $2-4 \mathrm{dm}$. long, each with a stout stipe and a slender beak.

In sandy soil, southern peninsular Florida and Key West. Naturalized from the West Indies, but originally from the East Indies.

\section{GLOTTIDÍUM Desv.}

Annual caulescent herbs, often with very tall and branching stems. Leaves alternate : blades equally pinnate : leaffets numerous, the blades entire. Flowers perfect, in axillary racemes. Calyx pedicelled : lobes nearly equal. Corolla yellow or reddish purple : standard with a blade often broader than high, short-clawed: keel-petals coherent above the middle. Stamens 10, diadelphous (9 and 1). Anthers similar or nearly so. Ovary stalked. Style incurved at the apex. Ovules commonly 2. Pod relatively short, flattened, narrowed at both ends, wingless, dehiscent, the outer and inner walls distinct. Seeds 2, enclosed in the bladder-like inner walls of the pod.

1. Glottidium vesicàrium (Jacq.) Desv. Foliage glabrous. Stems 1-4 m. tall, widely branching: leaves pinnate ; leaflets $24-52$, the blades oblong, $1.5-4 \mathrm{~cm}$. long, mucronate, racemes shorter than the leaves: pedicels $8-12 \mathrm{~mm}$. long: calyx campanulate; lobes triangular, much shorter than the tube : corolla yellow, tinged with purple in drying; standard reniform about $1 \mathrm{~cm}$. broad : pods oblong, 5-8 cm. long, acuminate at both ends, the stipe $1-1.5 \mathrm{~cm}$. long.

In damp soil, North Carolina to Florida and Texas. Summer.-A form from middle Florida, with black-purple corollas, is G. vesicarium atrorübrum (Nash) Small. [G. Floridanum atrorubrum Nash. $\mid$

\section{DAUBENTÒNIA DC.}

Shrubs, with branching stems. Leaves alternate, with oblong stipules : blades equally pinnate: leaflets numerous. Flowers perfect, in simple axillary racemes. Calyx pedicelled : tube campanulate: lobes 5, minute. Corolla yellow : standard with a short claw and rounded blade : wings and keel-petals rather similar, obtuse. Stamens 10, diadelphous ( 9 and 1$)$; tube and free filament geniculate at the base : anthers all similar. Ovary stalked. Style slender, glabrous. Ovules several. Pod 4-sided and 4-winged, leathery, indehiscent. Seeds several, separated by partitions.

1. Daubentonia longifolia (Cav.) I)C. A shrub or small tree. Leaves pinnate : leaflets $12-60$, the blades oblong, $1-2.5 \mathrm{~cm}$. long, mucronate: racemes shorter than the leaves: pedicels $5-10 \mathrm{~mm}$. long, curved at the apex : calyx campanulate; lobes acute, ciliate, much shorter than the tube : corolla scarlet or paler: standard with a blade 13-18 $\mathrm{mm}$. broad : pods linear-oblong, 5-7 cm. long, 4-winged, the stipe $1-1.5 \mathrm{~cm}$. long.

In sandy soil. Florida to Texas and Mexico. Summer.

\section{GEOPRÚMNON Rydb. ${ }^{1}$}

Perennial tufted herbs, with decumbent or ascending stems. Leaves alternate, the stipules distinct and nearly free from the petiole : leaflets numerous, the blades entire, not notched. Flowers perfect, in dense short racemes. Calyx deeply campanulate or nearly cylindric : lobes nearly equal. Corolla white or purple, or rarely ochroleucous : standard with a rather narrow partially erect notched blade, much longer than the wings: wings longer than the keel-petals. Stamens 10: filaments diadelphous : anthers alike. Ovary sessile. Ovules numerous. Pod globular to nearly fusiform, fleshy becoming spongy, 2-celled, with the partition formed by the intruded and modified lower suture meeting the upper suture. Seeds numerous.

Pods pubescent.

Pods curved, over $2 \mathrm{~cm}$. long, wrinkled, gradually pointed.

Pods glabrous. less than $2 \mathrm{~cm}$. long, barely wrinkled, abruptly pointed.

Pods oblon.

Pods oblong-ovoid, acuminate.

Pods globular, pointless.

Calyx woolly : corolla white or ochroleucous.

Calyx strigillose: corolla purple.

1. G. Tennesseense.

2. G. Plattense.

3. G. pachycarpum.

4. G. Mexicanum.

5. G. crassicarpum.

1. Geoprumnon Tennesseénse (A. Gray) Rydb. Plant villous-hirsute. Stems long: branched at the base, the branches ascending or spreading, often stout, 1-3 dm. long: leaves $5-10 \mathrm{~cm}$. long: stipules membranous, broadly ovate, often $1 \mathrm{~cm}$. long; leaf-

${ }^{1}$ This genus, and the following Astragalus segregates, revised by Dr. Per Axel Rydberg. 
lets $15-33$, the blades narrowly oblong to oval, 4-12 $\mathrm{mm}$. long, obtuse or notched at the apex, short-stalked : peduncles about as long as the subtending leaves : racemes subglobose to oblong: calyx very thin ; lobes narrowly lanceolate, shorter than the oblong-campanulate tube : corolla $1.5-2 \mathrm{~cm}$. long : pods fleshy, $3-3.5 \mathrm{~cm}$. long, long-beaked, prominently ridged-reticulated, pubescent. [Astragalus Tennesseensis A. Gray.]

On hillsides, Missouri to Tennessee and Alabama. Spring.

2. Geoprumnon Platténse (Nutt.) Rydb. Plant villous or villous-strigillose. Stems more or less diffusely branched at the base, the branches 1-4 dm. long, becoming woody : leaves 4-10 cm. long; leaflets $13-23$, the blades oblong to elliptic or cuneate, 5-15 $\mathrm{mm}$. long, acute or rounded at the apex, short-stalked: peduncles shorter than the subtending leaves: racemes few-flowered : calyx membranous; lobes nearly subulate, shorter than the oblong tube : corolla about $1.5 \mathrm{~cm}$. long : pods fleshy, ovoid to subglobose, 1-1.5 cm. in diameter, sharply pointed, villous. [Astragalus Plattensis Nutt.]

In dry soil, on prairies, Minnesota to Indiana, Alabama and Texas. Spring.

3. Geoprumnon pachycárpum (T. \& G.) Rydb. Plant nearly glabrous or thinly pubescent. Stems more or less spreading, 1-2 dm. long, somewhat branched above : leaves $5-8 \mathrm{~cm}$. long; leaflets $17-31$, the blades oblong to cuneate, $5-14 \mathrm{~mm}$. long, obtuse, sometimes mucronulate, short-stalked : peduncles shorter than the accompanying leaves : calyx appressed-pubescent : corolla not seen : pods oblong-ovoid, 2-2.8 cm. long, flattened on the back, acuminate, but glabrous. [Astragalus pachycarpus T. \& G.]

On prairies, Arkansas and the Indian Territory. Summer.

4. Geoprumnon Mexicànum (A. DC.) Rydb. Plant villous-strigillose. Stems branched at the base, the branches stout, spreading, or decumbent, rather fleshy : leaves $5-10 \mathrm{~cm}$. long; leaflets $17-33$, the blades ovate to ovate-lanceolate, rounded or notched at the apex, short-stalked : peduncles commonly surpassing the subtending leaf-like bracts: racemes $2-8 \mathrm{~cm}$. long: calyx densely pubescent; lobes triangular to triangular-lanceolate, much shorter than the oblong tube: corolla cream-color, bluish at the tip, fully $1.5 \mathrm{~cm}$. long : pods fleshy, subglobose, $2.5-3 \mathrm{~cm}$. in diameter, glabrous, obtuse, sessile in the calyx. [Astragalus Mexicanus A. DC.]

On prairies, Illinois to Nebraska, Arkansas and Texas. Spring.

5. Geoprumnon crassicárpum (Nutt.) Rydb. Plant strigillose. Stems more or less diffusely branched at the base, the branches spreading or prostrate, 1-4 dm. long: leaves $3-10 \mathrm{~cm}$. long; leaflets $13-27$, the blades elliptic, oblong or oblong-lanceolate, 8-20 $\mathrm{mm}$. long, acute or obtuse, rarely notched at the apex, short-stalked : peduncles shorter than the subtending leaves or longer : racemes few-flowered : calyx membranous; lobes lanceolate to subulate-lanceolate, much shorter than the tube: corolla violet-purple, $1.5-2$ cm. long: pods subglobose or oval, fleshy, 2-2.5 cm. thick, short-pointed. [Astragalus crassicarpus Nutt.]

On prairies, Northwest Territory to Minnesota, Texas and Colorado. Spring.

\section{ASTRÁGALUS L.}

Perennial or annual herbs, various in habit. Leaves alternate, the stipules various: leaflets many or several, the blades entire, sometimes notched. Flowers perfect, in racemes. Calyx campanulate to tubular: lobes more or less unequal. Corolla variously colored : standard with a broad erect blade, often much longer than the other petals: wings about as long as the keel-petals. Stamens 10 : filaments diadelphous : anthers alike. Ovary sessile. Ovules few or numerous. Pod ovoid to oblong, sometimes nearly didymous, leathery or woody, perfectly 2-celled, dehiscent. Seeds few or many.

Pods copiously pubescent with spreading hairs. Pods glabrous or essentially so.

Corolla less than $1 \mathrm{~cm}$. long: pods $4-8 \mathrm{~mm}$. long.

Pods stipitate, about as broad as long.
Pods sessile, much longer than broad.

Corolla over $1 \mathrm{~cm}$. long: pods $12-18 \mathrm{~mm}$. long.

\section{A. Wrightii.}

\section{A. Brazoensis.}

3. A. reflexus.

4. A. Carolinianus.

1. Astragalus Wrightii A. Gray. Plant villous-strigillose. Stems simple and erect or branched at the base, the branches decumbent, $0.5-3 \mathrm{dm}$. long, commonly simple: leaves relatively few, often approximate; leaflets $7-11$, the blades oblong or narrowly elliptic, 5-15 mm. long, acute or acutish, short-stalked : peduncles surpassing the subtending leaves: racemes capitate: calyx densely villous; lobes linear-subulate, somewhat $1 \mathrm{~cm}$. long, pubescent, straight, capitate.

In dry soil, Texas. Spring. 
2. Astragalus Brazoénsis Buckl. Plant villous-strigillose. Stems mostly branched at the base, the branches decumbent or ascending, 3-20 $\mathrm{cm}$. long, sparsely hairy: leaves 3-6 cm. long; leaflets $9-21$, the blades oblong to obovate, $3-6 \mathrm{~mm}$. long, notched at the apex, short-stalked: peduncles surpassing the subtending leaves: racemes ovoid to oblong, 1-3 $\mathrm{cm}$. long: calyx membranous; lobes subulate-lanceolate, about as long as the tube : corolla whitish or violet, $5-8 \mathrm{~mm}$. long: pods nearly as thick as long, 6-8 $\mathrm{mm}$. in diameter, abruptly pointed.

In sandy soil, Texas. Spring.

3. Astragalus refléxus T. \& G. Plant finely villous. Stems simple and erect or branched at the base, the branches ascending or spreading, 1-4 dm. long : leaves 5-10 $\mathrm{cm}$. long; leaflets 13-15, the blades cuneate-obovate, 6-12 mm. long, notehed at the apex, short-stalked : peduncles surpassing the subtending leaves : racemes capitate : calyx membranous; lobes nearly subulate, about as long as the tube : corolla bluish white, 6-7 mm. long: pods leathery, narrowly conic, 7-8 $\mathrm{mm}$. long, deflexed, short-beaked, transversely wrinkled, deeply grooved above.

In dry soil, Texas. Spring and summer.

4. Astragalus Caroliniànus L. Plant glabrous or sparingly pubescent. Stems erect or ascending, 3-12 dm. tall, simple or branching above : leaves 1-3 dm. long; leaflets 1530 , the blades oblong, elliptic, or oblong-lanceolate, $2-4 \mathrm{~cm}$. long, obtuse or slightly notched at the apex, short-stalked : peduncles shorter than the subtending leaves or longer: racemes 3-15 cm. long, many-flowered: calyx membranous; lobes subulate-lanceolate, shorter than the tube : corolla greenish yellow, about $1.5 \mathrm{~cm}$. long: pods oblong, $12-18 \mathrm{~mm}$. long, inflated, 2-celled, glabrous, erect or ascending. [A. Canadensis L.]

In dry soil, Quebec to the Rocky Mountains, Georgia, Louisiana and Colorado. Summer.

\section{HAMOSA Medic.}

Annual or biennial herbs (our species), with decumbent stems. Leaves alternate, the stipules almost free and distinct: leaflets numerous, the blades entire, often truncate or notched at the apex. Flowers perfect, few, in short racemes. Calyx short-campanulate: lobes almost equal, mostly subulate. Corolla usually purplish : standard with a relatively broad blade: wings somewhat longer than the keel-petals. Stamens 10: filaments diadelphous : anthers alike. Ovary sessile. Ovules numerous. Pod linear, often elongated, laterally flattened, membranous or thin-walled, if at all sulcate only slightly so along the lower suture, 2-celled, the partition as in the 2 preceding genera. Seeds numerous.

Pods straight.

Pods curved.

Corolla over $12 \mathrm{~mm}$. long: pods $4.5-5.5 \mathrm{~mm}$. wide.

Corolla less than $11 \mathrm{~mm}$. long: pods $2-2,5 \mathrm{~mm}$. wide.

Pods glabrous.

Corolla 6-8 mm. long: leaflets cuneate to oblong, notched. Corolla 9-10 mm. long: leaflets linear, acute.

Pods pubescent.

1. Hamosa leptocárpa (T. \& G.) Rydb. Plant more or less densely strigillose. Stems nearly simple and erect or branched at the base, the branches ascending or spreading, 1-3 dm. long : leaves $3-8 \mathrm{~cm}$. long; leaflets $9-19$, the blades oblong to cuneate-oblong, 3-8 $\mathrm{mm}$. long, notched at the apex, short-stalked: peduncles surpassing the subtending leaves : racemes few-flowered : calyx thin; lobes lanceolate or triangular-lanceolate, acuminate, about as long as the tube : corolla purplish, $8-10 \mathrm{~cm}$. long: pods linear, $2.5-3 \mathrm{~cm}$. long, straight or nearly so, acute. [Astragalus leptocarpus T. \& G.]

In dry soil, Texas. Spring.

2. Hamosa Lindheìmeri (Engelm.) Rydb. Plant strigillose. Stems branched at the base, the branches ascending or prostrate, 1-4 dm. long: leaves $2-7 \mathrm{~cm}$. long, rather numerous ; leaflets $15-23$, the blades oblong to oval or oval-obovate, usually notehed at the apex, approximate, short-stalked: peduncles about as long as the subtending leaves or longer: racemes few-flowered : calyx membranous; lobes subulate-filiform, longer than the campanulate tube : corolla purplish, about $1.5 \mathrm{~cm}$. long : pods linear-scythe-shaped, $2.5-3$ $\mathrm{cm}$. long, beaked, finely reticulated. [Astragalus Lindheimeri Engelm.]

On plains and on rocky hills, Texas. Spring and summer.

3. Hamosa Nuttalliàna (DC.) Rydb. Plant sparingly silky-strigillose or nearly glabrous. Stems simple and erect or branched at the base, the branches ascending or spreading, 2-30 cm. long: leaves $2-5 \mathrm{~cm}$. long; leaflets $11-15$, the blades oblong, obovate or cuneate, 2-10 mm. long, mainly notehed at the apex, short-stalked : peduncles usually surpassing the subtending leaves: racemes loosely flowered: calyx membranous; lobes 
subulate-lanceolate, mostly longer than the tube : corolla purplish, 5-6 mm. long: pods linear, about $2 \mathrm{~cm}$. long, slightly curved, short-beaked. [Astragalus Nuttallianus DC.]

In dry soil, Arkansas and Texas to Arizona. Spring.

4. Hamosa macilénta Small. Plant somewhat strigillose. Stems tufted, 1-1.5 dm. long, ascending: leaves $2.5-4.5 \mathrm{~cm}$. long; leaflets 7-9, the blades linear, 9-12 $\mathrm{mm}$. long, acute, sessile or essentially so: peduncles surpassing the accompanying leaves : calyx sparingly pubescent ; lobes subulate, the lower ones longer than the tube : corolla purplish, nearly $1 \mathrm{~cm}$. long: pods linear, $2-2.5 \mathrm{~cm}$. long, glabrous.

On hillsides and prairies, near the Blanco, Texas. Summer.

5. Hamosa austrìna Small. Plant copiously strigillose. Stems branched at the base, the branches ascending or decumbent, 1-4 dm. long, mostly simple : leaves numerous, $1.5-5 \mathrm{~cm}$. long; leaflets mostly $9-11$, the blades oblong to oval, $2-6 \mathrm{~mm}$. long, acute or blunt : racemes head-like, on slender peduncles $1-4 \mathrm{~cm}$. long: calyx $4 \mathrm{~mm}$. long, very short-pedicelled; tube densely pubescent ; lobes subulate-lanceolate, longer than the tube: corolla purplish, 5-6 mm. long: pods linear, $1.5-2 \mathrm{~cm}$. long, strongly curved at the base, finely pubescent and very delicately reticulated.

On plains and prairies, Texas to California and Mexico. Spring.

\section{HOLCOPHÀCOS Rydb.}

Perennial low spreading herbs. Leaves alternate, the stipules nearly free and distinct : leaflets numerous, the blades entire, mostly truncate or notched at the apex. Flowers perfect, few in short racemes. Calyx short-campanulate: lobes short, relatively broad. Corolla pink or purplish : standard with a broad deeply notched blade : wings slightly longer than the keel-petals. Stamens 10 : filaments diadelphous: anthers alike. Ovary sessile. Ovules many. Pod linear or oblong, leathery, deeply sulcate along both sutures, but 1-celled, without even a partial partition. Seeds numerous.

Calyx-lobes triangular: pods about twice as long as broad.

Calyx-lobes lanceolate: pods 3-4 times as long as broad.

1. H. Engelmannii.

2. H. distortus.

1. Holcophacos Engelmánnii (Sheldon) Rydb. Plant nearly glabrous. Stems branching at the base, the branches diffuse or procumbent, $8-35 \mathrm{~cm}$. long, simple or branching: leaves $3-15 \mathrm{~cm}$. long; leaflets $15-25$, the blades oblong to obovate, $3-7 \mathrm{~mm}$. long, rounded or notched at the apex, short-stalked : peduncles surpassing the subtending leaves : racemes ovoid or oblong: calyx strigillose ; lobes triangular, shorter than the tube, more or less spreading: corolla purplish, about $1 \mathrm{~cm}$. long: pods 1-celled, glabrous, $1-1.8 \mathrm{~cm}$. long, about twice as long as broad. [Astragalus Engelmannii Sheldon.]

In dry soil, Texas. Spring and summer.

2. Holcophacos distórtus (T. \& G.) Rydb. Plant glabrous or sparingly pubescent. Stems branched at the base, the branches ascending or prostrate, $1-4 \mathrm{dm}$. long : leaves $3-8$ $\mathrm{cm}$. long ; leaflets $17-23$, the blades oval, obovate or cuneate, 3-10 mm. long, rounded or notched at the apex, short-stalked: peduncles about as long as the subtending leaves or longer : racemes ovoid or cylindric : calyx minutely pubescent; lobes lanceolate, shorter than the tube, erect: corolla purplish blue, $8-10 \mathrm{~mm}$. long : pods crescent-shaped, $2-2.5$ $\mathrm{cm}$. long, 3 to 4 times as long as broad, short-beaked. [Astragalus distortus $\therefore$. \& G.]

In dry soil, Iowa to West Virginia, Mississippi and Texas. Spring and summer.

\section{TİUM Medic.}

Perennial caulescent herbs, various in habit. Leaves alternate, the stipules nearly free and distinct: leaflets numerous, the blades entire. Flowers perfect, in short or elongated racemes. Calyx mostly campanulate: lobes nearly equal, sometimes relatively long. Corolla purple or ochroleucous, or white : standard with a relatively broad, sometimes notched, blade. Stamens 10: filaments diadelphous: anthers alike. Ovary more or less distinctly stipitate. Ovules numerous. Pod narrow, more or less tapering at both ends, usually stipitate, membranous or rather firm, 1-celled, obcordate or triangular in cross-section, the ventral suture strongly sulcate and rarely with a narrow partial partition.

Pods densely pubescent.

Pods glabrous.

Leaflets with obcordate blades : corolla less than $10 \mathrm{~mm}$. long : pods reticulated.

Leaflets with linear blades: corolla over $10 \mathrm{~mm}$. long: pods not reticulated.

1. T. intonsum.

2. T. obcordatum.

3. T. apilosum. 
1. Tium intónsum (Sheldon) Rydb. Plant villous. Stems branched at the base, the branches ascending or prostrate, $2-10 \mathrm{~cm}$. long, often branching: leaves 4-10 cm. long; leaflets $9-15$, the blades oblong, obovate to suborbicular, 3-10 mm. long, usually notched at the apex, slender-stalked : peduncles as long as the subtending leaves or longer: racemes suborbicular to ovoid, 1-2 $\mathrm{cm}$. long: calyx densely pubescent ; lobes lanceolatesubulate, as long as the tube or longer: corolla dull yellow, about $1 \mathrm{~cm}$. long: pods narrow, about $2 \mathrm{~cm}$. long, villous, slightly curved. [Astragalus villosus Michx. A. intonsus Sheldon.]

In sandy pine lands, South Carolina to Georgia and Florida. Spring.

2. Tium obcordàtum (Ell.) Rydb. Plant glabrous or nearly so. Stems branched at the base, the branches ascending or prostrate, 1-3 dm. long, sometimes sparingly branched : leaves numerous; leaflets 15-25, the blades obcordate or oblong-obcordate, 3-8 $\mathrm{mm}$. long, short-stalked : peduncles about as long as the subtending leaves : racemes ovoid to cylindric, $1-3 \mathrm{~cm}$. long : ealyx more or less pubescent ; Jobes narrowly lanceolate, about as long as the tube : corolla pale purple or blue, 7-10 mm. long: pods crescent-shaped, 3-3.5 cm. long, 1-celled, short-beaked, delicately reticulated. [Astragalus obcordatus Ell.]

In dry pine lands, Georgia and Florida. Spring.

3. Tium apilòsum (Sheldon) Rydb. Plant silky when young, glabrous in age. Stems erect, $3-9 \mathrm{dm}$. tall, sparingly branched : leaves few, $1-1.5 \mathrm{dm}$. long; leaflets $15-25$, the blades linear or nearly so, 1-2 cm. long, mucronulate or notched at the apex, shortstalked : peduncles surpassing the subtending leaves : racemes few-flowered, 4-10 cm. long: calyx more or less silky : lobes triangular or triangular-lanceolate, shorter than the tube : corolla white, $1.5 \mathrm{~cm}$. long: pods $3.5-4 \mathrm{~cm}$. long, acute, transversely wrinkled. [Astragalus glaber Michx. A. apilosus Sheldon.]

In pine lands, North Carolina to Florida. Spring.

\section{PHÀCA L.}

Perennial or annual herbs, sometimes almost acaulescent. Leaves alternate, the stipules nearly free, often partially united : leaflets many, the blades entire. Flowers perfect, in short or elongated racemes, or sometimes nearly sessile in the axils of the leaves. Calyx campanulate: lobes more or less unequal, sometimes longer than the tube. Corolla mostly ochroleucous, occasionally purple: standard with a relatively broad blade: wings longer than the keel-petals. Stamens 10: filaments diadelphous: anthers alike. Ovary sessile or stipitate. Ovules numerous. Pod membranous, inflated, neither suture intruded, 1-celled, without even a partial partition. Seeds numerous.

Leaflets 7-13: pods mostly less than $2.5 \mathrm{~cm}$. long.

Leaflets $13-17$ : pods mostly over $2.5 \mathrm{~cm}$. long.

1. P. lotiflora.

2. P. Reverchonii.

1. Phaca lotiflòra (Hook.) Nutt. Plant silky-villous. Stems wanting or short: leaves numerous; leaflets $7-15$, the blades oblong, elliptic or oblanceolate, $5-15 \mathrm{~mm}$. long, acute or obtuse, usually short-stalked: peduncles very short or surpassing the leaves in length: calyx densely pubescent; lobes narrowly lanceolate or almost subulate, longer than the tube : corolla yellowish, about $1 \mathrm{~cm}$. long: pods 1 -celled, less than $2.5 \mathrm{~cm}$. long.

On prairies, Northwest Territory to Nebraska, Texas and Colorado. Summer.

2. Phaca Reverchònii (A. Gray) Rydb. Plant silky or silky-pilose. Stems short, branching at the base, leafy : leaflets $13-17$, the blades narrowly elliptic to oblong, $6-15$ $\mathrm{mm}$. long, acute or obtuse, sessile or nearly so: peduncles $2-10 \mathrm{~cm}$. long, usually about as long as the leaves: racemes $1-2 \mathrm{~cm}$. long: calyx densely pubescent; lobes subulate-lanceolate, acuminate, usually longer than the tube : corolla yellowish, about $1 \mathrm{~cm}$. long: pods fully $2.5-3.5 \mathrm{~cm}$. long, canescent, acuminate. [Astragalus Reverchonii A. Gray.]

In dry limestome soil, the Indian Territory and Texas. Spring.

\section{XYLOPHÀCOS Rydb.}

Perennial mostly copiously pubescent, usually low, herbs, often essentially acaulescent. Leaves alternate, the stipules nearly free, distinct: blades entire. Flowers perfect, in short, often almost capitate, racemes. Calyx cylindric: lobes shorter than the tube. Corolla purple, or very rarely ochroleucous or crimson: standard with a narrow blade. only slightly longer than the wings. Stamens 10 : filaments diadelphous: anthers alike, Ovary sessile. Ovules many. Pod fusiform to ovoid, leathery or woody, pubescent, 1celled, without a partition, but the lower suture sometimes slightly sulcate. Seeds numerous. 
1. Xylophacos Missouriénsis (Nutt.) Rydb. Plant silky-strigillose with silvery hairs. Stems mostly tufted, often 1-10 cm. long: leaves approximate, mostly $5-15 \mathrm{~cm}$. long; stipules ovate-lanceolate, acute ; leaflets 7-21, the blades elliptic, oval to obovate, 6-10 $\mathrm{mm}$. long, acute or obtuse and mucronate: racemes few-flowered, $1-7 \mathrm{~cm}$. long: peduncles $5-20 \mathrm{~cm}$. long: pedicels $2-3 \mathrm{~mm}$. long: calyx mostly 9-10 mm. long; lobes about $\frac{1}{2}$ as long as the tube : corolla violet-purple, $2 \mathrm{~cm}$. long or slightly shorter : pods about $2.5 \mathrm{~cm}$. long, acuminate, transversely wrinkled, dehiscent, slightly keeled along the ventral suture. [Astragalus Missouriensis Nutt.] summer.

On prairies and plains, Northwest Territcry to Nebraska, Texas and New Mexico. Spring and

27. DALBÉRGIA L. f.

Shrubs, with upright or climbing branched stems. Leaves alternate : blades 1-foliolate or rarely unequally pinnate : leaflets often leathery. Flowers perfect, in small racemes or panicles, or cyme-like axillary clusters. Calyx pedicelled : lobes disposed in 2 lips, the 2 upper relatively broad, the 3 lower relatively narrow. Corolla white: standard with a broad blade: wings about as broad as the slightly incurved keel-petals. Stamens 8-10, monadelphous or diadelphous. Anthers erect: sacs opening by cracks at the apex. Ovary stalked. Style almost straight. Ovules 2 or sometimes solitary. Pod flat, suborbicular, indehiscent. Seed solitary.

1. Dalbergia Bròwnei (Pers.) Kuntze. A shrub 1-5 m. tall, with long wide-spreading branches. Leaves 1-foliolate, attenuate; leaflets leathery, the blades $5-15 \mathrm{~cm}$. long, ovate, oblong or elliptic, short-acuminate, minutely pubescent beneath, rounded or truncate at the base; petiolule as long as the petiole or shorter : panicles 1-2 cm. long, in the axils : pedicels $1-3 \mathrm{~mm}$. long : calyx campanulate, $1.5-2 \mathrm{~mm}$. long; lobes shorter than the tube : corolla white or pink, 7-9 mm. long : pods suborbicular, $2-3 \mathrm{~cm}$. in diameter, 1seeded, reticulated.

On river banks and shores, southern Florida and tropical America.

\section{ICHTHYOMÉNTHIA P. Br.}

Tropical trees, with a reddish brown scaly bark and stout branches. Leaves alternate without stipules: blades unequally pinnate : leaflets opposite, leathery, thickened at the margins, on slightly swollen petiolules. Flowers perfect, in large axillary thyrsoid panicles arising from the branches of the previous year. Calyx pedicelled : tube campanulate, persistent: lobes 5. Corolla white tinged with red, standard with a suborbicular, emarginate blade, canescent on the outer surface, with a green blotch on the inner; claw almost as long as the calyx : wings oblong-spatulate, auricled on the upper side : keel-petals broadly falcate; claws connate. Stamens 10 : filaments diadelphous (9 and 1$):$ anthers versatileuniform in size. Ovary linear, sessile, silky. Style subulate, incurved. Stigma capitate. Ovules numerous, pendulous, amphitropous. Pod linear, flattened, on a stalk which exceeds the calyx-tube, more or less constricted between the seeds, indehiscent, furnished with 4 broad wings, 2 to each suture. Seeds flattened, with a dull crustaceous testa.

2. Ichthyomenthia piscípula (L.) A. S. Hitchcock. An irregularly branched tree, sometimes $17 \mathrm{~m}$. tall, with pubescent young foliage. Leaves pinnate, 1-3 dm. long; leaflets $7-9$, the blades oblong varying to oval, obovate or rarely ovate, $2-10 \mathrm{~cm}$. long, abruptly acute or acuminate, undulate or shallowly toothed ; petiolules 4-7 $\mathrm{mm}$. long: panicles $1-1.5 \mathrm{dm}$. long, short-peduncled : pedicels $5-10 \mathrm{~mm}$. long: calyx campanulate; tube silky; lobes broadly triangular, shorter than the tube : corolla white : petals mostly striped with red ; standard with a suborbicular notched blade : pods elongated, 5-10 $\mathrm{cm}$. long, broadly 4-winged, the wings undulate or incised. [Piscidia Erythrina L.] thern Mexico.

In sand, near the coast, southern Florida and the Keys. Also in the West Indies and in nor-

\section{PSORÀLEA L.}

Herbs or shrubs, with fibrous or much enlarged woody roots and dark or pellucid, glandular foliage. Leaves alternate : blades $3-5$-foliolate : leaflets with entire or toothed blades. Flowers perfect, in axillary, usually peduncled spikes or racemes. Calyx-lobes nearly equal or the lower longer. Corolla of various colors, often variegated : standard broad, narrowed into a claw, the blades sometimes auricled : wings slightly scythe-shaped : keel often shorter than the other petals, incurved. Stamens diadelphous or monadel- 
phous: anthers alike or nearly so. Ovary sessile or short-stalked. Style filiform or dilated at the base. Ovules solitary or rarely 2 in a cavity. Pod broad, indehiscent.

Leaf-blades palmately 3 -5-foliolate or rarely 7 -foliolate.

Plants tall, with erect or ascending stems or branches.

Corolla 4-8 mm. long.

Pods lunate, with wrinkled sides.

Pods ovoid or ovate.

Pod abruptly narrowed into a short beak.

Pod gradually narrowed into a slender elongated beak.

Leaflets mostly 3: calyx filiform-pediceled, finely pubescent.

Leaflets mostly 5 : calyx sessile or nearly so, densely silky.

Corolla $10-20 \mathrm{~mm}$. long.

Bract fully as long as the calyx.

Leaflets broadest at the middle: corollas about $1 \mathrm{~cm}$. long.

Leaflets broadest above the middle : corollas $1.5-2 \mathrm{~cm}$. long.

Bract about as long as the pedicel or shorter.

Leaflets linear, many times longer than broad : stems simple or nearly so.

Leaflets broadest abore the middle, barely twice as long as broad : stems widely branched.

Plants low, acaulescent or acaulescent-like, with spreading stems or branches. Petioles strigose.

Petioles hirsute.

Leaflets glabrous except the margins and midnerve : calyx-lobes about as broad as long.

Leaflets pubescent: calyx-lobes elongated.

Leaflets pinnately 3 -foliolate or rarely 1 -foliolate.

Racemes short, subglobose to oblong.

Corolla 5-7 mm. long.

Pods suborbicular, reticulated.

Pods ovoid, not reticulated.

Stems or branches trailing: leaflets with entire blades.

Stems or branches erect: leaflets with toothed blades.

Corolla 10-20 mm. long.

Racemes elongated, cylindric.

Leaflets less than $2 \mathrm{~cm}$. broad : pods suborbicular, about $5 \mathrm{~mm}$. long.

Upper calyx-lobes triangular or triangular-ovate. Upper calyx-lobes lanceolate.

Leaflets over $2 \mathrm{~cm}$, broad: pods ovate, about $10 \mathrm{~mm}$. long.

Blades of the leaflets with rounded bases: standard with a blade $2-3 \mathrm{~mm}$. wide.

Blades of the leaflets with cordate bases: standard with a blade 7-8 mm. broad.

1. P. Lupinellus.

2. P. floribunda.

3. P. linearifolia.

4. P. digitata.

5. P. Reverchonii.

6. P. cuspidata.

7. P. cyphocalyx.

8. P. canescens.

9. P. hypogaea.

10. P. subacaulis.

11. P. esculenta.

12. P. virgata.

13. P. rhombifolia.

14. P. Americana.

15. P. simplex.

16. P. gracilis.

17. $P$. pedunculata.

18. P. Onobrychis.

19. P. macrophylla.

1. Psoralea Lupinéllus Michx. Foliage glabrous, somewhat glandular. Stems erect or nearly so, 2-6 dm. tall, often branched throughout: stipules setaceous : petioles usually shorter than the leaflets: leaflets 5-7, the blades linear-filiform, or those on the lower part of the stem narrowly linear, $3-8 \mathrm{~cm}$. long: peduncles surpassing the subtending bracts : racemes shorter than the peduncles: calyx campanulate; lobes triangular to triangular-lanceolate, the shorter ones nearly as long as the tube: corolla blue or violet, 4-6 mm. long: pods lunate, about $1 \mathrm{~cm}$. long, twisted, longitudinally wrinkled, with a curved beak.

In sandy pine lands, North Carolina to Florida. Spring and summer.

2. Psoralea floribùnda Nutt. Foliage canescent. Stems erect, $3-12 \mathrm{dm}$. tall, profusely branched: stipules subulate: petioles shorter than the leaflets : leaflets $3-7$, the blades oblong-linear or oblong-oblanceolate, 1-3.5 cm. long, glandular : peduncles surpassing the subtending bracts : racemes commonly about as long as the peduncles : calyx campanulate; lobes triangular, except the lower one, shorter than the tube : corolla bluish purple, 4-5 mm. long: pods ovoid, 6-8 $\mathrm{mm}$. long, glandular, with stout straight beak.

On prairies, Illinois to Montana, Texas, Arizona and Mexico. Spring to fall.

3. Psoralea linearifòlia T. \& G. Foliage strigillose or glabrate in age, more or less glandular. Stems erect, 2-6 dm. tall, widely branched : stipules setaceous to narrowly lanceolate : leaflets $1-3$, the blades linear, 2-6 $\mathrm{cm}$. long, wrinkled : peduncles much longer than the subtending bracts : racemes as long as the peduncles or shorter: calyx slightly pubescent; tube campanulate; lobes ovate or oblong-ovate, about as long as the tube: corolla blue, 7-8 $\mathrm{mm}$. long: pods oblong-ovoid, $8 \mathrm{~mm}$. long, glandular, with a straight short beak.

On prairies, Nebraska to Texas. Spring and summer.

4. Psoralea digitàta Nutt. Foliage pubescent with appressed hairs. Stems erect, 2-6 dm. tall, branched : stipules lanceolate : leaflets $3-5$, the blades linear to narrowly oblanceolate, $2-3.5 \mathrm{~cm}$. long, acute, somewhat glandular: peduncles elongated, longer than the racemes: calyx silky, accrescent ; tube turbinate-campanulate; lobes acuminate, the lower one longer than the tube : corolla $7-8 \mathrm{~mm}$. long; pods obliquely oval, included in the calyx, minutely pubescent, the body $5-6 \mathrm{~mm}$. long, the beak $4-5 \mathrm{~mm}$. long.

In sandy soil and on prairies, South Dakota to Texas. Spring and summer. 
5 Psoralea Reverchònii S. Wats. Foliage strigose, or glabrate below. Stems erect, 6-9 dm. tall, branching: stipules subulate: petioles shorter than the leaflets : leaflets 3-5, the blades linear-oblong or linear-elliptic, $1.5-3.5 \mathrm{~cm}$. long, acute at each end, glandular: peduncles sometimes shorter than the subtending leaves, corymbosely branched: calyx silky-strigose ; tube shorter than the narrowly lanceolate lobes : corolla fully $1 \mathrm{~cm}$. long: pods not seen.

On rocky prairies, the Indian Territory and Texas. Spring and summer.

6. Psoralea cuspidàta Pursh. Foliage strigillose-canescent or glabrate below. Stems erect, 4-6 dm. tall, branching : stipules subulate-lanceolate : leaflets 5 , the blades elliptic-oblanceolate to spatulate, $1.5-4 \mathrm{~cm}$. long, glandular, usually apiculate : racemes as long as the stout peduncles or shorter: calyx very glandular, somewhat accrescent; tube gibbous on the upper side; lobes oblong-lanceolate, longer than the tube, awn-tipped: corolla 1.5-2 cm. long: pods enclosed in the calyx, about $8 \mathrm{~mm}$. long, glabrous, each tipped with a short recurved beak.

On plains or prairies, Northwest Territory to Texas and New Mexico. Spring.

7. Psoralea cyphocàlyx A. Gray. Foliage strigillose. Root perpendicular with a globose thickening below the summit: stems erect, simple or sparingly branched, $4-9 \mathrm{dm}$. tall, rather wand-like: stipules linear: petioles much shorter than the leaflets: leaflets $3-5$, the blades linear to linear-oblanceolate, $1.5-10 \mathrm{~cm}$. long, glandular, acute : peduncles longer than the racemes: calyx densely strigose; tube gibbous on the upper side; lobes lanceolate, shorter than the tube : corolla $1 \mathrm{~cm}$. to nearly $1.5 \mathrm{~cm}$. in length : pods not seen.

In sandy soil and on dry bluffs, Texas. Spring.

8. Psoralea canéscens Michx. Foliage canescent. Root oval or fusiform: stems erect, 3-9 dm. tall, widely branching: stipules subulate-lanceolate : leaflets 3 , or 1 on the upper leaves, the blades glandular, varying from obovate or oval to suborbicular, $1.5-6 \mathrm{~cm}$. long, usually rounded at the apex, attenuate into petiolules: peduncles as long as the subbtending leaves or twice as long: calyx glandular, accrescent ; tube gibbous on the upper side ; lobes lanceolate or oblong-lanceolate, longer than the tube : corolla about $1 \mathrm{~cm}$. long: pods less than $1 \mathrm{~cm}$. long, with an oval or ovoid body and a straight acute beak.

In sand, North Carolina to Florida and Alabama. Spring.

9. Psoralea hypogaèa Nutt. Foliage strigose. Root globose or fusiform : leaves erect or spreading, with petioles much longer than the leaflets: : stipules lanceolate or oblonglanceolate : leaflets $5-7$, the blades linear to linear-oblanceolate, $1.5-4 \mathrm{~cm}$. long, acute: racemes subglobose to oblong, nearly sessile or on peduncles overtopping the leaves : calyx conspicuously pubescent; tube campanulate; lobes lanceolate, longer than the tube : corolla about $1 \mathrm{~cm}$. long: pods narrow, about $1 \mathrm{~cm}$. long, each with a slender attenuate beak.

On prairies, Nebraska to Colorado, Texas and New Mexico. Spring and summer.

10. Psoralea subacaùlis T. \& G. Foliage hirsute. Root elongated fusiform : stem subterranean : leaves with ascending or spreading petioles which are much longer than the leaflets : stipules ovate-lanceolate : leaflets $5-7$, the blades narrowly oblong, or oblongoblanceolate or obovate-oblong, $1.5-3 \mathrm{~cm}$. long, usually obtuse : peduncles often surpassing the leaves : racemes dense, shorter than the peduncles : calyx hairy; tube campanulate; lobes ovate, or the lower one oblong-ovate, much longer than the rest: corolla blue, $1-1.5^{*} \mathrm{~cm}$. long: pods not seen.

In rocky soil, Nashville, Tennessee. Spring.

11. Psoralea esculénta Pursh. Foliage hirsute. Root obovoid or fusiform : stems erect or spreading, $0.5-3 \mathrm{dm}$. long, usually branching: leaves with petioles surpassing the leaflets in length : stipules lanceolate to linear: leaflets 5 , the blades oblong, oblanceolate, or linear-elliptic or rarely cuneate, $2-5 \mathrm{~cm}$. long, commonly apiculate : peduncles usually glandular; tube gibbous on the top; lobes lanceolate, about as long as the tube, except the longer lower ones: corolla $1.5-2 \mathrm{~cm}$. long: pods enclosed in the calyx, the obovoid body shorter than the slender beak. and summer.

On plains or prairies, Northwest Territory to Montana, Wisconsin, Texas and Louisiana. Spring

12. Psoralea virgàta Nutt. Foliage strigillose, or glabrate below. Root fusiform or obovoid: stems erect, 3-7 dm. tall, simple or sparingly branched: stipules subulatelanceolate : leaflets mostly 1 , the blades glandular, linear or the lower ones oblong or ovate-oblong, acutish, reticulated, much longer than the petiole : racemes $2-4 \mathrm{~cm}$. long, 
surpassing the peduncles in length : calyx hirsute ; lobes lanceolate or oblong-lanceolate, acute, longer than the tube : corolla $6-7 \mathrm{~mm}$. long: pods suborbicular, oblique, about 5 $\mathrm{mm}$. long, strongly transversely wrinkled, with a curved beak.

In sand, eastern Georgia and Florida. Spring and summer.

13. Psoralea rhombifòlia T. \& G. Foliage more or less densely strigose. Roots short or elongated : stems branching at the base, the branches decumbent or prostrate, 1-9 dm. long, simple or branched: stipules lanceolate to ovate : leaflets 3 , the blades ovalrhomboidal varying to ovate or obovate, or those of the lower leaves suborbicular, 1-3 cm. long, acute or obtuse, sometimes mucronate: racemes head-like, much shorter than the peduncles : calyx pubescent : lobes lanceolate to oblong-lanceolate ; tube somewhat gibbous on top : corolla dark blue or reddish, about $5 \mathrm{~mm}$. long : pods about $1 \mathrm{~cm}$. long, hirsute, each with a long straight beak.

In dry soil, Texas and adjacent Mexico. Spring and summer.

14. Psoralea Americàna L. Perennial from a shrubby base, glandular throughout. Stems branched below, the branches erect or ascending, 6-12 dm. long: stipules lanceolate : leaflets 3 , the blades suborbicular in outline, $1.5-3.5 \mathrm{~cm}$. in diameter, irregularly crenate-dentate, the terminal one broadly cuneate at the base, the lateral ones oblique: racemes shorter than the peduncles which are longer or shorter than the petioles: calyx pubescent; lobes very unequal, the lower one much longer and broader than the lanceolate upper ones: corolla about $5 \mathrm{~mm}$. long: pods barely exceeding the calyx-lobes.

In waste places, Florida. Spring to fall.

15. Psoralea símplex Nutt. Foliage more or less strigose. Roots cylindric or turbinate : stems erect, $3-6 \mathrm{dm}$. tall, sometimes branched at the base, paniculate above: stipules subulate-setaceous : leaflets 3 , the blades lanceolate or oblong-lanceolate, $2-6 \mathrm{~cm}$, long, mucronate, reticulated : racemes usually shorter than the peduncles: calyx hirsute ; lobes lanceolate or the lower ones oblong, all longer than the tube : corolla fully $1 \mathrm{~cm}$. long: pods about $4 \mathrm{~mm}$. long, broader than long, with a high crest, obliquely wrinkeled, the beak short, upcurved.

In sandy soil, Arkansas to the Indian Territory, Alabama and Texas. Spring.

16. Psoralea grácilis Chapm. Foliage glabrous or sparingly strigillose. Stems usually branched at the base, the branches wiry, ascending or spreading, 2-7 dm. long. simple or sparingly branched above: stipules linear-lanceolate: leaflets 3 , the blades elliptic, oblong or oblong-lanceolate, or some of them on the lower part of the plant broadest above the middle, $1-3.5 \mathrm{~cm}$. long, usually obtuse or retuse, sometimes mucronate : peduncles much longer than the accompanying leaves: racemes $1-3 \mathrm{~cm}$. long: calyx sparingly pubescent; tube campanulate; the upper lobes triangular or triangular-ovate, mostly shorter than the tube: corolla purplish, 4-5 mm. long: pods suborbicular.

In sandy pine lands, southern Georgia and Florida. Spring and summer.

17. Psoralea pedunculàta (Mill.) Vail. Foliage strigillose, sometimes sparingly so. Stems 3-8 dm. tall, simple below or branched at the base, the branches erect or ascending, paniculate above : stipules linear-subulate: leaflets 3 , the blades lanceolate to narrowly oblong, or those of the lower part of the stem oblong-oblanceolate, 3-7 cm. long, usually acute: peduncles much longer than the subtending leaves, surpassing the racemes in length : calyx short-pedicelled; tube campanulate ; the upper lobes lanceolate, acute, longer than the tube: corolla purplish, $5-7 \mathrm{~mm}$. long: pods suborbicular, nearly $5 \mathrm{~mm}$. long, margined, transversely wrinkled. [P. melilotoides Michx.] summer.

In sandy soil or dry woods, Indiana to Kansas, North Carolina, Florida and Texas. Spring and

1-2 18. Psoralea Onóbrychis Nutt. Foliage softly pubescent or glabrate. Stems erect, $1-2 \mathrm{~m}$. tall, branched at least above: stipules nearly subulate: leaflets 3 , the blades ovate to ovate-lanceolate, $3-12 \mathrm{~cm}$. long, acuminate, ciliate, rounded at the base : peduncles surpassing the subtending petioles: racemes shorter than the peduncles: calyx campanulate; lobes ovate, obtuse, shorter than the tube: corolla $5-7 \mathrm{~mm}$. long : pods ovoid, $1 \mathrm{~cm}$. long, black, transversely prominently reticulated, twisted at the apex.

Along streams, Ontario to Missouri, South Carolina and Tennessee. Summer.

19. Psoralea macrophýlla Rowlee. Foliage finely pubescent. Stems erect or ascending, $5-9 \mathrm{dm}$. tall, simple or nearly so : leaflets 3 , the blades ovate, $6-10 \mathrm{~cm}$. long, blunt or notched at the apex, undulate, finely reticulated and slightly paler beneath than above, cordate or subcordate at the base, about as long as the petioles or shorter on the lower part of the stem : racemes $10-15 \mathrm{~cm}$. long; rachis closely pubescent, and with longstalked glands: pedicels $2-3 \mathrm{~mm}$. long: caly $\mathbf{x}$ pubescent like the rachis and pedicels; lobes lanceolate, acuminate, longer than the tube : corolla $8-9 \mathrm{~mm}$. long.

In woods, Tryon Mountain, North Carolina. Spring and summer. 


\section{AMÓRPBA L. ${ }^{1}$}

Shrubs, with glandular-punctate foliage. Leaves alternate: blades odd-pinnate. Flowers small, blue, purple or white, in spike-like racemes. Calyx subcampanulate, 5-lobed. Corolla incomplete : standard erect, clawed, folded around the stamens and style; wings and keel none. Stamens 10 : filaments united at the base, exserted. Ovary 2-celled. Style slender, bearded. Stigma terminal. Pod short, nearly indehiscent, 1-2-seeded.

Grayish or white-canescent shrubs: lowest pair of leaflets approximate to the stem. Calyx-lobes nearly equal, $2-2.5 \mathrm{~mm}$. long: pod with a stout divergent beak.

Calyx-lobes unequal, the longest about $1.5 \mathrm{~mm}$. long: pod with a slender, nearly erect beak.

Glabrous or inconspicuously pubescent shrubs : lowest pair of leaflets remote from the stem.

Leaflets with the veins very prominent beneath: inflorescence a long branched panicle.

Leaflets with the veins not noticeably prominent: inflorescence simple or of clustered racemes.

Pods curved on the back.

Blades of the leaflets mostly rounded at both ends, the midrib sometimes prolonged into a short mucro.

Flowers in long solitary racemes : pods not punctate or merely with few minute glands.

Flowers mostly clustered : pods punctate with many conspicuous raised glands.

Pods slender, about $6 \mathrm{~mm}$. long, about $2 \mathrm{~mm}$. broad.

Pods stout, about $8 \mathrm{~mm}$. long, about $3 \mathrm{~mm}$. broad.

Blades of the leaflets mostly acute at the apex, cuneate at the base: the midrib prolonged into a prominent awn-like cusp.

Pods nearly straight on the back.

Mature pods $7-8 \mathrm{~mm}$. long.

Calyx-lobes triangular, sharp-pointed, the sinuses narrow and acute. Length of leaflets not twice their width. Length of leaflets more than twice their width.

Calyx-lobes nearly obsolete or at most very shallow, the sinuses broad and obtuse : Jeaflets with thin and smooth blades.

1. A. canescens.

2. A. herbacea.

3. A. paniculata. Mature pods 4-6 mm. long.

Blades of the leaflets cuneate at the base: standard reniform, broader than long.

Blades of the leaflets rounded at the base: standard broadly spatulate, longer than broad.

4. A. nitens.

5. A. Tennesseensis.

6. A. fruticosa.

7. A. angustifolia.

8. A. Texana.

9. A. virgata.

10. A. montana.

11. A. laevigata.

12. A. glabra.

1. Amorpha canéscens Pursh. Suffruticose, $3-9 \mathrm{dm}$. high, the whole plant whitecanescent. Leaves curved, 5-12 cm. long; blades sessile or nearly so ; leaflets $15-47$, crowded, the blades oval or ovate-lanceolate, $9-18 \mathrm{~mm}$. long, rounded at the base, subacute at the apex : racemes dense, clustered, $5-18 \mathrm{~cm}$. long, the flowers on very short pedicels : calyx about $5 \mathrm{~mm}$. long: lobes subulate-lanceolate, nearly equal, $2-2.5 \mathrm{~mm}$. long: standard obovate or broadly spatulate, about $5 \mathrm{~mm}$. long, light blue : pods about $4 \mathrm{~mm}$. long, densely tomentose.

On dry prairies, Texas, New Mexico and northward. Summer.

2. Amorpha herbàcea Walt. Low and suffruticose, the whole plant grayish-pubescent. Leaves numerous ; blades very short-petioled, $4-16 \mathrm{~cm}$. long ; leaflets 11-37, the blades elliptic, oblong or oblong-ovate, $9-16 \mathrm{~mm}$. long, rounded at both ends, plainly dotted with dark glands; petiolules about $1 \mathrm{~mm}$. long: racemes clustered, $4-30 \mathrm{~cm}$. long: calyx about $4 \mathrm{~mm}$. long, the two upper lobes broader and shorter than the acute lower ones : standard broadly spatulate, 4-5 mm. long, varying from violet-purple to white : pods 4-5 mm. long, 2-2.5 mm. wide, rounded on the ventral and nearly straight on the dorsal suture, marked with numerous dark glands.

In sandy and sterile soil, North Carolina to Florida. Spring.

3. Amorpha paniculàta T. \& G. A coarse shrub $2-4 \mathrm{~m}$. high, with tomentosecanescent shoots. Leaves $12-30 \mathrm{~cm}$. long; leaflets $11-17$, the blades ovate- or ellipticoblong, 2-5 cm. long, rounded and often emarginate at the apex, obtuse or subcordate at the base, densely velvety-tomentose beneath, the upper surface shining and sparsely tomentose when young, becoming glabrate in age, the veins impressed on the upper surface and prominently raised on the lower : racemes long and slender, disposed in a large branching panicle : calyx about $4 \mathrm{~mm}$. long, the lobes subulate-lanceolate, about $2 \mathrm{~mm}$. long.

In swamps and salt marshes, eastern Texas. Summer.

4. Amorpha nitens Boynton. A branching nearly glabrous shrub $1.5-3 \mathrm{~m}$. high, with glossy twigs and shining leaves. Leaves $12-25 \mathrm{~cm}$. long; leaflets $7-19$, the blades thin, oblong-ovate or ovate, $2-6 \mathrm{~cm}$. long, obtuse, rounded at the base, lower surface dull

${ }^{1}$ Contributed by Mr. F. E. Boynton. 
and sparsely pubescent or glabrate: racemes slender, usually solitary, $12-25 \mathrm{~cm}$. long: caly $\mathrm{x}$ obconic, about $3 \mathrm{~mm}$. long; lobes short and rounded or the three lower short-pointed, ciliate on the margins : pods about $7 \mathrm{~mm}$. long, narrow, much curved and nearly glandless.

In swamps near Waynesboro, Georgia. Summer.

5. Amorpha Tennesseénsis Shuttl. A branching shrub $1.5-6 \mathrm{~m}$. high, with the young growth more or less elothed with fine tomentum. Leaves $6-20 \mathrm{~cm}$. long; blades petioled; leaflets $13-55$, the blades elliptic-oblong to oblong-ovate, $0.5-2 \mathrm{~cm}$. long, obtuse, rounded at the base and borne on short petiolules : racemes mostly clustered, $7-15 \mathrm{~cm}$. long: calyx about $3 \mathrm{~mm}$. long, the two upper lobes rounded, the three lower ones triangular, acute, the middle one a little longer than the others : standard obovate, narrowed into a claw-like base, about $4.5 \mathrm{~mm}$. long : pods 5-7 mm. long, much curved, marked with many raised glands.

On banks of streams, middle Tennessee, southward and eastward. Spring and summer.

6. Amorpha fruticòsa $L$. A branching shrub $1.5-6 \mathrm{~m}$. high, with the young growth more or less clothed with fine tomentum. Leaves 7-25 cm. long; blades petioled; leaflets 11-25, the blades oblong-ovate, oval or elliptic-oblong, 1.5-4 cm. long, obtuse, rounded at the base, on petiolules about $2 \mathrm{~mm}$. long : racemes usually clustered, $7-15 \mathrm{~cm}$. long: calyx about $3.5 \mathrm{~mm}$. long, the two upper lobes rounded, the three lower ones triangular, acute, the middle one a little longer than the others: standard round-obovate, emarginate, abruptly narrowed at the base, about $6 \mathrm{~mm}$. long : pods 7-9 $\mathrm{mm}$. long, usually much curved, conspicuously marked with large amber-colored, raised glands.

In swamps and on river banks, North Carolina to Florida and Louisiana, and naturalized northward. Spring and summer.

7. Amorpha angustifòlia (Pursh) Boynton. A much-branched shrub $1.5-3 \mathrm{~m}$. high, the young growth finely strigose-pubescent with grayish hairs. Leaves $7-20 \mathrm{~cm}$. long; leaflets $9-27$, the blades elliptic- to linear-oblong, 2-4 cm. long, mostly acute at both ends, the surfaces minutely puberulent : racemes single or a few in a cluster, $5-20 \mathrm{~cm}$. long : calyx about $3.5 \mathrm{~mm}$. long, the two upper lobes rounded, the lower sharp-pointed, the middle one the longest : standard broadly obovate, short-clawed, $4.5-5 \mathrm{~mm}$. long: pods 6-7 mm. long, strongly curved, plainly marked with raised glands.

On banks of streams, Texas and northward. Spring.

8. Amorpha Texàna Buckl. A branching shrub 1-3 m. high, the young growth slightly pubescent or glabrous. Leaves $8-18 \mathrm{~cm}$. long; blades petioled; leaflets $7-13$, the blades coriaceous, broadly oval, elliptic- or broadly oblong, 1-3 cm. long, 1-2.5 cm. broad, very obtuse and commonly emarginate, rounded or subcordate at the base, smooth and shining above, sparsely pilose or glabrate below, the petiolules $3-4 \mathrm{~mm}$. long: racemes 1-4, densely flowered, $5-12 \mathrm{~cm}$. long: calyx pubescent, about $4 \mathrm{~mm}$. long, the two upper lobes broad and rounded, the three lower ones acute, the middle one the longest : standard orbicular, abruptly narrowed at the base, about $7 \mathrm{~mm}$. long: pods about $7 \mathrm{~mm}$. long and half as broad, rounded on the ventral edge, nearly straight on the dorsal, marked with dark glands.

In rich soil, eastern Texas. Spring.-A variety, A. Texana mollis Boynton [A. laevigata var. pubescens A. Gray], differs in having all the parts clothed with fine, soft tomentum.

9. Amorpha virgàta Small. A glabrate shrub 1-2 m. high, with simple stems, or branching only at the summit. Leaves $8-16 \mathrm{~cm}$. long: leaflets 11-19, the blades firm in texture, oblong, oblong-ovate or ovate, $2-5 \mathrm{~cm}$. long, obtuse, emarginate or often subacute, rounded or subcordate at the base, nearly smooth above, sparsely pubescent beneath, the petiolules $2-3 \mathrm{~mm}$. long: racemes one or several, $8-15 \mathrm{~cm}$. long: calyx about $3 \mathrm{~mm}$. long, sparsely pubescent; lobes triangular, acute: standard orbicular, about $6 \mathrm{~mm}$. long, abruptly narrowed at the base : pods about $7 \mathrm{~mm}$. long, rounded on the ventral edge, nearly straight on the dorsal, dark brown, marked with small glands.

In rocky soil, Tennessee to Georgia and Florida. Spring.

10. Amorpha montàna Boynton. A glabrous, much-branched shrub 1-2 m. high. Leaves $7-15 \mathrm{~cm}$. long; leaflets $9-19$, the blades ovate, oblong-ovate or oval, $2-5 \mathrm{~cm}$. long. thin, glabrous on both surfaces, obtuse, often emarginate, rounded or subcordate at the base : racemes usually clustered, $6-15 \mathrm{~cm}$. long, glabrous : calyx campanulate, about $3 \mathrm{~mm}$.

- long; lobes very shallow and sparsely ciliate : standard orbicular, short-clawed, about 7 $\mathrm{mm}$. long: pods $7-8 \mathrm{~mm}$. long, rounded on the ventral edge, nearly straight on the dorsal, light brown, marked with few small glands.

In dry soil in the mountains, North Carolina to Tennessee, Georgia and Alabama. spring.

11. Amorpha laevigàta Nutt. A glabrous shrub. Leaves $9-18 \mathrm{~cm}$. long; leaflets 9-21, distant, the blades elliptic or elliptic-oblong, $2-4 \mathrm{~cm}$. long, obtuse or emarginate, 
cuneate at the base, on petiolules about $3 \mathrm{~mm}$. long : racemes single or clustered, $15-30 \mathrm{~cm}$. long: calyx glabrous ; lobes ciliate, the two upper rounded, the lower sharp-pointed: standard reniform, about $6 \mathrm{~mm}$. long, broader than long, short-clawed: pods about $5 \mathrm{~mm}$. long, rounded on the ventral edge, nearly straight on the dorsal, marked with numerous dark glands.

On river banks and moist prairies, Arkansas to eastern Texas. Spring.

12. Amorpha glábra Desf. A nearly glabrous shrub $1-2 \mathrm{~m}$. high. Leaves $7-16 \mathrm{~cm}$. long; leaflets numerous, the blades elliptic-oblong, 9-18 $\mathrm{mm}$. long, rounded at both ends, dotted with dark glands, the petiolules about $1 \mathrm{~mm}$. long : racemes one or several, $9-20 \mathrm{~cm}$. long, nearly glabrous : calyx 3-4 mm. long; lobes ciliate, the two upper rounded, the lower subulate-pointed : pods 4-5 mm. long, rounded on the ventral edge, nearly straight on the dorsal, marked with numerous dark glands.

In the coastal region, North Carolina to Florida. Summer.

\section{EYSENHÁRDTIA H.B.K.}

Shrubs or shrubby herbs, with glabrous or pubescent and often glandular-punctate foliage. Leaves alternate: blades unequally pinnate: leaflets numerous, with minute stipels. Flowers perfect, in terminal simple or panicled spike-like racemes. Calyx pedicelled : lobes nearly equal. Corolla white : petals erect, distinct, nearly equal in length; standard with blade broadened upward, concave; wings and keel-petals similar. Stamens 10: filaments united into a cleft tube. Anthers similar. Ovary nearly sessile. Style stout, hooked at the end. Stigma introrse. Ovules 2-3, or rarely 4. Pod flattened, straight or curved.

1. Eysenhardtia amorphoìdes H.B.K. A branching shrub 1-2.5 m. tall, with a whitish bark and more or less pubescent young foliage. Leaves numerous, 3-8 cm. long, short-petioled: leaflets 11-29, usually 20 , the blades oblong or oval-oblong, 2-10 mm. long, obtuse or retuse at the apex, reticulated above, paler and barely reticulated beneath: racemes spike-like, $2-10 \mathrm{~cm}$. long, sessile or nearly so : pedicels usually $1 \mathrm{~mm}$. long : calyx 2-3 mm. long, turbinate; lobes much less than $1 \mathrm{~mm}$. long: corolla $6-7 \mathrm{~mm}$. long: pods about $1 \mathrm{~cm}$. long, erect, curved.

On plains and prairies, Texas and adjacent Mexico. Spring and summer.

\section{PAROSÈlla Cav.}

Herbs or shrubs, with glandular foliage and erect or prostrate stems. Leaves alternate: blades unequally pinnately compound, or 3-foliolate: leaflets relatively small. Flowers perfect, in terminal or lateral spikes. Calyx-lobes nearly equal. Corolla white, purple or yellow : standard broad, above a long claw; blade cordate or auricled at the base : wings and keel-petals commonly longer than the standard, their claws adnate to the staminal tube. Stamens 10 or 9 , monadelphous. Anthers alike. Ovary sessile or shortstalked. Styles ubulate. Ovules 2 or 3 in a cavity. Pod membranous, included in the calyx, usually indehiscent. Seeds mostly solitary. [Dalea Willd.]

Calyx pubescent all over.

I Foliage glabrous to the inflorescence.

Leaf-blades mostly 5-many-foliolate : corolla white, purple or reddish.

Annual or perennial herbs.

Leaflets numerous : annual plants.

Leaflets 7-13: perennial plants.

Spikes more or less interrupted, not cylindric.

Spikes continuous, cylindric or oblong.

Calyx-lobes longer than the tube.

Calyx-lobes shorter than the tube.

Spreading shrubs.

Leaf-blades mostly 3-foliolate : corolla yellow.

Foliage variously pubescent.

Spikes stout and dense.

Leaflets appressed-silky.

Calyx-lobes subulate or bristle-like.

Calyx-lobes as long as the tube or little longer.

Spikes usually long-peduneled and solitary on the branches. Spikes short-peduncled and several on the branches.

Calyx-lobes about twice as long as the tube. Calyx-lobes lanceolate.

Leaflets villous.

Spikes loosely flowered.

Leaflets 9-13.

Calyx-lobes dilated at the base, the longer ones shorter than the tube. Calyx-lobes subulate, the longer ones surpassing the tube in length.

Leaflets 5-9.

Calyx glabrous except the ciliate lobes.

\section{P.'Dalea. \\ 2. P. enneandra. \\ 3. $P$. pogonathera. \\ 4. P. lasiathera \\ 5. P. formosa
6. P. Hallii.}
7. P. aurea.
8. P. nana.
9. P. Wrightii.
10. P. argyrea.
11. P. mollis.

12. P. lanata.

13. $P$. Domingensis.

14. P. thyrsiflora.

15. $P$. frutescens. 
1. Parosela Dàlea (L:) Britton. Foliage glabrous below the inflorescence. Stems simple and erect, or branched at the base, the branches decumbent or ascending, 2-6 dm. long: leaflets 15-41, the blades oblong, cuneate or oblanceolate, 3-8 mm. long, obtuse, at the apex, often cuneate at the base : spikes cylindric, $2-7 \mathrm{~cm}$. long : bracts ovate to lanceolate, acuminate, hyaline-margined: calyx densely silky, about equalling the bract in length : lobes linear-lanceolate, long-acuminate, plumose : corolla pink or pale violet, or the standard white. [Dalea alopecuroides Willd.]

On prairies and in dry soil, Minnesota to Alabama, Texas, New Mexico and Mexico. Spring to fall.

2. Parosela enneándra (Nutt.) Britton. Foliage glabrous to the inflorescence. Stems erect, 3-10 dm. tall, wand-like or usually branched, the branches ascending or spreading: leaflets $5-11$, the blades linear-oblong, or cuneate-oblanceolate, 5-10 mm. long, glandular, obtuse or acute, involute: spikes more or less interrupted, 2-11 cm. long, bracts suborbicular, about $4 \mathrm{~mm}$. long, mucronate : calyx silky, conspicuously surpassing the bract; lobes filiform-subulate, plumose, much longer than the tube: corolla white; standard ovate, cordate; wing-petals shorter than the keel : stamens 9.

On prairies, Iowa to South Dakota, Mississippi, Texas and Colorado. Spring and summer.

3. Parosela pogonáthera (A. Gray) Vail. Foliage glabrous. Stems branched at the base, the branches spreading or prostrate, $5-30 \mathrm{~cm}$. long, simple or branching : leaflets $5-11$, the blades linear-oblong to oblanceolate, $5-10 \mathrm{~mm}$. long, involute, obtuse or retuse at the apex : spikes oblong or cylindric, 1-6 $\mathrm{cm}$. long: bracts ovate, concave, mucronate, pale, glandular: calyx densely pubescent, surpassing the bract; lobes setaceous or subulate, plumose, much longer than the tube: corolla purple : stamens 10.

In dry soil, Texas to New Mexico and Mexico. Spring to fall.

4. Parosela lasiáthera (A. Gray) Heller. Foliage more or less glaucous or bright green. Stems branching at the base, the branches erect or ascending, 1-3 dm. long, simple or branching: leaflets 5-9, the blades linear-oblong or oblong-oblanceolate, 5-12 $\mathrm{mm}$. long, obtuse or retuse at the apex: spikes cylindric, $3-8 \mathrm{~cm}$. long: bracts ovateorbicular, 4-6 mm. long, cuspidate : calyx densely pubescent ; lobes subulate, shorter than the tube: corolla purple-red.

In dry soil, Texas to New Mexico and Mexico. Spring to fall.

5. Parosela formòsa (Torr.) Vail. Foliage glabrous. Stems woody, much branched, several dm. long, zigzag, sometimes with many short lateral branches: leaves inconspicuous, mostly about $1 \mathrm{~cm}$. long: leaflets $9-12$, the blades cuneate to oblong-cuneate, $2-4 \mathrm{~mm}$. long, thick, retuse at the apex, revolute: peduncles usually $5-10 \mathrm{~mm}$. long: bracts ovate, acuminate, ciliate, about $5 \mathrm{~mm}$. long : spikes head-like, 6 -10-flowered : calyx villous, fully $1 \mathrm{~cm}$. long: lobes subulate-setaceous, plumose, about twice as long as the campanulate tube : corolla bright purple, about $1.5 \mathrm{~cm}$. long.

In dry soil, Texas to New Mexico. Spring and summer.

6. Parosela Hállii (A. Gray) Heller. Foliage strigillose. Stems more or less copiously branched at the base, the branches 1-4 dm. long, ascending or spreading, slender, simple or with spreading hranches: leaves with petioles seldom $1 \mathrm{~cm}$. long: leaflets usually 3 , the blades linear, rather narrowly so, 1-2 cm. long, acute, pale, silky: spikes sessile or nearly so, $2-5 \mathrm{~cm}$. long, few-flowered, $1-1.5 \mathrm{~cm}$. thick, interrupted at maturity : bracts ovate, acuminate, about $5 \mathrm{~mm}$. long: calyx villous-hirsute, barely $1 \mathrm{~cm}$. long; lobes slender-subulate, somewhat longer than the tube, slightly plumose : corolla yellow about $1.5 \mathrm{~cm}$. long.

On rocky prairies, Texas. Spring to fall.

7. Parosela aùrea (Nutt.) Britton. Foliage pubescent with whitish appressed hairs. Stems often tufted, sometimes branched at the base, the branches usually simple: leaflets $5-9$, the blades oblong, obovate or oblanceolate, 6-18 $\mathrm{mm}$. long, obtuse or mucronulate, ciliate: spikes oblong or ovoid, $2-7 \mathrm{~cm}$. long, densely pubescent : bracts triangular-ovate or ovate, boat-shaped: calyx surpassing the bracts; lobes filiform-subulate, plumose : corolla yellow; standard shorter than the other petals.

On prairies, South Dakota to Missouri and Texas. Spring and summer.

8. Parosela nàna (Torr.) Heller. Foliage silky-strigillose. Stems branched at the base, the branches $5-15 \mathrm{~cm}$. long, ascending or spreading : leaflets $3-5$, the blades obovate, oblong-obovate or cuneate-oblanceolate, 5-10 mm. long, obtuse or mucronulate: spikes ovoid or oblong, 1-2 cm. long, short-peduncled : bracts oval or nearly so, 3-3.5 mm. long, mucronate: calyx surpassing the bracts; lobes subulate-filiform, plumose, longer than the tube : corolla white.

In dry soil, Texas to Arizona and Mexico. Spring to fall.

branched Parosela Wrightii (A. Gray) Vail. Foliage copiously pubescent. Stems branched at the base, the branches erect or ascending, $0.5-1.5 \mathrm{dm}$. tall : leaflets $3-5$, the 
blades elliptic to slighly obovate, $0.5-1.5 \mathrm{~cm}$. long, appressed-silky, acute : spikes stout, dense, 2-6 $\mathrm{cm}$. long: bracts lanceolate or oblong-lanceolate, $7-9 \mathrm{~mm}$. long, acuminate : flowers persistent : calyx densely villous-hirsute; lobes bristle-like, about twice as long as the tube : corolla purplish.

on plains and prairies, Texas to Arizona. Summer and fall.

10. Parosela argýrea (A. Gray) Heller. Foliage silky-pubescent. Stems erect, 3-6 dm. tall, corymbosely branched: leaflets $7-13$, the blades oblong to oblong-obovate, 5-12 mm. long, obtuse, glandular beneath, the pubescence lustrous on the upper surface: spikes subglobose becoming oblong, 1-3 cm. long: bracts ovate, $2.5 \mathrm{~mm}$. long, acuminate: calyx densely pubescent, surpassing the bracts; lobes lanceolate, somewhat shorter than the tube: corolla yellowish purple.

In dry soil, Texas and Mexico. Spring to fall.

11. Parosela móllis (Benth.) Heller. Foliage finely pubescent. Stems branched at the base, the branches pale, more or less spreading, irregular: leaflets $9-13$, the blades obovate to cuneate, 3-8 $\mathrm{mm}$. long, truncate or retuse at the apex, villous: spikes conspicuously elongating, but the flowers deciduous : bracts linear-lanceolate, 3-7 mm. long, acuminate, early deciduous : calyx densely pubescent; lobes subulate, much longer than the tube : corolla purple.

On plains, Texas to California and adjacent Mexico. Spring to fall.

12. Parosela lanàta (Spreng.) Britton. Foliage silky-woolly or merely woolly. Stems branched at the base, the branches decumbent, $2-6 \mathrm{dm}$. long, more or less diffusely branched : leaflets $9-13$, the blades 4-12 mm. long, obtuse, truncate or retuse at the apex, mostly cuneate, often contiguous : spikes $2-10 \mathrm{~cm}$. long, about $1 \mathrm{~cm}$. thick during anthesis, many-flowered, on peduncles $1-2 \mathrm{~cm}$. long : bracts ovate, acuminate, $3-4 \mathrm{~mm}$. long : calyx campanulate, $3-3.5 \mathrm{~mm}$. long; lobes lanceolate or deltoid-lanceolate below the subulate tips, shorter than the tube : corolla deep purple or red, 6-7 $\mathrm{mm}$. long.

On plains and prairies, Kansas to Utah, Texas and New Mexico. Summer.

13. Parosela Domingénsis (DC.) Heller. Foliage more or less densely velvety pubescent and glandular. Stems erect, 1-3 m. tall, branching: leaflets $13-15$, the blades oval, oblong, obovate or cuneate, 4-8 mm. long, rounded or retuse at the apex, flat : spikes solitary or paniculate, 1-3 cm. long: bracts ovate, acuminate : calyx silky, surpassing the bract; lobes subulate, plumose, longer than the tube: corolla mainly purplish, or sometimes nearly white.

In sand or dry soil, Florida and Texas. Also in tropical America. Throughout the year.

14. Parosela thyrsiflòra (A. Gray) Vail. Foliage finely and often closely pubescent. Stems erect, often 1-2 m. tall, branching, woody : leaves numerous, often spreading or reflexed, $2-6 \mathrm{~cm}$. long, with short petioles: leaflets $7-9$, the blades oblong, oval or broadest above the middle, 5-10 mm. long, obtuse or retuse at the apex, much paler beneath than above : spikes sessile or nearly so, in the upper axils, 1-2 cm. long: bracts lanceolate or oblong-lanceolate, acuminate : calyx becoming about $5 \mathrm{~mm}$. long ; tube ribbed at maturity ; lobes subulate, sparingly plumose, slightly longer than the tube : corolla 6-7 $\mathrm{mm}$. long. [Dalea Domingensis var. paucifolia Coulter.]

In dry soil, Texas and adjacent Mexico. Spring to fall.

15. Parosela frutéscens (A. Gray) Vail. Foliage glabrous. Stems erect, 3-6 $\mathrm{dm}$. tall, widely branched: leaflets $13-17$, the blades obovate to cuneate, $1-5 \mathrm{~m}$. long, retuse or notched at the apex, glandular beneath : spikes subglobose to oblong, $1-2 \mathrm{~cm}$. long, few-flowered : bracts ovate, obtuse : calyx strongly ribbed ; tube glabrous, covered with large glands; lobes triangular, acute, ciliate, much shorter than the tube: corolla violet.

In dry soil, Texas to New México and Mexico. Spring to fall.

\section{PETALÓstemon Michx.}

Perennial caulescent herbs, with glandular foliage. Leaves alternate : blades unequally pinnately compound: leaflets often broadest above the middle and involute. Flowers perfect, in short or elongated spikes; these not subtended by involucres. Calyslobes rather broad, shorter than the tube. Corolla white, pink, purple, violet or yellowish : standard broad, more or less abruptly narrowed into a claw : wings and keel-petals similar. Stamens 5, monadelphous. Ovary sessile. Style subulate. Ovules mostly 2 in each cavity. Pod short, mostly indehiscent. Seed solitary. Prairie-clover. 
Corolla white or yellowish.

Foliage densely villous-silky : corolla yellowish.

Foliage glabrous or thinly pubescent : corolla white.

1. P. obovatus.

Leaflets $13-37$.

Calyx pubescent: leaflets $29-37$.

Calyx merely ciliate : leaflets $13-17$.

Leaflets $3-11$.

Spikes cylindric or oblong.

Standard with a relatively narrow blade cuneate or constricted at the base.

Standard with a very broad blade cordate at the base.

Bracts with long-acuminate tips.

Bracts with short tips.

Stems and branches prostrate-spreading : spikes mainly $1-2 \mathrm{~cm}$. long. $6 . P$. gracilis. Spikes globular or ovoid.

stems and branches erect or ascending: spikes mainly $2-3 \mathrm{~cm}$. long. 7 . P. oligophyllus.

Corolla colored, usually pink, rose or purple.

Upper leaves with 11-31 leaflets.

Foliage densely villous.

Foliage glabrous or minutely pubescent.

Calyx silky-villous : annual.

Calyx glabrous; perennial.

Leaflets of an oblong type : calyx $4, \mathrm{~mm}$. long, about equalling the persistent bracts.

Leaflets of a linear type : calyx $3 \mathrm{~mm}$. long, much surpassed by the deciduous bracts.

Upper leaves with 3-9 leaflets.

Calyx copiously pubescent.

Pubescence of the calyx villous or silky-villous.

Leaflets linear or nearly so: bracts surpassing the buds.

Bracts with glabrous or merely puberulent tips.

Upper part of the plant with gray pubescence : calyx not ribbed: spikes dense.

Upper part of the plant with tawny pubescence : calyx ribbed: spikes loose.

Bracts with pubescent tips.

Tips of the bracts about as long as the bodies: pubescence tawny : leaflets obtuse.

2. P, microphyllus.

3. P. phleoides.

4. P. albidus.

5. P. candidus.

8. P. multiflorus.

9. $P$. griseus.

10. P. emarginatus.

11. P. foliosus.

12. P. Sabinalis.

13. P. purpureus.

14. P. Porterianus.

15. P. tenuifolius.

16. P. Gattingeri.

17. P. Reverchonii.

Leaflets oblong or oblanceolate: bracts shorter than the buds.

Pubescence of the calyx of short close-set appressed hairs.

Calyx-tube glabrate, glaucous.

Calyx-tube copiously pubescent, not glaucous.

Bracts shorter than the buds, and mature calyx : leaflets with tightly involute blades, about $1 \mathrm{~mm}$. wide.

Spikes less than $1 \mathrm{~cm}$. thick, slender: calyx $3 \mathrm{~mm}$. long

Spikes over $1 \mathrm{~cm}$. thick, stout : calyx $4 \mathrm{~mm}$. long.

Bracts longer than the buds, and mature calyx: leaflets with nearly flat blades $2-4 \mathrm{~mm}$. wide.

Calyx glabrate or merely eiliate.'

Spikes, or the most them, cylindric.

spikes subglobose.

18. P. pubescens.

19. P. Stanfieldii.

20. P. tenuis.

21. P. decumbens.

22. P. carneus.

23. P. Feayi.

1. Petalostemon obovàtus T. \& G. Plant densely villous-silky. Stems erect or ascending, several $\mathrm{dm}$. tall : leaflets $5-9$, the blades obovate to elliptic, $8-10 \mathrm{~mm}$. long, truncate or acute at the apex, cuneate to rounded at the base : spikes cylindric, $5-11 \mathrm{~cm}$. long: bracts oval-elliptic, with slender tips : calyx copiously pubescent; tube somewhat ribbed; lobes subulate-lanceolate, nearly as long as the tube: corolla yellowish, rather inconspicuous.

In dry soil, Texas. Spring and summer.

2. Petalostemon microphýllus T. \& G. Plant somewhat villous and glandular. Stems more or less branched at the base, the branches erect or ascending, 2-6 dm. tall : leaflets 29-37, the blades oblong to oblong-cuneate, 4-6 $\mathrm{mm}$. long, emarginate, glandulardotted : spikes narrowly cylindric, $2-5 \mathrm{~cm}$. long : bracts closely pubescent, with long filiform-subulate tips : calyx much shorter than the bracts; tube eampanulate; lobes triangular, barely $\frac{1}{2}$ as long as the tube : corolla white; standard with a broadly ovate cordate blade, the other petals with linear or nearly linear blades.

In dry soil, Texas. Spring and summer.

3. Petalostemon phleoìdes T. \& G. Plant sparingly villous or glabrate. Stems usually branched at the base, the branches erect or ascending, 3-7,dm. long, simple or sparingly branched: leaflets $13-17$, the blades oblong to cuneate-oblong, $3-10 \mathrm{~mm}$. long, usually rounded at the apex, glandular beneath, cuneate at the base: spikes cylindric, $1.5-6 \mathrm{~cm}$. long: bracts with subulate-filiform tips, early deciduous : calyx oblique ; tube campanulate ; lobes very short, often only $\frac{1}{5}$ or $\frac{1}{6}$ as long as the tube : corolla white ; standard with a hooded cordate blade; the other petals with linear blades.

In dry soil, Arkansas and Texas. Spring and summer. 
4. Petalostemon álbidus (T. \& G.) Small. Plant glabrous. Stems often branched at the base, the branches erect or ascending, 6-10 dm. tall, more or less branched: leaves usually clustered : leaflets 5-7, the blades oblong to oblanceolate, 4-8 mm. long, acute, involute : spikes subglobose to cylindric, $1-2 \mathrm{~cm}$. long, peduncled : bracts narrow, about as long as the calyxes, persistent : calyx glabrous, $2.5 \mathrm{~mm}$. long ; lobes triangular to triangular-lanceolate, shorter than the tube : corolla white ; standard usually retuse, the blade slightly broader than the rest of the petals. [P. carneus $\beta$ albidus T. \& G.]

On sand hills and in pine lands, Georgia and Florida. Summer.

5. Petalostemon cándidus (Willd.) Michx. Plant glabrous or nearly so. Stems erect, 3-7 dm. tall, branched at the base or above : leaflets $7-9$, the blades linear, oblong, oblanceolate or obovate-oblanceolate, 1-3 cm. long, acute, or mucronulate, glandular benoath, more or less cuneate at the base : spikes cylindric or oblong-cylindric $2-10 \mathrm{~cm}$. long: bracts lanceolate with subulate tips: calyx shorter than the bract; tube campanulate, angled; lobes triangular to triangular-lanceolate, slightly pubescent, shorter than the tube : corolla white; standard with a suborbicular cordate blade; keel-petals with oval blades, the claws longer than the blades.

On prairies, Northwest Territory to Minnesota, Indiana, Mississippi, Texas and Colorado. Summer.

6. Petalostemon grácilis Nutt. Plant glabrous. Stems branched at the base, the branches $3-6 \mathrm{~cm}$. long, slender, simple or branching, decumbent: leaflets $5-7$, the blades linear or linear-oblong, rarely oblong-oblanceolate, 6-12 mm. long, acute, involute, distant : spikes oval or ovoid, becoming cylindric, 1-2 cm. long : bracts elliptic, with subulate tips: calyx shorter than the bract; tube campanulate; lobes triangular, purple, acute, ciliate, hardly $\frac{1}{2}$ as long as the tube : corolla white; standard with a broad cordate blade.

In sand, Florida to Louisiana. Spring and summer.

7. Petalostemon oligophýllus (Torr.) Rydb. Plant glabrous. Stems erect, 3-9 dm. tall, much branched above, the branches ascending: leaflets firm, $5-9$, usually 7 , the blades linear, linear-oblong or varying to oblanceolate, $0.5-2 \mathrm{~cm}$. long, acute, or mucronulate, glandular, sometimes early deciduous : spikes oblong, becoming oblong-cylindric, 2-3 $\mathrm{cm}$. long: bracts lanceolate or ovate-lanceolate with filiform-subulate tips: calyx shorter than the bract; tube campanulate, ribbed; lobes triangular, often pubescent, acute : corolla white ; standard with a very broad cordate blade.

On prairies, South Dakota and Wyoming, Texas, Arizona and Mexico. Spring to fall.

8. Petalostemon multiflòrus Nutt. Plant glabrous. Stems usually several together, rigid, 3-6 dm. tall, much branched throughout: leaflets $3-9$, the blades linear to linearoblong, or oblanceolate, acute or obtuse, glandular on both sides, mostly involute : spikes globular or ovoid, $1-1.5 \mathrm{~cm}$. long: bracts subulate: calyx surpassing the bract; tube campanulate, ribbed; lobes triangular, shorter than the tube: corolla white; standard with an ovate blade cordate or subcordate at the base.

In dry soll on prairies, Kansas to Texas. Spring and summer.

9. Petalostemon griseus T. \& G. Plant villous. Stems erect or ascending, $2-7 \mathrm{dm}$. tall, more or less branched : leaflets 9-17, the blades oblong, oblanceolate or linear-oblong, 6-12 mm. long, mucronate, glandular, finely pubescent: spikes narrowly cylindric, $2.5-4$ cm. long: bracts deciduous, with long slender tips : calyx densely pubescent; tube campanulate; lobes triangular-lanceolate, shorter than the tube : corolla pink or pink-purple; standard with a broad cordate blade.

In dry soil, the Indian Territory and Texas. Spring and summer.

10. Petalostemon emarginatus T. \& G. Plant glaucous. Stems branched at the base, the branches decumbent, $2-5 \mathrm{dm}$. long, simple or sometimes branched : leaflets $15-17$, the blades cuneate or narrowly oblong-cuneate, $2-7 \mathrm{~mm}$. long, emarginate at the apex, glandular, rather cuneate at the base: spikes ovoid to oblong-cylindric, $1-3 \mathrm{~cm}$. long: bracts abruptly acuminate, villous : calyx villous; tube campanulate, oblique ; lobes lanceoor truncate blade, the other petals with oblong blades.

In dry soil, Texas. Spring and summer.

11. Petalostemon foliòsus A. Gray. Plant glabrous. Stems erect or decumbent, 3-9 dm. long, simple or branched : leaflets 13-31, the blades oblong to oblong-oblanceolate, paler beneath than above : spikes oblong-conic becoming cylindric, $2-5 \mathrm{~cm}$. long: bracts lanceolate, with subulate tips much surpassing the calyxes, persistent: calyx glabrous, $4 \mathrm{~mm}$. long; tube obliquely campanulate; lobes triangular-lanceolate, shorter than the tube, acute : corolla rose-purple; standard with a very broad cordate blade, the other petals somewhat narrower.

On river banks, Illinois, Kentucky and Tennessee. Summer. 
12. Petalostemon Sabinàlis S. Wats. Plant glabrous, yellowish green. Stems branched at the base, the branches ascending, 2-4 dm. long, commonly simple: leaflets 11-15, the blades linear or slightly broadened upward, 10-15 mm. long, nearly flat, glandular-dotted beneath, blunt: spikes cylindric, 4-6 cm. long, about $1 \mathrm{~cm}$. thick, excluding the corollas, peduncled : bracts about as long as the calyxes, deciduous : calyx glabrous without, about $3 \mathrm{~mm}$. long; tube ribhed at maturity; lobes triangular, shorter than the tube: corolla rose-colored; standard notched at the apex, the other petals obtuse.

on dry plains or prairies, Texas. Spring and summer.

13. Petalostemon purpùreus (Vent.) Rydb. Plant glabrous or sparingly pubescent. Stems often tufted, erect or ascending, 3-9 dm. tall, more or less branched above : leaflets $3-5$, the blades narrowly linear, $8-20 \mathrm{~mm}$. long, acute, strongly involute : spikes oval to cylindric, $1.5-5 \mathrm{~cm}$. long : bracts oblanceolate, abruptly acuminate : calyx silky, usually surpassing the bract; tube campanulate; lobes triangular, much shorter than the tube : corolla violet or purple; standard with a dilated blade cordate or subcordate at the base. [Petalostemon violaceus Michx.]

On prairies, Northwest Territory to Minnesota, Indiana, Texas and Colorado. Summer.

14. Petalostemon Porterianus Small. Plant sparingly pubescent, but the upper parts, at least, tawny-pubescent. Stems $2-3 \mathrm{dm}$. tall, or sometimes taller, more or less branched : leaflets $3-5$, the blades nearly linear, $8-14 \mathrm{~mm}$. long, strongly involute : spikes oblong or cylindric, $1.5-2 \mathrm{~cm}$. long : bracts surpassing the buds: calyx villous; tube prominently ribbed; lobes shorter than the tube : corolla violet-purple.

On prairies, Arkansas. Summer.

15. Petalostemon tenuifolius A. Gray. Plant somewhat pubescent. Stems usually branched at the base, with erect or ascending branches, $1.5-3 \mathrm{dm}$. tall, pale : leaflets $3-5$, the blades linear to linear-spatulate, $8-18 \mathrm{~mm}$. long, involute, blunt, sparingly glandular: spikes cylindric, $2-4 \mathrm{~cm}$. long, barely $1 \mathrm{~cm}$. thick : bracts rather abruptly contracted into slender subulate tips : calyx silky-villous like the bracts, becoming about $4 \mathrm{~mm}$. long: lobes triangular-lanceolate, about as long as the tube: petals rose-colored; standard with a cordate hooded blade.

On plains or prairies, Arkansas to Arizona. Summer.

16. Petalostemon Gattíngeri Heller. Plant sparingly pilose or glabrous below. Stems usually several together, $2-5 \mathrm{dm}$. long, ascending or decumbent, simple or much branched : leaflets 5-7, the blades narrowly linear or linear-oblong, 1-2 cm. long, glandular, slender at the base: spikes cylindric, $3-10 \mathrm{~cm}$. long : bract oval-lanceolate with snbulate tips, pubescent: calyx villous-pilose, shorter than the bract; tube campanulate, ribbed; lobes lanceolate or triangular-lanceolate, acute: corolla rose-purple; standard with a broad blade truncate or cordate at the base.

On rocky barrens and in cedar glades, Tennessee. Spring and summer.

17. Petalostemon Reverchònii S. Wats. Plant bright green. Stems branched at the base, the branches more or less diffuse, 1-2 dm. long, finely pubescent : leaflets glabrous, 5-11, the blades linear or linear-oblanceolate, 7-10 mm. long, acutish, somewhat involute: spikes subglobose or oblong-globose, $1-1.5 \mathrm{~cm}$. long, becoming 4-7 cm. long at maturity, about $1 \mathrm{~cm}$. thick : rachis tomentulose : bracts mostly shorter than the calyxes, deciduous : calyx about $4 \mathrm{~mm}$. long, silky-villous ; lobes acute or acuminate: corolla red or deep pink.

On the summit of Comanche Peak, Texas. Spring and summer.

18. Petalostemon pubéscens (A. Gray) Heller. Plant glaucous. Stems usually several together, erect or ascending, $3-7 \mathrm{dm}$. tall, simple or nearly so: leaflets $3-7$, the blades linear, $10-14 \mathrm{~mm}$. long, acute, glandular beneath, involute, slender-stalked : spikes oblong or oval, $2-4 \mathrm{~cm}$. long: bracts broadly ovate, short-tipped : calyx surpassing the bract ; tube campanulate, glabrate; lobes triangular-lanceolate, acuminate, silvery pubescent : corolla rose-purple; standard with a cordate or subcordate blade.

In dry soil, Texas. Spring and summer.

19. Petalostemon Stanfieldii Small. Plant glabrous to the inflorescence. Stems tufted, 1-3 dm. tall, often branched near the base, the peduncles or most of them slightly shorter than the leafy stem: leaflets $3-5$, the blades linear or narrowly linear-spatulate, 5-12 mm. long, acute, strongly involute : spikes cylindric or oblong-cylindric, 1-2.5 $\mathrm{cm}$. long, less than $1 \mathrm{~cm}$. thick: calyx puberulent; lobes triangular, about one-half as long as the tube: corolla rose-purple; standard with a broad cordate or subcordate blade. On plains or prairies, Texas. Summer. 20. Petalostemon ténuis (Coulter) Heller. Plant nearly glabrous below the in-
florescence. Stems 3-4 dm. tall, relatively slender, somewhat glaucous, branched: leaf- 
lets mostly 3, the blades strongly involute, thus almost linear-subulate, 5-11 mm. long, acute : spikes globular or oval, $1.2-1.6 \mathrm{~cm}$. long, fully or nearly as thick: calyx $4 \mathrm{~mm}$. long, minutely and closely appressed-pubescent with somewhat lustrous hairs, surpassing the bract : corolla pink-purple.

In dry soil, central Texas. Spring and summer.

21. Petalostemon decúmbens Nutt. Plant thinly pubescent above or glabrate. Stems solitary or several together, ascending or decumbent, 3-6 dm. long, mostly simple : leaflets 5-7, the blades linear or linear-oblong, $8-18 \mathrm{~mm}$. long, acute or mucronulate, glandular, more or less involute : spikes ovoid or oblong, 1-2 cm. long : bracts ovate-lanceolate, with subulate tips: calyx strigillose, shorter than the bract; tube campanulate; lobes lanceolate or ovate-lanceolate, shorter than the tube, acute: corolla pink or rose-purple; standard with an oblong-ovate cordate blade, the other petals with oblong blades.

In dry soil, northeastern Texas. Summer.

22. Petalostemon cárneus Michx. Plant glabrous or nearly so. Stems solitary or several together, erect, 5-10 dm. tall, more or less branched, the branches erect or ascending: leaflets $5-7$, the blades linear, linear-elliptic or linear-oblanceolate, 5-10 $\mathrm{mm}$. long, acute or acuminate, more or less involute : spikes subglobose or oblong, becoming cylindric, 1-4 cm. long: bracts lanceolate with subulate tips: calyx shorter than the bract; tube campanulate; lobes triangular, acute, shorter than the tube : corolla deep pink; standard abruptly contracted or truncate at the base, the other petals with elliptic-oblong blades.

In sand, Georgia and Florida. Spring and summer.

23. Petalostemon Feaỳi Chapm. Plant glabrous. Stems usually many together, 2-5 dm. long, erect or decumbent, branched, especially above : leaflets mostly $3-5$, the blades linear, 8-18 mm. long, involute-filiform, obtuse or truncate, apparently acute, glandular : spikes subglobose, 1-1.5 $\mathrm{cm}$. long: bracts inconspicuous or early deciduous : calyx shorter than the bract ; tube campanulate, glabrous ; lobes ovate, acute, ciliate, about $\frac{1}{2}$ as long as the tube: corolla lavender or deep pink; standard with the broad blade usually truncate at the base.

In dry sand, peninsular Florida. Spring and summer.

\section{KUHNÍSTERA Lam.}

Perennial herbs, with long tough roots and more or less glandular foliage. Leaves alternate : blades unequally pinnately compound; leaflets with narrow blades. Flowers perfect, in involucrate corymbose spikes resembling heads of Carduaceae. Calyx pubescent : lobes bristle-like, nearly equal, longer than the tube. Corolla white : standard broad, abruptly narrowed into a claw or cordate : wings and keel-petals similar, their claws adnate to the staminal tube. Stamens 5, monadelphous. Ovary sessile. Style subulate. Ovules 2 in each cavity. Pod membraneous, included in the calyx, indehiscent. Seed solitary.

1. Kuhnistera pinnàta (Walt.) Kuntze. Plant glandular. Stems $3-11 \mathrm{dm}$. tall, usually branched at the base, corymbose above: leaflets $3-15$, the blades linear-filiform to linear-cuneate, 5-10 cm. long, obtuse : spikes subglobose, about $1 \mathrm{~mm}$. thick, subtended by an imbricated involucre: lower bracts imbricated, suborbicular in outline, acute, ciliate: calyx villous; tube campanulate; lobes filiform-setaceous, much longer than the tube, plumose and conspicuous: corolla white ; standard with a relatively narrow blade, but truncate or subcordate at the base. [Petalostemon corymbosum Michx. P. corymbosus var. trifoliatus Chapm.?]

In dry sandy pine lands, North Carolina to Florida and Mississippi. Summer and fall.

\section{AESCHYNÓMENE L.}

Herbs or shrubs, with erect or prostrate stems. Leaves alternate : blades commonly unequally pinnate : leaflets numerous. Flowers perfect, in axillary racemes or terminal clusters, racemes or panicles. Calyx pedicelled : lobes nearly equal, the 2 upper and the 3 lower more or less united into two lips. Corolla usually yellow, sometimes variegated with other colors: standard broad, with a short claw: wings oblique, keel-petals curved. Stamens diadelphous (5 and 5). Anthers alike. Ovary stalked. Style glabrous, incurved. Ovules few or numerous. Pod flattened, separating into as many indehiscent sections as there are joints. JorNT VETCH. 
1. Aeschynomene viscidula Michx. Perennial, the plant more or less densely sticky-pubescent. Stems branched at the base, the branches spreading or prostrate, 1-12 dm. long, curved: leaves 1-2 cm. long: leaflets 5-9, the blades firm, obovate, $3-12 \mathrm{~mm}$. long, oblique, reticulated, mucronate, short-stalked: peduncles few-flowered: pedicels spreading : calyx campanulate ; tube prominently veined : corolla yellowish or purplish ; standard with a broadly orbicular retuse blade : pods 1-2 cm. long, 2-3-jointed, the joints half-orbicular.

In sandy pine lands, Georgia to Florida and Mississippi. Spring to fall.

2. Aeschynomene Virgínica (L.) B.S.P. Annual, the plant glabrate or hispid. Stems erect, $2-15 \mathrm{dm}$. tall, branching : leaves $2-10 \mathrm{~cm}$. long, the rachis more or less glandular, especially near the base : leaflets numerous, the blades linear or oblong-linear, 3-12 $\mathrm{mm}$. long, mucronulate, not reticulated: peduncles several-flowered : pedicels 4-6 mm. long: calyx campanulate; tube not prominently veined : corolla nearly $1 \mathrm{~cm}$. long, reddish yellow; standard with an orbicular-ovate blade notched at the apex : pods linear, 3-8 cm. long, the joints nearly square, easily separable. [A. hispida Willd.] and fall.

In sandy soil, on river banks, New Jersey and Pennsylvania to Florida and Louisiana. Summer

\section{ZÒRNIA Gmel.}

Annual or perennial herbs, with erect or prostrate stems. Leaves alternate : blades 2-4-foliolate, commonly petioled : leaflets often glandular-punctate. Flowers perfect, in axillary or terminal conspicuously bracted spikes. Calyx membranous, the 2 upper lobes forming a lip about as large as the lower lobe, the 2 lateral lobes smaller. Corolla of various colors, ours yellow: standard with a broad clawed blade: wings oblique, often shorter than the somewhat lunate keel. Stamens monadelphous. Anthers alternately larger, attached at the base, and shorter, versatile. Ovary sessile : style filiform. Ovules numerous. Loment flattened, several-jointed, smooth or bristly, the joints indehiscent.

1. Zornia bracteàta (Walt.) Gmel. Perennial by a long root, more or less densely strigilose. Stems branched at the base, the branches spreading or prostrate, 1-7 dm. long, simple or branching: leaves distant; leaflets often 4 , the blades oval to elliptic or nearly linear, often somewhat broadest above the middle mucronate; petioles shorter than the leaflets or longer: peduncles longer than the subtending leaves, few-flowered : bracts elliptic or oval, 7-11 long, acute, reticulated, with an auricle at the base : calyx-lohes ciliate, the lateral ones much shorter than the others: corolla yellow; standard with a hooded blade and a slender claw : pods 3-4-jointed, $1-2 \mathrm{~cm}$. long; joints echinate. [Z. tetraphylla Michx.]

In sandy soil, Virginia to Florida, Texas and Mexico. Spring and summer.

\section{STYLOSÁNTHES Sw.}

Perennial, rigid herbs, with bristly or sticky-pubescent foliage. Leaves alternate : blades pinnately 3 -foliolate: leaflets prominently nerved. Flowers of two kinds, the one complete but sterile, the other destitute of perianth and stamens but fertile, in axillary or terminal spikes or heads. Calyx sessile: tube slender: lobes 5, membranous, disposed in 2 lips by the union of the 4 upper lobes. Corolla yellow or orange : standard with a spreading blade: wings oblong : keel incurved, entire. Stamens monadelphous. Anthers alternately longer and attached at the base, and shorter and versatile. Ovary sessile or nearly so : style filiform. Ovules 2-3. Loment 1-2-jointed, the lower joint empty, the upper opening at the apex. Pencil-Flower.

Flowers accompanied by an appendage within the bract.

1. S. hamata.

Blade of accompanied by an appendage within the bract.

Blade of the standard longer than broad; spurs curved: terminal joint of the pod
with an almost and

Blade with an almost axile beak.

triangular, with broader than long; spurs straight: terminal joint of the pod

2. S. biflora.

triangular, with the beak lateral.

3. S. riparia.

1. Stylosanthes hamàta (L.) Taubert. Root elongated. Stems usually several, ascending or procumbent, $2-7 \mathrm{dm}$. long, often branched, lightly striate, with pubescent lines below the stipules : leaflets 3 , the blades oblong to oblong-lanceolate, $7-17 \mathrm{~mm}$. long, acute at both ends and often short-mucronate, prominently nerved, glabrous except occasional marginal hairs: spikes terminal, about $15 \mathrm{~mm}$. long, few-flowered : calyx finely pubescent : corolla yellow : pods 2 -jointed, the lower joint usually abortive, the terminal one with 1-ribbed sides and a hooked pubescent beak.

In sand, peninsular Florida and tropical America. Throughout the year. 
2. Stylosanthes biflòra (L.) B.S.P. Root stout, elongated. Stems several, loosely tufted, erect or ascending, 2-5 dm. long, more or less flexuous, villous on one side below the stipules, simple or branched above: stipules adnate to above the middle of the petiole, their free tips subulate, sparingly ciliate: leaflets 3 , the blades elliptic, linear-elliptic, lanceolate or oblanceolate, $1-3.5 \mathrm{~cm}$. long, mucronate or apiculate, entire, on short pubescent petiolules, with prominent straight nerves and often whitened beneath : corolla orange ; standard suborbicular, but longer than broad, $8 \mathrm{~mm}$. broad, pale orange, notched at the apex, short-clawed, the spurs curved; wings obliquely obovate, 4-5 mm. long, pale-orange, with short slender claws and acute auricles; keel-petals sickle-like, greenish, as long as the wings : pods 2 -jointed, the terminal joint with an almost axile beak.

In dry or sandy soil, New York to Kansas, south to Florida and Texas. Spring to fall.-A campestrian form, with hirsute stems, is S. biflora hispidissima (Michx.) Pollard \& Ball.

3. Stylosanthes ripària Kearney. Root woody, often $3 \mathrm{dm}$. long. Stems few or several, 1-3.5 dm. long, decumbent, branched, with a line of pubescence below the stipules: leaflets 3 , the blades elliptic, oblanceolate or cuneate-obovate, 10-18 $\mathrm{mm}$. long or sometimes shorter, usually rounded at the apex, sometimes truncate, retuse or cuspidate at the apex, entire, pale beneath, glabrous except for some marginal hairs, prominently nerved, especially beneath : spikes terminating the stem and its branches, about 6 -flowered : upper and lower flowers usually abortive : corolla orange-yellow; standard with a blade broader than long, about $5 \mathrm{~mm}$. broad, the basal spurs straight; wings $3.5 \mathrm{~mm}$. long, obovate ; keelpetals about as long as the wings: pods 2 -jointed, the lower joint small and infertile, the terminal joint triangular, 3-3.5 mm. long, excluding the lateral hooked beak.

In woods and on dry banks, Delaware to Kentucky and Florida. Summer and fall.

38. CHAPMÁNIA T. \& G.

Perennial herbs, with upright stems, often branched at the base. Leaves alternate: blades unequally pinnate, with subulate stipules: leaflets few. Flowers in terminal racemes perfect, but sterile, and imperfect and fertile. Calyx membranous : tube with a stipe-like base : four upper lobes united, lower lobe distinct, narrow. Corolla yellow : standard with a suborbicular blade: wings oblique, broadest above the middle: keel obtuse, incurved. Stamens monadelphous. Anthers alike or nearly so, alternately attached at the base, and versatile. Ovary sessile: style slender, elongated. Ovules numerous. Pod elongated, nearly terete, the joints longitudinally striate, glandular-roughened.

1. Chapmania Floridàna T. \& G. Foliage hirsute. Stems more or less branchèd at the base, the branches ascending, wand-like or branching, 2-11 dm. tall : leaves 1.5-4 $\mathrm{cm}$. long, with short petioles: leaflets $5-7$, the blades narrowly oblong, oblanceolate, cuneate or obovate, $0.5-2 \mathrm{~cm}$. long : racemes $5-15 \mathrm{~cm}$. long : calyx campanulate, $7-10 \mathrm{~mm}$. high; lobes ovate, shorter than the tube : corolla yellow : pods $1-2 \mathrm{~cm}$. long, acute, hispid.

In sandy pine lands, Florida. Spring and summer.

\section{MEIBÒmIA Heister. ${ }^{1}$}

Herbs, shrubs or vines, with glabrous or pubescent foliage. Leaves alternate : blades pinnately 3 -foliolate or rarely 1 - or 5 -foliolate; leaflets stipellate. Flowers perfect, in axillary or terminal racemes or panicles, or sometimes in clusters. Calyx with bractlets at the base : lobes unequal, the upper two more or less united, the 3 lower forming a larger lip than the upper. Corolla of various colors: standard broad, sometimes narrowed into a claw : wings oblique, more or less coherent with the obtuse straight or incurved keel-petals. Stamens monadelphous or partly diadelphous. Anthers alike. Ovary sessile or stalked. Style filiform, incurved or inflexed. Ovules 2-many. Loment usually exserted from the calyx on the stipe or stipe-like base, the joints indehiscent, flat or inflated. [Desmodium Desv.] Tick-treforl. BegGaR's Ticks.

A. Loments constricted into separate rhomboidal or half-rhomboidal joints.

Loments straight above, deeply constricted below, long-stalked.

Peduncles arising from the base of the plant.

Peduncles terminating the stems.

Leaves clustered at the base of the peduncle.

Leaves scattered along the stem.

Loments constricted above and below :

a. Constrictions deeper below than above.

* Stems trailing or reclining.

† Leaflets with suborbicular blades, or if narrower, the racemes axillary. Leaflets mostly less than $2.5 \mathrm{~cm}$. long. leathery, the blades glabrate.

Leaflets mostly over $2.5 \mathrm{~cm}$. long, the blades membranous, pubescent.

1. M. nudiflora.

2. M. grandiflora.

3. M. paucifiora.

4. M. arenicola.

5. M. Michanxii.

${ }^{1}$ Contributed by Miss Anna Murray Vail. 
t+ Leaflets with ovate or oval blades: racemes terminal as well as axillary.

Corolla cream-colored or ochroleucous : stipules ovate: racemes mostly simple.

Corolla purple: stipules subulate : racemes mostly paniculate.

** Stems erect or ascending.

Petioles wanting or very short.

Petioles manifest.

Leaflets with narrowly linear blades.

Joints of the pod with a straight or depressed back, triangular in outline.

Joints of the pod with a rounded back, not triangular in outline.

Leaflets with lanceolate to ovate or rhomboidal blades, never linear. Joints of the loments manifestly longer than broad.

Bracts subtending the flowers small and inconspicuous : blades of the leaflets reticulated.

Pods not more pubescent on the edges than the sides.

Pods copiously ciliate.

Blades of the lateral leaflets not subcordate at the base : pods deeply constricted along the back.

Blades of the lateral leaflets subcordate at the base: pods not much constricted along the back.

Bracts subtending the flowers conspicuous, mostly over $1 \mathrm{~cm}$. long: blades of the leaflets not reticulated.

Leaves pubescent : bracts ciliate and pubescent.

$\begin{array}{ll}\text { Leaves pubescent: bracts ciliate and pubescent. } & 14 . \text { M. longifolia. } \\ \text { Leaves glabrous: bracts not ciliate and otherwise glabrous. } & 15 . \text { M. bracteosa. }\end{array}$ Joints of the loments barely longer than broad.

Foliage glabrous or slightly pubescent.

Leaflets green beneath.

Leaflets conspicuously glaucous beneath.

Foliage variously pubescent.

Loments distinctly stalked (or sometimes sessile in M. Illinoensis).

Leaflets with leathery blades.

Corolla about $10 \mathrm{~mm}$. long : standard $5-7 \mathrm{~mm}$. broad. Blades of the leaflets prominently reticulated. Blades of the leaflets not reticulated.

Corolla $5-7 \mathrm{~mm}$. long: standard about $4 \mathrm{~mm}$. broad. Leaflets with membranous blades.

Loments sessile or relatively short-stalked.

Joints of the loments $4-7,5 \mathrm{~mm}$. long: corolla about 1 cm. long.

Leaflets with leathery blades.

Leaflets with relatively thin blades.

Joints of the loments1-3, 3-5 mm, long : corolla 7-5 mm. long.

Leaflets scabrous or pubescent and ciliate. Terminal leaflet usually twice as long as broad. Terminal leaflet little longer than broad. Leaflets glabrous.

b. Constrictions equally deep on both sides of the loment.

B. Loments not constricted into separate joints, straight above, undulate below. Shrub: blades of the leaflets broadest below the middle.

Herb: blades of the leaflets broadest below the middle.

6. M. ochroleuca.

7. M. glabella.

8. M. sessilifolia.

9. M. stricta.

10. M. tenuifolia.

11. M. canescens.

12. M. Lindheimeri.

13. M. Tweedyi. 16. M. paniculata. 17. M. laevigata.

18. M. rhombifolia.

19. $M$. viridifiora.

20. M. Dillenii.

21. M. Illinoensis.

22. M. Canadensis.

23. M. rigida.

24. M. nbtusa.

25. M. Marylandica.

26. M. purpurea.

27. M. supina.

28. M, triflora.

1. Meibomia nudiflòra (L.) Kuntze. Foliage somewhat pubescent. Leaves in a cluster at the summit of the $2-3 \mathrm{dm}$. high ascending or decumbent sterile stem : scapes mostly naked, $3-8 \mathrm{dm}$. long: stipules setaceous, caducous : petioles $3-10 \mathrm{~cm}$. long : leaflets 3 , the blades oval or ovate, $2-8 \mathrm{~cm}$. long, slightly acuminate to the blunt apex, glabrous or sparingly pubescent, usually ciliate, pale beneath, the terminal leaflet somewhat rhombic, the lateral inequilateral : panicle narrow, few-flowered : calyx-lobes unequal, obtuse, the lower one the longest : corolla purplish; standard with two dark spots at the base : loment 2-3-jointed, rarely 4-jointed, the joints 10-13 mm. long, straight or slightly concave on the dorsal suture, glabrous, the stipe nearly as long as the pedicel.

In dry woods, Ontario to Missouri, Kansas, Florida and Louisiana. Summer.

2. Meibomia grandiflòra (Walt.) Kuntze. Foliage pubescent with soft scattered hairs or nearly glabrous. Stems erect, over $3 \mathrm{dm}$. high, angled: leaves in a cluster at the summit of the stem, from which rises the long naked peduncle: petioles 7-15 $\mathrm{cm}$. long; stipules setaceous, mostly persistent ; leaflets 3 , the blades ovate, $5-13 \mathrm{~cm}$. long, acuminate, pubescent with scattered hairs on both surfaces, the terminal leaflet orbicular-ovate; panicles often spreading: bracts caducous : calyx-lobes minute, acutish : corolla conspicuous, bright rose-purple : loment 2-3-jointed, the joints about $1 \mathrm{~cm}$. long, concave above, obliquely rounded or semi-rhomboid on the ventral suture, uncinate-pubescent, but the suture glabrous or nearly so, the stipe as long as the pedicel.

In dry or rocky woods, Quebec to Minnesota, Nebraska, Florida and Texas. Summer and fall.

3. Meibomia pauciflòra (Nutt.) Kuntze. Foliage sparingly pubescent. Stems decumbent or ascending, 3-5 dm. long, pubescent with scattered hairs : leaves distant; stipules caducous; leaflets 3 , the blades ovate or rhombic-ovate, $2.5-8 \mathrm{~cm}$. long, acuminate or 
bluntish, somewhat pubescent, paler beneath, the terminal leaflet rhomboid: racemes simple, terminal or rarely axillary, few-flowered : calyx-lobes acute, ciliate : corolla white: loment 1-3-jointed or rarely 4 -jointed, the joints rounded on the ventral suture, $10-12 \mathrm{~mm}$. long, uncinate-pubescent, the stipe slightly shorter than the pedicel.

In woods and forests, Ontario to Ohio, Florida, Arkansas, Louisiana and Texas. Summer.

4. Meibomia arenícola Vail. Foliage thinly pubescent or glabrate. Stems decumbent and spreading flat on the ground from a long stout root, striate-angled : leaves spreading; petioles shorter than the leaflets; stipules subulate, persistent: basal leaves varying from 1-5-foliolate; leaflets 1-5, the blades ovate-orbicular or suborbicular, 1-2.5 cm. long, leathery, reticulated beneath : racemes terminal or axillary, simple and elongated : flowers slender-pedicelled : calyx-lobes acute, the upper lip triangular, minutely 2-toothed : corolla purplish : loment 2-4-jointed, less sinuate above than below, the joints nearly oval, about $4 \mathrm{~mm}$. long, uncinate-pubescent, the stipe about as long as the calyx-lobes. [Desmodium lineatum (Michx.) DC.]

In dry sandy soil, Maryland and Virginia to Florida and Louisiana. Summer and fall.-A state with narrower often oblong or linear leaflets found in pine lands from Florida to Louisiana, is $M$. arenicola polymórpha (A. Gray) Vail.

5. Meibomia Michaùxii Vail. Foliage soft-hirsute or glabrate. Stems branched at the base, the branches prostrate from a stout spreading root, $5-10 \mathrm{dm}$. long, straight, the upper portion often nearly villous : leaves spreading; petioles about the length of the leaflets ; stipules ovate-cordate, acuminate, striate, ciliate, reflexed and persistent ; leaflets 3 , the blades 3-6 $\mathrm{cm}$. long, nearly orbicular, sparingly pubescent or glabrate above, pubescent and lighter beneath ; terminal leaflet dilated or depressed-orbicular and broader than long: racemes terminal and axillary: bracts ovate, caducous : calyx-lobes ciliate, the upper lip 2-toothed : corolla purplish : loment $2.5 \mathrm{~cm}$. long or more, 3-5-jointed, the joints slightly rounded on the dorsal, obliquely half-rhomboid on the ventral suture, uncinatepubescent throughout, the stipe as long as the calyx-lobes or a little shorter. [Desmodium rotundifolium (Michx.) DC.]

In dry rocky woods, Ontario to Minnesota, Florida and Louisiana. Summer.

6. Meibomia ochroleùca (M. A. Curtis) Kuntze. Stems decumbent, terete, below, angled above, sparingly hirsute : leaves spreading; stipules broadly ovate-cordate, striate, reflexed, persistent; petioles $1-4 \mathrm{~cm}$. long; leaflets 3 , the blades rhombic-ovate, yellowish green, 2-5 cm. long, leathery, somewhat scabrous above, reticulated beneath, terminal leaflet obtuse, the lateral leaflets obliquely ovate and smaller: racemes simple, terminal and axillary : bracts lanceolate, caducous: calyx-lobes attenuate, ciliate, the upper two mostly united : corolla cream-colored or ochroleucous : loment $2-3$-jointed, nearly equally sinuate on both densely uncinate-pubescent sutures, the joints oval, 8-10 mm. long, twisted, reticulated, glabrous, the stipe nearly as long as the calyx-lobes.

In woodlands. New Jersey to Missouri, Florida and Alabama. Summer and fall.

7. Meibomia glabélla (Michx.) Kuntze. Foliage deep green. Stems procumbent or rarely ascending, sometimes over $2 \mathrm{~m}$. long, terete below, angled and striate above, glabrous or sparingly soft-hirsute : leaves few; stipules lanceolate or ovate-lancenlate; leafsparingly pubescent above, paler beneath : racemes panicled, terminal and axillary : bracts caducous: calyx-lobes attenuate, the upper two partially united, the two lateral of the lower lip shorter than the middle one: corolla purple: loment $3-5$-jointed, less sinuate above long.

In dry sandy soil, Massachusetts to Pennsylvania and South Carolina. Summer and fall.

8. Meibomia sessilifòlia (Torr.) Kuntze. Foliage bright green. Stems erect, 3-8 dm. long, striate, uncinate-pubescent : leaves with sessile or very short-petioled blades ; stipules linear, attenuated, caducous or rarely persisting; leaflets 3 , the blades $2.5 \mathrm{~cm}$. long, linear or linear-oblong, obtuse at each end, thick and reticulated, scabrous or glabrate above, somewhat downy or pubescent beneath : racemes terminal, simple or panicled: bracts caducous: calyx very short-pedicelled; lobes acute, somewhat attenuate, the middle lower one longer than the triangular lateral ones, the upper lip obliquely 2-toothed: corolla purplish, turning greenish, 4-5 mm. broad : loment 1-3-jointed, less sinuate above than below, somewhat twisted, the joints $5 \mathrm{~mm}$. long or shorter, obliquely half-obovate, hispid, the stipe not longer than the calyx-lobes.

In copses, Massachusetts to Michigan, Kansas, Mississippi and Texas. Summer and fall.

9. Meibomia strícta (Pursh) Kuntze. Foliage finely pubescent. Stems erect, 3-6 dm. high, simple, slender, minutely pubescent : leaves spreading; stipules setaceous, caducous; petioles 5-15 mm. long; leaflets 3 , the blades $2-5 \mathrm{~cm}$. long, linear, obtuse, thick, 
reticulated, glabrous : racemes narrow, rough-glandular, elongated; calyx short-pedicelled: lobes acute, the upper lip 2-toothed: corolla purplish, about $3 \mathrm{~mm}$. broad: loment 1-3-jointed, mostly straight or somewhat concave on the back, the joints 4-5 mm. long, half-obovate, or half-rhomboid, uncinate-pubescent, the stipe as long as the calyx-lobes.

In pine lands and woods, New Jersey to Missouri, Florida and Louisiana. Summer and fall.

10. Meibomia tenuifòiia (T. \& G.) Kuntze. Foliage nearly glabrous, at least below. Stems lax, 2-6 dm. long, striate, rough with hooked hairs: leaves distant; stipules subulate, mostly caducous; petioles $0.5-2 \mathrm{~cm}$. long; leaflets 3 , the blades linear, 3-8 $\mathrm{cm}$. long, obtuse, glabrous above, reticulated and pubescent with hooked hairs beneath: panicle lax: calyx-lobes subulate, the upper lip minutely 2-toothed: corolla pinkish purple, $3-5 \mathrm{~mm}$. long : loment 2-3-jointed on a short diverging pedicel, the joints $3-5 \mathrm{~mm}$. long, mostly rounded on the dorsal and obliquely-obovate on the ventral suture, minutely pubescent with hooked hairs, the stipe shorter than the calyx-lobes or about the same length.

In pine lands, North Carolina to Florida and Louisiana. Summer and fall.

11. Meibomia canéscens (L.) Kuntze. Foliage pale green, pubescent all over. Stems erect, 6-10 dm. tall or taller, branched, clothed with a close-set hooked hairs and often also with longer spreading hairs or sometimes glabrate below: leaves conspicuous; stipules 8-15 mm. long, ovate, cordate, cuspidate, striate, ciliate, persistent, spreading or reflexed ; petioles $3-10 \mathrm{~mm}$. long or longer ; leaflets 3 , the blades $3-10 \mathrm{~cm}$. long, broadly ovate or ovate-rhomboid, rough on both surfaces, ciliate, pale and reticulated beneath, the terminal one the larger, sometimes truncate at the base: racemes panicled, the branches widely spreading: bracts caducous : pedicels spreading: calyx ciliate, the upper lip 2toothed, the middle tooth of the lower lip longer and attenuate : corolla violet-purple, 1 $\mathrm{cm}$. long or longer: loment 4-6-jointed, straight or somewhat concave on the dorsal or nearly equally sinuate on both sides, the joints 8-15 $\mathrm{mm}$. long, pubescent with hooked hairs, varying from nearly triangular or half-rhomboid to obliquely oval, the stipe as long as the upper calyx-lobes.

In moist ground and on borders of woods, Canada to Minnesota, Nebraska, Florida and Texas. Summer and fall.

12. Meibomia Lindheimeri Vail. Foliage bright green. Stem erect, $6 \mathrm{dm}$. high or more, branched, stout, conspicuously angled and channeled, downy with a close fine pubescence : stipules lanceolate, cuspidate, 6-8 mm. long, pubescent, reflexed, persistent or caducous : petioles $2-5 \mathrm{~cm}$. long or more : leaflets 3 , the blades scabrous or minutely pubescent above, reticulated, velvety or villous-pubescent and the nerves conspicuous beneath, ovate or ovate-lanceolate, $2.5-8 \mathrm{~cm}$. long, the terminal leaflet mostly somewhat rhombic, truncate at base and acutish, the others inequilateral, smaller and more obtuse : racemes panicled, the branches spreading: bracts ovate-lanceolate, cuspidate, caducous : calyxlobes acute, nearly equal : corolla purple, 5-8 mm. long : loment 2-4 $\mathrm{cm}$. long or more, 4-6jointed, the joints obliquely oval, about $1 \mathrm{~cm}$. long, glabrous except the sutures, the stipe $2 \mathrm{~mm}$. long or less.

On prairies, Texas and Mexico. Summer and fall.

13. Meibomia Tweèdyi (Britton) Vail. Foliage finely pubescent. Stems stout, erect or ascending, $9 \mathrm{dm}$. long or longer, angled and channeled, minutely pubescent : stipules $10-15 \mathrm{~cm}$. long, ovate, attenuate, ciliate, persistent: petioles $7-10 \mathrm{~cm}$. long or more, the terminal petiolule $1.5-4 \mathrm{~cm}$. long; leaflets 3 , the blades $7-10 \mathrm{~cm}$. long, ovate, truncate, obtuse, mucronulate, yellowish green, glabrate or scabrous above, scabrous and strongly reticulated beneath : racemes panicled, apparently naked, $3-4 \mathrm{dm}$. long or more : flowers few : pedicels spreading, $1-2.5 \mathrm{~cm}$. long: bracts lanceolate, attenuate, 4-6 mm. long, caducous : calyx-lobes acute : corolla ochroleucous or yellow, $8 \mathrm{~mm}$. long : loment $2-3$ - or 4 -jointed, the joints $8-10 \mathrm{~cm}$. long, half-rhomboid, straightish or somewhat rounded on the dorsal suture, minutely pubescent with hooked hairs; the stipe not exceeding the calyx.

On prairies, Texas. Summer. 14. Meibomia longifòlia (T. \& G.) Vail. Stems stout, erect, $6 \mathrm{dm}$. high or
higher, branched, angled, striate, pubescent in lines, sometimes glabrate : leaves large ; stipules ovate-lanceolate, cuspidate, persistent, caducous ; petioles $1.5-5 \mathrm{~cm}$. long, striate, pubescent ; stipules $5 \mathrm{~mm}$. long, often conspicuous and persisting; leaflets 3 , the blades $5-11$ $\mathrm{cm}$. long, $2.5-5 \mathrm{~cm}$. broad, the blades lanceolate or lanceolate-ovate, or ovate, acuminate, slightly rugose or scabrous with seattered hairs and becoming glabrate above, much lighter and appressed-pubescent beneath, the terminal leaflet usually much larger than the lateral ones : panicles spreading : flowers numerous : pedicels slender, spreading, pubescent : bracts striate, 5-10 mm. long, ovate or ovate-lanceolate, ciliate, caducous : calyx-lobes attenuated, the upper lip 2-toothed, the other lobes longer: corolla lilac-purple, about $1 \mathrm{~cm}$. long: loment 4-6-jointed, $3.5-6 \mathrm{~cm}$. long, pubescent with hooked hairs, straight or somewhat rounded on the dorsal, and deeply triangular on the ventral suture, or nearly 
equally sinuate above and below, the joints $8-10 \mathrm{~mm}$. long, reticulated, appearing almost lozenge-shaped, the stipe about the length of the calyx-lobes.

On plains and prairies, Illinois to Alabama and Louisiana. Spring and fall.

15. Meibomia bractiòsa (Michx.) Kuntze. Stems erect, glabrous or nearly so, $1 \mathrm{~m}$. high or higher, branched, angled : leaves large ; stipules $8-15 \mathrm{~mm}$. long, lanceolate, cuspidate, somewhat cordate at the base, caducous; petioles $3-8 \mathrm{~cm}$. long, flat and channeled; stipels conspicuous, setaceous, $5-15 \mathrm{~mm}$. long, mostly persistent; leaflets 3 , the blades ovate or ovate-lanceolate, $0.5-1.5 \mathrm{dm}$. long, cuspidate or long-acuminate, glabrous or nearly so, paler and often glaucous beneath : panicles spreading, the upper part minutely pubescent : bracts striate, cuspidate, glabrous, caducous : flowers numerous : pedicels slender, spreading: upper calyx-lip 2-toothed: corolla lilac-purple, showy, about $1 \mathrm{~cm}$. long: loment 2.5-5 cm. long, rather broad at the joints, 3-7-jointed, the joints about $1 \mathrm{~cm}$. long, straight or slightly rounded on the dorsal and half-rhombic on the ventral suture, reticulated, the stipe about the length of the lower calyx-lip.

In thickets, Ontario to Michigan, Florida, Missouri and Texas. Summer and fall.

16. Meibomia paniculàta (L.) Kuntze. Stems slender, erect, 5-10 dm. high, paniculately branched, nearly glabrous: stipules small, setaceous, caducous: petioles 1-3.5 cm. long; leaflets 3 , the blades $3-5 \mathrm{~cm}$. long, oblong-lanceolate, oval or linear-lanceolate, obtuse, rarely acutish, glabrous or rarely minutely pubescent, paler beneath: racemes panicled, the branches spreading: bracts caducous: calyx-lobes attenuate, the upper lip deeply 2-toothed, the middle lower lobe much elongated : corolla purplish, turning green, $5-6 \mathrm{~mm}$. long: loment $2.5 \mathrm{~cm}$. long or longer, mostly angled on the dorsal suture, the joints 5-8 $\mathrm{mm}$. long, obliquely triangular or half-rhombic, minutely pubescent, the stipe as long as the calyx-lobes.

In copses, Ontario to Nebraska, Florida, Louisiana and Texas. Summer and fall.-A slender form with narrow more acute leaflets $5-8 \mathrm{~mm}$. wide, is $M$. paniculata Chapmánii Britton, while the form with copiously puberulent stems and firm oblong-lanceolate leaflets pubescent beneath, and loments more strongly angled on the dorsal suture, is M. paniculata puibens (T. \& G.) Vail.

17. Melbomia laevigàta (Nutt.) Kuntze. Stems terete, erect, $8-12 \mathrm{dm}$. high, glabrous or minutely uncinate-pubescent above, often glaucous: stipules subulate, caducous : petioles $2.5-8 \mathrm{~cm}$. long : leaflets 3 , the blades $4-11 \mathrm{~cm}$. long, ovate or ovate-oblong, acutish or obtuse, sometimes mucronulate, paler beneath, the terminal leaflet sometimes rhomboid : racemes panicled, the branches spreading: bracts very small, caducous : upper calyx-lip entire or minutely 2 -toothed : corolla blue-purple, $7-9 \mathrm{~mm}$. long: loment 3-6or rarely 8 -jointed, $2-3 \mathrm{~cm}$. long or longer, straight or somewhat angled on the dorsal suture ; the joints $6-7 \mathrm{~mm}$. long, half-rhombic, the stipe mostly as long as the lower joint.

In pine lands, New Jersey to Missouri, Florida, Louisiana and Texas. Summer and fall.

18. Meibomia rhombifòlia (Ell.) Vail. Stems rigid, erect or ascending, $6-10 \mathrm{dm}$. high, simple or branched, pubescent : basal leaves (in the case of small plants, or rarely all the leaves ) 1-foliolate : stipules 5-10 mm. long, subulate, taper-pointed, persistent or caducous ; petioles $1-4 \mathrm{~cm}$. long; leaflets 3 , the blades $5-9 \mathrm{~cm}$. long, ovate or ovate-lanceolate, sometimes truncate at the base, obtuse or acutish, often mucronulate, leathery, scabrous above, pubescent or densely villous and strongly reticulated beneath: racemes simple or panicled, mostly elongated, leafless : bracts minute, setaceous, caducous : calyx-lobes acute, the upper lip 2-toothed : corolla purple, 6-8 mm. long: loment 1-3 cm. long, 2-5-jointed, somewhat twisted, the joints about $7 \mathrm{~mm}$. long, obliquely half-rhomboid, slightly rounded or obscurely angled on the dorsal suture, the stipe often half as long as the joint.

In pine lands, Virginia to Florida, Alabama and Louisiana. Spring to fall.

19. Meibomia viridiflòra (L.) Kuntze. Stems erect, 6-10 dm. high, terete, mostly downy : stipules lanceolate, attenuated, when persistent, spreading or reflexed : petioles 1-3 $\mathrm{cm}$. long: leaflets 3 , the blades $4-9 \mathrm{~cm}$. long, scabrous above, villous or tomentose beneath, the terminal leaflet ovate or ovate-oblong, often rhomboid, not truncate, the others oblong: racemes panicled, the branches spreading: bracts $2-3 \mathrm{~mm}$. long, broadly ovate, cordate, caducous : calyx hirsute, the upper lip triangular, minutely 2 -toothed, the lower lip the longer: corolla pale purple, turning green, $6-9 \mathrm{~mm}$. long: loment $1-2 \mathrm{~cm}$. long, 2-4-jointed, the joints about $5 \mathrm{~mm}$. long, half-rhombic, straightish or obtusely angled on the dorsal suture, uncinate-pubescent, the stipe not quite the length of the lower joint.

In woods, southern New York to Michigan, Missouri, Florida and Texas. Summer and fall.

20. Meibomia Dillenii (Darl.) Kuntze. Stems erect, $6 \mathrm{dm}$. high, sulcate, glabrous or sparingly pubescent: stipules subulate, mostly caducous: petioles $2.5-5 \mathrm{~cm}$. long : leaflets 3 , the blades 4-10 cm. long, oblong or ovate-oblong, mostly obtuse, sometimes mucronulate, often very thin, scabrous or with a few scattered soft hairs above, appressed-pubescent or softly hirsute beneath, the terminal leaflet larger than the lateral ones: racemes panicled, the branches spreading: bracts small, caducous: upper calyx-lip entire or minutely 
2-toothed, the lower lobes attenuate, the middle lobe twice the length of the later ones: corolla purple, $6-8 \mathrm{~mm}$. long: loment $1-3 \mathrm{~cm}$. long or longer, 3-6-jointed, the joints 5-12 $\mathrm{mm}$. long, half-rhombic, straightish, somewhat convex, or sharply angled on the dorsal suture, the stipe half the length of the lower joint or less, sometimes nearly as long.

In woodlands, Ontario to Minnesota, Florida and Texas. Summer and fall.

21. Meibomia IIllinoénsis (A. Gray) Kuntze. Stems erect, 6-9 dm. high, stout, sulcate, pubescent: stipules 1-1.5 $\mathrm{cm}$. long, ovate, acute, cordate, ciliate, persistent: petioles $2.5-5 \mathrm{~cm}$. long: leaflets 3 , the blades $5-9 \mathrm{~cm}$. long, light yellowish green, oblong or ovate-lanceolate or lanceolate, obtuse, leathery, ciliate, scabrous on both surfaces, strongly reticulated and cinereous beneath, the lateral leaflets somewhat shorter and narrower than the terminal one : racemes simple or rarely panicled, naked: bracts caducous, 5-8 mm. long, ovate-lanceolate, ciliate : upper calyx-lip minutely 2-toothed, the lower one deeply 3 -toothed, with the middle lobe attenuated : corolla purple, turning brown in drying, 8-10 mm. long: loment 3-7-jointed, 2-4 cm. long, mostly in pairs, merely sinuate on both sutures, the joints about $5 \mathrm{~mm}$. long, oval or nearly orbicular, densely uncinate-pubescent, the stipe longer than the calyx-lobes.

In dry grounds and on prairies, Illinois to Nebraska and Texas. Summer and fall.

22. Meibomia Canađénsis (L. ) Kuntze. Stems erect, 6-9 dm. high, striate, somewhat hirsute with short spreading hairs or nearly glabrous : stipules lanceolate-linear, 5$10 \mathrm{~mm}$. long, ciliate, mostly persistent : lower petioles 1-2 $\mathrm{cm}$. long : upper leaves sessile or nearly so ; leaflets 3 , the blades $4-10 \mathrm{~cm}$. long, oblong or oblong-lanceolate, obtuse, glabrous or somewhat scabrous and dark-green above, appressed-pubescent, paler and sometimes reticulated beneath : racemes mostly panicled : bracts ovate-lanceolate, $6-9 \mathrm{~mm}$. long, attenuated, striate, ciliate, pubescent, caducous : calyx-lobes attenuate, the upper lip 2-toothed; lower lobes elongated : corolla bluish purple, or rarely whitish, 8-12 mm. long, showy : loment about $2.5 \mathrm{~cm}$. long, 3-5-jointed, somewhat curved, sessile in the calyx or very short-stalked, the joints $5 \mathrm{~mm}$. long, nearly oval or obtusely half-rhomboid, the stipe rarely as long as the calyx.

In dry rich woods, New Brunswick to Saskatchewan, North Carolina and the Indian Territory. Summer and fall.

23. Meibomia rígida (Ell.) Kuntze. Stems erect, 6-9 dm. high, rigid, striate, minutely pubescent : stipules small, caducous : upper leaves sessile or nearly so, the lower short-petioled ; leaflets 3 , the blades ovate-oblong or elliptic, $2.5-8 \mathrm{~cm}$. long, obtuse, often mucronulate, yellowish green and mostly scabrous above, pubescent and reticulated beneath, the lateral leaflets smaller : racemes panicled, or sometimes simple, 4-5 $\mathrm{mm}$. long: bracts caducous, very small : upper calyx-lip entire or minutely 2-toothed : loment 2-3jointed or rarely 4-jointed, 8-15 mm. long, the joints $3-5 \mathrm{~mm}$. long, obliquely oval or half-obovate, rarely angled on the dorsal suture, very short-stipitate.

In dry soil, Massachusetts to Michigan, Nebraska, Florida and Texas. Summer and fall.

24. Melbomia obtùsa (Muhl.) Vail. Stems erect, 6-12 dm. high, hirsute or minutely pubescent: leaves mostly crowded; stipules subulate; petioles ciliate, shorter than the leaflets; leaflets 3 , the blades mostly less than $2-5 \mathrm{~cm}$. long, round-ovate or oval, rather leathery, somewhat scabrous above, paler, glaucous and sparingly pubescent beneath: racemes panicled : bracts caducous : upper calyx-lip entire or minutely 2 -toothed, the lower lobes acute : corolla purple, 2-4 mm. long : loment 2-3-jointed, 10-15 mm. long, the joints half-orbicular or half-obovate, the stipe not longer than the calyx. [Desmodium ciliare (Muhl.) DC.]

On dry hills and in sandy fields, Ontario to Michigan, Missouri, Florida, Texas and Mexico. Summer and fall.

25. Meibomia Marylándica (L. ) Kuntze. Stems erect, 6-9 dm. high, slender, striate, glabrous or rarely with a few scattered hairs: leaves crowded ; stipules subulate, caducous; petioles as long as the leaflets ; leaflets 3 , the blades ovate or sometimes suborbicular, rarely elliptical, $1-2.5 \mathrm{~cm}$. long, obtuse, glabrous or rarely with a few hairs and glaucous beneath : racemes simple or panicled: upper calyx-lip emarginate, obliquely and minutely 2-toothed; the lower lobes acute: loment 10-15 mm. long, 1-3-jointed, the joints obliquely oval or half-orbicular, the stipe mostly longer than the calyx.

In copses, Massachusetts to Michigan, Missouri, Florida and Louisiana. Summer and fall.

26. Meibomia purpùrea (Mill.) Vail. Shrubby. Stems stout, $6 \mathrm{dm}$. high or taller, erect, terete, pubescent : leaves 4-20 $\mathrm{cm}$. long; stipules 10-15 mm. long, ovate, obliquely cordate, attenuate, ciliate, striate, often turning purplish, spreading or reflexed, persistent ; petioles $2-8 \mathrm{~cm}$. long or more; stipels 4-8 $\mathrm{mm}$. long, linear-lanceolate; leaflets 3 , the blades ovate, ovate-oblong or elliptical, $2-11 \mathrm{~cm}$. long, obtuse, mucronate or mucronulate, glabrate or scabrous above, pubescent and often reticulated beneath, the lateral leaflets 
much smaller than the terminal one : racemes panicled : bracts caducous : pedicels usually in pairs, very slender, $1-2 \mathrm{~cm}$. long or more, spreading : calyx-lobes acute, the upper lip minutely 2-toothed : corolla about $3 \mathrm{~mm}$. long, purple: loment sessile in the calyx or nearly so, 4-7-jointed, the joints about $4 \mathrm{~mm}$. long, oval, much twisted, minutely pubescent.

In dry fields, Florida and Mexico to Colombia, the West Indies and South America. Spring to fall.

27. Meibomia supina (Sw.) Britton. A small shrub, with erect or procumbent diffuse terete stems $6 \mathrm{dm}$. high or higher, the foliage glabrous or sparingly pubescent below, often finely pubescent above: stipules lanceolate or ovate-lanceolate, 5-10 $\mathrm{mm}$. long, acuminate: petioles $1-3 \mathrm{~cm}$. long or more: leaflets 3 , the blades oval or elliptic, $2 \mathrm{~cm}$. long, thick and leathery, dark green, scabrous or glabrate and becoming lustrous above, glaucous, pubescent and reticulated beneath; leaflets of the basal leaves ovate or orbicular: racemes terminal, elongated : pedicels slender, 1-1.5 mm. long : bracts linear or lanceolate, caducous : calyx-lobes acute : corolla $5-8 \mathrm{~mm}$. long, rose-colored : loment $2.5-3 \mathrm{~cm}$. long, 3-8-jointed, the joints about $4 \mathrm{~mm}$. long, straight on the back, rounded below, densely pubescent, the stipe not longer than the calyx-lobes.

In pine woods, about Biscayne Bay. Florida. Also in the West Indies, Central and South America. Occurs also in Africa and in the Island of Mauritius.

28. Meibomia triflòra (L.) Kuntze. Stems low, procumbent and trailing, branched, the branches spreading on the ground, pubescent: stipules ovate or subulate: petioles about as long as the leaflets : leaflets 3 , the blades obcordate, $3-12 \mathrm{~mm}$. long, retuse : pedicels $0.5-1 \mathrm{~mm}$. long, very slender: calyx-lobes acute, the upper lip deeply 2-toothed: flowers 2-3 together in the axils of the upper leaves: loment sessile in the calyx, 2-5jointed, the joints about $3 \mathrm{~mm}$. long, straight on the dorsal suture, slightly rounded below.

In sand, peninsular Florida. Also circumtropical.

\section{LESPEDÈzA Michx.}

Herbs or shrubs, with variously pubescent foliage. Leaves pinnately 3-foliolate, or rarely 1 -foliolate, with mucronate stipules: leaflets often veiny, not stipellate. Flowers perfect, all complete or some of them apetalous. Calyx of 5 slightly united sepals : lobes nearly equal or the two upper ones somewhat united. Corolla white, pink, or purple, or rarely yellow: standard broad, with a claw: wings curved: keel obtuse or beaked, incurved. Stamens diadelphous ( 9 and 1), or partially monadelphous. Anthers alike. Ovary sessile or stalked. Style filiform, often incurved. Ovule solitary. Pod of 1 or 2 lenticular joints, indehiscent, prominently nerved. BuSH-CLOVER.

Annual : stipules ovate : calyx-lobes about as broad as long.

1. L. striata.

Perennial: stipules subulate: calyx-lobes much longer than broad.

Flowers both petaliferous and apetalous: calyx-lobes shorter than the pod: corolla purple or purplish.

Flower-clusters slender-peduncled, mostly surpassing the leaves.

Petaliferous flowers in spike-like or head-like clusters.

Stems branched at the base; branches trailing or procumbent.

Foliage glabrous or pubescent with appressed hairs. Pods $3-4 \mathrm{~mm}$. long: stems pubescent.

Pods 5-6 mm. long: stems essentially glabrous, at least below. Foliage downy or woolly.

Stems upright.

Calyx-lobes $5-7 \mathrm{~mm}$. long, as long as the pod or longer.

Calyx-lobes 3-4 mm. long, much shorter than the pod.

Leaflets mostly with linear-elliptic blades: pods sparingly pubescent. Leaflets mostly with oval blades: pods copiously pubescent.

Petaliferous flowers in loose or close panicles.

Peduncles short, the inflorescence close : calyx-lobes about $1 / 2$ as longlas the pod.

Peduncles elongated, the inflorescence lax : calyx-lobes about. $1 / 4$ as long as the pod.

Flower-clusters of both kinds sessile or nearly so.

Leaflets with suborbicular, oval or oblong blades.

Calyx 5-6 mm. long; lobes as long as the pod or longer.

Caly $\times 3-4 \mathrm{~mm}$. long; lobes much shorter than the pod. Foliage downy.

Foliage glabrate, or pubescent with appressed hairs.

Leaflets with linear or oblong-finear blades.

Flowers all petaliferous : calyx-lobes fully as long as the pod: corolla whitish or yellowish.

Leaflets with suborbicular to oval, ovate or oblong blades.

Peduncles surpassing the leaves.

Peduncles shorter than the leaves.

Leaflets with linear or oblong-linear blades.

2. L. repens.

3. L. Texana.
4. procumbens.

5. L. Manniana.

6. L. acuticarpa.

7. L. Nuttallii.

8. L. violacea.

9. L. prairea.

10. L. simulata.

11. L. Stuvei.

12. L. frutescens.

14. L. hirta.

15. L. capitata.

15. L. angustifolia. 
1. Lespedeza striàta (Thunb.) H. \& A. Annual, sparingly appressed-pubescent. Stems erect, or usually much branched and diffusely spreading, 1-4 dm. long, slender : leaflets 3 , the blades oblong to oblong-obovate, $8-25 \mathrm{~mm}$. long, obtuse, commonly ciliate, much longer than the petioles: flowers solitary or 2-3 together and sessile or nearly sessile in the axils : calyx-lobes about as broad as long : corolla white, pink or purple, 6-8 mm. long: pods oval or suborbicular, acute, surpassing the sepals. Summer.

In dry soil and in fields, Virginia to Missouri, Florida and Texas. Naturalized from eastern Asia.

2. Lespedeza rèpens L.) Bart. Perennial, appressed-pubescent or glabrate. Stems procumbent or trailing, 2-7 dm. long, usually branched : leaflets 3 , the blades oval or obovate, $6-15 \mathrm{~mm}$. long, obtuse or retuse at the apex, rounded or narrowed at the base, longer than the petioles: inflorescence rather lax : peduncles of the petaliferous flower-clusters surpassing the leaves: calyx-lobes less than $\frac{1}{2}$ as long as the pod : corolla violet-purple, 4-6 mm. long: pods oval-orbicular, 3-4 mm. long, acute, finely pubescent, surpassing the calyx-lobes.

In dry and sandy soil, Long Island to Minnesota, Florida and Texas. Summer and fall.

3. Lespedeza Texàna Britton. Perennial, similar to L. repens in habit, but less pubescent. Stems procumbent, $2-5 \mathrm{dm}$. long, glabrous below : leaflets 3 , the blades oblong or oblong-obovate, $1-2.5 \mathrm{~cm}$. long, usually mucronulate, prominently veined, glabrous above, sparingly pubescent beneath: inflorescence scant and very lax : calyxlobes barely $\frac{1}{5}$ as long as the pod : corolla purplish : pods oval, 5-6 $\mathrm{mm}$. long, minutely pubescent.

In dry soil, southeru Texas. Spring and summer.

4. Lespedeza procúmbens Michx. Perennial, woolly or downy. Stems procumbent, trailing or rarely ascending, $3-9 \mathrm{dm}$. long, stouter than those of $L$. repens : leaflets 3 , the blades oval or elliptic, sometimes obovate, $10-25 \mathrm{~mm}$. long, obtuse or retuse at the apex, rounded at the base, much longer than the petioles : inflorescence lax : peduncles of the petaliferous flower-clusters surpassing the leaves: calyx-lobes less than $\frac{1}{2}$ as long as the pods : corolla violet-purple to pinkish purple, $6-7 \mathrm{~mm}$. long: pods oval-orbicular, $3 \mathrm{~mm}$. long, acute, pubescent, surpassing the calyx-lobes.

In dry soil or on roadsides, Massachusetts to the Indian Territory, Florida and Louisiana. Summer and fall.

5. Lespedeza Manniàna Mackenzie \& Bush. Perennial, copiously pubescent, at least above. Stems 4-9 dm. tall : leaflets 3, the blades oblong to somewhat cuneate, 1-4 $\mathrm{cm}$. long, mucronulate, sparingly appressed-pubescent above, densely so beneath : calyxlobes 5-7 mm. long, as long as the pods or longer : corolla purplish, 5-6 mm. long: pods oval, mostly $5-6 \mathrm{~mm}$. long, minutely pubescent.

On barrens or in open woods, Missouri and Arkansas. Summer and fall.

6. Lespedeza acuticárpa Mackenzie \& Bush. Perennial, more or less pubescent. Stems erect or nearly so, 2.5-5 dm. tall, with erect-ascending branches: leaflets 3 , the blades oblong-elliptic, 8-22 mm. long, glabrate above, appressed-pubescent beneath : flowers 6 or fewer in a spike : calyx-lobes about $3 \mathrm{~mm}$. long, $\frac{1}{2}$ as long as the pod: corolla purplish, 6-8 mm. long: pods elliptic or ovate-elliptic, sharply acute or somewhat acuminate, slightly pubescent or nearly glabrous.

In open woods or on barrens, Missouri and Arkansas. Summer and fall.

7. Lespedeza Nuttállii Darl. Perennial, often copiously pubescent. Stems erect or ascending, 5-10 dm. tall, simple or branching above : leaflets 3 , the blades leathery, obovate, oval or suborbicular, $8-20 \mathrm{~mm}$. long, obtuse or notched at the apex, dark green and glabrous or nearly so above, closely pubescent beneath, longer than the petioles: inflorescence capitate or densely spicate : peduncles usually surpassing the leaves: calyx-lobes fully $\frac{1}{2}$ as long as the pod: corolla $5-7 \mathrm{~mm}$. long: pods oval to oblong, 5-6 mm. long, acute or acuminate at both ends, densely pubescent.

In dry soil, New England to Michigan, Kansas and Florida. Summer and fall.

8. Lespedeza violàcea (L.) Pers. Perennial, sparingly pubescent. Stems usually branched at the base, the branches erect or ascending, or spreading, 3-9 dm. long, branched: leaflets 3 , the blades rather thin, elliptic, oblong-elliptic or oval, 10-20 mm. long, obtuse or retuse at the apex, appressed-pubescent beneath, as long as the petioles or longer : inflorescence close : peduncles relatively short : calyx-lobes about one-half as long as the pod : corolla violet-purple, $6-10 \mathrm{~mm}$. long : pods ovate or oval, 4-6 mm. long, acute, sparingly and finely pubescent.

In dry soil, New England to Minnesota, Kansas, Florida, Louisiana and Mexico. Summer and fall.

9. Lezpedeza prairea (Mackenzie \& Bush) Britton. Perennial, glabrous below, finely appressed-pubescent above. Stems ascending, several dm. long, copiously branched, 
the branches often interwoven : leaflets 3 , the blades mainly obovate, sometimes obcordate, 6-18 mm. long, mucronulate, glabrous above, finely appressed-pubescent beneath : inflorescence lax and very open, the peduncles usually much elongated: calyx-lobes about $\frac{1}{4}$ as long as the pod: corolla purplish, $6-8 \mathrm{~mm}$. long: pods broadly oval, 3-4 $\mathrm{mm}$. long, prominently veined, much exceeding the calyx.

In dry soil, Iowa to Nebraska, Arkansas and Texas. Summer and fall.

10. Lespedeza simulàta Mackenzie \& Bush. Perennial, more or less pubescent, sometimes almost glabrous. Stems erect, 6-9 dm. tall, with few appressed-ascending branches: leaflets 3 , the blades linear-oblong to oblong-elliptic, $1.2-3 \mathrm{~cm}$. long, rounded at both ends but mucronate at the apex, silvery pubescent with appressed hairs on both sides, but especially so beneath : calyx-lobes slender, 4-5 $\mathrm{mm}$. long, about as long as the pod or longer: corolla purple, $6-8 \mathrm{~mm}$. long: pods oval, $4.5-5 \mathrm{~mm}$. long, usually copiously pubescent.

On rocky mounds and prairies, Missouri to Arkansas and Texas. Summer and fall.

11. Lespedeza Stùvei Nutt. Perennial, densely velvety or downy pubescent. Stems erect or ascending, 6-12 dm. tall, simple or narrowly branched above: leaflets 3 , the blades oblong, oval or suborbicular, 10-20 $\mathrm{mm}$. long or rarely longer, obtuse or retuse at the apex, longer than the petioles : inflorescence rather dense, the clusters of both kinds of flowers sessile or nearly sessile in the axils : calyx-lobes less than $\frac{1}{2}$ as long as the pod: corolla violet-purple, 4-6 mm. long: pods oblong-ovate to suborbicular, 4-6 $\mathrm{mm}$. long, acute, densely pubescent.

In dry soil, Long Island to Michigan, Georgia and the Indian Territory. Summer and fall--A variety, $L$. Stuvei neglécta Britton, with linear or linear-oblong mucronulate blades of the leaflets, occurs from New Jersey to Missouri, south to Georgia and Texas.

12. Lespedeza frutéscens (L.) Britton. Perennial, finely appressed-pubescent or glabrate. Stems erect or ascending, 3-10 dm. tall, simple or branched: leaflets 3 , the blades oval, oblong or elliptic, 10-35 mm. long, obtuse, truncate or retuse at the apex, dark green and glabrous above, paler and slightly pubescent beneath, as long as the petioles or longer : inflorescence often dense: clusters of both kinds of flowers nearly sessile or shortpeduncled in the axils, usually crowded near the summit of the stem: calyx-lobes $\frac{1}{2}$ as long as the pod or shorter: corolla violet-purple, 4-6 $\mathrm{mm}$. long: pods ovate-oblong, about $4 \mathrm{~mm}$. long, acute, pubescent, surpassing the calyx-lobes.

In dry soil, Massachusetts to Ontario, Michigan, Florida and Texas. Summer and fall.

13. Lespedeza Virgínica (L. ) Britton. Perennial, similar to I. frutescens, but more slender. Stems erect or ascending, 4-11 dm. tall, simple or sparingly branched: leaflets 3 , the blades linear or oblong-linear, 12-35 $\mathrm{mm}$. long, truncate, obtuse or sometimes acute at the apex, glabrate on both surfaces or finely pubescent beneath : inflorescence rather dense : clusters of both kinds of flowers sessile or nearly sessile and crowded in the upper axils: calyx-lobes less than $\frac{1}{2}$ as long as the pod : corolla violet-purple, 4-6 mm. long : pods ovate or oval-orbicular, about $4 \mathrm{~mm}$. long, acute or obtuse, pubescent or glabrate, surpassing the calyx-lobes.

In dry soil, Massachusetts to Minnesota, Florida and Texas. Summer and fall.

14. Lespedeza hírta (L. ) Ell. Perennial. Stems erect or ascending, 5-12 dm. tall, mostly branched above: leaflets 3 , the blades oval or suborbicular, $12-40 \mathrm{~mm}$. long, rounded at both ends or notched at the apex : racenes rather dense, 1-4 cm. long, disposed in panicles : peduncles often surpassing the leaves: flowers all complete: calyx-lobes surpassing the pod: corolla about $6 \mathrm{~mm}$. long, yellowish white; standard sometimes purplespotted: pods oval or obovate, 7-8 mm. long, acute, about as long as the calyx-lobes.

In dry soil, Maine to Ontario, Minnesota, Florida and Louisiana. Summer and fall.-A A variety with loose spikes, a densely pubescent calyx and leaflets with oblong blades, is $L$. hirta oblongifolia Britton; it ranges from New Jersey to the Gulf States.

15. Lespedeza capitàta Michx. Perennial, silky or silvery pubescent. Stems erect or ascending, rigid, $5-16 \mathrm{dm}$. tall, usually simple to the inflorescence: leaflets 3 , the blades oblong to oval, $2.5-3.5 \mathrm{~cm}$. long, obtuse, or acute at both ends, several times longer than the very short petioles: flowers all complete: racemes oblong-globose, sessile or short-peduncled : calyx-lobes much longer than the pod: corolla about $6 \mathrm{~mm}$. long, yellowish white, or standard with a purple spot: pods oblong-ovate, $5-5.5 \mathrm{~mm}$. long, acute, pubescent, $\frac{1}{2}-\frac{2}{3}$ as long as the calyx-lobes.

In dry soil, Maine to Ontario, Minnesota, Florida, Louisiana and Nebraska. Summer and fall.

16. Lespedeza angustifolia (Pursh) Ell. Perennial, appressed-pubescent. Stems erect or ascending, $6-10 \mathrm{dm}$. tall, rather slender, usually branched above : leaflets 3 , the blades linear or oblong-linear, or sometimes linear-lanceolate on the lower part of the stem, $2-3.5 \mathrm{~cm}$. long, truncate, obtuse or acutish at the apex, much longer than the very short petioles: racemes subglobose or oblong, slender-peduncled: calyx-lobes much 
longer than the pod: corolla yellowish or yellowish white, 5-7 mm. long: pods ovateorbicular, 4-4.5 mm. long.

In dry, usually sandy soil, Massachusetts to Michigan, Florida and Louisiana. Summer and fall.

\section{PITCHÈrIA Nutt. ${ }^{1}$}

Perennial branching herbs, with erect stems. Leaves 3 -foliolate, subsessile or very shortpetioled: leaflets resinous-dotted. Flowers short-pedicelled, solitary, or 2-3 in the axils of the upper leaf-like bracts. Calyx very slightly bilabiate : lobes 4, about equal, the lower lobe the longest; upper lip 2-toothed. Corolla yellow, soon deciduous: standard glabrous; blade obovate to nearly orbicular, without callosities, the margins of the short claw folded in : wings smaller than the keel-petals, narrowly oblong, somewhat falcate, with a subulate tooth at the base: keel rounded, somewhat falcate, shorter than the standard. Stamens diadelphous : free filament articulated at the base, the lateral filaments sometimes free to above or near the middle of the tube. Ovary hairy, 2-ovuled. Style filiform, bearded below. Stigma subcapitate. Pod oblong, tapering at the base, sessile, compressed, 1-2-seeded.

1. Pitcheria galactioìdes Nutt. Stems woody at the base, 6-10 dm. high, rigid, widely and mostly symmetrically branched, pubescent : leaves numerous, $1-2.5 \mathrm{~cm}$. long ; leaflets 5-20 mm. long, the blades oval or obovate-oval, obtuse, reticulated and minutely resinous-dotted and sparingly pubescent, especially on the midvein and margins beneath, the terminal leaflet longer than the lateral sessile or very short-petioluled ones : flowers about $1 \mathrm{~cm}$. long: calyx $5 \mathrm{~mm}$. long, minutely pubescent; lobes lanceolate, long-acuminate : corolla mainly yellow; the petals sometimes partially reddish or purplish-veined ; standard short-unguiculate, the blade oval, apiculate, the short spurs very acute : pods $1.5-2$ $\mathrm{cm}$. long, 7-8 $\mathrm{mm}$. wide, tapering to the base, minutely pubescent, obscurely resinousdotted, and with few scattered longer hairs.

In sandy pine lands, Florida and Alabama. Spring and summer.

\section{DoLICHÒuUs Medic. ${ }^{1}$}

Perennial, twining, trailing or erect herbs or shrubs, with short or elongated stems. Leaves with 1 -foliolate or pinnately 3 -foliolate blades : stipules commonly persisting. Leaflets punctate with resinous dots, usually leathery and prominently veined. Flowers perfect in axillary or terminal racemes, or in axillary clusters. Calyx somewhat 2-lipped : lobes 5, the upper lobes usually more united than the 3 lower. Corolla yellow : standard broad, spreading or reflexed, mostly auricled at the base : wings narrow : keel-petals incurved at the apex. Stamens diadelphous. Anthers all alike. Ovary sessile. Style stoutish, incurved at the apex. Ovules 1 or 2 . Pod flattened, orbicular to oblong, 2-valved. Seeds 1 or 2 in a pod. [Rhynchosia Lour.]

Corolla much longer than the calyx.

Racemes very slender, many-flowered, exceeding the leaves : flowers and legumes reflexed.

Racemes 1-6-flowered, as long as or shorter than the leaves.

Leaflets with leathery obtuse or merely acute blades.

Blades of the leaflets velvety above, tomentulose and veiny beneath.

Blades of the leaflets strigillose above, puberulent or minutely strigillose beneath.

Leaflets with membranous acuminate blades.

Corolla about as long as the calyx or much shorter.

Prostrate or climbing perennial vines.

Leaves unifoliolate, or in D. Michauxii rarely the uppermost trifoliolate: racemes axillary.

Leaflets with reniform blades, cordate at the base.

Leaflets with reniform blades, truncate at the base.

Leaves trifoliolate.

Racemes very short-peduncled or sessile. Stems prostrate, leaflets cinereous. Stems generally climbing.

Racemes peduncled or the uppermost short-peduncled, elongating. Prostrate : leaflets apiculate, $2.5-3.5 \mathrm{~cm}$. long.
Climbing vines.

Leaflets with obovate-orbicular, thin, blades rounded at the broad apex, narrowed at the subcordate base.

Leaflets with ovate or ovate-rhombic, thick, velvety-pubescent blades: racemes commonly much elongated.

1. D. minimus.

2. D. parvifolius.

3. D. Texensis.

4. D. Swartzii.

Leennial herbs.

Leaves unifoliolate, the leaflets with reniform blades.

Leaves trifoliolate or some of the basal ones unifoliolate.

5. D. Americanus.

6. D. Michauxii.

7. D. cinereus.

8. D. tomentosus.

9. D. Torreyi.

10. D. Lewtonii.

11. D. latifolius.

12. D. simplicifolius.

${ }^{1}$ Contributed by Miss Anna Murray Vail. 
Racemes terminal and axillary, never long-peduncled and elongated. Stems simple, 1-2 dm. high. stems simple or branched.

Racemes numerous, short, axillary: leaflets with thick, velvety pubescent blades, acutish or obtuse.

Racemes numerous, short, axillary : leaflets with densely velutinous, acute blades.

Racemes terminal or a few of them axillary, commonly much elongated.

13. D. intermedius.

14. D. erectus.

15. D. Drummondii.

16. D. mollissimus.

1. Dolicholus mínimus (L.) Medic. Stems numerous, slender, prostrate or climbing over bushes, pubescent, especially on the angles, resinous-dotted: stipules subulate, 2 mm. long, soon caducous : leaflets $8-40 \mathrm{~mm}$. long, minutely cinereous-pubescent, at least when young, coriaceous, the terminal one with a broad rhombic-orbicular, acutish or obtuse, mucronulate blade, the others smaller and obliquely semi-rhombic : racemes axillary, 4-10 cm. long, loosely and somewhat distantly flowered, much surpassing the leaves: peduncles $2-4 \mathrm{~cm}$. long : calyx-lobes subulate-setaceous : corolla pale yellow, $6-7 \mathrm{~mm}$. long, much exceeding the calyx ; standard obovate-orbicular, retuse, commonly purple-veined, with a very short claw, resinous-dotted and minutely pubescent on the outer surface: keelpetals bright yellow : pods $1-1.7 \mathrm{~cm}$. long, $4 \mathrm{~mm}$. wide, scythe-shaped, minutely pubescent, reflexed : seeds oblong-ovoid, pale brown or grayish, mottled, smooth and shining.

In pine woods, South Carolina to Florida, Texas and southward to Brazil. May to October.

2. Dolicholus parvifolius (DC.) Vail. Stems somewhat woody at the base, slender, climbing on grasses and low bushes, or barely climbing above, pubescent with close grayish down or tomentum : stipules subulate-setaceous, about $1 \mathrm{~mm}$. long: leaflets 3 , the blades elliptic or elliptic-lanceolate, those of the basal ones ovate-elliptical or rarely ovate, acutish or obtuse, emarginate, velvety-pubescent or tomentose on both surfaces, strongly reticulated beneath, the terminal one $2-3.5 \mathrm{~cm}$. long, the others inequilateral, $1.5-2.5 \mathrm{~cm}$. long: racemes $2-4 \mathrm{~cm}$. long, usually exceeding the leaves, several-flowered : peduncles $2-3 \mathrm{~cm}$. long, angled : calyx $7 \mathrm{~mm}$. long, pubescent and resinuous-dotted; lobes acuminate: corolla yellow; standard retuse, resinous-dotted, minutely retrose-pubescent above the middle : pods $1.3-1.5 \mathrm{~cm}$. long, 4-5 mm. wide, oblong, clothed with a short close-set pubescence and scattered longer rigid yellowish hairs : mature seeds not seen.

In sandy soil, Florida and the West Indies. September to January.

3. Dolicholus Texénsis (T. \& G.) Vail. Stems somewhat woody at the base, slender, erect or at length much elongated, prostrate and twining over bushes, clothed with fine retrorse grayish pubescence: stipules subulate-setaceous, $1 \mathrm{~mm}$. long, soon deciduous : leaflets 3 , the blades 1-2.5 $\mathrm{cm}$. long, oval, rounded or rhombic-ovate, or lanceolate-ovate, obtuse, minutely apiculate, emarginate, minutely rugose and pubescent above, minutely pubescent and often somewhat reticulated beneath, the terminal leaflet largest: flowers solitary or often 2-4 together in the axils of the upper leaves: pedicels $2-3 \mathrm{~mm}$. long: calyx $3 \mathrm{~mm}$. long; lobes about equal : corolla yellow; standard with a suborbicular blade, minutely retrorse-pubescent along the apex: pods scythe-shaped, $1-1.5 \mathrm{~cm}$. long, 4-5 $\mathrm{mm}$. wide, acutish at the base, with a minute acute termination, pubescent : seeds 2$2.5 \mathrm{~mm}$. broad, suborbicular, lenticular, brown.

In dry soil, Texas to Arizona and northern Mexico. Also in Brazil and Argentina. May to August. $-A$ Texano-Mexican variety with oblong-lanceolate or linear-lanceolate leaflets often tivice as long as those of the type, is $D$. Texensis angustifólius (Engelm.) Vail.

4. Dolicholus Swártzii Vail. A slender twining perennial or woody vine. Stems apparently branching at the base, pubescent, sparingly resinous-dotted : stipules $4 \mathrm{~mm}$. long, linear-lanceolate, ciliate, reflexed, at length deciduous : terminal leaflet 4-6 cm. long, the blade ovate, long-acuminate, rather thin, soft-pubescent on both surfaces, resinous-dotted beneath; lateral leaflets smaller : racemes 1-2 $\mathrm{cm}$. long or less, 2-3-flowered, the short peduncles very slender: pedicels filiform, $3-4 \mathrm{~mm}$. long, puberulent : calyx 3 $\mathrm{mm}$. long, resinous-dotted; lobes shorter than the tube : corolla yellow, much exceeding the caly $\mathrm{x}$; standard obovate, $8 \mathrm{~mm}$. long, minutely puberulent and dotted with elevated yellow resinous spots or glands on the outside : pods $2.5-3 \mathrm{~cm}$. long, 5-7 mm. wide, falcate, acute at the apex, dark brown and coriaceous, pubescent, resinous-dotted : mature seeds $5-6 \mathrm{~mm}$. long, oblong-ovoid, bright red.

In sandy soil, southern Florida and Cuba. Throughout the year.

5. Dolicholus Americànus (Mill.) Vail. Stems slender, prostrate, trailing or often twining, 3-5 dm. long or longer, minutely retrorse-pubescent, especially on the angles: stipules reddish, oval or ovate, spreading, pubescent without, glabrous within: leaves distant ; leaflets solitary, the blade grayish green, reniform, $2-4 \mathrm{~cm}$. long, $2-6 \mathrm{~cm}$. broad, obtuse or rarely acutish at the apex, cordate at the base, thick, appressed velvety-pubescent on both surfaces, reticulated and conspicuously veined beneath : flowers short-pedicelled, solitary, or 2-6 in clusters much shorter than the leaves: calyx 8-10 $\mathrm{cm}$. long; lobes 
narrowly elliptic, acuminate, veined, pubescent and ciliate, reflexed in fruit : corolla yellow; standard minutely pubescent on the outer surface, with a suborbicular blade 6-8 $\mathrm{mm}$. in diameter : pods 1-1.5 $\mathrm{cm}$. long, 6-7 cm. wide, sessile, obliquely oblong, acute, pubescent : seeds 2 , oblong, truncate at the base, black.

In dry soil, Texas and Mexico. May to June.

6. Dolicholus Michaùxii Vail. Stems prostrate, 6-9 dm. long, or more, twining above, clothed, especially on the angles, with a short matted grayish pubescence: stipules 2-5 mm. long, ovate-lanceolate, spreading, persistent: leaflets $2.5-5 \mathrm{~cm}$. long, the blades much dilated, broader than long, obtuse, sometimes obscurely mucronulate, rugose and minutely hirsute above, sparingly resinous-dotted, reticulated and softly hirsute beneath ; upper leaves rarely 3 -foliolate with obtuse obliquely suborbicular lateral leaflets : racemes 1-several-flowered, peduncled : calyx $1-1.5 \mathrm{~cm}$. long, pubescent, resinous-dotted ; lobes oblong-lanceolate or elliptic, acuminate, conspicuously foliaceous : corolla pale yellow ; standard minutely pubescent : pods about $1.4 \mathrm{~cm}$. long, $6 \mathrm{~mm}$. wide, obliquely acute : seed 2-5 $\mathrm{mm}$. in diameter, red-brown.

In dry pine lands, Florida. March to September.

7. Dolicholus cinèreus (Nash) Vail. Stems numerous, prostrate and trailing, branched, 6-10 dm. long, appressed cinereous-pubescent: stipules turning brown, ovate, acuminate, ciliate, 3-4 $\mathrm{mm}$. long : leaves $3-6 \mathrm{~cm}$. long: leaflets 3 , the blades appressedpubescent above and somewhat rugose on the veins and sparingly resinous-dotted beneath, the lateral leaflets obliquely ovate or orbicular-ovate, $1-2.3 \mathrm{~cm}$. long, 9-18 mm. wide; terminal leaflet larger, orbicular-ovate to depressed-orbicular, $1.5-2.6 \mathrm{~cm}$. long, $1.3-3 \mathrm{~cm}$. wide : flowers 2-several together in short axillary clusters not exceeding the petioles : pedicels slender, 1-3 mm. long: calyx-lobes lanceolate, acuminate, 3-nerved, usually reflexed in fruit, the middle lobe 1-1.3 $\mathrm{cm}$. long, somewhat exceeding the lateral ones : corolla yellow; standard minutely pubescent along the summit: pods oblong, obliquely acute at the apex, $1.6 \mathrm{~cm}$. long, $8 \mathrm{~mm}$. wide, appressed-pubescent: seeds lenticular, $5 \mathrm{~mm}$. in diameter, mottled, brown.

In high pine lands, peninsular Florida and Pelican Key. June to July.

8. Dolicholus tomentòsus (L.) Vail. Stems rather stout, softly retrorse-hirsute, especially on the prominent angles, twining above, $3-6 \mathrm{dm}$. long or more : stipules ovate or ovate-lanceolate, reddish brown, 5-7 mm. long: leaves rather distant, 4-12 cm. long, (basal ones often 1 -foliolate): leaflets mainly 3 , the blades ovate or ovate-rhombic, (basal ones often dilated and depressed-orbicular), 3-6 cm. long, obtuse, clothed with soft pubescence ; terminal leaflet the largest, the others obliquely ovate : racemes few-flowered, shortpeduncled, much shorter than the petioles : flowers 9-14 mm. long: calyx-lobes acuminate, 3-nerved, the 3 lower approximately equal : corolla yellow ; standard retuse, obscurely hirsute near the apex : pods $1.5 \mathrm{~cm}$. long, $8 \mathrm{~mm}$. wide, obliquely oblong, each with a very short, acute or slightly oblique apex : seeds lenticular, $2.5-3 \mathrm{~mm}$. in diameter, dark brown.

In dry soil, Virginia to Florida, Mississippi and probably Texas.-A less densely pubescent form, with relatively narrow and thinner, undulate leaflets, is $D$. tomentosus unduldtus Vail.

9. Dolicholus Torreỳi Vail. Stems slender, branched, prostrate, spreading, or probably twining above, minutely pubescent : stipules 4-6 mm. long, lanceolate, slender, caducous: leaves 3 -foliolate: leaflets $2.5-3.5 \mathrm{~cm}$. long, the blades orbicular-ovate or oblong-ovate, obtuse or with a short abrupt acumination, narrowed at the base, minutely and sparingly pubescent on both surfaces or nearly glabrous, beset with scattered resinous dots beneath; terminal leaflet largest: racemes $5-8 \mathrm{~cm}$. long, the scattered flowers about $1 \mathrm{~cm}$. long: calyx $8 \mathrm{~mm}$. long, pubescent, resinous-dotted; lobes linear or linearlanceolate: corolla yellow ; standard nearly orbicular, $8 \mathrm{~mm}$. long, pubescent on the outer surface, with a small, internal crescent-shaped callosity above the claw : pods not seen.

On sand hills, Texas. Spring to fall.

10. Dolicholus Lewtònil Vail. Soft-pubescent and minutely resinous-dotted throughout. Stems prostrate, $3-5 \mathrm{dm}$. long or longer, obscurely retrorsely hirsute-pubescent, apparently not twining at the summit : stipules obliquely lanceolate, 6-8 mm. long : terminal leaflet 4-6 cm. long, 4-8 cm. wide, the blade dilated or obovate-orbicular, commonly broadest above the middle, broadly rounded and sometimes slightly retuse at the apex, narrowly subcordate at the base; lateral leaflets with obliquely obovate-oblong reticulated blades : upper racemes sessile, $2-4 \mathrm{~cm}$. long, the others on peduncles $2-4 \mathrm{~cm}$. long calyx $9-$ $10 \mathrm{~mm}$. long; lobes foliaceous, exceeding the glabrous yellow corolla : pods not seen.

In dry sandy soil, Orange County, Florida. March to October.

11. Dolicholus latifolius (Nutt.) Vail. Stems stout, $6 \mathrm{dm}$. long, clothed with a close soft pubescence, twining above : stipules lanceolate, $3-5 \mathrm{~mm}$. long, soon deciduous : leaves $5-15 \mathrm{~cm}$. long: leaflets $3-8 \mathrm{~cm}$. long, the blades ovate or ovate-rhombic, often somewhat 
dilated, usually obtuse, $3-8 \mathrm{~cm}$. long, 2-7 $\mathrm{cm}$. wide, clothed on both surfaces with a velvety pubescence; terminal leaflet much larger and broader than the lateral : racemes 1-2.5 dm. long, the upper ones shorter than the leaves and fewer flowered: flowers scattered along the angled peduncle for more than half its length, forming an interrupted spike-like raceme, 4-20 cm. long: calyx $1-1.3 \mathrm{~cm}$. long, hirsute; lobes veined, nearly equal : corolla yellow ; standard broadly oblong, hirsute along the top : pods obliquely oblong, 1.5-2 cm. long, nearly straight along the dorsal and deeply rounded along the ventral suture : seeds lenticular, 3.5-4 mm. in diameter, brown or sometimes light with dark markings.

In dry soil, Missouri to Louisiana and Texas. July to October.

12. Dolicholus simplicifòlius (Walt.) Vail. Stems erect, simple, rarely branched above, several from the same root, 1-3 dm. high, hirsute, especially on the angles, with spreading or reflexed hairs : stipules ovate or ovate-lanceolate, $5-10 \mathrm{~cm}$. long, reticulated, persistent : leaves 1-foliolate, the blades $2-8 \mathrm{~cm}$. broad, $2-5 \mathrm{~cm}$. long, depressed orbicular or reniform, leathery, velvety-pubescent above, resinous-dotted, reticulated, and hirsute on the veins beneath, becoming glabrate with age : racemes sessile or short-peduncled, $2-3 \mathrm{~cm}$. long, axillary or commonly aggregated at the summit of the stem : calyx 7-10 mm. long, resinous-dotted, somewhat hirsute and ciliate: corolla yellow : pods oblong, $1.5 \mathrm{~cm}$. long, 6 $\mathrm{mm}$. wide, obscurely falcate, pubescent and resinous-dotted : seeds lenticular, $3 \mathrm{~mm}$. broad, brownish, mottled with black.

In dry soil, Virginia to Florida, and Louisiana. May to September.

13. Dolicholus interméđius (T. \& G.) Vail. Stems erect, simple, or possibly with few branches, softly pubescent-tomentose, especially on the angles, $1.2-3 \mathrm{dm}$. high : stipules obliquely lanceolate, 6-9 mm. long, striate, red-brown, persistent : basal leaves 1-foliolate, the blades nearly orbicular or rhombic-orbicular, obtuse or depressed; upper leaves or only the uppermost 3-foliolate, the terminal leaflet $2.5-5 \mathrm{~cm}$. long, its blade oval or ovate-orbicular, obtuse, sparingly pubescent above, pubescent and rugosely veined beneath when old ; lateral leaflets obliquely oval or oblong, 2-3 cm. long, mucronulate, some of them subcordate at the base: racemes terminal and axillary, sessile or short-peduncled: calyx 8-9 mm. long; lobes slender, veined, pubescent, resinous-dotted : corolla yellow ; standard glabrous, the teeth at the base much shorter than the claw : pods not seen.

In sandy soil, Georgia to Florida and Alabama. May to June.

14. Dolicholus eréctus (Walt.) Vail. Stems erect, $2 \mathrm{dm}$. high or taller, simple or branched above, with a soft fine pubescence : stipules lanceolate or linear-lanceolate, acuminate, reddish brown, 4-8 mm. long, at length reflexed : leaves distant, 4-15 $\mathrm{cm}$. long, the basal ones often 1-foliolate ; leaflets mainly 3 , the blades oval, oblong, or oblong-oval, acutish or obtuse, $2.5-4.5 \mathrm{~cm}$. long, $1.5-3.5 \mathrm{~cm}$. wide, pubescent above, velvety pubescent, somewhat reticulated and resinous-dotted beneath, often drooping, the terminal leaflet the longest: racemes numerous, usually shorter than the petioles, very short-peduncled in the axils of the leaves : flowers in compact clusters: calyx about $6 \mathrm{~mm}$. long, pubescent; lobes not conspicuously foliaceous, lanceolate, acuminate, veined : corolla yellow ; standard suborbicular, glabrous : pods $1.5-2 \mathrm{~cm}$. long, 6-7 mm. wide, oblong, attenuate, with a somewhat curved apex, rounded on the ventral suture : seeds lenticular, $3 \mathrm{~mm}$. in diameter, flattened, brownish.

In dry soil, Delaware to Tennessee, Florida and Louisiana. May to October.

15. Dolicholus Drummóndii Vail. Stems erect, densely velutinous-tomentose, 1.5$3 \mathrm{dm}$. high : stipules lanceolate, acuminate, becoming reflexed, deciduous: leaflets 3 , the blade of the terminal one oblong-lanceolate or sometimes oblong, 3-6 cm. long, $2-3 \mathrm{~cm}$. wide, acute, densely velutinous-tomentose on both surfaces, silvery above, the whole lower surface dotted with numerous orange-colored glands beneath the tomentum, and the prominent veins reticulated beneath; lateral leaflets with narrower inequilateral acute blades: racemes subsessile or very short-peduncled : calyx $6 \mathrm{~mm}$. long, foliaceous, tomentulose and ciliate, resinous-dotted, the upper lobe 2-toothed to considerably below the middle: corolla included in the calyx, apparently a deep orange-yellow color ; standard round-ovate, the auricles at the base rounded, minutely glandular-puberulent on the outer surface: pods not seen.

In sandy soil, Louisiana. June to October.

16. Dolicholus mollíssimus (Ell.) Vail. Stems erect, commonly simple, $3-6 \mathrm{dm}$. high, clothed with a close, fine soft pubescence : stipules $6 \mathrm{~mm}$. long, red-brown, lanceolate, acuminate : leaves rather remote, $5-9 \mathrm{~cm}$. long: leaflets 3 , the blades oval or oval-oblong, acutish, $2.5-4.5 \mathrm{~cm}$. long, $2-3.5 \mathrm{~cm}$. wide, minutely apiculate, obscurely emarginate, clothed with a short pubescence, especially on the reticulated, resinous-dotted under surface ; terminal leaflet the largest, the others not conspicuously inequilateral : racemes terminal, elongated, $6 \mathrm{~cm} .-1.8 \mathrm{dm}$. long, and often a few short racemes in the axils of the 
upper leaves: flowers scattered along the whole length of the rachis: calyx 6-8 mm. long, pubescent, resinous-dotted, 4-parted about two-thirds to the base ; lobes lanceolate : corolla yellow ; standard glabrous, the spurs of the claw obtuse: pods oblong, $2 \mathrm{~cm}$. long, $6 \mathrm{~mm}$. wide, attenuated below, somewhat rounded on the ventral suture, with a short acute, slightly curved acumination : seeds lenticular, $3-4 \mathrm{~mm}$. broad, brown, mottled.

In pine lands, Florida. February to October.

\section{ERYTHRINA L.}

Shrubs or trees, with erect stems, or more or less reclining herbs. Leaves alternate with small stipules: blades pinnately 3 -foliolate : stipules gland-like. Flowers perfect, showy, in terminal, more or less leafy-bracted racemes and axillary naked racemes. Calyx oblique : tube truncate or with 5 partially distinct sepals. Corolla often bright scarlet: standard broad or elongated, erect or spreading, nearly sessile or with a long claw : wings small or wanting: keel-petals longer or shorter than the wings. Stamens diadelphous ( 9 and 1) or monadelphous at the base. Anthers alike. Ovary stalked. Style slender, with a subulate apex, incurved, glabrous. Ovules numerous. Pod slightly flattened, torulose.

Herb: stems annual: racemes many-flowered. Shrub or tree: stems persistent: racemes few-flowered.

1. E. herbacea. 2. E. arborea.

1. Erythrina herbàcea L. Herbaceous above the root. Stems more or less spreading, 6-12 dm. long, sometimes sparingly armed: leaflets 3 , the blades thinnish, deltoid to hastate, 3-9 $\mathrm{cm}$. long : racemes $3-6 \mathrm{dm}$. long : pedicels $2-6 \mathrm{~mm}$. long : calyx campanulate, 6-8 mm. long: corolla scarlet, $3.5-5 \mathrm{~cm}$. long : pods 7-12 cm. long, more or less spreading, deeply constricted between the seeds.

In sand or pine lands, North Carolina to Florida and Texas. Spring.

2. Erythrina arbòrea (Chapm.) Small. A shrub or small tree sometimes $6 \mathrm{~m}$. tall. Stems solitary or thickly tufted, armed : petiole and rachis wire-like : leaflets 3 , the blades membranous, deltoid to hastately 3 -lobed, $3.5-10 \mathrm{~cm}$. long : racemes 1-2 dm. long : pedicels slender, 4-8 $\mathrm{mm}$. long : calyx campanulate, $7-9 \mathrm{~mm}$. long, shallowly lobed : corolla scarlet, 3-4 cm. long: pods 8-12 cm. long, constricted between the seeds. [E. herbacea var. arborea Chapm.]

In sandy soil, peninsular Florida and the Keys. Spring.

\section{DIOCLÈA H.B.K.}

High-climbing shrubs or shrubby herbs, with twining stems. Leaves alternate : blades 3 -foliolate. Flowers perfect, in axillary racemes: peduncles more or less elongated. Calyx pedicelled: lobes unequal, the 2 upper united, the 2 lateral smaller, the lower one longer Corolla white, blue or violet: standard reflexed; blade broad, auricled at the base : wings free from the shorter incurved, obtuse or beaked keel. Stamens 10, diadelphous ( 9 and 1 ) or monadelphous to the middle, the filament opposite the standard partially adnate to it. Anthers alike or alternately perfect and imperfect. Ovary nearly sessile. Ovules several. Pod narrow or half-orbicular, flattish or turgid, 2-valved, sometimes winged.

1. Dioclea multiflòra (T. \& G.) C. Mohr. Perennial, minutely pubescent. Stems trailing or climbing, 1-4 m. long, branching: leaflets 3 , the blades membranous, ovate, suborbicular or reniform, $5-15 \mathrm{~cm}$. in diameter, usually abruptly acuminate, glabrate above, acute to subcordate at the base : peduncle and raceme shorter than the subtending leaves: pedicels 1-3 mm. long: calyx about $5 \mathrm{~mm}$. long; lobes lanceolate, or the upper one triangular, all longer than the tube : corolla purple ; standard 12-15 mm. long; keel-petals somewhat shorter: pods oblong, $5-6 \mathrm{~cm}$. long. [D. Boykinii A. Gray.]

On river banks, Georgia to Arkansas and Louisiana. Summer.

\section{GALÁCtia P. Br.}

Perennial herbs, with prostrate or twining stems, or rarely shrubby plants, with erect stems. Leaves alternate: blades 3-foliolate or rarely 1-7-foliolate: stipules deciduous. Leaflets with entire, often firm or leathery blades. Flowers perfect, in axillary usually peduncled raceme-like panicles often much reduced. Calyx-lobes unequal, the two upper mainly united, the lateral small, the lower one longer than the rest. Corolla white, violet or red: standard broad, erect or spreading : wings oblong or obovate : keel slightly shorter 
or longer than the wings to which it coheres. Stamens diadelphous, or monadelphous to the middle, wholly free from the standard. Anthers all alike. Style filiform, not bearded. Ovules several. Pod elongated, somewhat flattened, 2-valved, straight or curved, sometimes produced from underground apetalous flowers. Seeds few. Milk Pea.

Plants with erect, decumbent or prostrate stems, not twining.

Leaves 1-foliolate: leaflet with strongly developed marginal nerves.

Leaves mainly 3 -foliolate: leaflets without marginal nerves.

Panicles shorter than the leaves or slightly longer, the flower or flower-clusters approximate.

Rachis not prolonged beyond the lower leaflets.

Rachis in 3-foliolate leaves, manifestly prolonged beyond the lower leaflets.

Plants with both 3-foliolate and 5-foliolate leaves: leaflets relatively small.

Plants with only 3 -foliolate leaves : leaflets relatively large.

Leaflets with narrowly or linear-oblong blades: racemes few-flowered. Leaflets with oval or oval-oblong blades: racemes many-flowered.

Panicles much longer than the leaves, the flowers or flower-clusters remote.

Plants with twining stems, sometimes prostrate or climbing over bushes.

Leaves with 3 leaflets.

Panicles 2-7 together at the nodes.

Petiole shorter than the lateral leaflets : racemes about as long as the leaves: Floridian species.

Petiole longer than the lateral leaflets: racemes much longer than the leaves: Texan species.

Panicles solitary at the nodes, occasionally accompanied by an accessory one. Panicles mainly shorter than the leaves or about equalling them.

Leaflets pale on both sides, the terminal one relatively broad : rachis prolonged about $1 \mathrm{~cm}$. beyond the lateral leaflets.

Leaflets deep green above, pale beneath, the terminal one relatively narrow: rachis prolonged much less than $1 \mathrm{~cm}$. beyond the lateral leaflets.

Panicles mainly longer than the leaves, often much longer.

Peduncle shorter than the rachis.

Panicles with remote flowers or flower-clusters : leaflets with membranous blades.

Panicles with approximate flowers or flower-clusters: leaflets with leathery blades.

Peduncle longer than the rachis.

Leaves with 7-9 leaflets.

1. G. heterophylla.

\section{G. erecta.}

3. G. Grayi.

4. G. brachypoda.

5. G. Floridana.

6. G. brevipes.

\section{G. fasciculata.}

8. G. canescens.

9. G. Texana.

10. G. regularis.

11. G. volubilis.

12. G. Cubensis.

13. G. mollis.

14. G. Elliottii.

1. Galactia heterophýlla (Gillies) Vail. Roots woody. Stems procumbent, nearly simple, 1-3 dm. long, minutely retrorse-hirsute, becoming glabrous : leaflet 1 , the blade leathery, that of each basal leaf oblong, $2-4 \mathrm{~cm}$. long, the others $3-9 \mathrm{~cm}$. long, or longer, oblong-lanceolate or linear, acutish at each end, glabrous above, minutely strigillose beneath, the reticulated nerves confluent with the conspicuous marginal nerve: pedicels 1-3 mm. long, solitary, or 2-3 on short peduncles in the axils of the upper leaves: calyx 6-7 mm. long, strigillose-hirsute ; lobes acuminate, scarious-margined, the 3 lower more slender, the middle one the narrowest and longest : corolla rose-purple ; standard fully $10 \mathrm{~mm}$. broad, the blade with a conspicuous indentation at the apex and 2 minute appendages at the base : pods $2.5-3.5 \mathrm{~cm}$. long, leathery, acuminate, retrorsely hirsute, the suture thickened.

In dry soil, eastern Texas to Central America. Also in South America. Spring and summer.

2. Gallactia erécta (Walt.) Vail. Roots woody, slender, somewhat fusiform. Stems erect, often several together, $2-3 \mathrm{dm}$. high or somewhat taller, glabrous or nearly so : leaves few ; leaflets 3 , or solitary on the lower leaves, the blades oblong, oblong-linear or linear, $2.5-4 \mathrm{~cm}$. long, of ten reflexed, obtuse or rarely acutish, leathery, glabrous, glaucous, reticulated beneath : flowers $2-5$, in obscurely peduncled axillary raceme-like or cluster-like panicles : pedicels $1-2 \mathrm{~mm}$. long : calyx 5-6 mm. long, hirsute ; lobes scarious-margined, unequal, the lower slender, acuminate, the upper one broader, minutely 2-toothed : corolla purplish, the standard with a suborbicular ovate retuse blade : pods linear-oblong, about $2 \mathrm{~cm}$. long, hirsute. [G. marginalis Benth.]

In dry pine lands, North Carolina to Florida, Alabama and Louisiana. Spring and summer.

3. Galactia Graỳi Vail. Foliage canescent-sericeous throughout. Stems several from a large thick woody root, slender, decumbent, retrorsely pubescent, $3-6 \mathrm{dm}$. long or longer: leaves several ; leaflets $3-5$, the blades $7-16 \mathrm{~mm}$. long, oblong, cuneate or nearly
linear, obtuse, retuse, mucronate or acutish, when 5 the terminal leaflet short-petioluled, the accessory ones affixed to the lateral pair : panicles much reduced, 1-4-flowered: peduncles 1-2.5 $\mathrm{cm}$. long: pedicels 4-7 mm. long : calyx 8-10 mm. long; lobes slender, acuminate : corolla $1.5-1.8 \mathrm{~cm}$. long, the standard yellowish, oblong-ovate, retuse, acute at the base; the other petals rose-purple; keel conspicuously longer than the narrow wings: pods linear-oblong, about $8 \mathrm{~cm}$. long, $5 \mathrm{~mm}$. wide, acute.

In dry soil, Texas. Spring to fall. 
4. Galactia brachýpoda T. \& G. Foliage nearly glabrous. Stems slender, erect or at length decumbent, 4-6 dm. long, somewhat puberulous, or nearly glabrous: leaves 3foliolate ; leaflets 3 , the blades oblong or linear-oblong, $2-3.5 \mathrm{~mm}$. long, thinnish, obtuse or emarginate, glabrous or minutely appressed-hirsute above, paler, somewhat strigose or glabrate beneath: calyx sessile or very short-pedicelled, $5 \mathrm{~mm}$. long, clothed with spreading yellowish hairs, the lower lobes acutish, the middle one somewhat the longest: corolla purple or rose-purple, $8-10 \mathrm{~mm}$. long, the standard $7-8 \mathrm{~mm}$. long, its blade roundovate, apparently not retuse at the apex, paler than the other petals.

In dry pine lands, Florida. Summer.

5. Galactia Floridàna T. \& G. Foliage hoary-pubescent. Stems prostrate, 2-10 $\mathrm{dm}$. long or longer, the upper part often densely and retrorsely tomentose: leaves commonly longer than the internodes, the basal 1-foliolate: leaflets mainly 3 , the blades oval or oblong-oval, $1.5-4.5 \mathrm{~cm}$. long, obtuse, rarely acutish, usually mucronulate, leathery, reticulated and paler beneath : calyx $7-8 \mathrm{~mm}$. long ; lobes scarious-margined, long-acuminate, the middle lower one considerably longer than the rest : corolla rose-purple, 1.2-1.5 $\mathrm{cm}$. long, the standard with an obovate blade rounded above, acute at the base: pods linear, 4-5 cm. long, 4-5 $\mathrm{mm}$. wide, acuminate, tomentose.

In sand, Florida. Summer.-A small form with the petioles less than $1 \mathrm{~cm}$. long and few flowers in nearly sessile clusters, is G. Floridana microphylla Vail; while a larger form with more elongated panicles bearing 2-4 flowers at regular intervals above the middle of the rachis is G. Floridana longiracemòsa Vail.

6. Galactia brévipes Small. Somewhat resembling G. Floridana. Stems spreading, 6-15 dm. long, closely pubescent and somewhat clammy : leaves numerous, longer than the internodes: leaflets normally 3 , the blades mainly oval, $2-4 \mathrm{~cm}$. long, deep green and finely reticulated above, paler and finely appressed-pubescent beneath, the terminal one as well as those of the lateral pair sessile or nearly so: petioles $1-1.5 \mathrm{~cm}$. long, more densely pubescent than the stem: panicles solitary at the nodes, much longer than the leaves, the flowers or flower-clusters not approximate: calyx 6-7 mm. long, strigillose; lobes acuminate : corolla lilac; standard fully $1 \mathrm{~cm}$. long, the blade obovate: pods linear.

In dry sand, near Trader's Hill, Georgia. Summer.

7. Galactia fasciculàta Vail. Foliage pubescent. Stems prostrate or climbing high on bushes, 1-2 m. long, clothed with a close fine retrorse-canescent tomentum: leaves shorter than the internodes : leaflets 3 , the blades suborbicular or oblong-orbicular, 1.5-3 $\mathrm{cm}$. long, retuse, finely appressed silky-pubescent above, appressed silky-villous and paler beneath : panicles several, fascicled in the axils of the leaves, forming conspicuous clusters at the slightly enlarged nodes: pedicels mostly 2 together: calyx $8 \mathrm{~mm}$. long, clothed with short white silky hairs; lobes acuminate, the middle lower one the longest: corolla pale lilac-purple, the standard $1.5 \mathrm{~cm}$. long, with an oblong-obovate blade, tapering to the base of the claw, obtuse or acutish at the apex.

In sand, Tampa, Florida. Spring to fall.

8. Galactia canéscens (Scheele) Benth. Foliage pubescent. Stems several from a slender woody root, branched at the base, the branches prostrate, creeping on the ground, canescent throughout, many of the flowers becoming subterranean and bearing short 1 -seeded pods : leaflets 3 , the blades broadly ovate or oval, $2-4 \mathrm{~cm}$. long, retuse, leathery, slightly hirsute above, silky canescent-pubescent, much paler and the veins prominently reticulated beneath : peduncles slender, elongated, few-flowered : calyx silky-hirsute; lobes acuminate : corolla rose-purple, the standard with an obovate blade: subterranean pods $8-10 \mathrm{~mm}$. long and nearly as broad, reticulated, appressed-hirsute, the seeds $6 \mathrm{~mm}$. long, $4 \mathrm{~mm}$. wide, ovoid-elliptic, slightly rounded at the ends, light brown : other pods linearoblong, $2-3 \mathrm{~cm}$. long, 6-7 mm. wide, acute, tapering to the base, densely pubescent, sometimes tomentose, the seeds elliptic-oblong.

In sandy soil, Texas. Spring to fall.

9. Galactia Texàna A. Gray. Foliage pubescent. Stems slender, procumbent, elongated, conspicuously twining, retrorse-pubescent or hirsute: stipules minute, caducous ; leaflets 3 , the blades oval, $2.5-5 \mathrm{~cm}$. long, retuse, mucronulate, minutely appressed cinereous-puberulous or glabrate above, sericeous or sparingly villous beneath, thin, becoming slightly leathery: panicles few-flowered, much shorter than the leaves, often much reduced: calyx $5 \mathrm{~mm}$. long; lobes attenuate : pods slightly falcate, $4-5 \mathrm{~cm}$. long, acute at each end, appressed-hirsute : seeds elliptic, 5-7.5 mm. long, truncate at the ends, light
brown.

On plains or prairies, western Texas. Spring to fall.

10. Galactia regulàris (L.) B.S.P. Foliage sparingly pubescent. Stems prostrate and climbing on bushes, 4-10 dm. long or longer, minutely retrorse-pubescent, becoming 
glabrate: leaves about as long as the internodes : stipules minute, subulate: leaflets 3 , the blades elliptic-oblong or ovate-oblong, $2-4.5 \mathrm{~cm}$. long, rather firm, obtuse, rarely acutish, often retuse and apiculate, emarginate, glabrous above, somewhat appressed-hirsute or pilose and paler beneath : panicles $3-9 \mathrm{~cm}$. long, usually rigid, and like the leaves erect on the prostrate stem; accessory ones occasional, smaller: calyx conspicuously acuminate in bud, 6-9 mm. long, glabrate, or with a few scattered hairs; lobes slender, obscurely scarious-margined : corolla violet-purple, showy, the standard with an obtuse or acutish blade tapering to the flat claw, with an obscure, brownish spot below the middle: pods linear, $2.5 \mathrm{~cm}$. long, rather acute at each end, appressed-hirsute, becoming glabrous : seeds oblong-orbicular, about $3 \mathrm{~mm}$. long, brown. [G. glabella Michx.]

In pine lands and sandy woods, New York to Florida and Mississippi. Spring and summer.

11. Galactia volùbilis (L.) Britton. Foliage pubescent. Stems prostrate and climbing over bushes, 4-12 dm. long, retrorsely and finely hirsute : leaves many ; leaflets 3 , the blades ovate-oblong or rarely lanceolate-oblong, $2-5 \mathrm{~cm}$. long, obtuse, often retuse, mucronulate, rarely acutish, glabrous or somewhat pilose above, paler, minutely pubescent or pilose beneath : panicle $2 \mathrm{dm}$. or even $3-3.4 \mathrm{dm}$. long; rachis slender or filiform : calyx 6-8 $\mathrm{mm}$. long, attenuate in the bud, glabrate or somewhat pilose ; lobes nearly equal, slender : corolla 8-10 mm. long, lilac or pink-purple, the standard with an obovate blade rounded above, with an appendage at the base, the claw slender : pods linear or linear-oblong, 3-5 cm. long, acute at each end : seeds $6-9$, when mature nearly as wide, truncate at each end, brown, with black markings. [G. pilosa Ell.]

In sandy soil, Long Island to Pennsylvania, Tennessee, Florida and Texas. Spring and summer.A very slender form with linear or linear-oblong leaflets, very slender panicles and pods only $2-3 \mathrm{~cm}$. long, is $G$. volubilis intermédia Vail.

12. Galactia Cubénsis H.B.K. Foliage more or less pubescent. Stems climbing on shrubs and trees, retrorse-pubescent, often becoming nearly glabrous : leaves numerous; leaflets 3 , the blades oblong, oblong-oval or elliptic, $2.5-8 \mathrm{~cm}$. long, obtuse and emarginate at both ends, rigid-leathery, glabrous and finely reticulated above, pubescent, paler and reticulated beneath : panicles mostly longer than the leaves, $5-14 \mathrm{~cm}$. long : caly $5-6 \mathrm{~mm}$. long; lobes attenuate, pubescent : corolla 10-12 $\mathrm{mm}$. long, pale purple, sessile or nearly so, the standard with an obovate blade: pods 4-5 $\mathrm{cm}$. long, acutish, hirsute, or at maturity glabrate, the conspicuous raised sutures glabrous : seeds 6-10, 3-4 mm. long, oblongovoid, brown, mottled with black. [G. spiciformis T. \& G.]

In sand, Florida Keys. Also in the West Indies and Central America.

13. Galactia móllis Michx. Foliage villous and somewhat hoary. Stems several from the same slender root, prostrate or climbing : leaves many ; leaflets 3 , the blades oval or oblong, $2.5-5 \mathrm{~cm}$. long, obtuse or emarginate at both ends, rarely retuse, or the upper ones often acutish, bright or light green, scabrous and villous above, villous and paler beneath, or the young ones tomentose, the lateral ones usually rounded at each end, the terminal more tapering at the base : panicles erect, solitary, 1-2 dm. long or longer: flowers short-pedicelled, approximate near the top of the peduncle: calyx about $6 \mathrm{~mm}$. long, densely villous: corolla bright red or rose-purple; the standard obovate, rounded above, tapering to the obscurely 2 -spurred base; keel-petals paler, considerably smaller than the slender wings : pods linear-oblong, $2.5-3.5 \mathrm{~cm}$. long, acutish, densely tomentose : seeds ovoid, acutish, brown.

In dry sandy pine lands and swamps, North Carolina to Florida. Summer.

14. Galactia Ellióttii Nutt. Root elongated, woody. Stems prostrate and climbing on tall bushes, $1-3 \mathrm{~m}$. long, angled, striate and somewhat retrorse-hirsute : leaves many ; leaflets $7-9$, the blades elliptic-oblong, 2-3 cm. long, obtuse or somewhat retuse, mucronulate, leathery, glabrous and shining above, pubescent beneath : panicles longer than the leaves, 1-3 dm. long; bracts and bractlets minute : calyx about $7 \mathrm{~mm}$. long, appressed-hirsute; lobes slender, attenuate : corolla white, tinged with red, 10-12 mm. long, the standard with an obovate, obtuse or acutish blade obscurely 2 -spurred at the base: pods oblong, 3-4 cm. long, or longer, acutish, emarginate, tomentose : seeds $3-5$, about $5 \mathrm{~mm}$. long, ovoid, blackish, lustrous.

In dry soil and pine lands, South Carolina to Florida, near the coast. Spring to fall.-A Floridian form, G. Elliottii Leavenwórthii T. \& G., has silky pubescent foliage.

\section{FALCÀTA Gmel.}

Perennial herbs, with slender twining stems. Leaves alternate : blades pinnately 3foliolate, stipulate : leaflets with blades broadest below the middle. Flowers perfect, mainly in axillary racemes. Caly $x$ oblique : lobes nearly equal or the upper ones shorter than the lower. Corolla white, blue or violet: standard spreading; blade obovate, wings curved: 
keel-petals obtuse, slightly incurved, slightly shorter than the wings to which they cohere. Stamens diadelphous (9 and 1). Anthers alike. Ovary nearly sessile or stalked. Style filiform, incurved, glabrous. Ovules several. Pod narrow, curved, 2-valved. HOG-PEANUT.

Foliage glabrate or sparingly pubescent: bracts usually shorter than the pedicels: pods pubescent on the margins.

Foliage copiously pubescent : bracts usually longer than the pedicels : pods pubescent all over.

1. F. comosr.

Falcata comòsa (L.) Kuntze. Foliage glabrate or sparingly villous. Stems twining, 1-3 m. long, branching, often matted : leaflets 3 , the blades ovate to ovate-lanceolate, 3-8 $\mathrm{cm}$. long, acute or apiculate, deep green above, broadly cuneate to subcordate at the base : racemes or panicles shorter than the subtending leaves : pedicels $3-5 \mathrm{~mm}$. long, usually longer than the bracts : calyx 8-10 mm. long, pubescent: corolla white or purplish, 10-14 mm. long ; standard with an oblong-obovate cordate blade : pods linear-oblong, $2.5-3 \mathrm{~cm}$. long, rather abruptly beaked. [Amphicarpaea monoica Ell.] fall.

In damp thickets, New Brunswick to Minnesota, Nebraska, Florida and Louisiana. Summer and

Falcata Pítcheri (T. \& G.) Kuntze. Foliage hirsute with brownish hairs. Stems climbing, several $\mathrm{m}$. long, branching: leaflets 3 , the blades ovate, often rhomboidal, 3-8 $\mathrm{cm}$. long, acute or short acuminate, ciliate, broadly cuneate or subcordate at the base, relatively firm: racemes or panicles shorter than the leaves: bracts usually longer than the pedicels: calyx minutely pubescent, about $1 \mathrm{~cm}$. long: corolla purple, $12-15 \mathrm{~mm}$. long ; standard with a fiddle-shaped but not cordate blade: pods linear-oblong, $3-3.5 \mathrm{~cm}$. long, rather gradually acuminate.

In thickets, western New York to Nebraska, Tennessee and Texas. Summer.

\section{BRADBÙRYA Raf.}

Perennial herbs, with prostrate or high-climbing stems. Leaves alternate: blades mostly pinnately 3 -foliolate or 5-7-foliolate: stipules persistent: leaflets with blades broadest below the middle. Flowers perfect, showy, solitary on axillary peduncles or several together. Calyx sessile: lobes nearly equal, or the 2 upper lobes united. Corolla white, pink, blue or violet: standard spreading; blade sometimes broader than high: wings curved : keel-petals incurved, little shorter than the wings. Stamens diadelphous (9 and 1 ), or partially monadelphous. Anthers alike. Ovary nearly sessile. Style incurved, somewhat pubescent about the dilated apex. Pod elongated, narrow, 2-valved, slightly flattened. [Centrosema Benth.] Butterfly Pea.

Upper calyx-lobe shorter than the tube: bracts acute: leaflets with cordate or subcordate blades.

Upper calyx-lobe twice as long as the tube: bracts slender-acuminate: leaflets with

1. B. arenisola.

cuneate or rounded blades.

2. B. Virginiana.

1. Bradburya arenícola Small. Plant, at least the young foliage, finely pubescent. Stems twining over bushes for fully 1 or $2 \mathrm{~m}$., more or less branched : leaflets 3 , the blades ovate or oblong-ovate, $2-5.5 \mathrm{~cm}$. long, retuse, blunt or sometimes minutely apiculate, thickish, slightly lustrous above, dull and sparingly reticulated beneath, cordate or subcordate at the base : bracts ovate, acute, less than $1 \mathrm{~cm}$. long: calyx minutely pubescent and ribbed; lobes relatively short, the upper one shorter than the tube, the lateral ones slightly longer: corolla purplish blue, similar to that of $B$. Virginiana.

In pine lands, near Eustis, Florida. Summer.

2. Bradburya Virginiàna (L.) Kuntze. Plant glabrous or puberulent. Stems twining, 5-12 dm. long: leaflets 3 , the blades thin but firm, ovate to oblong, linear or oblongobovate, 2-7 cm. long, acute, or mucronate, ciliate, rounded or subcordate at the base, prominently reticulated: bracts ovate-lanceolate, $1 \mathrm{~cm}$. long, or nearly so, slender-acuminate, prominently ribbed lengthwise : calyx ribbed like the bracts; lobes lanceolatesubulate, much longer than the tube, rough-pubescent, the upper one fully twice as long as the tube: corolla lilac; standard with a suborbicular blade, $4.5-5.5 \mathrm{~cm}$. broad: pods linear, 10-13 mm. long, slender-acuminate at the apex, thick-margined.

fall. In sandy soil, New Jersey to Florida, Arkansas and Texas. Also in tropical America. Spring to

\section{CLITÒria L.}

Perennial herbs or shrubby plants, with erect, or slightly twining stems. Leaves alternate: blades pinnately 3 -foliolate, or many-foliolate : stipules persistent : leaflets with 
blades broadest below the middle. Flowers perfect, showy, solitary in the axils, or in dense racemes. Calyx much longer than broad. Corolla white, blue, purple or red: standard large, erect; blade notched at the apex : wings curved : keel-petals shorter than the wings, incurved, acute. Stamens diadelphous (9 and 1), or partially monadelphous. Anthers alike. Ovary stalked. Style slender, incurved, the apex horizontally flattened. Pod narrow, somewhat flattened. Butterfly Pea.

1. Clitoria Mariàna L. Foliage glabrous or nearly so. Stems erect, ascending or climbing, 3-12 dm. long, branching: leaflets 3, the blades ovate-lanceolate or narrowly ovate, mucronate at the apex, rounded or subcordate at the base: peduncles much shorter than the petioles: calyx-tube slightly dilated upward, 10-15 mm. long; lobes ovate, acuminate, about $\frac{1}{3}$ as long as the tube : corolla lilac or pale blue : standard with an obovate blade $5-6 \mathrm{~cm}$. long, notched at the apex, striped with magenta near the center : pods linear or linear-oblong, $2.5-3 \mathrm{~cm}$. long, acute.

In sandy soil, New York to Missouri, Florida and Texas. Spring and summer.

\section{APIOS Moench.}

Vines, with twining stems and very large roots. Leaves alternate, with small stipules : blades pinnately 3 -foliolate : leaflets with blades broadest below the middle. Flowers perfect, in dense racemes or panicles. Calyx pedicelled, the 2 upper lobes united into a broad lip, the 2 lateral ones small, the lower one longer, acute. Corolla red, purple or chocolate-colored, often variegated: standard reflexed; blade broad, auricled at the base: wings oblique, shorter than the standard: keel elongated, more or less strongly spirally twisted, cohering to the wings. Stamens diadelphous (9 and 1). Anthers alike. Ovary nearly sessile. Style glabrous, thickish, inflexed above. Pod elongated, curved, somewhat flattened. Ground-NuT.

Standard with the blade rounded or retuse at the apex.

Standard with the blade produced into a spongy appendage at the apex.

1. A. Apios.

2. A. Priceana.

1. Apios Àpios (L.) MacM. Roots tuberous, 1-several cm. thick. Foliage glabrate or roughish-pubescent. Stems branching, the branches twining and climbing, 3-12 dm. long, slender : leaves $1-2 \mathrm{dm}$. long; leaflets 5-7 or rarely 3 , the blades ovate to lanceolate, $3-10$ $\mathrm{cm}$. long, acute or acuminate at the apex, rounded or subcordate at the base, on short hairy petiolules : panicles $3-10 \mathrm{~cm}$. long: calyx with a campanulate tube $2-4 \mathrm{~mm}$. long; lobes unequal, but all very short, the margin of the calyx often merely undulate : corolla brownish purple; standard with a broad blade about $1 \mathrm{~cm}$. long : pods linear, $6-12 \mathrm{~cm}$. long, acute, straight or curved, especially near the apex. [A. tuberosa Moench.]

In thickets and low grounds, New Brunswick to Minnesota, Florida and Texas. Summer and fall.

2. Apios Priceàna Robinson. Roots oblate-spheroidal, often $18 \mathrm{~cm}$. thick. Stems herbaceous, twining, 1-3 m. long, more or less copiously pubescent with reflexed hairs, or usually glabrate: leaves $2-2.5 \mathrm{dm}$. long or shorter on the branches; leaflets $5-9$, or rarely 3 , the blades thinnish, ovate or ovate-lanceolate, 4-10 $\mathrm{cm}$. long, acuminate, sparingly pubescent on both sides, scarcely paler beneath than above, rounded or obtuse at the base: panicles densely flowered, commonly 2-3 together in an axil, those of the main stem 10-15 cm. long, with 50-70 flowers; those of the branches smaller: calyx with a hemispheric tube and slender lower lobe : corolla greenish white tinged near the apex with rose purple, or magenta ; standard with the suborbicular blade about $2.5 \mathrm{~cm}$. long, produced into a spongy appendage at the apex : pods linear, clustered, $12-15 \mathrm{~cm}$. long, $1 \mathrm{~cm}$. broad, acuminate at the apex : seeds often $10,8 \mathrm{~mm}$. long, olive-green.

In rocky woods, Kentucky and Tennessee. Summer.

\section{PHASEOIOUS L.}

Perennial vines, with prostrate or twining stems. Leaves alternate : blades pinnately 3 -foliolate or rarely 1 -foliolate, with persistent stipules : leaflets with entire or lobed blades, commonly membranous. Flowers perfect in axillary, peduncled racemes or panicles. Calyx pedicelled: lobes 5 , nearly equal, or the 2 upper partially united. Corolla of various colors, often variegated : standard with a suborbicular, spreading or recurved blade, the margin sometimes inflexed : wings broadest above the middle : keel-petals spirally twisted, with a long obtuse beak. Stamens 10 , diadelphous (9 and 1). Anthers uni- 
form. Style bearded. Stigma oblique or lateral. Pod slightly flattened, straight or curved. Seeds with rounded ends. Wild Bean. Bean-vine.

Stems trailing : leaflets mostly broader than long.

Stems climbing; leaflets mostly longer than broad.

Blade of the terminal leaflet not hastate.

Blade of the terminal leaflet hastate.

1. P. sinuatus.

2. P. polystachyus. 3. P. smilacifolius.

1. Phaseolus sinuàtus Nutt. Foliage glahrous or nearly so. Stems trailing, 1-4 m. long, branching: leaflets 3 , the blades deltoid-ovate in outline with 3 more or less prominent lobes, $2-4 \mathrm{~cm}$. long, reticulated, mucronulate, truncate or very broadly cuneate at the base : racemes several times longer than the subtending leaves, simple; rachis wirelike : pedicels $5-10 \mathrm{~mm}$. long: calyx campanulate, $2.5-3 \mathrm{~mm}$. long; lobes rounded or apiculate : corolla pale purple; standard with a blade nearly $1 \mathrm{~cm}$. wide : pods somewhat scimitar-shaped, $3.5-4 \mathrm{~cm}$. long.

In dry pine lands or hammocks, Florida to Mississippi. Summer.

2. Phaseolus polystáchyus (L.) B.S.P. Foliage minutely pubescent. Stems climbing, 1-4 m. long, branching: leaflets 3 , the blades ovate to orbicular-ovate, 4-10 cm. long, acuminate, often conspicuously nerved, rounded or subcordate at the base: racemes or panicles slender, surpassing the subtending leaves, simple or compound, short-peduncled : pedicels 4-8 mm. long: calyx campanulate, $2.5-3 \mathrm{~mm}$. long; lobes rounded or somewhat triangular : corolla purple or whitish : pods scimitar-shaped, 4-8 cm. long, often glaucous. [P. perennis Walt. $]$

In thickets, Canada to Minnesota, Florida, Louisiana and Nebraska. Summer.

3. Phaseolus smilacifòlius Pollard. Foliage minutely pubescent. Stems twining, 1-4 m. long, branching: leaflets 3 , the blades very thin, ovate in outline, 4-8 $\mathrm{cm}$. long, acute, more or less distinctly 3 -lobed, soon glabrous: racemes usually shorter than the subtending leaves : pedicels slender, $5-15 \mathrm{~mm}$. long: calyx glabrous, canapanulate, $2.5-3 \mathrm{~mm}$. long; lobes rounded: corolla pink or white; keel-petals $1 \mathrm{~cm}$. long; standard with a broad blade nearly $1 \mathrm{~cm}$. long : pods $5-6 \mathrm{~cm}$. long.

In hammocks, Florida. Summer and fall.

\section{STROPHOSTỲLES Ell.}

Annual or perennial herbaceous vines, with trailing or twining stems. Leaves alternate: blades pinnately 3 -foliolate, stipulate: leaflets with thickish, entire or lobed blades. Flowers perfect, in clusters terminating long axillary peduncles. Calyx sessile or short-pedicelled : lobes 5 , equal or the upper 2 more or less united. Corolla white or pink-purple: standard with a blade about as broad as long: wings broadened upward : keel-petals curved. Stamens 10, diadelphous (9 and 1). Anthers similar. Style bent, bearded, persistent. Pod narrow, somewhat flattened, straight or nearly so. Seeds truncate, smooth or granular. WILD BEAN.

Perennial.

Aunual.

Leaflets fully thrice as long as broad.

Leaflets less than twice as long as broad.

Stems 1-2 m. long, trailing or low-twining: leaflets, or some of them, with lobed blades.

Stems 3-9 m. long, high-climbing: leaflets with entire blades.

1. S. umbellata.

2. S. pauciflora.

1. Strophostyles umbellàta (Muhl.) Britton. Perennial, more or less pubescent. Stems trailing, 3-15 $\mathrm{dm}$. long, branching: leaflets 3 , the blades oblong-lanceolate, varying to ovate or lanceolate, 1-4 $\mathrm{cm}$. long, obtuse or acute, sometimes slightly lobed : peduncle 3-6 times longer than the subtending leaf-like bracts: pedicels very short: calyx broadly campanulate, 2.5-3 mm. long, the lower lobe acute, somewhat shorter than the tube : corolla pink or pale purple, often fading yellowish; standard with a blade 1-2 $\mathrm{cm}$. broad : pods linear, slightly flattened, $2.5-5 \mathrm{~cm}$. long, straight.

In dry sandy soil, New York to Missouri, Florida and Louisiana. Summer and fall.

2. Strophostyles pauciflòra (Benth.) S. Wats. Annual, minutely pubescent. Stems trailing or climbing, 3-9 dm. long, branching: leaflets 3 , the blades linear to lanceolate, $1.5-3.5 \mathrm{~cm}$. long, apiculate at the apex, scarcely ever Jobed, short-stalked : peduncles surpassing the subtending leaves : pedicels very short : calyx hirsute, about $1.5 \mathrm{~mm}$. long, the lower lobes slender, about as long as the tube : corolla pale purple; standard with a blade less than $1 \mathrm{~cm}$. broad : pods linear, flattish, $2-3 \mathrm{~cm}$. long, strigose.

On river banks, Minnesota to Indiana, Nebraska, Louisiana and Texas. Summer and fall.

3. Strophostyles hélvola (L.) Ell. Annual, often villous-hirsute. Stems often branching at the base; branches trailing, 3-12 dm. long, widely branching: leaflets 3 , the 
blades rhomboidal-oval to 3-lobed, 2-4 cm. long, acute or acutish: peduncles twice or thrice as long as the leaves: pedicels stout, about $1 \mathrm{~mm}$. long: calyx glabrate, $3-3.5 \mathrm{~mm}$. long; lobes abruptly pointed, about as long as the tube : corolla purple or purplish, fading greenish; standard with a blade fully $1 \mathrm{~cm}$. wide: pods linear, nearly terete, $6-10 \mathrm{~cm}$. long. [Phaseolus helvolus L.]

In sandy soil, Quebec to Minnesota, Massachusetts, Florida and Texas. Summer and fall.

4. Strophostyles Missouriénsis (S. Wats.) Small. Annual, sparingly pubescent. Stems climbing, 3-9 m. long, branching, retrorsely pubescent: leaflets 3 , the blades ovate, $3-8 \mathrm{~cm}$. long, often somewhat rhomboidal, lustrous above, abruptly acuminate or apiculate, short-stalked: peduncles becoming longer than the subtending leaves: calyx sparingly pubescent, the lower and middle lobes lanceolate, as long as the tube or longer: corolla pink or bluish ; standard with a thin blade $1-1.5 \mathrm{~cm}$. wide : pods linear, 7-9 mm. long, somewhat flattened. [S. angulosa var. Missouriensis S. Wats.]

In alluvial soil, Missouri and Arkansas. Fall.

\section{VÍGNA Savi.}

Vines, with prostrate or twining stems. Leaves alternate: blades pinnately 3 -foliolate: stipules usually sessile at the base of the petiole: leaflets with entire or sometimes lobed blades. Flowers perfect, few in cluster-like racemes terminating axillary peduncles. Calyx slightly 2-lipped: lobes all unequal, relatively short. Corolla yellowish or purplish, sometimes variegated: standard with a suborbicular blade auricled at the base: wings curved : keel about as long as the wings, incurved with or without a spirally twisted beak. Stamens diadelphous (9 and 1). Anthers alike. Style filiform, thickened or dilated. Stigma oblique or lateral. Ovules numerous. Pod narrow, nearly terete, straight or curved. China Bean. Cow Pea.

Standard less than $2 \mathrm{~cm}$. long: pods pubescent. Standard over $2 \mathrm{~cm}$. long: pods glabrous.

1. V. repens.

2. V. Sinensis.

1. Vigna rèpens (L.) Kuntze. Foliage usually pubescent with rather appressed hairs. Stems trailing or climbing, branching, when pubescent the hairs reflexed: leaflets 3 , the blades ovate to lanceolate or linear, $2-8 \mathrm{~cm}$. long, acute, more or less distinctly reticulated, short-stalked: petioles usually longer than the leaflets : peduncles surpassing the subtending leaves, retrorsely pubescent at the top: pedicels $1-3 \mathrm{~mm}$. long, corymbose : calyx campanulate, oblique ; lobes triangular to lanceolate : corolla yellow; standard with a nearly reniform, notched blade, less than $2 \mathrm{~cm}$. long: pods linear, 4-5 mm. long, nearly terete, pubescent. [V. luteola (Jacq.) Benth.]

In marshes and thickets along the coast, Georgia to Florida and Texas. Also in tropical America.

2. Vigna Sinénsis (L.) Endl. Foliage glabrous or sparingly pubescent. Stems trailing or climbing, $0.3-2 \mathrm{~m}$. long, branching : leaflets 3 , the blades ovate or ovate-hastate, $8-15 \mathrm{~cm}$. long, acutish to acuminate, the lateral ones very inequilateral : peduncles usually shorter than the leaves, minutely pubescent near the ends : pedicels stout, 1-2 mm. long: calyx campanulate, $7-8 \mathrm{~mm}$. long; lobes acuminate, somewhat shorter than the tube: corolla yellowish tinged with purple; standard over $2 \mathrm{~cm}$. long: pods fleshy, 10-18 cm. long, slightly curved, glabrous.

In thickets and waste places, North Carolina to Missouri, Florida and Texas. Cultivated and adventive or naturalized. Summer and fall.

\section{CaNAVALIA DC.}

Perennial herbs, with prostrate or twining stems. Leaves alternate, with small stipules : blades pinnately 3 -foliolate: leaflets with entire, often ample, thickish blades. Flowers perfect, in axillary peduncled racemes. Calyx 2-lipped, the upper lip truncate or 2-lobed, the lower one entire or 3-lobed. Corolla of various colors : standard reflexed ; blade suborbicular, large : wings curved or twisted : keel-petals incurved, broader than the wings, obtuse or with an inflexed or spiral beak. Stamens diadelphous ( 9 and 1 ) or monadelphous to the middle. Style glabrous, incurved, or involute with the keel. Ovules several. Pod flat or slightly swollen, oblong or broadly linear, 2-valved. Seeds white, red or brown.

Leaflets rounded or retuse at the apex : pods $10-12 \mathrm{~cm}$. long : corolla mainly pink. Leaflets abruptly pointed : pods $20-30 \mathrm{~cm}$. long: corolla mainly white.

1. C. obtusifolia.

1. Canavalia obtusifòlia (Lam.) DC. Foliage finely strigillose. Stems prostrate or climbing, 1-5 m. long, branching: leaflets 3 , the blades leathery, suborbicular to oval 
or obovate, $4-10 \mathrm{~cm}$. long, rounded or broadly cuneate at the base : racemes surpassing the subtending leaves: peduncles often longer than the racemes: pedicels spur-like: calyx helmet-like, 14-17 mm. long, constricted at the base : corolla pink : pods broadly linear, 10-12 cm. long: seeds oblong, brown.

On sandy shores, southern Florida and Texas. Also in tropical America.

2. Canavalia gladiàta (Savi) DC. Foliage glabrous, or finely pubescent when young. Stems climbing, 1-14 m. long, branching: leaflets 3 , the blades membranous, ovate, oval or oblong-ovate, $5-10 \mathrm{~cm}$. long, usually abruptly pointed, undulate : racemes axillary, surpassing the subtending leaves: pedicels $2-5 \mathrm{~mm}$. long: calyx 10-12 $\mathrm{mm}$. long: corolla white or tinged with purple or yellow : pods linear-oblong, somewhat curved, $10-25 \mathrm{~cm}$. long, acute : seeds oblong, brown or reddish, or rarely white.

In thickets or woods, southern Florida, and introduced in Oklahoma. Also throughout the tropics.

\section{VÍCIA L.}

Trailing or climbing herbs, with tendrils terminating the leaves. Stems terete or angled. Leaves alternate: blades equally pinnate: leaflets few or many, the blades entire or toothed at the apex. Flowers perfect, in sessile or long-peduncled racemes, or rarely solitary in the axils. Calyx often oblique, the upper lobes usually shorter than the lower. Corolla white, blue, violet or yellow : standard broad ; blade emarginate : wings oblique, cohering to the middle of the shorter keel. Stamens diadelphous, or monadelphous below. Anthers alike. Style filiform, pubescent at the apex or on the side opposite keel, inflexed. Ovules numerous or rarely 2. Pod short or elongated, flattened, 2-valved. Seeds usually subglobose. Vetch. Pea Vine.

Peduncles manifest, sometimes surpassing the leaves.

Annuals, except $V$. Cracca: species naturalized.

Leaflets 6-12: pods pubescent: seeds 2 .

Leaflets 12-24: pods glabrous: seeds $3-8$.

Leaflets 12-14: corolla 5-6 mm. long: pods obtuse.

Leaflets 18-24: corolla $10-12 \mathrm{~mm}$. long: pods acute.

Perennials, or rarely annuals: species native.

Racemes 8-20-flowered.

Leaflets with blades of an oblong type.

Leaflets with blades of a linear type.

Corolla 5-6 mm. long: calyx $1.5 \mathrm{~mm}$. long : pods less than $2.5 \mathrm{~cm}$. long.

Corolla $7-8 \mathrm{~mm}$, long: calyx $2 \mathrm{~mm}$. long: pods over $2.5 \mathrm{~cm}$. long.

Racemes 1-6-flowered.

Pods pubescent.

Pods glabrous.

Peduncles longer than the leaflets.

Leaflets 4-6.

Leaflets $8-12$.

Leaflets about 5 times as long as broad.

Leaflets less than 3 times as long as broad.

Stems pubescent: calyx-lobes longer than the tube. Stems glabrous: calyx-lobes shorter than the tube.

Peduncles shorter than the leaflets.

Peduncles wanting: calyx nearly sessile or short-pedicelled.

Corolla over $1.5 \mathrm{~cm}$. long : leaflets of the upper leaves inclined to be oblong.

Corolla less than $1.5 \mathrm{~cm}$. long: leaflets of the upper leaves inclined to be linear.

1. V.hirsuta.

2. $V$. tetrasperma.

3. V. Cracea.

4. V. Caroliniana.

5. V. Hugeri.

6. V. acutifolia.

7. V. Reverchonii.

8. V. Floridana.

9. V. Texana.

10. V. Leavenworthii.

11. V. Ludoviciana.

12. V. mierantha.

13. V. sativa.

14. V. angustifolia.

1. Vicia hirsùta (L.) Koch. Annual, glabrate or sparingly pubescent. Stems usually branched at the base, the branches spreading or climbing, 3-7 dm. long: leaves $2-6 \mathrm{~cm}$. long; rachis terminating in a slender, usually forking tendril ; leaflets 6-12, the blades linear or oblong, 6-15 mm. long, truncate or notched at the apex, mucronulate : peduncles mostly shorter than the subtending leaves: pedicels $1-2 \mathrm{~mm}$. long: calyx minutely pubescent; lobes subulate, about as long as the turbinate tube : corolla whitish or purplish blue; keel-petals 2-3 $\mathrm{mm}$. long : pods oblong, 6-8 $\mathrm{mm}$. long, short-beaked, oblique at both ends, puhescent, 2 -seeded.

In waste places, New Brunswick to Ohio, Virginia and Georgia. Native of Europe. Spring to fall.

2. Vicla tetraspérma (L.) Moench. Annual, glabrous or minutely pubescent. Stems ascending or reclining, 2-7 dm. long, slender, more or less branched : leaves 2-6 $\mathrm{cm}$. long; rachis terminating in a simple or forking tendril ; leaflets $12-14$, the blades linear or linear-oblong, 8-20 mm. long, acute or mucronate, short-stalked : peduncles filiform, 2-4 cm. long, 1-4-flowered : pedicels $1.5-2 \mathrm{~mm}$. long, curved: calyx strigillose, about $2 \mathrm{~mm}$. long when young; tube angled; lobes lanceolate, the longer as long as the tube : corolla usually pale blue; keel-petals $5 \mathrm{~mm}$. long: pods oblong, 9-12 mm. long, glabrous : seeds $2 \mathrm{~mm}$. broad, granular.

In waste places, Nova Scotia and Ontario to North Carolina. Native of Europe. Spring to fall. 
3. Vicia Crácca L. Perennial, usually finely pubescent. Stems $3-12 \mathrm{dm}$. long, sometimes tufted, climbing or trailing, mostly simple: leaves $5-10 \mathrm{~cm}$. long; blades sessile or nearly so ; stipules linear-subulate; leaflets $18-24$, the blades linear or oblonglinear, 1-2 cm. long, acute or mucronulate: peduncles sometimes surpassing the subtending leaves : racemes $3-10 \mathrm{~cm}$. long, dense, 15-40-flowered, 1 -sided : calyx about $5 \mathrm{~mm}$. long, reflexed: corolla bluish purple, $10-12 \mathrm{~mm}$. long: pods linear, $2-2.5 \mathrm{~cm}$. long, 5-8-seeded.

In dry soil or cultivated grounds, Newfoundland to British Columbia, North Carolina, Kentucky and Iowa. Also in Europe and Asia. Summer.

4. Vicia Caroliniàna Walt. Perennial, glabrous or strigillose. Stems branched at the base, the branches spreading or climbing, 4-12 dm. long: leaf-rachis terminating in a simple or forking tendril ; leaflets 8-16, the blades oblong or oval-oblong, mucronate, short-stalked : peduncles becoming longer than the subtending leaves, manyflowered: pedicels 1-2 mm. long, curved: calyx glabrous or nearly so ; tube thin, campanulate; lobes triangular, much shorter than the tube: corolla white or bluish; keelpetals about $1 \mathrm{~cm}$. long: pods oblong, $2.5-3 \mathrm{~cm}$. long, oblique at each end.

In open woods, Ontario to Minnesota, Georgia and Kansas. Spring and summer.

5. Vicia Hùgeri Small. Perennial, very slender, bright green, minutely and sparsely pubescent or glabrate in age. Stems ascending, decumbent or reclining, solitary or several together, 3-7 dm. long, more or less angled, sometimes branched above, rarely branched below: leaves $4-8 \mathrm{~cm}$. long, the tendril simple or forked; leaflets usually 10-12, the blades linear, $2-3.5 \mathrm{~cm}$. long, mucronulate, straight or slightly curved, short-petioled : peduncles $5-8 \mathrm{~cm}$. long, ascending: flowers $10-14$ in secund racemes: pedicels $1.5-2 \mathrm{~mm}$. long: calyx campanulate, $1.5 \mathrm{~mm}$. long; lobes triangular, $\frac{1}{4-\frac{1}{3}}$ as long as the tube, acute : corolla white or pale blue; keel-petals about $5 \mathrm{~mm}$. long: pods linear-oblong, $2 \mathrm{~cm}$. long.

In open woods, Georgia and Alabama. Spring.

6. Vicia acutifòlia Ell. Perennial, glabrous or nearly so. Stems branched at the base, the branches spreading or climbing, 5-12 dm. long, more or less branched: leaves $2-6 \mathrm{~cm}$. long ; rachis terminating in a simple or forking tendril ; leaflets $2-6$, usually 4 , the blades linear to linear-oblong, $1.5-4 \mathrm{~cm}$. long, acute or mucronate, short-stalked: peduncles surpassing the leaves, few-flowered : pedicels 1-2 mm. long: calyx often minutely pubescent ; tube oblique ; lobes triangular, shorter than the tube : corolla pale blue; keelpetals about $6 \mathrm{~mm}$. long; standard tipped with purple: pods linear, $2.8-3 \mathrm{~cm}$. long, oblique and acute at both ends, 4-8-seeded.

In sandy soil, mostly near the coast, Georgia, Florida and Alabama. Spring to fall.

7. Vicia Reverchònii S. Wats. Annual, tomentose when young. Stems branched at the base, the branches ascending, decumbent or reclining, simple or branched: leaves numerous, terminating in simple or usually branching tendrils; leaflets $4-10$, the blades elliptic, oblanceolate or oblong-cuneate, $5-12 \mathrm{~mm}$. long, emarginate and mucronate at the apex : peduncles stout, shorter than the subtending leaves : pedicels $2-3 \mathrm{~mm}$. long: calyx firm ; tube densely pubescent, turbinate-campanulate; lobes lanceolate, the longer about as long as the tube : corolla blue or bluish; keel-petals 6-7 mm. long: pods linear-oblong, nearly $3 \mathrm{~cm}$. long.

On dry prairies, Texas. Spring.

8. Vicia Floridàna S. Wats. Perennial, glabrous or nearly so, delicate. Stems weak, reclining, simple or sparingly branched, $3-8 \mathrm{dm}$. long: leaves $3-5 \mathrm{~cm}$. long, ending in very slender tendrils; leaflets $4-6$, the blades thin, oblong to oblong-oblanceolate, $0.5-1.5 \mathrm{~cm}$. long, mucronulate, very short-stalked: peduncles shorter than the subtending leaves, 1-2-flowered, sparingly glandular above : pedicels $1 \mathrm{~mm}$. long: calyx more or less glandular; tube campanulate; lobes triangular-acuminate, shorter than the tube: corolla white or bluish ; keel-petals about $5 \mathrm{~mm}$. long : pods linear-oblong, about $1.5 \mathrm{~cm}$. long.

In sandy soil, Florida. Spring to fall.

9. Vicia Texàna (T. \& G.) Small. Perennial, more or less densely strigillose. Stems branched at the base, the branches spreading or climbing, angled, 2-4 dm. long, branching : leaves $2-8 \mathrm{~cm}$. long ; rachis terminating in a forking tendril ; leaflets $6-10$, the blades linear, 8-15 mm. long, mucronulate, short-stalked: peduncles about as long as the subtending leaves, few-flowered : pedicels $1 \mathrm{~mm}$. long: calyx rather densely pubescent; tube turbinate-campanulate, $1 \mathrm{~mm}$. long; lobes filiform-subulate, longer than the tube : corolla bluish ; keel-petals $5-6 \mathrm{~mm}$. long: pods $2-2.5 \mathrm{~cm}$. long.

T. \& G. 7

On plains and prairies, Arkansas to Mississippi and Texas. Spring and summer.

10. Vicia Leavenwórthii T. \& G. Perennial, with strigillose young foliage. Stems reclining or climbing, 3-6 dm. long, branching : leaves $3-6 \mathrm{~cm}$. long, ending in branching 
tendrils; leaflets mostly 10-14, the blades oblong to oblanceolate, 5-12 mm. long, mucronulate and sometimes notched at the apex, sessile or nearly so: peduncles shorter than the subtending leaves, or longer : pedicels curved, $1-2 \mathrm{~mm}$. long : calyx pubescent; tube turbinate; lobes lanceolate-subulate, the longer ones about as long as the tube : corolla bluish; keel-petals about $5 \mathrm{~mm}$. long: pods oblong, about $2 \mathrm{~cm}$. long, oblique at each end.

In dry soil, Arkansas to Texas. Spring.

11. Vicia Ludoviciàna Nutt. Perennial, rather stout, glabrous, or young foliage sparingly pubescent. Stems angled, usually branched at the base, the branches decumbent or climbing, 3-9 dm. long, more or less branched : leaves $3-10 \mathrm{~cm}$. long ; rachis ending in a usually forking tendril ; leaflets $6-12$, the blades oblong to oval, varying to broadest above or below the middle or rarely linear-oblong, 7-23 mm. long, notched or rounded at the apex, sometimes mucronulate: peduncles shorter than the subtending leaves or sometimes longer at maturity: pedicels stout, about $1 \mathrm{~mm}$. long: calyx membranous; lobes lanceolate or subulate-lanceolate, about as long as the whitish tube: corolla bluish; keel-petals $5 \mathrm{~mm}$. long: pods oblong, $2.5-3 \mathrm{~cm}$. long, oblique at both ends.

In dry soil, Kansas to Arkansas, the Indian Territory, Florida and Texas. Spring.

12. Vicia micrántha Nutt. Annual, minutely pubescent or glabrate. Stems reclining or climbing, 3-9 dm. long, more or less branched : leaves $2-6 \mathrm{~cm}$. long ; rachis ending in a forking tendril; leaflets variable, the blades of those of the lower leaves obovate to oval, $5-12 \mathrm{~mm}$. long, those of the upper leaves narrowly oblong or linear, $1-3.5 \mathrm{~cm}$. long : peduncles $5-20 \mathrm{~mm}$. long, 1-2-flowered : pedicels $2-4 \mathrm{~mm}$. long : calyx campanulate ; tube minutely pubescent; lobes variable, the shorter triangular, the longer triangular-lanceolate : corolla pale blue or white ; keel-petals about $5 \mathrm{~mm}$. long, oblique at each end : pods narrowly oblong, about $1 \mathrm{~cm}$. long.

In thickets on river banks, Tennessee to Missouri, Alabama and Texas. Spring.

13. Vicia sativa L. Annual, sometimes sparingly strigillose. Stems branched at the base, the branches angled, trailing or climbing, 2-10 dm. long, often branching: leaves $5-10 \mathrm{~cm}$. long; rachis terminating in a forking tendril ; leaflets $8-14$, the blades linear, linear-lanceolate or oblong, 1-4 cm. long, mucronate, short-stalked : peduncles very short or almost none, 1-2-flowered : calyx usually pubescent ; tube 5-6 mm. long, membranous; lobes subulate-lanceolate, about as long as the tube or shorter: corolla bluish purple; keel-petals $1.5-2.5 \mathrm{~cm}$. long: pods linear-oblong, 4-8 cm. long, glabrous.

In waste places and fields, throughout North America, except northern British America. Naturalized from Europe. Spring and summer.

14. Vicia angustifolia Roth. Annual, often sparingly strigillose. Stems branched at the base, the branching trailing or climbing, 3-9 $\mathrm{dm}$. long, angled : leaves $5-10 \mathrm{~cm}$. long ; rachis terminating in a forking tendril ; leaflets $8-16$, the blades linear, varying to lanceolate or oblanceolate, $1-3.5 \mathrm{~cm}$. long, truncate or notched at the apex, mucronate: peduncles usually none: pedicels $1-3 \mathrm{~mm}$. long: calyx minutely pubescent; tube pale, ridged, $5-6 \mathrm{~mm}$. long; lobes subulate, shorter than the tube : corolla purplish; keel-petals $1-1.5 \mathrm{~cm}$. long: pods linear, 4-5 cm. long, acute, glabrous, oblique at each end.

In waste places, Nova Scotia to Florida. Native of Europe. Spring and summer.

\section{LÁTHYRUUS L.}

Vines or bushy herbs, with tendrils terminating the leaves. Stems usually angled or winged. Leaves alternate: blades equally pinnate: leaflets with entire blades. Flowers perfect, solitary on axillary peduncles or in racemes. Calyx usually oblique : tube sometimes gibbous at the base: lobes nearly equal or the upper ones shorter than the lower. Corolla of various colors, often showy : standard with a broad emarginate blade and a short claw : wings curved, partially coherent with the shorter incurved obtuse keel-petals. Stamens diadelphous, or monadelphous below. Anthers alike. Style flattened, pubescent on the side opposite the standard. Pod elongated, terete or flattened. Seeds subglobose or angled.

Annual: leaflets 2: keel-petals less than $10 \mathrm{~mm}$. long.

Perennial : leaflets 4 or more: keel-petals over $10 \mathrm{~mm}$. long.

flabrous or nearly so: racemes 3-8-fowered : stipules much broader than the stem.

1. L. pusillus.

Stems finely pubescent: racemes 10-20-flowered : stipules about as broad as the stem.

2. L. myrtifolius.

1. Lathyrus pusillus Ell. Annual, glabrous. Stems usually branched at the base, the branches spreading or climbing, 1-6 dm. long, 2 -winged : leaves numerous ; rachis terminating in a simple or forking tendril ; stipules lanceolate, slightly curved, prolonged 
below into a lanceolate-subulate auricle ; leaflets 2 , the blades narrowly linear or linearelliptic, $1-5 \mathrm{~cm}$. long, acute : peduncles $2-5 \mathrm{~cm}$. long, 1-2-flowered : pedicels $2-3 \mathrm{~mm}$. long: calyx glabrous; tube turbinate-campanulate ; lobes subulate-lanceolate, longer than the tube : corolla purple ; keel-petals $6-7 \mathrm{~mm}$. long: pods linear, $1.5-4 \mathrm{~cm}$. long.

In sandy soil, North Carolina to Florida and Texas. Spring.

2. Lathyrus myrtifòlius Muhl. Perennial, glabrous. Stems freely branching, the branches $3-10 \mathrm{dm}$. long, angled : leaves $5-15 \mathrm{~cm}$. long ; rachis ending in a forking tendril ; stipules half-sagittate ; leaflets $4-8$, the blades elliptic to oval, $1.5-4 \mathrm{~cm}$. long, mucronate, glaucous beneath and prominently nerved : peduncles $5-12 \mathrm{~cm}$. long, curved, 3-8-flowered : pedicels 1-4 mm. long : calyx campanulate ; tube ribbed; lobes lanceolate, about as long as the tube, or the shorter ones triangular-lanceolate: corolla purple or blue ; keel-petals 12-15 mm. long: pods linear, 4-6 $\mathrm{cm}$. long, each with a short curved beak.

In damp places, New Brunswick to Manitoba, North Carolina and Tennessee. Spring and summer.

3. Lathyrus venòsus Muhl. Perennial, usually minutely pubescent. Stems branching, 4-10 dm. long, trailing or climbing, 4-angled: leaves 1-3 dm. long; stipules lanceolate to ovate, half-sagittate, entire, or toothed at the base ; leaflets 8-14, the blades firm, ovate, oval, elliptic or oblong, mucronate, more or less glaucous beneath, often conspicuously nerved: peduncles $5-15 \mathrm{~cm}$. long, many-flowered, shorter than the leaves: pedicels 2-4 mm. long: calyx campanulate; lobes lanceolate, acuminate, the longer ones as long as the tube : corolla purple ; keel-petals about $1.5 \mathrm{~cm}$. long: pods linear, 3.5$4.5 \mathrm{~cm}$. long, prominently nerved.

On river banks, Assiniboia to New Jersey, Georgia, Louisiana and Kansas. Spring and summer.

\section{Order 15. GERANIÀLES.}

Herbs, shrubs or trees. Leaves alternate or opposite: blades simple or compound. Flowers perfect, monoecious or dioecious, variously disposed, mostly regular. Calyx of distinct sepals. Corolla of distinct or nearly distinct petals, rarely wanting. Androecium of as many stamens as there are sepals, or twice as many, or rarely more. Filaments distinct or united. Anthers opening lengthwise, distinct, or united in BALSAMINACEAE. Gynoecium of 2 or several united carpels, superior. Ovules pendulous, 1 or 2 in each cavity, the raphe turned toward the axis of the gynoecium. Seeds various.

Plants destitute of secreting glands or cells in the tissues.

Sepals without dorsal glands.

Styles united around a central column from which they break at maturity.

Styles distinct or permanently united.

Flowers very irregular: one sepal spurred : anthers united.

Flowers regular: no sepal spurred : anthers distinct.

Styles distinet or partially united, the tips and the stigmas distinct.

Leaves simple: stamens 5.

Leaves compound: stamens 10-15.

Styles and stigmas permanently united.

Filaments normally appendaged: seed straight or nearly so. Fam. 5. ZYGopHYLlacEAE.

Filaments unappendaged: seed strongly bent.

Sepals bearing 1 or 2 dorsal glands (except Thryallis).

Plants with secreting glands, these often in the leaves, or only in the bark.

Filaments distinct, nearly or quite to the base.

Leaf-blades punctate by oil-glands.

Leaf-blades not punctate.

Gynoecium of distinct carpels.

Gynoecium of more or less united carpels.

Bitter-barked shrubs or trees with oil-sacs in the bark.

Resiniferous shrubs or trees.

Filaments united into a cup or tube, wholly or in part.

Fam. 1. Geraniaceae.

Fam. 2. BALSAMINACEAE.

Fam. 3. LINACEAE.

Fam. 4. OXALIDACEAE.

Fam. 6. KOEBERLINIACEAE.

Fam. 7. MalpigiacEaE.

Fam. 8. Rutaceae.

Fam. 9. SURIANACEAE.

Fam. 10. Simarubaceae.

Fam. 11. BURSERACEAE.

Fam. 12. Meliaceae.

\section{Family 1. Geraniàceae J. St. Hill. Geranium Family.}

Herbs or shrubby plants, usually caulescent and leafy. Foliage generally pubescent or glandular. Leaves alternate or opposite : blades usually lobed or dissected. Flowers perfect, regular, sometimes solitary. Calyx of mostly 5
persistent sepals. Corolla of mostly 5 hypogynous petals, deciduous. Androecium of as many stamens as there are sepals or 2-3 times as many. Filaments distinct. Anthers 2-celled, versatile. Gynoecium of 5 united carpels. Ovary 
5-celled, superior. Styles 5, united into a column. Stigmas terminal. Ovules 1 or 2 in each cavity. Fruit capsular. Seed often solitary. Embryo straight, with flat or plaited cotyledons.

Anthers usually 10 : carpel-talls glabrous within: carpel-bodies rounded at the base. Anthers 5: carpel-tails pubescent within: carpel-bodies acute at the base.

1. Geranium.

2. ERODIUM.

\section{GERÀNIUM L.}

Annual or perennial, sometimes shrubby, caulescent herbs. Leaves alternate or opposite : blades toothed, or usually deeply lobed or dissected : petioles furnished with stipules. Flowers solitary or two together on axillary peduncles. Sepals 5, imbricated. Petals 5, imbricated, alternating with 5 glands. Stamens 10, 5 longer alternating with 5 shorter, or rarely only 5 : filaments distinct or slightly united at the base. Ovary 5-lobed, prolonged into a beak formed by the united styles. Capsule 5-lobed, each lobe separating elastically from an axis and curling back on the style. Seed solitary in each cavity. Endosperm scant or wanting. Crane's-bill. Wild Geranium.

Plants annual or biennial : corolla less than $1 \mathrm{~cm}$. wide.

Sepals without subulate tips: seeds smooth.

Carpel-bodies wrinkled: stamens 10.

Carpel-bodies pubescent: stamens 5 .

Sepals with subulate tips: seeds reticulated or pitted.

Seeds pitted.

Style-columu glandular-pubescent: carpel-bodies pubescent with minute spreading hairs: petioles and pedicels with spreading hairs.

Style-column pubescent, not glandular: carpel-bodies pilose with erect hairs: petioles and pedicels retrorsely pubescent.

Seeds reticulated.

Inflorescence congested, normally many-flowered.

Inflorescence open, few-flowered.

Plants perennial from stout rootstocks : corolla over $2 \mathrm{~cm}$. wide.

1. G. molle

2. G. pusillum.

3. G. dissectum.

4. G. Texanum.

5. G. Carolinianum.

6. G. Langloisii.

7. G. maculatum.

1. Geranium mólle L. Annual or biennial. Stem branched at the base, the branches spreading or decumbent, 1-5 dm. long, often forking, delicately pubescent: leaf-blades reniform to orbicular-reniform in outline, 2-6 $\mathrm{cm}$. broad, those of the lower leaves 6-9-cleft, those of the upper 3-5-cleft or 3-5-parted, the segments toothed or lobed at the apex : petioles pubescent like the branches: pedicels minutely but copiously glandular-pubescent : sepals awnless, the outer ovate to elliptic-ovate, $3-4 \mathrm{~mm}$. long: petals deep purple, somewhat longer than the sepals: stamens 10 : carpel-bodies 2-2.5 mm. long, wrinkled : style-column $8-9 \mathrm{~mm}$. long at maturity : seeds smooth.

In waste places, Maine to Vancouver Island, North Carolina and Ohio. Introduced from Europe. Spring and summer.

2. Geranium pusillum Burm. Annual or biennial. Stem branched at the base, the branches decumbent or prostrate, 1.5-5 dm. long, forking, pubescent : leaf-blades reniform in outline, $1.5-5 \mathrm{~cm}$. broad, 5-7-parted, the segments toothed or lobed at the apex : petioles puberulent and with few spreading hairs : pedicels minutely glandular-pubescent : sepals awnless, the outer elliptic to ovate-elliptic, $2.5-4 \mathrm{~mm}$. long : petals violet, often pale, longer than the sepals : stamens 5 : carpel-bodies about $2 \mathrm{~mm}$. long, finely pubescent : style-column $8-9 \mathrm{~mm}$. long, finely pubescent : seeds smooth.

In waste places and woods, Ontario to British Columbia, New Jersey, North Carolina, Nebraska and Utah. Naturalized from Europe. Spring to fall.

3. Geranium disséctum L. Annual or biennial. Stem often branched at the base, the branches ascending or spreading, 2-7 dm. long, retrorsely pubescent : leaf-blades 2-4 $\mathrm{cm}$. wide, reniform in outline, or those on the upper part of the stem more angular, the main segments parted into linear lobes: petioles finely hirsute : pedicels glandular-hirsute : outer sepals ovate or oblong-ovate, 6-9 mm. long, glandular-ciliate, awn-tipped : petals purple, about as long as the sepals: carpel-bodies $2-2.5 \mathrm{~mm}$. long, sparingly pubescent : style-column 10-15 mm. long, glandular-pubescent : seeds pitted.

In waste places, established about the large cities of the United States and southern British America, in our range as far south as South Carolina. Summer and fall.

4. Geranium Texànum (Trelease) Heller. Annual or biennial. Stem branched at the base, the branches ascending or spreading, 1-3 dm. long, pubescent with appressedretrorse hairs : leaf-blades reniform or orbicular in outline, $2-3.5 \mathrm{~cm}$. broad, 3-5-parted, the segments toothed or incised: pedicels like the petioles, retrorsely pubescent: sepals awn-tipped, the outer orbicular-ovate to suborbicular, $5-5.5 \mathrm{~mm}$. long, pubescent with very short hairs: petals pale purple, slightly longer than the sepals : carpel-bodies $2.5-3 \mathrm{~mm}$. long, sparingly villous: style-column 10-12 mm. long, appressed-pubescent : seeds pitted.

On plains or prairies, southern Texas. Spring and summer. 
5. Geranium Caroliniànum L. Annual or biennial. Stem simple below and erect, or branched at the base, the branches ascending or spreading, more or less glandular-pubescent : leaf-blades $3-6 \mathrm{~cm}$. broad, reniform or orbicular-reniform in outline, slightly angular, the main segments cleft or parted into oblong or linear-oblong lobes: peduncles and pedicels relatively short, thus causing the flower-clusters to be somewhat congested: outer sepals ovate, sometimes broadly so, 6-10 mm. long, each with a rather long awn-tip: petals pink or whitish, about as long as the sepals : carpel-bodies $3-3.5 \mathrm{~mm}$. long, pilose with erect hairs : style-column $12-18 \mathrm{~mm}$. long, with somewhat spreading often glandular hairs : seeds reticulated.

In dry soil, southern British America and the United States. Also in Mexico and Bermuda. Spring and summer.

6. Geranium Langloìsii Greene. Resembling $G$. dissectum in habit, but stouter: leaves with relatively larger and less finely cleft blades: inflorescence not congested as in G. Carolinianum, copiously villous-hirsute, but the glands of the hairs inconspicuous: corolla pale rose-purple: seeds reticulated.

In sandy soil, southern Louisiana. Spring.

7. Geranium maculàtum L. Stems erect, $2-6 \mathrm{dm}$. tall, from thick astringent rootstocks, pubescent with spreading or retrorse hairs, forked above. Leaves mainly basal; blades 5-12 cm. broad, reniform or suborbicular in outline, deeply 3-7-parted, the segments toothed, incised or lobed; petioles of the basal leaves several times longer than the blades: cymes open : peduncles 2-flowered : sepals 5, elliptic or elliptic-lanceolate or oblong, 8-10 $\mathrm{mm}$. long, awn-tipped, ciliate, villous especially near the edges : corolla rose-purple, 2.5-3 $\mathrm{cm}$. broad : petals 5, entire, pubescent at the base : carpel-bodies $3-3.5 \mathrm{~mm}$. long, hirsute : style-column $2-3 \mathrm{~cm}$. long, finely pubescent : seeds minutely wrinkled.

In rich woods, Newfoundland to Manitoba, Georgia, Alabama and Nebraska. Spring and summer.

\section{ERÒDIUM L'Her.}

Annual or perennial, caulescent or scapose herbs, or shrubby plants. Leaves opposite or alternate, subtended by stipules : blades lobed or pinnately dissected, petioled. Flowers solitary or umbellately disposed at the end of axillary peduncles. Sepals 5, imbricated. Petals 5, imbricated, alternating with 5 glands. Stamens 5, alternating with 5 staminodia : filaments slender. Ovary 5-lobed, beaked: styles united. Capsule 5-lobed, each lobe separating elastically from an axis and rolled back with the curling style. Seed solitary in each cavity. Endosperm wanting. Stork's-Bill. Pine Needle.

Leaf-blades pinnately divided : petioles pubescent with spreading hairs. Leaf-blades palmately lobed : petioles densely puberulent.

1. E. cicutarium.

1. Erodium cicutàrium (L. ) L'Her. Annual or biennial, villous, somewhat viscid. Stems simple, or branched at the base ; branches tufted, erect or ascending, usually forked above : leaves often numerous; blades pinnately divided, $5-16 \mathrm{~cm}$. long, the segments finely and sharply pinnatifid; petioles shorter than the blades, or upper blades sessile: peduncles longer than the subtending leaves, topped by a 2-12-rayed umbel-like cyme: sepals oblong, 4-5 mm. long, apiculate : corolla pink or purple, $8-10 \mathrm{~mm}$. broad : petals 5 , oblong-obovate, hardly longer than the sepals, entire : carpels pubescent, 4-6 mm. long; beak slender, $2-4 \mathrm{~cm}$. long.

In waste places, Nova Scotia/to Oregon, New Jersey, Texas and Mexico. Adventive or naturalized from Europe. Spring to fall.

2. Erodium Texànum A. Gray. Annual or biennial, strigose, not viscid. Stems more or less diffusely branched at the base ; branches spreading, 5-31 cm. long, usually forking : leaves several; blades ovate in outline, palmately lobed, 1-3 cm. long, cordate, the lobes toothed or incised; petioles longer than the blades, except the upper ones: peduncles longer than the subtending leaf, topped by a several-rayed umbel-like cyme: sepals elliptic, 6-10 mm. long, puberulent, awn-tipped : petals cuneate or obovate-cuneate, often nearly twice as long as the sepals : carpels $7-9 \mathrm{~mm}$. long, silky ; beak slender, $3.5-7.5 \mathrm{~cm}$. long.

In dry soil, Texas to California and Lower California. Spring and summer.

\section{Family 2. Balsaminàceaf Dumort. Jewel-weed Family.}

Herbs, with succulent tissues. Leaves alternate or sometimes opposite: blades simple. Flowers perfect, irregular, unsymmetrical, loosely disposed, sometimes accompanied by cleistogamous ones. Calyx of 3 sepals ( 2 suppressed); posterior one petaloid, saccate and spurred; all deciduous. Corolla of 5 petals, 
the lateral pair on each side united, deciduous. Receptacle without glands. Androecium of 5 perfect stamens. Filaments appendaged and partially united. Anthers more or less united or converging. Gynoecium of 5 united carpels. Ovary 5-celled, somewhat elongated. Styles very short or wanting. Stigmas 5. Ovules several in each cavity. Fruit a more or less elongated capsule, with elastically bursting and coiling valves. Seeds ribbed. Endosperm wanting. Embryo with nearly flat cotyledons.

\section{IMPÀTIENS L.}

Herbs, with commonly pellucid watery stems. Leaves alternate or opposite : blades mostly toothed: petioles without stipules, or these represented by glands. Flowers of various colors, often mottled, solitary or several on axillary peduncles. Sepals mostly 3 , imbricated, the two lateral ones flat, the lower one spurred or saccate. Petals mostly 5 , the lateral pair on each side united. Stamens 5 : filaments very short, each furnished with a scale : anthers often cohering to the pistil, introrse. Ovary elongated, 5-celled : stigma sessile, 5-lobed. Ovules numerous in each cavity, in 1 series. Capsules various, loculicidally opening by the elastic valves. Seeds numerous, 4-ribbed, with a glabrous or pubescent testa. Embryo straight. Touch-ME-NOT.

Flowers orange: saccate sepal contracted into a spur one-half as long as the body. Flowers pale yellow: saccate sepal contracted into a spur $\frac{1}{4}$ or $\frac{1}{5}$ as long as the body.

1. I. biflora.

2. I. aurea.

1. Impatiens biflòra Walt. Foliage deep green. Stem at length much branched, 1-2 m. tall, enlarged at the nodes : leaf-blades ovate or elliptic, 2-12 cm. long, obtuse or acutish, distantly and shallowly crenate, somewhat obliquely narrowed at the base into a slender petiole which is $\frac{1}{3}-\frac{2}{3}$ as long as the blade: flowers orange, with reddish brown spots, or rarely white, loosely panicled and gracefully pendulous from the slender pedicels : saccate sepal conic, longer than broad, 1.7-2.4 cm. long, gradually prolonged into a slender incurved spur about $\frac{1}{2}$ as long as the body. [I. fulva Nutt. ?]

In moist soil, Nova Scotia to Oregon, Florida and Missouri. Summer to fall.

2. Impatiens aùrea Muhl. Foliage glaucescent. Stems 1-2 m. tall, swollen at the nodes, finally much branched : leaf-blades oval, ovate or elliptic, $2 \mathrm{~cm}$. long, obtuse or apiculate, coarsely crenate-serrate, narrowed into short petioles $\frac{1}{3}-\frac{1}{2}$ as long as the blade : flowers pale yellow, often slightly mottled, loosely panicled, gracefully pendant from slender scaly pedicels : saccate sepal cup-like, about as broad as long, 1.5-2 cm. long, abruptly contracted into a short deflexed spur, $\frac{1}{4}-\frac{1}{5}$ as long as the body. [I. pallida Nutt.]

In shaded places, Quebec to Oregon, Georgia and Kansas. Summer.

\section{Family 3. LINÀceae Dumort. Flax Family.}

Herbs or shrubby plants, usually caulescent and branching. Leaves alternate or opposite, without stipules: blades narrow, commonly sessile. Flowers perfect, regular and usually symmetrical, solitary in the axils or in terminal racemes, or paniculate or corymbose cymes. Calyx of 4-6 imbricated persistent or deciduous sepals. Corolla of 4-6 imbricated generally convolute petals, ephemeral. Androecium of as many stamens as there are /petals and alternate with them. Filaments monadelphous at the base. Anthers 2-celled, versatile. Gynoecium 2-5 united carpels. Ovary 2-5-celled or by false partitions 4-10celled. Styles 2-5, distinct, at least above. Ovules 1 or 2 in each cavity. Fruit capsular. Seeds 1 or 2 in each cavity, oily. Endosperm little or wanting. Embryo with flat cotyledons.

\section{LìnUM L.}

Herbs or sometimes shrubby plants, with a tough bark. Leaves alternate or opposite : blades narrow, erect or spreading, entire. Flowers commonly yellow or blue, variously disposed. Sepals 5, entire, eroded or glandular-toothed or sometimes strongly ciliate. Petals 5, convolute, fugacious. Stamens 5, often alternating with as many small staminodia : filaments distinct or united to near the apex. Glands 5, adnate to the outside of the filament-tube. Ovary 5-celled, or rarely 2-celled, each cavity with a false partition. Styles 5, or rarely 2, distinct or united. Stigmas small. Ovules 2 in each cavity. Cap- 
sule 5-celled, or rarely 2 -celled, septicidally 5 -valved, or rarely 2 -valved, or separating into 10 one-seeded carpels. Seeds flattened. Flax.

Corolla blue.

Perennial : sepals much shorter than the capsule, the inner not ciliate: native species.

Annual: sepals slightly shorter than the capsule, the inner eiliate: naturalized species.

1. L. Lewisii.

Corolla yellow.

Styles distinct.

Inner and outer sepals entire, sometimes erose, but not glandular-toothed. Stems ridged, angled or winged. Stems terete or essentially so.

Inner sepals glandular-toothed, outer sepals entire or toothed. Outer sepals entire : stipular glands wanting.

Capsule spheroidal, shorter than the sepals: inner sepals with relatively short teeth.

Capsule ovoid, longer than the sepals : inner sepals with relatively long teeth.

Outer sepals glandular-toothed : stipular glands present.

2. L. usitatissimum.

. L. striatum.

4. L. Virginianum.

5. L. medium.

6. L. Floridanum.

7. L. rupestre.

Styles more or less united.

Capsules 10-valved: styles united below the middle.

Sepals $2.5-3 \mathrm{~mm}$. long, merely acute : filaments pubescent at the base, without interposed teeth.

Sepals $4.5-6 \mathrm{~mm}$. long, slenderly acuminate : filaments not pubescent at the base, with interposed teeth.

Capsules 5-valved: styles united to near the apex.

Sepals merely acuminate, serrulate or serrate, deciduous, the outer mostly over $5 \mathrm{~mm}$. long.

Outer sepals $5-7 \mathrm{~mm}$. long.

Sepals with wide coarsely toothed scarious margins, the outer ovate to ovate-lanceolate.

Sepals with narrow, finely toothed margins, the outer lanceolate to oblong-lanceolate.

Outer sepals 8-12 mm. long.

Innersepals slightly shorter than the outer, usually less than $\frac{1}{5}$ shorter : leaf-blades $1.5-4.5 \mathrm{~mm}$. wide, acuminate.

Inner sepals much shorter than the outer, usually over $\frac{2}{5}$ shorter: leaf-blades $5.5-7.5 \mathrm{~mm}$. wide, mostly acute.

Sepals abruptly cuspidate-awned beyond the broad scarious ciliolate margin, persistent, the outer mostly less than $5 \mathrm{~mm}$. long.

8. L. Harperi.

9. L. sulcatum.

11. L. rigidum.

12. L. Berlandieri.

13.L. sanctum.

14. L. multicaule.

1. Linum Lewísii Pursh. Perennial by a woody rootstock, glabrous, glaucous. Stems often tufted, 2-7 dm. tall, branching above: leaves alternate, erect, or nearly so, often crowded; blades linear to oblong, 0.6-2 cm. long, acute or acutish, sessile : pedicels 1-2 cm. long, drooping at maturity : sepals ovate or elliptic-ovate, or oval, 5-6 $\mathrm{mm}$. long, acute, 3-nerved, the inner not ciliate : capsule globose-ovoid, 7-9 mm. long, 2-3 times longer than the sepals.

In stony or dry soil, Alaska to Manitoba, Texas and Arizona. Summer.

2. Linum usitatíssimum L. Annual, glabrous, deep green. Stems $2-8 \mathrm{dm}$. tall, simple or branching above, striate, somewhat angled above : leaves alternate, erect or ascending; blades linear or linear-lanceolate, 1-3 cm. long, acute, sessile, 3-nerved : sepals elliptic or elliptic-ovate, 5-7 mm. long, acuminate, 3-nerved at the base, the inner ciliate: corolla blue, 1.2-2 $\mathrm{cm}$. broad : capsules globose or depressed, 6-8 mm. long, often striate, slightly surpassing the sepals : seeds flattened.

In waste places, along railroads, more or less common throughout the civilized world. Summer.

3. Linum striàtum Walt. Perennial, bright green, more or less viscid. Stems sometimes decumbent, $2-8 \mathrm{dm}$. tall, paniculately branched above, winged below the nodes and angled, the branches spreading : leaves opposite, except those in or near the inflorescence ; blades thinnish, narrowly oblong or elliptic, $1-3 \mathrm{~cm}$. long, acute or obtuse, sessile : pedicels as long as the calyx or longer: corolla pale yellow, $6-10 \mathrm{~mm}$. broad: outer sepals lanceolate to oblong-lanceolate, 2-2.5 mm. long, acuminate, entire; inner sepals ovate to obovate or suborbicular, about $0.5 \mathrm{~mm}$. shorter than the outer, erose-toothed near the abruptly pointed apex : capsules depressed-globose, $2 \mathrm{~mm}$. broad, surpassing the sepals.

In or near swamps, Ontario to Arkansas, Florida and Texas. Summer.

4. Linum Virginiànum L. Annual or perennial, glabrous, often deep green. Stems 2-6 dm. tall, often several together, corymbosely branched above, the branches lax, spreading or drooping at the ends : leaves spreading or ascending; blades thinnish, 1-3 cm. long, the lower ones opposite, spatulate to oblanceolate, the upper alternate, elliptic or ellipticoblanceolate, obtuse or acute, sessile: pedicels slender, becoming longer than the sepals : outer sepals lanceolate to oblong-lanceolate, $2-3.5 \mathrm{~mm}$. long, entire, acuminate; inner sepals rather broader and shorter than the outer, erose-toothed near the abruptly pointed apex: corolla sulphur-yellow, 10-12 $\mathrm{mm}$. broad: capsules depressed, $2 \mathrm{~mm}$. broad, longer than the sepals or equalling them.

In dry soil and woods, Maine and Ontario, middle Georgia and Alabama. Summer. 
5. Linum mèdium (Planch. ) Britton. Perennial or sometimes annual, bright green, glabrous. Stems 3-6 dm. tall, often tufted, strict, rigid, corymbosely branched above, the branches stiff, erect-ascending : leaves firm, appressed or strongly ascending ; blades 0.6-2 cm. long, the lower ones often opposite, spatulate, the rest linear-elliptic or linearlanceolate, acute, sessile : pedicels mostly shorter than the sepals or the lower ones sometimes longer : outer sepals oblong to lanceolate, $2-4 \mathrm{~mm}$. long, acuminate, entire ; inner sepals shorter and broader than the outer, glandular-toothed, especially above the middle, abruptly pointed : corolla light yellow : capsules depressed-globose, $2-3 \mathrm{~mm}$. broad, shorter than the persistent sepals.

In dry soil, Ontario to Florida and Texas. Summer.

6. Linum Floridànum (Planch.) Trelease. Perennial, glabrous, bright green. Stems 3-8 dm. tall, strict, rigid, branching above or near the top: leaves firm, nearly erect or appressed ; blades acute, $0.8-1.8 \mathrm{~cm}$. long, the lower ones usually opposite, oblanceolate to linear-lanceolate, the upper ones linear or linear-elliptic : outer sepals lanceolate or oblonglanceolate, 3-4 mm. long, entire, acuminate; inner sepals shorter and narrower than the outer, glandular-toothed : corolla yellow, $12-15 \mathrm{~mm}$. broad : capsules ovoid or sometimes broadly so, about $3 \mathrm{~cm}$. long, longer than the sepals, about as long as the pedicels or longer.

In sandy soil, South Carolina to Florida and Louisiana. Summer.

7. Linum rupéstre Engelm. Perennial. Stems tufted, often densely so, $2-7 \mathrm{dm}$. tall, grooved or angled, sparingly branched above, the branches ascending, corymbose : leaves firm, few, scattered ; blades linear-subulate, $3-10 \mathrm{~mm}$. long, acute : pedicels shorter than the sepals or the lower ones rarely longer: onter sepals lanceolate to elliptic, $3 \mathrm{~mm}$. long, mostly acuminate, glandular-toothed; inner sepals elliptic or ovate, about $0.5 \mathrm{~mm}$. shorter than the outer, more finely glandular-toothed and abruptly pointed: corolla yellow : capsule spheroidal-ovoid, broader than long, about $2 \mathrm{~mm}$. broad, longer than the sepals.

On plains and prairies, Texas and adjacent Mexico. Spring and summer.

8. Linum Hárperi Small. Annual. Stems $3-8 \mathrm{dm}$. tall, nearly simple or sparingly branched, corymbose above or virgate : leaves mainly alternate, erect or nearly so ; blades narrowly linear, $0.5-2 \mathrm{~cm}$. long, slender-tipped, sessile, glabrous, the marginal nerves inconspicuous : stipular glands black : pedicels mainly shorter than the sepals : outer sepals lanceolate, 3.5-4 mm. long, acuminate, sparingly glandular-toothed ; inner sepals somewhat shorter than the outer, acuminate, more copiously toothed : corolla pale yellow, $12-15 \mathrm{~mm}$. broad : capsules ovoid, $2.5-3 \mathrm{~mm}$. long, obtuse, about as long as the sepals.

In dry pine lands, Georgia. Summer.

9. Linum sulcàtum Ridd. Annual. Stems 2-7 dm. tall, simple or corymbosely branched, sharply angled or winged, at least above : leaves firm, alternate, erect or ascending; blades linear or linear-lanceolate, $0.8-2.5 \mathrm{~cm}$. long, acute or acuminate, 3-nerved (the marginal nerves prominent), sessile, glabrous : stipular glands black : pedicels shorter than the sepals : outer sepals lanceolate, $5-6 \mathrm{~mm}$. long, long-acuminate, glandular-toothed ; inner sepals shaped like the outer, slightly shorter, more finely toothed: corolla light yellow, $10-13 \mathrm{~mm}$. broad : capsules ovoid, about $3 \mathrm{~mm}$. long, acute, surpassed by the sepals, incompletely 10-celled, the septa ciliate.

In dry soil, Ontario to Manitoba, Georgia and Texas. Summer.

10. Linum marginàtum Small. Annual, smooth and glabrous. Stems simple or branched at the base, $1-1.5 \mathrm{dm}$. tall : leaf-blades linear and linear-lanceolate, 1-2 cm. long, acuminate, more or less involute : corymbs usually few-flowered : bracts linear-lanceolate : outer sepals oblong-ovate, $5-6 \mathrm{~mm}$. long, acute or slightly acuminate, with a broad coarsely glandular-toothed margin; inner sepals slightly broader and shorter than the outer, and with more and rather smaller teeth : corolla yellow, about $2 \mathrm{~cm}$. broad : capsules broadly ovoid, about $4 \mathrm{~mm}$. high.

In dry soil, Texas. Spring to fall.

11. Linum rígidum Pursh. Annual or perhaps perennial, glabrous or puberulent, glaucous. Stems 1-5 dm. tall, simple below, corymbosely branched and angled above, the branches rigid : leaves firm; blades linear or linear-lanceolate, erect or appressed, $0.6-$ $2.5 \mathrm{~cm}$. long, acute or acuminate, sessile, the upper ones glandular-ciliate : pedicels longer or shorter than the sepals : outer sepals lanceolate, 5-7 mm. long, long-acuninate, rather finely glandular-serrate; inner sepals nearly like the outer, sometimes slightly broader and shorter, similarly toothed : corolla yellow, $1.5-3.5 \mathrm{~cm}$. broad : capsules ovoid, 4-5 mm. long, shorter than the sepals.

In dry soil on prairies, Manitoba to Texas, Arizona and Mexico. Summer. 
22 Linum Berlandièri Hook. Annual or perhaps perennial, nearly glabrous. Stems simple, 1-2.5 dm tall, or branched at the base, the branches erect or ascending, corymbose : leaves clear green ; blades lanceolate or linear, $1-2.5 \mathrm{~cm}$. long, spreading or ascending, acuminate, the lateral nerves marginal : pedicels stout, angled. longer than the calyx : outer sepals lanceolate, $8-11 \mathrm{~mm}$. long, acuminate, copiously glandular-serrate; inner sepals nearly like the outer but with slightly finer teeth : corolla yellow, 4-4.5 cm. broad : capsules globose-ovoid, 4-4.5 mm. long, obtuse, much shorter than the sepals.

On plains and praries, Texas. Spring and summer.

13. Linum sánctum Small. Annual or perennial, deep green. Stems $1.5-3 \mathrm{dm}$. tall, corymbosely branched above : leaves approximate ; blades narrowly oblong to linearoblong, $1.5-3.5 \mathrm{~cm}$. long, ascending, the lateral nerves not marginal: pedicels shorter than the calyx : outer sepals lanceolate, $10-12 \mathrm{~mm}$. long, acuminate, rather sparingly glandular toothed; inner sepals much shorter than the outer but with many approximate finer teeth : corolla yellow, about $3 \mathrm{~cm}$. broad : capsule not seen.

On plains or prairies, southern Texas. Summer.

14. Linum multicaùle Hook. Annual or perhaps perennial, puberulent. Stems more or less densely tufted, 1-3 dm. tall, simple or corymbosely branched above : leaves numerous, firm, appressed or erect, commonly imbricated ; blades linear or linear-subulate, 3-8 $\mathrm{mm}$. long, acute, finely ciliate: pedicels stout, mostly longer than the sepals: outer sepals 4.5-5 mm. long, each with an elliptic to oval ciliate body and a subulate terminal awn ; inner sepals similar but slightly smaller : corolla yellow, $1.5 \mathrm{~cm}$. broad : capsules subglobose, $4 \mathrm{~mm}$. long, shorter than the sepals.

On plains and prairies, Texas. Spring and summer.

\section{FAmily 4. OXALIDÀCEAE Lindl. Wood-sorrel FAmily.}

Annual or perennial acaulescent or leafy-stemmed herbs, or rarely shrubs, with rootstocks or scaly bulbs, and a sour sap. Leaves basal or cauline: petioles with free or adnate stipules, or these obsolete: blades usually 3 -foliolate, sometimes 1-foliolate, usually pinnate or digitate: leaflets commonly notched at the apex. Flowers perfect, essentially regular, solitary or in axillary or terminal, peduncled, umbel-like or dichotomous cymes. Calyx of 5 often unequal, imbricated, persistent sepals. Corolla of 5 white, pink, rose, purple or yellow convolute petals, usually broadened upward, entire or notched at the apex. Androecium of 10-15 stamens, or twice or thrice as many as the sepals. Filaments united below, in 2 sets of different lengths. Gynoecium of 5 united carpels. Ovary 5-celled, 5-lobed. Styles 5, distinct. Stigmas capitate. Ovules 2-many in each cavity. Fruit a globose or columnar loculicidal capsule, or rarely berrylike. Seeds with a dehiscent arilloid outer coat and a firm, often ridged, inner coat. Embryo straight in fleshy endosperm. Cotyledons flat.

Plants acaulescent, perennial, succulent : corolla not yellow.

Rootstocks elongated, scaly near the ends : flowers homogonous.

Rootstocks abbreviated, bulb-like: flowers heterogonous.

Plants caulescent, annual or perennial, not succulent : corolla yellow.

Leaf-blades 1-foliolate: stipules free, bristle-like.

Leaf-blades 3-foliolate: stipules adnate, a dilation of the base of the petioles or obsolete.

Leaflets pinnate : ovary and capsule drooping, depressed at the apex : stigmas 2-cleft.

Leaflets palmate: ovary and capsule erect, narrowed at the apex: stigmas capitate.

1. OxALIS.

2. IONOXALIS.

3. Monoxalis.

4. Lotoxalis.

5. Xanthoxalis.

\section{1. ÓXALIs L.}

Perennial herbs, with slender more or less scaly rootstocks. Leaves basal, solitary or several together : petioles dilated at the base; blades palmately 3 -foliolate; leaflets notched at the apex, usually with a membranous fold in the sinus. Scapes solitary or sereral together, topped by a single pedicel or rarely with an umbel-like cyme. Flowers perfect, homogonous. Sepals 5, the inner longer than the outer. Petals white or pink, delicate, much longer than the sepals, often obliquely notched at the apex. Stamens 10: filaments commonly glabrous. Capsule relatively short. Seeds few or several in each cavity, pitted and grooved or striate. WOOD-SORREL.

1. Oxalis Acetosélla L. Rootstocks slender, scaly at the ends. Foliage pubescent with scattered brownish hairs : leaves $2-6$ together: leaflets 3 , the blades obcordate, 10-15 
mm. long, wider : scapes 1-3, erect or ascending, 5-15 $\mathrm{cm}$. high, simple: flower solitary, overtopping the leaves : sepals oblong to lanceolate, ciliate, obtusish, purple-tipped : petals white or pink, delicately marked with deep pink, $1-1.5 \mathrm{~mm}$. long, 3-4 times longer than the sepals : capsules ovoid-globose, 2-4 mm. long, acutish : seeds 1-2 in each cavity, obovoid, longitudinally 5-grooved on each face, minutely pitted.

In cold damp woods, Nova Scotia to Manitoba and southward on the mountains to North Carolina and Tennessee. Spring and summer. Also in Europe and Asia.

\section{IONÓXALIS Small.}

Perennial acaulescent herbs, with scaly bulbs. Leaves basal, few or many together : petioles dilated at the base : blades palmately 3-10-foliolate; leaflets notched at the apex, with short or elongated lobes, usually with orange tubercles in each sinus, commonly drooping. Scapes erect, solitary or clustered, usually topped by umbel-like cymes. Flowers perfect, heterogonous. Sepals 5, with tubercles at the apex. Petals 5, rosepurple, rose-violet or white, much longer than the sepals, commonly rounded at the apex. Stamens 10: filaments usually pubescent, united at the base. Capsule sometimes elongated, 5-celled. Seeds wrinkled, grooved or tubercled. Violet Wood-sorrel.

Leaflets with obcordate or obreniform blades : sepals with 2 distinct or confluent apical tubercles.

Capsules globose-ovoid: tubereles more or less confluent.

Capsules oblong-ovoid : tubercles distinet.

Leaflets with V-shaped or Y-shaped blades : sepals with 4-6 more or less confluent tubercles.

1. I violacea.

2. I. Martiana.

1. Ionoxalis violàcea (L.) Small. Bulb coated with brown ciliate scales, rarely producing a tap-root: leaves 4-8 or more: leaflets 3 , the blades obcordate or obreniform, 6-16 mm. long, wider, sometimes pubescent on the midrib beneath : scapes erect, solitary or several together, $0.5-3 \mathrm{dm}$. tall, surpassing the leaves, sometimes twice as high, each topped by a 3-15-flowered cyme: pedicels rarely pubescent, recurved before and after flowering: flowers heterogonous: sepals oblong or ovate-oblong, 4-6 mm. long, obtuse, with 2 confluent tubercles at the apex: petals rose-purple, lighter toward the base, or white, 14-20 mm. long, thrice as long as the sepals, obtuse or truncate at the apex : capsules globose-ovoid, 4-5 mm. long, slightly surpassing the sepals : seeds ovoid, $1.5 \mathrm{~mm}$. long, flattened, rugose-tuberculate. [Oxalis violacea L.]

In woods and on open slopes, New England to Minnesota and the Rocky Mountains, Florida and New Mexico. Spring and summer.

2. Ionoxalis Martiàna (Zucc.) Small. Bulb scaly. Foliage deep green : leaves erect or ascending : leaflets 3 , the blades thin, obcordate to obreniform, with a deep, narrow sinus and a marginal row of small orange tubercles, sessile, often drooping : scapes erect, usually surpassing the leaves, villous, the cymes several-flowered: pedicels glabrous or nearly so: sepals oblong or narrowly oblong, 5-6 mm. long, ciliate, each with 2 distinct apical tubercles : petals rose-purple, often pale, $12-15 \mathrm{~mm}$. long: filaments ciliate : capsules oblong-ovoid. [Oxalis Martiana Zuce.]

In waste places, in the Gulf States, introduced from tropical America. Throughout the year.

3. Ionoxalis vespertiliònis (T. \& G.) Small. Bulbs scaly. Foliage glabrous or nearly so: leaves basal: leaflets 3 , the blades commonly broadly V-shaped, 6-10 mm. long, much broader, the lobes usually narrow: scapes erect, several together, commonly twice as long as the petioles, the cymes few-flowered: pedicels slender, elongating at maturity: flowers heterogonous: sepals narrowly oblong or oblong-lanceolate, 4-5 mm. long, with usually 4-6 apical tubercles: petals violet, oblanceolate or spatulate, $1.5-2 \mathrm{~cm}$. long, rounded at the apex : filaments ciliate : capsules oblong-ovoid, 8-10 mm. long, somewhat pubescent : seeds ovoid-globose, $1 \mathrm{~mm}$. long, wrinkled. [Oxals vespertilionis T. \& G.] On prairies, Texas to Arizona. Summer and fall.

\section{MONÓXALIS Small.}

Perennial caulescent herbs, with woody branched rootstocks and pubescent foliage. Leaves alternate : petioles little elongated, with free bristle-like stipules at the base : blades 1-foliolate: leaflets thickish, barely stalked. Peduncles axillary, with 2 bristle-like bracts at the base of the single pedicel, and shorter than the peduncle. Flowers perfect, solitary. Sepals 5, auricled at the base. Corolla yellow. Petals 5, rather narrow, surpassing the sepals, narrowed into claws below the middle. Stamens 10 : filaments glabrous. Capsule little longer than thick, 5 -celled. Seeds about 3 in cavity, tubercled. 
1. Monoxalis dichondraèfolia (A. Gray) Small. Foliage closely pubescent with short gray hairs. Stems woody below, the branches tufted, more or less spreading or decumbent, 1-3 dm. long: leaves rather numerous: leaflet 1 , the blade suborbicular, inclined to obovate, oblong or ovate, $1-3 \mathrm{~cm}$. long, retuse and somewhat apiculate at the apex, undulate, ciliate, cordate at the base: pedicels $0.5-1 \mathrm{~cm}$. long, with 2 bracts like the stipules, enlarged upward : sepals lanceolate or triangular-lanceolate, 5-10 $\mathrm{mm}$. long, acute or acuminate, auriculate-cordate at the base : petals about twice as long as the sepals, eroseundulate at the apex, the claw about as long as the blade: capsules oblong or ovoidoblong, $8-10 \mathrm{~mm}$. long, about as long as the sepals : seeds about $2 \mathrm{~mm}$. long, with prominent somewhat confluent tubercles, lustrous. [Oxalis dichondraefolia A. Gray.]

In dry soil, southern and southwestern Texas and adjacent Mexico. Spring to fall.

\section{LOTÓXALIS Small.}

Perennial caulescent herbs, with horizontal rootstocks. Stems branched at the base, the branches woody below, corymbosely branched above. Leaves alternate: petioles without stipules: blades pinnately 3-foliolate: leaflets more or less oblique. Peduncles axillary, topped by umbel-like cymes. Pedicels recurved before and after flowering, not deflexed. Flowers perfect. Sepals 5, thin, acute, erect, imbricated. Petals yellow, much longer than the sepals. Stamens 10: longer filaments ciliate. Stigmas 2-cleft. Capsule oblong-ovoid, surpassing the sepals, drooping. Seeds slightly flattened, with 5-8 longitudinal rows of sharp tubercles. WOOD-SORREL.

1. Lotoxalis Berlandièri (Torr.) Small. Rootstocks woody. Foliage gray or tawny-pilose. Stems branched at the base, the branches erect or ascending, $5-25 \mathrm{~cm}$. long, woody below, commonly branched: leaflets 3 , the blades thickish, cuneate, obovate or oblong, 5-20 mm. long, unequally notched at the apex, ciliate, mostly pubescent on both surfaces, rounded at the base, the lateral much smaller than the terminal : pedicels often 3 , recurved at maturity : sepals oblong, $5-8 \mathrm{~mm}$. long : petals yellow, about twice as long as the sepals : longer filaments ciliate : capsules oblong-ovoid, 7-8 mm. high, depressed at the apex : seeds fusiform or nearly elliptic, $1.5-2 \mathrm{~mm}$. long, with sharp tooth-like tubercles in longitudinal rows. [Oxalis Berlandieri Torr.]

In dry or sandy soil, southern Texas and adjacent Mexico. Spring to fall.

\section{XANTHÓXALIS Small.}

Annual or perennial caulescent herbs, with descending or horizontal rootsocks. Stems sometimes woody at the base. Leaves alternate: stipules obsolete or appearing as narrow dilations at the base of the petiole : blades palmately 3 -foliolate; leaflets broadly obcordate, usually inequilateral, nearly sessile or rarely stalked, sometimes sensitive. Flowers per-1 fect, heterogonous or homogonous. Sepals 5, narrow, imbricated. Corolla yellow, sometimes with a darker eye. Petals 5, surpassing the sepals, rounded or notched at the apex. Stamens 10: filaments glabrous or the longer ciliate. Capsule more or less elongated, columnar or narrowed upward, angled, 5-celled. Seeds several in each cavity, transversely ridged or tuberculate by broken ridges. Yellow Wood-SORREL. Sour-(iRass.

Plants with creeping elongated stems or branches.

Sepals eiliate at the tip or only near it : longer filaments glabrous.

Sepals ciliate nearly all around : longer filaments ciliate above.

Plants with erect stems, or if branched at the base the branches sometimes decumbent, often with horizontal rootstocks.

Stems and petioles strigillose with decidedly appressed hairs.

Longer filaments clliate above.

Sepals $2-4 \mathrm{~mm}$. long, ciliate mainly or only at the tip : corolla pale yellow, $0.5-1.5 \mathrm{~cm}$. broad. Sepals $4-5 \mathrm{~mm}$. long, copiously ciliate all around : corolla golden yellow,
$1.5-2.5 \mathrm{~cm}$. broad.

Longer filaments glabrous.

Leafiets strigillose: sepals copiously ciliate : corolla golden yellow.

Leaflets glabrous or merely with a few scattered hairs: sepals sparingly ciliate : corolla pale or light yellow.

Stems and petioles villous or with loosely spreading hairs.

1. X. corniculata.

2. $X$. Langloisii.

A. Pedicels with erect or appressed hairs.

Longer filaments glabrous.

Sepals ciliate nearly all around: leaflets bright green. Sepals ciliate only at the apex: leaflets reddish purple.

Longer filaments ciliate above or throughout.

Leaf-blades red or purple.

Leaf-blades bright green.

a. Sepals ciliate nearly all around: leaflets mainly less than $15 \mathrm{~mm}$. broad.

3. X. filipes.

4. X. macrantha.

5. X. Texana.

6. X. stricta.
7. X. Bushii.

8. X. rufa.

9. X. colorea. 
Short styles with recurved tips during anthesis: corolla golden yellow.

Short styles with erect tips during anthesis: corolla light yellow. $11 . X$. recurva.

b. Sepals ciliate only at the apex or near it : leaflets mainly over 20 mm. broad.

Leaflets strigillose, the margins green : capsules $10-12 \mathrm{~mm}$. long.

Leaflets essentially glabrous except the brown ciliate margins : capsules 8-10 mm. long.

B. Pedicels villous or loosely pubescent.

Sepals ciliate only at the tip, 3.5-5 mm. long: cymes dichotomous : petals $7-10 \mathrm{~mm}$. long.

Sepals ciliate all around, about $7 \mathrm{~mm}$. long: cymes umbel-like: petals about $15 \mathrm{~mm}$. long.

Petals glabrous : longer filaments glabrous : copiously pubescent.

Petals pubescent without: longer filaments ciliate above : stem with few scattered hairs.

12. $X$. interior.

13. $X$. grandis.

14. X. cymosa.

15. X. hirsuticaulis.

16. X. Priceae.

1. Xanthoxalis corniculàta (L.) Small. Stem branched at the base, the branches 0:5-4 dm. long, creeping, somewhat pubescent with more or less appressed hairs: leaflets deep green, the blades 5-12 $\mathrm{mm}$. broad or sometimes larger, ciliate and commonly with scattered hairs on the surface : pedicels minutely strigillose : sepals oblong to oblong-lanceolate, 3-4 mm. long, ciliate at the apex or only near it: petals 7-10 mm. long: filaments glabrous : capsule $8-13 \mathrm{~mm}$. long. [Oxalis corniculata L.]

In waste places and in fields and on roadsides. New Jersey to the Indian Territory and the Gulf States. Adventive as far north as Ontario. Also in the tropics. Thtoughout the year.

2. Xanthoxalis Langloisii Small. Similar to $O$. corniculata in habit, but relatively smaller in all its parts : leaflets pale or light green, the blades 3-10 mm. broad, mostly less than $6 \mathrm{~mm}$. wide, somewhat ciliate and more or less pubescent on the surface: pedicels minutely strigillose: sepals oblong or oblong-lanceolate, $2.5-4 \mathrm{~mm}$. long, ciliate nearly all around : petals $5-8 \mathrm{~mm}$. long: longer filaments ciliate above : capsules 9-14 $\mathrm{mm}$. long.

In woods, sandy bottoms and door yards, Tennessee to Florida and Texas. Throughout the year.

3. Xanthoxalis filipes Small. Stems more or less tufted on the slender rootstocks, commonly decumbent, strigillose : leaves often irregularly clustered : leaflets bright green, the blades 7-8 $\mathrm{mm}$. wide, or sometimes wider, glabrous or with a few scattered hairs: pedicels strigillose : sepals lanceolate to oblong-lanceolate, $3-4 \mathrm{~mm}$. long, sparingly ciliate mainly at the tip or near it and otherwise sparingly pubescent: petals $5-9 \mathrm{~mm}$. long, light or pale yellow : longer filaments ciliate above : capsules slender, $8-12 \mathrm{~mm}$. long, erect on more or less reflexed pedicels. [Oxalis filipes Small.]

In woods or sandy soil, District of Columbia to Missouri and Georgia. Spring to fall.

4. Xanthoxalis macrántha (Trelease) Small. Stems solitary or sparingly tufted on woody rootstocks, erect or decumbent, strigillose : leaves often numerous : leaflets deep or bright green, the blades 7-12 $\mathrm{mm}$. wide, or some of them smaller, more or less pubescent and commonly cilate: pedicels strigillose: sepals oblong to oblong-lanceolate, $4-5 \mathrm{~mm}$. long, copiously ciliate all around, and otherwise densely pubescent : petals $10-20 \mathrm{~mm}$. long, golden yellow : longer filaments sparingly ciliate above : capsules stont, 10-14 mm. long, on more or less reflexed pedicels. [Oxalis corniculata var.? macrantha Trelease.]

In open woods and on shaded bakks, Georgia and Florida to Mississippi. Spring to fall.

5. Xanthoxalis Texàna Small. Stems commonly solitary along the woody rootstock, densely strigillose, erect or decumbent, 1-1.5 dm. long: leaves approximate: leaflets bright green, the blades $8-15 \mathrm{~mm}$. broad, more or less densely strigillose and ciliate: pedicels strigillose : sepals oblong, sometimes broadly so, or linear-oblong, $4.5-5.5 \mathrm{~mm}$. long, copiously ciliate all around and otherwise densely pubescent: petals 12-18 mm. long, golden yellow : longer filaments glabrous : capsules stout, columnar, 12-15 mm. long, on reflexed pedicels.

On plains and prairies, Texas. Spring to fail.

6. Xanthoxalis strícta (L.) Small. Stems tufted on woody rootstocks, or sometimes from mere annual roots, strigillose, often decumbent : leaves usually numerous : leaflets bright green, 8-16 mm. broad, glabrous or with a few scattered hairs : pedicels strigillose : sepals oblong or linear-lanceolate, 4-6 mm. long, sparingly ciliate, more or less pibescent on the back: petals $5-10 \mathrm{~mm}$. long, pale or yellow : longer filaments glabrous : capsules stout, columnar, $16-30 \mathrm{~mm}$. long. [Oxalis stricta L.]

In woods, cultivated grounds and on roadsides, Nova Scotia to South Dakota, Florida and Texas. Spring to fall.

7. Xanthoxalis Búshii Small. Stems solitary or rarely tufted on relatively slender rootstocks, erect or nearly so, 1-3 dm. tall, loosely pubescent : leaves few : leaflets bright green, the blades $7-8 \mathrm{~mm}$. broad, or rarely smaller, more or less strigillose and ciliate especially when young: cymes umbel-like, usually maturing one flower at a time which is 
accompanied by several drooping buds : pedicels strigillose : sepals oblong to linear-oblong, 3-4 mm. long, ciliate nearly all around: petals $9-12 \mathrm{~mm}$. long, pale yellow : longer filaments glabrous : capsules rather stout, $8-10 \mathrm{~mm}$. long. [Oxalis Bushii Small.]

In dry soil or thickets. Massachusetts, Missouri, Georgia and Arkansas. Bpring and summer.

8. Xanthoxalis rùfa Small. Stems usually solitary, sometimes on elongated rootstocks, 1.5-4 dm. tall, loosely pubescent : leaves usually numerous : leaflets reddish or purplish, the blades $8-20 \mathrm{~mm}$. wide, sparingly strigillose or glabrous, at least at maturity, except the ciliate margins : cymes dichotomous but the primary branches manifestly shortened, maturing several flowers at a time: pedicels strigillose, conspicuously short : sepals oblong, linear-oblong or oblong-lanceolate, 3-4 mm. long, ciliate at the tip, otherwise nearly glabrous: petals $7-10 \mathrm{~mm}$. long, rather bright yellow : longer filaments glabrous : capsules stout, 7-9 mm. long, on erect or spreading pedicels. [Oxalis rufa Small.]

In damp soil or woods, Massachusetts to Minnesota and Georgia. Spring to fall.

9. Xanthoxalis colòrea Small. Stems commonly tufted on slender woody rootstocks, erect or nearly so, villous : leaflets purple or purple on both sides of the green midrib, 4-11 $\mathrm{mm}$. broad, usually with a few scattered hairs on the surfaces, and more or less ciliate: cymes umbel-like, the peduncles scarcely overtopping the leaves: pedicels strigillose: sepals oblong to lanceolate or linear-lanceolate, $3-4 \mathrm{~mm}$. long, ciliate mainly at the apex and sparingly so along the margins : petals $8-11 \mathrm{~mm}$. long, light yellow : longer filaments ciliate above: capsules relatively slender, 9-12 $\mathrm{mm}$. long, on more or less reflexed pedicels.

In woods, North Carolina to Georgia and Mississippi. Spring and summer.

10. Xanthoxalis recúrva (Ell.) Small. Stems mostly tufted on the rootstocks, 1-3.5 $\mathrm{dm}$. tall, villous : leaflets bright green, the blades 6-11 mm. wide, glabrous or nearly so, except the margins: cymes umbel-like, the peduncles usually much overtopping the leaves: pedicels strigillose : sepals oblong to linear-lanceolate, $4-5.5 \mathrm{~mm}$. long, ciliate nearly all around: petals 11-15 mm. long, golden yellow : longer filaments ciliate at least above: short styles recurved during anthesis : capsules rather slender, 11-13 mm. long, on reflexed pedicels. [Oxalis recurva Ell.]

In dry or rocky soil, Missouri to North Carolina, Florida and Mississippi. Spring and summer.

11. Xanthoxalis Brittòniae Small. Stems solitary or tufted on slender woody rootstocks, 1-4 dm. long, erect or spreading, loosely hairy: leaflets bright green, $6-14 \mathrm{~mm}$. wide, commonly a little strigillose and ciliate: cymes dichotomous when well developed, often slightly raised above the leaves on the elongating peduncles: pedicels strigillose: sepals oblong to lanceolate, $3.5-5.5 \mathrm{~mm}$. long, sparingly ciliate all around: petals $5-10$ $\mathrm{mm}$. long, light yellow : longer filaments pubescent above : short styles not recurved during anthesis: capsules slender, 7-12 mm. long, on reflexed pedicels. [Oxalis Brittoniae Small.]

In woods and fields or on hillsides, New York to Missouri and Florida. Spring and summer.

12. Xanthoxalis intèrior Small. Stems usually solitary, $3-6 \mathrm{dm}$. tall, villous: leaflets bright green throughout, the blades $20-30 \mathrm{~mm}$. wide, or some of them smaller, strigillose, somewhat ciliate: cymes normally dichotomous, with some of the branches more or less suppressed, commonly raised above the leaves by the elongating peduncles: pedicels strigillose : sepals oblong to oblong-lanceolate, about $4 \mathrm{~mm}$. long, ciliate at the tip : petals $6-9 \mathrm{~mm}$. long, light yellow: longer filaments sparingly ciliate above : capsules rather slender, $8-10 \mathrm{~mm}$. long, on erect or ascending pedicels.

In woods or on partly shaded hillsides, Missouri and Arkansas. Summer and fall.

13. Xanthoxalis grándis Small. Stems commonly solitary on more or less elongated rootstocks, $3-12 \mathrm{dm}$. tall, sparingly or loosely pubescent with spreading hairs : leafoften strigillose along the nerves beneath : cymes dichotomous, with some of the branches suppressed, usually not projecting much beyond the leaves: pedicels strigillose : sepals oblong, narrowly oblong or ovate-oblong, 4.5-6 $\mathrm{mm}$. long, ciliate at the tip and for some distance below it : petals deep yellow, 13-18 mm. long: longer filaments ciliate : capsules stout, 7-10 mm. long on erect or spreading pedicels. [Oxalis grandis Small.]

On shaded banks, Pennsylvania to Indiana, Georgia and Alabama. Summer and fall.

14. Xanthoxalis cymòsa Small. Stems solitary or few together, 2-11 dnr. tall, loosely pubescent: leaflets bright or deep green, the blades $10-27 \mathrm{~mm}$. wide, nearly glabrous or sparingly strigillose about the nerves, especially beneath and ciliate: crmes dichotomous, commonly raised above the leaves by the elongating peduncles: pedicels villous : sepals oblong to oblong-lanceolate, $3-4 \mathrm{~mm}$. long, ciliate at the apex : petals deep
yellow, $7-10 \mathrm{~mm}$. long: longer filaments glabrous : capsules slender, $10-16 \mathrm{~mm}$. long, on erect or spreading pedicels. [Oxalis cymosa Small.]

In moist or shaded soil, Ontario to Michigan, Florida, Nebraska and Texas. Spring to fall. 
15. Xanthoxalis hirsuticaùlis Small. Stems loosely tufted on horizontal rootstocks, often stout, 1-2 dm. tall more or less copiously villous-hirsute: leaflets light green, the blades $8-17 \mathrm{~mm}$. wide, usually sparingly strigillose, especially beneath, ciliate: cymes umbel-like, slightly raised above the leaves by the elongating peduncle: pedicels loosely pubescent: sepals oblong or nearly so, $5-7 \mathrm{~mm}$. long, ciliate all around : petals about $15 \mathrm{~mm}$. long, golden yellow, glabrous : longer filaments glabrous : capsules stout, 10-12 mm. long, on more or less reflexed pedicels. [Oxalis hirsuticaulis Small.]

In rocky or sandy woods, Tennessee and Georgia. Spring and summer.

16. Xanthoxalis Prìceae Small. Stems erect or decumbent from horizontal rootstocks, 1-2 dm. tall, firm, loosely but sparingly pubescent : leaflets deep green, the blades 8-13 mm. wide, glabrous, except the sometimes ciliate margins: cymes umbel-like, scarcely surpassing the leaves: pedicels villous: sepals oblong or linear-oblong, about 7 $\mathrm{mm}$. long, sparingly ciliate all around : petals about $15 \mathrm{~mm}$. long, golden yellow, pubescent without: longer filaments ciliate above; capsules columnar, stout, 14-17 mm. long, on more or less reflexed pedicels. [Oxalis Priceae Small.]

In woods and fields, Kentucky to Alabama. Summer and fall.

\section{Family 5. Zygophyllàceae lindl. Caltrop family.}

Trees, shrubs, or perennial caulescent herbs, some with an extremely hard and heavy wood, others strong-scented and yielding a bitter and acid gum-resin. Leaves opposite, or alternate by the suppression of one leaf of each pair, the stipules sometimes spine-like: blades abruptly pinnate: leaflets with entire often inequilateral blades. Flowers perfect, regular or nearly so. Calyx of 5, or rarely 4-6, mostly imbricated or rarely valvate sepals. Disk obsolete or more or less elevated. Corolla of 5 or rarely 4-6, imbricated, valvate or convolute, hypogynous petals, rarely wanting. Androecium of twice as many stamens as there are petals, in 2 series. Filaments distinct, those opposite the petals. exterior, larger than the inner and sometimes adnate to the petals. Anthers. introrse Gynoecium of usually 2-5 united carpels. Ovary 2-5-celled or rarely 10-12-celled, sometimes winged. Styles united. Ovules 2-many, or rarely solitary, pendulous or ascending. Fruit capsular, but sometimes baccate at maturity, angled or winged, separating into $2-5$, or rarely 10 carpels. Seeds 1 or more in each cavity, with a membranous or fleshy testa. Endosperm wanting or hard. Embryo green, straight or nearly so, with large fleshy cotyledons.

\footnotetext{
Herbs : seeds with little or no endosperm.

Ovary 5-celled, each cavity with transverse septa: fruit armed : seeds several.

Ovary 10-12-celled, each cavity without transverse septa : fruit unarmed: seed

Shrubs or trees: seeds with hard endosperm.
Ovary sessile: fruit pubescent : carpels inde

Ovary sessile : fruit pubescent : carpels indehiscent.

vary short-stalked : fruit glabrous: carpels dehiscent.

Sepals deciduous : filaments without appendages.

Sepals persistent : filaments with appendages.

1. Tribulus.

2. Kallstroemia.

3. Covillea.

4. Guiacum.

5. Porlieria.
}

\section{TRÍBULUS L.}

Commonly diffuse more or less silky herbs, with weak often prostrate stems and branches. Leaves opposite: stipules narrow. Flowers solitary on axillary pedicels. Sepals 5, imbricated, deciduous. Disk 10-lobed. Petals 5, imbricated, spreading, white or yellow, fugacious. Stamens 10, inserted below the disk: filaments filiform, naked, the inner 5 alternate with the petals, shorter than the outer, each accompanied by a small gland. Ovary sessile, 5-celled, each cavity transversely several-celled: styles united into a short stout column : stigmas 5, nearly parallel. Ovules 3-5 in each cavity, pendulous, anatropous. Fruit 5-angled, spiny, at maturity separating into 5 several-seeded carpels, leaving no central axis. Seed solitary in each cavity of the carpels, with a membranous testa. Endosperm wanting. Caltrop. Bur-nut.

Pedicels $1-1.5 \mathrm{~cm}$. long: petals shorter than the sepals.

Pedicels $2.5-4 \mathrm{~cm}$. long: petals several times longer than the sepals.

1. T. terrestris.

2. T. cistoides.

1. Tribulus terréstris L. Stems radially branched at the base, the branches prostrate, 2-11 dm. long, forked: leaves numerous, $2-6 \mathrm{~cm}$. long: leaflets $10-14$, the biades oblong or oval, 3-12 mm. long, acute or somewhat apiculate, sessile : flowers on short axil- 
lary pedicels : sepals lanceolate, $3.5 \mathrm{~mm}$. long, acute, pubescent : corolla $5-10 \mathrm{~mm}$. broad : petals fan-shaped, about $2 \mathrm{~mm}$. long, commonly broader than long: stamens as long as the petals : filaments glabrous : ovary bristly pubescent : fruit about $1 \mathrm{~cm}$. long, armed with straight or curved spine-like thorns.

A native of southern Europe and the East Indies, introduced into America from New York, Florida, Texas and Mexico.

2. Tribulus cistoides $L$. Stems branched at the base, the branches $3-9 \mathrm{dm}$. long, prostrate, spreading radially, forked : leaves $3-4 \mathrm{~cm}$. long, silky: leaflets $6-16$, the blades firm, oblong or linear-oblong, 7-10 mm. long, apiculate, oblique, sessile : flowers on axillary pedicels which are nearly as long as the subtending leaf or longer: sepals lanceolate, 8-10 mm. long, acuminate, pubescent : corolla yellow, 4-5 cm. broad: petals obovate, usually about $2 \mathrm{~cm}$. long: stamens about $\frac{1}{5}$ as long as the petals: filaments glabrous : ovary bristly-pubescent : fruit about $1 \mathrm{~cm}$. in diameter, armed with more or less curved spine-like thorns.

In sandy soil, Florida to Lower California, southward through tropical America.

\section{KALLSTRO丶̇MIA Scop.}

Herbs resembling Tribulus. Leaves opposite or alternate: stipules very narrow. Flowers solitary on axillary pedicels. Sepals 5-6, imbricated, distinct or nearly so, persistent. Petals 5-6, spreading, imbricated or convolute, yellow or red, deciduous. Stamens 10-12: filaments filiform-subulate, those opposite the petals exterior and adnate to the base of the petals, those of the interior series alternate with those of the outer, shorter and each subtended by a small gland. Ovary sessile, 10-12-celled, without transverse septa: styles united into an elongated column: stigmas 10-12, parallel. Ovules solitary in each cavity, pendulous, anatropous or half anatropous. Fruit 10-12-angled, tuberculate, at maturity separating from a thick axis into 10-12 carpels. Seeds solitary in each carpel, with a membranous testa. Endosperm wanting. CaLtrop.

Sepals lanceolate, not hirsute, mainly appressed-pubescent.

Sepals linear-subulate, bristly hirsute.

Leaves and branchlets sparingly pubescent: plants slender : pedicel less than $1.5 \mathrm{~mm}$. thick under the fruit.

1. K. maxima.

Leaves and branchlets copiously and conspicuously hirsute : plants stout : pedicel over $1.5 \mathrm{~mm}$. thick under the fruit.

2. K. parviflora.

3. K. hirsutissima.

1 Kallstroemia máxima (L.) T. \& G. Stem branched at the base, the branches radially spreading, usually prostrate, 1-6 dm. long or longer, more or less forked, rather appressed-pubescent, succulent : leaves sparingly pubescent : leaflets mostly $6-8$, the blades of the terminal pair 9-18 mm. long: sepals lanceolate, sometimes narrowly so in age, $3-4$ $\mathrm{mm}$. long, rather appressed-pubescent: petals $6-8 \mathrm{~mm}$. long: fruit $7-10 \mathrm{~mm}$. long, the conic beak somewhat longer than the body.

In waste places and sandy soil, Gulf States. Also in tropical America.

2. Kallstroemia parviflòra Norton. Similar to $K$. maxima in habit, but with more spreading pubescence. Leaves thinly pubescent : leaflets $6-8$, the blades of the terminal pair 6-13 mm. long: sepals linear-subulate, $4.5-6 \mathrm{~mm}$. long, bristly hirsute : petals 6-8 $\mathrm{mm}$. long: fruit 10-12 mm. long, or rarely slightly smaller, the slender beak somewhat longer than the body.

In dry soil, Mississippi to Arizona and Mexico.

3. Kallstroemia hirsutíssima Vail. Similar to the two preceding species, but stouter. Leaves copiously and conspicuously pubescent : leatlets mainly $6-8$, shaggy pubescent at least beneath, the blades of the terminal pair mostly $10-23 \mathrm{~mm}$. long: sepals linear-subulate, $3.5-4.5 \mathrm{~mm}$. long, bristly hirsute : petals $5-7 \mathrm{~mm}$. long: fruit $6-8 \mathrm{~mm}$. long, the conic beak commonly as long as the body or somewhat shorter.

On plains and prairies, Kansas and Coiorado to Texas. New Mexico and Mexico.

\section{COVÍLLEA Vail.}

Heavy-scented evergreen shrubs, often excreting an acid resin. Leaves opposite: blades 2-foliolate or pinnate : stipules present : leaflets opposite, with inequilateral sessile blades. Flowers terminal on pedicels arising from between the stipules. Sepals 5, imbricated. Petals 5, yellow, imbricated, short-clawed, surpassing the sepals. Disk 10-lobed. Stamens 10, inserted below the disk : filaments filiform, each hearing a wing-like, 2-cleft scale. Ovary 5-celled, short-stalked, pubescent. Ovules 6 in each cavity, pendulous. 
Fruit subglobose, pubescent, separating into 5 carpels. Seeds solitary in each carpel. Creosote Bush.

1. Covillea tridentàta (Cav.) Vail. A diffuse shrub, $0.5-3 \mathrm{~m}$. tall, finely pubescent throughout. Leaves numerous, excreting a resinous heavy-scented gum: leaflets 2, the blades leathery, oblong-ovate, 6-12 mm. long, inequilateral, acute, sessile : sepals 5, obovate, concave, $5-6 \mathrm{~mm}$. long, finely pubescent: corolla bright yellow, nearly $2 \mathrm{~cm}$. broad : petals 5, oval-obovate, about $10 \mathrm{~mm}$. long, crisped and undulate at the apex; blades narrowed into short claws : ovary densely bristly-pubescent, separating into 5 indehiscent carpels.

On plains and prairies, Utah and Nevada to Texas, Arizona and Mexico. Spring to fall.

\section{GUAIÀCUM L.}

Shrubs or trees, with a pale, scaly bark and an exceedingly hard wood pervaded by a dark colored gum-resin. Leaves opposite, sometimes apparently fascicled : stipules small. Flowers irregular, on terminal peduncles. Sepals 5 , or rarely 4, imbricated, unequal, deciduous. Disk inconspicuous or elevated. Petals blue or purple, 5 or rarely 4 , imbricated, more or less clawed. Stamens 10, inserted on the disk : filaments filiform, naked : anthers cordate or sagittate. Ovary short-stalked, 2-5-celled, 2-5-angled : stigma entire or minutely 2-5-toothed. Ovules 8-10 in each cavity, pendulous, anatropous. Fruit 2-5angled or winged, at maturity separating into 2-5 leathery carpels. Seeds solitary, with a thick fleshy testa. Endosperm horny-cartilaginous. Lignum-vitae.

1. Guaiacum sánctum L. An evergreen shrub, or a small tree, sometimes $10 \mathrm{~m}$. tall : trunk rarely $1 \mathrm{~m}$. in diameter, clothed with a very pale or white bark : branches forking: leaves $5-10 \mathrm{~cm}$. long, becoming glabrous: leaflets $6-8$, the blades oblong or obovate, $2-3 \mathrm{~cm}$. long, usually apiculate, entire, inequilateral, sessile : flowers terminal on solitary or clustered pedicels, which are shorter than the subtending leaves : sepals 5, obovate or oblong-obovate, 6-7 mm. long, concave, often ciliate : corolla blue, about 2.5 $\mathrm{cm}$. wide: petals 5 , broadly obovate, cuneately narrowed below, twisted near the base, spreading : filaments glabrous, dilated at the base : ovary glabrous : fruit obovoid, 15-17 $\mathrm{mm}$. long, 5-angled, orange-colored : seeds elliptic, covered with a scarlet aril.

In sand, Florida Keys. Also in the Bahamas and the West Indies.

\section{PORLIÈrIA R. \& P.}

Rigid spreading shrubs. Leaves opposite: leaflets opposite, with narrow entire blades : stipules sometimes spine-like. Flowers terminal on clustered or solitary pedicels. Sepals 4-5, imbricated, broad, deciduous. Petals 4-5, imbricated, short-clawed, surpassing the sepals. Stamens 8-10; filaments filiform, each with a 2-cleft or cut scale below the middle : anthers becoming incurved. Ovary 2-5-celled, sessile or slightly immersed in the disk, 2-5-ribbed. Ovules 4 in each cavity, superposed in pairs. Fruit subglobose or obovoid, 2-5-lobed, 2-5-celled. Seeds solitary in each cavity. Testa fleshy. Endosperm hard.

1. Porlieria angustifolla (Engelm.) A. Gray. A shrub or small tree, 1-7 m. tall, with spreading or straggling branches. Leaves $1.5-2 \mathrm{~cm}$. long, glabrous : leaflets $8-12$, the blades linear, $0.5-1.5 \mathrm{~cm}$. long, reticulated, apiculate, entire or slightly crenate above, oblique at the base, sessile : flowers purple, about $12-20 \mathrm{~mm}$. broad : sepals suborbicular, concave, $5 \mathrm{~mm}$. long : petals nearly elliptic, $1 \mathrm{~cm}$. long, lilac, often notched at the apex : filaments pink : anthers bright yellow : ovary pubescent : capsule nearly 2 -lobed, $2 \mathrm{~cm}$. in diameter, reticulated.

On plains or prairies, Texas and Mexico. Spring and summer.

\section{FAMily 6. KOEBERLINIÀCEAE Engler. Junco FAmily.}

Very much branched, nearly leafless Texano-Mexican shrubs or trees, with a red-brown scaly bark, the branches terete, the branchlets pale-green, ending in straight or curved rigid spines. Leaves scale-like, alternate, broadest above the middle, caducous. Flowers small, perfect, in short racemes near the ends of the branchlets. Calyx of 4 or rarely 3, distinct, imbricated sepals, deciduous. Disk obsolete. Corolla of 4 or rarely 3 white, convolute, somewhat clawed petals. Androecium of 8 stamens, inserted under the ovary. Filaments nar- 
rowly spindle-shaped, distinct. Anthers introrse. Gynoecium of 2 united carpels. Ovary ovoid, 2-celled. Styles united. Stigma very short. Ovules numerous, horizontal or pendulous in several rows, anatropous. Fruit a 2-celled berry tipped with the persistent style, with a thin fleshy pulp. Seeds 1-several in each cavity, cochleate, with a wrinkled striate crustaceous testa. Endosperm thin, striate. Embryo coiled.

\section{KOEBERLINIA Zucc.}

\section{Characters of the family. Junco.}

1. Koeberlínia spinòsa Zucc. An intricately branched almost leafless shrub or small tree, sometimes $8 \mathrm{~m}$. tall, the branches all ending in firm thorns, clothed with a bright green puberulent bark. Leaves reduced to small scales : flowers in short lateral racemes: pedicels slender, $2-6 \mathrm{~mm}$. long: sepals 4 , imbricated, ovate, $1 \mathrm{~mm}$. long, obtuse : petals 4 , oblong, fiddle-shaped, $2.5 \mathrm{~mm}$. long, obtuse or notched at the apex : stamens 8 , shorter than the petals : filaments enlarged at the middle : ovary short-stalked : berries subglobose, about $6 \mathrm{~mm}$. in diameter, black, apiculate, fleshy.

In rocky or gravelly places, in the valley of the Rio Grand and its tributaries. Spring.

\section{Family 7. malpighiàceat Vent. Malpigia family.}

Shrubs or trees, or shrubby herbs, with erect or climbing stems. Leaves mostly opposite : blades entire: stipules sometimes present. Flowers usually perfect, of various colors, solitary or in terminal racemes, corymbs or umbel-like clusters. Calyx of 5, usually imbricated, sepals. Corolla of 5 mostly equal clawed, convolute petals, or rarely wanting. Androecium of 5-10 perfect or partly sterile stamens. Filaments often united at the base. Anthers 2-celled, often with enlarged connectives. Gynoecium of 2-4, or usually 3, distinct or united carpels. Ovary 1-celled, sometimes crested. Styles sometimes united. Ovules solitary in each cavity, nearly orthotropous. Fruit of 2-3 pulpy or hard drupes, or sometimes capsular or nut-like. Seeds pendulous. Endosperm wanting. Embryo straight or curved, with thick often unequal cotyledons.

Stamens 10 : styles 3 , distinct.

Sepals with glands: fruit drupaceous.

Filaments pubescent at the base : fruit of 3 united carpels.

Filaments glabrous: fruit of 3 distinct carpels.

Sepals glandless : fruit capsular.

Stamens 5-6: styles united.

1. BYRsonima.

2. MALPIGHIA.

3. THRYALLIS.

4. ASPICARPA.

\section{BYRSÒNIMA L. C. Rich.}

Shrubs or trees, with erect, prostrate or climbing stems. Leaves opposite: blades leathery, simple: stipules present. Flowers in terminal, simple or compound racemes. Sepals 5, each furnished with two glands. Petals 5, glabrous, reflexed, clawed : blades concave. Stamens 10 : filaments short, bearded at the united base. Carpels united. Ovary 3-celled : styles 3, distinct : stigmas acute. Drupe pulpy, 3-celled, stone bony or woody, angled. Seeds subglobose.

1. Byrsonima lùcida (Sw.) DC. An erect evergreen much-branched shrub, with pale bark and sparingly pubescent inflorescence, otherwise glabrous. Leaf-blades leathery, spatulate or obovate-spatulate, $2-4 \mathrm{~cm}$. long, rounded at the apex, bright green and lustrous above, dull beneath, short-petioled : racemes terminal, erect, $2-4 \mathrm{~cm}$. long : petals white, turning to yellow or rose, $7 \mathrm{~mm}$. long; claws slender, $3 \mathrm{~mm}$. long; blades reniform, undulate, 5-6 mm. broad : drupes subglobose, glabrous, 4-6 mm. in diameter, greenish.

In sand, peninsular Florida and the Keys. Also in the West Indies.

\section{MALPÍghia L.}

Shrubs, with glabrous foliage, or clothed with medifixed hairs. Leaves opposite, with small stipules: blades without glands, petioled. Flowers regular, generally in umbels terminating axillary peduncles. Sepals 5, all or most of them with a pair of thick glands on the back. Petals 5, reddish or purplish, not yellow. Stamens 10, all perfect : filaments glabrous at the base. Ovary 3-celled, sessile : styles 3, distinct : stigmas truncate. Fruit of 3 distinct carpels, each crested on the back. Embryo straight. 
1. Malpighia glàbra L. A glabrous shrub 2-12 dm. tall, with slender branches. Leaf-blades thinnish, ovate, $2-5 \mathrm{~cm}$. long, acute or acuminate, nearly sessile : peduncles $0.5-1 \mathrm{~cm}$. long, axillary : pedicels several, umbellately disposed, often longer than the peduncles, slender-clavate : sepals ovate, or oblong-ovate: petals rose-red, or sometimes rather pale pink ; blades about as broad as long, 4-6 mm. long, erose or fimbriate : drupe about $1 \mathrm{~cm}$. in diameter, red, the nutlets 4 -angled, transversely wrinkled between the crests or ridges.

In sandy soil, southern Texas and Mexico. Also in the West Indies. Spring and summer.

\section{THRYÁLLIS L.}

Shrubby plants, sometimes herbaceous above the base. Leaves opposite : blades with 2 glands at the base or on the upper part of the petiole. Flowers regular, in terminal racemes. Sepals 5, without glands. Petals 5, yellow or orange : blades finely toothed, distinctly clawed. Stamens 10, all perfect : filaments distinct or nearly so. Ovary 3-celled : styles 3, distinct : stigmas very small. Capsule 3-celled, the carpels separating and dehiscent. Embryo hooked.

1. Thryallis angustifòlia (Benth.) Kuntze. Somewhat woody at the base. Stems usually tufted, slender, 3-7 dm. tall, glabrate, or strigose with medifixed hairs : leafblades various, linear to lanceolate, with acute ends, or the lower oblong to oval, with obtuse ends and short-petioles, all glabrous or nearly so, glaucous : racemes virgate, loosely flowered : sepals lanceolate : petals yellow turning reddish; blades oblong-ovate, 2-4 mm. long, with a dark midrib : capsules $3-4 \mathrm{~mm}$. long.

In dry, usually rocky soil, Texas and adjacent Mexico and in Lower California. Summer.

\section{ASPICÁRPA L. C. Rich.}

Perennial herbs, more or less woody at the base, commonly diffuse in habit, sometimes almost twining vines. Leaves opposite : blades entire. Flowers solitary or clustered, dimorphous, the normal with 5 sepals, 8-20 glands, and petals with fringed blades ; stamens 5-6, 2-3 sometimes imperfect ; filaments monadelphous : gynoecium of 3 distinct or partially united carpels ; styles united ; stigma depressed-capitate or truncate. Cleistogamous flowers more fertile than the normal, with glandless sepals and usually a dicarpellary pistil with little or no style, usually maturing one carpel into a triangular nutlet incumbent on the receptacle.

1. Aspicarpa hyssopifolia A. Gray. Woody at the base. Stems erect, 1-3 dm. tall, more or less pubescent with medifixed hairs: lower leaves with oblong or oval blades, the upper with linear or linear-lanceolate blades $1-3 \mathrm{~cm}$. long, sessile or nearly so, and partly clasping, all glabrous: flowers solitary in the axils of the leaves, the normal with pedicels nearly as long as the leaves: petals 4-6 mm. long; blades fimbriate : cleistogamous flowers sessile : nutlets 4-5 mm. long, reticulated, with an acute crest on the back.

On plains and prairies, southern Texas and adjacent Mexico.

\section{Family 8. RUtàceae Juss. Rue Family.}

Aromatic shrubs or trees, or rarely shrubby herbs, often armed with prickles which are sometimes raised on corky ridges. Leaves alternate or opposite : blades simple or pinnately compound : leaflets glandular-punctate, the lateral with inequilateral blades. Flowers usually perfect, in paniculate or corymbose eymes, mostly regular. Calyx of $3-5$, or rarely more, imbricated sepals, more or less united at the base, or wanting. Corolla of 3-5, or rarely more, usually imbricated petals. Androecium of as many stamens as there are petals, or rarely thrice as many, inserted on a hypogynous disk, those opposite the petals usually shorter than the others. Filaments distinct or united below. Anthers introrse. Gynoecium of $2-5$ distinct or united carpels. Styles more or less united. Stigma often 3-5-angled. Ovules 2 , or rarely 4 or more, superposed in each cavity. Fruit capsular, or often a samara, drupe, or berry. Seeds solitary or several, with an often erustaceous furrowed or punctate testa. Endosperm fleshy or wanting.

A. Fruit dry, capsular or samaroid.

a. Fruit dehiscent, a capsule.

* Ovules 3 or more in each cavity : capsule lobed, solitary.

Gynoecium 4-5-carpellary : leaf-blades divided.

43

1. RUTA. 
Gynoecium 2-carpellary : leaf-blades entire.

** Ovules 2 in each cavity: capsule not lobed, $2-5$ together.

Calyx wanting.

Calyx present.

b. Fruit indehiscent, samaroid.

Filaments glabrous : fruit separating into $3-4$ carpels which are winged on the back.

Filaments pubescent : fruit winged all around.

B. Fruit a pulpy drupe or a berry.

Stamens 8 : fruit a drupe : leaf-blades 3-5-foliolate.

Stamens $20-60$ : fruit a berrv: leaf-blades 1-foliolate.
2. Thamnosma.

3. XaNthoXylum.

4. Fagara.

5. Helietta.

6. Ptelea.

7. AMYRIS.

8. Citrus.

\section{RƯTA L.}

Perennial caulescent sometimes partly woody herbs, with glandular-punctate foliage and often heavy scented herbage. Leaves alternate : blades divided. Flowers in terminal corymbose or panicled cymes. Sepals 4-5, persistent. Petals 4-5, yellow or greenish, imbricated. Disk thick, 8-10-lobed. Stamens 8-10. Ovary 4-5-celled, sessile, 4-5lobed: styles united: stigma terminal. Ovules several in each cavity of the ovary. Capsule 4-5-celled, 4-5-lobed, commonly opening at the apex. Seeds several.

1. Ruta gravèolens $\mathrm{L}$. Stems $2-8 \mathrm{dm}$. tall, corymbose at the ends : leaf-blades twice ternately divided, the ultimate segments rounded or notched at the apex : sepals triangular or ovate, $2.4-4 \mathrm{~mm}$. long: petals $5-7 \mathrm{~mm}$. long, the broad blade with involute margins and apex, abruptly narrowed into the claw : capsules depressed, $8-11 \mathrm{~mm}$. wide, $4-5$-lobed.

In waste places and cultivated grounds, eastern United States. Native of Europe. Spring to fall.

\section{THa MNÓSMa Torr. \& Frem.}

Strong-scented shrubs or shrubby herbs, usually densely glandular. Leaves alternate : blades simple, narrow, entire, often reduced to scales. Flowers perfect, regular, in racemes or racemose cymes. Sepals 4. Petals 4, yellow or purplish, sessile, often erect. Disk cup-like, entire or crenate. Stamens 8: filaments subulate or filiform. Ovary 2-celled, 2-lobed, long-stalked or nearly sessile : styles united : stigma capitate. Ovules 5-6 in each cavity. Capsule leathery, 2-celled, 2-lobed, opening at the apex. Seeds 4-6, nearly reniform. Testa crustaceous, smooth or rough. Embryo curved.

1. Thamnosma Texàna (A. Gray) Torr. A low partially herbaceous shrub, $1-5 \mathrm{dm}$. tall. Stems much branched, wiry, often densely glandular: leaf-blades linear or linearoblong, 5-10 mm. long, obtuse, more or less glandular-punctate, entire, sessile or nearly so, early deciduous: flowers in terminal interrupted racemes : pedicels $1-2 \mathrm{~mm}$. long: calyx about $2 \mathrm{~mm}$. hroad : sepals ovate, obtuse : petals yellow or purplish, elliptic, oblong-elliptic or oval, $2.5-3 \mathrm{~mm}$. long, obtuse, slightly involute: stamens shorter than the petals: filaments glabrous, subulate: capsules short-stalked, 5-6 mm. high, 2 -lobed, the valves extending to the middle: seeds nearly $2 \mathrm{~mm}$. broad, flattened, tuberculate.

On plains and prairies, Texas to New Mexico and Mexico. Spring to fall.

\section{XANTHÓXYLUM ${ }^{1} \mathrm{~L}$.}

Aromatic, often prickly, shrubs or trees, with relatively smooth stems. Leaves alternate: blades pinnately compound: leaflets with more or less pellucid-punctate, entire or toothed blades. Flowers greenish yellow, polygamous, in axillary cymes. Sepals wanting. Petals 4-5. Stamens 4-j, abortive in pistillate flowers. Carpels 1-5, short-stalked, 1-celled, oblique: styles distinct, or united above. Ovules 2 in each cavity. Capsular fruit a single carpel or 2-5 carpels together, not lobed, glandular-punctate, 2-valved. Seed solitary, finally exserted.

1. Xanthoxylum Americanum Mill. A prickly aromatic shrub, with spreading branches. Leaf-blades pinnately-compound, 1-3 dm. long, the rachis nearly terete : leaflets ovate or oblong or rarely oval, $4-8 \mathrm{~cm}$. long, obtuse or short-acuminate, deep green above, paler and more or less pubescent beneath, crenate with flat-topped teeth, sessile or vious season, slender-pedicelled : corolla yellowish and greenish, 3-3.5 mm. broad: capsules globose or ellipsoidal, $5 \mathrm{~mm}$. in diameter, wrinkled and glandular-punctate : seeds ovoid, $4 \mathrm{~mm}$. long, black, shining.

On river banks and in woods, Quebec and Ontario to Minnesota, Georgia, Missouri and Nebraska. spring. PRICKLY Ash. TOOTHACHE-Tree.

\footnotetext{
'Originally spelled ZANTHOXYLUM.
} 


\section{FÁGARA L.}

More or less aromatic shrubs or trees, the bark of the stem sometimes with corky, and spine-armed ridges. Leaves alternate: blades pinnately compound : leaflets with punctate, entire or toothed blades. Flowers white or whitish, polygamous, in terminal or rarely axillary panicled or corymbose cymes, or rarely clustered. Sepals 4-5, imbricated. Petals 4-5. Stamens 4-5, reduced in the pistillate flowers. Carpels 1-4, 1-celled, more or less united : styles occasionally nearly distinct. Ovules 2 in each cavity. Fruit nearly similar to that of Xanthoxylum.

Flowers in axillary cluster-like cymes : sepals and petals 4 .

1. F. Fagara.

Flowers in terminal cymes or corymbs: sepals and petals 3 or 5 .

Sepals and petals 5 : leaf-blades unequally pinnate.

Plants unarmed.

Plants armed with prickles.

Twigs and inflorescence hirsute: leaflets obtuse: seeds smooth.

Twigs and inflorescence glabrous: leaflets acuminate: seeds wrinkled.

Sepals and petals 3 : leaf-blades equally pinnate.

2. F. flava.

3. F. fruticosa.

4. F. Clava-Herculis.

5. F. coriacea.

1. Fagara Fágara (L.) Small. An evergreen shrub or small tree, sometimes $10 \mathrm{~m}$. tall, with zigzag branchlets and puberulent twigs and inflorescence. Leaf-blades pinnately compound, $6-8 \mathrm{~cm}$. long, the rachis winged : leaflets $5-13$, the blades leathery, obovate or oval, 1-2 cm. long, sessile or nearly so, usually notched at the apex, shallowly crenate, slightly revolute: flowers in axillary often cluster-like or raceme-like cymes: calyx 1.5 mm. broad: sepals triangular-ovate, acute: petals oblong or oblong-ovate, 2.5-3 mm. long, obtuse, concave : stamens longer than the petals : filaments filiform-subulate : carpels subglobose, $4 \mathrm{~mm}$. in diameter, rugose-tuberculate: seed subglobose, smooth and shining, black. [Xanthoxylum Plerota H.B.K.]

Along or near the coast, Florida to Texas. Also in the West Indies. Spring. Wild Lime.

2. Fagara flàva (Vahl) Krug \& Urban. An unarmed evergreen shrub or small tree, sometimes $30 \mathrm{~m}$. tall, its twigs, foliage and inflorescence tomentose, or glabrate in age. Leaf-blades pinnately compound, 1-2 dm. long : leaflets 5-11, the blades oblong or ovate, or the terminal one oval, 3.5-7 $\mathrm{cm}$. long, obtuse, rounded at the apex, slightly crenate or nearly entire, inequilateral, short-petioled, pubescent with stellate hairs when young, becoming glabrous : panicles $0.5-1.5 \mathrm{dm}$. long: pedicels $1-3 \mathrm{dm}$. long: flowers in terminal cymes: calyx about $1 \mathrm{~mm}$. broad: sepals triangular-ovate, acutish : petals 5 , oblong or oblong-ovate, $2.5 \mathrm{~mm}$. long, recurved, thickish : stamens longer than the petals: ovary glandular-punctate : carpels obovoid, $6 \mathrm{~mm}$. long, glandular-punctate : seeds lenticular, $4 \mathrm{~mm}$. broad, faintly reticulated, black. [Xanthoxylum Caribaeum S. Wats., not Lam.]

In sand, on the Florida Keys. Also in the West Indies. Spring. YelLow-wood. SATIN-wood.

3. Fagara fruticòsa (A. Gray) Small. An aromatic prickly shrub 1-5 m. tall, its twigs, petioles and inflorescence finely hirsute. Leaf-blades pinnately compound or rarely 3 -foliolate, $6-10 \mathrm{~cm}$. long; rachis hirsute : leaflets usually $5-11$, the blades ovate, oblong or oval, $1.5-4 \mathrm{~cm}$. long, obtuse, crenate, sessile or nearly so, lustrous above, dull beneath: panicles $1-5 \mathrm{~cm}$. long, hirsute : pedicels $2-3 \mathrm{~mm}$. long : calyx glabrous : sepals linear or linear-subulate, about $1 \mathrm{~mm}$. long, acute : petals elliptic, about $2 \mathrm{~mm}$. long, curved and concave, thickened at the apex : stamens shorter or just about as long as the petals : filaments shorter than the anthers : carpels usually solitary, about $5 \mathrm{~mm}$. in diameter, glandular-punctate, apiculate : seeds solitary, obliquely-ovoid, black, shining. [Xanthoxylum Carolinianum var. fruticosum A. Gray.]

On plains and prairies, Arkansas and Texas. Spring.

4. Fagara Clàva-Hérculis (L.) Small. A glabrate prickly shrub or tree, sometimes $17 \mathrm{~m}$. tall with a maximum trunk diameter of $5 \mathrm{dm}$. Leaf-blades pinnate, $2-3 \mathrm{dm}$. long, the rachis terete : leaflets $7-11$, the blades ovate, $4-5 \mathrm{~cm}$. long, acuminate, appressed-serrate, abruptly narrowed at the base into short winged petiolules, all except the terminal one very inequilateral, often somewhat curved : panicles corymbose, 1-2 $\mathrm{dm}$. long : calyx $2.5-3 \mathrm{~mm}$. broad : sepals triangular-ovate, obtuse : petals oblong-ovate, $3 \mathrm{~mm}$. long, concave, thickened at the obtuse apex : stamens longer than the petals : filaments stout : carpels $2-5$ in a cluster, globose-obovoid, $5-6 \mathrm{~mm}$. in diameter, rugose, apiculate: seeds 1-2 in a carpel, globose-oblong, black, coarsely wrinkled. [Xanthoxylum Clava-Herculis L.]

Along or near the coast, Virginia to Florida, Arkansas and Texas. Spring. PrICKLY Ash. ToothACHe-tree. SeA Ash. PEPPER WOOD.

5. Fagara coriàcea (A. Rich.) Krug \& Urban. A tree becoming 6 or $7 \mathrm{~m}$. tall, more or less spine-armed, glabrous or nearly so throughout. Leaf-blades pinnately 4-12-, foliolate, the rachis channeled above: leaflets usually $6-10$, the blades $2-6 \mathrm{~cm}$. long, 
leathery, obovate to cuneate or oblong with a cuneate base, rounded or notched at the apex, more or less revolute, somewhat lustrous above : cymes corymb-like, the branches occasionally with scattered hairs: pedicels stout : calyx minute : sepals reniform or ovatereniform, barely $0.5 \mathrm{~mm}$. long, obtuse : petals oval or oblong, $2-3 \mathrm{~mm}$. long: stamens 3 : filaments longer than the anthers : carpels 4-5 mm. long. [Xanthoxylum coriacea A. Rich.]

Along or near the coast, southern peninsular Florida and the Keys. Also in the West Indies. Spring and summer.

\section{HELIÉTTA Tulasne.}

Evergreen shrubs or small trees, with terete branches. Leaves mostly opposite : blades 3-foliolate: leaflets with entire glandular-punctate blades. Flowers mostly perfect, in axillary or terminal panicled cymes. Sepals 3-4, imbricated. Petals 3-4, elongated, spreading, imbricated. Disk cup-like. Stamens 3-4: filaments somewhat flattened, glabrous. Ovary 3-4-celled, depressed, 3-4-lobed : styles united : stigma 3-4-lobed. Ovules 2 in each cavity, side by side. Fruit a cluster of 3-4 samaras, the membranous wing projecting from the back. Seeds narrow. BARETTA.

1. Helietta parviflòra Benth. An evergreen glabrous shrub, or a small tree, reaching a height of $8 \mathrm{~m}$., the trunk clothed with a scaly bark. Petioles grooved : leaflets 3 , the blades leathery, spatulate or the lateral ones obovate or oblong, all obtuse or notched at the apex, 1-4 cm. long, sessile : panicles 2-5 cm. high : pedicels $1-4 \mathrm{~mm}$. long: calyx 1.5 $\mathrm{mm}$. broad : sepals ovate, acutish, erect: petals thick, oblong, $2.5 \mathrm{~mm}$. long, obtuse, slightly crisped, spreading : stamens shorter than the petals: filaments subulate, glabrous : ovary depressed-ovoid : samaras $3-4$, firm, 1-1.5 cm. long : seed nearly oblong.

On bluffs along the Rio Grande, Texas and Mexico. Spring and summer.

\section{PTÈLEA L.}

Unarmed shrubs or small trees, with an aromatic bark and foliage. Leaves alternate : blades 3 -foliolate, or rarely pinnately 5 -foliolate : leaflets with entire or toothed, pellucidpunctate blades. Flowers polygamous, greenish yellow, in corymbose or panicled cymes. Sepals 4-5, imbricated. Petals 4-5, imbricated, surpassing the sepals. Stamens 4-5, abortive in the pistillate flowers : filaments stout, pubescent. Ovary 2-3-celled, flattened: styles united : stigma 2-3-lobed. Ovules 2 in each cavity, superposed. Samara membranous, reticulated, 2-3-winged all around, indehiscent. Seeds solitary in each cavity. Shrubby Trefoll. Hop-tree. Whahoo. Water Ash.

Parts of the flowers usually in 5's.

Filaments slightly pubescent at the middle: petals glabrous within: Floridian. 1. P. Baldwinii.

Filaments pubescent throughout: petals pubescent within: Texano-Mexican. 2 . P. angustifolia.

Parts of the flowers usually in 4's.

Samaras obovate.

Leaflets with sharply serrate blades: samaras $16-19 \mathrm{~mm}$. long, acute at the base, the body merely glandular dotted.

Leaflets with entire or merely undulate blades: samaras 8-11 $\mathrm{mm}$. long, or rarely larger rounded or truncate at the base, the body pitted.

Samaras suborbicular.

Leaflets with entire or merely crenulate blades, the terminal one much longer than broad, acute or slightly acuminate.

Leaflets with crenate or crenate-lobed blades, the terminal one only slightly longer than broad, blunt.

Leaflets not lustrous: filaments nearly glabrous : anthers rounded or retuse at the apex.

Leaflets lustrous above: filaments densely [pubescent below: anthers apiculate.

3. P. serrata.

4. P. microcarpa.

5. P. trifoliata.

6. P. rhombifolia.

7. P. Toxicodendron.

1. Ptelea Baldwínii T. \& G. An almost glabrous shrub about $3 \mathrm{dm}$. tall, with irregularly branched stems. Leaflets 3 , the blades oval or ovate, 1-2 cm. long, obtuse at both ends, or the terminal one cuneate at the base, sessile, glabrous except the midrib and the ciliate margin when young: panicles few-flowered : calyx $1.5 \mathrm{~mm}$. broad : sepals oval, less than $1 \mathrm{~mm}$. long, acutish, ascending: petals 4 , oblong-oblanceolate, $4 \mathrm{~mm}$. long, obtuse, undulate : stamens shorter than the petals : filaments stout, hairy at the middle.

In the vicinity of St. Johns, eastern Florida. Spring.

2. Ptelea angustifolia Benth. A little-known species, originally described from Mexico, with pubescent foliage, wholly pubescent filaments and the petals hairy on both sides:

Is said to occur in southern and western Texas. 
3. Ptelea serràta Small. An irregularly branching shrub 1-2 m. tall, with glabrous foliage. Leaflets 3 , the blades thinnish, oval, elliptic, to elliptic-obovate, $2.5-7 \mathrm{~cm}$. long, sharply acuminate, or rarely only acute, rather shallowly serrate, deep green above, very pale green beneath, the terminal one with a slender base : panicles few-flowered : samaras obovate, 16-19 $\mathrm{mm}$. long, acute at the base, the wing rather delicate, the body glandular-dotted.

On granite rocks, Stone Mountain, Georgia. Spring.

4. Ptelea microcárpa Small. A branching shrub, 1.5-3 m. tall, with glabrous foliage. Leaflets 3 , the blades rather firm, elliptic to oval or elliptic-obovate, $5-10 \mathrm{~cm}$. long, bluntly pointed or slightly acuminate, entire or merely undulate, slightly paler beneath than above, the terminal one not conspicuously narrow at the base: panicles many-flowered : samaras obovate, $8-11 \mathrm{~mm}$. or rarely $12-20 \mathrm{~mm}$. long, rounded or truncate at the base, the wings slightly crisped, the bodies pitted.

On limestone or granite ridges or hillsides, Tennessee, Georgia and Alabama. Spring.

5. Ptelea trifoliàta L. An aromatic shrub or tree sometimes $8 \mathrm{~m}$. tall, the foliage glabrous or sometimes densely pubescent. Leaflets 3 , the blades ovate, oval, elliptic, oblong, oblong-lanceolate or oblanceolate, 4-12 $\mathrm{cm}$. long, acute or acuminate, entire or sometimes undulate or partially crenulate: panicles many-flowered : sepals ovate, $1.5 \mathrm{~mm}$. long, obtuse: petals nearly oblong, 4-5 $\mathrm{mm}$. long: samaras suborbicular or oval-orbicular, 2-2.5 $\mathrm{cm}$. long, rounded or notched at the base.

In rich soil or on river banks, Long Island to Ontario, Minnesota, Florida and Texas. Spring.The form with pubescent foliage, is $P$. trifoliata móllis M. A. Curtis.

6. Ptelea rhombifolia Heller. A shrub $2-2.5 \mathrm{~m}$. tall, branching above, the foliage densely pubescent. Leaflets 3 , the blades rhombic-ovate or rhombic-orbicular, $2.5-5 \mathrm{~cm}$. long, blunt, crenate, dull green above, the terminal one little longer than broad: petals pubescent without, about $4 \mathrm{~mm}$. long : filaments slightly pubescent near the base : samaras nearly orbicular, $1.5-2.5 \mathrm{~cm}$. broad.

In open woods, southern Texas. Spring.

7. Ptelea Toxicodéndron Small. A branching shrub 1-2 m. tall, with glabrous foliage. Leaflets 3 , the blades oval or rarely oval-ovate, $1.5-6 \mathrm{~cm}$. long, rounded or blunt at the apex, crenate or somewhat crenate-lobed, dark green and lustrous above, slightly paler beneath : panicles few-flowered : petals about $5 \mathrm{~mm}$. long, glabrous : filaments densely pubescent at the base : mature samaras not seen.

In gravelly soil, near Kerrville, Texas. Spring.

\section{AMỲrRIS L.}

Glabrous shrubs or trees, containing a resinous aromatic sap. Leaves alternate or opposite : blades compound, sometimes unifoliate : leaflets with entire or crenulate blades, punctate. Flowers perfect or polygamous, in axillary or terminal panicles, white. Pedicels often with 2 scales. Hypanthium urn-shaped. Sepals 4. Petals 4, imbricated. Stamens 8, inserted on the disk : filaments filiform : anthers opening lengthwise. Ovary 1-celled: style short or wanting: stigma flat or capitate. Ovules 2, pendulous from the top of the cavity. Drupe obovoid, oval or globose, with a parchment-like stone. Seed solitary. Testa membranous. Cotyledons thick. ToRcH-wood.

Leaves alternate: leaflets with crenate blades, the terminal one sessile or short-stalked.

Leaves opposite : leaflets with entire blades, the terminal one long-stalked.

Gynophore obsolete, the receptacle flat.

Gynophore well developed, surrounded by the elongated receptacle.

Leaflets shining beneath: ovary glabrous: fruit globose.

Leaflets dull beneath: ovary pubescent: fruit obovoid to oval-elliptic.

1. A. parvifolia.

2. A. elemifera.

3. A. maritima.

1. Amyris parvifòlia A. Gray. An unarmed glabrous aromatic shrub 1-3 m. tall, usually densely branched, the twigs and inflorescence densely glandular. Leaf-blades 3-foliolate, petioled : leaflets 3 , the blades leathery, 1-2.5 cm. long, ovate, obtuse, coarsely crenate, sessile or nearly so, firm, punctate on both sides : panicles $2-3 \mathrm{~cm}$. long: flowers in terminal corymbose panicles: calyx $1 \mathrm{~mm}$. broad: sepals broadly ovate, acute, $\frac{1}{4}-\frac{1}{5}$ as long as the thick, club-shaped pedicel : petals $1-2 \mathrm{~mm}$. long, oval, obtuse : stamens included : filaments and anthers of the same length. [Xanthoxylum Texunum Buckl.]

Along or near the Rio Grande, southern Texas and adjacent Mexico. Spring. 
2. Amyris elemifera L. An evergreen glabrous shrub or tree, becoming $17 \mathrm{~m}$. tall, with a trunk diameter of about $3 \mathrm{dm}$. Leaflets $1-3$, the blades firm, ovate or elliptic-ovate, often somewhat rhombic, 2-8 cm. long, obtuse, acute or acuminate, undulate, obtuse or truncate at the base, finely reticulated: panicles $3-8 \mathrm{~cm}$. long, short-peduncled : pedicels 4-6 $\mathrm{mm}$. long: sepals ovate, nearly $1 \mathrm{~mm}$. long: petals nearly oblong, $2.5-3 \mathrm{~mm}$. long, yellowish white, obtuse, spreading or recurved: drupes globose, 4-6 mm. long, black with a bloom, aromatic.

In sand, southern peninsular Florida and the Keys. Also in the Bahamas and the West Indies. Summer to winter.

3. Amyris marítima Jacq. A tree resembling A. balsamifera, but taller, and with glabrous branchlets. Leaflets 3 , the blades shining beneath: ovary glabrous: drupes globose, 6-8 $\mathrm{mm}$. in diameter.

In sand, Key West, Florida. Also in the West Indies. Throughout the year.

4. Amyris balsamífera L. A branching shrub or small tree, sometimes $4 \mathrm{~m}$. tall, with a maximum trunk diameter of about $2.5 \mathrm{dm}$., the branchlets slightly pubescent. Leaves persistent: leaflets $3-5$, the blades ovate-lanceolate, $5-8 \mathrm{~cm}$. long, attenuate-acuminate, dull beneath, entire : inflorescence resembling that of $A$. elemifera: ovary pubescent: drupes obovoid to elliptic-oval, 6-13 mm. long, black beneath the bloom.

In sand, southern Florida. Also in the West Indies and South America. Throughout the year.

\section{CÍTRUS L.}

Shrubs and trees, with more or less spinescent branches, pervaded by a fragrant volatile oil. Leaves persistent: blades 1-foliolate, leathery : petiole often winged. Flowers perfect, regular, axillary. Sepals united into a cup-like calyx. Petals 5 or rarely 4-8, white, at least within, deciduous. Stamens 20-60: filaments inserted around an annular or cup-like disk. Ovary several-celled, superior : styles united, deciduous. Ovules several in each cavity. Berries various, with a bitter oily rind. Seeds pale, several in each cavity. Endosperm wanting. Embryo with fleshy cotyledons. Various species and varieties of this genus are cultivated, and either spontaneous or naturalized in the Gulf States :

Petioles with wings or margins.

Wings of the petiole very broad.

Wings of the petiole very narrow or represented by mere margins.

Leaflets with entire blades: berry with a separable rind and a sweet pulp.

Petioles wingless and marginless.

Leaflets with toothed blades : berries with a thin rind.

Leaflets with entire blades: berries with a very thick rind.

1. C. vulgaris.

2. C. Aurantium.

3. C. Limonium.

1. Citrus vulgàris Risso. The bitter-sweet orange ; with a broadly winged petiole, a subglobose berry, an orange-colored and very fragrant rind and a bitter-sweet or bitter and sour pulp.

Thoroughly naturalized in peninsular Florida.

2. Citrus Aurántium L. The sweet orange; with a narrowly winged petiole, a subglobose berry, an orange-colored rind and a sweet pulp.

Widely cultivated and spontaneous in peninsular Florida and others of the Gulf States.

3. Citrus Limònium Risso. The lemon; with a narrowly winged petiole, a more or less elongated berry, a pale yellow rind and a very sour and acid pulp.

Cultivated and spontaneous in peninsular Florida.

4. Citrus Limétta Risso. The lime; with wingless petioles, small, nearly globular berries, a pale thin rind and a sweetish somewhat acid pulp.

Cultivated and naturalized in peninsular Florida.

5. Citrus Médica L. The citron; with wingless petioles, large somewhat elongated berries, a very thick adherent rind and a slightly acid pulp.

Sparingly cultivated and spontaneous in peninsular Florida.

\section{Family 9. SURIanàceae lindl. Suriana Family.}

Shrubs of tropical coasts. Leaves alternate : blades narrow, rather fleshy. Flowers perfect, solitary, or in few-flowered terminal clusters. Calyx of 5 persistent sepals. Corolla of 5 imbricated petals with claws. Androecium of 10 stamens. Filaments slender, those opposite the petals shorter, or sometimes obsolete. Disk adnate to the base of the calyx or obsolete. Gynoecium of 5 distinct carpels opposite the petals. Carpels pubescent, 1-celled. Styles fili- 
form. Stigmas capitate. Ovules 2, collateral, ascending, campylotropous. Fruit achene-like. Seeds with a horseshoe-shaped embryo and thick incumbent cotyledons.

Characters of the family.

\section{SURIÀNA L.}

1. Suriana marítima L. A copiously branched shrub 1-2 m. tall, with softly pubescent foliage. Leaves numerous and approximate; blades linear-spatulate, $1.5-4 \mathrm{~cm}$. long, entire, nerveless: flower-clusters not surpassing the leaves: sepals ovate, $6-8 \mathrm{~mm}$. long, acuminate: petals yellow, broadened upward, about as long as the sepals : fruit $8-10 \mathrm{~mm}$. broad, the achene-like carpels $4-4.5 \mathrm{~mm}$. high, finely pubescent.

On sandy beaches, Florida. Widely distributed in the tropies.

\section{FAmily 10. SIMARUBÀCEAE DC. QUassia Family.}

Tropical shrubs or trees, or rarely herbs, with a bitter milky sap. Leaves alternate or rarely opposite, without stipules : blades pinnately compound, rarely 1-3-foliolate, or simple: leaflets not glandular-punctate. Inflorescence mostly axillary, racemose or paniculate, or rarely spicate. Flowers sometimes solitary, dioecious, polygamous, or rarely perfect, regular. Calyx of 3-5 persistent sepals. Disk annular, cup-like or elongated into a stalk, entire or lobed. Corolla of 3-5 imbricated or valvate deciduous petals, or rarely wanting. Androecium of as many stamens as there are petals, or twice as many, rarely numerous, inserted under the disk. Filaments distinct, naked or each with a scale at the base, sometimes pilose. Anthers introrse. Gynoecium of 2-5, more or less united carpels. Ovary 2-5-celled, deeply 2-5-lobed, or rarely 1-5celled and entire. Styles 2-5, more or less united. Ovules usually solitary in each cavity, rarely numerous, pendulous, anatropous. Fruit a drupe or samara. Seed mostly solitary, pendulous, with a membranous testa. Endosperm fleshy, sometimes wanting.

Leaves with simple blades.

Leaves with pinnately-compound blades.

Carpels united at the base or by their styles.

Fruit a drupe.

Fruit a samara.

Carpels wholly united up to the styles.

1. Castela.

2. Simaruba.

3. Ailanthus.

4. Pigraminia.

\section{CÁSTELA Turpin.}

Low rigid spinescent shrubs, with spreading branches and very bitter bark and wood. Leaves alternate, often clustered: blades leathery, small, simple, entire, revolute. Flowers small, polygamo-dioecious, solitary or clustered. Sepals 4 , relatively small. Petals 4, imbricated in the bud. Stamens 8 , represented by staminodia in the pistillate flowers, inserted below the 8-lobed disk : filaments often pubescent. Ovary 4-lobed, 4-celled, sessile : styles united to the middle, the tips recurved, stigmatic on the inner side. Fruit a cluster of 4, or fewer, fleshy drupes. Stone crustaceous. Endosperm scant. Cotyledons thick.

1. Castela Nicholsònii Hook. A rigid spinescent shrub 1-2 m. tall, with pale bark and tomentose twigs. Leaf-blades oblong or oblanceolate, 8-20 mm. long, obtuse or apiculate, revolute, nearly glabrous above, pale-tomentose beneath, nearly sessile, sometimes clustered : corolla orange-red : filaments hirsute : drupes flattened, 6-8 mm. long, red, oblique, acute, coarsely reticulated.

On bluffs along the Rio Grande and its tributaries, Texas and Mexico. GoAtвusH.

\section{SIMARÙBA Aubl.}

Tropical trees, with a resinous sap. Leaves alternate, without stipules : blades leathery, abruptly-pinnate. Leaflets mostly alternate, entire, conduplicate in vernation. Flowers small, monoecious or dioecious, in elongated panicles. Sepals 4-5, imbricated. Disk somewhat cup-shaped, pubescent. Petals 4-5, imbricated, spreading. Stamens 8-10, inserted below the disk, reduced to scales in pistillate flowers: filaments filiform, enlarged at the base, inserted on the back of a fringed scale. Ovary sessile in the disk, deeply 4-5lobed, rudimentary or wanting in the staminate flowers: styles united: stigmas spreading or recurved, longer than the style. Drupes solitary, or 5 together, with a thin fleshy pulp and a crustaceous stone. Endosperm wanting. Cotyledons plano-convex. 
1. Simaruba glaùca DC. An evergreen glabrous tree, sometimes $16 \mathrm{~m}$. tall, with a maximum trunk diameter of $5 \mathrm{dm}$. Leaf-blades 1-3 dm. long: rachis wingless : leaflets 6-12, the blades oblong, 4-8 cm. long, apiculate or obtuse at the apex, entire and slightly revolute, bright green and lustrous above, paler and dull beneath, often cuneately narrowed at the base: staminate flowers with 5 triangular-ovate ciliolate sepals, 5 oblong-lanceolate, fleshy, acute or apiculate recurved petals, and 5 glabrous stamens, each with a manytoothed scale at the base: pistillate flowers with 5 ovate sepals, 5 erect fleshy ovate, obliquely-apiculate petals, and a 5-lobed ovary with 5 styles which are recurved and curled above: drupes oval, somewhat oblique, about $2 \mathrm{~cm}$. long, scarlet or dark purple : seeds roughened.

In sandy soil, southern peninsular Florida and the Keys. Early spring. Also in the West Indies and Brazil. Paradise-tree. GUMbo Limbo. Bitter-Wood.

\section{AILÁNTHUS Desf.}

Handsome trees, with a pale bark, sometimes ill-smelling. Leaves alternate : blades unequally pinnate, ample: leaflets numerous, the blades oblique, entire or coarselytoothed. Flowers polygamo-dioecious, in large terminal panicled racemes. Pedicels subtended by small bracts. Sepals 5, imbricated. Disk hemispheric, 10-lobed. Petals 5, valvate, spreading. Stamens mostly 10, inserted at the base of the disk : filaments naked. Ovary 2-5-celled, deeply lobed, the lobes flattened: styles 2-5, united. Samaras solitary or 5 together, elongated, membranous-winged, 1-celled. Endosperm scant. Cotyledons flat, suborbicular. Tree-of-Heaven.

1. Ailanthus glandulòsus Desf. A tree sometimes $30 \mathrm{~m}$. tall, the stout trunk clothed with a pale smoothish bark. Leaf-blades 3-6 dm. long, the rachis nearly terete : leaflets 13-41, the blades lanceolate or oblong-lanceolate, 7-18 cm. long, acuminate, undulate, obtuse or subcordate at the base : flowers in panicles varying from $1-3 \mathrm{dm}$. in length, the staminate with 5 triangular-ovate acute ciliolate sepals, 5 oval involute petals which are 3-4 $\mathrm{mm}$. long and villous near the base within, and 5 stamens whose filaments are villous near the base: pistillate flowers often smaller than staminate : stamens more or less imperfect: ovary 5-winged, surmounted by the united styles and a large stigma : samara 4-5 $\mathrm{cm}$. long, linear-elliptic, curved, the flat seed in the middle.

In waste places and along streams, more or less extensively naturalized in the United States and southern British America. Native of China. Spring and early summer.

\section{PICRÁMNIA Sw.}

Tropical dioecious shrubs or trees, pervaded by a very bitter principle. Leaves alternate, without stipules: blades unequally pinnate: leaflets opposite or nearly so. Flowers small, dioecious, clustered in elongated spikes or racemes opposite the leaves. Sepals $3-5$, imbricated. Disk flat, lobed. Petals 3-5, narrow, imbricated, inflexed at the apex, rarely wanting. Stamens $3-5$, opposite the petals, reduced to linear scales in the pistillate flowers: filaments naked, inflexed. Ovary sessile on the disk, 2-3-celled: styles partially united, or rarely wanting: stigmas 2-3, recurved. Ovules 2, pendulous, collateral. Berry oblong, 1-2-celled. Cotyledons undivided.

1. Picramnia pentándra Sw. A shrub or small tree, its trunk rarely $1.5 \mathrm{dm}$. thick, the twigs and inflorescence appressed-pubescent. Leaf-blades 1-3 dm. long, the rachis terete: leaflets $5-7$, the blades leathery, elliptic or oblong-elliptic, or rarely ovate, 5-10 $\mathrm{cm}$. long, acuminate at both ends or acute at the base, dark green and lustrous above, paler beneath, glabrous: panicles relatively few-flowered, lax: staminate flowers with corollas about $3-3.5 \mathrm{~mm}$. wide: pistillate flowers with narrowly triangular-ovate acute sepals : berries oblong, $10-15 \mathrm{~mm}$. long.

In sandy soil, southern peninsular Florida and the Keys. Also in the West Indies.

\section{FAMILY 11. BURSERÀCEAE Kunth. TORCH-WOOD FAMILY.}

Trees, producing a copious resinous sap which hardens into a resin on exposure. Leaves alternate, without stipules: blades unequally pinnate, rarely 3 -foliolate or 1-foliolate: leaflets with pellucid glands. Inflorescence racemose or paniculate. Flowers perfect or polygamo-dioecious, regular. Calyx of 3-6 imbrieated or valvate persistent sepals. Disk annular or cup-shaped. Corolla of 3-6 distinct or slightly united deciduous imbricated or valvate petals. Androecium of 6-12 stamens, inserted under the disk. Filaments subulate, dis- 
tinct, naked. Anthers often versatile, introrse. Gynoecium of 2-5 united carpels. Ovary 2-5-celled, free. Styles united, sometimes wanting. Stigma 2-5-lobed. Ovules 2, or rarely 1, in each cavity, pendulous, anatropous. Fruit drupaceous, sometimes with a more or less valvular epicarp. Seeds terete or angled, the testa membranous. Endosperm wanting. Cotyledons thin.

\section{Búrsera Jacq.}

Tropical, sometimes evergreen trees, with a balsamic-resinous sap. Leaves sparse, often crowded at the ends of the branches: leaflets opposite, commonly pellucid-punctate, the rachis terete or winged. Flowers clustered, or in short or elongated lateral racemes or panicles. Sepals 4-6, at length reflexed. Disk annular, crenate. Petals 4-6, valvate or rarely imbricated. Stamens 6-12, inserted at the base of the disk : filaments nearly equal, distinct. Ovary 3-5-celled, sessile : stigmas 3-5. Ovules 2. Drupe ovoid or globose, oblique, somewhat 3 -angled, indehiscent or sometimes with 2-3 valves. Seeds solitary. Cotyledons sometimes 3-parted, contorted and folded.

1. Bursera Simarùba (L.) Sarg. A large glabrous forest tree, with a maximum height of $20 \mathrm{~m}$. and a trunk diameter of $1 \mathrm{~m}$. Leaves 1-2 dm. long, usually deciduous : leaflets $3-7$, the blades rather leathery, oval or elliptic, varying to ovate or obovate, $3-5 \mathrm{~cm}$. long, usually short-acuminate, entire, inequilateral : racemes simple, $5-10 \mathrm{~cm}$. long, longer than the peduncles : pedicels 4-8 $\mathrm{mm}$. long: sepals ovate or triangular-ovate, about $1 \mathrm{~mm}$. long: petals oblong-lanceolate or ovate, spreading, 2-2.5 mm. long, acute : stamens erect : drupes oblong, 3-angled, $5-6 \mathrm{~mm}$. long, the epicarp leathery, separating into 3 valves: seeds 1 or 2, 3-angled. [B. gummifera L.?]

On the coast, southern peninsular Florida and the Keys. Also in tropical America. Spring. West Indian Birch. GUMbo LIMbo. GUM Elemi.

\section{Family 12. Meliàceaf Vent. Mahogany Family.}

Mostly tropical shrubs, trees, or sometimes shrubby herbs, with an often hard and odorous wood. Leaves alternate, without stipules: blades pinnately compound, sometimes thrice pinnate : leaflets with entire or toothed blades. Inflorescence paniculate. Flowers perfect or polygamo-dioecious, regular. Calyx of 3-5 imbricated or rarely valvate sepals. Disk variable. Corolla of 3-5 distinct or somewhat united contorted or imbricated petals which are sometimes adnate to the stamen-tube and valvate. Androecium of 8-10 stamens, or rarely fewer or more, inserted at the base of the disk. Filaments united into a tube whose edge is variously toothed or cleft. Anthers sessile or stalked on the tube, sometimes apiculate. Gynoecium of 3-5 united carpels. Ovary 3-5-celled, free. Styles united. Ovules 2-many in each cavity, anatropous. Fruit a berry, capsule or drupe. Seeds sometimes winged. Endosperm wanting or fleshy. Embryo with leafy cotyledons.

Ovules 2 in a cavity : fruit a drupe: seeds without wings.

Ovules many in a cavity : fruit a capsule: seeds winged.

1. Melia.

2. SwiETENia.

\section{MÈLIA L.}

Tropical and Australian trees, commonly with a variegated wood and scarred branches. Leaves alternate : blades unequally pinnate, often thrice compound ; leaflets often numerous, the blades toothed. Flowers perfect, white or purple, in ample axillary muchbranched panicles. Sepals 5-6, imbricated. Disk annular. Petals 5-6, distinct, narrow, contorted, spreading. Staminal tube nearly cylindric, dilated at the mouth, 10-12-lobed, each lobe 2-or 3-cleft : anthers 10-12, erect, scarcely apiculate. Ovary subglobose, 3-6celled : stigma $3-6$-lobed. Ovules 2 in each cavity, pendulous, one above the otherDrupe leathery-fleshy, with a 1-5-celled stone. Seed solitary in each cavity, wingless. Endosperm fleshy or very thick. China-tree. Pride-of-India.

1. Melia Azédarach L. A large ornamental tree, reaching a height of $15 \mathrm{~m}$. and with a trunk diameter of nearly $2 \mathrm{~m}$. Bark furrowed : leaf-blades twice compound, 3-9 dm. long, petioled : leaflets numerous, the blades ovate, oval or elliptic, $3-7 \mathrm{~cm}$. long, acute or short acuminate, incised-serrate or lobed, acute or subcordate at the base : panicles 6-15 
$\mathrm{cm}$. long, open, about as long as the peduncles : pedicels 4-10 mm. long: sepals elliptic or oblong-lanceolate, $2 \mathrm{~mm}$. long, acute: petals purplish, narrowly oblong or oblanceolate, about $1 \mathrm{~cm}$. long, obtuse, spreading: drupes subglobose, $1.5-2 \mathrm{~cm}$. in diameter, yellow, smooth : seeds lobed, very rough, wingless.

Nearly throughout our range, naturalized from Asia.-M. Azedarach umbraculifera Sarg., is the form with a depressed umbrella-like top, it is cultivated and spontaneous in the Gulf States.

\section{SWIETÈnIA Jacq.}

Tropical American lofty trees, with dark red wood. Leaves alternate, with abruptly pinnate blades : leaflets opposite, the blades leathery, oblique, undulate. Flowers perfect, in axillary or nearly terminal panicles. Sepals 5, imbricated, united to above the middle. Disk annular. Petals 5, contorted, spreading. Staminal tube urn-shaped, 10-toothed: anthers 10, attached below the sinuses of the tube. Ovary ovoid, 5-celled: stigma discoid. - Ovules numerous in each cavity, pendulous, half-anatropous. Capsule 5-celled, opening septicidally from the base by 5 valves from the 5 -angled or 5 -winged axis, its valves of 2 layers. Seeds numerous, imbricated in 2 rows in each cavity, each produced into a long membranous wing. Endosperm thin, fleshy. Embryo transverse, with large closely united cotyledons. Mahogany. Madeira Redwood.

1. Swietenia Mahàgoni Jacq. A massive evergreen forest tree, with a maximum height of $25 \mathrm{~m}$. and with a trunk diameter of 3 or $4 \mathrm{~m}$. at the swollen base. Bark separating in large scales: leaf-blades $1-3 \mathrm{dm}$. long, petioled : leaflets $4-8$, the blades leathery, ovate or ovate-lanceolate, $3-8 \mathrm{~cm}$. long, very inequilateral, acuminate, undulate, acute or rounded at the curved base : panicles $8-15 \mathrm{~cm}$. long, open, about as long as the peduncles : sepals half-orbicular, about $1 \mathrm{~mm}$. long, united below : corolla 8-9 $\mathrm{mm}$. broad: petals oblong-obovate, usually 3-4 mm. long, obtuse, spreading : staminal tube as long as the pistil, its lobes acute or acuminate : capsule ovoid, $6-12 \mathrm{~cm}$. long: seeds $1-1.5 \mathrm{~cm}$. long, the wing about $1 \frac{1}{2}$ times longer than the body, membranous, red.

In sand and coral rock, Florida Keys. Also in the West India and Bahama Islands, Central and northern South America. Summer; fruit ripening in the fall or winter.

\section{Order 15. POLYGALÀLES.}

Herbs or shrubs, or trees. Leaves alternate, opposite or whorled, sometimes much reduced. Flowers perfect. Perianth of two series. Calyx of 5 or rarely 3 or 4 sepals. Corolla apparently papilionaceous, or regular (TREMANDRACEAE). Androecium of 6,8 or 10 stamens. Filaments distinct or united and sometimes partially adnate to the corolla. Anthers opening by terminal pores or cracks. Gynoecium of 2 united carpels, or rarely more. Style often bent. Ovules mostly solitary in each cavity. Fruit capsular. Seeds usually carunculate and often hairy.

\section{Family 1. POLYGaldàceat Reichenb. Milkwort Family.}

Herbs, or rarely shrubs or trees in the tropics, with a watery sap, at least above the roots. Leaves alternate, or opposite or whorled, sometimes scalelike : stipules wanting. Flowers irregular, apparently papilionaceous, variously disposed. Calyx of 5 , mostly free, imbricated sepals, the 2 inner petaloid, called wings. Corolla of 5 or often 3 petals ; lower one concave, often beaked or crested, called the keel, more or less united to the others. Androecium of 4 or usually 8 stamens. Filaments usually united into a tube cleft on the back, rarely free. Anthers innate, becoming 1-celled, opening by terminal pores or cracks. Gynoecium of 2 or rarely 5 united carpels, or apparently 1-carpellary.
Ovary 2-celled. Styles united. Stigma curved, dilated or lobed. Ovule solitary, pendulous, anatropous. Fruit mostly capsular, 2-celled. Seeds with or without endosperm, often pubescent, usually caruncled at the hilum. Embryo straight.

\section{POLÝGALA L.}

Herbs or shrubby plants, some species producing racemes of cleistogamous flowers at the base. Leaves alternate, opposite or whorled. Flowers perfect, often showy, often in densely crowded spikes or racemes. Sepals 5, unequal, the two lateral ones petal-like 
(wings), larger than the other three. Petals 3 , or rarely 5 , united below, the middle one (keel) commonly lobed at the apex and crested, the others smaller. Stamens 8, or rarely 6: filaments united into a tube, or into 2 sets of 3 or 4 each, sometimes adnate to the petals : anthers 1-2-celled. Style curved, often club-shaped: stigmas sometimes 2-4lobed. Capsule flattened, 2-celled. Seed 1 in each cavity, usually bearing a caruncle. Embryo straight in the thin endosperm. MrLkwort.

Keel without beak or crest.

Calyx caducous: capsules pubescent: shrubby plants.

Foliage puberulent: wings obovate : capsules $8 \mathrm{~mm}$. long.

Foliage tomentose: wings lanceolate: capsules $10 \mathrm{~mm}$. long.

Calyx persistent: capsules glabrous : herbaceous plants.

Keel with a beak or a papillose or tufted crest.

Keel with a horn-like or hooded beak.

Upper leaves with relatively broad blades, linear.

Foliage pubescent with spreading hairs: rachides with 4-6 joints : wings acute at the base.

Foliage pubescent with appressed or incurved hairs : rachides with 1218 joints : wings barely narrowed at the base.

Upper leaves with linear blades.

Keel with a papillose or tufted crest.

Sepals not decurrent on the pedicels: corolla white, pink, cream-color or purple.

Perennial.

Flowers both normal and cleistogamous.

Flowers axillary : capsules $5-8 \mathrm{~mm}$. long.

Flowers in terminal racemes: capsules $2-5 \mathrm{~mm}$. long.

Leaves not clustered : capsules slightly longer than broad.

Leaves clustered: capsules twice longer than broad.

Flowers all normal.

Corolla greenish white: leaves flat.

Corolla white or pink : leaves scale-like.

Annual or biennial, or perhaps sometimes perennial in $P$. Boykinii and $P$. alba.

Petals united into a tube fully twice as long as the wings.

Petals not united into an elongated tube.

Racemes interrupted the flowers remote.

Racemes continuous, dense.

Racemes slender, elongated, tapering.

Leaves alternate.

Mature racemes over $5 \mathrm{~mm}$. thick : wings $3 \mathrm{~mm}$. long; blades 9-nerved.

Mature racemes less than $5 \mathrm{~mm}$. thick : wings $1-2 \mathrm{~mm}$. long ; blades 3-nerved.

Leaves wholly or partly whorled.

Capsules about as broad as long.

Capsules manifestly longer than broad.

Stems several from the base.

Capsules 1-1.5 mm. long, elliptic-oval: leaves less than $10 \mathrm{~mm}$. long.

Capsules 2-3 mm. long, oblong: leaves over $10 \mathrm{~mm}$. long.

Stems solitary.

Stem with internodes 4-6 times longer than the leaves. Stem with internodes less than 4 times as long as the leaves

Leaves prevailingly alternate: wings shorter than the capsule.

Leaves prevailingly whorled: wings as long as the a capsule.

Racemes stout, abbreviated.

Leaves alternate.

Racemes mostly less than $11 \mathrm{~mm}$. in diameter.

Racemes ovoid: wings nearly $4 \mathrm{~mm}$. long.

Racemes eylindric: wings barely $2 \mathrm{~mm}$. long.

Racemes mostly over $11 \mathrm{~mm}$. in diameter.

Wings 3-4 mm. broad: seeds flask-shaped.

Wings $1.5-2 \mathrm{~mm}$. broad : seeds pyriform.

Bracts persistent : seeds $1.5 \mathrm{~mm}$. long.

Bracts deciduous : seeds $1 \mathrm{~mm}$. long.

Leaves wholly or partially whorled.

Racemes loosely flowered, pointed.

Racemes dense, blunt.

Racemes long-peduncled: wings apiculate.

Racemes sessile or short-peduncled : wings caudate-acumi-

nate.
Sepals more or less conspicuously decurrent on the pedicel: corolla yellow, orange or rarely white.

A. Racemes solitary or several.

Wings acuminate.

Wings cuspidate.

Wings $4-6 \mathrm{~mm}$. long, $3 \mathrm{~mm}$. broad : raceme orange-yellow.

Wings $7 \mathrm{~mm}$. long, $4 \mathrm{~mm}$. broad : raceme lemon-yellow.

1. P. puberula.

2. P. ovatifolia.

3. P. grandiflora.

4. P. Lindheimeri.

5. P. Texensis.

6. P. Tweedyi.

7. P. paucifolia.

8. P. polygama.

9. P. Lewtonii.

10. P. Senega.

11. P. setacea.

12. P. incarnata.

13. P. Hugeri.

14. P. Chapmanii.

15. P. paludosa.

16. P. Boykinit.

17. P. sparsifolia.

18. P. alba.

19. P. leptostachys.

20. P. ambigua.

21. P. verticillata.

22. P. Mariana.

23. P. Nuttallii.

24. P. viridescens.

25. P. Curtissii.

26. P. Harperi.

27. P. Hookeri.

28. P. brevifolia.

29. $P$, cruciata.

30. P. nane.

31. P. lntea.

32. P. Rugelii. 
B. Racemes several or many in terminal dichotomous or branched cymes or corymbs.

Corolla white.

Corolla yellow.

Basal leaves $2-3 \mathrm{~cm}$. long, blunt: wings acuminate.

Basal leaves 5-20 cm. long, attenuate: wings abruptly cuspidate.

33. P. Balduinii.

34. $P$. ramosa.

35. P. cymosa.

1. Polygala pubérula A. Gray. Shrubby, puberulent. Stems branched at the base, the branches 1-5 dm. tall : leaves various; blades oval near the base of the stem, or linear, linear-oblong or linear-lanceolate throughout, 1-2.5 $\mathrm{cm}$. long: racemes spike-like, 2-10 $\mathrm{cm}$. long : pedicels about $2 \mathrm{~mm}$. long : flowers purplish or bluish, 4-6 mm. long: wings obovate, 4-6 mm. long, obtuse, slightly shorter than the keel : lateral petals somewhat shorter than the keel, nearly spatulate : capsule suborbicular, $8 \mathrm{~mm}$. broad, notched, pubescent on the narrow margin, otherwise glabrous or puberulent: seeds pubescent.

In dry soil, Texas to Arizona, Mexico and Lower California.

2. Polygala ovatifòlia A. Gray. Perennial, tomentose. Stems branching at the woody base, the branches more or less densely tufted, $0.5-3 \mathrm{dm}$. long, erect or ascending, usually flexuous: leaves numerous; blades ovate, oval or elliptic-oval, $0.5-2 \mathrm{~cm}$. long, acute or mucronate, ciliate, short-petioled, those of the upper leaves often narrower than those of the lower : racemes terminal, 1-4 cm. long : pedicels 2-4 mm. long, their bracts deciduous : Howers greenish yellow, more or less pendulous : wings lanceolate, $5 \mathrm{~mm}$. long, pubescent, ciliate: lateral petals commonly $\frac{1}{2}$ as long as the naked unappendaged conspicuous keel: stamens 8: style slender, curved, neither dilated nor auricled: stigma terminal, 2-lobed: capsule suborbicular, $1 \mathrm{~cm}$. in diameter, notched at the apex, the sides glabrous, the edges ciliate : seeds silky, each with a hood-like caruncle.

In dry soil, Texas and New Mexico to Mexico. Summer.

3. Polygala grandiflòra Walt. Perennial, pubescent. Stems branched at the base, the branches erect or spreading, 2-5 dm. long, simple or sparingly branched above, the pubescence appressed or ascending: leaves alternate; blades elliptic, elliptic-lanceolate or lanceolate, $1-3.5 \mathrm{~cm}$. long, acute or mucronate, often short-petioled: racemes loosely flowered, $2-10 \mathrm{~cm}$. long: pedicels $3-4 \mathrm{~mm}$. long: flowers pink or violet-purple, becoming greenish, the lower ones drooping: wings obovate-cuneate or fan-shaped, 6-8 cm. broad, with short claws, glabrous: lateral petals spatulate or dilated above, much shorter than the naked hooded keel : stamens 8 ; filaments united below the middle : style slender, dilated above the middle, abruptly bent above the middle, bearded below the terminal stigma : capsule obovoid or oblong-obovoid, 5-6 mm. long, notched : seeds slightly flattened, densely silky, each with a conspicuous helmet-shaped caruncle.

In dry sand or pine woods, South Carolina to Florida and Mississippi. Summer and fall.-The form with narrowly linear acute leaf-blades, slightly smaller flowers and somewhat narrower wings, is P. grandiflora angustifòlia T. \& G., it occurs in peninsular Florida.

4. Polygala Lindheimeri A. Gray. Shrubby, pubescent with spreading hairs. Stems branching, 1-3 dm. tall, erect or ascending: leaves alternate; blades leathery, obovate, oval, ovate, elliptic or the upper ones lanceolate, varying from $0.5-1.5 \mathrm{~cm}$. long, cuspidate, reticulate, minutely glandular, sessile or short-petioled : racemes few-flowered, terminal or becoming lateral ; rachis becoming zigzag, 4-6-jointed, with unequal bracts at each angle : flowers purple, nearly sessile : outer sepals narrow, pubescent, ciliate : wings ovalobovate, cuneate at the base, 4-5 mm. long : lateral petals narrow, notehed or mitten-shaped, reaching to the beak of the keel : stamens 8 or rarely $7:$ filaments dilated above, united to near the anthers: style slender, zigzag, dilated near the apex, the edges toothed : capsule elliptic-oblong, 6-7 mm. long, notched at the apex, with spreading pubescence: seeds densely pubescent, the 2 lobes of the caruncle more than $\frac{1}{2}$ as long as the seed-body.

In rocky soil, Texas and New Mexico. Summer.

5. Polygala'Texénsis Robinson. Shrubby, pubescent with fine appressed or incurved hairs. Stems branched at the base, the branches erect or ascending, 1-3 dm. long: leaves alternate; blades various, those of the upper leaves narrowly lanceolate : racemes $5-12 \mathrm{~cm}$. long; rachis with 12-18 joints : flowers purplish : outer sepals elliptic-oblong, $3 \mathrm{~mm}$. long, pubescent without with incurved hairs: wings narrowly obovate, rounded at the apex,
cuneate at the base, $4.5 \mathrm{~mm}$. long: keel with a narrowly oblong appendage: capsule oblong, $4 \mathrm{~mm}$. long, $2.5 \mathrm{~mm}$. broad.

In rocky soil, Texas. Spring and summer.

6. Polygala Toreedyi Britton. Perennial, glaucous, pubescent with incurved hairs. Stems branched at the base, the branches erect or ascending, 1-2 dm. tall, usually simple leafy to the top: leaves thick, the lower ones oblong or linear-oblong, $1.5-2.5 \mathrm{~cm}$. long, the upper leaves linear, shorter than the lower ones, acute, sessile, erect or ascending: flowers $3-4$, in a spike-like raceme about $4 \mathrm{~mm}$. long: wings obovate, about as long as the 
corolla : keel with a slender beak about $1 \mathrm{~mm}$. long: stamens 6 or 7 ; filaments united to about the middle : style slender, neither dilated nor appendaged : stigma terminal : capsule $3 \mathrm{~mm}$. long: seeds flattened, pubescent, the 3 lobes of the caruncle unequal, 2 about $\frac{1}{2}$ as long as the seed-body, the third much shorter.

In dry soil, Texas to Arizona. Summer.

7. Polygala paucifòlia Willd. Perennial, bright green, glabrous below. Stems simple or branched below, the branches $5-20 \mathrm{~cm}$. tall, often pubescent above : leaves 3-6, near the ends of the branches ; blades elliptic, oval or ovate, 1-3 cm. long, acute or mucronate, narrowed into short petioles, often pubescent above near the base : raceme 3-4-flowered: pedicels $6-12 \mathrm{~mm}$. long : flowers rose, purple or rarely white, showy, $1.5-2 \mathrm{~cm}$. long : wings obovate, $1-1.5 \mathrm{~cm}$. long, narrowed at the base : lateral petals oblong: keel with a conspicuous fimbriate crest : stamens 6 : style club-shaped, neither dilated nor auricled, toothed at the apex : capsule subglobose, $5-8 \mathrm{~mm}$. broad, notched at the apex and sometimes at the base : seeds pubescent, the 2 subulate lobes of the caruncle often longer than the seed-body.

In moist woods, Anticosti and New Brunswick to Saskatchewan, south along the mountains to Georgia, and Illinois. Spring and summer. Flowering Wintergreen. Fringed MiLKWort.

8. Polygala polýgama Walt. Perennial, bright green, glabrous. Stems branched at the base; branches slender, erect or ascending, 1-5 dm. tall, striate, usually simple : leaves alternate ; blades spatulate, oblanceolate, oblong-oblanceolate or linear, 1-4 cm. long or the lower ones shorter, all usually apiculate : racemes loosely flowered, short-peduncled, the rachis 12-15 $\mathrm{cm}$. long : pedicels $2-7 \mathrm{~mm}$. long, their bracts deciduous : flowers rose-purple to pink, the lower ones often drooping: cleistogene flowers on elongated radiating, more or less buried racemes at the base of the plant: wings obovate, 4-6 $\mathrm{mm}$. long, often unequal, obtuse : keel crested with several large branching processes : stamens $8:$ style short, hooded at the stalked stigma, the tufted appendage curved toward the stigma: capsule oblong or oblong-obovoid, about $2 \mathrm{~mm}$. long : seeds very pubescent, the 2 lobes of the caruncle lacelike, about $\frac{3}{4}$ as long as the seed-body.

In dry sandy soil, Nova Scotia to the Lake of the:Woods, Florida and Texas. Summer.

9. Polygala Lewtònii Small. Perennial or perhaps biennial, the foliage glabrous, bright green. Stems much branched at the base, the branches numerous, ascending or decumbent, 1-2 dm. long, simple, sharply angled: leaves clustered, crowded, fleshy, spatulate or linear-spatulate, $1-2 \mathrm{~cm}$. long, acute or acutish, wrinkled in drying: racemes 1-5. $\mathrm{cm}$. long, loosely flowered : pedicels slender, $1-2 \mathrm{~mm}$. long : sepals various; dorsal broadly oblong; anterior narrowly-oblong, both $2 \mathrm{~mm}$. long, obtuse : wings deep pink, inequilateral, half-rhombic, 4.5-5.5 mm. long: corolla deep pink : petals about $4 \mathrm{~mm}$. long, the keel more finely lacerate than in $P$. polygama: style ascending from the truncate top of ovary, cucullate above the middle, the tufted appendage and stigmatic gland not approximate : capsule oblong-prismatic, $5 \mathrm{~mm}$. long, glabrous : cleistogamous racemes slender, few-flowered, their pedicels slender, $1-1.5 \mathrm{~cm}$. long, curved.

In sand, peninsular Florida. Summer.

10. Polygala Sénega L. Perennial, more or less puberulent. Stems several from the thick root, erect or ascending, 1-5 dm. long, usually simple : leaves alternate, numerous ; blades linear-lanceolate to lanceolate-elliptic, $1-3.5 \mathrm{~cm}$. long (the lower ones often scalelike), scabrous-margined : racemes spike-like, $2-6 \mathrm{~cm}$. long: corolla greenish white, 3-4 $\mathrm{mm}$. long: wings orbicular-obovate, $2-3 \mathrm{~mm}$. long, rather persistent : keel with a crest of several thick processes: capsule flat, broader than long, 3.5-4.5 mm. broad: seeds pubescent, with caruncle-lobes about as long as the seed-body.

In dry soil, New Brunswick to the Hudson Bay region and the Canadian Rocky Mountains, south to North Carolina and Arkansas. Spring.-A form with taller stems, larger leaves with ovate or oblongovate serrulate blades, laxer racemes and larger capsules and seeds, is known as P. Senega latifolia $\mathrm{T}$ \& G., it ranges from Pennsylvanía to Michigan and South Dakota south to Tennessee. SENECA SNAKEROOT.

11. Polygala setàcea Michx. Annual, slender, glabrous. Stems erect, 1-5 dm. tall, wire-like, simple throughout or branched at the base or above : leaves scale-like, $0.5-$ $1.5 \mathrm{~mm}$. long, subulate, acute, scattered : racemes spike-like, conic-ovoid, 4-6 mm. thick, acute, dense, the rachis $1-3 \mathrm{~cm}$. long : pedicels $0.5-1 \mathrm{~mm}$. long, their bracts deciduous : flowers pink or whitish : wings narrowly obovoid, $2 \mathrm{~mm}$. long, scarcely mucronate, thrice longer than the other sepals: keel crested with a few short processes : stamens $6:$ style short, auricled on either side of the stalked stigma, prolonged into a short tufted appendage : capsule rather deltoid : seeds pubescent, beaked, the 2 spongy caruncle-lobes enveloping the beak.

In low pine lands, North Carolina to Florida. Spring and summer.

12. Polygala incarnàta L. Annual, glaucous. Stems erect or ascending, 2-7 dm. tall, simple and wand-like or branched above, striate or angled, sometimes nearly naked: leaves scattered; blades linear-subulate or subulate, $0.5-1.5 \mathrm{~cm}$. long, acute, fleshy, sessile : 
racemes spike-like, cylindric, 8-10 mm. thick, long-peduncled, usually dense : pedicels $0.5-1 \mathrm{~mm}$. long, the bracts deciduous : flowers pink or purple, rarely white : wings lanceolate, $4 \mathrm{~mm}$. long, 5-nerved, mucronate, conduplicate at the apex : petals united below into a cleft tube, $6-8 \mathrm{~mm}$. long, the keel crested with several entire or cleft processes : stamens 8 : style filiform, auricled near the almost sessile stigma, prolonged into a short tufted appendage : capsule $4 \mathrm{~mm}$. long, grooved : seeds pubescent, beaked, the 2 lobes of the caruncle spongy, lenticular, enveloping the beak.

In sandy soil, New Jersey to Ontario and Wisconsin, south to Florida, the Indian Territory and Mexico. Summer.

13. Polygala Hùgeri Small. Annual, glabrous. Stems about $1.5 \mathrm{dm}$. tall, branched from near the base and thence throughout: leaves numerous ; blades linear, $1-2 \mathrm{~cm}$. long, acute, sessile, somewhat fleshy: racemes lax, interrupted, few-flowered: pedicels 1.5-2 $\mathrm{mm}$. long, surpassed by the bracts : flowers pink : wings oblong, 3-3.5 mm. long, somewhat narrowed near the apex and apiculate: keel crested with few very short processes: style slightly auricled just above the stigma and tipped with a tufted appendage : seeds about $1 \mathrm{~mm}$. long.

On hillsides, Andrews, North Carolina. Summer.

14. Polygala Chapmánii T. \& G. Annual, slender, glabrous. Stems erect, wirelike, 2-5 dm. tall, simple or sparingly branched above : leaves alternate, bristle-like, 0.4-2 $\mathrm{cm}$. long, sometimes appressed : racemes ovoid to cylindric, 6-8 $\mathrm{mm}$. thick, slenderpeduncled, the rachis $2-4 \mathrm{~cm}$. long: pedicels slender, 1-1.5 mm. long, their bracts persistent: flowers pink or purplish; wings ovate-oval or oval, about $3 \mathrm{~mm}$. long, minutely apiculate, 9-nerved, the midnerve thickened at the tip: keel crested with 2 or a few papillæ: stamens 8 : style auricled at the sessile stigma, prolonged into a curved appendage : seeds beaked, pubescent with pale hairs, the 2 caruncle-lobes $\frac{1}{5}-\frac{1}{4}$ as long as the seedbody, straddling the beak.

In low pine lands, near the coast, Florida and Mississippi. Spring to summer.

15. Polygala paludòsa St. Hil. Annual, very slender, glabrous. Stems erect or ascending, 2-6 dm. tall, often almost filiform, usually sparingly branched above: leaves alternate, acicular or filiform, few, $0.5-2 \mathrm{~cm}$. long : racemes spike-like, 2-4 mm. thick, elongated, slender-peduncled, the rachis $2-10 \mathrm{~cm}$. long, loosely-flowered: pedicels $0.5-1$ $\mathrm{mm}$. long, their bracts deciduous : flowers pale-purple : wings spatulate, elliptic-obovate or oblong, 1-2 mm. long, the blades often 3-nerved, narrowed into a short claw, twice larger than the other sepals: keel crested with a few processes: stamens 8 : style minute, hooded at the sessile or nearly sessile stigma, prolonged into a filiform tufted appendage, or the tuft sometimes sessile or wanting : capsule about $1.5 \mathrm{~mm}$. long: seeds very pubescent, the 2 lobes of the caruncle minute.

In sandy soil, Mississippi to Texas and Mexico. Spring and summer.

16. Polygala Boykínii Nutt. Annual or perhaps perennial. Stems branched at the base, the branches erect or ascending, 2-6 dm. tall, wire-like, angled, simple or sparingly branched: leaves in whorls of 4's or 5's, the lower ones with obovate or oblong-obovate blades, 0.5-1 cm. long, gradually becoming narrower and longer to linear-lanceolate or linear, $1-3 \mathrm{~cm}$. long at the top of the stem, acute or acutish, those on the branchlets alternate: racemes spike-like, 4-6 mm. thick below, narrowly conic, long-peduncled, the rachis $2-15 \mathrm{~cm}$. long: pedicels $1 \mathrm{~mm}$. long, their bracts deciduous : flowers white or greenish white: wings suborbicular, varying to ovate or obovate, fully $2 \mathrm{~mm}$. long, obtuse, several times larger than the other sepals: keel crested with a few broad processes: stamens 8: style hooded above the stalked stigma, produced above into a curved tufted appendage : capsule 3-4 mm. long : seeds stout, pubescent, the 2 lobes of the caruncle $\frac{1}{2}-\frac{3}{4}$ as long as the seed-body or rarely longer, sometimes overlapping.

In calcareous soil, Georgia to Florida and Louisiana. Spring and summer.

17. Polygala sparsifòlia (Wheelock) Small. Annual, glabrous. Stems $3-6 \mathrm{dm}$. tall, sparingly branched or bushy, sometimes nearly naked : leaves in a few approximate whorls, near the base of the stem or alternate; blades linear to lanceolate, 8-10 mm. long or smaller, acute or sharp-tipped, sessile : racemes spike-like, $2-5 \mathrm{~cm}$. long, $3-4 \mathrm{~mm}$. thick, on long and slender peduncles, tapering: flowers pale, early deciduous, leaving a long naked rachis: wings oval or orbicular-oval, about $2 \mathrm{~mm}$. long : capsule oval-elliptic, barely 2 $\mathrm{mm}$. long : seeds slender, strigillose, with a 2-lobed caruncle about $\frac{1}{2}$ the length of the seed-body. [P. Boykinii var. sparsifolia Wheelock.]

In coral soil, Pine and Cudjoe Keys, Florida.

18. Polygala álba Nutt. Annual or biennial or perhaps perennial, glabrous. Stems branched at the base; branches usually numerous, erect or ascending, 1-5 dm. tall, angled, usually simple : leaves alternate; blades linear, linear-lanceolate or nearly subulate, 1-2.5 
cm. long, acute, the lower ones sometimes oblanceolate, apparently whorled : racemes spikelike, narrowly conic, 4-6 $\mathrm{mm}$. thick, long-peduncled, the rachis $2-5 \mathrm{~cm}$. long: pedicels $0.5-1 \mathrm{~mm}$. long, the bracts deciduous: flowers white : wings oval or obovate, $2-3 \mathrm{~mm}$. long, obtuse : keel with a fimbriate crest : stamens $8:$ style short, auricled above the middle and above the stalked stigma, prolonged into a filiform, minutely tufted appendage : capsule ovoid, $2-3 \mathrm{~mm}$. long: seeds strigose, the 2 lobes of the caruncle about $\frac{1}{2}$ as long as the seed-body.

In dry soil, Minnesota to Kansas, Texas, Arizona and Mexico. Spring and summer.

19. Polygala leptostáchys Shuttlw. Annual, very slender, glabrous. Stems erect, wire-like, or filiform, 1-5 dm. tall, solitary, simple or sparingly branched: leaves few, in distant whorls of 4's or 5's; blades linear-subulate or filiform, $0.5-2 \mathrm{~cm}$. long, acute: racemes spike-like, slender-pediceled, $2-4 \mathrm{~mm}$. thick at the base, narrowly conic, the rachis $1-5 \mathrm{~cm}$. long: pedicels very short, their bracts deciduous : flowers greenish : wings oval, nearly $2 \mathrm{~mm}$. long, obtuse : keel crested with a few short processes: stamens 8 : style minute, hooded above and auricled on either side of the stalked stigma, the short appendage tufted : capsule about $2 \mathrm{~mm}$. long: seeds glabrous or pubescent at the apex, the 2 lobes of the caruncle $\frac{1}{2}-\frac{3}{4}$ as long as the seed-body.

On dry sand hills, Florida. Spring to summer.

20. Polygala ambígua Nutt. Annual, very slender, glabrous. Stems erect, wirelike, 1-3 dm. tall, simple or sparingly branched above; branches not spreading: leaves prevailingly alternate; blades linear, $0.5-1.5 \mathrm{~cm}$. long, the lower ones sometimes whorled, acute, sessile : racemes spike-like, 3-5 mm. thick, narrowly conic, often interrupted below, long-peduncled, the rachis 1-8 $\mathrm{cm}$. long : pedicels $0.5-1 \mathrm{~mm}$. long, their bracts deciduous : flowers purplish or greenish purple: wings suborbicular, nearly $1.5 \mathrm{~mm}$. long, obtuse, at least 3-nerved: capsule suborbicular, fully $1.5 \mathrm{~mm}$. long, surpassing the wings: seeds pubescent.

In dry soil, Maine to Missouri, Georgia, Louisiana and the Indian Territory. Summer.

21. Polygala verticillàta L. Annual, slender, glabrous. Stems $5-30 \mathrm{~cm}$. tall, angled, sometimes short with many alternate or whorled spreading branches or long and slender with ascending or erect branches: leaves usually in whorls of 4's or 5's, or sometimes alternate; blades linear to linear-lanceolate, 1-3 cm. long, acute : racemes spike-like, 3-6 mm. thick, narrowly conic, sessile or slender-peduncled, the rachis $0.5-6 \mathrm{~cm}$. long: pedicels about $5 \mathrm{~mm}$. long, their bracts deciduous : flowers greenish or greenish white : wings ovate, about $1 \mathrm{~mm}$. long, nerveless : keel crested with several thick processes: capsule about $2 \mathrm{~mm}$. long, barely surpassing the wings : seeds pubescent or rarely glabrous, the 2 lobes of the caruncle about $\frac{1}{2}$ as long as the seed-body.

In dry soil, Quebec to Maine and Manitoba, Florida and Mexico. Spring to fall.

22. Polygala Marlàna Mill. Annual, deep green, glabrous. Stems erect, 1-5 dm. tall, slender, simple or branching above : leaves alternate; blades linear, $0.4-1.7 \mathrm{~cm}$. long, often erect, acute or cuspidate, often much reduced above : racemes cylindric-ovoid, or subglobose, $6-10 \mathrm{~mm}$. thick, peduncled : pedicels slender, 1-3 $\mathrm{mm}$. long, their bracts deciduous : flowers pink : wings ovate to elliptic, about $3 \mathrm{~mm}$. long, 5 -nerved, the midnerve thickened at the apex : keel crested with a few short blunt, or 2-cleft processes : stamens 8 : style slender, auricled above the sessile stigma, prolonged into a curved, tufted appendage : capsule turgid: seeds with a long neck, apiculate at the larger end, pubescent, the 2 lobes of the caruncle embracing the smaller end of the seed-body.

In low pine lands, Delaware to Florida and Texas. Summer to fall.

23. Polygala Nuttállii T. \& G. Resembling P. Mariana. Stems 1-2.5 dm. tall, with few upright branches : leaves alternate ; blades spatulate to almost linear, 5-10 mm. long, the upper much narrower than the lower : racemes cylindric, 4-6 mm. thick, obtuse or acutish, peduncled : corolla purplish or greenish white, about $2 \mathrm{~mm}$. long: wings ellipticlanceolate, about $2 \mathrm{~mm}$. long, acutish : capsule broader than long: seeds pubescent, each with 2 caruncle-lobes about $\frac{1}{3}$ as long as the seed-body.

In poor soil, Massachusetts to Missouri, North Carolina, Alabama and Arkansas. Summer.

24. Polygala viridéscens L. Annual, bright green, glabrous. Stems erect, 1-5 dm. tall, angled, simple or branching above: leaves alternate; blades linear to linearoblong, 1-3 dm. long, acute or cuspidate, sessile : racemes ovoid or subglobose, 8-12 mm. thick, blunt, short-peduncled : pedicels slender, 1-2 mm. long, their lanceolate bracts persistent : flowers reddish purple, green or white : wings broadly ovate, $3-6 \mathrm{~mm}$. long, about 9 -nerved, imbricated, the midnerve thickened above the middle, usually prolonged into a mucro: keel crested with a few thick processes: stamens 8: style auricled at the almost sessile stigma, prolonged into a curved tufted appendage : capsule suborbicular, about 2 
mm. broad : seeds pubescent, the 2 lobes of the caruncle collateral, diverging or straddling the seed, as long as the seed-body or only $\frac{1}{2}$ as long. $\quad[P$. sanguinea L. $]$

In swamps, Nova Scotia and Ontario to Minnesota, south to North Carolina, Kentucky and the Indian Territory. Summer.

25. Polygala Curtíssii A. Gray. Annual, glabrous throughout. Stems erect, 1-3 dm. tall, simple or sometimes much branched : leaves alternate, more or less spreading; blades linear, 1-2 $\mathrm{cm}$. long, acute, sessile : racemes cylindric-ovoid or subglobose, 10-13 $\mathrm{mm}$. thick, apiculate, long-peduncled : pedicels 1.5-2.5 mm. long, surpassing the persistent bracts : flowers rose-purple : wings narrowly ovate, or ovate-elliptic, $4 \mathrm{~mm}$. long, mucronate, about 7 -nerved, the midnerve thickened only at the apex : keel crested with a few obtuse processes: stamens 8: style markedly auricled at the almost sessile stigma, prolonged into a slender curved, tufted appendage: capsule cuneate or obovate-cuneate, about $2 \mathrm{~mm}$. long: seeds $15 \mathrm{~mm}$. long, pubescent, apiculate at the larger end, the 2 lobes of the caruncle scale-like, obovate, about $\frac{1}{4}$ as long as the seed-body.

In sandy soil, Pennsylvania to Kentucky, Georgia and Alabama. Summer.

26. Polygala Hárperi Small. Annual, glabrous. Stems erect, $1.5-4 \mathrm{dm}$. tall, usually somewhat branched: leaves alternate, erect or the upper ones appressed ; blades linearspatulate on the lower part of the stem passing to linear or linear-subulate above, $1-1.5 \mathrm{~cm}$. long or shorter on the branches, acute or minutely subulate-tipped, sessile : racemes globoseovoid, or broader than high, 10-12 mm. thick: pedicels $1.5-2.5 \mathrm{~mm}$. long, twice or thrice as long as the deciduous bracts: flowers pink: wings elliptic, $4 \mathrm{~mm}$. long, 7 -nerved, the midnerve slightly thickened at the apex : keel crested with blunt processes: stamens 8 : style slightly auricled at the closely sessile stigma, prolonged into a stout tufted appendage: capsule obovate or orbicular-obovate, $2 \mathrm{~mm}$. long : seeds $1 \mathrm{~mm}$. long, sparingly pubescent, the 2 lobes of the caruncle nearly $\frac{1}{2}$ as long as the seed-body.

In pine lands, Georgia to Louisiana. Spring and summer.

27 Polygala Hoòkeri T. \& G. Annual, slender, glabrous. Stems erect, 1-3 dm. tall, simple or branched, 4-angled: leaf-blades linear, usually in whorls of 4's, acute, the lower ones very small, the others $3-12 \mathrm{~mm}$. long, sessile, those of the branches scattered : racemes long-peduncled, $7-8 \mathrm{~mm}$. thick, attenuate at the apex, the rachis $1-4 \mathrm{~cm}$. long: pedicels $1.5-2 \mathrm{~mm}$. long, their persistent bracts ovate, about $\frac{1}{3}$ as long as the pedicels: flowers pink : wings ovate-lanceolate, about $4 \mathrm{~mm}$. long, mucronate, 6 -nerved : keel with a small fimbriate crest : stamens 8: capsule orbicular or reniform-orbicular, barely $2 \mathrm{~mm}$. long: seeds barely $1 \mathrm{~mm}$. long, sparingly pubescent, the 2 lobes of the caruncle as long as the seed-body or longer.

In grassy pine lands, Florida to Texas. Summer to fall.

28. Polygala brevifolia Nutt. Annual, glabrous throughout. Stems 1-6 dm. long, erect, or weak and decumbent, sometimes flexuous, simple or with spreading branches, 4-angled : leaves in whorls of 4's except the upper ones ; blades oblanceolate, linear to narrowly elliptic, $1-2.5 \mathrm{~cm}$. long, punctate, acute : racemes rather dense, ovoid, mainly 7-8 $\mathrm{mm}$. thick, often apiculate, peduncled : pedicels 1-2 mm. long, surpassing their persistent bracts : flowers rose-purple : wings ovate or ovate-oblong, $3.5-4.5 \mathrm{~mm}$. long, apiculate by the thickened excurrent midnerve : keel with a crest of a few thick processes: stamens 8 : capsule orbicular or reniform-orbicular, $2 \mathrm{~mm}$. wide : seeds $1.5 \mathrm{~mm}$. long, sparingly pubescent, the 2 lobes of the caruncle about as long as the seed-body.

In sandy swamps, Rhode Island to Florida and Mississippi. Summer and fall.

29. Polygala cruciàta L. Annual, glabrous. Stems $0.5-4 \mathrm{dm}$. tall, more or less branched, 4-angled : leaves in whorls of 4's or 5's ; blades spatulate, linear-spatulate or almost linear, 1-3 cm. long, acute or acutish : racemes dense, 1-5 cm. long, $1-2 \mathrm{~cm}$. thick, cylindric, sessile or short-peduncled : flowers rose purplish or greenish : wings deltoid, each tipped with a tail-like acumination, variable in size : keel with a crest of few, rather thick processes : stamens 8 : seeds about $1.5 \mathrm{~mm}$. long, the caruncle-lobes as long as the seed-body or somewhat shorter.

In bogs or moist soil, Maine to Minnesota Florida and Louisiana. Summer.-A robust form from the Gulf States, with relatively narrower leaf-blades, pedunculate racemes and more purple flowers, is $P$. cruciata ramosior Nash.

30. Polygala nàna (Michx.) DC. Biennial, glabrous throughout. Stems erect or ascending, simple, solitary, or of ten tufted, $1-15 \mathrm{~cm}$. tall, sometimes almost wanting : leaves
thick, the basal often numerous, spatulate, $1-4 \mathrm{~cm}$. long, rounded or mucronate at the apex, stem-leaves few, scattered, with narrowly spatulate or oblanceolate cuspidate blades, or wanting : racemes subglobose or cylindric, $1-1.5 \mathrm{~cm}$. thick, dense, the early ones sessile, the later ones peduncled; rachis $2-5 \mathrm{~cm}$. long: flowers yellow or greenish yellow, turning dark green or nearly black in drying: wings ovate-lanceolate, about $3 \mathrm{~mm}$. long, long- 
acuminate : keel with a crest of several acute, entire or cleft processes : stamens usually 6 : style slender: seeds fully $1 \mathrm{~mm}$. long, pubescent, the 2 lobes of the caruncle spreading, about $\frac{1}{2}$ as long as the seed-body.

In sandy pine lands, South Carolina to Florida, Louisiana and Arkansas. Throughout the year.

31. Polygala lùtea L. Biennial, bright green, glabrous. Stems ascending or decumbent, 1-3 dm. long, sometimes tufted, simple or sparingly branched: leaves fleshy, the basal spatulate or obovate, or the blades ovate, $1-5 \mathrm{~cm}$. long, rounded or notched at the apex ; lower stem-leaves similar to the basal, the upper ones varying through oblanceolate to linear-elliptic or nearly linear, acute or acutish, sessile or the petioles short: racemes dense, ovoid, subglobose or oblong, 1-1.5 cm. thick, long- or short-peduncled; rachis 1-5 $\mathrm{cm}$. long: pedicels $1.5-2 \mathrm{~mm}$. long, their bracts deciduous : flowers orange-yellow, drying greenish yellow : wings obovate-elliptic, 4-6 mm. long, cuspidate, commonly 7 -nerved : keel with a small fimbriate crest: stamens 8 : style slender: prolonged into a curved tufted appendage : seeds nearly $1.5 \mathrm{~mm}$. long, slightly pubescent, the 2 lobes of the caruncle narrow, nearly as long as the seed-body.

In low pine lands, New York to Florida and Mississippi, Spring and summer. Wild Bachelor's ButTon.

32. Polygala Rugélii Shuttlw. Biennial, bright green, glabrous Stems erect or ascending, 3-7 dm. tall, sometimes tufted, simple or sparingly branched above : leaves fleshy, the basal and lower stem-leaves spatulate, $2.5-5 \mathrm{~cm}$. long, obtuse, upper stem-leaves alternate, oblanceolate to lanceolate, shorter and smaller than the stem-leaves, acute, sessile : racemes dense, ovoid or subglobose, $15-20 \mathrm{~mm}$. thick, long-peduncled : rachis $2-3.5 \mathrm{~cm}$. long : pedicels $3-4 \mathrm{~mm}$. long, their bracts deciduous : flowers yellow, turning dark green in drying: wings obovate or elliptic-obovate, about $7 \mathrm{~mm}$. long, cuspidate, 7-9-nerved as the other sepals : keel crested with a few thick processes, entire or 2-cleft: stamens $8:$ style slender, auricled at the base of the slender-stalked drooping stigma, produced into a tufted appendage: seeds $1.5 \mathrm{~mm}$. long, pubescent, the 2 lobes of the caruncle about as long as the seed-body, spongy.

In pine lands, Florida. Spring to fall.

33. Polygala Baldwínii Nutt. Biennial, pale green, glabrous. Stems erect, 2-6 dm. tall, simple or branching above, corymbosely branched at the top, sometimes tufted : leaves thickish, the basal spatulate or obovate, 1-3 cm. long: stem-leaves alternate; blades obovate, narrowly spatulate to lanceolate, shorter than the basal leaves, acute: corymbs simple or compound : racemes ovoid or subglobose, the rachis 1-3 $\mathrm{cm}$. long: flowers white, fragrant, nearly sessile : wings ovate-lanceolate, about $4 \mathrm{~mm}$. long, narrowed into a slender tip : keel with a minute fimbriate crest : stamens $8:$ style slender : capsule minute, barely $0.7 \mathrm{~mm}$. broad : seeds about $0.5 \mathrm{~mm}$. long, pubescent, brown, the caruncle with 2 minute scale-like lobes.

In pine lands and swamps, Georgia and Florida to Mississippi. Summer.

34. Polygala ramòsa Ell. Biennial, bright green, glabrous. Stems simple below and erect or branched at the base, $1-5 \mathrm{dm}$. tall, corymbosely branched above : leaves thickish, the basal with spatulate or obovate blades, $2-3 \mathrm{~cm}$. long and short petioles : stem-leaves alternate; blades narrowly spatulate, oblanceolate to linear, shorter than the basal, acute ; corymbs compound : racemes ovoid or oblong; rachis $1-2 \mathrm{~cm}$. long : pedicels about $2 \mathrm{~mm}$. long, the bracts lanceolate, 1-1.5 mm. long: flowers yellow, turning dark green or blackish in drying: wings ovate-lanceolate or oblong, about $3 \mathrm{~mm}$. long, acuminate, twice or thrice larger than the other sepals: keel with a small fimbriate crest : stamens 8 : style slender, broadened and auricled near the almost sessile stigma, prolonged into a curled appendage with a tufted sometimes 2 -lobed end : seeds about $0.5 \mathrm{~mm}$. broad, pubescent, brown, the caruncle of 2 scale-like lobes.

In swamps, Delaware to Florida and Texas. Summer and fall.

35. Polygala cymòsa Walt. Biennial, glabrous throughout. Stems solitary, erect, 4-12 dm. tall, seape-like, corymbosely branched above : leaves thick, the basal numerous; blades linear, spreading, $5-20 \mathrm{~cm}$. long, acuminate, sessile : stem-leaves smaller, few, scattered : corymbs simple or compound : racemes ovoid or cylindric; rachis $1-5 \mathrm{~cm}$. long: pedicels about $2 \mathrm{~mm}$. long, their bracts lanceolate, persistent: flowers lemon-yellow, turning blackish green in drying: wings elliptic or narrowly obovate, mucronate, about $4 \mathrm{~mm}$. long, nearly twice as large as the other sepals : keel with a crest of a few small processes: stamens $8:$ style broadened at the middle, prolonged into a curved appendage: stigma lateral, short-stalked: seeds $0.8 \mathrm{~mm}$. in diameter, brown, glabrous, the caruncle ob-
solete.

In pine-land pools, Delaware to Florida and Louisiana. Spring and summer. 


\section{Order 16. EUPHORBIÀLES.}

Herbs, shrubs or trees, sometimes aquatic or amphibious, but mainly terrestrial, commonly with a milky juice. Leaves various, sometimes reduced to scales or almost wanting. Flowers mainly monoecious or dioecious, regular. Calyx of several sepals. Corolla of several petals, or often wanting. Androecium of more than one stamen, except when the staminate flowers are scattered over the inside of an involucre or in the flowers of Callitriche. Filaments distinct or united into a column. Anthers opening by longitudinal or transverse valves. Gynoecium of 2,3 or 4 united carpels, superior. Styles or stigmas usually distinct and cleft or foliaceous, united by pairs in CALLITRICHACEAE. Ovules 1, 2 or 3 in each cavity. Fruit capsular, sometimes achene-like. Seeds often carunculate.

Styles or stigmas distinct or mainly so, cleft or foliaceous : ovary 3-celled or rarely 1-2-celled : stamens . several, except when on the inside of an involucre. Styles united by pairs : ovary 4-celled: stamen solitary.

Fam. 1. EUPHORBIACEAE.

Fam. 2. Callitrichaceae.

\section{Family 1. euphorbiàceat J. St. Hil. Spurge Family.}

Monoecious or dioecious herbs, shrubs or trees, with acrid often milky sap. Leaves opposite, alternate or verticillate, entire or toothed, sessile or petioled, sometimes with glands at the base. Stipules present, obsolete or wanting. Inflorescence various. Flowers apetalous or petaliferous, sometimes much reduced and subtended by an involucre which resembles a calyx (Euphorbia and related genera), the number of parts in the floral whorls often different in the staminate and pistillate flowers. Stamens few, or numerous, in one series or many Filaments separate or united. Ovary usually 3-celled. Ovules 1 or 2 in each cavity, pendulous. Styles as many as the cavities of the ovary, simple, divided, or many-cleft. Fruit a mostly 3 -lobed capsule, separating at maturity, often elastically, into 32 -valved carpels from a persistent axis. Seeds anatropous. Embryo straight, or slightly curved, in fleshy or oily endosperm, the broad cotyledons almost filling the seed-coats.

A. Flowers not in an involucre: calyx of several sepals.

Ovules and seeds 2 in each cavity.

Monoecious or rarely dioecious: ovary 3-celled ; fruit capsular.

Stamens 5-6.

Stamens 2-3.

Stamens 3: filaments partially united.

Stamens 2 : filaments distinct.

Dioecious : ovary 1-2-celled: fruit drupaceous or baccate.

1. ANDrachne.

2. Phyllanthus.

3. REVERCHONIA.

4. DRYPETES.

Ovules and seeds solitary in each cavity.

a. Flowers either staminate or pistillate or both in more or less elongated spikes or racemes (pistillate basal), if clustered on spurs corolla wanting. Corolla present in either staminate or pistillate flowers or in both (except in (roton maritimus).

Stamens 5-6: filaments distinct.

Filaments 6: capsules 3-celled, dehiscent.

Filaments 5: capsules 1-celled, achene-like.

Stamens 10: filaments monadelphous.

Corolla wanting.

Styles 2-3: ovary 2-3-celled.

Ovary and capsule 2-celled : styles 2 : sepals distinct.

Ovary and capsule 3-celled: styles 3 (gynoecium sometimes 2-carpellary in Sapium, but sepals partially united).

Stamens numerous, 8-20, rarely few in some flowers.

Staminate flowers clustered in the axils.

Staminate flowers in spikes or racemes.

Stigmas 2-cleft (in our species): pistillate flowers terminal. Stigmas dissected: pistillate flowers axillary.

Stamens 1-5.

Pistillate flowers and capsules pedicelled. Calyx manifest. Calyx obsolete or rudimentary.

Pistillate flowers and capsules sessile. Receptacle with a central column. Fruit dry : seeds with caruncles. Fruit fleshy: seeds without caruncles. Receptacle with 3 horns.

Styles 6-8: ovary 6-8-celled.

5. CROTON.

6. CROTONOPSIS.

7. Ditaxis.

8. Mercuralis.

9. Ricinelia.

10. BERNARDIA.

11. ACALYPHA.

12. Tragia.

13. GYMNANTHES.

14. Sebastiana.

15. Sapium.

16. Stillingia.

17. HIPPOMANE. 
b. Flowers either staminate or pistillate or both in cymes or corymbs, or if racemose pistillate terminal, if clustered on spurs corolla present. Leaf-blades peltate.

Leaf-blades not peltate.

Flowers clustered on leafy spurs.

Flowers in more or less open cymes or panicles.

Flowers in forking cyme-like panicles. Stamens 10 or more : petals wanting. Stamens 10 or fewer: petals present.

Flowers in simple or branched racemes.

B. Flowers in involucres: calyx represented by a minute scale at the base of a filament-like pedicel. ${ }^{1}$

Glands of the involucres with petal-like appendages, these sometimes much reduced.

Leaves all opposite.

Leaf-blades inequilateral, oblique at the base.

Leaf-blades equilateral, not oblique at the base.

Leaves alternate or scattered at least below the inflorescence.

Stems terminating in a spicate or racemose inflorescence. Stems topped by simple or compound umbels.

Annual or biennial : stipules narrow: bracts petal-like.

Perennial: stipules nonel: bracts not petal-like.

Glands of the involucres without petal-like appendages, entirely naked, sometimes with crescent-like horns.

Stem topped by an umbel : stipules none: involucres in open cymes, each with 4 glands and entire or toothed lobes.

Stem not topped by an umbel : stipules gland-like: involucres in cluster-like cymes, each with a single gland or rarely 4 glands and fimbriate lobes.

18. Ricinus.

19. Mozinna.

20. CNidoscolus.

21. JATROPHA.

22. MANIHOT.

\section{ANDRÁCHNE L.}

Herbs or shrubby plants, with branching, sometimes diffuse stems. Leaves alternate: blades often entire, petioled. Flowers monoecious, axillary : staminate commonly clustered; calyx of 5 or 6 sepals ; petals 5 or 6 ; disk glandular or lobed ; stamens 5 or 6 , their filaments distinct. Pistillate flowers solitary : calyx of 5 or 6 sepals : petals minute or wanting : ovary 3-celled : styles distinct, 2-cleft or 2-parted. Ovules 2 in each cavity. Capsule becoming dry, separating into three 2-valved carpels. Seeds somewhat curved, with a rugose testa.

Foliage glabrous to the twigs: leaf-blades longer than broad, rounded or cuneate at the base.

Foliage somewhat hirsute: leaf-blades as broad as long, subcordate at the base. $\quad$ 2. A. Reverchomii.

1. Andrachne phyllanthoìdes (Nutt.) Muell. Arg. A straggling much branched shrub $3-9 \mathrm{dm}$. tall, with lustrous glabrous branches and minutely pubescent twigs. Leaves numerous, bright green : blades obovate or oval, 7-20 mm. long, obtuse or retuse at the apex, often mucronulate, paler beneath than above: pedicels filiform, $5-20 \mathrm{~mm}$. long, glabrous : sepals oblong-obovate, $1.5-3 \mathrm{~mm}$. long, spreading: petals various, those of the staminate flowers greenish yellow, narrowly obovate or oblong-obovate, 3-5-toothed : those of pistillate flowers much smaller, broadly obovate, entire : capsules subglobose, rather fleshy until mature.

On rocky barrens, Missouri to Arkansas and Texas. Summer.

2. Andrachne Reverchònii Coulter. A branching shrub 3-6 dm. tall, with sparingly hirsute foliage, and reddish more or less curved stems. Leaves alternate, approximate : blades suborbicular or cuneate-orbicular, 8-16 $\mathrm{mm}$. long, glabrate above, pale-green, truncate or retuse at the apex, entire, subcordate at the base : sepals oblong or nearly so, ciliate : petals cuneate, shorter than the sepals, those of staminate flowers more distinctly denticulate than those of pistillate flowers: capsules depressed, less than $1 \mathrm{~cm}$. broad.

On rocky prairies, Texas. Spring.

\section{PHYLLÁNTHUS L.}

Annual or perennial herbs, or often shrubs or trees in the tropics. Leaves alternate, often numerous, sometimes so arranged as to appear like the leaflets of a compound leaf: blades entire, commonly sessile. Flowers monoecious, apetalous, sessile or pedicelled, a staminate and a pistillate one together in an axil, sometimes on the edges of leaf-like branches. Sepals mostly 5-6, imbricated. Stamens usually 3: filaments more or less united, rarely separate. Ovary 3-celled : styles 3, each 2-cleft. Ovules 2 in each cavity. Capsule globose or depressed, each carpel 2-seeded.

A. Annual, or perhaps sometimes perennial, species : stems solitary and mostly simple at the base.

Capsules $3 \mathrm{~mm}$. broad.

Capsules $2 \mathrm{~mm}$. broad.

a. Branches erect or ascending : sepals 6 .

1. P. Avicularia.

2. P. Carolinensis.

${ }^{1}$ The following genera are commonly included in the composite genus Euphorbia, but the name Euphorbia is to be associated with certain of the Cactus-like relatives of the Old World. 
b. Branches spreading or recurved : sepals 5 .

Staminate flowers with orbicular outer sepals: pedicels of the staminate flowers not thickened above.

Staminate flowers with ovate outer sepals : pedicels of the staminate flowers much thickened above.

B. Perennial species : stems clustered on the rootstock.

Leaf-blades of an oblong type.

Leaves mostly thrice as long as broad: Floridian species.

Leaves mostly twice as long as broad: Texan species.

Leaf-blades of an obovate or cuneate type.

Stems naked, with internodes longer than the leaves.

Stems leafy with internodes shorter than the leaves.

3. P. Niruri.

4. P. abnormis.

5. P. Garberi.

6. P. Drummondii.

7. $P$. radicans.

8. P. polygonoides.

1. Phyllanthus Aviculària Small. Annual, or perhaps also perennial, bright green. Stems simple or sparingly branched near the base and above, 3-6 dm. long, pubescent, striate in age : leaves ascending ; blades oblong, or slightly broadest above the middle, 8$18 \mathrm{~mm}$. long, blunt or barely pointed, slightly paler beneath than above, rounded or truncate at the base; petioles $1 \mathrm{~mm}$. long or shorter: calyx short-pedicelled; staminate delicate, barely $2 \mathrm{~mm}$. broad, the sepals orbicular-obovate or suborbicular ; pistillate firmer, fully $2 \mathrm{~mm}$. broad or barely $3 \mathrm{~mm}$. at maturity, the sepals oblong or oval, scarious-margined, persistent : capsules spheroidal, $3 \mathrm{~mm}$. broad.

In dry soil, Texas and northern Mexico. Summer and fall.

2. Phyllanthus Carolinénsis Walt. Annual, dark green, glabrous. Stem slender, erect or ascending, 1-5 dm. high, simple or branched, the branches 2-ranked : leaves rather numerous; blades obovate or nearly oblong, 6-20 $\mathrm{mm}$. long, obtuse, narrowed to a very short petiole, or nearly sessile: flowers inconspicuous, nearly sessile in the axils: sepals linear-cuneate or oblong-cuneate : capsules about $2 \mathrm{~mm}$. broad : seeds 1-1.5 mm. long, marked with lines and minute papillæ.

In sandy or gravelly soil and moist woods, Pennsylvania to Illinois, Florida, Texas and Central America. Spring to fall.

3. Phyllanthus Nirùri L. Annual, glabrous. Stems erect or ascending, 1-3 dm. tall, the branches $3-10 \mathrm{~cm}$. long, spreading or recurving : leaves alternate; blades thin, oblong or slightly broadest above the middle, $3-10 \mathrm{~mm}$. long, obtuse, short-petioled, approximate on the branchlets : pedicels about $1 \mathrm{~mm}$. long: sepals orbicular or oval, barely $1 \mathrm{~mm}$. long, the outer ones orbicular, all abruptly pointed : capsules 3-lobed, about $2 \mathrm{~mm}$. broad, smooth : seeds about $1 \mathrm{~mm}$. long.

In sand, peninsular Florida and the Keys. Also in tropical America. Spring to winter.

4. Phyllanthus abnórmis Baill. Annual, bright green. Stem erect or ascending, 2-4 dm. tall, more or less branched near the top, the short branches spreading or ascending: leaves alternate; blades thick, oblong or nearly so, 3-7 mm. long, obtuse, nearly sessile : sepals ovate, the outer somewhat broader than the inner, fully $1 \mathrm{~mm}$. long: capsules manifestly depressed, $2-2.5 \mathrm{~mm}$. broad, smooth : seeds fully $1 \mathrm{~mm}$. long.

In sand or coral rock, Florida Keys. Spring to winter.

5. Phyllanthus Gárberi Small. Perennial, glabrous, glaucescent. Stems branched at the base, the branches ascending or decumbent, 1-3 dm. long, more or less again branched : leaves alternate ; blades thickish, oblong or nearly so, 6-8 mm. long, obtuse or retuse at the apex, flat, abruptly narrowed or truncate at the base: pedicels abont $1 \mathrm{~mm}$. long, enlarged upward: sepals oblong, ovate or oval, $0.5-0.8 \mathrm{~mm}$. long, those of the staminate flowers much more delicate than those of the pistillate : capsules spheroidal, $2.5-3$ $\mathrm{mm}$. broad, smooth : seeds nearly $1.5 \mathrm{~mm}$. long, smooth.

In sand, peninsular Florida. Spring.

6. Phyllanthus Drummóndii Small. Perennial, deep green. Stems branched at the base, the branches erect or ascending, 0.5-2.5 dm. long, sparingly branched, rather wiry : leaves numerous ; blades oblong or nearly so, 3-6 mm. long, about twice as long as wide, obtuse, nearly sessile : pedicels about $0.5 \mathrm{~mm}$. long : sepals suborbicular or ovalorbicular, barely $1 \mathrm{~mm}$. long, those of the staminate flowers somewhat smaller and more delicate than those of the pistillate flowers : capsules spheroidal, about $2 \mathrm{~mm}$. broad : seeds fully $1 \mathrm{~mm}$. long.

On sandy banks, middle and southern Texas. Spring to fall.

7. Phyllanthus radìcans (Muell. Arg.) Small. Perennial, glabrous. Stems numerous, tufted, $0.5-3 \mathrm{dm}$. long, wire-like, ascending or decumbent, rather rigid : leaves alternate; blades thin, oblong, cuneate or oval, 3-8 $\mathrm{mm}$. long, slightly revolute, pale beneath, usually approximate on the branchlets : sepals oblong-oval or ovate, barely $1 \mathrm{~mm}$. long, obtuse : capsules spheroidal, $1-1.3 \mathrm{~mm}$. broad : seeds nearly $1 \mathrm{~mm}$. long. $[P$. Niruri var. radicans Muell. Arg.]

In sand, peninsular Florida and the Keys, and in Cuba. Spring to winter. 
8. Phyllanthus polygonoides Nutt. Perennial, slender. Stems more or less diffusely branched at the base ; branches wire-like, $0.5-3 \mathrm{dm}$. long, simple or branching: leaves alternate ; blades oblong or oblong-cuneate, $5-15 \mathrm{~mm}$. long, obtuse or apiculate, entire, short-petioled : flowers $2-3$ in an axil or sometimes solitary: pedicels slender, $2-5 \mathrm{~mm}$, long : sepals oval or rhombic, $1-1.5 \mathrm{~mm}$. long, white-margined, acute : capsules spheroidal. 3-3.5 mm. broad, glabrous : seeds $1.5 \mathrm{~mm}$. long, minutely warty.

In sandy or rocky soil, Texas. Spring to fall.

\section{REVERCHÒNIA A. Gray.}

Annual monoecious or dioecious herbs, with glabrous foliage. Stems terete, forking. Leaves alternate : blades entire, petioled. Flowers inconspicuous : staminate with a calyx of 4 sepals; stamens 2, short ; filaments distinct; anthers introrse, opening lengthwise, Pistillate flowers with a calyx of 5 sepals and a 6 -lobed disk; ovary 3-celled; styles 3 . distinct; stigmas notched. Ovules 2 in each cavity. Capsule becoming dry, usually depressed. Seeds 2 in each cavity.

1. Reverchonia arenària A. Gray. Annual, glabrous, glaucous. Stems 3-6 dm. tall, zigzag, widely branched, rarely diffuse : leaf-blades linear to oblong or oblong-spatulate, 2-4 cm. long, acute or rather obtuse, entire, flat, sessile : flowers inconspicuous ; staminate clustered; pistillate axillary, short-pedicelled, sometimes solitary in the staminate clusters : perianth greenish, turning purplish : sepals 6 , linear or linear-lanceolate : capsules spheroidal, $8-10 \mathrm{~mm}$. broad, faintly reticulated : seeds mottled, 5-6 mm. long.

In dry soil, Texas and adjacent Mexico. Spring and summer.

\section{DRYPÈTES Vahl.}

Evergreen shrubs or trees, with glabrous foliage and milky sap. Leaves alternate, persistent: blades leathery, entire or undulately toothed. Flowers dioecious, apetalous: staminate in rather dense axillary clusters : pistillate solitary or few in axillary clusters. Pedicels short and often stout. Sepals 4-8, imbricated. Petals wanting. Stamens inserted under the edge of a flat or concave disk: filaments filiform, distinct: anthers extrorse, erect. Ovary sessile on the disk, 1-2-celled: style almost wanting: stigmas disk-like or 2 -lobed. Ovules 2 in each cavity, pendulous, anatropous. Berry or drupe globose or oblong, with a fleshy pulp and a bony stone. Seed with a crustaceous or membranous testa. Guiana Plum. Whitewood.

Sepals 4: ovary 2-celled: drupe subglobose.

Sepals 8: ovary 1-celled : drupe slightly elongated.

1. D. lateriflora. 2. D. Keyensis.

1. Drypetes lateriflòra (Sw.) Urban. A shrub or tree, reaching a height of $10 \mathrm{~m}$., the foliage glabrous in age. Leaf-blades leathery, oblong or elliptic, $5-12 \mathrm{~cm}$. long, acute or short-acuminate at both ends, entire, lustrous, delicately reticulated beneath : petioles $5-10 \mathrm{~mm}$. long: clusters few-flowered : pedicels shorter than the petioles : calyx greenish white, campanulate : sepals oblong, or ovate, obtuse, $1.5-2 \mathrm{~mm}$. long, pubescent without : stamens 4 : drupes subglobose, 6-8 $\mathrm{mm}$. in diameter, dark brown, tomentulose, ripe in spring or summer. [D. crocea Poir.]

In woods, southern peninsular Florida and the Keys. Also in the Bahamas and West Indies.

2. Drypetes Keyénsis Urban. A shrub or tree, sometimes $12 \mathrm{~m}$. tall, with a milkwhite bark and glabrous and glaucous foliage. Leaf-blades leathery, oblong, elliptic or oval, 4-10 $\mathrm{cm}$. long, obtuse, acute or slightly acuminate at both ends, delicately nerved beneath : petioles 5-10 mm. long: clusters few-flowered; the staminate with more flowers than the pistillate, the pistillate flowers sometimes solitary : pedicels much shorter than the petioles: calyx yellowish : sepals oblong or oval, sometimes slightly rhombic, obtuse, pubescent without : stamens 8 : stigmas lightly oblique : drupes broadly oblong or ovoid, $2-2.5 \mathrm{~cm}$. long, tomentulose, ripe in fall. [D. glauca Nutt., not Vahl.]

In dry sand, Florida Keys.

\section{CRÒTON L. ${ }^{1}$}

Herbs or shrubs, monoecious or rarely dioecious, strong-scented, stellate-pubescent, or scaly, and often more or less glandular. Leaves mostly alternate : blades entire, toothed, or lobed, sometimes with 2 glands at the base. Flowers in axillary or terminal clusters, usually spicate, or racemose. Staminate flowers uppermost : sepals 4-6, usually 5 : petals

\footnotetext{
${ }^{1}$ Contributed by Mr. A. M. Ferguson.
} 
usually present, but often small or rudimentary, alternating with glands: stamens 5 or more, inflexed in the bud. Pistillate flowers clustered or loosely racemose below the staminate : sepals 5-10 : petals usually wanting : ovary mostly 3 -celled : ovule one in each cavity : styles or stigmas once, twice or many times 2-cleft. Capsule splitting into 2-4 (usually 3 ) 2-valved carpels. Seeds one in each carpel, smooth or minutely pitted. The plants flower from spring to fall or throughout the year in many cases.

Staminate and pistillate flowers with petals.

Staminate flowers with petals, or both staminate and pistillate without petals.

Petals present in the staminate flowers, wanting or rudimentary in the pistillate.

Plants with scaly foliage.

Plants with stellate-pubescent foliage.

Pistillate calyx mostly not accrescent : leaf-blades entire.

Leaf-blades ovate to oblong or broadly lanceolate.

Leaves with ovate to narrowly ovate blades.

Stamens 10.

Stamens more than 10 .

Styles 3, twice 2-parted or 4-parted. Styles 3, 2-parted.

Leaves with oblong or broadly lanceolate blades. Staminate raceme less than $5 \mathrm{~cm}$. long.

Staminate raceme more than $5 \mathrm{~cm}$. long.

Leaf-blades linear or narrowly oblong.

Blades narrowly linear, glabrate above.

Blades narrowly oblong, minutely stellate above.

Pistillate calyx mostly accrescent: leaf-blades toothed or entire.

Leaves with toothed blades.

Shrubs.

Herbaceous annuals.

Sepals of pistillate flowers glabrous or nearly so.

Sepals of pistillate flowers pubescent.

Leaves with entire blades.

Plants annual.

Pistillate flowers not pendulous from the base of the'racemes.

Sepals 6-8, equal or nearly so: styles twice or more 2-cleft. Lower leaves with lanceolate, oval or ovate blades: sepals not hooded.

Petioles long, tomentum of inflorescence purplish. Petioles short, tomentum of inflorescence yellowish.
Lower leaves with linear or linear-lanceolate blades: sepals hooded.

Sepals 5, very unequal: styles 2-cleft.

Pistillate flowers early drooping from the base of the racemes. Ovary 3-celled : capsules 3-seeded.

Ovary 2-celled: capsule 1-seeded.

Plants shrubby.

Petals wanting in both the staminate and pistillate flowers.

Plants perennial or shrubby.

Staminate raceme short, $3 \mathrm{~cm}$. or less.

Staminate raceme long, $3 \mathrm{~cm}$. or more.

1. C. Alabamensis.

\section{C. argyranthemus.}

3. C. fruticulosus.

4. C. Berlandieri.

5. C. suaveolens.

6. C. Torreyanus.

7. C. Cortesianus.

8. C. linearis.

9. C. Fergusonii.

10. C. betulinus.

11. C. Floridanus.

12. C. glandulosus.

13. C. capitatus.

14. C. Engelmannii.

15. C. Elliottii.

16. C. leucophyllus.

17. C. Lindheimerianus.

18. C. monanthogynus.

19. C. corymbulosus.

Plants annual.

20. C. punctatus.

21. C. Neo-Mexicanus.

22. C. Texensis.

1. Croton Alabaménsis E. A. Smith. A much branched evergreen shrub 2-3 m. tall, with a grayish white bark, the stem sometimes becoming $6 \mathrm{~cm}$. thick. Leaf-blades oblong to oblong-lanceolate, $5-8 \mathrm{~cm}$. long, firm-membranous, green and glabrate above, clothed beneath with silvery overlapping scales, usually without glands at the slightly oblique base, short-petioled : racemes $3-5 \mathrm{~cm}$. long: flowers sometimes numerous: staminate $10-20$; sepals and petals ciliate; stamens $10-25$ : pistillate flowers 4-7, their pedicels becoming 4-8 mm. long; sepals 3-4 mm. long; petals scaly without; glands 5 : capsules 3-lobed, 6-8 mm. long, depressed at the apex, scaly : seeds oval, biconvex, 5-7 mm. long.

On limestone hills. middle Alabama.

2. Croton argyránthemus Michx. A perennial shrubby plant $3-6 \mathrm{dm}$. tall, with silvery or somewhat rusty foliage and approximate branches. Leaf-blades various, the lower ones obovate to oval, the upper oblong to oblong-lanceolate, $1-5 \mathrm{~cm}$. long, blunt, scaly or glabrate above, clothed with silvery scales beneath, narrowed to petioles which are $\frac{1}{4}-\frac{1}{2}$ as long as the blades : racemes $2-5 \mathrm{~cm}$. long: staminate flowers often $10-15$; sepals lanceolate, acute; petals oblong, scaly without; stamens mostly 10 ; filaments swollen at the base: pistillate flowers few, often nearly sessile ; sepals $5-7$, partially united, acute ; petals wanting; glandular disk entire or 5-lobed : capsules 3-lobed, globular or ovalglobose, about $5 \mathrm{~mm}$. long, depressed at the apex : seeds biconvex, less than $5 \mathrm{~mm}$. long.

In dry soil and pine lands, Georgia and Florida to Texas and New Mexico.

3. Croton fruticulòsus Engelm. A slender branched shrub 1-2 m. tall, with gray or yellowish tomentum, the branches densely stellate-tomentose. Leaf-blades ovate to narrowly ovate, $3-8 \mathrm{~cm}$. long, acute or acuminate, entire or remotely glandular-denticulate, 
more or less puberulent above, tomentose beneath, truncate or cordate at the base ; petioles $\frac{1}{3}-\frac{1}{2}$ as long as the blades: racemes $3-12 \mathrm{~cm}$. long: flowers mostly monoecious, the staminate in interrupted racemes, with pedicels $3-4 \mathrm{~mm}$. long, sepals 5 , oval, acute ; petals 5 , oblongspatulate; glands oval ; stamens $9-10$ : pistillate flowers $2-5$, nearly sessile ; sepals oblong to oblanceolate; petals obsolete or mere rudiments; glands united into an annular disk: capsules globose, 5-6 mm. high, depressed at the apex : seeds oval, 4-5 mm. long, each with an oblong caruncle.

In rocky soil or on bluffs, Texas, New Mexico and Mexico.

4. Croton Berlandièri Torr. A low shrub 3-8 dm. tall, the younger branches pubescent, viscid, becoming smooth and whitish. Leaf-blades ovate to oblong, 2.5-3.5 $\mathrm{cm}$. long, base rounded to subcordate, the basilar glands often abortive, the apex usually abruptly acute, the edges slightly repand and glandular, tomentose above when young, pubescent and paler below : flowers monoecious or dioecious : racemes $3-7 \mathrm{~cm}$. long : stami-, nate flowers on slender pedicels with $15-20$ stamens (30-35 in western forms): pistillate flowers $2-6$ at base of raceme, usually short pedicelled; sepals oblong-spatulate with sessile or short-stipitate marginal glands ; petals reduced to short subulate processes ; styles 3, palmately 4-parted or twice 2-parted, 3-5 mm. long: capsules globose, 4-5 mm. high.

In sandy or dry soil, Florida, the lower coastal regions of Texas and Mexico.

5. Croton suavèolens Torr. A stout much branched, short-jointed, glandular shrub, densely and grayish or yellowish stellate-tomentose throughout. Leaf-blades thickish, ovate or elliptical, $2-4 \mathrm{~cm}$. long, rounded or narrowed at base, loose-tomentose on both sides, whitish below, darker above; petioles short, 5-15 mm. long; stipular glands papillae-like or cylindric, not often rising above the tomentum: racemes bisexual or unisexual (or plants dioecious), stout, $2-4 \mathrm{~cm}$. long and closely flowered; bracts simple or variously lobed or divided, glandular: staminate flowers long-pedicelled; stamens about 15 : pistillate flowers few, short-pedicelled; petals reduced to subulate glands; styles 3 , 2-parted, 3-6 $\mathrm{mm}$. long : capsules globose, 6-7 $\mathrm{mm}$. long.

In dry soil, northern and western Texas and Chihuahua.

6. Croton Torreyànus Muell. Arg. A slender shrub 1-2 m. tall, the branches velvety-stellate. Leaf-blades oblong or narrowly oblong, 3-5 cm. long, obtuse or mucronulate, dark green and tomentose above, whitish and densely stellate-tomentose beneath, shortpetioled : racemes $2-4 \mathrm{~cm}$. long: staminate flowers numerous; sepals 5 , oblong, rather acute ; petals oblanceolate; stamens 12-15: pistillate flowers usually 3 , at the base of the racemes; sepals 5 , acuminate; petals rudimentary : capsules oblong, $6.5-7 \mathrm{~mm}$. long, densely pubescent : seeds about $6 \mathrm{~mm}$. long, biconvex, depressed below the stalked caruncle.

In dry or sandy soil, Texas and New Mexico to Mexico.

7. Croton Cortesiànus Kunth. A shrub 2-3 m. tall, with gray stellate-pubescent dichotomously or trichotomously forked branches. Leaf-blades oblong-ovate to ovatelanceolate, $3-10 \mathrm{~cm}$. long, acute or acuminate, entire or slightly toothed, green and glabrous above, gray beneath, petioled : staminate racemes $1-2 \mathrm{dm}$. long, interrupted, rather rigid : stamens 12-16: pistillate spikes many-flowered, often $3-4 \mathrm{~cm}$. long, dense, the rachis swollen: sepals deltoid: petals linear or rudimentary : glands forming a 5-lobed disk: capsules globose, 6-8 $\mathrm{mm}$. high, coarsely hispid : seeds about $5 \mathrm{~mm}$. long.

In dry soil, southern Texas and Mexico.

8. Croton lineàris Jacq. A shrub 1-2 m. tall, with gray and scabrous dichotomously or trichotomously forked branches and yellowish and densely stellate twigs. Leaf-blades narrowly linear, 4-7 cm. long, 3-5 mm. wide, obtuse, dark green and smooth above, silvery beneath with stellate tomentum, narrowed to the 2 -glandular base : petioles less than $5 \mathrm{~mm}$. long: staminate racemes $4-8 \mathrm{~cm}$. long or becoming longer : sepals $5-6$, triangular : petals spatulate, surpassing the sepals, obtuse, ciliate : stamens about 15 : pistillate racemes 4-5 cm. long, frequently exceeded by the leaves: sepals narrow, acuminate : petals obsolete or rudimentary : capsules subglobose, $5 \mathrm{~mm}$. high, yellowish floccose : seeds broadly oblong, about $3 \mathrm{~mm}$. long.

In pine lands, peninsular Florida and the Keys. Also in tropical America.

9. Croton Fergusònii Small. A much-branched shrub about $1 \mathrm{~m}$. tall, with whitish or grayish stems and densely stellate twigs. Leaf-blades narrowly oblong or broadly linear, $3-4.5 \mathrm{~cm}$. long, 6-12 mm. wide, blunt, entire, their lower surface yellowish and stellate like the twigs, the upper surface channeled and green but minutely stellate, shortpetioled : flowers dioecious ; staminate $12-25$ in stout interrupted racemes $3-5 \mathrm{~cm}$. long ; sepals deltoid, acute; petals spatulate, 2.5-3 mm. long, surpassing the sepals, ciliate; stamens about 15 : pistillate Howers about 6 , in racemes $2-3 \mathrm{~cm}$. long: capsules subglobose, about $5 \mathrm{~mm}$. long : seeds punctate, $3.5-4 \mathrm{~mm}$. long.

In sand, peninsular Florida. Also in the Bahamas. 
10. Croton betulìnus Vahl. A trichotomously branched shrub 1-2 m. tall. Leafblades ovate, 1-2 cm. long, blunt, crenate-dentate, rounded or truncate at the biglandular base, the pubescence more appressed beneath than above: petioles about $\frac{1}{2}$ as long as the blades : flowers monoecious ; staminate subtended by lanceolate bracts 1-2 mm. long; sepals oblong-oval, acute ; petals oblanceolate, ciliate; stamens 9-12 ; filaments pilose at the base: pistillate flowers solitary or 2-3 below the staminate; sepals spatulate, accrescent; petals smaller, subulate, or obsolete : capsules globose-oval, 4.5-5 mm. long: seeds oblong, 3-3.5 $\mathrm{mm}$. long, punctate.

In rocky or sandy soil, peninsular Florida. Also in tropical America.

11. Croton Floridànus Ferguson. A slender, woody annual plant, 2-5 dm. tall, with dichotomous or trichotomous scabro-stellate branches. Leaf-blades various, elliptic to ovate on the lower part of the stem, oblong to lanceolate above, 1-2 cm. long, serratecrenate, biglandular at the base, short-petioled : flowers monoecious, $10-20$ in sessile racemes 2-4 cm. long; staminate inconspicuous; sepals ovate or oblong-ovate; petals oblong or nearly so, narrower than the sepals, ciliate ; stamens about 10 : pistillate flowers solitary or several below the staminate, subtended by deltoid bracts; sepals linear to oblanceolate or spatulate, accrescent; petals rudimentary, subulate: capsules oblong-oval, about $4 \mathrm{~mm}$. long : seeds oval, about $3 \mathrm{~mm}$. long, each tipped with a thick caruncle.

In sand, peninsular Florida.

12. Croton glandulòsus L. A tropical American species represented in our area by the following varieties: C. glandulosus septentrionalis Muell. Arg. with coarsely-stellate foliage and serrate mainly oblong leaf-blades, ranges from Virginia to Iowa, Florida and Texas; C. glandulosus Cróftiae [C. glandulosus Lindheimeri Muell. Arg., not C. Lindheimerianus Scheele], with appressed-stellate foliage, and irregularly elliptic shallowly toothed leaf-blades 1-2 cm. long, occurs in Texas; C. glandulosus Simpsònii Ferguson, with densely stellate foliage and coarsely serrate-crenate ovate leaf-blades, occurs in southern peninsular Florida; C. glandulosus crenatifolius Ferguson, with thinly appressed-stellate foliage and crenate elongated oblong upper leaf-blades, occurs in southern peninsular Florida and on the Keys; C. glandulosus angustifolius Muell. Arg., with thinly appressed stellate foliage and linear remotely serrate upper leaf-blades, occurs in Florida and Texas.

13. Croton capitàtus Michx. Annual, 3-8 dm. tall, the branches approximate above. Leaf-blades various, those of the lower leaves oval, those of the upper leaves oblong, sometimes narrowly so, $2-5 \mathrm{~cm}$. long, mucronate, entire, rounded or rarely cordate at the base and occasionally biglandular, velvety above, densely stellate-tomentose and paler beneath : petioles of the lower leaves as long as the blades or longer: racemes $1-3 \mathrm{~cm}$. long, with loose purplish tinged tomentum : flowers monoecious; staminate short-pedicelled ; sepals 5 , oval, nearly equal ; petals 5 , spatulate, ciliate ; stamens $7-12$; filaments pubescent below ; pistillate flowers usually clustered below the staminate; sepals $6-8$, oblong to oblanceolate ; petals wanting ; styles $3,2-3$ times 2-cleft, 5-6 mm. long : capsules globular, $7-9 \mathrm{~mm}$. long, slightly shorter than the accrescent sepals : seeds suborbicular, much swollen, $5 \mathrm{~mm}$. long.

In dry soil, New Jersey to Iowa, Georgia and Texas.

14. Croton Engelmánnii Ferguson. Annual, 5-20 dm. tall, densely stellate-tomentose, the branches approximate or umbellate above. Leaf-blades lanceolate, sometimes broadly so, those of the lower leaves $10-20 \mathrm{~cm}$. long, those of the upper much shorter, acute or somewhat acuminate, often shallowly and unevenly toothed, rounded or usually cordate at the base: petioles of the lower leaves about as long as the blades, those of the upper shorter: racemes more or less interrupted, $5-15 \mathrm{~cm}$. long, with yellow-tinged tomentum : flowers monoecious ; staminate distinctly pedicelled ; sepals ovate, acute ; petals spatulate, ciliate ; stamens 9-12 ; filaments stellate-pubescent below : pistillate flowers usually 3 , short-pedicelled; sepals 7-8, acuminate, the inner ones smaller; petals wanting; styles 3, twice 2-cleft, 6-10 mm. long : capsules depressed, 6-8 $\mathrm{mm}$. long: seeds oval-orbicular, 4.5-5 mm. long.

In dry soil, Georgia to Arkansas and Texas.-A larger, stouter and more branched form, with broadly ovate lower leaf-blades and white pubescence, is C. Engelmannii albinoides Ferguson; it ranges from the Indian Territory to Texas and New Mexico.

15. Croton Ellióttii Chapm. Annual, 5-9 dm. tall, the stem scabrous below, stellatepubescent above, repeatedly branched, the branches approximate. Leaf-blades linear or linear-lanceolate, 4-5 cm. long, or shorter above, entire, usually blunt, 3-nerved at the narrowed base, velvety stellate above, gray-tomentose beneath, slender-petioled : racemes $1-2 \mathrm{~cm}$. long: flowers monoecious ; staminate short-pedicelled; sepals 5 , narrowly oblong; petals linear, ciliate; stamens 8-10: pistillate flowers clustered; sepals 6-7, unequal; 
petais wanting; styles 3 , twice 2 -cleft, 2-3 $\mathrm{mm}$. long: capsules globose, 4-5 $\mathrm{mm}$. long, sometimes surpassed by the accrescent hooded sepals : seeds oval, $3-4 \mathrm{~mm}$. long.

In sandy soil, South Carolina, Georgia and Florida.

16. Croton leucophýllus Muell. Arg. Annual, 3-5 dm. tall, densely white or yellowish stellate-tomentose, the stem 2-3-dichotomous. Leaf-blades ovate or oblong-ovate, 2-3.5 $\mathrm{cm}$. long, blunt, entire, dark and rough above, pale beneath, rounded at the base : petioles as long as the blades or somewhat shorter: racemes 1-2 cm. long, congested; flowers monoecious; staminate short-pedicelled; sepals 5 , oval; petals oblong-spatulate ; stamens 8-10 : pistillate flowers few ; sepals 5 , the 3 outer oblong, the 2 inner smaller and abruptly subulate; petals wanting; styles 3, 2-cleft, 1-2 mm. long: capsules globular, often depressed, 4-5 $\mathrm{mm}$. long, $\frac{1}{3}$ longer than the sepals : seeds oval, $3-4 \mathrm{~mm}$. long.

In sandy soil, southern Texas.

17. Croton Lindheimeriànus Scheele. Annual, 3-5 dm. tall, greenish pubescent throughout, the stem 2-4-chotomous. Leaf-blades oval to ovate, often somewhat rhombic, 1-3 cm. long, rounded or retuse at the apex, entire or undulate, truncate or cordate at the base: petioles mostly about as long as the blades: racemes few-flowered : flowers monoecious; staminate short-pedicelled; sepals 5 , ovate; petals 5 , spatulate, copiously ciliate ; stamens 7-12; filaments nearly glabrous: pistillate flowers solitary or 2 or 3 together, at the base of the raceme, the long pedicels becoming reflexed; sepals 5 , spatulate to lanceolate, nearly equal; petals wanting or obsolete; styles 3, 2-parted, about $3 \mathrm{~mm}$. long: capsules oval or ovoid-cylindric, 4-5 $\mathrm{mm}$. long, more or less depressed at both ends, usually less than twice as long as the sepals : seeds oblong, 3-4 mm. long.

On prairies or in sandy soil, Kansas to Texas and Mexico.

18. Croton monanthógynus Michx. Annual, $3-5 \mathrm{dm}$. tall, whitish, or sometimes rusty stellate-pubescent or becoming papillate, the stem repeatedly 2 -4-chotomous. Leafblades various, those of the lower leaves suborbicular on long petioles, those of the upper leaves ovate or oblong-ovate, 1-4 cm. long, or slightly longer, usually mucronate, entire, on petioles about $\frac{1}{2}$ their length: racemes about $1 \mathrm{~cm}$. long: flowers monoecious ; staminate short-pedicelled; sepals $3-5$, ovate; petals spatulate, ciliate; stamens 3 to 10 : pistillate flowers $1-4$ below the staminate, reflex at maturity; sepals 5 , oblong; petals obsolete ; ovary 2-celled : capsules ovoid or oval, $3-4 \mathrm{~mm}$. long : seed solitary by the abortion of one ovule, $2.5-3.5 \mathrm{~mm}$. long.

In rocky soil and waste places, Iowa to Illinois, Georgia, Texas and Mexico.

19. Croton corymbulòsus Engelm. Shrubby, silvery throughout, with several stems, simple below, more or less corymbose above. Leaf-blades oval to broadly oblong or suborbicular, $2-4.5 \mathrm{~cm}$. long, mostly mucronate, entire, more loosely pubescent beneath than above, rounded at the base : petioles mostly $\frac{1}{2}$ as long as the blades : racemes becoming quite loose : flowers monoecious or frequently dioecious; staminate relatively longpedicelled; sepals 5, oblong, blunt ; petals spatulate, densely ciliate; stamens 6-18: filaments pubescent below, much exserted : pistillate flowers on much longer pedicels than the staminate and at length recurved; sepals 5-6; petals wanting or mere subulate rudiments ; styles 3, 2-parted, 3-8 mm. long: capsules oval or oblong, 4-7 mm. long, usually $\frac{2}{3}$ longer than the sepals : seeds oblong, $3-5 \mathrm{~mm}$. long.

In sandy soil, Texas to Arizona and Mexico.

20. Croton punctàtus Jacq. Perennial, 5-10 dm. tall, the stem 2-3-chotomous, like the branches gray or rusty tomentose. Leaf-blades elliptic, oblong or ovate, $1-5 \mathrm{~cm}$. long, entire or merely undulate, truncate or cordate at the base, pale or whitish throughout, puberulent above, densely scaly-tomentose beneath: petioles $\frac{1}{2}$ as long as the blades or shorter above: racemes few-flowered: flowers monoecious or dioecious; staminate in racemes 1-2 cm. long, short-pedicelled ; sepals 5-6, triangular, nearly equal ; petals wanting or rudimentary ; stamens normally 12, barely exserted ; filaments pubescent : pistillate flowers $1-3$ in a raceme; sepals 5 , equal, oblong or cuneate; petals wanting; ovary $3-$ celled : capsules subglobose, more or less depressed, 5-8 mm. long, seated in the unchanged calyx : seeds about $6 \mathrm{~mm}$. long. [C. maritimus Walt.]

In sand or sandy soil along sea shores, North Carolina to Florida, Texas and Mexico. Also in tropical America.

21. Croton Neo-Mexicànus Muell. Arg. Shrubby, 3-16 dm. tall, with several erect dichotomous stems from a woody base, silvery throughout, except the upper leaf-surfaces. Leaf-blades narrowly oblong, lanceolate, or elliptic, 1-4 cm. long, entire, green or greenish above, short-petioled: racemes 4-8 $\mathrm{cm}$. long, or the pistillate shorter: flowers dioecious ; staminate often numerous, short-pedicelled ; sepals 5 , lanceolate, equal, relatively thin ; petals wanting; stamens 10-12; filaments pubescent : pistillate flowers 2 -several, or 
sometimes solitary ; sepals often 5, ovate-oblong, obtuse ; petals wanting : capsules globular, 5-6 mm. long : seeds oval, 4-5 mm. long.

On plains and prairies, Texas to New Mexico and Mexico.

22. Croton Texénsis (Kl.) Muell. Arg. Annual, 4-16 dm. tall, the slender stems 2-3-chotomous, the staminate plant more slender and with longer internodes and narrower leaf-blades than those of the pistillate. Leaf-blades linear, lanceolate or oblong, 4-12 cm. long, entire, rounded or blunt at the apex : petioles much shorter than the blades : racemes few-flowered : flowers dioecious ; staminate in racemes $1-3 \mathrm{~cm}$. long ; sepals oblong to ovateoblong; petals wanting; stamens 8-12 ; filaments pubescent : pistillate flowers $2-4$, toothed or solitary; sepals triangular; petals wanting : capsules oval or globular, 4-6 mm. long: seeds orbicular, 3-5 $\mathrm{mm}$. long.

In dry soil, Wyoming to South Dakota, Illinois, Alabama, Arizona and Mexico.

\section{CROTONÓPSIS Michx.}

Annual, slender, silvery-scurfy monoecious herbs, with branched stems. Leaves alternate or rarely opposite: blades narrow, entire, short-petioled. Staminate flowers uppermost in the clusters, each with a calyx of 5 equal sepals, 5 petals and 5 inflexed stamens opposite the petals, the filaments distinct, enlarged at the top. Pistillate flowers each with a calyx of $3-5$ sepals, no petals, 5 petal-like glands opposite the sepals, and a 1-celled ovary. Style twice- or thrice-cleft. Ovule solitary. Fruit a small scaly or spiny achenelike capsule. Seed lenticular or terete, longitudinally wrinkled.

Fruit covered with flat scales.

Fruit covered with spine-like scales.

1. C. linearis.

2. C. spinosa.

1. Crotonopsis lineàris Michx. Stem wiry, 1-4 dm. tall, mostly branched : leaves few ; blades oblong-ovate to linear-lanceolate, 1-2.5 cm. long, entire : staminate flowers uppermost; calyx $1-1.5 \mathrm{~mm}$. broad; sepals ovate; petals spatulate : pistillate flowers inconspicuous; sepals $3-5$, unequal : fruit scaly, ovoid-elliptic : seed ovoid, $2-3 \mathrm{~mm}$. long. and fall.

In dry sandy soil, often on dry granite rocks, New Jersey to Kansas, Florida and Texas. Summer

2. Crotonopsis spinòsa Nash. Stems erect, 3-7 dm. tall, slender, the branches often numerous, erect or ascending : leaves few ; blades linear to narrowly linear-oblong, 1-3 cm. long, acute at both ends, green above, silvery beneath, entire, short-petioled : pedicels less. than $1 \mathrm{~mm}$. long : calyx barely $2 \mathrm{~mm}$. broad, white : sepals broadly oblong or ovate-oblong, incurved : stamens exserted : fruit spiny : seed ovoid or ellipsoid-ovoid, about $2 \mathrm{~mm}$. long, slightly flattened, minutely pitted.

In grassy swamps, Georgia and Florida. Spring to fall.

\section{DITÁXIs Vahl.}

Monoecious or rarely dioecious herbs or shrubs, often perennial by rootstocks, with silky or pilose foliage and purplish sap. Leaves alternate : blades entire, or rarely toothed, often strongly nerved. Flowers in axillary, or axillary and terminal clusters, often racemed, usually bracted. Staminate flowers often crowded at the ends of the racemes. Sepals 4-5, valvate. Petals 4 or 5 , alternate with the sepals and with the lobes of the disk. Stamens of the same number as the petals or two or three times as many : filaments united into a column. Pistillate flowers with the sepals imbricated and smaller or rudimentary petals. Ovary 3-celled, each cavity with 1 ovule: styles 3, distinct, 2-cleft. Capsule 3-lobed, depressed, separating into 3 2-valved carpels. Seed subglobose, wrinkled, or muricate, sometimes crested.

Flowers dioecious : glands abbreviated.

1. D. aphoroides.

Flowers monoecious : glands more or less elongated.

Pistillate flowers with normal petals.

Perennial: leaf-blades entire.

Annual or biennial : leaf-blades toothed.

Pistillate flowers with rudimentary petals.

Foliage shaggy-pubescent : capsules shaggy-hirsute : seeds prominently reticulated.

Foliage strigose-pubescent : capsules minutely pubescent: seeds slightly if at all reticulated.

1. Ditaxis aphoroides (Muell. Arg.) Pax. A low shrub. Leaf-blades obovate, elliptic, ovate or lanceolate, $1.5-4 \mathrm{~cm}$. long, entire, 3-nerved, sessile or nearly so : racemes surpassing the accompanying leaves, long-peduncled, few-flowered: staminate flowers with acute sepals, spatulate-obovate obtuse petals and 8-15 stamens in 2 or 3 series: pistillate flowers with lanceolate sepals and small petals : capsules $6-8 \mathrm{~mm}$. broad, villous.

On plains or prairies, southern Texas. Spring and summer. 
2. Ditaxis hùmilis (Engelm. \& Gray) Pax. Perennial. Stem slender, much branched, pubescent, the branches spreading, 1-3 dm. long: leaf-blades ovate, oblong or oblanceolate, 1-3 cm. long, entire, narrowed into short petioles : flowers in axillary clusters, the staminate with petals a little longer than the 5 sepals and longer than the lobes of the disk : pistillate flowers with 5 sepals and three usually twice 2-cleft styles : capsules shortpedicelled, much depressed, 4-6 mm. in diameter, 3-4-lobed: seeds oval-globose, about 2 mm. long, muricate.

On prairies, Kansas to Louisiana and Texas. Spring to fall.

3. Ditaxis Blodgéttii (Torr.) Pax. Annual or biennial, sparsely pubescent. Stems usually branched at the base, the branches erect, ascending or decumbent, 1-6 dm. long, often slightly zigzag : leaf-blades oval, elliptic or oblong, or spatulate at base of stem, 1.5$4 \mathrm{~cm}$. long, acute or acuminate, serrate, somewhat acuminate at the base, short-petioled: staminate flowers $3-5$ in a cluster: pistillate flowers usually solitary ; calyx strigillose ; sepals linear-lanceolate, acute, $3-5 \mathrm{~mm}$. long; petals greenish white, oblong, slightly longer than the sepals, or shorter and more acute in pistillate flowers : capsules 3-lobed, 4-5 $\mathrm{mm}$. broad, strigose : seeds nearly $2 \mathrm{~mm}$. long, reticulated.

In sandy soil, Key West, Florida. Spring to fall.

4. Ditaxis pilosíssima (Benth.) Heller. Perennial, densely pubescent with woolly hairs. Stems erect or ascending : leaf-blades elliptic, elliptic-ovate or oblong-spatulate at base of stem, 2-5 m. long, obtuse or acutish, several-nerved, sessile : racemes surpassing the leaves, few-flowered : pedicels $3-10 \mathrm{~mm}$. long: caly x pubescent : sepals narrowly lanceolate or linear-lanceolate, becoming $5-7 \mathrm{~mm}$. long, acuminate : petals narrowly spatulate or cuneate, about as long as the sepals, acute, rudimentary in the pistillate flowers: glands villoushirsute : capsules 3-lobed, about $1 \mathrm{~cm}$. broad, densely hairy : seeds subglobose, 4-5 $\mathrm{mm}$. in diameter, reticulated with sharp ridges.

On prairies, Texas. Spring to fall.

5. Ditaxis mercurialina (Nutt.) Coulter. Perennial. Stem slender, strict, usually simple, channeled, silky, 1-6 dm. high. Leaf-blades ovate to narrowly lanceolate or oblanceolate near the base of the stem, 2-5 cm. long, undulate, sessile, often strongly 3-nerved, glabrate : flowers in terminal and axillary racemes; the staminate with lanceolate or linearlanceolate, acute, ciliate sepals, and spatulate-oblong, undulate petals : pistillate flowers with 5 spreading lanceolate sepals, 3 times as long as those of the staminate: petals wanting : capsules depressed, 6-9 mm. in diameter, somewhat silky, 3-lobed : seeds globoseovoid, $4 \mathrm{~mm}$. long, pointed, wrinkled, indistinctly 2 -crested.

In dry soil, Kansas and Arkansas to Texas. Spring to fall.

\section{MERCURIÀLIS L.}

Annual or perennial herbs or shrubby plants, with firm or succulent tissues. Leaves opposite : blades entire or often toothed. Flowers mostly dioecious, apetalous. Staminate flowers in more or less elongated spikes or racemes. Calyx membranous, of 3 valvate sepals. Stamens 8-20 : filaments distinct : anthers opening lengthwise. Pistillate flowers with a calyx of 3 sepals. Ovary 2-celled: styles 2, distinct or nearly so: stigmas entire. Ovules solitary in each cavity. Capsule usually 2-lobed. Seed solitary in each cavity, with a smooth or tuberculate crustaceous testa.

1. Mercurialis ánnua L. Annual, glabrous. Stems $2-6 \mathrm{dm}$. tall, more or less widely branched: leaf-blades thinnish, ovate to lanceolate, acute or slightly acuminate, serrate with rounded teeth, or crenate: petioles $5-15 \mathrm{~mm}$. long: staminate flowers in interrupted spikes which surpass the leaves: pistillate flowers clustered in the axils: capsules 2-lobed, 4-5 mm. broad, hispid : seeds subglobose, $1.5 \mathrm{~mm}$. in diameter, pitted.

In waste places, South Carolina to Florida and Texas and in other parts of North America. Native of Europe and Africa.

\section{RICINÉLLa Muell. Arg.}

Dioecious shrubs, with glabrous or rarely tomentose foliage, the branchlets sometimes spine-tipped. Leaves alternate, often clustered at the nodes: blades membranous or parchment-like, entire. Flowers apetalous : staminate nearly sessile in axillary clusters. Stamens 8-15: filaments short, distinct: anthers versatile. Pistillate flowers solitary, long-pedicelled. Ovary 3-celled: styles 3, distinct, lacerate. Ovules solitary in each cavity. Capsule 3-lobed, crustaceous. Seed solitary in each cavity, with a smooth testa.

1. Ricinella Vaseỳi (Coulter) Coult. \& Fish. A shrub branching from the base, the branches 1.5-2 m. tall, puberulent, or glabrous in age. Leaves rather few, clustered on the 
short spur-like pubescent branchlets ; blades cuneate or obovate-cuneate, $1.5-3 \mathrm{~cm}$. long, 3-nerved, nearly sessile : pistillate flowers few, each terminating a pubescent pedicel arising from a leaf-cluster: sepals 5, lanceolate, pubescent: stamens 10 : capsules depressed, 3lobed, about $6 \mathrm{~mm}$. long, 9-10 $\mathrm{mm}$. broad, sometimes slightly granular: seeds broadly ovoid, about $4 \mathrm{~mm}$. long.

In dry grounds, southern Texas. Spring and summer.

\section{BERNÁRDIA P. Br.}

Monoecious or dioecious shrubs or rarely herbs, the foliage pubescent with simple or stellate hairs. Leaves alternate : blades toothed or rarely entire. Flowers inconspicuous, apetalous, the staminate with 3 or 4 partially united valvate sepals. Stamens 3-20: filaments often accompanied by small glands: anthers erect or rarely nodding. Pistillate flowers with a calyx of 6 or sometimes 5-9 sepals. Ovary 3 -celled : styles 3 , short : stigmas 2 -cleft, in our species. Ovules solitary in each cavity. Capsule 3-lobed. Seed with a crustaceous testa.

1. Bernardia myricaefòlia (Scheele) S. Wats. An irregularly branched shrub 8-30 $\mathrm{dm}$. tall, the foliage gray-green, sometimes densely pubescent. Leaf-blades oblong, cuneate, or sometimes broadest below the middle, 1-5 $\mathrm{cm}$. long, repand-dentate, rather prominently nerved, short-petioled : sepals obovate, ovate, oval or oblong: capsules depressed, about $1 \mathrm{~cm}$. broad, more or less densely pubescent, 3-lobed, the lobes rounded: seeds oval-globose, 6-7 mm. long, nearly smooth.

On prairies or mountain slopes, Texas and New Mexico. Spring to fall.

\section{ACALỲPHA L.}

Annual or perennial monoecious caulescent herbs or shrubs. Leaves alternate: blades entire or toothed, petioled : stipules present. Flowers in axillary and terminal spikes or spike-like racemes, apetalous : staminate cluster peduncled, each flower in the axil of a minute bractlet, with a calyx of 4 sepals, and 8-16 stamens united by their bases. Pistillate flowers subtended by a foliaceous bract which often equals or overtops the staminate : calyx of 3-5 sepals. Ovary 3-celled : stigmas fringed. Capsule usually of 32 -valved carpels, each 1-seeded. The plants flower from spring to fall, or throughout the year in the South.

THREE-SEeded MERCURY.

Staminate and pistillate flowers in the same spike.

Plants perennial.

Stems wire-like : seeds barely $1 \mathrm{~mm}$. long.

Stems relatively stout: seeds $1.5 \mathrm{~mm}$. long.

Plants annual.

Foliage not glandular: bracts usually surpassing the spikes.

Foliage glandular: bracts usually shorter than the spikes.

Staminate and pistillate flowers in separate spikes.

Flowers mainly dioecious.

Foliage villous : leaf-blades cleft.

Foliage closely puberulent pubescent: leaf-blades crenate.

Flowers monoecious.

1. A. corchorifolia

2. A. Lindheimeri.

3. A. Virginica.

4. A. gracilens.

1. Acalypha corchorifòlia Willd. Perennial, pubescent, but not conspicuously so. Stems tufted, and often branched at the base, the branches spreading or decumbent, 5-20 $\mathrm{cm}$. long, rigid, wire-like, often irregularly bent: leaf-blades leathery, ovate or oblonglanceolate, 7-20 mm. long, crenate-serrate, truncate or subcordate at the base, short-petioled : spikes mostly terminal ; the staminate very slender, all parts minute : pistillate spikes stout, below the staminate : bracts 5-6 mm. long, coarsely 6-12-toothed: capsules fully $1 \mathrm{~mm}$. long, glabrous or nearly so : seeds barely $1 \mathrm{~mm}$. long, smooth.

In sand, peninsular Florida and the Keys.

2. Acalypha Lindheìmeri Muell. Arg. Perennial, more or less hirsute. Stems tufted, ascending or decumbent, 1-4 dm. long, simple or branched : leaf-blades ovate to lanceolate, more or less distinctly rhombic, or suborbicular at the base of the stem, 1.5-4 $\mathrm{cm}$. long, acute or acutish, serrate, slightly inequilateral at the base, short-petioled : spikes erect, $3-10 \mathrm{~cm}$. long; staminate portion very slender, all parts minute; pistillate portion conspicuously bracted : bracts 4-6 mm. long, several-cleft, the segments acute : capsules 2 $\mathrm{mm}$. long, glabrous : seeds globose-ovoid, $1.5 \mathrm{~mm}$. long, minutely pitted in lines.

In dry soil, Texas to Arizona and adjacent Mexico.

3. Acalyphia Virgínica L. Annual, dark green or becoming purplish, somewhat pubescent. Stem erect or ascending, 1-7 dm. tall : leaf-blades ovate or elliptic, $2-10 \mathrm{~cm}$. 
long, thin, coarsely serrate except near the base, long-petioled: staminate and pistillate flowers in the same axillary clusters; staminate spike peduncled, usually included in the large palmately lobed bract: pistillate flowers 1-3 at the base of the staminate peduncle: capsules 3-lobed, subglobose, about $3 \mathrm{~mm}$. in diameter, smooth, sometimes slightly pubescent : seeds ovoid, reddish, striate.

In woods and thickets, Ontario to Minnesota, Florida and Texas.

4. Acalypha grácilens A. Gray. Annual, pale green. Stems erect, 1-8 dm. tall, slender, with very slender branches : leaf-blades lanceolate to linear-oblong, $1-5 \mathrm{~cm}$. long, acutish, rather firm, serrate, short-petioled : staminate spike very slender : pistillate flowers one, or several together : capsules subglobose, about $3 \mathrm{~mm}$. in diameter : seeds globose-ovoid, striate-pitted, dark red or gray mottled with red.

In dry woods and thickets, Massachusetts to Kansas, Florida and Texas.

5. Acalypha rádians Torr. Perennial, densely villous. Stems tufted, ascending, spreading or decumbent, 1-4 dm. long, commonly branched : leaf-blades reniform or orbicular-reniform, 1-1.5 cm. broad, 7-15-cleft, the segments linear, lanceolate or oblong, obtuse or acutish : petioles about as long as the blades or longer : spikes dioecious ; staminate linearcylindric, manifestly peduncled: pistillate spikes oblong-cylindric, sessile or short-peduncled : bracts 9-10-toothed : capsules depressed, $2-2.5 \mathrm{~mm}$. broad, hirsute : seeds oval or ovoid, $1.5 \mathrm{~mm}$. long, minutely pitted.

In sandy soil, Texas and adjacent Mexico.

6. Acalypha hederàcea Torr. Perennial, softly pubescent. Stems tufted, ascending, spreading or decumbent and diffuse, 1-4 dm. long, mostly forking above : leaf-blades thick, oval, orbicular or orbicular-reniform, $5-15 \mathrm{~mm}$. long, crenate, truncate or cordate at the base; petioles somewhat shorter than the blades or longer : spikes mostly dioecious ; staminate slender, long-peduncled ; pistillate short, with shorter peduncles than the staminate : bracts 4-5 mm. long, densely pubescent, obtusely 8-10-toothed: capsules about $2 \mathrm{~mm}$. long, pubescent : seeds oval-ovoid, $1.5 \mathrm{~mm}$. long, obscurely pitted, variegated.

In low grounds, Texas and adjacent Mexico.

7. Acalypha ostryaefòlia Ridd. Annual, dark-green, minutely pubescent. Stems erect, rather stout, simple or branched, 3-8 dm. tall : leaf-blades thin or membranous, ovate, 5-10 cm. long, short-acuminate, serrate, obtuse or cordate at the base ; petioles often as long as the blades: staminate and pistillate flowers in separate spikes, the bractlets of the staminate minute, those of the pistillate conspicuous, lobed: capsules much depressed, 3-4 mm. in diameter, spiny: seeds ovoid, $2 \mathrm{~mm}$. long, wrinkled. [A. Caroliniana Ell.]

In thickets and waste places, New Jersey to Kansas, Florida and Mexico.

\section{TRÀGIA L.}

Perennial monoecious herbs or shrubs, sometimes climbing, usually armed with stiff stinging hairs. Leaves alternate : blades entire, toothed or somewhat lobed, mostly cordate, petioled. Flowers in racemes or spicate racemes, bracteolate, apetalous; staminate with a calyx of 3-5 sepals, and 1-3 or rarely numerous stamens : pistillate flowers with a calyx of 3-8 entire or pinnatifid sepals. Ovary 3 -celled with one ovule in each cavity : styles 3 , often united to above the middle. Capsule 3-lobed, separating into 3 2-valved carpels. Seeds subglobose. The plants flower from spring to fall.

Stems not twining.

Leaf-blades linear, entire.

Leaf-blades broader and manifestly broadest above or below the middle.

Leaves with more or less cuneately narrowed blades.

Stems closely and softly pubescent: leaf-blades bluntly toothed or entire: racemes longer than the leaves.

Stems essentially glabrous : leaf-blades sharply toothed: racemes shorter than the leaves.

Leaves. at least the lower ones, truncate or cordate at the base.

Leaf-blades of a triangular or lanceolate type.

Staminate calyx with 3 sepals: stamens 3 .

Stems hirsute: sepals of the staminate flowers ovate or oval: sepals of the pistillate flowers becoming 2-2.5 mm. long.

Stems rather appressed-pubescent: sepals of the staminate flowers lanceolate: sepals of the pistillate flowers becoming $3-3.5 \mathrm{~mm}$. long.

Staminate calyx with 4-5 sepals: stamens $4-5$.

1. T. linearifolia.

2. T. urens.

3. T. nigricans.

4. T. urticaefolia.

5. T. nepetaefolia.

6. T. ramosa.

7. T. saxicola.

8. T. betonicaefolia.

9. T. macrocarpa. 
1. Tragia linearifolia Ell. Plants closely and minutely pubescent. Stems solitary or several from the base, erect or spreading, 1-4 dm. long, sparingly or diffusely branched, strict or slightly zigzag : leaf-blades linear, $3-10 \mathrm{~cm}$. long, entire or undulate, sometimes curved, sessile or nearly so : racemes slender, often surpassing the leaves, branched in vigorous specimens : bracts $1-1.5 \mathrm{~mm}$. long : calyx sometimes minutely pubescent, that of the staminate flowers with 4-5 unequal sepals and 2 stamens : capsules $7-8 \mathrm{~mm}$. broad, strigillose, one cavity often suppressed : seeds subglobose, 3-3.5 mm. in diameter, granular.

In sand, Georgia and Florida.

2. Tragia ùrens L. Plants softly pubescent with minute hairs. Stems solitary or several from the same base, erect or spreading, 1-4 dm. long, nearly simple or diffusely branched, rather rigid : leaf-blades oblong to cuneate, $2-5 \mathrm{~cm}$. long, undulate or commonly toothed, often very variable on the same plant, sessile or nearly so: racemes slender, much surpassing the leaves, the rachis filiform : bracts about $1 \mathrm{~mm}$. long : pedicels $1-3 \mathrm{~mm}$. long: calyx puberulent, that of the staminate flowers with 4 sepals and 2 stamens: capsules less than 8-10 mm. broad, much depressed, strigillose : seeds subglobose, $3.5-4 \mathrm{~mm}$. in diameter, smooth. [T. innocua Walt.]

In dry sandy soil, Virginia to Florida and Texas.

3. Tragia nìgricans Bush. Plants sparingly hispid, purple-green. Stems usually branched at the base, the branches erect or ascending, 2-4 dm. tall, commonly simple, essentially glabrous: leaf-blades oblong, sometimes narrowly so, $3-7 \mathrm{~cm}$. long, acute, thinnish, coarsely serrate with rather flaring teeth, with scattered hairs, narrowly or broadly cuneate at the base, short-petioled: racemes few-flowered, much shorter than the leaves: bracts lanceolate, $1.5-2.5 \mathrm{~mm}$. long: pedicels shorter than the bracts: staminate flowers with a calyx of 4 puberulent sepals and 4 stamens : pistillate flowers with a calyx of 6 hispid sepals : capsule depressed, about $10 \mathrm{~mm}$. broad.

In woods, west-central Texas.

4. Tragia urticaefolla Michx. Plants with stinging hairs. Stems erect or spreading, 1-4 dm. long, often branched, hispid : leaf-blades triangular, ovate to lanceolate, $3-7 \mathrm{~cm}$. long, coarsely and doubly serrate, truncate or cordate at the base, stout-petioled : racemes $0.5-2.5 \mathrm{~cm}$. long: staminate flowers with a calyx of 3 sepals, and 3 stamens : pistillate flowers with a calyx of 4 or 5 sepals : capsule much depressed, 7-10 mm. broad, hispid: seeds globular, $3.5-4 \mathrm{~mm}$. in diameter, dark brown.

In dry or sandy soil, South Carolina to Arkansas. Florida and Texas.

5. Tragia nepetaefollia Cav. Plants with stinging hairs. Stems slender, erect, or reclining, 1-4 dm. long, rather appressed pubescent: leaf-blades triangular-ovate or lanceolate, 1-5 dm. long, dentate-serrate, cordate, slender-petioled, the lower sometimes orbicular: racemes $1-3.5 \mathrm{~cm}$. long, many-flowered: staminate flowers mostly with a calyx of 3 sepals and 3 stamens : pistillate flowers with a caly $\mathbf{x}$ of 5 sepals : capsule much depressed, 5-6 mm. in diameter, hirsute : seeds globose, chestnut brown, smooth, $4 \mathrm{~mm}$. in diameter.

In sandy soil, Kansas to Mexico and New Mexico.

6. Tragia ramòsa Torr. Plants light green, bristly with stinging hairs. Stems 5-30 cm. long, slender, usually much branched, sometimes spreading: leaf-blades lanceolate, ovate-lanceolate or triangular-lanceolate, $1.2-5 \mathrm{~cm}$. long, acute at the apex, coarsely and sharply serrate, truncate or cordate at the base, short-petioled: staminate flowers with a calyx of 4-5 sepals, and 4-6 stamens ; pistillate flowers solitary with a calyx of 5 sepals subtended by a 3-lobed bract : capsules much depressed, $6-8 \mathrm{~mm}$. in diameter, orange, more or less variegated.

In dry soil, Missouri to Texas, Colorado and Arizona.

7. Tragia saxícola Small. Plants somewhat bristly with stinging hairs. Stem branched at the base ; the branches ascending or spreading, slender or wiry, 0.5-2 dm. long: leaf-blades suborbicular to broadly ovate, $1-2.5 \mathrm{~cm}$. long, rounded at the apex, crenatedentate, subcordate or cordate at the base, slender-petioled : staminate flowers short-pedicelled, with 3 ovate sepals about $1 \mathrm{~mm}$. long, and 3 stamens : pistillate flowers usually solitary, with 4 lanceolate or oblong-lanceolate sepals becoming 2.5-3 mm. long: capsules much depressed, 7-8 $\mathrm{mm}$. broad, hairy.

In rocky pine woods, southern peninsular Florida and the Keys.

8. Tragia betonicaefolia Nutt. Plants softly pubescent and somewhat villous. Stems usually branched at the base, the branches erect or ascending, 1-3 dm. tall, simple or sparingly branched, often slightly zigzag: leaf-blades orbicular to broadly oblong, $2-4 \mathrm{~cm}$. long, serrate, crenate-serrate or somewhat lobed, mostly rounded or cordate at the base, short-petioled or nearly sessile : racemes usually less than $1 \mathrm{~cm}$. long; bracts surpassing the pedicels : staminate calyx with 4 sepals : stamens 2 : pistillate calyx with $4-5$ sepals : ovary densely pubescent : capsules 3 -lobed, less than $1 \mathrm{~cm}$. broad.

In sandy soil, Florida to Louisiana. 
9 Tragia macrocárpa Willd. Plants slightly hirsute. Stems slender, twining, 4-15 dm. long, branched : leaf-blades ovate, 5-12 cm. long, deeply cordate, coarsely dentate, serrate, long-acuminate; petioles mostly shorter than the blades: staminate flowers with a calyx of 3 sepals and 3 stamens : pistillate flowers several at the base of each spike, shortpedicelled : sepals 5 : capsules depressed, 12-16 mm. in diameter : seeds subglobose, $5 \mathrm{~mm}$. long, smooth, variegated.

In dry or rocky soil, Kentucky to Missouri, Florida and Mexico.

\section{GYMNÁNTHES Sw.}

Evergreen shrubs or trees, with glabrous foliage and a milky sap. Leaves alternate : blades leathery, entire or crenate-serrate. Flowers monoecious or rarely dioecious : staminate in slender, axillary racemes furnished with bracts and bractlets : pistillate flowers solitary on long peduncles, 1,2 or 3 of which arise from the axils with the staminate flowers. Perianth rudimentary or wanting. Stamens 2-3: filaments distinct or united at the base. sometimes subtended by the scale-like rudimentary perianth : anthers erect. Ovary 3-celled, sometimes long-stalked, subtended by the rudimentary perianth of 3 scale-like parts, prolonged into 3 recurved styles. Ovules solitary in each cavity, suspended, anatropous. Capsule 3 -lobed, separating into 32 -valved bodies. Seeds pendulous, with a membranouscrustaceous testa.

1. Gymnanthes lùcida Sw. An evergreen shrub or tree, reaching a height of $10 \mathrm{~m}$., the foliage glabrous. Leaf-blades leathery, cuneate to oblong-spatulate, or nearly oblong, 4-10 cm. long, lustrous above, undulate or obscurely toothed near the apex, short-petioled : spikes staminate, shorter than the leaves, continuous : bracts reniform : perianth none: stamens $2-3$, subtended by reniform bractlets : pistillate flowers solitary, on curved peduncles, these somewhat shorter than the spikes: ovary stalked: capsules depressed, about 1 cm. broad, 3-lobed, the lobes rounded : seeds ovoid, 6-8 $\mathrm{mm}$. long.

In coral soil, peninsular Florida and the Keys. Also in the Bahamas and the Antilles. PorsonWOod. Crabwood.

\section{SEBAstiñNa Muell. Arg.}

Monoecious shrubs or rarely herbs, with rather slender branches. Leaves alternate: blades entire or barely toothed, never large. Flowers inconspicuous, apetalous, in slender spikes or racemes. Disk wanting. Staminate flowers with a membranous calyx of 3-5 unequal sepals. Stamens $2-3$ or rarely 4 : filaments distinct or slightly united at the base : anthers opening lengthwise. Pistillate flowers below the staminate, with a calyx of 3 more or less united sepals. Ovary 3-celled: styles 3, simple. Ovules solitary in each cavity. Capsule 3-celled, 3-lobed. Seeds solitary, with a smooth testa.

1. Sebastiana ligustrìna (Michx.) Muell. Arg. An erect widely branched shrub 1-4 m. tall, the foliage glabrous. Leaf-blades thickish, oblong, elliptic or oval, $3-8 \mathrm{~cm}$. long, usually slightly acuminate at both ends, rarely obtuse, undulate, short-petioled: spikes shorter than the leaves, sometimes in pairs: calyx yellowish, that of the staminate flowers with 3 ovate acute or acuminate serrulate sepals : stamens 3 : calyx of pistillate flowers nearly similar to that of the staminate: capsules nearly $1 \mathrm{~cm}$. broad, depressed, 3-celled smooth : seeds subglobose, $4 \mathrm{~mm}$. long.

On banks and in swamps, North Carolina to Florida and Louisiana. Spring to fall.

\section{SÀPIUM P. Br.}

Dioecious or rarely monoecious shrubs or trees, with glabrous foliage. Leaves alternate or opposite: blades entire or sparingly toothed, often leathery, sometimes longpetioled. Flowers apetalous, in axillary, lateral or apparently terminal spikes or racemes. Disk wanting. Staminate flowers with a calyx of 2 or rarely 3 nearly equal united sepals : stamens 2-3: filaments distinct : anthers opening lengthwise. Pistillate flowers below the staminate, with a calyx of 2 or 3 more or less united sepals. Ovary 2-3-celled : styles 2-3 slightly united at the base, entire. Ovules solitary in each cavity. Capsule 2-3-lobed, 2-3-celled. Seeds solitary, with a crustaceous testa. 
1. Sapium sebiferum (L.) Roxb. A large tree reaching a height of $15 \mathrm{~m}$., the foliage glabrous deep green. Leaf-blades rhombic, $4-8 \mathrm{~cm}$. long, acuminate, undulate, broadly cuneate at the base ; petioles slender, about as long as the blades or longer : spikes terminal, 5-10 cm. long, continuous : capsules depressed, 3-lobed, $1.5 \mathrm{~cm}$. broad, abruptly pointed : seeds $8-9 \mathrm{~mm}$. long, white.

In sandy soil, South Carolina to Florida and Louisiana. Native of China and Japan. Spring.

2. Sapium glandulòsum (L. ) Morong. A shrub or a tree becoming fully $13 \mathrm{~m}$. tall, Leaf-blades linear-oblong or narrowly oblong, 8-16 cm. long, serrulate ; petioles 10-16 mm. long: spikes $5-9 \mathrm{~cm}$. long, more or less interrupted: capsules 2 -lobed, about $1 \mathrm{~cm}$. broad : seeds 6-7 mm. long.

In sandy soil, Pensacola, Florida. Native of South America. Spring.

\section{STILLÍNGIA L.}

Monoecious herbs or shrubs, with glabrous foliage and simple or branched stems. Leaves alternate or rarely opposite, often with 2 glands at the base : blades entire or toothed. Staminate flowers several together in the axils of the bractlets. Calyx slightly 2-3-lobed. Stamens 2-3, exserted. Pistillate flowers solitary in the axils of the lower bractlets. Calyx 3-lobed. Ovary 2-3-celled, with a solitary ovule in each cavity : styles stout, somewhat united at the base. Capsule 2-3-lobed, separating into 2 or 32 -valved carpels. Seeds ovoid or subglobose. The plants flower in the spring and summer or throughout the year in the extreme South. Quens's Delight. QueEn-Root.

Plants annual.

Plants perennial.

Plants herbaceous.

Capsules less than $10 \mathrm{~mm}$. wide: seeds 4-6 $\mathrm{mm}$. long.

Stem leaves with linear blades.

Leaf-blades evenly serrulate with black-tipped teeth: lobes of the gynophore wider than high: stems simple or umbellate above: species Texano-Mexican.

Leaf-blades very shallowly and crenulate serrulate: lobes of the gynophore higher than wide: stem dichotomous : species Floridian.

1. S. dentata. phore higher thate or oblong-spatulate blades.
tem leaves with spatulat

Capsules over $10 \mathrm{~mm}$. wide: seeds 7-9 mm. long.

Stem leaves with lanceolate or elliptic serrulate blades.

Stem leaves with obovate, oval or oblong crenulate blades.

Plants shrubby.

\section{S. linearifolium.}

3. S. angustifolia. 4. S. spathulata.

5. S. salicifolia.

6. S. sylvatica.

7. S. aquatica.

1. Stillingia dentàta (Torr.) Britt. \& Rusby. Herbaceous. Stems branched at the base, the branches spreading or decumbent, often branched again, angled, 1-3 dm. long: leaf-blades spatulate to oblong-spatulate, 1-2.5 cm. long, sharply toothed with flaring or rarely curved teeth, narrowed to the base and almost sessile : spikes shorter than the leaves or slightly longer, rather loosely flowered : bracts triangular or triangular-lanceolate : calyx very delicate, less than $1 \mathrm{~mm}$. long : filaments long-exserted : capsules ovoid-globose, 4-4.5 $\mathrm{mm}$. in diameter : seeds $3 \mathrm{~mm}$. long, smooth or nearly so, not reticulated.

In ravines, or on plains and prairies, Texas and adjacent Mexico.

2. Stillingia linearifòlia (Muell. Arg.) Small. Herbaceous. Stems usually several together, 3-6 dm. tall, slender, simple or umbellately branched above : leaf-blades linear, often narrowly so, 3-8 cm. long, acute, evenly serrulate with black-tipped teeth : spikes continuous, 5-7 mm. long, erect : bracts broader than high : capsules 5-7 mm. wide : seeds 3-4 mm. long. [S. sylvatica Y linearifolia Muell. Arg.]

In dry or sandy soil, Texas to New Mexico and adjacent Mexico.

3. Stillingia angustifolia (Torr.) S. Wats. Herbaceous. Stems solitary or few together, 2.5-6 dm. tall, dichotomous, slender : leaf-blades linear or essentially so, $2-5 \mathrm{~cm}$. long, rather blunt, shallowly and unevenly crenulate-serrulate : spikes slender, $2-4.5 \mathrm{~cm}$. long : capsules slightly depressed, 5-6 mm. wide : seeds about $4 \mathrm{~mm}$. long.

In sandy soil and about ponds, peninsular Florida and the Keys.

4. Stillingia spathulàta (Muell. Arg.) Small. Herbaceous. Stems solitary or few together, 3-7 dm. tall, sometimes branched below the sparingly umbellate top, or merely dichotomous : leaf-blades spatulate to oblong-spatulate, or linear-spatulate on the branches, $7-15 \mathrm{~cm}$. long, evenly crenulate, rather blunt : spikes 4-14 cm. long: capsules depressed, 7-9 mm. wide : seeds about $5 \mathrm{~mm}$. long. [S. sylvatica a spathulata Muell. Arg.]

In pine lands, Georgia, Alabama and Florida.

5. Stillingia salicifolia (Torr.) Small. Herbaceous. Stems usually several together, 3-11 dm. tall, simple or umbellately branched above : leaf-blades lanceolate to elliptic, 4$11 \mathrm{~cm}$. long, acute, serrulate : spikes $4-9 \mathrm{~cm}$. long : capsules $12-15 \mathrm{~mm}$. wide : seeds 7-8 mm. long. [S. sylvatica $\beta$ salicifolia.]

In sandy soil, Kansas to Arkansas and Texas. 
6. Stillingia sylvática $L$. Herbaceous. Stems commonly several together, 4-12 dm. tall, stout, usually topped by a simple or compound umbel : leaf-blades obovate, oval or oblong, 3-11 cm. long, obtuse, crenulate : spikes 5-12 cm. long : capsules 12-15 cm. wide : seeds 7-9 mm. long.

In sandy soil and open woods, Virginia to Missouri, Florida and Texas.

7. Stillingia aquática Chapm. Shrubby. Stems erect, 6-20 dm. tall, often standing in shallow water, conspicuous on account of the umbel-like top : leaf-blades linear or linearoblong, sometimes broader above or below the middle, acute, finely serrate, narrowed into short slender petioles, the upper ones yellowish: spikes as long as the leaves or shorter: bracts $1-1.5 \mathrm{~mm}$. high : calyx $1 \mathrm{~mm}$. long, rather delicate: capsules about $1 \mathrm{~cm}$. broad, smooth : seeds subglobose, $3-3.5 \mathrm{~mm}$. in diameter, rugose, pitted at the end.

In swamps and wet pine lands, South Carolina, Florida and Alabama.

\section{HIPPOMÀNE L.}

Trees, with glabrous foliage and an acrid poisonous milky sap. Leaves alternate: blades leathery, entire or serrate, somewhat persistent, on rather long petioles. Flowers monoecious, in terminal ament-like spikes with a stout rachis, the staminate above the pistillate in clusters of 8-15 subtended by broad bracts which are furnished with 2 glands. Calyx membranous, 2-3-lobed. Stamens 2-3, exserted: filaments more or less united; anthers erect, extrorse. Pistillate flowers few and solitary in the axils below the staminate. Calyx ovoid, 3-parted, closely surrounding the ovary, furnished with several glands. Ovary 6-8-celled, sessile. Styles 6-8, recurved, stigmatic on the inner faces. Ovules solitary in each cavity, pendulous, anatropous. Drupe spheroidal, slightly 6-8-lobed, variegated, with a milky pulp and a bony 6-8-celled endocarp. Seeds elongated, flattened, with a double membranous testa, the outer coat darker than the inner. MANCHINEEL.

1. Hippomane Mancinélla L. An evergreen tree 4-18 m. tall, resembling a pear tree, the foliage glabrous. Leaf-blades thickish, ovate, oblong or oval, 4-10 cm. long, acute or short-acuminate, undulate or shallowly serrate, lustrous above, rounded or subcordate at the base; petioles slender, as long as the blades or shorter : spikes 4-8 cm. long, curved : bracts broader than long, crenulate : calyx of the staminate flowers with 3 unequal acute sepals, that of the pistillate flowers with broadly ovate or orbicular-ovate sepals, about as long as the ovary: drupe spheroidal, $2.5-3.5 \mathrm{~cm}$. broad, yellowish green or light yellow with a scarlet cheek : nut depressed with many short thorn-like projections.

On sandy beaches, peninsular Florida and the Keys. Also in the Bahamas, West Indies and tropical America. Spring.

\section{RÍCINUS L.}

Tall stout monoecious herbs, with glabrous and glaucous foliage. Leaves alternate : blades large, peltate, palmately lobed, petioled. Flowers numerous, small, apetalous, greenish, in terminal racemes, the pistillate above the staminate. Staminate flowers with a calyx of 3-5 valvate sepals, and numerous crowded stamens : filaments repeatedly branched. Pistillate flowers with a caducous calyx. Ovary 3-celled, 3-ovuled : styles 3, red, united at the base, 2-cleft. Capsule subglobose, or oval, smooth or spiny, separating into 32 -valved carpels. Seeds ovoid or oblong, usually mottled. Castor Oil Plant. Castor-bean.

1. Ricinus commùnis L. Stem erect, 1-5 m. tall, more or less branched, becoming tree-like in warm regions. Leaves conspicuous ; blades nearly orbicular in outline, 10$40 \mathrm{~cm}$. broad, palmately 6-11-lobed and peltate, the lobes toothed, acute or acuminate : capsule 12-16 mm. in diameter, usually spiny, sometimes smooth: seeds shining, smooth, black variegated with white, or mottled with gray and brown markings.

In waste places, escaped from cultivation, New Jersey to Florida and Texas. Widely naturalized In waste places, escaped from cultivation,
in warm and tropical regions. PALMA CHRISTI.

\section{MOZÍNNA Ortega.}

Monoecious, rather succulent shrubs. Leaves alternate, clustered on lateral spurs : blades broadened upward, entire or lobed. Flowers inconspicuous, sessile or short-pedicelled on the spurs with the leaves. Sepals 5, distinct or nearly so. Corolla urn-shaped, surpassing the calyx : lobes shorter than the tube. Stamens 8-13: filaments monadelphous : anthers introrse. Ovary often 2-celled. Styles 2, distinct. Stigmas more or less deeply notched. Ovules solitary in each cavity. Capsule often 2-lobed, sometimes of a single carpel. Seed solitary in each cavity. 
1. Mozinna sessiliflòra (Hook.) Small. ${ }^{1}$ Perennial, glabrous, shrubby, but somewhat succulent. Stems several $\mathrm{dm}$. tall, with a smooth olive-green bark : leaves clustered on short stout spurs ; blades spatulate or cuneate, $2-4 \mathrm{~cm}$. long, entire or merely toothed at the tip, sessile or nearly so : flowers clustered, the staminate pedicelled : caly $x$ pubescent, various, the staminate with ovate-lanceolate, acutish sepals, the pistillate with lanceolate acuminate sepals : corolla pubescent ; tube surpassing the calyx ; lobes oblong or ovate, obtuse, shorter than the tube : capsules about $2 \mathrm{~cm}$. long, sharp-tipped, oblique at the base, pubescent or glabrate : seeds less than $1.5 \mathrm{~cm}$. long, oblong-oval. [Jatropha spathulata var. sessliflora (Hook. ) Muell. Arg.]

On prairies and hillsides, Texas and adjacent Mexico.

\section{CNIDÓscorus Pohl.}

Perennial monoecious herbs or shrubs, with stinging-bristly foliage. Leaves alternate : blades entire, lobed or divided, petioled. Flowers apetalous, in cymes, the staminate with a corolla-like 5-lobed calyx. Stamens usually numerous (10-30) and in several series: filaments mostly united at the base, the inner sometimes imperfect. Pistillate flowers in the lower forks of the cymes. Ovary mostly 3-celled and 3-ovuled : styles united at the base. Capsule ovoid or subglobose, easily separating into 2-valved carpels. Seeds ovoid, or obovoid. Embryo stright in the fleshy endosperm. Tread-softly. Spurge Netrue. Staminate calyx glabrous or nearly so at maturity; tube 8-10 mm. long. $\quad 1$. C. stimulosus. Staminate caly x copiously armed with spreading bristle-like hairs; tube $15-25 \mathrm{~mm}$. long. 2 . $C$. Texanus.

1. Cnidoscolus stimulòsus (Michx.) A. Gray. Plant bright green, armed with stinging hairs. Stems rather slender, erect, simple or branched, 1-12 dm. tall : leaf-blades nearly orbicular in outline, $8-30 \mathrm{~cm}$. broad, truncate or cordate at the base, deeply 3-5lobed; the lobes entire, toothed or pinnatifid : calyx of the staminate flowers salverform, white or pink, glabrous or nearly so at maturity ; tube $8-10 \mathrm{~mm}$. long; lobes about as long as the tube : capsules oblong, 10-16 mm. long, papillose, wrinkled : seeds oblongobovoid, 10-12 mm. long, smooth, mottled. [Jatropha stimulosa Michx.]

In dry sandy soil, Virginia to Florida and Texas. Spring to fall.

2. Cnidoscolus Texànus (Muell. Arg.) Small. Plants copiously armed with rigid bristle-like hairs. Stems 3-6 dm. tall, simple or branched above, bristly : leaf-blades suborbicular in outline, deeply 3-5-lobed, $6-15 \mathrm{~cm}$. broad, the lobes toothed, angled or pinnatifid, acute or somewhat acuminate ; petioles nearly as long as the blades or longer, bristly like the stem : clusters many-flowered, densely bristly : calyx white; tube cylindric or nearly so, $2-2.5 \mathrm{~cm}$. long, pubescent with firm bristles; lobes oblong to spatulate-oblong, about as long as the tube or somewhat shorter, often sharply bristly without : capsules slightly larger than those of the preceding species. [Jatropha Texana Muell. Arg.]

In sandy soil, Arkansas and the Indian Territory to Texas. Spring to fall.

\section{JÁTROPHA L.}

Perennial caulescent monoecious herbs, often woody below. Leaves alternate: blades angled or lobed, petioled. Flowers petaliferous, cymose, the staminate inconspicuous, with 5 sepals and 5 more or less united petals. Stamens 10, the inner sometimes imperfect: filaments united below. Pistillate flowers mainly below the staminate. Ovary 2-3-celled, or rarely 4-celled. Capsule separating in 2 carpels or usually 3 carpels. Seeds usually minutely carunculate.

1. Jatropha gossypifolia L. Perennial, shrubby. Stems $3-7 \mathrm{dm}$. tall, branching: leaf-blades palmately $3-5$-lobed, $8-15 \mathrm{~cm}$. broad, often lustrous above, the segments shallowly toothed, glandular-ciliate, acute or acuminate ; petioles shorter than the blades, conspicuously glandular-pubescent, the hairs often in clusters : capsules globular-oblong, about $1 \mathrm{~cm}$. long, slightly warty : seeds oblong, 7-8 mm. long, mottled.

In sandy soil, Key West and tropical America. Also in Africa.

\section{MÁNIHOT Adans.}

Vigorous monoecious herbs or shrubs, commonly with glaucous and glabrous foliage. Leaves alternate : blades entire or palmately 3-7-lobed or 3-7-parted, the segments membranous or leathery, entire or lobed. Flowers apetalous, in racemes or panicles, the stami-

${ }^{1}$ Another species, Mozinna spathulata Ortega, of Mexico, western Texas and New Mexico, with some of the leaves lobed and slender-pedicelled staminate flowers, may be found within our range. 
nate with a calyx of 5 partially united sepals. Stamens 10, in 2 series : filaments slender, those of the inner series attached to the lobes of the disk : anthers opening lengthwise. Pistillate flowers with a calyx similar to that of the staminate but the tube often shorter. Ovary 3-celled: styles 3, slightly united at the base. Ovules solitary in each cavity. Capsule 3-celled. Seeds solitary in each cavity.

Leaf-segments lobed.

Leaf-segments entire.

1. M. Carthaginensis. 2. M. Manihot.

1. Manihot Carthaginénsis (Jacq.) Muell. Arg. Stems 4-10 dm. tall, often sparingly branched : leaf-blades orbicular or reniform in outline, 3-5-lobed, 8-12 cm. broad, the lobes ovate, fiddle-shaped, pinnatifid or the lower ones undulate, acute or acuminate; petioles about as long as the blades or shorter : racemes few-flowered : calyx of the staminate flowers salverform, the lobes linear or linear-lanceolate : pistillate flowers below the staminate; tube none or very short; lobes linear or linear-lanceolate : bracts surpassing the pedicels.

In sandy soil, southern Texas to Mexico and tropical America.

2. Manihot Manihót (L.) Cockerell. Stems 1-1.5 m. tall, more or less branched : leafblades 3-7-parted, the segments linear to elliptic, or slightly broadest above the middle, acute or acuminate, entire ; petioles about as long as the blades or longer : panicles spreading, often glaucous : bracts shorter than the pedicels : calyx campanulate, 7-8 mm. high ; lobes ovate, obtuse, about as long as the tube ; calyx of the pistillate flowers with a shorter tube than that of the staminate. [M. ulitissima Pohl.]

In sandy soil, Keys of Florida and tropical America.

\section{Chamaesìce S. F. Gray.}

Annual or perennial herbs or shrubs. Stems often radially branched at the base, the branches ascending or prostrate, sometimes creeping, forking. Leaves opposite : blades entire or toothed, more or less oblique at the base : stipules delicate, entire or fringed. Involucres solitary in the axils or in axillary cymes : glands 4, sessile or stalked, naked or usually with an appendage, one sinus of each involucre glandless. Capsule smooth, sometimes pubescent, the angles sharp or rounded. Seeds angled, with minute caruncles, white or black, the faces smooth or transversely wrinkled. SPURGE.

A. Leaf-blades entire.

Plants with relatively prostrate stems or branches.

Annuals or biennials.

Seeds over $1.5 \mathrm{~mm}$. long.

Leaf-blades fully thrice as long as broad, acute or apiculate: capsules $3-4 \mathrm{~mm}$. long. Leaf-blades twice as long as broad, obtuse or retuse : capsules $2.5 \mathrm{~mm}$

Seeds less than $1.5 \mathrm{~mm}$. long.

Leaf-blades fully twice as long as broad, or most of them manifestly longer than broad.

Seeds barely $1.5 \mathrm{~mm}$. long: species campestrian.

Seeds about $1 \mathrm{~mm}$. long: species Floridian.

Leaf-blades mostly with parallel sides: seeds ovoid, smooth. Ultimate divisions of the inflorescence open cymes.

Ultimate divisions of the inflorescence raceme-like clusters.

Leaf-blades never with parallel sides: seeds oblong, transversely wrinkled.

Leaf-blades as broad as long or nearly so.

Foliage and capsules glabrous.

Stipules toothed : appendages of the glands minute or obsolete. Stipules parted: appendages of the glands petal-like.

Foliage and capsules manifestly pubescent.

Stems or branches hirsute or villous-hirsute.

Leaf-blades hirsute, not cordate at the base : involucre peduncled; glands red: seeds nearly smooth.

Leaf-blades lanate, cordate at the base: involucre sessile; glands greenish brown: seeds transversely wrinkled.

Stems or branches finely canescent.

Leaf-blades apiculate : capsules pubescent all over.

Perennials.

Leaf-blades obtuse : capsules pubescent along the angles.

Involucres inconspicuous, less than $1 \mathrm{~mm}$. high ; appendages obsolete.

Involucres corolla-like, over $1 \mathrm{~mm}$. high ; appendages petal-like.

ants with relatively rigid, erect or ascending stems or branches.

a. Perennials.

Foliage glabrous.

Foliage pubescent.

* Stems simple at the base : glands with obsolete appendages : capsules less than $1 \mathrm{~mm}$. high.

1. C. polygonifolia.

2. $C$ Ingallsii.

3. C. Geyern.

4. C. ammannioides.

5. C. Nashii.

6. C. Chiogenes.

7. C. serpens.

8. C. cordifolia.

9. C. brachypoda.

10. C. Laredana.

11. C. Garberi.

12. C. cinerascens.

13. C. deltoidea.

14. C. albomarginata.

15. C. Fendleri.

16. c. adicioides. 
** Stems much branched at the base: glands with toothed appendages: capsules over $1.5 \mathrm{~mm}$. high.

Leaf-blades barely twice as long as broad: appendages of the glands narrow crenulate borders.

Leaf-blades several times longer than broad: appendages of the b. Annuals. glands nearly as long as broad, dentate or fimbriate.

17. C. lata.

18. C. angusta. Foliage glabrous.

Leaf-blades at least twice as long as broad.

Capsules less than $1.5 \mathrm{~mm}$. long

Capsules over $1.5 \mathrm{~mm}$. long.

Glands of the involucre with inconspicuous appendages.

Glands of the involucre with conspicuous appendages.

Appendages mostly longer than broad: seeds 4-angled.

Appendages mostly broader than long: nearly terete.

Leaf-blades about as long as broad.

Leaf-blades involute, veinless above, apiculate.

Leaf-blades revolute, manifestly veined above, rounded at the apex. Foliage pubescent.

B. Leaf-blades manifestly toothed, but sometimes only at the apex.

Capsules glabrous.

Leaf-blades of a triangular type or orbicular to oval.

Stems simple or sometimes branched at the base : leaf-blades mostly of a triangular type.

Stems copiously branched at the base : leaf-blades not triangular.

Leaf-blades of an oblong, oblong-lanceolate or cuneate type.

Stems or branches prostrate.

Seeds faintly if at all transversely wrinkled.

Involucres less than $1 \mathrm{~mm}$. high: capsules $1.5 \mathrm{~mm}$. broad.

Involucres over $1 \mathrm{~mm}$. high : capsules $2 \mathrm{~mm}$. broad.

Seeds strongly transversely wrinkled.

Stems or branches erect or ascending.

Seeds brown or nearly black under a grayish coat: ultimate branches slender.

Seeds light gray : ultimate branches filiform.

Capsules manifestly pubescent.

Stems or branches erect or ascending.

Stems or branches prostrate.

Involucres axillary, sometimes approximate on lateral branchlets.

Involucres deeply split on one side.

Foliage pale green : capsules over $1.5 \mathrm{~mm}$. high : seeds fully $1 \mathrm{~mm}$. long.

Foliage bluish green: capsules less than $1.5 \mathrm{~mm}$. high : seeds less than $1 \mathrm{~mm}$. long.

Involucres not split on one side.

Capsules pubescent along the angles.

Capsules pubescent all over, but mainly so below the middle.

Glands of the involucres with inconspicuous appendages.

Leaf-blades and involucres glabrous or sparingly pubescent.

Capsules with long spreading hairs along the angles: seeds fully $1 \mathrm{~mm}$. long, with strongly wrinkled faces.

Capsules with short-appressed hairs along the angles: seeds less than $1 \mathrm{~mm}$. long, with obscurely wrinkled faces. Leaf-blades and involucres copiously pubescent, usually hirsute.

Glands of the involucre with red or magenta appendages, 2 of them at least large and somewhat petal-like : capsules $1.5 \mathrm{~mm}$. long: seeds over $1 \mathrm{~mm}$. long.

Glands of the involucre with pale, minute or obsolete appendages: capsules $1 \mathrm{~mm}$. long : seeds much less than $1 \mathrm{~mm}$. long.

Glands of the involucres with conspicuous petal-like appendages.

Involucres in peduncled glomerules.

1. Chamaesyce polygonifolia (L.) Small. Annual, pale green, glabrous. Stems branched at the base, the branches radially spreading, prostrate, $1-2.5 \mathrm{dm}$. long, forked : leaf-blades narrowly oblong to linear-lanceolate, $6-20 \mathrm{~mm}$. long, fleshy, acute or apiculate, entire : involucres turbinate-campanulate, less than $2 \mathrm{~mm}$. long : glands 4 , columnar, nearly naked, shorter than the involucre-lobes ; appendages obsolete: capsules globose-ovoid, 3-4 $\mathrm{mm}$. long, wrinkled in age : seeds oblong-ovoid, pale gray, minutely pitted. [Euphorbia polygonifolia L.] and fall.

In sand, along or near the coast, New Hampshire to Florida, and along the Great Lakes. Summer

2. Chamaesyce Ingállsii Small. Annual, pale green, glabrous. Stems branched at the base, the branches prostrate, dichotomous, 1-5 dm. long: leaf-blades oblong to ovateoblong, 8-16 mm. long, fleshy, entire ; petioles 1-3 mm. long : bracts similar to the leaves but smaller : involucres campanulate, about $1 \mathrm{~mm}$. high, as long as the peduncles : glands about $0.3 \mathrm{~mm}$. broad; appendages obsolete: capsules ovoid-globose, $2.5 \mathrm{~mm}$. long, minutely wrinkled in age: seeds ovoid or globose-ovoid, less than $2 \mathrm{~mm}$. long, white, sparingly pitted.

In sandy soil, Florida to Louisiana and Texas. Summer. 
3. Chamaesyce Geỳeri (Engelm.) Small. Annual, olive-green, glabrous. Stems branched at the base, the branches radially spreading, prostrate, $0.5-4 \mathrm{dm}$. long, forking, wiry: leaf-blades oblong to ovate, 4-12 mm. long, obtuse, usually mucronulate, entire, mostly truncate or subcordate at the base, short-petioled: involucres turbinate, $1.5 \mathrm{~mm}$. high, usually longer than the peduncles : glands about $0.3 \mathrm{~mm}$. broad; appendages inconspicuous, white or red: capsules globose-reniform, about $2 \mathrm{~mm}$. high: seeds narrowly ovoid, $1.5 \mathrm{~mm}$. long, nearly terete, ash-colored. [Euphorbia Geyeri Engelm.]

On plains or prairies, Minnesota to Illinois, Kansas and the Indian Territory. Summer and fall.

4. Chamaesyce ammannioides (H.B.K.) Small. Annual, glabrous. Stems branched at the base, the branches prostrate, very slender, 3-9 $\mathrm{dm}$. long, the ultimate divisions nearly filiform : leaf-blades oblong, 4-6 $\mathrm{mm}$. long, obtuse or abruptly pointed, entire, oblique at the base, slender-petioled : involucres campanulate, barely $1 \mathrm{~mm}$. high, shorter than the peduncles : glands transversely oblong, $0.5 \mathrm{~mm}$. broad ; appendages whitish, represented by mere borders : capsules depressed, about $2-2.5 \mathrm{~mm}$. broad, smooth : seeds ovoid, $1 \mathrm{~mm}$. long, smooth. [Euphorbia ammannioides H.B.K.]

In sand, southern peninsular Florida. Spring to winter.

5. Chamaesyce Náshii Small. Annual or biennial, glabrous, rather fleshy. Stems branched at the base, the branches prostrate, $2-5 \mathrm{dm}$. long, forking, relatively stout : leaves sometimes numerous on the branches; blades broadly oblong, varying to slightly broadest above or below the middle, 3-8 $\mathrm{mm}$. long, inclined to be truncate or retuse at the apex, entire, obtuse or truncate at the oblique base : involucres turbinate-campanulate, nearly $1.5 \mathrm{~mm}$. high, glabrous, longer than the peduncle : glands nearly $0.3 \mathrm{~mm}$. broad; appendages narrow, delicate, entire or undulate : capsules fully $1.5 \mathrm{~mm}$. high, glabrous : seeds oblong-ovoid, about $1 \mathrm{~mm}$. long, the faces with shallow transverse wrinkles.

On sandy beaches, peninsular Florida and the Keys. Spring to winter.

6. Chamaesyce Chiógenes Small. Annual or biennial, deep green, glabrous. Stems branched at the base, the branches prostrate, wiry, 1-3 dm. long, forking, with rather long internodes : leaves rather few ; blades often becoming parchment-like, oval, ovate or oblong, 3-8 mm. long, acute or obtuse, and entire, or broadly oval or suborbicular and toothed, inequilateral, manifestly petioled : involucres turbinate-campanulate, about $1 \mathrm{~mm}$. high, short-peduncled : glands minute; appendages mere white or pale borders : capsules fully $1 \mathrm{~mm}$. high, glabrous, the angles rather sharp: seeds about $1 \mathrm{~mm}$. long, 4-angled, the faces uneven.

In sand, Florida Keys. Throughout the year.

7. Chamaesyce sérpens (H.B.K.) Small. Annual, pale green, glabrous, sometimes glaucescent. Stems branched at the base, the branches slender or filiform, prostrate, 5-30 $\mathrm{cm}$. long : leaf-blades orbicular, orbicular-ovate or oval, 2-6 mm. long, obtuse or emarginate, entire, often slightly revolute-margined, short-petioled, the base oblique, rounded or subcordate ; stipules triangular, somewhat toothed at the apex : peduncles slightly longer than the petioles : involucres solitary in the axils, nearly $1 \mathrm{~mm}$. high : glands 4 , sessile, saucershaped, shorter than the involucre-lobes; appendages minute, irregular, crenulate : capsules nodding, depressed-globose, $2 \mathrm{~mm}$. broad : seeds oblong-ovoid, $1 \mathrm{~mm}$. long, smooth, obtusely 4-angled, light gray. [Euphorbia serpens H.B.K.]

On prairies, Iowa to Illinois, Kansas and Mexico. Spring to fall.

8. Chamaesyce cordifolia (Ell.) Small. Annual, glabrous. Stems branched at the base, the branches spreading or prostrate, $1-5 \mathrm{dm}$. long, forking, often diffuse : leaf-blades broadly oblong to oval or sometimes slightly broadest below the middle, obtuse, entire, manifestly petioled: involucres campanulate, $1 \mathrm{~mm}$. high, shorter than the peduncles: glands transversely oblong ; appendages white, orbicular or ovate, $0.8 \mathrm{~mm}$. long : capsules broader than high, $1.5 \mathrm{~mm}$. high, the angles sharp: seeds ovoid, $1 \mathrm{~mm}$. long, smooth, obscurely 4-angled. [Euphorbia cordifolia Ell.]

In sand, South Carolina to Florida and Texas. Summer and fall.

9. Chamaesyce brachýpoda Small. Annual, hirsute or villous-hirsute. Stems often branched at the base, the branches spreading, prostrate, 1-3 dm. long, forking, barely zigzag, the branchlets $1-2 \mathrm{~cm}$. long, with many joints : leaf-blades oblong to ovate, 2-7 $\mathrm{mm}$. long, obtuse, hirsute, entire, thick, very oblique, short-petioled : involucres fully 1 $\mathrm{mm}$. high, campanulate, hirsute, longer than the peduncles: glands red, about $0.5 \mathrm{~mm}$. broad ; appendages very narrow, entire or obsolete: capsules fully $1 \mathrm{~mm}$. long, globoseovoid, copiously pubescent, acute-angled : seeds less than $1 \mathrm{~mm}$. long, nearly smooth.

In sand, southern peninsular Florida. Spring to fall.

10. Chamaesyce Iaredàna (Millsp.) Small. Annual, viscid-villous with white hairs. Stems branched at the base, the branches numerous, $0.5-3 \mathrm{dm}$. long: leaf-blades ovate or oval-ovate, 2-5 mm. long, obtuse, entire, lanate, cordate at base : involucres campanulate, 
sessile, completely clothed with white hairs: glands 4, somewhat elongated transversely, the appendages obsolete : capsules slightly depressed, $1.5-2 \mathrm{~mm}$. broad, glabrous near the base, the lobes keeled: seeds sharply 4-angled, the faces with 4-6 transverse ridges. [Euphorbia Laredana Millsp.]

In dry soil, near Laredo, southern Texas. Spring and summer.

11. Chamaesyce Gárberi (Engelm.) Small. Annual or biennial, finely canescent. Stems widely branched, sometimes from the base, the branches spreading or ascending or decumbent, 1-4 dm. long, more or less zigzag : leaf-blades ovate or oval, 4-10 mm. long, apiculate, entire, oblique at the base, short-petioled: involucres solitary or few in clusters, campanulate, about $1 \mathrm{~mm}$. high, as long as the peduncle or longer : nearly glabrous : glands transversely oblong, $0.4 \mathrm{~mm}$. broad; appendages mere narrow dentate borders: capsules slightly broader than high, $1.5 \mathrm{~mm}$. high, the angles rather sharp, sparingly pubescent all over: seeds reddish brown, barely $1 \mathrm{~mm}$. long, with indistinct transverse wrinkles. [Euphorbia Garberi Engelm.]

In sand, Florida and Alabama. Spring to winter.

12. Chamaesyce cineráscens (Engelm.) Small. Annual or biennial, finely canescent. Stems branched at the base, the branches spreading or prostrate, $0.5-2 \mathrm{dm}$. long, slender, forking : leaves numerous ; blades suborbicular to ovate or oval-oblong, 3-6 mm. long, obtuse, entire, truncate at the base, short-petioled : involucres turbinate-campanulate, less than $1 \mathrm{~mm}$. high, pale, stout-peduncled : glands minute, often purple, nearly naked; appendages minute or obsolete: capsules fully $1 \mathrm{~mm}$. high, a little broader, pubescent, the angles sharp: seeds pale gray, oblong, about $1 \mathrm{~mm}$. long, sharply 4-angled, the faces prominently wrinkled transversely. [Euphorbia cinerascens Engelm.]

In dry soil, Texas and adjacent Mexico. Spring to fall.

13. Chamaesyce deltoìdea (Engelm.) Small. Perennial, nearly glabrous. Stems more or less diffusely branched at the base, the branches slender, zigzag, $5-10 \mathrm{~cm}$. long, usually wiry : leaf-blades thickish, deltoid-ovate or reniform, $1.5-3 \mathrm{~mm}$. long, obtuse or retuse, oblique, slightly revolute, short-petioled: involucres globose-campanulate, less than $1 \mathrm{~mm}$. long, as long as the peduncles or shorter : glands transversely oblong, minute, $0.3 \mathrm{~mm}$. broad; appendages obsolete : capsules barely $1 \mathrm{~mm}$. long, smooth and glabrous : seeds minute. [Euphorbia deltoidea Engelm.]

In sand, southern peninsular Florida. Spring to winter.

14. Chamaesyce albomarginàta (T. \& G. ) Small. Perennial, glabrous. Stems diffusely much branched from the base, the branches wire-like, $2-15 \mathrm{~cm}$. long, sometimes very numerous : leaf-blades suborbicular or ovate-orbicular, 4-8 mm. long, obtuse or acutish, entire, truncate or subcordate at the base, manifestly petioled : involucres campanulate, fully $1 \mathrm{~mm}$. high, as long as the peduncles or shorter : glands transversely oval, about $0.5 \mathrm{~mm}$. wide; appendages white, petal-like, fan-shaped, $1.5-2 \mathrm{~mm}$. broad, entire or crenulate : capsules globose-ovoid, 2 mm. long, sharply 3 -angled : seeds oblong-ovoid, 1-1.3 mm. long. [Euphorbia albomarginata T. \& G.]

In dry soil, Texas to California. Spring to fall.

15. Chamaesyce Féndleri (T. \& G.) Small. Annual (or perennial by a woody root), pale green, glabrous. Stems diffusely branched from the base, the branches spreading, wiry, 1-2 mm. long, brittle : leaf-blades suborbicular, oval or elliptic, 3-8 mm. long, obtuse, entire, short-petioled, the base oblique, obtuse or subcordate; stipules usually a fringe of short bristles: involucres solitary in the axils, sometimes clustered toward the ends of the branches, campanulate, 2-5 mm. high : glands saucer-shaped, oval ; appendages irregular, entire or slightly lobed : peduncles about,as long as the involucres : capsules deflexed, $3 \mathrm{~mm}$. in diameter, sharply 3 -lobed : seeds ovoid, $1.5 \mathrm{~mm}$. long, transversely wrinkled. [Euphorbia Fendleri T. \& G.]

On plains or prairies, Nebraska and Colorado to Texas, Mexico and Arizona. Spring to fall.

16. Chamaesyce adicioides Small. Perennial, shrubby, finely pubescent with pale hairs. Stems ascending, 2-4 dm. tall, rather copiously branched above, zigzag, sometimes $1 \mathrm{~cm}$. thick at the base : leaves numerous; blades ovate to oval, 2-3 mm. long, acute or acutish, entire, short-petioled : involucres campanulate, barely $1 \mathrm{~mm}$. high, longer than the peduncles, minutely pubescent, deciduous : glands about $0.4 \mathrm{~mm}$. broad: appendages obsolete : capsules pubescent, less than $1 \mathrm{~mm}$. long.

In sand or coral rock, Elorida. Spring to winter.

17. Chamaesyce làta (Engelm.) Small. Perennial, pale green, canescent. Stems branched from the somewhat woody base, the branches spreading or ascending, 5-10 cm. long: leaf-blades ovate to lanceolate, 5-10 mm. long, revolute-margined, abruptly narrowed, truncate or cordate at the base, short-petioled; stipules obsolete, or of a few short 
bristles : involucres solitary in the axils, $1 \mathrm{~mm}$. long, short-peduncled : glands 4, disk-like ; appendages narrow, undulate : capsules subglobose, $2 \mathrm{~mm}$. in diameter : seeds oblong, 1.5 mm. long, acutish at both ends, 4-angled, the faces inconspicuously transverse-wrinkled. [Euphorbia lata Engelm.]

On plains and prairies, Kansas to Texas and New Mexico. Spring to fall.

18. Chamaesyce angústa (Engelm.) Small. Perennial, minutely pubescent. Stems densely tufted, branched at the base, the branches erect or ascending, 1-4 dm. long, rather rigid : leaf-blades linear or linear-lanceolate, 1-2.5 cm. long, acute, revolute, entire, firm, sessile or nearly so : involucres turbinate to campanulate-turbinate, 1-1.5 mm. long, longer than the peduncles : glands reniform, barely $0.5 \mathrm{~mm}$. broad ; appendages white, fan-shaped, dentate or erose fimbriate : capsules broader than high, 2.5-3 mm. broad, whitish : seeds ovoid, 1.5-2 mm. long, transversely wrinkled. [Euphorbia angusta Engelm.]

In dry soil, Texas. Spring to fall.

19. Chamaesyce revolùta (Engelm.) Small. Annual, delicate, glabrous. Stems erect, very slender, sometimes nearly filiform, $0.8-2 \mathrm{dm}$. tall, simple below, forking above, the branches spreading or ascending : leaves few ; blades narrowly linear, 1-3 cm. long, usually about $1 \mathrm{~mm}$. broad, acute, entire, short-petioled : involucres sessile or on slender peduncles about $1 \mathrm{~mm}$. long, campanulate or turbinate-campanulate, less than $1 \mathrm{~mm}$. high, erect : glands minute, broader than long, purple; appendages white or reddish, oblong or ovate, obtuse, entire : capsules about $1 \mathrm{~mm}$. long, rather sharply 3-angled : seeds oblong, less than $1 \mathrm{~mm}$. long, sharply 4-angled, the faces irregularly wrinkled. [Euphorbia revoluta Engelm.]

On hillsides, along the Rio Grande, Texas and northern Mexico. Summer.

20. Chamaesyce polyclàda (Boiss.) Small. Annual, glabrous. Stems branched at the base, the branches numerous, decumbent or spreading, 0.5-1 dm. long, forked, very slender : leaf-blades oblong or elliptic-oblong, 4-7 mm. long, obtuse and mucronulate, entire, rounded at the slightly oblique base, short-petioled: involucres turbinate, about $1 \mathrm{~mm}$. high, long-peduncled, the lobes triangular : glands minute ; appendages inconspicuous, pale or white, entire or 2-3-toothed : capsules fully $1.5 \mathrm{~mm}$. long : seeds over 1 mm. long. [Euphorbia polyclada Boiss.]

In sandy soil, Texas. Spring and summer.

21. Chamaesyce Nuttállii (Engelm.) Small. Annual, bright green, glabrous. Stems slender, erect or ascending, branched, 1-6 dm. high, the branches wiry : leafblades mostly linear, $1-2.5 \mathrm{~cm}$. long, mucronulate or truncate at the apex, often involute, obtuse or narrowed at the base, petioled, usually curved, the midvein prominent; stipules lanceolate : involucres solitary in the axils, campanulate, less than $2 \mathrm{~mm}$. long, longpeduncled : glands 4, sancer-shaped ; appendages white, entire, oblong or ovate : capsules about $2 \mathrm{~mm}$. long : seeds ovoid, $1.5 \mathrm{~mm}$. long, gray, 4-angled. [Euphorbia petaloidea var. Nuttallii Engelm.]

On prairies, Kansas to Texas and Mexico. Spring to fall.

22. Chamaesyce petaloìdea (Engelm.) Small. Annual, pale green, glabrous. Stems usually rather stout, erect, branched above, 1-6 dm. high : leaf-blades linear, oblong, or linear-lanceolate, 1-2.5 cm. long, obtuse, usually flat, straight, entire, slender-petioled ; stipules a fringe of bristles : involucres solitary in the axils, oblong-campanulate, $2 \mathrm{~mm}$. long: glands 4, wineglass-shaped, about as long as the lobes; appendage white, reniform, ovate or suborbicular, entire or undulate: peduncles as long as the involucres: capsules globose-reniform, fully $2 \mathrm{~mm}$. long : seeds oblong-ovoid, nearly $2 \mathrm{~mm}$. long, ash-colored, minutely pitted, nearly terete. [Euphorbia petaloidea Engelm.]

On prairies, Iowa to Wyoming and Texas. Summer to fall.

23. Chamaesyce buxifolia (Lam.) Small. Annual, glabrous. Stems erect or decumbent, 2-5 dm. long, branching, purple, with long or short internodes: leaf-blades ovate to broadly oblong or cuneate near the base of the stem, rather fleshy, 8-12 $\mathrm{mm}$. long, obtuse or acutish, involute, rounded or subcordate, nearly sessile : involucres campanulate, about $1.5 \mathrm{~mm}$. high, as long as the peduncles or shorter: glands transversely oblong, 0.5 $\mathrm{mm}$. broad; appendages consisting of mere whitish borders : capsules 2.5-3 mm. broad, glabrous, the angles sharp: seeds globose-ovoid, 1-1.5 mm. long. [Euphorbia buxifolia Lam.]

In sand on the coast, peninsular Florida and the Keys. Also in tropical America. Spring to winter.

24. Chamaesyce Porteriàna Small. Annual, glabrous, or puberulent, bluish green. Stems erect or ascending, sparingly branched, 1-2 dm. long: leaf-blades ovate, oval or suborbicular, 5.10 mm. long, obtuse or retuse, entire, ciliolate, thick, veined above, truncate or subcordate at the very oblique base, short-petioled : involucres hemispheric, nearly 
$1.5 \mathrm{~mm}$. high, about as long as the peduncles, glabrous : glands fully $0.5 \mathrm{~mm}$. broad ; appendages colored, undulate : capsules $1.5-2 \mathrm{~mm}$. in diameter.

In sand, southern peninsular Florida. Spring to fall.

25. Chamaesyce villifera (Scheele) Small. Annual, villous. Stems erect or ascending, 0.5-3 dm. tall, forking, slightly zigzag : leaf-blades ovate or triangular-ovate, 3-6 cm. long, obtuse or acutish, entire, truncate or subcordate at the oblique base, short-petioled : involucres campanulate, $1 \mathrm{~mm}$. long, longer than the peduncles : glands minute ; appendages white or rose-colored, oval or cuneate, 3-4 times longer than the width of the glands : capsules 3-lobed, $2 \mathrm{~mm}$. broad, $1.5 \mathrm{~mm}$. high, the angles rather acute : seeds ovoid, less than $1 \mathrm{~mm}$. long, transversely wrinkled. [Euphorbia villhfera Scheele.]

In dry soil, Texas. Spring to fall.

26. Chamaesyce Stanfièldii Small. Annual, sparingly villous or glabrate. Stems forking above, sometimes branched at the base, slender and wiry, slightly zigzag : leafblades triangular or ovate-triangular, 5-8 mm. long, serrate, sometimes slightly auricled on one side of the very oblique usually truncate base, short-petioled : involucres campanulate, about $1 \mathrm{~mm}$. high, usually longer than the peduncles, glabrous, ribbed : glands 0.2-0.3 mm. broad; appendages minute, white, petal-like, longer than broad : capsules about 1.5 $\mathrm{mm}$. high, sharp-angled, glabrous : seeds ovoid, about $1 \mathrm{~mm}$. long, with few shallow transverse wrinkles.

In dry soil, southern Texas. Summer and fall.

27. Chamaesyce Blodgéttii (Engelm.) Small. Annual or biennial, glabrous or nearly so. Stems branched at the base, the branches few or numerous, 1-4 dm. long, forking, prostrate : leaves numerous ; blades oblong or nearly so, 3-8 mm. long, minutely serrate near the apex, oblique at the base, manifestly petioled: involucres campanulate, less than $1 \mathrm{~mm}$. high, short-peduncled : glands minute, elevated; appendages irregular, white or slightly colored : capsules $1.5 \mathrm{~mm}$. high, about as broad, glabrous, the angles rather sharp: seeds about $1 \mathrm{~mm}$. long, gray, 4-angled, the faces faintly transversely wrinkled. [Euphorbia Blodgettii Engelm.]

In sand, Florida Keys. Spring to winter.

28. Chamaesyce serpyllifòlia (Pers.) Small. Annual, dark green, or becoming reddish, glabrous. Stems branched from the base, the branches slender, prostrate or ascending, 1-4 dm. long: leaf-blades oblong to spatulate, 3-12 $\mathrm{mm}$. long, obtuse or retuse, nearly entire, or serrulate to below the middle, short-petioled, the base oblique, mostly truncate or obtuse: stipules at length a fringe of weak bristles : involucres solitary in the axils, sometimes clustured toward the ends of the branchlets, over $1 \mathrm{~mm}$. long: glands 4, disk-like; appendages narrow, lobed: capsules $2 \mathrm{~mm}$. broad, slightly nodding : seeds ovoid, hardly $1 \mathrm{~mm}$. long, 4 -angled, the faces transversely wrinkled and pitted. [Euphorbia serpyllifolia Pers.]

In dry soil, Wisconsin to California and Mexico. Spring to fall.

29. Chamaesyce glyptospérma (Engelm.) Small. Annual, pale green, glabrous. Stems branched near the base, the branches ascending, spreading or prostrate, $4-40 \mathrm{~cm}$. long: leaves numerous; blades oblong, linear-oblong or rarely ovate, 2-12 mm. long, more or less falcate, obtuse at the apex, inequilateral, serrulate, very oblique and obtuse or subcordate at the base, short-petioled; stipules becoming fringed: involucres solitary in the axils, or often clustered, campanulate, fully $1 \mathrm{~mm}$. long, with 4 dark ribs : glands 4 , saucer-shaped; appendages narrow, crenulate, or slightly lobed : capsules depressedglobose, less than $2 \mathrm{~mm}$. in diameter, nodding : seeds oblong, $1 \mathrm{~mm}$. long, ash-colored, strongly transversely wrinkled, not pitted. [Euphorbia glyptosperma Engelm.]

In sandy soil, Ontario to British Columbia, Texas and Mexico. Spring to fall.

30. Chamaesyce nùtans (Lag.) Small. Annual, glabrous or sparingly pubescent. Stems branched, at least above, ascending or erect, 1.5-6 dm. high, the branches mostly spreading, and 2-ranked, often recurved at the ends, the flowering branches slender : leafblades oblong or linear-oblong, varying to ovate or obovate, often falcate, oblique, 3-nerved, unequally serrate, often with a red blotch and red margins, short-petioled; stipules slightly lacerate : involucres narrowly obovoid, $1 \mathrm{~mm}$. long, one-half or one third as long as the peduncles: glands 4 ; appendages orbicular or reniform, entire, white or red : capsules glabrous, fully $2 \mathrm{~mm}$. in diameter : seeds oblong-ovoid, $1.5 \mathrm{~mm}$. long, 4-angled, brown or nearly black under a grayish coat, transverse-ridged. [Euphorbia nutans Lag.]

In fields and thickets, throughout eastern North America, except the extreme north, extending west to the Rocky Mountains. Spring to fall.

31. Chamaesyce Brasiliénsis (Lam.) Small. Similar to C. nutans in habit. Stems sometimes woody at the base, the flowering branches filiform: leaf-blades more finely toothed : capsules usually less than $2 \mathrm{~mm}$. in diameter : seeds commonly about $1 \mathrm{~mm}$. long, black or nearly so. [Euphorbia Brasiliensis Lam.]

In waste places and dry soil, Gulf States to Mexico and tropical America. Spring to winter. 
32. Chamaesyce Tràcyi Small. Annual, somewhat pubescent. Stems simple below and erect, or branched at the base, the branches ascending. 1-5 dm. long, usually reddish, thinly canescent : leaf-blades oblong or slightly broadest above the middle, mostly 5-13 $\mathrm{mm}$. long, shallowly toothed near the apex, glabrous at maturity, short-petioled : involucres campanulate, about $1 \mathrm{~mm}$. high, not split: glands transversely oblong, about $0.4 \mathrm{~mm}$. broad; appendages minute, undulate: capsules about as broad as long, barely $1.5 \mathrm{~mm}$. high, slightly pubescent all over, but especially so below the middle: seeds 4-angled, oblong-ovoid, about $0.8 \mathrm{~mm}$. long, some or all of the faces slightly wrinkled.

In sandy soil, southern Mississippi. Summer.

33. Chamaesyce humistràta (Engelm.) Small. Annual, light green, puberulent or sparingly pilose. Stems branched from the base, the branches slender, radiately spreading, prostrate or ascending, 1-3 dm. long : leaf-blades ovate-oblong or sometimes narrower, 4-10 mm. long, serrulate at least above the middle, oblique, obtuse or subcordate at the base, short-petioled; stipules at length fringed : involucres in lateral clusters, split on one side, $.1 \mathrm{~mm}$. long, faintly nerved : glands 4, disk-like ; appendagesnarrow, irregular, red or white : capsules depressed-globose, less than $2 \mathrm{~mm}$. in diameter, its 3 lobes keeled : seeds oblong, 1 mm. long, papillose, ash-colored, obscurely transverse-wrinkled. [Euphorbia humistrata Engelm.]

In dry or sandy soil, Quebec to New York, Kansas and Mississippi. Summer and fall.

34. Chamaesyce pergemèna Small. Biennial or perennial, glaucescent. Stems branched at the base, the branches slender, wire-like, $0.5-1.5 \mathrm{dm}$. long, glabrous or nearly so, forking: leaf-blades parchment-like, oblong or ovate, very oblique, 3-6 mm. long, obtuse, serrulate, minutely pubescent on both sides, conspicuously inequilateral, cordate or subcordate at the base, short-petioled : involucres campanulate, $1.5 \mathrm{~mm}$. high, minutely pubescent, with a split on one side through which the pedicel protrudes: glands transversely oblong, variable in size, about $0.5 \mathrm{~mm}$. broad; appendages white or pink, as long as the glands or longer, one much longer than the others, more or less uneven along the edges : capsules about $1 \mathrm{~mm}$. high, minutely pubescent : seeds less than $1 \mathrm{~mm}$. long, the faces transversely wrinkled. [Euphorbia pergemena Small.]

In sand, peninsular Florida. Also in the West Indies. Spring to winter.

35. Chamaesyce prostràta (Ait.) Small. Annual, more or less pubescent or glabrate. Stems branched at the base, the branches prostrate, 0.5-2 dm. long, forking, commonly very leafy : leaf-blades oval, obovate or oblong, often a little broadest above the middle, 4-6 mm. long, obtuse, sparingly serrulate at the apex, oblique at the base, manifestly petioled : involucres turbinate, $0.5-0.7 \mathrm{~mm}$. high : glands minute, $0.3 \mathrm{~mm}$. broad; appendages narrow : capsules $1 \mathrm{~mm}$. high, somewhat broader, pubescent along the angles: seeds less than $1 \mathrm{~mm}$. long, transversely wrinkled. [Euphorbia prostrata Ait.]

In sandy soil, Florida to Texas and Mexico.

36. Chamaesyce málaca Small. Annual, pubescent. Stems branched at the base, the branches prostrate, closely and softly pubescent, especially when young, $2-5 \mathrm{dm}$. long, forked : leaf-blades broadly oblong, 1-1.5 cm. long, or shorter on the branchlets, obscurely toothed above the middle, mostly blunt, oblique at the base and very inequilateral, with slender but short petioles : involucres turbinate-campanulate, fully $1 \mathrm{~mm}$. high, minutely pubescent, longer than the peduncles : glands about $2 \mathrm{~mm}$. broad; appendages undulate, minute, very variable in size: capsules ovoid-globose, about $1.5 \mathrm{~mm}$. high, sparingly pubescent : seeds oblong-ovoid, fully $1 \mathrm{~mm}$. long, sharply angled, with strong transverse wrinkles.

On plains and prairies, the Indian Territory to Louisiana and Texas. Summer and fall.

37. Chamaesyce maculata (L.) Small. Annual, dark green, puberulent or pilose. Stems branched at the base, the branches slender, radiately spreading, prostrate, $5-40 \mathrm{~cm}$. long, often dark red : leaf-blades usually blotched, oblong or ovate-oblong, 4-16 mm. long, obtuse, more or less serrate, short-petioled, the base oblique, subcordate; stipules a fringe of bristles: involucres solitary in the axils, mostly $1 \mathrm{~mm}$. long: glands 4 , cup-shaped; appendages narrow, white or red, crenulate: peduncles shorter than the involucres: capsules ovoid-globose, about $2 \mathrm{~mm}$. in diameter, pubescent : seeds ovoid-oblong, less than 1 $\mathrm{mm}$. long, obtusely angled, ash-colored, minutely pitted and inconspicuously transversewrinkled.' [Euphorbia maculata L.]

Throughout North America, except the extreme north. Apparently introduced west of the Rocky Mountains. Spring to fall.

38. Chamaesyce conférta Small. Annual, more or less villous. Stems branched at the base, the branches spreading and prostrate, $0.5-2 \mathrm{dm}$. long, often forked, short-jointed : leaves approximate, clustered on short branchlets; blades oblong to ovate, 3-6 mm. long, acutish or obtuse, serrate, paler and more densely pubescent beneath than above, truncate 
at the oblique base, short-petioled: involucres turbinate-campanulate, villous, barely $2 \mathrm{~mm}$. high, sessile or nearly so: glands bearing very irregular reddish or magenta toothed appendages, 2 of them nearly as long as the body of the involucre : capsules ovoidglobose, about $1 \mathrm{~mm}$. long, minutely pubescent : seeds oblong-ovoid, $0.6 \mathrm{~mm}$. long, with strong transverse wrinkles.

In sand, southern peninsular Florida and tropical America. Spring to winter.

39. Chamaesyce stictospòra (Engelm.) Small. Annual, yellowish green, pilose throughout. Stem branched at the base, the branches ascending or radiating, 5-30 cm. long: leaves numerous; blades oblong to suborbicular, 4-6 mm. long, obtuse, dentate-serrate at the apex, short-petioled, the bases truncate or subcordate ; stipules fringed : involucres clustered, campanulate, $1 \mathrm{~mm}$. high : glands 4, cup-shaped; appendages rather inconspicuous, crenate, some of them irregular or obsolete : peduncles at length longer than the involucres : capsules ovoid, 1-2 mm. in diameter : seeds narrowly ovoid, 1.2-1. $5 \mathrm{~mm}$. long, pointed, pitted, gray or ash-colored, sharply 4-angled. [Euphorbia stictospora Engelm.]

On prairies, Kansas and Colorado to Mexico. Spring to fall.-A Texan variety, with less pubescent foliage, broader and more strongly nerved leaf-blades smaller and broader seeds and narrower appendages to the glands of the involucre, is C. stictospora Guadalupénsis Small. [Euphorbia stictospora var. Texensis Millsp., not Euphorbia Texana Boiss. I

40. Chamaesyce adenóptera (Bertol.) Small. Annual, closely villous. Stems branched at the base, the branches decumbent or prostrate, $0.5-1.5 \mathrm{dm}$. long, simple or forking : leaves numerous, approximate or nearly contiguous, blades oblong or ovateoblong, 4-8 mm. long, acute or acutish, serrulate, very oblique at the base, short-petioled : involucres about $1 \mathrm{~mm}$. high, campanulate or turbinate-campanulate, densely pubescent : glands minute; appendages white or rose, 2 often much longer than the others, oblique, toothed: capsules $1.5 \mathrm{~mm}$. long, densely pubescent, the angles sharp: seeds about $1 \mathrm{~mm}$. long, oblong, 4-angled, the faces transversely wrinkled. [Euphorbia adenoptera Bertol.]

In pine lands, Florida and tropical America. Spring to winter.

41. Chamaesyce pilulifera (L.) Small. Annual, pubescent. Stems usually branched at the base, the branches ascending or prostrate, 1-4 dm. long, forking or simple : leafblades oblong to oblong-lanceolate, $1-2.5 \mathrm{~cm}$. long, acute, finely serrate, blotched in the middle, oblique, manifestly petioled : involucres in dense short-stalked clusters, turbinate, less than $1 \mathrm{~mm}$. high : glands minute, $0.2 \mathrm{~mm}$. broad; appendages obsolete : capsules little over $1 \mathrm{~mm}$. broad, pubescent : seeds $0.9 \mathrm{~mm}$. long, the faces slightly wrinkled transversely. [Euphorbia pilulifera L.]

In sand, Florida to Texas, New Mexico and tropical America. Also in the tropics generally. Spring to winter.-The small form with closely prostrate branches and leaves commonly about $1 \mathrm{~cm}$. long, is C. pilulifera procumbens (Boiss.) Small. [E. pilulifera var. procumbens Boiss.]

\section{ZYGOPHYLLÍDIUM Small.}

Annual herbs, with erect forking stems. Leaves opposite or rarely alternate on the lower part of the stem : blades narrow, equilateral, not oblique at the base, entire : stipules gland-like, often obsolete. Involucres delicate, short-peduncled in the upper forks. Glands 5, broader than long, subtended by petal-like appendages. Capsules long-pedicelled, 3-lobed. Seeds terete, usually narrowed upward, more or Jess papillose, the caruncle sometimes wanting. SPURGE.

1. Zygophyilldium hexágonum (Nutt.) Small. Yellowish green, glabrous or sparingly pubescent. Stems slender, 1-5 dm. tall, branched, the branches ascending, often almost filiform : leaves mainly opposite ; blades linear, oblong or lanceolate, very short-petioled, obtuse or acute, equilateral; stipules obsolete or very narrow : involucres solitary in the axils, often clustered, 2-3 mm. long, ciliate, pubescent, short-peduncled, with 5 glands; appendages triangular-ovate whitish or green : capsules glabrous, $4 \mathrm{~mm}$. in diameter : seeds ovoid or oblong-ovoid, $3 \mathrm{~mm}$. long, terete, papillose. [Euphorbia hexagona Nutt.]

On prairies, lowa to Montana, Texas and Colorado. Spring to fall.

\section{TRICHEROSTÍGMA Kl. \& Garcke.}

Shrubs, with erect or procumbent stems and more or less succulent tissues. Leaves scattered, few, usually fugacions : blades small, becoming firm. Stipules none. Invocymes, hemispheric, pubescent within; lobes toothed or fimbriate. Glands 5, subtended wrinkled. 
1. Tricherostigma antisyphilítica (Zucc.) Kl. \& Garcke. Shrubby, glabrous. Stems procumbent ; branches erect or ascending, 2-8 dm. tall, stout, simple or nearly so, early leafless : leaves few, alternate ; blades linear, $10-18 \mathrm{~mm}$. long, rigid, acute, recurved : bracts scale-like, leathery, triangular : involucres sessile, or nearly so, constricted at the base, 2-3 mm. high : glands transversely oblong, barely $1 \mathrm{~mm}$. broad; appendages white, longer than the glands, undulate, somewhat cucullate : capsules globose-ovoid, $3-3.5 \mathrm{~mm}$. long, glabrous ; lobes rounded : seeds 2-2.5 mm. long, 4-sided, white, irregularly wrinkled.

On gravelly or limestone hillsides along the Rio Grande, Texas and Mexico.

\section{DICHROPHÝLLUM Kl. \& Garcke.}

Annual caulescent herbs, with the erect stems often topped by a several-rayed umbel. Leaves scattered below the umbel, thence opposite or whorled : blades often petal-like and very showy, entire : stipules at the base of the petioles or leaf-blades, fugacious. Involucres campanulate, in rather dense cymes, pubescent without and within : lobes fimbriate. Glands 5, peltate, somewhat concave, with white or pink petal-like appendages. Capsule exserted, large, pubescent, the lobes rounded. Seeds narrowed upward, reticulated, with caruncles. SPURGE.

Bracts of a linear type, reddish margined : involucral glands with reddish appendages.

\section{D. bicolor.}

Bracts of an oblong type, white margined : involucral glands with white appendages. 2. D. marginatum.

1. Dichrophyllum bícolor (Engelm. \& Gray) Kl. \& Garcke. Stem 3-15 dm. tall, usually topped by a 3-rayed simple or compound umbel : leaves scattered; blades oblong to oblong-lanceolate or the lower ones slightly broadest above the middle, all sessile, apiculate : bracts linear or linear-spatulate, about as long as the leaves or longer : involucres campanulate, 3.5-4 mm. high, hairy, longer than the peduncles : glands rather reniform, $1.5 \mathrm{~mm}$. broad ; appendages white, reniform or fan-shaped, 3-4 mm. long, crenulate : capsules woolly, becoming about $1 \mathrm{~cm}$. broad, much depressed, 3-lobed : seeds ovoid, 5-6 mm. long. [Euphorbia bicolor Engelm. \& Gray.]

On rich plains, Arkansas and the Indian Territory to Louisiana and Texas. Spring to fall.

2. Dichrophyllum marginàtum (Pursh) Kl. \& Garcke. Stem 3-9 dm. tall, somewhat channeled, usually pilose, topped by a mostly 3-rayed umbel : leaves scattered; blades ovate to obovate, $2-9 \mathrm{~cm}$. long, entire, sessile : rays of the umbel forked: bracts large, white-margined : involucres campanulate, often clustered, $4 \mathrm{~mm}$. long, usually pubescent, bearing 5 glands subtended by white reniform appendages: capsules depressed-globose, 6 $\mathrm{mm}$. in diameter, usually pubescent, the lobes rounded : seeds ovoid-globose, terete, about $4 \mathrm{~mm}$. long, dark ash-colored, reticulate-tuberculate. [Euphorbia marginata Pursh.]

In dry soil, Minnesota to Colorado and Texas. Introduced into waste places in the Central and Atlantic States. Spring to fall.

\section{TITHYMALÓPSIS Kl. \& Garcke.}

Perennial herbs, with tough rootstocks and glabrous or pubescent foliage. Stems solitary or tufted, topped by several-rayed umbels. Leaves alternate or scattered below the umbels, thence opposite or whorled : blades entire, more or less leathery, inclined to be revolute. Involucres sessile or peduncled, few and remote, or in rather close clusters and numerous: lobes toothed or fimbriate. Glands sessile or stalked, with white pink or rose petal-like appendages. Capsule exserted, sometimes conspicuously so, often broader than high : lobes rounded. Seeds narrowed upward, more or less conspicuously punctate, without caruncles. SPURGE.

Leaves exceedingly numerous, approximate or imbricated.

Leaves relatively few, never imbricated.

stems normally underground; branches of the inflorescence tufted; all leaves

or bracts opposite.
Glands of the involucre with inconspicuous margin-like appendages. Branches spreading or prostrate: leaf-blades fleshy. Branches erect or ascending : leaf-blades thin.

Glands of the involucre with conspicuous white appendages.

Stems erect, topped by the umbel-like inflorescence, their leaves alternate. Stem-leaves reduced to scales.

Stem-leaves with normally expanded blades.

A. Inflorescence of scattered long-peduncled involucres.

a. Involucres $2-4 \mathrm{~mm}$. across the appendages.

Stem-leaves with linear blades, fugacious.

Stem-leaves with oblong or lanceolate blades, persistent. Appendages about as broad as the glands or narrower. Appendages mainly much longer than the glands.

1. T. polyphylla.

2. T. Ipecacuanhae.

3. T. gracilis.

4. T. eriogonoides.

5. T. mercurialina.

6. T. Curtisii.

7. T. exserta.

8. T. Joorii. 
b. Involucres 6-10 $\mathrm{mm}$. across the appendages.

B. Inflorescence aggregated into terminal cymes or cymose clusters. Leaf-blades manifestly petioled, the petioles over $2 \mathrm{~mm}$. long.

Leaf-blades sessile or nearly so, the petioles, if present, less than $1 \mathrm{~mm}$. long.

Involucres $3.5 \mathrm{~mm}$. across the appendages or narrower.

Involucres $4-8 \mathrm{~mm}$. across the appendages. Appendages about as long as the involucre.

Appendages much longer than the involucre.

Appendages longer than wide: leaf-blades relatively narrow. Appendages as wide as long or wider: leaf-blades relatively broad.
9. T. zinniiflora.

10. T. apocynifolia.

11. T. discoidalis.

12. T. olivacea.

13. T. corollata.

14. T. paniculata.

1. Tithymalopsis polyphýlla (Engelm.) Small. Perennial, glabrous. Stems tufted or branched at the base, the branches erect or spreading, $0.5-2.5 \mathrm{dm}$. long, simple or more or less branched : leaves numerous, approximate, linear or linear-spatulate, $5-15 \mathrm{~mm}$. long, straight or slightly curved, sessile : bracts oblong or linear-oblong : involucres turbinatecampanulate, about $1.5 \mathrm{~mm}$. high, abruptly contracted at the base, shorter than the peduncles at maturity : glands $0.5-0.6 \mathrm{~mm}$. broad; appendages white or pinkish, reniform or mere undulate or crenate borders: capsules globular, $4-4.5 \mathrm{~mm}$. in diameter: seeds oval, 2.5 mm. long, smooth, white. [Euphorbia polyphylla Engelm.]

In sand, southern peninsular Florida.

2. Tithymalopsis Ipecacuánhae (L.) Small. Perennial by a subterranean stem and root, usually glabrous. Branches several or many, slender, spreading or ascending, 1-3 dm. long, forking : leaves mostly opposite, green or red; blades wonderfully variable in outline, from linear to orbicular, 1-7 cm. long, entire, the upper sometimes whorled, the lower sometimes alternate, short-petioled ; stipules triangular : involucres axillary, mostly hemispheric, about $2 \mathrm{~mm}$. long, slender-peduncled; bearing 5 transversely elliptic or oblong, green, sessile, narrowly appendaged glands : capsules $3 \mathrm{~mm}$. in diameter, nodding: seeds light gray, oblong-ovoid, about $2.5 \mathrm{~mm}$. long, pitted, obscurely 4-sided.

In dry sandy soil, Connecticut to Florida, mostly near the coast. Also in southern Indiana. Spring to fall.

3. Tithymalopsis grácilis (Ell.) Small. Perennial, glabrous. Branches wiry, tufted, 1-3 dm. long, trichotomous or dichotomous : leaves mainly opposite; blades suborbicular to ovate or linear, or rarely broader than long, 1-5 cm. long, obtuse or retuse, or in the case of narrow ones acute, all entire, sessile or nearly so ; stipules triangular : peduncles as long as the accompanying leaves or longer : involucres campanulate or turbinate-campanulate, $2 \mathrm{~mm}$. high : glands transversely oblong, less than $1 \mathrm{~mm}$. broad, undulate and narrowly appendaged : capsules exserted, drooping, $2.5 \mathrm{~mm}$. in diameter.

In sand, South Carolina to Georgia and Florida. Spring to fall.

4. Tithymalopsis eriogonoìdes Small. Perennial, deep green, glabrous. Branches several or many together, 1-3 dm. long, diffusely branched into a rounded head 1-3 dm. in diameter, the branches very slender, zigzag, the ultimate divisions nearly filiform : leaves opposite above, the larger ones often reflexed ; blades linear or linear-spatulate, $0.5-1.5 \mathrm{~mm}$. long, obtuse or acutish, entire, barely petioled: peduncles filiform, 3-8 mm. long at maturity : involucres campanulate, about $1 \mathrm{~mm}$. high, erect or ascending : glands reniform, about $0.5 \mathrm{~mm}$. broad; appendages somewhat reniform, white or pink, about $1 \mathrm{~mm}$. broad, longer than the gland, some rounded, others emarginate. [Euphorbia eriogonoides Small.]

In loose sand, eastern Georgia and Florida. Spring and summer.

5. Tithymalopsis mercurialina (Michx.) Small. Perennial, bright green, nearly glabrous. Stems erect or decumbent, often several together, glabrous except a few scattered hairs about the nodes, forking above: leaves reduced to scales at the base of the stem: bracts foliaceous, opposite ; blades oval, elliptic or oblong-ovate, $2-5 \mathrm{~cm}$. long, entire, somewhat undulate, obtuse, glabrous, except the ciliate margin, rather abruptly narrowed at the base, short-petioled: peduncles nearly filiform, 1-5 cm. long : involucres campanulate, $2 \mathrm{~mm}$. high, erect or nearly so: glands transversely oblong, about $1 \mathrm{~mm}$. broad; appendages white, undulate, narrower than the gland: capsules exserted beyond the involucre. [Euphorbia mercurialina Michx.]

On hillsides and sandy soil, Tennessee to Alabama and Florida. Spring and summer.

6. Tithymalopsis Curtísii (Engelm.) Small. Perennial, glabrous. Stems slender, solitary or several together, erect or ascending, 1-4 dm. tall, more or less branched : leaves scattered except the whorl subtending the umbel 3-5-rayed; blades linear, $1.5-4 \mathrm{~cm}$. long, usually acute : involucres campanulate, about $1 \mathrm{~mm}$. high, much shorter than the nearly filiform peduncles : glands green, transversely oblong, about $0.5 \mathrm{~mm}$. broad; appendages white, petal-like, much larger than the gland, undulate : capsules subglobose, 
$3 \mathrm{~mm}$. high, glabrous, seated on the involucre: seeds subglobose, about $2 \mathrm{~mm}$. long, smooth. [Euphorbia Curtisii Engelm.]

In pine lands, North Carolina to Florida. Summer.

7. Tithymalopsis exsérta Small. Perennial, glabrous, branched at the base, the branches closely or loosely tufted, 1-3 dm. long, forking above, reddish or purple : leaves alternate below the umbel, thence opposite ; blades oblong or lanceolate, $2-6 \mathrm{~cm}$. long, obtuse or acutish, somewhat undulate, sessile or nearly so : peduncles filiform, $1-3.5 \mathrm{~cm}$. long at maturity : involucres campanulate, nearly $2 \mathrm{~mm}$. high, white or whitish green, erect: glands transversely oblong, less than $1 \mathrm{~mm}$. broad; appendages narrow undulate borders or a mere line : capsules $4 \mathrm{~mm}$. in diameter, well exserted beyond the involucres: seeds 3-3.5 mm. long.

In pine lands, Florida. Summer.

8. Tithymalopsis Joòrii (Norton) Small. Perennial, glabrous or pubescent. Stems 1-1.5 dm. tall, sparingly branched at the base and above: leaves alternate, few ; blades ovate to broadly oblong, 1-2 $\mathrm{cm}$. long, obtuse, sometimes undulate, sessile : peduncles 10$25 \mathrm{~mm}$. high : involucres few, $2-2.5 \mathrm{~mm}$. high : glands narrow; appendages suborbicular to cuneate, one or two of them often imperfect: capsules globular, somewhat depressed, 3-4 mm. broad : seeds globose-ovoid. [Euphorbia corollata var. Joorii Norton.]

In dry soil, eastern Texas. Spring and summer.

9. Tithymalopsis zinniiflòra Small. Perennial, dark green. Stems usually solitary, erect, $3-5 \mathrm{dm}$. tall, with a few ascending branches below the 3-rayed umbel, pubescent with scattered hairs : leaves alternate except those subtending the umbel; blades narrowly linear-lanceolate, or nearly linear, $2-5 \mathrm{~cm}$. long, mostly reflexed, acute or rather obtuse, sparingly pubescent above, glabrate beneath, somewhat revolute, nearly sessile or with somewhat hairy petioles less than $1 \mathrm{~mm}$. long: peduncles slender, erect, $1-3.5 \mathrm{~cm}$. long, angled, especially above : involucres campanulate, $2 \mathrm{~mm}$. high, angled : glands oblongreniform, fully $1 \mathrm{~mm}$. broad; appendages white or pink, suborbicular or 4 -sided, $3 \mathrm{~mm}$. long, rounded or emarginate at the apex : capsules 4.5-5 mm. in diameter. [Euphorbia
[ zinniiflora Small.]

In sandy soil, Georgia and Alabama. Spring.

10. Tithymalopsis apocynifòlia Small. Perennial, bright green. Stems solitary or tufted, erect or ascending, $2-6 \mathrm{dm}$. tall, slender, pubescent or glabrate, zigzag, at least at maturity, the umbel 2-3-rayed, the rays dichotomous, wire-like or filiform, ascending: leaves alternate except the whorl or pair subtending the umbel ; blades thinnish, oblong to oval, 2-7 cm. long, obtuse, slightly revolute, pale beneath, with glaucous midrib sometimes pubescent on both sides ; petioles 3-6 mm. long, densely villous : bracts opposite, similar to the leaves but smaller : peduncles filiform, glabrous : involucres campanulate, barely 1.5 $\mathrm{mm}$. high, glabrous : glands transversely oblong, about $0.5 \mathrm{~mm}$. broad; appendages white, orbicular-cuneate, $1.5-2 \mathrm{~mm}$. long, rounded at the apex : capsules about $5 \mathrm{~mm}$. in diameter [Euphorbia apocynifolia Small.]

In sandy soil, Georgia and Florida to Mississippi. Summer and fall.

11. Tithymalopsis discoidàlis (Chapm.) Small. Perennial, sparingly pubescent or glabrous. Stems erect or ascending, the umbel usually 3-rayed, the rays mostly forked, slender : leaves scattered except those subtending the umbel ; blades linear, 2-6 cm. long, obtuse, revolute, paler beneath, sessile : involucres campanulate, at least $1 \mathrm{~mm}$. high, as long as the peduncle or shorter: glands deep red, transversely oblong, $1 \mathrm{~mm}$. broad ; appendages reniform, white : capsules subglobose, $3 \mathrm{~mm}$. high, the angles rounded: seeds ovoid, pale red. [Euphorbia discoidalis Chapm.]

In dry sand, Florida. Summer and fall.

12. Tithymalopsis olivàcea Small. Perennial, olive green, glabrous. Stems solitary or several together, $2-7 \mathrm{dm}$. tall, simple or branched at the base, the branches erect or ascending, forking above or topped by a 3-rayed umbel : leaves alternate below the umbel ; blades leathery, oblong, obovate-oblong or cuneate, 1-3 cm. long, obtuse, or notched at the apex and with a short mucro, sessile or short-petioled : involucres scattered along the slender branchlets, campanulate, about $1.5 \mathrm{~mm}$. high, angled: glands transversely oblong, about $0.5 \mathrm{~mm}$. broad; appendages white, 1-5 mm. long, orbicular cuneate, minutely erose at the top : capsules 3.5-4 mm. in diameter. [Euphorbia olivacea Small.]

In sandy soil, northern Mississippi. Summer.

13. Tithymalopsis corollàta (L.) Small. Perennial by a long stout rootstock, bright green, glabrous or somewhat pubescent. Stems erect, 2-9 dm. tall, often spotted, usually simple, the umbel several-rayed : leaves opposite ; blades linear, oblong, or oblong-spatulate, 2-4 cm. long, entire, short-petioled or sessile, the lower scattered, those subtending the 
umbel whorled : bracts ovate to linear, green : involucres mostly terminal, less than $2 \mathrm{~mm}$. long, bearing 4 or 5 yellowish green oblong glands subtended by white petal-like cuneate or orbicular-cuneate appendages: capsules erect, subglobose, 3-4 mm. in diameter: seeds smooth, sparingly pitted. [Euphorbia corollata L.]

In dry soil, Ontario to Minnesota, Massachusetts, Kansas, Florida and Texas. Spring to fall.

14. Tithymalopsis paniculata (Ell.) Small. Perennial, deep green. Stems often solitary, erect, 3-9 dm. tall, simple below, pubescent, especially about the nodes, the umbel 3-5-rayed, the rays more or less extensively forked : leaves alternate below the whorl, subtending the umbel ; blades oblong to oval, $2-6 \mathrm{~cm}$. long, obtuse, glabrous or hairy along the midrib and pale green beneath, somewhat revolute, abruptly narrowed or truncate at the base, short-petioled or nearly sessile : involucres rather crowded in loose terminal clusters, short-peduncled, campanulate, terete, $1.5 \mathrm{~mm}$. high : glands transversely oblong, about $1 \mathrm{~mm}$. broad ; appendages white, suborbicular or somewhat 4-sided, fully $1 \mathrm{~mm}$. long, entire : capsules about $3 \mathrm{~mm}$. long, glabrous. [Euphorbia paniculata Ell.]

In sandy soil, North Carolina to Georgia. Summer.

\section{TITHYMÀrUS Adans.}

Annual or perennial herbs or shrubby plants, with simple or branched stems, which are topped by several-rayed umbel-like cymes. Leaves below the umbel usually scattered or alternate, without stipules: blades often broadened upward. Bracts of the umbel quite different from the stem-leaves: blades entire or toothed. Involucres sessile or peduncled, axillary, disposed in open or close cymes : lobes often toothed. Glands 4, transversely oblong, reniform or crescent-shaped by the horn-like appendages, the missing one represented by a thin often ciliate lobe. Capsule exserted, smooth or tuberculate: lobes rounded, sharp or keeled. Seeds variously pitted, often with caruncles. SPURGE.

Leaf-blades entire: glands of the involucre crescent-shaped, reniform or truncate.

Leaves of the stem or main branches opposite.

Leaves alternate.

Bracts or leaves of the rays opposite: rays dichotomous.

Glands of the involucre without horn-like processes.

Glands with erose-crumpled edges.

Glands entire or merely undulate.

Bracts of the ravs longer than broad.

Stem-leaves linear to linear-lanceolate.

Stem-leaves obovate to oblanceolate.

Bracts of the rays fully as broad as long.

Glands of the involucre crescent-shaped by horn-like processes.

Seeds smooth.

Seeds variously pitted.

Surfaces of the seeds rather finely and irregularly pitted.

Bracts of the rays very inequilateral, longer than the internodes. 7. T. longicuris.

Bracts of the rays equilateral, shorter the internodes.

Stem-leaves with spatulate to ovate blades: bracts ovate-reni-

form : seeds pitted.
Stem-leaves with linear blades: bracts deltoid: seeds reticulated.

1. T. Lathyris.

Surfaces of the seeds longitudinally grooved or with large pits in longitudinal rows.

Capsules with prominently keeled lobes.

Capsules with rounded lobes.

Seeds with 2 grooves on the inner face.

Seeds with several pits on the inner face.

Bracts or leaves of the rays alternate: rays trichotomous.

2. T. sphaerosperma.

3. T. inundatus.

4. T. telephioides.

5. T. Darlingtonii.

6. T. Helleri.

8. T. commutatus.

9. T. austrina.

10. T. Peplus.

11. T. Peplidion.

12. T. tetraporus.

13. T. trichotomus.

Leaf-blades serrulate.

Glands of the involucres furnished with 2 horn-like appendages.

Glands of the involucres transversely oblong, unappendaged.

Capsules warty.

Stem-leaves with cordate or truncate bases.

14. T. Roemerianus.

Stem-leaves with narrowed bases.

Upper stem-leaves merely sessile : bracts of the umbel manifestly longer than broad.

Upper stem-leaves with small basal lobes: bracts of the umbel about as broad as long or broader.

Capsules smooth.

15. T. obtusatus.

16. T. Arkansanus.

17. T. Missonriensis.

18. T. leiococcus.

1. Tithymalus Iáthyris (L.) Hill. Annual or biennial, glabrous, glaucous. Stem usually erect, stout, 2-10 dm. tall, mostly simple below, umbellately branched above: leaves numerous, mostly opposite, the lower with linear reflexed blades, the upper with lanceolate or linear-lanceolate blades, $3.5-12 \mathrm{~cm}$. long, these entire, sessile, subcordate at the base : bracts of the rays opposite, ovate or ovate-lanceolate, truncate or subcordate : involucres $5 \mathrm{~mm}$. long, bearing 4 crescent-shaped unappendaged glands prolonged into short horns : capsules subglobose, 10-12 mm. in diameter, the lobes rounded : seeds oblong-ovoid, 5-6 mm. long, terete, usually wrinkled, dirty-brown. [Euphorbia Lathyris L.]

In waste places, New Jersey to North Carolina and Texas. Also in California. Native of Europe. Spring and summer. 
2. Tithymalus sphaerospérmus (Shuttlw.) Small. Perennial, glabrous. Stem erect, 2-6 dm. tall, topped by a 2-3-rayed umbel and often branched below : leaves alternate ; blades linear, 3-9 $\mathrm{cm}$. long, acute, entire, sessile : rays 3-5 cm. long, forking : bracts of the rays linear-lanceolate to ovate, variable in length, acute or slightly acuminate : involucres campanulate, 3.5-4 mm. high, shorter than the peduncles: glands fan-shaped, 1-2 mm. broad, thickened and crumpled on the edge : capsules 3-lobed, 8-11 mm. broad, about $\frac{1}{2}$ as high, the lobes obtuse : seeds subglobose, $4 \mathrm{~mm}$. in diameter or smaller, smooth. [Euphorbia sphaerosperma Shuttlw.]

In pine lands, Florida to Alabama. Summer.

3. Tithymalus inundàtus (Torr.) Small. Perennial, glabrous. Stem erect, 1-5 dm. tall, topped by a 2-3-rayed umbel, and simple or alternately branched below it: leaves alternate ; blades linear or oblong-linear, sometimes broadest above the middle, 3$10 \mathrm{~cm}$. long, acute, sessile : bracts of the rays ovate or oblong-lanceolate, acute : involucres campanulate or turbinate-campanulate, 2-4 mm. high, shorter than the peduncles : glands thick, reniform, $1.5 \mathrm{~mm}$. broad, outer margin thick and undulate: capsules about $5 \mathrm{~mm}$. high, much broader, smooth, the angles sharp : seeds subglobose or ovoid-globose, 3-3.5 mm. in diameter, smooth. [Euphorbia inundata Torr.]

In pine-land swamps, Florida. Spring.

4. Tithymalus telephioides (Chapm. ) Small. Perennial, somewhat fleshy, the foliage glabrous, light green. Stem erect, $0.5-2.5 \mathrm{dm}$. tall, topped by a 2-4-rayed umbel, commonly branched below : leaves alternate; blades broadly spatulate to oblong-obovate or obovate, $2-5 \mathrm{~cm}$. long, acutish or apiculate, thin-margined, approximate or rarely remote : rays forking, barely if at all surpassing the subtending bracts : bracts of the rays ovate to deltoid, entire, acute : involucres broadly campanulate, 1.5-2 mm. high, purple, shorter than the peduncles: glands peltate, rather reniform, somewhat cup-shaped, 1-1.5 mm. broad, undulate : capsules 3-lobed, 7-8 mm. broad, grannlar, the lobes rounded : seeds subglobose, $3 \mathrm{~mm}$. in diameter, smooth. [Euphorbia telephioides Chapm.]

In low pine lands, Florida. Spring.

5. Tithymalus Darlingtònii (A. Gray) Small. Perennial, dark green, often minutely pubescent, the rootstock 1-2 cm. thick, scarred. Stem rather stout, erect, $3-15 \mathrm{dm}$. tall, fleshy, topped by a 5-8-rayed umbel, branched above, the branches simple or forked : leaves alternate; blades oblong or oblanceolate, or lanceolate above, $3.5-10 \mathrm{~cm}$. long, mostly obtuse at the apex, sessile, often undulate, more or less pubescent beneath : bracts of the rays opposite, ovate, or nearly reniform: involucres campanulate, nearly $4 \mathrm{~mm}$. long, bearing 5 reniform undulate, unappendaged glands : capsules depressed-globose, 6-8 mm. high, minutely warty : seeds ovoid-globose, 3-4 mm. long, smooth or nearly so. [Euphorbia Darlingtonii A. Gray.]

In woods or thickets, New York, Pennsylvania and New Jersey to North Carolina. Spring to fall.

6. Tithymalus Hélleri (Millsp.) Small. Annual or biennial, glabrous. Stem branched at the base, the branches 1.5-2.5 dm. tall, sometimes branched below the 3-rayed umbel : leaves scattered; blades spatulate, 6-15 $\mathrm{mm}$. long, obtuse or retuse, the lower ones short-petioled : rays $3-5 \mathrm{~cm}$. long, dichotomous, with long internodes: bracts of the rays oblong, sessile or nearly so, slightly nnequal, orbicular-ovate, somewhat fiddle-shaped, mucronate at the apex, broadly cuneate or truncate at the base: involucres not crowded, turbinate-campanulate, about $1 \mathrm{~mm}$. high : glands elliptic, about twice as broad as long, with horns as long as the body of the gland: capsules depressed-globose, $3 \mathrm{~mm}$. broad: seeds ovoid, white, $1.6 \mathrm{~mm}$. long, with a 2-lobed caruncle. [Euphorbia Helleri Millsp.]

In sandy soil, southern Texas. Spring and summer.

7. Tithymalus longicùris (Scheele) Small. Annual, glabrous. Stem erect, 1-3 dm. tall, simple or branched at the base, often topped by a 3-5-rayed umbel : leaves alternate; blades spatulate to obovate, $1-1.5 \mathrm{~cm}$. long, obtuse, entire or nearly so, narrowed to slender bases : bracts somewhat reniform, $9-13 \mathrm{~mm}$. broad, very inequilateral, entire : involucres turbinate-campanulate, fully $1 \mathrm{~mm}$. high, glabrous: glands barely $1 \mathrm{~mm}$. broad, prolonged into 2 slender subulate horns : capsules $2.5-3 \mathrm{~mm}$. broad, barely as high, the lobes rounded: seeds oblong, fully $1.5 \mathrm{~mm}$. long, whitish, copiously pitted, the breadth of the pits less than $\frac{1}{2}$ the space between them. [Euphorbia longicuris Scheele.]

In dry soil, Arkansas and the Indian Territory to Texas. Summer.

8. Tithymalus commutàtus (Engelm.) Kl. \& Garcke. Annual or biennial, or perennial by creeping stems, yellowish green, often tinged with red, glabrous. Stem slender, usually decumbent at the base, 1-4 dm. long, branched, topped by a 3-rayed umbel : rays forked or umbellately branched : leaves alternate; blades spatulate to ovate, $1-3.5 \mathrm{~cm}$. long, obtuse or mucronulate, entire, flat, narrowed into a slender petiole : bracts subtending the umbel : bracts of the rays opposite, ovate-reniform : involucres campanulate, 2.5 
mm. long, sessile, bearing 3-4 crescent-shaped unappendaged glands prolonged into slender horns : capsules globose-ovoid, $3 \mathrm{~mm}$. in diameter, glabrous, the lobes rounded : seeds oblong or globose-oblong, barely $1.5 \mathrm{~mm}$. long, terete, irregularly pitted. [Euphorbia commutata Engelm.]

On hillsides, chiefly along streams, Pennsylvania to Minnesota, Florida and Missouri. Spring and summer.-A form occurring in Florida, known as T. commutata erécta (Norton) Small [Euphorbia commutata var. erecta Norton], is more erect in habit and has somewhat lanceolate leaf-blades.

9. Tithymalus austrìnus Small. Annual, bright green. Stem erect, $3-4 \mathrm{dm}$. tall, commonly branched near the base, each branch topped by a several-rayed umbel : rays dichotomous : leaves alternate; blades linear, 1-5 cm. long, entire, acute : bracts subtending the umbel a little broader than the leaf-blades : bracts of the rays opposite, deltoid : involucres 1-1.5 mm. long : glands crescent-shaped, with slender horn-like processes : capsules depressed, 3-3.5 mm. in diameter, glabrous, the lobes blunt : seeds ovoid, about $2 \mathrm{~mm}$. long, reticulated.

In pine woods, western Florida. Summer.

10. Tithymalus Péplus (L.) Hill. Annual, bright green, glabrous. Stem erect or assurgent, 1-3 dm. tall, simple or branched from the base or above and topped by a 3-5rayed umbel : leaves alternate; blades oblong or obovate, $1-4 \mathrm{~cm}$. long, obtuse or retuse, entire, more or less crisped, narrowed into slender petioles : bracts of the rays opposite, ovate or triangular-ovate, minutely apiculate, sessile : involucres campanulate, almost sessile in the axils of the bracts, 1-1.5 mm. high, bearing 4 crescent-shaped glands produced into subulate horns : capsules globose-ovoid, $2-3 \mathrm{~mm}$. in diameter, slightly nodding, smooth, the 3 lobes 2-keeled on the back : seeds oblong or oblong-ovoid, $1.5 \mathrm{~mm}$. long, whitish, nearly terete, marked with 1-4 series of pits. [Euphorbia Peplus L.]

In waste places, southern Canada to western New York, south to New Jersey, Pennsylvania, Alabama and in California. Naturalized from Europe. Spring to fall.

11. Tithymalus Peplídion (Engelm.) Small. Annual, glabrous. Stem simple below or usually branched at the base ; branches erect or ascending, 5-20 cm. long, topped by 3-rayed umbels : leaves alternate ; blades linear-spatulate or spatulate, $8-25 \mathrm{~mm}$. long, entire, rounded or emarginate at the apex, at least near the base of the stem, narrowed into slender bases : rays forked : bracts of the rays ovate to rhombic-lanceolate, inequilateral : involucres turbinate, barely $1 \mathrm{~mm}$. high, about as long as the peduncles or longer : glands transversely oblong, about $0.5 \mathrm{~mm}$. wide, furnished with 2 horn-like appendages : capsules about $3 \mathrm{~mm}$. broad, barely as high, lobes rounded, glabrous : seeds oblong, 1.3-1.5 mm. long, the faces deeply pitted. [Euphorbia Peplidion Engelm.]

In sandy and stony soil, Texas.

12. Tithymalus tetrapòrus (Engelm.) Small. Annual, glabrous. Stem erect, simple or branched at the base, the branches 1-2 dm. long, topped by 3-rayed umbels and commonly branched below : leaves alternate; blades spatulate, cuneate or oblong, obtuse or notched at the apex, entire, narrowed into slender petioles or nearly sessile : rays forked : bracts ovate or triangular, apiculate, sessile : involucres campanulate, $1.5 \mathrm{~mm}$. high, nearly sessile: glands transversely oblong, about $1 \mathrm{~mm}$. broad, with 2 horn-like appendages of about the same length : capsules 3-lobed, $2-2.5 \mathrm{~mm}$. broad, barely as high, glabrous, the angles obtuse : seeds broadly oblong, 1.3-1.4 mm. long, minutely pitted, gray. [Euphorbia tetrapora Engelm.]

In sandy soil, the Indian Territory to Georgia and Texas. Spring.

13. Tithymalus trichótomus (H.B.K.) Kl. \& Garcke. Perennial, glabrous. Stem commonly branched at the base, more or less woody at the base, the branches erect or ascending, 1-4 dm. tall, widely forking above: leaves numerous, rather approximate ; blades thickish, cuneate to oblong, obtuse or acutish, 5-12 $\mathrm{mm}$. long, minutely erose at maturity : rays trichotomous : involucres campanulate, $2 \mathrm{~mm}$. high, sessile or nearly so : glands obreniform, $1 \mathrm{~mm}$. broad, yellow: capsules 3 -lobed, $4 \mathrm{~mm}$. wide, about $\frac{1}{2}$ as high, the lobes rounded : seeds subglobose, fully $1.5 \mathrm{~mm}$. in diameter, white or pale gray, smooth. [Euphorbia trichotoma H.B.K.]

In sand, southern peninsular Florida and the Keys. Also in the West Indies and eastern Mexico.

14. Tithymalus Roemeriànus (Scheele) Small. Annual, glabrous. Stem erect, 2$4 \mathrm{dm}$. tall, terete, simple or branched below, topped by a 3-rayed umbel, the rays forking : leaves alternate, remote ; blades thin, spatulate-obovate or orbicular-spatulate below, $0.5-$ $2 \mathrm{~cm}$. long, slightly emarginate, mucronate, serrulate near the apex, glaucescent beneath : bracts of the rays half-orbicular, crenate to about the middle : bracts subtending the umbel ovate, about $1.5-2 \mathrm{~cm}$. long, obtuse : involucres campanulate, $1.5 \cdot 2 \mathrm{~mm}$. long : glands broad, furnished with 2 incurved horn-like processes : capsules subglobose, $3 \mathrm{~mm}$. broad, smooth; lobes keeled : seeds oblong-ovoid, 1.6-1.8 mm. long, gray, irregularly pitted. [Euphorbia Roemeriana Scheele.]

In woods, southern Texas. 
15. Tithymalus obtusàtus (Pursh) Kl. \& Garcke. Annual, yellowish green, 'glabrous. Stem slender, erect or assurgent, 3-6 dm. high, strict, branched above, topped by a 3-5-rayed umbel; rays simple or forked: leaves alternate; blades spatulate-oblong, obtuse, serrulate to below the middle, sessile, the base slightly auricled : bracts of the rays ovate, cordate, 1-2.5 cm. long: involucres short-peduncled, $1 \mathrm{~mm}$. long, bearing 4 stalked unappendaged glands: capsules subglobose, nearly $4 \mathrm{~mm}$. in diameter, with elongated warts, the lobes rounded : seeds lenticular, oblong, or orbicular-oblong, 1.7-2 mm. long, dark brown, faintly reticulated. [Euphorbia obtusata Pursh.]

In dry soil. Pennsylvania to Iowa, South Carolina and Texas. Spring and summer.

16. Tithymalus Arkansànus (Engelm. \& Gray) Kl. \& Garcke. Annual or biennial, olive-green, glabrous. Stem rather slender, $2-5 \mathrm{dm}$. high, topped by a compound 3-rayed umbel, the rays copiously dichotomous : stem-leaves alternate; blades spatulate or cuneate, 1-3 cm. long, acutish, serrate above the middle, sessile : bracts of the rays with triangular or ovate, inequilateral, small, serrate, truncate or cordate blades : involucres solitary in the axils, about $1 \mathrm{~mm}$. long, with 4 elliptic naked nearly sessile glands fully $0.5 \mathrm{~mm}$. long, less than $1 \mathrm{~mm}$. broad : capsules depressed-globose, $2.5-3 \mathrm{~mm}$. broad, with elongated warts : seeds ovoid-lenticular, 1.3-1.5 mm. long, reddish brown, finely but distinctly reticulated. [Euphorbia Arkansana Engelm. \& Gray.]

On plains or prairies, Kansas to Colorado, Alabama and Mexico. Spring and summer.

17. Tithymalus Missouriénsis (Norton) Small. Annual or biennial, olive-green. Stem 3-6 dm. tall, topped by a compound 3-rayed umbel : stem-leaves scattered; blades spatulate, $2-3.5 \mathrm{~cm}$. long, obtuse, serrate to below the middle, the upper ones slightly auricled at the base : bracts of the rays with oblong to ovate, inequilateral, acute, serrate blades: involucres less than $2 \mathrm{~mm}$. high, with 4 oblong glands and glabrous lobes: capsules 3-3.5 mm. in diameter, bearing elongated warts : seeds ovoid, distinctly and regularly reticulated, purplish brown. [Euphorbia Arkansana var. Missouriensis Norton.]

On plains and prairies, Minnesota to Washington, Kansas and New Mexico. Spring and summer.

18. Tithymalus leiocóccus (Engelm.) Small. Annual, glabrous. Stem branched at the base, the branches ascending or decumbent, 1-2 dm. tall, topped by 2-3-rayed umbels ; rays $2-3.5 \mathrm{~cm}$. long : stem-leaves alternate; blades spatulate, $0.5-1.5 \mathrm{~cm}$. long, obtuse or retuse at the apex, crenulate-serrate, narrowed into slender bases : bracts of the rays oblong or cuneate-oblong, acute, serrulate above the middle: involucres hemispheric, thin, less than $1 \mathrm{~mm}$. high, longer than the peduncles: glands transversely oblong, about $0.5 \mathrm{~mm}$. wide : capsules 3-lobed, $2.5-3 \mathrm{~mm}$. broad, the lobes rounded : seeds flattened, $1.5 \mathrm{~mm}$. long, finely reticulated, dark brown. [Euphorbia dictyosperma var. leiococca Engelm. E. Texana Boiss.]

In dry soil, Texas. Spring.

\section{POINSÉTTIA Graham.}

Annual or perennial herbs or shrubby plants, with green or partially, often more highly colored, foliage. Stems simple or branched, often irregularly so. Leaves alternate below, opposite above; blades similar throughout or very variable : stipules gland-like. Involu. cres in axillary or terminal cymes or solitary : lobes fimbriate. Glands fleshy, solitary, or rarely 3 or 4 , sessile or short-stalked, without appendages, the missing ones represented by narrow lobes. Capsule exserted, the lobes rounded. Seed narrowed upward, tuberculate, without a caruncle or with a minute one only. Spurge.

Gland or glands of the involucre stalked : bracts and upper leaves barely if at all discolored.

Leaf-blades linear or linear-lanceolate: seeds not prominently tuberculate: glands of the involucre 3 or 4 .

Leaf-blades ovate to ovate-lanceolate: seeds prominently tuberculate : glands of

Gland of the involucre sessile or nearly so: bracts and upper leaves discolored at

the base.

Leaf-blades pilose-bearded at the base, sharply serrate.

Leaf-blades not bearded at the base, not sharply serrate. Bracts pale at the base.

Bracts red, purple or scarlet at the base.

Upper leaves and bracts with narrowly linear entire blades.

Upper leaves and bracts with broad toothed or lobed blades.

1. P. cuphosperma.

2. P. dentata.

3. P. barbellata.

4. $P$. geniculata.

5. P. Havanensis.

6. $P$. heterophylla.

1. Poinsettia cuphospérma (Boiss.) Small. Annual, usually pubescent. Stems erect, slender, simple or sparingly branched, $2-4 \mathrm{dm}$. high : leaves opposite or alternate ; blades linear, oblong or linear-lanceolate, 2-8.5 mm. long, entire, undulate, or denticulate, narrowed into a slender petiole : involucres crowded at the ends of the branches, nearly sessile, glabrous or nearly so, almost $4 \mathrm{~mm}$. long, bearing about 4 long-stalked unappendaged glands : capsules glabrous, or sparingly pubescent, $5 \mathrm{~mm}$. in diameter : seeds narrowly 
ovoid, about $3 \mathrm{~mm}$. long, irregularly 4-angled, ridged and slightly tuberculate. [Euphorbia cuphosperma Boiss.]

On plains or prairies, South Dakota to Colorado and Mexico. Summer and fall.

2. Poinsettfa dentàta (Michx.) Small. Annual, dull green, pubescent. Stems erect or ascending, $2-4 \mathrm{~mm}$. high, somewhat woody below, branched, the branches mostly ascending : leaves opposite, or the lowest alternate ; blades varying from ovate to nearly linear or orbicular-oblong, 1-9 cm. long, coarsely dentate, narrowed into slender petioles, the nerves prominent beneath : involucres oblong-campanulate, about $3 \mathrm{~mm}$. long, 3-5-lobed, bearing 1-4 yellowish short-stalked glands without appendages : capsules glabrous, 4-5 mm. in diameter: seeds ovoid-globose, ash-colored, irregularly tuberculate, inconspicuously 4angled. [Euphorbia dentata Michx.]

In dry or moist soil, Pennsylvania to South Dakota, Louisiana and Mexico. Summer and fall.

3. Poinsettia barbellàta (Engelm.) Small. Annual or biennial, glabrous or nearly so. Stems erect or ascending, 3-7 dm. tall, somewhat branched : leaves alternate ; blades various, linear to oblong, 5-15 cm. long, acuminate, remotely serrate with often bristletipped teeth, or lobed, sparingly bearded at the base, short-petioled : bracts more or less discolored, the base pink, otherwise similar to the leaves : involucres aggregated in terminal clusters, campanulate, 4-5 mm. high, glabrous; lobes incise-toothed: gland solitary, oblong or oval, about $2 \mathrm{~mm}$. broad, sessile : capsules subglobose, $3-3.5 \mathrm{~mm}$. long: seeds oblong, fully $2 \mathrm{~mm}$. long. [Euphorbia barbellata Engelm.]

On plains and prairies, Texas. Spring to fall.

4. Poinsettia geniculàta (Ortega) Small. Annual. Stems erect or ascending, 3-9 dm. tall, forking above, corymbose : leaves alternate below, opposite above; blades oblong or ovate, 4-9 cm. long, acute or acuminate above, entire or obsoletely dentate, acuminate at the base, short-petioled : involucres in dense cymes, cylindric-turbinate, $3-3.5 \mathrm{~mm}$. high, short-peduncled; lobes dentate-fimbriate: glands solitary, somewhat stalked, fleshy, without appendages: capsules globular, $4-5 \mathrm{~mm}$. long: seeds ovoid, $3-3.5 \mathrm{~mm}$. long, blackish, truncate at the base, irregularly tuberculate-granular. [Euphorbia geniculata Ortega.]

On hillsides, on both sides of the Rio Grande, Texas and northern Mexico. Also in the West Indies.

5. Poinsettia Havanénsis (Willd.) Small. Annual or biennial, glabrous. Stems 3-10 dm. tall, usually branched, often copiously so, the branches more or less spreading: leaves alternate; blades narrowly linear or sometimes slightly widened near the base, 4-15 $\mathrm{cm}$. long, entire, often somewhat revolute : bracts similar to the leaves but with a purple red or scarlet blotch at the base : involucres clustered, $2-2.5 \mathrm{~mm}$. high, short-peduncled, with 5 ovate sparingly laciniate lobes, one sinus bearing a sessile unappendaged gland: capsules glabrous, strongly 3 -lobed, $5-6 \mathrm{~mm}$. broad : seeds broadly oblong, 2-5 mm. long, black, very rough. [Euphorbia graminifolia Michx., not Vill. E. Havanensis Willd.]

In dry or sandy soil, Georgia and Florida to Texas. Also in tropical America.

6. Poinsettia heterophýlla (L.) Small. Annual or biennial, bright green, pubescent or nearly glabrous. Stems mostly erect, $3-10 \mathrm{dm}$. tall, woody below, the branches ascending, or the lower spreading, leafy at the ends : leaves alternate; blades very variable, linear to orbicular; the lower ones often entire, the upper undulate, sinuate or dentate, the uppermost often fiddle-shaped and like the bracts blotched with red : involucres clustered at the ends of the branches, $3 \mathrm{~mm}$. long, about equalling the peduncles, with 5 ovate or oblong laciniate lobes, one sinus bearing a sessile gland without an appendage : capsules glabrous or minutely pubescent, $6 \mathrm{~mm}$. broad : seeds oblong-ovoid, 3-4 mm. long, transversely wrinkled and tuberculate. [Euphorbia heterophylla L.]

In sandy soil, Illinois to Montana, Florida and Central America. Widely distributed in tropical America. Spring to fall.

\section{Family 2. CaLlitrichàceas Lindl. Water Starwort Family.}

Small mainly aquatic mostly annual caulescent herbs. Leaves opposite: blades entire, 3-nerved, often imbricated at the end of the stem. Flowers minute, polygamous, solitary in the axils. Calyx wanting. Corolla wanting. Androecium of a solitary stamen, 2-bracted in the staminate flowers. Filaments filiform. Anthers 2-celled, the sacs sometimes confluent. Gynoecium of a single pistil. Ovary 4-celled. Styles united in pairs, slender. Stigmas acute.
Ovules solitary in each cavity, pendulous. Fruit leathery, indehiscent, 4-celled, 4-lobed. Seeds four. Testa membranous. Endosperm fleshy. Embryo straight, axile, terete. 


\section{CALLÍtriche L.}

Characters of the family. WATER Starwort.

Fruit manifestly pedicelled.

Fruit about $0.8 \mathrm{~mm}$. long: styles persistent.

Fruit about $0.7 \mathrm{~mm}$. long: styles deciduous.

Fruit essentially sessile.

Styles much shorter than the fruit.

Styles fully as long as the fruit.

Aquatic: fruit $1 \mathrm{~mm}$. broad.

Terrestrial : fruit $0.5 \mathrm{~mm}$. broad.

1. C. Austinii.

3.

3. C. palustris.

4. C. heterophylla.

5. C. peploides.

1. Callitriche Austínil Engelm. Terrestrial, glabrous, fragrant in drying. Stems erect or decumbent, 1-5 $\mathrm{cm}$. long : leaf-blades spatulate, $2-3 \mathrm{~mm}$. long, obtuse, 3-nerved, sessile or with winged petioles, destitute of scales : pedicels shorter than the fruit or rarely slightly longer : fruit broader than long, notched at both ends, about $0.8 \mathrm{~mm}$. broad, the 2 lobes grooved around the edges, the narrow wings denticulate : styles shorter than the fruit, persistent.

In damp shaded soil, New York to Missouri, New Jersey, Louisiana and Mexico. Summer to fall.

2. Callitriche Nuttállii Torr. Terrestrial, the foliage destitute of stellate scales. Stems $2-6 \mathrm{~cm}$. long, sometimes much branched, often creeping : leaf-blades spatulate or elliptic, 2-4 mm. long, obtuse, 3-nerved : pedicels shorter than the fruit, without scales, finally deflexed : fruit broader than long, $0.7 \mathrm{~mm}$. broad, notched at both ends, the 2 lobes deeply grooved, finally separating, the segments margined : styles deciduous.

In moist soil, Kentucky to Alabama and Louisiana. Spring and summer.

3. Callitriche palústris L. Aquatic, bright green, foliage with stellate scales. Stems usually floating, $2-30 \mathrm{~cm}$. long : leaf-blades $0.5-1.5 \mathrm{~cm}$. long, the submersed ones linear, sessile, notched or cleft at the apex, commonly 1-nerved : emersed leaves spatulate, the blades 3-nerved, rounded or retuse at the apex, narrowed into winged petioles : pedicels nearly wanting, furnished with 2 scales : fruit obovoid, about $1.5 \mathrm{~mm}$. long, slightly notched at the apex, the 2 lobes deeply grooved, the segments winged, especially above, the wings undulate: styles shorter than the fruit. [C. verna L.]

In ditches and streams, throughout southern British America and the United States. Also in South America, Europe and Asia. Spring to fall.

4. Callitriche heterophýlla Pursh. Usually aquatic, foliage furnished with stellate scales. Stems floating, or rarely creeping in the mud, 3-30 cm. long: leaves various; the submersed ones filiform or linear, the emersed ones with spatulate blades, rounded or retuse at the apex, 3-5-nerved, narrowed into winged petioles: pedicels with 2 scales : fruit broadly obovoid, about $1 \mathrm{~mm}$. long, notched at the apex, the 2 lobes shallowly grooved, the segments wingless or with narrow wings: styles longer than the fruit.

In slow-flowing streams, pools and ditches, North America except the extreme north and east of the Rocky Mountains. Summer.

5. Callitriche peploìdes Nutt. Terrestrial, fragrant in drying. Stems branching, 2-7 cm. long, forming wide mats : leaf-blades obovate, oblanceolate or elliptic, 2-5 mm. long, obtuse, sessile or 3-nerved blades narrowed into short petioles : fruit sessile or nearly so, minute, $0.5 \mathrm{~mm}$. broad, deeply notched at the apex, the 2 lobes grooved, their margins obtuse : styles as long as the fruit or longer.

On moist soil, Arkansas to Florida and Texas. Spring and summer.

\section{ORDER 17. SAPINDÀLES.}

Shrubs or trees, or in the case of LIMNANTHACEAE, herbs. Leaves various: blades simple and entire, toothed, or pinnately parted in the case of annual herbs, or compound. Calyx of distinct sepals. Corolla of distinct petals, regular or rarely irregular, or wanting. Androecium of as many stamens as there are petals, or twice as many, or rarely more or fewer. Filaments distinct. Gynoecium of one carpel or of several carpels united into a compound pistil. Ovary superior. Ovules 1 or 2 , or several in each cavity of the ovary, pendulous, with the raphe away from the axis of the ovary, or erect or ascending.

Corolla wanting: stamens 4 (in our genus) : styles wanting.

Corolla present or if wanting (Dodonaeaceae) stamens 6 : styles present, united.

A. Stigmas tufted or many-cleft.

Fam. 1. Buxaceae.

Fam. 2. EMpetraceae. 
B. Stigmas entire.

Low annuál herbs: leaves with pinnately parted blades: stamens twice as many as the petals.

Shrubs or trees, or rarely herbaceous vines: leaves with simple or compound blades: stamens usually as many as the petals. Plants with resin-bearing tissues.

Plants not resin-bearing.

Leaf-blades simple, pinnately veined.

Each cavity of the ovary with a single ovule. Flowers in racemes : fruit capsular or leathery. Flowers not racemose: fruit a drupe.

Each cavity of the ovary with 2 or more ovules.

Disk present: corolla present.

Anthers introrse: seeds arilled.

Anthers extrorse: seeds not arilled.

Disk obsolete: corolla wanting.

Leaf-blades simple and palmately veined or compound.

Leaves opposite.

Fruit capsular.

Flowers regular: fruit a membranous, bladdery 3lobed capsule : leaf-blades pinnately compound. Flowers irregular: fruit a leathery globular capsule : Fruit a samara.

\title{
Fam. 3. Limnanthaceab.
}

Fam. 4. Spondiaceae.

Fam. 5. Cyrillaceae.

Fam. 6. Aquifoliaceae.

Fam. 7. Celastraceae.

Fam. 8. HIPPOCRATEACEAE.

Fam. 9. Dodonaeaceae.

Leaves alternate.

\author{
Fam. 10. Staphyleaceae. \\ Fam. 11. Aesculaceat. \\ Fam. 12. ACERACEAE. \\ Fam. 13. SAPINDACEAE.
}

\section{Family 1. BUXÀCEAE Dumort. Box Family.}

Shrubs, trees or perennial herbs, with a watery sap. Leaves alternate or opposite, often persistent: blades simple, often leathery. Flowers monoecious or dioecious, regular, solitary or clustered. Calyx present or wanting. Corolla wanting. Staminate flower with an androecium of 4-7 stamens: filaments distinct: anthers 2-celled. Pistillate flower with a compound gynoecium. Ovary 3-celled or sometimes 2- or 4-celled. Stigmas 2 or 4, distinct. Ovules 1 or 2 in each cavity, anatropous. Fruit a capsule or drupe, with 1-2-seeded carpels. Endosperm fleshy, sometimes very scant. Embryo straight.

\section{PACHYSÁNDRA Michx.}

Herbs, with matted rootstocks and ascending or procumbent stems and branches. Leaves alternate, approximate, persistent, without stipules. Flowers monoecious, in spikes, the pistillate below the staminate, sometimes crowded. Staminate flowers with 4 sepals: stamens 4, opposite the sepals : filaments stout, exserted : anthers 2-celled, the sacs opening lengthwise. Pistillate flowers with 4 or more sepals : ovary 3-celled, the cavities partitioned at the base : styles 3 . Ovules 2 in each cavity. Capsule 3-celled, valvate. Seeds 2 in each cavity.

1. Pachysandra procúmbens Michx. Foliage finely pubescent. Stems decumbent or procumbent, 1-3 dm. long, stout, simple or nearly so : leaf-blades thickish, $3-12 \mathrm{~cm}$. long, obovate, oval or ovate, obtuse or acutish, entire or coarsely toothed above the middle ; petioles as long as the blades or often shorter: spikes in the axils of scales, $3-10 \mathrm{~cm}$. long, densely flowered : flowers odorous, the staminate numerous, the pistillate few at the base of the spike : sepals 4, ciliate, the outer ovate or elliptic, the inner oval or suborbicular, 4-6 mm. long, obtuse: stamens conspicuously exserted : filaments strap-like, stout, white, $1 \mathrm{~cm}$. long.

In woods, West Virginia to Florida and Louisiana. Spring. ALLEgheny Mountain SPURGe.

\section{FAMILY 2. EMPETRÀCEAE Dumont. COWBERRY FAMILY.}

Heath-like shrubs, with erect or prostrate stems. Leaves alternate or whorled, persistent, sometimes crowned: blades narrow, usually strongly revolute: stipules wanting. Flowers dioecious, or rarely polygamous, small, axillary or aggregated in terminal heads. Calyx of 2-3 scale-like sepals. Corolla of 2-3 small petals, or wanting. Staminate flowers with 2-4, mostly 3 stamens. Filaments slender. Anthers 2-celled; sacs opening lengthwise. Pistillate flowers : ovary subglobose, 2-several-celled ; styles short, united; stigmas tufted to many-cleft. Ovules solitary in each cavity, amphitropous. Fruit drupe-like, with a fleshy pulp : nutlets 2 -many, 1 -seeded. Seeds with a thin testa and fleshy endosperm. Embryo cylindric, straight, axile. 


\section{Ceratiòua Michx.}

Erect evergreen shrubs, with whorled branches. Leaves whorled : blades narrow, strongly revolute, and thus almost tubular. Flowers dioecious, 2-3 whorled in the axils, sessile, reddish. Calyx often subtended by 2 bracts: sepals 2, fringed. Petals 2. Stamens 2 : filaments filiform : anthers subglobose. Ovary sessile on a fleshy disk, 2-celled : stigma many-cleft. Drupe subglobose. Nutlets 2.

1. Ceratiola ericoìdes Michx. An aromatic much branched shrub, $3-15 \mathrm{dm}$. tall, with pubescent branches. Leaves spreading; blades revolute so that they appear filiformsubulate, 8-12 mm. long, acutish, short-petioled, often slightly curved : flowers reddish, whorled in the axils : bracts, sepals and petals strongly imbricated, concave, suborbicular, or broader than high, about $1 \mathrm{~mm}$. long, eroded: stamens 2, exserted: filaments about twice as long as the anthers: drupe subglobose, 4-6 $\mathrm{mm}$. in diameter, yellowish, rather persistent.

In dry pine lands, South Carolina to Florida and Alabama. Spring.

\section{Family 3. Limnanthàceae Lindl. False Mermaid Family.}

Annual herbs, with tender tissues and a watery sap. Leaves alternate, without stipules: blades pinnately divided. Flowers perfect, solitary on axillary peduncles. Calyx of 2-5 valvate persistent sepals. Corolla of 2-5 white or colored petals alternating with an equal number of glands. Androecium of 4-10 almost perigynous stamens. Filaments distinct, slender. Anthers 2-celled, the sacs opening lengthwise. Gynoecium of as many nearly distinct carpels as there are sepals and opposite them. Styles united. Stigmas as many as there are carpels. Ovules 1 in each cavity, ascending. Fruit 2-5-lobed, indehiscent, rough or tubercled. Endosperm wanting. Embryo straight, with thick cotyledons.

\section{FLO亡̀rRIA Willd.}

Weak herbs, with glabrous foliage and diffusely spreading stems. Leaves alternate : blades coarsely dissected, rather fleshy. Flowers regular, inconspicuous. Sepals 3, valvate. Petals white, 3 , entire, convolute, early withering. Stamens 6 ; filaments distinct. Ovary 3-celled, deeply 3-lobed. Fruit of 1-3 achenes. Seeds solitary. Cotyledons cordate.

1. Floerkia proserpinacoìdes Willd. Stems tender, fleshy, decumbent, 1-4 dm. long, simple or branched : leaves $2-8 \mathrm{~cm}$. long; blades pinnately 3-5 divided, the segments linear, elliptic or the terminal one oblanceolate, distant, acute or acutish, entire or incised ; petioles slender, the lower ones elongated : pedicels axillary, 1-3 cm. long : sepals 3, spreading, ovate-lanceolate or lanceolate, $3 \mathrm{~mm}$. long, acute : corolla white, about $3 \mathrm{~mm}$. broad : petals 3 , erect, $1.5 \mathrm{~mm}$. long, oblong-obovate, obtuse : stamens $\frac{1}{2}$ as long as the petals or finally nearly equalling them in length : achenes subglobose, 2-2.5 mm. in diameter, tuberculate-roughened.

In meadows and shaded soil, Quebec to Oregon, Pennsylvania, Tennessee and California. Spring. FALSE MERMaID.

\section{FAMILY 4. SPONDIÀCEAE Kunth. Sumac Family.}

Mostly monoecious or dioecious shrubs or trees, with a milky, resinous and often acid or caustic sap, which turns black in drying. Leaves alternate, without stipules: blades simple or pinnately compound : leaflets entire or toothed, not punctate. Inflorescence spicate, racemose or paniculate. Flowers small, rarely perfect, often polygamous, regular. Calyx of 3-5 sepals. Corolla of 3-5 petals inserted on the base of the calyx or on a hypogynous disk, as many as, alternate with and larger than the sepals, imbricated, or rarely valvate. Androecium of 3-5 stamens or rarely more, alternate with the petals. Filaments distinct or united to the disk. Anthers introrse. Gynoecium various, of 1 or 4-5 united, or nearly distinct carpels. Ovary usually free. Styles united or sometimes distinct, terminal or lateral. Stigmas entire. Ovules solitary, amphitropous or half-anatropous. Fruit a drupe or berry. Seeds solitary, with a membranous testa. Endosperm wanting. Embryo curved or bent. [Anacardiaceae Lindl.] 
Leaves with simple blades: ovary and drupe very oblique.

Leaves with compound blades: ovary and drupe not oblique.

Drupe somewhat elongated.

Drupe broader than long.

Drupe with a glabrous outer coat: stone ribbed.

Drupe with a pubescent outer coat: stone smooth.

1. Cotinus.

2. METOPIUM.

3. RHUS.

4. Schmaltzia.

\section{Cotìnus Adans.}

Shrubs or trees, with a yellow wood. Leaves alternate : blades simple, entire or slightly toothed. Flowers perfect, in large, loose, terminal panicles, whose divisions are often plumose. Sepals 5, imbricated, persistent. Petals 5, longer than the calyx. Stamens 5, inserted under the annular disk : filaments short, distinct : anthers shorter than the filaments. Ovary very oblique, sessile, 1-celled : styles 3, lateral. Ovules pendulous from a basal funicle. Drupe obliquely reniform, gibbous, the outer coat thin and veiny. Stone horny. SMoke Tree.

1. Cotinus cotinoìdes (Nutt.) Britton. A shrub or small tree, sometimes $12 \mathrm{~m}$. tall, with spreading or drooping branches. Leaves numerous; blades membranous, obovate or oval, 4-15 cm. long, obtuse or notched at the apex, entire, undulate, usually acute at the base, glabrate above, sparingly pubescent on or near the nerves beneath; petioles 1-3 cm. long: panicles 1-3 dm. high, the branches glandular-villous, becoming plumose : pedicels filiform, subtended by narrow, scarious, deciduous bracts : flowers greenish white, $3 \mathrm{~mm}$. broad : sepals ovate : petals very thin, oblong-ovate, obtuse, crisped : stamens 5, included; anthers as long as the subulate filaments : drupes obliquely oblong, $5 \mathrm{~mm}$. long, prominently veiny. [Rhus cotinoides Nutt.]

On rocky hills, Missouri to Tennessee, Alabama and Texas. Spring.

\section{METÒPIUM P. Br.}

Trees, with poisonous juices and flaky bark. Leaves alternate, pinnately compound: rachis almost terete; leaflets with leathery entire petioluled blades reticulated beneath. Flowers dioecious, in axillary open spreading panicles. Sepals 5, broad, imbricated. Petals 5, about twice as long as the sepals, ascending, imbricated. Disk annular, often slightly lobed. Stamens 5, shorter than the petals: filaments short, subulate: anthers opening lengthwise. Ovary 1-celled, seated in the disk : style short: stigma 3-lobed. Ovule solitary. Drupe somewhat elongated, glabrous, lustrous, apiculate: stone parchment-like. Poisonwood. Coral Sumach. Doctor Gum.

1. Metopium Metòpium (L. ) Small. A tree sometimes $14 \mathrm{~m}$. tall, abounding in a very poisonous resinous sap, the trunk rarely $6 \mathrm{dm}$. thick. Leaf-blades petioled; leaflets $3-7$, the blades ovate, $3-9 \mathrm{~cm}$. long, commonly abruptly acuminate, but rather obtuse, entire, obtuse or subcordate at the base, glabrate ; petioles 1-3 cm. long: panicles axillary, fewflowered, 1-2 dm. long : pedicels stout, subtended by minute bracts : sepals 5 , reniform or nearly orbicular, scarious-margined : corolla about $5 \mathrm{~mm}$. broad : petals 5 , oblong or ovate, nearly $3 \mathrm{~mm}$. long, leathery, usually obtuse, conspicuously nerved : drupes oblong or oblongovoid, 10-15 mm. long, orange or scarlet. [Rhus Metopium L.] Spring.

In sandy soil, peninsular Florida and the Keys. Also in the Bahamas and the West India Islands.

\section{RHÚ'S L.}

Shrubs, trees or vines, with a caustic and often very poisonous resinous sap. Leaves alternate, pinnately 3-several-foliolate : leaflets with entire or coarsely and irregularly toothed blades. Flowers polygamous or dioecious, in lax axillary or lateral panicles. Sepals 4-6, persistent. Petals 4-6, equal, imbricated. Disk annular. Stamens 4-6, or 10. Ovary 1-celled. Ovules pendulous from a basal funicle. Drupe pale, glabrous, with a thin outer coat which soon falls away from the wax-secreting sarcocarp which contains longitudinal and somewhat reticulated strands which tend to persist about the ribbed stone. Poison Ivy. Poison OAK.

A. Leaf-blades 3 -foliolate : vines or low shrubs.

Vine, climbing by aërial rootlets.

Drupes 5-6 mm. in diameter: sarcocarp with narrow irregular ridges.

Drupes 3-4 mm. in diameter: sarcocarp with broadly rounded ridges.

Upright shrubs.

a. Leaflets with entire blades, glabrous.

1. $R$. radicans.

2. $R$. Floridana.

3. R. Blodgettii. 
b. Leaflets with coarsely toothed or lobed blades.

Drupes 4-5 mm. thick.

Drupes 6-7 mm. thick.

B. Leaf-blades pinnately 7-11-foliolate: tall shrub or small tree.

4. R. rhomboidea.

5. $R$. Toxicodendron.

6. $R$. Vernix.

1. Rhus radìcans L. A deep green vine, with a poisonous sap. Stems climbing by rootlets : leaflets 3 , the blades membranous, ovate or ovate-lanceolate, $4-20 \mathrm{~cm}$. long, entire, coarsely toothed or rarely lobed, often sparingly pubescent, especially beneath, acuminate at the apex, rounded or acute at the base : panicles rather loosely-flowered, axillary : flowers greenish, 4-5 mm. long: sepals ovate, obtuse, $1 \mathrm{~mm}$. long: petals 5, oblong or oblongovate, obtuse, nerved, recurved : stamens 5, erect : filaments linear-subulate : drupes subglobose, 5-6 mm. in diameter.

In thickets, woods and fence rows, Nova Scotia to Minnesota, Florida, Arkansas and Nebraska. Spring and summer. POISON Ivy. POISON OAK.

2. Rhus Floridàna Mearns. Similar to R. radicans in habit, but smaller and more slender. Leaflets 3 , the blades relatively thin, lanceolate to narrowly ovate, entire or rarely undulate-toothed, glabrous or minutely pubescent : flowers smaller than those of $R$. radicans : drupes $3-4 \mathrm{~mm}$. in diameter.

In hammocks, peninsular Florida. Spring and summer.

3. Rhus Blodgéttii Kearney. Shrubby, several dm. tall, the twigs pubescent, reddish brown. Leaflets 3 , the blades leathery, ovate or oblong-ovate, $3-5 \mathrm{~cm}$. long, shortacuminate, entire, rounded or acutish at the base, the upper surface dark green and lustrous, the lower surface dull, pubescent in the axils and at the base of the midrib: drupes subglobose, 2.5-3 mm. in diameter, yellowish white, shining: stone minutely roughened, 10-12-ribbed, ash-colored.

In sand, Key West, Florida. Spring and summer.

4. Rhus rhomboìdea Small. A spreading shrub, about $1 \mathrm{~m}$. tall. Leaflets 3 , the blades ovate or sometimes obovate in outline, $2-6 \mathrm{~cm}$. long, 3-5-lobed, pubescent on both sides or glabrate above, dark green, the lobes entire or coarsely toothed : panicles many flowered but not dense, pubescent: pedicels slender, 4-5 mm. long, the bracts 1-2 $\mathrm{mm}$. long : flowers whitish, $5 \mathrm{~mm}$. broad : sepals 5 , ovate, $1 \mathrm{~mm}$. long, rounded at the apex : petals oblong-ovate, conspicuously nerved, $2 \mathrm{~mm}$. long, curled back and revolute, obtuse : stamens erect; filaments broadly subulate, flattened, about as long as the anthers: drupes subglobose, 4-5 $\mathrm{mm}$. in diameter.

In rocky hillsides, the Indian Territory and Texas. Spring.

5. Rhus Toxicodéndron L. A low shrub 2-10 dm. tall, with tomentose foliage and inflorescence, spreading by underground stems. Leaflets 3 , the blades leathery, ovate in outline or rarely obovate, coarsely crenate or lobed, obtuse, more densely tomentose beneath than above, the lateral ones sessile: panicles axillary, densely flowered : flowers greenish white, 3-4 mm. broad: sepals oblong, ascending, obtuse: petals 5, oblong to oblong-lanceolate, obtuse, about $2.5 \mathrm{~mm}$. long, curled back: stamens 5 , erect; filaments linear-subulate, about as long as the anthers: drupes depressed-globose, greenish yellow, 6-7 $\mathrm{mm}$. in diameter.

In pine lands and the foothills, North Carolina to Florida and Texas. Spring. PoIson OAK.

6. Rhus Vérnix L. A shrub or small tree, sometimes $8^{\prime} \mathrm{m}$. tall, with a very poisonous sap and a pale bark. Leaflets 7-13, the blades oblong, elliptic or oval, the terminal one sometimes obovate, 4-15 cm. long, acuminate at both ends, undulate, often inequilateral, more or less pubescent beneath, becoming glabrous above : panicles axillary, on elongated peduncles, rather loosely many-flowered : flowers greenish : sepals ovate, about $1 \mathrm{~mm}$. long apiculate ; petals linear-oblong, $2 \mathrm{~mm}$. long, obtuse, curved, erect, the tips slightly turned back: stamens longer than the petals in the staminate flowers, much shorter in the pistillate flowers : drupes subglobose, flattened, about $5 \mathrm{~mm}$. broad, in drooping panicles, white. [R. venenata DC.]

In swamps, Ontario to Minnesota, south to Florida and Louisiana. Spring. Porson Sumac. POISON OAK. POISON ELDER. POISON DOGWOOD. THUNDER-WOOD.

\section{SCHMÁLtzzia Desv.}

Shrubs or trees, usually with pubescent foliage and rarely if at all poisonous. Leaves alternate, 3-foliolate or pinnately several-foliolate : leaflets with generally toothed, or somewhat lobed blades. Flowers in terminal panicles, sometimes densely crowded, polygamous or dioecious. Sepals commonly 5. Petals commonly 5, imbricated. Ovary 1-celled. Ovule pendulous. Drupe red, clothed with acid-secreting hairs, the sarcocarp thin and never wax-secreting, its slender strands tending to persist with the outer coat than with the even and smooth stone. SuMac. 
Leaves 3-foliolate throughout.

Leaves $2-5 \mathrm{~cm}$. long; lateral leaflets with mostly obovate blades.

Leaves $5-10 \mathrm{~cm}$. long; lateral leaflets with mostly ovate blades.

1. S. trilobata.

eaves pinnately compound, 5-many-foliolate.

Rachis of the leaf winged.

Panicles contracted, raceme-like : leaves $2-2.5 \mathrm{~cm}$. long.

Panicles pyramidal: leaves $1-4 \mathrm{dm}$. long.

Leaflets acute or acuminate: wings of the rachis broad.

Leaflets long-acuminate, falcate: drupes about $6 \mathrm{~mm}$. broad.

Leaflets acute or short-acuminate, not falcate : drupes about $4 \mathrm{~mm}$. broad.

Leaflets rounded at the apex: wings of the rachis very narrow.

Rachis of the leaf not winged.

Leaflets with entire blades.

Leaflets with toothed blades.

Foliage more or less glaucous or pale.

Twigs, panicles and drupes bristly pubescent with long spreading hairs.

Twigs, panicles and drupes usually pubescent with soft very short hairs. Leaflets with acuminate, sharply serrate blades.

Leaflets with crenate-serrate blades, rounded at the apex.

Foliage densely pubescent with brownish hairs, not glaucous.

2. S. aromatica.

3. S. microphylla.

4. S. lanceolata.

5. S. copallina.

6. S. obtusifolia.

7. S. virens.

8. S. hirta.

9. S. glabra.

10. S. Ashei.

11. S. Michauxii.

1. Schmaltzia trilobàta (Nutt.) Small. An offensive-scented shrub $0.5-1 \mathrm{~m}$. or rarely $2 \mathrm{~m}$. tall, the branches often gnarled. Leaves $2-5 \mathrm{~cm}$. long, densely pubescent, or nearly glabrous, petioled; leaflets 3 , the blades firm, sessile, crenate or incised above, the terminal one cuneate, the lateral ones obovate, much smaller than the terminal one : flowers greenish, in dense spike-like racemes: sepals oblong, obtuse, $1.5 \mathrm{~mm}$. long, slightly concave : petals oblong, $3 \mathrm{~mm}$. long, obtuse : drupes subglobose, 6-7 $\mathrm{mm}$. in diameter, crowded, bristly pubescent : stone lenticular, broader than high, gibbous. [Rhus trilobata Nutt.]

On plains and prairies, Missouri to North Dakota, Washington, California and Texas. Spring. SKUNK BUSH. ILL-SOENTED SUMAC.

2. Schmaltzia aromática (Ait.) Desv. A straggling aromatic shrub $1-10 \mathrm{dm}$. tall. Leaves $5-10 \mathrm{~cm}$. long, petioled ; leaflets 3 , the blades leathery, coarsely crenate or serrate, sometimes incised, $2-6 \mathrm{~cm}$. long, pubescent or rarely glabrous, the terminal one ovate to obovate in outline, usually acute or acuminate at the apex, more or less cuneate at the base, the lateral leaflets mostly ovate, inequilateral : flowers yellow, in dense spike-like racemes: sepals oval, obtuse, about $1.5 \mathrm{~mm}$. long: petals 5 , oblong, $2.5 \mathrm{~mm}$. long, obtuse, nearly erect: stamens shorter than the petals: filaments subulate, about as long as the anthers: drupes subglobose, $7-8 \mathrm{~mm}$. in diameter, bristly pubescent. [Rhus aromatica Ait.] SUMAC.

In sandy soil and rocky woods, Ontario to Minnesota, Florida and Louisiana. Spring. Fragrant

3. Schmaltzia microphýlla (Engelm.) Small. A shrub 1-3 m. tall, with spreading branches, the twigs finely pubescent. Leaves pinnately compound, $2-2.5 \mathrm{~cm}$. long, the rachis winged; leaflets $7-9$, the blades oblong, elliptic or obovate, $6-8 \mathrm{~mm}$. long, sessile, acute or obtuse, more or less pubescent : flowers in dense axillary clusters : sepals orbicularovate, $1.5 \mathrm{~mm}$. long, ciliate : petals oblong, $2-2.5 \mathrm{~mm}$. long, very thin, fringed with long cilia : drupes subglobose, about $5 \mathrm{~mm}$. in diameter, bristly pubescent. [Rhus microphylla
[R Engelm.]

On rocky hillsides and thickets, Texas to New Mexico and northern Mexico. Spring.

4. Schmaltzia lanceolàta (A. Gray) Small. A shrub 1-2 m. tall, or rarely lower. Leaves pinnately compound, 1-2 dm. long, the rachis narrowly winged; leaflets 13-17, the blades lanceolate or linear-lanceolate, more or less falcate, 3-7 cm. long, acuminate, entire or indistinctly toothed, deep green and lustrous above, paler and softly pubescent beneath, often sessile : panicle erect, $5-14 \mathrm{~cm}$. high, its branches densely pubescent : flowers white or greenish : sepals ovate, erect, $1 \mathrm{~mm}$. long, obtuse : petals oblong-ovate, 2-2.5 $\mathrm{mm}$. long, obtuse, curled back : stamens exserted : drupes lenticular, $6 \mathrm{~mm}$. broad, pubescent, dark red. [Rhus copallina var. lanceolata A. Gray.]

In valleys and on dry uplands, Texas. Summer.

5. Schmaltzia copallìna (L.) Small. A shrub or tree, reaching a height of $10 \mathrm{~m}$., but often less than $1 \mathrm{~m}$. tall, with a sticky milky sap and glabrous or pubescent foliage. Leaves pinnately compound, $1-3 \mathrm{dm}$. long, the rachis winged; leaflets $9-21$, the blades oblong or lanceolate or sometimes oval, 3-10 cm. long, normally acuminate and acute, undulate, sessile, lustrous above, paler and dull beneath: panicles broad, 0.5-3 dm. long, densely flowered : flowers greenish : sepals ovate, erect, about $1 \mathrm{~mm}$. long, rather obtuse : petals oblong, obtuse, $2.5 \mathrm{~mm}$. long, curled back : stamens in the staminate flowers exserted: drupes lenticular, nearly orbicular, about $4 \mathrm{~mm}$. broad, finely pubescent, bright red : stone lenticular, shining. [Rhus copallina L.]

In dry often stony soil, Maine to Ontario, Minnesota, Florida and Texas. Summer. DWarf Sumac. SMOoth SUMAC. MOUNTAIN SUMAC. 
6. Schmaltzia obtusif òlia Small. An often evergreen shrub 1-3 m. tall, with pubescent foliage. Leaves pinnately compound, $2-3 \mathrm{dm}$. long, the rachis narrowly winged above ; leaflets 17-21, the blades ovate to oblong, inequilateral, 3-5 cm. long, rounded at the apex, slightly revolute, abruptly acuminate at the oblique base, short-stalked : panicles 2-3 dm. high, about as broad as high, leafy, densely pubescent with short spreading hairs : flowers greenish white : sepals triangular-ovate, with hyaline edges : petals 5, oblong, $2.5 \mathrm{~mm}$. long, curled back and revolute: filaments subulate : drupes about $4 \mathrm{~mm}$. in diameter.

In or near swamps, peninsular Florida. Summer.

7. Schmaltzia vírens (Lindh.) Small. An evergreen shrub 1-4 m. tall, with softly pubescent twigs. Leaves pinnately compound, 5-14 cm. long, the rachis softly pubescent ; leaflets $5-9$, the blades leathery, $1.5-6 \mathrm{~cm}$. long, obtuse or short-acuminate, entire, lustrous above and hairy on the nerves, more or less pubescent and dull beneath, commonly shortstalked: panicles $2-5 \mathrm{~cm}$. long, axillary, surpassed by the subtending leaf : flowers white : sepals triangular-ovate, $1.5 \mathrm{~mm}$. long, obtuse, hyaline on the margins, ciliate: petals oblong-ovate, $3.5 \mathrm{~mm}$. long, obtuse at the apex, obtuse or truncate at the base : drupes lenticular, oblique, $7-8 \mathrm{~mm}$. broad, pilose : stone lenticular, broader than high, smooth, slightly gibbous. [Rhus virens Lindh.]

In rocky places, Texas and New Mexico to northern Mexico. Spring.

8. Schmaltzia hírta (L.) Small. A shrub or small tree, sometimes $12 \mathrm{~m}$. tall, abounding in a milky sap, the twigs, petioles and panicles densely clothed with spreading hairs. Leaves pinnately compound, 2-4 dm. long, the rachis not winged; leaflets 11-31, the blades oblong to lanceolate, or the terminal one ovate-lanceolate, 4-15 cm. long, acuminate, coarsely serrate, sessile or nearly. so, glabrate above, more or less pubescent beneath : panicles 1-2 dm. long: flowers greenish : sepals lanceolate, $1.5 \mathrm{~mm}$. long, acuminate : petals oblong-oblanceolate, about $3 \mathrm{~mm}$. long, obtuse, finally curled back : drupes lenticular, 4 $\mathrm{mm}$. broad, bristly pubescent, bright red : stone smooth. [Rhus typhina L.]

In dry or rocky soil, New Brunswick to Ontario, Minnesota, Georgia and Mississippi. Spring and summer. Staghorn Sumad. Hairy Sumac.

9. Schmaltzia glàbra (L.) Small. An almost glabrous shrub, with glaucous foliage, the stem sometimes $4 \mathrm{~m}$. tall and $7 \mathrm{~cm}$. thick. Leaves pinnately compound, 1-3 dm. long, petioled, the rachis terete, pubescent when young; leaflets 11-13, the blades oblong or lanceolate (the terminal one often ovate), acuminate, serrate, sessile, dark green above, glaucous beneath : panicles densely flowered, $1-3 \mathrm{dm}$. long : flowers bright green : sepals triangular-lanceolate, $2 \mathrm{~mm}$. long: petals paler than the sepals, ovate, $2 \mathrm{~mm}$. long, hooded, with a tuft of hairs within near the base: drupes bright red, lenticular, $5 \mathrm{~mm}$. broad, viscid-pubescent : stone lenticular, oblique. [Rhus glabra L.]

In dry soil and about thickets, Nova Scotia to British Columbia, Florida, Mississippi and Arizona. spring and summer. SMOOTH OR SCARLET SUMAC.

10. Schmaltzia Áshei Small. A low glabrate shrub 3-6 dm. high, with erect glaucous stems. Leaves pinnately compound, $2-3 \mathrm{dm}$. long, the rachis terete; leaflets $13-17$, the blades oblong or oval-oblong, 3-9 cm. long, rounded at the apex, coarsely crenate-serrate, deep green above, pale green beneath, of ten short-stalked : panicles 8-14 cm. long, villous : flowers greenish : drupes lenticular, 4-5 mm. long, pubescent, dark red : stone transversely oblong, oblique, smooth. [Rhus Caroliniana Ashe, not Mill.]

In sandy soil, North Carolina. Spring.

11. Schmaltzia Michaùxii (Sarg.) Small. A low densely pubescent shrub, with decumbent stems, the branches $2-3 \mathrm{dm}$. tall. Leaves pinnately compound, $1.5-4 \mathrm{dm}$. long, the rachis not winged ; leaflets 9-15, the blades oblong, oval, or oblong-ovate (the terminal one often ovate), 5-10 cm. long, acuminate, coarsely serrate, often short-stalked: panicles 1-2 $\mathrm{dm}$. long, many-flowered : pedicels $2-5 \mathrm{~mm}$. long: sepals lanceolate, $2 \mathrm{~mm}$. long, nearly erect, obtuse : petals erect, 3-3.5 mm. long, hooded at the apex : stamens, included : filaments subulate, slightly longer than the anthers: drupes lenticular, 4-5 mm. long, oblique, deep, red, pubescent : stone lenticular, much broader than high, smooth. [Rhus pumila Michx. R. Michauxii Sarg.]

In sandy soil, North Carolina to Georgia. Spring.

\section{Family 5. CYRILLÀCEAE Lindl. Titi Family.}

Shrubs or small trees, with a watery sap, growing in swampy places. Leaves alternate, without stipules: blades simple, entire, mostly near the ends of the branchlets, rather persistent. Flowers perfect, regular, on pedicels which bear 2 scales. Calyx of 5 equal or unequal imbricated persistent sepals. Corolla of 5 hypogynous sessile or short-clawed sometimes cohering deciduous petals. 
Androecium of 5 or 10 stamens, those opposite the petals shorter. Filaments flattened, distinct. Anthers 2-celled, opening lengthwise. Disk annular, cuplike or cylindric. Gynoecium a single pistil. Ovary 2-5-angled, 2-5-celled. Style commonly wanting. Stigma 2-5-lobed. Ovules 1 or 4 in each cavity, anatropous, pendulous. Fruit small, crustaceous or spongy, dehiscent or indehiscent, sometimes winged. Seeds often solitary in each cavity, elongated, with a soft or somewhat mucous testa which merges into the fleshy endosperm. Embryo cylindric, axile.

Racemes lateral : sepals 5, equal : petals contorted, acute: stamens 5: ovary 2-celled : ovules 2-3: fruit dehiscent, not winged.

Racemes terminal : sepals 5-8, unequal : petals imbricated, obtuse : stamens 10 : ovary

3-4-celled : ovule 1: fruit indehiscent, winged.

1. Cyrilla.

2. Cliftonia.

\section{CYRÍLLA Garden.}

Glabrous shrubs or small trees, with a pale bark. Leaves alternate : blades leathery, commonly broadest above the middle. Flowers small, in slender lateral spike-like racemes arising from the twigs of the present year. Pedicels erect or spreading. Sepals 5, leathery, equal. Petals 5, somewhat leathery, longer than the sepals, involute toward the apex, acute, contorted. Stamens 5, inserted at the base of the corolla. Disk cylindric. Ovary elongated, 2-celled, stigma 2-lobed. Ovules 2-3 in each cavity. Capsule slightly elongated, 2-celled, opening loculicidally. Seeds pointed at one end, with a membranous testa. Embryo with a stout radicle. Ironwood. Leather-wood. Red or White TITI.

Larger leaves 1-4 cm. long: capsule subglobose, 1.5-2 mm. long. Larger leaves $5-10 \mathrm{~cm}$. long: capsule ovoid, $2.5 \mathrm{~mm}$. long.

1. C. parvifolia.

2. C. racemiflora.

1. Cyrilla parvifòlia Raf. A glabrous evergreen compact and much branched shrub 1-2 $\mathrm{m}$. tall. Leaf-blades leathery, oblanceolate or linear-oblanceolate, $1-4 \mathrm{~cm}$. long, acute or apiculate, lustrous above, paler beneath, more or less reticulated : racemes slender, 3-8 $\mathrm{cm}$. long: pedicels 1-2 mm. long, commonly surpassing the subulate bracts : sepals triangular, $1 \mathrm{~mm}$. long: corolla white, $3-4 \mathrm{~mm}$. broad : petals narrowly elliptic-ovate, $2.5 \mathrm{~mm}$. long, obtuse, thickened at the base and above the midrib : stamens included : capsule subglobose, 1.5-2 mm. long, slightly granular.

In swamps and streams, Florida and Louisiana. Spring.

2. Cyrilla racemiflòra $L$. A much branched glabrous shrub or small tree reaching a height of $10 \mathrm{~m}$. and a maximum trunk diameter of $3 \mathrm{dm}$., the trunks clothed with a close pale or whitish bark. Leaf-blades rather leathery, oblanceolate, obovate or nearly oblong, 2-10 cm. long, obtuse, acute or acuminate, more or less strongly reticulated, lustrous above, dull and paler beneath : racemes slender, $8-15 \mathrm{~cm}$. long: pedicels ascending or finally spreading, sometimes surpassed by their subulate bracts: sepals ovate or ovatelanceolate, $1 \mathrm{~mm}$. long, acute : corolla white, 4-5 mm. broad : petals lanceolate or oblonglanceolate, $2-2.5 \mathrm{~mm}$. long, acute : capsule ovoid, about $2.5 \mathrm{~mm}$. long, obtuse, minutely granular: seeds narrowly ovoid.

In swamps and along streams, Virginia to Florida and Texas. Spring and early summer.

\section{CLIFTònIa Gaertn.}

Glabrous shrubs or small trees, with a dark bark. Stems often contorted. Leaves alternate: blades leathery, mostly broadest above the middle. Flowers in terminal racemes. Pedicels drooping. Sepals 5-8, united at the base, unequal. Petals 5-8, narrowed into short claws, hooded at the apex, obtuse. Stamens 10, inserted at the base of the petals: filaments flattened below. Disk cup-like. Ovary elongated, 3-4-celled : stigma 3-4-lobed. Ovules solitary in each cavity. Fruit indehiscent, the angles developing 3-4 wings. Seeds elongated, pointed at both ends, with a soft testa. Embryo with a slender radicle. Trir. Buckwheat-tree. Black Titi. Iron-wood.

1. Cliftonia monophýlla (Lam.) Britton. An evergreen shrub or small tree, reaching a height of $6 \mathrm{~m}$. with a trunk diameter of $0.5 \mathrm{~m}$., the trunk clothed with a dark, slightly scaly bark. Leaf-blades leathery, narrowly-elliptic or elliptic-oblanceolate, 4-6 $\mathrm{cm}$. long, lustrous above, paler beneath, obtuse or acutish, entire, sessile : racemes $2-6 \mathrm{~cm}$. long, drooping when young, finally erect: flowers fragrant, 8-10 mm. broad : pedicels slender, 2-3 mm. long, subtended by caducous bracts : sepals ovate or orbicular, $0.5 \mathrm{~mm}$. long: 
petals white, obovate or oblong-obovate, $3-3.5 \mathrm{~mm}$. long, obtuse : stamens included : fruit ovoid, 6-7 mm. long, dry and indehiscent, 3-5-winged, rarely nearly as broad as long, the faces and wings strongly wrinkled. [Cliftonia ligustrina Spreng.]

In pine-land swamps, Georgia to Florida and Louisiana. Winter and spring.

\section{FAmily 6. AQUIFOLIÁceat DC. Holly Family.}

Usually evergreen shrubs or trees, with a watery sap. Leaves alternate, without stipules: blades simple, entire or toothed, sometimes spiny. Inflores. cence normally cymose. Flowers perfect or polygamous, regular. Calyx of 4-6 persistent imbricated sepals. Corolla white or greenish, of 4-6 deciduous imbricated petals which are alternate with the sepals and often united at the base. Androecium of 4-6 stamens inserted at the base of the corolla, alternate with the petals, all fertile. Filaments erect, shorter than the petals. Anthers introrse, the sacs opening lengthwise. Gynoecium a compound pistil. Ovary 2-6-celled (rarely with more cavities). Stigma commonly sessile, with as many lobes as cavities in the ovary. Ovules 1-2 in each cavity, suspended, anatropous. Fruit a drupe with 4-8 horny or crustaceous nutlets. Seeds with a membranous testa. Endosperm fleshy, copious. Embryo cylindric and straight, or globose. [Ilicaceae Lowe.]

\section{1. İLEX L.}

Commonly glabrous evergreen shrubs or trees. Leaves alternate: blades entire, toothed or rarely spiny. Flowers sometimes inclined to be dioecious, regular, the staminate in axillary clusters, the pistillate mostly solitary. Sepals $4-6$, persistent. Petals 4-6, usually united at the base, thus forming a rotate corolla. Stamens as many as the petals, alternate with them: filaments distinct. Ovary 4-6-celled or rarely 7-8-celled. Drupe subglobose, with 4-8 horny or crustaceous nutlets. Seed without an aril.

Nutlets smooth.

Leaves persistent: berries black.

Leaf-blades shallowly crenate near the apex : drupes 4-6 $\mathrm{mm}$. in diameter.

Leaf-blades spinescent-toothed below the apex or spine-tipped: drupes 6-8 $\mathrm{mm}$. in diameter.

Leaves deciduous: berries red or scarlet.

Staminate and pistillate flowers on pedicels of about equal length.

Staminate flowers on conspicuously slender and long pedicels.

Nutlets variously roughened.

Leaves deciduous.

Staminate flowers several on a common peduncle.

Staminate flowers solitary or clustered, without a common peduncle.

Pedicel several times longer than the berry.

Pedicel shorter than the berry.

Leaf-blades normally broadest above the middle.

Leaf-blades normally broadest below or at the middle.

Leaf-blades glabrous or with few hairs about the nerves: calyx glabrous without.

Leaf-blades 4-7 cm. long, inconspicuously toothed : Carolinian. Leaf-blades $6-20 \mathrm{~cm}$. long, conspicuously toothed : Alleghenian.
Leaf-blades densely pubescent beneath : calyx pubescent.

Leaves persistent.

Leaf-blades entire or with a few appressed teeth near the apex. Leaf-blades linear, 1-4 cm. long.

Leaf-blades oblong or oblanceolate, $4-10 \mathrm{~cm}$. long.

Leaf-blades toothed :

Teeth crenate.

Teeth spine-like and spreading, rarely only the terminal one present.

1. I. glabra.

2. I. lucida.

3. I. verticillata.

4. I. laevigata.

5. I. Amelanchier.

6. I. longipes.

7. I. decidua.

8. I. Caroliniana.

9. I. monticola.

10. I. Beadlei.

11. I. myrtifolia.

12. I. Cassine.

13. I. vomitoria.

14. I. opaca.

1. Ilex glàbra (L.) A. Gray. An erergreen shrub, with velvety-pubescent twigs. Stems more or less branched, 0.5-1.5 m. tall : leaf-blades leathery, obovate, oblanceolate, elliptic, oval or rarely ovate, $1-5 \mathrm{~cm}$. long, acute or obtuse, entire or distantly serrate above the middle, glabrous, deep green and lustrous above, paler and dull beneath ; petioles stout : flowers white, the staminate in corymbs, the pistillate often solitary : sepals broadly ovate, rounded at the apex : corolla about $7 \mathrm{~mm}$. broad ; lobes obtuse : drupes globose, 4-6 mm. in diameter, black, shining.

In sandy soil, along or near the coast, Massachusetts to Pennsylvania, Florida and Louisiana. Spring and early summer. INKBERRY. EVERGREEN WINTERBERRY.

2. Hex lùcida (Ait.) T. \& G. An evergreen shrub 1-3 m. tall, glabrous or nearly 8o. Leaf-blades leathery, obovate, oblong, oblong-oblanceolate, elliptic or oval, $2-9 \mathrm{~cm}$. long, acute or usually short-acuminate, entire or appressed-serrate above the middle, dark 
green and lustrous above, pale beneath ; petioles stout: flowers white, the staminate clustered, the pistillate often solitary : sepals ovate or triangular-ovate, acute : corolla 5.5-7 $\mathrm{mm}$. broad ; lobes obovate, obtuse : drupes globose, 6-8 $\mathrm{mm}$. in diameter, black, shining. [I. coriacea (Pursh) Chapm.]

In swamps, Virginia to Florida and Louisiana. Spring.

3. Ilex verticillàta (L.) A. Gray. A shrub or small tree, sometimes $7 \mathrm{~m}$. tall, with glabrous or slightly pubescent twigs. Leaf-blades thickish, elliptic or oval, varying to ovate or obovate, $2-8 \mathrm{~cm}$. long, acute or acuminate at both ends, glabrous or slightly pubescent above, more or less tomentose beneath, often strongly reticulated, serrate; petioles 5-10 mm. long: sepals ovate or triangular-ovate, ciliate, acutish : corolla white, 6-7 mm. broad ; lobes obtuse : drupes 6-8 $\mathrm{mm}$. in diameter, red.

In swamps or low grounds, Nova Scotia to Ontario, Wisconsin, Florida and Missouri. Summer. BLACK ALDER. WINTERBERRY. FEVER-BUSH.

4. Ilex laevigàta (Pursh) A. Gray. ${ }^{1}$ A shrub or small tree, rarely $6 \mathrm{~m}$. tall, with glabrous twigs. Leaf-blades thinnish, elliptic or oval or sometimes lanceolate or oblanceolate, 3-9 cm. long, acute or mostly acuminate, appressed-serrate, glabrous on both surfaces or sometimes sparingly pubescent on the nerves beneath, short-petioled : staminate flowers clustered, their pedicels 1-2 cm. long; pistillate mostly solitary on short pedicels : sepals triangular or ovate-triangular, sometimes ciliate, acute : corolla 6-7 mm. broad, white ; lobes obtuse : drupes subglobose, $8-10 \mathrm{~mm}$. in diameter, orange-red.

In swamps or wet woods, Maine to Pennsylvania, Georgia and Kentucky. Spring. Winterberry.

5. Ilex Amelánchier M. A. Curtis. A low branching shrub, with more or less persistently soft-pubescent foliage. Leaf-blades leathery, oblong or oblong-lanceolate, 4-8 cm. long, acute or short-acuminate, inconspicuously serrate, glabrous, dull and finely reticulated above, thinly tomentose beneath, acute or rounded at the base, $6-10 \mathrm{~mm}$. long, pubescent: flowers not seen : drupes globose, $7-10 \mathrm{~mm}$. in diameter, dull red : nutlets strongly 3ribbed on the back.

In sandy swamps, North Carolina to Louisiana. Spring.

6. Ilex lóngipes Chapm. A shrub 1-2 m. tall, with widely spreading branches and glabrous or almost glabrous foliage. Leaf-blades rather leathery, elliptic, varying to broadly oblanceolate or ovate, sometimes oval, short-acuminate, obtuse or acute, dark green and puberulent or glabrous above, more or less pubescent beneath, crenate-serrate, the teeth often tipped with appressed spine-like bristles; petioles stout, $5-10 \mathrm{~mm}$. long : flowers several in axillary clusters : pedicels $1.2-2 \mathrm{~cm}$. long, or longer at maturity : calyx glabrous : sepals triangular, acute : corolla 6-7 mm. broad, white; lobes obtuse : drupes globose, red, 6-8 $\mathrm{mm}$. in diameter.

On rocky banks, North Carolina and Tennessee to Georgia and Alabama. Spring.

7. Ilex decídua Walt. A much branched shrub or small tree 1-10 m. tall, the trunk sometimes $2.5 \mathrm{dm}$. in diameter. Leaf-blades thickish, spatulate, oblanceolate, elliptic or elliptic-oblanceolate, $2-6 \mathrm{~cm}$. long, obtuse or retuse at the apex, crenate-serrate, dark green and glabrous above, paler and usually pubescent beneath; petioles pubescent, $0.5-1 \mathrm{~cm}$. long: flowers several in axillary clusters : pedicels 5-15 $\mathrm{mm}$. long: calyx glabrous or minutely pubescent ; sepals triangular, acute, sometimes ciliate : corolla $4.5-6 \mathrm{~mm}$. broad, white ; lobes 4 , obovate or nearly oblong, obtuse : stamens shorter than the corolla-lobes: drupes globose, 7-9 $\mathrm{mm}$. in diameter, orange or nearly scarlet : nutlets strongly ribbed on the back.

In swamps and along streams, Virginia, Mlinois and Kansas to Florida and Texas. Spring.-A form with leaves $1-2 \mathrm{~cm}$. long and drupes $4-5 \mathrm{~mm}$. in diameter, is $I$. decidua Curtissii Fernald; it occurs in Florida. POSSUM Haw. BEARBERRY.

8. Ilex Caroliniàna (Walt.) Trelease. A shrub or small tree, rarely $6 \mathrm{~m}$. tall, with puberulent or almost glabrous twigs. Leaf-blades rather thin, broadly oval, varying to oyate or obovate or sometimes elliptic, 4-7 cm. long, acute or short-acuminate, serrate above the middle with appressed bristle-tipped teeth, glabrous, gradually or abruptly attenuate into short petioles : flowers solitary or several in axillary clusters : pedicels $2-5 \mathrm{~mm}$. long : calyx glabrous, 5-6 mm. broad : sepals broadly triangular, acutish, or obtuse in pistillate flowers: corolla 3-4 mm. broad, white; lobes obtuse : drupes globose-oblong, 6-7 $\mathrm{mm}$. in diameter: nutlets strongly ribbed. [I. ambigua (Michx.) Chapm.]

In sandy soil, North Carolina to Arkansas, Florida and Texas. Spring.

9. Ilex montícola A. Gray. A shrub or small tree, reaching a height of $12 \mathrm{~m}$. and with a trunk diameter of $3 \mathrm{dm}$., with almost glabrous foliage. Leaf-blades rather thin, elliptic, elliptic-lanceolate or sometimes suborbicular, 6-20 cm. long, acuminate, serrate,

${ }^{1}$ Including $I$. lanceolata (Pursh) Chapm. 
deep green above, paler beneath, glabrous except on the nerves, more or less abruptly narrowed into short petioles : staminate flowers several in axillary clusters; pistillate flowers solitary or several together: calyx glabrous, 5-6 mm. broad; sepals broadly triangular, acutish, eroded : corolla 4-5 mm. broad, white; lobes broadly obovate, obtuse : stamens shorter than the corolla-lobes : drupes globose, about $1 \mathrm{~cm}$. in diameter, bright scarlet : nutlets strongly ribbed.

In mountain woods, New York to Georgia and Alabama. Spring.-The form with pubescent leafblades, is I. monticola móllis (A. Gray) Britton. MountaIN Holly.

10. Ilex Beàdiei Ashe. A shrub or small tree, with pubescent foliage. Leaves often numerous; blades elliptic, oval or suborbicular, varying to slightly broader above or below the middle, 3-8 cm. long, acute or short acuminate, serrate, densely pubescent beneath and finely pubescent above, short-petioled : pedicels pubescent : calyx nearly 2 $\mathrm{mm}$. broad; sepals obtuse, pubescent : corolla $5-6 \mathrm{~mm}$. broad : drupes oblong-globose, 6-8 mm. long.

In rocky woods, North Carolina to Tennessee, Georgia and Alabama. Spring.

11. Ilex myrtifòlia Walt. A low, straggling shrub or small tree, with very rigid branches. Leaf-blades leathery, narrowly oblong or linear, or on shoots nearly oval, 1-4 $\mathrm{cm}$. long, apiculate, more or less revolute, dark green and glabrous above, pale and usually glabrous beneath, short-petioled : flowers solitary in the axils, or a few in a cluster : calyx 1-1.5 mm. broad; sepals triangular, acute : corolla 4-5 mm. broad, white; lobes 4, obovate or oval, obtuse : stamens 4, shorter than the corolla-lobes : drupes globose, about $6 \mathrm{~mm}$. in diameter, red, on pedicels about $5 \mathrm{~mm}$. long.

In swamps and wet pine lands, North Carolina to Florida and Louisiana. Spring.

12. Ilex Cassine L. An evergreen shrub or small tree, reaching a height of $12 \mathrm{~m}$. and a trunk diameter of $5 \mathrm{dm}$., with usually pubescent twigs. Leaf-blades leathery, oblanceolate or oblong or rarely obovate, 4-10 cm. long, obtuse, acute or rarely retuse at the apex, more or less revolute, dark green and glabrous above, pale and more or less pubescent beneath or sometimes glabrous; petioles $5-10 \mathrm{~mm}$. long, usually pubescent : flowers in simple or panicled umbel-like clusters, the common peduncles $3-20 \mathrm{~mm}$. long: calyx 1.5-2 mm. broad; sepals triangular-ovate, acutish, erose-ciliate : corolla 4-4.5 mm. broad, white; lobes obovate, obtuse: stamens mostly"shorter than the corolla-lobes : drupes globose, $6-8 \mathrm{~mm}$. in diameter, red or sometimes nearly yellow, solitary or 3 in a cluster, on stout pubescent pedicels : nutlets prominently ribbed. [I. Dahoon Walt.] YAUPON.

In swamps and along streams near the coast, Virginia to Florida and Louisiana. Spring. DAHOON.

13. Ilex vomitòria Ait. An evergreen shrub or small tree, reaching a height of 8 $\mathrm{m}$. with a trunk diameter of $2 \mathrm{dm}$., often forming dense thickets. Leaf-blades leathery, oblong, oval or elliptic, sometimes oblong-lanceolate on shoots, 1-2.5 cm. long, obtuse, crenate-serrate, deep green and lustrous above, pale green beneath, abruptly narrowed into short petioles : flowers several in axillary clusters : pedicels $2-3 \mathrm{~mm}$. long: calyx $2 \mathrm{~mm}$. broad; sepals 4 , triangular-ovate, obtuse : corolla $5-5.5 \mathrm{~mm}$. broad, white : lobes oval or obovate, obtuse : stamens 4, shorter than the corolla lobes in the pistillate flowers, longer in the staminate : drupes globose, red, 5-6 mm. in diameter, longer than their pedicels : nutlets slightly ribbed. [I. Cassine Walt.]

Along swamps and streams, Virginia to Florida, Arkansas and Texas. Spring. Cassine. YaUPON.

14. Ilex opàca Ait. A glabrous tree, reaching a height of $15 \mathrm{~m}$., rarely with a trunk diameter of about $1 \mathrm{~m}$., the bark close, white or pale gray, warty. Leaf-blades parchment-like, oval, elliptic or obovate, $4-10 \mathrm{~cm}$. long, spine-tipped at the apex and spinytoothed or sometimes entire, lustrous and dark green above, pale and dull beneath, shortpetioled: staminate flowers several on a common peduncle: pistillate flowers solitary ; sepals triangular, about $1 \mathrm{~mm}$. long, acute, ciliate : corolla $5.5-6.5 \mathrm{~mm}$. broad; lobes oblong, obtuse: stamens surpassing the corolla in the staminate flowers, shorter than the corollalobes in the pistillate : drupes globose or globose-ovoid, about $1 \mathrm{~cm}$. in diameter, glabrous, red or rarely yellow, longer than the pedicels : nutlets ribbed.

In moist woods and on dry mountain slopes, Maine to Missouri and the Gulf States. Spring. HOLLY. AMERICAN HOLLY. WHITE HOLLY.

\section{Family 7. Cellastràceat Lindl. ' Staff-tree Family.}

Shrubs or trees, with erect or twining stems, sometimes armed with spines. Leaves alternate, opposite or whorled, with or without stipules: blades simple. Inflorescence normally cymose, sometimes clustered. Flowers perfect, polyg-

${ }^{1}$ Revised by Mr. J. R. Gardner. 
amous or dioecious, regular, commonly pedicellate. Calyx of 4-5 imbricated sepals. Disk fleshy, or rarely none. Corolla of 4-5 petals, usually inserted under the disk, imbricated, not clawed. Androecium of 4-5 stamens inserted beneath, on the margin of, or on the upper side of the disk. Filaments terete or nearly so. Anthers introrse. Gynoecium a compound pistil. Ovary commonly merging into the disk, with 2-5 cavities. Styles short or wanting. Stigma 2-5-lobed. Ovules solitary or 2-many in each cavity, erect or suspended, anatropous. Fruit a capsule, drupe or berry, sometimes winged. Seeds solitary or several in each cavity, often enclosed in the bright-colored aril. Endosperm copious, fleshy or oily. Embryo straight.

Fruit capsular, dehiscent.

Leaves opposite.

Ovary 3-5-celled : capsule 3-5-lobed, 3-5-valved : aril red.

Ovary 2-celled : capsule not lobed, 2 -valved : aril white.

Leaves alternate.

Climbing shrubs : ovary free.

Erect shrubs : ovary confluent with the disk.

Fruit drupaceous, indehiscent.

Gynoecium 2-carpellary or 4-carpellary : stigmas 2 or 4 .

Flowers perfect : ovary 4-celled.

Flowers dioecious : ovary 2-celled.

Leaves opposite: ovules pendulous.

Leaves alternate: ovules erect.

Gynoecium 5-carpellary: stigmas 5.
1. EUONYMUS.
2. Pachystima.
3. Celastrus.
4. Maytenus.
5. Crossopetalum.
6. GYMINDA.
7. SCHAEFFERIA.
8. Mortonia.

\section{EUÓNYMUS L.}

Shrubs or trees, or rarely vines, with commonly 4-angled branches. Leaves opposite : blades entire or toothed, deciduous : stipules caducous. Flowers solitary or cymose. Sepals 4-5, spreading or recurved. Petals 4-5, inserted under the disk, entire, toothed or fringed. Stamens 4-5, inserted on the disk : filaments mostly very short : anther-sacs 2, diverging. Disk flat, 4-5-lobed. Ovary in the disk, with 3-5 cavities : stigma with 3-5 inconspicucus lobes. Ovules usually 2 in each cavity, ascending. Capsule 3-5-lobed, angled or winged, smooth or echinate, opening loculicidally. Seeds 2 in each cavity surrounded by an aril.

Stems creeping, trailing or spreading : capsules covered with spiny warts.

Leaves oval or lanceolate, usually acute or acuminate.

Leaves obovate, usually obtuse.

Stems erect: capsules smooth.

1. E. Americanus.

2. E. obovatus.

3. $\boldsymbol{E}$. atropurpureus.

1. Euonymus Americànus L. A glabrous shrub 2-20 dm. tall, with creeping or horizontal stems. Leaf-blades varying from oval to lanceolate, $2-10 \mathrm{~cm}$. long, acute or acuminate, serrate, dark green above, paler beneath, short-petioled : flowers solitary or 3 on a slender or filiform peduncle $1-2 \mathrm{~cm}$. long: sepals narrowly reniform, almost $3 \mathrm{~mm}$. broad, erose : corolla greenish purple, 8-12 $\mathrm{mm}$. broad : petals $3-4 \mathrm{~mm}$. in diameter, suborbicular, undulate : capsules $1.5-2 \mathrm{~cm}$. in diameter, 3-5-lobed, covered with bristly warts: seeds with scarlet arils.

On river banks, New York to Illinois, Florida, Arkansas and Texas. Summer.-The form with linear-lanceolate nearly entire leaf-blades $5-8 \mathrm{~cm}$. long, is $E$. Americanus biflòrus (Raf.) Gardner. STRAW BERRY BUSH.

2. Euonymus obovàtus Nutt. A spreading diffuse glabrous shrub $2-6 \mathrm{dm}$. tall, with trailing stems. Leaf-blades obovate, $2-6 \mathrm{~cm}$. long, obtuse or short-acuminate and sometimes acute, finely serrate, rather dull green above, paler beneath, often cuneately narrowed into short petioles : flowers 1 or 3 on slender or filiform peduncles $1-3 \mathrm{~cm}$. long : sepals reniform, nearly $3 \mathrm{~mm}$. broad, erose : corolla greenish purple, 6-8 $\mathrm{mm}$. broad : petals suborbicular, sessile, broader than long, erose : capsules $1.5-2 \mathrm{~cm}$. in diameter, 3lobed, covered with bristly warts, crimson : seeds with scarlet arils.

On river banks, Ontario to Pennsylvania, Illinois and Tennessee. Spring. STRAwBERRY Bush.

3. Euonymus atropurpùreus Jacq. A shrub or small tree, sometimes $8 \mathrm{~m}$. tall, its trunk reaching a diameter of $2 \mathrm{dm}$. Leaf-blades oblong, elliptic oval, ovate or obovate, $5-16 \mathrm{~cm}$. long, acute or acuminate, serrate, dark green and glabrous above, more or less pubescent beneath, acute or rounded at the base; petioles 8-15 mm. long: cymes twice or thrice forked : peduncles 4-8 cm. long: sepals usually 4, reniform, 2.5-3 mm. broad: corolla dark purple, $10-12 \mathrm{~mm}$. broad : petals 4 , orbicular-ovate, or suborbicular, $2-3 \mathrm{~mm}$. long, obtuse : capsules 4-lobed, pendulous, depressed, the lobes wing-like : seeds 8-10 mm. long, the arils scarlet.

On river banks. New York to Montana, Florida, Arkansas and the Indian Territory. Spring. WaAhoo. Spindle Tree. Burning Bush. Bleeding Heart. 


\section{PACHÝSTIMA Raf.}

Small or depressed evergreen shrubs. Leaves opposite : blades leathery, toothed or entire : stipules minute, deciduous. Flowers greenish, solitary or clustered in the axils of the leaves. Sepals 4, roundish. Petals 4, longer than the sepals. Stamens 4, inserted under the disk : filaments short. Disk flat, 4-angled. Ovary 2-celled, pyramidal, merging into the disk: style very short: stigma obscurely 2-lobed. Ovules 2 in each cavity, erect on thickish funicles. Capsule 2-celled, leathery, somewhat flattened, opening lengthwise by 2 valves. Seed surrounded by a white aril : cotyledons elongated.

1. Pachystima Cánbyi A. Gray. A diffuse glabrous undershrub. Stems much branched, the branches decumbent, often creeping, 1-4 dm. long, wiry : leaf-blades linear or linear-oblong or rarely oblanceolate, $0.5-2 \mathrm{~cm}$. long, obtuse, serrate, short-petioled, dark green above, paler beneath : pedicels slender, solitary or clustered, 3-6 mm. long: sepals broadly ovate, about $1 \mathrm{~mm}$. long, rounded at the apex : hypanthium a broadly campanulate tube : petals ovate, $1.5 \mathrm{~mm}$. long, obtuse, more or less revolute : capsules oblong, 4 $\mathrm{mm}$. in diameter, with 2 cavities, 1-2 erect seeds in each, dehiscent at maturity.

On cliffs and shaded banks, southwestern Virginia and northwestern North Carolina. Spring.

\section{CELÁSTRUS L.}

Usually twining unarmed shrubs. Leaves alternate : blades entire or toothed : stipules minute, slender. Flowers in axillary or terminal racemes, or panicles, sometimes inclined to be dioecious. Sepals 5, crowning the urn-shaped hypanthium. Petals 5, inserted under the disk. Stamens 5, inserted at the sinuses of the disk. Disk cup-shaped, 5-lobed. Ovary 2-4-celled, the septa not always complete : style short, stout: stigma 2-4lobed. Ovules 2 in each cavity, erect. Capsule oblong or subglobose, leathery, 2-4-celled, opening loculicidally. Seeds 1-2 in each cavity, erect, surrounded by an aril. STAFFtree. Shrubby or Climbing Bittersweet. Waxwork.

1. Celastrus scánaens L. A climbing shrub, with unarmed sometimes twining branches. Leaf-blades membranous, elliptic, oval, oblong, ovate or obovate, $6-10 \mathrm{~cm}$. long, acuminate, serrate, glabrous or nearly so, usually acute at the base; petioles 8-20 mm. long: panicles drooping, 4-8 cm. long : sepals 4, ovate, often eroded : corolla greenish, about $8 \mathrm{~mm}$. broad : petals 5, oblong or obovate, obtuse, eroded: stamens 5 , shorter than the petals: capsules subglobose, $1 \mathrm{~cm}$. in diameter, finely wrinkled, orange, opening by 3 valves : seeds enclosed in a scarlet aril.

Along streams, thickets and fences, Quebec to Manitoba, south to Georgia and the Indian Territory. Spring or early summer.

\section{MAYTÈNUS Molina.}

Glabrous evergreen shrubs or small trees. Bark pale. Leaves alternate: blades leathery or fleshy-leathery, entire or toothed : stipules minute, deciduous. Flowers polygamous or dioecious, solitary, clustered or cymose, axillary. Sepals 5. Petals 5, inserted on the edge of the disk. Stamens 5, inserted under the disk. Disk flat, undulate. Ovary immersed in the disk, 2-4-celled. Style none or columnar. Stigma 2-4-lobed. Ovules 1-2 in each cavity, erect. Capsules leathery, 1-3-celled, opening loculicidally, 2-3-valved. Seeds erect, surrounded at the base or throughout by an aril. Endosperm wanting or fleshy.

1. Maytenus phyllanthoìdes Benth. An evergreen shrub or small tree 1-3 m. tall with an ash-colored bark. Leaf-blades obovate or oblong-oblanceolate, $2-4 \mathrm{~cm}$. long, obtuse, glabrous, undulate or obscurely toothed, more or less cuneately narrowed into a short, stout petiole: clusters few-flowered: hypanthium broadly turbinate : sepals 5 , triangular or ovate-triangular, acutish : corolla $2-3 \mathrm{~mm}$. broad : petals 5 : stamens shorter than the petals : capsules obovoid, 8-12 mm. in diameter, deep red, glabrous, opening by 3 suborbicular valves : seeds oblong, $5 \mathrm{~mm}$. long, curved, minutely roughened, apiculate.

In thickets, southern peninsular Florida and the Keys. Also in Mexico and Central America.

\section{CROSSOPÉTALUM P. Br.}

Glabrous or pubescent shrubs, commonly with a pale bark. Leaves alternate, opposite or whorled : blades entire or toothed. Flowers perfect, solitary, or cymosely disposed in the axils. Hypanthium urn-like. Sepals 4-5, roundish. Disk flattish, 4-5-lobed. Petals 
4-5, inserted under the disk, reflexed. Stamens 4-5, between the lobes of the disk. Ovary 4-celled, merging into the disk: stigmas 4. Ovules solitary and erect in each cavity. Drupe with little or no pulp, 1-celled, with a crustaceous or bony stone. Seeds with or without arils.

Leaf-blades spiny-toothed.

Leaf-blades crenate or entire.

1. C. Floridanum.

2. C. austrinum.

1. Crossopetalum Floridànum Gardner. A small straggling or prostrate shrub, with branches $2-4 \mathrm{dm}$. long, the twigs terete, pubescent. Leaves merely opposite; blades oval or ovate, 10-15 mm. long, veiny, coarsely serrate with bristle-tipped teeth, and bristletipped at the apex, rounded at the base, short-petioled: peduncles shorter than the leaves: sepals 4, persistent: petals 4, oblong-orbicular : stamens 4 : drupes obovoid, $3-4 \mathrm{~mm}$. long, oblique, apiculate.

In sand or on coral rock, southern peninsular Florida and the Keys. Also in St. Domingo.

2. Crossopetalum austrìnum Gardner. A shrub or tree $6 \mathrm{~m}$. tall, with 4-angled brownish or ash-colored twigs. Leaves opposite or whorled; blades obovate, or rarely a few somewhat elliptic, 1-4 cm. long, lightly crenate, at least toward the mucronate apex, narrowed at the base, smooth and glabrous : peduncles about $1 \mathrm{~cm}$. long: sepals 4 , rounded : petals 4, oval: stamens 4 : drupes somewhat oblique, 5-6 mm. long, red.

In sand, southern peninsular Florida.

\section{GYMÍNDA Sarg.}

Glabrous evergreen dioecious shrubs or trees, with a pale bark and 4-angled branchlets. Leaves opposite: blades elongated, entire or slightly toothed above the middle, rounded or emarginate at the apex : stipules caducous. Flowers dioecious, in axillary cymes. Sepals 4 (rarely 3), rounded, persistent, imbricated. Disk cup-shaped, 4-lobed, filling the hypanthium. Petals 4 , reflexed, entire, longer than the sepals. Stamens 4, exserted : filaments slender, converging. Ovary elongated, confluent with the disk, 2-celled; a rudimentary 2-cleft column in the staminate flowers: stigmas sessile, 2-lobed. Ovules solitary, suspended. Drupe-like fruit with a thin pulp and a 2-celled, crustaceous stone. Seeds pendulous. False Boxwood.

1. Gyminda Grisebáchii Sarg. An evergreen glabrous shrub or small tree $1-7 \mathrm{~m}$. tall, with a maximum trunk diameter of $15 \mathrm{~cm}$. Leaf-blades leathery, obovate or ellipticobovate, $2-4 \mathrm{~cm}$. long, rounded or retuse at the apex, slightly revolute, nearly sessile : cymes few-flowered on peduncles usually less than $1 \mathrm{~cm}$. long: sepals broadly ovate, obtuse : corolla 4-5 mm. broad : petals oblong. or obovate-oblong, 1.5-2 mm. long, obtuse, spreading or recurved : stamens shorter than the petals : drupe oblong or ovoid, 7-8 mm. long, slightly apiculate, bluish black : seeds 1-2, suspended. [Myginda latifolia Chapm., not Sw.]

On islands and Keys of southern Florida. Also in the West Indies. Spring.-The form with leafblades about $2 \mathrm{~cm}$. long and glaucous above, is G. Grisebachii glancifólia (Griseb.) Sudw.

\section{SCHAEFFìria Jacq.}

Rigid glabrous dioecious shrubs or small trees, with a pale bark, the branches terete. Leaves alternate or fascicled : blades leathery, entire. Flowers dioecious, sessile or pedicelled, clustered in the axils of the leaves. Sepals 4, broad, imbricated. Disk small, knob-like in the staminate flowers. Petals 4, hypogynous, inserted under the disk. Stamens 4, opposite the sepals : filaments incurved. Ovary 2-celled : style very short or wanting: stigma 2-lobed. Ovules solitary, erect. Drupe-like fruit with little or no pulp, 2celled, with a horny stone and a tuberculate coat. Seed one in each cavity, with an aril. Leaf-blades cuneate, 5-12 mm. long. Leaf-blades oval to elliptic-oblanceolate, 4-6 cm. long.

1. S. cuneifolia. 2. S. frutescens.

1. Schaefferia cuneifolia A. Gray. A rigid glabrous evergreen shrub, with a much branched stem, 1-2 m. tall. Leaf-blades leathery, clustered, obovate-cuneate, 5-12 mm. long, obtuse or notched at the apex, pale green, more or less prominently reticulated, sessile: cymes 5-6 mm. broad : petals oblong, obtuse : drupes subglobose, $4 \mathrm{~mm}$. in diameter, deep scarlet. On prairies, Texas and New Mexico to northern Mexico.

2. Schaefferia frutéscens Jacq. An evergreen glabrous shrub or tree, reaching a height of $12 \mathrm{~m}$., with a maximum trunk diameter of nearly $3 \mathrm{dm}$. Leaf-blades leathery, elliptic, oval, elliptic-obovate or elliptic-oblanceolate, 4-6 cm. long, pale green, acute or retuse, 
shining above, dull beneath, reticulated on both sides, entire, alternate at the base, sessile or nearly so : cymes contracted into several-flowered clusters : pedicels $3-10 \mathrm{~mm}$. long: sepals orbicular-ovate, obtuse : corolla yellowish green, 4-6 $\mathrm{mm}$. broad : petals oblong or oval, obtuse : stamens shorter than the petals : drupes nearly oval or globular, $5 \mathrm{~mm}$. long, bright scarlet, slightly grooved and warty, apiculate.

In sand, southern peninsular Florida, chiefly on the islands and Keys. Also in the West Indies. YELLOWWOOD. BOXWOOD.

\section{MORTòNIA A. Gray.}

Shrubs, with erect, unarmed stems. Leaves alternate, evergreen : blades thick, sessile. Inflorescence terminal, of spike-like racemes. Flowers perfect. Sepals 5, with whitescarious margin. Petals 5, eroded, inserted under the margin of the disk. Stamens $\mathbf{5}_{\mathbf{p}}$ inserted in the lobes of the disk. Ovary ovoid, immersed, or free from the disk, imperfectly 5-celled. Ovules erect, usually 2 in each cavity. Stigma 5-lobed. Fruit capsular, indehiscent, slightly grooved, with 1 cavity. Seed solitary, filling the whole cavity.

1. Mortonia Gréggii A. Gray. A low branching shrub, with yellowish green rough twigs. Leaves approximate ; blades linear or linear-spatulate, 1-2 cm. long, mucronate at the apex, entire, narrowed at the base, glabrous at maturity ; petioles $1 \mathrm{~mm}$. long: sepals 5 , oval, acute, $1 \mathrm{~mm}$. long : petals 5 , white, oval, obtuse, $2 \mathrm{~mm}$. long: filaments slender : style long: stigma 5-lobed : capsule oblong, $5 \mathrm{~mm}$. long, the walls thick and firm : seed solitary, erect. [M. effusa Turcz.]

Southwestern Texas.

\section{Family 8. HIPPOCRATEÀCEAE H.B.K. Hippocratea Family.}

Shrubs or small trees, or vines with more or less twisted branches. Leaves opposite, rather persistent; blades simple: stipules caducous. Inflorescence axillary, racemose, paniculate or cymose. Flowers perfect, regular, inconspicuous. Calyx of 5 small persistent imbricated sepals. Disk large, conic, cuplike or spreading. Corolla of 5 sessile imbricated spreading petals inserted between the sepals. Androecium of 3 stamens inserted on the margin of the disk and the ovary. Filaments flattened and dilated at the base. Anthers 2-4-celled, extrorse. Gynoecium of 3 united carpels. Ovary 3-celled, more or less immersed in and merged into the disk, but free. Styles united. Stigma simple, or 3-lobed. Ovules few or many, inserted in 1, 2 or 3 rows, anatropous or halfanatropous. Fruit a berry, drupe or capsule of 3 or fewer flattened carpels cohering at the base. Seeds usually few, flattened, often winged at the base, with a membranous or crustaceous testa. Endosperm wanting. Embryo straight with large, often united cotyledons.

\section{HIPPOCRATÈA L.}

Twining shrubs or small trees, with terete branches. Leaves opposite : blades leathery, on petioles which are swollen at the base. Flowers in axillary cymes or panicles. Sepals and petals mostly 5, spreading. Stamens 3, inserted on the disk : filaments flattened and dilated at the base. Ovary 3-celled : stigma 3-lobed. Ovules 2-6 in each cavity, in 2 series, ascending. Capsule 3 -lobed (lobes sometimes suppressed), flattened, leathery, 1-celled, the lobes 2-valved. Seeds flattened, winged below.

1. Hippocratea ovàta Lam. A high-climbing shrub. Stems several m. long, much branched : leaf-blades leathery, oblong or elliptic varying to ovate or obovate, 5-14 $\mathrm{cm}$. long, obtuse or apiculate, crenate-serrate, short-petioled : cymes open, rusty pubescent : peduncles 4-8 $\mathrm{cm}$. long: sepals 5 or rarely 4 , rounded : corolla $5-6 \mathrm{~mm}$. broad : mature carpels broadly obovate, $2.5-3 \mathrm{~cm}$. long.

In deep woods, along water, peninsular Florida and the Keys. Also in the West Indies.

\section{Family 9. Dodonaeàceae H.B.K. Dodonaea Family.}

Shrubs or trees, commonly sticky with a resinous excretion. Leaves alternate, without stipules: blades simple. Flowers polygamous or polygamo-dioecious, variously disposed. Sepals 3-5 nearly equal, imbricated, or valvate. Corolla 
wanting. Androecium of 5-8 regularly inserted stamens, filaments distinct : anthers 4-angled. Disk wanting. Gynoecium of 3 or 4 united carpels, wholly superior. Ovary 3-4-celled : styles united. Ovules 2 in each cavity, half-anatropous, often superposed, the upper one ascending and the lower one pendulous. Capsule membranous or leathery, reticulated, 2-6-angled, the angles obtuse, or winged, opening septicidally by 2-6 valves. Seed subglobose or flattened, without an aril. Endosperm wanting. Embryo spiral.

\section{DODONAÈA L.}

Characters of the family, as given above.

1. Dodonaea viscòsa L. A nearly glabrous shrub, with sticky foliage. Stems solitary or clustered, 2-4 m. tall : leaf-blades simple, mostly oblanceolate or spatulate, $3-10 \mathrm{~cm}$. long, apiculate or retuse at the apex, entire, attenuate to the base, short-petioled : racemes chiefly axillary, $1-2 \mathrm{~cm}$. long : pedicels slender, slightly pubescent : calyx greenish, $5-7$ $\mathrm{mm}$. broad : sepals ovate, obtuse, $1.5 \mathrm{~mm}$. long, slightly pubescent : anthers longer than the sepals, about $2 \mathrm{~mm}$. long, curved, ascending: capsules 3-celled, 12-20 mm. broad, each carpel produced into a reniform reticulated wing : seeds solitary in each cavity, subglobose.

In sand, peninsular Florida and the Keys. Also in tropical America.

\section{Family 10. STAPHYLEACEAE DC. Bladdernut Family.}

Shrubs or trees, with erect stems. Leaves opposite or rarely alternate, with stipules : blades compound : leaflets opposite, involute in vernation. Inflorescence racemose or paniculate. Flowers perfect or polygamous, regular, pedicellate, subtended by deciduous bracts. Calyx of 5 sepals. Disk cup-like, its edge free. Corolla of 5 imbricated elongated petals which are inserted under the edge of the disk and are eommonly slightly longer than the sepals. Androecium of 5 stamens inserted under the edge of the disk. Filaments distinct. Anthers introrse. Gynoecium of 2 or 3 partially or wholly united carpels. Ovary sessile. Styles 3, distinct or united. Stigmas simple. Ovules anatropous, horizontal or ascending, inserted in 1 or 2 rows on the ventral suture. Fruit an inflated membranous capsule, or a berry. Seeds few or numerous, with a bony testa. Endosperm scant, fleshy. Embryo straight, with fleshy, plano-convex cotyledons.

\section{STAPHYLEA L.}

Shrubs, with terete branches. Leaves opposite : blades 3 -foliolate or pinnately compound. Flowers perfect, regular, mostly in axillary racemes or panicles. Sepals 5, equal, imbricated, deciduous. Disk lobed. Petals 5, about as long as the sepals, erect, inserted beneath the edge of the disk. Stamens 5 : filaments equal, erect : anthers apiculate. Carpels 2-3,1-celled, united at the base, or rarely throughout : stigmas capitate. Ovules numerous, in 2 series, anatropous, ascending. Capsule membranous, 2-3-celled, 2-3-lobed. Seeds solitary or many in each cavity, the aril wanting. BLAdDERNuT.

1. Staphylea trifoliàta $\mathrm{L}$. A slender shrub $1-5 \mathrm{~m}$. tall, with striped twigs. Leafblades 3-foliolate; petioles 4-10 $\mathrm{cm}$. long; leaflets oval or elliptic varying to ovate or obovate, $5-10 \mathrm{~cm}$. long, acuminate or obtuse, serrate, the lateral ones inequilateral : racemes $5-10 \mathrm{~cm}$. long, drooping : pedicels 8-12 mm. long, jointed above the middle : sepals lanceolate or oblong, 7-10 mm. long, obtuse, glabrous: petals spatulate, somewhat longer than the sepals, obtuse, pubescent at the base : filaments about as long as the petals, pubescent
below the middle : style exserted : ovary pubescent : capsules bladder-like, 3-lobed, 4-6 below the middle : style exserted : ovary pubesce
$\mathrm{cm}$. long, obovoid, the apex of each lobe apiculate.

In thickets, Quebec to Ontario and Minnesota, Georgia and Missouri. Spring.

\section{Family 11. afsculàceas Lindl. Buckeye Family.}

Shrubs or trees, with a tough wood and a close or flaky bark. Leaves opposite, without stipules : blades palmately compound. Inflorescence terminal, of thyrsoid racemes or panicles. Flowers polygamous, unsymmetrical and irregular. Calyx of 5 mostly united sepals. Disk annular or one-sided. 
Corolla of 4 or 5 unequal petals, which are distinguishable into blade and claw. Androecium of 5-8 stamens, inserted within the disk. Filaments distinct, much elongated. Anthers introrse Gynoecium of 3 united carpels. Ovary 3celled. Styles elongated, united. Stigma entire. Ovules 2 in each cavity, superposed. Fruit a leathery capsule opening loculicidally by 3 valves. Seed usually solitary with a thick leathery testa. Endosperm wanting. Embryo hemispheric, the cotyledons very thick. [Hippocastanaceae T. \& G.]

\section{1. ÀscuLUS L.}

Shrubs or trees, with terete branches. Leaves opposite : blades long-petioled, palmately 5-9-foliolate : leaflets mostly toothed. Flowers of various colors. Sepals 5, partially united : tube campanulate or tubular. Disk entire. Petals 4-5, narrowed into claws. Stamens 5-8 : filaments filiform : anthers opening lengthwise. Ovary sessile, 3celled : style slender. Ovules horizontal or the lower one ascending. Capsule subglobose or 3-lobed, smooth or echinate, often 1-2-celled by suppression. Seeds mostly solitary with a shining testa. Buckeye. Horsechestnut.

Capsules unarmed.

Stamens 2-3 times longer than the petals : corollas white.

Stamens included or slightly exserted: corollas yellow, purple or red. Calyx tubular, reddish.

Blades of the leaflets oval or oval-ovate, very oblique at the base, densely to-

mentose beneath : calyx $1 \hat{0-14} \mathrm{~mm}$. long.
Blades of the leaflets elliptic or elliptic-oblanceolate, not oblique at the base, glabrate beneath : calyx 15-17 mm. long.

Calyx oblong-campanulate, greenish.

Capsule armed with prickles.

Shrub: blades of the leaflets incised above the middle as well as serrate.

Tree: blades of the leaflets serrate only.

1. A. parviflora.

1. Aesculus parviflòra Walt. A shrub 1-5 m. tall, the inflorescence and the lower surface of the leaflets tomentose. Leaf-blades 1-3 dm. broad: leaflets 5-7, the blades elliptic-oblanceolate to obovate, $5-18 \mathrm{~cm}$. long, short-acuminate, obtuse or acute at the base, finely serrate, glabrate and deep green above, tomentose beneath : panicles 1-3 dm. long, raceme-like : flowers about $1.5 \mathrm{~cm}$. long: calyx nearly tubular, 5-7 mm. long, minutely glandular; lobes oblong-ovate, obtuse : corolla white : petals long-exserted, those of the upper pair linear-spatulate, the blades obtuse, narrowed into long winged sparingly villous claws, those of the lateral pair longer than the others with truncate or retuse more or less fiddle-shaped blades : stamens 6-7, 2-3 times longer than the petals : capsule globular, $2.5-3 \mathrm{~cm}$. in diameter.

In sandy soil, South Carolina to Alabama and Florida. Spring.

2. Aesculus austrìna Small. A shrub several $m$. tall, with pubescent foliage and inflorescence. Leaf-blades 1-3 dm. broad : leaflets $3-5$, the blades firm, oval or oval-ovate, short-acuminate at both ends or acute at the base, very oblique at the base (except the terminal one), glabrate and lustrous above, tomentose beneath, sharply serrate, commonly long-stalked : panicles 1-1.5 dm. high, pubescent : flowers about $3 \mathrm{~cm}$. long: calyx tubu-: lar, reddish, 10-14 mm. long, glabrous: lobes ovate, rounded : corolla red : petals minutely glandular, those of the upper pair with oval blades which are about as long as the slightly villous claw, those of the lateral pair with obovate blades, and claws several times longer: stamens exserted: filaments sparingly villous : capsule unarmed.

In woods, Louisiana. Spring.

3. Aesculus Pàvia L. A shrub or small tree 2-6 m. tall, with a smooth bark. Leafblades deep green, 1-3 dm. in diameter : leaflets 5-7, the blades oblanceolate or ellipticoblanceolate, 5-15 cm. long, becoming firm, acuminate at the apex, finely serrate, acute at the base, usually finely pubescent beneath: panicle $1-2 \mathrm{dm}$. long: flowers about $2.5 \mathrm{~cm}$. long: calyx tubular, $1.5-1.7 \mathrm{~cm}$. long, striate : lobes broadly ovate, rounded : corolla red : petals minutely glandular, the upper pair with oblong blades and villous claws as long as the blades, those of the lateral pair with suborbicular blades and winged villous claws several times longer than the blades : stamens exserted : filaments villous below : capsule unarmed, 3-5 cm. in diameter.

In woods and along streams, Virginia to Missouri, Florida and Texas. Spring. RED BUCKEYE.

4. Aesculus octándra Marsh. A shrub, or tree reaching a height of $35 \mathrm{~m}$., with a maximum trunk diameter of $1 \mathrm{~m}$, the bark finally broken into flat scales. Leaf-blades 1-3.5 dm. in diameter: leaflets mostly 5 , the blades oblanceolate or elliptic, 1-2.5 dm. 
long, acuminate at the apex, finely serrate, acute or acuminate at the base, finely pubescent or glabrate in age : panicles $1-3 \mathrm{dm}$. long : flowers $2-3 \mathrm{~cm}$. long: calyx oblong-campanulate, 1-1.5 cm. long, finely glandular: lobes broadly ovate, obtuse : corolla yellow or purplish : petals glandular, those of the upper pair with oval blades which are about as long as the villous claw, those of the lateral pair with oval or suborbicular blades narrowed into winged villous claws which exceed them in length several times : stamens exserted: filaments more or less villous : capsule unarmed, obovoid, 4-6 cm. in diameter : seeds depressed, $2-3.5 \mathrm{~cm}$. long. [A. flava Ait.]

In woods and along streams, Pennsylvania to Iowa, Georgia and Texas. Spring. Yellow BuckEYE. SWEET BUCKEYE. LARGE BUCKEYE.

5. Aesculus argùta Buckl. A shrub 1-3 m. tall, with a smooth bark. Leaf-blades 1-2 dm. in diameter : leaflets 7-9, the blades narrowly elliptic, 6-12 cm. long, acuminate at both ends, finely serrate and incised above the middle, lustrous above, dull beneath, villous beneath chiefly on the nerves: panicles 1-2 dm. long, finely villous : flowers 2.5 $\mathrm{cm}$. long : calyx campanulate, 4-5 mm. long, minutely glandular; lobes low and rounded: corolla pale yellow : petals pubescent, villous at the base of the blade where they are slightly dilated, those of the upper pair oval or broadly oblong, very thin, those of the lateral pair with oblong blades which are narrowed into a thick portion about as long as the claw : stamens exserted : anthers yellow: capsule subglobose, $3-4.5 \mathrm{~cm}$. in diameter, prickly : seeds $1.5-3 \mathrm{~cm}$. broad.

On plains or prairies, Missouri to Nebraska and Texas. Spring. Shrubby Buckeye.

6. Aesculus glàbra Willd. A tree sometimes $25 \mathrm{~m}$. tall, with a maximum trunk diameter of about $6 \mathrm{dm}$. Leaf-blades $1-3 \mathrm{dm}$. in diameter : leaflets 5 or rarely 7 , the blades elliptic or elliptic-oblanceolate, $7-18 \mathrm{~cm}$. long, short-acuminate, finely serrate, becoming glabrous, cuneate at the base, nearly sessile or short-stalked: panicles 1-2 dm. long, finely pubescent: pedicels about $5 \mathrm{~mm}$. long: flowers 12-18 $\mathrm{mm}$. long: calyx campanulate, 6-8 mm. long, finely pubescent; lobes broadly ovate, rounded: corolla greenish yellow : petals finely pubescent, crisped, dilated just above the claw, villous near the base, those of the upper pair linear-spatulate, those of the lateral pair oval or oblong: stamens 7 , exserted : anthers orange : capsule obovoid or subglobose, $3-7 \mathrm{~cm}$. in diameter, prickly : seeds depressed, $2-4 \mathrm{~cm}$. in diameter.

In woods, Pennsylvania to Kansas, Alabama and the Indian Territory. Spring. ОHio Buckeye. STINKING BUCKEYE.

\section{Family 12. ACERÀceat J. St. Hil. Maple Family.}

Shrubs or trees of temperate regions, of great economic value, often possessing a saccharine usually watery sap, the bark smooth or exfoliating. Leaves opposite : blades simple or compound, commonly 3-lobed : stipules wanting. Inflorescence racemose or cymose, more or less compound, often congested. Flowers perfect or polygamous, sometimes monoecious or dioecious, regular. Calyx of 4 or 5, rarely 6-9, imbricated often colored deciduous sepals. Corolla wanting, or often of as many petals as the sepals and alternate with them, inserted on the margin of a hypogynous sometimes obsolete disk. Androecium of as many stamens as there are sepals, often 8. Filaments filiform, distinct or sometimes almost wanting. Anthers introrse, versatile. Gynoecium of 2 more or less united carpels. Ovary free. Styles united. Stigma 2-cleft. Ovules 2. Fruit 2 nutlets with wings (samara). Seeds solitary, or rarely 2 , with a membranous testa. Endosperm wanting. Embryo with curved or coiled cotyledons.

Leaves with simple or rarely digitately compound blades : flowers polygamo-dioecious. 1. ACER. Leaves with pinnately compound blades: flowers dioecious.

2. RULAC.

\section{1. ÀCER L.}

Small or large trees, the trunk clothed with a close or exfoliating bark. Leaves opposite : blades simple, lobed or digitately compound, or rarely entire. Flowers polygamo-dioecious, regular, in axillary or terminal racemes or corymbs. Sepals 4 or 5 , rarely 6-9. Disk wanting or cup-like, mostly lobed. Petals wanting or as many as the sepals, imbricated. Stamens 4-9, often 8. Ovary 2-celled, 2-lobed, flattened contrary to the septum. Samaras 2 together, with leathery or membranous reticulated wings. Seeds solitary or rarely 2, flattened, ascending, the testa membranous. MAPLE. 
Flowers in lateral clusters:

Clusters expanding before the leaves, sessile or nearly so, not drooping. Petals wanting or obsolete : ovary pubescent.

Petals present : ovary glabrous.

Leaf-blades glabrous or glabrate beneath : samaras less than $4 \mathrm{~cm}$. long: wings rather spreading.

Leaf-blades copiously woolly beneath : samaras over $4 \mathrm{~cm}$. long; wings nearly contiguous.

Clusters expanding with the leaves, drooping.

Trunks with gray or nearly black bark : samaras mostly over $3 \mathrm{~cm}$. long. Leaf-blades scarcely paler beneath than above : lobes entire or undulate. Leaf-blades pale or glaucous beneath : lobes coarsely toothed.

Trunks with white bark : samaras mostly less than $2.5 \mathrm{~cm}$. long.

Leaf-blades glaucous and sometimes pale-pubescent beneath : samaras light green.

Leaf-blades green and velvety beneath : samaras red.

1. A. saccharinum.

2. A. rubrum.

3. A. Drummondii.

4. A. nigrum.

5. A. Saccharum.

6. A. Floridanum.

7. A. leucoderme.

Flowers in terminal racemes or panicles.

Flowers in panicles: petals linear or linear-spatulate, twice or thrice as long as the sepals: samaras less than $2.5 \mathrm{~cm}$. long.

Flowers in racemes: petals oblong, about as long as the sepals : samaras over $2.5 \mathrm{~cm}$. long.

8. A. spicatum.

9. A. Pennsylvanicum.

1. Acer saccharìnum L. A tree rarely $36 \mathrm{~m}$. tall, with a maximum trunk diameter of about $1.5 \mathrm{~m}$., the bark flaky at maturity, gray, or that of the twigs reddish brown : leaves appearing after the flowers; blades about as long as broad, $10-15 \mathrm{~cm}$. long, with 3-5 prominent incised lobes longer than the body, silky when young, glabrate, bright green above, glaucous or silvery-white beneath, truncate or cordate at' the base : flower-clusters sessile or nearly so : calyx greenish or yellowish : stamens exserted : fruit drooping : samaras 5-6 cm. long, tomentose or glabrate at maturity, at length widely spreading. $[A$. dasycarpum Ehrh.]

In woods and river swamps, New Brunswick to Ontario, North Dakota, Florida and the Indian Territory. Late winter and spring. Silver Maple. Soft Maple. White Maple. River Maple.

2. Acer rùbrum L. A tree, sometimes $35 \mathrm{~m}$. tall, with a maximum trunk diameter of about $13 \mathrm{dm}$., the bark fissured on the trunk, smooth and pale or white-gray on the branches. Leaves appearing after the flowers; blades as broad as long or often longer than broad, deep green above, pale or glaucous and glabrate beneath, shallowly 3-5-lobed, rather evenly serrate, rounded or subcordate at the base : flower-clusters dense, red or yellowish, appearing before the leaves from the ends of short branchlets or in the axils of last year's leaves; the pistillate with longer pedicels than the staminate : sepals nearly distinct : petals narrower than the sepals : ovary glabrous or glabrate : fruit drooping from the elongating pedicels, commonly red : samaras less than $4 \mathrm{~mm}$. long, the wings diverging at about 45 degrees.

In low grounds and swamps, New Brunswick to Manitoba, Florida and Texas. Late winter and early spring. Red Maple. SWaMp MAPLe. WATER Maple. Scarlet Maple.

3. Acer Drummóndii Hook. \& Arn. A tree reaching a height of $26 \mathrm{~m}$., with a maximum trunk diameter of about $1 \mathrm{~m}$., the bark pale or whitish, rough on the trunk. Leaves appearing after the flowers; blades varying from ovate to depressed orbicular in outline, 8-15 cm. broad or sometimes smaller, 3-lobed, coarsely and irregularly toothed, deep green above, white and woolly beneath, rounded or cordate at the base : flower-clusters red, terminating short branchlets in the axils of last year's leaves, the pistillate with longer pedicels than the staminate: sepals nearly distinct, oblong or slightly narrowed upward : petals nearly like the sepals only narrower: ovary glabrous : fruit drooping from the slender pedicels : samaras over $4 \mathrm{~cm}$. long, the wings tending to converge.

In river swamps, Missouri to Georgia, Florida and Texas. Spring. RED MAPLE.

4. Acer nìgrum Michx. f. A forest tree sometimes $40 \mathrm{~m}$. tall, with a maximum trunk diameter of fully $1.5 \mathrm{~m}$., the bark dark, coarsely flaky. Leaves appearing with the flowers ; blades mainly broader than long, often $15-20 \mathrm{~cm}$. broad, relatively thin, deep green above, scarcely paler and more or less downy beneath, with 3-5 entire or merely undulate lobes, sinus at the base closed at the overlapping lobes: pedicels drooping, pubescent when young : calyx campanulate, about $5 \mathrm{~mm}$. long : sepals rounded : petals wanting : fruit drooping : samaras 3-4 cm. long, slightly spreading.

In rich woods or open fields, Ontario to Minnesota, Georgia and Louisiana. Spring. BLACK MAPLE.

5. Acer Sáccharum Marsh. A forest tree with a maximum height of about $40 \mathrm{~m}$. and a trunk diameter of $1.5 \mathrm{~m}$., the wood firm, heavy, the bark usually separating in coarse scales at maturity. Leaves appearing with the flowers; blades firm, mostly with 5 sinuate toothed lobes, 8-15 cm. in diameter, deep green above, pale or glaucous and tomentulose at least when young, beneath, cordate with an open shallow sinus: pedicels villous, drooping: calyx campanulate, about $5 \mathrm{~mm}$. long: sepals obtuse : petals wanting: disk in the 
staminate flowers surrounded by the base of the filaments : fruit drooping : samaras slightly spreading, 3.5-4 cm. long. [A. saccharinum Wang., not L.]

In rich woods or open grounds, Newfoundland to Manitoba, south to Georgia and Texas. Spring. Sugar Maple. Hard Maple. Sugar-tree. Rock Maple. Black Maple.

6. Acer Floridànum (Chapm.) Pax. A graceful tree rarely over $18 \mathrm{~m}$. tall, with a maximum trunk diameter of about $1 \mathrm{~m}$., the bark rather close, but rough in age, chalky white. Leaves appearing with the flowers; blades rather broader than long, 5-6 $\mathrm{cm}$. broad, with 3-5 blunt few-toothed lobes about as long as the body, deep green above, glaucous and more or less pubescent beneath, truncate or shallowly cordate at the base: pedicels sparingly pubescent at least until the fruit matures : calyx campanulate, 1-1.5 mm. long : sepals broad, somewhat pubescent : fruit green : samaras 1.5-2 cm. long, sparingly pubescent near the base, the wings rather widely spreading.

In river swamps, Georgia to Florida and Louisiana. Spring.

7. Acer leucodérme Small. A shrub or small tree reaching a height of $8 \mathrm{~m}$., with a trunk diameter of 1-5 dm., clothed with a smooth white bark, except the gray or reddish branchlets. Leaves appearing with the flowers; blades broader than long, or rarely orbicular in outline, mostly 4-lobed, sometimes imperfectly 5-lobed, 4-9 cm. in diameter, cordate or truncate, with a rather open and shallow sinus, dark green, glabrous and marked with light nerves above, greenish, tinged with red, prominently nerved and velvety (especially to the touch) beneath, the lobes acute or acuminate (the 4th. or 5th., when present, obtuse), each, or the terminal one only with two obtuse teeth: fruit drooping : wings of the samaras oblong-spatulate, 1-2 cm. long, red, conspicuous, parallel or nearly so (more or less spreading when the fruits separate at maturity).

On rocky river banks, North Carolina to Georgia and Louisiana. Spring.

8. Acer spicàtum Lam. A shrub or small tree, sometimes $10 \mathrm{~m}$. tall, with a maximum trunk diameter of $20 \mathrm{dm}$., the bark thin, relatively smooth, the twigs tomentulose or glabrate in age. Leaves appearing before the flowers : blades mostly longer than broad, mainly 3-lobed, sometimes with 2 additional lobes near the base, serrate, glabrate above, paler and more or less tomenulose beneath, cordate or subcordate: panicles terminal, raceme-like, 8-15 cm. long, peduncled, erect or ascending, many-flowered : pedicels spreading, 6-10 mm. long, or longer at maturity: petals linear or spatulate, twice or thrice as long as the sepals: stamens mostly 8 , equal : staminate flowers with a pubescent rudimentary pistil : disk with almost distinct glands : fruit green, about $2.5-3.5 \mathrm{~cm}$. broad, the wings of the samaras spreading at about 90 degrees.

In damp rocky woods and on mountain slopes, Newfoundland to Manitoba, Minnesota and along the mountains to Georgia. Spring and early summer. MOUNTAIN MAPLE. LOW MAPLE.

9. Acer Pennsylvánicum L. A shrub or tree, rarely over $11 \mathrm{~m}$. tall, with a maximum trunk diameter of about $5 \mathrm{dm}$., the bark relatively smooth, longitudinally striped. Leaves appearing before the flowers; blades sometimes broader than long, 1-3 dm. broad, deep green, with 3 nearly erect acuminate lobes, sometimes with 2 additional lobes, finely and doubly serrate, glaobrous above, finely pubescent beneath, rounded or subcordate at the base : racemes drooping, $8-15 \mathrm{~cm}$. long, relatively few-flowered : pedicels not spreading, $5-10$ $\mathrm{mm}$. long : petals pale or yellowish green, obovate, slightly surpassing the oblong sepals : stamens included : filaments outside the well-developed crenate disk: staminate flowers with rudimentary pistils : fruit bright green, $3.5-5.5 \mathrm{~cm}$. broad, glabrous, the wings of the samaras spreading at an angle of about 120 degrees.

In rocky woods, Nova Scotia to Lake Superior, southward, especially along the mountains, to Georgia. Spring. STRIPED MAPLE. MOUNTAIN ALDER. STRIPED DOGWOOD.

\section{RÙLAC Adans.}

Widely branching trees, the trunk with scaly bark, the branches light green. Leaves opposite: blades pinnately compound, the leaflets usually toothed. Flowers dioecious, appearing before the leaves: the staminate in drooping clusters, the pistillate in drooping racemes. Sepals 4 or 5 , relatively small. Petals wanting. Stamens 4-5. Disk obsolete. Ovary, and fruit, nearly similar to that of Acer. BoxeLDER.

Twigs and petioles essentially glabrous: leaflets thin, coarsely toothed. Twigs and petioles copiously pubescent: leaflets thick, lobed.

1. R. Negundo.

2. R. Texana.

1. Rulac Negundo (L.) A. S. Hitchcock. A tree, with conspicuously light green foliage, rarely $25 \mathrm{~m}$. tall, with a maximum trunk diameter of fully $1 . \mathrm{m}$., the bark flaky at maturity: leaves numerous ; petioles essentially glabrous ; blades pinnately $3-9$-foliolate; leaflets oval, ovate or ovate-lanceolate, often 5-12 cm. long, accuminate, coarsely toothed, more or less pubescent on or near the nerves beneath : flowers dioecious, appear- 
ing before the leaves : staminate in drooping clusters : pistillate in racemes : fruit drooping : samaras light green, $2.5-3.5 \mathrm{~cm}$. long, the wings more or less incurved. [Negundo aceroides Moench.]

In low grounds and along streams, Ontario to Minnesota, Florida, Texas and Mexico. Spring.

2. Rulac Texàna (Pax) Small. A tree, resembling $R$. Negundo. Twigs copiously pubescent with very fine hairs : leaves pubescent; petioles clothed with fine hairs; leaflets smaller than those of the preceding species but thicker and lobed. [Acer Texana Pax.]

Along or near rivers, Saskatchewan to Manitoba, Texas and New Mexico. Spring.

\section{Family 13. SAPINDÀCEAE $\mathrm{R}$. Br, SoapberRy Family.}

Shrubs or trees, with erect or climbing stems. Leaves opposite or alternate, usually with stipules: blades simple, pinnately-compound, or sometimes 1foliolate : leaflets commonly opposite. Inflorescence racemose, paniculate or corymbose. Flowers dioecious, polygamous, polygamo-dioecious, or rarely perfect. Calyx of 4 or 5 imbricated sepals in 1 or 2 series. Disk entire or lobed. Corolla of 4-5 petals, or wanting. Androecium of 5 or 8-15 stamens, inserted on the disk. Filaments distinct or rarely united below. Anthers introrse, sometimes versatile. Gynoecium of 2-4 more or less united carpels. Ovary 3-celled or 2-4-celled. Styles partially united. 'Stigmas capitate or lobed. Ovules solitary or several, anatropous or half-anatropous, horizontal or somewhat ascending or pendulous. Fruit a leathery or membranous capsule, or berrylike. Seeds 1 or several in each cavity, with a bony leathery or crustaceous testa. Endosperm thin, fleshy, or wanting.

Vines: fruit septicidal or septifragal.

Fruit of 3 samaroid carpels : tendrils wanting.

Leaf-blades ternate.

Leaf-blades biternate.

Fruit of inflated capsules : tendrils present.

Shrubs or trees : fruit baccate, or if dehiscent, loculicidal.

Fruit baccate, not stalked : flowers regular.

Ovules solitary in each cavity.

Ovules 2 in each cavity.

Ovary 2-celled: ovules collateral : leaflets 2,4 or $\tilde{6}$.

Fruit a leathery loculicidally 3 -valved capsule, staiked.

Flowers regular : ovules solitary in each cavity of the ovary.

Flowers irregular: ovules 2 in each cavityof the ovary.

1. URVillea.

2. SERJANIA.

3. CARDIOSPERMUM.

4. SAPINDUS.

5. EXоTHEA.

6. Hypelate.

7. Cupania.

8. UNGUADIA.

\section{URVÍLIEA H.B.K.}

Chiefly tropical American shrubs or twining vines, with tendrils. Leaves alternate, stipulate : blades 3 -foliolate; leaflets often punctate. Flowers whitish, irregular, polygamo-dioecious, on jointed stalks. Sepals usually 5, imbricated, the outer ones smaller than the inner. Petals often 4, appendaged. Disk one-sided, produced into 4 glands opposite the 2 smaller petals. Stamens 8, declined. Filaments distinet or united at the base. Ovary eccentric, 3-celled : styles united to above the middle. Ovules 1 in each cavity attached about the middle of the axis. Fruit consisting of 3 samaras attached by their backs, each bearing a seed at the middle. Endosperm wanting.

1. Urvillea ulmàcea H.B.K. A shrubby tomentose climber. Leaves numerous, petioled : leaflets 3 , the blades ovate or oval, obtuse, acute or acuminate, $1-5 \mathrm{~cm}$. long, doubly serrate and often incised: racemes $3-10 \mathrm{~cm}$. long: sepals oblong or obovate, the 3 inner twice as long as the outer 2 : petals obovate, about as long as the inner sepals, concave, crisped, the scales villous hooded, about $\frac{1}{2}$ as long as the petals : stamens as long as the petals : samaras very thin, obovate or oval in outline, $2-2.5 \mathrm{~cm}$. long : seeds obovoid, 2.5-3 mm. long, black, smooth and'shining. [U. Mexicana A. Gray.]

On plains and prairies, southern Texas and Mexico. Spring to winter. Also in Central America and Colombia.

\section{SERJànta Plum.}

Mostly tropical American climbing or twining shrubs. Leaves alternate: blades biternate: leaflets toothed or lobed, somewhat punctate. Flowers yellowish, irregular, polygamous, in axillary racemes or panicles often furnished with 2 tendrils. Sepals 5, 2 sometimes more or less united, imbricated. Petals 4, appendaged. Disk usually wavy or 
with 2 small and 2 large glands. Stamens 8, filaments united at the base. Ovary 3-celled, styles united to above the middle. Ovules 1 in each cavity, attached below the apex. Fruit of 3 samaras attached to each other by their backs, each bearing a seed at the apex. Embryo curved.

Fruit $2.5-4 \mathrm{~cm}$. long, rounded at the base : leaflets $2.5-3 \mathrm{~cm}$. long.

Fruit 1-1.5 cm. long, deeply cordate at the base: leaflets less than $2.5 \mathrm{~cm}$. long.

1. S. incisa.

2. S. brachycarpa.

1. Serjania incìsa Torr. A climbing vine 1-2 m. high. Leaflets $9-15$, the blades ovate, more or less decidedly rhombic, $2.5-3 \mathrm{~cm}$. long, coarsely few-toothed, or incised : panicles raceme-like, $2.5-3 \mathrm{~cm}$. long, slender-peduncled : fruit $2.5-4 \mathrm{~cm}$. long, obtuse at the base, the wings $7-9 \mathrm{~mm}$. broad.

In river valleys, Texas and adjacent Mexico.

2. Serjania brachycárpa A. Gray. A climbing shrub several meters long. Leaflets often 15, the blades rhombic-ovate, 1-2 cm. long, acute or rather obtuse, incised-toothed, densely tomentose beneath : panicles thyrsoid, $2.5 \mathrm{~cm}$. long, or larger at maturity, appromimate : peduncles nearly as long as the panicles : fruit 1-1.5 cm. long, deeply cordate at the base, the wings 4-5 $\mathrm{mm}$. broad.

In dry soil, southern Texas and northern Mexico.

\section{CARDIOSPÉRMUM L.}

Herbs or shrubs, with channeled or angled much-branched stems climbing by tendrils. Leaves alternate : blades biternate or decompound, leaflets commonly toothed, punctate. Flowers polygamo-dioecious, irregular, in axillary racemes or corymbs, whose peduncles bear 2 tendrils. Sepals 4, herbaceous, imbricated, the 2 outer smaller. Disk one-sided, extra-staminal, enlarged into two glands opposite the lower petals. Petals 4, unequal, the two larger with a scale at the base, the smaller pair with a crest. Stamens 8, oblique : filaments unequal, distinct or united at the base. Ovary 3-celled, 3-angled : styles united at the base: stigmas 3 . Ovules solitary in each cavity, ascending from the axis. Capsule 3-angled, inflated, membranous and veiny, opening loculicidally. Seed solitary in each cavity, globose. Endosperm wanting. Embryo with transversely conduplicate cotyledons.

Capsules longer than broad, $3-3.5 \mathrm{~cm}$. long.

Capsules broader than long, 1-2 $\mathrm{cm}$. broad.

Leaf-blades 3-foliolate: capsules $10-15 \mathrm{~mm}$. broad.

Leaf-blades 5-foliolate: capsules $15-20 \mathrm{~mm}$. broad.

1. C. Halicacabum.

1. Cardiospermum Halicácabum L. An annual or biennial climbing or trailing herb, 1-5 m. long: leaflets 3 , the blades ovate or ovate-lanceolate, coarsely serrate, incised or parted, glabrous or sparingly pubescent : flower-clusters small : peduncles slender, 3-10 cm. long, furnished with tendrils : sepals very unequal, the outer broader than long, the inner longer than broad: petals obovate, much longer than the inner sepals, rounded or retuse at the apex, the upper pair with oblique scales, the lower with clawed scales which are produced into a spur on one side : filaments pubescent : capsules broadly obovoid, bladder-like, 3-3.5 cm. long, longer than broad, the carpels angled, very finely pubescent : seeds globose, about $5 \mathrm{~mm}$. in diameter, brown or black, each with a white aril. and fall.

In thickets and waste places, New Jersey, Missouri, Florida, Texas and tropical America. Summer

2. Cardiospermum microcárpum H.B.K. An annual or biennial, glabrous or sparingly pubescent climbing herb, 1-4 m. long, sometimes woody at the base: leaflets $\mathbf{3}$, the blades ovate in outline, incised-serrate or parted, usually nearly glabrous above, more or less appressed-pubescent beneath, acute or acuminate, slender-petioled : peduncles 3-8 cm. long, wiry, angled, with 2 tendrils below the cyme: capsules broadly obpyramidal, 10-15 mm. long, broader than long, the carpels angled, finely pubescent: seeds globose, 4 mm. in diameter, black, each with a small white aril.

In thickets, Florida to Texas and through the tropics to northern South America. Spring to fall.

3. Cardiospermum Coríndum L. An annual or biennial climbing or twining herb clothed throughout with a soft tomentum, 2-4 m. long, velvety: leaflets 5 , the blades ovate or ovate-lanceolate, coarsely serrate or incised, acute or acuminate, velvety : peduncles stoutish, 3-10 cm. long, furnished with 2 tendrils below the cyme: capsules depressedglobose, $1.5-2 \mathrm{~cm}$. in diameter, softly pubescent, the carpels angled : seeds globose, $4 \mathrm{~mm}$. in diameter, black, dull. [C. molle H.B.K.]

In dry soil, Texas to Mexico. Spring to fall. 


\section{SÁPINDUS L.}

Shrubs or trees, with erect or somewhat climbing stems. Leaves alternate : blades mostly pinnately compound: leaflets with entire or toothed blades. Flowers polygamous, regular, in axillary or terminal racemes or panicles. Sepals 4-5, imbricated in 2 series. Disk annular or cushion-like. Petals 4-5, inserted under the disk, naked or each bearing a scale at the base. Stamens 8-10, inserted on the disk : filaments distinct, often pubescent : anthers versatile. Ovary 2-4-celled : styles united or distinct : stigmas 2-4. Ovules 1 in each cavity, ascending from the inner angle. Berry-like fruit fleshy or leathery, subglobose. Seed 1 in each cavity, without an aril. Embryo straight or curved.

SOAPBERRY.

Leaflets obtuse at the apex, at least not acuminate.

1. S. Saponaria.

Leaflets acuminate at the apex.

Leaflets 7-13, 5-13 cm. long: petals of a lanceolate type.

Mature carpels globular, about $1.5 \mathrm{~cm}$. long.

Mature carpels oval, about $2 \mathrm{~cm}$. long.

Leaflets 8-19, 3.5-7 cm. long: petals of an ovate type.

2. S. marginatus.

3. S. Manatensis.

4. S. Drummondii.

1. Sapindus Saponària L. A shrub or small tree 5-10 m. tall, with rough grayish erect branches, the twigs, lower leaf-surfaces and the inflorescence tomentose. Leaves 6-25 $\mathrm{cm}$. long, the rachis winged: leaflets $4-7$, the blades oblong, oval or obovate, $3-12 \mathrm{~cm}$. long, obtuse, undulate or rarely toothed, sessile, bright green and lustrous above, more or less tomentose and reticulated beneath: panicles 1-2 dm. long, erect: calyx 3-4 mm. broad : sepals suborbicular, $1.5-2 \mathrm{~mm}$. in diameter, ciliate : petals obovate or orbicular-obovate, about $\frac{1}{3}$ longer than the sepals, nearly sessile, ciliate, pubescent without : stamens about as long as the petals : filaments pubescent to above the middle : each mature carpel globose, 14-18 mm. in diameter, solitary or 2-3 together, shining, the pulp orange-brown : seeds black, obovate.

In sandy soil, southern peninsular Florida and the Keys. Also in Central and northern South America. SOAPBERRY. FALSE DOGWOOD.

2. Sapindus marginàtus Willd. A small tree 10-15 m. tall, with usually erect branches, the twigs and inflorescence pubescent. Leaves 1-3 dm. long, the rachis usually margined above : leaflets $7-13$, the blades lanceolate or oblong-lanceolate, $5-15 \mathrm{~cm}$. long, more or less scythe-shaped, acuminate, undulate, short-petioluled, bright green above, paler and slightly pubescent on the nerves beneath : panicles 1-3 dm. long: sepals ovate, 1-1.5 mm. long, acute or acutish : petals white or tinged with red; blades ovate or oblongovate: claw produced into tufted scales at the base of the blade: stamens longer than the petals : filaments pubescent to the top : each mature carpel ( 1 or 2$)$ drupe-like, globular, about $1.5 \mathrm{~cm}$. long, the pulp orange, not drying black : seeds obovoid, brown.

In low sandy soil, South Carolina and Georgia to Florida. Spring: matures its fruit in the fall. WILD CHINA. SOAPBERRY.

3. Sapindus Manaténsis Radlk. A glabrous shrub or tree 3-10 m. tall, with widely spreading branches. Leaves $2-3 \mathrm{dm}$. long, the rachis not winged : leaflets $7-13$, the blades oblong-lanceolate, $3-10 \mathrm{~cm}$. long, acuminate, undulate, slightly curved, inequilateral, bright green above, paler beneath, oblique at the base, nearly sessile : panicles 1-2 dm. long: sepals ovate or oval-ovate, nearly $2.5 \mathrm{~mm}$. long, ciliolate : petals white or creamy, about $3 \mathrm{~mm}$. lonz; blades ovate, ciliate ; claw shorter than the blade, produced into tufted scales at the base of the blade : each mature carpel drupe-like, oval, about $2 \mathrm{~cm}$. long.

On the islands at the mouth of the Manatee River, Florida.

4. Sapindus Drummóndii Hook. \& Arn. A small tree, with spreading branches. Leaves numerous: leaflets 8-19, the blades narrowly lanceolate, 4-8 cm. long, acuminate, more or less falcate, glabrous above, softly pubescent beneath or tardily glabrate; rachis wingless : panicles $0.5-1.5 \mathrm{dm}$. long: calyx $3-3.5 \mathrm{~mm}$. broad : sepals ovate or oval-ovate obtuse : petals nearly twice as long as the sepals; blades rhombic-lanceolate, more or less lacerate at the blunt apex : fruit from a single carpel, globose, about $1.5 \mathrm{~cm}$. in diameter, not keeled, yellow, drying black.

In dry soil, often on hillsides, Kansas to Arkansas, Louisiana and Arizona. Also in Mexico Spring. WILD CHINA TREE.

\section{EXÓTHEA Macfadyen.}

Shrubs or trees. Leaves alternate : blades abruptly compound. Flowers mostly polygamous, irregular, panicled. Sepals 5 , partially united, imbricated, pubescent, becoming reflexed. Petals 5, unappendaged, narrowed into very short claws. Ovary 2-celled, sessile. Oviles 3 in each cavity, collateral, rather pendulous. Fruit 1-celled (by abortion). Seed solitary. Embryo with thick colytedons and a short radicle. 
1. Exothea paniculàta (Juss.) Radlk. A tree, with a hard but brittle wood and a reddish brown bark. Leaflets $2-4$ or rarely 6 , the blades rather thick, oblong or elliptic, $5-13 \mathrm{~cm}$. long, entire somewhat lustrous above, glabrous : flowers numerous, fragrant, from clove-shaped buds : panicles corymbose : bractlets subulate : sepals 4 , broadly ovate to suborbicular, 3-4 $\mathrm{mm}$. long, tomentose, persistent and reflexed : petals 4 , white, similar to the sepals but glabrous : fruit subglobose, 10-13 $\mathrm{mm}$. in diameter, orange turning purple, with a juicy pulp : seed solitary, papery coated, mahogany-colored.

In sandy places, peninsular Florida and the Keys. Also in the West Indies. Winter and spring. INKWOOD. IRONWOOD.

\section{HYPÉLATE P. Br.}

Evergreen shrubs or trees. Leaves alternate: blades palmately 3-foliolate : leaflets with leathery, prominently nerved blades. Flowers polygamo-dioecious in terminal or almost terminal panicles. Sepals 5, imbricated, nearly glabrous. Petals 5, unappendaged, sessile. Stamens 8-10, imperfect or wanting in the pistillate flowers : filaments glabrous. Ovary 3-celled, sessile : styles united. Ovules 2 in each cavity, superposed, the upper ascending, the lower rather pendulous. Fruit 1-celled (by abortion). Seed solitary. Embryo with thin crumpled cotyledons and a long radicle.

1. Hypelate trifoliàta Sw. A slender tree, with a smoothish bark and brittle branches. Leaves numerous; leaflets 3 , the blades spatulate to narrowly obovate, 2.5-4.5 $\mathrm{cm}$. long, leathery, rounded or retuse at the apex, cuneate at the base; rachis usually narrowly winged above : flowers in panicles surpassing the leaves : stamens $6-8:$ sepals suborbicular, pubescent within : corolla white, $3-4 \mathrm{~mm}$. broad : petals suborbicular : fruit. ovoid, 5-7 mm. long, black, with a single seed.

On the Florida Keys. Also in the West Indies. Spring and summer. WHIte Ironwood.

\section{CUPÀNIA L.}

Shrubs or trees. Leaves alternate, without stipules, pinnate: leaflets alternate or opposite, entire or shallowly toothed. Flowers regular, polygamo-dioecious, in racemes or panicles. Sepals $4-5$, or rarely 3 or 6 , broad. Corolla green; white or reddish, or wanting. Petals 4-5, each sometimes bearing 1 or 2 scales. Stamens 8 , or $5,6,10$ or 12 . Ovary 2-3-celled, or rarely 4-celled. Ovules solitary in each cavity. Capsule 2-4-lobed, commonly 3-lobed, leathery or firmer, loculicidal. Seeds globular or oblong.

1. Cupania glábra Sw. A tree, with glabrous or thinly pubescent branches. Leaves. 1.5-3.5 dm. long : leaflets leathery, few or several, the blades oblong with a cuneate base, 6-11 cm. long, more or less crenate or crenate-serrate above the middle : panicle-branches. pubescent : petals broad, about as long as the sepals : capsules turbinate, 3-lobed, 11-14 mm. broad, apiculate, stout-stipitate.

In hammocks, Pine Key, Florida. Also in tropical America.

\section{UNGNÀDIA Endl.}

Shrubs or small trees, with a pale bark and a brittle wood. Leaves alternate: blades pinnately compound, with a terminal leaflet: leaflets $5-7$ or rarely 3 , with leathery serrate blades. Flowers irregular, polygamous, pedicelled, deep pink, in lateral clusters. Sepals 5, imbricated. Petals 4-5, undulate or erose, nearly equal, strongly crested with fimbriate scales. Disk one-sided, oblique. Stamens 7-10, unequal in length, declined: filaments filiform. Ovary 3-celled, stalked: styles and stigmas united. Ovules 2 in each cavity, ascending, anatropous or amphitropous. Capsule leathery, 3-celled, 3-lobed. Seeds 1 in each cavity, globose, without an aril. Endosperm wanting. Cotyledons nearly hemispheric.

1. Ungnadia speciòsa Endl. A shrub or tree 2-10 m. tall, the twigs, foliage and inflorescence more or less pubescent. Leaves $1-2 \mathrm{dm}$. long, the rachis nearly terete; leaflets usually 5-7, the blades ovate, elliptic or lanceolate, $5-12 \mathrm{~cm}$. long, acutish or acuminate, appressed-serrate, rounded or subcordate at the base, deep green above, paler beneath : calyx 4-5 mm. long: sepals oblong-ovate, longer than the tube: corolla deep. pink, about $2 \mathrm{~cm}$. broad : petals obovate-spatulate, $9-13 \mathrm{~mm}$. long, the scale reaching to about. the middle : stamens exserted : capsules leathery, broadly obovoid, 3-5 cm. broad, shorter than broad, minutely pubescent or glabrous : seeds subglobose, nearly $1.5 \mathrm{~cm}$. in diameter, black, shining.

Chiefly along streams, Texas to New Mexico and Mexico. Spring. SPAnish Buckeye. Texas. BUCKEYE. 


\section{Order 18. RHAMNÀLES.}

Shrubs or small trees, or commonly vines. Leaves mostly alternate. Flowers regular, sometimes imperfect or incomplete. Calyx and corolla present, or the latter wanting. Androecium of as many stamens as there are sepals and alternate with them. Gynoecium a compound pistil, superior or mainly so. Fruit a capsule or a berry, or drupaceous.

Sepals manifest: petals involute : fruit capsular or drupaceous. Sepals minute or obsolete: petals valvate : fruit baccate.

Fam. 1. RHAMNACEAE. Fam. 2. VitaceaE.

\section{FAMILY 1. FRANGULÀCEAF DC. BUCKThorn FAmily.}

Armed or unarmed shrubs or trees, or vines, pervaded by a bitter and astringent principle. Leaves alternate or sometimes opposite: blades simple, commonly many-nerved : stipules small, often deciduous. Inflorescence various. Flowers often greenish, perfect or polygamous, or sometimes dioecious. Calyx of 4-5 valvate sepals. Disk lining or filling the hypanthium, sometimes produced into horns. Corolla usually present, of 4-5 petals, inserted at the throat of the hypanthium, or on the edge of the disk. Androecium of 4-5 stamens, inserted opposite to and with the petals. Filaments distinct. Anthers versatile, 2-celled, Gynoecium of 2-3 united carpels. Ovary 2-3-celled, partially immersed in and merging into the disk. Styles and stigmas more or less united. Ovules solitary, or rarely two in each cavity, anatropous, erect. Fruit capsular or drupaceous, rarely winged, commonly separating into several nutlets. Seeds with a smooth or furrowed fibrous membranous crustaceous or horny testa. Endosperm wanting or fleshy. Embryo with often broad cotyledons. [Rhamnaceae Dumort.]

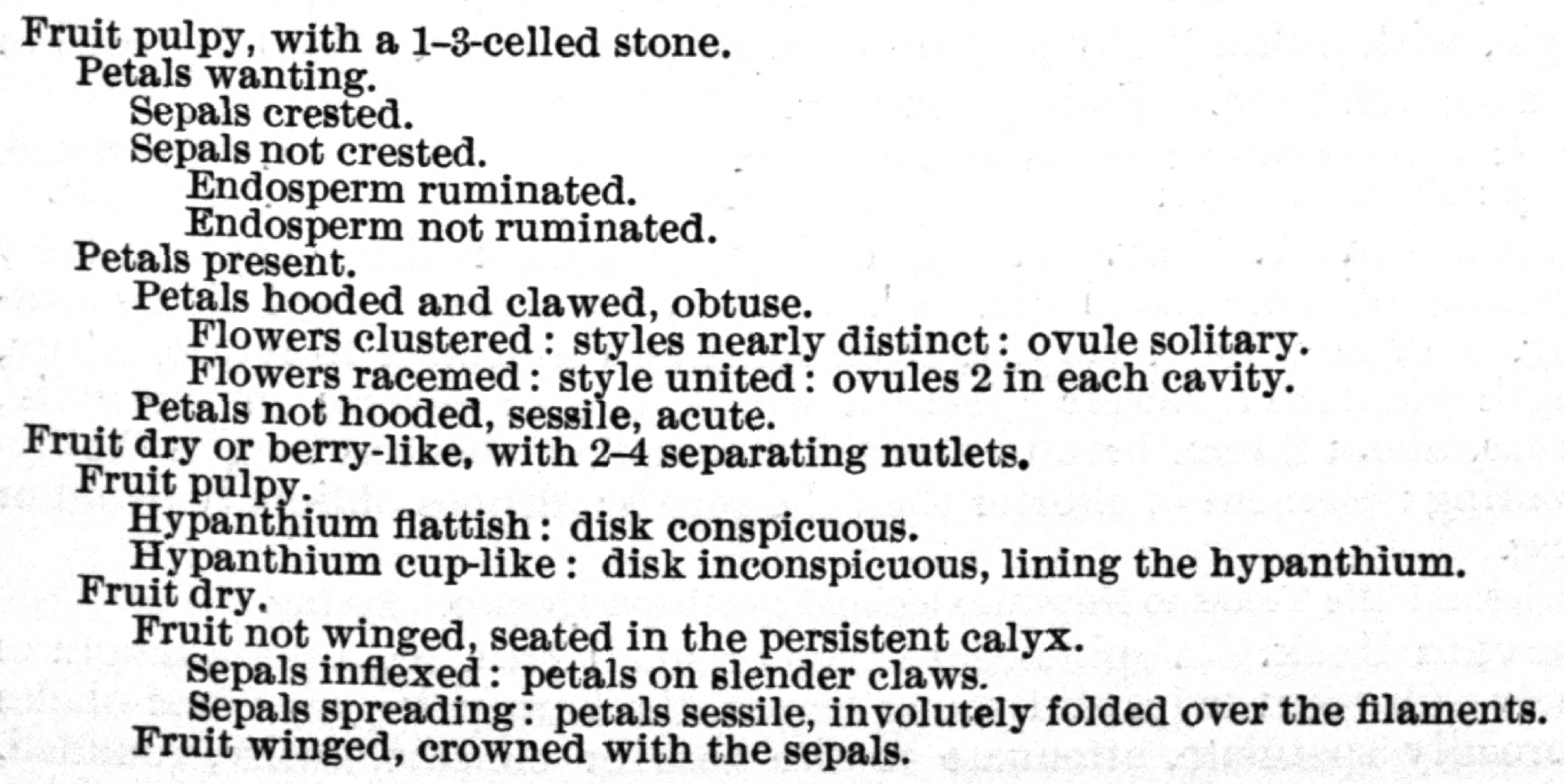

1. RHAMNIDIUM.

2. REYNOSIA.

3. Condalia.

4. ZiZYPHUS.

5. KARWINSKIA. 6. BERCHEMIA.

7. SAGERETIA. 8. RHAMNUS.

9. Ceanothus.

10. Colubrina.

11. GounNia.

\section{RHAMNÍDIUM Reiss.}

Shrubs or small trees, with unarmed branches. Leaves nearly opposite : blades firm, entire, pinnately nerved : stipules minute. Flowers perfect, in short-peduncled axillary cymes. Sepals 5, crested, longer than the hypanthium. Petals wanting. Stamens 5: filaments longer than the anthers. Ovary 2-celled : styles united, merely notched or 2-3lobed. Ovule solitary. Drupe with an incompletely 2-celled stone. Seed with a large embryo. Endosperm not ruminated.

1. Rhamnidium férreum (Vahl) Sarg. A shrub or small tree, reaching a height of $9 \mathrm{~m}$., with a trunk diameter of $25 \mathrm{~cm}$., its bark broken into rounded ridges. Leaf-blades thin but leathery, ovate or oval, 3-6 cm. long, usually notched and mucronulate at the apex, entire or undulate, abruptly narrowed or rounded at the base, becoming glabrous; petioles 3-6 mm. long, pubescent especially on the upper side : flowers inconspicuous, $3-5$ in axillary cymes: calyx 4-5 mm. broad, glabrous: sepals 5 , ovate, acute, prominently crested on the inner side: stamens 5, erect: drupes subglobose or oval, 5-8 mm. long, black. [Condalia ferrea (Vahl) Griseb.]

Along the coast, Florida and the Keys. Also in the West Indies. Spring. Black Ironwood. 


\section{REYNÒSIA Griseb.}

Unarmed evergreen shrubs or trees, with rigid branches. Leaves opposite : blades leathery, entire, emarginate : stipules small, caducous. Flowers perfect, very small, yellowish green, in sessile axillary umbel-like clusters. Hypanthium hemispheric, persistent. Sepals 5, valvate spreading. Disk fleshy, filling the hypanthium. Petals wanting. Stamens 5, inserted on the margin of the disk : filaments subulate, incurved, shorter than the sepals: anthers introrse. Ovary almost superior, 2-3-celled: styles short, thick, united : stigma 2-3-lobed. Ovules 1 in each cavity, erect. Drupe tipped with base of the style, with a thin fleshy pulp and a crustaceous stone. Seed solitary, with a thin, rugose, tuberculate testa. Endosperm ruminated.

1. Reynosia latifòlia Griseb. A slender evergreen tree, reaching a maximum height of about $9 \mathrm{~m}$., with a trunk sometimes $20 \mathrm{~cm}$. in diameter, clothed with a reddish brown scaly bark. Leaf-blades firm, oblong, varying to ovate or obovate, usually retuse at the apex and sometimes mucronate, entire, glabrous, short-petioled: flowers several together in axillary clusters : pedicels 4-5 $\mathrm{mm}$. long : calyx $5 \mathrm{~mm}$. broad; sepals 5 , triangular or ovate-triangular, longer than the hypanthium, acute: stamens 5 , shorter than the sepals : drupes subglobose, oval or obovoid, 1.5-2 cm. long, purple or nearly black, edible.

Near the coast, Florida and the Keys. Also in the Bahamas and West Indies. Spring. RED IroNwood. Darling Plum.

\section{CONDÀIIA Cav.}

Usually glabrous rigid shrubs or small trees, with thorn-like branchlets. Leaves alternate, deciduous : blades leathery. Flowers perfect, very small, greenish white, solitary or clustered in the axils. Hypanthium broadly turbinate. Sepals 5, persistent, valvate, spreading. Disk fleshy, filling the hypanthium, slightly 5-angled. Petals wanting. Stamens 5 , or rarely 4 , inserted on the margin of the disk : filaments incurved, shorter than the sepals: anthers introrse. Ovary almost superior, 1-celled or imperfectly 2-3-celled : styles stout, united : stigma 2-3-lobed. Ovules solitary, nearly erect. Drupe tipped with the remains of the style, with a thin fleshy pulp and a crustaceous stone. Seed flattened or subglobose, with a thin smooth testa. Endosperm thin.

Leaf-blades 5-12 mm. long : stigma 2-lobed : drupes 4-5 mm. long. Leaf-blades 12-25 mm. long: stigma 3-lobed: drupes 6-8 mm. long.

1. C. spathulata. 2. C. obovata.

1. Condalia spathulàta A. Gray. A rigid very spinescent shrub, with velvety pubescent twigs and young foliage, several $\mathrm{dm}$. tall, diffusely branched. Leaf-blades spatlate, elliptic or oblong, 5-12 mm. long, varying from acute and apiculate to retuse, entire, short-petioled, at length glabrous : flowers greenish white, one or several in the axils: calyx becoming glabrous, about $2 \mathrm{~mm}$. broad; sepals 5 , triangular, about as long as the hypanthium : petals wanting : stamens 5 , shorter than the sepals : drupes obliquely ovoid or obovoid, 4-5 mm. long.

On plains and prairies, middle Texas to New Mexico and northern Mexico. Spring.

2. Condalia obovàta Hook. A spinescent shrub or small tree, reaching a height of about $10 \mathrm{~m}$., with finely pubescent twigs and young leaves, the bark pale gray: leaf-blades obovate varying to broadly spatulate, attenuate to the base or cuneate, entire, rounded, truncate or retuse and mucronate at the apex or rarely acutish, at length glabrous, with a prominent midrib, short-petioled : flowers greenish white, solitary or 2-4 in axiliary clusters : calyx glabrous or nearly so, $1.5 \mathrm{~mm}$. broad : sepals triangular, about as long as the hypanthium : petals wanting: stamens 5 , shorter than the sepals : drupe subglobose, 6-8 $\mathrm{mm}$. in diameter, black, sweet to the taste.

In dry soil, central and southern Texas and northern Mexico. Spring. BLUEWOOD. LOGWOOD. PURPLE HaW.

\section{ZİYPHUS Juss.}

Spinescent shrubs. Leaves alternate, mostly 2-ranked : blades firm, 3-nerved: one or both of the stipules commonly spine-like. Flowers greenish, in axillary cymes or umbellike fascicles. Hypanthium broadly turbinate. Sepals 5, triangular, keeled on the upper side, valvate. Disk obscurely 5-lobed, nearly flat. Petals 5, alternate with the sepals, hood-like, at first surrounding the stamens. Stamens 5 , inserted with the petals at the edge of the disk : filaments subulate: anthers introrse : sacs opening lengthwise. Ovary 2-3celled, nearly immersed in the disk : styles 2-6 : stigmas terminal, or lateral on the inner faces of the styles. Ovule solitary, erect. Drupe sometimes berry-like, fleshy, the stone horny. Testa thin, membranous, smooth. 
1. Zizyphus obtusifòlia (Hook.) A. Gray. A rigid spinescent much-branched pubescent or glabrous shrub. Leaf-blades ovate or oblong-ovate, or rarely narrowly oblong, 1-3 cm. long, acutish varying to retuse, entire or shallowly crenate, more or less abruptly narrowed at the base, glabrous or nearly so, a little paler beneath than above; petioles mainly $\frac{1}{3}-\frac{1}{4}$ as long as the blades: clusters rarely surpassing the petioles: peduncles and pedicels 1-2 $\mathrm{mm}$. long, villous-pilose : calyx pubescent like the pedicels, about $3 \mathrm{~mm}$. broad : sepals triangular, acute : petals 5 , shorter than the sepals, longer than the 5 stamens : drupe subglobose, 8-10 mm. long, black.

On plains and prairies, Texas to Arizona. Spring. LotiBush. Texas Buckthorn.

\section{KARWÍNSKIA Zucc.}

Shrubs or small trees. Leaves opposite or nearly so: blades entire, prominently nerved : stipules deciduous. Flowers perfect, few together in axillary cymes. Hypanthium turbinate or hemispheric. Sepals 5, triangular, keeled within. Petals 5, hooded, clawed. Stamens 5, inserted with the petals under the edge of the disk which clothes the hypanthium: filaments subulate, surpassing the petals. Ovary immersed in the disk, 2-3-celled: styles united almost to the apex : stigmas obtuse. Ovules 2 in each cavity. Drupe varying from ovoid to subglobose, tipped with the persistent base of the style, the stone 1-2-celled. Seeds erect. Testa membranous, dark-veined. Endosperm thin.

1. Karwinskia Humboldtiàna Zucc. A shrub or small tree, reaching a height of $7 \mathrm{~m}$., the twigs and young leaves sometimes puberulent. Leaf-blades firm, oblong, oval, oblong-ovate or oblong-lanceolate, $3-9 \mathrm{~cm}$. long, rounded or acute at the apex, entire, more or less revolute, abruptly rounded or narrowed at the base, the lateral nerves prominent ; petioles slender, 5-15 mm. long : cymes about $1 \mathrm{~cm}$. long: calyx glabrous, $2.5-3 \mathrm{~mm}$. broad ; sepals triangular, about as long as the hypanthium, acute: drupes subglobose or oval, 10-12 $\mathrm{mm}$. long, apiculate by the persistent style, brownish black.

On dry plains or prairies, Texas to Lower California and Central America.

\section{BERCHÈMIA Neck.}

Erect or high-climbing shrubs. Leaves alternate : blades leathery, with ascending nerves straight and parallel : stipules small, deciduous. Flowers perfect or polygamous, axillary, or sometimes in terminal panicles. Hypanthium hemispheric or turbinate. Sepals 5. Disk clothing the hypanthium, its margin free. Petals 5, sessile, hooded. Stamens 5 : filaments filiform. Ovary half-immersed in the disk, but free, 2-celled : styles short, united : stigmas 2 . Ovules 2 in each cavity. Drupe somewhat flattened, with a leathery sarcocarp, and a 2-celled crustaceous or woody stone. Seeds with a membranous testa. Endosperm wanting.

1. Berchemia scándens (Hill) Trelease. A glabrous twining or climbing shrub. Stems much branched, 2-30 m. long, the branches spreading at right angles: leaf-blades firm, oval, elliptic, oblong, sometimes varying to lanceolate, $4-8 \mathrm{~cm}$. long, entire or undulate-crenate, abruptly narrowed or rounded at the base, the lateral nerves prominent; petioles slender, $0.5-1 \mathrm{~cm}$. long: panicles $1.5-5 \mathrm{~cm}$. long, terminal : calyx glabrous; sepals 5 , triangular or ovate-triangular, longer than the hypanthium, acute or short-acuminate: petals 5 , obovate, acute, about as long as the sepals, sessile, the edges more or less involute : drupes oblong or ovoid-oblong, 6-8 $\mathrm{mm}$. long. [B. volubilis DC.]
[B.

In damp soil, Virginia to Missouri, Florida and Texas. Spring.

\section{SAGERÈTIA Brongn.}

Armed or unarmed weak shrubs, with opposite or nearly opposite branchlets. Leaves opposite or nearly so: blades reticulated : stipules minute, deciduous. Flowers perfect, in axillary clusters or terminal panicled spikes. Sepals 5, keeled within. Disk cup-like, clothing the hypanthium, margin free, 5-lobed. Petals 5, clawed, hooded. Stamens 5: filaments distinct. Ovary immersed in the disk, free, 3-celled : style 3-grooved : stigmas 3. Drupe berry-like, separating into 3 leathery nutlets. Seeds elongated, not grooved. Endosperm thin.

I Sageretia minutiflòra (Michx.) Trelease. A trailing or straggling spinescent shrub, with tomentose twigs and young leaves, and diverging branches. Leaf-blades leathery, ovate or orbicular-ovate, $1-5 \mathrm{~cm}$. long, acute or short-acuminate or rarely submucronate, serrulate, shining above, rounded or subcordate at the base, short-petioled: 
spikes slender, 1-4 cm. long, sometimes compound : calyx 2-2.5 mm. broad : sepals triangular acute, slightly longer than the tube: petals 5, orbicular-ovate, emarginate, very short-clawed, about $\frac{1}{2}$ as long as the sepals : stamens 5, about as long as the petals: drupes subglobose, often gibbous, 7-9 mm. in diameter. [S. Michauxii Brongn.]

Near the coast, North Carolina to Florida and Alabama. Spring.

\section{RHÁMNUS L.}

Shrubs or trees, with unarmed branchlets. Leaves alternate : blades entire or toothed : stipules deciduous, many-nerved. Flowers perfect or polygamo-dioecious, axillary, often clustered, or in racemes or cymes. Sepals 4-5, keeled within, triangular-ovate. Disk lining the hypanthium, cup-like. Petals 4-5, or wanting, clawless, inserted on the margin of the disk, commonly concave, shorter than the calyx. Stamens 4-5, inserted on the edge of the disk : filaments very short. Ovary 3-4-celled, nearly free : styles 2-4, united at the base: stigmas often 2. Berry drupe-like, with 3-4 long or cartilaginous nutlets. Seeds elongated, with a membranous or crustaceous, smooth or furrowed testa. Endosperm fleshy. BuckthorN.

Flowers usually dioecious: nutlets deeply grooved on the back: raphe dorsal: cotyledens leaf-like.

$$
\text { Flowers usually dioecious: nutlets deeply grooved on the back: raphe dorsal: cotyledons leaf-like. }
$$

Flowers perfect: nutlets not grooved: raphe lateral: cotyledons thick.

2. R. Caroliniana.

1. Rhamnus lanceolàta Pursh. A shrub 1-2 m. tall, with puberulent branchlets and a smooth grayish bark. Leaf-blades firm, oblong or oblong-lanceolate or sometimes oval, acute or acuminate, serrulate, abruptly acute or rounded at the base, short-petioled: clusters 2-3-flowered : pedicels $2-6 \mathrm{~mm}$. long : calyx about $3 \mathrm{~mm}$. broad; sepals usually 4 , triangular-ovate, acute, about as long as the tube: petals suborbicular in outline, deeply notched at the apex, about one-half as long as the sepals : stamens as long as the petals : anthers obtuse : fruits globular, 5-7 mm. thick, 2-seeded : seeds furrowed on the back.

On river banks and moist hillsides, Pennsylvania to Iowa, Alabama, Texas and Colorado. Spring.

2. Rhamnus Caroliniàna Walt. A shrub or small tree, reaching a height of $11 \mathrm{~m}$. and a trunk diameter of $20 \mathrm{~cm}$., clothed with an ash-gray bark. Leaf-blades firm, oblong or elliptic or often slightly broadest above the middle, 5-12 cm. long, acute or shortacuminate, commonly slightly revolute, undulate or serrulate, abruptly pointed or rounded at the often inequilateral base, short-petioled, densely tomentose or becoming glabrous : umbel-like clusters few-flowered : calyx $4 \mathrm{~mm}$. broad; sepals 5 , triangular-ovate, acute, slightly shorter than the hypanthium : petals 5 , notched at the apex, about $\frac{1}{3}$ as long as the sepals : stamens 5 , nearly as long as the petals : fruits subglobose, 10-11 mm. thick, black, 3-seeded: seeds smooth on the back.

On river banks and hillsides, Virginia to Missouri, Kansas, Florida and Texas. Spring. INDIAN Cherry. Yellow-Wood. Polecat-tree.

\section{CeANÒthus L.}

Shrubs or small trees, often armed with spines. Leaves alternate, rarely almost scalelike : blades commonly 3-ribbed: stipules minute, caducous. Flowers perfect, crowded in terminal panicels or thyrsoid cymes or umbels. Hypanthium hemispheric or urn-shaped. Sepals 5, white, often triangular-ovate, membranous, converging, deciduous. Disk filling the hypanthium. Petals 5, inserted under the disk: blades long-clawed, protruding between the sepals, strongly hooded. Stamens 5, exserted: filaments filiform. Ovary immersed in the disk, somewhat cohering, or distinct, 3-celled: styles short, united below : stigmas 3, terminal or lateral. Drupe berry-like, 3-lobed, with a thin epicarp, separating into 3 crustaceous, or cartilagenous nutlets. Seeds flattened, with a smooth crustaceous testa. Endosperm fleshy.

Leaf-blades entire, fleshy.

Leaf-blades toothed, membranous or nearly so.

A low decumbent shrub: leaves $5-10 \mathrm{~mm}$. long, persistent.
Erect shrubs: leaves deciduous.

Common peduncles abbreviated.

Twigs and branchlets viscid-puberulent: lower surfaces of the leaf-blades glabrous or with few scattered hairs.

Twigs and branchlets copiously pubescent : lower surfaces of the leaf-blades closely and permanently pubescent.

Common peduncles elongated.

Leaves $1-3 \mathrm{~cm}$. long.

Leaves $3-10 \mathrm{~cm}$. long.

1. C. microphyllus.

2. C. serpyllifolius.

3. C. ovatus.

4. C. pubescens.

5. C. intermedius.

6. C. Americanus. 
1. Ceanothus microphýllus Michx. A slender evergreen shrub $3-6 \mathrm{dm}$. tall, glabrous, or nearly so. Stems much branched and diffuse: leaf-blades leathery, very small, 3-6 mm. long, suborbicular, oval or oblong, obtuse, often crowded, nearly sessile : panicles rather loosely flowered : sepals 5, triangular, acute, converging, about as long as the hypanthium : petals dipper-like, about $1.5 \mathrm{~mm}$. long, long-clawed: stamens 5 : filaments converging: anthers brown : fruit $4-5 \mathrm{~mm}$. in diameter, depressed, 3-lobed, the lobes slightly crested on the back.

In dry sandy pine lands, Georgia and Florida. Spring.

2. Ceanothus serpyllifòlius Nutt. A low slender evergreen shrub. Stems diffusely branched, decumbent, the branches very slender or filiform : leaf-blades oblong or ovateoblong, $5-10 \mathrm{~mm}$. long, obtuse or truncate at the apex, serrulate, obtuse at the base, glabrous above, strigose like the short petioles, beneath : flowers 11-15 in corymbose panicles, the panicles sometimes compound.

In pine lands, southeastern Georgia and peninsular Florida. Spring.

3. Ceanothus ovàtus Desf. A slender shrub 2-6 dm. tall, with nearly glabrous foliage, the twigs and branchlets viscid-puberulent. Leaf-blades varying from narrowly oblong to elliptic, oval or ovate, $1.5-6 \mathrm{~cm}$. long, obtuse or acutish, serrate with glandtipped teeth, not very prominently veined, acute or rounded at the base, glabrous or with few scattered hairs beneath, slender-petioled : panicles loosely flowered : sepals 5, triangular-oyate, longer than the hypanthium, acute, converging: petals dipper-like, 1.5-2 mm. long, long-clawed: filaments converging: anthers pale : fruit 4-4.5 mm. in diameter, 3 -lobed, the lobes not crested on the back.

In sandy soil, Arkansas to Georgia and Florida. Spring.

4. Ceanothus pubéscens (T. \& G.) Rydb. A shrub similar to C. ovatus in habit, the twigs and branchlets copiously pubescent. Leaf-blades relatively thick, oblong-ovate to narrowly oblong, copiously and permanently pubescent beneath, usually prominently veined.

On hillsides and in dry soil, Michigan to Iowa, Nebraska and Texas. Spring.

5. Ceanothus intermédius Pursh. A shrub 3-10 dm. tall, usually much branched, and finely pubescent throughout. Leaf-blades ovate to oblong-ovate or nearly oblong, 1-3 $\mathrm{cm}$. long, blunt or acute, finely serrate, rather thick, prominently nerved beneath ; petioles 1-5 mm. long: panicle $1-2.5 \mathrm{~cm}$. long: flowers much like those of $C$. Americanus, but somewhat smaller: fruit 4-5 mm. in diameter, less crested than that of the following species.

In pine lands, Georgia, Florida and Alabama. Spring.

6. Ceanothus Americànus L. A shrub 2-9 $\mathrm{dm}$. tall, with pubescent twigs and leaves which tend to become glabrous in age. Leaf-blades ovate or ovate-lanceolate or rarely orbicular-ovate, $3-10 \mathrm{~cm}$. long, thin, 3-nerved, acute or acutish, or rarely acuminate, serrate, abruptly narrowed or subcordate at the base, short-petioled : panicles $1-4 \mathrm{~cm}$. long, densely flowered: sepals 5, triangular, acute, about as long as the hypanthium, incurved: petals 5 , dipper-like, 1-1.5 mm. long, long-clawed : anthers chocolate-colored : fruit 5-6 $\mathrm{mm}$. in diameter, 3-lobed, the lobes crested on the back.

In dry woods and on hillsides, Ontario to Manitoba, Florida and Texas. Spring and summer. NEW JERSEY TEA. RED-ROOT.

\section{COLUBRINA L. C. Rich.}

Tropical shrubs or small trees, with erect or sarmentose stems. Leaves alternate : blades sometimes 3-nerved at the base, entire or toothed: stipules deciduous. Flowers perfect, in small axillary cymes or clusters. Hypanthium hemispheric. Sepals 5, herbaceous, triangular-ovate, spreading. Disk filling the hypanthium, 5-angled or 5-10lobed. Petals 5, inserted below the disk, the blades hooded. Stamens 5, included : filaments filiform. Ovary immersed in the disk and merging into it, 3-celled: styles 3, united below : stigmas obtuse. Drupe berry-like, slightly 3-lobed, with a dry or slightly fleshy epicarp, separating into 3 membranous crustaceous or cartilaginous capsule-like nutlets. Seeds flattened, 3-angled with a smooth, shining, leathery testa. Endosperm thin.

Flower-clusters sessile or nearly so: leaf-blades toothed : sepals and style long-persistent.

Flower-clusters manifestly peduncled : leaf-blades entire: sepals and style deciduous.

Leaf-blades glabrate, never rusty-tomentose, not 3-nerved.

1. C. Texensis.

Leaf-blades rusty-tomentose beneath, 3-nerved.

2. C. reclinata.

1. Colubrina Texénsis A. Gray. A pubescent much branched shrub 1-5 m. tall, its zigzag branches unarmed or nearly so. Leaf-blades leathery, ovate, oval, oblong, or obovate, 
1-4 cm. long, rounded but often apiculate at the apex, serrate-dentate, gradually or abruptly narrowed into short petioles or sometimes truncate or subcordate at the base : flower-clusters sessile or nearly so : hypanthium tomentose : sepals 5, rather persistent : drupes subglobose, 8-10 $\mathrm{mm}$. in diameter, on recurved pedicels, which are about as long as the diameter of the fruit.

On plains and prairies, Texas to New Mexico and northern Mexico.

2. Colubrina reclinàta (L'Her.) Brongn. A tree, reaching a maximum height of $20 \mathrm{~m}$., with a trunk diameter of about $1.5 \mathrm{~m}$., its twigs and young leaves puberulent, the bark exfoliating in paper-like scales. Leaf-blades leathery, ovate-oblong or rarely oval or obovate, 3-8 cm. long, short-acuminate but usually obtuse, entire, sometimes undulate, not 3 -nerved, never rusty-pubescent, rounded or somewhat cuneate at the base ; petioles 1-1.5 $\mathrm{cm}$. long: flowers in loose glabrate clusters which are usually surpassed by the petioles: calyx glabrate: sepals 5, ovate, slightly acuminate: petals sessile : drupes capsule-like, 4-6 $\mathrm{mm}$. in diameter, rather densely clustered.

In sahd, peninsular Florida and the Keys. Also in the West Indies and Bahamas. NAKED Wood. SOLDIERWOOD.

3. Colubrina colubrìna (L. ) Small. An evergreen shrub 2-5 m. tall, the foliage more or less persistently rusty-tomentose. Leaf-blades leathery, ovate, oblong, elliptic, or rarely oblanceolate, $5-15 \mathrm{~cm}$. long, obtuse or short-acuminate, smooth and glabrous above, rustypubescent and veiny beneath, 3-nerved, rounded or subcordate at the base; petioles 5-15 mm. long, densely rusty-pubescent: cymes shorter than the petioles, and pubescent like them : calyx $3.5-4.5 \mathrm{~mm}$. broad : sepals triangular-ovate, obtuse : petals spatulate, $1.5-2$ $\mathrm{mm}$. long, notched at the apex, surpassed by the sepals : drupes obovoid-globose, 8-9 mm. in diameter, on pedicels 8-10 mm. long. [Rhamnus colubrina L., C. ferruginosa Brongn].

In sand, southern Florida and the Keys. Also in the West Indies.

\section{GOUÀNIA Jacq.}

Shrubs, mostly high-climbing by tendrils, with slender elongated branchlets. Leaves alternate: blades petioled, commonly leathery, stipules elongated, deciduous. Flowers polygamous, in axillary or terminal, sometimes panicled spikes or racemes, whose rachis often gives off tendrils. Hypanthium obconic. Sepals 5, spreading. Disk epigynouss filling the hypanthium, 5 -angled or produced into 5 horns, glabrous or pubescent. Petal, 5 , inserted in the sinuses of the edge of the disk, shorter than the calyx : blades hooded. Stamens 5 : filaments hidden by the petals. Ovary immersed in the disk, 3-celled : styles 3 , united at the base. Drupe capsule-like, leathery, 3-winged, separating into 3 nutlets. Seeds plano-convex, with a shining horny testa. Endosperm thin.

1. Gouania Domingénsis L. A slender climbing shrub, with more or less pubescent branches. Stems much branched, elongated : leaf-blades oval or elliptic verging to ovate, 3-9 cm. long, short-acuminate, with obtuse commonly coarsely serrate blunt teeth, rounded or subcordate at the base, glabrous on both surfaces; petioles $3-12 \mathrm{~mm}$. long, clothed with appressed hairs : spikes interrupted, 6-15 $\mathrm{cm}$. long, villous-tomentose, producing tendrils at or near the base : flowers yellow : drupes subglobose, 3-winged, about 1 $\mathrm{cm}$. broad (including the wings), finally separating into three 2-winged nutlets.

In sand, southern Florida and the West Indies. Also in Mexico.

\section{Family 2. Vitàceae lindl. Grape family.}

Shrubby or tree-like vines, usually climbing by means of tendrils, possessing copious watery and sometimes gelatinous sap. Stems swollen at the nodes, clothed with a shreddy or close bark. Leaves simple or compound, the lower ones opposite, the upper alternate : blades petioled, coarsely toothed or lobed. Stipules present or wanting. Inflorescence axillary, cymose, umbel-like, racemose, thyrsoid or panicled. Flowers often fragrant; perfect, polygamous or dioecious, regular. Calyx of 4-5 sepals or sometimes obsolete. Disk filling the hypanthium or wanting. Corolla of 4-5 valvate and often caducous petals sometimes cohering by their tips. Androecium of 4-5 stamens opposite the petals. Filaments distinct. Anthers introrse. Ovary 2-celled or sometimes 3-6-celled, free or adnate to the disk at the base. Styles united. Stigma capitate or peltate. Ovules 1-2 in each cavity, anatropous, ascending. Fruit a berry, often with a very watery pulp. Seeds 1-2 in each cavity, erect, with a bony testa. Endo- 
sperm cartilaginous, sometimes channeled. Embryo at the base of the endosperm.

Hypogynous disk present, either annular, cup-shaped or glandular: leaf-blades simple or ternately compound.

Petals cohering into a cap, caducous, never separating.

Bark shreddy: pith interrupted by diaphragms at the nodes : tendrils forking. 1. VITis.

Bark not shreddy : pith continuous through the nodes: tendrils simple.

Petals distinct, spreading.

Floral envelopes mostly in 4's: disk 4-lobed : plant-tissues fleshy.

Floral envelopes mostly in 5's : disk entire or nearly so: tissues not fleshy.

Hypogynous disk wanting or obsolete: leaf-blades digitately 5-7-foliolate.

2. Muscadinia.

3. Cissus.

4. AMPELOPSIS.

5. PARTHENocissus.

\section{VİTIS L.}

Trailing or climbing vines, with a shreddy bark and forking tendrils. Pith interrupted at the nodes by diaphragms. Leaves alternate: blades simple, palmately lobed, angled or coarsely toothed, petioled. Stipules usually small, caducous. Flowers dioecious, polygamo-dioecious or rarely perfect, in elongated racemes, or panicles. Disk hypogynous, often glandular. Calyx minute. Corolla caducous : petals cohering at the top like a cap. Stamens exserted, alternating with the lobes or glands of the disk. Ovary 2-celled or rarely 3-4-celled: styles short or conic. Ovules 2 in each cavity. Berries juicy, mostly edible. Seeds few, pear-shaped with a constricted beak-like base. Grape.

Leaf-blades green and glabrous beneath at maturity or merely cobwebby about the nerves or in their axils.

Leaf-blades merely toothed, or sometimes angled or shallowily lobed.

Low shrub.

Elongated trailing or climbing vines.

Diaphragms thin.

Berries less than $14 \mathrm{~mm}$. in diameter.

Berries over $15 \mathrm{~mm}$. in diameter.

Diaphragms thick.

Shoots terete, glabrous or early becoming so.

Leaf-blades long-pointed, the teeth rather triangular, acute.

Leaf-blades mostly rounded at the apex, the teeth rounded and mucronate.

Shoots angled, pubescent throughout the year.

Leaf-blades not lustrous on either side : seeds $3-4 \mathrm{~mm}$. long.

Leaf-blades lustrous above and often below : seeds 4-5 mm. long.

Leaf-blades prominently lobed.

Lobes and sinuses of the leaf-blades acute: berries with a bloom.

Young foliage glabrous or essentially so: petioles green.

$\begin{array}{ll}\text { Young foliage manifestly pubescent: petioles white-floceulent. } & \text { 9. V. Longii. } \\ \text { Lobes of leaf-blades acuminate: sinuses obtuse: berries destitute of any bloom. } & \text { 10. V. palmata. }\end{array}$

Lobes of leaf-blades acuminate: sinuses obtuse: berries destitute of any bloom. 10. V. palmata.
Leaf-blades densely woolly, or glaucous and sparingly pubescent beneath.

Lower densely woolly, or glaucous and sparingly pubescent beneath.

Lower surface of leaf-blades glaucous, glabrate.

ower surface of leaf-blades more or less densely woolly.

Leaf-blades cobwebby or flocculent beneath at maturity.

Young foliage gray-cobwebby or white-tomentose.

Leaf-blades densely white-tomentose beneath.'

Leaf-blades gray-cobwebby beneath.

Young foliage ferrugineous-pubescent, at least on the nerves of the leafblades.

Twigs, and often the expanding leaves, clothed with a close felt-like pubescence.

Berries mostly less than $10 \mathrm{~mm}$. in diameter, not glaucous: Floridian species.

Berries mostly over $10 \mathrm{~mm}$. in diameter, glaucous: Texan species.

1. V. rupestris.

2. $V$, monticola.

3. V. Champinit.

4. V. cordifolia.

5. V. Helleri.

6. V. Baileyana.

7. V. Berlandieri.

8. V. vulpina.

11. V. bicolor.

12. V. Doaniana.

13. V. cinerea.

Twigs, and expanding leaves, more or less densely tomentose.

Twigs and petioles copiously tomentose: panicle-branches feltyflocculent during anthesis.

Leaf-blades not lobed, except on the shoots, the margins shal-

lowly sinuate-toothed.
Leaf-blades usually manifestly lobed, the margins coarsely toothed. 17. V. ruribaea.

Twigs, and often petioles, glabrous or nearly so: panicle-branches not felty-flocculent.

Leaf-blades felt-like or densely tomentose beneath at maturity.

Tendrils, or flower-clusters, intermittent, usually every third node without tendril or inflorescence.

Leaf-blades densely tomentose with white hairs.

Berries over $12 \mathrm{~mm}$, in diameter.

Berries less than $12 \mathrm{~mm}$. in diameter.

Leaf-blades densely tomentose with rusty or tawny hairs.

Tendrils continuous, usually every node with a tendril, or inflorescence.

18. V. aestivalis.

14. V. austrina.

15. V. Linsecomii.

19. V. candicans.

20. $V$. coriacea.

21. V. Simpsomii.

22. V. Labrusca.

1. Vitis rupéstris Scheele. Bushy, 1-2 m. tall, sometimes slightly climbing. Leafblades commonly broader than long, reniform to ovate-reniform, $4-10 \mathrm{~cm}$. in diameter, coarsely toothed and rarely slightly and sometimes somewhat irregularly lobed, and with an abrupt tip at the apex, mostly lustrous above, glabrous or sparingly pubescent on the nerves 
beneath, somewhat glaucescent on both sides, broadly cordate at the base ; petioles somewhat shorter than the blades, often woolly like the branches: panicles $2-10 \mathrm{~cm}$. long, slender, not dense : berries subglobose, 7-14 mm. in diameter, purple-black, somewhat glaucous, pleasant-tasted : seeds pear-shaped, $5 \mathrm{~mm}$. long, each with a conspicuous raphe.

On river banks and hillsides, Pennsylvania to Maryland and Texas. Spring; fruit ripening in August. SAND GraPe. SUgar GraPe.

2. Vitis montícola Buckl. A slender trailing or high-climbing vine, sometimes 10 m. long. Leaf-blades thinnish, $5-10 \mathrm{~cm}$. in diameter, orbicular or reniform, glabrous in age, acute at the apex with an often prolonged tip, coarsely toothed and often 3-lobed, dark green and lustrous above, often shining beneath and gray-green, cordate at the base, on rather short more or less woolly petioles: panicles $3-8 \mathrm{~cm}$. long: berries subglobose, 12-14 mm. in diameter, black or paler, sweet : seeds rather broadly pear-shaped, 5-7 mm. long, each with a conspicuous raphe.

In sandy or lime soil, Texas, Spring ; fruit ripening in September. MountaIn Grape.

3. Vitis Champínii Planch. A climbing vine. Leaf-blades thinnish, broader than long, more or less reniform, $5-10 \mathrm{~cm}$. broad, rather shiny above, coarsely toothed and sometimes indistinctly 3-lobed, glabrous at maturity, cordate at the base; petioles a little more than $\frac{1}{2}$ as long as the blades: panicles $2-10 \mathrm{~cm}$. long: berries globose, fully $15 \mathrm{~mm}$. in diameter, black, with a slight bloom, pleasant-tasted : seeds pear-shaped, 6-7 mm. long, each with a conspicuous raphe.

In valleys and on hillsides, Texas. Spring; fruit ripening in September.

4. Vitis cordifolia Lam. A very vigorous high-climbing vine, the stems sometimes obtaining a diameter of 3-6 dm. Leaf-blades thin, deep green, longer than broad, commonly ovate in outline, rarely 3 -lobed or 3-angled near the apex, rather coarsely and irregularly toothed, glabrous or sometimes sparingly pubescent beneath, more or less deeply cordate at the base, long-petioled : panicles 1-3 dm. long, commonly drooping: berries globose, $8-10 \mathrm{~mm}$. in diameter, black, under a slight bloom, pleasantly acid, or fetid-aromatic, persistent: seeds broadly pear-shaped, 5-6 mm. long, each with a conspicuous raphe.

In woods and thickets, New York to Kansas, Florida and Texas. Spring; fruit ripening in September and October, especially after frost.-Two varieties of this species have been recognized: $V$. cordifolia foetida Engelm., a native of the Mississippi valley produces fetidly aromatic berries: $V$. cordifolia sempérvirens Munson, a native of peninsular Florida bears rather persistent leaves with lustrous blades, sometimes suggesting those of $V$. palmata. Frost GraPE. CHICKEN GraPE.

5. Vitis Hélleri (Bailey) Small. A high-climbing vine. Leaf-blades bright green, thin, suborbicular to ovate-orbicular, $5-10 \mathrm{~cm}$. in diameter, nostly rounded at the apex, more or less pubescent on the nerves beneath, crenate, the teeth mucronate; petioles about $\frac{1}{2}$ as long as the blades : panicles many-flowered, $5-10 \mathrm{~cm}$. long, short-peduncled: berries not seen. [V. cordifolia var. Helleri Bailey.]

In thickets and on hillsides, Kerrville. Texas. Spring; fruit ripening in August or September.

6. Vitis Baileyàna Munson. A high-climbing vine, the stems with short internodes and often many short branches. Leaf-blades thinnish but firm, ovate or orbicular-ovate, $5-10 \mathrm{~cm}$. long, glabrous and somewhat rugose above in age or pubescent on the nerves beneath, toothed, otherwise entire or angularly 3-lobed near the apex, cordate at the base: panicles 8-13 cm. long, compact : berries globose, 7-10 mm. in diameter, black, destitute of bloom or nearly so: seeds broadly pear-shaped, sometimes nearly as broad as long, 3-4 mm. long, each with a conspicuous raphe.

In woods and on mountain slopes, Virginia and West Virginia to Georgia and Alabama. Spring and summer; fruit ripening in the fall.

7. Vitis Berlandièr Planch. A stocky vine, not extensively climbing. Leaf-blades thinnish, suborbicular or ovate-orbicular in outline, $5-15 \mathrm{~cm}$. broad, toothed, angularly 3 -lobed near the triangular apex, glabrous above in age, mostly sparingly pubescent on the nerves and gray-nerved beneath, cordate at the base ; petioles cottony, about $\frac{1}{2}$ as long as the blades: panicles 1-2 dm. long, compact : berries subglobose, 8-10 mm. in diameter, purple, slightly glaucous, juicy and pleasant-tasted : seeds pear-shaped, often broadly so, 4-5 mm. long, each with a conspicuous raphe, frequently solitary.

On limestone hills, Texas and adjacent Mexico. Spring; fruit ripening in September.

8. Vitis vulpìna L. A low bushy vine straggling over rocks and bushes, or highclimbing. Leaf-blades thin, commonly longer than broad, 5-20 cm. broad, mostly sharply 3 -lobed and coarsely and irregularly toothed, glabrate or pubescent on and about the nerves beneath, cordate or nearly truncate at the base, the teeth and lobes acuminate; petioles $\frac{1}{2}$ as long as the blades or nearly equalling them in length, commonly with ample stipules, glabrous or densely pubescent: panicles $6-20 \mathrm{~cm}$. long, often much branched: 
berries globose, 8-10 mm. in diameter, very dark with a copious bloom, the pulp sour : seeds pear-shaped, $6 \mathrm{~mm}$. long, each with a conspicuous raphe.

Mostly on banks, New Brunswick and Ontario to Montana, Florida, Texas and Colorado. Spring; fruit ripening in September, mostly after frost. RIVERSIDE GRAPE.

9. Vitis Lóngii Prince. A vigorous vine, the foliage woolly pubescent when young. Leaf-blades firm, longer than broad, or about as long as broad, $5-15 \mathrm{~cm}$. hroad, 3-lobed and coarsely toothed with angular apiculate teeth, cordate at the base ; petioles about $\frac{1}{2}$ as long as the blades: panicles $3-10 \mathrm{~cm}$. long, pubescent : berries globose, $10 \mathrm{~mm}$. in diameter, nearly black, with a pale bloom : seeds peir-shaped, $6 \mathrm{~mm}$. long, each with a conspicuous raphe.

In thickets or river valleys, the Indian Territory to Texas and New Mexico. Spring; fruit ripening in September.-A variety, $V$. Longii microspérma (Munson) Bailey, represented by very vigorous plants which produce smaller seeds and which seem especially adapted to resisting drought, grows along the Red River in northern Texas.

10. Vitis palmàta Vahl. A slender trailing but strong and handsome vine, several meters long. Leaf-blades thin, deeply 3-5-lobed and very coarsely toothed, green and glabrous on both sides or glaucescent beneath and sparingly pubescent on the nerves, cordate at the base, on long slender red petioles : panicles 5-12 $\mathrm{cm}$. long, slender : berries subglobose, 7-10 mm. in diameter, black, destitute of any bloom : seeds subglobose, a little flattened, often solitary, 5-6 mm. in diameter, each with a conspicuous raphe.

In sandy or rocky places, Illinois to Missouri, Louisiana and Texas. Late spring and summer; maturing its fruit in September and October.

11. Vitis bícolor LeConte. A vigorous high-climbing vine. Leaf-blades thinnish, mostly longer than broad, 1-3 dm. in diameter, 3-5-lobed, shallowly toothed, glabrous above, glaucous and glabrous beneath or the nerves sparingly pubescent, or dull green at maturity ; petioles elongated : panicles $5-10 \mathrm{~cm}$. long, commonly long-peduncled : berries globose, 10-14 mm. in diameter, black beneath the bloom, rather sour but pleasant-tasted : seeds nearly as broad as long, abruptly constricted near the base, each with a conspicuous raphe.

In rocky woods and on river banks, New York to Illinois, North Carolina and Tennessee. Spring ; matures its fruit in September, chiefly before frost. BLUE GRAPE. WINTER GRAPE.

12. Vitis Doaniàna Munson. A vigorous bushy or high-climbing vine, with short internodes. Leaf-blades of a bluish green hue, about as broad as long, 8-14 cm. in diameter, 3 -lobed and coarsely toothed, firm-leathery, permanently densely pubescent beneath and more or less floccose above, cordate at the base, the lobes acuminate or sometimes only acute; petioles somewhat more than $\frac{1}{2}$ as long as the blades: panicles rather small : berries subglobose, 12-16 $\mathrm{mm}$. in diameter, black beneath the bloom, with much sweet pulp : seeds pear-shaped, 6-10 mm. long, each with a conspicuous raphe, often solitary.

In valleys, Oklahoma to Texas and New Mexico. Spring; fruit ripening in September.

13. Vitis cinèrea Engelm. A high-climbing vine. Leaf-blades thinnish, mostly longer than broad, 8-20 cm. in diameter, shallowly toothed, otherwise entire, or distinctly angularly 3-lobed near the apex, cobwebby above or glabrous and rugose in age, more or less softly pubescent beneath, with ashy or dark brown webby hairs, cordate at the base ; petioles $\frac{1}{2}$ as long as the blades or longer : panicles 1.5-3 dm. long, irregular drooping : berries subglobose, $10-14 \mathrm{~mm}$. in diameter, black, barely glaucous, rather numerous : seeds broadly pear-shaped, $4.5-5 \mathrm{~mm}$. long, each with a conspicuous raphe. In lime soil and along streams, Illinois to Kansas, Florida, Texas and Mexico. Spring ; maturing
its fruit in the fall, especially after frost.-A variety, V. cinerea canéscens (Engelm.) Bailey, with leafblades more nearly as broad as long, rather rounded and destitute of the triangular outline and the 3-lobed upper portion, occurs from Illinois to Missouri and Texas. DOWNY GRAPE.

14. Vitis austrìna Small. A vigorous vine, with rusty felt-covered twigs. Leafblades thinnish, orbicular or ovate-orbicular, $10-15 \mathrm{~cm}$. in diameter, more or less distinctly 3-lobed, triangular at the apex, finely pubescent beneath and often rusty on the nerves, dull green above, cordate, the teeth very low, remote ; petioles rather short : panicles relatively small : peduncles often about as long as the panicles : berries mostly $6-9 \mathrm{~mm}$. in diameter, black, without a bloom : seeds obovoid, 4-5 mm. long. [V. cinerea var. Floridana Munson, not $V$. Floridana Raf.]

In woods and thickets, Florida. Spring.

15. Vitis Linsecòmii Buckl. A bushy or high-climbing but stocky vine. Leaf-blades firm, as long as broad or a little longer than broad, 3-lobed and toothed, cordate, glabrate above, densely cottony or velvety beneath; petioles more than $\frac{1}{2}$ as long as the blades: panicles $5-10 \mathrm{~cm}$. long : berries subglobose, mostly $12-20 \mathrm{~mm}$. in diameter, black beneath the bloom, pleasantly tasted: seeds pear-shaped, 6-10 mm. long, each with a conspicuous raphe. In dry oak lands, Missouri to Tennessee, Louisiana and Texas. Spring; fruit ripening in Septem-
ber. -A variety with glaucous-blue lower leaf-surfaces, except the rusty nerves, is V. Linsecomii lactea Small [ V. Linsecomii var. glauca Munson] it occurs from Missouri to Texas, and may be a distinet species. 
16. Vitis Caribaèa DC. A climbing vine, with woolly tomentose or rarely glabrate and striate shoots. Leaf-blades ovate or orbicular-ovate, 5-14 cm. long, acuminate, sinuate with mucronate teeth, not lobed, except rarely on shoots near the ends of the branches, glabrous above at maturity, usually reddish tomentose beneath, cordate, long-petioled: panicles elongated, 1-2 dm. long, long-peduncled, branched : berries globose, 10-12 $\mathrm{mm}$. in diameter, purple : seeds obovate, grooved on the back.

In sandy soil, Florida to Louisiana and Texas. Also in tropical America.

17. Vitis rufotomentòsa Small. A high-climbing vine, with twigs and young foliage copiously red or reddish tomentose. Leaf-blades suborbicular to ovate-orbicular, $10-20 \mathrm{~cm}$. long or sometimes shorter, dull green above, finely and closely tomentose beneath, especially rusty on and about the nerves, rather coarsely and irregularly toothed, cordate at the base : panicles rather small or ample, sometimes $2.5-3 \mathrm{dm}$. long: peduncles much shorter than the panicles : berries black, with little or no bloom, often 5-6 mm. in diameter

In sandy soil, Florida to Louisiana. Spring; fruit ripening in the fall.

18. Vitis aestivàlis Michx. A vigorous high-climbing vine. Leaf-blades varying from broader than long to longer than broad, 1-3 dm. in diameter, angularly or deeply 3-5. lobed, shallowly toothed, dull green and glabrate above, more or less densely often unevenly tomentose beneath, with rusty or brown hairs, cordate ; petioles usually glabrous : panicles 1-2.5 dm. long, often conspicuously elongated and quite simple : berries globose, 8-10 mm. in diameter, black, under a bloom, with a tough skin, and pulp varying from sweet to very astringent : seeds broadly pear-shaped, $6 \mathrm{~mm}$. long, each with a conspicuous raphe.

In thickets or rocky places, New York to Missouri, Florida and Mississippi. Spring; fruit ripening in the fall. SUMMER GRAPE.

19. Vitis cándicans Engelm. A vigorous high-climbing vine, with woolly foliage. Leaf-blades reniform, suborbicular, ovate or triangular in outline, 5-12 cm. broad, the young ones many lobed, at maturity coarsely and shallowly toothed and sometimes angularly lobed, dull and glabrate above, densely white-woolly beneath; petioles about $\frac{1}{2}$ as long as the blades: panicles $5-12 \mathrm{~cm}$. long : berries globose, about $1.5-2 \mathrm{~cm}$. in diameter, claretcolored to dark purple, with a tough skin and disagreeable taste : seeds broadly pear-shaped, $6 \mathrm{~mm}$. long, each with a conspicuous raphe. GraPe.

In low places, mostly in lime soil, Texas. Spring; fruit ripening in June and July. Mustang

20. Vitis coriàcea Shuttlw. A high-climbing vine, with rusty young foliage. Leafblades reniform to suborbicular in outline, $3-10 \mathrm{~cm}$. broad, shallowly toothed or angularly lobed (those of shoots often deeply lobed), becoming glabrate above, densely cottony beneath, cordate or truncate and subcordate at the base ; petioles $\frac{1}{2}$ as long as the blades or of equal length : panicles 5-12 cm. long : berries subglobose, less than $10 \mathrm{~mm}$. in diameter, pleasantly acid : seeds broadly pear-shaped, $6 \mathrm{~mm}$. long, each with a conspicuous raphe.

In sandy soil, peninsular Florida. Spring; fruit ripening in late summer or fall.

21. Vitis Simpsònii Munson. A shrubby vine climbing over bushes. Leaf-blades suborbicular in outline, $5-18 \mathrm{~cm}$. broad, prominently or mostly deeply 3-5-lobed, and shallowly toothed, glabrate above, more or less densely brownish white-tomentose beneath, cordate, long-petioled : panicles $5-10 \mathrm{~cm}$. long, usually compact : berries commonly 15 $\mathrm{mm}$. in diameter, black, mostly 4-seeded : seeds broadly pear-shaped, 5-6 mm. long, each with a conspicuous raphe.

In sandy soil or especially on shell mounds near the salt water, peninsular Florida. Spring; fruit ripening in September.

22. Vitis Labrúsca L. A vigorous high-climbing vine with densely tomentose foliage. Leaf-blades thickish, suborbicular to broadly ovate, mostly longer than broad, shallowly toothed, or scalloped, otherwise entire, or 3-lobed near the apex, becoming glabrous above, densely tomentose beneath, with a rounded or acute sinus : petioles more than $\frac{1}{2}$ as long as the blades : panicles 5-12 cm. long, usually simple : berries globose, $1.5-2 \mathrm{~cm}$. in diameter, amber to purple, with a slight bloom, the skin and tough pulp sweet and musky, or astringent : seeds abruptly constricted near the base, 7-10 mm. long, each with a conspicuous raphe.

In thickets and low places, New England to Minnesota, Georgia and Mississippi. Spring; fruit ripening in September and October. Fox GRAPE. PLUM GraPE.

\section{MUSCADinta Small:}

Trailing or climbing vines, with a close bark and simple tendrils. Stems sometimes producing aërial roots. Pith continuous, not interrupted at the nodes by diaphragms. Leaves alternate : blades simple, angled or coarsely toothed, never densely pubescent. 
Stipules caducous. Flowers polygamo-dioecious or dioecious, in alternate racemes or panicles. Disk hypogynous. Calyx minute. Corolla caducous : petals cohering at the top as a cap, never expanding. Stamens exserted, alternating with the lobes or glands of the disk. Ovary mostly 2-celled. Styles stout. Ovules 2 in each cavity. Berry globose, finally edible. Seeds shaped like a coffee-grain. Bullace Grape.

Berries 1-1.5 cm. in diameter; the skin and pulp tender, the latter acid : seeds 3-5 mm. long.

Berries 1.5-2.5 $\mathrm{cm}$. in diameter; the skin and pulp tough, the latter musky : seeds

1. M. Munsoniana. 6-9 mm. long.

2. M. rotundrfolia.

1. Muscadinia Munsoniàna (Simpson) Small. A slender trailing or low-climbing vine. Leaf-blades thinnish, but rather firm, suborbicular or reniform, 4-8 cm. broad, coarsely toothed, glabrous, except the axils of the nerves beneath, persistent, cordate at the base ; petioles sometimes as long as the blades: panicles $2-8 \mathrm{~cm}$. long: berries globose, $1-1.5 \mathrm{~cm}$. in diameter, nearly black with a slight bloom or shining, quite acid, with a thinnish skin, and tender pulp destitute of a musky taste : seeds $3-5 \mathrm{~mm}$. long. [Vitis Munsoniana Simpson.]

In sandy soil, Georgia and Florida. Flowering and fruiting throughout the year.

2. Muscadinia rotundifolia (Michx.) Small. A bushy, spreading or high climbing vine sometimes $30 \mathrm{~m}$. long, the stems often producing aërial roots. Leaf-blades'firm or leathery, suborbicular to ovate-orbicular, $4-9 \mathrm{~cm}$. in diameter or longer, usually acuminate, coarsely toothed, glabrous, except the axils and sometimes the nerves beneath, cordate; petioles mostly shorter than the blades : panicles $2-4 \mathrm{~cm}$. long, the staminate longer than the fruit bearing: berries subglobose, $1.5-2.5 \mathrm{~cm}$. in diameter, dull purple, without bloom, with a tough skin and musky pulp, the bunches globular: seeds 6-9 mm. long. [Vitis rotundifolia Michx.]

In sandy soil, on banks or in swamps and thickets, Delaware to Kansas, Florida and Texas. Spring and summer; fruit ripening in the summer and fall.

\section{3. císsus $\mathrm{L}$.}

Climbing vines, with fleshy tissues and strong tendrils. Leaves alternate: blades simple or 3-foliolate or at least 3-parted, the segments or leaflets entire or toothed, deciduous. Flowers perfect or sometimes polygamous, in small cymes. Floral envelopes mostly in 4's. Petals distinct, expanding during anthesis. Disk cup-like, 4-lobed. Stamens often 4, inserted on the margin of the disk. Ovary 2-celled, adnate to the base of the disk : style subulate. Ovules 2 in each cavity. Berries rather small, inedible, with scant pulps. Seeds more or less 3 -angled.

Leaf-blades simple.

Leaf-blades 3-foliolate or 3-divided.

Flowers in compound umbel-like cymes: berries thickest below the middle.

Flowers in trichotomous cymes : berries thickest above the middle.

1. C. sicyoides

1. Cissus stcyoides L. A pubescent high-climbing vine, with striate branches. Leaves fleshy ; blades simple, ovate or oblong-ovate, 2-8 cm. long, acute or often acuminate, distantly serrate with bristle-tipped teeth, rounded, often glabrate above, truncate or cordate at the base : petioles 1-4 cm. long: flower-clusters umbel-like, peduncled : berries subglobose, about $1 \mathrm{~cm}$. in diameter, black: seeds solitary, 4-5 mm. long, acute at the base.

On banks and in low places, peninsular Florida. Also in the West Indies and southward in the American tropics. The inflorescence is often infected by a fungus, Ustilago Cissi, which transforms the flowers into cigar-shaped bodies.

2. Cissus ácida L. A low-climbing glabrous vine, with forking somewhat succulent branches and stout elongated tendrils. Leaves rigid; blades 3 -foliolate, the leaflets fleshy, 1-3 cm. long, suborbicular varying to ovate or obovate, often flabellate, more or less cuneately narrowed at the base, sharply toothed near the tip: flowers in more or less compound umbel-like or corymb-like clusters, the rays stout : berries globose-ovoid or ovoid, abruptly pointed, 5-7 mm. in diameter, dark-purple, on recurved pedicels : seeds solitary, or sometimes 2, obovoid, $7 \mathrm{~mm}$. long, apiculate at the base.

In sandy soil, Key West and southern peninsular Florida. Also in tropical America.

3. Cissus incisa Desmoul. A succulent vine, 1-10 m. long, with warty bark and forking sometimes penetrating tendrils, the roots sometimes with tuberous thickenings. Leaves fleshy : blades 3-foliolate, the leaflets pale green, very fleshy, $3-10 \mathrm{~cm}$. long, coarsely toothed and incised, the terminal one sometimes 3-lobed, the lateral ones 2-lobed, all more or less cuneately narrowed at the base, on stout petiolules : flowers in trichotomous umbellike cymes : berries obovoid or obovoid-globose, 10-12 mm. long, apiculate, blackish, on 
recurved pedicels : seeds solitary or sometimes 2, obovoid, 6-7 mm. long, pointed at the base.

On sandy shores, Florida to Texas and Arkansas.

\section{AMPELÓPsis Michx.}

Bushy or climbing vines, with few tendrils and firm tissues. Leaves alternate : blades simple and toothed, or lobed, or bipinnately compound. Flowers mostly perfect, in flat cymes. Floral envelopes mostly in 5's. Calyx pedicelled. Petals distinct, expanding. Disk entire or merely crenulate-undulate. Stamens exserted. Ovary 2-celled, adnate at the base to the disk. Style slender. Ovules 2 in each cavity. Berries with scant pulp or nearly dry, inedible. Seeds. $2-4$, somewhat 3-angled.

Leaf-blades simple: ovary not surpassing the disk but nearly free from it.

Leaf-blades bipinnate: ovary surpassing the disk, the latter mostly adnate to it.

1. A. cordata.

2. A. arborea.

1. Ampelopsis cordàta Michx. A high climbing vine, with forking tendrils and a warty bark. Leaf-blades simple, ovate or triangular-ovate, 4-12 cm. long, acuminate, shallowly, but acutely, serrate, glabrous or sparingly pubescent about the nerves and their axils beneath, truncate or subcordate at the base ; petioles shorter than the blades, often pubescent : cymes slender-peduncled, 3-8 cm. broad : disk cup-shaped, as high as the ovary but nearly free from it: style slender: berries subglobose, 6-8 mm. in diameter, insipid, bluish or greenish blue: seeds $1-3$, about $5 \mathrm{~mm}$. in diameter, nearly as broad as long, granular, the raphe indistinct. [Cissus Ampelopsis Pers.]

On river banks and in woods, Virginia to Ohio and Illinois, Florida, Texas and Mexico. Spring; fruit ripening in summer and fall.

2. Ampelopsis arbòrea (L.) Rusby. A stout climber, with few forking tendrils, the stems sometimes very long. Leaf-blades bipinnate, 1-2 dm. long, petioled : leaflets several or many, the blades ovate, often broadly so or cuneate-obovate, 1-3 cm. long, acute or acuminate, coarsely toothed, incised or lobed, glabrous or sparingly pubescent, sessile : cymes long-peduncled but shorter than the leaves: disk surpassed by the ovary, mainly adnate to it: styles conic-subulate : berries subglobose, $10-13 \mathrm{~mm}$. in diameter, dark purple: seeds 2-4, 4.5-5 mm. long, granular, each with a conspicuous raphe. [Cissus bipinnata (Michx.) Nutt.]

In low places or swamps, Virginia to Missouri, Florida and Texas. Also in the West Indies and Mexico. Spring to fall; fruit ripening in the fall. PEPPER-vINE.

\section{PARThENOCíssus Pianch.}

Trailing or climbing vines, with forking tendrils, whose tips often bear adhering disks, or are merely coiling. Leaves alternate : blades digitately 5-7-foliolate : leaflets entire or toothed. Flowers perfect or polygamo-monoecious, in compound cymes. Calyx pedicelled. Petals 5, expanding, often fugacious. Disk obsolete or wanting. Stamens 5 . Ovary 2-celled, sessile : style stout. Ovules 2 in each cavity. Berries with scant pulp, inedible. Seeds 3-angled. Virainia Creeper. American Ivy.

Foliage pubescent, usually densely so.

Foliage glabrous.

Leaf-blades 5-6-foliolate: Alleghenian and campestrian species.

Tendrils with disks: leaf-blades with appressed, at least not flaring, teeth.

Tendrils without disks : leaf-blades with flaring teeth.

Leaf-blades 7-foliolate: Texan species.

1. P. hirsutus.

2. P. quinquefolia.

3. P. laciniata.

4. $P$. heptaphylla.

1. Parthenocissus hirsùtus (Donn.) Small. A spreading vine, with pubescent twigs, leaves and inflorescence, and slender tendrils, the stems trailing. Leaflets 5 , the blades oval, elliptic, oblong or ovate, acute or short-acuminate, coarsely toothed above the middle, all except the terminal one, inequilateral : corymbs $8-12 \mathrm{~cm}$. broad : berries subglobose, dark blue, with a slight bloom, slightly pulpy : seeds $5 \mathrm{~mm}$. long, glossy, notched at the top, with a conspicuous spatulate raphe. [Ampelopsis hirsutus Donn.]

In rocky places, Georgia to Texas and Mexico. Spring; fruit ripening in August and September.

2. Parthenocissus quinquef òlia (L.) Planch. A high-climbing or sometimes trailing vine, with stout tendrils which adhere by disks. Leaflets 5 , the blades usually thinnish, oval, elliptic or oblong, the lateral ones inequilateral, coarsely serrate above the middle with rather appressed or at least not flaring teeth, short-petioluled : corymbs 8-12 $\mathrm{cm}$. broad : berries subglobose, 8-9 $\mathrm{mm}$. in diameter, deep blue with a scant bloom, often quite pulpy : seeds 4-4.5 mm. long, prominently rugose, rather dull, each with an orbicular raphe. [Ampelopsis quinquefolia (L.) Michx.]

In woods and on banks, Quebec to Manitoba, Florida and Texas. Spring; fruit ripening in the fall. 
3. Parthenocissus laciniàta (Planch.) Small. A straggling vine, with long tendrils destitute of disks, the stems with a smooth or slightly roughened bark. Leaflets 5-6, the blades thin, 4-10 cm. long, coarsely toothed with more or less flaring teeth, manifestly petioluled : corymbs $5 \mathrm{~cm}$. broad, many-flowered, drooping in fruit: berries $5-7 \mathrm{~mm}$. in diameter. [Parthenocissus quinquefolia var. laciniata Planch.] the fall.

On river banks and in woods, Iowa to Michigan, Ohio and Colorado. Spring ; fruit ripening in

4. Parthenocissus heptaphýlla (Buckl.) Britton. A glabrous vine, sometimes climbing to the height of $10 \mathrm{~m}$., with long forking tendrils. Leaflets mostly 7 , the blades oblanceolate or oblong-oblanceolate (or the lateral ones oblong-lanceolate), acuminate, coarsely toothed above the middle or incised, often cuneately narrowed at the base, sessile or short-petioluled : corymbs $4-8 \mathrm{~cm}$. broad, pendulous : berries subglobose, about $5 \mathrm{~mm}$. in diameter, dark blue or nearly black: seeds 3-4, nearly $4 \mathrm{~mm}$. long. [Ampelopsis heptaphylla Buckl.]

In rocky or sandy soil, chiefly in or near the mountains, Texas. Spring.

\section{Order 19. MALVÀLES.}

Herbs, shrubs or trees. Leaves various: blades simple, commonly lobed. Flowers often showy, commonly involucrate. Calyx of distinct or partially united valvate sepals. Corolla of distinct petals. Androecium of numerous stamens with monadelphous filaments or these collected into several sets, or few in BuETtNeriaceae. Gynoecium of several united or distinct carpels. Ovaries with axile placentae. Mature carpels sometimes separating from each other.

Stamens numerous (in our genera).

Stamens distinet or in several groups: anthers 2-celled.

Stamens monadelphous: anthers 1-celled.

Stamens as many as the sepals.

Fam. 1. Tiliacear.

Fam. 2. Malvaceae.

Fam. 3. Buettneriaceae.

\section{FAMILY 1. TILIÀCEAE Juss. Linden Family.}

Shrubs or stately trees, or rarely herbs, pubescent with simple or branched hairs. Leaves alternate or rarely opposite : blades simple : stipules free, often deciduous. Inflorescence sometimes opposite the leaves, often racemose, cymose or corymbose. Flowers usually perfect, regular. Calyx of 4-5 valvate deciduous sepals. Corolla of 4-5 hypogynous imbricated or convolute often clawed petals which sometimes develop a more or less petaloid scale at the base. Androecium of usually numerous stamens or sometimes twice as many as the sepals. Filaments distinct, sometimes collected in groups opposite the petals, simple or forked. Anthers 2-celled, erect or versatile., Pollen smooth. Gynoecium a compound pistil. Ovary free, sessile or stalked, 2-10-celled, each cavity with an incomplete secondary partition. Styles united. Stigma capitate, dilated or several-lobed. Ovules 2-many, in two rows in each cavity, anatropous. Fruit a loculicidal, a rarely septicidal capsule, or sometimes nut-like or berry-like. Seeds numerous or sometimes solitary, with a crustaceous or membranous testa. Endosperm fleshy or rarely wanting. Cotyledons sometimes lobed.

Peduncles or pedicels without a conspicuous bract: filaments not forked : fruit capsular.

Petals inserted with the stamens:

Petals inserted below the stamens, at the base of an elevated receptacle : capsule

subglobose.
Peduncles each with a conspicuous adnate bract: flaments forked : fruit nut-like.

i. Corchorus.

2. TRIUMFETTA. 3. Tilia.

\section{CÓRCHORUS L.}

Herbs or small shrubs. Leaves alternate : blades serrate. Flowers solitary or several, usually on short peduncles opposite the leaves. Sepals 5 or rarely 4 . Petals yellow, 5 or rarely 4, naked at the base, convolute. Stamens numerous, or twice as many as the sepals, inserted with the petals: filaments filiform, not forked : anthers introrse. Ovary 2-5celled, superior : stigma dilated, undulate. Ovules numerous in each cavity. Capsule 
usually elongated and silique-like, smooth or echinate. Seeds numerous, pendulous or horizontal. Embryo folded, in the axis of the endosperm, with entire cotyledons.

Capsules with 4 tooth-like beaks.

Capsules with a single beak.

1. C. siliquosus.

2. C. pilolobus.

1. Corchorus siliquòsus L. Plant glabrous. Stems $3-10 \mathrm{dm}$. tall, often widely branched: leaf-blades oval-ovate to oblong-lanceolate, 1-5 cm. long (those of the ultimate branches smaller and rounder), acute or slightly acuminate, serrate, slender-petioled : clusters often 2-flowered, short-peduncled: pedicels as long as the peduncles or longer: sepals linear or oblong-linear, 5-6 mm. long: petals obovate, 4.5-5 mm. long: capsules 5-8 cm. long, ascending or spreading, truncate at the apex and each with 4 tooth-like beaks.

In waste places, peninsular Florida and the Keys. Naturalized from the West Indies.

2. Corchorus pilólobus Link. Plant minutely pubescent or glabrate. Stems 2-8 dm. tall, usually sparingly branched, hairy in lines : leaf-blades oblong to lanceolate, 2-5 cm. long, acute or slightly acuminate, serrate, short-petioled : clusters 2-3-flowered or flowers sometimes solitary: pedicels $1-5 \mathrm{~mm}$. long: sepals longer than the pedicels, acuminate : petals spatulate, about as long as the sepals : stamens commonly 10 : capsules 4-5 $\mathrm{cm}$. long, ascending or spreading, flattened contrary to the septa, each short-beaked with a single process.

In waste places, Florida to Texas, Arizona and Mexico.

\section{TRIUMFÉTTA L.}

Herbs or shrubs. Leaves alternate : blades entire, toothed or 3-5-lobed. Flowers perfect, in more or less clustered cymules, axillary or opposite the leaves. Sepals 5, narrow, often mucronate. Petals yellow, 5, convolute, with a pit at the base, or rarely wanting. Stamens numerous or rarely twice as many as the sepals, inserted on an elongated receptacle above 5 glands: filaments filiform, unequal, not forked: anthers introrse. Ovary 2-5-celled, in the cup-shaped top of the receptacle : stigma 2-5-lobed. Ovules 2 in each cavity. Capsule subglobose, echinate, commonly separable into 2-5 carpels. Seeds solitary or 2 in each cavity. Embryo with flat, entire cotyledons.

1. Triumfetta semitríloba Jacq. Annual, stellate-tomentulose. Stems 1-1.5 m. tall, branched : leaf-blades ovate, rhombic or suborbicular in outline, 3-6 cm. long, serrate, angulate or often shallowly 3 -lobed, rounded or truncate at the base; petioles as long as the leaves or shorter : panicles narrow, elongated : sepals lanceolate, 5-6 mm. long, appendaged below the apex : petals cuneate-spatulate, slightly pubescent at the base : stamens often 15 : fruit 4-5 mm. in diameter, 2-celled, copiously prickle-armed, the prickles about as long as the diameter of the body, hooked at the apex.

In waste places, peninsular Florida and the Keys. Naturalized from the West Indies.

\section{TútIA $\mathrm{L}$.}

Trees, possessing a mucilaginous sap and a tough inner bark. Leaves alternate : blades oblique, crenate or serrate, petioled. Flowers fragrant, in axillary or terminal cymes whose elongated peduncles are adnate to a conspicuous bract. Sepals 5, thickish. Petals 5, naked, or with a petaloid scale at the base, imbricated. Stamens numerous, inserted in a short receptacle : filaments filiform, forked, often collected in 5 groups, one at the base of each scale : anthers extrorse. Ovary superior, 5-celled : stigma 5-toothed. Ovules 2 in each cavity. Fruit a berry, but nut-like, with a hard coat. Seeds 1 or 2 in each fruit, with a cartilaginous testa. Embryo with crumpled 5-lobed cotyledons. Linden. Basswood. Linn. Lime-tree. Bee-tree. Wahoo.

Leaf-blades glabrous or essentially so, sometimes glaucous beneath.

Leaf-blades green beneath, the teeth slender-tipped.

Leaf-blades glaucous beneath, the teeth not slender-tipped. Cyme-branches glabrous : staminodia entire.

Cyme-branches pubescent: staminodia erose.

Leaf-blades copiously and closely pubescent beneath, not glaucous.

Leaf-blades white, gray or silvery beneath.

Bracts mostly abruptly narrowed to the base of the peduncle.

Leaf-blades gray or silvery-gray beneath, the hairs very short and close-set.

Leaf-blades white beneath, the hairs rather long and cottony.

Bracts mostly gradually narrowed and terminating remote from the base of the peduncle.

Leaf-blades brown or somewhat rusty pubescent beneath.

Leaf-blades thick and firm, copiously pubescent beneath.

Leaf-blades very thin, thinly pubescent beneath.

1. T. Americana.

2. T. australis.

3. T. Floridana.

4. T. heterophylla.

5. T. eburnea.

6. T. Michauxii.

7. T. pubescens.

8. T. leptophylla. 
1. Tilia Americàna L. A tree, reaching a maximum height of $40 \mathrm{~m}$., with a trunk diameter of about $1 \mathrm{~m}$., the bark furrowed, its ridges flat. Leaf-blades firm, ovate or orbicular-ovate, 8-15 cm. long, abruptly acuminate, serrate with acuminate gland-tipped teeth, oblique at the base, cordate or subcordate, essentially glabrous or minutely pubescent beneath, especially in the axils of the prominent nerves when young: bracts decurrent nearly to the base of the peduncles: sepals ovate-lanceolate to lanceolate, 6-8 $\mathrm{mm}$. long, acute, puberulent : petals 9-11 mm. long, pale yellow, obtuse : staminodia spatulate, nearly as long as the petals : berries oval, about $1 \mathrm{~cm}$. long, densely tomentulose.

In woods, New Brunswick to the Assiniboine River, North Dakota, Georgia and Texas. Early summer.

2. Tilia austràlis Small. A tree, becoming $20 \mathrm{~m}$. tall. Leaf-blades relatively thin, ovate to oval-ovate, 7-17 cm. long, abruptly acuminate, serrate with prominently glandtipped teeth, deep green above, glaucous beneath, essentially glabrous, cordate or nearly truncate at the base : bracts relatively large, often $4 \mathrm{~cm}$. wide, decurrent to the base of the peduncle or near it, glaucous, glabrous : peduncle glabrous, the free portion 2-4 cm. long: sepals narrowly ovate to ovate-lanceolate, $3.5-4 \mathrm{~mm}$. long : petals $5.5-7 \mathrm{~mm}$. long : staminodia linear-spatulate, slightly shorter than the petals : berries globular.

On wooded hillsides, Blount County, Alabama. Late spring and early summer.

3. Tilia Floridàna Small. A tree, sometimes $9 \mathrm{~m}$. tall, with a furrowed bark. Leafblades thin, ovate or oval-ovate, $4-11 \mathrm{~cm}$. long, abruptly short-acuminate, serrate with conspicuously gland-tipped teeth, deep green above, glaucous beneath and with scattered hairs when young, obliquely truncate or subcordate at the base: bracts relatively small, mostly much less than $2 \mathrm{~cm}$. wide, decurrent to within 0.5 or $1.5 \mathrm{~cm}$. of the base of the peduncle, somewhat pubescent : peduncle pubescent, the free portion $0.5-1.5 \mathrm{~cm}$. long : sepals lanceolate to linear-lanceolate, $3-3.5 \mathrm{~mm}$. long: petals $4.5-5.5 \mathrm{~mm}$. long : staminodia nearly linear or linear-spatulate, slightly shorter than the petals : berries globular.

In rich woods, Jackson County, Florida. Late spring and early summer.

4. Tilia heterophýlla Vent. A tree, reaching a maximum height of $30 \mathrm{~m}$., with a trunk diameter of about $1 \mathrm{~m}$., the bark furrowed, its ridges flat. Leaf-blades varying from orbicular-ovate to oblong-ovate, $10-20 \mathrm{~cm}$. long, short-acuminate, serrate with more or less appressed mucronate teeth, cordate or truncate at the oblique base, silvery or closely graytomentulose beneath : bracts spatulate, decurrent to the base of the peduncle or nearly to it, mostly abruptly narrowed at the base, thinly pubescent or glabrate : free portion of the peduncle relatively long: sepals ovate-lanceolate to oblong-lanceolate, 6-8 mm. long, acutish : petals 8-9 mm. long: staminodia oblong-lanceolate, about $\frac{1}{4}$ shorter than the petals : berries globular, 7-9 $\mathrm{mm}$. long.

In rich woods, New York to Florida, Tennessee and Alabama. Late spring and early summer.

5. Tilia ebúrnea Ashe. A tree, becoming $22 \mathrm{~m}$. tall, the bark furrowed. Leaf-blades thick, ovate to orbicular-ovate, $8-14 \mathrm{~cm}$. long, abruptly acuminate at the apex, sharply serrate, densely white-tomentose beneath, obliquely cordate or truncate at the base : bracts nearly oblong to spatulate, decurrent to the base of the peduncle or nearly so, thinly pubescent beneath : free portion of the peduncle short : somewhat shorter than that of T. heterophylla: sepals ovate-lanceolate : petals $5-6 \mathrm{~mm}$. long : staminodia spatulate : berries globular, sometimes spheroidal, 5-7 mm. long. summer.

In low woods or along streams, middle North Carolina to northern Georgia. Late spring and early

6. Tilia Michaùxil Nutt. A tree, sometimes fully $30 \mathrm{~m}$. tall, with a broadly furrowed bark. Leaf-blades thick, $7-22 \mathrm{~cm}$. long, acuminate at the apex, serrate, silvery or graytomentulose beneath, cordate or sometimes truncate at the usually very oblique base : bracts spatulate, often elongated, decurrent to within 1 or $3 \mathrm{~cm}$. of the base of the peduncle, usually tapering at the base, thinly pubescent beneath : free portion of the peduncle relatively long, glabrous : sepals narrowly ovate to oblong-lanceolate, $4.5-6 \mathrm{~mm}$. long: petals $6-9 \mathrm{~mm}$. long: staminodia spatulate, somewhat shorter than the petals : berries mostly oval, 7-11 mm. long.

In woods, Pennsylvania and Ohio to Georgia and Alabama. Late spring and early summer.

7. Tilia pubéscens Ait. A tree, becoming $14 \mathrm{~m}$. tall, with a coarsely furrowed bark. Leaf-blades thick and firm, broadly ovate to oblong-ovate, 8-17 cm. long, acute or abruptly acuminate, more or less coarsely serrate, copiously brown or rusty pubescent beneath, truncate or subcordate at the oblique base : bracts oblong to oblong-spatulate, decurrent to the base of the peduncle, copiously pubescent beneath : peduncle pubescent : sepals lanceolate, $3.5-4.5 \mathrm{~mm}$. long : petals $6-7.5 \mathrm{~mm}$. long : staminodia spatulate, about $\frac{1}{2}$ as long as the petals : berries globular.

In low or rich woods, along or near the coast, Virginia to Florida and Louisiana. Late spring and
y summer. early summer. 
8. Tilia leptophýlla (Vent.) Small. A tree, resembling ' $\Gamma$. pubescens in habit, but with relatively smaller, and thin and less copiously pubescent leaf-blades : bracts smaller, 4-7 cm. long, almost glabrous beneath or thinly pubescent : flowers and fruit smaller.

In woods, Louisiana and Texas. Spring.

\section{FAMily 2. MALVÀCEAE Neck. Mallow Family.}

Herbs, shrubs or rarely trees, of great economic importance, the vegetative parts destitute of any unwholesome substance. Foliage often pubescent with simple or branching hairs. Leaves alternate, stipulate : blades palmately nerved and often lobed, usually crenate or toothed. Inflorescence axillary, racemose, paniculate or corymbose, sometimes congested. Flowers regular, perfect, often subtended by an involucre resembling a second calyx. Calyx of 5 more or less united sepals, these valvate, mostly persistent. Corolla of 5 hypogynous convolute petals, these alternate with the sepals, united : blades often inequilateral. Androecium of numerous stamens. Filaments monadelphous, united with the claws of the petals. Anthers reniform, 1-celled. Pollen-grains hispid. Gynoecium of several carpels. Ovary several-celled, or the several pistils distinct. Styles terminal. Stigmas capitate. Ovules amphitropous or semianatropous, pendulous or ascending, inserted in the inner angles of the cavities. Fruit capsular, or the carpels separate or separable. Seeds solitary or numerous, with a crustaceous, smooth or rough sometimes pubescent testa. Endosperm scant, fleshy, mucilaginous. Embryo large, curved or folded, with foliaceous cotyledons.

Fruit of several radially disposed carpels, which separate from each other at maturity.

Carpels as many as there are stigmas.

Carpels 2-several-seeded.

Carpels 1-celled.

Carpels leathery or parchment-like, never bladdery.

Carpels membranous, bladder-like.

Carpels 2-celled, sometimes imperfectly so.

Involucel wanting.

Involucel of 3 bractlets.

Carpels 1-seeded.

Stigmas decurrent on the inner side of the styles.

Petals notched at the apex: carpels beakless, without internal processes.

Petals erose at the apex: carpels beaked, with an internal process above the seed.

Stigmas terminal, capitate.

Involucel of $2-3$ bractlets.

Involucel wanting.

Carpels $1 / 2$ as many as there are stigmas.

Carpels dry, achene-like.

Involucel wanting: inflorescence capitate.

Involucel of several bractlets: inflorescence axillary or racemose.

Involucel of 5 partially united bractlets : carpels spiny all over.

Involucel of 5-15 distinct bractlets : carpels unarmed or with 1-3 spines on the back.

Carpels forming a drupe-like perry, but separating at maturity.

Fruit a loculicidal capsule, or rarely indehiscent.

Styles distinct, spreading: seeds usually reniform.

Capsules as long as broad or much longer, the cavities 2-many-seeded.

Capsules much depressed, the cavities 1-seeded.

Styles united: seeds not reniform.

Bractlets of the involucels entire, rather inconspicuous.

Trees: sepals wholly united or nearly so: capsules indehiscent.

Shrubby plants : sepals merely united at the base : capsules loculicidally 3-5-valved.

Bractlets of the involucels laciniate, conspicuous.

1. Abutilon.

2. GAYOIDES.

3. WISSADULA.

4. MODIOLA.

5. Malva.

6. Callirrhö.

7. Malvastrum.

8. SIDA.

9. Malachra.

10. URENA.

11. Pavonia.

12. Malvaviscus.

13. HiBISCUS.

14. KOSTELETZKYA.

15. THESPESIA.

16. Cienfuegosia. 17. GOSSYPIUM.

\section{ABÙtriLON Gaertn.}

Herbs, shrubs or rarely trees, with softly pubescent foliage and branching stems. Leaves alternate: blades entire, toothed, angled or lobed, usually cordate at the base. Flowers perfect, mostly axillary. Involucel wanting. Sepals 5, united below. Petals 5, of various colors, often yellow, distinct. Carpels 5-30. Styles filiform or club-shaped. Stigmas terminal. Ovules 3-9 in each cavity. Carpels 1-celled, leathery or parchmentlike, not bladdery, disposed about a central axis, more or less prominently beaked, 2-valved 
at the apex or on the back, tardily separating. Seeds 1-6 in each carpel, nearly reniform. INDIAN MaLLOW.

Carpels 11-30.

Annual species.

Perennial species.

Peduncles, or most of them, shorter than the petioles : petals yellow above the purple base.

1. A. Abutilon.

Peduncles, or most of them, longer than the petioles : petals rose-colored. Carpels 5-10.

Carpels over $10 \mathrm{~mm}$. high.

Leaf-blades velvety white-tomentose beneath. Calyx-lobes shorter than the carpels. Calyx-lobes surpassing the carpels.

Leaf-blades gray-canescent beneath.

Carpels less than $10 \mathrm{~mm}$. high.

Corolla yellow: carpels 8-9 mm. high.

Corolla red or pink : carpels 4-7 mm. high.

Leaf-blades dentate, about as broad as long.

Leaf-blades serrate, much longer than broad.

2. A. hirtum.

3. A. pedunculare.

1. Abutilon Abùtilon (L.) Rusby. Annual, velvety-pubescent. Stems erect,

4. A. permolle.

5. A. Wrightii.

6. A. Berlandieri.

7. A. incanum.

8. A. parvulum.

9 A. Texense. 3-18 dm. tall, simple or widely branching, the branches ascending : leaf-blades suborbicular in outline varying to ovate or reniform-orbicular, 1-3 dm. in diameter, abruptly acuminate, dentate or crenate, cordate ; petioles commonly as long as the blades or longer : peduncles much shorter than the petioles : calyx slightly accrescent; lobes ovate to orbicular-ovate, abruptly pointed, acute: petals yellow, $1-1.5 \mathrm{~cm}$. long, obovate or cuneate-obovate, truncate or retuse at the apex : fruit $2-2.5 \mathrm{~cm}$. broad : carpels $1.5-2 \mathrm{~cm}$. long, villous, subulatetipped : seeds granular, glabrous. [A. Avicennae Gaertn.]

In waste places, Maine to South Dakota, Florida and Texas. Also on the Pacific slope. Naturalized from Asia. Summer and fall. VELVET LEAF.

2. Abutilon hírtum Sweet. Perennial and often shrubby, velvety canescent and more or less villous-hirsute with clammy hairs. Stems erect, more or less widely branched, $1-3.5 \mathrm{dm}$. tall : leaf-blades ovate to suborbicular, $2-15 \mathrm{~cm}$. long, unequally crenate, and sometimes slightly lobed, cordate ; petioles about as long as the blades or shorter : peduncles as long as the petioles or shorter : calyx slightly accrescent; lobes ovate, acute or acuminate : petals yellow, mostly with a purple base, 1.5-2 cm. long : carpels 15-30, somewhat surpassing the calyx, 8-10 $\mathrm{mm}$. high, barely mucronate.

In sand, coast of peninsular Florida and the Keys. Also in the West and East Indies.

3. Abutilon pedunculàre H.B.K. Perennial, light green. Stems erect, 1-4 m. tall, branching, hirsute to the peduncles : leaf-blades ovate to suborbicular, velvety tomentose, pale beneath, obtuse, shallowly and unequally crenate, deeply cordate: peduncles axillary, shorter than the subtending leaves or longer : calyx somewhat accrescent ; lobes ovate or ovate-lanceolate, acuminate, ciliate, longer than the tube : petals salmon-colored, orbicular-obovate, $2-2.5 \mathrm{~cm}$. long : carpels hispid, $15-17 \mathrm{~mm}$. high, surpassing the calyx, their beaks spreading.

In sandy soil, peninsular Florida and the Keys. Also in the West Indies and South America.

4. Abutilon permólle (Willd.) Sweet. Perennial, more or less densely velvety tomentose. Stems erect, 5-16 dm. tall, branched : leaf-blades ovate, $2.5-10 \mathrm{~cm}$. long, acuminate, greener above than beneath, finely crenate: petioles as long as the blades or shorter : inflorescence paniculate : calyx hardly accrescent ; lobes ovate or ovate-lanceolate, acuminate, longer than the tube : petals yellow, cuneate or obovate, 1-1.5 cm. long: carpels $7-10$, nearly $1 \mathrm{~cm}$. long, slender-beaked, surpassing the calyx : seeds minutely and sparsely warty.

In sandy soil, peninsular Florida and the Keys. Also in the West Indies.

5. Abutilon Wrightii A. Gray. Perennial, velvety pubescent. Stems much branched at the base; branches ascending or decumbent, 1-4 dm. long, usually branched, more or less hirsute : leaf-blades broadly ovate to orbicular-ovate, $1.5-5 \mathrm{~cm}$. in diameter, obtuse or acute, crenate or dentate, cordate : petioles as long as the blades or shorter: peduncles shorter than the subtending petioles or longer: calyx accrescent; lobes ovate-lanceolate, acuminate, 10-15 mm. long: petals yellow, 1.5-2 cm. long, very broad: carpels 7-8, softly pubescent, shorter than the calyx-lobes, subulate-tipped : seeds granular, glabrous.

On dry prairies, Texas to Arizona and Mexico. Spring to fall.

6. Abutilon Berlandièri A. Gray. Perennial, velvety pubescent. Stems erect, 1-2 $\mathrm{m}$. tall, branching, the branches ascending : leaf-blades ovate, or triangular-ovate, 3-7 cm. long, barely acuminate, obtuse, slightly paler beneath than above, irregularly crenate-dentate, prominently nerved beneath, cordate ; petioles about $\frac{1}{2}$ as long as the blades : peduncles about as long as the subtending petioles : calyx somewhat accrescent; lobes ovate, acuminate, becoming $1 \mathrm{~cm}$. long : petals yellow, 1-1.5 cm. long, rounded or nearly trun- 
cate at the apex : fruit 10-12 mm. broad: carpels shorter al. ne calyx-lobes, beaked seeds finely pilose.

On dry prairies, Texas and adjacent Mexico. Spring to fall.

7. Abutilon incànum (Link) Sweet. Perennial, felty or rat'ner thinly pubescent. Stems erect, 5-15 dm. tall, branched: leaves rather numerous : blades ovate, 2-10 cm. long, acute, or the larger ones acuminate, dentate, cordate: petioles as long as the blades or shorter: peduncles solitary in the axils : calyx not accrescent, reflexed at maturity; lobes triangular-lanceolate, acuminate, longer than the tube, finally reflexed : petals yellow, 6-10 mm. long: carpels 8-9 $\mathrm{mm}$. high, naked, surmounting the calyx: seeds minutely pubescent.

In dry soil, Arkansas to Texas and Arizona. Also in adjacent Mexico. Spring and summer.

8. Abutilon párvulum A. Gray. Perennial, more or less densely pubescent with stellate hairs and often somewhat hirsute. Stems diffusely branched at the base ; branches spreading or decumbent, 2-6 dm. long, simple or branching: leaves variable in size; blades ovate to suborbicular in outline, 1-5 cm. long, obtuse to acutish, dentate, and often 3-lobed, cordate; petioles shorter than the blades: peduncles solitary, surpassing the subtending leaves : calyx 2-4 mm. long; lobes ovate, acuminate, ribbed, with the tube finally reflexed : petals brick-red, 4-6 mm. long: carpels nearly $1 \mathrm{~cm}$. high, with erect tips.

In dry soil, Colorado to Texas and Arizona. Spring and summer.

9. Abutilon Texénse T. \& G. Perennial, minutely but densely velvety tomentose. Stems erect or ascending, 3-9 dm. tall, much branched : leaves numerous; blades ovate or ovate-lanceolate, $0.8-2 \mathrm{~cm}$. long, obtuse or acutish, serrate, truncate to cordate at the base, prominently nerved beneath; petioles $\frac{1}{2}$ as long as the blades or shorter: peduncles longer than the subtending petioles: calyx campanulate, 4-5 $\mathrm{mm}$. high ; lobes triangular or triangular-ovate, about as long as the tube, acute : petals red, 7-10 mm. long: fruit ovate or globose-ovoid, 6-8 mm. high : carpels with erect merely acute tips.

In dry soil, Texas. Spring and summer.

\section{GAYOİDES Small.}

Perennial, often vine-like herbs, with pubescent foliage. Leaves alternate: blades mostly broadest below the middle, commonly toothed, often crenate, cordate: petioles commonly shorter than the blades. Flowers perfect, on more or less elongated axillary peduncles. Involucel wanting. Sepals united below. Petals 5, distinct. Carpels numerous, 1-celled. Styles slender. Stigmas terminal. Ovules 2-6 in each cavity. Carpels membranous, bladder-like at maturity, rounded at the apex. Seeds 2-3 in each cavity.

Caly $\mathrm{x}$ villous or hispidulous.

Calyx merely velvety.

1. G. crispum.

2. G. imberbe.

1. Gayoides críspum (L.) Small. Velvety and more or less villous. Stems branched at the base, the branches diffuse, 3-7 dm. long, with diverging or ascending branchlets : leaf-blades ovate, $2-6 \mathrm{~cm}$. long, acuminate, crenate, cordate, prominently nerved beneath ; petioles usually less than $\frac{1}{2}$ as long as the blades : peduncles slender, variable in length : pedicels more or less strongly refracted: calyx villous; lobes ovate to triangular-lanceolate, acuminate, barely $\frac{1}{2}$ as long as the petals : petals yellow or whitish, 10-12 mm. long, obovate, or spatulate-obovate : fruit $1.5-2 \mathrm{~cm}$. broad : carpels bladdery, about 12, veiny, discolored : seeds glabrous. [Abutilon crispum (L.) Medic.]

In dry or sandy soil, Texas to Arizona and Mexico. Throughout the tropics.

2. Gayoides imbèrbe (Griseb.) Small. Minutely velvety. Stems sometimes erect, branched at the base, the branches vine-like, diffuse or trailing, 3-9 dm. long, divergently branched : leaf-blades ovate, 1-5 cm. long, acute or rather obtuse, crenulate, cordate, rugose beneath ; petioles much shorter than the blades or almost wanting: peduncles commonly as long as the subtending leaves or longer : pedicels finally bent at an angle : calyx merely velvety, not villous; lobes lanceolate to ovate-lanceolate, acuminate : petals yellow or yellowish, orbicular-obovate : fruit $1.5-2 \mathrm{~cm}$. thick : carpels bladdery, somewhat hispid above : seeds glabrous. [Abutilon crispum var. imberbe Griseb.]

In sand, peninsular Florida and the Keys, Texas and New Mexico.

Also throughout the tropics.

\section{WIssádULA Medic.}

Perennial upright herbs, resembling species of Abutilon. Leaves alternate : blades broadest below the middle, entire or toothed. Flowers perfect, in terminal ample, or narrow panicles. Involucres wanting. Sepals 5, partially united. Petals 5, yellow or whitish, distinct. Carpels 5, transversely 2-celled or sometimes imperfectly 2-celled or 
merely constricted at the middle. Styles short. Stigmas terminal. Ovules 1 or 2 and horizontal, or ascending in the divergent and 2-valved upper portion, and solitary and pendulous in the lower portion. Seeds minutely pitted and often with groups of hairs.

Plant minutely pubescent: calyx shorter than the carpels : petals less than $5 \mathrm{~mm}$. long.

1. W. periplocifolia Plant densely velvety-tomentose : calyx surpassing the carpels : petals over $10 \mathrm{~mm}$. long.

2. W. holosericea.

1. Wissadula periplocifolia (L.) Griseb. Plant minutely and inconspicuously pubescent. Stems 1-2 m. tall, paniculately branched : leaf-blades orbicular-ovate to lanceolate, commonly 5-10 cm. long, acuminate, entire or merely undulate, deep green and glabrate above, cordate : petioles as long as the blades or shorter : panicles often ample : calyx 2-4 mm. long, not accrescent : lobes acute : petals pale yellow, 4-5 mm. long: fruit 5-6 mm. high, conspicuously surpassing the calyx: carpels mucronate : seeds 3-4, the lower one pubescent, the upper puberulent.

On hillsides or in dry soil, southern Texas and adjacent Mexico. Also in the West Indies and South America, and Africa.

2. Wissadula holoserícea (Scheele) Garcke. Plant densely velvety tomentose, heavy scented. Stems 1-2 m. tall, branching: leaf-blades ovate to suborbicular in outline, $5-25 \mathrm{~cm}$. long, acute or usually acuminate, more or less distinctly dentate and often 3-lobed, cordate: petioles usually shorter than the blades: peduncles solitary : calyx accrescent : lobes triangular-ovate, about as long as the tube, acute : petals orange-yellow, 14-18 mm. long: carpels pubescent, $6 \mathrm{~mm}$. high, surpassed by the calyx-lobes: seeds granularpitted, glabrous.

In rocky soil, Texas and adjacent Mexico.

\section{MODÍOLA Moench.}

Annual or perennial herbs, with prostrate creeping stems or branches. Leaves alternate : blades palmately divided, angular, or lobed. Involucel of three distinct bractlets. Flowers perfect, inconspicuous, pedicelled, axillary. Sepals 5, united below. Petals 5, mostly broadest above the middle, entire. Carpels many. Styles filiform : stigmas capitate. Ovules 2, in each cavity of the transversely septate carpels. Mature carpels disposed about a central axis, 2 -valved, each valve slender-tipped. Seeds reniform, two in each carpel, that is, 1 in each cavity.

1. Modiola Caroliniàna (L.) G. Don. Annual or biennial, strigose or hirsute. Stems branched at the base, the branches spreading, 1-7 dm. long, usually branched : leafblades ovate to suborbicular in outline, pedately or palmately 3-5-cleft or parted, $2-6 \mathrm{~cm}$. long, the divisions coarsely serrate or incised : petioles shorter than the blades: peduncles mostly longer than the subtending petioles: bractlets of the involucels broadest above the middle or below it : calyx surpassing the bractlets; lobes ovate or ovate-lanceolate, acuminate, longer than the tube : petals obovate or oval-obovate, $6-10 \mathrm{~mm}$. long: carpels in a depressed head. [M. multifida Moench.]

In waste places, Virginia to Florida and Texas. Also in Central and South America. Summer.

\section{MÁLVA L.}

Annual, biennial or perennial herbs, usually with pubescent foliage. Leaves alternate : blades lobed or dissected. Flowers solitary or clustered in the axils or rarely in terminal spikes or racemes. Involucel of 3 or rarely 2 distinct bractlets. Sepals 5, partially united. Petals 5, of various colors, emarginate, sometimes eroded. Carpels many, 1-celled. Styles 9-20, stigmatic on the inner side. Ovules solitary. Mature carpels reniform, numerous, indehiscent, disposed around a central axis, forming a disk-like fruit, beakless. Seeds ascending. Embryo circular. MaLLow.

Corolla less than $2 \mathrm{~cm}$. broad : bractlets linear to lanceolate.

Branches erect or ascending: carpels glabrous and reticulated on the back.

Branches procumbent: carpels finels pubescent and smooth on the back. Corolla over $2 \mathrm{~cm}$. broad : bractlets oblung to ovate-lanceolate.

1. M. parvifiora.

2. M. rotundifolia.

3. M. sylvestris.

1. Malva parviflòra L. Annual, glabrous or sparingly pubescent. Stems branched : leaf-blades reniform or suborbicular, angulately or obtusely lobed, crenate, cordate : petioles usually several times longer than the blades: calyx widely spreading at maturity but clasping the fruit in drying; lobes triangular, acute: petals whitish or purple-tinged, $3.5-7 \mathrm{~mm}$. long: fruit 7-8 mm. broad : carpels glabrous, $2-2.5 \mathrm{~mm}$. long, sharply transverse-rugose on the back, the margins slightly winged and denticulate.

In waste places, British Columbia to California Texas Florida and Mexico. Naturalized from Europe. Summer. 
2. Malva rotundifolia L. Annual or biennial, pubescent. Stems branched at the base, the branches procumbent or decumbent, 1-5 dm. long: leaf-blades orbicular to reniform, 2-10 cm. broad, crenate-dentate, cordate, with 5-9 undulations or shallow lobes: petioles much longer than the blades: flowers in axillary clusters : calyx puberulent or finely pubescent; lobes ovate or triangular-ovate, often longer than the tube, acute : petals light blue to white, very delicate, $9-14 \mathrm{~mm}$. long : fruit $6-8 \mathrm{~mm}$. broad : carpels about 15 , finely pubescent, $1.5-2 \mathrm{~mm}$. high.

In waste places, throughout North America, except the extreme north. Naturalized from Europe and Asia. Spring to fall. CHEEses.

3. Malva sylvéstris $L$. Biennial, villous. Stems erect or ascending, 3-4 dm. tall, branching: leaf-blades suborbicular or reniform, 4-12 $\mathrm{cm}$. broad, crenate-dentate, truncate or cordate at the base : petioles much longer than the blades : flowers in axillary clusters: bractlets oblong to ovate : calyx less villous than the pedicel; lobes triangular or nearly so, shorter than the tube, acute : corolla over $2 \mathrm{~cm}$. broad: petals light purple or reddish purple, $2-2.5 \mathrm{~cm}$. long : fruit $7-10 \mathrm{~mm}$. broad : carpels about 10, reticulated, flat on the back, about $3 \mathrm{~mm}$. high.

In waste places, in British America, the United States and Mexico. Naturalized from Europe and Asia. Spring to fall.

\section{CALLÍRRHOË Nutt.}

Perennial herbs, resembling species of Malva, with thick farinaceous roots. Leaves alternate : blades lobed or cleft, or those of the stem palmately or pedately dissected, the segments entire, toothed or cleft, commonly narrow. Flowers showy, pedicelled, axillary, or sometimes in terminal racemes. Involucel of 1-3 distinct bractlets, or wanting. Sepals 5, united below. Petals white or pink to crimson-purple, often cuneately narrowed to the base or fan-shaped, sometimes erose-fimbriate. Carpels 10-20, 1-celled. Styles filiform, stigmatic on the inner side. Ovules solitary. Mature carpels beaked, and with a slender appendage below the beak, disposed around an axis forming a disk-like fruit. Seed ascend ing in a cavity separated from that forming the beak. Embryo curved. Poppy Mallow.

Perennials or probably sometimes biennials.

Peduncles several-flowered.

Peduncles 1-flowered.

Involucels present.

Bractlets of the involucels contiguous to the calyx. Leaf-blades with crenate or cleft-crenate lobes.

Leaf-blades with remotely incised or pinnately-parted segments.

Corolla lilac or pink : carpels 2.5-3 mm. high : leaf-blades mostly less than $5 \mathrm{~cm}$. broad.

Corolla crimson-purple or cherry-red: carpel $3.5-4 \mathrm{~mm}$. high : leafblades mostly over $5 \mathrm{~cm}$. broad.

Bractlets of the involucel separated from the calyx.

Involucels wanting.

Lower petioles strigose.

Annuals.

Lower petioles hirsute.

Involucel present : carpels densely pubescent, each with a short beak.

Involucel wanting : carpels glabrous, each with a beak nearly as long as the body. 9. C. pedata.

1. C. triangulata.

2. C. geranioides.

3. C. lineariloba.

4. C. involucrata.

5. C. Papaver.

6. C. alcaeoides.

7. C. digitata.

8. C. scabriuscula.

1. Callirrhoë triangulàta (Leavenw.) A. Gray. Perennial, from a long thick root, roughish pubescent. Stems 3-9 dm. tall, branched above : leaves mainly basal ; petioles very pubescent; blades triangular-ovate to triangular-hastate, $3-15 \mathrm{~cm}$. long, crenate or lobed or the upper ones 3-5-cleft or parted : peduncles shorter than the bracts or longer : involucels of several spatulate bractlets : calyx $1.5-2 \mathrm{~cm}$. broad; lobes deltoidovate, acute, ciliate, 1-nerved : petals deep purple, $2-2.5 \mathrm{~cm}$. long, undulate at the top: carpels 3.5-4 mm. long, pubescent, short-beaked.

On prairies, Minnesota to Illinois, North Carolina and Texas. Spring and summer.

2. Callirrhoë geranioìdes Small. Perennial, closely pubescent with very short hairs. Stems mostly branched at the base, the branches ascending or spreading, 1-3 dm. long, simple or nearly so: leaves few ; blades $2-2.5 \mathrm{~cm}$. broad, pentagonal in outline, 5-lobed, or 5-cleft, cordate, the lobes cuneate, coarsely toothed or cleft, mostly rounded or obtuse ; petioles longer than the blades: peduncles surpassing the leaves, often 8-10 cm. long: bractlets linear or linear-oblong, acute : calyx rather conspicuous, 10-12 mm. long, about twice as long as the bractlets; lobes lanceolate, somewhat acuminate : petals pinkish or pink-purple, minutely eroded at the top, $2-2.5 \mathrm{~cm}$. long.

In sandy bottoms, southern Texas. Spring and summer. 
3. Callirrhoë linearíloba (T. \& G.) A. Gray. Perennial, sparingly hirsute or glabrate. Stems usually branched at the base, the branches spreading or decumbent, 1-5 dm. long: leaves few ; blades mostly less than $5 \mathrm{~cm}$. broad, palmately or pedately parted, longpetioled, the segments narrowly linear, entire or parted : lower leaves with broader often cuneate segments : peduncles surpassing the leaves : bractlets linear: calyx conspicuous, commonly about twice as long as the bractlets; lobes lanceolate, several-nerved: petals pink or lilac, often white at the base, eroded at the top : carpels 12-18, glabrous or nearly so, strongly reticulated, $2.5-3 \mathrm{~mm}$. high.

On plains or prairies, Texas and adjacent Mexico. Spring to fall.

4. Callirrhoë involucràta (Nutt.) A. Gray. Perennial, hirsute or hispid-hirsute, the hairs often tending to be appressed. Stems ascending or branched at the base, the branches spreading or procumbent, 1-8 dm. long, more or less branched : leaves several; blades palmately or pedately 5-7-parted, mainly 5-10 cm. broad, long-petioled, the segments often more or less cuneate, entire, toothed, lobed or parted : peduncles surpassing the leaves : bractlets linear to oblong or oblong-lanceolate : calyx conspicuous, about twice as long as the bractlets; lobes lanceolate, ribbed : petals crimson-purple to cherry-red, about $2.5 \mathrm{~cm}$. long, eroded at the top : carpels 18-25, manifestly pubescent, 3.5-4 mm. high.

On plains and sandy soil, Minnesota to Nebraska, Missouri and Texas. Spring to fall.

5. Callirrhoë Papàver (Cass.) A. Gray. Perennial by a stout root, strigillose or glabrate. Stems solitary or several together, decumbent or ascending, 2-7 dm. long, simple or corymbose above : leaves with slender petioles; blades palmately 3-5-lobed or parted, the segments entire, lobed or parted, those of the basal leaves oblong, ovate or oblanceolate: those of the stem leaves linear or nearly so : peduncles slender, 1-3 dm. long : involucels usually of 3 narrow bractlets, separated from the calyx : calyx hirsute ; lobes lanceolate to oblong-lanceolate, acuminate, 1-1.5 cm. long: petals red-purple, obovate, $2-4.5 \mathrm{~cm}$. long, erose-denticulate at the apex : carpels $3 \mathrm{~mm}$. long, tuberculate on the back.

In sandy soil, Georgia to Florida and Texas. Spring and summer.

6. Callirrhoë alceoìdes (Michx.) A. Gray. Perennial by a thick root, strigillose. Stems erect, $2-5 \mathrm{dm}$. tall, more or less branched at the base : basal leaves with petioles much longer than the blades; blades ovate to triangular, palmately lobed or incised : stemleaves with shorter petioles; blades palmately cleft or parted into linear or linear-cuneate segments : flowers in terminal racemes or corymbs : calyx pubescent; lobes triangular or triangular-lanceolate, acuminate, less than $1 \mathrm{~cm}$. long : petals pink or rose, 1-1.5 cm. long, erose-fimbriate at the top : carpels $4 \mathrm{~mm}$. long, coarsely wrinkled on the back and sides, strigillose on top.

In dry soil, Kentucky to Nebraska, Tennessee and Texas. Spring and summer.

7. Callirrhoë digitàta Nutt. Perennial by a thick root, more or less villous-hirsute below, glabrous above. Stems erect or decumbent, solitary or several together, 3-8 cm. long, corymbose above : basal leaves with petioles about as long as the blades or longer; blades palmately lobed or parted or the earliér ones coarsely crenate : stem-leaves few, with shorter petioles; blades palmately divided, the linear or narrow divisions usually entire, $3-8 \mathrm{~cm}$. long : peduncles slender or filiform : involucels wanting : calyx nearly glabrous ; lobes ovate to lanceolate, $7-10 \mathrm{~mm}$. long: petals red-purple, white or violet, $1.5-2 \mathrm{~cm}$. long, erose-fimbriate : carpels nearly $4 \mathrm{~mm}$. high, prominently reticulate rugose, glabrous or nearly so.

In dry soil, Missouri to Kansas and Texas. Spring and summer.

8. Callirrhoë scabriúscula Robinson. Annual, closely rough-tomentose with stellate hairs. Stems erect, $3-5 \mathrm{dm}$. tall, simple or nearly so: leaves several ; blades suborbicular in outline, $3-7 \mathrm{~cm}$. in diameter, deeply palmately 3-5-cleft, the segments oblong to lanceolate, obtuse, entire or few-toothed; petioles $7-10 \mathrm{~cm}$. long near the base of the stem, shorter above: stipules linear-lanceolate : peduncles firm, much longer than the subtending leaves : bractlets of the involucels linear, 4-6 mm. long: calyx about $2 \mathrm{~cm}$. broad : lobes lanceolate, 8-10 mm. long, acuminate, 3-nerved : petals obovate, $2.5-3 \mathrm{~cm}$. long: carpels 4-5 mm. high, densely pubescent with more or less evanescent lateral walls.

Along the Colorado River, Texas. Summer.

9. Calliłrhoë pedàta A. Gray. Annual, strigillose or glabrate. Stems erect, 3-9 dm. tall, simple or branched: leaves with slender petioles; blades suborbicular in outline, palmately 3-5-lobed, cleft or parted, the segments narrow, entire or toothed: peduncles surpassing the subtending leaves : calyx glabrate or puberulent; lobes lanceolate, 8-10 mm. long, acuminate : petals red-purple or sometimes lilac or cherry-red, $2-2.5 \mathrm{~cm}$. long, erose at the top: carpels $4 \mathrm{~mm}$. long, slightly wrinkled on the sides.

On prairies, Missouri to the Indian Territory and Texas. Spring and summer. 


\section{MALVÁstrum A. Gray.}

Annual or perennial herbs, or shrubby plants, with pubescent foliage. Leaves alternate : blades various, narrow or broad, entire, lobed or parted. Involucels of 1-3 small bractlets, or wanting. F lowers perfect, axillary or in terminal spike-like racemes. Sepals 5, partially united. Petals 5, yellow, golden or scarlet, distinct. Carpels 5 or more, 1celled. Styles filiform or club-shaped. Stigmas truncate or capitate. Ovule solitary, ascending. Mature carpels sometimes with erect converging beaks, indehiscent or 2-valved. Seed filling the cavity. False Mallow.

Annual.

Perennial.

Petals yellow.

Stems clothed with appressed or spreading hairs.

Flowers solitary in the axils or in terminal interrupted spikes or spike-like racemes: stems strigose.

Carpels 15, sometimes with an obscure tip behind the apex.

Carpels 8-12, beaked behind the apex.

Flowers in congested terminal and axillary spikes: stems hirsute.

Stems clothed with very short scale-like stellate hairs.

Petals red or crimson.

Upper leaves with entire blades.

Upper leaves with 3-5-lobed blades.

1. M. angustum.

1. Malvastrum angústum A. Gray. Annual, strigose. Stems erect, 1-3 dm. tall, simple or with ascending branches : leaf-blades oblong-lanceolate to linear-oblong, $2-4 \mathrm{~cm}$. long, remotely serrate with appressed or flaring teeth: petioles much shorter than the blades : flowers axillary : pedicels longer than the petioles or shorter : bractlets of the involucels linear-setaceous : calyx accrescent; tube angled ; lobes broadly triangular, acuminate : petals yellow, about equalling the tips of the calyx-lobes: carpels 5-6, finely pubescent, reniform, finally 2-valved.

In dry soil, Iowa to Tennessee and Kansas. Summer.

2. Malvastrum Rugélii S. Wats. Perennial, strigose or hirsute-strigillose. Stems erect or decumbent, 3-9 dm. long, branching : leaf-blades ovate to oblong-lanceolate, 2-6 $\mathrm{cm}$. long, usually acute, coarsely serrate, often broadly cuneate at the base : petioles as long as the blades or usually shorter : flowers on short axillary pedicels and crowded at the ends of the branches : caly $x$ accrescent ; lobes triangular-ovate, acuminate, $3-5 \mathrm{~mm}$. long, surpassing the tube in length : petals orange-yellow, surpassing the calyx-lobes : carpels about 15, hispidulous, flattened, often with an obscure tip behind the inflexed apex.

In sand, peninsular Florida. Also in the West Indies.

3. Malvastrum Americànum (L. ) Torr. Perennial, or sometimes annual northward, strigose with simple or 2-3-rayed hairs. Stems 3-9 dm. tall, branched : leaf-blades orbicularovate to oblong-ovate, $2-8 \mathrm{~cm}$. long, acute, sharply serrate, the teeth often flaring : petioles $\frac{1}{3}-\frac{1}{2}$ as long as the blades: flowers axillary: pedicels usually solitary, shorter than the petioles : involucels of three bractlets : calyx accrescent; lobes triangular, acute, longer than the tube : petals light yellow, obliquely truncate, surpassing the sepals, expanding about noon : carpels 8-12, conduplicate, hirsute on the top, with a beak back of the inflexed apex and 2 beaks on the back.

In sandy soil, Texas and Florida. Also in tropical America and on other tropical shores. Spring and summer.

4. Malvastrum spicàtum (L.) A. Gray. Perennial, rough-pubescent. Stems erect or ascending, 3-9 dm. tall, more or less branched : leaf-blades ovate or deltoid-ovate, 3-8 $\mathrm{cm}$. long, obtuse or acutish, crenate-serrate, sometimes slightly lobed, nearly truncate or
subcordate at the base : petioles $\frac{1}{4}-\frac{1}{2}$ as long as the blades : flowers in dense terminal spikes: calyx densely pubescent; lobes triangular-lanceolate, acuminate, $3.5-4 \mathrm{~mm}$. long: petals yellow-red, 8-11 mm. long: carpels conduplicate, $3 \mathrm{~mm}$. long, hirsute on top, not beaked, the tip inflexed.

In sandy soil, Texas and Florida. Also in tropical America.

5. Malvastrum Wrightii A. Gray. Perennial, scaly pubescent. Stems branching, the branches ascending, 3-6 dm. tall, rigid : leaf-blades suborbicular to ovate or ovate-oblong, obtuse, coarsely crenate-serrate, rounded or subcordate at the base : petioles $\frac{1}{2}$ as long as the blades or equalling them in length : involucels of foliaceous ovate or lanceolate sometimes cordate bractlets, adnate to the calyx-tube : flowers nearly sessile in the axils: calyx densely scaly; lobes triangular-ovate, 5-7 mm. long, acuminate, longer than the tube : petals yellow, 11-14 mm. long : carpels $15-20$, hirsute on top, and there also 2-gibbous, ventrally 2-pointed.

In dry soil, usually in mesquite thickets, Texas. Summer. 
6. Malvastrum leptophýllum A. Gray. Perennial, scaly pubescent with silvery peltate and fringed hairs. Stems usually densely branched at the base. the branches wiry: leaves various, the lower ones with 3-cleft or 3-parted blades and short petioles, the upper leaves with narrow or filiform blades : flowers few, in interrupted terminal racemes, shortpedicelled: calyx silvery; lobes triangular or triangular-ovate, $2-2.5 \mathrm{~cm}$. long: petals copper-red, about $1 \mathrm{~cm}$. long: carpels $9-10$, pubescent, surpassing the calyx, the back rounded, the sides reticulated.

In dry soil, southern Utah to Texas and New Mexico. Spring to fall.

7. Malvastrum coccíneum (Pursh) A. Gray. Perennial, silvery stellate-canescent. Stems erect or ascending, usually branched at the base, the branches 1-3 dm. long: leaves with petioles and palmately 3-5-parted blades, the segments cuneate to linear, irregularly toothed or incised : flowers in terminal racemes : pedicels several $\mathrm{mm}$. long : calyx tomentose ; lobes triangular-lanceolate, about as long as the tube : petals of various shades of red, 11-17 mm. long: carpels 10-15, rugose-reticulated, more or less woolly.

On prairies and plains, Manitoba and British Columbia to Texas and New Mexico. Spring to fall.

\section{SìdA L.}

Annual or perennial herbs, or shrubby plants, with pubescent foliage. Leaves alternate: blades various, commonly relatively narrow, usually toothed, sometimes with discolored margins. Flowers perfect, solitary or clustered in the axils of the leaves or sometimes in terminal spikes or racemes. Involucels wanting or rarely of 1-3 bractlets. Sepals 5 , partially united into a usually angular base. Petals 5, of various colors, delicate. Carpels 5-many, 1-celled. Styles filiform or nearly so. Stigmas usually capitate. Ovules solitary. Mature carpels disposed around an axis, unarmed, or prolonged into a single or double beak or spine, indehiscent or partially 2-valved. Seed pendulous, 3-angled, filling the cavity.

Calyx accompanied by 1-3 slender bractlets.

Petals yellow: carpels acuminate.

Petals copper-colored : carpels obtuse.

Calyx not accompanied by bractlets.

Calyx accrescent, membranous or scarious at maturity.

Calyx not accrescent.

Flowers or flower-clusters in leafy involucres at the ends of the branches.

Flowers or flower-clusters axillary or sometimes in terminal panicles. Leaf-blades palmately lobed: petals white.

Leaf-blades merely toothed: petals of various colors. Calyx 5-angled.

Stems or branches decumbent or prostrate.

Petals mostly over $6 \mathrm{~mm}$. long, conspicuously surpassing the! calyx.

Stems or branches merely canescent-puberulent : calyx-lobes acute, about as long as the tube.

Stems or branches with spreading hairs: calyx-lobes acuminate, longer than the tube.

Petals mostly less than $6 \mathrm{~mm}$. long, slightly surpassing the calyx. Stems erect or ascending.

Leaf-blades cordate.

Leaf-blades acute, rounded or truncate at the base.

Leaf-blades ovate to cuneate or lanceolate.

Peduncles, at least those arising from the stem, much longer than the pedicels.

Peduncles'shorter than the pedicels or only slightly longer. Stem-leaves with petioles less than $1 \mathrm{~cm}$. long.

Stem-leaves with petioles over $1 \mathrm{~cm}$. long.

1. S. cuneifolia.

2. S. Helleri.

3. S. hastata.

4. S. ciliaris.

5. S. hermaphrodita.

Leaf-blades linear or linear-oblong.

Peduncles, and usually both peduncle and pedicel, shorter than the subtending leaves.

Calyx less than $6 \mathrm{~mm}$. high at maturity.

Calyx over $8 \mathrm{~mm}$. high at maturity.

Leaf-blades and calyx with red margins.

Leaf-blades of a narrowly linear type: mature carpels 4-5 mm. high.

Leaf-blades broader: mature carpels $3-4 \mathrm{~mm}$. high.

Leaf-blades and calyx with green margins, not discolored.

Peduncles less than $1 \mathrm{~cm}$. long.

Peduncles over $1 \mathrm{~cm}$. long.

Peduncles conspicuously elongated, much surpassing the

subtending leaves.
Calyx not angled, subglobose in the bud.

6. S. filiformis.

7. S. diffusa.

8. S. supina.

9. S. cordifolia.

10. S. rhombifolia.

11. S. acuta.

12. S. spinosa.

13. S. angustifolia.

14. S. Elliottii.

15. S. rubromarginata.

16. S. leptophylla.

17. S. Texana.

18. S. longipes.

19. S. filipes.

1. Sida cuneifolla A. Gray. Perennial, tomentulose-canescent. Stems branched at the base, the branches ascending, 2-6 dm. long, often again branched : leaf-blades cunei49 
form or fan-shaped, or some of them suborbicular, 7-16 mm. long, repand-dentate or crenate, closely pubescent; stipules linear : flowers nearly sessile : calyx campanulate; lobes lanceolate, 4-6 mm. long, somewhat acuminate : petals yellow, 5-7 mm. long : fruit oval, surpassing the calyx : carpels about 5 , thin-walled, acuminate, 2-beaked on dehiscing.

In saline or partly saline soil along the Rio Grande, Texas and adjacent Mexico. Spring to fall.

2. Sida Hélleri Rose. Perennial, thinly cinereous-tomentose. Stems much branched at the base, the branches erect or spreading, 1-3 dm. long: leaf-blades suborbicular, 1-2 $\mathrm{cm}$. in diameter, crenate, rounded or subcordate at the base; petioles about $\frac{1}{2}$ as long as the blades : peduncles very short or the flowers sometimes nearly sessile: calyx campanulate ; lobes ovate, 6-9 mm. long, obtuse, or acutish : petals pale copper-colored, surpassing the calyx, slightly oblique, expanding at about 4 o' clock in the afternoon: fruit globular or spheroidal : carpels obtuse.

In sand, near Corpus Christi, Texas. Spring and summer.

3. Sida hastàta St. Hil. Perennial, hirsute or strigillose with stellate hairs. Stems branched at the base, the branches decumbent or prostrate, 2-7 dm. long: leaf-blades rather succulent, ovate, oblong or oval, $2-7 \mathrm{~cm}$. long, crenate or serrate-crenate, obtuse at the apex, truncate or cordate at the base; petioles as long as the blades or shorter, finally recurving : calyx more or less hirsute, accrescent ; lobes much longer than the tube, ovate to suborbicular, mucronate, $6 \mathrm{~mm}$. long, becoming $12 \mathrm{~mm}$. at maturity, cordate, converging, forming a 5-winged bladder in fruit : petals buff, hardly surpassing the calyx : carpels 10, 2.5-3.5 mm. long, membranous, grooved on the back, reticulated. [S. physocalyx A. Gray.]

In valleys, Texas to Arizona and Mexico. Also in northern South America. Spring to fall.

4. Sida ciliàris L. Perennial, strigose or hirsute-strigose. Stems diffusely branched at the base, the branches prostrate, 1-3 dm. long, more or less branched : leaf-blades oblong to cuneate, $1-4 \mathrm{~cm}$. long, obtuse or retuse at the apex, serrate, especially above the middle, obtuse or subcordate at the base : petioles $3-8 \mathrm{~mm}$. long: flowers clustered at the ends of the branches: pedicels slender, shorter than the subtending petioles and ciliate linear or spatulate stipules : calyx hirsute ; lobes triangular, about as long as the tube: petals reddish purple, 6-12 mm. long : carpels 5-8, sharply reticulate-wrinkled or tuberculate on the back, 2-beaked at the apex.

In sand, Florida Keys and Texas. Also in tropical America. Spring to winter.

5. Sida hermaphrodita (L.) Rusby. Perennial, glabrous, or the young foliage pubescent. Stems erect, 1-4 m. tall, branched : leaf-blades $5-30 \mathrm{~cm}$. in diameter, palmately 3-7-lobed, cordate, the lobes triangular, acuminate, irregularly serrate, the middle one longest ; petioles shorter than the blades, at least above : peduncles corymbosely disposed: calyx softly puberulent; lobes triangular, acute, shorter than the campanulate tube : petals white, obovate, rounded at the apex, 12-15 mm. long: carpels 6-7 mm. long, nearly glabrous, with acuminate beaks. [S. Napaea Cav.]

On river banks, Pennsylvania to Virginia and Tennessee. Summer and fall.

6. Sida filifórmis Moric. Perennial, minutely canescent-puberulent. Stems several or many from the top of the root, simple or branched, 1-4 dm. long: leaf-blades ovate, lanceolate or oblong, 1-2 cm. long, crenate-dentate, truncate or subcordate at the base ; petioles as long as the blades or somewhat shorter; stipules subulate: pedicels $1-2 \mathrm{~cm}$. long, much longer than the petioles: calyx becoming $5 \mathrm{~mm}$. long; tube ribbed; lobes triangular or deltoid, acute, about as long as the tube: corolla yellow or yellowish white, $1-1.5 \mathrm{~cm}$. broad : carpels about $3 \mathrm{~mm}$. high, each with 2 short-subulate teeth.

In sandy soil, Texas to Arizona and Mexico. Spring and summer.

7. Sida diffùsa H.B.K. Similar to S. filiformis in habit, but commonly somewhat stouter. Leaf-blades smaller and commonly narrower : calyx becoming 6-8 mm. long; lobes lanceolate or triangular-lanceolate, acuminate, much longer than the tube : carpels about $3 \mathrm{~mm}$. high, each with 2 short awns.

In dry soil, southern Texas to New Mexico and Mexico. Spring and summer.

8. Sida supina L'Her. Annual or perennial, finely tomentose. Stems branched at the base, the branches ascending or prostrate, 1-6 dm. long, more or less branched : leafblades suborbicular to ovate, $1.2 .5 \mathrm{~cm}$. long, obtuse, crenate, usually cordate at the base ; petioles somewhat shorter than the blades: flowers axillary, not conspicuous : pedicels very slender, shorter than the petioles : calyx slightly accrescent; lobes acuminate, shorter $5,2 \mathrm{~mm}$. long, reticulate-wrinkled, puberulent, slightly 2-beaked at the apex.

In sand, Florida Keys. Also in the West Indies and South America. Throughout the year.

9. Sida cordifolia L. Annual (within our range), velvety tomentose. Stems erect, 6-15 dm. tall, much-branched : leaf-blades ovate or suborbicular, 4-10 cm. long, obtuse or 
somewhat acuminate, irregularly crenate, sometimes slightly angular, cordate at the base : flowers in terminal often congested racemes or panicles: pedicels shorter than the subtending petioles : calyx very densely pubescent; tube 10-angled; lobes triangular, longer than the tube: petals tawny yellow, 5-7 mm. long: carpels often 10 or 12 , the body $3 \mathrm{~mm}$. long, slightly wrinkled, tipped with 2 subulate retrorsely pubescent awns about equalling it in length.

In sand, Florida Keys and about southern seaports. Spring to fall.

10. Sida rhombifolia L. Annual, puberulent to glabrate. Stems erect, 5-9 dm. tall, branching: leaf-blades rhombic, elliptic-obovate or oblanceolate, $1.5-8 \mathrm{~cm}$. long, acute or obtuse, serrate except near the base, pubescent with pale hairs beneath; petioles 3-8 mm. long, sometimes with an obscure tubercle at the base : peduncles, at least those arising from the stem, much longer than the pedicels, mostly $1.5-4 \mathrm{~cm}$. long: calyx puberulent; tube finally 5-10-ribbed ; lobes triangular, acuminate, about as long as the tube: petals pale yellow, 6-7 mm. long, sometimes blotched with red at the base : carpels 10 or 12, subulatebeaked.

In waste places, North Carolina to Florida and Texas.

11. Sida acùta Burm. Annual, puberulent or glabrous. Stems erect, 3-9 dm. tall, branching: leaf-blades lanceolate, oblong-ovate or ovate, $2-10 \mathrm{~cm}$. long, acute or acuminate, irregularly serrate, obtuse or subcordate at the base ; petioles 3-7 mm. long; stipules conspicuous, narrowly linear to lanceolate, surpassing the petioles: peduncles mostly shorter than the pedicels, commonly 1-7 mm. long: calyx 5-10-ribbed; lobes triangular, slightly acuminate, about as long as the tube : petals yellow to white, 6-12 nm. long, unequally lobed : carpels reticulate-wrinkled, 3-5 mm. long, 2-beaked on top. [S. carpinifolia L. f. ]

In waste grounds, Florida to Alabama, and throughout the tropics.

12. Sida spinòsa L. Annual, minutely pubescent. Stems erect, 1-6 dm. tall, simple or much-branched : leaf-blades oblong to ovate, or ovate-lanceolate to linear-lanceolate, 1-5 $\mathrm{cm}$. long, obtuse or acutish, serrate, cordate at the base or the upper ones truncate ; petioles slender, about $\frac{1}{2}$ as long as the blades, those of the larger leaves with a spine at the base : flowers axillary : pedicels shorter than the subtending petioles : calyx slightly accrescent ; lobes triangular, acute, about as long as the tube: corolla pale yellow, $1-1.5 \mathrm{~cm}$. broad : carpels about 5, $4 \mathrm{~mm}$. long, slightly wrinkled, 2-beaked.

In cultivated grounds, waste places and on roadsides, New York to Iowa, Florida and Texas. Summer. Widely distributed in the tropics.

13. Sida angustif òlia Lam. Annual, minutely canescent. Stems more or less diffusely branched, the branches 1-6 dm. long, sometimes virgate : leaf-blades linear or narrowly lanceolate, or linear-oblong on the lower part of the stem, serrate-dentate, pale green above, whitish beneath, acute or nearly truncate at the base; petioles mostly 5-10 mm. long, with tubercle-like stipules at the base: pedicels shorter than the petioles : calyx becoming $5 \mathrm{~mm}$. high; tube sharply ribbed; lobes triangular, slightly shorter than the tube, acute : corolla copper-yellow, $2-3 \mathrm{~cm}$. broad : carpels about $3 \mathrm{~mm}$. high.

In dry soil, Texas to Arizona. Also in Mexico and tropical America. Spring to fall.

14. Sida Ellióttii T. \& G. Perennial, roughish pubescent or nearly glabrous. Stems erect, or branched at the base, the branches ascending, 3-5 dm. tall, simple or diffusely branched above : leaf-blades linear or nearly so, $2-7 \mathrm{~cm}$. long, acute, serrate; petioles 2-4 $\mathrm{mm}$. long: flowers axillary : pedicels variable in length, 4-15 $\mathrm{mm}$. long : calyx glabrous ; lobes triangular, about as long as the tube, with discolored margins : corolla yellow, 2.5-3 cm. wide : carpels 8-12, 4-5 mm. long, strongly rugose-reticulated, 2-beaked.

In sandy soil, Virginia to Florida and Alabama. Summer.

15. Sida rubromarginàta Nash. Perennial, glabrous or puberulent. Stems erect, 5-10 dm. tall, purple, much branched : leaf-blades varying from narrowly obovate, oblong, elliptic to oblong-lanceolate, $1.5-5.5 \mathrm{~cm}$. long, acutish, light green and purple-margined, serrate, above the base; petioles $3-5 \mathrm{~mm}$. long: peduncles and pedicels shorter than the subtending bracts : calyx angled; lobes triangular, about $5 \mathrm{~mm}$. long, slightly acuminate, somewhat longer than the tube : corolla light orange, $2.5-3.5 \mathrm{~cm}$. broad : carpels 8-10, 3-4 mm. long, 2-awned at the apex, rugose-pitted on the back.

In sand, Florida. Spring to fall.

16. Sida leptophýlla Small. Apparently perennial, thinly pubescent. Stems erect, over $10 \mathrm{dm}$. tall, widely branching: leaf-blades thin, linear to linear-oblong, $2-10 \mathrm{~cm}$. long, acute, sharply serrate with short flaring teeth above a short entire base, paler beneath than above, obtuse or rounded at the base ; petioles 3-10 mm. long; stipules subulate-filiform : peduncles $2-8 \mathrm{~mm}$. long : calyx finely pubescent; lobes 4-5 mm. long, tri- 
angular, acute, or somewhat acuminate, about as long as the tube : corolla about $2.5 \mathrm{~cm}$. broad : fruit 6-7 mm. broad : carpels 2-ridged above, not pointed, glabrous.

In sandy soil, Georgia to Louisiana. Spring to fall.

17. Sida Texàna (T. \& G.) Small. Perennial, pubescent with fine ashen hairs. Stems erect, 3-9 dm. tall, branched : leaf-blades broadly linear to linear-oblong, 2-7 cm. long, serrate-dentate; petioles $3-6 \mathrm{~mm}$. long: peduncles and pedicels about as long as the subtending bracts : calyx angled; lobes triangular-acute, longer than the tube : corolla yellow, 2.5-4 cm. wide : carpels 9-12, about $3 \mathrm{~mm}$. long, more or less puberulent on the back, cuspidate, the sides and back coarsely rugose-reticulated. [S. Elliottii var. Texana T. \& G., S. Lindheimeri Engelm. \& Gray.]

In dry soil, Louisiana to Texas and Mexico. Spring to fall.

18. Sida lóngipes A. Gray. Perennial, scabro-puberulent. Stems erect, 2-4 dm. tall, simple, or branching above : leaf-blades linear or narrowly-linear, 2-8 cm. long, obtuse or acutish, serrulate or serrulate-crenulate, delicately rugose, truncate or subcordate at the base ; petioles $3-10^{\circ} \mathrm{mm}$. long : peduncles elongated, 8-20 cm. long, erect or nearly so, slender but not filiform : calyx ribbed; lobes triangular, acuminate, about as long as the tube : corolla orange, $3-4 \mathrm{~cm}$. wide : carpels nearly $3 \mathrm{~mm}$. long, glabrous, slightly pitted, minutely beaked.

In dry soil, Texas. Spring to fall.

19. Sida fillipes A. Gray. Perennial, velvety tomentose. Stems erect, 5-9 dm. tall, paniculately branched : leaf-blades narrowly oblong to lanceolate, $2-7 \mathrm{~cm}$. long, acutish or obtuse, serrate or crenate-serrate, rugose ; petioles 1-3 $\mathrm{mm}$. long: peduncles filiform, surpassing the leaves : flowers nodding: calyx subglobose in the bud, not angled; lobes ovate, about $2 \mathrm{~mm}$. long, obtuse : corolla violet-purple, about $1 \mathrm{~cm}$. wide : carpels about 7, $2.5 \mathrm{~mm}$. long, pale, pitted, obtusely beaked.

In dry soil, Texas and Mexico. Summer.

\section{MALÁCHRA L.}

Herbs or shrubby plants, with hispid or rigid-pubescent foliage, the hairs sometimes stinging. Leaves alternate: blades with angled or rounded lobes, petioled. Flowers perfect, in dense axillary or terminal head-like clusters. Involucres of 3-5 bracts, often variegated or sometimes wanting. Sepals 5, partially united: lobes 3-nerved. Petals white, yellow or red. Carpels 5, 1-celled. Ovules solitary. Mature carpels 5, separating from the central axis, indehiscent or valvate at the ventral angle. Seeds reniform, ascending. The plants flower throughout the year.

Foliage densely stellate-pubescent in addition to hirsute or hispid : upper leaf-blades not lobed at the base.

Foliage merely hirsute or hispid : upper leaf-blades lobed at the base.

1. M. capitata.

1. Malachra capitàta L. Hispid, and minutely and densely pubescent with stellate hairs. Leaf-blades suborbicular, to ovate-orbicular, $1.5-4 \mathrm{~cm}$. in diameter, crenate, or the lower ones sometimes palmately $3-5$-lobed ; petioles shorter than the blades : flower-clusters peduncled : bracts of involucres variegated with white and purple, rather conspicuous, the outer suborbicular, the inner broadly ovate, acute : calyx-lobes ovate-lanceolate, obtuse : petals yellow : carpels $3 \mathrm{~mm}$. long, nearly glabrous, slightly shorter than the calyx-lobes.,

In dry soil, Texas and Mexico. Also in tropical America.

2. Malachra ùrens Poit. Hispid, usually without fine stellate hairs. Leaf-blades ovate or lanceolate, angulately $3-5$-lobed or somewhat hastate with rounded basal lobes, 3-10 cm. long, dentate, truncate or rarely cordate at the base; petioles shorter than the blades : flower-clusters nearly sessile or short-peduncled: bracts of the involucres triangular or hastate, long-acuminate, ciliate-dentate, the base or often the whole surface variegated with purple: calyx-lobes subulate-tipped : petals red : carpels 3-3.5 mm. long, puberulent or glabrate, much surpassed by the calyx-lobes.

In sand, Keys of Florida. Also in the West Indies.

\section{URÈNA $\mathrm{L}$.}

Shrubs or shrubby herbs, with rigid branches and pubescent foliage. Leaves alternate: blades angled or lobed. Flowers perfect, often inconspicuous, sessile or short-peduncled, in the axils of the leaves, sometimes clustered. Involucres wanting. Involucels of 5 more or less united bractlets. Sepals 5, united below, often adnate to the involucel. Petals 5, yellowish or purplish. Carpels 1-celled. Stigmas capitate. Ovules solitary, ascending. Mature carpels separating from the central axis, indehiscent, bristly with barbed awns, thus forming a bur-like fruit, or sometimes unarmed. 
1. Urena lobàta L. Shrubby, tomentose. Leaf-blades orbicular-reniform, suborbicular or oval on the upper part of the stem, shallowly 3-5-lobed, serrulate, cordate or rounded at the base, whitish and prominently nerved beneath; petioles shorter than the blades : peduncles axillary, several $\mathrm{mm}$. long: bractlets of the involucel $5-7$, linear-lanceolate, 3-5 mm. long: calyx about as long as the bractlets or shorter; lobes often ovate, acute: petals pink or rose-colored, about $2 \mathrm{~cm}$. long, very delicate : carpels subglobose, 4-5 $\mathrm{mm}$. in diameter, bristly.

In waste places, Florida. Naturalized from the West Indies, but originally from India. Throughout the year.

\section{PAvÒNIA Cav.}

Shrubs or shrubby herbs, with pubescent foliage. Stems usually upright. Leaves alternate, stipulate: blades angled or lobed. Flowers perfect, commonly solitary on axillary pedicels. Involucels of 5-15 bractlets. Sepals 5, partially united. Petals 5, of various colors. Carpels 5, 1-celled. Styles 10. Stigmas capitate. Ovules solitary. Mature carpels separating from the axis, 1-3-beaked on the back, or unarmed, rarely 2-winged, indehiscent or more or less deeply 2 -valved. Seeds solitary, ascending. The plants flower from spring to fall or throughout the year.

Carpels awnless and pointless.

Leaf-blades hastate: petals blotched at the base.

Leaf-blades ovate to orbicular-ovate: petals not blotched.

Carpels 3-awned or 2-3-horned.

Leaf-blades toothed: bractlets 5 : carpels with 2 lateral awns.

Leaf-blades nearly entire: bractlets 9-11: carpels with 2 lateral cusps.

1. P. hastata.

2. P. lasiopetala.

3. P. spinifex.

4. P. racemosa.

1. Pavonia hastàta Cav. A much branched, shrubby plant, 1-2 m. tall, the foliage roughish-canescent. Leaf-blades hastate or ovate-hastate, acutish, crenate-dentate, 2-5 cm. long, cordate ; petioles much shorter than the blades : peduncles much longer than the petioles : bractlets of the involucels 5-6, ovate to obovate, 4-5 mm. long, slightly united at the base : calyx about as long as the bractlets; lobes broadly ovate, short-acuminate : petals obovate, $1.5-2.5 \mathrm{~cm}$. long, pale red with a dark blotch at the base, delicately striped : carpels obovate, 4.5-5 mm. long, prominently reticulated, without either awns or tips.

In sandy soil, Georgia. Naturalized from South America. Spring to fall.

2. Pavonia lasiopétala Scheele. A branching shrubby plant 4-12 dm. tall, the foliage velvety tomentose. Leaf-blades ovate to suborbicular, $2-8 \mathrm{~cm}$. long, obtuse or acutish, dentate or crenate-dentate, paler beneath than above, cordate; petioles as long as the blades or nearly so: peduncles as long as the petioles or longer: bractlets of the involucels linear, 1-1.5 cm. long: calyx shorter than the bractlets; lobes ovate, acuminate, $3-5$-nerved : petals pink, $1.5-2 \mathrm{~cm}$. long, glabrous or pubescent, often undulate : carpels 5-6 mm. long, pointless, more or less strongly reticulated. [P. Wrightii A. Gray.]

In dry and rocky woods, Texas and adjacent Mexico.

3. Pavonia spínifex (L.) Cav. A branching shrub, 1-3 m. tall, with hirsute and strigillose foliage. Leaf-blades membranous, ovate or oblong-ovate, 5-10 $\mathrm{cm}$. long, acute or somewhat acuminate, more or less distinctly doubly crenate-dentate, truncate or subcordate at the base; petioles densely pubescent, shorter than the blades : peduncles axillary, much longer than the petioles: bractlets of the involucel 5 , linear to lanceolate, acute, nearly 1 $\mathrm{cm}$. long : calyx about as long as the bractlets; lobes lanceolate to ovate-lanceolate : petals yellow, $2.5 \mathrm{~cm}$. long, rather cuneate : carpels 5-6 mm. high, with 1 medial and 2 lateral retrorsely barbed awns.

In sandy soil, near the coast, South Carolina to Florida. Naturalized from tropical America.

4. Pavonia racemòsa L. A sparingly-branched, shrubby plant ranging from 1-3 $\mathrm{m}$. in height, the foliage more or less densely puberulent. Leaf-blades ovate to oblong-ovate, 6-15 cm. long, acuminate, remotely serrate or repand, rounded or subcordate at the base, prominently 3-nerved beneath; petioles shorter than the blades : racemes terminal, loosely flowered: bractlets of the involucels $6-8$, oblong-lanceolate, $9-11 \mathrm{~mm}$. long : calyx equalling the bractlets or longer; lobes ovate, acute, thickish: petals twice as long as the calyx, greenish yellow or whitish, finely pubescent without: carpels about $1 \mathrm{~cm}$. long, reticulated on the back, with a medial crest and 2 lateral cusps.

In or near swamps, Florida and tropical America.

\section{MaIVAvíscus Dill.}

Shrubs, trees, or shrubby herbs, commonly with hispid foliage. Leaves alternate: blades entire, toothed or rarely angulately lobed, petioled. Involucels of 7-12 narrow bractlets. Flowers perfect, on axillary peduncles. Sepals 5, partially united. Petals 5, 
often red, inequilateral, each with a lateral auricle. Ovary 5-celled. Styles 2-parted, the branches thus 10. Stigmas capitate. Ovules solitary in each cavity. Fruit berry-like, by the union of the fleshy carpels.

1. Malvaviscus Drummóndii T. \& G. Perennial, tomentulose. Stems erect, 8-19 dm. tall, simple or more or less widely branched : leaf-blades suborbicular in outline, angulately 3-lobed, crenate, cordate, dark green above; petioles shorter then the blades: peduncles axillary, about as long as the subtending petioles: bractlets of the involucels narrowly spatulate : calyx about as long as the bractlets; lobes ovate, shorter than the tube : petals vermilion, $2.5 \mathrm{~cm}$. long : fruit berry-like, $1 \mathrm{~cm}$. in diameter, red, subglobose : carpels finally separable.

In sandy soil, Florida to Texas and Mexico. Spring to fall.

\section{HIBÍsCUS L.}

Perennial herbs, shrubs or trees, various in habit. Leaves alternate : blades entire, lobed or parted : petioles commonly subtended by stipules. Flowers perfect, showy, on short axillary peduncles. Involucel of several, or rarely 3-5 distinct or united bractlets. Sepals 5, more or less united. Petals 5, of various colors, often blotched. Ovary 5-celled, sessile : styles 5, usually spreading : stigmas capitate or peltate. Ovules 2-many in each cavity. Capsules oblong to globose, 5-celled, loculicidally 5-valved. Seeds of various shapes, glabrous or pubescent. Rose Mallow.

Bractlets of the involucels distinct.

Calyx persistent, not spathe-like.

Corolla cylindric, or only the tips of the petals slightly spreading : seeds woolly.

Corolla with more or less widely spreading petals : seeds glabrous or hirsute.

Calyx fitting closely to the capsules.

Sepals united only at the base, spreading.

Sepals partially united into a campanulate tube.

Shrub or small tree.

Herbs, usually perennial.

Bractlets dilated or forked at the apex, often with 2 lateral segments.

Foliage finely tomentose.

Foliage hispidulous.

Bractlets entire, not dilated at the apex.

Foliage variously pubescent.

Leaf-blades strigose or with plush-like pubescence above : bractlets conspicuously ciliate.

Leaf-blades glabrate or densely velvety above: bractlets merely pubescent.

Leaf-blades about as broad as long. strongly lobed.

Leaf-blades much longer than broad, merely toothed.

Leaf-blades glabrous or nearly so above: capsules glabrous.

Foliage glabrous.

Leaf-blades densely velvety above : capsules hispid.

Leaf-blades parted into 5-7 segments.

Leaf-blades merely toothed or lobed.

Calyx-lobes longer than the tube.

Calyx-lobes shorter than the tube.
Calyx inflated and bladder-like, enclosing the smaller capsule.

Calyx spathe-like, splitting on one side and deciduous.

Bractlets oblong or oblong-lanceolate.

Bractlets narrowly linear.

Bractlets of the involucels united into a cup with 8-10 lobes.

1. H. tubiflorus.

2. H. cardiophyllus.

3. H. Syriacus.

4. H. furcellatus.

5. H. aculeatus.

6. H. lasiocarpus.

7. H. grandiflorus.

8. H. Moscheutos.

9. H. incanus.

10. H. coccineus.

11. H. integrifolius.

12. H. militaris.

13. H. Trionum.

14. H. Manihot.

15. H. esculentus.

16. H. tiliaceus.

1. Hibiscus tubiflòrus DC. A branching shrub 3-18 dm. tall, with stellularhirsute foliage. Leaf-blades triangular-ovate or angulately 3 -lobed, $1-4 \mathrm{~cm}$. long, obtuse or acutish, serrate-dentate, truncate or cordate at the base; petioles shorter than the blades : peduncles as long as the subtending petioles or longer, recurving: bractlets of the involucel about 10, linear or nearly so, 7-9 mm. long, hispid : calyx slightly longer than the bractlets ; lobes triangular or triangular-lanceolate, acuminate, about as long as the tube : corolla crimson, $2-2.5 \mathrm{~cm}$. long, cylindric, or the petals with slightly spreading tips : capsule over $1 \mathrm{~cm}$. long : seeds woolly.

In woods, Florida Keys, also in Mexico and the West Indies. Throughout the year.

2. Hibiscus cardiophýllus A. Gray. Perennial from a woody base, rough velvety tomentose. Stems 3-8 dm. tall, usually branched: leaf-blades ovate to suborbicular, more or less constricted above the middle, thus somewhat 3 -lobed, 3-8 cm. long, obtuse or acutish, dentate, prominently nerved beneath, cordate; petioles about as long as the blades or shorter : bractlets of the involucel about $10,1.5 \mathrm{~cm}$. long, with lanceolate blades : calyx surpassing the involucel; lobes lanceolate, sometimes broadly so, acute, 3-ribbed and re- 
ticulated, nearly distinct : petals deep pink or vermilion, $2.5-3 \mathrm{~cm}$. long, oblong-obovate, spreading : capsule shorter than the calyx, and closely invested by it : seeds puberulent.

In dry soil or rocky places, Texas and adjacent Mexico. Spring to fall.

3. Hibiscus Syriacus L. A branching shrub or small tree 1-6 m. tall, with minutely stellate-pubescent young foliage. Leaf-blades firm, oblong-ovate, elliptic or oval in outline, more or less deeply 3 -lobed, $3-12 \mathrm{~cm}$. long, coarsely crenate, cuneate at the base ; petioles much shorter than the blades : peduncles usually less than $1 \mathrm{~cm}$. long: bractlets of the involucels linear to linear-spatulate, 1-2 cm. long : calyx longer than the bractlets or shorter; lobes triangular-ovate, about as long as the tube : petals deep pink or white, with a crimson blotch at the base, 4-7 cm. long, undulate : capsule oblong-ovoid, 2-2.5 cm. long, pinched at the apex, stellate-pubescent, surpassing the calyx.

In various situations, New Jersey and Pennsylvania to Florida and Texas. Summer and fall. Shrubby Althaea. Róse-OF-Sharon.

4. Hibiscus furcellàtus Lam. A branching shrubby plant, with grayish finely tomentose foliage. Leaf-blades orbicular-ovate to ovate or lanceolate, 5-15 cm. Jong, angulate or 3-5-lobed, or the upper ones hastate, denticulate, or crenate-serrate, paler beneath than above, cordate at the base; petioles longer than the blades or shorter above : peduncles mostly shorter than the subtending petioles: bractlets of the involucel narrow, about $\frac{1}{2}$ as long as the calyx at maturity, dilated and forked at the apex, not bristly : calyx becoming 2.5-3 cm. long; lobes lanceolate or triangular-lanceolate, longer than the tube, with stout lateral nerves and midrib and prominent connecting nerves: corolla $8-10 \mathrm{~cm}$. long, yellow : capsule nearly as long as the calyx, densely strigose with lustrous hairs.

In sand, shores of the Indian River, Florida. Naturalized from the West Indies and South America. Throughout the year.

5. Hibiscus aculeàtus Walt. Perennial, herbaceous, the foliage very rough-pubescent. Stems 1-2 m. tall, simple or sparingly branched: leaf-blades 4-12 cm. in diameter, the lower ones angulate or 3-5-lobed, the upper ones 3-5-parted, the segments linear to oblanceolate, coarsely toothed or incised; petioles as long as the blades or shorter : peduncles shorter than the subtending petioles: bractlets of the involucels 10-12, linear, about $1.5 \mathrm{~cm}$. long, forking, bristly: calyx surpassing the bractlets; lobes lanceolate, acuminate, hristly, 3-nerved: petals $7-8 \mathrm{~cm}$. long, yellow or cream-colored with a dark purple blotch at the base : capsule conic-ovoid, $2-2.5 \mathrm{~cm}$. long, acuminate.

In sand, often near swamps, South Carolina to Florida and Louisiana. Summer.

6. Hibiscus lasiocárpus Cav. Perennial, with densely pubescent foliage. Stems 1-2 m. tall, tomentose, sometimes branched above : leaf-blades ovate, $5-14 \mathrm{~cm}$. long, acuminate, more or less distinctly serrate-dentate, sometimes angulately lobed, densely strigose above with lustrous hairs, softly tomentose beneath, rounded or cordate at the base; petioles shorter than the blades: peduncles much shorter than the subtending petiole : bractlets of the involucel $2-3 \mathrm{~cm}$. long, linear-subulate, bristly : calyx about as long as the bractlets or shorter; tube campanulate ; lobes ovate or ovate-lanceolate, acuminate, longer than the tube : petals $6-8 \mathrm{~cm}$. long, pink with a purple or crimson blotch at the base : capsule hirsute.

In swamps, Illinois and Missouri to Georgia and Texas. Summer and fall.

7. Hibiscus grandiflòrus Michx. Perennial, with soft velvety-tomentose foliage. Stems erect, 1-2 m. tall, solitary or several together, soon glabrous : leaf-blades $1-3 \mathrm{dm}$. in diameter, mostly broader than long, hastately 3-lobed, bright green above, whitish beneath, truncate or cordate at the base ; lobes triangular or triangular-ovate, acute or acuminate, irregularly toothed; petioles usually shorter than the blades: peduncles $4-8 \mathrm{~cm}$. long: bractlets of the involucels linear, $2-3 \mathrm{~cm}$. long: calyx about twice as long as the bractlets ; tube campanulate ; lobes ovate or ovate-lanceolate, as long as the tube or longer: petals 12-15 $\mathrm{cm}$. long, pale pink with a reddish blotch at the base.

In marshes, chiefly near the coast, Georgia to Florida and Mississippi. Spring to fall.

8. Hibiscus Moscheùtos L. Perennial, velvety tomentose, or some parts glabrate. Stems 1-2 m. tall, often clustered: leaf-blades lanceolate to broadly ovate, 1-2 dm. long, acuminate, dentate-serrate, rounded or subcordate at the base, some often angulately 3-5lobed, glabrous or nearly so above; petioles shorter than the blades: peduncles usually corymbosely disposed: bractlets of the involucel linear, $1.5-2 \mathrm{~cm}$. long : calyx surpassing the bractlets; tube campanulate; lobes triangular-ovate, acuminate, shorter than the tube : petals pink with a crimson blotch at the base, 10-12 cm. long: capsule ovoid, $2.5 \mathrm{~cm}$. long, glabrous.

In swamps, chiefly near the coast, Ontario to Florida and Texas. Summer and fall. Mallow Rose. SWAMP ROSE-MALLOW.

9. Hibiscus incànus Wendl. Perennial, velvety tomentose with pale hairs. Stems solitary or clustered, 1-2 m. tall : leaf-blades broadly ovate to broadly lanceolate, $5-15 \mathrm{~cm}$. 
long, acuminate, serrate-dentate, rounded or subcordate at the base, greenish above and densely velvety tomentose and whitish below; petioles shorter than the blades : peduncles corymbose or racemose: bractlets of the involucel linear, $1.5-2 \mathrm{~cm}$. long : calyx surpassing the bractlets ; tube campanulate ; lobes ovate to triangular-lanceolate, acuminate, ribbed, shorter than the tube : petals white, sulphur yellow or pinkish, with a crimson blotch at the base, $8-10 \mathrm{~cm}$. long : capsule ovoid, $2.5-3 \mathrm{~cm}$. long, hispid.

In swamps, chiefly near the coast, Maryland to Florida and Alabama. Spring to fall.

10. Hibiscus coccíneus Walt. Perennial, glabrous. Stems 1-3 m. tall, simple or branching, glaucous: leaf-blades 5-parted (or the upper ones 3-parted or 3-lobed), the segments linear to lanceolate, 4-25 cm. long, coarsely toothed or incised, long-acuminate ; petioles as long as the blades or shorter : bractlets of the involucels $2.5-3 \mathrm{~cm}$. long, curved: calyx large, 4-5 cm. long; lobes lanceolate, acuminate, longer than the tube: petals crimson or deep-red, spatulate-obovate, $8-12 \mathrm{~cm}$. long, rounded at the apex : capsule 2-2.5 cm. long, acute.

In swamps near the coast, Georgia and Florida. Summer.

11. Hibiscus integrifòlius (Chapm.) Small. Perennial, glabrous. Stems 1-2 m. tall, simple or sparingly branched : leaf-blades orbicular or ovate in outline, $8-15 \mathrm{~cm}$. in diameter, 3-5-lobed, coarsely serrate, cordate, the lobes acuminate or the lateral ones angular: bractlets of the involucel about $2-2.5 \mathrm{~cm}$. long, linear : calyx large, 4-5 cm. long; lobes lanceolate, acute, much longer than the tube: petals crimson, $8-10 \mathrm{~cm}$. long, spatulate-obovate or cuneate-spatulate. [H. coccineus var. integrifolius Chapm. H. semilobatus Chapm.]

In deep swamps, eastern Florida. Spring to fall.

12. Hibiscus militàris Cav. Perennıal, glabrous or nearly so. Stems 1-2 m. tall, more or less branched : leaf-blades ovate or broadly lanceolate in outline, 6-16 cm. long, some or all hastately 3-5-lobed, serrate-dentate, truncate or cordate at the base, the lobes acute or acuminate; petioles as long as the blades or shorter : peduncles shorter than the subtending petioles: bractlets of the involucels numerous, linear, $1.5-2 \mathrm{~cm}$. long: calyx accrescent; tube campanulate; lobes ovate, shorter than the tube, acuminate : petals pink with a purple blotch at the base, $5-8 \mathrm{~cm}$. long: capsule $1.5-2.5 \mathrm{~cm}$. long, abruptly pointed. WEED.

On river banks, Pennsylvania to Minnesota, Florida and Louisiana. Summer and fall. SwEativg-

13. Hibiscus Triònum L. Annual, more or less hispid. Stems branching at the base, the branches spreading, 1-4 dm. long: leaf-blades ovate to suborbicular in outline, pedately 3-5-lobed or parted, the divisions coarsely toothed or incised, the teeth obtuse : peduncles shorter than the subtending petioles: bractlets of the involucels linear, about 1 cm. long: calyx longer than the bractlets ; lobes triangular, prominently nerved, shorter than the tube: petals pale yellow or whitish with a purple or brown-purple blotch at the base, $2.5-4 \mathrm{~cm}$. long, broadly spatulate : capsule ovoid-globose, about $1.5 \mathrm{~cm}$. high, each surrounded by a bladder-like calyx.

In waste places, Nova Scotia to Minnesota and Florida. Native of Europe. Summer and fall.

14. Hibiscus Mánihot L. Annual, stout, glabrous, or the young foliage bristly. Stems usually $2 \mathrm{~m}$. tall, or taller: leaves ample; blades $1-4 \mathrm{dm}$. in diameter, palmately or pedately 5-9-lobed, the lobes coarsely toothed, incised or lobed; petioles commonly about as long as the blades : peduncles club-shaped, 3-6 cm. long: bractlets of the involucel oblong-lanceolate $1.5-2.5 \mathrm{~cm}$. long: calyx persistent; lobes lanceolate to oblong-lanceolate : petals suborbicular, yellow or straw-colored, blotched with purple at the base: capsule oblongprismatic, 4-8 cm. long, hispid.

In waste places and on banks or in cultivated grounds, Florida to Texas. Naturalized from Asia.

15. Hibiscus esculéntus L. Annual, more or less densely hirsute. Stems 1-2 m. tall, simple or sparingly branched : leaves ample ; blades 1-3 dm. broad, palmately or pedately 5-7-lobed, the lobes ovate to lanceolate or oblanceolate, coarsely toothed or incised; petioles often about as long as the blades : peduncles short, 1-3 cm. long: bractlets of the involucels linear, bristly, $1.5 \mathrm{~cm}$. long: calyx campanulate; lobes $1-2 \mathrm{~cm}$. long : petals yellowish and red or purple at the base, broad, $2-4 \mathrm{~cm}$. long : capsule columnar, angled, 9-21 cm. long, tapering at the apex.

In waste places, gardens and cultivated lands in the warmer parts of the southeastern United States. Introduced from Africa and the West Indies. OKRA. GUMBo.

16. Hibiscus tiliàceus $\mathrm{L}$. A shrub or small tree, with velvety tomentose young foliage. Leaf-blades suborbicular, 1-2 dm. in diameter, shallowly toothed, abruptly acuminate, deeply cordate, prominently nerved beneath; petioles as long as the blades or shorter : peduncles stout, as long as the calyx or longer: bractlets of the involucel partially 
united into a calyx-like cup with triangular teeth : calyx accrescent; lobes lanceolate or triangular-lanceolate, longer than the tube, acute or acuminate: petals yellow, 5-6 cm. long, pubescent without : capsule oblong, $2.5-3 \mathrm{~cm}$. long, abruptly apiculate.

In sandy soil, Florida Keys. Also in the West Indies. Spring to fall.

\section{KOSTELÉTZKYA Presl.}

Perennial herbs, or shrubby plants, with erect branching stems, and often pubescent foliage. Leaves alternate: blades angularly lobed, or sometimes sagittate, petioled. Flowers perfect, axillary, or in terminal racemes or panicles. Involucels of 7-10 bractlets or sometimes almost wanting. Sepals 5, more or less united. Petals 5, of various colors. Ovary 5-celled: styles 5, slender, spreading: stigmas capitate. Ovule solitary in each cavity. Capsule 5-angled, depressed, opening loculicidally. Seeds solitary in each cavity, reniform.

Folige glabrous or barely puberulent, not markedly pubescent.

Foliage copiously pubescent.

Calyx canescent: leaf-blades scabro-pubescent.

Calyx hirsute as well as canescent: leaf-blades velvety.

1. K. smilacifolia.

2. $K$. Virginica.

3. $K$. althaeifolia.

1. Kosteletzkya smilacifolia A. Gray. Foliage nearly glabrous. Stems $0.5-1 \mathrm{~m}$. tall, somewhat puberulent and often slightly pubescent : leaf-blades $5-10 \mathrm{~cm}$. long, those above the base of the stem hastate, with a linear-lanceolate or linear entire or denticulate middle lobe and linear or nearly linear reflexed entire toothed or basal lobes; petioles mostly 1-3 cm. long : calyx minutely canescent ; lobes lanceolate or ovate-lanceolate, acute or slightly acuminate, about as long as the bractlets : petals $2.5-3.5 \mathrm{~cm}$. long : capsules hispid, about $1 \mathrm{~cm}$. broad, much depressed, surpassed by the sepals : seeds glabrous or obscurely woolly.

In low grounds, southern peninsular Florida. Spring to fall.

2. Kosteletzkya Virgínica (L.) A. Gray. Foliage pubescent with stellate hairs but not velvety, often scabrous. Stems 3-12 dm. tall, branching : leaf-blades 3-15 cm. long, ovate to ovate-hastate, serrate-dentate, the lateral lobes triangular, acute: panicles leafy : bractlets of the involucels linear: calyx canescent; lobes lanceolate or oblonglanceolate, acute or acuminate, 6-8 $\mathrm{mm}$. long: petals pink or purple, 2-4 cm. long, rounded at the apex : capsules about $10 \mathrm{~mm}$. broad, hirsute at maturity : seeds glabrous or obscurely woolly.

In marshes along the coast, New York to Florida and Louisiana. Spring to fall.

3. Kosteletzkya althaeif òlia (Chapm.) A. Gray. Foliage mainly velvety pubescent. Stems 1-2 dm. tall, hirsute, the branches ascending: leaf-blades ovate to ovatelanceolate or nearly lanceolate above, $5-15 \mathrm{~cm}$. long, acuminate, irregularly dentate, the lower ones angularly 3-lobed, cordate, the upper ones truncate or subcordate at the base : bractlets of the involucel linear-subulate, $8-11 \mathrm{~mm}$. long : calyx hirsute as well as canescent; lobes lanceolate, acuminate, surpassing the involucel : petals pink, about $4 \mathrm{~cm}$. long: capsules $12-15 \mathrm{~mm}$. broad, hirsute-hispid : seeds glabrous, striate-lineolate.

In marshes near the coast, North Carolina to Florida and Texas. Spring to fall.

\section{THESPÈsIA Soland.}

Shrubs or trees, resembling species of Hibiscus. Leaves alternate : blades entire or merely angularly lobed, commonly ample, usually cordate, petioled. Flowers perfect, showy. Involucels of 3-5 narrow deciduous bractlets. Sepals 5, more or less united, commonly wholly so. Petals 5, of various colors. Ovary sessile, 5-celled : styles 5, united or rarely distinct : stigmas decurrent on the styles. Ovules few in each cavity. Capsule firm, woody-leathery, 5-celled, loculicidally 5-valved or indehiscent. Seeds several in each cavity, glabrous or pubescent.

1. Thespesia popúlnea (L.) Soland. An evergreen shrub or a low tree. Leafblades leathery, ovate, $5-12 \mathrm{~cm}$. long, acute or acuminate, undulate, cordate; petioles shorter than the blades: peduncles stout, shorter than the subtending petioles: bractlets of the involucels linear, early deciduous: calyx cup-shaped, entire : petals $5-7 \mathrm{~cm}$. long: capsule $3-4.5 \mathrm{~cm}$. wide : seeds veiny, appressed-pubescent.

In sand, Florida Keys and throughout the tropics.

\section{CImnfungòsta Cav.}

Shrubs or shrubby herbs, resembling species of Hibiscus. Leaves alternate: blades entire or lobed, petioled. Involucels of 3-many narrow bractlets. Flowers perfect, soli- 
tary on axillary peduncles. Sepals 5, united below. Petals 5, usually yellow. Ovary sessile, 3-4-celled : styles united into a 3-4-grooved column : stigmas 3-4. Ovules 3-8 in each cavity. Capsule loculicidally 3-4-valved. Seeds few or numerous, usually woolly. The plants flower from spring to fall or throughout the year.

Leaf-blades entire or 3-lobed : bractlets subulate.

Leaf-blades coarsely toothed: bractlets broadened upward.

1. C. heterophylla.

2. C. sulphurea.

1. Cienfuegosia heterophýlla (Vent.) Garcke. Stems erect or decumbent, 1-5 dm. long, glabrous, the branches erect or spreading : leaf-blades linear-oblong varying to lanceolate or rarely obovate, $1.5-5 \mathrm{~cm}$. long, entire or three-lobed; petioles rarely $\frac{1}{2}$ as long as the blades: peduncles shorter than the blades or longer, gradually enlarged under the calyx : bractlets of the involucels linear-subulate, 1-5 $\mathrm{mm}$. long: calyx glandular; lobes lanceolate, 6-12 mm. long, acuminate : petals yellow and purple-blotched at the base, $1.5-2 \mathrm{~cm}$. long : capsules oblong or oval-oblong, about $1 \mathrm{~cm}$. long, abruptly pointed.

In sand, Florida Keys. Also in the West Indies and Brazil.

2. Cienfuegosia sulphùrea (St. Hil.) Garcke. Stems glabrous or scurfy at the nodes, branched at the base, the branches 1-5 dm. long: leaf-blades broadly oblong to suborbicular, 3-7 cm. long, obtuse, repand or repand-lobed, rounded or truncate at the base ; petioles about $\frac{1}{2}$ as long as the blades : peduncles about as long as the petioles or longer: bractlets of the involucels linear to linear-spatulate : calyx glandular; lobes lanceolate or linear-lanceolate, acute, $8-13 \mathrm{~mm}$. long: petals greenish yellow, or sulphur-colored and brown at the base, 1-2 cm. long: capsules subglobose, or oval-globose, $1 \mathrm{~cm}$. in diameter.

In sandy soil, Texas. Also in Brazil and Paraguay.

\section{GOSSÝPIUM L.}

Annual or perennial herbs, or shrubs or trees, with erect branching stems. Leaves alternate : blades palmately lobed, or rarely entire, thickish, petioled. Involucel of 3 large cordate toothed or incised bracts. Flowers showy, on axillary peduncles. Sepals 5, united into a cup-like calyx. Petals 5, white or yellowish, often turning pink or magenta. Ovary sessile, 5-celled: styles united into a five-grooved column. Ovules numerous in each cavity. Capsule loculicidally 5-valved, leathery. Seeds various, usually densely clothed with long white hairs. CotTon.

Seeds 4-5 mm. broad, glabrous, that is, completely separable from the wool : lobes of the leaf-blades mostly longer than the body.

Seeds 6-7 mm. broad, woolly: lobes of the leaf-blades mostly shorter than the body.

Wool white: plants herbaceous : foliage if pubescent, hirsute.

Wool tawny: plants shrubby: foliage closely pubescent with very short hairs.

1. G. Barbadense.

1. Gossypium Barbadénse L. Annual or perennial, glabrous. Stems often $2 \mathrm{~m}$. tall or more, widely branching : leaf-blades $1-2 \mathrm{dm}$. in diameter, with $3-5$ lanceolate or ovate-lanceolate acuminate lobes which are longer than the body of the blade; petioles shorter than the blades : peduncles 1-2 cm. long: bractlets of the involucels $2-6 \mathrm{~cm}$. long, pectinate-laciniate, cordate : petals $5-10 \mathrm{~cm}$. long : capsules ovoid, acute, $3.5-5 \mathrm{~cm}$. long, containing white cotton : seeds smooth and glabrous, completely separating from the cotton.

In sandy soil, especially near the coast, North Carolina to Florida, and in tropical America. Throughout the year. SEA-ISLAND CoTTON.

2. Gossypium herbàceum L. Annual, or perennial in the extreme South, glabrous, or pubescent with spreading hairs. Stems widely branching, 3-15 dm. tall : leaf-blades 1-2 dm. in diameter, with 3-5 triangular or ovate lobes, mostly shorter than the body of the blade ; petioles about as long as the blades or shorter: peduncles $1-3 \mathrm{~cm}$. long: bractlets of the involucels pectinate-laciniate: petals surpassing the involucel, white, turning pink or purple: capsules subglobose, containing white cotton : seeds ciothed with a close woolly coat.

In fields and waste places, Virginia and Arkansas to Florida and Texas. Summer and fall, hroughout the year in southern Florida. COMMON COTTON.

3. Gossypium religiòsum Roxb. Annual, shrubby, closely pubescent with very short hairs. Stems 1-4 m. tall, branching: leaf-blades 3-8 cm. in diameter, angular or with 3 triangular or ovate lobes; petioles mostly shorter than the blades : peduncles 1-2 capsules $2-2.5 \mathrm{~cm}$. high, containing tawny cotton: seeds with a close persistent woolly coat.

Along the coast, Florida and Texas. Also in the West Indies and other parts of tropical America. 


\section{Family 3. BUETTNERIÀCeae H.B.K. Chocolate Family.}

Shrubs, trees or herbs, often resembling Malvaceae in habit. Leaves alternate: blades simple, entire or toothed. Flowers mostly perfect, regular, in spikes, racemes or panicles. Calyx of 5 distinct or nearly distinct sepals. Corolla of 5 distinct petals, or wanting. Androecium of as many fertile stamens as there are sepals and alternate with them, or numerous : filaments sometimes aggregated into groups : anthers with 2 or 3 parallel sacs, opening extrorsely. Gynoecium of 5 united carpels or rarely of 1 carpel. Ovary 5-celled or 1-celled. Styles distinct or united. Ovules few or several, ascending or horizontal. Fruit a capsule or follicle.

Corolla present.

Petals with flat blades.

Gynoecium of 5 united carpels : styles 5 , not eccentric: stigmas capitate. Staminodia wanting: ovules several in each cavity: embryo curved.

Staminodia present : ovules 2 in each cavity : embryo straight. Involucel wanting : capsule pyramidal, loculicidal.

Involucel of 3 or more bractlets: capsule globose, loculicidal and septicidal.

Gynoecium of a single carpel : style 1, eccentric: stigma brush-like.

Petals with hooded blades.

Ovary stipitate: petals appendaged.

Ovary sessile: petals unappendaged. Corolla wanting.

1. Hermannia.

2. Melochia.

3. RIEDLEA.

4. WALTHERIA.

5. Ayenta.

6. NEPHROPETALUM.

7. Firmiana.

\section{HERMÁNNIA L.}

Shrubs or shrubby herbs, with more or less pubescent foliage. Leaves alternate : blades toothed. Flowers perfect, in axillary cymes. Involucel wanting. Sepals 5, nearly distinct. Petals 5, broadened upward : claws involute. Stamens 5, not accompanied by staminodia : filaments united at the base : anthers sometimes with tapering sacs. Ovary 5-celled: styles nearly distinct, converging. Ovules numerous in each cavity. Capsule 5-celled, loculicidal. Seeds reniform. Endosperm fleshy. Embryo curved, with narrow cotyledons.

1. Hermannia Texàna A. Gray. Shrubby, 5-12 dm. tall, the foliage tomentosecanescent with stellate hairs. Leaf-blades suborbicular to ovate or oval, $1.5-6 \mathrm{~cm}$. long, rounded at the apex, serrate or dentate, mostly subcordate at the base : peduncles axillary, $1-1.5 \mathrm{~cm}$. long, few-flowered: pedicels shorter than the peduncles, becoming recurved: sepals lanceolate or triangular-lanceolate: corolla dull scarlet : petals crimson, 7-9 mm. long: capsules globose, short-stalked, 10-12 mm. long, villous-tomentose, each valve with a filiform crest on the back.

In dry or rocky soil, Texas and adjacent Mexico.

\section{MELÓchia L.}

Herbs, shrubs or rarely trees, mostly pubescent with stellate and often simple hairs. Leaves alternate : blades toothed. Involucel wanting. Sepals 5, united below. Petals 5, convolute, flat, early withering. Stamens 5 : filaments more or less united into a cup, sometimes with as many tooth-like staminodia. Ovary 5-celled, sessile or nearly so : styles 5 , distinct, at least above : stigmas club-shaped. Ovules mostly 2 in each cavity. Capsule pyramidal, 5-celled, loculicidally 5 -valved. Seeds solitary in each cavity, ascending. Endosperm fleshy. Embryo straight, with broad cotyledons.

Foliage tomentose : leaf-blades leathery : filaments well united : capsules with rounded basal angles.

Foliage glabrous : leaf-blades membranous : filaments slightly united: capsules with long-tipped basal angles.

1. M. tomentosa.

1. Melochia tomentòsa L. A branching shrub several dm. tall, the foliage finely tomentose. Stems with relatively stout branches: leaf-blades rather firm, ovate or oblong, 1.5-6 $\mathrm{cm}$. long, serrate to crenate, mostly acute, truncate or cordate at the base : peduncles several-flowered : pedicels $2-5 \mathrm{~mm}$. long: sepals lanceolate or linear-lanceolate : corolla often rose-purple : petals fully $1 \mathrm{~cm}$. long : filaments united quite high up : capsules about $1 \mathrm{~cm}$. broad, tomentulose, the prominent angles rounded or bluntly tipped at the base.

In rocky soil, near the lower Rio Grande and in tropical America.

2. Melochia pyramiaata L. A shrubby herb, sometimes annual, the foliage glabrous. Stems with slender branches : leaf-blades rather thin, ovate-oblong below, oblonglanceolate above, serrate, mostly rounded or truncate at the base : peduncles 1-few-flowered, 
o-10 mm. long, terminal or opposite the leaves: sepals lanceolate with subulate tips, 3-5 $\mathrm{mm}$. long: corolla rose-red or nearly violet : petals surpassing the sepals : filaments united only at the base : capsules bladdery, $1-1.5 \mathrm{~cm}$. broad, the wing-like angles with prominent tips near the base.

In dry or rocky soil, Texas and tropical America.

\section{RIÈDLEA Vent.}

Shrubs or shrubby herbs, often with pubescent foliage. Leaves alternate: blades toothed. Flowers perfect, in axillary or terminal clusters. Involucel of 3 bractlets. Sepals 5, nearly distinct, barely accrescent. Petals 5, convolute, flat, marcescent. Stamens 5 : filaments more or less united at the base. Ovary 5 -celled : styles sometimes united below : stigmas 5. Ovules 2 in each cavity. Capsule subglobose, 5-celled, loculicidal and later septicidal. Seeds commonly solitary in each cavity. Endosperm fleshy. Embryo straight. Flowers in terminal spike-like panicles, chiefly with small bracts : petals fully $10 \mathrm{~mm}$. long.

Flowers in terminal head-like clusters, with leaf-like bracts : petals 4-6 $\mathrm{mm}$. long. $\quad \begin{aligned} & 1 . \\ & 2 .\end{aligned}$. corchorifolia

1. Riedlea glabréscens (Presl.) Small. A shrubby herb, 3-12 dm. tall, with somewhat hirsute foliage. Leaf-blades ovate to lanceolate, $1.5-6 \mathrm{~cm}$. long, usually acute or acuminate, serrate, rounded or subcordate at the base; petioles $2-10 \mathrm{~mm}$. long : flowerclusters in terminal interrupted spike-like panicles, subtended by small inconspicuous bracts, or sometimes 1 or 2 of the lower clusters accompanied by leaf-like bracts : sepals linear or linear-lanceolate, 4-5 mm. long: petals purple, about $1 \mathrm{~cm}$. long : capsules 4-4.5 mm. long. [ $R$. serrata var. glabrescens Presl.]

In pine lands, southern peninsular Florida. Summer.

2. Riedlea corchorifollia (L.) DC. An herb, sometimes more or less woody at the base, 4-11 dm. tall, glabrous or sparingly hispidulous. Leaf-blades ovate or ovate-lanceolate, $2-6 \mathrm{~cm}$. long; acute, serrate or dentate-serrate, rounded or truncate at the base ; petioles 1-3 cm. long: flower clusters chiefly in dense terminal heads accompanied by leaflike bracts : sepals linear, 5-6 $\mathrm{mm}$. long: petals pale purple above the yellow claws, 4-6 $\mathrm{mm}$. long: capsules about $4 \mathrm{~mm}$. high.

In waste grounds or about rice-fields, Georgia to Alabama and Florida. Spring to fall.

\section{WALTHËIA L.}

Herbs, shrubs or trees, with stellate and simple pubescence. Leaves alternate: blades toothed: stipules narrow. Flowers small, perfect, usually in axillary clusters or small cymes. Involucel of 3 deciduous bracts. Sepals 5, united at the base into a turbinate 10nerved tube. Petals 5, spatulate, convolute, withering-persistent. Stamens 5: filaments united below, not accompanied by staminodia : anthers with parallel sacs. Ovary 1-celled, sessile : style simple, not central : stigma club-shaped or brush-like. Ovules 2 in a cavity. Follicles 1-celled, 2-valved lengthwise. Seed solitary, ascending. Endosperm fleshy. Embryo straight, axile.

1. Waltheria Americàna L. Foliage tomentose. Stems 6-12 dm. tall, stiff : leafblades ovate to oblong, $1-5 \mathrm{~cm}$. long, serrate, rounded or cordate at the base, on stout petioles: flowers in dense sessile or peduncled axillary clusters: sepals subulate, about $5 \mathrm{~mm}$. long, villous-hirsute, similar to the bractlets: petals yellow, slightly longer than the sepals : follicles $2.5-3 \mathrm{~mm}$. long, pubescent at the top.

In sand, Florida Keys. Circumtropical.

\section{AYÈNIA L.}

Low shrubby herbs, resembling EUPHORBIACEAE, commonly clothed with stellate hairs. Leaves alternate : blades toothed. Flowers minute, in axillary clusters or cymes, pedicelled. Involucel wanting. Sepals 5. Petals 5, with long involute claws, the blades converging over the stigma. Stamens 5, alternating with 1-2 staminodia : filaments united below into an urn-shaped cup : anthers with 3 parallel sacs. Ovary 5-celled, stalked : styles united : stigma 5-lobed or capitate. Ovules 2 in each cavity. Capsule 5-celled, 5-angled, muricate, the carpels separating from the central column, then septicidally from each other, finally loculicidal. Seeds solitary in each cavity, transversely wrinkled. Endosperm wanting. Cotyledons spirally convolute. 
1. Ayenia pusílla L. Herbaceous from a woody base, the foliage puberulent. Stems diffusely branched, 1-3 dm. long: leaf-blades various, suborbicular to ovate or lanceolate, 5-12 mm. long, serrate or nearly entire, the broader ones subcordate at the base, all slenderpetioled : flowers solitary on peduncles $5-10 \mathrm{~mm}$. long, or 2-3 in a cluster : sepals lanceolate, about $2 \mathrm{~mm}$. long, acuminate: petals nearly twice as long as the sepals, with filiform claws and a dorsal appendage to each hooded blade: staminal column with a cup-like top :staminodia rounded : ovary shorter than its stalk : capsules depressed, 4-5 mm. broad. America.

In dry or sandy soil, Florida Keys and Texas to California. Also in the West Indies and tropical

\section{NEPHROPÉTALUM Robinson \& Greenman.}

Shrubs, resembling species of Ayenia in habit, with stellate-tomentulose foliage. Leaves alternate : blades broadest below the middle, toothed. Flowers perfect, inconspicuous, few in peduncled umbel-like cymes. Sepals 5, nearly distinct. Petals 5, with slender claws and concave reniform unappendaged blades. Stamens 5: filaments united into a tube with the staminodia alternating with the 3-celled anthers. Ovary 5-celled: styles united : stigma capitate. Ovules 2 in each cavity. Capsule globular, muricate. Seed solitary. Endosperm wanting. Embryo with convolute cotyledons.

1. Nephropetalum Prínglei Robinson \& Greenman. A branching shrub, with cinereous-tomentulose or early glabrate branches. Leaf-blades ovate, 8-13 cm. long, acuminate but blunt, crenate-dentate, palmately 7 -nerved, pale-tomentulose beneath, with a deep narrow sinus: peduncles 10-14 mm. long: cymes 2-3-flowered, 2-2.5 $\mathrm{cm}$. long : pedicels about as long as the peduncles: sepals ovate: corolla greenish, about $2 \mathrm{~mm}$. broad.

In the Rio Grande valley, southern Texas.

\section{FIRMIÀna Marsigli.}

Trees or shrubs. Leaves alternate : blades entire or lobed. Flowers paniculate or rarely racemose, unisexual or polygamous. Sepals 5 or rarely 4 , partially united, often petaloid. Petals wanting. Staminal column broad, bearing 15 , or rarely 10 , anthers. Carpels 5, nearly distinct, each terminating in a peltate, sometimes lobed stigma. Ovules 2-many in each carpel. Capsule leathery, opening long before maturity, the carpels distinct, stellately spreading. Seeds usually wingless.

1. Firmiana platinifòlia (L.) R. Br. A shrub, or a tree often $12 \mathrm{~m}$. tall. Leafblades 1-3 dm. broad, suborbicular or reniform in outline, palmately, but sometimes shallowly, 3-5-lobed, copiously pubescent beneath, at least when young, long-petiolod : panicles commonly 2-3 dm. long, the branches pubescent : sepals linear or nearly so, $8-10 \mathrm{~mm}$. long, reflexed, greenish : capsule stipitate, the carpels $6-9 \mathrm{~cm}$. long, finely pubescent and veiny.

On roadsides, in thickets and fields, Georgia and the Gulf States. Native of eastern Asia. JAPAnese Varnish Tree. Chinese Parasol Tree.

\section{Order 20. HYPERICÀLES.}

Herbs, shrubs or trees. Leaves various. Flowers mostly perfect, complete and regular (irregular in VIOLACEAE), sometimes involucrate. Calyx of distinct or essentially distinct sepals. Corolla of distinct petals (partially united in FouQUIERIACEAE) rarely wanting. Androecium of usually numerous stamens, but sometimes as few as five. Gynoecium of several united carpels. Ovary superior, mostly with parietal placentae.

Stamens united into a tube which surrounds or encloses the gynoecium.

Placentae parietal.

Placentae axile.

Stamens distinct.

Styles wanting : stigmas introrse.

Placentae axile : herbs or shrubby plants.

Placentae basal: shrubs or trees.

Styles present, distinct or united: stigmas terminal.

Petals united to above the middle.

Petals distinct or merely coherent at the base.

A. Styles distinct or partially united or coherent until maturity, if united to the stigmas, then grooved.

a. Stigmas not brush-like: endosperm little or none.

Herbs or shrubby plants, with opposite or whorled leaves. Shrubs or trees, with alternate leaves.

Fam. 1. Canellaceae.

Fam. 2. Clusiaceae.

Fam. 3. Elatinaceae.

Fam. 4. TAMARICACEAE.

Fam. 5. Fouquieriaceae. 
b. Stigmas brush-like: endosperm copious.

B. Styles wholly and permanently united.

Corolla regular.

Anther-sacs opening by apical chinks.

Anther-sacs opening longitudinally.

Corolla irregular, the petals markedly unequal and one of them spurred : stamens 5.

Fam. 8. Turneraceae.

Fam. 9. BIXACEAE.

Fam. 10. Cistaceae.

Fam. 11. VIOLACEAE.

\section{Family 1. CANELlàCEAE Mart. Wild Cinnamon Family.}

Tropical American trees, with a pale aromatic bark. Leaves alternate, without stipules: blades entire, pellucid-punctate. Inflorescence corymbosecymose. Flowers perfect, regular. Calyx of 3 thick imbricated sepals. Corolla of 4-12 narrow imbricated thick petals, or wanting. Androecium of numerous stamens. Filaments united into a tube which encloses the pistil. Anthers narrow, extrorse, adnate to the filament-tube. Gynoecium of 2-5 united carpels. Ovary free, 1-celled, with 2-5 parietal placentae. Style thick. Stigma 2-5-lobed. Ovules 2-several, horizontal, almost anatropous. Fruit a berry. Seeds 2 or several, with a shining crustaceous testa. Endosperm fleshy, oily. Embryo straight, or slightly curved in the endosperm.

\section{CANÉlLa P. Br.}

Trees, with a gray bark and glabrous foliage. Leaves alternate: blades leathery, broadest above the middle. Flowers small, in terminal cymes. Sepals 3, much longer than the bractlets. Petals 5. Stamens mostly 15-20: filament-tube projecting beyond the anthers. Ovary elongated, with 2 parietal placentae, enclosed in the filament-tube. Ovules 3-4. Berry subglobose. Seeds 3-4, filling the cavity of the berry. Embryo slightly curved and to one side of the axis of the endosperm.

1. Canella Wintertàna (L.) Gaertn. A glabrous spicy tree, $5-15 \mathrm{~m}$. tall. Trunk sometimes 2-2.5 dm. thick : leaf-blades oblanceolate, spatulate or oblong-spatulate, 3-10 $\mathrm{cm}$. long, obtuse, deep green and lustrous above, paler beneath, slightly revolute, entire, short-petioled : cymes few-flowered: sepals 3, orbicular-reniform, 2.5-3 mm. broad, very thick : petals 5, oblong, $4.5-5 \mathrm{~mm}$. long, obtuse, leathery, purple, deciduous: staminal tube about $3 \mathrm{~mm}$. high, ovoid: anthers linear, 15-20: style nearly columnar: berry subglobose, about $1 \mathrm{~cm}$. in diameter, bright crimson, subtended by the persistent sepals : seeds obovoid. [C. alba Murr.]

In dense forests on the Florida Keys. Also in the West Indies. Flowers in the fall. Crnvamonbark. Wild CINNAMON. WhiteWood.

\section{Family 2. Clusiàceat lindl. Balsam-tree Family.}

Shrubs or trees, with an acrid resinous sap. Leaves opposite, sometimes whorled : blades entire. Flowers mostly dioecious or polygamous, solitary or in cymes. Calyx of 2-6 strongly imbricated sepals. Corolla white, pink or yellow, of 4-9 hypogynous petals. Androecium of numerous stamens, reduced in the pistillate flowers. Filaments wholly or partially united. Gynoecium of 2 or more united thick carpels. Ovary 2 -several-celled, its base, at least, surrounded by the united parts of the androecium. Styles very stout or wanting. Stigmas thick. Ovules several or many. Fruit baccate, drupaceous or capsular. Seeds sometimes arillate. Endosperm wanting.

\section{CLÙsia L.}

Commonly evergreen epiphytic shrubs or trees, with erect or climbing stems. Leafblades broadest above the middle. Flowers solitary or few in axillary or terminal cymes. Sepals 4-6, imbricated. Petals 4-9, commonly broadest above the middle, leathery. Staminodia several to many in the pistillate flowers. Ovary 8-10-celled: stigma radiate. Ovules numerous, on axile placentae. Capsules mostly leathery, angled, septicidal.

1. Clusia flàva Jacq. A glabrous evergreen tree sometimes becoming $20 \mathrm{~m}$. tall Leaf-blades leathery, cuneate-obovate, $1-2.5 \mathrm{dm}$. long, obtuse or retuse at the apex, entire many-ribbed, short-petioled : sepals suborbicular, leathery : petals yellow, broadly obovate, $2.5-3 \mathrm{~mm}$. long, somewhat unequal : capsule pyriform or globular : seeds usually 12 , glohular, embedded in a thin pulp.

In sand or coral rock, Florida Keys. Also in tropical America. 


\section{FAMily 3. ELATINÀCeat Lindl. Water-wort Family.}

Herbs or shrubby plants, with erect or creeping stems. Leaves opposite or whorled, with stipules. Flowers perfect, regular, solitary or clustered in the axils. Calyx of 2-5 imbricated sepals. Corolla of as many hypogynous petals as there are sepals. Androecium of 2-5 or sometimes 10 stamens inserted with the petals. Filaments slender. Gynoecium of 2-5 united carpels. Ovary 2-5-celled with central placentae. Stigmas 2-5, distinct, introrse. Ovules several, anatropous. Fruit a capsule opening septicidally. Seeds with a ribbed or wrinkled crustaceous testa.

Plants glabrous : flowers 2-4-merous: sepals membranous, obtuse.

Plants pubescent: flowers 5-merous: sepals with a thick center, acute or acuminate.

1. Elatine. 2. Bergia.

\section{ELATINE L.}

Low, soft, often aquatic herbs, with glabrous foliage. Leaves opposite or whorled : blades commonly entire. Flowers usually solitary in the axils. Sepals 2-4, membranous, obtuse, nerveless. Petals as many as the sepals. Stamens as many as the sepals or twice as many. Ovary 2-4-celled : styles 2-4. Capsule membranous, subglobose, 2-4-valved. WATER-WORT. MUD-PURSLANE.

1. Elatine Americàna (Pursh) Arn. Terrestrial or aquatic, often submerged. Stems tufted, 1-4 cm. long, erect or spreading : leaf-blades obovate or oblong-obovate, 2-6 $\mathrm{mm}$. long, obtuse : flowers minute, sessile in the axils : sepals 2, obtuse : petals $2:$ stamens 2 , barely as long as the perianth, or sepals, petals and stamens 3 in terrestrial forms : capsules subglobose, nearly $1 \mathrm{~mm}$. diameter: seeds slightly curved, $0.5-0.7 \mathrm{~mm}$. long, with 9-10 striae and $20-30$ cross bars. Summer.

On margins of ponds and in slow streams, Ontario to Oregon, Virginia, Texas and Colorado.

\section{BÉRGIA L.}

Herbs or shrubby plants, with erect or prostrate stems and pubescent foliage. Leaves opposite : blades toothed or entire, sometimes thickish. Flowers solitary in the axils or clustered. Sepals usually 5, acute, with a herbaceous or ribbed middle, and hyaline edges. Petals usually 5. Stamens as many as there are sepals. Ovary 5-celled : styles 5. Capsule somewhat crustaceous, septicidally or septifragally 5 -valved.

1. Bergia Texàna (Hook.) Seubert. Stems branched at the base, the branches prostrate or ascending, 1-3 dm. long, more or less forked : leaf-blades elliptic or spatulateelliptic, $1-2.5 \mathrm{~cm}$. long, acute or obtuse, serrulate, prominently nerved beneath in age, narrowed into short petioles : flowers solitary or 2-3 together in the axils : sepals ovate or ovate-lanceolate, $2.5-3 \mathrm{~mm}$. long, acuminate, denticulate : petals oblong or slightly broadened upward, obtuse, shorter than the sepals : capsules subglobose, about $2 \mathrm{~mm}$. in diameter : seeds oblong, the striae connected by cross bars.

In alluvial or sandy soil, Illinois to California and Texas. Summer.

\section{Family 4. Tamaricàceae lindl. Tamarix Family.}

Shrubs or trees, or partially woody herbs. Leaves alternate, without stipules, relatively small or scale-like, entire, often imbricated. Flowers mainly perfect, regular, usually in spikes, racemes or panicles. Calyx of 5 , or rarely 4 or 6 , imbricated sepals. Corolla of 5 , or rarely 4 or 6 , distinct imbricated petals. Disk 10-lobed or obsolete. Androecium of 5-many stamens. Filaments distinct, free. Anthers opening lengthwise. Gynoecium 2-5-carpellary, superior. Ovary 1-celled, with 3-5 basal placentae. Stigmas 3-5, distinct. Ovules 2many on each placenta. Fruit a capsule. Seeds erect, each terminating in a coma.

\section{TÁMARIX L.}

Shrubs or trees, with irregularly and widely branching stems, the wood firm. Leaves small, scale-like, clasping or sheathing. Flowers in dense spikes, racemes or panicles. Sepals 4-5, or rarely 6, distinct. Corolla white or pink. Petals inserted under the lobed disk, distinct or essentially so. Stamens 5-10, or rarely 4 or 12 : filaments not adnate 
to the corolla. Ovary with basal placentae. Stigmas $3-4$, or rarely 2 or 5 , short. Fruit capsular. Seeds numerous. Endosperm wanting.

1. Tamarix Gállica L. A shrub or a small tree, with slender spreading branches, the branchlets very numerous, approximate or clustered, completely clothed with the imbricated scale-like acute leaves which are $1 \mathrm{~mm}$. long or less: spikes numerous, in conspicuous panicles: sepals triangular, about $0.5 \mathrm{~mm}$. long : petals white or pinkish : capsule pyramidal, about $1 \mathrm{~mm}$. long.

On roadsides, in thickets and in waste places. warmer parts of the southern United States. Naturalized from southern Europe. Spring. TAMARISK.

\section{FAMily 5. FOUQUIERÀCeAe DC. Coach-whip Family.}

Shrubs or trees, with soft wood, the short branches greatly out of proportion to the narrowly conic trunk. Leaves solitary or clustered on the spiny branches : blades thick, entire. Flowers perfect, in thyrsoid panicles. Calyx of 5 distinct sepals. Corolla crimson, of 5 well united petals, the lobes recurved. Androecium of 10-many stamens, in 1 or 2 series. Filaments partially adnate to the corolla. Gynoecium 3-carpellary. Ovary 1-celled, but with 3 septumlike parietal placentae. Styles united, elongated. Fruit capsular. Seeds few, each with a wing or a fringe of white hairs. Endosperm present.

\section{FOUQUIERA H.B.K.}

Characters of the family. CANDLEwOod.

1. Fouquiera spléndens Engelm. A shrub or a tree, sometimes $7 \mathrm{~m}$. tall, the gray ridges of some of the branches terminating in spines : leaves clustered; blades oblong to spatulate, leathery, 1-2.5 cm. long, obtuse : flowers short-pedicelled : sepals 5-6 mm. long, rounded at the apex : corolla scarlet or brick-red, about $1.5 \mathrm{~mm}$. long, the lobes ovate to triangular, 3-4 mm. long, recurved : capsules conic, 7-10 mm. long.

In rocky soil, southern Texas to California and adjacent Mexico. Spring. Jacob's Stafr. OCOTILlo. COACH-WHiP.

\section{FAmily 6. HYPERICÀCeAe Lindl. St. John's-wort FAmily.}

Herbs or shrubby plants. Leaves opposite or rarely whorled, without stipules : blades pellucid-punctate, entire or nearly so, sometimes reduced to scales. Flowers perfect, regular or nearly so, in cymes. Calyx of 4-5 herbaceous equal or unequal sepals. Corolla of 4-5 yellow or flesh-colored petals. Androecium of few or many stamens, commonly collected in 3 or 5 groups, sometimes accompanied by interposed glands. Filaments slender. Anthers 2-celled, versatile. Gynoecium of several united carpels. Ovary sessile, 1-celled, with parietal placentae, or 3-7-celled with axile placentae. Styles distinct or united. Stigmas often capitate. Fruit a septicidally dehiscent capsule seated in the persistent calyx. Seeds small, without endosperm.

Sepals 4 , in more or less unequal pairs : petals mostly 4 .

Pairs of sepals very unequal in size or shape or both, the outer pair enclosing the capsule.

Pairs of sepals nearly equal in size and shape, much surpassed by the capsule. 2 . CROOKEA. Sepals and petals mostly 5 .

Petals yellow.

Leaves with flat more or less spreading blades.

Leaves reduced to erect or appressed minute or slightly elongated scales without

blades.
Petals pink sometimes tinged with green or purple.

3. HYPERICUM.

4. SAROTHRA.

5. TRIADENUM.

\section{1. ÁSCYRUM L.}

Low shrubs, with 2-edged branches. Leaves small : blades entire, sessile or clasping. Flowers yellow, terminal, often showy. Sepals 4, very unequal, the 2 exterior much larger than the inner. Petals 4, equal, oblique, convolute. Stamens numerous: filaments distinct or slightly united at the base: anthers adnate; sacs opening lengthwise. Glands wanting. Ovary 1-celled, with 2-3, or rarely 4, parietal placentae: styles distinct or cohering at the base. Ovules numerous. Capsules narrowed upward, embraced by the outer sepals. Seeds numerous, straight or nearly so. St. Peter's-wort. 
Styles 2: inner sepals very small, petal-like or obsolete.

Peduncles reflexed at maturity : calyx without bractlets, conspicuously surpassing the leaves.

Peduncles not recurved: calyx subtended by a pair of bractlets, not conspicuously surpassing the leaves.

Outer sepals cuneate-obovate to oblong-lanceolate or oblong, about as long as the capsule.

Outer sepals ovate or oblong-ovate, often much longer than the capsules.

Styles $3-4$ : inner sepals slightly smaller than the outer.

Leaf-blades merely sessile: outer sepals fully as broad as long.

Leaf-blades clasping: outer sepals longer than broad.

Outer sepals broader than the leaf-blades: inner sepals shorter than the outer. 5. A. stans.

Outer sepals narrower than the leaf-blades: inner sepals as long as the outer. 6. A. tetrapetalum.

1. Ascyrum pùmilum Michx. A low or depressed shrubby plant, with diffusely branched stems, the spreading 2-edged or 2-winged branches 5-20 $\mathrm{cm}$. long. Leaves numerous; blades oval, obovate or linear-oblong, often cuneately narrowed at the base, 3-9 mm. long, obtuse, sessile : peduncles slender, 1-2 cm. long or shorter, finally recurved : sepals very unequal, the 2 outer ovate or suborbicular, $6-10 \mathrm{~mm}$. long, obtuse or acutish, the 2 inner obsolete or nearly so : corolla bright yellow, $1.5-2 \mathrm{~cm}$. broad : petals cuneate or obovate : capsules oblong or oval-oblong, about $5 \mathrm{~mm}$. long.

In sandy soil, Georgia and Florida. Spring and summer.

2. Ascyrum hypericoìdes L. A low diffusely branched shrubby plant, with irregular stems varying from 1-5 dm. long. Leaves conspicuously numerous, rather crowded on the branchlets; blades narrowly linear, $0.5-1.5 \mathrm{~cm}$. long, acute, somewhat revolute, sessile : flowers few in narrow terminal racemes or panicled cymes: sepals very unequal, the outer cuneate-obovate to oblong or oblong-lanceolate, $7-9 \mathrm{~mm}$. long, acute or rather obtuse, the inner sepals manifest, petaloid : petals yellow : capsules oblong, about as long as the outer sepals.

In sandy soil, Florida to Texas, mainly introduced from tropical America. Spring to fall. ST. ANDREW's Cross.

3. Ascyrum multicaùle Michx. A shrubby plant 1-9 dm. tall with a solitary or several erect ascending or decumbent stems. Leaves commonly numerous, sometimes conspicuously so ; blades linear-spatulate to oblanceolate, oblong or obovate-oblong, 1-3.5 cm. long, obtuse, acutish or sometimes minutely mucronate : flowers few : sepals very unequal, the outer ovate or oblong-ovate, 6-9 $\mathrm{mm}$. long, obtuse or acute at the apex, truncate or subcordate at the base, the inner sepals manifest, petaloid : capsules oblong-ovoid or nearly oblong, as long as the outer sepals or shorter.

In low grounds or on dry hillsides and in thickets, Massachusetts to Illinois, south to Florida and Texas. Spring to fall.

4. Ascyrum cuneifòlium Chapm. A shrubby plant 1-2 dm. tall, with erect, widely branching stems. Leaves few ; blades leathery, cuneate or obovate, 5-20 mm. long, obtuse, minutely black punctate, sessile : flowers few : sepals thick, the 2 outer suborbicular, $1-1.5 \mathrm{~cm}$. long, the 2 inner oblong or nearly so, shorter than the outer : corolla bright yellow, $2.5-3 \mathrm{~cm}$. broad : petals obovate, delicately striped : capsules ovoid, 7-8 mm. long, abruptly pointed.

In low pine lands, Florida. Summer and fall.

5. Ascyrum stáns Michx. A branching shrubby plant 3-9 dm. tall, with erect stems, the branches 2-edged or 2-winged. Leaves rather numerous; blades leathery, oblong-elliptic varying to obovate, $1-4 \mathrm{~cm}$. long, obtuse, spreading or ascending, sessile, partially clasping : cymes few-flowered: pedicels stout, 4-10 $\mathrm{mm}$. long, longer than the peduncles, subtended by 2 small bractlets: sepals thick, the outer broadly ovate or suborbicular, 8-15 $\mathrm{mm}$. long, obtuse, cordate, the inner lanceolate, shorter than the outer : corolla bright yellow, $2.5-4 \mathrm{~cm}$. broad : petals somewhat persistent : styles $3-4$, short: capsules ovoid, 7-9 mm. long, abruptly pointed. winter.

In swamps or moist sandy soil, Long Island to Pennsylvania, Florida and Texas. Summer to

6. Ascyrum tetrapétalum (Lam.) Vail. A showy shrub 2-9 dm. tall, with forking stems. Leaves mostly approximate ; blades leathery, ovate to oval, $0.8-3.5 \mathrm{~cm}$. long, obtuse or acutish, conspicuously punctate, sessile and clasping : pedicels 3-12 mm. long, often subtended by 2 bractlets : sepals leathery, the outer resembling the leaves, $8-15 \mathrm{~mm}$. long, acute or short-acuminate, the 2 inner lanceolate or linear, about as long as the outer ones: corolla bright yellow, $2-3 \mathrm{~cm}$. broad : styles 3 : capsules ovoid, about $\frac{1}{2}$ as long as the sepals. [A. amplexicaule Michx.]

In moist sandy soil, Georgia and Florida. Spring to fall. 


\section{CROÒKEA Small.}

Weak branching shrubby plants, with the habit of species of Ascyrum. Leaves numerous, nearly equal throughout the plant: blades narrow, obtuse. Flowers solitary at the ends of the branches, or clustered. Sepals 4, in slightly unequal pairs, the members of both pairs differing very little either in size or shape. Petals 4, yellow, quite unequal in size or shape, fully twice as long as the sepals. Stamens numerous : filaments distinct. Glands none. Ovary 1-celled : styles 3, coherent, but at length separating. Capsule much longer than the sepals. Seeds numerous.

1. Crookea microsèpala (T. \& G.) Small. A branching shrub, with decumbent or ascending stems. Leaves numerous ; blades cuneate to linear-cuneate or narrowly oblong, 6-14 mm. long, rounded at the apex, often slightly revolute, sessile : flowers showy, $2-2.5 \mathrm{~cm}$. broad : sepals 4 , linear to oblong, obtuse : petals 4 , yellow, unequal, the smaller oblong, the larger obovate, obtuse : stamens numerous, distinct : capsules oblong, 7-8 mm. long, much surpassing the sepals : seeds oblong, less than $1 \mathrm{~mm}$. long, striate and pitted. [Ascyrum microsepalum T. \& G., Hypericum microsepalum (T. \& G.) A. Gray.]

In sandy soil, southern Georgia and Florida. Spring.

\section{HYPÉRICUM L.}

Showy shrubby plants or herbs, with erect or depressed stems. Leaves opposite : blades usually thickish, commonly sessile or clasping, entire or nearly so, more or less punctate. Flowers solitary, or in more or less compound cymes. Sepals 5, slightly unequal. Petals 5 , yellow, smooth and glabrous, oblique, convolute. Stamens numerous : filaments distinct, or more or less united at the base and aggregated into 3-8 groups without hypogynous glands. Ovary 1-celled, with 3-5 parietal placentae or 3-5-celled: styles 3-5, sometimes coherent. Capsule tapering upward. Seeds numerous, variously marked. Sт. JoHs's-wort.

Stamens few or several, 5-12, usually in 3 clusters.

Leaf-blades linear.

Leaf-blades ovate, oval or oblong.

Sepals obtuse or somewhat acute : leaf-blades obtuse.

Sepals acuminate: leaf-blades acute.

Stamens numerous, 15-40, distinct or in clusters : capsules 3-5-celled or with intruding placentae.

A. Styles 3 or rarely 4 : capsules 3 -celled or with 3 more or less intruding placentae.

a. Capsules 1-celled or incompletely 3-celled.

Capsules with parietal placentae, 1-celled. Styles distinct: stigmas capitate.

Foliage glabrous : sepals not ciliate.

Sepals conspicuously imbricated, at least the outer broadest at the base : leaf-blades broadest about the middle.

Sepals not conspicuously imbricated, at least the outer broadest about the middle: leaf-blades broadest about the base.

Foliage tomentose: sepals ciliate.

Styles coherent, at least below : stigmas minute.

Corolla over $18 \mathrm{~mm}$. broad : capsules over $6 \mathrm{~mm}$. high.

Corolla less than $18 \mathrm{~mm}$. broad: capsules less than $6 \mathrm{~mm}$. high.

Capsules broadest at the top, about as long as the sepals.

Capsules broadest at the base.

Sepals obtuse: seeds striate and pitted.

Sepals acute or acutish : seeds transversely wrinkled.

Capsules incompletely 3-celled by the intrusion of the placentae.

* Sepals very small or at least not foliaceous.

Leaves never in conspicuous axillary clusters ; blades relatively broad.

Sepals obtuse or merely acutish.

Sepals less than $1 / 2$ as long as the petals : capsules $6-7 \mathrm{~mm}$. long.

Sepals over $1 / 2$ as long as the petals : capsules $12-13 \mathrm{~mm}$. long.

Sepals manifestly acute or acuminate.

1. H. Canadense.

2. H. mutilum.

3. H. gymnanthum.

\section{H. virgatum.}

5. H. acutifolium.

6. H. setosum.

7. H. dolabriforme.

8. H. turgidum.

9. H. орасит.

10. H. sphaerocarpum.

Leaves in conspicuous axillary clusters ; blades narrow.

+ Leaves of the axillary clusters mostly much smaller than the main pair; blades neither subulate, nor fleshy.

Cymes in terminal congested corymbs: buds broadly ovoid : mountain species.

Cymes in elongated narrow panicles: buds conic : lowland species.

$\ddagger$ Leaves linear-oblong, spatulate or'oblanceolate. Sepals oblong to lanceolate, not narrowed at the base.

Sepals spatulate to elliptic-spatulate, narrowed at the base.

11. H. nudiflorum.

12. H. apocynifolium. 13. H. adpressum.

14. H. glomeratum. 
$\ddagger \ddagger$ Leaves narrowly linear or narrowly linear-spatulate. $17 . H$. galioides.

t† Leaves of the axillary clusters about as large as the main

pair; blades subulate or linear-subulate, fleshy, about as thick as wide.

Sepals as long as the petals or fully $1 / 2$ as long: leaves mostly over $10 \mathrm{~mm}$. long.

Sepals less than $1 / 2$ as long as the petals: leaves mostly less than $10 \mathrm{~mm}$. long.

** Sepals foliaceous.

Leaf blades cordate-clasping.

Leaf-blades more or less narrowed to the sessile or short-petioled base.

Flowers sessile : buds ovoid-globose. b. Capsules completely 3-celled.
Herbs.

Flowers pedicelled: buds conic.

18. H. fasciculatum.

19. H. aspalathoides.

20. H. myrtifolium.

21. H. aureum.

22. H. splendens.

Corolla less than $15 \mathrm{~mm}$. broad.

Leaf-blades short-petioled or merely sessile, with a rounded base. Leaf-blades sessile and more or less clasping.

Corolla over $15 \mathrm{~mm}$. broad.

Upper leaves and bracts with ovate or ovate-lanceolate blades : petals spotted all over.

Upper leaves and bracts with oblong blades: petals spotted around the edges.

Sepals and petals merely dotted : capsules usually less than $6 \mathrm{~mm}$. high.

Sepals and petais striped with black: capsules usually over

Shrubs. $6 \mathrm{~mm}$. high.

Stems diffusely spreading or decumbent.

Stems erect, relatively tall.

Flowers few in narrow panicles : corolla over $1.5 \mathrm{~cm}$. broad.

Flowers numerous in rather corymb-like panicles: corolla less than $1.5 \mathrm{~cm}$. broad.

B. Styles 5: capsules 5-celled.

23. H. subpetiolatum.

24. H. maculatum.

25. H. pseudomaculatum.

26. H. perforatum.

27. H. graveolens.

28. H. Buckleyi.

29. H. prolificum.

30. H. densiflorum.

31. H. lobocarpum.

1. Hypericum Canadénse L. Annual, slender. Stems 1-6 dm. tall, angled, nearly simple or much branched: leaf-blades linear, obtuse or acutish, 3-nerved, tapering at the base : cymes few, many-flowered, the branches often elongated : bracts subulate: sepals lanceolate, 3-5 mm. long, acute or somewhat acuminate : corolla yellow, 7-9 mm. broad : stamens 5-10: styles 3 : capsules conic, 4-8 $\mathrm{mm}$. long, acute, much surpassing the sepals.

In moist sandy soil, Newfoundland to Manitoba, Georgia and Wisconsin. Summer.

2. Hypericum mùtilum L. Annual, slender. Stems 1-8 dm. tall, narrowly 4-winged or 4-angled, simple below, or branched at the base or throughout : leaf-blades oblong-ovate or the upper ones ovate, sometimes oblong, $0.5-2.5 \mathrm{~cm}$. long, obtuse, entire, 5-nerved, sessile and somewhat clasping, minutely punctate, glaucescent beneath : cymes open : bracts subulate : sepals oblong or oblong-lanceolate, 3-3.5 $\mathrm{mm}$. long, acute with several pellucid nerves : corolla yellow, 7-9 mm. broad : petals oblong, about $3.5 \cdot \mathrm{mm}$. long, obtuse : stamens 5-12 : capsules ovoid to oblong, 2-3 mm. long, obtuse, surpassing the sepals.

In low places, Nova Scotia to Manitoba, Florida and Texas. Summer and fall.

3. Hypericum gymnánthum Engelm. \&. Gray. Annual, glabrous. Stems 2-9 dm. tall, simple or sparingly branched above : leaf-blades firm, ovate, $0.5-2 \mathrm{~cm}$. long, acute or acuminate, or the lower ones obtuse, 5-7-nerved, sessile, clasping : corymbs often flat-topped, the cymes few-flowered : bracts subulate : flowers short-pedicelled : sepals lanceolate, 3-4 mm. long, acuminate, nerved : corolla yellow, 4-5 mm. broad : stamens 10-12 : capsules ovoid or oblong, about $4 \mathrm{~mm}$. long, acute, as long as the sepals or usually surpassing them.

In moist places, New Jersey to Missouri, North Carolina, Louisiana and Texas. Summer.

4. Hypericum virgàtum Lam. Perennial, herbaceous. Stems slender, 2-9 dm. tall, 4-angled, simple, or branched above: leaf-blades thinnish, oblong, or nearly so, 1-3 cm. long, acute or acutish, flat or revolute, sessile: cymes dichotomous, forming terminal bracted corymbs: bracts subulate, usually very slender: sepals more or less foliaceous, variable, lanceolate, oblong-lanceolate or slightly broadest above the middle, but the outer broadest at the base, 4-10 mm. long, acute or acuminate : corolla copper-yellow, $1-1.5 \mathrm{~cm}$. broad : capsules ovoid, 3-5 mm. long. [H. angulosum Michx.]

In sandy soil or pine lands, New Jersey to mlinois and Florida. Summer.

5. Hypericum acutifolium Ell. Perennial, glabrous, herbaceous. Stems simple or branched, at the base, thence often simple to the inflorescence, 2-6 dm. tall, angled, usually strict : leaf-blades narrowly lanceolate to linear-lanceolate, $1-2.5 \mathrm{~cm}$. long, acute or slightly acuminate, somewhat revolute, sessile : cymes forming several-flowered corymbs : sepals linear to linear-lanceolate, not conspicuously imbricated at the base, 3.5-5 mm. long, acute or acuminate, erect, the outer broadest about the middle : corolla copper-yellow, $15 \mathrm{~mm}$. 
broad : petals often about twice as long as the sepals : capsules ovoid, about $4 \mathrm{~mm}$. high, commonly surpassed by the sepals.

In pine lands, North Carolina to Florida. Summer.

6. Hypericum setòsum L. Annual or biennial, rough-tomentose. Stems erect or ascending, 3-6 dm. tall, terete, simple or sparingly branched : leaf-blades elliptic, oval to ovate-lanceolate, 3-15 mm. long, acute, longer than the internodes or slightly shorter, sessile : cymes few-flowered, dichotomous, corymbose : bracts lanceolate or subulate-lanceolate : sepals oval, ovate, or ovate-lanceolate, $2.5-3.5 \mathrm{~mm}$. long, ciliate, acute or somewhat acuminate : corolla yellow, $7-10 \mathrm{~mm}$. broad: petals involute at maturity : capsules oval or ovoid-oval, 4-5 mm, long. [H. pilosum Walt.]

In moist pine lands and low grounds, North Carolina to Florida and Louisiana. Summer.

7. Hypericum dolabrifórme Vent. Perennial, herbaceous. Stems decumbent, usually branched at the base, the branches $2-5 \mathrm{dm}$. tall, slightly angled : leaf-blades linear or nearly so, $2-5 \mathrm{~cm}$. long, with shorter leaves usually clustered in the axils, acute or acutish, more or less revolute, sessile : cymes simple or dichotomous, and forming broad few-flowered corymbs : bracts oblong to lanceolate : sepals unequal, foliaceous, lanceolate to ovate-lanceolate, $6-10 \mathrm{~mm}$. long : corolla yellow, about $2 \mathrm{~cm}$. broad : capsules leathery, conic-ovoid, 7-9 mm. high, acuminate.

On dry hillsides, Kentucky to Missouri, Georgia and Tennessee. Spring and summer.

8. Hypericum túrgidum Small. Perennial, shrubby. Stems branching, 3-6 dm. high or taller, with slightly winged or merely sharply angled branchlets: leaf-blades almost linear to linear-oblanceolate, $1-2.5 \mathrm{~cm}$. long, acute, revolute, somewhat paler beneath than above, sessile: flowers several in terminal cymes: sepals ovate to elliptic, about $3 \mathrm{~mm}$. long, acute or slightly acuminate : corolla yellow, about $1 \mathrm{~cm}$. broad: stamens numerous: capsules subglobose, about $3.5 \mathrm{~mm}$. in diameter, abruptly pointed, turgid.

On mountain slopes, between Huntsville and Summerville, Alabama. Summer.

9. Hypericum opàcum T. \& G. Perennial, herbaceous. Stems erect, $3-12$ dm. tall, simple, or sparingly branched, the twigs 2-winged: leaf-blades firm, oblong to oblonglanceolate, or sometimes linear-oblong, 1-3 cm. long, sessile, often somewhat clasping: cymes dichotomous, forming open corymbs $2-10 \mathrm{~cm}$. broad: bracts subulate, $2-10 \mathrm{~mm}$. long: sepals obovate to oblong, $2.5-4 \mathrm{~mm}$. long: corolla yellow, $7-11 \mathrm{~mm}$. broad : petals fully twice as long as the sepals, oblique and obliquely acute : capsules ovoid, 5-6 mm. long, 3-lobed, abruptly narrowed at the apex.

In sandy soil, South Carolina to Florida and Mississippi. Summer.

10. Hypericum sphaerocárpum Michx. Perennial, herbaceous. Stems $3-9 \mathrm{dm}$. tall, woody below, simple or sparingly branched above, the branches 4-angled : leaf-blades firm, linear-oblong to linear-lanceolate or sometimes narrowly oblong, $1.5-8 \mathrm{~cm}$. long, obtuse or acutish, more or less revolute, sessile, often slightly clasping: cymes dichotomous, forming loosely several-flowered corymbs: bracts linear to oblong, 2-10 mm. long: sepals ovate to lanceolate, $3-4 \mathrm{~mm}$. long, acute : corolla yellow, $1-1.5 \mathrm{~cm}$. broad: petals obliquely cuneate or obovate-cuneate, laterally apiculate : capsules varying from globose to globose-ovoid, 4-6 $\mathrm{mm}$. long.

On river banks, Ohio to Illinois, Alabama and Arkansas. Summer.

11. Hypericum nudiflòrum Michx. Perennial, shrubby. Stems $3-10 \mathrm{dm}$. tall, the twigs 2-winged: leaf-blades thinnish, elliptic-oblong or elliptic-lanceolate, $1.5-6 \mathrm{~cm}$. long, obtuse, flat, with a narrow edge, sessile: cymes dichotomous, forming naked peduncled loosely-flowered corymbs $4-12 \mathrm{~cm}$. broad : bracts subulate: flowers light yellow, about $2 \mathrm{~cm}$. broad, short-pedicelled: sepals elliptic-oblong or elliptic-oblanceolate, $3-4 \mathrm{~mm}$. long, obtuse or acutish : petals bright yellow, 6-8 mm. long, over twice as long as the sepals: placentae extending to near the axis of the ovary: capsules conicovoid, 6-7 mm. long, acuminate.

In sandy soil, North Carolina to Florida and Alabama. Summer.

12. Hypericum apocynifòlium Small. Perennial, shrubby. Stems 4-7 dm. tall, with a red somewhat shreddy bark, the branchlets narrowly 4-winged: leaf-blades oblong or slightly broadest near the middle, $2-4 \mathrm{~cm}$. long, bright green, rounded or emarginate at the apex, rarely revolute, pale beneath, minutely punctate, more or less cuneate at the base, nearly sessile : flowers $3-5$, in terminal cymes : sepals spatulate, elliptic or oval, $3-5$
$\mathrm{~mm}$. long, fully one-half as long as the petals, obtuse or acutish, persistent : petals yellow, oblong, 8-9 mm. long : capsules oblong-conic, 12-13 mm. long, acute.

In swamps, Georgia to Florida, Arkansas and Texas. Summer.

13. Hypericum adpréssum Bart. Perennial, shrubby below. Stems erect or ascending from a decumbent or creeping base, $2-6 \mathrm{dm}$. tall, simple or nearly so, 2-edged 
above : leaf-blades leathery, narrowly oblong to lanceolate, $2-6 \mathrm{~cm}$. long, with smaller ones often clustered in the axils, conspicuously nerved, sessile : flowers in terminal corymbose cymes : sepals lanceolate or ovate-lanceolate, 4-6 mm. long, acute : corolla yellow, 1-1.5 $\mathrm{cm}$. broad : petals cuneate : capsules ovoid, the body $5-6 \mathrm{~mm}$. long, slender-beaked.

In swamps or about ponds, Massachusetts to Georgia and Louisiana. Summer.

14. Hypericum glomeràtum Small. Perennial, shrubby. Stems branching, 3-10 dm. tall, with somewhat scaly bark, the foliage glabrous: leaf-blades narrowly oblong to linear-oblong or nearly linear, $2-4 \mathrm{~cm}$. long or those clustered in the axils shorter, more or less distinctly apiculate, often somewhat revolute, paler beneath than above, sessile: flowers in dense cymes terminating the branchlets : pedicels $2-8 \mathrm{~mm}$. long: buds ovoid, acutish : sepals rather foliaceous, narrowly oblong to linear-oblong, 5-6 $\mathrm{mm}$. long, acutish, strongly nerved, reflexed at maturity : petals bright yellow, cuneate-spatulate, fully $1 \mathrm{~cm}$. long, undulate at the apex : stamens numerous : capsules densely clustered, oblong-ovoid, 5-6 $\mathrm{mm}$. high, slightly lobed, the placentae only slightly intruded.

On mountains, North Carolina, especially on the Grandfather and Table Rock. Summer.

15. Hypericum intèrior Small. Perennial, shrubby. Stems several dm. tall, much branched, the branches sharply angled, glabrous: leaf-blades narrowly oblanceolate to linear-oblanceolate, $1-3 \mathrm{~cm}$. long, acute, slightly revolute, pale beneath, narrowed into slender petioles : panicles many-flowered : sepals linear or narrowly oblong, 3-4 mm. long, acute, rather rigid, more or less spreading at maturity : corolla yellow, about $1 \mathrm{~cm}$. broad : petals cuneate : capsules conic-ovoid, 5-6 mm. long.

Along streams, Texas. Summer.

16. Hypericum ambíguum Ell. Perennial, shrubby. Stems $0.5-1.5 \mathrm{~m}$. tall, widely branched, with a scaly bark : leaf-blades linear-oblong or spatulate, 1-2.5 cm. long, acute or apiculate, flat or slightly revolute, narrowed into short petiole-like bases : flowers few, in axillary cymes disposed in narrow panicles: bracts similar to the leaves but much smaller : sepals linear or slightly broadened upward, 3-5 mm. long, acute : corolla yellow, $15-18 \mathrm{~mm}$. broad : petals obliquely obovate or cuneate, almost laterally apiculate : capsules almost conic, $5-6 \mathrm{~mm}$. high, surpassing the sepals.

In and about river swamps, South Carolina to Florida and Alabama. Spring and summer.

17. Hypericum galioìdes Lam. Perennial, shrubby. Stems $3-8 \mathrm{dm}$. high or taller, glabrous : leaf-blades narrowly linear or slightly broadened upward, $0.5-1.5 \mathrm{~cm}$. long, acute, slightly revolute, each tapering into a very short petiole-like base or sessile : flowers solitary or in axillary cymes forming narrow panicles: sepals linear or linear-spatulate, 3-4 $\mathrm{mm}$. long, more or less revolute : corolla yellow, about $1.5 \mathrm{~cm}$. broad: petals cuneately narrowed, obliquely or almost laterally pointed : capsules conic, 5-6 mm. long, acute.

In low pine lands, Florida and Alabama. Summer and fall.

18. Hypericum fasciculàtum Lam. Perennial, shrubby. Stems 1-5 m. tall, with numerous sharply angled branchlets: leaves numerous, a bunch usually clustered in the axils of the larger ones; blades leathery, linear-filiform, 1-2 cm. long, or shorter in the clusters, acutish, revolute, sessile: Howers in loose narrow panicles, or at first rather corymbose: sepals linear, $3-4 \mathrm{~mm}$. long, about $1 \mathrm{~cm}$. wide: petals bright yellow, obliquely apiculate : capsules ovoid or conic-ovoid, 4-5 $\mathrm{mm}$. long, acute.

In wet sandy pine lands, North Carolina to Florida and Texas. Spring and summer.

19. Hypericum aspalathoides Willd. Perennial, shrubby. Stems nearly simple, or much branched, 2-8 dm. tall, with sharply angled branchlets: leaves very numerous, clusters of small ones borne in the axils of the large ; blades linear-subulate or linear-filiform, 5-8 mm. long, or shorter in the clusters, obtuse, revolute, sessile : flowers several, in terminal corymbose cymes, slender-pedicelled : sepals linear, 3-4 mm. long, resembling the small leaves : corolla bright yellow, about $1-5 \mathrm{~cm}$. broad: petals oblique, not apiculate : capsules conic, 5-7 mm. long, acuminate.

In pine lands and open places, North Carolina to Florida and Louisiana. Spring and summer.

20. Hypericum myrtifolium Lam. Perennial, shrubby. Stems branching, 3-10 $\mathrm{dm}$. tall, erect or creeping: leaves persistent, leathery; blades ovate to oblong-ovate, or ovate-lanceolate or rarely nearly oblong, 1-3 cm. long, obtuse at the apex or rarely acute, often slightly revolute, clasping: bracts like the leaves, but smaller, sometimes narrower: flowers showy, sometimes very numerous : sepals foliaceous, ovate, 5-8 mm. long, acute or acutish, united at the base : corolla golden yellow, about $2 \mathrm{~cm}$. broad: stamens numerous : capsules pyramidal-ovoid, incompletely 3-celled or rarely 4-celled, 5-6 mm. high, 3-4lobed or 3-4-sided.

In sandy pine lands, especially in wet soil, South Carolina to Florida and Alabama. Summer. 
21. Bypericum aùreum Bartr. Perennial, shrubby. Stems wide-branching, $6-12 \mathrm{dm}$. tall, the twigs obseurely winged: leaf-blades leathery, oblong to ovate-oblong, $2.5-7 \mathrm{~cm}$. long, obtuse or mucronate, flat or slightly revolute, glaucous beneath, narrowed into very short petioles : buds ovoid-globose : flowers very showy, sessile, usually solitary, sometimes 3 in terminal or axillary cymes : sepals very unequal, broadened upward : corolla golden yellow, $2.5-5 \mathrm{~cm}$. broad : petals quite oblique: stamens very numerous: styles 3 : capsules conic, 10-12 mm. high, acuminate at the apex.

On bluffs and in low grounds, South Carolina to Tennessee, Georgia and Texas. Summer.

22. Hypericum spléndens Small. Perennial, shrubby, much branched. Stems 0.5$1.5 \mathrm{~m}$. tall, with 2-edged glaucous twigs: leaf-blades oblong, $1.5-2.5 \mathrm{~cm}$. long, obtuse or rounded at the apex, slightly revolute, glaucous, especially beneath, narrowed at the sessile base : buds conic : flowers very showy, several or many in terminal or axillary cymes: sepals unequal, oblong, firm, apiculate, the outer about $8 \mathrm{~mm}$. long, the inner $5 \mathrm{~mm}$. long: corolla $3.5-4 \mathrm{~cm}$. broad : petals golden yellow, cuneate, oblique, $1.5-2 \mathrm{~cm}$. long: stamens very numerous, orange colored: styles 3 , slender : capsules often crowded, conic, $1.5 \mathrm{~cm}$. high, acuminate at the apex, partially 3 -celled, about thrice as long as the sepals with 3 narrow wings and 6 obtuse angles.

On granite rocks, Stone Mountain, Georgia. Summer.

23. Hypericum subpetiolàtum Bicknell. Perennial from horizontal rootstocks, herbaceous, bright green, heavy-scented. Stems $2-8 \mathrm{dm}$. tall, nearly simple or branched, especially above, the branches corymbose : leaf-blades thinnish, oblong or elliptic, varying to elliptic-obovate or elliptic-ovate, obtuse or retuse and often apiculate at the apex, gradually narrowed or truncate at the base, nearly sessile or short-petioled : sepals oblong to lanceolate, $1.5-2 \mathrm{~mm}$. long, obtuse or acutish : corolla dull yellow, 5-8 mm. broad : petals very delicate, oblong to elliptic, finely spotted : capsules ovoid or globose-ovoid, 4-6 mm. high, rather acute, much surpassing the sepals.

In woods and thickets, Maine to New York, Georgia and Tennessee. Summer.

24. Hypericum maculàtum Walt. Perennial from horizontal rootstocks, herbaceous, dark green, not heavy-scented. Stems 2-9 dm. tall, nearly simple, or considerably branched above : corymbs open or congested: leaf-blades leathery, ovate to oblong-ovate or nearly oblong, 1-6 cm. long, obtuse, punctate, sessile and clasping: sepals lanceolate, $3-4 \mathrm{~mm}$. long, long-acuminate, dotted: corolla deep yellow, $8-13 \mathrm{~mm}$. broad: petals delicate, copiously black-dotted : capsules ovoid, $3-5 \mathrm{~mm}$. long, acutish, about twice as long as the sepals.

In dry soil or on hillsides, Ontario to Florida, Kansas and Texas. Summer.

25. Hypericum pseudomaculàtum Bush. Perennial from horizontal rootstocks, herbaceous, glabrous, not heavy-scented. Stems erect, 4-8 dm. tall, corymbosely branched above, black-dotted: leaf-blades ovate to lanceolate or oblong, $1.5-4 \mathrm{~cm}$. long, obtuse or acutish, often strongly revolute, black-dotted, sessile and partly clasping: flowers in terminal rather crowded cymes : sepals lanceolate or oblong-lanceolate, 4-5 mm. long, acute or slightly acuminate : corolla copper-yellow, $2-3 \mathrm{~cm}$. broad : petals very delicate, blackdotted : capsules ovoid.

In woods and dry soil, Illinois, Missouri and Arkansas. Spring and summer.

26. Hypericum perforàtum L. Perennial, herbaceous, producing runners from the base, especially in winter. Stems simple, or branched at the base, the branches like the stems, 4-7 dm. long, flattened, much branched above and topped by corymbs : leaf-blades linear-oblong, or elliptic-oblong or obovate on the runners, 5-20 mm. long, rounded or acutish at the apex, sessile, glandular-punctate, those of the main stem usually subtending leafy branches : sepals linear-lanceolate, 3-4 mm. long, acute, glandular-punctate : corolla deep yellow, $2-2.5 \mathrm{~cm}$. broad: petals obliquely obovoid, $10-12 \mathrm{~mm}$. long, toothed on one side from the middle to the apex, bearing black glands near the teeth : styles 3 , shorter than the stamens: capsules ovoid, oblique, $6-8 \mathrm{~mm}$. high.

In waste places and fields, throughout North America, except the extreme north and south. Naturalized from Europe and northern Asia. Spring to fall.

27. Hypericum gravèolens Buckl. Perennial from horizontal rootstocks, herbaceous, glabrous, heavy-scented. Stems erect or decumbent, 2-9 dm. tall, simple or sparingly branched above : leaf-blades thickish, oblong or ovate-oblong, $2-6 \mathrm{~cm}$. long, obtuse, punctate, sessile or clasping : flowers few, in terminal cymes or rarely solitary : sepals lanceolate, spotted with dark brown : capsules ovoid, 8-10 mm. long, acute.

On mountain slopes, Virginia to North Carolina. Summer.

28. Hypericum Buckleỳi M. A. Curtis. Perennial, shrubby. Stems branching, 1-3 $\mathrm{dm}$. tall, decumbent or ascending, often diffuse, the twigs narrowly winged : leaf-blades 
obovate, elliptic-obovate or elliptic, $0.5-2 \mathrm{~cm}$. long, rounded at the apex or retuse, pale beneath, narrowed into short petioles: flowers solitary or a few (3) in terminal cymes: sepals obovate or spatulate, 4-5 mm. long, obtuse : corolla yellow, $2-2.5 \mathrm{~cm}$. broad : petals rather delicate, about twice as long as the sepals : styles mostly $3:$ capsules conic, $6-10 \mathrm{~mm}$. long, 3-celled.

On cliffs and rocky mountain summits, North Carolina to South Carolina and Georgia. Summer.

29. Hypericum prolíficum L. Perennial, shrubby. Stems $3-12 \mathrm{dm}$. tall with erect or ascending branches, the branchlets narrowly 2-winged: leaf-blades narrowly oblong or rarely lanceolate, $2-8 \mathrm{~cm}$. long, acute, usually slightly revolute, narrowed into short petioles : flowers mostly $2-3$ in short-peduncled axillary cymes forming narrowly cylindric panicles or sometimes solitary : sepals usually 5, unequal, mostly obovate, 4-6 $\mathrm{mm}$. long : corolla deep yellow, $1.5-2 \mathrm{~cm}$. broad : stamens very numerous, distinct : styles 3 or rarely 4 : capsules conic or narrowly ovoid, $8-10 \mathrm{~mm}$. long, 3-celled.

In sandy soil or rocky places, New Jersey to Minnesota, Georgia and Arkansas. Summer.

30. Hypericum densiflòrum Pursh. Perennial, shrubby. Stems slender, often diffusely branched, $6-18 \mathrm{dm}$. tall, with narrowly winged branchlets: leaf-blades linear, linear-oblanceolate or linear-oblong, 1-5 cm. long, acute, more or less revolute, narrowed into short petioles, small leaves usually clustered in the axils : flowers in terminal, mostly dense, corymbose cymes : sepals unequal, oblong to elliptic-oblong, $2-2.5 \mathrm{~mm}$. long: corolla bright yellow, 1-1.5 $\mathrm{cm}$. broad: petals obliquely pointed: stamens numerous, distinct: styles mostly 3 : capsules ovoid, 4-6 mm. long, slightly 3-lobed, completely 3-celled.

In swamps and on river banks, New Jersey to Missouri, Florida and Texas. Summer.

31. Hypericum lobocárpum Gattinger. Perennial, shrubby. Stems 1-2 m. tall, with erect or strongly ascending branches, the twigs and branches of the inflorescence narrowly winged : leaf-blades narrowly oblong or oblanceolate, $2-7 \mathrm{~cm}$. long, obtuse or apiculate, more or less revolute, sessile or narrowed into short, winged petioles: cymes dense, in corymbose or cylindric panicles: flowers numerous : sepals oblong to obovate-oblong, 2.5$3.5 \mathrm{~mm}$. long, rather obtuse : corolla yellow, $1-1.5 \mathrm{~cm}$. broad: petals rather cuneate : styles usually 5 : capsules 5 -celled, 5-lobed, 5-7 $\mathrm{mm}$. long, separating into 5 carpels at maturity.

In swamps and low grounds, North Carolina and Tennessee. Spring and summer.

\section{SARÒTHRA L.}

Firm-fleshy herbs, with erect branched stems and more or less black-dotted foliage. Leaves reduced to erect or appressed scales; these very short or somewhat elongated but destitute of blades. Flowers scattered along the branchlets, forming open or irregular cymes. Sepals 5, equal or nearly so, short or elongated. Petals 5, nearly equal. Stamens $5-20$, shorter than the petals. Glands none. Ovary 1-celled, sessile. Styles 3, distinct. Ovules several or numerous on the parietal placentae. Capsule more or less elongated, 1-celled, as long as the appressed sepals or much longer. Seeds ribbed or striate and pitted.

Flowers sessile or nearly so: sepals much shorter than the conic capsules.

1. S. gentianoides. Flowers pedicelled: sepals and ovoid or oval-ovoid capsules about equal in length. 2. S. Drummondii.

1. Sarothra gentianoìdes L. Annual, somewhat fleshy, but rather rigid. Stems 1-5 dm. tall, often bushy-branched, or rarely simple, the branches wire-like, mostly opposite, sometimes filiform: leaves scale-like, appressed, often subulate or those on the lower part of the stem sometimes linear or narrowly-oblong: flowers scattered along the branches, sessile or nearly so: sepals linear or linear-lanceolate, $2-3 \mathrm{~mm}$. long, acute or acuminate : corolla yellow, 4-8 mm. broad : stamens 5-10: capsules conic, 4-5 mm. long, much surpassing the sepals. [Hypericum Sarothra Michx.]

In sandy soil and on rocks, Maine to Minnesota, Florida and Texas. Spring to fall. PINE-WeEd. PINE-TASSLE. ORANGE-GRASS.

2. Sarothra Drummóndii Grev. \& Hook. Annual, rigid. Stems 1-6 dm. tall, simple or bushy-branched, strongly wing-angled, the branches alternate : leaves scale-like, narrowly linear or linear-subulate, erect or strongly ascending, 1-ribbed: cymes elongated : flowers scattered along the upper parts of the branches, pedicelled: sepals linearlanceolate, 3-4 mm. long, strongly nerved or slightly keeled below : corolla yellow, 10-12 $\mathrm{mm}$. broad: stamens 10-20: capsules ovoid, or oval-ovoid, shorter than the sepals or rarely longer. [Hypericum Drummondii (Grev. \& Hook.) T. \& G.]

In dry soil, Virginia to Missouri, Florida and Texas. Summer. 


\section{TRIADENUM Raf.}

Perennial glabrous, Hypericum-like marsh herbs, with horizontal rootstocks. Leaves opposite : blades elongated, thickish, punctate, with nerves conspicuously curving along the margins. Flowers rather few, usually in contracted cymes. Sepals 5, erect, equal. Petals 5, pink to greenish purple, imbricated, not oblique, deciduous. Stamens mostly 9 : filaments united in groups of 3 's, which alternate with scale-like, orange-colored glands. Ovary 3-celled, sessile. Styles 3, distinct. Ovules numerous. Capsule 3-celled, opening by 3 valves at the top, surpassing the sepals. Seeds numerous. [Elodea Pursh, not Michx.] Marsh St. John's-wort.

Leaf-blades sessile, partly clasping or truncate.

Leaf-blades broadest at the base or below the middle, partly clasping.

Leaf-blades mostly broadest above the middle, merely sessile.

Leaf-blades petioled, narrowed at the base.

1. T. Virginicum.

2. T. longifolium.

3. T. petiolatum.

1. Triadenum Virgínicum (L.) Raf. Stems $2-6 \mathrm{dm}$. tall, often sparingly branched, rooting at the lower joints : leaf-blades oblong, elliptic or ovate. $2-10 \mathrm{~cm}$. long, spreading, rounded or emarginate at the apex, glaucous and usually black-punctate beneath, sessile, the broad base clasping : cymes peduncled, few-flowered : bracts like the leaves but smaller : sepals lanceolate or oblong, 5-6 $\mathrm{mm}$. long, acute, pale-margined : petals obovate to oblanceolate or nearly oblong, $8-10 \mathrm{~mm}$. long, acute, delicately nerved : capsules oblong, $8-10 \mathrm{~mm}$. long, acute, fully as long as the sepals.

In swamps, Nova Scotia and Labrador to Manitoba, Florida and Louisiana. Summer.

2. Triadenum longifolium Small. Stems $3-6 \mathrm{dm}$. tall, simple below the inflorescence : leaf-blades oblanceolate, oblong or elliptic, thinnish, obtuse or notched at the apex, undulate, truncate or subcordate at the base, sessile : cymes terminal or axillary, few-flowered, sessile or short-peduncled : pedicels stout, 1-2 $\mathrm{mm}$. long : sepals lanceolate or linearlanceolate, 3-4 mm. long, acuminate : capsules oblong, about $1 \mathrm{~cm}$. long, acute, glabrous, striate.

In swamps and low grounds, Alabama and Florida. Summer.

3. Triadenum petiolàtum (Walt.) Britton. Stems $3-10 \mathrm{dm}$. tall, usually branched, sometimes copiously leafy above : leaf-blades oblong, or elliptic-oblong, 2-15 cm. long, obtuse or notched at the apex, glaucescent beneath, sparingly black-dotted, gradually or abruptly narrowed into short petioles: cymes few-flowered : bracts similar to the leaves: bractlets minute: pedicels $1-5 \mathrm{~mm}$. long: sepals oblong or nearly so, $2-2.5 \mathrm{~mm}$. long, obtuse, pale-margined: petals elliptic-obovate, 4-7.5 mm. long, obtuse : capsules oblong, prismatic, 8-10 $\mathrm{mm}$. long, acute.

In swamps, New Jersey to Missouri, Florida and Louisiana. Summer.

\section{Family 7. Theàceat DC. Camellia Family.}

Shrubs or trees, or rarely climbing vines. Leaves alternate : blades entire, toothed, or rarely digitately $3-5$-foliolate: stipules wanting, or rarely minute and caducous. Inflorescence commonly axillary, sometimes crowded into axillary or terminal racemes or panicles. Flowers mostly perfect, regular, showy. Calyx (usually subtended by several bractlets) of 5 , or rarely $4-7$, imbricated sepals. Corolla of 5, or rarely 4-7, distinct, or somewhat united, imbricated or contorted petals. Androecium of numerous stamens, or these rarely as many as the petals : anthers erect or versatile, opening lengthwise, or by terminal pores. Gynoecium of 3-5 united carpels. Ovary mostly 3-5-celled, sometimes partially immersed in the receptacle: styles as many as the cavities in the ovary, sometimes united. Ovules 2-many in each cavity, erect, horizontal or pendulous, anatropous, amphitropous or campylotropous. Fruit leathery or woody, dehiscent or indehiscent. Seeds few or many. Endosperm wanting or fleshy. Embryo straight or nearly so, sometimes oblique, with flat or fluted cotyledons.

Sepals slightly unequal : ovules 2 , ascending : seeds lenticular, sometimes margined.

Sepals ovate, united at the base: filaments united at the base : styles united : capsule not beaked: seeds marginless.

Sepals narrowly oblong, distinct: filaments distinct : styles distinct : capsule long-beaked: seeds margined.

Sepals very unequal : ovules 4-8, pendulous : seeds strongly angled or winged.

Leaf-blades membranous, deciduous : flowers nearly sessile : filaments united into a thick tube: capsule globose : seeds angled.

Leaf-blades leathery, persistent : flowers long-pedicelled : filaments distinct : capsules ovoid: seeds winged.

\section{Stuartia.}

2. MALACHODENDRON.

3. FrankLinta.

4. GORDONIA. 


\section{STUÁRTIA L.}

Shrubs, with upright branched stems. Leaves alternate, deciduous: blades membranous, usually toothed. Flowers perfect, showy, solitary on short axillary peduncles. Sepals mostly 5, slightly unequal, united at the base, persistent, relatively broad, subtended by 2 bractlets. Petals mostly 5, imbricated, cream-colored, silky throughout, crenulate, coherent at the base, deciduous. Stamens numerous in 3-4 series: filaments united into a ring at the base: anthers introrse, versatile. Ovary 5-celled: styles 5, united: stigma terminal. Ovules 2 in each cavity, ascending, anatropous. Capsule globular, hard-crustaceous, loculicidal. Seeds lenticular, with a thick crustaceous testa, marginless. Endosperm fleshy.

1. Stuartia Malacodéndron L. A shrub 1-5 m. tall, its twigs, petioles, lower leafsurfaces and the outer surfaces of the sepals and petals pubescent. Leaf-blades oval, elliptic, or sometimes nearly ovate or obovate, short-acuminate and usually acute, sharply but finely serrate, usually acute at the base, short-petioled: sepals ovate, about $1 \mathrm{~cm}$. long, acute : corolla $8-10 \mathrm{~cm}$. broad : petals obovate, $3-5 \mathrm{~cm}$. long, erose : filaments united into a short tube at the base: styles united, surpassed by the stamens: capsule depressed-globose, $12-17 \mathrm{~mm}$. in diameter, slightly apiculate, its angles very low. [S. Virginica Cav.]

In woods and on hillsides, Virginia to Florida and Alabama. Spring.

\section{MALACHODÉNDRON Cav.}

Shrubs, resembling Stuartia in habit. Flowers perfect, showy. Sepals mostly 6, distinct, relatively narrow, persistent. Petals mostly 6, deciduous. Stamens numerous: filaments distinct: anthers introrse. Ovary 5-celled: styles 5, distinct: stigmas somewhat introrse. Ovules 2 in each cavity. Capsule slightly elongated, sharply 5 -angled, terminating in a stout beak. Seeds margined.

1. Malachodendron pentágynum (L'Her.) Small. A shrub 1-5 m. tall, its petioles, lower leaf-surfaces, outer surfaces of the calyx and corolla pubescent. Leaf-blades ovate, oval or elliptic, $6-12 \mathrm{~cm}$. long, usually acute and short-acuminate, finely but distantly and often inconspicuously serrate, ciliate, varying from acute to subcordate at the base: sepals $5-6$, narrowly oblong, $1-1.5 \mathrm{~cm}$. long, obtuse : corolla $6-7 \mathrm{~cm}$. broad : petals $5-6$, obovate, $3-3.5 \mathrm{~cm}$. long, erose : filaments distinct : styles distinct, about equalling the stamen in length: capsule ovoid, $15-20 \mathrm{~mm}$. long, pubescent, acuminate, with prominent, sharp angles : seeds obovate, $7-8 \mathrm{~mm}$. long, strongly rugose, winged. [Stuartia pentagyna L'Her.]

Along streams, chiefly in the mountains, Kentucky to Georgia. Spring and early summer.

\section{FRANKLÍNIA Marsh.}

Trees, with deciduous leaves, or sometimes shrubs. Leaves alternate : blades membranous, entire or toothed : stipules wanting. Flowers perfect, showy, white, solitary, nearly sessile. Sepals 5 , very unequal, concave, silky, persistent, subtended by $2-4$ bractlets. Petals 5 , concave, nearly distinct, somewhat silky without, the inner the larger, deciduous. Stamens numerous : filaments elongated, often united into 5 groups each adnate to one of the petals : anthers versatile. Ovary 5-celled: styles slender, united: stigmas united into a crenate disk. Ovules 6-8 in each cavity, pendulous. Capsule woody, blunt, loculicidally 5 -valved from top to bottom and septicidually from the bottom. Seeds more or less flattened, angled, with a woody testa. Endosperm wanting.

1. Franklinia Alatamàha Marsh. A shrub or small tree, reaching a height of about $7 \mathrm{~m}$. Leaf-blades oblanceolate or oblong-obovate, $6-15 \mathrm{~cm}$. long, obtuse or acute, sharply serrate, chiefly above the middle, deep green above, tomentose beneath, attenuate into short petioles : sepals suborbicular, $12-14 \mathrm{~mm}$. in diameter, silky, ciliate : corolla 7-9 $\mathrm{cm}$. broad, nearly sessile : petals obovate, somewhat crisped, rounded at the apex, silky without: filaments distinct : capsule subglobose, $1.5-2 \mathrm{~cm}$. in diameter, depressed at the apex : seeds oblong, 12-14 mm. long, wingless. [Gordonia pubescens L'Her.]

In low grounds, along the Altamaha River, near Ft. Barrington, Georgia. Spring.

\section{GORDÒNIA Ellis.}

Trees, with evergreen leaves, or sometimes tall shrubs. Leaves alternate: blades leathery, toothed : stipules wanting. Flowers perfect, long-pedicelled. Sepals 5, unequal, 
silky, persistent. Petals 5, united at the base. Stamens numerous, on the top and inner face of 5 disk-like lobes confluent at the base : filaments distinct, relatively short: anthers versatile. Ovary 3-5-celled : styles united. Ovules 4 in each cavity. Capsule pointed, loculicidally 5 -valved, the valves entire. Seeds 4 , or mostly 2 , in each cavity, each with a membranous wing at the top. Endosperm wanting.

1. Gordonia Lasiánthus (L.) Ellis. An evergreen tree, reaching a height of $25 \mathrm{~m}$., with a maximum trunk diameter of $5 \mathrm{dm}$., the bark thick, in flat parallel ridges. Leafblades narrowly elliptic or oblanceolate, $5-15 \mathrm{~cm}$. long, acutish, obtuse or notched at the apex, appressed-serrate, glabrous, lustrous above, dull beneath, narrowed into short winged petioles : peduncles stout, $3-7 \mathrm{~cm}$. long : sepals suborbicular, $8-10 \mathrm{~mm}$. in diameter, silky with silvery hairs, ciliate : corolla showy, $5-7 \mathrm{~cm}$. broad : petals obovate, oblong or elliptic, obtuse, $2.5-3.5 \mathrm{~cm}$. long, silky without or at length glabrous : filaments united into a thick, fleshy, 5-lobed tube, pubescent within : capsule ovoid, 15-18 mm. long, acutish, silky: seeds somewhat S-shaped, 6-7 mm. long; wing membranous, about as long as the seed-body.

In swamps and hammocks, Virginia to Florida and Louisiana. Flowers in the summer and matures its fruit in the fall. LOBLOLLY BAY. TAN BAY. BLACK LAUREL.

\section{Family 8. TURneràceat H.B.K. Turnera Family.}

Perennial herbs or shrubby plants, with stingless hairs, or glabrous. Leaves alternate : blades simple, sometimes with 2 glands at the base. Flowers mostly perfect, regular, axillary. Calyx of 5 imbricated sepals. Corolla of 5 convolute deciduous petals, often delicate. Androecium of 5 stamens inserted with or near the petals. Filaments distinct, free. Anther-sacs opening lengthwise. Gynoecium compound, of 3 united carpels. Ovary free, 1-celled. Styles 3, entire, at least to the stigma. Stigmas dilated or usually many-cleft. Ovules numerous in 2 rows on the 3 parietal placentae, these opposite the three styles. Capsule 1-celled, 3-valved at the apex or to the base. Seeds slightly curved. Embryo straight in the copious fleshy endosperm.

Herbaceous : stigmas 2-cleft.

Shrubby : stigmas not 2-cleft.

1. Piriqueta.

2. TURNERA.

\section{PIRIQUÈTA Aubl.}

Perennial herbs, sometimes shrubby at the base, with glabrous tomentose hirsute or stellate-pubescent foliage. Leaves alternate: blades entire, toothed or pinnatifid, often biglandular at the base. Flowers axillary, or in reduced panicles. Sepals 5 , imbricated. Petals yellow, 5, inserted below the stamens. Filaments flattened. Anthers somewhat elongated. Stigmas 3, 2-cleft, brush-like. Capsule 1-celled, loculicidally 3-valved to the base. Seeds numerous, curved, with a crustaceous often roughened testa. The plants flower mainly in the spring and summer.

Foliage glabrous, at least to the inflorescence.

Pedicel and calyx glabrous: bracts leaf-like.

Pedicel and calyx pubescent: bracts scale-like.

Foliage tomentose or hirsute throughout.

Stems tomentose.

Stems hirsute as well as tomentose.

1. Piriqueta víridis Small. Glabrous, deep green. Stems simple or sparingly branched near the base, smooth : leaf-blades linear or linear-spatulate on the lower part of the stem, 3-8 cm. long, acute or acutish, repand, not prominently nerved beneath, sessile or short-petioled below : bracts leaf-like: pedicels glabrous : calyx glabrous, turbinate; lobes lanceolate, $6-8 \mathrm{~mm}$. long, acute, ribbed : petals yellow, about $1.5 \mathrm{~cm}$. long: capsules subglobose, $7-8 \mathrm{~mm}$. in diameter, glabrous : seeds about $2 \mathrm{~mm}$. long.

In pine lands, Florida.

2. Piriqueta glabréscens Small. Slender, glabrous to the inflorescence. Stems erect or ascending, often sparingly branched, 4-6 dm. tall, smooth : leaf-blades narrowly linear, $1-5 \mathrm{~cm}$. long, acute or acutish, entire, not prominently nerved beneath, sessile or shortpetioled below, much reduced above : bracts not foliaceous: pedicels tomentose : calyx turbinate, tomentose ; lobes oblong or oblong-lanceolate, acute: petals yellow, spatulate, 1-1.5 cm. long; capsules subglobose, about $5 \mathrm{~mm}$. in diameter. $[P$. glabra Chapm., not Turnera glabra DC.]

In pine lands, peninsular Florida. 
3. Piriqueta tomentòsa H.B.K. Pubescent with stellate tomentum. Stems erect or decumbent, $2-4 \mathrm{dm}$. tall, simple or branched, leafy : leaf-blades leathery, oval, oblong or rarely narrowly oblong-lanceolate, $1-4 \mathrm{~cm}$. long, obtuse, slightly crenate-serrate, sessile or short-petioled below : calyx turbinate or campanulate-turbinate; lobes lanceolate, 5-8 mm. long, acute, slightly spreading: petals yellow, obovate, about $1.5 \mathrm{~cm}$. long: capsules subglobose, $5-6 \mathrm{~mm}$. in diameter, minutely pubescent : seeds fully $2 \mathrm{~mm}$. long.

In pine lands, peninsular Florida.

4. Piriqueta Caroliniàna (Walt.) Urban. Pubescent with fulvous hirsute hairs and stellate tomentum. Stems erect, 1-4 dm. tall, simple or sparingly branched : leaf-blades obovate, oblong or cuneate, lanceolate, or rarely oval, 1-7 cm. long, obtuse, repand or crenate-serrate, sessile or with short petioles: pedicels shorter than the peduncles: calyx turbinate; lobes lanceolate, $8-10 \mathrm{~mm}$. long, acute, slightly spreading: petals yellow, obovate, $1.5-2 \mathrm{~cm}$. long: capsules subglobose, $5-7 \mathrm{~mm}$. in diameter, minutely pubescent: seeds fully $2 \mathrm{~mm}$. long.

In pine lands, North Carolina to Florida and Alabama.

\section{TÚRNERA L.}

Shrubs or shrubby plants, with glabrous or pubescent foliage. Leaves few, alternate: blades entire, toothed or pinnatifid. Flowers solitary in the axils, or sometimes in clusters or racemes, with or without bractlets. Sepals 5, more or less united, imbricated. Petals 5, usually yellow, convolute, inserted at the throat of the calyx-tube. Stamens 5, inserted near the petals. Filaments somewhat flattened, distinct. Anthers 2-celled. Stigmas 3, brush-like. Capsule barely elongated, 3-valved. Seeds curved, with a pitted or rough testa.

1. Turnera aphrodisiaca Ward. A low diffuse shrub, with strigose foliage, or glabrate. Leaves approximate or clustered on the branchlets; blades spatulate or oblongspatulate, leathery, $1-2.5 \mathrm{~cm}$. long, acute, coarsely few-toothed, narrowed into slender petioles, the nerves prominent beneath, impressed above : calyx $4 \mathrm{~mm}$. long, sessile, tubu, lar; lobes oblong or ovate-oblong, shorter than the tube, tips recurving: petals yellow6-8 $\mathrm{mm}$. long, narrowly cuneate : capsules ovoid, 4-6 mm. long.

In dry soil, southern Texas and adjacent Mexico.

\section{FAmily 9. BIXÀCEAE Reichenb. Bixa FAmily.}

Shrubs or small trees. Leaves alternate: blades simple, toothed, lobed or rarely entire. Flowers perfect, solitary or several to many and variously disposed. Calyx of 4-5 usually imbricated sepals. Corolla wanting, or of as many petals as the sepals, deciduous. Androecium of numerous or rarely few stamens. Anthers opening by apical chinks. Gynoecium of 2-several united carpels. Ovary superior, 1-celled, with 2-several parietal placentae which are sometimes well intruded. Styles as many as the placentae, but united. Ovules 2-many on each placenta. Fruit a valvate capsule, the valves bearing the placentae. Seeds numerous, often hairy.

\section{AMOREÙXIA Moç \& Sess.}

Branching shrubs. Leaves alternate: blades palmately lobed. Flowers in terminal panicles. Sepals 5, deciduous. Corolla showy. Petals 5. Stamens numerous : anthers narrow. Ovary 2-celled by the meeting of the placentae. Ovules numerous. Capsule loculicidally 3-valved, the valves leathery, separating from the endocarp and scarious partitions. Seeds numerous, smooth, the bony testa surrounded with a membranous coat.

1. Amoreuxia Wrightii A. Gray. Stems solitary or several from a stout base, $2-5$ dm. tall : leaf-blades $2.5-5 \mathrm{~cm}$. broad, deeply $5-7$-lobed, the lobes mainly obovate, regularly toothed: sepals $1.5-2 \mathrm{~cm}$. long: petals twice as long as the sepals, orange above the brownish base : capsules ovoid to oblong-ovoid, mainly 4-5 $\mathrm{cm}$. long : seeds obovoid.

On dry or stony hills, Texas to Arizona and Central America. Spring to fall.

\section{Family 10. CISTÀCEAE Lindl. Rock-Rose FAmily.}

Shrubs or low woody herbs, with erect or spreading stems. Leaves alternate or opposite : blades simple. Flowers regular, generally perfect, solitary, racemose, 
clustered or paniculate. Sepals 3-5, persistent, when 5 the 2 exterior ones smaller and scale-like, the 3 inner convolute. Petals 5 or 3 , or sometimes wanting, often fugacious. Stamens 8, hypogynous. Gynoecium of several united carpels. Ovary sessile, 1-several-celled. Ovules orthotropous, stalked. Styles united. Stigma entire or 3-lobed. Capsule dehiscent by valves. Seeds several or numerous. Embryo slender, straight or curved. Endosperm starchy or fleshy.

Petals 5, yellow, fugacious or wanting.

Styles obsolete or relatively short: leaves with flat or merely revolute blades.

Styles slender, elongated: leaves scale-like, sometimes subulate.

Petals 3 , not yellow, persistent.

1. Helianthemum.

2. HUDSONIA.

3. LECHEA.

\section{HeLIÁNTHemum Pers. ${ }^{1}$}

Woody herbs or low shrubby plants. Leaves with flat or revolute blades. Flowers complete or some species with both petaliferous and apetalous ones, the petaliferous often showy, with 12-30 long stamens and 20-60 or rarely 8-10 ovules in each ovary. Apetalous flowers with 3-8 short stamens and 6-20, or rarely 3-6 ovules in each ovary, as a rule less than one-half the number in the petaliferous flowers. Style obsolete or short: stigma capitate or 3-lobed. Capsules of the petaliferous larger than those of the apetalous flowers. Embryo curved. The plants flower in the spring or in the spring and summer. Frost-weEd.

Flowers all alike and petaliferous.

Flowers of two kinds, some petaliferous others apetalous.

Petaliferous and apetalous flowers in the same clusters.

Flowers in a dense terminal cyme.

Flowers in scattered or panicled clusters.

1. H. Carolinianum.

Flower-clusters scattered or solitary.

Sepals becoming $6-8 \mathrm{~mm}$. long: lateral nerves of leaves not prominent beneath.

Sepals becoming $4 \mathrm{~mm}$. long: lateral nerves of leaves prominent beneath.

Flower-clusters in more or less elongated thyrsoid panieles.

Sepals of the apetalous flowers fully $2 \mathrm{~mm}$. long at maturity. Sepals canescent-puberulent. Sepals hirsute.

Sepals of the apetalous flowers less than $2 \mathrm{~mm}$. long.

Petaliferous flowers solitary or few, vernal; apetalous flowers numerous, clustered, autumnal.

Petaliferous flowers 1 or 2 , their capsules far overtopped by the apetalous inflorescence.

Petaliferous flowers 5-12, the apetalous inflorescence on short lateral branches.

2. H. corymbosum.

3. H. arenicola.

4. H. Georgianum.

5. H. Nashii.

6. H. thyrsoideum.

7. H. rosmarinifolium.

\section{H. Canadense.}

9. H. majus.

1. Helianthemum Caroliniànum Michx. Stems villous-hirsute or hirsute, erect or ascending, 1-3 dm. tall, often branched at the base, thence simple, or corymbose above : leaves few, often mostly at the base of the stem; blades obovate, oval, oblong or somewhat spatulate, $2-5 \mathrm{~cm}$. long, obtuse or apiculate, ciliate, the upper ones manifestly petioled: flowers few : pedicels becoming 1-2 $\mathrm{cm}$. long : sepals various, the larger ovate, becoming 12$14 \mathrm{~mm}$. long, acuminate, involute at the apex, much longer than broad : corolla yellow, 2.5-3 cm. broad : petals very delicate : capsules subglobose, 7-9 mm. in diameter.

In pine lands, South Carolina to Florida and Texas.

2. Helianthemum corymbòsum Michx. Stems finely and densely canescent, erect, branching from the base, 1.5-3 dm. high : leaf-blades oblong, or the lowest obovate, 2-2.5 cm. long, obtuse or acutish, 6-10 mm. wide, entire, slightly revolute in drying, pale beneath, dark green above, short-petioled: flowers in a nearly naked terminal fastigiate cyme, the petaliferous with $25-30$ stamens and 20 ovules, the apetalous with $3-6$ stamens and 9 ovules: corolla $16-20 \mathrm{~mm}$. broad: pedicels slender, 6-16 $\mathrm{mm}$. long: apetalous flowers nearly sessile : calyx of both kinds woolly-pubescent : outer sepals about equalling the inner: capsules of the larger flowers 4-6 mm. broad, many-seeded, those of the apetalous ones smaller and few-seeded.

In sandy soil, Virginia and North Carolina to Florida and Louisiana.

3. Helianthemum arenícola Chapm. Stems canescent-tomentulose, several from the woody base, erect or spreading, 1-2 dm. long, often branched above : leaf-blades linearoblong, 1-2.5 cm. long, obtuse, only the midrib prominent beneath : flowers solitary or few in terminal clusters, the petaliferous with 25 stamens and 20 ovules, the apetalous with 5 stamens and 10 ovules: sepals various, the larger ovate or oval-ovate, becoming 6-8 $\mathrm{mm}$. long : corolla yellow, $16-20 \mathrm{~mm}$. broad: capsules oval, about $4 \mathrm{~mm}$. long.

In shifting sand, along or near the coast, Florida.

${ }^{1}$ Revised by Dr. John H. Barnhart. 
4. Helianthemum Georgiànum Chapm. Stems erect or spreading, 1-3 dm. long, usually branched at the base and above, often zigzag: leaf-blades oblong or slightly narrower below the middle, $1-2 \mathrm{~cm}$. long, flat or slightly revolute, paler beneath than above, the lateral nerves as well as the midrib prominent beneath : flowers few, the petaliferous with 12-16 stamens and 35 ovules, the apetalous with 8 stamens and 17 ovules: sepals various, the larger ovate or oval, becoming $4 \mathrm{~mm}$. long, acute or slightly acuminate: corolla yellow, 15-18 mm. broad : capsules ovoid-globose, about $4 \mathrm{~mm}$. long, apiculate.

In sandy soil, Georgia to Mississippi and Texas.

5. Helianthemum Náshii Britton. Stems several or numerous, ascending or decumbent, 1.5-4 dm. long, simple or sparingly branched above : leaf-blades oblong or linearoblong, 1.5-3 cm. long, acute or obtuse low down on the stem, the midrib and lateral nerves rather prominent beneath : flowers in thyrsoid panicles, the petaliferous with 15 stamens and 8-10 ovules, the apetalous with 3 stamens and 3 ovules : sepals various, the inner oval or oval-oblong, becoming 3-4 mm. long, obtuse : corolla yellow, 16-20 mm. broad: petals broadly cuneate, slightly eroded : capsules broadly ovoid, $3-3.5 \mathrm{~mm}$. long, blunt.

In the scrub, peninsular Florida.

6. Helianthemum thyrsoideum Barnhart. Similar to $H$. Nashii in habit, but the leaves scarcely veined beneath, the inflorescence less widely branched, and the pedicels and the sepals densely hirsute.

In dry sandy soil, Hillsborough County, Florida.

7. Helianthemum rosmarinifòlium Pursh. Stems erect, $2-7 \mathrm{dm}$. tall, often branching throughout: leaf-blades linear or narrowly linear-oblanceolate, or those on basal shoots broader, $1-2.5 \mathrm{~cm}$. long, revolute, paler beneath than above, the midrib prominent beneath : petaliferous flowers few, on filiform pedicels $1-1.5 \mathrm{~cm}$. long, with 12-20 stamens and 8 ovules, their sepals ovate, $2-2.5 \mathrm{~mm}$. long, their corollas $12-15 \mathrm{~mm}$. broad, their capsules $2-2.5$ $\mathrm{cm}$. long: apetalous flowers in dense clusters, with 3 stamens and 3 ovules, their capsules short-pedicelled, about $1 \mathrm{~mm}$. broad.

In sandy soil, South Carolina and Arkansas to Florida, Mississippi and Texas.

8. Helianthemum Canadénse (L.) Michx. Stem at first simple, later with slender elongated branches, erect, ascending, or sometimes diffuse, 1-6 dm. high : leaf-blades oblong, linear-oblong or oblanceolate, nearly sessile, $1.2-3 \mathrm{~cm}$. long, 4-8 mm. wide, rough and dark green above, paler and canescent beneath, the margins commonly revolute in drying: petaliferous flowers solitary, or rarely 2 together, with 30 stamens and 30-60 ovules, their sepals pilose, their corollas bright yellow, $1.8-3 \mathrm{~cm}$. broad, their capsules ovoid or obovoid, rounded above, $6-8 \mathrm{~mm}$. long, much overtopped by the later elongating axillary branches : apetalous flowers appearing later, axillary, nearly sessile, with 4 stamens and 6-20 ovules, their capsules about $4 \mathrm{~mm}$. in diameter : seeds papillose.

In dry rocky or sandy soil, Maine to Indiana, Wisconsin, North Carolina and Kentucky.

9. Helianthemum màjus (L.) B.S.P. Stem erect, 3-6 dm. !high, at first simple, later with numerous short ascending branches : leaf-blades oblong-lanceolate or oblanceolate, acute or obtuse, $1.5-3.5 \mathrm{~cm}$. long, stellate-canescent beneath, darker above, short-petioled : petaliferous flowers 5-12 in a terminal cymose raceme with 30 stamens and 30-60 ovules, their sepals densely canescent, the outer nearly as long as the inner, their corollas 1.5$2.5 \mathrm{~cm}$. broad, light yellow, their capsules ovoid, 3-4 mm. long, little if at all overtopped by the later axillary branches : apetalous flowers appearing later, with 4 stamens and 6-20 ovules, minute, clustered in the axils, nearly sessile, their capsules about $2 \mathrm{~mm}$. in diameter : seeds evenly reticulated.

In dry soil, Maine to Minnesota, South Dakota, Georgia and Texas.

\section{HUDSÒNIA L.}

Shrubs, with low tufted diffusely branched stems. Leaves small, subulate or scalelike, imbricated. Flowers numerous, yellow, terminating branches. Petals 5, obovateoblong. Stamens 8. Style filiform. Stigma minute. Capsule 3-valved, included in the calyx. Seeds few. Embryo slender, spirally curved. Beach Heather.

Flowers slender-pedicelled : leaves subulate : ovary pubescent.

Ovary pubescent all over: one sepal, at least, with a linear-subulate lobe.

Ovary pubescent at the top: one sepal, at least, with a tooth near the apex. Flowers sessile or nearly so: leaves scale-like: ovary glabrous.

1. H. montana.

2. H. ericoides.

3. H. tomentosa.

1. Hudsonia montàna Nutt. Bushy, somewhat villous throughout, the branches tufted $1-1.5 \mathrm{dm}$. long. Leaves commonly erect, sometimes spreading in age, filiform-subulate, 3-6 mm. long, approximate: pedicels 8-10 $\mathrm{mm}$. long, slender, woolly-villous: flowers 
several : sepals 5-6 mm. long, acuminate, densely pubescent: corolla yellow, 9-11 mm. broad : capsules oval-oblong or broadly oblong, 3-4 mm. long, sparingly pubescent.

On the dry summit of Table Rock and adjacent peaks, North Carolina. Summer.

2. Hudsonia ericoides L. Bushy-branched from the base, greenish, softly-pubescent throughout, 1-2 dm. high, the principal branches slender, ascending. Leaves subulate, 6-8 $\mathrm{mm}$. long, somewhat spreading, densely imbricated on the younger branches, more scattered on the older ones : pedicels very slender, $10-15 \mathrm{~mm}$. long : flowers numerous : corolla about $8 \mathrm{~mm}$. broad : sepals $4-6 \mathrm{~mm}$. long, obtuse or acutish : capsules oblong, slightly pubescent: seeds about 3 .

In dry sandy soil, especially in pine lands near the coast, Nova Scotia to North Carolina. Spring.

3. Hudsonia tomentòsa Nutt. Densely tufted and intricately branched, matted hoary-pubescent, pale, 1-2 dm. high, the branches stout, ascending. Leaves $2 \mathrm{~mm}$. long, oval or oblong, densely imbricated and appressed : flowers sessile, or nearly so, numerous, slightly smaller than those of the preceding species: sepals obtuse: capsules ovoid, glabrous, usually 1 -seeded.

In sands of the seashore and in pine lands, New Brunswick to North Carolina, and on lake and river shores west to Slave Lake and the Lake of the Woods. Spring and early summer.

\section{LÉCHEA L.}

Perennial branching herbs, often woody at the base, with erect or spreading stems, producing leafy shoots at the base in the fall. Leaves numerous : blades entire. Flowers minute, panicled, greenish or purplish. Sepals 5, the two outer smaller and narrower. Petals 3, ovate to linear, inconspicuous, persistent. Stamens 3-12. Stigmas 3, nearly sessile, laciniate, prominent when the plant is in flower. Capsule 3-valved, 3-celled, or by obliteration of the dissepiments 1-celled, about 6-seeded. Embryo curved or spiral. PIN-WEed.

Placentae of the capsule fragile, separating from the thin dissepiments, the margins revolute.

Leaf-blades of the basal shoots ovate or oblong, not more than about 3 times as long as wide.

Outer sepals longer than the inner.

Outer sepals shorter than the inner or about equalling them in length.

Capsules oblong: pedicels $2-4 \mathrm{~mm}$. long.

Capsules globose : pedicels about $1 \mathrm{~mm}$. long.

Foliage villous : stems erect.

Stem-leaves $15-25 \mathrm{~mm}$. long : branches erect or ascending.

Stem-leaves 4-8 $\mathrm{mm}$. long: branches spreading.

Foliage tomentose-canescent: stems ascending. Leaf-blades of the basal shoots linear or lanceolate, more than 3 times as long
as wide.

Stem-leaves with narrowly linear blades : inner sepals 1-nerved.

Stem-leaves with linear or oblong-linear blades : inner sepals 3-nerved. Capsules $1 \mathrm{~mm}$. in diameter.

Capsules $1.5 \mathrm{~mm}$. in diameter.

Capsules ellipsoidal : plant cinereous.

Capsules obovoid: plant green.

2. L. racemulosa.

3. L. villosa.

4. L. divaricata.

5. L. maritima.

6. L. tenuifolia.

7. L. patula.

8. L. Torreyi.

9. L. Leggettii.

Placentae of the capsule leathery, the margins not revolute: dissepiments persistent. 10. L. Drummondii.

1. Lechea mìnor L. Foliage more or less pubescent with appressed hairs. Stems erect, 1.5-6 dm. high, freely branching above, the branches slender, erect or ascending : stemleaves with oval or oblong blades 8-15 $\mathrm{mm}$. long, 4-6 mm. wide, acutish or obtuse, ciliate, the upper smaller than the lower; petioles $2 \mathrm{~mm}$. long: leaves of the basal shoots oval or oblong, obtuse, $6-10 \mathrm{~mm}$. long, 5-6 mm. wide : panicle very leafy : flowers close together, somewhat secund : petals red-purple: outer sepals longer than the inner and longer than the obovoid or globose pod.

In dry open grounds, eastern Massachusetts to Michigan, south to Florida and Louisiana. Summer.

2. Lechea racemulòsa Michx. Foliage slightly pilose-pubescent throughout with appressed hairs. Stems erect, 1.5-5 dm. high, freely branching above, the branches slender, divergent or ascending : leaves of the stem with oblong or linear-oblong, obtuse or acutish blades narrowed at the base, $8-18 \mathrm{~mm}$. long, $3-4 \mathrm{~mm}$. wide: leaves of the basal shoots oval or oblong, 4-8 mm. long, 3-6 $\mathrm{mm}$. wide, obtuse; petioles about $2 \mathrm{~mm}$. long: panicle sparsely leafy, the branches spreading or ascending: flowers on slender divergent pedicels. 2-4 mm. long: outer sepals equalling or shorter than the inner: pod oblong or ellipsoid.

In dry rocky or sandy soil, Martha's Vineyard to Indiana, Florida and Tennessee. Summer.

3. Lechea villòsa Ell. Foliage villous-pubescent with spreading hairs. Stems erect, 3-8 dm. high, branching above, leafy, the branches rather stout, ascending: leaves of the stem with oblong-elliptic acute or acutish blades, 15-25 mm. long, 6-10 mm. wide ; petioles 1 
$\mathrm{mm}$. long : leaves of the basal shoots oval or oblong, obtuse, $6-8 \mathrm{~mm}$. long, 4-6 mm. wide : branches of the panicle ascending, the ultimate branchlets often recurved: pedicels $1 \mathrm{~mm}$. long : flowers more or less secund-scorpioid, close together : petals greenish purple : outer sepals about equalling the inner : pod depressed-globose, $1 \mathrm{~mm}$. in diameter.

In dry soil, Massachusetts to southern Ontario, Nebraska to Florida and Texas. Summer.

4. Lechea divaricàta Shuttlw. Foliage densely villous-pubescent. Stems erect, divaricately branched, the branches slender, very leafy : leaves of the stem and branches small, 4-8 $\mathrm{mm}$. long; blades oval, oblong or linear-oblong, acute, clothed with spreading hairs on both surfaces: inflorescence very leafy : flowers obovoid: pedicels about $2 \mathrm{~mm}$. long, not secund: outer sepals shorter than the inner: pod globose, nearly $2 \mathrm{~mm}$. in diameter.

In dry soil, Florida and Texas. Summer.

5. Lechea marítima Leggett. Foliage tomentose-canescent with whitish hairs. Stems densely tufted, branching from the base, stout, rigid, $1.5-3 \mathrm{dm}$. high, the primary branches spreading or ascending, numerous: flowering branches slender, stiff, divergent, elongated : leaves of the stem 8-20 $\mathrm{mm}$. long, 2-4 mm. wide; blades linear or linear-oblong, blunt or acute: leaves of the basal shoots oblong or ovate-oblong, mainly acute, 6-8 mm, long, 3-4 mm. wide, densely canescent: pedicels $1 \mathrm{~mm}$. long: flowers numerous, clustered: petals reddish: outer sepals shorter than the inner: pod globose, $1 \mathrm{~mm}$. in diameter.

In sands of the seashore and in sandy pine lands, Massachusetts to Virginia and Georgia. Summer.

6. Lechea tenuif òlia Michx. Foliage minutely strigose-pubescent. Stems densely tufted, erect, slender, 1-3 dm. high, divaricately branched above, the branches slender, elongated: leaves of the stem 4-15 mm. long, $1 \mathrm{~mm}$. wide or less ; blades narrowly linear, or sometimes nearly filiform, acute, sessile, or very nearly so: leaves of the basal shoots linear, sessile, 6-8 mm. long, about $1 \mathrm{~mm}$. wide : pedicels $2 \mathrm{~mm}$. long : flowers more or less secund, conspicuously bracted : petals red-purple : outer sepals equalling or exceeding the inner in length : pod globose-oval, $1 \mathrm{~mm}$. in diameter, or slightly more.

In dry.open places, eastern Massachusetts to Wisconsin, Florida and Texas. Summer.

7. Lechea pátula Leggett. Bushy, $1.5-4.5 \mathrm{dm}$. high, the foliage appressed-pubescent. Stems usually divergently branched, but the branches sometimes ascending. Leaves of the stem and branches 4-9 mm. long, $1 \mathrm{~mm}$. or less wide; blades linear or oblong, acute : leaves of the basal shoots canescent ; blades linear-oblong or somewhat spatulate, subacute, 6-10 $\mathrm{mm}$. long, 1-2 mm. wide: flowers minute: outer sepals about equalling the inner in length : pod globose, $1 \mathrm{~mm}$. in diameter.

In dry soil, South Carolina and Florida. Summer.

8. Lechea Torreỳi Leggett. Foliage cinereous-pubescent. Stems much branched, $2.5-4.5 \mathrm{dm}$. high, the branches ascending: leaves of the stem and branches linear, 8-12 mm. long, about $2 \mathrm{~mm}$. wide, acute, those of the basal shoots smaller and narrower, finely appressed-pubescent: flowers numerous, short-pedicelled : calyx densely covered with appressed white hairs: outer sepals shorter than the inner: pod ellipsoidal, $1.5 \mathrm{~mm}$. in diameter.

In dry soil, South Carolina and Florida. Summer.

9. Lechea Leggéttii Britt. \& Holl. Foliage strigose-pubescent but green. Stems erect, 2-6 dm. high, rather slender, spreading or ascending: leaves of the stem $10-25 \mathrm{~mm}$. long, 1-2 mm. wide; blades linear or linear-oblong, acute or obtuse, sessile or nearly so : leaves of the basal shoots oblong-linear, $4-6 \mathrm{~mm}$. long, $1 \mathrm{~mm}$. wide, acute : panicle open, its branches slender and divergent: racemes somewhat secund : pedicels 1-2 mm. long: petals brownish purple : outer sepals nearly equalling the inner in length : pod obovoid, $1.5 \mathrm{~mm}$. in diameter.

In dry open places, Long Island, New York to Indiana and North Carolina. Summer.

10. Lechea Drummóndii (Spach) T. \& G. Foliage sparingly pubescent. Stems 1-2 dm. high, slender, wiry, much branched, decumbent or erect, the branches ascending : leaf-blades narrowly linear, 6-12 $\mathrm{mm}$. long, $0.5 \mathrm{~mm}$. wide, scattered, the upper minute : flowers solitary in the axils of the subulate bracts, secund, slender-pedicelled : pedicels deflexed, 2-4 mm. long in fruit; calyx strigose-pubescent: outer sepals about as long as the inner: pod depressed-globose, $2 \mathrm{~mm}$. in diameter.

In dry soil, Texas. Summer. 


\section{Family 11. Violàceae DC. ${ }^{1}$ Violet Family.}

Herbs, or in tropical regions occasionally shrubs or trees, with simple alternate or basal stipulate leaves, and perfect usually irregular solitary or clustered flowers. Sepals and petals 5, the latter hypogynous, imbricated in the bud, the lowermost often spurred. Stamens 5, the anthers erect, syngenesious or connivent. Gynoecium 3-carpellary. Ovary 1-celled, enclosing numerous ovules on the 3 parietal placentae and becoming in fruit a loculicidal capsule. Seeds anatropous.

Sepals auriculate at base.

Sepals not auriculate at base.

Anthers syngenesious: upper and lateral petals nearly equal.

Anthers connivent: upper and lateral petals markedly unequal.

\section{1. vìorA L.}

1. Viola.

2. Cubelium.

3. Calceolaria.

Leafy-stemmed or acaulescent and scapose herbs, with usually prominent stipules and solitary axillary flowers, often succeeded in the late season by apetalous or cleistogamous freely fruit-producing flowers. Petals spreading, the lowermost saccate or spurred. Stamens 5, the lowermost two appendaged. Capsule 3-valved, elastically dehiscent.

I. Acaulescent : flowers scapose.

Plants not stoloniferous.

Leaf-blades lobed or parted (except in $V$. palmata asarifolia).

Cleistogamous flowers wanting: petals beardless. PedataE.

Cleistogamous flowers present: petals bearded. HETEROPHYLLAE.

Plants always more or less pubescent.

Leaf-blade with the central lobe the largest.

Leaf-blade with the two outer lobes the largest.

Plants comparatively glabrous, or with slight traces of pubescence.

Lobes extending to the center of the leaf-blade. Scapes surpassing the leaves: blades of the latter pedately 5-7lobed.

Scapes not surpassing the leaves: blades variously 3-lobed.

Lobes very shallow.

Leaf-blades subsinuately toothed or parted.

Leaf-blades somewhat palmately 5 -lobed.

Leaf-blades merely crenate or dentate, cordate-ovate in outline, none lobed. COMMUNES.

Plants small (less than $1 \mathrm{dm}$. high).

Leaf-blades reniform-orbicular.

Corolla reddish purple: spur small.

Corolla blue: spur large and broadly saccate.

Leaf-blades deltoid-triangular.

Petioles slightly exceeding the blades.

Petioles usually twice as long as the blades.

Plants large (more than $1 \mathrm{dm}$. high).

Leaves not cucullate; blades attenuate at apex.

Leaves cucullate; blades abruptly acute. Corolla deep purple: scapes exceeding the leaves.

Corolla pale purple: scapes not exceeding the leaves.

Leaf-blades crenate, dentate, or somewhat incised at the base, ovate-sagittate or ovate-lanceolate. SAGITTATAE.

Plants distinctly villous.

Plants glabrate or only ciliate.

Leaf-blades sagittate-lanceolate.

Leaf-blades broader.

Leaf-blades oblong-elliptical.

Leaf-blades deltoid-triangular.

Plants stoloniferous.

Introduced species: corolla purple. ODORATAE.

Native species: corolla not purple.

Corolla yellow. ORBICUlataE.

Corolla white. BLANDAE.

Leaf-blades from broadly ovate to orbicular: cleistogenes deflexed.

Upper and lateral petals twice as long as broad: petioles not spotted.

Upper and lateral petals thrice as long as broad: petioles redspotted.

Leaf-blades from narrowly oval to linear: cleistogenes erect.

Leaf-blades oval or ovate-oblong.

Leaf-blades from lanceolate to linear-lanceolate.

Corolla $2 \mathrm{~cm}$. broad.

Corolla less than $1.5 \mathrm{~cm}$. broad.

Blade and petiole distinct, of nearly equal length.

Blade and petiole coalescent.

II. Caulescent, leafy-stemmed : flowers axillary.

a. Corolla yellow. Hastatae.

a. Rootstock tuberous, white and succulent.

1. V. pedata.

2. V. palmata.

3. V. falcata.

4. V. septemloba.

5. V. vicinalis.

6. V. subsinuata.

7. V. heterophylla.

8. V. villosa.

9. V. Carolina.

10. V. Langloisii.

11. V. Alabamensis.

12. V. affinis.

13. V. papilionacea.

14. V. Missonriensis.

15. V. fimbriatula.

16. V. sagittata.

17. V. amorphophylla.

18. V. emarginata.

19. V. odorata.

20. V. rotundifolia.

21. V. blanda.

22. V. LeConteana.

23. V. primulaefolia.

24. V. denticulosa.

25. V. lanceolata.

26. V. vittata.

27. V. hastata.

${ }^{1}$ Contributed by Mr. Charles Louis Pollard. 
b. Rootstock thick, not succulent, fibrous rooted.

Leaf-blades lobed.

Leaf-blades entire.

Blades from hastate-lanceolate to rhomboidal.

Plant $8-15 \mathrm{~cm}$. high : corolla scarcely veined.

Plant 2-4 dm. high : corolla conspicuously veined.

Blades ovate-reniform.

Plant pubescent: root-leaves usually wanting.

Plant glabrate: root-leaves usually present.

B. Corolla purple, white or cream-colored.

Stipules entire. CANADENSES.

Stipules incised or pinnatifid.

Perennials: stipules much smaller than the leaf-blades. Caninae.

Petals cream-colored, the lower ones purple-veined.

Petals blue or purple, rarely white.

Spur shorter than the petals : stems prostrate.

Spur longer than the petals: stems erect.

Annual: stipules nearly as large as the blades. Tricolores.

28. V. tripartita.

29. V. tenuipes.

28. V. tripartita.

30. V. pubescens.

31. V. scabriuscula.

32. V. Canadensis.

33. V. striata.

34. V. multicaulis.

35. V. rostrata.

36. V. Rafinesquii.

1. Viola pedàta L. Plant glabrous, from a short vertical rootstock : leaves with blades nearly orbicular in outline, pedately divided into 5-11 linear, frequently dentate, lobes, those of the earlier ones broader and spatulate : corolla 2-3.5 cm. broad, blue, pale lilac or rarely white, the two upper petals occasionally deep purple: stigma erostrate : capsules prismatic, $1-1.4 \mathrm{~cm}$. long.

In dry fields, woods and meadows, $\mid$ Maine to Ontario, Minnesota, Florida and Missouri. Spring.

2. Viola palmàta L. Plant mostly solitary from a horizontal rootstock : leaves pubescent, or occasionally glabrate, the blades much shorter than the petioles, cordateovate in outline, more or less deeply 5-13-lobed, 5-15 $\mathrm{cm}$. long when mature, the middle lobe commonly the broadest; blades of the earlier leaves merely crenate-dentate, unlobed : scapes rarely exceeding the leaves: sepals lanceolate, acute: petals deep blue, 1-2.5 $\mathrm{cm}$. long : capsules $8-12 \mathrm{~mm}$. long : cleistogamous flowers and capsules on horizontal or deflexed peduncles.

In woods in upland regions, Maine to Ontario, Minnesota, Georgia and Arkansas. Spring. $-V$. palmata dilatita Ell. has the blades of all or most of the leaves 3-lobed, the large middle lobe ovate, the smaller lateral ones lunate or subfalcate; it occurs with the type and is the prevailing form southward. V. palmata asarifolia (Pursh) House, is villous and has the blades of all or most of the leaves unlobed, the margins merely crenate; it occurs with the type but is not common.

3. Viola falcàta Greene. Plant solitary, from a long perpendicular rootstock : leaves sparingly pubescent, the blades $6-10 \mathrm{~cm}$. long, broadly cordate-deltoid, cleft into several segments, these either simple or lobed, the outer ones distinctly falcate : flowers resembling those of $V$. palmata: cleistogamous flowers and capsules on slender horizontal peduncles, the capsules often partially hypogaeous.

In dry but rich woods, southern Illinois to the mountains of North Carolina and Alabama. Spring and early summer.

4. Viola septémloba Le Conte. Leaves glabrous and succulent, mostly spreading, the earlier ones very short-petioled ; blades cordate-ovate in outline, the first entire, the later dentate or lobed, those of the aestival leaves pedate, 7-lobed, the central lobe the largest, the lowermost lobes frequently runcinate : scapes 1-2 dm. high, surpassing the leaves : sepals lanceolate, whitish margined : corolla $2-4 \mathrm{~cm}$. broad, rather light purple, the petals prominently veined.

In pine lands, Georgia and Florida to Louisiana. Winter and spring.

5. Viola vicinalis Greene. Plant glabrous, $2-5 \mathrm{dm}$. high : leaves long-petioled, the blades of the earlier ones cordate-ovate, those of the later broadly trigonous, with truncate base and very obtuse apex, variously 3 -lobed, the central lobe the largest, the margins entire or obscurely crenate : scapes not surpassing the leaves: corolla large, $4 \mathrm{~cm}$. in diameter, deep purple : petals oblong, nearly equal, the lateral copiously bearded : sepals narrowly lanceolate and acuminate. [V. insignis Pollard. $]$

In dry pine lands, Florida to Mississippi, near the coast. Winter and early spring.

6. Viola subsinuàta Greene. Plant similar to $V$. heterophylla in habit: leaves with traces of pubescence, the blades trigonous in outline, all, even the earliest, subsinuately toothed or parted; petioles very short : scapes slender, ascending, exceeding the leaves: corolla light blue, the petals broad and obtuse : capsules, particularly those from the horizontal cleistogenes, small and short.

On mountain slopes, eastern Tennessee. Spring.

7. Viola heterophýlla Muhl. Plant of low, spreading habit, glabrous and more or less succulent: leaves with blades somewhat rugose-veined, elongated-ovate, cordate, acute, crenate-dentate, entire or somewhat palmately 5-lobed, the middle lobe much the largest; petioles shorter than the blades : scapes $8-15 \mathrm{~cm}$. high : corolla $2-2.5 \mathrm{~cm}$. in diameter, purple, whitish at the base, veiny: sepals linear.

In river swamps and clay soils, Georgia and Florida to Lnuisiana. Spring. 
8. Viola villòsa Walt. Plant low in habit, with a short rootstock : leaves more or less appressed to the ground ; blades reniform or orbicular with a narrow sinus, crenate, obtuse, 2.5-6 cm. wide, dark green, often purple-veined above, hirsute with silvery pubescence, particularly above : scapes exceeding the leaves : corolla reddish purple, 10$16 \mathrm{~mm}$. wide : sepals obtuse, lanceolate : capsules oblong, 6-8 mm. long : cleistogenes on short horizontal peduncles. Spring.

In dry but rich woods and on hillsides, New Jersey and Yennsylvania to Georgia and Alabama.

9. Viola Carolìna Greene. Plant low, depressed, from a stout rootstock : leaves of thick texture, the blades and petioles of nearly equal length, the former cordate ovate, very obtuse, with rounded basal lobes and a narrow sinus, the surface minutely hirsutulous, the margins crenulate; petioles usually densely villous: scapes scarcely exceeding the leaves : sepals ovate-oblong : corolla blue, 1-2 cm. broad, the petals obovate-oblong; spur large and broadly saccate : capsules oblong.

In dry ground, North Carolina to Mississippi. Spring.

10. Viola Langloìsii Greene. Plant low, 4-16 cm. high, spreading, from a short erect rootstock : leaves of firm texture, glabrous ; blades from reniform-cordate to deltoid-triangular, acute, crenate-dentate, 2-4 cm. long, sonewhat shorter than the petioles: scapes exceeding the leaves: corolla large, light blue, with a blunt spur : sepals narrowly lanceolate.

In moist woods, Mississippi to Texas. Spring.

11. Viola Alabaménsis Pollard. Plant low, from a slender, nearly vertical rootstock : leaves small, sparsely hirsute ; blades $1.5-2 \mathrm{~cm}$. long, suborbicular, cordate at base, the slender petiole often twice as long: scape much exceeding the leaves : corolla purple, $2.5 \mathrm{~cm}$. broad : petals oblong, the margins obscurely erose or fimbriate : sepals small, ovate-lanceolate : cleistogenes not observed.

In dry open copses, Cullman and Sucksville, Alabama. Spring.

12. Viola affinis Le Conte. Plant slender and usually solitary, 1-2.5 dm. high, from a short ascending rootstock : leaves dark green, glabrous or somewhat pubescent ; blades long-petioled, cordate-ovate, usually attenuate at apex, with a deep sinus at base, the margins crenate-dentate, $2.5-7 \mathrm{~cm}$. broad, usually spreading at a right angle from the petiole : scapes about as long as the leaves : corolla pale blue : capsules oblong-oval : cleistogenes on filiform deflexed peduncles. [V. obliqua Hill. $]$

In rich shady woods, New York to Georgia and Alabama. Spring.

13. Viola papilionàcea Pursh. Plant stout, with bright green glabrous foliage, from a branching caudex : blades of the leaves $5-13 \mathrm{~cm}$. long, from ovate to reniform, mostly cucullate, cordate at base, the margins crenate : scapes at flowering time exceeding the leaves: corolla $1.5-2.5 \mathrm{~cm}$. broad, deep violet purple, the two upper petals reflexed, the keel petal smaller than the others : sepals lanceolate : capsules oblong.

In meadows and woodlands, Nova Scotia to Minnesota, Georgia andlAlabama. Spring.

14. Viola Missouriénsis Greene. Habit of the next preceding species: blades of the earlier leaves obtuse, subcordate ; those of the later from deltoid to hastate-triangular, glabrous, 4-7 cm. long, the margins remotely crenate-serrate: scapes not surpassing the leaves : sepals oblong-lanceolate, ciliolate : corolla from pale violet to nearly white, the petals obovate and obtuse : cleistogenes short-pedunculate, frequently hypogaeous.

In woods, Missouri to Arkansas and Texas. Spring.

15. Viola fimbriátula J. E. Smith. Plant tufted, densely villous : leaf-blades exceeding the petioles, from ovate-lanceolate and ovate-hastate to oblong, obscurely crenate on the margin, the base truncate or subcordate, occasionally incised or even auriculate: scapes exceeding the leaves: corolla blue, $8-14 \mathrm{~mm}$. broad, the petals oblong: capsules oval : cleistogenes borne on erect peduncles. [ $V$. ovata Nutt.]

In dry soil, Nova Scotia to Missouri, Georgia and Louisiana. Spring.

16. Viola sagittàta Ait. Plant strict, from a stout erect rootstock : leaves glabrous or with very slight traces of pubescence ; blades sagittate, ovate-lanceolate or oblonglanceolate, acute, crenate-dentate toward the apex, the base subcordate or truncate with laciniately toothed or incised auricles: scapes shorter than the leaves : corolla dark purple, the petals entire : capsules prismatic : cleistogenes on erect peduncles.

In wet meadows and marshes, Maine to Michigan, Georgia and Alabama. Spring.

17. Viola amorphophýlla Pollard. Plant spreading in habit, from a stout vertical rootstock, glabrous throughout, and succulent : blades of the leaves elliptical or oblongelliptical, the margins entire or obscurely crenate near the obtuse apex, the base rounded or slightly tapering, rarely with small auricles or incisions; petioles mostly shorter than 
the blades: scapes surpassing the leaves: corolla purple, $2.5 \mathrm{~cm}$. broad : sepals ovatelanceolate: petals oblong, the short spur blunt: cleistogenes borne on erect peduncles. On mountain slopes, Tryon, North Carolina. Spring.

18. Viola emarginàta (Nutt.) Le Conte. Plants usually solitary or sometimes clustered, from an ascending rootstock : leaves glabrous; blades on elongated petioles, from deltoid-triangular to broadly ovate, dentate below the middle, or occasionally deeply cleft or lobed, subcordate at base, the margin slightly decurrent: scapes not surpassing the leaves occasionally branched : corolla bright blue, with oblong distinctly emarginate petals : capsules somewhat angled : peduncles of the cleistogenes erect.

In dry soil, New York to Stone Mountain, Georgia. Spring.

19. Viola odoràta L. Stoloniferous, the stolons rooting freely at the nodes : leaves from pubescent to glabrate ; blades broadly ovate or suborbicular, cordate, obtuse, crenate on the margins : scapes equalling the leaves : flowers fragrant: corolla 1-2 cm. broad, blue : sepals oblong, obtuse : petals beardless: cleistogenes borne on short decumbent peduncles. [V. Thompsonae Chapm. ] Spring.

Locally escaped from gardens in the Atlantic and Pacific States ; established at Smithville, Georgia

20. Viola rotundifòlia Michx. Apparently acaulescent at flowering time, but producing stolons in late summer: leaves glabrate, somewhat pubescent along the petioles ; blades yellowish green, paler beneath, from ovate to orbicular, cordate, crenate, at first 1-5 cm. broad, later 10-13 $\mathrm{cm}$. broad and closely appressed to the ground : corolla yellow, 8-12 mm. broad : sepals obtuse, narrowly oblong, the lateral petals bearded and marked with brown veins : capsules ovoid : cleistogenes on short deflexed peduncles.

In woods, Labrador to Minnesota, and to the mountains of North Carolina and,Tennessee. Spring

21. Viola blánda Willd. Plant glabrate, stoloniferous, from a very slender rootstock : leaves light green; blades thin, from orbicular to subreniform, cordate, with a shallow basal sinus, obtuse at apex, the margins crenate : flower fragrant : corolla white, 6-12 $\mathrm{mm}$. broad, the petals beardless, mostly marked with purple veins: sepals lanceolate, acute : capsules small, oval : cleistogenes few.

In swamps and meadows, New Foundland to British Columbia and southward to the higher mountains of North and South Carolina and Tennessee. April-May.

22. Viola LeConteàna G. Don. Plant abundantly stoloniferous : leaves sparsely pubescent or glabrate, the petioles more or less distinctly flecked with red ; blades bright green above, paler beneath, ovate or suborbicular, obtuse, the basal sinus deep and narrow : scapes not surpassing the leaves : flowers scarcely fragrant : corolla white, $1-2 \mathrm{~cm}$. broad, the petals very narrow, the two uppermost occasionally contorted : capsules larger than those of $V$. blanda. [V. blanda var.amoena (Le Conte) B.S.P. V. alsophila Greene.]

In moist woods, in upland regions, New England to Illinois, Georgia and Alabama. Spring.

23. Viola primulaefolia L. Plant glabrous or rarely somewhat pubescent. stoloniferous in late summer: leaf-blades oval or ovate-oblong, truncate or subcordate at base, the latter somewhat decurrent, the margins entire or crenulate : sepals lanceolate, acuminate : corolla white, 8-12 mm. wide, the petals veined with purple, and almost beardless : capsules oval, 6-10 mm. long, those from the cleistogenes cernuous on short erect peduncles.

In moist ground, New Brunswick to Florida and Texas. Spring.-V. primulaefolia austrdilis Pollard, has much larger and thicker leaf-blades, reddish petioles and larger flowers, with the corolla $1-1.5 \mathrm{~cm}$. broad; more common than the type throughout its southern range.

24. Viola denticulòsa Pollard. Plant 1-2 dm. high at flowering time, 3-4 dm. high in late summer, producing filiform stolons often fully this length: leaf-blades of thin texture, lanceolate, equalling or surpassing the petiole, acute at apex and strongly decurrent, the margin denticulate or subentire, the upper surface sparsely hirsute : scapes not surpassing the leaves : corolla white, $2 \mathrm{~cm}$. broad, the keel petal alone dark purple-veined : sepals lanceolate, scarious margined : cleistogenes erect.

In wet woods near Douglas, Georgia. Spring.

25. Viola lanceolàta L. Plant glabrous, abundantly stoloniferous: leaf-blades lanceolate or linear-lanceolate, decurrent upon the petiole, 5-12 cm. long, obtuse or acutish, the margins obscurely crenulate ; petioles longer than the blades: scapes not surpassing the leaves: sepals lanceolate, acuminate: corolla white, $8-10 \mathrm{~mm}$. broad, the petals beardless, the lower three marked with purple veins : capsules oval, 6-10 mm. long: cleistogenes erect, frequently borne on the stolons.

In wet meadows and on banks of streams, Nova Scotia to Minnesota, Florida and Texas. Spring.

26. Viola vittàta Greene. Plant sparingly stoloniferous, glabrous : leaf-blades linear, 4-10 cm. long, the apex obtuse, mucronate, the margins obscurely crenate ; petioles 
one-third as long as the blades: scapes shorter than the leaves, with long filiform scales: corolla white, the petals small and narrow, thickly beset with brown veins.

In moist pine lands, Florida to Texas. Spring.

27. Viola hastàta Michx. Stem simple, erect, glabrous, 1-3 dm. high, from a short horizontal and succulent tuberous rootstock : cauline leaves short-petioled, borne near the summit of the stem, the blades hastate or ovate-hastate, $2-10 \mathrm{~cm}$. long, denticulate or repand, acute ; basal leaves when present larger, cordate : corolla yellow, 8-16 mm. wide, the spur short : lateral petals bearded : sepals acute, linear-lanceolate : capsules 8-10 mm. long.

In woods in upland regions, Pennsylvania and Ohio to Florida and Alabama. Spring and summer.

28. Viola tripartita Ell. Stem stout, erect, tall, $2-4 \mathrm{dm}$. high, from a thick horizontal rootstock with numerous fibrous roots: leaves $3-5$, borne near the summit of the stem : blades various, an occasional one rhombic-ovate, entire, the majority deeply 3-5lobed or digitately 3-5-divided, the segments pubescent or glabrate, oblong-lanceolate, tapering to base, obtuse at apex, the margins remotely denticulate ; stipules in pairs, scarious, ovate, persistent : peduncles exceeding the leaves at flowering time : corolla yellow, 1.5-2 cm. broad, faintly veined: sepals linear, acuminate: capsules prismatic, glabrous, often bracteate.

In rich woods, North Carolina and Tennessee to Georgia, Florida and Alabama. Spring and early summer. $-V$. tripartita glabérrima (Ging.) Harper is similar to the type, but with the leaf-blades merely toothed, darker green and glabrous : corolla more conspicuously marked with brown veins; it occurs with the type.

29. Viola tenùipes Pollard. Stem simple, erect, low, $8-15 \mathrm{~cm}$. high, from a rootstock similar to that of $V$. tripartita: leaves 3-5, borne at the summit of the stem ; blades glabrate, ovate-lanceolate or hastate-lanceolate, with truncate base and acute apex, the margins repand-denticulate, finely ciliate; stipules ovate, membranaceous ; petiole much shorter than the blade : flowers on filiform peduncles greatly exceeding the leaves : corolla yellow, $1.5 \mathrm{~cm}$. broad : petals narrow, beardless, and quite free from markings : sepals irregular, from linear to linear-ovate : capsules ovoid. [ $V$. hastata var. glaberrima Chapm.]

In dry soil, Georgia to northern Florida and Alabama. Spring.

30. Viola pubéscens Ait. Stem simple, erect, usually villous-pubescent, bearing the cauline leaves near the summit: basal leaves with long petioles, usually absent at lowering time; blades of the cauline leaves ovate-reniform, 5-12 cm. broad, acute or abruptly attenuate, pubescent, the margins crenate-dentate; petioles shorter than the blades : sepals oblong-lanceolate : corolla bright yellow, $12-16 \mathrm{~mm}$. broad, the petals very faintly marked with purple veins : capsule oblong, glabrous or white-tomentose, 10-16 $\mathrm{mm}$. long.

In woods, Quebec to Sou th Dakota southward, especially in the mountains, to South Carolina and Tennessee. Spring.

31. Viola scabriúscula (T. \& G.) Schwein. Stems several, clustered, ascending or somewhat decumbent, glabrous : basal leaves more or less persistent, the blades hroadly ovate, long-petioled: cauline leaves with blades from cordate-ovate to reniform, acute, glabrous, $2.5-6 \mathrm{~cm}$. broad, the margins crenate : sepals linear-lanceolate: corolla pale yellow, 10-16 mm. broad, the petals conspicuously purple-veined : capsule oval, glabrous or white-tomentose, $6-10 \mathrm{~mm}$. long.

In woods, Nova Scotia to Manitoba and southward, especially along the mountains, to South Carolina and Tennessee. Spring.

32. Viola Canadénsis L. Stems clustered, leafy, ascending, 0.7-4 dm. high : leaves short-petioled, glabrous, the blades cordate-ovate, acute or acuminate, $2.5-6 \mathrm{~cm}$. long, the margins serrate; stipules ovate-lanceolate, entire : corolla white or pale violet, 1-2 cm. broad : lateral petals purple-veined, bearded : sepals linear, acuminate : capsule oval, glabrous, 6-8 mm. long.

In woods, Newfoundland to Saskatchewan, North Carolina and Nebraska. Spring and summer.

33. Viola striàta Ait. Stems clustered, glabrous, leafy, usually decumbent, becoming fully $6 \mathrm{dm}$. long in late summer : leaves with slender petioles, the blades ovate or suborbicular, 2.5-6 cm. broad, somewhat pubescent, the later ones acute ; stipules large, ovate, dentate or laciniate: flowers long-peduncled: corolla white or cream-colored, occasionally bluish, 1-2 cm. broad : petals marked with darker veins, the lateral ones bearded: capsule ovoid, glabrous.

In rich or dry woods, Ontario to Minnesota, Georgia and Missouri. Spring.

34. Viola multicaùlis (T. \& G.) Britton. Stems slender, clustered, prostrate or decumbent, 5-20 cm. long : leaves numerous, slender-petioled ; blades finely puberulent, orbicular, cordate at base with a narrow sinus, often mottled or dark-veined, $2.5-4 \mathrm{~cm}$. 
broad, the margins crenulate ; stipules laciniate : peduncles exceeding the leaves : corolla violet-blue, $10-14 \mathrm{~mm}$. wide: petals bearded : sepals lanceolate, acuminate : capsules . glabrous, 6-8 mm. long : late shoots of the season bearing short-stalked cleistogenes.

In woods and thickets, North Carolina to Kentucky, Florida and Texas. Winter to early summer.

35. Viola rostràta Pursh. Stems clustered, erect, leafy: leaves glabrous, with slender petioles, the blades cordate-ovate or the lower reniform, acuminate, 1-4 cm. long, the margin serrulate; stipules laciniate, ciliate : corolla pale violet, $1.5-2 \mathrm{~cm}$. broad, the petals marked with dark veins, and beardless; spur exceeding the petals : sepals linearlanceolate : capsule glabrous, $8 \mathrm{~mm}$. long.

In woods, Quebec to Michigan and along the mountains to Georgia. Spring and early summer.

36. Viola Rafinésquii Greene. Stem slender, glabrous, branching, 7-45 cm. high : leaves glabrous, the blades short-petioled or subsessile, ovate to oblong-lanceolate, crenatedentate or entire; stipules large, foliaceous, pinnatifid: corolla yellowish white, the uppermost petals bluish-tinged, $10-16 \mathrm{~mm}$. wide : sepals linear, nearly as long as the petals : capsule 4-6 mm. long. [V. tenellı Muhl., not Poir.]

In fields and open woodlands, Maine to Michigan, Georgia and Texas. Winter and spring.

\section{CUBÈLIUM Raf.}

A herbaceous caulescent perennial, with nearly entire alternate leaves and small greenish axillary flowers. Sepals 5, equal, not auriculate. Corolla irregular. Petals erect, imbricated in the bud, the lowermost one largest and gibbous below. Stamens 5 , syngenesious, forming a sheath bearing minute glands at the base. Style hooked at the apex. Capsule 3-valved, obscurely 3-lobed. [Solea Ging.]

1. Cubelium cóncolor (Forst.) Raf. Plant pubescent, 3-9 dm. high : leaf-blades oblong or elliptic, acute or acuminate at the apex, tapering at the base to a short petiole: stipules linear : flowers $8 \mathrm{~mm}$. long, on short recurved peduncles, 1-3 in the axils: seeds large.

In moist woods, Ontario to Michigan, North Carolina and Kansas. Spring.

\section{CALCEOLÀria Loefl.}

Perennial herbs or rarely shrubs, with alternate or opposite leaves and small axillary or racemose flowers. Sepals equal, not auriculate. Petals very unequal, the two upper smallest, the lowermost largest, gibbous at base. Anthers connivent, the filaments distinct, the two lower glandular at the base. Capsule elastically 3-valved.

1. Calceolaria verticillàta (Ortega.) Kuntze. Stems clustered, ascending or erect, slightly pubescent, 1-4 dm. high : leaves alternate, often fascicled ; blades linear, 1.5-4 $\mathrm{cm}$. long : stipules subulate or wanting : flowers solitary, white, nodding, 4-6 mm. long.

In dry ground, Kansas to Colorado, Texas and Mexico. Spring and summer.

\section{Order 21. PASSIFLORÀLES.}

Herbs, tendril-bearing vines, shrubby plants or succulent trees with a milky sap. Leaves alternate: blades entire or lobed. Flowers perfect, or mainly dioecious, the staminate and pistillate very different. Calyx of 5 more or less united sepals. Corolla of 5 distinct or partially united petals, sometimes accompanied by a fringed crown. Androecium of 5 stamens, or of 10 stamens in 2 unequal rows. Gynoecium of 3-5 united carpels. Ovary superior, 1-celled, with 3-5 parietal placentae. Stigmas entire, notched or forked. Fruit a berry or a capsule.

Corolla not accompanied by a crown : flowers mainly dioecious, the staminate and pistillate different. Corolla accompanied by a crown : flowers perfect, all alike.

Fam. 1. PAPAYACEAE.

Fam. 2. Passifloraceae.

\section{Family 1. Papayàceae Blume. Papaw Family.}

Shrubs or trees, with a milky sap. Leaves alternate : blades ample, broad, palmately 7-9-lobed. Flowers unisexual, or rarely perfect. Calyx short. Staminate flowers with a salver-shaped corolla : tube slender : lobes 5, valvate or convolute. Androecium of 10 stamens, inserted in the throat of the corolla. Filaments short: anthers adnate to the filaments, 2-celled. Pistillate flowers with 
5 distinct petals and no staminodia. Gynoecium a compound pistil. Ovary 1-celled, or sometimes spuriously 5-celled, free, sessile. Stigmas 5, sessile. Ovules numerous, inserted in two or many series on the 5 placentae. Fruit a fleshy berry, indehiscent. Seeds numerous, flattened, with a variously roughened testa. Endosperm fleshy. Embryo axile. [Caricaceae Dumort.]

\section{CARÌCA L.}

Characters of the family. Custard Apple. Papaw.

1. Carica Papàya L. A small tree, with a simple wand-like stem, 3-6 m. tall, leafy at the top. Leaves large ; blades thick, suborbicular in outline, $2-6 \mathrm{~cm}$. broad, mostly palmately 7 -lobed, pale or glaucous beneath, each lobe pinnately lobed, the segments obtuse or acute, or the larger ones often acuminate; petioles stout: staminate flowers in slender panicles 1-several dm. long, the ultimate clusters rather dense : calyx of the staminate flowers $1-1.5 \mathrm{~mm}$. high, that of the pistillate flowers $5-10 \mathrm{~mm}$. high, the lobes longer than the tube, curved like the bractlets: corolla yellow or reddish, that of the staminate flowers 2.5-3 cm. long; tube slender, dilated near the top; lobes lanceolate or ellipticlanceolate, barely $\frac{1}{2}$ as long as the tube: corolla of the pistillate flowers longer: petals distinct, lanceolate, twisted : berries oblong to subglobose, mainly 2-12 cm. long, yellow or orange, with a milky juice.

In woods, peninsular Florida and the Keys. Throughout tropical America.-Two well-marked forms occur in Florida; the one with a slender green stem and relatively small fruit, the other with a stout purple or purplish stem and large fruit.

\section{Family 2. PASSifloràceat Dumort. Passion-Flower Family.}

Perennial, mostly tropical herbs, vines or shrubby plants, often climbing by means of tendrils, with poisonous emetic and narcotic roots. Leaves alternate : blades simple or rarely compound : stipules usually present. Tendrils arising from the axils of the leaves. Inflorescence axillary. Flowers perfect or rarely polygamous, regular. Calyx of 5 partially united sepals. Corolla of 5 petals inserted in the throat of the calyx, near a filamentous crown, or obsolete. Androecium of 5 stamens. Filaments monadelphous, adhering to the stalk of the ovary. Gynoecium a compound pistil. Ovary usually stalked, 1-celled, with parietal placentae. Styles as many as the placentae, usually 3 , club-shaped. Ovules numerous, anatropous. Fruit fleshy, berry-like, indehiscent. Seeds numerous, enclosed in a pulp, with a brittle sculptured testa. Endosperm thin, fleshy. Embryo straight in the axis of the endosperm.

\section{PASSIFLORA L.}

Perennial herbaceous or shrubby vines, climbing by simple lateral tendrils. Leafblades entire, lobed or variously parted. Flowers perfect, usually showy, solitary or clustered in the axils, or racemously disposed. Calyx sometimes colored: lobes 4-5, narrow, sometimes horned near the apex. Petals $4-5$, about as long as the calyx, or rarely wanting. Crown single, double or triple, its filaments spreading, often filiform. Stamens 4-5: filaments adnate below to the gynophore: anthers elongated, versatile. Stigmas 3, capitate. Berry dry or pulpy. Seeds flattened. Passion-FLower.

Peduncle bearing a conspicuous involucre of 3 bracts near the calyx.

Leaf-blades hastately lobed : bracts of the involucre pinnately 1-3-divided into very slender segments.

Leaf-blades palmately lobed: bracts of the involucre entire.

1. P. foetida.

duncle without an involucre, or this obsolete.

Petioles without glands.

Peduncles destitute of bractlets: upper leaf-blades with lobes broader than long

Peduncles with 2 or 3 bractlets : upper leaf-blades with lobes about as broad as long.

Petioles with glands at the middle or at the base of the leaf-blade.

Glands of the petiole conspicuously remote from the blade.

Upper leaf-blades lobed nearly to the base: peduncles shorter than the petioles.

Upper leaf-blades shallowly lobed: peduncles surpassing the petioles.

2. P. incarnata.

Glands of the petiole contiguous with blade or approximate to it.

A. Foliage glabrous or sparingly pubescent : peduncles solitary or by pairs.

a. Glands elevated from the petioles.

Leaf-blades mostly entire.

Leaf-blades mostly 3-lobed.

3. P. lutea.

4. P. affinis.

5. P. inamoena.

6. P. suberosa.

7. P. pallida.

8. $P$. angustifolia. 
b. Glands sessile at the base of the leaf-blades.

Midale lobe of the leaf-blade less than $1 / 3$ as long as the nearly linear lateral ones.

Middle lobe of the leaf-blade as long as or nearly as long as the cuneate lateral ones.

B. Foliage velvety-pubescent: peduncles clustered in the axils.

9. P. tenuiloba.

10. P. Bigelovii.

11. P. multiflora.

1. Passiflora foètida L. A herbaceous climbing vine, with villous and glandular foliage. Leaf-blades ovate or orbicular-ovate in outline, hastately 3-lobed, 3-10 cm. long, densely pubescent, ciliate, with the more or less prominent denticulations gland-tipped, cordate or subcordate at the base ; petioles as long as the blades or shorter: peduncles shorter than the leaves: bracts 3 , conspicuous, once or thrice pinnately divided into slender segments, the ultimate ones filiform, terminating in glands : sepals $1.5-2 \mathrm{~cm}$. long, pale or somewhat colored within : corolla white or pinkish : petals about as long as the sepals : crown pink, triple : berries ovoid, 3-6 $\mathrm{cm}$. long, dry and inflated.

In valleys, along the Rio Grande, Texas. Also in tropical America.

2. Passiflora incarnàta $L$. A trailing or climbing vine, with minutely pubescent foliage, the stems $3-20 \mathrm{dm}$. long, simple or sparingly branched. Leaf-blades palmately 3-5-lobed, 8-12 cm. long, each bearing 2 glands at the base of the blade, the lobes acute or short-acuminate, serrate; petioles 1-3 cm. long : peduncles 3 -angled, $6-8 \mathrm{~cm}$. long: pedicel stout, about $3 \mathrm{~mm}$. long : bracts 3 , ovate, $3-5 \mathrm{~mm}$. long, entire, glandular : sepals linear-oblong, boat-shaped, each with a horn near the apex, $2.5-3 \mathrm{~cm}$. long, green without, tinged with lavender within : petals linear-oblong, as long as the sepals, pale-lavender, obtuse : filaments of the crown longer or shorter than the petals, lavender, striped with darkpurple and white near the middle: staminal column about $1 \mathrm{~cm}$. long: filaments $5-8 \mathrm{~mm}$. long, spotted with purple: styles club-shaped, $1 \mathrm{~cm}$. long, spotted with lavender, spreading and recurved : berries oblong or oval, 4-10 $\mathrm{cm}$. long, edible.

In dry soil or thickets, Virginia to Missouri, Florida and the Indian Territory. Spring and summer. MAY-POP.

3. Passiflora lùtea L. A slender often high-climbing vine, with a scattered pubescence. Leaf-blades $3-15 \mathrm{~cm}$. broad, 3-lobed, sometimes shallowly so, truncate or cordate at the base; lobes ovate or broader than high, entire, obtuse; petioles without glands : peduncles simple or in pairs, shorter than the leaves, naked: sepals oblong or linear-oblong, $8-12 \mathrm{~mm}$. long: corolla greenish yellow, about $2 \mathrm{~cm}$. broad: petals similar to the sepals in shape : crown of 3 series of filaments : berries subglobose or oval, $1-1.5 \mathrm{~cm}$. in diameter, purple, glabrous.

In woods and thickets, Pennsylvania to Missouri, Florida and Louisiana. Spring and summer.

4. Passiflora affinis Engelm. A glabrous high-climbing vine, with slender tendrils, the stems angled. Leaf-blades $5-10 \mathrm{~cm}$. broad, 3-lobed, glaucous beneath, the lower cordate, the upper truncate or acutish at the base, lobes obovate or oblong, nearly equal, entire, setaceous-mucronate; petioles without glands : stipules setaceous : peduncles $3-6 \mathrm{~cm}$. long, with 2 or 3 setaceous bractlets : sepals $1.5 \mathrm{~cm}$. long: corolla $3-3.5 \mathrm{~cm}$. hroad : petals obtuse, shorter and narrower than the sepals, yellowish: crown with fringe about as long as the sepals : berries subglobose, about $12 \mathrm{~mm}$. in diameter, bluish black, the stipe as long as the diameter of the berry.

In valleys, from the Colorado River to the Rio Grande, Texas. Summer and fall.

5. Passiflora inamoèna A. Gray. A reclining or climbing vine $3-9 \mathrm{dm}$. long, with hirsute foliage, the hairs barbed. Leaf-blades very thin, 8-12 cm. in diameter, deeply 3 -lobed, usually cordate ; lobes oblong to oblong-elliptic or oval, irregularly toothed, or the lateral ones sometimes lobed; petioles each with 2 glands near the apex : peduncles shorter than the petioles, with several setaceous bractlets: sepals triangular-lanceolate, $10-14 \mathrm{~mm}$. long, green : corolla greenish, $2.5-3 \mathrm{~cm}$. broad : berries ovoid or elliptic-ovoid, $3-3.5 \mathrm{~cm}$. long, the stipe not surpassing the persistent calyx.

In valleys, Texas to New Mexico and adjacent Mexico. Spring to fall.

6. Passiflora suberòsa L. A climbing vine, with nearly glabrous foliage. Leaf-blades ovate in outline, $6-15 \mathrm{~cm}$. long, ciliate, 5-nerved at the broadly cuneate or cordate base, 3 -lobed to above the middle ; lobes ovate or triangular, acute or acuminate, the middle one much the larger; petioles 5-15 mm. long, each with 2 glands at or above the middle : peduncles surpassing the petioles, commonly in pairs : calyx greenish, $2-2.5 \mathrm{~cm}$. broad : sepals lanceolate or linear-lanceolate, 8-12 mm. long : corolla wanting : crown-filaments purple at the base, shorter than the sepals: berries subglobose or oval, 10-12 $\mathrm{mm}$. in diameter.

In sandy woods, southern peninsular Florida and the Keys, and in the West Indies.

7. Passiflora pállida L. A slender rather high-climbing vine, with glabrous foliage. Leaf-blades various, entire, oblong to ovate-oblong, 4-10 cm. long, acute or apiculate, 
rounded or subcordate at the base, eciliate: petioles 4-10 $\mathrm{mm}$. long, each with 2 glands near the top : peduncles slightly longer than the petioles, commonly in pairs: involucre wanting : calyx 10-14 mm, broad : sepals linear-oblong : corolla wanting: crown-filaments few, shorter than the sepals : berries ovoid or subglobose, $8-10 \mathrm{~mm}$. long.

In sand, southern peninsular Florida and the Keys. Also in the West Indies.

8. Passiflora angustifòlia Sw. A bushy vine 3-7 dm. tall, with glabrous foliage. Leaf-blades mostly 3-lobed, narrowly oblong, lanceolate or linear, $2-10 \mathrm{~cm}$. long, acute or apiculate, the middle lobe longest ; petioles 1-6 mm. long, each with 2 glands near the top : peduncles surpassing the petioles, often in pairs : involucre wanting : calyx yellowish, 7-12 $\mathrm{mm}$. broad : sepals linear or linear-lanceolate : corolla wanting : crown-filaments in 2 rows : berries subglobose, $5-8 \mathrm{~mm}$. in diameter.

In sand, southern peninsular Florida and the Keys. Also in the West Indies.

9. Passiflora tenuíloba Engelm. A slender bushy or somewhat climbing vine, with glabrous or nearly glabrous foliage. Leaf-blades curious, usually less than $2 \mathrm{~cm}$. long, 8-15 $\mathrm{cm}$. broad; petioles shorter than the usually 3-lobed or entire middle lobe, each with 2 glands, the lateral lobes spreading or recurving, rather prominently nerved, linear, entire, or with 1 or few spreading teeth or lobes, slightly revolute: peduncles slightly longer than the petioles : involucre wanting : sepals oblong, 8-10 $\mathrm{mm}$. long, obtuse, green : corolla wanting : berries subglobose, 1-1.5 mm. in diameter.

In dry soil or on hillsides, Texas to New Mexico and adjacent Mexico. Spring to fall.

10. Passiflora Bigelòvii Small. A slender climbing vine, with glabrous foliage. Leaf-blades as long as broad or nearly so, $2-8 \mathrm{~cm}$. broad, reticulated at maturity, deeply 3 -lobed, the middle lobe often cuneate, 3 -lobed, the lateral lobes unequally once or twice lobed, all segments usually bristle-tipped; petioles $2-6 \mathrm{~mm}$. long, each with 2 glands at the top: peduncles surpassing the petioles: involucre wanting: sepals oblong, $1 \mathrm{~cm}$. long, obtuse : corolla wanting: filaments of the crown shorter than the sepals: berries subglobose, about $1 \mathrm{~cm}$. in diameter.

In sandy or rocky soil, Texas. Spring to fall.

11. Passiflora multiflòra L. A high-climbing vine, with velvety pubescence. Leaf-blades leathery, oblong or slightly broadest below the middle, 5-12 cm. long, apiculate, entire, more or less prominently rugose beneath, rounded or subcordate at the base; petioles 5-12 $\mathrm{mm}$. long, each with 2 glands near the top : peduncles 5-15 mm. long, clustered in the axils : involucre none : sepals oblong or oblong-lanceolate, $5-6 \mathrm{~mm}$. long: petals linear or nearly so, delicate : berries subglobose, 6-8 $\mathrm{mm}$. in diameter.

On prairies or mountain slopes, southern Texas. Summer and fall.

\section{Order 22. OPUNTIÀLES.}

Succulent herbs, shrubs or trees, armed with spines, leafless or essentially so, or rigid leafy herbs, furnished with more or less specialized hairs. Flowers perfect, solitary or cymose. Hypanthium present. Calyx of 4 or 5, or many sepals surmounting the hypanthium. Corolla of 4 or 5 , or many petals. Androecium of usually numerous stamens in several series or collected into groups and partially reduced to staminodia. Gynoecium of 4 or 2-several united carpels. Ovary inferior, 1-celled, with 4 or several parietal placentae. Ovules numerous. Fruit baccate or capsular.

Sepals and petals 4 or 5 each, very different : leaves entire or dissected : erect or climbing plants, with rigid hairs.

Sepals and petals nearly alike, at least the latter numerous : leaves typically mere scales or wanting: succulent plants, usually armed with spines.

Fam. 1. LoAsaceaE.

Fam. 2. OPUNTIACEAE.

\section{Family 1. LOASÀCEAE Reichenb. Loasa Family.}

Herbs or rarely shrubs, with erect trailing or climbing stems, the foliage often pubescent with rigid hairs. Leaves opposite or alternate, without stipules: blades entire, lobed or pinnatifid. Flowers perfect, regular, variously disposed, often opposite the leaves. Hypanthium straight or spirally twisted. Sepals 4-5, imbricated or convolute, often persistent. Corolla white, yellow or red. Petals 4-5, sessile, or with claws. Androecium of numerous stamens or rarely of only 5. Filaments filiform, sometimes collected into groups, often accompanied 
by filiform or petal-like staminodia. Anthers introrse. Gynoecium of 2-5 united carpels. Ovary 1-celled, inferior. 'Styles 2-5, sometimes united. Ovules solitary or numerous at the top of the cavity or on parietal placentae. Fruit a ribbed or angled straight or spiral capsule. Seed with a membranous, cellular or reticulated testa. Embryo straight in the fleshy or rarely horny endosperm or this wanting.

Stamens numerous : style lobed : capsules several-many-seeded.

Filaments inserted below the petals: style 3-lobed : placentae 3.

Outer filaments not petal-like: seeds in 1 row, ascending, angled, wingless.

Outer filaments petal-like: seeds in two rows, horizontal, flattened, winged.

Filaments inserted with the petals and adnate to their bases: style 5-lobed: placentae 5 .

Stamens 5: style entire: capsules 1-seeded.

1. MENTZELIA.

2. TOUTEREA.

3. EUCNIDE.

4. Cevallia.

\section{MENTZELIA L.}

Annual, biennial or perennial herbs, usually armed to the corolla with hooked or barbed rigid hairs. Bark often papery. Leaves alternate : blades relatively broad, sinuate, or lobed. Sepals 5, persistent. Petals 5, equal, deciduous. Stamens numerous. Ovary with 3 parietal placentae. Capsule dry, irregularly opening or 3-valved at the top. Seeds several, angled, ascending, wingless.

Flowers and capsules sessile in the forks of the branches : petals abruptly pointed. Flowers and capsules short-pedicelled: petals truncate and often with a minute apiculation.

1. M. oligosperma.

2. M. Floridana.

1. Mentzelia oligospérma Nutt. Stems erect or ascending, $3-10 \mathrm{dm}$. long, branched at the base or throughout, sometimes diffusely so, brittle: leaf-blades ovate to oblong, more or less rhombic, $1.5-6 \mathrm{~cm}$. long, coarsely toothed or slightly lobed : flowers sessile: hypanthium bristly: sepals narrowly linear-lanceolate, 5-7 $\mathrm{mm}$. long, rigid : petals yellow, obovate or elliptic-obovate, $8-9 \mathrm{~mm}$. long, abruptly pointed, barely distinguishable into blade and claw : capsules cylindric-prismatic, nearly $2 \mathrm{~cm}$. long.

On prairies and plains, Illinois to Colorado, Louisiana, Texas and Mexico. Spring and summer.

2. Mentzelia Floridàna Nutt. Stems branching at the base, the branches trailing or climbing, $5-18 \mathrm{dm}$. long, pale : leaf-blades firm, ovate to deltoid-ovate, $2-8 \mathrm{~cm}$. long, 3 -lobed, toothed, acute at the apex, truncate at the base, the terminal lobe the largest: hypanthium densely pubescent : sepals lanceolate, $5-6 \mathrm{~mm}$. long, acuminate : corolla golden yellow, fully $2 \mathrm{~cm}$. broad : petals cuneate, truncate, and often with a minute apiculation, spreading: capsules cylindric-prismatic, $1-1.5 \mathrm{~cm}$. long, 6 -seeded.

In sandy soil, peninsular Florida and the Keys. Spring and summer.

\section{TOUTÈREA Eaton \& Wright.}

Herbs, pubescent like Mentzelia, with diffuse or climbing stems. Leaves alternate : blades relatively long and narrow, sinuate or pinnatifid. Sepals 5, persistent. Petals 5, often apparently 10 on account of the petal-like outer filaments. Stamens numerous : filaments various, the outer petal-like. Ovules in 2 rows on each placenta. Capsule relatively stout. Seeds numerous, horizontal, flattened, winged. The plants flower mainly in the summer.

Petals less than $1 \mathrm{~cm}$. long: sepals about $1 / 4$ as long as the capsule.

Petals over $1 \mathrm{~cm}$. long: sepals about $1 / 2$ as long as the capsule.

Petals $1.5-2 \mathrm{~cm}$. long : capsules about $5 \mathrm{~mm}$. thick.

Petals 2.5-3.5 cm. long: capsules about $10 \mathrm{~mm}$. thick.

1. T. Wrightii.

2. T. multiflora. 3. T. stricta.

1. Touterea Wrìghtii (A. Gray) Rydb. Stem 3-9 dm. tall, somewhat corymbose above : stem-leaves few ; blades oblong to lanceolate, $2-8 \mathrm{~cm}$. long, sinuate, rather obtuse : flowers several : sepals lanceolate, acuminate, about $\frac{1}{4}$ as long as the mature hypanthium: petals ochroleucous, $5-8 \mathrm{~mm}$. long, obtuse : capsules cylindric, $2-2.5 \mathrm{~cm}$. long.

On plains and prairies, Texas and New Mexico.

2. Touterea multiflòra (A. Gray) Rydb. Stem $3-8 \mathrm{dm}$. tall, widely corymbose above : leaf-blades oblanceolate on the lower part of the stem to narrowly oblong or lanceolate above, $2-10 \mathrm{~cm}$. long, pinnatifid, the teeth narrow, mainly acute : sepals lanceolate from a narrow base, about $\frac{1}{2}$ as long as the mature bypanthium : petals golden yellow, 1.5-2 $\mathrm{cm}$. long, abruptly pointed: capsules slender, about $5 \mathrm{~mm}$. thick.

In dry or stony soil, Colorado to Texas and New Mexico. 
3. Touterea strícta (Osterhout) Rydb. Stem 4-12 dm. tall, more or less corymbose above: leaf-blades oblong to lanceolate, $2-11 \mathrm{~cm}$. long, sinuate-pinnatifid, the teeth broad, obtuse : sepals lanceolate from a broad base, about $\frac{1}{2}$ as long as the mature hypanthium: petals ochroleucous or straw-colored, $2.5-3.5 \mathrm{~cm}$. long, gradually pointed : capsules stout, about $10 \mathrm{~mm}$. thick.

In dry or stony soil, South Dakota to Nebraska, Colorado and Texas.

\section{EUCNÌDE Zucc.}

Annual or biennial herbs, sometimes with succulent tissues. Foliage armed with stinging and barbed pubescence. Stems often weak, widely branched. Leaves alternate: blades broad, toothed or shallowly lobed, or both, commonly long-petioled. Flowers solitary or in cymes. Hypanthium elongating in age. Sepals 5. Petals 5, united at the base. Stamens numerous : filaments united into a ring at the base and adnate to the petals with which they are deciduous. Ovary with 5 parietal placentae. Style 5-lobed. Ovules numerous. Capsule broadened upward, 5-valved at the top. Seeds numerous.

5. Eucnide bartonioides Zucc. Delicate, succulent, the foliage softly and rather thinly hirsute. Stems weak, usually much branched, the branches 1-4 dm. long, spreading and often decumbent : leaf-blades suborbicular, $3-8 \mathrm{~cm}$. in diameter, cordate, coarsely toothed and shallowly lobed; petioles as long as the blades or longer : pedicels surpassing the petioles, 5-15 cm. long, simple: hypanthium bristly-hirsute: sepals lanceolate to linear-lanceolate, much longer than the hypanthium: petals 5 , yellow, oblanceolate to spatulate-oblanceolate, $2-4 \mathrm{~cm}$. long : stamens exserted : capsules turbinate, $1.5-2 \mathrm{~cm}$. long.

In valleys, from the Colorado River, Texas to New Mexico and northern Mexico.

\section{CeVállita lag.}

Herbs, resembling species of Scabiosa, with pale-pubescent and bristly stinging foliage, and papery bark. Leaves alternate : blades sinuate-pinnatifid, rigid. Flowers collected in terminal, hemispheric heads. Hypanthium, like the calyx and petals, plumose-pubescent. Sepals 5, narrow, much longer than the hypanthium. Petals 5, narrow, about as long as the sepals. Stamens 5: filaments short: anthers pubescent, with the connective produced into a narrow tubular appendage. Ovary 1-celled, inferior : style short: stigma capitate. Ovule solitary, suspended. Capsule indehiscent, crowned with the persistent plumose perianth. Seed solitary.

1. Cevallia sinuàta Lag. Bark pale, armed like the rest of the plant with stinging hairs. Stems 1-8 dm. tall, more or less branched : stem-leaves alternate, $2-8 \mathrm{~cm}$. long; blades pinnatifid or sinuate-pinnatifid, scabrous or strigose above, tomentose beneath, the segments obtuse or acutish : heads $2-2.5 \mathrm{~cm}$. broad, plumose as are all the members: hypanthium about $5 \mathrm{~mm}$. high: calyx plumose-pubescent : sepals 5 , linear, much longer than the hypanthium: petals 5 , linear, $7-9 \mathrm{~mm}$. long: filaments 5 , shorter than the petals : capsules about $5 \mathrm{~mm}$. long : seeds $3-3.5 \mathrm{~mm}$. long.

In dry soil or on hillsides, Texas to New Mexico and Mexico.

\section{Family 2. OPUntiàceae H.B.K. Cactus Family.}

Succulent shrubby plants, mostly peculiar to America, usually copiously furnished with spines, which arise from cushions of small or minute bristles (areolae). Leaves usually wanting. Stems depressed, globose, columnar and terete or angled, or flattened and jointed or continuous. Inflorescence often axillary or lateral. Flowers usually large and showy, perfect, solitary. Calyx of few or numerous imbricated sepals, the inner series petal-like. Corolla of numerous petals in 2 or many series. Androecium of numerous stamens in several series. Filaments filiform, sometimes cohering with the base of the petals. Anthers introrse. Gynoecium of several united carpels. Ovary inferior, 1-celled, with several parietal placentae. Styles united, terminal, simple, elongated or pyramidal. Stigmas of the same number as the placentae, variable in shape. Ovules numerous, anatropous, horizontal. Fruit a fleshy berry, or rarely dry, smooth or more or less spiny. Seeds numerous, shining or tubercled, often with a dark more or less furrowed testa. Embryo curved, or thick, fleshy and rounded, in scant or copious endosperm. [Cactaceae Lindl.] 
Stems continuous or not conspicuously jointed : leaves obsolete : spines not barbed : spine-bearing and flower-bearing areolae distinct, with barbed bristles in the former.

Flowers not arising from the tubercles, but from their axils: ovary naked.

Flowers arising from the tubercles or ribs: ovary scaly.

Flowers arising from near to fully developed spine-bearing areolae.

Stems mostly low: seeds tuberculate: embryo straight.

Stems elongated: seeds smooth or pitted: embryo curved.

Flowers arising near the areolae which later develop spines.

Stems conspicuously jointed : leaves scale-like: spines barbed: flowers arising from spine-bearing areolae, which also usually contain barbed bristles.

1. Cactus.

2. ECHINOCERUS.

3. Cereus.

4. ECHINOCACTUS.

5. Opuntia.

\section{CÁctús L.}

Fleshy plants, with globular cylindric or oval simple solitary or clustered stems whose surface is completely covered with variously shaped tubercles, which are usually spirally disposed and bear at the apex, spine-bearing areolae. Leaves obsolete. Flowers arising from near woolly and sometimes also bristly areolae in the axils of or near the base of terete or angled tubercles. Hypanthium naked, funnelform or campanulate, prolonged beyond the ovary. Petals in several rows. Ovary hidden between the tubercles: style filiform. Berry fleshy, more or less emersed. [Mamillaria Haw.]

Flowers from the axils of old or mature tubercles which are not grooved.

Tubercles 4-angled.

Stems less than $1 / 3$ as high as broad.

Stems about $1 / 2$ as high as broad.

Radial spines 9 or more: tubercles densely crowded, much flattened at the base.

Radial spines 7 or fewer : tubercles more loosely disposed, nearly as thick as wide at the base.

Tubercles terete.

Radial spines less than 15, the central solitary : flowers $3.5 \mathrm{~cm}$. long.

Radial spines 40 or more, the centrals $5-8$ : flowers $1.5-2 \mathrm{~cm}$. long.

1. C. Heyderi.

2. C. hemisphaericus.

3. C. meiacanthus.

4. C. sphaericus.

5. C. Texanus.

Flowers from the base of grooves on the upper side of young or developing tubercles.

Flowers yellow.

Flowers at first central and fruit soon pushed aside by the developing tubercles.

Radial spines 12 or more: stigmas $2-5$.

Stems simple or nearly so: seeds $1 \mathrm{~mm}$. in diameter or smaller.

Stems branched into dense tufts: seeds fully $1.5 \mathrm{~mm}$. in diameter.

Radial spines 12 or fewer: stigmas $7-8$.

Flowers and fruit permanently terminal in the woolly top of the stem.

Flowers purple, violet or reddish.

Radial spines 20-30, the centrals 4-5, tawny or yellowish: seeds fully $2 \mathrm{~mm}$. long.

Radial spines $12-40$, the centrals $3-12$, purplish : seeds $1.5 \mathrm{~mm}$. long.

6. C. Missouriensis.

7. C. similis.

8. C. robustior.

9. C. sulcatus.

10. C. radiosus.

11. C. Neo-Mexicanus.

1. Cactus Heỳderi (Muhlenpf.) Kuntze. Stems depressed and flat-topped, 8-12 $\mathrm{cm}$. broad, 2.5-4 cm. high, with numerous elongated tubercles : spines various, radials 10-22, whitish, 5-12 mm. long, the upper mostly shorter more slender and paler than the lower; central solitary, yellowish brown, 4-8 $\mathrm{mm}$. long, stout, straight or nearly so ; flowers reddish white, $2-2.5 \mathrm{~cm}$. long : fruit club-shaped, $1.5-3 \mathrm{~cm}$. long, incurved : seeds decidedly rugose.

In dry soil, Texas to Arizona and Sonora.

2. Cactus hemisphaèricus (Engelm.) Small. Stems hemispheric round-topped, $7-12 \mathrm{~cm}$. broad, with rather long-pyramidal tubercles : spines various ; radials $9-12$, nearly equal, 4-8 $\mathrm{mm}$. long; central solitary, 4-6 mm. long: flowers $2-5 \mathrm{~cm}$. long and broad, dirty white or reddish : fruit club-shaped $2-3 \mathrm{~cm}$. long, incurved : seeds slightly rugose. [Mamillaria hemisphaerica Engelm.]

In sandy soil, northern Texas to New Mexico and adjacent Mexico.

3. Cactus meiacánthus (Engelm.) Kuntze. Stems hemispheric or nearly so, from a top-shaped base, $7.5-12.5 \mathrm{~cm}$. broad, with numerous flattened tubercles varying from 7$18 \mathrm{~mm}$. in length : spines various ; radials 5-9 often $6,6-10 \mathrm{~mm}$. long, straight or slightly curved, whitish or yellowish, the upper ones often shorter than the lower or rarely wanting; central solitary, shorter and stouter than the radials, stout, rarely wanting: flowers reddish white, $2.8-3 \mathrm{~cm}$. long : fruit club-shaped, slightly incurved, $2-3 \mathrm{~cm}$. long.

In sandy soil, Texas to New Mexico and adjacent Mexico.

4. Cactus sphaèricus (Dietr.) Kuntze. Stems proliferous, becoming densely tufted, the branches obovate to club-shaped, $5 \mathrm{~cm}$. high or higher, with narrowly ovoid acutish tubercles varying from 12-16 mm. in length, furnished with wool in their axils: spines narrow ; radials 12-14, bristle-like from a thick base, 7-9 mm. long, white, often curved; central spine subulate, shorter than the radials, straight : flowers yellow, $3.5-5 \mathrm{~cm}$. long: fruit not seen.

On sandy ridges along the Rio Grande, Texas and adjacent Mexico. 
5. Cactus Texànus (Engelm.) Small. Stems proliferous, forming a tufted mass $2.5-6 \mathrm{~cm}$. high, the branches ovoid to globose-obovoid, with tubercles varying from 7-9 $\mathrm{mm}$. in length, their axils furnished with wool and twisted bristles: spines various; radials very numerous in many series, those of the outer series, 30-50, white, hair-like, 12-16 $\mathrm{mm}$. long, more or less crisped, those of the inner series, $10-12$, shorter, about $\frac{1}{2}$ as long as the outer, puberulent, sometimes varying to yellow ; central spines $5-8$, straight, rigid, white or darker above the base, pubescent : flowers yellowish white, $1.5-2 \mathrm{~cm}$. long: fruit club-shaped, 1.5-2 cm. long: seeds 1-2 mm. long, black, shining, pitted. [Mamillaria pusilla var. Texana Engelm.]

In sandy soil, Texas and adjacent Mexico.

6. Cactus Missouriénsis (Sweet) Kuntze. Stems usually simple, subglobose, about $3-5 \mathrm{~cm}$. high, with cylindric-ovoid tubercles $12-14 \mathrm{~mm}$. long, these slightly grooved: spines narrow ; radials $13-17$, whitish, bristle-like, $8-10 \mathrm{~mm}$. long, straight ; central solitary, stouter, 10-12 mm. long, puberulent, or often wanting : flowers yellow to reddish, mostly 2-4 cm. long : stigmas 2-5: fruit subglobose, $6-8 \mathrm{~mm}$. in diameter, scarlet : seeds subglobose, about $1 \mathrm{~mm}$. in diameter or a little smaller, black, pitted.

In dry soil and on prairies, South Dakota to Colorado, Kansas and Texas.

7. Cactus símilis (Engelm.) Small. Stems proliferous, forming tufts $2-3 \mathrm{dm}$. broad : tubercles crowded, often in 8 rows, with woolly axils : spines various; radials $12-15$, white, straight, puberulent, very slender, commonly equal ; central solitary, stouter or wanting: flowers yellow or reddish yellow, $2.5-5 \mathrm{~cm}$. long : stigmas 5 : fruit globose-obovoid, scarlet, $3.5-5 \mathrm{~mm}$. long: seeds subglobose, $1.5 \mathrm{~mm}$. to fully $2 \mathrm{~mm}$. in diameter, conspicuously pitted. [Mamillaria similis Engelm.]

In dry soil, Kansas to Colorado and Texas.

8. Cactus robústior (Engelm.) Small. Stems usually simple, obovoid, $3.5-5 \mathrm{~cm}$. high, with the loosely arranged tubercles often in 13 rows : spines various; radials $10-12$, rather stout, 6-16 $\mathrm{mm}$. long; central solitary, stout, about $12 \mathrm{~mm}$. long: flowers pale yellow, $3.5-4 \mathrm{~cm}$. long and broad : stigmas 7-8: fruit globose-obovoid, $6-10 \mathrm{~mm}$. long: seeds about $2 \mathrm{~mm}$. long. [Mamillaria simnlis var. robustior Engelm.]

In sandy soil, Oklahoma and the Indian Territory to Texas.

9. Cactus sulcàtus (Engelm. ) Small. Stems proliferous forming tufted masses several $\mathrm{dm}$. high : tubercles oblong-ovoid, spreading from dilated bases: spines various; radials 8-12, straight, gray or whitish; central solitary, longer, slightly recurved : flowers yellowish, fully $5 \mathrm{~cm}$. long and broad: stigmas 7-10: fruit greenish, oblong: seeds about twice as long as broad, nearly smooth. [Mamillaria sulcata Engelm.]

In dry soil, Texas.

10. Cactus radiòsus (Engelm.) Coulter. Stems oblong-ovoid or cylindric, 5-12 cm. high, simple or sparingly proliferous : spines various; radials 20-30, white, or darker near the apex, 6-8 mm. long, conspicuously unequal, straight; centrals 4-5, stouter than the radials, 8-12 mm. long, yellowish tawny, the lower shorter than the upper: flowers violet or deep purple, $3.5-5.5 \mathrm{~cm}$. long and broad : fruit oval, about $2 \mathrm{~cm}$. long, green : seeds narrowly obovoid, fully $2 \mathrm{~mm}$. long, yellowish or brown, pitted.

In dry soil, southern Texas to New Mexico and adjacent Mexico.

11. Cactus Neo-Mexicànus (Engelm.) Small. Stems subglobose to ovoid or cylindric, $3.5-10 \mathrm{~cm}$. high, simple or proliferous near the base : spines various : radials $12-40$, slender, mostly $6-9 \mathrm{~mm}$. long; centrals $3-12$, purple : flowers purplish, flat, $5-6 \mathrm{~cm}$. broad : fruit oval-obovoid, $2 \mathrm{~cm}$. long : seeds oblong-obovoid, about $1.5 \mathrm{~mm}$. long, nearly smooth. [Mamillaria vivapara $\beta$ radiosa Neo-Mexicana Engelm.]

In dry soil, Kansas to Utah, Oklahoma, Texas, Arizona and adjacent Mexico.

\section{ECHINOCÈREUS Engelm.}

Plants with ribbed and angled or tubercled ovoid cylindric or columnar nearly continuous stems, the vertical ribs angled or tubercled with numerous spine-bearing areolae. Leaves wanting. Flowers arising from areolae situated just above fully developed, spinebearing areolae. Hypanthium prolonged beyond the ovary, bearing naked or pubescent scales which are sometimes spiny in their axils. Style filiform. Fruit fleshy. Seeds tuberculate, almost destitute of endosperm. Embryo straight.

Radial spines $20-30$, pectinate.

Radial spines 4-12, not pectinate.

A. Joints over $2 \mathrm{~cm}$. thick.

Central spines usually $2-4$.

Central spines al ways solitary.

1. E. caespitosus.

2. E. dubius. 
Longer radial spines over $1 \mathrm{~cm}$. long: stems erect.

Longer radial spines less than $1 \mathrm{~cm}$. long: stems procumbent.

3. E. Fendleri.

B. Joints less than $2 \mathrm{~cm}$. thick.

Radial spines 4-6: stems more or less angled : flowers over $7 \mathrm{~cm}$. broad.

Radial spines 9-12: stems terete: flowers less than $6 \mathrm{~cm}$. broad.

4. E. Berlandieri.

5. E. procumbens.

6. E. Poselgeri.

1. Echinocereus caespitòsus Engelm. \& Gray. Stems ovoid, globose or cylindricovoid, $2.5-5$ or rarely nearly $15 \mathrm{~cm}$. high, solitary or commonly $6-12$ stems together, the ribs 12-13, straight; tubercles confluent: areolae close together : spines numerous, white or rarely pink or brown; outer 20-30, straight or slightly recurved, pectinate, the lateral ones 4-8 mm. long, the upper and lower shorter; central spines wanting or rarely 1 or 2 but very short : flowers rose-purple, $5-7.5 \mathrm{~cm}$. long an d nearly as broad : hypanthium furnished with cushions bearing brown or black bristles : fruit ovoid, green, $18-20 \mathrm{~mm}$. long: seeds black, 1.2-1.4 mm. long, tuberculate.

On prairies, Kansas to Texas and adjacent Mexico.-A variety with reddish or chestnut-brown spines, is E. caespitosus castàneus Engelm.

2. Echinocereus dùbius (Engelm.) Small. Stems ovoid-cylindric, $12-20 \mathrm{~cm}$. high, pale green, rather flabby, usually tufted, the ribs 7-9, with tubercles: areolae remote : spines white, somewhat translucent ; lateral ones radiant, $12-30 \mathrm{~mm}$. long, terete or slightly angled, upper ones reduced or obsolete ; central spines 1-4, straight or curved, 3.5-7.5 cm. long, angled : flowers pale purple, $6 \mathrm{~cm}$. long and broad : fruit green or purplish, 2.5-3.5 $\mathrm{cm}$. long, spiny: seeds globose-ovoid, 1.2-1.4 $\mathrm{mm}$. long, tuberculate. [Cereus dubius Engelm.]

In river bottoms, southern Texas and adjacent Mexico.

3. Echinocereus Féndleri (Engelm.) Small. Stems ovoid to cylindric-ovoid, 7.5-20 $\mathrm{cm}$. high, $5-7.5 \mathrm{~cm}$. thick, simple or branched at the base, the branches tufted, the ribs 9-12, sometimes oblique, tuberculate : areolae less than $1.5 \mathrm{~cm}$. distant: spines short ; radials $5-10$, straight or sometimes curved, variable, lowest one 12-25 mm. long, shorter than the rest, angled, the next 2 about as long or longer, more or less blackish; succeeding ones shorter and weaker, 6-14 $\mathrm{mm}$. long, occasionally accompanied by a spine at the top of the areolae surpassing all the rest in length; central spine solitary, nearly terete, $2.5-5 \mathrm{~cm}$. long, reddish black, upcurved from a bulb like-base: flowers $6-8.5 \mathrm{~cm}$. broad, deep violet purple : fruit $2.5 \mathrm{~cm}$. long, purplish green, edible : seeds less than $1.5 \mathrm{~mm}$. long. [Cereus Fendleri Engelm. ]

In dry soil, Utah to Texas, Arizona and northern Mexico.

4. Echinocereus Berlandièri (Engelm.) Small. Stems jointed, spreading, decumbent, much-branched, the joints nearly terete, $3.5-15 \mathrm{~cm}$. long, $2-2.5 \mathrm{~cm}$. thick, their ribs $5-6$, with distinct tubercles: areolae quite close together: spines various; outer white, 6-8, radiant, 8-10 mm. long ; central solitary, $10-25 \mathrm{~mm}$. long, yellowish brown : flowers purple, $5-10 \mathrm{~cm}$. long: fruit ovoid, nearly $2 \mathrm{~cm}$. long, green, furnished with bristles : seeds 1 mm. long, tuberculate. [Cereus Berlandieri Engelm.]

In river valleys, southern Texas.

5. Echinocereus procúmbens (Engelm.) Small. Stems jointed, diffusely branched, the joints nearly terete or 4-5-angled, $1.5-10 \mathrm{~cm}$. long, 12-16 mm. thick, contracted at the base, with 4 or 5 rows of distinct tubercles : spines rigid, rather slender; outer white, radiant, 5 or $4-6,2-4 \mathrm{~mm}$. long ; central solitary, stouter than the outer, 4-6 mm. long, ascending or wanting: flowers delicate purple, fully $7.5 \mathrm{~cm}$. long : fruit green, ovoid, 12-16 $\mathrm{mm}$. long: seeds lenticular, nearly $1 \mathrm{~mm}$. thick. [Cereus procumbens Engelm.]

In river valleys, southern Texas.

6. Echinocereus Posélgeri (Coulter) Small. Stems weak, erect or reclining, sparingly branched, the joints slender, $30-60 \mathrm{~cm}$. long, 8-16 mm. thick, the ribs 8 , not very prominent, furnished with closely set areolae : spines bristle-like; outer white, 9-12, straight, barely $2 \mathrm{~mm}$. long; central solitary, 4-6 mm. long, whitish to brown or black : flowers rose or purple, $5 \mathrm{~cm}$. long and broad : fruit about $2 \mathrm{~cm}$. long, clothed with white and black bristles and wool: seeds less than $1 \mathrm{~mm}$. long, tuberculate. [Cereus Poselgeri Coulter.]

On rocky ridges, northern Texas and adjacent Mexico.

\section{CÈrEUS Mill.}

Plants with elongated cylindric prismatic or narrow angled or ribbed stems. Spinebearing areolae more or less remote. Leaves obsolete. Flowers arising from areolae situated above fully developed spine-bearing areolae. Hypanthium prolonged beyond the ovary. Styles slender. Stigmas several. Fruit fleshy or dry. Seeds smooth or pitted. Embryo curved. 
Stems erect: branches equally 3-8-angled. Branches 6-8-angled. Branches 3-4-angled.

Stems reclining or procumbent: branches climbing, unequally 3-5-sided. Central spine minute: radial spines conic: plants with aërial roots.

Central spine 1-2 cm. long: radial spines subulate: plants without aërial roots.

1. C. monoclonos.

2. C. princeps.

3. C. triangularis.

4. C. Baxaniensis.

1. Cereus monoclònos DC. Stems columnar, 1-3 m. tall, erect, green, the ribs 6-8, obtuse: spines brownish, radiant, varying from very short to $3.5 \mathrm{~cm}$. in length : flowers mainly white, $15 \mathrm{~cm}$. long : fruit about $5 \mathrm{~cm}$. long.

In sand, peninsular Florida and the West Indies.

2. Cereus prínceps Pfeif. Stems erect, $1-3 \mathrm{~m}$. tall, $5 \mathrm{~cm}$. thick, 3-4-angled : areolae distant: spines unequal ; outer radiant, 4-6, stout, often 2.5-3.5 mm. long; central deflexed : flowers white, $17-20 \mathrm{~cm}$. long, 13-15 cm. broad : fruit oval, 5-7.5 cm. long, spiny, scarlet without, red and pulpy within: seeds $3-3.5 \mathrm{~mm}$. long, smooth and shining.

Along the lower Rio Grande on the Mexican side and probably on the Texas side. WUerzle.

3. Cereus triangulàris (L.) Haw. Stems reclining or procumbent, elongated, branched, the branches often rooting at the joints, 3-angled or with a flat side and 2 grooved sides, the joints commonly $32 \mathrm{~cm}$. long, $5-7.5 \mathrm{~cm}$. broad, occasionally twisted, the ribs at first wing-like, with remote areolae : spines $3-5$, rigid, blackish, somewhat recurved, 2-4 $\mathrm{mm}$. long, upper ones shorter than the lower : flowers white, $20 \mathrm{~cm}$. broad : fruit commonly $10 \mathrm{~cm}$. long, scarlet, smooth.

In sand, peninsular Florida, the West Indies and Central America.

4. Cereus Baxaniénsis Karw. Similar to $C$. triangularis in habit, but lacking the aërial roots. Stems sometimes $8 \mathrm{~m}$. long, the joints various, a 3-angled one often arising from a 5-angled one: spines 5-8, the radial bristle-like or subulate, brittle, the central one 1-2 cm. long: flowers and fruit unknown.

In sandy soil or coral rock, Florida Keys and the coasts of the West Indies and tropical America

\section{ECHINOCÁCTUS Link \& Otto.}

Fleshy plants, with globular oblong or cylindric stems, with spine-bearing ribs or vertical or spiral rows of tubercles. Leaves obsolete, flowers arising from areolae on the tubercles near the areolae which later produce spines. Hypanthium with naked scales or others bearing wool in their axils, prolonged beyond the ovary. Petals numerous, merging into the sepals. Ovary 1-celled: style columnar. Stigmas slender, numerous. Berry fleshy or dry, with scales, or tufts of bristles. Seeds often with endosperm. Embryo curved. Spines, especially the central, very slender, terete.

Ribs less than 10 : central spines 4 .

Ribs more than 12: central spines 1-3.

Spines, especially the central, stout, flattened.

Central spines straight or slightly eurved.

Central spines hooked.

Radial spines mostly 8 : central spines $5-15 \mathrm{~cm}$. long : flowers $2.5-3.5 \mathrm{~cm}$. long.

Radial spines 10-12 : central spines $25-35 \mathrm{~mm}$. long : flowers 5-7 cm. long.

1. E. Schottii.

2. E. setispinus.

3. E. Texensis.

4. E. Wrightii.

5. E. Muhlenpfordtii.

1. Echinocactus Schóttil (Engelm.) Small. Stems ovoid or cylindric-ovoid, 10-15 $\mathrm{cm}$. high, $5-7.5 \mathrm{~cm}$. thick, usually solitary, the ribs often 8 , oblique : spines all or some variegated with red and white; outer 15-17 radiant, straight, variable in length; central usually 4 , of 2 kinds; uppermost $3-4 \mathrm{~cm}$. long, flat above, keeled beneath, straight or slightly curved, the three lower ones much shorter, nearly terete or somewhat flattened, straight : flowers mainly purple, $5-7.5 \mathrm{~cm}$. long. [E. bicolor var. Schottii Engelm.]

On limestone hills, southern Texas and adjacent Mexico.

2. Echinocactus setispìnus Engelm. Stems subglobose, solitary, $5-9.5 \mathrm{~cm}$. in diameter, the ribs 13 , somewhat oblique, more or less undulate or even slightly interrupted : spines various; radials $14-16$, bristle-like, $1-2 \mathrm{~cm}$. long, the upper longer than the rest and like the lower, yellowish brown, the lateral ones white; centrals $1-3$, darker than the radials, 24-32 $\mathrm{mm}$. long, bristle-like : flowers $4-7 \mathrm{~cm}$. long, yellow and scarlet within: fruit subglobose, about $8 \mathrm{~mm}$. in diameter, red : seeds obliquely globose-ovoid, 1.2-1.6 $\mathrm{mm}$. long, tuberculate.

In mesquite thickets and dry soil, from the valley of the Brazos, Texas, southward into Mexico.

3. Echinocactus Texénsis Hoepf. Stems depressed or rarely subglobose, 2-3 dm. broad, seldom over $15 \mathrm{~cm}$. high, solitary, simple, the ribs 13-27, usually 21 , wavy : spines reddish, stout, flattened, clustered ; radials $6-7$, straight or slightly curved, spreading, 12-20 $\mathrm{mm}$. long, rarely longer or shorter; central one surpassing the outer, commonly 4-5 mm. broad or slightly broader, straight or slightly curved : flowers orange and scarlet below to 
white above, about $5 \mathrm{~cm}$. long : fruit scarlet, subglobose, $16-18 \mathrm{~mm}$. in diameter : seeds reniform, 2.4-2.8 mm. long, black, smooth and shining or minutely pitted.

On prairies, south-central Texas and adjacent Mexico.

4. Echinocactus Wrìghtii (Engelm.) Small. Stems ovoid or oval, $7.5-15 \mathrm{~cm}$. high, 5-8.5 cm. thick, the ribs 13 , with interrupting tubercles grooved to the base : spines various ; radials about $8,3-5 \mathrm{~cm}$. long, the upper straight, flattened, the 3 lower hooked, terete, darker than the upper; central solitary, 5-15 cm. long, erect, straw-colored with a dark tip, zigzag, hooked : flowers dark purple, 2.5-3.5 cm. long: fruit reddish, 1.5-2.5 $\mathrm{cm}$. long, fleshy : seeds flattened, curved, 1.4-1.6 mm. long, tuberculate, keeled along the back. [E. uncinatus var.? Wrightii Engelm.]

In dry soil, along the Rio Grande, Texas and adjacent Mexico.

5. Echinocactus Muhlenpfórdtii Fen. Stems globose-ovoid to oblong-cylindric, 10$20 \mathrm{~cm}$. high, the ribs often 13 , more or less oblique: spines various ; radials 10-12, subulate, bristle-like, 12-32 mm. long, the upper longer than the lower ; central solitary, firm, $25-35 \mathrm{~mm}$. long, hooked : flowers $5-7 \mathrm{~cm}$. long, yellow and scarlet within : fruit globular, red, $8-10 \mathrm{~mm}$. long.

In sandy soil, Texas and adjacent Mexico.

\section{OPÚNTIA Mi}

Fleshy plants, with conspicuously jointed stems, the joints flat or terete. Leaves scalelike, caducous, spirally arranged. Areolae axillary, usually spine-bearing. Flowers lateral, arising from the cushions of remote bristles of the areolae. Hypanthiun bearing areolae, not prolonged beyond the ovary. Sepals spreading, in several rows. Petals forming a rotate corolla. Ovary 1-celled : style cylindric : stigma 5-8-lobed. Berry more or less pearshaped, fleshy or sometimes dry. Seeds flattened or disk-like. Embryo curved around the endosperm. Prickly Pear.

Joints flat.

Spines wanting.

Spines present, sometimes deciduous.

Fruit fleshy.

Spines flattened.

Stems erect.

Plants usually less than $12 \mathrm{dm}$. tall : flowers mostly over $7.5 \mathrm{~cm}$. broad.

Plants usually over $12 \mathrm{dm}$. tall : flowers mostly less than $7.5 \mathrm{~cm}$. broad.

Stems procumbent.

Spines terete or nearly so, sometimes barely angled.

Flowers over $5 \mathrm{~cm}$. broad.

Joints mainly over $12 \mathrm{~cm}$. long: flowers over $11 \mathrm{~cm}$. long.

Joints mainly less than $12 \mathrm{~cm}$. long : flowers less than $9 \mathrm{~cm}$. long.

Roots fusiform or tuberous.

Joints narrowly obovateor oblong-obovate : species campestrian. Joints broadly obovate or orbicular-obovate : species Floridian. Roots fibrous.

Spines white tinged at the ends. Spines brownish black.

Flowers less than $5 \mathrm{~cm}$. broad.

Spines less than $2.5 \mathrm{~cm}$. long: joints about twice as long aswide, or

Spines over $2.5 \mathrm{~cm}$. long : joints_many times as long as thick.

Fruit dry.

Joints terete, slender.

1. O. Ficus-Indica.

2. O. Tuna.

3. O. Engelmannii.

4. O. tortispina.

5. O. grandiflora.

6. O. macrorhiza.

7. O. austrina.

8. O. humifusa.

9. O. fusco-atra.

10. O. Opuntia.

11. O. Pes-Corvi.

12. O. polyacantha.

13. O. leptocaulis.

1. Opuntia Fìcus-Índica (L.) Mill. Stems erect, 12-18 dm. tall, proliferous : trunk cylindric, woody in age, the joints thick, obovate to elliptic, 10-15 $\mathrm{cm}$. long, with the cushions of bristles immersed, spineless or sometimes with a very short spine : flowers yellow, $7.5-10 \mathrm{~cm}$. broad : fruit obovoid, bristly, 5-6 cm. long, edible, the pulp red.

In sand, peninsular Florida and the West Indies.

2. Opuntia Tùna (L.) Mill. Stems erect, $9-12 \mathrm{dm}$. tall, proliferous, the joints oval or elliptic, $10-20 \mathrm{~cm}$. long: cushions or bristles remote above, a cluster of 4-6 short rigid or subulate yellow spines, varying from very short to $3.5 \mathrm{~cm}$. in length : flowers yellow or reddish yellow, $7.5-10 \mathrm{~cm}$. broad : fruit rather pear-shaped, 5-6 cm. long, edible.

In sandy soil, peninsular Florida, the West Indies and Central America.

3. Opuntia Engelmánnii Salm-Dyck. Stems erect, $12-18 \mathrm{dm}$. tall, forming a woody trunk, sometimes $15 \mathrm{~cm}$. thick and clothed with a grayish bark, the joints pale green, obovate or orbicular-obovate, becoming $30 \mathrm{~cm}$. long and sometimes $22 \mathrm{~cm}$. broad ; cushions of bristles remote : spines few, $2.5-3.5 \mathrm{~cm}$. long, or some shorter, flattened or angled, straw- 
colored to red, straight or curved, deflexed or spreading : flowers yellow within, red without, $6-7.5 \mathrm{~cm}$. broad : fruit globose-obovoid or nearly so, $5 \mathrm{~cm}$. long, purplish without, the pulp insipid or nauseous : seeds $3-4 \mathrm{~mm}$. long, margined.

In valleys, Texas to California and Mexico.

4. Opuntia tortíspina Engelm. Stems procumbent, the branches ascending, the joints orbicular-obovate, $15-20 \mathrm{~cm}$. long, with cushions or yellowish bristles, $2.5-3.5 \mathrm{~cm}$. distant : spines white, $3-5$ together, $3.5-6 \mathrm{~cm}$. long, angled, channeled, often spirally twisted, accompanied by $2-4$ spines about $\frac{1}{2}$ as long, below them : flowers sulphur-yellow, $6-7.5 \mathrm{~cm}$. long : seeds suborbicular, 4-6 mm. broad.

On plains, Nebraska to the Indian Territory and Texas.

5. Opuntla grandiflòra (Engelm.) Small. Stems ascending, branching, the joints suborbicular to obovate, $12-15 \mathrm{~cm}$. long, bright green : bristle-cushions remote, the bristles slender : spines sometimes wanting or obsolete : flowers yellow except the red center, 11$12.5 \mathrm{~cm}$. broad : fruit narrowly club-shaped, $6 \mathrm{~cm}$. long: seeds $5-6 \mathrm{~mm}$. broad. [ 0 . Rafinesquei var. grandiflora Engelm. ]

In sandy soil, along the Brazos River, Texas.

6. Opuntia macrorhìza Engelm. Stems prostrate or ascending from fusiform or thick-tuberous roots, the joints narrowly obovate or oblong-obovate, bright green, 5-8 $\mathrm{cm}$. long, with small leaves about $10 \mathrm{~mm}$. long : bristle-cushions remote, near the base or margins of the joints, the bristles yellowish brown: spines scattered over the joints or chiefly near the top, solitary or 2-3 together, white or variegated, slender, spreading or deflexed : flowers pale yellow, red at the base, $5-7.5 \mathrm{~cm}$. broad : fruit obovoid, green or pale purple, $3.5 \mathrm{~cm}$. long : seeds $5 \mathrm{~mm}$. thick, acute-margined.

In sterile soil, Kansas to Arkansas, Texas and Arizona.

7. Opuntia austrìna Small. Stems more or less spreading, shrubby at the base, from tuberous roots, the joints broadly obovate or orbicular-obovate, deep green, $5-11 \mathrm{~cm}$. long, or rarely somewhat longer, with early deciduous leaves mostly less than $10 \mathrm{~mm}$. long: bristle-cushions chiefly near the margins of the joints, the bristles sordid or tawny : spines above the middle of the joints and near the edge, usually 2 together but one of them very small or deciduous, whitish or pinkish and reddish near the base and apex, twisted: flowers bright yellow, 6-7 $\mathrm{cm}$. broad : petals cuneate, truncate or retuse at the slightly eroded top, and mucronate: fruit $2.5-3 \mathrm{~cm}$. long.

In coral sand, southern peninsular Florida and the Keys.

8. Opuntia humifùsa Raf. Stems prostrate, from fibrous roots, diffusely spreading, the joints obovate to suborbicular, $7.5-12 \mathrm{~cm}$. long, deep green, with subulate leaves often 6-8 $\mathrm{mm}$. long : bristle-cushions remote, with reddish brown bristles, usually unarmed, or spines few, straight, whitish or often reddish at the base and apex, terete, mostly marginal, $1.5-2.5 \mathrm{~cm}$. long, straight : flowers sulphur-yellow and often reddish in the center, $6-8.5$ $\mathrm{cm}$. broad : fruit club-shaped, $3.5 \mathrm{~cm}$. long, barely $\frac{1}{2}$ as thick with an edible purplish acid or sweetish pulp: seeds $5 \mathrm{~mm}$. broad, flattened, acutish margined. [O. Rafinesquei Engelm. ]

In sandy or rocky soil, Minnesota to Missouri, Kentucky and Texas.

9. Opuntia fúsco-àtra Engelm. Stems diffusely branched, the joints orbicularobovate, 6-7.5 cm. long, tuberculate : bristle-cushions rather remote, tomentose, the upper one unarmed, the bristles reddish brown : spines brownish black, usually solitary, 2.5-3 $\mathrm{cm}$. long, short, rather erect, an additional short deflexed one sometimes present: flowers yellow, $7.5 \mathrm{~cm}$. broad : fruit unknown.

In sterile soil or on prairies, Texas.

10. Opuntia Opúntia (L.) Coulter. Stems prostrate or diffusely ascending from fibrous roots, the joints orbicular to obovate, pale or light green, $5-10 \mathrm{~cm}$. long, bearing thick leaves 4-5 mm. long: bristle-cushions rather remote, usually unarmed : bristles few, yellowish green : spines few, when present solitary, less than $2.5 \mathrm{~cm}$. long, variegated: flowers pale yellow, $5-6 \mathrm{~cm}$. broad : fruit obovoid or clavate-obovoid, $2-3 \mathrm{~cm}$. long : seeds $5 \mathrm{~mm}$. long, thick-margined. [O. vulgaris Mill.]

In sand or sandy soil, or on rocks, Massachusetts to Florida and Alabama. Spring to fall.

11. Opuntia Pès-Còrvi LeConte. Stems prostrate or diffusely spreading, 3-7 dn. long, the joints narrowly ovoid to obovoid, nearly terete, $2.5-7.5 \mathrm{~cm}$. long, light green, loosely attached to each other: bristle-cushions quite numerous, the upper ones armed, the bristles pale : spines slender, solitary or 2-3 together, straight, $2.5-3.5 \mathrm{~cm}$. long, often flattened at the base and twisted : flowers yellow, $3.5-4 \mathrm{~cm}$. broad: fruit obovoid, 12-15 mm. long, rose-purple, bristly : seeds often 4-5 mm. long, with an obtuse margin.

On sandy coasts or adjacent ridges, Georgia and Florida. 
12. Opuntia polyacántha Haw. Stems prostrate, branching into large masses, the joints suborbicular, $5-10 \mathrm{~cm}$. or rarely $15 \mathrm{~cm}$. long, light-green, tuberculate, bearing leaves $3-4 \mathrm{~mm}$. long: bristle-cushions rather numerous, all armed, the bristles reddish brown: spines 8-15 together, the 5-10 outer radiant, very slender, whitish, variegated with red, numerous, stouter, reddish brown with paler tips, $3-5 \mathrm{~cm}$. long, half of them deflexed: flowers yellow or orange, varying to purple : fruit obovoid, $3-5 \mathrm{~cm}$. long, spiny : seeds 5-6 $\mathrm{mm}$. broad, irregular in shape.

In dry soil and on plains and prairies, British Columbia to Nebraska, the Indian Territory, New Mexico and Utah.

13. Opuntia leptocaùlis $P$. DC. Stems with a hard close-grained wood, and a gray scaly bark, branching, often 12-15 dm. tall, the branches slender, terete, or angled in age; the outer joints loosely attached to one another, $2-3 \mathrm{~cm}$. long, with terete, subulate leaves : spines mostly solitary, about $8 \mathrm{~mm}$. long, in a close sheath : flowers sulphur-yellow, 14-20 $\mathrm{mm}$. broad : fruit scarlet, $10-18 \mathrm{~mm}$. long, not juicy, more often proliferous : seeds $2-5$, white, flattened.

In river valleys, Texas and adjacent Mexico.

\section{Order 22. BEGONIÀLES.}

Succulent herbs or shubby plants or vines, often with large rootstocks. Leaves alternate: blades commonly inequilateral, toothed or lobed. Flowers monoceious, usually somewhat irregular, in simple or compound cymes. Staminate flowers with 2 or more sepals, 5 minute petals and numerous stamens whose anthers open by pores or valves. Pistillate flowers with calyx and corolla, and a gynoecium of 2-5 united carpels. Ovary inferior, 2-several-celled or rarely 1-celled, the placentae entire or variously lobed. Stigmas curved, twisted or coiled. Ovules numerous. Fruit capsular, equally or unequally winged.

\section{Family 1. Begoniàceat R. Br. Begonia Family.}

Characters of the order.

\section{BEGÒNIA L.}

Succulent plants, but sometimes shrubby. Leaves alternate : blades oblique, usually toothed, petioled. Flowers in simple or compound cymes, monoecious, the staminate with 2 unequal pairs of petals and many stamens, the pistillate with 5 somewhat unequal petals and an inferior 3-celled ovary. Style very short: stigmas spirally twisted. Ovules numerous, on 2-lobed placentae. Capsule membranous, unequally 3-winged, one wing much larger than the rest. Seeds numerous, minute. Elephant's Ear.

1. Begonia semperflòrens Link \& Otto. Stems $3-10 \mathrm{dm}$. tall, more or less branched, usually red : leaf-blades obliquely ovate or reniform, 4-7 $\mathrm{cm}$. broad, palmately nerved, crenate with minutely apiculate teeth; petioles shorter than the blades: peduncles axillary, simply dichotomous : bracts ciliate-fimbriate : corolla white : larger petals of the staminate flowers 6-14 mm. long and broad, the smaller petals spatulate: capsules drooping; two angles with narrow rounded wings, the broad wing of the other angle with a rounded outer margin and a straight upper margin.

In and about swamps, peninsular Florida. Naturalized from South America.

\section{Order 23. PROTEÀLES.}

Perennial herbs, or shrubs or trees, natives of the Southern Hemisphere. Leaves alternate, or rarely opposite or whorled: blades simple or compound. Flowers perfect, or occasionally polygamous or dioecious. Perianth of 4 valvate partially united sepals. Androecium of 4 stamens, one on each sepal. Gynoecium of a single carpel. Ovary free, 1-celled, often oblique. Style terminal. Stigma disk-like, nipple-shaped or capitate. Ovules 1 or two in a cavity. Fruit indehiscent, or often follicular or capsular. Seed with a straight embryo. 


\section{Family 1. PROteàceae J. St. Hil. Protea Family.}

Characters of the order.

\section{GREVÍLLEA R. Br.}

Shrubs or trees, often pubescent with medifixed or forked hairs. Leaves alternate : blades sometimes pinnately parted. Flowers perfect, sometimes irregular, in variously modified terminal racemes. Calyx-tube mostly cleft, often swollen at the base and curved above : limb oblique. Anthers sessile or nearly so. Ovary stalked: style rather elongated, often protruding from the cleft in the calyx-tube. Ovules 2, collateral, amphitropous. Fruit either follicular or sometimes 2-valved, often curved. Seeds mostly winged.

1. Grevillea robústa A. Cunn. A tree often $10-20 \mathrm{~m}$. tall. Leaf-blades 2-4 dm. long, bipinnately parted, the segments narrow, entire or more or less incised, acute or acuminate : panicle showy ; racemes 1-2 dm. long, many-flowered : calyx-lobes elliptic or oval, much surpassed by the bent style.

In waste grounds and about gardens, Florida. Adventive from Australia.

\section{Order 24. THYMELEÀLES.}

Shrubs or trees, or nearly herbaceous plants, with firm or woody tissues, and unarmed. Leaves opposite or alternate. Flowers perfect, polygamous or dioecious, regular or nearly so. Calyx of 5 or fewer sepals. Corolla wanting, in our species. Androecium of as many stamens as sepals or twice as many. Anthers opening by slits or hinged valves. Gynoecium of a single carpel. Ovary inferior. Ovule mostly solitary. Fruit usually baccate or drupaceous.

Anthers opening by slits.

Ovule and seed pendulous : leaves green, sometimes merely pubescent.

Ovule and seed erect: leaves silvery-scurfy.

Anthers opening by hinged valves.

Leafy shrubs or trees: fruit seated on the hypanthium.

Leafless, twining, parasitic vines: fruit enclosed in the accrescent hypanthium.

Fam. 1. DAPHNACEAE.

Fam. 2. Elaeagnaceae.

Fam. 3. Lauraceae.

Fam. 4. Cassythaceae.

\section{Family 1. DaphNaceat J. St. Hil. Mezereon Family.}

Shrubs or trees, or rarely herbs, with a tough bark and an acrid sap. Leaves opposite or alternate, without stipules : blades entire, not glandular-punctate. Flowers perfect or polygamous, or dioecious, variously disposed. Calyx of 4-5 sepals bearing 4-5 scales within, or naked. Corolla wanting. Androecium of as many stamens as the sepals, or twice as many. Filaments filiform, distinct. Anthers 2-celled: sacs opening lengthwise. Gynoecium a single pistil. Ovary usually 1-celled. Style variable in length, simple, often eccentric. Stigma small. Ovule mostly solitary, anatropous, pendulous. Fruit usually indehiscent, drupaceous or baccate. Seed solitary, pendulous. Testa crustaceous or membranous. Endosperm fleshy, often scant, or wanting. Embryo straight, with fleshy cotyledons. [Thymeleaceae Reichenb.]

\section{DÍRCA L.}

Shrubs, with erect branching stems. Leaves alternate, deciduous : blades membranous. Flowers appearing before the leaves from scaly buds, perfect, in short racemes. Hypanthium usually longer than the sepals. Corolla wanting. Stamens 8, exserted : filaments unequal in length. Ovary 1-celled, sessile, glabrous : style entire, filiform. Ovule solitary. Drupe slightly elongated, barely stalked. Testa crustaceous. Endosperm wanting. Leather-wood. MOOSE-WOOD.

1. Dirca palústris L. A slender branching shrub $0.5-2 \mathrm{~m}$. tall, with a smooth shining bark and pubescent buds. Leaf-blades oval or obovate, $4-8 \mathrm{~cm}$. long, obtuse at both ends, or acutish at the apex, sometimes subcordate at the base, entire, more or less glaucous beneath, short-petioled : flowers lemon-yellow, 3 commonly in a raceme: hypanthium tubular or tubular-campanulate, $7-8 \mathrm{~mm}$. long: sepals very short: stamens and style exserted : drupe oval, 7-9 $\mathrm{mm}$. long, red.

In woods and along streams, New Brunswick to Minnesota and Florida. Spring. 


\section{Family 2. elaeagnàceat Lindl. Oleaster Family.}

Shrubs or trees, with silvery scaly or stellate-pubescent foliage. Leaves opposite or alternate : blades entire. Flowers perfect, polygamous or dioecious, usually clustered at the nodes of branches of the present or preceding year. Calyx of 4 or rarely 2 , sepals, surmounting the hypanthium. Corolla wanting. Androecium of 4 or 8 stamens, inserted near the base of the calyx. Filaments short. Anthers 2-celled, opening lengthwise. Gynoecium a single pistil. Ovary 1-celled, sessile. Style simple. Stigma entire. Ovule 1, erect, anatropous. Fruit drupe-like, the achene surrounded with the accrescent hypanthium. Seed solitary, erect. Testa thin. Endosperm scant or wanting.

\section{1. elLAEÁGNUS L.}

Silvery scaly shrubs or rarely trees. Leaves alternate. Flowers perfect or polygamous. Often clustered in the leaf axils. Sepals 4, valvate. Stamens 4. Mature hypanthium mealy or fleshy, including the achene.

1. Elaeagnus umbellàtus Thunb. A shrub, 1-3 m. tall. Leaves numerous; blades oblong to elliptic, $2-4 \mathrm{~cm}$. long; mainly obtuse, green above, silvery beneath, shortpetioled : flowers few, in umbel-like clusters, short-pedicelled : hypanthium narrowly funnelform, 4-6 mm. long during anthesis : sepals ovate, $2.5-3 \mathrm{~mm}$. long, silvery scaly without like the hypanthium : fruit oblong to oval, $6-8 \mathrm{~mm}$. long.

On banks and in thickets, about Augusta, Georgia, and other cities. Introduced from Japan.

\section{Family 3. LAURÀCEAE Lindl. LaURel Family .}

Aromatic shrubs or trees. Leaves alternate, opposite or whorled, without stipules: blades entire or lobed, generally glandular-punctate. Flowers perfect, polygamous or dioecious, regular or nearly so, variously disposed, often in clusters. Perianth of 6 (rarely $4-10$ ) sepals in 2 series, imbricated. Androecium usually of a greater number of stamens than the sepals, in 2-4 series, inserted on the edge of a disk at the base of the calyx, those of the third series often bearing sessile or stalked glands, those of the fourth series and those in pistillate flowers changed to staminodia. Filaments distinct. Anthers 2-4celled, the sacs opening by uplifting valves. Gynoecium a single pistil. Ovary 1-celled. Style simple. Stigma entire or 3-lobed. Ovule anatropous, pendulous. Fruit a drupe seated on the accrescent hypanthium. Seed solitary. Endosperm wanting.

Leaves persistent: flowers mostly perfect : stamens 12 , the 3 inner staminodia.

Sepals persistent: hypanthium not accrescent.

Sepals deciduous : hypanthium accrescent.

1. Persea.

Leaves deciduous : flowers mostly dioecious : stamens 9.

Anthers 4-celled.

Flowers racemose: trees.

Flowers in lateral clusters : low shrubs.

Anthers 2-celled.

2. NECTANDRA.

3. SAsSaFras.

4. Malapoenna.

5. BenzoIn.

\section{PÉRSEA Gaertn.}

Evergreen pleasantly aromatic shrubs or trees, with a furrowed bark and naked buds. Leaves alternate : blades entire, leathery. Flowers perfect, yellowish green, cymose, more or less panicled, on axillary or terminal peduncles. Sepals 6 , those of the outer series shorter than the others. Stamens 12, in 4 series, those of the inner, or the third and inner series reduced to staminodia : filaments inserted near the base of the calyx, flattened, sometimes shorter than the anthers, those of the third series with 2 glands near the base : anthers erect, flattened, 4-celled, the sacs opening by lids hinged at the top, extrorse in the third row, introrse in the outer. Styles gradually enlarged upward. Drupe subglobose. The plants flower in the spring and mature their fruit in the fall.

Flowers in naked panicled cymes: fruit 8-18 cm. long.

1. P. Persea.

Flowers in axillary peduncled cymes : fruit less than $2 \mathrm{~cm}$. long.

Peduncles, pedicels and petioles glabrous or appressed-pubescent : fruit over $1 \mathrm{~cm}$. thick.

Leaf-blades glabrous or nearly so, except sometimes the nerves beneath.

Leaf-blades finely reticulated beneath, mainly over thrice as long as wide.

Leaf-blades not reticulated beneath, mainly about twice as long as wide. Leaf-blades lustrous-pubescent beneath.

Peduncles, pedicels and petioles tomentose : fruit less than $1 \mathrm{~cm}$. thick.

2. P. Borbonia.

3. P. littoralis.

4. P. humilis.

5. P. pubescens. 
1. Persea Pérsea (L.) Cockerell. A tree becoming $10 \mathrm{~m}$. tall. Leaf-blades oblong, elliptic or oval, or slightly broadest below the middle, glabrous in age, finely reticulated, at least beneath : flowers in naked panicled cymes, the branches of the panicle finely pubescent: inner sepals 4-5 mm. long, somewhat surpassing the outer: fruit more or less elongated, often somewhat pyriform, $8-18 \mathrm{~cm}$. long, the flesh butter-like, edible.

In woods and hammocks, peninsular Florida and the Keys. Naturalized from tropical America. Alligator Pear. Avocado Pear.

2. Persea Borbònia (L.) Spreng. A tree, reaching a height of $20 \mathrm{~m}$., with a maximum trunk diameter of nearly $1 \mathrm{~m}$., its bark broken into flat ridges. Leaf-blades elliptic or elliptic-oblong, $5-15 \mathrm{~cm}$. long, often acuminate at both ends, bright green and lustrous above, glaucescent and finely reticulated beneath : peduncles axillary, 1-2 cm. long, 3-6flowered : sepals ascending, the inner ovate, 2-3 times longer than the outer, acutish : fruit obovoid or globose-obovoid, 1-1.5 cm. long, dark blue or nearly black, lustrous. $\quad[P$. Carolinensis (Michx.) Nees.]

In swamps and along streams, near the coast. Virginia to Florida and Texas. RED BAY. SwEET Bay. Florida mahogany. Tisswood. Laurel Tree.

3. Persea littoràlis Small. A copiously branched shrub, or a tree $5 \mathrm{~m}$. tall. Leafblades elliptic or oblong-elliptic, 2-5.5 cm. long, mostly obtuse at the apex, bright green and lustrous above, pale and glabrous beneath, not reticulated, the lateral veins inconspicuous : fruit globular, 12-14 mm. long, purple-black under the bloom.

On sand ridges, near the coast, peninsular Florida.

4. Persea hùmilis Nash. A small tree 2-4 m. tall, the twigs, lower leaf-surfaces and the inflorescence silky-pubescent. Leaf-blades elliptic or oblong, 4-10 cm. long, more or less revolute, glabrous and shining above, lustrous beneath : sepals erect, obtuse, the inner oblong, $5 \mathrm{~mm}$. long: fruit globular, about $1.5 \mathrm{~cm}$. long, purplish black under the bloom.

In sand, peninsular Florida.

5. Persea pubéscens (Pursh) Sarg. A shrub or small tree, reaching a height of 12 m., with a trunk diameter of 3-4 dm., its twigs, lower leaf-surfaces and inflorescence tomentose. Leaf-blades narrowly elliptic or elliptic-lanceolate or rarely oval, 5-20 cm. long, usually obtuse, often acuminate at the apex, slightly revolute: sepals erect, acutish, the inner oblong-ovate, about twice as long as the outer: fruit oval, 8-11 mm. long, dark blue with a thin bloom. [P. Carolinensis var. palustris Chapm. $]$

In swamps and hammocks, North Carolina to Florida and Texas. SWAMP RED BAy. SWAMp BAy.

\section{OCÒTEA Aubl.}

Aromatic shrubs or trees, resembling Persea. Flowers perfect or polygamo-dioecious, in axillary or nearly terminal pedunculate panicled cymes, the pedicels bearing 2 deciduous scales. Sepals 6, nearly equal, deciduous. Stamens 12, in 4 series, those of the inner series reduced to staminodia : anthers 4-celled, the sacs opening introrsely in the two outer series, usually extrorse in the third series. Style cylindric. Drupe varying from ellipsoidal to oblong, with a thin fleshy pulp.

1. Ocotea Catesbyàna (Michx.) Sarg. An evergreen glabrous shrub, or a small tree 2-10 m. tall, with a quite smooth bark, the trunk sometimes $2 \mathrm{dm}$. thick. Leaf-blades narrowly elliptic or elliptic-lanceolate, $5-12 \mathrm{~cm}$. long, acuminate or sometimes obtuse at the apex, nearly flat, acute at the base, deep green and lustrous above, paler beneath: peduncles $2-5 \mathrm{~cm}$. long: calyx creamy-white, 8-9 mm. wide: sepals oblong, obtuse, spreading or recurved : filaments shorter than the anthers : drupe subglobose or oval, 1-1.5 $\mathrm{cm}$. in diameter, dark blue or black, lustrous, seated in the red hypanthium. [Nectandra Willdenoviana Nees.]

In sandy soil, peninsular Florida and adjacent islands. Also in the West Indies. Early spring ; matures its fruit in the fall. LANCE WOOD.

\section{SÁSSAFras Nees.}

Commonly dioecious strongly aromatic trees, with a brown furrowed bark and brittle branchlets. Leaves alternate : blades rather membranous, commonly lobed, rarely entire, each narrowed into a slender petiole. Flowers dioecious or rarely perfect, yellowish green, in loose, axillary often corymbose racemes. Sepals 6 , nearly equal. Stamens 9 , in three series: filaments flattened, those of the inner series with 2 stalked orange-colored glands at the base : anthers 4-celled, introrse, each sac opening by a lid hinged at the top. Style elongated, enlarged towards the apex. Drupe subglobose or oval, with a thin pulp. 
1. Sassafras Sássafras (L.) Karst. A tree sometimes $30 \mathrm{~m}$. tall, with a maximum trunk diameter of nearly $2 \mathrm{~m}$., the bark broken into flat ridges. Leaf-blades varying from oblong to suborbicular in outline, usually 3-lobed, otherwise entire, sometimes lobed on one side only, sometimes entire, bright green above, glaucescent and glabrous beneath or nearly so, petioled, the lobes obtuse or acutish : racemes $2-5 \mathrm{~cm}$. long, pubescent : flowers greenish yellow, usually numerous : sepals 6 , narrowly oblong, obtuse, $2.5-3 \mathrm{~mm}$. long : stamens slightly longer than the sepals : drupe oval, $8-10 \mathrm{~mm}$. long, red or orange, often apiculate, seated in the thick hypanthium. [S. officinalis Nees \& Eberm.]

In woods and fields, Maine to Ontario, Iowa, Nebraska, Florida and Texas. Spring; matures its fruit in the summer. Sassafras. Sassafrax. Ague Tree.

\section{MALAPOÈNNA Adans.}

Shrubs or trees, with often zigzag forking branches. Leaves alternate: blades entire, firm. Flowers in clusters or clustered umbels, dioecious. Calyx of 6 or sometimes 4 sepals, deciduous. Stamens or staminodia 9, in 3 series, those of the first and second series without glands, those of the third row with glands : anthers 4-celled, introrse. Style entire. Drupe subglobose or oblong. [Litsea Lam.]

1. Malapoenna geniculàta (Walt.) Coulter. A spreading glabrous shrub $2-3 \mathrm{~m}$. tall, with zigzag forking branches. Leaf-blades firm, oblong or elliptic, $1.5-6 \mathrm{~cm}$. long, acute or obtuse at both ends, dark green above, paler beneath, slightly reticulated, shortpetioled, deciduous : flowers 2-4 together, appearing before the leaves, about $8 \mathrm{~mm}$. broad, nearly sessile : sepals oval or elliptic, obtuse, yellow, spreading: stamens shorter than the sepals : filaments filiform, glabrous : anthers ovoid : drupe subglobose, $5-6 \mathrm{~mm}$. long, red. [Litsea geniculata (Walt.) Benth. \& Hook.] summer.

In shallow ponds, Georgia to Florida and Louisiana. Winter and spring; matures its fruit in the

\section{BÉNZOIN Fabr.}

Shrubs or trees, with a spicy aromatic bark Leaves alternate : blades thinnish, entire, deciduous. Flowers dioecious, yellow, in clusters or umbels, appearing before the leaves. Calyx of 6 or rarely 7-9 nearly equal sepals. Stamens usually 9 , in 3 series, all reduced to staminodia in the pistillate flowers, those of the first and second series usually without glands, those of the third series usually with glands. Anthers 2-celled, introrse. Style variable in length. Drupe pulpy. Spice-bush. Benjamin-Bush. $\begin{array}{ll}\text { Leaf-blades rounded or cordate at the base, pubescent on both sides. } & \text { 1. B. melissaefoli } \\ \text { Leaf-blades acute at the base, glabrous on both sides or sparingly pubescent beneath. } & 2 . \text { B. Benzoin. }\end{array}$

1. Benzoin melissaefollum (Walt.) Nees. A low shrub $3-10 \mathrm{dm}$. tall, its branches foliage and inflorescence pubescent. Leaf-blades quite firm, oblong or oval, 3-12 cm. long, acutish, usually short-acuminate, more or less densely pubescent on both sides, rounded or cordate at the base, short-petioled : flowers yellow, in dense lateral clusters, appearing before the leaves : pedicels equalling the sepals or longer : sepals thin, 1-1.5 mm. long: stamens dilated below : drupe obovoid, nearly $1 \mathrm{~cm}$. long. [Lindera melissaefolia (Walt.) Blume.] spring.

About ponds and swamps, North Carolina to Illinois, Missouri, Florida and Alabama. Winter and

2. Benzoin Bénzoin (L.) Coulter. A strong-scented and spicy shrub 1-3 m. tall. Leaf-blades obovate, oval or elliptic, $5-12 \mathrm{~cm}$. long, thin, obtuse or usually short-acuminate and acute at the apex, often slightly ciliate, acute or acuminate at the base, deep green and glabrous above, pale or glaucescent and glabrous or sparingly pubescent beneath, short-petioled, deciduous : flowers yellow, in dense clusters appearing before the leaves, 6-8 $\mathrm{mm}$. broad : pedicels $3-5 \mathrm{~cm}$. long: sepals thin, obovate or oblong, obtuse, truncate or retuse at the apex : stamens shorter than the sepals, slightly dilated below: drupe oval about $1 \mathrm{~cm}$. long, longer than the pedicel. [Lindera Benzoin (L.) Blume.]

In swamps and along streams, Massachusetts to Ontario, Michigan, middle Georgia, Tennessee and Kansas. Spring: fruit ripening in August.

\section{Family 4, CAssythàceaf Dumort. Cassytha Family.}

Parasitic vines, with slender or filiform stems. Leaves wanting or represented by mere scales. Flowers perfect, inconspicuous, in heads, spikes or racemes. Calyx of 6 sepals surmounting an obovoid or top-shaped hypanthium : outer sepals much smaller than the inner. Corolla wanting. Androecium of 9 stamens, those of the first and second series without glands, their anthers 2-celled, 
introrse, those of the third usually perfect, with glands at the base, their anthers 2-celled, extrorse, those of the fourth series reduced to staminodia. Gynoecium a single pistil. Ovary nearly sessile, 1-celled, included in the hypanthium. Stigma capitate, nearly sessile. Ovule pendulous, anatropous. Fruit a drupe included in the accrescent hypanthium, crowned with the persistent sepals. Seed solitary, with a membranous testa.

Characters of the family.

\section{CASSỲTHA L.}

1. Cassytha filifórmis L. A leafless plant parasitic on bushes. Stems filiform, twining, usually matted, often sparingly pubescent, yellowish green : flowers 3-6 in a spike, 2 mm. broad : calyx glabrous: outer sepals ovate, acute or acutish, the inner triangularovate, 2-3 times larger than the outer: stamens included: filaments shorter than the anthers : drupe subglobose, 5-7 mm. in diameter, included.

On bushes, peninsular Florida and the Keys. Circumtropical.

\section{Order 25. MYRTÀLES.}

Herbs, shrubs or trees, unarmed, sometimes aquatic or amphibious. Leaves alternate or opposite : blades sometimes prominently 3-nerved. Flowers regular or irregular, complete, and often showy, or reduced to a stamen and pistil adnate to the hypanthium. Hypanthium merely enclosing the ovary or adnate to it. Androecium of few or many stamens. Anthers opening by slits or pores. Gynoecium 1-several-carpellary. Stigma terminating the style, or sessile. Fruit capsular or baccate, or resembling an achene.
Style present, simple or compound: stigma terminal.
Anthers opening by pores.
Anthers opening by longitudinal valves.
Hypanthium merely enclosing the ovary.
Hypanthium adnate to the ovary or mainly so.
Cotyledons spirally convolute in the embryo. Ovary several-celled: ovules numerous, not pendulous. Ovary 1-celled : ovules $2-5$, pendulous.
Cotyledons not spirally convolute.
Sepals imbricated or united and the calyx falling away as a cap. Sepals valvate.
Leaves stipulate: sepals leathery.
Styles wanting : stigmas sessile.

Fam. 1. Melastomaceak.

Fam. 2. LythraceaE.

Fam. 3. Punicaceae.

Fam. 4. Terminaliaceae.

Fam. 5. Myrtaceae.

Fam. 6. RHIZOPHORACEAE. Fam. 7. EPILOBIACEAE. Fam. 8. GUNNERACEAE.

\section{Family 1. melastomàceae R. Br. Meadow-beauty family.}

Perennial herbs, shrubs or trees, of little economic importance. Stems sometimes enlarged at the joints. Leaves opposite or rarely whorled, exstipulate : blades with two or more lateral ribs, not punctate. Flowers mostly showy, perfect, regular or nearly so. Hypanthinm glabrous or pubescent, campanulate, urn-shaped or tubular. Calyx of 3-6 valvate sepals. Corolla of 3-6 petals, contorted in aestivation, oblique. Androecium of twice as many stamens as there are petals, or sometimes of the same number, inserted with them, all fertile or those opposite the petals smaller and sterile. Anthers appendaged, opening by pores. Gynoecium compound. Ovary free, or adnate to the hypanthium, 2-manycelled, often 4-celled. Styles united. Stigma undivided. Ovules numerous, anatropous. Fruit berry-like or capsular, dehiscing by longitudinal valves, 2-manycelled, many-seeded. Endosperm wanting. Embryo straight or curved.

\section{RHÉXIA L.}

Perennial herbs, with horizontal often tuber-bearing rootstocks. Stems terete or angled, the branches opposite. Leaves opposite : blades usually 3-5-nerved, commonly toothed. Flowers somewhat irregular, solitary or in terminal cymes. Hypanthium urnshaped, prolonged beyond the ovary and constricted. Sepals 4 , varying from subulate to triangular. Petals 4, oblique, retuse or awn-tipped at the apex, deciduous. Stamens 8 , exserted : filaments equal in length : anthers various, 1-celled, each sac opening by a ter- 
minal pore. Ovary sessile, 4-celled, free : style slender : stigma truncate. Ovules numerous on the 4 placentae. Capsules 4-celled, 4-valved, included. Seeds variously roughened, coiled or bent. MEADOW-BEAUTy.

Anthers relatively short, oblong, not spurred at the base.

Corolla purple or rarely white.

Hypanthium glandular-pubescent: upper surface of the leaf-blades glabrous.

Hypanthium glabrous: upper surface of the leaf-blades bristly. Corolla yellow.

Anthers elongated, linear, spurred at the base.

Neck of the mature hypanthium as long as the body or longer.

Leaf-blades narrowly linear, the midrib only prominent and conspicuous.

Leaf-blades not linear, the 3 nerves prominent and conspicuous.

Stems rather sparingly pubescent with delicate hairs: leaf-blades nearly glabrous.

Stems densely pubescent with coarse yellow hairs: leaf-blades shaggy-pubescent with hairs like those on the stem.

Neck of the mature hypanthium much shorter than the body.

Stems and branches terete or nearly so.

Hypanthium glabrous or with a few scattered hairs.

Leaf-blades over $2 \mathrm{~mm}$. broad : hypanthium with a few scattered hairs Leaf-blades linear to lanceolate.

Leaf-blades oval, elliptic or oblong-ovate, very thin.

Leaf-blades less than $2 \mathrm{~mm}$. broad: hypanthium glabrous.

Hypanthium densely glandular-pubescent.

Stems sharply angled or narrowly 4-winged.

Corolla over $2 \mathrm{~cm}$. broad, colored.

Sepals less than $1 / 2$ as long as the hypanthium at maturity.

Stems with pubescent internodes: hypanthium pubescent at maturity. Stems with glabrous internodes: hypanthium glabrous at maturity.

Sepals fully $1 / 2$ as long as the hypanthium at maturity.

Corolla less than $2 \mathrm{~cm}$. broad, white.

1. $R$. serrulata.

2. R. ciliosa.

3. R. lutea.

4. $R$. Floridana.

5. R. Mariana.

6. R. Nashii.

7. lanceolata.

8. R. delicatula.

9. $R$. filiformis.

10. R. glabella.

1. Rhexia serrulàta Nutt. Stems slender, glabrous below, erect, 5-30 cm. tall, 4angled, sometimes sparingly branched : leaf-blades thickish, ovate, oval or suborbicular, 0.5-1 cm. long, obtuse or acute, bristly serrulate, sessile or nearly so : flowers solitary or in congested cymes : hypanthium bristly with glandular hairs when young : sepals triangular : petals purple, about $10 \mathrm{~mm}$. long, apiculate : anthers oblong, not spurred : capsules spheroidal, $4 \mathrm{~mm}$. broad, much longer than the very short neck of the hypanthium.

In pine-land swamps and low ground, Georgia and Florida. Summer.

2. Rhexia cillòsa Michx. Stems rather slender, erect, $2-6 \mathrm{dm}$. tall, 4 -angled, glabrous or nearly so, the branches erect or strongly ascending: leaf-blades 1-2 cm. long, broadly ovate to ovate-lanceolate, or elliptic, acute, bristly serrulate, usually with scattered hairs above, rounded at the base, sessile or short-petioled: flowers usually in congested cymes, short-pedicelled : hypanthium becoming glabrous : sepals triangular, acute : petals 9-15 $\mathrm{mm}$. long, violet-purple or deep pink, rounded or apiculate at the apex : anthers oblong, not spurred : capsules subglobose, 4-5 $\mathrm{mm}$. in diameter, much longer than the neck of the hypanthium.

In sandy swamps, Maryland to Florida and Louisiana. Spring and summer.

3. Rhexia lùtea Walt. Stems deep green, bristly-pubescent, erect, 1-3 dm. tall, 4-angled, simple, or finally with numerous short branches above: leaf-blades 1-2.5 cm. long, the upper ones linear-oblong to oblong, acute, the lower cuneate, obtuse, all bristlyserrulate, more or less reflexed : flowers rather short-pedicelled or nearly sessile, numerous : hypanthium glabrous in age : sepals lanceolate or ovate-lanceolate, acuminate : petals deep green, 9-13 mm. long, spreading, more or less distinctly awn-tipped : anthers narrowly oblong, often shorter than the filaments : capsules subglobose, $4 \mathrm{~mm}$. in diameter, longer than the neck of the hypanthium.

In low sandy pine lands, North Carolina to Florida and Mississippi. Summer.

4. Rhexia Floridàna Nash. Stems olive-green, erect, 2-5 dm. tall, 4-angled, often diffusely branched, glandular-hirsute : leaf-blades linear, 1.5-4 cm. long, glabrous, acute, remotely bristly-serrulate, sessile: flowers short-pedicelled, in open cymes: hypanthium bristly when young, glabrous in age: sepals lanceolate or triangular-lanceolate, acuminate : petals purple, 11-17 mm. long, awn-tipped, each awn terminating in a gland: anthers linear, mainly $1 \mathrm{~cm}$. long, slightly spurred at the base : capsules ovoid, 6-7 $\mathrm{mm}$. long, about as long as the neck of the hypanthium.

In sand or clayey swamps, southern Georgia and Florida to Mississippi. Summer.

5. Rhexia Mariàna L. Stems erect, 2-8 dm. tall, villous-hirsute, simple or much branched, nearly terete : leaf-blades narrowly oblong, lanceolate or elliptic-lanceolate, $1.5-8 \mathrm{~cm}$. long, acute, bristly-serrulate, nearly glabrous, narrowed into short petioles: flowers in open cymes, short-pedicelled: hypanthium sparingly pubescent, or glabrous in age : sepals ovate or triangular, acute : petals pale or deep purple, 14-28 $\mathrm{mm}$. long, often 
minutely awn-tipped : anthers linear, 8-9 mm. long, spurred at the base: capsules subglobose, 6-7 $\mathrm{mm}$. in diameter, shorter than the neck of the accrescent hypanthium.

In sandy swamps, Long Island to Missouri, Florida and Texas. Spring to fall.

6. Rhexia Náshii Small. Stems erect from tuberous roots, $3-6 \mathrm{dm}$. tall, 4 -angled, densely hirsute, yellowish green like the rest of the foliage, often sparingly branched: leaf-blades thickish, narrowly oblong-lanceolate, 2-5 $\mathrm{cm}$. long, acute, slightly bristly-serrulate, with 3 prominent yellow nerves, sessile: flowers in open cymes, short-pedicelled: hypanthium glabrous or nearly so: sepals triangular, acute: petals purple, 14-17 mm. long : anthers $1 \mathrm{~cm}$. long, spurred at the base : capsules subglobose, $5-6 \mathrm{~mm}$. in diameter, about as long as the neck of the hypanthium.

In sandy swamps, peninsular Florida. Spring and summer.

7. Rhexia lanceolàta Walt. Stems erect, 1-4 dm. tall, slender, villous-hirsute like the rest of the foliage, terete or nearly so: leaf-blades oblanceolate, elliptic-oblanceolate, or linear-lanceolate, $1-2.5 \mathrm{~cm}$. long, acute, bristly serrulate, sparingly pubescent on both surfaces, short-petioled or nearly sessile : flowers in open cymes, short-pedicelled : hypanthium glabrous or sparingly pubescent when young: sepals lanceolate, hooked at the apex : petals white to pale purple, apiculate or awn-tipped : anthers linear, 6-7 mm. long, spurred at the base : capsules subglobose, 3.5-4 mm. in diameter, longer than the neck of the hypanthium. summer.

In dry or moist sandy soil, North Carolina and Tennessee to Florida and Louisiana. Spring and

8. Rhexia delicátula Small. Stems slender, erect, 1-4 dm. tall, solitary, obscurely 4-angled, clothed with spreading very delicate hairs: leaf-blades thin, oblong or elliptic to ovate, abruptly acute or obtusish, conspicuously bristly-serrate, with a few delicate hairs on both surfaces, narrowed into slender petioles : flowers usually 3 , in terminal cymes, shortpedicelled: hypanthium glabrous, or with a few hairs below the throat: sepals narrowly triangular, recurved : petals pale purple, $10-15 \mathrm{~cm}$. long: anthers linear, $6 \mathrm{~mm}$. long, slightly spurred at the base : capsules subglobose, 4-5 mm. in diameter, longer than the neck of the hypanthium.

Along streams in the mountains, Georgia. Summer.

9. Rhexia filifórmis Small. Stems erect, wire-like, 1-4 dm. tall, sparingly pubescent, villous-hirsute, simple or branched, terete or nearly so, the branches filiform: leafblades quite numerous, linear-filiform or filiform, 1-3 cm. long, acute, serrulate, sessile, the larger ones involutely folded : flowers in open cymes, short-pedicelled: hypanthium glabrous: sepals lanceolate, acuminate: petals white or pale purple, less than $1 \mathrm{~cm}$. long: anthers linear, $6 \mathrm{~mm}$. long, spurred at the base : capsules subglobose.

In sandy soil, Georgia and Florida. Summer.

10. Rhexia glabélla Michx. Stems erect, $3-10 \mathrm{dm}$. tall, terete or obscurely 4 -angled, glabrous, often tufted, the base spongy when growing in water : leaf-blades leathery, 3-8 cm. long, more or less glaucous, lanceolate to linear-lanceolate, acute or acuminate, entire or inconspicuously serrulate, sessile: flowers in open cymes: hypanthium bristly with glandular hairs: sepals triangular, acuminate: petals bright purple, 17-22 mm. long, apiculate : anthers linear, 7-8 mm. long, spurred at the base : capsules subglobose, 6-7 $\mathrm{mm}$. in diameter, longer than the neck of the hypanthium.

In moist pine lands, North Carolina to Florida and Louisiana. Spring and summer.

11. Rhexia Virgínica L. Stems erect, 2-10 dm. tall, bristly pubescent or glabrate, sharply 4-angled, the angles sometimes slightly winged: leaf-blades very variable, oblongelliptic, oval, lanceolate or ovate-lanceolate, $2-10 \mathrm{~cm}$. long, acute or obtuse, bristly serrulate, 5-nerved, sessile : flowers short-pedicelled, in open cymes : hypanthium glandularpubescent : sepals lanceolate or triangular-lanceolate : petals bright purple, 11-17 mm. long, rounded or retuse at the apex : anthers linear, spurred at the base: capsules subglobose, 5-6 mm. in diameter, much longer than the neck of the hypanthium. GRASS.

In sandy swamps or damp soil, Maine to Missouri, Florida and Louisiana. Spring to fall. DEEk-

12. Rhexia strícta Pursh. Stems erect, 6-13 dm. tall, sometimes much branched, tufted, 4-winged, often spongy at the base : leaf-blades thickish, lanceolate to oblong-lanceolate, $2-10 \mathrm{~cm}$. long, acute or acuminate, bristly-serrulate, with 3 main nerves and 2 less prominent marginal nerves, sessile : flowers short-pedicelled, in panicled cymes : hypanthium glabrous: sepals triangular, acute: petals purple, 12-16 $\mathrm{mm}$. long: anthers linear, spurred at the base : capsules ovoid, 6-7 mm. long, longer than the short neck of the hypanthium.

In pine-land swamps, Georgia and Florida. Summer. 
13. Rhexia aristòsa Britton. Stems erect, 2-6 dm. tall, 4-angled, glabrous, sometimes branching above, sometimes spongy at the base, the branches erect or strongly ascending: leaf-blades thickish, linear or linear-lanceolate, or sometimes linear-oblong, 1-3 cm. long, obtusish or acute at the apex, distantly bristly serrulate, sessile, glabrous or with a few scattered hairs above: flowers short-pedicelled: hypanthium bristly, or the tube glabrate in age : sepals linear or linear-lanceolate, acuminate : petals magenta-red, $12-20 \mathrm{~mm}$. long, awn-tipped : anthers linear, minutely spurred : capsules subglobose, $6 \mathrm{~mm}$. long, longer than the neck of the hypanthium.

In sandy swamps and pine lands, New Jersey to South Carolina. Summer.

14. Rhexia parviflòra Chapm. Stems erect, less than $3 \mathrm{dm}$. tall, 4 -angled, usually branched at the base and above, sparingly pubescent : leaf-blades oblong, elliptic or nearly oval, 1-2 cm. long, acute, bristly serrulate, short-petioled: cymes few-flowered: hypanthium nearly glabrous at maturity : petals white, less than $10 \mathrm{~mm}$. long, often awn-tipped : anthers narrow, nearly straight, appendaged, fully as long as the filaments: capsules subglobose, about $3 \mathrm{~mm}$. in diameter : mature hypanthium with a broad neck much shorter than the diameter of the body.

In shallow ponds, Apalachicola, Florida. Summer.

\section{FAMILy 2. LYTHRÀCEAE Lindl. LOOSESTRIFE FAMILY.}

Herbs, shrubs, or often trees in the tropics, with firm or succulent tissues. Leaves mostly opposite: blades usually entire, sometimes auricled at the base. Flowers perfect, solitary or clustered in the axils, or in axillary cymes. Hypanthium enclosing the ovary, but free. Calyx of 4-5 sepals, commonly accompanied by accessory teeth. Corolla of 4-5 petals, or wanting. Androecium of few or many stamens in 1 or several series. Filaments mostly filiform : anthers versatile. Gynoecium compound. Ovary 2-6-celled, or rarely 1-celled. Styles united. Stigmas entire or rarely 2-lobed. Ovules numerous, or rarely few, anatropous. Fruit a thin-walled or firm capsule enclosed in the hypanthium, sometimes indehiscent. Seeds variously marked or roughened. Embryo straight.

Hypanthium campanulate or turbinate, becoming hemispheric or globose.
Herbs.

Flowers inconspicuous.

Petals wanting: capsules indehiscent.

Petals 4 : capsules dehiscent, sometimes irregularly so. Capsules bursting irregularly.

Capsules septicidally dehiscent.

Flowers conspicuous.

Shrubs or trees.

Flowers in axillary cymes: aquatic shrubs.

Flowers in terminal panicles: terrestrial shrubs or trees.

Hypanthium elongated, cylindric or tubular.

Flowers regular: hypanthium symmetrical.

Flowers irregular: hypanthium oblique.
1. Didiplis.
2. Ammannia.
3. Rotala.
4. Heimia.
5. DECODON.
6. Lagerstroemia.
7. LYTHRUM.
8. Parsonsia.

\section{DÍDIPLIS Raf.}

Flaccid aquatic or swamp herbs, resembling species of Callitriche. Stems elongated, 4-angled. Leaves opposite: blades narrow, entire, pellucid. Flowers inconspicuous, sessile and solitary in the axils. Hypanthium prismatic-campanulate, 4-angled. Sepals 4, without accessory teeth. Petals none. Stamens 2-4, mostly 4: filaments very short. Ovary 2-celled: style very short: stigma slightly 2-lobed. Capsule subglobose, 2-celled, opening irregularly. Seeds minute. Testa membranous. Embryo clavate.

1. Didiplis diándra (Nutt.) Wood. Stems flaccid, submerged or creeping on mud, 1-3 dm. long, glabrous: leaves of two kinds, the submersed thin; blades linear to linearlanceolate, acute or acuminate, the emersed ones thicker in texture; blades linear to linearspatulate, often obtuse, all 1-2 cm. long: flowers inconspicuous : hypanthium campanulate, angled, about $1 \mathrm{~mm}$. high : petals none : capsule urn-shaped, about $1 \mathrm{~mm}$. in diameter. [D. linearis Raf.]

In ponds or on wet shores, Minnesota to North Carolina, Florida, Texas and Mexico. Spring to fall. In Wonds or on wet

\section{AMMÁNNIA L.}

Annual, leathery-succulent herbs. Stems usually 4-angled. Leaves opposite: blades entire, often auricled at the base. Flowers inconspicuous, solitary or clustered (cymose) in 
the axils. Hypanthium campanulate, often becoming globular, 4-angled. Sepals 4, often accompanied by small teeth in the sinuses. Petals 4, mostly early deciduous. Stamens 4-8 : filaments filiform, sometimes short. Ovary subglobose, commonly 2-4-celled, enclosed in the hypanthium : style filiform, sometimes short: stigma capitate. Capsule membranous, subglobose, opening irregularly. Seeds angular, minute. Testa coriaceous. Embryo with broad auricled cotyledons.

Flowers or capsules sessile or nearly so.

Leaves broadest above the middle: capsules $5-6 \mathrm{~mm}$. in diameter.

Leaves broadest below the middle: capsules $3-4 \mathrm{~mm}$. in diameter. Flowers or capsules in long-peduncled cymes.

1. A. Koehnei.

2. A. coccinea.

3. A. auriculata.

1. Ammannia Koèhnei Britton. Stems stout, glabrous, 1-6 dm. tall, simple or branched below or throughout : leaf-blades spatulate, oblanceolate or oblong, $2-8 \mathrm{~cm}$. long, obtuse, entire, the lower ones sessile, the upper partially clasping by the auricled bases: flowers sessile, 1-3 in an axil : hypanthium campanulate, becoming globular : sepals acute : petals white or pink, spatulate, often fugacious : stamens and short style included : capsules subglobose, 5-6 mm. in diameter. [A. latifolia Chapm., not L.]

In swamps and along streams, New Jersey to Florida. Summer and fall.

2. Ammannia coccínea Rottb. Stems stoutish, glabrous, $1-5 \mathrm{dm}$. tall, simple or branched below : leaf-blades linear or linear-lanceolate, $2-6 \mathrm{~cm}$. long, acute or acuminate at the apex, entire, dilated at the cordate obtusely auricled base, sessile : flowers 1-5 in an axil, sessile or on peduncles much shorter than the calyx : hypanthium campanulate and somewhat angled when young: sepals acute: petals broadly obovate, obtuse, purple or pink : stamens and slender style exserted : capsules subglobose, $3-4 \mathrm{~mm}$. in diameter : seeds $0.5-0.7 \mathrm{~mm}$. long.

In swamps and low places, Iowa to Indiana, Kansas, Florida and Texas, and through Mexico and Central America to Brazil. Summer and fall.

3. Ammannia auriculàta Willd. Stems rather slender, glabrous, $0.5-2.5 \mathrm{dm}$. tall, simple or finally widely branching : leaf-blades oblong to linear-lanceolate, $1-3 \mathrm{~cm}$. long, acute or acutish, entire, sessile, more or less clasping by the auricled bases: flowers small, in axillary peduncled cymes, or rarely solitary on peduncles $5-10 \mathrm{~mm}$. long: hypanthium campanulate, becoming subglobose : sepals acute : petals white or pink, broadly spatulate: stamens and slender style exserted : capsules subglobose, $2-2.5 \mathrm{~mm}$. in diameter : seeds 0.4 mm. in diameter.

About ponds and swamps, Nebraska to Texas, New Mexico and through Central America to Brazil. Spring and summer.

\section{RÒTALA L.}

Annual or biennial swamp-inhabiting herbs. Stems 4-angled. Leaves opposite : blades narrow, entire. Flowers inconspicuous, usually solitary in the axils. Hypanthium campanulate becoming subglobose. Sepals very small. Petals usually 4. Stamens 4: filaments short : anthers 2-celled. Ovary subglobose, 4-celled, free : style very short : stigma entire or nearly so. Capsules 4-celled, subglobose, septicidally 4-valved, the valves transversely triate. Seeds minute.

1. Rotala ramòsior (L.) Koehne. Stems erect or ascending from a decumbent base, $0.5-4 \mathrm{dm}$. long, glabrous : leaf-blades oblong to linear or spatulate, 1-3 cm. long, obtuse or acutish, entire, narrowed at the base, sessile or short-petioled : flowers inconspicuous, 1 , or rarely 3 together, sessile or nearly sessile in the axils: hypanthium becoming subglobose, 2.5-3.5 mm. in diameter : sepals acute : petals very small, white: style almost wanting: capsules subglobose, $2.5-3.5 \mathrm{~mm}$. in diameter.

In swamps, about ditches and in wet sand, Massachusetts to Nebraska, Florida, Texas and Mexico. Also on the Pacific slope and in South America. Summer and fall.

\section{HEìmIA Link \& Otto.}

Low spreading shrubby herbs, with elongated branches. Leaves opposite or whorled : blades narrow, entire. Flowers solitary on axillary peduncles which are shorter than the flowers, bearing 2 scales. Hypanthium hemispheric-campanulate. Sepals 6, erect, alternating with spreading teeth at the sinuses. Petals 6 , spreading, usually about as broad as long. Stamens 12, about uniform : filaments slender. Ovary sessile, 4-celled : style elongated. Capsule 4-celled. Seeds minute, wingless.

1. Heimia salicifòlia (H.B.K.) Link \& Otto. A bright green glabrous herb, 0.5-2 m. tall, with much-branched stems : leaf-blades narrowly oblong or oblong-lanceolate, 
2-4 cm. long, obtuse or acutish, more or less revolute, paler beneath than above, sessile or nearly so: pedicels stout, 1-2 $\mathrm{mm}$. long: hypanthium campanulate, often becoming turbinate-campanulate, $3-4 \mathrm{~mm}$. high, ribbed : sepals triangular, acute, $\frac{1}{2}$ as long as the hypanthium, erect or converging, their accessory teeth subulate, spreading-upcurved, surpassing the sepals: petals yellow, obovate or orbicular-obovate, 6-10 $\mathrm{mm}$. long, retuse or notched at the apex, somewhat crisped : stamens exserted: style surpassing the stamens: capsules obovoid, $5 \mathrm{~mm}$. high.

Along streams, southern Texas and through the tropics to Paraguay. Spring to fall.

\section{DÉCODON J. F. Gmel.}

Aquatic shrubs, with elongated virgate branches. Leaves opposite or whorled: blades entire. Flowers trimorphous, in axillary short-peduncled eymes. Hypanthium campanulate, ribbed. Sepals 5-7, furnished with as many accessory teeth at the sinuses. Petals purple. Stamens 10 or rarely 8 , alternately shorter and longer, the longer exserted :- filaments filiform. Ovary 3-6-celled, globular: style filiform: stigma capitate. Capsules subglobose, loculicidally 3-6-valved. Seeds angled. Testa leathery. Swamp LooseSTRIFE.

1. Decodon verticillàtus (L.) Ell. An aquatic or marsh-inhabiting shrub, with pubescent or rarely glabrous foliage and wand-like curving stems, the submerged portions more or less densely coated with spongy tissue : leaf-blades lanceolate or elliptic-lanceolate, 3-20 cm. long, acuminate, often undulate, acute or acuminate at the base, short-petioled: peduncles short and stout: pedicels 2-8 together, 5-10 $\mathrm{mm}$. long: hypanthium campanulate, 4-5 mm. high, glabrous in age, ribbed: sepals triangular, acuminate, about $\frac{1}{2}$ as long as the tube, the accessory teeth subulate, surpassing the sepals: petals purple, lanceolate to ovate, 7-9 $\mathrm{mm}$. long, acuminate at both ends, crisped: longer stamens conspicuously exserted: capsules subglobose, $5 \mathrm{~mm}$. in diameter: seeds angled, 1.5-2 mm. thick. [Nesaea verticillata (L.) H. B.K.]

In swamps and lakes, Massachusetts to Ontario, Minnesota, Florida and Louisiana. Summer.

\section{LAGERSTROĖMIA L.}

Shrubs or trees, with opposite or whorled branches and 4-angled twigs. Leaves mainly opposite : blades entire. Flowers usually showy, in terminal panicles. Hypanthium turbinate or campanulate-turbinate, sometimes grooved. Sepals 6, shorter than the hypanthium. Petals 6, clawed, crisped. Stamens numerous : filaments filiform, exserted : anthers versatile. Ovary 1-6-celled, included : style filiform : stigma capitate. Capsule leathery, loculicidally 3-6-valved. Seeds flattened, winged above. Testa membranous. Embryo with orbicular cotyledons.

1. Lagerstroemia Índica L. A glabrous deep green shrub, 1-7 m. tall. Trunk clothed with a rough brownish bark, the branches erect or ascending : leaf-blades leathery, obovate or oval, 1-2.5 $\mathrm{cm}$. long, obtuse or apiculate, entire, sessile or nearly so: panicles showy, 1-3 dm. long, many-flowered : pedicels angled, $5-10 \mathrm{~mm}$. long: hypanthium broadly turbinate, oblique, 4-6 mm. high, glaucescent: sepals triangular, acute, unequal, shorter than the hypanthium : petals 6 , purple, pink or nearly white, the blades orbicular or reniform in outline, lobed, strongly crisped, the claws mostly shorter than the blades : stamens exserted ; filaments twisted : capsules oval-globose, $8-9 \mathrm{~mm}$. high, obtuse at the ends.

In waste places, in and near gardens, widely cultivated and sparingly naturalized, from Maryland to Florida and Texas. Spring to fall.

\section{LÝTHRUM L.}

Herbs or shrubs, with angled stems, our species perennial. Leaves alternate or opposite, or rarely whorled: blades entire. Flowers axillary, or in terminal spikes or racemes. Hypanthium tubular, ribbed or flnted, straight or nearly so, not spurred at the base. Sepals 4-6, accompanied by as many erect or spreading teeth. Petals 4-6, broadest above the middle, hardly clawed, essentially equal. Stamens 8-12, in 1 or 2 rows: filaments filiform. Ovary 2-celled : style filiform : stigma capitate. Capsule included, membranous, 2-celled, or becoming 1-celled by the breaking down of the septum, septicidally 2valved or opening irregularly. Seeds plano-convex. Testa leathery, smooth. Embryo with auricled cotyledons. LOOSESTRIFE. 
Leaves mostly opposite.

Leaf-blades oblong to orbicular or rarely cuneate.

Hypanthium trumpet-shaped : leaf-blades short-petioled.

Hypanthium tubular or nearly so: leaf-blades sessile.

Leaf-blades linear.

Leaves mostly alternate.

Leaf-blades narrowed at the base.

Larger leaves with linear blades: sepals broadly triangular, the accessory teeth short and stout.

Larger leaves with elliptic or lanceolate blades : sepals mucro-like, the accessory teeth subulate.

Leaf-blades thick, those of the branches numerous, approximate, mostly less than $1.5 \mathrm{~cm}$. long : hypanthium $6-8 \mathrm{~mm}$. long.

Leaf blades thin, those of the branches few, mostly over $1.5 \mathrm{~cm}$. long : hy panthium 3-5 mm. long.

Leaf-blades rounded or cordate at the base.

1. L. Vulneraria.

2. L. ovalifolium.

3. L. lineare.

4. L. linearifolium.

5. L. lanceolatum.

6. L. Curtissii.

7. L. alatum.

1. Lythrum Vulnerària Ait. Stems more or less creeping, spreading or ascending, 1-12 $\mathrm{dm}$. long, very slender : leaves opposite ; blades leathery, oblong to oval, $0.5-1 \mathrm{~cm}$. long, obtuse, flat, rounded or cordate at the base, short-petioled : flowers axillary, about $1 \mathrm{~cm}$. broad: hypanthium 5-6 mm. long, short-pedicelled, slightly trumpeted-shaped, fluted: sepals low, mucronate, the accessory teeth subulate, ascending: petals purple, cuneateobovate, obtuse: stamens in short-styled flowers, exserted : capsules 4-7 mm. long.

On margins of ponds and swamps, Florida to Texas and Mexico. Spring to fall.

2. Lythrum ovalifolium Engelm. Stems erect 'or decumbent, 1-3 dm. tall, simple or branched, the branches very slender: leaves opposite; blades oblong to orbicularoblong, or the lower ones cuneate, 1-1.5 cm. long, obtuse or acutish, entire, sessile : flowers axillary, 7-9 mm. broad: hypanthium nearly tubular, $4 \mathrm{~mm}$. long, fluted-angled: sepals short, apiculate, shorter than the subulate accessory teeth : petals violet, cuneate, rounded at the apex, spreading : stamens exserted : capsules narrowly oblong, included : seeds $0.4 \mathrm{~mm}$. in diameter. [L. alatum var. pumilum A. Gray.]

In damp soil, Texas. Spring and summer.

3. Lythrum lineàre L. Stems wand-like, 3-12 dm. tall, 4-angled, branched above : leaves opposite; blades linear, 1-4 $\mathrm{cm}$. long, leathery, acute, or the lower ones obtuse, slightly revolute, sessile: flowers dimorphous, $7-8 \mathrm{~mm}$. broad: hypanthium rather short, about $4 \mathrm{~mm}$. long, trumpet-shaped, fluted : sepals triangular, awn-tipped, about as long as the short horn-like accessory teeth : petals cuneate or cuneate-oblong, rounded at the apex, pale purple or pink: stamens included, or exserted in the case of short-styled flowers: capsules oblong-clavate, hardly $4 \mathrm{~mm}$. long: seeds $0.8 \mathrm{~mm}$. long.

In or near salt meadows, New Jersey to Florida and Texas. Summer.

4. Iythrum linearifolium (A. Gray) Small. Stems slender, simple, or branched at the base or above, angled, the branches erect or spreading : leaves alternate, firm ; blades linear or linear-oblong, acute or acutish at the apex, slightly revolute, sessile: hypanthium trumpet-shaped, $5 \mathrm{~mm}$. long: sepals broadly triangular, acute, their accessory teeth short and stout : corolla nearly $1 \mathrm{~cm}$. broad : petals obovate, rounded at the apex, purple, drying violet-purple : capsules narrowly clavate-oblong. [L. alatum var. linearifolium A. Gray.]

In moist ground, Texas to Arizona and Mexico. Spring to fall.

5. Lythrum lanceolàtum Ell. Stems erect or ascending, 6-16 dm. tall, sharply angled or slightly winged, usually with numerous strongly ascending branches: leaves alternate or some of the lower ones opposite ; blades elliptic to linear-elliptic, 1-6 cm. long, acute at the apex, narrowed to the sessile base, those of the branches numerous, approximate mainly about $1 \mathrm{~cm}$. long: hypanthium slender, $6-8 \mathrm{~mm}$. long, fluted : sepals mucrolike, acute, their accessory teeth subulate, ascending : corolla violet-purple, $8-10 \mathrm{~mm}$. broad : petals rose-purple, obovate or cuneate-obovate, obtuse : stamens included : capsule narrowly oblong, included : seeds $0.8 \mathrm{~mm}$. long.

In low grounds and in swamps, South Carolina to the Indian Territory, Florida and Texas. Summer.

6. Lythrum Curtíssii Fernald. Similar to L. lanceolatum in habit, but less rigid. Stem wing-angled, the branches pliable : leaves mainly alternate ; blades relatively thin, those of the main stem $2-5.5 \mathrm{~cm}$. long, those of the branches relatively few, distant, usuaily about $2 \mathrm{~cm}$. long: hypanthium $3-5 \mathrm{~mm}$. long: sepals somewhat longer than the bristlelike teeth : petals pale purple.

In low grounds and marshes, Georgia and Florida. Summer and fall.

7. Lythrum alàtum Pursh. Stems erect or ascending, 3-13 dm. tall, angled and often slightly winged, much branched, the branches erect or ascending: leaves alternate, or some of the lower ones opposite; blades lanceolate, oblong or ovate-lanceolate, 1-5. cm. long, acute at the apex, rounded or cordate at the more or less clasping base, sessile : flowers conspicuous, dimorphous, on short 2-scaled pedicels : hypanthium 5-8 mm. long, 
fluted, slightly expanding above the middle: sepals triangular, acute, the accessory teeth subulate, surpassing the sepals, conspicuous : petals 6 , deep or violet-purple, obovate or cuneate-obovate, slightly crisped, rounded at the apex : stamens 6 : capsules oblong, about $\frac{1}{2}$ as long as the hypanthium.

In swamps and along streams, Ontario to Minnesota, Kentucky and Arkansas. Summer and fall.

\section{PARSÓNSIA P. Br.}

Herbs or shubby plants, usually with a clammy pubescence. Stems terete or nearly so. Leaves opposite or whorled, or rarely alternate: blades entire. Flowers of various colors, irregular. Hypanthium elongated, saccate or spurred at the base, more or less oblique at the mouth, many-ribbed. Sepals 6, augmented by as many narrow teeth at their sinuses, or these sometimes wanting. Petals 6, unequal, clawed. Stamens 11 or 12 , filaments short. Ovary unequally 2-celled, sessile or obliquely stalked: style filiform: stigma 2lobed. Capsule oblong, included, 1-celled, thin-membranous, sometimes oblique. Seeds flattened. Testa leathery. Embryo with orbicular cotyledons. [Cuphea P. Br.]

Hypanthium over $1.5 \mathrm{~cm}$. long: corolla with the upper petals fully $10 \mathrm{~mm}$. long.

Hypanthium less than $1.5 \mathrm{~cm}$. long: corolla with the upper petals less than $10 \mathrm{~mm}$. long.

Pedicels 1-2 mm. long: leaf-blades manifestly petioled : plants annual.

Pedicels 10-18 mm. long: leaf-blades sessile or nearly so : plants perennial.

1. P. procumbens.

Stems. Parsonsia procumbens (Cav.) Small. Perennial, hispid with clammy hairs. and angled : leaf-blades lanceolate or ovate-lanceolate, $2-6 \mathrm{~cm}$. long, acute or acutish, sparingly ciliate, narrowed or truncate at the sometimes oblique base, short-petioled : hypanthium about $2 \mathrm{~mm}$. long, bristly, spurred at the base, flaring at the throat : sepals broadly triangular except the half-orbicular upper one, the accessory teeth gland-like, often bristly: corolla showy : petals purple, clawed, the 4 lower ones cuneate-spatulate, the 2 upper with broadly oblong blades : capsule oblong, about $1 \mathrm{~cm}$. long. [Cuphea procumbens Cav.]

In waste places, western North Carolina. Introduced from Mexico. Summer and fall.

2. Parsonsia petiolata (L.) Rusby. Annual, deep green, the foliage, except the leafblades, clammy pubescent. Stems erect, 1-7 dm. tall, branched above, the branches ascending: leaf-blades ciliate, lanceolate or ovate-lanceolate, $1-4.5 \mathrm{~cm}$. long, rather obtuse but often somewhat acuminate, cuneately narrowed at the more or less oblique base ; petioles $0.5-2 \mathrm{~cm}$. long : pedicels $1-3 \mathrm{~mm}$. long: hypanthium tubular, $10-15 \mathrm{~mm}$. long, bristly, becoming more or less swollen at the middle, spurred at the base : sepals triangular, acute, the accessory teeth small, blunt: petals violet-purple, unequal, elliptic, oval or broadly obovate, rounded or retuse at the apex : stamens 12, included: capsule oblong, 8-9 mm. long, very thin : seeds lenticular, about $3 \mathrm{~mm}$. broad. [Cuphea viscosissima Jacq.]

In dry rocky soil or on hillsides, Rhode Island to Ontario, Kansas, Georgia and Louisiana. Summer and fall. TAR-WEED. WAX-WEED.

3. Parsonsia lythroides Small. Perennial by a woody rootstock, the roots tuberous. Stems erect or assurgent, 2-6 dm. tall, simple or sparingly branched, hispid with clammy hairs : leaf-blades oblong or elliptic, in whorls of 3's or 4's, 1-2 cm. long, acute or acutish, sessile, or nearly so : pedicel longer than the hypanthium, clammy: hypanthium tubular, 8-10 mm. long, somewhat expanded toward the throat, bent, spurred at the base, spinypubescent except near the top: sepals triangular, except the somewhat reniform upper one, acute, the accessory teeth subulate: petals white or pale purple, spatulate, $5-6 \mathrm{~mm}$. long, obtuse. [Cuphea aspera Chapm., not Willd.]

In low pine lands, western Florida. Spring and summer.

\section{Family 3. PUNICÀCEAE Horan. Pomegranate Family.}

Shrubs or small trees, with terete branches. Leaves opposite or nearly so, sometimes clustered : blades entire. Flowers perfect, showy, solitary or clustered in the axils, short-peduncled. Hypanthium leathery, turbinate, adnate to the ovary. Sepals 5-7, ascending. Corolla of 5-7 petals inserted at the throat of the hypanthium, wrinkled. Androecium of numerous stamens in many series on the hypanthium. Filaments filiform. Anthers versatile. Gynoecium of several united carpels. Ovary several-celled, inferior. Styles united. Stigma slightly lobed. Ovules numerous, superposed in 2 series. Fruit a several-celled berry crowned with the caly $x$, with a leathery coat, its septa membranous. Seeds angled, in a watery pulp, with a leathery testa. Embryo with spirally convolute cotyledons, each auricled at the base. 


\section{PÙNICA L.}

Characters of the family. Pomegranate.

1. Punica Granàtum L. A shrub, or a tree reaching a height of $6 \mathrm{~m}$. Foliage glabrous : leaf-blades leathery, oval, elliptic or oblong, varying to broadest slightly above or below the middle, 1-8 $\mathrm{cm}$. long, obtuse or acute, or rarely retuse, flat, short-petioled: peduncles stout, 1-several-flowered: hypanthium turbinate, becoming campanulate, later subglobose : sepals triangular or triangular-lanceolate, much shorter than the tube, acute, finally deciduous : petals scarlet ; blades suborbicular or orbicular-obovate, $1.5-2.5 \mathrm{~cm}$. long, short-clawed : berries subglobose or spheroidal, $5-10 \mathrm{~cm}$. thick.

In woods and waste places, Florida. Cultivated in the tropics. Native of southern Europe.

\section{Family 4. Terminaliàceat J. St. Hil. White Mangrove Family.}

Shrubs or trees, or vines in tropical regions. Leaves alternate or opposite : blades simple, leathery: stipules wanting: petioles often bearing two glands. Inflorescence racemose or capitate. Flowers often apetalous, regular, perfect or polygamous. Calyx of 4-5 valvate deciduous or rarely persistent sepals. Corolla of 4-5 petals, inserted at the base of the calyx, or wanting. Androecium of twice, or rarely thrice, as many stamens as the petals. Filaments distinct. Anthers introrse, erect or incumbent. Gynoecium of a single carpel. Ovary 1-celled. Style terminal. Stigma entire or nearly so. Ovules few, (2-5), suspended, anatropous. Fruit drupaceous or berry-like, indehiscent, often crowned with the accrescent calyx. Seed solitary, filling the cavity. Endosperm wanting. Embryo straight, with convolute cotyledons. [Combretaceae R. Br.]

Petals wanting : calyx deciduous.

Flowers spicate: hypanthium terete.

Flowers in heads: hypanthium flattened. Petals 5: caly $x$ persistent.
1. Terminalia.

2. CONOCARPUS.

3. Laguncularia.

\section{TERMINÀLIA L.}

Shrubs or trees. Leaves opposite or alternate: blades entire : petioles often glandular. Flowers perfect or polygamous, in simple or compound spikes. Hypanthium vase-shaped, green or white, or rarely colored, constricted above the ovary. Sepals often deciduous. Corolla wanting. Stamens 10, in two series, exserted: filaments filiform or subulate. Ovules 2-3. Drupe dry, indehiscent, flattened, or sometimes winged. Seed almond-like.

1. Terminalia Bucèras (P. Br.) Benth. \& Hook. A small tree sometimes 15 m. tall, with naked buds. Leaves often clustered ; blades $2-9 \mathrm{~cm}$. long, spatulate to obovate oval or elliptic, obtuse or notched at the apex, undulate, short-petioled : peduncles 1-3 cm. long: spikes clustered, thinly tomentose, $3-10 \mathrm{~cm}$. long: hypanthium $3 \mathrm{~mm}$. high, tomentose ; limb saucer-shaped : sepals broadly triangular, acute : stamens 10 , conspicuously exserted: style villous : drupe ovoid-conic or flask-shaped, 7-8 mm. long, thinly tomentose, the neck slightly curved.

In coral soil, Elliott's Key, Florida. Also in the West Indies and tropical America. Spring. Black OLIVE Tree.

2. Terminalia Catáppa L. A shrub, or a tree sometimes $17 \mathrm{~m}$. tall. Leaves alternate ; blades leathery, 1-3 dm. long, cuneate or oblanceolate, rounded or apiculate at the apex, undulate, acute, rounded or cordate at the base, on short stout petioles : spikes slender, $5-15$ cm. long, peduncled, many-flowered : hypanthium pubescent, elongated : sepals ovate or triangular, about as long as the rest of the limb : stamens exserted : anthers cordate : drupe elliptic or nearly so, 4-7 cm. long, 2-edged or slightly winged.

In sandy soil, peninsular Florida and Key West. Also in the West Indies and tropical America. Native of the East Indies.

\section{CONOCÁRPUS L.}

Maritime shrubs or trees. Leaves alternate : blades entire, leathery : petioles bearing 2 glands. Flowers perfect, minute, greenish, in dense spicate or panicled heads. Hypanthium flattened, not prolonged beyond the ovary. Sepals 5, deciduous. Stamens usually 5, 
exserted : filaments elongated : anthers cordate. Style pubescent. Ovules 2 in each cavity. Fruit an aggregation of imbricated scale-like drupes. Seeds flattened. Embryo with convolute cotyledons. Butronwood.

1. Conocarpus erécta L. A glabrate or silky-pubescent shrub or tree, sometimes 20 $\mathrm{m}$. tall, with angled or winged twigs. Leaf-blades $2-5 \mathrm{~cm}$. long, elliptic to oval, acute or acuminate at both ends, entire, short-petioled : racemes $3-5 \mathrm{~cm}$. long, peduncled : heads $5-8$ $\mathrm{mm}$. in diameter at flowering time : hypanthium funnel-like, greenish, a little over $1 \mathrm{~mm}$. long: sepals triangular-ovate, about as long as the limb of the hypanthium, pubescent: stamens and style conspicuously exserted : heads of fruit 9-14 mm. long : drupes scale-like, 2-winged, 4-7 mm. long.

On muddy or sandy shores, peninsular Florida and the Keys. Common in the West Indies and on the shores of Central America and tropical South America. Summer.

\section{LAGUNCULÀrIA Gaertn.}

Maritime shrubs or trees. Leaves fleshy, opposite : blades entire, obscurely nerved : petioles bearing 2 glands. Flowers polygamous, inconspicuous, in simple or compound spikes. Hypanthium terete or nearly so, scarcely produced beyond the ovary. Sepals 5, persistent. Petals 5, minute, caducous. Stamens 10, included : filaments subulate, in 2 series : anthers cordate. Ovary surmounted by an epigynous disk with a scalloped edge: style glabrous: stigma slightly 2 -lobed. Ovules 2 in each cavity. Drupe leathery, somewhat angled. Seed solitary, germinating in the drupe. Cotyledons convolnte. WHITE Buttonwood. White Mangrove.

1. Laguncularia racemòsa Gaertn. f. A shrub or tree, sometimes $20 \mathrm{~m}$. tall, with a maximum trunk diameter of about $5 \mathrm{dm}$. Leaf-blades oblong, varying to oval or obovate, $2-5 \mathrm{~cm}$. long, rounded or usually notched at the apex, undulate, rounded or subcordate at the base ; petioles stout, 5-20 mm. long: spikes rather rigid, 3-6 cm. long, rather fewflowered: hypanthium subtended by minute scales, oblong or obovoid, ribbed, finely tomentose, often bearing 2 minute scales above the middle : sepals semiorbicular, acutish : petals 5, suborbicular, not surpassing the sepals : drupes oblong-obovoid, $2 \mathrm{~cm}$. long, strongly ribbed, constricted below the crown of sepals. [L. glabrifolia Presl.]

On the coast, peninsular Florida. Also in the Bermudas, West Indies and tropical America.

\section{FAmily 5. Myrtàceae R. Br. Myrtle Family.}

Shrubs or trees, or rarely herbs, abounding in pungent and aromatic volatile oil. Leaves opposite, or rarely alternate or whorled: blades often simple, pellucid-punctate, flat, terete or semiterete, with nerves parallel with the margins. Stipules wanting. Flowers perfect, regular. Calyx of 4-5 or many valvate or imbricated persistent sepals, or cup-like and deciduous. Petals inserted on the margin of a disk, or sometimes wanting. Androecium of numerous stamens, very rarely as many as the sepals. Filaments distinct or partially united. Anthers opening longitudinally. Gynoecium compound. Ovary inferior or partly so, in a fleshy disk, 1-many-celled. Styles terminal or rarely lateral, united. Stigma usually terminal, entire. Ovules solitary or numerous. Fruit sometimes dehiscent, often crowned with the calyx. Seeds straight, often angled. Testa membranous or crustaceous. Endosperm wanting.

Calyx of several persistent valvate sepals : petals present.

Calyx of regularly separating sepals.

Inflorescence centripetal: flowers in raceme-like umbel-like or contracted clusters.

Inflorescence centrifugal : flowers in cymes.

Calyx of irregularly separating sepals.

Calyx lid-like, deciduous : petals wanting.

1. EUGENIA.

2. ANAMONIS.

3. Psidium.

4. Chytraculia.

\section{FUGÈNIA L.}

Shrubs or trees, with usually glabrous foliage. Leaves opposite : blades commonly leathery, feather-nerved. Flowers axillary, solitary, or in umbel-like raceme-like or congested clusters. Sepals 4-5, imbricated or valvate. Petals white, 4-5, spreading or converging and united. Stamens numerous: filaments filiform, distinct and in several series, or aggregated into 4 groups and slightly united : anthers versatile. Ovary sessile, 2-3-celled. Ovules several in each cavity. Berries pulpy, or rather dry and leathery, crowned with the calyx. Seeds often 1-4. STOPPER. 
Flowers in very short racemes.

Leaf-blades broadest above the middle: fruit longer than broad.

Leaf-blades broadest below the middle : fruit broader than long.

Flowers solitary in the axils, or in umbel-like clusters.

Peduncles shorter than the subtending leaf-like bracts.

Leaf-blades acute or slightly acuminate : corolla about $10 \mathrm{~mm}$. broad : fruit much broader than long.

Leaf-blades abruptly and conspicuously acuminate : corolla about $6 \mathrm{~mm}$. broad : fruit as long as broad.

Peduncles surpassing the subtending leaf-like bracts.

1. E. buxifolia.

2. E. monticola.

3. E. procera.

4. E. Garberi.

5. E. longipes.

1. Eugenia buxifòlia (Sw.) Willd. A shrub or small tree, rarely $6 \mathrm{~m}$. tall, with a maximum trunk diameter of about $3 \mathrm{dm}$., the bark scaly, the branchlets terete. Leafblades oblong-cuneate, cuneate-spatulate or nearly oblong, $2-3 \mathrm{~cm}$. long, blunt, revolute, entire or nearly so, deep green above, yellowish green and black-dotted beneath, shortpetioled: clusters arising from the axils of old leaves: pedicels rufous-pubescent: sepals 4, obtuse : corolla 3-4 mm. broad : petals white, much longer than the sepals, ciliate, glandular-punctate : fruit oval or oblong-oval, oblique, 7-8 mm. long, aromatic, black. and fall.

On sandy shores, southern peninsular Florida and the Keys. Also in the West Indies. Summer

2. Eugenia montícola (Sw.) DC. A shrub or tree, reaching a height of $8 \mathrm{~m}$., with a maximum trunk diameter of about $3 \mathrm{dm}$., the bark shallowly fissured, the branchlets terete. Leaf-blades elliptic-ovate or nearly elliptic, but broadest just below the middle, 3-5 cm. long, often slightly pinched below the apex, entire, revolute, paler beneath than above and black-dotted; petioles $2-5 \mathrm{~mm}$. long, margined : racemes cluster-like, axillary: pedicels pubescent: sepals 4 , rounded : corolla $3-4 \mathrm{~mm}$. broad : petals 4 , surpassing the sepals, glandular-punctate : fruit depressed-globose, 10-12 $\mathrm{mm}$. in diameter, black, glandular-punctate, sweet.

On sandy shores, peninsular Florida and the Keys. Also in the West Indies. Summer.

3. Eugenia pròcera (Sw.) Poir. A tree, reaching a height of $8 \mathrm{~m}$., with a maximum trunk diameter of $3 \mathrm{dm}$., the bark smooth, the branchlets terete. Leaf-blades ovate to elliptic, 3-6 cm. long, acute or slightly acuminate, firm at maturity, olive-green above, paler beneath, slightly thickened along the margins; petioles margined, 4-12 $\mathrm{mm}$. long: clusters several-flowered, axillary : pedicels glandular: sepals 4, rounded : corolla white, about $10 \mathrm{~mm}$. broad: petals about twice as long as the sepals, glandular-punctate : fruit depressed, globose, $16-22 \mathrm{~mm}$. broad, orange, tinged with red or black at maturity, conspicuously crowned with the calyx.

In sandy shores, Key West and the West Indies. Spring.

4. Eugenia Gárberi Sarg. A tree, reaching a height of $18 \mathrm{~m}$., with a maximum trunk diameter of $5 \mathrm{dm}$., the bark scaly, the branchlets terete. Leaf-blades ovate or ovalovate or oblong-ovate, 3-5 cm. long, conspicuously acuminate, lustrous above, paler and black-dotted beneath, revolute, oblique at the base ; petioles $2-6 \mathrm{~mm}$. long : clusters axillary, several-flowered: pedicels glabrous : calyx glabrous: sepals 4 , acute or acutish : corolla white, about $6 \mathrm{~mm}$. broad: petals 4 , ovate or orbicular-ovate, surpassing the sepals: fruit subglobose or globose-obovoid, 5-6 mm. in diameter, scarlet, conspicuously crowned with the calyx.

In rich hammocks, southern peninsular Florida and the Keys. Also in the Bahamas. Late summer and fall.

5. Eugenia lóngipes Berg. A shrub or small tree. Leaf-blades oblong to oval or slightly broadest above or below the middle, 1-3 $\mathrm{cm}$. long, leathery, obtuse or acutish, finely reticulated, short-petioled: peduncles by pairs from a short, stout stalk, $2-6 \mathrm{~cm}$. long: calyx glabrous, glandular-punctate: sepals 4 , ovate or orbicular-ovate: corolla white, 8-9 mm. long: petals oblong or nearly so, much longer than the sepals: fruit subglobose, 6-9 mm. in diameter, with an ample crown of the sepals.

On sandy shores, Florida Keys and the West Indies.

\section{ANAMÒNIS Griseb.}

Shrubs or small trees, possessing an aromatic principle, the branchlets terete. Leaves opposite: blades leathery or parchment-like, persistent. Flowers perfect, 3, 5 or 7 in peduncled cymes, or sometimes solitary. Sepals 4 or rarely 5 , persistent. Corolla inserted under a thick disk. Petals 4 or rarely 5, glandular-punctate. Stamens numerous : filaments filiform, inflexed : anthers versatile, introrse. Ovary 4-celled. Ovules numerous in each cavity, half-anatropous. Fruit berry-like, more or less oblique, or globose. Seeds 1 or rarely 2. NAKED StPoPER. NAKED-WOOD. 
1. Anomonis dichótoma (Poir.) Sarg. A shrub or tree, reaching a height of $8 \mathrm{~m}$., with a maximum trunk diameter of about $1.5 \mathrm{dm}$., the bark smooth but finally separating in small scales. Leaf-blades parchment-like or rather leathery at maturity, oblong to cuneate or obovate-cuneate, $2-4 \mathrm{~cm}$. long, revolute, rarely acute; petioles 1-2 mm. long, silky or glabrous at maturity : peduncles sometimes surpassing the leaves, silky, at least when young : terminal flowers sessile in the forks of the cyme-branches : caly $\mathrm{x}$ tomentose ; sepals 4 , ovate, obtuse : corolla $4-5 \mathrm{~mm}$. broad, white : petals fully twice as long as the sepals : fruit oval or subglobose, 6-7 mm. long, reddish brown, oblique, crowned with the calyx.

On sandy shores, peninsular Florida and the Keys. Also in the West Indies. Spring.

\section{PSÍDIUM L.}

Shrubs or trees. Leaves opposite: blades leathery, prominently ribbed. Flowers solitary or several together on axillary pedicels. Sepals 4-5, irregularly separating from each other. Petals 4-5, relatively large. Stamens very numerous. Ovary inferior, 2-5celled or sometimes 7-celled. Ovules numerous in each cavity of the ovary. Berry pulpy, often aromatic and somewhat acid. Seeds numerous. Guava.

1. Psidium Guajàva Raddi. A shrub, or a small tree sometimes $5 \mathrm{~m}$. tall, with pubescent 4-angled branchlets. Leaf-blades firm-leathery, oblong or nearly so, 4-8 cm. long, mostly obtuse, pubescent beneath, with prominent rib-like lateral nerves, short-petioled : sepals $1-1.5 \mathrm{~cm}$. long: petals $1.5-2 \mathrm{~cm}$. long : berries globular or pyriform, $3-6 \mathrm{~cm}$. in diameter.

In fields and thickets, peninsular Florida and southern California. Introduced from the tropics.

\section{CHYTRACÙLIA P. Br.}

Shrubs or trees, somewhat aromatic. Leaves opposite : blades often leathery, feathernerved. Flowers inconspicuous, numerous, in clustered open cymes at the ends of axillary peduncles. Sepals persistently united into a cap-like body. Corolla wanting. Stamens numerous, inserted in many series : filaments filiform, distinct : anthers opening lengthwise. Ovary sessile, 2-3-celled. Ovules 2 in each cavity, side-by-side. Berry shorter than the remains of the hypanthium. Seeds usually 1-2. STOPPER.

1. Chytraculia Chytracùlia (L.) Millsp. A shrub or tree, sometimes $8 \mathrm{~m}$. tall, with a maximum trunk diameter of about $1 \mathrm{dm}$., the bark smooth, or with broad scales in age. Leaf-blades elliptic or nearly so, 3-8 cm. long, acuminate at both ends or merely acute at the base, deep green and lustrous above, pubescent beneath, at least when young; petioles $5-12 \mathrm{~mm}$. long: panicles 5-10 $\mathrm{cm}$. long and about as broad: hypanthium pubescent with red hairs : sepals suborbicular, deciduous : corolla wanting: fruit subglobose or oval, 5-7 $\mathrm{mm}$. in diameter, reddish brown.

In hammocks, southern peninsular Florida and the Keys. Also in the West Indies and Mexico.

\section{FAMILY 6. RHIZOPHORÀCEAE Lindl. MaNgrove Family.}

Maritime shrubs or trees, with terete branches and usually glabrous foliage. Leaves usually opposite, with stipules : blades leathery. Flowers perfect, solitary in the axils or variously disposed in spikes, racemes, cymes or panicles. Calyx of 3-4 valvate sepals. Corolla sometimes showy. Petals as many as the sepals, 2-cleft or lacerate. Androecium of twice or 4 times as many stamens as the petals, or rarely of the same number, inserted at the base of a more or less conspicuous disk. Filaments short or elongated. Anthers 2-celled, opening lengthwise. Gynoecium of 2-5 united carpels. Ovary inferior, or partly inferior, usually 2-5-celled or rarely 1-celled. Styles united. Stigmas various, sometimes lobed. Ovules 2 or rarely 4 or more in each cavity, pendulous. Fruit leathery, crowned with the calyx, indehiscent or tardily septicidal.

\section{RHIZÓPHORA L.}

Evergreen trees, with an astringent bark, and stout pithy branchlets. Leaves opposite : blades entire : stipules elongated, interpetiolar, caducous. Flowers cream-colored or yellow, 2 or several on forking peduncles. Hypanthium short, adnate to the base of the ovary. Sepals 4, leathery. Petals 4, emarginate, leathery. Stamens 4-12, alternate with the petals : filaments short. Ovary 2-celled, half-inferior, produced into a fleshy cone. 
Stigma 2-lobed. Ovules 2 in each cavity. Fruit pendulous, 1-celled, leathery. Seed solitary, germinating in the persistent fruit, the elongating radicle sometimes reaching the ground before the fruit falls. Endosperm wanting. Mangrove.

1. Rhizophora Mángle L. A shrub or tree, reaching a height of $10 \mathrm{~m}$., forming impenetrable thickets by the precocious and greatly elongating radicles of the embryo and the numerous roots. Leaves $5-15 \mathrm{~cm}$. long; blades leathery, elliptic or elliptic-obovate, obtuse, with a stout midrib ; petioles $0.5-1.5 \mathrm{~cm}$. in length : peduncles $1-4 \mathrm{~cm}$. long, 2-3flowered: pedicels stout, 5-10 mm. long: bractlets scale-like: hypanthium fleshy, turbinate or campanulate, $3-5 \mathrm{~mm}$. long: sepals lanceolate, about $1 \mathrm{~cm}$. long, involute, keeled within, very firm, recurved at maturity: petals pale yellow, leathery, linear or nearly so, cleft at the tip, involute above the middle, cobwebby along the edges: anthers clustered around the style : fruit $2-3 \mathrm{~cm}$. long, curved, the radicle protruding as a narrowly clavate pendent body.

Along the coast of peninsular Florida and the Keys. Also in tropical America.

\section{Family 7. epilobiàceat de. Evening-primrose Family.}

Herbs, or rarely shrubs. Leaves alternate or opposite, without stipules, or with mere glands in their place: blades simple. Flowers usually perfect. Hypanthium often elongated. Calyx of 2-6, usually 4, sepals. Corolla of 2-9, usually 4, petals, convolute in the bud, or rarely wanting. Androecium of as many stamens as the sepals or twice as many. Gynoecium of several, usually 4, united carpels. Ovary 1-6-celled, usually 4-celled, inferior. Styles united. Stigmas distinct, or united, and capitate or discoid. Ovules generally anatropous. Fruit capsular or rarely nut-like. Seeds sometimes appendaged, the appendage either tubercle-like or a tuft of hairs. Endosperm scant or wanting.

\section{[Onagraceae Dumort.]}

Floral whorls of 4 parts or more.

Fruit a many-seeded capsule, opening by valves or by a pore, or by the breaking down of the walls.

Hypanthium not prolonged beyond the ovary.

Seeds naked, $i$. $e$., without a tuft of hairs.

Stamens 4 , in 1 row.

Leaves opposite : stems prostrate, creeping or floating : flowers sessile or on peduncles longer than the leaves.

Flowers sessile: petals wanting or very small : leaf-blades petioled : capsules sessile, short, flat at the apex.

Flowers long-peduncled: petals conspicuous : leaf-blades sessile: capsule long-peduncled, elongated, eurved, with a prominent 4-lobed stylopodium at the apex.

Leaves alternate: stems erect or ascending: flowers sessile, the hypanthium and ovary sometimes narrowed into a pedicel-like base.

Stamens $8-12$ in 2 rows.

Seeds furnished with a tuft of silky hairs.

Hypanthium prolonged beyond the ovary.

Seeds with a tuft of silky hairs.

Seeds naked or merely tuberculate.

Stigmas 4, linear.

Flowers with all the stamens equal in length.

Ovules and seeds horizontal, borne in 2 or rarely more rows, prismatic-angled.

Ovules and seeds ascending, not angled.

Buds erect: corolla yellow: ovules and seeds in 2 rows.

Buds drooping : corolla white turning pink : ovules and seeds

in 1 row.

Ovules and seeds numerous, not tuberculate, clustered on slender funiculi.

Corolla yellow: capsules depressed at the apex.

Corolla red, purple or white: capsules pointed.

Ovules and seeds few, sessile in 1 or 2 rows.

Plants normally acaulescent.

Plants caulescent.

Capsules sharply 4-angled : stems wiry, diffuse : leaves $0.5-$ $2.5 \mathrm{~cm}$. long.

Capsules broadly-winged : stems not diffused, stout : leaves 4-15 cm. long.

Stigma disk-like, entire or rarely 4-toothed.

Free portion of the hypanthium longer than the ovary : stigma entire: stamens equal in length.

Free portion of the hypanthium shorter than the ovary : stigma slightly 4-toothed : stamens unequal in length.

Filaments each with a scale at the base : ovary 4 -celled.

Filaments naked : ovary 1-eelled.

1. IsNARDIA.

2. Ludwigiantha.

3. LUDWIGIA.

4. JUSSIAEA.

5. CHAMAENERION.

6. Epilobium.

\section{ONAGRA.}

8. OENOTHERA.

9. ANOGRA.

10. KNEIFFIA.

11. Hartmannia.

12. LavaUxia.

13. Gaurelli.

14. MEgAPTERIUM.

15. Galpinsia.

16. Meriolix.

17. GAURA.

18. STENOSIPHON.

19. CircaEa. 


\section{ISNÁRDIA L.}

Succulent herbs. Stems creeping or floating. Leaves opposite, relatively few : blades more or less petioled. Flowers axillary, sessile. Sepals 4, shorter than the hypanthium or slightly longer. Corolla not yellow. Filaments very short. Ovary very short: style often almost wanting. Capsule obovoid or turbinate, straight, sessile. Marsh Pursuane.

Fruit $2.5-4 \mathrm{~mm}$. long : corolla usually wanting.

Plant pubescent : fruit $2.5-3 \mathrm{~mm}$. long.

Plant glabrous : fruit $3-4 \mathrm{~mm}$. long.

Fruit 6-7 mm. long: corolla usually present.

1. I. spathulata.

2. I. palustris.

3. I. natans.

1. Isnardia spathulàta (T. \& G.) Small. Stem diffusely branched at the base, the branches 1-3 dm. long, decumbent and creeping, appressed-pubescent : leaf-blades spatulate or oval, sometimes obtuse, $2-2.5 \mathrm{~cm}$. long, winged, petioled : flowers inconspicuous, hypanthium densely pubescent : sepals 4 , broader than high or as broad as high : petals wanting: capsules globose-obovoid or obovoid, $2.5-3 \mathrm{~mm}$. long, obscurely 4-sided, pubescent. ' [Ludwigia spathulata T. \& G.]

Around pine-land ponds, middle Florida. Summer.

2. Isnardia palústris $\mathrm{L}$. Stems branching, 1-5 dm. long : leaf-blades oval, ovate or spatulate, 12-25 mm. long, narrowed into slender petioles: flowers solitary, about $2 \mathrm{~mm}$. broad : bractlets at base of the hypanthium usually none : sepals triangular, acute : petals small, reddish, or usually wanting: capsules 4-sided, slightly longer than wide, 3-4 mm. long, slightly exceeding the sepals in length. [Ludwigia palustris (L.) Ell.]

In muddy ditches and swamps, Nova Scotia to Manitoba, Oregon, Florida, California and Mexico. Widely distributed in the Old World. Spring to fall.

3. Isnardia nàtans (Ell.) Small. Stems creeping or floating, more or less branched, usually diffuse, 1-5 dm. long, glabrous : leaf-blades ovate, elliptic or oval, 1-3 cm. long, petioled, or the lower ones sometimes nearly sessile: sepals 4, ovate-lanceolate, acute : petals 4, as long as the sepals, inconspicuous : capsules inversely pyramidal, $6-7 \mathrm{~mm}$. long, 4-sided. [Ludwigia natans Ell.]

In streams and marshes, North Carolina to Florida and Mexico. Spring to fall.

\section{LUDWIGIÁNTHA Small.}

Fleshy herbs. Stems prostrate, creeping. Leaves opposite, numerous : blades sessile. Flowers on slender bracted peduncles. Sepals narrow, longer than the hypanthium. Corolla yellow. Petals conspicuous, surpassing the sepals. Filaments elongated. Ovary relatively long: style filiform, elongated. Capsule club-shaped, curved at the base, surmounted by a 4-lobed stylopodium, about as long as the persistent sepals.

1. Ludwigiantha arcuàta (Walt.) Small. Stems glabrous or nearly so, $8-30 \mathrm{~cm}$. long. Leaf-blades oblanceolate, leathery, smooth, obtusish at the apex, narrowed at the base, 12-25 $\mathrm{mm}$. long: flowers axillary, solitary: sepals linear-lanceolate, acuminate, shorter than the obovate petals: corolla bright yellow, $8-12 \mathrm{~mm}$. broad : capsules clubshaped, somewhat curved, glabrous, 8-10 mm. long. [Ludwigia arcuata Walt.]

In swamps, Virginia to Florida. Spring and summer.

\section{LUDWÍGIA L.}

Perennial or annual herbs. Stems erect or ascending, sometimes angled or winged. Leaves alternate : blades usually entire. Flowers axillary or terminal. Sepals generally persistent. Petals usually 4. Stamens usually 4. Ovary 4-5-celled. Capsule terete, ribbed or winged, septicidal, or opening by an apical pore.

Corolla inconspicuous, obsolete or wanting: valves of the capsule separating from the disk-like top.

A. Petals wanting or minute, shorter than the sepals.

Capsules 1-2 mm. long: stem-leaves of a spatulate type. Leaf-blades entire.

Leaf-blades toothed near the apex.

Leaf-blades broadly spatulate: sepals much shorter than the hypanthium. 2. L. Simpsonii.

Leaf-blades narrowly spatulate: sepals about as long as the hypanthium. 3 . $L$. Curtissii.

Capsules 3-8 mm. long: stem-leaves not spatulate.

a. Capsules about as thick as long, not cylindric.

* Foliage and fruit glabrous or merely appressed-puberulent.

Flowers in a terminal head or congested panicle.

Flowers in elongated interrupted spikes or axillary.

+ Fruit turbinate, cubic-turbinate or obpyramidai.

\& Fruit slightly longer than broad, the angles rounded or merely square. 
Fruit glabrous, the angles rounded : bractlets adnate to the hypanthium.

Fruit puberulent, the angles square : bractlets not adnate to the hypanthium.

\&\& Fruit slightly broader than long, the angles winged or margined.

Sepals nearly as broad as long, almost as long as the capsule: seeds oval.

Sepals broader than long, $1 / 2$ as long as the capsule: seeds cylindric.

+ Fruit globular.

** Foliage and fruit copiously pilose-tomentose.

b. Capsules cylindric.

B. Petals longer than the sepals.

Fruit cylindric, terete or nearly so.

Fruit narrowly obpyramidal.

Corolla conspicuous: flowers peduncled : capsule opening by a terminal pore.

Foliage, sepals and fruit hirsute.

Foliage, sepals and fruit glabrous, puberulent or minutely appressed-pubescent.

Stem-leaves with closely sessile blades: petals about twice as long as the sepals: pedicels longer than the capsules.

Stem-leaves with short-petioled blades: petals about as long as the sepals : pedicels shorter than the capsules.

5. L. polycarpa.

6. L. simulata.

7. L. alata.

8. L. lanceolata.

9. L. sphaerocarpa.

10. L. pilosa.

11. L. glandulosa.

12. L. linifolia.

13. L. linearis.

14. L. hirtella.

15. L. virgata.

16. L. alternifolia.

1. Ludwigia microcárpa Michx. Stems slender, glabrous, erect or decumbent and creeping, 1-4 dm. long, 3-angled, simple or much branched, often stoloniferous, the angles sometimes slightly winged : leaf-blades spatulate or obovate-spatulate, $0.5-3 \mathrm{~cm}$. long, acute or obtuse, short-petioled : leaves of the stolons with orbicular blades : flowers inconspicuous, axillary, sessile : sepals triangular, acute : petals wanting : capsules broadly obpyramidal, 1.5-2 mm. long.

In muddy places, North Carolina to Florida and Mississippi. Spring to fall.

2. Ludwigia Simpsònii Chapm. Stems often branched near the base, the branches glabrous, simple or again branched, often slightly decumbent, 1-3 dm. long: leaf-blades broadly spatulate, 1-2.5 cm. long, finely toothed near the apex : leaves of the stolons with very broadly spatulate blades : flowers inconspicuous, axillary, sessile : sepals triangular, much shorter than the hypanthium : petals wanting : capsules broadly turbinate, about 2 $\mathrm{mm}$. long, depressed.

In ditches and low grounds, western peninsular Florida. Spring to fall.

3. Ludwigia Curtíssii Chapm. Stems glabrous, erect, $2-5 \mathrm{dm}$. tall, simple or branched, especially above, nearly terete, often spongy below : leaf-blades narrowly spatulate, acute, toothed above, narrowed at the base, sessile : flowers inconspicuous, axillary, sessile : sepals glabrous, about as long as the hypanthium, triangular: petals wanting: capsules turbinate, about $2 \mathrm{~mm}$. long, terete.

In ponds, eastern peninsular Florida. Summer and fall.

4. Ludwigia suffruticòsa Walt. Stems glabrous or rarely puberulent, $3-10 \mathrm{dm}$. tall, erect or decumbent, simple and virgate or virgately branched : leaf-blades narrowly oblong to narrowly lanceolate or linear, $2-10 \mathrm{~cm}$. long, acute or acuminate, sessile, those of the stolons broadly oblong to obovate, short-petioled : flowers inconspicuous, crowded into a terminal head or congested panicle : sepals broadly ovate or triangular-ovate, acute : petals minute or wanting: capsules broadly obpyramidal, 4-5 $\mathrm{mm}$. long, longer than the persistent sepals.

In wet pine lands, North Carolina to Florida. Spring to fall.

5. Ludwigia polycárpa Short \& Peter. Stems glabrous, erect or nearly so, 3-9 dm. tall, more or less winged : leaf-blades narrowly lanceolate, acute at each end, $5-10 \mathrm{~cm}$. long, rough-margined, sessile, those of the stolons spatulate : flowers inconspicuous, sessile : bractlets adnate to the hypanthium : sepals triangular-lanceolate, acute, sometimes serrulate, much shorter than the mature hypanthium: petals minute, greenish : capsules glabrous, slightly 4-sided, about $5 \mathrm{~mm}$. high, often twice the length of the sepals.

In swamps, Ontario to Minnesota, Massachusetts, Tennessee and Nebraska. Summer and fall.

6. Ludwigia simulàta Small. Stems puberulent, freely branching, 4-9 dm. tall, nearly terete : leaf-blades narrowly elliptic to almost linear, $1.5-5.5 \mathrm{~cm}$. long, acute at both ends, entire, sessile, those of the stolons obovate to suborbicular: bractlets not adnate to the hypanthium : sepals triangular or ovate-triangular, about as long as the mature hypanthium : petals minute : capsules puberulent, obpyramidal, manifestly 4 -sided, about $4 \mathrm{~mm}$. long.

In swamps, eastern North Carolina. Spring to fall.

7. Ludwigia alàta Ell. Stems glabrous, $3-9 \mathrm{dm}$. tall, narrowly winged, often stoloniferous : leaf-blades linear-oblanceolate to linear-lanceolate, or sometimes nearly linear, 2.5-
$10 \mathrm{~cm}$. long, those of the stolons suborbicular or spatulate : flowers inconspicuous : sepals 
glabrous, nearly as broad as long, almost as long as the capsule : petals wanting : capsules 3-4 $\mathrm{mm}$. high, the angles winged.

In marshes, North Carolina to Missouri, Florida and Louisiana. Spring to fall.

8. Ludwoigia lanceolàta Ell. Stems glabrous, erect, $3-7 \mathrm{dm}$. tall, angled or sometimes winged. often much branched, sometimes stoloniferous : leaf-blades linear-oblanceolate to linear-lanceolate, $2-10 \mathrm{~cm}$. long, acute, entire, sessile, those of the stolons suborbicular or spatulate : flowers inconspicuous : sepals glabrous, about $\frac{1}{2}$ as long as the capsule, broader than long, acute : petals wanting : capsules cubic-turbinate, about 4-5 mm. high, the angles margined, about twice as long as the sepals.

In swamps, North Carolina to Florida. Summer and fall.

9. Ludwigia sphaerocárpa Ell. Stems generally finely pubescent, $6-9 \mathrm{dm}$. high, the lower part clothed with aerenchyma when growing in water: leaf-blades variable, those of the stem and branches lanceolate, acute at both ends, $5-10 \mathrm{~cm}$. long, scabrous and minutely denticulate, sessile, those of the stolons obovate : flowers sessile : sepals triangular, acute: petals commonly wanting: capsules globular, about $4 \mathrm{~mm}$. high, scarcely longer than the sepals.

In swamps, eastern Massachusetts to Florida and Louisiana. Summer and fall.

10. Ludwigia pilòsa Walt. Stems woody, rather densely pilose, erect or assurgent, 6-12 dm. tall, nearly terete, usually much branched, often stoloniferous : leaf-blades lanceolate, oblong or linear-oblong, 1-6 cm. long, acute, sessile or nearly so, those of the branches much smaller than those of the stem, those of the stolons more or less spatulate : flowers inconspicuous: sepals silky when young, triangular-ovate, acuminate: petals minute or wanting : capsules subglobose-cubic, 4-6 $\mathrm{mm}$. in diameter, hoary, sessile.

In swamps, North Carolina to Florida and Louisiana. Summer and fall.

11. Ludwigia glandulòsa Walt. Stems glabrous, much branched, 3-9 dm. tall : leaf-blades oblong-lanceolate, acute at each end, 5-10 mm. long, sessile or short-petioled : flowers axillary, rarely 2 together: bractlets at the base of the hypanthium minute or wanting: sepals triangular-ovate, acute: petals wanting: capsules 4-grooved, 6-8 mm. long, glabrous, 4-5 times as long as the sepals.

In swamps, Illinois to Kansas, South Carolina, Florida and Texas. Summer and fall.

12. Ludwigia linifolia Poir. Stems glabrous, erect or assurgent, 1-5 dm. tall, simple or diffusely branched, often purplish, stoloniferous at the base, 4-angled : leaf-blades linear-oblanceolate or linear, $2-6 \mathrm{~cm}$. long, obtuse or acute, sessile or nearly so : flowers inconspicuous, sessile : sepals glabrous, lanceolate or ovate-lanceolate, acuminate : petals about as long as the sepals : capsules cylindric, $1 \mathrm{~cm}$. long, sessile.

In pine-land swamps, North Carolina to Florida and Alabama. Spring to fall.

13. Ludwigia lineàris Walt. Stems glabrous, 3-7.5 dm. high, branching, often stoloniferous, the lower part clothed with aerenchyma: leaf-blades narrowly linear, sessile, acute at each end, $2.5-5 \mathrm{~cm}$. long, about $2 \mathrm{~mm}$. wide, with roughish margins, those of the stolons obovate: flowers sessile: sepals triangular-ovate, acute: petals yellowish, slightly longer than the sepals : capsules narrowed at the base, $6-8 \mathrm{~mm}$. long, 3-5 times as long as the sepals.

In swamps, New York to Florida and Louisiana. Summer and fall.

14. Ludwigia hirtélla Raf. Stems hirsute, branching, 3-6 dm. tall : leaf-blades oblong-lanceolate or ovate-lanceolate, $2.5-3 \mathrm{~cm}$. long, obtuse at the apex, rounded at the base, sessile : flowers solitary, peduncled : corolla $20-30 \mathrm{~mm}$. broad : sepals ovate-lanceolate, acute : corolla 12-20 mm. broad : petals yellow, longer than the sepals : capsules cubic above a rounded base, about $5 \mathrm{~mm}$. high, shorter than the sepals, each opening by an apical pore.

In swamps, mainly in pine lands, New Jersey to Florida and Texas. Spring to fall.

15. Ludwigia virgàta Michx. Stems from more or less thickened tuberous roots, slender, puberulent, erect or ascending, 4-13 dm. tall, simple and wand-like or branched at the base or above, angled, especially above : leaf-blades variable, the lower ones mostly oval or oblong, 1-5 cm. long, the upper linear, 2-10 cm. long, all obtuse or minutely apiculate, sessile : flowers in elongated interrupted racemes: pedicels 8-15 mm. long: sepals puberulent, ovate, acute, reflexed : corolla bright yellow, 3-4 cm. broad : petals about twice as long as the sepals : capsules globular-cubic, 5-8 mm. long, the angles often slightly winged.

In dry pine lands, North Carolina to Florida and Louisiana. Spring to fall.

16. Ludwigia alternifolia L. Stems glabrous or puberulent, often from tuberous roots, branching, 6-12 dm. high : leaf-blades lanceolate, acute or acuminate at the apex, $5-12 \mathrm{~cm}$. long, short-petioled : flowers short-peduncled, axillary : sepals ovate, acuminate : corolla $12-16 \mathrm{~mm}$. broad : petals about equalling the sepals, falling away when the plant 
is shocked : capsules cubic above a rounded base, slightly wing-angled, $5-7 \mathrm{~mm}$. high, each opening by a pore.

In swamps, New Hampshire to Ontario, Michigan, Florida, Kansas and Texas. Spring to fall.

\section{JUSSIAÈA L.}

Perennial herbs or shrubby plants, with erect or creeping stems. Leaves alternate : blades usually entire. Flowers perfect, axillary. Sepals 4-6, acute, persistent. Petals 4-6 (rarely more), white or yellow. Stamens 8-12, in 2 rows. Ovary 4-6-celled. Capsule linear, oblong or club-shaped, the body often narrowed into a pedicel-like base, angular or ribbed, septicidal or opening by the breaking down of the capsule-walls. The plants flower from spring to fall.

Capsule-body narrowly cylindric, $2.5-5 \mathrm{~cm}$. long.

Sepals 5 or 6.

Petals much surpassing the sepals: stems decumbent: sepals 5. Corolla 2-2.5 $\mathrm{cm}$. broad : leaf-blades long-petioled. Corolla 4-5 $\mathrm{cm}$. broad : leaf-blades short-petioled.

Petals about as long as the sepals: stems erect or ascending : sepals mostly 6. Sepals 4.

Branches and leaves glabrous or nearly so, if pubescent the hairs appressed. Branches and leaves hirsute.

Capsule-body oblong or oblong-obovate, $1.5-2 \mathrm{~cm}$. long.

Leaf-blades sessile, decurrent as wings on the angles of the stem : fruit winged.

Leaf-blades short-petioled : fruit not winged.

Corolla about $1 \mathrm{~cm}$. broad : fruit $2-3 \mathrm{~mm}$. thick.

Corolla 4-5 $\mathrm{cm}$. broad : fruit 7-9 mm. thick.

1. $J$. diffusa.

2. J. grandiflora.

3. J. leptocarpa.

4. J. suffruticosa.

5. J. scabra.

6. J. decurrens.

7. J. erecta.

8. J. Peruviana.

1. Jussiaea diffùsa Forskl. Stem creeping or floating, glabrous, 3-9 dm. long: leaf-blades oval, oblong, spatulate or obovate, 2.5-10 $\mathrm{cm}$. long, obtuse or acute at the apex, slender-petioled: peduncles slender: sepals 5, lanceolate: corolla yellow, 2-2.5 cm. broad: stamens 10 : capsule-body $2.5-4 \mathrm{~cm}$. long.

In and about ponds, Kentucky to Kansas, Florida and Texas. Also in tropical America and Asia.

2. Jussiaea grandiflòra Michx. Stems villous or hirsute, 6-10 dm. long, decumbent, creeping or floating, the ends erect: leaf-blades various, spatulate on the lower part of the stem, narrowly elliptic or lanceolate above, 3-12 cm. long, acute or acutish, gradually narrowed into short petioles: sepals 5 , about $12 \mathrm{~mm}$. long, lanceolate, acuminate : corolla $4-5 \mathrm{~cm}$. broad, yellow: petals suborbicular, retuse, narrowed into short claws, $2-2.3 \mathrm{~cm}$. long: fruit not seen.

In ponds and streams, North Carolina to Florida and Louisiana.

3. Jussiaea leptocárpa Nutt. Stems mostly bristly hirsute, especially above, erect or ascending, 6-20 dm. tall, much branched : leaf-blades oblanceolate to lanceolate, $3-20 \mathrm{~cm}$. long, acute or acuminate, more or less hirsute, especially along the midrib beneath, narrowed into short petioles or nearly sessile: hypanthium hirsute, elongated : sepals 6 or sometimes 5 , lanceolate, acuminate : corolla yellow, about $1.5 \mathrm{~cm}$. broad: petals about as long as the sepals : fruit narrowly cylindric, $3.5-6 \mathrm{~cm}$. long, the body $6-8$ times longer than the pedicel-like base.

In swamps, Georgia to Arkansas, Florida and Texas.

4. Jussiaea suffruticòsa L. Stems glabrous, or sparingly appressed-pubescent above, erect, 4-16 dm. tall, angled, more or less branched : leaf-blades narrowly oblong or lanceolate, 4-15 cm. long, acute or acutish, short-petioled: hypanthium sparingly pubescent, elongated : sepals 4, ovate, acute or acuminate, 3-5-nerved : corolla yellow, $2-3 \mathrm{~cm}$. broad: petals broadly obovate, retuse, nearly twice as long as the sepals : capsule-body narrowly cylindric, 4-5.5 cm. long, 4-sided, 8-nerved, narrowed into a short pedicel-like base.

On moist banks, North Carolina and Arkansas to Florida and Texas. Also through the tropics to Brazil and in the West Indies.

5. Jussiaea scábra Willd. Stems often woody, hirsute throughout, much-branched, 6-14 dm. tall, the leafy branches spreading: leaf-blades various, ovate to obovate, $2-6 \mathrm{~cm}$. long, obtuse or acutish, densely pubescent on both surfaces, short-petioled : hypanthium hirsute, elongated : sepals 4, ovate, acute or short acuminate, 3-nerved: corolla yellow, $2-2.5 \mathrm{~cm}$. broad : petals 4 , longer than the sepals : capsule-body narrowly cylindric, $2.5-3$ cm. long, 3-4 times longer than the hirsute pedicel-like base.

In moist soil, Florida and tropical America.

6. Jussiaea decúrrens (Walt.) DC. Stems angled, branching, 3-6 dm. tall: leafblades lanceolate, acute or acuminate at the apex, decurrent on the stem, $2.5-10 \mathrm{~cm}$. long: sepals 4 , ovate-lanceolate : corolla yellow, $8-12 \mathrm{~mm}$. broad : stamens 8 : capsule-body $2-2.5$ cm. long, 2-3 times longer than the pedicel-like base, 4-sided, the angles somewhat winged.

In swamps, Maryland to Illinois, Arkansas, Florida and Texas. 
7. Jussiaea erécta L. Stems glabrous, erect or ascending, 1-2 m. tall, branched : leafblades lanceolate or linear-lanceolate, $5-12 \mathrm{~cm}$. long, acuminate, flat, short-petioled : hypanthium slender, elongated : sepals 4 , lanceolate, $5 \mathrm{~mm}$. long, acuminate : corolla deep yellow, $1 \mathrm{~cm}$. broad : petals about as long as the sepals : capsule--body cylindric, $1.5-2 \mathrm{~cm}$. long, 4-sided, narrowed into a very short pedicel-like base.

In sand or sandy soil, Manatee, peninsular Florida. Also in tropical America.

8. Jusslaea Peruviàna L. Stems shrubby, 1-4 m. tall, hirsute, much branched, the branches wide-spreading : leaf-blades ovate, oval, lanceolate or oblong-lanceolate, 4-10 cm. long, abruptly or gradually acuminate, leathery, short-petioled : hypanthium hirsute, shortobconic: sepals 4, lanceolate or ovate-lanceolate, 1-1.5 cm. long, ciliate : corolla large, yellow, 4-5 $\mathrm{cm}$. broad : petals broad, $2-3 \mathrm{~cm}$. long: capsule-body oblong-obovate, $1.5-2$ $\mathrm{cm}$. long, 4-sided, somewhat longer than the stout pedicel-like base.

On banks of rivers, lakes and in swamps, peninsular Florida. Also in tropical America.

\section{Chamaenèrion Adans.}

Perennial herbs, with tufted stems, often woody at the base. Leaves mostly alternate : blades entire. Flowers irregular, showy, in terminal racemes. Hypanthium not prolonged beyond the ovary. Sepals 4, deciduous. Petals 4, entire. Stamens 8, declined : filaments dilated at the base. Ovary 4-celled : stigma 4-cleft. Capsule obtusely 4-angled, elongated, loculicidal. Seeds with a tuft of hairs (coma) at the end. Fire-weed. Willow-herb.

1. Chamaenerion angustifollium (L.) Scop. Stems erect, often finely pubescent above, $0.5-2.5 \mathrm{~m}$. high : leaf-blades lanceolate, $5-15 \mathrm{~cm}$. long, pale beneath, acute at the apex : flowers in elongated terminal spike-like racemes : corolla $1.5-3 \mathrm{~cm}$. broad, purple, or sometimes white : capsules $5-7.5 \mathrm{~cm}$. long, finely canescent, at least when young: seeds about $1 \mathrm{~mm}$. long, the coma about $10 \mathrm{~mm}$. long, whitish. [Epilobium angustifolium L.]

In dry soil, Labrador to Alaska, North Carolina. Kansas, Arizona and California. Also in Europe and Asia. Summer to fall.

\section{EPILÒBIUM L.}

Caulescent herbs, or sometimes shrubby plants. Leaves alternate or opposite : blades often toothed. Flowers solitary, spicate or racemose. Hypanthium prolonged beyond the ovary. Sepals 4, deciduous. Petals 4, often notched. Stamens 8. Ovary 4-celled : stigma club-shaped or 4-lobed. Capsule narrow, elongated, 4-sided, loculicidal. Seeds terminating in a tuft of hairs. WILLOW-HERB. The plants flower in summer and fall.

Leaf-blades linear or linear-lanceolate, mostly entire. Leaf-blades lanceolate to ovate-lanceolate, serrate.

1. E. lineare.

2. E. coloratum.

1. Epilobium lineàre Muhl. Stems canescent throughout with incurved hairs, 3-6 dm. tall, at length much branched: leaf-blades linear or linear-lanceolate, acute at both ends, $2.5-5 \mathrm{~cm}$. long, mostly entire, usually short-petioled, the veins obscure : flowers erect : corolla pink or whitish, 4-8 mm. broad : capsules about $5 \mathrm{~cm}$. long : seeds less than $2 \mathrm{~mm}$. long, slightly papillose.

In swamps, New Brunswick to British Columbia, Delaware, the Indian Territory and Wyoming.

2. Epilobium coloràtum Muhl. Stems commonly much branched, 3-9 dm. tall, more or less canescent above with incurved hairs which are often arranged in lines. Stem and leaves often purplish : leaf-blades mainly lanceolate, acute or acuminate, $5-15 \mathrm{~cm}$. long, sharply serrulate or denticulate, generally short-petioled but sometimes sessile: flowers generally nodding : corolla pink or white, 4-6 mm. broad : capsules short-pedicelled, finely pubescent, $2.5-5 \mathrm{~cm}$. long : seeds papillose, less than $1 \mathrm{~mm}$. long.

In low grounds, Maine to Ontario, Wisconsin, South Dakota, South Carolina and Kansas.

\section{7. ÓNAGRA Adans.}

Annual or biennial herbs, with mostly erect stems. Leaves alternate : blades undulate or toothed. Buds erect. Flowers nocturnal, in terminal spikes. Sepals elongated. Corolla yellow. Ovary 4-celled. Ovules in 2 or more rows, horizontal. Capsule 4-angled, more or less tapering, loculicidal. Seeds prismatic-angled. EvenING-PRIMrose.

Hypanthium slender, $2.5-5 \mathrm{~cm}$, long : corolla $2.5-5 \mathrm{~cm}$. broad. Hypanthium stout, 6-11 cm. long : corolla 8-13 $\mathrm{cm}$. broad.

1. O. biennis.

2. O. Jamesii.

1. Onagra biénnis (L.) Scop. Stems generally stout, 3-25 dm. tall, more or less hirsute : leaf-blades oblong to lanceolate, $2.5-15 \mathrm{~cm}$. long, acute or acuminate, repanddenticulate : sepals slender, much longer than the hypanthium : corolla bright yellow, 2.5-5 
cm. broad : capsules narrowly oblong-conic, erect, pubescent, $18-25 \mathrm{~mm}$. long, nearly terete. [Oenothera biennis L.]

In dry or stony soil, Labrador to Florida west to the Mississippi Valley. Summer and fall.-A variety, $O$. biennis grandiftòra (Ait.) Lindl., is larger and stouter, has larger, thicker and broader leafblades and a corolla 5-8 cm. broad ; it is more common in the southern part of the range.

2. Onagra Jamèsii (T. \& G. ) Small. Stems stout, canescently strigillose, decumbent, 1-4 m. long, more or less branched : leaf-blades narrowly oblong or lanceolate, $5-20 \mathrm{~cm}$. long, often curved, acute, repandly denticulate, the lower ones narrowed into short petiole-like bases, the upper sessile or nearly so : hypanthium stout, $5-11 \mathrm{~cm}$. long : sepals nearly linear, about half as long as the hypanthium : corolla showy, yellow, turning to rose : capsules tapering upward, 35-40 mm. long. [Oenothera Jamesii T. \& G.]

In dry soil, southern Utah to Texas and Arizona. Summer.

\section{OENOTHÈRA L.}

Caulescent annual biennial or perennial herbs, with depressed or erect stems. Leaves alternate : blades sinuate or pinnatifid. Flowers axillary, or sometimes in terminal spikes, nocturnal. Buds erect. Hypanthium filiform or slender. Sepals deciduous. Corolla yellow. Ovary 4-celled, elongated. Ovules in 2 rows, ascending. Capsule usually narrowly cylindric, sometimes slightly tapering, spreading or ascending. Seeds terete, each crowned with a tubercle. Evening PRIMrose.

Flowers axillary.

Stems clothed with dense appressed or ascending hairs.

Corolla 2-3 cm. broad : species native along the Atlantic Coast.

Corolla 7-9 cm. broad: species native along the western Gulf Coast, occasionally naturalized on the Atlantic Coast.

Stems glabrous or rarely with spreading hairs.

Flowers in a terminal bracted spike.

Spike lax : bracts ovate: hypanthium villous.

Spike dense: bracts narrow : hypanthium silky-strigose.

1. O. humifusa.

2. O. Drummondii. 3. O. laciniata.

4. O. heterophylla.

5. O. rhombipetala.

1. Oenothera humifùsa Nutt. Stems branched at the base, the branches spreading, decumbent or ascending, 2-5 dm. long, silky canescent: leaves various, the basal with oblong-spatulate pinnatifid blades, the cauline with oblanceolate to lanceolate acute, undulate repand or toothed blades, $2-3.5 \mathrm{~cm}$.long : flowers axillary : hypanthium $2-3 \mathrm{~cm}$. long: sepals about $\frac{1}{2}$ as long as the hypanthium : corolla $2-3 \mathrm{~cm}$. broad : capsules narrowly cylindric, $2-3$ $\mathrm{cm}$. long, somewhat curved upward : seeds $1.5-2 \mathrm{~mm}$. long, striate.

In drifting sand along the coast, New Jersey to Florida. Spring to fall.

2. Oenothera Drummóndii Hook. Stems branched at the base, the branches decumbent, 2-7 cm. long, pubescent with appressed stiff-silky hairs : leaves various ; blades spatulate to lanceolate, or sometimes ovate or obovate towards the ends of the branches, $1-4 \mathrm{~cm}$. long, entire or distantly toothed : flowers axillary: hypanthium stout, $2-4 \mathrm{~cm}$. long: sepals nearly linear, more than $\frac{3}{4}$ as long as the hypanthium : corolla 7-9 cm. broad: capsules cylindric, $2.5-4 \mathrm{~cm}$. long, spreading, curved upward: seeds nearly $1.5 \mathrm{~mm}$. long, pitted.

On the coast of Texas. Spring to fall.

3. Oenothera laciniàta Hill. Stems decumbent or ascending, sometimes branched, 1-5 dm. tall, glabrous or sparingly hirsute : leaf-blades oval, lanceolate, oblong, or oblanceolate to spatulate at the base of the plant, $2.5-5 \mathrm{~cm}$. long, acute or obtusish at the apex, sinuate-dentate or often pinnatifid : flowers axillary : hypanthium $3-4 \mathrm{~cm}$. long : sepals reflexed : corolla 12-36 mm. broad : capsules linear-cylindric, $2.5-3.5 \mathrm{~cm}$. long, more or less pubescent : seeds $1.2-1.5 \mathrm{~mm}$. long, strongly pitted. [Oenothera sinuata L.]

In dry sandy soil, southern Vermont to New Jersey, Nebraska, Florida, Texas and Mexico, extending into South America. Spring and summer-D. laciniata grándis Britton, with more prominently toothed leaf-blades and corollas 5-7 $\mathrm{cm}$. wide, ranges from Missouri to Kansas and Texas, and $O_{\dot{1}}$ laciniata Mexicana (Spach.) Small, with shaggy hirsute stems, leaves and capsules, occurs in Texas and northern Mexico.

4. Oenothera heterophýlla Spach. Stems relatively slender, erect, 4-9 dm. tall, rather sparingly appressed-pubescent : leaf-blades narrowly oblong to lanceolate, sometimes narrowly lanceolate or spatulate on the lower part of the stem, 1-6 cm. long, acute, undulate or remotely and shallowly toothed, sessile and slightly clasping on the upper part of the stem : corolla $2-4 \mathrm{~cm}$. broad : sepals sparingly and loosely glandular-pubescent : petals obovoid, 1-2 cm. long: capsules columnar, but slightly tapering to the apex, curved, $1.5-2 \mathrm{~cm}$. long, loosely pubescent : seeds fully $1 \mathrm{~mm}$. long.

In sandy soil, sometimes in woods, Florida to Texas. Spring and summer.

5. Oenothera rhombipétala Nutt. Stems relatively stout, erect, 6-12 dm. high, finely and densely appressed-pubescent : leaf-blades lanceolate to linear-lanceolate or 
broadest above the middle on the lower part of the stem, 5-10 $\mathrm{cm}$. long, sessile and rounded at the base or the lower narrowed into petioles, acuminate at the apex, remotely denticulate : sepals closely strigose: petals rhombic-obovate, $2-3 \mathrm{~cm}$. long: capsules columnar, curved, 12-16 mm. long, closely pubescent: seeds obovoid, tuberculate at the top.

On prairies, Minnesota to Indiana, Nebraska and the Indian Territory. Spring and summer.

\section{9. ÁNOGRA Spach.}

Caulescent annual or perennial herbs, often with a papery bark. Stems often somewhat woody. Leaves alternate: blades usually pinnatifid. Buds drooping. Flowers usually axillary, diurnal. Hypanthium elongated. Sepals narrow. Corolla white or pink. Ovary slender. Ovules numerous, in 1 row in each cavity, ascending. Capsules elongated, spreading or ascending, loculicidal. Seeds terete. EvEnING PRIMrose.

Sepals without free tips in the bud.

Sepals with free tips in the bud.

Hypanthium villous in the throat.

Hypanthium glabrous in the throat.

1. A. albicaulis.

2. A. coronopifolia.

3. A. Nuttallii.

1. Anogra albicaùlis (Pursh) Britton. Stems diffusely branched, the branches decumbent or ascending, 1-3 dm. long, more or less hirsute or puberulent, with whitish and often shreddy bark : leaves alternate; blades oblanceolate or lanceolate, deeply pinnatifid or the lower ones repand-dentate (rarely entire), 2.5-10 cm. long: sepals lanceolate, acuminate, hirsute, the tips not free in the bud : corolla $3.5-7.5 \mathrm{~cm}$. broad, white, becoming rose-color: capsules linear-cylindric, $2.5-3.5 \mathrm{~cm}$. long: seeds finely pitted. [Oenothera albicaulis Pursh.]

On prairies, North Dakota and Nebraska to Mexico. Spring and summer.

2. Anogra coronopifòlia (T. \& G.) Britton. Stems erect or nearly so, branched, 1.5-6 dm. tall, more or less hispid or canescent : leaf-blades lanceolate or oblanceolate in outline, $1.2-5 \mathrm{~cm}$. long, usually finely and deeply pinnatifid into linear-oblong lobes: sepals linear : corolla white, turning pink, 1.8-3 cm. broad : capsules oblong, abruptly constricted at the top, straight, $8-20 \mathrm{~mm}$. long, about $4 \mathrm{~mm}$. thick: seeds tuberculate. [Oenothera coronopifolia T. \& G.]

On prairies, South Dakota to Utah, Texas and New Mexico. Spring to fall.

3. Anogra Nuttállii (Sweet) Rydb. Stems erect, 1.5-12 dm. tall, white or pale, rarely with scattered hairs, the bark often shreddy: leaf-blades linear or oblong-linear, $2.5-8.5 \mathrm{~cm}$. long, entire, repand or somewhat pinnatifid : sepals linear: corolla white, turning pink, $2.5-3.5 \mathrm{~cm}$. broad : capsules linear, curved, $2.5-5 \mathrm{~cm}$. long, about $3 \mathrm{~mm}$. thick: seeds smooth. [Oenothera Nuttallii Sweet].

On prairies, Minnesota to Idaho and Texas. Spring and summer.

\section{KNĖ̀rFIA Spach.}

Annual or perennial caulescent often shrubby herbs. Leaves alternate: blades mostly narrow, entire or shallowly toothed. Buds erect. Flowers diurnal, in terminal spikes or racemes. Sepals narrow. Corolla yellow. Ovary usually club-shaped, 4-angled. Ovules numerous, on slender stalks, in many rows. Capsule club-shaped, or oblong by the wings, 4-winged or rarely sharply 4-angled. Seeds not angled, without a tubercle. SundRoPs.

Stem-leaves linear-filiform: capsules 4-angled or 4-margined.

1. K. linifolia.

Stem-leaves with relatively broad blades: capsules winged.

A. Capsules club-shaped, the body gradually narrowed into the pedicel-like base or essentially sessile.

a. Petals over $15 \mathrm{~mm}$. long: capsules pubescent.

Capsule-body less than twice as long as thick.

Leaves silvery-strigose: capsules hirsute, the body stout-stalked.

Leaves glabrous or minutely and inconspicuously pubescent: capsules minutely appressed-pubescent, the body slender-stalked.

Capsule-body over twice as long as thick.

Body of the capsule shorter than the pedicel-like base.

Body of the capsule longer than the pedicel-like base.

sepals less than $1.5 \mathrm{~cm}$. long, the tips united in the bud or if distinct less than $1 \mathrm{~mm}$. long: corolla less than $4 \mathrm{~cm}$. wide : capsules mostly less than $1.5 \mathrm{~cm}$. long.

Capsule-body and slender pedicel-like base clearly defined, the wings thin and commonly glabrous.

Capsule-body narrowed into a stout, little differentiated base, the wings thick and copiously pubescent.

Sepals over $1.5 \mathrm{~cm}$. long, the tips distinet, $2.5-4 \mathrm{~mm}$. long : corolla

2. K. arenicola.

3. K. subglobosa.

4. $K$. longipedicellata.

5. $K$. linearis.

6. K. Spachiana. 
over $4 \mathrm{~cm}$. wide: capsules mostly over $2 \mathrm{~cm}$. long.

Plants glabrous or minutely pubescent : leaf-blades mainly of a linear or narrowly oblong type.

Plants hirsute :leaf-blades of an elliptic or elliptic-lanceolate type.

b. Petals less than $13 \mathrm{~mm}$ long: capsules glabrous or nearly so.

7. K. riparia.

8. K. pratensis.

9. K. pumila.

B. Capsules oblong or nearly so, sometimes abruptıy narrowed into a short pedicel-like base.

Capsule-body less than $1 \mathrm{~cm}$. long: plants not glaucous.

Capsule-body over $1 \mathrm{~cm}$. long: plants glaucous.

10. K. fruticosa.

11. $K$. glauca.

1. Kneiffia linifòlia (Nutt.) Spach. Stems slender, $1.5-4.5 \mathrm{dm}$. tall, finely pubescent above: basal leaves tufted, with oblanceolate or spatulate blades about $2-5 \mathrm{~cm}$. long; stem-leaves filiform-linear, entire, 1-3 cm. long: flowers in loose spike-like racemes : sepals 2-3.5 mm. long: corolla 6-8 mm. broad: stigma-lobes very short : capsule-body ovoid, 4-6 mm. long, puberulent, sharply 4-angled or slightly winged. [Oenothera linifolia Nutt.]

In dry soil, Illinois to Kansas, Georgia, Louisiana and Texas. Spring and summer.

2. Kneiffia arenícola Small. Stems erect, $1.5-4.5 \mathrm{dm}$. tall, branched above, strigillose : leaf-blades linear or nearly so, or some of them narrowly oblong, $1.5-5 \mathrm{~cm}$. long, rather obtuse, silvery strigose, thick, often revolute, entire or essentially so: hypanthium somewhat hirsute : sepals $5.5-8 \mathrm{~mm}$. long : petals $16-23 \mathrm{~mm}$. long: capsule-body globular or obovoid-globose, about $4 \mathrm{~mm}$. long, more or less hirsute, broadly winged above, narrowed into a relatively stout hairy pedicel-like base.

On sand hills or in pine lands, North Carolina to Georgia and Alabama. Sunmer and fall.

3. Kneiffia subglobòsa Small. Stems slender, $2-3 \mathrm{dm}$. tall, much branched, puberulent, widely stoloniferous, red: basal leaves 4-10 $\mathrm{cm}$. long, with spatulate undulately toothed blades, each gradually narrowed into a short petiole-like base : stem-leaves often numerous; blades linear or nearly so, $2-7 \mathrm{~cm}$. long, entire or distantly toothed: hypanthium villous or silky : sepals $6-9.5 \mathrm{~mm}$. long: petals 1.5 to almost $2 \mathrm{~cm}$. long: capsulebody globose-obovoid, $6-7 \mathrm{~mm}$. long, terminating a much longer pedicel-like base, the angles strongly winged, the faces strongly ridged.

In sandy soil, North Carolina to Georgia and Alabama. Summer and fall.

4. Kneiffia longipedicellàta Small. Stems slender, puberulent, erect or assurgent, $3-8.5 \mathrm{dm}$. tall : basal leaves with spatulate or obovate-spatulate blades $3.5-7.5 \mathrm{~cm}$. long: stem-leaves few ; blades linear-lanceolate, $2.5-6.5 \mathrm{~cm}$. long, entire, sometimes undulate: sepals hirsute, $12-19 \mathrm{~mm}$. long : petals mostly over $2 \mathrm{~cm}$. long : capsule-body narrowly obovoid, 6-10 mm. long, terminating a much longer pedicel, the angles with stout closely pubescent wings, the faces strongly ridged.

In dry soil, New York to West Virginia, Florida and Alabama. Spring and summer.

5. Kneiffia lineàris (Michx.) Spach. Stems slender, pilose or nearly glabrous, erect or ascending, $1.5-5 \mathrm{dm}$. tall, finally angled : basal leaves with spatulate or broadly oblanceolate blades, $5-8 \mathrm{~cm}$. long, entire or nearly so: stem-leaves usually few ; blades linear or linear-lanceolate, $2.5-7.5 \mathrm{~cm}$. long, slightly toothed : sepals about $1 \mathrm{~cm}$. long, pubescent: petals mostly $1.5-2 \mathrm{~cm}$. long : capsule-body oblong-clavate, $7-14 \mathrm{~mm}$. long, the angles with papery glabrous or loosely pubescent wings, its faces ridged. [Oenothera linearis Michx.]

In dry or sandy soil, Connecticut to Arkansas and Georgia. Spring to fall.

6. Kneiffia Spachiàna (T. \& G.) Small. Stems minutely puberulent and somewhat hoary, erect, 1-4 dm. tall, terete, branched at the base or above : basal leaves spatulate or oblong-spatulate : stem-leaves few ; blades linear, 2-6 cm. long, nearly flat, obtuse or acute, undulate, slender-petioled : sepals about $10 \mathrm{~mm}$. long, minutely pubescent : petals broad, 9-15 mm. long: capsule-body club-shaped, 1-1.5 cm. long, 4-winged, essentially sessile. [Oenothera Spachiana T. \& G.]

In sandy soil, Texas and Louisiana. Spring and summer.

7. Kneiffia ripària (Nutt.) Small. Stems stout, finely pubescent, 5-12 dm. tall, often sparingly branched : basal leaves with spatulate blades commonly over $10 \mathrm{~cm}$. long: stemleaves often numerous; blades linear to linear-lanceolate, $5-13 \mathrm{~cm}$. long, or shorter on branches, acute or acutish, entire or undulate-denticulate: sepals about $2 \mathrm{~cm}$. long, finely pubescent : petals over $2 \mathrm{~cm}$. long : capsule-body clavate, pubescent all over, mostly over 2 cm. long. [Oenothera riparia Nutt.]

On river banks or low grounds, North Carolina to Georgia. Spring and summer.

8. Kneiffia praténsis Small. Stems erect or nearly so, 5-11 dm. tall, often sparingly branched above, hirsute : leaf-blades narrowly elliptic to elliptic-lanceolate, $3-11 \mathrm{~cm}$. long, undulate or sinuate, acute, thin, hirsute, flat : hypanthium more or less hirsute : sepals 17-22 mm. long, the free tips $2.5-4 \mathrm{~mm}$. long: petals $2-3.5 \mathrm{~cm}$. long: capsule-body clavate, 17-21 mm. long, narrowly winged, hirsute, the pedicel-like base usually very short.

In low grounds, Ohio to Missouri and Arkansas. Summer and fall. 
9. Kneiffia pùmila (L.) Spach. Stems sometimes finely puberulent, erect, 2-6 dm. high : basal leaves with oblanceolate or spatulate blades : stem-leaves few or many ; blades oblong, linear or elliptic, $2-8 \mathrm{~cm}$. long, entire or very nearly so: sepals 5-7 $\mathrm{mm}$. long : petals 6-9 mm. long : capsule-body obovoid or oblong -obovoid, 6-12 mm. long, sessile or short-pedicelled, glabrous or nearly so, the 4 wings thick. [Oenothera pumila I.]

In dry soil, Nova Scotia to Manitoba, Georgia and Kansas. Spring and summer.

10. Kneiffia fruticòsa (L.) Raimann. Stems usually branched, $3-9 \mathrm{dm}$. tall, commonly slightly pubescent: leaf-blades lanceolate, ovate-lanceolate or oblong, $2.5-10 \mathrm{~cm}$. long, repand-denticulate, or rarely nearly entire : sepals $15-20 \mathrm{~mm}$. long: petals $2-3 \mathrm{~cm}$. long: capsule-body oblong, 6-9 mm. long, prominently winged, glabrous or slightly pubescent, sometimes abruptly narrowed into pedicel-like base. [Oenothera fruticosa L.]

In dry soil, Nova Scotia to Georgia, Minnesota and Louisiana. Spring and summer--Kneiffia fruticosa pilosélla (Raf.) Britton, is pubescent with long spreading hairs throughout and is widely distributed in the range of the species.

11. Kneiffia glaùca (Michx.) Spach. Stems glabrous and glaucous, 4-9 dm. high : leaf-blades ovate or oval, $5-14 \mathrm{~cm}$. long, repand-denticulate : sepals $20-25 \mathrm{~mm}$. long : petals 2.5-3 cm. long : capsule-body oblong, 11-13 $\mathrm{mm}$. long, broadly 4-winged, glabrous, abruptly narrowed into the short pedicel-like base. [Oenothera glauca Michx.]

In dry woods, mountains of Virginia to Georgia and Alabama. Spring to fall.

\section{HARTMÁNNIA Spach.}

Annual or perennial herbs, with branched stems. Leaves alternate: blades commonly pinnatifid or lyrate. Buds drooping. Flowers diurnal, in terminal spikes or apparent racemes. Hypanthium funnelform. Corolla white, red or purple. Ovary elongated. Ovules numerous, on slender stalks, in many rows. Capsule club-shaped, oblong or elliptic, 4-winged, the body sometimes narrowed into a pedicel-like base. Seeds not tuberculate. The plants flower from spring to fall. Primrose.

Petals less than $20 \mathrm{~mm}$. long: capsule-body shorter than the pedicel-like base.

Petals over $20 \mathrm{~mm}$. long: capsule-body longer than the pedicel-like base.

Stem with spreading hairs: capsule-body with a pedicel-like base.

Stem with appressed hairs: capsule-body without a pedicel-like base.

1. H. rosea.

2. H. tetraptera.

3. H. speciosa.

1. Hartmannia ròsea (Ait.) G. Don. Stems slender, puberulent, erect or ascending, 2-6 dm. tall, branched at the base or throughout: basal leaves with oblanceolate blades 4-6 cm. long: stem-leaves often numerous; blades ovate-lanceolate or oblong, 1-5 cm. long, obtuse or acute, entire or distantly toothed, the lower ones sometimes pinnatifid at the base: spikes much interrupted, with leaf-like bracts: sepals 7-9 mm. long: petals deep pink or purple, suborbicular, $9-13 \mathrm{~mm}$. long, entire : capsules club-shaped, the body $5-10 \mathrm{~mm}$. long, the angles winged, the faces prominently ridged, the pedicel-like base usually longer than the body. [Oenothera rosea Ait.]

On plains or prairies, Texas to New Mexico, Central and northern South America.

2. Hartmannia tetráptera (Cav.) Small. Stem rather slender, hirsute, erect or decumbent, 1-3 dm. long, simple or usually branched at the base: leaf-blades mostly pinnatifid, rarely only coarsely toothed, $2-7 \mathrm{~cm}$. long, variable in shape, the lower ones often ovate in outline, the rest varying from lanceolate to oblanceolate, acute : spikes few-flowered : sepals 14-18 mm. long: petals purple or rose-purple, often rounded, $2.2-3 \mathrm{~cm}$. long: capsules club-shaped, $3-4 \mathrm{~cm}$. long, the body obovoid, usually longer than the pedicel-like base, its angles winged, the faces ridged. [Oenothera tetraptera Cav.]

On plains or prairies, Texas to Arizona, Mexico, Central America and northern South America.

3. Hartmannia speclòsa (Nutt.) Small. Stems relatively stout, strigillose-canescent, erect, ascending or somewhat decumbent, 2-7 dm. tall, simple or branched: leafblades lanceolate or oblong, or sometimes nearly linear, 2-12 cm. long, obtuse or acute, distantly toothed or pinnatifid, the lower ones sometimes lyrate: spikes lax : sepals 2-4 $\mathrm{cm}$. long : petals white, turning pink, obovate or suborbicular, $2.5-5 \mathrm{~cm}$. long, retuse or emarginate at the apex : capsules oblong or elliptic, 1-2 cm. long, not narrowed into a pedicel-like base, the angles stoutly winged, the faces each with a stout ridge. [Oenothera speciosa Nutt.]

On plains and prairies, Missouri and Kansas to Louisiana, Texas, Arizona and northern Mexico, and extensively naturalized in Illinois, South Carolina and Georgia.

\section{LAVAÙXIA Spach.}

Perennial or annual usually low acaulescent herbs. Leaves mostly basal : blades pinnatifid. Flowers few. Sepals narrow. Corolla white, pink or pale yellow. Ovary short, 
4-angled. Ovules few. Capsule stout, the angles sometimes winged above. Seeds few. Primrose.

Perennial : corolla 4-6.5 $\mathrm{cm}$. broad, widely expanding : capsule $20-30 \mathrm{~mm}$. long. Annual : corolla 1-2 cm. broad, barely, if at all, expanding: capsule 10-15 mm. long.

1. L. triloba.

2. L. Watsomii.

1. Lavauxia tríloba (Nutt.) Spach. Perennial, nearly glabrous throughout. Leaves basal ; blades oblong-lanceolate in outline, $7-30 \mathrm{~cm}$. long, runcinate-pinnatifid or sinuate, sometimes ciliate : corolla white or pink, 4-6.5 cm. broad : petals often 3-lobed : capsules ovoid, 20-30 mm. long, manifestly longer than broad, 4-winged above, reticulate-veined. [Oenothera triloba Nutt.]

In dry soil, Kentucky and Tennessee to Wyoming, California, Mississippi, Texas and northern Mexico. Spring and summer.

2. Lavauxia Watsònii (Britton) Small. Similar to L. triloba in habit, but smaller and annual. Leaf-blades thinner and less finely pinnatifid : flowers fertilized mainly in the bud, the corolla barely, if at all, expanding, 1-2 cm. broad : capsules 10-15 mm. long, as broad as long at maturity, strongly ridged, few, or sometimes in a dense globular mass. [Lavauxia triloba Watsonii Britton.]

On prairies, Kansas to Oklahoma. Spring and summer.

\section{GAURÉLLA Small.}

Low perennial herbs, with wiry diffusely branched stems. Leaves alternate: blades nearly entire or distantly toothed. Flowers axillary, sessile. Hypanthium slightly dilated at the throat. Sepals slightly longer than the hypanthium. Petals white or pink, spotted or striped with red. Ovary short: style stout, enlarged above. Capsule sessile, with a curved beak, the faces swollen. Seeds angled, delicately striate.

1. Gaurella guttulàta (Geyer) Small. Stems $1-5 \mathrm{dm}$. long, canescent with appressed hairs, the branches decumbent or ascending: leaf-blades lanceolate or linear-lanceolate, 8-16 mm. long, repand-denticulate or entire : corolla white or pink, 18-25 mm. wide: petals obovate, entire : capsules canescent, 8-10 mm. long, angled, not winged: seeds angled, slipper-shaped. [Oenothera guttulata Geyer.]

On prairies, Nebraska to New Mexico. Summer and fall.

\section{MEGAPTÈRIUM Spach.}

Perennial herbs, with stout spreading stems. Leaves alternate: blades entire or slightly toothed, or rarely partly pinnatifid. Flowers few, but large and showy, axillary to leaf-like bracts. Sepals elongated. Corolla yellow. Ovary 4-angled or 4-winged : style filiform. Ovules few, sessile. Capsules broadly 4-winged. Seeds crested. Primrose.

Petals 2-4 cm. long: capsules less than $5 \mathrm{~cm}$. long, oblong to oval.

Stem and leaves closely pubescent: capsules less than $2 \mathrm{~cm}$. wide.

Stem and leaves glabrous: capsules over $2 \mathrm{~cm}$. wide.

Petals 5-7 cm. long: capsules over $5 \mathrm{~cm}$. long, suborbicular.

1. M. Fremohtii.

2. M. Oklahomense.

1. Megapterium Fremóntii (S. Wats.) Britton. Stems ascending, 5-15 cm. long, closely appressed-pubescent : leaf-blades lanceolate to somewhat oblanceolate, or linear, $3.5-7.5 \mathrm{~cm}$. long, acuminate at the apex, entire or very nearly so, silvery canescent: sepals $2.5-3.5 \mathrm{~cm}$. long: petals $3-4 \mathrm{~cm}$. long : capsules oblong, $2-2.5 \mathrm{~cm}$. long, winged, rounded at the summit. [Oenothera Fremontii S. Wats.]

On plains and prairies, Kansas to Texas. Summer.

2. Megapterium Oklahoménse Norton. Stems or branches $1.5-3 \mathrm{dm}$. long, glabrous : leaves rather numerous; blades lanceolate or almost oblong, 4-9 cm. long, remotely toothed or merely undulate, glabrous : sepals nearly $2 \mathrm{~cm}$. long : petals $1.5-2.5 \mathrm{~cm}$. broad : capsules oblong or oval, $2.5-3.5 \mathrm{~cm}$. long, rounded at the summit.

On prairies and hillsides, Kansas to Oklahoma and Texas. Summer.

3. Megapterium Missouriénse (Sims) Spach. Stems decumbent or ascending, densely canescent, $1.5-6 \mathrm{~cm}$. long: leaf-blades thick, linear-lanceolate or oblong-lanceolate, $5-15 \mathrm{~cm}$. long, acuminate or acute at the apex, entire or remotely denticulate: sepals $4.5-5.5 \mathrm{~cm}$. long: petals $5-7 \mathrm{~cm}$. long : capsules nearly orbicular, fully $5 \mathrm{~cm}$. long, very broadly winged. [Oenothera Missouriense Sims.]

On plains or prairies, Missouri and Nebraska to Texas. Spring and summer.

\section{GALPÍNSIA Britton.}

Perennial herbs or shrubby plants, with branched stems. Leaves alternate. Flowers axillary to leaf-like bracts. Hypanthium slender, the upper portion longer than the 
ovary. Corolla yellow. Ovary 4-celled, elongated: stigma disk-like, entire. Capsule elongated, narrowed at the base, more or less curved. Seeds sometimes tuberculate. Primrose.

Free portion of the hypanthium 9-13 mm. long, the lower portion very slender.

Free portion of the hypanthium $30-50 \mathrm{~mm}$. long, the lower portion relatively stout.

1. G. tubicula.

Low copiously tufted plants about $1 \mathrm{dm}$. tall: leaves very numerous and crowded.
Relatively tall, not copiously tufted plants, mostly 2 or $3 \mathrm{dm}$. tall: leaves not conspicuously numerous.

Hypanthium about $10 \mathrm{~mm}$. wide at the mouth.

Stem and lower portion of the hypanthium glabrous or slightly canescent : leaf-blades mainly linear.

Stem and lower portion of the hypanthium hirsute-tomentose: leafblades mainly oblong.

Hypanthium about $15 \mathrm{~mm}$. wide at the mouth.

3. G. Hartwegii.

4. G. interior.

5. G. Fendleri.

1. Galpinsia tubícula (A. Gray) Small. Stems erect, 1-3 dm. tall, somewhat branched, flexuous, its bark thin and papery : leaves numerous but not crowded; blades linear or lanceolate, 1-2 cm. long, acute, entire, nearly glabrous or slightly glandularpubescent, short-petioled or nearly sessile : flowers usually near the ends of the branches : hypanthium abruptly and widely dilated above : sepals lanceolate, $6-8 \mathrm{~mm}$. long : petals 9-12 mm. long, obtuse or apiculate : capsules cylindric, $1.2-1.8 \mathrm{~cm}$. long, constricted below the summit, somewhat angled. [Oenothera tubicula A. Gray.]

On plains, Texas and New Mexico. Spring and summer.

2 Galpinsia lavendulaefòlia (T. \& G.) Small. Stems copiously tufted, radially spreading and seldom rising more than $1 \mathrm{dm}$., the internodes very short : leaves very numerous and crowded; blades linear or linear-spatulate on the lower part of the stem, entire or essentially so, finely but closely pale-pubescent: flowers few : hypanthium elongated, rather gradually dilated : sepals 11-16 mm. long: petals $13-19 \mathrm{~mm}$. long : capsules narrow, 2-2.5 cm. long. [Oenothera lavendulaefolia T. \& G.]

On plains or prairies, Kansas to Wyoming, Texas, Arizona and New Mexico. Spring to fall.

3. Galpinsia Hartwègii (Benth.) Britton. Stems more or less branched, but not densely tufted, mostly 2-4 dm. tall : leaves sometimes many but not crowded; blades linear, 1-3.5 $\mathrm{cm}$. long, entire or slightly repand-denticulate : flowers few : hypanthium elongated, rather gradually dilated : sepals about $2 \mathrm{~cm}$. long : petals $2-3 \mathrm{~cm}$. long : capsule narrowly cylindric, 12-25 mm. long. [Oenothera Hartwegii Benth.]

On prairies, Nebraska and Colorado to Texas and northern Mexico. Spring to fall.

4. Galpinsia intèrior Small. Stems somewhat tufted, erect or ascending, 2-3 dm. tall, hirsute-tomentose: leaves often rather numerous but not densely crowded; blades mainly oblong, 1-2.5 $\mathrm{cm}$. long, entire, sessile and partly clasping : flowers few : hypanthium elongated, rather gradually dilated, about $10 \mathrm{~mm}$. wide at the mouth, hirsute-tomentose near the base : sepals 1-1.5 cm. long : petals $1.5-2.5 \mathrm{~cm}$. long : capsules $1.5-2 \mathrm{~cm}$. long.

On plains or prairies, Nebraska to Texas. Spring and summer.

5. Galpinsia Féndleri (A. Gray) Heller. Stems loosely tufted, more or less spreading, 2-4 dm. tall, rather stout, slightly glandular-pubescent: leaves relatively few ; blades mainly oblong, varying to oblong-lanceolate, $2-3 \mathrm{~cm}$. long, abruptly narrowed at the base, sessile : flowers few : hypanthium elongated, gradually dilated, about $15 \mathrm{~mm}$. wide at the mouth : sepals $2-2.5 \mathrm{~cm}$. long: petals $2.5-3.5 \mathrm{~cm}$. long: capsules narrow, $2-2.5 \mathrm{~cm}$. long. [Oenothera Fendleri A. Gray.]

In dry or stony soil, Texas and New Mexico. Spring and summer.

\section{MERIOLIX Raf.}

Biennial or perennial herbs, with branched stems, or sometimes shrubby plants. Leaves alternate: blades narrow, entire or sharply serrate. Flowers regular, axillary, yellow. Hypanthium funnelform, the free portion mostly shorter than the ovary, abruptly and widely dilated above. Sepals keeled on the back. Petals mostly yellow, often blotched at the base. Stigma disk-like, 4-toothed. Capsule linear, 4-angled, sessile. Seeds longitudinally grooved. The plants flower mainly in the spring and summer. Primrose.

A. Free portion of the hypanthium yellow within : stigma yellow.

Petals less than $15 \mathrm{~mm}$. long.

Petals over $15 \mathrm{~mm}$. long.

a. Leaf-blades spatulate to oblanceolate or linear.

Stem and leaves markedly whitish or grayish pubescent.

Stem and leaves glabrous or nearly so.

* Lower cauline leaves with acute blades, scarcely wider than those of the upper leaves, the teeth sharp or spinulose.

1. M. serrulata.

2. M. intermedia.

3. M. spinulosa. 
** Lower cauline leaves with obtuse blades, manifestly wider than those of the upper leaves, the teeth rather blunt.

b. Leaf-blades linear-filiform.

B. Free portion of the hypanthium brown-purple within : stigma brown-purple. Plant, at least the upper portions. pale-pubescent: petals over $15 \mathrm{~mm}$. long. Plant glabrous or nearly so: petals less than $15 \mathrm{~mm}$. long.

4. M. Drummondiana.

5. M. capillifolia.

6. M. melanoglottis.

7. M. Hillii.

1. Meriolix serrulàta (Nutt.) Walp. Stems often copiously branched at the base, the branches canescent, 1-5 dm. high : leaf-blades spatulate to linear-oblong, or linear, 2-5 cm. long, serrate : hypanthium 3-4 mm. broad at the mouth, the free portion yellow within : sepals 5-7 mm. long : petals obovate, $8-12 \mathrm{~mm}$. long, crenulate : anthers $2.5-3 \mathrm{~mm}$. long: capsules linear-cylindric, $1.5-2 \mathrm{~cm}$. long, about $1.5 \mathrm{~mm}$. thick. [Oenothera serrulata Nutt.]

In dry soil, Manitoba and Minnesota to Texas and New Mexico.

2. Meriolix intermédia Rydb. Similar to $M$. serrulata in habit, but mostly taller, and larger throughout. Stem and leaves, especially on the upper part of the plant, markedly whitish or grayish pubescent: leaf-blades spatulate to linear, $4-7 \mathrm{~cm}$. long, or shorter on the branches, serrate : hypanthium $6-10 \mathrm{~mm}$. broad at the mouth, the free portion yellow within : sepals $7-8 \mathrm{~mm}$. long : petals $2-2.5 \mathrm{~cm}$. long : capsules $2-2.5 \mathrm{~cm}$. long, pubescent.

In dry or stony soil, Manitoba to Minnesota and Texas.

3. Meriolix spinulòsa (T. \& G.) Heller. Similar to $M$. serrulata in habit, but more slender : leaf-blades linear-spatulate to narrowly linear, $3-8 \mathrm{~cm}$. long, or sometimes shorter, spinulose-serrate, or sharply serrate : hypanthium 4-5 $\mathrm{mm}$. broad at the mouth, the free portion yellow within : sepals 5-6 mm. long: petals $18-22 \mathrm{~mm}$. long: anthers 4-4.5 mm. long: capsules $2-3 \mathrm{~cm}$. long, about $2 \mathrm{~mm}$. thick, sparingly pubescent. [Oenothera serrulata T. \& G.]

On plains or prairies, Arkansas to Texas and New Mexico.

4. Meriolix Drummondiana (Spach.) Small. Stem branched at the base, the branches ascending or decumbent, $0.5-3 \mathrm{dm}$. long, sometimes branched above : leaf-blades various, those of the lower cauline leaves spatulate, 1-2 cm. long, obtuse, rather bluntly toothed, those of the upper cauline leaves linear, usually narrowly so, more sharply but less prominently toothed than those of the lower leaves: hypanthium 5-6 mm. wide at the mouth, the free portion yellow within : sepals $5-6 \mathrm{~mm}$. long: petals $2-2.5 \mathrm{~cm}$. long: anthers 4-4.5 mm. long: capsules $1-1.5 \mathrm{~cm}$. long, sparingly pubescent. [Calylophis Drummondiana Spach.]

In open woods or dry soil, Texas.

5. Meriolix capillifòlia (Scheele) Small. Stem branched at the base, the branches 3-5 dm. tall, slender, glabrous or nearly so : leaf-blades linear-filiform or very narrowly linear, $2-5 \mathrm{~cm}$. long, entire or essentially so, revolute: hypanthium $3-4 \mathrm{~mm}$. broad at the throat, yellow within: sepals $5-6 \mathrm{~mm}$. long: petals $15-20 \mathrm{~mm}$. long: anthers $3-4 \mathrm{~mm}$. long: capsules 2-2.5 cm. long, 1-1.5 mm. thick. [Oenothera capillifolia Scheele. Oenothera serrulata var. pinifolia Engelm.]

In dry or stony soil, Texas.

6. Meriollx melanoglóttis Rydb. Stem usually branched at the base, the branches ascending or decumbent, $2.5-4 \mathrm{dm}$. tall, the upper portion as well as the leaves, palepubescent, the bark yellowish : leaf-blades spatulate to almost linear, 2.5-6 cm. long, rather shallowly serrate, flat: hypanthium $5-6 \mathrm{~mm}$. wide at the mouth, the free portion brown-purple within : capsules straight, nearly $2 \mathrm{~cm}$. long, copiously pubescent.

In dry soil, Texas to Colorado.

7. Meriolix Hillii Small. More slender than M. melanoglottis, glabrous or nearly so, the branches often wiry, the bark whitish : leaf-blades narrowly linear-spatulate to narrowly linear, $2-4.5 \mathrm{~cm}$. long, sinuate-toothed, involute : hypanthium 3-4 mm. wide at the mouth, the free portion brown-purple within: capsules more slender than those of $M$. melanoglottis, incurved, nearly glabrous.

In dry or sandy soil, Texas.

\section{GAÙRA L.}

Annual, biennial or perennial herbs, with branching stems. Leaves alternate: blades narrow, or relatively so. Flowers in terminal spikes or racemes. Hypanthium narrow, prolonged beyond the ovary. Sepals 4 or rarely 3 . Petals unequal, with clawed blades. Stamens usually 8, declined, each filament with a small scale at the base. Ovary 4-celled: style declined : stigma 4-lobed, surrounded by a cup-like border. Ovules usually 4, pen- 
dulous. Fruit nut-like, ribbed or angled, indehiscent or nearly so, 1-4-seeded, sessile or often with a pedicel-like base.

Anthers oval, attached near the middle.

1. G. parviflora.

Anthers linear or narrowly oblong, attached near the base.

Fruit sessile or essentially so, that is, without a pedicel-like base.

Petals over $15 \mathrm{~mm}$. long.

Petals less than 12 min. long.

2. G. Lindheimeri.

Fruit ovoid, elliptic, oval-elliptic or obovoid.

Fruit pubescent: buds puberulent or pubescent.

Fruit 6-8 mm. long: huds less than $2 \mathrm{~cm}$. long.

Fruit with rounded or obtuse angles.

Stems hirsute: leaf-blades relatively thin.

Stems puberulent or puberulent-canescent: leaf-blades relatively thick.

Fruit with sharp angles.

Stem simple or with few ascending branches above: species ranging from South Carolina to Florida and Alabama.

Stem diffusely much branched : species of the lower Mississippi valley.

Fruit 3-4 mm. long : buds over $2 \mathrm{~cm}$. long.

Fruit glabrous: buds glabrous or essentially so.

Fruit pyramidal.

Fruit mainly 3-angled, the base and angles rounded.

Fruit mainly 4-angled, the base flat, the angles auricled at the base.

Fruit contracted into a slender or stout neck-like or pedicel-like base.

Pedicel-like base of the fruit very stout and short, angled or ribbed, but less so than the body of the fruit.

Fruit 5-7 mm. long: bracts persistent: sepals slightly longer than the free part of the hypanthium.

Fruit 8-11.5 mm. long : bracts caducous : sepals about twice as long as the free part of the hypanthium.

Pedicel-like base of the fruit relatively slender and long.

Body of the fruit 3-4 mm. long, ovoid, pubescent.

Body of the fruit 7-10 mm. long, oblong or fusiform, glabrous.

Fruit-body fusiform, merely angled: leaves finely and inconspicuously pubescent.

Fruit-body oblong or nearly so, wing-angled: leaves copiously pubescent.

3. G. biennis.

4. G. Pitcheri.

5. G. angustifolia.

6. G. filiformis.

7. G. longiflora.

8. G. suffulta.

9. G. tripetala.

10. G. brachycarpa.

11. G. coccinea.

12. G. Drummondii.

13. G. Michauxii.

14. G. sinuata.

15. G. villosa.

1. Gaura parviflòra Dougl. Stem 6-15 dm. tall, villous-hirsute with whitish hairs: leaf-blades lanceolate, ovate-lanceolate or elliptic, $3.5-10 \mathrm{~cm}$. long, acute or acuminate, repand-dentate, softly pubescent: spikes elongated, many-flowered: buds glabrous or nearly so: flowers crowded or approximate: petals $2.5-4 \mathrm{~mm}$. long: fruit fusiform, 6-8 $\mathrm{mm}$. long, 4-nerved, obtuse between the angles, glabrous or nearly so.

In dry soil, South Dakota to Oregon, Missouri, Louisiana and Mexico. Spring and summer.

2. Gaura Lindheimeri Engelm. \& Gray. Stem 5-9 dm. tall, strigose, or somewhat hirsute below, more or less branched above : leaf-blades spatulate or oblong to lanceolate, $2.5-7 \mathrm{~cm}$. long, or shorter above, acute, sinuate, strigose : spikes several-flowered : buds pilose : flowers not crowded : petals $17-22 \mathrm{~mm}$. long : fruit oblong or elliptic-oblong, 5-7 $\mathrm{mm}$. long, glabrous, with acute angles and 1-ribbed faces.

On prairies, Louisiana and Texas. Spring and summer.

3. Gaura biénnis L. Stem 6-15 dm. tall, villous-hirsute : leaf-blades relatively thin, lanceolate, oblong-lanceolate or elliptic, $3-10 \mathrm{~cm}$. long, acute or acuminate at each end, remotely denticulate or merely undulate : spikes slender, often elongated : buds pubescent : flowers numerous : corolla white, sometimes turning pink : petals 7-11 mm. long: fruit elliptic to oval-elliptic, 6-10 mm. long, 4-ribbed, more or less hirsute.

In dry soil, Quebec and Ontario to Minnesota, Georgia and Mississippi. Summer and fall.

4. Gaura Pítcherl (T. \& G.) Small. Similar to G. biennis in habit, but larger and stouter, often copiously branched, merely puberulent or puberulent-canescent : leaf-blades thick, narrowly elliptic to lanceolate or linear-lanceolate, 4-11 cm. long, remotely denticulate or almost entire : spikes many-flowered, often elongated : buds puberulent : flowers not densely crowded : corolla pinkish : petals $6-9 \mathrm{~mm}$. long : fruit elliptic to ovoid-elliptic, 6-8 mm. long, puberulent.

On prairies, Iowa to Nebraska and Arkansas. Summer and fall.

5. Gaura angustifolia Michx. Stem 7-12 dm. tall, simple or sparingly branched above, finely appressed-pubescent : leaves relatively few ; blades spatulate to linear or linearlanceolate, 1-6 cm. long, acute, sinuate or nearly entire, sparingly pubescent : spikes virgate, sometimes greatly elongated : buds finely pubescent to glabrate : petals white or pink, 4-7 mm. long : fruit elliptic, 5-9 mm. long, 4-angled or sometimes 5-angled, the faces occasionally transvierse-wrinkled.

In dry or sandy soil, North Carolina to Florida and Alabama. Spring to fall.

6. Gaura filifórmis Small. Stem 1-2.5 m. tall, canescent-puberulent, widely and often diffusely branched above, the branches slender or filiform : leaves numerous; blades linear 
to narrowly linear-lanceolate, $2-10 \mathrm{~cm}$. long, acute or acuminate, sharply, but finely toothed, or entire and somewhat reduced, especially toward the inflorescence : spikes elongated, interrupted : buds puberulent, less than $1.5 \mathrm{~cm}$. long : petals pink-purple, about $7 \mathrm{~mm}$. long: fruit narrowly elliptic, 6-7 mm. long, sessile, canescent.

On banks or in sandy soil, Arkansas to Mississippi and Texas. Summer and fall.

7. Guara longiflòra Spach. Similar to $G$. anqustifolia in habit. Leaves rather numerous; blades linear, narrowly so above, remotely and inconspicuously toothed or entire, somewhat revolute, acute or acuminate: spikes elongated, interrupted: buds canescent-puberulent, over $2 \mathrm{~cm}$. long : petals pink, about $10 \mathrm{~mm}$. long : fruit oval-elliptic, about $4 \mathrm{~mm}$. long, canescent, sessile.

In sandy soil, Mississippi, Louisiana and Texas. Spring and summer.

8. Gaura suffúlta Engelm. Stem simple or usually branched at the base, the branches ascending, 3-6 dm. tall, hirsute, at least below : leaf-blades spatulate to linear, $2.5-7 \mathrm{~cm}$. long, acute or acuminate, sinuate or undulate: spikes virgate, usually simple, interrupted : buds glabrous or essentially so : petals $8-9 \mathrm{~mm}$. long : fruit ovoid or ovalovoid, 4-5 mm. long, wing-angled above, obtusely angled below, glabrous, sessile.

On prairies or mountain slopes, Texas and northern Mexico. Spring to fall.

9. Gaura tripétala Cav. Stem simple or branched at the base, the branches $3-5 \mathrm{dm}$. tall, hirsute, sometimes with few branches: leaf-blades relatively thick, spatulate to oblong, or linear-elliptic, $2.5-5 \mathrm{~cm}$. long, acute or slightly acuminate, shallowly, but sometimes rather sharply, toothed : spikes elongated, interrupted : buds more or less pubescent: petals 5-7 mm. long: fruit pyramidal with the base rounded, mostly 3 -angled and the angles rounded at the base, 6-7 $\mathrm{mm}$. long, the faces somewhat transverse-wrinkled.

On plains and prairies, the Indian Territory, Texas and Mexico. Spring and summer.

10 Gaura brachycárpa Small. Stem usually branched at the base, the branches decumbent 1-3.5 dm. long, simple or sparingly branched, finely hirsute : leaf-blades relatively thin, spatulate to lanceolate or almost linear, $1.5-4.5 \mathrm{~cm}$. long, acute, undulate or sinuate, or the lower ones lyrate-sinuate: spikes slender, much interrupted at maturity: buds pubescent : petals $8-9 \mathrm{~mm}$. long: fruit pyramidal with the base flat, $5-7 \mathrm{~mm}$. long, nearly glabrous, mostly 4 -angled and the angles auricled at the base, the faces prominently tranverse-wrinkled.

In dry soil, southern Texas. Spring and summer.

11. Gaura coccínea Pursh. Stem branched at the base, the branches erect or decumbent, often much branched, $1.5-6 \mathrm{dm}$. high, hirsute and canescent: leaves numerous; blades oblong, lanceolate, linear-oblong or linear-lanceolate, repand or on the ultimate branches entire, acute or obtuse at the apex, $1-3.5 \mathrm{~cm}$. long: racemes elongating in age : bracts persistent : corolla red, turning scarlet : fruit $5-7 \mathrm{~mm}$. long, the neck-like base nearly as long as the body.

On prairies and in dry soil. Manitoba to Minnesota, Montana. Texas, Utah and Arizona, and in Mexico. Spring and summer.-The form with merely canescent stems has been separated as a species by Lehmann as G. marginata.

12. Gaura Drummóndii T. \& G. Stem branched at the base, the branches spreading or decumbent, $3-7 \mathrm{dm}$. long, more or less branched, more or less hirsute : leaf-blades oblong-spatulate to oblong, elliptic or lanceolate, $2-4 \mathrm{~cm}$. long, sinuate-toothed, or sometimes merely undulate, acute or obtuse : racemes elongating in age: bracts caducous : corolla red or scarlet : fruit 8-11.5 mm. long, the obconic neck-like base much shorter than the body.

On prairies or river banks, Texas to New Mexico and adjacent Mexico. Spring and summer.

13. Gaura Michaùxii Spach. Stem $6-18 \mathrm{dm}$. tall, puberulent, paniculately branched above: leaf-blades linear or linear-oblong, acute or acuminate at both ends, sinuate or remotely dentate, $2.5-8 \mathrm{~cm}$. long : racemes loosely flowered, slender, elongated: buds canescent: petals white, turning reddish, $4-6 \mathrm{~mm}$. long : fruit puberulent, the body $3-4$
$\mathrm{~mm}$. long, sharply 4 -angled above, the pedicel-like base as long as the body or nearly so.

In dry fields, Virginia to Kansas, Florida and Louisiana. Summer and fall.

14. Gaura sinuàta Nutt. Stem erect or decumbent, $3-9 \mathrm{dm}$. tall, glabrous or nearly so, branched at the base: leaf-blades spatulate to lanceolate, or nearly linear, sinuatetoothed or pinnatifid, $2.5-8 \mathrm{~cm}$. long, acute or acuminate : buds slightly pubescent : petals $8-10 \mathrm{~mm}$. long: fruit glabrous, at least at maturity, the body 4-ridged and 4-grooved
above, fusiform, $5-7 \mathrm{~mm}$. long, merely angled, much longer than the relatively thick pedicel-like base.

In dry soil, Kansas to Arkan :as, Texas and Mexico. Spring and summer. 
15. Gaura villòsa Torr. Stem erect or nearly so, $3-9 \mathrm{dm}$. tall, canescent or villous : leaf-blades varying from spatulate to lanceolate or sometimes nearly linear, $2.5-7.5 \mathrm{~cm}$. long, sinuate-toothed or pinnatifid, acute or acuminate : buds canescent : petals 10-14 mm. long: fruit glabrous, the body oblong, wing-angled, abruptly narrowed into the much shorter and relatively slender pedicel-like base.

On plains or prairies, Kansas to Arkansas and Texas. Summer and fall.

\section{STENOSİPHON Spach.}

Perennial herbs, with erect stems. Leaves alternate : blades sessile, narrow. Flowers in elongated terminal spikes. Hypanthium filiform, much prolonged beyond the ovary. Sepals 4. Petals white, with clawed blades. Stamens 8, declined, the filaments without scales at the base. Ovary 1-celled : stigma as in Gaura. Fruit 8-ribbed, indehiscent, 1celled, 1-seeded. Seed pendulous.

1. Stenosiphon linifòlium (Nutt.) Britton. Stems slender, glabrous, $6-15 \mathrm{dm}$. tall : leaf-blades lanceolate, linear-lanceolate or linear, $2.5-5 \mathrm{~cm}$. long, acuminate or acute at the apex, entire: spikes dense, narrow, sometimes $3 \mathrm{dm}$. long at maturity : sepals very narrow, 8-10 mm. long: corolla 8-12 $\mathrm{mm}$. broad : fruit ovoid, pubescent, 2-3 mm. long, very much shorter than the linear-subulate bracts.

On prairies, Nebraska and Colorado to the Indian Territory and Texas. Summer.

\section{CIRCAÈA L.}

Low perennial herbs, with watery or relatively succulent stems. Leaves opposite: blades petioled. Flowers small, in racemes. Hypanthium slightly prolonged beyond the ovary. Sepals 2. Petals 2, white, notched. Stamens 2, alternate with the petals. Ovary 1-2-celled. Ovules usually 1 in each cavity. Fruit obovoid, indehiscent, bristly with hooked hairs or rarely glabrous. ENCHANTER's Nightshade.

Fruit 1-celled : bracts small : leaf-blades mainly of a cordate type.

Fruit 2-celled : bracts obsolete : leaf-blades mainly of an ovate type.

1. C. alpina.

2. C. Lutetiana.

1. Circaea alpina L. Stems $7-20 \mathrm{~cm}$. tall, weak, glabrate or pubescent above : leafblades ovate, mostly cordate at the base, $2.5-5 \mathrm{~cm}$. long, acute or acuminate at the apex, coarsely dentate : pedicels $3-4 \mathrm{~mm}$. long: bracts small : corolla about $2 \mathrm{~mm}$. broad : fruit narrowly obovoid, about $2 \mathrm{~mm}$. long, covered with weak soft hooked hairs, 1-celled.

In cold moist woods, Labrador to Alaska, Georgia, Indiana and South Dakota. Also in Europe and Asia. Summer and fall.

1. Circaea Lutetiàna L. Stems pubescent, at least above, $3-6 \mathrm{dm}$. high : leaf-blades ovate, 5-10 cm. long, acuminate at the apex, mainly rounded or rarely slightly cordate at the base, remotely denticulate : pedicels $4-8 \mathrm{~mm}$. long: bracts deciduous or obsolete: corolla about $3 \mathrm{~mm}$. broad : fruit broadly obovoid, nearly $4 \mathrm{~mm}$. long, densely covered with stiff hooked hairs, 2-celled.

Sum woods, Nova Scotia to Ontario, South Dakota, Georgia and Kansas. Also in Europe and Asia.

\section{Family 8. GUNNERÀceat Endl. Water Milfoil Family.}

Perennial, or rarely annual, caulescent mainly aquatic or amphibious herbs. Leaves alternate or whorled : blades all alike or of two kinds, the submerged finely divided, the emersed entire or merely toothed. Flowers perfect or monoecious, solitary or clustered, either in the axils or in terminal spikes. Calyx of 2-4 sepals. Corolla of 2-4 small petals, or wanting. Androecium of 1-8 comparatively large stamens. Filaments sometimes elongated. Anthers 2-celled. Gynoecium of 1-4 sometimes united carpels. Ovary 1-4-celled, inferior, 2-8angled or rarely 2-4-winged. Styles wanting. Stigmas 1-4, papillose, or plumose. Ovules 1-4, anatropous, pendulous. Fruit an angled ribbed or winged nutlet or drupe with 1-4 carpels. Embryo in the fleshy endosperm. [Haloragidaceae Kl. \& Garcke.]

Fruit 3-4-angled.

Fruit of $2-4$ bony nutlets.

1. Proserpinaca.

2. MYRIOPHYLLUM.

1. PROSERPINACA L.

Aquatic herbs, with glabrous foliage. Stems usually simple, creeping. Leaves alternate: blades toothed to pectinate-pinnatifid, the lower ones more finely dissected than the 
upper. Flowers perfect, minute, axillary, greenish. Hypanthium sessile or nearly so, 3-4-angled, adnate to the ovary. Sepals 3-4, broad. Petals wanting. Stamens 3-4, included. Ovary 3-4-celled. Stigmas 3-4, cylindric or conic-subulate. Ovules solitary in each cavity. Nut-like fruit bony or crustaceous, 3-4-angled, 3-4 celled. Seeds 3-4 in each fruit, cylindric. MERMAID-WEED.

Leaves all nearly alike: sepals obtuse: fruit with obtuse angles.

1. P. pectinata. Leaves of 2 kinds; submerged and emersed, different: sepals acute: fruit with acute angles. 2. P. palustris.

1. Proserpinaca pectinàta Lam. Stems decumbent and creeping, 1-4 dm. long, simple or branched : leaves all nearly alike ; blades pectinate or pectinate-pinnatifid, 1-3 cm. long, the segments linear or filiform, entire or sparingly toothed, acute: flowers sessile or nearly so : sepals ovate, obtuse, persistent, erect : petals wanting : fruit ovoid-pyramidal, 3.5-4 mm. long, the angles rather obtuse, the faces transversely wrinkled or slightly tuberculate.

In pools and wet sandy soil, Massachusetts to Florida and Louisiana. Spring to fall.

2. Proserpinaca palústris $L$. Stems decumbent at the base, rooting, $2-7 \mathrm{dm}$. long, sometimes branched : leaves usually of 2 kinds; blades linear to elliptic or oblong, often varying to broadest above or below the middle, the submerged ones coarsely serrate or pectinate, the segments entire or serrulate, the emersed leaves more entire, usually merely serrate : flowers sessile, often clustered : sepals triangular, acute, ascending or converging: petals wanting: fruit pyramidal or ovoid-pyramidal, $3 \mathrm{~mm}$. long, the angles acute, the faces concave, more or less distinctly tuberculate.

In ponds, ditches and slow-flowing streams, New Brunswick to Iowa, Florida and Central America. Spring to fall. Also in the West Indies.

\section{MYRIOPHÝLLUM L.}

Aquatic, often delicate herbs, with glabrous foliage. Stems commonly floating. Leaves alternate or whorled, the emersed ones with entire toothed or pectinate blades, the submersed ones with pectinate blades, their segments more delicate than those of the emersed. Flowers usually monoecious, minute, axillary or often in terminal spikes, the upper ones commonly staminate, with a short hypanthium, 2-4 sepals, or these obsolete, 2-4 petals and 4-8 stamens ; intermediate flowers generally perfect ; lower ones pistillate, with a 4-grooved hypanthium, 4 minute sepals, 4 small petals, or these wanting, and a 4-celled or rarely 2-celled ovary, with 2-4 often plumose stigmas and 1 ovule in each cavity. Fruit bony, at maturity splitting into 2 or 4 angled, smooth or tuberculate nutlets. Seed solitary in each nutlet. WATER MILFOIL.

Emersed leaves or bracts minute, shorter than the flowers.

Emersed leaves or bracts much longer than the flowers.

Carpels essentially smooth.

Carpels 2-keeled and roughened on the back.

Slender: emersed leaves pectinate or pectinate-serrate.

Stout: emersed leaves nearly entire or serrate.

1. M. laxum.

2. M. verticillatum.

3. M. pinnatum.

4. M. heterophyllum.

1. Myriophyllum láxum Shuttl. Slender, 2-8 dm. long. Leaves in whorls of 4's, of two kinds, the submersed ones ones 1-3 cm. long, rather crowded, the hair-like segments in about 3-5 pairs, the emersed leaves minute, less than $1 \mathrm{~mm}$. long, spatulate, entire or nearly so: spikes 1-2 cm. long, delicate : flowers longer than the subtending leaves, nearly $1 \mathrm{~mm}$. long: fruit minutely warty.

In ponds and lakes, middle and western Florida. Summer.

2. Myriophyllum verticillàtum L. Slender, 2-12 dm. long. Leaves of 2 kinds, the submerged in whorls of 3's or 4's, rather crowded, 2.5-3.5 cm. long, the hair-like segments in about 10 pairs, often minutely roughened, the emersed leaves, or bracts smaller, $5-10 \mathrm{~mm}$. long, pectinate-pinnatifid : spike 4-15 $\mathrm{cm}$. long, erect: flowers shorter than the bracts : staminate flowers about $2-2.5 \mathrm{~mm}$. broad, with 4 purple hooded petals and 8 stamens : fruit smooth or nearly so, $2-2.5 \mathrm{~mm}$. long, enlarged below the middle.

In still water, Quebec to Minnesota, California and Florida. Also in Europe and Asia. Summer.

3. Myriophyllum pinnàtum (Walt.) B.S.P. Slender, 1-2 dm. or sometimes $6 \mathrm{dm}$. long. Leaves in whorls of 3's to 6's, of two kinds, the submersed ones rather crowded, 1-2 cm. long, the hair-like segments usually in 3-5 pairs, the emersed leaves linear, shorter than the submersed, pectinate or serrate-pectinate : spike erect, $6-20 \mathrm{~cm}$. long, simple : flowers shorter than the bracts, the staminate about $2.5 \mathrm{~mm}$. broad, with 4 purple petals 
and 4 or rarely 8 stamens : fruit globose-ovoid, $2 \mathrm{~mm}$. long, each carpel strongly 2-keeled on the back and roughened. [M. scabratum Michx.]

In shailow ponds and ditches, Rhode Island to Missouri, Florida, Texas and Mexico. Also in Central America. Spring and summer.

4. Myriophyllum heterophýllum Michx. Normally stout, 2-10 dm. long. Leaves of 2 kinds, the submersed ones crowded, more or less scattered, $1.5-5 \mathrm{~cm}$. long, the hairlike segments in 6-10 pairs, the emersed leaves in whorls of 3's to 6's, linear to oblong, sometimes varying to lanceolate or oblanceolate, sharply serrate : spikes erect or slightly nodding, 1-5 dm. long, simple or branched : flowers shorter than the bracts, the staminate about $3 \mathrm{~mm}$. broad, with 4 oblong or ovate-oblong petals and 4-6 stamens : fruit 2-2.5 mm. long, each carpel 2 -keeled on the back and slightly roughened.

In ponds and slow-running water, Quebec to Minnesota, Florida, Texas and Mexico. Summer.

\section{Order 27. AMMIÀLES.}

Herbs, shrubs, trees or vines. Leaves alternate or opposite : blades mostly toothed, lobed, divided or compound. Flowers perfect, polygamous or dioecious, variously clustered, but commonly in umbels. Hypanthium present. Calyx of typically 5 relatively small sepals surmounting the hypanthium. Corolla typically of 5 petals. Androecium of as many stamens as there are sepals or petals. Gynoecium of 2 united carpels or rarely more, or sometimes 1-carpellary. Ovary inferior, 1-several-celled, sometimes surmounted by a stylopodium. Stigmas terminal or introrse. Fruit drupaceous or baccate, or dry and a cremocarp with smooth or spiny, ribbed or winged carpels.

Fruit drupaceous or baccate: gynoecium 1-several-carpellary, if 2-carpellary, stigmas introrse.

Ovule with a dorsal raphe : leaves mostly opposite; blades entire or merely toothed.

Ovule with a ventral raphe: leaves mostly alternate; blades lobed or com-

Fruit dry, a cremocarp: gynoecium 2-carpellary : stigmas terminal.

Fam. 1. Nyssaceat.

Fam. 2. Hederaceae. Fam. 3. AMmiaceae.

\section{Family 1. NYSSÀCEAE Dumort. Dogwood Family.}

Shrubs or trees, or rarely herbaceous shrubs. Leaves alternate or opposite, without stipules : blades mostly firm or leathery, usually entire. Flowers perfect or unisexual, in cymes or heads, sometimes subtended by involucres. Calyx of mostly 4-5 sepals. Corolla of 4-5 or rarely many, imbricated or valvate petals, inserted at the base of an epigynous disk, or wanting. Androecium of usually as many stamens as there are petals and inserted with them. Filaments terete or flattened. Anthers attached at the base or the back. Gynoecium of 1-4 united carpels. Ovary 1-4-celled, inferior. Styles united. Stigmas entire, lobed or cleft. Ovules solitary in each cavity or rarely 2, anatropous, pendulous. Fruit mostly a drupe, with an acid pulp, stones solitary or rarely 2, 1-4-celled. Seed with a membranous or thin-leathery testa. Endosperm fleshy. [Cornaceae Link.]

Flowers dioecious or polygamo-dioecious : stigmas lateral.

Stigmas 2: ovules 2 in each cavity: staminate flowers in ament-like spikes.

Stigma 1: ovule 1 in each cavity : staminate flowers capitate.

1. GARRYA.

2. NYSSA.

Flowers perfect: stigmas terminal.

Flowers in open cymes, not subtended by an involucre: fruit surmounted by the style.

Flowers in a head subtended by a large involucre: fruit surmounted by the calyx. 4. CYNOXYLON. ${ }^{1}$

\section{GÁRRYA Dougl.}

Shrubs, with 4-angled branches. Leaves opposite, persistent : blades entire or slightly toothed. Flowers dioecious, inconspicuous, in axillary ament-like spikes, the staminate with 4 narrow sepals, no petals, 4 stamens with distinct filaments and linear anthers, and an obsolete gynoecium. Pistillate flowers with 2 more or less manifest sepals and a gynoecium with a 1-celled ovary, 2 stigmas and 2 pendulous ovules. Drupe short, terminating $i_{n}$ the 2 persistent stigmas. Seeds 2 , or sometimes 1 , flattened.

${ }^{1}$ The genera Svida and Cynoxylon are commonly included in the genus Cornus. 
1. Garrya Lindheimeri Torr. A branching shrub $5-20 \mathrm{dm}$. tall, with tomentulose twigs : leaf-blades leathery, oblong to oval or obovate, $2.5-5 \mathrm{~cm}$. long, mucronate, tomentulose on both sides, but less so or glabrate above: drupes globular, 6-9 $\mathrm{mm}$. long.

In dry soil, central and southern Texas. Spring.

\section{NÝSSA L.}

Shrubs or lofty trees, with a tough wood. Branches alternate. Leaves alternate: blades entire or rarely with a few lobe-like teeth. Flowers polygamo-dioecious, greenish; staminate numerous, with 5 -several sepals, 5-many petals, 5-many stamens, a large swollen entire or lobed disk and a rudimentary ovary; pistillate flowers fewer, with 5 sepals, no petals, rudimentary stamens, a swollen disk and a 1-celled sessile ovary. Drupes solitary or clustered, slightly elongated, pulpy : stone terete or flattened, sometimes ribbed. Seed filling the cavity. Testa membranous. Tupelo.

Pistillate flowers 2-several together: drupes 1-2 cm. long, the stone with rounded ridges.

Pistillate flowers usually $2:$ stone of the drupe prominently ridged.

Pistillate flowers 3 or more: stone of the drupe indistinctly ribbed.

Pistillate flowers solitary : drupes 3-4 cm. long, the stone with acute or winged angles.

Low shrub : leaf-blades glabrous or nearly so.

Tall trees: leaf-blades pubescent beneath and on the midrib above.

Leaf-blades abruptly pointed: pedicel shorter than the fruit.

Leaf-blades acuminate: pedicel longer than the fruit.

1. N. biflora.

2. N. sylvatica.

3. N. acuminata.

4. N. Ogeche.

5. N. aquatica.

1. Nyssa biflòra Walt. A forest tree, with a maximum height of $40 \mathrm{~m}$. and a trunk diameter of $2 \mathrm{~m}$., its bark usually broken into longitudinal ridges. Leaf-blades oblanceolate, oblong, elliptic, oval or rarely ovate, $5-15 \mathrm{~cm}$. long, obtuse or acute, entire, becoming glabrous, acute or rarely truncate at the base, short-petioled: staminate flowers rather few in loose heads: pistillate flowers usually 2 at the end of a slender peduncle: bracts ovate: petals ovate, obtuse : fruiting peduncles $2-6 \mathrm{~cm}$. long: drupes oval or elliptic, 10-13 $\mathrm{mm}$. long, dark-blue, the pulp acid : stone oval, strongly ribbed, blunt at both ends.

In swamps and on margins of ponds, New Jersey to Florida and Louisiana. Spring. BLACK GUM WATER TUPELO.

2. Nyssa sylvática Marsh. A forest tree, reaching a height of $50 \mathrm{~m}$. with a maximum trunk diameter of $1.5 \mathrm{~m}$., its bark finally breaking into hexagonal blocks. Leaf-blades oval or obovate to rarely oblanceolate, $5-15 \mathrm{~cm}$. long, obtuse or acute and usually acuminate, entire or angulariy lobed above, acute or rounded at the base, short-petioled, glabrous and often lustrous above, more or less pubescent, or glabrate beneath : staminate flowers numerous, in dense heads: pistillate flowers usually 3 at the end of a slender peduncle : bracts ovate : petals ovate, obtuse : fruiting pedicels $1-6 \mathrm{~cm}$. long: drupes oval, nearly $1.5 \mathrm{~cm}$. long, dark blue, the pulp acid, thin : stone narrowly ovoid, acute at the apex with 10-12 indistinct ribs.

In swamps and on hillsides, Maine to Ontario and Michigan, south to Florida and Texas. Spring. SOUR GUM. PEPPERIDGE. BLACK GUM.

3. Nyssa acuminàta Small. An almost glabrous shrub 2-3 m. tall, with a smooth bark, the branches and twigs red, spreading. Leaf-blades narrowly elliptic or oblanceolate, 4-15 cm. long, acuminate at both ends, entire, slightly revolute, glabrous, dark green above, pale and prominently nerved beneath; petioles about $1 \mathrm{~cm}$. long: pistillate flowers solitary on short pedicels : fruiting pedicels $1-1.5 \mathrm{~cm}$. long, pubescent with brown hairs: drupes oblong, inequilateral, about $2 \mathrm{~cm}$. long, slightly curved.

In pine-land swamps near the coast, Georgia. Spring.

4. Nyssa Ogèche Marsh. A tree sometimes $20 \mathrm{~m}$. tall, with a maximum trunk diameter of about $6 \mathrm{dm}$, the bark irregularly fissured. Leaf-blades firm, oblong varying to oblanceolate or lanceolate, or rarely oval, $5-20 \mathrm{~cm}$. long, rounded at both ends or apiculate at the apex, or sometimes acute at both ends, glabrate above, softly pubescent beneath ; petioles about $1 \mathrm{~cm}$. long: staminate flowers in heads, 1-1.5 cm. in diameter, with oblong pedicels: pistillate flowers solitary with suborbicular petals : fruiting pedicels $1-1.5 \mathrm{~cm}$. long: drupes oblong, $3-4 \mathrm{~cm}$. long, red, very acid : stone flattened, with 10-12 papery wings. [N. capitata Walt.]

In river swamps, South Carolina to Georgia and Florida. Spring. OGEeche PluM.

5. Nyssa aquática L. A forest tree, reaching a height of $35 \mathrm{~m}$., with a maximum trunk diameter of $1.5 \mathrm{~m}$. above the much enlarged base. Leaf-blades ovate to elliptic, 1-3 $\mathrm{dm}$. long, acute or acuminate, usually angularly toothed, glabrate above, thinly tomentose beneath, acute to cordate at the base; petioles stout, $2-5 \mathrm{~cm}$. long: staminate flowers in heads $1-1.5 \mathrm{~cm}$. in diameter : pistillate flowers solitary : bracts linear : petals oblong, obtuse : 
fruiting pedicels curved, 4-9 cm. long: drupes oblong or oblong-obovate, nearly $3 \mathrm{~cm}$. long, dark purple, acid : stone with about 10 sharp ridges, slightly flattened. [N. uniflora Wang.] In river swamps, Virginia to Missouri, Florida and Texas. Spring. Tupelo Gum. Cotton Gum.

\section{SVÌDA Opiz.}

Shrubs or trees with a hard close-grained wood. Branches mostly opposite. Leaves opposite or rarely alternate: blades entire. Flowers perfect, in naked dichotomous cymes. Sepals 4. Petals 4, valvate, elongated, white. Stamens 4: filaments filiform or subulate. Ovary 2- or rarely 3-celled. Drupe with a thin pulp: stone crustaceous or bony, 2-seeded. Seeds variously flattened, with a membranous testa. Cornel. DogwooD.

Leaves alternate.

Leaves opposite.

Lower leaf-surfaces glabrous.

Twigs gray: drupes white : stones broader than high.

Twigs reddish brown: drupes pale blue: stones mostly longer than broad.

Lower leaf-surfaces with straight or curled hairs.

Stones longer than broad: drupes $3-4 \mathrm{~mm}$. in diameter.

Leaf-blades membranous, those below a peduncle oblong or oval.

Leaf-blades leathery, those below a peduncle ovate to ovate-lanceolate.

Stones broader than long: drupes 6-8 $\mathrm{mm}$. in diameter.

Sepals much shorter than the hypanthium: drupe white: stone sharply 4-angled.

Sepals about as long as the hypanthium: drupe pale-blue: stone slightly angled.

1. S. alternifolia.

2. S. candidissima.

3. S. stricta.

4. S. microcarpa.

5. S. Priceae.

6. S. asperifolia.

7. S. Amomum.

1. Svida alternifòlia (L. f.) Small. A shrub or tree sometimes $9 \mathrm{~m}$. tall, with a smooth or shallowly fissured bark. Leaves alternate; blades elliptic or oval, varying to ovate or obovate, $5-15 \mathrm{~cm}$. long, acuminate at both ends or rounded at the base, prominently nerved, sparingly pubescent when young giabrous in age, whitish beneath ; petioles slender, 1-5 cm. long: cymes open, $5-10 \mathrm{~cm}$. broad: hypanthium campanulate : sepals minute, acute : corolla $7 \mathrm{~mm}$. broad : petals oblong-ovate, recurved, thickened at the apex : drupe depressed-globose, 8-10 mm. broad, blue-black : stone broader than high, obovoid, 5-6 mm. broad, with many longitudinal furrows. [Cornus alternifolia L. f.]

On hillsides, New Brunswick to Minnesota, south to Georgia and Alabama. Spring.

2. Svida candidíssima (Marsh.) Small. A slender shrub 1-5 m. tall, with gray glabrous branchlets. Leaves opposite; blades firm, elliptic or lanceolate, 4-15 cm. long, acute or acuminate at both ends, sparingly appressed-pubescent or glabrous, pale- or glaucescent beneath; petioles 6-18 $\mathrm{mm}$. long: cymes $3-6 \mathrm{~cm}$. broad, loose, paniculate : hypanthium urn-shaped : sepals triangular, acute : corolla 6-7 mm. broad : petals oblong or oblong-lanceolate, rather obtuse : stamens sometimes longer than the petals : drupe subglobose, white, 4-5 mm. in diameter : stone broader than high, 3-4 mm. broad, slightly oblique, faintly ribbed and furrowed. [Cornus candidissima Marsh.]

In rich or dry soil, Maine and Ontario to Minnesota, south to Georgia and Nebraska. Spring.

3. Svida strícta (Lam.) Small. A shrub or tree $2-5 \mathrm{~m}$. tall, with reddish brown twigs and glabrous or sparingly pubescent foliage. Leaves opposite; blades elliptic, oval or ovate, $4-12 \mathrm{~cm}$. long, firm, acuminate at both ends or acute at the base, undulate, paler beneath than above; petioles $5-10 \mathrm{~mm}$. long, often sparingly appressed-pubescent : cymes 3-6 cm. broad, flat-topped : hypanthium urn-shaped : sepals triangular, about $0.5 \mathrm{~mm}$. long, acute : corolla 5-6 mm. broad : petals linear-oblong or linear-lanceolate, acutish : drupe subglobose, 5-6 mm. in diameter, pale blue : stone mostly longer than broad, slightly oblique, faintly ribbed, hardly furrowed. [Cornus stricta Lam.]

In swamps, Virginia to Missouri, Florida and Texas. Spring.

4. Svida microcárpa (Nash) Small. A shrub 3-4 m. tall, with recurved stems, branched above, the twigs brownish, sparingly pubescent. Leaves opposite ; blades thinnish, oval or elliptic, $3-9 \mathrm{~cm}$. long, acute at each end and acuminate at the apex, appressedpubescent on both sides, the hairs on the lower surface more or less curled ; petioles 2-10 $\mathrm{mm}$. long: cymes $2-5 \mathrm{~cm}$. broad, pubescent : hypanthium pubescent, urn-shaped : sepals triangular, acute : corolla $5 \mathrm{~mm}$. broad : petals ovate-lanceolate or oblong-lanceolate, recurved, rather obtuse : stamens slightly longer than the petals: drupe subglobose, $4 \mathrm{~mm}$. in diameter, light blue : stone much longer than broad, very slightly compressed, slightly oblique. [Cornus microcarpa Nash.]

In low woods, Georgia and Florida. Spring. 
5. Svida Prìceae Small. A branching shrub 1-2 $\mathrm{m}$. tall, with red finely pubescent twigs. Leaves numerous ; blades elliptic to ovate-elliptic or ovate, $5-12 \mathrm{~cm}$. long, usually acuminate, deep green and roughish pubescent above, pale and more copiously but more softly pubescent and prominently nerved beneath; petioles 1-2 cm. long, pubescent like the twigs : corymbs 4-6 $\mathrm{cm}$. broad at maturity : drupe about $3 \mathrm{~mm}$. in diameter, subglobose, white: stone $2.5 \mathrm{~mm}$. long, slightly longer than broad, faintly ribbed. [Cornus Priceae Small.]

On river banks, southern Kentucky and northern Tennessee. Spring.

6. Svida asperifòlia (Michx.) Small. A shrub 1-5 m. tall, with reddish brown twigs and rough pubescent foliage. Leaves opposite ; blades firm, ovate to elliptic or oval, 4-15 $\mathrm{cm}$. long, acuminate, prominently nerved beneath, acute to subcordate at the base, the pubescence less harsh beneath than above; petioles $4-18 \mathrm{~mm}$. long: cymes $3-6 \mathrm{~cm}$. broad, often paniculate : hypanthium minutely pubescent : sepals triangular, $0.5 \mathrm{~mm}$. high, acute : petals lanceolate or oblong-lanceolate, obtuse, recurved : stamens about as long as the petals: drupe subglobose, 5-6 mm. in diameter, white: stone oblique, about $3 \mathrm{~mm}$. broad, very slightly angled, furrowed around the edge. [Cornus asperifolia Michx.]

In low grounds or moist banks, Ontario to Iowa, south to Alabama and Texas. Early summer.

7. Svida Amòmum (Mill. ) Small. A shrub 1-4 m. tall, with slightly pubescent foliage and purple branchlets. Leaves opposite; blades firm, varying from lanceolate to broadly ovate, acuminate, glabrate ăbove, silky or rusty-pubescent beneath, acute or rounded at the base ; petioles $0.5-1.5 \mathrm{~cm}$. long : cymes rather densely flowered, $5-10 \mathrm{~cm}$. broad : hypanthium urn-shaped: sepals oblong or oblong-lanceolate, about as long as the tube : petals linear-lanceolate, about $5 \mathrm{~mm}$. long, spreading or recurved : stamens shorter than the petals: drupe subglobose, pale blue, $6-8:$ stone oblique, about $5 \mathrm{~mm}$. in diameter, usually pointed at both ends, broader than high, sharply longitudinally ridged. [Cornus sericea L.]

Along streams, New Brunswick to Ontario and Dakota, south to Florida and Texas. Spring.

\section{CYNÓXYLON Raf.}

Trees, with spreading branches and a very rough bark. Leaves opposite: blades rather thick, prominently several-nerved, entire. Flowers perfect, in dense clusters subtended by conspicuous involucres of usually 4 petal-like bracts. Sepals erect, about as broad as long, persistent. Corolla greenish or yellow-green : petals 4, valvate. Stamens 4, exserted. Filaments slender. Ovary 2-celled, sessile : styles united: stigma depressed, Ovules solitary in each cavity, pendulous, anatropous. Drupe manifestly elongated, red, with a somewhat elongated stone. Flowering Dogwood.

1. Cynoxylon flóridum (L.) Raf. A shrub or small tree sometimes $15 \mathrm{~m}$. tall, with a maximum trunk diameter of about $0.5 \mathrm{~m}$., the bark black, in high ridges, the wood hard and close-grained. Leaf-blades elliptic to oval, 6-18 $\mathrm{cm}$. long, acute or short-acuminate at both ends, bright green and sparingly pubescent above, pale and more densely pubescent beneath, short-petioled : bracts showy, white or pink, obovate, 4-6 cm. long, notched and thickened at the apex : hypanthium cylindric-funnelform : sepals as broad as long: petals linear, 3-4.5 mm. long, obtuse, curled back: stamens exserted : drupes oblong, usually clustered, about $1.5 \mathrm{~cm}$. long, red : stone elliptic, rather pointed at both ends, 2-grooved. [Cornus florida L.]

In woods with deciduous-leaved trees, Massachusetts to Ontario and Missouri, south to Florida, Texas and Mexico. Spring; fruit ripening in the fall. DoGWood.

\section{FAMILY 2. HEDERÀCEAE L. Ivy FAMiLy.}

Aromatic herbs, shrubs, trees or vines, possessing stimulant and somewhat tonic properties. Leaves alternate or whorled: blades simple or compound. Inflorescence variously disposed, the ultimate divisions often umbels. Flowers perfect or polygamous, regular, sometimes involucrate. Calyx of 5 sepals, these sometimes'very short. Corolla of five or ten valvate petals, inserted in the margin of an epigynous disk. Androecium of 5 or 10 stamens inserted with the Gynoecium of 2-5 united carpels. Ovary 2-5-celled, crowned with an epigynous disk. Styles as many as the cavities of the ovary, spreading or converging, sometimes united. Stigma simple. Ovules solitary, anatropous. Fruit a berry 
or a drupe. Seed solitary, with a crustaceous testa. Endosperm copious, fleshy. Embryo straight. [Araliaceae Vent.]

Vines: leaf-blades simple.

Herbs, shrubs or trees : leaf-blades compound.

Scapose : bracts whorled; blades digitately compound.

Caulescent: leaves alternate; blades pinnately decompound.

1. HEDERA.

2. PANAX.

3. Aralia.

\section{HÉDERA L.}

High-climbing vines, with rope-like stems. Leaves without stipules : blades simple, entire or lobed, leathery, often lustrous. Flowers polygamous, in panicled umbels, jointed to the pedicels. Calyx truncate or of 5 sepals. Petals 5 , valvate, inconspicuous. Stamens 5 : filaments short. Ovary 5-celled. Styles united into a conic or cylindric column. Berry-like fruit angled, somewhat pulpy : nutlets papery or membranous. Seeds solitary. Endosperm ruminated.

1. Hedera Hélix L. An evergreen high-climbing vine. Stems rope-like, clinging by rootlets: leaves alternate; blades leathery, dark green and lustrous above, dull beneath, ovate, angular or 3-5-lobed or 3-5-cleft, 2-10 $\mathrm{cm}$. long: flowering branches stiff : umbels solitary or a few in terminal racemes or panicles: hypanthium pubescent, turbinate : sepals obsolete: corolla yellowish green : petals ovate or oblong-ovate, $2-3 \mathrm{~mm}$. long, obtuse : stamens 5, ascending : fruit subglobose, about $1 \mathrm{~cm}$. in diameter, $2-5$-seeded.

A bout houses and cemeteries, sparingly naturalized from Europe. Ivy.

\section{PÀNAX L.}

Perennial scapose herbs, with globose or elongated tuberous rootstocks. Scapes simple, topped by a whorl of digitatèly compound petioled bracts. Peduncle erect, naked. Umbel simple, terminal, solitary. Flowers polygamous, inconspicuous. Sepals minute or nearly obsolete. Petals 5, valvate, spreading, white or greenish. Stamens 5: filaments short. Ovary 2-3-celled, or rarely 5-celled. Styles 2-3, distinct. Stigmas obliquely facing inward. Berries drupe-like, pulpy without, 2-3-celled within, red or yellowish. Seeds more or less flattened.

Rootstock globular: leaflets sessile, obtuse: berries yellow. Rootstock fusiform: leaflets stalked, acuminate : berries bright crimson.

1. P. trifolium.

2. P. quinquefolium

1. Panax trifolíum L. Rootstock subglobose : scape erect, 1-2 dm. tall, topped by a whorl of 3 bracts, simple : bracts with petioles; blades digitately 3 -foliolate ; leaflets oblong or elliptic, often varying to lanceolate or oblanceolate, 1-8 cm. long, obtuse, more or less distinctly doubly serrate, acute or abruptly contracted at the base, sessile : peduncles 1-8 $\mathrm{cm}$. long: umbel solitary, the pedicels $2-5 \mathrm{~mm}$. long: hypanthium turbinate in flower : petals ovate to oblong, $0.5-1 \mathrm{~mm}$. long, obtuse : berry 3-angled or didymous, 4-5 $\mathrm{mm}$. broad, yellow.

In open woods, Nova Scotia to Minnesota, south to Georgia and Illinois. Spring and early summer. Ground-NUT, DWARF GINSENG.

2. Panax quinquefòlium $L$. Rootstock fusiform, simple or forking: scape $2-4 \mathrm{dm}$. tall, topped by a whorl of 3 or 4 bracts, simple : bracts with long petioles ; blades digitately 5 -foliolate or rarely 6 -7-foliolate ; leaflets obovate or the lower ones oval or suborbicular, 2-15 cm. long, acuminate at the apex, doubly serrate, acute to subcordate at the base : peduncles $2-10 \mathrm{~cm}$. long, topped by a solitary umbel : hypanthium campanulate : sepals triangular : petals ovate, $1-1.5 \mathrm{~mm}$. long, yellowish green : berries flattened, rather didymous, $8-10 \mathrm{~mm}$. broad, bright crimson.

In rich soil in woods, Quebec to Minnesota and Nebraska, south to Florida and Alabama. Summer. Ginseng. Sang.

\section{ARÁLIA L.}

Perennial caulescent herbs, shrubs or trees, with glabrous pubescent or prickle-armed foliage. Stems erect, horizontal or creeping. Leaves alternate: blades petioled, pinnately or ternately decompound : leaflets usually toothed. Flowers perfect or polygamomonoecious, white or whitish, in racemose or paniculate umbels, or in compound umbels. Sepals 5 or obsolete. Petals 5, more or less imbricated, obtuse or with inflexed tips. Stamens 5 : filaments curved. Ovary 5-celled. Styles 5, spreading. Ovules solitary in each cavity. Berry 5-lobed, black, fleshy : nutlets crustaceous. Seeds flattened. SpIKENARD. SARSAPARILLA. 
Umbels few, in terminal corymbs or few-rayed umbels.

Plants with elongated rootstocks, a peduncle or a leaf, or both arising together at intervals from the rootstock.

Plants with leafy branches arising from the rootstocks.

Umbels numerous in terminal or axillary racemes or panicles.

Large unarmed herb: leaflets membranous.

Shrub or small tree with prickle-armed stems : leaflets leathery.

1. A. nudicaulis.

2. A. hispida.

3. A. racemosa.

4. A. spinosa.

1. Aralia nudicaùlis L. Stems (rootstocks) horizontal or creeping. Leaves few, one usually arising from the very short branch ; petioles $2-3 \mathrm{dm}$. long, erect, dividıng into 3 branches: primary leaf-divisions 3-5-foliolate, $6-15 \mathrm{~cm}$. long, oblong to ovate or the terminal one oblanceolate, acuminate at the apex, doubly serrate : peduncles erect, shorter than the leaves, topped by 3 rays, each of which terminates in an umbel : hypanthium turbinate: sepals rounded: petals greenish, ovate, shorter than the hypanthium: berries subglobose, 6-8 mm. in diameter, dark purple or black.

In woods and on ledges, Newfoundland to Manitoba, south to North Carolina and Missouri spring and fall. Wild SARSAParilla.

2. Aralia híspida Vent. Stems (rootstocks) horizontal or creeping, the branches erect, 2-9 dm. tall, simple or sparingly branched, bristly with rather rigid hairs or glabrate : leaves alternate, bipinnate, the lower ones long-petioled, the upper short-petioled : leaflets oblong, elliptic, oval or ovate, $1.5-5 \mathrm{~cm}$. long, acute, irregularly serrate, acute or rounded at the base, glabrous or pubescent on the nerves beneath : umbels several in a terminal corymb : peduncles slender : bractlets of the involucels subulate : hypanthium turbinate: sepals minute, acute: petals oblong or oblong-oval, $1.5-2 \mathrm{~mm}$. long, white, recurved: berries subglobose, $6-8 \mathrm{~mm}$. in diameter, dark-purple.

In rocky soil and open woods, Newfoundland and Labrador to Minnesota, south to North Carolina and Indiana. Summer.

3. Aralia racemòsa $\mathrm{L}$. A spreading shrubby herb with large aromatic roots. Stem much branched, 1-2 m. tall, often purple or spotted: leaves thrice or five times pinnately compound: leaflets thin, ovate to suborbicular, 4-20 $\mathrm{cm}$. long, acuminate at the apex, doubly serrate, cordate at the base, more or less pubescent on the nerves beneath, petioluled : umbels numerous, in compound racemes which vary from $5-10 \mathrm{~cm}$. in length : peduncles and pedicels hairy : bractlets of the involucels subulate: sepals minute, hooked : corolla greenish, about $2 \mathrm{~mm}$. broad : petals ovate or ovate-lanceolate : berries subglobose, about 5 $\mathrm{mm}$. in diameter, dark red or purple.

In woeds, New Brunswick to Minnesota, Missouri and Georgia. Summer. Indian-Root.

4. Aralia spinòsa L. A shrub or small tree sometimes $12 \mathrm{~m}$. high, the stems and branches armed with hard prickles. Leaves large, long-petioled, twice or thrice pinnate, usually with a leaflet at the base of each division; leaflets thickish, ovate, oval or ellipticlanceolate, $2-10 \mathrm{~cm}$. long, acuminate at the apex, more or less sharply serrate, cordate or rarely acute at the base, pale or glaucous or sometimes slightly pubescent beneath, shortstalked : umbels numerous, in panicled racemes, varying from 1.5-5 $\mathrm{dm}$. long : peduncles and pedicels pubescent: sepals triangular: petals ovate, whitish, $2 \mathrm{~mm}$. long: berries $6-7$ mm. in diameter, black.

In woods and low grounds, New York to Missouri, south to Florida and Texas. Summer. ToorH ache-tree. Prickly ash. Hercules' Club.

\section{Family 3. ammiàceae Presl. Carrot family.}

Herbs of wide distribution, all possessing a volatile oil or balsam, many with an alkaloid principle and acrid-narcotic poison, many yield odorous gumresins with active stimulant properties. Stems hollow. Leaves alternate, sometimes all basal, or rarely opposite : blades more or less dissected, or merely toothed or entire; petiole dilated at the base. Inflorescence umbellate, usually compound, the umbels sometimes contracted into heads. Flowers perfect or polygamous. Calyx of 5 tooth-like sepals or a mere border. Corolla of five valvate petals, inserted on a disk which crowns the ovary. Androecium of five stamens, inserted with the petals. Gynoecium of 2 1-celled carpels, inferior. Styles 2, their bases often united and thickened. Fruit dry, a cremocarp, of two united carpels, separating at maturity from each other and often from a
slender axis, as two achene-like mericarps which are either ribbed or winged. Seed with the pericarp and testa united. Endosperm copious. Embryo straight. [Umbelliferae B. Juss.]

A. Fruit with obscure or obsolete oil tubes.

a. Fruit strongly flattened laterally.

* Involucre wanting: fruit without secondary ribs or reticulations.

1. HYDROCOTYLE. 
** Involucre conspicuous : fruit with secondary ribs and reticulations.

b. Fruit not strongly flattened, sometimes turgid.

Seed-face concave.

Stylopodium conic.

Fruit bristly, elongated.

Fruit smooth, of almost distinct globular carpels.

Stylopodium obsolete or flat.

Seed-face essentially flat.

B. Fruit with distinet oil tubes.

Inflorescence glomerate, the flowers aggregated into dense heads.

Inflorescence manifestly umbellate.

Fruit strongly flattened dorsally, the lateral ribs of the carpels more or less prominently winged.

Oil tubes solitary in the intervals.

Stylopodium conic.

Fruit not notched at the apex, the carpels not very flat.

Fruit notched at the apex, the carpels very flat.

Stylopodium obsolete or flat.

Plants caulescent.

Corolla white.

Fruit armed with barbed spines.

Fruit spineless.

Leaf-blades pinnately dissected : fruit with filiform dorsal ribs.

Leaf-blades ternately or pinnately compound : fruit with stout dorsal ribs.

Corolla yellow.

Plants acaulescent or essentially so.

Oil tubes more than one in the intervals.

Plants caulescent.

Fruit with obsolete dorsal ribs, the lateral ribs corky thickened : corolla yellow.

Fruit with prominent dorsal ribs, the lateral ribs not corky thickened : corolla white.

Leaf-blades 1-2-ternately divided.

Leaf-blades much more divided.

Plants acaulescent or essentially so.

Lateral wings of the fruit thin.

Lateral wings of the fruit thick.

Fruit more or less flattened laterally, or sometimes slightly dorsally flattened.

Oil tubes solitary in the intervals.

Stylopodium conic.

Upper leaves with narrowly linear segments.

Involucre wanting : naturalized species.

Corolla white.

Corolla yellow.

Involucre present.

Low plants with diffusely branched stems.

Taller plants with erect. not diffusely branched, stems.

Leaves with finely dissected blades, the segments numerous. Fruit about as thick as long. Fruit smooth.

Fruit bristly or tuberculate.

Fruit long and narrow.

Leaves with few segments.

Upper leaves with relatively broad segments.

Seed-face concave.

Fruit glabrous or merely pubescent.

Fruit spiny.

Seed-face flat.

Fruit nearly as broad as long.

Fruit linear-oblong.

Stylopodium obsolete or flat.

Corolla white.

Fruit with thick corky ribs, at least the lateral ones.

Dorsal ribs filiform: plants aquatic.

Dorsal and lateral ribs corky and prominent. Stylopodium flat or flattish.

Corolla regular or nearly so, the petals with inflexed tips: rays of the secondary umbels not concreted at the base.

Corolla markedly irregular, the petals cleft at the apex : rays of the secondary umbels concreted at the base. Stylopodium obsolete.

Fruit with obsolete or obscure ribs.

Corolla yellow.

Fruit with winged ribs.

Fruit with merely filiform ribs.

9. CORIANDRUM.

31. Foeniculum.

18. Ammoselinum.

10. BipHIN

14. Bupletrum.

3. BOWlesia.

5. Eryngium.

39. OXYPOLIS.

42. Heracleum.

43. Daucus.

30. Eurytaenia.

35. ANGelica,

41. PASTINACA.

40. Lomatium.

38. Polytaenia.

35. ANgelica.

34. Conioselinum.

40. Lomatium.

37. CYMOPTERUS.

27. Ptilliminiu.

17. SPERMOLEPIS.

15. TREPOCARPUS.

28. Cynosciadium.

6. ChaErophyllum.

8. TORILIS.

20. Cicuta.

21. DERINGa.

29. LilaAEOPSIS.

16. APIUM.

22. Аммі.

25. SIUM.

11. Apiastrum.

33. Thaspium.

19. Zizia.

Oil tubes more than one in the intervals.

Stylopodium conic.

Fruit rounded, the globular carpels with slender inconspicuous ribs.

Fruit of an ovate or oblong type.

Mature carpels with stout equal ribs.

Mature carpels with filiform ribs.

26. Berula.

32. LigusticuM.

24. EULOPHUS.

Stylopodium flat or obsolete.

Seed-face grooved or markedly concave : plants acaulescent or essentially so. 
Fruit not notched at the apex.

Fruit notched at the apex.

Seed-face flat or nearly so: plants evidently caulescent (except Phellopterus).

Fruit without ribs, spiny.

Fruit ribbed, spineless.

Carpels with prominently winged ribs.

Carpels with wingless ribs.

Ribs filiform.

Ribs corky, at least the lateral ones.

Oil-tubes continuous around the seed cavity. Oil-tubes $2-3$ in the intervals.
13. MUSENIOPSIS.

12. ERIGENIA.

\section{SANICULA.}

36. Phellopterus.

23. TAENIDIA.

14. Bupleurum.

25. SIUM.

\section{HYDROCÓTYLE L.}

Perennial herbs of damp situations, with creeping stems. Leaves alternate, one at a node, with long petioles; blades entire or lobed, palmately nerved, sometimes peltately attached to the petiole. Bracts of the involucre obsolete, or wanting. Flowers perfect or unisexual, inconspicuous, in simple or proliferous peduncled umbels. Sepals manifest. Petals white, acute, valvate. Disk flat or nearly so. Fruit lenticular, laterally flattened, orbicular or depressed, smooth : carpels with 5 primary distinct ribs, without large oiltubes but a layer of oil-bearing tissues beneath the epidermis. Seeds lenticular.

\section{Marsh Pennywort. Water Pennywort.}

Leaf-blades suborbicular to transversely oblong, peltate.

Fruit notched at the base and the apex at maturity: intermediate ribs corky.

Umbels not proliferous at least not normally so.

Umbels or most of them proliferous.

Peduncle produced beyond the first umbel as a single rachis, bearing one or more umbels beyond it.

Fruit between 2 and $3 \mathrm{~mm}$. broad: dorsal ribs obtuse.

Fruit between 3 and $4 \mathrm{~mm}$. broad : dorsal ribs acute.

Peduncle produced beyond the first umbel branching and bearing several more or less proliferous umbels.

Fruit rounded at the base and the apex or cuneate at the base: intermediate ribs not corky, very slender.

Fruit rounded or truncate at the base, not cuneate.

Fruit sessile or nearly so.

Fruit pedicelled.

Fruit cuneate at the base.

Leaf-blades reniform to suborbicular, not peltate.

Umbels long-peduncled : leaf-blades deeply lobed.

Umbel nearly sessile : leaf-blades shallowly lobed.

1. H. umbellata.

2. H. prolifera.

3. H. Canbyi.

4. H. Bonariensis.

5. H. verticillata.

6. H. australis.

7. H. cuneata.

8. H. ranunculoides.

9. H. Americana.

1. Hydrocotyle umbellàta L. Rootstock producing tubers on its descending branches: leaf-blades peltate, suborbicular, $2-5 \mathrm{~cm}$. broad, crenate or crenate-lobed : peduncles as long as the petioles or longer : umbels many-flowered, normally not proliferous : pedicels 4-12 $\mathrm{mm}$. long: fruit $2 \mathrm{~mm}$. long, about $3 \mathrm{~mm}$. broad, notched at the base and apex, the prominent dorsal ribs obtuse.

In swamps and meadows, Massachusetts to Minnesota, California, Florida, Texas and Mexico. Also in the West Indies. Spring to fall.

2. Hydrocotyle prolifera Kellogg. Rootstocks producing tubers on descending branches: leaf-blades peltate, suborbicular, $2-5 \mathrm{~cm}$. broad, crenate : peduncles as long as the leaves or longer : umbels commonly proliferous, the whorls with 5-20 flowers: peduncles prolonged beyond the first umbel : pedicels slender, $2-6 \mathrm{~mm}$. long: fruit between 2 and 3 $\mathrm{mm}$. broad, slightly notched at base and apex, the dorsal ribs obtuse.

In low grounds, Texas to California and Central America. Spring to fall.

3. Hydrocotyle Cánbyi Coult. \& Rose. Rootstocks sometimes tuberous at the joints : leaf-blades peltate, suborbicular, $1.5-4 \mathrm{~cm}$. broad, shallowly crenate-lobed : peduncles shorter than the leaves or longer : umbels generally proliferous, the whorls 3-9-flowered: pedicels slender, 1-4 mm. long : fruit between 3 and $4 \mathrm{~mm}$. broad, slightly notched at base and apex, the dorsal ribs,acute.

In damp sandy soil, New Jersey to Maryland and perhaps to Florida. Spring to fall.

4. Hydrocotyle Bonariénsis Lam. Kootstocks often greatly elongated : leaf-blades depressed orbicular or orbicular-reniform, $3.5-9.5 \mathrm{~cm}$. broad, shallowly several-many-lobed, the lobes crenate : petioles and peduncles $6-11 \mathrm{~cm}$. long or sometimes greatly elongated : umbels proliferous and branching, the whorls often many-flowered : pedicels variable, sometimes $2 \mathrm{~cm}$. long: fruit $2 \mathrm{~mm}$. long, about $3 \mathrm{~mm}$. wide, slightly notched.

In waste grounds and on ballast, North Carolina to Florida and Texas. Also in Central and South America.

5. Hydrocotyle verticillàta Thunb. Rootstocks much elongated : leaf-blades peltate, suborbicular or oval, 1-6 cm. broad, shallowly crenate : peduncles much shorter than the 
leaves or longer : umbels proliferous, and forming an interrupted raceme, the whorls fewflowered: pedicels usually $1-3 \mathrm{~mm}$. long: fruit depressed, $2 \mathrm{~mm}$. high, $3-4 \mathrm{~mm}$. broad, rounded or truncate at the base and apex, the ribs prominent, the dorsal acute, none of them corky. [H. interrupta Muhl.]

In low grounds or swamps, Massachusetts to Arkansas, Florida and Texas. Spring to fall.

6. Hydrocotyle austràlís Coult. \& Rose. Similar to H. Canbyi in habit. Umbels proliferous, the 3-6 whorls few-flowered : pedicels $2-4 \mathrm{~mm}$. long: fruit $2 \mathrm{~mm}$. long and slightly broader, rounded at the base.

In low grounds, Virginia to Florida and Texas. Spring to fall.

7. Hydrocotyle cuneàta Coult. \& Rose. Resembling H. australis in habit. Umbels proliferous, the few whorls few-flowered: pedicels very short : fruit $2 \mathrm{~mm}$. long, $3-4 \mathrm{~mm}$. broad, tapering to the pedicels by a cuneate base.

In damp places, Texas to California. Spring to fall.

8. Hydrocotyle ranunculoìdes L. f. Rootstocks extensively creeping, or often floating: leaf-blades rather fleshy, not peltate, reniform or orbicular-reniform, $2-5 \mathrm{~cm}$. broad, 3-7-lobed, cordate, the lobes crenate: peduncles 1-8 cm. long, shorter than the leaves: umbels capitate, 5-10-flowered : pedicels often 1-2 mm. long at maturity : fruit 2-3 mm. broad, obscurely ribbed, oblong in cross-section.

In ditches, swamps and shallow ponds, Pennsylvania to Florida and Texas. Also on the Pacific Coast from Oregon to Lower California. Spring to fall.

9. Hydrocotyle Americàna L. Rootstocks creeping, often producing elongated tubers: leaf-blades thin, not peltate, reniform, $2-5 \mathrm{~cm}$. broad, crenate and crenate-lobed, cordate: peduncles very short: umbels axillary, few-flowered: nearly sessile: pedicels commonly less than $1 \mathrm{~mm}$. long : fruit $1-1.5 \mathrm{~mm}$. broad, slightly ribbed, oval in cross-section, the oil-bearing layer obsolete.

In damp soil, Nova Scotia to Ontario and Minnesota, south to Pennsylvania and in the mountains to North Carolina. Spring to fall.

\section{CENTÉLLA L.}

Perennial herbs, with creeping or horizontal rootstocks. Leaves clustered at the nodes, with long erect petioles: blades entire or toothed, palmately nerved. Bracts of the involucre 2-4, small. Flowers in capitate long-peduncled umbels. Hypanthium truncate. Sepals obsolete. Petals white, obtuse, imbricated. Disk flat or concave. Fruit lenticular, laterally flattened, suborbicular, cordate or reniform, smooth : carpels without large oiltubes, the prominent ribs anastomosing. Seeds lenticular.

1. Centella repánda (Pers.) Small. Foliage glabrate or slightly pubescent. Rootstocks elongated : leaves clustered; petioles erect, $10-30 \mathrm{~cm}$. long; blades thickish, ovate, $2-6 \mathrm{~cm}$. long, obtuse, repand, cordate or nearly truncate at the base : peduncles usually several together, villous, $1-6 \mathrm{~cm}$. long, mostly shorter than the petioles : umbels 2-4 flowered, chiefly capitate : fruit depressed, $4-5 \mathrm{~mm}$. broad, prominently ribbed and reticulated. [Hydrocotyle repanda Pers.]

In sand or moist pine lands, Maryland to Florida and Texas.-A form from eastern Florida, with petioies about $2.5 \mathrm{~cm}$. long and larger fruit, is C. repanda Floridana (Coult. \& Rose) Small. [Hydrocotyle Asiatica var. Floridana Coult. \& Rose.]

\section{BOWLÈsIA R. \& P.}

Annual caulescent herbs, with stellate pubescence. Leaves opposite: blades merely lobed. Flowers in simple, few-flowered umbels which terminate axillary peduncles. Sepals 5, prominent. Corolla white. Disk rather flat. Fruit turgid, smooth : carpels ribless, becoming depressed on the back, nearly distinct : oil-tubes wanting or obsolete. Seed dorsally flattened, the face essentially flat.

1. Bowlesia septentrionàlis Coult. \& Rose. Stems weak, $0.5-6 \mathrm{dm}$. long, dichotomously branched : leaf-blades reniform to ovate-cordate, $1.5-3 \mathrm{~cm}$. broad, thin, 3-5-lobed, slender-petioled : umbels short-peduncled, 1-4-flowered: fruit about $2 \mathrm{~mm}$. long, sessile or nearly so.

In rich or shaded ground, Texas to California. Spring.

\section{SANÍCULA L. ${ }^{1}$}

Biennial or perennial caulescent herbs. Leaves alternate: blades pinnatifid or palmately 3-7-foliolate: leaflets toothed or incised. Flowers usually unisexual, in irregular

${ }^{1}$ Contributed by Mr. E. P. Bicknell. 
compound few-rayed umbels. Bracts of the involucres resembling the leaves. Sepals 5. persistent. Petals white, yellowish or purple, broadest above the middle, emarginate. Disk flat. Fruit subglobose or oblong, somewhat dorsally flattened, armed with hooked bristles : carpels without ribs : oil-tubes usually 5. Snake-root. Black SNake-root.

Perennial : stamens and style exserted.

Roots slender: leaf-blades 5-divided or 5-foliolate: stamens and styles slenderly exserted. Petals and anthers greenish white: sepals linear-subulate: fruit about $6 \mathrm{~mm}$. long.

Petals and anthers yellow: sepals ovate: fruit about $3 \mathrm{~mm}$. long.

Roots tuberous thickened: leaf-blades 3-divided or 3-foliolate: stamens and style short-exserted.

Biennial: stamens and style included.

Pedicels of the staminate flowers $3-4$ times the length of the hypanthium and calyx : seeds with 2 large oil tubes.

Pedicels of the staminate flowers 1-2 times the length of the hypanthium and calyx: seeds with 5 large oil-tubes.

Leaf-bades becoming $8-15 \mathrm{~cm}$. broad : leaflets or leaf-segments thin, the teeth weakly aculeate.

Leaf-blades mostly less than $6 \mathrm{~cm}$. broad : leaflets or leaf-segments thickish, the teeth spinulose-cuspidate.

1. S. Marylandica.

2. S. gregaria.

3. S. Smallii.

4. S. trifoliata.

5. S. Canadensis.

6. S. Floridana.

1. Sanicula Marylándica L. Rather stout, $4.5-13 \mathrm{dm}$. tall. Stems usually simple below the 3-branched umbel, the branches bearing simple or compound secondary umbels : basal leaves with long petioles : stem-leaves $2-3$, the upper sessile, all firm, bluish green, paler beneath than above; segments $4-15 \mathrm{~cm}$. long, the lower pair obovate to oblanceolate, parted or divided, mucronate-serrate or dentate, often incised above : involucre of small 3-cleft bracts : involucel of scale-like bractlets: ultimate rays 3 : staminate flowers numerous, their pedicels $3-6 \mathrm{~mm}$. long : caly $\mathrm{x}$ and hypanthium $1.5-2 \mathrm{~mm}$. long: petals oblanceolate, slightly longer than the sepals : fruits $2-6$ together or solitary, obovoid, sessile, with recurved spreading styles and strong bristles: pericarp corky-thickened, with five large oil-tubes: seeds dorsally 3 -grooved.

In rich woods, Newfoundland to the Rocky Mountain region, south to Georgia and Colorado. Spring and summer.

2. Sanicula gregària Bicknell. Slender, $3-9 \mathrm{dm}$. tall. Stems weak, often clustered, the slender ascending branches umbellately compound : leaves mainly basal; blades thin, bright green, the segments mostly less than $8 \mathrm{~cm}$. long, obovate-cuneate to lanceolate, doubly serrate with bristle-tipped teeth and sharply incised, the lower pair usually cleft: stem-leaves 1-2, or wanting, petioled: involucre of large 3-parted bracts : involucels of foliaceous bractlets ; rays $2-3$, slender, $12-30 \mathrm{~cm}$. long : staminate flowers numerous, their pedicels $2-3 \mathrm{~mm}$. long, $3-4$ times the length of the minute campanulate hypanthium and calyx : petals obovate, much surpassing the sepals : fruits $3-5$ together, stipitate, broadly obovoid, with widely recurved styles and minute weak bristles, the pericarp thin, with 5 small oil-tubes : seeds not grooved.

In moist woods and thickets, Vermont to Wisconsin and Nebraska, south to North Carolina and Kansas. Spring and summer.

3. Sanicula Smállii Bicknell. Stems 2.5-6 dm. tall, widely 2 -forked above. Basal leaves slender-petioled, the divisions obovate or broadly rhombic, $4-8 \mathrm{~cm}$. long, mostly obtuse, dentate-serrate with aculeate teeth or sparingly incised above, somewhat leathery, deep and dull green above, paler beneath, the lateral segments cleft or parted; stem-leaves 3-4: involucre of nearly sessile 3 -cleft bracts: involucels of very small bractlets: rays $2-6$, rigid, spreading, $2-3.5 \mathrm{~cm}$. long: staminate flowers numerous, their pedicels $2-4$ $\mathrm{mm}$. long: sepals linear-cuspidate, $1.5-2 \mathrm{~mm}$. long: petals obovate, not surpassing the sepals, yellowish or greenish : fruits 3-6 together, ovoid, 4-6 mm. long, sessile, with numerous slender bristles, the pericarp somewhat thickened, with 5 oil-tubes : seeds not grooved.

In rich or rocky woods, North Carolina to Missouri, south to Florida and Mississippi. Summer.

4. Sanicula trifoliàta Bicknell. Stems slender, $3-8 \mathrm{dm}$. tall, often with simple or widely forking branches. Leaf-blades ample, thin, bright green, the divisions ovate or rhombic, manifestly acute, the lateral pair 6-9 dm. long, coarsely and doubly serrate, sometimes cleft, the teeth somewhat spinulose-tipped: involucre of foliaceous bracts : rays stiff, 10-20 $\mathrm{mm}$. long: staminate flowers few, their pedicels about $4 \mathrm{~mm}$. long: calyx and hypanthium about $1 \mathrm{~mm}$. long: sepals linear-aculeate : petals minute, white : fruits 3-5 together, ellipsoid or broader, becoming $7 \mathrm{~mm}$. long, sessile, the pericarp thickened, with slender bristles : seeds not grooved, with a large oil-tube on one or both sides and several small ones.

In rich woods, Vermont and Ontario to Indiana, Pennsylvania and Tennessee summer.

5. Sanicula Canadénsis L. Stems solitary, 3-13 dm. tall, leafy, the branches alternate, dichotomously compound. Leaf-blades dull green, those of the upper stem-leaves shortpetioled, 3-divided, the lateral divisions parted or divided again, sometimes becoming 9 
cm. long, cuneate-obovate to narrowly oblong, acute, serrate or incised, the teeth weakly mucronate : involucre of minute bracts: rays mostly 2 , only $2-10 \mathrm{~mm}$. long: staminate flowers very few or wanting: calyx and hypanthium $1 \mathrm{~mm}$. long : sepals linear, acute : petals minute, shorter than the sepals : fruits three together, short-stalked, subglobose, the pericarp thickish, with slender bristles : seeds 3-grooved on the back, with 5 oil-tubes.

In woodlands, Vermont to Nebraska, south to Florida and Texas. Spring to fall.

6. Sanicula Floridàna Bicknell. Similar to S. Canadensis, but smaller and stiffer, the stems more closely leafy. Leaves much smaller; blades thicker, the divisions abruptly cuneate with concave sides, acutely dentate-serrate and cut-lobed, with yellowish spinycuspidate teeth : branches of the inflorescence slender, dichotomous, the branchlets stiff and wide-spreading : involucre of very small or minute bracts : fruits very small.

In sandy soil, South Carolina to Florida and Mississippi. Spring to fall.

\section{ERÝNGIUM L.}

Biennial or perennial often rigid herbs, with erect or creeping stems. Leaves alternate or whorled, sometimes mainly basal : blades spiny-toothed, lobed or incised, or rarely entire. Flowers in dense capitate or elongated spikes. Bracts of the involucre various, often colored, resembling the leaves. Sepals rigid, acute or spine-like. Petals 5, prolonged into an inflexed acumination. Fruit varying from ovoid to obovoid, slightly laterally flattened : carpels with obsolete ribs and 5 oil-tubes. Seeds slightly flattened. Eryngo Button SNake-Root.

Leaf-blades not parallel-veined.

Blades of the basal leaves entire or merely toothed, sometimes spinulose, not spiny-toothed. Stems filiform or relatively slender, like the branches mostly prostrate: plants biennial.

Bractlets longer than the flowers: stem-leaves with narrow blades or segments : fruit strongly tuberculate.

Bractlets shorter than the flowers : stem-leaves with broad blades or segments : fruit not strongly tuberculate.

Stems relatively stout, erect or ascending: plants perennial or perhaps

1. E. Baldwinii.

2. E. prostratum. rarely biennial.

Lower leaves with elongated hollow petioles and long blades. Bractlets entire.

Bractlets 3-pronged.

Teeth of the bractlets unequal, the lateral teeth smaller.

Teeth of the bractlets about equal.

Heads fully $1.5 \mathrm{~cm}$. long : plant mostly over $11 \mathrm{dm}$. tall.

Heads about $1 \mathrm{~cm}$. long: plant mostly less than $10 \mathrm{dm}$. tall.

Lower leaves with short petioles and blades.

Bractlets 3-toothed: upper leaves with merely toothed blades.

Leaf-blades ovate, oblong or lanceolate, serrate or crenate: heads mostly over $7 \mathrm{~mm}$. high.

Leaf-blades linear or linear-lanceolate, laciniately toothed, at least near the base: heads mostly less than $7 \mathrm{~mm}$. high.

Bractlets entire : upper leaves with palmately 5-7-parted blades.

Blades of the basal leaves lobed or parted, the segments spine-tipped, sometimes reduced to nodose phyllodes.

Heads $12 \mathrm{~cm}$. long or less : sepals entire.

Bracts of the involucre cleft or toothed : heads depressed or ovoid.

Bracts of the involucre 3-cleft: bractlets 3-toothed.

Bracts of the involucre spiny-toothed: bractlets entire.

Heads subglobose or depressed : bracts green within.

Heads longer than broad: bracts conspicuously colored.

Bracts of the involucre entire: heads oblong or cylindric.

Heads 25-40 mm. long: sepals 3-5-toothed.

Leaf-blades parallel-veined.

Bristles of the leaf-margins 2-4 together.

Bristles of the leaf-margins solitary.

3. E. Floridanum.

4. E. Virginianum.

5. E. Mettaueri.

6. E. Ravenelii.

7. E. integrifolium.

8. E. Ludovicianum.

9. E. Hookeri.

1. Eryngium Baldwinii Spreng. Biennial, glabrous. Stems often branched at the base, the branches very slender or filiform, 1-6 dm. long, prostrate or creeping: leaf-blades various, those of basal leaves oblong, varying to broadest above or below the middle, 2-6 cm. long, entire or incised, long-petioled, those of stem-leaves smaller, 3-parted, the segments filiform, linear or oblong, entire or toothed : heads ovoid to cylindric, 4-6 mm. long: bracts of the involucres subulate, shorter than the heads: bractlets similar but smaller: fruit $1 \mathrm{~mm}$. long or shorter, prominently tuberculate.

In sandy soil, Georgia to Florida and Louisiana. Also reported from Missouri. Spring to fall.

2. Eryngium prostràtum Nutt. Biennial, glabrous or nearly so. Stems usually branched at the base, the branches prostrate, often creeping, $2-5 \mathrm{dm}$. long, sometimes nearly filiform : leaf-blades various, those of the basal and lower stem-leaves oblong or ovate, 2-4 $\mathrm{cm}$. long, entire or repand, long-petioled, those of upper stem-leaves smaller, often clustered at the nodes, some entire, others often 3-cleft : heads oblong, $5-6 \mathrm{~mm}$. long: bracts of the 
involucres linear-lanceolate or linear-spatulate, reflexed at maturity, longer than the head : fruit about $1 \mathrm{~mm}$. long, sparingly tuberculate.

In low grounds and pine lands, Kentucky to Missouri, Georgia, Florida and Texas. Summer.

3. Eryngium Floridànum Coult. \& Rose. Perennial. Stems 6-9 dm. tall, often sparingly branched : leaf-blades various, those of the basal leaves narrowly oblong, 2.5-10 $\mathrm{cm}$. long, usually entire, long-petioled, those of the upper stem-leaves long-linear, mostly remotely serrulate, sessile or nearly so : heads subglobose, $10-12 \mathrm{~mm}$. long: bracts of the involucre linear-lanceolate, reflexed, longer than the head : bractlets linear, much longer than the flowers, entire, sharp-pointed : fruit about $2 \mathrm{~mm}$. long, crowned with the ovate acute sepals.

In brackish marshes, Florida. Spring to fall.

4. Eryngium Virginiànum Lam. Perennial. Stems 3-9 dm. tall, more or less corymbosely branched above : leaf-blades linear or oblong-lanceolate, 1-3 dm. long or longer, serrate or laciniate above, acute, sessile or those of the lower cauline or basal-leaves undulate and long-petioled : heads cylindric or oblong-ovoid, $1-1.5 \mathrm{~cm}$. long, bur-like : bracts of the involucre linear, entire or spiny-toothed, as long as the heads or longer : bractlets rigid, 3 -pronged, the middle prong longer than the lateral : fruit scaly, crowned with the lanceolate acuminate sepals.

In swamps and on margins of ponds, New Jersey to Florida and Texas. Spring to fall.

5. Eryngium Mettaùeri Wood. Perennial, glabrous. Stems 10-18 dm. tall, simple or nearly so below : leaf-blades linear or linear-lanceolate, those of basal or lower stemleaves 1-2 dm. long, undulate, their petioles often 2-3 dm long, jointed, those of upper stem-leaves attenuate, more or less spiny-toothed near the base: heads ovoid or globoseovoid, about $1.5 \mathrm{~cm}$. long, robust: bracts of the involucres linear or narrowly linear-lanceolate, spiny-toothed, as long as the heads or longer, reflexed : bractlets with three equal prongs : fruit about $2 \mathrm{~mm}$. long, crowned with the ovate acute sepals.

In low grounds, Florida. Summer and fall.

6. Eryngium Ravenèlii A. Gray. Perennial. Stems $5-10 \mathrm{dm}$. tall, branched above : leaf-blades linear, elongated, conduplicate, undulate or slightly toothed, those of basal and lower stem-leaves $3-5 \mathrm{dm}$. long, those of the upper stem-leaves shorter: heads subglobose, about $1 \mathrm{~cm}$. long: bracts of the involucre spiny-toothed or entire, reflexed at maturity: bractlets 3-pronged : fruit about $2 \mathrm{~mm}$. long, crowned with the short mucronate sepals.

In swampy pine lands, South Carolina to Florida. Summer and fall.

7. Eryngium integrifolium Walt. Perennial. Stems 4-9 dm. tall branching above, or sometimes also at the base : leaf-blades oblong to ovate-oblong or oblong-lanceolate, 3-8 $\mathrm{cm}$. long, shallowly serrate or crenate, acute or obtuse, crenate or subcordate at the base, all but the upper ones with broad petioles seldom over $1 \mathrm{~cm}$. long: heads few, 8-10 $\mathrm{mm}$. long, often broader than high: bracts of the involucres linear, entire or with few spine-like teeth, longer than the head, spreading: bractlets 3-pronged, surpassing the flowers : fruit over $2 \mathrm{~mm}$. long, crowned with lanceolate acuminate sepals. [E. virgatum Lam.]

In pine woods, North Carolina to Florida and Texas. Summer and fall.

8. Eryngium Ludovicianum Morong. Similar to E. integrifolium in habit, but more slender : leaf-blades linear or linear-lanceolate, $2.5-7 \mathrm{~cm}$. long, laciniately toothed at least near the base : heads numerous, mostly less than $7 \mathrm{~mm}$. long: bracts of the involucre very narrowly linear or linear-filiform, commonly less than $1 \mathrm{~cm}$. long: fruit less than $1.5 \mathrm{~mm}$. long, crowned with the triangular sepals.

In thickets and low grounds, Louisiana and Texas. Summer and fall.

9. Eryngium Hoòkeri Walp. Perennial. Stems $2 \cdot 7 \mathrm{dm}$. tall, branching above : leaf-blades various, those of basal leaves oblong or ovate-oblong, 3-6 cm. long, shallowly toothed, their petioles shorter than the blades, those of the lower stem-leaves lanceolate, laciniately-toothed and spinulose, with a pair of small laciniate segments at the base. sessile or nearly so, those of upper leaves palmately 5-7-parted: heads ovoid-globose, 8-12 mm. high : bracts of the involucres linear or linear-lanceolate, longer than the head, spinytoothed : bractlets entire, spine-tipped, the terminal ones elongated: fruit scaly, $1 \mathrm{~mm}$. long, crowned with the spine-tipped sepals.

In low grounds, Texas. Spring and summer.

10. Eryngium aromáticum Baldw. Perennial. Stems often branched at the base, the branches ascending or prostrate, 1-6 dm. long, corymbosely branched near the top: leaf-blades rigid, $1-3 \mathrm{~cm}$. long, pinnately parted, the segments various, the lower setaceous, the upper lanceolate to oblong or oval, spine-tipped and cartilaginous margined : heads subglobose, 5-10 mm. in diameter, bristly : bracts of the involucres 3-cleft, longer than the head : bractlets 3 -toothed : fruit $1 \mathrm{~mm}$. long, tuberculate, crowned with the longer bristlelike sepals.

In dry pine lands, Florida and Alabama. Summer and fall. 
11. Eryngium diffùsum Torr. Biennial or perennial, glabrous. Stems 1-3 dm. tall, more or less diffusely branched above or even from the base, prominently ridged : leafblades rigid and leathery, palmately parted, the segments incised-serrate, spinose, thickmargined : heads subglobose or depressed, 10-12 $\mathrm{mm}$. in diameter, bristly : bracts of the involucres incised-spinose, resembling the leaves, longer than the heads : bractlets lanceolate, entire, spine-tipped : fruit scaly, $1.5 \mathrm{~mm}$. long, crowned with the long-tipped sepals.

On sandy plains, Arkansas to Oklahoma, Texas and Mexico. Summer and fall.

12. Eryngium Wrìghtil A. Gray. Perennial. Stems $3-7 \mathrm{dm}$. tall, branching : leaf-blades rigid, various, those of basal leaves oblanceolate or spatulate, $5-15 \mathrm{~cm}$. long, pectinate-dentate or pinnatifid, the triangular teeth tipped with long bristles; blades of upper stem-leaves $2-4 \mathrm{~cm}$. long, pinnately laciniate or pinnately parted, the segments bristle-tipped : heads ovoid or oblong, 10-12 mm. long: bracts of the involucres linear or linear-lanceolate, entire or remotely spiny-toothed, about twice as long as the head: bractlets subulate, surpassing the flowers, the terminal ones elongated : fruit $1 \mathrm{~mm}$. long, crowned with the ovate mucronate sepals.

On hillsides, Texas to Arizona and Mexico. Summer.

13. Eryngium compáctum Small. Similar to $E$. diffusum in habit, but smaller and more slender. Stems terete or nearly so: leaf-segments pinnately incised, the margins barely thickened : heads oblong or cylindric, $5-9 \mathrm{~mm}$. long, slightly bristly : bracts of the involucre linear, entire, mainly longer than the heads : bractlets linear-lanceolate, entire, spine-tipped : fruit scaly, about $1 \mathrm{~mm}$. long, crowned with the acuminate sepals.

In low grounds, near the lower Rio Grande, Texas. Spring.

14. Eryngium Leavenwórthii T. \& G. Perennial, glabrous. Stems $3-10 \mathrm{dm}$. tall, branching above: leaf-blades various, those of basal or lower stem-leaves oblanceolate, spiny-toothed, 4-10 cm. long, passing into palmately cleft or parted ones on the upper part of the stem ; segments incised-pinnatifid, very spiny : heads cylindric or oblong-cylindric, $2.5-4 \mathrm{~cm}$. long, each topped with a tuft of bractlets : bracts of the involucres rigid, incisedpinnatifid, spinose, about as long as the head: bractlets 3-7-toothed, the terminal ones elongated, resembling the bracts : fruit $1 \mathrm{~mm}$. long, crowned with the 3-5-toothed sepals.

On dry prairies, Kansas to Texas. Summer and fall.

15. Eryngium synchaètum (A. Gray) Rose. Perennial, bright green. Stems slender, 3-7 dm. tall, corymbose above, often almost leafless : leaf-blades linear, 1-4 dm. long, attenuate, few and shorter on the stem, the marginal bristles commonly in clusters of $2-4$ : heads $1-1.5 \mathrm{~cm}$. long, oval or ovoid : bracts of the involucres lanceolate or oblonglanceolate, often toothed, shorter than the length of the head: bractlets similar to the bracts but smaller and entire : fruit about $2 \mathrm{~mm}$. long.

In pine lands, Georgia to Arkansas, Florida and Texas. Spring and summer.

16. Eryngium aquáticum L. Perennial, glaucous. Stems $3-18 \mathrm{dm}$. tall, corymbose above : leaf-blades linear, often broadly so, 1-9 dm. long or shorter on the upper part of the stem, remotely bristly along the margins, their bases folded around the stem: heads peduncled, ovoid or subglobose, $10-20 \mathrm{~mm}$. thick : bracts of the involucres lanceolate or ovate-lanceolate, entire, with strong midrib and marginal nerves, shorter than the diameter of the heads: bractlets similar, but smaller : fruit $3-4 \mathrm{~mm}$. long, scaly. [E. yuccafoelium Michx.]

In low grounds or meadows, Connecticut to Minnesota, Florida and Texas. Spring to fall.

\section{CHAEROPHÝLLUM L.}

Annual caulescent herbs. Leaves alternate: blades ternately decompound into often delicate segments. Flowers often polygamous, in irregular compound umbels. Involucres of 1-2 bracts, or mainly wanting. Involucels of several small bracts. Hypanthium truncate. Sepals obsolete. Petals white, usually unequal, inflexed at the apex. Disk with a small conic stylopodium. Fruit elongated, laterally flattened : carpels more or less distinctly 5 -angled, the angles equally ribbed: oil-tubes solitary in the intervals and 2 in the inner face. Chervil.

Fruit sometimes contracted below the apex, but beakless : plants glabrous.

Mature umbels with 2-4 fruits on lax and spreading pedicels. Fruit less than $2 \mathrm{~mm}$. broad, constricted below the apex. Fruit fully $2 \mathrm{~mm}$. broad, not constricted below the apex.

Mature umbels with 10-17 fruits on stout pedicels, or fruit sessile.

Fruit beaked or narrowed to the apex : plants more or less pubescent.

Fruit with the ribs narrower than the intervals. Fruit pubescent. Fruit glabrous.

Fruit with the ribs broader than the intervals.

1. C. procumbens.

2. C. Shortii.

3. C. Texanum.

4. C. dasycarpum. 5. C. Floridanum. 6. C. Teinturieri. 
1. Chaerophyllum procúmbens (L.) Crantz. Stems weak, decumbent or spreading, 1-5 dm. long, simple or sparingly branched : umbels few-rayed, peduncled or nearly sessile: pedicels sometimes $8 \mathrm{~mm}$. long, lax and spreading : fruit narrow, about $8 \mathrm{~mm}$. long, glabrous, contracted below the apex, the ribs narrower than the intervals.

In open woods and copses, Ontario to Michigan, south to North Carolina and Kansas. Spring.

2. Chaerophyllum Shórtii (T. \& G. ) Bush. Stems $2-5 \mathrm{dm}$. long, spreading or decumbent, often branched : umbels few-rayed, sessile or peduncled : fruit oblong, 5-6 mm. long, not contracted below the apex, the ribs narrower than the intervals. [C. procumbens var. Shortii T. \& G.]

In fields and prairies, Pennsylvania to Kentucky and Virginia. Spring.

3. Chaerophyllum Texànum Coult. \& Rose. Stems erect, $3-7 \mathrm{dm}$. tall, glabrous: umbels several-rayed, at maturity with 10-17 fruits on stout pedicels, or fruits sessile, beakless, 4-5 mm. long, glabrous, the very prominent ribs almost obliterating the intervals.

In moist grounds, Missouri to Texas. Spring.

4. Chaerophyllum dasycárpum Nutt. Stems erect, $2-6 \mathrm{dm}$. tall, branching: umbels sessile or short-peduncled, the rays ascending or spreading, $3-5 \mathrm{~cm}$. long: fruit narrow, $5-6 \mathrm{~mm}$. long, pubescent, beaked, the ribs prominent, narrower than the intervals. [C. Teinturieri var. dasycarpum (Nutt.) Hook.]

On prairies and hillsides, Mississippi and Texas. Spring.

5. Chaerophyllum Floridànum (Coult. \& Rose) Bush. Stems erect, $2-6 \mathrm{dm}$. tall, glabrous or somewhat pubescent : umbels peduncled, the rays $2-5 \mathrm{~cm}$. long: fruit narrow, $7 \mathrm{~mm}$. long, glabrous, the beak $\frac{1}{4}$ or $\frac{1}{5}$ as long as tbe body.

In low sandy soil, South Carolına to Florida, and in Missouri. Spring.

6. Chaerophyllum Teinturièri Hook. Stems erect, 2-7 dm. tall, more or less branched : umbels sessile or short-peduncled : rays $2-3,2-5 \mathrm{~cm}$. long: fruit narrow, $6-7$ $\mathrm{mm}$. long, beaked, glabrous or nearly so, the ribs prominent, broader than the intervals.

In waste places and thickets, Virginia and Kentucky to Florida and Texas. Spring and summer.

\section{WASHINGTÒNIA Raf.}

Perennial caulescent herbs, with more or less aromatic roots. Leaves alternate : blades ternately compound. Flowers in loose compound umbels. Involucres and involucels of few bracts, or wanting. Hypanthium truncate. Petals white, inflexed at the apex. Disk with a conic stylopodium. Fruit elongated, laterally flattened: carpels 5-angled, with nearly equal ribs : oil-tubes obsolete or wanting. [Osmorrhiza Raf.] SwEet Cicely. Rachis of leaf-blades glabrous or with short hairs : stylopodium and styles fully $3 \mathrm{~mm}$. long. Rachis of leaf-blades glabrous or with short hairs : stylopodium and styles fully $3 \mathrm{~mm}$. long.
Rachis of leaf-blades with villous hairs : stylopodium and styles about $1 \mathrm{~mm}$. long. $\quad 2$. W. Whistylis.

1. Washingtonia longístylis (Torr.) Britton. Roots sweet, aromatic. Foliage glabrous or finely pubescent : leaf-segments mainly ovate or oblong-ovate, $5-10 \mathrm{~cm}$. long, acute or short-acuminate, coarsely serrate or incised, or even divided : umbel-rays usually 3-6, ascending : corolla white, 4-5 mm. broad : fruit narrowly oblong, $15-18 \mathrm{~mm}$. long: the body longer than the slender very strigose base. [Osmorrhiza longistylis (Torr.) DC.]

In woods and copses, Nova Scotia to Montana, North Carolina and Colorado. Spring.

2. Washingtonia Claytònii (Michx.) Britton. Roots slightly if at all aromatic. Foliage villous-hirsute : stems erect or ascending, 3-9 dm. tall, usually branched : leafsegments $4-8 \mathrm{~cm}$. long, acute or acuminate, coarsely toothed, cleft, incised or divided : umbel-rays $4-6,2-5 \mathrm{~cm}$. long: bracts of the involucres, and bractlets, linear to oblongthe body longer than the slender strigose base. [Osmorrhiza brevistylis DC.]

On shaded hillsides and in copses, Nova Scotia to Minnesota, North Carolina and Nebraska. Spring.

\section{TóRILIS Adans.}

Annual caulescent herbs, with pubescent foliage. Leaves alternate : blades pinnately decompound. Flowers in compound head-like or spreading umbels. Involucres of few bracts, or wanting. Involucels of several or many narrow bracts. Sepals prominent, acute. Petals often unequal, obovate or cuneate, inflexed at the apex. Disk with a conic stylopodium. Fruit flattened laterally, spiny : carpels with 5 primary ribs and 4 winged secondary ribs. Oil-tubes solitary, nnder the secondary ribs and two in the inner face. Seeds with sulcate faces. HedGe-PARsLey. 
1. Torilis nodòsa (L.) Gaertn. Foliage hispid. Stems usually branched from the base, the branches ascending, spreading or decumbent, 1-4 dm. long, often zigzag : leafblades once or twice pinnate, $2-6 \mathrm{~cm}$. long; segments pinnatifid : umbels sessile or shortpeduncled, forming clusters opposite the leaf-bases : bracts narrow : rays $1-3$, very short : fruit ovoid or oblong-ovoid, about $3 \mathrm{~mm}$. long, the outer armed with barbed spines, the inner sharply tuberculate.

In waste places, Pennsylvania to Iowa, California, Florida, Texas and Central America. Naturalized from Europe and Africa. Spring to summer.

\section{CORIÁNDRUM L.}

Annual slender caulescent herbs. Leaves alternate : blades pinnately dissected. Flowers perfect, in compound umbels. Involucres wanting. Sepals acute, unequal. Petals white, often unequal, broadest above the middle, inflexed at the apex. Disk with a conic stylopodium. Fruit subglobose, not constricted at the commissure : carpels with 5 delicate ribs : oil-tubes solitary under the secondary ribs. CORIANDER.

1. Coriandrum sativum L. Foliage glabrous. Stems erect or ascending, 2-6 dm. tall, branched: leaf-blades various, dissected, those of the lower cauline and basal leaves with coarse-toothed incised or lobed segments, those of the upper leaves with narrowly linear segments : umbels peduncled, $1.8-5 \mathrm{~cm}$. broad : rays 4-8, spreading or ascending, 1-2 mm; long: pedicels 1-3 mm. long: corolla white : fruit subglobose or ovoid-globose, 3-3.5 $\mathrm{mm}$. long, slightly ribbed.

In waste places, in and about most of the larger cities of the United States. Naturalized from the Mediterranean region. Summer.

\section{BIFÒRA Hoffm.}

Annual caulescent herbs, with glabrous foliage. Leaves alternate : blades pinnately dissected. Flowers perfect, in compound umbels. Involucres and involucels of few bracts or wanting. Hypanthium truncate, or sepals very small. Petals white, broadest above the middle, inflexed at the tip. Disk with a small conic stylopodium. Fruit broader than long, laterally flattened : carpels without primary ribs and with 4 secondary ribs : oil-tubes wanting.

1. Bifora Americàna (DC.) S. Wats. Foliage more or less scabrous. Stems 2-6 dm. tall, corymbosely branching above : leaf-blades $2-6 \mathrm{~cm}$. long, the segments narrowly linear or linear-filiform: umbels $1.5-5 \mathrm{~cm}$. broad : bracts linear-subulate, or pinnatifid: rays 5-8, nearly equal, $10-20 \mathrm{~mm}$. long: pedicels $2-3 \mathrm{~mm}$. long: corolla white, 3-3.5 $\mathrm{mm}$. broad : fruit 4-5 $\mathrm{mm}$. broad, faintly ridged, each carpel subglobose.

In dry soil, Arkansas and the Indian Territory to Texas. Spring and summer.

\section{APIÁSTRUM Nutt.}

Annual, usually slender caulescent herbs, with glabrous foliage. Leaves alternate : blades finely dissected. Flowers in naked or nearly naked compound umbels. Involucels rarely present. Hypanthium truncate or nearly so. Sepals obsolete. Petals white, entire, flat or inflexed at the apex. Disk with a small stylopodium. Styles short. Fruit longer than broad, laterally flattened: carpels tuberculate, not ribbed : oil-tubes solitary in the intervals and under the secondary ribs, and 2 in the inner side.

1. Aplastrum pàtens (Nutt.) Coult. \& Rose. Stems $2-6 \mathrm{dm}$. tall, branched above, the branches slender, more or less spreading: leaf-blades $2-5 \mathrm{~cm}$. long, once or twice ternately parted, the segments filiform: umbels long-peduncled : rays very variable in length, 1-15 mm. long, erect or ascending : corolla white, minute : fruit ovoid, stout, $1 \mathrm{~mm}$. long, granular.

On prairies and plains, Indiana to Nebraska, Texas and New Mexico. Spring and summer.

\section{ERIGÈNIA Nutt.}

Low perennial caulescent herbs, with tuberous roots. Leaves alternate: blades ternately decompound. Flowers in few-rayed compound umbels. Involucres usually of a single bract. Hypanthium truncate. Petals white, broadest above the middle, flat. Fruit broader than high, laterally flattened : carpels with 5 delicate ribs: oil-tubes $2-3$ in each interval. 
1. Erigenia bulbòsa (Michx.) Nutt. Tuber deep-seated, subglobose, 5-12 mm. in diameter. Foliage glabrous: leaves basal, 3-5 cm. long; petioles dilated at the base; blades ternately twice compound ; segments of an oblong type : scapes erect, $5-20 \mathrm{~cm}$. tall, sometimes branched at the base : involucres foliaceous : fruit about $2 \mathrm{~mm}$. high, 3-4 mm. broad, conspicuously ribbed.

In open woods or copses, Ontario to Minnesota, District of Columbia, Alabama and Kansas Spring. HARBINGER OF SPRING.

\section{MUSENIÓPsis Coult. \& Rose.}

Perennial acaulescent herbs, with thick and elongated roots. Leaves basal : blades pinnate. Involucre wanting. Involucels of few small bractlets. Flowers perfect, in simple umbels. Hypanthium truncate or nearly so. Sepals obsolete. Petals yellow. Fruit laterally flattened, smooth, considerably longer than broad: carpels with equal filiform ribs, the pericarp thin : oil-tubes 3 or 4 in the intervals and 4 on the commissural side. Seed-face with a deep groove.

1. Museniopsis Texàna (A. Gray) Coult. \& Rose. Glabrous. Leaf-blades 5-7-pinnate, the lower divisions stalked and pinnately parted, the segments cuneate, 3-5-cleft: scape 5-20 cm. tall, surpassing the leaves, somewhat scabrous near the umbels : umbels 5-8rayed : fruit oblong-ovoid, about $3 \mathrm{~mm}$. long, smooth and glabrous.

On plains or prairies, Texas and adjacent Mexico. Spring.

\section{BUPLEÙRUM L.}

Annual or perennial herbs, with glabrous or glaucous foliage. Leaves alternate: blades entire, sessile, clasping or perfoliate. Flowers perfect, in compound umbels. Involucres wanting (in our species). Involucels whorls of entire bracts. Hypanthium truncate or nearly so. Sepals obsolete. Petals broad, yellow or greenish, with inflexed or infolded tips. Styles short. Fruit oval to oblong, somewhat laterally flattened: carpels with slender ribs and no oil-tubes in our species.

1. Bupleurum rotundifòlium L. Plant glaucescent. Stems $3-10 \mathrm{dm}$. tall, branched above : leaf-blades thickish, oblong, ovate or elliptic, $2-8 \mathrm{~cm}$. long, perfoliate, palmately nerved : bracts of the involucre wanting : bractlets of the involucels oblong, oval, ovate or suborbicular, abruptly pointed, prominently nerved: fruit 3-3.5 mm. long, about $2.5 \mathrm{~mm}$. broad, the ribs slender; oil-tubes wanting.

In fields and on roadsides, New York to South Dakota, south to North Carolina and Arkansas. Summer. HARE'S EAR.

\section{TREPOCÁRPUS Nutt.}

Annual caulescent herbs, with glabrous foliage. Leaves alternate : blades pinnately decompound, the segments slender. Flowers mostly perfect, in compound umbels. Sepals unequal. Petals broadest above the middle, inflexed at the apex. Disk with a short conic stylopodium. Fruit crustaceous, elongated, laterally flattened : carpels with 4 secondary ribs, the primary ribs wanting: oil-tubes solitary under the secondary ribs.

1. Trepocarpus Aethùsae Nutt. Stems $1-10 \mathrm{dm}$. tall, branched : leaf-blades $5-10 \mathrm{~cm}$. long, finely dissected, the lower ones with petioles about equal to them in length, the upper short-petioled, the segments narrowly linear, entire or incised : umbels commonly long-peduncled : rays $2-5$, becoming $1-2 \mathrm{~cm}$. long: flowers few in each umbellet : fruit oblong, 8-10 $\mathrm{mm}$. long, sharply ribbed.

On prairies, Arkansas and the Indian Territory to Louisiana and Texas. Spring and summer.

\section{6. ÁPIUM L.}

Annual or perennial caulescent herbs. Leaves alternate : blades pinnate or ternately decompound: leaflets toothed or incised. Flowers in compound umbels. Involucres present or wanting. Hypanthium truncate or nearly so. Petals white, broad, inflexed at the apex. Fruit somewhat latterly flattened, smooth or tuberculate : carpels 5-angled or ribbed with 1 oil-tube in each interval or two in the inner face. Seeds terete or slightly angled.

Leaf-blades ternately divided into filiform entire segments. Leaf-blades pinnately divided into broad-toothed segments.

1. A. Ammi. 2. A. nodiflorum.

1. Apium Ámmi (L.) Urban. Stems erect, 1-6 dm. tall, more or less branched : leaf-blades ternately divided ; segments filiform or narrowly linear, acute : corolla white, 
less than $1 \mathrm{~mm}$. broad : fruit oval or ovoid-oval, 1.5-2 mm. long, prominently ribbed. [A. leptophyllum (DC.) F. Muell.]

In sandy soil, New Jersey and Missouri, south to Florida and Texas. Widely distributed in tropical countries. Spring and summer. MARSH PARSLEY.

2. Apium nodiflòrum (DC.) B. \& H. Stems prostrate, often creeping, 3-7 dm. long, sparingly branched : leaf-blades pinnately compound, $5-10 \mathrm{~cm}$. long; leaflets oblong, ovatelanceolate or lanceolate, serrate, mostly acute : umbels opposite the leaves, $1.5-3 \mathrm{~cm}$. broad, short-peduncled : bractlets of the involucels $5-6$ : corolla white, about $1 \mathrm{~mm}$. broad : fruit oval or orbicular-oval, about $2 \mathrm{~mm}$. long.

In ditches and waste places, near Charleston and other seaport towns. Introduced from Europe. Spring and summer.

\section{SPERMÓLEPIS Raf.}

Annual herbs, with erect slender branching stems. Leaves alternate : blades dissected into narrow segments. Flowers in compound umbels. Involucres wanting. Involucels of a few narrow bracts. Hypanthium truncate. Petals white. Disk with a thick conic stylopodium. Fruit somewhat laterally flattened, tuberculate or bristly: carpels with 5 prominent or obsolete ribs between which is a single oil-tube, except in the inner side where there are two. Seeds angled. [Leptocaulis Nutt.]

Fruit tuberculate, broadest at the middle, the ribs rather prominent. Fruit with hooked hairs, broadest above the middle, the ribs obsolete.

1. S. divaricatus. 2. S. echinatus.

1. Spermolepis divaricàtus (Walt.) Raf. Stems 1-6 dm. tall, often widely branched, sometimes diffusely so, the branches very slender or nearly filiform : leaf-blades 2$8 \mathrm{~cm}$. long, twice or thrice pinnately parted; segments narrowly linear or filiform : corolla white, about $1 \mathrm{~mm}$. broad : fruit broadest about the middle, about $1 \mathrm{~mm}$. long, tuberculate, prominently ribbed.

In sandy soil and on prairies, Missouri and Kansas to North Cårolina, Florida and Texas. Spring.

2. Spermolepis echinàtus (Nutt.) Heller. Stems 1-5 dm. tall, more or less diffusely branched : leaves 1-6 cm. long; blades twice or thrice pinnately parted; segments narrowly linear or filiform : umbels slender-peduncled, $1.5-4 \mathrm{~cm}$. broad : rays slender, more or less variable in length : corolla white, less than $1 \mathrm{~mm}$. broad : fruit broadest below the middle, $2 \mathrm{~mm}$. long, covered with hooked bristles, the ribs obsolete.

In dry soil, Missouri to California, Alabama and Texas. Spring.

\section{AMMOSELINNUM T. \& G.}

Annual caulescent diffuse herbs. Leaves alternate : blades ternately dissected. Flowers perfect in compound umbels. Involucres and involucels of several entire or dissected bracts. Hypanthium truncate or nearly so. Petals white, broadest above the middle, often nearly flat. Disk with a short conic stylopodium. Fruit longer than broad : carpels terete or slightly laterally flattened, with 5 prominent ribs which are tuberculate or spiny : oil-tubes solitary in the intervals and 2 in the inner side. SAND Parslex.

Plant nearly grabrous : fruit $2 \mathrm{~mm}$. long.

1. A. Butleri. Plant manifestly scabrous : fruit 4-5 mm. long.

2. A. Popei.

1. Ammoselinum Bútleri (Engelm.) Coult. \& Rose. Plant nearly glabrous. Stems branched from the base ; branches spreading or ascending, $0.5-1 \mathrm{dm}$. long, zigzag : leaf-blades 1-2 cm. long, the lower ones long-petioled, the upper sessile; segments narrowly oblong or spatulate : umbels small, $5-15 \mathrm{~mm}$. broad : bracts similar to the leaves but smaller : rays $3-6$, unequal : corolla about $1 \mathrm{~mm}$. broad : fruit oblong or ovate-oblong, $2 \mathrm{~mm}$. long, the ribs prominent, more or less scabrous.

In wet soil, Missouri and the Indian Territory, south to Texas. Spring.

2. Ammoselinum Pòpei T. \& G. Foliage manifestly scabrous. Stems usually branching from the base ; branches spreading or ascending, 1-3 dm. long: leaf-blades 1-4 $\mathrm{cm}$. long, dissected, the lower ones slender-petioled, the upper sessile; segments linear or linear-oblong : umbels sessile or on short stout peduncles: bracts usually smaller than the leaves: rays $2-5$, stiff, $0.5-2.5 \mathrm{~cm}$. long: sepals oblong: corolla about $1 \mathrm{~mm}$. broad : fruit ovate-oblong, 4-5 mm. long, the ribs more or less sharply tuberculate.

In sandy soil, Missouri and Kansas to Texas and New Mexico. Spring.

\section{9. zízIA Koch.}

Perennial caulescent herbs. Leaves alternate : blades 3 -foliolate or ternately compound or the basal ones sometimes simple. Flowers in compound umbels, the central umbellet 
sessile. Involucres wanting. Involucels of a few bracts. Sepals prominent. Petals yellow. Disk flat. Fruit somewhat elongated, laterally flattened : carpels with 5 slender wingless ribs and an oil-tube in each interval and under each rib. Seeds angled. The plants flower in spring and summer.

Basal leaves with merely toothed cordate blades.

Basal leaves with 2-3-ternately compound blades.

Foliage light green : rays of the umbel stiff, ascending : fruit $4 \mathrm{~mm}$. long.

Foliage dark green : rays of the umbel filiform, irregularly spreading : fruit less than 3 $\mathrm{mm}$. long.

1. Z. cordata.

2. Z. aurea.

3. Z. Bebbii.

1. Zizia cordàta (Walt.) DC. Stems 4-10 dm. tall, mostly branched, pale green : leaf-blades various, those of the basal leaves ovate or suborbicular, $3-10 \mathrm{~cm}$. long, crenate, deeply cordate, those of the stem-leaves mostly 3 -foliolate or sometimes 5 -foliolate ; segments crenate or serrate-crenate : umbels $2-6 \mathrm{~cm}$. broad : rays $7-16$, ascending, $1-5 \mathrm{~cm}$. long: corolla yellow, about $2 \mathrm{~mm}$. broad : fruit ovate or oval, $3 \mathrm{~mm}$. long, 10-ribbed.

In woods and copses, Connecticut to the Northwest Territory, Georgia, Missouri and Oregon,

2. Zizia aùrea (L.) Koch. Stems $3-8 \mathrm{dm}$. tall, simple or branched above : leafblades once to thrice ternately compound, those of the basal and lower stem-leaves long-petioled, those of the upper stem-leaves once ternate, on short winged petioles; segments oblong-ovate to lanceolate, $2-8 \mathrm{~cm}$. long, sharply serrate : umbel $3-6 \mathrm{~cm}$. broad : rays $9-25$, stiff, ascending, unequal, $2-5 \mathrm{~cm}$. long: corolla yellow, $3-3.5 \mathrm{~mm}$. broad : fruit oblong, about $4 \mathrm{~mm}$. long.

In meadows and swamps, New Brunswick to Ontario, Montana, Florida and Texas.

3. Zizia Bébbii (Coult. \& Rose) Britton. Stems often tufted, 1-6 dm. tall, simple or branching, dark green : leaf-blades once to thrice ternately compound, the lower ones long-petioled, the upper with winged petioles: leaflets thickish, oval, oblong, elliptic or lanceolate, 1-4 cm. long, serrate : umbels slender-peduncled, straggling : rays 2-12, filiform, unequal, 2-8 mm. long, unequally spreading: fruit suborbicular or broader than high, 2-2.5 mm. long. [ $Z$. aurea var. Bebbii Coult. \& Rose.]

In woods on mountain slopes, Virginia and West Virginia to Georgia.

\section{CICÙta L.}

Perennial herbs, with tuberous roots. Leaves alternate : blades pinnately compound, or decompound: leaflets toothed. Flowers in compound umbels. Involucres of few bracts or wanting. Involucels of several small bracts. Sepals acute. Petals white, broad, the tips inflexed. Fruit slightly laterally flattened : carpels with 5 corky ribs and an oil-tube in each interval, and 2 in the inner face. Seeds nearly terete. Water Hemlock.

$\begin{array}{ll}\text { Fruit oval or ovoid, } 4 \mathrm{~mm} \text {. long, not constricted at the commissure. } & \text { 1. C. maculata. } \\ \text { Fruit orbicular, } 2 \mathrm{~mm} \text {. Curtissii. }\end{array}$ Fruit orbicular, $2 \mathrm{~mm}$. long, constricted at the commissure.

1. Cicuta maculàta L. Tubers clustered, elongated. Stems 1-2 m. tall, glaucons marked with purple ridges, at length branched throughout: leaf-blades ample, triangular in outline, 1-6 dm. long, twice or thrice compound, the lower ones long-petioled, the upper with short dilated involute petioles: leaf-segments lanceolate or elliptic-lanceolate, 2-14 cm. long, acuminate, coarsely serrate, their nerves impressed above, very prominent beneath, ending in the notches: bracts subtending the compound umbels linear-subulate, deciduous : rays numerous, very unequal : sepals triangular : petals white, about $1 \mathrm{~mm}$. in diameter, broader than long, apiculate and rolled in at the apex, short-clawed : fruit ovoid or oval, $4 \mathrm{~mm}$. long, not constricted at the commissure, the lateral ribs much the largest, wedge-shaped in section and contiguous: oil-tubes large. Rоот.

In swamps and meadows, New Brunswick to Manitoba, Virginia and Texas. Summer. MusquasH

2. Cicuta Curtíssii Coult. \& Rose. Resembling C. maculata, but with a stouter rootstock, thicker and more reticulated leaf-segments : fruit orbicular, $2 \mathrm{~mm}$. long, constricted at the commissure, the ribs apparently nearly equal, but the lateral ones largest, neither wedge-shaped nor contiguous.

In swamps and low grounds, Virginia to Florida and Louisiana. Summer and fall.

\section{DERÍNGA Adans.}

Perennial caulescent herbs. Leaves alternate : blades 3 -foliolate : leaflets toothed, incised or lobed. Flowers perfect, in irregular compound umbels. Involucres and involucels wanting. Hypanthium truncate. Petals white. Disk with a conic stylopodium. Fruit elongated, latterally flattened : carpels slightly 5-angled with low ribs, and an oil-tube beneath each rib and in each interval. Seeds nearly terete. Honewort. 
1. Deringa Canadénsis (L.) Kuntze. Glabrous or nearly so. Stems $3-10 \mathrm{dm}$. tall, finally widely branched : leaf-blades 3-foliolate; leaflets ovate, oval or elliptic, 4-10 cm. long, acute or abruptly pointed, doubly serrate with sharp teeth, the lateral ones often lobed : umbels peduncled : rays few, slender, unequal in length : pedicels 2-25 $\mathrm{mm}$. long : corolla white, $2-3 \mathrm{~mm}$. broad : fruit oblong, 4-6 mm. long, straight, or curved at full maturity. [Cryptotaenia Canadensis (L.) DC.]

In thickets and copses, New Brunswick to South Dakota, Georgia and Texas. Spring and summer.

\section{2. ÁMMI L.}

Herbs resembling Daucus in habit and inflorescence. Leaves alternate : blades finely divided or dissected, the segments entire or toothed. Flowers perfect, very numerous in compound umbels. Involucres and involucels present, the bracts of the involucre, at least, divided. Hypanthium truncate. Petals white, very unequal, cleft at the apex. Stylopodium flat. Fruit short, laterally flattened : carpels 5-angled, with prominent ribs and an oil tube in each interval. Seeds terete or half-terete.

Ultimate segments of the leaf-blades toothed : mature umbel open.

Ultimate segments of the leaf-blades entire : mature umbel contracted.

1. A. majus.

2. A. Visnaga:

1. Ammi màjus L. Stem $3-8 \mathrm{dm}$. tall, branched. Ultimate segments of the leafblades toothed: mature umbels and umbellets open, the concreted bases of the rays of the latter barely $2 \mathrm{~mm}$. broad : fruit $1.5-2 \mathrm{~mm}$. long.

In waste places, southern Texas. Introduced from Europe.

2. Ammi Visnàga (L.) Lam. Stem $5-12 \mathrm{dm}$. tall. Ultimate segments of the leafblades entire : mature umbels and umbellets contracted, the concreted bases of the rays of the latter 3-4 mm. broad : fruit 2-2.5 $\mathrm{mm}$. long.

In waste places, near Pensacola, Florida, and on ballast at other seaports. Introduced from Europe.

\section{TAENÍDIA Drude.}

Perennial caulescent herbs, with glabrous or glaucous foliage. Leaves alternate: blades pinnate or ternately compound : leaflets entire or toothed. Flowers in spreading naked umbels. Hypanthium with a truncate or nearly truncate margin. Petals 5, their tips inflexed. Stylopodium wanting. Styles slender. Fruit oblong, more or less strongly laterally flattened: carpels 5-angled, with slender ribs and 3 oil-tubes in the intervals. Seeds nearly terete except the flat face. Pimpernel.

1. Taenidia integérrima (L.) Drude. Root stout, tough. Foliage glaucous: stems sometimes branched at the base, 3-9 dm. tall, branching above : leaf-blades $5-20 \mathrm{~cm}$. long : twice or thrice ternately compound; leaflets ovate to oblong or oblong-lanceolate, entire, 1-3 cm. long, apiculate : umbels long-peduncled ; rays 10-20, wire-like, 5-8 cm. long, unequal : pedicels $8-15 \mathrm{~mm}$. long : corolla yellow, 1-1.5 mm. broad : fruit broadly oblong, 3.5-4 mm. long.

On rocky hillsides and in sandy soil, Quebec to Minnesota, Georgia and Mississippi. Spring.

\section{EULÒPHUS Nutt.}

Perennial caulescent herbs, with tuberous roots. Leaves alternate : blades ternately compound. Flowers in compound umbels. Involucre wanting or of 1 bract. Involucels usually of 2 bracts. Sepals prominent. Petals white or pink, broadest above the middle, inflexed at the tip. Disk with a conic stylopodium. Fruit somewhat elongated, laterally flattened : carpels delicately ribbed : oil-tubes $2-5$ in the intervals.

1. Eulophus Americànus Nutt. Foliage glabrous. Stems $8-15 \mathrm{dm}$. tall, branched above, leaf-blades various, those of the basal and lower stem-leaves 1-4 dm. long, biternately compound, with linear or oblong-linear leaf-segments, those of the upper stem-leaves ternate, their leaf segments narrowly linear and elongated : umbels with $10-20$ rays : bracts of the involucres much reduced or none; those of the involucels linear-lanceolate, $2 \mathrm{~mm}$. long : fruit oblong or oblong-ovoid, 4-6 $\mathrm{mm}$. long, 3-4 $\mathrm{mm}$. broad, the oil-tubes 3 between the more or less obsolete ribs, 4 in the inner side.

In low grounds, Ohio to Missouri, Tennessee and Arkansas.

\section{Sìm L.}

Perennial caulescent herbs of swamps or marshy places. pinnately compound: leaflets toothed, pinnatifid or dissected. Flowers perfect, in com- 
pound umbels. Involucres and involucels of narrow bracts. Sepals small, acute. Petals white, inflexed at the apex. Disk with a conic or rounded stylopodium. Styles short. Fruit stout, somewhat laterally flattened : carpels ribbed, the intervals with 1-3 oil-tubes. Seeds 5-angled. WAter Parsnip.

1. Sium cicutaefòlium J. F. Gmel. Stems 5-18 dm. tall, more or less branched: leaf-blades 1-8 dm. long, pinnately compound; leaflets 7-17, linear, oblong or lanceolate, 4-15 cm. long, acute, sharply serrate; submersed leaf-blades sometimes finely dissected: umbels peduncled, many-rayed, $3-10 \mathrm{~cm}$. broad; rays $2.5-4 \mathrm{~cm}$. long: corolla white, about $2 \mathrm{~mm}$. broad : fruit orbicular or oblong-orbicular, $3-3.5 \mathrm{~mm}$. long, prominently ribbed, with 2-6 oil-tubes on the commissural sides. [S. lineare Michx.]

In low grounds or shallow water, Nova Scotia and Newfoundland to British Columbia, Florida, Louisiana and California. Summer and fall.

\section{BÉRULA Hoffm.}

Perennial more or less aquatic caulescent herbs. Leaves alternate: blades pinnate, the segments variously cleft. Involucres and involucels present. Flowers in many-rayed umbels. Hypanthium supporting minute sepals. Corolla white. Stylopodium conic. Fruit laterally flattened, about as broad as long, notched at the base : carpels turgid, with slender inconspicuous ribs and a corky pericarp : oil-tubes several, contiguous around the seed cavity. Seeds nearly terete.

1. Berula erécta (Huds.) Coville. Stems $1.5-9 \mathrm{dm}$. tall, sometimes lower: leaves glabrous, the segments $10-18$, linear to oblong or even ovate, $1-7.5 \mathrm{~cm}$. long, mostly serrate, incised or laciniately lobed : umbels many-rayed, the rays $5 \mathrm{~cm}$. long or shorter : fruit suborbicular or orbicular-ovoid, nearly $2 \mathrm{~mm}$. long, scarcely ribbed.

In swamps and streams, Ontario to British Columbia, Texas, Mexico and California. Spring to fall.

\section{PTILÍMNIUM Raf.}

Annual caulescent herbs. Leaves alternate: blades pinnately or ternately dissected into narrow or filiform segments. Flowers in compound umbels. Involucres and involucels of several slender often dissected bracts. Hypanthium truncate. Petals white, broadened upward. Disk with a thick stylopodium. Fruit slightly flattened, smooth: carpels wide, the dorsal and contiguous ribs prominent, the lateral ones thick and corky, between each of which is an oil-tube. Seed angled. [Discopleura DC.] BisHop-wEED.

Fruitsubglobose or ovoid, 1-2 mm. long: leaf-segments less than $1 \mathrm{~mm}$. broad, entire.

Bracts of the involucre pinnate: fruit barely $2 \mathrm{~mm}$. long.

Bracts of the involucre entire : fruit fully $2 \mathrm{~mm}$. long.

Fruit oblong, 3-4 mm. long : leaf-segments over $2 \mathrm{~mm}$. broad, laciniate-toothed.

1. P. capillaceum.

2. $P$. Nuttallii.

1. Ptilimnium capillàceum (Michx.) Hollick. Stems slender, erect or decumbent, 2-18 dm. tall, more or less branched : leaf-blades finely dissected ; segments filiform : bracts of the involucres filiform, cleft or parted : umbels peduncled, $2-6 \mathrm{~cm}$. broad : rays $5-20$, $8-25 \mathrm{~mm}$. long, rather uniform in length : pedicels $3-6 \mathrm{~mm}$. long, filiform : corolla white, about $1 \mathrm{~mm}$. broad: fruit broadly ovoid, barely $2 \mathrm{~mm}$. long, pinched under the apex, prominently ribbed.

In wet sandy soil, often in brackish meadows, Massachusetts to Florida and Texas. Spring to fall.

2. Ptilimnium Nuttállii (DC.) Britton. Stems erect or ascending, stouter than those of the preceding species, 4-10 $\mathrm{dm}$. tall, branching above: leaf-blades dissected like those of $R$. capillacum, but rather firmer: bracts of the involucres linear, mostly entire: corolla white, about $2 \mathrm{~mm}$. broad : fruit oval or globose-oval, fully $2 \mathrm{~mm}$. long, not pinched under the apex.

In swamps and on damp hillsides, Illinois and Arkansas to Georgia and Texas. Spring to fall.

3. Ptilimnium laciniàtum (Engelm. \& Gray) Kuntze. Stems erect, 5-10 dm. tall, branching above : leaf-blades coarsely dissected; segments linear or lanceolate, acute or acuminate, laciniately pinnatifid or toothed : umbels peduncled, $4-8 \mathrm{~cm}$. broad : rays $8-18$, 1.5-3 cm. long, nearly equal in length : bracts of the involucres 3-5-parted, with slender segments : bractlets similar but smaller : corolla white, $3-3.5 \mathrm{~mm}$. broad : fruit oblong, 3-4 mm. long, the dorsal ribs flat, the lateral forming a prominent acute margin.

On prairies, Texas. Spring and summer. 


\section{CYNOSCIÀDIUM DC.}

Annual caulescent herbs. Leaves alternate : blades pinnately or palmately divided into narrow segments, or the basal leaves with entire blades : flowers perfect, in compound umbels. Involucres and involucels of persistent or deciduous narrow bracts. Sepals persistent. Petals broadest above the middle, inflexed at the apex. Disk with a conic stylopodium. Fruit elongated, dorsally flattened: carpels with strong ribs, the lateral ribs more prominent : oil-tubes solitary in each interval or two in the inner face.

Leaf-segments palmately disposed : fruit with an oval or globose body and a long beak. 1. C. digitatum. Leaf-segments pinnately disposed: fruit with an oblong body and no beak.

Stems simple at the base : fruit fully $3 \mathrm{~mm}$. long.

Stems branched at the base: fruit about $2 \mathrm{~mm}$. long.

2. C. pinnatum.

1. Cynosciadium digitàtum DC. Stems erect or ascending, 2-6 dm. tall, branching above: leaf-blades various; those of the basal leaves linear or linear-lanceolate, entire, those of the stem-leaves palmately 3-5-parted ; segments linear or nearly so, each narrowed to a slender tip : umbels peduncled, rather irregular : rays usually $3-8,2-3 \mathrm{~mm}$. long : pedicels unequal, $6-20 \mathrm{~mm}$. long: fruit $3 \mathrm{~mm}$. long, the body oval or subglobose, longer than the beak, prominently ribbed.

In wet grounds, Arkansas to Alabama and Texas. Spring and summer.

2. Cynosciadium pinnàtum DC. Stems erect or decumbent, 1-5 dm. tall, sparingly branched : leaf-blades various; those of the basal leaves entire, $3-8 \mathrm{~cm}$. long, longer than those of the stem, or like those of the stem pinnately divided ; segments few, linear, attenuate, the terminal one larger: umbels many-flowered, $2-5 \mathrm{~cm}$. broad : rays $5-10$, often uniform in length, $1-2.5 \mathrm{~cm}$. long : pedicels $2-8 \mathrm{~mm}$. long, very slender : fruit oblong, $3 \mathrm{~mm}$. long, not beaked, less prominently ribbed than in $C$. digitatum.

In wet grounds, Missouri to Arkansas and Texas. Spring and summer.

3. Cynosciadium pùmilum (Engelm. \& Gray) Coult. \& Rose. Stems low and diffusely branched : leaf-blades similar to those of $C$. pinnatum: umbels with 3-6 rays : sepals larger than in C. pinnatum: fruit oval to suborbicular, about $2 \mathrm{~mm}$. long, terminating in the small stylopodium.

On prairies, southern Texas. Spring.

\section{LILAFóPSIS Greene.}

Low succulent herbs of marshy situations, with creeping stems. Leaves clustered at the nodes, reduced to terete club-shaped septate organs, sometimes dilated above. Bracts of the involucre several. Flowers perfect, several in simple peduncled umbels. Sepals acute. Petals white, concave, somewhat hooded at the apex. Fruit subglobose, or lenticular, laterally flattened : carpels with thick, corky lateral ribs and filiform dorsal and intermediate ribs or all sometimes corky, with oil-tubes solitary in the intervals. Seeds terete. [Crantzia Nutt.]

Peduncles surpassing the leaves: fruit pinched at the base; lateral ribs only corky. 1. L. lineata.

Peduncles shorter than the leaves: fruit not pinched at the base; all ribs corky. 2 . L. Carolinensis.

1. Lilaeopsis lineàta (Michx.) Greene. Stems creeping in the mud. Leaves 2-5 $\mathrm{cm}$. long ; petioles dilated upward, usually linear-spatulate, barely broadened into blades, conspicuously cross-partitioned : peduncles $3-7 \mathrm{~cm}$. long, surpassing the leaves: fruit orbicular-ovoid, pinched near the base, about $2 \mathrm{~mm}$. long, the lateral ribs corky, the dorsal not at all corky. [Crantzia lineata Nutt.]

In salt and brackish marshes and low grounds, Massachusetts to Florida and Mississippi. Summer.

2. Lilaeopsis Carolinénsis Coult. \& Rose. Stems creeping in the mud. Leaves $5-25 \mathrm{~cm}$. long ; petioles elongated; blades oblong or spatulate : shorter than the petioles: peduncles 1-1.5 cm. shorter than the leaves: fruit suborbicular or oval-orbicular, about $3 \mathrm{~mm}$. long, not pinched near the base; all the ribs corky.

In low grounds, eastern North Carolina and Louisiana. Summer.

30. FURYTAÈNIA T. \& G.

Herbs, with slender branching stems and glabrous foliage. Leaves alternate : blades pinnately dissected. Flowers perfect, in compound umbels. Involucres and involucels of cleft bracts. Sepals prominent, thin. Corolla white. Disk with a depressed stylopodium. Fruit usually flattened : carpels with slender dorsal and contiguous ribs and lateral wings : oil-tubes solitary in the intervals. 
1. Eurytaenia Texàna T. \& G. Stems $2-8 \mathrm{dm}$. tall, branching especially above : leaf-blades 5-12 cm. long, pinnately dissected; segments narrowly linear or oblong, often toothed : umbels $5-8 \mathrm{~cm}$. broad : bracts pinnately parted: rays $8-15$, slender, variable in length, $2-5 \mathrm{~cm}$. long : pedicels $5-10 \mathrm{~mm}$. long : corolla white, $3-4 \mathrm{~mm}$. broad : fruit oval, $4 \mathrm{~mm}$. long, with pale conspicuous wings.

On prairies, the Indian Territory, Oklahoma and Texas. Spring and summer.

\section{FOENÍCULUM Adans.}

Biennial or perennial caulescent herbs, often aromatic. Leaves alternate: blades delicately pinnately decompound. Flowers in naked compound umbels. Hypanthium truncate. Petals yellow or yellowish. Disk with a stout conic stylopodium. Styles short. Fruit elongated, nearly terete : carpels 5-ribbed : oil-tubes solitary in the intervals, and 2 on the inner side. FenNeL.

1. Foeniculum Foenículum (L.) Karst. Foliage glabrous, glaucescent. Stems 5-15 dm. tall, branched : leaf-blades finely dissected; segments filiform or linear-filiform : umbels peduncled, $2-10 \mathrm{~cm}$. broad ; rays $5-6$, often glaucous, $2-5.8 \mathrm{~mm}$. long at maturity : corolla yellowish green : fruit oblong, $5 \mathrm{~mm}$. long. [F. vulgare Gaertn.]

In waste places and fields, New Jersey, Pennsylvania to Florida and Texas. Summer and fall.

\section{LIGÚSTICUM L.}

Perennial aromatic herbs. Leaves alternate: blades ternately compound; leaflets toothed. Flowers perfect, in compound umbels. Involucres of a few narrow bracts. Involucels of numerous narrow bractlets. Hypanthium truncate. Petals white, broadened upward, inflexed at the apex. Disk with a conic stylopodium. Fruit more or less elongated, scarcely flattened : carpels with sharp prominent ribs and 2-6 oil-tubes in each interval. Seeds dorsally flattened, sometimes angled. Angelico. Nondo.

1. Ligusticum Canadénse (L.) Britton. Foliage glabrous or nearly so. Stems 5-20 dm. tall, branched above: leaf-blades 3-4 times ternately compound ; leaflets oblong, elliptic-oval or ovate, $3-8 \mathrm{~cm}$. long, serrate or dentate-serrate, the teeth often acuminate : rays $8-20,2-8 \mathrm{~cm}$. long : fruit oblong or oval, 4-6 $\mathrm{mm}$. long, the ribs narrowly winged : oiltubes $2-3$ in the intervals, and 6 in the commissural side.

In rocky or rich woods, Pennsylvania to Missouri, Georgia and Alabama. Spring and summer.

\section{THÁSPIUM Nutt.}

Perennial caulescent herbs. Leaves alternate: blades 3-foliolate or ternately compound or the basal ones sometimes simple: leaflets toothed, incised or lobed. Flowers perfect, in compound umbels. Involucres and involucels wanting or the latter of a few bractlets. Sepals deciduous. Petals yellow, or deep purple, inflexed at the apex. Disk flat. Style slender. Fruit somewhat longer than broad, terete, slightly dorsally flattened : carpels with more or less strongly winged ribs and 1 oil-tube in each interval. Seeds slightly angled. Meadow Parsnir.

Leaf-blades mostly ternate, the divisions thick, finely toothed.

Leaf-blades mostly biternate or more divided, the divisions thinnish, incised or lobed, or pinnatifid.

Leaf-divisions toothed or cleft : fruit fully $5 \mathrm{~mm}$. long.

Leaf-divisions pinnatifid : fruit less than $5 \mathrm{~mm}$. long.

1. Thaspium trifoliàtum (L.) A Gray Foliage glabrous Stems $2-7$ innatifdum. 1. T. trifoliatum.

1. Thaspium trifoliàtum (L.) A. Gray. Foliage glabrous. Stems 2-7 dm. tall,
sparingly branched, often zigzag : leaf-blades various, those of the basal or lower stem-leaves sparingly branched, often zigzag : leaf-blades various, those of the basal or lower stem-leaves
ovate and undivided or 3 -foliolate; segments ovate to lanceolate, serrate ; petioles slender, often longer than the blades : upper stem-leaves similar to the divided basal leaves; petioles shorter than the blades, winged : umbels peduncled, $2-5 \mathrm{~cm}$. broad : rays variable in length : corolla dark purple : fruit oval, $4 \mathrm{~mm}$. long, the ribs prominently winged.

In thickets and on sunny slopes, Rhode Island to Illinois. North Carolina and Tennessee. Summer and fall.- The state with yellow corollas, is T. trifoliatum aùreum (Nutt.) Britton; it is rather more widely distributed than the form with purple corollas.

2. Thaspium barbinòde (Michx.) Nutt. Finely pubescent or glabrate. Stems 3-12 $\mathrm{dm}$. tall, more or less widely branched, pubescent about the nodes: leaf-blades once to twice ternately compound, $5-15 \mathrm{~cm}$. long; segments commonly ovate, coarsely toothed to ternately cleft or parted: umbels peduncled, $3-7 \mathrm{~cm}$. broad : rays sometimes uniform in length : corolla rather pale or light yellow : fruit oblong or oval, fully $5 \mathrm{~mm}$. long, glabrous 
or nearly so ; ribs mostly winged, 7 of them prominently winged, the other 3 sometimes nearly wingless.

In woods and on banks, Ontario to Minnesota. Florida and Arkansas. Spring and summer.-7. barbinode Chapmánii Coult. \& Rose. has more finely divided leaf-segments and puberulent; fruit; it occurs in southern Georgia and northern Florida.

3. Thaspium pinnatífidum (Buckl.) A. Gray. Often finely pubescent. Stems 5-12 dm. tall, more or less widely branched : leaf-blades $5-15 \mathrm{~cm}$. long, once to twice ternately compound ; basal longer than the rest ; segments 1-2-pinnatifid, rather delicate, suggesting those of leaf-blades of many Fumariaceae : umbels peduncled, $2-4.5 \mathrm{~cm}$. broad ; rays $7-14$, usually quite uniform in length : corolla light yellow, $2.5-3 \mathrm{~mm}$. broad : fruit oblong, barely $5 \mathrm{~mm}$. long, all ribs winged, 3-5 of the wings commonly narrower than the rest.

In woods and copses, North Carolina to Kentucky and Tennessee. Spring and summer.

\section{CONIOSELİNUM Hoffm.}

Perennial, caulescent herbs, with glabrous foliage. Leaves alternate : blades 2-3 pinnately decompound, the alternate segments narrow, incised or lobed. Flowers perfect, in compound umbels. Involucres and involucels of several narrow bracts or the former wanting. Hypanthium truncate. Corolla white : petals inflexed at the tip. Disk with a round-conic stylopodium. Fruit longer than broad, dorsally flattened : earpels with the dorsal and contiguous ribs prominent and the lateral ones winged : oil-tubes $2-3$ in the intervals, and 4-8 in the inner face. Hemlock Parsley.

1. Conioselinum Chinénse (L.) B.S.P. Stems 5-15 dm. tall, simple or sparingly branched above : leaf-blades twice compound, the lower long-petioled, the upper short-petioled or nearly sessile; segments acute, incised : umbels peduncled, $5-10 \mathrm{~cm}$. broad : bracts narrow or wanting : rays $9-20$, slender, $2-4 \mathrm{~cm}$. long : pedicels $6-8 \mathrm{~mm}$. long : corolla white, 3-4 mm. broad : fruit oval or oblong-oval, 4-5 $\mathrm{mm}$. long, rather prominently winged, the faces prominently ridged. [C.(?) Canadense T. \& G.]

In swamps and on wet cliffs, Labrador to Minnesota, New York and Incliana and in the mountains to North Carolina. Summer and fall.

\section{ANGÉLICA L.}

Perennial caulescent heavy-scented herbs. Leaves alternate : blades pinnate or decompound : leaflets usually toothed. Flowers perfect, in compound umbels. Involucres and involucels present or wanting. Hypanthium truncate, or sepals small. Petals white or greenish, broadest above the middle, inflexed at the tip. Disk with a rounded stylopodium. Fruit longer than broad, dorsally flattened : carpels with the dorsal and contiguous ribs prominent, and broadly winged lateral ribs: oil-tubes solitary or several in the intervals and 2-10 in the inner face. ANGelica.

Peduncles and rays pubescent.

Peduncles and rays glabrous.

Leaflets thin; lobes ascending: oil-tubes 1-3 in each interval.

Leaflets leathery; lobes spreading: oil-tubes about 20 , contiguous and continuous.

1. A. villosa.

1. Angellica villòsa (Walt.) B.S.P. Foliage Stems 6-18 dm. tall, commonly branching above : leaf-blades once or twice ternately compound : leaflets thickish, oblong, oblong-lanceolate or oval, $2-5 \mathrm{~cm}$. long, serrate : umbels dense, becoming looser, 3-8 cm. broad : rays $7-30,2-5 \mathrm{~cm}$. long : pedicels slender, 3-4 $\mathrm{mm}$. long: corolla white : fruit oval or obovate, $5-6 \mathrm{~mm}$. long, finely pubescent, broadly winged; oil-tubes generally 3-6 in each interval. [ $A$. hirsuta Muhl.]

In rocky woods and dry soil, Connecticut to Minnesota. Florida and Tennessee. Summer.

2. Angelica Curtísil Buckl. Foliage glabrous, at least below. Stems 6-18 dm. tall, commonly branched above: leaf-blades twice ternately compound, 1-4 dm. long, longpetioled: leaflets thinnish, ovate to lanceolate, sharply serrate or incised, acuminate: umbels $5-15 \mathrm{~cm}$. broad : rays $12-25$, ascending, $3-10 \mathrm{~cm}$. long: pedicels $6-12 \mathrm{~mm}$. long : corolla greenish : fruit oblong or oval, 4-6 mm. long, broadly winged, glabrous, notched at the base; oil-tubes mostly solitary in the intervals.

In woods on mountain slopes and summits, Pennsylvania to Georgia. Summer and fall.

3. Angelica dentàta (Chapm.) Coult. \& Rose. Foliage glabrous to the inflorescence. Stems 5-10 dm. tall, simple or branching above : leaf-blades ternately compound : petioles longer than the blades: leaflets rather remote; thickish, oblong to lanceolate, acute, 1-2.5 $\mathrm{mm}$. long, incised or incised-serrate : umbels solitary or few, $3-8 \mathrm{~cm}$. broad : rays $5-12$, $1-4 \mathrm{~cm}$. long : corolla white : fruit oval, $5-6 \mathrm{~mm}$. long, glabrous or minutely pubescent, broadly winged; oil-tubes about 20 , continuous, 8 on the commissural side.

In dry pine lands, Florida. Summer. 


\section{PHELLÓPTERUS Nutt.}

Perennial acaulescent or nearly acaulescent herbs, with thick roots. Leaves basal : blades bipinnate. Flowers inconspicuous. Involucres rarely present. Involucels of hyaline bractlets. Sepals manifest. Petals pink, purple or rarely white, inflexed at the apex. Disk flat, stylopodium wanting. Fruit oblong to orbicular, slightly dorsally flattened : carpels with 3-5 wings of about equal breadth : oil-tubes usually 3 in the intervals. Seeds flattened. Corolla white: bractlets of the involucel entire : fruit 8-12 mm. long. Corolla pink : bractlets of the involucel fringed : fruit $4 \mathrm{~mm}$. long.

1. P. montanus.

1. Phellopterus montànus Nutt. Roots elongated, sometimes fusiform. Foliage often pubescent when young. Leaves clustered; blades glaucous, bipinnately parted or bipinnate, 4-10 $\mathrm{cm}$. long, the segments pinnatifid, suggesting pinnae of many common species of ferns : peduncles very short, solitary or clustered, the umbels during anthesis appearing sessile in the cluster of leaves : rays 6-12, unequal, 6-18 mm. long: bracts of the involucre and involucels conspicuous, membranous, entire: fruit oblong in outline, $8-12 \mathrm{~mm}$. long: wings of the carpels $3-5$, very thin, from a thicker base ; oil-tubes $1-3$ in the intervals, and 4-8 on the commissural side.

On dry slopes or hillsides, Wyoming to Nebraska and Texas. Spring.

2. Phellopterus macrorhìzus (Buckl.) Coult. \& Rose. Similar to P. montanus in habit, but with peduncles becoming twice as long as the leaves: umbels with longer rays and pedicels : bractlets of the involucels lacerate at the apex : corolla pink : fruit $4 \mathrm{~mm}$. long.

On prairies, eastern Texas. Spring and summer.

\section{CYMÓPTERUS Raf.}

Perennial dwarf acaulescent herbs. Leaves alternate, basal : blades pinnate or bipinnate. Involucre generally wanting. Involucel of foliaceous bractlets. Umbels dense. Hypanthium truncate or supporting small sepals. Corolla white or yellow. Stylopodium wanting. Fruit dorsally flattened, broad, normally glabrous : carpels with the dorsal and intermediate ribs filiform or winged, the lateral wings broad, corky, those of each carpel coherent until maturity : oil-tubes small, 4-8 in each interval, and 8-14 on the commissural side. Seeds flat.

1. Cymopteris acaùlis (Pursh) Rydb. Plant glabrous, 7-20 cm. tall. Peduncles clustered, mostly surpassed by the leaves: umbels congested: bractlets linear, entire: corolla white : fruit oval, 6-8 $\mathrm{mm}$. long, each carpel with 3-5 broad wings.

On dry plains, Assiniboia to Arkansas and Colorado. Spring.

\section{POLYTAÈNIA DC.}

Perennial caulescent herbs, with thick roots. Leaves alternate: blades pinnately decompound. Flowers in compound umbels. Involucres and involucels of few narrow bracts or the former wanting. Sepals triangular. Petals broadest above the middle, inflexed at the apex. Disk without a stylopodium. Fruit strongly flattened dorsally : carpels with the dorsal and contiguous ribs corky but obscure and thick broadly winged lateral ribs with a nerve near the margin : oil-tubes numerous, 12-18 accompanied by smaller ones irregularly disposed.

1. Polytaenia Nuttállii DC. Root fusiform. Foliage nearly glabrous : stems 2-9 dm. tall, often branching above, slightly scabrous: leaf-blades twice pinnately divided or parted, 5-20 cm. long, the lower ones long-petioled, the upper nearly sessile ; segments narrowly cuneate, toothed or lobed: umbels peduncled, $2-7 \mathrm{~cm}$. broad: bracts of the involucres wanting : rays $6-12,2-3 \mathrm{~cm}$. long, a few conspicuously short : pedicels 2-4 mm. long: corolla $2.5-3 \mathrm{~mm}$. broad : fruit broadly oblong, 6-10 $\mathrm{mm}$. long, the edges thickened, the faces often depressed.

In dry soil, Michigan to Wisconsin, Tennessee and Texas. Spring.-P. Nuttallii Texàna Coult. \& Rose, has obovate fruit with thinner wings, filiform dorsal and intermediate ribs and broader more distinct oil-tubes; it occurs in southern Texas.

\section{OXÝPOLIS Raf.}

Perennial caulescent herbs of marshy localities, with glabrous foliage. Leaves alternate: blades pinnate or ternate, or rarely reduced to hollow septate phyllodes : leaflets toothed. Flowers perfect, in compound umbels. Sepals acute. Petals white. Disk with 
a conic stylopodium. Fruit longer than broad, dorsally flattened : carpels with the dorsal and contiguous ribs thin, and winged lateral ribs, the latter nerved near the inner part of the wing: oil tubes solitary in the intervals and 2-6 in the inner face. Seeds much flattened dorsally. [Tiedemannia DC.]

Leaves reduced to hollow, terete, transversely-jointed petioles (phyllodes). Leaves with simple, pinnate or palmate blades.

Leaf-blades simple, or of 3 palmately disposed leaflets at the end of an elongated petiole.

Leaf-blades pinnately divided.

Leaflets conspicuously elongated, less than $3 \mathrm{~mm}$. wide: fruit $4 \mathrm{~mm}$. long.

Leaflets not conspicuously elongated, over $3 \mathrm{~mm}$. wide : fruit 5-6 $\mathrm{mm}$. wide.

1. O. filiformis.

1. Oxypolis filiformis (Walt.) Britton. Stems 5-18 dm. tall, simple or branched above : leaf-blades reduced to elongated hollow jointed phyllodes, $0.3-6 \mathrm{dm}$. long, attenuate : bracts of the involucres linear-subulate : umbels $3-10 \mathrm{~cm}$. broad : rays slender, 6-16, 2-7 $\mathrm{cm}$. long : corolla white, about $2 \mathrm{~mm}$. broad : pedicels $4-8 \mathrm{~mm}$. long : fruit oblong-oval or oval-obovate, $5-6 \mathrm{~mm}$. long, broadly winged; oil-tubes one in each interval, and 2-4 in the commissural side. ['Tiedemannia teretifolia DC.]

In swamps, Virginia to Florida and Louisiana. Summer and fall.

2. Oxypolis ternàta (Nutt.) Heller. Stems $5-9 \mathrm{dm}$. tall, usually somewhat branched : leaf-blades entire or divided into 3 elongated linear or filiform entire leaflets: umbels $3-10 \mathrm{~cm}$. broad : rays very slender, $2-6 \mathrm{~cm}$. long, ascending or curved upward : corolla white, $2-2.5 \mathrm{~mm}$. broad : fruit oblong, 4-5 mm. long, winged, rather delicately ribbed.

In low pine lands, North Carolina to Florida. Fall.

3. Oxopolis longifolia (Pursh) Small. Similar to O. rigidior in habit. Leaves with conspicuously elongated entire leaflets less than $3 \mathrm{~mm}$. wide : umbels few-rayed : fruit $4 \mathrm{~mm}$. long. [Sium longifolium Pursh.]

In low grounds and swamps, New Jersey to South Carolina and Tennessee. Summer and fall.

4. Oxypolis rigidior (L.) Raf. Stems $5-18 \mathrm{dm}$. tall, nearly simple or widely branched : leaf-blades pinnately divided; leaflets $3-9$, thinnish, linear to oblong or lanceolate, acute or acuminate, $3-12 \mathrm{~cm}$. long, entire or sharply toothed or incised : umbels $5-15 \mathrm{~cm}$. broad : rays 7-25, 2-10 $\mathrm{cm}$. long : corolla white, 3-3.5 mm. broad : fruit oblong or oval, 5-7 mm. long, winged ; oil-tubes 1 on each interval, 4-6 on the commissural side.

In swamps or on wet banks, New York to Minnesota, Florida and Louisiana. Summer and fall. COW-BANE. WATER DROPWORT.

\section{LOMÀTIUM Raf.}

Perennial herbs, with tuberous or thick roots, often acaulescent. Leaves basal : blades pinnate, ternate, or more or less finely dissected. Flowers in compound umbels. Involucres wanting. Involucels of several or many bractlets. Hypanthium truncate, or nearly so. Petals white or variously colored. Disk with a depressed stylopodium, or flat. Fruit of various shapes, dorsally flattened: carpels with slender dorsal and contiguous ribs and lateral wings : oil-tubes usually 1-4 in the intervals and 2-10 in the inner side.

1. Lomatium daucifollium (Nutt.) Coult. \& Rose. Foliage tomentose, less densely so in age. Stems very short : leaves clustered at base; blades $5-15 \mathrm{~cm}$. long, finely dissected, the ultimate segments narrowly linear or filiform : peduncles usually overtopping the leaves, $1-2 \mathrm{dm}$. tall : umbels irregular, $2-10 \mathrm{~cm}$. broad : rays $3-20$, stoutish, $2.5-8 \mathrm{~cm}$. long, those of the same umbel very variable in length : fruit broadly oblong, $5-8 \mathrm{~mm}$. long, the wings $\frac{1}{2}$ as wide as the body, glabrous ; oil-tubes $1-3$ in each interval, and 2-4 on the commissural side.

On prairies, Missouri to Nebraska and Texas. Spring.

\section{PASTINACA L.}

Annual or biennial herbs, with thick conic roots and heavy scented. Leaves alternate : blades pinnately compound; leaflets toothed or lobed. Flowers perfect, in compound umbels. Involucres and involucels usually wanting. Hypanthium truncate. Petals yellow. Disk with a depressed stylopodium. Fruit somewhat longer than broad, much dorsally flattened : carpels with the dorsal and contiguous ribs slender, and thin lateral wings: oiltubes solitary in the intervals and 2-4 in the inner side. Seeds flat. Wind Parsnip.

1. Pastinaca sativa L. Biennial, glabrous below. Root narrowly conic, strongscented : stems 6-20 dm. tall, simple or widely branched, sharply ridged: leaf-blades 
pinnately compound, oblong or oblong-ovate in outline, $5-30 \mathrm{~cm}$. long ; segments ovate or oblong, oblique, crenate-serrate, incised or lobed : umbels very variable, $5-20 \mathrm{~cm}$. broad, flat: rays unequal, $1.5-5 \mathrm{~cm}$. long: sepals obsolete : corolla yellow : petals about $1 \mathrm{~mm}$. long, strongly revolute: fruit obovate, oval or orbicular-oval, 5-6 mm. long.

In waste places and fields, common throughout the United States and southern British America. Summer and fall.

\section{HERÁCLEUM L.}

Perennial caulescent herbs, with a heavy odor. Leaves alternate: blades ternately compound ; leaflets broad, toothed or lobed. Flowers perfect, in compound umbels. Involucres and involucels of few often deciduous bracts or the former wanting. Hypanthium truncate, or sepals small. Petals white, broadest above the niddle, those of the outer and inner flowers different in shape. Disk with a thick conic stylopodium. Fruit usually longer than broad, strongly dorsally flattened: carpels with the dorsal and contiguous ribs slender, and broadly winged lateral ribs, the latter nerved near the outer edge : oil-tubes solitary in each interval, and 2-4 in the inner face, rarely extending beyound the middle of the carpel. Cow Pansnip.

1. Heracleum lanàtum Michx. Heavy scented, more or less densely pubescent. Stems stout, 6-25 dm. tall, often branched : leaf-blades ample, ternately divided, 1-4 dm. long; segments ovate to suborbicular, lobed, sharply serrate; petioles with conspicuous wing-like stipules : umbels $8-30 \mathrm{~cm}$. broad, flat: bracts of the involucres mainly wanting: rays $8-30$, stout, $3-15 \mathrm{~cm}$. long: pedicels $6-20 \mathrm{~mm}$. long, rather slender at maturity: corolla white : fruit oval or obovate-oval, $8-12 \mathrm{~mm}$. long, minutely pubescent, emarginate at the apex.

:In low ground, Labrador to Alaska, Georgia and California. Spring and summer.

\section{DAÙCUS L.}

Annual or biennial caulescent herbs, with rough-pubescent foliage. Leaves alternate : blades pinnately decompound. Flowers in spreading compound umbels. Involucres and involucels various, or wanting : hypanthium truncate or nearly so. Sepals obsolete. Petals white or rarely colored, often unequal, broadest above the middle, inflexed at the apex. Disk often with a depressed or conic stylopodium. Fruit longer than broad, dorsally flattened : carpels with 5 low primary ribs and 4 winged secondary ribs, which are armed with a row of barbed bristles; oil-tubes solitary under the secondary ribs and 2 in the inner face. Carrot.

Carpels broadest at the middle; wings divided into 12 or more bristle-like prickles. Carpels broadest below the middle; wings parted into 1-8 flat prickles.

1. D. Carota.

2. D. pusillus.

1. Daucus Caròta L. Bristly-hispid. Stem erect, 4-12 dm. tall, often branched, channeled : leaf-segments acute or cuspidate, cleft or toothed: rays of the compound umbel numerous: corolla white, a few in each umbel larger than the rest, the central one often purple : petals very unequal, suborbicular, unequally cleft, crisped : fruit 3-4 mm. long, the carpels broadest at the middle, the wings divided into 12 or more bristle-like prickles.

In fields and waste places, nearly throughout North America; except the extreme north and south. Naturalized from Europe and Asia. Spring to fall.

2. Daucus pusílus Michx. Hispid. Stem erect, 1-8 dm. tall : umbels longpeduncled : rays several or numerous, $1-2 \mathrm{~cm}$. long, nearly equal : corolla white, or the central one larger and purple : fruit ovoid-oblong, $3-4 \mathrm{~mm}$. long, the wings parted into 1-8 flat prickles.

In fields and waste places, Virginia and British Columbia to Florida and California. Spring to fall.

\section{Series 2. GAMOPETALAE.}

Petals partly or almost wholly united, or occasionally distinct, or very rarely wanting.

\section{Order 1. ERICÀLES.}

Herbs, undershrubs, shrubs, trees, or sometimes humus-plants or saprophytes. Leaves alternate, often evergreen, often reduced to scales: blades commonly leathery. Flowers mainly perfect and complete, regular or nearly so. 
Calyx of $2-8$, often 5 partially united sepals. Corolla of $2-8$, often 5 , more or less united petals or these occasionally distinct. Androecium of as many stamens as there are petals or twice as many, sometimes partially reduced to staminodia, mostly free from the corolla. Gynoecium of several united carpels. Ovary superior or inferior, 1-several-celled. Styles united. Fruit capsular, baccate or drupaceous.

Stamens free and separate.

Gynoecium superior: fruit capsular, sometimes fleshy but not truly baccate or drupaceous.

Corolla of essentially distinct petals.

Ovary 3-celled: shrubs or trees: leaves deciduous.

Ovary 4-5-celled : Iow evergreen herbs or saprophytes.

Herbaceous perennials with persistent green leaves.

Herbaceous saprophytes destitute of green leaves.

Corolla of manifestly united petals.

Herbaceous saprophytes destitute of green leaves.

Shrubs or trees with deciduous or persistent green leaves.

Gynoecium inferior: fruit baccate or drupaceous.

Stamens adnate to the corolla-tube, or partially united into a lobed tube.

Caulescent plants : staminodia wanting.

Scapose plants : staminodia present.

Fam. 1. Clethraceae.

Fam. 2. Pyrolaceae.

Fam. 3. MONOTROPACEAE.

Fam. 3. Monotropaceae. Fam. 4. Ericaceate.

Fam. 5. VACCINIACEAE.

Fam. 6. Diapensiaceae.

Fam. 7. Galacaceae.

\section{FAmily 1. CLeTHRÀCEAF Klotzsch. White Alder Family.}

Shrubs or trees, with stellately branched pubescence. Leaves alternate, deciduous: blades simple, often toothed, pinnately nerved. Flowers perfect, in showy terminal, elongated racemes or panicles. Sepals 5, imbricated, persistent. Corolla white, of 5 essentially distinct imbricated deciduous petals, these usually broadest above the middle. Stamens 10. Filaments slender. Anthers sagittate, inverted in anthesis: sacs opening by apical pores. Pollen of simple grains. Disk obsolete. Ovary superior, 3-celled, pubescent, 3-lobed. Styles united, topped by a 3-lobed stigma. Ovules numerous. Fruit a subglobose 3-lobed loculicidally 3 -valved capsule, the valves 2 -cleft at maturity.

\section{CLÈthrA L.}

Characters of the family. Pepperbush.

Leaves glabrous or nearly so: both filaments and style glabrous.

Leaves pubescent, at least beneath: either filaments or style glabrous.

Sepals obtuse : filaments glabrous or nearly so: style pubescent : cap
Sepals acute : filaments pubescent : style glabrous : capsules ovoid.

1. C. alnifolia.

2. C. tomentosa.

1. Clethra alnifòlia L. A shrub 1-3 m. tall, with erect or ascending branches and sparingly pubescent twigs. Leaf-blades obovate or cuneate, $3-8 \mathrm{~cm}$. long, usually acute or short-acuminate at the apex, sharply serrate, at least beyond the middle, glabrous or nearly so on both sides, short-petioled : racemes erect, canescent, $5-15 \mathrm{~cm}$. long, simple or paniculately branched: pedicels 1-3 $\mathrm{mm}$. long, subtended by narrow bracts : flowers fragrant: sepals oblong or oblong-lanceolate, $2-2.5 \mathrm{~mm}$. long, obtuse or sometimes acute, longitudinally ridged in age : corolla white, $8-9 \mathrm{~mm}$. broad: petals oblong or cuneate-oblong, $5-6$ $\mathrm{mm}$. broad, hooded and often notched at the apex : filaments glabrous : style glabrous : capsule subglobose, about $3 \mathrm{~mm}$. in diameter, erect or ascending.

In swamps and moist woods, Maine to New Jersey, Pennsylvania and Florida. Summer. SwEET PepPerbush. White Alder.

2. Clethra tomentòsa Lam. A shrub 1-3 m. tall, with tomentose foliage, the branches erect or ascending. Leaf-blades cbovate, narrowly or broadly cuneate, $4-10 \mathrm{~cm}$. long, acute or short-acuminate, abruptly serrate, mainly above the middle, more or less pubescent above, densely white-tomentose beneath, short-petioled: racemes solitary or paniculate, $6-15 \mathrm{~cm}$. long: pedicels $2-5 \mathrm{~mm}$. long, shorter than the narrow subtending bracts : flowers fragrant: sepals ovate or ovate-oblong, 3-3.5 $\mathrm{mm}$. long, slightly ridged in age : petals white, spatulate or oblong-spatulate, 5-6 mm. long, concave above : filaments glabrous or nearly so: style pubescent : capsule depressed-globose, 4-4.5 $\mathrm{mm}$. broad, drooping.

In swamps, North Carolina to Florida and Alabama. Summer.

3. Clethra acuminata Michx. A shrub, or a small tree, with a maximum height of $6 \mathrm{~m}$., the branches erect or rarely spreading. Leaves crowded near thee nds of branchlets; blades thinnish, oval or elliptic, $10-20 \mathrm{~cm}$. long, acuminate at the apex, finely serrate except the cuneate or rounded base, deep green above, paler and more or less pubes- 
cent beneath, at least on the nerves, short-petioled : racemes $5-20 \mathrm{~cm}$. long, usually simple, densely pubescent : pedicels $3-8 \mathrm{~mm}$. long: flowers secund : sepals ovate, $3.5-4 \mathrm{~mm}$. long, acute, strongly ribbed : petals erect, cuneate, $6-7 \mathrm{~mm}$. long, notched at the apex : filaments villous: style glabrous : capsule ovoid, $5 \mathrm{~mm}$. long, drooping.

On cliffs and in mountain woods, Virginia to West Virginia, Georgia and Alabama. Summer.

\section{Family 2. Pyrolàceat Agardh. Wintergreen Family.}

Perennial mostly evergreen herbs, with elongated branching rootstocks. Leaves basal, or approximate on the short stems or branches: blades thickish, entire or toothed. Flowers perfect, often slightly irregular, solitary or in terminal racemes or corymbs. Calyx of 4-5 persistent sepals. Corolla often white or pink, of 4-5 distinct or slightly united wax-like petals. Androecium of twice as many stamens as there are petals. Filaments often subulate. Anthers introrse, becoming inverted in anthesis : sacs opening by pores or slits. Pollen grains in 4's. Gynoecium of 4-5 united carpels. Ovary superior, 4-5-celled. Styles united, sometimes declined. Stigma 5-lobed. Ovules very numerous, anatropous. Fruit a 4-5-celled loculicidally valved capsule. Seeds minute, numerous. Testa loosely fitting the very slightly differentiated embryo.

Flowers in racemes: style elongated : capsules opening from base to top, the valves cobwebby.

Flowers solitary or in corymbs : style short, covered by the stigma : capsules opening from top to base, the valves glabrous.

1. Pyrola.

2. Chimaphila.

\section{PÝROLA L.}

Low scapose often stoloniferous herbs. Leaves mainly basal, persistent: blades often leathery and lustrous, entire or finely toothed. Flowers wax-like, nodding or ascending, short-pedicelled. Sepals spreading. Corolla deciduous: petals 5, concave. Stamens 10, declined or converging: filaments glabrous. Anthers erect in the bud, mostly inverted in anthesis: sacs usually beaked at the base, opening apparently by apical pores. Ovary 5-celled. Capsule 5-celled, j-lobed, loculicidally 5-valved, often nodding; valves opening from the base, with cobwebby margins. Seeds very numerous. Wintergreen.

Leaf-blades about as long as broad, leathery, mainly shorter than the petioles. Leaf-blades longer than broad, membranous, longer than the petioles.

1. $P$. rotundifolia.

2. P. elliptica.

1. Pyrola rotundifòlia L. Dark green. Leaves basal; blades leathery, suborbicular, $2-5 \mathrm{~cm}$. in diameter, obtuse or rounded at both ends, veiny, on 3 -sided red petioles (the inner side channeled), which usually exceed the blade in length: scapes erect, 2-3 $\mathrm{dm}$. tall, 3-angled, furnished with a few scales : racemes $3-10 \mathrm{~cm}$. long : flowers wax-like, on spreading or reflexed pedicels which are less than $1 \mathrm{~cm}$. long, and subtended by linearlanceolate acute bracts : sepals ovate to triangular, acute, with narrow white margins: corolla $1.5 \mathrm{~cm}$. broad : petals concave, obovate, $8-9 \mathrm{~mm}$. long, obtuse : stamens bent back: style strongly declined : capsules depressed, 6-7 $\mathrm{mm}$. broad.

In dry woods, Nova Scotia to Minnesota, south in the mountains to Georgia, and Ohio. Summer.

2. Pyrola ellíptica Nutt. Deep green. Leaves basal; blades thinnish, ellipticoval or oblong, 3-9 cm. long, usually mucronulate, crenate with low teeth, narrowed into petioles which are shorter than the blades : scapes erect, 1-3 dm. tall, simple : racemes 6-16-flowered: pedicels as long as the subtending bracts or longer : sepals triangular or ovate-triangular, acute or acuminate, about as long as the tube: corolla about $1.5 \mathrm{~cm}$. broad : petals oblong-cuneate, obtuse or truncate : anthers scarcely beaked : style declined, exserted : capsule depressed-globose, about $6 \mathrm{~mm}$. in diameter.

In rich soil, Nova Scotia to British Columbia, south to the District of Columbia, Tennessee and New Mexico. Summer. SHIN-Lkaf.

\section{CHIMÁPHILA Pursh.}

Low almost scapose perennial herbs. Leaves persistent, approximate : blades leathery, sometimes variegated. Flowers perfect, in terminal corymbs. Pedicels commonly with small bracts. Sepals 5, persistent. Corolla white or pink, wax-like : petals 5, broad, concave, sessile. Stamens 10. Filaments often slightly pubescent. Anther-sacs opening by pores at the apices of the basal (then erect) beaks. Ovary 5-celled. Capsule 5-lobed, 
erect, loculicidally 5-valved from the top; valves not cobwebby on the margins. Seeds numerous, with the loose testa somewhat produced at both ends.

Leaves variegated, broadest below the middle: sepals longer than broad.

-Leaves not variegated, broadest above the middle: sepals as broad as long.

1. C. maculata.

2. C. umbellata.

1. Chimaphila maculàta (L.) Pursh. Leaf-blades ovate or lanceolate, $2-5 \mathrm{~cm}$. long, acute or obtusish, distantly serrate with somewhat spreading teeth, short-petioled, dark green, variegated with pale green above : peduncles 5-12 dm. long: flowers wax-like, nodding, 2-5 in a terminal cluster or sometimes solitary, on pedicels $1-3 \mathrm{~cm}$. long : sepals 5 , ovate, 4-5 mm. long, green, ciliolate: petals 5, oblong or suborbicular, 10-12 mm. long, ciliolate, concave, more or less reflexed : filaments dilated below, with 2 tufts of hairs below the middle: anthers tan-colored: capsules depressed, 7-8 mm. broad.

In woods, Maine to Minnesota, Georgia and Mississippi. Summer. SPotted Wintergreen.

2. Chimaphila umbellàta (L.) Nutt. Leaf-blades deep green, oblanceolate, cuneate or obovate-cuneate, $2-10 \mathrm{~cm}$. long, obtuse or acute, sharply serrate, shining above, paler beneath, short-petioled : peduncles erect, $5-15 \mathrm{~cm}$. tall, glabrous or nearly so, corymbosely branched above : pedicels 1-2 cm. long, erect or ascending: sepals half-orbicular or orbicular-ovate, $2 \mathrm{~mm}$. long, obtuse, erose-ciliate : petals suborbicular or orbicular-obovate, erose along the edges : filaments glabrous : capsules depressed-globose, 7-8 mm. broad.

In dry woods, Nova Scotia to British Columbia, south to Georgia, Mexico and California. Summer. Pipsissewa. Prince's Pine.

\section{FAmily 3. MONOTROPÀCEAE Lindl. Indin-Pipe FAmily.}

Saprophytic or root-parasitic herbs, with densely matted roots and with foliage destitute of green coloring matter. Stems solitary or clustered, scape-like. Leaves reduced to scales, these often imbricated at the base and top of the stem. Flowers perfect, or nearly so, usually drooping. Calyx free, of 2-6 imbricated deciduous sepals. Corolla white or colored, of 3-6 distinct or partially united petals, or wanting in the western genus Allotropa. Androecium of 6-12, hypogynous stamens. Filaments distinct or united at the base. Anthers 2-celled, or with confluent sacs, opening by valves or pores. Pollen of simple grains. Disk 8-10-toothed or more. Gynoecium of a single pistil. Ovary 1-6-celled, superior. Styles united. Stigma capitate, disk-like or funnelform. Ovules numerous, anatropous. Fruit a 1-6-celled loculicidally opening capsule. Seeds numerous, minute. Testa reticulated.

Corolla of several distinct petals, deciduous.

Flowers solitary: plants white or pink (black in drying).

Flowers severai : plants yellowish or red.

Corolla gamopetalous, campanulate, persistent.

1. MoNotropa.

2. HYPOPITYS.

3. Monotropsis.

\section{MONÓTROPA L.}

Scapose odorless herbs, with white or pink foliage. Leaves reduced to sessile scales. Flowers perfect, solitary, nodding. Sepals 2-4, imperfectly distinguished from the upper

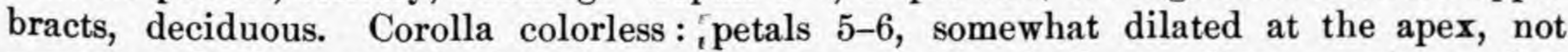
saccate at the base, tardily deciduous. Stamens 10-12. Anthers peltate, opening at first by 2 transverse chinks, becoming transversely 2-valved. Disk 10-12-toothed. Ovary 5celled, confluent with the disk at the base. Stigma funnelform, with a glabrous obscurely crenate edge. Capsule 5-celled, Ioculicidally 5-valved, erect. Seeds numerous, minute, with the testa produced at each end. IndIAN PIPE.

1. Monotropa uniflòra L. Foliage white or pink, turning blackish in drying, glabrous. Stems scape-like, usually gregarious, 1-3 dm. tall, simple, wax-like as is the rest of the plant : scales remote or approximate, $10-15 \mathrm{~mm}$. long, succulent : flowers solitary, nodding, odorless: sepals broadened upward, 10-15 mm. long, obtuse : petals surpassing the calyx, abruptly dilated near the apex, strigillose within : filaments usually 10 , pubescent : capsule erect, 10-18 $\mathrm{mm}$. high, obtusely angled.

In moist woods, Anticosti to British Columbia, Florida, California and Mexico. Summer and fall.

\section{HYPÓPITYS Adans.}

Scapose, often violet-scented herbs, with tawny or red more or less pubescent foliage. Leaves reduced to sessile scales. Flowers perfect, few or several in terminal racemes, the 
terminal (earliest) with usually 5 members in each perianth-whorl, the lateral with 3-4 members. Calyx regular or nearly so : sepals dissimilar from the bracts. Corolla colored: petals distinct, as many as the sepals, saccate at the base. Stamens 6-10. Anthers horizontal : sacs confluent, opening by 2 unequal valves, the smaller erect, the larger spreading or reflexed. Disk 6-10-toothed. Ovary 3-5-celled, confluent with the disk at the base. Stigma funnelform or disk-like, sometimes retrorsely bearded. Capsule 3-5-celled, erect, loculicidally 3-5-valved. Seeds numerous, minute. Pine-sap. False Beech-drops.

Stigma not retrorsely bearded : style sparingly pubescent : sepals and petals with short cilia.

1. H. Americana.

Stigma retrorsely bearded : style copiously pubescent: sepals and petals with long cilia. 2 . H. lanuginosa.

1. Hypopitys Americàna (DC.) Small. Plants tawny or deep pink, finely pubescent. Stems 1-3 dm. tall : scales crowded at base of the stem, 4-12 mm. long, the upper ones sometimes irregularly toothed : flowers several : sepals spatulate to oblanceolate, 7-10 $\mathrm{mm}$. long, often irregularly toothed, ciliate with very short hairs : petals mainly cuneate, 8-13 $\mathrm{mm}$. long, sparingly pubescent and ciliate like the sepals : style sparingly pubescent: stigma not retrorsely bearded : capsule oval or oblong-oval, 7-10 mm. long. [H. multiflora $\beta$ Americana DC.]

In woods, Newfoundland to Ontario and New York and southward in the Alleghenies.

2. Hypopitys lanuginòsa (Michx.) Nutt. Plants yellowish and crimson, markedly or copiously pubescent. Stems $0.5-3.5 \mathrm{dm}$. tall : scales $5-15 \mathrm{~mm}$. long : flowers few : sepals cuneate, oblanceolate or narrowly elliptic-spatulate, 6-9 $\mathrm{mm}$. long, acute or acuminate, ciliate with relatively long hairs : petals cuneate to almost oblong, 10-11 mm. long, markedly pubescent without, ciliate like the sepals : style copiously pubescent : stigma retrorsely bearded : capsule globular, 4-5 mm. long.

In woods, Nova Scotia southward, especially in and near the mountains, to South Carolina, Tennessee and Florida.

\section{MONOTRÓPSIS Schwein.}

Succulent herbs, with glabrous more or less colored foliage and scape-like stems. Leaves reduced to scales. Flowers perfect, fragrant. Calyx persistent : sepals 5. Corolla campanulate, gamopetalous: tube 5 -saccate at the base: lobes 5, erect or spreading. Stamens 10, included. Anthers awnless : sacs confluent, opening by large terminal pores. Disk 10-toothed. Ovary 5-celled, slightly lobed. Stigma rather discoid, 5-angled. Capsule 5-celled. Seeds minute, very numerous. [Schweinitzia Nutt.] Sweet PrNe-SaP.

Sepals oblong: corolla pink or purple. slightly longer than the calyx. Sepals ovate to lanceolate: corolla white, twice as long as the sepals.

1. M. odorata.

2. M. Reynoldsiae.

1. Monotropsis odoràta Ell. Stems scape-like, usually clustered, $5-10 \mathrm{~cm}$. tall, purple or purplish brown : scales several, remote, ovate, $3-8 \mathrm{~mm}$. long, acute, appressed, membranous in age : flowers fragrant, 4-9, more or less nodding, becoming erect: spikes continuous: calyx usually subtended by 2 bracts: sepals oblong or oblong-lanceolate, acute or acutish : corolla pink, about $1 \mathrm{~cm}$. long; lobes ovate or oblong-ovate, obtuse.

In moist woods in or near the mountains, Maryland to Kentucky, Georgia and Tennessee; rare. Early spring. CAROLINA BEECH-DROPS.

2. Monotropsis Reynóldsiae (A. Gray) Heller. Stems scape-like, clustered, 9-12 $\mathrm{cm}$. tall, purple : scales numerous, imbricated, ovate, 4-6 mm. long, obtuse or acutish, appressed or ascending, membranous in age : flowers usually 5-14, nodding or spreading : racemes continuous : calyx short-pedicelled : sepals linear, acute: corolla white, 7-9 mm. long, surpassing the sepals, persistent ; lobes ovate, acute.

In sandy thickets, Florida; local. Fall.

\section{Family 4. eRicàceas dC. Heath Family.}

Perennial herbs, or shrubs or trees, sometimes aromatic. Leaves alternate, opposite or whorled, without stipules: blades commonly leathery and persistent. Flowers perfect or typically so. Calyx of 4-7 distinct or partially united sepals. Corolla regular or slightly 2-lipped, of 4-7 distinct or partially united petals. Androecium of as many or twice as many hypogynous stamens as there are petals or corolla-lobes. Filaments usually distinct. Anthers 2-celled: sacs sometimes prolonged into terminal tubes, like the filaments often awned, opening by terminal pores or chinks, or lengthwise. Gynoecium of 2-5 united car- 
pels. Ovary 2-6-celled. Styles united. Stigmas capitate or peltate. Ovules usually numerous, anatropous. Fruit a capsule, or sometimes baccate or drupaceous. Seeds numerous or sometimes solitary in each cavity. Endosperm fleshy. Embryo central.

Capsule opening septicidally, naked.

Corolla of 3-7 distinct petals.

Anther-sacs opening at the apex : petals 6-7.

Anther-sacs opening lengthwise: petals $3-5$.

Petals 3-4.

Petals 5.

Corolla of several united petals.

Corolla funnelform, limb 2-lipped.

Corolla campanulate, urn-shaped or saucer-shaped.

Corolla without sacs for the anthers.

Corolla campanulate or rotate-campanulate.

Upper corolla-lobe exterior: sepals minute or obsolete: leaves deciduous; blades membranous.

Upper corolla-lobe interior : sepals prominent : leaves persistent ; blades leathery. Corolla urn-shaped.

Corolla with 10 sacs for the anthers.

Sepals persistent: capsule spheroidal : corolla-lobes rounded.

Sepals deciduous: capsule ovoid : corolla-lobes acute.

Capsule opening loculicidally, sometimes enclosed in the berry-like hypanthium.

Calyx and hypanthium neither accrescent nor enclosing the capsule like a

berry.

Anther-sacs opening by terminal pores or chinks.

Sepals imbricate, at least in the bud.

Capsule opening by a single layer of 5 valves.

1. BEJARIA.

2. Elliottia.

3. DENDRIUM.

4. Azalea.

Capsule opening by 2 layers, the outer 5 -valved, the inner 10-valved. 11. CHAMAEDAP Sepals valvate or separated even in the bud.

Anthers or filaments 2-awned on the back.

Corolla campanulate: sepals manifestly united.

Corolla urn-shaped or cylindraceous : sepals distinct.

Anthers and filaments awnless.

Anther-sacs opening lengthwise.

Corolla contracted at the throat: upright shrubs or trees.

Corolla dilated at the throat: creeping, shrubby plants.

Calyx and hypanthium accrescent, enclosing the capsule like a berry.

\section{Biltia.}

6. RHODODENDRON.

7. MENZIESIA.

8. Kalmia.

9. Kalmiella.

\section{BEJÀrIA Mutis.}

Evergreen shrubs, with branching stems. Leaves alternate: blades entire, leathery. Flowers perfect, in terminal racemes or corymbs. Calyx often glutinous : sepals 6-7. Corolla white, yellow or red: petals 6-7, spreading, or ascending, somewhat unequal, imbricated. Stamens 12-14. Filaments filiform, somewhat declined. Anthers versatile, opening by terminal pores. Ovary 6-7-celled. Stigma 6-7-lobed, or nearly entire. Ovules numerous. Capsule depressed, 6-7-lobed, septicidally 6-7-valved.

1. Bejaria racemòsa Vent. An evergreen shrub 1-2 m. tall, with sparingly hispid branches. Leaf-blades oblong to oval or sometimes broadest above the middle, glabrous, usually lustrous above, acute or obtuse at the apex, short-petioled : racemes terminal, 1-2 dm. long, simple or compound, with bracts $5-12 \mathrm{~mm}$. long: pedicels $1-1.5 \mathrm{~cm}$. long: calyx $5-6 \mathrm{~mm}$. broad: sepals about 7 , triangular or rounded : corolla white, glutinous ; lobes linear-spatulate, $2-2.5 \mathrm{~cm}$. long, spreading: capsules $6-8 \mathrm{~mm}$. broad, depressed, 7lobed, 7-celled.

In sandy soil, southeastern Georgia and Florida. Spring and summer.

\section{ELLIÓTtia Muhl.}

Shrubs, with erect branching stems and glabrous foliage. Leaves alternate: blades entire, with alternate nerves. Flowers perfect, in terminal racemes or panicles. Sepals $3-5$, often 4. Corolla white or pink: petals elongated, unequal, imbricated. Stamen 4-10. Filaments flattened. Anthers sagittate, opening lengthwise. Ovary 3-5-celled, curved or declined. Stigma minutely lobed. Ovules variable in number. Capsule 3-5lobed, septicidally 3-5-valved.

1. Elliottia racemòsa Muhl. A glabrous shrub 1-3 m. tall. Leaf-blades firm, oblong, elliptic or oblong-oblanceolate, $4-12 \mathrm{~cm}$. long, acuminate at both ends and bristlepointed, more or less glaucous beneath, short-petioled : racemes narrow, 1-4 dm. long, simple or compound: pedicels $8-20 \mathrm{~mm}$. long: calyx $3-3.5 \mathrm{~mm}$. broad: sepals broadly triangular : petals linear-oblong, about $1 \mathrm{~cm}$. long, more or less strongly recurved.

On sand hills, eastern Georgia and adjacent South Carolina. Spring. 


\section{DÉNDRIUM Desv.}

Low evergreen shrubs, with much branched stems. Leaves alternate or opposite : blades leathery, entire. Flowers perfect, in terminal corymbs, pedicelled. Calyx persistent: sepals 5, rigid. Corolla white or pink : petals 5, sessile, imbricated. Stamens 10, exserted. Filaments filiform, glabrous. Anthers awnless, opening lengthwise. Disk 10-lobed. Ovary 2-5-celled. United styles straight. Stigma truncate. Ovules numerous. Capsule ovoid, septicidally 2-5-valved. [Leiophyllum Pers.] SAND Myrthe.

Leaves mainly opposite; blades oval or broadly oblong: lobes of the capsules toothed on back.

Leaves mainly alternate; blades oblong : capsules smooth or nearly so.

Leaf-blades 4-8 mm. long: filaments nearly twice as long as the petals: capsules about thrice as long as the sepals.

Leaf-blades $1-1.5 \mathrm{~cm}$. long : filaments about as long as the petals : capsules about twice as long as the sepals.

1. D. prostratum.

2. D. buxifolium.

3. D. Hugeri.

1. Dendrium prostràtum (Loud.) Small. An evergreen shrub 1-2 dm. tall, with diffuse and depressed branches. Leaves mainly opposite; blades leathery, oval or broadly oblong, 4-7 mm. long, obtuse, revolute, lustrous above, pale and dull beneath, narrowed into petioles 1-2 mm. long; flower-clusters loose or dense : bracts mostly oblong-ovate, obtuse: pedicels 5-8 mm. long, minutely glandular: sepals variable, lanceolate to linear, obtusish : corolla white; petals oval-oblong or sometimes somewhat ovate, $3.5 \mathrm{~mm}$. long, obtuse : filaments club-shaped, longer than the petals : capsules broadly ovate or orbicularovate, $2.5-3 \mathrm{~mm}$. long, somewhat lobed, the lobes toothed on the back, more than twice as long as the sepals, commonly elevated on a disk-like stipe.

On rocky mountain summits, North Carolina and Tennessee. Spring.

2. Dendrium buxifòlium (Berg.) Desv. An evergreen shrub $0.5-5 \mathrm{dm}$. tall, with erect or spreading much-branched stems. Leaves mainly alternate; blades leathery, oblong, obtusish or acutish, lustrous above, paler and dull beneath, narrowed into petioles about $1 \mathrm{~mm}$. long: flower clusters dense : bracts oblong or nearly so, 1-1.5 mm. long: pedicels $2-6 \mathrm{~mm}$. long, glabrous or very sparingly glandular : sepals oblong-lanceolate, 1 $\mathrm{mm}$. long, obtusish : corolla white ; petals oblong-ovate, $2-2.5 \mathrm{~mm}$. long, obtuse : filaments club-shaped, nearly twice as long as the petals : capsules ovoid, $3 \mathrm{~mm}$. long, glabrous or nearly so, prominently lobed, about thrice as long as the sepals.

In sandy pine lands, New Jersey to Florida. Spring.

3. Dendrium Hùgeri Small. An evergreen shrub 2-4 dm. tall, with erect muchbranched stems. Leaves mainly alternate; blades leathery, oblong, $1-1.5 \mathrm{~cm}$. long, lustrous and dark green, paler beneath, obtuse, revolute, somewhat obliquely narrowed into petioles 1-2 $\mathrm{mm}$. long: flower-clusters dense : bracts oblong-ovate, $3 \mathrm{~mm}$. long, obtuse : pedicels $5-10 \mathrm{~mm}$. long, minutely glandular : sepals lanceolate, almost $1 \mathrm{~mm}$. long, acute : corolla white ; petals ovate, $4 \mathrm{~mm}$. long, obtuse : filaments club-shaped, as long. as the petals : capsules ovoid, $3.5-4 \mathrm{~mm}$. long, glabrous or nearly so, obtusely lobed, twice as long as the sepals, abruptly contracted into the stoutish style which is about as long as the capsule-body.

On cliffs and rocky mountain summits, North Carolina.

\section{AZÀlea L.}

Shrubs, with erect irregularly branching stems. Leaves alternate, deciduous : blades entire or bristle-toothed. Flowers perfect, in terminal clusters. Sepals 5. Corolla funnelform, of various colors : tube narrow, elongated : lobes 5 , unequal, spreading, disposed in 2 lips. Stamens 5 , or rarely 10, conspicuously exserted. Filaments often colored, declined. Anthers awnless, opening by terminal pores. Ovary 5-celled. Styles declined, long-exserted. Ovules numerous in each cavity. Capsule elongated, septicidally 5 -valved.

Corollas expanding before the leaves.

Corolla red, orange or yellow.

Corolla pink or white.

Leaf-blades canescent beneath: corolla-tube glandular-pubescent.
Leaf-blades strigose especially on the midnerve beneath: corolla-tube hirsute. Corollas expanding after the leaves.

Leaf-blades densely white-tomentose beneath.

Leaf-blades glabrous or with scattered hairs beneath.

A. Midnerve strigose beneath at maturity.

a. Corolla-tube less than $3 \mathrm{~cm}$. long: eastern species.

1. A. lutea.

2. A. canescens.

3. A. nudiflora.

4. A. candida.

5. A. viscosa. 
b. Corolla-tube over $3 \mathrm{~cm}$. long: Texan species.

B. Midnerve glabrous beneath at maturity.

Leaf-blades broadest at the middle : corolla-tube contracted upward : Floridian species.

Leaf-blades broadest above the middle : corolla-tube dilated upward : Appalachian species.

7. A. serrulata.

8. A. arborescens.

1. Azalea lùtea $\mathrm{L}$. A branching shrub $0.5-5 \mathrm{~m}$. tall, with glabrate or sparingly pubescent foliage. Leaves unfolding after the corollas; blades oval, elliptic or obovate, 3-8 cm. long, usually acute at both ends, ciliate, more or less densely canescent beneath, short-petioled : pedicels stout, $0.5-1 \mathrm{~cm}$. long, glandular-pubescent : corolla yellow to red, often variegated; tube gradually dilated upward, $1.5-2.5 \mathrm{~cm}$. long, glandular-pubescent : capsules oblong or oblong-ovoid, 1-2.5 cm. long, hirsute. [A. calendulacea Michx.]

In dry and rocky woods, New York to Pennsylvania and chiefly in the mountains to Georgia and Alabama. Spring. Flame Azalea.

2. Azalea canéscens Michx. An asymmetrical shrub 1-5 m. tall, with more or less densely pubescent young foliage. Leaves unfolding after the corollas; blades thinnish, oval or elliptic, varying to obovate, $2-8 \mathrm{~cm}$. long, obtuse at the apex, or usually shortacuminate at both ends, ciliate, canescent beneath : pedicels $1.5-2.5 \mathrm{~cm}$. long, glandular : corolla rose-colored to whitish; tube $1.5-2 \mathrm{~cm}$. long, widely dilated above the middle, glandular : capsules oblong or ovoid-oblong, 1-2 cm. long, glandular-pubescent.

In rocky woods, Massachusetts to New York, south, chiefly in the mountains, to Florida and Louisiana. Spring. Mountain Azalea.

3. Azalea nudiflòra L. An irregularly branching shrub $0.5-3 \mathrm{~m}$. tall, with more or less densely pubescent young foliage. Leaves unfolding after the corollas; blades firm, oblong to obovate, $3-10 \mathrm{~cm}$. long, acute or short-acuminate at both ends or apiculate at the apex : pedicels $1-2 \mathrm{~cm}$. long, strigose : corolla pink to white; tube gradually dilated above the middle, $1.5-2.5 \mathrm{~cm}$. long, pilose and rarely sparingly glandular : capsules oblong or linear-oblong, 1-3 cm. long, strigose or hirsute-strigose.

On dry hillsides and in wet woods, Maine to Illinois, south to Florida and Texas. Spring. WiLD HONEYSUCKLE.

4. Azalea cándida Small. A rigid shrub 1-2 m. tall, with wide branching stems and white-tomentose young foliage. Leaves unfolding before the corollas; blades leathery, obovate-oblanceolate or oblong, 1-5 $\mathrm{cm}$. long, acute or apiculate, somewhat revolute, thinly tomentose above, densely white-tomentose and reticulated beneath, short-petioled: corolla white or pinkish ; tube about $2.5 \mathrm{~cm}$. long; limb about as broad as the length of the corollatube: capsules $1.5-2 \mathrm{~cm}$. long, canescent, curved.

In hammocks along the Withlacoochee River, southern Georgia. Spring.

5. Azalea viscòsa L. A shrub 1-3 m. tall, with more or less densely pubescent young foliage. Leaves firm; blades oblong or elliptic-oblanceolate, cuneate or obovate, 2-6 cm. long, obtuse or mucronate, ciliate, dull or shining, short-petioled; pedicels glandular-hirsute : corolla white or pink ; tube relatively slender, rather abruptly dilated near the limb, which is $2-3 \mathrm{~cm}$. broad : capsules $1.5-2 \mathrm{~cm}$. long, hirsute. SUCKLE.

In swamps, Maine to Ohio, south to Florida and Texas. Spring and summer. SWAMP HONEY-

6. Azalea oblongifòlia Small. A shrub 1-2 m. tall with branching erect or more or less spreading stems. Leaves rather firm; blades oblong or oblong-oblanceolate, $5-10 \mathrm{~cm}$. long, mucronate, dull and strigillose on both surfaces, ciliate, short-petioled: pedicels glandular-hirsute, 1-1.5 cm. long: corolla white or pinkish, glandular-pubescent ; tube stoutish, over $3 \mathrm{~cm}$. long, rather abruptly dilated near the limb.

In sandy bogs, Tom Green County, Texas. Spring.

7. Azalea serrulàta Small. An asymmetrical shrub $2-4 \mathrm{~m}$. tall, with almost glabrous foliage. Leaves clustered at the ends of the branches: blades thinnish, oblong to oval or elliptical-oblanceolate, 4-9 $\mathrm{cm}$. long, mucronate, lustrous, serrulate with bristle-tipped teeth, narrowed into short petioles: clusters few-flowered: pedicels rather slender, 9-13 mm. long, glandular-hirsute : corolla white : tube more or less expanded at each end, $2.5-3 \mathrm{~cm}$. long, glandular-hirsute.

In wet hammocks, Lake County, Florida. Spring.

8. Azalea arboréscens Pursh. A shrub or small tree $0.5-6 \mathrm{~m}$. tall, with almost glabrous foliage, fragrant in drying. Leaves firm; blades elliptic, oval, oblanceolate or cuneate, 4-10 $\mathrm{cm}$. long, usually abruptly pointed at the apex, ciliate, usually lustrous above, short-petioled: pedicels 5-10 $\mathrm{mm}$. long: corolla white or pink; tube dilated above the middle, about $2.5 \mathrm{~cm}$. long, glandular-pilose ; limb 4-5 cm. broad ; lobes irregularly spreading: styles red : capsules oblong, 1-2 cm. long, bristly-glandular.

Along streams in the mountains, Pennsylvania to Georgia. Spring and summer. 


\section{BÍLtía small.}

Shrubs, with glabrous or nearly glabrous mature foliage. Leaves alternate, deciduous : blades thinnish, not scurfy. Flowers preceding the leaves, in clusters, from few-scaled buds. Calyx a mere undulate border. Corolla irregular: tube short, oblique, campanulate: lobes 5 ; the 2 lower overlapping, larger than the others and spreading, the 3 upper spreading, the middle one exterior. Stamens $5-7$, commonly $7:$ filaments declined : anthers opening by terminal pores. Ovary 5-celled : style curved. Capsule slightly narrowed upward, ribbed, glandular-pubescent.

1. Biltia Vaseỳi (A. Gray) Small. A nearly glabrous asymmetrical shrub 1-5 m. tall. Leaf-blades elliptic or oblong-elliptic, 6-15 $\mathrm{cm}$. long, membranous, acuminate at both ends, ciliate, with a prominent midrib beneath; petioles $3-6 \mathrm{~mm}$. long: pedicels $1-1.5 \mathrm{~cm}$. long, somewhat glandular : corolla mainly pale rose-colored, rotate-campanulate ; lobes 5 , ovate to obovate, unequal, the 2 lower divergent, inequilateral, the 3 upper spreading with yellow-orange or reddish-orange spots: stamens 7 or sometimes 5: capsules oblong-ovoid, about $1 \mathrm{~cm}$. long, lobed. [Rhododendron Vaseyi A. Gray.]

On rocky mountain slopes and summits, North Carolina. Spring.

\section{RHODODÉNDRON L.}

Evergreen shrubs or small trees, with glabrous pubescent or waxy foliage. Leaves alternate : blades entire, leathery. Flowers perfect, showy, in terminal clusters. Calyx persistent : sepals 5 . Corolla variously colored, campanulate, somewhat irregular : lobes 5 , the 3 upper a little more spreading than the lower, the middle one interior : stamens usually 10, slightly exserted. Filaments sometimes declined. Anthers awnless, opening by terminal pores. Disk lobed. Ovary 5-20-celled. Stigma capitate or 10-lobed. Ovules numerous. Capsule variable, often elongated, septicidally 5-20-valved.

Foliage glabrous or with scurfy pubescence which is soon deciduous. Sepals oblong or ovate, obtuse, 4-6 mm. long: corollas white or pink. Sepals triangular, acute, 1-2 mm. long: corollas lilac-purple.

Foliage persistently lepidote with peltate scales.

Corolla-tube less than $1.5 \mathrm{~cm}$. long : corolla-lobes not crisped.

Corolla-tube over $1.5 \mathrm{~cm}$. long: corolla-lobes crisped.

Leaf-blades rounded at the apex: upper corolla-lobe not yellow-blotched.

Leaf-blades acute

1. Rhododendron máximum L. An evergreen shrub or small tree nearly $12 \mathrm{~m}$. tall, with glabrous or sometimes sticky foliage or this thinly tomentose when young. Leafblades oblong or oblong-oblanceolate, $10-25 \mathrm{~cm}$. long, acute or abruptly acuminate, lustrous above, more or less densely scurfy beneath; petioles stout, $2-5 \mathrm{~cm}$. long : flower-clusters dense : pedicels stout, glandular, $2-5 \mathrm{~cm}$. long: calyx campanulate; lobes ovate to oblong, obtuse, longer than the tube : corolla white or pink, mottled within with yellow or orange, $3-6 \mathrm{~cm}$. broad : capsules oblong or ovoid-oblong, about $1.5 \mathrm{~cm}$. long.

On hillsides and mountain slopes, Nova Scotia to Ontario and Ohio, south to Georgia and Alabama. Spring and summer. GREAT LAUREL. ROSE BAY LAUREL.

2. Rhododendron Catawbiénse Michx. An evergreen shrub or small tree 0.5-6 m. tall, with glabrous foliage, except the young twigs and petioles. Leaf-blades oblong or oval, usually abruptly pointed, dark green above, more or less revolute, mostly rounded or subcordate at the base; petioles stout, $1-2.5 \mathrm{~cm}$. long: flower-clusters dense : pedicels $2-3.5 \mathrm{~cm}$. long, glabrous or pubescent : sepals obtuse : corolla lilac-purple, 3-6 cm. broad ; lobes 5 , somewhat longer than broad, erose-crenulate, notched at the apex : capsules oblong or oblong-ovoid, $1.5-2 \mathrm{~cm}$. broad.

On mountain slopes, Virginia to West Virginia, Georgia and Alabama. Spring and early summer.

3. Rhododendron punctàtum Andr. A branching shrub 0.5-2 m. tall, with resinous-dotted foliage. Leaf-blades elliptic or oval, 8-12 cm. long, acute or acuminate at both ends, lustrous above; midrib prominent beneath; petioles stout, $1-1.5 \mathrm{~cm}$. long : flower clusters dense : pedicels $1-2 \mathrm{~cm}$. long: corolla rose-colored, often mottled; tube broadly funnelform ; limb spreading, its 5 lobes obovate or ovate: stamens mainly shorter than the corolla : capsules oblong-ovoid, 8-11 mm. long, resinous dotted.

In sandy soil on mountain slopes, North Carolina and Tennessee, to Georgia and Alabama. Spring.

4. Rhododendron Chapmànii A. Gray. An evergreen shrub 1-2 m. tall, with erect rigid branches. Leaf-blades oblong or oval, $2-5 \mathrm{~cm}$. long, obtuse, revolute, resinous-dotted beneath, somewhat lustrous above; petioles $3-6 \mathrm{~mm}$. long : flower-clusters dense : pedicels 5-15 mm. long: corolla rose-colored, mottled within ; tube broadly funnelform, $1.5-2 \mathrm{~cm}$. 
long ; limb $2.5-3 \mathrm{~cm}$. broad, the lobes rounded, more or less crisped : capsule nearly $1 \mathrm{~cm}$. long.

In sandy pine lands, western Florida. Spring.

5. Rhododendron Cuthbértii Small. A branching straggling shrub 1-3.5 m. tall, with resinous-dotted foliage. Leaf-blades elliptic, 3-7 $\mathrm{cm}$. long, acute at both ends, or acuminate at the apex, revolute, somewhat reticulated above, scurfy beneath; petioles $5-10 \mathrm{~mm}$. long, stout : flower-clusters rather dense : pedicels 1-1.5 cm. long : corolla clear rose-colored ; tube narrowly funnelform, $1.5 \mathrm{~cm}$. long, abruptly expanded about the middle ; limb about $3.5 \mathrm{~cm}$. broad, the upper lobe copiously blotched : capsule oblong-ovoid, $8-12 \mathrm{~mm}$. long.

In sandy woods, middle Georgia. Spring.

\section{MENZIÈsIA J. E. Smith.}

Shrubs, with erect branching stems. Leaves alternate, deciduous: blades membranous, entire. Flowers perfect, in terminal clusters. Sepals 4-5. Corolla white, greenish or reddish, globose, campanulate or urn-shaped : lobes 4-5. Stamens 5, 8 or 10, included : filaments flattened, sometimes dilated below: anthers elongated, awnless, opening by terminal pores or chinks. Disk 8-10-lobed. Ovary 4-5-celled, usually 4-celled. Stigma truncate or 4-5-lobed. Ovules numerous in each cavity. Capsule depressed or elongated, septicidally 4 -valved.

1. Menziesia pilòsa (Michx.) Pers. An asymmetrical shrub $0.5-2 \mathrm{~m}$. tall, with sparingly pubescent foliage. Bark scaly: leaf-blades membranous, elliptic to oval or elliptic-oblanceolate, $1.5-5 \mathrm{~cm}$. long, abruptly glandular-pointed, ciliate, glaucescent beneath, acute or acuminate at the base, short-petioled : flower-clusters loose : pedicels 1-2.5 $\mathrm{cm}$. long, glandular-pubescent : calyx flattish, $2-2.5 \mathrm{~mm}$. broad : sepals pectinate-ciliate : corolla white or pink, ovoid becoming ovoid-campanulate, 6-7 mm. long; lobes rounded, shorter than the tube: capsules ovoid, 5-6 mm. long, bristly with gland-tipped rigid hairs.

In mountain woods, Pennsylvania to Georgia and Alabama. Summer.

\section{KÁLMIA L.}

Evergreen shrubs or trees with glabrous or finely glandular-pubescent foliage. Leaves alternate, opposite or whorled : blades entire, often lustrous, not ciliate. Flowers perfect, showy. in terminal or axillary corymbs or umbels, the bracts early deciduous. Sepals 5, leathery, persistent, obtuse or acute. Corolla white or pink, rotate : tube short, with 10 sacs : limb 10-keeled, with 5 rounded lobes. Stamens 10 : filaments shorter than the corolla, straightening elastically at maturity : anthers awnless, opening by terminal pores attached to the filaments near the top. Disk 10-lobed. Ovary 5-celled. Capsule spheroidal, depressed at the apex, septicidally 5 -valved.

Inflorescence lateral: sepals not ciliate.

Leaves mostly alternate: corolla $15 \mathrm{~mm}$. broad : capsules $4-5 \mathrm{~mm}$. broad.

Leaves mostly opposite or whorled : corolla $6-8 \mathrm{~mm}$. broad : capsules $3-3.5 \mathrm{~mm}$. broad.

Leaf-blades glabrous, at least at maturity : style glabrous.

Leaf-blades permanently canescent-tomentulose, at least beneath : style pubescent.

Inflorescence terminal : sepals ciliate.

1. K. cuneata.

2. K. angustifolia.

3. K. Carolina.

4. K. latifolia.

1. Kalmia cuneàta Michx. A low branched shrub, with pubescent foliage. Leaves mostly alternate, deciduous : blades spatulate or cuneate, $1.5-5 \mathrm{~cm}$. long, mucronulate, sparingly pubescent and pale beneath, deep green and somewhat shining above, sessile : clusters few-flowered : pedicels 1-1.5 cm. long, becoming glabrous : sepals oblong, $3-3.5 \mathrm{~mm}$. long : corolla white or pinkish, about $1.5 \mathrm{~cm}$. broad : capsules spheroidal, 4-5 mm. broad.

In swamps, eastern North Carolina. Spring. WHITE WICKY.

2. Kalmia angustifollia L. A branched sbrub 2-12 dm. tall, with glabrate foliage. Leaves numerous, persistent ; blades leathery, oblong to lanceolate, $2-6 \mathrm{~cm}$. long, usually obtuse or acutish, slightly revolute, short-petioled : corymbs lateral, few-many-flowered: pedicels slender, $1-2 \mathrm{~cm}$. long, minutely glandular: calyx glandular : sepals ovate, 1-1.5 $\mathrm{mm}$. long : corolla purple to crimson, $6-8 \mathrm{~mm}$. broad : style glabrous : capsules spheroidal, 3-3.5 mm. broad, minutely and inconspicuously glandular, on recurved pedicels.

In various situations, Newfoundland to Hudson Bay, south to Georgia. Summer. Sheep Laurel. LAMBKILL. WICKY. 
3. Kalmia Carolina Small. Similar to $K$. angustifolia in habit, but with the foliage, especially the younger parts, copiously pubescent. Leaf-blades oval to oblong, 1.5-4.5 cm. long, obtuse, permanently canescent-tomentulose, at least beneath : sepals oblong-lanceolate : corolla 5-7 mm. broad: style finely pubescent: capsules spheroidal, pale-pubescent and somewhat glandular.

In open woods, mountains of North Carolina. Summer.

4. Kalmia latifòlia L. An evergreen asymmetrical shrub or small tree rarely $12 \mathrm{~m}$. tall. Bark flaky : leaves dark green; blades leathery, elliptic or oval, usually acute at both ends or abruptly acuminate at the apex, lustrous above, short-petioled : corymbs often dense, terminal : pedicels slender, 1-3 cm. long, glandular-pubescent : calyx glabrous or nearly so ; sepals oblong or oblong-ovate, $2 \mathrm{~mm}$. long: corolla white or pink, $2-2.5 \mathrm{~cm}$. broad, sticky : capsules spheroidal, 5-7 mm. broad, glandular-viscid, erect.

In rocky or sandy woods, New Brunswick to Ohio, south to Florida and Louisiana. Summer. Calico-bush. Laurel. Spoonwood. Ivy. Poison laurel.

\section{KALMIÉLLA Small.}

Low shrubs, with hirsute foliage. Leaves alternate: blades relatively small. Flowers usually solitary on slender pedicels axillary to the leaf-like bracts. Sepals 5, foliaceous, acuminate, deciduous. Corolla pink, similar to those of Kalmia, but with acute lobes. Stamens 10: anthers attached to the filaments near the middle. Disk prominently lobed. Ovary 5-celled. Capsules ovoid, not depressed at the apex.

1. Kalmiella hirsùta (Walt.) Small. A much branched shrub 1-6 dm. tall, with hirsute foliage. Leaves $5-10 \mathrm{~mm}$. long; blades oblong, lanceolate or oval-orbicular, acute or acutish, more or less strongly revolute, nearly sessile : flowers solitary or several together in the axils : pedicels slender, 4-10 mm. long, hirsute : calyx bristly ; sepals oblonglanceolate, 5-7 mm. long, acuminate : corolla rose-purple, 10-15 mm. broad : capsules about $3 \mathrm{~mm}$. long. [Kalmia hirsuta Walt.]

In pine lands, Virginia to Florida. Spring and summer.

\section{LЕUС́́тHӧ̈ D. Don.}

Shhrubs, with terete branching stems. Leaves alternate, sometimes persistent: blades entire or toothed, the teeth often bristle-pointed. Flowers perfect, in one-sided racemes. Calyx subtended by 1 or 2 bracts : sepals 5, more or less elongated. Corolla white, ovoid, urn-shaped or cylindric, with 5 erect or spreading lobes. Stamens 10, included : filaments adnate to the base of the corolla-tube: anthers often awned at the apex, opening by terminal pores. Disk 10-lobed. Ovary 5-celled. Stigma entire, or 5-lobed. Ovules numerous in each cavity. Capsule depressed, loculicidally 5-valved.

Racemes from the axils of the persistent leaves of the preceding season : anthers awnless.

Filaments merely scabrous, nearly straight : anthers more or less manifestly bimucronate.

Twigs puberulent; sepals imbricated.

Larger sepals ovate: corolla 5-6 mm. long : leaf-blades mainly oblong.

Larger sepals orbicular-ovate : corolla $6-7 \mathrm{~mm}$. long : leaf-blades mainly oval. Twigs glabrous: sepals not imbricated.

Filaments pubescent, sigmoid-curved above: anthers pointless.

Racemes terminal: leaves deciduous : anthers awned.

Racemes curved: capsules manifestly lobed.

Racemes straight or nearly so: capsules not lobed.

Sepals $1 / 4-1 / 3$ as long as the corolla, shorter than the capsules.

Sepals about $1 / 2$ as long as the corolla, surpassing the capsules.

1. L. axillaris.

2. L. platyphylla.

3. L. Catesbaei.

4. L. acuminata.

5. L. recurva

6. L. racemosa.

7. L. elongata.

1. Leucothoë axillàris (Lam.) D. Don. An evergreen shrub 1-2 m. tall, with puberulent twigs. Leaf-blades leathery, oval, oblong or oblong-lanceolate, 4-15 cm. long, acute or acuminate, rather remotely serrate, revolute, often sparingly pubescent beneath, acute to rounded at the base ; petioles $0.5-1 \mathrm{~cm}$. long: racemes axillary, 2-7 $\mathrm{cm}$. long, simple or compound : bracts broadly ovate, $2-3 \mathrm{~mm}$. long, acute : pedicels 1-4 mm. long, minutely pubescent : calyx 4-5 mm. broad: sepals ovate, $2 \mathrm{~mm}$. long, acute : corolla white, cylindric-ovoid, 5-6 mm. long : capsules spheroidal, 6-7 mm. broad.

In damp woods and swamps near the coast, Virginia to Florida and Alabama. Spring.

2. Leucothoë platyphýlla Small. A straggling shrub $0.5-1 \mathrm{~m}$. tall, with spreading or drooping branches, the twigs and branches finely pubescent. Leaf-blades suborbicular to oval, broadly oblong or oblong-ovate, $5-8 \mathrm{~cm}$. long, abruptly pointed or slightly acuminate, serrulate with very fine spinulose teeth, especially above the middle; petioles stout, 4-8 $\mathrm{mm}$. long, pubescent: racemes $2-5 \mathrm{~cm}$. long; rachis pubescent like the twigs: pedicels 
3-5 mm. long: calyx glabrous; larger sepals orbicular-ovate: corolla white, 6-7 mm. long: capsules $5.5 \mathrm{~mm}$. broad, $4 \mathrm{~mm}$. high.

In low thickets, Georgia to Mississippi. Spring.

3. Leucothoë Catesbaèi (Walt.) A. Gray. An evergreen shrub 1-2 m. tall, with more or less densely puberulent twigs, the stems and branches often reclining. Leaf-blades lanceolate to narrowly elliptic, 6-15 cm. long, leathery, acuminate, serrate with spinetipped teeth, lustrous above, acute or rounded at the base; petioles 1-1.5 cm. long: racemes axillary, $4-8 \mathrm{~cm}$. long, simple : bracts broadly ovate, acute, $4-5 \mathrm{~mm}$. long: pedicels 4-8 $\mathrm{mm}$. long: calyx about $5 \mathrm{~mm}$. broad: sepals ovate, about $2 \mathrm{~mm}$. long, acute : corolla white or pinkish, cylindric-ovoid, $5-6 \mathrm{~mm}$. long : capsules spheroidal, lobed, about $5 \mathrm{~mm}$. broad.

Along streams, chiefly in the mountains, Virginia to Tennessee and Georgia. Spring.

4. Leucothoë acuminàta (Ait.) D. Don. An evergreen shrub 1-4 m. tall, with hollow branches. Leaf-blades lanceolate to ovate-lanceolate, $3-10 \mathrm{~cm}$. long, leathery, acute or usually acuminate, finely reticulated : racemes corymb-like, axillary, $1-3 \mathrm{~cm}$. long, fewflowered : calyx puberulent, about $3 \mathrm{~mm}$. broad : sepals broadly ovate, acute : corolla oblongcylindric, 8-10 mm. long: capsules spheroidal, 5-6 $\mathrm{mm}$. broad, lobed

In swamps and about ponds, South Carolina to Florida. Spring.

5. Leucothoë recúrva (Buckl.) A. Gray. A widely branching shrub 1-4 m. tall, with glabrate or minutely pubescent foliage. Leaves deciduous; blades thinnish but often quite firm, oval, elliptic, or oval, $4-10 \mathrm{~cm}$. long, acute or short-acuminate, serrate, rarely rounded at the base, short-petioled : racemes $2-10 \mathrm{~cm}$. long, simple or branching, often many-flowered : pedicels stout, 1-2 $\mathrm{mm}$. long : calyx glabrous : sepals oblong-ovate, nearly $2 \mathrm{~mm}$. long, acute, involute : corolla white, $6-7 \mathrm{~mm}$. long, oblong-cylindric ; lobes ovate, recurved: anthers with slender awns : capsules spheroidal, 5-6 $\mathrm{mm}$. broad, lobed.

On mountain slopes, Virginia to Georgia and Alabama. Spring.

6. Leucothoë racemòsa (L.) A. Gray. A wide-branching shrub 1-4 m. tall, with glabrous or puberulent twigs. Leaves firm ; blades oblong or elliptic, $2-7 \mathrm{~cm}$. long, acute or slightly acuminate, serrulate, short-petioled: racemes $3-10 \mathrm{~cm}$. long, simple or branched : pedicels 1-2 mm. long: calyx glabrous : sepals triangular, becoming triangularlanceolate, $2-3 \mathrm{~mm}$. long, acute, ciliolate : corolla white or pink, $8-9 \mathrm{~mm}$. long, cylindric, constricted at the throat; lobes ovate, recurved: anthers with long subulate awns : capsules spheroidal, $4 \mathrm{~mm}$. broad, surpassing the sepals.

In swamps and damp thickets, Massachusetts to Florida and Louisiana. Spring.

7. Leucothoë elongàta Small. A branching shrub 1-3 m. tall, with puberulent or glabrate foliage. Leaves firm ; blades oblong, elliptic, or sometimes oblong-oblanceolate, or oblong-obovate, $2-5 \mathrm{~cm}$. long, acute or slightly acuminate, serrulate, gradually or abruptly narrowed into short petioles: racemes $10-20 \mathrm{~cm}$. long: pedicels $1.5-3 \mathrm{~mm}$. long: calyx usually puberulent : sepals lanceolate, often narrowly so, 3-4 mm. long, acuminate, ciliolate : corolla white or pinkish, 7-8 mm. long, cylindric, somewhat constricted at the throat; lobes ovate, recurved: anthers with short subulate awns: capsules spheroidal, $3.5-4 \mathrm{~mm}$. broad, much shorter than the sepals.

In swamps, Virginia to Florida. Spring.

\section{ChamaEDÁPHNE Moench.}

Evergreen shrubs, with branching stems. Leaves alternate : blades leathery, slightly toothed. Fowers perfect, in one-sided leafy-bracted racemes. Calyx subtended by 2 bracts, the 5 sepals nearly distinct, persistent. Corolla urn-shaped, with 5 recurved lobes. Stamens 10, included : filaments adnate to the base of the corolla: anthers prolonged into tubes, opening by terminal pores. Disk 10-lobed. Ovary 5-celled, 5-grooved. Stigma entire. Ovules numerous in each cavity. Capsule depressed, loculicidally 5-valved. [Cassandra D. Don.]

1. Chamaedaphne calyculàta (L.) Moench. An asymmetrical shrub, 1-12 dm. tall, with scurfy foliage. Leaf-blades oblong, elliptic, obovate or oblanceolate, $1-5 \mathrm{~cm}$. long, obtuse or acute, serrulate, narrowed into very short petioles : racemes $2-12 \mathrm{~cm}$. long, conspicuously bracted : bracts similar to the leaves but smaller : pedicels $1-3 \mathrm{~mm}$. long: sepals triangular or triangular-ovate, $1.5-2 \mathrm{~mm}$. long, acute : corolla white, $6-7 \mathrm{~mm}$. long : capsules spheroidal-angular, $4 \mathrm{~mm}$. broad. [Cassandra calyculata D. Don.]

In cold or sphagnous swamps, Newfoundland to Alaska, south to :Georgia, Illinois and British Columbia. Also in northern Europe and Asia. Spring. 


\section{ZENÒBIA D. Don.}

Shrubs, with glabrous or glaucous foliage. Branches terete. Leaves alternate: blades entire or irregularly toothed, reticulated. Flowers perfect, in axillary clusters. Calyx free : sepals 5, manifestly united. Corolla white or pink, campanulate : lobes 5, rounded. Stamens 10, included: filaments dilated at the base: anthers narrow, each sac with 2 slender awns. Disk 10-lobed. Ovary 5-celled. Style columnar. Stigma entire. Ovules numerous. Capsule depressed, loculicidally 5-valved.

Pedicels and lower surface of the leaf-blades green.

Pedicels and lower surface of the leaf-blades densely glaucous.

1. Z. cassinifolia.

2. Z. pulverulenta.

1. Zenobia cassinifòlia (Vent.) Pollard. A branching shrub 1-2 m. tall, with glabrous foliage. Leaves deciduous; blades oblong, varying towards ovate or obovate, 2-6 cm. long, leathery, acute, retuse, reticulated, irregularly and shallowly serrate, narrowed into short petioles: flower-clusters in racemes 1-3 dm. long, the rachis zigzag: pedicels 1-2 $\mathrm{cm}$. long: calyx 5-6 mm. broad: sepals ovate or triangular-ovate : corolla white, campanulate, 6-8 mm. long. [Andromeda speciosa Michx.]

In sandy soil, North Carolina to Florida.

2. Zenobia pulverulénta (Willd.) Pollard. A branching shrub 1-2 $\mathrm{m}$. tall, with densely glaucous foliage. Leaves deciduous; blades leathery, oblong to oval, $2-7 \mathrm{~cm}$. long, cuspidate or obtuse in age, entire or obscurely serrate, slightly reticulated above, short-petioled : flower-clusters in elongated racemes: pedicels 1-2 cm. long: sepals triangular, acute or short-acuminate, appressed : corolla white, campanulate, 6-7 mm. long. [Andromeda pulverulenta Willd.]

In sandy pine lands, North Carolina to Florida.

\section{PİEIS D. Don.}

Shrubs or trees, often evergreen. Leaves alternate: blades leathery, entire or toothed, often lustrous. Flowers perfect, in one-sided racemes or axillary umbel-like clusters. Calyx usually subtended by several bracts : sepals essentially distinct, persistent. Corolla white, urn-shaped or elongated, with 5 recurved lobes. Stamens 10, included : filaments often pubescent, adnate to the base of the corolla-tube: anthers usually awned on the back, opening by terminal pores. Disk 10-lobed. Ovary 5-celled. Stigma truncate. Ovules numerous in each cavity. Capsule 5-lobed, depressed or elongated. Fetrerbush.

Filaments unappendaged: anthers awned.

Twigs strigose: racemes in terminal panicles.

Twigs glabrous : racemes solitary in the axils.

Filaments appendaged : anthers awnless.

Leaves and sepals persistent : corolla $4-5 \mathrm{~mm}$. thick : capsules ovoid-globose.

Leaves and sepals deciduous : corolla $5-6 \mathrm{~mm}$, thick : capsules ovoid-pyramidal. 4 . P. Mariana.

1. Pieris floribúnda (Pursh) B. \& H. A handsome shrub 3-18 dm. tall, with strigose or somewhat bristly twigs and erect branches. Leaf-blades leathery oblong, elliptic or oblong-lanceolate, $2-8 \mathrm{~cm}$. long, acute or short-acuminate, serrulate, bristly-ciliate, obtuse or subcordate at the base : petioles $3-10 \mathrm{~mm}$. long, strigose : panicles rather dense, $5-10 \mathrm{~cm}$. long : pedicels 1-3 mm. long: calyx glabrate: sepals lanceolate or ovate-lanceolate, 3-4 mm. long, acute : corolla white, conic-urceolate, 4.5-6 mm. long: capsules oblong-globose or ovoid-globose, 5-6 mm. long, somewhat angled, longer than the style. [Andromeda floribunda Pursh.]

On dry mountain slopes, Virginia to Georgia. Spring.

2. Pieris phillyreifòlia (Hook.) DC. A branching shrub 3-6 dm. tall with glabrate foliage. Leaf-blades oblong to elliptic, oval, or oblong-oblanceolate or rarely obovate, 2-7 cm. long, leathery, serrate near the apex, revolute, more or less lustrous above, narrowed into short petioles : racemes 1-4 cm. long, solitary in the axils, 4-12-flowered:pedicels 2-6 mm. long, with small subulate-lanceolate bracts : sepals lanceolate or triangularlanceolate, 4-5 mm. long, acute, lustrous : yorolla ovoid, 7-8 mm. long, terete : capsules ellipsoidal, 4-5 mm. broad, ribbed, shorter than the style. [Andromeda phillyreifolia Hook.]

In wet pine lands and swamps, Florida and adjacent Georgia. Winter and spring.

3. Pieris nítida (Bartr. ) B. \& H. An evergreen shrub $1.5-2 \mathrm{~m}$. tall, with sharply angled branches. Leaf-blades leathery, elliptic to oval or obovate, $2-8 \mathrm{~cm}$. long, abruptly acuminate, revolute, narrowed into short petioles: flower-clusters axillary, often contiguous: pedicels $3-8 \mathrm{~mm}$. long, club-shaped: calyx often minutely pubescent: sepals lanceolate, 4-5 mm. long, acuminate, lustrous : corolla white to red, ovoid-cylindric, 
7-9 mm. long, somewhat constricted at the throat, the short lobes recurved : capsules subglobose, $4 \mathrm{~mm}$. high, surpassed by the sepals. [Andromeda nitida Bartr.]

In sandy bogs and pine lands, Virginia to Florida and Louisiana. Spring.

4. Pieris Mariàna (L. ) B. \& H. A shrub 1-2 m. tall with glabrate foliage and erect or nearly erect branches. Leaves deciduous ; blades firm, oblong to oval, sometimes broadest slightly above or below the middle, $2-6 \mathrm{~cm}$. long, obtuse or apiculate, somewhat reticulated, short-petioled: flower-clusters in elongated racemes: pedicels about $1 \mathrm{~cm}$. long, club-shaped : calyx often puberulent : sepals lanceolate, about $5 \mathrm{~mm}$. long, acute, firm in age and slightly accrescent : corolla white or pinkish, ovoid-cylindric, 9-11 mm. long; lobes mostly spreading: filaments pubescent without, usually with 2 appendages below the top : capsules ovoid-pyramidal, 7-9 mm. long. [Andromeda Mariana L.]

In low grounds, Rhode Island to Florida, Tennessee and Arkansas. Spring.

\section{XOLÍSMA Raf.}

Shrubs or trees, with terete branches. Leaves alternate : blades entire or nearly so, sometimes persistent. Flowers perfect, in racemes or panicles. Sepals 4-6, broad, often slightly united. Corolla white, subglobose to urn-shaped, with 4-6 recurved lobes. Stamens 8-12, included : filaments flat, incurved, pubescent : anthers not awned, opening by terminal pores. Disk 8-12-lobed. Ovary 4-6-celled. Stigma truncate. Ovules numerous in each cavity, pendulous. Capsule dry, loculicidally 4-6-valved.

Flowers clustered in the axils of persistent leaf-like bracts : foliage lepidote-scurfy.

Leaves conspicuously reduced towards the ends of the branchlets: blades prominently reticulated.

Leaves barely if at all reduced towards the ends of the branchlets : blades inconspicously reticulated.

Flowers in racemes or panicles : leaves deciduous : foliage glabrous or pubescent. Racemes or panicles leafy-bracted.

Racemes or panicles naked or nearly so.

1. $\boldsymbol{X}$. fruticosa.

1. Xolisma fruticòsa (Michx.) Nash. An evergreen erect shrub 1-1.5 m. tall, with scurfy young foliage. Leaves conspicuously reduced towards the ends of the branchlets ; blades leathery, oval or obovate to oblanceolate, acute or abruptly acuminate at both ends or sometimes obtuse, glabrous and reticulated above, prominently nerved beneath, revolute, short-petioled : panicles narrow, leafy-bracted, often elongated : pedicels 4-10 mm. long: caly $\times 2.5-3 \mathrm{~mm}$. broad, accrescent and $6-7 \mathrm{~mm}$. broad in fruit: sepals broader than long, acute : corolla pale, subglobose, scaly, 3-4 mm. in diameter: capsules ovoid, 4-5 mm. high, 5-6-ribbed. [Andromeda ferruginea var. fruticosa Michx.]

In sandy woods, South Carolina to Florida.

2. Xolisma ferrugìnea (Walt.) Heller. An evergreen wide branching shrub or small tree sometimes $5 \mathrm{~m}$. tall, with scurfy twigs. Leaves barely if at all reduced towards the ends of the branchlets; blades leathery, elliptic to oval or obovate to oblanceolate, $2.5-7 \mathrm{~cm}$. long, glabrous above, acute or short-acuminate, revolute, scurfy-pubescent beneath, shortpetioled : panicles leafy-bracted : pedicels $5-10 \mathrm{~mm}$. long : caly $\times 3.5-4 \mathrm{~mm}$. broad : sepals about as broad as long, abruptly-pointed : corolla white or pinkish, $2.5-3 \mathrm{~mm}$. in diameter, scurfy : capsules oblong-ovoid, or oval, 4-6 mm. high, 5-6-ribbed. [Andromeda ferruginea Walt. ]

In pine lands, South Carolina to Florida.

3. Xolisma foliosiflòra (Michx.) Small. A widely branching shrub 1-4 m. tall, with glabrous or sparingly pubescent foliage. Leaf-blades leathery, oblong to narrowly elliptic or sometimes oval or obovate, $2-8 \mathrm{~cm}$. long, acute or acuminate at both ends, distinctly serrulate, usually lustrous above, short-petioled : panicles copiously leafy-bracted : pedicels 3-8 mm. long : calyx flattish, 3-4 mm. broad : sepals ovate or half-orbicular : corolla white or pinkish, subglobose, $2-3 \mathrm{~mm}$. in diameter : capsules subglobose or spheroidal, 3-3.5 mm. long, 5-6-ribbed. [Andromeda paniculata var. foliosiflora Michx.]

In swamps and low pine lands, Virginia to Florida and Louisiana. Spring.

4. Xolisma ligústrina (L.) Britton. A branching shrub 1-4 m. tall, with more or less densely pubescent foliage. Leaves firm; blades oblong, elliptic or obovate, $3-7 \mathrm{~cm}$. long, usually acute or abruptly acuminate, nearly entire or serrulate, narrowed into short petioles: panicles elongated or cluster-like, naked : pedicels $1-6 \mathrm{~mm}$. long: calyx $3.5-4$ $\mathrm{mm}$. broad : sepals triangular-ovate, acute or acutish, spreading : corolla white, subglobose or ovoid-globose, $2.5-3.5 \mathrm{~mm}$. in diameter : capsules spheroidal, $3 \mathrm{~mm}$. in diameter, 5-6ribbed. [Andromeda ligustrina Muhl.]

In swamps and on hillsides, Canada to Florida and Arkansas. 


\section{OXYDÉNDRON DC.}

Trees, with a furrowed bark and terete branches. Leaves alternate, deciduous : blades toothed, elongated. Flowers perfect, in graceful horizontally expanded panicles. Calyx persistent, of 5 valvate sepals. Corolla ovoid, drooping, with 5 short lobes. Stamens 10, included : filaments broadened: anthers linear, awnless, the sacs opening by terminal chinks. Disk 10-lobed. Ovary 5-celled. Stigma entire. Ovules numerous. Capsule erect, ovoid, loculicidally 5-valved.

1. Oxydendron arbòreum (L.) DC. A shrub or tree sometimes $20 \mathrm{~m}$. tall, with shallowly furrowed bark, the trunk sometimes $6 \mathrm{dm}$. in diameter. Leaf-blades oblong, elliptic or oblong-lanceolate, $8-20 \mathrm{~cm}$. long, acuminate, serrate, lustrous above: panicles 1-2 dm. long, the branches distichous: pedicels $3-10 \mathrm{~mm}$. long, drooping in flower, erect in fruit, often with several ovate scales : calyx puberulent: sepals ovate, $1.5 \mathrm{~mm}$. long, acute or acuminate : corolla white, wax-like, conic, $6-7 \mathrm{~mm}$. long, constricted at the throat ; lobes ovate, obtuse or mucronulate: capsules 4-5 mm. high, angled, canescent.

In woods, Pennsylvania to Ohio, Florida and Alabama. Summer. Sour-wood. Sorrel-tree. SOUR GuM. Titi.

\section{EPIGAìA L.}

Low evergreen shrubby plants, with creeping stems. Leaves alternate: blades leathery, entire. Flowers perfect or dioecious, often heteromorphous, in axillary clusters. Calyx subtended by several bracts : sepals 5, imbricated, persistent. Corolla white or pink, salverform: limb usually with 5 lobes. Stamens 10, included: filaments adnate to the base of the corolla-tube : anthers elongated, awnless. Disk 10-lobed. Ovary 5-celled, 5lobed, pubescent. Stigma 5-lobed. Ovules numerous in each cavity. Capsule depressedglobose, loculicidally 5-valved, hirsute. Training Arbutus.

1. Epigaea rèpens L. Bright green, hirsute. Stems branched at the base, the branches creeping, 0.5-3 dm. long: leaves persistent; blades leathery, oblong to oblongovate or suborbicular, $2-10 \mathrm{~cm}$. Iong, apiculate or acute, reticulated, ciliate, rounded or cordate at the base; petioles $6-30 \mathrm{~mm}$. long: clusters few-many-flowered : bracts ovate to lanceolate, acute : calyx glabrous or nearly so : sepals lanceolate, acuminate, 5-6 mm. long: corolla pink or white; tube cylindric, nearly twice as long as the sepals ; lobes spreading, ovate obtuse, about $\frac{1}{2}$ as long as the tube, pubescent within : capsules spheroidal, pubescent.

In sandy or rocky soil, Newfoundland to the Northwest Territory, south to Florida, Kentucky and Michigan. Spring. MAYFLOWER.

\section{GAULTHÈRIA L.}

Evergreen shrubs, various in habit, with horizontal or erect stems. Leaves usually alternate: blades leathery. Flowers solitary in the axils, or in racemes. Calyx sometimes subtended by several bracts : sepals longer than the hypanthium, often accrescent. Corolla campanulate or urn-shaped, with 5 spreading or recurved lobes. Stamens 10, included: filaments adnate to the base of the corolla-tube: anthers usually 2 -awned, opening by terminal pores. Disk 10-lobed. Ovary 5-celled, 5-lobed, glabrous. Stigma entire. Ovules numerous in each cavity. Berry fleshy, inclosed in the accrescent hypanthium and calyx, often highly colored and aromatic.

1. Gaultheria procúmbens L. Perennial, glabrous or minutely pubescent with upcurved hairs. Stems creeping, the branches erect or ascending, 3-15 mm. high, rarely branching, leafy at the top : leaves persistent; blades leathery, oval or elliptic, varying to ovate or obovate, or often apiculate, serrate with bristle-tipped teeth, commonly variegated above, narrowed into short petioles: pedicels $4-8 \mathrm{~mm}$. long, recurved, with 2 broadly ovate bractlets : calyx white : sepals ovate, acutish, ciliolate : corolla white, wax-like, ovoid, 6-7 mm. long, with a flat base ; tube constricted at the throat; lobes ovate, obtuse, recurved, villous within : filaments densely villous : fruit subglobose, 7-11 mm. in diameter, bright red or white, spicy.

In woods, Newfoundland to Manitoba, Georgia and Michigan. Spring and summer. Creeping WINTERGREEN.

\section{Family 5. VACCintàceat lindl. HuCkleberry Family.}

Shrubs or small trees, sometimes evergreen. Leaves alternate : blades simple, mostly ciliate. Flowers perfect, regular, in variously disposed clusters, or solitary. Calyx of $4-5$ sepals. Corolla usually gamopetalous. Androecium of 
twice as many stamens as there are corolla-lobes. Filaments usually flattened, epigynous or adnate to the base of the corolla. Anthers 2-celled, attached by the back, sometimes 2-awned. Gynoecium compound. Ovary 2-10 celled, inferior, crowned with the epigynous disk. Styles united. Stigmas simple or minutely 4-5-toothed. Ovules anatropous, solitary or several in each cavity. Fruit a berry or drupe, pulpy. Seeds or nutlets 1-several. Testa bony. Endosperm fleshy. Embryo central.

Ovary 10-celled: fruit a berry-like drupe with 10 nutlets.

Ovary 4-5-celled : fruit a many-seeded berry.

1. Gaylussacia.

Petals more or less united.

Petals united to near their tips into a variously shaped corolla.

Upright shrubs or trees: ovary wholly inferior: berries variously colored.

Corolla campanulate.

Stamens included: hypanthium jointed to the pedicel.

Stamens exserted: hypanthium continuous with the pedicel.

Corolla globose, ovoid, urn-shaped to eylindric.

Creeping shrubby plants : ovary half-inferior: berries white, acute.

Petals united only near the base, the lobes curled back. Petals distinct.

2. BATODENDRON.

3. POLYCODIUM.

4. VACCINIUM.

5. CHIOGENES.

6. Hugeria.

7. OXYCoccus.

\section{GAYLUSSACIA H.B.K.}

Often evergreen shrubs, with erect or underground stems. Leaves alternate: blades mostly entire, usually glandular. Flowers varying from white to red, in axillary drooping racemes. Sepals 5. Corolla campanulate to tubular-conic, terete or 5-angled : lobes 5, erect or reflexed. Stamens 10, usually included : filaments distinct, more or less winged : anther-sacs prolonged into tubes. Disk ring-like or swollen. Ovary 10-celled: style often exserted. Ovules solitary in each cavity, pendulous. Drupe with a 10-celled stone, the 10 nutlets bony or horny. Seeds solitary, flattened. Testa very thin. Huckleberry. The plants flower in the spring and mature their fruit in the summer.

Corolla campanulate or globose-campanulate: leaves destitute of sticky resin.

Stems horizontal, underground, the branches erect.

Pubescence consisting of gland-tipped hairs.

Twigs and racemes pubescent with short close-set hairs. $\quad 1$. G. dumosa.

Twigs and racemes bristly-hispid.

Pubescence consisting of simple non-glandular hairs.

Leaves glaucous, glabrous or nearly so.

Leaves densely tomentose, especially beneath.

Stems erect. the branches spreading.

Leaves firm; blades obtuse or retuse : drupe glaucous.

Leaves flaccid ; blades acuminate and apiculate: drupe black.

Corolla conic: leaves sticky with a resinous secretion.

2. G. hirtella.

3. G. nana.

4. G. tomentosa.

5. G. fromdosa.

6. G. ursina.

7. G. resinosa.

1. Gaylussacia dumòsa (Andr.) T. \& G. A low shrub, 1-5 dm. tall, with underground stems and erect solitary or tufted branches, the twigs, leaves and inflorescence glandular-pubescent. Leaf-blades leathery, oval, obovate or oblanceolate, rarely linear-lanceolate, 2-4 cm. long, apiculate at the apex, ciliate, short-petioled, deep green above, paler beneath : calyx glandular, about $5 \mathrm{~mm}$. broad : sepals triangular or triangular-ovate, acute, about as long as the hypanthium : corolla campanulate, $5-6 \mathrm{~mm}$. long, white or pink, wax-like; lobes broadly ovate, more or less recurved or revolute : filaments pubescent : anthers longer than the filaments, prolonged into filiform tubes : drupes globose, black, 6- 8 $\mathrm{mm}$. in diameter, commonly somewhat pubescent.

In sandy soil, Newfoundland and along the coast to New York, south to eastern Pennsylvania, North Carolina, Florida and Louisiana. DWARF HUCKLEBERRY.

2. Gaylussacia hirtélla (Ait.) Klotzsch. A shrub, with underground stems, the branches, twigs and inflorescence bristly-hispid, the tips of the hairs with minute glands. Leaf-blades oblanceolate-spatulate or elliptic, 3-6 $\mathrm{cm}$. long, apiculate, glandular-ciliate, sparingly hispid above, short-petioled: racemes many-flowered: calyx hispid, $6 \mathrm{~mm}$. broad: sepals triangular, rather acuminate, about as long as the hypanthium: corolla broadly campanulate, $7-8 \mathrm{~mm}$. long; lobes broader than long, the tips recurved, the edges revolute : filaments pubescent: anthers longer than the filaments, prolonged into filiform tubes: drupes not seen. [G. dumosa var. hirtella A. Gray.]

In sand, Florida to Louisiana.

3. Gaylussacia nàna (A. Gray) Small. A low glaucous shrub 1-4 dm. tall, spreading by underground stems. Leaf-blades leathery, elliptic, obovate or nearly spatulate, $2-3 \mathrm{~cm}$. long, obtuse or minutely apiculate at the apex, glaucous on both sides, becoming bright green above, prominently rugose and sprinkled with amber-colored resin beneath, short-petioled: racemes few-flowered: pedicels slender, puberulent when young: calyx 
glabrous, $3 \mathrm{~mm}$. broad : sepals triangular, acute, about as long as the tube : corolla globosecampanulate, $3 \mathrm{~mm}$. long; lobes ovate, acutish, longer than broad : filaments glabrous: anthers longer than the filaments, prolonged into slender tubes: drupes subglobose, $6-7$ $\mathrm{mm}$. in diameter, rather dry, glaucous.

In sandy pine lands, Georgia to Florida and Alabama.

4. Gaylussacia tomentòsa (Pursh) Chapm. A low shrub, spreading by underground stems, the foliage tomentose with brownish hairs. Leaf-blades leathery, oblong or elliptic, often slightly broadest above the middle, $2.5-7 \mathrm{~cm}$. long, obtuse and apiculate at the apex or sometimes notched, brown-tomentose on both sides, densely so beneath, shortpetioled : racemes few-flowered : pedicels $5-15 \mathrm{~mm}$. long: calyx glabrous, about $3.5 \mathrm{~mm}$. broad : sepals ovate, acute, about as long as the hypanthium : corolla white or pink, campanulate, $3.5 \mathrm{~mm}$. long; lobes ovate, about as long as broad, the tips recurved, the edges revolute : filaments dilated, glabrous : anthers longer than the filaments : drupes depressedglobose, $8-9 \mathrm{~mm}$. in diameter, glaucous.

In sand or sandy soil, Georgia and Florida.

5. Gaylussacia frondòsa (L.) T. \& G. An irregularly branched shrub 1-3 m. tall, with puberulent twigs and young leaves. Leaf-blades oblong-oblanceolate, ovate, oval or obovate, obtuse or notched at the apex, delicately revolute, short-petioled, bright green and glabrate above, glaucous and sprinkled with minute golden globules of resin beneath: racemes loose : pedicels long and slender : calyx glabrous, $3-4 \mathrm{~cm}$. broad : sepals triangular, acute or acutish, about as long as the hypanthium : corolla globose-campanulate, about 4 mm. long, green to purplish ; lobes triangular, broader than long, recurved and revolute : filaments dilated, glabrous:-anthers longer than the filaments, prolonged into slender tubes : drupes globose, $8-10 \mathrm{~mm}$. in diameter, with a pale bloom.

In sandy soil or cold swamps, New Hampshire to Kentucky, Florida and Louisiana. TANGLEBERRY. Dangleberry. BLUe Tangle.

6. Gaylussacia ursìna (M. A. Curtis) T. \& G. A straggling branching shrub, 6-15 dm. tall, with sparingly pubescent twigs and young foliage. Leaf-blades dark green, thin, oblong, elliptic or oblanceolate, usually rhomboidal, $4-10 \mathrm{~cm}$. long, usually short-acuminate, apiculate, ciliate, deep green above, paler beneath, pubescent on the nerves on both sides, obtuse or rounded at the base, short-petioled : flowers few, in lateral somewhat drooping racemes: calyx and hypanthium with numerous golden glands, about $3 \mathrm{~mm}$. broad: sepals 5, very low, obtuse : corolla globose-campanulate, greenish white or twany-red, about 4-5 mm. long; lobes triangular, acutish, recurved, revolute: filaments dilated, pubescent, incurved at the apex, longer than the anthers each sac of which is prolonged into a short tube at the apex : drupes globose, $10-12 \mathrm{~mm}$. in diameter, black, shining, sweet.

In deep forests on the mountains, North Carolina and northern Georgia. BEAR HUCKLEBERRY.

7. Gaylussacia resinòsa (Ait.) T. \& G. A rigid branching shrub $3-10 \mathrm{dm}$. tall, its twigs and foliage more or less pubescent and sticky with a resinous secretion when young. Leaf-blades elliptic, oval or oblong, sometimes broadest above the middle, firm, obtuse or apiculate, entire, ciliolate, short-petioled : racemes drooping: pedicels $2-8 \mathrm{~mm}$. long, usually with two narrow bracts : calyx about $2 \mathrm{~mm}$. broad : sepals 5 , ovate, obtuse, about as long as the hypanthium: corolla obconic, red or reddish green, 5-6 mm. long, more or less constricted near the apex ; lobes ovate, spreading or recurved, revolute, obtuse : filaments winged, pubescent, shorter than the anthers, each sac of which is prolonged into a tube : drupes globose, 6-10 $\mathrm{mm}$. in diameter, black or rarely white, sweet.

In rocky woods and on hillsides, Newfoundland to the Saskatchewan, south to Georgia.-A form ranging from Maine to North Carolina, with larger fruit which is blue and with a bloom, is known as $G$. resinosa glaucocárpa Robinson. BLACK OR HIGH BUSH HUCKLEBERRY.

\section{BATODÉNDRON Nutt.}

Shrubs or small trees. Leaves alternate : blades leathery, often lustrous, commonly entire or nearly so, or glandular-denticulate. Flowers in leafy-bracted sometimes dilated racemes or panicles. Calyx persistent: sepals 5, free. Corolla campanulate, white or pink: lobes 5 , erect or slightly recurved. Stamens 10 : anthers included. Filaments distinct. Anthers 2-awned on the back : sacs prolonged into slender tubes. Ovary inferior, 5-celled. Berries black: mostly inedible. Seeds numerous. FarkLEbERry. SPARKLEBerry. Tree Huckleberry. Gooseberry.

Bracts of the racemes or panicles much smaller than the leaves and mainly differently shaped: corolla open-campanulate.

Bracts of the racemes or panicles similar to the leaves and but slightly smaller : corolla globular-campanulate.

Leaves green : blades mainly oval, less than $2.5 \mathrm{~cm}$. long, finely toothed.

Leaves glaucous: blades mainly cuneate, over $2.5 \mathrm{~cm}$. long, entire.

1. B. arboreum.

2. B. andrachneforme.

3. B. glaucescens. 
1. Batodendron arbòreum (Marsh.) Nutt. A shrub or small tree, usually much branched. Leaves numerous; blades leathery oval or obovate, $2.5-5 \mathrm{~cm}$. long, usually acute or apiculate at the apex, entire or glandular-toothed, deep green and lustrous above, slightly paler beneath, short-petioled : racemes or panicles spreading, more or less copiously bracted : pedicels slender : corolla open campanulate, white or pinkish ; lobes $\frac{1}{2}$ or $\frac{1}{3}$ as long as the tube : anthers included : style exserted : berries subglobose, 5-6 $\mathrm{mm}$. in diameter, scarcely edible, black. [ Vaccinium arboreum Marsh.]

In sandy woods and sandy soil, North Carolina to Illinois and the Indian Territory, Florida and Texas. Late spring.

2. Batodendron andrachnefórme Small. A much branched shrub resembling $B$. arboreum, but with very numerous and conspicuously smaller leaves, the twigs finely pubescent. Leaf-blades leathery, mainly oval, $1-1.5 \mathrm{~cm}$. long or slightly larger but less than 2 $\mathrm{cm}$. long, finely toothed, deep green and shining above, paler, dull and finely pubescent beneath : racemes or panicles with leaf-like bracts : pedicels $2-6 \mathrm{~mm}$. long : corolla globular-campanulate, about $4 \mathrm{~mm}$. long, the lobes barely $\frac{1}{4}$ as long as the tube.

On bluffs, Missouri and Arkansas. Spring.

3. Batodendron glaucéscens Greene. An irregularly branched shrub, the twigs finely pubescent. Leaf-blades leathery, mainly cuneate, $3-6 \mathrm{~cm}$. long, glaucescent on both sides, but less copiously so above : racemes or panicles with leaf-like bracts : pedicels 6-13 $\mathrm{mm}$. long: corolla about $5 \mathrm{~mm}$. long, the lobes barely $\frac{1}{4}$ as long as the tube.

In dry or sandy soil, the Indian Territory. Spring.

\section{POLYCÒDIUM Raf.}

Shrubs, with erect or horizontal stems. Leaves alternate : blades longer than broad, entire. Flowers in simple or branched more or less copiously bracted racemes. Calyx persistent: sepals 5. Corolla campanulate, white or pink or purplish green : lobes not contiguous in the bud, nearly erect at maturity. Stamens 10, erect : anthers conspicuously exserted : filaments distinct: anthers 2 -awned on the back : sacs prolonged into slender tubes. Ovary inferior, 5-celled. Berries subglobose, green or yellowish, often mawkish. Seeds few. Buckberry. Squaw Huckleberry Deerberry.

Racemes with bracts resembling the leaves.

Racemes with bracts conspicuously smaller than the leaves.

Leaf-blades glabrous.

Leaf-blades more or less pubescent, especially beneath.

Berries green, greenish, yellowish or glaucous.

Leaf-blades green beneath, the hairs inconspicuous : berries green or yellowish.

Leaf-blades glaucous beneath, the hairs pale or white: fruit glaucous. Berries dark plum-purple.

1. P. caesium.

2. P. neglectum.

3. P. stamineum.

4. P. candicans.

5. P. melanocarpum.

1. Polycodium caèsium Greene. An irregularly branched shrub 2-12 dm. tall, with sparingly pubescent or glabrate green or more or less glaucous foliage. Leaf-blades various, relatively thin, elliptic, oblong or oblong-ovate, $1.5-4 \mathrm{~cm}$. long, obtuse, acute or apiculate, ciliolate, often revolute and slightly rugose in age, short-petioled, the broader ones subcordate at the base : racemes or panicles conspicuously bracted, few-flowered : bracts mainly similar to the leaves: pedicels shorter than the bracts : berries subglobose, about $10 \mathrm{~mm}$. in diameter. 「Vaccinium caesium Greene. $\rceil$

In pine lands or hammocks. South Carolina to Florida.-P. oblongum Greene, a little known species of western Tennessee, is said to have corolla-lobes $1 / 2$ as long as the tube, and pedicels longer than the bracts, at least during anthesis.

2. Polycodium negléctum Small. A branching shrub $1-1.5 \mathrm{~m}$. tall, with glabrous foliage. Leaf-blades relatively thin, sometimes firm at maturity, elliptic to oblong or oblong-lanceolate, or occasionally cuneate, $3-10 \mathrm{~cm}$. long, acute or slightly acuminate, gradually or abruptly narrowed at the base, glabrous, sometimes glaucous at least when young : racemes or panicles few-or often many-flowered : bracts much smaller than leaves : corolla white or pink : berries subglobose or globose-obovoid, $5-8 \mathrm{~mm}$. in diameter, green or yellow, mostly inedible.

In open woods and thickets, Virginia to Kansas, Florida, Alabama and Louisiana.

3. Polycodium stamineum (L.) Greene. A branching shrub, 1-2 m. tall, with more or less pubescent foliage. Leaf-blades oblong or elliptic, varying to oblong-lanceolate or oblong-cuneate, $3-7 \mathrm{~cm}$. long, green and inconspicuonsly pubescent beneath : rachis of the raceme or panicle, and the pedicels, pubescent : corolla $4-5 \mathrm{~mm}$. long: berries globular, about $10 \mathrm{~mm}$. in diameter, green. [Vaccinium stamineum L.]

In open woods and on hillsides, Maine and Ontario to Minnesota, Georgia and Alabama.-A form, 
perhaps specifically distinct, with relatively narrower and more acuminate leaf-blades and more exserted stamens, occurs from Tennessee to Louisiana.

4. Polycodium cándicans (C. Mohr) Small. An erect branching shrub 1-2 m. tall, with pale and pubescent foliage. Leaf-blades narrowly oblong or elliptic, 3-8 cm. long, acuminate or sometimes only acute, deep green or bright green above, glaucous and pubescent beneath with pale or white hairs, narrowly subcordate or truncate at the base : rachis of the raceme or panicle and the pedicels pubescent like the twigs: hypanthium glabrous: corolla white, about $5 \mathrm{~mm}$. long : berries globular, fully $10 \mathrm{~mm}$. in diameter, glaucous. [ Vaccinium melanocarpum candicans C. Mohr.]

In woods, Pennsylvania to Georgia and Alabama.

5. Polycodium melanocárpum (C. Mohr) Small. An irregularly branching shrub 0.5-1.5 m. tall, with tomentose or tomentulose young foliage. Leaf-blades firm at maturity, oblong to oblong-lanceolate, $2-10 \mathrm{~cm}$. long, acute or slightly acuminate, ciliate, permanently tomentose at least beneath, short-petioled, never subcordate : racemes or panicles few or many-flowered : pedicels curved, slightly enlarged upward, $5-10 \mathrm{~mm}$. long, hairy: bracts oblong to ovate, acute or apiculate, persistent: hypanthium usually more or less pubescent : lerries globular or pyriform, $8-10 \mathrm{~mm}$. in diameter, deep plum-purple, shining, palatable but slightly tart; pulp juicy, deep purple. [Vaccinium stamineum var. melanocarpum C. Mohr. 1

In mountain woods, North Carolina to Missouri, Georgia and Alabama.

\section{VACCÍNIUM L.}

Shrubs or small trees. Leaves alternate, sometimes persistent: blades membranous or leathery, entire or toothed. Flowers in terminal or axillary racemes or clusters or rarely solitary, appearing before the leaves or with them. Calyx persistent : sepals 4-5. Corolla white, pink or red, campanulate, tubular or urn-shaped. Stamens twice as many as the sepals : anthers sometimes awned; sacs prolonged into terminal tubes, opening by pores or chinks. Ovary 4-5-celled or 8-10-celled by false partitions. Berries red, blue or black, sometimes with a bloom. BluEBERRY.

Leaves persistent, evergreen; blades leathery.

Vine-like shrub, with elongated, spreading, decumbent or procumbent branches : corolla campanulate, $4 \mathrm{~mm}$. long.

Erect shrubs : corolla cylindric or conic-cylindric, $6 \mathrm{~mm}$. long.

Sepals obtuse : leaf-blades glandular-toothed: berries black.

Sepals acute: leaf-blades bristly-toothed: berries blue.

Leaves deciduous, or somewhat persistent southward: blades membranous, or

thicker southward but not truly leathery.

Corolla cylindric or nearly so, mostly over twice as long as thick.

Leaf-blades more or less pubescent beneath.

Leaves with serrulate blades.

Flowers appearing after the leaves: leaf-blades mainly less than $2 \mathrm{~cm}$. long.

Leaf-blades narrowly elliptic or elliptic-spatulate, not rounded at the base: berries glaucous: plants mainly less than $4 \mathrm{dm}$. tall.

Leaf-blades oval or ovate, rounded at the base: berries not glaucous: plants mainly over $15 \mathrm{dm}$. tall.

Flowers appearing before the leaves: leaf-blades mainly over $3 \mathrm{~cm}$. long. Leaves with entire blades.

Corolla rose-red : berries not glaucous.

Corolla white : berries glaucous.

Leaf-blades copiously brown-pubescent beneath.

Leaf-blades sparingly and inconspicuously pubescent beneath.

Leaf-blades glabrous beneath.

Corolla urn-shaped, or somewhat campanulate, mostly less than twice as long as thick.

Ovary and berry glabrous.

Leaf-blades pubescent beneath.

Leaf-blades entire: berries not glaucous.

Leaf-blades serrulate: berries glaucous.

Leaf-blades glabrous beneath.

Berries 8-12 mm. in diameter: stout shrub mostly over $1 \mathrm{~m}$. tall.

Berries $6 \mathrm{~mm}$. in diameter or less : low shrub mostly less than $0.8 \mathrm{~m}$. tall. Ovary and berry glandular-hirsute.
4. V. tenellum.
5. V. Elliottii.
6. V. virgatum.
7. V.formosum.
8. V. fiscatum.
9. V. corymbosum.
10. V. australe.

1. Vaccinium crassifòlium Andr. A vine-like shrub, with elongated spreading decumbent or procumbent branches, the twigs finely pubescent. Leaves numerous: blades leathery, oval or elliptic, varying to ovate or obovate, or suborbicular near the base of the plant, obtuse, shallowly toothed or nearly entire : hypanthium and calyx glabrous : corolla rose-red, campanulate, $4 \mathrm{~mm}$. long.

In moist sandy pine lands, North Carolina to Georgia. Spring. 
2. Vaccinium nítidum Andr. A branching shrub 3-6 dm. tall, with smooth and glabrous foliage, or the branches sometimes finely pubescent. Leaves numerous; blades obovate to elliptic, 6-12 $\mathrm{mm}$. long, acute or apiculate, shallowly toothed and often glandular-ciliate, lustrous at least above, nearly sessile : racemes umbel-like : sepals rounded, obtuse, like the bracts: corolla rose-red, often becoming white, $6 \mathrm{~mm}$. long, slightly narrowed upward : berries obovoid-globose or subglobose, 4-5 $\mathrm{mm}$. long, black.

In dry pine lands, Georgia and Florida. Spring.

3. Vaccinium Myrsinites Lam. A much branched shrub 2-6 dm. tall with glabrous and sometimes glaucous foliage at maturity, the young foliage usually puberulent. Leafblades obovate to oblanceolate, oblong or elliptic, $8-20 \mathrm{~mm}$. long, acute or cuspidate or sometimes rather obtuse, shallowly toothed or nearly entire, lustrous above, paler or glaucous beneath, sessile or nearly so : racemes very short or umbel-like : sepals acite or acutish : corolla white, slightly narrowed upward or becoming cylindric, $6 \mathrm{~mm}$. long: berries subglobose, 5-8 mm. in diameter, blue.

In pine lands, North Carolina to Florida and Louisiana. Spring.

4. Vaccinium tenéllum Ait. A relatively low shrub, with underground stems, the branches upright, $2-4 \mathrm{dm}$. tall, finely pubescent, mostly branched: leaves numerous ; blades elliptic to elliptic-spatulate, 1-2 cm. long, acute or slightly acuminate at both ends, serrulate, pale green and rather conspicuously but delicately nerved beneath, nearly sessile : racemes often umbel-like, appearing after the leaves: pedicels shorter than the corollas, slightly pubescent : corolla white or nearly so, oblong-cylindric, 5-6 $\mathrm{mm}$. long, slightly constricted at the throat ; lobes very short, obtuse : berries subglobose, about $6 \mathrm{~mm}$. long, black, with a bloom.

In pine lands, Virginia to Florida and Mississippi. Spring.

5. Vaccinium Ellióttii Chapm. A shrub 1-2.5 m. tall, with glabrous or sparingly pubescent zigzag branches. Leaves often numerous ; blades ovate, oval or elliptic, 1-2.5 $\mathrm{cm}$. long, acute at the apex, or rounded at the base, ciliate-serrulate, somewhat lustrous above, dull and more or less pubescent beneath, nearly sessile: racemes umbel-like, few flowered, appearing after the leaves : pedicels shorter than the corollas, glabrous or nearly so : corolla reddish, conic, $5-6 \mathrm{~mm}$. long; lobes very short: berries subglobose, $7-8 \mathrm{~mm}$. in diameter, black.

In pine lands. South Carolina to Florida and Texas. Early spring.

6. Vaccinium virgàtum Ait. A shrub 1-3.5 $\mathrm{m}$. tall, with slender branches and puberulent twigs. Leaf-blades oblong-elliptic or oval-oblong, $2.5-6 \mathrm{~cm}$. long, narrowed at both ends, serrulate, deep green above, pale or glaucescent beneath, short-petioled : racemes cluster-like or only slightly elongated, appearing before the leaves: corolla white or pinkish, 6-8 $\mathrm{mm}$. long, nearly cylindric, slightly narrowed at the throat: berries subglobose, 5-7 mm. in diameter, black, sometimes with a slight bloom.

In sandy swamps, Virginia to Florida and Louisiana. Spring.

7. Vaccinium formòsum Andr. A branching shrub 3-12 dm. tall, with bright green twigs. Leaf-blades ovate, elliptic or oblong, 2.5-6 cm. long, acute at the apex, entire, rounded at the base, deep green and almost glabrous above, more or less pubescent, shortpetioled : flowers in clusters appearing before the leaves : corolla rose-red, 7-8 mm. long, cylindric-conic ; lobes very small : berries globular, 5-6 mm. in diameter, not glaucous.

In and about swamps, Georgia and Florida. Spring.

8. Vaccinium fuscatum Ait. A branching shrub, 1-2 m. tall, the twigs finely and often copiously pubescent. Leaf-blades thickish, oblong or elliptic, $2-4.5 \mathrm{~cm}$. long, acute, entire, more or less copiously pubescent beneath with brownish hairs: flowers appearing with the leaves: corolla white, 6-7 $\mathrm{mm}$. long : berries globular, $6-7 \mathrm{~mm}$. in diameter, somewhat glaucous.

In and about swamps, Georgia to Florida, Arkansas and Lonisiana. Spring.

9. Vaccinium corymbòsum L. A shrub $1-4 \mathrm{~m}$. tall, with rigid spreading branches and puberulent or glabrous twigs. Leaf-blades oblong to elliptic, $2.5-8 \mathrm{~cm}$. long, usually acute at both ends, entire, mostly ciliate, pubescent at least on or near the nerves beneath, short-petioled : racemes appearing before the leaves, fully as long as the peduncles: bracts deciduous : corolla white or pale pink, cylindric or slightly constricted near the throat, 6-12 mm. long; lobes 5 : berries subglobose, 6-8 mm. in diameter, deep blue, beneath the bloom, edible.

In swamps about meadows and in moist woods, Newfoundland to Minnesota, south to Florida and Louisiana. Spring. TALL BLUEBERRY.

10. Vaccinium austràle Small. A branching shrub $3-15 \mathrm{dm}$. tall, with wholly glabrous foliage. Leaf-blades elliptic or oval, or elliptic-ovate to oblong-elliptic, mainly 4-8 
cm. long, rarely shorter, acute, entire, deep-green above, pale beneath, glabrous, shortpetioled: corolla white or whitish, nearly cylindric, 7-8 mm. long : berries globular, 7-9 $\mathrm{mm}$. in diameter, glaucous.

In and about swamps and along rivers, Georgia and Florida, and perhaps northward along the Atlantic coast. Spring.

11. Vaccinium atrocóccum (A. Gray) Heller. A shrub similar to V. corymbosum in habit, more or less pubescent. Leaf-blades oval to elliptic or sometimes slightly broadest above the middle, acute, entire, dark green above, paler beneath and more or less pubescent : flowers appearing with the leaves : corolla white or pinkish, campanulate, 4-6 mm. long: berries globular, $6-10 \mathrm{~mm}$. in diameter, not glaucous.

In swamps and moist woods, New Brunswick to Ontario and North Carolina. Spring.

12. Vaccinium simulàtum Small. A shrub resembling V. pallidum. Leaf-blades thinnish, elliptic to oblong or elliptic-lanceolate, $2.5-7 \mathrm{~cm}$. long, somewhat acuminate or merely acute, serrulate, bright green above, more or less pubescent and pale or glaucescent beneath : flowers appearing after the leaves: corolla white or pinkish green, urn-shaped, $3.5-4.5 \mathrm{~mm}$. long : berries globular, 5-7 $\mathrm{mm}$. in diameter, somewhat glaucous.

In woods, southern New York and Pennsylvania to Georgia and Alabama. Spring.

13. Vaccinium pállidum Ait. An asymmetrical shrub 1-2.5 m. tall, with glabrous, bright green twigs. Leaf-blades ovate, oval or oblong, 2.5-7 cm. long, acute or acuminate at the apex, ciliate-serrulate, bright green above, pale or glaucous and wholly glabrous beneath, short-petioled : racemes several-flowered : corolla greenish pink, campanulate or slightly urn-shaped, 4-5 mm. long : berries subglobose, $8-12 \mathrm{~mm}$. in diameter, deep blue, with a bloom, delicious.

In woods, and on open slopes or summits, mountains of Virginia to Georgia and Alabama. Spring MOUNTAIN BLUEBERRY.

14. Vaccinium vacillans Kalm. A shrub 1-2 dm. tall, with rigid glabrous yellowish green branches and twigs. Leaf-blades oval, broadly oblong or sometimes ovate to obuvate, 2-5 cm. long, usually apiculate, nearly entire or serrulate, glabrous, pale or glaucous beneath, short-petioled : racemes short or cluster-like, few-flowered : corolla pink or whitish, cylindric-oblong, slightly constricted at the throat, 4-6 mm. long; lobes 5: berries subglobose, 4-7 mm. in diameter, blue, with a bloom, sweet.

In dry or rocky soil, Maine to Ontario and Michigan, south to Georgia and Missouri. Spring BLUE HUCKLEBERRY.

15. Vaccinium hirsùtum Buckl. An irregularly branching shrub $3-10 \mathrm{dm}$. tall, with finely hirsute foliage at least when young. Leaf-blades oblong to elliptic or oblongovate, 2-3 cm. long, acute or cuspidate, entire, deep green above, paler and more pubescent beneath especially on the nerves, very short-petioled: racemes few-flowered: hypanthium and calyx, like the pedicel, closely hirsute : sepals acute : corolla pale or reddish, ovoid-campanulate, 9-12 mm. long, persistently hirsute : ovary glandular-hirsute : berries subglobose, 6-7 mm. in diameter, purplish black.

On shaded mountain slopes, North Carolina to Tennessee and Georgia. Summer.

\section{CHIÓGenes Salisb.}

Evergreen shrubs, with prostrate creeping stems, the foliage finely pubescent. Leaves small, alternate, 2-ranked. Flowers solitary, subtended by 2 bracts. Sepals 4 , free. Corolla campanulate, with 4 rounded lobes. Stamens 8, included: filaments rough: anthers destitute of awns; sacs not prolonged into tubes at the apex, opening from apex to middle. Ovary 4-celled, crowned with an 8-lobed disk. Berry white, 4-celled, mealy. Seeds numerous. SNowbERRY.

1. Chiogenes hispídula (L.) T. \& G. Perennial, evergreen. Stems branched at the base, the branches creeping, strigose : leaf-blades leathery, oval or suborbicular, 3-13 $\mathrm{mm}$. long, abruptly pointed, ciliate, pale beneath, revolute, short-petioled : pedicels solitary in the axils, 1-3 mm. long: calyx minutely pubescent: sepals 4 , the outer much broader than the inner: corolla white, campanulate, somewhat longer than the calyx;
lobes acute: berries subglobose, $5-6 \mathrm{~mm}$. in diameter, white, bristly, aromatic, crowned with the calyx.

In damp woods and swamps, Newfoundland to 'British Columbia south along the mountains to North Carolina, and Michigan. Spring.

\section{HUGÈRIA Small.}

Shrubs, with upright branching stems. Leaves alternate, deciduous : blades rather thin, finely serrate, short-petioled. Flowers solitary on axillary pedicels, drooping. Sepals 
4 , or rarely 5, broad. Petals 4-5, markedly united at the base, the narrow lobes curled back. Stamens 8-10: anthers conspicuously exserted : filaments pubescent. Ovary 4-5celled : style elongated. Berries subglobose, drooping, red. Mountain Cranberry.

2. Hugeria erythrocárpa (Michx.) Small. A widely branching shrub 1-2 m. tall. Leaf-blades oblong or ovate-lanceolate, or ovate, $2.5-7.5 \mathrm{~cm}$. long, rather thin, acuminate, finely serrate with bristle-tipped teeth, flat, green on both sides but paler beneath, shortpetioled : pedicels solitary, axillary, recurved, less than $\frac{1}{2}$ as long as the leaves: sepals acuminate : corolla red; lobes lanceolate, $8-10 \mathrm{~mm}$. long, curled back : filaments villous, about $\frac{1}{2}$ as long as the anthers : berries subglobose, 4-6 mm. in diameter, deep red, acid. [Vaccinium erythrocarpon Michx.]

On mountain slopes or summits, Virginia to Tennessee and Georgia. Spring and summer.

\section{OXYcóccus Hill.}

Shrubs, with trailing or creeping stems. Leaves alternate, persistent: blades entire, leathery. Flowers solitary or several together, nodding from axillary or terminal stalks. Sepals 4-5. Petals 4-5, pink or red, conic in bud, distinct, narrow, recurved. Stamens 8-10. Anthers converging into a conspicuous long-exserted cone: sacs prolonged into slender tubes opening by apical pores. Ovary 4-5-celled. Berries globose or somewhat elongated or rarely depressed, red, very juicy, sour or tart. Cranberry.

1. Oxycoccus macrocárpus (Ait.) Pers. Foliage glabrous. Stems creeping, elongated, sometimes $1 \mathrm{~m}$. long, branched: leaves numerous; blades oblong, or rarely varying to ovate or orbicular, 6-14 $\mathrm{mm}$. long, obtuse at both ends, entire, more or less copiously glaucous beneath, revolute, short-petioled : pedicels slender, recurved at the tip : flowers usually few, nodding : sepals acutish : petals white or pale pink, 7-8 mm. long, lanceolate : filaments puberulent, about $\frac{1}{3}$ as long as the anthers: berries subglobose or often oval, ovoid or depressed, 1-2 cm. in diameter, red, acid. [Vaccinium macrocarpon Ait.]

In bogs or low sandy soil, Newfoundland to the Northwest Territory, south to North Carolina, Michigan and Minnesota. Summer.

\section{Family 6. DIAPENSIÀCeat link. Diapensia Family.}

Perennial, caulescent shrubby herbs. Leaves alternate, sometimes numerous and crowded, without stipules: blades mostly leathery, simple. Flowers perfect, solitary or in terminal racemes. Calyx of 5 partially united sepals, persistent. Corolla white, pink or purple, of 5 distinct or partially united equal petals. Androecium of 5 stamens. Filaments adnate to the throat of the corolla-tube. Staminodia wanting. Anthers 1-2-celled. Pollen of simple grains. Gynoecium of 3 united carpels. Ovary superior, 3-celled, free. Styles united, Stigma 3-lobed. Ovules many, anatropous or amphitropous. Fruit a 3-celled. loculicidally 3-valved capsule. Seeds minute. Embryo terete, in fleshy endosperm.

\section{PYXIDANTHÈRA Michx.}

Evergreen herbs, with creeping stems. Leaves numerous, imbricated : blades entire, ciliate at the base, sessile. Flowers solitary and sessile in an involucre of imbricated bracts. Calyx-lobes parchment-like, imbricated, obtuse, ciliate. Corolla white or pink, persistent: tube short: lobes 5, spreading, eroded. Stamens 5, near the sinuses of the corolla: filaments broad: anther-sacs transversely 2-valved, the lower valve cuspidate. Staminodia none. Ovary 3-celled : stigma obscurely 3-lobed. Ovules numerous in each cavity, amphitropous. Capsule 3-celled, loculicidally 3-valved. Seeds few, the testa pitted, close.

1. Pyxidanthera barbulàta Michx. Depressed, nearly glabrous. Stems branched at the base, the branches creeping, forming large mats, 1-4 dm. long, leafy throughout : leaves numerous; blades leathery, linear-oblanceolate, or linear-elliptic, imbricated, 3-8 $\mathrm{mm}$. long, acute or spine-tipped, glabrous, except the ciliate base, sessile: bracts of the involucre lanceolate, about $4 \mathrm{~mm}$. long, densely ciliate, silky within : flowers about $9 \mathrm{~mm}$. broad : calyx campanulate, nearly $4 \mathrm{~mm}$. high; lobes 5 , broadly oblong, concave, obtuse : corolla white; tube oblong-campanulate; lobes 5 , broadly spatulate or cuneate-obovate, about as long as the tube, spreading : anthers yellow : capsules subglobose, about $2 \mathrm{~mm}$. in diameter, sessile.

In sandy pine lands, New Jersey and North Carolina. Spring. Pyxie. Flowering Moss. 


\section{Family 7. GALACÀCEAE Small. Galax Family.}

Perennial scapose herbs. Leaves alternate, basal, few, not crowded, without stipules: blades ieathery, merely toothed, relatively broad. Flowers perfect, solitary or in a terminal raceme. Calyx of 5 partially united sepals, persistent. Corolla white, of 5 partially united petals. Androecium of 5 stamens. Filaments united below. Staminodia 5, partially adnate to the corolla and sometimes to the filaments. Gynoecium of 3 united carpels. Ovary superior, 3celled, free. Styles united. Stigma 3-lobed. Ovules numerous in each cavity of the ovary. Fruit a loculicidally 3-valved capsule. Seeds minute.

Flowers solitary : corolla-lobes erose : staminodia distinct at the base of the corolla-tube. 1. SHortia. Flowers in elongated racemes: corolla-lobes entire: staminodia united to the filaments below.

2. Galax.

\section{SHÓRtia T. \& G.}

Evergreen scapose herbs, perennial by slender branching rootstocks. Leaves persistent : blades toothed, cordate or truncate at the base, lustrous : petioles elongated, dilated at the base. Scapes often scaly, simple, each topped with a nodding flower. Calyx-lobes 5, strongly imbricated, those of the outer and inner series dissimilar, striate-nerved. Corolla white or pink: tube campanulate : lobes 5, imbricated, more or less spreading, strongly erose at the apex. Stamens 5: filaments distinct above, short: anther-sacs opening obliquely. Staminodia 5 , scale-like, on the base of the corolla-tube. Ovary 3-celled : stigma obscurely 3lobed. Ovules numerous, inserted in axile placentae. Capsule 3-celled, loculicidally 3valved. Seeds in three rows, the testa granular.

1. Shortia galacifòlia T. \& G. Acaulescent, glabrous. Leaves basal ; blades leathery, oval to suborbicular, 1-7 cm. long, rounded or emarginate at the apex, crenatedentate with more or less mucronate teeth, truncate or cordate at the base, lustrous above ; petioles much longer than the blades: scapes $5-15 \mathrm{~cm}$. tall, from a set of acuminate imbricated bracts, simple, naked or with several thin scales near the top : calyx glabrous; lobes unequal, oblong or ovate-oblong, often 'becoming broadly lanceolate, 7-10 mm. long, obtuse or acutish, finely ribbed in age : corolla white, $2-3 \mathrm{~cm}$. broad; lobes obovate or broadly cuneate, coarsely erose or erose-laciniate, longer than the tube : stamens included: staminodia ovate, barely $\frac{1}{3}$ as long as the tube: style exserted : capsules ovoid, 5-6 mm. long, surrounded by the sepals.

Near mountain streams, North Carolina and South Carolina. Spring. SHoRTr.

\section{GÀLAX L.}

Acaulescent herbs, perennial by colored horizontal scaly rootstocks. Leaves basal, persistent : blades thick, suborbicular, crenate, palmately-nerved, cordate : petioles elongated somewhat sheathing at the base. Scapes erect, naked. Flowers in dense elongated spike-like racemes, short-pedicelled. Bracts small, deciduous. Calyx-lobes 5, imbricated, nerveless, persistent. Corolla white, with a short tube and 5 entire spreading lobes. Stamens 5: filaments spatulate, united below with 5 alternating spatulate staminodia: anthers 1-celled, transversely 2-valved, introrse. Ovary 3-celled : stigma 3-lobed. Ovules numerous in each cavity, anatropous. Capsule ovoid, 3-celled, 3-valved. Seeds numerous, angled, the testa loose.

1. Galax aphýlla L. Scapose, glabrous. Leaves basal ; blades leathery, suborbicular in outline, $4-10 \mathrm{~cm}$. broad, copiously crenate with apiculate teeth, cordate, lustrous ; petioles several times longer than the blades: scapes erect, solitary or clustered, 2-7 cm. tall : racemes spike-like, virgate, strict, densely-flowered : pedicels slender, 1-3 mm. long; bracts deciduous : calyx $1.5 \mathrm{~mm}$. high; lobes oblong, slightly narrowed at the base, 3.5-4 mm. long, obtuse, often crisped : stamens not exserted : capsules ovoid, nearly 3 $\mathrm{mm}$. long, erect or ascending, acute.

In dry soil, chiefly in the mountains, Virginia to middle Georgia, and near the coast of Virginia and North Carolina. Spring and summer. GALAXY. BEETLE-wEed.

\section{Order 2. PRIMULÀLES.}

Herbs, shrubs, trees or vines. Leaves alternate or opposite, sometimes all basal: blades mostly entire. Flowers perfect or polygamo-dioecious, variously 
disposed. Calyx of 4-several partially united sepals. Corolla of 4-several distinct or partially united petals, or wanting. Androecium of as many stamens as there are petals or sepals, and sometimes accompanied by as many staminodia, mainly partially adnate to the corolla. Gynoecium of 4-6 united carpels, or rarely more. Ovary superior, or mainly so, mostly 1-celled. Styles distinct or united. Fruit capsular or drupaceous, or rarely an achene or a utricle.

Styles distinct: fruit an achene or utricle: ovule 1.

Styles united : fruit capsular or drupe-like: ovules several.

Herbs: ovules or seeds not immersed : fruit capsular.

Shrubs or trees : ovules or seeds immersed : fruit drupe-like. Staminodia at the sinuses of the corolla-lobes : fruit containing few or many seeds.

Staminodia wanting : fruit containing a single seed.
Fam. 1. Armeriaceae.

Fam. 2. Primulaceae.

Fam. 3. THEOPHRASTACEAE. Fam. 4. Ardisiacea E.

\section{Family 1. armeriaceat Dumort. Plumbago Family.}

Perennial or rarely annual mostly acaulescent herbs, or shrubby plants, with erect or climbing stems. Leaves various: petioles dilated at the base, or clasping. Flowers perfect, regular, in widely branching panicles, or dense terminal heads. Calyx tubular or funnelform : tube 5-15-ribbed, the main ribs converging or uniting above by pairs and prolonged into the 4-5 lobes. Corolla hypogynous : petals 4-5, their claws distinct, or united into a tube. Androecium of 5 stamens opposite the petals. Filaments distinct or united into a tube. Anthers 2-celled, attached by the back. Gynoecium of 5 united carpels. Ovary 1-celled, often 5-angled. Styles distinct or united. Stigmas capitate, or elongated. Ovule solitary, anatropous, pendulous, its funicle from the base of the cavity. Fruit a utricle or achene, or rarely capsular, enclosed in the calyx. Seed solitary, filling the cavity. Testa membranous. Endosperm mealy, sometimes none. Embryo straight. [Plumbaginaceae Lindl.]

Calyx glandular: claws of petals united into a tube : styles united to near the top. Calyx not glandular: claws of petals distinct or nearly so: styles distinct or united at the base.

1. Plumbago.

2. Limonium.

\section{PLUMBÀGO L.}

Perennial herbs, shrubby plants or vines. Leaves alternate: blades auricled at the base and clasping, or with short often clasping petioles. Flowers in terminal bracted spikes. Calyx tubular, glandular : lobes 4-5, erect, hyaline in the sinuses. Petals 4-5, of various colors : claws united : tube slender : blades entire, spreading, equal. Stamens 5, free and distinct: filaments dilated at the base: anthers rather elongated. Ovary 1celled : styles filiform, stigmatic within. Capsule membranous, circumscissile or 5-valved. Seed filling the cavity. Endosperm mealy, scant.

1. Plumbago scándens L. Shrubby, glabrous. Stems erect, decumbent or climbing, 5-12 dm. long, much-branched, the branches slightly grooved : leaf-blades oblong to oblong-lanceolate or ovate, $2-10 \mathrm{~cm}$. long, shining, acute or short-acuminate, undulate, narrowed into short petioles with clasping bases : spikes terminal, $2-8 \mathrm{~cm}$. long: calyx bristlyglandular; tube about $1 \mathrm{~cm}$. long, the green nerves alternating with white wings; lobes 4-5, terminating in minute hooks : corolla white or purplish; tube slender, about $2 \mathrm{~cm}$. long; lobes 4-5, spreading, oblong, obtuse : stamens 4, exserted: anthers blue: capsules slender, invested by the hardened calyx.

In sandy soil, peninsular Florida. Also in tropical America. Spring and summer.

\section{LIMÒNIUM Adans.}

Perennial or rarely annual acaulescent herbs, with glabrous or scaly foliage. Leaves mostly basal : blades flat, entire or rarely pinnatifid or dissected. Scapes branched, often densely so. Bracts scale-like. Flowers one or more, subtended by a single bract. Calyx funnelform: tube 10-ribbed, the ribs uniting by pairs above: limb scarious, plicate, its lobes often awn-tipped. Petals 5 : claws distinct or merely united at the base : blades entire or 2-cleft. Stamens 5, inserted with the petals : filaments distinct or united below, sometimes adnate to the petals. Ovary 1-celled, 5-angled : styles 5, distinct : stigmas capitate or minute. Utricle included, membranous. Seed filling the cavity. Endosperm mealy, 
usually scant. [Statice Willd.] The plants flower mainly in the spring and summer. SEA Lavender. Marsh Rosemary. Cankerroot.

Calyx-tube glabrous.

Leaf-blades linear.

Leaf-blades oblong or spatulate.

Bracts oval, obtuse: calyx-lobes round-ovate: species of the southeastern states.

Bracts suborbicular, abruptly pointed : calyx-lobes triangular, mucronate : species of the southwestern states.

1. L. angustatum.

2. L. Brasiliense.

3. L. Californicum.

Calyx-tube pubescent.

Branches spreading, the tips recurved : bracts oval : calyx-tube sparingly pubescent at the base.

Branches ascending, the tips curved upward: bracts mainly suborbicular: calyx-tube bristly-pubescent.

Limb of calyx erect : species of the southeastern states.

Limb of calyx spreading: species of the southwestern states.

4. L. Nashii.

5. L. Carolinianum.

6. L. limbatum.

1. Limonium angustàtum (A. Gray) Small. Leaves basal, few ; blades linear, 4-7 $\mathrm{cm}$. long, cuspidate, 1-nerved, narrowed into petioles which are somewhat shorter than the blades and with dilated bases: scapes erect, about $3 \mathrm{dm}$. tall, with several scale-like clasping bracts sparingly branched above: bracts subtending the flowers broadly oblong, 4 $\mathrm{mm}$. long, acute: calyx about $5 \mathrm{~mm}$. long; tube glabrous ; lobes 5 , ovate, the connecting membranes eroded.

In salt marshes, Pine Key, Florida.

2. Limonium Brasiliénse (Boiss.) Small. Leaves basal ; blades oblong, 6-12 cm. long, rounded or retuse at the apex, usually cuspidate or mucronate, gradually narrowed at the base ; petioles about equalling the blades in length or surpassing them: scapes erect, bearing a few scales, branched above, the slender elongated branches spreading: bracts subtending the flowers broadly oval, $3 \mathrm{~mm}$. long, eroded at the rounded apex : calyx $3-4$ $\mathrm{mm}$. long; tube glabrous; lobes round-ovate, about $5 \mathrm{~mm}$. long, obtusish : corolla white.

In salt marshes or on beaches, North Carolina to Florida. Also in South America.

3. Limonium Califórnicum (Boiss.) Heller. Resembling L. Brasiliense in habit, but stouter. Bracts suborbicular, abruptly pointed : calyx-lobes triangular, mucronate.

In saline places, California, extending eastward along the southern border of the United States, probably to within our range.

4. Limonium Náshii Small. Leaves basal; blades oblong or elliptic, sometimes varying to narrowly obovate, 4-10 $\mathrm{cm}$. long, rounded or notched at the apex, occasionally mucronate, narrowed into petioles which are shorter than the blades or longer: scapes erect, 3-7 dm. tall, furnished with a few scales, widely branching above, the tips of the spreading branches recurved : bracts subtending the flowers oval, about $4 \mathrm{~mm}$. long, obtuse : calyx 6-7 mm long; tube $4 \mathrm{~mm}$. long, sparingly pubescent with soft hairs at the base only; lobes 5, triangular, slightly acuminate, more than $1 \mathrm{~mm}$. long: corolla deep blue.

In salt marshes, Georgia to Florida and Mississippi.

5. Limonium Caroliniànum (Walt.) Britton. Leaves basal ; blades elliptic or oblanceolate, 4-12 cm. long, cuspidate, narrowed at the base; petioles shorter than the blades or usually longer: scapes erect, $2-6 \mathrm{dm}$. tall, bearing a few scales below, much branched, the tips of the branches usually erect or curved upward: bracts subtending the flowers suborbicular, about $4 \mathrm{~mm}$. long, eroded at the apex : calyx 5-6 mm. long; tube bristly to above the middle with ascending or spreading hairs; lobes 5 , ovate, about 1 $\mathrm{mm}$. long, acute : corolla $4-5 \mathrm{~mm}$. broad, pale purple.

In salt meadows, Labrador to Florida.

6. Limonium limbàtum Small. Leaves basal ; blades leathery, spatulate or oblongspatulate, $0.5-1.5 \mathrm{dm}$. long, obtuse or notched at the apex, prominently nerved beneath in
drying; petioles shorter than the blades or rarely longer, margined : scapes erect, solitary or several together, corymbosely branched, the branches zigzag, ascending : spikes in dense terminal corymbs : bracts suborbicular or sometimes orbicular-oval, obtuse, often eroded at the apex, hyaline-margined : calyx trumpet-shaped with a flaring limb, nearly $4 \mathrm{~mm}$. long: tube hirsute; lobes broadly deltoid, apiculate : corolla bright blue.

In alkaline soil, Texas and New Mexico.

\section{Family 2. PRIMUlàceat Vent. Primrose Family.}

Caulescent or scapose herbs, various in habit. Leaves alternate or opposite, or whorled, sometimes all basal, without stipules: blades commonly simple. Inflorescence variously disposed. Flowers perfect, usually regular. Calyx of gamopetalous, with 4-9 manifest lobes, or rarely wanting. Androecium of as 
many stamens as there are corolla-lobes and opposite them, adnate to the tube or on the calyx, rarely alternating with staminodia. Filaments sometimes united at the base. Anthers 2-celled: sacs opening introrsely. Gynoecium a single pistil. Ovary free or nearly so, 1-celled, with a free central placenta. Style entire. Stigma entire or lobed. Ovules amphitropous, numerous or two. Fruit a 1-celled capsule opening by 2 to 8 valves. Seeds 2 or many, with a smooth roughened or furrowed testa. Endosperm fleshy or horny. Embryo usually transverse.

Corolla-lobes erect or spreading.

Lobes of the corolla imbricated.

Ovary superior: plants with dissected leaf-blades.

Ovary partly inferior: with entire leaf-blades.

Lobes of the corolla valvate or convolute.

Capsules opening lengthwise.

Staminodia wanting: filaments united at the base.

Staminodia present: filaments distinct or essentially so.

Capsules circumscissile.

Corolla longer than the calyx : filaments pubescent, adnate to the base of the corolla.

Corolla shorter than the calyx: filaments glabrous, adnate to the corollatube.

Corolla-lobes reflexed.

\section{HOTTÒNIA L.}

1. Hottonia.

2. SAMOLUS.

3. LySIMACHIA.

4. Steironema.

\section{Anagalis.}

6. Centunuulus. 7. DODECATHEON.

Aquatic herbs, with glabrous foliage. Stems submerged. Leaves numerous, the submersed with pinnately dissected blades: petioles often inflated. Scapes erect, the internodes inflated. Bracts whorled. Flowers whorled at the nodes, pedicelled. Calyx persistent: lobes 5, narrow, imbricated, longer than the tube. Corolla white, salverform: tube longer than the 5 imbricated lobes of the spreading limb. Stamens 5, adnate to the corolla-tube below the middle: filaments about as long as the anthers. Ovary sessile: style filiform: stigma capitate. Ovules numerous, anatropous, inserted on a rounded stalked placenta. Capsule membranous, partially 5 -valved. Seeds numerous, slightly angular. FeatherfoIL.

1. Hottonia inflàta Ell. Stems submerged, spongy, 2-6 dm. long, leafy, simple or branching : leaf-blades ovate to oblong in outline, 5-10 cm. long, finely divided almost to the middle into linear-filiform segments: scapes tufted, 1-3 dm. long, jointed, the lower joint often $2.5 \mathrm{~cm}$. thick, the upper ones successively smaller : bracts linear or linear-spatulate, $5-15 \mathrm{~mm}$. long: flowers whorled at the nodes : pedicels variable in length, $0.3-5 \mathrm{~cm}$. long: calyx often minutely glandular; tube very short; lobes linear, 5-10 mm. long, rather obtuse : corolla white, $3 \mathrm{~mm}$. long, shorter than the calyx, the lobes oblong, obtuse, $\frac{1}{2}$ as long as the tube: stamens included: capsules subglobose, about $3 \mathrm{~mm}$. in diameter, glabrous : seeds about $0.5 \mathrm{~mm}$. long.

In ponds and ditches, Massachusetts to New York, Florida and Louisiana. Spring and summer.

\section{SÁMOLUS L.}

Annual or perennial caulescent herbs. Leaves alternate, various: blades entire. Flowers white or pink, in simple or panicled bracted or naked racemes. Sepals united at the base, persistent. Corolla perigynous : tube very short, the rounded lobes of the limb imbricated. Stamens 5, adnate to the corolla-tube, sometimes alternating with 5 narrow staminodia in the sinuses of the corolla-lobes. Anthers cordate, erect. Ovary 1-celled: stigma obtuse or capitate. Ovules numerous, half-anatropous, in a subglobose placenta. Capsule barely, if at all, elongated, 5-valved at the apex. Seeds numerous. WATER Pimpernel. Brookweed.

Racemes sessile or nearly so: staminodia at the sinuses of the corolla. Racemes long-peduncled : staminodia wanting.

Peduncles glandular-pilose: corolla 4-5 mm. broad; lobes broadly cuneate.

Peduncles glabrous : corolla $6-9 \mathrm{~mm}$. broad; lobes suborbicular.

Glaucous : corolla 8-9 mm. broad.

Bright green : corolla 6-7 mm. broad.

1. S. floribundus.

2. S. cuneatus.

3. S. alyssoides.

4. S. ebracteatıs.

1. Samolus floribúndus H.B.K. Light green, glabrous, 1-6 dm. tall. Stems simple or diffuse : leaves few ; blades obtuse, mainly 3-15 cm. long, spatulate or oval, or obovate, narrowed into winged petioles, the lower stem-leaves like the basal, passing through oval to ovate, the upper ones sessile or nearly so: racemes sessile or very shortpeduncled : pedicels 1-2 cm. long, spreading or ascending: calyx campanulate; lobes 
ovate or triangular-ovate, acute, about as long as the tube : corolla white, $3 \mathrm{~mm}$. broad; lobes oblong, rounded or emarginate at the apex, longer than the tube : staminodia 5 : capsules subglobose, $2.5-3 \mathrm{~mm}$. in diameter.

In wet soil and marshes, fresh, brackish and salt, Newfoundland to British Columbia, south to Florida, Mexico and California. Spring and summer.

2. Samolus cuneàtus Small. Deep green, 1-3 dm. tall. Stems solitary or tufted, ascending or reclining, usually branched : leaves opposite or mainly so ; blades obdeltoidspatulate or broadly spatulate, 4-12 cm. long, truncate or coarsely mucronulate at the apex, the bases decurrent as broad wings : racemes $1-3 \mathrm{dm}$. long, their peduncles longer than the stems, like the racemes, glandular-pilose : pedicels slender, spreading or ascending, 1-3 cm. long: calyx campanulate; lobes triangular, acute, longer than the tube, or at maturity shorter : corolla white, 4-5 mm. broad ; lobes 5 , broadly cuneate, flattish or truncate at the apex, toothed, as long as the tube: stamens included: capsules depressed-globose, 3-3.5 mm. in diameter.

On wet limestone rocks or in moist soil, Texas. Spring.

3. Samolus alyssoìdes Heller. Glabrous, glaucous, $2-3 \mathrm{dm}$. tall. Stems more or less tufted, erect or ascending, usually branched: leaves numerous, 4-7 cm. long; blades spatulate, acute or acutish, narrowed into winged often purple petioles, which are shorter than the blades : racemes $2-4 \mathrm{~cm}$. long, on peduncles as long as the stem or longer : pedicels 5-10 mm. long, ascending: calyx campanulate; lobes triangular or triangular-lanceolate, acute, about as long as the tube : corolla white, $8-9 \mathrm{~mm}$. broad ; lobes $5-6$, suborbicular, shorter than the tube, rounded at the apex, glandular at the base: stamens included: stigma nearly entire : capsules subglobose, $3-3.5 \mathrm{~mm}$. in diameter.

In dry sandy soil, on the coast, southern Texas. Spring.

4. Samolus ebracteàtus H.B.K. Glabrous or nearly so, 1-3 dm. tall. Stems solitary or tufted, often sparingly branched: leaves alternate; blades spatulate or obovate, 3-10 cm. long, obtuse or apiculate, sessile or with short winged petioles, decurrent : racemes 2-20 cm. long, their peduncles usually elongated, commonly longer than the stem : pedicels 1-5 cm. long or rarely shorter, ascending: calyx campanulate; lobes triangularovate, acute or acutish, about twice as long as the tube : corolla pink, 6-7 mm. broad ; lobes suborbicular, conspicuously retuse at the apex, densely glandular at the base, shorter than the tube: stamens included : stigma notched: capsules subglobose, about $4 \mathrm{~mm}$. in diameter.

In salt marshes, saline and brackish soil, Florida to Texas and Mexico. Also in the West Indies. Spring to fall.

\section{LYSIMÀCHIA L.}

Perennial or sometimes annual caulescent herbs, with glandular-punctate foliage. Leaves opposite or whorled, various : blades entire, prevailingly narrow. Flowers yellow, solitary on slender pedicels or racemosely disposed. Sepals 5. Petals 5, united into a rotate or short funnelform corolla: lobes entire, convolute. Stamens 5. Staminodia wanting. Filaments united at the base. Anthers short. Ovary 1-celled : style filiform. Capsule globose or subglobose. Loosestrife.

Corolla without dark dots or streaks.

Stems creeping : flowers axillary to leaf-like bracts : calyx-lobes ovate.

1. L. Nummularia.

Stems erect: flowers in terminal panicles: calyx-lobes linear or linear-lanceolate. $2 . \quad L$. Fraseri.

Corolla with dark dots or streaks.

Inflorescence extending nearly the length of the plant: flowers axillary to the leaf-like bracts.

Inflorescence terminal : flowers axillary to bracts smaller than the leaves.

Pedicels shorter than the bracts. Pedicels 1.5-2 cm. long: leaf-blades 1-ribbed. Pedicels $0.5-1.5 \mathrm{~cm}$. long: leaf-blades 3-ribbed.

Pedicels longer than the bracts.

Bracts mostly over $1 / 2$ as long as the pedicels : leaf-blades linear.

Bracts mostly much less than $1 / 2$ as long as the pedicels : leaf-blades broader. 7 . L. terrestris.

1. Lysimachla Nummulària L. Perennial, deep green, glabrous. Stems prostrate, creeping 1-7 dm. long, usually branching: leaves opposite, the blades suborbicular, $0.8-3$ $\mathrm{cm}$. in diameter, rounded or retuse and sometimes apiculate at the apex, punctate, rounded, truncate or cordate at the base; petioles usually $2-3 \mathrm{~mm}$. long: flowers axillary : pedicel stoutish, 1-2 $\mathrm{cm}$. long: calyx punctate, the lobes ovate, $8-9 \mathrm{~mm}$. long, acute at the apex, cordate at the base : corolla bright yellow, about $2 \mathrm{~cm}$. broad, the lobes obovate, punctate : filaments glandular, united at the base.

In waste places and meadows, Newfoundland to Indiana, New Jersey and Georgia. Naturalized from Europe. Spring and summer. 
2. Iysimachia Fràseri Duby. Perennial, glabrous or nearly so below. Stems erect, 1-2 m. tall, simple or sparingly branched, slightly grooved, often glaucous, commonly glandular near the nodes: leaves in whorls of 3's or 4's, or the upper ones opposite, the blades lanceolate, narrowly elliptic or oblanceolate, sometimes ovate-lanceolate, $6-15 \mathrm{~cm}$. long, usually acuminate at both ends, or acute at the base, punctate; petioles $2-8 \mathrm{~mm}$. long: panicle $0.5-1.5 \mathrm{dm}$. long, glandular : bracts linear-lanceolate to subulate : pedicels lanceolate, about $5 \mathrm{~mm}$. long, glandular-ciliate, reddish margined, acute : corolla yellow, about $1.5 \mathrm{~cm}$. broad, the lobes elliptic or oval, obtuse or retuse at the apex, many times longer than the tube: filaments glandular, unequal, united into a cup at the base : capsules $3-4 \mathrm{~mm}$. long.

In open woods, South Carolina to Tennessee, Georgia and Alabama. Summer.

3. Lysimachia quadrifòlia L. Perennial, more or less villous. Stems erect or ascending, 2-9 dm. tall, usually simple : leaves in whorls of $3-7$, mostly 4 , or rarely some or all opposite; blades lanceolate to oval, acute, or short-acuminate, sessile or shortpetioled : flowers axillary : pedicels filiform, $2-4 \mathrm{~cm}$. long : calyx punctate, the lobes lanceolate, 5-6 mm. long, ciliate, acuminate : corolla yellow, $12-15 \mathrm{~mm}$. broad, the lobes oblong or oblong-ovate, rounded at the apex, usually spotted or streaked : filaments unequal, glandular: capsules subglobose, more or less oblique, $3 \mathrm{~mm}$. thick.

In woods and thickets, New Brunswick to Minnesota, south to Georgia and Missouri. Summer.

4. Lysimachia foliòsa Small. Stems 3-6 dm. tall, simple, glabrous or sparingly pubescent. Leaves in whorls of 3's, or rarely opposite or 4 in a whorl; blades lanceolate or oblong-lanceolate, $2-8 \mathrm{dm}$. tall, much paler beneath than above, sessile or nearly so: flowers in terminal leafy-bracted racemes 1-2 dm. long: pedicels $1-2.5 \mathrm{~cm}$. long, slender, shorter than the bracts : calyx streaked; lobes narrowly oblong-lanceolate, $3 \mathrm{~mm}$. long, acute or acutish, ciliate : corolla $10-12 \mathrm{~mm}$. broad, firm ; lobes ovate to oblong-ovate, more or less notched at the apex : filaments unequal, glandular: capsules subglobose, about $2 \mathrm{~mm}$. thick.

In woods or thickets, District of Columbia to North Carolina. Summer.

5. Lysimachia asperulaefòlia Poir. Stems erect, 2-6 dm. tall, simple or "sparingly branched above : leaves in whorls of 3's or 4's, or sometimes merely opposite; blades lanceolate, $2-5 \mathrm{~cm}$. long, acute or acuminate, 3-5-ribbed, sessile, glaucous beneath, finely wrinkled above : raceme terminal, $5-12 \mathrm{~cm}$. long: pedicels slender, $0.5-2 \mathrm{~cm}$. long, glandular: calyx glandular, the lobes lanceolate, $4-5 \mathrm{~mm}$. long, ciliate, acute, concave: corolla yellow, 12-15 mm. broad, the lobes lanceolate or oblong-lanceolate, glandular-ciliate, acute : filaments unequal, glandular : capsules spheroidal, $3.5-4.5 \mathrm{~mm}$. thick.

In pine woods, North Carolina to Georgia. Summer.

6. Lysimachia Loomísii Torr. Stems 3-8 dm. tall, more or less branched, glabrous or nearly so, ridged: leaves opposite or alternate; blades linear, 1-3 cm. long, blunt, reduced to scales at the base of the stem, sessile or nearly so: flowers yellow, in cylindric racemes varying from 2-20 cm. in length : pedicels very slender, 6-10 $\mathrm{mm}$. long: calyx mottled; lobes lanceolate, $2.5-3 \mathrm{~mm}$. long, acnte, glandular-ciliate : corolla yellow, about $1 \mathrm{~cm}$. broad; lobes oblong or ovate-oblong, obtuse, striped with purple: filaments glandular : capsules subglobose, about $2.5 \mathrm{~mm}$. in diameter.

In low ground, North Carolina to Georgia. Summer.

7. Lysimachia terréstris (L.) B.S.P. Stems glabrous, 5-8 dm. long, simple or branching, sometimes producing suppressed branchlets in the form of elongated axillary bulblets : leaves opposite, or rarely alternate; blades lanceolate, oblong-lanceolate or narrowly elliptic, $2-6 \mathrm{~cm}$. long, acute or acuminate at both ends, sessile or short-petioled, abruptly reduced at the base of the raceme: flowers yellow, in terminal simple or branching usually elongated cylindric racemes: pedicels $1-1.5 \mathrm{~cm}$. long: calyx mottled with black ; lobes oblong-lanceolate, $2 \mathrm{~mm}$. long, acute or obtusish : corolla yellow, 11-13 mm. broad; lobes oblong-lanceolate, obtuse or emarginate, streaked with purple: filaments glandular-pilose : capsules depressed-globose, $2 \mathrm{~mm}$. in diameter. [L. stricta Ait.]

In swamps and low places, Newfoundland to Manitoba, south to Georgia and Arkansas. Summer.

\section{STEIRONEMA Raf.}

Perennial caulescent almost glabrous herbs. Leaves opposite, often whorled above : blades destitute of glandular dots : petioles mostly ciliate. Flowers nodding, on slender axillary peduncles. Sepals 5. Corolla yellow : lobes 5, erose-denticulate, each convolute or involute about its stamen. Stamens 5 , alternating with 5 staminodia : filaments distinct or nearly so: anthers linear. Ovary 1-celled: style filiform. Capsule rounded, naked.

Beeds 10-20. LoOsestrife. 
Upper stem-leaves with ovate or broadly lanceolate blades.

Stems reclining or decumbent : calyx-lobes less than $5 \mathrm{~mm}$. long : corolla $8-10 \mathrm{~mm}$. broad.

Stems erect : calyx-lobes over $5 \mathrm{~mm}$. long at maturity : corolla 15-25 mm. broad.

Petioles glabrous : leaf-blades with glabrous margins.

Petioles ciliate: leaf-blades ciliolate.

Upper stem-leaves with linear, oblong or narrowly lanceolate blades.

Petioles ciliate only or mainly near the base: staminodia lanceolate.

Petioles ciliate throughout, the cilia extending along the base of the blade: staminodia subulate.

Leaf-blades mainly linear: upper stem-leaves with blades mostly narrowed at the base.

Leaf-blades mainly oblong to narrowly lanceolate: upper stem-leaves with manifestly petioled blades.

1. S. radicans.

2. S. tonsum.

3. S. ciliatum.

4. S. lanceolatum.

5. S. heterophyllum.

6. S. hybridum.

1. Steironema radìcans (Hook.) A. Gray. Stems weak, 3-8 dm. long, erect when young, finally decumbent or reclining, and often rooting at the nodes : leaf-blades membranous, ovate to lanceolate $2-8 \mathrm{~cm}$. long, acute at both ends or truncate at the often oblique base : more or less ciliolate ; petioles $\frac{1}{2}$ as long as the blades or shorter, winged, glabrous : flowers axillary : pedicels filiform, 1-2.5 cm. long : calyx glabrous ; lobes lanceolate, about $4 \mathrm{~mm}$. long, acute : corolla sulphur-yellow, $8-10 \mathrm{~mm}$. broad; lobes broadly clawed, eroded at the apex, minutely apiculate : filaments distinct, subulate, glabrous or nearly so : staminodia triangular-ovate, glandular : capsules globose, $3 \mathrm{~mm}$. thick, about as long as the sepals.

In swamps, Virginia to Missouri and Louisiana. Summer.

2. Steironema tónsum (Wood) Bicknell. Stems erect, 2-7 dm. tall, sparingly glandular above, obtusely 4-angled, often purple: leaf-blades membranous, ovate to ovatelanceolate, $1.5-8 \mathrm{~cm}$. long, acute or somewhat acuminate, glabrous, rounded or cordate at the base ; petioles not ciliate, the lower ones often as long as the blades, the upper much shorter : flowers axillary : pedicels slender, 1-2 cm. long: caly $\mathrm{x}$ glandular at the base like the pedicels ; lobes lanceolate, almost $5-6 \mathrm{~mm}$. long, acute : corolla sulphur-yellow, 1.5-2 cm. broad; lobes suborbicular, erose-lacerate above the middle: filaments glandular, nearly distinct : staminodia subulate: capsules subglobose, about $4 \mathrm{~mm}$. thick, $\frac{1}{3}$ shorter than the calyx. [S. intermedium Kearney.]

In dry woods, Virginia to Tennessee and Alabama. Spring and summer.

3. Steironema ciliàtum (L.) Raf. Stems erect, 2-15 dm. tall, sometimes much branched : leaf-blades membranous, ovate, oblong-ovate or lanceolate, 4-12 cm. long, acute or acuminate, ciliate, rounded to cordate at the base ; petioles slightly winged, conspicuously ciliate, the lower ones often as long as the blades or longer, the upper very short: Howers axillary: pedicels slender, $2-5 \mathrm{~cm}$. long: calyx glabrous or slightly glandular below ; lobes lanceolate, 5-6 mm. long, acuminate, spreading or recurved : corolla sulphuryellow, $2-2.5 \mathrm{~cm}$. broad; lobes obovate, strongly apiculate, eroded especially near the apex : filaments glandular, nearly distinct: staminodia subulate, shorter than the filaments : capsules subglobose, 4-5 mm. thick, much shorter than the calyx.

In dry soil or along streams, Nova Scotia to British Columbia, south to Florida and Arizona. Naturalized in Europe. Spring and summer.

4. Steironema lanceolàtum (Walt.) A. Gray. Stems 3-9 dm. tall, simple or sparingly branched: leaves few ; blades narrowly lanceolate to oblong-lanceolate, $2.5-5 \mathrm{~cm}$. long, acute or slightly acuminate at the apex, acute at the base; petioles slender, $1-2 \mathrm{~cm}$. long, except near the top of the stem, ciliate only at the base, or sparingly so throughout, the cilia never extending up on the blade: pedicels slender, commonly surpassing the bracts : calyx glabrous; lobes lanceolate, acuminate, becoming 6-7 mm. long: corolla sulphur yellow, $1.5-2 \mathrm{~cm}$. broad ; lobes obovate: staminodia lanceolate : capsules $4.5-5$ mm. long.

In low grounds and thickets, Maine to New York and Georgia. Summer.

5. Steironema heterophýllum (Michx.) Raf. Stems 1-6 dm. tall, more or less branched : leaves often numerous, various, the basal with oblong oval or ovate blades 1-3 cm. long and slender ciliate petioles, the upper ones abruptly narrower and longer; blades nearly linear, attenuate, $3-15 \mathrm{~cm}$. long, merely narrowed to the ciliate base, not distinctly petioled : pedicels often shorter than the bracts : calyx glabrous; lobes lanceolate, acuminate, becoming $5 \mathrm{~mm}$. long: corolla bright yellow, $1-1.5 \mathrm{~cm}$. broad; lobes eroded, each terminating in a slender tail-like tip : staminodia subulate : capsules about $4 \mathrm{~mm}$. long.

In woods and meadows and on banks, Virginia and Kentucky to Florida and Mississippi. Summer.

6. Steironema hýbridum (Michx.) Raf. Stems $0.5-4 \mathrm{dm}$. tall, simple or sparingly branched : leaves various, the basal with oblong or oval blades and ciliate petioles, the upper stem-leaves more numerous ; blades mainly oblong to narrowly lanceolate, $2-10 \mathrm{~cm}$. long, acute or slightly acuminate, narrowed into marked by ciliate petioles : pedicels usually shorter 
than the bracts : calyx glabrous; lobes lanceolate or linear-lanceolate, becoming 6-7 mm. long, acuminate : corolla bright yellow, $1.5-2 \mathrm{~cm}$. broad; lobes toothed : staminodia subulate : capsules $4-4.5 \mathrm{~mm}$. long.

In thickets or moist soil, Minnesota to New Jersey, Florida and Arizona. Spring and summer.

\section{ANAGÁLLIS L.}

Annual or rarely perennial often glabrous caulescent herbs. Leaves mostly opposite or whorled: blades entire. Flowers on slender axillary peduncles. Sepals 5, united below, narrow, persistent. Corolla rotate: lobes 5, usually entire, convolute. Stamens 5, adnate to the base of the corolla : filaments slender, sometimes pubescent. Ovary 1-celled: style filiform: stigma capitate. Ovules half-anatropous, in a subglobose placenta. Capsule subglobose, circumscissile. Seeds numerous. Poor Man's or Shepherd's Weatherglass. Pimpernel.

1. Anagallis arvénsis L. Annual, glabrous. Stems simple or usually branched, the branches slender, spreading, 5-30 cm. long, 4-angled : leaf-blades ovate or oval, $5-20 \mathrm{~mm}$. long, obtuse or acutish, punctate, entire, sessile or clasping, the upper ones sometimes alternate: peduncles filiform, 1-2 cm. long, recurving at maturity: sepals narrowly lanceolate, about $2 \mathrm{~mm}$. long, keeled, acuminate : corolla scarlet or rarely white, mostly darker in the center, $5-7 \mathrm{~mm}$. broad, the lobes glandular-ciliate : capsules subglobose, about $4 \mathrm{~mm}$. in diameter.

In waste places. Newfoundland to Vancouver Island, south to Florida and Mexico. Naturalized from Europe. Also in Asia and Africa. Spring and summer.-A state with blue corollas, is known as A. arvensis caerùlea (Lam.) Ledeb.

\section{CENTÚNCULUS L.}

Small annual caulescent herbs, with glabrous foliage. Leaves alternate, or the lower opposite : blades entire. Flowers minute, solitary, on axillary pedicels or nearly sessile. Sepals 4-5, united below, persistent. Corolla not exceeding the calyx : tube subglobose : lobes entire, spreading. Stamens 4-5, inserted on the throat of the corolla-tube : filaments somewhat dilated: anthers sometimes cordate. Ovary 1-celled: style filiform : stigma capitate. Ovules numerous, half-anatropous, in a subglobose placenta. Capsule subglobose, circumscissile. Seeds numerous. False Pimpernel.

Flowers on pedicels about as long as the leaves : parts of the flowers in 5 's. Flowers sessile or nearly so: parts of the flowers in 4's.

1. C. pentandrus.

2. C. minimus.

1. Centunculus pentándrus R.Br. Stems erect, $5-20 \mathrm{~cm}$. tall, often branching: leaf-blades oval to suborbicular, 3-10 mm. long, apiculate, entire, the lower ones shortpetioled, the upper sessile : pedicels slender or filiform, 5-15 mm. long, usually as long as the leaves or longer: sepals 5, lanceolate, acuminate, $2-2.5 \mathrm{~mm}$. long : corolla about $2 \mathrm{~mm}$. broad : stamens 5 : capsule about $2 \mathrm{~mm}$. in diameter.

In low grounds, peninsular Florida. Also in tropical America. Spring to fall.

2. Centunculus mínimus L. Stems erect, $2-15 \mathrm{~cm}$. tall, simple or branched : leafblades spatulate, oblong or obovate, $3-8 \mathrm{~mm}$. long, acutish or obtuse at the apex, shortpetioled or the upper sessile : flowers sessile or nearly so: calyx much shorter than the leaves: sepals $4-5$, subulate-lanceolate, $2-2.5 \mathrm{~mm}$. long, acuminate : corolla pink ; tube globose, lobes 4 : capsule nearly $2 \mathrm{~mm}$. long.

In low grounds and moist soil, Minnesota to British Columbia, south to Illinois, Texas and Mexico. Also in South America and Europe. Spring to fall.

\section{DODECÁTHEON L.}

Perennial showy scapose chiefly cliff-inhabiting herbs. Rootstocks short. Leaves basal : blades entire or coarsely toothed, various : petioles winged. Scape solitary, topped by a few-to many-rayed umbel. Flowers pink, purple or white, nodding at the ends of slender pedicels. Calyx-lobes 5, reflexed in flower, longer than the tube. Corolla hypogynous : tube very short: lobes 5 , imbricated in the bud, reflexed, many times longer than the tube. Stamens 5, exserted: filaments usually united: anthers attached by their bases. Ovary free: style filiform : stigma capitate. Ovules numerous, half-anatropous, inserted in a rounded stalked placenta. Capsule partially 5-valved. Seeds numerous, the testa punctate. Meadra. Shooting Star. American Cowsir. 
Connective-body broad, less than $1 / 2$ as long as the anther-sacs : corolla-lobes linear or spatulate. Anthers prominently auricled at the base: corolla typically white.

Anthers scarcely if at all auricled at the base: corolla typically pink-purple.

Capsules oblong-cylindric, over $1 \mathrm{~cm}$. long: filament-tube over $1 \mathrm{~mm}$. long.

Capsules ovoid, less than $1 \mathrm{~cm}$. long: filament-tube very short or filaments distinet.

Connective-body narrow, over $1 / 2$ as long as the anther-sacs : corolla lobes obovate.

1. D. Hugeri.

2. D. Meadia.

3. D. brachycarpa.

4. D. Stanfieldii.

1. Dodecatheon Hùgeri Small. Leaf-blades spatulate, oblong or oblong-oblanceolate, 5-40 cm. long, often undulate or repand-crenate: scapes erect, overtopping the leaves : calyx-lobes lanceolate, somewhat longer than the tube : corolla white or delicately tinged with purple, 1-2 cm. long: anthers prominently auricled at the base : capsules oblong-conic, 1-1.5 cm. long, much longer than the calyx.

On river banks and bluffs, Maryland to Kentucky, Georgia and Alabama. Spring.

2. Dodecatheon Meàdia L. Leaf-blades spatulate to oblong, $5-20 \mathrm{~cm}$. long, entire to coarsely crenate: scapes overtopping the leaves: calyx-lobes linear to linear-lanceolate, much longer than the tube : corolla pink-purple or almost white: petals $1-1.5 \mathrm{~cm}$. long: filaments mostly united, the tube over $1 \mathrm{~mm}$. long: anthers scarcely if at all auricled at the base : capsules oblong-cylindric, $1.2-1.5 \mathrm{~cm}$. long, much longer than the calyx. summer.

On rocky bluffs and river banks, Pennsylvania to Wisconsin, Georgia and Texas. Spring and

3. Dodecatheon brachycárpa Small. Similar to the two preceding species in habit. Corolla pink-purple: filaments mostly united but the tube very short: anthers scarcely if at all auricled at the base : capsules ovoid, less than $1 \mathrm{~cm}$. long, slightly longer than the sepals.

On prairies, Maryland to Missouri, Alabama, and Arkansas. Spring and summer.

4. Dodecatheon Stanfièldia Small. Leaf-blades spatulate, 7-13 cm. long, entire, undulate and obtuse, the petiole-like bases relatively slender : scapes erect, $3-4 \mathrm{dm}$. tall, slender, glabrous: umbels few-flowered: calyx-lobes lanceolate, 3-5 mm. long, acute: corolla rose-purple, showy ; lobes obovate, mainly about $2 \mathrm{~cm}$. long.

In moist soil, San Marcos, Texas. Spring.

\section{Family 3. TheOphrastàceat D. Don. Jacquinia Family.}

Shrubs or small trees, with a light bark. Leaves opposite or somewhat whorled : blades leathery, yellowish, varying from retuse to apiculate, persistent. Flowers perfect, yellowish, in racemes, corymbs or panicles. Calyx campanulate, of 5 imbricated sepals. Corolla campanulate or rotate-salverform : lobes 5 , imbricated in the bud, spreading, with a series of staminodia which represent the outer series of stamens, attached below each sinus. Androecium of 5 stamens adnate to the base of the corolla-tube. Staminodia at the sinuses of the corolla. Gynoecium of 5 united carpels. Styles united, mostly hidden by the converging anthers. Ovules not immersed in the placentae. Berry leathery, subglobose. Seeds few or many.

\section{JACQUÍNIA L.}

Characters of the family, as given above. JoEwoop.

1. Jacquinia Keyénsis Mez. A shrub or small tree, reaching a height of $5 \mathrm{~m}$. and a maximum trunk diameter of $10 \mathrm{~cm}$., with a smooth blue-gray blotched bark, branched above into a round top, the young branchlets angled, rusty-puberulent, sometimes orange or yellowish green, becoming terete, darker and glabrous with age and marked with conspicuous orbicular leaf-scars. Leaf-blades leathery, cuneate-spatulate or oblong-obovate, $1-5 \mathrm{~cm}$.
long, yellowish green, 3-nerved, glabrous, shining, retuse or obtuse, often mucronulate, revolute, short-petioled : racemes $2-6 \mathrm{~cm}$. long : calyx campanulate, $2-3 \mathrm{~mm}$. high, narrowed to the club-shaped pedicel : sepals orbicular-ovate, obtuse : corolla straw-colored, salverform, about $1 \mathrm{~cm}$. broad ; lobes longer than the tube, spreading, oblong, obtuse : staminodia shorter than the corolla-lobes, oblong, erose at the apex: stamens shorter than the staminodia: berry subglobose, $8-10 \mathrm{~mm}$. in diameter. [J. armillaris Chapm., not Jacq.]

On and near the coast, southern peninsular Florida and the Keys.

\section{Family 4. ARdisiàceat Juss. Myrsine Family.}

Shrubs or trees, with rather compact wood and usually a gray bark. Leaves mostly alternate: blades leathery, entire, punctate : stipules none. Inflores- 
cence racemose, corymbose, cymose, or clustered on scaly spurs. Flowers regular, perfect or polygamo-dioicous. Calyx persistent : sepals 4-6, or rarely more. Corolla flat, salverform or rotate, white, pink or yellowish : tube very short: lobes spreading, reflexed or even curled back, sometimes glandular-spotted like the sepals. Androecium of 4-7 stamens adnate to the base or the throat of the corolla-tube or at the base of the corolla lobes. Filaments sometimes forming a tube. Staminodia wanting. Gynoecium of 4-7 united carpels. Styles united. Stigma capitate, truncate or somewhat foliaceous. Ovules immersed in the fleshy placenta. Fruit a rather dry berry, sometimes leathery, globose or subglobose, rarely obovoid, often tipped with the base of the style. Seed solitary, filling the fruit-cavity, often lobed at the base.

Stamens adnate to the base of the corolla-lobes ; anthers blunt. Stamens adnate to the throat of the corolla-tube; anthers acute.

1. RAPANEA. 2. ICACOREA.

\section{RAPÀNEA Aubl.}

Shrubs or small trees, with a dark gray bark. Trunks often densely branched. Leaves alternate: blades leathery. Flowers small, polygamo-dioecious, sessile or pedicelled, mostly clustered on scaly spurs. Calyx free, campanulate : sepals persistent, 4-5, or sometimes 7 . Corolla rotate : lobes usually 4-5, imbricated, spreading, often marked with dark lines or dots. Staminodia wanting. Stamens as many as the corolla-lobes, adnate to their bases. Filaments very short. Anthers introrse, lying against the corolla-lobes, usually obtuse. Style somewhat elongated. Stigma capitate or foliaceous. Ovules immersed in the fleshy placenta, only one maturing. Fruit a rather dry berry, pea-like. Seed solitary.

1. Rapanea Guyanénsis Aubl. A branching shrub or small tree, reaching a height of $6 \mathrm{~m}$. and sometimes with a trunk diameter of $16 \mathrm{~cm}$., with white, rather dense wood and a grayish bark, sparingly branched, the branches straight, rather naked. Leaves mostly confined to the ends of the branchlets; blades obovate-oblong, 4-10 cm. long, leathery, obtuse or retuse, revolute, mostly shining, paler on the lower side, short-petioled : flowers sessile or nearly so on short stout scaly spurs scattered along the naked branchlets: calyx campanulate, $1 \mathrm{~mm}$. high ; sepals 5-6, broadly ovate, obtuse or acutish, spotted with purple: corolla rotate, whitish, $4 \mathrm{~mm}$. broad, 3 times longer than the calyx ; lobes $5-6$, unequal, oblong, spotted and striped with purple, usually obtuse, somewhat erose and glandularciliate : anthers rather sagittate, somewhat shorter than the lobes of the corolla : fruit subglobose, $4 \mathrm{~mm}$. in diameter, bluish or black, often depressed and apiculate, short-pedicelled. [Myrsine Rapanea Roem. \& Schult.]

Near the coast, Florida, from the Indian River, southward through the Keys and the West Indies to Paraguay.

\section{ICACÒREA Aubl.}

Shrubs or trees, usually much branched. Leaves alternate: blades mostly entire, punctate. Flowers perfect or polygamo-dioecious, in panicles or cymes or sometimes umbellate. Calyx free, persistent, campanulate: sepals 4-5, mostly imbricated. Corolla white or pink, rotate, more or less reflexed : tube short : lobes sometimes curled, marked with dark lines and dots. Stamens as many as the corolla-lobes, exserted. Filaments bent, inserted at the top of the corolla-tube. Anthers introrse, erect, acute. Stigma truncate or disk-like. Ovules immersed in a fleshy placenta. Fruit a rather dry berry, varying from black to scarlet. Seed solitary, depressed-globose, roughened. Embryo transverse in the plentiful endosperm. Marlberry. Cherry.

1. Icacorea paniculàta (Nutt.) Sudw. A shrub or small tree, reaching a height of $7 \mathrm{~m}$. and a diameter of $15 \mathrm{~cm}$. with a hard, close-grained wood, and a light gray or nearly white scaly bark: branches and branchlets numerous, rather erect, terete, the latter often contorted, usually rusty. Leaf-blades usually oblanceolate, sometimes elliptic, 4-18 cm. long, leathery, acute or obtuse, glabrous, slightly revolute, narrowed into short grooved petioles, the nerves prominent beneath : panicles $5-12 \mathrm{~cm}$. long: calyx campanulate, $2 \mathrm{~mm}$. high ; sepals 4-6, ovate or obovate, obtuse, marked with purple dots and lines, ciliolate, the tips more or less reflexed : pedicel as long as the calyx : corolla rotate-reflexed, $1 \mathrm{~cm}$. broad; lobes 5 , or rarely 4-6, oblong, obtuse, marked with several purple dots and lines, reflexed or curled back: fruit depressed-globose, 7-8 mm. in diameter, apiculate, papillose, black and lustrous : seeds somewhat reniform. [Ardisia Pickeringia T. \& G.]

On the coast, south Florida, from $26^{\circ}$ on the west and $29^{\circ}$ on the east coast south ward through the Keys and the West Indies. Also in Mexico. 


\section{Order 3. EBENÀLES.}

Shrubs or trees. Leaves alternate, opposite or whorled, sometimes persistent: blades simple, commonly entire. Flowers perfect, monoecious or dioecious. Calyx of 3-12 partially united sepals. Corolla of 3-12 partially united petals. Androecium of as many stamens as there are corolla-lobes or twice as many, or more, sometimes accompanied by staminodia. Gynoecium of 3-several united carpels. Ovary superior or inferior. Styles and stigmas distinct or united. Ovules solitary or several in each cavity of the ovary. Fruit capsular or baccate.

Styles or stigmas distinct: flowers mostly monoecious or dioecious.

Styles and stigmas united: flowers mostly perfect.

Stamens as many as the corolla-lobes, at least in our representatives.

Stamens twice as many as the corolla-lobes or more.

Stamens in several series.

Stamens in 1 series.

Fam. 1. Ebenaceae.

Fam. 2. SAPOTACEAE.

Fam. 3. SymplocaceaE. Fam. 4. STYracaceab.

\section{Family 1. EBENÀCEAE Vent. Ebony Family.}

Shrubs or trees, with a watery or milky sap, a compact wood and a very astringent bark. Leaves alternate, or rarely opposite or whorled: blades simple: stipules wanting. Flowers inconspicuous, dioecious, or rarely polygamous or perfect, regular, solitary or in cymes. Calyx inferior, 3-7-lobed, persistent, accrescent. Corolla gamopetalous, variable in shape, with 3-7 valvate, imbricated or contorted lobes. Androecium of 3 or 4 times as many stamens as the petals, adnate to the corolla-tube. Anthers introrse, opening lengthwise or by pores. Ovary 3-several-celled. Styles commonly united at the base. Stigmas simple or 2-cleft. Ovules solitary, or 2 in each cavity, pendulous, anatropous. Fruit a fleshy berry or sometimes capsular. Seeds mostly flattened, with a smooth membranous or leathery testa. Endosperm copious, cartilaginous, sometimes channeled. Embryo straight or slightly curved in the axis of the endosperm. Styles distinct : anthers opening length wise : filaments pubescent : pistillate flowers with staminodia.

Styles united : anthers opening by nearly apical pores : filaments glabrous : pistil1. DIOSPYROS.

late flowers without staminodia.

2. BRAYODENDRON.

\section{DIOSPỲROS L.}

Shrubs or trees, with hard wood and watery sap. Leaves alternate or rarely nearly opposite: blades entire. Flowers dioecious, or rarely polygamous, solitary or in axillary cymes. Calyx 3-7-lobed. Corolla varying from urn-shaped to salver-form, 3-7-lobed: lobes contorted or imbricated. Stamens 4, 8, 16 or more, inserted, sometimes in pairs, at the base of the corolla, or hypogynous, reduced to staminodia in pistillate flowers: anthersacs opening by lateral chinks. Ovary 4-12-celled: styles 2-6, distinct. Berry spheroidal, globose or conic, subtended by the accrescent calyx.

1. Diospyros Virginiàna L. A tree, reaching a maximum height of about $35 \mathrm{~m}$., with a trunk diameter of less than $1 \mathrm{~m}$. Bark deep brown or black, finally divided into small blocks : leaf-blades rather leathery, ovate, oval or elliptic, 8-20 cm. long, acute or acuminate, entire, undulate, varying from acute to cordate at the base, becoming glabrous, deep green above, pale beneath; petioles $1-3 \mathrm{~cm}$. long: calyx-lobes 4 , triangular, ovatetriangular or sometimes ovate-lanceolate, obtuse or acutish : corolla urn-shaped, 8-13 mm. long; lobes 4 , more or less reniform, the tips recurved : staminodia 8 , lanceolate-sagittate: stamens mostly 16 , included : anthers often bearded at the base : ovary glabrous or nearly so : berry depressed-globose or obovoid-globose, $3-4 \mathrm{~cm}$. in diameter, very astringent when green, sweet and luscious when mature.

In fields and woods, Connecticut to Iowa, Florida and Texas. Flowers in the spring and matures its fruit after frost. Persimmon. Date Plum. Simmon. Possumwood.

\section{BRAYODÉNDRON Small.}

Shrubs or small trees, with a relatively smooth bark. Leaves alternate, approximated near the ends of twigs: blades leathery, broadened upward, entire. Flowers dioecious, solitary or 2-3 together in clusters. Calyx mostly 5-lobed. Corolla urn-shaped, pubes- 
cent without : lobes 5 , spreading. Stamens 16 , included: anther sacs opening by nearly terminal pores. Staminodia wanting. Ovary sessile, often 4-8-celled, pubescent: styles united : stigmas narrow, spreading or recurved. Berry spheroidal.

1. Brayodendron Texànum (Scheele) Small. An intricately branched shrub, or tree reaching a height of $16 \mathrm{~m}$., with a trunk diameter of $6 \mathrm{dm}$. Bark smooth, gray : leafblades leathery, cuneate, oblong-cuneate or obovate, 1-5 cm. long, obtuse or retuse at the apex, entire, commonly abruptly narrowed at the base, nearly sessile, becoming glabrous above, more or less tomentose beneath : calyx-lobes 5-6, ovate, obtuse, spreading or reflexed : corolla urn-shaped, pubescent without, 5-8 $\mathrm{mm}$. long; lobes 5, suborbicular, notched at the apex, spreading: stamens $16-20$; anthers glabrous : staminodia wanting: ovary pubescent : berry depressed-globose, about $2 \mathrm{~cm}$. in diameter, black, apiculate, becoming luscious: seeds $3-8$.

In river valleys, Texas and northern Mexico. spring; matures its fruit in August. BLACK PkRsimmon. mexican Persimmon. Chapote.

\section{FAmily 2. SAPOTÀCEAF Reichenb. SAPodilla Family.}

Shrubs or trees, sometimes thorn-armed, usually possessing a milky sap. Leaves mostly alternate, without stipules: blades entire, commonly densely nerved. Inflorescence clustered. Flowers perfect or rarely polygamous, complete. Calyx of 4-12 sepals, imbricated in one or two series. Corolla often white, with 4-several lobes, deciduous, with or without appendages at the sinuses. Androecium of usually as many stamens as the corolla-lobes, adnate to the corolla-tube, often to the bases of the lobes and opposite them, alternating with commonly conspicuous staminodia. Filaments distinct. Anthers often attached at the base, opening somewhat extrorsely. Gynoecium of several united carpels. Ovary 4-12-celled, free, sessile. Styles united. Stigmas entire or slightly lobed. Ovules solitary in each cavity, ascending, anatropous. Fruit a many-celled or by suppression a one-celled berry. Seeds nut-like, with a shining testa. Endosperm fleshy or wanting. Embryo straight, central or somewhat lateral.

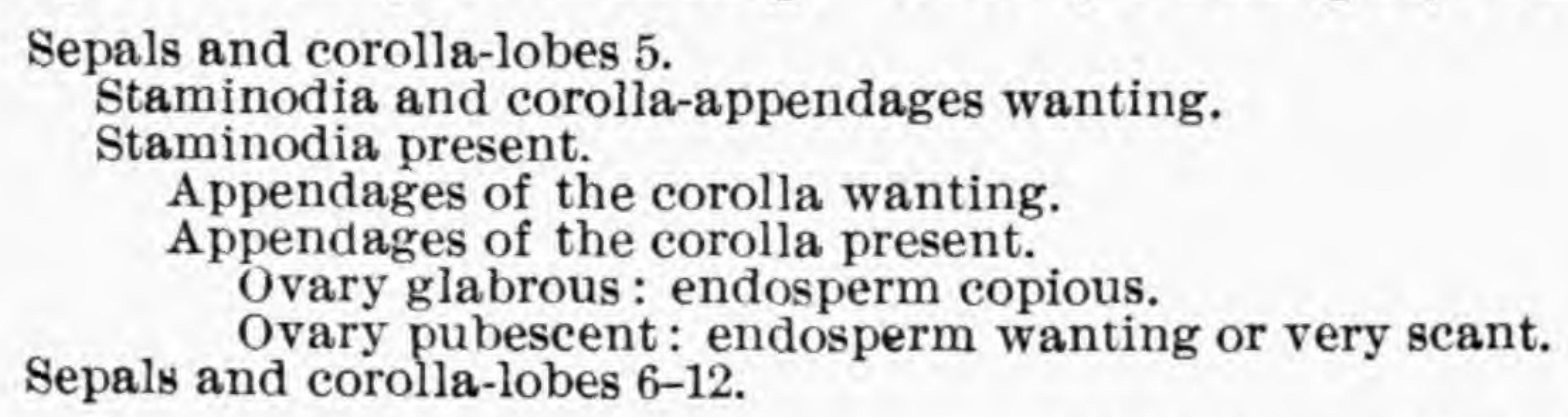

ppendages of the corolla present. Sepals and corolla-lobes 6-12.

1. Chrybophyllum.

2. SIDEROXYLON.

Ovary glabrous : endosperm copious. 3 . DrPHolis.

\section{CHRYSOPHÝLLUM L.}

Shrubs or trees, with a milky sap, and sometimes lustrous-pubescent foliage. Leaves alternate : blades leathery. Flowers small, in axillary or lateral clusters. Sepals mostly 5 , nearly equal. Corolla-lobes mostly 5, without appendages at the sinuses. Stamens 5 , adnate to the bases of the corolla-lobes, or on the tube, included. Anthers often pubescent, opening longitudinally. Staminodia wanting. Ovary mostly 5-celled, pubescent. Berry 1-seeded, pulpy. Seed compressed, with a leathery opaque or shining testa. Endosperm fleshy. Embryo straight. Satinleaf.

1. Chrysophyllum monopyrènum Sw. A small evergreen tree, sometimes $10 \mathrm{~m}$. tall, with a maximum trunk diameter of $3 \mathrm{dm}$., the twigs and lower leaf-surface and inflorescence with a lustrous copper-colored pubescence. Leaf-blades leathery, oblong, elliptic or oval, 3-10 cm. long, acute or short-acuminate, glabrous and lustrous above, acute or rounded at the base; petioles stout, about $1 \mathrm{~cm}$. long : clusters few-flowered : pedicels 5-8 $\mathrm{mm}$. long, thickened upward : calyx silky ; sepals suborbicular, $1.5 \mathrm{~cm}$. long : corolla 5 $\mathrm{mm}$. broad, white; lobes suborbicular, obtuse : appendages and staminodia none : anthers nearly sessile: berries oval, about $2 \mathrm{~cm}$. long, dark purple: seed smooth. [C. oliviforme Lam., not L.]

Southern Florida, on the peninsula and the Keys. Also on the Bahamas and the West Indies. Flowers throughout the year.

\section{SIDERÓXYLON L.}

Unarmed shrubs or trees. Leaves alternate: blades leathery, sometimes rather thin. Flowers small, in often dense axillary or lateral clusters. Sepals ovate to obovate, commonly obtuse, strongly imbricated. Corolla-lobes 5, shorter or longer than the tube, 
usually obtuse. Stamens mostly 5, included, adnate to the base of the corolla-lobes or on the tube opposite the lobes: anthers opening lengthwise. Staminodia scale-like, or petaloid, entire or toothed. Ovary 5-celled or rarely 2-4-celled : style variable. Berry ovoid or subglobose. Seed mostly solitary, with a crustaceous often shining testa. Endosperm fleshy. Embryo central. Mastic. Wild Olive.

1. Sideroxylon mastichodéndron Jacq. A massive tree, sometimes $25 \mathrm{~m}$. tall, with a maximum trunk diameter of about $1.5 \mathrm{~m}$. Leaf-blades leathery, oblong to oval or rarely ovate, 4-15 $\mathrm{cm}$. long, obtuse or short-acuminate at both ends, undulate, bright green and lustrous above, yellowish green and dull beneath, becoming glabrous; petioles slender, commonly $\frac{1}{2}$ as long as the blade or longer: pedicels 4-7 mm. long: calyx glabrous ; sepals suborbicular, about $2 \mathrm{~mm}$. long : corolla $6-7 \mathrm{~mm}$. broad, light yellow; lobes 5 , oblong or ovate-oblong, obtuse : staminodia lanceolate, long-acuminate, $1 \mathrm{~mm}$. long : stamens about as long as the petals: drupes oval, nearly $2.5 \mathrm{~cm}$. long, yellow : seed obovoid, smooth : pulp rather dry, somewhat acid.

In hammocks, southern peninsular Florida and the Keys. Fall and spring.

\section{DÍPHOLIS A. DC.}

Unarmed shrubs or small trees. Leaves alternate. Flowers in axillary or lateral clusters. Sepals 5, ovate to suborbicular, strongly imbricated, nearly equal. Corolla-lobes 5 , furnished with 2 appendages at each sinus. Stamens 5, adnate to the corolla-tube, opposite the lobes, exserted: filaments filiform: anthers opening lengthwise. Staminodia 5, petaloid, commonly acuminate, keeled. Ovary 5-celled, somewhat 5-lobed, glabrous : style elongated. Berry ovoid or oblong, fleshy. Seed usually solitary, with a leathery testa. Endosperm fleshy. Embryo somewhat lateral. Bustic. Cassada.

1. Dipholis salicifòlia (L.) A. DC. An evergreen tree, sometimes $16 \mathrm{~m}$. tall, with a maximum trunk diameter of about $5 \mathrm{dm}$. Leaf-blades leathery, elliptic or elliptic-oblanceolate, 5-12 cm. long, usually acute at the apex, entire, acuminate at the base into slender petioles, glabrous and lustrous above, dull and glabrous or rarely pubescent beneath : pedicels stout, enlarged upward, 2-3 mm. long: calyx pubescent; sepals ovate or oblong, $1.5 \mathrm{~mm}$. long, obtuse : corolla $4 \mathrm{~mm}$. broad; lobes oblong or oval, rounded at the apex, about as long as the tube: staminodia ovate or ovate-lanceolate, laciniatetoothed: appendages at least $\frac{1}{2}$ as long as the corolla-lobes : berries subglobose or oval, about $8 \mathrm{~mm}$. in diameter, black.

In hammocks, southern peninsular Florida and the Keys. Also in the West Indies. Spring.

\section{BUMÈLIA Sw.}

Shrubs or small trees, with a milky or gummy sap and a very hard wood. Leaves alternate, their axils sometimes spine-bearing : blades sometimes conspicuously or prominently nerved. Flowers mostly perfect, few or many in axillary clusters. Calyx longpedicelled or nearly sessile, persistent. Sepals unequal, strongly imbricated. Corolla white, deciduous: lobes longer than the tube, with an appendage on each side. Stamens 5 , adnate to the corolla-tube : anthers versatile. Staminodia 5, petal-like. Ovary 5-celled, pubescent. Ovules 5. Berry drupe-like. Seed mostly solitary, erect. Endosperm wanting or nearly so. The plants flower in spring and summer. Buckthorn.

A. Leaf-blades glabrous, or merely with scattered hairs or inconspicuously cobwebby beneath. Fruit oblong-cylindric.

Fruit subglobose or oval.

Leaf-blades of an obovate or spatulate type, mainly broadest above the middle. Twigs copiously pubescent with deep red hairs.

Twigs glabrous or soon becoming so.

Fruit less than $8 \mathrm{~mm}$. long.

Corolla-lobes about $1.5 \mathrm{~mm}$. long : leaf-blades blunt : fruit $5 \mathrm{~mm}$. long. Corolla-lobes about $2 \mathrm{~mm}$. long: leaf-blades retuse: fruit $6-7 \mathrm{~mm}$. long. Fruit over $9 \mathrm{~mm}$. long.

Leaf-blades 1-3.5 $\mathrm{cm}$. long : fruit over $10 \mathrm{~mm}$. broad.

Leaf-blades $4-10 \mathrm{~cm}$. long : fruit less than $10 \mathrm{~mm}$. broad. Corolla-lobes erose-denticulate: staminodia serrulate: sepals glabrous.

Corolla-lobes entire : staminodia entire : sepals pubescent.

1. B. angustifolia.

2. B. rufotomentosa.

3. B. microcarpa.

4. B. reclinata.

5. B. megacocca.

6. B. cassinifolia.

7. B. monticola.

Leaf-blades of an elliptic type broadest at the middle.

Pedicels and sepals pubescent.

Pedicels and sepals glabrous.

Corolla $3 \mathrm{~mm}$. long; lobes as broad as long: leaf-blades not reticulated.

Corolla $4 \mathrm{~mm}$. long; lobes longer than broad: leaf-blades copiously reticulated.

8. B. Texana.

9. B. lucida.

10. B. lycioides. 
B. Leaf-blades manifestly or copiously pubescent beneath.

Pubescence woolly, not at all lustrous.

Leaf-blades cuneate, mostly $1-3 \mathrm{~cm}$. long.

Leaf-blades not cuneate, mostly 4-10 cm. long.

Pubescence lustrous, white, becoming tawny, brown or coppery.

11. B. rigida.

12. B. lanuginosa.

13. B. tenax.

1. Bumelia angustifolia Nutt. A glabrous depressed shrub, or a small tree reaching a height of $8 \mathrm{~m}$. Stems sometimes $15 \mathrm{~cm}$. in diameter: leaves persistent; blades leathery, varying from narrowly oblanceolate-spatulate to obovate, cuneately narrowed at the base, $2-4 \mathrm{~cm}$. long, entire, usually rounded at the apex, somewhat shining above, paler and dull beneath, short-petioled: fascicles few-flowered or many-flowered, sometimes dense: pedicels 3-6 mm. long, slightly thickened upward: sepals ovate, $2 \mathrm{~mm}$. long, obtuse, the inner much broader than the outer: corolla-lobes suborbicular, erose-denticulate; appendages narrowly-lanceolate, acuminate : staminodia ovate or ovate-lanceolate, $2 \mathrm{~mm}$. long, obtuse or acute, erose-dentate: berries oblong, 1.5-2 cm. long, fleshy, edible.

Florida, on the peninsula and the Keys. Also in the lower Rio Grande valley, Texas and Mexico. Flowers in November and October: matures its fruit in the spring. SAFFroN PLUM. ANTS-WOOD. DOWNWARD PLUM.

2. Bumelia rufotomentòsa Small. A thorny shrub, with densely and deep red tomentose twigs and petioles. Stems stout, rigid, spreading or ascending, several dm. long, slightly zigzag: leaves firm ; blades obovate or oval, $1.5-2 \mathrm{~cm}$. long, obtuse or slightly retuse at the apex, more or less undulate, prominently reticulated, especially beneath, shining and becoming glabrous above, paler, dull and usually sparingly pubescent beneath with red hairs, on short slender petioles: fascicles many-flowered : pedicels slender, $2-3 \mathrm{~mm}$. long, gradually enlarged upward, like the calyx, pubescent with straggling hairs : sepals suborbicular, nearly $1.5 \mathrm{~mm}$. broad, the inner slightly larger than the outer: corollalobes suborbicular, often slightly broader than long, about $1.5 \mathrm{~mm}$. in diameter; appendages ovate or ovate-lanceolate, acutish: staminodia ovate-lanceolate, a little over 1 $\mathrm{mm}$. long, obtuse : berries subglobose, about $5 \mathrm{~mm}$. in diameter.

In pine woods, peninsular Florida.

3. Bumelia microcárpa Small. A low shrub, with zigzag branches and spreading thorn-armed twigs. Leaves firm; blades spatulate, oblanceolate or rarely oblongobovate, rounded or acutish at the apex, lustrous and finely reticulated above, cobwebbypubescent beneath or glabrate in age, attenuate into slender petioles 2-6 mm. in length : fascicles dense, on short scaly spurs: pedicels $1-4 \mathrm{~mm}$. long, rather thinly tomentose: sepals suborbicular, concave, 1-1.5 mm. broad, tomentose or glabrous in age : corollalobes white, depressed-orbicular, about $1.5 \mathrm{~mm}$. broad, rounded at the apex; appendages broadly lanceolate, $0.7 \mathrm{~mm}$. long: staminodia lanceolate or ovate-lanceolate, about $1 \mathrm{~mm}$. long, barely acute : berries subglobose, $5 \mathrm{~mm}$. in diameter.

In sandy soil, peninsular Florida.

4. Bumelia reclinàta Vent. A low decumbent or ascending armed glabrous shrub, 1-2 m. tall, the spine-like branches often leafy and hearing flowers. Stems commonly zigzag or somewhat twisted : leaves numerous; blades thinnish, oblanceolate ovate, obovate or spatulate, $2-5 \mathrm{~cm}$. long, rounded or retuse at the apex, deep green and shining above, paler and dull beneath, somewhat prominently reticulate, narrowed into petioles varying from 2 to $4 \mathrm{~mm}$. in length : fascicles few-flowered : pedicels glabrous, $3-5 \mathrm{~mm}$. long, enlarged upward: sepals broadly ovate or orbicular-ovate, $1.8 \mathrm{~mm}$. long: berries oval, 6-7 mm. long.

In sandy soil, Georgia to Florida and Louisiana.

5. Bumelia megacócca Small. An evergreen glabrous thorny shrub, with spreading or procumbent branches. Bark pale, raised in angular corky ridges which are broken by numerous lenticels : leaves few ; blades leathery, obovate or oblong-oblanceolate, $1-3.5 \mathrm{~cm}$. long, obtuse or retuse at the apex, deep green and somewhat shining above, paler and prominently reticulated beneath, slightly revolute, short-petioled : pedicels stout, 1-3 mm. long : berries globose or oblong-globose, 11-13 mm. in diameter, black : seeds 9-10 mm. in diameter, pale, smooth and shining, variegated.

In sandy soil, peninsular Florida.

6. Bumelia cassinifolia Small. A glabrous or glabrate commonly armed shrub, or small tree, 5-10 m. tall, the twigs and the lower surface of the leaves puberulent. Stems rarely more than $16 \mathrm{~cm}$. thick, clothed with a reddish brown bark : leaves numerous; blades thinnish, oblong-obovate, or oblanceolate, $2-10 \mathrm{~cm}$. long, rounded or retuse at the apex, undulate, narrowly revolute, dark green above, somewhat paler beneath, the main nerves slightly prominent beneath; petioles slender, varying from 8-12 mm. in length : fascicles many-flowered : pedicels glabrous, $2-5 \mathrm{~mm}$. long, slightly enlarged upward: sepals suborbicular, $2 \mathrm{~mm}$. long, the inner with a broad scarious margin : corolla-lobes suborbicular, 
1.5-2 mm. in diameter, often erose-toothed; appendages lanceolate or ovate-lanceolate, crisped or erose : staminodia ovate, about $2 \mathrm{~mm}$. long, obtuse, serrulate : berries oval or globose-oval, $1-1.5 \mathrm{~cm}$. long.

In sandy soil or woods, Louisiana.

7. Bumelia montícola Buckl. A straggling thorn-armed shrub 1-3 $\mathrm{m}$. tall, the petioles, nerves of the lower surface of the leaf-blades and inflorescence sparingly pubescent. Stem clothed with a reddish brown bark : leaves stiff ; blades spatulate or oblong-oblanceolate, rounded and often slightly apiculate at the apex, slightly revolute, usually acuminate or cuneately narrowed at the base, the nerves prominent and reticulate on the pale under surface, not prominent on the dark green upper surface; petioles slender, $3-8 \mathrm{~mm}$. long: fascicles often many-flowered : pedicels slender, much thickened toward the apex : sepals suborbicular, about $2 \mathrm{~mm}$. long, the inner slightly broader than the outer: corolla-lobes suborbicular, a little broader than long, about $1.5 \mathrm{~mm}$. in diameter ; appendages lanceolate, rather obtuse : staminodia ovate-lanceolate, obtuse or acutish, less than $2 \mathrm{~mm}$. long: ovary hairy : berries elliptic, 1-1.3 mm. long, often tipped by the persistent style : seeds subglobose, slightly longer than thick.

In dry soil, western and southern Texas.

8. Bumelia Texàna Buckl. A rigid somewhat thorny shrub or small tree, several $\mathrm{m}$. tall, glabrous or with a slight inconspicuous pubescence on the petioles, and midrib of the leaf-blades beneath. Leaves firm ; blades leathery, oval or oblong, $2-3 \mathrm{~cm}$. long, rounded, truncate or retuse at the apex, hardly revolute, prominently nerved and pale green on both surfaces, sometimes cuneately narrowed at the base; petioles slender, 5-10 $\mathrm{mm}$. long: fascicles few-flowered: pedicels stoutish, 1-3 mm. long: berries oblong or elliptic, about $1 \mathrm{~cm}$. long.

On plains and mountains, southwestern Texas.

9. Bumelia lùcida Small. A glabrous shrub, or a small tree 2-7 m. tall, with rigid thorny branches. Leaves numerous; blades leathery, elliptic varying to elliptic-ovate or elliptic-oblanceolate, $2-5 \mathrm{~cm}$. long, acute or obtuse at both ends, deep-green, shining and hardly reticulated above, paler, dull and prominently reticulated beneath ; petioles slender, 2-5 mm. long: fascicles rather many-flowered : pedicels glabrous, slender, 3-7 mm. long, very slightly if at all enlarged at the apex : sepals suborbicular, about $2 \mathrm{~mm}$. in diameter, the outer somewhat smaller than the inner: corolla-lobes suborbicular; appendages lanceolate, obtuse : staminodia ovate, $2 \mathrm{~mm}$. long, sometimes inequilateral, obtuse : berries mostly oval, about $7-8 \mathrm{~mm}$. long.

In woods, Louisiana and eastern Texas.

10. Bumelia lycioides (L.) Gaertn. A glabrous usually armed shrub, or a small tree reaching a height of $8 \mathrm{~m}$., the stems clothed with a gray bark. Leaves numerous; blades thickish but barely leathery, oblong, elliptic or rarely oblanceolate, 4-12 cm. long, acute or acuminate or rarely rounded at the apex, pale green and prominently reticulate on both surfaces, narrowed into petioles which are 5-12 mm. long: fascicles densely flowered: pedicels slender, 7-10 mm. long, hardly enlarged at the apex : sepals oval, or orbicularovate, $2 \mathrm{~mm}$. long, the inner somewhat broader than the outer: corolla-lobes longer than broad; appendages lanceolate or ovate-lanceolate : staminodia ovate, $2-2.5 \mathrm{~mm}$. long, boatlike, obtuse, often keeled : ovary hairy : berries oval, fully $1 \mathrm{~cm}$. long.

In low or damp soil, Virginia to Illinois, south to Florida and Texas. BUCKTHorn. Ironwood. Mock Orange. Shittimwood.

11. Bumelia rígida (A. Gray) Small. A low tree with rigid spreading branches. Leaves numerous : blades cuneate or oblong-cuneate, $1.5-3 \mathrm{~cm}$. long, rounded or retuse at the apex, dark green and glabrous above, woolly beneath; petioles $1-3 \mathrm{~mm}$. long : fascicles rather few-flowered : pedicels 4-8 mm. long, slightly thickened above : sepals suborbicular, in diameter, truncate at the base, erose ; appendages lanceolate or ovate-lanceolate, acute : staminodia ovate-lanceolate, erose, obtuse : ovary hairy : berries oblong-oval or oval, 10-12 $\mathrm{mm}$. long, often tipped with the persistent style.

Along streams, Texas to Arizona and northern Mexico.

12. Bumelia lanuginòsa (Michx.) Pers. An armed or thornless shrub or tree, 3-20 m. tall, its twigs, the lower surface of the leaves and the inflorescence tomentose with pale or reddish hairs, never lustrous, the stems rarely becoming nearly $1 \mathrm{~m}$. thick. Leaves various; blades oblong-oblanceolate, oblong-obovate or elliptic, acutish, rounded or retuse at the apex, glabrous above, gradually or cuneately narrowed at the base; petioles $2-15 \mathrm{~mm}$. long: fascicles few- or many-flowered: pedicels 5-8 $\mathrm{mm}$. long, considerably enlarged towards the base of the calyx : sepals suborbicular or orbicular-ovate, about $3 \mathrm{~mm}$. long, 
concave : corolla-lobes orbicular-ovate, $2 \mathrm{~mm}$. long; appendages ovate-lanceolate or lanceolate, acute or acutish : staminodia ovate, acute or acutish, usually erose-denticulate, about as long as the petals : ovary hairy : berries oval or obovoid-oblong, 10-15 $\mathrm{mm}$. long.

In sandy soil, Missouri and Kansas to Georgia, Florida and Texas. GuM Elastic. Black Haw. SHITTIMWOOD.

13. Bumelia tènax (L.) Willd. An unarmed or thorny shrub, or small tree, 2-9 m. tall, its twigs, the lower surface of the leaf-blades and the inflorescence clothed with a lustrous silky pubescence, at first whitish, becoming tawny or brownish, the stem seldom over $16 \mathrm{~cm}$. in diameter. Leaves numerous ; blades oblanceolate, obovate-spatulate or obovate (those of the twigs sometimes inclined toward oblong-elliptic), $2-7 \mathrm{~mm}$. long, obtuse or retuse, glabrous above, slightly revolute ; petioles $2-5 \mathrm{~mm}$. long: fascicles many-flowered : pedicels slender, 8-13 mm. long; or rarely shorter, very slightly enlarged upward: sepals concave, suborbicular, 1-1.5 mm. long, erose-denticulate or entire, rounded at the apex or notched ; appendages ovate or ovate-lanceolate, often erose on one side : staminodia ovate, 1.5-2 mm. long, obtuse : berries obovoid or oblong-obovoid, 10-14 mm. long, often tipped with the slender persistent style.

In thickets and sandy soil, mostly near the coast, North Carolina to Cape Canaveral and Cedar Keys, Florida. BLACK Haw. IronwoOd. TOUgh BUCKTHORN.

\section{MÍMUSOPS L.}

Tropical shrubs or trees, with a milky sap. Leaves alternate: blades leathery, with fine and often indistinct venation. Flowers in clusters at the ends of short branches. Sepals $6-12$, in 2 rows, the exterior set valvate. Corolla-lobes mostly included in the calyx, 6-12, with two appendages at each sinus, the tube short. Stamens 6-12, adnate to the corolla-tube, opposite the appendages : filaments slightly dilated below, anthers often slightly pubescent and toothed at the end: sacs opening lengthwise. Staminodia 6-12, sometimes cohering with the stamens, commonly toothed or cut. Ovary 6-8-celled, pubescent. Berry subglobose, fleshy. Seeds mostly solitary, rarely few, oblique, slightly compressed, with a crustaceous or hard testa. Endosperm fleshy. Embryo nearly central.

1. Mimusops Sièberi A. DC. An evergreen tree, sometimes $10 \mathrm{~m}$. tall, with a distorted trunk nearly $3 \mathrm{dm}$. in diameter, the young foliage finely pubescent. Leaves clustered at the ends of branchlets ; blades leathery, oblong, $3-10 \mathrm{~cm}$. long, notched at the apex, slightly revolute, glabrous in age, rounded or acute at the base, with numerous obscure lateral nerves ; petioles rather slender, 1-2 cm. long : clusters few- or many-flowered : pedicels red-tomentose, drooping, $1-3 \mathrm{~cm}$. long: calyx pubescent like the pedicels : sepals lanceolate or ovate-lanceolate, rather acute : corolla about $1.5-2 \mathrm{~cm}$. broad, light yellaw ; lobes linear, commonly toothed at the apex : appendages much like the corolla-lobes, but only $\frac{1}{2}$ as long : staminodia triangular : stamens shorter than the petals : berry depressed-globose, nearly $3 \mathrm{~cm}$. in diameter, scaly, with a milky juice : seed smooth.

Southern Florida, on the Keys. Also in the Bahamas and the West Indies. Spring; fruit maturing in the fall. Wild SAPODILla. Wild Dilly.

\section{FAMily 3. SYMPLOCÀCEAE Miers. SweEt-Leaf Family.}

Shrubs or trees, with glabrous foliage, or the pubescence, if present, of simple hairs. Leaves alternate : blades usually leathery, often yellowish and yielding a yellow dye: stipules wanting. Inflorescence axillary, variously disposed, sometimes fascicled. Flowers often polygamo-dioecious, or sometimes perfect, regular. Calyx inferior: lobes 5, imbricated, the whole accrescent. Corolla of 5 nearly distinct, or united petals, often imbricated. Stamens numerous, adnate, in several series, to the corolla-tube. Flaments more or less flattened, distinct or cohering. Anthers short, innate. Ovary 2-5-celled. Styles terminal, united. Stigmas entire or slightly lobed. Ovules 2 or rarely 4 in each cavity, pendulous from the upper part of the angle. Fruit a berry, or a drupe with a thin or thick hard endocarp. Seeds often solitary. Embryo terete, straight or curved, axile or nearly so.

\section{SÝMPLOCOS L.}

Characters of the family. SweEt-leaf.

1. Symplocos tinctòria (L.) L'Her. An often evergreen shrub or small tree, reaching a height of $10 \mathrm{~m}$., with a trunk diameter of less than $3 \mathrm{dm}$., the bark smooth or warty. 
Leaf-blades elliptic, oblong or oblong-oblanceolate, 4-15 $\mathrm{cm}$. long, usually short-acuminate and acute or acutish at the apex, undulate or shallowly toothed, glabrous and shining above, more or less tomentose beneath, often tinged with yellow or bronze, attenuate or abruptly narrowed into short petioles : flowers sessile, 5-17 in axillary clusters : calyx campanulate, $2-2.5 \mathrm{~mm}$. high ; lobes ovate to triangular-ovate, obtuse, slightly shorter than the tube: petals 5, obovate, or obovate-spatulate, $6-8 \mathrm{~mm}$. long, united below, rounded or notched at the apex, yellowish : stamens exserted : drupe nut-like, oblong or ovoid, 10-14 $\mathrm{mm}$. long, glabrous, crowned with the persistent calyx-lobes.

Chiefly in rich soil, Delaware to Florida and Louisiana. Spring. Yellowwood. Horse Sugar. Wild LaURel.

\section{Family 4. Styracàdeat A. DC. Storax Family.}

Commonly stellate-pubescent or scurfy shrubs or trees, some yielding a fragrant balsamic resin. Leaves alternate, without stipules: blades entire or toothed. Inflorescence racemose, cymose or fascicled. Flowers perfect, regular. Calyx with 5, or rarely 4-8, short or obsolete lobes. Corolla of 5, or rarely 4-8, distinct or nearly distinct petals. Stamens few (8-16), adnate, in one series, to the corolla-tube. Filaments flattened and coherent at the base. Anthers introrse, adnate. Ovary 2-5-celled, the cavities opposite the calyx-lobes. Styles united. Ovules solitary or few in each cavity, anatropous, ascending or pendulous, or both. Fruit commonly a drupe or a capsule. Seeds mostly solitary, with a thin or leathery testa. Endosperm fleshy or horny. Embryo usually straight, axile.

Ovary superior: fruit drupaceous, subglobose.

Ovary inferior: fruit nut-like, elongated, winged.

1. Styrax.

2. MOHRODENDRON.

\section{STYYRAX L.}

Shrubs or trees, often clothed with scurfy or stellate pubescence. Leaves alternate: blades entire or slightly toothed. Flowers in short racemes, white, often drooping, subtended by small bracts. Calyx slightly adherent to the ovary, not accrescent, entire or slightly 5-toothed. Petals 5, distinct, or somewhat united, valvate or imbricated. Stamens 10 or rarely more, adnate to the base of the corolla: anthers elongated, erect, the sacs united. Ovary superior, 3-celled or at length 1-celled by the obliteration of the septa. Ovules several in each cavity, ascending: stigma 3-toothed or 3-lobed. Drupe dry, subglobose, superior. Seeds commonly solitary. Storax. The plants flower in spring.

Corolla-lobes valvate in the bud.

1. S. Americana.

Corolla-lobes manifestly imbricated or convolute in the bud.

Corolla-lobes lightly imbricated or convolute: pedicel and calyx canescent.

Bracts of the inflorescence mostly leaf-like: leaf-blades slightly pubescent beneath.

Bracts of the inflorescence only leaf-like at the base of the panicle or raceme: leaf-blades densely pubescent beneath.

Corolla-lobes strongly imbricated or convolute : pedicel and calyx glabrous or nearly so.

2. S. pulverulenta.

3. S. grandifolia.

4. S. platanifolia.

1. Styrax Americàna Lam. A shrub 1-3 m. tall, with glandular and slightly pubescent twigs, peduncles and petioles. Leaf-blades oval, elliptic or oblong, often varying to ovate or obovate, 2-10 cm. long, acute or short-acuminate at the apex, entire or distantly toothed, usually acute at the base, dark green above, pale beneath, becoming glabrous, short-petioled : flowers white, about $2.5 \mathrm{~cm}$. broad, drooping, their pedicels $12-14 \mathrm{~mm}$. long, often slightly pubescent : calyx about $4 \mathrm{~mm}$. high, 5-lobed, much shorter than the pedicel : corolla rotate; lobes valvate in the bud, elliptic-oblong or lanceolate-oblong, acute, slightly pubescent without : filaments erect : anthers bright yellow : drupe subglobose, $6-8 \mathrm{~mm}$. in diameter, finely tomentose.

On banks of streams, Virginia to Florida, Louisiana and Arkansas.

2. Styrax pulverulénta Michx. A shrub, ranging from 1-4 m. in height, with canescent or hoary young foliage. Leaf-blades ovate, oval or obovate, acute or acuminate, sharply serrate or rarely undulate, acute at the base, dark green above, more or less canescent beneath, short-petioled : flowers white, fragrant, loosely racemed, drooping: pedicels 2-4 cm. long, canescent or hoary : calyx 3-4 mm. long, 5-lobed, about as long as the pedicel : corolla rotate; lobes 5 , imbricated in the bud, oblong or oblong-lanceolate, rather obtuse, pubescent : filaments nearly erect : anthers yellow : drupe subglobose, 7-9 $\mathrm{mm}$. in diameter, minutely but densely pubescent.

In pine-land swamps or along streams, Virginia and Kentucky to Florida and Texas. 
3. Styrax grandifòlia Ait. A shrub $0.5-3 \mathrm{~m}$. tall, with pubescent young foliage. Leafblades thinnish, obovate, oval or sometimes elliptic, 10-20 cm. long, obtuse or short-acuminate, coarsely toothed or nearly entire, cuneately narrowed or nearly rounded at the base, becoming glabrous above or minutely pubescent on the impressed nerves, densely and finely tomentose beneath; petioles $3-7 \mathrm{~mm}$. long: racemes $0.5-1 \mathrm{~cm}$. long, often leafy : flowers white, solitary or 2 together: pedicels 4-9 mm. long: calyx 4-5 mm. long; lobes 5 , triangular, acute : corolla 2-2.5 $\mathrm{cm}$. broad; lobes elliptic, acute, 10-12 mm. long, slightly pubescent without : anthers bright yellow : filaments pubescent : drupe subglobose, 8-12 mm. in diameter, apiculate, pubescent.

In woods, Virginia to Florida and Louisiana.

4. Styrax platanifòlia Engelm. A branching shrub 1-4 m. tall, with glabrous or almost glabrous foliage. Leaf-blades suborbicular in outline, undulate, angu late, or sinuate-lobed, $5-10 \mathrm{~cm}$. broad, more or less abruptly acuminate, reticulateveined,truncate or subcordate at the base, slender-petioled: racemes corymbiform : pedicels glabrous or nearly so, subtended by minute bracts: calyx glabrous, or nearly so : petals oblong or oblong-obovate, $15-19 \mathrm{~mm}$. long : drupe globular, $8-10 \mathrm{~mm}$. in diameter, apiculate.

In wooded bottom lands, Texas.

\section{MOHRODÉNDRON Britton.}

Shrubs or trees, often with some stellate pubescence. Leaves alternate, deciduous ; blades commonly membranous. Flowers in racemes, white, mostly drooping. Hypanthium adnate to the ovary, 4-5-ribbed, 4-5-lobed, accrescent. Petals 4-5, sometimes almost distinct, imbricated, erect or nearly so, convolute or imbricated. Stamens 8, 10, 12 or 16 in one series, often exserted : anthers elongated, the sacs commonly free at the base. Ovary inferior, 3-5-celled : style elongated : stigma scarcely enlarged. Ovules 4 in each cavity, the upper pair ascending, the lower pair pendulous. Fruit nut-like, becoming dry, crowned with the calyx-lobes, 2-4-winged. Seeds 1-3, elongated. [Halesia Ellis.] The plants flower in the spring.

Fruit 2-winged, the stipe wholly included in the wings.

Corolla 8-12 mm. long: fruit less than $3 \mathrm{~cm}$. long.

Corolla $20-30 \mathrm{~mm}$. long: fruit over $3 \mathrm{~cm}$. long.

Fruit 4-winged, the base of the stipe not included.

1. M. parviflorum.

2. M. dipterum.

3. M. Carolinum.

1. Mohrodendron parviflòrum (Michx.) Britton. A shrub similar to $M$. Carolinum in habit, but smaller, the young leaves, pedicels and calyx densely pubescent. Corolla white, $8-12 \mathrm{~mm}$. long : drupe less than $3 \mathrm{~cm}$. long, the two wings, including the stipe.

In sandy soil, southern Georgia and Florida.

2. Mohrodendron dípterum (Ellis) Britton. A shrub or small tree, reaching a height of $15 \mathrm{~m}$. with a trunk diameter of $3 \mathrm{dm}$. Bark broadly fissured : twigs, leaves and flowers pubescent : leaf-blades firm or somewhat leathery, oval, oblong or obovate, acuminate, coarsely toothed, acute or subcordate at the base, softly pubescent beneath, finely and sparsely pubescent, at least on the nerves above; petioles stout, 1-2 $\mathrm{cm}$. long: pedicel about as long as the corolla: calyx 6-7 mm. long, densely pubescent; lobes triangular, acuminate : corolla campanulate, $2-3 \mathrm{~cm}$. long; lobes pubescent without, oblong or oblong-obovate, obtuse or notched : stamens included : filaments and style pubescent : drupe oblong or elliptic, 4-5 $\mathrm{cm}$. long, 2-winged.

In wet woods, Tennessee and South Carolina to Florida and Texas. Spring. SNowdrop Tree. Silverbell Tree. Cow Licks.

3. Mohrodendron Carolìnum (L.) Britton. A shrub or tree, reaching a maximum height of $25 \mathrm{~m}$. and a trunk diameter of less than $1 \mathrm{~m}$. Bark broken into flat ridges : twigs, lower leaf-surfaces and pedicels pubescent. Leaf-blades thinnish, oblong, oval or obovate, 5-17 cm. long, acuminate, finely serrate, acute or truncate at the base, glabrous or minutely pubescent on the nerves above, more or less densely pubescent beneath ; petioles 1-2 $\mathrm{cm}$. long: pedicel about as long as the corolla: calyx $5-6 \mathrm{~mm}$. long, glabrous: lobes triangular, acute: corolla campanulate, $2-2.5 \mathrm{~cm}$. long; lobes glabrous without, rounded, shorter than the tube: stamens included: filaments and style glabrous : drupe oblong or oblong-obovoid, $4-5 \mathrm{~cm}$. long, 4-winged, tipped with the persistent style.

In woods, Virginia to Illinois, south to Florida and Texas. SNOWDrop Tree. Silverbell Trer. Wild Olive Tree, Bell Tree. Opossum Wood. Rattlebox. Calico Wood. Tiss Wood. 


\section{Order 4. OLEÀLES.}

Shrubs or trees, or rarely herbaceous plants, of great economic value. Stems erect or climbing. Leaves opposite, or rarely alternate or whorled, sometimes persistent: blades simple or pinnately-compound: stipules wanting: leaflets entire or toothed. Inflorescence variously disposed. Flowers perfect, or polygamous or dioecious, complete or incomplete, mostly regular. Calyx free : sepals 4 or more, partially united, sometimes wanting. Corolla of 2-6 distinct or partially united narrow imbricated or valvate petals, or sometimes wanting. Androecium of 2 or 4 stamens adnate to the base of the corolla. Filaments commonly short. Anthers variable. Ovary free, 2-celled. Stigmas capitate or 2-lobed. Ovules 2 in each cavity, pendulous, anatropous or amphitropous. Fruit a capsule opening loculicidally by 2 valves, a samara or a berry, usually by suppression 1-celled. Seeds commonly solitary, sometimes $2-4$ with a usually thin testa. Endosperm fleshy or somewhat horny, often oily, sometimes wanting. Embryo straight.

\section{Family 1. OLEÀCeat Lindl. Olive Family.}

Characters of the order.

Fruit dry, an indehiscent or dehiscent capsule.

Fruit a variously dehiscent capsule : leaf-blades simple.

Capsule not paired, opening loculicidally by 2 valves: ovules and seeds pendulous : calyx-lobes 4.

Capsules paired, opening septicidally by 2 valves : ovules and seeds erect or ascending : calyx-lobes 7-15.

Corolla rotate or campanulate: stamens exserted; filaments filiform.

Corolla salverform; stamens included : anthers nearly sessile.

Fruit a samara: leaf-blades compound at least in our species.

1. SYRINGA.

2. MENODORA.

3. MENODOROPBI8.

4. Fraxinus.

Fruit fleshy, a drupe or rarely a berry.

Flowers apetalous or sometimes with 1 or 2 small petals, mainly polygamo-dioecious : styles slender.

Flowers with a corolla, perfect or polygamous : styles short or stout.

Corolla rotate, with elongated strap-like nearly distinct petals: leaves deciduous.

Corolla funnelform or salverform, with short lobes: leaves mostly persistent. Corolla funnelform, white; lobes induplicate-valvate.

Corolla salverform, greenish; lobes imbricated.

5. Adelia.

6. Chionanthus.

7. LigUSTRUM.

8. Osmanthus.

\section{SYRÍNGA L.}

Shrubs, with much-branched stems. Leaves opposite: blades entire. Flowers in terminal panicles, fragrant. Calyx-lobes unequal. Corolla white or purple: tube cylindric: lobes 4. Ovary 2-celled : styles united, elongated : stigma 2-cleft. Ovules 2 in each cavity, pendulous. Capsule leathery, somewhat elongated, terete or slightly flattened, loculicidally 2-valved. Seeds flattened, obliquely winged. Endosperm fleshy.

1. Syringa vulgàris L. An erect shrub, with glandular-puberulent young foliage. Leaves numerous; blades thickish, ovate, $5-10 \mathrm{~cm}$. long, acuminate, varying from acute to cordate at the base; petioles 1-4 $\mathrm{cm}$. long: panicles short-peduncled, 1-3 dm. long: pedicels club-shaped, $2-6 \mathrm{~mm}$. long: calyx oblique, $2-2.5 \mathrm{~mm}$. long; lobes ovate to triangular, acute : corolla lilac or white; lobes oval, varying to ovate or obovate: capsules oblong, about $1.5 \mathrm{~cm}$. long.

In waste places and gardens. Native of eastern Europe. Spring. LILAC.

\section{MENODÓRA H.B.K.}

Shrubs or herbaceous perennials, with glabrous, or rarely pubescent foliage. Leaves opposite or alternate: blades entire, toothed or pinnately lobed. Flowers showy, solitary at the ends of branchlets, or sometimes in corymbose cymes. Calyx persistent: tube short: lobes 5-15, narrow. Corolla white, yellow or reddish, campanulate to rotate: tube relatively short: lobes 5-6, imbricated, blunt. Stamens 2-3, exserted : filaments filiform. Ovary 2-celled : stigma capitate. Ovules 4, or rarely 2. Capsule membranous, didymous, circumscissile near the middle. Seeds usually two in each cavity. Endosperm wanting. 
1. Menodora scàbra A. Gray. Resembling species of Linum. Stems tufted, often branched at the base, the branches ascending or spreading, 1-4 dm. long, corymbose at the top : leaves mostly alternate, $8-20 \mathrm{~mm}$. long; blades linear, oblong or oblanceolate, acute, entire or undulate, the lower ones sometimes short-petioled: peduncles always erect: calyx-lobes linear-subulate, $5-6 \mathrm{~mm}$. long, acute : corolla bright yellow; lobes obovate, 6-10 long: capsules 6-8 $\mathrm{mm}$. broad.

In dry soil, Texas to Arizona. Spring and summer.

2. Menodora heterophýlla Moric. Stems branching at the base, the branches $0.5-2$ $\mathrm{dm}$. long, decumbent or spreading: leaves mainly opposite, $0.5-2 \mathrm{~cm}$. long; blades pinnately 3-7-cleft or 3-7-parted ; segments mostly linear-oblong, acute: flowers few : peduncles finally recurved : calyx-lobes narrowly linear, $3-6 \mathrm{~mm}$. long : corolla light yellow or reddish purple without; tube shorter than the calyx-lobes, obovate, 6-10 $\mathrm{mm}$. long, obtuse : capsules 10-12 mm. broad. [Bolivaria Grisebachii Scheele.]

In sandy soil, Texas and adjacent Mexico. Spring and summer.

\section{MENODORÓPSIS Small.}

Shrubby herbs, with tufted stems. Leaves mostly opposite: blades firm, relatively narrow, entire or sometimes cleft near the base of the stem. Flowers few in terminal corymbs. Calyx pedicelled : tube ribbed : lobe 10, narrow. Corolla salverform, bright yellow : tube elongated, glabrous within: limb spreading: lobes mucronate or abruptly acuminate. Stamens included: anthers nearly sessile in the throat of the corolla-tube. Gynoecium similar to that of the next preceding genus. Capsule didymous, circumscissile near the middle.

1. Menodoropsis longiflòra (A. Gray) Small. Stems tufted, erect or ascending, 2-4 dm. tall, simple or branched. Leaves opposite or the upper ones sometimes alternate, $1-2.5 \mathrm{~cm}$. long; blades linear to lanceolate, acute, revolute, entire or the lower ones sometimes 3-cleft, sessile or the lower ones short-petioled : calyx-lobes linear-filiform, acute, erect : corolla light yellow ; tube gradually dilated upward, $3-5 \mathrm{~cm}$. long; lobes ovatelanceolate or oblong, acute : capsules nearly $15 \mathrm{~mm}$. broad. [Menodora longiflora A. Gray.]

On plains and prairies, southern and western Texas. Spring and summer.

\section{FRÁXINUS L.}

Shrubs or trees. Leaves opposite: blades unequally pinnate, or rarely simple : leaflets entire or toothed. Flowers inconspicuous, polygamous or dioecious, or rarely perfect, in clusters or panicles. Calyx wanting, or with a short tube and 4 unequal lobes. Corolla none, or of 2-4 petals, these distinct or united by pairs at the base. Stamens 2 or rarely 3-4 : filaments short or elongated, inserted at the base of the petals or hypogynous : anthers oval to linear, rather extrorse. Ovary 2-celled : styles united : stigma 2-cleft. Ovules 2 in each cavity, pendulous. Samara various : body flat or terete : wings terminal or surrounding the body, 2 or rarely 3 . The plants flower in the spring and mature their fruit in the summer. AsH.

Lateral leaflets sessile : calyx wanting : samara with the wing extending around its base.

Lateral leaflets stalked : calyx present in the pistillate flowers.

Samara with a flat body, the wing extending to its base or around it.

Leaflets 7-11: twigs 4-sided: samara rounded or obtuse at the base.

Leaflets 5-7: twigs terete: samara narrowed and acute at the base. Samara spatulate or oblong-spatulate.

Samaras elliptic to ovate or obovate.

Samara with a terete or nearly terete body, the wing terminal or merely decurrent on the body.

Wing of the samara extending along the sides of the body.

Twigs, petioles and pedicels velvety pubescent.

Samaras 5-7 cm. long; body not sharply differentiated from the wing. Samaras $2-5 \mathrm{~cm}$. long; body sharply differentiated from the wing.

Twigs, petioles and pedicels glabrous. Lateral leaflets cuneate at the base : leaflets $3-5$.

Lateral leaflets not cuneate at the base : leaflets 5-9.

1. F. nigra.

2. F. quadrangulata.

3. $F$. pauciflora.

4. F. Caroliniana.

Wings of the samara terminalior nearly so.

Twigs and leaves glabrous or nearly so.

Samara-body fully or nearly as long as the spatulate wing.

Samara-body much shorter than the linear or oblong-linear wing.

Twigs and leaves densely pubescent.

5. $F$. profunda.

6. F. Pennsylvanica.

7. F. Berlandieri.

8. F. lanceolata.

9. F. Texensis.

10. F. Americana.

11. F. Biltmoreana.

1. Fraxinus nìgra Marsh. A forest tree rarely over $32 \mathrm{~m}$. tall, with almost glabrous foliage. Leaves 2-4 dm. long, resembling those of Sambucus Canadensis; leaflets 7-11, the blades of the lateral ones lanceolate to oblong, acuminate, $8-15 \mathrm{~cm}$. long, serrate, nore 
or less pubescent on the nerves beneath, narrowed or truncate at the base, sessile : samaras oblong or linear-oblong, 3-4 cm. long, longitudinally nerved ; body flat, winged all around, $\frac{1}{2}$ as long as the wing or longer.

In swamps or damp soil, Newfoundland to Manitoba, Virginia and Arkansas. Black Ash. Brown ASH. WATER ASH.

2. Fraxinus quadrangulàta Michx. A forest tree, rarely $36 \mathrm{~m}$. tall, with glabrous or nearly glabrous foliage and 4-sided twigs. Leaves $2-3 \mathrm{dm}$. long; leaflets 7-11, the blades of the lateral ones lanceolate, oblong-elliptic or ovate, 5-15 $\mathrm{cm}$. long, acuminate, serrate, rounded or acute at the base, with short stalks: samaras linear-oblong or oblongcuneate, $3-4 \mathrm{~cm}$. long, longitudinally nerved; body flat, longer than the part of the wing beyond it.

In rich woods, Ontario to Minnesota and Alabama. BLUE AsH.

3. Fraxinus pauciflòra Nutt. A shrub or small tree, reaching a height of about 10 m., with glabrous foliage. Leaves $2-3 \mathrm{dm}$. long; leaflets firm, $5-7$, the blades of the lateral ones lanceolate, elliptic or oblong or some ovate, $4-15 \mathrm{~cm}$. long, acute or acuminate at the apex, undulate or repand, rounded or acute at the base: samaras oblong or spatulate, 4-6 $\mathrm{cm}$. long, longitudinally nerved ; body flat, about as long as the part of the wing beyond it or shorter.

In river swamps, southern Georgia to Florida and Louisiana.

4. Fraxinus Caroliniàna Mill. A shrub, or a small tree sometimes $12 \mathrm{~m}$. tall, with glabrous or pubescent twigs. Leaves 1-3 dm. long; leaflets 5-9, usually 5-7, the blades of the lateral ones elliptic-lanceolate, 4-12 cm. long, usually acute at both ends, shallowly serrate or nearly entire: samaras elliptic or nearly so, varying to ovate or obovate, 4-5 $\mathrm{cm}$. long, acute at both ends or sometimes obtuse at the apex, the linear body flat, the 2-3 wings pinnately nerved. [F. platycarpa Michx. $]$

In swamps and low ground, Virginia and Arkansas to Florida and Texas. WATER AsH. POP AsH. Poppy Ash.

5. Fraxinus profúnda Bush. A forest tree sometimes $35 \mathrm{~m}$. tall, the twigs, petioles and lower leaflet-surfaces usually velvety pubescent. Leaves $2-4 \mathrm{dm}$. long; leaflets leathery, $7-9$, the blades of the lateral ones lanceolate-ovate, elliptic or rarely oblong, 6-12 cm. long, acuminate at both ends or rounded and more or less inequilateral at the base, entire or undulate, dark green, glabrous and sometimes lustrous above: samaras 4-5 cm. long, each with a thick oblong body and a linear-oblong wing which is decurrent to about the middle of the body and emarginate or with a deep sinus at the apex.

In swamps or on river banks, Yennsylvania to Missouri, south to Georgia. PUMPKIN AsH.

6. Fraxinus Pennsylvánica Marsh. A small tree, sometimes $26 \mathrm{~m}$. tall, with pubescent twigs, petioles and lower leaflet-surfaces. Leaves $1.5-3 \mathrm{dm}$. long; leaflets 5-7, the blades of the lateral ones lanceolate, elliptic-lanceolate or elliptic, 5-15 cm. long, pale green, acute or acuminate at both ends, undulate or irregularly serrulate : samaras $2-6 \mathrm{~cm}$. long, each with a linear wing mostly longer than the slender body on which it is decurrent to the middle or below it. RED ASH.

Along streams and on river banks, New Brunswick to South Dakota, North Carolina and Kansas.

7. Fraxinus Berlandièri DC. A shrub or small tree, with glabrous young foliage. Leaves 1-2 dm. long; leaflets $3-5$, the blades of the lateral ones lanceolate to elliptic, the terminal one, and rarely the rest broadest above the middle, acute or acuminate, rather sharply serrate, narrowed at the base : samaras with a club-shaped body and an ellipticspatulate or lanceolate wing which is decurrent to the middle of the body or below it.

On river banks, Texas and northern Mexico.

8. Fraxinus lanceolàta Borck. A tree, sometimes $20 \mathrm{~m}$. tall, with glabrous foliage. Leaves 1-3 dm. long ; leaflets firm, 5-7, the blades of the lateral ones lanceolate or ellipticlanceolate and sometimes elliptic, $5-20 \mathrm{~cm}$. long, pale or light green, usually acuminate at both ends, entire or serrate, especially near the apex : samaras $3.5-6 \mathrm{~cm}$. long, each with a slender linear body and a linear or linear-oblong wing which is much longer than the body or rarely about equal in length and decurrent to the middle or near it.

Along streams, Quebec to the Northwest Territory, Florida, Louisiana and the Indian Territory. GrenN ASH. SWAMP ASH.

9. Fraxinus Texénsis (A. Gray) Sargent. A tree 8-12 m. tall, with glabrous or nearly glabrous foliage. Leaves 1-2 dm. long; leaflets 5-7, the blades of the lateral ones lanceolate to oval, 4-8 cm. long, usually toothed, glabrous or with few scattered hairs beneath : samara about $2 \mathrm{~cm}$. long, the body oblong, terete, fully or nearly as long as the spatulate terminal wing.

On rocky hills, Texas. 
10. Fraxinus Americàna L. A forest tree, reaching a height of $40 \mathrm{~m}$., with a maximum trunk diameter or nearly $2 \mathrm{~m}$., the foliage glabrous or nearly so. Leaves 1-4 dm. long; leaflets 5-9, the blades of the lateral ones lanceolate, oblong or elliptic, $5-15 \mathrm{~cm}$. long, deep green and often lustrous above, pale and commonly glaucous or rarely with scattered hairs beneath, entire or shallowly toothed, inequlateral or strongly oblique at the base : samaras $2.5-3.5 \mathrm{~cm}$. long, each with a stout oblong-cylindric body and a linear-oblong or oblong-spatulate wing which is terminal or nearly so.

In rich woods, Nova Scotia to Minnesota, Florida and Texas. White Ash. Cane Ash.

11. Fraxinus Biltmoreàna Beadle. A tree, reaching a height of about $18 \mathrm{~m}$., with a maximum trunk diameter of about $4 \mathrm{dm}$., the branches widely spreading, the branchlets stout, the young ones densely and softly pubescent. Leaves $2-3 \mathrm{dm}$. long; leaflets $7-9$, the blades of the lateral ones ovate to oblong-lanceolate, 7-14 cm. long, acuminate, entire or obscurely toothed, dark green and slightly lustrous above, whitish and more or less copiously pubescent beneath, sometimes falcate ; petiolules like the petiole and rachis closely pubescent to puberulent: samaras $3.5-5 \mathrm{~cm}$. long, the wing $2 \frac{1}{2}-3$ times longer than the stout terete body.

In valleys and on river banks, Pennsylvania to Georgia.

\section{ADÈLIA P. Br.}

Shrubs or trees, often wide-branching. Leaves opposite, deciduous : blades simple. Flowers inconspicuous, mainly polygamo-dioecious, appearing before the leaves in lateral clusters or racemes on the branchlets of the preceding year. Calyx usually present but small : tube very short : lobes 4-6, unequal. Corolla usually wanting, rarely of 1-2 deciduous petals. Stamens 2-4: anthers rather extrorse. Ovary 2-celled : stigmas thick, sometimes 2-lobed. Ovules 2 in each cavity, pendulous. Drupe various. Seeds solitary or rarely 2. Testa membranous. Endosperm fleshy. [Forestiera Poir.]

Leaves persistent; blades leathery, punctate.

Leaf-blades linear to linear-cuneate, less than $4 \mathrm{~mm}$. wide.

Leaf-blades oblong-lanceolate or spatulate, over $5 \mathrm{~mm}$. wide.

Leaves deciduous; blades membranous, not punctate.

Leaf-blades pubescent, at least beneath.

Pistillate flowers and drupes pedicelled.

Pistillate flowers and drupes sessile or nearly so.

Leaf-blades glabrous.

Calyx persistent: drupes $4-5 \mathrm{~mm}$. long.

Calyx fugacious: drupes $12-15 \mathrm{~mm}$. long.

1. A. angustifolia.

2. A. segregata.

3. A. pubescens.

4. A. ligustrina.

5. A. parvifolia.

6. A. acuminata.

1. Adelia angustifòlia (Torr.) Kuntze. An evergreen, often large shrub, with glabrous foliage. Leaves firm-leathery, $1-2.5 \mathrm{~cm}$. long; blades linear to linear-cuneate, obtuse, entire, revolute, lustrous above, not reticulated beneath, sessile : flowers often perfect, in small clusters : drupes ovoid, acute, short-pediceled.

In dry soil, southern Texas and adjacent Mexico. Spring.

2. Adelia segregàta (Jacq.) Small. An evergreen shrub, with glabrous foliage. Leaves thin-leathery, $1.5-5 \mathrm{~cm}$. long ; blades oblong-lanceolate, or spatulate, obtuse, slightly revolute, lustrous above, finely reticulated beneath, narrowed into short petioles: flowers from the branchlets of the previous year: drupes oval or ovoid, 7-8 $\mathrm{mm}$. long, shortpedicelled : stone longitudinally many-ribbed. [Myrica segregata Jacq.]

In dry woods and sand, peninsular Florida and the Keys. Also in the West Indies. Spring.

3. Adelia pubéscens (Nutt.) Kuntze. A shrub, with widely branching stems and densely hairy twigs. Leaves deciduous, 1-4 cm. long; blades elliptic-oval or oblongobovate, obtuse, somewhat serrate, narrowed into short petioles : flowers from the branchlets of the preceding year, the pistillate in clusters in short spurs, slender-pedicelled : drupes oblong, 6-7 mm. long, the pedicels somewhat shorter: stone ribbed.

On river banks, Arkansas to Florida and Texas. Spring.

4. Adelia ligustrìna Michx. A shrub 1-3 m. tall, with widely branched stems, the twigs and leaves pubescent, or glabrate in age. Leaves becoming firm, deciduous, 1-4 cm. long; blades elliptic, oblong, oval or approaching obovate, finely serrate, obtuse or acute, manifestly petioled: flowers from the branchlets of the preceding year; staminate in numerous dense sessile clusters; pistillate in clusters on very short spurs : calyx minute : drupes nearly sessile, broadly oblong or oval, $7-8 \mathrm{~mm}$. long.

On river banks and in damp soil, Tennessee to Georgia and Florida. Summer.

5. Adelia parvifolia (A. Gray) Small. A glabrous shrub 2-3 m. tall, with muchbranched stems. Leaves $1-4 \mathrm{~cm}$. long, deciduous; blades firm, oblong, elliptic or spatulate, 
obtuse or acutish, serrate, acuminate into short petioles: flowers from the branchlets of the preceding year : staminate in sessile clusters : pistillate in clusters on short spurs : calyx quite persistent : drupes oval-oblong, 4-5 mm. long, acute. [Forestiera acuminata var. parvifolia A. Gray.]

In dry soil, Texas and Colorado. Spring.

6. Adelia acuminàta Michx. A shrub, or a small tree sometimes $10 \mathrm{~m}$. tall, with glabrous foliage, the trunk widely branching. Leaves deciduous ; blades membranous, elliptic-oval or ovate-elliptic, 3-10 cm. long, acuminate at both ends, slightly serrate especially about the middle; petioles 5-15 $\mathrm{mm}$. long: flowers from the branchlets of the preceding year ; staminate flowers in clusters ; pistillate in short panicles : calyx obsolete or caducous : drupes narrowly oblong, 12-15 mm. long, finally straight, deep purple.

On river banks and in river swamps, Illinois to Missouri, Georgia and Texas. Spring.

\section{ChIONÁNTHUS L.}

Shrubs or small trees. Leaves opposite : blades entire. Flowers perfect or polygamous in axillary drooping panicles. Calyx persistent : tube short : lobes 4 . Corolla white: tube very short: lobes 4 , narrow, elongated, induplicate in the bud. Stamens 2 : filaments adnate to the corolla-tube : anthers rather extrorse, with an apiculate connective. Ovary 2-celled : stigmas notched or 2-lobed. Ovules 2 in each cavity, pendulous. Drupe oval to subglobose, with a hard sometimes bony endocarp. Seed usually solitary. Testa thin. Endosperm fleshy.

1. Chionanthus Virgínica $\mathrm{L}$. A shrub or small tree, rarely $10 \mathrm{~m}$. tall, with glabrous or softly pubescent foliage. Leaf-blades oval, oblong or elliptic, varying to obovate, 5-15 $\mathrm{cm}$. long, rounded at the apex, or acute or acuminate, undulate, narrowed into short petioles : panicles drooping, 5-20 cm. long, usually with leaf-like bracts : calyx-lobes ovate to lanceolate, acute, longer than the tube : petals white, linear, $1.5-2.5 \mathrm{~cm}$. long, acute, somewhat spreading: drupes oblong or oval-oblong, 1.5-2 cm. long, deep purple or nearly black.

In rocky soiland along streams, Pennsylvania to Florida and Texas. Spring. Fringe Tree. OLD MAN'S BEARD. FLOWERING ASH. SUNFLOWER TREE.

\section{LIGÚSTRUM L.}

Shrubs or trees. Leaves opposite: blades simple. Flowers in terminal panicles. Calyx-tube short, sometimes truncate: lobes usually 4 . Corolla white or greenish, funnelform: tube short: lobes 4 . Stamens $2:$ filaments attached to the corolla-tube : anthers rather extrorse. Ovary 2-celled: stigma thickened. Ovules 2 in each cavity, pendulous. Drupe berry-like, with a membranous or parchment-like endocarp. Seeds 1-3, pendulous. Testa thin. Endosperm fleshy.

1. Ligustrum vulgàre L. A shrub $0.5-3 \mathrm{~m}$. tall, with much-branched stems and glabrous or nearly glabrous foliage. Leaves 1-6 cm. long, tardily deciduous; blades leathery, oblong, elliptic or oblong-lanceolate, deep green, acute or obtuse, entire, narrowed into short petioles: panicles erect, $2-15 \mathrm{~cm}$. long, dense when young : corolla white, 4-6 $\mathrm{mm}$. long; tube about as long as the lobes or sometimes shorter : drupes subglobose, 6-8 mm. in diameter, black.

In thickets and on roadsides, Ontario to Pennsylvania and North Carolina. June. Priver.

\section{OSMÁNTHUS Lour.}

Evergreen shrubs or trees. Leaves opposite : blades leathery. Flowers polygamous, in axillary clusters or short racemes. Calyx persistent: tube short: lobes 4 . Corolla greenish : tube short: lobes 4, imbricated. Stamens 2 or rarely 4, included : filaments inserted on the corolla-tube: anthers rather extrorse. Ovary 2-celled: stigma entire. Ovules 2 in each cavity, pendulous. Drupe ovoid to subglobose, with a thick bony or horny endocarp. Seeds usually solitary. Testa thin. Endosperm fleshy. DeviLwood. WInD Ourve.

Panicles glabrous : drupe dark purple.

1. O. Americana. Panicles pubescent: drupe yellowish green.

2. O. Floridana.

1. Osmanthus Americàna (L.) B. \& H. An evergreen glabrous slender shrub or tree, reaching a height of $15 \mathrm{~m}$., the bark pale. Leaves leathery, $5-20 \mathrm{~cm}$. long; blades narrowly elliptic, varying to lanceolate or oblanceolate, entire, lustrous above, somewhat 
polygamous or dioecious : calyx glabrous; lobes triangular or ovate-triangular : corolla 3-4 mm. long; lobes spreading, ovate to suborbicular : drupes oval-ovoid or oval-obovoid, 10-14 mm. long, deep purple.

In sandy soil, North Carolina to Florida and Mississippi. Spring.

2. Osmanthus Floridàna Chapm. An evergreen shrub or tree similar to the preceding in habit. Leaves sometimes larger and with thicker blades: inflorescence finely pubescent : calyx pubescent; lobes acute: corolla 4-5 $\mathrm{mm}$. long; lobes recurved : drupes yellowish green, $16-20 \mathrm{~mm}$. long.

In hammocks, peninsular Florida. Spring.

\section{Order 5. GENTIANÀLES.}

Herbs, shrubs or trees, sometimes aquatic plants, sometimes vines, rarely saprophytes. Leaves mainly opposite: blades simple, typically entire. Flowers mostly perfect, in variously modified cymes, or solitary. Calyx of 5 partially united sepals or fewer. Corolla of 5 partially united petals, or fewer. Androecium of as many stamens as there are corolla-lobes. Filaments free or partially adnate to the corolla-tube. Anthers erect or versatile. Gynoecium of 2 more or less united carpels, or rarely of more. Styles distinct or united. Ovules numerous. Fruit capsular, baccate or drupaceous.

Ovary 2-celled : leaves stipulate or the bases connected by stipular lines. Ovary 1-celled: leaves not stipulate.

Corolla-lobes convolute or imbricated in the bud.

Corolla-lobes induplicate-valvate in the bud.

Fam. 1. SPigeliacrae.

Fam. 2. Gentianaceat.

Fam. 3. Menyanthaceae.

\section{FAmily 1. SPIgELIÀCEAf Mart. Logania Family.}

Herbs, shrubs or vines, or sometimes trees in the tropics. Leaves opposite or whorled, with stipules: blades simple. Flowers perfect, or rarely somewhat dioecious, regular, in cymes or panicles, or somewhat capitate, of various colors. Calyx inferior: limb 4-5-lobed, the lobes imbricated or valvate. Corolla gamopetalous, 4-5-lobed : lobes valvate, imbricated or convolute. Androecium of 4-5 stamens alternate with the corolla-lobes. Filaments filiform or subulate. Anthers 2-celled, opening lengthwise. Pollen granular. Ovary superior, 2-celled or rarely 3-5-celled. Styles united, sometimes only partially so. Stigmas distinct or united. Ovules solitary or 2 , or sometimes numerous in each cavity of the ovary, amphitropous or anatropous. Fruit sometimes capsular, dehiscent by 2 valves, or baccate or drupacous and indehiscent. Seeds winged, or wingless, with a smooth rugose or tuberculate testa. Endosperm copious. Embryo straight or curved in the endosperm. [Loganiaceae Dumort.]

Shrubby vines: stigmas 4 : corolla yellow.

1. Gelsemium.

Herbs : stigmas entire or barely 2-lobed : corolla not yellow without.

Corolla-lobes valvate.

Corolla funnelform or salverform : styles permanently united.

Flowers in the forks of leafy branches: style jointed near the middle.

Flowers in terminal spikes or spike-like racemes: style jointed near the base. Corolla urn-shaped : styles soon distinct.

Corolla-lobes imbricated.

Annual herb: sepals nearly distinct : capsule loculicidal.

Shrubs, trees or shrubby herbs: sepals chiefly united: capsule septicidal.

2. Coelostylis.

3. SPIgELia.

4. CYNoctonum.

5. POLYPREMUM.

6. BUDDLEIA.

\section{GELSÈMIUM Juss.}

Shrubby vines. Leaves opposite : stipules minute, caducous, leaving only an inconspicuous scar. Inflorescence cymose. Flowers solitary or sometimes four together. Calyxlobes 5: membranous. Corolla funnelform, dilated, 5-lobed, the lobes imbricated. Stamens 5, adnate to the base of the corolla-tube. Ovary 2-celled: style filiform: stigma 4, flat. Ovules numerous in each cavity of the ovary, borne in several rows on narrow placentae. Capsule compressed contrary to the narrow septum, septicidal: valves 2, at length two-cleft at the apex. Seeds usually numerous, compressed, winged. Endosperm fleshy. Yellow Jessamine. Evening Trumpet-flower.

1. Gelsemium sempérvirens (L.) Ait. f. An evergreen high-twining vine. Stems often tangled and matted : leaf-blades thickish. lanceolate, oblong-lanceolate or sometimes 
ovate, $1.5-9 \mathrm{~cm}$. long, entire, dark green, acute, or acuminate, short-petioled : flowers on short scaly pedicels : calyx-lobes ovate or ovate-lanceolate, 3-4 mm. long, acutish or obtuse : corolla deep yellow : capsules elliptic, oblong or ovoid, 1-1.5 cm. long, marked with a conspicuous suture on each flat side, veiny : seeds obliquely-oblong, 5-6 mm. long, strongly papillose, each prolonged into a hyaline wing $5 \mathrm{~mm}$. long with a toothed end.

In sandy soil, Virginia to Florida and Texas. Also in Mexico and Central America. Spring.

\section{COELÓSTYLIS T. \& G.}

Caulescent herbs. Leaves opposite: blades entire. Flowers in the forks of leafy branches, or axillary to leaves. Calyx-lobes narrow. Corolla white or whitish, salverform : limb plaited in the bud, the edges turned outward. Stamens 5, included, adnate to the corolla tube. Ovary 2-celled : styles permanently united, included, jointed near the middle. Fruit didymous.

Corollas 12-14 mm. long: species of Florida.

Corollas 8-10 mm. long: species Texano-Mexican.

Scabrous: capsules lineolate: calyx-lobes with erose-denticulate margins.

Smooth: capsules smooth: calyx-lobes with scabrous margins.

1. C. loganioides.

2. C. Lindheimeri.

3. C. Texana.

1. Coelostylis loganioìdes T. \& G. Annual or perennial, glabrous, dull green. Stems ascending, 1-3 dm. tall, sometimes branched at the base, rather wiry : leaf-blades leathery, oval, elliptic or lanceolate, $1.5-3.5 \mathrm{~cm}$. long, obtuse or acute, conspicuously nerved: flowers white, solitary in the axils of the leaves or three in terminal clusters: calyx-lobes narrowly linear, long-pointed, the margins scarious and denticulate: corolla narrowly funnelform, $1 \mathrm{~cm}$. long; lobes lanceolate or acutish, about $\frac{1}{2}$ as long as the tube.

In sandy soil, eastern Florida.

2. Coelostylis Lindheìmeri (A. Gray) Small. Annual, low, tufted, puberulent, pale green. Stems diffusely branched from the base, somewhat scabrous, the branches 1-2 dm. long, branched throughout: leaf-blades lanceolate or oblanceolate, or those of the branches often oblong-spatulate, 1-3 cm. long, obtuse or acute, even slightly apiculate, slightly revolute, ciliolate, more or less narrowed at the base, the lower short-petioled: flowers terminal and axillary : calyx slender; lobes linear, $4 \mathrm{~mm}$. long, scarious-margined and erose-denticulate, persistent and at length twisted: corolla funnelform, $1 \mathrm{~cm}$. long; lobes ovate, $2-5 \mathrm{~mm}$. long, obtuse : capsule 2 -lobed, $4 \mathrm{~mm}$. high, $5 \mathrm{~mm}$. broad, longitudinally marked with distinct lines: seeds dark brown or black, $2 \mathrm{~mm}$. in diameter, tuberculate and pitted. [Spigelua Lindheimeri A. Gray.]

On dry prairies, western and southern Texas to New Mexico, and northern Mexico.

3. Coelostylis Texàna T. \& G. Annual, glabrous, slender, dark green. Stems simple or sparingly branched from the base, $3-4 \mathrm{dm}$. tall, branched above : leaf-blades lanceolate, ovate-lanceolate or elliptic, $3-5 \mathrm{~cm}$. long, thinnish, acute, ciliolate, narrowed at the base, sessile or very short-petioled : stipules triangular : flowers terminal or axillary on the upper branches: calyx-lobes linear-subulate, $3 \mathrm{~mm}$. long, the margin scabrous : corolla $8 \mathrm{~mm}$. long, funnelform; lobes narrowly ovate, acutish, more than twice shorter than the
tube : capsule $5 \mathrm{~mm}$. broad, $3 \mathrm{~mm}$. high, smooth and glabrous, somewhat 2-lobed: seeds dark brown, $1 \mathrm{~mm}$. in diameter, minutely rugose and punctate.

In dry soil, eastern Texas.

\section{SPIGÈLIA L.}

Annual or perennial herbs, rarely somewhat shrubby. Stems often branched, mainly from the base. Leaves opposite, subtended by small inconspicuous caducous stipules: blades entire. Flowers often showy, in terminal spikes or spike-like racemes. Calyx slender : tube often bearing 5 or more glands within at the base : lobes narrow. Corolla tubular or funnelform : lobes 5, their edges barely turned outward. Stamens 5 , often with exserted anthers, adnate to the corolla-tube. Ovary 2-celled: style jointed near the base. Ovules numerous in each cavity, densely attached to peltate placentae. Fruit 2-celled, borne on a cup-shaped base.

Annual: inflorescence subtended by a whorl of bracts larger than the leaves.

Perennial : inflorescence not subtended by a whorl of bracts.

Corolla scarlet without, $4-5 \mathrm{~cm}$. long: anthers and style exserted.
Corolla white or purplish without, $1.5-2.5 \mathrm{~cm}$. long : anthers and style included.

1. S. anthelmia.

2. S. Marylandica.

3. S. gentianoides.

1. Spigelia anthélmia L. Annual, deep green. Stem 1-4 dm. tall, often branched : leaf-blades lanceolate, $3-12 \mathrm{~cm}$. long, finely ciliolate, acute or slightly acuminate, paler 
beneath: inflorescence subtended by a whorl of bracts larger than the leaves: spikes 5-15 $\mathrm{cm}$. long : calyx-lobes linear or linear-lanceolate, $1.5-2 \mathrm{~mm}$. long : corolla 5-9 $\mathrm{mm}$. long, inconspicuous : capsules $5-6 \mathrm{~mm}$. broad, copiously tuberculate.

In sandy soil and fields, peninsular Florida and the Keys. Also in tropical America.

2. Spigelia Marylándica L. Perennial, nearly glabrous, dark green. Stem branched from the base ; branches $2-6 \mathrm{~cm}$. tall, slender : leaf-blades ovate or lanceolate, sometimes elliptic, 3-10 $\mathrm{cm}$. long, acuminate or rarely acute, sessile, rounded at the base, threenerved or five-nerved, sometimes very sparingly pubescent, especially on the nerves: spikes one-sided, more or less recurved, $5-15 \mathrm{~cm}$. long: calyx slender; lobes nearly subulate, long-pointed, the tips pubescent: corolla showy, somewhat club-shaped, $4-5 \mathrm{~cm}$. long, scarlet without, yellow within ; lobes usually lanceolate, acute, $\frac{1}{4}$ or $\frac{1}{5}$ as long as the tube : capsules 7-11 mm. broad, smooth.

In dry woods and on hillsides, New Jersey to Wisconsin, south to Florida and Texas. Spring. INDIAN Or CAROLINA PINK. PINK-ROOT.

3. Spigelia gentianoìdes Chapm. Perennial, light green, sometimes glaucescent. Stem usually branched at the base ; branches $2-3 \mathrm{dm}$. tall, rarely branched above, puberulent: leaf-blades ovate, sometimes ovate-lanceolate near the base of the stem or nearly orbicular, $1.5-5 \mathrm{~cm}$. long, obtuse or acute, the uppermost sometimes acuminate, nearly glabrous, sessile, the bases rounded: spikes few-flowered: calyx slender; lobes 7-9 mm. long, linear-subulate, ciliate, the tips dark green : corolla white or purplish without, $1.5-2.5 \mathrm{~cm}$. long; lobes $\frac{1}{3}-\frac{1}{5}$ as long as the tube, erect or converging : stamens included : style included.

In light dry soil, western Florida. Spring.

\section{CYNÓCTONUM J. F. Gmel.}

Caulescent herbs, often with short rootstocks. Leaves opposite: blades entire, leathery, sometimes finely nerved: stipules small, entire. Flowers white or slightly colored, in terminal compound cymes, whose ultimate divisions are secund spikes or spike-like racemes. Calyx shorter than the corolla, usually 5-lobed. Corolla urn-shaped : tube often swollen below and contracted at the throat, which is usually closed by jointed hairs : lobes 5, spreading or converging. Stamens 5, included, adnate to the corolla-tube. Ovary 2-celled, terminating in 2 styles, whose tips are more or less united when young, but at length distinct. Ovules numerous, attached to peltate placentae. Capsule mitreshaped, tipped with 2 curved horns. Seeds smooth or variously roughened. The plants flower mainly in the summer and fall. [Mitreola R. Br.] Mitrewort.

Leaf-blades more or less petioled, membranous : inflorescence lax.

Leaf blades sessile, fleshy-leathery : inflorescence dense.

Leaf-blades ovate, oval or orbicular.

Leaf-blades linear, linear-oblong or narrowly lanceolate.

1. C. Mitreola.

2. C. sessilifolium.

3. C. angustifolium.

1. Cynoctonum Mitrèola (L.) Britton. Deep green. Stems 1-7 dm. tall, sometimes branched throughout, slightly four-angled: leaf-blades rather membranous, ellipticoblong, ovate, lanceolate, or linear-lanceolate, the lowest sometimes oblanceolate, 1.5-8 $\mathrm{cm}$. long, acute or acuminate, spreading, not prominently nerved, narrowed at the base, petioled : calyx campanulate, about $1 \mathrm{~mm}$. long, sessile ; lobes ovate, entire, about as long as the tube : corolla about $2 \mathrm{~mm}$. long, marked with dark stripes, constricted at the throat and closed by a ring of jointed hairs, its tube purplish, longer than the white, rather acute, converging 3-nerved lobes : capsule 2-2.5 mm. long, its two horns slightly longer than the body. [Mitreola petiolata (Walt.) T. \& G.]

In damp or muddy places, Virginia to Texas and Mexico and Florida. Also in the West Indies.

2. Cynoctonum sessilifolium (Walt.) J. F. Gmel. Pale green. Stems 1-5 dm. tall, simple, virgate, four-angled leaf-blades almost leathery, ovate or orbicular, 1-5 $\mathrm{cm}$. long, obtuse or apiculate at the apex, sessile, appressed to the stem, often revolute and prominently nerved beneath: calyx campanulate, $1 \mathrm{~mm}$. high; lobes lanceolate, obtuse, denticulate : corolla nearly $1 \mathrm{~mm}$. long, surpassing the calyx, marked with dark stripes, expanding at the throat which is stopped by jointed hairs; tube longer than the ovateoblong, acute or acutish 3-nerved lobes : capsule nearly oblong or subglobose, $4 \mathrm{~mm}$. long, yellowish, almost smooth.

In low grounds and sandy bogs, North Carolina to Florida and Louisiana.

3. Cynoctonum angustifolium (T. \& G.) Small. Pale green and Sabbatia-like. Stems 2-6 dm. tall, virgate : leaf-blades narrowly oblong to lanceolate, 2-4 cm. long, obtuse or acutish at the apex, sessile or the lowest pair narrowed into short petiole-like bases, 
not prominently nerved : calyx narrowly campanulate, $2.5-3 \mathrm{~mm}$. long; lobes ovate-lanceolate, obtuse, denticulate : corolla at length much longer than the calyx, whitish, 3-5 mm. long, marked with dark stripes; tube somewhat constricted at the throat, about as long. as the linear-lanceolate erect or converging, rather obtuse lobes : capsule sessile or nearly so, $4 \mathrm{~mm}$. long, its two horns slightly longer than the body, converging.

In wet places, southern Georgia and Florida. Summer and fall.

\section{POLYPRÈMUM L.}

Annual glabrous herbs. Stem diffusely branched at the base: branches dichotomous, four-angled. Leaves basal and clustered, cauline and opposite: blades narrow, the bases dilated and somewhat connate. Flowers solitary and sessile in the forks of branchlets and axils of the leaves. Calyx longer than the corolla : lobes 4 or 5 , somewhat foliaceous, rigid. Corolla campanulate : tube slightly constricted near the top : lobes 4 or 5 , shorter than the tube, imbricated, bearing a ring of villous hairs at their junction with the tube. Stamens 4 or rarely 5, adnate to about the middle of the corolla-tube. Ovary 2-celled : style very short, tipped with a capitate or somewhat 2-lobed stigma. Ovules numerous in each cavity, attached to placentae which are fixed by their bases to the septum. Capsule slightly 2-lobed, somewhat flattened contrary to the septum, loculicidal. Seeds numerous, smooth.

1. Polypremum procúmbens L. Stems diffusely branched, often tufted, the branches erect or spreading, 1-3 dm. long: leaf-blades acute, obscurely scabrous in the margins with spine-like hairs, dilated at the base and somewhat connate by their narrow stipules: flowers axillary or in small terminal cymose clusters : calyx about $3 \mathrm{~mm}$. high ; lobes lanceolate, with a strong midrib, scarious margins and spine-like hairs : corolla white : capsules obovoid or subglobose, about $2 \mathrm{~mm}$. long, flattened contrary to the septum, each tipped with the short style : seeds numerous, subglobose or obscurely angled, $0.4 \mathrm{~mm}$. in diameter.

In dry sandy soil, Pennsylvania to Florida and Texas. Also in the West Indies and Mexico.

\section{BUDDLÉIA L.}

Shrubs or trees, or shrubby herbs, usually with pubescent, scurfy or granular foliage. Leaves opposite : stipules evident, but sometimes a mere line. Flowers in dense heads or more rarely in open panicles. Calyx campanulate, 4-lobed or rarely 5-lobed. Corolla rotate-campanulate, or sometimes salverform: tube straight or curved: lobes broad. Stamens 4 or rarely 5 : filaments adnate to the corolla-tube, sometimes up to the throat. Ovary 2-celled : styles united. Capsule globular or oblong, septicidally 2-valved, the valves mostly 2-cleft at the apex and separating from the united placentae.

Flowers in panicles: corolla $12-15 \mathrm{~mm}$. long; tube curved : leaf-blades entire. $\quad 1$. B. Lindleyana. Flowers in racemed heads : corolla $2-2.5 \mathrm{~mm}$. long; tube straight : leaf-blades toothed. 2 . B. racemosa.

1. Buddleia Lindleyàna Fort. A diffusely branching shrub $1-2 \mathrm{~m}$. tall, the branches angled. Leaf-blades ovate to lanceolate, $3-9 \mathrm{~cm}$. long, acuminate, entire, glabrous and paler beneath than above: panicles raceme-like, loosely spreading or somewhat drooping : calyx $2-2.5 \mathrm{~mm}$. long, puberulent: corolla purplish violet or reddish, 12-15 mm. long, granular-puberulent: tube curved.

In waste places and about gardens, throughout the Gulf States and in some of the contiguous states. Introduced from China. Summer and fall.

2. Buddleia racemòsa Torr. A branching shrub, 4-11 $\mathrm{dm}$. tall, the branches nearly terete. Leaf-blades ovate-oblong to oblong-lanceolate or lanceolate, $2.5-11 \mathrm{~cm}$. long, acute or obtusish, coarsely toothed, broadly cuneate or truncate and often somewhat hastate at the base, puberulent beneath: branches of the panicle terminating in globular heads $5-8 \mathrm{~mm}$. in diameter : calyx tomentulose : corolla $2-2.5 \mathrm{~mm}$. long; tube straight, the upper part tomentulose.

In rocky soil or on banks, southern and western Texas. Spring and summer.

\section{Family 2. Gentianàceae Dúmort. Gentian Family.}

Annual or perennial caulescent herbs, or rarely shrubs, with a watery sap, and pervaded with a bitter tonic principle. Leaves typically opposite : blades simple, sometimes connate at the base and sheathing. Inflorescence cymose, often congested. Flowers perfect, regular, often showy. Calyx of 2, 4 or 5 more or less united sepals, persistent. Corolla of 4 or 5 , or more, mostly convolute, sometimes imbricated petals : limb often spreading, commonly showy : lobes 
entire or fringed. Androecium of as many stamens as there are corolla-lobes and alternate with them, partially adnate to the corolla-tube or in the throat. Filaments filiform or dilated at the base. Anthers erect or versatile. Gynoecium compound. Ovary 1-celled, superior, with two parietal more or less intruded placentae. Styles mostly united. Stigmas 2, distinct or united. Ovules numerous, inserted on the placenta or over the whole surface of the cavity of the ovary, anatropous or amphitropous. Fruit a capsule. Seeds with a membranous or crustaceous variously roughened testa. Endosperm fleshy.

Corolla-lobes convolute in the bud : leaves present.

Style filiform, mostly deciduous : anthers recurving or twisting at maturity.

Stigmas roundish, much shorter than the style. Corolla-tube surpassing the calyx. Corolla-tube much shorter than the calyx.

Stigmas linear or nearly so, about as long as the style. Flowers pedicelled, when more than one, paniculate: anthers coiled. Flowers sessile, when more than one, capitate: anthers curved.

Style stout, short or wanting : anthers straight at maturity.

Corolla not furnished with nectariferous pits, glands or scales. Corolla without plaits in the sinuses of the lobes: calyx without an interior membrane.

Sepals unequal, the inner much broader than the outer and thinmargined : corolla-lobes fimbriate or erose.

Sepals essentially equal, or if unequal the inner narrower than the outer : corolla-lobes entire or merely toothed.

Corolla with plaits in the sinuses of the lobes: calyx with an interior membrane.

Corolla furnished with nectariferous pits, glands or scales, 1 or 2 for each lobe.

Corolla rotate, with a fringed gland at each lobe.

Corolla campanulate, with spurs at the base.

Corolla-lobes imbricated in the bud : leaves, or those of the stem, reduced to scales. Stigmas 2, distinct: foliage green.

Calyx-lobes 4, narrowed upward.

Calyx-lobes 2, broadened upward.

Stigmas united, dilated : foliage white.
1. Erythraea.
2. Eustoma.
3. SABBAtia.
4. LAPITHEA.

\section{ERYTHRAÈA Neck.}

\section{Anthopogon. \\ 6. Gentianella.}

7. Dasystephana.

8. Frasera.

9. Tetragonanthus.

10. BARTONIA.

11. OBOLARIA.

12. VOYRIA.

Annual, biennial or sometimes perennial caulescent herbs. Leaves opposite: blades entire, mostly sessile or clasping. Flowers in terminal cymes, often numerous. Calyx pedicelled: lobes 4-5, narrow, keeled. Corolla white, pink, rose or yellow, salverform : tube more or less elongated : lobes 4-5, spreading, convolute or contorted. Stamens 4-5, partially adnate to the corolla-tube : filaments short, but filiform : anthers twisted at maturity. Ovary 1-celled, with the placentae sometimes intruded: stigmas 2. Capsules ovoid-oblong to fusiform, 2-valved. Seeds several or numerous, reticulated. Centaury. Corolla-lobes much less than $1 / 2$ as long as the tube.

Corolla-lobes obtuse: species naturalized eastward.

Corolla-lobes acute: species native, Texan.

Corolla-lobes fully $1 / 2$ as long as the tube or nearly equalling it in length.

Corolla-lobes acute.

Corolla-lobes obtuse.

1. E. pulchella.

2. E. Texensis.

1. Erythraea pulchélla (Sw.) Fries. Stem square, $3-25 \mathrm{~cm}$. tall, more or less branched : leaf-blades spatulate at the base of the stem, to oblong or ovate above, usually 1-2 cm. long, obtuse, entire, sessile : flowers in diffuse cymes : calyx-lobes linear-subulate, $6-8 \mathrm{~mm}$. long, unequal in length, mostly shorter than the corolla-tube : corolla glabrous ; tube greenish, 8-10 mm. long; lobes deep pink, $5-6.5 \mathrm{~mm}$. long, ovate-oblong, obtuse: stamens slightly exserted: anthers lemon-yellow : capsule 7-9 mm. long, as long as the calyx or longer.

In fields and waste places, New York to Georgia. Naturalized from Europe. Summer and fall.

2. Erythraea Texénsis Griseb. Stems $0.5-2 \mathrm{dm}$. tall, corymbosely branched above, not diffuse : leaf-blades lanceolate to linear or subulate above, $0.5-1 . \overline{\mathrm{c}} \mathrm{cm}$. long, acute, entire, sessile: calyx 8-10 mm. long; lobes subulate : corolla light rose-colored; tube surpassing the caly $\mathrm{x}$; lobes oblong to oblong-lanceolate, acute, much shorter than the tube : capsule surpassing the calyx.

In rocky soil, Texas. Spring.

3. Erythraea Beyríchii T. \& G. Stems erect, or branched at the base, the branches ascending, $0.5-2 \mathrm{dm}$. long, often densely branched above the middle: leaf-blades linearspatulate to linear, usually narrowly so, $1-2.5 \mathrm{~cm}$. long, acute, the lower ones slender-petioled : calyx 8-10 mm. long; lobes setaceous-subulate: corolla deep pink; lobes oblong-lanceo- 
late to linear-lanceolate, $8-12 \mathrm{~mm}$. long, acute, more than $\frac{1}{2}$ as long as the tube: capsule often shorter than the calyx.

In dry soil, Arkansas to Texas. Spring to fall.

4. Erythraea calycòsa Buckl. Stems 1-6 dm. tall, more or less branched, the branches ascending or spreading: leaves spatulate to oblong or linear, 1-3 cm. long, acute or apiculate, entire, sessile : calyx 8-10 mm. long; lobes linear-setaceous : corolla pink ; lobes oval or oblong, obtuse ; 7-10 mm. long ; tube slightly surpassing the calyx : capsule 8-10 mm. long, cylindric-oblong.

In wet soil, Missouri to Texas and New Mexico. Spring to fall.

\section{EUSTOMA Salisb.}

Annual caulescent herbs, with glabrous and usually glaucous foliage. Leaves opposite: blades sessile or clasping. Flowers in terminal panicles, or sometimes solitary. Calyx with 5-6 narrow keeled lobes. Corolla white, blue or purple: tube campanulate : lobes 5-6, oblong or broadened upward, convolute in the bud, usually erose-denticulate. Stamens 5-6, adnate to the throat of the corolla-tube: filaments filiform: anthers versatile, nearly straight, or recurved at maturity. Ovary 1-celled: stigmas 2. Ovules numerous. Seeds pitted. The plants flower from spring to fall.

Style short, little longer than the stigmas : corolla-lobes oblong or nearly so: capsule oval-elliptic.

Style elongated, much longer than the stigmas: corolla-lobes obovate: capsule

1. E. exaltatum.

oblong-cylindric.

Leaves below the inflorescence with ovate to oblong blades: capsule acuminatetipped.

Leaves below the inflorescence with lanceolate blades: capsule blunt.

2. E. Russellianum.

3. E. gracile.

1. Eustoma exaltàtum (L.) Griseb. Stems 1-9 dm. tall, simple or branching. Leaf-blades oblong to oblong-lanceolate, $1.5-7 \mathrm{~cm}$. long, apiculate or acute, entire, sessile and partly clasping : calyx about $1.5 \mathrm{~cm}$. long; lobes subulate from a broader base : curolla blue, $3-3.5 \mathrm{~cm}$. long; tube barely as long as the calyx ; lobes mainly oblong, about twice as long as the tube : capsules oblong, $2-2.5 \mathrm{~cm}$. long, obtuse.

In sandy soil, Florida to Texas, California and Mexico. Also in the West Indies.

2. Eustoma Russelliànum (Hook.) Griseb. Stems 3-9 dm. tall, more or less branched. Leaf-blades ovate to oblong, $2-8 \mathrm{~cm}$. long, acute or apiculate, sessile and partly clasping: calyx glabrous, $1.5-2 \mathrm{~cm}$. long; lobes subulate from a broader base : corolla lavender-purple, $4-5.5 \mathrm{~cm}$. long; tube often barely as long as the calyx; lobes cuneate to obovate, about 4 times as long as the tube : capsules oblong, about $1.5 \mathrm{~cm}$. long, pointed.

In dry soil, Nebraska to Colorada, Texas and New Mexico.

3. Eustoma grácile Engelm. Smaller than E. Russellianum and more slender. Leaves few ; blades lanceolate, sometimes narrowly so, acuminate : corolla $3.5-4 \mathrm{~cm}$. long: capsule oblong, about $1 \mathrm{~cm}$. long, blunt.

On plains, southern Texas and northern Mexico.

\section{SABBÀtiA Adans.}

Annual or biennial caulescent herbs, with glabrous foliage. Leaves opposite or rarely whorled: blades sessile or rarely petioled, or clasping. Flowers solitary or in terminal open cymes. Calyx pedicelled : lobes 4, 2 narrow. Corolla white, pink, cream-colored or rose, with a distinct eye, rotate : lobes 4-12. Stamens 4-12: filaments adnate to the short corolla-tube, filiform: anthers coiled. Ovary 1-celled, with intruding placentae : styles united : stigmas shorter than the style or longer. Capsule short, 2-valved. Seeds numerous, reticulated.

A. Corolla-lobes 4-5, or sometimes 6-7.

Branches of the stem all opposite.

Stems terete: caly x-lobes shorter than the tube.

Stems 4-angled or 4-winged: calyx-lobes longer than the tube.

Stigmas longer than the style.

Upper leaf-blades acute: calyx-lobes subulate.

Upper leaf-blades obtuse, apiculate : calyx-lobes linear.

Stigmas shorter than the style.

Stem-leaves with blades several times longer than broad, sessile.

Stem-leaves with blades little longer than broad at the most, clasping.
Branches of the stem alternate, or some of the lower ones rarely opposite.

a. Calyx-tube prominently 5 -ribbed, mostly enclosing the capsule.

Leaf-blades mostly broadest near the base, clasping.

Leaf-blades mostly broadest at the middle, sessile.

1. S. macrophylla.

2. S. lanceolata.

3. S. paniculata.

4. S. angustifolia.

5. S. angularis.

6. S. campestris.

7. S. carnosa. 
b. Calyx-tube not prominently ribbed, surrounding the base of the capsule only. Calyx-lobes foliaceous, often surpassing the corolla.

Calyx-lobes very narrow, slender, usually shorter than the corolla, if nearly as long as the corolla-lobes, then filiform.

Stigmas longer than the style. Calyx-lobes less than $1 / 2$ as long as the corolla. Calyx-lobes fully as long as the corolla.

Stigmas shorter than the style. Corolla-lobes 1-1.5 $\mathrm{cm}$. long.

B. Corolla-lobes 8-12. Corolla-lobes $2-3 \mathrm{~cm}$. long.

Corolla-lobes less than $2.5 \mathrm{~cm}$. long.

Calyx-lobes about $1 / 2$ as long as the corolla.

Leaf-blades narrowed at the base, merely sessile: calyx-lobes narrowed upward.

Leaf-blades broad at the base, partly clasping: calyx-lobes broadened upward.

Calyx-lobes as long as the corolla or nearly so.

Corolla-lobes over $2.5 \mathrm{~cm}$. long.
9. S. Elliottii.
10. S. stellaris.
11. S. campanulata.
12. S. grandiflora.

1. Sabbatia macrophýlla Hook. Stems erect or ascending, 6-10 dm. tall, terete ; branches opposite : leaf-blades oblong to lanceolate or ovate-lanceolate, or rarely ovate, $2-6 \mathrm{~cm}$. long, acute, sessile : calyx glabrous; lobes lanceolate to triangular-lanceolate, shorter than the tube : corolla white; lobes oblong or oblong-spatulate, 6-8 $\mathrm{mm}$. long, obtuse : capsules subglobose or ovoid, 3-4 mm. long.

In wet pine lands or bogs, Georgia to Florida and Louisiana. Summer.

2. Sabbatia lanceolàta (Walt.) T. \& G. Stems erect, 4-9 dm. tall, corymbose above, narrowly wing-angled ; branches opposite: leaf-blades suborbicular to ovate or lanceolate above, 1-3 cm. long, apiculate or acute, sessile: calyx glabrous; lobes narrowly linear or linear-filiform, longer than the tube : corolla white, drying yellowish; lobes spatulate or obovate-oblong, $12-15 \mathrm{~mm}$. long: styles shorter than the stigmas : capsules ovoid or globose-ovoid, 6-7 mm. long.

In wet pine lands, New Jersey to Florida. Spring and summer.

3. Sabbatia paniculàta (Michx.) Pursh. Stems erect often branched at the base : branches ascending, 1-4 dm. long, corymbose at the top, wing-angled : leaf-blades oblongspatulate to oblong, oblong-lanceolate or nearly linear, 1-3 cm. long, obtuse but usually apiculate, partly clasping : calyx glabrous; lobes linear or linear-lanceolate, about thrice as long as the tube: corolla white; lobes oblong-spatulate, 1-1.5 cm. long, obtuse : style shorter than the stigmas: capsules oblong, 7-9 mm. long.

In meadows and pine lands, Virginia to Florida and Alabama. Spring and summer.

4. Sabbatia angustifòlia (Michx.) Britton. Stems erect, 1-4 dm. tall, with several opposite branches above or sometimes branched at the base : leaf-blades narrowly oblong to linear-lanceolate, or oblong-spatulate at the base of the stem, $1.2-3.5 \mathrm{~cm}$. long, acute or obtuse, sessile : calyx glabrous ; lobes narrowly linear, 8-10 $\mathrm{mm}$. long, often variable in length : corolla rose-colored; lobes oblong to spatulate-oblong, often barely surpassing the calyx-lobes : style longer than the stigmas : capsules oval, $5-7 \mathrm{~mm}$. long. [S. brachiata Ell.]

In moist soil, Indiana and North Carolina, Florida and Louisiana. Summer.

5. Sabbatia angulàris (L.) Pursh. Stems erect, $3-8 \mathrm{dm}$. tall, narrowly 4-winged ; branches opposite: leaf-blades broadly ovate, to ovate-lanceolate, or orbicular to orbicularovate at the base of the stem : calyx glabrous ; lobes linear or linear-lanceolate, 10-14 mm. long, much shorter than the corolla : corolla deep pink or rarely white, with a lemon or greenish eye; lobes oblong or cuneate-obovate, $1.5-2 \mathrm{~cm}$. long, obtuse : anthers bright lemon : capsules oblong, about $5 \mathrm{~mm}$. long.

In rich soil, Ontario to Florida, Michigan and the Indian Territory. Summer and fall.

6. Sabbatia campéstris Nutt. Stems erect, 1-4 dm. tall, more or less widely branched above : leaf-blades ovate to ovate-lanceolate, $1.5-4 \mathrm{~cm}$. long, apiculate or acute, broadest near the base and partly clasping: calyx deep green; tube prominently ribbed ; lobes linear, or narrowly linear-lanceolate, $2-3 \mathrm{~cm}$. long, acute, with prominent marginal ribs : corolla lilac; lobes oval or obovate, as long as the calyx-lobes or shorter : capsules wholly or mostly enclosed by the calyx-tube, $8-10 \mathrm{~mm}$. long.

On prairies, Missouri to Arkansas and Texas. Spring and summer.

7. Sabbatia carnòsa Small. Stems erect, often branched at the base ; branches ascending, 1-3 dm. long, zigzag: leaf-blades oblong, spatulate-oblong or oblong-lanceolate in the inflorescence, 1-2 cm. long, obtuse, usually broadest about the middle, sessile, not clasping: calyx bright green; tube prominently-ribbed; calyx-lobes linear-lanceolate, 8-12 mm. long, with prominent marginal nerves: corolla pink or lilac ; lobes cuneate or oblongcuneate, $6-9 \mathrm{~mm}$. long, usually surpassed by the calyx-lobes, inequilateral : capsules mostly included in the calyx-tube, about $8 \mathrm{~mm}$. long.

In sandy soil, Texas. Summer and fall. 
8. Sabbatia calycina (Lam.) Heller. Stems erect, 1-4 dm. tall, terete, with all or the upper branches opposite : leaf-blades thinnish, spatulate to oblong or oblong-lanceolate, 2-6 $\mathrm{cm}$. long, apiculate or acutish or sometimes obtuse, narrowed into short margined petioles or sessile : calyx deep green ; lobes foliaceous, linear or linear-oblanceolate, 1-2 $\mathrm{cm}$. long, commonly surpassing the corolla : corolla rose or nearly white; lobes spatulate or oblong-spatulate, rarely surpassing the calyx-lobes: capsules subglobose or oval, 7-8 mm. long. [S. calycosa Pursh.]

'In sand on or near the coast, Virginia to Florida and Texas. Spring and summer.

9. Sabbatia Ellióttii Stend. Stems erect, $2-7 \mathrm{dm}$. tall, more or less effusely branched : leaf-blades obovate to oblong or linear, $0.5-2 \mathrm{~cm}$. long, acute or obtuse, sessile : calyx glabrous; lobes subulate, 4-5 $\mathrm{mm}$. long, about twice or thrice as long as the tube : corolla white or cream-colored ; lobes spatulate to oblanceolate, 10-12 mm. long, fully twice as long as the calyx-lobes: capsules oblong or oval, 4-5 mm. long.

In pine lands, Virginia to Florida. Summer and fall.

10. Sabbatia stellàris Pursh. Stems erect, $2-4 \mathrm{dm}$. tall, more or less hranched; branches mostly alternate : leaf-blades spatulate to narrowly elliptic or linear, $2-6 \mathrm{~cm}$. long, acute, or obtuse at the base of the stem : calyx glabrous; lobes narrowly linear, 8-12 mm. long, acute, fully $\frac{1}{2}$ as long as the corolla-lobes: corolla pink or white; lobes oblong or oblong-spatulate, rarely surpassing the calyx-lobes obtuse : capsules oblong, 5-6 mm. long.

In brackish marshes, Maine to Florida and Louisiana. Summer and fall.

11. Sabbatia campanulàta (L.) Britton. Stems erect, often branched at the base ; branches alternate, ascending, 1-4 dm. long, sometimes zigzag: leaf-blades spatulate at the base of the stem, oblong-lanceolate to linear above, 1-3 cm. long, acute or acutish : calyx glabrous; lobes linear-filiform, 8-12 $\mathrm{mm}$. long: corolla deep rose or magenta with a yellow eye ; lobes oblong to oblong-spatulate, about twice as long as the calyx-lobes : capsules oblong or oblong-obovoid, 6-8 $\mathrm{mm}$. long. [S. gracilis Salisb.]

In swamps and meadows, Massachusetts to Florida and Louisiana. Summer and fall.

12. Sabbatia grandiflòra (A. Gray) Small. Stems 8-12 dm. tall, more or less branched above : leaf-blades linear-oblong at base of the stem to linear or linear-filiform above, $3-10 \mathrm{~cm}$. long, acute, of ten erect: calyx glabrous; lobes narrowly linear to linearfiliform, 1.5-2 cm. long : corolla pink to white, sometimes with delicate stripes; lobes oval, elliptic or rhombic-obovate, somewhat longer than the calyx-lobes : capsules oblong or oval or slightly narrowed at the base, $8-10 \mathrm{~mm}$. long. [S. gracilis var. grandiflora A.
[S. Gray.]

On sandy shores, Florida. Spring.

13. Sabbatia dodecándra (L.) B.S.P. Stems erect, 2-4 dm. tall, simple or sparingly branched above : leaf-blades linear-spatulate at the base of the stem to lanceolate or linear above, $2-4 \mathrm{~cm}$. long, acute or the broader ones obtuse: calyx glabrous; lobes linear or linear-spatulate, $10-17 \mathrm{~mm}$. long : corolla rose-purple to white, with a yellow eye ; lobes spatulate or oblong-spatulate : capsules broadly oblong, $8-9 \mathrm{~mm}$. long. [S. chloroides Pursh.]

In pine lands, Massachusetts to Florida and Alabama. Summer and fall.

14. Sabbatia Hárperi Small. Stems erect, $2-6 \mathrm{dm}$. tall, simple or sparingly branched above, stoloniferous : leaf-blades thin, lanceolate or oblong-lanceolate, or spatulate at the base of the stem, 1.5-3.5 cm. long, acute, broad at the base and partly clasping, mainly about as long as the internodes or longer : calyx glabrous; lobes slightly broadened upward, about $\frac{1}{2}$ as long as the corolla, flat or nearly so: corolla bright pink, or whitish, with a yellowish eye ; lobes spatulate or elliptic-spatulate, $1.5-2.5 \mathrm{~cm}$. long: capsules oval, $5-7.5 \mathrm{~mm}$. long.

In swamps or on pond margins, South Carolina to Georgia and Alabama. Spring and summer.

15. Sabbatia foliòsa Fernald. Stems erect, 1-5 dm. tall, simple or sparingly branched, stoloniferous : leaf-blades thin, linear-oblong, to linear-lanceolate or almost linear, or spatulate at the base of the stem, $2-6.5 \mathrm{~cm}$. long, more or less spreading, sessile, mainly as long as the internodes or longer : calyx glabrous; lobes linear, acute, as long as the corolla or nearly so, flat: corolla rose-colored, with a yellowish eye ; lobes oblanceolate to elliptic-spatulate, $1.2-2.5 \mathrm{~cm}$. long: capsules oval, $5-7 \mathrm{~mm}$. long.

In low grounds, Florida and Alabama. Spring to fall. 16. Sabbatia decándra (Walt.) Harper. Stems erect, 6-9 dm. tall, simple or spar-
ingly branched above : leaf-blades thick, spatulate at base of stem to narrowly linear above, 3-10 cm. long, usually erect: calyx glabrous; lobes subulate, 7-12 mm. long, acute, strongly revolute: corolla deep rose to white, with a yellow eye; lobes $2.5-3 \mathrm{~cm}$. long, 
spatulate or oblong-spatulate, twice or thrice as long as the calyx-lobes: capsules oval, about $1 \mathrm{~cm}$. long. [S. chloroides var. stricta A. Gray.]

In pine-land swamps, Georgia to Florida and Alabama. Summer and fall.

\section{LAPÍtheA Griseb.}

Annual or biennial caulescent herbs, with glabrous foliage. Leaves opposite: blades narrow, sessile. Flowers solitary or few in congested terminal cymes. Calyx sessile, membranous: lobes mostly $7-10$, narrow, unequal. Corolla red, purple or pink, rotate : lobes $7-10$, spreading, narrow, contorted. Stamens $7-10$, partially adnate to the corolla tube. Filaments short, but filiform. Anthers merely curved. Ovary 1-celled with intruding placentae: styles wholly united: stigmas 2. Capsules little longer than broad, 2-valved. Seeds numerous, reticulated.

Stem-leaves with oblong or oblong-lanceolate blades : bracts oval or oblong. Stem-leaves with narrowly linear blades: bracts linear.

1. L. Boykinii.

2. L. gentianoides.

1. Lapithea Boykínii (A. Gray) Small. Stems erect, $2-4$ dm. tall, simple or nearly so : leaf-blades broadly oblong to oblong-lanceolate, $1.5-4 \mathrm{~cm}$. long, obtuse or acutish, partially clasping: Howers solitary or clustered: bracts oval or oblong: calyx glabrous ; lobes lanceolate or linear-lanceolate, $5-9 \mathrm{~mm}$. long: corolla pink or whitish ; lobes spatulate or oblong-spatulate, $1.5-2 \mathrm{~cm}$. long, longer than the calyx-lobes. [Sabbatıa Boykinii A. Gray.]

In swamps, Georgia and Alabama. Summer and fall.

2. Lapithea gentianoìdes (Ell.) Griseb. Stems erect, $2-7 \mathrm{dm}$. tall, simple or nearly so: leaf-blades spatulate to oblong at the base of stem, $2-5 \mathrm{~cm}$. long, the upper linear, $3-10 \mathrm{~cm}$. long, involute : flowers solitary or in terminal clusters: calyx glabrous; lobes lanceolate-subulate, $8-12 \mathrm{~mm}$. long : corolla reddish, lilac or pink-purple ; lohes spatulate or oblong-spatulate, $2-2.5 \mathrm{~cm}$. long, much longer than the calyx-lobes. [Sabbatia gentianoides Ell.]

About pine-barren ponds, Georgia to Florida. Summer.

\section{ANTHOPÒGON Neck.}

Annual, biennial or rarely perennial herbs. Leaves opposite: blades entire, sessile. Flowers perfect, solitary at the end of the stem or its branches, the whorls mostly of 4 parts each. Calyx relatively large: lobes unequal, keeled, the inner broader and markedly wider than the outer, scarious- or hyaline-margined. Corolla showy : tube campanulatefunnelform : lobes more or less spreading, erose or fimbriate, not accompanied by plaits in the sinuses. Stamens usually accompanied by a row of glands at the base of the filaments. Ovary 1-celled. Ovules numerous. Capsule stipitate. Fringed Gentian.

1. Anthopogon crinitum (Froel.) Raf. Annual. Stems $2-5 \mathrm{dm}$. tall, commonly branched: leaf-blades ovate to lanceolate, mainly $2-5 \mathrm{~cm}$. long, sessile and partly clasping: calyx 2.5-3 cm. long, glabrous, the outer lobes lanceolate, acuminate, the inner much broader, scarious-margined : corolla deep sky-blue, 4-5 cm. long; lobes spreading, copiously fimbriate beyond the middle : capsule about $3 \mathrm{~cm}$. long. [Gentiana crinita Froel.]

In low grounds, Quebec to Minnesota, Georgia and Iowa. Late summer and fall.

\section{GentianÉrLa Moench.}

Annual, biennial or perennial herbs. Leaves opposite : blades entire, mainly sessile. Flowers perfect, solitary or in open or contracted cymes, the whorls of 4 parts each or sometimes of 5 parts. Calyx relatively small : lobes imbricated, essentially equal, or the outer broader than the inner. Corolla funnelform or salverform : lobes entire or sparingly toothed, not accompanied by plaits in the sinuses, but often filamentose at the base. Ovary 1-celled. Ovules numerous. Capsule mainly sessile.

1. Gentianella quinquefòlia (L.) Small. Annual or biennial. Stems 1-11 dm. tall, more or less branched, 4-winged : leaf-blades ovate to lanceolate, $2-8 \mathrm{~cm}$. long, acute, sessile and partly clasping: flowers solitary or sometimes fully 360 on a single plant: calyx deep green, 6-9 mm. long; lobes linear, acute or acuminate, much longer than the tube: corolla blue or purplish blue, about $2 \mathrm{~cm}$. long; lobes $5-7 \mathrm{~mm}$. long, slenderly acuminate : capsule about $1.5 \mathrm{~cm}$. long. [Gentiana quinquefolia L.]

In moist soil or woods, Maine and Ontario to Michigan, Florida and Missouri. Summer and fall.The form with larger foliaceous calyx-lobes and a more funnelform corolla, is G. quinquefolia occidentalis (A. Gray) Small. [Gentiana quinqueflora var. occidentalis A. Gray.] 


\section{DASYSTEPHANA Adans.}

Annual, biennial or mainly perennial herbs. Leaves opposite : blades entire or essentially so, but the margins often more or less ciliolate-scabrous or erose. Flowers perfect, commonly sessile and clustered, rarely solitary and pedicelled, the whorls mainly of 5 parts each. Calyx persistent: lobes minute or foliaceous, smooth and glabrous or ciliolatescabrous. Corolla salverform, funnelform or clavate, with neither glands at the base of the tube nor filaments at the base of the lobes: lobes converging, erect or spreading, accompanied by plaits in the sinuses. Stamens with converging or cohering anthers. Ovary 1-celled. Ovules numerous, mainly over the whole ovary-cavity. Capsule stipitate. The plants flower in summer and fall. Gentian.

Calyx-lobes ciliolate-scabrous.

Corolla open funnelform: anthers separate, often converging.

Corolla campanulate-funnelform or clavate: anthers coherent into a ring or tube.

Corolla-lobes larger than the plaits, surpassing them or equalling them in length. Corolla-lobes much longer than the plaits : stem pubescent.

Calyx-tube glabrous.

Leaf-blades rounded or subcordate at the base: corolla-plaits with 2 unequal fimbriate lobes.

Leaf-blades narrowed at the base: corolla-lobes with 2 equal nearly entire lokes.

Calyx-tube pubescent.

Corolla-lobes about as long as the plaits : stem glabrous.

Corolla-lobes minute or obsolete.

Calyx-lobes smonth and glabrous or essentially so.

Flowers sessile, clustered: corolla-plaits entire or 1-2-toothed.

Flower solitary, pedicelled: corolla-plaits fimbriate.

1. D. puberula.

1. Dasystephana pubérula (Michx.) Small. Stems $2-4.5 \mathrm{dm}$. tall, finely pubescent or rather puberulent : leaf-blades lanceolate to oblong-lanceolate, $2.5-4 \mathrm{~cm}$. long, slightly revolute, sessile : calyx about $2 \mathrm{~cm}$. long; lobes linear to narrowly linear-lanceolate, about as long as the tube : corolla rose-purple, $3.5-4.5 \mathrm{~cm}$. long, campanulate-funnelform ; lobes ovate, 9-12 mm. long, spreading, much larger than the cleft and laciniate plaits : capsulebody about $2 \mathrm{~cm}$. long : seeds oblong, conspicuously winged. [Gentiana puberula Michx.]

In dry or stony soil, Ohio to the Northwest Territory, Georgia and Kansas.

2. Dasystephana parvifòlia (Chapm.) Small. Stems $3-7 \mathrm{dm}$. tall, finely pubescent : leaf-blades ovate to lanceolate or oblong-lanceolate, $1-4.5 \mathrm{~cm}$. long, rounded or subcordate at the base : calyx $2.5-3 \mathrm{~cm}$. long; lobes erect, linear-elliptic to almost linear, much longer than the glabrous tube : corolla rose-purple, $4-5 \mathrm{~cm}$. long, funnelform ; lobes ovate, much longer than the unequally cleft and fimbriate plaits : capsule-body about $2.5 \mathrm{~cm}$. long: seeds conspicuously winged. [Gentiana Elliottii Chapm., not Raf. G. Elliottii var. parvifolia Chapm.]

On river banks and in ditches, Virginia to Florida.

3. Dasystephana latifòlia (Chapm.) Small. Stems $3-5 \mathrm{dm}$. tall, finely pubescent : leaf-blades oblong to broadly elliptiç, or sometimes nearly linear, $2-8 \mathrm{~cm}$. long, more or less narrowed at the base: calyx $1.5-2.5 \mathrm{~cm}$. long; lobes spreading, linear to linear-lanceolate, about as long as the glabrous tube or sometimes slightly shorter or longer: corolla rosepurple, $4-5 \mathrm{~cm}$. long, funnelform; lobes ovate, relatively narrower and more acute than those of $D$. parvifolia, much longer than the nearly equally cleft and almost entire plaits : capsule-body nearly $2.5 \mathrm{~cm}$. long : seeds conspicuously winged. [Gentiana Elliottii var. latifolia Chapm.]

In moist soil, especially on river banks, Virginia to Florida and Alabama.

4. Dasystephana décora (Pollard) Small. Similar to $G$. latifolia in habit: leafblades thinner and more decidedly acuminate : calyx less than $1.5 \mathrm{~cm}$. long; lobes spreading, subulate to linear-subulate, shorter than the pubescent tube : corolla purple, $2.5-3 \mathrm{~cm}$. long; lobes ovate, much longer than the cleft plaits : capsule-body about $2 \mathrm{~cm}$. long: seeds winged. [Gentiana decora Pollard.]

In moist soil, in mountain woods, Virginia to Georgia.

5. Dasystephana Saponària (L.) Small. Stems $3-8 \mathrm{dm}$. tall, glabrous : leaf-blades lanceolate to oblong or elliptic, $2.5-7.5 \mathrm{~cm}$. long: calyx $1.5-2 \mathrm{~cm}$. long; lobes spatulate to linear-spatulate, mainly slightly shorter than the glabrous tube : corolla blue or purplish blue, 3.5-4 cm. long; lobes broad, scarcely, if at all, longer than the broad cleft and manytoothed plaits: capsule-body fully $1.5 \mathrm{~cm}$. long: seeds winged. [Gentiana Saponaria L.]

In swamps and moist soil, Ontario to Minnesota, Florida and Louisiana.

6. Dasystephana Andrèwsii (Griseb.) Small. Stems 3-6 dm. tall, glabrous : leafblades lanceolate varying to linear-lanceolate or more often ovate-lanceolate, mainly 4-9 $\mathrm{cm}$. long, acute or acuminate: calyx $1 \mathrm{~cm}$. or barely $1.5 \mathrm{~cm}$. long; lobes elliptic, oval 
or ovate, acute, shorter than the tube : corolla blue, or purplish or rarely white, 2.5-3.5 $\mathrm{cm}$. long, stout-clavate; lobes minute or obsolete, shorter than the broad fimbriate-toothed pale or white plaits : capsule-body $2-2.5 \mathrm{~cm}$. long: seeds conspicuously winged. [Gentiana Andrewsii Griseb.]

In moist soil or thickets, Quebec to the Northwest Territory, Georgia and Missouri.

7. Dasystephana villòsa (L.) Small.' Stem 1-6 dm. tall, glabrous : leaf-blades spatulate to obovate, oblong or oval, $2-8 \mathrm{~cm}$. long, those on the lower part on the stem often much smaller than those on the upper : flowers clustered, sessile : calyx $3-5 \mathrm{~cm}$. long; lobes linear to linear-spatulate, much longer than the thin glabrous tube, sometimes surpassing the corolla, smooth-edged: corolla greenish white or purplish green, $4-5.5 \mathrm{~cm}$. long, funnelform; lobes ovate or triangular-ovate, erect, much longer than the oblique entire or sparingly toothed appendages: capsule-body $2.5-3 \mathrm{~cm}$. long, longer than the stipe : seeds wingless. [Gentiana villosa L. G. ochroleuca Froel.]

In shaded places, New Jersey and Pennsylvania to Florida and Louisiana.

8. Dasystephana Porphỳrio (J. F. Gmel.) Small. Stems $1.5-4.5 \mathrm{dm}$. tall, glabrous : leaf-blades linear-spatulate to linear, $2-6.5 \mathrm{~cm}$. long: flowers solitary, pedicelled : calyx 2.5-3 cm. long; lobes narrowly linear, longer than the tube : corolla deep or brilliant azure-blue, or rarely nearly white, $4-5.5 \mathrm{~cm}$. long, funnelform; lobes ovate, much longer than the broad fimbriate plaits : capsule-body about $1.5 \mathrm{~cm}$. long, shorter than the stipe : seeds wingless. [Gentiana Porphyrio J. F. Gmel. G. angustifolia Michx.]

In moist pine lands, New Jersey to Florida.

\section{FRÀSERA Walt.}

Biennial or perennial herbs, with hollow stems and glabrous foliage. Leaves opposite or whorled: blades entire, thickish. Flowers in terminal panicled cymes. Calyx pedicelled : tube short : lobes 4, narrow. Corolla whitish, yellowish or blue, rotate : tube short : lobes 4 , convolute, each furnished with 1 or 2 fringed glands on the inner side. Stamens 4 , adnate to the throat of the corolla-tube : filaments distinct or united at the base : anthers versatile. Ovary 1-celled : stigma nearly entire, or 2-lobed. Capsule leathery, somewhat flattened, 2-valved. Seeds flattened, margined or winged. American Columbo.

1. Frasera Carolinénsis Walt. Stems erect, 1-2.5 m. tall, stout: leaves usu\$̣ally in whorls of 4 ; blades spatulate to oblong or oblong-lanceolate, 1-3 dm. long, acute or acuminate, the lower narrowed into winged petiole-like bases, the upper sessile : pedicels becoming 3-6 cm. long: calyx glabrous ; lobes linear or linear-lanceolate, $1-1.5 \mathrm{~cm}$. long, acuminate : corolla ochroleucous, dotted with purple, $2.5-3 \mathrm{~cm}$. broad ; lobes broadly oblong or oval, each with a fringed gland just below the middle : capsules ovoid, $2 \mathrm{~cm}$. long, acute : seeds 7-8 mm. long, granular.

In woods, Ontario to Michigan, Georgia, Tennessee and Alabama. Spring and summer.

\section{TETRAgONÁNTHUS J. F. Gmel.}

Annual or perennial caulescent herbs, with glabrous foliage. Leaves opposite : blades entire, leathery. Flowers in terminal or axillary cymes or panicles. Calyx pedicelled: tube short: lobes 4, longer than the tube. Corolla white, yellow, blue or purple: tube short : lobes 4 , each produced into a spur at the base; this glandular within at the apex. Stamens 4, adnate on the lower part of the corolla-tube : filaments filiform or dilated at the base : anthers versatile. Ovary 1-celled, with more or less intruded placentae : style stout or wanting: stigma 2-lobed. Ovules numerous. Capsule ovoid to oblong, 2-valved. Seeds often slightly flattened. Testa smooth. [Halenia Borck.] Spurred Gentian.

1. Tetragonanthus defléxus (J. E. Smith) Kuntze. Stems simple or sparingly branched, 1-5 dm. tall : leaf-blades often spatulate and petioled at the base of the stem, ovate to oblong or lanceolate above, $2-6 \mathrm{~cm}$. long, or shorter above, obtuse or acute, 3-5nerved, entire, sessile : calyx glabrous; lobes narrow, constricted below the middle, acute : corolla white or purplish, 6-8 mm. broad : lobes ovate or triangular-lanceolate, acute ; spurs $\frac{1}{2}$ or $\frac{1}{4}$ as long as the corolla, deflexed : capsules 10-14 mm. long, conic-oblong, acute.

In woods and thickets, Labrador to South Dakota, south to New York, Michigan and the Indian Territory. Summer.

\section{BARTÒNIA Muhl.}

Annual or biennial slender caulescent herbs, with glabrous foliage. Leaves reduced to scales; these opposite or sometimes alternate. Flowers in terminal racemes or panicles, or 
sometimes solitary. Calyx-lobes 4, keeled. Corolla white or yellowish : lobes 4, imbricated. Stamens 4, included: filaments adnate to the sinuses of the corolla. Ovary 1-celled, with 4 intruded placentae : style very short or wanting: stigma 2-lobed. Ovules numerous. Capsule longer than thick, 2-valved. Seeds minute.

Corolla $6 \mathrm{~mm}$. long or more ; lobes spatulate to obovate-spatulate. Corolla $5 \mathrm{~mm}$. long or less ; lobes lanceolate to oblong.

Corolla-lobes oblong, more or less erose, abruptly pointed.

Corolla-lobes lanceolate, entire, acute or acuminate.

1. B. verna.

2. B. Virginica.

3. B. lanceolata.

1. Bartonia vérna (Michx.) Muhl. Stems 0.5-3 dm. tall, simple or sparingly branched above: leaves (scales) few, opposite, 1-2 $\mathrm{mm}$. long: calyx lobes linear-lanceolate, about $3 \mathrm{~mm}$. long, acute : corolla white, fully $1 \mathrm{~cm}$. broad ; lobes spatulate to obovatespatulate, 7-10-mm. long: capsules oblong or ovoid-oblong, 5-6 $\mathrm{cm}$. long.

In wet pine lands, Virginia to Florida and Louisiana. Late winter and spring.

2. Bartonia Virgínica (L.) B. S. P. Stem 1-4 dm. tall, simple or commonly branched, the pedicels or branches erect or appressed : leaves opposite or commonly alternate in the case of depauperate plants, often approximate near the base of the stem : calyxlobes subulate or lanceolate-subulate, 2-3 mm. long: corolla $3-5 \mathrm{~mm}$. broad, yellowish white; lobes oblong, erose near the apex, abruptly pointed : capsules 3-ó $\mathrm{mm}$. long.

In open woods or swamps, Newfoundland to Michigan, Florida and Louisiana, Summer.

3. Bartonia lanceolàta Small. Stem 2-6 dm. tall, simple, or typically paniculately branched, the pedicels or branches lax or spreading : leaves opposite or alternate : calyxlobes subulate or lanceolate-subulate, $2-3 \mathrm{~mm}$. long : corolla commonly about as large as that of $B$. Virginica; lobes lanceolate, entire, acute or acuminate : capsules 4-5 mm. long.

In moist soil or wet pine lands, New York to Florida and Arkansas. Summer and fall.

\section{OBOLÀrIA L.}

Perennial caulescent herbs, with fleshy tissues and glabrous foliage. Leaves reduced to scales, typically opposite. Flowers in short spikes, few, subtended by thick bracts. Calyx-lobes 2, spatulate. Corolla white or purplish: lobes 4, about as long as the tube, toothed. Stamens 4, included: filaments adnate to the sinuses of the corolla. Ovary 1-celled, with 4 placentae: style slender: stigmas 2. Ovules numerous. Capsule 2-valved or opening irregularly. Seeds minute. Pennywort.

1. Obolaria Virgínica L. Foliage purplish green. Stems $0.5-2 \mathrm{dm}$. tall, simple or branched: leaves various, the lower ones reduced to small scales, the upper cuneate or cuneate-obovate, $5-10 \mathrm{~mm}$. long, obtuse : calyx sessile or nearly so ; lobes 2 , nearly oblong or oblong-spatulate, shorter than the corolla : corolla white or pinkish, 7-10 mm. long; lobes slightly shorter than the tube, acute, toothed near the apex: capsules oblong or oval-oblong, 5-6 mm. long.

In woods and thickets, New Jersey to Illinois, Florida and Texas. Spring.

\section{VOỲrIA Aubl.}

Annual or perennial caulescent herbs, growing in humus, often with colorless foliage. Leaves reduced to scales, opposite, or alternate on the lower part of the simple or sparingly branched stem. Flowers solitary or in cymes. Calyx pale : lobes 4 or 5 . Corolla white, yellow or golden or rarely pink or blue, salverform : lobes 4-5, spreading, contorted. Stamens 4-5, included, partially adnate to the corolla-tube : anthers opening introrsely. Ovary 1-celled, with entire or 2-parted placentae: style single : stigma dilated. Capsule longer than thick, 2-valved. Seeds wrinkled or reticulated.

1. Voyria Mexicàna Griseb. Foliage colorless, glabrous. Stems $1-4 \mathrm{dm}$. tall, often mainly subterranean, simple or sparingly branched above, rather slender: leaves (scales) opposite, 3-5 mm. long, usually few : calyx slightly fleshy; lobes lanceolate or oblonglanceolate, acute : corolla white or pink, 6-8 mm. long; lobes triangular, acute, 1-1.5 $\mathrm{mm}$. long : capsules $5-6 \mathrm{~mm}$. long.

In sandy woods, Florida Keys. Also in the West Indies and Mexico.

\section{Family 3. menyanthàceae G. Don. Buckbean Family.}

Perennial aquatic or bog herbs, with horizontal rootstocks. Leaves alternate, often all basal: blades simple or 3-foliolate. Flowers perfect, solitary or in terminal clusters or racemes. Calyx of 5 partially united sepals. Corolla 
white or colored, rotate or funnelform; lobes induplicate-valvate. Androecium of 5 stamens. Filaments adnate to the corolla-tube. Anthers versatile. Pollengrains 3-angled. Gynoecium compound. Ovary 1-celled, with placentae at the sutures. Style entire, terminal. Stigmas terminal, of 2 blades, sometimes nearly sessile. Ovules few or many. Fruit a capsule, this indehiscent, irregularly opening or valvate. Seeds with a smooth or variously roughened testa.

\section{LIMNÁNTHEMUM J. F. Gmel.}

Aquatic herbs, with floating or creeping stems. Leaves often all basal : petioles elongated : blades always broad, leathery, or membranous when submerged, with a deep sinus, or peltate. Flowers solitary or clustered at the nodes, their pedicels sometimes accompanied by tubers. Calyx green: lobes 5, rather narrow. Corolla white or yellow, somewhat rotate : lobes 5, surpassing the sepals. Stamens 5 : filaments very short, adnate to the base of the corolla. Ovary 1-celled. Capsules slightly longer than broad, indehiscent, or opening irregularly. Seeds with a smooth or tuberculate testa. Floating Heart.

Leaf-blades relatively small : corolla about twice as long as the calyx : capsule slightly longer than the calyx : seeds smooth.

Leaf-blades relatively large: corolla about thrice as long as the calyx : capsule about

twice as long as the caly $x$ : seeds tuberculate.

1. L. lacunosum.

1. Limnanthemum lacunòsum (Vent.) Griseb. Leaf-blades ovate to orbicularovate, $2-4 \mathrm{~cm}$. long, undulate, sometimes pubescent beneath, deeply cordate : flower-clusters usually accompanied by a cluster of slender tubers : calyx usually glabrous, $3-4 \mathrm{~mm}$. long : lobes linear-oblong or linear-lanceolate : corolla white, 6-9 $\mathrm{mm}$. broad : capsules slightly longer than the calyx : seeds smooth.

In shallow ponds, Nova Scotia to Ontario, Minnesota, Florida and Louisiana. Spring to fall.

2. Limnanthemum aquáticum (Walt.) Britton. Leaf-blades suborbicular to reniform, $5-15 \mathrm{~cm}$. in diameter, undulate or repand, cordate, reticulated and pitted on the lower discolored surface : flower-clusters commonly destitute of tubers: calyx 4-5 mm. long: lobes oblong to lanceolate : corolla white, $12-20 \mathrm{~mm}$. broad : capsules twice as long as the calyx : seeds rough. [L. trachyspermum A. Gray.]

In ponds, Delaware and Maryland to Florida and Texas. Spring and summer.

\section{Order 6. ASCLEPIADÀLES.}

Herbs, shrubs or trees, commonly with a milky juice. Leaves alternate or opposite: blades entire. Inflorescence cymose, sometimes umbellate. Calyx of usually 5 partially united sepals. Corolla of usually 5 partially united petals, Androecium of 5 distinct or monadelphous stamens, partially adnate to the corolla in Asclepiadacean and accompanied by a 5-lobed crown. Pollen granular or in waxy masses. Gynoecium of usually 2 carpels sometimes only united at the apex. Stigma terminal. Fruit a pair of follicles, or drupaceous.

Styles united: stamens distinct: pollen loosely granular. Styles distinct: stamens usually monadelphous: pollen united into waxy masses, or the grains in groups of 4 .

Fam. 1. Apocynaceae.

Fam. 2. Asclepiadaceae.

\section{Family 1. apocynáceat Lindl. Dogbane Family.}

Perennial herbs, vines, shrubs or trees, mostly with a milky acrid juice. Leaves alternate or opposite, without stipules: blades simple. Flowers perfect, regular. Calyx of 5 persistent sepals imbricated in the bud. Corolla of 5 partially united petals, the lobes convolute in the bud. Androecium of 5 stamens alternating with the corolla-lobes. Filaments partially adnate to the corollatube. Anthers 2-celled. Pollen-grains simple. Gynoecium of two distinct carpels or 2 united carpels. Ovary superior, 1-celled with 2 parietal placentae, or 2-celled. Styles united. Stigmas simple. Ovules anatropous or amphitropous. Fruit usually of 2 follicles or drupes. Seed often appendaged. Endosperm fleshy. Embryo with straight cotyledons.

Anthers unappendaged at the base, not connected with the stigma : corolla-lobes sinistrorsely convolute.

Corolla salverform, relatively small; lobes equilateral, shorter than the tube. 
Corolla funnelform, reiatively large ; lobes inequilateral, longer than the tube.

Fruit a pair of follicles : herbs sometimes partially shrubby.

Flower without a disk : leaves alternate.

Flower with a 2-lobed disk: leaves opposite.

Anther with a foliaceous connective: carpels 6-8-ovuled: stigma glabrous : corolla funnelform.

Anther with an inconspicuous connective : carpels several-ovuled: stigma pubescent : corolla salverform.

Anthers appendaged at the base, converging around the stigma and partially adherent to it: corolla-lobes mostly dextrorsely convolute.

Shrubs or trees.

Herbs or vines.

Corolla appendaged within: calyx-tube partially attached to the gynoecium by the thick disk : upright herbs.

Corolla unappendaged: caly $x$-tube wholly free : vines.

Stigma appendaged with a reversed cup or 5 lobes. Corolla funnelform, the throat widened upward

Calyx-lobes relatively long and narrow : scale-like glands borne at the base of the caly $x$ within.

Calyx-lobes relatively broad and short: scale-like glands wanting. Corolla salverform, the throat narrowed upward. Stigma merely thickened.

2. Thevetia.

3. AMsonia.

4. VINCA.

5. Ammocallis.

6. Nerium.

7. Apocynum.

8. URECHITES.

9. RHABDADENIA.

10. ECHITES.

11. TRACHELOSPERMUM.

1. VALLÈsia R. \& P.

Shrubs, with branching stems. Leaves alternate, relatively few : blades entire. Flowers in long-peduncled cymes becoming opposite the leaves. Calyx-lobes 5, relatively short. Corolla salverform : tube swollen into a short neck which is constricted at the mouth: lobes 5 , shorter than the tube, equilateral. Stamens adnate up to the throat of the corolla-tube : anthers cordate, unappendaged. Disk wanting. Carpels 2. Stigma clavate. Drupe mostly from 1 carpel, 1-2-seeded. Seeds clavate, naked.

1. Vallesia glàbra Cav. Shrub several m. tall, the bark pale. Leaves remote; blades elliptic to oblong or oblong-lanceolate, 4-7 $\mathrm{cm}$. long, acute or slightly acuminate, fleshy-leathery, glabrous, short-petioled : cymes few-flowered : calyx-lobes triangular, less than $1 \mathrm{~mm}$. long: corolla white: tube $5-6 \mathrm{~mm}$. long: lobes spreading, $3-4 \mathrm{~mm}$. long; drupe narrow, 10-14 mm. long, rather dry.

In thickets, Key West, Florida. Also in tropical America and Chile.

\section{THEVÈTIA L.}

Shrubs or trees, with stout branches. Leaves alternate, numerous : blades narrow, entire. Flowers solitary or few together. Calyx-lobes 5, relatively long. Corolla funnelform : tube dilated into a throat not constricted at the mouth : lobes 5 , longer than the tube, inequilateral. Stamens adnate up to the bearded throat of the corolla: anthers unappendaged. Disk lobed. Carpels 2. Stigma 2-pointed. Drupe from 2 carpels, broad, 2-4seeded. Seeds rather triangular, naked.

1. Thevetia Thevètia (L.) Millsp. Branching shrub. Leaves approximate; blades narrowly linear, 8-16 $\mathrm{mm}$. long, lustrous above, slightly revolute, glabrous, sessile : calyxlobes lanceolate, 5-7 mm. long, acuminate : corolla saffron-colored; tube $2-2.5 \mathrm{~cm}$. long; lobes ascending, $3-4 \mathrm{~cm}$. long: drupe depressed, $3-4 \mathrm{~cm}$. broad. [Thevetia neriifolia Juss.]
[The

In dry soil, Key West, Florida. Also in tropical America.

\section{AMSÒNIA Walt.}

Herbs. Leaves alternate : blades entire. Flowers in terminal thyrsoid or corymbose cymes. Calyx-lobes 5, acuminate. Corolla mainly salverform : tube slightly dilated upward, villous within: lobes narrow. Disk wanting. Stamens included: anthers unappendaged. Carpels 2, connected by the slender styles. Stigma appendaged by a reflexed membrane. Follicles 2 together, erect, several-seeded. Seeds unappendaged.

A. Corolla or corolla-lobes pubescent without.

Leaf-blades densely white-tomentose beneath : follicles pubescent.

Leaf-blades glabrous beneath or rarely with scattered hairs: follicles glabrous.

Leaf-blades relatively broad, oval to broadly oblong-lanceolate, not glaucous beneath at maturity, not callous-margined.

Leaf-blades relatively narrow, lanceolate to linear-lanceolate, glaucous beB. Corolla glabrous without. neath at maturity and callous-margined.

Leaf-blades elliptic, glaucous beneath.

1. A. Ludoviciana.

2. A. Amsonia.

3. A. salicifolia.

4. A. rigida.

Leaf-blades oblong, linear or linear-filiform, green heneath. 
Longer calyx-lobes about $2 \mathrm{~mm}$. long: corolla-tube 9-11 $\mathrm{mm}$. long: stem and branches glabrous.

Longer calyx-lobes about $1 \mathrm{~mm}$. long: corolla-tube $6-8 \mathrm{~mm}$. long: stem and branches pubescent.

\section{A. Texana.}

6. A. ciliata.

1. Amsonia Ludoviciàna Vail. Stems $5-11 \mathrm{dm}$. tall, sparingly branched, pubescent, at least when young : leaves few ; blades broadly elliptic to oval-elliptic, $6-9 \mathrm{~cm}$. long, acute or acuminate at both ends, essentially glabrous above, densely white-tomentose beneath, the short petiole pubescent : calyx-lobes triangular or triangular-lanceolate, barely $1 \mathrm{~mm}$. long: corolla bluish ; tube 6-7 $\mathrm{mm}$. long, pubescent about the base of the limb; lobes lanceolate, slightly shorter than the tube : follicles $8-10 \mathrm{~cm}$. long, pubescent, at least the upper portion manifestly hairy.

In moist or shaded grounds, southern Louisiana. Spring.

2. Amsonia Amsònia (L.) Britton. Stems 6-13 dm. tall, more or less branched above, glabrous or sometimes with scattered hairs on the upper parts : leaves relatively few ; blades relatively broad, oval to broadly oblong-lanceolate, acute or acuminate, dull above, green and sometimes thinly pubescent beneath, thin-margined and ciliolate at maturity : calyx-lobes triangular, barely $1 \mathrm{~mm}$. long : corolla purplish blue ; tube 6-8 mm. long, pubescent about the base of the limb; lobes linear to linear-lanceolate, shorter than the tube : follicles $9-12 \mathrm{~cm}$. long, glabrons, green.

On river banks or in moist woods, New Jersey to Kansas, Florida and Texas. Spring and summer.

3. Amsonia salicifolia Pursh. Similar to the next preceding species in size and habit : leaves relatively few ; blades relatively narrow, lanceolate to linear-lanceolate, 7-16 $\mathrm{cm}$. long, acuminate, more or less lustrous above, glaucous beneath, callous-margined, not ciliolate : corolla purplish blue; lobes as long as the tube or longer : follicles 8-12 cm. long, glabrous, glaucous.

In low grounds or thickets, Missouri to Tennessee, Alabama and Texas. Spring and summer.

4. Amsonia rígida Shuttlw. Stems $8-13 \mathrm{dm}$. tall, regularly branched above, glabrous, more or less glaucous: leaves very numerous; blades elliptic or rarely oblong-ovate, $2.5-6 \mathrm{~cm}$. long, acute at each end or slightly acuminate at the apex, glabrous, deep green above, glaucescent beneath, short-petioled : calyx-lobes triangular or triangular-lanceolate, about $1 \mathrm{~mm}$. long : corolla purple-blue ; tube 4-6 mm. long, glabrous; lobes lanceolate or oblong-lanceolate, as long as the tube or longer: follicles 7-12 cm. long, glabrous.

In moist pine lands, Georgia and Florida. Spring and summer.

5. Amsonia Texàna (A. Gray) Heller. Stems $1.5-7 \mathrm{dm}$. tall, often sparingly branched, glabrous : leaves numerous; blades oblong to narrowly elliptic or linear, conspicuously narrower on the upper part of the plant, $2.5-6 \mathrm{~cm}$. long, acute or blunt, often somewhat lustrous above, glabrous at least at maturity : calyx-lobes acuminate, the longer about $2 \mathrm{~mm}$. long: corolla glabrous; tube $9-11 \mathrm{~mm}$. long ; lobes usually about as long as the tube : follicles $6-10 \mathrm{~cm}$. long, glabrous.

In rocky soil, Texas. Spring and early summer.

6. Amsonia ciliàta Walt. Similar to the next preceding species in habit, but taller and more widely branched, the stem and branches pubescent: leaves numerous; blades linear, or filiform-linear on the upper part of the plant, broader below, pubescent or glabrous in age : calyx-lobes acute, the larger about $1 \mathrm{~mm}$. long: corolla glabrous; tube 6-8 mm. long, as long as the tube or slightly shorter : follicles 8-16 cm. long, glabrous.

In dry soil or pine lands, North Carolina and Arkansas to Florida and Texas. Spring and summer.

\section{4. víNCA L.}

Perennial herbs, with creeping or trailing stems. Leaves opposite : blades thickish, entire. Flowers mostly solitary in the axils. Calyx-lobes 5, acuminate. Corolla funnelform : tube terete, pubescent within: lobes broad, oblique. Stamens included : anther with a foliaceous connective. Disk of 2 glands alternating with the carpels. Carpels 2, united by the slender styles. Stigma glabrous. Ovules 6-8 in each carpel. Follicles 2 together, few-seeded. Seeds slightly elongated, truncate at each end. Periwinkle.

1. Vinca minor L. Stems $2-7 \mathrm{dm}$. long, brancherl : leaf-blades thick, ovate to oblong, 1.5-4 cm. long, blunt, lustrous on both sides but paler beneath, short-petioled: calyx-lobes lanceolate or subulate-lanceolate, $3-3.5 \mathrm{~mm}$. long, glabrous: corolla blue ; tube funnelform, about $1 \mathrm{~cm}$. long; lobes as long as the tube or nearly so, almost truncate.

On roadsides and about gardens, Ontario to Georgia. Naturalized from Europe. Spring and summer.

5. AMMOCÁLLIS Small.

Shrubby plants, with erect stems. Leaves opposite : blades flat, entire. Flowers axillary, often 2 together. Calyx-lobes 5, slender. Corolla salverform: tube narrow, 
somewhat swollen near the top: lobes broad, spreading. Stamens included: anther with an inconspicuous connective. Disk of 2 glands alternating with the carpels. Carpels 2 , united by the styles. Stigma pubescent. Ovules several. Follicles 2 together, severalseeded. Seeds unappendaged.

1. Ammocallis ròsea (L.) Small. Stems $2-7 \mathrm{dm}$. tall, usually somewhat branched, pubescent, woody, at least below : leaf-blades rather fleshy, oblong or slightly narrower below the middle, $4-8 \mathrm{~cm}$. long, rounded or retuse at the apex and mucronulate, pubescent, short-petioled : calyx-lobes linear-subulate, 3-4 mm. long, pubescent : corolla-tube 2.5-3 $\mathrm{cm}$. long, finely pubescent, with a protruding pit behind each anther; limb white or pink or white with a pink eye, the lobes $1.5-2.5 \mathrm{~cm}$. long, oblique: follicles cylindric, 2-3 cm. long, pubescent. [Vinca rosea L.]

In sandy soil, Florida. Also in the tropies generally.

\section{NËRIUM L.}

Shrubs or trees, with stout branches. Leaves opposite, numerous : blades leathery, entire. Flowers in terminal compound cymes. Calyx-lobes 5, narrow. Corolla rather salverform : tube dilated into a narrowly campanulate throat: lobes spreading, about as long as the throat. Stamens adnate to the corolla-tube : anthers appendaged at the base. Carpels 2. Stigma surrounded by the anthers. Follicles narrow. OLeander.

1. Nerium Oleánder L. A shrub, or a tree becoming $10 \mathrm{~m}$. tall, with smooth branches. Leaf-blades narrowly elliptic or linear-elliptic, $6-15 \mathrm{~cm}$. long, acute or acuminate at both ends, conspicuously many-nerved : calyx-lobes lanceolate, 4.5-6 mm. long, acuminate, puberulent : corolla showy, rose-purple; limb $3-4.5 \mathrm{~cm}$. broad, the lobes obliquely apiculate : follicles erect or nearly so, 1-2 dm. long.

In fields and on roadsides, Gulf States and adjacent territory. Naturalized from the Old World.

\section{APÓCYNUM L.}

Herbs, with upright more or less branched stems. Leaves opposite : blades entire. Flowers small, in corymbed cymes. Sepals 5, acute. Corolla white or pink, campanulate: tube terete or angled, with 5 small appendages alternating with the stamens: lobes 5 . Stamens adnate to the base of the corolla-tube : anthers sagittate, converging about the stigma and slightly adherent to it. Disk 5-lobed. Carpels 2, united only by the slender styles. Stigma ovoid or sometimes 2 -lobed. Ovules several in each carpel. Follicles 2 together, terete. Seeds numerous, each tipped with a long coma. Dogbane. Indian Hemp. Corolla pink, $5-7 \mathrm{~mm}$. long: lobes revolute.

Corolla greenish white, $3-3.5 \mathrm{~mm}$. long: lobes erect or nearly so.

1. A. androsaemifolium.

1. Apocynum androsaemifòlium L. Stems $3-15 \mathrm{dm}$. tall, like the widely-spreading branches, mostly glabrous : leaf-blades ovate, oblong or oval, 4-11 cm. long, deep green and glabrous above, pale and more or less pubescent beneath, short-petioled : cymes rather lax : calyx-lobes ovate to ovate-lanceolate, $2-2.5 \mathrm{~mm}$. long: corolla pink, 5-7 mm. long ; lobes revolute : follicles $10-17 \mathrm{~cm}$. long.

In thickets and woodlands, Anticosti to British Columbia, Georgia and Texas. Summer.

2. Apocynum cannábinum L. Stems $8-18 \mathrm{dm}$. tall, the branches erect or ascending, glabrous at maturity : leaf-blades oblong to ovate-oblong or oblong-lanceolate, 5-12 $\mathrm{cm}$. long, glabrous, or slightly pubescent beneath, short-petioled: cymes rather dense : calyx-lobes lanceolate, $2.5-3 \mathrm{~mm}$. long: corolla greenish white, $3-3.5 \mathrm{~mm}$. long; lobes erect or nearly so : follicles $12-20 \mathrm{~cm}$. long.

In fields and thickets, Anticosti to British Columbia, Florida and Texas. Spring and summer.

\section{URECHITES Muell. Arg.}

Twining vines, with somewhat woody stems. Leaves opposite : blades flat, entire. Flowers in cymes terminating axillary or terminal peduncles. Calyx-lobes 5, relatively long and narrow. Corolla relatively large, funnelform, the tube abruptly dilated into a campanulate throat. Carpels 2. Follicles 2, spreading at maturity, usually very long.

Leaf-blades glabrous : peduncles and pedicels glabrous or sparingly puberulent. Leaf-blades densely soft-pubescent beneath: peduncles and pedicels more or less pu-
bescent.

1. U. Andrewsii.

1. Urechites Andrèwsii (Chapm.) Small. Stems 3-30 dm. long, reclining or twining, glabrous : leaf-blades leathery, oval to ovate or suborbicular, $2.5-5 \mathrm{~cm}$. long, glabrous, paler beneath than above, short-petioled: cymes 3-5-Howered: calyx-lobes lanceolate, 
$8-11 \mathrm{~mm}$. long, acuminate : corolla yellow; the campanulate throat over $2 \mathrm{~cm}$. long : anthers with a linear-filiform appendage at the apex : follicles incurved, 12-15 $\mathrm{cm}$. long: seeds with the lower part of the beak naked. [Echites Andrewsii Chapm.]

In sandy or rich thickets, southern peninsular Florida and the Keys

2. Urechites neriándra (Griseb.) Small. Similar to U. Andrewsii, but more pubescent, sometimes hirsute : leaf-blades relatively narrower, often oblong: corolla yellow, the cylindric throat often less than $2 \mathrm{~cm}$. long, more hairy, much longer than the limb.

In thickets, peninsular Florida and the Keys. Also in the West Indies.

\section{RHABDADÈnIA Muell. Arg.}

Vines, similar to Trechites in habit. Calyx lacking the scale-like glands at the base within, or these obsolete: lobes relatively broad and short. Corolla-tube usually gradually dilated into the funnelform throat. Carpels and follicles as in Urechites.

Corolla yellow, less than $3 \mathrm{~cm}$. long; limb $1 / 2$ as long as the throat : calyx-lobes acuminate.

Corolla white, over $4 \mathrm{~cm}$. long; limb about as long as the throat: calyx-lobes acute.

i. R. Sagraei.

1. Rhabdadenia Ságraei (A. DC.) Muell. Arg. Similar to R. biflora in habit, but smaller. Leaf-blades $1.5-2.5 \mathrm{~cm}$. long, revolute: cymes several-flowered: peduncles longer than the leaves: calyx-lobes subulate above an ovate base : corolla yellow, the throat $1-1.5 \mathrm{~cm}$. long; lobes about $\frac{1}{2}$ as long as the throat : follicles slender, $8-12 \mathrm{~cm}$. long: seed with the beak plumose to the base. [Echites Sagraei A. DC.]

In sandy thickets, Pine Key. Florida. Also in the West Indies.

2. Rhabdadenia biflòra (Jacq.) Muell. Arg. Stems greatly elongated, often very woody, branched, twining or floating: leaf-blades leathery, oblong, or oblong-lanceolate, 4-9 cm. long, apiculate, glabrous, short-petioled : cymes 1-3-flowered : calyx-lobes oblong or nearly so, 5-6 mm. long, merely acute : corolla white, the throat campanulate ; lobes about as long as the throat: follicles slender, 12-15 cm. long. [Echites paludosa A. DC.]

On muddy shores, southern peninsular Florida and the Keys. Also in the West Indies.

\section{ECHITES P. Br.}

Twining vines, with somewhat woody stems. Leaves opposite: blades flat, entire. Flowers in terminal or axillary cymes. Calyx-lobes 5. Corolla relatively large, salverform, the tube cylindric, but abruptly somewhat swollen. Stamens included: anthers appendaged at the base. Carpels 2. Ovules numerous. Follicles 2, spreading at maturity.

1. Echites umbellàta Jacq. Stems widely twining: leaf-blades leathery, ovate to oval, 4-9 cm. long, short-pointed, truncate or cordate at the base, more or less involutely folded and recurved : cymes several-flowered : calyx-lobes triangular, 2.5-3.5 mm. long: corolla white or greenish white; tube $5-6 \mathrm{~cm}$. long, swollen about the middle; lobes $1.5-$ $2.5 \mathrm{~cm}$. long, rounded: follicles $15-20 \mathrm{~cm}$. long.

In sandy soil, southern peninsular Florida and the Keys. Also in the West Indies.

\section{TRACHELOSPÉRMUM Lemaire.}

Vines, with woody stems or sometimes nearly erect shrubs. Leaves opposite : blades entire. Flowers relatively small, in compound cymes. Sepals narrow, glandular within. Corolla funnelform or salverform : tube slightly dilated above : lobes 5 . Stamens mainly included: anthers sagittate, converging about the stigma. Disk 5-lobed. Carpels 2, united by the somewhat thickened styles. Stigmas ovoid or globular. Ovules numerous. Follicles 2 together, much elongated. Seeds many, each tipped with a long coma.

1. Trachelospermum diffórme (Walt. ) A. Gray. Stems $3-5 \mathrm{~m}$. long, twining, more or less pubescent when young : leaf-blades ovate or oval to elliptic or lanceolate, rather thin, $3.5-9 \mathrm{~cm}$. long, acuminate, sometimes abruptly so, paler beneath than above, shortpetioled ; cymes several-flowered : calyx-lobes lanceolate-subulate, $3-3.5 \mathrm{~cm}$. long : corolla greenish; tube 5-6 mm. long with a prominently swollen throat; lobes ovate, shorter than the tube: follicles slender, $15-22 \mathrm{~cm}$. long.

In low grounds and on river banks, Delaware to Florida, Texas and Mexico, mostly near the coast. Spring and summer.

\section{Family 2. Asclepiadàceae Lindl.1 Milkweed Family.}

Perennial herbs, vine or shrubs, mostly with milky juice. Leaves alternate, opposite or whorled, exstipulate. Flowers perfect, regular, mostly umbellately

\footnotetext{
${ }^{1}$ Contributed by Miss Anna Murray Vail.
} 
disposed. Calyx inferior : tube very short or none : sepals imbricated or separate in the bud. Corolla campanulate, urceolate, rotate or funnelform, 5-lobed: lobes commonly reflexed. A 5-lobed crown (corona) is borne between the corolla and the stamens, and adnate to the one or the other, or to both. Stamens 5 , adnate to the corolla, usually near its base. Filaments mostly monadelphous, or distinct. Anthers attached at the base, introrse, 2-celled, converging around the stigma, sometimes united to each other: sacs tipped with an inflexed or erect scarious membrane, or unappendaged at the top, sometimes appendaged at the base. Pollen coherent into waxy or granular masses, one or rarely 2 such masses in each sac, connected with the stigma in pairs or fours by 5 glandular corpuscles alternate with the anthers. Disk none. Gynoecium of 2 carpels. Styles 2, connected at the summit by the peltate-discoid stigma. Ovules numerous in each cavity, mostly anatropous, pendulous. Fruit of 2 several-manyseeded follicles. Seeds compressed, usually appendaged by a long coma. Endosperm cartilaginous. Embryo nearly as long as the seed : cotyledons flat.

Pollen granular, the grains grouped in 4's : caudicles spoon-shaped, without a corpuscle.

Pollen united in 2 waxy masses (pollinia): caudicles united by a corpuscle.

1. PERIPLOCA.

Pollinia pendulous.

Crown double, the outer a shallow ring, the inner consisting of 5 fleshy hoodlike scales.

Crown single.

Erect, ascending or procumbent herbs.

Corolla oblong-campanulate: lobes erect.

Corolla rotate. the lobes spreading or reflexed in anthesis.

Corolla-lobes reflexed during anthesis.

Anther-wings corneous.

Hoods of the crown involute-concave, entire or auricled below the middle, crestless within, or in Acerates angustifolia with an obscure crest-like midrib.

Hoods of the crown erect, involute or complicate, each with an acute horn-like process within.

Anther-wings membranous or papery: hoods of the crown oblong-clavate, ascending and incurved over the anthers, with a narrow, lamelliform, pointless crest within.

Corolla-lobes erect-spreading during anthesis : hoods of the crown pendulous or saccate at the base, curved upwards, obtuse, crested within, at least in the upper part.

Twining vines.

Crown-lobes entire or more or less 3-lobed.

Lateral margins of the crown-lobes not involute: leaf-blades relatively narrow and not cordate at the base.

Lateral margins of the crown-lobes involute: leaf-blades cordate at the base.

Crown-lobes notched or 2-awned at the apex.

Crown-lobes 2-awned at the apex: follicles stout, strongly and sharply angled.

Crown-lobes merely.notched at the apex : follicles slender, essentially terete.

Pollinia horizontal or nearly so: stigma sharply 5-angled, depressed.

2. Philibertella.

3. Podostigma.
3. PODOSTGMTA.

4. Acerates.
5. Asclepias.

6. Anantherix.

7. AsClepiodora.

8. metastelma.

9. Rouliniella.

10. Gonolobes.

11. SEUTERA.

12. VINCETOXICUM.

\section{PERIPLÒCA L.}

Woody twining plants. Leaves opposite : blades entire. Flowers in umbels. Calyx 5 -lobed, glandular within. Corolla deeply 5 -lobed, the lobes obtuse, dextrorsely rotate, villous on the inner surface. Crown adnate to the base of the corolla, with 10 broad or 5 slender elongated, entire or lobed scales or appendages. Filaments short, free, converging at the short appendiculate apex. Pollen granular, the grains aggregated into groups of 4 each. Follicles slender, glabrous, generally united at the apex. Seeds comose.

1. Periploca Graeca L. Plant glabrous. Leaf-blades ovate-oblong, acute, paler beneath than above : umbels cymose : peduncles shorter than the leaves : corolla-lobes dull brownish or greenish, each with a darker line down the middle and a whitish spot at the base within : appendages of the crown slender, ligulate, 2-toothed at the apex.

Escaped, Massachusetts to Kansas and Florida. Native of Syria and the Grecian Islands. SILK VINE.

\section{PHILIBERTÉLLA Vail.}

Twining perennial caulescent herbs, or partly shrubby plants. Leaves opposite : blades linear or cordate-hastate. Flowers in umbels, often fragrant and showy. Calyx small : lobes 5, acute. Corolla campanulate or rotate, a shallow entire or undulate ring forming an outer crown in its throat: lobes 5 , longer than the tube. Inner or stamineal 
crown consisting of 5 turgid fleshy or hard scales, or flattish appendages, attached in a circle at the base of the sessile or slightly stalked gynostegium (column), forming a hollow entire or undulate spreading surface near the level of the conical stigmas. Follicles naked, slender. The plants flower mainly during the summer. [Philibertia B. \& H., not H.B.K.]

Gynostegium distinctly raised on a stalk or column : follicles fusiform, attenuate at each end.

Gynostegium sessile.

1. P. crispa.

Leaf-blades ovate-oblong or lanceolate-oblong: peduncles much longer than the leaves.

Leaf-blades cordate at the base, sagittate to almost hastate : peduncles as long as the leaves or a little longer.

2. P. clausa.

3. P. cynanchoides.

1. Philibertella críspa (Benth.) Vail. Stems cinereous-puberulent, becoming glabrous, pale gray-green, 1-10 dm. long or longer: leaves 4-8 cm. long; blades varying from linear-lanceolate and long-acuminate to linear or lanceolate, with a hastate or auricular-cordate base, the margins undulate-crisped or entire, usually puberulous, and the midvein conspicuously white above: peduncles longer than the petioles, 5-10-flowered : calyx-lobes linear-lanceolate, puberulous : corolla $15 \mathrm{~mm}$. long, broad, dull greenish purple; lobes oblong, obtuse, ciliolate, obscurely undulate, glabrous above, puberulous beneath : outer crown deep saucer-shaped : scales of the stamineal or inner crown truncate at the apex with a slightly protruding angled ridge midway between it and the base: follicles $6-13 \mathrm{~cm}$. long, slender, somewhat puberulous: seeds about $7 \mathrm{~mm}$. long, minutely tuberculate or granulose, margins slightly revolute when old: coma $3-3.5 \mathrm{~cm}$. long.

In dry soil, Texas to Arizona and Mexico.

2. Philibertella claùsa (Jacq.) Vail. Stems glabrous, or minutely pubescent at the nodes : leaves $3-8 \mathrm{~cm}$. long; blades ovate-oblong or lanceolate-oblong, acute or acuminate at the apex, rounded or subcordate at the base, glabrous or glabrate, usually leathery, commonly with a cluster of small bristle-shaped glands at the base of the midvein, which is sometimes pubescent beneath : peduncles twice as long as the leaves or more: flowers many : pedicels $1.5-2 \mathrm{~cm}$. long, hirsute or minutely tomentose : calyx-lobes oblong-lanceolate, acute, pubescent : corolla white, $1-1.8 \mathrm{~cm}$. broad; lobes oblong, fimbriate-ciliate, pubescent beneath : outer crown shallow and appearing as if contiguous with the oblongoval scales of the stamineal crown : follicles somewhat oblique, many-seeded, 4-7 cm. long, ovate-lanceolate, attenuate above, obtuse at the base, puberulous, becoming glabrate : seeds $3 \mathrm{~mm}$. long, ragged or erose along the apex, granulose on the outside, granulose and slightly pitted and with a prominent ridge or vein down the center on the inside : coma about $2.5 \mathrm{~cm}$. long.

In sandy soil, Indian River region and the Keys, Florida. Also in the West Indies.

3. Philibertella cynanchoides (Decne.) Vail. Stems glabrous or nearly so : leaves $1.5-6 \mathrm{~cm}$. long; blades deeply cordate, sagittate or almost hastate, cuspidate or shortacuminate, with a few obscure elevated glands near the base of the midvein above, and rarely a few appressed hairs : peduncle about $3 \mathrm{~cm}$. long : flowers $15-25$ in an umbel : pedicels very slender, puberulent, $1.5-2 \mathrm{~cm}$. long : caly x-lobes ovate, acute, puberulent : corolla white or cream-colored, with a few faint traces of purple near the apex of each acute lobe ciliolate, minutely puberulent beneath : outer crown very shallow : scales of the stamineal crown broadly oval, obtuse or acutish, slightly flattened : follicles $3-7 \mathrm{~cm}$. long, longattenuate at the apex : seeds about $6 \mathrm{~mm}$. long, the margin undulate at the apex by reason of the excrescent pitted tubercles, the outer surface somewhat tuberculate and pitted, the inner surface more prominently tuberculate and granulose : coma $3-3.5 \mathrm{~cm}$. long.

Along rivers, southern Utah to Texas, Arizona and Guatemala.

\section{PODOSTÍGMA Ell.}

Perennial herbs, with erect stems. Leaves opposite. Peduncles terminal and axillary, umbellately several-flowered. Calyx-lobes longer than the tube, acute. Corolla with a 5 -angulate base, and 5 erect oblong obtuse or acutish lobes. Crown consisting of 5 incurved pitcher-shaped bodies with involute ventral margins, remote from the anthers at the base of the long column; the latter very slender, nearly as high as the corolla-lobes. Anther-wings widened toward the truncate salient base, accompanied by 5 small gland-like processes alternating with them. Stigma concave. Follicles linear-fusiform, naked.

1. Podostigma pedicellàta (Walt.) Vail. Foliage pubescent. Stems rarely branched above, $2-4 \mathrm{dm}$. high : leaf-blades linear-lanceolate or linear-oblong, nearly sessile, $2-6 \mathrm{~cm}$. long, often revolute, scabro-pubescent on both surfaces, often becoming glabrate in age: peduncles $2-4$ or rarely $5,5-12 \mathrm{~mm}$. long, several-flowered : corolla 5-10 mm. long, yel- 
lowish or greenish yellow, fragrant: follicles very slender, 1-4 dm. long, $7 \mathrm{~mm}$. wide, attenuate at each end, hairy: seeds $5 \mathrm{~mm}$. long: coma $2-2.5 \mathrm{~cm}$. long. [P. pubescens Ell.]

In sandy soil, North Carolina to Florida. Spring to fall.

\section{ACERÀTES Ell.}

Perennial caulescent herbs. Leaves opposite, alternate or scattered. Pedicels subtended by numerous involucral bracts. Flowers greenish or occasionally purplish tinged. Calyx small : lobes 5, acute, usually biglandulose at the sinus. Corolla rotate : lobes 5, small, reflexed in anthesis. Column very short, not always apparent, with commonly 5-10 small glands or processes alternating with the anther-wings. Hoods mostly attached over the whole of the column, erect, equalling or shorter than the anthers, involute-concave, and somewhat pitcher-shaped, often pendulous and saccate at the base, entire, emarginate or 2-3-lobed or toothed at the apex, the ventral margins spreading towards the base into broad auricles or small infolded concealed lobes, either destitute of horns or crests or these rarely rudimentary. Anther-wings angulate near or somewhat below the middle, narrowed and rounded towards the base or rarely of the same width from the apex downwards, entire or notched. Follicles as Asclepias. Green Milkweed.

Auricles of the hood, when present concealed within.

Hoods rounded, entire at the summit, much shorter than the anthers.

Hoods entire, rounded or acutish at the summit, as high as the anthers.

Auricles of the hood conspicuously spreading.

Hoods emarginate or truncate at the summit, crestless within.

Hoods 3-lobed at the summit, with an internal crest-like midrib, terminating in the middle lobe.

1. A. Floridana.

2. A. viridiflora.

3. A. auriculata.

4. A. angustifolia.

1. Acerates Floridàna (Lam.) A. S. Hitchcock. Plant minutely scrabo-pubescent, becoming glabrate. Stems 3-8 dm. high or higher : leaf-blades linear to elongated linearlanceolate, $7-16 \mathrm{~cm}$. long, 3-5 cm. wide : umbels 2 or 3-several, usually many-flowered: pedicels 1-1.3 cm. long: corolla-lobes oblong, about $3 \mathrm{~mm}$. long, dull purple without: hoods purplish, oval, obtuse, slightly pendulous at the base, adnate at the base to the upper part of the distinct column, rising to about the middle of the anthers: anther-wings angled at the middle : follicles erect on recurved fruiting pedicels, fusiform, $7-10 \mathrm{~cm}$. long, minutely puberulent : seeds $7 \mathrm{~mm}$. long: coma $3-4 \mathrm{~cm}$. long. [A. longifolia Ell.]

On prairies and in wet pine lands, Wisconsin and Ohio to Florida and Texas. Spring to fall.

2. Acerates viridiflòra (Raf.) Eaton. Plant tomentose-puberulent, becoming glabrate. Stems 2-6 dm. high, often procumbent : leaves opposite or some of them scattered; blades short-petioled, 4-6 cm. long, oval or oblong, obtuse and retuse or acutish, usually mucronate, sometimes with undulate margins, becoming leathery : umbels globose, sessile or nearly so, $2-5$ or more, lateral, densely many-flowered : pedicels about $1 \mathrm{~cm}$. long: corolla-lobes oblong-lanceolate, about $5 \mathrm{~min}$. long: hoods inserted over the whole short column, dull purplish or at least tinged with purple, erect, nearly equalling the anthers, lanceolate-oblong, entire, except for a pair of small infolded and concealed auricles at the base : accessory processes $5:$ anther-wings salient above the middle, half-rhomboid, entire, or possibly obscurely notched, tapering towards the base: pollinia $2-5 \mathrm{~mm}$. long, attenuated to the short caudicles : follicles $6-10 \mathrm{~cm}$. long, erect on recurved pedicels, fusiform, attenuate, glabrous or minutely puberulent: seeds $7 \mathrm{~mm}$. long: coma $2.5-3 \mathrm{~cm}$. long.

In dry and sterile soil, New England to Saskatchewan, southward to Florida, Texas, New Mexico and north Mexico. Summer.-A. viridiflora IVèsii Britton, with elongated lanceolate leaf-blades, and anther-wings rather more abruptly tapering at the base, ranges from Illinois and Nebraska to Virginia, Georgia and Louisiana. Another form, A. viridiflora linearis A. Gray, with low stems, elongated, linear leaf-blades, and often a solitary umbel, ranges from the Northwest Territory to Minnesota, Louisiana and New Mexico.

3. Acerates auriculàta Engelm. Plant glabrous, glaucous. Stems $2-8 \mathrm{dm}$. high, mostly solitary, sinuous above when old and rarely branched : leaves alternate-scattered, sometimes crowded ; blades narrowly linear or filiform-linear, 5-14 cm. long, the scabrous margins not always revolute, becoming leathery and often twisted with age : pedicels $1 \mathrm{~cm}$. long, slender : involucral bracts slender, minutely puberulent : umbels many-flowered, lateral, 1 or 2 , or sometimes 16 on the same stem : column very short : calyx-lobes minutely puberulent: corolla-lobes greenish, tinged with dull purple on the outside, about $4 \mathrm{~mm}$. long: hoods yellowish, with often a purplish keel, erect, crenately truncate or emarginate at the apex, the involute sides spreading at the base into broad,obscurely crenate auricles: anther-wings narrow and of equal width, entire or notched and twisted at the middle, incurved over the anthers at the summit, the intermediate spaces marked by a vertical dark 
purple line : follicles erect on reflexed fruiting pedicels, about $8 \mathrm{~cm}$. long, obliquely fusiform, glabrous : seeds $6 \mathrm{~mm}$. long, very thin : coma $2 \mathrm{~cm}$. long.

In rocky ground and on prairies, Nebraska and Colorado to New Mexico and Texas. Summer.

4. Acerates angustifòlia (Nutt.) Decne. Plants nearly glabrous in age. Stems mostly several from the same tuberous rootstock, straight, $3-6 \mathrm{dm}$. high, clothed with a minute, mostly retrorse puberulence, becoming glabrate below : leaves alternate, scattered or some of the lower ones opposite ; blades sessile, narrowly linear, 5-12 cm. long or longer, glabrous, the revolute margins and thick midrib scabrous beneath: umbels small, 10-15flowered, lateral, 7-13, or more, on the same stem : pedicels 7-10 mm. long, ninutely pubescent with spreading or retrorse hairs : corolla-lobes $5 \mathrm{~mm}$. long, oblong, greenish : hoods white, attached over the whole of the short column, erect, as high as the short anthers, laterally compressed, 3-dentate at the apex, the acute central tooth merely a prolongation of the thickened crest-like midrib and much shorter than the erect obtuse lateral ones, each inner margin spreading into an erosely truncate lobe which usually overlaps that of the next hood and terminates in an interior ring of five 2-lobed minute processes or appendages between the anthers : anther-wings salient and conspicuously auriculately notched slightly below the middle, narrowed at the base : follicles slender-fusiform, straight, erect on erect fruiting pedicels, about $8 \mathrm{~cm}$. long, minutely pubescent : seeds about $5 \mathrm{~mm}$. long, thin : coma $3 \mathrm{~cm}$. long.

On dry sandy prairies, Nebraska and Colorado to Texas. Summer and fall.

\section{ASCLÉPIAS L.}

Herbs from deep perennial roots, sometimes woody at the base. Stems solitary or clustered, erect or decumbent, simple or branched. Leaves opposite, alternate or whorled. Inflorescence umbelliform, terminal or axillary, from few- to many-flowered. Calyx small, with commonly few to many minute glands at the base of the lobes. Corolla rotate, deeply 5-parted: lobes dextrorsely valvate-convolute in bud, reflexed in anthesis. Hoods of the crown involute, complicate, arising from the base of the corolla-lobes or raised on a column which is shorter than the anthers, erect, concave-cucullate, bearing an acute or rarely obtuse horn or tooth-like process projecting from the base or summit within, and sometimes with minute accessory processes alternating between the anthers. Anther-wings corneous, commonly widening toward the salient usually triangular base, which is truncate, semihastate, not rarely rounded, entire or auriculate-notched, sometimes salient at the middle. Stigma 5-angular, flat-topped. Caudicles very slender. Follicles naked, or in few species warty or echinate with soft processes. Coma of the seed mostly present. MilkweEd.

A. Hoods sessile, broader or at least not attenuate and stalked at base : horn variously inserted, conspicuous and usually exserted : anther-wings broadest and salient at base.

Follicles erect on deflexed fruiting pedicels.

Hoods oblong or dorsally hastate-lanceolate, acute.

Corolla and hoods orange-yellow.

Hoods linear-oblong or linear-lanceolate, the interior folds meeting the margins near the apex : calyx-lobes barely $1 / 3$ as long as the corolla-lobes.

Leaf-blades oblong, obtuse : follicles slender-fusiform.

Leaf-blades lanceolate-oblong or linear-lanceolate, acute or rarely obtuse: follicles fusiform.

Hoods broadly oblong, the interior folds vanishing remote from the apex: calyx-lobes nearly $1 / 2$ as long as the corolla-lobes.

Corolla and hoods white or yellowish green: anther-wings angled above the base.

Hoods not conspicuously hastate-lanceolate on the back.

a. Leaf-blades large and broad; primary veins transversely spreading (except in $A$. exaltata).

* Leaf-blades sessile or subcordate at base.

Leaf-blades broader than long: umbels typically all lateral.

Leaf-blades longer than broad.

Leaf-blades oblong or elliptic, wavy-margined : umbel long-peduncled, typically solitary.

Leaf-blades ovate, succulent, ultimately reddish veined : umbels several.

** Leaf-blades petioled, tomentose or pubescent.

+ Flowers pinkish purple or dark purple.

Leaf-blades typically oblong, commonly obtuse : umbels numerous: hoods not exceeding the anthers.

Leaf-blades typically ovate-oblong, acutish : umbels solitary or few : hoods exceeding the anthers.

i† Flowers greenish: hoods yellowish.

Leaf-blades oblong-elliptic, acute or acutish at each end : umbels numerous, lateral.

Leaf-blades oblanceolate, obtuse, tapering at the base.

*k* Leaf-blades petioled, glabrous or nearly so: flowers white or tinged

1. A. decumbens.

2. A. tuberosa.

2a. A. Rolfsii.

3. A. Curtissii.

with greenish purple.

4. A. latifolia.

5. A. amplexicaulis.

6. A. humistrata.

7. A. Syriaca.

8. A. purpurascens.

9. A. tomentosa.

10. A. aceratoides. 
Leaf-blades typically oval: umbels globose: pedicels $2 \mathrm{~cm}$. long.

Leaf-blades mainly elliptic or elliptic-lanceolate, tapering to each end : pedicels drooping, $5 \mathrm{~cm}$. long.

b. Leaf-blades ovate-lanceolate to linear, glabrous ; primary veins ascending, never conspicuously transverse, (see also $A$. exaltata).

Leaf-blades ovate-lanceolate or long-lanceolate, long-acuminate: corolla purple-red.

Leaf-blades lanceolate to oblong-linear, short-petioled: corolla purplish: hoods orange, exceeding the anthers.

Follicles erect on erect fruiting pedicels: primary veins of the leaf-blades never transversely ascending.

Leaf-blades broad, ovate to ovate-lanceolate, oblong-lanceolate or sometimes lanceolate.

Some of the leaves whorled in 4's or 6's: flowers rose-pink.

Leaves all opposite.

Corolla and hoods rose-colored or rarely white.

Plants glabrous throughout or nearly so: leaves oblong-lanceolate, in the variety elongated-linear.

Plants hirsute-pubescent : leaves broader.

Corolla red-purple : hoods bright orange : leaves oblong to oblong-lanceolate.

Corolla and hoods white, tinged with green or pink : flowers very small.

Leaf-blades oblong-lanceolate or lanceolate, tapering at each end, glabrous : seed destitute of coma.

Leaf-blades oval-oblong, broad at the petioled base.

Leaf-blades linear or filiform: flowers very small, white or greenish tinged.

Hoods each terminating in a horizontal or erect lobe: horns exserted.

Crown slender-stalked, the stalk less than $1 \mathrm{~mm}$. thick : horn exceeding the hood.

Leaf-blades filiform or linear-filiform.

Stems ty pically solitary: leaves numerous, but not crowded.

Stems tufted: leaves contiguous or approximate, very numerous and crowded.

Leaf-blades linear.

Crown short-stalked, the stalk over $1 \mathrm{~mm}$, thick: horn not exceeding the hood.

Umbel typically solitary, sessile: leaves many times longer than the internodes.

Umbels several, peduncled: leaves shorter than the internodes or less than twice their length.

Hoods notched or emarginate: horn included.

B. Hoods erect, dilated above the anthers into a lobed or erose open or closed lamina: anther-wings entire or notched at the middle or corniculate at the base.

Leaf-blades with ascending veins : umbels all lateral.

Hoods $5 \mathrm{~mm}$. high: horn single, arising from the apex of the hood.

Hoods $8 \mathrm{~mm}$. high, very slender at the stalked base: horn with an acute dorsal accessory process.

Leaf-blades with transversely spreading veins: horn arising from the base of the hood, exserted over the anthers.

1. Asclepias decúmbens L. Stems decumbent, 3-6 dm. long, hispid or hirsutepubescent, the ends ascending or erect: leaves various, the lower commonly alternate, the upper opposite and often notably smaller; blades oblong, obtuse at the apex, mostly narrowed and often inequilateral and sometimes hastate at the base, usually revolute on the margins, 3-19 cm. long : umbels several or numerous, many-flowered, racemose along the branches, one usually in each of the upper axils, on peduncles $1-3 \mathrm{~cm}$. long : pedicels slender, somewhat pubescent, $1.5-3 \mathrm{~cm}$. long : corolla lobes narrowly oblong, acutish, dark or pinkish orange color, $7 \mathrm{~mm}$. long : column distinct : hoods erect, linear, oblong, orangeyellow, slightly longer than the subulate inflexed horn, the ventral margins entire or barely lobed at the base : follicles 10-14 cm. long, slender-fusiform, hipsid-pubescent : seeds $7 \mathrm{~mm}$. long, glabrous, marked by fine broken diverging ridges: coma long and abundant.

In dry fields, New York, Ohio and Illinois to North Carolina and Florida. Occurring also probably elsewhere further north. Summer. BUTterfly WEEd. PLeURIsY-Root.

2. Asclepias tuberòsa L. Stems solitary or several, hirsute or rough hirsute-pubescent, commonly erect or ascending, 3-6 dm. high or more, simple or branched near the summit, very leafy, the milky sap scanty : leaves usually all alternate ; blades lanceolate-oblong, sometimes lanceolate-linear, acute or more rarely obtuse at the apex, 3-9 dm. long, with margins narrowly revolute: umbels cymose at the ends of the stems or branches, or on old plants sometimes racemose, many-flowered : pedicels pubescent, $1-1.5 \mathrm{~cm}$. long: corollalobes narrowly oblong, obtuse, $6-8 \mathrm{~mm}$. long, greenish or reddish orange : column distinct : hoods erect, linear-oblong or linear-lanceolate, bright orange-color or rarely yellow, considerably exceeding the anthers and slightly longer than the filiform exserted incurved horn, the ventral margins entire or barely lobed and overlapping at the base : anther-wings salient at the entire base : follicles $7-10 \mathrm{~cm}$. long, minutely pubescent : seeds $7 \mathrm{~mm}$. long, glabrous, marked with fine diverging broken ridges: coma long and abundant.

In dry fields, Maine to Ontario, Minnesota, Colorado, Florida, Texas and Arizona. Summer and fall. Butterfly Weed. Pleurisy-root. 
2a. Asclepias Rólfsii Britton. Similar to the two preceding species in habit. Leaves rather numerous; blades thinnish, mainly oblong, sometimes narrowly so, when broad often fiddle-shaped, truncate or cordate at the base: umbels in terminal leafy cymes: calyx-lobes nearly $\frac{1}{2}$ as long as the corolla-lobes, pubescent : corolla orange ; lobes oblong, 6-7 mm. long: column stout : hoods erect, broadly oblong, 5-6 mm. long, considerably exceeding the horns.

In pine lands, southern peninsular Florida. Spring and summer.

3. Asclepias Curtíssii A. Gray. Stems decumbent or suberect, $5 \mathrm{dm}$. long or more, from a much thickened tuberous rootstock, simple or branched, puberulent, purplish : leaf-blades broadly oblong or some round-oblong, 3-5 cm. long, truncate, rounded or some of the lower ones acutish at the base, apiculate or retuse at the apex, glabrous : umbels 2-several in the axils of the upper leaves, many-flowered, on peduncles $2-4 \mathrm{~cm}$. long: pedicels very slender, $1-1.5 \mathrm{~cm}$. long, puberulent : corolla greenish, purple-tinged on the outside ; lobes $6 \mathrm{~mm}$. long, oblong-lanceolate : column scarcely apparent : hoods erect, distinctly stalked, white, the keel purple-tinged, $5 \mathrm{~mm}$. high, exceeding the anthers, acute at the apex, the ventral margins rounded and infolded, distinctly clawed at the hastate base : horn short, subulate, affixed to about the middle of the hood, horizontally exserted and incurved over the anthers : anther-wings very short, triangular-sagittate, angled and sharply salient at the entire base : follicles $1 \mathrm{dm}$. long, long-attenuate at the apex, puberulent : seeds $8 \mathrm{~mm}$. long, erose-undulate on the margin : coma $3 \mathrm{~cm}$. long.

In sandy soil in the scrub, Florida. Spring to fall.

4. Asclepias latifòlia (Torr.) Raf. Stems usually simple, 3-8 dm. high, stout, minutely puberulent when young, glabrous when old, very leafy : leaf-blades broader than long, commonly broadly emarginate and mucronulate at the apex and cordate or subcordate at the base, $7-15 \mathrm{~cm}$. long and nearly as wide, the primary nerves notably wide-spreading : umbels $2-4$ or more, short-peduncled in the axils of the upper leaves and rarely terminal, many-flowered, often $8 \mathrm{~cm}$. in diameter : pedicels canescent, nearly $3 \mathrm{~cm}$. long: corollalobes ovate, acute, 7-9 or $10 \mathrm{~cm}$. long, greenish : column short and thick : hoods truncate, about equalling the anthers, the horn broadly triangular, the exserted subulate apex projecting over the acute ventral sides of the hood and exserted over the stigma: anther-wings notched or somewhat auriculate, spreading at the base : follicles erect on deflexed pedicels, ovoid, acutish, $6 \mathrm{~cm}$. long, glabrate : seeds $8 \mathrm{~mm}$. long, glabrous, marked with fine broken ridges and dots, the wing-like margin narrow : coma rather stiff, $2.5-3.5 \mathrm{~cm}$. long.

On dry plains, Kansas to Colorado, Texas and Arizona. Summer and fall.

5. Asclepias amplexicaùlis J. E. Smith. Stems glabrous, $3 \mathrm{dm}$. to $1 \mathrm{~m}$. high: leaves opposite or rarely in fours at the base of the stem; blades sessile, oblong or elliptic, $6-12 \mathrm{~cm}$. long, $3.5-8 \mathrm{~cm}$. wide, clasping at the base, rounded, retuse and apiculate at the apex, wavy-margined, glabrous, lighter and glaucous beneath : peduncles much longer than the leaves, terminal, solitary or rarely two: umbels loosely many-flowered : pedicels slender, $2-3 \mathrm{~cm}$. long: flowers rather large and showy: corolla-lobes greenish or dull greenish purple, $6-10 \mathrm{~mm}$. long, acutish : hoods erect, flesh colored or reddish, sessile at the summit of the short column, slightly gibbous or saccate at the base, truncate at the undulate-erose and toothed summit, as high as or somewhat exceeding the anthers: horn falcate, angled above the middle, strongly inflexed and attenuated at the long-exserted apex : antherwings conspicuously bicorniculate at the base : follicles 10-16 cm. long, acute or long-attenuate: seeds $7 \mathrm{~mm}$. long, glabrous, marked with minute broken lines, the margins rather broad, paler than the body : coma $5 \mathrm{~cm}$. long or more, very soft and silky. [A. obtusifolia Michx. ]

In dry or sandy soil, New England to Nebraska, Florida and Texas. Spring and summer.

6. Asclepias humistràta Walt. Stems glabrous and glaucous throughout, decumbent from a long tuberous root, simple or branched above, stout and thick, succulent, $3-6 \mathrm{dm}$. long: leaves rather crowded, usually decreased in size at the base or toward the summit of the stem, the successive pairs parallel ; blades sessile, vertical, nearly alike on both sides, ovate, $5-13 \mathrm{~cm}$. long, 4-10 cm. wide, cordate-clasping and somewhat auriculate at the base, obtuse at the apex, thick and succulent when fresh, becoming thin and papery when dry, sometimes undulate on the margins, the whitish transverse and reticulated veins turning reddish : peduncles as long as or commonly shorter than the leaves: pedicels slender, about $2 \mathrm{~cm}$. long : corolla-lobes dull greenish purple, $7 \mathrm{~mm}$. long: column short : hoods whitish, about $5 \mathrm{~mm}$. high, obovate-truncate, rounded at the apex, the ventral margins with a broad rounded tooth on each side about the middle: horn broad, flat, angular-arcuate, only slightly exceeding the hood : anther-wings obscurely notched at the base : follicles $1-1.5$ $\mathrm{dm}$. long, $1.5-2 \mathrm{~cm}$. wide, attenuated and acutish at the apex, glabrous and glaucous: 
seeds about $8 \mathrm{~mm}$. long, marked by fine broken diverging ridges, the paler margin coriaceous and much wrinkled : coma $3 \mathrm{~cm}$. long. [A. amplexicaulis Michx.]

In dry sandy soil, North Carolina to Florida. Spring and early summer.

7. Asclepias Syriàca L. Stems canescently tomentose, becoming glabrate in age, from a horizontal or branching rootstock, $5 \mathrm{dm} .-1.5 \mathrm{~m}$. high : leaf-blades short-petioled, typically oblong, or rarely lanceolate-oblong, 1-1.5 dm. long, 4-11 cm. wide, truncate, rounded or sometimes tapering at the base, commonly obtuse, sometimes mucronate at the apex, green and glabrate or nearly so above, soft-pubescent or tomentulose beneath : umbels usually several, lateral, many-flowered : peduncles 4-8 $\mathrm{cm}$. long : corolla-lobes dull greenish purple, $8 \mathrm{~mm}$. long, puberulous on the outside, and sometimes minutely so on the inner surface: column very short: hoods whitish or dull greenish purple, erect, longer than the anthers, ovate, obtuse or rounded, with an upcurved tooth or auricle on each side below the middle : horn short, subulate, inflexed over the anthers : anther-wings notched or corniculate at the spreading base: follicles 7-9 cm. long, ovate, ventricose, tomentose, mostly erect on recurving pedicels : seeds $7 \mathrm{~mm}$. long, glabrous, the wing-like margin wrinkled, paler than the body : coma very abundant, $3 \mathrm{~cm}$. long. [A. Cornu' $i$ Decne.]

In fields and waste places, New Brunswick to Saskatchewan, Georgia and Kansas. Summer.

8. Asclepias purpuráscens L. Stems glabrous or somewhat tomentulose, stout, 3-10 dm. high or more : leaf-blades typically ovate-oblong, 1-2 dm. long, truncate or obscurely tapering to the short petiole, mostly acutish or mucronate at the apex, rather thin, glabrous above, tomentulose and sometimes becoming glabrate beneath: umbels short-peduncled, 2-5, cymosely terminal or sometimes 1-2 in the upper axils : corolla-lobes dark or dull purple, oblong, obtuse, $8-10 \mathrm{~mm}$. long: column very short: hoods shorter than the corolla-lobes, twice as high as the anthers, pale reddish or purple, erect, oblong, with an obscure rounded lobe near the middle of each ventral margin : horn short, incurved, exserted over the stigmas : anther-wings very short and sharply salient, entire or minutely notched at the base : follicles erect on recurving pedicels, $10-12 \mathrm{~cm}$. long, attenuated at the apex, tomentulose : seeds $7 \mathrm{~mm}$. long, minutely granulose, marked with diverging broken lines, the margin very thin and brittle : coma $3-4 \mathrm{~cm}$. long.

In dry grounds, New England to Wisconsin, Tennessee and North Carolina. Summer.

9. Asclepias tomentòsa Ell. Stems tomentulose or soft-pubescent, erect, simple or rarely branched, $3-9 \mathrm{dm}$. high or more : leaves numerous, often crowded, much decreased in size at the summit of the stem; blades mainly oblong-elliptic, $5-8 \mathrm{~cm}$. long, acute or acutish at each end, rather thick and rigid, glabrate or minutely pubescent above, tomentulose beneath: umbels numerous, sessile or short-peduncled, loosely many-flowered, crowded in axils of the upper leaves : pedicels $2-2.5 \mathrm{~cm}$. long, tomentulose : corolla-lobes greenish, broadly ovate, acute, scarious-margined, 7-8 mm. long: hoods sessile or nearly so, not exceeding the anthers, truncate at the summit, slightly gibbous at the base on the outside, laterally compressed, the wing-like ventral margins obtuse or acutish, glabrous or rarely somewhat pubescent: horn broadly subulate, adnate below the apex of the hood, notched below the slender acuminate erect apex, which is exserted for about a third its length : anther-wings entire or obscurely notched: follicles about $12 \mathrm{~cm}$. long, erect on recurving pedicels, slender, tapering to each end, tomentulose : seeds 6-7 mm. long, thin : coma $3-4 \mathrm{~cm}$. long.

In dry sandy soil and high pine lands, Georgia and Florida. Spring and summer.

10. Ascelpias aceratoides M. A. Curtis. Stems tomentulose, simple, erect, $33 \mathrm{~cm}$. high or more, from a long horizontal rootstock : leaves few ; blades 7-10 cm. long, oblanceolate, obtuse and mucronulate at the apex, tapering at the base, the transverse veins somewhat ascending: umbels 2-several, loosely many-flowered, sessile or nearly so in the upper axils : pedicels tomentulose, $2.5 \mathrm{~cm}$. long: corolla-lobes greenish, $7 \mathrm{~mm}$. long, broadly oblong, acute, scarious-margined: hoods erect or nearly so on the very short column, slightly gibbous at the base, obliquely truncate at the summit, laterally compressed, minutely tomentulose, not exceeding the anthers : horn granulose, broadly triangular, straight along the top, the apex acute, horizontally exserted a little beyond the obtuse wing-like ventral angles of the hood: anther-wings entire at the broad angled base : follicles not seen.

In sandy pine woods, North Carolina and South Carolina. Spring.

11. Ascelpias variegàta L. Stems glabrous, or minutely pubescent above, $3-9 \mathrm{dm}$. high, erect from a ligneous rootstock : leaves in 3-7 pairs, the middle pairs rarely whorled in 4's; blades typically oval, sometimes ovate or oblong, or obovate, 6-14 cm. long, acute. 
at each end or short-acuminate above, or obtuse and mucronate-apiculate, sometimes undulate, bright light green above, much paler, glaucescent and sometimes tomentulose beneath: peduncles $1-3$, rarely 4 , terminal and subterminal, $2-4 \mathrm{~cm}$. long, and usually longer than the numerous slender tomentulose pedicels of the crowded commonly globose umbel : flowers white, except the stout purplish column and anthers: corolla-lobes $6-8 \mathrm{~cm}$. long, acute : hoods erect, $4 \mathrm{~mm}$. high, globular-ventricose above a narrow claw-like base, the ventral margins open, spreading, obtuse at the erect angles, exceeding the anthers: horn semilunate, the attenuated apex horizontally exserted for nearly half its length: antherwings salient and angled at about the middle, commonly entire, rounded toward the base : follicles slender-fusiform, erect on recurving pedicels 1-1.3 dm. long, long-acuminate, tomentulose : seeds $5 \mathrm{~mm}$. long, thinnish, granulose under a lens : coma $3.5-4.5 \mathrm{~cm}$. long.

In dry shaded grounds, Connecticut to Illinois, Florida and Texas. Spring and summer.

12. Asclepias exaltàta (L.) Muhl. Stems bright green and glabrous, or the upper portion minutely pubescent, usually in two opposite lines, simple, stont, $1-1.5 \mathrm{~m}$. high : leaves various, the upper ones much reduced; blades elliptic or elliptic-lanceolate, the lower rarely obovate, acuminate at each end, and glabrous above, lighter and sometimes minutely and sparingly pubescent beneath, becoming glabrate: umbels $2-5$, lateral, many-flowered, on peduncles $2-8 \mathrm{~cm}$. long : pedicels $2-3 \mathrm{~cm}$. long, very slender, pubescent in lines: corolla greenish, often tinged with purple on the outside; lobes $8 \mathrm{~mm}$. long, minutely pubescent on the inside: hoods raised on a short distinct column, white, pale flesh-color or bluish, erect, saccate at the base, slightly shorter than the anthers, truncate at the summit, the ventral margins entire or obscurely erose, with often a slender tooth above the erect inner angles, much surpassed by the mostly erect or somewhat incurved slender horn : anther-wings rounded at the sometimes notched and spreading base: follicles 1.2-1.6 dm. long, slender-fusiform, long-acuminate, minutely pubescent, or at length glabrous : seeds 7-8 mm. long, granulose, dark brown at the center, paler on the undulateerose margin : coma 4-5 cm. long. [A. phytolaccoides Pursh.]

In thickets and moist woods, Maine to Minnesota, Georgia and Missouri. Summer.

13. Asclepias rùbra L. Stems glabrous, usually simple, erect, from a somewhat rounded tuberous rootstock, $3 \mathrm{dm}$. high or more : leaves commonly remote ; blades $7 \mathrm{~cm}$.$2 \mathrm{dm}$. long, ovate to ovate-lanceolate, or long-lanceolate, tapering from the rounded or somewhat cordate, sessile or very short-petioled base to a long-acuminate apex : umbels solitary, terminal, or 2-3 in a terminal naked cyme: corolla-lobes purple-red, lanceolate-oblong, about $8 \mathrm{~mm}$. long, acutish : column slender, distinct: hoods lanceolate, pale orange-colored, or yellowish, erect, as long as the corolla-lobes and much exceeding the anthers, the ventral margins infolded : horns slender, incurved, much exserted: antherwings entire, or obscurely notched at the angled base : follicles erect on recurved pedicels, $1 \mathrm{dm}$. long, slender, glabrous : seeds $7 \mathrm{~mm}$. long, minutely pitted under a lens : coma 4 cm. long.

In swamps and moist grounds, New Jersey and Pennsylvania to Florida and Texas. Summer.

14. Asclepias lanceolàta Walt. Stems nearly glabrous throughout, slender, mostly simple, naked above, 4-11 dm. high or more, from a ligneous rootstock: leaves distant; blades lanceolate to oblong-linear, 1-2 dm. long or more, $5 \mathrm{~mm} .-2.5 \mathrm{~cm}$. wide, elongated and acuminate at the apex, narrowed at the base, rough on the margins, the primary veins ascending: umbels terminal, solitary, or 2-4 and somewhat cymose, fewflowered : peduncles about equalling the slender pubescent pedicels : corolla-lobes oblong, 8-9 $\mathrm{mm}$. long, deep reddish purple : column thick, 1-2 $\mathrm{mm}$. high: hoods orange-color, obovate or oblong, nearly as high as the anthers, the ventral margins auriculately toothed near the base : horn slender, arising from the base of the hood, exserted over the anthers : anther-wings notched and spreading at the base : follicles erect on recurved pedicels, fusiform, about $1 \mathrm{dm}$. long, long-attenuate to the apex, less tapering to the base, minutely pubescent : seeds $8 \mathrm{~mm}$. long, glabrous, thin, the wing-like margin very broad: coma 2-3 cm. long. [A. paupercula Michx.]

In swamps, New Jersey to Florida and Texas, mostly near the coast. Summer.

15. Asclepias quadrifolia Jacq. Stems glabrous or minutely puberulent, erect, simple, 3-6 dm. high, usually leafless below, from a slender somewhat horizontal or creeping rootstock: leaves distant, commonly in 3 or 4 pairs, the lower or upper pairs in a whorl of 4, or rarely 3 pairs in 6's, 4-10 $\mathrm{cm}$. long; blades ovate to ovate-lanceolate, acute or acuminate, on short somewhat margined petioles, glabrous and thin or minutely pubescent on the veins beneath: umbels terminal or lateral, loosely many-flowered: peduncles 1-4 cm. long: pedicels filiform, 1-2 mm. long, minutely pubescent : corolla from pink to nearly white; lobes oblong, about $5 \mathrm{~mm}$. long: hoods white, erect-spreading, 4-5 mm. high, twice the length of the anthers, ovate-oblong, broadly obtuse at the apex, 
with a salient, acute or obtuse tooth or lobe on each side near the base : horn short, broadly falcate-subulate, incurved over the anthers: follicles very slender, 10-12 cm. long, erect on erect fruiting pedicels, linear-fusiform, glabrous : seeds $6 \mathrm{~mm}$. long, pale brown when fresh, very thin : coma $3-4 \mathrm{~cm}$. long.

In dry soil, woods and thickets, Maine and Ontario to Minnesota to North Carolina and Arkansas. Spring and summer.

16. Asclepias incarnàta L. Stems glabrous or minutely pubescent, $6-10 \mathrm{dm}$. high or more, usually branched and often pubescent in lines above, very leafy : leaves opposite ; blades manifestly petioled, 4-17 cm. long, oblong-lanceolate, acuminate at the apex, obtuse or obscurely subcordate at the base, thinnish, with sometimes a few scattered hairs beneath : umbels rather small, several, corymbose at the summit of the stem, many-flowered: pedicels $1-1.5 \mathrm{~cm}$. long, minutely pubescent : corolla deep rose-purple to pale pink or rarely white; lobes oblong, 4-6 mm. long: hoods scarcely exceeding the stigmas, erect on the distinct (1-1.5 mm. high) slender column, oblong, obtuse at the apex, the rounded ventral margins overlapping on the inside, dorsally biauriculate-hastate at the base, slightly exceeded by the slender incurved horn: anther-wings minutely notched at the base : follicles erect on erect fruiting pedicels, $5-7 \mathrm{~cm}$. long, ovoid-fusiform, acuminate at the apex, glabrous or minutely pubescent: seeds $7-11 \mathrm{~mm}$. long, red-brown, shining, minutely granulose under a lens, the margins paler, very thin and papery : coma about $2 \mathrm{~cm}$. long.

In swamps, New Brunswick to the North west Territory, Kansas, Tennessee and Louisiana. Summer. - A. incarnata longifölia A. Gray, is between 1 and $2 \mathrm{~m}$. tall, and has paler flowers and greatly elongated leaf-blades; it occurs in Texas and New Mexico.

17. Asclepias púlchra Ehrh. Stems hirsute-pubescent, $5-1.5 \mathrm{dm}$. high, branched above, very leafy to the top: leaf-blades short-petioled or some of the upper ones sessile, broadly lanceolate, lanceolate-oblong or oblong, 6-12 $\mathrm{cm}$. long, $3-5.5 \mathrm{~cm}$. wide, acute or acuminate at the apex, mostly rounded or subcordate and rarely subhastate at the base: umbels numerous, corymbose, about $3 \mathrm{~cm}$. broad, many-flowered : pedicels $15 \mathrm{~mm}$. long, hirsute-pubescent : corolla small, rose-purple, rarely white; lobes obtuse, often notched: column $1 \mathrm{~mm}$. high, very slender but distinct: hoods erect, $2 \mathrm{~mm}$. high, oblong, obtuse, slightly exceeding the anthers, dorsally biauriculate-hastate at the base, the ventral margins infolded : horn flat, slender, exserted-incurved over the anthers : anther-wings notched at the base: follicles erect on erect fruiting pedicels, $4 \mathrm{~cm}$. long, slender, acuminate, minutely hirsute-pubescent : seeds $8-10 \mathrm{~mm}$. long, $5-7 \mathrm{~mm}$. wide, the apex often crenate : coma $2 \mathrm{~cm}$. long. [A. incarnata var. pulchra Pers.]

In moist fields and swamps, Maine to Minnesota and Georgia. Summer and fall.

18. Asclepias Curassávica L. Stems somewhat woody at the base, glabrous or minutely pubescent above, $3-6 \mathrm{dm}$. high or more : leaves opposite; blades $5-10 \mathrm{~cm}$. long or more, oblong to oblong-lanceolate, commonly acuminate : umbels terminal and lateral, 5-10-flowered : pedicels 1-2 cm. long: corolla-lobes deep red-purple, $6-8 \mathrm{~mm}$. long, ovateoblong : column distinct : hoods erect, $4 \mathrm{~mm}$. high, ovate, obtuse at the broad apex, laterally compressed, shorter than the flat broad attenuate curved horn, which arises from the slightly gibbous base of the hood : follicles erect on erect fruiting pedicels, $3-10 \mathrm{~cm}$. long, slender-fusiform, acuminate, glabrous or minutely pubescent and slightly glaucous : seeds $6 \mathrm{~mm}$. long, rather thin: coma $3-4 \mathrm{~cm}$. long. Plants very variable as to length and breadth of the leaves.

In sandy soil, western Florida and Louisiana. Probably introduced from tropical America. Known from nearly all warm countries. Spring to fall.

19. Asclepias perénnis Walt. Stems puberulent above, glabrous below, woody at the base from a short clustered rootstock, simple or sometimes branched, $3-9 \mathrm{dm}$. high, slender : leaf-blades $5-15 \mathrm{~cm}$. long, oblong-lanceolate or rarely lanceolate, acuminate or acute at each end, thin : umbels solitary or when several together corymbose : pedicels $1-2.5 \mathrm{~cm}$. long, slender : flowers small, mainly white : corolla-lobes oblong, $2-3.5 \mathrm{~mm}$. long, tipped with dull pink on the outside : column slender but distinct : hoods oval, erect, entire, obscurely sagittate-hastate on the back at the base, not exceeding the top of the anthers and shorter than the filiform incurved horn: follicles erect on erect fruiting pedicels, 5-8 cm. long, ovoid-fusiform, acuminate above, tapering at the base, glabrous : seeds 1-1.5 $\mathrm{mm}$. long, thin, oblong-orbicular, rounded at the apex, tapering to the much narrower base, apparently destitute of coma, the margin $2-3 \mathrm{~mm}$. wide, undulate.

On wet and muddy shores, Indiana to Missouri, Florida, Louisiana and Texas. Spring and summer.

20. Asclepias Texàna Heller. Stems glabrous or minutely pubescent : simple from a woody base, 3-5 $\mathrm{dm}$. high, cymosely branched, gray-green and glaucous above, purplish below, commonly marked with 1 or 2 narrow pubescent lines : leaves opposite ; blades 2.5-4 am. long, oval-oblong, acutish at the apex, broader, obscurely oblique or even truncate end sometimes also tapering at the base; petioles 1-14 cm. long, slightly margined: 
umbels 15-20-flowered: pedicels $1 \mathrm{~cm}$. long, stout, minutely pubescent: corolla-lobes 4 $\mathrm{mm}$. long, oblong, white : column very slender, tinged with purple : hoods erect, purpleveined, and obscurely sagittate-hastate on the back, the ventral margins entire, slightly infolded : horns broadish, prominently exserted over the anthers : follicles not seen.

On plains or prairies, southern Texas. Summer.

21. Asclepias verticillàta L. Stems glabrous or minutely hirsute-pubescent, typically solitary from the short rootstock, simple or rarely branched, $3-5 \mathrm{dm}$. tall or more, commonly pubescent in lines: leaves numerous, in whorls of 3-6, but not crowded, or in depauperate forms the upper ones scattered; blades slender, filiform-linear, 2-6 $\mathrm{cm}$. long, 1-3 $\mathrm{mm}$. wide, the margins revolute, the midvein lighter, conspicuous beneath: umbels terminal and lateral, $1.5-2.5 \mathrm{~cm}$. in diameter, loosely few-flowered to many-flowered: corolla-lobes greenish white, $3-4 \mathrm{~mm}$. long: column nearly $1 \mathrm{~mm}$. high : hoods erect or erect-spreading, white, turning yellowish in drying, broadly oblong, as high as or slightly shorter than the anthers, truncate at the summit as well as at the hastate-sagittate base : ventral margins auriculate-involute at about the middle : horn rather flat, arising from the base of the hood, elongated subulate-falcate, horizontally exserted over the anthers, usually much exceeding the hood : anther-wings slender and narrow, entire or minutely notched at the angled and salient base : follicles erect on erect fruiting pedicels, very slender, 7-10 $\mathrm{cm}$. long, attenuated at each end, glabrous or minutely puberulous : seeds $7 \mathrm{~mm}$. long, thin, pale brown, minutely pitted under a lens : coma $3 \mathrm{~cm}$. long.

In dry and sterile soil, Canada to Nebraska, Florida and Texas. Spring to fall.

22. Asclepias pùmila (A. Gray) Vail. Stems glabrous or nearly so, tufted, 1-25. $\mathrm{dm}$. high, simple or rarely branched : leaves contiguous or approximate, very numerous and crowded, $3.5 \mathrm{~cm}$. long ; blades filiform-linear, the revolute margins glabrous or minutely scabrous-pubescent : umbels 2 -several, few-flowered, short-peduncled, solitary or cymose at the summit of the stem: corolla greenish white; lobes oblong, 4-5 mm. long: hoods arising from the summit of the short column, oblong, erect, entire, equalling the anthers, shorter than the slender incurved horn : follicles erect on erect fruiting pedicels, narrowly fusiform, 3-5 cm. long, minutely puberulent. [A. verticillata var. pumila A. Gray.]

On dry plains, South Dakota to Colorado, Arkansas and New Mexico. Summer.

23. Asclepias lineàris Scheele. Stems minutely pubescent, terete, angulate above, 2-5 dm. high, simple or branched near the base, minutely pubescent, commonly in lines above: leaf-blades glabrous, narrowly linear, 4-8 cm. long or $10 \mathrm{~cm}$. long, acute, glabrous or with few scattered hairs, coriaceous, 1-nerved, the veins obsolete, the margins revolute or plain : umbels $3-8$, all lateral, $1.5-2.5 \mathrm{~cm}$. in diameter, few-to several-flowered: column slender, conspicuous : corolla-lobes greenish white, about $4 \mathrm{~mm}$. long, ellipticaloblong, acutish : hoods erect-spreading, broadly truncate at the summit, truncate at the hastate-sagittate obscurely clawed base, the ventral margins with rounded angles or lobes at the middle, somewhat involute: horn flat, arising from the keel of the hood near its base within, arcuate, horizontally long-exserted over the anthers, often dorsally angled at about the middle : anther-wings very slender, minutely notched at the angled base: follicles not seen.

In damp clay soil, southern Texas. Summer and fall.

24. Asclepias Michaùxii Decne. Stems minutely puberulent, often clustered, 2-3 dn. high from a stout ligneous fusiform rootstock, ascending or decumbent : leaves numerous, opposite, or some of them scattered ; blades linear or narrowly linear, 4-9 dm. long, scabrous or minutely scabrate, the margins sometimes becoming revolute : umbels typically solitary or rarely 2, sessile, 1-3 : corolla greenish, tinged with dull purple on the outside ; lobes oval, $5 \mathrm{~mm}$. long : column distinct: hoods erect-spreading, orange-color or yellowish, with apparently a purplish keel or mid-vein, ovate, entire, surpassing the anthers : ventral margins obscurely lobed : horn flat, inserted above the base and inflexed-exserted over the anthers at the middle of the hood : anther-wings entire or slightly notched at the angled and salient base : follicles slender-fusiform, erect on erect fruiting pedicels, $8-14 \mathrm{~cm}$. long, 6-7 mm. or $8 \mathrm{~mm}$. wide, attenuate at each end, usually minutely puberulent : seeds $7 \mathrm{~mm}$. long, about $5 \mathrm{~mm}$. wide, with the margin conspicuously broad: coma $2.5 \mathrm{~cm}$. long.

In pine lands and on sand hills, South Carolina to Florida and Mississippi. Spring.

25. Asclepias virídula Chapm. Stems nearly glabrous, $3-6 \mathrm{dm}$. high, sometimes pubescent in lines, very slender: leaves opposite; blades narrowly linear, 1-3 mm. wide, the margins sometimes revolute: umbels several, peduncled, 1-4-flowered : corolla-lobes greenish, oblong, 3-4 mm. long: hoods oblong, surpassing the anthers, the ventral mar- 
gins infolded, with an auriculate tooth or lobe below the middle: horn subulate, arising from the middle of the hood, incurved over the anthers : anther-wings auriculate-spreading : follicles erect, $9 \mathrm{~cm}$. long, slender-fusiform, minutely puberulent : seeds $4 \mathrm{~mm}$. long: coma $2 \mathrm{~cm}$. long.

In wet pine lands, near Apalachicola, Florida. Summer and fall.

26. Asclepias cinèrea Walt. Stems glabrous or nearly so, slender, erect, $3 \mathrm{dm}$. high or more, sometimes slightly pubescent in lines : leaves opposite, $3-9 \mathrm{~cm}$. long, rather distant; blades narrowly linear or filiform : umbels $2-6$, terminal and lateral, 3-8-flowered : peduncles short : corolla purplish on the outside; lobes oval, $5 \mathrm{~mm}$. long, with whitish scarious margins, ash-colored within : hoods much shorter than the anthers, whitish and purple-keeled, slightly pendulous at the base over the short or obsolete column, truncate at the apex, the involute ventral margins extended into acute erect ascending lobes or angles: horn erect, included, broadly triangular, inserted about the middle of the hood : follicles slender-fusiform, $8 \mathrm{~cm}$. long, $5-6 \mathrm{~mm}$. wide, attenuated at each end, erect on erect pedicels, glabrous: seeds $5 \mathrm{~mm}$. long, with a thick coriaceous margin : coma $3 \mathrm{~cm}$. long.

In rather dry pine lands, South Carolina to Florida. Summer.

27. Asclepias Emòryi (Greene) Vail. Stems minutely and cinereously pubescent with somewhat curved hairs, becoming less so with age, $3-4 \mathrm{dm}$. high or more, floriferous for nearly their whole length : leaves $4-10 \mathrm{~cm}$. long; blades elongated-lanceolate, acute, tapering to the short margined petioles: umbels small, sessile or very short-peduncled, 4-6-flowered : corolla-lobes 6-7 mm. long, apparently greenish white: hoods white, 5 $\mathrm{mm}$. high and twice as high as the anthers, fleshy, adnate only at the very base, solid at the back and below the ventral margins free to near the base, spreading at the summit into a short open 2-lobed lamina: horn broad, fleshy, subulate, inflexed, arising from the apex of the hood, wrinkled at the insertion, downcurved, barely exserted : accessory processes minute near the base of the hood: anther-wings semi-rhomboid, narrow, obtusely angled below the middle, rounded at the base, tapering above, entire or nearly so: follicles $5.5 \mathrm{~cm}$. long, erect on recurved pedicels lanceolate-fusiform, puberulent: seeds $7 \mathrm{~mm}$. long, round-oblong, granulose : coma $2-2.5 \mathrm{~cm}$. long. [Podostemma Emory Greene.]

On plains or prairies, southern Texas. Summer.

28. Asclepias Lindheímeri Engelm. Stems minutely puberulent or minutely scabrous, simple or branched, rather stout, 3-4 dm. high, decumbent or ascending: leafblades deltoid, broadly oval or oblong-oval, some of the upper ones narrower and lanceolate-oblong, 5-9 cm. long, obtuse or commonly broadly rounded at the apex, tapering at the base or each abruptly or truncately contracted into a $(1-2 \mathrm{~cm}$. long) flat petiole: umbels abundant, the upper sessile, the lower on peduncles $5 \mathrm{~mm}$. long or less, few- to many-flowered : corolla-lobes greenish, $1 \mathrm{~cm}$. long : hoods white, over twice the height of the anthers, slender at the stalked base, dilated above into a 3-lobed or obscurely 4-lobed lamina: horn attached to the solid keel-like portion of the hood, slender, attenuate, inflexed, scarcely exserted, the accessory process much shorter, erect, obtuse: anther-wings semi-ovate, the rounded base broader than the tapering upper portion, minutely notched at the middle : accessory 5 processes very broad, with acutish angles grasping the base of the anther-wing : follicles ovate-lanceolate, long-attenuated, 8-10 cm. long, erect on recurving pedicels, puberulous : seeds $6 \mathrm{~mm}$. long, round-ovate: coma $3-3.5 \mathrm{~cm}$. long.

On plains or prairies, Texas to New Mexico and Mexico. Summer and fall.

29. Asclepias obovàta Ell. Stems cinereous with soft pubescence or tomentum, 29. Asclepias obovata $\mathrm{m}$.
them obovate, $3-10 \mathrm{~cm}$. long, $1.5-4.5 \mathrm{~cm}$. wide or more, mucronate-apiculate at the apex, rounded or subcordate at the base, tomentose, at length glabrate or nearly so, undulate on the margins, the midvein broad and conspicuous : umbels 2-6, lateral in the upper axils, nearly sessile : corolla-lobes greenish yellow, oblong, about $1 \mathrm{~cm}$. long : column very short : hood purplish, erect, $7 \mathrm{~mm}$. high, much exceeding the anthers, truncate at the apex, dorsally bigibbous at the base by reason of an excrescent fold on each side, the thin ventral margins rounded, involute and meeting for nearly their whole length, a pair of broad short fleshy processes or auricles at the base within on either side of the anther-wings : horn
narrowly falcate, fleshy, horizontally exserted for nearly half its length, arising from the base of the hood : anther-wings bicorniculate at the salient basal angle : follicles $8-11$ cm.
long, erect on erect fruiting pedicels, obtuse at the tapering apex, tomentulose : seeds 8 $\mathrm{mm}$. long, thin, minutely pitted : coma $3 \mathrm{~cm}$. long.

In dry grounds, mainly near the coast, South Carolina to Florida and Texas. Summer. 


\section{ANÁNTHERIX Nutt.}

Perennial erect herbs. Leaves opposite. Inflorescence terminal and lateral, consisting of small umbels of large green and white flowers. Calyx-lobes 5, small, acute. Corolla campanulate or rotate : lobes 5, longer than the tube, acutish, reflexed in anthesis. Column very short but distinct, with a very narrow protruding undulating fold simulating an outer crown, from which rise the hoods. Hoods as long as the corolla-lobes, oblong-clavate, ascending and incurved high over the anthers, mainly solid and laterally compressed, with a narrow, lamelliform crest within. Anther-wings membranous or papery, spreading at the widened, horizontally truncate base : caudicles capillary, more than double the length of the short oblong pollinia. Follicles on recurving pedicels.

1. Anantherix connivens (Baldw.) A. Gray. Stems glabrous or minutely pubescent, 3-6 dm. high, solitary or two together : leaf-blades sessile, oblong or lanceolate, 3-8 $\mathrm{cm}$. long, transversely veined, thick and fleshy : umbels $2-5$ or 6 , disposed along the summit of the usually naked stem: peduncles longer than the pedicels : corolla-lobes $1 \mathrm{~cm}$. long or more, oblong, greenish : hoods white, $8 \mathrm{~mm}$. high, $3-5 \mathrm{~mm}$. wide at the rounded laterally flat conniving apex, the solid portion outlined by a marginal vein : anther-wings spreading toward the base, with two small fleshy appendages alternating with the hoods.

In wet pine lands and swamps, Georgia, Florida and Alabama. Summer.

\section{ASCLEPIODÒRA A. Gray.}

Perennial, erect or procumbent herbs. Leaves opposite or alternate. Umbels terminal, solitary or corymbose, of mostly large purple, greenish or white flowers. Calyxlobes 5, narrow, acute. Corolla rotate: lobes 5, acutish, erect or spreading in anthesis. Hoods inserted over the whole of the very short column and arising from the base of the corolla-lobes, shorter than or slightly surpassing the anthers, pendulous or saccate at the base, arcuate-assurgent or merely erect-assurgent, the apex rounded, closed, crested within at least in the upper part. Between the hoods are borne 1 or 2 small lobes or appendages, alternate with the anther-wings, simulating an inner crown. Anther-wings corneous, narrowed at the base and salient about the middle, or horizontally truncate, rounded at the base and somewhat sagittate, the edges flattened laterally and meeting up the center. Caudicles shorter than the pyriform pollinia. Follicles resembling those of Asclepias, often soft-spinulose.

Leaves alternate.

Umbel solitary.

Umbels 2-several, cymose at the summit of the stem.

Leaves opposite ; blades linear-filiform: umbels solitary, or two or three together.

1. A. decumbens.

2. A. viridis.

3. A. Feayi.

1. Asclepiodora decúmbens (Nutt.) A. Gray. Stems scabrous-puberulent, solitary or several together, usually simple, strongly angled, $2-4 \mathrm{dm}$. long: leaves $4-15 \mathrm{~cm}$. long; blades lanceolate to linear, tapering at the apex, thick and coriaceous, often appearing as if remotely whorled in three's : peduncles varying in length : umbel $4-5 \mathrm{~cm}$. broad, manyflowered : corolla depressed globular in bud; lobes greenish, about one third longer than the purplish hoods: hoods incurved, obtuse, 2-lobed on the ventral margin, slightly overtopping the broad depressed anther-column : crest attached close to the downcurving apex, irregularly undulate, salient and then tapering to the base : anther-wings salient above the angulate middle ; appendage at the base, broad, obtuse, entire : follicles about $8 \mathrm{~cm}$. long, naked or with soft spine-like processes, erect, on recurving pedicels : seeds thin, about 6 mm. long.

On dry plains, Arkansas to Utah, Texas, Arizona and northern Mexico. Spring and summer.

2. Asclepiodora víridis (Walt.) A. Gray. Stems nearly glabrous, decumbent or assurgent, 2-6 dm. high, angled, leafy to the top : leaves remote; blades oblong or oblonglance late, $6-10 \mathrm{~cm}$. long, $1.5-4 \mathrm{~cm}$. wide, obtuse and mucronulate or acutish at the apex, mostly narrowed and rounded at the base, rather thin : peduncles shorter than the leaves : umbels $2-5$ or rarely solitary, few-flowered : pedicels slender, shorter than the umbels: corolla globose-ovoid in bud; lobes greenish, 10-12 mm. long, oblong, obtuse or acutish : hoods entire on the ventral margins, purplish or violet, spreading-assurgent, pendulous below the anther-column, less than half the length of the corolla-lobes: anther-wings angled at about the middle, tapering or nearly straight at the base, the accessory processes obscurely 2-3-lobed: pollinia narrow, little longer than the caudicles : follicles erect, on 
deflexed pedicels, $6-11 \mathrm{~cm}$. long, obtuse, $1.5-2 \mathrm{~cm}$. wide, with or without soft spinous projections : seeds $6 \mathrm{~cm}$. long, broadly rounded at the apex : coma $3-3.5 \mathrm{~cm}$. long.

In dry soil, Illinois and Kentucky to South Carolina, Texas and New Mexico. Spring and summer.

3. Asclepiodora Feàyi Chapm. Stems erect, very slender, $2-4 \mathrm{dm}$. high, minutely puberulent in lines, or glabrous : leaves opposite, in 3-6 pairs ; blades linear-filiform, 3-10 cm. long, with revolute margins: umbels $2-3$ at the summit of the stem, very shortpeduncled, 3-6-flowered : pedicels about $12 \mathrm{~mm}$. long, filiform, minutely puberulent : corolla globose-ovoid in bud ; lobes white, oblong-lanceolate, about $7 \mathrm{~mm}$. long, acutish : hoods erect-spreading, shorter than the anther-column, white, concave, not down-curved at the rounded or obtuse apex : crest a semi-oval entire, fleshy fold or ridge attached to the thickened midrib within : anther-wings membranous above, corneous below, sagittate at the base : hood-appendages minutely and obscurely 2 -lobed : follicles very slender, $3 \mathrm{~cm}$. long or more, long-acuminate.

In pine lands. Florida. Spring to fall.

\section{METASTÉLMA R. Br.}

Slender twining perennial vines or woody climbers. Leaves opposite: blades narrow. Flowers very small, in sessile or very short-peduncled few-flowered cymes or umbels. Calyx-lobes 5, acutish or obtuse, with a gland in each sinus. Corolla rotately spreading or subcampanulate: lobes 5, commonly tomentose or retrorsely pubescent or puberulent along the apex within. Crown 5-parted, inserted at the base of the corolla or on the column at the base of the anthers, the lateral margins of the lobes not involute. Gynostegium sessile or raised on a column. Stigma flat. Follicles slender, acuminate, smooth. The plants flower mainly from spring to fall.

Crown adnate to the corolla; lobes united at the base.

Crown adnate to the column; lobes very slender, incurved over the anthers.

Crown adnate to the column and partly adnate to the base of the corolla: leafblades linear or nearly so, thin: stems filiform.

Crown adnate to the top of the column, entirely free from the base of the corolla.

Flowers 2-several together in sessile or very short-peduncled cymes. Corolla $3 \mathrm{~mm}$. long: leaf-blades linear-lanceolate, $1-2.5 \mathrm{~cm}$. long, leathery. Corolla 4-5 mm. long : leaf-blades oblong, oblong-lanceolate or ovate-lanceo-

late, $2.5-5 \mathrm{~cm}$. long, thin.
Flowers in peduncled cymes : peduncles $5-10 \mathrm{~cm}$. long : leaf-blades oblong or round-oval.

1. M. scoparium.

2. M. Blodgettii.

3. M. Palmeri.

4. M. barbigerum.

5. M. Bahamense.

1. Metastelma scopàrium (Nutt.) Vail. Stems filiform, from a ligneous base, much branched, diffuse and twining, becoming leafless : leaf-blades narrowly linear, thin, acute, $2-5 \mathrm{~cm}$. long: umbels sessile and few-flowered : calyx-lobes with a minute gland in each sinus : corolla 1-1.5 mm. long, greenish ; lobes narrowly lanceolate, acute, almost valvate in the bud : crown-lobes shorter than the anthers, manifestly united at the base, crenately 5 -lobed, the middle lobe the longest: pollinia pyriform, narrowed toward the apex, the caudicles very slender, the corpuscle narrow, spreading at the base: follicles $3.5-4.5 \mathrm{~cm}$. long, linear, very slender, widely spreading, acute, few-seeded: seeds $7 \mathrm{~mm}$. long, thin and rarely $1 \mathrm{~mm}$. wide : coma $5-10 \mathrm{~mm}$. long.

In dry rich soil, South Carolina to eastern Florida.

2. Metastelma Blodgéttii A. Gray. Stems nearly glabrous, filiform, twining, $6 \mathrm{dm}$. long, or more: leaf-blades linear or nearly so, $9 \mathrm{~mm}$. long, or more, rounded at the base, tapering to the cuspidate apex, rather thick, with revolute margins and thick midvein: cymes 3-6-flowered: calyx-lobes subulate, less than $1 \mathrm{~mm}$. long: corolla $2.5-3 \mathrm{~mm}$. long, whitish, tinged with purple ; lobes linear-lanceolate, acuminate, densely and retrorsely. penicillate-bearded below the apex, and sparingly pubescent towards the base within: crown-lobes adnate to the base of the column and partly adnate to the corolla, linearsubulate, very slender, erect, surpassing the anthers: anther-wings corneous, slightly salient at the angled base : pollinia inverted club-shaped, tapering to the broad-winged and angled caudicles, the corpuscle oblong, obtuse at the obovate apex : follicles filiform, 4-5 $\mathrm{cm}$. long, glabrous : seeds $3 \mathrm{~mm}$. long, very narrow : coma $15 \mathrm{~mm}$. long.

In sandy soil, peninsular Florida and the Keys.

3. Metastelma Pálmeri S. Wats. Stems glabrous, filiform : leaf-blades linear-lanceolate, acute and cuspidate at the apex, acute or obtuse at the base ; petioles $2-4 \mathrm{~mm}$. long, slender: cymes subsessile, 1-5-flowered : calyx-lobes ovate, acute : corolla dull purplish, $3 \mathrm{~mm}$. long; lobes oblong-lanceolate with a whitish margin and minutely retrorse-bearded within: crown-lobes adnate to the summit of the stout column, linear-subulate, slightly surpassing the anthers, obscurely decurrent on the column: anther-wings very small: anther-tips nearly concealing the flattish stigma : follicles not seen.

In dry soil, southern Texas and Mexico. 
4. Metastelma barbígerum Scheele. Stems glabrous, slender, filiform above : leafblades oblong or oblong-lanceolate, sometimes a few of them ovate-lanceolate, $2.5-5 \mathrm{~cm}$. long, acuminate and cuspidate, rounded at the base, thinnish, glabrous except for a few hairs on the midvein beneath and with a few glands above at the base of the blade, rarely thicker and a little coriaceous : cymes 1-5-flowered: calyx-lobes ovate-lanceolate, 1-5 mm. long, obtuse : corolla 4-5 mm. long, campanulate, dull greenish white; lobes elongated, linear-lanceolate, acute, the tips slightly revolute, densely and retrorsely white-bearded to below the middle within : crown-lobes slender, linear-subulate, attached to the showy very short column and appearing as if wing-angled towards its base, considerably exceeding the anthers : anther-wings short, angled or rounded at the salient base : pollinia pear-shaped, tapering upward to the broadish angled caudicle : the corpuscle obovate-oblong, obtuse at the apex: follicles $4-5 \mathrm{~cm}$. long, slender-fusiform, acuminate : seeds $6 \mathrm{~mm}$. long, pale brown : coma $2.5 \mathrm{~cm}$. long.

In open woods and on rocky banks, Texas and New Mexico.

5. Metastelma Bahaménse Griseb. Stems nearly glabrous, sometimes minutely pubescent in lines: leaf-blades $1.5-2.5 \mathrm{~cm}$. long: blades round-oval to oblong, mucronatecuspidate; petioles slender, $5-7 \mathrm{~mm}$. long: cymes $3-6$-flowered, the pedicels $2-3 \mathrm{~mm}$. long, very slender, unequal : corolla white, open-campanulate, fleshy ; lobes obtuse. slightly spreading, densely white-tomentose within : crown adnate to the whole of the high slender column; lobes linear-falcate, obtuse, not exceeding the anthers, wing-angled, internally carinate: stigma flat or slightly depressed, obscurely 5-angled : follicles $5-6.5 \mathrm{~cm}$. long, fusiform, very slender, long-acuminate, glabrous, thickish, striate, dark purplish : seeds 5 $\mathrm{mm}$. long, dark brown, slender, thin, with one or two rows of elevated tubercles along the margin : coma about $2 \mathrm{~cm}$. long.

In sand, usually in open woods, Florida Keys.

\section{ROULINIÉLLA Vail.}

Twining shrubby plants. Leaves opposite: blades cordate at the base, long-petioled. Inflorescence cymose or somewhat paniculate or racemiform. Calyx small, glandulose. Corolla rotate, with oblong, dextrorsely convolute lobes. Crown 5-lobed, attached at the base of the corolla-tube and the gynostegium : lobes broad, often fleshy or leathery, the lateral margins involute. Stigma flat and depressed, obscurely 5-rayed and 2-lobed. Follicles thick, acute, smooth. Seeds comose. [Roulinia Decne., not Brongn.]

1. Rouliniella unifària (Scheele) Vail. A slender climbing and twining vine. Stems pale gray-green when fresh, striate, glabrous or minutely pubescent in lines on the upper portion and somewhat sulcate : leaf-blades 3-7 cm. long, ovate, hastately cordate, gradually acuminate, glabrous, thin, the auriculate basal lobes rounded, with an open sinus and a few glands at the base of the blade above: calyx-lobes lanceolate-oblong, $4 \mathrm{~mm}$. long, with a gland in each sinus: corolla 4-6 mm. long, white; lobes $3 \mathrm{~mm}$. long, linear-oblong, 2.5 $\mathrm{mm}$. wide, broadly obtuse or nearly truncate, thin, 3 -veined, the revolute margins with two thickened callous ridges at the revolute apex within : crown adnate to the base of the column, 5-lobed to near the base ; lobes erect, obtuse, not exceeding the anthers, 3-lobed, the middle lobe slightly the longest: anther-wings small; anther-tips semi-orbicular, inflexed on the scarcely conic stigma: pollinia elliptical-ovoid, the candicles broad at the attachment, orange-red on the upper margin, the corpuscle acute at the apex : follicles 6 cm. long, ovate, acuminate with an obtuse apex, coriaceous, glabrous : seeds $5 \mathrm{~mm}$. long: coma $1 \mathrm{~cm}$. long.

In thickets, southern Texas and New Mexico. Spring to fall.

\section{GoNólobus Michx.}

Perennial twining herbaceous vines. Leaves opposite, cordate, thin. Flowers in axillary peduncled cymes. Calyx-lobes 5 , glandular within, lanceolate. Corolla white, campanulate : lobes 5, slightly contorted, nearly erect. Crown nearly sessile, of 5 membranous, erect truncate lobes, each appendaged by 2 terminal awns. Stamens inserted at the base of the corolla : filaments united into a short tube : anthers terminated by an erect or slightly inflexed membrane. Anther-wings corneous, salient at the base after the manner of Asclepias. Pollinia oblong-elliptical on rather broad caudicles, pendulous. Stigma conic, slightly 2-lobed. Follicles thick, strongly and sharply angled. Seeds comose.

1. Gonolobus laèvis Michx. Stems high-climbing, slender, glabrous or minutely pubescent in lines: leaves $4-15 \mathrm{~cm}$. long; blades ovate, gradually acuminate at the apex, 
deeply cordate with rounded basal lobes, palmately veined, glabrous or nearly so above, the veins minutely pubescent beneath, midvein with a small cluster of subulate glands at the base above : cymes usually numerous, rather densely many-flowered, not exceeding the petioles: pedicels 4-5 mm. long : corolla-lobes ovate, $4 \mathrm{~mm}$. long, linear-lanceolate, acutish with reflexed tips : crown-lobes ovate, barely truncate, the slender awns nearly as long as the corolla-lobes : anther-tips conspicuous, cordate at the base : follicles erect on spreading pedicels, $10-15 \mathrm{~cm}$. long, glabrous, wing-angled : seeds $9-10 \mathrm{~mm}$. long, thin, crenate at the apex : coma $4 \mathrm{~cm}$. long. [Enslenia albida Nutt.]

On river banks and in thickets, southern Pennsylvania to Kansas, Florida and Texas. Summer.

\section{SEUTÈrA Reichenb.}

Slender twining vines. Leaves mostly opposite : blades narrowly linear. Flowers in peduncled umbels. Calyx small : lobes 5, acute, with a gland in each sinus. Corolla subrotate: lobes 5, spreading, acuminate. Crown adnate to the short column below the anther-wings, united at base : lobes merely notched at the apex. Anther-wings corneous, angled at the base. Pollinia pendulous. Stigma conic, obscurely bifid. Follicles smooth, slender, essentially terete.

1. Seutera palústris (Pursh) Vail. Stems filiform, herbaceous, glabrous, freely twining over grasses and low bushes : leaves $2-7 \mathrm{~cm}$. long ; blades linear, somewhat fleshy, acute, glabrous, pendent : peduncles commonly longer than the leaves : umbels several- to many-flowered: caly $\mathrm{x}$-lobes lanceolate, acute : corolla purplish or greenish white, $3-4 \mathrm{~cm}$. long; lobes ovate-lanceolate, acuminate : crown 5-lobed, adnate to the summit of the very short column; lobes oblong-obovate, entire, retuse or emarginate at the apex, about one half the length of the corolla : anthers sagittate at base: pollinia oblong-elliptical in outline on rather broad, stout caudicles: follicles slender-fusiform, acuminate, $5 \mathrm{~cm}$. long, glabrate : seeds $3-3.5 \mathrm{~mm}$. long, very thin, glabrous: coma $2 \mathrm{~cm}$. long. [S. maritima
[ Decne.]

In salt marshes along the coast, North Carolina to Florida and Texas. Summer and fall.

\section{VINCETÓXICUM Walt.}

Twining perennial vines or low shrubby plants, mostly pubescent. Leaves opposite : blades commonly heart-shaped. Inflorescence axillary, peduncled or sessile. Flowers solitary or few in small clusters, or more commonly in loosely-flowered umbel-like cymes. Calyxlobes oblong or lanceolate, acute or acuminate, commonly with 1-2 glands in each sinus. Corolla variously colored or white, rotate: lobes 5 , dextrorsely convolute in bud. Crown annular, saucer-shaped or cup-shaped, single or double, the outer sometimes surrounded by a fleshy ring or fold, simulating a third ring, often annular and cohering with the base of the corolla, entire, crested or appendaged within, sometimes connected with the gynostegium by 5 fleshy ribs. Gynostegium arising from the base of the corolla, sessile or raised on a column. Anthers usually with a short narrow, if any, scarious tip, borne on the margin of or close under the disk of the stigma, often dorsally appendaged by a short corneous projection ; sacs opening more or less transversely and outwardly, or from above. Pollinia horizontal, sometimes pointing inwards. Stigma depressed, sometimes barely conic in the center, sharply 5 -angled, usually with radiating raised margins. Follicles thick, tapering, glabrous, muricate or warty, or 3-5-costate-angled. [Gonolobus Michx. in part.]

A. Stems twining: vines with large leaves.

Pollinia pyriform on broad angled caudicles : crown a low, fleshy entire or 10-undulate ring : anthers with a narrow dorsal projection.

Corolla green-reticulate: crown entire : stigma raised on a slender 5-angled column: follicles muricate.

Column slender, unappendaged : corolla $1.4 \mathrm{~cm}$. broad.

Column stout, appendaged at the base by 5 erect horn-like projections : corolla $2 \mathrm{~cm}$. broad.

Corolla not reticulate: crown 10-undulate, unappendaged within : follicles 4-5-angled or costate or winged.

Leaf-blades oblong-ovate or oblong-oval, thickish, abruptly acuminate at the apex.

Leaf-blades broadly ovate or sometimes oblong-ovate, thin.

Pollinia oblong on slender twisted caudicles: crown low, 10-crenate, with 5 crenations broader, obscurely crested within, the 5 alternate divisions truncate or bifid at the apex: follicles muricate.

a. Corolla dull reddish or greenish purple, some of them turning yellowish. Corolla greenish purple.

Alternate longer divisions of the crown truncate and bifid, thinner than the rounded, broader, obscurely crested divisions.

1. V. reticulatum.

2. V. Alabamense.

3. V. suberosum.

4. V. gonocarpos. 
Crown prominently toothed; crest a narrow ridge or fold that is barely free within.

Crown merely crenulate, crest double.

Alternate divisions of the crown distinctly 2-toothed, thinner and narrower than the rounded somewhat crenate divisions that are more or less obscurely crested within : crests entire, crenate or bifid.

Corolla dull reddish, in the variety greenish yellow or straw-colored.

b. Corolla white: crown-divisions broad, quadrate, alternating with 5 slender deeply 2 -toothed segments that much surpass the anthers.

Pollinia oblong: crown 5-crenate, the divisions each 4-toothed: flowers in short racemes or fascicles.

B. Stems low, procumbent or diffuse, in $V$. productum twining : leaves small.

Flowers solitary or 2, rarely 3 in a fascicle, never long-peduncled.

Corolla rotately spreading.

Crown 5-undulate, each lobe with an obtuse or subquadrate inflexed adnate crest, the intermediate sinus fringe-toothed : follicles muricate and hirsute.

Crown 5-parted: lobes broadly retuse, appendaged within by a thick fleshy ligule: follicles large and thick, muricate.

Corolla campanulate.

Crown 5-parted or apparently 10-parted, each alternate division with an incurved beak terminating the adnate crest within: follicles muricate.

Crown saucer-shaped, with 5 internal, barely free processes terminating the adnate crests within : follicles smooth: stem twining.

Flowers several in a slender long-peduncled raceme: corolla rotate, small.

Crown-lobes deeply 2-toothed, each with a slender, much longer, erect or incurved process within.

Crown-lobes emarginate or truncate, each with a slender, erect process within.

1. Vincetoxicum reticulàtum (Engelm.) Heller. Stems high-climbing, hirsute with long stiff spreading hairs and a minute glandular pubescence: leaf-blades ovateoblong, deeply cordate with incurved rounded and often overlapping auricles, tapering to a long-acuminate apex, $5-10 \mathrm{~cm}$. long, glabrate or sparingly pubescent above, minutely puberulent and granulose beneath : peduncles as long as the petioles $(2-10 \mathrm{~cm}$.) or longer: cymes 3-10-flowered: calyx with a gland at each sinus: corolla dull purplish green, $1.4 \mathrm{~cm}$. broad; lobes oval, obtuse, scarious-margined, minutely and sparingly papillose or pubescent outside, green and white-reticulated within : crown an obscure ring attached to the base of the corolla : column slender, $1 \mathrm{~mm}$. high, 5-angled, with a fleshy, rather obscure, angled ring approximated above that of the crown: stigma obtusely 5-angled, obscurely conic : pollinia pyriform : ovaries glabrate : follicles $8-12 \mathrm{~cm}$. long, fusiform, long-acuminate, glabrate or minutely puberulous, strongly muricate : seeds $7 \mathrm{~mm}$. long, minutely granulose : coma $3.5 \mathrm{~cm}$. long.

In thickets and on rocky banks, Texas to Arizona and Mexico. Spring to fall.

2. Vincetoxicum Alabaménse Vail. Stems high-climbing, sparingly hirsute with long rather weak hairs and a minute glandular pubescence : leaf-blades $6-15 \mathrm{~cm}$. long, $5-10 \mathrm{~cm}$. broad, rather thin, ovate or oblong-cordate, acuminate at the apex, the basal auricles rounded and never overlapping, the sinus narrowed at the base, sparingly puberulent and dark green above, lighter and more closely puberulent beneath: peduncles shorter than the petioles: cymes 3-6-flowered : calyx biglandulose; lobes lanceolate, acute : corolla dull greenish yellow, $2 \mathrm{~cm}$. in diameter; lobes oval, obtuse, puberulent, and minutely papillose, on the outer surface, conspicuously reticulated within: gynostegium raised on a low broad column : crown orange-yellow, consisting of a low saucer-shaped ring attached to the base of the corolla, 5-parted, each division minutely and irregularly toothed or entire, appendaged within by 5 tooth-like erect crests attached to the base of the column : stigma white, flat, obtusely 5-angled : anther-tips white, scarious : pollinia pyriform : ovaries minutely puberulent : follicles $8-9 \mathrm{~cm}$. long, glandular-puberulent, closely and strongly muricate : seeds 8-9 mm. long, obovate, granulose : coma $3.5-4.5 \mathrm{~cm}$. long.

In thickets and on sandy hillsides, Dale County, Alabama. Summer and fall.

3. Vincetoxicum suberòsum (L.) Britton. Stems slender, twining, pubescent or glabrate, often with few scattered and spreading hairs: leaf-blades ovate-oblong or the smaller ones oblong-oval, thickish, 6-12 cm. long, $2.5-8 \mathrm{~cm}$. wide, abruptly acuminate at the apex, sometimes a little contracted at the middle, cordate or subcordate at the base, the sinus shallow, rather wide and open, the basal lobes rounded: racemes few-severalflowered : peduncles shorter than the pedicels, which are $1-2.5 \mathrm{~cm}$. long, stout and fleshy : calyx with a subulate gland in each sinus : corolla brown-purple or some of them yellowish, broadly conic in the bud; lobes lanceolate or ovate-lanceolate, acute, pubescent or granulose within, $7-8 \mathrm{~mm}$. long, erect or rotately spreading : crown an annular disk, undulately 5 - or barely 10-crenate, adnate to the corolla and but obscurely connected with the very short column by 5 faint ascending ridges : stigma depressed, barely 5-rayed : pollinia pyriform, rounded at the base, with broad winged caudicles: follicles $10-12 \mathrm{~cm}$. long, $2.5-3$ 
cm. wide, 3-5-angled or winged, fleshy when young, dry and spongy when mature: seeds $8-9 \mathrm{~mm}$. long, thin, minutely warty, erenate along the apex : coma $4-5 \mathrm{~cm}$. long.

In thickets and on river banks, Virginia to Florida and Louisiana, mainly near the coast. Spring and summer.

4. Vincetoxicum gonocárpos Walt. Stems high-climbing, rather slender, minutely puberulent and thinly hirsute, sometimes the upper portion glabrate : leaf-blades 7-18 $\mathrm{cm}$. long, broadly ovate or sometimes ovate-oblong, cordate at the base, with the sinus broad, in the case of larger leaves, the basal lobes approximated and often overlapping, abruptly acuminate at the apex, usually thin, becoming sometimes thicker and coriaceous when old, glabrous above or nearly so, granular-puberulent beneath, the margins sometimes a little wavy : midrib with 2 -several glands at the base above: cymes mainly few-flowered: peduncles fleshy, glabrous or nearly so: pedicels 1-2 cm. long, glabrous or nearly so : calyxlobes ovate-lanceolate, acute, glabrous, minutely ciliolate near the apex : corolla elongatedconical in bud, dull-greenish ; lobes narrowly lanceolate-linear, 9-12 mm. long, not twisted, glabrous, rather thick and fleshy : crown a low 10-undulate fleshy ring: stigma depressed, not 5-rayed : anthers with a scarious-membrane that overlaps the edge of the stigma : pollinia pear-shaped, the broad flat caudicles twisted : follicles 3-5-costate or angled, 8-10 cm. long, glabrous, fleshy when mature, dry and spongy when old: seeds 8-9 $\mathrm{mm}$. long, minutely granular-puberulent, the rugose margin irregularly crenate along the apex : coma $3.5-4 \mathrm{~cm}$. long. [Gonolobus macrophyllus Michx.]

Along rivers and in moist thickets, Kentucky to Missouri, Georgia and Texas. Spring and summer. ANGLE-POD.

5. Vincetoxicum Shòrtii (A. Gray) Britton. Stems high-climbing, puberulent and thinly hirsute with rather stiff spreading hairs : leaf-blades $5-14 \mathrm{~cm}$. long or more, broadly ovate, short-acuminate at the apex, deeply cordate at the base, the lobes rounded, commonly with a narrow and closed sinus, rather thin, minute soft-hirsute above, more densely so and with longer spreading hairs on the midrib beneath; the latter with a few glands at the base above: cymes several-flowered: peduncles minutely puberulent and sparingly hirsute : pedicels $1-2.5 \mathrm{~cm}$. long, fleshy and puberulent: calyx-lobes with a gland in each sinus, lanceolate, $3 \mathrm{~mm}$. long, puberulent : corolla dark greenish purple, oblongconic in bud, 10-15 mm. long; lobes linear-ligulate, glabrous within, puberulent on the outer surface: crown with a 10-dentate margin, the narrow intermediate teeth truncate, retuse or obscurely bifid, thinnish, a little higher than the alternate broader ones which are thicker and obscurely crested within ; crest a narrow ridge or fold that is barely free within : stigma barely 5 -angled : pollinia oblong : caudicles long. and narrow : follicles $8-10 \mathrm{~cm}$. long, rather slender, muricate with soft, obtuse protuberances, puberulent : seeds $8 \mathrm{~mm}$. long, broadly obovate, glabrous, the thin margin barely wrinkled: coma $3 \mathrm{~cm}$. long. Flowers said to have the odor of the fragrant flowers of species of Butnera.

In dry woods, Pennsylvania to Kentucky and Georgia. Summer.

6. Vincetoxicum oblìquum (Jacq.) Britton. Stems high-climbing, puberulent and hirsute, often densely so at the base, rather slender above : leaf-blades 7-20 cm. long, 6-16 $\mathrm{cm}$. wide, broadly ovate, some of the larger ones orbicular-ovate, gradually or abruptly acuminate at the apex, deeply cordate at the base, with narrowly mostly closed sinus and in the larger leaves the broad rounded lobes conspicuously overlapping (sometimes leaves are found that are distinctly oblique at the base), minutely pubescent above, pubescent beneath and thinly hirsute on the veins: glands at the base of the midvein above, 1-several or obsolete : umbel many-flowered, commonly cymosely compound, except on the upper portion of the stem where they are simple and few-flowered : peduncles $3-8 \mathrm{~cm}$. long, puberulent and hirsute: calyx-lobes lanceolate-subulate, puberulent and ciliolate, obscurely glandular in each sinus : corolla oblong-conic in bud ; lobes 10-14 mm. long, linear-ligulate, dark crimson-purple and glabrous within, dull greenish and puberulent on the outside : crown 10-crenulate, the alternate thinner divisions truncate, entire or bifid, the others much shorter, broadly rounded, thickened at the apparently double summit, the inner appendage tooth-like and simulating an internal crest : stigma depressed, 5-rayed : pollinia broadly spinous processes, minutely puberulent: seeds $7 \mathrm{~mm}$. long: coma $2-2.5 \mathrm{~cm}$. long.

In thickets, Pennsylvania to Ohio, Virginia and Tennessee. Summer.

7. Vincetoxicum Carolinénse (Jacq.) Britton. Stems and petioles minutely puberulent as well as thinly hirsute with spreading hairs: leaf-blades obovate, acute or shortacuminate at the apex, deeply cordate at the base, with a narrow or closed sinus, $6-18 \mathrm{~cm}$. long, 5-15 cm. wide, closely and softly pubescent on both surfaces: peduncles pubescent : pedicels 1-3 cm. long: corolla brown-purple, oblong-conic in the bud, puberulent without ;
lobes linear-oblong, or linear-lanceolate, mostly obtuse, 12-15 mm. long: crown cup-shaped,
10-parted, the alternate divisions bifid, the others 10-parted, the alternate divisions bifid, the others shorter, rounded, mostly irregularly crested 
within : crests often broadly triangular, incurved over the anthers : pollinia broadly oblongelliptic ; corpuscle narrowly linear-elliptic: follicles muricate.

In thickets, District of Columbia and Virginia to Missouri, South Carolina, Louisiana and the Indian Territory. Flowers said to have a cimicine odor. Summer.

8. Vincetoxicum hirsùtum (Michx.) Britton. Stems puberulent and thinly hirsute : leaf-blades ovate, acuminate at the apex, deeply cordate at the base, 5-10 cm. long, 3-6 $\mathrm{cm}$. wide, the basal lobes rounded with open or in the larger specimens with closed sinus and overlapping lobes: peduncles commonly about the length of the petioles, rarely somewhat longer: umbels few- to several-flowered: corolla brown-purple to greenish yellow, ovoid, acute in the bud ; lobes oblong, obtuse or acutish, 7-10 mm. long, minutely puberulent within : crown cup-shaped, fleshy, as high as the anthers, the alternate bifid divisions thinner, mostly shorter than the thicker broad irregularly crested lobes, the crests variable, bifid or laciniate-toothed : pollinia oblong; corpuscle narrow at the base : follicles minutely puberulent as well as muricate.

In thickets, Maryland to Florida and Tennessee. Summer- $-A$ form ranging from South Carolina to Florida with a greenish yellow or dull straw-colored corolla, is V. hirsutum flavidulum (Chapm.) Vail. [Gonolobus flavidulus Chapm.]

9. Vincetoxicum Baldwiniànum (Sweet) Britton. Stem elimbing over bushes, puberulent and thinly hirsute : leaf-blades $6-14 \mathrm{~cm}$. long, broadly ovate, acute or acuminate at the apex, deeply and apparently somewhat obliquely cordate at the base, the sinus open or in the larger leaves the rounded basal lobes overlapping, puberulent : cymes manyflowered : peduncles $2-5 \mathrm{~cm}$. long: calyx-lobes linear-lanceolate, $2 \mathrm{~mm}$. long, glandular in the sinus: corolla white, long-conic in the bud; lobes thin, erect or barely spreading, linear-oblong, $9 \mathrm{~mm}$. long: crown 10 -lobed, the 5 broader lobes quadrate, emarginate or somewhat callous, 2-toothed, the outer margin with 2 or more minute accessory processes ; the alternate narrower lobes divided into a pair of very slender linear teeth that much surpass the anthers : stigma much depressed, obscurely 5-rayed : follicles $8 \mathrm{~cm}$. long, muricate, puberulent: seeds $9 \mathrm{~mm}$. long, thin, red-brown, the wing-like margin barely wrinkled, pale reddish : coma $2.5-3 \mathrm{~cm}$. long. Flowers said to have an offensive odor.

In thickets, Georgia and Alabama to Arkansas. Spring and summer.

10. Vincetoxicum Floridànum Vail. Stems puberulent throughout, very slender, hirsute with short scattered hairs: leaf-blades $2-5 \mathrm{~cm}$. long, ovate, tapering to the acuminate apex, cordate at the base with rounded lobes and open sinus, about equally puberulent on both surfaces, the midvein obscurely biglandulose at the base above : racemes about the length of the petioles : pedicels $1-2 \mathrm{~mm}$. long: calyx very small; lobes $2 \mathrm{~mm}$. long, linear-lanceolate, with a minute subulate gland in each sinus : corolla dull greenish or purplish ; lobes slightly longer than the tube, linear-lanceolate, acutish, 3-5 mm. long, somewhat fleshy, minutely puberulent on the outer surface, glabrous within : crown redpurple, saucer-shaped, with 5 broad undulations, each bidentate at the callous thickened apex and a smaller tooth on each side at about the middle: stigma depressed scarcely 5 -angled : pollinia oblong, the caudicles broad and apparently not twisted : follicles not seen.

In sandy soil, eastern Florida. Summer.

11. Vincetoxicum biflòrum (Raf.) Heller. Stems hirsute-villous, prostrate, several from a slender ligneous rootstock, simple or branched : leaf-blades $1.5-4.5 \mathrm{~cm}$. long, ovate or triangular-cordate, acute or acuminate, the basal lobes rounded, rather thin and coriaceous, glabrous above, sparingly villous beneath, the upper leaves much reduced in size : pedicels in pairs or sometimes solitary in the upper axils, nearly as long as the petioles: corolla rotate; lobes 6-8 $\mathrm{mm}$. long, linear-oblong, dull dark purple, sparsely pubescent on both surfaces and apparently granular-papillose within : crown saucer-shaped, 5-undulate, the sinuses 2-3-denticulate or nearly entire, each lobe traversed by a salient crest adnate to the base of the column, canaliculate on the lower edge, extending at the summit into a conspicuous fleshy truncate acumination, which incurves over the anthers: membranous anther-tips reflexed over the flat stigmatic disk : follicles muricate, hirsute : seeds not seen.

On stony and dry prairies, Arkansas and Texas. Spring.

12. Vincetoxicum cynanchoìdes (Engelm.) Vail. Stems pubescent and somewhat hirsute, reclining, slender, from a ligneous rootstock, branched near the base: leaf-blades 2.5-4 cm. long, ovate-lanceolate, subcordate or some of them round cordate, the basal lobes rounded, the upper leaves much reduced and often bract-like: inflorescence racemosely clustered at the summit of the nearly naked stem or a few pedicels in the lower axils: pedicels in pairs, 4-8 $\mathrm{mm}$. long: corolla rotate or nearly so ; lobes erect-spreading, $3 \mathrm{~mm}$. long and longer than the shallow tube, ovate-oblong, pubescent outside, glabrous within : crown saucer-shaped, 5-parted, the lobes fleshy, callous at the retusely truncate apex, the angles rounded, with a narrow ligulate closely adnate crest which is decurrent on the 
column and is free at the short canaliculate obtuse apex : anther-tips membranous, incurved over the anthers: pollinia oblong, truncate at the attachment of the caudicle: follicles 9 $\mathrm{em}$. long, $3 \mathrm{~cm}$. broad, narrowly oval, tapering each way, thick and coriaceous, pubescent, short-muricate : seeds $10 \mathrm{~mm}$. long, thick and coriaceous, red-brown, crenate at the apex : coma $3.5 \mathrm{~cm}$. long, rather coarse.

On dry prairies, Arkansas and Texas. Spring and summer.

13. Vincetoxicum pubiflòrum (Decne.) Vail. Stems from a slender perennial rootstock, branched at the base, the branches spreading or procumbent and diffuse, $2-4 \mathrm{dm}$. long, clothed with a short glandular pubescence and longer spreading hairs : leaf-blades broadly cordate or reniform, $2-4 \mathrm{~cm}$. long, acutish or apiculate or some of them acuminate, the basal lobes rounded : peduncles none or merely a terminal one by the reduction of the upper leaves to bracts : pedicels 2 or 3 in a faseicle : calyx-lobes acute, very small : corolla campanulate; lobes about as long as the tube, oblong-ovate, 4-5 mm long, dull purplish, acutish, minutely hirsute on both surfaces, reticulated within : crown shallow cup-shaper, with 10 rounded undulations, each alternate one with an adnate fleshy acute beak or horn terminating the adnate crest or rib within, with minute auricles at the base: stigmatic disk acutely angled: follicles $4 \mathrm{~cm}$. long, ovate, muricate, much wrinkled: seeds $4 \mathrm{~mm}$. long : mature fruit not seen.

In dry grounds or thickets, Georgia and Florida. Summer and fall.

14. Vincetoxicum prodúctum (Torr.) Vail. Stems minutely pubescent, low and twining, $4 \mathrm{dm}$. long or more : leaf-blades sagittate, cordate, $3-4.5 \mathrm{~cm}$. long, tapering to a long-acuminate apex, the basal lobes round, shorter than the $(7-10 \mathrm{~cm}$. long) petioles: peduncles axillary, as long as the petioles, 3-4-flowered : caly $\mathrm{x}$-lobes with a small gland a little below each sinus: corolla narrowly-campanulate, dull greenish purple, puberulous outside, nearly glabrous within; lobes about as long as the tube, linear or oblong, nearly erect: crown nearly equalling the anthers and stigma, entire or barely undulate, thin, inserted at the base of the short column and connected with it by 5 adnate crests which are free at the 2-toothed or entire apex and canaliculate on the inner side: anther-wings small, nearly acute : stigma obtusely 5-angled : pollinia obliquely ovoid, on broad-winged caudicles : follicles ovate, $3 \mathrm{~cm}$. long or more, minutely puberulous : follicles smooth.

On plains, Texas to Arizona and adjacent Mexico. Summer and fall.

15. Vincetoxicum parviflòrum (Torr.) Vail. Stems villous-hirsute, decumbent, diffuse, 1-2 dm. or $3 \mathrm{dm}$. long, branched, fascicled on a slender vertical perennial rootstock: leaf-blades ovate or orbicular-cordate, obtuse or acutish, 1-3 cm. long: peduncles $6-10 \mathrm{~cm}$. long, slender, terminal and lateral, somewhat racemosely several-flowered : flowers shortpedicelled: calyx-lobes lanceolate-elliptical : corolla rotate; lobes much longer than the tube, oblong, obtuse, $2.5 \mathrm{~mm}$. long, thick and fleshy with a whitish scarious margin, papillose within : crown of 5 separate bidentate erect whitish fleshy lobes, which exceed the anthers, each with an erect, slightly incurved, linear, flat, obtuse or acutish process, arising from near the base of the segment and commonly surpassing it : stigmatic disk flat or slightly depressed : pollinia obliquely ovoid-obovate; caudicles broad with 1 or 2 winglike appendages : follicles $3-4 \mathrm{~cm}$. long, or more, ovate, tapering and obtuse at the apex, obtuse at the base, pubescent, tuberculate and coarsely muricate : seeds $5 \mathrm{~mm}$. long, roundoblong, erenate at the apex, thin : coma $1 \mathrm{~cm}$. long.

In rocky soil, southern Texas. Summer.

16. Vincetoxicum brevicoronàtum (Robinson) Vail. Stems villous-hirsute, diffuse, ascending, 1-3 dm. long: leaf-blades sessile or short-petioled, ovate or ovateorbicular, 1-2.5 cm. long, 1-1.5 cm. wide, cordate at the base, acute or acuminate at the apex, glabrous or puberulent above, wrinkled or undulate on the margins, villous-hirsute and the midrib and veins whitish beneath : flowers short-pedicelled, $3-8$ at the apex of the slender $2-7 \mathrm{~cm}$. long axillary peduncle, minutely bracteolate : calyx-lobes oblong-lanceolate, acutish : corolla 2-3 mm. long, dark dull purplish; lobes erect, rather thick and fleshy, narrowly lanceolate, with white margins : crown of 5 short, thick, whitish rather fleshy truncate lobes not exceeding the stigma, each with an erect slender once or twice longer internal horn or process: anther wings very small, corneous : stigma a little depressed : pollinia subglobose : corpuscle linear-oblong, nearly as long as the pollinia : follicles about $4 \mathrm{~cm}$. long, coarsely muricate : seeds not seen.

On sandy plains, Texas. Summer.

\section{Order 7. POLEMONIÀLES.}

Herbs, or sometimes shrubs or trees, the plants of some families parasitic. Leaves with dilated blades, or scale-like. Flowers mainly perfect, variously 
disposed. Calyx of partially united sepals. Corolla gamopetalous, regular or irregular. Androecium of as many stamens as there are corolla-lobes, or fewer, sometimes partially represented by staminodia, sometimes partially obsolete. Gynoecium of 2 distinct or several united carpels. Fruit a capsule, berry, drupe or a group of nuts, or utricle-like.

Stamens 5.

Gynoecium of 2 distinct carpels.

Gynoecium of 2 or more partially or wholly united carpels.

Fruit capsular or baccate : ovary not 4-lobed. Styles or stigmas distinct.

Ovary 1-2-celled, or rarely 4-celled: stigmas 2.

Ovary 2-celled or 4-celled.

Corolla unappendaged within: plants with normal leaves, at least if vines.

Corolla appendaged within: parasitic twining plants with scale-like leaves.

Ovary 1-celled (2-celled in Nama).

Ovary 3-celled : stigmas 3.

Caly x-lobes imbricated : corolla mostly plaited in the bud.

Calyx-lobes valvate: corolla merely convolute in the bud.

Styles or stigmas wholly united.

Median axis of the gynoecium in the same axis as the stem: seeds mostly pitted.

Median axis of the gynoecium not in the axis of the stem : seeds mostly tuberculate.

Fruit drupaceous, or of 2 or 4 nutlets.

Style or stigmas not furnished with a glandular ring.

Fruit a group of 2 or 4 nutlets : style arising from between the lobes of the ovary.

Fruit drupaceous : style terminating the lobeless ovary.

Style or stigmas furnished with a glandular ring.

Stamens 4 and didynamous, or 1 or 2 .

Carpels ripening into a group of 4 nutlets, an achene or a drupe.

Style apical on the lobeless ovary.

Ovary 2-celled.

Ovary 1-celled.

Style arising between the 4 lobes of the ovary.

Carpels ripening into a capsule.

Placentae of the ovary axile.

Ovary 2-celled, or rarely 3-5-celled.

Corolla-lobes imbricated : capsule not elastically dehiscent.

Corolla-lobes convolute: capsules elastically dehiscent.

Ovary 1-celled.

Placentae of the ovary parietal.

Herbs parasitic on the roots of other plants : leaves scale-like: foliage not green.

Trees, shrubs or woody vines, or herbs, but not parasitic: leaves not scale-like: foliage green.

Ovary and capsule 2-celled: trees, shrubs or woody vines : seeds winged.

Ovary and capsule 1-celled : herbs: seeds wingless.

Fam. 1. Dichoniraceae.

Fam. 2. Convolvulaceae.

Fam. 3. Cuscutaceae.

Fam. 4. HYDROLEACEAE.

Fam. 2. Convolvulaceae.

Fam. 5. Polemoniaceae.

Fam. 6. SolanaceaE.

Fam. 13. Rhinanthaceat.

Fam. 7. Borraginaceae.

Fam. 8. EHRETIACEAE.

Fam. 9. Heliotropiaceae.

Fam. 10. Verbenaceae.

Fam. 11. Phrymaceae.

Fam. 12. LAMIACEAE.

Fam. 13. RHiNanthaceaE.

Fam. 14. ACANTHACEAE.

Fam. 15. Pinguiculacea F.

Fam. 16. OROBANCHACEAE.

Fam. 17. BignONIACEAE.

Fam. 18. MartyniaceaE.

\section{Family 1. DIChONDRÀCEAE Dumort. Dichondra Family.}

Annual or perennial herbs, with creeping stems. Leaves alternate; blades about as broad as long or broader, entire. Flowers solitary in the axils, commonly pedicelled. Calyx of 5 distinct or nearly distinct sepals, sometimes slightly broadened upward. Corolla rotate or campanulate, 5-lobed, the lobes induplicate in the bud. Androecium of stamens 5, shorter than the corolla. Filaments filiform or subulate. Gynoecium of 2 distinct carpels, pubescent. Styles 2, distinct, basal. Stigmas capitate. Capsules 2 together, utricle-like, indehiscent. Seeds usually solitary or two, with a smooth testa.

\section{DICHÓNDRA Forst.}

Characters of the family.

1. Dichondra Carolinénsis Michx. ${ }^{1}$ Perennial, softly pubescent. Stems creeping, 1-4 dm. long, often branching: leaf-blades reniform or suborbicular, $5-20 \mathrm{~mm}$. broad, rounded or retuse at the apex, entire, cordate; petioles much longer than the blades: pedicels shorter than the petioles : calyx silky; lobes cuneate or cuneate-ohovate,

${ }^{1}$ Another species, similar in habit, D. argentea Willd., common westward, with silvery silky-pubescent foliage and villous corolla-lobes, many occur in the western part of our range. 
2-3 mm. long, obtuse : corolla greenish white, $5-6 \mathrm{~mm}$. broad : capsules 2-2.5 $\mathrm{mm}$. high, utricle-like.

In low grounds, Virginia to Florida and Texas. Also widely distributed in tropical America and the old World. Spring to fall.

\section{Family 2. CONVOLVULÀCEAE Vent. Morning-Glory Family.}

Annual or perennial herbs or vines, or rarely shrubs or trees. Leaves alternate, without stipules: blades various. Flowers perfect, regular, sometimes solitary, often in cymes. Calyx of 5 more or less united sepals; these imbricated, persistent, equal or unequal, in one or two series. Corolla superior, convolute in aestivation, its limb often entire, after flowering often involute. Androecium of 5 stamens partially adnate to the corolla-tube, alternate with the lobes. Filaments often of the same length, commonly enlarged at the base and pubescent. Anthers 2-celled, erect or incumbent. Gynoecium free, of 2 united carpels. Ovary 2-5-celled, seated in a fleshy disk. Styles often united. Stigma simple, acute or capitate, sometimes 2-lobed. Ovules erect, solitary or two in each cavity. Fruit a 2-4-celled or 5-celled capsule (or by breaking down of the septum 1-celled). Seeds large, usually fewer than the ovules, with a membranous or coriaceous testa, often villous. Endosperm mucilaginous. Embryo curved, with foliaceous usually crumpled or plaited cotyledons.

Styles distinct or partly so.

Styles nearly distinet or partially united, entire.

Corolla plaited: stamens included: vines.

Corolla not plaited : stamens exserted : erect herbs.

Styles distinet, each 2-cleft.

Styles united to the stigma.

Stigmas ovoid or subglobose.

Corolla salverform: stamens and style exserted.

Corolla-tube slender-cylindric : limb very broad.

Corolla-tube narrowly funnelform: limb narrow.

Corolla funnelform or campanulate: stamens and style included.

Stigma subglobose.

Sepals blunt to acuminate : ovary 2 or 4-celled : capsule 4-seeded.

Sepals with long tips: ovary 3 or 5 -celled : capsules 6 or 10-seeded.

Stigmas somewhat flattened.

Stigmas filiform or oblong-cylindric.

1. BREWERIA.

2. Cressa.

3. Evolvulus.

4. CALONYCTION.

5. QUAMOCLIT.

6. IPOMOEA.

7. PHARBITIS.

8. JACQUEMONTIA.

9. Convolvulus.

\section{BREWERIA R. Br.}

Perennial herbs, with prostrate or twining stems. Leaves alternate : blades very narrow or broad, entire. Flowers 1-5, terminating axillary peduncles. Calyx often pubescent : sepals 5 , slightly united at the base. Corolla white, pink, purple or yellow, campanulate or funnelform-campanulate: limb plaited, 5-angled or slightly 5-lobed. Stamens 5, included : filaments filiform or dilated at the base. Ovary 2-celled. Styles wholly or partially united. Stigmas capitate. Capsule 2-celled, seated in the calyx, 2-4-valved. Seeds $1-4$, sometimes pubescent. The plants flower from spring to fall.

Sepals fully $2 \mathrm{~cm}$. long : capsules over $10 \mathrm{~mm}$. long.

1. B. grandiflora.

Sepals less than $1 \mathrm{~cm}$. long: capsules less than $10 \mathrm{~mm}$. long.

Sepals glabrous or nearly so, sometimes ciliate.

Leaf-blades narrowly linear.

Leaf-blades oblong.

Sepals densely pubescent.

Filaments pubescent.

Foliage sparingly pubescent: mature peduncles $1-3 \mathrm{~cm}$. long: corollas

Foliage densely brown-tomentose : mature peduncles $4-6 \mathrm{~cm}$. iong : corollas about $2 \mathrm{~cm}$. long.

Filaments glabrous or nearly so.

Leaf-blades oblong to narrowly lanceolate.

Leaf-blades narrowly linear, or slightly broadest above the middle.

2. B. angustifolia.

3. B. humistrata.

4. B. trichosanthes.

5. B. villosa.

6. B. aquatica.

7. B. Pickeringii.

1. Breweria grandiflòra A. Gray. Foliage softly pubescent. Stems trailing, 0.5-3 in. long, simple or branching : leaf-blades leathery, oblong, ovate or oval, $2.5-5 \mathrm{~cm}$. long, usually apiculate, entire, rounded or cordate at the base; petioles 1-5 mm. long: pedicels about $\frac{1}{2}$ as long as the peduncles : bracts linear or oblong : sepals lanceolate, oblong or ovate-lanceolate, acute, $2-2.5 \mathrm{~cm}$. long : corolla light blue, $6-7 \mathrm{~cm}$. long, $7-10 \mathrm{~cm}$. broad : capsules ovoid or globose-ovoid, 1.2-1.5 cm. long, 4-seeded.

In sandy soil, peninsular Florida. 
2. Breweria angustifòlia Nash. Foliage more or less densely pubescent. Stems much branched at the base, the branches trailing or reclining, 6-10 dm. long, sparingly branched above : leaf-blades narrowly linear, $2.5-7 \mathrm{~cm}$. long, often glabrate, acute, entire, sessile or short-petioled : peduncles slender, about as long as the blades or shorter: sepals glabrous or nearly so, oblong-lanceolate to elliptic, 7-10 mm. long, ciliate, acute to acuminate, with more or less spreading tips : corolla white, about $2 \mathrm{~cm}$. broad: capsules oval or oblong-oval, 6-8 $\mathrm{mm}$. long, bearded at the apex.

In dry soil, peninsular Florida.

3. Breweria humistràta (Walt.) A. Gray. Foliage villous-hirsute, or glabrate. Stems often branching at the base ; branches trailing or climbing, 3-15 dm. long, sometimes sparingly branched : leaf-blades oblong or nearly so, 2-7 cm. long, apiculate, entire, truncate or cordate at the base; petioles $2-8 \mathrm{~mm}$. long: peduncles very slender, $3-8 \mathrm{~cm}$. long: sepals glabrous or nearly so, oblong or oblong-lanceolate, $5-7 \mathrm{~mm}$. long, acute or acuminate : corolla white or pinkish, fully $2 \mathrm{~cm}$. broad : capsules $4-5 \mathrm{~mm}$. long.

In sandy soil, Virginia to Florida and Louisiana.

4. Breweria trichosánthes (Michx.) Small. Foliage finely pubescent. Stems branched at the base ; branches prostrate or reclining, slender : leaf-blades oblong-linear, $1-4 \mathrm{~cm}$. long, apiculate or mucronate, entire, often somewhat viscid, narrowed into short petioles : peduncles as long as the leaves or longer: sepals strigillose, glabrate, oblong or nearly so, 6-8 mm. long, more or less acuminate : corolla white, $1.5-2 \mathrm{~cm}$. broad : capsules about $5 \mathrm{~mm}$. long, bearded at the apex. [Convolvulus trichosanthes Michx.]

In sandy soil, North Carolina to Florida and Alabama.

5. Breweria villòsa Nash. Foliage villous-tomentulose. Stems usually branched at the base ; branches trailing, 3-14 dm. long, branched : leaf-blades oblong or linear, 2.5-7 cm. long, apiculate, entire, rather abruptly narrowed or subcordate at the base; petioles $2-8 \mathrm{~mm}$. long: peduncles as long as the leaves or surpassing them : sepals villous-tomentulose, oblong to ovate-lanceolate, $8-11 \mathrm{~mm}$. long, acuminate : corolla white, $2.5-3 \mathrm{~cm}$. broad : capsules ovoid or globose-ovoid, 6-7 mm. long, closely pubescent.

In dry sand, peninsular Florida.

6. Breweria aquática (Walt.) A. Gray. Foliage softly pubescent, or tomentulose. Stems branched at the base ; branches trailing or rarely climbing, 5-12 dm. long, commonly branched : leaf-blades oblong to narrowly lanceolate, $1-2.5 \mathrm{~cm}$. long, apiculate, entire, prominently nerved beneath, obtuse or cordate at the base : peduncles as long as the leaves or longer: sepals silky-tomentose, acuminate, $5-6 \mathrm{~mm}$. long: corolla rose-purple, fully $1.5 \mathrm{~cm}$. broad : filaments glabrous : capsules $8-9 \mathrm{~mm}$. long, pubescent, at least near the top.

In pine lands, Virginia to Florida and Texas.

7. Breweria Pickeríngii (M. A. Curtis) A. Gray. Foliage more or less densely pubescent. Stems commonly branched at the base; branches prostrate or reclining, with many short spreading branchlets : leaf-blades linear-spatulate to narrowly linear, 2-6 cm. long, acute, entire, narrowed into short petioles or nearly sessile : peduncles shorter than the leaves or longer: bracts linear, surpassing the calyxes : sepals lanuginose, oval or elliptic-oval, 4-5 mm. long: corolla white, $1-1.5 \mathrm{~cm}$. broad : capsules ovoid-conic, 6-8 mm. long, pubescent.

In pine lands, New Jersey and Illinois, south to Florida and Texas.

\section{CRÉSSA L.}

Perennial shrubby plants, with sparingly or diffusely branched stems. Leaves alternate: blades small or reduced to scales. Flowers solitary in the upper axils. Calyx sessile or short-pedicelled : sepals nearly equal and distinct, imbricated, unchanged at maturity. Corolla funnelform, persistent: lobes 5, about as long as the tube. Stamens 5 , exserted : filaments filiform. Ovary more or less perfectly 2-celled. Styles distinct. Ovules 2 in each cavity. Capsules little longer than thick, 2-4-valved. Seeds smooth and shining, often solitary.

Leaves not scale-like, numerous : filaments glabrous : corolla-lobes lanceolate. Leaves reduced to a few scales : filaments pubescent below: corolla-lobes ovate.

1. C. Truxillensis.

2. C. aphylla.

1. Cressa Truxillénsis H.B.K. Foliage silky. Stems much branched at the base; branches copiously leafy, spreading or prostrate, $5-25 \mathrm{~cm}$. long : leaves numerous ; blades elliptic, oblong or elliptic-lanceolate, 3-9 $\mathrm{mm}$. long, acute, entire, sessile or nearly so : pedicels much shorter than the leaves : sepals longer than the pedicels, oblong to oval or slightly broadest above the middle, $4-5 \mathrm{~mm}$. long, obtuse : corolla white; tube about as 
long as the calyx ; lobes narrow, lanceolate, curling back, about as long as the tube: filaments glabrous.

In saline soil, Texas to southern California and tropical America. Spring and summer.

2. Cressa aphýlla Heller. Foliage cinereous. Stems erect, 1-2 dm. tall, destitute of typical leaves, branched from near the base and throughout: leaves reduced to small scales : pedicels about $1 \mathrm{~mm}$. long: bracts barely $\frac{1}{2}$ as long as the calyxes, lanceolate to ovate-lanceolate : sepals closely pubescent, oblong-lanceolate or elliptic, 3-4 mm. long, acute or slightly acuminate: corolla yellowish white; tube as long as the calyx; lobes ovate, shorter than the tube: filaments pubescent below the middle.

In dry or sandy soil, Texas. Spring.

\section{EvóLvulus L.}

Annual or perennial caulescent herbs, with shaggy or appressed pubescence. Leaves alternate : blades entire. Flowers solitary in the axils, or in terminal racemes or panicles. Calyx usually pedicelled: sepals 5, nearly equal. Corolla white, pink or blue, funnelform, campanulate or rotate: limb plaited, 5-angled or 5-lobed. Stamens 5: filaments filiform. Ovary 2-celled, globular. Styles distinct, each 2-cleft. Stigmas slender. Ovules few. Capsules but little longer than broad, 2-4-valved. Seeds 1-4, glabrous. The plants flower from spring to fall.

Peduncles as long as the leaves or longer.

Leaf-blades glabrous or nearly so at maturity.

Leaf-blades copiously pubescent.

Peduncles wanting or very short: pedicels shorter than the leaves.

Leaf-blades glabrous above.

Leaf-blades copiously pubescent on both sides.

Pubescence silky : sepals acute, erect or nearly so.

Pubescence shaggy: sepals acuminate, the tips spreading.

1. E. mucronatus.

2. E. alsinoides.

3. E. sericeus.

4. E. mollis.

5. E. pilosus.

1. Evolvulus mucronàtus Sw. Silky when young, soon glabrate. Stems branched at the base; branches spreading or prostrate, 1-4 dm. long, very slender : leaf-blades oblong to obovate, $1-1.5 \mathrm{~cm}$. long, mucronate, entire, narrowed into short petioles : peduncles as long as the leaves or longer: pedicels shorter and stouter than the peduncles: sepals glabrate, $3-4.5 \mathrm{~mm}$. long, oblong to oblong-ovate, acute : corolla rotate, about $1 \mathrm{~cm}$. broad: capsules subglobose, $2-2.5 \mathrm{~mm}$. in diameter.

In sandy soil, Florida and the West Indies.

2. Evolvulus alsinoides L. Strigillose and more or less densely villous-hirsute. Stems branched at the base ; branches decumbent or prostrate, 1-6 dm. long, slender : leaf-blades oblong-oval or oblong-lanceolate, 6-25 mm. long, acute, entire, narrowed into short petioles : peduncles as long as the leaves or longer : pedicels recurved or refracted : sepals 2-4 mm. long, ovate or oblong-lanceolete, acute : corolla rotate, 8-12 mm. broad: capsules subglobose, 3-4 mm. in diameter.

In sandy soil, Florida to Texas.

3. Evolvulus seríceus Sw. Silky. Stems branched at the base ; branches ascending or decumbent, 1-3 dm. long, slender, commonly zigzag : leaf-blades linear to oblong, $1-2.5 \mathrm{~cm}$. long, acute at the ends, glabrous above, sessile: pedicels shorter than the calyxes, slightly thickened upward : sepals silky, 4-6 mm. long, oblong to broadly elliptic, acute to acuminate : corolla white or blue, rotate, $8-10 \mathrm{~mm}$. broad : capsules subglobose, $3-4 \mathrm{~mm}$. in diameter.

In low grounds, Georgia and Florida to Texas and Arizona. Throughout tropical America.

4. Evolvulus móllis Small. Silky. Stems branched at the base; branches ascending or decumbent, 5-20 cm. long, slender : leaf-blades linear to linear-oblong or linearlanceolate, $1-2.5 \mathrm{~cm}$. long, acute, sometimes scythe-shaped, entire, sessile or nearly so : pedicels shorter than the calyxes: sepals more or less densely lanuginose, 4-6 mm. long oblong or lanceolate, 4-5 mm. long, narrowly acute, erect or nearly so : corolla bluish, 10$14 \mathrm{~mm}$. broad : capsules globose-ovoid, 4-5 mm. in diameter.

In dry soil, Texas.

5. Evolvulus pilòsus Nutt. Densely silky-hirsute, silvery, becoming tawny or ferruginous. Stems much branched at the base; branches ascending or spreading, $15-25 \mathrm{~cm}$. long, stout: leaf-blades oblong or broadest above the middle or below it, 1-1.5 cm. long, acute, densely pubescent on both sides, sessile or short-petioled : pedicels curved, shorter long, long-acuminate, the tips widely spreading: corolla about $1 \mathrm{~cm}$. broad : capsules about
$3 \mathrm{~mm}$. long. [E. argenteus Pursh.]

In dry soil, Kansas to Colorado, south to Texas, Arizona and Mexico. Also on Key West, Florida. 


\section{CALONÝCtron Choisy.}

Perennial twining vines, often with a milky sap. Leaves alternate: blades broad. Flowers fragrant. Calyx pedicelled: sepals 5, herbaceous, becoming leathery, the outer sometimes horned at the apex. Corolla white, expanding in the evening, salverform : tube elongated, not dilated at the throat : limb ample, contorted. Stamens 5. Ovary 2-4celled. Styles united to the capitate-didymous stigma. Ovules 4, 2 in 2 cavities, or solitary in four cavities. Capsule longer than broad.

1. Calonyction Bòna-nóx (L.) Small. Foliage glabrous. Stems extensively twining, 3-25 m. long, with a milk-like sap : leaf-blades ovate or suborbicular, 5-15 cm. long, entire or hastately 3-5-lobed, acuminate, cordate ; petioles as long as the blades or longer : peduncles stout, 1-7-flowered : sepals appressed to the corolla-tube, about $1 \mathrm{~cm}$. long, oblong or ovate-oblong, the outer ones with inf raterminal tail-like or horn-like appendages : corolla salverform ; tube slender, 10-12 cm. long; limb 10-13 cm. broad, the externally green ribs ending in short cusps : capsules ovoid or oblong-ovoid, $2 \mathrm{~cm}$. long, acute : seeds glabrous or nearly so. [Ipomoea Bona-nox L.] fall.

In swamps and thickets, peninsular Florida and the Keys. Throughout the tropies. Spring to

\section{QUÁMOCLIT Moench.}

Annual or perennial twining vines, with often glabrous foliage. Leaves alternate : blades entire, lobed or pinnately parted. Flowers in axillary cymes, or solitary. Sepals 5 , membranous or herbaceous, equal or nearly so. Corolla often scarlet, salverform, expanding during the daytime : tube narrowly funnelform: limb spreading, shorter than the tube, 5-lobed. Stamens 5, exserted : filaments filiform. Ovary 2-celled or falsely 4-celled. Styles united. Stigma capitate. Ovules 4. Capsules subglobose or somewhat elongated, usually 4-celled. Seeds 4. Our species annual. The plants bloom in the summer and fall. Leaf-blades pinnately parted into narrow segments : sepals obtuse or mucronate. Leaf-blades entire: sepals acuminate.

1. Q. Quamoclit.

1. Quamoclit Quámoclit (L.) Britton. Stems twining, several m. long: leafblades 2-10 cm. long, pinnately-parted; segments narrowly linear: peduncles 1-3-flowered: pedicels club-shaped: sepals appressed to the corolla-tube, oblong, $3-5 \mathrm{~mm}$. long, obtuse or mucronate, without appendages : corolla scarlet-red ; tube club-shaped, $2.5-3 \mathrm{~cm}$. long ; lobes ovate or triangular : capsules ovoid, 8-10 $\mathrm{mm}$. long. [Ipomoea Quamoclit L.]

In waste places and cultivated grounds, Virginia to Kansas, Florida, Texas and tropical America, whence naturalized. CYPRESS VINE.

2. Quamoclit coccínea (L.) Moench. Stems climbing, several m. long, branching: leaf-blades ovate, $3-10 \mathrm{~cm}$. long, acuminate, entire, cordate; petioles as long as the blades, or shorter: peduncles 2-several-flowered, commonly stouter than the pedicels : sepals appressed to the tips, oblong, with infraterminal appendages, outer as broad as long: corolla scarlet or orange-tinged ; tube $2-4 \mathrm{~cm}$. long ; limb cup-like, $1.5-2 \mathrm{~cm}$. broad : capsules subglobose, 7-8 mm. in diameter : seeds nearly glabrous. [Ipomoea coccinea $\mathrm{L}$.]

On banks and in thickets, Pennsylvania to Missouri, Florida, Arizona and tropical America. Naturalized eastward. RED MORNING-GLORY.

\section{IPOMOÈA L.}

Annual or perennial climbing or trailing vines, or rarely upright plants. Leaves alternate: blades entire, angled or lobed. Flowers solitary on axillary peduncles, or in cymes. Sepals 5, membranous or rather fleshy sometimes becoming leathery, closely imbricated, not elongated. Corolla white, pink, blue, purple or crimson, funnelform : limb usually spreading. Stamens 5, included. Ovary 2- or 4-celled, the cavities more or less completely divided between the ovules. Styles united. Capsule mostly septifragally 2 or 4-valved. Seeds often pubescent. The plants flower mainly in the summer, or throughout the year in the south. MorNING-GLORY.

A. Stems prostrate and creeping or climbing.

Stems creeping.

Corolla-limb white : leaf-blades oblong to ovate in outline, mainly lobed.

Corolla-limb purple : leaf-blades suborbicular or broader than long, notehed at the apex.

Stems twining or rarely trailing but never creeping.

1. I. littoralis.

2. I. Pes-Caprat.

a. Leaf-blades entire or 3-lobed.

Sepals obtuse or mucronate. 61

Leaf-blades never sagittate : inner sepals over $1 \mathrm{~cm}$. long. 
Leaf-blades cordate at the base, of an ovate type. Sepals pubescent: seeds with long wool all over. Sepals glabrous: seeds with long wool on the angles.

Leaf-blades acute or truncate at the base, of a lanceolate type. Leaf-blades sagittate: inner sepals less than $1 \mathrm{~cm}$. long.

Sepals acute or acuminate.

Perennial: calyx glabrous.

Annual: calyx pubescent, at least sepals ciliate,

Corolla $3 \mathrm{~cm}$. long or longer.

Corolla less than $3 \mathrm{~cm}$. Iong.

Peduncles shorter than the petioles: corolla-tube white.

Peduncles longer than the petioles: corolla-tube purple.

b. Leaf-blades palmately 7-parted.

Terminal leaf-segment entire: sepals becoming $2.5-3 \mathrm{~cm}$. long, longer than the capsule.

Terminal leaf-segment pinnatifid : sepals becoming 4-8 $\mathrm{mm}$. long, shorter than the capsule.

B. Stems erect or diffusely spreading, sometimes shrubby.

Annual plants: leaf-blades pedately parted : corolla less than $2 \mathrm{~cm}$. long.

Perennial plants : leaf-blades entire : corolla fully $4 \mathrm{~cm}$. long.

Leaf-blades ovate : corolla puberulent without : seeds shaggy-pubescent.

Leaf-blades linear: corolla glabrous without : seeds finely pubescent.

3. I. Jalapa.

4. I. pandurata.

5. I. longifolia.

6. I. speciosa.

7. I. trifida.

8. I. Caroliniana.

9. I. lacunosa.

10. I. triloba.

\section{I. cairica.}

12. I. dissecta.

13. I. costellata.

14. I. fistulosa.

15. I. leptophylla.

1. Ipomoea littoràlis (L.) Boiss. Perennial, glabrous, fleshy. Stems prostrate, creeping, several $\mathrm{m}$. long, branching : leaf-blades $2-5 \mathrm{~cm}$. long, the early ones ovate to oblong, the later fiddle-shaped or more deeply lobed, more or less deeply notched at the apex, mostly truncate or cordate at the base: sepals glabrous, oblong or oval, 1-1.5 cm. long, mucronate or acuminate : corolla white, with a yellow throat; tube funnelform ; limb 4-7 $\mathrm{cm}$, broad : capsules subglobose, $1.5 \mathrm{~cm}$. in diameter : seeds woolly. [Convolvulus littoralis L. Ipomoea acetosaefolia R. \& S.]

On sandy beaches, South Carolina to Florida and Texas.

2. Ipomoea Pès-Cáprae (L.) Sweet. Perennial, glabrous, succulent. Stems prostrate, creeping, several $\mathrm{m}$. long, branching: leaf-blades suborbicular, 6-10 cm. broad, usually notched at the apex, rounded or cordate at the base; petioles as long as the blades or shorter: peduncle stout, 1-several-flowered : pedicels more slender than the peduncles : sepals glabrous, oval or suborbicular, about $1 \mathrm{~cm}$. long, obtuse : corolla purple, 4-5 cm. long ; tube broadly funnelform; limb undulately-lobed, $5-8 \mathrm{~cm}$. broad : capsules broadly ovoid or globose-ovoid, $1.5 \mathrm{~cm}$. high : seeds pubescent.

On sandy beaches, Georgia and Florida to Texas. In all tropies.

3. Ipomoea Jalápa (L.) Pursh. Perennial, finely pubescent. Stems trailing or twining, several $\mathrm{m}$. long, branching: leaf-blades broad-ovate, $6-15 \mathrm{~cm}$. long, acuminate, erose-crenulate, truncate or subcordate at the base; petioles nearly as long as the blades or shorter : peduncles longer than the petioles : sepals minutely pubescent, oblong or oblonglanceolate, $1.5-2 \mathrm{~cm}$. long: corolla white or pink-purple ; tube $5-8 \mathrm{~cm}$. long, funnelform ; limb 5-10 cm. broad : capsules ovoid, $1.5 \mathrm{~cm}$. long: seeds with long silky-villous wool.

In sandy soil, on or near the coast, South Carolina to Florida. Also in tropical America.

4. Ipomoea panduràta L. Perennial by a huge root, the foliage glabrous or glabrate, deep green. Stems trailing or twining, 1-4 m. long, commonly branched : leaf-blades ovate, often fiddle-shaped, 3-10 cm. long, acuminate, acute or obtuse, undulate, cordate, on slender petioles which are $\frac{1}{2}$ as long as or as long as the blades : peduncles solitary or 2 together, 5-10 cm. long, 1-5-flowered; pedicels subtended by ovate bracts : sepals ovate or oblong, 12-18 mm. long, more or less colored, obtuse, slightly mucronate, imbricated, erect and forming a tube: corolla white or pinkish, $7-10 \mathrm{~cm}$. broad, its tube swollen about the middle, lavender within, its spreading limb with 5 shallow lobes, each lobe impressed with a linear-lanceolate rib which ends in a broad mucro; filaments shorter than and adnate to the corolla-tube for about $1 \mathrm{~cm}$. from the base, villous at the junction : anthers $6-7 \mathrm{~mm}$. long.

In dry soil, Ontario to Michigan, Connecticut, Florida and Texas.

5. Ipomoea longifollia Benth. Perennial, the foliage glabrous or nearly so. Stems trailing, several $\mathrm{dm}$. long, much branched : leaves alternate; blades lanceolate or oblonglanceolate, 3-7 cm. long, mucronate, entire, acute or truncate at the base, slender-petioled: peduncles 1-3 cm. long, simple or branched: pedicels usually shorter than the peduncle : sepals ovate or oblong-ovate, $10-12 \mathrm{~mm}$. long, rounded at the apex and sometimes mucrenulate, the inner somewhat longer than the outer : corolla $5-7.5 \mathrm{~cm}$. long, nearly as broad : filaments densely pubescent at the base.

On plains and prairies, Oklahoma to Texas and Arizona. Summer.

6. Ipomoea speciòsa Walt. Perennial, glabrous. Stems twining, several m. long, branching, relatively slender : leaf-blades $3-10 \mathrm{~cm}$. long, sagittate or hastate-sagittate, the 
segments linear or lanceolate, the lateral about $\frac{1}{2}$ as long as the terminal one ; petioles about as long as the basal lobes: peduncles usually 1-flowered: sepals glabrous, oblong to suborbicular, 6-9 $\mathrm{mm}$. long, obtuse or cuspidate : corolla purple, 5-6 cm. long ; tube funnelform ; limb $6-7 \mathrm{~cm}$. broad : capsules ovoid, 1-1.5 cm. long : seeds villous. [I. sagittata Cav.]

In sandy soil, North Carolina to Florida and Texas. Spring to fall.

7. Ipomoea trífida (H.B.K.) G. Don. Perennial, pubescent, or glabrate. Stems twining or trailing, 4-20 dm. long: leaf-blades $2-6 \mathrm{~cm}$. long, acuminate, the lower ones often entire, upper 3-lobed, all cordate; petioles as long as the blades or shorter: peduncles 3-10-flowered : sepals glabrous, 10-12 mm. long, oblong to lanceolate or ovate-lanceolate, acuminate : corolla pink or lilac-purple, $2.5-3 \mathrm{~cm}$. long; tube funnelform; limb 3-4 cm. broad : capsules subglobose, 7-9 $\mathrm{mm}$. in diameter, more or less pubescent near the top : seeds smooth and glabrous.

In valleys and light soil, Texas to Mexico and tropical America.

8. Ipomoea Caroliniàna Pursh. Annual, hirsute or glabrate. Stems trailing or twining, 1-several m. long, often branching: leaf-blades ovate in outline, entire or deeply 3 -lobed, cordate, the lobes acuminate or rarely obtuse ; petioles longer than the blades or shorter: peduncles stout, 1-3-flowered : sepals hirsute, oblong or oblong-lanceolate, 9-12 $\mathrm{mm}$. long, acute or acuminate : corolla pink or purple, $2.5-4 \mathrm{~cm}$. long; tube often whitish ; limb 4-6 cm. broad : capsules subglobose, 7-8 $\mathrm{mm}$. in diameter, more or less pubescent : seeds glabrous. [I. commutata R. \& S.]

In sandy soil, South Carolina to Florida and Texas.

9. Ipomoea lacunòsa L. Annual, sparingly hirsute, or glabrate. Stems twining, 5-25 dm. long, branching, rather slender: leaf-blades ovate, entire or 4-lobed, 2-7 cm. long, deeply cordate; petioles shorter than the blades: peduncles usually 1-3-flowered: sepals nearly glabrous, oblong or ovate, $10-12 \mathrm{~mm}$. long, acute or acuminate, ciliate : corolla 1.5-2 cm. long; tube white, funnelform; limb often purple-margined, 1-1.5 cm. broad : capsules subglobose, over $1 \mathrm{~cm}$. in diameter, pilose : seeds glabrous.

In fields and low grounds, Pennsylvania to Kansas, South Carolina and Texas.

10. Ipomoea tríloba L. Annual, more or less hirsute, or glabrate. Stems twining, often high-climbing, branching : leaf-blades ovate, 4-10 cm. long, entire or hastately 3lobed, acuminate, glabrate ; petioles shorter than the blades : peduncles commonly surpassing the leaves: sepals pubescent, oblong or suborbicular, 8-10 $\mathrm{mm}$. long, acute or acuminate : corolla purple, $1.5 \mathrm{~cm}$. long ; limb 1-1.5 $\mathrm{cm}$. broad : capsules subglobose, 6 $8 \mathrm{~mm}$. in diameter, often pubescent : seeds glabrous or nearly so.

In sandy soil, peninsular Florida.

11. Ipomoea cairìca (L.) House. Perennial, glabrous or nearly so, bright green. Stem twining, more or less branched: leaf-blades suborbicular, 4-9 cm. in diameter, 5-7parted ; segments mainly elliptic-lanceolate, acute or acuminate, entire or the lower pair lobed at the base; petioles mostly shorter than the blades, glabrous : sepals glabrous, 4-8 $\mathrm{mm}$. long, obtuse : corolla purplish, funnelform ; tube 3-4 cm. long ; limb 5-6.5 cm. broad : capsules ovoid, 10-12 mm. long : seeds granular, finely pubescent. [I. palmata Forsk.]

In waste places, Pensacola, Florida. Native of northern Africa.

12. Ipomoea dissécta (Jacq.) Pursh. Perennial, villous-hirsute, or glabrate. Stems twining, branching : leaf-blades suborbicular, $3-10 \mathrm{~cm}$. in diameter, 5-7-parted ; segments oval to oblong or lanceolate, coarsely toothed or pinnatifid; petioles as long as the blades or longer, villous-hirsute : sepals glabrate, oblong to oblong-oval, $1-2.5 \mathrm{~cm}$. long, or $3 \mathrm{~cm}$. long at maturity, obtuse: corolla white with purple throat; tube funnelform, $2-3 \mathrm{~cm}$. long ; limb 3-5 cm. broad : capsules about $1.5 \mathrm{~cm}$. long : seeds smooth and glabrous.

In sand near the coast, Georgia and Florida to Texas.

13. Ipomoea costellàta Torr. Annual, more or less hirsute. Stems erect or diffusely branched : leaves relatively few ; blades pedately 7-9-parted, the segments linear or spatulate or some of them linear-filiform : peduncles filiform, longer than the leaves: sepals ovate-lanceolate or oblong, acute, the outer ones with 1-3 crest-like keels: corolla rosepurple, about $1 \mathrm{~cm}$. long: capsules globular, about $5 \mathrm{~mm}$. in diameter : seeds puberulent.

In dry soil, southern Texas to Arizona and Mexico.

14. Ipomoea fistulòsa Mart. Perennial, shrubby, the young parts puberulent. Stems several from a root, $1-2.5 \mathrm{~m}$. tall : leaf-blades ovate, $5-9 \mathrm{~cm}$. long, somewhat acuminate, entire, cordate at the base, long-petioled : peduncles 4-12 cm. long, usually severalflowered : sepals suborbicular or orbicular-ovate, $5-7.5 \mathrm{~mm}$. long, the inner scarcely longer than the outer : corolla light purple or rose-colored, $6-8 \mathrm{~cm}$. long : capsules ovoid, about $1.5 \mathrm{~mm}$. long: seeds shaggy pubescent.

In waste places, Pensacola, Florida. Native of South America. 
15. Ipomoea leptophýlla Torr. Perennial, glabrous. Stems erect or ascending, 3-12 dm. tall, the branches spreading or recurving : leaf-blades linear, 5-12 cm. long, acute, entire, short-petioled : peduncles 1-6 cm. long, 1-3-flowered : sepals ovate or orbicular-ovate, $5-10 \mathrm{~mm}$. long, the inner much larger and longer than the outer : corolla pink-purple, 5-7 cm. long : capsules ovoid, $1.5-2 \mathrm{~cm}$. long: seeds finely pubescent.

On plains and prairies, Wyoming to Nebraska, Texas and New Mexico.

\section{PHÁRBITIS Choisy.}

Annual or perennial climbing or trailing vines. Leaves alternate: blades entire, angled or lobed. Flowers solitary on axillary pedicels, or in cymes. Sepals equal or unequal, herbaceous, elongated, each with a pubescent base and a narrow tip. Corolla white, blue or purple, funnelform : limb 5-angled or 5-lobed. Stamens 5, included. Filaments filiform. Ovary 3 or 5-celled. Styles united, included. Capsules depressed or elongated, usually septifragally 3 or 5 -valved. Seeds smooth. The plants flower from spring to fall. Morning-GLORY.

Calyx bristly pubescent especially near the base.

Tips of the sepals merely acute or acuminate.

Tips of the sepals conspicuous narrow prolongations from the base. Leaf-blades entire.

Leaf-blades conspicuously lobed. Annual: leaf-blades 3-lobed. Perennial: leaf-blades 5-lobed.

Caly $\mathrm{x}$ glabrous or nearly so, not bristly.

1. P. purpurea.

2. P. barbigera.

3. P. hederacea.

4. P. Lindheimeri

5. P. cathartica.

1. Pharbitis purpùrea (L.) Voigt. Annual, finely pubescent, or hirsute. Stems twining, several m. long, branching : leaf-blades ovate or orbicular-ovate, $6-18 \mathrm{~cm}$. long, entire, short-acuminate, undulate, deeply cordate; petioles longer than the blades or shorter : peduncles commonly longer than the subtending petioles: sepals hispid near the base, $10-15 \mathrm{~mm}$. long, oblong, oblong-lanceolate or nearly linear, acute or acuminate : corolla 5-6 m. long; tube pink or white ; limb purple or rarely pink or white, slightly 5lobed : capsules 10-12 mm. in diameter, apiculate. [Ipomoea purpurea (L.) Roth.]

In thickets and waste places, Nova Scotia and Ontario to Nebraska, Florida and Texas. Naturalized from tropical America.

2. Pharbitis barbígera (Sims.) G. Don. Annual, hirsute. Stems twining, several $\mathrm{m}$. long, branching : leaf-blades orbicular-ovate, $5-12 \mathrm{~cm}$. long, abruptly acuminate, ciliate, cordate ; petioles as long as the blades or shorter : peduncles shorter than the subtending petioles: sepals densely hirsute below the middle, $1.5-3 \mathrm{~cm}$. long, with ovate or linearlanceolate base and linear tips, these ciliate : corolla $3-3.5 \mathrm{~cm}$. long; tube white or pink ; limb purple or partly so, $3-4 \mathrm{~cm}$. broad : capsules depressed, fully $1 \mathrm{~cm}$. broad. [Ipomoea barbigera Sims.]

In thickets, Georgia, Alabama and Florida.

3. Pharbitis hederàcea (L.) Choisy. Annual, pubescent. Stems twining, several $\mathrm{m}$. long, more or less hirsute : leaf-blades $5-12 \mathrm{~cm}$. long, as broad as long or broader, deeply 3-lobed, cordate; lobes acuminate, more or less constricted at the base; petioles as long as the blades or shorter : peduncles commonly shorter than the petioles: sepals densely hispid at the base, $2-3 \mathrm{~cm}$. long, the bases ovate or oval, the tips longer, linear or linearspatulate : corolla deep blue or tube white within and without, $3 \mathrm{~cm}$. long; limb $3 \mathrm{~cm}$. broad, shallowly 5-lobed and with 5 small mucronations : capsules subglobose, 10-12 mm. in diameter: seeds velvety. [Ipomoea hederacea (L.) Jacq. I. Nil (L.) Pursh.]

In dry or sandy soil, New York to South Dakota. Florida and Mexico.

4. Pharbitis Lindheimeri (A. Gray) Small. Perennial, finely pubescent. Stems more or less twining, more or less branched, retrorsely pubescent: leaf-blades $5-10 \mathrm{~cm}$. in diameter, suborbicular in outline, 5-parted, strigillose ; lobes ovate or ovate-lanceolate, 3 interior ones abruptly contracted at the base : peduncles as long as the subtending petioles or longer: sepals bristly at the base, linear or linear-lanceolate, $2-3.5 \mathrm{~cm}$. long : corolla light blue, 6-9 cm. long; limb 6-8 cm. broad : capsules globular, about $1 \mathrm{~cm}$. in diameter. [Ipomoea Lindheimeri A. Gray.]

In rocky soil, Texas and New Mexico.

5. Pharbitis cathártica (Poir.) Choisy. Perennial, minutely strigillose or glabrate. Stems more or less twining, branching : leaf-blades broadly ovate, $5-9 \mathrm{~cm}$. long, entire or 3-lobed, acuminate, cordate : peduncles shorter than the subtending petioles: sepals glabrate, linear-lanceolate or ovate-lanceolate, 1-2 cm. long, acuminate : corolla pink-purple or crimson; limb 6-8 cm. broad, undulate: capsules spheroidal, about $1 \mathrm{~cm}$. broad. [Ipomoea cathartica Poir.]

In thickets, peninsular Florida. Also from the Bahamas to Brazil. 


\section{JACQUEMÓNTIA Choisy.}

Annual or usually perennial trailing or twining vines, or upright herbs or shrubs. Leaves alternate: blades entire or rarely toothed or lobed. Flowers usually in loose or congested cymes, these sometimes conspicuous on account of densely pubescent bracts. Sepals nearly equal, or the outer much broader than the inner. Corolla white, blue or violet, companulate: limb pläited, 5-angled or 5-lobed. Stamens 5, not surpassing the corolla. Filaments filiform or dilated at the base, adnate to the base of the corolla-tube. Ovary 2-celled. Styles united to the stigmas. Ovules 4, 2 in each cavity. Capsule subglobose, 4-valved. Seeds glabrous. The plants flower mainly from spring to fall.

Bracts and caly $\mathrm{x}$ glabrous, at least not conspicuously pubescent.

Leaf-blades acuminate or cuneate at the base: flowers solitary or 2 together,

Leaf-blades abruptly narrowed or truncate at the base : flowers several together. Bracts and calyx conspicuous on account of the dense spreading pubescence.

1. J. Curtissii.

2. J. pentantha.

3. J. tamnifolia.

1. Jacquemontia Curtíssii Peter. Perennial, glabrous, or slightly cobwebby-pubescent. Stems prostrate or spreading, branching, 2-9 dm. long: leaves alternate; blades leathery, oblong to oblong-spatulate, varying to slightly broadest below the middle, 1-2 cm. long, obtuse or abruptly pointed, entire, slightly revolute, short-petioled: peduncles usually shorter than the leaves, 1-2-flowered : pedicels commonly longer than the peduncle : sepals orbicular-ovate to oval, becoming $6-8 \mathrm{~mm}$. long: corolla violet or whitish, $2.5-3$ $\mathrm{cm}$. broad, the lobes rounded: capsules $8-9 \mathrm{~mm}$. long.

In rocky or calcareous soil, southern peninsular Florida.

2. Jacquemontia pentántha (Jacq.) G. Don. Annual or biennial, minutely pubescent or glabrate. Stems more or less diffusely branched, the branches 3-10 dm. long : leaf-blades ovate to oblong or ovate-lanceolate, $1.5-5 \mathrm{~cm}$. long, acuminate, undulate, abruptly contracted or truncate at the base ; petioles $5-30 \mathrm{~cm}$. long : peduncles usually longer than the subtending leaves: sepals minutely pubescent at least when young, ovate or broadly ovate, 5-6 $\mathrm{mm}$. long, acute or acuminate: corolla about $2 \mathrm{~cm}$. broad, the angular lobes acute : capsules oval or oval-ovate, about $5 \mathrm{~mm}$. long. [J. violacea (Vahl.) Choisy. ]

In sand, Florida Keys and tropical America.

3. Jacquemontia tamnifòlia (L.) Griseb. Annual, pubescent with tawny hairs. Stems erect or twining, branching, $2-12 \mathrm{dm}$. long: leaf-blades ovate to oblong-ovate, 5-12 $\mathrm{cm}$. long, acuminate, undulate, rounded or cordate at the base; petioles shorter than the blades: peduncles as long as the subtending leaves or longer : clusters rather dense, conspicuously bracted: sepals rusty-hirsute, linear-subulate, $7-9 \mathrm{~mm}$. long, attenuate : corolla violet or blue, $1.5-3 \mathrm{~cm}$. wide : capsules spheroidal, 4-5 $\mathrm{mm}$. in diameter.

In fields and thickets, South Carolina and Arkansas to Florida and tropical America.

\section{CONVÓLvULUS L.}

Ann al or perennial, trailing or twining vines, or upright herbs or shrubs. Leaves alternate : blades usually hastate or cordate at the base. Flowers solitary or clustered on axillary peduncles. Calyx naked or subtended by bracts : sepals 5, rearly equal, or the outer larger. Corolla white, pink or purple, funnelform or campanulate : limb plaited, entire, or 5-lobed or 5-angled. Stamens 5, included. Filaments filiform or dilated at the base. Ovary 1-2-celled. Styles united up to the stigmas. Ovules 4. Capsule globose or nearly so, 2-4-valved. Seeds glabrous. Our species are perennials. Bindween.

Calyx enclosed by the 2 large bracts which subtend it.

Stems trailing or climbing.

Mature stem and leaves glabrous or glabrate: leaf-blades ovate or hastate.

Leaf-blades with more or less angular spreading basal lobes.

Leaf-blades with rounded or scarcely angular basal lobes which are not

Mature stem and leaves copiously and softly pubescent: leaf-blades more or less sagittate.

Stems ereet or ascending.

Calyx without bracts.

Herbaceous : leaf-blades not leathery.

Foliage glabrous or nearly so.

Foliage densely pubescent.

Sepals auricled at the base.

Sepals not auricled.

Shrubby : leaf-blades leathery.

1. C. Americanus.

2. C. sepium.

3. C. repens,

4. C: spithamaeus.

5. C. arvensis.

6. C. hermannivides.

7. C. incanus.

8. C. Havanensis.

1. Convolvulus Americànus (Sims) Greene. Stems twining, 1-3 m. long, glabrate, more or less twisted : leaf-blades broadly hastate or ovate-hastate, $5-12 \mathrm{~cm}$. long, acuminate or apiculate, undulate, cordate; petioles as long as the blades or much shorter : peduncles 
longer than the subtending petioles or Jonger than the leaves: bracts ovate or oblongovate, $2-3 \mathrm{~cm}$. long: calyx glabrous, enclosed by the bracts : sepals oblong to oblong-lanceolate, $10-13 \mathrm{~mm}$. long, obtuse or acutish : corolla 4-5 cm. long, pink or rose-purple ; limb 5-7 cm. broad, sometimes variegated : capsules ovoid-globose, $1 \mathrm{~cm}$. in diameter.

In thickets and along fences, Nova Scotia to Montana, North Carolina and Utah. Summer.

2. Convolvulus sepium L. Similar to C. Americanus in habit: leaf-blades relatively broader and more rounded to the apex, the basal lobes rounded or angulately toothed, directed backward, not spreading.

In thickets and waste places, locally naturalized in North America, except the extreme north.

3. Convolvulus rèpens L. Softly pubescent. Stems trailing or twining, sometimes twisted : leaf-blades typically narrowly or broadly sagittate, $5-8 \mathrm{~cm}$. long, cordate at the base ; petioles about $\frac{1}{2}$ as long as the blades except the lower ones: peduncle surpassing the leaves or at least the petioles : bracts ovate-oblong or oblong-lanceolate, $1.5-2.5 \mathrm{~cm}$. long : calyx included by the bracts, glabrous or glabrate: sepals lanceolate or oblong to ovate-lanceolate, acute : corolla white or pinkish, 4-5 cm. long; limb 4-6 cm. broad, undulate : capsules globular, about $1 \mathrm{~cm}$. in diameter.

In dry soil or old fields, Virginia to South Dakota, Florida and Texas. Spring and summer.

4. Convolvulus spithamaèus L. Finely pubescent. Stems erect or decumbent, 1$7 \mathrm{dm}$. long, not twining, simple or sparingly branched : leaf-blades oblong-ovate or fiddleshaped, 4-10 cm. long, apiculate, entire, rounded or subcordate at the base ; petioles 5-15 $\mathrm{mm}$. long : peduncles longer than the leaves or shorter : bracts ovate or oblong, $1.5-3 \mathrm{~cm}$. long: calyx delicate : sepals acute, or acuminate, as long as the bracts or shorter : corolla white or pink, 3-4 cm. long; limb 4-6 $\mathrm{cm}$. broad, undulate : capsules globular, about 1 cm. in diameter.

In dry or rocky soil, Nova Scotia to the Northwest Territory and Florida. Spring and summer.

5. Convolvulus arvénsis L. Glabrate. Stems branched at the base; branches prostrate or low twining : leaves alternate ; blades oblong or ovate-sagittate or linear-hastate, 1-5 cm. long, obtuse or acutish ; petioles seldom $\frac{1}{2}$ as long as the blades: peduncles shorter than the subtending leaves: calyx naked : sepals oval to suborbicular, obtuse or acutish, 3-3.5 mm. long: corolla white or rose-tinged; limb 1.5-2 $\mathrm{cm}$. broad : capsules oval or ovoid, $5-7 \mathrm{~mm}$. long.

In waste places and fields, commonly established in northeastern North America and sparingly so in the southeastern United States. Native of Europe and Asia. Spring and summer.

6. Convolvulus hermannioìdes A. Gray. Silky tomentulose. Stems commonly branched at the base; branches spreading or procumbent, 3-15 $\mathrm{dm}$. long: leaf-blades ovate, oblong or oblong-lanceolate, 1.5-7 dm. long, sinuate or incised-toothed, cordate at the base ; petioles $\frac{1}{2}$ as long as the blades or shorter: peduncles shorter than the subtending leaves : sepals becoming about $1 \mathrm{~cm}$. long, auricled at the base : corolla white, about $2-2.5 \mathrm{~cm}$. long; limb 1.5-2 cm. broad, angulate : capsules depressed, 8-10 mm. high including the long beak.

On dry prairies, Texas. Spring to fall.

7. Convolvulus incànus Vahl. Cinereous. Stems often branched at the base; branches mainly procumbent, $3-10 \mathrm{dm}$. long : leaf-blades very variable, linear-sagittate to lanceolate or hastate, with more or less lobed basal auricles, or pedate, $2.5-5 \mathrm{~cm}$. long, often mucronate : peduncles 1-2-flowered: sepals becoming 6-8 mm. long, not auricled at the base : corolla white or pink, about $12 \mathrm{~mm}$. long, and $15 \mathrm{~mm}$. broad, the lobes acuminate : capsules $6-8 \mathrm{~mm}$. high, including the short beak.

On dry hills and prairies, Nebraska to Arkansas, Colorado, Texas and A rizona. Spring and summer

8. Convolvulus Havanénsis Jacq. Minutely pubescent or glabrate. Stems branching at the base; branches shrubby, procumbent or somewhat twining: leaves numerous ; blades leathery, oblong, elliptic or suborbicular, or commonly slightly broadest below the middle, $1-2.5 \mathrm{~cm}$. long, obtuse or retuse and mucronate, somewhat revolute, short-petioled : peduncles several-flowered or rarely 1 -flowered: sepals ovate, becoming $2.5-3 \mathrm{~mm}$. long: corolla white, $10-12 \mathrm{~mm}$. broad, the lobes acute : capsules ovoid, 4-5 mm. long, freely splitting into several lanceolate valves.

In sandy soil, peninsular Florida and the Keys. Also in the West Indies. Throughout the year.

\section{Family 3. CUSCUTÀCEAE Dumort. Dodder Family.}

Herbaceous parasites, with white, yellow or orange foliage which sometimes contains a coloring matter, possibly chlorophyll. Stems starting from the ground 
but soon decaying above the root, thence attached to host-plants by suckers, dextrorsely twining. Leaves reduced to minute alternate scales. Flowers perfect, in variously disposed cymes. Calyx inferior : sepals 5 or rarely 4 , distinct or partly united. Corolla regular: petals 5 or 'rarely 4, partly united, imbricated, accompanied by 4-5 alternating crenulate or appendaged scales, or these obsolete. Stamens 5 or rarely 4, adnate to the throat of or near the sinuses of the corolla above the scales. Filaments never elongated. Anthers 2-celled: sacs opening lengthwise. Ovary 2-celled, seldom much longer than broad. Styles 2, mostly distinct. Stigmas capitate. Ovules 2 in each cavity. Capsule subglobose, depressed or slightly elongated, 2-celled, circumscissile or indehiscent, 1-4-seeded. Seeds globose or angular. Embryo curved or spiral in the fleshy endosperm, with 1-4 minute scales at the apex.

\section{CUSCÙTA L.}

Characters of the family. Dodder. Love Vine.

Styles separate.

Calyx of 4-5 distinct sepals, these subtended by imbricated bracts.

Flowers pedicelled, in open cymes: bracts entire.

Flowers sessile, in dense clusters: bracts erose-serrulate.

Bracts few, short, erect: styles about as long as the ovary.

$\begin{array}{ll}\text { Bracts few, short, erect: styles about as long as the ovary. } & \text { 2. C. compacta. } \\ \text { Bracts elongated, with recurved tips: styles much longer than the ovary. } & \text { 3. C. paradoxa }\end{array}$

Calyx of 4-5 partially united sepals, unaccompanied by bracts.

Corolla-lobes acute.

Capsule seated in the persistent corolla.

Calyx-lobes acute or acutish: scales rather broad, fringed all around. Calyx-lobes obtuse: scales much reduced, often of 1-3 small processes.

Capsule capped with or enclosed by the persistent corolla. Calyx-lobes erose-crenulate: scales shorter than the tube.

Capsule enclosed by the corolla: scales broad, copiously fringed.

Capsule capped by the corolla: scales reduced to few irregular processes.

Calyx-lobes entire : scales surpassing the corolla-tube.

Corolla-lobes obtuse.

Scales shorter than the corolla-tube.

Capsules spheroidal, each capped with the corolla.

Capsules ovoid or globose-ovoid, seated in the corollas.

Scales fully as long as the corolla-tube or surpassing it.

Inflorescence not glandular: capsules longer than broad or subglobose. Scales sparingly fringed above, widest near base: capsule partially enclosed by or seated in the persistent corolla.

Scales copiously fringed above, widest at the top: capsule capped with the persistent corolla.

Inflorescence glandular: capsules broader than long.

Styles united nearly to the top.

1. C. cuspidata.

4. C. arvensis.

5. C. Polygonorum.

6. C. indecora.

7. C. Coryli.

8. C. umbellata.

9. C. Cephalanthi.

10. C. rostrata.

11. C. Gronovii.

12. C. calyptrata.

13. C. glandulosa.

14. C. exaltata.

1. Cuscuta cuspidàta Engelm. Foliage yellowish, little darker in age. Stems slender; branches often numerous, but not widely matted : flowers short-pedicelled, in large branching cymes: calyx subtended by several imbricated bracts : sepals 5 , distinct, entire, shorter than the corolla-tube, as broad as long: corolla nearly salverform, about $3 \mathrm{~mm}$. long; lobes 5, oblong to triangular-lanceolate, acute or cuspidate, spreading barely $\frac{1}{2}$ as long as the tube; scales oblong, fully $\frac{1}{2}$ as long as the corolla-tube, fringed throughout with short irregular processes : capsules subglobose, $1.5-2 \mathrm{~mm}$. long, each capped with the persistent corolla.

On coarse herbs, Missouri to Nebraska, south to Texas. Summer and fall.

2. Cuscuta compácta Juss. Foliage yellowish white, deeper in age. Stems rather stout; branches often in wide mats when young: flowers sessile, crowded into dense masses : calyx subtended by several ribbed imbricated bracts; these rhombic-orbicular, serrulate : sepals 5 or rarely 4 , distinct, oval, obtuse, crenulate, about as broad as long: corolla exserted, $4 \mathrm{~mm}$. long, salverform; tube cylindric ; lobes ovate or oblong, obtuse, spreading, much shorter than the tube ; scales oblong, fully $\frac{1}{2}$ the length of the corollatube, fringed, mainly near the top, with numerous processes : capsules subglobose or ovoidglobose, 3-3.5 mm. long, each enclosed by or capped with the rather persistent corolla.

On shrubs, Ontario to Kansas, New York, Georgia and Texas. Summer and fall.

3. Cuscuta paradóxa Raf. Foliage yellowish white, very slightly deeper at maturity. Stems slender; branches forming very dense spiral masses, closely investing the hosts: flowers very numerous, crowded in dense confluent masses closely investing portions of the host-plants: calyx sessile, subtended by several strongly ribbed imbricated serrulate bracts : sepals 5 , distinct, oblong, obtuse, serrulate, broader than the bracts but less strongly ribbed : corolla exserted, $3 \mathrm{~mm}$. long, salverform; tube cylindric ; lobes oblong-lanceolate to ovate-triangular, $\frac{1}{4}$ the length of the tube, obtuse, spreading or recurved; scales 
linear, $\frac{2}{3}$ the length of the tube, copiously fringed near the top and sparingly on the sides with slender processes : capsules longer than thick, about $2 \mathrm{~mm}$. long, each capped with the rather persistent corolla. [C. glomerata Choisy.]

On tall herbs, mainly on Polygona, Ohio to Minnesota, Tennessee and Texas. Summer and fall.

4. Cuscuta arvénsis Beyrich. Foliage pale yellow, deeper in age. Stems filiform, becoming loosely matted : flowers short-pedicelled in small rather loose clusters : calyx campanulate; lobes 5, broad, obtuse, barely as long as the corolla-tube: corolla rather campanulate; lobes 5, lanceolate or triangular-lanceolate, acute or acuminate, as long as the tube, with inflexed tips; scales ovate or oblong-ovate, as long as the corolla-tube or slightly longer, fringed all around with short irregular processes: capsules spheroidal, $2 \mathrm{~mm}$. broad, each seated in the persistent corolla, indehiscent.

On herbs and low shrubs, New York to the Northwest Territory and California, south to Florida, Texas and Mexico. Summer.

5. Cuscuta Polygonòrum Engelm. Foliage orange-yellow. Stems rather coarse ; branches often loosely matted : flowers sessile or nearly so, in small rather lax clusters : calyx broad; lobes 4-5, ovate-oblong, acute or acutish : corolla little exserted ; lobes 4-5, triangular or ovate-triangular, longer than the tube, acute ; scales obsolete, usually of 1-3 processes on either side of the base of the filament: capsules subglobose, $2.5-3 \mathrm{~mm}$. in diameter, each seated in the persistent corolla.

On Polygona and other herbs, Pennsylvania to Minnesota, south to Delaware and Arkansas. Summer and fall.

6. Cuscuta indecòra Choisy. Foliage light yellow, deeper in age. Stems rather stout, branched; branches loosely matted : flowers pedicelled, in loose umbel-like cymes : calyx more or less papillose; lobes 5 , ovate to lanceolate, acute, barely equalling the corolla-tube : corolla white, campanulate, about $3 \mathrm{~mm}$. long; lobes 5 , triangular, erosecrenulate, acute, slightly shorter than the tube, with incurved tips; scales ovate or ovaloblong, extending nearly to the sinuses, irregularly fringed with short processes throughout : capsules spheroidal, $3 \mathrm{~mm}$. long, acute, each enveloped by the persistent corolla. [C. decora var. pulcherrima Engelm.]

On herbs and low shrubs, Illinois to Nebraska, south to Florida, Texas and Mexico. Spring and summer.

7. Cuscuta Córyli Engelm. Foliage yellowish, or orange in age. Stems coarse ; branches sometimes loosely matted: flowers short-pedicelled, in loose or rather dense umbel-like cymes: calyx-lobes 4-5, triangular or triangular-lanceolate, acutish, about equalling the corolla-tube : corolla campanulate or cylindric-campanulate, about $2 \mathrm{~mm}$. long ; lobes 4-5, triangular or ovate-triangular, about as long as the tube, erose-crenulate, acute, with strongly inflexed tips; scales small, oblong, rounded at the apex, with few processes on each side : capsules much depressed, $2.5-3 \mathrm{~mm}$. long, each enclosed by or at maturity capped with the persistent corolla. [C. inflexa Engelm.]

On the hazels and other shrubs or shrubby herbs, Virginia to Nebraska, south to Georgia and Arkansas. Summer.

8. Cuscuta umbellàta H.B.K. Foliage pale yellow, slightly deeper in age. Stems filiform ; branches loosely matted : flowers short-pedicelled, in compound clustered cymes, these ending in umbel-like cymes : calyx broadly campanulate; lobes triangular, acute, as long as the corolla-tube or longer: corolla 3-4 mm. long; lobes lanceolate, acute, longer than the tube, spreading or reflexed; scales oval, longer than the corollatube, incurved : capsules spheroidal, 1.5-2 mm. broad, 4-lobed, each enclosed by the persistent corolla.

On herbs, Florida to Texas and Arizona, south to Mexico. Spring to fall.

9. Cuscuta Cephalánthi Engelm. Foliage yellow or yellowish white. Stems rather coarse, seldom matted : flowers short-pedicelled, in rather dense clusters : calyx-lobes 5, ovate, obtuse, shorter than the corolla-tube : corolla pale, about $2 \mathrm{~mm}$. long; lobes shorter than the corolla-tube, oblong or ovate-oblong, fringed mainly near the tip with short irregular processes: capsules subglobose, 3.5-4.5 mm. in diameter, enclosed by or capped with the corolla, which is finally deciduous.

On shrubs and tall herbs, Pennsylvania to Minnesota and the Northwest Territory, south to Texas and Arizona. Summer.

10. Cuscuta rostràta Shuttlw. Foliage yellowish white. Stems coarse; branches sometimes loosely matted : flowers pedicelled, larger than those of the other species, in rather loose cymes : calyx-lobes 5 , ovate-triangular, about $\frac{1}{3}$ the length of the corolla-tube: corolla white, campanulate, $4-6 \mathrm{~mm}$. long; lobes 5 , ovate, about $\frac{1}{3}$ the length of the tube,
obtuse ; scales about $\frac{1}{2}$ as long as the corolla-tube, the body linear to spatulate, fringed 
mainly near the top with rather coarse processes : capsules ovoid or globose-ovoid, 5-7 mm. long, 2-beaked.

On herbs and shrubs, Maryland to Georgia. Summer and fall.

11. Cuscuta Gronòvii Willd. Foliage yellowish, becoming orange. Stems slender, often high-climbing, sometimes matted: flowers short-pedicelled, usually numerous in dense clusters : calyx not subtended by bracts; lobes 5 , ovate, obtuse, much shorter than the corolla-tube : corolla about $3 \mathrm{~mm}$. long; lobes 5, ovate, obtuse, spreading, somewhat shorter than the tube ; scales narrow, equalling the corolla-tube, or surpassing it, broader above than below, sparingly fringed near the top and more sparingly along the sides with stoutish irregular processes : capsules subglobose, $3 \mathrm{~mm}$. in diameter, sometimes abruptly pointed, partially enclosed by or seated in the persistent corolla.

On herbs and low shrubs, Nova Scotia to Manitoba, south to Florida and Texas. Summer and fall.

12. Cuscuta calyptràta Engelm. Foliage pale, turning yellowish at maturity. Stems branching; branches slender, not matted : flowers few or rather numerous in small clustered cymes, these becoming dense at maturity, sessile or nearly so: calyx glabrous ; lobes orbicular-ovate or deltoid-ovate, obtuse, often slightly eroded : corolla early exserted; lobes ovate, obtuse, spreading or reflexed at maturity ; scales densely fringed, especially at the top, with rather long regular processes, narrower above than below: capsules subglobose, 4-4.5 mm. in diameter, each capped with the persistent corolla.

On herbs and shrubs, New York to Florida and Texas. Summer and fall.

13. Cuscuta glandulòsa (Engelm.) Small. Foliage bright orange, that of the inflorescence with red shining glands. Stems widely branched and spreading, commonly matted : flowers short-pedicelled, in loose subglobose clusters : calyx glandular; lobes 5, ovate to orbicular-ovate, obtuse : corolla $2-2.5 \mathrm{~mm}$. long, pale ; tube barely exserted; lobes 5, spreading, obtuse; scales as broad as long, sometimes surpassing the corolla-tube, fringed all around with quite regular processes: capsules spheroidal, $3-3.5 \mathrm{~mm}$. in diameter. [C. obtusifolia var. glandulosa Engelm.]

On species of Polygonum and other herbs, Georgia to Florida and Texas. Also in the West Indies.

14. Cuscuta exaltàta Engelm. Foliage yellowish, deeper at maturity. Stem much branched; branches cord-like, high-twining, 2-6 m. long, often twisted together : flowers short-pedicelled, rather crowded in short spike-like racemes or panicles: calyx subglobose, becoming flattened; lobes suborbicular, fully as long as the corolla-tube : corolla about $4 \mathrm{~mm}$. long; lobes 5 , suborbicular, about $\frac{1}{2}$ as long as the tube, erect or ascending ; scales much shorter than the corolla-tube, 2 -cleft, dentate: styles united : capsules globoseovoid, 4-5 mm. high, obtuse.

On shrubs and trees, southern Texas. Spring to fall.

\section{FAMILY 4. HYDROLEÀCEAE H.B.K. WATER-LEAF FAMily.}

Annual or perennial caulescent herbs, with a watery sap. Leaves alternate, or sometimes opposite near the base of the stem, without stipules : blades lobed or pinnatifid, or rarely entire. Inflorescence cymose or in one-sided racemes, more or less clustered. Flowers perfect. Calyx of 5 more or less united sepals, free, the sinuses often appendaged. Corolla regular: lobes 5, convolute or imbricated in aestivation, often appendaged inside. Androecium of 5 stamens adnate to the base of the corolla and alternate with the lobes. Filaments distinct, often bearded. Anthers introrse, versatile. Gynoecium compound. Ovary free, 1-celled, or rarely 2-celled, with parietal placentae. Styles partly united. Stigma somewhat capitate. Ovules few or numerous. Fruit a capsule with one or two incomplete cavities. Seeds few or sometimes numerous, amphitropous, with a crustaceous testa. Endosperm cartilaginous. Embryo eccentric. [Hydrophyllaceae Lindl.]

Ovary 1-celled: styles 2-cleft : leaf-blades usually toothed, lobed or dissected.

Corolla-lobes convolute in the bud : piacentae dilated.

Stamens exserted.

Stamens included.

Calyx not much enlarged at maturity, the sinuses appendaged.

Calyx much enlarged at maturity, the sinuses not appendaged.

Corolla-lobes imbricated in the bud: placentae narrow.

Ovary 2-celled, but imperfectly so in Marilaunidium : styles 2, distinct : leaf-blades entire.

Corolla funnelform or salverform: capsule loculicidal: valves bearing the seeds.

Corolla rotate to campanulate : capsule septicidal; axis bearing the seeds.

1. HYDROPH YLLUM.

2. NEMOPHILA.

3. Macrodalyx.

4. Phacelia.

5. Marilatenium. 6. NAMA. 


\section{HYDROPHÝLLUM L.}

Biennial or perennial herbs, with pubescent foliage. Leaves alternate: blades lobed, pinnatifid or pinnately divided. Cymes peduncled, more or less scorpioid. Calyx pedicelled : tube short: lobes 5, narrow, with naked or appendaged sinuses. Corolla white, blue or purple: tube short: lobes 5 , convolute, each furnished with a linear appendage within. Stamens 5, exserted: filaments partially pubescent. Ovary 1-celled, pubescent. Style 2-cleft. Ovules 4, enclosed by the fleshy placenta which is attached to the top and bottom of the cavity. Capsule 2-valved. Seeds 1-4, thick. Water-Leaf.

Perennials ; calyx destitute of reflexed appendages at the sinuses.

Leaf-blades pinnate or pinnatifid : inflorescence conspicuously hirsute.

Stems barely pubescent: calyx-lobes nearly distinct, linear.

Stems hispid or hirsute: calyx-lobes longer than the tube, lanceolate or oblong-lanceolate.

Leaf-blades palmately 5-7-lobed.

Biennial: calyx with reflexed appendages at the sinuses.

1. H. Virginicum.

2. H. macrophyllum.

3. H. Canadense.

4. H. appendiculatum.

1. Hydrophyllum Virginícum L. Foliage strigillose. Stems $2-7 \mathrm{dm}$. tall, simple or branched, nearly glabrous : leaves 1-3 dm. long, or the upper ones shorter; blades pinnately divided, the segments coarsely toothed or incised, acute or acuminate; petioles longer than the blades or the upper ones shorter: peduncles longer than the subtending petioles, simple or forked : cymes becoming open : calyx bristly; lobes linear, about $5 \mathrm{~mm}$. long, strigillose on the back, nearly distinct : corolla white or purplish, about $1 \mathrm{~cm}$. long : filaments slightly pubescent : capsules subglobose, $3-4 \mathrm{~mm}$. in diameter.

In moist woods, Quebec to Manitoba, South Carolina and Kansas. Spring and summer.

2. Hydrophyllum macrophýllum Nutt. Foliage hispid. Stems 2-6 dm. tall, simple or branched : leaves 2-3 din. long, or the upper ones smaller; blades pinnatifid, longer than the petioles; segments oblong, elliptic or oval, coarsely serrate or incised, the upper ones confluent: peduncles stout, 1-3 dm. long, simple or branched above : cymes capitate or somewhat open : calyx bristly; lobes lanceolate or oblong-lanceolate, longer than the tube, acute: corolla white, about $1 \mathrm{~cm}$. broad; lobes oblong, notched at the apex, their subulate appendages pubescent at the base : capsules $3-4 \mathrm{~mm}$. broad, hirsute.

In woods, Ohio to Virginia, Illinois and Alabama. Spring.

3. Hydrophyllum Canadénse L. Foliage hirsute or glabrate. Stems solitary or tufted, 2-7 dm. tall, sometimes sparingly branched : leaves few ; blades palmately 5-7lobed, $0.5-3 \mathrm{dm}$. in diameter; lobes coarsely toothed or slightly lobed; petioles commonly longer than the blades: cymes $2-6 \mathrm{~cm}$. broad : peduncles simple or commonly forked: calyx sparingly hispid, or nearly glabrous ; lobes linear or nearly so, 4-5 mm. long : corolla white, $1-1.5 \mathrm{~cm}$. broad : filaments densely villous: capsules about $4 \mathrm{~mm}$. in diameter, finely pubescent.

In damp woods, Massachusetts to Illinois and North Carolina. Summer.

4. Hydrophyllum appendiculàtum Michx. Foliage hirsute. Stems erect, $3-6 \mathrm{dm}$. tall, usually branching : leaves variable; blades oblong to suborbicular in outline, cordate, those of the lower leaves pinnatifid; others palmately 5-7-lobed; lobes or segments coarsely toothed, acute or acuminate : cymes rather open : pedicels slender, becoming $1-2 \mathrm{~cm}$. long: calyx bristly; lobes subulate-lanceolate, accompanied by a reflexed appendage at each sinus : corolla violet or purple, $1-1.5 \mathrm{~cm}$. broad : capsules about $3 \mathrm{~mm}$. in diameter.

In damp woods, Ontario to Minuesota, North Carolina and Kansas. Spring.

\section{NEMÓPHILA Nutt.}

Annual diffuse herbs, with pubescent foliage. Leaves alternate or opposite: blades lobed or pinnatifid. Flowers solitary on axillary or terminal pedicels. Calyx not accrescent : lobes 5 , accompanied by a spreading or reflexed appendage in each sinus. Corolla white, blue or variegated, campanulate or rotate: tube usually with 10 appendages within near the base : lobes convolute, surpassing the calyx. Stamens 5, included: filaments short. Ovary 1-celled. Styles 2-cleft. Ovules 2-12 in each fleshy placenta which is attached to the top and bottom of the cavity. Capsule 2-valved. Seeds usually 1-4.

Leaf-segments 3-5: calyx with inconspicuous appendages : corolla less than $3 \mathrm{~mm}$. broad.

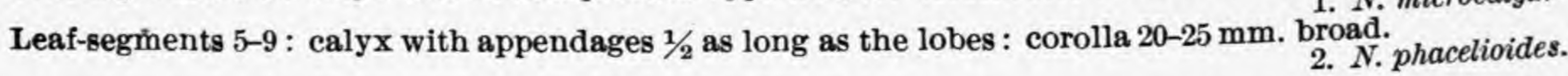

1. Nemophila micrócalyx (Nutt.) F. \& M. Foliage sparingly pubescent or glabrate in age. Stems branched at the base ; branches diffusely spreading or prostrate, $0.5-4$ 
$\mathrm{dm}$. long: leaves numerous; blades pinnately divided; segments $3-5$ : pedicels $0.5-1.5$ cm. long: calyx campanulate; lobes lanceolate or ovate-lanceolate, 1-1.5 mm. long, acute, accompanied by minute appendages : corolla white or bluish, less than $3 \mathrm{~mm}$. broad ; lobes rounded, $\frac{1}{2}$ as long as the tube : capsules subglobose, $4-5 \mathrm{~mm}$. in diameter : seeds subglobose, pitted in lines. [Ellisia microcalyx Nutt.]

On shaded banks, Virginia to Arkansas, Florida and Texas. Spring.

2. Nemophila phacelioides Nutt. Foliage hirsute, or glabrate in age. Stems branched at the base, the branches $0.5-6 \mathrm{dm}$. long, often simple: leaves $5-10 \mathrm{~cm}$. long ; blades pinnately divided; segments usually incised, the upper ones confluent; petioles shorter than the blades : pedicels slender, 4-12 $\mathrm{cm}$. long: calyx bristly ; lobes lanceolate, 8-9 mm. long, acute, ciliate, accompanied by ovate or oblong-lanceolate appendages, 4-5 $\mathrm{mm}$. long: corolla $2-2.5 \mathrm{~mm}$. broad; lobes obovate to cuneate, retuse or notched at the apex : capsules globular, $5-6 \mathrm{~mm}$. broad : seeds impressed-punctate.

On prairies, Arkansas and Texas. Spring.

\section{MACRÓCALYX Trew.}

Annual caulescent herbs, with pubescent foliage. Leaves alternate, or opposite : blades pinnately divided or 1-3-pinnatifid. Flowers solitary in the axils, or sometimes in racemes. Calyx accrescent: lobes 5, spreading, not accompanied by appendages at the sinuses. Corolla shorter than the calyx or slightly surpassing it: tube campanulate to cylindric, usually with 5 minute appendages within: lobes 5 , convolute. Stamens 5 , included. Ovary 1-celled. Styles 2-cleft. Ovules 2-4 in each fleshy placenta which is attached to the top and bottom of the cavity. [Ellisia L.]

1. Macrocalyx Nyctèlea (L.) Kuntze. Foliage sparingly hirsute or glabrate. Stems erect, $0.5-3 \mathrm{dm}$. tall, at length radially or diffusely branched : leaves $5-10 \mathrm{~cm}$. long ; blades pinnatifid, longer than the petioles; segments spreading, entire, toothed or incised : pedicels very slender, spreading, or nodding, 1-2 cm. long: calyx-lobes triangular-lanceolate, becoming 7-8 $\mathrm{mm}$. long, acute, more or less pubescent like the rest of the inflorescence : corolla bluish or white, $7-8 \mathrm{~mm}$. broad : capsules subglobose, pubescent, $5-6 \mathrm{~mm}$. in diameter : seeds usually pitted. [Ellisia Nyctelea L.]

In moist or shaded places, New Jersey to Minnesota, North Carolina, Missouri and Kansas. Spring and summer.

\section{PHACÈLIA Juss.}

Annual or perennial caulescent herbs, with usually pubescent or puberulent foliage. Leaves alternate or opposite below : blades various. Flowers in scorpioid racemes or cymes. Calyx slightly accrescent : lobes 5 , not accompanied by appendages. Corolla white, blue, violet or purple, of various shapes : tube often appendaged within : lobes 5 , imbricated, spreading. Stamens 5: filaments adnate to the base of the corolla-tube. Ovary 1-celled, with 2 narrow placentae attached to the walls of the cavity. Style 2-cleft. Ovules 2-several on each placenta. Capsules 1-celled or falsely almost 2-celled by the dilation of the placentae, 2-valved. Seeds reticulated or roughened.

Corolla with entire lobes, or these merely crenulate.

Appendages of the corolla-tube between the stamens conspicuous.

Stamens longer than the corolla.

Leaf-blades 2-divided or parted.

Leaf-blades 1-divided or parted.

Pedicel much shorter than the calyx at maturity : corolla-appendages broad, glabrous.

Pedicel as long as the calyx or longer at maturity : corolla-appendages long and narrow, villous on the edge.

Stamens shorter than the corolla.

Appendages of the corolla-tube inconspicuous or obsolete.

Ovules, and sometimes seeds $2-4$ on each placenta: corolla-lobes entire.

Foliage glabrous, or if pubescent, hairs only on the margins of the leaves and calyx-lobes.

Foliage more or less copiously pubescent.

Puberulent: corolla white or pink, $8-10 \mathrm{~mm}$. broad.

Hirsute: corolla violet-purple, $12-15 \mathrm{~mm}$. broad.

Ovules, and sometimes seeds about 8 on each placenta : corolla-lobes crenulate.

Pedicels longer than the calyx-lobes.

Calyx-lobes very unequal, the broader suborbicular: corolla $1 \mathrm{~cm}$. broad.

Calyx-lobes nearly equal, broader, oblong : corolla $2 \mathrm{~cm}$. broad.

Pedicels shorter than the calyx-lobes.

Corolla with fimbriate laciniate or fimbriate-dentate lobes.

1. P. dissecta.

2. P. congesta.

3. P. bipinnatifida.

4. P. brevistylis.

5. P. glabra.

6. P. dubia.

7. P. hirsuta.

8. P.laxa.

9. P. patulifiora.

10. P. strictiflora.

a. Pedicels as long as the calyx-lobes or a little longer at maturity. 
Calyx-lobes oblong: corolla about $8 \mathrm{~mm}$. broad ; lobes laciniate. Calyx-lobes linear : corolla about $4 \mathrm{~mm}$. broad; lobes toothed.

b. Pedicels fully twice as long as the calyx-lobes at maturity. Corolla blue or rose: stems erect.

Corolla white or pinkish : stems spreading or decumbent.
11. P. Boykinii.

12. P. Bicknellii.

13. P. Purshii.

14. P. fimbriata.

1. Phacelia dissécta (A. Gray) Small. Annual, finely hirsute. Stems 3-5 dm. tall, sometimes branched above : leaves $5-10 \mathrm{~cm}$. long; blades 2-divided or parted, the segments mostly acute, toothed or incised: calyx slightly bristly ; lobes linear, about 5 $\mathrm{mm}$. long: corolla about $10 \mathrm{~mm}$. broad ; lobes entire : capsules subglobose, barely $\frac{1}{2}$ as long as the calyx-lobes. [P. congesta var. dissecta A. Gray.]

On dry hills and shaded rocks, Texas. Spring.

2. Phacelia congésta Hook. Annual, softly hirsute or cinereous. Stems 1-7 dm. tall, simple or sparingly branched: leaves $5-12 \mathrm{~cm}$. long; blades pinnately divided or parted, the segments blunt, 3-7 with smaller ones interposed, coarsely toothed or incised: calyx bristly; lobes linear to linear-spatulate, 3-4 mm. long, acute : corolla 6-8 $\mathrm{mm}$. broad ; lobes rounded, $\frac{1}{2}$ as long as the tube : capsules ovoid, $3 \mathrm{~mm}$. long, minutely hirsute.

About thickets, Texas, Spring.

3. Phacelia bipinnatífida Michx. Biennial, glandular-pubescent, or softly hirsute below, often heavy scented. Stems often decumbent, 1-6 dm. long, branching, sometimes diffuse : leaf-blades pinnately divided; segments incised or pinnatifid, acute or acuminate, thinnish; petioles longer than the blades except the upper ones: pedicels longer than the calyx at maturity : calyx hirsute; lobes linear-subulate, 4-6 $\mathrm{mm}$. long, acute : corolla violet-blue, $1.5-2 \mathrm{~cm}$. broad ; lobes rounded, longer than the tube ; appendages conspicuous : filaments sparingly villous, exserted : style exserted : capsules ovoid-globose, 5-6 mm. long, apiculate, hairy.

On damp slopes and thickets, Ohio to Illinois, Virginia, Georgia and Alabama. Spring and summer.

4. Phacelia brevístylis Buckl. Biennial, softly hirsute below, glandular-pilose above. Stems 1-4 dm. tall, branched : leaf-blades pinnately divided, the segments coarsely incised or pinnatifid : pedicels longer than the calyx, at maturity : calyx bristly ; lobes linear or linear-subulate, 5-6 mm. long, acute : corolla $5-8 \mathrm{~mm}$. broad; lobes rounded, shorter than the tube; appendages conspicuous : filaments delicately pubescent, included : styles included : capsules depressed, 4-5 mm. long.

In shaded slopes, North Carolina to Alabama. Spring and summer.

5. Phacelia glàbra Nutt. Annual, sparingly pubescent. Stems simple or branched at the base; branches erect or ascending, $0.5-1.5 \mathrm{dm}$. long: leaves $0.5-2.5 \mathrm{~cm}$. long, the basal with pinnate blades as long as the petioles or longer; stem-leaves variable, the lower resembling the basal, the upper sessile, pinnatifid; segments rather obtuse: racemes fewflowered : pedicels longer than the calyx at maturity: calyx sparingly bristly ; lobes oblong, 2.5-3 mm. long, obtuse : corolla $6-8 \mathrm{~mm}$. broad; lobes broadly ovate, undulate ; appendages narrow : tilaments exserted, glabrous : capsules subglobose, $3 \mathrm{~mm}$. long.

On prairies, Arkansas and Texas. Spring.

6. Phacelia dùbia (L.) Small. Annual, bright green, sparingly pubescent. Stems branched at the base ; branches $0.5-4 \mathrm{dm}$. long, minutely glandular as well as appressedpubescent, often zigzag : leaves pubescent with appressed hairs and less glandular than the branches; basal leaves petioled, $1-3 \mathrm{~cm}$. long, the segments varying from oval to orbicular; stem-leaves nearly sessile, $0-1.5 \mathrm{~cm}$. long, with $3-5$ segments, the terminal one oblong to obovate, acute : flowers rather few on pedicels $0.5-1 \mathrm{~cm}$. long: calyx-lobes oblong, 3-4 mm. long, slightly revolute, rather obtuse : corolla $7-11 \mathrm{~mm}$. long, pale lilac to greenish near the center; lobes broadly ovate, undulate, often blotched near the base : filaments pubescent, lilac at the tips : capsules oblong-orbicular, 2.5-3 mm. long. [P. parviflora Pursh.]

On banks, Pennsylvania to Kansas, Georgia and Texas. Spring.

7. Phacelia hirsùta Nutt. Annual or biennial, hirsute. Stems simple, or branched at the base ; branches $0.5-3 \mathrm{dm}$. long : leaves $2-7 \mathrm{~cm}$. long; primary ones spatulate or oblong-spatulate; basal and lower stem-leaves with pinnate blades and slender petioles: upper leaves sessile, pinnatifid, the segments acute, often curved : racemes many-flowered, $2-10 \mathrm{~cm}$. long : pedicels somewhat longer than the calyx at maturity : calyx bristly ; lobes oblong or linear-spatulate : corolla dark-purple or purplish blue, 12-15 mm. broad ; lobes rounded, undulate; appendages narrow : filaments barely exserted : capsules rather broader than high, 3.5-4 mm. long.

In dry soil and open woods, Virginia to Missouri and middle Georgia. Spring.

8. Phacelia láxa Small. Annual, sparingly hirsute. Stems branched at the base; branches spreading, 1-3 dm. long, simple or forked, slender : leaves $2-6 \mathrm{~cm}$. long; blades pinnately lobed, the lower ones long-petioled, the upper short-petioled ; lobes entire, as- 
cending : racemes lax, few-flowered, 4-12 cm. long: pedicels spreading or recurved, much longer than the calyxes at maturity: calyx sparingly bristly ; lobes obovate or suborbicular, 4-6 mm. long, obtuse, ciliate, variable in same calyx : corolla lilac or light blue, $1 \mathrm{~cm}$. broad; lobes rounded, entire, about as long as the tube; appendages present: stamens glabrous, shorter than the corolla : capsules suborbicular, hirsute near the top.

On the coast, Texas. Spring.

9. Phacelia patuliflòra (Engelm. \& Gray) A. Gray. Annual, rather densely hirsute. Stems branching at the base ; branches often spreading, 1-3 dm. long : leaves 2-8 $\mathrm{cm}$. long; blades pinnatifid, the lobes incised or toothed; basal or lower stem-leaves with petioles; the upper sessile or somewhat clasping: racemes rather few-flowered : pedicels slender, glandular-pilose, longer than the calyxes at maturity : calyx bristly ; lobes oblong or linear-oblong, 6-7 mm. long, obtuse : corolla deep blue, yellow within, $2 \mathrm{~cm}$. broad; lobes suborbicular, undulate ; appendages narrow : filaments barely exserted : capsules 2.5$3.5 \mathrm{~mm}$. long.

On prairies, Texas. Spring.

10. Phacelia strictiflòra (Engelm. \& Gray) A. Gray. Annual, densely hirsute. Stems simple, or branched at the base; branches often decumbent, 1-3 dm. long: leaves strigose, 2-6 cm. long; blades pinnatifid, the lower and basal petioled, the upper sessile : racemes usually many-flowered, $2-10 \mathrm{~cm}$. long: pedicels about as long as the calyxes at maturity : calyx hispid; lobes oblong to linear-spatulate, 5-10 mm. long : corolla $1.5-2 \mathrm{~cm}$. broad ; lobes rounded, erose ; appendages narrow : filaments barely exserted : capsules subglobose, 4-5 $\mathrm{mm}$. long, pubescent near the top.

On prairies, Texas. Spring.

11. Phacelia Boykínii (A. Gray) Small. Annual, sparingly strigillose. Stems erect, more or less branched, 1-2 dm. tall, glabrate in age: leaves 1-3 cm. long; blades pinnatifid, rough, the lower ones petioled, the upper sessile, the segments obtuse, abruptly pointed or mucronate : racemes many-flowered, $3-7 \mathrm{~cm}$. long : pedicels erect, about as long as the calyxes at maturity : calyx bristly ; lobes oblong, $3-3.5 \mathrm{~mm}$. long, prominently nerved, obtuse : corolla bluish, $7-8 \mathrm{~mm}$. broad; lobes oblong-obovate, laciniate ; appendages obsolete: filaments exserted, sparingly villous: capsules ovoid-globose, $2.5 \mathrm{~mm}$. in diameter. [P. fimbriata var. Boykinii A. Gray.]

In dry soil, Columbus, Georgia. Spring.

12. Phacelia Bicknéllii Small. Annual, strigose. Stems branched at the base; branches erect or ascending, 1-3 dm. tall, commonly branching: leaves 1-4 cm. long; blades pinnatifid, the lower ones petioled, the upper sessile and somewhat clasping, the segments acute : racemes many-flowered, $4-10 \mathrm{~cm}$. long : pedicels about as long as the caly xes at maturity : calyx bristly; lobes linear, $5 \mathrm{~mm}$. long, revolute : corolla pale blue, $4 \mathrm{~mm}$. broad; lobes oblique, irregularly toothed, pubescent without; appendages obsolete : filaments included, about as long as the tube, glabrous: capsules subglobose, $2 \mathrm{~mm}$. in diameter : seeds sharply reticulated, reddish brown.

In barren soil, Tennessee. Spring.

13. Phacelia Púrshii Buckl. Annual, sparingly pubescent. Stems 1-3 dm. tall, simple or diffusely branched : leaves (cauline) 1-8 cm. long; blades pinnatifid, shortpetioled or the upper ones sessile; segments oblong or lanceolate, acute or acuminate, entire or toothed: pedicels 3-4 times as long as the calyxes at maturity, or the upper ones shorter: calyx bristly; lobes linear to oblong-spatulate, 4-5 mm. long, ciliate : corolla light blue or rarely rose, $1.5 \mathrm{~cm}$. broad; lobes rounded, fimbriate ; appendages present : filaments villous: capsules ovoid, about $4 \mathrm{~mm}$. long.

In thickets or woods, Pennsylvania to Minnesota, North Carolina, Alabama and Missouri. Spring.

14. Phacelia fimbriàta Michx. Annual, sparingly pubescent at least below. Stems weak, simple or branched at the base, spreading: leaves 2-10 $\mathrm{cm}$. long; basal with pinnate blades, the terminal segment much larger than the rest, usually lobed; stem-leaves variable, the lower ones resembling the basal, with long petioles, the upper ones pinnatifid, sessile ; segments acute : racemes few-flowered : pedicels glabrate or softly pubescent, several times longer than the calyxes at maturity : calyx bristly ; lobes oblong or oblong-spatulate : corolla white or pinkish, $1.5 \mathrm{~cm}$. broad ; lobes fimbriate : filaments included, sparingly villous : capsules ovoid-spheroidal, $5 \mathrm{~mm}$. high, sparingly pubescent.

On mountain slopes, Virginia to Alabama. Spring.

\section{MARILAUNÍDIUM Kuntze.}

Annual or perennial herbs, with pubescent foliage and forking stems. Leaves alternate : blades entire, sometimes decurrent. Flowers solitary in the axils. Calyx sessile or 
pedicelled: lobes 5, narrow. Corolla often blue, funnelform or salverform: lobes 5, broad, imbricated. Stamens 5, included or nearly so : filaments irregularly adnate to the corollatube. Ovary 1-celled or sometimes imperfectly 2-celled. Styles distinct. Ovules numerous on each placenta. Capsule subglobose to oblong, 2-valved. Seeds very small, rugose. The plants flower mainly in the spring.

Leaves decurrent on the stem.

Leaves not decurrent on the stem.

Stem-leaves with sessile more or less manifestly clasping bases.

Calyx-manifestly pedicelled : capsule about $1 / 2$ as long as the calyx.

Calyx sessile or nearly so: capsule more than $1 / 2$ as long as the calyx.

Calyx-lobes linear-spatulate : capsules oblong, shorter than the caly $x$-lobes.

Calyx-lobes narrowly linear : capsules cylindric, about as long as the calyxlobes.

Stem-leaves nearly sessile, often narrowed to the base, lower ones often manifestly petioled.

Corolla narrowly funnelform, much longer than the calyx. Capsule slightly shorter than the calyx-lobes: corolla about $9 \mathrm{~mm}$. long. Capsule slightly over $1 / 2$ as long as the calyx-lobes: corolla about $10 \mathrm{~mm}$. long.

Corolla short-funnelform, barely surpassing the calyx, or only slightly longer. Annual plants : capsule $3 / 4$ as long as the calyx : seeds pitted in rows. Perennial plants : capsule about $1 / 2$ as long as the calyx : seeds smooth.

1. M. Jamaicense.

2. M. macranthum.

3. M. undulatum.

4. M. stenocarpum.

5. M, hispidum.

6. M. tenue.

7. M. angustifolium. 8. M. origanifolium.

1. Marilaunidium Jamaicénse (L.) Kuntze. Annual, pubescent. Stems branched at the base; branches spreading or prostrate, 1-4 dm. long: leaf-blades spatulate, often broadly so, 1-5 cm. long, each tapering into a petiole-like base decurrent on the stem as a wing : pedicel stout, $1-5 \mathrm{~mm}$. long: calyx hirsute; lobes narrowly linear or linear-spatulate, $6-8 \mathrm{~mm}$. long, acute, ciliate : corolla white or purple, about as long as the calyx-lobes : capsules narrowly oblong, 8-10 $\mathrm{mm}$. long. [Nama Jamaicense L.]

In moist soil, Florida and Texas. Also in the West Indies and Mexico.

2. Marilaunidium macránthum (Choisy) Kuntze. Annual, hirsute. Stems branched at the base; branches spreading or prostrate, $0.5-3 \mathrm{dm}$. long: leaves numerous; blades spatulate to oblong-spatulate, 1-4 cm. long, obtuse or acutish: pedicels 4-10 $\mathrm{mm}$. long: calyx bristly; lobes linear-spatulate, $8-10 \mathrm{~mm}$. long, acute, ciliate : corolla about twice as long as the calyx : capsules oblong, about $\frac{1}{2}$ as long as the calyx. [Nama undulatum var. macranthum Choisy.]

On plains and prairies, Texas and Mexico.

3. Marilaunidium undulàtum (H.B.K.) Kuntze. Annual, hirsute. Stems becoming diffusely branched, prostrate, $1-3 \mathrm{dm}$. long : leaves variable; lower ones with spatulate short-petioled blades; upper sessile, oblong, all varying from 1-3 cm. long, often crowded : pedicels solitary or several together, $1-2 \mathrm{~mm}$. long : calyx bristly ; lobes linearspatulate, $6-10 \mathrm{~mm}$. long: corolla funnelform, slightly surpassing the calyx : capsules oblong, shorter than the calyx, granular. [Nama undulatum H.B.K.]

On plains and prairies, southern Texas and Mexico.

4. Marilaunidium stenocárpum (A. Gray) Kuntze. Annual, hirsute. Stems more or less diffusely branched; branches spreading or prostrate, 1-3 dm. long: leaf-blades spatulate to oblong, 1-2 $\mathrm{cm}$. long, blunt, crisped: pedicels very short or none : calyx bristly ; lobes narrowly linear, 7-9 $\mathrm{mm}$. long, keeled : corolla about $8 \mathrm{~mm}$. long: capsules cylindric, shorter than the calyx. [Nama stenocarpum A. Gray.]

On plains and prairies, Texas and Mexico to Arizona.

5. Marilaunidium híspidum (A. Gray) Kuntze. Annual, hispid or hirsute. Stems branched at the base; branches spreading or prostrate, $0.5-2 \mathrm{dm}$. long: leaf-blades spatulate or linear-spatulate, 1-4 cm. long, obtuse, the lower short-petioled ; upper sessile : pedicels 1-2 mm. long: calyx bristly; Iobes narrowly linear, 4-6 mm. long, often slightly broadened upward: corolla about $8 \mathrm{~mm}$. long; tube surpassing the calyx: capsules narrowly oblong, shorter than the calyx, wrinkled. [Nama hispidum A. Gray.]

On prairies, Texas to Arizona.

6. Marilaunidium ténue Small. ${ }^{1}$ Annual, hirsute. Stems erect, 1-1.5 dm. tall, simple below, dichotomous above, wiry : leaves opposite ; blades linear or slightly broadened upward, $1.5-3 \mathrm{~cm}$. long, sessile : pedicels slender, 1-3 mm. long: calyx bristly; lobes linear-filiform, 4-5 mm. long, erect, acute : corolla purplish, 5-6 mm. long, much

${ }^{1}$ Marilaunidium stenophyllum (A. Gray) Kuntze, a shrubby plant with densely hispid foliage, corolla longer than the calyx and capsule about $\frac{1}{2}$ as long as the calyx-lobes, nay occur within our range. It was first found in Coahuila, Mexico, and later on the Texas side of the Rio Grande. 
surpassing the calyx ; tube funnelform, about $6 \mathrm{~mm}$. long; lobes suborbicular 3-3.5 mm. broad : capsules slightly over $\frac{1}{2}$ as long as the caly $x$-lobes.

In dry soil, Indian Territory and Texas.

7. Marilaunidium angustifolium (A. Gray) Kuntze. Annual, minutely glandularpubescent. Stems 1-3 dm. tall, dichotomously branched above the base : leaf-blades linear or nearly so, 1-3 cm. long, rather obtuse : calyx nearly sessile in the forks; lobes narrowly linear or slightly broadened upward : corolla about $2 \mathrm{~mm}$. long : capsules oblong-ovoid, 4-5 mm. long. [Nama dichotomum var. angustifolium A. Gray.]

On plains and prairies, Colorado to Texas and New Mexico.

8. Marilaunidium origanifòlium (H.B.K.) Kuntze. Perennial, softly hirsute. Stems diffusely branched, shrubby below, 1-3.5 dm. tall : leaves numerous; blades oblong or oval to obovate, $3-10 \mathrm{~mm}$. long, obtuse, nearly sessile or short-petioled : pedicels slender, 2-10 mm. long: calyx bristly ; lobes narrowly linear or slightly broadened near the top, 6-7 mm. long: corolla 7-8 mm. long; tube funnelform, about as long as the caly $\mathrm{x}$ : capsules oblong, more than $\frac{1}{2}$ as long as the calyx. [Nama origanifolium H.B.K.]

In dry soil, southern Texas and Mexico.

\section{NÀMA L.}

Perennial herbs, or shrubby plants sometimes armed with spines. Leaves alternate : blades entire. Cymes open or clustered. Calyx often pubescent : lobes almost distinct. Corolla blue or rarely white, rotate to campanulate : tube without appendages : lobes 5 , imbricated. Stamens 5: filaments inserted at the base of the corolla-tube, dilated at the base. Ovary 2-celled or rarely 3-celled. Styles distinct. Stigmas capitate. Ovules numerous on each adherent placenta. Capsule ovoid or subglobose, opening septicidally often somewhat irregularly. Seeds numerous. [Hydrolea L.]

Leaf-blades over 5 times longer than broad.

Flowers in terminal cymes: spines wanting or very few.

Flowers solitary in the axils of the leaves or in axillary clusters : spines present.

Stems villous-hirsute : calyx-lobes linear or linear-lanceolate.

Stems glabrous or merely puberulent: calyx-lobes ovate to ovate-lanceolate. Stems glabrous or merely puberulent: caly
Leaf-blades less than 4 times longer than broad.

1. N. corymbosum.

2. N. quadrivalvis.

3. N. affine.

4. N. ovatum.

1. Nama corymbòsum (Ell.) Kuntze. Unarmed or nearly so. Stem puberulent above, 2-7 dm. tall, simple below, corymbosely branched above : leaf-blades oblong to oblong-lanceolate, $2-5 \mathrm{~cm}$. long, acute, commonly lustrous above, sessile or short-petioled : corymbs $5-15 \mathrm{~cm}$. broad, leafy-bracted : pedicels very short : calyx bristly ; lobes linearlanceolate : corolla azure-blue, with yellowish nerves and 5 white spots near the base ; lobes ovate, obtuse : stamens and style exserted : capsules globular, 4-6 mm. in diameter, [Hydrolea corymbosa Ell.]

In and about swamps, South Carolina to Florida. Summer.

2. Nama quadriválvis (Walt.) Kuntze. Spine-armed. Foliage villous-hirsute, especially when young: stems often decumbent, $2-10 \mathrm{dm}$. long, mostly simple : leaf-blades narrowly elliptic, sometimes broadest above or below the middle, 4-12 $\mathrm{cm}$. long, acute or acuminate at both ends : clusters few-flowered or reduced to a single flower near the top of the stem : calyx sparingly pubescent ; lobes linear or linear-lanceolate, $6-8 \mathrm{~mm}$. long, acute : corolla blue or lilac, 1-1.5 cm. broad ; lobes ovate, obtuse : capsules subglobose, $5-6 \mathrm{~mm}$. in diameter, surpassed by the calyx-lobes. [Hydrolea quadrivalvis Walt.]

In low or muddy situations, Virginia to Florida and Louisiana. Summer.

3. Nama affine (A. Gray) Kuntze. Spine-armed. Foliage glabrous, or puberulent when young : stems sometimes decumbent and creeping, 2-7 dm. long, simple or branching : leaf-blades linear-elliptic varying to broadest above or below the middle, $3-10 \mathrm{~cm}$. long, acute at both ends, short-petioled : clusters few-flowered, leafy-bracted, short-peduncled : calyx sparingly hispid ; lobes ovate to ovate-lanceolate, $5 \mathrm{~mm}$. long, acute, ciliate : corolla violet, $1.5 \mathrm{~cm}$. broad ; lobes linear or linear-lanceolate : capsules 6-7 mm. in diameter, surpassing the calyx. [Hydrolea affinis A. Gray.]

In swampy places, Indiana to Missouri, Mississippi and Texas. Summer and fall.

4. Nama ovàtum (Nutt.) Britton. Spine-armed. Foliage softly pubescent or glabrate in age : stems $2-7 \mathrm{dm}$. tall, paniculately branched above: leaf-blades ovate to elliptic, 2-6 cm. long, somewhat acuminate, ciliolate, acute to subcordate at the base, short-petioled : panicles leafy-bracted ; clusters terminating the branches : pedicels $2-5 \mathrm{~mm}$. long : calyx hirsute; lobes linear-lanceolate or lanceolate, 7-9 $\mathrm{mm}$. long, acuminate : corolla purplish or white, about $2 \mathrm{~cm}$. broad ; lobes ovate : capsules globose-ovoid, about $4 \mathrm{~mm}$. high. [Hydrolea ovata Nutt.]

In swamps, Missouri to Louisiana and Texas. Summer. 


\section{Family 5. Polemoniàceat Vent. Phlox Family.}

Annual or usually perennial herbs or shrubby plants. Leaves alternate or opposite, often crowded: blades entire or pinnately compound. Inflorescence paniculate, corymbose, sometimes clustered. Flowers perfect, regular or nearly so. Calyx of 5 partially united sepals. Corolla regular : limb five-lobed : lobes convolute in aestivation. Androecium of 5 often unequal stamens adnate to the corolla-tube. Anthers opening lengthwise and introrsely. Gynoecium of a single carpel. Ovary 3-celled with a thick axis. Styles united. Stigmas 3. Ovules solitary, erect, anatropous, or several in two series, ascending, amphitropous. Fruit a 3-celled loculicidal capsule : valves usually separating from the central axis to which the seeds are attached. Seeds solitary or several in each cavity, with a spongy or mucilaginous testa. Endosperm fleshy or horny. Embryo straight, axile.

Calyx-tube distended and ruptured by the capsule at maturity.

Corolla salverform: leaves opposite; blades entire.

Corolla funnelform or rotate (in our species): leaves often alternate; blades commonly pinnatifid.

Calyx-tube neither distended nor ruptured at maturity.
1. Phlox.
2. Gilia.
3. POLEMONILM.

\section{PHLÓX L.}

Annual or usually perennial, sometimes shrubby herbs, with erect or diffuse and creeping stems. Leaves opposite, or sometimes alternate above: blades entire. Flowers in terminal corymbose or panicled cymes. Calyx pedicelled: tube narrow, 5-ribbed: lobes 5 , often tooth-like. Corolla white, blue, purple or red, salverform : tube slender: lobes spreading, obovate to orbicular, or obcordate. Stamens 5, included. Filaments, unequally adnate to the corolla-tube. Ovules 1-5 in each cavity. Capsule included in the calyxtube which it ruptures at maturity. Seeds sometimes narrowly winged, not emitting spiral threads when wetted.

Calyx-lobes fully as long as the tube or much longer.

Annual plants.

Corolla-tube not surpassing the calyx, glabrous : ovules 4 or 5 in each cavity.

1. P. Roemeriana.

Corolla-tube surpassing the calyx, pubescent: ovule 1 in each cavity.

Leaves mostly alternate; blades thin.

Stems mostly less than $10 \mathrm{~cm}$. long: leaf-blades narrowed at the base: corolla-lobes about $6 \mathrm{~mm}$. long.

Stems mostly over $10 \mathrm{~cm}$. long: leaf-blades broadest at the base: corolla-lobes about $10 \mathrm{~mm}$. long.

Leaves mostly opposite; blades thick.

Stems villous-hirsute : leaf-blades bristly : capsules oblong.

Stems scabrous-pubescent: leaf-blades slightly pubescent : capsules subglobose.

Perennial plants.

Plants with prostrate or creeping sterile"shoots.

Leaf-blades of the!sterile shoots of a spatulate type, petioled.

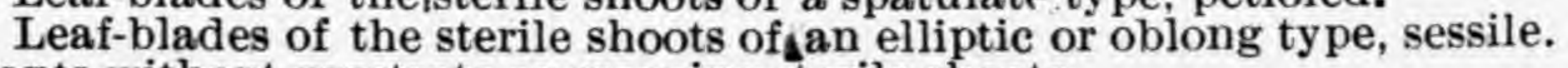

Plants without piostrate or creeping sterile shoots.

Caly $x$-lobes linear-subulate, the tips not bristle-like.

Cymes compact, involucrate : capsules less than $4 \mathrm{~mm}$. long.

Upper leaves with blunt or merely acute blades.

Upper leaves with somewhat acuminate blades.

Cymes open, not involucrate: capsules fully $5 \mathrm{~mm}$. long.

Calyx-lobes with bristle-like tips.

Calyx copiously pubescent : branches of the inflorescence closely pubescent.

Calyx glabrous or nearly so: branches of the inflorescence glabrous or with few scattered hairs.

Calyx-lobes shorter than the tube, sometimes apparently, longer by the splitting of the sinuses.

Stems prostrate, spreading, forming large mats.

Leaves little if at all clustered : corolla-lobes cleft to the middle or below it.

Leaves conspicuously or densely clustered : corolla-lobes entire or notched.

Calyx 4-6 mm. long: plants forming dense mats.

Upper part of plant glandular: corolla-lobes deeply notched.

Upper part of plant not glandular: corolla-lobes shallowly notehed.

Caly x 8-10 mm. long: plants not in dense mats.

2. P. tenuis.

3. P. Drummondii.

4. P. villosissima.

5. P. aspera.

6. $P$. reptans.

7. P. divaricata.

8. P. amoena.

9. P. Lighthipei.

10. P. Floridana.

11. P. pilos .

12. P. detonsa.

13. P. bifida.

14. P. Brittonii.

15. P. subulata.

16. P. Hentzii.

Stems erect or ascending, not forming mats.

A. Calyx-lobes lanceolate, subulate-lanceolate or nearly triangular.

a. Calyx-lobes $1 / 3$ or $1 / 2$ as long as the tube.

Upper leaf-blades with broadly rounded or cordate bases ; lower leaves with petioled blades.

Upper leaf-blades obtuse or acute at the base; lower leaves with sessile blades.

17. P. ovata.

18. P. glaberrima. 
b. Caly $x$-lobes less than $1 / 3$ as long as the tube.

B. Calyx-lobes bristle-like.

Leaves conspicuously decurrent on the internodes: calyx-lobes about as long as the tube : corolla-tube pubescent.

Leaves not decurrent on the internodes: calyx-lobes shorter than the tube: corolla-tube glabrous.

Stems glabrous or puberulent: leaf-blades relatively narrow.

Stems villous, and glandular above: leaf-blades relatively broad.

19. P. maculata.

20. P. acuminata.

21. P. paniculata.

22. P. amplifolia.

1. Phlox Roemeriàna Scheele. Annual, sparingly hirsute, or glabrate below. Stems usually branched at the base ; branches erect or ascending, $0.5-3 \mathrm{dm}$. tall : leaves mostly alternate ; blades spatulate-oblong or lanceolate, $2-4 \mathrm{~cm}$. long, mostly acute or acuminate, sessile: calyx villous-hirsute, $8-10 \mathrm{~mm}$. long; lobes subulate, as long as the tube or longer, spreading: corolla-tube glabrous, $1 \mathrm{~cm}$. long; limb about $2 \mathrm{~cm}$. broad : capsules 5-6 mm. long.

On high prairies, Texas. Spring.

2. Phlox ténuis (A. Gray) E. Nelson. Annual, glabrous or slightly pubescent, not villous. Stems $5-10 \mathrm{~cm}$. long, erect or diffuse : leaves mostly opposite ; blades linear or narrowly linear-lanceolate, $1-2.5 \mathrm{~cm}$. long, acute : calyx 6-7 mm. long; lobes subulate, about as long as the tube : corolla lavender ; tube finely pubescent, surpassing the calyx ; limb $12-15 \mathrm{~mm}$. broad, the lobes rhombic-obovate, acute : capsules about $4 \mathrm{~mm}$. long.

In low grounds, eastern and southern Texas, Spring.

3. Phlox Drummóndii Hook. Annual, somewhat villous, at least below, and viscid. Stems 1-3 dm. tall, often branched at the base and sometimes above : leaves alternate; blades narrowly oblong to lanceolate, or those at the base of the stem spatulate-oblanceolate, $1.5-4 \mathrm{~cm}$. long, acute, sessile : calyx 8-9 mm. long; lobes subulate : corolla lavender; tube pubescent, surpassing the calyx; limb $1.5-2 \mathrm{~cm}$. broad, the lobes obovate, abruptly pointed : capsules about $4 \mathrm{~mm}$. long.

In sand or sandy soil, Texas. Spring.

4. Phlox villosíssima (A. Gray) Small. Annual, conspicuously villous-hirsute throughout. Stems 1-3 dm. tall, simple or much-branched: leaves mainly opposite ; blades linear-lanceolate to almost linear, 2-6 cm. long, acute or somewhat acuminate, bristly, sessile : calyx densely pubescent, 9-12 mm. long; lobes lanceolate-subulate, nearly erect, about as long as the tube : corolla pale lavender; tube finely pubescent, somewhat surpassing the calyx ; limb $2-2.5 \mathrm{~cm}$. broad, the lobes orbicular-obovate or orbicularcuneate, often abruptly pointed : capsules $5-6 \mathrm{~mm}$. long. $\quad[P$. Drummondii var. villosissima A. Gray.]

In river valleys, southern Texas. Spring.

5. Phlox áspera E. Nelson. Annual, pubescent with short rigid hairs. Stems branched from the base ; branches $12-17 \mathrm{~cm}$. tall, often with a few longer hairs mixed with the puberulence : leaves opposite; blades narrowly lanceolate to linear, $2-4.5 \mathrm{~cm}$. long, thick and firm: calyx, like the pedicels, glandular; lobes twice as long as the tube, awntipped : corolla violet; tube glandular-pubescent, about twice as long as the calyx ; lobes cuneate-obovate, about $11 \mathrm{~mm}$. long, mucronate-acute : capsules 4-5 mm. long.

In dry soil, southern Texas. Spring.

6. Phlox réptans Michx. Perennial, often sparingly pubescent. Stems branched at the base, the branches of 2 kinds ; sterile prostrate or creeping; fertile erect or ascending : leaves of $3 \mathrm{kinds}$, basal 4-10 cm. long, with spatulate or ovate blades and margined petioles, those of the sterile shoots similar but smaller, those of the fertile stems usually oblong or oblong-lanceolate : calyx 10-13 mm. long, sparingly pubescent; lobes narrowly linear or linear-subulate, about as long as the tube : corolla purple or violet ; tube $2-2.5 \mathrm{~cm}$. long ; limb $2.5-3 \mathrm{~cm}$. broad ; lobes obovate or cuneate-obovate : capsules 2.5-3 mm. long.

In open woods, Pennsylvania to Kentucky, south to Georgia and Alabama. Spring.

7. Phlox divaricàta L. Perennial, more or less densely viscid-hirsute. Stems erect or ascending, 2-5 dm. long, usually tufted, producing decumbent or creeping shoots at the base : leaves opposite; blades oblong to lanceolate, or ovate-lanceolate, $1.5-5 \mathrm{~cm}$. long, usually acute, entire, sessile, the upper ones sometimes cordate; those of the shoots often longer, sometimes broadest above the middle, sessile : caly x $6-10 \mathrm{~mm}$. long; lobes linearsubulate, curved at maturity : corolla lavander or bluish ; tube 1-1.5 cm. long ; limb $2.5-3$ $\mathrm{cm}$. broad ; lobes apiculate or notched : capsules subglobose, 4-5 $\mathrm{mm}$. long.

In damp woods, Ontario to Minnesota, south to Florida and Louisiana. Spring.

8. Phlox amoèna Sims. Perennial, villous or hirsute. Stems ascending or decumbent, 1-2.5 dm. long, often branched at the base : leaves opposite; blades leathery, spatulate to oblong or linear, $1-4.5 \mathrm{~cm}$. long, obtuse or merely acute, often erect or ascending, sessile : corymbs compact, often congested : calyx bristly-pubescent, less than $1 \mathrm{~cm}$. long; 
lobes linear-subulate, commonly longer than the tube : corolla purple, pink or white; tube glabrous, $1-1.5 \mathrm{~cm}$. long; limb $2-2.5 \mathrm{~cm}$. broad ; lobes cuneate or obovate, apiculate or rarely notched : capsules oval, $3-4 \mathrm{~mm}$. long.

On dry hillsides and in pine woods, Virginia to Tennessee and Florida. Spring.

9. Phlox Lighthìpei Small Resembling $P$. amoena, but larger. Stem erect or nearly so, 2-4 dm. tall : leaf-blades narrower than those of $P$. amoena, those of the sterile shoots linear or nearly so, those of the flowering stems linear or linear-lanceolate, the upper ones, at least, somewhat acuminate : calyx bristly pubescent, over $1 \mathrm{~cm}$. long; lobes longer than the tube: corolla pink or pink-purple ; tube $1.5-2 \mathrm{~cm}$. long : capsules oblong, 4-5 $\mathrm{mm}$. long.

In pine lands, southern Georgia and Florida. Spring.

10. Phlox Floridàna Benth. Perennial, finely pubescent or glabrate below. Stems erect, sometimes tufted, 2-6 dm. tall, corymbose above : leaves opposite ; blades linear or linear-lanceolate, $2-10 \mathrm{~cm}$. long, sessile : corymbs glandular-pubescent : calyx about $1 \mathrm{~cm}$. long; lobes subulate-setaceous, as long as the tube or longer: corolla light purple ; tube $1.5-2 \mathrm{~cm}$. long; limb about $2 \mathrm{~cm}$. broad ; lobes cuneate or cuneate-obovate, entire : capsules oblong, 5-6 mm. long.

In open woods, Georgia and Alabama to Florida. Spring.

11. Phlox pilòsa L. Perennial, villous-hirsute. Stems erect or ascending, often tufted, $2-5 \mathrm{~cm}$. tall, corymbose above : leaves opposite ; blades linear to narrowly lanceolate, 3-8 $\mathrm{cm}$. long, gradually attenuate, sessile : corymbs becoming lax : calyx about 1 cm. long; lobes subulate-setaceous, as long as the tube or longer : corolla pink-purple or white ; tube 1-1.5 cm. long, more or less pubescent; limb $2 \mathrm{~cm}$. broad ; lobes obovate or cuneate, sometimes apiculate : capsules globose-oblong, about $5 \mathrm{~mm}$. long.

In sandy woods or meadows, Ontario to Manitoba, south to New Jersey, Florida and Texas. Spring.

12. Phlox detónsa (A. Gray) Small. Similar to $P$. pilosa in habit, but glabrous, at least below the inflorescence : leaf-blades narrowly linear to linear-lanceolate, acuminate : branches of the inflorescence sometimes merely puberulent: calyx glabrous or essentially so : capsules about $4 \mathrm{~mm}$. long. [P. pilosa var. detonsa A. Gray.]

In pine woods and on prairies, Florida to Texas. Spring.

13. Phlox bífida Beck. Perennial, minutely pubescent. Stems diffusely branched at the base; branches 1-2 dm. long: leaves opposite ; blades linear, 2-5 cm. long, acute, sessile; midnerve prominent beneath : calyx 6-8 mm. long; lobes subulate, shorter than the tube : corolla violet purple; tube often $1 \mathrm{~cm}$. long; limb $1.5 \mathrm{~cm}$. broad, the lobes cleft to below the middle; the segments oblong or linear: capsules oblong, 3-4 mm. long.

On prairies or barrens, Michigan to Tennessee and Illinois. Spring.

14. Phlox Brittònii Small. Perennial, deep green. Stems copiously branched; branches matted, forming wide mats, glandular-pilose : leaves numerous, small ones often clustered in the axils of the larger; blades subulate or narrowly linear-subulate, 5-10 mm. long, ciliate especially near the base : calyx 5-6 mm. long, glandular-pubescent like the branches; lobes subulate, about as long as the tube : corolla mainly white; tube about 1 cm. long; limb 12-13 mm. broad; lobes cuneate, with 2 pale magenta spots at the base, cleft by a V-shaped sinus about $3 \mathrm{~mm}$. deep at the apex, a minute tooth in each sinus, the tips acute or acutish.

On dry mountain slopes, Virginia, West Virginia and North Carolina. Spring.

15. Phlox subulàta L. Perennial, evergreen, more or less pubescent. Stems decumbent, forming mats, the fertile branches erect, 1-1.5 dm. tall, pilose with fine hairs : leaves opposite, often clustered ; blades linear or linear-subulate, $1-1.5 \mathrm{~cm}$. long, acute, sessile : calyx 8-9 mm. long, pubescent like the stem; lobes lanceolate-subulate, about as long as the tube : corolla purple, pink or white; tube $1-1.5 \mathrm{~cm}$. long; limb $1.6-2 \mathrm{~cm}$. broad ; lobes cuneate, emarginate or slightly notched, the sinuses toothless, but with 2 deep magenta spots at the base : capsules oblong-obovoid, 4-4.5 mm. long.

On rocky hillsides or in barren places, New York to Michigan, Georgia and Kentucky. Spring. Ground or Moss Pink.

16. Phlox Héntzii Nutt. Perennial, minutely pubescent. Stems branched at the base ; branches erect or ascending, 2-4 dm. tall, sometimes quite stout and very leafy : leaves opposite, often clustered ; blades narrowly linear or linear-subulate, $1-2 \mathrm{~cm}$. long, acute or acuminate, sessile, with smaller ones clustered in their axils : calyx at least $1 \mathrm{~cm}$. long, glandular-pubescent ; lobes subulate, as long as the tube or longer : corolla purple, lavender or white ; tube 1-1.5 cm. long; limb 2-2.5 cm. long; lobes notched or erose: capsules 4-5 mm. long.

In sandy pine lands, North Carolina to Florida. Spring. 
17. Phlox ovàta L. Perennial, glabrous. Stems erect or decumbent, $2-6 \mathrm{dm}$. tall : leaves opposite; blades elliptic, oblong or lanceolate, $3-10 \mathrm{~cm}$. long, acute or acuminate, the lower narrowed into petioles, the upper sessile, often partly clasping : calyx glabrous ; lobes triangular or triangular-lanceolate, much shorter than the tube: corolla bright purple ; tube 1-2 $\mathrm{cm}$. long; limb 2-2.5 $\mathrm{cm}$. broad; lobes rounded or retuse : capsules about $4 \mathrm{~mm}$. long.

In open woods, Pennsylvania to North Carolina, Tennessee and Alabama. Spring and summer.

18. Phlox glabérrima L. Perennial, glabrous or nearly so. Stems erect or ascending, sometimes tufted, $3-8 \mathrm{dm}$. tall, rarely pubescent with spreading hairs : leaves opposite ; blades oblong, lanceolate or linear, $2.5-10 \mathrm{~cm}$. long, acute or acuminate, sessile : calyx 8-10 $\mathrm{mm}$. long; lobes triangular or triangular-lanceolate, very acute : corolla purple or pink purple, or rarely white ; tube $2-3 \mathrm{~cm}$. long ; limb $2-2.5 \mathrm{~cm}$. broad ; lobes rounded or truncate, sometimes undulate : capsules $4-4.5 \mathrm{~mm}$. long.

In open woods, Wisconsin to Virginia, Florida and Alabama. Spring and summer.

19. Phlox maculàta L. Perennial, glabrous or nearly so below. Stems erect, often clustered, 3-10 dm. tall : leaves opposite, remote ; blades oblong-lanceolate, lanceolate or linear, 5-12 cm. long, acuminate, becoming parchment-like in texture, sessile or nearly so : panicles cylindric, 1-4 dm. long, often glandular-pubescent : calyx mostly deep green; lobes lanceolate or triangular-lanceolate, about $\frac{1}{2}$ as long as the tube : corolla pink-purple ; tube $1.5-2 \mathrm{~cm}$. long; limb $2-2.5 \mathrm{~cm}$. broad; lobes orbicular-obovate or broadly cuneate : capsules oblong, $4 \mathrm{~mm}$. long.

In low grounds, New Jersey to Minnesota, Florida and Tennessee. Summer. SweEt Wrllitam.

20. Phlox acuminàta Pursh. Perennial, glabrate. Stems erect or ascending, 6-10 dm. tall, sparingly branched above, angled or narrowly winged by the decurrent petioles : leaves opposite ; blades linear-elliptic or oblong-lanceolate, 5-16 cm. long, acuminate, undulate, short-petioled : panicles often large and broad : caly $x$ glabrous or very minutely pubescent; lobes bristle-like, as long as the tube or nearly so : corolla purple or pink purple ; tube $2-2.5 \mathrm{~cm}$. long, $1.5 \mathrm{~mm}$. thick ; limb $1.5 \mathrm{~cm}$. broad; lobes cuneate : capsules $5 \mathrm{~mm}$. long.

In mountain woods, North Carolina and Alabama. Summer.

21. Phlox paniculàta L. Perennial, minutely pubescent or glabrate. Stems 6-12 dm. tall, branched above : leaves opposite ; blades elliptic, elliptic-lanceolate or narrowly oblong-elliptic, $8-20 \mathrm{~cm}$. long, acuminate, undulate, narrowed into margined petioles or nearly sessile: panicles corymbose-pyramidal : calyx granular or sparingly pubescent ; lobes subulate, shorter than the tube : corolla pink-purple or white; tube about $2 \mathrm{~cm}$. long, $1.5-2 \mathrm{~mm}$. thick ; limb 15-17 mm. broad ; lobes obovate or cuneate-obovate : capsules oval, 4-5 mm. long.

In open woods, Pennsylvania to Mlinois, Florida and Louisiana. Summer. SweEt WilliaM.

22. Phlox amplifolla Britton. Perennial, pubescent. Stems 5-13 dm. tall, villous, or glandular-villous, at least above : leaves opposite ; blades ovate, oval, elliptic or lanceolate on the upper part of the stem, thin, mostly 5-15 cm. long, acuminate, narrowed into broad bases or winged petioles, scabrous above: inflorescence similar to that of the next preceding species : calyx glandular-villous : corolla about $2 \mathrm{~cm}$. long; tube glabrous : capsules 4-4.5 mm. long.

In woods, and thickets, Kentucky to Missouri and Tennessee. Summer.

\section{GÍLIA R. \& P.}

Annual or perennial sometimes shrubby herbs, with diffuse or erect and elongated stems. Leaves alternate or opposite : blades entire, narrowly cleft or dissected. Flowers solitary in the axils, variously disposed. Calyx pedicelled : tube campanulate to tubular : lobes 5, often shorter than the tube. Corolla white or highly colored : tube short or elongated : lobes 5, erect or spreading. Stamens 5, sometimes exserted : filaments evenly or irregularly adnate to the corolla-tube. Ovules solitary or several in each cavity. Capsule mainly included in the calyx whose tube it ruptures at maturity. Seeds often mucilaginous, those of some species emitting spiral threads. The plants flower in the summer, or southward in the spring and summer.

Corolla rotate.

Annual: leaf-blades incised-toothed: corolla less than $15 \mathrm{~mm}$. broad.

Perennial : leaf-blades parted : corolla over $20 \mathrm{~mm}$. broad. Corolla funnelform, rather narrowly so.

1. G. incisa.

2. G. rigidula.

3. G. rubra.

1. Gilia incisa Benth. Annual, puberulent. Stems 1-4 dm. tall, sparingly branched or sometimes diffusely so: leaves alternate; blades various, incised-toothed : calyx 3-5 
cm. long; lobes lanceolate-subulate, longer than the tube : corolla white or blue, about $1.5 \mathrm{~cm}$. broad ; lobes ovate : capsule oval or ovoid, $4-6 \mathrm{~mm}$. long, surpassing the calyx.

On banks and in thickets, Texas and adjacent Mexico.

2. Gilia rigidula Benth. Perennial, viscid or glabrate. Stems branched at the base ; branches ascending or spreading, $0.5-3 \mathrm{dm}$. long : leaves alternate; blades usually pinnately or palmately cleft or parted; lobes linear or lanceolate : calyx 5-8 mm. long; lobes subulate-tipped, shorter than the tube : corolla blue, $2-3 \mathrm{~cm}$. broad, 5 -parted; lobes ovate : capsule ovoid, 4-5 mm. long, included in the calyx.

On hills and stony plains, Texas to New Mexico and adjacent Mexico.

3. Gilia rùbra (L.) Heller. Biennial, minutely pubescent. Stems erect or ascending, 5-18 dm. tall, narrowly paniculate above : leaves numerous; blades pinnately parted, the segments linear-filiform : racemes or panicle 1-7 dm. long, narrow : calyx 6-8 mm. long ; tube campanulate ; lobes subulate, as long as the tube or longer : corolla scarlet or yellow, dotted with red within, $2.5-3 \mathrm{~cm}$. long; lobes oblong or ovate-oblong: capsule oblong, $8 \mathrm{~mm}$. long. [G. coronopifolia Pers. ]

In sandy soil, South Carolina to Arkansas, Florida and Texas.

\section{POLEMÒNIUM L.}

Annual, or usually perennial caulescent herbs, with horizontal rootstocks. Leaves alternate, sometimes mainly basal : blades pinnate. Flowers in terminal panicled cymes. Calyx accrescent : tube terete : lobes 5, about as long as the tube. Corolla white, blue or yellow, tubular-campanulate to tubular-funnelform or rarely rotate: limb more or less spreading: lobes 5, broad. Stamens 5, declined. Filaments adnate to the base of the corolla-tube, often pubescent at the base. Ovules few or several in each cavity. Capsules surrounded by the calyx. Seeds sometimes narrowly winged, emitting spiral threads when wetted.

1. Polemonium réptans L. Foliage glabrous. Stems erect or finally spreading, 3-7 dm. long, more or less branched: leaf-blades pinnate, shorter than the petioles; leaflets oblong, elliptic or oblong-lanceolate, acute or apiculate, sessile or nearly so: pedicels becoming $5-10 \mathrm{~mm}$. long : calyx $5 \mathrm{~mm}$. becoming $1 \mathrm{~cm}$. long; lobes triangular to triangular-ovate, as long as the tube or shorter : corolla blue, $1.5-2 \mathrm{~cm}$. broad ; lobes spatulate or cuneate : capsules oval or ovoid-oval, 5-6.5 mm. long.

In thickets and woods, New York to Minnesota, Georgia and Missouri. Spring. Greek Valerian.

\section{Family 6. Solanàceae Pers, Potato Family.}

Herbaceous plants, or shrubs or vines, some of them of great economic value, possessing stimulant and narcotic properties. Leaves alternate, commonly without stipules : blades various. Inflorescence variously disposed. Flowers usually regular, perfect, on naked pedicels. Calyx free, of 5 or rarely 4-6 more or less united sepals, mostly persistent, sometimes accrescent. Corolla hypogynous, rotate, campanulate, infundibuliform or hypocrateriform : limb 5-lobed or 4-6lobed. Androecium of 5 , or 4 or 6 stamens, all fertile, adnate to the tube of the corolla alternate with the lobes. Filaments equal or unequal, often toothed. Anthers introrse, opening lengthwise, or by pores. Gynoecium compound. Ovary superior, 2-celled or sometimes 3-5-celled. Styles terminal, united. Stigmas entire or essentially so. Ovules numerous, amphitropous. Fruit a berry or a capsule, with two or rarely several cavities. Seeds numerous, flattened, with a crustaceous often tuberculate or rarely membranous testa. Endosperm fleshy, plentiful.

A. Fruit a berry.

a. Corolla plicate; lobes usually induplicate.

Berry enclosed in the accrescent calyx : anthers not connected; sacs opening lengthwise.

Calyx inflated and bladder-like at maturity.

Ovary 3-5-celled : sepals nearly distinct, auricled at the base.

Ovary 2-celled: sepals united to near the tips.

Corolla open campanulate, yellow to white, often with a dark center : seeds finely pitted.

Corolla flat-rotate, violet or purple : seeds rugose-tuberculate. Calyx closely investing the berry, open at the mouth.

Berry seated in the little changed calyx (exceptionally enclosed in species of Solanum) : anthers connate or converging.

Anther-sacs commonly opening by terminal pores or short slits.

1. Physalodes.

2. PHYSALIS.

3. QUINCULA.

4. Chamaesaracha.

5. Solanum. 
Anther-sacs opening lengthwise and introrsely.

b. Corolla little if at all plicate; lobes imbricate,valvate or valvate-induplicate. Anthers converging around the style: corolla urn-shaped.

Anthers not converging: corolla rotate or salverform, or funnelform.

Stamens adnate to the base of the corolla-tube: corolla rotate.

Stamens adnate to the middle or the mouth of the corolla-tube : corolla salverform to funnelform.

Stamens unequal: filaments adnate to the mouth of the corollatube: seeds flattened.

Stamens equal or nearly so: filaments adnate to about the middle of the corolla-tube: seeds not flattened.

B. Fruit a capsule: corolla funnelform.

Capsules armed with prickles.

Capsules unarmed.

Flowers in racemes or panicles : filaments nearly equal in length.

Flowers solitary in the axils or opposite the leaves : filaments unequal in length.

Sepals nearly distinct: anther-sacs distinct.

Sepals united to above the middle: anther-sacs somewhat confluent.
6. LYCOPERSICON.

7. Perizoma.

8. Capsicum.

\section{LYCIUM.}

10. Cestrum.

11. Datura.

12. Nicotiana.

13. Petunia.

14. Bovchetia.

\section{PHYSALÒDES Boehm.}

Annual caulescent herbs, with deep green foliage. Leaves alternate; blades broad, sinuate-toothed or lobed. Flowers nodding, solitary in the axils. Calyx accrescent, angled, inflated at maturity: sepals nearly distinct, cordate or sagittate at the base. Corolla blue or violet, plicate in the bud, campanulate, slightly 5-lobed. Stamens 5, included : filaments adnate to the base of the corolla, filiform from a dilated and pubescent base : anther-sacs opening lengthwise. Ovary 3-5-celled: stigma 3-5-lobed. Berry subglobose, rather dry, enclosed in the calyx. [Nicandra Adans.]

1. Physalodes Physalòdes (L.) Britton. Plant nearly glabrous. Stems 3-9 dm. tall, widely branching : leaf-blades ovate, oval or oblong, 5-15 cm. long, angulately lobed or sinuate, narrowed into margined petioles : pedicels puberulent, recurving: calyx 1.5 cm. becoming $3.5 \mathrm{~cm}$. long, reticulated; sepals broadly ovate, narrowed into slender tips : corolla blue or violet, $2.5 \mathrm{~cm}$. broad; limb nearly entire : berries $1.5-2 \mathrm{~cm}$. in diameter. and fall.

In waste places, eastern Canada and the Atlantic United States. Naturalized from Peru. Summer

\section{PHÝSALIS L. ${ }^{1}$}

Annual or perennial herbs, sometimes a little woody at the base, with simple or branching hairs, or glabrous. Leaves alternate: blades entire or sinuately toothed. Pedicels generally solitary from the axils of the leaves, but sometimes in clusters of 2-4. Calyx campanulate, 5-lobed, accrescent, membranaceous, 5-angled or prominently 10 -ribbed and reticulate, wholly enclosing the pulpy berry : lobes in most cases connivent. Corolla yellowish or whitish, often with a much darker, brownish or purplish center, open campanulate or rarely campanulate-rotate, plicate, with very short and broad lobes which are slightly imbricate in the bud. Stamens adnate to the base of the corolla. Anther-sacs opening by longitudinal slits. Stigma minute. Seeds numerous, kidney-shaped, flattened, with a thin edge, finely pitted. The plants flower in summer, or from spring to fall in the South. Ground Cherry. Jerusalem Cherry.

A. Annuals, with much branched roots.

Plants more or less viscid pubescent.

Fruiting calyx sharply 5-angled, deeply sunken at the base, calyx-lobes at flowering time fully as long as the tube.

Fruiting calyx not long-acuminate: leaf-blades very oblique.

Leaf-blades ovate, subentire at the base : stem slender, diffuse, sharply angled.

Leaf-blades cordate, strongly sinuately toothed to the base : stem obtusely angled.

Leaves broadly rounded, cordate, $2-5 \mathrm{~cm}$. long: stem weak, diffuse. Leaves elongated, cordate, 4-10 $\mathrm{cm}$. long: stem stout.

Fruiting calyx long-acuminate: leaf-blades scarcely oblique at the base, cordate, abruptly acuminate.

Fruiting caly $\mathrm{x}$ obtusely or indistinctly 5-10-angled; calyx-lobes at flowering time shorter than the tube (except sometimes in $P$. Carpenteri).

Leaf-blades not long-acuminate: flowers solitary.

Leaf-blades long-acuminate: flowers often fascicled.

Plants glabrous or only the upper parts sparingly beset with short hairs $(P$.

ixocarpa sometimes a little puberulent when young).

a. Fruiting calyx sharply 5-angled, deeply sunken at the base.

1. P. pubescens.

2. P. Floridana.

3. P. pruinosa.

4. P. Barbadensis.

5. P. Lagascae.

6. P. Carpenteri.

7. P. obscura.

${ }^{1}$ Contributed by Dr. Per Axel Rydberg. 
b. Fruiting calyx obtusely 5-10-angled, scarcely sunken at the base.

Corolla yellow, the center sometimes a little darker but not brown or purple.

Peduncles much longer than the fruiting calyx: corolla $5-8 \mathrm{~mm}$. in diameter.

Peduncles scarcely exceeding the fruiting calyx : corolla 8-10 $\mathrm{mm}$. in diameter.

Corolla yellow with a distinctly brown or purple center.

Peduncles scarcely longer than the flowers : corolla 10-15 mm. in diameter.

Peduncles longer than the flowers: corolla 15-25 mm. in diameter.

B. Perennials, mostly with horizontal rootstocks.

Pubescence not of stellate hairs.

Pubescence sparse, seldom, if at all, glandular or viscid.

Leaves glabrous: upper part of the stem, calyx and veins of the leaves with few, if any, short appressed hairs.

Fruiting calyx ovoid, nearly filled with the berry, scarcely sunken at the base.

Plants tall, erect : leaf-blades thin. Leaf-blades ovate or ovate-lanceolate.

Leaf-blades lanceolate, linear or oblanceolate.

Plants low, spreading: leaf-blades fleshy, elliptic-oblong, tapering into a winged petiole.

Fruiting calyx pyramidal, very much inflated and deeply sunken at the base.

Leaves and stem sparingly hairy with longer, flat, spreading or reflexed, often jointed, and in $P$. pumila branched, hairs (some of the species are slightly viscid).

Fruiting calyx ovold, scarcely angled and scarcely sunken at the base: leaf-blades thick, subentire.

Leaf-blades obovate or spatulate: hairs all simple.

Leaf-blades broader, inclined to be rhomboid: hairs of the lower surface of the leaves branched.

Fruiting calyx pyramidal, more or less 5-angled and deeply sunken at the base : leaf-blades thin.

Fruiting calyx ovoid-pyramidal : leaf-blades mostly ovate or lanceolate, tapering at the base.

Leaf-blades more or less sinuately dentate.

Leaf-blades subentire or wavy margined.

Leaf-blades firm : plant not at all viscid.

Leaf-blades very thin : plant more or less viscid above when young.

Fruiting caly x oblong-pyramidal or nearly cylindrical : leaf-blades broadly ovate, truncate or cordate at the base.

Leaf-blades coarsely toothed and reticulate.

Leaf-blades subentire, the veins not prominent.

Pubescence denser, viscid or glandular, generally consisting of a mixture of short fine hairs and long flat jointed ones.

Leaf-blades generally over $5 \mathrm{~cm}$. long, more or less cordate.

Apex, and teeth of the leaves rounded.

Apex, and teeth (if any) of the leaves acutish to acuminate.

Stem densely and leaves more sparingly pubescent with very long ( $2 \mathrm{~mm}$. or more) white hairs.

Stem erect: anthers purple: leaf-blades rounded or subcordate at the base.

Stem spreading: anthers yellow: leaf-blades usually cuneate or acute at the base.

Stem and leaves very densely pubescent with short, very viscid hairs : anthers yellow.

Leaf-blades generally $5 \mathrm{~cm}$. long or less.

Stem with long hairs.

Stem with very short hairs.

Leaf-blades rounded, ovate or rhombic.

Leaf-blades reniform or cordate.

Pubescence mainly of stellate hairs.

Plants densely white-pubescent or grayish pubescent.

Hairs all stellate.

Leaf-blades cordate. reniform or round, angulately toothed.

Leaf-blades elliptic, sometimes cordate at the base, to oblanceolate, subentire or repand.

Hairs partly simple, partly stellate: leaf-blades oblong, subentire.

Plants nearly glabrous, except on the margins of the caly x-lobes, rarely stellate all over when young.

Leaf-blades oblong, oblanceolate or spatulate, the lateral veins distinct.

Leaf-blades linear, thick ; midrib prominent, the lateral veuns obsolete.

8. P. pendula.

9. P. angulata.

10. P. ixocarpa.

11. P. Philadelphica.
12. P. subglabrata.

13. P. longifolia,

14. P. Texana.

15. P. macrophysa.

16. P. lanceolata.

17. P. pumila.

18. P. Virginiana.

19. P. rigida.

20. P. intermedia.

21. P. arenicola.

22. P. ciliosa.

23. P. sinuata.

24. P. ambigua.

25. P. nyctaginea.

26. $P$. heterophylla.

22. P. ciliosa.

27. $P$. comata.

28. $P$. hederaefolia.

29. P. mollis.

30. $P$. viscosa.

31. P. fuscomaculata.

32. P. Elliottii.

33. $P$. angustifolia.

1. Physalis pubéscens L. Annual, more or less villous and viscid. Stems much branched, angled, often a little swollen at the nodes, sometimes nearly glabrous : leafblades thin, 2-6 $\mathrm{cm}$. long, ovate, acute or acuminate, at the base oblique, slightly cordate and generally entire, upwardly repand-denticulate, or entire, pubescent, becoming nearly glabrous except along the nerves : peduncles short, 3-5 mm., or at maturity about $1 \mathrm{~cm}$. long: calyx-lobes narrow, not subulate tipped : corolla $5-10 \mathrm{~mm}$. in diameter, yellow, with dark center : anthers usually purplish : fruiting calyx membranous, $2-3 \mathrm{~cm}$. long, pyramidal-ovoid, acuminate and more or less retuse at the base.

In sandy soil, Pennsylvania to California, Florida and Central America. Also found in South America and in India. 
2. Physalis Floridàna Rydb. Annual, pubescent and viscid throughout. Stems diffusely branched, angled, densely villous with long white viscid hairs : leaf-blades rounded, cordate, oblique at the base, $2-5 \mathrm{~cm}$. long, coarsely sinuately toothed, obtuse, sparingly viscid-pubescent on both sides : peduncles short, in fruit about $1 \mathrm{~cm}$. long: calyx densely viscid pubescent ; lobes lanceolate, acuminate : corolla $6-8 \mathrm{~mm}$. in diameter, yellow with purple spots : anthers purplish : fruiting calyx $2-2.5 \mathrm{~cm}$. long, 5-angled, deeply retuse at the base.

In rich soil in pine woods, Walton County and Punta Rassa, Florida.

3. Physalis pruinòsa L. Annual, more hairy and viscid than the two preceding and the next following species. Stems stout, generally erect or often ascending and obtusely angled, finely villous or viscid : leaf-blades firm, 3-10 cm. long, finely pubescent, ovate-cordate, generally very oblique at the base, and deeply sinuately toothed with broad and often obtuse teeth : peduncles $2-4 \mathrm{~mm}$., at maturity about $1 \mathrm{~cm}$. long : calyx villous or viscid ; lobes as long as the tube, narrow, but without subulate tips : corolla $3-8 \mathrm{~mm}$. in diameter: anthers yellow or tinged with purple : fruiting calyx of a little firmer texture and more pubescent than that of the preceding two species, reticulate, $2-3 \mathrm{~cm}$. long, ovoidcordate: berry yellow or green.

In rich soil, Massachusetts to Iowa and Florida.

4. Physalis Barbadénsis Jacq. Annual, generally pubescent and viscid. Stems stouter than those of $P$. pubescens, tall and erect, or widely spreading, acutely 3-4-angled : leaf-blades 3-6 cm. long, heart-shaped, acute or generally abruptly acuminate, sharply repand-dentate, pubescent with short hairs : peduncles $3-4 \mathrm{~mm}$. long, at maturity sometimes $2 \mathrm{~cm}$. long : calyx generally densely viscid-hirsute; lobes lanceolate, acuminate, but not subulate-tipped : corolla $5-10 \mathrm{~mm}$. in diameter : anthers generally purplish : fruiting calyx $2.5-3 \mathrm{~cm}$. long, attenuate, almost conical and reticulate, retuse at the base.

In rich shaded soil, Pennsylvania to the Indian Territory, Florida and Mexico. Also found in the West Indies and in Venezuela.

5. Physalis Lagáscae R. \& S. Annual, finely pubescent aud sometimes slightly viscid. Stems spreading, often zigzag, branched, striate or slightly angled, villous with short hairs : leaf-blades $1-8 \mathrm{~cm}$. long, ovate, oblique and cuneate, obtuse or cordate at the base, acute but not acuminate, repand or sinuately dentate, hairy at least on the nerves : peduncles 3-5 $\mathrm{mm}$. becoming 5-10 $\mathrm{mm}$. long at maturity, reflexed, shorter than the fruiting calyx : calyx villous; lobes shorter than the tube, triangular : corolla $3-8 \mathrm{~mm}$. in diameter, yellow, generally with a dark center : anthers generally yellow : fruiting calyx $1.5-2 \mathrm{~cm}$. long, round-ovoid, nearly filled with the berry, not sunken at the base.

In rich soil, Florida to Alabama and Mexico. Also in the West and East Indies.

6. Physalis Carpénteri Riddell. Annual, characterized by its generally fascicled flowers, the foliage finely pubescent. Stems branching above, somewhat angled and striate, closely and finely puberulent: leaf-blades very thin, oval or ovate, abruptly contracted into a long acumination, entire or slightly wavy, nearly glabrous or puberulent, somewhat cordate and oblique at the base : peduncles about $1 \mathrm{~cm}$. long, very slender, often in fascicles of 2-4: corolla about $1 \mathrm{~cm}$. wide, open-campanulate : fruiting calyx small, only $1 \mathrm{~cm}$. in diameter, nearly globose, scarcely angled, faintly nerved, the lobes sometimes very unequal.

In sandy soil, Florida to Alabama and Louisiana ; rare.

7. Physalis obscúra Michx. Annual, glabrous, or minutely puberulent when young. Stems rather stout, acutely angled and divaricately branched : leaf-blades broadly ovate, obtuse or cordate and slightly oblique at the base, thin and dark green, repand-dentate, short acuminate : calyx minutely cilate on the margins and veins or glabrate : peduncles short, in fruit about $1.5 \mathrm{~cm}$. long; lobes lanceolate, acuminate : corolla 8-10 mm. wide, yellow with purplish spots : fruiting calyx $3-3.5 \mathrm{~cm}$. long, long-attenuate, almost pyramidal, deeply retuse at the base.

In rich soil, Pennsylvania to the Indian Territory, Florida and Mexico. Also in the West Indies.

8. Physalis péndula Rydb. Annual, glabrous. Stems angled, generally $5 \mathrm{dm}$. tall, branched : leaf-blades lanceolate, or ovate-lanceolate, sinuate-dentate with sharp teeth or sometimes nearly entire : calyx cylindric-campanulate; lobes broadly triangular, shorter than the tube: peduncles filiform, 1-2 cm. long, erect with nodding flower, 4-5 $\mathrm{cm}$. long and reflexed and drooping at maturity : corolla $5-8 \mathrm{~mm}$. in diameter, campanulate, yellow, without a dark spot : anthers yellow, more or less tinged with purple : fruiting calyx about $2 \mathrm{~cm}$. long, rounded ovoid, indistinctly 10 -angled and purple-nerved, nearly filled with the berry. [P. lanceifolia Rydb. in part, not Nees.]

In rich soil, Illinois to Kansas and Texas.

9. Physalis angulàta L. Annual, glabrous. Stems angular, 0.5-1 m. tall, glabrous : leaf-blades ovate, with a more or less cuneate base, sharply sinuate, with long-acuminate 
teeth, thin, 4-7 cm. long ; nerves not prominent ; petioles slender, $2-4 \mathrm{~cm}$. long : peduncles slender, $2-3 \mathrm{~cm}$. long, erect, often reflexed at maturity, but seldom exceeding the fruiting calyx in length : calyx glabrous; lobes triangular to lanceolate, generally shorter than the tube : corolla $5-10 \mathrm{~cm}$. in diameter : anthers more or less purplish tinged : fruiting calyx about $3 \mathrm{~cm}$. long, ovoid, not prominently 5-10-angled, sometimes purple-nerved and at length nearly filled with the yellow berry.

In rich soil, North Carolina to Texas, Central America, Brazil and the West Indies. Also in India.

10. Physalis ixocárpa Brot. Annual, glabrous or nearly so. Stems at first erect, later widely spreading, much branched, angled, the younger parts often sparingly hairy : leaf-blades cordate to ovate and cuneate at the base, which is somewhat oblique, sinuately dentate or entire, $3-6 \mathrm{~cm}$. long: peduncles $2-5 \mathrm{~mm}$. long: calyx sparingly hairy ; lobes broadly triangular, shorter than the tube : corolla bright yellow with purple throat, $1-1.5 \mathrm{~cm}$. (sometimes nearly $2 \mathrm{~cm}$.) in diameter : fruiting calyx rounded ovoid, obscurely 10-angled, often purple-veined, at maturity often filled with the purple berry, which sometimes bursts it.

In loose soil, Texas to California and Mexico. Also introduced in Massachusetts, Virginia and Washington.

11. Physalis Philadélphica Lam. Annual, glabrous or nearly so. Stems $0.5-1.5$ m. tall, angled, dichotomously branched, glabrous or sometimes slightly pubescent with sparse and short hairs on the upper parts : leaf-blades ovate to ovate-lanceolate, often very oblique at the base and more or less acuminate, entire or repand-denticulate, $6-10 \mathrm{~cm}$. long ; petioles 4-6 cm. long : peduncles slender, often in pairs, 1-2 cm. long, generally longer than the flower: calyx glabrous, or minutely ciliolate; lobes ovate-lanceolate or triangular, sometimes broadly ovate and unequal, generally equalling the tube: corolla yellow or greenish yellow with purplish throat, $1.5-2.5 \mathrm{~cm}$. in diameter: anthers tinged with purple : fruiting calyx at first somewhat 10 -angled and sunken at the base, at maturity often filled with or even burst by the large red or purple berry.

In rich soil, Rhode Island to Kentucky, Georgia and Texas.

12. Physalis subglabràta Mackenzie \& Bush. Perennial from a thick rootstock, glabrous or sparingly hairy with short appressed hairs. Stems stout, 3-9 dm. tall, branched, glabrous or the upper part with short hairs on the angles: leaf-blades ovate or ovate-lanceolate, $2.5-7.5 \mathrm{~cm}$. long, $1.25-5 \mathrm{~cm}$. wide, undulate or entire, oblique and rounded or subcordate at the base, glabrous or with a few scattered hairs on the veins : calyx $6-8 \mathrm{~mm}$. long, appressed-hairy on the veins and at the base ; lobes triangular, about the length of the tube : corolla yellow with a darker center, 10-15 mm. broad: fruiting calyx ovoid, slightly depressed at the base, slightly angled : berry globular, stiped. nessee.

In loose soil, along railroads, in fields and river bottoms, Ontario to Nebraska, Arkansas and Ten-

13. Physalis longifòlia Nutt. Perennial from thick rootstocks, almost glabrous. Stems in the common form stout and tall, $0.5-1 \mathrm{~m}$. high, slightly angled, branched above; branches strict, glabrous : leaf-blades lanceolate, oblanceolate or linear, tapering into a stout short petiole $1-2 \mathrm{~cm}$. long, nearly entire or repand : peduncles $1-2 \mathrm{~cm}$. long, in fruit often recurved : calyx generally glabrous ; lobes triangular-lanceolate, about the length of the tube : corolla $1-2 \mathrm{~cm}$. in diameter, yellow with a dark commonly brownish center : anthers yellow, tinged with purple: fruiting calyx ovoid, about $3 \mathrm{~cm}$. long, not sunken at the base : berry yellow, the lower portion and the stipe glutinous.

In rich soil, on prairies and plains, Iowa to Montana, Texas and Mexico.

14. Physalis Texàna Rydb. Perennial from deep rootstocks, glabrous. Stems angular and striate, somewhat fleshy, diffuse : leaf-blades broadly ovate, generally very oblique at the base and decurrent on the long-margined petiole, somewhat fleshy, entire or slightly wavy and with the veins prominent on the lower surface : peduncles about $1 \mathrm{~cm}$. long, scarcely longer than the corolla, at maturity $2-3 \mathrm{~cm}$. long : caly $\mathrm{x}$-lobes broadly ovate$\mathrm{cm}$. in diameter, very villous in the throat: anthers yellow: fruiting calyx about $3 \mathrm{~cm}$. long, ovoid, indistinctly 10 -angled, not sunken at the base : berry purplish.

In rich soil, southern Texas.

15. Physalis macrophỳsa Rydb. Perennial, almost glabrous, the rootstock rather thick and fleshy. Stems $0.5-1 \mathrm{~m}$. tall, comparatively slender, angled, perfectly glabrous, long, 2-5 cm. wide, the lower obtuse, the upper acute or acuminate, on slender petioles $2-4 \mathrm{~cm}$. long: peduncles $1-1.5 \mathrm{~cm}$. long, erect, reflexed at maturity : calyx glabrous ; lobes ovate-triangular or broadly lanceolate, generally a little shorter than the tube : 
corolla yellow with a dark center, about $2 \mathrm{~cm}$. in diameter: anthers generally yellow, sometimes tinged with purple: fruiting calyx $3-4 \mathrm{~cm}$. long, $2.5-3 \mathrm{~cm}$. in diameter, py ramidal to ovoid-conic, indistinctly 10-angled, deeply sunken at the base: berry small, in the center of the calyx.

In rich soil, Arkansas and Texas.

16. Physalis lanceolàta Michx. Perennial, sparingly hairy, the rootstock apparently, as a rule, slender and creeping. Stems about $5 \mathrm{dm}$. tall, at first erect, later spreading or diffuse, only slightly angled, sparingly hirsute with flat hairs : leaf-blades broadly oblanceolate or spatulate, tapering into the petiole, acute or obtuse, nearly always entire, rarely wavy, but not sinuately toothed, thickish, sparingly pubescent with short hairs: peduncles $1-2 \mathrm{~cm}$. long, in fruit reflexed : calyx strigose or vilious, rarely glabrous ; lobes triangular-lanceolate : corolla dullish yellow with a brownish center, about $1.5 \mathrm{~cm}$. in diameter : fruiting calyx rounded ovoid, not sunken at the base, indistinctly 10-angled : berry yellow or greenish yellow.

On dry plains, North Carolina to Wyoming, South Carolina and New Mexico,

17. Physalis pùmila Nutt. Perennial from slender rootstocks, $0.5-1 \mathrm{~m}$. high, hirsute. Stems obscurely angled : leaf-blades thick, generally broadly ovate, acute at both ends and somewhat rhomboid, the lower often obtuse and obovate, generally much larger than in the preceding species, $5-10 \mathrm{~cm}$. long, entire or seldom sinuate, on petioles $2-3 \mathrm{~cm}$. long at maturity : calyx densely hirsute, not stellate; lobes triangular, generally a little shorter than the tube : corolla yellow with brown center, $1.5-2 \mathrm{~cm}$. in diameter : fruiting calyx generally more elongated than in the preceding, 4-5 cm. long, oblong-ovoid, a little sunken at the base, indistinctly 10 -angled.

On plains and prairies, Missouri to Colorado and Texas.

18. Physalis Virginiàna Mill. Perennial from a somewhat fleshy rootstock, pubescent. Stems $0.5-1 \mathrm{~m}$. tall, dichotomously branched, somewhat angular, pubescent with appressed hairs, sometimes somewhat glandular, or in some forms nearly glabrous : leafblades ovate-lanceolate, tapering to both ends, 3-6 $\mathrm{cm}$. long, generally more or less sinuately dentate, often yellowish green: peduncles $1-2 \mathrm{~cm}$. long, generally erect, or becoming curved, but scarcely reflexed: calyx strigose-hirsute, or at least puberulent ; lobes triangular or broadly lanceolate, nearly equalling the tube in length ${ }^{4}$ : corolla sulphur-yellow with purplish spots, $1.5-2.5 \mathrm{~cm}$. in diameter : anthers yellow : fruiting ealyx pyramidalovoid, 5-angled and sunken at the base : berry reddish. $[P$. lanceolata Chapm., not Michx. P. monticola Mohr.]

In loose soil, New York to Manitoba and Colorado, south to Florida and Louisiana.

19. Physalis rígida Pollard \& Ball. Perennial from a thick rootstock, resembling in habit $P$. subglabrata. Stems strict, angled, more or less branching, 3-4 dm. tall, hispidpubescent with flat hairs, especially above: leaf-blades firm, ovate-lanceolate, wavy-margined, densely pubescent when young, tapering at both ends: calyx pubescent with flat hairs, especially on the veins and at the base: lobes triangular: corolla $1-1.5 \mathrm{~cm}$. wide, yellow with purple center : fruiting calyx ovoid, nearly glabrous, obscurely 10 -angled, $2.5-3$ $\mathrm{cm}$. long, somewhat retuse at the base.

In waste grounds, Louisiana to Arkansas and Tennessee.

20. Physalis intermédia Rydb. Perennial, puberulent, and sometimes a little viscid when young. Stems $3-8 \mathrm{dm}$. tall, dichotomously branched, angled and striate, the upper portion with longer hairs and somewhat viscid : leaf-blades ovate or ovate-lanceolate, acute, 4-6 $\mathrm{cm}$. long, often oblique at the base, slightly sinuately toothed or nearly entire, very thin, light green, puberulent or glabrate : peduncles 1-2 $\mathrm{cm}$. long, recurved at maturity, hairy : calyx puberulent or hirsute with appressed hairs; lobes broadly lanceolate, abont equalling the tube: corolla sulphur-yellow with purplish spots, $1-2 \mathrm{~cm}$. in diameter : anthers yellow : fruiting calyx ovoid, slightly 5 -angled and slightly sunken at the base. [P. Virginiana intermedia Rydb.]

In dry soil, Pennsylvania to Indiana, southward to Florida and Texas.

21. Physalis arenícola Kearney. Perennial from slender horizontal rootstocks, sparingly hairy. Stems $2-4 \mathrm{dm}$. tall, diffuse, striate, light green, the pubescence mostly of simple hairs, but sometimes a little glandular, in age deciduous except on the nerves of the calyx : leaf-blades relatively small, $1.5-6 \mathrm{~cm}$. long, but sometimes $8 \mathrm{~cm}$, ovate-cordate, truncate or cuneate at the base, irregularly angulate-dentate, pubescence, if any, along the veins, which are generally prominent and conspicuously reticulated: peduncles slender: calyx-lobes triangular-lanceolate, equalling the tube in length : corolla $1.5-2 \mathrm{~cm}$. in diameter, light yellow : anthers yellow : fruiting calyx $3 \mathrm{~cm}$. long, narrowly ovoid or rather oblong-pyramidal or nearly cylindric, conspicuously reticulated : berry light yellow.

In sandy soil, Florida. 
22. Physalis ciliòsa Rydb. Perennial from slender creeping rootstocks. Stems upright, branched, 2-3 dm. tall, terete, scarcely striate, together with the pedicels and calyxes ciliate with long and white jointed hairs: leaf-blades 4-7 cm. long, ovate, truncate or slightly cordate at the base, nearly entire or with a few coarse teeth, sparsely hairy on the nerves, long-petioled, thin and not conspicuously veiny : peduncles very slender : calyx turbinate, resembling that of $P$. arenicola: corolla funnelform-campanulate, apparently without dark markings : fruiting calyx ovoid-pyramidal, sunken at the base.

In sandy soil, Tennessee to Georgia and Florida.

23. Physalis sinuàta Rydb. Perennial, villous and viscid. Stems decumbent, striate and angled, villous with long flat hairs and very viscid : leaf-blades rounded ovate, very oblique at the base and often subcordate, pubescent with long flat hairs especially on the veins, dark, obtuse, undulate, sinuate : peduncles about $1 \mathrm{~cm}$. long, long-villous: calyx densely villous with flat hairs and viscid; lobes triangular-lanceolate, about equalling the tube : corolla yellow with darker spots : fruiting ealyx and berry unknown.

In sand, Florida. Summer.

24. Physalis ambígua (A. Gray) Britton. Perennial, villous, scarcely at all viscid. Stems 3-8 dm. tall, light green, slightly angled, villous with long flat hairs : leaves with the finer pubescence sparse ; blades over $5 \mathrm{~cm}$. long, thin, light green, round-ovate or cordate, somewhat sinuately toothed or nearly entire, acute, but rarely acuminate: peduncles 1-2 cm. long, long-villous like the calyx : calyx-lobes triangular, generally shorter than the tube : corolla $1.5-2 \mathrm{~cm}$. in diameter, yellow with dark spots : anthers generally purple : fruiting calyx ovoid, somewhat sunken at the base : berry yellow.

In rich soil, especially in thickets, Vermont to Iowa, south to Virginia and Tennessee.

25. Physalis nyctagínea Dunal. Perennial from slender horizontal rootstocks. Stems puberulent and villous with long flat hairs and somewhat viscid, generally zigzag, decumbent and spreading, and branched, slightly angled : leaf-blades dark green, ovate, often oblique, but very rarely cordate at the base, more or less acuminate, mostly entire, or occasionally sinuately dentate and rather thick, sparingly hairy, not at all puberulent; the long hairs often confined to the veins of the lower surface : peduncles long-villous, 1-2 cm. long, reflexed in fruit: calyx villous; lobes triangular, shorter than the tube : corolla $1-1.5 \mathrm{~cm}$. in diameter, yellow with darker spots : anthers yellow : fruiting calyx ovoid, 5 -angled and sunken at the base : berry yellow.

In dry soil, Rhode Island to Iowa and south to Georgia and Louisiana.

26. Physalis heterophýlla Nees. Perennial from slender creeping rootstocks. Stems $0.5-1 \mathrm{~m}$. tall, erect, or later generally decumbent and spreading, viscid and glandular, villous with moderately long jointed flat hairs: leaf-blades generally over $5 \mathrm{~cm}$. long, generally broadly cordate, often acute but very rarely with an acumination, thick, more or less sinuately toothed, or sometimes subentire: pubescence short and fine with a mixture of longer flat jointed hairs : calyx long-villous ; lobes triangular,'generally shorter than the tube : corolla 1-1.5 cm. in diameter : anthers generally yellow : berry yellow. Colorado.

In loose, rich soil, especially in fields, New Brunswick to Saskatchewan, Florida, Texas and

27. Physalis comàta Rydb. Perennial. Stems about $5 \mathrm{dm}$. tall, pubescent with fine and short hairs, those on the calyx, peduncles and upper branches mixed with long, white, flat, jointed hairs; quite similar to $P$. heterophylla Nees, but leaves smaller; blades not over $0.5 \mathrm{dm}$. long, rounded ovate, scarcely at all cordate at the base, about $5 \mathrm{~cm}$. long, thin, somewhat repand-dentate or nearly entire ; petioles as long as the blades : peduncles as long as the fruiting calyx or longer : corolla mainly greenish yellow, brown in the center, $1.3-2 \mathrm{~cm}$. in diameter : fruiting calyx as in $P$. hederaefolia but thinner in texture, $3-4$ $\mathrm{cm}$. long, rounded ovoid, somewhat 10 -angled, scarcely sunken at the base.

On the plains, Nebraska and Colorado to Texas.

28. Physalis hederaefollia A. Gray. Perennial. Stems erect and branched, rarely decumbent, $3-5 \mathrm{~cm}$. high, from a thick caudex, finely viscid-pubescent or villous, the hairs generally short: leaf-blades in the typical form broadly cordate or subreniform, coarsely peduncles generally short, but in one form ( $P$. Palmeri A. Gray), a little longer than the fruiting calyx : calyx finely viscid-pubescent : corolla about $1.5 \mathrm{~cm}$. wide: fruiting calyx ovoid, 5-10-angled, pubescent, $2-3 \mathrm{~cm}$. long.

In dry soil, Texas, Colorado and Arizona, south to Mexico.

29. Physalis móllis Nutt. Perennial from horizontal rootstocks. Stems 3-6 cm. high, densely whitish or grayish tomentose with stellate pubescence : leaf-blades rounded cordate or the upper broadly ovate, coarsely sinuately toothed : peduncles $2-4 \mathrm{~cm}$. long or 
4-6 cm. and reflexed at maturity : calyx densely stellate; lobes triangular, generally a little shorter than the tube : corolla $1.5-2 \mathrm{~cm}$. in diameter, bright yellow and with a purplish center, more or less stellate-pubescent without : anthers yellow or tinged with purple : fruiting calyx $3-5 \mathrm{~cm}$. long, ovoid, acuminate, slightly 5 -angled and a little sunken at the base.

In thickets and along streams, Arkansas to California, Texas and Mexico.-A greener, less pubescent form with more rounded and less toothed leaf-blades is $P$. mollis cineráscens (Dunal) A. Gray, and another form with small leaves $1-2 \mathrm{~cm}$. long and small fruiting calyx is $P$. mollis parvifolia Rydb.

30. Physalis viscòsa L. Perennial from slender horizontal rootstocks. Stems slender, creeping, cinereous with a dense stellate pubescence or in age rarely glabrate: leaf-blades elliptic, oval or ovate, obtuse, thinnish, entire or undulate, in the typical South American form often cordate at the base, only rarely so in our plant : peduncles 1-2 cm. long: calyx stellate-pubescent ; lobes triangular, generally shorter than the tube : corolla greenish yellow with a darker center, $1.5-2 \mathrm{~cm}$. in diameter : fruiting calyx $2-3 \mathrm{~cm}$. long, rounded ovoid, scarcely sunken at the base : berry orange or yellow.

On sea beaches and in sand near the coast, Virginia to Texas and south to the Argentine Republic. - The form with spatulate or oblong leaf-blades tapering into the petiole, is $P$. viscosa maritima (M. A. Curtis) Rydb.

31. Physalis fuscomaculata DeRouv. Perennial, greener than the other stellatepubescent species. Stems decumbent or ascending, terete, with decurrent ridges, a little pruinose-stellate : leaf-blades $2-4 \mathrm{~cm}$. long, ovate, somewhat oblique at the base, entire or repand, the upper often opposite: peduncles $1-3 \mathrm{~cm}$. long, longer than the petioles and often as long as the leaves at maturity : calyx pruinose, a little stellate and stellate-ciliate ; lobes triangular, shorter than the tube : corolla yellow with a dark spot: fruiting calyx subglobose, 10-angled, somewhat sunken at the base.

A South American species found on or near ballast and in waste places at Mobile, Alabama.

32. Physalis Ellióttii Kunze. Perennial from slender horizontal rootstocks, the foliage glabrous to the flowers, or sparingly stellate-pubescent when young. Stems ascending, branched, slightly stellate or glabrate, $3-5 \mathrm{dm}$. tall : leaf-blades very thin and veiny, oblong, spatulate, broadly oblanceolate, or in luxuriant specimens broadly oval, entire or wavy-margined, decurrent into a winged petiole: peduncles $2-3 \mathrm{~cm}$. long, slender, erect, but reflexed and often $5 \mathrm{~cm}$. long at maturity : calyx generally glabrous except the margin which is stellate-ciliate; lobes triangular : corolla $1.5-2 \mathrm{~cm}$. in diameter, yellow with dark center: fruiting calyx generally a little shorter than in the next species.

On the seacoast, Florida to Texas.

33. Physalis angustlfòlia Nutt. Perennial from slender elongated and creeping rootstocks, the foliage often perfectly glabrous except the margins of the calyx-lobes or rarely sparsely stellate all over when young. Stems diffusely branched, angled: leafblades linear or linear-oblanceolate, tapering into the petiole, entire, thickish ; nerves except the midrib, generally obsolete : peduncles $2-3 \mathrm{~cm}$. long, filiform, generally erect, 4-5 $\mathrm{cm}$. long and reflexed at maturity : calyx glabrous, except the stellate-ciliate margins of the rounded triangular lobes: corolla about $2 \mathrm{~cm}$. broad, yellow and with purple center : anthers yellow : fruiting calyx small, $1.5-2 \mathrm{~cm}$. long, ovate, obscurely angled and scarcely sunken at the base.

On sea beaches or in sand near the coast, Florida to Louisiana.

\section{QUíncura Raf.}

Perennial herbs, with scurfy-granuliferous foliage and diffuse stems. Leaves alternate : blades sinuate to pinnatifid, somewhat fleshy. Peduncles most commonly in pairs from the axils of the leaves, sometimes solitary or in clusters of 3-5. Flowers erect during anthesis. Calyx campanulate, inflated at maturity, sharply 5-angular and reticulated, enclosing the fruit : lobes 5, converging. Corolla flat-rotate, pentagonal in outline, veiny, violet or purplish. Anthers opening by longitudinal slits. Seeds comparatively few, reniform, somewhat flattened, thick-margined, rugose-tuberculate.

1. Quincula lobàta (Torr.) Raf. Stems spreading or prostrate, obtusely angled and striate, much branched: leaf-blades oblanceolate or spatulate to oblong, sinuately toothed or pinnatifid with rounded lobes, or rarely nearly entire, cuneate at the base, tapering into margined petioles, thickish and veiny : peduncles $2-5 \mathrm{~cm}$. long, reflexed at maturity : calyxlobes triangular, acute, shorter than the tube : corolla purplish, $2-3 \mathrm{dm}$. in diameter : anthers yellow, tinged with purple : fruiting calyx about as wide as long, sharply 5-angled, sunken at the base.

On high plains, at the base of the Rocky Mountains, extending from Kansas to California, Texas and northern Mexico. Summer. 


\section{Chamaesáracha A. Gray.}

Perennial herbs, with entire or pinnatifid leaf-blades, these decurrent on the petiole. Peduncles solitary, or in clusters of 2-4 from the axils of the leaves. Calyx campanulate, 5-lobed, somewhat enlarged at maturity, but not bladdery-inflated, close-fitting to the berry, thin, neither angled nor ribbed, and faintly, if at all, veiny, open at the mouth, not exceeding the berry. Corolla rotate, white or ochroleucous, often tinged with purple : limb plicate. Stamens adnate to the base of the corolla. Anthers oblong, opening by longitudinal slits. Style and stigma as in Physalis. Seeds reniform, flattened, rugosefavose or punctate. The plants flower in the summer.

Foliage puberulent and hirsute: pubescence dense.

1. C. conioides. Foliage puberulent or stellate-pubescent, the calyx only sometimes hirsute: pubescence sparse.

2. C. Coronopus.

1. Chamaesaracha conioìdes (Moric.) Britton. Foliage cinereous-puberulent with short branched somewhat glutinous or viscid hairs, generally also viscidly hirsute or villous with long and branched hairs, especially on the calyx. Stems much branched from the base, at first upright, at length spreading: leaf-blades oblanceolate to obovate-rhombic, generally acutish and tapering into short petioles, generally deeply lobed, but varying from nearly entire to pinnatifid : calyx-lobes triangular, generally acutish : corolla about $1 \mathrm{~cm}$. in diameter, white or ochroleucous, sometimes violet purplish : berry from $5-8 \mathrm{~cm}$. in diameter.

In dry clayey soil, Kansas to California and Mexico.

2. Chamaesaracha Corónopus (Dunal) A. Gray. Foliage pruinose or stellatepubescent or glabrate. Stems branched from the base and diffuse, obtusely angled : leafblades linear or lanceolate, tapering at the base, more or less sinuately lobed, occasionally subentire, sometimes pinnatifid: calyx stellate-pubescent or sometimes hirsute; lobes triangular, acute : corolla white or ochroleucous, the appendages of the throat often protuberant : berry $5-8 \mathrm{~mm}$. in diameter, nearly white.

In clayey soil, Kansas to Utah, Texas and Mexico.

\section{SOLÀNUM L.}

Annual or perennial often spiny herbs or shrubs, or sometimes vines. Leaves alternate : blades entire, toothed, pinnatifid or variously lobed. Flowers in cymes, racemes, panicles or umbel-like clusters. Calyx varying from campanulate to rotate, sometimes accrescent: lobes usually 5. Corolla white, yellow, blue or purple, rotate: tube very short: limb 5-angled or 5-lobed, plaited. Stamens 5, adnate to near the throat of the corolla-tube. Anthers narrow, converging or united into a cone: sacs opening by terminal pores, slits or sometimes lengthwise. Ovary mostly 2-celled. Berries subglobose or oval, seated in the calyxes or rarely enclosed by them. Seeds flattened.

A. Plants destitute of prickles.

Vines or vine-like shrubs.

Berries oval.

Berries globose.

Middle lobes of the leaf-blades prevailingly lanceolate or ovate : anthers fully $1 \mathrm{~mm}$. broad.

Middle lobe of the leaf-blades prevailingly linear: anthers less than $1 \mathrm{~mm}$. broad.

Herbs or shrubs.
Annual herbs.

Leaf-blades repand or entire : berries black.

Foliage glabrous or nearly so : corolla $6-8 \mathrm{~mm}$. broad : calyx-lobes spreading at maturity.

Foliage puberulent or finely pubescent: corolla $8-10 \mathrm{~mm}$. broad: calyx-lobes appressed to the berry.

Leaf-blades deeply pinnatifid: berries green.

Perennials, more or less shrubby.

Foliage glabrous.

Corolla 11-14 mm. wide: berries mainly over $1 \mathrm{~cm}$. thick : leafblades with pale margins.

Corolla $25-30 \mathrm{~mm}$. wide : berries mainly less than $1 \mathrm{~cm}$. thick : leafblades without distinct margins.

Foliage more or less pubescent.

Calyx-lobes very narrow, several times longer than broad.:

Caly $\mathrm{x}$-lobes broad, often fully as broad as long. Leaf-blades velvety beneath. Corolla-lobes ovate: ovary pubescent. Corolla-lobes lanceolate: ovary glabrous. Leaf-blades rather harshly pubescent beneath.

1. S. Dulcamara.

2. S. triquetrum.

3. S. Lindheimerianum.

4. S. nigrum.

5. S. gracile.

6. S. triflorum.

7. S. Pseudo-Capsicum.

8. S. glaucum.

12. S. elaeagnifolium.

9. S. verbascifolium.

10. S. Blodgettii.

11. S. Bahamense. 
B. Plants more or less copiously armed with prickles.

Berry merely seated in the calyx.

Prickles bristle-like.

Prickles subulate.

Calyx merely pubescent.

Leaf-blades entire, sometimes undulate.

Leaf-blades pinnately lobed or pinnatifid.

Annual: berries $5-30 \mathrm{~cm}$. long.

Perennial: berries $1.5-2 \mathrm{~cm}$. long.

Calyx armed with prickles.

Perennial plants.

Corolla less than $2.5 \mathrm{~cm}$. broad.

Corolla over $3 \mathrm{~cm}$. broad.

Annual plants.

Leaf-blades sinuate-pinnatifid.

Berry enclosed in the calyx.

12. S. elaeagnifolium.

11. S. Bahamense.

13. S. Melongena.

14. S. Carolinense.

15. S. Floridanum.

16. S. Torreyi.

17. S. aculeatissimum.

18. S. sisymbriifolium.

19. S. rostratum.

1. Solanum Dulcamàra L. Perennial, often minutely pubescent, unarmed. Stems climbing, sometimes twining, 4-15 dm. long, branching : leaf-blades ovate, 3-10 cm. long, acute or acuminate, undulate, entire or with a lobe on one or both sides at the base, truncate or cordate; petioles $\frac{1}{2}$ as long as the blades or shorter: peduncles spreading : calyx glabrous; tube broadly turbinate; lobes rather triangular, much shorter than the tube : corolla blue or white, about $1.5 \mathrm{~cm}$. wide ; lobes lanceolate to oblong-lanceolate, recurved, minutely pubescent near the tips : berries oval, scarlet, $9-15 \mathrm{~mm}$. long.

In thickets, New Brunswick to Minnesota, Georgia and Kansas. Spring to fall. BitTerswert.

2. Solanum triquétrum Cav. Perennial, glabrous or nearly so. Stems spreading or reclining, 3-10 dm. long, more or less branched : leaf-blades ovate to lanceolate, 2-6 $\mathrm{cm}$. long, sometimes acuminate, entire or somewhat 3-lobed at the truncate or cordate base ; petioles barely $\frac{1}{2}$ as long as the blades or shorter : pedicels club-shaped : calyx glabrous ; tube turbinate ; lobes triangular-ovate, acutish : corolla purplish or paler, $1.5 \mathrm{~cm}$. broad; lobes oblong-lanceolate, ciliolate near the tip : berries subglobose, $8-10 \mathrm{~mm}$. in diameter.

In thickets in low grounds, Texas and adjacent Mexico. Summer.

3. Solanum LIndheimeriànum Scheele. Perennial, nearly glabrous. Stems spreading, reclining, several dm. long, branching, zigzag: leaf-blades linear to oblong, 1-3 cm. long, entire or hastately lobed at the base; petioles 1-4 $\mathrm{mm}$. long: pedicels club-shaped, 5-10 mm. long: calyx glabrous; tube companulate; lobes lanceolate or triangular-lanceolate, acute : corolla purplish, blue or pale, $10-12 \mathrm{~mm}$. broad ; lobes oblong to oblonglanceolate : berries subglobose, often $6-9 \mathrm{~mm}$. in diameter.

In dry soil, Texas and New Mexico. Summer.

4. Solanum nìgrum L. Annual, minutely pubescent to glabrate, unarmed. Stems erect or much branched and spreading, 1-12 dm. long: leaf-blades ovate or oblong-ovate, $2-8 \mathrm{~cm}$. long, obtuse or acute, undulate or deeply repand, cuneate at the base ; petioles as long as the blades or shorter : calyx pubescent ; tube turbinate ; lobes oblong or triangular, acute, spreading at maturity : corolla white, $6-8 \mathrm{~mm}$. broad ; lobes lanceolate to oblonglanceolate : berries subglobose, $4-6 \mathrm{~mm}$. in diameter, black.

In waste places or cultivated lands, Nova Scotia to the Northwest Territory, Florida and Texas. Widely distributed in other parts of the world. Summer and fall. COMMON NIGHTSHADE.

5. Solanum grácile Link. Annual, more or less cinereous-pubescent. Stems erect, 3-10 dm. tall, branching : leaf-blades oblong-lanceolate or ovate-lanceolate, $2-6 \mathrm{~cm}$. long, undulate or coarsely toothed near the base, cuneately narrowed into short petioles : calyx pubescent; tube campanulate; lobes ovate or oblong-ovate, about as long as the tube : corolla white or bluish, about $10 \mathrm{~mm}$. broad; lobes linear to oblong : berries subglobose, 5-8 $\mathrm{mm}$. in diameter, black.

In sandy soil, North Carolina to Florida. Naturalized from South America. Spring to fall.

6. Solanum triflòrum Nutt. Annual, sparingly pubescent with simple hairs or nearly glabrous. Stems commonly branched at the base, the branches more or less spreading, 2-9 $\mathrm{dm}$. long: leaf-blades oblong or ovate in outline, pinnatifid, 3-9 $\mathrm{cm}$. long, the lobes acute, entire or toothed, short-petioled: calyx usually pubescent ; tube campanulate ; lobes oblong to oblong-lanceolate, longer than the tube : corolla white, 8-10 $\mathrm{mm}$. broad: berries globular, $10-15 \mathrm{~mm}$. in diameter.

On prairies and in waste places, Ontario to the Northwest Territory, Oklahoma and Arizona. Spring to fall.

7. Solanum Pseùdo-Cápsicum L. Shrubby, unarmed. Stems erect, 8-19 dm. tall, with spreading branches: leaves numerous; blades oblong or oblanceolate, $3-10 \mathrm{~cm}$. long, undulate or repand, narrowed into short petioles: pedicels $5-10 \mathrm{~mm}$. long, clubshaped: calyx glabrous; tube broadly turbinate-campanulate; lobes oblong-lanceolate. 
about as long as the tube: corolla white, $11-14 \mathrm{~mm}$. broad ; lobes oval or oval-ovate, acute : berries globose, 1-1.5 $\mathrm{cm}$. in diameter, scarlet.

In waste place or open woods, Gulf States. Introduced. Spring to fall. Jerusalem Cherry.

8. Solanum glaùcum Dunal. Somewhat woody, at least below, unarmed. Stem 1-2.5 m. tall, often copiously branched, pale, glabrous: leaves rather numerous; blades narrowly oblong to oblong-lanceolate, $8-16 \mathrm{~cm}$. long, acute or slightly acuminate, smooth and glabrous, white-margined, narrowed into short petiole-like bases: pedicels slender, slightly thickened under the calyx : calyx glabrous ; tube nearly flat; lobes much broader than high : corolla blue, $25-30 \mathrm{~mm}$. broad; lobes broadly ovate, abruptly acute : berries globose-ovoid, 6-8 $\mathrm{mm}$. in diameter, glaucous.

In waste places, Pensacola, Florida. Native of South America.

9 Solanum verbascifòlium L. Shrubby, tomentose throughout, unarmed. Stems 6-16 dm. tall, branching: leaf-blades leathery, oblong or oblong-obovate, or ovate, 1-3 $\mathrm{dm}$. long, obtuse or acuminate, entire, one third as long as the blades or shorter: peduncles longer than the petioles: pedicels fully $1 \mathrm{~mm}$. thick: calyx 5-6 mm. long; tube broadly turbinate ; lobes ovate, about as long as the tube : corolla white, $1.5 \mathrm{~cm}$. broad; lobes ovate or oval-ovate, acutish : ovary pubescent : berries subglobose, 1-2 cm. in diameter.

In sandy soil, southern peninsular Florida and the Keys and southern Mexico, throughout tropical America. Throughout the year.

10. Solanum Blodgéttii Chapm. Shrubby, hoary-scurfy or slightly tomentulose. unarmed. Stems spreading, 8-18 dm. long, branching: leaf-blades oblong, 5-15 cm, long, rather obtuse at both ends, undulate : petioles $\frac{1}{4}$ as long as the blades or shorter: peduncles longer than the petioles : pedicels densely pubescent : calyx pubescent, $2.5 \mathrm{~mm}$. long; tube broadly turbinate; lobes broadly oblong, abruptly pointed, longer than the tube : corolla white, $14-17 \mathrm{~mm}$. broad ; lobes linear or linear-lanceolate : ovary glabrous : berries subglobose, green turning red.

In sand, Key West, Florida. Spring to fall.

11. Solanum Bahaménse L. Shrubby, roughish pubescent, sparingly armed, or unarmed. Stems 5-18 dm. tall, branching : leaf-blades oblong, 4-12 cm. long, obtuse or acutish, undulate, oblique at the base ; petioles $1-2 \mathrm{~cm}$. long : pedicels club-shaped : calyx $1.5 \mathrm{~cm}$. long; lobes oblong or ovate-oblong, longer than the tube : corolla pale, 10-12 mm. broad ; lobes linear, relatively long: berries subglobose, 6-8 mm. in diameter.

In sandy soil, southern peninsular Florida and the Keys.

12. Solanum elaeagnifòlium Cav. Perennial, silvery canescent with scurfy-hairs, more or less copiously armed with acicular spines, or unarmed. Stems erect, 3-11 dm. tall, branching : leaf-blades broadly oblong to linear-oblong, 5-15 $\mathrm{cm}$. long, usually obtuse, undulate or repand, oblique at the base ; petioles $1-2 \mathrm{~cm}$. long : pedicels barely enlarged upward : calyx 5-ridged; tube campanulate; lobes linear-subulate from a broad base, much longer than the tube : corolla violet, or white, $2-2.5 \mathrm{~cm}$. broad; lobes triangular-ovate, longer than the limb : berries subglobose, 1-1.5 cm. in diameter, yellow or black.

In dry soil, Missouri to Kansas, Texas and Arizona. Spring to fall.

13. Solanum Melongèna L. Perennial, more or densely felty tomentose, armed with short subulate prickles. Stems 3-9 dm. tall, simple or branching above : leaf-blades 1-3 dm. long, oval or ovate in outline, sinuate-lobed or shallowly pinnately lobed, cuneate or subcordate at the base ; petioles $1-5 \mathrm{~cm}$. long: pedicel slightly enlarged under the calyx : calyx pubescent; tube saucer-shaped; lobes broadly ovate, acuminate at the tip, about as long as the tube : corolla purplish, $4-5 \mathrm{~cm}$. broad; lobes triangular, longer than the limb : filaments glabrous : anthers narrow, $8-9 \mathrm{~mm}$. long : berries $5-30 \mathrm{~cm}$. long.

On hillsides and sandy soil, Georgia and Florida. Much cultivated. Spring to fall. EgG-PLANT.

14. Solanum Carolinénse L. Perennial, hirsute or scabro-pubescent, armed with subulate prickles. Stems erect or ascending, 2-7 dm. tall, branching : leaf-blades oblong to ovate in outline, $5-12 \mathrm{~cm}$. long, sinuate or pinnately sinuate-lobed, with the lobes of a triangular type, armed with subulate prickles, petioled : pedicels usually only pubescent : calyx-lobes lanceolate to triangular, acuminate : corolla violet or white, $2.5-3 \mathrm{~cm}$. broad : berries globular, $1.5-2 \mathrm{~cm}$. in diameter, orange-yellow.

In dry or sandy soil, Ontario to Illinois, Massachusetts, Florida and Texas. Spring to fall.

15. Sulanum Floridànum Shuttlw. Similar to S. Carolinense in habit. Leaf-blades deeply pinnatifid, the lobes of an oblong type, the terminal one often elongated : pedicels commonly prickle-armed : calyx-lobes lanceolate or narrowly lanceolate, each narrowed into a slender tip : corolla violet, $2-2.5 \mathrm{~cm}$. broad : berries globular.

In waste places or on roadsides, Florida. Spring to fall. 
16. Solanum Torreỳi A. Gray. Perennial, cinereous with somewhat scurfy pubescence, sparingly armed with subulate prickles. Stems erect or ascending, 3-8 dm. tall, slightly branched : leaf-blades oblong to oval in outline, 6-15 cm. long, sinuately lobed, cuneate to subcordate at the base: petioles $\frac{1}{3}$ as long as the blades or shorter: pedicels prickly and closely pubescent : calyx densely pubescent; tube campanulate; lobes rather ovate, abruptly contracted into subulate tips : corolla $2.5-3 \mathrm{~cm}$. broad, blue or white ; lobes triangular-ovate : berries subglobose, $1-1.5 \mathrm{~cm}$. in diameter, yellow.

In sandy soil, Kansas to Arkansas. Spring and summer.

17. Solanum aculeatíssimum Jacq. Shrubby, sparingly pubescent or glabrate, armed to the flowers with subulate prickles. Stems $3-7 \mathrm{dm}$. tall, branching : leaf-blades membranous, ovate or suborbicular in outline, 6-12 cm. long, angulately-toothed or sinuately-pinnatifid, truncate or cordate at the base : petioles $\frac{1}{2}$ as long as the blades or shorter : calyx bristly; lobes oblong to ovate, as long as the tube or longer : corolla white, 12-18 $\mathrm{mm}$. broad ; lobes lanceolate, recurved : berries subglobose, yellow, $3-6 \mathrm{~cm}$. in diameter.

In sandy soil, North Carolina to Florida and Texas. Throughout the year.

18. Solanum sísymbriifòlium Lam. Annual, villous, bright green, armed often to the flowers with subulate prickles. Stems erect, $3-7 \mathrm{dm}$. tall, widely branching ; leaf-blades oblong or oval in outline, $8-20 \mathrm{~cm}$. long, deeply pinnatifid, the segments oblong or lanceolate, sinuate or pinnatifid, commonly acute: pedicels bristly and glandular-pubescent: calyx bristly; lobes lanceolate, much longer than the campanulate tube : corolla white or light blue, 3-4 cm. broad : berries subglobose, $1.5-2 \mathrm{~cm}$. in diameter.

In waste places, Gulf States and contiguous territory. Introduced from the tropics. Throughout the year.

19. Solanum rostràtum Dunal. Annual, hoary or yellowish pubescent, copiously armed with subulate prickles. Stems $2-7 \mathrm{dm}$. tall, more or less widely branching : leafblades 5-12 cm. long, once or twice pinnatifid; segments coarse, undulate or sinuate : pedicels barely enlarged upward: calyx bristly; lobes linear-lanceolate, longer than the campanulate tube : corolla yellow, about $2.5 \mathrm{~cm}$. broad ; lobes broadly ovate : berries subglobose, each enclosed in a closely armed calyx.

In waste places and on prairies, South Dakota to Tennessee, Mississippi and Mexico. Adventive eastward.

\section{LYCOPÉRSICON Mill.}

Annual or rarely perennial herbs, with strong-smelling herbage and often clammy pubescent foliage. Leaves alternate: blades 1-2-pinnately divided. Flowers in lateral raceme-like cymes. Calyx spreading : tube short: lobes 5 or 6 , narrow. Corolla yellow, rotate : tube very short : limb plaited, spreading : lobes 5 or 6 . Stamens 5 or 6 , exserted. Filaments very short. Anthers elongated, converging or connate, opening lengthwise and introrsely. Ovary 2-several-celled. Stigma capitate. Berries very pulpy, subglobose or pear-shaped, or variously modified in cultivation. Seeds numerous, flattened. Tомато. Berries several-celled. Berries 2-celled.

1. L. Lycopersicon.

1. Lycopersicon Lycopérsicon (L.) Karst. Annual, pubescent and clammy. Stems erect or decumbent, 3-10 dm. long, branching, stout: leaf-blades 1-2-pinnate, 1-4 $\mathrm{dm}$. long, the main leaflets ovate or oblong, coarsely toothed, incised or parted, 3-8 cm. long, the smaller ones more or less numerous: calyx-lobes linear or nearly so, $1-2 \mathrm{~cm}$. long, acute : corolla yellow : berries subglobose or flattened, mainly red, several-celled.

In waste places and about gardens, chiefly about towns and cities, eastern United States. Summer.

2. Iycopersicon cerasifórme Dunal. Similar to the preceding species in habit, but more slender and weaker. Leaves smaller : berries globose, 2-celled.

In dry soil, southern Texas. Native of tropical America, Spring to fall.

\section{PERIZÒMA Miers.}

Herbs or shrubby plants. Leaves alternate : blades entire. Flowers solitary in the axils. Calyx barely accrescent of 5 narrow partially united sepals. Corolla white or yellow, urn-shaped or somewhat tubular, the lobes valvate-induplicate in the bud. Stamens 5 , adnate to the lower half of the corolla tube: anthers converging around the style. Ovary sometimes depressed, sessile : style slender. Berry globular or oblong.

1. Perizoma rhomboidea (J Fook.) Small. Stems branched, the branches spreading or reclining, usually again much-branched : leaf-blades ovate, 1-2.5 $\mathrm{cm}$. long, obtuse or 
acutish, entire, rather slender petioled : calyx-lobes lanceolate-subulate, $2.5-3 \mathrm{~mm}$. long : corolla 6-8 mm. long; lobes spreading, lanceolate : berries oblong, $2-2.5 \mathrm{~cm}$. 'long. [Atropa rhomboidea Hook.]

In waste places, near Jacksonville, Florida. Native of South America.

\section{CÁPSICUM L.}

Annual or perennial herbs or shrubs, with forking stems. Leaves various: blades flat, entire or repand. Flowers solitary in the axils, or in small cymes. Calyx barely accrescent, of 5 wholly or partially united sepals. Corolla usually white, nearly rotate : lobes 5, imbricated. Stamens 5, adnate to the base of the corolla : anthers bluish, the sacs opening lengthwise. Ovary 2-3-celled. Stigma club-shaped or dilated. Berries various, red, yellow or green, nodding, pervaded by a very pungent acridity. Seeds flattened.

Calyx markedly toothed at maturity.

1. C. baccatum. Calyx truncate at maturity.

2. C. frutescens.

1. Capsicum baccàtum L. Shrubby, more or less pubescent. Stems 1-3 m. tall, widely branching : leaf-blades ovate, oblong-ovate or ovate-lanceolate, $2-5 \mathrm{~cm}$. long, acute or acuminate, entire, abruptly narrowed or truncate at the base; petioles $\frac{1}{2}$ as long as the blades or shorter: pedicels narrowly club-shaped, 1-2 cm. long: calyx 2.5-3 mm. long; lobes as long as the tube or somewhat shorter: berries globose to elliptic, 5-10 mm. long, red.

In hammocks and thickets, Florida, Texas and Arizona. Also in the tropics.

2. Capsicum frutéscens L. Shrubby, glabrous or sparingly pubescent. Stems 3-8 dm. tall, widely branching: leaf-blades ovate to ovate-lanceolate, 1-3 cm. long, obtuse, sometimes slightly acuminate, entire, abruptly narrowed or truncate at the base : pedicels slightly enlarged under the calyx : calyx $1.5-2 \mathrm{~mm}$. high, truncate or merely undulate, not toothed : berries oblong or elliptic, $8-12 \mathrm{~mm}$. long, red.

In sandy soil or hammocks, southern Florida. Also in the tropics.

\section{LÝCIUM L.}

Shrubs or woody vines, commonly armed with spines. Leaves alternate, smaller ones often clustered in the axils : blades often thick. Flowers solitary or clustered in the axils. Calyx of 5 partially united sepals, enlarged and persistent at the base of the fruit. Corolla whitish, yellowish or purple, funnelform, salverform or nearly campanulate : tube short or slender: lobes 5 or rarely 4 , imbricated, obtuse. Stamens 5 or rarely 4 , mostly exserted: filaments adnate to the mouth of the corolla-tube: anthers-sacs opening lengthwise. Ovary 2-celled : stigma 2-lobed or capitate. Berry globose to oblong, rather dry.

Tube and throat of the corolla over $4 \mathrm{~mm}$. long.

Leaf-blades flat, some broadest below the middle.

Leaf-blades clavate or spatulate-clavate, broadest above the middle. Tube and throat of the corolla less than $4 \mathrm{~mm}$. long.

1. L. vulgare.

2. L. Carolinianum.

3. L. Berlandieri.

1. Lycium vulgàre (Ait.) Dunal. An irregularly branched and usually straggling vine, with glabrous often armed angled stems and branches 1-7 m. long. Leaf-blades oblong, oval, ovate, lanceolate or spatulate, $1.5-5 \mathrm{~cm}$. long, entire, short-petioled : flowers solitary or 2-5 together in the axils : pedicels slender, $1-2.5 \mathrm{~cm}$. long: calyx-lobes triangular or ovate, obtuse, usually slightly shorter than the tube : corolla funnelform, purplish becoming greenish, about $1 \mathrm{~cm}$. long ; lobes ovate or oblong-ovate, spreading : stamens slightly exserted : berries oval, orange or orange-red.

In thickets, fence rows or waste places, Ontario to Minnesota, Georgia and Kansas. Naturalized from Europe. Spring and summer. Matrimony Vine.

2. Lycium Caroliniànum Walt. A spiny shrub 3-15 dm. tall, glabrous. Stems erect, widely branched: leaves clustered; blades thick, clavate or spatulate-clavate, $0.5-2 \mathrm{~cm}$. long, obtuse, entire, fleshy : pedicels 5-15 $\mathrm{cm}$. long, enlarged under the flowers : calyx 2-4 mm. long; lobes triangular-ovate, acute : corolla 5-6 mm. long; lobes ovate to oblong-ovate, 3-6 mm. long, obtuse or notched : filaments villous-woolly at the base : berries subglobose, $8-12 \mathrm{~mm}$. in diameter, red.

In sandy soil, chiefly on sea shores, South Carolina to Florida and Texas. Spring to fall.

3. Lycium Berlandièri Dunal. A spiny shrub 1-2.5 m. tall, glabrous. Stems erect, 1-2.5 m. tall, branched : leaves clustered ; blades linear or linear-spatulate, 1-2.5 cm. long, entire: pedicels $2-7 \mathrm{~mm}$. Iong, gradually enlarged to the flowers : caly $2-2.5 \mathrm{~mm}$. long ; 
lobes ovate, about as long as the tube : corolla $5-6 \mathrm{~mm}$. long; lobes broader than long: filaments villous at the base : berries globose, $4-6 \mathrm{~mm}$. in diameter.

In river valleys, Texas and Arizona. Spring, to fall.

\section{CÉSTRUM L.}

Shrubs or trees. Leaves alternate : blades entire. Cymes or clusters axillary. Calyx pedicelled : tube campanulate or tubular: lobes 5, valvate. Corolla white, green or yellowish, or rarely golden or scarlet, funnelform or salverform : tube rather long: lobes 5, spreading. Stamens 5, included : filaments adnate to about the middle of the corolla-tube : anther-sacs parallel. Ovary 2-celled, often short-stalked : stigma peltate or slightly 2-lobed. Berry globose to oblong. Seeds few or sometimes solitary, smooth or nearly so.

Calyx less than $3.5 \mathrm{~mm}$. long : corolla less than $1.5 \mathrm{~cm}$. long. Calyx over $3.5 \mathrm{~mm}$. long : corolla over $1.5 \mathrm{~cm}$. long.

1. C. diurnum.

2. C. Parqui.

1. Cestrum diúrnum L. Shrubby, minutely pubescent. Stems erect, 1-2.5 m. tall, branching : leaf-blades oblong to oblong-lanceolate, $5-12 \mathrm{~cm}$. long, acute or acutish, entire, oblique at the base; petioles 5-10 $\mathrm{mm}$. long: calyx $3 \mathrm{~mm}$. long; tube campanulate; lobes broadly ovate : corolla greenish, 11-13 mm. long; tube gradually dilated; lobes ovate, rounded.

In sandy soil, southern Florida and Texas. Naturalized from the West Indies. Spring to fall.

2. Cestrum Párqui L'Her. Shrubby, nearly glabrous. Stems 1-2 m. tall, branching: leaf-blades oblong to oblong-lanceolate, 1-2 dm. long, acute or somewhat acuminate, entire ; petioles 1-1.5 $\mathrm{cm}$. long: calyx 4-4.5 mm. long; tube nearly cylindric ; lobes triangular to triangular-ovate : corolla greenish, $2-2.5 \mathrm{~cm}$. long; tube gradually dilated; lobes broadly ovate, obtuse, $3-4 \mathrm{~mm}$. long.

In woods and waste places, Georgia and Florida to Texas. Naturalized from tropical America. Spring and summer.

\section{DATÙRA L.}

Annual or perennial rank smelling herbs, shrubs or trees, pervaded by a narcotic principle. Leaves alternate : blades various. Flowers solitary in the axils. Calyx shortpedicelled : tube elongated, sometimes prismatic, spathe-like or with 5 short lobes, often circumscissile near the base. Corolla white, purple or violet, funnelform : tube much surpassing the calyx : limb plaited : lobes 5, acuminate. Stamens 5, included or nearly so : filaments filiform, adnate to about the middle of the corolla-tube or below it. Ovary 2celled or falsely 4-celled : stigma 2-lobed. Capsule more or less prickly, 4-valved or opening irregularly. Thonn Apple. Jimson Weed. Jamestown Weed. Stramonium.

Foliage glabrous or nearly so: capsules erect.

Stems green: corolla white.

Stems purple : corolla violet or lavender.

Foliage closely pubescent or downy: capsules nodding.

Capsules armed with stout prickles which are corrugated at the base : corolla violet without, white within.

Capsules armed with slender prickles : corolla white or violet.

Corolla-limb 5-lobed, usually $12-15 \mathrm{~cm}$. broad.

Corolla-limb 10 -lobed, usually $10 \mathrm{~cm}$. broad.

1. D. Stramonium.

2. D. Tatula.

1. Datura Stramònium L. Annual, glabrous or glabrate, the foliage green. Stems 2-12 dm. tall, widely branching, stout : leaf-blades ovate to oblong, 1-2 dm. long, acute, sinuate or laciniately toothed or angled ; petioles as long as the blades or shorter : pedicels 5-10 mm. long: calyx $3-5 \mathrm{~cm}$. long; lobes triangular or triangular-lanceolate, 5-7 mm. long: corolla white, 6-10 cm. long; lobes prolonged into slender tips : capsules 4-6 cm. long, thickly armed with stout prickles.

In waste places and cultivated grounds, Nova Scotia to Minnesota, Florida and Texas. Naturalized from tropical regions. Summer and fall.

2. Datura Tátula L. Annual, glabrate, the foliage; especially the stem, purplish. Stems 2-12 dm. tall, often widely branched : leaf-blades ovate or oblong, sinuately or angulately toothed : pedicels stout, $5-15 \mathrm{~mm}$. long: caly x $3-6 \mathrm{~cm}$. long; lobes triangular-lanceolate, 4-7 mm. long: corolla violet or lavender, 8-11 cm. long; lobes prolonged into slender tips : capsules oval or ovoid, 4-6 $\mathrm{cm}$. long, closely armed with stont prickles.

In waste places and fields, Ontario to Minnesota, Connecticut, Florida and Texas. Naturalized from tropical America. Spring to fall.

3. Datura fastuòsa L. Annual, nearly glabrous. Stems erect, 1-2 m. tall, somewhat branched : leaf-blades ovate-lanceolate, elliptic or oval, 5-15 cm. long, acute or 
acuminate, glabrous, undulate or repand-dentate, slender-petioled : calyx 5-6.5 cm. long ; lobes ovate to triangular-ovate, acute or short-acuminate : corolla violet without, white within, 14-18 cm. long: capsules oval or ovoid, 4-6 $\mathrm{cm}$. long, armed with stout prickles with corrugated bases.

In waste places, Gulf States. Introduced from the tropics. Spring to fall.

4. Datura meteloìdes DC. Annual, closely and finely pubescent. Stems erect, 3-11 dm. tall, somewhat branched : leaf-blades ovate to oval-ovate, $10-15 \mathrm{~cm}$. long, acute or acuminate, sinuate-toothed : calyx 10-12 cm. long; lobes lanceolate, acuminate : corolla white, suffused with violet, 15-20 cm. long, the limb 12-15 $\mathrm{cm}$. broad, 5-lobed : capsules subglobose, 4-5 cm. in diameter.

In river valleys, Texas to California and adjacent Mexico. Spring to fall.

5. Datura Mètel L. Annual, finely pubescent. Stems $8-15 \mathrm{dm}$. tall, more or less branched : leaf-blades ovate or oblong-ovate, 1-2 dm. long, often abruptly pointed, undulate, or slightly angled, rounded or subcordate at the oblique base ; petioles usually shorter than the blades: pedicels stout, 1-2 cm. long: calyx 7-12 cm. long; lobes lanceolote or triangular-lanceolate, acuminate : corolla white, 10-15 cm. long, the limb about $10 \mathrm{~cm}$. broad, 10-lobed : capsules oval or globose-ovoid, $3 \mathrm{~cm}$. long, copiously armed with sharp prickles.

In waste places, Rhode Island to Florida. Naturalized from tropical America. Summer and fall.

\section{NICOTIANA L.}

Annual or perennial herbs, with an acid narcotic principle and viscid-pubescent foliage. Leaves alternate : blades entire or repand. Racemes or panicles terminal. Calyx pedicelled: tube campanulate to tubular or ovoid: lobes 5. Corolla white, green, yellow or purple, funnelform, salverform or nearly tubular: tube commonly longer than the limb : lobes 5, spreading. Stamens 5, included : filaments adnate to the base of the corolla-tube or free: anther sacs opening lengthwise. Ovary 2-celled or rarely 4-celled : stigmas capitate. Capsule 2-valved or 4-valved near the top. Seeds very numerous.

Corolla-tube very slender, many times longer than the calyx.

Leaf-blades sessile: calyx-lobes narrowed upward.

Leaf-blades clasping: calyx-lobes dilated upward.

Corolla-tube stout, 2-4 times longer than the calyx.

Leaf-blades somewhat clasping : caly x-lobes linear or lanceolate-subulate.

Leaf-blades petioled: calyx-lobes triangular or ovate-triangular.

Corolla $1.5-2 \mathrm{~cm}$. long: caly x-lobes acute, fully as broad as long: paniclebranches pubescent.

Corolla $3.5-4 \mathrm{~cm}$. long; calyx-lobes acuminate, longer than broad: paniclebranches glabrous.

1. N. longiflora.

2. N. repanda.

3. N. trigonophylla.

4. N. rustica.

5. N. glauca.

1. Nicotiana longiflòra Cav. Annual, viscid and rough-puberulent. Stems 3-10 dm. tall, branched : leaf-blades spatulate, oblanceolate or oblong, or linear on the upper part of the stem, 8-25 cm. long, undulate, sessile : racemes elongated and much interrupted: pedicels $5-15 \mathrm{~mm}$. long: calyx 10-12 mm. long; lobes attenuate, rather shorter than the tube: corolla white or purplish, 7-10 cm. long; tube slender; limb $2.5-3 \mathrm{~cm}$. broad, the lobes ovate to ovate-lanceolate: capsules oblong-ovoid, about as long as the calyx.

In waste places, eastern and southern United States. Native of South America. Summer and fall.

2. Nicotiana repánda Willd. Annual, minutely pubescent or glabrate above. Stems 3-7 dm. tall, often widely branching : leaf-blades membranous, suborbicular or ovaloblong, 5-15 cm. long, repand, the lower abruptly contracted into petiole-like bases, the upper sessile and clasping : pedicels $5-12 \mathrm{~mm}$. long : calyx $8 \mathrm{~mm}$. becoming $12 \mathrm{~mm}$. long ; tube campanulate; lobes linear, or nearly so, longer than the tube : corolla $4-6 \mathrm{~cm}$. Iong ; limb white or tinged with pink, $1.5-2.5 \mathrm{~cm}$. broad, the lobes ovate : capsules ovoid, about $1 \mathrm{~cm}$. broad.

In sandy soil, Texas and Mexico. Spring.

3. Nicotiana trigonophýlla Dunal. Annual, viscid-pubescent. Stems erect, 3-10 dm. tall, simple or widely branched : leaf-blades oblong or oblanceolate, $3-10 \mathrm{~cm}$. long, entire, somewhat clasping : racemes simple or loosely paniculate : pedicels $3-11 \mathrm{~mm}$. long : calyx usually longer than the pedicels; lobes linear or lanceolate-subulate, about as long as the tube : corolla $1.5-2 \mathrm{~cm}$. long, yellowish or greenish white; tube stout, slightly constricted at the throat; limb $8-12 \mathrm{~mm}$. broad, the lobes triangular or ovate-triangular : capsules ovoid, 5-10 mm. long.

In sandy soil, Texas to California and Mexico. Spring to fall.

4. Nicotiana rústica L. Annual, finely pubescent. Stems 5-12 dm. tall, branched : leaf-blades ovate or broadly ovate, $5-20 \mathrm{~cm}$. long, entire, thin, petioled : panicles open : 
pedicels $5-11 \mathrm{~cm}$. long : calyx $5-7 \mathrm{~mm}$. long, becoming $10 \mathrm{~mm}$. long at maturity ; lobes broadly triangular or ovate-triangular, shorter than the tube: corolla lurid yellow or greenish, 1.5-2 cm. long; tube inflated and constricted near the throat; limb 10-15 mm. broad, the rounded lobes veiny : capsules broadly ovoid, or globose-ovoid, 8-10 $\mathrm{mm}$. long.

In fields and waste places, Ontario to Minnesota, New York and Florida. Escaped from cultivation. Summer.

5. Nicotiana glaùca Graham. A branching shrub, or a tree becoming $6 \mathrm{~m}$. tall : leaf-blades ovate or oblong-ovate, $5-30 \mathrm{~cm}$. long or sometimes larger, undulate, long or slender-petioled : panicles long : pedicels mostly less than $10 \mathrm{~mm}$. long: calyx 11-15 mm. long; lobes lanceolate or triangular-lanceolate, shorter than the tube : corolla yellow or yellowish, 3.5-4 cm. long; tube gradually enlarged to the slightly constricted throat; limb about $10 \mathrm{~mm}$. broad, the lobes broad but acutish : capsules narrowly ovoid or oblongovoid, 10-12 mm. long.

In waste places, seaports of the Gulf States and California, and on ballast further northward. Also in tropical America. Native of Argentina.

\section{PETÙNIA Juss.}

Annual or perennial herbs, with viscid-pubescent foliage and branching stems. Leaves alternate: blades entire. Flowers solitary in the axils. Calyx of 5 partially united sepals : tube rather short: lobes narrow. Corolla white, violet, purple or variegated, funnelform or salverform : limb spreading, plaited, nearly regular. Stamens 5, 4 didynamous, fertile, the fifth smaller or obsolete : filaments adnate to the base of the corolla-tube. Ovary 2-celled. Stigma 2-lobed. Capsule 2-valved: valves entire. Seeds numerous, rugose.

1. Petunia parviflòra Juss. Annual, somewhat pubescent. Stems more or less diffusely branched, 1-4 dm. long: leaves rather fleshy; blades spatulate to oblong, 0.5-1.5 $\mathrm{cm}$. long, entire : calyx glandular-pubescent; lobes linear or linear-spatulate, 4-6 mm. long: corolla about $5 \mathrm{~mm}$. long; tube yellowish or pale white; limb purple, $6-8 \mathrm{~mm}$. broad : capsules ovoid, 3-4 mm. long, surpassed by the calyx-lobes.

In dry soil, Fiorida to Texas and California. Throughout tropical America. Spring to fall.

\section{BOUCHËTIA DC.}

Perennial herbs, with viscid-pubescent foliage and decumbent or ascending stems. Leaves alternate: blades entire. Flowers on solitary pedicels terminating the branches, or opposite the leaves. Calyx of 5 partially united sepals : tube rather long-campanulate: lobes narrow. Corolla commonly white, funnelform : tube dilated above : lobes 5, broad, plicate. Stamens 5, included, 4 didynamous, the fifth smaller : filaments adnate to the lower part of the corolla-tube. Anther-sacs confluent at the apex. Ovary 2-celled. Capsule 2-4-valved. Seeds numerous, granular.

1. Bouchetia anómala (Miers) Britt. \& Rusby. Stem more or less branched, 1-3 dm. tall, finely pubescent. Leaf-blades oblong, elliptic, oblong-spatulate or lanceolate to broadly linear above, $1-3 \mathrm{~cm}$. long, entire, the lower ones petioled : pedicels terminal, 1-1.5 cm. long: calyx 6-10 mm. long; lobes lanceolate or linear-lanceolate, as long as the tube or somewhat shorter : corolla mainly white with delicate purple lines, about $1 \mathrm{~cm}$. long, broadly funnelform; lobes broad and rounded: capsules oblong or ovoid-oblong, 7-8 mm. long.

On prairies and rocky hillsides, Texas. Also in tropical America. Spring to fall.

\section{Family 7. BorRaginàceat A. Gray. Borage Family.}

Herbs or shrubby plants, with watery sap. Foliage commonly clothed with bristly pubescence. Leaves alternate, without stipules: blades simple, mainly entire. Flowers typically perfect, regular, or sometimes irregular, more or less remote from the bracts, cymose, but apparently in spikes or racemes, which are often scorpioid. Calyx of 5, or rarely 4, more or less united sepals, persistent, sometimes corolloid. Corolla hypogynous, deciduous: limb 5-lobed: lobes usually equal, convolute, plicate or induplicate. Androecium of 5 stamens, adnate to the corolla-tube, sometimes as high as the throat. Filaments often appendaged. Anthers introrse. Gynoecium of 4 nearly distinct or more or less cohering carpels. Styles united, arising from between the ovary-lobes. Stigma 
simple or 2-lobed. Ovules solitary in each cavity, anatropous. Fruit of two or four pyrenae or a group of 4 distinct or cohering nutlets.

Corolla regular.

Nutlets armed with barbed prickles.

Nutlets spreading, covered with prickles.

Nutlets erect or incurved, with prickles on the back or angles.

Nutlets unarmed.

Receptacle conic or elongated.

Receptacle flat or merely convex.

Nutlets attached laterally to the receptacle.

Nutlets attached to the receptacle by their bases.

Nutlets each with a small, flat scar where attached.

Corolla funnelform or salverform; lobes obtuse, spreading.

Racemes without bracts.

Racemes with bracts.

Corolla tubular: lobes acute or acuminate, erect.

Corolla irregular.

Nutlets each with a large hollow scar where attached.

Stamens included : corolla-throat closed by scales.

Stamens exserted : corolla-throat dilated and open.

1. CYNOGLOSSUM.

2. Lappula.

3. Cryptanthe.

4. Mertensia.

5. Myosotis.

6. LITHOSPERMUM.

7. ONOSMODIUM.

8. SYMPHYTUM.

9. LYCOPSIS.

10. ECHIUM.

\section{CYNOGLÓSSUM L.}

Annual, biennial or perennial caulescent herbs, with usually pubescent foliage. Leaves alternate: blades entire. Flowers in more or less strongly scorpioid racemes. Calyx slightly accrescent : lobes 5, spreading or reflexed. Corolla white, blue or purple, salverform or funnelform : tube short, the throat closed by 5 scales: lobes 5 , imbricated. Stamens 5, included : filaments short, adnate to the corolla-tube. Ovary of 4 nearly distinct lobes. Ovules laterally attached to the central axis. Nutlets 4, flat or convex, distinct, armed with short barbed prickles.

Foliage softly pubescent : stems copiously leafy to the top: nutlets flat : naturalized biennial plant.

Foliage hirsute : stems terminated by a long naked peduncle : nutlets convex : native perennial plant.

2. C. Virginicum.

1. Cynoglossum officinàle L. Biennial, softly pubescent. Stems $2-6 \mathrm{dm}$. tall, leafy to the top: leaves numerous; blades oblong to linear-oblong or linear-lanceolate, $5-15 \mathrm{~cm}$. long, the lower ones petioled, the upper sessile or nearly so : racernes elongating, interrupted : pedicels $5-10 \mathrm{~mm}$. Iong : calyx densely pubescent ; lobes ovate or oval, 3-6 $\mathrm{mm}$. long, obtuse : corolla dull reddish purple or white, about $1 \mathrm{~cm}$. broad : fruit about 1 $\mathrm{cm}$. broad, echinate.

In waste places, Quebec to Minnesota, south to Georgia and Kansas. Spring to fall. Naturalized from Europe. HOUND'S TONGUE.

2. Cynoglossum Virgínicum L. Perennial, hirsute. Stems 2-9 dm. tall, simple below, naked and branched above : leaves few; blades oval to oblong, the lower narrowed into margined petioles, the upper sessile and clasping : peduncle 1-3 dm. long: racemes contracted or elongating at maturity : pedicels $3-6 \mathrm{~mm}$. long, more or less curved : calyx rather softly pubescent; lobes ovate to oblong, obtuse : corolla white or purplish, 8-10 $\mathrm{mm}$. broad : fruit $1 \mathrm{~cm}$. broad, echinate.

In woods and copses, New Brunswick to Ontario and Kansas, south to Florida and Louisiana. Spring. WILD COMFREY.

\section{LÁPPULA Moench.}

Annual biennial or perennial herbs, with pubescent foliage. Leaves alternate: blades entire, often narrow. Flowers in terminal racemes. Calyx little if at accrescent : lobes 5, narrow. Corolla white or blue, salverform or funnelform : tube very short, the throat closed by 5 scales: lobes 5 , obtuse, imbricated. Stamens 5, included. Filaments very short. Ovary of 4 more or less distinct carpels. Fruit of 4 finally distinct nutlets, these with papillose or tuberculate sides and prickle-armed angles or back. The plants flower in spring and summer. [Echinospermum Sw.] STICKSEed. BURSEed.

Racemes with all pedicels subtended by bracts : fruit erect or ascending.

Spines distinet, in 2 rows on the margins of the nutlets.

Spines more or less confluent, in 1 row on the margins of the nutlets. Racemes with only the lower pedicels subtended by bracts : fruit drooping.

1. L. Lappula.

2. L. Texana.

3. L. Virginiana.

1. Lappula Láppula (L.) Karst. Annual, hirsute. Stems 2-6 dm. tall, branching above : leaves erect or ascending; blades linear or linear-spatulate, $2-5 \mathrm{~cm}$. long, usually acute : racemes elongating at maturity: pedicels 1-4 mm. long: nutlets with 2 rows of distinct spines on the edges and granulose or tuberculate on the back.

In waste places and dry soil, Nova Scotia to British Columbia, New Jersey and Texas. Naturalized from Europe. 
2. Lappula Texàna (Scheele) Britton. Annual or biennial, hispid. Stems 1-4 dm. tall, usually branched above and sometimes at the base : leaves mostly erect or ascending; blades linear or spatulate-linear, or the basal sometimes spatulate, obtuse : flowers nearly sessile, or short-pedicelled : nutlets with spines in one row on the margins, the bases of the spines of 2 or 3 of the nutlets confluent and forming a cup.

In dry soil, Colorado to Texas and Arizona.

3. Lappula Virginiàna (L ) Greene. Annual or biennial, somewhat hirsute or finely pubescent. Stems 3-9 dm. tall, branched above; branches spreading : leaves alternate; blades thin, oblong, elliptic or oblong-lanceolate, acute or short-acuminate, undulate, the lower 1-2 dm. long, petioled, the upper $3-10 \mathrm{~cm}$. long, sessile or nearly so: racemes elongating, interrupted : pedicels $2-6 \mathrm{~mm}$. long : calyx-lobes lanceolate to oblong-lanceolate, $2-3 \mathrm{~mm}$. long : corolla white or pale blue, $2-3 \mathrm{~mm}$. broad : fruit subglobose, about 4 $\mathrm{mm}$. in diameter : nutlets papillose and spiny.

In woods and thickets, New Brunswick to Minnesota, south to Georgia, Louisiana and Nebraska.

\section{CRYPTÁNTHE Lehm.}

Annual caulescent herbs, with pubescent foliage. Leaves alternate: blades narrow, entire. Flowers in narrow scorpioid spikes or racemes. Calyx-lobes 5, erect, usually converging at maturity. Corolla white, funnelform, the tube usually closed by 5 scales in the throat: lobes 5, imbricated. Stamens 5, included : filaments short. Ovary of 4 nearly distinct carpels. Fruit of 4 nutlets with rounded backs and obtuse, acute or winged margins, laterally attached to the receptacle.

1. Cryptanthe Texàna (A. DC.) Greene. Stems $2-3 \mathrm{dm}$. tall, hispid like the rest of the foliage, loosely branching. Leaves few ; blades oblong to oblong-spatulate, or broadly linear above, 1-2.5 cm. long: racemes mostly bractless: flowers almost sessile : calyx bristly : sepals linear, becoming 4-5 $\mathrm{mm}$. long: nutlets usually solitary, ovoid or oblong-ovoid, about $2 \mathrm{~mm}$. long, acute.

In dry soil, eastern Texas. Spring and summer.

\section{MERTÉnsia Roth.}

Perennial caulescent herbs, with rather succulent herbage and glabrous glaucous or pubescent foliage. Leaves alternate: blades entire, sometimes punctate. Flowers in racemes, panicles or cymes. Calyx-lobes 5, narrow, unchanged or little enlarged at maturity. Corolla often showy, white, blue or purple, tubular-funnelform or trumpetshaped, the tube sometimes appendaged in the throat : lobes 5 , imbricated, obtuse. Stamens 5 , included or barely exserted : filaments filiform or flattened, adnate to the corolla-tube. Ovary of 4 nearly distinct carpels. Nutlets 4, leathery, erect, wrinkled at maturity, laterally attached to the receptacle above their bases. LUNGWORT.

1. Mertensia Virgínica (L.) DC. Perennial, glabrous, often glaucescent. Stems clustered, erect or ascending, 2-6 dm. tall, simple below the inflorescence : leaves $5-20 \mathrm{~cm}$. long; blades oblong-elliptic or oval, obtuse, often undulate, the lower narrowed into winged petioles, the upper sessile : panicles short, corymb-like : pedicels slender, $2-10 \mathrm{~mm}$. long, curved : calyx 2-2.5 mm. long; lobes oblong or lanceolate, longer than the tube : corolla blue or rarely white, about $3 \mathrm{~mm}$. long; tube narrowly funnelform, abruptly expanding into the limb, which is cup-shaped, lightly lobed, $1-1.5 \mathrm{~cm}$. broad.

On rich banks, Ontario to Minnesota, Georgia, Tennessee and Kansas. Spring. Blukbelis.

\section{MYOSÒTIS L.}

Annual biennial or perennial caulescent herbs. Leaves alternate : blades entire, often narrow. Flowers in simple or branched 1-sided racemes. Calyx-lobes 5, spreading or erect. Corolla white, pink or blue often with a discolored eye, salverform, the tube short : lobes 5, spreading, rounded, convolute. Stamens 5, included : filaments filiform, adnate to the corolla-tube. Ovary of 4 nearly distinct carpels. Nutlets 4, attached to the receptacle by their bases, glabrous or pubescent. Forget-ME-NOT. Scorpion-Grass.

Calyx pubescent with straight appressed hairs, open at maturity.

Caly $\mathrm{x}$-lobes shorter than the tube : corolla $6-8 \mathrm{~mm}$. broad.

Calyx-lobes as long as the tube : corolla 4-6 mm. broad.

Calyx pubescent with more bristly and more hooked hairs, closed or with erect lobes at maturity.

a. Pedicels longer than the calyxes at maturity.

1. M. palustris.

2. M. laxa.

3. M. arvensis. 
b. Pedicels shorter than the calyxes.

Fruiting racemes with many approximate erect or ascending pedicels : calyx less than $5 \mathrm{~mm}$. long at maturity : seeds $1.5 \mathrm{~mm}$. long.

Fruiting racemes with few more or less recurving pedicels : calyx over 5 $\mathrm{mm}$. long at maturity : seeds $2 \mathrm{~mm}$. long.

4. M. Virginica.

5. M. macrosperma.

1. Myosotis palústris (L.) Lam. Stems pubescent with appressed hairs, soon decumbent and creeping, 2-6 dm. long, branching : leaf-blades spatulate to oblong or oblonglanceolate, obtuse or acutish, entire, the lower often short-petioled, the upper sessile : racemes elongating, much interrupted: pedicels 4-7 mm. long, spreading: calyx-lobes triangular, shorter than the tube : corolla sky-blue and with a yellow eye, 6-8 mm. broad : nutlets shining, about $1.5 \mathrm{~mm}$. long.

In low grounds or brooks, Nova Scotia to New York and Georgia. Spring and summer. Naturalized from Europe.

2. Myosotis láxa Lehm. Stems strigillose, soon decumbent, creeping, 1-5 dm. long, branched : leaf-blades spatulate, oblong or oblong-lanceolate, 1-8 cm. long, obtuse, entire, the lower ones short-petioled, the upper sessile : racemes elongating, interrupted: pedicels spreading, 5-10 mm. long : caly x-lobes triangular or triangular-lanceolate, as long as the tube or longer, acute : corolla mainly pale-blue ; limb concave, 4-6 mm. broad : nutlets about $1 \mathrm{~mm}$. long, lenticular.

In low grounds and swamps. Nova Scotia and Ontario to Georgia and Tennessee. Spring and summer. Also in Europe.

3. Myosotis arvénsis (L.) Willd. Stems hirsute, erect, 1-3 dm. tall, loosely branched above : leaf-blades spatulate to oblong or oblong-lanceolate, 1-5 cm. long, obtuse or acutish, entire, sessile or nearly so : racemes loosely flowered, elongating: pedicels 2-5 $\mathrm{mm}$. long, spreading : calyx bristly ; lobes equal or nearly so, lanceolate or linear-lanceolate, $2-3 \mathrm{~mm}$. long: corolla white or mostly blue; limb $2-3 \mathrm{~mm}$. broad, concave : fruit enclosed in the calyx : nutlets oblong, $1.5 \mathrm{~mm}$. long.

In waste places, New Brunswick to Ontario, Minnesota, North earolina and West Virginia. Summer. Also in Europe.

4. Myosotis Virgínica (L.) B.S.P. Stems hirsute, erect, 1-4 dm. tall, the branches strongly ascending or erect : leaf-blades spatulate to oblong or oblong-lanceolate, 1-3 cm. long, obtuse or acutish, entire, sessile : racemes elongating, loosely flowered : pedicels 1-3 $\mathrm{mm}$. long, erect or ascending: calyx beset with spreading hairs, those near the base hooked ; lobes unequal, lanceolate, often narrowly so, $2-3 \mathrm{~mm}$. long, acute : corolla white ; limb $2.5-3 \mathrm{~mm}$. broad : fruit enclosed in the calyx : nutlets elliptic, a little more than 1.5 mm. long. [Myosotis verna Nutt.]

In dry soil and on open hillsides, Maine to Ontario, Minnesota, Florida and Texas. Spring.

5. Myosotis macrospérma Engelm. Stems hirsute, erect, 2-5 dm. tall, loosely branched: leaf-blades spatulate to oblong or oblong-lanceolate, mucronate, entire, sessile : racemes much interrupted, elongating: pedicels ascending or spreading, 3-5 mm. long: calyx beset in hooked hairs; lobes very unequal, lanceolate to linear-lanceolate, the lower 4-5 mm. long, twice as long as the upper : corolla white, 4-5 mm. broad : fruit enclosed in the calyx : nutlets oblong-obovoid, over $2 \mathrm{~mm}$. long.

On hillsides, Maryland to Arkansas, Florida and Texas. Spring.

\section{LITHOSPÉRMUM L.}

Annual or perennial caulescent herbs, often with large or long colored roots. Leaves alternate : blades entire. Flowers in bracted spikes or racemes. Calyx pubescent: lobes 5 , narrow. Corolla white, yellow or blue, salverform or funnelform, the tube with a naked pubescent or appendaged throat : lobes 5, entire, erose or toothed. Stamens 5, included. Ovary of 4 nearly distinct carpels. Stigmas capitate or 2 -lobed. Nutlets 4 or fewer, white and shiny or brown and wrinkled, attached by their bases to the almost flat receptacle. Gromwell. Puccoon.

Annual plants : corolla white or whitish, slightly surpassing the calyx.

Pubescent with appressed hairs : bracts of a linear type : corolla about $6 \mathrm{~mm}$. long.

Hirsute or hispid : bracts of an oblong type : corolla about $4 \mathrm{~mm}$. long.
Perennial plants : corolla yellow or sometimes greenish white.

1. L. arvense.

Cauline leaves with broadly linear or oblong-linear blades: nutlets papillose, spurred near the base.

Cauline leaves with broader blades, mainly elliptic or oblong : nutlets sparingly and shallowly pitted.

Corolla-tube shorter than the calyx or but slightly surpassing it. Pubescence of stem strictly appressed. Pubescence of stem more or less spreading.

Corolla-tube, of the complete flowers, much longer than the calyx, the

2. L. Matamorense. limb deep yellow or orange.

3. L. mirabile.

4. L. latifolivm.

5. L. tuberosum. 
Corolla-lobes entire: all flowers complete.

Stems hirsute: corolla-tube beardless at the base within.

Stems hispid: corolla-tube bearded at the base within.

Corolla-lobes erose or laciniate: later flowers cleistogamous Corolla-tube $2.5-3 \mathrm{~cm}$. long, the limb fully $1.5 \mathrm{~cm}$. wide.

Corolla-tube $1-1.5 \mathrm{~cm}$. long, the limb less than $1.5 \mathrm{~cm}$. wide. Corolla-tube about $1.5 \mathrm{~cm}$. long, the limb over $1 \mathrm{~cm}$. wide. Corolla-tube about $1 \mathrm{~cm}$. long, the limb less than $1 \mathrm{~cm}$. wide.

6. L. canescens.

7. L. Gmelinii.

8. L. linearifolium.

9. L. Mandanense.

10. L. breviflorum.

1. Lithospermum arvense L. Annual or biennial, hoary-strigose. Stems erect or spreading, 1-8 dm. long, branching, mainly near the base : leaf-blades linear-oblanceolate to linear-lanceolate, $1.5-5 \mathrm{~cm}$. long, acutish, entire, sessile: racemes spike-like, interrupted : calyx bristly ; lobes linear or linear-subulate, $8-10 \mathrm{~mm}$. long, ciliate : corolla white or tinged with pink, pubescent in throat; tube funnelform; limb $5 \mathrm{~mm}$. broad, with j oblong-ovate lobes : nutlets ovoid, $3 \mathrm{~mm}$. long, pitted and wrinkled.

In copses and waste places, Quebec to Ontario, Michigan, middle Georgia and Kansas. Naturalized from Europe. Spring and summer. CORN GROMWELL.

2. Lithospermum Matamorénse DC. Annual, hirsute or hispid. Stems more or less branched at the base; branches ascending or spreading, 1-3 dm. long: leaf-blades spatulate to oblong, obtuse or apiculate, entire, rough, sessile, or the lower with short petioles : racemes leafy, interrupted : pedicels very short : calyx bristly ; lobes linear, $3-5$ $\mathrm{mm}$. long : corolla white; tube funnelform; limb about $5 \mathrm{~mm}$. broad : nutlets ovoid, $3 \mathrm{~mm}$. long, shining, pitted.

In sandy soil, Texas and adjacent Mexico. Spring.

3. Lithospermum miràbile Small. Perennial, resembling L. Matamorense in habit. Branches strigose: leaves various, those of the basal leaves narrowly spatulate to oblanceolate, 3-5 cm. long, those of the cauline leaves broadly linear to oblong-linear, $2-3 \mathrm{~cm}$. long, mainly obtuse, entire, copiously pubescent : flowers axillary to leaf-like bracts, early separated, short-pedicelled : calyx bristly ; lobes linear, becoming $6-8 \mathrm{~mm}$. long, persistent : nutlets triangular or ovoid-triangular, about $3.5 \mathrm{~mm}$. long, densely papillose, spurred on both sides near the base, sharply keeled on the inner side.

On plains, San Antonio, Texas. Spring.

4. Lithospermum latifòlium Michx. Perennial, strigillose. Stems 3-7 dm. tall, sparingly branched : leaf-blades elliptic to elliptic-lanceolate, 4-12 cm. long, acuminate, undulate, 4-8-ribbed beneath, narrowed into short petioles : pedicels axiliary, 2-10 mm. long: calyx strigillose; lobes linear, $5-10 \mathrm{~mm}$. long : corolla yellowish white or pale yellow, about $5 \mathrm{~mm}$. long; tube funnelform; limb $6-7 \mathrm{~mm}$. broad : nutlets ovoid, $3-3.5 \mathrm{~mm}$. long, whitish, lustrous, sparingly pitted.

In dry soil. Ontario to Minnesota, Virginia and Tennessee. Spring and summer.

5. Lithospermum tuberòsum Rugel. Perennial, hispid, the roots bearing elongated tubers. Stems 2-7 dm. tall, sparingly branched above: basal leaves with spatulate or oblongspatulate blades, $8-20 \mathrm{~cm}$. long, rather densely hispid above: stem-leaves $2-10 \mathrm{~cm}$. long, oblanceolate to oblong or ovate-oblong: pedicels axillary, 1-3 mm. long: calyx bristly ; lobes linear or linear-spatulate, 3-6 mm. long: corolla yellowish white, 4-6 mm. long; lobes oblong or nearly so, shorter than the tube: nutlets oval-obovoid, $2 \mathrm{~mm}$. long, whitish, lustrous, sparingly pitted.

On river bluffs, Tennessee to Florida and Texas. Spring.

6. Lithospermum canéscens (Michx.) Lehm. Perennial, hirsute, or canescent when young. Stems usually clustered, 1-4 dm. tall, branching above: leaves rather numerous ; blades linear to oblong or sometimes ovate-oblong, obtuse, entire, sessile or nearly so : calyx short-pedicelled; lobes 2-5 mm. long, linear or nearly so : corolla orange-yellow, about 1 $\mathrm{cm}$. long; tube funnelform, prominently crested in the throat; limb 10-14 $\mathrm{mm}$. broad, with rounded lobes : nutlets ovoid, $2.5 \mathrm{~mm}$. long, lustrous, keeled.

In dry soil, Ontario to the Northwest Territory, Georgia and Arizona. Spring.

7. Lithospermum Gmélini (Michx.) A. S. Hitchcock. Perennial, hirsute or hispid. Stems usually clustered, 1-5 dm. tall, simple or sparingly branched above: leaf-blades variable, the lower reduced to scales, the others linear to lanceolate or oblong, $1-5 \mathrm{~cm}$. long, obtuse or apiculate, entire, sessile or nearly so : calyx short-pedicelled ; lobes lanceolate or narrowly lanceolate, $6-10 \mathrm{~mm}$. long, acute : corolla bright orange, $1.2-1.6 \mathrm{~cm}$. long ; tube surpassing the calyx, nearly cylindric; lobes rounded, undulate, shorter than the tube : nutlets ovoid, $3-3.5 \mathrm{~mm}$. long, lustrous.

In dry soil or woods, New York to Minnesota, Florida and New Mexico. Spring.

8. Lithospermum linearifòlium Goldie. Perennial, strigose. Stems tufted, usually 1-3 dm. long, simple or sparingly branched above : leaves numerous; blades linear, diffuse or linear-lanceolate, acute, entire, sessile or nearly so : calyx short-pedicelled ; lobes linear, 
5-10 mm. long : corollas of 2 kinds, the earlier of a bright yellow color, with tube 2.5-3 $\mathrm{cm}$. long, crested in the throat and rounded lacerate lobes, the later form not surpassing the calyx, pale-yellow : nutlets oblong-ovoid, 3-4 mm. long, keeled, sparingly pitted.

In dry soil, often on prairies, Manitoba to British Columbia, Illinois, Texas and Arizona. Spring and summer.

9. Lithospermum Mandanénse Spreng. Perennial, strigose. Stems tufted, typically less than $2 \mathrm{dm}$. tall, commonly simple : leaf-blades linear or nearly so, $2-5 \mathrm{~cm}$. long : corolliferous flowers clustered : corolla yellow; tube about $1.5 \mathrm{~cm}$. long; limb over $1 \mathrm{~cm}$. wide, the lobes erose : nutlets ovoid, about $3 \mathrm{~mm}$. long.

On plains and in woods, Alberta to Texas and Arizona. Spring and summer.

10. Lithospermum breviflòrum Engelm. \& Gray. Perennial, strigose, similar to L. Mandanense in habit but often more slender and taller. Stems tufted, typically over $2 \mathrm{dm}$. tall, commonly branched : leaf-blades narrowly linear, $1.5-4 \mathrm{~cm}$. long : corolliferous flowers clustered: corolla yellow; tube about $1 \mathrm{~cm}$. long; limb less than $1 \mathrm{~cm}$. wide, the lobes erose : nutlets $3.5-4 \mathrm{~mm}$. long, strongly keeled.

On plains and prairies, Colorado to Texas. Spring and summer.

\section{ONOSMÒDIUM Michx. ${ }^{1}$}

Perennial coarse caulescent herbs, with pubescent foliage. Leaves alternate : blades prominently nerved. Flowers in terminal scorpioid spikes or racemes. Calyx pubescent : lobes 5, narrow. Corolla white, greenish or yellowish, tubular or tubular-funnelform, the tube surpassing the calyx, without appendages, but with the sinuses often inflexed, and a 10-lobed band within near the base : lobes 5, often erect. Stamens 5, included: anthers almost sessile, glabrous, the lobes diverging. Ovary of 4 slightly united carpels. Nutlets 4 , or usually only 1 or 2 maturing, white, smooth and shiny or sparingly pitted, attached to the receptacle by their bases. False Gromwell.

Bracts broad, of an ovate type, rounded at the base.

1. O. Helleri.

Bracts narrow, tapering at the base.

Corolla-lobes triangular-ovate.

Stem below the branches of the inflorescence more or less hairy. Nutlets strongly constricted at the base.

Nutlets not constricted at the base. Corolla-lobes long-acuminate. Corolla-lobes meiely acute.

Stem below the branches of the inflorescence glabrous.

Corolla-lobes lanceolate-subulate.

2. O. Carolinianum.

3. O. Bejariense.

4. O. molle.

5. O. subsetosum.

6. O. Virginianum.

1. Onosmodium Hélleri Small. Rootstock horizontal. Foliage hispid : stems 3-6 $\mathrm{dm}$. tall, simple or sparingly branched above : leaves rather few ; blades oblong or spatulate-oblong below to ovate above, $5-10 \mathrm{~cm}$. long, obtuse, undulate, hispid above, rather more softly pubescent beneath, subsessile or the lower narrowed into short petioles: racemes leafy-bracted ; rachis zigzag : pedicels erect or strongly ascending, 1-1.5 cm. long, with spreading hairs: calyx bristly; lobes linear or barely enlarged upward, 8-10 mm. long: corolla $8-10 \mathrm{~mm}$. long; lobes lanceolate : nutlets $3 \mathrm{~mm}$. long, pitted.

On prairies or plains, Texas. Spring.

2. Onosmodium Caroliniànum (Lam.) A. DC. Foliage hispid. Stems 5-12 dm. tall, branching above : leaves numerous; blades oblong to oblong- or linear-lanceolate, 3-12 cm. long, acute, hispid on both sides, sessile or nearly so: racemes leafy-bracted: pedicels $4 \mathrm{~mm}$. long or less : calyx somewhat bristly ; lobes linear, obtusish, 4-6 mm. long: corolla yellowish white, $8-16 \mathrm{~mm}$. long; tube funnelform; lobes triangular-ovate, acute, little canescent without but with a strongly developed apical tuft of hairs: nutlets ovoid, $2 \mathrm{~mm}$. or $4 \mathrm{~mm}$. long, acutish, smooth or sparingly pitted.

In dry soil, Ontario to Minnesota, Georgia and Texas. Spring to fall.

3. Onosmodium Bejariénse DC. Foliage hispid. Stems 3-9 dm. tall, simple or sparingly branched above : leaves rather numerous ; blades oblong or oblong-oblanceolate, $3-12 \mathrm{~cm}$. long, apiculate or acutish, hirsute-strigose above, more softly pubescent and
usually noticeably paler beneath, sessile or nearly so: pedicels $6 \mathrm{~mm}$. long or less or calyx sessile; lobes linear, erect, 6-10 mm. long : corolla whitish ; tube funnelform, 10-15 mm. long; lobes triangular-ovate, long-acuminate, about $\frac{1}{4}$ as long as the tube, sparingly pubescent without : nutlets $1.5-3 \mathrm{~mm}$. long, minutely pitted.

In dry soil, Texas. Spring.

4. Onosmodium mólle Michx. Foliage strigose or hispid-strigose. Stems $2-8 \mathrm{dm}$. tall, sparingly branched above : leaves numerous ; blades oblong or elliptic-lanceolate to linear-oblong, 2-6 cm. long, acute or obtusish, prominently nerved beneath, densely stri-

${ }^{1}$ Revised by Mr. K. K. Mackenzie. 
gose, sessile or nearly so : racemes densely bracted: pedicels $5 \mathrm{~mm}$. long or less : calyx bristly-strigose; lobes 6-12 mm. long, linear: corolla white or tinged with yellow; tube funnelform; lobes triangular-lanceolate, one third as long as the tube, acute: nutlets ovoid, $4 \mathrm{~mm}$. long, not constricted at base.

On dry prairies or harrens, Saskatchewan to Illinois, Texas, Utah and Arizona. Spring and summer.

5. Onosmodium subsetòsum Mackenzie \& Bush. Foliage strigose. Stems about $6 \mathrm{dm}$. tall, branching above : leaves numerous ; blades oblong-lanceolate, typically $7.5 \mathrm{~cm}$. long, $1.5 \mathrm{~cm}$. wide, acutish, strongly 5-7-nerved, papillose and hispid-strigose above, whitish strigose beneath : pedicels $3-6 \mathrm{~mm}$. long at maturity : calyx-lobes narrowly obtuse, whitish hairy, $6 \mathrm{~mm}$. long : corolla greenish white, $8-18 \mathrm{~mm}$. long; tube funnelform; lobes triangular, acute, much shorter than the tube : nutlets ovoid, 2-3 mm. long, very sparingly pitted, somewhat constricted at the base.

In dry soil, Ozark Mountain region, Missouri and Arkansas. Late spring.

6. Onosmodium Virginiànum (L.) A. DC. Foliage hispid-strigose. Stems 2-7 dm. tall, pubescent with appressed or occasionally strongly spreading hairs, more or less widely branching above : leaves rather numerous ; blades firm, linear-oblong to oblong or oblong- or linear-lanceolate, $2.5-12 \mathrm{~cm}$. long, acute or apiculate, the lower narrowed into winged petioles, the upper sessile : racemes conspicuously bracted: pedicels 1-2 mm. long, elongating to $1-2.5 \mathrm{~cm}$. at maturity : calyx bristly ; lobes narrowly linear-lanceolate, 5-7 mm. long: corolla yellowish, about $8 \mathrm{~mm}$. long; tube funnelform; lobes lanceolate-subulate, slightly shorter than the tube: nutlets ovoid, $3 \mathrm{~mm}$. long, more or less densely pitted.

In sandy soil, New England to Florida and thence west to Mississippi. Spring.

\section{SÝMPHYTUM L.}

Perennial coarse caulescent herbs, with thick mucilaginous roots. Leaves alternate : blades often sessile and clasping on the upper part of the stem. Flowers in terminal scorpioid racemes. Calyx-lobes 5. Corolla yellow, blue or purple, tubular or the tube slightly dilated above, with 5 appendages in the throat: lobes 5, short. Stamens 5, included. Carpels 4, nearly distinct. Nutlets 4, oblique, wrinkled, each with a concave and toothed scar of attachment. Comfrey. Healing-Herb.

1. Symphytum officinàle L. Roots stout. Stems $3-10 \mathrm{dm}$. tall, usually branched, hirsute : leaf-blades oblong, lanceolate or ovate-lanceolate, or sometimes ovate at the base of the stem, 1-3 dm. long, undulate, acute or acuminate, the lower ones long-petioled, the upper sessile and often decurrent on the branches: sepals ovate to lanceolate, 6-10 mm. long, acuminate : corolla yellowish or purplish, 10-15 mm. long; lobes ovate, obtuse : nutlets $3-4 \mathrm{~mm}$. high, shining, wrinkled.

In waste places and thickets. Newfoundland to Minnesota, Virginia and Tennessee. Naturalized from Europe and Asia. Spring and summer. Comfrey.

\section{LYCÓPSIS L.}

Annual caulescent herbs, with bristly-hispid foliage. Leaves alternate: blades relatively narrow, entire or shallowly toothed. Flowers in terminal scorpioid racemes. Sepals 5, nearly distinct. Corolla blue, salverform, slightly irregular: tube curved, its throat clothed with hispid hairs : limb unequally 5-lobed. Stamens 5, included, adnate to about the middle of the corolla-tube. Carpels 4, nearly distinct : stigma entire. Nutlets 4, erect from the flat receptacle, wrinkled, the scar of attachment concave. Bugloss.

1. Lycopsis arvénsis L. Foliage bristly-hispid. Stems becoming widely or diffusely branched, 3-7 dm. long; branches often procumbent: leaf-blades oblanceolate below, to narrowly oblong or lanceolate above, $2.5-10 \mathrm{~cm}$. long, undulate or sinuate, sessile or the lower ones on long petioles: racemes often $5-10 \mathrm{~cm}$. long: calyx becoming 7-8 $\mathrm{mm}$. long ; sepals linear or linear-lanceolate, acute : corolla blue, 5-7 $\mathrm{mm}$. long; tube curved : nutlets about $3 \mathrm{~mm}$. long, coarsely wrinkled.

In waste places, Nova Scotia to Ontario, Virginia and Tennessee. Naturalized from Europe and Asia. Spring to fall.

\section{0. ÉCHIUM L.}

Biennial or perennial caulescent herbs, with pubescent foliage. Leaves alternate : blades entire. Flowers in scorpioid spikes or racemes. Calyx pubescent : lobes 5, narrow. Corolla white or usually blue or violet, tubular-funnelform, irregular : tube with an open 
unappendaged throat: lobes 5, unequal, rounded. Stamens 5, partially exserted. Filaments unequal in length, dilated at the base. Carpels 4, nearly distinct. Stigma 2-lobed. Nutlets 4, erect, wrinkled, attached to the flat receptacle by their bases, the scar of attachment not concave. VIPER's Bugloss. Blueweed.

1. Echium vulgàre L. Biennial, bristly-pubescent, deep green. Stems $3-7 \mathrm{dm}$. tall, simple or branched throughout; branches ascending: leaf-blades linear or linear-lanceolate, or linear-oblanceolate below, acute or short-acuminate, $2-15 \mathrm{~cm}$. long, undulate, sessile, bristly on both sides : spikes rather dense, becoming 2-10 $\mathrm{cm}$. long: bracts obliquely lanceolate, acuminate : calyx bristly ; lobes linear or linear-lanceolate, $6-12 \mathrm{~mm}$. long, unequal : corolla pale blue or purplish, or rarely white, obliquely campanulate, $1.6-1.8 \mathrm{~cm}$. long, narrowed into a short tube which is somewhat plaited; lobes ovate or triangularovate, ciliolate : filaments and style exserted, magenta.

In sterile soil, especially in waste places, New Brunswick to Ontario and Nebraska, south to Georgia. Spring and summer.

\section{Family 8. Ehretiàceae Schrad. Ehretia Family.}

Shrubs or trees, or sometimes herbs, with watery sap. Leaves mainly alternate, without stipules: blades simple, commonly entire. Flowers perfect, regular, in compound cymes. Calyx of 5 or fewer partially united sepals, persistent. Corolla of 5 , or rarely 4 or 6 , partially united petals, deciduous : lobes spreading. Stamens 5 , or 4 or 6 , adnate to the base of the corolla-tube : filaments often united at the base : anthers introrse. Gynoecium 2-4-carpellary. Ovary 2-4-celled or 1-celled, some of the partitions being imperfect: styles 2, and distinct or partially united, or 4 and united by pairs. Ovules 1 or 2 in each cavity of the ovary. Fruit drupaceous, with a 4-celled but only 1 -seeded stone or 2 two-seeded or 4 one-seeded stones.

Styles 4 , unequally united by pairs.

Styles 2 .

Styles partially united: shrubs or trees.

Calyx almost closed, valvately $2-5$-cleft at the apex.

Calyx of 5 slightly united sepals.

Styles distinet: annual or perennial herbs.

1. CORDIA.

2. BOURRERIA.

3. EHRETIA.

4. Coldenia.

1. CÓRDIA L.

Shrubs or trees, or sometimes vines, with scabrous or villous foliage, or rarely glabrous. Leaves alternate: stipules wanting. Flowers perfect or polygamous, in terminal scirpioid cymes, or contracted into dense spikes or clusters. Calyx tubular or campanulate, with 3-5 lobes, sometimes ribbed, accrescent, shorter than the fruit or enclosing it. Corolla white or colored, varying from campanulate to salverform : lobes 5 or rarely 4-6, flat or plaited. Stamens as many as the corolla-lobes, adnate to the corolla-tube: filaments filiform: anthers variable, introrse. Ovary 4-celled, sessile in a thin annular disk: styles slender, unequally united by pairs : stigmas 4 . Drupe partially or entirely enclosed in the accrescent calyx, tipped with the persistent style, with a dry or juicy exocarp and an often bony stone. Seeds solitary, or rarely 2. Endosperm wanting.

Flowers in open cymes: corolla over $2.5 \mathrm{~cm}$. long: leaf-blades entire or undulately toothed. Calyx pedicelled; tube glabrous at maturity: corolla orange or flame-color. 1 . C. Sebestena.

Calyx sessile: tube tomentulose at maturity: corolla white with a yellow center. 2 . C. Bossieri.

Flowers in dense heads : corolla less than $2.5 \mathrm{~cm}$. long: leaf-blades serrate.

Shrubby throughout: corolla less than $11 \mathrm{~mm}$. long.

Herbaceous above the base : corolla over $11 \mathrm{~mm}$. long.

3. C. globosa.

4. C. podocephala.

1. Cordia Sebestèna L. An evergreen shrub, or a small tree, sometimes $10 \mathrm{~m}$. tall, with scabro-pubescent foliage and tomentose twigs. Leaf-blades ovate or oblong-ovate, 8-12 cm. long, obtuse or acutish, repand-serrate or undulate; petioles 1-2.5 $\mathrm{cm}$. long: corymbs 1-2 dm. broad : pedicels very short : calyx-tube cylindric, $1-1.5 \mathrm{~cm}$. long; lobes triangular : corolla orange or flame-colored, puberulent without; tube funnelform, surpassing the calyx; lobes spreading, suborbicular, shorter than the tube, undulate or erose: fruit ovoid, $1.5-2 \mathrm{~cm}$. long, enclosed in the thick accrescent calyx.

In sand, Florida Keys. Also in the Bahamas, Antilles and northern South America.

2. Cordia Boissièri A.DC. An evergreen shrub, or a small tree sometimes $8 \mathrm{~m}$. tall, with a crooked stem and velvety-tomentose foliage. Leaf-blades ovate or oblong-ovate, 8-12 cm. long, obtuse or acutish, repand-serrate, obtuse or cordate at the base; petioles 
1-2.5 $\mathrm{cm}$. long: corymbs $1-1.5 \mathrm{dm}$. broad: calyx-tube slightly dilated upward, about 1 cm. long; lobes triangular, acute: corolla white, yellow in the center; tube funnelform, much surpassing the calyx ; lobes suborbicular, crisped, shorter than the tube : fruit ovoid, $2.5-3 \mathrm{~cm}$. long, more or less enclosed in the thin accrescent calyx.

Chiefly in limestone soil, Texas to New Mexico and adjacent Mexico.

3. Cordia globòsa (L.) H.B.K. A branching shrub, 1-3 m. tall, with hirsute and somewhat hoary pubescence. Leaf-blades firm, ovate to oblong-ovate, $1-5 \mathrm{~cm}$. long, serrate, rugose, scabrous, cuneate at the base: petioles much shorter than the blades: heads subglobose, about $1 \mathrm{~cm}$. in diameter : peduncles $1-3 \mathrm{~cm}$. long : calyx ovoid ; lobes subulate, shorter than the tube: corolla white, 4-6 mm. long; tube funnelform, pubescent in the throat; lobes ovate, shorter than the tube : fruit $2-3 \mathrm{~mm}$. long.

In sand, Florida Keys. Also in the West Indies and tropical America to Panama.

4. Cordia podocéphala Torr. A shrubby plant $3-7 \mathrm{dm}$. tall with strigose-hirsute foliage. Leaf-blades firm, linear-lanceolate to ovate-lanceolate, $1-2.5 \mathrm{~cm}$. long, coarsely serrate, scabrous, short-petioled : peduncles 5-12 $\mathrm{cm}$. long: heads dense, $5-8 \mathrm{~mm}$. in diameter : calyx-tube campanulate, strigose ; lobes triangular-subulate to ovate, shorter than the tube : corolla white, or purple within; tube narrowly funnelform, barely surpassing the calyx ; lobes ovate, notched, shorter than the tube : fruit $3-4 \mathrm{~mm}$. long.

In dry soil, along the lower Rio Grande, Texas and adjacent Mexico.

\section{BOURRÈRIA P. Br.}

Shrubs or small trees. Leaves alternate or whorled: stipules wanting. Flowers in terminal corymbose cymes, numerous or rarely solitary. Calyx-pedicelled : tube campanulate, persistent and sometimes slightly accrescent: lobes 2-5. Corolla campanulate or infundibuliform : tube variable in length : lobes 5. Stamens as many as the corolla-lobes, adnate to the corolla-tube. Filaments filiform. Ovary 2-celled (incompletely 4-celled), sessile in a thin annular disk : styles united to near the apex, sometimes enlarged upward : stigmas somewhat flattened. Drupe subglobose, tipped with the base of the style, the exocarp thin-fleshy, the 4 hony nutlets each furnished with a ridged appendage on the back. Seeds curved, terete, with a brown membranous testa. Endosperm fleshy.

Leaf-blades very scabrous above; petioles less than $5 \mathrm{~mm}$. long. Leaf-blades smooth above; petioles over $10 \mathrm{~mm}$. long.

1. B. Radula.

2. B. Havanensis.

1. Bourreria Rádula (Poir.) G. Don. Shrub or small tree sometimes $13 \mathrm{~m}$. tall, with finely pubescent twigs and very scabro-pubescent upper leaf-surfaces. Leaf-blades firm, obovate or oblong-obovate to cuneate, 2-4 cm. long, rounded or notched at the apex, revolute, short-petioled : corymbs few-flowered, $2-6 \mathrm{~cm}$. broad: pedicels sparingly pubescent or glabrous in age : calyx campanulate, $6-7 \mathrm{~mm}$. long; lobes oblong to ovate- or lanceolate-oblong, shorter than the tube : corolla white, $1 \mathrm{~cm}$. long ; tube funnelform, surpassing the caly $\mathrm{x}$; limb 1-1.2 cm. broad ; lobes orbicular-reniform : fruit subglobose, 9-14 $\mathrm{mm}$. in diameter.

In sand, Florida Keys. Also in the West Indies.

2. Bourreria Havanénsis (L.) Miers. A shrub or tree sometimes $12 \mathrm{~m}$. tall, with glabrous foliage. Leaf-blades firm, obovate to oblong- or oval-obovate, 4-12 cm. long, rounded or notched at the apex, lustrous above, narrowly or broadly cuneate; petioles 11-15 mm. long: corymbs $2-10 \mathrm{~cm}$. hroad: pedicels $2-10 \mathrm{~mm}$. long: calyx campanulate, 5-6 mm. long; lobes triangular-ovate to rounded, shorter than the tube : corolla creamy white, about $2 \mathrm{~cm}$. long; tube slightly longer than the calyx; limb barely $2 \mathrm{~mm}$. broad, lobes suborbicular or orbicular-obovate : fruits subglobose, $10-13 \mathrm{~mm}$. in diameter, orange.

In sand, Florida Keys. Also in the Bahamas and the West Indies.

\section{EHRÈTIA P. Br.}

Shrubs or trees. Leaves alternate: stipules wanting. Flowers small, in corymbose or paniculate cymes. Calyx campanulate, persistent : lobes 5. Corolla white : lobes 5, spreading. Stamens 5, adnate to the corolla-tube : filaments filiform-subulate : anther-sacs spreading below. Ovary 1-celled or incompletely 4-celled by the development of 2 parietal placentae, in an annular disk : styles 2, filiform, partialiy united : stigmas depressed-capitate or clavate. Drupe berry-like, seated in the persistent calyx, with a dry or juicy exocarp and bony 2 -seeded nutlets. Seeds curved, terete, with a brown membranous testa. Endosperm fleshy. 
1. Ehretia ellíptica DC. A shrub or small tree rarely $14 \mathrm{~m}$. tall, with deeply furrowed bark. Leaf-blades firm, oblong, oval or oblong-ovate, $3-5 \mathrm{~cm}$. long, obtuse or acute, undulate or irregularly serrate, scabrous, short-petioled : corymbs $2-6 \mathrm{~cm}$. broad, pubescent: pedicels variable, 1-10 $\mathrm{mm}$. long: calyx scabro-pubescent; lobes lanceolate, 2-2.5 $\mathrm{mm}$. long, acute, ciliate : corolla white, $7-9 \mathrm{~mm}$. broad ; tube campanulate-funnelform, surpassing the calyx ; lobes rounded, spreading, shorter than the tube: stamens somewhat exserted : fruit subglobose, $5-8 \mathrm{~mm}$. in diameter, with two nutlets.

In valleys and on ridges, southern and western Texas and adjacent Mexico.

\section{COLDÈnIA L.}

Annual or perennial diffusely branching herbs. Leaves alternate. Flowers solitary in the axils, or in terminal spikes or racemes. Caly $\mathrm{x}$ sessile or pedicelled : tube relatively short : lobes 4-5, rather narrow. Corolla usually white : tube short, naked or scaly within : lobes 4-5, spreading, imbricated. Stamens 4-5, included : filaments short, adnate to the corolla tube. Ovary 2-celled or rarely 4-celled by the septum-like placentae, 4-lobed: styles distinct or somewhat coherent: stigmas capitate. Ovules pendulous. Drupe with a thin fleshy or rather dry exocarp and a stone separating into 4 nutlets.

1. Coldenia canéscens DC. Perennial from a woody base. Foliage whitish tomentose or somewhat silky : stems branched at the base, the branches spreading or prostrate, 1-4 dm. long, forking: leaves clustered; blades elliptic or oval, sometimes broadest above or below the middle, acute, entire, short-petioled : clusters axillary, few-flowered, or flowers solitary : caly $x$-lobes narrowly lanceolate, acute, $3-4 \mathrm{~mm}$. long : corolla about $4 \mathrm{~mm}$. broad ; tube funnelform, surpassing the calyx; lobes suborbicular, usually broader than high, spreading, somewhat crisped: stamens included : fruit spheroidal, $2.5-3 \mathrm{~mm}$. in diameter with 4 nutlets, these smooth on the back, slightly rugose on the faces.

On plains and prairies, Texas to Arizona and adjacent Mexico.

\section{Family 9. Hellotropiàceae Small. Heliotrope Family.}

Herbs, shrubs or woody vines. Leaves alternate, without stipules: blades entire or rarely toothed. Flowers perfect, mainly in scorpioid spikes or racemes. Calyx of 5 partially united or nearly distinct sepals. Corolla of 5 partially united petals, campanulate, funnelform or salverform. Androecium of 5 stamens with the filaments wholly or almost wholly adnate to the corolla tube. Gynoecium of 2-4 united carpels. Ovary 2-4-celled, often somewhat 4-lobed. Styles united. Stigma annular, surmounted by a 2-lobed appendage. Ovules pendulous. Fruit drupaceous or dry and separating, usually into 2 or 4 one-seeded nutlets.

Shrubs, trees or woody twiners: fruit drupaceous.

1. TOURnefortia.

Herbs or shrubby herbs: fruit dry, separating into nutlets.

Fruit of 4 more or less readily separating nutlets.

Cone of the stigma not penicillate-setose.

Cone of the stigma penicillate-setose.

Fruit of 2 completely 2-celled nutlets, or sometimes 1-celled and 1-seeded.

2. HELIOTROPIUM.

3. EUPLOCA.

4. COCHRANEA.

\section{TOURNEFÓRTIA L.}

Shrubs, trees or vines, with often densely pubescent foliage. Leaves alternate : blades various. Flowers inconspicuous, in simple or dichotomous cymes. Calyx persistent : lobes 5 , narrow, imbricated or distant. Corolla white or pale : tube cylindric, or sometimes dilated at the point where the filaments become free : lobes 5 , spreading, imbricated or induplicate. Stamens 5, included. Ovary 4-celled: styles united. Ovules pendulous from lateral attachments. Drupe with a thin fleshy or corky exocarp and a stone of 4 or fewer distinct or united nutlets.

A shrubby vine: foliage minutely pubescent: corolla-lobes lanceolate or subulate. 1. T. volubilis. A fleshy shrub: foliage densely white silky-tomentose: corolla-lobes ovate or oblong-ovate.

2. T. gnaphaloides.

1. Tournefortia volùbilis I. A slender climbing shrubby vine, the foliage minutely, usually rusty-pubescent. Leaf-blades ovate to oblong-lanceolate, 2-6 cm. long, acute or short-acuminate, entire, often oblique at the base; petioles much shorter than the blades: cymes with widely spreading branches: calyx nearly sessile; lobes lanceolate, $1 \mathrm{~mm}$. long, acuminate : corolla white; tube somewhat constricted below the middle and at the throat; lobes lanceolate or subulate, shorter than the tube, erect, acuminate: 
stamens included : fruit depressed, lobed, $2.5-3 \mathrm{~mm}$. broad with 2-3 nutlets, or sometimes solitary.

In sand, Florida Keys. Also in the West Indies and tropical America.

2. Tournefortia gnaphaloides (Jacq.) R. Br. An erect somewhat fleshy shrub, 3-12 dm. tall, with silky tomentose foliage. Leaves numerous; blades linear-spatulate, 4-10 cm. long, obtuse, often imbricated: cymes with 2-4 recurved branches: calyx campanulate; lobes $2-3 \mathrm{~mm}$. long, oblong: corolla white, surpassing the calyx : stamens included : fruit ovoid, $5 \mathrm{~mm}$. high, black, with 2 nutlets.

Along the coast. Florida Keys. Also in the West Indies.

\section{HELIOTRÒPIUM L.}

Annual or perennial caulescent herbs or shrubs, with usually pubescent foliage. Leaves alternate or rarely nearly opposite: blades various. Flowers usually in terminal often scorpioid spikes or racemes, or rarely axillary. Calyx-lobes 5, narrow. Corolla often colored : tube cylindric, often naked at the throat : lobes 5 , imbricated or induplicate, inflexed at the tip. Stamens 5, included: filaments short, adnate to the corolla-tube. Anther-sacs sometimes appendaged at the tip. Ovary 4-celled or 2-celled, with 2 more or less intruding placentae: styles united. Ovules pendulous from lateral attachments. Fruit 4-grooved or 4-lobed, or sometimes didymous, but separating into 4 nutlets. The plants flower mainly from spring to fall. HeLiotrope.

Anthers unappendaged.

The 4 nutlets of the fruit early separating from each other.

Foliage pubescent: anthers obtuse or merely mucronate.

Foliage merely glaucous: anthers acuminate.

The nutlets of the fruit persistently united by pairs, ultimately separating. Each nutlet 2-celled and 2-seeded.

Each nutlet with 2 seed-bearing and 2-4 empty cavities.

Anthers terminating in an appendage, sometimes glandular-hairy.

Inflorescence bractless.

Fruit 4-lobed, about $1.5 \mathrm{~mm}$. broad : corolla-lobes acute.

Fruit 2-lobed, $2.5-3 \mathrm{~mm}$. broad : corslla-lobes obtuse.

Inflorescence bracted.

Spikes or racemes scorpioid.

Corolla golden yellow.

Corolla white.

Spikes or racemes not scorpioid.

Flowers terminating short branchlets.

Flowers, or some of them, sessile in the axils of leaf-like bracts. Perennial plants : foliage silky hirsute. Annual plants, strigose-hirsute.

1. H. Europaeum.

2. H. Curassavicum.

3. H. parviflorum.

4. H. Indicum.

5. H. inundatum.

6. H. glabriusculum.

7. H. Leavenuorthii.

8. H. polyphyllum.

9. H. tenellum.

10. H. confertifolium.

11. H. phyllostachyum.

1. Heliotropium Europaèum L. Annual, cinereous-pubescent. Stems 1-5 dm. tall, branching : leaf-blades oblong or oval, sometimes varying to ovate or obovate, 2-6 $\mathrm{cm}$. long, obtuse or acutish, undulate; petioles about as long as the blades or shorter: spikes solitary or several together, elongating in age, scorpioid: calyx sessile; lobes oblong or oblong-lanceolate, $2 \mathrm{~mm}$. long : corolla white or bluish ; tube about as long as the calyx ; limb angulately 5-lobed, 3-4 mm. broad: fruit broader than high, about $3 \mathrm{~mm}$. broad : nutlets slightly hispid.

In waste places, New York to Florida. Naturalized from Europe.

2. Heliotropium Curassávicum L. Annual, or mostly perennial, fleshy, glaucous. Stems diffusely branched, the branches 1-4 dm. long: leaves succulent; blades spatulate varying to linear or obovate, obtuse, narrowed into thick petioles : spikes solitary or 2 together, simple or forked, elongating, scorpioid : calyx sessile ; lobes lanceolate to oblonglanceolate, $1.5 \mathrm{~mm}$. long, acute : corolla white, with a yellow center, turning blue; limb 3-6 mm. broad, with 5 rounded lobes: fruit $2-2.5 \mathrm{~mm}$. broad, surpassed by the calyxlobes. the world.

On the coast, Virginia to Florida and Texas and on the Pacific coast. Also in the warmer parts of

3. Heliotropium parviflòrum L. Annual, more or less densely pubescent. Stems 2-7 dm. tall, branching : leaves rather numerous; blades elliptic to oblong-lanceolate, 2-6 $\mathrm{cm}$. long, acute or short-acuminate at the apex, narrowed into short petioles: spikes solitary or in pairs, slender, 5-15 cm. long : calyx sessile; lobes lanceolate or linear, acute : corolla white; tube about as long as the calyx, bearded in the throat; limb about $2 \mathrm{~mm}$. broad : fruit much depressed, $2 \mathrm{~mm}$. long, surpassing the calyx-lobes.'

In sand, Florida Keys and southern Texas. Also in tropical America.

4. Heliotropium Índicum L. Annual, coarse, more or less densely hirsute. Stems v 1-7 dm. tall, branching : leaf-blades ovate, oval or oblong, 2-10 cm. long, obtuse or acutish, 
repand or undulate, narrowed into petioles or cordate: spikes mostly solitary, 1-3 dm. long, scorpioid at the tip, densely flowered : calyx sessile ; lobes linear to linear-lanceolate, 1-2 mm. long: corolla blue ; limb 4-6 mm. broad : fruit miter-shaped, $3 \mathrm{~mm}$. high, glabrous, sharply ribbed.

In waste places and on roadsides, Virginia to Illinois, Florida and Texas. Naturalized from India.

5. Heliotropium inundàtum Sw. Annual, strigose with gray hairs. Stems 1-6 dm. tall, branching from the base: leaf-blades spatulate to oblong or oval, $2-4.5 \mathrm{~mm}$. long, obtuse or acutish, undulate, narrowed into slender petioles : spikes solitary or several together, scorpioid, very slender, elongating: calyx sessile; lobes linear-lanceolate or lanceolate, 1.5-2 mm. long, acute : corolla white or whitish, about $2 \mathrm{~mm}$. long; tube slightly surpassing the calyx-lobes; lobes lanceolate-sagittate : fruit about $1.5 \mathrm{~mm}$. broad.

In low grounds, Louisianta to California, the Antilles and tropical America.

6. Heliotropium glabriúsculum A. Gray. Perennial, finely pubescent. Stems 0.5$1.5 \mathrm{dm}$. tall, rather copiously branched at the base, the branches closely strigose : leaf-blades lanceolate to oblong-lanceolate, 1-3 cm. long, acute or acutish, undulate, narrowed into short petiole-like bases, sparingly or minutely pubescent, except on the midrib: spikes peduncled, solitary or two together, scorpioid, stoutish : calyx sessile; lobes lanceolate, 1.5-2 mm. long, acute : corolla white with a green eye, $3-4 \mathrm{~mm}$. long; tube longer than the calyx-lobes; lobes about as long as the tube : fruit $2.5-3 \mathrm{~mm}$. broad.

In dry soil, Texas, eastern New Mexico and adjacent Mexico.

7. Heliotropium Leavenwórthii Torr. Perennial, sometimes shrubby strigose-hirsute. Stems 2-6 dm. tall, branching : leaves erect or ascending; blades linear or linearelliptic, 1-2 cm. long, acute, narrowed into short petioles or nearly sessile : racemes 2-10 $\mathrm{cm}$. long : pedicels very short : calyx sparingly pubescent; lobes lanceolate, acute, $3-4 \mathrm{~mm}$. long: corolla golden yellow; tube nearly cylindric, about as long as the calyx; limb angulately 5 -lobed, $7-8 \mathrm{~mm}$. broad : nutlets about $1 \mathrm{~mm}$. long.

In sand and coral rock, southern Florida.

8. Heliotropium polyphýllum Lehm. Perennial from a woody root, strigose. Stems several together, erect or ascending, 1-2 dm. tall, more or less branched : leaves numerous; blades linear-spatulate to oblong, $0.5-2 \mathrm{~cm}$. long, acute, gradually or abruptly narrowed into short petioles: racemes scorpioid at the tip, slender: calyx-lobes lanceolate or some ovate-lanceolate, about $2 \mathrm{~mm}$. long, acute : corolla white; tube about as long as the calyx ; limb $6-8 \mathrm{~mm}$. broad, angulately 5-lobed: nutlets with 2 pits in the inner faces.

In sand, Florida. Also in tropical America.

9. Heliotropium tenéllum (Nutt.) Torr. Annual, strigose. Stems 1-3 dm. tall, forking above : leaves erect or ascending; blades linear or narrowly linear-lanceolate, $1.5-5 \mathrm{~cm}$. long, acute, more or less revolute, sessile or short-petioled: calyx pedicelled; lobes linear, unequal, 3-6 mm. long, acute: corolla white, pubescent in the throat; tube nearly cylindric, about as long as the calyx ; lobes oblong-elliptic or oval, shorter than the tube, obtuse : fruit 4-lobed, broader than high, 3-3.5 mm. broad, pubescent, surpassed by the calyx.

In dry soil, Kentucky and Kansas to Alabama and Texas.

10. Heliotropium confertlfolium Torr. Perennial from a shrubby base, silvery with a silky hirsute pubescence. Stems much branched; branches tufted : leaves crowded, imbricated ; blades linear to narrowly oblong, 5-10 mm. long, acute, revolute, short-petioled : spikes leafy, commonly cluster-like, not scorpioid : calyx sessile ; lobes linear-lanceolate, $2-2.5 \mathrm{~mm}$. long: corolla pale purple ; tube about as long as the calyx, pubescent; limb angulately 5 -lobed, about $4-5 \mathrm{~mm}$. broad.

In dry soil, southern and western Texas.

11. Hellotropium phyllostáchyum Torr. Annual, strigose-hirsute. Stems much branched at the base; branches $0.5-2 \mathrm{dm}$. long, spreading, diffuse : leaves firm; blades oblong or elliptic, 1-2.5 cm. long, acute or obtuse, somewhat revolute, narrowed into short petioles : spikes or racemes slender, loosely-flowered, leafy-bracted, one-sided : calyx 3 mm. long at maturity; lobes unequal, lanceolate or one larger and ovate-lanceolate : or produced into a tooth at the base : fruit subglobose, broader than high.

In sandy soil, Key West and southern Arizona.

\section{EÚPLOCA Nutt.}

Annual caulescent herbs, usually pubescent. Leaves alternate : blades flat. Flowers axillary to leaf-like bracts, scattered. Calyx-lobes 5, narrow. Corolla salverform: tub nearly cylindric, naked in the throat : limb 5-angled, strongly plicate in aestivation. Sta- 
mens 5, included : anthers cohering by the minutely bearded tips. Ovary 4-celled : style elongated, slender: cone of the stigma panicellate-setose. Ovules as in Heliotropium. Fruit didymous, the two lobes separating into 2 hemispherical 1 -seeded nutlets.

1. Euploca convolvulàcea Nutt. Annual, pale strigose-hirsute. Stem much branched : leaf-blades oblong, sometimes narrowly so, lanceolate or ovate, acute, entire, narrowed into short petioles: flowers short-pedicelled: calyx-lobes strigose, each with a broad base and a subulate tip: corolla white; tube strigose-hirsute; limb angulate-lobed, $1.5-2 \mathrm{~cm}$. wide : fruit $3.5-4 \mathrm{~mm}$. broad, much shorter than the calyx.

On sandy plains, Nebraska to California, Arkansas and Mexico. Spring to fall.

\section{COCHRÀNEA Miers.}

Perennial, more or less shrubby plants, with branching stems. Leaves alternate: blades relatively narrow, undulate or slightly toothed. Flowers in scorpioid, cymosely disposed spikes. Calyx-lobes 5, narrow. Corolla colored: tube cylindric: lobes short. Stamens 5, included. Ovary 4-celled. Fruit dry or nearly so, with 2 usually two-celled and 2 -seeded nutlets.

1. Cochranea anchusaefòlia (Poir.) Gürke. Perennial, hirsute. Stems often diffusely branched at the base ; branches ascending or spreading, 1-4 dm. long: leaf-blades linear-oblong, oblong or oblanceolate, $2-8 \mathrm{~cm}$. long, acute or obtuse, repand : cymes of several spikes, compact or elongating in age : calyx sessile; lobes linear or linear-lanceolate, $3 \mathrm{~mm}$. long: corolla violet-blue ; tube surpassing the calyx; limb 4-6 $\mathrm{mm}$. broad: fruit $2.5-3 \mathrm{~mm}$. broad, surpassed by the calyx-lobes. America.

In waste places, Georgia and Florida to Mississippi. Spring to fall. Also in tropical and South

\section{Family 10. Verbenàceae J. St. Hil. Vervain Family.}

Annual or perennial herbs, or sometimes shrubs or trees. Stems commonly 4-angled. Leaves usually alternate, sometimes clustered on short spurs, rarely opposite or whorled : blades simple, or rarely compound. Flowers perfect, more or less irregular. Calyx of 4-5 partially united sepals, persistent, usually subtended by bractlets. Corolla of 4-5 partially united petals, sometimes 2-lipped, hypogynous. Androecium of 2 or 4 didynamous stamens. Filaments sometimes appendaged, adnate to the tube of the corolla, sometimes up to the throat. Anthers erect or incumbent. Gynoecium 2 or 4-carpellary. Styles united, terminal. Stigma entire or 2 or 4 -lobed. Ovules solitary or 2 in each cavity, anatropous, erect or ascending. Fruit various, drupe-like, berry-like or dry and then separating into 2 or 4 nutlets. Seeds commonly solitary. Endosperm scant, slightly fleshy, or wanting. Embryo straight.

Ovules solitary in each cavity.

Inflorescence centripetal : ovules erect.

Flowers in heads, spikes or spike-like racemes.

Fruit of 2 or 4 nutlets, dry.

Stamens 4: fruit not imbedded in the rachis.

Fruit of 4 nutlets.

Ovary and 4-lobed fruit with no stylopodium at the apex.

Ovary and fruit surmounted by a large stylopodium.

Fruit of 2 nutlets.

Calyx not inflated at maturity.

Herbs with procumbent or creeping stems.

Shrubs or shrubby plants, with upright stems.

Flowers in short dense spikes, with persistent bracts: caly x 2-lobod.

Corolla-tube not swollen: bracts several-ranked, concave or flat.

Corolla-tube swollen near the middle : bracts 4-ranked, carinate-conduplicate.

Flowers in elongated loose spikes or racemes, with narrow deciduous bracts: calyx 4-lobed.

Calyx inflated and inclosing the fruit.

Stamens 2: fruit imbedded in excavations of the thick rachis. Fruit drupaceous.

Flowers in open racemes.

Drupes seated in the calyx: nutlets 2: stigma 2-lobed.

Drupes enclosed in the calyx: nutlets 4 : stigma 4-lobed.

Inflorescence centrifugal, cymose: ovules laterally attached.

Corolla regular: leaf-blades simple.

Corolla irregular: leaf-blades compound.

ovules 2 in each cavity, suspended.

1. Verbina.

2. Hellera NTHUS.

3. Phyla.

\section{Lippia.}

5. Goniostachyum.

6. Aloysia.

7. Priva.

8. ABENA.

9. Lantana.

10. Citharexylon.

11. Duranta.

12. CALLICA RPA.

18. ViteX.

14. AVicennia. 


\section{VERBÈNA L.}

Annual biennial or perennial herbs or shrubby plants. Leaves opposite: blades entire, toothed, cleft or dissected. Flowers in spikes. Calyx sessile : tube often funnelform or salverform. Corolla white or of various colors : tube straight or curved : lobes 5, nearly equal, or unequal and the limb 2-lipped. Stamens 4, didynamous or rarely 2, included. Anthers with connectives sometimes furnished with a gland. Ovary 4-celled: stigma 2-lobed, one lobe stigmatic. Ovules solitary in each cavity. Fruit an aggregate of 4 nutlets enclosed in the calyx, without a stylopodium. Verbena.

Anthers not appendaged.

Spikes very slender and much interrupted at maturity.

Leaf-blades 1-2 pinnately cleft or incised.

Bract much shorter than the calyx at maturity.

Fruit little longer than thick.

Fruit about twice as long as thick.

Bracts as long as the caly xes during anthesis.

Bracts $1 / 2$ as long as the caly xes during anthesis.

Bract about as long as the caly $x$ at maturity, or about equalling it.

Leaf-blades merely toothed.

Leaf-blades petioled : bract less than $1 / 2$ as long as the calyx : fruit little longer than thick.

Mature sepals little longer than the fruit, the tips not meeting over the top.

Mature sepals much longer than the fruit, converging over the top and meeting.

Leaf-blades sessile: bract over $1 / 2$ as long as the calyx : fruit about twice as long as thick.

spikes stout, continuous by the imbricated or contiguous fruits or, if interrupted below. bract as long as the calyx or surpassing it.

Corolla-limb 2-9 mm. broad.

Bract shorter than the calyx.

Spikes sessile or nearly so: corolla-limb 8-9 mm. broad : pubescence dense, soft.

Spikes peduncled : corolla-limb 2.5-6 mm. broad : pubescence sparse, rigid or wanting.

Spikes elongated, $6-20 \mathrm{~cm}$. long, many times longer than thick. Leaf-blades of a lanceolate type, petioled. Leaf-blades of a linear type, sessile.

Spikes short and stout, $2-4 \mathrm{~cm}$. long, commonly $4-5$ times longer than thick.

Leaf-blades sessile : spikes not crowded.

Leaf-blades clasping: spikes crowded.

Bract as long as the caly $x$ or longer.

Stems upright.

Spikes stout, $2-5 \mathrm{~cm}$. long, dense : bract conspicuously surpassing the calyx : corolla-limb 6-7 $\mathrm{mm}$. broad.

Spikes elongated, interrupted : bract as long as the calyx or a little longer: corolla-limb about $4 \mathrm{~mm}$. broad.

Stems branched at the base, the branches prostrate or decumbent. Corolla-limb 10-13 mm. broad.

Anthers of the Ionger stamens appendaged by a gland on the connective.

Calyx-lobes subulate: corolla 8-15 mm. long.

Corolla-tube about $1 / 2$ longer than the calyx, the limb $7-8 \mathrm{~mm}$. wide.

Corolla-tube slightly longer than the calyx, the limb $3-4 \mathrm{~mm}$. wide.

Calyx-lobes setaceous-tipped : corolla $15-25 \mathrm{~mm}$. long.

Corolla-tube about $1 / 2$ longer than the calyx, the limb $8-10 \mathrm{~mm}$. wide.

Bracts setaceous-attenuate, longer than the calyx at maturity : leaf-segments typically linear.

Bracts narrowly lanceolate, shorter than the calyx at maturity : leaf-segments typically lanceolate.

Corolla-tube about twice as long as the calyx, the limb 11-15 mm. wide.

Leaf-blades pinnatifid or bipinnatifid.

Leaf-blades merely incised or incised-lobed.

Leaf-blades typically of a lanceolate type, more or less cuneate at the

base.
Leaf-blades typically of an ovate type, cordate or broadly truncate at the base.
1. V. officinalis.
2. V. riparia.
3. V. Halei.
4. V. xutha.

5. V. urticaefolia.

6. V. polystachya.

7. V. Carolinensis.

8. V. stricta.

9. V. hastata.

10. V. angustifolia.

11. V. littoralis.

12. V. Bomariensis.

13. V. venosa.

14. V. Neo-Mexicana.

15. V. bracteosa.

16. V. Tampensis.

17. V. ciliata.

18. V. pumila.

19. V. bipinnatifida.

20. V. ambrosifolia.

21. V. Drummondii.

22. V. Lambertii.

23. V. Canadensis.

1. Verbena officinàlis L. Annual, slender. Stems $3-6 \mathrm{dm}$. tall, branching, nearly glabrous : leaves $2-6 \mathrm{~cm}$. long; blades ovate to oblong or lanceolate in outline, 1-2-pinnatifid, more or less incised : spikes very slender : calyx minutely puberulent to strigillose, becoming about $2 \mathrm{~mm}$. long : corolla blue or purple; tube $3 \mathrm{~mm}$. long; limb $4 \mathrm{~mm}$. broad : nutlets oblong, barely $2 \mathrm{~mm}$. long.

In waste places and dry soil. Maine to Texas and Florida. Native of the old World. Spring to fall.

2. Verbena ripària Raf. Annual, stoutish. Stems 6-15 dm. tall, sparingly pubescent, widely branching : leaf-blades oblong to ovate, 4-12 cm. long, pinnatifid or nearly 3 -parted below, prominently nerved beneath : spikes slender, interrupted : calyx minutely 
glandular-pubescent, becoming $3 \mathrm{~mm}$. long : corolla light blue ; tube surpassing the calyx ; limb $3.5 \mathrm{~mm}$. long: nutlets oblong, 2-2.5 mm. long.

On river banks, New Jersey to Virginia and North Carolina. Summer.

3. Verbena Hàlei Small. Annual, slender. Stems 2-9 dm. tall, glabrous, or strigillose above, branching near the top or rarely at the base : leaves $3-10 \mathrm{~cm}$. long; blades various, those of the basal and lower stem-leaves oblong to ovate, irregularly toothed and incised, long-petioled, those on middle part of stem commonly broader, 1-2-pinnatifid, those of the upper leaves sparingly toothed or entire : spikes slender : caly $\mathbf{x}$ becoming 3--3.5 $\mathrm{mm}$. long, strigillose : corolla blue ; tube about $3 \mathrm{~mm}$. long; limb $6-7 \mathrm{~mm}$. broad : nutlets linear-oblong, about $2.5 \mathrm{~mm}$. long.

In sandy soil, Indian Territory to Louisiana and Texas. Spring and summer.

4. V.erbena xùtha Lehm. Perennial, or perhaps annual, pubescent. Stems 6-10 dm. tall, simple or sparingly branched : leaf-blades incised-pinnatifid, or 3-parted on the lower part of stem, strigose to canescent, the segments coarsely toothed to laciniate : spikes rather slender, strict : calyx becoming $4 \mathrm{~mm}$. long, strigose ; lobes acuminate, pubescent : corolla blue to purple; tube shorter than the calyx ; limb $3.5-4 \mathrm{~mm}$. broad : nutlets narrowly oblong, about $2 \mathrm{~mm}$. long.

In open grounds, Louisiana, Texas and California to Mexico. Spring to fall.

5. Verbena urticaefòlia L. Annual or perennial, sparingly pubescent with spreading hairs, or glabrous. Stems 4-15 dm. tall, often much branched: leaf-blades broadly lanceolate or ovate-lanceolate, or sometimes ovate or oval, 8-20 cm. long, coarsely and doubly crenate-serrate, the rounded or subcordate base decurrent on the petiole : spikes slender, interrupted: calyx $2 \mathrm{~mm}$. long; lobes slightly longer than the fruit, but the tips not meeting over its top : corolla white, $4 \mathrm{~mm}$. long; tube cylindric, curved, pubescent in the throat : nutlets oblong, $2.2 \mathrm{~mm}$. long, smooth.

In waste places or on roadsides, New Brunswick to Minnesota, Florida and Texas. Summer.

6. Verbena polystáchya H.B.K. Similar to V. urticaefolia in habit. Leaf-blades relatively smaller and thicker, commonly less gradually acute or acuminate, coarsely roughpubescent : spikes usually copiously and rather closely flowered: calyx-lobes acuminate or slenderly acute, much longer that the fruit over whose top they converge and meet.

In dry or sandy soil, Florida, through the Gulf States to California. Also in tropical America Spring to fall.

7. Verbena Carolinénsis (Walt.) J. F. Gmel. Perennial, scabro-pubescent. Stems 2-8 dm. tall, simple, or sparingly branched above : leaf-blades spatulate to oblong or oblonghastate above, $2-10 \mathrm{~cm}$. long, more or less doubly serrate, prominently nerved beneath : spikes slender, becoming interrupted : bracts lanceolate, shorter than the calyxes : calyx becoming about $4 \mathrm{~mm}$. long, minutely glandular-pubescent; lobes acute : corolla pink or bluish, pilose without; tube surpassing the calyx : limb $5-6 \mathrm{~mm}$. broad: nutlets $3 \mathrm{~mm}$. long, glabrous.

In sandy soil or sand, Virginia to Florida and Alabama. Spring.

8. Verbena strícta Vent. Perennial, densely pubescent with pale hairs. Stems rather stout, $2-12 \mathrm{dm}$. tall, simple or branching above : leaf-blades oblong, oval or suborbicular, 3-10 $\mathrm{cm}$. long, sharply doubly serrate or incised, rugose, sessile or nearly so : spikes stout: bracts lanceolate, as long as the calyxes: calyx hirsute, becoming $5 \mathrm{~mm}$. long; lobes acuminate : corolla deep blue; tube slightly surpassing calyx, pubescent; limb 8-9 mm. broad: nutlets linear, $3.5 \mathrm{~mm}$. long, glabrous, strongly reticulated. and fall.

In dry soil, Minnesota to Pennsylvania, Texas and New Mexico. Naturalized eastward. Summer

9. Verbena hastàta L. Perennial, rough-pubescent with short" ascending hairs. Stems 4-15 dm. tall, often branched above; leaf-blades lanceolate, ovate-lanceolate or sometimes oblong-lanceolate, 4-12 cm. long, acute or acuminate, sharply and doubly serrate, often incised and hastate at the base : spikes erect, narrow, $2-15 \mathrm{~cm}$. long, continuous : calyx 2.5 $\mathrm{mm}$. long, pubescent; lobes triangnlar-ovate, acute : corolla purplish blue, $4-4.5 \mathrm{~mm}$. broad ; tube pubescent without : nutlets linear, fully $1.5 \mathrm{~mm}$. long, smooth.

In waste places and thickets, Nova Scotia to British Columbia, Florida and New Mexico. Summer.

10. Verbena angustifòlia Michx. Perennial, puberulent or sparsely pubescent. Stems commonly branched, 1-5 dm. tall, the branches mostly erect: leaf-blades linear, linear-oblong or linear-spatulate at the base of the stem, 2-10 cm. long, distantly or coarsely serrate, rugose : spikes strict, commonly continuous: calyx nearly glabrous, becoming $4 \mathrm{~mm}$. long; lobes acuminate: corolla blue, pubescent without; tube much surpassing the calyx, sparingly pubescent ; limb $5-6 \mathrm{~mm}$. broad : nutlets linear, $3 \mathrm{~mm}$. long, glabrous, prominently reticulated.

In dry soil, Massachusetts to Wisconsin, Florida, Mississippi and Missouri. Summer. 
11. Verbena littoràlis H.B.K. Annual, finely pubescent above, the hairs stiff, not spreading. Stems 6-10 dm. tall, rather sparingly branched : leaf-blades lanceolate to elliptic or linear-oblong, 3-8 cm. long, sharply serrate from below the middle to the apex, sessile: spikes dense, $1.5-3.5 \mathrm{~cm}$. long, less than $5 \mathrm{~mm}$. thick, in corymbose cymes but not crowded : calyx minutely pubescent, becoming 3.5 or $4 \mathrm{~mm}$. long; lobes acuminate : corolla pubescent ; tube about $\frac{1}{3}$ longer than the calyx ; limb $2.5 \mathrm{~mm}$. broad : nutlets $1.5 \mathrm{~mm}$. long, glabrous.

In waste places, North Carolina to Florida. Naturalized from Mexico and South America. Summer.

12. Verbena Bonariénsis L. Annual, villous-hirsute above. Stems 6-12 dm. tall, branching above: leaf-blades oblong to oblong-lanceolate, 4-10 $\mathrm{cm}$. long, serrate with broad teeth or nearly entire below the middle, partly clasping: spikes $0.5-2.5 \mathrm{~cm}$. long, about $5 \mathrm{~mm}$. thick, in rather compact cymes: calyx delicately pubescent, becoming 3-3.5 $\mathrm{mm}$. long; lobes acute : corolla pubescent without ; tube nearly twice as long as the calyx ; limb $2 \mathrm{~mm}$. broad : nutlets about $2 \mathrm{~mm}$. long, glabrous.

In waste places and shaded banks, South Carolina. Native of South America. Spring and summer.

13. Verbena venòsa Gillies \& Hook. Annual, finely pubescent. Stems $2-6 \mathrm{dm}$. tall, rather widely branched above : leaf-blades oblong or oblong-lanceolate,4-12 cm. long, acute, sharply and coarsely serrate, sessile and more or less clasping, nerves conspicuous, impressed above, prominent beneath : spikes narrowly cylindric, becoming $2-5 \mathrm{~cm}$. long: calyx becoming 4-5 mm. long; lobes very short, unequal : corolla lilac or bluish, pubescent ; tube fully twice as long as the calyx ; limb 6-7 mm. broad.

In waste places, near Houston, Texas. Naturalized from South America. Summer.

14. Verbena Nèo-Mexicàna (A. Gray) Small. Annual or perennial, canescenthirsute. Stems branched at the base; branches $1-3 \mathrm{dm}$. tall : leaf-blades firm, 1-5 cm. long, ovate to linear in outline, coarsely toothed, incised or pinnatifid, with broadly margined bases, prominently nerved beneath : spikes interrupted, conspicuously bracted: corolla purple or whitish; tube slightly surpassing the calyx; limb about $4 \mathrm{~mm}$. broad: nutlets linear-oblong, $2 \mathrm{~mm}$. long, strongly reticulated except at the base.

In dry soil, Texas and New Mexico. Spring.

15. Verbena bracteòsa Michx. Annual or perennial, hirsute. Stems branched at the base; branches prostrate or procumbent, 1-5 dm. long, more or less branched : leafblades pinnatifid, 1-6 $\mathrm{cm}$. long, prominently nerved beneath in age : spikes conspicuously bracted, continuous or nearly so: bracts much longer than the calyxes: calyx bristly, becoming $3 \mathrm{~mm}$. long; lobes acute : corolla purple or bluish; tube about twice as long as the calyx ; limb about $2 \mathrm{~mm}$. broad : nutlets linear, $2 \mathrm{~mm}$. long, strongly reticulated.

In waste places and on prairies, Minnesota to British Columbia, Georgia, Florida, Texas and California. Spring and summer.

16. Verbena Tampénsis Nash. Perennial, glabrate or strigillose. Stems often branched at the base, the branches 1-6 dm. long: leaf-blades ovate to oblong, $2-8 \mathrm{~cm}$. long, coarsely serrate or incised, cuneate at the base : spikes $2-10 \mathrm{~cm}$. long, at length interrupted : bracts about $\frac{1}{2}$ as long as the calyxes : calyx 12-15 mm. long; lobes subulate, 2-4 $\mathrm{mm}$. long: corolla purple; tube pubescent without and at throat, $1.5 \mathrm{~cm}$. long; limb 10-13 mm. broad : anthers without glands on the connective : nutlets $4 \mathrm{~mm}$. long, ridged, enlarged at the base, pitted above the middle.

In sand, peninsular Florida. Spring to fall.

17. Verbena ciliàta Benth. Mainly perennial. Stem branched at the base, the branches 5-20 cm. long, hirsute : leaf-blades $1.5-3 \mathrm{~cm}$. long, once or twice 3-cleft or parted, the segments narrow : calyx becoming 7 or $8 \mathrm{~mm}$. long; lobes subulate : corolla $10-15 \mathrm{~mm}$. long; tube about $\frac{1}{2}$ longer than the calyx; limb $7-8 \mathrm{~mm}$. wide : nutlets fully $3 \mathrm{~mm}$. long, strongly wrinkled.

On plains or dry hills, Colorado to Texas and Mexico. Spring to fall.

18. Verbena pùmila Rydb. Similar to $V$. ciliata in habit. Leaf-blades typically less deeply and less finely cut : calyx becoming about $6 \mathrm{~mm}$. long; lobes subulate : corolla $8-10 \mathrm{~mm}$. long; tube slightly longer than the calyx : limb 3-4 mm. wide : nutlets barely $3 \mathrm{~mm}$. long, wrinkled.

In dry soil, the Indian Territory and Texas. Spring and summer.

19. Verbena bipinnatifida Nutt. Perennial, sometimes flowering the first year. Stems often branched at the base, the branches 1-4 dm. long, hirsute : leaf-blades $2-5 \mathrm{~cm}$. long, hipinnately parted, and often primarily 3-divided, the segments typically linear: calyx becoming 9 or $10 \mathrm{~mm}$. long; lobes setaceous-tipped, surpassed by the bracts: corollalimb $7-9 \mathrm{~mm}$. wide : nutlets $3 \mathrm{~mm}$. long, prominently wrinkled above.

On plains or in dry ground, South Dakota to Louisiana, Texas and Mexico. Spring and summer 
20. Verbena ambrosifòlia Rydb. Resembling $V$. bipinnatifida but larger. Stems and foliage less hirsute: leaf-blades less deeply and less finely divided, the segments typically lanceolate: calyx becoming $8-9 \mathrm{~mm}$. long; lobes setaceous-tipped, surpassing the bracts : corolla limb $6-8 \mathrm{~mm}$. wide : nutlets $2.5 \mathrm{~mm}$. long, coarsely wrinkled all over. summer.

In dry or stony soil, South Dakota and Colorado to Texas, Arizona and Mexico. Spring and

21. Verbena Drummóndii (Lindl.) Baxt. Perennial, but often flowering early. Stems often branched at the base, the branches $2-4 \mathrm{dm}$. long, hirsute : leaf-blades $2-5 \mathrm{~cm}$. long, pinnatifid or bipinnatifid, the segments typically narrow : calyx becoming 9-10 $\mathrm{mm}$. long, surpassing the bract at maturity : corolla limb fully $11 \mathrm{~mm}$. wide : nutlets over $3 \mathrm{~mm}$. long, wrinkled from below the middle to the apex.

On prairies, or in sandy bottoms or woods, Virginia to Kansas, Texas and New Mexico. Spring and summer.

22. Verbena Lambértii Sims. Perennial. Stem commonly branched at the base, the branches hirsute : leaf-blades 3-9 cm. long, typically of a lanceolate type, incised or incised-lobed, acute or acuminate at the apex, more or less cuneately narrowed at the base : calyx becoming 11-13 mm. long, surpassing the bract : corolla-limb 11-13 mm. wide : nutlets about $3 \mathrm{~mm}$. long, shallowly wrinkled throughout. summer.

In sandy or dry soil, Tennessee to Arkansas, South Carolina, Florida and Texas. Spring and

23. Verbena Canadensis (L.) Britton. Perennial, stouter than the two preceding species. Stem or branches 3-6 dm. long, minutely pubescent or puberulent : leaf-blades $3-8 \mathrm{~cm}$. long, typically of an ovate type, incised or incised-lobed, rather rounded at the apex, cordate or broadly truncate at the base : calyx becoming $12-14 \mathrm{~mm}$. long, mainly surpassing the bract : corolla-limb $12-15 \mathrm{~mm}$. wide : nutlets $3.5 \mathrm{~mm}$. long, wrinkled all over.

On prairies, Illinois to Florida and Texas. Spring to fall.

\section{HELLERÁNTHUS Small.}

Annual pubescent herbs, more or less diffusely branched from the base. Leaves opposite : blades pinnatifid or parted. Flowers in terminal compact spikes, each subtended by a narrow bract. Calyx tubular, 5-lobed. Corolla white or pink : tube terete : limb 5lobed. Stamens 4, didynamous: anthers unappendaged. Ovary 4-celled, surmounted by a hemispheric stylopodium. Stigma 2-lobed, one lobe stigmatic. Ovules solitary in each cavity. Fruit an aggregate of 4 tardily separating nutlets, the group surmounted by a pyramidal stylopodium, the whole enclosed in the calyx.

1. Helleranthus quadrangulàtus (Heller) Small. Foliage hirsute. Stems branched at the base; branches spreading or prostrate, 1-3 dm. long, forking: leaves numerous ; blades 1-2.5 cm. long, broadly ovate, incised-pinnatifid, or some 3-parted, the lobes incised or cleft, surfaces strigose-hirsute : spikes dense, 1-3 $\mathrm{cm}$. long : bracts narrowly lanceolate, shorter than the calyx : calyx bristly, becoming $5 \mathrm{~mm}$. long; lobes acute : corolla white to pink; tube surpassing the calyx ; limb $2.5-3 \mathrm{~mm}$. broad, the lobes notched : fruit included, constricted at the middle, surmounted by a pyramidal stylopodium whose angles alternate with lobes. [Verbena quadrangulata Heller.]

In dry soil, Texas. Summer.

\section{PHỲLA Lour.}

Perennial caulescent procumbent or creeping herbs. Leaves opposite: blades flat, toothed or lobed. Flowers perfect, in congested peduncled axillary spikes, each subtended by a conspicuous persistent bract. Calyx membranous: tube flattened and 2-keeled, the 2 lateral lobes conduplicate. Corolla 2-lipped: tube incurved, terete: limb oblique, the segments 4 , often retuse or eroded. Stamens 4, didynamous, included : filaments short : anthers with unappendaged connectives. Ovary 2-celled. Stigma oblique or recurved. Ovules solitary in each cavity. Fruit dry, with a crustaceous or corky coat, tardily separating into 2 nutlets. The plants flower from spring to fall.

Leaf-blades with 1-4 pairs of salient remote teeth near the apex.

Peduncles shorter than the subtending bracts or but little longer: fruit oval.

Peduncles much longer than the subtending bracts : fruit obovoid.

1. P. cuneifolia.

Leaf-blades with several pairs of low approximate teeth.

Leaf-blades mostly broadest above the middle, toothed from above the middle to the apex : calyx-lobes shorter than the tube : fruit pubescent at the apex.

Leaf-blades mostly broadest below the middle, toothed from below the middle to the apex : calyx-lobes longer than the tube : fruit glabrous.

2. P. incisa.

3. P. nodifora.

4. P. lanceolata.

1. Phyla cuneifòlia (Torr.) Greene. Foliage strigillose-canescent. Stems branched at the base ; branches procumbent, rarely, if ever, creeping, 2-10 $\mathrm{dm}$. long, often branch- 
ing: leaves opposite, commonly clustered in the axils ; blades linear-cuneate, 1-3 m. long, incisely 2-8-toothed above the middle, nearly nerveless except the prominent midrib, sessile: peduncles shorter than the subtending leaves or slightly longer: bracts 3-4 mm. long, apiculate, with wing-like shoulders at top: calyx $3 \mathrm{~mm}$. long, pubescent : corolla purplish or whitish, $4 \mathrm{~mm}$. long, glabrous ; tube slightly surpassing the calyx ; lower lip of limb about as long as the tube: fruit oval, about $1.5 \mathrm{~mm}$. long. [Lippia cuneifolia Torr.]

In dry soil, Wyoming to Nebraska, south to Texas and Arizona.

2. Phyla incìsa Small. Foliage strigillose-canescent. Stems branching at the base ; branches spreading or prostrate, often creeping, simple or branched : leaves opposite, some often clustered in the axils; blades linear-cuneate, $1-3.5 \mathrm{~cm}$. long, incisely 2-8-toothed above the middle, nerveless except the prominent midrib : peduncles at least twice as long as the subtending bracts : heads subglobose, becoming cylindric, 1-2 cm. long: bracts rhomboidal, $2 \mathrm{~mm}$. long, acute, ciliolate : calyx barely $2 \mathrm{~mm}$. long, puberulent : corolla white or bluish, 2.5-3 mm. long; tube becoming funnelform ; lower lip with a middle lobe somewhat larger than the lateral ones: fruit broadly obovoid, $1.5-2 \mathrm{~mm}$. long.

In sand, Texas.

3. Phyla nodiflòra (L.) Greene. Foliage strigillose. Stems branched at the base ; branches prostrate, creeping, 2-7 dm. long, more or less branched : leaves opposite, some commonly clustered; blades spatulate, $1-3 \mathrm{~cm}$. long, serrate from above the middle to apex, nearly sessile or short-petioled: peduncles much longer than the subtending bracts : spikes becoming cylindric, $1 \mathrm{~cm}$. long, $5 \mathrm{~mm}$. thick : bracts flabellate, $1.5-2 \mathrm{~mm}$. long, often $3 \mathrm{~mm}$. broad, apiculate : calyx puberulent, $2 \mathrm{~mm}$. long : corolla purple to white, 2 $\mathrm{mm}$. long: fruit obovoid, $1 \mathrm{~mm}$. long. [Lippia nodiflora L.]

In sandy soil, Georgia to Florida.

4. Phyla lanceolàta (Michx.) Greene. Foliage strigillose. Stems commonly branched at the base; branches procumbent, creeping, 1-4 dm. long, simple or branching: leaves opposite, some occasionally clustered in the axils; blades elliptic-lanceolate, $1.5-5 \mathrm{~cm}$. long, acute, sharply serrate, except the cuneate base, short-petioled, the nerves ending in the sinuses: peduncles longer than the subtending leaves : heads globular, becoming cylindric, $9-15 \mathrm{~mm}$. long at maturity : bracts rhombic, $2-3 \mathrm{~mm}$. long, acute : calyx about $2 \mathrm{~mm}$. long : corolla pale blue, $2-2.5 \mathrm{~mm}$. long: fruit $1-1.5 \mathrm{~mm}$. long.

\section{IÍPPIA L.}

Shrubs or shrubby plants, more or less aromatic. Leaves opposite : blades usually toothed. Flowers in short-peduncled axillary congested spikes, each subtended by a persistent imbricated bract of an acute or lanceolate type, in several series. Calyx 2-lobed, compressed and keeled. Corolla much longer than the caly $x$ : tube incurved, not swollen ; limb 2-lipped. Stamens 4, didynamous. Ovary 2-celled, with 1 ovule in each cavity. Fruit separating into 2 nutlets.

1. Lippia geminàta H.B.K. Perennial, minutely pubescent. Stems 4-9 dm. tall: leaf-blades ovate to oblong-ovate, $1.5-4 \mathrm{~cm}$. long, acute, serrate, with nerves impressed above, canescent beneath, abruptly narrowed or truncate at the base; petioles shorter than the blades: peduncles mostly solitary, somewhat longer than the subtending petioles: bracts ovate-lanceolate, acuminate, $3-5 \mathrm{~mm}$. long, ciliate: calyx $1.5 \mathrm{~mm}$. long, villous-hirsute : corolla purple or violet, about $4 \mathrm{~mm}$. long; tube minutely hirsute above the middle ; limb about $2.5 \mathrm{~mm}$. high, the lower lip much the largest.

In low grounds, southern Texas and tropical America.

\section{GONIOSTÁCHYUM Small.}

Shrubs or shrubby plants, mostly aromatic. Leaves opposite : blades mostly toothed. Flowers in peduncled axillary congested spikes, which are often in pairs. Bracts broad, 4-ranked, carinate-conduplicate, persistent. Calyx 2-lobed, compressed and somewhat keeled. Corolla surpassing the calyx: tube abruptly swollen near the middle; limb 2lipped. Ovary 2-celled, with 1 ovule in each cavity. Fruit separating into 2 nutlets.

1. Goniostachyum gravèolens (H.B.K.) Small. A branching shrub 5-12 dm. tall, with finely pubescent foliage. Leaf-blades oblong-ovate to ovate, $1-3 \mathrm{~cm}$. long, rounded at the apex, finely crenate, rugose, scabrous above, rounded or subcordate at base : petioles much shorter than blades : peduncles $3-6$ at an axil, shorter than subtending leaves : bracts imbricated, ovate or hastate, $3 \mathrm{~mm}$. long, longer than calyx, acute: calyx $2 \mathrm{~mm}$. long; lobes triangular, much shorter than the tube : corolla yellowish white, about $4 \mathrm{~mm}$. long, puberulent ; tube swollen above the middle; limb $2.5-3 \mathrm{~mm}$. broad, the lobes crisped. [Lippia graveolens H.B.K.]

In dry soil. Texas near the Rio Grande to Mexico. 


\section{ALOỲsIA Ortega.}

Shrubs, usually sweet-aromatic. Leaves opposite : blades entire or toothed. Flowers perfect, in axillary slender loosely flowered spikes or racemes, each subtended by a narrow inconspicuous deciduous bract. Calyx usually pubescent: tube angled, not flattened: lobes 4, slender, nearly equal. Corolla 2-lipped, the upper lip and the lobes of the lower lip nearly equal. Nutlets thin-walled.

1. Aloysia ligustrìna (Lag.) Small. A branching shrub $1-3 \mathrm{~m}$. tall, with puberulent foliage, sometimes spinescent. Leaves opposite ; blades oblong to oblong-lanceolate, 6-25 $\mathrm{mm}$. long, acute or acutish, commonly entire, short-petioled : racemes spike-like, shortpeduncled, $1-8 \mathrm{~cm}$. long : bracts about as long as the calyx, acuminate: calyx hirsute, 2-2.5 mm. long; lobes subulate or lanceolate-subulate, about as long as the tube : corolla white, tinged with violet, $3 \mathrm{~mm}$. long; tube slightly curved; limb $2.5 \mathrm{~mm}$. high, the lobes crisped, the lower one largest. [Verbena ligustrina Lag. Lippia lycioides Steud.]

In rocky soil, Texas to California and Mexico.

\section{PRİvA Adans.}

Perennial caulescent herbs. Leaves opposite : blades membranous, toothed. Flowers in slender peduncled spikes. Calyx sessile or nearly so : tube 5-ribbed : lobes 5 . Corolla salverform: tube straight or incurved, slightly dilated above: limb spreading, oblique, slightly 2-lipped : lobes 5, short. Stamens 4, didynamous, included : anthers with parallel or slightly divergent sacs. Staminodium minute or wanting. Ovary 2-celled, each cavity with more or less well developed septa. Ovules 2, or by abortion 1, at the base of each cavity. Fruit enclosed in the calyx, separating into 2 nutlets.

1. Priva echinàta Juss. Foliage more or less pubescent. Stems 2-6 dm. tall, branching : leaf-blades ovate, 2-10 $\mathrm{cm}$. long, acute or acuminate, serrate, truncate or cordate at the base; petioles much shorter than the blades : racemes loosely flowered, $5-15 \mathrm{~cm}$. long : pedicels 1-2 mm. long: calyx cylindric-prismatic, $2-3 \mathrm{~mm}$. long, accrescent, pubescent : corolla slightly surpassing the calyx, salverform, with short rounded lobes: fruit ovoid-pyramidal, 5-7 mm. long: nutlets included in the calyx, spiny-tuberculate on the back, 3-4 $\mathrm{mm}$. long.

In sandy soil, Florida. Also in tropical America.

\section{ABÈNA Neck.}

Annual or perennial herbs, or shrubs. Leaves opposite or alternate: blades toothed, often rugose. Flowers solitary and sessile in the axils of bracts, or imbedded in excavations of the thick rachis. Calyx membranous or herbaceous: lobes 5, equal or unequal, usually unchanged at maturity. Corolla white or of various colors: tube sometimes slightly dilated above : limb spreading : lobes 5, equal or unequal. Stamens 2, included : anthers with unappendaged connectives. Staminodia 2, small. Ovary 2-celled. Ovules solitary in each cavity. Fruit included in the calyx, separating into 2 nutlets.

1. Abena Jamaicénsis (L.) A. S. Hitchcock. An annual shrubby plant, with sparingly pubescent or glabrate foliage. Stems 6-15 dm. tall : leaves alternate or opposite ; blades oblong, ovate or oval, $2-8 \mathrm{~cm}$. long, coarsely serrate, abruptly or gradually narrowed at the base ; petioles margined, as long as the blades or shorter: spikes $1.5-5 \mathrm{dm}$. long, quill-like : bracts imbricated, lanceolate to oblong-lanceolate, acuminate, serrulate, 5-8 $\mathrm{mm}$. long: flowers in depressions of rachis : calyx-lobes triangular or triangular-ovate : corolla blue, $8-11 \mathrm{~mm}$. long; tube slightly curved; limb $8 \mathrm{~mm}$. broad : nutlets $3 \mathrm{~mm}$. long, buried in the rachis. [Stachytarpheta Jamaicensis (L.) Vahl.]

In sandy soil, Florida. Also in tropical America.

\section{LANTÀNA L.}

Shrubs, or rarely herbs, with pubescent foliage, sometimes armed with prickles. Leaves opposite: blades toothed, often rugose. Flowers in dense or congested peduncled spikes. Calyx membranous, with a truncate or sinuate border. Corolla white or of various colors : tube slender, often curved, sometimes slightly dilated above : limb more or less 2 -lipped : lobes $4-5$, obtuse or retuse. Stamens 4 , didynamous : filaments adnate to about the middle of the corolla-tube. Ovary 2-celled. Stigma oblique. Ovules solitary 
in each cavity. Fruit drupe-like, with a more or less watery pulp. Nutlets 2-celled or separating into 2 one-seeded nutlets. The plants flower throughout the year.

Flower-heads bracted, but not involucrate.

Leaf-blades cuneate to rounded at the base, rather finely crenate-serrate.

Leaf-blades truncate or cordate at the base, coarsely crenate or serrate-crenate.

Flower-heads decidedly involucrate.

Leaf-blades acute or acutish, coarsely toothed : corolla-tube about $10 \mathrm{~mm}$. long.

Leaf-blades rounded or retuse at the apex, crenulate: corolla-tube $2-4 \mathrm{~mm}$. long. Outer bracts of the involucre ovate.

Outer bracts of the involucre lanceolate or oblong-lanceolate.

1. L. Camara.

2. L. horrida.

3. L. Sellowiana.

4. L. involucrata.

5. L. odorata.

1. Lantana Camàra L. A branching shrub 1-1.5 m. tall, rigid-pubescent, unarmed, or prickly. Leaf-blades ovate to oblong-ovate, 4-12 $\mathrm{cm}$. long, obtuse, acute, or shortacuminate, finely crenate-serrate, rounded or narrowed at the base: bracts oblong to lanceolate, $4-7 \mathrm{~mm}$. long: calyx very thin, $3 \mathrm{~mm}$. long: corolla yellow or orange; tube about $1 \mathrm{~cm}$. long, puberulent, slightly curved, barely enlarged above the middle ; limb $6-8$ mm. high.

In sandy soil, Georgia to Florida and Texas. Also in tropical America.

2. Lantana hórrida H.B.K. A branching shrub mostly 1-2 m. tall, more or less prickly and hirsute. Leaf-blades ovate to orbicular-ovate or deltoid-ovate, $2-7 \mathrm{~cm}$. long, obtuse or acute, coarsely crenate or serrate-crenate, truncate or cordate at the base : bracts narrow : calyx about $2 \mathrm{~mm}$. long : corolla deep yellow or orange-red ; tube 7-9 $\mathrm{mm}$. long, enlarged above the middle; limb $7-8 \mathrm{~mm}$. high.

In sandy soil or thickets, Gulf States, Mexico and Central America.

3. Lantana Sellowiàna Link \& Otto. A branching shrub $3-18 \mathrm{dm}$. tall, with tomentulose foliage. Leaf-blades ovate, oval or elliptic-ovate, $1-3 \mathrm{~cm}$. long, acute or acutish, relatively coarsely crenate, abruptly narrowed or truncate at the base; petioles generally winged below the blade : bracts of the involucre ovate or oblong-elliptic, ciliate, $5-6 \mathrm{~mm}$. long : calyx $1 \mathrm{~mm}$. high : corolla magenta or lilac ; tube about $1 \mathrm{~cm}$. long, puberulent ; limb 8-10 mm. high, the lower lobe much longer than the others.

In waste places, pine lands and thickets, Florida. Common in tropical America.

4. Lantana involucràta $\mathrm{L}$. A much-branched shrub 4-17 dm. tall, with puberulent or thickly tomentulose foliage. Leaves sometimes clustered in the axils; blades oval, obovate to suborbicular, 1-3 cm. long, rounded or retuse at the apex, finely crenate, usually cuneately narrowed at the base : outer bracts of the involucre ovate, 4-7 $\mathrm{mm}$. long, ciliolate : calyx becoming $1.5 \mathrm{~mm}$. long : corolla white, puberulent; tube $2-4 \mathrm{~mm}$. long, slightly enlarged at the middle ; limb 2-4 mm. high, the lower lobe the largest.

In sandy soil, pine lands and open hammocks, Florida. Also in tropical America.

5. Lantana odoràta L. Similar to $L$. involucrata in habit. Leaves similar, but commonly larger : bracts of the involucre narrower, the outer lanceolate or oblong-lanceolate. [L. involucrata var. Floridana Chapm.]

In pine lands and hammocks, peninsular Florida. Also in tropical America.

\section{CITHARÉXYLUM L.}

Evergreen shrubs, sometimes armed with axillary spines. Leaves opposite, without stipules. Flowers small, in axillary or terminal racemes. Pedicels subtended by minute persistent bracts. Calyx membranous : tube narrowly campanulate, minutely 5-lobed, persistent. Corolla mostly white, salverform : tube symmetrical: limb slightly oblique : lobes 5, nearly equal. Stamens 4, adnate, like the staminodium, to the corolla-tube below the middle : filaments filiform-subulate : anthers introrse. Ovary sessile, incompletely 4celled by the development of 2 parietal placentae. Stigma 2-lobed. Ovules solitary, ascending, anatropous. Drupe berry-like, subtended by the persistent calyx, with a fleshy pulp and a thick bony stone which separates into 2 flattened 2 -seeded nutlets. Seeds elongated, with a membranous testa. Endosperm wanting.

Leaves 6-12 mm. long: flowers clustered on short spur-like branches. Leaves 5-15 cm. long: flowers in slender spikes.

1. C. brachyanthum.

2. C. villosum.

1. Citharexylum brachyánthum A. Gray. A much branched shrub, with puberulent foliage, the branchlets 4-angled: leaves few, often clustered; blades linear-spatulate to cuneate or obovate, 6-12 mm. long, obtuse, nerveless, sessile or nearly so, on falling their bases becoming spinescent : flowers clustered on short spur-like branches : calyx pubescent, nearly $4 \mathrm{~mm}$. long; lobes 5 , low : corolla white; tube about $4 \mathrm{~mm}$. long, campanulate; lobes rounded, shorter than the tube : fruit subglobose, $6 \mathrm{~mm}$. in diameter.

On dry plains or hillsides, southern Texas. 
2. Citharexylum villòsum Jacq. A shrub or small tree, sometimes $7 \mathrm{~m}$. tall, with softly pubescent or glabrate foliage. Leaf-blades rather leathery, elliptic, oblong or oblong-obovate, $5-15 \mathrm{~cm}$. long, rounded at the apex or acuminate at both ends, undulate, lustrous above, short-petioled : racemes spike-like, 5-12 cm. long, short-peduncled : calyx campanulate, $3 \mathrm{~mm}$. long, pubescent, undulately lobed : corolla white, glabrous without ; tube pubescent within, surpassing the calyx ; limb 5-7 mm. broad; lobes rounded, spreading : fruit subglobose, about $1 \mathrm{~cm}$. in diameter, reddish brown, lustrous.

In sandy soil, Florida. Also in tropical America.

\section{DURÁNTA L.}

Shrubs or small trees, with sometimes armed branches. Leaves opposite or whorled : blades entire or often toothed. Flowers small, in elongated terminal or short axillary racemes. Calyx pedicelled : tube campanulate or tubular, truncate or minutely 5-lobed. Corolla funnelform or salverform : tube cylindric, straight or incurved : limb spreading, oblique or of 5 equal lobes. Stamens 4, didynamous, included. Anthers with unappendaged connectives : sacs distinct. Ovary partially or imperfectly 8-celled. Stigna oblique, sometimes unequally 4-lobed. Ovules solitary or 2 in each cavity. Drupe included in the calyx, of 4 nutlets. Seeds without endosperm.

1. Duranta rèpens $\mathrm{L}$. A shrub or small tree reaching a height of $6 \mathrm{~m}$., with glabrate or finely pubescent foliage and unarmed or spiny branches. Leaves numerous ; blades ovate-elliptic, oval or obovate, $1.5-5 \mathrm{~cm}$. long, obtuse or apiculate, entire or serrate above the middle, short-petioled : racemes $5-15 \mathrm{~cm}$. long, recurving, paniculate : pedicels 1-5 mm. long: calyx 3-4 mm. long, angled; lobes acute, shorter than the tube: corolla lilac ; tube surpassing the calyx ; limb $7-9 \mathrm{~mm}$. broad : fruit yellow, globular, 7-11 mm. in diameter, enclosed by accrescent yellowish calyx which is produced into a curved beak.

In sandy soil, Florida. Also in tropical America.

\section{CALLICÁRPA L.}

Shrubs or trees, with usually pubescent foliage. Leaves opposite : blades entire, toothed or rarely lobed. Flowers in axillary sessile or peduncled cymes. Calyx unchanged at maturity : tube campanulate, truncate, or with 4 short lobes. Corolla white, blue or purple: tube very short, straight: limb spreading, with 4 equal imbricate lobes. Stamens 4, equal, often exserted: anthers with parallel sacs. Ovary imperfectly 2-celled. Stigma 2-lobed. Ovules 2 in each cavity, laterally attached. Drupe globose or depressed, seated in the calyx, pulpy, white, purple, violet or red.

1. Callicarpa Americàna L. A bushy shrub 1-2 m. tall, with scurfy-stellate pubescence. Leaf-blades thinnish, ovate, elliptic or oval, acute or acuminate at both ends, serrate, glabrate above; petioles 1-2 cm. long: cymes axillary, many-flowered, shorter than subtending petioles : calyx campanulate, $1-1.5 \mathrm{~mm}$. long, with 5 low lobes : corolla bluish or pink; limb about $5 \mathrm{~mm}$. broad, the lobes rounded: fruit violet, subglobose, 4-5 mm. in diameter.

In dry sandy soil, Virginia and Arkansas, south to Florida and Texas. Spring and summer.

\section{VÍtreX L.}

Shrubs or trees. Leaves opposite : blades usually 3-7 digitately compound, or rarely 1-foliolate. Flowers in cymes, which are sometimes whorled. Calyx campanulate or rarely tubular-funnelform, with 5 or rarely 3 lobes. Corolla white, yellow, blue or purplish: tube variable in length, straight or nearly so: limb spreading, oblique, somewhat 2-lipped. Stamens 4, didynamous, often exserted. Anthers with distinct nearly parallel, arched or spreading sacs. Ovary at first imperfectly 2-celled, becoming 4-celled. Ovules 4, solitary in each cavity. Drupe seated in the calyx or rarely nearly included, usually rather dry. Seeds without endosperm.

1. Vitex Ágnus-Cástus L. A branching shrub 1-3 m. tall, with finely pale pubescent foliage. Leaf-blades 7 -foliolate; petioles shorter than the longer leaflets, often spreading; leaflets linear to linear-elliptic, 2-10 cm. long, acutish, entire, glabrate above, slender-petioluled : panicles narrow, $5-15 \mathrm{~cm}$. long ; clusters interrupted : calyx campanulate, $2-2.5 \mathrm{~mm}$. long, white; lobes triangular, shorter than tube : corolla blue or purplish, 
$7-8 \mathrm{~mm}$. long, puberulent without ; tube much longer than the calyx ; limb $5-6 \mathrm{~mm}$. broad, the lobes unequal, the smaller broadly ovate: stamens exserted : fruit $3.5-4 \mathrm{~mm}$. long.

In sand or sandy soil, North Carolina to Florida and Texas. Naturalized from the Old World.

\section{AVICÉNNIA L.}

Evergreen maritime shrubs or trees, with stout nodose branches. Leaves opposite, without stipules: blades leathery, entire, persistent. Flowers opposite, in spikes or heads : peduncles stoutish, axillary or 3 at the ends of the bractlets. Bracts and bractlets alike, shorter than the calyx. Calyx cup-like, pubescent like the bracts: lobes 5, concave, persistent. Corolla campanulate, inserted on an inconspicuous disk : tube short, nearly cylindric ; limb 4-lobed, spreading, the posterior lobe often broader than the rest. Stamens 4, adnate to the upper part of the corolla-tube: anthers introrse. Ovary 1-celled with a free central placenta. Stigma 2-cleft. Ovules 4, suspended from the central placenta. Capsule oblique, subtended by the persistent calyx, apiculate.

1. Avicennia nítida Jacq. An evergreen shrub or tree sometimes $25 \mathrm{~m}$. tall, with pubescent young foliage, but soon glabrous. Leaves numerous ; blades leathery, oblong or slightly broadest above or below the middle, $3-8 \mathrm{~cm}$. long, obtuse or apiculate, slightly revolute, dark green above, pale and minutely canescent beneath, short-petioled: panicles 2-5 cm. long, rather few-flowered : calyx somewhat silky; lobes $3-4 \mathrm{~mm}$. long, acute or acutish : corolla pubescent within and without, 1-1.5 $\mathrm{cm}$. broad; lobes usually broadest above the middle : fruit oblong or elliptic, $3-5 \mathrm{~cm}$. long, acutish.

In sandy soil, Florida, Mississippi and Texas. Also in tropical America. Black Mangrove.

\section{Family 11. PhrYmàceae Schauer. Lopseed Family.}

Perennial caulescent herbs, with irregular rootstocks and upright angled stems. Leaves opposite: blades membranous, simple. Inflorescence spicate. Flowers perfect, irregular, subtended by small bracts. Calyx spreading, becoming reflexed at maturity, 2-lipped : tube cylindric at flowering time ; upper lip with 2 lobes, the lower with 3 much longer lobes. Corolla colored, 2-lipped : tube cylindric : lips unequal, the upper erect, concave, notched, the lower lip larger, spreading, convex, with 3 obtuse lobes. Stamens 4, included, didynamous. Gynoecium of 2 united carpels. Ovary 1-celled, oblique. Style slender. Stigmas 2. Ovules solitary orthotropous, ascending. Fruit a narrow achene surrounded by the accrescent deflexed ribbed closed calyx. Embryo with convolute cotyledons in the endosperm.

\section{PHRỲMA L.}

Characters of the family. LOPSEED.

2. Phryma leptostáchya L. Slender, minutely pubescent, dark green. Stems 3-10 dm. tall, simple below, branched above, clothed with reflexed hairs, enlarged and purple above the nodes: leaf-blades ovate or elliptic-ovate to ovate-lanceolate, $3-15 \mathrm{~cm}$. long, acute, acuminate or obtusish, serrate or serrate-crenate, abruptly narrowed into slender petioles; these nearly equalling the blades on the lower part of the stem, very short above : spikes puberulent, 2-20 cm. long: calyx cylindric, $3-5 \mathrm{~mm}$. long, accrescent ; tube fluted ; lobes tooth-like, the 3 upper linear, magenta, hooked at the tip, the 2 lower triangular-ovate : corolla $8 \mathrm{~mm}$. long, white, and usually tinged with magenta; upper lip ovate, magenta, notched at the apex; lower lip 3-lobed, the lobes obtuse: fruit 4-5 mm. long, rounded at both ends, enclosed in the hardened calyx-tube, which is terminated by the rigid lobes.

In woods and thickets, Ontario to Minnesota, Florida and Kansas. Spring and fall.

\section{Family 12. Lamiàceate Lindl. Mint Family.}

Aromatic herbs or shrubby plants, or rarely trees, whose vegetative parts abound in a volatile oil and a bitter principle. Stems 4-sided. Leaves opposite or whorled: blades simple, entire, or variously toothed, lobed or cleft. Inflorescence of axillary often congested or reduced cymes. Flowers perfect, irregular 
or nearly regular. Calyx free, persistent, regular or irregular, often oblique : lobes 5, commonly slender. Corolla gamopetalous, bilabiate, or nearly regular, deciduous. Androecium of 4 didynamous stamens (one of the pairs sometimes wanting or abortive) adnate to the corolla tube, variable in position. Filaments naked or bearded. Anthers 2-celled. Gynoecium compound. Ovary free, deeply 4-lobed, 4-celled. Styles central, united, arising from between the lobes. Stigma terminal, often inconspicuous. Ovules solitary, erect. Fruit usually of 4 small nutlets or achenes, included in the persistent calyx. Seed solitary, erect. Endosperm fleshy or wanting. Embryo straight. [Labiatae B. Juss.]

Ovary of 4 united carpels, 4-lobed: style not basal : nutlets laterally attached.

Corolla very irregular: limb nearly 1 -lipped, the upper lip very short.

Flowers in congested cymes axillary to small bracts, disposed in a racemelike panicle: calyx-lobes shorter than the tube.

Flowers solitary in the axils of bracts nearly similar to the leaves: calyxlobes longer than the tube.

Corolla nearly regular.

Stamens only slightly exserted, nearly equal.

Stamens conspicuously exserted, strongly didynamous.

Ovary of 4 distinct or nearly distinct carpels : style basal : nutlets basally attached.

Calyx with a crest on the upper side or upper lip; lips 2, entire.

Caly $x$ without a crest on the upper side: lips not entire.

Stamens included.

Stamens exserted (except in Dicerandra odoratissima).

Corolla conspicuously 2-lipped: lips different, the upper concave. Anther-bearing stamens 4.

Upper pair of filaments longer than the lower.

Anther-sacs parallel or nearly so.

Upper pair of stamens declined, lower pair ascending : erect herbs.

Upper and lower pair of stamens ascending : trailing herbs.

Anther-sacs diverging.

Calyx barely 2-lipped, with 5 nearly equal lobes : erect herbs. Caly $x$ 2-lipped, with unequal lobes: trailing herbs.

Upper pair of filaments shorter than the lower.

Calyx manifestly 2 -lipped.

Upper lip of the calyx broad, with 3 lobes, the lower with 2 tooth-like lobes.

Anther-sacs divaricate : flowers 3 together, or 6 in a whorl : calyx dorsally fiattened.

Anther-sacs parallel: flowers solitary, or 2 in a whorl: calyx somewhat inflated.

Upper lip of the calyx narrow, entire, the lower lip of 2 equal broad lobes.

Calyx not 2-lipped, often slightly irregular, but the lobes essentially similar.

Tube of the calyx faintly nerved, inflated at maturity.

Calyx-lobes 5.

Caly $x$-lobes 4.

Tube of the calyx prominently 5-10-nerved, not inflated at maturity.

Anther-sacs transversely 2-valved.

Anther-sacs not transversely 2-valved.

Nutlets 3-sided, truncate above.

Calyx-lobes not spine-tipped.

Calyx-lobes spine-tipped.

Calyx-lobes 5.

Calyx-lobes 8-10.

Nutlets nearly terete, rounded above.

1. TeUCrium.

2. Melosmon.

3. IsANTHus.

4. TRIOHOSTEMA.

5. Scutellaria,

6. marrubium.

T.

8. MEEHANIA.

9. NEPETA.

10. GLECOMA.

Anther-bearing stamens 2.

-Connective of the anther elongated, bearing a perfect sac at one end and a rudimentary one at the other.

Calyx-throat glabrous or merely ciliate at the base of the lobes.

Calyx-throat densely bearded with white hairs and closed by them at maturity.

Connective short : anther-sacs confluent.

Calyx not 2-lipped ; tube 15-ribbed; teeth nearly equal.

Calyx 2-lipped; tube 13-ribbed; teeth unequal.

Corolla nearly regular or if 2-lipped, the upper lip flat or not concave.

A. Stamens 2-4: filaments straight and spreading or converging under the upper lip of the corolla.

Flowers in axillary whorls or clusters; these sometimes forming terminal spike-like racemes or panicles.

* Corolla 2-lipped.

+ Filaments curved, converging under the upper lip of the corolla.

Anther-bearing stamens 2.

Calyx gibbous; throat closed by hairs : corolla without folds in the throat.

Calyx not gibbous ; throat not closed by hairs : corolla with 2 folds in the throat.

11. Prunella.

12. Brazoria.

13. MACBRIDEA.

14. Physostegia.

15. SYNANDRA.

16. GALEOPSIs.

17. LAMIUM.

18. LEONURUS.

19. LEONOTIS.

20. STACHY8.

21. Salvia.

22. Salviastrum.

23. Monarda.

24. BLEPHIJIA.

25. HedEOMA.

26. STACHYDEOMA.

Anther-bearing stamens 4 .

Corolla-tube strongly bent.

Anther-sacs divergent.

Anther-sacs parallel.

27. Melissa.

Corolla-tube straight.

Calyx with 5 nearly equal lobes, not 2 -lipped.

28. CONRADINA. 
Calyx-tube 10-ribbed.

Caly $x$-tube 13-ribbed.

Calyx 2-lipped.

Anther-sacs awnless.

Anther-sacs awned.

i† Filaments straight, often spreading.

Calyx-tube 15-nerved.

Calyx-tube 10-13-nerved.

Änther-bearing stamens 4 .

Anther-sacs divergent.

Anther sacs parallel.

Anther-bearing stamens 2.

** Corolla nearly regular, with 4-5 lobes.

Anther-bearing stamens 2: foliage barely aromatic.

Anther-bearing stamens $4:$ foliage strongly aromatic.

b. Flowers in loose terminal panicles.

Lower lip of the corolla fringed: native genera.

Anther-bearing stamens 4.

Anther-bearing stamens 2.

Lower lip of the corolla not fringed: naturalized genus.

B. Stamens 4, didynamous; lower pair longer, lying on the lower lip of the corolla.

Caly with nearly equal lobes: corolla with a saccate drooping lower lip.

Calyx with a broad decurrent upper lobe: corolla-lobes nearly equal.

29. PYCNOTHYMUS

30. Micromeria.

31. Clinopodium.

32. Dicerandra.

33. Hyssopus.

34. THYMUS.

35. Koellia.

36. Cunila.

37. LyCOPUS.

38. Mentha.

39. MiCHELIELLA

40. COLlinsonia.

41. Perilla.

42. MESOSPHAERUM.

43. OCIMUM.

\section{TEÙCRIUM L.}

Perennial herbs or shrubby plants, with usually pubescent foliage. Leaves opposite : blades merely toothed. Flowers in raceme-like panicles. Calyx campanulate or tubularcampanulate : tube 10-ribbed : lobes 5, unequal. Corolla white, pink or purplish, very irregular : upper lip short: lower lip with 2 short lateral lobes and an elongated declined middle lobe. Stamens 4, exserted between the lobes of the upper lip of the corolla, the anterior pair the longer : anthers with divergent sacs confluent at the base. Nutlets variously marked.

Stems hoary-canescent.

Stems closely canescent : leaf-blades rounded at the base.

Stems downy-canescent : leaf-blades narrowed at the base.

Calyx prominently ribbed at maturity : corolla glandular-puberulent.

Calyx not ribbed at maturity: corolla pilose.

Stems villous-hirsute, with relatively long spreading or recurved-spreading hairs.

1. T. Canadensc.

2. T. Nashii.

3. T. littorale.

4. T. occidentale.

1. Teucrium Canadénse L. Stems $2-12 \mathrm{dm}$. tall, closely canescent, simple, at least below the inflorescence : leaf-blades relatively thin, ovate to oblong-ovate, $6-14 \mathrm{~cm}$. long, acute or acuminate, closely dentate-serrate, rounded or rarely subcordate at the base, green and glabrate or thinly appressed hispidulous above, pale-pubescent beneath : panicle dense : bract mostly shorter than the mature calyx : calyx canescent, often purplish, 5-7 mm. long; tube turbinate; lobes various, the upper acute or obtuse, the lower pair slightly longer, triangular-subulate : corolla pink, 15-20 mm. long, minutely granular-puberulent.

In low grounds and on river banks, New England to Nebraska, Georgia and Texas. Summer.

2. Teucrium Náshii Kearney. Stems 4-14 dm. tall, simple or sparingly branched above, closely canescent : leaf-blades narrowly oblong to lanceolate, 4-13 cm. long, acute or slightly acuminate, quite evenly serrate, narrowed at the more or less inequilateral base, short-petioled : panicle somewhat interrupted below, at least in age : bract as long as the mature calyx or longer : calyx closely pubescent, ribbed at maturity ; lobes erect, the upper obtuse, the lower ones acute : corolla pink, about $1.5 \mathrm{~cm}$. long, granular-puberulent.

In hammocks, thickets and on brackish shores, Florida to Mississippi. Spring and summer.

3. Teucrium littoràle Bicknell. Stems 3-5 dm. tall, often sparingly branched, pale and closely canescent: leaf-blades relatively thick, oblong, usually narrowly so, to narrowly oblong-lanceolate, $6-11 \mathrm{~cm}$. long, acute or blunt-pointed, finely serrate or becoming dentate-serrate, rugose, softly appressed-pubescent above, pale or whitish tomentulose beneath: panicle narrow, often interrupted: bract about as long as the mature calyx, acuminate : calyx downy, 4-5 mm. long, not ribbed; tube becoming somewhat urceolate; lobes erect, the upper obtuse, the lower acute or acuminate: corolla pale pink, about $15 \mathrm{~mm}$. long, loosely pilose.

On or near the coast, Maine to Florida. Summer.

4. Teucrium occidentàle A. Gray. Stem 3-8 dm. tall, villous-hirsute with spreading or recurved hairs, with few or several erect branches : leaf-blades ovate-oblong, oblong 
or oblong-lanceolate, 4-9 $\mathrm{cm}$. long, acute, sharply serrate, mostly rounded at the base, tomentulose or hirsute beneath with spreading hairs on the larger veins: panicles narrow, dense, sometimes elongated : bract mostly shorter than the calyx, acuminate : calyx 5- 6 $\mathrm{mm}$. long, often purple; lobes various, the upper acute, the lower ones lanceolate-subulate : corolla pinkish purple, 8-12 $\mathrm{mm}$. long, tomentulose and glandular without.

In low grounds and thickets, Ontario to British Columbia, Arkansas and California. Summer.

\section{MELÓsMon Raf.}

Perennial or annual diffuse herbs, with glabrous or finely pubescent foliage. Leaves opposite : blades incised or parted. Flowers solitary in the axils of the leaf-like bracts. Calyx pedicelled : tube 10-ribbed, very short: lobes 5, equal or essentially so. Corolla white, blue or lilac, very irregular : upper lip relatively small : lower lip with 2 lateral lobes and a much longer middle lobe. Stamens 4, exserted as in Teucrium. Nutlets smooth or ribbed, sometimes corky thickened.

Leaf-blades incised, the tooth-like lobes blunt.

Leaf-blades parted, the divisions narrow and mostly acute.

Corolla between 1 and $1.5 \mathrm{~cm}$. long: leaves not approximate.

Corolla between $1.5-2 \mathrm{~cm}$. long: leaves approximate and imbricated.

1. M. Cubense.

2. M. laevigatum.

3. M. laciniatum.

1. Melosmon Cubénse (L.) Small. Stems often branched at the base, the branches erect or ascending, 2-5 dm. tall, commonly branched above : leaf-blades spatulate to ovate in outline, cuneate at the base, 1-3 cm. long, incised, the tooth-like lobes mostly entire : bracts similar to the leaves : pedicels $2-5 \mathrm{~mm}$. long: caly x 4-5.5 mm. long; lobes lanceolate to linear-lanceolate, acuminate, several times longer than the tube, finely pubescent : corolla bluish white, 11-14 mm. long : nutlets fully $2 \mathrm{~mm}$. long, irregularly roughened.

In sandy soil, Texas and Mexico. Also in the West Indies.

2. Melosmon laevigatum (Vahl) Small. Stems branched at the base, the branches ascending or spreading, 1-6 dm. long, simple or irregularly branched, not densely leafy : leaf-blades 1-4 cm. long, laciniately 3-5-lobed, the lobes linear, entire or toothed, acute : bracts leafy : pedicels slender, 3-6 $\mathrm{mm}$. long: calyx 7-8 $\mathrm{mm}$. long; lobes linear-lanceolate, acute, several times longer than the tube, glabrous or nearly so: corolla white or bluish, 1-1.5 cm. long, the upper lobes 3-4 mm. long, acutish, the lower lip nearly $1 \mathrm{~cm}$. long, sparingly villous without, its middle lobe pendant, oblong or elliptic : nutlets $2 \mathrm{~mm}$. long, longitudinally ribbed and pitted between the ribs. [Teucrium laevigatum Vahl.]

In sandy soil, Texas. Also in South America. Spring.

3. Melosmon lacíniatum (Torr.) Small. Stems usually branched at the base, the branches 5-15 cm. long, ascending or spreading, densely leafy, except near the base : leafblades pinnately 3-7-parted, 1-3 cm. long, the segments narrowly linear, entire, incised or lobed: bracts leafy : pedicels 2-6 $\mathrm{mm}$. Iong: calyx 10-12 $\mathrm{mm}$. long; tube turbinate, strongly ribbed; lobes linear-subulate, acuminate, several times longer than the tube: corolla pale blue or lilac, sparingly pubescent without, $1.5-2 \mathrm{~cm}$. long, the upper lobes ovate, the lower lip much surpassing the calyx, its middle Iobe oblong-spatulate, concave : nutlets $2.5 \mathrm{~mm}$. long, reticulated and granular. [Teucrium laciniatum Torr.]

On plains, Colorado to Texas and Arizona. Spring.

\section{ISÁNTHUUS Michx.}

Annual herbs, with viscid-pubescent foliage and branching stems. Leaves opposite : blades narrow, entire or sparingly toothed. Flowers in axillary cymes. Calyx campanulate: tube 10-ribbed : lobes 5, nearly equal, narrow. Corolla blue, nearly regular : lobes broadened upward, spreading. Stamens 4, slightly didynamous, surpassing the corollatube, thus slightly exserted: anthers with diverging sacs at maturity. Nutlets reticulated.

1. Isanthus brachiàtus (L.) B.S.P. Annual, minutely viscid-pubescent. Stems 1-4 dm. tall, branching : leaf-blades elliptic or linear-elliptic, 1-4 cm. long, acute at both ends, entire or rarely toothed, 3-nerved, short-petioled : peduncles axillary, 1-3-flowered : calyx green or purple; tube campanulate, $2-5 \mathrm{~mm}$. long, ridged; lobes lanceolate or triangular-lanceolate, as long as the tube or longer: corolla blue, 5-8 mm. long: nutlets 2-2.5 mm. long, strongly reticulated. [I. coeruleus Michx.]

In dry soil, Quebec and Ontario to Minnesota, Georgia and Texas. Summer and fall.

\section{TRICHOSTÈMA L.}

Annual or perennial herbs or shrubby plants, with glabrous or viscid foliage and branching stems. Leaves opposite: blades rather narrow, entire or merely repand. 
Flowers in axillary cymes, or often disposed in panicles. Calyx campanulate : tube short : lobes 5, unequal. Corolla white, pink, blue or purple, slightly irregular : lobes somewhat declined. Stamens 4, conspicuously exerted : filaments curved, the anterior pair longer, all spirally coiled in the bud : anthers with divergent sacs. Nutlets reticulated.

Annual plants : leaf-blades of a linear or oblong type.

Foliage glabrous or viscid-puberulent: leaf-blades linear.

Foliage viscid-pubescent : leaf-blades oblong or oblong-lanceolate.

Perennial or biennial plant: leaf-blades of an obovate or cuneate type.

1. T. lineare.

2. T. dichotomum.

3. T. suffrutescens.

1. Trichostema lineàre Nutt. Annual, somewhat viscid-puberulent or glabrous. Stems 1-3 dm. tall, branching : leaf-blades linear, 1-4 cm. long, acute at both ends, entire, sessile or short-petioled : calyx $3 \mathrm{~mm}$. long, becoming $5 \mathrm{~mm}$. long; tube turbinate or inflated in age; larger lip with 3 acuminate lobes; smaller lip with 2 much smaller ovatelanceolate lobes : corolla blue or rarely white, about $1 \mathrm{~cm}$. long, the middle lobe of the lower lip cuneate : nutlets $1.5 \mathrm{~mm}$. long.

In sandy soil and pine lands, Connecticut to Florida and Louisiana. Summer.

2. Trichostema dichòtomum L. Annual, minutely viscid-pubescent. Stems commonly much-branched, $1-20 \mathrm{dm}$. tall : leaf-blades thickish, oblong to oblong-lanceolate, $2-7$ cm. long, obtuse or abruptly pointed, entire, acuminate at the base, short-petioled : pedicels 3-8 mm. long, spreading or somewhat recurved at maturity : calyx $4 \mathrm{~mm}$. long, becoming $8 \mathrm{~mm}$. long; tube turbinate or inflated in age, the large lip sharply 3-lobed : corolla blue, pink or white, less than $1 \mathrm{~cm}$. long: nutlets $2 \mathrm{~mm}$. long.

In sandy soil and thickets, Maine to Florida, Kentucky and Texas. Summer and fall.

3. Trichostema suffrutéscens Kearney. Biennial or perennial, puberulent. Stems branched throughout, $2-4 \mathrm{dm}$. tall, the branches erect or ascending: leaves often clustered in axils ; blades obovate, oblong-obovate, more or less cuneate at the base, 0.5-1 cm. long, thickish, rounded or retuse at apex, ciliolate, short-petioled: pedicel about as long at the calyx : calyx $3 \mathrm{~mm}$., becoming $5-6 \mathrm{~mm}$. long; tube turbinate or inflated in age, the larger lip sharply 3 -toothed : corolla bright blue : filaments $2-2.5 \mathrm{~cm}$. long, closely coiled : nutlets obovoid, $1.5 \mathrm{~mm}$. long.

In scrub, peninsular Florida. Spring.

\section{SCUTELLÀrIA L.}

Annual or perennial, sometimes shrubby herbs, with glandular-punctate and bitter foliage. Leaves opposite: blades various, entire or toothed. Flowers in terminal racemes or panicles. Calyx campanulate, 2-lipped : lips entire, the upper one with a crest or protuberance. Corolla white, blue or violet, erect or ascending by the recurved tube, this dilated into a throat, 2-lipped, the upper lip arched, the lower lip with 2 small lateral lobes and a large, more or less spreading, middle lobe. Stamens 4 : filaments all antherbearing : anthers ciliate, those of the upper pair of filaments 2-celled, those of the lower 1-celled. Nutlets papillose or tuberculate, wingless or rarely winged.

A. Nutlets wingless.

a. Flowers in terminal or axillary racemes or panicles.

Corolla less than $1 \mathrm{~cm}$. long.

Corolla over $1 \mathrm{~cm}$. long.

Leaf-blades above the middle of the stem cordate.

Foliage, especially the internodes. of the stem and inflorescence, copiously pubescent.

Corolla over $15 \mathrm{~mm}$. long.

Larger leaves with petioles less than $1 / 2$ as long as the blades : inflorescence pubescent with very short close-set hairs.

Larger leaves with petioles over $1 / 2$ as long as the blades: inflorescence pubescent with villous hairs.

Corolla less than $15 \mathrm{~mm}$. long.

Foliage glabrous or with scattered hairs at the nodes of the stem and in the inflorescence.

Leaf-blades above the middle of the stem abruptly or gradually narrowed at the base.

* Leaves all with toothed blades.

† Corolla over $2 \mathrm{~cm}$. long.

Foliage glabrous or nearly so.

Foliage, especially the stem, finely and closely pubescent.

Corolla between 2.5 and $3 \mathrm{~cm}$. Jong.

Leaf-blades acute, not prominently nerved beneath : Alleghenianspecies.

Leaf-blades obtuse, prominently nerved beneath: Floridian species.

Corolla between 2 and $2.5 \mathrm{~cm}$. long.

1. S. lateriflora.

2. S. Ocmulgee.

3. S. cordifolia.

4. S. arguta.

5. S. saxatilis.

6. S. serrata.

7. S. montana.

8. S. arenicola.

9. S. Mellichampii. 
i† Corolla less than $2 \mathrm{~cm}$. long.

Corolla copiously pubescent Leaf-blades glabrous above. Leaf-blades pubescent above. Corolla glabrous or nearly so.

** Leaves, all or those above the middle of the stem, with entire blades.

Upper lip of the corolla shorter than the throat.

Leaf-blades and corollas glabrous or nearly so.

Leaf-blades and corollas variously pubescent. Foliage manifestly pubescent.

Upper lip of the corolla surpassing the lower.

Upper lip of the corolla surpassed by the lower. Foliage merely puberulent.

Upper lip of the corolla longer than the throat.

b. Flowers solitary in the axils of the leaf-like bracts.

Corolla less than $1.5 \mathrm{~cm}$. long.

Plants annual or biennial.

Foliage merely puberulent: leaf-blades coarsely toothed.

Foliage merely puberulent: leaf-blades coarsely toothed.
Foliage manifestly pubescent: leaf-blades entire or shallowly toothed. 19 . S. Drummondiophila.

Plants perennial.

Perennial from a woody base and root.

Foliage manifestly pubescent: nutlets over $1 \mathrm{~mm}$. thick.

Foliage merely puberulent: nutlets less than $1 \mathrm{~mm}$. thick.

Perennial from slender or tuberous rootstocks: stems wholiy herbaceous.

Foliage glabrous or nearly so.

Foliage copiously pubescent.

Corolla over $1.5 \mathrm{~cm}$. long.

B. Nutlets with membranous wings.

10. S. incana.

11. S. Altamaha.

12. S. pilosa.

13. S. glabriuscula.

14. S. integrifolia.

15. S. multiglandulosa

i6. S. brevifolia.

17. S. Floridana.

20. S. Helleri.

21. S. resinosa.

22. S. parvula.

23. S. campestris.

24. S. galericulata.

25. S. nervosa.

1. Scutellaria lateriflòra L. Perennial, glabrous, or puberulent above. Stems erect or reclining, 2-10 dm. long, more or less widely branching: leaf-blades thinnish, ovate to ovate-lanceolate, 2-6 cm. long, acute, coarsely serrate, rounded or cordate at the base : racemes axillary, $2-6 \mathrm{~cm}$. long, slender : pedicels $1-4 \mathrm{~mm}$. long: calyx 2-4 mm. long, the crest at the middle of the upper lip : corolla blue, sometimes pale, 6-7 mm. long; tube gradually enlarged, the lips about equal in size : nutlets about $1 \mathrm{~mm}$. long, papillose.

In swamps or along streams, Newfoundland to British Columbia, Florida, New Mexico and Washington. Summer and fall.

2. Scutellaria Ocmúlgee Small. Perennial, softly pubescent. Stems erect, 4-8 dm. tall, more or less branched above, densely pubescent with short close-set hairs: leaf-blades ovate to suborbicular, 3-8 $\mathrm{cm}$. long, obtuse or acutish, crenate, cordate, or the uppermost truncate : racemes panicled, $5-10 \mathrm{~cm}$. long : bracts similar to the leaves but smaller : pedicels stout, 1-3 mm. long: corolla bright blue, $2 \mathrm{~cm}$. long; tube short, gradually dilated, the lower lip broad, 6-7 mm. broad, entire, the upper lip with an entire middle lobe.

On river banks, middle Georgia. Summer.

3. Scutellaria cordifolia Muhl. Perennial, softly pubescent. Stems erect or ascending, 1-6 dm. tall, simple or branching: leaf-blades orbicular-ovate to oblong-ovate, 3-10 cm. long, obtuse or acutish, crenate or serrate-crenate, cordate : racemes or panicles manyflowered: pedicel shorter than the calyx : bract shorter than the calyx or surpassing it : calyx 4-5 mm. long, glandular-pilose, the crest about the middle : corolla bright blue, nearly $2 \mathrm{~cm}$. long; tube slender, dilated from below the middle, the upper lip with a notched middle lobe and lateral lobes broader than long, the lower lip with a conspicuously spotted middle lobe : nutlets fully $1 \mathrm{~mm}$. in diameter, tuberculate.

On moist banks, Wisconsin to Pennsylvania, Florida and Texas. Spring and summer.-A form with leaf-blades of firmer texture and larger bracts, is $S$. cordifolia bractedta (Benth.) Small. [S. versicolor var, bracteata Benth.] Texas.

4. Scutellaria argùta Buckl. Perennial, pilose. Stems erect, 3-5 dm. tall, simple or nearly so: leaf-blades thin, ovate to oblong-ovate, $2-5 \mathrm{~cm}$. long, acute or acutish, paler beneath, deeply crenate-dentate or almost incised, cordate : racemes few-flowered: pedicel becoming about as long as the calyx : bracts longer than the pedicels : caly $\times 3-3.5$ $\mathrm{mm}$. long, minutely glandular-pilose, the crest slightly below the middle: corolla blue, 15-18 cm. long; tube gradually enlarged to the slightly dilated throat, the lower lip barely retuse at the apex : nutlets $1.5 \mathrm{~mm}$. long.

On hillsides, North Carolina and Georgia. Spring and summer.

5. Scutellaria saxátilis Riddell. Perennial, glabrate or sparingly pubescent. Stems simple and erect or diffusely branched and spreading, 1-3 dm. long: leaf-blades ovate or suborbicular or ovate-lanceolate above, 1-4 cm. long, mostly obtuse, coarsely crenate or serrate-crenate, truncate to cordate at the base: racemes few-flowered : pedicel becoming as long as the calyx, or longer at maturity : calyx $2.5-3.5 \mathrm{~mm}$. long, minutely glandularpilose, the crest slightly above the middle: corolla light blue, $12-16 \mathrm{~mm}$. long; tube grad- 
ually enlarged to the dilated throat, the upper lip with a hooded middle lobe and lateral lobes as broad as long, the lower lip notched: nutlets fully $1 \mathrm{~mm}$. long, tuberculate.

In stony soil or on shaded banks, Delaware to Ohio, Georgia and Tennessee. Spring and summer.

6. Scutellaria serrata Andr. Perennial, glabrate or puberulent. Stems erect, 2-7 $\mathrm{dm}$. tall, simple or branching: leaf-blades thin, ovate, elliptic or oval, 4-10 cm. long, acute or short-acuminate at the apex, serrate or crenate-serrate, the upper more or less cuneate at the base : racemes few-flowered: pedicel slightly longer than the calyx, or shorter: calyx minutely puberulent, $4 \mathrm{~mm}$. becoming $6 \mathrm{~mm}$. long, the crest about the middle: corolla blue, $2.5 \mathrm{~cm}$. long, gradually dilated to the large throat, the upper lip with slightly notched middle lobe, the lower lip notched, undulate or crenulate : nutlets $2 \mathrm{~mm}$. long.

In woods, New York to Illinois and Alabama. Spring.

7. Scutellaria montàna Chapm. Perennial, softly pubescent. Stems erect, $3-5 \mathrm{dm}$. tall, simple or nearly so: leaf-blades ovate to ovate-lanceolate or oblong, 2-8 cm. long, acute or acutish, coarsely crenate-serrate, more or less cuneate at the sometimes almost hastate base, short-petioled : racemes few-flowered, $3-15 \mathrm{~cm}$. long : pedicel shorter than the calyx, spreading : calyx $3 \mathrm{~mm}$. becoming $8 \mathrm{~mm}$. long, the crest slightly beyond the middle : corolla blue, $3-3.5 \mathrm{~cm}$. long; tube gradually enlarged, about twice as long as the lips : nutlets fully $2 \mathrm{~mm}$. in diameter, tuberculate.

In dry woods or thickets in the mountains, Georgia. Summer.

8. Scutellarla arenícola Small. Perennial, pubescent with short upcurved hairs. Stems erect or ascending, simple or branched near the base; branches $2-4 \mathrm{dm}$. long, more or less branched above : leaf-blades ovate to elliptic, $1.5-3 \mathrm{~cm}$. long, sharply or crenately serrate, the lower ones truncate at the base, the upper cuneate: racemes 2-10 cm. long: bracts with oblong-oblanceolate or oblanceolate blades : pedicels 2-7 $\mathrm{mm}$. long: corolla blue, $2-2.5 \mathrm{~cm}$. long; tube gradually dilated, the lower lip suborbicular, $1 \mathrm{~cm}$. broad slightly lobed, notched, the upper lip usually apiculate : nutlets about $1 \mathrm{~mm}$. long.

In sand, peninsular Florida. Summer.

9. Scutellaria Mellichámpii Small. Perennial, finely and closely pubescent, except the leaf-blades. Stems erect, several $\mathrm{dm}$. tall : leaf-blades ovate to oblong-oval, $3-6 \mathrm{~cm}$. long, rather blunt, crenate, cuneate or nearly truncate at the base: bracts spatulate or elliptic-spatulate : pedicels $1-3 \mathrm{~mm}$. long: calyx strigillose, becoming about $4 \mathrm{~mm}$. long: corolla bluish, fully $2 \mathrm{~cm}$. long, minutely glandular-pubescent; tube less than twice as long as the upper lip.

In sandy soil, near Bluffton, South Carolina. Summer.

10. Scutellaria incàna Muhl. Perennial, finely pubescent. Stems erect, $5-12 \mathrm{dm}$. tall, usually branching above : leaf-blades 4-12 $\mathrm{cm}$. long, acute, serrate or crenate-serrate, truncate or cordate at the base, or the upper ones acuminate at the base: racemes often branching, many-flowered : pedicel shorter than the calyx, erect or ascending: calyx 3-5 $\mathrm{mm}$. long, glandular, the crest about middle : corolla blue, $15-18 \mathrm{~mm}$. Iong; tube gradually dilated from near the base, the upper lip with a retuse middle lobe and ovate lateral lobes, the lower lip undulate, sometimes notched: nutlets $1 \mathrm{~mm}$. in diameter, strongly tuberculate. [S. canescens Nutt. ]

In woods and copses, Ontario to Illinois, Georgia and Alabama. Summer.

11. Scutellaria Altamàha Small. Perennial, hirsute-canescent. Stems erect or assurgent, 2-4 dm. tall, obtusely 4-angled, simple, strict, purplish : leaf-blades ovate or elliptic, $1.5-5 \mathrm{~cm}$. long, obtuse or acutish, serrate, densely punctate, sessile or nearly so, with prominent lateral nerves: racemes rather crowded at the end of the stem : calyx campanulate, 2-5 mm. long, faintly ribbed, glandular-punctate, with both lips of about the same size : corolla pale blue, 1-1.3 cm. long, contracted and curved near the base, glandular-punctate and glandular-pilose, the lower lip suborbicular, notched at the side, the upper lip much larger than the lower, nearly truncate at the apex.

In pine lands, Georgia and Florida. Spring and summer.?

12. Scutellaria pilòsa Michx. Perennial, softly pilose or somewhat hirsute. Stems erect, 1-9 dm. tall, nearly simple or branching above : leaf-blades ovate or oval to deltoiddate, entire : racemes or panicles rather many-flowered : pedicel as long as the calyx, or shorter : calyx $3 \mathrm{~mm}$. becoming $4 \mathrm{~mm}$. long, glandular-pilose, the crest about the middle of the upper lip : corolla blue, sometimes pale, about $1.5 \mathrm{~mm}$. long, minutely pubescent ; 
tube gradually dilated from near the base, the lower lip deltoid-reniform, crisped, notched at the apex, the upper lip surpassing the lower, notched: nutlets over $1 \mathrm{~mm}$. in diameter, tuberculate.

In open woods and thickets, New York to Michigan, Florida and Texas. Spring and summer-The larger, very hirsute form of the eastern campestrian region is S. pilosa hirsuta (Short) A. Gray.

13. Scutellaria glabriúscula Fernald. Perennial, puberulent, slender. Stems mainly erect, 3-6 dm. tall, corymbosely branched above, or simple : leaf-blades linear to linear-spatulate or oblong to oblong-ovate near the base of the stem, 1-4 cm. long, obtuse or acutish, entire or undulate above the lower pair or two, gradually or abruptly narrowed into slender petioles : pedicel as long as the calyx, or barely as long at maturity, surpassed by the bract : calyx $2.5 \mathrm{~mm}$. becoming $5 \mathrm{~mm}$. long, the crest about the middle of the upper lip: corolla blue, fully $2 \mathrm{~mm}$. long, glabrous, the lower lip flat, notched, the upper lip shallowly notched at the apex : anthers bearded: nutlets about $1 \mathrm{~mm}$. in diameter.

In sandy soil, Florida. Spring to fall.

14. Scutellaria integrifòlia L. Perennial, softly or finely pubescent, glandular above. Stems erect, $2-6 \mathrm{dm}$. tall, nearly simple or branching above : leaf-blades various, the lower ones ovate to oblong-ovate, 1-3 cm. long, coarsely toothed, the upper oblong, oblong-lanceolate to linear, $1-5 \mathrm{~cm}$. long, entire, all petioled : racemes or panicles usually many-flowered; pedicel shorter than the calyx, 3-4 mm. long, surpassed by the bract, the crest about the middle, accrescent: corolla blue, $2-2.3 \mathrm{~cm}$. long, more or less densely pubescent ; tube rather abruptly dilated about the middle, the lower lip notched : anthers ciliate : nutlets barely $1 \mathrm{~mm}$. in diameter, tuberculate.

In dry soil, thickets or open woods, Rhode Island to Florida, Ohio and Texas. Spring and summer.

15. Scutellaria multiglandulòsa (Kearney) Small. Perennial, glandular-pubescent. Stems erect, 1-3 dm. tall, simple or sparingly branched: leaf-blades various, the lower ones oval or oblong, 1-2 cm. long, often coarsely crenate, manifestly petioled, the upper oblong to nearly linear, $1-4 \mathrm{~cm}$. long, obtuse, entire, acuminate at base, not much reduced above, sessile or short-petioled : racemes few-flowered : pedicel longer than the calyx, spreading : calyx 2-4 mm. long, the crest slightly above the middle: corolla blue or white, $2 \mathrm{~cm}$. long; tube widely dilated, the lower lip equalling or surpassing the upper : anthers barely ciliate : nutlets fully $1 \mathrm{~mm}$. long. [S. integrifolia multiglandulosa Kearney.]

In pine lands and dry fields, Georgia and Florida. Spring.

16. Scutellaria brevifolia A. Gray. Perennial, cinereous-puberulent. Stems erect, 1-2 dm. tall, often branching at the base or near it : leaf-blades oblong to oblong-lanceolate, 1-1.5 cm. long, obtuse or acutish, entire, sessile or short-petioled, little reduced above : racemes leafy-bracted, few-flowered: pedicel shorter than the calyx, surpassed by the bract : calyx 2-3 mm. long, closely pubescent, the crest thick, beyond the middle : corolla blue, pubescent with recurved hairs; tube dilated into a wide throat, the lower lip large, drooping, notched, undulate : anthers barely ciliate : nutlets about $1 \mathrm{~mm}$. long, granular.

On rocky banks, Texas. Spring and summer.

17. Scutellaria Floridàna Chapm. Perennial, puberulent. Stems erect, simple or nearly so, 2-4 dm. tall, sometimes slightly flexuous above : leaf-blades narrowly linear, $1-2.5 \mathrm{~cm}$. long, rather blunt, entire, revolute, sessile, scale-like at the base of the stem : racemes few-flowered : pedicel usually longer than the calyx, surpassed by the bract : calyx 4-8 min. long, densely punctate, the crest above the middle : corolla blue, $2.5 \mathrm{~cm}$. long; tube much dilated at throat; lips about as long as the tube, nearly equal in length, the lower one drooping : anthers long-bearded : nutlets about $1.5 \mathrm{~mm}$. long.

In pine-land swamps, Florida. Summer.

18. Scutellaria carđiophýlla Engelm. \& Gray. Annual, puberulent. Stems erect or ascending, 3-9 dm. long, more or less branched : leaf-blades ovate to triangular-ovate or deltoid-ovate, 1-3 cm. long, acutish, coarsely crenate-serrate, truncate or cordate at base : racemes leafy-bracted : pedicel shorter than the calyx, much surpassed by the bract: calyx $4 \mathrm{~mm}$. long, becoming $5 \mathrm{~mm}$. long, the crest beyond the middle, often purplish : corolla blue, 7-9 mm. long, the upper lip much smaller than the lower one: nutlets about $1 \mathrm{~mm}$. long, granular.

On prairies and in open woods, Arkansas and Texas. Spring.

19. Scutellaria Drummóndii Benth. Annual or biennial, hirsute or villous-hirsute. Stems erect, or more or less diffusely branched at the base, $0.5-2 \mathrm{dm}$. long, the branches decumbent or ascending : leaf-blades ovate-oblong or oval, 1-1.5 cm. long, obtuse, entire or crenate-undulate, cuneate or abruptly narrowed at the base : racemes leafy-bracted : pedicel shorter than the calyx, erect or ascending : caly $2-4 \mathrm{~mm}$. long, becoming $6 \mathrm{~mm}$. long, the crest beyond the middle: corolla blue or purple, pilose, 10-12 mm. long, the 
lower lip $5 \mathrm{~mm}$. broad, 4-lobed, notched, the upper lip much smaller than lower, the lateral lobes about as long as middle one : anthers barely ciliate: nutlets $1 \mathrm{~mm}$. broad, granular. On prairies. Kansas to Texas. Spring.

20. Scutellaria Hélleri Small. Perennial, villous-hirsute. Stem usually branched at the base, the branches $0.5-3 \mathrm{dm}$. tall, commonly branched above : leaf-blades ovate, sometimes narrowly so, 1-2 $\mathrm{cm}$. long, shallowly toothed or undulate, those of the lower leaves petioled: pedicel shorter than the calyx : calyx becoming 4-5 $\mathrm{mm}$. long, finely hirsute : corolla minutely pubescent, about $1 \mathrm{~cm}$. long: nutlets over $1 \mathrm{~mm}$. thick.

On rocky or calcareous prairies, Texas and adjacent Mexico. Spring.

21. Scutellaria resinòsa Torr. Perennial, more or less cinereous-puberulent and resinous-dotted. Stems diffusely branched at the base, the branches erect or spreading, 1-3 dm. long : leaf-blades ovate oval elliptic to oblong-spatulate, $1-1.5 \mathrm{~cm}$. long, obtuse, entire, gradually or abruptly narrowed at the base, the lower ones short-petioled, the upper sessile or nearly so : pedicel as long as the calyx or shorter : calyx $3-5 \mathrm{~mm}$. long, merely resinous, the erest near the apex of upper lip : corolla blue or purplish, minutely pilose, $1 \mathrm{~cm}$. long, the upper lip with lateral lobes as long as the middle one, the lower lip with a yellow or a white blotch in the center, the terminal one notched: anthers glabrous or nearly 8o: nutlets less than $1 \mathrm{~mm}$. broad, granular.

On prairies or hillsides, Kansas to Texas. Spring.

22. Scutellaria párvula Michx. Perennial, glabrate or minutely pubescent, the rootstocks producing chains of small tubers. Stems erect, simple or diffusely branched, $0.5-3 \mathrm{dm}$. tall : leaf-blades broadly ovate to lanceolate, 1-2 cm. long, obtuse or acutish, or often prominently nerved beneath, commonly revolute, truncate or subcordate at the base, closely sessile: pedicel as long as the calyx, or shorter : calyx puberulent, $2-4 \mathrm{~mm}$. long, the crest near the middle of the upper lip : corolla blue, 4-8 $\mathrm{mm}$. long, minutely pilose, the lower lip suborbicular, about $3 \mathrm{~mm}$. broad, emarginate, the upper lip shorter than the lower, 3-lobed : nutlets about $1 \mathrm{~mm}$. in diameter, papillose.

In dry sandy or clay soil, Quebec to Minnesota, Florida and Texas. Spring and summer.

23. Scutellaria campéstris Britton. Perennial, densely soft-pubescent and somewhat viscid. Stems simple and erect or diffusely branched, the branches ascending or spreading, $0.5-2 \mathrm{~cm}$. long: leaf-blades ovate, suborbicular or reniform at the base of the stem or ovate-lanceolate at the top, obtuse, entire or shallowly toothed, prominently nerved beneath, the lower ones short-petioled, the upper sessile : pedicel as long as the calyx, or shorter: calyx 2-4 mm. long, minutely glandular-pilose, the crest about the middle: corolla blue, 6-7 mm. long, the lower lip 4-lobed, the upper lip 3-lobed, the lobes nearly equal : anthers nearly glabrous : nutlets $1 \mathrm{~mm}$. in diameter, tuberculate.

In sandy soil, North Carolina to Iowa and the Indian Territory. Spring and early summer.

24. Scutellaria galericulàta $L$. Perennial, glabrate or finely pubescent. Stems erect or reclining, 2-9 dm. long, simple or much branched : leaf-blades membranous, oblong or oblong-lanceolate, acute, shallowly serrate, truncate or cordate at the base, the lower ones short-petioled, the upper sessile : pedicel shorter than calyx : calyx $3.5-5 \mathrm{~mm}$. long, minutely pubescent, the crest below the middle : corolla blue or white, 15-18 mm. long, the lower lip broadly reniform, undulate, the upper lip shorter than the lower, 3lobed, the middle lobe notched : anthers short-ciliate : nutlets fully $2 \mathrm{~mm}$. long, tuberculate.

In low grounds or swamps, Newfoundland to Alaska, New Jersey, North Carolina, Nebraska, Arizona and Washington. Also in Europe and Asia. Summer and fall.

25. Scutellaria nervòsa Pursh. Perennial, minutely pubescent. Stems erect, 1-4 $\mathrm{dm}$. tall, simple or sparingly branched: leaf-blades suborbicular to oval or lanceolate above, undulate or coarsely serrate, rounded or cordate at the base, the lower ones short-petioled, the upper sessile : flowers axillary to bracts somewhat narrower than the leaves: pedicels 2-4 mm. long : calyx becoming 5 or $6 \mathrm{~mm}$. long : corolla blue or purplish, 8-10 mm. long, minutely pubescent : nutlets raised on a slender gynobase, each with a membranous wing.

In woods and thickets, New York to Missouri, and North Carolina. Spring and summer.

\section{MARRÙBIUM L.}

Perennial caulescent herbs, with woolly foliage. Leaves opposite: blades toothed, often rugose. Flowers in dense axillary clusters. Calyx tubular: tube 5-10-ribbed : lobes 10, equal or alternately long and short, slender, spreading or recurved at maturity. Corolla white or purplish, 2-lipped : upper lip erect, entire or notched : lower lip spreading with 2 small lateral lobes and a broad middle lobe. Stamens 4, included: filaments slender, anterior pair longer : anthers 2-celled : sacs divergent. Nutlets smooth or granular. 
1. Marrubium vulgàre L. Stems white-woolly, branched at the base and often throughout, $2-9 \mathrm{dm}$. tall, usually strict: leaf-blades suborbicular, oval or ovate, $1-4 \mathrm{~cm}$. long, crenate, strongly rugose, broadly or narrowly cuneate at the base : flower-clusters 1-2 cm. in diameter, not contiguous : bracts subulate, with hooked ends : calyx 4-5 mm. long; tube cylindric-prismatic, 10-ribbed; lobes 10, shorter than the tube, rigid, hooked : corolla white, $5-6 \mathrm{~mm}$. long, puberulent, the lips shorter than the tube : nutlets $2 \mathrm{~mm}$. long, granular.

In waste places and on roadsides, Maine, Ontario and British Columbia, Florida, Texas and Mexico. Naturalized from Europe. Spring and summer.

\section{AGASTÁCHE Clayt.}

Perennial herbs, with tall stems. Leaves opposite: blades broad, toothed, petioled. Flowers in dense terminal continuous or interrupted panicles. Calyx narrowly campanulate or nearly tubular, often slightly 2-lipped : lobes about equal, or the upper one slightly larger. Corolla yellowish, purplish or blue, 2-lipped: upper lip erect, notched : lower lip with 2 lateral lobes and a larger often toothed or undulate middle lobe. Stamens 4, exserted : filaments all anther-bearing: anthers with almost parallel sacs. Nutlets smooth or merely granular. [Lophanthus Benth., not Adans.]

Foliage glabrous or nearly so: caly x-lobes barely acute: corolla greenish yellow. 1. A. nepetoides. Foliage finely hirsute: calyx-lobes acuminate: corolla purplish.

2. A. scrophulariaefolia.

1. Agastache nepetoìdes (L.) Kuntze. Stems glabrous or nearly so, 1-2 m. tall, branching : leaf-blades ovate or ovate-lanceolate, $5-12 \mathrm{~cm}$. long, acute or slightly acuminate, serrate or crenate-serrate, truncate or cordate at the base: panicles $0 . \overline{5}-4 \mathrm{dm}$. long, $1.5-2 \mathrm{~cm}$. thick, sometimes interrupted below, erect : calyx short-pedicelled, 5-6 mm. long; lobes ovate or oblong-ovate, barely acute, shorter than the tube : corolla greenish yellow, 7-9 $\mathrm{mm}$. long, the lower lip with a broad undulate lip : nutlets $2 \mathrm{~mm}$. long, granular and minutely pubescent.

On hillsides, Ontario to Wisconsin, Georgia and Kentucky. Summer.

2. Agastache scrophulariaefòlia (Willd.) Kuntze. Stems finely hirsute, 1-2 m. tall, branching, sharply angled : leaf-blades ovate, ovate-lanceolate or nearly elliptic above, acute or short-acuminate, coarsely serrate, rounded or subcordate at the base: panicles spike-like, $0.5-3 \mathrm{dm}$. long, 1-1.5 $\mathrm{cm}$. thick or rarely thicker: pedicel shorter than the calyx : calyx 6-7 mm. long ; lobes lanceolate, acuminate : corolla purplish, 6-8 $\mathrm{mm}$. long, the lower lip with broad middle lobe : nutlets barely $2 \mathrm{~mm}$. long, hispidulous. and fall.

On hillsides and in thickets, Connecticut to Wisconsin, North Carolina and Kentucky. Bummer

\section{MEEHANIA Britton.}

Perennial herbs, with pubescent foliage and decumbent and creeping stems. Leaves opposite : blades broad, toothed, petioled. Flowers in terminal one-sided racemes. Calyx campanulate : tube 15-ribbed : lobes 5, acute, the upper longer than the lower. Corolla blue or sometimes white, puberulent without, with a wide throat and a 2-lipped limb: upper lip arched, notched: lower lip spreading with 2 lateral lobes and a notched middle lobe. Stamens 4, included : filaments all anther-bearing: anther-sacs almost parallel. Nutlets smooth.

1. Meehania cordàta (Nutt.) Britton. Stems sparingly hirsute, creeping or ascending, 1.5-11 dm. long, commonly branching, producing leafy runners at the base : leaf-blades ovate or orbicular-ovate, $2-7 \mathrm{~cm}$. long, obtuse, crenate, cordate : racemes $5-10 \mathrm{~cm}$. long : pedicels stout, $2-5 \mathrm{~mm}$. long : bracts ovate to narrowly-elliptic: calyx puberulent, 13-14 mm. long; tube campanulate; lobes triangular, acute or slightly acuminate, $\frac{1}{2}$ as long as the tube : corolla blue or rarely white, $2.5-3 \mathrm{~cm}$. long, the lower lip 3 -lobed, the upper lip 3-lobed. [Cedronella cordata (Nutt.) Benth.]

In rich woods, Pennsylvania to North Carolina, Kentucky and Tennessee. Spring and summer.

\section{NÉPETA L.}

Annual or perennial caulescent herbs, with usually pubescent foliage. Leaves opposite : blades broad, tonthed or incised. Flowers in clustered axillary cymes, sometimes approximate or contiguous. Calyx often inflated at maturity : tube 15-ribbed, incurved: lobes 5 , the upper slightly longer than the lower. Corolla white or blue, 2-lipped: tube enlarged above : upper lip entire or notched : lower lip larger, with two lateral lobes and a larger middle lobe. Stamens 4, exserted : filaments all anther-bearing: anthers with divergent sacs. Nutlets flattened, smooth. 
1. Nepeta Catària L. Perennial, pale green. Stems erect or ascending, square, 3-9 dm. tall, puberulent with more or less recurved hairs, the branches ascending: leaf-blades ovate or triangular-ovate, softly pubescent, acute or acutish, coarsely crenate or serratecrenate, cordate: panicles narrow, $0.5-3 \mathrm{dm}$. long: calyx 5-6 $\mathrm{mm}$. long: tube inflated, ribbed ; lobes subulate or subulate-lanceolate, about $\frac{1}{2}$ as long as the tube : corolla pale ; tube abruptly dilated at the middle, its throat magenta-spotted within, the lower lip bearded: anthers garnet: nutlets oblong, about $1 \mathrm{~mm}$. long.

In various situations commonly in waste places, New Brunswick and Quebec to Minnesota, Georgia and Kansas. Naturalized from Europe. Summer and fall.

\section{GLECOMMA L.}

Perennial herbs, with diffuse often creeping stems. Leaves opposite : blades commonly as broad as long, usually crenate. Flowers in axillary clusters. Calyx tubular or nearly so : tube 15-ribbed, oblique at the throat: lobes 5, unequal. Corolla blue, violet or rarely white, 2 lipped : upper lip more or less deeply notched: lower lip spreading with 2 lateral lobes and an emarginate longer middle lobe. Stamens 4: filaments all anther-bearing: anthers with divergent sacs. Nutlets smooth.

1. Glecoma hederàcea L. Stems more or less hirsute, commonly branching at the base, the branches prostrate or decumbent, creeping, 1-11 dm. long: leaf-blades reniform or suborbicular, $2-4 \mathrm{~cm}$. in diameter, coarsely crenate, cordate : flowers few in a cluster : pedicels 1-3 mm. long: calyx 5-7 mm. long, hispidulous; tube ribbed, pubescent; lobes acuminate, subulate-tipped : corolla blue or white, $1-1.5 \mathrm{~cm}$. long; tube much longer than the calyx, the lower lip 4-lobed : nutlets about $1.5 \mathrm{~mm}$. long. [Nepeta Glechoma Benth.]

In various situations, especially common in thickets and copses, Newfoundland and Ontario to Minnesota, Georgia and Kansas. Spring.

\section{PRUNÉLLA L.}

Perennial caulescent herbs, with pubescent foliage. Leaves opposite : blades toothed, petioled. Flowers in axillary clusters, which are often collected in terminal continuous panicles. Calyx 2-lipped, closed at maturity: tube about 10-ribbed: upper lip with 3 short lobes or nearly truncate: lower lip with 2 narrow lobes. Corolla white or purple, 2lipped : tube slightly narrowed at the mouth: upper lip arched : lower lip with 2 lateral lobes and a larger middle lobe. Stamens 4 : filaments various, 2 sterile, 2 forked at the apex, one prong bearing an anther: anthers 2-celled, with divergent sacs. Nutlets smooth.

1. Prunella vulgàris $\mathrm{L}$. Stems erect or decumbent, $0.5-4 \mathrm{dm}$. long: leaf-blades oblong, ovate or lanceolate, obtuse or acute, undulate, gradually or abruptly narrowed at the base : panicles dense: bracts mostly reniform, abruptly pointed, ciliate with jointed hairs : calyx 5-8 mm. long, dilated upward, oblique at the mouth, the ribs prolonged into subulate tips, the connecting membranes undulate : corolla purple or white, $15-18 \mathrm{~mm}$. long, glabrous or slightly pubescent, the upper lip notched, the lower lip fringed: nutlets elliptic, $2 \mathrm{~mm}$. long, acute at both ends.

In all situations, throughout North America, except the extreme north. Chiefly naturalized from Europe and Asia. Spring to fall.

\section{BRAZÒRIA Engelm. \& Gray.}

Annual or perennial caulescent herbs, with more or less glandular foliage. Leaves opposite: blades rather narrow, sparingly toothed, mostly sessile and partly clasping. Flowers in terminal racemes. Calyx more or less inflated and closed at maturity: upper lip with 3 lobes: lower lip with 2 short lobes. Corolla pink or bluish, somewhat variegated : tube somewhat dilated: upper lip erect, arched, entire or notched: lower lip spreading, with 3 rounded lobes. Stamens 4 : flaments all anther-bearing: anthers 2celled ; sacs parallel or nearly so. Nutlets 3-angled, glabrous or pubescent.

Calyx with equal lips, the lips obscurely lobed: corolla-lobes denticulate. $\quad$ 1. B. truncata. Calyx with unequal lips, the lips strongly toothed : corolla-lobes not toothed.

2. B. scutellarioides.

1. Brazoria truncàta (Benth.) Engelm. \& Gray. Annual, pubescent. Stems erect, 1-3 dm. tall, often branching at the base, stout : leaf-blades spatulate to oblong, 4-10 cm. long, acutish, dentate above the middle, sessile and often partly clasping : racemes becoming stout, continuous, $3-12 \mathrm{~cm}$. long: calyx $5 \mathrm{~mm}$. becoming $8-9 \mathrm{~mm}$. Iong; tube with a dense viscid-villous beard, the upper lip of 3 broad truncate-apiculate lobes, the lower lip broader than long, dentate and notched: corolla slightly puberulent along the back, $1.5-2$ cm. long, the lips crisped and undulate, the upper lip with 2 oblong lobes, the lower with 3 In sandy soil, Texas. Summer. 
2. Brazoria scutellarioìdes (Hook.) Engelm. \& Gray. Perennial, glabrous below the inflorescence. Stems erect, about $3 \mathrm{dm}$. tall, paniculately branched : leaf-blades oblong or oblong-lanceolate, or oblong-spatulate, acute, serrate above the middle, sessile and partly clasping at the base : racemes densely glandular-puberulent, $3-15 \mathrm{~cm}$. long, interrupted below : bracts ovate, $3-4 \mathrm{~mm}$. long, acuminate : calyx $3-4 \mathrm{~mm}$. becoming $5 \mathrm{~mm}$. long, glandular-puberulent : tube turbinate-campanulate, abruptly contracted at the base, the upper lip with ovate-reniform acuminate lobes, about as long as the tube, the lower lip with ovate acuminate teeth : corolla about $1 \mathrm{~cm}$. long; tube abruptly dilated at the middle, the upper lip suborbicular, rather broader than long, the lower lip with 3 broad lobes, the middle one retuse : nutlets a little more than $1 \mathrm{~mm}$. thick, rather granular, glabrous.

On rich prairies, Texas. Spring.

\section{MACBRIDEA Ell.}

Perennial herbs, with glabrous or sparingly puberulent foliage and simple or rarely branched stems. Leaves opposite : blades thickish, entire or repand-toothed. Flowers in axillary clusters, which are often approximate and form contracted panicles. Calyx membranous: tube campanulate : lobes 3 , the 2 lower broad. Corolla white, pink or purple : tube dilated above : upper lip arching, entire or notched: lower lip with rounded lobes, the middle one largest. Stamens 4 : filaments all anther-bearing: anthers pubescent; sacs divergent; nutlets smooth or nearly so.

Corolla white, the upper lip notched.

Corolla rose-purple, streaked with purple and white, the upper lip entire.

1. M. alba.

2. M. pulchra.

1. Macbridea álba Chapm. Stems erect, 3-5 dm. tall, simple or rarely branched: leaf-blades cuneate-spatulate or oblong, rather fleshy, 2-8 cm. long, obtuse, undulate or repand, the lower ones with margined petioles, the upper sessile : panicles few flowered : bracts oblong-ovate or orbicular, obtuse : pedicels very short: calyx becoming $1 \mathrm{~cm}$. long, glabrous or nearly so; lobes about as long as the tube, the larger ones slightly notched: corolla white, $2.5-3 \mathrm{~cm}$. long, the upper lip hooded, nearly erect, the lower lip spreading, the lobes emarginate or nearly truncate.

In pine-land swamps, Florida. Summer.

2. Macbridea púlchra Ell. Stems erect, 3-6 dm. tall, usually simple : leaf-blades elliptic, oblong or linear-elliptic, 4-8 cm. long, acute or acuminate at both ends, undulate or repand-serrate, the lower slender-petioled, the upper sessile: panicles few-flowered: bracts ovate or oblong, mostly obtuse : pedicels very short: calyx becoming $1 \mathrm{~cm}$. long ; lobes shorter than the tube, entire or the larger ones oblique or emarginate: corolla rosepurple striped with white and purple, $3-3.5 \mathrm{~cm}$. long; tube abruptly dilated near the middle, the upper lip suborbicular, $1 \mathrm{~cm}$. in diameter, the lower lip with a notched middle lobe and truncate lateral lobes.

In swamps, North Carolina to Florida and Alabama. Summer and fall.

\section{PHYSOSTÈgIA L.}

Perennial herbs, with glabrous or puberulent foliage and simple or sparingly branched stems. Leaves opposite: blades rather narrow, usually toothed above an entire base. Flowers in terminal spike-like racemes. Calyx campanulate, more or less inflated and open at maturity : tube 5-ribbed : lobes 5, equal. Corolla white, pink, violet or purple, showy, 2-lipped : tube dilated upward : upper lip entire : lower lip 3-lobed, the middle lobe often emarginate. Stamens 4 : filaments all anther-bearing: anthers 2-celled; sacs parallel or nearly so. Nutlets somewhat 3 -angled, smooth.

Corolla less than $2 \mathrm{~cm}$. long.

Mature calyx campanulate, $5 \mathrm{~mm}$. long, or shorter: stems naked or sparingly leafy above: Texan species.

Mature calyx tubular, $8-9 \mathrm{~mm}$. long : stems copiously leafy to the inflorescence : Georgian species.

Corolla over $2 \mathrm{~cm}$. long.

Leaf-blades entire or with blunt teeth.

Racemes loosely and relatively few-flowered, interrupted at maturity. Mature calyx campanulate, $5-6.5 \mathrm{~mm}$. long : upper leaves but slightly reduced.

Mature calyx tubular, 9-11 mm. long : upper leaves conspicuously reduced. Racemes closely many-flowered, continuous.

Leaf-blades copiously toothed with very acute serrations.

3. P. leptophylla.

4. $P$. denticulata.

5. P. Digitalis.

6. $P$. Virginiana.

1. Physostegia intermédia (Nutt.) A. Gray. Stems erect or ascending, 3-9 dm. long, simple or rarely branched : leaves few ; blades linear to linear-lanceolate, $2-6 \mathrm{~cm}$. long, acute or acuminate, nearly entire or repand-denticulate, sessile: racemes spike-like : 
pedicels very short: bracts ovate to reniform-ovate, acuminate: calyx 4-5 mm. long, puberulent; tube campanulate; lobes triangular, acute, barely as long as tube : corolla puberulent, 10-12 mm. long; tube much dilated upward, the upper lip nearly erect, undulate, the lower lip spreading, the middle lobe about twice as long as the lateral ones: nutlets $2 \mathrm{~mm}$. long, sharply angled.

In low barrens, Kentucky to Arkansas, Louisiana and Texas. Spring.

2. Physostegia veronicifórmis Small. Stems erect, 5-7 dm. tall, relatively stout, simple, leafy to the inflorescence or near it: leaves several; blades various, the lower lanceolate to oblong-lanceolate, $5-8 \mathrm{~cm}$. long, narrowed into stout petiole-like bases, the upper blades sessile, narrowly fiddle-shaped or lanceolate, mostly longer than the lower, sessile, all undulate or crenate-undulate, acute : racemes simple, few-flowered : calyx becoming 8-9 mm. long: tube tubular; lobes triangular or lanceolate-triangular, acute : corolla about $1.5 \mathrm{~cm}$. long.

In low grounds, Georgia. Summer.

3. Physostegia leptophýlla Small. Stems erect or ascending, 6-10 dm. Iong, simple, regularly leafy to near the raceme, rather slender : leaves few ; blades thin, oblong or some slightly broadest above or below the middle, obtuse or acute above, repand, narrowed into margined petiole-like bases : racemes 1-3 dm. long, slender, remotely flowered : pedicels $1-3 \mathrm{~mm}$. long, often as long as the bracts at maturity : calyx $5-6.5 \mathrm{~mm}$. long; tube turbinate or campanulate in age, accrescent, somewhat inflated at maturity, faintly ribbed, much longer than the pedicel ; lobes triangular to lanceolate, acute or acuminate, about $\frac{1}{3}$ as long as the tube : corolla blue, about $2 \mathrm{~cm}$. long; tube rather abruptly dilated just beyond the calyx, especially dilated beneath the lips, about one-third as long as the tube: nutlets suborbicular, 3-3.5 mm. long, with sharp edges.

On river shores, peninsular Florida. Spring to fall.

4. Physostegia denticulàta (Ait.) Britton. Stems slender, erect or ascending, 3-9 dm. tall, sometimes branched: leaves few ; blades spatulate to ollong, repand-crenate, obtuse, the lower ones with petiole-like bases, the upper sessile: racemes spike-like, 3-15 cm. long, interrupted, puberulent: bracts ovate or elliptic-ovate, acuminate: calyx 9-11 $\mathrm{cm}$. long; tube nearly cylindric; lobes triangular, acute or slightly acuminate, about $\frac{1}{4}$ as long as the tube: corolla bright pink, $2-2.5 \mathrm{~cm}$. long, the lower lip broader than long, entire, the upper lip with a notched terminal lobe : nutlets $2 \mathrm{~mm}$. long, the angles margined.

In swamps, Virginia to Florida and Texas. Summer and fall.

5. Physostegia Digitàlis Small. Stems erect, 7-12 dm. long, stout, sharply angled : leaves several; blades oblong to elliptic-oblong, 10-22 cm. long, acute or acutish, undulate or repand-serrate above the middle, sessile and partly clasping at the base: racemes simple or compound, finely pubescent : bracts lanceolate or ovate-lanceolate, 4-6 mm. long: pedicels very short: calyx 8-10 mm. long; tube turbinate or cylindric-turbinate ; lobes lanceolate, acuminate, about $\frac{1}{2}$ as long as the tube : corolla barely puberulent along the back, $2-2.5 \mathrm{~cm}$. long, the lower lip spreading, the lobes oblong, its middle one emarginate, about twice as large as the others, the upper lip slightly undulate.

In low grounds, Missouri and Arkansas to Louisiana and Texas. Summer and fall.

6. Physostegia Virginiàna (L.) Benth. Stems erect or trailing, 3-15 dm. long, simple or sparingly branched : leaves several or many; blades narrowly or linear-oblong or oblong-lanceolate near top of stem, acute, serrate or incised-serrate, at least above the middle, narrowed at the base, sessile : racemes spike-like, simple or compound : pedicel much shorter than the calyx : bracts lanceolate or ovate-lanceolate: calyx glabrous or nearly so, 6-8 mm. long; tube cylindric; lobes lanceolate or ovate-lanceolate, acute or somewhat acuminate, more or less spreading, $\frac{1}{3}$ as long as the tube : corolla bright pink, $2.5-3 \mathrm{~cm}$. long, the lower lip irregularly denticulate, the upper lip with 3 lobes notched and apiculate in each notch: nutlets $3 \mathrm{~mm}$. long, sharply angled.

In swamps and low grounds, Quebec to the Northwest Territory, Florida and Texas. Summer.

\section{SYNÁNDRA Nutt.}

Annual or biennial caulescent herbs, with pubescent foliage. Leaves opposite : blades broad, toothed, petioled. Flowers in terminal interrupted racemes, often disposed in panicles. Calyx campanulate : tube somewhat inflated at maturity: lobes 4, narrow, the lower longer than the upper. Corolla white, 2-lipped: tube dilated above : upper lip arched, entire : lower lip spreading with 2 lateral lobes and a larger middle lobe. Stamens 4 : filaments all anther-bearing, pubescent, but the upper pair contiguous and their anthers connate, sterile : anthers glabrous ; sacs divergent. Nutlets angled, smooth. 
1. Synandra hispídula (Michx.) Britton. Stems softly hispid or somewhat villous, erect or decumbent, 2-8 dm. long, simple or branching, fleshy : leaf-blades ovate or orbicular-ovate, 2-10 cm. long, obtuse or acute, or somewhat acuminate, crenate or serrate above, cordate: panicles few-flowered, elongating, with sessile or clasping bracts : pedicels stout : calyx becoming $1 \mathrm{~cm}$. long at maturity; tube constricted at the base, campanulate ; lobes lanceolate, curved, slightly crisped : corolla white, $2.5-3 \mathrm{~cm}$. long, minutely pubescent, the upper lip oval or obovate, undulate, the lower lip with the middle lobe irregularly toothed : filaments villous : nutlets $4 \mathrm{~mm}$. long. [ $S$. grandiflora Nutt.]

In wet woods and along streams, Ohio and Illinois to Virginia and Tennessee. Spring.

\section{GALEÓPSis L.}

Annual caulescent herbs, with often bristly pubescent foliage. Leaves opposite : blades flat, toothed, often petioled. Flowers in crowded cymes. Caly $\mathbf{x}$ campanulate to tubular-campanulate: tube 5-10-ribbed: lobes 5, nearly equal, spine-tipped. Corolla yellow, red or purple, sometimes mottled, 2-lipped : upper lip erect, concave : lower lip spreading, 3-lobed, the middle lobe emarginate or notched. Stamens 4: filaments all anther-bearing: anthers 2-celled; sacs opening transversely, the inner ciliate, the outer glabrous. Nutlets smooth.

1. Galeopsis Tetràhit L. Stems more or less hirsute, $2-5 \mathrm{dm}$. tall, usually branched : leaf-blades ovate to ovate-lanceolate or oblong-lanceolate, $2.5-7 \mathrm{~cm}$. long, shallowly serrate, acute or short-acuminate, more pubescent on the upper surface than on the lower, slenderpetioled : flower-clusters bristly pubescent : calyx 7-10 $\mathrm{mm}$. long; tube delicate ; lobes spinescent, bristly pubescent about the base : corolla pink-purple, $1-1.5 \mathrm{~cm}$. iong : nutlets about $3 \mathrm{~mm}$. long.

In waste places, New foundland to Alaska and North Carolina. Native of Europe. Summer and fall.

\section{LÀMIUUM L.}

Annual or perennial herbs, with diffusely branching stems. Leaves opposite : blades flat, toothed or incised, usually petioled. Flowers in axillary more or less remote clusters. Calyx campanulate to tubular-campanulate: tube usually 5 -nerved : lobes 5 , equal or the upper longer. Corolla white or blue, 2-lipped : upper lip erect, concave, usually entire : lower lip spreading with 3 lobes, the lateral lobes narrow, the middle one dilated, often notched. Stamens 4 : filaments all anther-bearing: anthers 2-celled; sacs divergent, often pubescent. Nutlets smooth or tuberculate.

Upper leaf-blades sessile, clasping, uniformly green : corolla about $1.5 \mathrm{~cm}$. long. All leaf-blades petioled, blotched in the center: corolla $2-2.5 \mathrm{~cm}$. long.

1. L. amplexicaule.

2. L. maculatum.

1. Lamium amplexicaùle L. Biennial, sparingly pubescent. Stems usually branching at the base, the branches 1-4 cm. long, erect or decumbent : leaf-blades suborbicular to orbicular-reniform, $1-3 \mathrm{~cm}$. broad, crenate-lobed, truncate or cordate: bracts subtending the flower-clusters, sessile, clasping: calyx villous-hirsute, becoming 5-6 mm. long; lobes lanceolate, somewhat shorter than the tube: corolla blue, $1.5 \mathrm{~cm}$. long; tube slender, dilated into a pocket near the upper end, the lower lip cleft by V-shaped sinus, the upper lip pilose on top: nutlets $2 \mathrm{~mm}$. long.

In waste and cultivated grounds, New Brunswick to Ontario, Minnesota, Florida and Arkansas. Naturalized from Europe. Winter to fall.

2. Lamium maculàtum L. Perennial, slightly pubescent. Stem and branches decumbent or ascending, $2-4.5 \mathrm{dm}$. long : leaf-blades ovate or triangular-ovate, $2-6 \mathrm{~cm}$. long, crenate or incised-crenate, blotched near the midrib, truncate or cordate at the base, slender-petioled : cymes few-flowered : calyx pubescent; lobes lanceolate-subulate, as long as the tube or slightly longer : corolla red-purple, $2-2.5 \mathrm{~cm}$. long; tube with a constriction and ring of hairs within near the base.

In waste places and along roadsides, Maine to North Carolina and Tennessee. Native of Europe and Asia. Spring to fall.

\section{LEONÙRUS L.}

Annual, biennial, or perennial caulescent herbs. Leaves opposite : blades flat, toothed or palmately cleft or parted. Flowers in dense axillary clusters. Calyx tubular-campanulate: tube 5-ribbed, not oblique : lobes 5, about equal, subulate or awn-tipped. Corolla white or pink, 2-lipped : tube included or slightly exserted : upper lip erect, nearly flat or concave: lower lip spreading or reflexed, 3-lobed, the middle lobe broad truncate to 
notched. Stamens 4 : filaments all anther-bearing : anthers 2-celled; sacs mostly parallel. Nutlets 3-angled, smooth.

Leaf-blades coarsely crenate-serrate : upper lip of the corolla scarcely longer than the lower. puberulent.

1. L. Marrubiastrum.

Leaf-blades 2-5-cleft : upper lip of the corolla much longer than the lower, villous. 2. L. Cardiaca.

1. Leonurus Marrubiástrum L. Biennial, puberulent or pubescent. Stems 5-15 dm. tall, more or less branched : leaf-blades ovate to oblong-ovate, $2.5-7.5 \mathrm{~cm}$. long, crenate or incised-crenate, cuneately narrowed at the base, petioled : cymes dense, often numerous : calyx puberulent or glabrate; lobes subulate-setaceous, shorter than the tube: corolla white or nearly so, 7-8 mm. long; tube glabrous within.

In waste places, New Jersey and Pennsylvania to Florida. Summer and fall.

2. Leonurus Cardiaca L. Perennial, more or less pubescent. Stems erect, 3-10 dm. tall, simple or branching above : leaf-blades $2-10 \mathrm{~cm}$. long, palmately cleft or incised or 3-cleft on the upper part of stem, the lobes acute, entire or sharply toothed or crenate : clusters few-flowered, sessile: calyx rigid, becoming about $5 \mathrm{~mm}$. long, angled: lobes spine-like, 3 ascending, 2 erect-spreading: corolla pale purple or white, villous without, 9-10 mm. long; tube swollen in middle, the upper lip as long as the tube, the lower lip reflexed : nutlets $2 \mathrm{~mm}$. long, pubescent on top.

In waste places and along roadsides, Nova Scotia to Minnesota, North Carolina and Nebraska. Naturalized from Europe. Spring to fall.

\section{LEONÒTIS L.}

Annual or perennial caulescent herbs or shrubby plants. Leaves opposite: blades broad, toothed, petioled. Flowers in dense whorls. Calyx short-pedicelled: tube 10nerved, oblique at the mouth : lobes $8-10$, unequal, bristle-tipped. Corolla yellow, orange or scarlet, 2-lipped : tube dilated above, curved: upper lip erect, rather long: lower lip with 3 lobes, the middle lobe scarcely longer than the lateral. Stamens 4: filaments all anther-bearing: anthers 2-celled; sacs diverging. Nutlets 3-angled, smooth.

1. Leonotis nepetaefolia R. Br. Annual, softly pubescent. Stems $3-20 \mathrm{dm}$. tall, simple or branched : leaf-blades ovate or ovate-deltoid, \&-12 cm. long, coarsely crenate, cuneate or subcordate at the base: clusters dense, 4-6 cm. in diameter: pedicels 1-2 mm. long: calyx puberulent, becoming at least $2 \mathrm{~cm}$. long; tube reticulated above the middle ; lobes 8 , awn-tipped : corolla scarlet or orange-yellow, $2-2.5 \mathrm{~cm}$. long, villous-hirsute ; tube curved, the upper lip as long as the tube, the lower lip much shorter than the upper, with 3 narrow lobes: nutlets $3 \mathrm{~mm}$. long, sharply angled.

In waste places, Tennessee to Florida and Louisiana. Also in the tropics. Summer and fall.

\section{STÀCHYS L.}

Annual or perennial caulescent herbs, with glabrous or variously pubescent foliage. Leaves opposite : blades entire or toothed, commonly petioled. Flowers in axillary clusters, the upper ones sometimes approximate or contiguous. Calyx mostly campanulate: tube 5-10-ribbed :.lobes 5, equal or nearly so. Corolla purple or white or rarely red or yellow, 2-lipped : upper lip erect, entire or notched : lower lip spreading, with 3 lobes, the middle lobe largest, entire or 2-lobed. Stamens $4:$ filaments all anther-bearing: anthers 2-celled; sacs mostly diverging. Nutlets blunt at the apex.

Plants with annual or biennial roots.

Lower lip of the corolla slightly surpassing the calyx : mature calyx $3-4 \mathrm{~mm}$. long.

Lower lip of the corolla much surpassing the calyx : mature calyx $5-6 \mathrm{~mm}$. long. 2 . S. Drummondii.

1. S. agraria. Plants with perennial roots.

Leaf-blades narrowed at the base.

Leaf-blades glabrous, entire or with shallow teeth: calyx-lobes glabrous at maturity.

Calyx-lobes subulate-tipped : leaf-blades entire or nearly so.

Calyx-lobes not subulate-tipped: leaf-blades markedly but shallowly toothed.

Leaf-hlades pubescent, prominently serrate: calyx-lobes ciliate.

Leaf-blades, all or some of them, kordate or truncate at the base.

A. Petioles less than $1 / 4$ as long as the blades.

Lower leaves with petioles but little longer than those of the upper. Foliage copiously pubescent: corolla-tube slightly longer than the calyx.

Lower leaves with petioles several times longer than those of the upper.

a. Calyx-lobes merely acute or acuminate, not awn-tipped.

* Foliage of the inflorescence glabrous or bristly-pubescent. Inflorescence glabrous or nearly so.

Inflorescence bristly-pubescent.

3. S. hyssopifolia.

4. S. lythroides.

5. S. ambigua.
6. S. Nuttallit.

7. S. latidens.

8. S. tenuifolia.

9. S. aspera. 
** Foliage of the inflorescence puberulent or puberulent-pubescent. b. Calyx-lobes awn-tipped.

B. Petioles fully $1 / 3$ or usually $1 / 2$ as long as the blades.

Leaf-blades acuminate, $6-15 \mathrm{~cm}$. long: species Alleghenian.

Leaf-blades obtuse or merely acute, $1-4 \mathrm{~cm}$. long : species Floridian.

10. S. salvioides.

11. S. Clingmanii.

12. S. cordata.

13. S. Floridana.

1. Stachys agrària Cham. \& Schl. Annual or biennial, hirsute. Stems usually branched at the base, the branches erect or decumbent, 1-3 dm. long: leaf-blades oblong to ovate, 1-4 cm. long, obtuse, crenate, truncate to cordate at the base: clusters fewflowered : pedicels 1-2 mm. long: bracts oval or suborbicular, subulate-tipped : calyx 2-4 $\mathrm{mm}$. long; lobes lanceolate to ovate-lanceolate with subulate tips, shorter than the tube, glabrous beyond the middle : corolla 5-6 min. long, glabrous except the bearded upper lip, the lobes of the lower lip rounded or the middle one barely emarginate : nutlets about $1 \mathrm{~mm}$. long, granular.

In shaded ground, Texas and Mexico. Spring to fall.

2. Stachys Drummóndii Benth. Annual or biennial, softly hirsute. Stems 1-7 dm. tall, solitary or tufted, usually branched above: leaf-blades ovate to oblong-ovate, 1.5-5) $\mathrm{cm}$. long, obtuse, crenate, truncate to cordate at the base; petioles nearly as long as the blades or shorter: clusters few-flowered: pedicels 1-2 $\mathrm{mm}$. long: bracts spine-tipped: calyx 5-6 $\mathrm{mm}$. long; tube turbinate ; lobes lanceolate, acuminate, subulate-tipped, as long as the tube or longer: corolla appressed-pubescent, $1 \mathrm{~cm}$. long; tube shorter than the calyx, the upper lip notched, the lower lip twice as long as the upper, its lobes truncate or retuse at the apex : nutlets nearly $2 \mathrm{~mm}$. long, dull.

In moist soil, Texas and Mexico. Spring to fall.

3. Stachys hyssopifolia Michx. Perennial, glabrous, or hirsute at the nodes of the stem. Stems erect or ascending, 2-4 dm. tall, simple or branched : leaf-blades linear or nearly so, 1-5 cm. long, acute, entire or nearly so, sessile: clusters 2-6-flowered, interrupted : pedicels very short, often almost wanting : calyx 6-7 mm. long, sometimes bristly : lobes lanceolate, subulate-tipped, about as long as the tube: corolla purple, about $1 \mathrm{~cm}$. long; tube about as long as the calyx ; lower lip drooping, about as long as the tube, the upper lip concave and usually pubescent on the back : filaments pubescent : nutlets nearly $2 \mathrm{~mm}$. long, minutely pubescent.

In sandy swamps, meadows and thickets, Massachusetts to Michigan and Florida. Summer.

4. Stachys lythroides Small. Perennial, deep green. Stem 4-9 dm. tall, sparingly hirsute, usually branched above : leaf-blades broadly linear or oblong-linear, $1.5-6 \mathrm{~cm}$. long, acute or acutish, shallowly serrate, smooth and glabrous, nearly sessile : clusters 3-6flowered : pedicels very short: calyx $6-7 \mathrm{~mm}$. long; tube sparingly pubescent, becoming ribbed; lobes lanceolate, somewhat shorter than the tube, barely subulate-tipped, ciliate: corolla purplish, $1 \mathrm{~cm}$. long.

In sandy soil, near Tallahassee, Florida. Summer.

5. Stachys ambígua (A. Gray) Britton. Perennial, hirsute. Stems erect, $3-10 \mathrm{dm}$. tall, more or less branched : leaf-blades narrowly oblong to oblong-lanceolate, 3-6 cm. long, acute, serrate, acute or truncate at the base, short-petioled: clusters $2-6$-flowered, interrinpted : bracts lanceolate, rather blunt-pointed : pedicels very short or nearly wanting: calyx 6-8 mm. long, bristly; lobes lanceolate, slightly subulate-tipped, as long as the tube or shorter, ciliate : corolla light purple, about $1 \mathrm{cn}$. long; tube surpassing the calyx, the lower lip as long as the tube, drooping, the upper lip concave, pubescent on the back: filaments pubescent : nutlets over $2 \mathrm{~mm}$. long, granular.

In moist sandy soil, New Jersey to Illinois and Georgia. Summer.

6. Stachys Nuttàllii Shuttlw. Perennial, conspicuously hirsute. Stems erect, 4-11 dm. tall, simple : leaf-blades oblong or oblong-lanceolate, 5-10 cm. long, acuminate, serrate-dentate, rounded or truncate at the base ; petioles $0.5-1 \mathrm{~cm}$. long, hirsute : spikes interrupted : bract surpassing the calyx, the upper ones with 3 tooth-like lobes: calyx $5 \mathrm{~mm}$. long, hirsute ; tube campanulate; lobes triangular-lanceolate, acuminate, $\frac{1}{2}$ as long as the tube: corolla purple, $1 \mathrm{~cm}$. long; tube saccate about the middle, surpassing the calyx, the upper lip eoncave, hairy on back, the lower lip drooping, as long as the tube : filaments minutely pubescent : nutlets about $2 \mathrm{~mm}$. long.

On mountain slopes, Virginia and Tennessee. Spring.

7. Stachys làtidens Small. Perrennial, glałtrous almost to the inflorescence. Stems erect, 3-7 dm. tall, mostly simple, slightly rough on the angles: leaf-blades various, the lower oval or ovate to oblong, 4-10 $\mathrm{cm}$. long, the upper longer, narrow, oblong-elliptic to lanceolate, acute or acuminate, all crenate-serrate with rather small teeth, rather abruptly narrowed or subcordate at the base ; petioles $1-6 \mathrm{~mm}$. long: inflorescence closely pubescent: pedicels less than $1 \mathrm{~mm}$. long: calyx often sessile, $5-6 \mathrm{~mm}$. long; tube cam- 
panulate; lobes triangular, very short : corolla about $1 \mathrm{~cm}$. long: nutlets fully $2 \mathrm{~mm}$. long, minutely wrinkled.

On mountain slopes and summits, Virginia to North Carolina and Tennessee. Summer.

8. Stachys tenuifòlia Willd. Perennial, glabrous or nearly so. Stems erect, 3-9 dm. tall, simple or branching : leaf-blades oblong or oblong-lanceolate, sometimes broadest above the middle, acute, serrate, truncate or cordate at the base; petioles usually $1-2 \mathrm{~cm}$. long: clusters few-flowered : calyx $5-6 \mathrm{~mm}$. long; tube campanulate-turbinate, sometimes sparingly pubescent; lobes lanceolate, acuminate, as long as the tube or shorter: corolla about $1 \mathrm{~cm}$. long; tube surpassing the calyx; lower lip drooping, slightly shorter than the tube, the upper lip concave, glandular-puhescent on the back : filaments villous at the base : nutlets $2 \mathrm{~mm}$. long, somewhat lustrous.

In copses and fields, New York to Kansas, North Carolina and Louisiana. Summer.

9. Stachys áspera Michx. Perennial, hirsute. Stems erect, 5-12 dm. tall, simple or branching: leaf-blades oblong, oblong-lanceolate or ovate-oblong, $3-10 \mathrm{~cm}$. long, acute, crenate-serrate, truncate or cordate at the base, petioled : clusters few-flowered, interrupted: caly x 5-6 mm. long; tube turbinate; lobes triangular-acuminate, not rigidly pointed : corolla 10-12 mm. long, pubescent along the back with simple hairs; tube much surpassing the calyx, the upper lip concave, glandular-pilose on the back, the lower lip drooping, shorter than the tube, its middle lobe orbicular-reniform, the lateral ones ovate: filaments villous : nutlets about $2 \mathrm{~mm}$. long.

In moist soil, Ontario to Minnesota, Florida and Louisiana. Summer.

10. Stachys salvioides Small. Perennial, rather finely and often closely puberulent or puberulent-pubescent. Stems erect, 3-9 dm. tall, commonly branched, rough along the angles : leaf-blades oblong to oblong-ovate or rarely ovate, 6-12 $\mathrm{cm}$. long, or shorter on the lower part of the stem, pubescent on both sides, acute or acutish, crenate, truncate or cordate at the base; petioles barely $\frac{1}{4}$ as long as the blades : calyx sessile or nearly so, becoming $5 \mathrm{~mm}$. long; tube campanulate-turbinate; lobes triangular at maturity : corolla nearly $1 \mathrm{~cm}$. long: nutlets nearly $2.5 \mathrm{~mm}$. long, faintly reticulated.

In stony soil, Virginia and West Virginia to Tennessee. Summer.

11. Stachys Clingmánii SmaIl. Perennial, hispid-hirsute. Stems erect, 5-9 dm. tall, simple, its hairs spreading : leaf-blades oblong or oblong-lanceolate, $6-12 \mathrm{~cm}$. long, acuminate, dentate, truncate or subcordate at the base ; petioles $\frac{1}{5}-\frac{1}{6}$ as long as the blades: clusters in the upper axils of leaf-like bracts : bract surpassing the calyx : calyx $6-7 \mathrm{~mm}$. long, villous; tube turbinate; lobes lanceolate-subulate, at least $\frac{1}{2}$ as long as the tube: corolla bluish, $1.5 \mathrm{~cm}$. long; tube saccate a little above the base, the upper lip pilose on back, the lower lip as long as the tube, with a suborbicular middle lobe and ovate lateral lobes: filaments villous : nutlets about $2 \mathrm{~mm}$. long.

On open slopes, Clingman's Dome, North Carolina. Summer.

12. Stachys cordàta Riddell. Perennial, hirsute. Stems erect or ascending, 3-10 dm. long, simple or branching above : leaf-blades ovate, oval or oblong, 6-15 cm. long, acute or acuminate, crenate, rounded or cordate at the base ; petioles slender, $\frac{1}{2}$ as long as the blades or shorter: spikes conspicuous, $8-15 \mathrm{~cm}$. long, nearly naked : bract shorter than the calyx, except in the lower clusters: calyx 4-5 mm. long, minutely hirsute-glandular; tube campanulate; lobes triangular, acuminate, $\frac{1}{3}$ or barely $\frac{1}{2}$ as Iong as the tube : corolla light purple, $1 \mathrm{~cm}$. long: tube much surpassing the calyx, abruptly enlarged beneath near the base, the upper lip puberulent without, the lower lip drooping, with a reniform middle lobe and rounded undulate lateral lobes: filaments finely pubescent: nutlets $2 \mathrm{~mm}$. long, suborbicular, granular.

On banks of streams or in thickets, Ohio to North Carolina and Tennessee. Summer.

13. Stachys Floridàna Shuttlw. Perennial, more or less hirsute, the rootstocks slender, terminating in tubers. Stems erect, 1-4 dm. tall, or branched at the base, the branches ascending or spreading : leaf-blades oblong to ovate, $1-4 \mathrm{~cm}$. long, acute or acutish, serrate or dentate, truncate to cordate at the base; petioles nearly as long as blades or much shorter on upper part of stem: calyx puberulent, 5-6 mm. long; tube turbinate ; lobes lanceolate, slender-acuminate : corolla nearly glabrous, about $1 \mathrm{~mm}$. long; tube surpassing the calyx, the upper lip concave, bearded, the lower lip nearly as long as the tube, rounded: filaments pubescent: nutlets about $0.5 \mathrm{~mm}$. long.

In sandy soil, Florida. Spring.

\section{SÁLVIA L.}

Annual or perennial herbs, or shrubby plants, with leafy or scape-like stems. Leaves opposite, sometimes mainly basal : blades flat, entire, toothed or variously lobed. Flowers 
in axillary clusters, disposed in spikes, racemes or panicles. Calyx various in shape, 2-lipped : tube ribbed, usually glabrous in the throat or merely ciliate near the base of the lobes: upper lip with 3 lobes: lower lip with 2 longer and narrower lobes. Corolla usually highly colored, strongly 2-lipped : upper lip short or elongated: lower lip longer, spreading, with 3 lobes. Stamens 4 , but only 2 anther-bearing, or only 2 : filaments various, the posterior pair sometimes completely reduced, anther-bearing ones with a transverse connective at the apex, this bearing an anther at one end, dilated or capitate at the other. Nutlets smooth.

Stems copiously leafy.

Corolla scarlet, red or crimson.

Leaves less than 3 times as long as broad : corolla-pubescent within.

Leaf-blades broader than long or rarelylonger than broad, sinuate-toothed.

Leaf-blades manifestly longer than broad : entire or crenate-serrate. Shrubby: leaf-blades leathery, entire.

Herbaceous : leaf-blades membranous, toothed.

Leaves fully 4 times as long as broad.

Corolla blue. purplish or white.

Leaf-blades over 4 times as long as broad.

Corolla less than $1 \mathrm{~cm}$. long, the tube not surpassing the calyx.

Corolla over $1 \mathrm{~cm}$. long, the tube surpassing the calyx.

Inflorescence, especially the calyx, conspicuously and densely tomentose with white or violet hairs.

Inflorescence, including the calyx, glabrous or pubescent, but not densely or conspicuously so.

Calyx puberulent or minutely pubescent.

Calyx silky-tomentose.

Leaf-blades mostly less than twice as long as broad.

1. S. Roemeriana.

2. S. Greggii.

3. S. coccinea.

4. S. pentstemonoides.

5. S. lanceolata.

6. S. farinacea.

7. S. azurea.

8. S. Pitcheri.

Herbaceous plants.

Calyx over $5 \mathrm{~mm}$. long at maturity.

Leaf-blades decurrent on the petioles to their bases. Calyx-lobes acute: flower-clusters approximate or contiguous. Calyx-lobes awn-tipped.

Leaf-blades very slightly decurrent on the petioles. Corolla over $1 \mathrm{~cm}$. long: calyx-lobes nearly erect, Corolla less than $1 \mathrm{~cm}$. long : calyx-lobes spreading.

Calyx less'than $5 \mathrm{~mm}$. long at maturity.

Petioles filiform, wingless: stigmas subulate.

Petioles winged by the decurrent blades: stigmas broad. Shrubby plant.

stems scape-like : leaves mainly basal.

Corolla 8-10 mm. long.

Corolla 20-25 mm. long.

1. Salvia Roemeriàna Scheele. Perennial, closely pubescent and more or less hirsute. Stems erect, 3-7 dm. tall : leaf-blades ovate, suborbicular or reniform, $2-4 \mathrm{~cm}$. broad, the lower ones often compound, the leaflets then similar to the blades of the upper leaves, all repand-angulate, truncate or cordate at the base, slender-petioled: panicles 1-3 dm. long, the clusters few-flowered : pedicels $2-7 \mathrm{~mm}$. long: calyx finely pubescent and somewhat glandular, $8-10 \mathrm{~mm}$. long, the upper lip destitute of a middle tooth, the lower lobes lanceolate, acuminate: corolla scarlet-red, $2.5 \mathrm{~cm}$. long ; tube slightly curved, the lower lip with a broad cleft middle lobe, its lateral lobes rounded: nutlets $2 \mathrm{~mm}$. long, granular.

In light soil, Texas. Spring and summer.

2. Salvia Gréggii A. Gray. Perennial, more or less puberulent. Stems erect, several $\mathrm{dm}$. tall, branched : leaf-blades firm, oblong or nearly so, $0.5-1.5 \mathrm{~cm}$. long, obtuse, nearly veinless, short-petioled : panicles $2-10 \mathrm{~cm}$. long, the clusters few-flowered : pedicels 2-5 mm. long: caly x 10-13 mm. long; tube many-ribbed, the upper lip acutish, the lower lobes ovate, abruptly acuminate, about $\frac{1}{2}$ as long as the tube : corolla red or purplish red, $2.5-3 \mathrm{~cm}$. long; tube saccate beneath, the upper lip concave, notched, glandular-pubescent on back, the lower lip with a middle lobe $1.5 \mathrm{~cm}$. broad, this cleft into 2 rounded segments with a slender tooth between them: style pubescent on top : nutlets $3 \mathrm{~mm}$. long.

In valleys, southern Texas. Spring and summer.

3. Salvia coccínea L. Annual or perennial, softly pubescent. Stems erect, 3-7 dm. tall, simple or sparingly branched : leaf-blades ovate or deltoid-ovate, $3-6 \mathrm{~cm}$. long, obtuse or acutish, crenate-serrate, truncate to subcordate at the base : panicles $5-20 \mathrm{~cm}$. long: pedicels $2-6 \mathrm{~mm}$. long, slender : calyx minutely pubescent, 10-12 $\mathrm{mm}$. long; tube many-ribbed, the upper lip reniform, abruptly pointed, the lower lobes ovate-apiculate : corolla deep scarlet, $2-2.5 \mathrm{~cm}$. long, puberulent; tube contracted above the base, then gradually enlarged, the lower lip 7-8 $\mathrm{mm}$. broad, merely notched at the apex : nutlets 2.5 $\mathrm{mm}$. long, slightly variegated.

In sandy soil, South Carolina, Florida, Texas and adjacent Mexico. Spring to fall. 
4. Salvia pentstemonoìdes Kunth. Perennial, glabrous or sparingly hirsute below. Stems erect, 6-15 dm. tall, sparingly branched above : leaf-blades leathery, lanceolate to elliptic-lanceolate or elliptic, $5-15 \mathrm{~cm}$. long, acute or acuminate, entire or denticulate, acuminate at the base : panicles $3-6 \mathrm{dm}$. long : pedicels $5-10 \mathrm{~mm}$. long: calyx glandularpuberulent, 1-1.5 cm. long; tube ribbed-angled, the upper lip with 3 teeth, the lower lobes lanceolate, acuminate, slightly surpassing the upper : corolla crimson, $4 \mathrm{~cm}$. long, sparingly pubescent ; tube twice as long as the calyx, the upper lip about $\frac{1}{2}$ as long as the tube, pubescent on top, the lower lip 3-lobed, the middle lobe entire : style glabrous : nutlets 2.5 $\mathrm{mm}$. long, nearly smooth.

In valleys, Texas. Spring and summer.

5. Salvia lanceolàta Willd. Perennial, glabrate-puberulent. Stems erect, 1-4 dm. tall, more or less branched : leaf-blades oblong-lanceolate to oblong or linear-oblong, 2-8 cm. long, obtuse or apiculate, remotely serrate, repand or undulate: panicles 5-15 cm. long: clusters more or less remote : pedicels $2-5 \mathrm{~mm}$. long : calyx 7-8 mm. long, minutely pubescent; tube prominently-ribbed, the upper lip abruptly pointed, the lower lobes triangular or ovate-triangular, acuminate: corolla purplish, sometimes pale, nearly $1 \mathrm{~cm}$. long; tube slightly constricted above the base, the upper lip minutely puberulent, the lower lip 3-lobed, the middle lobe much broader than long: style sparingly pubescent : nutlets nearly $2.5 \mathrm{~mm}$. long, granular.

On plains, Nebraska to Colorado, Texas, Arizona and Mexico. Spring to fall.

6. Salvia farinàcea Benth. Perennial, puberulent or glabrous below, densely canescent-tomentose above. Stems often clustered, erect or ascending, 3-6 dm. tall, sometimes sparingly branched above : leaf-blades oblong-lanceolate to almost linear or rarely oblongovate, $3-10 \mathrm{~cm}$. long, acute or acutish, undulate or shallowly serrate, acuminate or cuneate at the base : panicles 5-20 $\mathrm{cm}$. long, interrupted below, with colored pubescence similar to that of the calyx : calyx densely canescent with white or violet hairs, $7-8 \mathrm{~mm}$. long, truncate or undulate-toothed : corolla violet-blue, $2 \mathrm{~cm}$. long : tube saccate above the middle, the upper lip 2-parted, bearded on the back, the lower lip 3-lobed, much longer than the upper lip : nutlets fully $2 \mathrm{~mm}$. long, pale.

In rich soil, Texas. Spring and summer.

7. Salvia azùrea Lam. Perennial, glabrous or puberulent above. Stems erect, 3-10 dm. tall, more or less branched : leaf-blades oblong or lanceolate to linear, obtuse or acutish, repand or serrate, narrowed into short petioles: panicles $5-20 \mathrm{~cm}$. long: pedicels 1-4 $\mathrm{mm}$. long: clusters subtended by narrow bracts : calyx puberulent, $7-9 \mathrm{~mm}$. long, the upper lip abruptly pointed, the lower lobes ovate, acuminate : corolla blue or white, about $1.5 \mathrm{~cm}$. long; tube somewhat saccate above the middle, the upper lip densely bearded on the back, the lower lip 3-lobed, its middle lobe much broader than long, deeply notched, crisped: style pubescent beneath : nutlets about $2 \mathrm{~mm}$. long, slightly resinous-granulose.

In dry soil, South Carolina to Florida and Texas. Spring to fall.

8. Salvia Pítcheri Torr. Perennial, closely pubescent. Stems erect, 4-12 dm. tall, more or less branched, often simple : leaf-blades linear-oblong to linear, $3-12 \mathrm{~cm}$. long, acute, sharply toothed or nearly entire, narrowed at the base: panicles 1-3 dm. long; clusters often contiguous : pedicels 1-5 mm. long : calyx densely canescent-tomentose, 6-8 $\mathrm{mm}$. long; tube many-ribbed, the upper lip barely pointed, the lower lobes triangularovate, acute, as broad as long: corolla blue or white, $2-2.5 \mathrm{~cm}$. long; tube saccate above the middle, the upper lip densely bearded on the back, the lower lip 3-lobed, its middle lobe $1 \mathrm{~cm}$. broad, crisped, reniform, notched : style pubescent : nutlets nearly $3 \mathrm{~mm}$. long. on dry plains, Nebraska to Colorado, Texas, Arizona and Mexico. Summer and fall.

9. Salvia serótina L. Perennial, finely pubescent. Stems $1.5-7 \mathrm{dm}$. tall, much branched : leaf-blades ovate or orbicular-ovate, 1-4 cm. long, obtuse, crenate-serrate, truncate or subcordate at the base, slender-petioled: panicles 2-10 $\mathrm{cm}$. long, cylindric, rather dense : calyx longer than the pedicels, glandular-hirsute, becoming 5-8 mm. long; lips about $\frac{1}{3}$ as long as the long-campanulate tube : corolla $6-10 \mathrm{~mm}$. long; tube included : style glabrous : nutlets fully $2 \mathrm{~mm}$. long.

In sand, peninsular Florida and the Keys. Also in tropical America.

10. Salvia privoìdes Benth. Annual, more or less pubescent. Stems 5-18 dm. tall, more or less branched : leaf-blades ovate, $1-3 \mathrm{~cm}$. long, acute, sharply serrate, cuneate or truncate at the base, short-petioled : panicles slender, 5-30 cm. long, much interrupted: calyx 5-7 mm. long, glandular-pilose, the upper lip and the lobes of the lower lip cuspidate : corolla 5-6 mm. long; tube not surpassing the calyx, the upper lip minutely bearded, the lower lip with a notched or eroded middle lobe : nutlets barely $2 \mathrm{~mm}$. long.

In sand, peninsular Florida and its Keys. 
11. Salvia urticifolia L. Perennial, finely pubescent and somewhat viseid. Stems erect, solitary or tufted, $2-7 \mathrm{dm}$. tall, usually simple above : leaf-blades ovate to deltoid, $3-8 \mathrm{~cm}$. long, acute or short-acuminate, dentate or crenate, abruptly narrowed or truncate at the base : panicles 5-15 cm. long, the clusters few-flowered : calyx $6-8 \mathrm{~mm}$. long, glandular-pubescent and glandular-dotted ; lobes all cuspidate : corolla purplish or white, about $12 \mathrm{~mm}$. long; tube gibbous about the middle, the upper lip glandular-pubescent on the back, the lower lip 3-lobed, the middle lobe reniform, about $8 \mathrm{~mm}$. broad, notched: style pubescent : nutlets $2 \mathrm{~mm}$. long.

In open woods or thickets, Maryland and Kentucky to Florida and Louisiana. Spring and summer.

12. Salvia Chapmánii A. Gray. Perennial, rather closely pubescent. Stems erect, 1-2 m. tall, branching : leaf-blades thickish, ovate to ovate-lanceolate, $2.5-8 \mathrm{~cm}$. long, longacuminate, crenate-serrate, cuneate at the base, short-petioled : panicle much interrupted, $5-10 \mathrm{~cm}$. long ; clusters 2-6-flowered : bracts mostly $5-10 \mathrm{~cm}$. long, acuminate : calyx becoming $4-5 \mathrm{~mm}$. long, finely pubescent; tube campanulate, the lips very short : corolla blue or whitish, 8-9 $\mathrm{mm}$. long; tube much surpassing the calyx, the lower lip about twice as long as the upper: nutlets about $1.5 \mathrm{~mm}$. long.

In sandy soil, Florida and Alabama. Spring.

13. Salvia Blodgéttii Chapm. Annual, minutely pubescent. Stems much branched, the branches slender, 1-3 dm. long: leaf-blades ovate to suborbicular, 1-2 cm. long, obtuse, shallowly toothed, cuneate or truncate at the base : panicles slender, $1-3 \mathrm{~cm}$. long: bracts subulate, shorter than the pedicels : calyx $4 \mathrm{~mm}$. long, glandular-villous, the upper lip twice as long as the lower one : corolla about $8 \mathrm{~mm}$. long.

In sand, Key West, Florida.

14. Salvia occidentàlis Sw. Annual, sparingly pubescent to the inflorescence, thence closely so. Stems erect or decumbent and creeping, 0.5-2 m. long, more or less diffusely branched : leaf-blades ovate, acute or short-acuminate, serrate, cuneate or nearly truncate at the base, short-petioled : panicles slender, 5-30 cm. long; clusters few-flowered, the lower ones distant : calyx densely glandular-hirsute, $3-3.5 \mathrm{~mm}$. long; tube strongly ribbed, the upper lip rounded, the lower lobes acute: corolla blue, about $5 \mathrm{~mm}$. long; tube not surpassing the calyx : style or stigma with thin broad obtuse or truncate lobes: nutlets $2 \mathrm{~mm}$. long.

In sandy soil, peninsular Florida. Spring to fall.:

15. Salvia ballotaeflòra Benth. A much branched shrub. Stem 1-3 m. tall, with tomentulose-canescent young foliage : leaf-blades ovate to deltoid, 1-2 cm. long, acute or obtusish, crenate, truncate or cuneate at the base, slender-petioled : panicles 1-2 cm. long, few-flowered : calyx densely puberulent, $5 \mathrm{~mm}$. becoming $8-10 \mathrm{~mm}$. long and drooping at maturity, the lobes nearly equal, broadly ovate, obtuse or acutish : corolla purple or bluish, 6-7 mm. long; tube shorter than calyx, the upper lip ample, bearded on the back, the lower lip 3-lobed : nutlets barely $2 \mathrm{~mm}$. long.

In dry soil, Texas and adjacent Mexico. Spring and summer.

16. Salvia verbenàcea L. Perennial, hirsute or villous-hirsute. Stems erect, 1-6 dm. tall, simple or branching : leaves mainly basal ; blades ovate to oblong, $3-15 \mathrm{~cm}$. long, incised or pinnatifid, obtuse or subcordate at the base : panicles 5-30 $\mathrm{cm}$. long; clusters rarely contiguous : calyx shaggy, 6-8 $\mathrm{mm}$. long, the upper lip erect, with three converging teeth, the lower lobes lanceolate, rigidly pointed : corolla bluish white or blue, about $8 \mathrm{~mm}$. long; tube shorter than the calyx, lips ample, the upper one hooded, minutely bearded with curved hairs, the lower with a reniform middle lobe: nutlets $2 \mathrm{~mm}$. long, nearly smooth.

In sandy soil, Ohio to South Carolina and Georgia. Naturalized from Europe. Summer.

17. Salvia lyràta L. Perennial, pilose or hirsute. Stems erect, more or less scapelike, 1-6 dm. tall, simple or sparingly branched: leaves mainly basal; blades spatulate, oblanceolate, oblong or oval, lyrate-pinnatifid, $5-20 \mathrm{~cm}$. long, the lobes undulate or repand: panicles 1-4 cm. long, much interrupted; clusters few-flowered : pedicels 1-5 $\mathrm{mm}$. long : calyx hirsute, becoming 9-11 cm. long; tube strongly ribbed, the upper lip with 3 teeth, the lower lobes lanceolate, acuminate, with rigid tips: corolla purplish blue, $2-2.5 \mathrm{~cm}$. long, the lower lip with a middle lobe broader than long, notched: filaments glabrous: nutlets $2 \mathrm{~mm}$. long, glabrous, granular.

In dry, often sandy woods or thickets, New Jersey to Missouri, Florida and Texas. Spring and early summer.

\section{SALVIÁSTRUM Scheele.}

Perennial caulescent herbs, with puberulent or pubescent foliage. Leaves opposite : blades narrow, mostly entire, sometimes sparingly toothed. Flowers 1-3 in the axils of the 
bracts, disposed in terminal contracted panicles. Calyx very irregular, ringent: tube densely bearded with white hairs in the throat and closed by them at maturity, 2-lipped: lobes cuspidate, those of upper lip short and broad, those of the lower lip more elongated. Corolla blue or purple: tube pubescent within, 2-lipped: upper lip 2-lobed : lower lip spreading, ample, 3-lobed, the middle lobe 2-lobed. Stamens 2, with a transverse connective, lower branches with more or less polleniferous anther-sacs. Staminodia 2, sometimes 2-toothed at the apex. Nutlets subglobose.

1. Salviastrum Texànum Scheele. Stems hirsute, commonly tufted, erect or ascending, 1-3 dm. tall, simple or branched : leaf-blades linear or linear-oblanceolate at the base of the stem, entire or rarely few-toothed : panicles 4-15 cm. long, continuous or interrupted: caly $\mathrm{x} 7-10 \mathrm{~mm}$. long; tube campanulate, the upper lip with 3 cuspidate teeth, the lower lobes lanceolate, acuminate : corolla blue, $2 \mathrm{~cm}$. long; tube barely as long as the calyx ; lips longer than the tube, the upper notched, the lower 3-lobed, the middle lobe reniform, deeply notched: style glabrous: nutlets $2.5 \mathrm{~mm}$. long, somewhat shining.

In dry soil, Texas and New Mexico. Spring.

\section{MONÁRDA L.}

Annual or usually perennial caulescent herbs, with glabrous or pubescent foliage. Leaves opposite: blades flat, broadest below the middle, usually toothed. Flowers in dense remote or contiguous axillary clusters. Calyx tubular or nearly so, mostly pubescent in the throat : tube 15-ribbed: lobes 5, nearly equal. Corolla white, yellow, red or purple, sometimes variegated, 2-lipped : tube glabrous within, often puberulent or glandular without, dilated into a throat : upper lip narrow, erect or arched, entire or notched: lower lip spreading, 3-lobed, the middle lobe much longer than the lateral. Anther-bearing stamens 2: 2 filaments rudimentary or wanting: anthers narrow, 2-celled, versatile; sacs divergent, somewhat confluent at the base. Nutlets smooth.

Flower-clusters solitary and terminal, or rarely axillary in robust plants.

Leaf-blades relatively long-petioled or manifestly petioled.

Corolla scarlet.

Corolla white, pink or purple.

Leaf-blades membranous, deep green : corolla greenish or cream-colored.

Leaf-blades firmer, barely membranous, dull or bright green : corolla pink, purple or purple-red.

Pubescence of spreading hairs.

Leaf-blades, all or many, fully twice as long as broad. Corolla, and often the bracts, pink or purplish. Corolla, and the bracts, deep purple or purple-red.

Leaf-blades all less than twice as long as broad.

Pubescence of very short appressed hairs.

Leaves on the upper part of the stem with petioles less than $5 \mathrm{~mm}$. long.

Leaves onthe upper part of the stem with petioles over $5 \mathrm{~mm}$. long. Leaf-blades sessile or nearly so.

Calyx pubescent at the mouth; lobes not glandular.

Calyx glabrous at the mouth; lobes glandular.

1. M. didyma.

2. M. Clinopodia.

Flower-clusters axillary and terminal.

Perennials, sometimes flowering the first year: calyx-lobes triangular to lanceolate: corolla yellowish or rarely white.

Bractlets plumose: calyx densely bearded in the throat ; lobes acute, copiously pubescent.

Calyx 9-10 mm. long; lobes lanceolate.

Calyx 6-7 mm. long; lobes triangular.

Bractlets merely ciliate : calyx glabrous in the throat or nearly so; lobes acuminate, puberulent or glabrous at maturity.

Annuals or biennials: calyx-lobes setaceous : corolla pink, purplish or white.

Calyx-tube merely puberulent, the lobes spreading : bractlets merely ciliate. Bractlets typically oblong and abruptly narrowed into the terminal bristie: corolla about $2.5 \mathrm{~cm}$. long.

Bractlets typically lanceolate or linear-lanceolate, gradually narrowed into the terminal bristle: corolla about $2 \mathrm{~cm}$. long.

Calyx-tube pubescent, the lobes erect or nearly so: bractlets pubescent on the back and copiously ciliate.

3. M. fistulosa.

4. M. media.

5. M. hirsutissima.

6. M. scabra.

7. M. mollis.

8. M. Bradburiana.

9. M. Russelliana.

1. Monarda dídyma L. Perennial, glabrate or sparingly pubescent. Stems often tufted, 3-12 dm. tall : leaf-blades lanceolate, oblong-lanceolate to ovate, $8-15 \mathrm{~cm}$. long, acuminate, serrate, rounded or cordate at the base: heads showy : bracts more or less colored : calyx glandular-puberulent, 7-10 mm. long; tube slightly curved, sharply ribbed ; lobes subulate, $1.5-2 \mathrm{~mm}$. long, ascending: corolla scarlet, minutely pubescent, $3.5-5 \mathrm{~cm}$. long; tube dilated above the middle, the lower lip oblong: nutlets $1 \mathrm{~mm}$. long.

In moist soil, especially along mountain streams, New Brunswick to Ontario and Michigan, south to Georgia and Alabama. Summer and fall. Oswego Tea. BeE BalM. 
2. Monarda Clinopòdia L. Perennial, glabrous or sparingly pubescent. Stems 3-8 dm. tall, simple or branching above : leaf-blades ovate to lanceolate, $3-12 \mathrm{~cm}$. long, acute or acuminate, serrate, rounded or cordate at base: heads not showy, the bracts green or slightly colored : caly x 7-9 mm. long; tube slightly curved, hirsute in the throat; lobes subulate, 1-1.5 mm. long, more or less pubescent : corolla greenish or cream-colored; tube slightly dilated upward, the lower lip with an oblong base, 2 rounded lateral lobes and a narrow notched middle lobe : nutlets $0.5 \mathrm{~mm}$. thick.

On hillsides and in woods or thickets, Ontario to Georgia and Kentucky. Spring to fall.

3. Monarda fistulòsa L. Perennial, sparingly villous, bright green. Stems 5-12 dm. tall, purple or purple-spotted, usually branched above : leaf-blades ovate or lanceolate, 2-12 cm. long, acute or acuminate, remotely but sharply serrate, rounded or subcordate at base, slender-petioled : bracts of the involucre pale or purplish : calyx nearly cylindric, 7-12 mm. long; tube slightly curved, villous in the throat; lobes subulate, many times shorter than the tube : corolla lilac, about $3 \mathrm{~cm}$. long, usually minutely pilose, the lower lip obovate-spatulate, with a broad notched upturned mucro: nutlets $1-1.5 \mathrm{~mm}$. long.

On dry hillsides and in thickets, Maine to Ontario and Minnesota, south to Florida and Louisiana. summer and fall. HoRse-MINT. WILD BERGAMOT.

4. Monarda mèdia Willd. Perennial, glabrate or softly hirsute, deep green. Stems 6-12 dm. tall, commonly branching above : leaf-blades ovate, lanceolate or oblong, acuminate, serrate, rounded or truncate at base, slender-petioled: head showy, the bracts deep purple foliaceous : calyx becoming $10 \mathrm{~mm}$. long; tube finely ribbed; lobes subulate, $1 \mathrm{~mm}$. long or slightly longer : corolla red-purple, $1.5-2 \mathrm{~cm}$. long, villous-hirsute ; tube dilated above the middle, the upper lip linear-lanceolate, the lower lip oblong, 3-lobed at the apex, its middle lobe linear : nutlets nearly $1.5 \mathrm{~mm}$. long.

In moist thickets, Maine to Pennsylvania, North Carolina and Tennessee. Summer.

5. Monarda hirsutíssima Small. Perennial, densely hirsute. Stems apparently 4-7 dm. tall, simple or usually so: leaf-blades thick, ovate, $1.5-3 \mathrm{~cm}$. long, acute or slightly acuminate, serrate, truncate or subcordate at base, short-petioled : heads showy, solitary, subtended by ciliate bracts : bractlets slender, pectinate-ciliate : calyx puberulent and glandular-dotted, becoming $8-9 \mathrm{~mm}$. long; tube nearly straight, finely ribbed, bristly about the throat; lobes subulate, about $1 \mathrm{~mm}$. long: corolla lilac or purplish, villous and glandular-dotted, 1.5-2 cm. long, the lower lip crisped, its narrow middle lobe bearded : nutlets nearly $1.5 \mathrm{~mm}$. long.

In dry soil, Texas. Summer.

6. Monarda scàbra Beck. Perennial, closely velvety-pubescent. Stems $2-10 \mathrm{dm}$. tall, commonly branching above : leaf-blades firm, ovate to lanceolate, $2-8 \mathrm{~cm}$. long, acute or slightly acuminate, sharply often rather remotely serrate, rounded, truncate or cordate at base : those of the lower leaves short-petioled, those of the upper nearly sessile : heads showy, subtended by colored bracts : calyx 7-9 mm. long, lobes $1 \mathrm{~mm}$. long or shorter : corolla lilac or bluish, $2-2.5 \mathrm{~cm}$. long, villous and minutely glandular-dotted ; tube gradually dilated, the upper lip linear-lanceolate, conspicuously bearded at the apex, the lower lip 3-lobed at the apex, its middle lobe linear, notched : nutlets about $1.5 \mathrm{~mm}$. long.

On dry plains and prairies, Northwest Territory and British Columbia to Missouri, Texas and Arizona. Summer.

7. Monarda móllis L. Perennial, similar to $M$. fistulosa in habit and to $M$. scabra in its short close pubescence. Stems finely and often copiously puberulent-canescent : leafblades ovate to lanceolate, coarsely serrate, usually gradually or abruptly narrowed at the base ; petioles slender, those of the lower leaves 1-1.5 $\mathrm{cm}$. long, those of the upper somewhat shorter: heads subtended by bracts more or less colored like the corollas.

In dry soil, New England to South Dakota, Georgia and Texas. Summer.

8. Monarda Bradburiàna Beck. Perennial, villous-hirsute above, or glabrate. Stems 3-6 dm. tall : leaf-blades ovate to lanceolate, $3-10 \mathrm{~cm}$. long, acute or acuminate, ciliate, serrate or nearly entire, sessile or nearly so, rounded or cordate at the base : heads showy, the bracts more or less deeply colored, ciliate : calyx becoming about $10 \mathrm{~mm}$. long; tube slightly curved, little pubescent in the throat; lobes slender-subulate, $2-2.5 \mathrm{~mm}$. long, glandular-ciliate : corolla $2-2.5 \mathrm{~mm}$. long, tube dilated above, the upper lip linear-lanceolate, bearded, the lower lip 3-lobed, the middle lobe cleft : nutlets fully $1 \mathrm{~mm}$. long.

In thickets and on dry hillsides, Illinois to Kansas and Alabama. Spring and summer.

9. Monarda Russelliàna Nutt. Perennial, sparingly hirsute above. Stems slender, 3-6 dm. tall, simple or sparingly branched, commonly pubescent on the angles : leaf-blades lanceolate to ovate-lanceolate, acute or acuminate, shallowly serrate, rounded or subcordate at the base, sessile or short-petioled : heads often solitary, showy : calyx sparingly pubescent 
or glabrate, becoming 8-9 $\mathrm{mm}$. long; tube finely ribbed, curved; lobes subulate, 1.5-2 $\mathrm{mm}$. long, glandular-ciliate : corolla slender, $2-3 \mathrm{~cm}$. long : nutlets about $1 \mathrm{~mm}$. long.

On hillsides, Arkansas. Summer and fall.

10. Monarda Stanfièldii Small. Perennial, 4-9 dm. tall. Stem and branches finely and closely pubescent: leaf-blades lanceolate, 4-7 cm. long, rather coarsely serrate, glabrous or nearly so, slender-petioled : bracts foliaceous, pale : bractlets plumose : calyx 9-10 $\mathrm{mm}$. long ; tube finely pubescent, copiously bearded in the throat; lobes lanceolate, copiously pubescent : corolla about $1.5 \mathrm{~cm}$. long : nutlets less than $1.5 \mathrm{~mm}$. long.

On prairies, the Indian Territory and Texas. Spring.

11. Monarda lasiodónta (A. Gray) Small. Perennial, 1.5-4 dm. tall. Stems mainly simple or branched near the base, puberulent: leaf-blades linear-oblong to linearlanceolate, $2-5 \mathrm{~cm}$. long, shallowly serrate: bracts white or pale, foliaceous: bractlets plumose : calyx 6-7 mm. long; tube finely pubescent, densely bearded in the throat; lobes triangular, copiously pubescent : corolla $1.5 \mathrm{~cm}$. long : nutlets less than $1.5 \mathrm{~mm}$. long.

On plains or prairies, the Indian Territory and Texas to Arizona. Spring and summer.

12. Monarda punctàta L. Perennial, $3-10 \mathrm{dm}$, tall. Stems and branches finely pubescent : leaf-blades linear-oblong to lanceolate, $2-8 \mathrm{~cm}$. long, serrate, usually remotely or shallowly so: bracts foliaceous, more or less colored: bractlets merely ciliate : calyx $8-10 \mathrm{~mm}$. long; tube minutely puberulent or nearly glabrous at maturity, the throat not bearded; lobes triangular, puberulent or glabrous at maturity : corolla about $2 \mathrm{~cm}$. long: nutlets fully $1.5 \mathrm{~mm}$. long.

In sandy soil, swamps or meadows, New York to Wisconsin, Florida and Texas. Summer and fall. -A form, M. punctata leucántha Nash, with white corollas, occurs in Florida.

13. Monarda dispérsa Small. Annual, 2-8 dm. tall. Stems often branched, the branches puberulent: leaf-blades oblong to oblong-spatulate or oblanceolate on the lower part of the stem, narrowly oblong to linear above, $2-11 \mathrm{~cm}$. long, shallowly serrate : bractlets typically oblong and abruptly narrowed into the terminal bristle, $1.5-2 \mathrm{~cm}$. long, often colored within : calyx-tube $8-9 \mathrm{~mm}$. long, puberulent, the lobes setaceous, spreading, sparingly ciliate : corolla about $2.5 \mathrm{~cm}$. long : nutlets $1.5 \mathrm{~mm}$. long.

On plains and prairies and in meadows, Kansas and Missouri to Georgia, Florida, Texas, New Mexico and Mexico. Spring and summer. Naturalized eastward.

14. Monarda tenuiaristàta (A. Gray) Small. Annual and similar to $M$. dispersa in habit, but relatively more slender : leaf-blades mainly tapering to the base : bractlets typically lanceolate or linear-lanceolate and gradually narrowed into the terminal bristle: calyx-tube 7-8 mm. long, puberulent, the lobes setaceous, sparingly ciliate, spreading: corolla about $2 \mathrm{~cm}$. long: nutlets about $1.5 \mathrm{~mm}$. long. [ $M$. aristata Nutt., not Hook. $M$. citriodora var. tenuiaristata A. Gray.]

On plains and prairies, Kansas to Arkansas, Texas, Arizona and Mexico. Spring and summer.

15. Monarda clinopodioìdes A. Gray. Annual, 3-6 dm. tall. Stems usually branched at the base, the branches closely pubescent : leaf-blades oblong to narrowly linearoblong, 2-5.5 cm. long, sharply serrate : bractlets elliptic or lanceolate-elliptic, gradually narrowed into the terminal bristle, pubescent on the back and copiously ciliate : calyx-tube pubescent, 6-7 mm. long, the lobes setaceous, erect, plumose-ciliate : corolla $2-2.5 \mathrm{~cm}$. long: nutlets $1.5 \mathrm{~mm}$. long.

On plains and prairies, the Indian Territory and Texas. Spring and summer.

24. BLEPHILIA Raf.

Perennial caulescent herbs, with pubescent foliage. Leaves opposite: blades flat, usually shallowly toothed. Flowers in dense remote or contiguous axillary clusters. Calyx glabrous in the throat, 2-lipped : tube nearly tubular, 13-nerved : lobes of the lower lip much longer than those of the upper. Corolla bluish or purplish, much longer than the calyx : tube glabrous within : upper lip erect, entire : lower lip 3-lobed, spreading: filaments various, 2 anther-bearing, sometimes exserted; the other 2 reduced to staminodia or wanting: anthers 2-celled; sacs somewhat confluent at the base. Nutlets smooth.

Foliage softly pubescent with short hairs: leaf-blades shallowly toothed.

Foliage hirsute or villous-hirsute: leaf-blades decidedly serrate.

1. B. ciliato.

2. B. hirsuta.

1. Blephilia ciliàta (L.) Raf. Stems softly pubescent, 3-6 dm. tall, simple or rarely branched: leaf-blades lanceolate, $5-10 \mathrm{~cm}$. Iong, acutish, remotely serrate, rounded or subcordate at base, short-petioled or nearly sessile : heads contiguous or lower ones remote, $2-2.5 \mathrm{~cm}$. thick : calyx 8-10 mm. long; tube ribbed, the upper lip with 3 subulate lobes, the lower lip with 2 subulate-lanceolate lobes : corolla pink or purplish, about $1 \mathrm{~cm}$. long; 
pubescent, the upper lip oblong-lanceolate, the lower lip 3-lobed, its middle lobe linearoblong, notched : filaments and style glabrous : nutlets about $1 \mathrm{~mm}$. long.

In dry woods and thickets, Massachusetts to Wisconsin, middle Georgia and Missouri. Summer.

2. Blephilia hirsùta (Pursh) Torr. Stems hirsute or villous-hirsute, giving off numerous runners with ovate leaf-blades in spring, $3-10 \mathrm{dm}$. tall : leaf-blades ovate to lanceolate, $5-12 \mathrm{~cm}$. long, acute or acuminate, serrate, rounded or subcordate at base : heads about $2 \mathrm{~cm}$. thick : calyx 6-8 $\mathrm{mm}$. long; tube delicately ribbed, the upper lip with 3 subulate bearded lobes, the lower lip with 2 lobes, their bases ovate, subulate-tipped: corolla pale, about $1 \mathrm{~cm}$. long, pubescent; tube curved, the upper lip lanceolate, the lower lip 3-lohed, its lateral lobes rounded, its middle lobe linear, usually notched: nutlets 1 mm. long.

In shaded ground or copses, Vermont to Wisconsin, Georgia and Texas. Summer.

\section{HEDEOMMA Pers.}

Annual or perennial herbs, usually strongly aromatic and pungent. Leaves opposite, often small : blades entire or sparingly toothed. Flowers in remote or contiguous axillary clusters. Calyx pubescent in the more or less constricted throat : tube 13-ribbed, commonly gibbous at the base, with 5 nearly equal lobes, or 2-lipped. Corolla blue or purple : tube but little enlarged below the lips : upper lip erect, entire to 2-lobed : lower lip spreading, 3-lobed. Stamens 4, or usually only 2 fertile: filaments 4, 2 usually sterile, much reduced or wanting. Nutlets smooth.

Calyx strongly 2-lipped, with the lobes of the two lips very dissimilar: filaments of posterior stamens manifest.

Calyx with similar or nearly similar lobes: filaments of posterior stamens rudimentary or obsolete.

Caly x-lobes of both lips about equal in length.

Calyx-lobes $1 / 3$ as long as the tube : corolla about twice as long as the calyx.

Caly x-lobes $1 / 2$ as long as the tube : corolla barely as long as the calyx.

Calyx-lobes of the 2 lips unequal in length, those of the lower much longer than those of the upper.

Calyx-tube barely if at all swollen at the base.

Calyx-tube manifestly swollen at the base. Calrx 5-6 mm. long.

Leaf about equalling the calyx it subtends or surpassed by it. Bracts petioled : calyx coarsely pubescent. Bracts sessile: calyx finely pubescent.

Leaf surpassing the caly $\mathrm{x}$ it subtends.

Calyx 7-8 mm. long.

Stems or branches branched throughout: calyx minutely hispid.

1. H. pulegioides.

Stems or branches simple above the base : calyx copiously bristly hispid.

2. H. acinoides.

3. H. hispida.

4. H. Drummondii.

5. H. serpyllifolia.

6. H. nana.

7. H. sancta.

8. H. lata.

9. H. Reverchonii.

1. Hedeoma pulegioìdes (L.) Pers. Annual, finely pubescent. Stems erect, 1-4 $\mathrm{dm}$. tall, more or less bushy-branched: leaf-blades oval-elliptic or oblong, 1-2 cm. long, obtuse, sparingly serrate : clusters loosely flowered, separated : calyx strongly ribbed, 3-4 $\mathrm{mm}$. long; tube stout, gibbous at base, the three upper lobes triangular or triangular-ovate, acute, the two lower lobes subulate, ciliate : corolla 4-5 mm. long; lips nearly equal, with blunt teeth : filaments and style glabrous: nutlets oval, nearly $1 \mathrm{~mm}$. long.

In dry soil, Cape Breton Island to Ontario, Minnesota, Florida and Nebraska. Summer.

2. Hedeoma acinoides Scheele. Annual, minutely pubescent. Stems erect, 1-2 dm. tall, or branched at the base, the branches ascending : leaf-blades oval to oblong, 1-1.5 cm. long, obtuse, slightly serrate or nearly entire: clusters aggregated into terminal raceme-like panicles: calyx 5-6 $\mathrm{mm}$. long, minutely pubescent, slightly enlarged at base but not gibbous ; tube slender; lobes nearly equal, subulate-lanceolate : corolla 7-8 mm. long; tube finely pubescent, nearly filiform, the upper lip oblong, usually minutely notched at the apex, the lower lip 3-lobed, its middle lobe nearly oblong, notched, lateral lobes ovate, rounded : filaments and style glabrous : nutlets $0.8 \mathrm{~mm}$. long.

On plains or prairies, Arkansas and Texas. Spring and summer.

3. Hedeoma híspida Pursh. Annual, hirsute. Stems erect, $0.5-3 \mathrm{dm}$. tall, simple or branching : leaf-blades linear, thickish, aeutish, entire or nearly so, 1-3 cm. long, sessile or very short-petioled : clusters numerous, contiguous or separated below : calyx hirsute, 4-5 mm. long, the three upper lobes linear-subulate, the lower lobes subulate, ciliate : corolla about $7 \mathrm{~mm}$. long, nearly glabrous ; tube gradually dilated, the upper lip suborbicular, notched, the lower lip 3-lobed, the middle lobe nearly as broad as long, retuse : filaments and style glabrous : nutlets oblong, $1 \mathrm{~mm}$. long.

On dry plains, Northwest Territory to Illinois, Louisiana and Colorado. Spring and summer.

4. Hedeoma Drummóndii Benth. Annual or perennial, minutely cinereous-pubescent. Stems erect, or assurgent, often diffusely branched, 1-4 dm. long : leaf-blades linear, oblong or oval at the base of the stem, thickish, $0.5-1 \mathrm{~cm}$. long, obtuse, entire, sessile or 
very short-petioled : clusters often numerous : pedicel at least $\frac{1}{2}$ as long as calyx : calyx tubular, 6-7 $\mathrm{mm}$. long; tube hispidulous, barely if at all swollen at maturity, the lobes of lower lip about twice as long as those of the upper lip : corolla pinkish, about $1 \mathrm{~cm}$. long : nutlets about $1.5 \mathrm{~mm}$. long.

On prairies, Texas. Summer.

5. Hedeoma serpyllifòlia Small. Perennial, softly hirsute. Stems tufted, ascending or decumbent, 1-2 dm. long, considerably branched, rather woody : leaf-blades oval to oblong, 5-8 mm. long, obtuse, softly pubescent, entire, manifestly petioled : clusters 2-4flowered : pedicel shorter than the calyx : calyx 5-6 mm. long, hirsute ; tube slightly constricted above the middle, finely ribbed; lobes subulate, the lower twice as long as the upper : corolla pinkish, $5 \mathrm{~mm}$. long, only slightly longer than calyx ; tube dilated above the middle, minutely pubescent, the upper lip rounded, minutely notched, smaller than lobes of the lower lip, its middle lobe larger than the others, deeply notched: nutlets 1 mm. long, puberulent.

In dry soil, Texas. Spring.

6. Hedeoma nàna (Torr.) Greene. Annual or perennial, puberulent or canescenthirsute, the hairs gray. Stems erect, more or less diffusely branched, the branches stiff: leaf-blades oblong to ovate, $5-12 \mathrm{~mm}$. long, entire or barely toothed, nearly sessile : calyx 4-6 mm. long, hispidulous, surpassing the leaves, especially above ; tube swollen, considerably so at maturity, the lobes of the lower lip between twice and thrice as long as those of the upper : corolla 6-7 mm. long; tube slender, the upper lip and middle lobe of the lower lip notched, other lobes obtuse: nutlets $1.2-1.3 \mathrm{~mm}$. long. [H. thymoides A. Gray.]

On plains or prairies, Texas to Arizona. Summer.

7. Hedeoma sáncta Small. Annual or biennial, finely cinereous-pubescent. Stems erect, 1-3 dm. tall, somewhat branched, rather slender: leaf-blades oval, oblong or narrowly oblong, $1-1.5 \mathrm{~cm}$. long, entire, slightly revolute, very short-petioled : calyx 5-6 mm. long, hispidulous, surpassed by the leaves; tube somewhat swollen, the lobes of the lower lip about twice as long as those of the upper : corolla 4-5 mm. long, puberulent; tube slender, the upper lip and middle lobe of the lower lip truncate or barely emarginate, the other lobes rounded: nutlets fully $1 \mathrm{~mm}$. long.

In dry soil, Texas. Spring.

8. Hedeoma làta Small. Perennial, firm, finely hirsute. Stems 1-3 dm. tall, repeatedly branched above: leaf-blades oblong to linear-oblong, 1-1.5 cm. long, obtuse or acutish, closely pubescent, sessile or nearly so: calyx 7-9 mm. long, finely hirsute ; tube constricted or bent on the back near the throat; lobes subulate, the lower abont twice as long as the upper: corolla $10-12 \mathrm{~mm}$. long, minutely pubescent, considerabiy longer than the calyx: nutlets fully $1 \mathrm{~mm}$. long.

On rocky prairies, Texas and New Mexico. Spring to fall.

9. Hedeoma Reverchòni A. Gray. Perennial, rigid, finely hirsute. Stems tufted, erect or ascending, 1-2 dm. tall, simple, softly pubescent : leaf-blades leathery, oblong or nearly so, 5-15 mm. long, obtuse, entire, finely pubescent, very short-petioled : calyx 8-10 mm. long, conspicuously bristly hispid ; tube constricted on the back above the middle ; lobes
subulate, the lower twice as long as the upper : corolla 13-15 mm. long, minutely pubescent, nearly twice as long as calyx; tube gradually dilated, the upper lip ovate, slightly notched, the lower lip 3-lobed, its middle lobe deeply notched: filaments and style glabrous : nutlets nearly $1.5 \mathrm{~mm}$. long, granular.

In rocky soil, middle Texas. Summer.

\section{STACHYDEÒMA Small.}

Annual or perennial caulescent pubescent herbs. Leaves opposite : blades entire or shallowly toothed, sessile or nearly so, the upper at least hirsute-ciliate. Flowers in terminal continuous or slightly interrupted spike-like panicles. Bracts narrow or subulate. Calyx short-pedicelled, hirsute: tube not gibbous: lobes subulate or setaceous. Corolla pink or purple, the throat with a pair of longitudinal projecting folds under the lower lip. Style pubescent. Nutlets nearly smooth.

Spike-like inflorescence continuous, abbreviated : leaf-blades entire; plants annual : Texan species.

Spike-like inflorescence interrupted below, elongated: leaf-blades toothed: plants

perennial : Floridian species.

2. S. graveolens.

1. Stachydeoma ciliàta (Benth.) Small. Annual, puberulent, and hirsute above. Stems 1-3 dm. tall, branching above : leaf-blades oblong to oblong-ovate, 1-2 cm. long, acutish, slightly toothed, sessile : clusters aggregated into terminal panicles, 1-2 cm. long: 
bracts subulate, bristly : calyx purplish, becoming 6-7 $\mathrm{mm}$. long, bristly-hispid ; tube 15ribbed ; lobes subulate, about equal in length, finally converging : corolla slightly surpassing the calyx, rose-purple, $8-10 \mathrm{~mm}$. long; tube not exserted, hairy in the throat; upper lip notched, the lower lip 3-lobed : sterile filament wanting: nutlets barely $1 \mathrm{~mm}$. long.

In sandy soil, Texas. Spring and summer.

2. Stachydeoma gravèolens (Chapm.) Small. Perennial, hirsute. Stems 2-6 dm. tall, simple or branched: leaf-blades ovate to suborbicular, 1-1.5 $\mathrm{cm}$. long, sparingly toothed, truncate or subcordate at base, sessile or very short-petioled : panicles elongated, leafy-bracted : calyx becoming about $5 \mathrm{~mm}$. long: tube 12-13-ribbed, the upper lip with deltoid lobes, the lower lip with subulate lobes : corolla purple, spotted, 6-8 mm. long; tube about equaling the longer calyx-lobes, the upper lip truncate, often undulate, the lower lip with a notched middle lobe : sterile filaments present : nutlets $0.5 \mathrm{~mm}$. long.

In low pine lands, Florida. Summer.

\section{MELÍSSA L.}

Perennial herbs, with branching stems. Leaves opposite : blades flat, broad, usually toothed. Flowers in axillary, often one-sided clusters. Calyx reflexed at maturity, 2lipped : tube 13-ribbed, nearly glabrous in the throat : upper lip with 3 short lobes : lower lip with 2 longer lobes. Corolla white or yellowish, surpassing the calyx, 2-lipped : tube curved, glabrous within: upper lip nearly erect, entire or notched: lower lip 3-lobed, spreading. Stamens 4: anthers 2-celled; sacs diverging. Nutlets smooth. BEe-Balm.

1. Melissa officinàlis L. Perennial, very softly hirsute, lemon-scented. Stems erect or much branched and spreading, 3-6 dm. long : leaf-blades ovate to ovate-oblong, $2-8 \mathrm{~cm}$. long, crenate-serrate, ciliate, rounded or subcordate at base or sometimes acute : flowerclusters leafy-bracted: calyx ringent, $8 \mathrm{~mm}$. long, hairy within and without; tube flat above, sharply ribbed, the upper lip with upcurved lobes, the lower lip with 2 narrower converging lobes : corolla white or cream-colored, about $1 \mathrm{~cm}$. long, the upper lip inflated, cleft at the apex, its segments recurved, the lower lip drooping, with a suborbicular middle lobe, bearded especially near the base.

In waste places and copses, Maine to Ohio and Florida. Summer. Lemon-Balm.

\section{CONRADINA A. Gray.}

Shrubs of low habit, with pubescent foliage. Leaves opposite, approximate or clustered : blades narrow, entire, often revolute. Flowers in loose axillary clusters. Calyx declined at maturity : tube 13-nerved, 2-lipped : upper lip of 3 short lobes: lower lip of 2 longer narrow lobes. Corolla purplish, surpassing the calyx, 2-lipped : upper lip erect, retuse : lower lip spreading, 3-lobed: middle lobe notched. Stamens 4: anthers 2-celled; sacs awnless, parallel. Nutlets smooth.

Foliage canescent : leaves less than $1 \mathrm{~cm}$. long: upper lip of the corolla rounded. Foliage puberulent: leaves over $1 \mathrm{~cm}$. long: upper lip of the corolla retuse.

1. C. canescens. 2. C. puberula.

1. Conradina canéscens (T. \& G.) A. Gray. A much branched shrub, 2-4 dm. tall, the foliage finely canescent : leaves very numerous, often clustered in axils; blades linear, $5-9 \mathrm{~mm}$. long, obtuse, entire, strongly revolute, sessile : clusters $2-6$-flowered : pedicels 1-2 $\mathrm{mm}$. long: calyx about $5 \mathrm{~mm}$. long, villous, prominently ridged, the upper lip with 3 acute or mucronate recurved lobes, the lower lobes lanceolate-subulate, all ciliate : corolla about $1.5 \mathrm{~cm}$. long; tube nearly as long as the calyx, the npper lip orbicular-ovate, obtuse, the lower lip 3-lobed, its lateral lobes oblong or oblong-obovate, its middle lobe broader than long, truncate at apex : nutlets about $1 \mathrm{~mm}$. long.

In sand on the west coast of Florida and Alabama. Spring and summer.

2. Conradina pubérula Small. A much branched shrub, 3-7 dm. tall, the foliage cinereous-puberulent : leaves numerous, often clustered in axils ; blades narrowly linear, 12-25 mm. long, obtuse, entire, strongly revolute, sessile : clusters 2-6-flowered, often forming a continuous panicle : pedicels commonly $1-2 \mathrm{~mm}$. long : calyx 5-6 mm. long, puberulent : tube slightly ribbed, the upper lip with 3 ovate or ovate-lanceolate acute ascending lobes, the lower lip with 2 lanceolate-subulate lobes : corolla 12-15 mm. long; tube as long as the calyx or nearly so, the upper lip retuse, the lower lip 3-lobed, the lateral lobes rounded, the middle lobe cuneate-flabellate, deeply notched: nutlets $1 \mathrm{~mm}$. long, globoseoval, smooth and glabrous.

In sand, Florida. Spring and summer. 


\section{PYCNOTHỲMUS Small.}

Perennial shrubby plants, glabrous or nearly so below the inflorescence. Leaves opposite, sometimes with smaller ones clustered in the axils: blades narrow, entire, revolute. Flowers in dense conspicuously pubescent bracted terminal raceme-like panicles. Calyx very delicate: tube campanulate, 10-ribbed: lobes 5, silky. Corolla purple or whitish : tube several times longer than the calyx : limb 2-lipped, the upper lip erect, entire or notched : lower lip 3-lobed, spreading. Stamens 4: anthers 2-celled; sacs separated. Nutlets smooth, dull.

1. Pycnothymus rígidus (Bart.) Small. Stems diffusely branched, the branches spreading, 1-6 dm. long, widely branched : leaves numerous ; blades rigid, lanceolate, 5-11 $\mathrm{mm}$. long, acute, sharply revolute, sessile or nearly so: head-like racemes subglobose or cylindric, 1-4 cm. long: calyx softly hirsute, $2.5-3 \mathrm{~mm}$. long; lobes lanceolate or oblonglanceolate, acutish, much longer than the tube : corolla light purple, minutely pubescent; tube gradually dilated, the lips rounded, the lobes of the lower one nearly equal : nutlets less than $1 \mathrm{~mm}$. long. [Satureia rigida Bart.]

In sand and pine lands, Florida. Spring.

\section{MICROMÈRIA Benth.}

Perennial herbs or shrubby plants, often with creeping stems. Leaves opposite: blades various, often broad, entire or sparingly toothed. Flowers few or many in remote or contiguous axillary clusters, or sumetimes solitary in the axils. Calyx nearly tubular: tube usually 13-ribbed: lobes 5, nearly equal, sometimes disposed so as to give the calyx a 2-lipped character. Corolla small, often very small, somewhat lorger than the calyx, 2lipped : upper lip erect, commonly much reduced : lower lip 3-lobed : middle lobe often notched. Stamens 4 : anthers 2-celled; sacs distinct, diverging. Nutlets smooth.

Pedicel about as long as the calyx: Texas species.

Pedicel much longer than the calyx : Floridian species.
1. M. pilosiuscula.

2. M. Brownei.

1. Micromeria pilosiúscula (Benth.) Small. Stems sparingly pubescent, branched at the base, the branches ascending or spreading, 1-2 dm. long : leaf-blades broadly ovate or orbicular, $5-10 \mathrm{~mm}$. in diameter, undulate-crenate, truncate or cordate at the base, shortpetioled : pedicels filiform, usually shorter than the subtending bracts : calyx hirsute, $4-5$ mm. long; tube turbinate, slightly ribbed ; lobes ovate, the upper one often 2-3-toothed, barely $\frac{1}{2}$ as long as tube: corolla $5 \mathrm{~mm}$. long; tube considerably dilated, the upper lip broadly cuneate-obovate, notched at the apex. [M. Brownei var. pilosiuscula A. Gray.]

In wet sandy soil, Texas and adjacent Mexico. Spring and summer.

2. Micromeria Bròwnei (Sw.) Benth. Stems glabrous or nearly so, branching at the base, the branches prostrate, creeping, 1-4 dm. long: leaf-blades suborbicular or broadly ovate, 5-12 $\mathrm{mm}$. in diameter, undulate or crenulate, truncate or subcordate at base, shortpetioled : pedicels filiform, as long as subtending bracts or longer : calyx glabrate, narrowly turbinate, $4-5 \mathrm{~mm}$. long, fluted ; lobes triangular or ovate, barely $\frac{1}{2}$ as long as tube, ciliolate : corolla 7-8 mm. long; tube funnelform, the upper lip ovate, sometimes retuse.

On river banks or muddy shores, Florida. Summer.

\section{CLINOPÒDIUM L.}

Annual or perennial herbs, or shrubs, with branching stems. Leaves opposite: blades narrow or broad, entire or toothed. Flowers in sessile or peduncled axillary clusters. Calyx glabrous or pubescent in the throat, 2-lipped : tube usually 13-ribbed, often swollen at the base : upper lip with 3 short lobes: lower lip of 2 longer lobes. Corolla surpassing the calyx, 2-lipped : tube rather abruptly dilated at the throat: upper lip erect, entire or notched: lower lip spreading, 3-lobed. Stamens 4 : filaments all anther-bearing: anthers 2-celled; sacs awnless. Nutlets smooth. [Calamintha Moench.] BAsIL.

Flowers in dense axillary clusters, accompanied by linear-filiform bracts. $\quad$ 1. . vulgare.

Flowers few or solitary in the axils of the leaves, with minute bracts.

Stems glabrous or minutely pubescent at the nodes.

Corolla less than $10 \mathrm{~mm}$. long.

Corolla over $10 \mathrm{~mm}$. long.

Stems pubescent or puberulent.

A. Plants shrubby : corolla over $10 \mathrm{~mm}$. long.

a. Leaf-blades entire: corolla over $25 \mathrm{~mm}$. long.

* Calyx less than $1.5 \mathrm{~cm}$. long: corolla $3-4 \mathrm{~cm}$. long.

2. C. glabrum.

3. C. glabellum.

4. C. coccineum. 
** Calyx over $1.5 \mathrm{~cm}$. long : corolla $4-5 \mathrm{~cm}$. long.

b. Leaf-blades toothed: corolla less than $15 \mathrm{~mm}$. long

Clusters 5-6-flowered : leaf-blades broadest below the middle, sessile or nearly so.

Clusters 1-3-flowered : leaf-blades broadest above the middle, petioled.

B. Plants herbaceous: corolla less than $10 \mathrm{~mm}$. long.

5. C. macrocalyx.

6. C. Carolinianum

7. C. dentatum.

8. C. Nepeta.

1. Clinopodium vulgàre L. Perennial, hirsute. Stems erect or ascending, 1-5 dm. tall, simple or sparingly branched : leaf-blades oval to ovate or ovate-lanceolate, 1-4 cm. long, obtuse, undulate or crenate, narrowed into slender petioles : clusters dense, $1-3 \mathrm{~cm}$. in diameter : bracts linear-filiform, bristly : calyx $8-9 \mathrm{~mm}$. long, villous-hirsute ; tube strongly ribbed; lobes of both lips subulate-tipped, the lower lip barely surpassing the upper: corolla white or purple; tube dilated from near the base, the upper lip notched, the lower lip with 3 obtuse lobes. [Calamintha Clinopodium Benth.]

In thickets and copses, Nova Scotia to Manitoba, North Carolina and Colorado. Summer and fall.

2. Clinopodium glàbrum (Nutt.) Kuntze. Perennial, stoloniferous, glabrous. Stems erect, often tufted, 1-3 dm. tall, simple or branched: leaves of stolons with obovate or oval blades, those of lower part of stem spatulate; upper stem-leaves numerous; blades linear, obtuse or acutish, entire or sparingly toothed : clusters 2-6-flowered : pedicel longer than calyx : calyx 4-5 mm. long; tube strongly ribbed; lobes lanceolate-subulate or the upper 3 narrowly triangular, the lower narrower and a little longer than upper: corolla 8-9 mm. long, puberulent, the upper lip notched, $1 \mathrm{~mm}$. long. [Calamintha Nuttallii Benth.]

On rocks and rocky banks, Ontario to Minnesota, New York and Texas. Spring and summer.

3. Clinopodium glabéllum (Michx.) Kuntze. Perennial, lax, nearly glabrous. Stems weak, ascending, or decumbent, 1-4 dm. long, simple or branched : leaf-blades oblong or elliptic, 1-4 cm. long, obtuse, sparingly serrate, short-petioled : clusters 2-10-flowered : pedicel as long as the calyx or longer : calyx $5-6 \mathrm{~mm}$. long; tube strongly ribbed, the upper lobes lanceolate-subulate, upcurved ; the lower lobes subulate, nearly straight, $\frac{1}{2}$ as long as the tube : corolla 12-14 mm. long; tube pubescent, the upper lip notched, the lower lip with a rather square middle lobe : nutlets $0.8 \mathrm{~mm}$. long, granular. [Calamintha glabella (Michx.) Benth.]

On limestone banks, Kentucky and Tennessee. Spring and summer.

4. Clinopodium coccíneum (Nutt.) Kuntze. A branching shrub 3-9 dm. tall, the foliage cinereous-puberulent or glabrate : leaf-blades leathery, obovate, spatulate to linearspatulate or linear-oblong, $0.5-2 \mathrm{~cm}$. long, obtuse or acutish, entire, sessile or nearly so : pedicels 2-4 mm. long : caly x 8-11 $\mathrm{mm}$. long; tube nearly cylindric, puberulent, the upper lip mucronate, the lobes of the lower lip lanceolate-acuminate, $1.2-2.5 \mathrm{~mm}$. long: corolla scarlet, puberulent, 3-4 cm. long, the upper lip deeply notched; nutlets barely $1.5 \mathrm{~mm}$. long. [Calamintha coccinea (Nutt.) Benth.]

In sandy soil, Florida to Alabama. Summer and fall.

5. Clinopodium macrocályx Small. Similar to C. coccineum in habit: leaf-blades broadly spatulate, $1-1.5 \mathrm{~cm}$. long, obtuse or slightly apiculate, somewhat revolute, copiously punctate, contracted to the narrow base: pedicels 2-4 mm. long: caly x 16-18 mm. long; tube striate, puberulent, the upper lip acute, the lobes of the lower lip subulate, $4.5-6 \mathrm{~mm}$. long: corolla scarlet, minutely pubescent, 4-5 $\mathrm{cm}$. long, the upper lip notched.

In pine lands, Indian River region, Florida. Summer.

6. Clinopodium Caroliniànum (Michx.) Heller. A branching shrub 2-6 dm. tall, the branches finely pubescent: leaf-blades firm, ovate, oval or oblong, obtuse, $1-3 \mathrm{~cm}$. long, shallowly serrate, narrowed into short petioles : clusters few-flowered, sometimes peduncled: calyx 5-6 mm. long, glandular-dotted; tube strongly ribbed, villous in the throat ; upper lip curving upward, 2-3-toothed, the lower lip of 2 lanceolate lobes : corolla white or pinkpurple, and purple spotted, $10-13 \mathrm{~mm}$. long, minutely pubescent, the upper lip notched, the lower lip 3-lobed : filaments and style glabrous: nutlets about $1 \mathrm{~mm}$. long, granular. [Calamintha Caroliniana (Michx. ) Benth.]

In dry soil, North Carolina to Florida. Summer and fall.

7. Clinopodium dentàtum (Chapm.) Kuntze. A diffusely branched shrub, cinereous-tomentulose. Stems 3-7 dm. tall : leaf-blades leathery, obovate to oblongcuneate, 5-12 mm. long, entire or 2-4-toothed at the apex, sessile or nearly so : clusters 2-6flowered : pedicels shorter than calyx : calyx 6-7 mm. long; tabe strongly ribbed, the upper lip 2-3-toothed, upcurved, the lower lip of 2 subulate-lanceolate ciliate lobes : corolla white or purplish, 11-13 mm. long. [Calamintha dentata Chapm.]

In sand, Florida. Spring to fall.

8. Clínopodium Népeta (L.) Kuntze. Perennial, villous-hirsute or cinereous. Stems simple or branched at the base, the branches erect or ascending, 2-9 dm. tall, more 
or less branched : leaf-blades ovate to orbicular-ovate, 1-2 $\mathrm{cm}$. long, obtuse or acutish, slightly serrate, short-petioled: clusters remote, few-flowered: calyx 4-6 mm. long, minutely pubescent; tube at length constricted above the middle ; upper lobes triangular or lanceolate, curving upward; lower lobes subulate, curved : corolla $8-9 \mathrm{~mm}$. long; tube gradually dilated, puberulent, the upper lip notched, the lower lip with a reniform niddle lobe : nutlets barely $1 \mathrm{~mm}$. long, granular. [Calamintha Nepeta (L.) Link \& Hoffmansg.]

In waste places and fields, Maryland and Kentucky to Georgia and Arkansas. Naturalized from Europe. Summer and fall. FIELD-BALM.

\section{DICERÁNDRA Benth. ${ }^{1}$}

Annual caulescent herbs, with puberulent foliage. Leaves opposite : blades flat, narrow, entire. Flowers in axillary clusters. Calyx pedicelled: tube about 13-ribbed, 2lipped : upper lip truncate or with 3 short lobes: lower lip of 2 narrower and longer lobes. Corolla pink-purple or white, spotted, surpassing the calyx, 2-lipped: upper lip erect, nearly entire: lower lip 3-lobed. Stamens 4 : anthers 2-celled; sacs awned. Nutlets smooth. Corolla pink-purple: anthers exserted.

Cymes nearly sessile: anther-horns blunt.

Cymes markedly peduncled: anther-horns acute. Corolla white: anthers included.

1. D. densiflora.

2. D. linearifolia.

3. D. odoratissima.

1. Dicerandra densiflòra Benth. Stems 1-4 dm. tall, branching: leaf-blades narrowly oblong or linear-oblong, $2-4 \mathrm{~cm}$. long, obtuse, sessile or short-petioled : cymes fewflowered, sometimes compact, nearly sessile : calyx purple-tinged, $6-7 \mathrm{~mm}$. long; tube ribbed, the upper lip upcurved, more or less distinetly notched, the lower lip of 2 lanceolate or triangular-lanceolate acute lobes : corolla pink-purple, spotted, nearly $1.5 \mathrm{~cm}$. long ; tube shorter than the calyx, the upper lip retuse, the lower lip 3-lobed, its lobes oblong, the middle one eroded at the apex : filaments glabrous : style minutely pubescent.

In sandy soil, Georgia, Florida and Alabama. Summer and fall.

2. Dicerandra linearifòlia (Ell.) Benth. Stems $2-4 \mathrm{dm}$. tall, branching: leaves opposite; blades linear or lanceolate, 1-3 cm. long, rather obtuse, entire, more or less revolute, sessile or short-petioled : cymes few-flowered, peduncled : pedicels $1-3 \mathrm{~mm}$. long: calyx 5-6 mm. long, purple-tinged; tube slightly ribbed, the upper lip curved upward, barely notched, the lower lobes triangular, acuminate: corolla pink-purple and spotted, $1.5 \mathrm{~cm}$. long; tube about as long as calyx, the throat broadly funnelform, the upper lip retuse, the lower lip 3 -lobed, its lobes oblong or nearly so, the middle lobe notched: filaments glabrous : style minutely pubescent.

In dry sandy soil, Georgia, Florida and Alabama. Fall.

3. Dicerandra odoratíssima Harper. Stems $2-4 \mathrm{dm}$. tall, fastigiately branched from near the base : leaf-blades linear, $2-3 \mathrm{~cm}$. long, obtuse, sessile : cymes few-or severalflowered, often contiguous : calyx light green below, white above, 7-8.5 mm. long; tube strongly ribbed, the upper lip rounded, entire or nearly so, the two lobes of the lower lip delicate, incurved : corolla white, with many purple spots, 14-17 mm. long; tube surpassing the calyx, the upper lip arched, the lower lip spreading or deflexed.

On sand hills, eastern Georgia. Fall.

\section{HYSSÒPUS L.}

Perennial caulescent herbs, sometimes woody at the base. Leaves opposite : blades narrow, entire. Flowers in dense axillary or terminal clusters. Calyx glabrous at the throat: tube 15-ribbed: lobes 5 , about equal. Corolla blue or purple, surpassing the calyx, 2-lipped : upper lip notched: lower lip 3-lobed. Stamens 4, at least 2 exserted: anthers 2-celled; sacs divergent. Nutlets slightly 3-angled, smooth. Hyssop.

1. Hyssopus officinalis L. Stems usually branched from the woody base, the branches 2-9 dm. tall, puberulent: leaf-blades linear to oblong or oblong-lanceolate, 1-3 cm. long, thickish, entire, faintly veined, sessile or nearly so: panicles rather dense, becoming $2 \mathrm{~cm}$. thick : calyx short-pedicelled; lobes ovate to lanceolate, acute, $\frac{1}{4}-\frac{1}{3}$ as long as the strongly ribbed tube : corolla blue or purplish, 8-10 $\mathrm{mm}$. long: stamens and style exserted.

In waste places and on roadsides, Ontario and Maine to North Carolina, and on the Pacific Coast Naturalized from Europe. Summer.

${ }^{1}$ Revised by Mr. Roland M. Harper. 


\section{THỲMUS L.}

Perennial herbs, with low or creeping stems. Leaves opposite : blades small, flat, mostly entire. Flowers perfect, in axillary or terminal clusters. Calyx narrow : tube relatively short, 10-13-ribbed, 2-lipped: upper lip ascending: lower lip of 2 narrow, longer lobes. Corolla purple or pale, surpassing the calyx, 2-lipped: upper lip erect, emarginate : lower lip 3-lobed, spreading. Stamens 4: filaments mostly surpassing the corolla : anthers 2-celled; sacs diverging. Nutlets smooth. Tнуме.

1. Thymus Serpýllum L. Diffusely spreading or forming wide mats. Stems and branches wiry, tough, pubescent in lines: leaf-blades oblong to oval or ovate, $3-10 \mathrm{~mm}$. long, obtuse, entire, short-petioled : bracts like the leaves but smaller : panicles spike-like, dense : calyx becoming 3-4 mm. long; lobes of the lower lip slender, about as long as the tube : corolla purplish ; tube about as long as the calyx : nutlets about $0.5 \mathrm{~mm}$. long.

on roadsides and in woods, and in waste places, Nova Scotia to Pennsylvania and North Carolina. Naturalized from Europe and Asia. Summer.

\section{KOÈLLIA Moench.}

Perennial caulescent herbs, with glabrous or pubescent foliage. Leaves opposite, often numerous on short branches: blades narrow or broad, flat, entire or toothed. Flowers in dense axillary and terminal clusters. Calyx ovoid to tubular : tube 10-13-ribbed, not conspicuously pubescent in the throat : lobes 5, equal or unequal. Corolla white or purplish, surpassing the calyx, 2-lipped: upper lip erect, entire or notched: lower lip 3-lobed. Stamens 4, often nearly equal : filaments often surpassing the corolla : anthers 2-celled; sacs parallel. Nutlets smooth, variously roughened or pubescent. [Pycnanthemum Michx.] Mountain Mint. Horse Mint.

Calyx not 2-lipped; lobes equal or nearly so.

Calyx-lobes much surpassed by the corolla.

Flower-clusters relatively loose, in terminal apparently naked corymbs: bracts shorter than the clusters.

Flower-clusters very dense, in terminal conspicuously bracted corymbs.

Calyx-lobes not awn-tipped.

Bractlets ciliolate.

Caly $x$-lobes triangular or ovate-triangular.

Calyx-lobes subulate to lanceolate.

Leaf-blades or most of them over 3 times as long as broad.

Leaves with strictly entire blades.

Leaves. or the larger ones, with toothed blades.

Flower-clusters 1-2 cm. broad at maturity, compact.

Flower-clusters conspicuously woolly at maturity: stems copiously pubescent.

Calyx-lobes acute: leaf-blades firm; species campestrian.

Calyx-lobes acuminate: leaf-blades thin : species Alleghenian.

Flower-clusters not woolly at maturity : stems pilose or slightly pubescent.

Flower-clusters $2-3 \mathrm{~cm}$. broad at maturity, not crowded. Leaf-blades or most of them less than 3 times as long as broad. Bractlets copiously villous-eiliate. Calyx-lobes awn-tipped.

Calyx-lobes equalling the corolla.

Calyx-lobes, at least the lower ones, shorter than the tube: bracts with tips mostly shorter than the body: coastal species.

Calyx-lobes, at least the lower ones, longer than the tube: bracts with tips mostly longer than the body: Alleghenian species.

Calyx manifestly 2-lipped by the partial union of the 3 upper lobes.

Calyx-lobes destitute of long hairs, or only a few at the tip of a lobe.

Calyx-lobes ovate or triangular-ovate, obtuse, incurved at maturity.

Calyx-lobes lanceolate or triangular-lanceolate, subulate-tipped, erect.

Calyx-lobes furnished with long hairs.

Upper leaf-blades whitened.

Upper leaf-blades green.

Stems pilose: calyx-lobes plumose.

Stems puberulent: calyx-lobes sparingly hairy.

1. K. nuda.

2. K. Virginiana.

3. $K$. flexuosa.

Koellia nùda (Nutt.) Kuntze. Stems glabrous or nearly so, 3-7 dm. tall, corymbosely branched above : leaf-blades rather thick, oblong, elliptic or oval, $1-2 \mathrm{~cm}$. long, acute or obtuse, entire or nearly so, sessile : calyx $3-4 \mathrm{~mm}$. long, slightly enlarged upward ; lobes triangular, acute, ciliate : corolla $6 \mathrm{~mm}$. long, pubescent, the lips oblong, $\frac{1}{2}$ as long as the tube, obtuse, or the lower lip 3-lobed : filaments and style glabrous.

In pine lands, North Carolina to Florida and Alabama. Summer and fall. 
2. Koellia Virginiàna (L.) Britton. Stems minutely pubescent, 4-9 dm. tall, branched above: leaf-blades lanceolate or linear-lanceolate, $2-5 \mathrm{~cm}$. long, acute, mostly entire, sessile or nearly so : clusters $8-10 \mathrm{~mm}$. in diameter : bracts linear-lanceolate to narrowly linear : calyx $3.5-4 \mathrm{~mm}$. long, finely pubescent ; lobes triangular, acute, about $\frac{1}{3}$ as long as the tube : corolla $6-7 \mathrm{~mm}$. long, the upper lip ovate, notched, the lobes of the lower lip oblong or ovate. [Pycnanthemum lanceolatum Pursh.]

In dry soil, often in thickets, Quebec and Ontario to Minnesota, Georgia, Alabama and Nebraska. Summer and fall.

3. Koellia flexuòsa (Walt.) MacM. Stems slender, glabrous, solitary or tufted, 3-8 dm. tall, branched above : leaf-blades narrowly linear to linear-filiform, 1-4 cm. long, acute, entire, sessile : clusters dense, $6-8 \mathrm{~mm}$. in diameter : bracts lanceolate, acuminate : calyx $3.5 \mathrm{~mm}$. long, woolly; lobes triangular-lanceolate, somewhat acuminate : corolla pink or white, $6-7 \mathrm{~mm}$. long, pubescent within and without, the upper lip ovate, minutely notched, magenta-spotted, the lower lip 3-lobed, its middle lobe longer and narrower than the lateral lobes. [Pycnanthemum linifolium Pursh.]

In dry soil, mostly in meadows or thickets, Ontario to Minnesota, Massachusetts, Florida and Texas. Summer and fall.

4. Koellia pilòsa (Nutt.) Britton. Stems densely somewhat cinereous-pubescent, 4-13 dm. tall, often branched above : leaf-blades lanceolate to linear-lanceolate, 2-6 cm. long, acute, sessile or nearly so : clusters $1-1.5 \mathrm{~cm}$. thick : bracts about as long as the calyx, densely pubescent: calyx 4-5 mm. long, minutely pubescent: lobes lanceolate, acute, about $\frac{1}{3}$ as long as the tube : corolla $7-8 \mathrm{~mm}$. long, minutely pubescent, the upper lip oblong-ovate, the lower lip with ovate lateral lobes and a linear-oblong middle lobe : filaments and style glabrous.

On prairies and in dry woods, Ohio to Missouri, Georgia and Arkansas. Summer and fall.

5. Koellia léptodon (A. Gray) Small. Stems softly pubescent, or glabrate below, 5-11 dm. tall, loosely branched : leaf-blades lanceolate to oblong-lanceolate, 2-5 cm. long, acute, shallowly serrate or entire: clusters $1-2 \mathrm{~cm}$. thick: bracts mostly shorter than the calyx, densely pubescent : calyx 5-5.5 mm. long, rather villous; lobes lanceolate, acuminate, about $\frac{1}{3}$ as long as the tube, conspicuously hairy : corolla about $7 \mathrm{~mm}$. long, minutely pubescent, the upper lip ovate, the lower lip with rounded lateral lobes and an oblong middle lobe : filaments and style g]abrous. [Pycnanthemum pilosum var. ?leptodon A. Gray.]

In woods, mountains of North Carolina. Summer.

6. Koellía verticillàta (Michx. ) Kuntze. Stems minutely pubescent, deep green, 3-12 dm. tall, more or less branched : leaf-blades lanceolate to almost linear, $2-6 \mathrm{~cm}$. long, acute, remotely or shallowly serrate, ciliolate, sessile : clusters dense, 1-2 cm. thick : bracts lanceolate to linear: calyx 4-5 mm. long, puberulent; lobes subulate-lanceolate, ciliolate, $\frac{1}{3}$ as long as the tube : corolla pink or pinkish, 7-8 mm. long, the upper lip oblong, bearded at the apex, the lower lip spotted with garnet, its 3 lobes obtuse.

In open woods and thickets, Rhode Is!and to Missouri and Georgia. Summer and fall.-The form with narrow leaf-blades, $K$. Torreyi (Pursh) Kuntze, is probably distinct.

7. Koellia clinopodioìdes (T. \& G.) Kuntze. Stems softly pubescent, 4-12 dm. tall, often widely branching : leaf-blades lanceolate, narrowly oblong or elliptic, $2-8 \mathrm{~cm}$. long, acute, more or less distinctly serrate, narrowed into petioles: clusters rather loose, $2-3 \mathrm{~cm}$. thick : calyx $4 \mathrm{~mm}$. long; tube ribbed ; lobes lanceolate-subulate, nearly $\frac{1}{2}$ as long as the tube : corolla pink or purplish, $6 \mathrm{~mm}$. long ; tube surpassing the calyx, the upper lip oblong, minutely pubescent, the lower lip with the middle lobe undulate, broadened above the middle, twice as long as lateral lobes.

In dry open woods, New York to Pennsylvania, Virginia and Tennessee. Summer.

8. Koellia mùtica (Michx.) Britton. Stems finely pubescent, densely so above, 6-10 dm. tall, branching: leaf-blades ovate to lanceolate, 2-6 dm. long, acute, more or less distinctly toothed, sessile or very short-petioled, the upper mealy pubescent: clusters dense, 1-1.5 cm. thick : bracts narrow, ciliate : calyx $3.5-4 \mathrm{~mm}$. long, finely pubescent, or puberulent in age ; lobes triangular or lanceolate-triangular, $\frac{1}{3}$ as long as the tube : corolla pink or purplish, about $8 \mathrm{~mm}$. long, the upper lip orbicular-ovate, notched, or sometimes all the lobes obtuse : nutlets fully $1 \mathrm{~mm}$. long.

In sandy soil, Maine to Missouri and Florida. Summer and fall.

9. Koellia montàna (Michx.) Kuntze. Stems glabrous or nearly so, 3-9 dm. tall, branched : leaf-blades thinnish, lanceolate, oblong- or ovate-lanceolate, acute or acuminate, sharply serrate, gradually or abruptly narrowed into short petioles: clusters becoming dense, $1-2.5 \mathrm{~cm}$. thick: bracts linear or lanceolate, ciliate: calyx 4-5 mm. long; lobes lanceolate, acute, branched at the apex, at least when young, $\frac{1}{4}$ as long as the tube : corolla 
7-8 $\mathrm{mm}$. long, the upper lip oblong, retuse, the lower lip 3-lobed; lobes nearly oblong, obtuse, the middle one narrower and longer than the others.

In woods in the mountains, Virginia and West Virginia to Georgia and Alabama. Summer.

10. Koellia aristàta (Michx.) Kuntze. Stems more or less densely puberulent, 4-9 $\mathrm{dm}$. tall, branched above : leaf-blades oblong-lanceolate to ovate-lanceolate, $1.5-5 \mathrm{~cm}$. long, acute or rather obtuse, entire or shallowly serrate, rounded or subcordate at base, short-petioled or nearly sessile : heads dense : calyx 5-6 mm. long; lobes slightly unequal, lanceolate-subulate, about $\frac{1}{2}$ as long as the tube : corolla pink or whitish, slightly longer than the calyx, the upper lip and lobes of lower lip rounded.

In pine lands, New Jersey to Florida and Louisiana. Summer and fall.

11. Koellia hyssopifòlia (Benth.) Britton. Stems puberulent, 4-10 dm. tall, branching above: leaf-blades narrowly oblong to linear, 1-3.5 $\mathrm{cm}$. long, usually entire, sessile or nearly so : clusters dense, subglobose : calyx $5-6 \mathrm{~mm}$. long; tube prominently ribbed ; lobes subulate-tipped, nearly equal, at least $\frac{1}{2}$ as long as the tube : corolla pink or whitish, slightly longer than the calyx, the upper lip minutely toothed at the apex, the lower lip with a middle lobe much longer than the lateral lobes: style pubescent above.

In pine lands, Virginia to Florida. Summer.

12. Koellia Hùgeri Small. Stems densely cinereous-tomentulose, 5-7 dm. tall, branching above : leaf-blades oblong, $1.5-4 \mathrm{~cm}$. long, acute, entire or sparingly serrate, sessile or nearly so : clusters dense : calyx 7-8 mm. long, puberulent ; lobes nearly equal, aristate-tipped, pale, as long as tube or longer : corolla pink, surpassed by the calyx-lobes, the upper lip truncate, the lower lip 3-lobed, its middle lobe oblong, its lateral lobes roundovate : style glabrous.

On mountain slopes and in meadows, summit of the Blue Ridge, North Carolina. Summer.

13. Koellia albéscens (T. \& G.) Kuntze. Stems whitish with minute velvety pubescence throughout. Stems 4-10 dm. tall, sparingly or finely and corymbosely branched above: leaf-blades ovate to elliptic or ovate-lanceolate, $2-7 \mathrm{~cm}$. long, serrate, acute or slightly acuminate : bracts minutely velvety, but beardless : calyx 2-3 mm. long, slightly curved, beardless; lobes triangular to ovate-triangular : corolla pink, 5-6 mm. long, the lobes rounded, or the upper lip and middle lobe of the lower lip barely emarginate.

In sandy soil, often in dry woods, Virginia to Missouri, Florida and Texas. Summer and fall.

14. Koellia incàna (L.) Kuntze. Stems softly pubescent and more or less hirsute, 5-12 dm. tall, simple below, branched above, 4-angled : leaf-blades ovate, elliptic or lanceolate, 3-10 cm. long, acute or short-acuminate, remotely serrate, narrowed into short petioles, hoary beneath, and the upper ones on both sides: clusters rather loose, 2-3.5 cm. broad: calyx tubular, curved near the top, subtended by narrow subulate bracts; tube ribbed, $4 \mathrm{~mm}$. long; lobes triangular or triangular-lanceolate, awn-tipped : corolla 7-8 $\mathrm{mm}$. long, the upper lip oblong, pale lilac, minutely notched and ciliolate at the apex, the lower lip 3-lobed, spotted with lilac, the lateral lobes rounded, the terminal one obovate, crenulate, with a yellowish spot in the center.

In thickets and on wooded hillsides, Maine and Ontario to Ohio and Florida. Summer and fall.

15. Koellia pycnanthemoides (Leavenw.) Kuntze. Stems canescent or glabrous below, $6-14 \mathrm{dm}$. tall, more or less widely branching : leaf-blades ovate, elliptic or ellipticlanceolate, $2-10 \mathrm{~cm}$. long, the upper ones white-canescent, acute or acuminate, serrate, narrowed into short villous-hirsute petioles : clusters rather loose, $1.5-3.5 \mathrm{~cm}$. broad : bracts often linear-spatulate, with long hairs near the apex : calyx 5-6 mm. long; lobes lanceolate-subulate, with long hairs : corolla pale lilac, 7-8 $\mathrm{mm}$. long, the upper lip narrowly oblong, obtuse, the lower lip spotted with garnet and magenta, 3-lobed, the middle lobe obIong, curved upward. [Pycnanthemum Tullia Benth.]

In mountain woods and thickets, Virginia to Kentucky, Georgia and Alabama. Summer.

16. Koellia dùbia (A. Gray.) Small. Stems finely hirsute, 4-9 dm. tall, branching : leaf-blades lanceolate to linear-elliptic, $2-8 \mathrm{~cm}$. long, acute or acuminate, serrate or nearly entire, narrowed into short petioles: clusters becoming dense, 1-2 $\mathrm{cm}$. thick: bracts linear-filiform or slightly broadened at the middle: calyx about $4 \mathrm{~mm}$. long; tube finely pubescent; lobes at least $\frac{1}{2}$ as long as the tube, each with a triangular or lanceolate body and a subulate conspicuously bearded tip : corolla pink or lilac, 6-7 mm. long; tube slightly eurved, the upper lip, and lobes of lower lip, mostly rounded. [Pyenanthemum Tullia var.

dubium A. Gray.]

On mountain slopes, Ashe County, North Carolina. Summer.

17. Koellia Beadlel Small. Stems minutely pubescent, $5-8 \mathrm{dm}$. tall, simple or sparingly branched : leaf-blades resinous-dotted, the floral ones slightly canescent, oblong- 
lanceolate, or those of the branches elliptic-lanceolate to ovate, all acute or acuminate, 3-8 $\mathrm{cm}$. long, serrate, rounded or subcordate at the base ; petioles 1-3 mm. long: clusters solitary or few, terminal, dense, 1-2 cm. broad : bracts narrowly linear or slightly broadened at the middle: calyx puberulent, $4-5 \mathrm{~mm}$. long; tube finely ribbed; lobes triangularlanceolate, with subulate tips barely $\frac{1}{3}$ as long as the tube : corolla $6-7 \mathrm{~mm}$. long ; tube not surpassing the calyx, the upper lip oblong, obtuse, the lower lip 3-lobed, its middle lobe oblong, notched, its lateral lobes rounded : filaments and style glabrous.

On rocks, mountains of North Carolina. Summer and fall.

\section{CUNÌLA L.}

Perennial caulescent herbs or shrubby plants, with aromatic herbage. Leaves opposite : blades flat, entire or toothed, sometimes punctate. Flowers in axillary clusters. Calyx slender: tube relatively short, pubescent in the throat, 10-13-ribbed: lobes 5, equal, shorter than the tube. Corolla surpassing the calyx, 2-lipped: upper lip erect: lower lip larger, spreading, 3-lobed. Stamens exserted : filaments various, 2 anther-bearing, 2 much reduced or obsolete : anthers short; sacs parallel. Nutlets smooth. DitTany.

1. Cunila origanoides (L.) Britton. Foliage glabrous or nearly so. Stems $2-4 \mathrm{dm}$. tall, wire-like, more or less branched : leaf-blades ovate to ovate-lanceolate, $1.5-2.5 \mathrm{~cm}$. long, acute or obtusish, serrate, rounded or subcordate at the base, sessile or nearly so: cymes loosely flowered, short-peduncled: calyx narrowly campanulate, $2 \mathrm{~mm}$. long; tube finely ribbed; lobes ovate acutish, pilose within: corolla $4-5 \mathrm{~mm}$. long; tube surpassing the calyx, pubescent, the upper lip rounded or notched, the middle lobe of the lower lip deeply notched. [C. Mariana L.]

In dry soil, New York and Ohio to Florida. Summer and fall. Stone Mint.

\section{LÝCOPUS L.}

Perennial caulescent nearly odorless herbs. Stems often producing stolons or suckers. Leaves opposite : blades entire, toothed, incised or pinnatifid. Flowers in remote axillary clusters. Calyx regular or nearly so: lobes $4-5$, equal or very slightly unequal. Corolla equalling the calyx or surpassing it, white or purplish: tube cylindric to funnelform: Iobes 4, equal or one broader than the rest and often emarginate. Anther-bearing stamens 2 , included : filaments 4 , or the posterior pair reduced or wanting: anthers 2-celled; sacs parallel. Nutlets 3 -angled, truncate, smooth. Bugle-weed. Water Hoarhound.

Calyx-lobes ovate to oblong or oblong-lanceolate, 4-5: nutlets longer than the calyx-lobes.

Corollas $1.5-2 \mathrm{~mm}$. long: style included : calyx-lobes rather acute.

Calyx-lobes subulate to lanceolate, mostly $5:$ nutlets shorter than the calyx-lobes.

Corolla twice as long as the calyx: bracts minute: blades of the lower leaves merely toothed.

Leaf-blades sessile, sometimes partly clasping. Stems glabrous,"at least below: bracts subtending the cymes gradually"narrowed at the base.

Stems densely puberulent or finely pubescent: bracts subtending the cymes truncate at the base.

Leaf-blades manifestly petioled or with petiole-like bases.

Stem glabrous or merely puberulent : calyx glabrous or nearly so; lobes straight: corolla sparingly punctate.

Stem copiously pubescent : calyx closely pubescent ; lobes, at least the upper

ones, recurved: corolla copiously punctate.
Corolla but little longer than the calyx: blades of the lower leaves pinnatifid.

1. L. Virginicus.

2. L. communis.

\section{L. sessilifolius.}

4. L. pubens.

5. L. rubellus.

6. L. velutinus.

7. L. Americanus.

1. Lycopus Virgínicus L. Purplish or green-purple, puberulent. Stems 1-8 dm. tall, obtusely angled, not tuberous at the base, but with tuber-bearing stolons : leaf-blades ovate to oblong-ovate or elliptic, $2-14 \mathrm{~cm}$. long, usually acuminate at both ends, coarsely toothed, manifestly petioled: calyx tubular; lobes erect, oblong or oblong-lanceolate, acutish : corolla $2 \mathrm{~mm}$. long, or shorter, less than twice as long as the calyx; lobes almost equal, erect or nearly so: stamens and style included : staminodia manifest : nutlets 1.5-2 $\mathrm{mm}$. long, transversely notched and denticulate.

In moist soil, New York to Nebraska, Georgia, Alabama and Arkansas. Summer and fall.

2. Lycopus commùnis Bicknell. Green or sometimes purplish, less puberulent than L. Virginicus. Stems $1-8 \mathrm{dm}$. tall, rather acutely angled, tuberous at the base, the stolons rarely tuber-bearing: leaf-blades oblong or oblong-lanceolate, $2-8 \mathrm{~cm}$. long, serrate, sessile or nearly so: calyx campanulate; lobes ovate to ovate-oblong, rather obtuse : corolla 2-3 
$\mathrm{mm}$. long; tube abruptly dilated at the throat; lobes spreading: staminodia obsolete or minute : nutlets 1-1.5 mm. long, oblique at the apex.

In low grounds, Newfoundland to British Columbia, North Carolina, Nebraska and Oregon. Summer and fall.

3. Lycopus sessilifòlius A. Gray. Green, glabrous, or slightly puberulent above. Stems 2-6 dm. tall, with stolons and suckers: leaf-blades ovate to oblong or lanceolate, acute or acutish, or slightly acuminate, $1.5-6 \mathrm{~cm}$. long, shallowly serrate, sessile : bracts minute : calyx campanulate; lobes usually 5 , rigid, subulate, about as long as the tube : corolla white, about twice as long as the calyx : nutlets shorter than the calyx-lobes.

In wet soil, Massachusetts to Florida. Summer and fall.

4. Lycopus pùbens Britton. Closely puberulent or pubescent, green or purplish. Stems 6-12 dm. tall, rather obtusely angled, from long rootstocks and producing tuberbearing stolons : leaf-blades oblong, oblong-lanceolate or linear-oblong, acute or somewhat acuminate, sharply serrate, sessile : calyx $2-2.5 \mathrm{~mm}$. long, campanulate-turbinate; lobes lanceolate, fully as long as the tube: corolla twice as long as the calyx, puberulent : nutlets shorter than the calyx-lobes.

In swampy pine lands, Georgia to Florida and Mississippi. Summer and fall.

5. Lycopus rubéllus Moench. Glabrous or finely puberulent, green or purplish tinged. Stems 5-10 dm. tall, rather sharply angled, usually with scaly or leafy stolons: leaf-blades oblong to elliptic, lanceolate or ovate-oblong, 3-15 cm. long, acuminate, sharply serrate or dentate-serrate, petioled : bracts minute : calyx $2-5.3 \mathrm{~mm}$. long; lobes lanceolate or triangular-subulate, straight, herbaceous; corolla fully twice as long as the calyx, sparingly glandular-punctate : staminodia oblong or oval, or obsolete.

In low grounds, New York to Ohio, Missouri, Florida and Louisiana. Summer and fall.

6. Lycopus velutìnus Rydb. Similar to L. rubellus in habit, but copiously pubescent, the stem and branches often densely so: leaf-blades elliptic, sometimes broadly so, to elliptic-lanceolate, coarsely toothed, petioled or with petiole-like bases : calyx campanulate, copiously pubescent, $2.5 \mathrm{~mm}$. long; lobes lanceolate, acuminate, longer than the tube, the upper two, at least, recurved : corolla $3.5 \mathrm{~mm}$. long, copiously glandular-punctate : nutlets surpassing the calyx-tube.

In low grounds and swamps, Colorado to Texas and Mississippi. Summer and fall.

7. Lycopus Americànus Muhl. Glabrous or puberulent, green. Stems 1-9 dm. tall, sharply angled : leaf-blades lanceolate to ovate-lanceolate, $2-10 \mathrm{~cm}$. long, acuminate, incised or pinnatifid, or those on the upper part of the stem merely toothed : calyx 2-3 mm. long; lobes lanceolate to triangular-subulate, rigid: corolla but little longer than the caly $\mathbf{x}$ : staminodia thickened at the apex : nutlets slightly longer than the calyx-tube.

In wet soil or meadows, Newfoundland to British Columbia, Florida, Texas and California. Summer and fall.

\section{MÉNTHA L.}

Perennial herbs, with erect or diffuse stems and aromatic herbage. Leaves opposite : blades flat, punctate, toothed or incised, often petioled. Flowers in dense remote or contiguous clusters. Calyx often punctate : tube campanulate to tubular, 10-ribbed : lobes 5, equal or nearly so. Corolla white, pink or purple, nearly regular: tube surpassed by the calyx : lobes unequal, the upper larger than the rest, entire or emarginate. Stamens 4, erect: filaments equal : anthers 2-celled; sacs parallel. Nutlets smooth. Mint.

Flower-clusters axillary.

Calyx-lobes triangular.

Calyx-lobes subulate or lanceolate.

Calyx with ciliate lobes and a glabrous or nearly glabrous tube.

Caly $x$ closely pubescent all over.

Flower-clusters collected into terminal raceme-like or spike-like panicles.

Foliage glabrous.

Panicles less than $1 \mathrm{~cm}$. thick.

Panicles over $1 \mathrm{~cm}$. thick.

Leaf-blades fully twice as long as broad, narrowed at the base.

Leaf-blades nearly as long as broad, truncate or subcordate at the base.

Foliage copiously pubescent.

1. M. arvensis.

2. M. gentilis.

3. M. Canadensis. 1. Mentha arvénsis L. Stems 1.5-6 dm. tall, sometimes decumbent, closely pubescent. Leaf-blades oblong, oblong-lanceolate, oval or ovate, 2-6 cm. long, shallowly serrate or cuneate-serrate, short-petioled : clusters axillary : calyx $2-3 \mathrm{~mm}$. long, finely pubescent ; tube campanulate; lobes triangular, each about as long as the width of the base, or $\frac{1}{3}$ as long as the tube : corolla bright pink, $4-5 \mathrm{~mm}$. long.

In waste places or on river banks, New Brunswick to New York and Florida. Also in California and Mexico. Naturalized from Europe. Summer and fall. 
2. Mentha gentilis L. Stems sparingly pubescent, erect and $2-7 \mathrm{dm}$. tall, or much branched, the branches spreading : leaf-blades oval, ovate or elliptic, $1.5-5 \mathrm{~cm}$. long, acute, serrate, the entire base narrowed to a short petiole : clusters about $1 \mathrm{~cm}$. thick: calyx 1.5 $\mathrm{mm}$. long, slightly bristly ; tube campanulate; lobes triangular, acute or slightly acuminate : corolla deep pink or lilac, $2.5 \mathrm{~mm}$. long, the upper lip as broad as long, deeply notched, the lower lip 3-lobed, the middle lobe oblong, its lateral lobes ovate or oval, all obtuse.

In waste places and along roads, Maine to New York and Georgia. Summer and fall.

3. Mentha Canadénsis L. Stems erect, $2-6 \mathrm{dm}$. tall, simple or much branched, pubescent with recurved or retrorse hairs : leaf-blades oblong, elliptic or oblong-lanceolate, 2-7 cm. long, acute, serrate, the entire bases gradually or abruptly narrowed into margined petioles: clusters $1-1.5 \mathrm{~cm}$. thick: calyx nearly $2 \mathrm{~mm}$. long, minutely pubescent; tube campanulate; lobes lanceolate-subulate, about $\frac{1}{2}$ as long as the tube : corolla pink or white, $3 \mathrm{~mm}$. long, the upper lip broadly oblong, notched, the lower lip 3-lobed, its middle lobe narrowed upward, barely notched, its lateral lobes ovate, obtuse.

In moist soil or meadows. New Brunswick to the Northwest Territory and British Columbia, North Carolina, Nebraska and New Mexico. Summer and fall.

4. Mentha spicàta L. Stems glabrous or nearly so, 2-5 dm. tall, commonly much branched : leaf-blades oblong, elliptic or elliptic-lanceolate, acute, sharply serrate, shortpetioled : panicles spike-like, slender, $3-10 \mathrm{~cm}$. long, $5-8 \mathrm{~mm}$. thick, often interrupted below : calyx nearly glabrous, $1 \mathrm{~mm}$. long; tube campanulate; lobes subulate from a broad base, as long as the tube : corolla pale pink, $2.5 \mathrm{~mm}$. long, the upper lip broader than long, notched, the lower lip 3-lobed, its lobes ovate, obtuse.

In waste places and on roadsides, Nova Scotia and Ontario to Minnesota, Florida and Kansas. Summer and fall. SPEARMint.

5. Mentha piperita L. Stems glabrous, erect or ascending, 2-7 dm. tall, more or less branched : leaf-blades oblong, oval, oblong-lanceolate or oblong-ovate, $1.5-5 \mathrm{~cm}$. long, acute, sharply serrate, short-petioled : panicles spike-like, $2-15 \mathrm{~cm}$. long, $1-1.5 \mathrm{~cm}$. thick, often interrupted : pedicels slender: calyx glabrous, $2.5 \mathrm{~mm}$. long; tube cylindric-campanulate; lobes subulate from a broad base, shorter than the tube: corolla $4 \mathrm{~mm}$. long, the upper lip notched, the lower lip with an oblong middle lobe and oval or oblong-oval lateral lobes.

In wet places, Nova Scotia to Minnesota, Florida and Alabama. Summer and fall. PepPermint.

6. Mentha citràta Ehrh. Stems glabrous or nearly so, erect or decumbent, 3-11 dm. long, simple or branching: leaf-blades ovate to orbicular-ovate, $1.5-4 \mathrm{~cm}$. long, acute, sharply serrate, rounded or subcordate at the base; petioles $\frac{1}{2}$ as long as the blades or shorter : panicles $1.5 \mathrm{~cm}$. thick : calyx nearly $4 \mathrm{~mm}$. long; tube cylindric-turbinate ; lobes subulate from a broader base, shorter than the tube: corolla pink or whitish, $4.5 \mathrm{~mm}$. long, the upper lip notched, the lower lip with oblong-ovate obtuse lobes.

In wet places, New York and Ohio to Georgia. Summer and fall.

7. Mentha rotundifolia (L.) Huds. Stems canescent-tomentose, erect or ascending from a creeping base, $3-8 \mathrm{dm}$. tall, simple or branching : leaf-blades oblong, oval or ovate, $2-9 \mathrm{~cm}$. long, finely serrate, sessile or nearly so and often partly clasping: panicles spikelike, 1-5 cm. long, about $1 \mathrm{~cm}$. thick : calyx pubescent, $2.5 \mathrm{~mm}$. long ; tube campanulate, constricted at the middle in age ; lobes lanceolate, acute, or subulate-tipped at maturity and then as long as the tube : corolla pink or pale lilac, $3-3.5 \mathrm{~mm}$. long, the upper lip, and lobes of lower lip, oblong or nearly so, obtuse.

In open grounds or copses, Maine, Georgia. Texas and Mexico. Summer and fall.

\section{MICHELIÉLLA Briq.}

Perennial caulescent aromatic herbs, sometimes with glandular-pubescent foliage. Leaves opposite, rarely essentially whorled: blades flat, rather coarsely toothed, petioled. Flowers in terminal racemes or panicled racemes. Calyx spreading or declined at maturity : tube campanulate, 10-ribbed, 2-lipped : upper lip of 3 short lobes : lower lip of 2 longer and narrower segments. Corolla reddish or cream color. Anther-bearing stamens 4, exserted : filaments more or less coiled. Nutlets smooth. STone-root.

Leaves 4 or rarely 6, approximate, sometimes almost whorled at the top of the stem. 1 . M. verticillata. Leaves several, in pairs along the stem.

1. Micheliella verticillàta (Baldw.) Briq. Rootstock irregular. Stem finely pubescent, 1-5 dm. tall, simple, naked below : leaves usually 4, in 2 approximate pairs at the top of the stem ; blades thin, ovate to obovate or cuneate-obovate, 8-16 mm. long, acute or abruptly acuminate, coarsely crenate-dentate : racemes usually simple, $5-15 \mathrm{~cm}$. 
long: pedicels slender, $5-10 \mathrm{~mm}$. long: calyx glandular-pilose, $4 \mathrm{~mm}$. long, becoming 7 $\mathrm{mm}$. long, the upper lip of 3 triangular or triangular-lanceolate lobes, the lower lip of 2 lanceolate subulate-tipped lobes : corolla tawny, $1 \mathrm{~cm}$. long, the upper lip of 2 broad lobes, the lower lip of 2 ovate lateral lobes and a large laciniate middle lobe. [Collinsonia verticillata Baldw.]

In rich woods, North Carolina to Tennessee, Georgia and Mississippi. Spring and summer.

2. Micheliella anisàta (Sims) Briq. Rootstock knotted. Stems glandular-pubescent, often tufted, 3-6 dm. tall, branching above: leaves opposite ; blades thickish, oblong, elliptic to broadly oval, $8-15 \mathrm{~cm}$. long, acute or slightly acuminate, serrate or serrate-dentate, cuneate to subcordate at the base ; petioles $1-5 \mathrm{~cm}$. long: pedicels $3-9 \mathrm{~mm}$. Iong: calyx glandular-pilose, $4 \mathrm{~mm}$. becoming $10 \mathrm{~mm}$. long, the upper lip with 3 triangular lobes, the lower lip with 2 lanceolate lobes : corolla cream-colored, 12-13 $\mathrm{mm}$. long, the upper lip of 2 broadly ovate lobes, the lower lip with lateral lobes similar to those of upper lip and a large lacerate middle lobe. [Collinsonia anisata Sims.]

In sandy pine or oak woods, South Carolina to Florida and Alabama. Summer.

\section{COLLINSÒNIA L.}

Perennial caulescent herbs, with aromatic herbage. Leaves opposite: blades flat, toothed, petioled. Flowers in terminal panicled racemes. Calyx spreading or declined at maturity : tube campanulate, 10-ribbed, 2-lipped : upper lip of 3 short lobes : lower lip of 2 longer narrower lobes. Corolla colored, not showy: tube obliquely campanulate : lobes 5,4 nearly equal, the fifth much larger, pendant or declined, lacerate or fringed. Antherbearing stamens 2 , exserted : filaments coiled before anthesis, connected by a woolly ring at the base. Nutlets smooth. Horse-batm. Stone-root.

Branches of the inflorescence glandular-pubescent.

Branches of the inflorescence puberulent.

Stems rigid : leaf-blades mostly over $10 \mathrm{~cm}$. long, many-toothed : pedicels becoming $6-9 \mathrm{~mm}$, long.

Stems reclining: leaf-blades mostly less than $8 \mathrm{~cm}$. long, coarsely few-toothed: pedicels becoming $2-4 \mathrm{~mm}$. long.

1. C. punctata.

2. C. Canadensis.

3. C. tuberosa.

1. Collinsonia punctàta Ell. Stems erect, 4-9 dm. tall, more or less branched : leaf-blades rhombic-ovate or ovate, or elliptic to ovate on upper part of stem, $2-8 \mathrm{~cm}$. long, acute or slightly acuminate, serrate, cuneate at the base : panicles with glandular-pubescent branches: pedicels $3-8 \mathrm{~mm}$. long: calyx glandular-pilose, $2 \mathrm{~mm}$. becoming $8 \mathrm{~mm}$. long, the upper lip of 3 acute hooked lobes, the lower lip of 2 lanceolate Iobes, these much longer than the tube : corolla about $1 \mathrm{~cm}$. long, the upper lip of 2 ovate lobes, the lower lip with lateral lobes similar to those of upper lip and a large lacerate middle lobe : nutlets subglobose, at least $1.5 \mathrm{~mm}$. in diameter.

In woods, North Carolina to Georgia and Louisiana. Summer and fall.

2. Collinsonia Canadénsis L. Stems erect, solitary or tufted, 3-8 dm. tall, branching above : leaf-blades oblong, elliptic or oval, short-acuminate, rather coarsely dentateserrate, cuneate to truncate at the base : panicles with puberulent branches : pedicels 4-8 $\mathrm{mm}$. long: calyx minutely glandular-pubescent, $3 \mathrm{~mm}$. long, becoming $10 \mathrm{~mm}$. long at maturity, the upper lip with 3 acute upcurved lobes, the lower lip of 2 subulate lobes: corolla about $1 \mathrm{~cm}$. long, the upper lip of 2 rounded-ovate lobes, the lower lip with lateral Iobes much like those of upper lip, its middle lobe larger, lacerate-fimbriate, $3-5 \mathrm{~mm}$. long: nutlets suborbicular, about $2 \mathrm{~mm}$. in diameter.

In moist woods, Maine to Ontario, Wisconsin, Florida and Kansas. Summer and fall.

3. Collinsonia tuberòsa Michx. Stems spreading or reclining, 3-10 dm. long, simple or loosely branched: leaf-blades thin, ovate, $5-8 \mathrm{~cm}$. long, acute or acuminate, coarsely serrate, broadly cuneate or almost truncate at the base : panicles with puberulent branches : calyx about $2 \mathrm{~mm}$. becoming $3.5-4 \mathrm{~mm}$. long, puberulent, the upper lip of 3 lanceolate-acuminate hooked lobes, the lower lip of 2 lanceolate-subulate lobes, these much longer than the tube: corolla 6-7 mm. long, the upper lip with 2 broad rather obtuse lobes, the lower lip with 2 broad acutish lateral lobes and a large lacerate middle lobe.

In woods, North Carolina to Georgia and Alabama. Fall.

\section{PERÍLIA Ard.}

Annual caulescent herbs, with more or less purple foliage. Leaves opposite: blades flat, toothed, petioled. Flowers in terminal racemes or panicles. Calyx usually pubescent : tube campanulate, 10-ribbed : lobes nearly equal during anthesis, more or less accrescent and disposed into 2 lips at maturity. Corolla dull-colored, oblique at the throat, 
barely 2 -lipped : lobes 5 , the lower one slightly larger than the others, not fringed. Stamens 4, nearly equal, erect : filaments all anther-bearing: anthers 2-celled. Nutlets reticulated.

1. Perilla frutéscens (L.) Britton. Stems minutely pubescent, dark green or purplish, 2-6 dm. tall, more or less branched : leaf-blades ovate or oval, 4-10 cm. long, acute or abruptly acuminate, serrate or crenate-serrate, rounded or cuneate at the base : racemes slender, 2-10 $\mathrm{cm}$. long: pedicels 1-4 mm. long: calyx bristly, $2 \mathrm{~mm}$. long becoming 6 $\mathrm{mm}$. long, the upper lip with 3 ovate lobes, the lateral oblique, the lower lip of 2 lanceolate lobes: corolla inconspicuous, $3.5 \mathrm{~mm}$. long, pubescent; lobes of upper lip and the lateral lobes of the lower lip similar, the middle lobe of the lower lip larger, broadly oblong, rounded at the apex : nutlets subglobose, about $1 \mathrm{~mm}$. in diameter, delicately reticulated.

In waste places and on roadsides, New York to Illinois and Georgia. Naturalized from India. Summer and fall.

\section{MESOSPHAÈRUM P. Br.}

Annual or perennial caulescent herbs or shrubs various in habit. Leaves opposite : blades commonly toothed. Flowers in approximate or remote, often dense axillary clusters. Calyx straight or oblique: tube ovoid to campanulate or tubular: lobes 5, nearly equal, acute or awn-tipped. Corolla of various colors, 2-lipped : upper lip erect or spreading: lower lip larger, saccate, drooping. Stamens 4, declined: filaments all anther-bearing, distinct, unappendaged : anthers confluently 2-celled. Nutlets smooth, granular or slightly rugulose. [Hyptis Jacq.]

Perennial plants.

Flower-clusters in more or less elongated raceme-like panicles.

Flower-clusters aggregated in a dense head.

Annual plants.

Flower-clusters more or less remote.

Leaf-blades cordate or truncate at the base : caly $\mathrm{x}$-lobes lanceolate.

Leaf-blades cuneate at the base : caly $x$-lobes subulate.

Flower-clusters contiguous, forming dense raceme-like panicles.

1. M. pectinatum.

2. M. rugosum.

1. Mesophaerum pectinàtum (Poir.) Kuntze. Perennial, finely pubescent. Stems erect, 3-18 dm. tall, branching : leaf-blades ovate, $2-8 \mathrm{~cm}$. long, acute, serrate, commonly rounded or subcordate at the base, petioled: calyx minutely pubescent, $3-4 \mathrm{~mm}$. long; tube slightly curved, hairy in the throat; lobes subulate, nearly as long as the tube: corolla hardly exceeding the calyx ; tube abruptly expanded at the throat, the upper lip of 2 ovate lobes, the lateral lobes of the lower lip similar to those of the upper, but smaller, the middle lobe dipper-like, notched : nutlets about $1 \mathrm{~mm}$. long, granular.

In waste places and woods, Florida. Also in tropical America. Spring to fall.

2. Mesosphaerum rugòsum (L.) Pollard. Perennial, puberulent, or glabrous below. Stems erect or ascending, often tufted, 5-12 dm. tall, simple or sparingly branched : leafblades ovate to lanceolate or linear-lanceolate, $2-8 \mathrm{~cm}$. long, acute, rather remotely serrate, decurrent on the petioles : heads dense, $1-1.5 \mathrm{~cm}$. thick : calyx densely pubescent, $3-5$ $\mathrm{mm}$. long; lobes lanceolate or subulate-lanceolate, shorter than the tube : corolla about 6 $\mathrm{mm}$. long, pubescent, the upper lip of 2 rounded lobes, the lower lip with 2 spreading lateral lobes and a dipper-like erose middle lobe: nutlets nearly $1.5 \mathrm{~mm}$. long. [H. radiata Willd.]

In damp soil and swamps, North Carolina to Florida and Texas. Also in tropical America. Summer and fall.

3. Mesosphaerum spicàtum (Poir.) Small. Annual, pubescent. Stems̄erect, 5-15 dm. tall, muricate-pubescent especially on the angles, branching above : leaf-blades deltoidovate to deltoid, $2-5 \mathrm{~cm}$. long, acute or acuminate, rather finely and doubly crenateserrate, truncate to subcordate at the base, petioled: flower-clusters nearly sessile, rarely contiguous : calyx becoming $5 \mathrm{~mm}$. long, minutely pubescent; lobes lanceolate but short, much shorter than the tube: corolla 4-5 mm. long; tube much surpassing the calyx, the upper lip of 2 round-ovate lobes, the lower lip with 2 spreading oblong lateral lobes and a dipper-shaped middle lobe: longer filaments pubescent: nutlets $1 \mathrm{~mm}$. long, granular. [Hyptis spicata Poir.]

In sandy woods, Florida and Alabama. Also in tropical America. Spring to fall.

4. Mesosphaerum mutábile (L. C. Rich.) Kuntze. Similar to M. spicatum in habit, but much less pubescent, sometimes nearly glabrous : leaf-blades ovate, sometimes narrowly so, 4-8 cm. long, acute or slightly acuminate, coarsely serrate or crenate-serrate, cuneate at the base, slender-petioled : flower-clusters short-peduncled : calyx becoming 4.5 or $5 \mathrm{~mm}$. long, often finely pubescent; lobes subulate, longer than those of $M$. spicatum, but 
much shorter than the tube : corolla smaller than that of $M$. spicatum, the lower lip not much larger than the upper, the middle lobe concave: longer filaments glabrous.

In sand or sandy soil, Florida. Also in tropical America. Spring to fall.

5. Mesosphaerum spicígerum (Lam.) Kuntze. Annual, pubescent. Stems erect or ascending, 4-9 dm. tall, muricate-pubescent, especially on the angles: leaf-blades ovate, oval or elliptic, $2-6 \mathrm{~cm}$. long, acute, serrate, usually rounded at the oblique base, petioled: clusters dense, contiguous, forming dense racemes : calyx $2 \mathrm{~mm}$. becoming $4-5 \mathrm{~mm}$. long, minutely pubescent; lobes filiform-subulate, shorter than the tube : corolla $3-4 \mathrm{~mm}$. long, finely pubescent, the upper lip of 2 ovate lobes, the lower lip with 2 spreading oblong lateral lobes and a dipper-like middle lobe. [Hyptis spicigera Lam.]

In sand, southern Florida. Also in tropical America. Spring to fall.

\section{3. ÒCIMUM L.}

Annual or perennial herbs or shrubs, with branching stems. Leaves opposite : blades often toothed. Flowers in axillary clusters, these disposed in racemes or panicles. Calyx deflexed at maturity : tube ovoid to campanulate: lobes various, the upper broad, the lateral narrower, the lower still narrower, more or less united. Corolla often white : tube mostly shorter than the calyx : lobes nearly equal. Stamens 4 : filaments often distinct, naked or with a tooth-like appendage or tuft of hairs. Nutlets smooth or slightly rugose. BASIL.

1. Ocimum micránthum Willd. Annual, more or less pubescent. Stems erect, 2-5 dm. tall, branched : leaf-blades ovate or oblong-ovate, 1-4 cm. long, acute, serrate, cuneate or nearly truncate at the base: panicles $2-10 \mathrm{~cm}$. long, nearly continuous : calyx $2 \mathrm{~mm}$. becoming $6-7 \mathrm{~mm}$. long, minutely pubescent, the upper lip boat-like, the free portion rounded, the lower lip of 4 subulate-tipped lobes: corolla often white, $4 \mathrm{~mm}$. long: tube abruptly dilated about the middle, the upper lip minutely bearded, of 2 rounded ovate lobes, the lower lip with 2 ovate lateral lobes and a deeply notched middle lobe: nutlets about $1 \mathrm{~mm}$. long, granular.

In sand, Florida. Also in the West Indies and South America.

\section{Family 13. RHINANThàCEAE J. St. Hil. Figwort Family.}

Herbs, shrubs or trees, with commonly terete stems. Leaves opposite, sometimes whorled, or alternate, without stipules: blades simple, entire, toothed or divided. Flowers perfect. Calyx free, of 4-5 more or less imbricated united sepals, persistent. Corolla mostly irregular, commonly only slightly so, generally 2-lipped, hypogynous. Androecium of 4 usually didynamous stamens and sometimes a fifth or also a sixth one represented by a sterile filament, all partially adnate to the corolla-tube, one pair of the usually fertile ones sometimes suppressed. Filaments often appendaged. Gynoecium of a single superior 2-celled pistil, the placentae united in the axis. Styles united or rarely distinct. Fruit a 2-valved capsule or rarely baccate. Seeds usually numerous. Endosperm fleshy or cartilaginous, surrounding the endosperm. [Scrophulariaceae Lindl.]

A. Upper lip or lobes of the corolla external in the bud, or wanting (with exceptions in Mimulus).

Leaves prevailingly alternate.

Herbs: corolla rotate: perfect stamens 5.

Shrubs: corolla funnelform or campanulate : perfect stamens 4 .

1. VERBASCUM.

Leaves prevailingly opposite.

Corolla-tube with a spur, sac or swelling on the lower side near the base.

Corolla-tube with an elongated spur.

Flowers axillary to leaf-like bracts and remote.

Flowers approximate in terminal spikes : racemes or panicles.

Corolla-tube with a sac or swelling.

Throat of the corolla closed by a palate : capsules opening by $2-3$ pores. Throat of the corolla open, merely with 2 bearded lines or plates: capsules opening by transverse or irregular chinks.

Corolla-tube without either spur, sac or swelling on the lower side.

Filaments 5, 4 anther-bearing, 1 sterile, more or less different from the others.

Staminodium a scale, adnate to the upper side of the corolla-tube. Corolla-tube shorter than the calyx, the lobes of the lower lip induplicate.

Corolla-tube longer than the calyx, the lobes of the lower lip flat. Staminodium elongated.

Filaments longer than the staminodium : seeds winged. Filaments shorter than the staminodium; seeds wingless.

2. LEUCOPHYLLUM.

Filaments 2 or 4 .

3. KICKXIA.

4. LINARIA.

5. Antirrhinum.

6. Maurandia.

7. COLlinsia.

8. SCROPHUlA RIA.

9. Chelone.

10. Pentstemon. 
Trees.

Herbs.

Anther-bearing filamens 4 or rarely 3.

Sepals united into an angled tube.

Sepals distinct or nearly so.

Anther-bearing filaments 4 .

Sepals equal or nearly so.

Anther-sacs separated on stalks.

Anther-sacs contiguous.

Sepals very unequal, the upper one largest.

Corolla nearly regular, about equally 5-lobed.

Corolla irregular, manifestly 2-lipped.

Flowers peduncled : hypogynous disk present : leafblades palmately nerved.

Flowers pedicelled : hypogynous disk wanting: leafblades pinnately nerved.

Anther-bearing filaments 3.

Anther-bearing filaments 2.

Calyx of 5 nearly distinct sepals.

Filaments short, stout or almost wanting.

Anther-sacs transverse, separated on a dilated connective : succulent herbaceous herbs.

Anther-sacs vertical, contiguous : rigid herbs.

Filaments elongated and slender.

Calyx of 4-5 partially united sepals.

Corolla exceedingly irregular, the upper lip wanting or oblete: anther-sacs divergent.

Corolla nearly regular, the upper lip present: anther-sacs parallel.

Calyx-lobes 4 : corolla-tube barely surpassing the calyx the lobes spreading.

Calyx-lobes 5: corolla-tube much surpassing the calyx the lobes erect.

B. Lower lip or lobes of the corolla external in the bud.

Sepals distinct or nearly so.

Corolla rotate or campanulate: stamens not surpassing the corolla.

Corolla-lobes 5 : leaves alternate: corolla campanulate.

Corolla-lobes 4 : leaves opposite : corolla rotate.

Capsules neither notched nor lobed, septicidal: stamens 4 .

Capsules notched or lobed at the apex, loculicidal: stamens 2 .

Corolla tubular: stamens exserted.

Sepals almost wholly or only partially united into a tube.

Corolla various, but only slightly 2 -lipped : stamens not ascending under the upper lip.

Corolla campanulate, funnelform or tubular: capsule not included in the calyx.

Stamens equal or nearly so.

Stamens exserted : style elongated, filiform : stigmas minute. Corolla tubular: anther-sacs not distinct.

Corolla rotate-campanulate: anther-sacs distinct.

Stamens included: style short, columnar: stigma dilated and 2-lobed.

Stamens manifestly didynamous.

Anther-sacs awned at the base : corolla yellow.

Anther-sacs awnless : corolla rose-purple, pink or white.

Anthers of 2 sizes: upper leaves auricled at the base.

Anthers equal: leaves not auricled.

Corolla salverform : capsule mostly included in the calyx.

Corolla strongly 2-lipped : stamens ascending under the upper lip.

Anther-sacs unlike, the inner pendulous.

Anther-sacs alike, parallel.

Ovules 1-2 in each cavity : capsules 1-4-seeded.

Ovules several-many in each cavity : capsules many-seeded.

Calyx split, not accompanied by bractlets.

Calyx not split, accompanied by 2 bractlets.
11. Paulownia.

12. Mimulus.

13. StEmodia.

14. CONOBEA.

15. MONNIERA.

16. Septilia.

17. MeCARDONIA.

18. HYDRANTHELIUM.

19. Gratiola.

20. SOPHRONANTHE.

21. ILYSANTHES.

22. Hemianthus.

23. Micranthemum

24. Amphianthus.

25. CAPraria.

6. SCOPARIA.

27. VERONICA.

28. LEPTANDRA.

29. Macranthera.

30. AFZEI.IA.

31. BRACHYgYNE.

32. Dasystoma.

33. OTOPHYLLA.

34. Gerardia.

35. BUCHNERA.

36. Castilleja.

37. Melampyrum.

38. Pediculatis.

39. SCHWALBEA.

\section{VERBÁSCUM L.}

Annual, biennial or rarely perennial caulescent herbs, often glandular or densely pubescent. Leaves alternate: blades entire, toothed or pinnatifid, sometimes decurrent on the stem. Flowers in terminal spikes, racemes or panicles. Sepals 5, partially united. Corolla white, yellow or purple, rotate : lobes 5, slightly unequal, the upper one exterior in the bud. Stamens 5, exserted, the upper 3, or all of the filaments pubescent : anthersacs confluent. Ovary 2-celled, sessile: styles dilated or flattened at the apex. Ovules numerous. Capsule oblong to subglobose, septicidally 2-valved : valves usually cleft at the apex. Seeds rugose, wingless. Our species bloom in the summer and fall. Mullen. 
1. Verbascum Blattària L. Stems rather slender, 4-12 dm. tall, sometimes glandular above. Leaf-blades oblong to ovate, $2-12 \mathrm{~cm}$. long, usually doubly serrate-crenate, or pinnatifid, the upper ones more or less clasping: racemes interrupted, 1-9 dm. long: pedicels glandular, $1-1.5 \mathrm{~cm}$. long : bracts ovate to ovate-lanceolate, $5-20 \mathrm{~mm}$. long: calyxlobes linear or linear-elliptic, acute, recurved : corolla white or yellow, 3-4 cm. broad; lobes obovate or orbicular-obovate, spreading, the lower one with narrow auricles at the base : filaments magenta, with slender glandular hairs : capsules subglobose, or depressed, 6-8 $\mathrm{mm}$. in diameter.

In fields and waste places, Quebec to Minnesota, south to Florida and Kansas. Native of Europe.

2. Verbascum Lychnitis L. Stems stout, tomentose with short soft hairs, dusty green, 10-20 dm. tall, branched above. Leaf-blades narrowly elliptic or elliptic-lanceolate on the lower part of the stem, lanceolate or elliptic above, all crenate, often glabrate on the upper surface: calyx woolly; lobes lanceolate or linear-lanceolate, $3-3.5 \mathrm{~mm}$. long: corolla yellow, pubescent without; lobes oblong, obtuse, 4-6 $\mathrm{mm}$. long, or one of them longer : capsules oblong or ovoid-oblong, 4-6 $\mathrm{mm}$. long, hairy.

In fields and waste places, Ontario and Kansas, south to North Carolina. Naturalized from Europe.

3. Verbascum Thápsus L. Stems stout, $3-18 \mathrm{dm}$. tall, woolly with densely matted hairs, normally simple, winged with the decurrent leaf-bases: basal and lower stem-leaves with spatulate or elliptic-spatulate blades $1-4 \mathrm{~cm}$. long, upper stem-leaves with oblanceolate or elliptic-obovate blades : raceme spike-like, dense and continuous, 1-9 dm. long : calyx 8-10 mm. long; lobes triangular-lanceolate, longer than the tube, acute : corolla deep yellow or rarely white, $1.7-2.5 \mathrm{~cm}$. wide, pubescent without; lobes 5 , obovate, ciliolate, obtuse : anthers reddish : capsules ovoid, 7-10 $\mathrm{mm}$. long.

In fields and exposed situations generally, Nova Scotia to Minnesota, south to Florida and Kansas. Naturalized from Europe.

\section{LEUCOPHÝLLUM H. \& B.}

Spreading shrubs, with scurfy-pubescent foliage. Leaves alternate, sometimes clustered : blades relatively small, flat, entire. Flowers on solitary axillary pedicels. Calyx-lobes rather valvate. Corolla violet-purple : tube funnelform or broadly campanulate; lobes 5, rounded, spreading, the 2 upper ones exterior. Stamens 4, included. Styles united. Ovules numerous. Capsule 2-valved. Seeds strongly wrinkled.

Leaf-blades silvery canescent: corolla funnelform; limb 10-12 mm. broad. Leaf-blades tomentose: corolla campanulate; $1 \mathrm{mb} 20-25 \mathrm{~mm}$. broad.

1. L. minus.

2. L. Texanum.

1. Leucophyllum mìnus A. Gray. A shrub 3-7 dm. tall. Leaf-blades spatulate or obovate-spatulate, usually $1 \mathrm{~cm}$. long or less, blunt or slightly apiculate, silvery canescent, conspicuously narrowed into petiole-like bases : outer caly $x$-lobes linear or nearly so, 3-4.5 mm. long: corolla sparingly pubescent within : capsules about $4 \mathrm{~mm}$. high.

In dry soil, southern and western Texas. Spring and summer.

2. Leucophyllum Texànum Benth. A shrub 6-25 dm. tall. Leaf-blades oblong, elliptic or obovate, 1-2 $\mathrm{cm}$. long, apiculate pale-tomentose with very densely set hairs, gradually or rather abruptly narrowed to the manifestly sessile base: outer calyx-lobes oblong to oblong-lanceolate, 5-6 mm. long: corolla villous within : capsules $4-5 \mathrm{~mm}$. high

In dry soil, southern Texas and adjacent Mexico. Spring and summer.

\section{KÍCKXIA Dumort.}

Annual herbs, with spreading or creeping stems. Leaves alternate : blades flat, entire, toothed or lobed. Flowers on solitary axillary pedicels. Sepals 5, slightly united. Corolla white, yellow or variegated, irregular, 2-lipped : tube spurred, the throat closed by a palet, the lips lobed. Stamens 4, included. Styles united. Ovules numerous. Capsule ovoid to subglobose, opening by 1 or 2 terminal slits, pores or valves. Seeds tubercled or merely roughened.

1. Kickxia Elátine (L.) Dumort. Foliage villous or hirsute. Stems branched at the base ; branches spreading or prostrate, 1-5 dm. long: leaf-blades hastate, or ovate to elliptic near the ends of the branches, $1-2.5 \mathrm{~cm}$. long, short-petioled : pedicels filiform, surpassing the subtending leaf-like bracts : calyx densely pubescent ; lobes lanceolate, $1.5-$ $2.5 \mathrm{~mm}$. long, acuminate : corolla $5-6 \mathrm{~mm}$. long, minutely pubescent; lobes rounded, the spur about as long as the lower lip : capsules $3-4 \mathrm{~mm}$. in diameter.

In waste places and on stone walls, Canada to Georgia. Naturalized from Europe. Spring. 


\section{LINÀRIA L.}

Annual biennial or perennial herbs, or shrubby plants, with upright stems. Leaves alternate or opposite, or whorled on shoots: blades flat, often narrow, entire, toothed or lobed. Flowers in terminal spikes, racemes or panicles. Sepals 5, partially united. Corolla white, or of various colors, or variegated, irregular, 2-lipped : tube spurred at the base, the throat partially closed by a palet. Stamens 4, included. Styles united. Ovules numerous. Capsule short, opening by 1-few usually 3-toothed pores below the apex. Seeds angled or wrinkled, sometimes winged. TOAD-FLAX.

Corolla blue : native species.

Leaves with terete blades: pedicels longer than the corollas.

Leaves with flat blades: pedicels shorter than the corollas or spur. Corolla less than $8 \mathrm{~mm}$. long exeluding the spur. Corolla over $10 \mathrm{~mm}$. long excluding the spur.

Corolla yellow: naturalized species.

1. L. Floridana.

2. L. Canadensis.

3. L. Texana.

4. L. Linaria.

1. Linaria Floridàna Chapm. Annual or biennial, sparingly glandular-pubescent. Stems 1-4 dm. tall, simple or paniculately branched above: leaves of $2 \mathrm{kinds}$, those on the basal branches with oblong or obovate blades $2-5 \mathrm{~mm}$. long, those on the stem fleshy, terete, linear or club-shaped, less than $25 \mathrm{~mm}$. in length : racemes loosely flowered : pedicels 3-13 mm. long: calyx-lobes glandular, 1-1.5 mm. long, linear to linear-lanceolate: corolla blue, 4-5 mm. Iong; tube surpassing the calyx; spur subulate, slightly projecting below the calyx : capsules subglobose, about $2 \mathrm{~mm}$. long, surpassing the calyx-lobes.

In sand, Florida and Alabama. Spring and summer.

2. Linaria Canadénsis (L.) Dumort. Annual or biennial, glabrous or nearly so. Stems 1-6 dm. tall, sometimes branched at the base : leaf-blades narrowly linear, flat, acute, $1-2.5 \mathrm{~cm}$. long: racemes usually many-flowered, $4-15 \mathrm{~cm}$. long: pedicels $2.5 \mathrm{~mm}$. long: calyx-lobes sometimes sparingly glandular, linear-oblong or lanceolate: corolla light blue, 5-7 mm. long (excluding the spur), the lobes barely retuse, the spur 4-5 mm. long: capsule subglobose or oval-globose, $2.5 \mathrm{~mm}$. long, about as long as the calyx-lobes.

In sandy soil, Nova Scotia, south to Florida. Spring to fall.

3. Linaria Texàna Scheele. Similar to L. Canadensis, but more robust, often turning black in drying. Stems 2-8 dm. tall : leaf-blades thick but flat, linear-spatulate to linear, $1-2.5 \mathrm{~cm}$. long, acute or rather blunt: racemes few-flowered, $5-30 \mathrm{~cm}$. long: calyx-lobes glabrous, linear-lanceolate to broadly lanceolate, acute: corolla blue, at least $1 \mathrm{~cm}$. long (excluding the spur), the lobes retuse, the spur about $1 \mathrm{~cm}$. long: capsules oblong to oval, 3-3.5 mm. long.

In sandy soil, Indian Territory to Florida, Texas, Oregon and California. Spring and summer.

4. Linaria Linària (L.) Karst. Perennial, glabrous or minutely pubescent above, glaucous. Stems 1-10 dm. tall, commonly branched at the base : leaves numerous; blades linear or nearly so, $2-7 \mathrm{~cm}$. long, acute, entire : racemes showy, $3-40 \mathrm{~cm}$. long : pedicels erect or ascending, $2-5 \mathrm{~mm}$. long: calyx-lobes glabrous, ovate, $3-4 \mathrm{~mm}$. long, acute or acuminate : corolla yellow, $2.5-3 \mathrm{~cm}$. long; spur nearly as long as the lower lip: capsules oblong-ovoid, 9-12 $\mathrm{mm}$. long: seeds $2 \mathrm{~mm}$. broad, winged. [L. vulgaris (L.) Mill.]

In fields and waste places. Nova Scotia to Manitoba, south to Georgia and Nebraska. Naturalized from Europe. Spring to fall. BUTTER-AND-EGGS.

\section{ANTIRRHINUM L.}

Annual or perennial caulescent herbs, sometimes glandular or pubescent. Leaves alternate, or opposite on young parts : blades flat, entire. Flowers solitary in the upper axils, or in terminal racemes or panicles. Sepals partially united. Corolla white or colored, or variegated, irregular, 2-lipped: tube more or less saccate at the base, the throat closed by a palate. Stamens 4 , included : filaments sometimes dilated above. Styles united. Orules numerous. Capsule short, opening by 2 or 3 pores below the apex. Seeds wingless, smooth or wrinkled.

1. Antirrhinum antirrhiniflòrum (Poir.) Small. Stems low or high-climbing. Leafblades hastate, varying from triangular to ovate in outline, 1-4 cm. long, usually cordate, one or both basal lobes sometimes with a tooth; petioles and pedicels tendril-like, often nearly equal in length : calyx-lobes linear or linear-lanceolate, $1-1.5 \mathrm{~cm}$. long : corolla
purple or white, $1.5-2.5 \mathrm{~cm}$. long: capsules subglobose, $5-8 \mathrm{~mm}$. in diameter : seeds with irregular corky ridges. [A. maurandioides A. Gray.]

In dry or rocky soil, Texas to Arizona and Mexico. Spring to fall. SNapdragon. 


\section{MAURÁNDIA Ortega.}

Annual or perennial herbs, with spreading or climbing stems. Leaves alternate, or opposite below : blades flat, hastate, angulate or coarsely toothed. Flowers on axillary pedicels. Sepals partially united. Corolla showy, pink, purple or violet, irregular : tube scarcely gibbous at the base, with 2 often pubescent lines or plaits in the throat. Stamens 4, included : filaments thickened at the apex. Anther-sacs often confluent. Styles with 2 dilated lobes at the apex. Ovules numerous. Capsule short, opening by transverse or irregular chinks. Seeds sometimes winged, wrinkled or tuberculate.

1. Maurandia Wislizèni Engelm. Stems glabrous, usually low-climbing : leaf-blades hastate or some of them sagittate, 1-4 cm. long, all but the lower ones with acute or acuminate tips and basal lobes: pedicels much shorter than the petioles: calyx-lobes linearlanceolate, becoming rigid, triangular-lanceolate, prominently reticulated, saccate and keeled near the base and often $2 \mathrm{~cm}$. long at maturity : corolla pale or purplish blue, 2-2.5 $\mathrm{cm}$. long : style becoming sword-like, surmounting the globose-ovoid capsule which is usually about $1 \mathrm{~cm}$. high: seeds narrowly winged.

In dry soil, southern Texas to New Mexico and Mexico. Spring to fall.

\section{COLLÍNSIA Nutt.}

Annual caulescent herbs. Leaves opposite or whorled: blades flat, often narrow, entire or toothed. Flowers solitary or clustered in the upper axils. Calyx-lobes 5. Corolla white, pink, violet or variegated, 2-lipped : tube short, the middle lobe of the lower lip involute. Stamens 4, declined, enclosed in the middle lobe of the lower lip of the corolla. Staminodium gland-like near the base of the corolla tube. Anther-sacs confluent near the top. Styles united. Capsule globose or ovoid, the 2 valves each 2 -cleft. Seeds peltate, concave on the inner side.

Pedicels as long as the corollas : corolla-lobes deeply notched or cleft. Pedicels longer than the corollas : corolla-lobes retuse or emarginate.

1. C. violacea.

2. C. verna.

1. Collinsia violàcea Nutt. Stems $0.5-2 \mathrm{dm}$. tall, often branching. Leaf-blades suborbicular to oblong, lanceolate or linear-lanceolate, $0.5-4 \mathrm{~cm}$. long, undulate or sparingly serrate, the upper ones sessile: flowers $2-4$ in a whorl : calyx finely pubescent ; lobes lanceolate, about as long as the tube : corolla violet, about $1 \mathrm{~cm}$. long, and as long as the pedicel, the upper lip much smaller than the lower, all the lobes deeply notched or cleft: capsules subglobose, 4-5 mm. in diameter.

On prairies, Kansas to Arkansas and the Indian Territory. Spring.

2. Collinsia vérna Nutt. Stems 1-5 dm. tall, sometimes branche 1 at the base. Leaf-blades suborbicular or ovate at the base of the stem to ovate-oblong or ovate-lancenlate above, $0.5-5 \mathrm{~cm}$. long, undulate or sharply serrate, the upper partly clasping : flowers often 6 in a whorl or sometimes solitary : calyx glabrous; lobes lanceolate : corolla about 1 $\mathrm{cm}$. long, shorter than the pedicel; the lower lip bright blue, the upper white or purplish, the lobes of both lips retuse or emarginate: capsules oval-globose, 4-5 mm. long.

In moist woods and copses, New York and Wisconsin to Minnesota, south to Kentucky and the Indian Territory. Spring.

\section{SCROPHULÀRIA L.}

Perennial, caulescent, strong-scented herbs. Leaves opposite: blades flat, broadest below the middle, toothed or incised. Flowers proterogynous, in terminal panicled cymes. Calyx-lobes 5, relatively broad. Corolla purple, yellowish or green, 2-lipped : tube neither gibbous nor spurred at the base, the upper lip erect, the middle lobe of the lower lip spreading or reflexed. Stamens 4: sterile filament scale-like on the upper side of the corolla : anther-sacs confluent. Styles united. Ovules numerous. Capsule ovoid. Seeds wingless, wrinkled. Figwort.

Leaf-blades serrulate.

1. S. serrulata.

Leaf-blades coarsely serrate or incised.

Corolla dull without : sterile filament deep purple.

Leaf-blades glabrous beneath or essentially sol: corolla 4-6 mm. long: capsules mostly less than $6 \mathrm{~mm}$. long.

Leaf-blades closely pubescent beneath : corolla $8-9 \mathrm{~mm}$. long: capsules mostly over $6 \mathrm{~mm}$. long.

Corolla lustrous without : sterile filament greenish yellow.

3. S. neglecta. 
Upper lip of the corolla as long as the tube: panicle-branches sparingly glandular: leaf-blades not hastate-incised at the base.

Upper lip of the corolla much shorter than the tube: panicle-branches densely glandular: leaf-blades, especially the lower ones, incised-hastate at the base.

4. S. leporella.

5. S. occidentalis.

1. Scrophularia serrulàta Small. Sparingly pubescent and glandular above. Stems 6-10 dm. tall, simple or sparingly branched : leaf-blades lanceolate to oblong-lanceolate, 5-12 cm. long, acute, serrulate, rounded or subcordate at the base : panicles narrow, 1-2 $\mathrm{dm}$. long: cymes few-flowered: calyx-lobes glabrous, ovate, $2.5-3 \mathrm{~mm}$. long, obtuse : corolla $6-7 \mathrm{~mm}$. long, the upper lip with a recurved margin, the lower lip with a broadly ovate middle lobe and 2 small lateral lobes: capsules conic-ovoid, about $6 \mathrm{~mm}$. long.

In woods, Georgia. Summer.

2. Scrophularia Marylándica L. Glabrous or nearly so. Stems 1-2 m. tall, often widely branched above: leaf-blades oblong-ovate to lanceolate, 5-20 $\mathrm{cm}$. long, serrate or crenate-serrate, glabrous beneath, or essentially so : panicles broad : calyx-lobes oblong to orbicular, obtuse : corolla green or yellowish, dull without, lustrous within, 6-8 mm. long: sterile filament deep purple : capsules broadly ovoid to globose-ovoid, 4-6 $\mathrm{mm}$. long, abruptly pointed.

In woodlands, New York to Kansas, south to Georgia and Tennessee. Summer.

3. Scrophularia neglécta Rydb. Similar to S. Marylandica in habit. Stems minutely pubescent : leaf-blades ovate to lanceolate or oblong-lanceolate, serrate or crenate-serrate, closely pubescent beneath: calyx-lobes ovate or oblong-ovate, obtuse : corolla 8-9 mm. long, the upper lip shorter than the tube : capsules ovoid or globose-ovoid, 6-7 mm. long.

In woods and thickets, Pennsylvania to Kansas, Tennessee and Arkansas. Summer and fall.

4. Scrophularia leporélla Bicknell. Nearly glabrous. Stems $0.5-1.5 \mathrm{~m}$. tall, usually sparingly branched : leaf-blades ovate, oval-hastate or lanceolate, $5-20 \mathrm{~cm}$. long, incised-serrate or deeply incised: panicles narrow : calyx-lobes ovate, acute or obtuse : corolla lustrous without, $8-10 \mathrm{~mm}$. long, the upper lip as long as the tube : sterile filament greenish yellow : capsules conic-ovoid or conic, $7-10 \mathrm{~mm}$. long, attenuate to the apex.

On hillsides or in open woods, Connecticut to Minnesota, south to North Carolina and Nebraska. Spring and summer.

5. Scrophularia occidentàlis (Rydb.) Bicknell. Similar to S. leporella in habit, but with densely glandular panicle-branches. Stem more or less glandular : leaf-blades ovate to lanceolate or oblong-lanceolate, incised or incised-serrate, those of the lower leaves especially, hastately incised at the base : corolla $8-10 \mathrm{~mm}$. long, the upper lip much shorter than the tube: capsules ovoid, 7-8 $\mathrm{mm}$. long. Summer.

In low grounds and thickets, South Dakota to the Indian Territory, Washington and California

\section{ChELÒNE L.}

Perennial caulescent herbs, with glabrous or nearly glabrous foliage. Leaves opposite : hlades flat, toothed. Flowers in dense terminal spike-like racemes. Calyx subtended by sepal-like bracts: lobes 5 . Corolla irregular, white, cream, rose-purple or red, dilated into a quite ample throat, the upper lip concave, exterior in the bud; the lower lip pubescent within, with 2 lateral lobes larger than the middle one. Stamens 4 : filaments pubescent, the sterile one small : anthers woolly. Styles united. Ovules numerous. Capsule ovoid. Seeds flattened, winged. The plants flower in summer and fall. Turtle-HeAD.

Calyx-lobes and bracts glabrous, not ciliolate: corolla white or cream-colored. Leaf-blades sessile and somewhat clasping.

Leaf-blades manifestly petioled.

Calyx-lobes and bracts puberulent, or at least ciliolate : corolla pink or rose-purple. Corolla pink : campestrian species.

Corolla rose-purple: Alleghenian species.

1. C. Cuthbertii.

2. C. glabra.

3. C. obliqua.

4. C. Lyonii.

1. Chelone Cuthbértii Small. Stems 5-11 dm. tall, simple : leaf-blades lanceolate to narrowly linear-lanceolate, long-acuminate, 4-10 $\mathrm{cm}$. long, finely or shallowly serrate, truncate or cordate, and somewhat clasping at the base : racemes few-flowered, 3-8 $\mathrm{cm}$. long: bracts glabrous : calyx-lobes broadly oblong to oblong-obovate, $7-8 \mathrm{~mm}$. long: $\mathrm{co}^{-}$ rolla cream-colored, $2-2.5 \mathrm{~cm}$. long, the lower lip copiously bearded within : capsules ovoid, less than $10 \mathrm{~mm}$. long.

In wet meadows, mountains of North Carolina and South Carolina.

2. Chelone glàbra L. Stems $3-18 \mathrm{dm}$. tall, often branched: leaf-blades broadly linear to oblong, elliptic or lanceolate, $6-15 \mathrm{~cm}$. Iong, acuminate, petioled : racemes 2-12 cm. long, dense : bracts glabrous: calyx-lobes $8-10 \mathrm{~mm}$. long, broadly oblong to oval, 
obtuse : corolla white or cream-colored, $2.5-3 \mathrm{~cm}$. long, the lower lip copiously bearded within : capsules ovoid, 10-12 mm long.

In low thickets and swamps, Newfoundland to Manitoba, Florida and Kansas.

3. Chelone oblìqua L. Similar in habit to $C$. glabra, but seldom as tall. Leafblades of ten more sharply serrate or incised : bracts and calyx-lobes puberulent and manifestly ciliolate : corolla pink, fully $2 \mathrm{~cm}$. long, the lower lip rather sparingly bearded.

In damp thickets and along streams, Virginia to Illinois, south to Florida.

4. Chelone Lyònii Pursh. Stems $3-8 \mathrm{dm}$. tall, usually simple : leaf-blades ovate to elliptic, 5-15 cm. long, acuminate, sharply serrate, cuneate, rounded or truncate at the base : racemes $2-5 \mathrm{~cm}$. long: calyx-lobes oval to suborbicular, $6-8 \mathrm{~mm}$. long, like the bracts ciliolate at least at the tip : corolla deep rose-purple, about $2.5 \mathrm{~cm}$. long : capsules ovoid, 11-14 mm. long.

On damp mountain slopes and summits, Virginia to North Carolina, Tennessee and Georgia.

\section{PÉNTSTEMON Soland.}

Perennial caulescent herbs, with glabrous glaucous or pubescent foliage. Leaves opposite : blades entire, toothed or dissected, sometimes clasping at the base. Flowers in terminal racemes or panicles. Calyx-lobes 5, entire or toothed. Corolla usually showy, rather elongated, 2-lipped. Stamens 4 : filaments about equal in length : staminodium slender, bearded. Styles united: stigma capitate. Ovules numerous. Capsule often ovoid. Seeds wingless, angled or rounded. BEARD-TONGue.

Leaf-blades pinnately dissected or pinnately parted.

1. P. dissectus.

Leaf-blades entire or merely toothed.

Foliage more or less pubescent or puberulent, sometimes only in the inflorescence.

Stems glabrous below the inflorescence, or rarely puberulent in lines. Corolla-tube gradually dilated. Corolla-tube abruptly dilated about the middle.

Calyx-lobes lanceolate to ovate, much less than $1 \mathrm{~cm}$. long.

Corolla purplish ; tube not gibbous above the point of enlargement.

Corolla white or pinkish; tube gibbous above the point of enlargement.

Calyx-lobes linear-subulate from a narrowly lanceolate base, becoming fully $1 \mathrm{~cm}$. long.

Stems pubescent or puberulent.

Throat of the corolla less than $1 \mathrm{~cm}$. in diameter.

Primary branches of the inflorescence elongated or manifest.

Stems hirsute or canescent, often glandular.

Corolla densely bearded in the throat: upper leaves with narrowly lanceolate blades.

Corolla scarcely bearded in the throat: upper leaves with ovate or broadly lanceolate blades.

Stems puberulent.

Upper leaves or lower bracts not dilated at the base.

Leaf-bases not decurrent on the stem. Calyx-lobes lanceolate, at least during anthesis: capsules 8-10 mm. long.

Calyx-lobes ovate to triangular: capsules $5-6 \mathrm{~mm}$. long.

Leaf-bases manifestly decurrent on the stem.

Upper leaves and lower bracts with dilated and rounded bases.

Calyx-lobes acute or short-acuminate : corollas $2 \mathrm{~cm}$. long or longer: capsules longer than the calyx.

Corolla-tube gradually dilated, the lower lip sparingly bearded.

Corolla-tube abruptly gibbous, the lower lip copiously bearded.

Calyx-lobes with long slender tips: corollas $1.5 \mathrm{~cm}$. long or shorter: capsules shorter than the calyx.

Primary branches of the inflorescence suppressed or very short.

Mature calyx-lobes lanceolate: capsules not veined.

Mature calyx-lobes ovate or ovate-lanceolate: capsules promi-

nently veined.
Throat of the corolla over $1 \mathrm{~cm}$. in diameter.

Staminodium glabrous.

Staminodium bearded.

Corolla less than $3 \mathrm{~cm}$. long: capsules smooth, much longer than the calyx-lobes.

Corolla over $3 \mathrm{~cm}$. long: capsules prominently veined, about as long as the calyx-lobes.

Foliage perfectly glabrous, manifestly glaucous.

Leaf-blades distinct at the base : corolla lilac or lavender-blue : staminodium bearded.

Leaf-blades connate-perfoliate : corolla deep scarlet : staminodium glabrous.

2. P. tubiflorus.

3. P. Pentstemon.

4. P. Digitalis.

5. P. calycosus.

\section{P. hirsutus.}

7. P. canescens.

\section{P. australis.}

9. P. pallidus.

10. P. multiflorus.

11. P. Mackayanus.

12. P. Smallii.

13. P. tenuis.

14. P. albidus.

15. P. Guadalupensis.

16. P. triflorus.

\section{P. Helleri.}

18. P. Cobaea.

19. P. grandiflorus. 20. P. Murrayanus.

1. Pentstemon dísséctus Ell. Puberulent. Stems about $6 \mathrm{dm}$. tall : leaves opposite ; blades pinnately dissected or pinnatifid above, the segments $7-11$, linear, 1-2 mm. wide, 
rather obtuse: panicles few-flowered : calyx-lobes ovate-oblong, 4-5 mm. long: corolla purple, 6-19 $\mathrm{mm}$. long: staminodium bearded at the apex.

In dry soil, near Louisville, Georgia.

2. Pentstemon tubiflòrus Nutt. Glabrous to the inflorescence. Stems $5-12 \mathrm{dm}$. tall, sometimes rather naked above : leaf-blades various, those of the basal and lower stemleaves spatulate to oblanceolate or oblong, those of the upper stem-leaves lanceolate to ovate, $3-15 \mathrm{~cm}$. long, entire or rarely minutely toothed : panicle narrow, $0.5-5 \mathrm{dm}$. long, the lower branches remote : calyx-lobes ovate to oblong-lanceolate, $3-5 \mathrm{~mm}$. long : corolla white, $1.5-2 \mathrm{~cm}$. long, not strongly 2 -lipped; the tube gradually dilated: staminodium slightly bearded at the apex : capsules $6-8 \mathrm{~mm}$. long.

On low prairies, Missouri to Kansas, Arkansas and the Indian Territory. Spring and summer.

3. Pentstemon Péntstemon (L.) Britton. Glabrous below the inflorescence. Stems 3-7 dm. tall, sometimes tufted: basal and lower stem-leaves $8-15 \mathrm{~cm}$. long, with oblong or spatulate blades; upper stem-leaves with oblong-lanceolate or broadly linear sessile blades, sometimes undulate or slightly toothed : calyx-lobes glandular-pubescent or glabrate in age, $3-4 \mathrm{~mm}$. long or $5 \mathrm{~mm}$. at maturity, ovate-lanceolate or lanceolate, erect or nearly so, acute : corolla purplish, usually $16-18 \mathrm{~mm}$. long; tube dilated about the middle but not gibbous : staminodium densely bearded : capsules ovoid, 5-6 $\mathrm{mm}$. long, much surpassing the calyx. [P. laevigatus Soland.]

In woods and thickets, Pennsylvania to Kentucky, Florida and Louisiana. Spring and summer.

4. Pentstemon Digitalis (Sweet) Nutt. Glabrous below the inflorescence. Stems 3-10 dm. tall : basal and lower stem-leaves with spatulate or oblong blades and broad petiolelike bases; upper stem-leaves oblong, lanceolate or ovate-lanceolate, $5-15 \mathrm{~cm}$. long, entire or remotely toothed: panicle lax : calyx-lobes lanceolate, 5-7 mm. long, glandular pubescent, spreading or recurved : corolla white or pinkish, $2-2.5 \mathrm{~cm}$. long; tube abruptly dilated and gibbous about the middle: staminodium strongly bearded: capsules ovoid, 7-9 mm. long, somewhat surpassing the calyx.

In fields and copses, Maine to Illinois, south to Georgia and Arkansas. Spring and summer.

5. Pentstemon calycòsus Small. Glabrous below the very sparingly pubescent inflorescence. Stems 4-9 dm. tall : basal and lower stem-leaves with spatulate blades ; upper stem-leaves oblong to lanceolate or ovate-lanceolate, acute or acuminate, sharply serrate or nearly entire, partly clasping: panicle often lax : calyx-lobes sparingly glandular-pubescent when young, with a narrowly lanceolate base and linear-subulate tip, becoming fully $1 \mathrm{~cm}$. long : corolla purple, about $2.5 \mathrm{~cm}$. long, abruptly dilated at the middle : staminodium strongly bearded above the middle : capsules ovoid, $5-6 \mathrm{~mm}$. long.

On banks and river bluffs, Kentucky to Missouri, south to Alabama and Arkansas. Spring.

6. Pentstemon hirsùtus (L.) Willd. Stems sometimes tufted, $2-7 \mathrm{dm}$. tall, hirsute and more or less glandular. Basal and lower stem-leaves with ovate, oval, elliptic or spatulate blades and petiole-like bases : upper stem-leaves oblong to lanceolate, $4-10 \mathrm{~cm}$. long, sessile, more or less toothed: panicles lax : calyx-lobes glandular-pubescent, ovate to lanceolate, 5-6 mm. long : corolla purplish, about $2 \mathrm{~cm}$. long, densely bearded in the throat: staminodium copiously bearded above the middle : capsules conic-ovoid, 7-9 mm. long.

In rocky soil and dry woods, Maine to Manitoba, Florida and Texas. Spring and summer.

7. Pentstemon canéscens Britton. Stems canescent, 2-7 dm. tall. Basal and lower stem-leaves oblong or elliptic, narowed into petiole-like bases; upper stem-leaves with oblong, fiddle-shaped, lanceolate-ovate or ovate blades, clasping, usually dentate : calyx-lobes lanceolate, 4-7 mm. long, glandular-pilose : corolla white or pinkish, 2-2.5 cm. long; tube abruptly enlarged at the middle, scarcely bearded in the throat: staminodium bearded with long hairs : capsules ovoid, 6-7 mm. long, slightly surpassing the calyx.

On mountain slopes, Virginia and West Virginia to North Carolina. Spring.

8. Pentstemon austràlis Small. Stems puberulent, often purple, $3-10 \mathrm{dm}$. tall, often branched at the base. Basal and lower stem-leaves with spatulate to oblong blades, narrowed into narrowly winged petioles; upper stem-leaves few, the blades lanceolate to almost linear, remotely toothed or undulate, partly clasping, but not decurrent: panicle narrow : calyx-lobes lanceolate or ovate-lanceolate in age, 5-6 mm. long, acute or acutish, often purple or purplish-tinged : corolla purple, $1.5-2 \mathrm{~cm}$. long, the lower lip sparingly bearded : staminodium densely bearded: capsules conic-ovoid, 8-10 mm. long, about twice as long as the calyx.

In sandy soil, Georgia and Arkansas to Florida and Texas. Spring.

9. Pentstemon pállidus Small. Stems puberulent, or sometimes canescent-puberulent, 3-9 dm. tall. Basal and lower stem-leaves with oblong elliptic or nearly spatulate 
blades; upper stem-leaves few, the blades oblong, lanceolate or linear-lanceolate, rather remotely toothed, partly clasping: panicles narrow : calyx-lobes ovate, becoming triangular, acute, closely puberulent or pubescent during anthesis: corolla white or purplish, $2-2.5 \mathrm{~cm}$. long; tube rather gradually dilated, the throat sparingly bearded: staminodium bearded with very short hairs : capsules ovoid with a flat base, 5-6 mm. long, much surpassing the calyx.

In sandy,soil or swamps, New York to Missouri, Georgia and the Indian Territory. Spring.

10. Pentstemon multiflòrus Chapm. Stems merely puberulent below the inflorescence, 4-12 dm. tall. Basal and lower stem-leaves with spatulate or oblong blades narrowed into petiole-like bases; upper stem-leaves few; blades narrowly oblong to oblonglanceolate, obtuse, entire or undulately toothed, manifestly decurrent on the stem : panicle often ample and many-flowered : calyx-lobes glandular-pubescent, ovate, 3-4 mm. long, obtuse : corolla white, about $1.5 \mathrm{~cm}$. long, glabrous or nearly so in the throat: staminodium sparingly bearded near the tip or nearly glabrous : capsules conic, 8-10 $\mathrm{mm}$. long, rather narrow at the base, abruptly constricted at the apex, usually fully twice as long as the calyx.

In pine lands, Florida. Spring and summer.

11. Pentstemon Mackayànus Knowles \& Westc. Stems minutely puberulent. Leaves bright green ; blades various, those of the basal and lower stem-leaves lanceolate or ovate to oblong; those of the upper stem-leaves lanceolate or broadly lanceolate, acute or somewhat acuminate, irregularly serrate, partly clasping by the dilated bases : panicle open : calyx-lobes ovate to oblong-ovate, merely acuminate, 4-5 $\mathrm{mm}$. long, sparingly pubescent : corolla purple without, $1.5-2 \mathrm{~cm}$. long; tube funnelform, sparingly bearded in the throat : staminodium rather copiously bearded : capsules not seen.

In open woods, Texas. Spring.

12. Pentstemon Smállii Heller. Stems puberulent below the inflorescence, 3-12 dm. tall. Basal leaves with ovate or oval coarsely toothed blades abruptly narrowed into margined petioles; upper stem-leaves few ; blades lanceolate to ovate-lanceolate, successively broader at the base, $8-15 \mathrm{~cm}$. long, often acuminate, regularly and rather finely toothed, clasping : panicle secund : calyx-lobes lanceolate or oblong-lanceolate, 5-6 mm. long, acute or acuminate: corolla showy, pink-purple, striped with white especially within, $2.5-3 \mathrm{~cm}$. long; tube abruptly dilated near the middle, with long yellow hairs in the throat: staminodium bearded to the base : capsules ovoid, $8-10 \mathrm{~mm}$. long, often twice as long as the calyx.

On mountain slopes and river bluffs, North Carolina and Tennessee. Spring.

13. Pentstemon ténuis Small. Stems 4-6 dm. tall, puberulent. Stem leaves opposite; blades oblong to oblong-lanceolate or ovate, $6-10 \mathrm{~cm}$. Iong, acute or acuminate, sharply serrate-dentate, partly clasping: panicles open, rather few-flowered : calyx-lobes minutely glandular-pubescent, 4-5 mm. long, becoming $7 \mathrm{~mm}$. at maturity, lanceolate, with attenuate spreading or recurving tips : corolla purplish, barely $1.5 \mathrm{~cm}$. long, glandular ; tube hardly dilated, but with a slight gibbosity near the middle: sterile filament bearded above the middle: capsules broadly ovoid, about $5 \mathrm{~mm}$. high, surpassed by the calyx.

In woods and thickets, Alabama and Louisiana. Spring.

14. Pentstemon álbidus Nutt. Foliage dark green, puberulent or somewhat canescent above, viscid. Stems tufted, 1-3 dm. tall : basal and lower stem-leaves with oblong or spatulate blades; upper stem-leaves lanceolate, sometimes narrowly so, not lustrous, entire or shallowly toothed, sessile: panicle raceme-like, the main branches more or less suppressed, the cymes clustered : calyx-lobes lanceolate, 6-8 $\mathrm{mm}$. long, densely viscidpubescent : corolla white or purple-tinged, about $1.5 \mathrm{~cm}$. long, the lips spreading : staminodium bearded: capsules ovoid, about $10 \mathrm{~mm}$. long, smooth.

On sand hills or plains, Assiniboia to Kansas, Texas and Colorado. Spring and summer.

15. Pentstemon Guadalupénsis Heller. Foliage bright green. Stems tufted, 1-4 dm. tall, puberulent : basal and lower stem-leaves with linear or nearly linear often elongated blades ; upper stem-leaves numerous, approximate; blades linear-lanceolate to lanceolate, $2-6 \mathrm{~cm}$. long, entire or nearly so, lustrous, sessile: panicle raceme-like, viscid-pubescent : calyx-lobes lanceolate or ovate-lanceolate, 5-7 mm. long: corolla white or tinged with purple, about $1.5 \mathrm{~cm}$. long, sparingly glandular-pubescent : staminodium bearded to about the middle : capsules ovoid, about $10 \mathrm{~mm}$. long, veiny.

In stony soil, central Texas. Spring.

16. Pentstemon triflòrus Heller. Glabrous or nearly so to the inflorescence. Stems 3-9 dm. tall : basal and lower stem-leaves with spatulate or oblong almost entire blades narrowed into margined petioles; upper stem-leaves oblong to ovate, mostly acute, $3-10$ $\mathrm{cm}$. long, successively more sharply and deeply toothed, partly clasping : peduncles usually 
3-flowered, glandular-pubescent: calyx-lobes lanceolate or oblong-lanceolate, 6-10 mm. long, acute : corolla rose-purple, about $2.5 \mathrm{~cm}$. long, the tube gradually dilated: staminodium glabrous.

On hillsides, central Texas. Spring.

17. Pentstemon Hélleri Small. Puberulent, or glabrate below the inflorescence, thence minutely glandular-pubescent. Stems 3-6 dm. tall : leaves lustrous ; blades various, those of the basal and lower stem-leaves oblong-spatulate or nearly linear, 6-10 cm. long, acute, narrowed into winged petioles, those of the upper leaves oblong to broadly ovate, acute, sessile, all undulate or slightly toothed: calyx-lobes densely glandular-pubescent, ovate to elliptic-ovate, 8-10 $\mathrm{mm}$. long, acutish: corolla white or rose, sometimes tinged with blue, minutely glandular-pubescent, $3-3.5 \mathrm{~cm}$. long, rather gradually enlarged: capsules conic-ovoid, at least $1 \mathrm{~cm}$. long, not reticulated, much surpassing the calyx.

On prairies, central Texas. Spring.

18. Pentstemon Cobaèa Nutt. Pubescent, at least above. Stems 3-6 dm. tall ; leaves various; those of the basal and lower stem-leaves with spatulate or oblong blades narrowed into margined petioles ; upper stem-leaves few ; blades oblong to ovate, 4-12 cm. long, partly clasping, nearly entire or sharply serrate : calyx-lobes ovate-lanceolate, 1-1.5 $\mathrm{cm}$. long, rather acute : corolla $3.5-6 \mathrm{~cm}$. long, dull reddish purple or paler, glabrous within: staminodium sparingly bearded : capsules ovoid, about $1.5 \mathrm{~cm}$. long, reticulated, shorter than the calyx or barely surpassing it.

On prairies, Kansas to Texas. Spring.

19. Pentstemon grandiflòrus Nutt. Glaucous. Stems $3-9 \mathrm{dm}$. tall, simple or nearly so. Basal and lower stem-leaves with spatulate or oblong blades $5-10 \mathrm{~cm}$. long, petioled : upper stem-leaves orbicular or ovate, $3-9 \mathrm{~cm}$. long: panicle narrow: calyx-lobes glabrous, lanceolate to oblong-lanceolate, 7-9 mm. long: corolla lilac or lavender-blue, $4.5-5 \mathrm{~cm}$. long; tube abruptly dilated below the middle: staminodium sparingly pubescent near the apex : capsules ovoid, $2-2.5 \mathrm{~cm}$. long, reticulated at maturity.

On plains, Minnesota to South Dakota, south to Illinois, Indian Territory and Kansas. Summer.

20. Pentstemon Murrayànus Hook. Glaucous. Stems 3-10 dm. tall : basal and lower stem-leaves with spatulate or oblong blades $7-10 \mathrm{~cm}$. long, narrowed into petiole-like bases; upper stem-leaves leathery; blades connate-perfoliate, ovate to broadly oblong, 4-8 $\mathrm{cm}$. long, often abruptly pointed : panicle narrow : calyx-lobes ovate, 4-5 mm. long, or slightly larger at maturity, acute : corolla deep scarlet, $2.5-3 \mathrm{~cm}$. long; tube gradually dilated : staminodium glabrous : capsules ovoid, $1.5 \mathrm{~cm}$. long, about $\frac{2}{3}$ longer than the calyx.

On prairies, Texas. Summer.

\section{PAULÒWNIA Sieb. \& Zucc.}

Trees simulating Catalpa, with flaky bark. Leaves opposite: blades ample, broadest below the middle, entire or 3-lobed, long-petioled. Flowers in large terminal panicles. Calyx-lobes 5. Corolla violet or pink-purple, 2-lipped : tube trumpet-shaped, the lobes of both lips spreading. Stamens 4, included : anther-sacs divergent. Styles mostly united, the tips stigmatic on the inner side. Capsule ovoid, leathery, loculicidally dehiscent. Seeds numerous, winged.

1. Paulownia tomentòsa (Thunb.) Baill. A tree with large spreading branches. Leaf-blades ovate or suborbicular, $1.5-4 \mathrm{dm}$. long, acute or acuminate, densely tomentose beneath, cordate, prominently nerved beneath : calyx 10-14 mm. long, densely tomentose; lobes ovate to oblong : corolla violet, pubescent without, 4-5 cm. long, the limb $3.5-4.5$ $\mathrm{cm}$. broad, the lobes rounded : capsules ovoid, $3-4 \mathrm{~cm}$. long, acute.

In waste places and thickets, New York to Florida and Texas. Naturalized from eastern Asia. Spring and summer.

\section{MímuLus L.}

Annual or perennial caulescent herbs. Leaves opposite: blades flat, toothed. Flowers solitary in the axils, sometimes disposed in racemes or panicles. Calyx-tube angled, longer than the lobes. Corolla of various colors, 2-lipped: tube with 2 ridges within on the lower side : upper lip spreading or reflexed: lower lip erect. Stamens 4 : filaments partly adnate to the corolla-tube: anther-sacs divergent. Styles united to the 2-lobed stigma. Capsule loculicidally dehiscent, enclosed in the calyx. Monkey-FLower. 
Corolla yellow : leaf-blades nearly as broad as long.

Corolla blue, violet or white: leaf-blades much longer than broad. Leaf-blades petioled: calyx longer than the pedicel.

Leaf-blades sessile: calyx shorter than the pedicel.

1. M. Jamesii.

2. M. alatus.

3. M. ringens.

1. Mimulus Jamèsii Torr. Stems usually branched at the base ; branches 1-4 dm. long, spreading and creeping: leaf-blades ovate to orbicular-reniform, 1-4 cm. long, dentate or sinuate-dentate, most of them short-petioled : calyx 5-6 mm. long, often slightly accrescent, the upper lip merely acute, longer than the lower lip : corolla yellow, fully 1 $\mathrm{cm}$. long, the lower lip bearded within : capsules $5-8 \mathrm{~mm}$. long.

In swamps and streams, Ontario to Montana, Texas, Arizona and Mexico. Summer and fall.

2. Mimulus alàtus Soland. Rootstocks often tuberous-thickened. Stems $2-10 \mathrm{dm}$. tall, square and 4-winged : leaf-blades thickish, elliptic to elliptic-lanceolate, 5-15 cm. long, serrate; petioles 1-2 cm. long: pedicels stout, 5-6 mm. long, 4-winged : calyx 12-15 mm. long, slightly dilated upward, each plait ending in a short folded mucro about $1 \mathrm{~mm}$. long: corolla about $2 \mathrm{~cm}$. long: capsule hardly distending the calyx-tube.

In swamps and meadows, Connecticut to Illinois, south to Florida and Texas. Summer and fall.

3. Mimulus ríngens $L$. Rootstocks elongated. Stem $3-12 \mathrm{dm}$. tall, flattened, the edges grooved : leaf-blades lanceolate or narrowly elliptic, $5-20 \mathrm{~cm}$. long, shallowly and remotely serrate, sessile, the lower ones constricted above the base, more or less auricled and clasping : pedicels slender, 2-4 $\mathrm{cm}$. long, 2-winged above : calyx 12-20 $\mathrm{mm}$. long, each plait ending in a folded mucro ranging from $3-6 \mathrm{~mm}$. in length : corolla $2 . \dot{\delta}-3 \mathrm{~cm}$. long : capsule manifestly distending the calyx-tube.

In swamps and in damp banks, Nova Scotia to Manitoba, Georgia and Texas. Summer and fall.

\section{STEMÒdIA L.}

Annual or perennial caulescent of ten aromatic herbs, with pubescent foliage. Leaves opposite or whorled: blades flat, toothed. Flowers solitary in the axils, sometimes in dense spike-like racemes. Calyx-lobes equal or nearly so. Corolla blue or purplish, 2-lipped. Stamens 4, included : filaments filiform : anther-sacs widely separated. Styles dilated to the 2-lobed or dilated stigma. Capsule septicidally 2-valved, the valves 2-cleft. Seed s striate or reticulated.

Foliage viscid-pubescent : stems and branches erect or ascending.

Foliage white-woolly: stems and branches prostrate or procumbent.

1. S. durantifolia.

2. S. lanata.

1. Stemodia durantifòlia (L.) Sw. Foliage viscid-pubescent. Stems 3-6 dm. tall, simple or sparingly branched : leaves opposite or in whorls of 3 or 4 ; blades oblong to lanceolate or linear-lanceolate, acute or acuminate, serrate, more or less auricled at the base and partly clasping: racemes elongated : calyx-lobes linear-subulate, 5-6 $\mathrm{mm}$. long: corolla azure-blue or purplish, about $1 \mathrm{~cm}$. long; tube somewhat dilated about the middle ; lobes truncate or retuse : capsules conic-ovoid, $3-4 \mathrm{~mm}$. long.

In wet soil, Texas to Arizona and tropical America.

2. Stemodia lanàta R. \& P. Foliage white-woolly. Stems more or less branched, the branches prostrate or procumbent, several $\mathrm{dm}$. long: leaf-blades mainly oblong, 1-4 cm. long, dentate, sessile and clasping by the cordate base.

In low places, southern Texas and Mexico.

\section{CONÒBEA Aubl.}

Annual or perennial caulescent often glandular-pubescent herbs. Leaves opposite : blades toothed, incised, pinnatifid or parted. Flowers solitary or 2 together in the axils. Calyx-lobes unequal, longer than the tube. Corolla white or blue, 2-lipped. Stamens 4, included: anther-sacs parallel, contiguous. Styles united, incurved. Capsules septicidally dehiscent, the valves entire or 2-cleft. Seeds striate.

1. Conobea multífida (Michx.) Benth. Annual, viscid-pubescent. Stems 1-2 dm. tall, often mnch branched : leaf-blades 1-2 $\mathrm{cm}$. long, pinnately parted into narrow entire or toothed segments: peduncles much shorter than the subtending bracts: calyx sessile, rather surpassed by the 2 subtending bractlets; lobes narrowly linear, 2-2.5 $\mathrm{mm}$. long; corolla about $3 \mathrm{~mm}$. long : capsules narrowly ovoid, $3 \mathrm{~mm}$. long.

On river banks and prairies. Pennsylvania to Iowa, Tennessee and Texas. Summer and fall.

\section{MONNIÈRA P. Br.}

Perennial succulent odorless herbs, with terete creeping stems. Leaves opposite: blades entire or very slightly toothed, broadest above the middle, palmately nerved, sessile. 
Flowers usually solitary on axillary peduncles. Calyx sessile in 2 small bractlets : sepals nearly distinct, the upper one broadest. Corolla blue or white, nearly regular, the 5 lobes almost equal, spreading. Stamens 4, included : filaments adnate to near the throat of the corolla. Capsule ovoid or oval, septicidally dehiscent, the valves cleft or parted. Seeds numerous. [Herpestis Gaertn.]

Leaf-blades spatulate or cuneate: capsules acuminate at the apex.

Leaf-blades obovate or orbicular-obovate: capsules blunt at the apex.

1. M. Monniera.

2. M. rotundifolia.

1. Monniera Monnièra (L.) Britton. Stem and branches glabrous, 1-6 dm. long: leaf-blades spatulate or cuneate, 1-2 cm. long, obtuse, entire or inconspicuously toothed near the apex : peduncles glabrous, mostly longer than the subtending bract at maturity: outer sepals becoming 5-6 mm. long, usually acute : corolla white or pale blue, the upper lobes often retuse : capsules conic-ovoid, $5-8 \mathrm{~mm}$. long, acuminate at the apex.

On banks and shores, Maryland to Florida and Texas. Also in the tropics. Spring to fall.

2. Monniera rotundifòlia Michx. Stem and branches pubescent or glabrate in age, 1-5 dm. long: leaf-blades broadly obovate to orbicular-obovate, $1-2.5 \mathrm{~cm}$. long, rounded at the apex, partly clasping: peduncles pubescent, usually shorter than the subtending bracts : outer sepals becoming $3-4 \mathrm{~mm}$. long, rounded at the apex : corolla white or whitish, the upper lobes rounded: capsules oval, about $4 \mathrm{~mm}$. long, blunt at the apex.

On muddy shores, Illinois to South Dakota, south to Tennessee, Louisiana and Texas. Summer.

\section{SEPTÍLIA Raf.}

Perennial, aromatic, succulent, creeping herbs, usually pubescent. Stems terete. Leaves opposite: blades broadest below the middle, palmately nerved, entire or shallowly toothed, punctate, partly clasping. Flowers solitary on short axillary peduncles. Calyx subtended by 2 small bractlets. Sepals nearly distinct, the outer ones cordate, the upper one broadest. Corolla blue or white, manifestly 2-lipped, the upper lip merely notched. Hypogynous disk present. Stamens 4, included: filaments adnate to near the throat of the corolla-tube. Capsule ovoid to conic, septicidally dehiscent, the valves cleft. Seeds numerous.

Stems merely puberulent above : hypogynous disk entire.

Stems manifestly pubescent above: hypogynous disk 10-12-toothed.

Upper leaf-blades oblong or ovate-oblong, entire or undulate.

Upper leaf-blades orbicular or ovate-orbicular, shallowly toothed.

1. S. repens.

2. S. Caroliniana.

3. S. crenulata.

1. Septilia rèpens (Sw.) Raf. Stems and branches several dm. long, puberulent above, sometimes diffusely branched. Leaf-blades broadly ovate or oblong-ovate, $0.5-1.5$ cm. long, obtuse, clasping : peduncles about as long as the corolla : outer sepals becoming $3-3.5 \mathrm{~mm}$. long, glabrous or nearly so, reticulated: corolla white or whitish, little surpassing the calyx: capsules oblong-ovoid, 2-2.5 mm. long. [Herpestis repens Cham. \& Schlecht. ]

In low grounds, South Carolina to Florida. Also in tropical America. Spring to fall.

2. Septilia Caroliniàna (Walt.) Small. Stems 2-6 dm. long, manifestly pubescent, at least above. Leaf-blades ovate-oblong or oblong, 1-2 cm. long, entire or undulate, clasping: peduncles 1-5 mm. long: outer sepals becoming 6-7 mm. long, glabrous or nearly so : corolla blue, $8-9 \mathrm{~mm}$. long: capsules ovoid-conic, about $4 \mathrm{~mm}$. long. [Herpestis amplexicaulis Pursh.]

A bout pine-land ponds, New Jersey to Florida and Louisiana. Spring to fall.

3. Septilia crenulàta Small. Resembling C. Caroliniana, but stouter. Stems copiously pubescent throughout: leaf-blades suborbicular to orbicular-ovate, $1.5-2.5 \mathrm{~cm}$. long, obtuse or notched at the apex, shallowly toothed, partly clasping: peduncles 1-1.5 $\mathrm{cm}$. long : outer sepals becoming fully $1 \mathrm{~cm}$. long, pubescent : corolla fully $10 \mathrm{~mm}$. long, blue : capsules ovoid-oblong, about $5 \mathrm{~mm}$. long. [Monniera crenulata Small.]

In ditches and low places, Florida. Spring and summer.

\section{MECARDÒNIA R. \& P.}

Perennial relatively rigid herbs, with 4-angled erect or diffuse, but rarely creeping stems. Leaves opposite; blades toothed, narrowed at the base, pinnately nerved. Flowers solitary on slender axillary pedicels subtended by two small bractlets. Calyx not subtended by bractlets : sepals 5, unequal, the upper one broadest : corolla white, purple or yellow, 
2-lipped, the upper lip notched. Stamens adnate to near the corolla-throat. Hypogynous disk wanting. Stigma 2-lobed. Capsule septicidal, the valves cleft. Seeds numerous.

Stems or branches erect or ascending. Stems or branches prostrate or decumbent.

Pedicels about as long as the leaves or somewhat longer.

Upper sepals ovate, $5-6 \mathrm{~mm}$. long, barely surpassing the others.

Upper sepals linear or oblong-lanceolate, 7-9 $\mathrm{mm}$. long, manifestly surpassing the others.

Pedicels several times longer than the leaves.

Stems sparingly branched, the branches merely procumbent: upper sepal over $7 \mathrm{~mm}$. long.

Stems diffusely branched, the branches prostrate: upper sepal less than 7 mm. long.

1. Mecardonia acuminàta (Walt.) Small. Stems and branches erect or ascending, 1-6 dm. tall, leaf-blades spatulate to oblong or elliptic, 2-5 $\mathrm{cm}$. long, serrate, the lower ones narrowed into short petioles: pedicels usually somewhat longer than the leaves: sepal becoming 8-10 mm. long, ribbed or slightly keeled: corolla white or pink, the upper lip bearded within, the lower lip with apiculate lobes : capsules oblong, 5-6 mm. long. [Herpestis nigrescens Benth.]

In meadows or wet grounds, Maryland to Florida and Texas. Summer and fall.

2. Mecardonia procúmbens (Mill.) Small. Stems and branches decumbent, 0.5-2 dm. long. Leaf-blades oval to elliptic or ovate, $1-1.5 \mathrm{~cm}$. long, serrate or crenate-serrate, the lower ones short-petioled : pedicels as long as the leaves or slightly longer: upper sepal ovate, barely, if at all, -longer than the others, 5-6 mm. long: corolla yellow, 5-7 mm. long: capsules 4-5 mm. long. [Herpestis chamaedryoides H.B.K.]

In sand, Florida and Texas. Also in tropical America. Summer and fall.

3. Mecardonia víridis Small. Resembling $M$. procumbens but light green and unchanged in drying. Stems or branches 1-3 dm. long, merely decumbent : leaf-blades oval to ovate or elliptic above, 1-2 cm. long, obtuse, bluntly serrate, contracted into margined petioles near the base of the stem : pedicels as long as the leaves or longer: upper sepal linear or oblong-lanceolate, becoming 7-9 $\mathrm{mm}$. long, manifestly surpassing the others: corolla $6-7 \mathrm{~mm}$. long, yellow : capsules about $7 \mathrm{~mm}$. long.

In sandy soil, coast of Texas. Spring.

4. Mecardonia peđunculàris (Benth.) Small. Resembling $M$. procumbens and $M$. viridis but smaller. Stems and branches often less leafy above : leaves fewer: blades narrower, gradually narrowed into narrow petioles or petiole-like bases: pedicels slender, several times longer than the leaves: upper sepal becoming $8-10 \mathrm{~mm}$. long, barely longer than the others: corolla about $1 \mathrm{~cm}$. long.

On prairies, Texas to Arizona. Spring and summer.

5. Mecardonia ténuis Small. Stems diffusely branched; branches prostrate, 0.5-4 $\mathrm{dm}$. long, filiform or wire-like. Leaf-blades spatulate to oblong, oblanceolate or lanceolate, 5-12 $\mathrm{mm}$. long, sharply serrate, except the gradually narrowed base : pedicels filiform, several times longer than the leaves: upper sepal oblong-ovate, becoming $6 \mathrm{~mm}$. long, barely longer than the others : corolla 6-7 mm. long: capsules 5-6 mm. long.

On coral rock and in sand, Key West, Florida.

\section{HYDRANTHELIUM H.B.K.}

Annual or perennial amphibious herbs, with floating or creeping stems. Leaves opposite : blades broad. Flowers solitary in the axils. Calyx of 4 partially united sepals. Corolla white, 3-lobed. Stamens 3, exserted : filaments adnate as far as the throat of the corolla-tube : anther-sacs distinct, parallel. Stigma 2-lobed. Capsule membranous, 2-valved. Seeds curved.

1. Hydranthelium Egénse Poepp. \& Endl. Aquatic, minutely pubescent. Stems several cm. long, branched : upper leaf-blades cuneate, obovate or suborbicular, $1-1.5 \mathrm{~cm}$. long, shallowly toothed above the base: pedicels $5-12 \mathrm{~mm}$. long: calyx-lobes lanceolate, acute : capsules subglobose or ovoid-globose.

In swamps, near New Orleans, Louisiana. Also in tropical South America. Not recently collected.

\section{GRATIOLA L.}

Annual or perennial rather succulent herbs, with glabrous or softly pubescent foliage. Leaves opposite: blades entire or toothed, rather fleshy. Flowers solitary on axillary peduncles. Calyx sessile in 2 bractlets : sepals 5, nearly distinct. Corolla white, yellow or purplish, 2-lipped. Stamens 2, included. Staminodia wanting, scale-like or filiform. 
Anther-sacs transverse, separated by a dilated membranous connective. Capsule globose or ovoid, often blunt. Seeds striate. HEDGE-Hyssop.

Staminodia wanting or mere scales.

Peduncles as long as the bracts or longer.

Corollas golden yellow.

Capsules conic, much longer than the sepals.

Capsules subglobose, about as long as the sepals.

Corollas white or merely yellowish.

Corollas about $6 \mathrm{~mm}$. long: capsules globular.

Corollas 8-20 mm. long: capsules ovoid.

Sepals $5 \mathrm{~mm}$. long: corollas $15-20 \mathrm{~mm}$. long : capsules $3-3.5 \mathrm{~mm}$. long. Sepals 4-4.5 mm, long: corollas 8-11 mm. long: capsules 4-5 mm. long. Peduncles much shorter than the bracts.

Staminodia conspicuous with capitate tips.

Corollas golden yellow.

Corollas white or tinged with purple, or the tube often yellowish within.

Bractlets nearly as long as the sepals or surpassing them.

Plants wholly glabrous.

Leaf-blades thick, oblong to lanceolate, partly clasping: sepals acute.

Leaf-blades thin, oblong. obovate to oblanceolate, short-petioled or merely sessile : sepals obtuse.

Plants pubescent or puberulent, often viscid.

Sepals lanceolate to oblong-lanceolate: leaf-blades mostly less than twice as long as broad.

Sepals linear to linear-subulate: leaf-blades mostly over twice as long as broad.

Bractlets minute or obsolete.

1. G. pusilla.

2. G. Torreyi.

3. G. gracilis.

4. G. Floridana.

5. G. Virginiana.

6. G. sphaerocarpa.

7. G. aurea.

8. G. officinalis.

9. G. macrantha.

10. G. viscosa.

11. G. Drummondii. 12. G. ramosa.

1. Gratiola pusílla Torr. Stems viscid or viscid-puberulent, $5-10 \mathrm{~cm}$. tall, very slender, often sparingly branched. Leaf-blades linear-spatulate to linear, 2-6 mm. long, obtuse, entire, sessile : pednncles slender, longer than the subtending bracts : sepals linear or linear-oblong, rather obtuse, $2-3 \mathrm{~mm}$. long: corolla golden-yellow, 7-8 mm. long, the lobes retuse or notched: capsules conic-ovoid, $4 \mathrm{~mm}$. long, acute.

On prairies, Arkansas and Texas. Spring.

2. Gratiola Torreỳi Small. Stems glabrous or nearly so, 5-10 cm. tall, usually simple. Leaf-blades linear-spatulate to linear, 5-20 mm. long, entire or sparingly toothed, the lower ones narrowed into petiole-like bases : peduncles as long as the subtending bracts or longer: sepals linear or oblong-linear, $2 \mathrm{~mm}$. long, surpassed by the linear-clavate bractlets: corolla golden yellow, about $10 \mathrm{~mm}$. long: capsules subglobose, about $3 \mathrm{~mm}$. in diameter.

In river valleys, Texas. Spring.

3. Gratiola grácilis Benth. Stems glabrous, $15-25 \mathrm{~cm}$. tall, slender. Leaf-blades oblong to oblong-lanceolate, entire or sparingly toothed, sessile: peduncles much longer than the subtending bracts: sepals lanceolate, obtuse, $2-2.5 \mathrm{~mm}$. long, about as long as the similar bractlets: corolla yellowish white, $6-7 \mathrm{~mm}$. long : capsules subglobose or ovoidglobose, about as long as the calyx.

In low grounds, eastern Texas, Spring.

4. Gratiola Floridàna Nutt. Stems glabrous or nearly so, 1-3 dm. tall, often branched at the base. Leaf-blades oblanceolate to spatulate, elliptic or oblong, 1-5 cm. long, often obtuse, entire, repand or denticulate, the lowest pair at least narrowed into petiole-like bases : peduncles as long as the subtending bracts or longer: sepals glabrous, nearly linear, about $5 \mathrm{~mm}$. long, often slightly surpassed by the bractlets : corolla 15-20 $\mathrm{mm}$. long; tube yellow; lobes white : capsules globose-ovoid, 3-3.5 mm. long, not pointed.

On muddy banks, Tennessee to Georgia, Florida and Alabama. Spring.

5. Gratiola Virginiàna L. Stems viscid-puberulent or pubescent above, 1-3 dm. tall, often branched at the base. Leaf-blades elliptic-spatulate to elliptic or oblong, 1.5-5 $\mathrm{cm}$. long, often acute, undulate or shallowly toothed, the lower ones narrowed into petiolelike bases : peduncles as long as the subtending bracts or shorter : sepals viscid-puberulent, linear or linear-lanceolate, 4-4.5 mm. long, about as long as the bractlets : corolla 8-11 $\mathrm{mm}$. long; tube yellowish; lobes whitish : capsules ovoid, 4-5 mm. long, acute.

In mud or on wet banks, Quebec to British Columbia, south to Florida, Texas and California. spring to fall.

6. Gratiola sphaerocárpa Ell. Stems glabrous or nearly so, 1-4 dm. tall, often diffusely branched. Leaf-blades oblong, elliptic or elliptic-lanceolate, often cuneately narrowed at the base, $1.5-5 \mathrm{~cm}$. long, repand to dentate-serrate : peduncles rarely $\frac{1}{2}$ as long as the subtending bracts: sepals linear-lanceolate, 4-5 $\mathrm{mm}$. long, about as long as the linear bractlets : corolla white, $8-12 \mathrm{~mm}$. long; tube barely twice as long as the calyx : capsules subglobose, $5-6 \mathrm{~mm}$. in diameter.

In low grounds, New Jersey to Illinois, south to Florida, Texas and Mexico. Summer and fall. 
7. Gratiola aùrea Muhl. Stems viscid or viscid-pubescent, $0.5-2 \mathrm{dm}$. long, often decumbent and creeping, simple or sparingly branched. Leaf-blades linear to lanceolate, $1-2.5 \mathrm{~cm}$. long, entire or sparingly toothed, sessile: peduncles as long as the subtending bracts or shorter: sepals lanceolate, $4 \mathrm{~mm}$. long, about as long as the nearly linear bractlets: corolla golden yellow, $1-1.5 \mathrm{~cm}$. long, puberulent; tube slightly gibbous near the middle : capsules.

In wet soil and pine lands, Quebec and Ontario, south to Florida. Summer and fall.

8. Gratiola officinàlis L. Stems glabrous, $2-5 \mathrm{dm}$. tall, more or less branched. Leaf-blades thick, oblong to lanceolate, 2-4 cm. long, acute, entire or serrulate, sessile and partly clasping: peduncles slender, shorter than the subtending bracts: sepals linear to linear-lanceolate, $5-6 \mathrm{~mm}$. long, acute, usually surpassed by the narrow bractlets : corolla white, striped with a darker color, $1.7-2 \mathrm{~cm}$. long: capsules ovoid, 5-7 mm. long, acute.

In low grounds, Georgia. Native of Europe. Summer.

9. Gratiola macrántha Chapm. Stem glabrous, ascending from a creeping base, 1.5-3 dm. long, branching: leaf-blades thin, oblong-obovate to oblanceolate, $2.5-4.5 \mathrm{~cm}$. long, obtuse, entire, short-petioled or merely sessile : peduncles mostly longer than the subtending bracts: sepals linear, obtuse, usually surpassed by the spatulate bractlets: corolla white, $12-18 \mathrm{~mm}$. long.

In cool spring, near Quiney, Florida. Spring.

10. Gratiola viscòsa Schwein. Stems viscid-puberulent or pubescent, 1-4 dm. tall, sometimes decumbent, simple or sparingly branched. Leaf-blades ovate, oval or oblong, $0.5-2 \mathrm{~cm}$. long, acute, sharply serrate, sessile and partly clasping: peduncles longer than the subtending bracts or occasionally shorter: sepals lanceolate to oblong-lanceolate, 5-7 $\mathrm{mm}$. long, rather obtuse, shorter than the bractlets: corolla yellowish white, 8-10 mm. long, the upper lip bearded with glandular hairs : staminodium sometimes obsolete : capsules ovoid-globose, $2-3 \mathrm{~mm}$. long.

In muddy places and brooks, Kentucky to North Carolina and Georgia. Spring to fall.

11. Gratiola Drummóndii Benth. Stems viscid-pubescent, 1-4 dm. tall, often sparingly branched. Leaf-blades oblong, lanceolate or linear, 1-1.5 mm. long, acute, sharply toothed, especially near the apex, sessile and partly clasping: peduncles slender, fully as long as the subtending bracts, or shorter: sepals minutely glandular, linear or linear-subulate, 5-7 mm. long, about as long as the bractlets: corolla whitish or yellowish, 10-12 mm. long : capsules subglobose, 1.5-2 mm. long.

In muddy places and shallow streams, Arkansas to Georgia, Florida and Texas. Summer.

12. Gratiola ramòsa Walt. Stems viscid-puberulent, 1-3 dm. tall, sometimes sparingly branched, often tufted. Leaf-blades lanceolate or linear-lanceolate, 1-1.5 cm. long, acute, with few sharp teeth, sessile : peduncles as long as the subtending bracts or longer: sepals glandular, linear-subulate or narrowly linear-lanceolate, 4-6 mm. long, accompanied by minute or obsolete bractlets : corolla whitish, 10-12 mm. long ; tube glandular-pubescent : capsules depressed, 1.5-2 mm. long.

In wet soil, South Carolina to Florida. Summer and fall.

\section{SOPHRONÁNTHE Benth.}

Annual or perennial rigid caulescent herbs, with rough-pubescent foliage. Leaves opposite : blades entire or toothed, sessile. Flowers solitary in the axils, short-peduncled or nearly sessile. Calyx sessile in 2 bractlets : sepals 5, nearly distinct. Corolla white or purplish, 2-lipped. Stamens 2, included. Staminodia filiform, capitate at the apex. Anther-sacs parallel, contiguous. Capsule somewhat elongated, acuminate.

Leaf-blades linear, entire : corolla-tube about twice as long as the sepals.

Leaf-blades ovate, oval or oblong, toothed: corolla-tube barely surpassing the sepals.

1. S. hispida.

2. S. pilosa.

1. Sophronanthe híspida Benth. Stems hispidulous, $0.5-2 \mathrm{dm}$. tall, usually clustered. Leaves numerous; blades firm, linear-lanceolate, 1-1.5 cm. long, strongly revolute : bractlets linear or linear-lanceolate, surpassing the calyx : peduncles 1-2 mm. long, or the calyx almost sessile: sepals linear-lanceolate, unequal, rigidly pubescent: corolla about $1 \mathrm{~cm}$. long, salverform : capsules conic-ovoid, about $5 \mathrm{~mm}$. long. [Gratiola subulata Baldw.]

In sand, Florida to Louisiana. Spring to fall.

2. Sophronanthe pilòsa (Michx.) Small. Stems hirsute, 2-6 dm. tall, simple or sparingly branched. Leaf-blades ovate, oval or oblong, 1-2 cm. long, acute or obtuse, sparingly toothed, sessile or partly clasping: pedicels $1-2 \mathrm{~mm}$. long, or the calyx nearly 
sessile : sepals linear to linear-subulate, bristly : corolla about $5 \mathrm{~mm}$. long, tubular : capsules conic, 4-5 mm. long. [Gratiola pilosa Michx.]

In low sandy grounds, New Jersey to Florida and Texas. Spring to fall.

\section{ILYSÁNTHES Raf.}

Annual or biennial caulescent herbs, with glabrous foliage. Leaves opposite : blades entire or shallowly toothed, mostly sessile. Bracts mostly similar to the leaves. Flowers solitary in the axils, slender-pedicelled. Sepals 5, united at the base. Corolla whitish or purplish, 2-lipped, the upper lip 2-lobed, erect, the lower lip spreading. Stamens 2: anther-sacs divergent. Staminodia 2, 2-lobed, the one lobe capitate and glandular, the other smaller, glabrous. Stigma 2-lobed. Capsule narrowly ovoid to oblong, septicidally dehiscent. Seeds wrinkled. False Pimpernel.

Stems creeping: leaf-blades orbicular or ovate-orbicular, rounded at the base and closely sessile.

Stems erect or ascending : leaf-blades more or less elongated, the lower ones narrowed

1. I. grandiflora.

at the base.

Pedicels shorter than the subtending bracts: sepals as long as the capsule or longer. 2. I. attenuata.

Pedicels longer than the subtending bracts : sepals shorter than the eapsule.

Leaves or bracts slightly reduced above : pedicels erect or ascending.

Upper leaves with partially clasping blades: capsules much longer than the sepals.

Upper leaves with merely sessile blades: capsules slightly longer than the sepals.

Leaves or bracts reduced to scales above: pedicels reflexed.

3. I. gratioloides.

4. I. saxicola.

5. I. refracta.

1. Ilysanthes grandiflòra (Nutt.) Benth. Stems slender, creeping, 2-20 cm. long, leafy throughout, rarely branched. Leaf-blades suborbicular or ovate-orbicular, $0.5-1 \mathrm{~cm}$. long, leathery, entire, rounded and partially clasping at the base : pedicels filiform, 2-4 $\mathrm{cm}$. long, several times longer than the bracts : sepals linear-lanceolate, about $3 \mathrm{~mm}$. long, acute : corolla blue, about $10 \mathrm{~mm}$. long, the upper lip much shorter than the lower : capsules narrowly oblong or oblong-ovoid, 4.5-5 $\mathrm{mm}$. Iong, acute or acuminate, much longer than the calyx.

In low or wet grounds, eastern Georgia and Florida. Spring to fall.

2. Ilysanthes attenuàta (Muhl.) Small. Stems relatively stout, 1-5 dm. tall, often much branched. Leaf-blades oblong to ovate, or oblanceolate to obovate below, 1-3 cm. long, thin-fleshy, obtuse, distantly and shallowly serrate, $\check{\nu}$-nerved, the lower ones at least narrower at the base : pedicels stout, shorter than the subtending bracts : sepals linearsubulate, 4-5 mm. long: corolla 8-10 $\mathrm{mm}$. long : capsules narrowly ovoid, usually surpassed by the calyx.

In wet places, Ontario to Wisconsin and Missouri, south to Florida and Texas. Spring to fall.

3. Ilysanthes gratioloides (L.) Benth. Stems wiry, 1-2 dm. long, nearly simple or considerably branched, the lower branches sometimes decumbent. Leaf-blades leatheryfleshy, obovate to oblong below, to ovate above, $0.6-2 \mathrm{~cm}$. long, entire or nearly so, the lower ones gradually and the upper ones more abruptly narrowed at the base, sessile and partly clasping: pedicels filiform, surpassing the subtending bracts : sepals linear, 3-4 $\mathrm{mm}$. long : corolla 5-7 mm. long : capsules ovoid or oblong-ovoid, 4-5 mm. long, surpassing the calyx.

In damp or wet soil, New England to Nebraska, south to Florida and Texas. Summer and fall.

4. Ilysanthes saxícola (M. A. Curtis) Chapm. Stems slender, more or less tufted, 2-20 cm. tall, often dwarf, simple or sparingly branched. Leaf-blades fleshy-leathery, $0.5-1.5 \mathrm{~cm}$. long, the basal and those on the lower part of the stem spatulate or oblong, the upper ones ovate, lanceolate, or narrowly elliptic, acutish, nearly sessile: pedicels wiry, 3-4 times longer than the subtending bracts : sepals linear-lanceolate, about $2 \mathrm{~mm}$. long: corolla pale blue and variegated, about $10 \mathrm{~mm}$. long: capsule ovoid, $3 \mathrm{~mm}$. long, surpassing the calyx.

On damp rocks, Tallulah Falls, Georgia and on the Hiawassee River, North Carolina. Summer.

5. Ilysanthes refrácta (Ell.) Benth. Stems wiry, usually several together or densely tufted, 0.8-3 dm. tall, nearly naked, sometimes diffuse at maturity. Leaves mainly basal ; blades spatulate to obovate, $1-3 \mathrm{~cm}$. long, entire or undulate, those of the stem reduced to scales : pedicels filiform, 2-4 mm. long, at length reflexed: sepals almost linear, $2-3 \mathrm{mn}$. long: corolla 10-13 mm. long: capsules narrowly oblong, about $4 \mathrm{~mm}$. long, about twice as long as the calyx.

On wet rocks and in damp pine lands, North Carolina to Mississippi and Florida. Spring to fall. 


\section{HEMIÁNTHUS Nutt.}

Annual or perennial diminutive herbs, with creeping stems. Leaves opposite: blades manifestly longer than broad, indistinctly nerved. Flowers inconspicuous, solitary in the axils. Calyx of 4 mostly united sepals. Corolla purple or whitish, very irregular, the upper lip obsolete and the tube there cleft, the lower lip relatively large, with a long incurved middle lobe. Stamens 2: filaments with long basal appendages : anther-sacs divaricate. Style-tips slender, each with 2 subulate stigmas. Capsule subglobose, many-seeded.

1. Hemianthus micranthemoìdes Nutt. Stems often matted, glabrous, $2-8 \mathrm{~cm}$. long, with erect or ascending tips. Leaf-blades spatulate to obovate or oblong, 1-6 mm. long: pedicels about as long as the calyx or becoming longer: calyx about $1 \mathrm{~mm}$. long, with oblong lobes : corolla often $2 \mathrm{~mm}$. or sometimes $2.5 \mathrm{~mm}$. long, the upper lip obsolete, the lower lip with a linear incurved middle lobe and 2 shorter lateral lobes: each filament with a basal appendage similar to itself: capsules subglobose, about $1 \mathrm{~mm}$. in diameter.

On muddy banks, New Jersey to Florida. Summer and fall.

\section{MICRÁNTHEMUM Michx.}

Annual or perennial diminutive herbs, with diffuse or creeping stems. Leaves opposite : blades entire, commonly suborbicular, manifestly nerved, sessile. Flowers inconspicuous, solitary in the axils. Sepals 4, united at the base. Corolla white or purplish, obscurely 2-lipped, the upper lip entire, this and the 3 lobes of the lower lip nearly equal, or the middle lobe of the lower lip slightly larger, the corolla thus appearing more or less equally 4-lobed. Stamens 2 : filaments dilated at the base : anther-sacs parallel. Styletips club-shaped or capitate. Capsule subglobose, many-seeded.

1. Micranthemum orbiculàtum Michx. Stems glabrous, 1-4 dm. long, sometimes densely tufted and erect at the ends. Leaf-blades suborbicular, 5-10 mm. in diameter, - rounded or retuse at the apex : pedicels shorter than the calyx : calyx-lobes $1 \mathrm{~mm}$. becoming $1.5 \mathrm{~mm}$. long, narrowly oblong: corolla about $1-1.5 \mathrm{~mm}$. broad, the lobes oblong: capsules subglobose, $1-1.5 \mathrm{~mm}$. in diameter.

On muddy banks and in swamps and streams, North Carolina to Florida and Texas. Spring to fall.

\section{AMPHIÁNTHUS Torr.}

Annual or biennial amphibious glabrous herbs, with very short stems. Leaves mainly basal : blades narrow, entire, sessile. Flowers variously disposed, some sessile or nearly sessile on the short stem, others terminating elongated slender peduncles. Calyx of 5 unequal slightly united sepals. Corolla white, slightly 2 -lipped, the upper lip and the lobes of the lower lip short, rather square, retuse or notched. Stamens 2, included : filaments adnate to about the middle of the corolla-tube: anther-sacs distinct. Stigma 2lobed. Capsule flattened, loculicidally dehiscent. Seeds narrow, regularly pitted.

1. Amphianthus pusillus Torr. Stems clustered, usually less than $1 \mathrm{~cm}$. long. Leaves basal ; blades linear, 5-10 mm. long, blunt : flowers clustered on the short stem or those surmounting the filiform peduncles which vary in length with the depth of the water, solitary, subtended by a pair of oblong oval or ovate bracts, 3-8 $\mathrm{mm}$. long : calyx-lobes oblong or nearly so: corolla white, 6-8 mm. long; tube funnelform: capsules 2-2.5 mm. in diameter, 2-lobed.

In water filling depressions in granite rocks, Georgia. Flowering and fruiting whenever there is sufficient water present.

\section{CAPrària L.}

Perennial caulescent herbs or shrubby plants. Leaves alternate: blades longer than broad, toothed. Flowers on axillary pedicels. Calyx of 5 narrow, almost equal sepals. Corolla white, campanulate, with 5 flat lobes. Stamens usually 4: anther-sacs 2, divergent, confluent. Stigmas dilated or 2-lobed. Capsule short, 2-grooved, loculicidally dehiscent. Seeds reticulated.

1. Capraria biflòra L. Stems 3-9 dm. tall, branching, sometimes pubescent. Leafblades oblanceolate, cuneate or oblong, 1-4 cm. long, acute, sharply serrate above the middle: pedicels solitary or 2 together, shorter than the subtending bracts : sepals linear- 
lanceolate to linear-subulate, 4-6 $\mathrm{mm}$. long: corolla about $1 \mathrm{~cm}$. long ; tuve campanulate lobes lanceolate, about as long as the tube : capsules oval or oval-ovoid, about as long as the sepals.

On sandy shores, peninsular Florida and Texas. Spring to fall.

\section{SCOPÀRIA L.}

Annual or perennial caulescent herbs or shrubby plants. Leaves opposite or whorled: blades often narrow, punctate. Flowers solitary in the axils. Calyx of 4-5 nearly distinct sepals. Corolla white, yellow or blue, rotate: tube pubescent in the throat : lobes 4, nearly equal. Stamens 4, scarcely didynamous : anthers slightly sagittate; sacs distinct: Stigmas truncate or notched. Capsule ovoid or subglobose, septicidally dehiscent. Seeds angled. Sepals not ciliolate: corollas $3 \mathrm{~mm}$. broad : capsules surpassing the sepals. Sepals ciliolate : corollas $10 \mathrm{~mm}$. broad : capsules not surpassing the sepals.

1. Scoparia dúlcis L. Stems glabrous, $2-10 \mathrm{dm}$. tall, often much branched. Leafblades ovate, elliptic-oblong or oblong-oblanceolate, 1-3 cm. long, serrate, often cuneate at the base : pedicels slender, 3-6 mm. long: sepals oblong to oblong-obovate, $1.5 \mathrm{~mm}$. long, not ciliolate : corolla white, $3 \mathrm{~mm}$. broad ; lobes oval or suborbicular : capsules subglobose or ovoid-globose, $2 \mathrm{~mm}$. long, surpassing the sepals.

In sand, Georgia and Florida to Texas. Spring to fall.

2. Scoparia grandiflòra Nash. Stems more or less puberulent, 7-12 dm. tall, usually much branched: leaf-blades oblanceolate to linear-oblanceolate, $1.5-5 \mathrm{~mm}$. long, acute, serrate or incised above the middle : pedicels filiform, $4-8 \mathrm{~mm}$. long : sepals oblong to ovaloblong, 2-2.5 mm. long, ciliolate : corolla white, $10 \mathrm{~mm}$. broad; lobes oblong-obovoid, obtuse : capsules ovoid, shorter than the sepals.

In open sandy woods, peninsular Florida. Spring to fall.

\section{VERÓNICA L.}

Annual or perennial caulescent herbs. Leaves opposite or sometimes alternate : blades various, entire, toothed or lobed. Flowers solitary in the axils, sometimes collected into racemes or panicles. Calyx of 4 or rarely 5, slightly united sepals. Corolla white or of various colors, rotate, slightly irregular, the tube very short, the lower lobe usually narrower than the rest. Stamens 2, on either side of the upper corolla-lobe : filaments divergent : anther-sacs confluent at the apex. Stigma capitate. Capsule flattened, notched or 2-lobed at the apex, loculicidal. Seeds flattened or concave. SPEedwell.

Flowers solitary and axillary, the subtending bracts leaf-like, and similar to the leaves.

Pedicels as long as the subtending bracts or longer.

Corolla longer than the calyx : capsules nearly twice as wide as high.

Corolla not longer than the calyx : capsules barely broader than high.

1. V. Byzantina.

Pedicels shorter than the subtending bracts.

Annual: capsules deeply notched.

Foliage pubescent.

Foliage glabrous or glandular.

Perennial: capsules merely retuse or truncate.

Flowers in axillary racemes ; bracts small.

Foliage pubescent: species of dry soil.

Foliage glabrous or glandular: species of low grounds or brooks.

Stem-leaves with petioled blades : pedicel and calyx glabrous.

Stem-leaves with sessile and clasping blades: pedicel and calyx glandular.

2. V. agrestis.

1. Veronica Byzantìna (Sibth. \& Smith) B.S.P. Annual, finely pubescent. Stems 1-4 dm. tall, usually branched at the base : leaves mainly opposite ; blades ovate to suborbicular or oval, 8-15 mm. long, serrate, broadly cuneate or subcordate at the base : pedicels surpassing the subtending bracts : sepals pubescent, elliptic to elliptic-lanceolate, 4-5 $\mathrm{mm}$. long, acute : corolla blue, $9-11 \mathrm{~mm}$. broad, the lobes surpassing the calyx : capsules nearly reniform, 7-8 $\mathrm{mm}$. broad, pubescent.

In fields and waste places, New York to Pennsylvania and Georgia. Naturalized from Europe and Asia. Spring and summer.

2. Veronica agréstis L. Annual, pubescent. Stems usually branched at the base, the branches sometimes spreading, $0.5-3 \mathrm{dm}$. long: leaves opposite; blades ovate to suborbicular or deltoid, 5-15 mm. long, crenate or serrate, rounded or subcordate at the base : pedicels becoming as long as the subtending bracts or longer, recurving : sepals elliptic to elliptic-ovate, $3-5 \mathrm{~mm}$. long: corolla $5-7 \mathrm{~mm}$. broad, the lobes not surpassing the calyx : capsules 7-8 $\mathrm{mm}$. broad, the lobes widely diverging. In fields and waste places, Nova Scotia to Georgia and Texas. Naturalized from Europe and
Asia. Spring and summer. 
3. Veronica arvénsis L. Annual, finely pubescent. Stems simple and erect or diffusely hranched, 0.5-3 dm. tall : leaves opposite; blades ovate to oval, 5-12 mm. long, crenate, abruptly narrowed into short petioles, or the upper ones sessile: pedicels shorter than the subtending bracts: sepals glandular-pubescent, oblong to oblong-lanceolate, 1-2.5 mm. long: corolla $1.5-2 \mathrm{~mm}$. broad; the lobes surpassing the calyx : capsules $3 \mathrm{~mm}$. broad, deeply notched at the apex.

In dry, mostly cultivated soil, Nova Scotia to Ontario and Minnesota, south to Florida, Texas and Kansas. Naturalized from Europe. Spring and summer.

4. Veronica peregrìna L. Annual, glabrous or glandular-pubescent. Stems $0.5-4$ $\mathrm{dm}$. tall, simple or branched, especially below : leaves opposite; blades leathery-fleshy, oblanceolate to oblong or linear, 1-3 cm. long, obtuse, crenate or serrate-dentate, or entire above : pedicels much shorter than the subtending bracts : sepals linear or slightly broadest above the middle : corolla $2-3 \mathrm{~mm}$. broad : capsules $4 \mathrm{~mm}$. broader than high, deeply notched, glabrous.

In low grounds and fields, Nova Scotia to British Columbia, south to Florida, Mexico and California. Spring to fall.

5. Veronica serpyllifòlia L. Perennial, glabrous or puberulent. Stems often decumbent and creeping, branched at the base, 0.5-2.5 dm. long: leaves opposite ; blades oblong, oval or suborbicular, 5-15 mm. long, obtuse, entire or crenulate, often short-petioled : pedicels shorter than the subtending bracts : sepals nearly glabrous, oblong to oblong-cuneate, 1-2 mm. long, obtuse : corolla white or purplish, 2-3 mm. broad, the lobes surpassing the calyx: capsules $3 \mathrm{~mm}$. broad, ciliate, truncate or retuse at the apex, minutely pubescent.

In fields and thickets, Labrador to Alaska, south to Georgia, Texas and California. Almost cosmopolitan. Spring to fall.

6. Veronica officinàlis L. Perennial, softly pubescent. Stems prostrate and creeping, 0.5-3 dm. long, often branched. Leaf-blades oblong to oval, varying to obovate or ovate, $1-4 \mathrm{~cm}$. long, serrate, short-petioled : racemes spike-like : pedicels mostly less than $1.5 \mathrm{~mm}$. in length, surpassed by their bracts : sepals oblong, $2-3 \mathrm{~mm}$. long, pubescent : corolla blue, 5-8 mm. broad, the lobes surpassing the calyx : capsules broadly cuneate or obovate-cuneate, $3-3.5 \mathrm{~mm}$. broad, truncate or retuse at the apex, minutely glandular.

In dry woods or stony soil, Nova Scotia to Ontario and Michigan, south to Georgia and Tennessee. Also in Europe and Asia. Spring and summer.

7. Veronica Americàna Schwein. Perennial, glabrous. Stems erect or decumbent, 1-6 dm. tall, sometimes branched : leaf-blades ovate to oblong or oblong-lanceolate, bluntly or sharply serrate, abruptly contracted or truncate at the base : racemes loosely flowered : pedicels very slender, 4-15 mm. long : sepals glabrous, oblong to oblong-lanceolate, $2.5-3$ $\mathrm{mm}$. long, acute : corolla blue or nearly white, usually purple-striped, 4-5 $\mathrm{mm}$. broad: capsules $3-3.5 \mathrm{~mm}$. broad, broader than high, 2-lobed.

In low grounds or brooks, Anticosti to Alaska, south to North Carolina, Nebraska, New Mexico and California. Spring and summer.

8. Veronica Anagállis-aquática L. Perennial, glandular-pubescent above. Stems 2-9 dm. tall, often somewhat branched : leaf-blades lanceolate to oblong, 2-12 cm. long, acute, finely serrate or nearly entire, sessile and partly clasping: racemes spreading, many-flowered : pedicels 3-7 $\mathrm{mm}$. long: sepals glandular, lanceolate to ovate-lanceolate, 3-3.5 mm. long: corolla blue, often purple-striped, 4-5 mm. broad : capsules suborbicular or rhombic-orbicular, $2.5 \mathrm{~mm}$. broad, minutely notched.

In wet places or brooks, Nova Scotia to British Columbia, south to North Carolina, Nebraska and New Mexico. Also in Europe and Asia. Spring and summer.

\section{IEPTÁNDRA Nutt.}

Perennial relatively tall caulescent herbs. Leaves opposite or whorled in 3's or 9's : blades flat, toothed. Flowers in terminal spike-like racemes. Calyx of 4 slightly united sepals. Corolla white, pink or blue, slightly 2-lipped, the lobes of the lips much shorter than the tube. Stamens 2, exserted : filaments filiform, adnate to the base of the corolla tube. Stigma minute. Capsule relatively narrow, nearly terete, tapering to the 4-valved apex. Seeds minutely reticulated. CuLVER's-ROOT.

1. Leptandra Virgínica (L. ) Nutt. Stems $3-18 \mathrm{dm}$. tall, normally simple below the inflorescence. Leaf-blades oblong, elliptic or lanceolate, acute or acuminate, finely serrate : racemes erect, usually in conic panicles : calyx-lobes lanceolate or linear-lanceolate, 1-1.5 $\mathrm{mm}$. long, acuminate : corolla white or pink, 5-6 $\mathrm{mm}$. long, the upper lip ovate, the lower 
lip of 3 ovate lobes, the middle one narrower : filaments villous below the middle : capsules oblong or oval, 3-4 mm. long. [Veronica Virginica L.]

In meadows and moist thickets, Nova Scotia to British Columbia, south to Alabama, Mississippi and Kansas. Summer and fall.

\section{MACRÁNTHERA Torr.}

Perennial caulescent herbs, glabrous below the inflorescence, blackening in drying. Leaves opposite: blades pinnatifid or pinnately parted. Flowers in 1-sided racemes. Calyx erect, of 5 partially united sepals : lobes entire or incised. Corolla yellow or orange : tube cylindric, elongated, barely dilated at the throat: lobes 5, oblique, spreading. Stamens 4, exserted : filaments nearly equal : anther-sacs parallel. Stigma clavate. Capsule short, loculicidally dehiscent.

Calyx-lobes entire : corolla-tube much longer than the calyx. Calyx-lobes toothed or incised: corolla-tube about as long as the calyx.

1. M. LeContei.

2. M. fuchsioides.

1. Macranthera LeCóntei Torr. Stems 5-12 dm. tall, puberulent or minutely glandular-pubescent, simple or sparingly branched. Stem-leaves with pinnatifid shortpetioled blades $4-9 \mathrm{~cm}$. long : pedicels spreading or declined, $1-2.5 \mathrm{~cm}$. long : calyx 9-13 $\mathrm{mm}$. long; tube broadly campanulate ; lobes subulate or linear-subulate, entire, much surpassed by the corolla-tube: corolla yellow or orange-yellow, $2 \mathrm{~cm}$. long; lobes oblong or oblong-ovate : capsules ovoid, about $1 \mathrm{~cm}$. long.

In pine lands, Georgia, Alabama and Florida. Summer and fall.

2. Macranthera fuchsioìdes Torr. Stems 6-15 dm. tall, often sparingly branched, glabrate or minutely glandular. Basal leaves clustered, with oblong-ovate or oblong inequilateral obtuse undulate blades narrowed into winged petioles; stem-leaves smaller, with pinnatifid or pinnately parted acute blades with entire or incised lobes or segments: pedicels spreading, $1-3 \mathrm{~cm}$. long : calyx becoming nearly $2 \mathrm{~cm}$. long; lobes linear or broadened upward, tonthed or incised, about equalling the corolla-tube : corolla orange, $2-3 \mathrm{~cm}$. long ; lobes ovate or oblong-ovate : capsules fully $1 \mathrm{~cm}$. long.

In damp pine lands, Georgia, Alabama and Florida. Fall.

\section{AFZÈLIA J. F. Gmel.}

Annual, caulescent, much branched herbs. Leaves opposite, relatively small : blades 1-2-pinnately parted or dissected. Flowers solitary in the axils of more or less leaf-like bracts, manifestly pedicelled. Calyx of 5 sepals united into a campanulate tube at the base, the lobes generally longer than the tube. Corolla mainly yellow, rotate-campanulate, the lobes nearly equal, longer than the tube, not dilated at the base. Stamens 4 , nearly equal, conspicuously exerted : filaments glabrous or sparingly pubescent: anthers sagittate, longer than the filaments; sacs distinct. Style filiform, long-exserted: stigma minute. Capsule flattened at the acute or acuminate apex. [Seymeria Pursh.]

Segments of the leaf-blades filiform or subulate : corolla glabrous without.

Segments of the leaf-blades linear or broader: corolla pubescent or glandular without.

Corolla pubescent without : pedicels mostly over $5 \mathrm{~mm}$. long.

Corolla glandular without: pedicels mostly less than $5 \mathrm{~mm}$. iong.

1. A. cassioides.

2. A. pectinata.

3. A. Texana.

1. Afzelia cassioìdes (Walt.) J. F. Gmel. Stems minutely pubescent, 5-12 dm. tall, widely branched. Leaves very numerous; blades pinnately 1-2-dissected into subulate or filiform segments : pedicels slender, $3-6 \mathrm{~mm}$. long: calyx-lobes glabrous, subulate, 1-1.5 mm. long: corolla glabrous without; limb barely $1 \mathrm{~cm}$. broad, the lobes oblong or nearly so: filaments glabrous or merely puberulent below : capsules 5-6 mm. long, glabrous, the flattened tip fully $\frac{1}{2}$ as long as the globular base. [Seymeria tenuifolia Pursh.]

In low grounds or pine lands, North Carolina to Florida and Texas. Summer and fall.

2. Afzelia pectinàta (Pursh) Kuntze. Stems copiously viscid-pubescent, 2-5 dm. tall, rather widely branched. Leaves numerous; blades pinnately parted or pinnatifid to entirs above, the segments linear or oblong: pedicels 5-10 mm. long: calyx-lobes pubescent, linear, 2-3 mm. long : corolla pubescent without; limb about $1 \mathrm{~cm}$. broad, the lobes mostly oval or suborbicular : filaments pubescent : capsules hispidulous, 5-6 mm. long, the flattened apex less than $\frac{1}{2}$ as long as the broadly ovoid base.

In dry sandy soil, North Carolina to Florida and Alabama. Summer and fall.

3. Afzelia Texàna (A. Gray) Small. Stems 4-10 dm. tall, widely branched, densely pubescent, at least above, with viscid-glandular hairs. Leaves relatively few ; blades mostly 2-pinnatifid, the lower sometimes 3-pinnatifid and the upper often merely 
pinnatifid, the segments linear or oblong : pedicels mostly $2-5 \mathrm{~mm}$. long : calyx-lobes pubescent, oblong to oblong-lanceolate, $3-4 \mathrm{~mm}$. long, obtuse : corolla glandular without; limb stout, less than $1 \mathrm{~cm}$. broad, the lobes oval or oval-orbicular : filaments pubescent : capsules 5-6 mm. long, glandular. [Seymeria bipinnatisecta var. Texana A. Gray.]

On prairies, Texas and probably in adjacent Mexico. Summer.

\section{BRACHYGYNE Small.}

Perennial sparingly branched caulescent berbs. Leaves opposite, relatively large, the lower ones often ample: blades pinnately parted or pinnatifid, the segments toothed or pinnatifid. Flowers solitary in the axils of leaf-like bracts, sessile or nearly so. Calyx of 5 sepals usually united to beyond the middle into a campanulate or hemispheric tube, the lobes therefore shorter than the tube. Corolla yellow, with a short funnelform tube and spreading lobes much dilated at the base. Stamens 4, nearly equal, included : filaments densely pubescent : anthers oblong; sacs united. Style columnar, included : stigma dilated and 2-lobed. Capsule with a very short flattened apex.

1. Brachygyne macrophýlla (Nutt.) Small. Stems finely pubescent, $9-15 \mathrm{dm}$. tall : leaf-blades 1-4 dm. long, twice pinnately parted and pinnatifid near the base of the stem, to merely pinnatifid above : calyx $5-8 \mathrm{~mm}$. long; tube campanulate, the lobes oval, ovate or lanceolate, mostly shorter than the tube, obtuse : corolla about $1 \mathrm{~cm}$. long; lobes reniform, at least broader than long: capsules ovoid-globose, 7-8 mm. long, acute. [Seymeria macrophylla Nutt.]

In thickets and fence corners, Iowa to Ohio, Kentucky, Nebraska and Texas. Summer and fall.

\section{DASÝSTOMA Raf.}

Annual biennial or perennial caulescent herbs, usually with pubescent or glandular foliage. Leaves mostly opposite : blades entire, toothed or 1-2-pinnatifid. Flowers in bracted racemes or panicles. Calyx of 5 partially united sepals: tube campanulate or turbinate: lobes entire or toothed. Corolla yellow, slightly irregular : tube funnelform : lobes 5, spreading. Stamens 5, didynamous, included: filaments pubescent: anthers alike; sacs distinct, parallel, awned at the base. Capsule acute, short or long-beaked, loculicidal. FALSE FoXgrove.

Annual or biennial : corollas pubescent or glandular without.

Pedicel shorter than the calyx at maturity : calyx-tube densely glandular-hirsute.

Pedicel longer than the calyx at maturity : calyx-tube sparingly glandularpubescent or glabrate.

Perennial : corollas glabrous without.

Stems manifestly pubescent or puberulent.

Upper leaves and bracts with pinnatifid blades.

Upper leaves and bracts with entire blades, or merely toothed.

Pedicel shorter than the calyx.

Upper leaves and bracts with toothed blades.

Upper leaves and bracts with entire blades.

Racemes continuous: flowers approximate: calyx usually densely pubescent.

Capsules about $1 \mathrm{~cm}$. long, scarcely beaked.

Capsules about $1.5 \mathrm{~cm}$. long, long-beaked.

Racemes much interrupted: flowers remote: calyx puberulent or glabrate.

Pedicel longer than the calyx.

1. D. pectinata.

2. D. Pedicuiaria.

3. D. grandiflora.

4. D. serrata. Stems glabrous.

Lower leaves with 1-2 pinnatifid blades.

Upper leaves and bracts of a spatulate type, entire.

Upper leaves and bracts of a lanceolate type, toothed or pinnatifid.

Lower leaves with entire, repand or incised blades.

5. D. brachycarpa.

6. D. flava.

7. D. dispersa.

8. D. patula.

1. Dasystoma pectinàta (Nutt.) Benth. Annual or biennial, copiously glandularhirsute. Stems 5-10 dm. tall, widely branched : leaf-blades lanceolate to ovate, 2-7 dm. long, 1-2-pinnatifid, the segments finely toothed or incised: pedicel shorter than the calyx at maturity : calyx densely glandular-hirsute; lobes incised or pinnatifid, somewhat resembling the leaves, much longer than the tube: corolla $3-4 \mathrm{~cm}$. long; tube widely dilated : capsules oval or elliptic, $10-13 \mathrm{~mm}$. long, acute, surpassed by the calyx-lobes.

On hillsides and in sandy soil, Missouri to Georgia, North Carolina and Texas. Summer and fall.

2. Dasystoma Pediculària (L. ) Benth. Annual or biennial, puberulent or sparingly glandular pubescent above. Stems $3-12 \mathrm{dm}$. tall, widely branched : leaf-blades lanceolate 
to ovate, $2-6 \mathrm{~cm}$. long, pinnatifid, the segments coarsely toothed or incised : pedicel longer than the calyx at maturity : calyx sparingly glandular-pubescent or glabrate; lobes coarsely toothed, about as long as the tube or longer in age : corolla $2.5-3 \mathrm{~cm}$. long : capsules 12-15 $\mathrm{mm}$. long, sometimes surpassing the calyx-lobes.

On wooded hillsides; Maine to Ontario, Minnesota and Georgia. Summer and fall.

3. Dasystoma grandiflòra (Benth.) Wood. Perennial, grayish pubescent. Stems $5-10 \mathrm{dm}$. tall, usually branched: leaf-blades lanceolate to ovate, pinnatifid throughout, the segments of the lower ones coarsely toothed : calyx-tube $6-7 \mathrm{~mm}$. broad during anthesis ; lobes oblong to lanceolate or linear-lanceolate, entire or toothed: corolla $3-3.5 \mathrm{~cm}$. long: capsules ovoid, about $1 \mathrm{~cm}$. long, glabrous, beaked.

In open woods, Wisconsin and Minnesota to Tennessee and Texas. Summer and fall.

4. Dasystoma serròta (Torr.) Small. Perennial, grayish puberulent or finely pubescent. Stems 4-12 dm. tall, often widely branched: leaf-blades pinnatifid on the lower part of the stem and their segments entire, merely serrate and much smaller above : calyx-tube 5-6 mm. broad during anthesis ; lobes linear-lanceolate to lanceolate, entire : corolla $2.5-4 \mathrm{~cm}$. long : capsules ovoid or globose-ovoid, 1-1.5 cm. long, short-beaked.

In dry soil, Missouri to Louisiana and Texas. Summer and fall.

5. Dasystoma brachycárpa Small. Perennial, puberulent or finely pubescent. Stems 6-15 dm. tall, usually simple, or simple below the inflorescence : leaf-blades leathery, oblong-ovate, oblong-lanceolate or lanceolate, $5-12 \mathrm{~cm}$. long, incised or repand on the lower part of the stem, entire or merely undulate and shorter above : racemes continuous : calyx very short-pedicelled; tube campanulate at maturity : lobes as long as the tube or longer : corolla $2.5-3 \mathrm{~cm}$. long, with a widely dilated tube : capsules globose-ovoid, about $1 \mathrm{~cm}$. long, scarcely beaked.

In dry or sandy soil, Stone Mountain, Georgia. Summer and fall.

6. Dasystoma flàva (L.) Wood. Perennial, grayish pubescent or sometimes merely puberulent. Stems 3-12 dm. tall, simple or branched above : leaf-blades lanceolate to oblong, 4-14 cm. long, repand, coarsely toothed or rarely pinnatifid on the lower part of the stem, entire or merely undulate above : racemes continuous, at least during anthesis : calyxtube turbinate at maturity ; lobes as long as the tube or much longer : corolla $3-4 \mathrm{~cm}$. long: capsules ovoid-conic, about $1.5 \mathrm{~cm}$. long, long-beaked.

In woods and thickets, Ontario to Wisconsin, Massachusetts, Florida and Mississippi. Summer.

7. Dasystoma dispérsa Small. Perennial, inconspicuously puberulent, blackish in drying. Stems 4-10 dm. tall, simple or wídely, but rather sparingly branched : leafblades spatulate, oblong, elliptic or oblong-oblanceolate, entire, $2-6 \mathrm{~cm}$. long, or longer, and sometimes repand near the base of the stem, slender-petioled : racemes conspicuously interrupted, the pairs of flowers quite regularly separated by internodes $2-4 \mathrm{~cm}$. long: calyx-tube 7-8 mm. broad during anthesis, puberulent or glabrate; lobes about as long as the tube or usually shorter : corolla $3-3.5 \mathrm{~cm}$. long: capsules fully $1 \mathrm{~cm}$. long.

In pine woods and on hillsides, Alabama, Mississippi and Louisiana. Summer and fall.

8. Dasystoma pátula Chapm. Perennial, finely pubescent or puberulent, at least on the stem. Stems 5-12 dm. tall, widely and loosely branching: leaf-blades various, those of the lower leaves 1-2-pinnatifid, ovate or ovate-lanceolate, 10-15 cm. long, those of the upper leaves oblong to oblong-lanceolate, entire or some of those about the middle of the stem serrate : pedicel slender or filiform, longer than the calyx and sometimes surpassing the spreading or reflexed bracts : calyx-lobes linear or nearly so, longer than the tube : corolla $3-3.5 \mathrm{~cm}$. long : capsules ovoid, $1-1.5 \mathrm{~cm}$. long.

On river banks, Tennessee and Georgia. Summer and fall.

9. Dasystoma bignonifflòra Small. Perennial, glabrous. Stems 1-2 m. tall, somewhat glaucous, with ascending branches: leaf-blades $4-15 \mathrm{~cm}$. long, the lower ones 1-2pinnatifid, slender-petioled, the upper entire, mostly broadest above the middle : calyxtube 4-5 mm. broad during anthesis, the lobes often shorter than the tube : corolla $3.5-4.5$ $\mathrm{cm}$. long; tube narrowly trumpet-shaped : capsules ovoid, 10-12 $\mathrm{mm}$. long, acute.

In sandy soil, Florida to Alabama and Louisiana. Summer and fall.

10. Dasystoma Virgínica (L.) Britton. Perennial, glabrous. Stems $8-15 \mathrm{dm}$. tall, manifestly glaucous, often sparingly branched above : leaf-blades 1-2-pinnatifid throughout, 1-2 dm. long on the lower part of the stem, shorter above, ovate-lanceolate to lanceo-
late or linear-lanceolate : calyx-tube $5-6 \mathrm{~mm}$. broad during anthesis, the lobes often shorter than the tube : corolla 3-4 cm. long: capsules oval or oval-ovoid, $10-15 \mathrm{~mm}$. long.

In dry woods and thickets, Maine to Minnesota, Georgia, Alabama and Illinois. Summer and fall. 
11. Dasystoma laevigàta Raf. Perennial, glabrous, pale green. Stems $3-12 \mathrm{dm}$. tall, simple or sparingly branched : leaf-blades lanceolate to elliptic, $3-12 \mathrm{~cm}$. long, acute or acuminate, merely undulate or repand or incised on the lower part of the stem : calyx longer than the pedicel; tube campanulate; lobes triangular-lanceolate or lanceolate, as long as the tube or longer : corolla pale or lemon yellow, $2.5-3 \mathrm{~cm}$. long: capsules ovoid, 10-12 mm. long.

In open woods or thickets, Pennsylvania to Michigan, Georgia, Alabama and Tennessee. Summer.

\section{OTOPHÝLLA Benth.}

Annual caulescent herbs, with rigidly pubescent foliage. Leaves opposite: blades entire or pinnately divided, all or some of them auricled at the base, sessile. Flowers in terminal spikes. Calyx of 5 partially united sepals. Corolla purple or rarely white : tube broadly dilated at the throat: lobes spreading. Stamens 4, didynamous, included: filaments glabrous or nearly so: anthers of the shorter stamens much smaller than the others. Style slender. Stigma entire. Capsule oval or globose-oval, often minutely pointed. Seeds angled.

Leaf-blades or some of them with 2 auricles at the base: corolla less than $2 \mathrm{~mm}$. long: capsules over $10 \mathrm{~mm}$. long.

Leaf-blades parted into 3-7 linear segments : corolla over $2 \mathrm{~cm}$. long: capsules less

than $10 \mathrm{~mm}$. long.

1. O. auriculata.

1. Otophylla auriculàta (Michx.) Small. Foliage hirsute. Stems 3-6 dm. tall, simple or sparingly branched : leaf-blades lanceolate or ovate-lanceolate, 1-4 cm. long, acute, the upper ones or sometimes all with lanceolate auricles at the base: spikes interrupted, not dense : calyx-tube campanulate, the lobes lanceolate or oblong-lanceolate, often longer than the tube : corolla less than $2 \mathrm{~cm}$. long: capsules oval, 11-13 mm. long.

In low grounds or on prairies, New Jersey to Minnesota, North Carolina and Kansas. Summer.

2. Otophylla densiflòra (Benth.) Small. Foliage hispid. Stems $2-5 \mathrm{dm}$. tall, usually branched above: leaf-blades $1.5-3 \mathrm{~cm}$. long, parted into 3-7 narrowly linear segments, rigidly ciliate : spikes continuous, dense : calyx-tube campanulate, the lobes lanceolate, folded, longer than the tube: corolla over $2 \mathrm{~cm}$. long: capsules oval, about $8 \mathrm{~mm}$. long.

On prairies, Kansas, Oklahoma, the Indian Territory and Texas. Spring and summer.

\section{GERÁRDIA L.}

Annual or perennial caulescent usually slender herbs. Leaves mainly opposite : blades narrow, or scale-like, entire. Flowers solitary in the axils of narrow bracts. Calyx of 5 sepals usually united to beyond the middle, the lobes tooth-like. Corolla often rose-purple, sometimes white or yellowish pink, 2-lipped, the lower lobes exterior in the bud. Stamens 4, didynamous, included : filaments pubescent : anthers all alike ; sacs obtuse or mucronate at the base. Style filiform. Capsule rounded at the apex, loculicidally dehiscent. Seeds mostly angled.

Perennial plant, with horizontal rootstock.

1. G. linifolia.

Annual plants, with fibrous roots.

Pedicel shorter than the calyx or the calyx and the capsule.

Leaves above the base of the stem represented by minute scales.

Corolla over $15 \mathrm{~mm}$. long : flowers approximate : pedicels stout, 1-3 mm. long.

Corolla less than $15 \mathrm{~mm}$. long : flowers remote: pedicels filiform, $5-10 \mathrm{~mm}$. long.

Leaves normal, never scale-like.

Caly $x$-lobes about as long as the tube.

Caly $x$-lobes much shorter than the tube. Corolla about $2 \mathrm{~cm}$. long or longer.

Calyx-tube turbinate: caly $x$-lobes $1 / 2$ as long as the tube: capsules elliptic or elliptic-ovoid.

Caly $x$-tube campanulate: calyx-lobes minute or less than $1 / 2$ as long as the tube: capsules globular.

Stem-leaves with conspicuous clusters of smaller leaves in their axils.

Stem-leaves without clusters in their axils.

Calyx-lobes mostly $1.5-2 \mathrm{~mm}$. long : leaf-blades flat or slightly revolute.

Calyx-lobes mostly $1 \mathrm{~mm}$. long or shorter : leaf-blades filiform.

2. G. aphylla.

3. G. filicaulis.

1. G. heterophylla.

5. G. aspera.

6. G. farciculata.

7. G. purpurea.

8. G. Plukenetii.

Corolla about $1.5 \mathrm{~cm}$. long, or shorter.

Calyx-lobes acute or acuminate: plants not succulent.

Blades of stem-leaves linear, linear-spatulate or fliform.

Capsules $2-4 \mathrm{~mm}$. in diameter: calyx-lobes mostly $0.5-1 \mathrm{~mm}$. long. 
Leaf-blades filiform: stem-leaves without clusters of smaller leaves in their axils.

Leaf-blades linear-spatulate: stem-leaves with conspicuous clusters of leaves in their axils.

Capsules 5-7 mm. in diameter: calyx-lobes mostly $1.5-2 \mathrm{~mm}$. long.

Blades of stem-leaves subulate.

Calyx-lobes blunt : plant succulent.

Pedicel much longer than the caly $\mathrm{x}$ and capsule.

Leaf-blades broadened upward.

Leaf-blades not broadened upward.

Leaf-blades mainly filiform or subulate.

Stem-leaves or most of them furnished with clusters of leaves in their axils.

Leaves mostly alternate.

Leaves mostly opposite.

Stem-leaves, or most of them, with conspicuous clusters in their axils.

Stem-leaves with inconspicuous clusters in their axils.

Pedicels longer than the bracts : corollas over $1 \mathrm{~cm}$. long.

Pedicels shorter than the bracts : corollas less than $1 \mathrm{~cm}$. long.

Stem-leaves, or most of them, without clusters of smaller leaves in their axils.

Bracts surpassing the pedicels.

Bracts shorter than the pedicels.

Calyx-lobes less than $1 \mathrm{~mm}$. long.

Pedicels over twice as long as the bracts.

Pedicels less than twice as long as the bracts.

Calyx-lobes fully $1 \mathrm{~mm}$. long.

Leaves of the branches filiform, not rigid.

Leaves of the branches subulate, rigid.

Leaf-blades mainly linear, their margins sometimes slightly revolute.

Calyx-lobes less than $1 \mathrm{~mm}$. long: leaf-blades smooth or nearly so.

Calyx-lobes fully $1 \mathrm{~mm}$. long: leaf-blades scabrous.

Corolla rose-purple, fully $1 \mathrm{~cm}$. long.

Corolla yellowish pink, less than $1 \mathrm{~cm}$. long.

8. G. Plukenetii.

9. G. Georgiana.

10. G. paupercula.

11. G. microphylla.

12. G. maritima.

13. G. Skinneriana.

14. G. filifolia.

15. G. setacea.

16. G. Holmiana.

17. G. polyphylla.

17. G. polyphylla.

18. G. divaricata.

19. G. Gattingeri.

20. G. asperula.

21. G. strictiflora.

22. G. tenuifolia.

23. G. Besseyana.

24. G. viridis.

1. Gerardia linifollia Nutt. Stems $5-9 \mathrm{dm}$. tall, smooth and glabrous, sparingly and virgately branched. Leaf-blades thickish, linear, 1-5 $\mathrm{cm}$. long, rarely over $2 \mathrm{~mm}$. broad, acute: pedicel longer than the calyx, enlarged at the top : calyx-tube 4-5 mm. high, the lobes acute, much less than $1 \mathrm{~mm}$. long: corolla rose-purple, $2-2.5 \mathrm{~cm}$. long: capsules 5-7 $\mathrm{mm}$. in diameter.

In low pine lands, Delaware to Florida. Fall.

2. Gerardia aphýlla Nutt. Stems $2-9 \mathrm{dm}$. tall, nearly smooth, simple or usually sparingly branched above, 4-angled, nearly naked. Leaves various, those near the base of the stem with oval or oblong leathery blades $5-10 \mathrm{~mm}$. long and fugaceous; those higher up on the stem and branches reduced to scattered subulate appressed scales: pedicels usually 1-3 mm. long: bracts similar to the upper leaves: calyx-tube campanulate, $2-2.5$ $\mathrm{mm}$. high, the lobes minute: corolla rose-purple, $1-1.5 \mathrm{~cm}$. long: capsules subglobose, 3-3.5 mm. in diameter.

In low pine lands, North Carolina to Florida and Louisiana. Fall.

3. Gerardia filicaùlis Chapm. Stems $2-5 \mathrm{dm}$. tall, smooth, glaucescent, usually much branched, apparently leafless. Leaves reduced to minute subulate scales: pedicels 5-10 mm. long, club-shaped : calyx-tube campanulate, $2.5 \mathrm{~mm}$. high, the teeth minute, rather triangular : corolla rose-purple, $6-10 \mathrm{~mm}$. long, delicate : capsules about $4 \mathrm{~mm}$. in diameter.

In low pine lands, Florida to Louisiana. Fall.

4. Gerardia heterophýlla Nutt. Stems 1-6 dm. tall, smooth or nearly so, branching above. Leaf-blades linear or narrowly linear-lanceolate below, 1-5 $\mathrm{cm}$. long, rarely $4 \mathrm{~mm}$. broad, acute, erect or erect-ascending, somewhat scabrous along the margins : pedicel shorter than the calyx, enlarged upward: calyx-tube campanulate, $3-4 \mathrm{~mm}$. high, the lobes lanceolate or subulate-lanceolate, about as long as the tube : corolla rose-purple, about $2 \mathrm{~cm}$. long: capsules $5-6 \mathrm{~mm}$. long.

On prairies, Arkansas and the Indian Territory to Texas. Summer and fall.

5. Gerardia áspera Dougl. Stems 1-6 dm. tall, more or less scabrous, branching above. Leaf-blades linear, mostly less than $1.5 \mathrm{~mm}$. wide, $1-3 \mathrm{~cm}$. long, acute : pedicel mostly as long as the calyx-tube or longer: calyx-tube 5-7 $\mathrm{mm}$. long, turbinate, the lobes deltoid or triangular-lanceolate, about $\frac{1}{2}$ as long as the tube : corolla rose-purple, about 2 cm. long : capsules elliptic or ovoid-elliptic, 8-10 mm. long.

On plains or prairies, Indiana to South Dakota and Arkansas. Summer and fall.

6. Gerardia fasciculàta Ell. Stems $5-12 \mathrm{dm}$. tall, often puberulent or sparingly hispidulous, branching. Leaves numerous, the larger ones with clusters of smaller ones in 
their axils; blades linear, mostly less than $2 \mathrm{~mm}$. wide, acute, very scabrous : pedicel shorter than the calyx, glabrous or nearly so: calyx-tube campanulate, $2.5-3.5 \mathrm{~mm}$. high, the lobes usually minute, often less than $0.5 \mathrm{~mm}$. long: corolla rose-purple, $2-2.5$ cm. long: capsules 4-5 $\mathrm{mm}$. in diameter.

In marshes or sometimes in dry soil, Virginia to Florida and Texas. Summer and fall.

7. Gerardia purpùrea L. Stems $2-7 \mathrm{dm}$. tall, simple or widely branched, smooth or slightly scabrous. Leaves with few or no clusters in their axils; blades linear, mostly less than $3 \mathrm{~mm}$. wide, $1-5 \mathrm{~cm}$. long, slightly or not at all revolute: pedicel shorter than the calyx : calyx-tube campanulate, 3-4 $\mathrm{mm}$. high, the lobes triangular or lanceolate-triangular, about $\frac{1}{2}$ as long as the tube: corolla rose-purple, $2-2.5 \mathrm{~cm}$. long: capsules 4-5 mm. in diameter.

In swamps or low grounds, Maine and Ontario to Florida, Missouri and Texas. Summer and fall.

8. Gerardia Plukenétii Ell. Stems $3-7 \mathrm{dm}$. tall, freely branching, nearly smooth. Leaves with few or no clusters in the axils; blades filiform, $1-3 \mathrm{~cm}$. long, incurved in age : pedicel often apparently terminal, shorter than the calyx and capsule: calyx-tube 3$3.5 \mathrm{~mm}$. high, commonly surpassed by the bracts, the lobes about $\frac{1}{4}$ as long as the tube: corolla 1 ose-purple, mostly less than $1.5 \mathrm{~cm}$. long : capsules subglobose, $4-5 \mathrm{~mm}$. in diameter.

In pine lands or dry woods, South Carolina to Florida and Alabama. Summer and fall.

9. Gerardia Georgiàna C. L. Boynton. Stems 6-7 dm. tall, smooth, with several erect or ascending elongated branches above. Leaves numerous, those of the stem and branches with clusters of smaller ones in their axils and approximate; blades linearspatulate, revolute, mostly $8-12 \mathrm{~mm}$. long, acute, scabrous: pedicels $1-3 \mathrm{~mm}$. long: calyx-tube campanulate, $2.5-3 \mathrm{~mm}$. high, the lobes about $1 \mathrm{~mm}$. long : corolla rose-purple, about $1 \mathrm{~cm}$. long: capsules about $2 \mathrm{~mm}$. in diameter.

In sand, Georgia and Florida. Fall.

10. Gerardia paupércula (A. Gray) Britton. Stems stout, 1-5 dm. tall, simple or branched above, smooth. Leaves thickish, the larger ones often with clusters of smaller ones in their axils; blades linear, 1-3 cm. long, acute, scabrous : pedicels usually shorter than the calyx-tube, stout : calyx-tube campanulate, 3-4 mm. long, the lobes often nearly $\frac{1}{2}$ as long as the tube : corolla rose-purple, $1-1.5 \mathrm{~cm}$. long: capsules $5-7 \mathrm{~mm}$. in diameter.

In bogs or low meadows, Quebec to Manitoba, Georgia, Alabama and the Indian Territory. Summer and fall.

11. Gerardia microphýlla (A. Gray) Small. Stems slender, 3-3 dm. tall, slightly scabrous, with several or many wire-like or filiform branches above. Leaves few and inconspicuous; blades subulate or subulate-setaceous, 2-10 $\mathrm{mm}$. long, acute, erect or nearly so : pedicel often apparently terminal, mostly shorter than the calyx and capsule : calyxtube campanulate, $2.5-3 \mathrm{~mm}$. long, the lobes about $\frac{1}{4}$ as long as the tube: corolla rosepurple, $1-1.5 \mathrm{~cm}$. long: capsules $4-6 \mathrm{~mm}$. in diameter. [G. Plukenetii var. microphylla A. Gray.]

In damp pine lands, Florida to Louisiana. Summer and fall.

12. Gerardia marítima Raf. Stems 1-3 dm. tall, smooth, simple or branched above. Leaf-blades rather succulent, linear or those on the lower part of the stem broadened upward, 1-3 cm. long, obtuse, drying black: pedicels club-shaped, 2-5 $\mathrm{mm}$. long: calyxtube campanulate, $2-2.5 \mathrm{~mm}$. high, the lobes rounded, barely $\frac{1}{3}$ as long as the tube : corolla rose-purple or rarely white, $1-1.5 \mathrm{~cm}$. long : capsules 4-6 $\mathrm{mm}$. in diameter.

In salt marshes, Maine to Florida and Texas. Summer.

13. Gerardia Skinneriàna Wood. Stems 2-7 dm. tall, often slightly scabrous, simple or branched above, angled. Leaves few, remote; blades linear-spatulate, more or less revolute, $0.5-1 \mathrm{~cm}$. long, or rarely slightly longer: pedicel surpassing the calyx and the bract: calyx-tube turbinate-campanulate, becoming campanulate, 2-3 $\mathrm{mm}$. high, the lobes minute, triangular: corolla light rose-colored, about $1 \mathrm{~cm}$. long, or shorter: capsules globose-ovoid, 3-4 mm. long.

In sandy soil, Massachusetts to Minnesota. Florida and Louisiana. Summer and fall.

14. Gerardia filifòlia Nutt. Stems 3-7 dm. tall, branching, smooth and glabrous, Leaves numerous, mostly alternate, small ones usually clustered in the axils of the larger; blades filiform or nearly so, $1-2.5 \mathrm{~cm}$. long, smooth or nearly so: pedicels $1-3 \mathrm{~cm}$. long, surpassing the bracts : calyx-tube campanulate, $3-4 \mathrm{~mm}$. high, the lobes about $\frac{1}{4}$ as long as the tube ; corolla rose-purple, $1.5-2 \mathrm{~cm}$. long: capsules $4-5 \mathrm{~mm}$. in diameter.

In low or dry pine lands, Georgia, Florida and Alabama. Fall.

15. Gerardia setàcea Walt. Stems $3-6 \mathrm{dm}$. tall, loosely branching, scabrous. Leaves rather numerons, mostly opposite; blades linear-filiform or setaceous-filiform, $1-2.5 \mathrm{~cm}$. long, scabrous: pedicels $1-4 \mathrm{~cm}$. long, surpassing the bracts: calyx-tube cam- 
panulate, 3-4 mm. long, the lobes about $\frac{1}{5}$ as long the tube : corolla rose-purple, 1-1.5 $\mathrm{cm}$. long: capsules 4-5 mm. in diameter.

In pine lands, New Jersey to Florida and Texas. Summer and fall.

16. Gerardia Holmiàna Greene. Stems $3-6 \mathrm{dm}$. tall, nearly smooth and glabrous, somewhat branched. Leaves numerous; blades filiform-linear or nearly filiform, 1.5-3 cm. long, acute, minutely roughened : pedicels filiform, longer than their bracts : calyxtube campanulate, $2.5-3 \mathrm{~mm}$. high, the lobes less than $1 \mathrm{~mm}$. long, at least during anthesis : corolla rose-purple, about $1.5 \mathrm{~cm}$. long : capsules globose-oval, $4 \mathrm{~mm}$. long.

In sandy soil or sandy woods, Long Island to Georgia. Fall.

17. Gerardia polyphýlla Small. Stems 1-4 dm. tall, smooth and glabrous, copiously branched, the branches wire-like or filiform. Leaves very numerous, sometimes inconspicuously clustered ; blades filiform or setaceous, 1-2.5 cm. long, acute, smooth : pedicels filiform, i-2 dm. long, shorter than their bracts : calyx-tube turbinate, $2-3 \mathrm{~mm}$. high, the lobes about $\frac{1}{4}$ as long as the tube : corolla pink or pink-purple, less than $1 \mathrm{~cm}$. long : capsules $2-3 \mathrm{~mm}$. in diameter.

In sandy soil, Georgia to Arkansas and Texas. Summer and fall.

18. Gerardia divaricàta Chapm. Stems $2-6 \mathrm{dm}$. tall, smooth or nearly so, wire-like, with wide-spreading very slender or filiform branches. Leaves few; blades filiform or nearly so, 1-3 cm. long, acute, spreading, slightly scabrous : pedicels filiform, $1.5-4 \mathrm{~cm}$. long, spreading, fully twice as long as the bracts : calyx-tube campanulate, $2-3 \mathrm{~mm}$. high, the lobes minute, about $\frac{1}{4}$ as long as the tube : corolla rose-purple, about $1 \mathrm{~cm}$. long: capsules $3 \mathrm{~mm}$. long.

In low pine lands, Florida. Fall.

19. Gerardia Gattíngeri Small. Stems $2-5 \mathrm{dm}$. tall, wiry, with smooth, very slonder long branches. Leaves numerous ; blades linear-filiform or almost filiform, $1.5-3 \mathrm{~cm}$. long, acute, smooth or slightly roughened: pedicels filiform, 1-2.5 cm. long, less than twice the length of the bracts: calyx-tube campanulate, $2.5-3.5 \mathrm{~mm}$. long, the lobes minute, less than $1 \mathrm{~mm}$. long, at least during anthesis : corolla rose-purple, about $1 \mathrm{~cm}$. ong: capsules $3.5-4 \mathrm{~mm}$. in diameter.

In dry soil or woods, Missouri to Tennessee, Alabama and Texas. Summer and fall.

20. Gerardia aspérula (A. Gray) Small. Stem 2-5 dm. tall, branching, with scabrous slender branches. Leaves rather few; blades very narrowly linear to linear-filiform, or those on the branches filiform, $1-2.5 \mathrm{~cm}$. long, acute, very scabrous : pedicels slender, much longer than the bracts : calyx-tube campanulate, $2.5-3.5 \mathrm{~mm}$. high, the lobes prominent, fully $1 \mathrm{~mm}$. long: corolla rose-purple, about $1 \mathrm{~cm}$. long : capsules globular, 4-4.5 $\mathrm{mm}$. in diameter.

In dry soil, Michigan to Minnesota and Arkansas. Summer and fall.

21. Gerardia strictiflòra Benth. Stems $2-4 \mathrm{~cm}$. tall, slightly scabrous, more or less branched above. Leaves sometimes alternate above; blades subulate or setaceous-subulate, $0.5-1 \mathrm{~cm}$. long, or rarely slightly longer, acute, erect or nearly so: pedicels $1-1.5 \mathrm{~cm}$. long, surpassing their bracts: calyx-tube campanulate, $2-3 \mathrm{~mm}$. high, the lobes $\frac{1}{3}-\frac{1}{4}$ as long as the tube : corolla rose-purple, about $1 \mathrm{~cm}$. long: capsules about $4 \mathrm{~mm}$. in diameter.

On plains or prairies, Texas and the Indian Territory. Summer.

22. Gerardia tenuifòlia Vahl. Stems 1-6 dm. tall, smooth, commonly much branched, sometimes bushy, the branches 4-angled and striped. Leaves mostly without clusters in their axils; blades linear, $1-4 \mathrm{~cm}$. long, acute, smooth or nearly so: pedicels filiform, shorter than their bracts : calyx-tube campanulate, $2-3 \mathrm{~mm}$. high, the lobes $\frac{1}{3}-\frac{1}{4}$ as long as the tube: corolla rose-purple, about $1 \mathrm{~cm}$. long: capsules about $4 \mathrm{~mm}$. in diameter.

In dry woods and thickets, Quebec to Ontario, Georgia and Louisiana. Summer and fall.

22. Gerardia Besseyàna Britton. Stems $2-6 \mathrm{dm}$. tall, usually somewhat scabrous, branching above. Leaves rather numerous; blades linear or narrowly linear-lanceolate, 1-5 cm. long, acute, manifestly scrabrous, drying dark or black: pedicels slender, much shorter than their bracts : calyx-tube campanulate, 4-5 mm. high, the lobes fully $1 \mathrm{~mm}$. long : corolla rose-purple, fully $1 \mathrm{~cm}$.'long : capsules $5-6 \mathrm{~mm}$. in diameter.

On dry hills and prairies, Iowa to Colorado, Ohio and Louisiana. Summer.

24. Gerardia víridis Small. Stems $2-6 \mathrm{dm}$. tall, sharply angled, scabrous. Leaves, mostly opposite; blades linear, 1-2 cm. long, acute, revolute, scabrous along the edges drying light green : pedicels rather slender, shorter than their bracts : calyx-tube turbinate or becoming turbinate-campanulate, $3-4 \mathrm{~mm}$. high, the lobes often fully $\frac{1}{3}$ as long as the tube : corolla yellowish pink, less than $1 \mathrm{~cm}$. long : capsules $3-4 \mathrm{~mm}$. in diameter.

In sandy soil, Missouri to Arkansas, Texas and Louisiana. Summer and fall. 


\section{BUCHNÈRA L.}

Biennial or perennial rigid caulescent herbs, with pubescent foliage, black in drying. Leaves opposite or mainly so: blades usually toothed. Flowers in elongated terminal spikes. Calyx of 5 united sepals : tube 5-10-nerved, much longer than the lobes. Corolla white, blue or purple, salverform : tube curved: lobes 5, slightly unequal, spreading, the lateral exterior in the bud. Stamens 4, didynamous: anther-sacs confluent. Stigmas entire or slightly notched. Capsule short, enclosed in the calyx, loculicidally dehiscent. Seeds reticulated. BLuE-HEARTs.

Corolla-lobes less than $4 \mathrm{~mm}$. long, the tube less than twice as long as the calyx. Corolla-lobes over $6 \mathrm{~mm}$. long, the tube over twice as long as the calyx.

1. B. elongata.

2. B. Americana.

1. Buchnera elongàta Sw. Stems 2-5 dm. tall, scabrous or hispidulous, sometimes branched above. Leaf-blades various, those of basal leaves obovate to oblong, 1-3 cm. long, usually short-petioled, those of the stem-leaves oblong to linear, $1.5-8 \mathrm{~cm}$. long, entire or sparingly toothed : spikes loosely flowered : calyx strigillose-hispidulous, 5-6 $\mathrm{mm}$. long, the upper lobes triangular, acute : corolla blue or white, 9-12 mm. long; tube slightly hairy : capsules ovoid, 6-7 $\mathrm{mm}$. long.

In low pine lands, South Carolina to Florida and Texas. Summer.

2. Buchnera Americàna L. Stems $3-10 \mathrm{dm}$. tall, usually branched, hispid. Leafblades various, those of the basal leaves oblong, elliptic or ovate, those of the stem-leaves oblong to lanceolate, $2-9 \mathrm{~cm}$. long, acute or acutish, commonly sharply toothed : spikes more copiously flowered than in $B$. elongata: calyx hispidulous, $5-6 \mathrm{~mm}$. long ; lobes triangular-lanceolate to lanceolate, acuminate : corolla purple, 10-12 mm. long: tube villous ; the lobes cuneate: capsules ovoid, 6-7 mm. long.

In meadows and low pine lands, New York to Minnesota, south to Virginia and Louisiana. Summer and fall.

\section{CASTILLÈJA Mutis.}

Annual or perennial caulescent herbs, often partially parasitic on the roots of other plants. Leaves alternate : blades entire, toothed or lobed. Flowers in terminal spikes or racemes, subtended by large or highly colored bracts. Calyx of several almost wholly united sepals : tube laterally compressed : lobes irregular, sometimes toothed. Corolla often highly colored, strongly 2-lipped : tube not surpassing the calyx : upper lip arched ; lower lip very short. Stamens 4, didynamous, embraced by the upper lip of the corolla : anther-sacs unequal, the outer attached at the middle, the inner pendulous by its apex. Stigma entire or 2-lobed. Capsule loculicidal. Seeds reticulated. Parnted-cup.

Annual or biennial plants.

Stem-leaves with entire or almost entire blades.

Stem-leaves with deeply and irregularly incised blades.

1. C. indivisa.

2. C. coccinea.

Perennial plants.

Lip of the corolla about as long as the saccate portion : bracts and calyxes brickred, rose or sulphur-yellow.

Lip of the corolla much longer than the obscurely saccate portion: bracts and calyxes purple or magenta.

3. C. Lindheimeri.

4. C. purpurea.

1. Castilleja indivisa Engelm. Annual, slightly hirsute. Stems 1-4 dm. tall, sometimes branched at the base: stem-leaves with linear or linear-lanceolate blades, 2-10 $\mathrm{cm}$. long, entire or some with several narrow lateral segments: bracts similar to the stem-leaves or dilated upward, bright-red : calyx colored like the bracts; lobes spatulate or obovate : corolla with the upper lip shorter than the tube and but little surpassing the calyx.

In sandy soil, Texas. Spring.

2. Castilleja coccínea (L.) Spreng. Commonly biennial, hirsute. Stems 1-6 dm. tall, often branched near the base : stem-leaves with narrow 3-5-cleft or laciniate blades often $3-8 \mathrm{~cm}$. long : bracts similar to the stem-leaves, red, scarlet or rarely yellow : caly $x$ usually colored like the bracts; lobes quadrate-oblong : corolla quite similar to that of the preceding species in shape : capsules narrowly oblong, 1-1.5 $\mathrm{cm}$. long, acute.

In low grounds or bogs, Maine to Manitoba, Georgia and Texas. Spring and summer.

3. Castilleja Lindheimeri A. Gray. Perennial, more or less gray-tomentulose. Stems 1-3 dm. tall, commonly tufted : stem-leaves with entire or 3-5-cleft blades $2-6 \mathrm{~cm}$. long, passing into the brick-red rose or sulphur-yellow bracts: calyx colored like the bracts : corolla colored like the bracts, the upper almost as long as the saccate portion: capsules oblong or oblong-ovoid, 1-1.5 cm. long.

On prairies. Texas. Spring. 
4. Castilleja purpùrea G. Don. Perennial, gray-tomentose or tomentulose. Stemss 1-3 dm. tall, commonly tufted: stem-leaves with linear simple or once or twice 3-cleft or laciniate blades: bracts similar to the leaves but with broader bases: calyx colored like the bracts : corolla fully $2.5 \mathrm{~cm}$. long, colored like the bracts, the upper lip longer than the obscurely saccate portion : capsules $1.5-2 \mathrm{~cm}$. long.

On hillsides, Arkansas to Texas and Arizona. Spring.

\section{MELAMPỲRUM L.}

Annual caulescent, often glandular-pubescent herbs. Leaves opposite : blades entire or toothed or ciliate-toothed at the base. Flowers solitary in the axils, sometimes in terminal racemes. Calyx of 4 partially united sepals : lobes unequal, the two upper longer than the lower. Corolla white, yellow, violet or variegated, 2-lipped, the upper lip arched, the lower lip 3-lobed, 2-plaited. Stamens 4, didynamous ascending under the upper lip of the corolla: anthers alike; sacs parallel, mucronulate at the base. Stigma minute. Capsule flattened, oblique, loculicidally dehiscent. Seeds 1-4, smooth.

Leaf-blades linear or linear-lanceolate: bracts with several cilium-like teeth near the base.

Leaf-blades mainly ovate: bracts entire.

1. M. lineare.

2 M. latifolium.

1. Melampyrum lineàre Lam. Stems 1-3 dm. tall, branching above : leaves numerous ; blades linear or linear-lanceolate, $1-4 \mathrm{~cm}$. long, acutish : pedicels 1-4 mm. long, densely glandular : calyx $3-6 \mathrm{~cm}$. long; lobes linear-lanceolate to linear-subulate, longer than the tube: corolla whitish, mostly less than $10 \mathrm{~mm}$. long: capsules $6-8 \mathrm{~mm}$. long. [M. Americanum Michx.]

In woods and thickets, Nova Scotia to British Columbia, south to North Carolina, Kentucky and Minnesota. Spring and summer.

2. Melampyrum latifòlium Muhl. Stems 2-4 dm. tall, nearly simple or branching above. Leaves few ; blades mainly ovate, sometimes ovate-lanceolate or even spatulate near the base of the stem, $2-7 \mathrm{~cm}$. long, acute or acuminate, abruptly narrowed or subcordate at the ba :e : pedicels $2-5 \mathrm{~mm}$. long: calyx $3-5 \mathrm{~mm}$. long; lobes subulate, becoming as long as the tube or longer, with few silvery hairs: corolla whitish, mostly over $10 \mathrm{~mm}$. long: capsules 5-7 mm. long.

On mountain slopes, Pennsylvania to North Carolina, Georgia and Tennessee. Spring and summer

\section{PEDICULÀRIS L.}

Annual biennial or perennial caulescent herbs. Leaves alternate or opposite or rarely whorled: blades pinnatifid, pinnately lobed or pinnately parted. Flowers in terminal spikes or racemes. Calyx of 5 mostly united sepals, often with a cleft on the lower side and sometimes also on the upper: lobes shorter than the tube : corolla white or of various colors, strongly 2-lipped : upper lip concave or conduplicate, laterally flattened : lower lip erect or spreading. Stamens 4, didynamous, ascending under the upper lip of the corolla : anthers and their sacs alike. Capsule flattened, oblique, or curved, beaked, loculicidally dehiscent. Seeds numerous, reticulated, striate, pitted or ribbed. LOUSEWORT.

Leaf-blades pinnately parted : capsule linear-lanceolate, thrice as long as the calyx. 1. $P$. Canadensis. Leaf-blades shallowly pinnatifid or toothed : capsule ovoid, little longer than the calyx. 2 . P. lanceolata.

1. Pedicularis Canadénsis L. Perennial, of ten sparingly hirsute. Stems tufted, 1-4 dm. tall, sometimes decumbent. Basal leaves clustered; blades oblong to lanceolate, 5-12 cm. long, pinnately parted, slender-petioled, the segments toothed or incised; stem-leaves similar to the basal but smaller: calyx $5-7 \mathrm{~mm}$. long, villous, parted on the lower side, with 2 tooth-like lobes on the upper side : corolla ochroleucous, more or less tinged with red or purple, about $1.5 \mathrm{~cm}$. long, the upper lip much surpassing the lower: capsules linear-lanceolate, nearly $2 \mathrm{~cm}$. long, the beak longer than the body.

In open woods and thickets, Nova Scotia to Manitoba, Florida, Texas and Mexico. Spring and summer.

2. Pedicularis lanceolàta Michx. Perennial, sparingly pubescent below the inflorescence, or glabrous. Stems 3-12 dm. tall, sometimes branching : stem-leaves alternate or opposite ; blades oblong to lanceolate, 5-12 cm. long, shallowly pinnatifid or toothed, the segments or teeth crenulate or dentate; basal leaves nearly similar to those of the stem but larger: calyx fully $10 \mathrm{~mm}$. long, 2-lobed, each lobe truncate and surmounted by an oval or suborbicular appendage : corolla straw-colored, about $2 \mathrm{~cm}$. long, the upper lip little surpassing the lower : capsules ovoid, about $1 \mathrm{~cm}$. long, minutely beaked.

In swamps and meadows, Ontario to Manitoba, Connecticut, North Carolina, Ohio and Nebraska. summer and fall. 


\section{SCHWÁLBEA L.}

Perennial caulescent herbs, finely pubescent and glandular. Leaves alternate: blades entire, 5-nerved, sessile. Flowers in terminal bracted racemes. Calyx of 5 well-united sepals: tube 10-12-ribbed, oblique: lobes shorter than the tube. Corolla yellowish purple, very irregular: upper lip arched, entire; lower lip shorter, 3-lobed, 2-plaited. Stamens 4, didynamous, ascending under the upper lip of the corolla : anthers, and the sacs, alike. Capsule narrow, loculicidal. Seeds numerous, with a loose reticulated testa.

1. Schwalbea Americàna L. Stems 3-8 dm. tall, simple or sparingly branched. Leaf-blades oblong, elliptic or ovate-elliptic, $1.5-3.5 \mathrm{~cm}$. long, acute, entire : flowers shortpedicelled: calyx thinly lanuginous, $1.5-2 \mathrm{~cm}$. long; upper and lateral lobes lanceolate, the upper $\frac{1}{2}$ as long as the lateral ; lower lobe oblong, with a V-shaped sinus at the apex : corolla $3-3.5 \mathrm{~cm}$. long, pubescent without; tube surpassing the calyx, longer than the lips : capsules oblong, 10-12 mm. long.

In swamps or low grounds, Massachusetts to Florida and Louisiana. Spring and summer.

\section{Family 14. ACANThàceaE J. St. Hil. ACANthus Family.}

Annual or perennial herbs, or shrubby plants pervaded by bitter, acrid or often emollient properties, otherwise of little economic value. Stems enlarged at the jointed nodes. Leaves alternate, opposite or rarely whorled, without stipules: blades simple. Flowers perfect, irregular, sometimes solitary, often subtended by conspicuous bracts. Calyx of 5 nearly distinct or variously united sepals, sometimes subtended by bractlets. Corolla of 5 partially united petals, 2-lipped or sometimes almost regularly 5-lobed; lobes convolute or contorted. Androecium of four didynamous, or two equal stamens, the other pair abortive or obsolete. Filaments filiform or subulate. Anthers with 2 equal or unequal sacs. Gynoecium 2-carpellary. Ovary free, 2-celled with the placentae in the axis. Styles terminal, united. Stigmas entire or 2 . Ovules often few, commonly 2 in each cavity, sessile, amphitropous or campylotropous. Fruit a membranous, leathery or cartilaginous capsule, typically with 2 cavities, opening loculicidally and elastically. Seeds usually flattened, with a leathery, fibrous or loose, often tuberculate, sometimes pilose, testa. Embryo curved or rarely straight, with large cotyledons.

Leaves normal only at the base of the stem, those on the stem reduced to firm sheathing imbricated scales and passing into the inflorescence.

1. TUBIFLORA.

Leaves normal on the stem.

Corolla convolute in the bud.

Corolla conspicuously 2-lipped : capsule terete, not constricted at the base.

Corolla barely if at all 2-lipped: capsule constricted into a stipe-like base.

Calyx-lobes bristle-like: anther-sacs awned or pointed at the base: ovules 2 in each cavity.

Calyx-lobes linear or lanceolate: anther-sacs pointless: ovules 3-10 in each cavity.

Corolla imbricated in the bud.

Stamens 4: anthers 1-celled.
Stamens 2: anthers 2-celled.

Placentae separating from the valves of the capsuie.

Flowers and their subtending bractlets covered by a large bract. Flowers and their subtending bractlets not covered by a large bract.

Placentae persistently attached to the valves of the capsule.

Anther-sacs equal, contiguous, parallel.

Anther-sacs unequal or unequally inserted, one lower than the other. Lower anther-sac with a spurred or mucronate base.

Corolla-tube elongated, slender or filiform : anther-sacs unequally inserted, one lower than the other.

Corolla-tube very short: anther-sacs separated, oblique.

Both anther-sacs rounded. or rarely both mueronate at the base.

Corolla with 4 nearly equal lobes: anther-sacs contiguous, unequally inserted.

Corolla manifestly 2-lipped: anther-sacs separated on a dilated connective.

Flowers on axillary peduncles: anther-sacs wholly separated,

very oblique.
Flowers solitary in the axils of the leaves or in terminal bracted spikes: anther-sacs approximate, slightly oblique.

2. HYGROPHILA.

3. Calophanes.

4. Ruelija.

5. Stenandrium.

6. Tetramerium.

7. Diapedium.

8. ANisacanthus.

9. SiPHONOG LOSSA.

10. Justicia.

11. Yeatesia.

12. Dianthera.

13. Croftia.

\section{TUBIfLòra J. F. Gmel.}

Perennial caulescent herbs, with glabrous foliage. Stems sometimes scape-like. Leaves alternate or nearly opposite, basal or crowded at the ends of the branches: blades 
membranous or nearly so, entire. Flowers perfect, in dense spikes: bracts imbricated. Calyx scarious : lobes narrow, entire or toothed near the apex. Corolla white or blue : tube slender, terete : limb 2-lipped : upper lip notched or 2-lobed : lower lip 3-lobed. Stamens 2, barely exserted : anthers 2-celled; sacs equal, parallel, sometimes awn-tipped at the base. Staminodia usually wanting. Ovary 2-celled. Ovules 6-10 in each cavity. Capsule narrow, contracted at the base, acute or beaked at the apex. [Elytraria Michx.]

Bracts with ovate or suborbicular bodies.

Stems much longer than the leaves: bracts scarious.

Stems shorter than the leaves or sometimes slightly surpassing them. Bracts with linear or linear-oblong bodies.

1. T. Carolinensis.

2. T. squamosa.

3. T. acuminata.

1. Tubiflora Carolinénsis (Walt.) J. F. Gmel. Foliage deep green, nearly glabrous. Leaves basal; blades oblong, spatulate or elongated linear-spatulate, $0.5-3 \mathrm{dm}$. long, obtuse, undulate, sessile or short-petioled: stems scape-like, $2-4 \mathrm{dm}$. tall, virgate, rigid, solitary or clustered, simple, densely scaly : scales appressed, with spreading tips, lanceolate, 6-12 mm. long, acuminate, ciliate: spikes 1-5 cm. long, dense; bracts with oval or suborbicular bodies, abruptly pointed: calyx about $8 \mathrm{~mm}$. long; lobes attenuate, bearded at the tip : corolla white, $7-9 \mathrm{~mm}$. long; lobes nearly equal : capsules 4-5 mm. long, cylindric, each with a conic tip. [Elytraria virgata Michx.]

In low grounds and on river banks, South Carolina to Florida. Summer.-A small form occurring in Florida, with linear or narrowly oblanceolate leaf-blades, is T. Carolinensis angustifolia (Fernald) Small. [Elytraria virgata var. angustifolia Fernald.]

2. Tubiflora squamòsa (Jacq.) Kuntze. Foliage pale green. Stems more or less spreading, 1-6 dm. long, commonly branched, clothed with appressed imbricated acute scale-like leaves : normal leaves basal or mainly so: blades oblong, elliptic or narrowly ovate, 4-12 cm. long, entire or sinuate, often slightly pubescent, narrowed into petiolelike bases : spikes $1-3 \mathrm{~cm}$. long : bracts firm, 6-8 mm. long, the body ovate, acute or slightly acuminate : bractlets lanceolate, ciliate : calyx-lobes $5-6 \mathrm{~mm}$. long, ciliate : corolla 5-6 mm. long, the lower lip retuse : capsules $6 \mathrm{~mm}$. long.

In low ground, Texas to Arizona. Also in tropical America and Africa.

3. Tubiflora acuminàta Small. Foliage pale green. Stems ascending or spreading, 3-6 cm. long, simple or sparingly branched above, clothed with the appressed acuminatescale-like leaves : normal leaves basal ; blades oblong or oblong-spatulate, 2-6 cm. long, obtuse or rounded, spreading, sparingly pubescent especially on the nerves beneath, sessile or short-petioled: spikes $1-2.5 \mathrm{~cm}$. long: bracts rigid, about $1 \mathrm{~cm}$. long, long-attenuate, woolly above within: bractlets ciliate along the back: calyx-lobes about $7 \mathrm{~mm}$. long, attenuate, barely pubescent at the tip : corolla 5-6 mm. long, the lower lip notched: capsules 4-5 mm. long, each with a conic tip.

In sandy soil, coast of Texas.

\section{HYGRÓPHILA R. Br.}

Annual or perennial caulescent herbs, sometimes armed with axillary spines. Leaves opposite: blades entire. Flowers solitary in the axils, or usually clustered. Calyx persistent: lobes 5, narrow, slightly unequal. Corolla commonly white, 2-lipped : tube slightly dilated upward : limb 2-lipped; upper lip erect, concave, notched or 2-lobed; lower lip more or less spreading, 2-lobed: Stamens 4, didynamous : filaments slightly dilated at the base : anthers 2-celled : sacs equal, parallel. Staminodium small or obsolete. Ovary 2-celled. Ovules 2, 4 or more in each cavity. Capsule terete or flattened contrary to the septum.

1. Hygrophila lacústris (Schlecht.) Nees. Perennial, sparingly pubescent. Stems creeping at the base, the erect or ascending part 3-9 dm. long, 4-angled: leaf-blades nearly linear to narrowly linear-oblanceolate, 5-12 cm. long, rather acuminate, undulate, narrowed into dilated bases : cymes few-flowered, nearly sessile in the axils: calyx minutely pubescent ; lobes narrowly linear-subulate, 5-7 mm. long : corolla white, $7 \mathrm{~mm}$. long,
lipped; lobes of the lower lip oblong: capsules cylindric, $7-8 \mathrm{~mm}$. long, nearly terete.

In swamps and on muddy banks, Florida to Texas and adjacent Mexico. Summer and fall.

\section{Calóphanes D. Don.}

Perennial herbs or shrubby plants. Leaves opposite: blades entire. Flowers solitary or clustered in the axils. Sepals slender or nearly bristle-like, distinct or united to below the middle. Corolla blue or purple, funnelform : tube slightly curved, more or less dilated upward : limb somewhat 2-lipped : lobes 5, spreading, convolute. Stamens 4, didynamous, 
included. Anther-sacs awned or mucronate at the base. Ovary 2-celled. Ovules 2 in each cavity. Capsule oblong or broadened upward. Seeds flat, suborbicular.

Calyx-lobes united to below the middle: Texano-Arizonian species.

Calyx-lobes distinct or nearly so: eastern species.

Calyx-lobes nearly as long as the corolla; corollas and the bractlets about equal in length.

Calyx-lobes less than $1 / 2$ as long as the corolla; which is fully twice as long as the bractlets.

Corolla $1 \mathrm{~cm}$. long or shorter: leaf-blades of a linear type.

Corolla fully $2 \mathrm{~cm}$. long : leaf-blades mainly of an oblong type.

1. C. linearis.

2. C. humistrata.

1. Calophanes lineàris (T. \& G.) A. Gray. Foliage hirsute or glabrous. Stems commonly tufted, 1-3 dm. tall, simple and strict, or diffusely branched : leaves numerous ; blades spatulate below to linear above, $2-4 \mathrm{~cm}$. long, obtuse to acute, often undulate, narrowed at the base: calyx slightly bristly; lobes linear-subulate, $8-10 \mathrm{~mm}$. long, at least twice as long as the tube: corolla inconspicuously pubescent, $2 \mathrm{~cm}$. long; tube (proper) barely as long as the dilated throat ; limb $15-20 \mathrm{~mm}$. broad ; lobes slightly broadened upward, about as long as the throat, rounded or retuse at the apex : capsules 10-12 mm. long, acute, much shorter than the calyx-lobes.

In dry soil, Texas to New Mexico and adjacent Mexico. Spring and summer.

2. Calophanes humistràta (Michx.) Nees. Foliage glabrous to puberulent. Stems erect or decumbent, 1-4 dm. long, weak, often sparingly branched, slightly zigzag : leaves few ; blades elliptic-oblong or oblong-ovate, obtuse or acute, undulate, attenuate to the base : petioles shorter than the blades: calyx puberulent; lobes subulate-setaceous from a lanceolate base, $6-8 \mathrm{~mm}$. long : corolla white, about $1 \mathrm{~cm}$. long; tube much shorter than the dilated throat; limb about $1 \mathrm{~mm}$. broad; lobes truncate or retuse : capsules slender, 8-10 $\mathrm{mm}$. long, surpassed by the calyx-lobes.

In low sandy pine lands or river swamps, Georgia to Florida. Spring.

3. Calophanes angústa A. Gray. Foliage puberulent. Stems erect, 1-2 dm. tall, usually much branched: leaves numerous; blades linear or linear-oblong, or spatulate below, 1-2.5 $\mathrm{cm}$. long, acute or acutish, obscurely nerved, sessile or nearly so : calyx minutely pubescent; lobes linear-subulate, 9-11 mm. long, slender-tipped : corolla retrorsely pubescent, barely $1 \mathrm{~cm}$. long, finely pubescent without; tube slender; limb about $1 \mathrm{~cm}$. broad; lobes broadly cuneate, truncate, eroded at the apex : capsules club-shaped, 7-8 mm. long, acute, rather longer than the calyx-lobes.

In sand, southern Florida. Throughout the year.

4. Calophanes oblongifòlia (Michx.) D. Don. Foliage minutely but rather densely pubescent. Stems more or less branched, 1-3 dm. tall; leaf-blades oblong or the lower ones obovate or cuneate, 1-3 cm. long, obtuse, often undulate, sessile or the lower short-petioled : calyx hirsute; lobes subulate, $12-15 \mathrm{~mm}$. long, very slender-tipped: corolla inconspicuously pubescent, blue often mottled with purple; tube (proper) shorter than the broadly funnelform throat; limb about $1.5 \mathrm{~cm}$. broad; lobes nearly as long as the throat, truncate or retuse : capsules oblong-clavate, 10-13 mm. lóng, acute.

In sandy soil or pine lands, Virginia to Florida. Spring to fall.

\section{RUÉLLIA L.}

Perennial herbs or shrubs, with erect or diffuse stems. Leaves opposite: blades entire or toothed, often petioled. Flowers perfect, solitary or clustered in the axils or in terminal cymes or panicles. Calyx narrow: lobes linear-filiform to lanceolate. Corolla funnelform or salverform : tube narrow, dilated into a more or less ample throat: lobes 5, somewhat unequal, spreading, convolute. Stamens 4, included or exserted: anther-sacs not mucronate. Ovary 2-celled. Styles recurved at the apex. Ovules 3-10 in each cavity. Capsule oblong or clavate, terete or flattened. Seeds flattened.

Flowers or flower-clusters peduncled.

Bracts small and narrow.

Bracts foliaceous.

Flowers or flower-clusters sessile or essentially so.

A. Calyx-lobes linear-filiform or with filiform tips, longer than the capsule.

Corolla 7-10 cm. long.

Corolla $4-6 \mathrm{~cm}$, long.

Plants less than $1 \mathrm{dm}$. tall.

Plants over $2 \mathrm{dm}$. tall.

Leaf-blades sessile or essentially so.

Leaf-blades manifestly petioled.

Plants green: leaf-blades not conspicuously nerved beneath.

Plants grayish pubescent: leaf-blades conspicuously nerved beneath.

1. R. tuberosa.

2. R. pedunculata.

\section{R. noctiflora.}

4. R. humilis.

5. R. ciliosa.

6. R. parviflora. 
Leaves of the main stem mostly less than $6 \mathrm{~cm}$. long: eastern species.

Leares of the main stem mostly over $6 \mathrm{~cm}$. long: Texan species.

B. Calyx-lobes linear-lanceolate or broadly linear, scarcely longer than the capsule.

7. R. hybrida.

8. R. Drummondiana.

1. Ruellia tuberòsa L. Foliage finely hirsute or canescent. Stems erect, from somewhat tuberous-thickened roots, $2-6 \mathrm{dm}$. tall, branching: leaf-blades thickish, oblong to ovate, $3-8 \mathrm{~cm}$. long, undulate-crisped, gradually or abruptly narrowed into margined petioles which are shorter than the blades: cymes on erect or ascending peduncles : bracts small and narrow : calyx bristly ; lobes narrowly linear, $10-12 \mathrm{~mm}$. long or sometimes 2 $\mathrm{cm}$. long: corolla blue or rarely white, 4-6 cm. long; tube about $3 \mathrm{~mm}$. in diameter, rather abruptly dilated into the shorter throat; limb 3-4 cm. long: capsules $1.5-1.7 \mathrm{~mm}$. long, puberulent.

In valleys, Texas. Also in tropical America.

2. Ruellia pedunculàta Torr. Foilage mainly puberulent. Stems erect, 3-6 dm. tall, with wide-spreading branches: leaf-blades oblong-elliptic to ovate-lanceolate, 2-10 $\mathrm{cm}$. long, acute or acutish, undulate ; petioles $4-10 \mathrm{~mm}$. long : peduncles spreading, bearing 2 leaf-like bracts near the end: calyx puberulent; lobes subulate-filiform, $1-1.5 \mathrm{~cm}$. long: corolla blue or pale; tube about $2 \mathrm{~mm}$. thick, as long as the funnelform throat or longer; limb 3-4 cm. broad : capsules $1.5-2 \mathrm{~cm}$. long.

In dry woods, Missouri to Louisiana and Texas. Spring to fall.

3. Ruellia noctiflòra (Nees) A. Gray. Foliage minutely pubescent. Stems erect, 1-3 dm. tall or diffusely branched : leaf-blades oblong, sometimes narrowly so or oblonglanceolate, rather obtuse, undulate, sessile: calyx softly pubesent; lobes linear-filiform, $2.5-3.5 \mathrm{~cm}$. long: corolla white or bluish; tube about $2 \mathrm{~mm}$. thick, $5-6 \mathrm{~cm}$. long, several times longer than the comparatively short funnelform throat; limb 4-5 cm. broad: capsules spindle-shaped, $2.5 \mathrm{~cm}$. long, puberulent.

In low sandy pine lands, Georgia and Florida to Mississippi. Spring and summer.

4. Ruellia hùmilis Nutt. Foliage finely hirsute or villous-hirsute. Stems very short, 1-3 cm. long, or almost wanting, simple or sparingly branched: leaves few ; blades spatulate to oblong or oval, 3-10 cm. long, mostly obtuse, sessile or short-petioled : pedicels very short: calyx bristly ; lobes linear-subulate, $1.5-2 \mathrm{~cm}$. long: corolla blue or nearly white, $4 \mathrm{~cm}$. long; tube somewhat longer than the broadly dilated throat; limb 3-4 cm. broad: capsules nearly oblong, fully $1.5 \mathrm{~cm}$. long.

In sandy soil, Georgia and Florida to Mississippi. Spring to fall.

5. Ruellia ciliòsa Pursh. Foliage hirsute to the corolla, which also is sometimes finely hirsute. Stems erect, 2-6 dm. tall, more or less branched: leaf-blades oval, ovate or oblong, $2-5 \mathrm{~cm}$. long, acute or obtusish, undulate, ciliate, sessile or essentially so : calyx bristly ; lobes filiform-subulate, $1.5-2 \mathrm{~cm}$. long: corolla blne, $5-7 \mathrm{~cm}$. long ; tube about $\frac{1}{2}$ as long as the throat; limb $3-4 \mathrm{~cm}$. broad ; lobes suborbicular, about as long as the throat: capsules oblong, 1-1.5 cm. long, glabrous or nearly so.

In dry soil, New Jersey to Michigan, Kansas, Florida and Texas. Spring to fall.

6. Ruellia parviflòra (Nees) Britton. Foliage sparingly pubescent, but green. Stems erect, 2-6 dm. tall, simple or sometimes sparingly branched : leaf-blades oblong to oblong-lanceolate, $3-10 \mathrm{~cm}$. long, obtuse or acutish, undulate, rather acuminately narrowed at the base, manifestly petioled: pedicels very short: calyx bristly ; lobes linear-filiform, $1.5-2 \mathrm{~cm}$. long: corolla blue, $4-5 \mathrm{~cm}$. long; tube somewhat longer than the throat; limb 2-3 cm. broad : capsules oblong above the stipe-like base, barely $1.5 \mathrm{~cm}$. long.

In sandy soil, Maryland to Indiana, Florida and Texas. Spring and summer.

7. Ruellia hỳbrida Pursh. Foliage finely and closely grayish-pubescent. Stems 2-5 dm. tall, erect or diffuse, the branches at least, spreading : leaf-blades ovate to oblong, $2.5-5 \mathrm{~cm}$. long, obtuse or acutish, undulate or sinuate, conspicuously pale-nerved beneath, short-petioled: calyx minutely bristly or canescent-bristly ; lobes linear-filiform, 1-1.5 cm. long: corolla $2-4 \mathrm{~cm}$. long; limb 2-3 cm. wide : capsules less than $1.5 \mathrm{~cm}$. long.

In sandy or dry soil, Florida. Spring and summer.

8. Ruellia Drummondiàna (Nees) A. Gray. Foliage finely grayish pubescent. Stems erect, 5-9 dm. tall, simple or sparingly branched: leaf-blades ovate to oblong-lanceolate, $5-18 \mathrm{~cm}$. long, acute or short-acuminate, repand, narrowed into manifest petioles : calyx canescent ; lobes bristle-like, $2-2.5 \mathrm{~cm}$. long : corolla blue or pale, $2.5-3.5 \mathrm{~cm}$. long ; tube somewhat longer than the throat; limb $2.5-3 \mathrm{~cm}$. broad: capsules over $1.5 \mathrm{~cm}$. long.

In dry soil, Texas. Spring to fall.

9. Ruella strèpens L. Foliage bright green, glabrous or finely pubescent. Stems erect, 2-12 dm. tall, simple or branched : leaf-blades ovate to oblong, $5-15 \mathrm{~cm}$. long, acute 
or short acuminate, undulate, acuminate or rounded at the base, manifestly petioled: calyx bristly; lobes linear-lanceolate to broadly linear, $2.5-3 \mathrm{~cm}$. long: corolla blue or nearly white, $5-6 \mathrm{~cm}$. long; tube about as long as the throat: limb 5-7 cm. broad: capsules $1-1.5 \mathrm{~cm}$. long.

In dry soil, Pennsylvania to Wiseonsin, Florida and Texas. Spring and summer-A variety with narrower leaf-blades and mostly_cleistogamous flowers, is $R$. strepens micrántha (Engelm. \& Gray) Britton.

\section{STENÁNDRIUM Nees.}

Perennial acaulescent or short-stemmed herbs, with pubescent foliage. Leaves approximate: blades flat, entire. Flower-spikes terminal, bracted. Calyx sessile: lobes 5, narrow, slightly unequal. Corolla rose-colored or purplish : tube terete, slender, slightly curved at the throat: limb oblique, spreading: lobes 5, unequal, imbricated. Stamens 4, didynamous, included : anthers 1-celled. Ovary 2-celled. Stigmas 2-lobed. Ovules 2 in each cavity. Capsule oblong or nearly fusiform, slightly angled. Seeds somewhat flattened, roughened or pubescent.

1. Stenandrium Floridànum (A. Gray) Small. Foliage deep green. Leaves basal, few : blades ovate or oblong-ovate, $2-3 \mathrm{~cm}$. long, obtuse, glabrous except the upper side of the midrib near the base, slightly undulate, rounded or subcordate at the base ; petioles $\frac{1}{2}$ as long as the blades, hirsute : scapes erect, solitary or clustered, surpassing the leaves: spikes few-flowered, 2-5 cm. long: bracts linear-lanceolate, 10-13 mm. long, acuminate and bristly-tipped, ciliate ; upper ones hispidly so: calyx puberulent : lobes linear-subulate, 6-9 mm. long: corolla about $2 \mathrm{~cm}$. long : capsules about $1 \mathrm{~cm}$. long : seeds $4 \mathrm{~mm}$. in diameter, densely strigose with yellowish hairs. [S. dulce var. Floridanum A. Gray.]

In pine woods, Florida. Spring to fall.

\section{TETRAMÈRIUM Nees.}

Perennial caulescent herbs or partly shrubby plants, with pubescent foliage. Leaves opposite: blades entire. Flowers sessile or short-pedicelled and often solitary in the axils of the bracts. Calyx relatively small : lobes 4-5, slender. Corolla 2-lipped : tube slender, terete : upper lip entire, concave : lower lip flat, spreading, 3-lobed. Stamens 2, about equalling the corolla : filaments adnate to the mouth of the corolla-tube: anthers 2-celled, the sacs equal, disjoined by the connective. Staminodia wanting. Ovary 2-celled. Ovules 2 in each cavity. Capsule contracted into a solid stipe-like base.

1. Tetramerium platystègium Torr. Foliage puberulent. Stems more or less branched, 3-6 dm. tall : leaf-blades narrowly oblong to oblong-lanceolate, $2-5 \mathrm{~cm}$. long, obtuse or acutish, somewhat undulate, short-petioled : spikes $1.5-5 \mathrm{~cm}$. long : bracts ovate to ovatelanceolate, acuminate, about $1.5 \mathrm{~cm}$. long, imbricated: calyx about $2 \mathrm{~mm}$. long; lobes subulate, much longer than the tube : corolla purple, 10-15 $\mathrm{mm}$. long; tube slender, longer than the narrowly oblong lobes : capsules less than $1 \mathrm{~cm}$. long, body longer than the stipelike base.

In valleys, southern Texas. Spring.

\section{DIAPÈDIUM Konig.}

Annual or usually perennial caulescent herbs. Leaves opposite : blades entire. Spikes conspicuously bracted. Calyx sessile, hyaline: lobes narrow or bristle-like, equal or nearly so. Corolla blue, violet or red, elongated, 2-lipped : tube terete, slightly dilated above : upper lip erect, concave, entire or notched : lower lip more or less spreading, 2lobed. Stamens 2, barely equalling the lips: filaments adnate to the mouth of the corolla-tube: anthers 2-celled. Staminodia wanting. Ovary 2-celled. Styles filiform, with entire or slightly 2-lobed stigmas. Ovules 2 in each cavity. Capsule with an ovoid or suborbicular body and a solid stipe-like base. Seeds 4 or fewer, smooth or coarsely granular.

Corolla red or crimson, curved : tube longer than the lips.

Corolla purple or pink, nearly straight: tube and lips about equal in length.

Bracts rounded or merely mucronulate at the apex.

Bracts acuminate or cuspidate-acuminate at the apex.

1. D. assurgens.

2. D. brachiatum.

3. D. attenuatum.

1. Diapedium assúrgens (L.) Kuntze. Foliage glabrous or puberulent. Stem, 3-9 dm. tall, rather widely branched : leaf-blades ovate to elliptic or oblong-lanceolates 2-10 cm. long, acute or obtusish, undulate, slender-petioled : outer bracts spatulate or linear-spatulate, 8-12 mm. long; inner bracts subulate, shorter: calyx about $4 \mathrm{~mm}$. Jong: 
lobes narrowly lanceolate, as long as the tube or longer : corolla red or crimson, $2-2.5 \mathrm{~cm}$. long, curved ; lips nearly as long as the tube or much shorter : capsules 7-8 $\mathrm{mm}$. long.

In sand, Florida. Also in the West Indies and Central America. Throughout the year.

2. Diapedium brachiàtum (Pursh.) Kuntze. Foliage glabrous or sparingly pilose. Stems 3-7 dm. tall, with wide-spreading branches : leaf-blades ovate to oblong-ovate, 2-10 cm. long, acute or somewhat acuminate, undulate, slender-petioled: bracts obovate to oblong-spatulate, more or less strongly mucronate, $4-8 \mathrm{~mm}$. long: calyx 4-5 $\mathrm{mm}$. long; lobes linear-subulate: corolla pink to purple, 1.5-2 cm. long; lips about as long as the tube, the upper one 3-toothed : capsules about $5 \mathrm{~mm}$. long.

In dry soil, North Carolina to Florida and Texas. Summer and fall.

3. Diapedium attenuàtum (A. Gray) Heller. Similar to D. brachiatum in habit. Stems more or less branched and spreading, 4-8 dm. long: leaf-blades lanceolate or ovatelanceolate, 4-8 cm. long, markedly acuminate, slender-petioled : bracts acuminate or cuspidate-acuminate: calyx $2-3 \mathrm{~mm}$. long; lobes subulate: corolla pinkish purple, about $1 \mathrm{~cm}$. long: capsules 4-5 mm. long.

On prairies, Arkansas and eastern Texas. Summer and fall.

\section{ANISACÁNTHUS Nees.}

Shrubs, with glabrous or pubescent foliage. Leaves opposite, often clustered : blades broadest below the middle, entire. Flower-spikes terminal, one-sided, interrupted. Calyx sessile: lobes 5 , narrow, nearly equal, acute or acuminate. Corolla red or purplish : tube slender, elongated, straight or slightly curved, dilated above, 2-lipped : upper lip narrow, entire : lower lip 3-parted. Stamens 2, as long as the corolla or longer : filaments adnate to above the middle of the tube : anthers 2-celled. Staminodia wanting. Ovary 2-celled. Stigmas capitate. Ovules 2 in each cavity. Capsule contracted into a long stipe-like base. Seeds 4, flat, wrinkled, orbicular.

1. Anisacanthus Wrìghtii (Torr.) A. Gray. Foliage puberulent or glabrate. Stems 6-12 dm. tall, branching: leaf-blades lanceolate, to oblong- or ovate-lanceolate, 2-5 $\mathrm{cm}$. long, acute or acuminate, abruptly narrowed into short slender petioles or rounded at the base : racemes slender, panicled : calyx 4-5 mm. long; lobes oblong to oblong-lanceolate, longer than the tube : corolla purplish red or vermilion, 3-4 cm. long; lips shorter than the tube, the upper one notched, the lower 3-cleft ; lobes narrow : capsules $2 \mathrm{~cm}$. long, stipe-like base longer than the acute body.

In rich soil or thickets, Texas. Spring to fall.

\section{SIPHONOGLÓSSA Oersted.}

Shrubs or shrubby herbs, with diffuse stems. Leaves opposite: blades entire. Flowers solitary in the axils. Calyx sessile or nearly so: lobes 4, narrow. Corolla white, blue or purple, 2-lipped : tube slender, elongated, terete : upper lip entire or 2-cleft : lower lip spreading, 3-lobed. Stamens included or at least surpassed by the upper lip : filaments adnate to the throat of the corolla-tube: anthers 2-celled, the sacs unequally inserted, one lower. Staminodia wanting. Ovary 2-celled. Stigmas slightly 2-lobed. Ovules 2 in each cavity. Capsule contracted into a solid stipe-like base. Seeds 4 or fewer.

Corolla 1-2 cm. long: calyx 3-6 mm. long.

Foliage glabrous or nearly so: calyx $3 \mathrm{~mm}$. long: corolla less than $15 \mathrm{~mm}$. long. 1. S. Dipteracantha.

Foliage pilose-hirsute: calyx $5-6 \mathrm{~mm}$. long : corolla over $15 \mathrm{~mm}$. long. Corolla $3-4 \mathrm{~cm}$. long: calyx 7-9 mm. long.

2. S. Pilosella.

3. S. longiflora.

1. Siphonoglossa Dipteracántha (Nees) Heller. Stems branched at the base, the branches ascending or spreading, 5-30 cm. long, slender, nearly glabrous : leaf-blades oblong, varying to somewhat obovate or ovate, or sometimes loval, $3-12 \mathrm{~cm}$. long, obtuse often obscurely toothed, glabrous or sparingly pubescent beneath and ciliate near the base, short-petioled : bracts oblong or nearly so : bractlets oblong-spatulate : calyx about $3 \mathrm{~mm}$. long; lobes linear-lanceolate, acute or somewhat acuminate, ciliolate : corolla pale purple or white, 12-13 mm. long; tube about twice as long as the lips, pubescent above the middle, the upper lip notched, the lower lip with obtuse lateral lobes : capsules 5-6 mm. long.

In sandy soil, southeastern Texas and adjacent Mexico. Spring and summer.

2. Siphonoglossa Pilosélla (Nees) Torr. Stem branched at the base, the branches pilose-hirsute, $3-20 \mathrm{~cm}$. long: leaf-blades spatulate to oval or ovate or sometimes elliptic, 
$\mathrm{mm}$. long; lobes subulate, about $\frac{1}{2}$ as long as the subtending bracts : corolla pale blue or purple, 1.6-2 cm. long; tube slender, about twice as long as the tips, the upper lip notched, the lower one longer, its 3 lobes oblong or obovate-oblong : capsules 8-10 mm. long.

In dry ground, Texas to New Mexico and adjacent Mexico. Spring and summer.

3. Siphonoglossa longiflòra (Torr.) A. Gray. Stems branched at the base, the branches 1-2.5 dm. tall, cinereous-puberulent, erect or erect-ascending : leaf-blades lanceolate, 2-4 cm. long, blunt, undulate, often cuneate at the base, short-petioled: calyx 7-9 $\mathrm{mm}$. long: lobes subulate-linear, about as long as the subtending bracts : corolla white or yellowish white, $3-4 \mathrm{~cm}$. long ; tube slenderly cylindric, about twice as long as the lips, the upper lip notched, the lower lip with 3 lobes each about as large as the upper lip: capsules $8-9 \mathrm{~mm}$. long.

In dry or rocky soil, Texas to Arizona and Sonora. Summer.

\section{JUSTÍCIA L.}

Perennial caulescent herbs or rarely shrubs, various in habit. Leaves opposite : blades entire. Flowers solitary, clustered or cymose in the axils of the bracts. Calyx-lobes 4-5, narrow, equal or nearly so. Corolla white, pink, violet or red, 2 lipped : tube very short, straight or curved, manifestly dilated into a throat : upper lip erect or incurved, entire or 2-cleft : lower lip spreading, 3-lobed. Stamens 2, not surpassing the upper lip : filaments adnate to the mouth of the corolla-tube : anthers 2-celled; sacs separate, oblique. Staminodia wanting. Ovary 2-celled. Stigma entire or 2-toothed. Ovules 2 in each cavity, Capsule 8 more or less flattened, contracted into a solid stipe-like base. Seeds 4 or fewer. smooth or variously roughened.

1. Justicia Wrìghtii A. Gray. Stems branched at the woody base, the branches erect or ascending, $0.5-2 \mathrm{dm}$. tall, cinereous-pubescent : leaf-blades firm, those of the lower leaves obovate, barely $1 \mathrm{~cm}$. long, those of the upper leaves lanceolate or linear-lanceolate, 3-7 mm. long, entire, mucronate-acute : flowers solitary and sessile in the upper axils: bracts similar to the accompanying leaves: corolla purplish, 8-9 mm. long; tube rather campanulate; upper lip with two narrow lobes; lower lip with oval-obovate lobes.

On limestone ridges, mainly along the San Felipe River, Texas. Spring and summer.

\section{YEATÈSIA Small.}

Perennial caulescent herbs, with bright green foliage. Leaves opposite : blades entire. Spikes dense, conspicuously bracted. Calyx sessile : lobes slender, erect. Corolla white, slightly 2-lipped: tube slender, somewhat dilated into a throat: lobes 4, nearly equal, flat. Stamens 2: anthers 2-celled; sacs unequally inserted and one slightly oblique. Staminodia wanting. Ovary 2-celled. Stigma capitate. Ovules two in each cavity. Capsule narrowed into a stipe-like base. Seeds glabrous, minutely wrinkled.

1. Yeatesia viridiflòra (Nees) Small. Foliage nearly glabrous, or puberulent, bright green. Stems 2-6 dm. tall, branched, constricted above each node : leaf-blades elliptic or elliptic-lanceolate, $5-15 \mathrm{~cm}$. long, acuminate at both ends, undulate, bracts ovate to obovate, 1-1.5 cm. long, ciliate : calyx glabrous or nearly so ; lobes linear-subulate, 4-5 mm. long: corolla white or pink, $1.5 \mathrm{~cm}$. long, the lower lip 3-lobed, spreading, the upper reflexed, barely lobed: stamens exserted: capsule $1 \mathrm{~cm}$. long, the stipe-like base shorter than the body. [Justicia laetevirens Buckl., not Vahl. Rhytoglossa viridiflora Nees.]

In shaded soil, Tennessee to Georgia, Florida and Texas. Summer.

\section{DIANTHÈRA $L$.}

Perennial caulescent herbs, with glabrous or pubescent foliage. Leaves opposite : blades entire or rarely toothed. Flowers several, on axillary peduncles. Calyx-lobes 4-5, slender. Corolla white or colored, strongly 2-lipped : tube variable in length, straight or curved : upper lip erect or ascending, entire or 2-tooth : lower lip spreading, 3-lobed. Stamens 2: filaments adnate to near the mouth of the corolla-tube, not surpassing the upper lip: anthers 2-celled, the sacs separated by a broad connective. Ovary 2-celled. Stigma entire or 2-lobed. Ovules 2 in each cavity. Capsule contracted into a stipe-like base. Seeds 4 or fewer, flat, ovate to suborbicular. WATER WiLLow. 
Corolla $2-2.5 \mathrm{~cm}$. long.

Corolla $1 \mathrm{~cm}$. long or shorter.

1. D. crassifolia.

Flowers scattered along one side of the upper part of the peduncles. Leaves remote, reflexed : corolla-tube 5-6 mm. long.

Leaves approximate, spreading or ascending : corolla-tube $8-10 \mathrm{~mm}$. long.

Flowers in head-like spikes terminating the peduncle, or approximate at the end. Spikes loosely flowered: corolla-tube glabrous within: style glabrous.

Spikes densely flowered : corolla-tube villous within : style pubescent at the base.

2. D. angusta.

3. D. lanceolata.

4. D. ovata.

5. D. Americana.

1. Dianthera crassif òlia Chapm. Foliage glabrous. Stems $2-4 \mathrm{dm}$. tall, angled, simple or nearly so : leaves few ; blades linear, usually narrowly so or spatulate near the base of the stem, 3-15 cm. long, fleshy : peduncles commonly longer than the subtending leaves, often surpassing the stem : calyx-lobes linear, 1-1.5 cm. long, acuminate : corolla bright-purple, $2-2.5 \mathrm{~cm}$. long; lips longer than the tube, the lower one striped, all rounded or notched: capsules $2-2.5 \mathrm{~cm}$. long, the body and base about equal in length.

In wet pine lands, Florida. Spring.

2. Dianthera angústa (Chapm.) Small. Foliage glabrate. Stems $2-5 \mathrm{dm}$. tall, simple or nearly so : leaves very few ; blades linear or narrowly linear-lanceolate, acute or acuminate, $2-7 \mathrm{~cm}$. long, or oblong-spatulate at the base of the stem, sessile or subsessile, more or less strongly reflexed: peduncles somewhat longer than the leaves or shorter, bearing 2-few flowers near the end: calyx-lobes linear, 5-7 mm. long, ciliate, acute : corolla about $10 \mathrm{~mm}$. long; tube surpassing the calyx, the lower lip with a retuse middle lobe and obtuse lateral lobes: capsules about $1.2 \mathrm{~cm}$. long. [D. ovata var. angusta Chapm. ]

In pine-land ponds, Florida. Spring.

3. Dianthera lanceolàta (Chapm.) Small. Foliage puberulent. Stems erect or spreading, 1-3 dm. long, more or less branched: leaf-blades linear to linear-elliptic or elliptic-lanceolate, $3-10 \mathrm{~cm}$. long, more or less acuminate, undulate, sessile or nearly so: spikes slender, 3-10 $\mathrm{cm}$. long, interrupted along the peduncle : calyx-lobes narrowly linear, 5-7 mm. long : corolla about $1 \mathrm{~cm}$. long; lips nearly as long as the tube, which is saccate near the base, the upper lip truncate or retuse, the lower one 3-lobed, the middle lobe truncate or retuse, the lateral ones obtuse : capsules $1.5 \mathrm{~cm}$. long, the body as long as the stipe-like base or shorter. [D. ovata var. lanceolata Chapm.]

In swampy ground, Missouri to Tennessee, Florida and Texas. Spring and summer.

4. Dianthera ovàta Walt. Foliage puberulent or glabrous. Stems 1-3 dm. tall, simple or sparingly branched: leaf-blades oblong to elliptic, acute or acutish, often acuminate at the base, short-petioled: spike long-peduncled, $1-2 \mathrm{~cm}$. long, continuous : calyx-lobes narrowly linear-acuminate, 6-12 $\mathrm{mm}$. long: corolla pale purple to violet, about $1 \mathrm{~cm}$. long; limb as long as the tube, or sometimes longer, 2-lipped, the upper lip notched, the lower lip 3-lobed, spreading; lobes rounded : capsules $1 \mathrm{~cm}$. long, the stipe-like base as long as the body or shorter.

In swamps, Virginia to Florida and Texas. Spring and summer.

5. Dianthera Americàna L. Perennial by horizontal or creeping rootstocks, the foliage glabrous or puberulent. Stems 3-10 dm. tall, simple or branching, angled : leaf-blades linear to linear-lanceolate or narrowly oblong, 5-15 cm. long, acute, attenuate to the subsessile base : peduncles ascending, about as long as the leaves or longer: spikes 1-3. cm. long, continuous: calyx-lobes linear, $4-5 \mathrm{~mm}$. long, acute : corolla white, pink or purplish; lips as long as the tube or longer, the upper one notched, the lower lip with:3 obtuse lobes: capsules $1.5-2 \mathrm{~cm}$. long, the stipe-like base as long as the body or longer. summer.

In marshes and running water, Ontario to Michigan, south to Georgia and Texas. Spring and

\section{CRÓftia Small.}

Perennial caulescent shrubby herbs, with gray-pubescent foliage. Leaves opposite: blades relatively broad, entire or nearly so. Flowers axillary or disposed in terminal spikes axillary to leaf-like bracts or the bracts toward the ends of the spikes much reduced. Sepals 5, slender. Corolla 2-lipped, the upper lip entire, the lower 3-lobed, drooping. Stamens 2: filaments adnate to the top of the corolla-tube. Ovary 2-celled: styles united : stigma 2-lobed. Capsule with a stipe-like base.

1. Croftia parvifollia (Torr.) Small. Perennial by a stout root, finely pilose. Stems erect or diffuse, often numerous and tufted, 1-3 dm. long, simple or branching : leafblades ovate, oval or suborbicular, 1-3 cm. long, acute or short acuminate, undulate to repand, more or less abruptly contracted in short petioles : spikes interrupted: calyx-lobes linear-subulate, acuminate, $2.5-3 \mathrm{~mm}$. long: corolla white to purple, about $8 \mathrm{~mm}$. long; lips about as long as the tube, the upper lip obtuse or retuse, the lobes of the lower one 
oblong, obtuse : capsules 9-13 mm. long, the body ovoid, longer than the base, acute. [Shaueria parvifolia Torr. Dianthera parvifolu (Torr.) A. Gray.]

In dry soil, Texas and New Mexico.

\section{Family 15. Pinguidulàceae Dumort. ${ }^{1}$ Bladderwort Family.}

Small scapose or caulescent herbs, growing in water or in wet places. Stems often submersed. Leaves submersed and dissected into linear or filiform segments, sometimes resembling rootlets and often bladder-bearing; sometimes aërial, basal, entire ; or, rarely, wanting. Scapes naked or furnished with minute scales, bearing one or many flowers. Flowers irregular, perfect, often showy. Calyx of 2 or 5 herbaceous sepals. Corolla strongly or obscurely 2lipped: tube spurred or saccate: hypogynous. Androecium of 2 stamens, adnate to the base of the corolla-tube on its upper side. Filaments flattened, twisted. Anthers confluently 1-celled. Gynoecium a single 1-celled pistil, with a free-central usually globose placenta. Style thick and short. Stigma often 2-lipped, the lips unequal. Ovules numerous, anatropous. Fruit a capsule, 2 -valved or irregularly dehiscent. Seeds numerous, the testa rugose. Endosperm wanting. Embryo straight, sometimes undivided. [Lentibulariaceae Lindl.]

Calyx of 5 sepals: corolla-tube with an open throat.

1. Pinguicula.

Calyx of 2 sepals: corolla-tube closed by a palate.

Caly $x$ accompanied by 2 bractlets resembling the sepals, and like them, conspicuously ciliate.

Calyx without bractlets: sepals entire.

2. Cosmiza.

3. Utricularia.

\section{PINGUÍCULA L.}

Terrestrial scapose herbs, inhabiting wet ground. Leaves forming a basal rosette : blades flat, entire, furnished above with a secretion by which, together with the sensitive inrolling margins, insects are captured. Scapes usually several, 1-flowered. Sepals 5, often more or less united. Corolla yellow, violet or purple, more or less distinctly 2-lipped : palate subulate, not closing the throat : lobes entire or cleft: tube prolonged into a nectariferous spur at base: throat open. Stamens 2. Capsules 2-valved. Butrerwort.

Corolla violet or white, the limb distinctly 2-lipped.

Corolla, including spur, less than $2 \mathrm{~cm}$. long.

Corolla, including spur, more than $2 \mathrm{~cm}$. long.

Spur slender: scapes villous at the base.

Spur short and rather sac-like: scapes not villous at the base. Corolla golden-yellow, the limb nearly regular.

1. P. pumila.

2. P. elatior.

3. P. planifolia.

4. P. lutea.

1. Pinguicula pùmila Michx. Leaves clammy-pubescent; blades $1-3 \mathrm{~cm}$. long: scapes very slender, $5-20 \mathrm{~cm}$. tall, not villous at the base : calyx becoming $3-4 \mathrm{~mm}$. long: corolla light violet, varying to white; limb 1-2 $\mathrm{cm}$. broad; spur subulate, about $3 \mathrm{~mm}$. long, longer than the sac-like base of the corolla.

In low pine lands, South Carolina to Florida and Texas. Spring.

2. Pinguicula elàtior Michx. Leaves clammy-pubescent; blades $1.5-3.5 \mathrm{~cm}$. long : scapes 1-3 dm. tall, villous at the base: calyx becoming 4-5 mm. long: corolla purple, varying to white; limb $2-2.5 \mathrm{~cm}$. broad, the lobes 2-cleft; spur slender, 4-6 $\mathrm{mm}$. long, shorter than the sac-like base of the corolla, obtuse.

On margins of ponds, North Carolina to Florida. Spring.

3. Pinguicula planifolia Chapm. Leaves glabrous or nearly so; blades $3-10 \mathrm{~cm}$. long: scapes $2-4 \mathrm{dm}$. tall, not villous at the base : calyx becoming $5-6 \mathrm{~mm}$. long : corolla purple, varying to white, $2-3 \mathrm{~cm}$. wide : spur rather sac-like, only $3 \mathrm{~mm}$. long, obtuse.

In shallow water, Florida to Mississippi, near the Gulf coast. Spring.

4. Pinguicula lùtea Walt. Leaves clammy-pubescent; blades $2-6 \mathrm{~cm}$. long : scapes 1-4 dm. tall, pubescent : calyx becoming 4-5 mm. long: corolla golden-yellow; limb 2$3.5 \mathrm{~cm}$. broad ; lohes longer than the tube, 2-4-lobed; spur subulate, $5 \mathrm{~mm}$. long.

In low pine lands, North Carolina to Florida and Louisiana. Spring.

\section{Cosmìza Raf.}

Terrestrial scapose herbs, with the habit of the terrestrial species of Utricularia. Leaves basal, often fugacious: blades linear or narrowly spatulate, sometimes bladder-

${ }^{1}$ Revised by Dr. John H. Barnhart. 
bearing. Scapes simple, commonly with a few scales toward the base. Flowers racemose or sometimes solitary. Pedicels subtended by small bracts. Sepals 2, accompanied by 2 similar bractlets. Corolla surpassing the calyx, strongly 2-lipped. Stamens incurved: filaments stout. Capsules 2-valved. [Polypompholyx Lehm.]

1. Cosmiza longeciliàta (A. DC.) Small. Glabrous, bright green. Leaves few or many, often wanting; blades linear, 5-6 mm. long: scapes filiform, 5-15 cm. high, with several bristly scales, chiefly near the base: racemes 3-7-flowered, spike-like: pedicels shorter than the calyx : bracts, bractlets and calyx conspicuously ciliate with long hairs: corolla yellow, 6-8 mm. broad; lips unequal, the lower one larger, nearly entire; spur horn-shaped, about as long as the lower lip. [Utricularia longeciliata A. DC.]

In springy places, peninsular Florida. Also in the West Indies.

\section{UTRICULÀRIA L.}

Aquatic or terrestrial scapose herbs. Stems horizontal, creeping on the surface of the ground in wet places or in shallow water, or more or less free-swimming: some species essentially acaulescent, the stems minute or obsolete. Leaves commonly finely dissected, bladder-bearing, often reduced, rarely wanting. Bladders constricted at the mouth, which is closed by an operculum and often furnished with several projecting processes. Flowers solitary or racemose. Sepals 2, slightly united. Corolla 2-lipped, with a palate closing the throat : upper lip entire or 2-lobed : lower lip entire or 3-lobed, produced into a spur at the base. Capsule commonly irregularly dehiscent, several-or many-seeded. BladDerwort.

Scapes solitary at the nodes of elongated, more or less free-swimming stems.

Corolla violet-purple.

Corolla yellow.

Scapes each with a whorl of conspicuous inflated bracts.

Racemes 1-3-flowered : corolla about $1.5 \mathrm{~cm}$. broad.

Racemes 5-12-flowered: corolla"about $2 \mathrm{~cm}$. broad.

Scapes without conspicuous inflated bracts.

Racemes 5-10-flowered : leaves 2-3-pinnately dissected : mature bladders at least $3 \mathrm{~mm}$, long.

Racemes 10-20-flowered : leaves 4-5-pinnately dissected : bladders $2 \mathrm{~mm}$. long or less.

Pedicels recurving in fruit.

Pedicels erect or ascending in fruit.

Scapes solitary or several together, the stems radiating from their bases often more or less root-like.

Corolla yellow.

Spur much shorter than the lower lip of the corolla, conic, obtuse.

Spur about the length of the upper lip of the corolla.

Corolla less than $12 \mathrm{~mm}$. broad.

Corolla more than $12 \mathrm{~mm}$. broad.

Spur much exceeding in length the lower lip of the corolla.

Corolla violet-purple : flower solitary, transverse on the summit of the scape.

scapes solitary, rooting: stems, leaves and bladders so minute and delicate that they are usually overlooked.

Pedicels longer than the subtending bracts.

Pedicels shorter than the subtending bracts.

Corolla shorter than the calyx.

Corolla surpassing the calyx.

Corolla less than $1 \mathrm{~cm}$. broad ; spur about $6 \mathrm{~mm}$. long.

Corolla more than $1.5 \mathrm{~cm}$. broad; spur about $12 \mathrm{~mm}$. long.

1. U. purpurea.

2. U. radiata.

3. U. inflata.

4. U. vulgaris.

5. U. oligosperma.

6. U. Floridana.

1. Utricularia purpùrea Walt. Stems submersed, elongated, the branches numerous, whorled, verticillately decompound. Leaves none: bladders solitary, terminating many of the ultimate branchlets, the orifices without projecting processes: scapes erect, slender, spongy-thickened below, 1-3 dm. tall, often naked : racemes $1-4$-flowered : pedicels erect or ascending: calyx becoming $2-2.5 \mathrm{~mm}$. long: corolla violet-purple, $8-15 \mathrm{~cm}$. palate; spur conic, somewhat flattened, about $\frac{1}{2}$ as long as the middle lobe : capsules erect or ascending.

In ponds and ditches, Maine to Indiana and Florida. Spring to fall.

2. Utricularia radiàta Small. Stems submersed, slender, elongated. Leaves dichotomously dissected, copiously bladder-bearing: scapes erect, emersed, $6-12 \mathrm{~cm}$. tall, bearing near the middle a single whorl of 4-6 conspicuous inflated bracts, which are more or less confluent at the base and pinnately dissected near the tip : racemes 1-3-flowered : pedicels $0.5-1.5 \mathrm{~cm}$. long, erect or ascending in fruit: calyx becoming $2-3 \mathrm{~mm}$. long : corolla yellow, about $1.5 \mathrm{~cm}$. broad, the upper lip concave, nearly entire; the lower lip 3-lobed, about twice as long as the appressed conic emarginate spur. [U. inflata var. minor Chapm., not $U$. minor L.]

In ponds and ditches, Massachusetts to Florida and Texas. Spring to fall. 
3. Utricularia inflàta Walt. Stems submersed, often stout, elongated. Leaves dichotomously dissected, copiously bladder-bearing: scapes erect, emersed, 2-6 dm. tall, bearing near the middle a single whorl of 6-9 conspicuous inflated bracts, which are more or less confluent at the base and pinnately dissected near the tip: racemes 5-12flowered : pedicels 1-3 cm. long, spreading or recurving in fruit : calyx becoming 4-5 cm. long: corolla yellow, about $2 \mathrm{~cm}$. broad, the upper lip concave, nearly entire, the lower lip 3-lobed, about twice as long as the appressed conic emarginate spur.

In ponds and ditches, Maine to Florida and Texas. Spring to fall.

4. Utricularia vulgàris $\mathrm{L}$. Stems submersed, leafy, $3-12 \mathrm{dm}$. long. Leaves numerous, alternate; blades 2-3-pinnately dissected into filiform segments, usually bearing numerous bladders: bladders when fully developed $3-5 \mathrm{~mm}$. long: scapes erect, 1-3 dm. tall : racemes $5-10$-flowered : pedicels $5-15 \mathrm{~mm}$. long, recurving at maturity : caly $\mathrm{x}$ becoming 3-3.5 $\mathrm{mm}$. long : corolla yellow, $12-15 \mathrm{~mm}$. broad, the upper lip erect, nearly entire, the lower lip spreading, slightly 3-lobed; spur not appressed, horn-like, slightly curved, shorter than the lower lip : capsules many-seeded.

In ponds and ditches, throughout Canada and the United States. Also in Europe and Asia. Spring and summer.

5. Utricularia oligospérma St. Hil. Stems submersed, 9-30 dm. long. Leaves chiefly in alternate pairs, one of each pair much more copiously bladder-bearing, 3-10 cm. long; blades pinnately 4-5-dissected into very fine or capillary segments, the segments fewer when the bladders are more numerous: bladders $2 \mathrm{~mm}$. long or less : scapes erect, 1-3 dm. tall : racemes 10-20-flowered: pedicels $1-2 \mathrm{~cm}$. long, recurving at maturity : calyx becoming 4-5 mm. long: corolla yellow, 15-20 mm. broad, the upper lip erect, nearly entire, the lower lip spreading, slightly 3-lobed; spur not appressed, slenderly conic, slightly curved, shorter than the lower lip : capsules few-seeded.

In ponds, lakes and ditches, Florida to Louisiana. Also in tropical America.

6. Utricularia Floridàna Nash. Similar to the next preceding species. Scapes more or less tortuous, $1.5-4 \mathrm{dm}$. tall : pedicels erect or ascending at maturity : calyx becoming 3-4 mm. long : corolla $12-15 \mathrm{~mm}$. broad.

In ponds, peninsular Florida. Spring to fall.

7. Utricularia gíbba L. Stems radiating from the base of the scape or scapes, several $\mathrm{cm}$. long, delicate, root-like : leaves scattered, sparingly divided; segments capillary, with few minute bladders : scapes erect, wire-like, $2-10 \mathrm{~cm}$. tall : flowers 2 , or rarely $1-3$ near the top of the scape : pedicels very slender, erect or ascending: calyx becoming 2-3 $\mathrm{mm}$. long : corolla yellow, $5-7 \mathrm{~mm}$. broad; spur obtuse, shorter than the lower lip.

In shallow water, New England, Ontario and Missouri to Louisiana and Florida. Summer.

8. Utricularia biflòra Lam. Similar to the next preceding species. Corolla about $10 \mathrm{~mm}$. broad; spur subulate, about as long as the lower lip.

In shallow water, Massachusetts to Illinois, Florida and Texas. Spring to fall.

9. Utricularia fibròsa Walt. Stems radiating from the base of the scape or scapes, often 1-2 dm. long and free-swimming at the tip. Leaves numerons; blades 2-3-dichotomously dissected, or the bladder-bearing ones much reduced : scapes erect, slender, 1-3 dm. tall : racemes $2-5$-flowered, usually 3 -flowered : pedicels ascending, $5-20 \mathrm{~mm}$. long : calyx becoming $2-3 \mathrm{~mm}$. long: corolla yellow, about $15 \mathrm{~mm}$. broad; lips nearly equal; spur linear, appressed, about as long as the lower lip, obtuse or emarginate at the apex.

In and about ponds, chiefly in pine lands, New York to Florida and Louisiana.

10. Utricularia macrorhýncha Barnhart. Stems radiating from the base of the scape or scapes, short, root-like. Leaves few ; blades mostly bladder-bearing and much reduced : scapes erect, slender, 5-10 $\mathrm{cm}$. tall : racemes 1-3-flowered, usually 2-flowered : calyx becoming $2 \mathrm{~mm}$. long: corolla yellow, about $10 \mathrm{~mm}$. broad; lips nearly equal; spur slenderly conic, appressed, longer than the lower lip, obtuse or emarginate at the apex.

In shallow water, Georgia, Florida and Alabama.

11. Utricularia resupinata B. D. Greene. Stems radiating from the base of the scape or scapes, short, root-like. Leaves scattered; blades simple or forked near the base ; segments slender, capillary, often bladder-bearing: scapes erect, $2-5 \mathrm{~cm}$. tall : flowers solitary : calyx becoming 1.5-2 mm. long: corolla violet-purple, $6-10 \mathrm{~mm}$. long, reflexed so that it rests transversely on the top of the scape; spur conic, obtuse, shorter than the rest of the corolla, distant from the lower lip, with which it is parallel.

In sandy swamps and shallow ponds, Maine to Michigan and Florida. Spring to fall.

12. Utricularia subulàta L. Stems, leaves and bladders minute and delicate, evanescent. Scapes rooting in mud, filiform, bronze-colored, $2-20 \mathrm{~cm}$. tall : racemes $1-9$-flowered : rachis becoming zigzag when well-developed : pedicels ascending, 2-10 $\mathrm{mm}$. long, surpass- 
ing the bracts : calyx becoming $2-3 \mathrm{~mm}$. long : corolla yellow, 4-6 mm. broad, the lower lip much larger than the upper one, equally 3-lobed; spur oblong, appressed, nearly as long as the lower lip.

In wet places, chiefly in pine lands, Massachusetts to Florida and Texas. Also in tropical America. Spring to fall.

13. Utricularia símplex C. Wright. Stems, leaves and bladders minute and delicate. Scapes rooting in mud, erect, $8-20 \mathrm{~cm}$. tall, strict, slender : racemes spike-like, 2-6-flowered : calyx becoming $2-2.5 \mathrm{~mm}$. long: corolla shorter than the calyx; lips nearly equal : spur obtuse.

In pine lands, eastern Florida. Also in Cuba.

14. Utricularia júncea Vahl. Stems, leaves and bladders minute and delicate. Scapes rooting in mud, erect, $1-4 \mathrm{dm}$. tall : racemes spike-like, $3-12$-flowered : calyx becoming 3-3.5 mm. long: corolla yellow, less than $1 \mathrm{~cm}$. broad; lower lip larger than the upper, laterally flattened, rather pointed; spur horn-like, acute, slightly curved, pendant, about $6 \mathrm{~mm}$. long.

In bogs and meadows, New Jersey to Florida and Texas. Also in the West Indies and tropical America. Summer.

15. Utricularia cornùta Michx. Stems, leaves and bladders minute and delicate. Scapes rooting in mud, erect, 1-4 dm. tall : racemes spike-like, $2-8$-flowered, the flowers approximate: calyx becoming 4-5 cm. long: corolla yellow, $1.6-2 \mathrm{~cm}$. broad : lower lip much larger than the upper, laterally flattened, abruptly pointed; spur horn-like, acute, slightly curved, pendant, about $12 \mathrm{~mm}$. long. summer.

In sandy or sphagnous swamps, Newfoundland to Minnesota, Florida and Texas. Spring and

\section{Family 16. OROBANChàCeAa Lindl. Broom-Rape Family.}

Commonly perennial herbs, with astringent bitter and caustic properties, destitute of green foliage and parasitic on the roots of other plants. Stems sometimes almost wanting. Leaves scale-like. Flowers perfect, or rarely dioecious sometimes cleistogamous and complete on the same plant. Calyx of four or five more or less united sepals, persistent: tube campanulate or tubular, often oblique, rarely spathe-like. Corolla persistent or withering: limb more or less bilabiate and irregular. Androecium of 4 didynamous stamens, adnate to the corolla, mostly included. Filaments terete. Anthers 2-celled or rarely 1-celled, leathery. Gynoecium free, 2-carpellary with 2 parietal placentae, which are often 2-lobed or divided. Styles united, terminal. Stigma capitate or 2-lobed. Ovules mostly numerous, anatropous. Fruit a capsule, enclosed in the persistent corolla, with 1 or apparently 2 cavities. Seeds very numerous, minute, with a thickish shining furrowed or tuberculate testa. Endosperm white, transparent. Embryo at the extremity of the endosperm.

Flowers perfect and complete throughout.

Caly $x$ irregular, spathe-like, the lower side split, the upper with 3 or 4 tooth-like lobes.

Calyx regular or nearly so, with 2-5 equal or unequal lobes.

Calyx with a deep sinus above and below, the lateral lobes often 2-cleft.

Calyx nearly equally 5-lobed.

Flowers subtended by bractlets.

Flowers without bractlets.
Flowers various, cleistogamous on lower part of spike, complete but mostly sterile above. 5. LEPTAMNIUM.

1. CONOPHOLIs.

\section{CONÓPHOLIS Wallr.}

Parasitic herbs, with pale yellow or brownish glabrous foliage. Stems simple, very stout. Leaves scale-like, erect or appressed, often imbricated at the base of the stem. Flowers perfect, in dense terminal scaly-bracted spikes. Calyx accompanied by 2 bractlets, spathe-like, split on the lower side, 3-4-toothed on the upper. Corolla colored like the rest of the plant: tube curved : limb strongly 2-lipped; upper lip arching, notched : lower lip shorter, 3-lobed. Stamens 4, somewhat exserted: filaments in slightly unequal pairs, sometimes accompanied by a fifth one. Ovary 1-celled, with 4 placentae : stigma slightly 2-lobed. Ovules numerous. Capsule 2-valved. SQUAw-root.

1. Conopholis Americàna (L. f.) Wallr. Perennial, fleshy. Stems clustered, stout, 1-2 dm. tall, simple, clothed with ovate or lanceolate acute scales (reduced leaves): spikes as long as the sterile part of the stem or the flowers sometimes extending to the base: calyx 
sessile, surpassing the two bracts; tube split on the lower side, terminating in 3-4 teeth on the upper side: corolla yellowish or pale yellow, surpassing the calyx, the upper lip notched, the lobes of lower lip obtuse or notched: capsules ovoid, 1-1.5 cm. long, obliquely pointed.

In woods, Maine to Michigan and Florida. Spring and summer.

\section{OROBÁNCHE L.}

Parasitic herbs, on roots of various plants, commonly with yellowish or brownish pubescent foliage. Leaves scale-like. Flowers spicate, with bractlets. Calyx with a deep sinus above and below, the lateral lobes often 2-cleft. Corolla irregular: tube slightly curved: limb 2-lipped, the upper lip erect or incurved, the lower lip spreading. Ovary 1-celled. Capsule 2-valved. BRoom-RAPE.

1. Orobanche minor J. E. Smith. Foliage glandular-pubescent, yellowish or yellowish brown. Stems solitary or clustered, 1-5 dm. tall, simple : scales (leaves) ovate to lanceolate, 6-20 mm. long, acute, sessile : spikes interrupted below, continuous above, 1-2 $\mathrm{dm}$. long: bracts lanceolate, as long as the flowers or longer: calyx pubescent; lobes lanceolate-subulate : corolla glandular-pubescent especially along the back, 1-1.5 cm. long ; tube yellowish, the lips bluish, erose and irregularly toothed: capsules oblong, less than 1 cm. long. summer.

Parasitic on clover-roots, New Jersey to North Carolina. Naturalized from Europe. Spring and

\section{MYZORRHIZA Philippi.}

Parasitic herbs, on the roots of other plants, with more or less pubescent foliage. Leaves scale-like. Flowers spicate, or sometimes peduncled, subtended by bractlets. Calyx nearly equally 5-lobed, the lobes narrow. Corolla purplish : tube slightly curved: limb 2-lipped, the lips often nearly erect. Ovary 1-celled. Capsule 2-valved.

1. Myzorrhiza Ludoviciàna (Nutt.) Rydb. Foliage minutely glandular-pubescent. Stems solitary or clustered, simple or usually branched, $0.5-3 \mathrm{dm}$. tall, scaly, often stout : scales (leaves) ovate to ovate-lanceolate: spikes $2-15 \mathrm{~cm}$. long, dense, conspicuous : calyx densely glandular-pubescent; lobes linear-lanceolate or nearly linear: corolla purplish, $1.5 \mathrm{~cm}$. long: tube constricted above the ovary, the upper lip 2-lobed, the lower lip 3lobed, the lobes entire : capsules oblong-ovoid.

In sandy soil, Northwest Territory to Illinois, Texas and California. Summer.

\section{THALÈSIA Raf.}

Parasitic herbs, with pale or pink foliage. Stems solitary or tufted, simple or branched. Leaves scale-like, sometimes mainly at the base of the plant. Flowers perfect, occasionally solitary, peduncled or pediceled. Calyx erect or horizontal : lobes nearly equal, acute or acuminate. Corolla often more deeply colored than the rest of the foliage : tube curved : limb slightly 2-lipped, the upper lip often 2-lobed, the lower lip spreading, with 3 more or less unequal lobes. Stamens included. Ovary 1-celled, with 4 usually equidistant placentae. Stigmas peltate to slightly 2-cleft. Ovules numerous. Capsule erect or ascending, 2valved. [Aphyllon Mitch.] Broom-RApe.

1. Thalesia uniflòra (L.) Britton. Foliage glandular-pubescent. Stems very short, often branching, commonly subterranean, scaly : peduncles solitary or several together, $0.5-1.5 \mathrm{dm}$. tall, simple : flowers solitary, violet-scented : calyx campanulate; lobes lanceolate, acuminate, as long as the tube or longer : corolla cream-colored or tinged with purple; tube 1-1.5 cm. long; lobes oblong or obovate, ciliate, $\frac{1}{3}-\frac{1}{4}$ as long as the tube: capsules erect, conic-ovoid, about $1 \mathrm{~cm}$. long.

In woods, parasitic on roots, Newfoundland to British Columbia, middle Georgis, Texas and California. Spring and summer.

\section{LEPTÁMNIUM Raf.}

Parasitic caulescent herbs, with firm tissues and dark-colored foliage. Leaves scalelike, few. Flowers in elongated open spikes, of 2 kinds, cleistogamous on the lower part of the spike, and complete but mostly sterile above. Calyx nearly regular, 5-lobed. Corolla paler than the rest of the plant: tube curved and slightly enlarged upward : lobes 4, nearly equal, the slightly longer upper one concave or arching. Stamens slightly exserted. Ovary 1-celled, with 4 broad placentae in pairs. Stigma between capitate and 2-lobed. Ovules numerous. Capsule short, 2-valved at the apex. [Epiphegus Nutt.] BEEch-Drops. 
1. Leptamnium Virginiànum (L. ) Raf. Foliage purple or yellowish brown, sometimes puberulent. Stems from a short base, solitary or tufted, erect, branched, 1-4 dm. tall, sparingly scaly especially at the base : racemes spike-like : pedicels 1-2 mm. long, enlarged upward: calyx often variegated; lobes triangular or ovate-triangular, about as long as the tube, acute : cleistogamous flowers $2-3 \mathrm{~mm}$. long: corolla of the complete flowers ascending, 10-13 mm. long; tube curved, the upper lip notched, its lobes obtuse, the lower lip 3lobed, its lobes acute, somewhat plaited : capsules $3-5 \mathrm{~mm}$. broad, broader than high.

In beech woods, New Brunswick to Ontario, Michigan, Florida and Louisiana. Summer and fall.

\section{Family 17. Bignoniàceat Pers. Trumpet-creeper Family.}

Trees, twining or climbing shrubby plants, or rarely herbs. Leaves opposite, rarely alternate or whorled, often developing tendrils from the petioles, without stipules: blades simple or pinnately-compound. Inflorescence commonly spicate or racemose. Flowers showy, sometimes solitary, perfect, irregular. Calyx free, of usually 2 more or less united sepals. Corolla irregular, 5lobed or 2-lipped, hypogynous, deciduous : tube varying from campanulate to tubular. Androecium of 5 stamens, 1 or 3 reduced to sterile filaments, or 4 and then didynamous. Filaments filiform, adnate to the corolla-tube, mostly included. Anther-sacs commonly divaricate. Gynoecium 2-carpellary. Ovary 1celled with two parietal placentae or mainly 2-celled by a false partition between the placentae, surrounded by a fleshy disk: styles united: stigmas mostly 2 . Ovules numerous, horizontal or rarely pendulous or ascending, anatropous. Fruit a leathery or woody capsule, often flattened and with two cavities and two valves. Seeds numerous, winged, with a membranous or leathery testa. Endosperm wanting. Embryo with cordate cotyledons notched at the apex.

Leaf-blades compound : vines or rarely herbaceous plants.

Calyx with an undulate margin : capsule flattened parallel with its partition.

Calyx with 5 lobes: capsule flattened at right angles to its partition.

Upright mainly herbaceous plants: ovules in 2 rows in each cavity of the ovary.
Vines with twining stems : ovules in several rows in each cavity of the ovary.

Leaf-blades simple: shrubs or trees.

Anther-bearing stamens 2: leaves opposite.

Anther-bearing stamens 4 : leaves alternate or scattered.

Ovary 2-celled : fruit loculicidally valved: leaf-blades linear or nearly so.

Ovary 1-celled at least above : fruit indehiscent : leaf-blades relatively broad.

1. BIGNONIA.

2. STENolobium.

3. CAMPSIS.

4. Catalpa.

5. CHILOPSIs.

6. Crescentia.

\section{BIGNÒNIA L.}

High-climbing or shrubby vines. Leaves opposite : blades 2-3-foliolate, or 1-foliolate, (the terminal one often represented by a tendril), entire or rarely toothed. Flowers in axillary cymes or in terminal panicles. Caly $x$ campanulate or cup-shaped, nearly truncate or undulate. Corolla usually showy : limb spreading, more or less distinctly 2-lipped; lobes much shorter than the tube. Stamens 4 (fertile), didynamous : filaments adnate to the base of the corolla: anthers glabrous. Ovary short-stalked or nearly sessile, 2 -celled. Ovules in 1 row on each placenta or more or less distinctly in 2 or 3 rows. Capsule narrow, elongated, flattened parallel with its partition. Seeds flattened, winged.

1. Bignonia crucígera L. An evergreen high-climbing vine, with glabrate foliage and much-branched stems. Leaves compound: petioles 1-2 cm. long, prolonged into forking tendrils : leaflets 2 , oblong-oval or oblong-lanceolate, 5-15 cm. long, slightly acuminate but obtuse or mucronate, cordate or auricled at the base : flowers in axillary clusters : pedicels $2-4 \mathrm{~cm}$. long, stout: calyx campanulate, $5-8 \mathrm{~mm}$. long, lobes very shallow : corolla red-orange without, yellow within, $4-5 \mathrm{~cm}$. long; lobes rounded or ovate, about $\frac{1}{4}$ as long as the tube: stamens included: filaments villous at the base : capsules linear, 10$17 \mathrm{~cm}$. long, flattened. [B. capreolata L.]

In thickets, Virginia to Illinois, Florida and Louisiana. Spring. TRUMPET-FLOWER.

\section{STENOLÒbIUM D. Don.}

Upright mainly herbaceous plants. Leaves usually opposite : blades unequally pinnate, the leaflets with toothed blades. Flowers in terminal racemes or panicles. Calyx tubular-campanulate: lobes 5, nearly equal. Corolla funnelform. Stamens included: anthers often pubescent, with foliaceous connectives. Ovary with many ovules borne in 2 rows in each cavity. Capsule slender, with leathery boat-like valves. Seeds winged. 
1. Stenolobium stáns (L.) D. Don. A branching plant 3-14 dm. tall, with erect stem, the foliage glabrous or minutely pubescent. Leaves pinnate, $1-2 \mathrm{dm}$. long: leaflets $7-9$; blades lanceolate, narrowly elliptic or nearly linear, 4-10 cm. long, acuminate, sharply serrate, sessile or nearly so : racemes rather many-flowered : pedicels variable, 1-10 mm. long: calyx tubular-campanulate, $3-5 \mathrm{~mm}$. high ; lobes often triangular, acuminate, much shorter than the tube: corolla yellow, funnelform, $3.5-4.5 \mathrm{~cm}$. long; limb 4-5 cm. broad, the lobes undulate: capsules linear, 10-20 cm. long, acute. [Tecoma stans (L.) Juss.]

In sandy soil, Florida and southern Texas to Mexico. Also in tropical America.

\section{CÁMPSIS Lour.}

Vines. Leaves mainly opposite: blades unequally pinnate, the leaflets with toothed blades. Flowers in clusters or panicles. Calyx tubular-campanulate: lobes 5, nearly equal. Corolla tubular-funnelform. Stamens included. Ovary with numerous ovules borne in several rows in each cavity. Capsule narrow, with firm-leathery concave valves. Seeds winged. Trumpet-Flower. Trumpet-CREeper.

1. Campsis radìcans (L.) Seem. A bushy vine climbing by aërial rootlets, the foliage softly pubescent to glabrate, the stems several $\mathrm{m}$. long. Leaves pinnate: leaflets $7-11$; blades oval, ovate or elliptic, $2-6 \mathrm{~cm}$. long, acute or usually acuminate, coarsely serrate, gradually narrowed, short-petioluled: corymbs few-flowered: pedicels stout, $0.5-2 \mathrm{~cm}$. long: calyx tubular-campanulate, 14-18 mm. long; lobes triangular or triangular-ovate, much shorter than the tube: corolla red and orange, or yellow within, tubular-funnelform, 5-9 cm. long ; limb 3-5 cm. broad, oblique, the lobes suborbicular or reniform : capsules spindle-shaped, $1-1.8 \mathrm{~cm}$. long, acute. [Tecoma radicans (L.) DC.]

In woods, swamps and thickets, Pennsylvania to Missouri, Florida and Texas.

\section{CATÁLPA L.}

Shrubs or trees, with a watery sap, scaly bark and soft wood. Leaves opposite, whorled or alternate, deciduous, without stipules : blades membranous. Flowers large and showy, white or yellow, in terminal panicles or corymbs. Calyx closed, obovoid and apiculate when young, later splitting into two broad concave lobes. Corolla oblique, strongly blotched or spotted, its limb bilabiate, the upper lip 2-lobed, the lower 3-lobed. Stamens 2 or rarely 4, adnate to the base of the corolla, accompanied by several minute or rudimentary staminodia, included or slightly exserted : filaments filiform, flattened : anthers introrse, the sacs divergent, brought near the stigma by a bend in the filaments. Ovary 2-celled, sessile on a thick disk : style filiform : stigmas 2. Ovules numerous, inserted in many rows on the central placenta, horizontal, anatropous. Capsule much elongated, nearly terete, tapering at both ends, persistent, at length loculicidally 2-valved. Seeds numerous, in 2-4 ranks, flattened, much broader than long with a membranous testa which is constricted at either end of the seed and produced into long fimbriate wings at the sides. Indian Bean. Cigar-tree.

Panicles many-flowered, crowded: corolla with a limb 4-5 $\times 5-6 \mathrm{~cm}$. Panicles few-flowered, lax: corolla with a limb 6-7 $\times 7-8 \mathrm{~cm}$.

1. C. Catalpa.

2. C. speciosa.

1. Catalpa Catálpa (L.) Karst. A tree rarely $20 \mathrm{~m}$. tall, with wide spreading branches. Leaf-blades ovate, 1-3 dm. long, acuminate, more or less densely tomentose beneath, undulate, truncate or subcordate at the base; petioles usually shorter than the blades: panicles many-flowered: calyx glabrous or nearly so, 8-12 mm. long; lobes abruptly pointed : corolla white; tube campanulate, with 2 rows of yellow blotches within ; limb $4-5 \times 5-6 \mathrm{~cm}$. the 3 lower lobes with purple spots: capsules linear, $1.5-4 \mathrm{dm}$. long, terete. [C. bignonioides Walt.]

In woods, mostly on river banks, New York to Florida and Texas. Native southward. Spring.

2. Catalpa speciòsa Warder. A tree sometimes $40 \mathrm{~m}$. tall, with a thick scaly bark. Leaf-blades ovate or oblong-ovate, 1-3 dm. long, acuminate, undulate or angulately lobed, tomentose beneath, truncate or cordate at the base; petioles nearly as long as the blades or usually shorter: panicles few-flowered: pedicels $2-3 \mathrm{~cm}$. long: calyx purple; lobes abruptly acuminate: corolla white; tube conic-campanulate, with 2 rows of yellow blotches within ; limb $6-7 \times 7-8 \mathrm{~cm}$.; lobes of the lower lip blotched with purple: capsules linear, $3.5-5 \mathrm{dm}$. long, terete.

In damp soil or swamps, Illinois and Missouri to Alabama and Texas. Spring. 


\section{CHILÓPSis D. Don.}

Shrubs or trees, with furrowed bark and dark-colored coarse-grained wood. Leaves opposite or alternate, deciduous, without stipules: blades narrow, thin, entire, often 3nerved, sometimes glutinous. Flowers perfect, showy, white, tinged with purple, in terminal puberulent racemes or thyrsoid panicles, with narrow bracts. Calyx membranous, splitting into 2 concave lobes. Corolla oblique, enlarged at the throat and blotched with yellow, inconspicuously bilabiate, the upper lip 2-lobed, the lower 3-lobed, the margins undulate, the central lobe larger than the rest. Stamens 4, adnate together with a staminodium to the base of the corolla-tube, mostly included : filaments filiform, the 2 posterior much shorter than the anterior pair : anther-sacs divergent. Ovary 2-celled, sessile on the nearly obsolete annular disk: style filiform: stigmas 2. Ovules numerous, horizontally borne in many rows in the central placenta, anatropous. Capsule narrow, elongated, tapering to both sides, loculicidally 2 -valved. Seeds numerous, in 2 ranks, flattened, notched at both ends, with a membranous testa which is produced into lateral fimbriate wings. Endosperm wanting. Embryo with cotyledons which are much broader than long.

1. Chilopsis lineàrís (Cav.) DC. A straggling shrub or small tree, sometimes $9 \mathrm{~m}$. tall. Leaves numerous; blades linear, $10-20 \mathrm{~cm}$. long, acuminate, rather prominently nerved, gradually narrowed to the base, or short-petioled : racemes $6-10 \mathrm{~cm}$. long, villous: calyx short-pedicelled; lobes acute, villous, several-toothed at the apex : corolla white, with a shading of purple, funnelform ; lobes suborbicular, about $1 \mathrm{~cm}$. in diameter, crisped: capsules narrowly linear, 10-20 cm. long: seeds nearly $1.5 \mathrm{~cm}$. long, bearded at both ends.

Along streams, Texas to southern California and Mexico.

\section{CRESCÉNTIA L.}

Glabrous trees, with scaly bark and stout terete or angled branchlets. Leaves alternate, without stipules: blades leathery or membranous, solitary or fascicled, entire. Flowers perfect, clustered or solitary at the ends of branchlets. Calyx leathery, at length split into 2 lobes, or 5-cleft, deciduous. Corolla pale-vellow, striped with purple, oblique, tubular-campanulate: tube constricted near both ends and swollen on the lower side : limb inconspicuously hilabiate, obscurely 5 -lobed, the lobes laciniate-toothed. Stamens 4, adnate together with a posterior staminodium, to the lower part of the corolla-tube, slightly exserted or included : filaments filiform : anther-sacs divergent. Ovary 1-celled, sessile on a thick annular disk : style filiform : stigmas 2. Ovules numerous, borne on two 2-lobed parietal placentae, anatropous. Capsule short and stout, indehiscent.

Leaf-blades spatulate or oblanceolate, usually thrice as long as broad : capsules over $12 \mathrm{~cm}$. long.

1. C. Cujete.

Leaf-blades oblong to oblong-obovate, about twice as long as broad : capsules less than $12 \mathrm{~cm}$. long.

2. C. ovata.

1. Crescentia Cujète L. An evergreen tree 5-10 m. tall, with glabrous foliage. Leaves clustered; blades leathery, spatulate or oblanceolate, $8-15 \mathrm{~cm}$. long, abruptly acuminate, gradually narrowed to short-winged petioles: pedicels longer or shorter than the peduncles : calyx glabrous, $2-2.5 \mathrm{~cm}$. long; lobes obtuse, little longer than broad: corolla yellowish white, stout, tubular, $5-6 \mathrm{~cm}$. long; lobes crisped, usually acute, much shorter than the tube : capsules subglobose or oval, 1.5-3 dm. in diameter.

In sand, Key West, Florida. Also in the West Indies.

2. Crescentia ovàta Burm. f. An evergreen tree rarely $7 \mathrm{~m}$. tall, with glabrous foliage. Leaf-blades leathery, oblong to oblong-ovate, $7-15 \mathrm{~cm}$. long, abruptly pointed at the apex, acuminate at the base, short-petioled : pedicels $2-8 \mathrm{~cm}$. long, in terminal clusters: calyx glabrous; lobes $2.5-4 \mathrm{~cm}$. long, obtuse : corolla dull purple or creamy on the lower side, tubular-funnelform, 5-6 cm. long; tube indented below ; limb oblique, with a reflexed upper lip : capsules green, oblong or oval, 6-10 cm. long, blunt-pointed, obscurely 4-ridged : seeds 2 -lobed, about $2 \mathrm{~cm}$. broad, somewhat shorter.

In sand, Florida. Also in the Antilles and tropical America.

\section{FAMILY 18. MARTYNIÀCEAE Link. UniCorn-Plant FAMILY.}

Annual or perennial stocky herbs, with thick branching stems. Leaves opposite or rarely alternate: blades expanded, thick, simple, mostly contracted into petioles. Flowers perfect, irregular. Calyx inferior, sessile or stalked: 
lobes 4 or 5, equal or unequal. Corolla gamopetalous, commonly showy: tube oblique, often decurved: limb 2-lipped; lobes 5, spreading, slightly unequal, the 2 upper exterior in the bud. Stamens (fertile) 4, didynamous, or the two posterior ones without anthers. Filaments elongated. Anthers with spreading sacs. Gynoecium 2-carpellary. Ovary 1-celled, elongated, with 2 parietal placentae, which sometimes form a false partition, thus making the cavity apparently 2-4-celled. Style slender. Stigmas 2, sometimes dilated. Ovules few or numerous, in two rows on each blade of the placentae. Fruit a beaked capsule. Seeds flattened, with or without wings. Endosperm wanting. Embryo large, with more or less flattened cotyledons.

\section{MARTÝNIA L.}

Characters of the family. Unicorn Plant.

Corolla white or pink, 4-5 cm. long: leaf-blades merely sinuate. Corolla reddish or violet-purple, $2.5-3.5 \mathrm{~cm}$. long: leaf-blades lobed.

1. M. Louisiana.

2. M. fragrans.

1. Martynia Louisiàna Mill. Annual, densely viscid-pubescent, heavy-scented. Stems erect or much branched, the branches spreading or prostrate, $2-9 \mathrm{dm}$. long, fleshy, often zigzag : leaves alternate above; blades suborbicular or orbicular-ovate, often oblique, 0.5-3 dm. in diameter, ciliate, sinuate, cordate; petioles as long as the blades or shorter: peduncles 1-6 cm. long, becoming deflexed : bractlets linear or oblong, deciduous : flowers not fragrant: calyx cleft on the lower side; lobes ovate, obtuse: corolla white, or pink, spotted with yellow and purple within, 4-5 cm. long; lobes broad, undulate: stamens all fertile : capsule $8-15 \mathrm{~cm}$. long, strongly curved, separating into 2 elastically spreading valves; beak longer than the body. [M. proboscoidea Glox.]

On banks and in waste places, Maine to Iowa, Georgia and Texas. Naturalized eastward. Summer and fall. RAM's HoRN.

2. Martynia frágrans Lindl. Similar to $M$. Louisiana in habit, but smaller. Leafblades shallowly lobed as well as sinuate : flowers fragrant : corolla $2.5-3.5 \mathrm{~cm}$. long, reddish or violet-purple : capsule more slender than that of the preceding species.

In dry soil, southern Texas to Arizona and Mexico.

\section{Order 8. PLANTAGINÀLES.}

A gamopetalous order, of uncertain relationship. Herbs, commonly acaulescent. Leaves mainly or wholly basal: blades typically 1-several-ribbed. Flowers perfect, monoecious or dioecious, in spikes. Calyx of 4 partially united or nearly distinct sepals. Corolla of 4 partially united, scarious and veinless petals. Androecium of 4 or 2 stamens. Gynoecium a compound superior pistil. Fruit capular, commonly a pyxis.

\section{Family 1. PLANTAginàceat Lindl. ${ }^{1}$ Plantain Family.}

Annual or perennial, acaulescent or short-stemmed, rarely stoloniferous plants with basal or, in (all our) stemmed forms, alternate leaves. Inflorescence terminal spicate, on scapes or on axillary peduncles. Flowers bracteate, sessile, perfect, monoecious or dioecious. Calyx inferior, of 4 persistent often scarious-margined slightly united sepals. Corolla hypogynous, scarious or membranous, nerveless, usually persistent, with 4 erect or spreading imbricated lobes. Stamens (in ours) 4 or 2. Filaments adnate to the tube or throat of the corolla. Anthers versatile, 2-celled, opening lengthwise. Gynoecium of a single pistil. Ovary superior, sessile, 1-2-celled or apparently 3-4-celled. Stigma single, filiform or slender. Ovules 1-many, amphitropous, peltate. Fruit (in ours) a circumscissile capsule or pyxis. Seeds 1-several in each cavity. Endosperm fleshy. Embryo straight or nearly so.

\section{PLANTÀgo L.}

Annual or perennial herbs. Leaves with their blades narrow or expanded, often prominently ribbed, thin or leathery and thickish. Scapes usually simple, solitary to

${ }^{1}$ Revised by Mr. E. L. Morris. 
many or clustered. Spikes elongated or abbreviated, sometimes conspicuously bracted. Calyx-lobes equal or two larger than the others. Corolla rather inconspicuous, during anthesis, at least, salverform or nearly rotate, constricted at the throat, the two lateral lobes exterior. Stamens exserted or included : filaments usually capillary. Capsule more or less membranous. Seeds with flattened or concave faces. Plantain.

Flowers mainly dioecious: corolla-lobes erect or closed over the capsules.

Stamens 2: leaves linear to filiform.

Capsule about twice as long as the calyx: seeds 10-30.

Capsule slightly surpassing the calyx: seeds $2-4$.

Stamens 4 : leaves with comparatively broad blades.

Bracts and calyx-lobes obtuse: seeds golden yellow.

Bracts and calyx-lobes acute or acuminate: seeds red or fuscous.

Bracts and calyx-lobes acutish: seeds fuscous.

Bracts and calyx-lobes acuminate : seeds dark red.

Flowers perfect: corolla-lobes spreading or reflexed on top of the capsules.

Annuals; heterogenous: flowers mostly cleistogamous.

Bracts not aristate, not over two times as long as the flowers.

Bracts lanceolate to triangular, comparatively wide at the base.

Plants usually spreading: spikes delicate: corolla-lobes less than 2

mm. long.
Plants usually erect : spikes coarse : corolla-lobes more than $2 \mathrm{~mm}$. long. Plants glabrous or nearly so, drying dark brown.

Plants villous to tomentose, not drying dark brown.

Bracts linear-subulate to narrowly lanceolate, narrow at the base.

Plants villous, drying dark brown: spikes coarse, thick, conspicuous by the large corollas.

Plants white-woolly, not drying dark brown: spikes narrow-cylindri-

cal, not conspicuous.
Bracts aristate, two or more times as long as the flowers.

Plants lax and spreading: spikes plainly interrupted.

Plants rigid and ascending or erect: spikes slightly if at all interrupted.

Bracts linear-subulate to tapering-linear: plants not drying dark brown.

Perennials; proterogynous.

Calyx-lobes various, the lower united, the upper nearly distinct.

Calyx-lobes all essentially distinct.

Lateral nerves of the leaf-blades free and remote from the midrib.

Spikes interrupted throughout: bracts very small.

Spikes continuous at least above the base: bracts large.

Capsules conic or oblong-conic, circumscissile below the middle. Capsules ovoid, circumscissile at about the middle.

Lateral nerves of the leaf-blades partially confluent with the midrib.

1. P. heterophylla.

2. P. elongata.

3. P. Virginica.

4. P. occidentalis.

5. P. rhodosperma.

\section{P. lanatifolia.}

7. P. Wrightiana.

8. P. inflexa.

9. P. Helleri.

10. P. Purshii.

11. P. verticillata.

12. P. spinulosa.

13. P. aristata.

14. P. lanceulata.

15. P. sparsiflora.

16. P. Rugelii.

17. P. major.

18. P. cordata.

1. Plantago heterophýlla Nutt. Annual, slender, glabrous or sparingly puberulent. Leaves basal, 2-18 cm. long; blades linear or nearly filiform, acute, entire or with several remote teeth or spreading narrow lobes, narrowed to the dilated base: scapes usually numerous, ascending or spreading, $2-2.5 \mathrm{~cm}$. long, equalling or surpassing the leaves: spikes slender, $2-15 \mathrm{~cm}$. long, loosely-flowered, interrupted at maturity : bracts ovate, 1.5-2 mm. long, blunt : flowers dioecious or polygamous : calyx-lobes oval to rhombicobovate, about $1.5 \mathrm{~mm}$. long, very obtuse, scarious-margined, mostly shorter than the bracts : corolla glabrous; lobes erect, ovate, $0.5 \mathrm{~mm}$. long, acute : capsules oblong, 3-3.5 mm. long, about twice as long as the calyx-lobes, circumscissile below the middle: seeds 10-30, mainly $0.5-0.7 \mathrm{~mm}$. long, dark red.

In moist soil, New Jersey to Florida, Texas and southern California. Spring and summer.

2. Plantago elongàta Pursh. Annual, slender, sparingly pubescent. Leaves basal, several 2-12 cm. long; blades linear or nearly filiform, blunt-tipped, entire, obscurely 1-nerved, sometimes early deciduous: scapes usually several together, nearly filiform, 5-25 cm. long, surpassing the leaves, often glabrate above : spikes rather looselyflowered, slender: bracts ovate, 1-1.3 mm. long, acutish : flowers dioecious or polygamous : ealyx-lobes oval to obovate, $1.3-1.5 \mathrm{~mm}$. long, obtuse, about equalling the bracts in length, scarious-margined : corolla glabrous; lobes erect, lanceolate to ovate-lanceolate: capsules oblong or ovoid-oblong, about $2 \mathrm{~mm}$. long, slightly surpassing the calyx-lobes, circumscissile below the middle: seeds $2-4,1-1.5 \mathrm{~mm}$. long, dark red. [ $P$. pusilla Nutt.]

In dry sandy soil, Connecticut to Oregon, Virginia, Louisiana and Texas. Spring and summer.

3. Plantago Virgínica L. Annual or biennial, very variable, glabrate to rather coarsely pubescent with 1-7-septate hairs. Leaves basal, spreading or ascending, 1-15 cm. long; blades spatulate to obovate or elliptic, obtuse or acutish, entire or repand-denticulate, $3-5$-nerved, narrowed into margined petioles or nearly sessile: scapes erect or ascending, 0.5-20 dm. tall, much surpassing the leaves:-spikes dense, sometimes interrupted below : flowers dioecious : bracts linear-lanceolate to lanceolate : calyx-lobes oblong or ovate, 2-2.5 $\mathrm{mm}$. long, obtuse, scarious-margined, surpassing the bracts: corollas various, those of staminate flowers with spreading lobes, those of pistillate flowers with lobes usually un- 
equally erect after fertilization: capsules ovoid or oval-ovoid, 1.5-2 mm. long, circumscissile at about the middle : seeds $2-4,1.3 \mathrm{~mm}$. long, golden-yellow.

In dry soil, Connecticut to Michigan, Missouri, Florida and Arizona. Spring and summer.

4. Plantago occidentàlis Decne. Annual or biennial, pubescent with $3-5$-septate hairs. Leaves basal, $8-20 \mathrm{~cm}$. long or more, spreading; blades spatulate to spatulatelanceolate, obtusish, 3-5-nerved, subentire to strongly repand-lobed, narrowed into long somewhat margined petioles : scapes erect, $10-20 \mathrm{~cm}$. tall, equalling or surpassing the leaves : spikes 3-15 cm. long, densely flowered or interrupted below : flowers dioecious : bracts ovate-lanceolate, equalling the calyx-lobes : calyx-lobes linear-lanceolate to linearoblong, acutish, narrowly scarious-margined, somewhat ciliolate: corolla smooth; lobes narrowly ovate, subcordate, not closely connivent after fertilization : capsules oblong, about $2.5 \mathrm{~mm}$. long, circumscissile below the middle : seeds 2 , about $1.75 \mathrm{~mm}$. long, fuscous.

In dry soil, Texas. Spring and summer.

5. Plantago rhodospérma Decne. Annual or biennial, densely and coarsely pubescent with 1-7-septate hairs. Leaves basal, 5-18 cm. long, spreading or ascending; blades oblong to spatulate, obtuse, 3- (or 5-)nerved, subentire to repand-dentate, sometimes tinged with red, narrowed into short margined flat petioles: scapes erect or decumbent, $2.5-20 \mathrm{~cm}$. tall, usually much longer than the leaves : spike $1.5-15 \mathrm{~cm}$. long, densely flowered, often interrupted below : flowers dioecious : bracts narrowly ovate, shorter than the calyx-lobes: calyx-lobes oblong to ovate, $2-2.5 \mathrm{~mm}$. long, typically acuminate, scarious-margined, somewhat pubescent on the midrib : corolla glabrous or minutely papillose ; lobes ovate to deltoid-ovate, acute, usually connivent after fertilization : capsules oblong, about $3 \mathrm{~mm}$. long, obtuse, circumscissile below the middle, often purplish : seeds $2,2 \mathrm{~mm}$. long, dark red.

In sandy soil, Missouri and Oklahoma to Louisiana, Texas and Arizona. Spring and summer.

6. Plantago lanatifòlia (Coult. \& Fish.) Small. Annual, floccose with white silky wool at least at the base. Leaves numerous, basal, $3-10 \mathrm{~cm}$. long, spreading : blades narrowly oblanceolate or, when induplicate, appearing falcate, acute, entire or denticulate, gradually narrowed to the base : scapes ascending or spreading, solitary or several together, $3-13 \mathrm{~cm}$. tall, equalling or surpassing the leaves: spikes 1-3 cm. long, 6-8 $\mathrm{mm}$. thick, dense : flowers perfect: bracts deltoid-lanceolate, about $\frac{2}{3}$ the length of the calyx-lobes : calyx-lobes pilose, narrowly oblong, about $4 \mathrm{~mm}$. long, scarious-margined : corolla glabrous ; lobes spreading, triangular-ovate, obtuse, dark at the base : capsules ovoid, obtuse, circumscissile below the middle.

In dry ground, Texas. Spring.

7. Plantago Wrightiàna Decne. Annual, usually glabrous, except the spikes and upper part of the peduncles. Leaves alternate, erect or nearly so, rather rigid, $5-18 \mathrm{~cm}$. long ; blades linear or slightly broadened upward, obtuse and callous-tipped, 3-nerved, entire, glabrous or sparingly pubescent at the dilated base of the short petioles : peduncles erect or ascending, somewhat enlarged above, twice or thrice longer than the leaves, silky-strigillose : spikes cylindric, 2-6 cm. long, 6-8 mm. thick, dense : flowers perfect : bracts deltoid-ovate, not equalling the calyx-lobes, scarious-margined : calyx-lobes more or less silky, oval to cuneate, about $3 \mathrm{~mm}$. long, scarious-margined: corolla glabrous; lobes reflexed, ovate, cordate, 3-3.5 mm. long, obtuse, violet at the base : capsules broadly oblong, $4 \mathrm{~mm}$. long, rounded at the apex, surpassing the calyx-lobes : seeds 2 , about $3 \mathrm{~mm}$. long, brown.

In dry soil, Texas to Arizona. Spring and summer.

8. Plantago infléxa Morris. Annual, villous to matted-tomentose. Leaves alternate, ascending to erect, $10-20 \mathrm{~cm}$. long; blades oblanceolate-linear, acute and calloustipped, 5-7-nerved, entire or with scattered teeth: peduncles ascending to erect, very stout, terete, much surpassing the leaves, $12-40 \mathrm{~cm}$. high : spikes coarse, long-cylindric, 3-10 cm. long, 5-8 mm. thick, dense : flowers perfect : bracts lanceolate to ovate-lanceolate, slightly surpassing the calyx-lobes, scarious-margined : calyx-lobes more or less villous, spatulate-oblong, rounded or retuse, about $3 \mathrm{~mm}$. long, scarious-margined : corolla glabrous; lobes reflexed, broad-ovate, cordate, $2.5-3 \mathrm{~mm}$. long, obtuse, dark at the base : capsules broadly oblong, $4 \mathrm{~mm}$. long, rounded, surpassing the calyx-lobes : seeds 2 , about $3 \mathrm{~mm}$. long, brown.

In dry soil, Texas and adjacent Mexico. Spring and summer.

9. Plantago Hélleri Small. Annual, deep green, villous. Leaves basal, erect or ascending, rather numerous; blades linear, slightly broadened upward, to linear-spatulate, 2-14 cm. long, acute, 3-ribbed, entire and callous-tipped, glabrate in age, except near the base : scapes solitary or several together, erect or ascending, usually surpassing the leaves, villous : spikes oblong-cylindrical, 1-2 cm. long, 7-12 mm. thick, conspicuous on account of the corolla-lobes: bracts linear-subulate, surpassing the calyx-lobes : flowers perfect: 
calyx-lobes $4 \mathrm{~mm}$. long, silky, broadly oblong or oval, about $4.5 \mathrm{~mm}$. long, the scarious margins much broader than the green midrib: corolla glabrous ; tube often barely as long as the calyx ; lobes orbicular-ovate or suborbicular, about $4 \mathrm{~mm}$. long, spreading, as long as the tube: capsules oblong, 4-5 mm. long, circumscissile below the middle: seeds 2, about $4 \mathrm{~mm}$. long, brown.

In dry soil, Texas. Spring and summer.

10. Plantago Púrshii R. \& S. Annual, light green, white-woolly throughout. Leaves basal, 5-20 cm. long; blades linear, acute or acuminate, 1-3-nerved, entire or rarely remotely toothed, narrowed into margined petioles: scapes erect, solitary or several together, $5-40 \mathrm{~cm}$. tall, surpassing the leaves : spikes dense, $2-15 \mathrm{~cm}$. long, very woolly : bracts rigid, about as long as the flowers or slightly longer, linear-subulate, acute, sometimes elongated or conspicuous : flowers perfect: calyx-lobes oblong, 2-3 mm. long, obtuse, scarious-margined : corolla glabrous; lobes ovate, spreading: capsules oblong, nearly 3-4 mm. long, slightly surpassing the calyx-lobes, circumscissile at the middle : seeds $2,1.5-2 \mathrm{~mm}$. long, light brown.

On dry plains or prairies, Ontario to British Columbia, Texas and Mexico. Spring and summer.

11. Plantago verticillàta Morris. Annual, light green, lax, pubescent. Leaves basal or nearly so, $8-12 \mathrm{~cm}$. long; blades ascending, linear, acuminate, entire, narrowed into long-margined petioles, $3(-5)$-nerved : scapes ascending, several, $10-60 \mathrm{~cm}$. long, lax yet somewhat surpassing the leaves: spikes slender, with internodes 4-10 mm. long, ascending, long-interrupted, cylindrical, $3-7 \mathrm{~cm}$. long, pubescent : bracts slender, herbaceous, spreading, filiform-subulate, $6-14 \mathrm{~mm}$. long, three to five times as long as the flowers: flowers perfect : calyx-lobes spatulate-oblong, $2 \mathrm{~mm}$. long, rounded, with scarious margins : corolla glabrous; lohes narrowly ovate, $1.5 \mathrm{~mm}$. long, obtuse, reflexed : capsules lanceolate-oblong, about $1.5 \mathrm{~mm}$. long, circumscissile at the lower third: seeds two, dark brown.

On dry hills, southern Texas. Spring.

12. Plantago spinulòsa Decne. Annual, pale green, pubescent. Leaves basal, 5-12 cm. long; blades linear to spatulate-linear, acuminate and callous-tipped, entire, narrowed into margined petioles, 3-nerved : spikes erect, $5-10 \mathrm{~cm}$. high, villous : spikes rather interrupted, erect, 3-7 $\mathrm{cm}$. long, villous: bracts linear-subulate, 7-17 mm. long, spreading, two to five times as long as the flowers: flowers perfect: calyx-lobes spatulate-oblong, $2.5 \mathrm{~mm}$. long, obtuse, scarious, with green midribs : corolla glabrous ; lobes ovate, $2.5 \mathrm{~mm}$. long, obtuse, cordate: capsules equalling the calyx-lobes, oval, $2.5 \mathrm{~mm}$. long, obtuse, circumscissile at the middle: seeds 2 , dark brown.

On high prairies and foothills, Assiniboia to Texas. Spring and summer.

13. Plantago aristàta Michx. Annual, deep-green, glabrate to villous. Leaves nearly basal, $5-25 \mathrm{~cm}$. long: blades linear, acuminate, entire and callous-tipped, narrowed into margined petioles, 3-5-nerved: scapes erect, solitary or several together, 10-50 cm. tall, rigid, surpassing the leaves : spikes dense, $2-15 \mathrm{~cm}$. long, more or less pubescent but not woolly : bracts linear, puberulent, $1-3 \mathrm{~cm}$. long, surpassing the flowers by many times their length : flowers perfect: calyx-lobes spatulate-oblong or cuneate, $2-2.5 \mathrm{~mm}$. long, obtuse, the outer herbaceous, the inner widely scarious-margined : corolla glabrous; lobes ovate or orbicular-ovate, $2 \mathrm{~mm}$. long, obtuse, cordate: capsules slightly narrowed upward, $2.5-3 \mathrm{~mm}$. long, slightly surpassing the calyx-lobes, circumscissile at the middle : seeds 2 , 2-3 mm. long, dark brown.

In dry soil, Maine to British Columbia and Alaska, south to Florida and New Mexico. Natural ized in eastern North America. Spring to fall.

14. Plantago lanceolàta L. Biennial or perennial, very variable, pubescent. Leaves basal, often numerous, $4-30 \mathrm{~cm}$. long; blades linear-elliptic to broadly elliptic, acute and callous-tipped at the apex or acuminate at both ends, 3-7-nerved, entire or denticulate, narrowed into margined petioles; which are dilated and hairy at the base: scapes erect or nearly so, 1-7 dm. tall, ridged : spikes cylindric, dense, 1-8 cm. long, 6-8 mm. thick : bracts rhombic, $4-5 \mathrm{~mm}$. long, the tip bent : flowers perfect : calyx-lobes $2-3 \mathrm{~mm}$. long, broadly oblong to oval, obtuse, the 2 lower ones usually united, their midribs closely subparallel : corolla glabrous; lobes broadly lanceolate, $2-2.5 \mathrm{~mm}$. long : capsules oblong, $3 \mathrm{~mm}$. long, slightly longer than the calyx-lobes, circumscissile at about the middle: seeds 2 , fully $2 \mathrm{~mm}$. long.

In fields and waste places, New Brunswick to the Northwest Territory and Alaska, south to Florida and Kansas. Naturalized from Europe and Asia. Spring to fall. RIB-GRAss.

15. Plantago sparsiflòra Michx. Perennial, pubescent, or glabrate in age. Leaves basal, $8-30 \mathrm{~cm}$. long; petioles shorter than the blades, margined; blades lanceolate to very narrowly elliptic-lanceolate, acute or acuminate, $5(-7)$-nerved, entire or indistinctly denticulate : scapes erect, $2-7 \mathrm{dm}$. tall, slender, simple : spikes slender, sometimes $3.8 \mathrm{dm}$. 
long, glabrous or nearly so, loosely-flowered: bracts ovate, very much shorter than the calyx-lobes : flowers perfect : calyx-lobes orbicular to obovate, about $2 \mathrm{~mm}$. long, rounded, each with a green midrib and scarious margins : corolla with tube slightly surpassing the calyx, glabrous; lobes reflexed : capsules oblong-cylindric, $3-4 \mathrm{~mm}$. long, nearly twice as long as the calyx-lobes, circumscissile at the lower third: seeds 2 , fully $2 \mathrm{~mm}$. long.

In low pine lands, North Carolina to Florida. Spring to fall.

16. Plantago Rugélii Decne. Perennial, bright green, glabrous or minutely pubescent. Leaves basal, $5-40 \mathrm{~cm}$. long; petioles flattened or channeled on the upper side, usually purple at the base; blades broadly ovate to oblong, longer than the petioles or sometimes shorter, 5-7-nerved, entire or shallowly toothed, cuneately or abruptly narrowed at the base : scapes erect or ascending, solitary or several together, often surpassing the leaves, 10-50 $\mathrm{cm}$. tall : spikes $2-30 \mathrm{~cm}$. long, sometimes broadly bracted near the base : bracts fully one half as long as the calyx-lobes, acute: flowers perfect: sepals oblong, acute, $2-2.5 \mathrm{~mm}$. long, keeled, often scarious-margined : corolla glabrous; tubes slightly surpassing the calyx ; lobes spreading: capsules conic or oblong-conic, 4-4.5 mm. long, circumscissile below the middle : seeds $4-9,1.5-2 \mathrm{~mm}$. long.

In woods and waste places, Maine to Ontario, North Dakota, Florida and Texas, and introduced farther west. Spring to fall.

17. Plantago màjor L. Perennial, glabrous or sparingly pubescent. Leaves basal, $5-35 \mathrm{~cm}$. long; petioles flattened or channeled on the upper surface, usually green at the base; blades ovate or oval, or rarely oblong, obtuse or acutish, 5-7-nerved, entire or coarsely toothed, rounded or cordate at the base, longer than the petioles or shorter : scapes erect, solitary or several together, surpassing the leaves, $8-40 \mathrm{~cm}$. tall, rarely with several leaves under the spike, sometimes branched: spikes 4-20 $\mathrm{cm}$. long, dense : bracts ovate, barely equalling the calyx-lobes : flowers perfect : calyx-lobes ovate to obovate, obtuse, not keeled, scarious-margined : corolla inconspicuous; tube about as long as the calyx ; lobes spreading or reflexed : capsules ovoid, ahout $3 \mathrm{~mm}$. long, slightly surpassing the calyxlobes, circumscissile at the middle : seeds $6-18,0.7 \mathrm{~mm}$. long.

In waste places. throughout North America, except the extreme north. Chiefly naturalized eastward from Europe. Spring to fall.

18. Plantago cordàta Lam. Perennial, deep green, glabrous. Leaves basal, 1-4.5 $\mathrm{dm}$. long; petioles flattened, stout; blades ovate to suborbicular, $5-30 \mathrm{~cm}$. long, acute or obtuse, 7-9-nerved, these confluent with the midrib below the middle of blade, entire or shallowly toothed, rounded or cordate at the base.: scapes erect, solitary or several together, surpassing the leaves, $15-50 \mathrm{~cm}$. tall : spikes loosely-flowered, sometimes interrupted: bracts orbicular-ovate or reniform, $1.5-3 \mathrm{~mm}$. long: calyx-lobes ovate to suborbicular, 2.5-3 mm. long, obtuse or acutish : corolla surpassing the calyx ; lobes ovate or orbicularovate, spreading or reflexed in age : capsules globose-ovoid, 4-5 mm. long, circumscissile at the middle or slightly below it : seeds $1-4,3.5-4 \mathrm{~mm}$. long.

In swamps and on wet banks, New York to Missouri, Alabama and Louisiana. Spring and summer.

\section{Order 9. SANTALÀLES.}

Herbs, shrubs or trees, commonly parasitic on trees or on the roots of other plants. Leaves with expanded blades or often reduced to scales. Flowers perfect or imperfect, inconspicuous, variously disposed. Calyx present, often a mere border. Corolla present or wanting. Androecium mostly of as many stamens as there are petals or sepals, or twice as many. Gynoecium compound, more or less inferior. Fruit a drupe, a nut or a berry. Endosperm usually present, fleshy.

Stamens as many as the petals or sepals : ovules not freely pendulous from an erect placenta.

Leaves opposite : fruit a berry : tree-parasites.

Leaves mainly alternate: fruit a drupe or a nut : root-parasites.

Stamens twice as many as the petals, except in Schoepfia: ovules freely pendulous from the erect placenta.

Fam. 1. Loranthacear. Fam. 2. SANTAlaCeaE.

Fam. 3. Olacaceae.

\section{Family 1. LORANThàceate D. Don. Mistletoe Family.}

Green parasitic shrubs or herbs, with chlorophyll-bearing tissues, growing mostly on woody plants from whose sap they take food through specialized roots called haustoria. Leaves mostly opposite, sometimes reduced to scales. Flowers regular, solitary or variously disposed, monoecious or dioecious. Calyx often sessile, truncate or lobed. Corolla of 2-6 more or less united petals. Androecium of 2-6 stamens. Anthers 2-celled or confluently 1-celled. Gynoe- 
cium a single compound pistil. Ovary 1-celled. Stigma blunt, sometimes sessile. Ovule usually solitary and suspended. Fruit a berry. Seed solitary, with the testa and the copious endosperm indistinguishable. Embryo terete or angled.

\section{PHORADÉNDRON Nutt.}

Shrubs, parasitic on trees, with jointed terete angled or flattened stems. Leaves opposite: blades leathery, flat, sometimes reduced to scales. Spikes axillary or terminal, solitary or several together, each joint furnished with a bract. Flowers very small, mostly dioecious : staminate with a 3 -lobed or rarely a $2-5$-lobed calyx, one stamen inserted at the base of each petal : anthers 2-celled, broad, opening lengthwise. Pistillate flowers with a corolla like that of the staminate, and an inferior ovary adnate to the hypanthium: style very short, thick: stigma obtuse. Berry subglobose, sessile, often crowned with the persistent sepals, with a pale watery pulp. Seed solitary. Mistletoe.

1. Phoradendron flavéscens (Pursh) Nutt. A bright green or yellowish parasitic shrub growing in bunches on the limbs of deciduous-leaved trees. Stems 3-9 dm. long, often densely branched: leaves opposite; blades leathery, spatulate or oblong-spatulate or sometimes oblong, $2.5-5 \mathrm{~cm}$. long, obtuse at the apex, entire, usually cuneately narrowed at the base, obscurely 3-5-nerved, short-petioled : petals obtuse, somewhat hooded: berry subglobose, 4-5 mm. in diameter, white, the pulp glutinous : seeds oblong, flattened.

On various deciduous-leaved trees, New Jersey to Missouri, Florida and Texas. Spring.

\section{Family 2. SANTALACEAE R. Br. SANdalwood Family.}

Herbs, shrubs or trees, parasitic on the roots of other plants. Leaves opposite or alternate: blades entire: stipules wanting. Flowers perfect, monoecious or dioecious, solitary or clustered. Calyx of 3-6 valvate sepals. Corolla wanting. Androecium of as many stamens as there are sepals, and inserted at their bases or opposite them at the edge of a disk. Filaments distinct. Anthers opening lengthwise. Gynoecium a single compound pistil. Ovary 1-celled, sessile. Style cylindric or conic, sometimes wanting. Stigma capitate or lobed. Ovules 2-4, pendulous from the top of the central placenta. Fruit a drupe or nut. Seed solitary, nearly as thick as long. Testa wanting. Endosperm copious, fleshy. Embryo apical.

Herbaceous perennials : flowers perfect.

Shrubs: flowers dioecious or polygamous.

Staminate flowers in umbels: leaves opposite or nearly so.

Anthers connected with the sepals by a tuft of hairs.

Anthers not connected with the sepals.

Staminate flowers in racemes: leaves alternate.

1. Comandra.

2. NE⿱tRoNiA.

3. BUCKLEYA.

4. PYrUlaria.

\section{COMÁNDRA Nutt.}

Glabrous herbs, perennial by elongated rootstocks, parasitic on the roots of other plants. Stems erect, solitary or clustered. Leaves alternate: blades entire, narrow. Flowers perfect, greenish white, in axillary or terminal peduncled cymes. Calyx of 4-5 valvate sepals. Stamens 5 or rarely 4 , inserted at the base of the sepals : filaments distinct, alternating with the lobes of the disk : anthers attached to the calyx-lobes by a tuft of hairs. Ovary inferior, 1-celled : style elongated : stigma capitate. Ovules 2-4, pendulous from the end of the placenta. Drupe subglobose, with a thin somewhat fleshy pulp, and a crustaceous stone, crowned with the persistent calyx. Seed subglobose. Bastard Toad-FLAx.

1. Comandra umbellàta (L.) Nutt. Foliage bright green. Stens erect, solitary or clustered, leafy, angled, simple or branched : leaf-blades oblong, oval or oblong-lanceolate, 1-3.5 cm. long, obtuse or acute at the apex, entire, sessile, glabrous or minutely pubescent beneath : corymbs $1-3 \mathrm{~cm}$. broad : peduncles slender, glaucescent : calyx shortpedicelled, greenish, about $5 \mathrm{~mm}$. broad; tube deep green, turbinate; segments light green, oblong-ovate, $1.5-2 \mathrm{~mm}$. long, acute : stamens included : drupe subglobose, almost $5 \mathrm{~mm}$. in diameter, slightly ribbed, crowned with the persistent calyx-limb and with it forming an urn-shaped fruit. Spring.

In thickets and on sandy banks, Cape Breton Island to British Columbia, Georgia and California. 


\section{NESTRÒNIA Raf.}

Low shrubs parasitic on the roots of other plants, with bright green foliage and a smooth shining bark. Stems terete, branched. Leaves opposite : blades thickish, entire, short-petioled. Flowers polygamo-dioecious, greenish : staminate in axillary peduncled umbels : pistillate solitary in the axils. Calyx of 4-5 valvate or slightly imbricated sepals. Hypanthium turbinate, adnate to the ovary. Stamens 4-5, inserted at the base of the sepals, alternating with the lobes of the disk: filaments short. Ovary inferior, 1-celled: style stout, simple: stigma 3-4-lobed. Drupe nearly as thick as long, pedicelled. Seed solitary. [Darbya A. Gray.]

1. Nestronia umbéllula Raf. A low branching shrub, 3-10 dm. tall, with glabrous foliage. Leaves opposite or nearly so: blades membranous, oval varying to ovate or obovate, $2-7 \mathrm{~cm}$. long, obtuse or acute, or rarely acuminate at both ends, entire, undulate, bright green above, pale beneath, short-petioled: staminate flowers 3-9 in axillary umbels : peduncles $1-3 \mathrm{~cm}$. long: hypanthium top-shaped : calyx glaucescent, short-pedicelled : sepals oblong-ovate, $2 \mathrm{~mm}$. long, about equalling the hypanthium, obtuse: stamens shorter than the sepals: pistillate flowers solitary in the axils : pedicels $2-3 \mathrm{~mm}$. long: sepals ovate: drupe oval or oblong-oval, 10-13 mm. long, glaucous.

In woods and along streams, Virginia to Georgia and Alabama. Spring.

\section{BUCKLEỲA Torr.}

Slender upright shrubs, with 2-ranked branches and leaves. Leaves opposite or nearly so: blades narrow, membranous, entire. Flowers small, greenish, dioecious : staminate in terminal umbels; hypanthium club-shaped, slender; sepals 5, ovate or oval ; stamens 4, shorter than the sepals ; filaments filiform; anthers 2-celled, opening lengthwise. Pistillate flowers terminating branchlets, solitary: hypanthium thick, clavate: sepals narrow, rather persistent: disk 4-lobed: ovary 1-celled, adnate to the hypanthium: style slender : stigma 4-lobed. Ovules pendulous. Drupe solitary, slightly flattened, furrowed. Seed shaped like the drupe.

1. Buckleya distichophýlla (Nutt.) Torr. A shrub 2-4 m. tall, the pubescent branches 2-ranked. Leaves opposite or nearly so ; blades lanceolate or ovate-lanceolate, 2-7 cm. long, acuminate at both ends or acute at the base, entire, ciliate, undulate, 2ranked, sessile : staminate flowers in terminal umbels: peduncles $2-4 \mathrm{~mm}$. long: sepals 4 , ovate, $1.5-2 \mathrm{~cm}$. long, obtuse, ciliate : stamens 4 , shorter than the sepals : pistillate flowers solitary, terminal, minutely pubescent without: hypanthium club-shaped : sepals linear or linear-lanceolate, acuminate, spreading or reflexed: drupe oval or oblong-oval, 2-2.5 cm. long, yellowish green.

On river banks, North Carolina and Tennessee. Spring and summer.

\section{PYRULÀria Michx.}

Shrubs or trees, with more or less pubescent foliage. Stems with spreading brancher. Leaves alternate, deciduous: blades thickish, short-petioled. Flowers dioecious or polygamous, green, in terminal recemes, the staminate with a campanulate hypanthium, 3-5 sepals and 3-5 stamens inserted at the base of the calyx, alternating with as many scalelike lobes of the disk. Pistillate and perfect flowers with a turbinate hypanthium, and 3-5 sepals : style stout: stigma depressed-capitate. Drupe pyriform, drooping, with a thin exocarp. Stone thin. Seed subglobose. Endosperm very oily.

1. Pyrularia pùbera Michx. A branching shrub 1-3 m. tall, with finely puhescent foliage. Leaves alternate; blades thickish, oblong or elliptic, or commonly broadest above the middle, acute or acuminate at both ends, 4-15 $\mathrm{cm}$. long, entire, undulate, shortpetioled : racemes sometimes densely pubescent, short-peduncled : calyx greenish, broadly campanulate, about 4-5 mm. long, minutely pubescent : sepals ovate, recurved, about as long as the tube, acutish : stamens included : drupe globose-obovoid or subglobose, 1.5-2 cm. in diameter, yellowish, contracted into a long base. [P. oleifera (Muhl.) A. Gray.]

In woods, Pennsylvania to middle Georgia and Alabama. Spring. Oil-Nut. Buffalo-Nut.

\section{Family 3. Olacàceae Lindl. Ximenia Family.}

Shrubs or trees, or rarely shrubby herbs, with erect or twining stems. Leaves usually alternate: blades entire or rarely toothed: stipules wanting. 
Flowers perfect or polygamous, regular, in axillary cymes or racemes, which are sometimes contracted in heads. Hypanthium present. Calyx of 4-6-sepals or a mere border. Disk sometimes cup-shaped and free, or adnate to the ovary or calyx, sometimes annular, scale-like, or obsolete. Corolla of 4-6 petals, distinct or united into a more or less tubular corolla, inserted on the disk or receptacle, the lobes valvate. Androecium of 4-12 stamens inserted with the petals or adnate to the corolla-tube : filaments distinct or rarely united : anthers introrse. Gynoecium a single compound pistil. Ovary free or immersed in the disk, or partially inferior, 1-4-celled, the divisions often incomplete. Styles mostly united. Stigma entire or 3-4-lobed. Ovules anatropous. Fruit a drupe, naked or nearly enclosed in the accrescent disk. Seed with a membranous testa. Endosperm fleshy or rarely wanting. Embryo straight.

Petals united to above the middle: stamens as many as the corolla-lobes and opposite them: drupe nearly enclosed in the disk,

Petals nearly distinct: stamens twice as many as the petals : drupe naked.

1. SCHOEPFIA.

\section{SCHOҢ̈PFIA Schreb.}

Unarmed glabrous tropical shrubs or small trees, commonly with brittle wood. Leaves alternate: blades leathery, entire, often lustrous above. Flowers perfect, in solitary or clustered short-peduncled axillary cymes. Hypanthium short, cup-shaped, filled with a large hypogynous disk which is adnate to the ovary. Petals united to above the middle, varying from white to red : lobes $4-6$, valvate, recurved. Stamens as many as the corollalobes, adnate up to their bases: anthers sessile or terminating short filaments. Ovary 3-celled, mostly immersed in the disk: stigma 3-lobed. Ovule 1 in each cavity. Drupe enclosed to near the apex in the adnate accrescent disk : stone crustaceous or parchmentlike.

1. Schoepfia Schrèberi J. F. Gmel. An unarmed glabrous shrub or tree, several m. tall, with pale brittle branches. Leaf-blades ovate or oblong-ovate, leathery, $2-6 \mathrm{~cm}$. long, acute or obtusish, entire, acute or abruptly constricted at the base, on short winged petioles: peduncles usually 2-3-flowered, solitary or clustered: flowers red or reddish : hypanthium eup-like, $2 \mathrm{~mm}$. broad : disk hemispheric, slightly dilated at the entire rim : corolla leathery, tubular-campanulate, 4-ribbed, about $4 \mathrm{~mm}$. long, glabrous within and without, the 4 ovate lobes curled back, acute : drupe ovoid or oval-ovoid, 10-12 mm. long.

In coral rock or sand, peninsular Florida and the Keys.

\section{XIMÈNIA L.}

Tropical usually thorny shrubs or trees, with glabrous or pubescent foliage. Leaves alternate, often clustered: blades entire. Flowers perfect, solitary in the axils or in axillary cymes. Calyx small. Petals 4-5, valvate, white or yellow, nearly distinct, leathery, pubescent within. Stamens 8-10, shorter than the petals: filament filiform, erect : anthers linear, opening lengthwise. Ovary 3-4-celled : styles united : stigma capitate. Ovules 3-4 in each cavity. Drupe pulpy, crustaceous with a woody stone.

1. Ximenia Americàna L. A glabrous thorny shrub or small tree 4-6 $\mathrm{m}$. tall. Leaf-blades firm, oblong or elliptic, sometimes broadest above or below the middle, 3-7 $\mathrm{cm}$. long, obtuse or notched at the apex, entire, acute or rounded at the base, commonly clustered in 3 's ; petioles 5-10 mm. long: peduncles about as long as the petioles, 2-4flowered: flowers yellowish: sepals 4, triangular, acutish : petals 4, leathery, linear, 1 $\mathrm{cm}$. long, densely pubescent with bristly rusty hairs within, glabrous without, the tips curled back, minutely caudate: stamens shorter than the petals : filaments filiform, shorter than the anthers: drupe subglobose or broadly oval, 14-17 mm. in diameter, yellow : stone white.

In coral rock or sand, peninsular Florida and the Keys. Circumtropical.

\section{Order 10. RUBIÀLES.}

Herbs, shrubs or trees. Leaves opposite, sometimes whorled : blades mainly entire. Flowers perfect, or rarely polygamous, solitary or in variously modified cymes. Hypanthium well developed. Sepals $3-6$ or rarely 10 , sometimes very small. Corolla of 3-6 or rarely 10 partially united petals. Androecium of as 
many stamens as corolla-lobes or twice as many, or rarely fewer. Anthers separate. Gynoecium of several united carpels. Ovary 1-10-celled. Styles united. Ovules 1-many in each cavity of the ovary. Fruit a capsule, a berry or a drupe.

Leaves with stipules adnate to the stems between the leaf-bases.

Leaves without stipules, or if present these adnate to the petiole.
Fam. 1. RUBIACEAE.

Fam. 2. CAPrifoliaceae.

\section{Family 1. RUbiàceae B. Juss. Madder Family.}

Herbs, shrubs or trees of great economic importance, with terete, or often 4 -angled branches and swollen nodes. Leaves opposite or whorled : stipules usually interpetiolar : blades simple. Inflorescence cymose, often paniculate or capitate. Flowers perfect or polygamous, regular or nearly so, almost symmetrical. Hypanthium various, adnate to the ovary. Calyx a truncate limb or of several deciduous or persistent sepals. Corolla regular, inserted near the top of the hypanthium, of $3-6$, or rarely 10 , more or less united petals. Androecium of as many stamens as there are lobes of the corolla and alternate with them, adnate to the tube, often to near the throat. Filaments sometimes elongated, distinct or united. Anthers introse, erect or incumbent. Gynoecium a single compound pistil. Ovary more or less adnate to the hypanthium, 2-5celled. Styles united. Stigmas 2-many. Ovules sometimes solitary and erect, sometimes numerous, anatropous or amphitropous, ascending, horizontal or pendulous. Fruit a capsule, drupe or berry. Seeds often flattened on one side, with a smooth or rough testa. Endosperm fleshy, cartilaginous or horny, or sometimes nearly wanting. Embryo straight or curved either in the axis of the endosperm or near the back.

Cavities of the ovary with several or many ovules : seeds several or many.

Fruit dry.

Seeds wingless.

Ovules very numerous: shrubs or trees.

Ovules several: herbs, sometimes woody at the base.

Sepals and corolla-lobes 4 .

Top of the capsule not extending beyond the hypanthium.

Top of the capsule extending beyond the hypanthium.

Sepals and corolla-lobes 5 . Seeds winged.

Fruit pulpy.

Fruit 2-celled.

Flowers in cymes.

Flowers solitary.

Corolla-lobes 5 , convolute.

Corolla-lobes 4 , valvate.

Fruit 5-celled.

Cavities of the ovary with a single ovule each: seed solitary.

Flowers in dense heads.

Flowers solitary or in an open inflorescence.

Ovule pendulous.

Filaments wholly or partly adnate to the corolla-tube.

Filaments not adnate to the corolla-tube.

Inflorescence terminal.

Inflorescence axillary.

Ovule not pendulous.

Corolla-lobes imbricated.

Corolla-lobes valvate.

Ovule or seed with a basal attachment.

Flowers not patred, the ovaries distinct.

Flowers paired, the ovaries united.

Ovule or seed with a lateral attachment.

Shrubs or trees.

Herbs.

Stipules relatively small or inconspicuous, more or less cleft.

Ovary 3- or 4-celled.

Ovary 2-celled.

Fruit drupaceous, the carpels neither dehiscent nor separating.

Fruit not drupaceous, the carpels dehiscent or separating.

Mature carpels merely separating from each other. Carpel-walls very thin at maturity, the seed not free. Carpel-walls firm at maturity, the seed free.

Mature carpels dehiscent.

Fruit septicidal, and both carpels ventrally dehiscent. Fruit separating into carpels, one of which opens through the ventral face, the other remaining

Stipules foliaceous, usually resembling the leaves.

1. Pinckneya.

2. Oldeniandia.

3. Houstonia.

4. Pentodon.

5. Exostema.

6. GENIPA.

7. RANDIA.

8. CATESBAEA.

9. Hamelia.

10. Cephalanthus.

11. Guettardia.

12. Erithalis.

13. CHIOCOCCA.

14. Strumpfia.

15. Psychotria.

16. Mitchelia.

17. MORINDA.

18. Richardia.

19. ERNODEA.

20. Crusea.

21. Diodia.

22. BORRERIA.

23. SPERMACOJE

24. GALIUM. 


\section{PINCKNEYA Michx.}

Shrubs or small trees, with terete branches. Leaves opposite : blades entire : stipules narrow, caducous. Flowers showy, perfect, in terminal or axillary corymbose cymes. Hypanthium dilated upward. Sepals 5, one or two of them, at least in the outer flowers, transformed into pinkish leaf-like members. Corolla greenish, mottled with brown or purple: tube slightly dilated at the throat, pubescent within : lobes 5, obtuse, valvate, pubescent within. Stamens 5, adnate to the base of the corolla-tube. Disk annular. Ovary 2-celled. Styles somewhat club-shaped, 2-lobed at the apex. Ovules numerous in each cavity, horizontal. Capsule subglobose, 2-celled, opening loculicidally by 2 longitudinal valves, each valve septicidally splitting to the middle. Seeds numerous, minute, flattened, in 2 rows. Testa loosely reticulated. Endosperm fleshy. Embryo elongated.

1. Pinckneya pùbens Michx. A shrub or small tree sometimes $6 \mathrm{~m}$. tall, the foliage more or less densely tomentulose when young. Leaf-blades oblong, ovate or oval, 5-20 $\mathrm{cm}$. long, acute or abruptly acuminate, acute or truncate at the base : petioles $1-2 \mathrm{~cm}$. long: enlarged sepals similar to the leaves, but smaller and light pink: sepals linear to narrowly linear-lanceolate, $1-1.5 \mathrm{~cm}$. long, tomentulose, acute : corolla greenish, mottled with brown or purple; tube 1.5-2 cm. long; lobes linear or broadened upward, as long as the tube or shorter: capsules subglobose, nearly $2 \mathrm{~cm}$. in diameter.

In pine-Jand swamps or hammocks, South Carolina to Florida. Spring and summer.

\section{OLDENLÁNDIA L.}

Annual or perennial herbs or shrubby plants, with erect or diffusely forked stems. Leaves opposite: blades usually narrow with narrow stipules. Flowers in terminal or axillary panicles. Hypanthium turbinate or subglobose. Sepals 4. Corollas white or pink, varying from rotate to funnelform: tube usually glabrous in the throat: limb with 4 , or rarely 5 , valvate lobes. Stamens 4 , or rarely $5:$ filaments adnate up to the throat of the corolla-tube. Ovary 2-celled: styles united below, slender. Ovules usually several in each cavity. Capsule membranous, terete or angled, variable in shape, not extending beyond the hypanthium, opening loculicidally. Seeds often angled. Testa smooth or granular. Endosperm fleshy. Embryo clavate.

Annual plants : sepals acute, ciliate.

Stems hirsute: leaf-blades short-petioled.

Stems glabrous : leaf-blades sessile.

Perennial plants : sepals acuminate, not ciliate.

1. O. uniflora.

2. O. fasciculata.

3. O. Bosciz.

1. Oldenlandia uniflòra L. Annual, pubescent. Stems erect or decumbent, simple or branched at the base, the branches $1-4 \mathrm{dm}$. long: leaf-blades ovate to oblong, $0.5-2.5$ $\mathrm{cm}$. long, acute : flowers solitary or clustered in the axils: sepals ovate or oblong-ovate, acute, about as long as the hypanthium or longer at maturity : capsules globular, 1-1.5 mm. in diameter.

In moist sandy soil, New York to Florida and Texas. Spring to fall.

2. Oldenlandia fasciculàta (Bertol.) Small. Annual, glabrous or nearly so. Stems erect or diffusely branched, somewhat lustrous : leaf-blades oblong to lanceolate or ovate-lanceolate, $0.5-2 \mathrm{~cm}$. long, acute or somewhat acuminate, sessile : clusters loosely $2-5$-flowered : sepals ovate to ovate-lanceolate : capsules $1.5-2 \mathrm{~mm}$. in diameter, included in the hypanthium. [Hedyotis fasciculata Bertol. O. littoralis C. Mohr.]

On sandy beaches, Florida to Mississippi. Summer and fall.

3. Oldenlandia Bóscii (DC.) Chapm. Perennial, glabrous. Stems commonly diffusely branched, 1-3 dm. long : leaf-blades linear or attenuate to the base, $1-2 \mathrm{~cm}$. longacute at the apex : clusters few-flowered, or flowers sometimes solitary : sepals triangularsubulate, shorter than the hypanthium : corolla-lobes triangular or ovate-triangular, acute : capsule sabout $2 \mathrm{~mm}$. in diameter.

In wet sandy soil, South Carolina and Arkansas to Florida and Texas. Spring to fall.

\section{HOUSTONIA L.}

Annual or perennial herbs, with creeping or upright stems. Leaves opposite: blades entire, often ciliate. Flowers perfect, often dimorphous, solitary, or in corymbose cymes. Hypanthium subglobose or obovoid. Sepals 4, separated. Corolla white, blue or purple, funnelform or salver-shaped: tube with a glabrous or pubescent throat: lobes 4, valvate. Stamens 4 : filaments adnate to the tube or throat of the corolla. Ovary sessile, 2-celled: 
styles united to the narrow stigmas. Ovules several in each cavity. Capsule partly inferior, the top extending beyond the hypanthium, more or less distinctly 2-lobed, loculicidal above. Seeds rounded, few or several in each cavity, peltate, with a reticulated or rough testa. Endosperm horny. Embryo clavate. Bluers.

Peduncles and pedicels solitary or nearly so, terminal or lateral.

Flowers and fruits on straight upright, elongated peduncles or pedicels.

Perennial by slender creeping rootstocks.

Plants erect: sepals lanceolate: corolla-tube glabrous within.

Plants diffusely spreading: sepals oblong: corolla-tube pubescent within.

Annual, sometimes winter annuals, with delicate roots.

Sepals much surpassed by the corolla-tube.

Sepals about equalling the corolla-tube.

Flowers on short horizontal peduncles or pedicels which are recurved in fruit. Annual plants.

Corolla salverform : plant erect.

Corolla funnelform: plant depressed-spreading.

Flowers peduncled : corolla $6 \mathrm{~mm}$. long.

Flowers sessile : corolla $3 \mathrm{~mm}$. long.

Perennial plants.

Peduncles and pedicels aggregated in effuse cymes.

Sepals fully as long as the hypanthium.

Sepals conspicuously surpassing the capsule.

Corolla less than twice as long as the sepals : sepals $4-8 \mathrm{~mm}$. long.

Corolla over twice as long as the sepals: sepals $2-3 \mathrm{~mm}$. long.

Sepals slightly surpassing the capsule.

Leaf-blades, especially those of basal leaves, conspicuously ciliate.

Leaf-blades perfectly glabrous, at least never ciliate.

Corolla 8-9 mm.long: mature hypanthium and calyx $3.5-4 \mathrm{~mm}$. long.

Corolla 4-5.5 mm. long: mature hypanthium and calyx $2.5-3 \mathrm{~mm}$. long.

Sepals shorter than the hypanthium.

Stems erect or ascending, sometimes diffusely branched at the base; the branches neither spreading nor prostrate.

Capsules much longer than broad, $2.5-3 \mathrm{~mm}$. long. Capsules over $2 \mathrm{~mm}$. thick : leaves of the branches linear.

Capsules less than $2 \mathrm{~mm}$. thick: leaves of the branches filiform.

Capsules fully as broad as long, $1-1.5 \mathrm{~mm}$. long.

1. H. caerulea.

2. H. serpyllifolia.

3. H. minor.

4. H. minima.

5. H. subviscosa.

6. H. humifusa.

7. H. Croftiae.

8. $H$. rotundifolia.

Stems branched at the base, the branches prostrate or spreading.

Sepals as long as the hypanthium, at least during anthesis: Floridian species.

Sepals shorter than the hypanthium, at least during anthesis: Texan species.

9. H. lanceolata.

10. H. purpurea.

11. H. ciliolata.

12. H. longifolia.

13. H. tenuifolia.

1. Houstonia caerùlea L. Perennial, glabrous. Stems erect, often tufted, $2-15 \mathrm{~cm}$. tall, branching, or sometimes simple: leaves mainly basal ; blades oval, ovate or spatulate, $2-5 \mathrm{~mm}$. long, as long as the petiole or longer, obtuse : peduncles slender, $2-7 \mathrm{~cm}$. long: hypanthium becoming $2 \mathrm{~mm}$. high: sepals lanceolate, longer than the hypanthium: corolla lilac, blue or white, with a yellow eye ; lobes oval, acute, 5-7 mm. long, as long as the tube or shorter : capsules broader than high, 3-4 mm. broad.

In meadows and on banks, Nova Scotia to Quebec and Michigan, Georgia and Alabama. Spring and early summer. INNOCENCE.

2. Houstonia serpyllifòlia Michx. Perennial, glabrous. Stems spreading and creeping, 3-30 $\mathrm{cm}$. long, more or less branched and matted: leaves numerous; blades ovate, oval or suborbicular, 1-6 mm. long, mostly obtuse, as long as the petioles or longer : peduncles nearly filiform, $2-8 \mathrm{~cm}$. long, simple or branched : hypanthium becoming $2 \mathrm{~mm}$. long: sepals oblong, sometimes narrowly oblong, longer than the hypanthium: corolla usually deep blue, 9-12 mm. broad; lobes oval, acute, as long as the tube or longer: capsules $3-3.5 \mathrm{~mm}$. broad.

On mountain tops and slopes, Virginia and West Virginia to Georgia. Spring and summer.

3. Houstonia mìnor (Michx.) Britton. Annual, nearly glabrous, or rarely puberulent. Stems erect, 1-10 $\mathrm{cm}$. tall, simple or branched: leaves mainly basal ; blades oval, elliptic or ovate, acute, $2-10 \mathrm{~mm}$. long, ciliate, usually acute; petioles as long as the blades or shorter : pedicels slender, often 1-3 cm. long: hypanthium becoming $1.5-2 \mathrm{~mm}$. high : sepals oblong or linear-oblong, longer than the hypanthium : corolla deep blue ; tube 3-4 $\mathrm{mm}$. long, about twice as long as the sepals; lobes oblong or oval, acute, 3-5 $\mathrm{mm}$. long: capsules 3-4 mm. broad, notched at the apex. [H. patens Ell.]

In dry sandy soil, Virginia and Arkansas to Florida and Texas. Spring.-An apparently depauperate state, with narrow leaf-blades, is H. minor pusilla (A. Gray) Small, [H. patens var. pusilla A. Gray]; it occurs in the Gulf States.

4. Houstonia mínima Beck. Annual, glabrous or rough-pubescent. Stems branched at the base, the branches diffuse, 1-10 cm. long, more or less forking: leaves mainly basal ; blades spatulate to obovate or ovate, $2-8 \mathrm{~mm}$. long, acute, ciliate ; petioles shorter than the blades : pedicels $1-1.5 \mathrm{~cm}$. long : hypanthium becoming $1-1.5 \mathrm{~mm}$. high : sepals oblong-lanceolate, much longer than the ovary : corolla lilac or bluish ; tube about as long 
as the sepals or slightly longer; lobes oblong or elliptic, as long as the tube or longer: capsules $3-4 \mathrm{~mm}$. broad.

On dry hillsides, Missouri to Arkansas and Texas. Spring.

5. Houstonia subviscòsa (C. Wright) A. Gray. Annual, finely glandular-pubescent. Stems simple or usually branched at the base, the branches erect or ascending, 5-15 $\mathrm{cm}$. long, commonly forking : leaf-blades narrowly linear or some of the basal ones linearspatulate, 1-3 cm. long, acute: peduncles from the first fork and at the succeeding nodes, shorter than the subtending leaves, spreading, or at maturity reflexed: hypanthium glandular, becoming $2 \mathrm{~mm}$. high : sepals linear, longer than the hypanthium : corolla white, about 2.5-3.5 mm. long: capsules didymous, $3-3.5 \mathrm{~mm}$. broad.

On plains or prairies, Texas. Spring and summer.

6. Houstonia humifùsa A. Gray. Annual, depressed, glandular-puberulent. Stems ruvch branched, the branches finally forking and forming dense tufts: leaf-blades linear or linear-spatulate, $0.5-2 \mathrm{~cm}$. long, cuspidate, somewhat fleshy : flowers peduncled : peduncles in all the forks and all the nodes, several $\mathrm{mm}$. long, finally recurved : hypanthium minutely glandular, flat, barely $1 \mathrm{~mm}$. long at maturity : sepals setaceous-subulate, several times longer than the hypanthium: corolla pale purple or whitish ; tube openfunnelform, about $6 \mathrm{~mm}$. long; lobes oblong, puberulent within : capsules didymous, plump, 2.5-3 mim. broad.

On sandy or gravelly hills, Texas. Spring.

7. Houstonia Cróftiae Britt. \& Rusby. Annual, depressed, very sparingly pubescent. Stems branched at the base, the branches spreading, 1-2.5 cm. long, simple or forking: leaf-blades spatulate-oblanceolate, $5-10 \mathrm{~mm}$. long, obtuse, revolute, tapering into short petioles: flowers sessile : hypanthium becoming about $1 \mathrm{~mm}$. high, flattish : sepals triangular or triangular-lanceolate, acute : corolla white, about $3 \mathrm{~mm}$. long; tube funnelform, thrice as long as the sepals ; lobes oblong-ovate or ovate-lanceolate : capsules didymous, $2 \mathrm{~mm}$. broad, pubescent.

In dry soil, Texas. Spring.

8. Houstonia rotundifòlia Michx. Perennial, hispidulous or glabrate. Stems prostrate, usually creeping, $5-40 \mathrm{~cm}$. long, more or less branched : leaf-blades somewhat fleshy, oval to suborbieular, 5-18 $\mathrm{mm}$. long, obtuse or acutish, ciliate, narrowed into short petioles : pedicels $5-11 \mathrm{~mm}$. long : hypanthium becoming $1-1.5 \mathrm{~mm}$. high : sepals oblong, obtuse: corolla white, about $1 \mathrm{~cm}$. long; tube slender; lobes oval to ovate, obtuse or acutish, shorter than the tube : cleistogamous flowers numerous, with well developed but closed corollas : capsules didymous, $3-4 \mathrm{~mm}$. broad.

In low sandy soil, South Carolina to Florida and Louisiana. Spring to fall.

9. Houstonía lanceolàta (Poir.) Britton. Perennial, sparingly rough-pubescent. Stems more or less densely tufted, erect or ascending, 1-3 dm. tall, commonly branching above, pubescent in the angles especially near the nodes: leaves thickish; basal with oblong or spatulate blades and ciliate petioles; cauline sessile, lanceolate to oblong-lanceolate, ciliate, acute: pedicels $3-10 \mathrm{~mm}$. long: hypanthium becoming $1.5-2 \mathrm{~mm}$. long: sepals linear, 4-8 mm. long, the tips becoming recurved : corolla lilac or bluish, about 6 $\mathrm{mm}$. long; lobes ovate or nearly so : capsules subglobose, $3-3.5 \mathrm{~mm}$. in diameter.

In woods, Illinois to Tennessee, Alabama and Arkansas. Spring.

10. Houstonia purpùrea L. Perennial, glabrous or somewhat pubescent. Stems tufted, $0.5-4 \mathrm{dm}$. tall, simple or sparingly branched : leaf-blades ovate to broadly lanceolate, or the lower ones oval, oblong or spatulate-ovate, obtuse or acute, ciliate, 1-6 $\mathrm{cm}$. long, the upper one sessile, the lower, or basal ones petioled : pedicels slender, 1-6 mm. long: hypanthium becoming $1.5-2 \mathrm{~mm}$. high : sepals subulate or linear-lanceolate, $2-3$ $\mathrm{mm}$. long, about as long as the hypanthium at maturity: corolla lilac, light purple or white, 6-7 mm. long; lobes ovate or oblong-lanceolate : capsules subglobose, obscurely didymous, 2-2.5 $\mathrm{mm}$. in diameter.

In moist or dry soil, especially on or near the mountains, Maryland to Kentucky, Arkansas, Georgia and Alabama. Spring to fall.

11. Houstonia ciliolàta Torr. Perennial, deep green. Stems usually tufted, erect or ascending, 0.5-2 dm. tall, mostly branched : leaves mainly basal, 1-3 cm. long; blades oblong or elliptic to spatulate, obtuse or acutish, ciliate, short-petioled or the cauline sessile: pedicels 1-5 mm. long: hypanthium usually sparingly pubescent, becoming $2 \mathrm{~mm}$. high : sepals oblong or oblong-lanceolate, $2-3 \mathrm{~mm}$. long, rather foliaceous : corolla blue, 7-9 mm. long; tube funnelform ; lobes oblong-lanceolate, about twice as long as the tube : capsules subglobose, nearly $3 \mathrm{~mm}$. Iong, about $\frac{1}{2}$ free.

In rocky soil or open woods, Maine to Ontario, Michigan, Pennsylvania and Arkansas. Spring and summer. 
12. Houstonia longifòlia Gaertn. Perennial, slender, puberulent or sometimes minutely hispid below. Stems usually tufted, erect or ascending, $2-4 \mathrm{dm}$. tall, simple or branched, 4-angled and often narrowly winged : leaf-blades linear or linear-oblong, 1-3 cm. long, acute or obtusish, slightly revolute, sessile, ciliolate, dark green above, pale beneath : hypanthium becoming $1.5-2 \mathrm{~mm}$. high : sepals linear-subulate, $2 \mathrm{~mm}$. long at maturity, acute : corolla $8-9 \mathrm{~mm}$. long, pinkish; tube funnelform, striped with lilac within; lobes ovate or ovate-lanceolate, acutish, $\frac{1}{2}$ as long as the tube: capsules subglobose, $2.5-3 \mathrm{~mm}$. high.

In rocky or sandy soil, Maine to Ontario, Manitoba, Georgia and Missouri. Spring to fall.

13. Houstonia tenuifòlia Nutt. Perennial, glabrous or nearly so. Stems tufted, diffusely branched, slender, often wiry : leaves $1-5 \mathrm{~cm}$. long; blades varying from ovate to spatulate at the base of the stem to narrowly linear or linear-filiform by the revolute margins above, acute: pedicels filiform, $5-10 \mathrm{~mm}$. long : hypanthium glabrate, becoming 1-1.5 $\mathrm{mm}$. high : sepals lanceolate, $1-1.5 \mathrm{~mm}$. long, slightly longer than the hypanthium : corolla pale blue or whitish, $4-5.5 \mathrm{~mm}$. long; lobes lanceolate or oblong-lanceolate: capsules subglobose, about $2 \mathrm{~mm}$. long.

In poor dry soil, Ohio to Virginia, Georgia and Alabama. Spring and summer.

14. Houstonia angustifòlia Michx. Perennial, glabrous or nearly so. Stems much branched at the base, the branches diffuse, 1-6 dm. long, stoutish : leaves numerous; blades narrowly linear or the lower ones linear-spatulate, 1-4 cm. long, commonly clustered : pedicels 1-4 mm. long: hypanthium turbinate at least during anthesis, becoming fully $2 \mathrm{~mm}$. high : sepals lanceolate, about as long as the hypanthium during anthesis : corolla rather salverform, 4-6 mm. long; lobes oblong or ovate-oblong, pubescent within : capsules oblong except the slightly contracted base, fully $2 \mathrm{~mm}$. thick.

In dry soil or on prairies, Illinois to Kansas, Florida and Texas. Spring and summer.

15. Houstonia ténuis Small. Perennial, glabrous or essentially so. Stems branched at the base, the branches spreading, $1-2.5 \mathrm{dm}$. long, slender or wiry : leaves rather numerous ; blades filiform or those of the lower leaves narrowly linear-filiform, 1-2 cm. long: pedicels filiform or capillary, 4-11 $\mathrm{mm}$. long: hypanthium turbinate, becoming $2 \mathrm{~mm}$. high : sepals lanceolate, as long as the hypanthium during anthesis : corolla $3-4 \mathrm{~mm}$. long ; tube very slender; lobes lanceolate: capsules oblong-turbinate, less than $2 \mathrm{~mm}$. thick.

In dry soil, Texas. Spring and summer.

16. Houstonia filifòlía (A. Gray) Small. Perennial, glabrous. Stems diffusely branched at the base, the branches wiry, 0.5-2 dm. long, commonly much branched : leafblades narrowly linear or subulate by the revolute margins, $0.5-1.5 \mathrm{~cm}$. long: pedicels 2-10 mm. long, capillary : hypanthium turbinate, becoming $1 \mathrm{~mm}$. high : sepals lanceolate, about as long as the hypanthium : corolla white or purplish, 4-5 $\mathrm{mm}$. long; tube slender, somewhat expanded at the top ; lobes oblong-lanceolate : capsules globose-obovoid, 1-1.5 mm. long. [H. angustifolia var. filifolia A. Gray.]

In sand, southern peninsular Florida and the Keys.

17. Houstonia pulvinàta Small. Perennial, glabrous, the foliage turning black in drying. Stems branched at the base, the branches $8-12 \mathrm{~cm}$. long, angled, densely tufted, forming cushion-like masses : leaves numerous ; blades linear, 1-1.5 cm. long, acute, revolute, more or less curved, sessile: peduncles $1 \mathrm{~cm}$. long or usually shorter: pedicels $1 \mathrm{~mm}$. long or usually shorter, or somewhat longer at maturity, the cymes thus relatively dense: bracts minute, acute: hypanthium broadly turbinate, becoming $1.5 \mathrm{~mm}$. long: sepals triangular-ovate, acute : corolla bluish, $3.5-4 \mathrm{~mm}$. long; tube gradually enlarged ; lobes oblong-ovate, about $1.5 \mathrm{~mm}$. long, obtuse, pubescent within: capsules obovoid, fully $2 \mathrm{~mm}$. long, slightly notched.

In sand, peninsular Florida. Summer.

18. Houstonia salina Heller. Perennial, glabrous. Stems branched at the base, the branches prostrate, 1-2 dm. long, branching, more or less strongly winged : leaf-blades rather leathery, oblong or linear-oblong, 1-2 cm. long, acutish, revolute, sometimes reflexed or curved : pedicels $1 \mathrm{~mm}$. long or wanting: hypanthium turbinate during anthesis, becoming $2.5 \mathrm{~mm}$. high : sepals triangular-ovate or ovate-lanceolate, shorter than the hypanthium : corolla white or pink, 3-4 mm. high, funnelform; lobes lanceolate or oblong-lanceolate, pubescent or glandular within, especially near the margins : capsules oblong-obovoid, 3-3.5 mm. long.

In sand on the coast, Texas. Spring.

\section{PÉNTODON Hochst.}

Annual caulescent herbs, with glabrous foliage. Leaves opposite : blades flat, entire; stipules entire, or 2-3-toothed, adnate to the petioles or leaf-bases. Flowers perfect, in 
axillary or terminal cymes. Hypanthium clavate or turbinate. Sepals 5, persistent. Corolla mostly white, broadly funnelform, pubescent at the throat: lobes 5 , obtuse, valvate. Stamens 5, adnate to the throat of the corolla. Ovary 2-celled: styles partially united. Ovules several in each cavity. Capsule slightly 2-lobed, membranous, included in the hypanthium, loculicidal. Seeds numerous, angled. Testa smooth. Endosperm fleshy.

1. Pentcdon Hàlei (T. \& G.) A. Gray. Plant tender, glabrous. Stems weak, branching and diffuse, decumbent, often creeping : leaf-blades oblong to oval or oblonglanceolate, $1-5 \mathrm{~cm}$. long, acute or abruptly acuminate, entire, narrowed into margined petioles : peduncles shorter than the leaves : hypanthium clavate, shorter than the pedicel, 4-6 mm. long at maturity : sepals triangular-lanceolate, shorter than the hypanthium: corolla about $2 \mathrm{~mm}$. long, surpassing the sepals, glabrous within : capsules $3-4 \mathrm{~mm}$. long.

In swampy grounds, Florida to Louisiana. Spring to fall.

\section{5. exostìma L. C. Rich.}

Shrubs or trees, with terete branches. Leaves opposite : stipules interpetiolar, entire or 2-cleft. Flowers perfect, solitary and axillary, or in terminal panicles. Hypanthium clavate, turbinate or obovate. Sepals 5, narrow. Corolla white, salverform: tube elongated : lobes 5, narrow, imbricated, 2 exterior. Stamens 5, adnate to the base of the corolla-tube. Disk annular. Ovary 2-celled: styles united, filiform : stigma entire or 2lobed. Oviules numerous in each cavity, ascending. Capsule elongated, 2-celled, opening by 2 septicidal entire or 2 -parted valves. Seeds numerous in each cavity. Testa membranous, produced into wings. Endosperm fleshy.

1. Exostema Caribaèum (Jacq.) R. \& S. A shrub or small tree, 2-8 m. tall, the foliage glabrous. Leaf-blades oblong to elliptic, $2-6 \mathrm{~cm}$. long, acute or acuminate at both ends, entire, of ten slightly undulate; petioles $5-10 \mathrm{~mm}$. Iong: pedicels shorter than the petioles : hypanthium 4-7 $\mathrm{mm}$. long during anthesis : sepals triangular or triangular-subulate, shorter than the hypanthium : corolla white or rose-tinged; tube $3.5-4 \mathrm{~cm}$. long; lobes narrowly linear, shorter than the tube : filaments exserted : capsules 10-12 mm. long, elliptic: seeds about $3 \mathrm{~mm}$. long, winged.

In sand, Keys of Florida. Also in the West Indies and Mexico.

\section{GÉNIPA L.}

Shrubs or trees, with terete branches. Leaves opposite: blades leathery, lustrous: stipules deciduous. Flowers perfect, in short-peduncled axillary cymes. Hypanthium turbinate or campanulate. Calyx truncate or with 5-6 obtuse sepals, persistent. Corolla white or yellow, salverform or nearly rotate: tube pubescent in the throat: lobes 5-6, spreading, leathery, contorted. Stamens 5-6, adnate to the mouth of the corolla-tube: anthers sessile, narrow, the connective produced beyond the sacs. Disk cup-like. Ovary 1-2-celled : styles stout. Ovules numerous in each cavity. Fruit a thick pulpy berry. Seeds numerous, angled, flattened. Testa somewhat fibrous. Endosperm cartilaginous.

1. Genipa clusiifollia (Jacq.) Griseb. A branching shrub, 1-2 m. tall, the foliage glabrous, turning black in drying. Leaves clustered ; blades leathery, obovate to cuneate, $5-15 \mathrm{~cm}$. long, rounded or retuse at the apex, lustrous, often mucronate, entire, shortpetioled : hypanthium 8-10 mm. long, turbinate : sepals subulate, shorter than the hypanthium : corolla fleshy, glabrous; tube $1.5-2 \mathrm{~cm}$. long; lobes lanceolate or oblong-lanceolate, shorter than the tube : berries ovoid to obovoid, $5-7 \mathrm{~cm}$. long.

On the coast and Keys of southern Florida. Also in the Bahamas and West Indies.

\section{RÁNDIA L.}

Armed or unarmed shrubs or trees, with erect or climbing stems. Leaves opposite : blades often leathery. Flowers perfect, solitary, usually axillary. Hypanthium turbinate, obovoid or ovoid, terete or ribbed. Sepals 4 , very low, or obsolete. Corolla white, yellow or pink, funnelform, salverform or campanulate: tube variable in length : lobes 5 , convolute. Stamens 5, adnate to the throat of the corolla : filaments short or nearly wanting. Disk annular or cushion-like. Ovary 2-celled or very rarely 3-4-celled : styles rarely distinct, usually united, stout, terminating in a club-shaped, spindle-shaped or rarely cleft stigma. Ovules numerous, or sometimes 2 or more in each cavity, immersed in placenta 
arising from the septa. Berry usually 2-celled. Seeds free or in a pulp. Testa thin. Endosperm horny.

1. Randia aculeàta L. A branching shrub, 1-3 m. tall, often spiny, the foliage glabrous or nearly so. Leaves often clustered; blades spatulate, obovate elliptic, oval or some suborbicular, $1.5-5 \mathrm{~cm}$. long, often somewhat revolute, narrowed into short petioles : flowers short-pedicelled : sepals triangular or ovate, longer than the hypanthium : corolla white, 6-8 mm. long; lobes oblong, shorter than the tube: berries subglobose or oval, 8$10 \mathrm{~mm}$. long.

In sand, coast and Keys of Florida. Also in the West Indies.

\section{Catesbaìa L.}

Glabrous spinescent evergreen shrubs. Stem and branches terete. Leaves opposite, often crowded, with small deciduous interpetiolar stipules. Flowers solitary in the axils, short-pedicelled. Hypanthium oblong or campanulate, terete or 4-angled. Sepals 4 , very narrow, persistent. Corolla white, campanulate or infundibuliform, glabrous in the throat: lobes 4, short, valvate. Stamens 4, adnate to the base of the corolla: anthers narrow, sometimes appendaged. Disk annular. Ovary 2-celled: stigma 2-lobed. Ovules usually numerous, pendulous or nearly horizontal, in 2-many rows. Berry leathery-fleshy, 2-celled. Seeds flattened and angled. Testa nearly leathery, granular. Endosperm fleshy.

1. Catesbaea parviflòra Sw. A branching shrub 1-3 m. tall, armed with simple spines, the foliage bright green, glabrous. Leaves numerous, clustered; blades leathery, suborbicular, obovate or spatulate, $5-15 \mathrm{~mm}$. long, obtuse, more or less revolute, lustrous above, short-petioled or nearly sessile: sepals triangular to triangular-lanceolate, 1-1.5 $\mathrm{mm}$. long : corolla white, 6-8 $\mathrm{mm}$. long: berries subglobose, 6-8 $\mathrm{mm}$. long, blue or black.

In sand, Keys of Florida. Also in the West Indies.

\section{HAMÈLIA Jacq.}

Shrubs, with terete branches. Leaves opposite or whorled : blades membranous : stipules interpetiolar, deciduous. Flowers perfect, in terminal dichotomous cymes, secund on the branches. Hypanthium turbinate or obovoid. Sepals 5, erect. Corolla red or yellow, tubular or nearly campanulate: tube constricted at the base, 5-ribhed, glabrous in the throat: lobes 5, imbricated. Stamens 5, adnate to the base of the corolla-tube: anthers narrow, the connective prolonged. Disk cushion-like. Ovary 5-celled: stigma fusiform. Ovules numerous in each cavity, inserted in the placentae in the axis of the ovary. Berry small, each crowned with the disk, 5-lobed, 5-celled. Seeds numerous, minute. Testa membranous, reticulated. Endosperm fleshy.

1. Hamelia pàtens Jacq. A branching shrub 2-3 m. tall, the foliage minutely pubescent or glabrate : leaves opposite or in whorls of 3 ; blades elliptic, oblong or elliptic-ovate, $8-15 \mathrm{~cm}$. long, acute or acuminate at the ends; petioles $1-4 \mathrm{~cm}$. long : peduncles as long as the petioles or longer: hypanthium sessile, about $3 \mathrm{~mm}$. long during anthesis, turbinate : sepals triangular, shorter than the tube : corolla crimson, $1.5-2 \mathrm{~cm}$. long; tube narrowly cylindric; lobes triangular or lanceolate, $2-3 \mathrm{~mm}$. long : berries oval or ovoid, 5-7 mm. long, black.

In sand, peninsular Florida and the Keys. Also in the West Indies and Brazil.

\section{CEPHALÁNTHUS L.}

Shrubs or small trees, with terete or 4-angled branches. Leaves opposite or rarely whorled: blades entire. Flowers perfect, in axillary or terminal, solitary or panicled heads. Hypanthium enlarged upward. Sepals usually 4, accompanied by bristle-like or chaffy bractlets. Corolla white or yellowish, tubular-funnelform, glabrous or pilose in the throat: lobes 4 , imbricated. Stamens 4 , adnate up to the throat of the corolla: anthers bicuspidate. Disk minute. Ovary 2-celled: styles elongated, filiform. Ovules solitary, pendulous, anatropous. Fruit dry, broadened upward, of 2-4 nut-like bodies. Seeds elongated, with white arils. Testa membranous, sometimes produced into a narrow wing. Endosperm somewhat cartilaginous. ButTon-BusH. 
1. Cephalanthus occidentàlis $\mathrm{L}$. A shrub 1-4 m. tall, usually diffusely branched or a tree $7 \mathrm{~m}$. tall, the foliage softly pubescent or glabrous. Leaves opposite or in whorls of 3 ; blades oblong, lanceolate or ovate-lanceolate, $5-20 \mathrm{~cm}$. long, acute or somewhat acuminate, undulate, acute to subcordate at the base; petioles $5-20 \mathrm{~mm}$. long: peduncles longer than the heads, terminal or axillary : heads globose, $2.5-5 \mathrm{~cm}$. in diameter : hypanthium hairy at the base, about $2 \mathrm{~mm}$. long during anthesis: corolla white, about $1 \mathrm{~cm}$. long; tube slender, gradually dilated ; lobes ovate or oblong-ovate, obtuse : nutlets obpyramidal, $7-8 \mathrm{~mm}$. long.

In swamps and meadows, New Brunswick to Ontario, California, Florida, Texas and Arizona. Also in Cuba. Summer and fall.

\section{GUETTÁRDIA L.}

Shrubs or trees. Leaves opposite or rarely whorled: blades flat, often scabrous: stipules deciduous. Flowers perfect, or polygamo-dioecious, usually in axillary cymes. Hypanthium cylindric to globose. Sepals 2-4 and irregular or 4-9 and regular, deciduous or rarely persistent, or obsolete. Corolla salverform: tube with a glabrous throat: lobes 4-9, imbricated. Stamens 4-9: filaments wholly or partially adnate to the corolla-tube : anthers nearly sessile. Ovary 4-9-celled. Ovules solitary in each cavity, pendulous, anatropous. Fruit globose or slightly elongated, somewhat fleshy, with a terete or angled stone. Seed straight or curved. Testa membranous. Endosperm little or wanting. Leaf-blades less than $6 \mathrm{~cm}$. long, with 4-6 pairs of lateral nerves : corolla less than $1 \mathrm{~cm}$. long.

Leaf-blades over $6 \mathrm{~cm}$. long, with 9-11 pairs of lateral nerves : corolla over $2 \mathrm{~cm}$. long. $\quad 2$. G. . scabra.

1. Guettardia ellíptica Sw. A branching shrub, or a small tree reaching a height of about $6 \mathrm{~m}$., the foliage silky hispidulous. Leaf-blades membranous, oblong, oval or obovate or sometimes broadest above the middle, $2-4 \mathrm{~cm}$. long, or rarely longer, apiculate, with 4-6 pairs of lateral nerves, rounded or subcordate at the base : peduncles 1-2 $\mathrm{cm}$. long: pedicels $1-5 \mathrm{~mm}$. long: hypanthium densely pubescent, $2-3 \mathrm{~mm}$. long during anthesis, cylindric : corolla 6-8 mm. long ; tube nearly cylindric; lobes oblong or ovate-oblong, much shorter than the tube : drupes subglobose, $8-10 \mathrm{~mm}$. in diameter, 4-8-celled.

In sand, peninsular Florida and the Keys. Also in the Bahamas and the West Indies.

2. Guettardia scàbra Vent. A branching shrub or small tree sometimes $6 \mathrm{~m}$. tall, the foliage rusty-hispidulous. Leaf-blades leathery, $2.5-8 \mathrm{~cm}$. long, oval or oblong-ovate, varying to rhombic-obovate, prominently reticulated beneath, abruptly pointed, with 9-11 pairs of lateral nerves, cuneate to subcordate at the base; petioles $5-15 \mathrm{~mm}$. long: peduncles $5-10 \mathrm{~cm}$. long: pedicels $1-3 \mathrm{~mm}$. long or shorter : hypanthium densely pubescent, $3-4 \mathrm{~mm}$. long during anthesis : corolla nearly or quite $2.5 \mathrm{~cm}$. long ; tube retrorsely silky ; lobes oblong or nearly so, 5 or sometimes 6-7: drupes subglobose, about $6 \mathrm{~mm}$. in diameter, 4-6-celled.

In sandy soil, peninsular Florida and the Keys. Also in the West Indies.

\section{ERITHÀLIS L.}

Shrubs, with glabrous foliage, the stems and branches terete. Leaves opposite, with broad usually connate interpetiolar stipules: blades leathery. Flowers perfect, in terminal corymbose cymes, or very rarely solitary. Hypanthium obovoid or subglobose. Sepals $5-10$, or obsolete. Corolla funnelform or rotate : tube glabrous in the throat: lobes 5-10, narrow, often keeled within. Stamens 5-10, adnate to the base of the corolla: filaments filiform, usually pubescent. Ovary 5-10-celled : styles united, thickish. Ovules solitary in each cavity, pendulous. Berry subglobose, separating into 5-10 cartilaginous or bony nutlets. Seeds flattened. Testa membranous. Endosperm fleshy.

1. Erithalis fruticòsa L. A branching shrub, the foliage glabrous. Leaf-blades leathery, lustrous, oval or oblong-obovate, $2.5-5 \mathrm{~cm}$. long, acute or apiculate, or sometimes rounded at the apex, entire, narrowed into short-petioles: hypanthium 1-1.5 mm. long during anthesis, nearly truncate or undulate : corolla white, $2-3 \mathrm{~mm}$. long; tube about $1 \mathrm{~mm}$. long ; lobes oblong, about twice as long as the tube : berries subglobose, $3-4$ $\mathrm{mm}$. in diameter, purple.

On sand ridges, peninsular Florida and the Keys. Also in the West Indies.

13. CHIOCÒCCA L.

Shrubs, with upright or climbing stems. Leaves opposite: blades leathery, flat, lustrous: stipules persistent. Flowers perfect, in axillary simple or compound racemes. 
Hypanthium obovate or turbinate. Sepals 5, persistent. Corolla funnelform, with a glabrous throat: lobes 5, spreading or reflexed, valvate. Disk cushion-like. Stamens 5, essentially free from the corolla-tube. Ovary 2-celled or rarely 3-celled : styles united, filiform : stigmas terete, sometimes clavate. Ovules solitary in each cavity, pendulous. Fruit flattened, leathery, sometimes 2 -lobed. Seeds pendulous, flattened. Testa membranous. Endosperm fleshy.

1. Chiococca racemòsa L. A much-branched shrub, usually trailing or high twining, the foliage sparingly pubescent or glabrate. Leaf-blades leathery, lustrous, elliptic, ovate or oval, acute or short acuminate at the ends, 3-7 cm. long, or shorter on branchlets, short-petioled: racemes panicled : pedicels 1-4 mm. long: hypanthium 1-1.5 mm. long during anthesis: sepals triangular or ovate, shorter than the tube: corolla white, turning yellow, 6-8 mm. long; tube funnelform; lobes ovate to ovate-lanceolate, shorter than the tube: fruits subglobose, $5-6 \mathrm{~mm}$. in diameter.

On the coast, peninsular Florida and the Keys. Also in the West Indies and South America.

\section{STRÚMPFIA Jacq.}

Shrubs, with copiously branched stems and pubescent foliage. Leaves in whorls of 3 , numerous: blades narrow, leathery. Flowers perfect, very small, in axillary racemes. Hypanthium obovoid, ribbed. Sepals 5, persistent. Corolla white or mainly so : tube very short: lobes 5, long and narrow, imbricated. Stames 5, adnate to the base of the corolla-tube : filaments slightly monadelphous. Ovary 2-celled: styles united, pubescent. Ovule solitary in each cavity, erect, anatropous. Fruit a drupe with 1 or 2 stones. Seeds erect, oblong. Testa membranous. Endosperm fleshy.

1. Strumpfia marítima Jacq. A low much-branched shrub, rarely $9 \mathrm{dm}$. tall, the foliage minutely pubescent, the branches conspicuously short-jointed. Leaves in whorls of 3 ; blades leathery, firm, linear or linear-elliptic, $1-2.5 \mathrm{~cm}$. long, strongly revolute, obscurely short-petioled : peduncles $2-10 \mathrm{~mm}$. long, densely pubescent: hypanthium about $1 \mathrm{~mm}$. long during anthesis: sepals triangular or ovate-triangular, erect, acute : corolla white, pubescent, 3-4 mm. long; tube campanulate; lobes lanceolate or oblong: drupes commonly 4-6 $\mathrm{mm}$. in diameter, white or red.

On sandy or rocky coasts, Keys of Florida. Also in the West Indies.

\section{PSYCHÒTRIA L.}

Shrubs or trees, or rarely perennial herbs or vines. Leaves opposite or rarely whorled : stipules sometimes sheathing. Flowers perfect or rarely polygamo-dioecious, variously disposed in terminal or axillary clusters, not paired. Hypanthium short. Sepals 5, or rarely 4 or 6 , mostly deciduous. Corolla white, pink, green or yellow, tubular, funnelform or campanulate : tube straight: lobes 5 , or rarely 4 or 6 , valvate. Stamens as many as the corolla-lobes, adnate up to the throat or mouth of the corolla-tube : anthers attached at the base. Disk various. Ovary 2-celled. Ovules solitary in each cavity, erect, anatropous. Fruit a small berry or drupe, often ribbed. Seeds erect. Testa thin. Endosperm sometimes ruminated.

Stipules distinct: corolla-lobes as long as the tube : leaf-blades pubescent beneath.

1. P. tenuifolia. Stipules united and sheathing: corolla-lobes shorter than the tube : leaf-blades glabrous. 2 . P. undata.

1. Psychotria tenuifòlia Sw. A low branching shrub, 3-12 dm. tall. Leaf-blades narrowly oblong or elliptic or elliptic-lanceolate, $8-15 \mathrm{~cm}$. long, acuminate at both ends, undulate, pubescent beneath, often with conspicuous lateral nerves beneath : cymes fewflowered : hypanthium about $1 \mathrm{~mm}$. long during anthesis: sepals broadly deltoid or triangular: corolla funnelform, $2-2.5 \mathrm{~mm}$. long; lohes lanceolate or oblong-lanceolate, as long as the tube : fruits oval or oblong-oval, 5-6 mm. long.

In rich woods, peninsular Florida. Also in the West Indies.

2. Psychotria undàta Jacq. A widely branching shrub, or a small tree sometimes $5 \mathrm{~m}$. tall. Leaf-blades oval, elliptic or elliptic-lanceolate, 6-15 cm. long, acuminate at both ends, glabrous, short-petioled : cymes open: hypanthium $1 \mathrm{~mm}$. long: calyx undulately toothed : corolla $2.5-3 \mathrm{~mm}$. long, hairy in the throat; lobes oblong or oblong-lanceolate, shorter than the tube : fruits subglobose or ellipsoidal, 4-4.5 mm. long.

In open woods, coast of Florida and the Keys. Also in the West Indies. 


\section{MITCHÉLLA L.}

Perennial evergreen herbs, with creeping stems. Leaves opposite : blades flat, entire ; stipules minute. Flowers perfect, dimorphous, 2 together on axillary or terminal peduncles. Sepals 4 or sometimes 3-6. Corolla white or pink, funnelform; lobes mostly 4, spreading or recurved, pubescent within. Stamens as many as the corolla-lobes : filaments short and united. Ovary 4-celled : styles elongated and exserted or short and included. Stigmas 4, slender. Ovule solitary in each cavity, erect, anatropous. Fruit of 2 united drupelets, containing usually 8 nutlets. Testa firm. Endosperm cartilaginous.

1. Mitchella rèpens L. Foliage glabrous or nearly so. Stems prostrate or creeping, 1-4 dm. long, usually forming mats : leaf-blades thickish, ovate to suborbicular or sometimes elliptic, $8-30 \mathrm{~mm}$. long, usually truncate or subcordate at the base; petioles $\frac{1}{2}$ as long as the blades or shorter: peduncles 1-5 mm. long: sepals much shorter than the hypanthium : corolla white or pinkish, $10-13 \mathrm{~mm}$. long; tube dilated above the middle ; lobes ovate or oblong, spreading or slightly recurved: fruit suborbicular, $7-10 \mathrm{~mm}$. in diameter, bright red or white, somewhat aromatic.

In woods, Nova Scotia to Minnesota, Florida and Texas. Spring to fall. Partridge-Berry. TWIN-BERRY.

\section{MORÍNDA L.}

Shrubs or trees, with upright or climbing stems. Leaves opposite or rarely whorled in 3's : blades membranous. Flowers mostly perfect, in axillary or terminal peduncled clusters. Flowers aggregated and coalescent into a head. Calyx a truncate or shallowly toothed, persistent border. Corolla white or crimson, funnelform or salverform : lobes 5 or rarely 4-7, valvate, leathery. Stamens 5 or rarely 4-7: filaments short, adnate to the throat of the corolla. Ovary 2-celled or imperfectly 4-celled: styles united, sometimes pubescent: stigmas slender. Ovules solitary in each cavity. Fruit a syncarp. Seeds obovoid or reniform. Testa membranous. Endosperm fleshy.

1. Morinda Roìoc L. A branching shrub, with prostrate, or somewhat climbing stems, the foliage glabrous or nearly so. Leaf-blades oblong to cuneate, $5-10 \mathrm{~cm}$. long, abruptly pointed, undulate, thinnish, short-petioled: flowers aggregated into a dense sessile or short-peduncled head : corolla crimson, 6-8 mm. long; tube gradually dilated ; lobes oblong to oblong-lanceolate, shorter than the tube: fruit of 2-4 1-seeded carpels united into a fleshy head.

On or near the coast, peninsular Florida and the Keys. Also in the West Indies.

\section{RICHÁRDIA L.}

Annual or perennial herbs, with pubescent foliage and terete stems. Leaves opposite : blades flat, entire: stipules fringed. Flowers mostly perfect, in terminal involucrate clusters. Hypanthium turbinate to subglobose. Sepals 4-8, more or less persistent. Corolla white or pink, funnelform, glabrous in the throat: lobes 3-5, valvate. Stamens adnate to the throat of the corolla-tube. Disk inconspicuons. Ovary 3-4-celled : styles united, filiform : stigmas 3-4. Ovule solitary in each cavity, amphitropous. Fruit of 3-4 carpels, crowned with the sepals. Seeds 2 -grooved on the lower face. Endosperm horny.

Annual : mature carpels oblong, 3-3.5 mm. long : corolla 3-4 mm. long.

Perennial : mature carpels obovoid, 2-2.5 mm. long: corolla 4-6 mm. long.

1. R. scabra.

2. R. Brasiliensis.

1. Richardia scàbra St. Hil. Annual. Stems sparingly branched and erect, or copiously branched and diffusely spreading, 1-4 dm. long: leaf-blades oblong or elliptic to lanceolate or ovate, $2-8 \mathrm{~cm}$. long, acute or somewhat acuminate, undulate, narrowed into short margined petioles or nearly sessile : clusters depressed : involucre of 2 unequal pairs of bracts: sepals lanceolate or ovate-lanceolate, $1-1.5 \mathrm{~mm}$. long, about as long as the hypanthium : corolla 4-6 mm. Iong : tube funnelform; lobes 6 , "triangular or triangularlanceolate, more or less ciliate, much shorter than the tube.

In sandy soil, South Carolina to Florida, Texas, Mexico and South America. Introduced from tropical America.

2. Richardia Brasiliénsis (Moq.) Gomez. Perennial. Stems more or less diffusely branched from the base, the branches spreading or prostrate, 1-4 $\mathrm{dm}$. long: leaf-blades elliptic or oblong, 1.5-4 cm. long, acute or somewhat acuminate at both ends, entire, shortpetioled : clusters dense, closely sessile: sepals ovate or oblong-ovate, about $1 \mathrm{~mm}$. long: 
corolla $3-4 \mathrm{~mm}$. long; tube narrowly funnelform; lobes oblong or oblong-lanceolate, much shorter than the tube.

In sand, Florida. Native of South America. Spring to fall.

19. ERNÒdEA Sw.

Perennial shrubby plants, with decumbent stems and glabrous foliage. Leaves opposite : blades leathery, rather narrow, entire : stipules fringed, persistent. Flowers perfect, solitary and sessile in the axils. Sepals 4-6, persistent. Corolla yellowish, funnelform, rather fleshy, naked in the throat: lobes 4-6, narrow, valvate. Stamens 4-6, adnate to the corolla-tube. Disk fleshy. Ovary 2-celled: styles united, filiform: stigmas capitate or slightly 2-lobed. Ovule solitary in each cavity, amphitropous. Drupe somewhat fleshy, 2-grooved, the carpels permanently united, with cartilaginous nutlets. Seeds flattened on one side. Testa membranous. Endosperm fleshy.

1. Ernodea littoràlis Sw. A spreading or prostrate shrub, the foliage glabrous. Stems 4-angled, the branches alternate: leaves usually clustered; blades fleshy-leathery, linear-elliptic, varying to broadest above or below the middle, $1-2.5 \mathrm{~cm}$. long, entire, sessile or nearly so: sepals lanceolate-subulate or nearly so, longer than the tube: corolla yellow ; tube $1 \mathrm{~cm}$. long; lobes curved, shorter than the tube : drupes oval or subglobose, 4-6 mm. in diameter, yellow.

On or near the coast, southern peninsular Florida and the Keys. Also in the West Indies. Spring.

\section{CRÙSEA Cham.}

Annual or perennial caulescent herbs. Leaves opposite : blades flat : stipules sheathing. Flowers perfect, in clusters subtended by involucres of 4 bracts. Hypanthium flattened, ovoid or obovoid. Sepals 4, sometimes accompanied by several teeth, persistent. Corolla pink, funnelform : tube slender: lobes 4, valvate, spreading. Stamens 4, adnate up to the mouth of the corolla-tube: filaments bent: anthers exserted. Ovary 2-celled : styles wholly or partially united, capillary. Ovule solitary in each cavity, amphitropous. Capsule didymous, the carpels indehiscent but separating from each other, the walls very thin. Seeds mainly oblong.

1. Crusea tricócca (T. \& G.) Heller. Foliage hirsute or glabrate. Stems diffusely branched at the base, the branches $2-15 \mathrm{~cm}$. long, spreading or prostrate: leaf-blades linear to oblong-lanceolate, $1-2.5 \mathrm{~cm}$. long, acute or somewhat acuminate, often scytheshaped, sessile: sepals lanceolate, $1.5-2 \mathrm{~mm}$. long: corolla 3-4 mm. long; tube funnelform; lobes shorter than the tube : fruit ovoid-globose, $2-2.5 \mathrm{~mm}$. long. [C. allococca A. Gray.]

On plains or prairies, Texas and adjacent Mexico. Spring to fall.

\section{DIÒdIA L.}

Annual or perennial herbs. Stems decumbent or procumbent. Leaves opposite : blades entire, sessile, usually longitudinally striate : stipules sheathing. Flowers perfect, axillary. Hypanthium obovoid or obconic. Sepals 2-4, sometimes accompanied by smaller teeth. Corolla white or lilac, funnelform or salverform : lobes 4, short, valvate. Stamens mostly 4, adnate to the throat of the corolla-tube. Disk obsolete. Ovary typically 2-celled: styles united: stigma 2-lobed. Ovules solitary in each cavity, amphitropous. Fruit oblong or globose, the 2 or rarely 3-4 indehiscent carpels separating, the walls firm. Seeds elongated, free. ButTon-weEd.

Styles partially united : corolla salverform.

Foliage glabrous or sparingly pubescent.

Leaf-blades narrowed at the base: capsules oblong.

Leaf-blades truncate or subcordate at the base: capsules ovoid.

Foliage copiously hirsute.

Styles united to the entire or 2-lobed stigma : corolla funnelform.

1. D. Virginiana.

2. D. tetragona.

3. D. hirsuta.

4. D. teres.

1. Diodia Virginiana L. Perennial, glabrate or hirsute. Stems branched at the base, the branches prostrate, $1-15 \mathrm{dm}$. long, sometimes creeping : leaf-blades oblong, elliptic or linear-oblong, or oblong-spatulate at the base of the stem, 3-8 cm. long, acute or acuminate, attenuate to the base, sessile : flowers solitary in the axils or clustered : sepals linear or linear-lanceolate, 4-6 mm. long: corolla white; tube slender, 6-8 $\mathrm{mm}$. long; lobes oblong or oblong-lanceolate, shorter than the tube : capsules oblong, 7-9 $\mathrm{mm}$. long.

In wet soil, New Jersey to Missouri, Florida and Texas. Spring to fall. 
2. Diodia tetrágona Walt. Perennial, finely pubescent or glabrate. Stems usually branched at the base, the branches spreading or prostrate, 2-10 dm. long, 4-angled : leafblades oval, oblong, elliptic or oblong-rhombic, 1-4 cm. long, acute, usually abruptly narrowed at the base or cordate, short-petioled: sepals ovate or ovate-lanceolate, 4-5 mm. long, acute : corolla white or pink; tube slender, $5-7 \mathrm{~mm}$. long; lobes lanceolate to oblong, shorter than the tube: capsules $5 \mathrm{~mm}$. long, oval, ribbed.

In damp sandy soil, North Carolina to Florida and Louisiana. Spring to fall.

3. Diodia hirsùta Pursh. Perennial, densely hirsute. Stems more or less diffusely branched from the base, the branches 1-8 dm. long, sometimes creeping : leaf-blades linear or narrowly oblong, 1-2.5 cm. long, acute or somewhat acuminate, abruptly narrowed into short petioles or rarely sessile : sepals subulate-lanceolate, 4-5 mm. long: corolla white or pink; tube narrowly funnelform, $8-10 \mathrm{~mm}$. long; lobes shorter than the tube, lanceolate or oblong-lanceolate : capsules oblong, 7-9 mm. long, ribbed.

In sandy soil, Georgia and Florida. Spring and summer.

4. Diodia tères Walt. Annual, finely pubescent or hispidulous. Stems terete, or 4-angled above, mostly diffusely branched, 1-4 dm. long, the branches usually spreading, rarely creeping: leaf-blades linear or narrowly linear-lanceolate, 1-4 cm. long, acute, abruptly narrowed at the base, nearly sessile : sepals 4, triangular or triangular-lanceolate, 1-2 mm. long: corolla white or pinkish, about $6 \mathrm{~mm}$. long; tube funnelform ; lobes ovate or oblong-ovate, shorter than the tube : capsules obovoid, $2-3 \mathrm{~mm}$. long.

In dry or sandy soil, Connecticut to Missouri, Florida, Texas and New Mexico. Summer.

\section{BORRÈRIA Meyer.}

Annual or perennial caulescent herbs, or shrubby plants. Leaves opposite: blades flat, entire : stipules sheathing. Flowers perfect, solitary in the axils, or in axillary or terminal clustered cymes. Hypanthium obovoid or turbinate. Sepals 2-4, or rarely 5, persistent, sometimes accompanied by small teeth. Corolla white, pink or blue, funnelform or salverform: lobes 4, valvate, spreading. Stamens 4, adnate to the corolla-tube sometimes up to its throat. Disk obsolete or cushion-like. Ovary 2-celled: styles wholly or partially united. Ovules solitary in each cavity, amphitropous. Fruit leathery or crustaceous, the 2 carpels opening along the inner faces.

Annual : clusters in the axils of the leaves along the stem.

Perennial: clusters in a congested head terminating the peduncle-like end of the stem.

1. B. parviflora.

2. B. podocephala.

1. Borreria parviflòra Meyer. Annual, glabrous or nearly so. Stems erect or branched at the base, the branches spreading, $2-9 \mathrm{dm}$. long: leaves often clustered; blades narrowly lanceolate to almost linear or oblong-spatulate, 1-2.5 cm. long, obscurely nerved, sessile: flower-clusters subglobose, 4-8 mm. thick: sepals 4, subulate or lanceolate-subulate : corolla white, shorter than the sepals; Jobes ovate: fruit ovoid, $1 \mathrm{~mm}$. long, pubescent.

In waste places or pine woods, Florida.

2. Borreria podocéphala DC. Perennial, glabrous or nearly so. Stems simple and erect or branched at the base, the branches spreading or decumbent, $0.5-2 \mathrm{dm}$. long, upper internodes elongated: leaves often clustered; blades linear, often narrowly so, $1-2.5 \mathrm{~cm}$. long, acute, more or less strongly revolute, sessile : clusters 8-12 $\mathrm{mm}$. in diameter : sepals subulate, about $0.5 \mathrm{~mm}$. long: corolla $2-2.3 \mathrm{~mm}$. long; tube funnelform, glabrous within; lobes often 3 : fruit ovoid, 2-3 mm. long, pubescent.

In sand, peninsular Florida and the Keys, Texas and Mexico. Also in the West Indies.

\section{SPERMACOCE L.}

Annual or perennial herbs, or low shrubs. Stems usually 4-angled. Leaves opposite: blades feather-veined or longitudinally nerved: stipules sheathing. Flowers perfect, solitary in the axils, or variously disposed. Hypanthium varying from obovoid to turbinate. Sepals 2-4, or 5, often persistent, sometimes accompanied by small teeth. Corolla white, pink or blue, funnelform or salverform : lobes often 4, spreading, valvate. Stamens 4, adnate to the throat of the corolla-tube or lower down. Disk obsolete or cushion-like. Ovary 2-celled: styles wholly or partially united, filiform. Ovules solitary in each cavity, attached to the middle of the septa, amphitropous. Fruit leathery or crustaceous, of two carpels one opening through the ventral face, the other remaining closed. ButTon-W EeD. 
Corolla very villous in the throat.

Corolla glabrous or slightly pubescent in the throat.

Leaf-blades more or less scabro-pubescent: capsule didymous : perennial plant.

Leaf-blades smooth and glabrous: capsule subglobose: annual plant.

1. Spermacoce glábra Michx. Perennial, glabrous or sparingly pubescent. Stems simple and erect or diffusely branched, the branches spreading or decumbent, 1-6 dm. long, sometimes creeping : leaf-blades oblong, elliptic or oblong-lanceolate, $2-7 \mathrm{~cm}$. long, acute or acuminate at both ends, short-petioled : clusters subglobose, 5-12 mm. in diameter: sepals lanceolate, about as long as the hypanthium: corolla white, as long as the sepals or surpassing them; tube very villous in the throat; lobes ovate or oblong-ovate : fruit about $3 \mathrm{~mm}$. long.

On river banks, Ohio to Florida, Arkansas and Texas. Summer.

2. Spermacoce tenùior (L.) Lam. Perennial, glabrous or nearly so. Stems simple and erect or more or less diffusely branched from the base, the branches 1-3 dm. long, rarely creeping: leaf-blades oblong, elliptic or oblong-lanceolate, $2-5 \mathrm{~cm}$. long, acute or acuminate at both ends, narrowed into short margined petioles: sepals subulate or lanceolate-subulate, about $1 \mathrm{~mm}$. long, shorter than the hypanthium : corolla white, twice or thrice as long as the sepals ; tube funnelform ; lobes oblong or ovate-oblong, rounded : fruit about $2 \mathrm{~mm}$. long.

In dry soil or on river banks, Georgia to Florida and Louisiana. Also in the West Indies and tropical America. Summer.

3. Spermacoce Portoricénsis Balbis. Annual, smooth and glabrous. Stems more or less diffusely branched from the base, the branches $0.5-3 \mathrm{dm}$. long, slender or wire-like : leaf-blades oblong to linear-elliptic, $1-2.5 \mathrm{~cm}$. long, acute or acuminate at both ends, inconspicuously nerved, slender-petioled : clusters few-flowered, mostly less than $5 \mathrm{~mm}$. thick : sepals subulate-lanceolate, 1-1.5 mm. long: corolla white, glabrous within, $1 \mathrm{~mm}$. long; tube campanulate; lobes oblong-ovate : fruit subglobose, 1-1.5 mm. long.

In sandy soil, peninsular Florida and the Keys. Also in the West Indies.

\section{GÀLIUM L. ${ }^{1}$}

Annnal or perennial low herbs, with 4-angled stems. Leaves apparently whorled, the stipules often as large as the leaves. Flowers in our species perfect, small or minute, on axillary peduncles, often cymose. Sepals usually obsolete. Corolla rotate, white, greenish or purple: lobes 3-4. Stamens as many as the lobes of the corolla and alternate with them : filaments short. Ovary 2 -celled, with a solitary ovule in each cavity : styles 2 : stigmas capitate. Fruit composed of two nearly separate globular 1-seeded indehiscent carpels, either glabrous or uncinate-hispid, dry or fleshy, rarely spherical and hollow. BeDstraw.

Endosperm of the seed deeply lunate or annular in cross-section : leaves various.

Fruit uncinate-hispid.

Leaves and stipules in 7's, not punctate: annual.

Leaves and stipules in 4's, pellucid-punctate beneath.

Flowers solitary, axillary and terminal: annual.

Flowers on slender naked stalks, mostly terminal. Flowers on short leafy bracted stalks, mostly axillary.

Flowers cymose, terminal: perennial.

Fruit pedicelled.

Fruit sessile or nearly so.

Fruit smooth or nearly so.

Leaves $3-5 \mathrm{~cm}$. long : corolla purplish : endosperm lunate in section.

Leaf-blades narrowly lanceolate, 1- (rarely 3-) nerved,

Leaf-blades broadly lanceolate, 3-nerved.

Leaves $2.8 \mathrm{~cm}$. long or shorter.

Leaf-blades cuspidate, punctate beneath: fruit baccate: endosperm lunate in cross-section.

Leaf-blades oblong-oval, 5-25 mm. long.

Leaf-blades linear, $25-28 \mathrm{~mm}$. long.

Leaf-blades obtuse, not punctate : fruit dry : endosperm annular in crosssection.

Corolla-lobes 3 , obtuse : stem scabrous.

Corolla-lobes 4, acute: stem glabrous or nearly so.

Endosperm shallow-lunate, or flat, sometimes nearly circular in cross-section.

Fruit glabrous or nearly so.

Annual: leaves 5-8 mm. long: fruit papillose.

Perennial : leaves $10-20 \mathrm{~mm}$. long : fruit smooth.

Fruit uncinate-hispid.

1. Galium Aparìne L. Annual, weak, reclining. Stems 1-15 dm. long, nearly simple, the angles retrorse-scabrous, or prickly : leaves and stipules mostly in 7's, shorter than

${ }^{1}$ Contributed by Dr. Karl M. Wiegand.
1. G. Aparine.

2. G. Texanum.

3. G. virgatum.

4. G. pilosum.

5. G. circaezans.

6. G. Arkansanum.

7. G. latifolinm.

8. G. hispidulum.

9. G. uniflorum.

10. G. Claytonii.

11. G. tinctorium.

12. G. Parisiense.

13. G. asprellum.

14. G. triflorum. 
the internodes ; blades linear-spatulate, 1-8 cm. long, 1-nerved, strongly mucronate, margins and midrib below seabrous with short stout hairs as is also the whole upper surface : cymes few-flowered, on short lateral leafy-bracted branches : pedicels stiff : corolla minute, white, with four acute lobes : fruit on straight pedicels, 3-5 mm. in diameter, densely uncinate-hispid : endosperm very deeply grooved, almost annular in cross-section.

In damp shady places, New Brunswick to Alaska, Florida and Texas, possibly introduced from Europe. Also a native of Asia.-A smaller form, with leaves searcely over $2.5 \mathrm{~cm}$. long and more abundant longer-hispidulous fruit, is G. aparine Vaillantii Koch; it is found from Texas west ward and northward. Spring to fall. Spring Cleavers. Goose-Grass.

2. Galium Texànum (T. \& G.) Wiegand. Annual. Stems weak and slender, 4 dm. long or less, hispid, especially below : leaves and stipules in 4's ; blades broadly oval, equal, 6-10 mm. long, 1-nerved, thin, covered with straight bristly hairs, some of the axils with clusters of small leaves and a short peduncle : flowers mostly terminal : peduncles $6-25 \mathrm{~mm}$. long, filiform : fruit with short scarcely uncinate bristles.

On hills and river banks, Texas. Spring and summer.

3. Galium virgàtum Nutt. Annual. Stems branched from the base, the branches erect-spreading, 1-3 dm. high, more or less hispid ; internodes short: leaves and stipules in 4's, 3-10 mm. long; blades linear-oblong, mostly obtuse, 1-nerved, sessile, very hispid on the margins and midrib : flowers axillary, solitary or glomerate, on recurved leafybracted pedicels shorter than the leaves : corolla minute, white, with 4 acute lobes : fruit $3 \mathrm{~mm}$. in diameter, densely uncinate-hispid : endosperm deeply grooved, with a ridge opposite the embryo, the cross-section very deeply lunate.

In dry open soil and on prairies, Tennessee and Missouri to Louisiana and Texas. Spring.-A form with smooth and glabrous foliage and fruit, is $G$. virgatum leiocárpum T. \& G.

4. Galium pilòsum Ait. Perennial. Stems often diffusely and stiffly branched from the base, 3-8 dm. high, rarely slightly decumbent, more or less hirsute, but not scabrous, the joints swollen, 4-angled above, nearly terete below : leaves and stipules shorter than the internodes, in 4's, 8-20 mm. long; blades oval-ovate or elliptical, obtuse and rounded or callous-mucronate at the tip, nearly sessile, 1- (rarely 3-) nerved, sparingly hairy on both surfaces, densely pellucid-punctate below : flowers numerous, in groups of 2's or 3's, on short stiff pedicels, $2-10 \mathrm{~mm}$. long, on the divaricate branches of the ample rigid but diffuse nearly naked terminal and lateral cymes: corolla greenish yellow or purplish, the 4 lobes acuminate : fruit $4 \mathrm{~mm}$. in diameter, densely uncinate-hispid : endosperm deeply grooved, with a slight ridge opposite the embryo, the cross-section lunate.

In dry open sandy woods, Massachusetts to Indiana, south to Florida and Texas. Summer.-A form with smaller and narrower leaf-blades and nearly glabrous foliage, ranging from New Jersey to Florida and Texas, is G. pilosum puncticulósum (Michx.) T. \& G.

5. Galium circaèzans Michx. Perennial, glabrous or sparingly pubescent. Stems branched from the base, rather strict, 2-4 dm. high: leaves and stipules in 4's, shorter than the internodes, $15-30 \mathrm{~mm}$. or rarely $40 \mathrm{~mm}$. long; blades elliptic-ovate to oval, nearly sessile, obtuse or sometimes acutish and apiculate at the apex, sparingly hairy on both surfaces and with few pellucid dots below, 3-nerved: flowers few, sessile or nearly so along the divaricate branches of the terminal cyme : bracts minute: corolla hirsute, 2-5 mm. broad, greenish; lobes 4 , acuminate : fruit $4 \mathrm{~mm}$. in diameter, densely uncinate-hispid, deflexed: endosperm deeply grooved, with a slight ridge opposite the embryo, the cross-section deeply lunate.

In dry woods and copses, Quebec and Ontario to Minnesota, Florida and Texas. Summer. WILD LIQUORICE,

6. Galium Arkansànum A. Gray. Perennial. Stems $3 \mathrm{dm}$. high, erect and diffusely branched, smooth below, retrorse-scabrous above: leaves and stipules in 4's, 3-5 $\mathrm{cm}$. long, 9-12 mm. broad, equalling the internodes; blades lanceolate or linear-lanceolate, sessile, acute but not mucronate, 1-nerved or rarely 3 -nerved, the margins and midrib scabrous, the lower surface densely pellucid-punctate : flowers numerous, on long filiform roughened pedicels, in much-branched diffuse nearly naked terminal cymes: corolla brownish purple, $3 \mathrm{~mm}$. broad, with 4 acuminate lobes : fruit scabrous but not uncinate ( 1 carpel nsually sterile), rarely nearly glabrous, slightly fleshy, each carpel $2-3 \mathrm{~mm}$. in diameter: endosperm as in the next following species.

In dry soil, western Tennessee to Missouri and Arkansas. Summer.

7. Galium latifòlium Michx. Perennial. Stems mainly $3-6 \mathrm{dm}$. high, diffusely branched from near the base, glabrous: leaves and stipules in 4's, equalling or shorter than the internode; blades broadly ovate to lanceolate, 3-6 cm. long, 3-nerved, acute but not mucronate at the apex, abruptly contracted below into a sessile or stipitate base, pellucid-punctate beneath, the margins and nerves minutely hispid: flowers numerous, on filiform pedicels in somewhat naked diffuse cymes: corolla brownish, $3 \mathrm{~mm}$. broad, the 
lobes acuminate: fruit $6 \mathrm{~mm}$. in diameter, but usually only one carpel developing, glabrous, slightly fleshy: endosperm moderately grooved, lunate in cross-section.

In dry woods in mountainous districts, Pennsylvania to Georgia and Alabama. Spring and summer. - A form with more tufted densely hispid stems $3 \mathrm{dm}$. high and leaf-blades hispid on both surfaces, is G. latifolium hispidifòlium Small; it occurs on mountains along the boundary between Virginia and North Carolina.

8. Galium hispídulum Michx. Perennial. Stems diffusely branched, 1-6 dm. long, decumbent at the base or prostrate, glabrous, or hispidulous, but not scabrous: leaves and stipules in 4's, mostly equalling the internodes, 5-25 mm. long; blades elliptic-oblong, very acute at toth ends, cuspidate at the apex, rather thick, shining, cellular-papillose and nearly glabrous above, the lower surface pubescent and pellucid-punctate : flowers few, on short stout pedicels deflexed in fruit, in clusters of 3's or 5's from the involucrate whorls which are borne on short bracted lateral branches slightly exceeding the leaves: corolla greenish white, $2 \mathrm{~mm}$. broad; lobes 4 , acute and hairy : ovary minutely pubescent : fruit $5 \mathrm{~mm}$. in diameter, nearly smooth, rarely pubescent, baccate : endosperm deeply grooved, deeply lunate in cross-section.

In dry sandy soil, in the coastal plain, New Jersey to Florida. Spring and summer.

9. Galium uniflòrum Michx. Perennial. Stems smooth and glabrous, $3 \mathrm{dm}$. high, decumbent at the base or erect, sometimes simple : leaf-blades linear, acute, $2.5-2.8 \mathrm{~cm}$. long, the margins scabrous, the lower surface punctate: flowers solitary or in pairs, on short bracted axillary branches : corolla white : ovary glabrous : fruit baccate, dark-blue, mostly pendulous, glabrous.

In rich dry woods, South Carolina to Florida and Texas. Summer.

10. Galìum Claytònii Michx. Perennial. Stems erect or ascending, diffuse and weak when old, 15-60 $\mathrm{cm}$. high, retrorse-scabrous on the angles, diffusely branched : leaves and stipules commonly in 5's or 6's ; blades linear-spatulate or spatulate-oblong, 8$15 \mathrm{~mm}$. long, obtuse, cuneate at the base and nearly sessile, glabrous and dull, except the scabrous margin and midrib: flowers on rather short stright glabrous pedicels which in fruit are strongly divaricate, in terminal bracted clusters of 2's or 3's : corolla minute, white; lobes 3 , broadly oval, obtuse : fruit small, glabrous: endosperm with the margins incurved forming a hollow sphere, annular in cross-section.

In open marshes and ditches, Massachusetts to Michigan, Missouri, North Carolina and Texas. Spring and summer.

11. Galium tinctòrium L. Perennial. Stems $15-25 \mathrm{~cm}$. high, the branches numerous, several times forked, glabrous or nearly so: leaves and stipules mostly in 4's ; blades linear-lanceolate, broadest. below the middle, $15-25 \mathrm{~mm}$. long, obtuse, cuneate at the base, 1-nerved, glabrous, except the slightly scabrous margins and midrib, dull and darkgreen, not papillose: flowers few, in terminal clusters of 2's or 3's; pedicels slender, straight: corolla white, $2-3.5 \mathrm{~mm}$. broad; lobes 4 , acute: fruit rather small, 1 carpel usually sterile, very smooth : endosperm as in the next preceding species.

In damp shaded places and swamps, Canada to Michigan, Nebraska, North Carolina, Tennessee and Arizona. Summer.-A form growing in sandy swamps from Virginia to Florida, with more slender and diffuse branches, almost filiform strongly cellular-papillose leaves, minute bracts and open cymes, is G. tinctorium filifotium Wiegand. G. tinctorium Floridànum Wiegand, of Florida, is a weak slender decumbent form, with slightly scabrous stems, linear-spatulate flaccid leaf-blades, occasionally axillary, solitary flowers and rarely 3-lobed corollas.'

12. Galium Parisiénse L. Annual. Stems diffusely branched and intertangled, $15-30 \mathrm{~cm}$. high, sparsely retrorse-scabrous on the angles: leaves and stipules in 6's (rarely 5's or 7's), 5-8 mm. long; blades linear or linear-spatulate, acutely cuspidate at the apex, attenuate at the base, scabrous on both surfaces, somewhat shining and cellular-papillose : flowers on short filiform glabrous pedicels, in terminal and lateral few-flowered leafy cymes: corolla very minute, white; lobes 4 , mostly obtuse : fruit $1 \mathrm{~mm}$. in diameter, conspicuously papillose-roughened : endosperm very similar to that of $G$. triflorum, nearly spherical, the cross-section circular, groove very shallow, with a central ridge. [G. Anglicum Huds.]

On roadsides and in fields, naturalized from Europe, in Virginia, North Carolina and Tennessee. Summer.

13. Galium aspréllum L. Perennial. Stems 3-16 dm. long, weak and reclining, retrorse-scabrous, or prickly, the branches numerous but short: leaves and stipules of the main stem mostly in 6' s, much shorter than the internode, 1-2 cm. long; blades oblong-spatulate, or elliptical, cuspidate, tapering below into a very short petiole, glabrous except the scabrous margins and midribs, 1-nerved : flowers very numerous, white, on short filiform pedicels in much-branched terminal and lateral leafy bracted cymes : corolla $2 \mathrm{~mm}$. broad; lobes 4 , acute: fruit small, $2.5 \mathrm{~mm}$. in diameter, smooth and glabrous.

In open swamps and moist thickets, Newfoundland to Ontario, Wisconsin, Nebraska and North Carolina. Summer. ROUGH BED STRAw. 
14. Galium triflòrum Michx. Perennial, sweet-scented in drying. Stems weak, reclining or procumbent, 3-10 dm. long, sparsely hispid or rarely glabrous, shining : leaves and stipules in 6's, shorter than the internodes, 1-8 $\mathrm{cm}$. long; blades broadly linear to elliptic, 1-nerved, strongly mucronate, very short-petioled, glabrous except the hispid margins and midrib : flowers few on stout straight pedicels, in 3 's on the ultimate branches of the few-flowered axillary and terminal cymes which slightly exceed the leaves: corolla greenish or yellowish white, $2.5 \mathrm{~mm}$. broad ; lobes 4 , acuminate : fruit $3 \mathrm{~mm}$. in diameter, densely uncinate-hispid: endosperm with the groove very shallow or almost obsolete, the cross-section nearly circular.

In shady woods and copses, Nova Scotia to Alaska, Florida, Texas and California. Also in Europe, Japan and the Himalayas. Summer. SweEt-Scented Bed Straw.

\section{Family 2. CAPRIFOLIACEAE Vent. Honeysuckle Family.}

Shrubs, vines or trees, or sometimes perennial herbs, usually pervaded by a bitter nauseous principle. Stems usually terete, often enlarged at the nodes. Leaves opposite, mostly destitute of stipules : blades entire or pinnate, sometimes connate-perfoliate. Inflorescence axillary or terminal. Flowers clustered at the nodes. Flowers mostly perfect, regular or irregular, often showy and fragrant. Calyx superior. Sepals 4-5, or rarely fewer. Corolla tubular or infundibuliform or rarely rotate : lobes 4-5, imbricated. Androecium of 4-5 stamens sometimes partially adnate to the corolla tube, alternate with the lobes. Filaments equal or two shorter. Anthers versatile. Gynoecium a single compound pistil. Ovary 2-5-celled, inferior. Styles terminal, united, sometimes very short. Ovules pendulous, commonly solitary. Fruit a berry or drupe. Seeds inverted. Endosperm fleshy. Embryo nearly straight, in the axis of the endosperm near the hilum.

Corolla rotate to urn-shaped: stigmas 2-5-lobed, sessile.

Leaf-blades pinnate: drupe berry-like with $3-5$ nutlets.

Leaf-blades simple: drupe with one nutlet.

Corolla tubular to tubular-campanulate, sometimes with a 2-lipped limb: style elongated.

Flowers solitary in the axils : herbs.

Flowers in axillary or terminal clusters or open cymes : shrubs or vines. Fruit baccate.

Corolla regular or nearly so ; tube short,

Corolla irregular; limb 2-lipped; tube elongated.

Flowers in pairs each of which terminates an axillary peduncle, accompanied by a pair of bracts and bractlets.

Bracts foliaceous, resembling the leaves: corolla-tube gibbous at the base, upright shrubs.

Bracts minute, very different from the leaves: corolla-tube not gibbous at the base: vines.

Flowers in whorls at or near the ends of the branches, the bracts and usually some of the upper pairs of leaves connate-perfoliate.

1. Sambuous.

. VIBURNUM.

3. Triosteum.

4. SYMPHORICARPOS.

5. Xylosteon.

6. NinTooA.

7. LONICERA.

8. Diervilla. Fruit capsular.

\section{SAMBŨCUS L.}

Shrubs or trees, or rarely herbaceous plants, with pithy stems and branches. Leaves opposite : blades pinnately compound : leaflets toothed or cleft, sometimes furnished with stipules. Flowers white, yellow or red, thyrsoid or in umbel-like corymbose-cymes, their pedicels with 1 or 2 scales. Hypanthium turbinate or ovoid. Sepals 3-5, equal. Corolla rotate, with 3-5 equal imbricated or rarely valvate lobes. Stamens 5 , adnate to the base of the corolla : filaments filiform or subulate : anthers opening extrorsely by clefts. Disk wanting or somewhat convex. Ovary 3-5-celled. Ovules solitary in each cavity, pendulous. Drupe with 3-5 cartilaginous 1-seeded stones. Seeds elongated and somewhat flattened. ELDER.

Cymes fully as long as broad : fruit red or scarlet.

Cymes depressed, flat-topped : fruit purple or black.

Leaf-rachis glabrous or nearly so: leaflets usually with incurved teeth.

Leaf-rachis densely pubescent: leaflets usually with spreading teeth.
1. S. pubens.

2. S. Canadensis. 3. S. Mexicana.

1. Sambucus pùbens Michx. A widely branching shrub 1-4 m. tall, with sparingly pubescent foliage, at least when young. Leaflets $5-7$, the blades lanceolate, oblong or oblanceolate, sometimes nearly oval, 5-15 cm. long, acuminate, sharply serrate, narrowed or subcordate at the oblique base, short-stalked: cymes thirsoid, subglobose to oblong, 
longer than broad : corolla white, turning brown in age, 4-5 $\mathrm{mm}$. broad; lobes oblong or ovate-oblong : drupes red or scarlet, 4-6 mm. in diameter : nutlets minutely roughened.

In rich soil or on cliffs, New Brunswick to British Columbia, south to the mountains of Georgia, Colorado and California. Spring.

2. Sambucus Canadénsis L. A shrub or small tree, sometimes $5 \mathrm{~m}$. tall, with a maximum trunk diameter of about $3 \mathrm{dm}$., the foliage glabrous or slightly silky-pubescent : leaflets 5-11, the blades oblong to ovate or oval, 3-14 $\mathrm{cm}$. long, acuminate at the apex, sharply serrate with incurved teeth, rarely divided at the base : cymes much broader than high, convex, 1-3 dm. broad : corolla white, 5-6 mm. broad; lobes broadly oblong or oval: drupes deep purple or nearly black, 4-6 $\mathrm{mm}$. in diameter : nutlets conspicuously roughened.

In moist soil, New Brunswick to Manitoba, Florida, Texas and Arizona. Spring and early summer.

3. Sambucus Mexicàna Presl. A tree usually 7-9 m. tall, the trunk often $3 \mathrm{dm}$. thick near the base : leaflets mostly 5 , the blades pubescent on both sides, but more densely so beneath, dentate or serrate-dentate : cymes flat, 1-2 dm. broad : corolla creamy white, 3-3.5 mm. broad : drupes black or nearly so, about $6 \mathrm{~mm}$. in diameter.

In river valleys, Texas and Mexico. Spring and early summer.

\section{VIBÚRNUM L.}

Shrubs or trees, with a smooth or deely furrowed often strong-scented bark. Leaves opposite : blades simple, leathery or membranous, entire or toothed: stipules usually obsolete or small. Flowers disposed in corymbose cymes, those at the exterior of the corymb sometimes neutral, their pedicels furnished with 1-2 scales. Hypanthium turbinate or obovoid. Sepals 5, equal, persistent. Corolla white or pink, rotate, with 5 equal imbricated lobes. Stamens 5, adnate to the corolla-tube: filaments variable in length. Disk wanting. Ovary 1-3-celled. Ovules solitary, pendulous. Drupe fleshy, or sometimes dry, varying from globose to oblong, terete or flattened, the single stone flattened, usually grooved at least on one side. Endosperm rarely ruminated. Arrow-wood.

Some flowers at the margin of the cymes radiant and sterile : drupes mainly red or scarlet.

None of the flowers radiant: drupes blue or black.

Leaf-blades palmately nerved or lobed.

Leaf-blades with salient lobes, the teeth manifestly acute or flaring.

Leaf-blades merely toothed or obscurely lobed, the teeth rounded or relatively blunt.

Leaf-blades pinnately nerved.

Cymes manifestly peduncled.

Leaf-blades coarsely dentate.

Leaf-blades sessile or very short-petioled.

Leaf-blades relatively lons-petioled.

Lower surfaces of the leaf-blades glabrous or merely with tufts of hairs in the axils of the nerves.

Lower surfaces of the leaf-blades stellate-pubescent.

Leaf-blades entire or irregularly erose-crenulate.

Peduncles shorter than the cymes.

Peduncles as long as the cymes or longer.

Cymes sessile or nearly so.

Leaves with manifest distinction between the blade and petiole; blades toothed all around.

Leaf-blades prominently acuminate, serrate.

Leaf-blades obtuse or merely acute, serrulate.

Petioles and leaf-surfaces glabrous or nearly so: seeds oblong.

Petioles and leaf-surfaces more or less densely red-tomentose: seeds orbicular or nearly so.

Leaves without distinction between blade and petiole; blades entire or mainly so, sometimes unevenly crenate.

Drupes 6-7 mm. long; stone turgid, suborbicular.

Drupes 10-11 mm. long; stone flat, oblong-obovate.

1. V. alnifolium.

2. V. acerifolium.

3. V. densiflorum.

4. V. pubescens.

5. V. dentatum.

6. $V$. molle.

7. V. cassinoides.

8. V. nudum.

9. V. lentago.

10. V. prunifolium.

11. V. rufotomentosum.

12. V. obovatum.

13. V. Nashii.

1. Viburnum alnifolium Marsh. A low usually straggling shrub, with the twigs, leaves and inflorescence stellate-pubescent. Stems decumbent or sometimes erect, 1-4 m. long; bark often warty : leaf-blades broadly ovate or orbicular-ovate, $10-20 \mathrm{~cm}$. long, abruptly acuminate, finely and doubly serrate, cordate, glabrate above, especially scurfy on the nerves beneath : petioles $1-3 \mathrm{~cm}$. long: cymes sessile, $7-15 \mathrm{~cm}$. broad: inner flowers fruit-producing, with white corollas $5-6 \mathrm{~mm}$. broad : marginal ones often neutral and radiant, with corollas $2-2.5 \mathrm{~cm}$. broad: drupes red or scarlet, sometimes becoming purple, 10-15 mm. long; stone flattened, with 3 grooves on one side and one on the other. [V. lantanoides Michx.]

In damp woods, New Brunswick to Michigan and North Carolina. Spring. HoBbLE-BUsH. 
2. Viburnum acerffolium L. A low branched shrub, with soft stellate pubescence, the stem erect or ascending, 1-2 m. tall, its branches or twigs softly pubescent, becoming glabrous. Leaf-blades thin, suborbicular or ovate, $4-10 \mathrm{~cm}$. long, usually with 3 acute or acuminate straight or recurved lobes, sharply toothed, rounded or cordate at the base, sparingly pubescent or glabrous above, softly tomentose or glabrate beneath : petioles slender, 1-4 cm. long, pubescent like the twigs: cymes 7-10 cm. broad, long-peduncled : flowers all perfect : corolla white, 4-6 mm. broad : drupes black or nearly so, 9-10 mm. long; stone flattened, slightly 2-grooved on one side, 2-ridged on the other.

In rocky woods, New Brunswick to Ontario, Minnesota and Georgia. Spring.

3. Viburnum densiflòrum Chapm. A low branched shrub, with simple and stellate pubescence, the stems erect, $0.5-1.5 \mathrm{~m}$. tall, the twigs rusty pubescent. Leaf-blades ovate or obovate, or rarely oblong, 3-8 cm. long, shallowly toothed or undulate, with low lobes or these wanting, obtuse or short-acuminate at the apex, cordate at the base, glabrous or sparingly pubescent above, finely tomentose beneath and tufted in the axils of the nerves: petioles slender, $8-11 \mathrm{~mm}$. long, pubescent like the twigs : cymes $3-5 \mathrm{~cm}$. broad, often densely flowered, peduncled : flowers all perfect : corolla white, $4-4.5 \mathrm{~mm}$. broad; lobes rounded : drupes oblong.

On wooded hillsides, western Florida and Alabama. Spring.

4. Viburnum pubéscens (Ait.) Pursh. A low much branched shrub, with more or less pubescent foliage, the stems erect or ascending, $0.5-2 \mathrm{~m}$. tall, the branches ascending. Leaf-blades ovate, varying towards oblong or orbicular, $2-7 \mathrm{~cm}$. long, acuminate, usually sharply serrate-dentate, entire towards the base, and there rounded or subcordate, glabrous or glabrate and shining above, more or less densely tomentose beneath or glabrate except the nerves, sessile or nearly so : cymes $3-6 \mathrm{~cm}$. broad, peduncled : flowers all perfect: corolla white, 5-6 mm. broad : drupes black or nearly so, oblong, 7-9 mm. long; stone with 2 shallow grooves on both surfaces.

In rocky woods, Quebec to Ontario, Minnesota, Georgia and Iowa. Spring and early summer.

5. Viburnum dentàtum L. An erect much branched shrub, 2-5 m. tall, the little pubescence that is present on the foliage of simple hairs. Leaf-blades suborbicular, oval or ovate, $3-8 \mathrm{~cm}$. long, abruptly or gradually acuminate, usually acute, sharply dentate, rounded or subcordate at the base, glabrous above, pubescent in the axils of the nerves beneath : petioles slender, $1-2 \mathrm{~cm}$. long, usually sparingly pubescent : cymes $5-8 \mathrm{~cm}$. broad, long-peduncled : flowers all perfect: corolla white, 4-5 mm. broad: drupes deep blue or nearly black, globose-ovoid, $\tilde{5}-6 \mathrm{~mm}$. long; stone rounded on one side, grooved on the other.

In or about meadows and swamps, New Brunswick to Ontario, Minnesota and Florida. Spring and rarely fall.

6. Viburnum mólle Michx. A small branching shrub, 2-4 m. tall, with more or less stellate-pubescent foliage. Leaf-blades suborbicular, broadly ovate or rarely elliptic, 3-14 $\mathrm{cm}$. long, commonly short-acuminate, obtuse or acute, crenate-dentate or the teeth sometimes acute, rounded, truncate or cordate at the base, glabrous or sparingly pubescent above, more densely pubescent beneath : petioles stout, 1-2 cm. long: cymes 4-10 $\mathrm{cm}$. broad, peduncled : flowers all perfect: corolla white, $5-8 \mathrm{~mm}$. broad : drupes deep blue, globose-ovoid, 8-9 $\mathrm{mm}$. long; stone grooved on one side, rounded on the other.

In low grounds or deep swamps, Pennsylvania to Florida and Texas. Spring and early summer.

7. Viburnum cassinoides $L$. A slender branched shrub or small tree, $2-5 \mathrm{~m}$. tall, with very scurfy twigs, petioles and inflorescence. Leaf-blades thickish, ovate-elliptic, ovate-lanceolate or oblanceolate, mostly abruptly acuminate but rather obtuse, undulate or crenate, cuneate or rounded at the base, glabrous or glabrate above, mostly scurfy on the nerves beneath: petioles $1-2 \mathrm{~cm}$. long: cymes $5-12 \mathrm{~cm}$. broad, longer than the peduncles: flowers all perfect : corolla white, $4-5 \mathrm{~mm}$. broad : drupes deep blue or rarely pink at maturity, ovoid or globose-ovoid, 6-9 mu. long; stone flattened.

In swamps or wet thickets, Newfoundland to Manitoba and Florida. Spring to fall. WITHE-ROD.

8. Viburnum nùdum L. An erect branching shrub, 1-4 m. tall, with obscurely scurfy and pubescent twigs, petioles and inflorescence. Leaf-blades leathery, oval, ovate, oblong, broadly lanceolate or oblanceolate, $5-15 \mathrm{~cm}$. long, acute or obtuse, slightly revolute, undulate or obscurely toothed, glabrous or scurfy, especially on the nerves beneath, shining above : petioles $1.5 \mathrm{~cm}$. long or shorter : cymes $4-12 \mathrm{~cm}$. broad, usually shorter than the peduncles: flowers all perfect : corolla white, $4-5 \mathrm{~mm}$. broad : drupes deep blue, oval to subglobose, 6-10 mm. long ; stone flattened.

In swamps, Long Island to Kentucky, Florida and Louisiana. Spring and summer- -A form ranging from North Carolina to Florida and Louisiana, with linear-oblong or narrowly oblong-lanceolate leaf-blades, is $V$. nudum angustifolium T. \& G., while a little-known form from near Darien, Georgia, $V$. nudum serótinum Ravenel, is less branched and has smaller flowers than in the typical form. 
9. Viburnum Lentàgo L. An erect shrub or small tree, $3-10 \mathrm{~m}$. tall, with pliable branches, the twigs, inflorescence and petioles sparingly pubescent with simple hairs. Leafblades varying from ovate to obovate or rarely suborbicular, 4-10 $\mathrm{cm}$. long, prominently acuminate, finely and sharply serrate, gradually or abruptly narrowed at the base, glabrous on both surfaces : petioles slender, 1-2.5 cm. long: cymes 4-12 cm. broad, sessile : flowers all perfect : corolla white, 5-6 mm. broad : drupes bluish black, with a bloom, oval, 10-12 $\mathrm{mm}$. long, sweet and edible ; stone flat.

In rich soil, Ontario to Manitoba, Georgia and Missouri. Spring. Sheep-Berry. Nancy-berry.

10. Viburnum prunif òlium L. An erect shrub or shrub-like tree $2-8 \mathrm{~m}$. tall, with rigid branches. Leaf-blades thinnish, oval varying to ovate or obovate, rarely suborbicular, obtuse or acutish, rarely abruptly acuminate, very finely serrate, the teeth often obscure, obtuse or truncate at the base: petioles slender, 1-2 cm. long: cymes $3-10 \mathrm{~cm}$. broad, sessile or nearly so : flowers all perfect : corolla white, $5-6 \mathrm{~mm}$. broad : drupes bluish, black with a bloom, oblong or oval-oblong, 7-9 $\mathrm{mm}$. long, sweet and edible; stone flat on one side, convex on the other.

In woods and thickets, Connecticut to Michigan, Georgia and Arkansas. Spring. BLACK-HAw.

11. Viburnum rufotomentòsum Small. A shrub, or a small tree becoming $6 \mathrm{~m}$. tall, with a heavy scent when bruised. Leaf-blades leathery, oblong or elliptic, or varying to broadest above or below the middle, mostly obtuse, finely serrate, the nerves pubescent beneath with deep red tomentum : petioles stout, densely red-or brown-tomentose : cymes ample, 8-12 cm. broad, sessile or nearly so : flowers all perfect : corolla white, 7-10 $\mathrm{mm}$. broad : drupes deep blue, with a bloom, oval, 10-14 mm. long; stone broader than that of $V$. prunifolium and larger.

In woods and thickets, Virginia to Illinois, Florida and Texas. Spring. BLACK-HAw.

12. Viburnum obovàtum Walt. A strong scented shrub or slender tree, with a dark rough bark and glabrous foliage, the stems erect or ascending, 2-9 $\mathrm{m}$. tall. Leafblades oblanceolate, cuneate or obovate, $1.5-6 \mathrm{~cm}$. long, rounded or retuse at the apex, entire or slightly toothed especially towards the apex, dark green and shining above, paler beneath, cuneately narrowed at the base into a short petiole, varying from 2-4 mm. long: cymes $2.5-6 \mathrm{~cm}$. broad, sessile : flowers all perfect : corolla white, 5-6 mm. broad : drupes black, oval, 6-8 $\mathrm{mm}$. long; stone 6-7 mm. long, usually fully as broad as long.

In swamps and low grounds, Virginia to Florida. Spring.

13. Viburnum Náshii Small. A shrub or small tree, reaching a height of 4 or $5 \mathrm{~m}$., with spreading branches. Leaves often clustered on short branches; blades suborbicular or broadly obovate to spatulate, 4-5 $\mathrm{cm}$. long, leathery, truncate or retuse at the apex, more or less distinctly crenate, deep green and shining above, paler beneath, constricted into petioles which are grooved above, and vary from $0.5-1 \mathrm{~cm}$. in length : cymes mostly terminating spur-like branchlets, few-flowered : drupes oblong, 10-12 $\mathrm{mm}$. in length, black, lustrous; stone oblong or broadest below the middle, much longer than broad.

In river swamps, western Florida. Spring and summer.

\section{TRIÓSTEUM L.}

Perennial herbs, with simple terete or nearly terete stems. Leaves opposite: blades membranous, entire, sessile or connate-perfoliate. Flowers solitary or clustered in the axils, each subtended by two bractlets. Hypanthium ovoid. Sepals 5, often leaf-like, persistent. Corolla yellowish, yellow, purple or dull red, tubular-campanulate: tube gibbous : limb oblique, with 5 unequal imbricated lobes. Stamens 5, adnate to the corolla tube; filaments very short: anthers linear. Disk swollen. Ovary 3-5-celled. Ovule solitary in each cavity, pendulous. Drupe fleshy or leathery, 2-celled or rarely 3-5-celled. Seeds elongated, ribbed or angled. Horse Gentian.

Leaf-blades narrowed to the sessile or slightly connate-perfoliate bases.

Leaves over thrice as long as broad: corolla yellowish.

Leaves less than thrice as long as broad: corolla dull red.

Leaf-blades with broadly dilated connate-perfoliate bases.

1. T. angustifolium.

2. T. aurantiacum.

1. Triosteum angustifòlium L. Foliage rather coarsely pubescent. Stems erect, 3-9 dm. tall, hirsute or softly hispid, simple, solitary or several together : leaf-blades usually narrowly elliptic, varying to lanceolate or oblanceolate, $3-15 \mathrm{~cm}$. long, acuminate at both ends, sessile or the uppermost sometimes connate, the lower ones spatulate or obovate: sepals linear, 8-10 mm. long: corolla yellowish, 12-15 $\mathrm{mm}$. long: drupes about 1 cm. long.

In rich soil, Connecticut to Illinois, Alabama and Louisiana. Spring and summer. 
2. Triosteum aurantiacum Bicknell. Similar to $T$. perfoliatum in habit. Stems 5-12 dm. tall, glandular-puberulent to nearly hirsute : leaf-blades ovate-oblong to oblonglanceolate, $1.5-2.5 \mathrm{dm}$. long, acuminate, not broadly connate-perfoliate, minutely soft-pubescent beneath, thinly appressed pubescent above or nearly glabrous : sepals $12-20 \mathrm{~mm}$. long, obtuse : corolla dull red, 14-20 mm. long : drupes oblong-ovoid, 12-14 mm. long, orange-red.

In rich soil and thickets, Quebec to Minnesota, Massachusetts and North Carolina. Spring.

3. Triosteum perfoliàtum L. Foliage softly pubescent. Stems $5-12 \mathrm{dm}$. tall, simple, solitary or sometimes tufted, finely glandular-pubescent: leaf-blades ovate or broadly oval, 1-2.5 dn. long, acute or acuminate at the apex, abruptly narrowed at the base, and with broad connate bases, softly pubescent beneath, sometimes puberulent above: sepals linear, 11-15 $\mathrm{nm}$. long, acute : corolla purplish, 12-15 $\mathrm{mm}$. long, viscid-pubescent, about equalling the sepals : filaments pubescent: drupes obovoid to globular, $8-12 \mathrm{~mm}$. long, orange-yellow, finely pubescent.

In rich soil and thickets, New York to Minnesota, Alabama and Kansas. Spring and early summer.

\section{SYMPHORICÁRPOS L.}

Slender branching shrubs, with shreddy bark. Leaves opposite, without stipules: blades thick, entire, or sinuate on shoots, short-petioled, deciduous. Flowers in short axillary spikes, or racemes. Hypanthium cup-shaped to subglobose. Sepals unequal, 4-5. Corolla white or colored, campanulate or funnelform, often slightly gibbous at the base: limb with 4-5 rather unequal lobes. Disk annular or cup-like. Stamens 4-5, adnate to the throat of the corolla-tube. Ovary 4-celled: styles thickened at the base. Ovules few and abortive in 2 of the cavities, solitary, perfect and pendulous in the other two. Berries fleshy, white or purple, 4-celled, 2-seeded. Seeds elongated.

Style glabrous : fruit white.

Style pubescent : fruit red or purplish.

1. S.racemosus.

2. S. Symphoricarpos.

1. Symphoricarpos racemòsus Michx. A branching shrub 1-2 m. tall, with glabrous foliage. Leaf-blades varying from elliptic to usually orbicular-oval or orbicularovate, mostly $3-6 \mathrm{~cm}$. long, obtuse or abruptly pointed, undulate or slightly lobed, shortpetioled : flowers short-pedicelled : corolla white or pinkish, $6-7 \mathrm{~mm}$. long; tube slightly gibbous at the base; lobes bearded within: style glabrous, like the stamens, included : berries white, oval or globose, 6-10 $\mathrm{mm}$. long, pulpy.

In rocky places, often on river banks, Nova Scotia to British Columbia, North Carolina, Kentucky and Minnesota. Spring to fall. SNOW BERRY.

2. Symphoricarpos Symphoricárpos (L.) MacM. A spreading shrub, 1-2 dm. tall, with pubescent branchlets. Leaves often apparently 2-ranked; blades ovate, oval or elliptic, 1-4 cm., rarely $7 \mathrm{~cm}$. long, obtuse or acutish, undulate, glabrate or glabrous above, pubescent beneath, short-petioled: flowers sessile or nearly so: corolla greenish red, 2.5$3.5 \mathrm{~mm}$. long; tube barely, if at all gibbous at the base; lobes glabrous or sparingly pubescent within: style pubescent : berries red or purplish, globose-ovoid, $3-4 \mathrm{~mm}$. long.

[S. vulgaris Michx.]

On river banks or in rocky soil, New York to South Dakota, Georgia and Texas. Also sparingly introduced into New England. Summer. CORALBERrY.

\section{XYLÓSTeON B. Juss.}

Shrubs, with upright branching stems. Leaves opposite : blades relatively broad, entire, sessile or short-petioled. Flowers in pairs each of which terminates an axillary peduncle, accompanied by two minute bracts and 2 bractlets, the hypanthia more or less united. Calyx minute or obsolete. Corolla relatively short: tube gibbous at the base : limb 5-lobed, often irregular or 2-lipped. Stamens more or less adnate to the corollatube. Ovary usually 2-celled : style slender. Berries distinct or didymous. FuY HonEYSUCKLE.

1. Xylosteon ciliàtum (Muhl.) Pursh. An erect branching shrub 0.5-2 m. tall, with glabrous twigs. Leaf-blades thin, sometimes rather firm in age, ovate or oval-ovate, 3-8 cm. long, acute or apiculate, ciliate, deep green on both sides, rounded or cordate at the base ; petioles 4-6 $\mathrm{mm}$. long : peduncles very slender, shorter than the leaves, each terminated by a pair of flowers : corolla yellowish, $12-22 \mathrm{~mm}$. long; tube saccate at the base ; lobes nearly equal, 5-7 mm. long, obtuse : stamens and style included : berries distinct, ovoid or oval-ovoid, 5-6 mm. long, bright red. [Lonicera ciliata Muhl.]

In moist rocky woods, Nova Scotia to Manitoba, North Carolina and Michigan. Spring. 


\section{NINTOÒA Sweet.}

Shrubby twining vines. Leaves opposite: blades entire, short-petioled or nearly sessile. Flowers in pairs each of which terminates an axillary peduncle, accompanied by 2 foliaceous bracts and 2 small bractlets, the hypanthia distinct. Calyx of 5 slender or subulate sepals. Corolla relatively long: tube slender, not gibbous at the base: limb often longer than the tube, 2-lipped, the upper lip 4-lobed, the lower lip narrow. Stamens 5: filaments adnate to the corolla-tube. Ovary often 2-celled: style slender. Berries subglobose or slightly elongated, pulpy, distinet.

1. Nintooa Japónica (Thunb.) Sweet. A diffusely climbing vine, 2-6 m. long, with glabrate or finely pubescent foliage, the bark shreddy. Leaf-blades oblong, ovate or orbicular-ovate, $2-5 \mathrm{~cm}$. long, thickish, obtuse, acute or short-acuminate, often slightly ciliate, rounded or truncate at the base, short-petioled; petioles pubescent like the branches: flowers in pairs terminating peduncles from the upper axils: corolla white or pink, turning yellow, pubescent without; tube about $2 \mathrm{~cm}$. long, longer than the recurved lips: stamens and style exserted : berries subglobose or oval, 4-6 $\mathrm{mm}$. in diameter, black. [Lonicera Japonica Thunb.]

On roadsides and in moist woods or thickets, New York to West Virginia aud Florida. Naturalized from Eastern Asia. Spring to fall. JAPANESE or CHINESE HONEYSUCKLE.

\section{LONÍCERA L.}

Shrubby vines, with trailing or twining stems and shreddy bark. Leaves sopposite: blades entire, or pinnatifid on shoots, one or more pairs at the ends of branches connate-perfoliate. Flowers sessile, often clustered at the joints, disposed in whorls. Hypanthium subglobose or ovoid. Sepals 5, equal or unequal. Corolla tubular, tubular-infundibuliform or long-campanulate : tube more or less swollen at the base : limb oblique, 2-lipped or with 5 nearly equal imbricated lobes. Stamens 5, adnate to the corolla-tube. Disk cushion-like. Ovary 2-3-celled: styles filiform: stigma capitate. Ovules numerous, inserted in 2 rows on placentae arising from the inner angles of each cavity. Berry fleshy, 2-3-celled or by suppression of the septa 1-celled, few-seeded. Honeysuckle.

Corolla-limb 2-lipped, the upper lip 4-lobed, the lower lip entire.

Corolla-tube glabrous within.

Corolla-tube pubescent within.

Corolla white, lemon-yellow or reddish : tube more or less gibbous.

Corolla white or yellowish white: plants with typically only one pair of bracts or leaves connate.

Corolla lemon-yellow or reddish: plants with typically several pairs of bracts or leaves connate.

Corolla-tube less than $10 \mathrm{~mm}$. long.

Corolla-tube over $10 \mathrm{~mm}$. long.

Corolla pubescent without: leaf-blades finely pubescent beneath. Corolla glabrous without: leaf-blades glabrous.

Corolla deep yellow or orange; tube slightly gibbous.

Corolla pubescent about the throat within; tube about $15 \mathrm{~mm}$. long. $\quad 6$. L. flavescens.

Corolla glabrous within; tube about $20 \mathrm{~mm}$. long. $\quad 7$. L. flava.

Corolla-limb scarcely 2 -lipped, of 5 nearly equal lobes.

1. L. Caprifolium.

2. L. albiflora.

3. L. dioica.

4. L. glaucescens.

5. L. Sullivantii.

8. L. sempervirens.

1. Lonicera Caprifòlium L. A twining vine 2-6 m. long, with almost glabrous and more or less glaucous foliage, the twigs often pilose. Leaf-blades thickish, oblong, oval or obovate, $2-7 \mathrm{~cm}$. long, mostly obtuse, glaucous beneath, the lower ones shortpetioled, the upper sessile, or the upper one or two pairs connate : flowers in sessile terminal clusters : corolla purple without, $3.5-4 \mathrm{~cm}$. long, glabrous within ; tube $2.5-3 \mathrm{~cm}$. long, curved, longer than the lips: stamens and style exserted : berries red. [L. grata Ait.]

In thickets and rocky woods, New York to Michigan, south to Georgia and Louisiana. Native of Europe. Spring.

2. Lonicera albiflòra T. \& G. A shrubby, spreading or partially twining vine, with branches 1-3 m. long, the foliage glaucous, usually glabrous. Leaf-blades becoming thickish, broadly oval, orbicular-oval or obovate, $1.5-4 \mathrm{~cm}$. long, those of the distal pair, or typically one pair of bracts connate: flowers in a terminal cluster : corolla 2 lipped, white or yellowish white, 13-16 mm. long, glabrous without; tube slightly gibbous, pubescent within ; lobes of the lips obtuse : filaments glabrous or nearly so: style pubescent : berries globular, 8-10 $\mathrm{mm}$. in diameter.

In thickets or on banks, Arkansas to Texas and Arizona. Spring.

3. Lonicera dioìca L. A shrubby or twining vine 1-3 m. long, with glabrous and glaucous foliage. Leaf-blades thinnish, oblong or broadly ovate, oval or obovate, obtuse 
or acutish, usually very glaucous beneath, deep green above, sessile and 2 or several of the upper pairs connate: flowers in terminal clusters : corolla yellowish green, tinged with purple, glabrous without; tube about $1 \mathrm{~cm}$. long, gibbous at the base, barely longer than the lips: filaments pubescent, like the style, exserted: berries subglobose, $6-8 \mathrm{~mm}$. in diameter, red. [L. parviflora Lam.]

On dry rocky hillsides, Quebec to Manitoba, Georgia and Ohio. Spring.

4. Lonicera glaucéscens Rydb. A twining vine, with widely branched stems, the branches sometimes sparingly pubescent, often glaucescent : leaf-blades oblong or elliptic, varying to slightly broadest above or below the middle, $5-12 \mathrm{~cm}$. long, acute or apiculate, more or less pubescent and glaucous beneath, barely chartaceous margined, sessile : bracts connate: spikes short-peduncled : corolla yellow turning to reddish, barely $2 \mathrm{~cm}$. long, somewhat pubescent and often glandular-puberulent without; tube strongly gibbous at the base, pubescent within ; limb 2-lipped, shorter than the tube : filaments glabrous or pubescent: style hirsute: berries globose.

In thickets or ravines, Ontario to Saskatchewan, North Carolina and Nebraska. Spring.

5. Lonicera Sullivántii A. Gray. A rigid twining vine $2-5 \mathrm{~m}$. long, with copiously glaucous foliage. Leaf-blades oblong, oval or obovate, $2.5-8 \mathrm{~cm}$. long, obtuse, entire, firm at maturity, 1 or several of the upper pairs connate, glabrous : flowers in terminal clusters : corolla pale yellow, glabrous without; tube about $1 \mathrm{~cm}$. long, somewhat longer than the lips: filaments glabrous or nearly so, like the style, exserted : berries subglobose, $5-6 \mathrm{~mm}$. in diameter, yellow.

In rocky or dry woodlands, Ontario to Wisconsin and Tennessee. Spring.

6. Lonicera flavéscens Small. A trailing or slightly twining branching vine becoming several $\mathrm{m}$. long, the stem and branches glabrous. Leaf-blades oblanceolate to elliptic or rhombic-ovate, $8-12 \mathrm{~cm}$. long, acute, entire, not chartaceous-margined, finely pubescent beneath or glabrate, sessile or nearly so : bracts connate, abruptly pointed, green above : spikes showy : corolla light yellow, about $2 \mathrm{~cm}$. long, more or less pubescent within near the throat; tube slender, barely gibbous at the base; limb 2-lipped, the lips curled back : berries globular.

On bluffs and shaded banks, Kentucky and Tennessee. Spring.

7. Lonicera flàva Sims. A twining vine $1-3 \mathrm{~m}$. long, with glabrous and sparingly glaucous foliage. Leaf-blades broadly oval, broadly ovate or oblong, or rarely obovate or elliptic, the upper 1,2 or 3 pairs connate, obtuse or acutish, chartaceous-margined, gradually narrowed or sometimes cordate at the base, the lower ones short-petioled : flowers in terminal clusters, fragrant : corolla bright orange-yellow, glabrous without; tube fully $20 \mathrm{~mm}$. long, glabrous within, barely gibbous, about twice as long as the lips: filaments and style glabrous, exserted : berries subglobose or oval, 6-7 mm. long.

On rocks or in rocky soil, North Carolina, South Carolina, Georgia and Alabama. Spring.

8. Lonicera sempérvirens Ait. A commonly evergreen twining vine 1-6 m. long, with glabrous or sparingly pubescent and glaucous foliage. Leaf-blades leathery, oval or oblong or sometimes obovate, lanceolate or linear-lanceolate, $3-9 \mathrm{~cm}$. long, obtuse or apiculate, glaucous and sometimes softly pubescent beneath, the upper pair or several pairs connate, dark green, glabrous or nearly so above : clusters forming terminal interrupted spike-like panicles : corolla scarlet or yellow, $3-4 \mathrm{~cm}$. long, glabrous; tube slightly dilated upward; lobes 5, spreading, nearly equal: stamens and style scarcely exserted : berries clustered, about $6 \mathrm{~mm}$. long, scarlet.

In sandy soil, often on river banks, Connecticut to Nebraska, Florida and Texas. Summer to fall.

\section{DIERVÍLLA L.}

Shrubs, with erect branching stems. Leaves opposite: blades membranous, entire or toothed, sessile or short-petioled. Flowers pedicelled, in terminal or axillary dichotomous cymes. Hypanthium elongated, narrowed above. Sepals 5, narrow, erect, persistent. Corolla white, yellow, pink or purple, infundibuliform or somewhat campanulate: tube narrow : limb slightly oblique, with 5 imbricated lobes. Stamens 5, adnate to the corollatube : anthers linear. Disk variable in shape, entire or 2-lobed, fleshy, adnate to the base of the corolla-tube. Ovary 2-celled, or rarely 3-celled. Ovules numerous in each cavity, inserted in 2 rows on placentae arising from the inner angles. Capsule elongated, leathery or woody, opening septicidally by 2 valves. Seeds numerous, minute, flattened, angled. 
1. Diervilla Diervílla (L.) MacM. A low often diffuse shrub $0.5-1.5 \mathrm{~m}$. tall, with glabrous or nearly glabrous foliage, the bark scaly. Leaf-blades oval, or oblong-ovate, 3-15 cm. long, acuminate, serrate, ciliate, usually abruptly narrowed or cordate at the base ; petioles 4-10 $\mathrm{mm}$. long : peduncles shorter than the petioles, $1-5$-flowered : corolla yellow or greenish ; tube $7-9 \mathrm{~mm}$. long; lobes nearly equal, 3 sometimes partially united : capsules narrowly oblong, acute-beaked, 7-8.5 mm. long, glabrous. [D. trifida Moench.]

In dry or rocky woods, Newfoundland to the Northwest Territory and in or near the mountains to Georgia and Michigan. Spring. Bush Honeysuckle.

2. Diervilla sessiliròlia Buckl. A loosely branching shrub $0.5-1.5 \mathrm{~m}$. tall, with 4angled branches pubescent in lines. Leaf-blades lanceolate, ovate-lanceolate or sometimes ovate, 5-15 cm. long, acuminate, sharply serrate, abruptly narrowed at the base or cordate, glabrous or essentially so, sessile : peduncles mostly over $5 \mathrm{~mm}$. long : cymes several-flowered : sepals lanceolate or subulate-lanceolate : corolla sulphur-yellow or somewhat greenish, about $1 \mathrm{~cm}$. long: lobes shorter than the tube, one slightly pubescent within: capsules oblong, 9-12 mm. long.

In rocky mountain woods or ravines, North Carolina, Tennessee, Georgia and Alabama. Spring and early summer.

3. Diervilla rivulàris Gattinger. A branching shrub $0.5-2 \mathrm{~m}$. tall, with copiously pubescent twigs and inflorescence. Leaf-blades ovate to oblong-lanceolate, $3-8 \mathrm{~cm}$. long, acuminate, unevenly and doubly serrate, pubescent on both sides, pale beneath, truncate or cordate at the base, manifestly but short-petioled : cymes few-many-flowered : sepals lanceolate-subulate : corolla lemon-yellow, about $1 \mathrm{~cm}$. long : capsules oblong-ovoid, $5-6 \mathrm{~mm}$. long, sparingly pilose.

On damp banks, mountains of North Carolina, Tennessee, Georgia and Alabama. Summer.

\section{Order 11. VALERIANÀLES.}

Caulescent herbs, succulent or with firm tissues and coarse. Leaves opposite, sometimes whorled: blades entire, toothed or divided, sometimes connateperfoliate, without stipules. Flowers mainly perfect, in open or congested cymes or dense involucrate heads. Calyx of several bristles, or a mere cup or obsolete. Corolla of 2 or 5 partially united petals. Androecium usually of fewer stamens than there are corolla-lobes. Anthers separate. Gynoecium 1-3carpellary. Ovary inferior, 1-3-celled, 2 of the cavities commonly imperfect. Ovules solitary, pendulous. Fruit an achene, or nut-like.

Gynoecium 3-carpellary, two of the cavities empty : flowers not in involucrate heads.

Gynoecium 1-carpellary : flowers in dense involucrate heads.

Fam. 1. VAlerianacear.

Fam. 2. Morinacrae.

\section{FAmily 1. VALERIANÀCEAE Batsch. VAlerian Family.}

Annual or perennial herbs, with a watery sap, commonly heavy-scented roots and a bitter or acid taste. Stems often dichotomously branched. Leaves opposite (those near the base often clustered): blades entire or pinnately divided, often somewhat clasping at the base. Inflorescence cymose, paniculate or congested. Flowers perfect, monoecious or dioecious. Calyx of 3-5 sepals, sometimes pappus-like or obsolete. Corolla gamopetalous, tubular, funnelform, or sometimes salverform: tube sometimes produced into a sac near the base : limb with 3-5 imbricated lobes. Androecium of 1-4 stamens, adnate to the corolla-tube, fewer in number than the lobes. Filaments distinct or united. Anthers introrse, incumbent, separate. Gynoecium 3-carpellary. Ovary inferior, 3-celled, but only one cavity perfect, the other 2 abortive. Styles terminal, united. Stigmas sometimes united. Ovule pendulous, solitary in the perfect cavity of the ovary, anatropous. Fruit a kind of leathery or crustaceous nutlet, naked, or crowned with the calyx. Seed pendulous, with a membranous testa. Endosperm wanting or sometimes present. Embryo straight, with thickish cotyledons.

Sepals becoming bristle-like or awn-like : fruit 1-celled : tall herbs often with divided leaf-blades.

Sepals minute or wanting : fruit 3-celled: low herbs with undivided leaf-blades.

Corolla funnelform; tube not longer than the nearly regular limb.

Corolla salverform; tube 2-4 times as long as the irregularly 2-lipped limb.

1. VALERIANA.

2. VAlertanelia.

3. SiPHONELLA. 


\section{VALERIANA L.}

Perennial heavy-scented herbs. Stems occasionally almost wanting, or erect or elongated and climbing. Leaf-blades entire, toothed or pinnatifid. Flowers perfect, in close terminal, spicate or panicled cymes. Calyx-limb inrolled but at length spreading, developing 5-15 plumose bristles. Corolla white or pink, funnelform or salverform, 5-lobed : tube more or less gibbous or saccate : lobes spreading. Stamens 3 or rarely fewer. Ovary 1celled: style filiform, slightly 2-3-cleft at the apex. Achene flattened, 1-nerved on the back, 3-nerved on the front. Seed solitary. Embryo straight. VAlerian.

Stems climbing ; upper stem-leaves ternate : corolla $1.5 \mathrm{~mm}$. long. Stems erect: upper stem-leaves pinnate: corolla $2 \mathrm{~cm}$. long.

1. V. scandens.

2. V. pauciflora.

1. Valeriana scándens L. Foliage glabrous. Stems slender, climbing, branched: basal leaves with entire broadly ovate cordate blades: stem-leaves with mostly ternately divided long-petioled blades, the segments ovate, or deltoid-ovate, acute or acuminate, undulate or distinctly and shallowly toothed, the terminal one truncate or subcordate, the two lateral ones oblique at the base : panicles axillary and terminal, 1-2 dm. long, its branches zigzag, the ultimate divisions being spikes : flowers very small, their bracts $1-2 \mathrm{~mm}$. long: corolla short-funnelform, about $1.5 \mathrm{~mm}$. long: fruit narrowly ovoid.

In thickets, Florida, also in the West Indies, Central and South America.

2. Valeriana pauciflòra Michx. Foliage sometimes sparingly pubescent. Stems erect, 3-10 dm. tall, usually simple : leaves various ; basal and lower stem-leaves with undivided or nearly undivided, broadly ovate or triangular-ovate, acute or acutish crenate or dentate or rarely entire cordate long-petioled blades; upper stem-leaves with pinnately divided blades, with large segments and 1 or 2 pairs of smaller ones, one of which is near the base of the petiole, the larger segments ovate, toothed like the lower leaf-blades: corymbs terminal, 5-10 $\mathrm{cm}$. long: bracts 4-8 $\mathrm{mm}$. long: corolla white or pink, about $2 \mathrm{~cm}$. long; tube very slender, funnelform above; lobes about as long as broad, rounded at the apex.

On alluvial river banks, Pennsylvania to Missouri, Virginia and Tennessee. Spring.

\section{VALERIANÉLLA Moench.}

Annual vernal herbs, with fleshy tissues and usually glabrous foliage. Stems dichotomously branched. Leaves opposite, the basal rosulate: blades entire, toothed, lobed or rarely pinnatifid. Flowers perfect, in terminal clustered or corymbose cymes. Calyx small, lobed or obsolete. Corolla white, bluish or purplish, funnelform : tube not usually gibbous : limb of 5 spreading equal lobes. Stamens 3 . Fruit with the 2 sterile portions more or less enlarged, sometimes confluent, rarely bursting. CORN SALAD.

Corolla blue or purplish : fruit about twice as broad as thick: species introduced. Corolla white: fruit about as broad as thick : species native.

Fruit with the fertile portion fully as wide as the sterile portion.

Fruit 3-angled.

Fruit 4-angled.

Fruit ovoid-tetragonal, with a broad and shallow groove between the sterile portions.

Fruit oblong-tetragonal, with a very narrow groove between the sterile portions.

Fruit with the fertile portion much smaller and narrower than the sterile portion :

Empty cavities broad, bladder-like by the infolding of the edges and forming a cross-shaped umbilication.

Empty cavities never infolded so as to make a bladder-like body.

Empty cavities dilated and divergent, forming a saucer-shaped body notched at both ends.

Empty cavities contiguous, with an oblong depression between them.

1. V. Locusta.

2. V. amarella.

3. V. radiata.

4. V. stenocarpa.

5. V. umbilicata.

6. $V$. patellaria.

7. V. Woodsiana.

1. Valerianella Locústa (L. ) Bettke. Stems erect, 1-4 dm. tall, simple or branched throughout: leaves fleshy; basal and lower stem-leaves with spatulate or oblanceolate blades; upper stem-leaves with oblong or oblong-lanceolate, entire or sparingly toothed
blades, all obtuse, $1.5-7 \mathrm{~cm}$. long: corolla blue or purplish, funnelform ; tube not longer than the diameter of the limb : fruit about twice as broad as thick. [ $\mathrm{V}$. olitoria Poll. $]$

In waste places, woods and meadows, New York to New Jersey, Pennsylvania and Louisiana. Spring and early summer.

2. Valerianella amarélla Krok. Stems erect, 1-3 dm. tall, usually much branched throughout, or sometimes simple: basal and lower stem-leaves with oblanceolate or spatulate blades; upper stem-leaves with oblong or oblong-oblanceolate blades, all obtuse, more or less undulate or crenate, sessile : corolla white, funnelform : fruit 3-angled, with fertile 
portion fully as broad as the sterile portion, about $1 \mathrm{~mm}$. long, white-hirsute, all the angles obtuse or rounded.

In low grounds, Texas. Spring and summer.

3. Valerianella radiàta Dufr. Stems erect, $2-7 \mathrm{dm}$. tall or rarely very low, simple or branched above or throughout: leaves $2-10 \mathrm{~cm}$. long; basal and lower stem-leaves with spatulate obovate or somewhat fiddle-shaped entire blades; upper stem-leaves with oblong or oblanceolate blades, or the uppermost ovate, all obtuse, shallowly toothed, especially near the base or entire : corolla white, funnelform : fruit 4-angled, obovoid-tetragonal with a broad and shallow groove between the sterile portions. mer.

In meadows and low grounds, New York to Michigan, Florida and Texas. Spring and sum-

4. Valerianella stenocárpa Krok. Stems slender, erect, 1-3 dm. tall, branched above, or sometimes simple : leaves 1-8 cm. long; basal with spatulate blades ; lower stemleaves oblanceolate, entire ; upper leaves with oblong or oblong-ovate more or less distinctly toothed blades, all obtuse: peduncles nearly filiform : corolla white, funnelform : fruit 4angled, oblong-tetragonal, with a very narrow groove between the sterile portions, usually glabrous, rarely pubescent.

In low grounds, Missouri and Kansas to Texas. Spring.

5. Valerianella umbilicàta (Sulliv.) Krok. In habit and leaves resembling $V$. radiata. Fruit about $2 \mathrm{~mm}$. long with fertile portion much narrower and smaller than the sterile portion, which is bladder-like by the infolding of the edges, thus forming a crossshaped umbilication.

In low grounds, New York and Ohio to Pennsylvania and Tennessee. Spring and summer.

6. Valerianella patellària (Sulliv.) Krok. In habit and leaves resembling $V$. radiata. Fruit about $2 \mathrm{~mm}$. long, with the fertile portion much smaller and narrower than the sterile, edges never infolded, dialated, forming a saucer-shaped body with a notch at both ends.

In meadows and low grounds, Pennsylvania to Ohio and Tennessee. Spring.

7. Valerianella Woodsiàna (T. \& G.) Walp. In habit and leaves resembling $V$. radiata. Fruit about $2 \mathrm{~mm}$. long, with the fertile portions much smaller and narrower than the sterile; the cavities of this latter contiguous, with an oblong depression between them.

In low grounds, New York to Pennsylvania, Ohio, Tennessee and Texas. Spring and summer.

\section{SIPHONÉLIA Small.}

Annual vernal herbs, with glabrous foliage and fleshy tissues, resembling Valerianella in habit. Bracts of the inflorescence ciliate with gland-tipped teeth. Cymes congested. Corolla white, cream-colored, purplish or pink, salverform: tube slender, twice or four times as long as the lobes of the irregularly 2-lipped limb, commonly swollen or spurred near the middle or base ; the two posterior lobes more united than the rest. Stamens 3. Fruit with the fertile cavity much smaller than the two divergent empty sterile cavities.

Corolla pink or purplish ; tube over $6 \mathrm{~mm}$. long, often swollen at the base. Corolla white or cream-colored; tube less than $5 \mathrm{~mm}$. long, often swollen at the middle. 2 . V. Nuttallii.

1. Siphonella longiflòra (T. \& G.) Small. Stems erect, 1-3 dm. tall, simple or branched throughout: leaves 1-5 cm. long; basal spatulate, entire; upper stem-leaves with mostly oblong blades usually more or less sharply toothed at the base, obtuse : corolla pink or purplish, about $1 \mathrm{~cm}$. long; tube nearly filiform, often swollen near the base, 3-4 times as long as the obtuse lobes : fruit almost orbicular in outline, saucer-shaped, the sterile portions separated by a narrow partition, widely diverging, each larger than the fertile portion which is tipped with a short blunt apex. [Fedia longiflora T. \& G.]

In low rocky grounds or on cliffs, Missouri and Arkansas. Spring.

2. Siphonella Nuttállii (T. \& G.) Small. Stems erect, 1-2 dm. tall, simple or sparingly branched above : leaves 1-2 cm. long; basal spatulate ; lower stem-leaves with oblanceolate or oblanceolate-spatulate blades, and those of the upper leaves oblong, all obtuse or retuse, entire : cymes congested : corolla cream-colored or white, 5-6 mm. long ; tube slender, with a little sack near the middle, about twice as long as the obtuse lobes of the limb: fruit similar to that of $S$. longiflora, but the fertile portion with a soft elongated tip. [Fedia Nuttallii T. \& G.]

On low plains, Arkansas. Spring. 


\section{Family 2. MORINACeate Dumort. Teasel Family.}

Annual or perennial, sometimes prickly herbs, or shrubby plants. Leaves opposite or rarely whorled : blades entire, toothed or dissected. Flowers perfect, each with an involucel, commonly numerous, crowded on a common receptacle which is subtended by an involucre. Calyx entire and cup-like, or of several bristles. Corolla gamopetalous : tube enlarged upward : limb with $2-5$ imbricated lobes. Androecium of 2-4 stamens, adnate to the upper part of the corolla tube : filaments distinct, often inflexed : anthers versatile, opening lengthwise, separate. Gynoecium a single carpel. Ovary inferior, 1-celled: style elongated, entire: stigmas globose to elongated, terminal or lateral. Ovule solitary, pendulous, anatropous. Fruit an achene surrounded by the accrescent involucre and crowned with the persistent calyx. Seed with a membranous testa. Embryo straight in the fleshy endosperm. [Dipsacaceae Lindl.]

\section{DÍPSACUS L.}

Coarse or prickly biennial or perennial herbs, with channeled stems. Leaves opposite : blades often connate, coarsely toothed or pinnatifid, the nerves often prickly beneath. Involucral bracts and scales of the receptacle rigid. Flowers in terminal globose or oblong heads. Involucre calyx-like, inclosing the ovary. Calyx a cup-shaped, or 4-lobed limb. Corolla tubular-funnelform, 4-lobed, often slightly irregular, blue or white. Stamens 4. Style filiform: stigma oblique or lateral. Achene 8-ribbed, enclosed in, and more or less adnate to the involucre, its pericarp thin, crowned with the persistent calyx-limb.

1. Dipsacus sylvéstris Huds. Biennial, coarse, dark green, armed with short prickles. Stem erect, 1-2.5 m. tall, channeled, often sparingly branched, the branches ascending : basal leaves oblanceolate, obtuse, crenate-serrate, sessile, $2-4 \mathrm{dm}$. long ; stemleaves lanceolate, acutish, entire, often with a few prickles on the margin, more or less clasping, the midrib large and prominent beneath, flat and white above : heads ovoid, 5-6 $\mathrm{cm}$. long, subtended by linear-lanceolate rough involucral bracts: calyx fully $1 \mathrm{~mm}$. high, green, cup-shaped, 4-sided, pubescent, ciliate : corolla 11-13 mm. long; tube white, puberulent; lobes 4 , lilac, broadly ovate, converging, obtuse, many times shorter than the tube: stamens exserted.

Adventive or naturalized in waste places or fields. Native of Europe. Summer. WiLd TEAsEL.

\section{Order 12. ARISTOLOCHIÀLES.}

Herbs or vines, often with woody stems. Leaves alternate, sometimes all basal: blades mostly cordate or hastate. Flowers perfect, often conspicuous. Hypanthium present, mostly adnate to the ovary. Calyx present, regular or exceedingly irregular. Corolla wanting or rudimentary. Androecium of as many stamens as there are calyx-lobes, or more. Gynoecium of usually 6 united carpels. Ovary inferior or rarely superior. Fruit a capsule. Endosperm present.

\section{Family 1. ASARÀCEAE Link. Birthwort Family.}

Perennial, sometimes acaulescent, herbs or woody vines, often with a gingeraromatic or ill-smelling property. Leaves alternate, without stipules: blades various, often lobed, usually cordate. Flowers perfect, regular or very irregular, variable in size, solitary, or in cymes or racemes. Calyx usually colored : tube sometimes bent and inflated. Calyx various, of 3 distinct or united sepals. Androecium of 6-many stamens. Filaments inserted in 1-2 series, free from or adnate to the ovary or style-column. Disk wanting. Gynoecium a single pistil. Ovary 4-6-celled, inferior or superior. Styles commonly united. Ovules numerous in each cavity, anatropous, horizontal or pendulous. Fruit mostly a 6-celled capsule. Seeds usually numerous, with a crustaceous, smooth, wrinkled or granular testa. Endosperm fleshy. Embryo in the endosperm near the hilum. [Aristolochiaceae Blume.] 
Acaulescent herbs: calyx regular, persistent: capsule fleshy.

Ovary superior: filaments shorter than the anthers: styles distinct: leaves persistent.

Ovary inferior: filaments longer than the anthers : styles united : leaves deciduous. 2. AsA RUM. Caulescent herbs or vines : calyx irregular, deciduous : capsule dry.

3. Aristolochia.

\section{HEXÁSTYLIS Raf.}

Perennial evergreen, acaulescent gingerous-aromatic herbs, with branching rootstocks and thick fleshy roots. Leaves usually 1 every year : blades leathery, varying from suborbicular to triangular, entire or crenulate, cordate, often mottled. Flowers solitary on pedicels, axillary to a bract. Hypanthium glabrous without, turbinate, campanulate or urnshaped, terete. Sepals 3, persistent, valvate. Stamens 12: filaments shorter than the anthers or wanting. Ovary 6-celled, mainly free. Styles 6, distinct, prolonged beyond the extrorse stigmas, the tips 2-cleft. Ovules numerous, horizontal or pendulous. Capsule 6-celled, leathery, enveloped in the hypanthium. Seeds flattened. Wild Ginger.

Leaf-blades mostly of an ovate or suborbicular type.

Hypanthium turbinate, at least during anthesis.

Hypanthium campanulate, cylindric-campanulate or urn-shaped.

Flowers $2.5-5 \mathrm{~cm}$. long.

Flowers 1-2.5 cm. long.

Hypanthium campanulate at maturity : sepals about $1 / 2$ as long as the hypanthium.

Hypanthium urn-shaped at maturity: sepals barely $1 / 3$ as long as the hypanthium.

Leaf-blades entire: flowers $1-1.5 \mathrm{~cm}$. long.

Leaf-blades erose-crenulate : flowers $1.5-2.5 \mathrm{~cm}$. long.

Leaf-blades mostly of a hastate type.

Hypanthium constricted at the throat: sepals spreading.

Hypanthium not constricted at the throat: sepals erect.

1. H. heterophylla.

2. H. Shuttleworthii.

3. H. Virginica.

4. H. Memmingeri.

5. H. callifolia.

6. H. arifolia.

7. H. Ruthii.

1. Hexastylis heterophýlla (Ashe.) Small. Leaf-blades orbicular-reniform or triangular-ovate, $5-10 \mathrm{~cm}$. long, acute, or sometimes rounded or retuse at the apex, with a slightly open sinus : petioles as long as the blades or twice as long: flowers $1-1.5 \mathrm{~cm}$. long: hypanthium turbinate, at least during anthesis : sepals $8-12 \mathrm{~mm}$. broad, often nearly as long as the hypanthium, crisped, orange, purple or brown-purple without, lighter within : prolongations of the styles very short, barely notched: capsule hardly distending the hypanthium at maturity : seeds oval.

In mountain woods, Virginia and West Virginia, south to Georgia and Alabama. Spring.

2. Hexastylis Shuttlewórthii (J. Britten) Small. Leaf-blades ovate to suborbicular or rhombic-orbicular, 5-8 cm. long, apiculate or obtuse, with an open or closed sinus: petioles as long as the blades or much longer: flowers $2.5-5 \mathrm{~cm}$. long: hypanthium cylindric-campanulate: sepals $1.5-2 \mathrm{~cm}$. broad, often abruptly acute, mottled within : pedicel shorter than the diameter of the flower: prolongations of the style stout, barely notched at the apex : capsule hardly distending the hypanthium : seeds triangular in outline.

In high-mountain woods, Virginia to Georgia, Tennessee and Alabama. Spring and summer.

3. Hexastylis Virgínica (L.) Small. Leaf-blades ovate or rarely orbicular-ovate, 4-9 cm. long, mostly obtuse or retuse, usually with an open sinus: petioles as long as the blades or twice as long: flowers $1 . \bar{\delta}-2 \mathrm{~cm}$. long: hypanthium campanulate : sepals less than $1 \mathrm{~cm}$. broad, barely $\frac{1}{2}$ as long as the hypanthium, spreading, usually purplish and sometimes mottled within : pedicel about as long as the flower: prolongations of the style, stout, barely notched: capsule only slightly distending the hypanthium : seeds oblong. [Asarum Virginicum L.]

In woods, Virginia and West Virginia, south to South Carolina and Tennessee. Spring.

4. Hexastylis Memmíngeri (Ashe) Small. Leaf-blades suborbicular to ovate, 4-7 cm. long, mostly obtuse or retuse, sometimes mottled, with a slightly open sinus : petioles about as long as the blades or much longer: flowers 1-1.5 cm. long, urn-shaped : hypanthium more or less constricted at the throat: sepals rarely over $3 \mathrm{~mm}$. long, obtuse : pedicel as long as the flowers or shorter: prolongations of the styles slender, usually deeply cleft: capsule conspicuously distending the hypanthium: seeds sharply triangular.

In sandy woods, Virginia and West Virginia to Georgia. Spring and early summer.

5. Hexastylis callifòlia Small. Leaf-blades ovate, 5-9 cm. long, obtuse or sometimes acutish, finely undulate or crenulate, rarely mottled, deeply cordate at the base : petioles 2-3 times longer than the blades, sparingly pubescent : bracts reniform, ciliate : pedicel as long as the flower, or much shorter : flower urn-shaped, $1.5-2.5 \mathrm{~cm}$. long, dark 
green without, dark purple within : sepals broadly ovate or broader than high: prolongations of the style 2-cleft : capsule not seen. [Asarum callifolium Small.]

In shady woods, Florida.

6. Hexastylis arifòlia (Michx.) Small. Leaf-blades hastate, triangular or sometimes ovate-hastate (the basal lobes sometimes with parallel sides), 6-12 cm. long, mostly obtuse or retuse, entire, sometimes with a wide open sinus : petioles usually much longer than the blades: flowers $2-3 \mathrm{~cm}$. long, urn-shaped: hypanthium less than $8 \mathrm{~mm}$. in diameter at the constricted throat: sepals triangular or rounded, broader than long, spreading, purple from within: prolongations of the styles cleft to the top of the stigmas: capsule slightly distending the hypanthium. [Asarum arifolium Michx.]

In rich woods, Virginia to Georgia and Alabama. Spring and summer.

7. Hexastylis Rúthii (Ashe) Small. Leaf-blades hastate to triangular, occasionally slightly rhombic, $8-15 \mathrm{~cm}$. long, obtuse, retuse or abruptly pointed, with a rather narrow sinus : petioles longer than the blades : flowers $2-3 \mathrm{~cm}$. long : hypanthium narrowed to the mouth but not constricted, usually over $10 \mathrm{~mm}$. in diameter at the throat: sepals erect, mostly longer than broad, dull purplish green within: pedicel as long as the flower or much longer: prolongations of the styles notched to the top of the stigmas: capsule barely distending the hypanthium.

In sandy woods, southwestern Virginia to Tennessee and Alabama. Spring and early summer.

\section{2. ÁSARUM L.}

Perennial acaulescent gingerous herbs, with usually manifestly pubescent foliage. Rootstocks elongated, the roots fibrous. Leaves in pairs, deciduous : blades membranous mostly broader than long, cordate at the base. Flowers on pedicels arising from between the petioles. Hypanthium angled. Sepals 3, pubescent without, as long as the hypanthium or longer, inflexed in the bud. Stamens 12: filaments longer than the anthers. Ovary inferior: styles united : stigmas terminating the style-column. Capsule inferior, angled. Seeds plump. WILd Ginger.

Sepals lanceolate-acuminate, longer than the hypanthium.

Sepals slightly longer than the hypanthium, the tubular portion 4-8 mm. long: species mainly Alleghenian.

Sepals much longer than the hypanthium, the tubular portion 10-20 $\mathrm{mm}$. long: species campestrian.

Sepals triangular, merely acute, about as long as the hypanthium.

1. A. Canadense.

1. Asarum Canadénse L. Foliage bright green, pubescent throughout. Leafblades thinnish, reniform, $6-15 \mathrm{~cm}$. broad, rounded or abruptly acute at the apex, undulate, deeply cordate at the base, the sinus closed; petioles several times longer than the blades, $10-30 \mathrm{~cm}$. long : pedicels rather slender, 1-4 cm. long: hypanthium thinly pubescent : sepals erect or spreading, lanceolate, abruptly acuminate, 1-1.5 cm. long, the upper part revolute, thus very slender, 4-8 $\mathrm{mm}$. long, curving upward.

In rich or rocky woods, New Brunswick to Ontario, south to North Carolina. Spring.

2. Asarum acuminàtum (Ashe) Bicknell. Foliage similar to that of $A$. Canadense, but more pubescent, at least when young. Leaf-blades membranous, reniform-cordate, and acutely short-pointed or broadly reniform and blunt, 7-14 cm. broad, densely cinereoustomentulose beneath, the larger nerves usually somewhat bristly: hypanthium pubescent: sepals gradually caudate-acuminate or flagellate-tipped, with the termination recurvedspreading, 1-2 cm. long, dull brownish purple.

In rich woods, Wisconsin to Minnesota, south to Tennessee. Spring.

3. Asarum refléxum Bicknell. Foliage loosely pubescent. Rootstocks more elongated and slender than those of $A$. Canadense. Leaf-blades reniform, 6-14 cm. broad, bluntpointed, undulate, with a shallow or deep open sinus, the upper surface commonly almost
glabrous: flowers markedly smaller than those of $A$. Canadense: sepals purplish brown, triangular, 8-10 mm. long, early reflexed, each with an obtuse tip 2-4 mm. long.

In rich woods, chiefly along streams, Connecticut to Iowa, North Carolina and Kansas. Spring.

\section{ARISTOLÒchIA L.}

Herbs, shrubs or twining vines. Leaves alternate : blades entire or lobed, often cordate, palmately 3-many-nerved. Flowers irregular, on solitary clustered peduncles or racemose, sometimes at the base of the plant, often S-shaped or like a Dutch pipe, variously inflated. Calyx often corolloid. Stamens 6, or rarely 4-10 or more, adnate to a central column : anthers extrorse, opening lengthwise. Ovary inferior, 4-6-celled, with a 4-6 
parietal placentae: styles united into a 4-6-angled column. Ovules numerous in each cavity. Capsule pendulous, 4-6-valved. Seeds numerous, horizontal, often flattened. Testa hard, crustaceous.

Erect herbs.

Plants sparingly and indistinctly pubescent with soft hairs.

Leaf-blades hastate, delicate: capsule 5-6 mm. long.

Leaf-blades not hastate, membranous : capsule about $1 \mathrm{~cm}$. long.

Plants manifestly pubescent with stiff spreading hairs.

Leaf-blades petioled, firm, not prominently reticulated.

Leaf-blades nearly sessile, clasping, leathery, prominently reticulated.

Twining or prostrate vines,

Plants herbaceous: limb of the calyx expanded only on one side : stamens 5.

Plants woody : limb of the calyx spreading on all sides: stamens 6 .

Foliage densely tomentose: leaf-blades leathery: hypanthium tomentose.

Foliage minutely pubescent or glabrous : leaf-blades membranous : hypanthium glabrous.

1. Aristolochia Náshii Kearney. Foliage bright green, finely pubescent. Stems erect or reclining, 1-3 dm. long, flexuous, angled, simple or branched below : leaves delicate; blades very thin, linear or lanceolate, hastate, or the young leaves sometimes ovate, $2-10 \mathrm{~cm}$. long, acuminate, ciliate, short-petioled, cordate at the base : peduncles slender, 1-flowered : bracts 2-4 mm. long: flowers brownish purple, 10-12 $\mathrm{mm}$. long: calyx-limb slightly 3 -lobed, about $1 \mathrm{~cm}$. broad : hypanthium pilose : capsules subglobose, $5-6 \mathrm{~mm}$. in diameter, pilose, sharply angled.

In damp woods, Virginia to Florida and Louisiana. Summer. SNakeroot.

2. Aristolochia Serpentària L. Foliage deep green, sparingly pubescent. Stems erect, $2-5 \mathrm{dm}$. tall, simple or branched below, more or less zigzag, angled, leafy above, naked below : leaves few ; blades oblong-lanceolate to oval-lanceolate or rarely lanceolate, 4-15 $\mathrm{cm}$. long, acuminate, undulate, cordate at the base, 3-nerved, short-petioled : peduncles 1-flowered, bracted, solitary or clustered : bracts $2-3 \mathrm{~mm}$. long: flowers S-shaped, about $1 \mathrm{~cm}$. long: hypanthium inflated at the ovary and at the throat : calyx-limb slightly 3 -lobed : capsules subglobose, about $1 \mathrm{~cm}$. in diameter.

In woods, Connecticut to Michigan, Florida and Missouri. Summer to fall. SNAKERoot.

3. Aristolochia convolvulàcea Small. Foliage bristly-pubescent throughout. Stems erect or decumbent, 1-3 dm. long, angled, slightly zigzag, simple or rarely branched below : leaves few ; blades thinnish, becoming firm at maturity, broadly ovate to oval, 2-8 $\mathrm{cm}$. long, short-acuminate or rarely acute, ciliate, deeply cordate at the base ; petioles $0.5-1.5 \mathrm{~cm}$. long, hirsute: peduncles slender, 1-2-flowered, zigzag angled : hypanthium densely hirsute : flower $0.5-1 \mathrm{~cm}$. long : calyx-limb 6-8 mm. broad, scarcely lobed : capsules subglobose, $6-7 \mathrm{~mm}$. in diameter, pubescent.

In woods, Georgia. Spring and summer.

4. Aristolochia reticulàta Nutt. Foliage bright green, pubescent. Stems erect or decumbent, 1-3 dm. tall, angled, simple or branched below, zigzag, hirsute : leaves few ; blades oblong, angled, oval or broadly ovate, firm, 3-10 $\mathrm{cm}$. long, obtuse or acutish, undulate, prominently reticulated beneath, pubescent on both sides, nearly sessile, clasping: flowers corolloid, pubescent, dark brown, solitary or in bracted racemes: bracts ovate to to suborbicular.

On river banks, Arkansas to Louisiana. Summer.

5. Aristolochia pentándra Jacq. A diffusely twining vine, with minutely or sparingly pubescent foliage. Stems commonly several meters long; leaf-blades narrowly or broadly ovate, 4-10 cm. long, sometimes slightly 3-lobed, cordate at the base; petioles shorter than the blades : pedicel slightly shorter than the peduncle : hypanthium minutely pubescent : calyx nearly straight, the small limb not lobed, expanding on one side, nearly erect : capsules globular, $1.5-2 \mathrm{~cm}$. long.

In thickets, southern peninsular Florida and the Keys. Also in the West Indes.

6 Aristolochia tomentòsa Sims. A twining vine, with tomentose foliage. Stems often $10 \mathrm{~m}$. long, woody : leaf-blades firm, broadly ovate to suborbicular, $10-18 \mathrm{~cm}$. long, rounded at the apex, cordate at the base, finally reticulated ; petioles stout, densely tomentose; peduncle wanting: pedicel short, stout: hypanthium densely tomentose and yellowish green without : calyx abruptly bent above the ovary and contracted into a slender neck above the inflation, the limb expanded, 3-lobed, greenish purple, dark brown in the center, glabrous within : capsules cylindric-prismatic, 4-6 cm. long.

In woods, Missouri to the Indian Territory, North Carolina and Florida. Spring and summer. PIPEVINE.

7. Aristolochia macrophýlla Lam. A twining vine with a stem sometimes $10 \mathrm{~m}$. long and minutely pubescent or almost glabrous foliage. Leaf-blades thin, reniform, suborbicular or broadly ovate, $5-25 \mathrm{~cm}$. in diameter, abruptly acute or obtuse, glabrous above, 
sparingly pubescent beneath, cordate at the base; petiole about $\frac{1}{2}$ as long as the blade, glabrous: peduncle 1-2 $\mathrm{cm}$. long: pedicel 3-4 times longer than the peduncle, subtended by ovate or suborbicular bracts : flowers glabrous: bypanthium yellowish green without: calyx abruptly bent and somewhat contracted into a neck above the inflation, the limb 2-3 cm. broad, 3-lobed : capsules cylindric-prismatic, 5-6 cm. long. [A. Sipho L'Her.]

In woods, Minnesota, south to Kansas, Pennsylvania and Georgia. Spring and summer. DutcHMAN'S PIPE.

\section{Order 13. CAMPANULÀLES.}

Herbs, or rarely shrubs or trees. Leaves mainly alternate : blades simple, entire, toothed or lobed. Flowers perfect, monoecious or dioecious, regular or irregular. Hypanthium well developed, surrounding the ovary and adnate to it. Calyx of usually 5 distinct or partially united sepals. Corolla of 5 or rarely 6 distinct or usually partially equally or unequally united petals. Androecium of 3-5 stamens or rarely of only 1 stamen. Anthers distinct or sometimes connate. Gynoecium of $2-5$ or rarely more united carpels. Ovary inferior. Styles united. Fruit a capsule or a berry, sometimes a pepo.

Endosperm wanting: flowers monoecious or dioecious : plants mainly vines.

Endosperm present : flowers perfect or mainly so.

Corolla regular.

Corolla split on one side and otherwise more or less irregular.

Stigma not indusiate: stamens united by either the anthers or filaments or both.

Stigma indusiate: stamens distinct or rarely united by the anthers.

Fam. 1. Cucurbitaceae.

Fam. 2. Campanulaceae.

Fam. 3. Lobeliaceae.

Fam. 4. BRUNONIACEAE.

\section{FAmily 1. CUCURBitàceae B. Juss. Gourd Family.}

Annual or perennial succulent herbs, of great economic value, usually trailing, or climbing by means of tendrils. Leaves alternate : blades palmately nerved or lobed, often pubescent with rough hairs. Inflorescence axillary, clustered, panicled or racemose, only one flower in an axil. Flowers monoecious or dioecious. Calyx of 4 or 5 , rarely 6 , more or less united sepals, adherent to the ovary : lobes imbricated. Corolla of as many petals as the sepals, more or less united and adherent to the calyx : lobes entire or fringed. Androecium of 3 stamens, then two with 2-celled anthers and one with a 1-celled anther, or rarely 1, 2, 4 or 5 stamens. Filaments distinct or variously united. Anthers extrorse, more or less contorted. Gynoecium a single compound pistil. Ovary rarely 1-celled, with 1 pendulous ovule, often 3-celled with many horizontal, anatropous ovules in many series. Styles terminal, united. Stigmas thick, dilated or fringed. Fruit a fleshy or dry berry (pepo). Seeds rarely solitary and pendulous, usually numerous, flattened, horizontal. Endosperm wanting. Embryo straight, with foliaceous nerved cotyledons.

Ovary 1-celled, with 3-5 placentae : ovules numerous or rarely few, commonly horizontal.

Anthers straight or merely curved.

Disk at the base of the style annular or cup-like.

Disk at the base of the styje wanting/or obsolete.

1. MELOTHRIA.

2. IBERVILLEA.

Anthers contorted or conduplicate.

Ovules or seeds numerous. horizontal.

Corolla rotate, of 5 distinct or partially united petals.

Anthers distinct.

Bottom of the calyx furnished with 2-3 scales.

Bottom of the calyx without scales.

Connective not surpassing the anther-sacs : tendrils branched.

Connective produced beyond the anther-sacs: ftendrils simple. Anthers cohering in a head.

Corolla campanulate.

Ovules or seeds 1-4 in each cavity, erect or ascending.

Ovary 1-several-celled : ovules solitary or few, erect, ascending or pendulous.

Ovary usually 2-3-celled: ovules few, erect or ascending.

Stamens 2-3: leaf-blades lobed: fruit symmetrical, opening at the top.

stamens united into a single column : leaf-blades compound : fruit oblique, elastically bursting.

ovary 1-celled: ovule solitary, pendulous.

3. MOMORDICA.

4. Citrullus.

5. CUCUMIs.

6. LAgENARIA.

7. CUCURBITA.

8. CAYAPONIA.

9. Micrampeles.

10. CyClanthera. 11. SicYos.

\section{MELÒTHRIA L.}

Herbs, with slender trailing or climbing stems. Leaf-blades entire, lobed or palmately divided: petioles furnished with simple tendrils at the axils. Flowers monoecious or 
rarely dioecious, the staminate usually in racemes or corymbs. Sepals 5. Corolla white or yellow, with 5 lobes. Stamens 3, or rarely 5: anthers more or less connate. Pistillate flowers solitary, often slender-pedicelled, with a calyx which is narrowed below, spreading above, an early withering corolla, rudimentary stamens and globose or elongated ovary with a short style, inserted in a disk. Ovules numerous, horizontal. Berry small, pendulous, mostly many-seeded. Seeds flattened, with a leathery testa. Creeping Cucumber.

Berries globose or nearly so.

Berries less than $10 \mathrm{~mm}$. in diameter.

Berries over $10 \mathrm{~mm}$. in diameter.

1. M. microcarpa.

Berries oblong or oval.

Stems trailing or creeping: leaf-blades broader than long, the lobes low and rounded. 3. M. crassifolia.

Stems climbing : leaf-blades longer than broad, the lobes angular.

Berries dark purple or blackish : seeds $3-4 \mathrm{~mm}$. long.

Berries yellow : seeds 5-6 mm. long.

4. M. pendula.

5. M. chlorocarpa.

1. Melothria microcárpa (Cogn.) Shuttlw. Stems climbing, 5-15 dm. long, branched : leaf-blades commonly as broad as long, thinnish, shallowly $3-5$-lobed, 1-3 cm. long, cordate, the lobes irregularly toothed; petioles hispidulous, shorter than the blades: berries globose, 7-9 $\mathrm{mm}$. in diameter.

In thickets, northern Alabama. Spring and summer.

2. Melothria Náshii Small. Stems trailing and creeping, 3-12 dm. long, branched, angled : leaf-blades fleshy, suborbicular or triangular-ovate in outline, $2-3.5 \mathrm{~cm}$. broad, usually 5-lobed, very rough on the surfaces, the lobes entire or with 1-2 teeth or small lobes ; petioles hispid, about as long as the blades: staminate flowers in long-peduncled corymbs, the pistillate on solitary long peduncles: hypanthium minutely hispid : sepals triangular, acute, shorter than the hypanthium: corolla-lobes longer and narrower than the sepals : anthers pubescent at the tip, nearly sessile : berries globose, $12-15 \mathrm{~mm}$. in diameter, their peduncles about $3 \mathrm{~cm}$. long.

In sandy soil, peninsular Florida.

3. Melothria crassifòlia Small. Stems trailing and creeping, 6-15 dm. long, branched throughout, angled, sparingly pubescent : leaf-blades thick and fleshy, reniform or orbicular-reniform, 2-4 cm. broad, usually with 5 rounded obtuse lobes, which are undulate or shallowly toothed, cordate, the sinus closed or nearly closed; petioles hispid, about as long as the blades: staminate flowers in long-peduncled racemes, the pistillate solitary on long peduncles : hypanthium minutely hispid : sepals triangular-ovate, much shorter than the hypanthium, acute: anthers glabrous, nearly sessile: berries oblong, $1.5-2 \mathrm{~cm}$. long.

In moist places, peninsular Florida.

4. Melothria péndula L. Stems climbing, nearly glabrous : leaf-blades thin, drying membranous, suborbicular or ovate in outline, $3-8 \mathrm{~cm}$. broad, with $3-5$ angular shallowly toothed lobes and both surfaces pubescent with short hairs, cordate, the sinuses open ; petioles 1-3.5 cm. long, hispid : staminate flowers racemed : pistillate flowers solitary, the peduncles about as long as the petioles: hypanthium glabrous or puberulent : sepals very short : corolla yellow or greenish white, 3-4 mm. broad, pubescent without ; lobes ovate or obovate : berries oblong or oval, 10-25 mm. long, pendulous, dark purple or blackish : seeds obovoid, 3.5-4 mm. long, flattened.

In swamps and light soil, Pennsylvania to Missouri, Florida, Texas and Mexico. - The form with more or less hispidulous stems and petioles and deeply lobed leaf-blades, is $M$. pendula áspera Cogn.; it occurs chiefly in Florida.

5. Melothria chlorocárpa Engelm. Similar to $M$. pendula in habit. Leaf-blades thin, deeply and prominently lobed, often hispidulous on the veins beneath, as are the petioles : berries oval, about $1.5 \mathrm{~cm}$. long, yellow : seeds numerous, $5-6 \mathrm{~mm}$. long.

In thickets, eastern Texas. Spring.

\section{IBERVÍLLEA Greene.}

Perennial vines, with glabrous or nearly glabrous foliage and simple tendrils. Leafblades deeply 3-5-lobed; the lobes toothed or incised. Flowers dioecious, the staminate in racemes or clusters, or rarely solitary. Hypanthium cylindric or cylindric-campanulate. Corolla yellow, salverform. Stamens 3 , the connective not produced beyond the anther. Pistillate flowers solitary : calyx and corolla nearly like those of the staminate. Ovary 1-celled, with 2-3 placentae : stigma 3-lobed. Berry globose or subglobose, red or highly colored. Seeds more or less swollen. [Maximowiczia Cogn., not Rupr.] 
Leaf-blades with broad ovate or cuneate lobes : berries $2.5-5 \mathrm{~cm}$. in diameter.

Hypanthium of the staminate flowers cylindric.

Hypanthium of the staminate flowers campanulate.

Lobes of the leaf-blades rather evenly dentate, the lateral ones not divided.

Lobes of the leaf-blades again lobed, the lateral ones mostly divided.

Leaf-blades with linear or nearly linear lobes: berries $1-1.5 \mathrm{~cm}$. in diameter.

1. I. Lindheimeri.

2. I. tripartita.

3. I. tenella.

4. I. tenuisecta.

1. Ibervillea Lindheimeri (A. Gray) Greene. Stems slender, climbing or trailing, 2-4 m. long, sparingly branched : leaf-blades thinnish, more or less warty-papillose, 3-5lobed, the lobes coarsely toothed or again lobed ; petioles $\frac{1}{3}$ or $\frac{1}{4}$ as long as the blades: hypanthium of the staminate flowers cylindric, often slightly puberulent, 6-8 $\mathrm{mm}$. long, gradually narrowed to the base : sepals triangular, 2-3 mm. long, acute : corolla yellow, villous within, striped with green without : berry globose, $2.5-5 \mathrm{~cm}$. in diameter, apiculate, becoming red : seeds with swollen faces.

In valleys, Texas to southern California. Spring to fall.

2. Ibervillea tripartita (Naud.) Greene. Similar to I. Lindheimeri in habit. Leafblades more triangular in outline, 3-lobed or 3-parted, the lobes merely dentate: hypanthium of the staminate flowers campanulate: berries commonly $3-4 \mathrm{~cm}$. in diameter.

In thickets and along fences, Louisiana and Texas to Central America. Spring and summer.

3. Ibervillea tenélla (Naud.) Small. Stems slender, climbing or creeping, 1-2 m. long, obtusely angled : leaf-blades thickish or fleshy, usually 3-4 cm. in diameter, 3-parted, often warty, the terminal lobe coarsely toothed or again lobed, usually acute, more or less cuneate, the lateral lobes usually again 2-lobed, the lobes toothed; petioles about $1 \mathrm{~cm}$. long: hypanthium glabrous, campanulate, $3-4 \mathrm{~mm}$. long: sepals ovate, 1-1.5 $\mathrm{mm}$. long, acute : corolla yellow, broadly ovate, acutish, striped with green without, glandular-pilose within : berries globose, $2.5-4 \mathrm{~cm}$. long : seeds oval, $6-8 \mathrm{~mm}$. long, with 2 horns at the base, the faces swollen. [Sicydium tenellum Naud.]

In valleys, Texas. Spring and summer.

4. Ibervillea tenuisécta (A. Gray) Small. Stems very slender, prostrate or climbing, several meters long, often diffusely branched: leaf-blades thickish, $1-4 \mathrm{~cm}$. in diameter, 3-5-parted, the lobes deeply cleft or pinnatifid, the ultimate divisions linear or nearly so, acute or rarely obtuse ; petioles $0.5-1 \mathrm{~cm}$. long: hypanthium glabrous, campanulate, 3-4 mm. long: sepals triangular or ovate-triangular : corolla yellow : berries globose, 1$1.5 \mathrm{~cm}$. in diameter, becoming scarlet : seeds obovoid, $5-6 \mathrm{~mm}$. long, thick-margined, with two blunt horns at the base, the faces much swollen and transversely wrinkled. [Sicydium Lindheimeri var. tenuisectum A. Gray.]

In valleys, Texas and New Mexico to Mexico. Spring to fall.

\section{MOMÒRDICA L.}

Annual or perennial herbs, with climbing stems and simple tendrils. Leaf-blades entire, lobed or pedately compound. Flowers monoecious or dioecious, the staminate solitary or panicled: hypanthium short-campanulate : sepals 5: corolla rotate, 5-lobed, white or yellow : stamens 3 , or very rarely 2 ; filaments short, distinct; anthers at first slightly cohering, finally distinct. Pistillate flowers solitary : calyx and corolla like those of the staminate flowers : staminodia wanting or gland-like. Ovary 1-celled, with 3 placentae : style slender: stigmas 3. Ovules numerous, horizontal. Berry elongated, rarely 3-valved. Seeds usually numerous, flat or swollen, smooth or sculptured. BALSAM APPLE. Leaf-blades with acute or obtuse teeth: scale at the middle or base of the staminate peduncle.

Leaf-blades',with acuminate teeth : scale toothed at the apex of the staminate peduncle. 2. M. Balsamina.

1. Momordica Charántla L. Stems often high-climbing, at least 1-2 m. long, or longer, much branched, angled : leaf-blades thinnish, 4-12 cm. in diameter, cordate, 5- 7 lobed, the lobes obovate or oblanceolate, coarsely toothed or slightly again lobed, the teeth or lobes acute or obtuse, the sinuses usually rounded; petioles $3-5 \mathrm{~cm}$. long, villous or glabrate, angled : peduncles bearing entire ovate-cordate scales at the base or middle : hypanthium usually puberulent, campanulate : sepals oval or oval-ovate, $3-4.5 \mathrm{~mm}$. long, acute, ciliate : petals obovate, yellow, $1-2 \mathrm{~cm}$. long, striped : berries fusiform, 4-12 $\mathrm{cm}$. long, pointed at both ends, golden-yellow, tuberculate, narrowly winged : seeds oblong, $12-16 \mathrm{~mm}$. long, slightly flattened.

In sand, peninsular Florida, perhaps introduced. Common in tropical countries.

2. Momordica Balsamina L. Stems slender, climbing, $0.5-2 \mathrm{~m}$. long, much branched, grooved : leaf-blades thinnish, $3-8 \mathrm{~cm}$. broad, cordate, 3-5-lobed, the lobes 
long, usually puberulent: peduncle with a toothed scale at the end : hypanthium nearly glabrous, campanulate, $2-3 \mathrm{~mm}$. long, sepals oblong, about $6 \mathrm{~mm}$. long: petals goldenyellow, obovate, $1-1.5 \mathrm{~cm}$. long, obtusish : berries elongated, $3-6 \mathrm{~cm}$. long, orange, fleshy : seeds ovoid or oval, $10-12 \mathrm{~mm}$. long, flattened, the faces wrinkled.

In sandy soil, Louisiana and Texas to Mexico. Also in the tropies and in subtropical countries.

\section{CITRÚLLUS Schrad.}

Annual or perennial odorous herbs, with prostrate stems and 2-3-branched rarely spinelike tendrils. Leaf-blades 3-5-lobed, the lobes toothed or again lobed. Flowers monoecious, solitary: staminate with 5 sepals, a large yellow corolla with 5 lobes, 3 stamens whose filaments are very short; anthers cohering, their connectives not produced beyond the sacs : pistillate flowers with rudimentary stamens and a more or less elongated ovary : style short: stigmas reniform : ovules numerous, horizontal. Berry globose or oblong, many-seeded, very fleshy or rarely rather dry. Seeds flat, oblong or obovate.

1. Citrullus Citrúllus (L.) Small. Foliage pubescent with soft spreading hairs, bright green. Stems stout, trailing, 1-4 m. long, angled, zigzag: leaf-blades ovate in outline, deeply 3-7-lobed, the lobes shallowly toothed or again lobed; petioles about half as long as the blades: hypanthium campanulate-turbinate, $5 \mathrm{~mm}$. long: sepals linear or nearly so, nearly as long as the tube, obtuse or acute : corolla rotate; lobes ovate or obovate, pale-yellow, rugose, ciliate with glandular hairs, villous without, glandular within : berries globose or oblong-cylindric, 1-6 dm. long, smooth, edible : seeds flat, oblong or obovate, 1-2 cm. long, white or black. [C. vulgaris Schrad.]

In waste places, North Carolina to Florida and Texas. Watermelon,

\section{CUCÙMIS L.}

Annual or perennial trailing or climbing herbs, with simple tendrils. Stems often clothed with rough pubescence. Leaf-blades entire or 3-7-lobed, long-petioled. Flowers monoecious : staminate clustered or rarely solitary ; hypanthium campanulate or turbinate ; corolla yellow, of 5 more or less united petals ; stamens 3 ; filaments short, distinct ; connective produced beyond the anther sacs. Pistillate flowers solitary : calyx and corolla like those of the sterile: staminodia wanting. Ovary 1-celled, with 3-5 placentae: stigmas obtuse. Ovules numerous, horizontal. Berry pulpy, with a soft rind, smooth or echinate. Seeds numerous, flattened.

Corolla less than $2 \mathrm{~cm}$. broad : fruit prickly.

Corolla over $3 \mathrm{~cm}$. broad : fruit not prickly.

1. C. Anguria.

2. C. Melo.

1. Cucumis Angùria L. Stem slender, hispid, branched : leaf-blades mostly $5-8 \mathrm{~cm}$. long, deeply 3-5-lobed, the lobes shallowly toothed : corolla $1-1.5 \mathrm{~cm}$. broad : fruit oval to oblong, 3-6 cm. long.

In thickets and waste places, Florida and Texas to tropical America. BUR GHeRkin. West INDIAN GHERKIN. GOOSEBERRY GOURD.

2. Cucumis Melo L. Stem stout, somewhat hispid : leaf-blades larger than those of C. Anguria, merely toothed or shallowly lobed : corolla $3-5 \mathrm{~cm}$. broad : fruit of various shapes, depressed or elongated, not prickly.

In waste places and fields, more or less established in the Gulf States, and cultivated. Native of asia. Melon. Cantaloupe. Muskmelon.

\section{LAGENÀrIA Ser.}

Annual, musk-scented herbs, with clammy pubescent foliage. Stems climbing by means of 2-branched tendrils. Leaf-blades toothed or 3-5-lobed, petioled : petioles with 2 glands at the top. Flowers monoecious, or rarely dioecious, solitary : staminate longpedicelled : hypanthium campanulate or funnelform; sepals 5, spreading; corolla white, of 5 petals; stamens borne on the hypanthium; filaments distinct; anthers lightly cohering in a head. Pistillate flowers short-pedicelled : caly $x$ and corolla like those of the sterile flowers. Ovary variable in shape, 1-celled, with 5 placentae : style short : stigmas 3, 2-lobed. Ovules numerous, horizontal. Fruit very variable in shape, with a woody rind and fleshy pulp. Seeds numerous, flattened.

1. Lagenaria Lagenària (L.) Cockerell. A diffusely climbing vine, with finely clammy pubescent and musk-scented foliage. Leaf-blades ovate to triangular or orbicular- 
ovate, mostly 1-3 dm. long, sinuate and denticulate, cordate at the base: flowers longpedicelled : corolla white with green veins, $5-7 \mathrm{~cm}$. broad; lobes broadened upward, erose-crenate : fruit various, usually elongate and more or less clavate. [L. vulgaris Ser.] In thickets and waste places, Gulf States and throughout the tropics. Bottle Gourd. Calabash.

\section{CURCÚRBITA L.}

Annual or perennial, rough-pubescent trailing or creeping vines, with 2-manybranched tendrils. Leaf-blades nearly entire or lobed, usually cordate. Flowers showy, monoecious, solitary : staminate with a campanulate or rarely tubular hypanthium ; corolla yellow, campanulate, 5-lobed, the lobes recurved at the ends ; stamens 3 ; filaments distinct; anthers linear, cohering, contorted. Pistillate flowers with calyx and corolla like those of the staminate: staminodia 3. Ovary 1-celled, with 3-5 placentae: stigmas 3-5, 2lobed or 2-branched. Ovules numerous, horizontai. Berry usually large, fleshy, with a tough rind. Seeds numerous, flattened. Gourd. Pumprin.

Leaf-blades toothed or merely angulately lobed : pedicels less than $5 \mathrm{~cm}$. long. Leaf-blades prominently lobed: pedicels over $5 \mathrm{~cm}$. long.

1. C. foetidissima.

2. C. Texana.

1. Cucurbita foetidíssima H.B.K. Perennial by large fusiform roots, stout, roughpubescent, with a heavy foetid odor. Stems trailing or climbing, 1-5 m. long, angled: leaf-blades thick, triangular or triangular-ovate, acute or acutish, 1-4 dm. long, distantly toothed or angular-lobed, cordate or truncate, the surfaces more or less hoary; petioles less than $\frac{1}{2}$ as long as the blades: peduncles $2-4 \mathrm{~cm}$. long: hypanthium bristly with stout stiff hairs, campanulate, $15-18 \mathrm{~mm}$. long: sepals linear or nearly so, $1.5-4 \mathrm{~cm}$. long : corolla bright yellow or light orange, $7-10 \mathrm{~cm}$. long, pubescent within and without : berries globose or obovoid, 5-8 cm. in diameter, firm, green variegated with a pale green or yellow.

In valleys, Nebraska to Texas, California and Mexico. Spring to fall. Calibracilla.

2. Cucurbita Texàna (Scheele) A. Gray. Similar to C. foetidissima in habit, but more slender. Leaf-blades $3-5$-lobed, sometimes deeply so : berries pyriform. Perhaps a naturalized form of $C$. Pepo.

On river banks, in woods and thickets, southern Texas.

\section{CAYAPÒnia Manso.}

Perennial glabrous or pubescent vines, climbing by simple or compound tendrils. Leaf-blades 3-7-lobed, or rarely divided, or the upper one sometimes entire. Flowers monoecious or dioecious, rather small, in clusters, racemes or panicles or sometimes solitary : staminate with a campanulate hypanthium and a 5 -lobed calyx; corolla white or yellowish green, campanulate or rotate, 5 -lobed; stamens 3 ; filaments distinct ; anthers cohering above. Pistillate flowers with calyx and corolla like those of the staminate flowers : staminodia 3. Ovary 3-celled : stigmas 3, dilated. Ovules 1 to 4 in each cavity, ascending. Berry more or less fleshy, usually 3 -seeded. Seeds erect, with a hard testa.

Berries oval, less than $1.5 \mathrm{~cm}$. long: leaf-blades usually less than $10 \mathrm{~cm}$. broad. Berries oblong, over $1.5 \mathrm{~cm}$. long: leaf-blades usually over $10 \mathrm{~cm}$. broad.

1. C. Boykinii. 2. C. grandifolia.

1. Cayaponia Boykínii (T. \& G.) Cogn. Stems climbing, 3-6 m. long, angled, branched : leaf-blades thickish, scabrous on both surfaces, 5-10 cm. broad, 3-angled or 3lobed, distantly toothed, cordate, the lobes apiculate, or the terminal one short-acuminate ; petioles about $\frac{1}{2}$ as long as the blades, bristly villous : flowers small, 3-5 of the staminate and pistillate usually together, short-pedicelled: sepals triangular or lanceolate-triangular, 1-2 mm. long: corolla greenish white, $5-6 \mathrm{~cm}$. broad ; lobes ovate or ovate-lanceolate : berries oval, 12-14 mm. long, rounded at the ends, crimson, their pedicels about $2 \mathrm{~mm}$. long : seeds elliptic, $8-10 \mathrm{~mm}$. long, abruptly pointed at the base and with 2 lateral auriclelike teeth.

Along streams, Georgia to Louisiana. Summer.

2. Cayaponia grandifòlia (T. \& G.) Small. Stems stoutish, climbing by simple or branched tendrils $2-5 \mathrm{~m}$. long, angled, much branched : leaf-blades thin, scabrous on both surfaces, 3-lobed, distantly and minutely toothed, cordate, the terminal lobe ovateacuminate, the lateral lobes sometimes angled, slightly lobed again; petioles less than $\frac{1}{2}$ as long as the blade, softly villous : flowers rather large, several in the axils, short-pedicelled : sepals linear-subulate, $2-3 \mathrm{~mm}$. long: corolla greenish, 7-9 mm. broad : berries oblong, 16-20 $\mathrm{mm}$. long, orange, their pedicels 4-5 $\mathrm{mm}$. long.

In bottom lands of the lower Mississippi Valley. Summer. 


\section{MICRÁMPELES Raf.}

Annual or perennial herbaceous vines, climbing by simple or compound tendrils. Leaf-blades rather membranous, 5-7-lobed, the lobes angular, entire or toothed. Flowers monoecious, rather small : staminate racemed or panicled ; hypanthium broadly campanulate ; sepals 5-6 ; corolla white or greenish, rotate, $5-6$-lobed ; stamens $2-3$; filaments united ; anthers nearly horizontal, zigzag. Pistillate flowers usually solitary or sometimes clustered in axils with the staminate : calyx and corolla like those of the staminate flowers. Staminodia more or less prominent. Ovary echinate, 1-4-celled; stigmas lobed, or 2-3-parted. Ovules 1-4 in each cavity, erect or ascending. Berry echinate, 1-3-celled, fibrous within. Seeds usually smooth. [Echinocystis T. \& G.] MOck APPLE. BaLsam Apple.

1. Micrampeles lobàta (Michx.) Greene. Annual, bright green, nearly glabrous. Stems $2-5 \mathrm{~m}$. long, climbing by 3 -branched tendrils, angled, watery : leaf-blades thinnish, 4-15 cm. broad, minutely warty, palmately 3-5-lobed, cordate, the lobes triangular-ovate or lanceolate, apiculate or acuminate, distantly and shallowly toothed; petioles less than $\frac{1}{2}$ as long as the blades: staminate flowers in long-peduncled racemes: pistillate flowers clustered on short peduncles: sepals filiform-subulate, $2.5-3 \mathrm{~mm}$. long: corolla greenish white, rotate, 7-9 mm. broad ; lobes lanceolate : berry inflated, oblong or globose-oblong, $3-4.5 \mathrm{~cm}$. long, becoming dry and bursting at the summit, echinate : seeds narrowly obovoid, 1.5-2 cm. long, black.

In woods along streams, Nova Scotia to Saskatchewan, Georgia and Colorado. Summer and fall.

10. CYCLANTHERA Schrad.

Annual or perennial glabrous climbing vines, with simple or many-branched tendrils. Leaf-blades usually compound, often pedately 3-13-foliolate. Flowers monoecious, small, the staminate racemed or panicled; hypanthium flattish ; sepals 5-6, subulate or filiform, or wanting; corolla greenish yellow or white, rotate, 5-6-lobed; stamens united into an axile column. Pistillate flowers solitary in the axils with the staminate : calyx and corolla like those of the staminate flowers: staminodia none. Ovary 1-many-celled. Ovules in few-celled ovaries many in each cavity, in many-celled ovaries solitary in each cavity, erect or ascending. Fruit ovoid, oblique or reniform, echinate or rarely smooth, elastically opening. Seeds flattened, with a crustaceous testa. [Discanthera T. \& G.]

1. Cyclanthera dissécta (T. \& G.) Arn. Annual, bright green. Stems elongated, angled, glabrous : leaf-blades 4-7 cm. long, 3-7-parted or 3-7-divided, the lobes acute or acuminate, toothed or incised, the terminal one ovate to lanceolate: staminate flowers in racemes or small panicles at the ends of slender peduncles : hypanthium flat : sepals triangular or ovate-triangular, 1-2 mm. long: corolla $5-6 \mathrm{~mm}$. broad : berries slightly oblique, $2.5-3 \mathrm{~cm}$. long, armed with slender spines.

In woods and thickets and on river banks, Kansas to Louisiana, Texas and northern Mexico. Summer and fall.

\section{SÍCYOS L.}

Vines, with elongated branched stems, climbing by compound tendrils. Leaf-blades membranous, angular-lobed or rarely deeply 3-5-lobed. Flowers monoecious, the staminate in racemes or corymbs; hypanthium broadly campanulate or nearly flat ; sepals 5 , separated; corolla white or greenish, rotate, 5-lobed; stamens with their filaments united into a short column; anthers 2-5, distant or united. Pistillate flowers usually clustered at the end of a peduncle which arises from the same node as the longer staminate peduncle. Staminodia wanting. Ovary 1-celled, bristly or armed or rarely glabrous : style short: stigmas 3. Ovule solitary, pendulous. Fruit flat or angled, variable in shape. Seeds filling the cavity of the fruit, with a membranous testa.

1. Sicyos angulàta L. Foliage viscid-pubescent. Stems slender, 2-6 m. long, climbing by 3-5-branched tendrils, angled, often much branched : leaf-blades thinnish, 6-15 cm. broad, cordate, 5-angled or 5-lobed, the lobes acute or acuminate, distantly toothed; petioles less than $\frac{1}{2}$ as long as the blades or nearly as long: flowers monoecious, the staminate in elongated long-peduncled racemes, the pistillate usually from the same axils in short-peduncled clusters : hypanthium flattish : sepals of the staminate flower triangular, 3-5 mm. long: corolla rotate, white, striped with green, 10-12 $\mathrm{mm}$. broad: 
berries ovoid, 1.5-2 $\mathrm{cm}$. long, clustered, becoming membranous, villous and armed with bristles.

In thickets, Quebec to Minnesota, Florida and Texas. Summer and fall. Star Cucumber. NimBLE KATE.

\section{Family 2. CAMPANUlàceae Juss. Bellflower Family.}

Annual or perennial caulescent herbs or rarely shrubby plants, with a somewhat acid sap. Leaves alternate, without stipules: blades simple, entire, toothed and sometimes lobed, those of the cauline and the basal often very dissimilar. Inflorescence terminal or axillary, spicate or racemose. Flowers perfect, regular. Calyx of 5 partially united sepals, persistent. Corolla of 5 united sepals, campanulate, tubular or rotate, usually 5-lobed, withering or deciduous. Androecium of 5 stamens inserted with the corolla. Filaments distinct, often ciliate. Anthers introrse. Gynoecium of 2-5 united carpels. Ovary inferior or nearly inferior, mainly 2-5-celled. Styles united. Stigmas rarely capitate, usually with as many lobes as there are cavities in the ovary, spreading or recurved. Ovules horizontal, anatropous, on placentae or in the central angle of each cavity. Fruit a 2-8-celled capsule opening loculicidally, or by pores. Seeds numerous, sometimes angled or flattened, often with a rough testa. Endosperm fleshy. Embryo straight, axile.

Corolla campanulate or funnelform: inflorescence racemose or paniculate. Corolla rotate: inflorescence spicate.

Style declined: flowers complete throughout.

Style straight : flowers various, the earlier cleistogamous.

1. Campanula.

2. Campanulastrum. 3. SPECUlaria.

\section{CAMPÁNULA L.}

Perennial or sometimes annual herbs, with solitary or tufted stems. Leaves alternate : blades various, broader than long to linear, sometimes thus on a single plant, entire to lobed. Flowers perfect, all alike and complete, in racemes or panicles, often centrifugal. Sepals 5, narrow. Corolla campanulate or funnelform, with 5 lobes either longer or shorter than the tube. Stamens 5: filaments dilated at the base : anthers oblong or sometimes narrower. Ovary 3-5-celled : style straight: stigmas 3-5. Capsules not elongated, opening by perforations or by uplifting valves in the sides. Testa smooth. BeLLFLower.

Style shorter than the corolla or sometimes about equalling it in length: leaf-blades entire or slightly toothed.

Annual plant : stems erect.

Perennial plants : stems reclining or diffusely spreading.

Foliage scabrous with retrorse hairs: sepals much shorter than the corolla. Foliage smooth and glabrous : sepals as long as the corolla. style surpassing the corolla : leaf-blades laciniately toothed.

1. C. Reverchonii.

2. C. aparinoides.

3. C. Floridana.

4. C. flexuosa.

1. Campanula Reverchònii A. Gray. Annual, slender, minutely prickly below, glabrous above. Stems erect, 1-2 dm. tall, simple below and branched above or much branched throughout : leaf-blades thick, the basal spatulate, $1-1.5 \mathrm{~cm}$. long, toothed, those on the lower part of the stem oblanceolate or oblong, slightly toothed, the upper ones becoming linear-filiform, entire : buds erect : hypanthium glabrous, becoming slightly constricted above : sepals linear-subulate, $2-4 \mathrm{~mm}$. long, longer than the hypanthium : corolla blue, oblong-campanulate, nearly $1.5 \mathrm{~cm}$. long, its ovate-lanceolate lobes slightly shorter than the tube : capsules obovoid, $3-4 \mathrm{~mm}$. long, crowned with the erect sepals : seeds oval, $0.5 \mathrm{~mm}$. long, nearly smooth.

On granite rocks, middle Texas. Spring.

2. Campanula aparinoides Pursh. Perennial by slender rootstocks, minutely prickly. Stems almost filiform, wiry, diffuse or reclining, 2-6 dm. long, mostly simple below, leafy, strict or flexuous, the angles armed with minute retrorse prickles : leafblades linear or narrowly lanceolate, sometimes linear-lanceolate, 1-6 cm. long, acute, sessile or very short-petioled, entire or distantly and shallowly serrate, their edges and
mid-nerve armed like the stem : buds drooping : hypanthium slightly ribbed, hemispheric : sepals ovate or triangular-ovate, acute, about as long as the hypanthium : corolla white or pink, campanulate, rather open; lobes lanceolate or ovate-lanceolate, of ten longer than the tube : capsules globose obovoid, $3.5-4 \mathrm{~mm}$. long, crowned with the persistent nearly erect sepals : seeds oval, nearly $1 \mathrm{~mm}$. long, smooth.

In damp or wet places, Nova Scotia to the Saskatchewan, Georgia and Colorado. Summer.

3. Campanula Floridàna S. Wats. Perennial, smooth and glabrous throughout. Stems nearly filiform, wiry, 2-4 dm. long, diffuse or usually reclining, angled, simple or 
sparingly branched above: leaf-blades narrowly lanceolate or linear-lanceolate or the lower ones narrowly elliptic or oblanceolate, 1-4 cm. long, acute, distinctly serrate, more or less revolute, sessile or nearly so: buds drooping: hypanthium turbinate-campanulate : sepals linear-lanceolate, 6-9 mm. long, several times longer than the hypanthium, acute, usually 2-toothed near the base : corolla blue or pale-purple, short-campanulate, about as long as the sepals; lobes longer than the tube, ovate-lanceolate: capsules obovoid, $4 \mathrm{~mm}$. long, crowned by the spreading or recurved sepals : seeds oblong, about $0.5 \mathrm{~mm}$. long, rugose.

In grassy swamps, eastern and peninsular Florida. Spring and summer.

4. Campanula flexuòsa Michx. Perennial, slender, glabrous or nearly so. Stems solitary or tufted, $2-10 \mathrm{dm}$. long, erect or ascending, usually paniculately branched, more or less flexuous: leaf-blades thinnish, lanceolate, ovate-lanceolate, sometimes narrowly elliptic or nearly linear, 2-12 cm. long, acuminate, usually coarsely serrate with flaring teeth except near the base, narrowed into short petioles or nearly sessile : flowers drooping : hypanthium campanulate : sepals subulate, about as long as the hypanthium : corolla paleblue or white, campanulate, 6-8 mm. long, its triangular or triangular-ovate lobes much shorter than the tube: capsules turbinate-campanulate, about $5 \mathrm{~mm}$. long, ribbed : seeds narrowly oblong, a little more than $1 \mathrm{~mm}$. long, slightly wrinkled. [C. divaricata Michx.]

Chiefly in crevices of rocks, Virginia to West Virginia, Georgia and Alabama. Summer and fall.

\section{CAMPANUĹASTRUM Small.}

Annual or sometimes biennial herbs, with upright stems. Leaves alternate : blades flat, toothed, more or less abruptly narrowed into petioles. Flowers perfect, all complete, centripetally arranged in spikes. Hypanthium turbinate, elongating in age. Sepals 5, slender. Corolla rotate, showy, each lobe terminating in a thickened tip. Stamens 5, exserted: filaments filiform, somewhat declined : anthers narrow. Ovary inferior, 3-celled : styles united, upwardly curved, and declined : stigmas 3. Ovules several. Capsule of a clavate type, erect, sessile, with valvular openings near the top.

1. Campanulastrum Americànum (L.) Small. Annual or biennıal, coarsely pilose or nearly glabrous. Stems erect, $2-20 \mathrm{dm}$. tall, sometimes much branched, angled : leafblades thin, the lower ones orbicular or ovate, on petioles about $\frac{1}{2}$ as long as the blades ; the upper ones usually lanceolate, narrowed at the base, short-petioled or nearly sessile, all serrate, acuminate : spikes 1-8 dm. long, interrupted : hypanthium tubular-turbinate: sepals linear-subulate, 6-10 mm. long, much longer than the hypanthium, acuminate : corolla blue or white, rotate, 5-parted; lobes lanceolate or ovate-lanceolate, 1-1.3 cm. long, surpassing the sepals : style declined : capsules turbinate-clavate, $8-10 \mathrm{~mm}$. long, sessile : seeds almost oblong, $1 \mathrm{~mm}$. long, nearly smooth. [Campanula Americana L.]

On shaded hillsides, New Brunswick to South Dakota, Georgia, Kansas and Arkansas. Summer.

\section{SPECULARIA Heist.}

Annual or biennial herbs. Stems upright, angled. Leaves alternate : blades sessile or clasping, commonly toothed. Flowers dimorphous; earlier ones close-fertilized in the bud, with a calyx usually of 3 or 4 sepals and an undeveloped corolla; later flowers with a calyx of 5 sepals and a rotate or nearly rotate corolla. Stamens 5: filaments distinct : anthers linear. Ovary 3-celled : stigmas 3. Capsule prismatic or cylindric to narrowly obconic, opening mainly by valves near the top or the middle. Venus' Looking-glass.

Capsules less than $1 \mathrm{~cm}$. long: sepals of the corolliferous flowers triangular to lanceolate.

Leaf-blades clasping, fully as broad as long or nearly so: valves near the middle of the capsule.

Leaf-blades sessile, longer than broad : valves at the top of the capsule.

1. S. perfoliata.

Capsules over $1 \mathrm{~cm}$. long: sepals linear to subulate.

Lower flowers with 3 sepals : seeds oblong-lenticular.

Lower flowers with 5 sepals: seeds globose-lenticular.

2. S. biftora.

3. S. leptocarpa.

4. S. Coloradoensis.

1. Specularia perfoliata (L.) A. DC. Annual, commonly stoutish, more or less hirsute or hispid or rarely glabrate. Stems erect, 1-5 dm. tall, simple or often branched, usually slightly prickly on the angles: leaf-blades suborbicular or triangular-cordate, 1-2 cm. broad, crenate or crenate-serrate, clasping: flowers 1 or several, in each axil, sessile : calyx of the apetalous flower of 3-4 ovate or ovate-lanceolate sepals which are usually shorter than the hypanthium, that of the corolliferous flower with 5 lanceolate sepals which are usually as long or longer than the hypanthium : corolla blue, $1-1.5 \mathrm{~cm}$. broad : capsules oblong-prismatic or obconic, 5-6 mm. long : seeds globose-lenticular, about $0.5 \mathrm{~mm}$. long, dark, nearly smooth.

In fields and on hillsides, Ontario to British Columbia, Florida and Mexico. Spring to fall. 
2. Specularia biflòra (R. \& P.) A. Gray. Annual, slender, scabrous. Stems erect or assurgent, 1-5 dm. tall, simple or branched, especially at the base, the angles armed with more or less retrorse prickle-like hairs: leaf-blades ovate or oblong, or sometimes lanceolate above, $0.5-1.5 \mathrm{~mm}$. long, acute or rarely obtuse, entire or crenate-serrate, sessile, sparingly pubescent on the margins and principal nerves: flowers 1 or 2 in an axil, or rarely more, sessile: calyx of the apelatous flower with 3-4 ovate or nearly subulate sepals 1-2 mm. long; the corolliferous flowers with 4-5 longer lanceolate sepals : corolla blue, 1.5-2 cm. broad : capsules cylindric or fusiform, 6-9 mm. long, more or less ribbed : seeds globose-lenticular, nearly $1 \mathrm{~mm}$. in diameter, smooth and shining.

In fields and open places, Virginia to Oregon, Florida and Mexico, and in northern South America. Spring to fall.

3. Specularia leptocárpa (Nutt.) A. Gray. Annual, spiny-hispid or glabrate. Stems erect or nearly so, 2-5 dm. tall, simple or sparingly branched, especially at the base, the edges or the angles armed with small prickle-like hairs: leaf-blades sessile, oblong, lanceolate or linear-lanceolate, 1-3 cm. long, entire or inconspicuously toothed, acute, the nerves rough on both sides : flowers sessile or nearly so: calyx of the apetalous flowers with 3-4 linear sepals ; that of the corolliferous with 5 longer sepals : corolla magenta or blue, 1.5-2 mm. broad : capsules cylindric, $1.5-2 \mathrm{~mm}$. long, sessile, slightly curved or twisted : seeds oblong-lenticular, a little more than $1 \mathrm{~mm}$. long, shining.

In dry soil, Missouri to Montana and Texas. Spring to fall.

4. Specularia Coloradoénsis Buckl. Annual, nearly glabrous. Stems simple and erect, or much branched and spreading, 2-10 dm. long, the angles often armed with minute spine-like teeth : leaf-blades $1-6 \mathrm{~cm}$. long, armed on the edges and nerves like the stem, the lower ones oblong or spatulate, short-petioled, the upper lanceolate or linearlanceolate, sessile, all entire or distinctly toothed, acute : flowers axillary or terminating branches, nearly sessile or short-pedicelled: caly $\mathrm{x}$ of both kinds of flowers with 5 linear-subulate sepals, but those of the apetalous flowers shorter : corolla blue-purple, $2-2.5 \mathrm{~cm}$. broad: capsules cylindric-prismatic, $2-2.5 \mathrm{~cm}$. long, nearly sessile or short-stalked, straight or nearly so, opening by 2 or 3 valves near the top: seeds globose-lenticular, nearly $1 \mathrm{~mm}$. long, shining.

In dry soil, southern and western Texas. Spring and summer.

\section{FAmily 3. LOBELIÀCeAe Dumort. Lobelia Family.}

Annual or perennial herbs, or rarely trees, often with a milky sap which contains a narcotic-acid poison. Leaves alternate, without stipules : blades simple, entire, toothed or pinnately parted. Inflorescence axillary or terminal, variously disposed. Flowers perfect, or rarely dioecious, irregular. Calyx of 5 sepals. Corolla often bilabiate : tube open on one side nearly or quite to the base. Androecium of 5 epigynous stamens. Filaments sometimes cohering into a tube. Gynoecium a single compound pistil. Ovary 2-5-celled. Styles terminal, united. Stigmas fringed. Ovules numerous, sessile, horizontal, anatropous. Fruit a 1-several-celled capsule or a berry. Seeds numerous, with a smooth or furrowed testa. Endosperm fleshy. Embryo straight in the axis of the endosperm.

\section{LOBÈLIA L.}

Aquatic or terrestrial herbs, with leafy or scape-like stems. Leaves sometimes mainly basal : blades entire or variously toothed. Flowers perfect, in spikes, racemes or panicles, subtended by minute or leaf-like bracts. Hypanthium ribbed, adnate to the ovary. Sepals entire or toothed, often glandular. Corolla red, yellow, blue or white: tube straight, oblique or incurved, open to the base on one side: limb 2-lipped, upper lip with 2 spreading or reflexed lobes; lobes of lower lip more or less united. Stamens 5, free : filaments monadelphous, at least above. Anthers in a ring around the style, 2 often smaller than the rest, all, or 2, bearded at the apex. Ovary inferior, 2-celled : stigmas 2-lobed or 2-cleft. Capsule surmounted by the calyx, loculicidally 2-valved. LoBELIA.

Corolla red.

Blades of the upper leaves of an oblong or elliptic type, serrate or dentate.

Blades of the upper leaves of a linear or narrowly linear-lanceolate type, glan-

dular-denticulate.
Corolla blue or white, or variegated with blue and white.

Corolla, exclusive of the lower lip, over $1 \mathrm{~cm}$. long.

Stems leafy to the inflorescence.
1. L. cardinalis.

2. L. splendens. 
Leaves conspicuously numerous; blades mostly less than $2 \mathrm{~cm}$. long, closely toothed.

Leaves relatively few. never conspicuously numerous ; blades over $2 \mathrm{~cm}$. long, remotely and irregularly toothed.

Lower lip of the corolla glabrous.

Sepals with deflexed auricles at the base.

Anthers glabrous at the tip.

Anthers bearded at the tip.

Sepals without auricles.

Leaf-blades of a relatively broad type, spreading.

Bracts, at least the lower ones, longer than the calyxes during anthesis: leaf-blades undulate or sinuate-undulate. Bracts, at least the lower ones, shorter than the calyxes during anthesis: leaf-blades with salient gland-tipped teeth.

Leaf-blades linear, erect or nearly so.

Lower lip of the corolla pubescent or tuberculate within.

Sepals fully twice as long as the hypanthium: lower corolla-lip pubescent at the base.

Sepals about as long as the hypanthium: lower corolla-lip with 2 Stems scape-like. tubercles at the base.

Corolla, exclusive of the lower lip, less than $1 \mathrm{~cm}$. long.

Stems scape-like.

Stems leafy.

Racemes secund.

Sepals manifestly auricled at the base.

Corolla about $1.5 \mathrm{~cm}$. long: sepals glandular-toothed.

Corolla less than $1 \mathrm{~cm}$. long: sepals hispid-ciliate.

Sepals without auricles, or these callus-like.

Racemes not secund.

Stem-leaves with sessile blades.

Stem-leaves with relatively broad blades, never linear: flowers in continuous spike-like racemes.

Capsule partly inferior. Sepals not auricled at the base.

Sepals with deflexed auricles at the base.

Bracts not surpassing the corollas.

Bracts surpassing the corolias.

Capsule wholly inferior.

stem-leaves with linear blades, or of a linear type, or filiform : flowers in lax racemes.

Stem-leaves filiform: pedicels conspicuously longer than the corollas.

Stem-leaves with linear blades : pedicels shorter than the corollas. Corolla over $8 \mathrm{~mm}$. long: hypanthium oblong or turbinateoblong at maturity.

Corolla less than $8 \mathrm{~mm}$. long: hypanthium hemispheric at - maturity.

Stem-leaves with manifest petioles.

Pedicels over $10 \mathrm{~mm}$. long.

Capsules barely $1 / 2$ superior.

Capsules $2 / 3$ superior.

Pedicels less than $10 \mathrm{~mm}$. long.

Capsules $1 / 2$ superior.

Capsules $1 / 8$ superior.

3. L. brevifolia.

4. L. syphilitica.

5. L. puberula.

6. L. amoena.

7. L. glandulifera.

8. L. elongata.

9. L. glandulosa.

10. L. Halei.

11. L. Floridana.

12. L. paludosa.

13. L. flaccidifolia.

14. L. appendiculata.

15. L. Gattingeri.

16. L. spicata.

17. L. leptostachys.

18. L. bracteata.

19. L. inflata.

20. L. Boykinii.

21. L. Canbyi.

22. L. Nuttallii.

23. L. Cliffortiana.

24. L. Xalapensis.

25. L. brachypoda.

26. L. Feayana.

1. Lobelia cardinàlis L. Perennial, minutely pubescent or glabrous, deep-green. Stems erect, 3-12 dm. tall, usually simple: leaf-blades varying from ovate-lanceolate to narrowly oblong, or the lower ones sometimes oblong-spatulate, $3-15 \mathrm{~cm}$. long, acuminate at both ends, coarsely or finely serrate or dentate, sessile or short-petioled : raceme virgate, 1-4 dm. long: hypanthium commonly shorter than the pedicel : sepals linear or linearsubulate, 2-6 times longer than the hypanthium : corolla deep-red or rarely white ; tube longer than the lobes, straight; lobes on either side of the cleft linear-oblanceolate, longer than the other 3 narrowly oblong or oblong-oblanceolate lobes : capsules hemispheric, with a low beak, 8-10 mm. in diameter : seeds oblong, 1-1.2 mm. long, strongly tuberculate.

In swamps and on muddy or wet banks, New Brunswick to Saskatchewan, Florida and Texas. Summer and fall. CARDINAL-FLOWER.

2. Lobelia spléndens Willd. Perennial, slender, glabrous or rarely puberulent. Stems erect or ascending, 3-12 dm. tall, simple: leaf-blades linear or linear-lanceolate, or the lower ones narrowly oblanceolate, $3-12 \mathrm{~cm}$. long, acuminate, more or less distinctly glandular-toothed, the upper sessile the lower short-petioled : raceme $1.5-3.5 \mathrm{dm}$. long: pedicels erect or ascending: sepals linear-lanceolate or linear-subulate, several times longer than the hypanthium : corolla deep-red; tube longer than the lobes, the two of which on either side the cleft are linear or linear-oblanceolate, the other 3 oblong or oblong-oblanceolate : capsules subglobose-hemispheric, with a conic beak, $8-10 \mathrm{~mm}$. broad, prominently ribbed : seeds oblong or nearly so, $0.7-0.8 \mathrm{~mm}$. long, strongly tuberculate.

In wet places, Texas to California and Mexico. Summer and fall.

3. Lobelia brevifolia Nutt. Perennial, glabrous or puberulent. Stems erect, 3-8 dm. tall, virgate, simple or nearly so: leaf-blades fleshy, spreading or reflexed, the lower 
ones spatulate, obovate or cuneate, the upper narrowly or linear-oblong, $0.5-2.5 \mathrm{~cm}$. long, obtuse, strongly toothed, sessile : raceme $0.5-4 \mathrm{dm}$. long, spike-like : pedicels erect or appressed, more or less pubescent, about as long as the strongly toothed bracts: sepals rigid, pectinate-toothed, each with two obtuse auricles at the base : corolla pale blue : capsules 5-7 $\mathrm{mm}$. high, with a broadly turbinate ribbed base and a conic beak : seeds tuberculate.

In moist pine lands, Florida to Louisiana. Summer and fall.

4. Lobelia syphilítica L. Annual or perennial, slightly pubescent with scattered spreading hairs. Stems erect, $2-6 \mathrm{dm}$. tall, sometimes sparingly branched : leaf-blades oblanceolate, elliptic or lanceolate, $2.5-20 \mathrm{~cm}$. long, acute or obtuse, coarsely serrate or sinuate-dentate, the lower ones petioled, the upper sessile: raceme 1-5 $\mathrm{dm}$. long, the lower bracts leaf-like: hypanthium bristly-pubescent : sepals bristly-ciliate, long-acuminate, with an ovate base, each prolonged below into 2 acute auricles: corolla blue striped with white, or rarely white, tube slightly longer than the sepals, the lobes on either side of the cleft lanceolate, more or less curled, acuminate, the three lower lobes ovate, acute at the base, glabrous: capsules $8-10 \mathrm{~mm}$. in diameter: seeds $1 \mathrm{~mm}$. long, longitudinally wrinkled.

In wet places and swamps, valley of the St. Lawrence to South Dakota, Colorado, Georgia and Louisiana. Summer and fall.-A form, L. syphilitica Ludoviciàna A. DC., with glabrate foliage and nearly entire and thicker leaf-blades, occurs from Nebraska and Colorado to Louisiana.

5. Lobelia pubérula Michx. Perennial, softly pubescent with fine close hairs, or glabrate. Stems erect, $3-10 \mathrm{dm}$. tall, simple, virgate, sometimes zigzag : leaf-blades spreading or ascending, thick, $2-10 \mathrm{~cm}$. long, the lower ones oblanceolate, oblong or obovate, shortpetioled, the upper varying from oblong to lanceolate or ovate, sessile, all finely toothed or nearly entire: raceme $0.5-5 \mathrm{dm}$. long, its lower bracts sometimes leaf-like: pedicel shorter than the hypanthium : sepals sometimes bristly, lanceolate, entire or sparingly toothed, revolute, with short rounded auricles : corolla deep blue or rarely white, about $1.5 \mathrm{~cm}$. long; tube slightly longer than the sepals ; lobes on either side of the cleft lanceolate, the other 3 ovate or the middle one ovate-lanceolate, glabrous within : capsules 7-9 $\mathrm{mm}$. thick, the conic beak as long as the base : seeds obovoid or oval, $0.7-0.9 \mathrm{~mm}$. long, tuberculate.

In meadows and wet woods, New Jersey to Missouri, Florida and Texas. Summer and fall.-A more delicate form with glabrate foliage and more naked virgate racemes is $L$. puberula latviúscula $\mathrm{C}$. Mohr.

6. Lobelia amoèna Michx. Perennial, glabrous or finely pubescent in parts. Stems erect or ascending, 3-12 dm. tall, leafy throughout, usually simple : leaf-blades deep green, thinnish, oblong or elliptic, varying to broadest above or below the middle, undulate or rather coarsely sinuate, paler beneath than above, the lower ones narrowed into margined petioles, the upper sessile or nearly so : raceme usually 1-5 dm. long, often 1-sided : bracts variable in length, undulate or sharply toothed : sepals usually longer than the pedicels, narrowly linear or linear-subulate, $7-8 \mathrm{~mm}$. long, barely if at all auricled at the base, entire or nearly so : corolla blue or rarely white, $2-2.5 \mathrm{~cm}$. long, about as long as the sepals or much longer : capsules $6-7 \mathrm{~mm}$. broad, mostly inferior.

In swamps or on damp hillsides, North Carolina to Florida. Summer and fall.

7. Lobelia glandulífera (A. Gray) Small. Perennial, glabrous or nearly so. Stems erect, 3-7 dm. tall, simple, rather strict: leaves usually few; blades narrowly oblong to oblong-ovate, 3-12 cm. long, rather coarsely and irregularly dentate with gland-tipped teeth, the lower ones narrowed into margined petioles, the upper sessile : raceme virgate, few-flowered, 1-3 dm. long : bracts ovate to lanc solate, conspicuously glandular-toothed: hypanthium commonly surpassing the bract, much longer than the pedicel : sepals narrowly lanceolate or linear-lanceolate, $7-9 \mathrm{~mm}$. long, pectinately glandular-toothed, more or less strongly auricled at the base : corolla blue, about $1.5 \mathrm{~cm}$. long; tube surpassing the sepals : capsules 4-6 mm. broad. [ $L$. amoena var. glandulifera A. Gray.]

In low grounds, Virginia to Florida and Alabama. Summer and fall.

8. Lobelia elongàta Small. Perennial, at least by offsets, glabrous or nearly so. Stems erect or ascending, 3-12 dm. tall, simple, commonly wand-like : leaves rather few, erect or somewhat spreading; blades linear or nearly so, 2-10 cm. long, mostly acute, serrate or dentate-serrate with gland-tipped teeth, sessile or narrowed into petiole-like bases : raceme rather closely but not densely flowered, 1-3 dm. long, one-sided: bracts linear to lanceolate, serrate with gland-tipped teeth, the lower ones sometimes surpassing the corollas : flowers short-pedicelled : sepals elongated linear-subulate or linear-setaceous, entire, as long as the corolla or shorter : corolla deep blue, showy, ascending : capsules 6-8 mm. broad.

In low grounds or swamps, Virginia to Florida and Louisiana, Summer and fall.

9. Lobelia glandulòsa Walt. Perennial, glabrous below the inflorescence. Stems erect or decumbent, 3-12 dm. long, simple or nearly so, wand-like, sometimes zigzag: 
leaves few ; blades linear, narrowly linear, or linear-oblanceolate below, 2-15 $\mathrm{cm}$. long, obtuse or acutish, shallowly repand or glandular-toothed, slightly revolute, sessile or the lower ones short-petioled : racemes few-flowered, often recurved : pedicels $1-1.5 \mathrm{~cm}$. long, erect, often hirsute near the tip : hypanthium often sparingly hirsute, campanulate, 3-3.5 $\mathrm{mm}$. long : sepals linear-lanceolate, 3 or 4 times as long as the hypanthium, remotely denticulate with gland-tipped teeth : corolla showy, about $2 \mathrm{~cm}$. long; tube much longer than the calyx; limb 2-3 cm. broad ; lobes abruptly pointed or mucronate : capsules 5-7 mm. high.

In wet sandy pine lands, Virginia to Florida. Spring to fall.

10. Lobelia Hàlei Small. Perennial, slender, nearly glabrous. Stems erect or ascending, simple, sometimes zigzag: leaf-blades thick, 2-8 $\mathrm{cm}$. long, the lower with oblong-spatulate rather obtuse petioled blades, the upper narrowly lanceolate or linearlanceolate, acute, sessile, more or less denticulate : raceme 1-2 dm. long: pedicels erect or ascending, usually pubescent: hypanthium often minutely pubescent : sepals lanceolate to ovate-lanceolate, $3-5 \mathrm{~mm}$. long, entire or sparingly toothed, prominently auricled at the base: corolla blue; tube about twice as long as the sepals; lobes acute: capsules slightly shorter than the sepals. [L. Ludoviciana A. Gray, not L. syphilitica var. Ludoviciana A. DC.]

On wet prairies, Louisiana and Texas. Spring.

11. Lobelia Floridàna Chapm. Perennial, glabrous. Stems erect, 8-15 dm. tall, simple or branched above, scape-like : leaves mainly basal; blades linear or slightly broadened upward, strap-like, 1-4 dm. long, undulate or crenate-undulate, sessile ; those of the stem-leaves much reduced and remote : raceme usually many-flowered : bracts as long as the pedicels or slightly longer: hypanthium sometimes slightly glandular : sepals lanceolate, 4-5 mm. long, denticulate, auricled at the base : corolla blue, 15-18 mm. long; tube about twice as long as the sepals, minutely pubescent without: capsules about onehalf superior.

In wet pine lands, Florida to Mississippi. Spring to fall.

12. Lobelia paludòsa Nutt. Perennial, more or less aquatic, slender, glabrous. Stems scape-like, erect, 2-7 dm. tall, simple or sometimes branched above: leaves mostly basal ; blades linear or linear-spatulate, or rarely oblong-ovate, 3-25 cm. long, or rarely longer, obtuse, entire or sinuate-crenate, sessile or petioled : raceme slender, few-flowered or sometimes elongated and rather many-flowered : bracts mostly shorter than the pedicels: hypanthium glabrous: sepals lanceolate or linear-lanceolate, $2.5-3.5 \mathrm{~mm}$. long, acute, often entire : corolla pale blue or white, $1 \mathrm{~cm}$. long or shorter; tube fully twice as long as the sepals, pubescent at the base of the lips within : capsules more than one-half inferior.

In and about pine-land swamps, Delaware to Florida and Louisiana. Spring to fall.

13. Lobelia flaccidifòlia Small. Perennial, slender, deep green; glabrous or nearly so. Stems erect, 2-6 dm. tall, solitary, or loosely tufted, usually branched above : leaves few ; blades thin, the basal or lower cauline obovate or oblong-spatulate, the others linearoblong or rarely linear-lanceolate, $3-10 \mathrm{~cm}$. long, obtuse, undulate or crenate-undulate, short-petioled: raceme interrupted, $0.5-2 \mathrm{dm}$. long : pedicels erect, 4-5 mm. long, usually exceeded by their bracts : hypanthium glabrous, broadly turbinate, becoming globosehemispheric, acutely and strongly ribbed : sepals linear-lanceolate, 4-5 mm. long, glandular-toothed, auricled at the base, slightly revolute: corolla about $1.5 \mathrm{~cm}$. long, blue, sparingly pubescent without; lobes of the upper lip reflexed, crisped, about $\frac{1}{2}$ as long as the tube, the lower lip as long as the tube; lobes acute, the middle one lanceolate, the lateral ones oblong-lanceolate: anthers pubescent : capsules ovoid, 5-8 mm. long, beaked, more than one-half inferior.

In sand in deep river swamps, southern Georgia and Florida. Summer.

14. Lobella appendiculata A. DC. Annual or biennial, glabrous or rough-pubescent above. Stems erect, 3-6 dm. tall, often branched above, at length angled : leaves few ; blades thinnish, those of the basal leaves spatulate or oblong-spatulate, petioled, the upper ones ovate, oblong-obovate or oval or lanceolate, sessile, rather remote, distantly serrate, denticulate or undulate : raceme $0.5-3 \mathrm{dm}$. long, much interrupted : pedicels slender, ascending, curved, pubescent : sepals surpassing the bracts, subulate or linear-subulate, ciliate, 3-6 mm. long, prolonged at the base into reflexed distinct or more or less united appendages: corolla blue, 6-8 $\mathrm{mm}$. long; tube about as long as the sepals : anthers pubescent on the back, glabrous at the tip : capsules 4-5 mm. long, hemispheric at the base.

In low grounds or pine woods, Arkansas to Louisiana and Texas. Spring.

15. Lobelia Gattíngeri A. Gray. Annual or biennial, glabrous or nearly so. Stems erect, 2-4 dm. tall, simple, or branched mainly at the base, often hispid on the angles : leaves several ; blades thinnish, 1-4 cm. long, the basal obovate, short-petioled, the cauline ovate, oblong or oval, all obtuse, irregularly toothed or nearly entire : raceme $0.5-2$ 
dm. long, interrupted : pedicels erect or ascending, curved, scabrous : sepals surpassing the bracts, lanceolate-subulate, alternate, $3.5-5 \mathrm{~mm}$. long, glabrous, never ciliate, without auricles or with small callus-like appendages at the base: corolla blue, 7-8 mm. long; tube as long as the sepals: capsules $5-6 \mathrm{~mm}$. long.

In cedar glades, Tennessee. Spring.

16. Lobelia spícàta Lam. Annual or biennial, slender, puberulent, or sometimes nearly glabrous. Stems erect, 1-2 dm. tall, rarely branched : leaves firm, 1-10 $\mathrm{cm}$. long, the basal with spatulate obovate or suborbicular petioled blades, the upper ones varying from oblanceolate to lanceolate, sessile, all crenate-dentate or nearly entire, obtuse : raceme 1-5 dm. long, often continuous : pedicels slender, erect or ascending : sepals (and hypanthium) usually as long as the pedicel or longer, linear-subulate, 3-5 mm. long, without appendages at their bases : corolla blue or white, $6-9 \mathrm{~mm}$. long; tube surpassing the sepals : capsules $2.5-3 \mathrm{~mm}$. high.

In dry sandy soil or meadows. Ontario to the Northwest Territory, Florida and Texas. Summer.

17. Lobelia leptostáchys A. DC. Annual or biennial, puberulent or glabrate. Stems erect, 3-12 dm. tall, usually simple, somewhat angled : leaves firm, $3-10 \mathrm{~cm}$. long, the lower ones with oblanceolate or obovate, short-petioled blades, the upper ones with blades varying from oblong to lanceolate and sessile, all entire or distinctly toothed, mostly obtuse : raceme 1-4 dm. long: pedicels usually erect, more or less scabrous : flowers approximate or distant: hypanthium turbinate, becoming hemispheric: sepals subulatelanceolate, 5-6 mm. long, each with a pair of linear or subulate deflexed appendages at the base : corolla blue, 6-8 mm. long : capsules 3-3.5 mm. high.

In dry soil, Virginia to Ohio, Kansas and Georgia. Summer.

18. Lobella bracteàta Small. Biennial or perennial, pale green, nearly glabrous. Stems erect, 8-10 dm. tall, simple, angled: leaves few ; blades thickish, spatulate to oblong or linear-lanceolate, or linear, 3-10 cm. long, obtuse or acute above, glandular-toothed, paler beneath than above, ciliate or ciliolate near the base, the lower ones narrowed into margined petioles, the upper sessile : raceme 1-4 dm. long, conspicuously bracted, seldom densely flowered : bracts linear or linear-subulate, 8-15 $\mathrm{mm}$. long, glandular-toothed, surpassing the corollas, spreading or ascending-spreading : pedicels often puberulent : sepals linear-subulate, $3.5-4 \mathrm{~mm}$. long, prolonged into subulate deflexed appendages at the base, with the hypanthium longer than the pedicels: corolla blue, 8-9 mm. long; tube about equalling the sepals in length; lobes acute: capsules 5-7 mm. high.

In sandy pine woods, North Carolina and Georgia. Summer.

19. Lobelia inflàta L. Annual, pubescent with spreading hairs, light-green. Stems erect, 1-10 dm. tall, simple, or branched throughout, narrowly winged; branches very slender: leaf-blades ovate, oval or the lower ones obovate, all varying from $2-9 \mathrm{~cm}$. in length, obtuse or acutish, crenate, sessile, the nerves impressed above, prominent beneath : bracts ovate or lanceolate : pedicels slender, $3-10 \mathrm{~mm}$. long: hypanthium campanulate, at length much inflated, glabrous, marked with purple ribs: sepals linear, erect or ascending, acute, much longer than the tube : corolla pale lilac, 7-8 mm. long; lower lobes ovate, with 2 yellow blotches at the base; upper lobes linear-spatulate, all acute; tube slightly pubescent within : capsules oblong or oval, inflated, 5-8 mm. long, included in the accrescent hypanthium, crowned with the persistent sepals : seeds oblong, reticulated.

In dry soil and on hillsides, Labrador to the Northwest Territory, Georgia, Arkansas and Nebraska. spring to fall. INDIAN TOBACCO. WILD TOBACCO.

20. Lobelia Boykínii T. \& G. Perennial, slender, glabrous, usually aquatic. Stems erect, 3--8 dm. tall, virgate, hollow, simple or sparingly branched : leaves few, reduced; blades linear-filiform or filiform, 1-3 cm. long, distantly glandular-toothed, sessile : raceme interrupted, 1-2 dm. long: pedicels filiform-setaceous, mainly $1 \mathrm{~cm}$. long, subtended by subulate bracts which are usually about $\frac{1}{2}$ as long as the pedicels, each much longer than the hypanthium : sepals slender-subulate, $3.5-4.5 \mathrm{~mm}$. long, spreading: corolla bright blue, 8-10 mm. long; tube slightly surpassing the sepals : capsules half-inferior, $3-3.5 \mathrm{~mm}$. long.

In pine-land swamps, South Carolina to Georgia and Florida. Spring and summer.

21. Lobelia Cánbyi A. Gray. Annual, or perennial from offsets, slender, slightly puberulent or glabrate. Stems erect, $3-8 \mathrm{dm}$. tall, simple and wand-like or paniculately branched : leaves rather few ; blades linear or oblong-linear, $2-6 \mathrm{~cm}$. long, sessile, gian-
dular-denticulate : racemes $0.5-3 \mathrm{dm}$. long : pedicels slender, erect or ascending, shorter than the subtending bracts, each as long as the hypanthium or shorter : sepals linear-subulate, $2.5-3 \mathrm{~mm}$. long, glandular-denticulate : hypanthium elongating in age : corolla bright blue, 8.5-9.5 mm. long; tube surpassing the sepals : capsules wholly inferior, about $4 \mathrm{~mm}$. long.

In pine-land swamps, New Jersey to South Carolina. Summer and fall. 
22. Lobelia Nuttállii Roem. \& Schult. Annual or biennial, very slender, glabrous or nearly so. Stems erect or ascending, wiry, 2-7 dm. long, simple or commonly branched above, the branches sometimes filiform: leaves thickish; basal with ovate or obovate petioled blades : stem-leaves few ; blades oblanceolate or linear, $2-4 \mathrm{~cm}$. long, entire or distinctly toothed, sessile : racemes $0.5-3 \mathrm{dm}$. long, loosely-flowered : pedicels nearly filiform, mostly longer than the bracts: sepals subulate, 2-2.5 $\mathrm{mm}$. long: corolla pale or light blue, $6-7.5 \mathrm{~mm}$. long, usually surpassing the pedicel in length : capsules about 2.5 mm. broad, half-superior.

In low or moist pine lands, Long Island and Pennsylvania to Florida, and rarely on mountain summits in the Blue Ridge. Spring to fall.

23. Lobelia Cliffortiàna L. Annual, minutely pubescent or glabrous. Stems erect, 3-6 dm. tall, usually branched : leaf-blades ovate or ovate-lanceolate, $2-10 \mathrm{~cm}$. long, mostly obtuse, coarsely toothed or sinuate, the lower ones long-petioled, the upper shortpetioled or nearly sessile : racemes 1-3 dm. long, loosely-flowered : pedicels filiform, $1.2-4$ $\mathrm{cm}$. long, ascending or spreading: sepals subulate, $2.5-3 \mathrm{~mm}$. long, longer than the turbinate hypanthium : corolla blue, $6-7 \mathrm{~mm}$. long; tube just surpassing the sepals : capsules ovoid, 5-6 mm. long, about half-superior.

In waste places or cultivated ground in the Gulf States, introduced from tropical America.

24. Lobelia Xalapénsis H.B.K. Annual, glabrous or minutely pubescent. Stems 2-6 dm. long, commonly branched at the base or near it, the branches weak, often spreading : leaf-blades ovate to suborbicular, mostly obtuse, rather closely crenate or incised-dentate, cordate or subcordate, or the upper truncate; petioles as long as the blades or shorter: pedicels filiform, $1.2-2.5 \mathrm{~cm}$. long, ascending : sepals subulate, $2-2.5 \mathrm{~mm}$. long, longer than the hypanthium : corolla blue, $8-10 \mathrm{~mm}$. long ; tube surpassing the sepals : capsules nearly oblong, 6-7 $\mathrm{mm}$. long, fully two-thirds free.

In sand, peninsular Florida, introduced from Mexico and the West Indies.

25. Lobelia brachýpoda A. DC. Annual, glabrous or nearly so. Stems simple or erect, or branched at the base, the branches ascending, 3-8 dm. long: leaf-blades mainly obovate-spatulate to oblong or lanceolate, $2-5 \mathrm{~cm}$. long, acute or obtuse, serrate, gradually or abruptly narrowed into petioles : racemes several-flowered, elongated : pedicels slender, 4-8 mm. long, curved : sepals linear-subulate, $3-5 \mathrm{~mm}$. long, longer than the hypanthium : corolla blue, 6-8 mm. long; tube surpassing the sepals : capsules 4-5 mm. long, about halfsuperior.

In sandy soil, Texas and adjacent Mexico. Spring to fall.

26. Lobelia Feayàna A. Gray. Annual, slender, glabrous throughout. Stems erect or branched at the base and spreading, 1-3 dm. long, often naked above : leaves few ; basal with reniform, suborbicular or orbicular-ovate blades $0.5-1.5 \mathrm{~cm}$. broad; petioles longer than the blades or shorter: the upper leaves few ; blades obovate or ovate, smaller than the basal, short-petioled, entire or crenate: racemes few-flowered, $2-20 \mathrm{~cm}$. long : pedicels slender, 2-5 mm. long, surpassing the bracts : sepals subulate, $1.5-2 \mathrm{~mm}$. long, about as long as the tube : corolla bright blue, rather longer than the pedicel : capsules about equalling the sepals, one-third superior.

In pine lands, Florida.

\section{FAMily 4. BRUNONIÀCeat Reichenb. Goodenia Family.}

Herbaceous or shrubby plants, with watery sap. Leaves alternate or sometimes opposite, without stipules: blades entire or toothed or rarely pinnatifid. Flowers perfect, regular or irregular, variously disposed. Calyx 5-toothed, an entire border or sometimes obsolete. Corolla 5-lobed and more or less deeply split on one side, of various colors: lobes valvate, sometimes winged. Androecium of 5 distinct stamens. Anthers usually free, opening lengthwise. Gynoecium a single compound pistil. Ovary mostly inferior, 1-2-celled. Styles usually united. Stigma surrounded with an indusium. Ovules 1 or 2, or more in each cavity, mostly erect or ascending. Fruit drupaceous, berry-like or capsular. Seeds usually one in each cavity. Embryo straight in the axis of the fleshy endosperm.

\section{SCAEvòla L.}

Fleshy, stout herbs or shrubs. Leaves alternate or rarely opposite : blades mostly entire. Flowers irregular, axillary, in dichotomous cymes or rarely solitary. Calyx 5-lobed, or a mere border. Corolla white or blue : lobes winged : tube split to the base on one side, 
villous within. Stamens 5, free, epigynous : filaments distinct. Ovary inferior or nearly so, 2-celled or rarely 1-celled : stigma surrounded by a ciliate indusium. Ovules 1 in each cavity, or 2 in 1-celled ovaries, erect. Berry with a fleshy exocarp and a bony or woody endocarp.

1. Scaevola Plumièri Vahl. Perennial, nearly glabrous, more or less shrubby. Stem terete, low : leaves alternate; blades obovate, $4-6 \mathrm{~cm}$. long, entire, narrowed into very short winged petioles, or nearly sessile, bearing a tuft of silky hains in each axil : peduncles shorter than the leaves : calyx-lobes much broader than high, rounded: corolla glabrous without, about $2.5 \mathrm{~cm}$. long; tube shorter than the lobes, woolly within, split on one side to the base; lobes nearly linear, with broad crisped wings: stamens nearly as long as the corolla-tube hanging through the cleft : berry oval, 10-14 mm. long.

Coast of southern Florida and the Keys, also in the West Indies, South America, Africa and Asia.

\section{Order 14. CARDUÀLES.}

Herbs, shrubs or rarely trees. Leaves mainly alternate : blades entire or toothed. Flowers perfect, monoecious or dioecious, few or many aggregated on a receptacle and surrounded with an involucre of few or many bracts, or the involucre rarely obsolete. Calyx 1 or 2 rows of bristles, scales, a mere border or a crown, or obsolete or wholly wanting. Corolla of several more or less united petals. Androecium of usually 5 stamens, the anthers merely converging, or united. Gynoecium mostly of 2 united carpels. Ovary inferior. Styles or stigmas mostly 2. Fruit an achene.

Flowers with tubular corollas, or those of the outer ones prolonged into ligules.

Stamens distinct, the anthers merely converging about the stigma.

Stamens united by the anthers, thus forming a tube around the stigma, except in Kuhnia.

Flowers with each corolla prolonged into a ligule.

Fam. 1. Ambrosiaceae.

Fam. 2. CARDUACEAE.

Fam. 3. Cichoriacear.

\section{Family 1. AMBROSIÀCEAE Reichb. Ragweed Family.}

Annual or perennial herbs or rarely shrubby plants, commonly weeds or weed-like and either monoecious or dioecious. Leaves alternate, or opposite on the lower part of the stem. Flowers very small, in inconspicuous heads, with white or greenish disks, the staminate and pistillate in the same heads or in separate heads. Involucres of few distinct or united bracts, those subtending the pistillate flowers often longer than those of the staminate and usually nut-like or bur-like at maturity. Staminate flowers with tubular obconic or funnelform corollas; lobes 4-5: stamens usually 5, distinct : anthers merely converging, furnished with inflexed appendages. Pistillate flowers without a corolla or this represented by a mere border or short tube : calyx wanting or a mere border. Ovary 1-celled. Stigmas 2, hairy or brush-like at the top. Achene naked or enclosed in the accrescent pistillate involucre, which is commonly furnished either with tubercles or spines.

Staminate and pistillate flowers in different heads : involucre of the pistillate head bur-like or nut-like.

Bracts of the staminate involucres distinct: pistillate involucres bur-like.

Bracts of the staminate involucres united.

Pistillate involucres with numerous prickles in several rows.

Pistillate involucres with several tubercles or prickles in 1 row.

Staminate and pistillate flowers in the same heads.

1. XANTHIUM.

2. GAERTNERIA.

3. AMBROSIA.

4. IVA.

\section{XÁNTHIUM L.}

Annual or perennial, commonly coarse herbs with upright or diffuse smooth or pricklearmed stems. Leaves alternate : blades toothed or lobed, often ample. Heads monoecious : staminate in terminal spikes, racemes or clusters: pistillate axillary. Staminate involucres short, of several distinct bracts, in 1-3 rows. Receptacle chaffy, cylindric. Corolla tubular: lobes 5. Filaments monadelphous. Anthers mucronate, free. Style simple. Pistillate involucres closed, 1-3-beaked, oblong to ovoid, armed with spines, 2-celled. Corolla wanting. Stigmas 2. Achenes solitary in each cavity of the involucre. Pappus wanting. The plants bloom in summer and fall. Clotbur. Burweed, Cocklebur. 
Leaf-blades much longer than broad : leaf-bases accompanied by 3-pronged spines.

Leaf-blades as broad as long or but little longer: leaf-bases without spines. Fruit glabrous or nearly so, the beaks nearly straight.

Fruit pubescent, the beaks incurved or hooked.

Fruit less than $2.5 \mathrm{~cm}$. long.

Body of fruit oblong, twice as long as thick.

Body of fruit oval, less than twice as long as thick.

Fruit over $2.5 \mathrm{~cm}$. long.

1. X. spinosum.

2. X. glabratum.

3. X. Pennsylvanicum.

4. X. echinatum.

5. X. speciosum.

1. Xanthium spinòsum L. Bright green, armed with yellow 3 -forked spines. Stems erect, 2-10 dm. tall, usually much branched: leaf-blades thickish, lanceolate, entire or 3-lobed, the lobes acute or acuminate, minutely pale- or white-pubescent beneath : staminate involucres many-flowered ; bracts narrow : corolla $2-2.3 \mathrm{~mm}$. long ; lobes triangular : pistillate involucres solitary or few together : fruit oblong-cylindric, 10-13 mm. long, hard, pubescent, armed with hooked prickles and terminating in subulate beaks.

In waste places or on river banks, Ontario to Missouri, Florida and Texas.

2. Xanthium glabràtum (DC.) Britton. Glabrate, or finely pubescent, unarmed. Stems erect, 2-13 dm. tall, usually branching: leaf-blades ovate or deltoid, $5-30 \mathrm{~cm}$. long and broad or smaller above, acute or acutish, rather coarsely toothed and more or less distinctly lobed, truncate or cordate at the base; petioles about as long as the blades or shorter: fruit oblong, 1.5-2 cm. long, glabrous or merely puberulent, thickly beset with slender, more or less strongly hooked spines, terminating in straight or nearly straight beaks.

In waste places, New England to Nebraska, Florida and Mexico.

3. Xanthium Pennsylvánicum Wallr. Rough-pubescent, at least above. Stems 2-6 dm. tall, relatively slender : leaf-blades thin, glandular, sharply toothed or some of them 3-5-lobed : fruit oblong, 1.5-1.8 $\mathrm{cm}$. long, puberulent and resinous-glandular, and commonly with scattered hairs, with incurved and hooked beaks, the prickles numerous, nearly as long as the diameter of the fruit-body.

On river banks or in rich soil, Ontario to Minnesota, District of Columbia and Arkansas.

4. Xanthium echinàtum Murr. Rough-pubescent. Stems erect, $3-16 \mathrm{dm}$. tall, usually branching, often spotted with brown : leaf-blades ovate, deltoid to reniform, acute, coarsely toothed and often shallowly lobed, truncate or cordate at the base; petioles as long as the blades or shorter: fruit oval, $2-2.3 \mathrm{~cm}$. long, hispid, thickly beset with stout, rigid more or less strongly hooked prickles, terminating in incurved or hooked beaks.

On river banks, beaches and in waste places, the Great Lake region to Vermont, Massachusetts and North Carolina.

5. Xanthium speciòsum Kearney. Somewhat pubescent. Stems erect, 1-1.5 mm. tall, stout, much branched, 4-angled, zigzag above, rigid : leaf-blades thickish, dull-green, broadly triangular-ovate, often broader than long, $15-22 \mathrm{~cm}$. broad or smaller above, shallowly 3-5-lobed, scabro-pubescent on both sides, prominently nerved, especially beneath, cordate : petioles rather slender, 10-15 $\mathrm{cm}$. long or shorter above, pubescent especially along the deep groove : fruit ovoid, $2.5-4 \mathrm{~cm}$. long, with 2-3 stout more or less incurved beaks, 10-12 mm. long, closely armed with more or less incised prickles, 8-9 mm. long, pubescent and resinous-dotted.

In sandy bottoms, North Dakota to Tennessee and Texas.

\section{GAERTNÈria Medic.}

Annual or perennial caulescent herbs, simulating species of Ambrosia, with variously pubescent foliage. Leaves alternate or usually so : blades lobed or divided. Heads monoecious : staminate in terminal spikes or racemes: pistillate solitary or clustered below the staminate. Staminate involucre open, usually hemispheric, with the 5-12 bracts partially united: receptacle chaffy: corolla short; lobes 5: anthers scarcely coherent: styles simple. Pistillate involucres closed, globose to ovoid, with 1-4 cavities and beaks, and spines in several rows, becoming bur-like at maturity: stigmas 2 . Achenes broadest above the middle, solitary in each cavity of the involucre. [Franseria Cav.]

1. Gaertneria tenuifolia (A. Gray) Kuntze. Perennial, herbaceous, the foliage often hispid. Stems erect, 3-15 dm. tall, leafy to the inflorescence : leaves numerous, 5-15 $\mathrm{cm}$. long; blades 2-3-pinnately parted or even dissected into narrow segments: staminate heads in slender usually panicled racemes : pistillate heads clustered, usually numerous, involucre either 1- or 2-flowered : fruit fully $2 \mathrm{~mm}$. long, with $6-18$ short incurved spines.

In moist grounds, Texas to Colorado, California and Mexico. Summer and fall. 


\section{AMBROSIA L.}

Annual or perennial often woody caulescent herbs, with monoecious or rarely dioecious flowers. Leaves opposite or alternate : blades lobed or variously divided or rarely merely toothed. Heads not showy, the staminate in terminal spikes or racemes, the pistillate solitary or clustered below the staminate. Staminate involucres saucer-like to hemispheric, with the 5-12 partially united bracts or wanting: receptacle nearly flat, naked or with filiform chaff : corolla funnelform ; lobes 5 : anthers mucronate at the apex : style simple, often brush-like at the tip. Pistillate involucres turbinate to subglobose, 1-flowered, with several spines or tubercles in one row : corolla wanting: stigmas filiform. Achenes ovoid to obovoid. Pappus wanting. The plants flower in summer and fall. RAGweEd.

Staminate involucres wanting.
Staminate involucres peduncled.

1. A. bidentata.

Leaves all opposite: blades palmately 3-5-lobed or merely toothed : receptacle naked.

Petioles of the upper leaves margined: fruit 8-10 $\mathrm{mm}$. long.

Petioles not margined : fruit $4-6 \mathrm{~mm}$. long.

Leaves both alternate and opposite; blades 1-2-pinnatifid : receptacle chaffy. Annual plant: fruit with 4 tubercles or spine-like teeth.

Perennial plant: fruit with 4 tubercles, or these obsolete. Stems branched at the base, the branches spreading: upper leaf-blades 2-pinnatifid.

Stems erect: upper leaf-blades 1-pinnatifid.

2. A. trifida.

3. A. aptera.

4. A. artemisiifolia.

5. A. hispida.

6. A. psilostachya.

1. Ambrosia bidentàta L. Annual, rough hirsute. Stems erect, 3-9 dm. tall, branching, rough : leaves usually alternate; blades lanceolate to oblong, $2-8 \mathrm{~cm}$. long, acute, usually with an acute tooth-like lobe on either side near the base, otherwise entire or sometimes sparingly toothed : staminate heads numerous, often crowded ; involucres 3-3.5 $\mathrm{mm}$. broad, with a conspicuous, lanceolate reflexed lobe on the inner side : pistillate heads solitary or clustered : fruit nearly oblong, 6-8 mm. long, 4-angled, with 4 spines at the base of the beak.

On prairies, Illinois to Missouri, Louisiana and Texas.

2. Ambrosia trífida L. Annual, hirsute to hispid. Stems erect, $1-5 \mathrm{~m}$. tall : leaves opposite ; blades deeply 3-5-lobed or sometimes merely toothed, 1-3 dm. long, lobes acute or acuminate, serrate ; petioles shorter than the blades, margined : racemes of staminate heads 5-15 cm. long; involucres saucer-shaped, 3-ridged on the outer side, crenate: pistillate heads clustered in the axils of the leaf-like bracts; involucres turbinate or obovoid, 5-7-ridged: fruit pubescent, 8-10 mm. long, short-beaked, each rib terminating in a tubercle.

In moist soil or waste places, Quebec to the Northwest Territory, Florida, Arkansas and Colorado.

3. Ambrosia áptera DC. Annual, scabro-pubescent. Stems erect, 1-4 m. tall, branching, especially above : leaves opposite; blades merely toothed, 3-5-lobed, 1-3 dm. long; lobes acuminate, serrate, the middle one often $3-5$-lobed; petioles shorter than the blades, not margined : racemes of staminate heads slender, commonly panicled; involucres often sparingly pubescent on the outer side : pistillate heads clustered in the axils of leaflike bracts ; involucres 4-8-ridged : fruit nearly glabrous, 4-6 mm. long, stout-beaked, 4-6 of the ridges ending in tubercles or these nearly obsolete.

In low grounds, Texas to Arizona and adjacent Mexico.

4. Ambrosia artemisiifòlia L. Annual, more or less hirsute. Stems erect, 3-18 dm. tall, branched : leaves opposite or alternate; blades bipinnatifid or pinnately parted, with pinnatifid segments, or the upper leaves sometimes entire or merely toothed : racemes of staminate heads numerous, $2.5-15 \mathrm{~cm}$. long; involucres $3-4 \mathrm{~mm}$. broad, crenate; receptacle chaffy : pistillate heads clustered : fruit sparingly pubescent, subglobose or obovoid, 3-3.5 mm. long, short-beaked, with 4-6 spines or spine-like teeth near the top.

In dry soil or waste places, Nova Scotia to British Columbia, Florida and Mexico.

5. Ambrosia híspida Pursh. Perennial, hirsute to hispid. Stems branched at the base, the branches spreading, 2-8 dm. long, sometimes simple, often copiously leafy : leaves opposite ; blades 4-12 cm. long, 2-3-pinnatifid, or pinnately divided into short and small segments; petioles much shorter than the blades: racemes of staminate flowers usually elongated, solitary or more rarely panicled; involucres 4-5 mm. broad, rigidly or spiny-pubescent : pistillate heads clustered : fruit $2.5-3 \mathrm{~mm}$. long, with a short beak and usually 4 tubercles.

On sandy sea beaches, Florida and the West Indies.

6. Ambrosia psilostáchya DC: Perennial, both strigose and hirsute. Stems erect, 5-20 dm. tall, usually branching, rough : leaves numerous; blades 5-15 cm. long or shorter 
above, petioled, the lower 2-pinnatifid, the upper 1-pinnatifid, the segments often toothed, acute or acuminate : racemes of staminate heads several or numerous, $5-18 \mathrm{~cm}$. long ; involucre $3.5-5 \mathrm{~mm}$. broad, pubescent : pistillate heads mostly solitary : fruit 3-4 $\mathrm{mm}$. long, with an abrupt tip and 4 short tubercles, or these wanting.

On moist prairies, the Northwest Territory to Illinois,Texas, Mexico and California.

\section{IVA L.}

Annual or perennial herbs, or shrubby plants, with glabrous or coarsely pubescent foliage. Leaves opposite, or alternate above : blades narrow or broad, entire or toothed, often fleshy. Heads solitary or variously disposed. Involucre campanulate, hemispheric or cup-shaped : bracts few, distinct or partially united. Receptacle bearing with linear or spatulate chaff. Flowers inconspicuous, the marginal 1-6, pistillate, fructiferous, with tubular or obsolete corollas: disk-corollas perfect, not fruit-producing: corolla normal : tube funnelform ; lobes 5 ; stigmas simple, dilated above. Anthers entire at the base, with mucronate appendages. Achene broadest above the middle, without pappus. MarsH Elder.

Heads subtended by bracts similar to the leaves or conspicuous bracts.

Involucres peduncled.

Leaf-blades entire: involucre with $6-9$ bracts.

Leaf-blades glabrous, $2-5 \mathrm{~cm}$. long: involucres $4-5 \mathrm{~mm}$. high.

Leaf-blades strigose, $8-15 \mathrm{~mm}$. long: involucres about $2 \mathrm{~mm}$. high. Leaf-blades toothed: involucre with 4-5 bracts.

Involucres sessile.

Bracts subtending the heads ovate-lanceolate or rhomboidal.

Bracts subtending the heads linear or nearly so.

Leaf-blades ovate or elliptic.

Leaf-blades linear or nearly so, or linear-filiform.

Foliage glabrous or nearly so: fructiferous flowers 3 .

Foliage strigose-hirsute or hirsute: fructiferous flower 1.

Heads subtended by inconspicuous bracts or naked.

1. I. imbricata.

2. I. asperifolia.

3. I. frutescens.

4. I. ciliata.

5. I. caudata.

6. I. microcephala.

7. I. angustifolia.

8. 1. xanthiffolia.

1. Iva imbricata Walt. Perennial, smooth and glabrous, the foliage honey-scented. Stems erect or decumbent, 3-7 dm. long, branching: leaves fleshy, numerous, mostly alternate; blades narrowly linear-subulate to linear, 2-5 cm. long, acute, entire or barely repand, sessile : heads drooping, short-peduncled, subtended by linear bracts : involucre campanulate, 4-5 mm. high : bracts suborbicular or oblong-orbicular, obtuse or retuse : corolla 4-5 mm. long, sparingly glandular; lobes ovate, acute, recurved : achenes $2 \mathrm{~mm}$. long.

In sand on the coast, Virginia to Florida and Louisiana. Summer and fall.

2. Iva asperif òlia Less. Stem $2-4 \mathrm{dm}$. tall, simple or sparingly branched : leaves opposite on the lower part of the stem ; blades mainly linear-lanceolate, $8-15 \mathrm{~mm}$. long, acute, entire, strigose, narrow to the base : spikes slender : heads drooping, surpassed hy the subtending bracts : involucre somewhat 3 -angled, obpyramidal, about $2 \mathrm{~mm}$. high.

In waste places, near Pensacola, Florida. Native of Mexico. Spring to fall.

3. Iva frutéscens L. Perennial, shrubby or herbaceous. Stems erect, 1-3.5 m. tall, branching, minutely pubescent or puberulent : leaves mainly opposite, often pubescent like the stem ; blades ovate to linear, 5-10 $\mathrm{cm}$. long, acute, serrate, acuminate to cuneate at the base, short-petioled : bracts narrowly linear, usually surpassing the heads: heads drooping, short-peduncled: involucre campanulate, $3-3.5 \mathrm{~mm}$. high, often broader than high ; bracts orbicular to orbicular-cuneate, obtuse : corolla funnelform or in the fruitproducing flowers tubular, $2-2.5 \mathrm{~mm}$. long; lobes ovate, acute : achenes broadly cuneateobovate.

On beaches and brackish shores, Massachusetts to Florida and Texas. Summer and fall.

4. Iva ciliàta Willd. Annual, strigose-hispid or hispidulous. Stems erect, 5-18 $\mathrm{dm}$. tall, simple or branching, commonly mottled: leaves opposite or nearly so; blades ovate, elliptic or oval, 4-10 $\mathrm{cm}$. long, acuminate, serrate, narrowed into short petioles: spikes 3-20 cm. long, usually continuous : bracts ovate-lanceolate to rhomboidal, acuminate, ciliate : heads drooping : bracts of the involucre $3-5$, obovate to suborbicular, sometimes broader than high, about $2 \mathrm{~mm}$. long: staminate flowers 10-15: fructiferous flowers 3-5 : corolla $1.5-2 \mathrm{~mm}$. long: achenes $3 \mathrm{~mm}$. long.

In moist soil, Nebraska to Louisiana, Texas and New Mexico. Summer.

5. Iva caudàta Small. Annual, hispid or somewhat strigose. Stems erect, 4-10 dm. tall, branching, ridged : leaves opposite or nearly so; blades ovate or elliptic, 4-10 $\mathrm{cm}$. long, coarsely and irregularly serrate or incised, acuminate, acute to truncate at the base; petioles $\frac{1}{4}-\frac{1}{5}$ as long as the blades, bristly : spikes continuous or interrupted below, conspicuously bracted : bracts linear or with a narrowly elliptic base and linear tip, 7-15 
$\mathrm{mm}$. long, sparingly ciliate: heads drooping, sessile: bracts of the involucre cuneate, 3 $\mathrm{mm}$. high, ciliolate : corolla $2 \mathrm{~mm}$. long ; lobes spreading or recurved.

In swamps and low ground, Mississippi and Louisiana. Fall.

6. Iva microcéphala Nutt. Annual, glabrous or nearly so, slight. Stems erect, 3-9 dm. tall, much branched above, the branches slender, erect or ascending: leaves often alternate ; blades narrowly linear, $2-5 \mathrm{~cm}$. long, acute, entire, or slightly toothed : heads numerous, sessile or nearly so: bracts narrowly linear to linear-filiform, surpassing the heads : involucres $3-6$-flowered, campanulate, $2 \mathrm{~mm}$. high : bracts oblong to cuneate, obtuse to retuse at the apex : fructiferous flowers 3 : corolla nearly $2 \mathrm{~mm}$. long: achenes about $1 \mathrm{~mm}$. long.

In dry pine lands and waste places, Georgia and Florida. Summer and fall.

7. Iva angustifollia Nutt. Annual, strigose or hirsute-strigose. Stems erect, or ascending, 5-12 dm. tall, branching above : leaves various ; blades linear or linear-lanceolate, 4-6 $\mathrm{cm}$. long, or the upper 2-4 cm. long, narrowly linear or linear-filiform, acute, entire or sparingly toothed, ciliate: heads numerous, often crowded : bracts narrowly linear or linear-filiform : involucre turbinate, $3 \mathrm{~mm}$. high, bristly : bracts partially united into a cup, the free portions ciliate: fructiferous flowers solitary : corolla $3 \mathrm{~mm}$. long; lobe. ovate, acutish, recurved : achenes cuneate-obovate, $3 \mathrm{~mm}$. long.

In river bottoms, Arkansas to Louisiana and Texas. Spring to fall.

8. Iva xanthiifòlia (Fresen.) Nutt. Annual, bright green. Stems erect, 0.5-2 m, tall, much branched, glabrous below, pubescent or merely puberulent above : leaves chiefly opposite; blades broadly deltoid, ovate to lanceolate or elliptic above, 3-nerved, 8-16 cm. long, acuminate, coarsely and irregularly dentate, truncate to cuneate at the base, canescent or pale-puberulent beneath; petioles as long as the blades or shorter above: heads nearly sessile, $2-3 \mathrm{~mm}$. broad, in panicled spikes : bracts of the involucres in 2 series, the outer broadest below the middle, the inner broadest above the middle : staminate flowers $10-15$ : fructiferous flowers usually 5 , with rudimentary corollas : achenes cuneate, usually 5 , fully $2 \mathrm{~mm}$. long, striate.

In moist soil or in waste places, Northwest Territory to Michigan, Wisconsin, the Indian Territory, New Mexico and Utah. Summer.

\section{Family 2. Carduàceate Neck. Thistle Family.}

Herbs or rarely shrubs, or sometimes trees in the tropics, with watery or resinous, or rarely milky sap. Leaves opposite or alternate, sometimes all basal, without stipules. Flowers perfect, pistillate or neutral, or sometimes monoecious or dioecious, aggregated on a receptacle, surrounded by an involucre. Receptacle naked or scaly, smooth, pitted or honey-combed. Involucre of distinct or partially united bracts in one or several series. Calyx of bristles, awns, or scales, or crown or cup-like, forming pappus at maturity, or wanting. Corolla of 5 partially united petals, 5-lobed or in the case of the marginal flowers of the head the corolla is often produced on one side into a ligule; when ray-flowers are present the head is said to be radiate, when wanting it is said to be discoid. Androecium of 5 stamens partially adnate to the corolla tube : anthers often appendaged at the apex and sometimes at the base, united into a ring (syngenecious) except in Kuhnia. Gynoecium 2-carpellary. Ovary inferior, 1-celled. Stigmas of the fructiferous flowers 2 . Ovule solitary. Fruit an achene. Seed erect. Endosperm wanting.

A. Perfect flowers with regular corollas.

Stigmatic lines at the base of the stigma or below the middle. Stigmas filiform or subulate, hispidulous.

Stigma more or less clavate, papillose-puberulent.

Stigmatic lines extending to the tip of the stigma or to the appendages.

a. Anthers without elongated appendages at the top.

Anther-sacs tailed at the base.

Anther-sacs not tailed at the base.

Receptacle naked.

Bracts of the involucre well imbricated.

Stigmas of the perfect flowers with terminal appendages.

Stigmas of the perfect flowers with truncate or hairy or papillose tips.

Bracts of the involucre herbaceous.

Bracts of the involucre dry and scarious.

Bracts of the involucre little if at all imbricated, except when the broad outer ones overlap the inner.

TRIBE I. VERNONIEAE.

TRIBE II. EUPATORIEAE.

TRIBE IV. INULEAE.

TRIBE III. ASTEREAE.

TRIBE VI. HELENIEAE. TRIBE VII. ANTHEMIDEAE.

TRIBE VIII. SENECIONEAE.

Receptacle chaffy.

* Bracts of the involucre herbaceous, sometimes foliaceous. TRIBE V. HELIANTHEAE. 
** Bracts of the involucre dry and scarious.

b. Anthers with elongated, cartilaginous mostly connate appendages at the tip.

B. Perfect flowers, or all, with bilabiate corollas (corollas nearly regular in Gochnatia).

TRIBE I. VERNONIEAE.
TRIBE VII. ANTHEMIDEAE.

TRIBE IX. CYNAREAE.

Heads with corollas alike and equal : bracts of the involucres not appendaged. Pappus of 2 series: corollas regular: heads neither glomerate nor involucrate.

Pappus of 1 series : corollas irregular, split on the inner side : heads glomerate and involucrate.

Heads with marginal corollas much enlarged and ray-like: outer bracts of the involucre with fringed appendages at the tip.

\author{
1. Vernonia. \\ 2. Elephantopus.
}

3. STOKESIA.

\section{TRIBE II. EUPATORIEAE.}

Achenes 3-5-angled, ribless.

Anthers truncate and unappendaged at the apex.

Anthers appendaged at the apex.

Pappus various, never wholly of capillary bristles, sometimes wanting. Involucre many-flowered, campanulate or hemispheric.

Bracts of the involucre nerveless: corolla abruptly much dilated into a throat.

Receptacle conic : stigmas clavate-filiform : pappus of 5 broad scales.

Receptacle convex : stigmas linear: pappus a crown of many minute bristles.

Bracts of the involucre striate-nerved : corollar elatively narrow. Involucre 3-5-flowered, cylindric.

Pappus wholly of capillary bristles.

Involucre of more than 4 bracts, 5-many-flowered.

Receptacle flat.

Bracts of the involucre leathery or parchment-like, in many series, striate.

Bracts of the involucre membranous or herbaceous, in 1-few series, nerveless or few-nerved.

Receptacle conic or hemispheric.

Involucre of 4 bracts or rarely more, 4-flowered.

Achenes 8-10-ribbed, or 8-10-striate.

Bracts of the involucre herbaceous or partly colored, neither striate nor nerved.

Bracts of the involucre nearly equal and little imbricated.

Bracts of the involucre imbricated, the inner successively longer.

Pappus of linear-subulate erose-denticulate paleae: leaves opposite.

Pappus of capillary or filiform plumose or barbellate bristles : leaves alternate.

Receptacle naked: herbs with spicate racemose or cymosely disposed heads, or shrubs with corymbose heads.

Bracts of the involucre spirally imbricated: heads spicate or racemose, or rarely in a cyme: herbs.

Bracts of the involucre vertically imbricated : heads corymbose : shrubs.

Receptacle chaffy : herbs, with corymbosely disposed heads.

Bracts of the involucre not herbaceous, striate-nerved.

Involucre of many bracts: pappus-bristles scabrous to barbellate.

Involucre of few bracts: pappus-bristles plumose.

TRIBE III. ASTEREAE.

A. Ray-flowers present or rarely wanting : plants not dioecious.

a. Ray-flowers with yellow corollas (white in Solidago bicolor).

Pappus of few scales or awns. or wanting, not of numerous bristles.

Heads relatively small, individually inconspicuous : leaves with narrow entire blades.

Ray- and disk-flowers fruit-producing or essentially so.

Involucre ovoid or oblong: achenes 4-5-ribbed: pappus wanting or obsolete.

Involucre oblong-clavate, turbinate or campanulate : achenes terete or 5-angled: pappus of many scales, at least in the disk, or rarely crown-like.

Ray-flowers fructiferous : disk-flowers not fruit-producing

Heads relatively large, individually conspicuous: leaves with relatively broad spinulose-toothed blades.

Pappus of the ray-or disk-flowers, or of both, of numerous capillary bristles, with or without a series of shorter ones or of scales.

Pappus, at least that of the disk-flowers, of different series, the inner of capillary bristles, the outer of scales or of shorter bristles.

Achenes, at least those of the disk, flattened.

Pappus of the ray obsolete or a mere crown: achenes of the ray turgid.

Pappus of the ray copious : achenes of the ray flattened.

Achenes scarcely flattened.

Pappus wholly of capillary bristles (that of the disk of Mauchia of 2 or few bristles somewhat dilated at the base)

* Heads with disk-flowers only: ray-flowers wanting.

†Corolla with a cylindric tube and a cylindric throat: involucre
4. Hartwrightia.

5. SClerolepis.

6. TRICHOCORONIS.

7. Ageratum.

8. Stevia.

\section{Osmia.}

10. Eupatorium.

11. Conoclinum.

12. Willugbaeya.

13. Trillisa.

14. Carphochaete.

15. Laciniaria.

16. GARBERIA.

17. CARPHEPHORUS.

18. Coleosanthus.

19. KUHNIA.

20. GYMNOSPERMA.

21. GutierRezid.

23. GRINDELIA.

24. HeterotheoA.

25. CHRYsOPSIS.

26. Xanthisma.

27. CHONDROPHORA.
22. AMPHIACHYRIS. 
t+ Corolla merely funnelform: involucre broadly campanulate.

** Heads with both disk-and ray-flowers, with individual exceptions.

Pappus-bristles as long as the achene or longer, at least those of the ray : leaf-blades narrow or narrowed at the base, or if truncate or subcordate, narrowed into a broad petiolelike base.

Leaf-blades bristly serrate, pinnatifid or pinnately-parted. Achenes glabrous : pappus-bristles deciduous.

Achenes pubescent: pappus-bristles persistent. Corolla-tube slender. scarcely dilated above. Corolla-tube markedly dilated above.

Leaf-blades entire or merely toothed, the teeth not bristletipped.

Annual or biennial plants.

Pappus-bristles nearly equal: ray-flowers with soft curled ligules.

Pappus-bristles very unequal: ray-flowers with firm involute ligules.

Perennial plants.

Bracts of the involucre broad, longitudinally ribbed.

Ligules of the ray-flowers elongated-linear: diskcorollas with a cylindrical throat.

Ligules of the ray-flowers shorter than the tube: disk-corollas with a campanulate throat.

Bracts of the involucre narrow, not ribbed.

Plants woody at the base, or undershrubs.

Corolla-tube markedly dilated: leaves with even surfaces.

Corolla-tube scarcely dilated: leaves with rounded or angular depressions.

Plants wholly herbaceous.

Receptacle pubescent, fimbrillate: ray-flowers more numerous than those of the disk.

Receptacle alveolate: ray-flowers fewer than those of the disk.

Pappus-bristles shorter than the achene: leaf-blades, at least those of the basal and lower cauline leaves, cordate, narrowed into slender petioles.

b. Ray-flowers with white or colored corollas but not yellow.

Pappus a mere crown or of few awns, scales or awn-like bristles, or wanting.

Receptacle conic or strongly convex.

Pappus wanting or obsolete.

Pappus present.

Pappus an entire, toothed or ciliate crown

Pappus of short bristles with a pair of awns over each edge of the achene.

Bracts of the involucre essentially equal: pappus of several minute scales hidden in the hairs of the achene, in addition to the awns.

Bracts of the involucre very unequal: pappus of several longer scales in addition to the awns.

Receptacle flat, rarely with a central appendage.

Pappus a minute crown, sometimes evanescent.

Pappus of scales, awns or bristles.

Pappus of scales alternating with awns, or these wanting.

Heads 3-few-flowered: involucre turbinate. Heads discoid, sessile: pappus of lanceolate scales: bracts of the involucre appendaged at the tip.

Heads radiate, peduncled : pappus of scales and awns : bracts of the involucre unappendaged.

Heads many-flowered : involucre hemispheric to campanulate.

Pappus of rigid bristles, that of the ray sometimes scale-like.

Pappus, at least in the disk, of numerous capillary bristles.

Pappus of the ray-flowers a mere vestige or obsolete.

Pappus of the ray and disk essentially similar.

Pappus-bristles in a single series or mainly so.

Bracts of the involucre in 3-many series.

Bracts in $3-5$ series.

Ray-flowers few; ligules relatively short and broad: bracts of the involucre leathery.

Ray-flowers numerous; ligules relatively long and narrow : bracts of the involucre mainly herbaceous.

Bracts in many series.

Bracts of the involucre in 1 or 2 series.

Ray-flowers with ligules longer than the diameter of the disk.

Ray-flowers with ligules shorter than the diameter of the disk.

Pappus-bristles manifestly in 2 series.

Stigma-tips obtuse.

Stigma-tips acute or acuminate.

Involucre of 2-4 series of bracts, the inner bracts not much surpassing the achenes: ray-flowers with white ligules.

Involucre of 5-6 series of bracts, the inner bracts much surpassing the achenes: ray-flowers with violet ligules.

B. Ray-flowers wanting: plants dioecious.
28. Brintonia.

29. Prionopsis.

30. Sideranthus.

31. Isocoma.

32. IsopapPus.

33. Mauchia.

34. Stanfieldia.

35. Oligoneuron.

31. Isocoma.

36. Chrysoma.

37. Euthamia.

38. Solidago.

39. BRACHYCHAETA.

40. Bellis.

41. Aphanostephus.

42. Dichaetophora.

43. Boltonia.

44. Keerlia.

45. Thubovia.

46. ChaEtopappa.

47. Distasis.

48. TownSENDIA.

49. Psilactis.

50. SERICOCARPUS.

51. Aster.

52. MACHAERANTHERA.

53. ERIGERON.

54. LEPTILON.

53. ERIGERoN.

55. Doellingeria.

56. IONACTIS.

57. BACCHARIS. 
TRIBE IV. INULEAE.

Ray-flowers wanting: corollas white or pale: heads relatively small. Receptacle chaffy.

Receptacle convex or hemispheric.

Heads with several staminate not fruit-producing flowers.

Heads with all the flowers fruit-producing.

Receptacle subulate or obconic.

Receptacle naked.

Bracts of the involucre not scarious.

Bracts of the involucre broad, mainly persistent.

Bracts of the involucre linear to subulate, mainly deciduous.

Bracts of the involucre scarious.

Plants dioecious or polygamo-dioecious.

Pappus-bristles of the staminate flowers thickened above.

Pappus-bristles of the staminate flowers not thickened.

Plants not dioecious.

Pappus-bristles plumose.

Pappus-bristles not plumose.

Ray-flowers present : corollas yellow: heads relatively large.

58. Filago.

59. Calymmandra.

60. GIFOLA.

61. Pluched.

62. Chatelobus.

63. ANTENNARia.

64. ANaphalis.

65. FaCelis.

66. GNAPHALIUM.

67. INULA.

68. Polymina.

69. Melampodium.

70. Acanthospermum.

71. Silphium.

72. Chrysogonum.

73. BERLANDIERA.

74. LINDHEIMERA.

75. ENGELMANNIA.

76. PARThENiUm.

Ray-flowers with inconspicuous ligules, the heads apparently discoid. Disk-flowers fruit-producing.

Ray-flowers persistent on the achenes.

Achenes flattened or 3-4-angled : leaf-blades entire or essentially so.

Receptacle conic or cylindric.

Receptacle nearly flat.

Achenes not flattened: leaf-blades toothed.

Ray-flowers deciduous from the achene or wanting.

A. Pappus a mere crown or cap or of few teeth, awns or bristles.

a. Achenes. at least those of the disk, not compressed (except in Ratibida and Verbesina); bractlets mostly concave or clasping.

Involucre of 4 leaf-like partially united bracts together with an inner one of several much smaller bracts.

Involucre of several or numerous distinct bracts.

Bractlets of the receptacle mere chaffy awns or bristles.

Bractlets of the receptacle concave or clasping.

Each achene closely invested by the bractlet which appears as an outer coat.

Each achene merely subtended by a bractlet or loosely enclosed in it.

Ray-flowers uniformly wanting: bracts of the involucre dry or partially dry.

Achenes 4-5-angled.

Pappus of slender caducous awns : receptacle hemispheric.

Pappus wanting: receptacle conic or oblong.

Achenes terete, 8-15-nerved.

Ray-flowers present: bracts of the involucre herbaceous.

* Receptacle conic, subulate or columnar.

Ray-flowers fruit-producing: stigmas truncate or penicillate: leaves opposite.

Ray-flowers not fruit-producing: stigmas with acute or obtuse appendages: leaves mostly alternate.

Ligules of the ray-flowers yellow, or rarely wholly or partially brown-purple.

Achenes terete or 4-angled, wingless.

Achenes 4-angled.

Achenes quadrangular - compressed : achene-apex commonly covered with base of the corolla-tube.

Achenes nearly equally 4-angled: achene-apex not covered with the base of the corolla-tube.

Achenes terete.

Achenes flattened, broad-margined or winged.

Ligules of the ray-flowers rose-purple, or rarely yellow or white.
77. Crassina.

78. SANVITALIA.

79. HELIOPSIS.

80. Tetragonotheca.

81. Eclipta.

82. SCLEROCARPUS.

83. Melanthera.

84. ISOCA RPHA.

85. VARilla.

86. SPILANTHES.

87. Gymnolomi.

88. RUDBECKIA.

90. Ratibida.

91. Brauneria.
89. Dracopis. 
** Receptacle flat or convex.

Achenes of the disk neither sharp-edged, margined nor winged.

Ray-flowers fruit-producing.

Achenes turgid, those of the disk obtusely if at all angled: stems herbaceous.

Pappus of several scales partially united into a constricted cup or ring.

Pappus of several distinct scales, sometimes accompanied by 2 short awns.

Achenes acutely 4-angled, or 3-angled in the ray: stems woody.

Ray-flowers not fruit-producing, rarely wanting.

Pappus of 2 chaffy awns or scales, one over each main angle of the achene, or occasionally of 1 or 2 more awns, and of 2 or more intermediate truncate scales on each side.

Pappus of 2 scarious acute or awned scales, without intermediate scales, except more or less detached portions of their bases.

Achenes of the disk thin-edged,margined or winged.

Ray-flowers neutral (rarely wanting): achenes wingless or essentially so, sometimes villous-ciliate.

Pappus wanting, or an awn to each margin of the achene.

Pappus of scales between the 2 or more awns or teeth over each angle of the achene.

Ray-flowers fruit-producing, or sometimes neutral in Verbesina (rarely wanting): achenes, at least some of them, wing-margined.

Pappus-awns connected by dilated bases or with intermediate"distinct or confluent scales.

Ray-flowers fruit-producing.

Ray-flowers neutral or wanting.

Pappus-awns without intermediate scales, sometimes obsolete.

Involucre flat; bracts elongated, spreading: annual herbs.

Involucre campanulate or hemispheric ; bracts short, erect or appressed : perennial herbs.

b. Achenes markedly flattened parallel with the involucral bracts.

Involucre single.

Marginal fruit wingless.

Marginal fruit winged.

Involucre double.

Bracts of the involucre distinct.

Pappus of 2 fimbriolate awns, scales or teeth or a mere border, or wanting.

Pappus of 2-6 awns or teeth, upwardly or downwardly barbed or hispid.

Achenes beakless: ray-flowers with yellow or white ligules, or wanting.

Achenes beaked: ray-flowers with purple or rose ligules.

Bracts of the inner involucre partially united.

B. Pappus of numerous scales.

Receptacle honeycombed by the concretion of the bractlets,

Pits of the receptacle with truncate edges: head solitary : rayflowers 20-30.

Pits of the receptacle with subulate-toothed edges : heads corymbose: ray-flowers 8-10.

Receptacle with distinct bractlets.

Ray-flowers wanting.

Ray-flowers present.

Pappus-scales entire or fimbriate.

Pappus-scales plumose-ciliate.

\section{TRIBE VI. HELENIEAE.}

A. Plant-tissues without oil glands.

Leaf-blades or leaf-segments terete.

Leaf-blades or leaf-segments flat.

Bracts of the involuere petal-like, pale or colored, at least the margins and tips, scarious.

Corollas with ovate or oblong lobes.

Involucres of a broadly campanulate type or hemispheric: stigmas with short conic appendages.

Involucre of a turbinate-campanulate type: stigmas with attenuate-subulate appendages.

Corollas with linear lobes.

Bracts of the involucre narrow, herbaceous.

a. Receptacle naked.

* Bracts of the involucre appressed.

Achenes terete or 4-10-angled or merely 4-10-ribbed.

Achenes 4-angled.

Bracts of the involucre linear or nearly so, more or less embracing the approximate achenes.

92. Stemmodontia.

93. Pascalia.

94. BORRICHIA.

95. VIGUIERA.

96. Helianthus.

\section{ENCELIA.}

98. Helianthella.

99. ZEXMENIA.

100. ACTINOMERIS.

101. VERBESINA.

102. Ximenesia.

103. SYNEDRELLA.

104. CALYPTROCARPUS.

105. COREOPSIS.

106. BIDENS.

107. Cosmos.

108. THELESPERMA.

109. ENDORIMA.

110. ACtinosPERMUM.

111. Marshallia.

112. GALINSOGA.

113. TRIDAX.

114. ClapPIA.

115. HYMENOPAPPUS.

116. FLORESTINA.

117. POLYPTERIS. 
Bracts of the involucre relatively broad, not embracing achenes.

Achenes 5-10-ribbed or 5-10-angled.

Involucre many-flowered: pappus present. Outer bracts of the involucre separate. Outer bracts of the involucre united.

Involucre few-flowered: pappus wanting. Achenes flat.

** Bracts of the involucre spreading or reflexed.

Involucre of subulate or linear bracts : disk-corollas each with a very short tube and glandular-pubescent lobes.

Involucre of foliaceous bracts without an inner series of hyaline bracts: disk-corollas each with a manifest tube and glabrous lobes.

b. Receptacle with bristle-like chaff.

B. Plant-tissues, especially the leaves and bracts of the involucre, with oil giands.

Bracts of the involucre more or less united: stigmas of the disk-flowers elongated.

Bracts of the involucre united at the base.

Bracts of the involucre united into a cup.

Bracts of the involucre distinct: stigmas of the disk-flowers very short.

119. BAHIA.

120. Tetraneuris.

121. Picradenia.

122. Flaveria.

123. Laphamia.

\section{Helenium.}

125. AMBLYOLEPIS.

126. Gailla RdiA.

127. Boebera.

128. THYMOPHYLLA.

129. Pectis.

Receptacle chaffy.

TRIBE VII. ANTHEMIDEAE.

Achenes terete, at least not flattened : involucre hemispheric: heads large.

Achenes flattened: involucre obovoid to campanulate: heads small.

Receptacle naked, or sometimes merely pubescent.

Ray-flowers usually present.

Receptacle flat to hemispheric: bracts of the involucre in several series. Receptacle conic to ovoid: bracts of the involucre in few series.

Ray-flowers wanting,

Heads corymbed: pappus a short crown.

Heads spicate, racemose or panicled: pappus wanting.

Pistillate flowers with corollas.

Pistillate flowers without corollas.

TRIBE VIII. SENECIONEAE.

Bracts of thei nvolucre lax, the broad outer ones strongly overlapping the inner.

Bracts of the involucre erect-converging, narrow, not much overlapping.

Leaves opposite, sometimes mainly basal : pappus-bristles rigid.

Leaves alternate: pappus-bristles soft.

Corollas white, whitish or pinkish: ray-flowers wanting.

Disk-flowers perfect: marginal-flowers pistillate.

Disk-flowers and marginal-flowers perfect.

Involucre of about 5 main bracts.

Involucre of 12-15 principal bracts.

Corollas yellow: ray-flowers usually or typically present.

TRIBE IX. CYNAREAE.

Achenes inserted on the receptacle by their bases, not oblique.

Bracts of the involucre hooked at the tip: leaves not bristly.

Bracts of the involucre not hooked : leaves bristly.

Achenes obliquely inserted on the receptacle.

Heads not sessile in bristly leaves.

Heads sessile in bristly leaves.

Tribe X. MUTISIEAE.

Corollas essentially regular, deeply 5-lobed : shrubby plants.

Corollas all bilabiate, or the marginal ones ligulate : herbaceous plants.

Heads heterogamous, the marginal flowers radiate.

Heads homogamous, all the corollas bilabiate.

\section{Haplofsthes.}

138. Arnica.

139. Erechtites.

140. Mesadenia.

141. SYNOSMA.

142. SENECIO.

143. Arctium.

144. CarduUs.

145. Centaurea.

146. CNICUS.

147. Gochnatia.

148. Thy Rsanthema.

149. Perezia.

\section{VERNÒNIA Schreb.}

Perennial, caulescent herbs or shrubby plants, with upright stems. Leaves usually alternate : blades mostly toothed. Heads discoid, in panicled or corymbed open cymes Involucres hemispheric to cylindric or nearly turbinate : bracts imbricated in several series. Receptacle flat, naked. Corolla regular: lobes 5. Anthers sagittate, not caudate. Stigmas subulate, hispid. Achenes 8-10-ribbed, truncate. Pappus double, the outer series of scales or stout bristles, the inner of numerous, rough, hair-like bristles. Some of the species are called IRON WEED. The plants flower during the summer and fall, or in the extreme south somewhat earlier.

A. Leaves mainly or all cauline.

a. Bracts of the involucre or some of them with fliform or subulate tips.

Involucres over $15 \mathrm{~mm}$. broad.

Involucres less than $10 \mathrm{~mm}$. broad.

Leaf-blades smooth above.

Pappus purple or purplish.

Pappus straw-colored.

Outer bracts of the involucre filiform or subulate-filifo:m.

1. V. crinita.

2. V. Noveboracensis.

3. V.tomentosa. 
Outer bracts of the involucre merely acuminate.

Leaf-blades decidedly scabrous above.

Leaf-blades coarsely toothed or crisped: bracts of the involucre with soft tips.

Leaf-blades entire or minutely toothed : bracts of the involucre rigid.

b. Bracts of the involucre obtuse to acuminate.

Leaves with blades of various types, but not linear.

Leaf-blades glabrous or nearly so on both sides.

Involucres fully as broad as high.

Involucres much or manifestly higher than broad.

Bracts of the involucre obtuse or merely acute.

Involucres hemispheric-campanulate, rounded at the base; bracts appressed at maturity.

Involucres few-flowered, about $3 \mathrm{~mm}$. high; inner bracts narrowly oblong or linear-oblong.

Involucres many-flowered, $4 \mathrm{~mm}$. to almost $5 \mathrm{~mm}$. high ; inner bracts broadly oblong.

Involucres cylindric, narrowed at the base; bracts loosely spreading at maturity.

Bracts of the involucre, or some of them, acuminate.

Leaf-blades manifestly pubescent beneath, often densely so.

Involucres 4-6 mm. high.

Bracts of the involucre with recurved tips.

Bracts of the involucre with erect or slightly spreading tips.

Involucres 8-12 $\mathrm{mm}$. high.

Leaves with blades of a linear type.

Stems, lower surfaces of leaf-blades and involucres glabrous or somewhat pubescent, but not white-woolly.

Leaf-blades smooth above.

Lower surfaces of the leaf-blades, at least the midnerve, pubescent. 15. V. Guadalupensis.

Lower surfaces of the leaf-blades glabrous.

Leaves neither exceedingly numerous nor crowded.

Bracts of the involucres obtuse or merely acute.

Involucres about $5 \mathrm{~mm}$. broad.

Involucres about $8 \mathrm{~mm}$. broad.

Bracts of the involucres acuminate.

Leaves excedingly numerous and crowded.

Leaf-blades scabrous above.

Bracts of the involucres with slender spreading tips.

Bracts of the involucres with merely acute erect or appressed tips.

Leaf-blades, at least the lower ones, remotely toothed.

Leaf-blades entire.

Stems, lower leaf-surfaces and involucres conspicuously white-woolly. B. Leaves mainly or all basal.

1. Vernonia crinita Raf. Foliage glabrous or somewhat pubescent. Stems 1-4 m. tall, branched above : leaves numerous ; blades linear or linear-lanceolate, 1-3 dm. long, attenuate at both ends, finely serrate : corymbs 1-2 dm. broad : peduncles club-shaped : involucres hemispheric, becoming $1.5 \mathrm{~cm}$. high and fully $1.5 \mathrm{~cm}$. broad; bracts greenish, prolonged into filiform tips, the outer with little or no body : achenes $5 \mathrm{~mm}$. long, upwardly barbed on the angles: pappus purplish.

On plains and banks of streams, Missouri to Kansas and Texas.

2. Vernonia Noveboracénsis (L.) Willd. Foliage nearly glabrous, or pubescent. Stems 1-3 m. tall, branching above : leaves rather numerous; blades linear-lanceolate or elliptic-lanceolate, 1-2 dm. long, acuminate, finely serrate or nearly entire, often minutely pubescent beneath: corymbs 1-3 dm. broad, commonly irregular: peduncles angled, slightly enlarged above : involucres hemispheric, about $5 \mathrm{~mm}$. high ; bracts purple, ovate or ovate-lanceolate, prolonged into filiform tips: achenes $4 \mathrm{~mm}$. long, upwardly barbed along the sharp angles: pappus purple.

In thickets and open places, Massachusetts to Minnesota, Georgia and Missouri.

3. Vernonia tomentòsa (Walt.) Ell. Foliage rather thinly tomentose. Stems 1-2 m. tall, simple below : leaves rather numerous ; blades elliptic to narrowly elliptic-lanceolate, 1-2 dm. long, acute or acuminate, sharply serrate : corymbs 1-3 dm. broad : peduncles slightly, if at all, enlarged above: involucres hemispheric, about $6 \mathrm{~mm}$. high; bracts lanceolate to oblong-lanceolate, prolonged into subulate or filiform tips: achenes $3 \mathrm{~mm}$. long, sometimes nearly glabrous : pappus straw-colored.

On hillsides, New Jersey and Pennsylvania to North Carolina.

4. Vernonia glaùca (L.) Britton. Foliage thinly tomentose. Stems 1-2 m. tall, often widely branched above: leaves numerous; blades linear-lanceolate to elliptic or elliptic-oblanceolate, acute or short-acuminate, finely serrate: corymbs 1-3 dm. broad: peduncles angled or winged, barely enlarged above: involucres hemispheric, about $5 \mathrm{~mm}$. high ; bracts lanceolate to nearly oblong, purple, the outer ones merely acuminate : achenes 2-3 mm. long, with the sharp ribs barbed : pappus straw-colored.

On river banks, Virginia to Georgia.

5. Vernonia pulchélla Small. Foliage hirsute. Stems solitary or clustered, 3-10 dm. tall, branched above : leaves firm; blades oblong-lanceolate or oblong to nearly linear- 
lanceolate, 2-10 cm. long, acute, serrate, often sharply so, somewhat crisped, revolute, sessile, but not at all cordate : corymbs $1-1.5 \mathrm{dm}$. broad : peduncles $1-3 \mathrm{~cm}$. long, slightly enlarged upward, or some heads nearly sessile : involucres campanulate, 6-7 mm. high ; bracts lanceolate to linear-oblong, prolonged into soft linear-subulate spreading or recurved tips, often purplish : achenes about $3 \mathrm{~mm}$. long: pappus straw-colored.

On sand hills, Georgia.

6. Vernonia scabérrima Nutt. Foliage hirsute, or glabrate in age. Stems $3-8 \mathrm{dm}$. tall, usually branched : leaves firm; blades linear to linear-oblong, $1.5-8 \mathrm{~cm}$. long, acute, entire or remotely serrate, sessile or nearly so, cordate or truncate at the base : corymbs with comparatively few heads : peduncles barely enlarged, $1-3 \mathrm{~cm}$. long, or shorter: involucres campanulate, $5-6 \mathrm{~mm}$. high : bracts subulate-linear to oblong, prolonged into rigid subulate tips: achenes about $2 \mathrm{~mm}$. long, with scabrous ribs : pappus purplish.

In sandy soil, South Carolina to Florida.

7. Vernonia flaccidifòlia Small. Foliage sparingly pubescent, or glabrate. Stems 1-1.5 m. tall. with slender branches above: leaves rather numerous; blades thin, elliptic to linear-lanceolate, $0.8-2 \mathrm{dm}$. long, acuminate, sharply serrate, sometimes doubly so, short-petioled : corymbs 1-2 dm. broad; branches slender: peduncles barely enlarged at the top : involucres hemispheric, 3-4 mm. high ; bracts ovate to oblong, light green or deeper at the tip, obtuse, ciliate, not spreading: achenes $3 \mathrm{~mm}$. long, with sharp barbed ribs: pappus pale straw-colored.

On wooded hillsides, Tennessee, Georgia and Alabama.

8. Vernonia oligántha Greene. Foliage minutely and sparingly pubescent. Stems 4-11 dm. tall, simple below the few-branched inflorescence: leaves relatively few ; blades oblong or elliptic-oblong, 4-9 cm. long, acute, rather evenly serrate, those of the lower ones narrowed into petiole-like bases : corymbs mainly about $1 \mathrm{dm}$. wide, open, with few heads : involucres campanulate, about $3 \mathrm{~mm}$. high, rounded at the base; bracts obtuse, the outer oblong-ovate, the inner narrowly oblong or linear-oblong: achenes about $2 \mathrm{~mm}$. long: pappus purplish.

In sandy soil, peninsular Florida. Fall.

9. Vernonia máxima Small. Foliage glabrous or sparingly pubescent. Stems 1-3 m. tall, branching above : leaves rather numerous; blades narrowly elliptic to lanceolate or linear-lanceolate, 1-3 dm. long, acuminate, sharply serrate : corymbs 1-4 dm. broad; peduncles angled, barely enlarged above: involucres hemispheric-campanulate, $4 \mathrm{~mm}$. to almost $5 \mathrm{~mm}$. high, rounded at the base; bracts ovate to oblong, nearly flat, acute or mucronate, appressed, ciliate : achenes $3 \mathrm{~mm}$. long, with barbed ribs : pappus light or deep purple.

In low grounds, Ohio to Missouri, south to Alabama and Louisiana.

10. Vernonia gigantèa (Walt.) Britton. Foliage glabrous or nearly so. Stems 1-2.5 $\mathrm{m}$. tall, often widely branched above : leaves numerous; blades linear to oblong or elliptic, 0.8-3 dm. long, acute or acuminate, sharply serrate : corymbs 1-4 dm. broad : peduncles angled, barely enlarged above : involucres cylindric, 5-6 $\mathrm{mm}$. high, narrowed at the base ; bracts oblong-lanceolate to narrowly oblong, rounded on the back, the outer acutish, the inner obtuse, lax or loosely spreading at maturity : achenes $3 . \mathrm{mm}$. long, with scabrous angles : pappus purplish.

In low grounds, South Carolina to Florida and Alabama.

11. Vernonia ovalifòlia T. \& G. Foliage sparingly pubescent. Stems 1-2 m. tall, branching above : leaves rather numerous; blades elliptic, oblong or the upper oblonglanceolate, all acute, or short-acuminate, rather coarsely toothed, abruptly or sometimes gradually contracted at the base : corymbs $1-3 \mathrm{dm}$. broad : peduncles not enlarged upward : involucres campanulate, 5-7 mm. high ; bracts lanceolate to oblong, acute or cuspidate, mainly appressed : achenes $2.5-3 \mathrm{~mm}$. long, slightly barbed along the ribs: pappus strawcolored or pale purplish.

In dry woods, Georgia and Florida.

12. Vernonia Baldwínii Torr. Foliage finely tomentose. Stems 1-2 m. tall, branching above : leaves rather numerous; blades oblong to ovate-lanceolate or elliptic, $0.5-2$ $\mathrm{dm}$. long, acute or acuminate at both ends, sharply serrate : corymbs 1-3 dm. broad : peduncles angled, slightly enlarged upward : involucres campanulate, or subglobose when young, 5-6 mm. high, usually numerous; bracts oblong-ovate to narrowly oblong, with spreading or recurved tips: achenes $3 \mathrm{~mm}$. long, the sharp ribs barbed: pappus tinged with purple.

On prairies, Missouri and Kansas to Texas.

13. Vernonia intèrior Small. Foliage finely and closely pubescent. Stems 1-2 m. tall, simple below : leaves numerous; blades elliptic or elliptic-lanceolate, $6-20 \mathrm{~cm}$. long, 
acuminate, sharply and rather finely serrate: heads rather crowded: involucres 6-7 mm. long, 4-5 mm. wide; bracts pubescent, sometimes hoary, acute or with short keel-like acuminations, the tips erect or slightly spreading : achenes pubescent : pappus purple.

On plains or prairies, Missouri and Kansas, south to Texas.

14. Vernonia Drummóndii Shuttlw. Foliage tomentose. Stems 1-2 m. tall, branching above : leaves numerous ; blades elliptic to elliptic-lanceolate or linear-elliptic, 1-3 $\mathrm{dm}$. long, acute or short-acuminate, sharply serrate : corymbs usually 1-4 dm. broad: peduncles barely enlarged upward : involucres rounded at the base, $8-12 \mathrm{~mm}$. high ; bracts ovate to oblong, acute or apiculate: achenes $4-5 \mathrm{~mm}$. long, with smooth and glabrous ribs : pappus tinged with purple.

On prairies, Illinois to Kansas, Alabama and Texas.

15. Vernonia Guadalupénsis Heller. Foliage light green, minutely pubescent. Stems 3-15 dm. tall, corymbosely branched above, prominently ridged : leaves numerous ; blades linear or nearly so, $8-15 \mathrm{~cm}$. long, 4-12 mm. wide, attenuate, undulate or remotely denticulate : involucres campanulate, $6-8 \mathrm{~mm}$. high, $5-6 \mathrm{~mm}$. broad; bracts abruptly pointed, hoary, with erect or slightly spreading tips : achenes $3.5-4 \mathrm{~mm}$. long, prominently ribbed, slightly glandular: pappus purple.

In limestone river bottoms, Texas.

16. Vernonia fasciculàta Michx. Foliage glabrous, or pubescent above. Stems 0.5-2 m. tall, simple below the inflorescence : leaves numerous; blades linear to linearlanceolate, $5-15 \mathrm{~cm}$. long, attenuate, sharply serrate : corymbs $5-15 \mathrm{~cm}$. broad : peduncles slightly enlarged above: involucres campanulate at maturity, $5-6 \mathrm{~mm}$. high, about $5 \mathrm{~mm}$. broad; bracts firm, oblong-ovate to nearly oval, acute or acutish, appressed: achenes 3 $\mathrm{mm}$. long, with smooth ribs : pappus purple.

On plains and prairies, Ohio to South Dakota, south to Texas.

17. Vernonia tenuifòlia Small. Foliage thinly pubescent. Stems $0.5-1 \mathrm{~m}$. tall, branching above : leaves numerous ; blades linear or nearly so, $0.5-1.5 \mathrm{dm}$. long, acute, serrate, minutely punctate: corymbs $5-10 \mathrm{~cm}$. broad, with rather few heads: peduncles slightly enlarged upward : involucres campanulate, $8-10 \mathrm{~mm}$. high, purple; bracts ovate to oblong, erect, acute or mucronate : achenes about $4 \mathrm{~mm}$. long, with smooth and glabrous ribs: pappus straw-colored or tinged with purple.

In dry soil, southern and western Texas.

18. Vernonla marginàta (Torr.) Britton. Foliage pubescent above. Stems 1-1.5 m. tall, corymbosely branched above; leaves relatively few ; blades linear, $5-15 \mathrm{~cm}$. long, or longer near the base of the stem, acute, entire: peduncles slightly enlarged above : involucres cylindric-campanulate, about $1 \mathrm{~cm}$. high ; bracts ovate-lanceolate to oblong-lanceolate, acuminate, margined, with barely spreading tips: achenes $3-3.5 \mathrm{~mm}$. long.

In dry soil, Nebraska to Texas and New Mexico.

19. Vernonia Lettermánii Engelm. Foliage glabrous or nearly so. Stems $0.5-1.5$ m. tall, fastigiately branched above: leaves numerous and crowded; blades narrowly linear, 5-12 cm. long, acute, entire, each with a conspicuous midrib : peduncles angled, slightly enlarged upward : involucres cylindric or campanulate at maturity, 6-7 mm. high, narrowed at the base; bracts lanceolate to linear-oblong, acute or somewhat acuminate: achenes $4 \mathrm{~mm}$. long, glandular, slightly rough on the ribs : pappus purplish.

In sandy soil, Arkansas.

20. Vernonia angustifòlia Michx. Foliage nearly glabrous. Stems $0.5-1 \mathrm{~m}$. tall, often widely branched above : leaves numerous; blades linear, usually narrowly so, $5-15$ $\mathrm{cm}$. long, acute, revolute : peduncles variable, slightly enlarged near the top, 1-2 cm. long, or some heads sessile: involucres turbinate or turbinate-campanulate, 5-6 mm. high, acute or somewhat rounded at the base ; bracts lanceolate to oblong, acute or apiculate, with more or less spreading tips : achenes $2 \mathrm{~mm}$. long, with scabrous ribs : pappus purplish.

In sand, Georgia and Florida to Mississippi.

21. Vernonia Texàna (A. Gray) Small. Foliage glabrate. Stems wand-like, 4-12 dm. tall, branching above : leaves relatively few; blades oblong-oblanceolate to linearlanceolate or linear, 5-20 cm. long, acute or acuminate, at least the lower ones remotely toothed: corymbs with slender branches : peduncles variable, $0.5-5 \mathrm{~cm}$. long, barely enlarged above : involucres turbinate-campanulate, 5-6 mm. high ; bracts ovate to oblong, apiculate: achenes $3 \mathrm{~mm}$. long, with sparingly barbed ribs: pappus pale purple.

In sandy soil, Florida to Texas and Arkansas.

22. Vernonia Blodgéttii Small. Foliage glabrous below the inflorescence. Stems often branched near the base, 2-5 $\mathrm{dm}$. long, narrowly corymbose above: leaves mostly near the base of the stem ; blades oblong to linear, $2-4.5 \mathrm{~cm}$. long, obtuse or acutish, en- 
tire, erect or ascending, slightly revolute : involucres campanulate, about $5 \mathrm{~mm}$. high ; bracts oblong to linear-oblong, acute or apiculate, slightly pubescent: achenes $2.5 \mathrm{~mm}$. long, with pubescent ribs: pappus straw-colored, slightly roughened. [ $V$. angustifolia var. pumila Chapm.]

In sand, southern peninsular Florida and Key West.

23. Vernonia Lindheìmeri Engelm. \& Gray. Foliage lanose-tomentose. Stems 2-10 dm. tall, often branched above : leaves numerous; blades narrowly linear, $4-12 \mathrm{~cm}$. long, acute, revolute, often glabrate above : peduncles club-shaped : involucres campanulate, $5-7 \mathrm{~mm}$. high, densely white-lanose ; bracts mostly oblong, obtuse, commonly glandtipped: achenes $3 \mathrm{~mm}$. long, glabrous : pappus purplish.

In dry soil, Texas.

24. Vernonia oligophýlla Michx. Foliage minutely pubescent. Stems scape-like, 2-7 dm. tall : leaves mainly basal; blades elliptic, oblong, oblanceolate or spatulate, mainly 1-3 dm. long, obtuse or acutish, serrate or dentate, sometimes doubly so : peduncles sometimes slightly club-shaped : involucres campanulate, $7-8 \mathrm{~mm}$. high ; bracts linear to linear-lanceolate, narrowed into subulate tips : achenes $3 \mathrm{~mm}$. long, barbed upward in the ribs : pappus pale straw-colored.

In dry soil, North Carolina to Florida.

\section{ELEPHÁNTOPUS L.}

Perennial caulescent or scapose herbs, with short rootstocks. Leaves alternate : blades mostly broadened upward, shallowly toothed. Heads 2-5-flowered, discoid, glomerate at the ends of the corymbosely disposed branches, the glomerules subtended by 2-3 small foliaceous bracts. Involucres flattened : bracts chaffy, in 2 series, the outer bracts shorter than the inner. Receptacle naked. Corolla regular except for a deeper cleft on the inner side. Stigmas pubescent. Achenes truncate, 10-ribbed. Pappus single or double, of several rigid persistent bristles terminating scale-like bases. The plants of the several species bloom in the summer and fall.

Leaves mainly cauline.

Leaves mainly or all basal.

Larger leaf-blades over 3 times, sometimes 9 times, longer than broad.

Stems with spreading rather than appressed hairs: leaf-blades closely and softly pubescent: scale-like base of the pappus gradually narrowed into the tip.

Stems with appressed rather than spreading hairs: leaf-blades glabrate or sparingly pubescent: scale-like base of the pappus abruptly narrowed into the tip.

Larger leaf-blades less than 3 times as long as broad.

1. E. Carolinianus.

2. E. elatus.

3. E. nudatus.

4. E. tomentosus.

1. Elephantopus Carolintànus Willd. Stems $3-9 \mathrm{dm}$. tall, leafy, branching above, rather hirsute. Leaves mainly cauline ; blades thinnish, oblong, elliptic or oval, 5-15 cm. long, crenate-serrate or repand, the lower ones narrowed into margined petioles: bracts subtending the glomerules ovate to oblong-lanceolate, truncate or cordate, $1-3 \mathrm{~cm}$. long: bracts of the involucres chaffy, $1 \mathrm{~cm}$. long, or shorter, acute or acuminate : achenes $3.5-4$ mm. long.

In woods, Pennsylvania to Kansas, south to Florida and Texas.

F $=\bar{x}$ : 2. Elephantopus elàtus Bertol. Stems scape-like, 7-10 dm. tall, often nearly simple, with the hairs mainly spreading. Leaves mainly basal; blades 2-2.5 dm. long or some of them shorter, spatulate or the upper ones oblong, all crenate-serrate, conspicuously ciliate : peduncles densely silky-hirsute: bracts subtending the glomerules ovate or triangularovate, 1-1.5 cm. long, acute or short-acuminate, densely pubescent: corollas $2.5-3 \mathrm{~mm}$. long: pappus-bristles hair-like from a very narrow base.

In dry soil, Georgia to Arkansas.

3. Elephantopus nudàtus A. Gray. Stems 2-8 dm. tall, scape-like, strigose, or sometimes slightly hirsute at the base, forking above. Leaves mainly basal ; blades oblanceolate to spatulate or oblong, $0.5-3 \mathrm{dm}$. long, undulate or crenate-undulate: bracts subtending the glomerules ovate to ovate-lanceolate, acute or acuminate, $1-2 \mathrm{~cm}$. long, delicately reticulated, rounded or cordate and pubescent at the base : achenes $3 \mathrm{~mm}$. long : pappus-scales deltoid, shorter than the breadth of the achenes.

In sandy soil, Delaware to Florida, Arkansas and Louisiana.

4. Elephantopus tomentòsus L. Stems scape-like, 2-7 dm. tall, forking above, rather hirsute above the base. Leaves mainly basal; blades oblong, oval or oblongoblanceolate, 0.5-2 dm. long, obtuse, crenate-serrate: bracts subtending the glomerules ovate, 1-2 cm. long, revolute, coarsely reticulated without, rounded or cordate at the 
base, pubescent all over: achenes $4 \mathrm{~mm}$. long: pappus-scales longer than the breadth of the achene.

In dry soil, Virginia to Kentucky, south to Florida and Louisiana.

\section{STOKÈsIA L'Her.}

Perennial caulescent herbs, with woolly foliage. Leaves alternate : blades spinuloseciliate near the base, the upper clasping. Heads showy, mainly blue, many-flowered. Involucres depressed: bracts various, the outer foliaceous, spreading, the inner with appressed bases and spinulose-ciliate foliaceous tips. Receptacle flat, naked. Corollas various, the central ones nearly regular, the outer ones successively more palmately ligulate, the marginal ones with 5-cleft ligules each surpassing the tube in length. Anthers sagittate, not caudate. Stigmas subulate, hirsute. Achenes 3-4-angled, slightly constricted at the ends. Pappus of 4-5 white caducous scales.

1. Stokesia laèvis (Hill) Greene. Stems 2-5 dm. tall, usually branched, densely woolly above. Leaves glabrous or nearly so ; blades linear-elliptic, oblong-lanceolate or oblong-ovate, 3-20 $\mathrm{cm}$. long, the lower ones narrowed into petioles, the upper sessile, spinulose-ciliate near the base : heads often subtended by leaf-like bracts which pass into the involucre : bracts of the involucre $1-2 \mathrm{~cm}$. long, with conspicuously spinulose margins : corollas bright purplish blue, the marginal ones radiant, $2-3 \mathrm{~cm}$. long, the segments linearlanceolate. [S. cyanea L'Her.]

In moist soil, South Carolina to Louisiana. Spring and summer.

\section{HARTWRİGHTIA A. Gray.}

Perennial caulescent herbs, with glabrous foliage. Leaves alternate, mostly on the lower part of the stem : blades entire. Heads few-flowered, stalked. Involucres and flowers of each head punctate with resinous glands : bracts in two series, narrow. Receptacle naked. Corollas with a dilated limb, 5-lobed. Anthers appendaged. Achenes 5-angled. Pappus wanting.

1. Hartwrightia Floridàna A. Gray. Stems 4-10 dm. tall, corymbosely branched above. Leaves 1-3 dm. long; blades obtuse, inconspicuously nerved, the lower oblong, narrowed into margined petioles, the upper linear, much smaller and rather remote: heads peduncled : bracts of the involucres linear, obtuse : corollas white : achenes 4-5.5 mm. long. In swamps, peninsular Florida.

\section{SCLERÓLEPIS Cass.}

Perennial partly aquatic herbs, with decumbent creeping stems. Leaves whorled: blades narrow, entire. Heads discoid, solitary or rarely 2-4 together. Involucres hemispheric or broadly campanulate: bracts usually in 2 series. Receptacle conic, naked. Corollas regular: tube shorter than the limb; lobes 5 . Anther-sacs with obtuse bases. Stigmas long, obtuse. Achenes 5-angled, the faces without ribs. Pappus of 5 broad obtuse or truncate nerveless scales."

1. Sclerolepis uniflòra (Walt.) B.S.P. Glabrous or nearly so. Stems decumbent, 2-7 dm. long, usually simple : leaves 4-6 in each whorl ; blades linear or narrowly linearlanceolate to almost filiform, 1-2.5 cm. long, acute, 1-nerved : peduncles solitary, 2-10 cm. long: heads $6-15 \mathrm{~mm}$. broad : bracts of the involucre linear to linear-lanceolate, $2-2.5 \mathrm{~mm}$. long, acute, erose-serrulate : corollas rose-purple : achenes $1.5 \mathrm{~mm}$. long, enlarged upward.

In pine-land pools and streams, New Jersey to Florida. Spring and summer.

\section{TRICHOCORÒNIS A. Gray.}

Annual or perennial, swamp-inhabiting or aquatic herbs, with viscid-pubescent foliage. Leaves alternate or opposite, on the lower part of the stem : blades toothed, partly clasping. Heads discoid, relatively small. Involucres many-flowered, broad or flattish at maturity : bracts nearly equal. Receptacle convex, naked. Corollas regular, pink or rose-purple : tube abruptly dilated into the wide throat: lobes 5. Anther-sacs obtuse at the base. Stigmas relatively long, not enlarged upward. Achenes 5-angled, the faces ribbed. Pappus a crown of many minute bristles.

1. Trichocoronis Wrightii A. Gray. Stem usually branched at the base, the branches spreading, 1-3 dm. long, finely viscid-pubescent: leaf-blades oblong to oblong- 
lanceolate, 1-2.5 cm. long, coarsely toothed, sessile and partly clasping: involucres $2.5-3$ $\mathrm{mm}$. broad ; bracts slightly broadened upward, acute : disk pink or rose-purple : pappus more or less concreted.

On low prairies, southern Texas and adjacent Mexico.

\section{AGERÀTUM L.}

Perennial caulescent herbs, or shrubby plants. Leaves opposite, or alternate above: blades simple, usually toothed. Heads small, discoid, usually in corymbs, white, purple or blue. Involucres campanulate : bracts nearly equal, in 2-3 series. Receptacle flat or nearly so, naked, or with few caducous scales. Corollas regular, barely distinguishable into tube and limb. Stigmas elongated, obtuse. Achenes 5-angled. Pappus simple, of 5 or 10-20, distinct or partially united scales. The plants bloom from spring to fall.

Foliage pubescent: pappus of distinct scales.

Foliage glabrous : pappus cup-like or crown-like.

1. A. conyzoides.

2. A. littorale.

1. Ageratum conyzoides L. Foliage hirsute. Stems $3-9 \mathrm{dm}$. tall, often branched : leaf-blades ovate to deltoid, $2-5 \mathrm{~cm}$. long, serrate to crenate-serrate, truncate or subcordate or rarely broadly cuneate at the base; petioles shorter than the blades : involucres minutely pubescent, or glabrate in age; bracts linear-lanceolate, $2.5-3 \mathrm{~mm}$. long, firm, ibbed, acuminate, serrulate : corollas blue or white : achenes columnar, $1.5 \mathrm{~mm}$. long, each surmounted by $5-7$ rigid distinct pappus-scales.

In waste places, North Carolina to Florida.

2. Ageratum littoràle A. Gray. Foliage glabrous. Stems 3-7 dm. long, decumbent or assurgent, often diffusely branched: leaf-blades ovate, 1-5 $\mathrm{cm}$. long, crenate-serrate, rather fleshy, broadly cuneate at the base; petioles as long as the blades or longer : involucres glabrous; bracts linear-lanceolate, $2-2.5 \mathrm{~mm}$. long, acuminate, ribbed : corollas blue: achenes about $2 \mathrm{~mm}$. long, each surmounted by a narrow cup-like, rarely toothed pappus.

In sand, Florida Keys.

\section{STÈvia Cav.}

Herbs or shrubby plants, with rigidly or rarely diffusely branched stems. Leaves opposite, or the upper alternate : blades usually serrate, and 3-nerved, rarely entire or 3cleft. Heads 5-flowered, loosely or densely clustered. Involucres cylindric : bracts 5-6, narrow, rigid, nearly equal. Receptacle naked. Corollas all alike, regular. Anthers appendaged, obtuse at the base. Stigmas, slender, rather obtuse. Achenes slender sometimes flattened. Pappus of scales or awns, sometimes both forms together.

1. Stevia foliòsa Small. A branching shrub several dm. tall, with glabrous foliage. Leaves numerous, small ones clustered in the axils of the larger; blades narrowly linear to almost linear-filiform, 3-10 cm. long, acute, remotely serrate or nearly entire: heads few in each cyme : involucres narrowly cylindric, 7-8 mm. high, short-peduncled; bracts linear, acute, ribbed, appressed.

On plains or prairies, southern Texas and Mexico. Spring to fall.

\section{9. ÓSMIA Sch. Bip.}

Perennial caulescent herbs, or shrubby plants. Leaves opposite : blades broadest below the middle, petioled. Heads in corymbose cymules. Involucres ovoid to cylindric : bracts numerous, leathery or parchment-like, in several series, with more or less spreading colored somewhat foliaceous tips, or herbaceous, conspicuously ribbed, obtuse. Receptacle flat or slightly convex, naked. Corolla regular. Achenes 5-angled, narrow. Pappus of numerous hair-like bristles.

Tips of the involucral bracts not appressed, decidedly colored, much thinner than the bodies.

Tips of the involucral bracts appressed, more or less colored, the inner ones pale,

1. O. ivaefolia.

each with a very minute colored tip.

Bracts of the involucre 5-7-ribbed: receptacle convex.

Bracts of the involucre 3-ribbed : receptacle flat.

2. O. heteroclina.

3. O. conyzoides.

1. Osmia ivaef òlia (L.) Small. Finely pubescent or somewhat hirsute. Stems erect, 5-15 dm. tall, finally much branched : leaf-blades lanceolate to oblong-lanceolate or linear, acute, usually serrate above the base: involueres oblong-campanulate, $3-5 \mathrm{~mm}$. high, 10-2v-flowered; bracts oblong to linear-oblong, rounded or nearly truncate, some- 
what squarrose, the inner azure : corolla purplish blue or reddish : achenes $2 \mathrm{~mm}$. long, glabrous or nearly so, wing-angled. [Eupatorium ivaefolium L.]

In old fields, Mississippi to Texas and Mexico. Also in tropical America. Fall.

2. Osmia heteroclìna (Griseb.) Small. Minutely pubescent. Stems 5-10 dm. tall, branching : leaf-blades ovate-lanceolate to deltoid-ovate, $2-3 \mathrm{~cm}$. long, rather obtuse, serrate, cuneate to truncate at the base : involucres cylindric, $8-12 \mathrm{~mm}$. long, 20-25-flowered; bracts ovate to oblong, obtuse, appressed, shining, faintly ridged : corolla blue or purplish : achenes $3-3.5 \mathrm{~mm}$. long, nearly glabrous. [Eupatorium heteroclinum Griseb.]

In sand, Florida Keys. Also in Jamaica.

3. Osmia conyzoìdes (Vahl) Small. More or less densely pubescent. Stems 6-18 dm. tall, much branched : leaf-blades ovate to lanceolate, $4-10 \mathrm{~cm}$. long, acuminate, nearly entire or coarsely serrate, commonly cuneate at the base : involucres cylindric, 8-10 mm. high, 12-30-flowered ; bracts ovate to oblong or linear-oblong, 5-7-ridged, the outer obtuse, the inner often acute: corollas white or pale blue : achenes $3.5-4 \mathrm{~mm}$. long, nearly glabrous, sharply angled. [Eupatorium conyzoides Vahl.]

In sand, Florida to Texas. Also in tropical America.

\section{EUPATORIUM L.}

Annual or (all within our range) perennial caulescent herbs or shrubby plants, none vines. Leaves alternate, opposite or sometimes whorled: blades various, entire, toothed or dissected. Heads usually in corymbs. Involucres mostly narrow : bracts scarious to membranous, or herbaceous in one series or several, rarely inconspicuously ribbed. Receptacle flat, naked. Corollas regular, white to purple. Anthers appendaged at the apex, obtuse at the base. Stigmas elongated, obtuse, flattened or thickened above. Achenes 5angled, truncate. Pappus of numerous hair-like bristles in 1 series.

Leaf-blades mainly dissected into filiform or narrow segments or sometimes deeply pinnatifid.

Leaf-segments filiform.

Leaf-segments linear, linear-filiform or narrowly lanceolate.

Leaf-blades 1-2-parted.

Inflorescence paniculate or thyrsoid :

Heads 3-6-flowered: not glomerate on the inflorescence-branches: bracts of the involucre punctate and viscid.

Heads 6-9-flowered : glomerate or clustered at the ends of the inflorescence branches: bracts of the involucre neither punctate nor viscid.

Inflorescence corymbose.

Leaf-blades mainly pectinately pinnatifid.

Leaf-blades merely toothed or incised.

Leaves opposite or alternate, or rarely in 3's in 1 or 2 narrow-leaved species.

Leaf-blades manifestly petioled.

Larger leaf-blades fully twice as long as broad.

Larger leaf-blades but little longer than broad.

Heads 5-flowered.

Heads 10-30-flowered.

Shrubby perennial plants.

Leaf-blades entire or merely repand : involucres $3-4 \mathrm{~mm}$. high. Leaf-blades coarsely toothed: involucres $4-5 \mathrm{~mm}$. high.

Herbaceous perennial plants.

Corolla wholly glabrous.

Corolla with persistently bearded lobes.

Leaf-blades acuminate.

Leaf-blades obtuse or abruptly acute.

2. E. compositifolium.

3. E. Eugenei.

4. E. pinnatifidum.

5. E. pectinatum.

6. E. serotinum.

7. E. mikanioides.

8. E. villosum.

9. E. ageratifolium.

10. E. incarnatum.

11. E. ageratoides.

12. E. aromaticum

Leaf-blades sessile or essentially so, or connate-perfoliate.

A. Leaf-blades neither connate-perfoliate nor connate-clasping.

Base of the leaf-blade not broader than the rest of the blade or gradually narrowed.

Bracts of the involucre obtuse.

Leaf-blades linear, entire or shallowly and irregularlyłtoothed.

Leaf-blades less than $1 \mathrm{~mm}$. wide in their normally involute condition.

Leaf-blades over $2 \mathrm{~mm}$. wide, flat.

13. E. lecheaefolium.

14. E. hyssopifolium.

Leaf-blades lanceolate. oblong, ovate or oval, markedly toothed, except in $E$. tortifolium.

Lower leaf-blades broadest below the middle or about at the middle.

Upper leaf-blades toothed from near the base to the apex.

Leaf-blades shallowly and irregularly toothed. Leaves spreading : involucres over $4 \mathrm{~mm}$. high.

Leaves reflexed: involucres less than $4 \mathrm{~mm}$. high.

Leaf-blades deeply and regularly toothed.

15. E. Torreyanum.

16. E. recurvans.

17. E. anomalum.

Upper leaf-blades toothed above the middle.

Involucres 3-4 mm. high, less than $2 \mathrm{~mm}$. thick.

Stem glabrous, except sometimes near the inflorescence : involucres $3 \mathrm{~mm}$. high.

18. 'E. lancifolium. 
Stem pubescent: involucres $4 \mathrm{~mm}$. high.

Involucres 5-6 mm. high, over $2 \mathrm{~mm}$. thick.

Lower leaf-blades decidedly broadest above the middle.

Involucres about $5 \mathrm{~mm}$. high: cauline leaves with entire blades.

Involucres about $7 \mathrm{~mm}$. high : cauline leaves with toothed blades.

Bracts of the involucre acute, acuminate or mucronate.

Leaf-blades linear or of a linear type : involucre $6-7 \mathrm{~mm}$. high.

Inner bracts of the involucre merely acute: leaf-blades 1ribbed.

Inner bracts of the involucre awn-tipped: leaf-blades 3ribbed.

Leaf-blades of an oblong or lanceolate type: involucres 8-10 $\mathrm{mm}$. high.

Outer bracts of the involucre subulate-lanceolate, acuminate, inner bracts linear, not petaloid, acuminate.

Outer bracts of the involucre linear, acute: inner bracts spatulate, petaloid, mucronate.

Base of the leaf-blade broady rounded, cordate, truncate or broadly cuneate.

Leaf-blades crenate, crenate-serrate or crenate-dentate.

Branches of the inflorescence alternate: leaf-blades coarsely few-toothed.

Branches of the inflorescence opposite: leaf-blades more finely and evenly toothed.

Leaf-blades about as broad as long, truncate or subcordate at the base.

Leaf-blades manifestly longer than broad, rounded or broadly cuneate at the base.

Involucres over $4 \mathrm{~mm}$. high : leaf-blades rounded at the base.

Involucres less than $4 \mathrm{~mm}$. high : leaf-blades broadly cuneate at the base.

Leaf-blades sharply serrate.

B. Leaf-blades connate-perfoliate or connate-clasping.

Leaf-blades connate-clasping.

Involucre cylindric, about $5 \mathrm{~mm}$. high; bracts mainly linear leaf-blades oblong to oblong-ovate.

Involucre campanulate, $3.5-4 \mathrm{~mm}$. high ; bracts mainly oblong : leaf-blades lanceolate to oblong-lanceolate.

Leaf-blades connate-perfoliate, except in E. perfoliatum truncatum.

Leaves whorled in 3 's to 6 's; blades relatively broad.

Leaf-blades rugose, manifestly pubescent: inflorescence depressed.

Leaf-blades not rugose, nearly glabrous : inflorescence pyramidal.

Leaf-blades crenate, the teeth somewhat apiculate.

Leaf-blades sharply serrate.

1. Eupatorium capillifòlium (Lam.) Small. Villous to glabrate, fennel-scented. Stems 1-3 m. tall, paniculately much branched : leaves very numerous, mostly alternate ; blades much compound, the segments linear-filiform to filiform, acute : heads very numerous, in panicled racemes or panicles : involucres $2-3 \mathrm{~mm}$. high, 3-6-flowered ; bracts lanceolate to linear-lanceolate, glabrous, acuminate to mucronate, scarious-margined: corollas white : achenes $1 \mathrm{~mm}$. long, glabrous. [E. foeniculaceum Willd.]

In old fields and dry soil, Virginia to Florida. Fall,

2. Eupatorium compositif òlium Walt. Puberulent to finely pubescent, more or less viscid and aromatic. Stems 6-12 dm. tall, paniculately branched : leaves numerous ; blades twice 3-7-parted on the lower part of the stem, gradually less compound above, and entire near the top, the segments linear or nearly so: heads very numerous, in panicled racemes or panicles : involucres 3-4 mm. high, 3-6-flowered; bracts narrowly lanceolate, mucronate, or the inner acuminate pubescent, scarious-margined : corollas white : achenes $1.5 \mathrm{~mm}$. long, glabrous. [E. coronopifolium Willd.]

In dry soil or open woods, North Carolina to Florida and Texas. Summer and fall.

3. Eupatorium Eugènei Small. Similar to $E$. pinnatifidum in habit, but the segments of the leaves commonly narrower. Heads numerous, aggregated at the ends of the slender branches of the inflorescence and borne in a thyrsold panicle : involucres $3.5 \mathrm{~mm}$. high; bracts ovate to linear-spatulate, the inner mucronulate or nearly obtuse: corollas white : achenes fully $1 \mathrm{~mm}$. long. [E. Smithii Greene \& Mohr, not Robinson.]

In dry or sandy soil, Alabama and western Florida. Fall.

4. Eupatorium pinnatífidum Ell. Finely pubescent. Stems 6-12 dm. tall, branch, ing : leaves opposite or in whorls of 4 ; blades pinnately 2-3-parted, or the upper onetwice pinnately parted or entire, the segments linear or nearly so: heads very numerouss sometimes densely crowded : involucres about $3 \mathrm{~mm}$. high, 6-9-flowered; bracts ovate to linear, prominently cuspidate : corollas white: achenes about $1 \mathrm{~mm}$. long, glabrous.

In dry grounds, North Carolina to Florida and Alabama. Summer and fall.

5. Eupatorium pectinàtum Small. Finely pubescent. Stems 1-2 m. tall, corymobsely branched above : leaves rather numerous; blades mostly $5-15 \mathrm{~cm}$. long, larger on 
the lower part of the stem, pectinate-pinnatifid or the smaller ones on the upper part of the stem merely incised or repand, sessile or partly clasping: cymes disposed in a broad corymb : heads numerous, densely clustered : involucres $4-5 \mathrm{~mm}$. high; bracts lanceolate to linear-lanceolate or nearly linear, acuminate or acuminate-mucronate: corollas white : achenes about $1 \mathrm{~mm}$. long.

In sandy soil, southern Georgia and Florida. Summer and fall.

6. Eupatorium serótinum Michx. Puberulent. Stems 1-2 m. tall, corymbosely branched above : leaves opposite; blades thinnish, lanceolate to ovate-lanceolate, $5-25 \mathrm{~cm}$. long, acute or acuminate, coarsely serrate, obtuse or broadly cuneate at the base : corymbs ample: heads very numerous, usually crowded : involueres $3-4 \mathrm{~mm}$. high, 7-15-flowered ; bracts oblong-lanceolate to linear-oblong, obtuse, pubescent : corollas white : achenes $2 \mathrm{~mm}$. long, glabrous or nearly so.

In low grounds, Iowa to Maryland, Florida and Texas. Late summer and fall.

7. Eupatorium mikanioìdes Chapm. Tomentulose, or glabrate in age. Stems 5-9 $\mathrm{dm}$. tall : leaves mainly opposite; blades fleshy, deltoid-ovate to hastate-ovate or some oblong, 3-6 cm. long, obtuse or acutish, repand or crenate-dentate, broadly cuneate or subcordate at the base : corymbs with wide-spreading branches: heads numerous : involucres 5-6 mm. high, j-flowered ; bracts oblong-lanceolate to linear, acute or often cuspidate, or sometimes rather blunt : corollas white: achenes about $1 \mathrm{~mm}$. long, minutely glandular.

In low sandy ground, Florida. Summer and fall.

8. Eupatorium villòsum Sw. A branching shrub $0.5-2 \mathrm{~m}$. tall, with tomentulosehoary foliage. Leaves opposite ; blades leathery, ovate to deltoid-ovate, $1.5-7 \mathrm{~cm}$. long, obtuse, scabrous above, tomentulose beneath, entire or repand : heads numerous : involucres 3-4 mm. high, 8-15-flowered; bracts oblong to linear-oblong, obtuse : corolla white, sometimes purple-tinged: achenes $1.5-2 \mathrm{~mm}$. long.

In sandy soil, Florida. Also in the West Indies.

9. Eupatorium ageratifòlium DC. A shrub 1-3 m. tall, with spreading branches and nearly glabrous foliage. Leaves opposite; blades deltoid-ovate or ovate-lanceolate, 2-8 cm. long, obtuse or acutish, coarsely serrate-dentate or crenate-serrate, rounded or subcordate at the base : heads numerous : involucres $4-5 \mathrm{~mm}$. high, 10-30-flowered; bracts chaff-like, linear to linear-spatulate, obtuse or acutish : corollas usually white: achenes 2-3 mm. long.

In dry soil, Texas and Mexico. Also in the West Indies.

10. Eupatorium incarnàtum Walt. Minutely pubescent. Stems sometimes reclining, 5-10 dm. long, often diffusely branched: leaves opposite; blades ovate to deltoid, $2-6 \mathrm{~cm}$. long, acute or acuminate, rather coarsely serrate, truncate or cordate at the base ; petioles slender, often as long as the blades: involucres about $4 \mathrm{~mm}$. high, 20 -flowered; bracts few, narrowly linear, slightly ribbed when dry, acute: corollas white or pale purple: achenes $2.5 \mathrm{~mm}$. long, minutely pubescent.

In woods or sandy soil, South Carolina to Florida and Texas. Also in adjacent Mexico.

11. Eupatorium ageratoìdes L. f. Glabrate or puberulent. Stems 4-12 dm. tall; branched: leaves opposite; blades thin, ovate or rarely ovate-lanceolate, 4-12 cm. long, acuminate, coarsely serrate, acute, often rounded or subcordate at the base: heads numerous: involucres $3-4 \mathrm{~mm}$. high ; bracts linear, acute or acutish, pubescent : corollas white, with pubescent lobes: achenes $2.5 \mathrm{~mm}$. long, glabrous or nearly so.

In rich soil, New Brunswick to Ontario, Georgia, Louisiana, Nebraska and the Indian Territory. Summer and fall.

12. Eupatorium aromáticum L. Puberulent or minutely pubescent. Stems 3-10 dm. tall, often widely branched : leaves opposite ; blades thickish, ovate to ovate-lanceolate, $2-10 \mathrm{~cm}$. long, obtuse or acute, crenate, sometimes with coarse teeth, rounded or subcordate at the base: heads numerous : involucres $4-5 \mathrm{~mm}$. high; bracts linear or slightly broadened upward, acute or fimbriate at the apex, pubescent : corollas white or nearly so: achenes $2.5 \mathrm{~mm}$. long, glabrous or mainly so.

In dry woods, Massachusetts to Tennessee, Florida and Mississippi. Summer and fall.

13. Eupatorium lecheaefòlium Greene. Puberulent or finely pubescent. Stems 3-7 dm. tall, often slender: leaves numerous, small ones often clustered in the axils of the larger ; blades narrowly linear, 1-8 cm. long, entire, revolute: heads numerous, often crowded: involucres $3-4 \mathrm{~mm}$. high ; bracts oblong to linear, obtuse, sometimes lacerate at the apex, scarious-margined, pubescent and glandular: corollas white: achenes $2 \mathrm{~mm}$. long, glandular.

In sandy soil, Florida. Summer and fall.

14. Eupatorium hyssopifòlium L. Puberulent. Stems $3-8 \mathrm{dm}$. tall, corymbosely branched above: leaves numerous, small ones often clustered in the axils of the larger; 
blades linear, 2-6 cm. long, acute, sometimes undulate : heads numerous, sometimes very numerous : involucres $5-6 \mathrm{~mm}$. high ; bracts oblong to linear or linear-lanceolate, canescent and glandular, obtuse or apiculate : corollas white : achenes $2.5-3 \mathrm{~mm}$. long.

In sandy soil, Massachusetts to Florida and Mississippi.

15. Eupatorium Torreyànum Short. Finely pubescent. Stems 4-8dm. tall, corymbose above : leaves mainly opposite, spreading or ascending, small ones clustered in the axils of the larger ; blades broadly linear to oblong-lanceolate, coarsely serrate or laciniate, prominently nerved beneath : involucres $4.5-6 \mathrm{~mm}$. high ; bracts oblong or ovate-oblong to linear, scarious-margined, obtuse : corollas white : achenes $3 \mathrm{~mm}$. long, sparingly glandular. [E. hyssopifolium var. laciniatum A. Gray.]

In sandy soil, Pennsylvania and Kentucky, Florida and Tennessee.

16. Eupatorlum recúrvans Small. Similar to $E$. Tovreyanum in habit, but usually smaller. Stem often slender: leaves recurved or reflexed; blades narrowly oblong to lanceolate, $1.5-4 \mathrm{~cm}$. long, coarsely toothed: involucres $3-3.5 \mathrm{~mm}$. high : achenes about 2 $\mathrm{mm}$. long.

In pine lands, Georgia and Alabama to Florida.

17. Eupatorium anómalum Nash. Tomentulose. Stems $8-15 \mathrm{dm}$. tall, branching above : leaves opposite, small ones clustered in the axils of the larger ; blades ovate-lanceolate to ovate, 3-7 $\mathrm{cm}$. long, acute, rather coarsely and sharply serrate: involucres narrow, 5-6 $\mathrm{mm}$. high, 5-flowered; bracts linear-lanceolate to linear, pubescent and somewhat glandular, acute or acutish, scarious-margined : corollas white : achenes $2.5 \mathrm{~mm}$. long, glandular.

In sandy soil, Florida.

18. Eupatorium lancifòlium (T. \& G.) Small. Similar to E. semiserratum in habit, but more slender, the stem from the base to the inflorescence, or near it, and leaves glabrous: leaves spreading; blades linear-oblong, 2-5 cm. long, acute or acutish, shallowly but markedly toothed at least above the middle, prominently 3-ribbed from near the base : involucres about $3 \mathrm{~mm}$. high : achenes $2-2.5 \mathrm{~mm}$. long. [E. parviflorum var. lancifolium T. \& G.]

In dry soil, Louisiana and Texas.

19. Eupatorium semiserràtum DC. Tomentulose. Stems $5-12 \mathrm{dm}$. tall, branched above : leaves rather numerous; blades oblong to elliptic, sometimes narrowly so, 3-10 cm. long, acute, sharply serrate, especially above the middle, prominently nerved beneath: heads numerous : involucres $3-4 \mathrm{~mm}$. high ; bracts oblong-ovate to linear, obtuse, canescent : corollas white or pinkish : achenes about $2 \mathrm{~mm}$. long, minutely glandular.

In sandy soil, Virginia to Missouri, south to Florida and Texas.

20. Eupatorium altíssimum L. Hoary-tomentulose. Stems $8-20 \mathrm{dm}$. tall, branching above: leaves numerous ; blades linear-lanceolate, to linear-elliptic, often very narrowly so, acuminate at both ends, sharply serrate above the middle or the upper ones entire, conspicuously 3-nerved : heads very numerous, usually crowded : involucres 5-6 $\mathrm{mm}$. high; bracts oblong, canescent, obtuse, scarious-margined : corollas white : achenes $3.5 \mathrm{~mm}$. long, minutely glandular.

In dry soil, Iowa to Pennsylvania, North Carolina and Texas.

21. Eupatorium tortifòlium Chapm. Tomentulose above. Stems $3-7 \mathrm{dm}$. tall, branched above : leaves numerous, opposite and alternate; blades spatulate, oblanceolate or nearly linear, 1-3 cm. long, obtuse or acutish, vertical, the lower ones often reflexed : heads often crowded : involucres 4-5 mm. high; bracts linear-oblong to linear, obtuse or acute, hairy : corollas white : achenes $2.5 \mathrm{~mm}$. long, glandular.

In sand, South Carolina to Florida and Alabama.

22. Eupatorium cuneif òlium Willd. Tomentulose above. Stems 4-8 dm. tall, branching above : leaves rather numerous; blades cuneate, oblong-cuneate or linear-oblong, 1-3 cm. long, obtuse, serrate beyond the middle, or the upper ones entire: heads numerous : involucres 5-7 mm. high; bracts lanceolate to linear-oblong or linear, obtuse or acutish, with scarious margins and apex : corollas white : achenes nearly $3 \mathrm{~mm}$. long, glandular.

In sand, South Carolina to Florida and Alabama. Summer and fall.

23. Eupatorium leucólepis T. \& G. Rough pubescent or tomentulose above. Stems 3-8 dm. tall, corymbosely branched above : leaves mainly opposite; blades linear to lanceolate, 3-7 cm. long, acute, remotely serrate or nearly entire, 1-ribbed, scabrous : heads mostly few : involucres 6-7 mm. high ; bracts lanceolate to linear, acuminate, canescent, the inner with scarious tips : corollas white : achenes $2.5 \mathrm{~mm}$. long, glandular.

In low pine lands, New York to Florida and Louisiana. Summer and fall. 
24. Eupatorium Mòhrii Greene. Similar to E. leucolepis in habit. Stems slightly more coarsely pubescent : leaves spreading or the lower ones drooping ; blades $2-6 \mathrm{~cm}$. long, serrate, prominently 3 -ribbed beneath : involucre $6-7 \mathrm{~mm}$. high ; bracts densely pubescent, the inner minutely awn-tipped : achenes $2.5 \mathrm{~mm}$. long.

In sandy soil, South Carolina to Florida and Louisiana. Summer and fall.

25. Eupatorium álbum L. Dull green. Stems $3-9 \mathrm{dm}$. tall, rather harshly pubescent : leaves opposite ; blades oblong to lanceolate, 3-10 $\mathrm{cm}$. long, usually acute or acutish, serrate, prominently nerved beneath: corymbs $5-15 \mathrm{~cm}$. broad: heads numerous: involucres narrow, 8-9 mm. high, about 5-flowered; bracts subulate-lanceolate to linear, acuminate, the inner with white or whitish scarious tips: corollas white: achenes $3 \mathrm{~mm}$. long, sometimes sparingly glandular.

In sandy soil, New York to Florida and Louisiana. Summer and fall.

26. Eupatorium petaloìdeum Britton. Bright green. Stems $3-7 \mathrm{dm}$. tall, rough with rather rigid hairs : leaves mainly opposite; blades oblong to lanceolate, $2-8 \mathrm{~cm}$. long, obtuse or acutish, bluntly serrate or crenate-serrate, except the entire cuneate base, often pubescent on the nerves beneath: involucres trumpet-shaped, 9-10 mm. high; bracts various, the outer nearly linear, abruptly acute, the inner white, petal-like and conspicuous, mucronate, spatulate: corollas white: achenes nearly $3 \mathrm{~mm}$. long, almost glabrous.

In dry pine lands, Florida. Summer and fall.

27. Eupatorium verbenaefolium Michx. Finely pubescent. Stems 6-12 dm. tall, branching above : leaves opposite, few ; blades ovate to lanceolate, $2-12 \mathrm{~cm}$. long, acute or rather obtuse, serrate, rounded or truncate at the base, sessile: heads in rather dense cymules : involucres 4-5 mm. high; bracts oblong-lanceolate to linear, acutish, canescent : corollas white or nearly so: achenes $2 \mathrm{~mm}$. long, sparingly glandular. [E. teucriifolium Willd.]

In sandy soil, Massachusetts to Florida and Louisiana. Summer and fall.

28. Eupatortum rotundifòlium L. Tomentulose. Stems $3-12 \mathrm{dm}$. tall, corymbosely branched above : leaves opposite; blades suborbicular to orbicular-ovate, $2-4 \mathrm{~cm}$. long, obtuse or acutish, crenate or crenate-dentate, truncate or subcordate at the base, the lower ones sometimes incised : involucres $5-6 \mathrm{~mm}$. high; bracts lanceolate to linear, acutish or apiculate, scarious-margined, canescent: corollas white : achenes about $2.5 \mathrm{~mm}$. long, glandular.

In pine lands, New York to Arkansas, south to Florida and Texas. Summer and fall.

29. Eupatorium pubéscens Muhl. Canescent-tomentulose. Stems $3-15 \mathrm{dm}$. tall, corymbosely branched above : leaves opposite; blades ovate, $2-10 \mathrm{~cm}$. long, acute, serrate or incised-serrate, rounded or truncate at the base, sessile: involucres 5-6 mm. high; bracts lanceolate to linear, canescent, acute, scarious-margined : corollas white : achenes 2-2.5 mm. long, glandular.

In sandy soil, Massachusetts to Florida and Alabama. Summer and fall.

30. Eupatorium scábridum Ell. Canescent-tomentulose. Stems 4-12 dm. tall, corymbosely branched above : leaves opposite; blades elliptic to ovate-elliptic, $2-8 \mathrm{~cm}$. long, acute, serrate or incised-serrate, except the cuneate base, sessile or nearly so: heads numerous : involucres less than $4 \mathrm{~mm}$. high ; bracts oblong-lanceolate to lanceolate, acute or acuminate, canescent : corollas white : achenes $2 \mathrm{~mm}$. long, quite glandular.

In dry soil, South Carolina to Florida. Summer and fall.

31. Eupatorium sessilif òlium L. Tomentulose above. Stems 4-15 dm. tall, corymbosely branched above : leaves opposite, spreading; blades broadly lanceolate to linearlanceolate, 8-20 cm. long, attenuate, serrate, except the rounded base and the slender apex, sessile : heads numerous : involucres $4-5 \mathrm{~mm}$. high ; bracts ovate-oblong to oblong or linear-oblong, obtuse, minutely pubescent, the inner ribbed : corollas white or pinkish : achenes $3.5 \mathrm{~mm}$. long.

In rocky soil, Massachusetts to Illinois, south to Georgia and Alabama. Summer and fall.

32. Eupatorium Chapmánii Small. Tomentose above. Stems 4-12 dm. tall, corymbosely branched, sometimes extensively so : leaves opposite; blades firm, oblong to oblong-ovate, $2-10 \mathrm{~cm}$. long, merely acute, crenate, glandular as well as tomentose beneath, sessile and partly clasping: heads numerous: involucres cylindric, $5 \mathrm{~mm}$. high ; bracts mainly linear, pubescent, rather acute : corollas white : achenes $2 \mathrm{~mm}$. long.

In sandy soil, Florida. Summer.

33. Eupatorium cuneàtum Engelm. Tomentose above. Stems 5-16 dm. tall, corymbosely branched : leaves opposite or mainly so ; blades lanceolate or oblong-lanceolate, 1-2 dm. long or shorter near the top of the stem, acuminate, finely and evenly cren- 
ate-serrate, at least beyond the more or less cuneate connate-clasping bases: heads numerous : involucres campanulate, $3.5-4 \mathrm{~mm}$. high; bracts mainly oblong, obtusish : corolla white : achenes $1.5 \mathrm{~mm}$. long.

In low grounds, Missouri to Louisiana. Summer and fall.

34. Eupatorium perfoliàtum L. Tomentulose above. Stems $3-10 \mathrm{dm}$. tall : leaves opposite ; blades connate-perfoliate, lanceolate, $8-25 \mathrm{~cm}$. long, acuminate, finely crenateserrate : heads numerous : involucres narrowly eampanulate, $6-7 \mathrm{~mm}$. high, usually 10flowered ; bracts linear-lanceolate, scarious and acuminate at the apex : corollas white, pink or rarely blue : achenes $1.5-2 \mathrm{~mm}$. long.

In low grounds, New Brunswick to North Dakota, Florida and Texas. Summer and fall. A state with leaf-blades truncate at the base, is E. perfoliatum truncaitum A. Gray. BONESET.

35. Eupatorium maculàtum L. Foliage more or less pubescent, scabrous. Stems $0.5-2 \mathrm{~m}$. tall, spotted with purple: leaves in whorls of $3-5$; blades firm, ovate to ovatelanceolate, $0.5-2 \mathrm{dm}$. long, coarsely toothed : corymbs flat-topped : involucres $7-8.5 \mathrm{~mm}$. high, the outer bracts obtuse, pubescent : corollas pink or purple.

In moist soil or swamps, New York to British Columbia, south to Georgia, Kansas and New Mexico. Summer and fall. JOE-PYE WEED.

36. Eupatorium trifoliàtum L. Foliage glabrous or sparingly pubescent. Stems 1-2 m. tall, often purple: leaves in whorls of $3-6$; blades lanceolate to oblong-lanceolate, $1.5-2 \mathrm{dm}$. long, acute or acuminate, crenate : corymbs pyramidal : involucres 6-7 mm. high, the outer bracts obtuse, puberulent: corollas similar to those of the next preceding species.

In moist soil, New York to Wisconsin, Georgia and Mississippi. Summer and fall. JoE-PYE WEed.

37. Eupatorium purpùreum L. Foliage glabrous or sparingly pubescent. Stems 1-3 m. tall, green or purple : leaves in whorls of $3-6$; blades narrowly oblong, ovatelanceolate, oval or ovate, 1-3 dm. long, acuminate, serrate, sometimes pubescent on the nerves beneath : corymbs more or less elongated, round-topped : involucres $5.5-6.5 \mathrm{~mm}$. high, the outer bracts acutish : corollas pink or purple, or rarely white.

In moist soil or thickets, New Brunswick to Manitoba, Florida and Texas. JoE-PYE WEED.

\section{CONOCLINUM DC.}

Perennial caulescent branching herbs. Leaves opposite: blades broadest below the middle, often toothed or parted. Heads in corymbose clusters. Involucres campanulate or hemispheric, several-flowered. Receptacle conic or hemispheric, naked. Corollas blue, violet or rarely white, regular. Achenes narrow, 5-angled, truncate. Pappus of few hairlike bristles in one series. Mist-FLower.

Leaf-blades palmately 3-5-cleft, or 3-5-parted. Leaf-blades entire or merely toothed.

Larger leaf-blades about as broad as long.

Larger leaf-blades about twice as long as broad.

Stems or branches regularly leafy to the inflorescence.

Stems or branches peduncle-like above.

Leaf-blades manifestly toothed, cordate or subcordate at the base.

Leaf-blades entire or essentially so, cuneate or truncate-cuneate at the base. 5. C. integrifolium.

1. Conoclinum Gréggii (A. Gray) Small. Finely pubescent. Stems 3-7 dm. tall, each peduncle-like branch topped. by a compact or rarely open cyme : leaf-blades $2-6 \mathrm{~cm}$. long, palmately 3-5-cleft or 3-5-parted, the lobes narrow, often again lobed : heads usually crowded : involucres 4-5 mm. high ; bracts thin and pliable, very narrowly linear, acuminate, finely pubescent : corollas blue-purple. [Eupatorium Greggii A. Gray.]

In low grounds, southern Texas to Arizona and adjacent Mexico.

2. Conoclinum dichótomum Chapm. Pubescent above with spreading hairs. Stems erect or reclining, 3-9 dm. long, loosely forking : leaf-blades ovate, $1-4 \mathrm{~cm}$. long, acutish, shallowly crenate, broadly cordate at the base: heads few, not crowded: involucres 3-4 $\mathrm{mm}$. high ; bracts rigid, linear-subulate, acute, pubescent : corollas blue.

In sand, peninsular Florida.

3. Conoclinum coelestìnum (L.) DC. Pubescent with appressed hairs. Stems 2-9 dm. tall, branching especially above : leaf-blades ovate to deltoid-ovate, or rarely triangular-lanceolate, $3-12 \mathrm{~cm}$. long, obtuse, crenate to serrate-crenate, abruptly narrowed or subcordate at the base : involucres $3 \mathrm{~mm}$. high; bracts linear-subulate, acute, pubescent: receptacle obtusely conic : corollas blue. [Eupatorium coelestinum L.]

In shaded ground, New Jersey to Kansas, south to Florida and Texas. Summer and fall.

4. Conoclinum betónicum DC. Pubescent with more or less spreading hairs. Stems 3-6 dm. long, ascending or spreading, the peduncle-like branches terminating in often con- 
gested cymes: leaf-blades ovate to oblong-ovate, $3-6 \mathrm{~cm}$. long, obtuse, manifestly crenate, cordate or subcordate at the base, short-petioled: involucres $3 \mathrm{~mm}$. high : bracts linearsubulate, rather acuminate, finely pubescent : receptacle low-conic : corollas purplish blue : achenes $1.5 \mathrm{~mm}$. long.

In low grounds, southern Texas and adjacent Mexico.

5. Conoclinum integrifòlium (A. Gray) Small. Similar to C. betonicum in habit, but usually more slender, and much less and more finely pubescent : leaf-blades ovate or rhombic-ovate, 2-4 cm. long, rounded at the apex, entire or essentially so, cuneately narrowed with slender petioles: involucres about $4 \mathrm{~mm}$. high : bracts linear-subulate, acuminate: corollas purplish blue. [Eupatorium betonicum var. integrifolium A. Gray.]

In low grounds, southern Texas and adjacent Mexico.

\section{WILLUGBAÈYA Neck.}

Perennial herbaceous twining vines, with branching stems. Leaves opposite: blades usually of a hastate or deltoid type, slender-petioled. Heads discoid, in corymbose-cymose clusters. Involucres 4-flowered: bracts 4, or rarely 8, nearly equal. Receptacle small, naked. Corollas white or pink, regular. Anthers obtuse and entire at the base. Stigmas elongated, acutish. Achenes 5-angled, truncate. Pappus of one series of many scabrous hair-like bristles. [Mikania Willd.] The plants flower mainly in summer and fall.

Involucres less than $4 \mathrm{~mm}$. high.

Involucres over $4 \mathrm{~mm}$. high.

Tip of the leaf-blade acute: involucres about $5 \mathrm{~mm}$. high,

Tip of the leaf-blade obtuse: involucres about $6 \mathrm{~mm}$. high.

1. W. heterophylla.

2. W. scandens.

3. W. Halei.

1. Willugbaeya heterophýlla Small. Glabrous. Stems several m. long: leaves various, often clustered on short branchlets ; blades deltoid to hastate-ovate, $1-3 \mathrm{~cm}$. long, or sometimes smaller, acute or acuminate, entire or repand, cordate; petioles sometimes Ionger than the blades: corymbs 1-3 cm. broad: heads rather few : involucres narrow, about $3 \mathrm{~mm}$. high; bracts linear, obtuse, ribbed : achenes stout, 1-1.5 mm. long, glabrous or nearly so, the faces slightly concave: pappus-bristles $2.5 \mathrm{~mm}$. long.

In sandy fields, No Name Key, Florida.

2. Willugbaeya scándens (L.) Kuntze. Finely pubescent or nearly glabrous. Stems sometimes densely matted : leaf-blades deltoid-ovate or hastate, acuminate, undulate or angulately lobed, cordate; petioles often nearly as long as the blades : heads numerous: involucres narrow, about $5 \mathrm{~mm}$. high; bracts linear, acuminate or apiculate: achenes slender, $2 \mathrm{~mm}$. long, glabrous or nearly so, the faces nearly flat: pappus-bristles $2.5 \mathrm{~mm}$. long.

In moist thickets and swamps, Massachusetts to Ontario, Indiana, Florida and Texas.

3. Willugbaeya Hàlei Small. Puberulent or glabrate in age. Stems somewhat angled : leaf-blades triangular-hastate, $5-12 \mathrm{~cm}$. long, often acuminate, but blunt, repanddentate, cordate : corymbs rounded : heads in numerous globular clusters : involucres narrow, fully $6 \mathrm{~mm}$. high ; bracts linear, acuminate, chaffy : achenes 4-5 mm. long, sharply angled, the faces concave : pappus-bristles $5 \mathrm{~mm}$. long.

In low grounds, Louisiana.

\section{TRÍLISA Caśs.}

Perennial caulescent herbs, with fibrous roots. Leaves alternate: blades various, those of the basal leaves with broad petioles, those of the stem-leaves sessile or clasping. Heads discoid, in thyrsoid or corymbose panicles, 5-10-flowered. Involucres campanulate, peduncled: bracts slightly imbricated, nearly equal in length. Receptacle flat, naked. Corollas purplish or white, regular. Anthers obtuse at the base. Stigmas slender, obtuse. Achenes 10-ribbed, but nearly terete. Pappus of 1-2 series of barbellate hair-like bristles.

Stems viscid-pubescent : heads in thyrsoid panicles : achenes pubescent. Stems glabrous: heads in corymbose panicles: achenes glandular.

1. T. paniculata.

2. T. odoratissima.

1. Trilisa paniculàta (Walt.) Cass. Stems viscid-pubescent, 3-9 dm. tall. Basal leaves $6-30 \mathrm{~cm}$. long; blades elliptic to almost linear, acute or slightly acuminate : stem-leaves with elliptic or linear-lanceolate, sessile or somewhat clasping blades : involuobtuse : achenes $2 \mathrm{~mm}$. long, pubescent.

In damp pine lands, Virginia to Florida. Summer and fall. 
2. Trilisa odoratíssima (Walt.) Cass. Stems glabrous, 5-12 dm. tall, corymbosely branched above. Basal leaves 5-20 cm. long; blades spatulate, oblong or elliptic; upper stem-leaves with oblong-oval or ovate entire or irregularly toothed, sessile or partly clasping blades : involucres 3-4.5 mm. high; bracts linear to oblong and obtuse, or the inner linear-cuneate and acute : achenes $2 \mathrm{~mm}$. long, glandular.

In dry or wet pine woods, Virginia to Florida and Louisiana. Summer and fall. Vanilla-Plant.

\section{CARPHOCHAÈTE A. Gray.}

Perennial herbs or shrubby plants, with glabrous or glabrate foliage. Leaves opposite : blades narrow, leathery, sessile. Heads discoid, solitary or terminating leafy branches: involucres narrowly cylindric, 4-6-flowered: bracts few, in few series, acuminate, successively longer. Receptacle naked. Corollas regular, slender. Anthers often with a cleft appendage at the apex. Stigmas filiform, rather obtuse. Achenes elongated, 10-striate. Pappus of several linear-subulate erose-denticulate scarious scales, with the midnerve prolonged into a barbellulate awn.

1. Carphochaete Bigelòvii A. Gray. Woody at the base, puberulent above. Stems tufted, 1-4 dm. tall, branching: leaves numerous; blades oblong-spatulate to oblong or linear, 1-2.5 cm. long, or those clustered in the axils shorter, acute, punctate : heads showy, sessile or short-peduncled : involucres $1.5-2 \mathrm{~cm}$. high ; bracts lanceolate to linear, appressed, finely punctate : corollas $1.5 \mathrm{~cm}$. long, pubescent : achenes finely ribbed, 12-15 mm. long, upwardly barbed: pappus-bristles pink or reddish, somewhat longer than the achenes.

In dry soil, often on hillsides, Texas to New Mexico and adjacent Mexico. Spring.

\section{LACINIÀRIA Hill.}

Perennial caulescent herbs, with thick rootstocks. Leaves alternate : blades usually narrow, entire. Heads discoid, few or numerous, rose-purple or white. Involucres ovoid to cylindric, few-many-flowered : bracts in several series, the inner successively longer, rarely with petal-like tips. Receptacle nearly flat, naked. Corollas regular; lobes often elongated and conspicuous. Anthers obtuse at the base. Stigmas obtuse or flattened at the apex. Achenes 10-ribbed. Pappus of 1-2 series of barbellulate or plumose bristles. [Liatris Schreb.] Button-snakeroot. Blazing Star.

Inner bracts of the involucre terminating in rose-red or magenta petal-like appendages:

Petal-like tips much longer than wide, acuminate.
Petal-like tips about as broad as long, rounded and erose-denticulate.

Inner bracts of the involucre undifferentiated at the tip, or if thinner and colored, not petal-like.

A. Bracts of the involucre obtuse, or mainly so.

Involucres hemispheric, $1-2.5 \mathrm{~cm}$. wide, $15-45$-flowered.

Involucres campanulate, cylindric or turbinate, rarely over $5 \mathrm{~mm}$. wide, usually 5-10̄-flowered.

Involucres rounded at the base, of a campanulate type.

Heads sessile : bracts of the involucre glabrous or nearly so. Involucres 9-11 mm. high; bracts copiously punctate.

Involucres $6-8 \mathrm{~mm}$. high; bracts obscurely if at all punctate.

Heads peduncled: bracts of the involucre pubescent and densely ciliate.

Involucres narrowed at the base, of a turbinate or cylindric type.

Stem copiously pubescent.

Involucres peduncled; inner bracts ciliate, obtuse.

Involucres sessile; inner bracts glabrous, acutish.

Stem glabrous or nearly so.

Leaves conspicuously numerous and approximate on the lower part of the stem, much the same length throughout: blades 1-2 mm. wide.

Leaves few or not conspicuously numerous, the lower ones much longer than the upper; blades relatively wide.

Involucre cylindric : leaf-blades essentially without cilia.

Involucres turbinate: leaf-blades ciliate, especially near the base.

Involucres over $9 \mathrm{~mm}$. high.

Blades of the lower cauline leaves linear or narrowly linear: involucres narrowly turbinate.

Blades of the lower cauline leaves broadly linear or linearoblong: involueres broadly turbinate.

Involucres less than $8 \mathrm{~mm}$. high.

a. Heads sessile or on naked peduncles: involucres mostly over $6 \mathrm{~mm}$. high.

Lower cauline leaves relatively short, the blades over $4 \mathrm{~mm}$. wide: bracts of the involucre ciliate, copiously punctate.

1. L. elegans.

2. L. flabellata.

3. L. scariosa.

4. L. spicata.

5. L. vittata.

6. L. laxa.

7. L. gracilis.

8. L, serotina.

9. L. polyphylla.

10. L. microcephala.

11. L. graminifolia.

12. L. pilosa.

13. L. elegantula. 
Lower cauline leaves elongated, the blades less than 4 $\mathrm{mm}$. wide: bracts of the involucre obscurely if at all ciliate, obscurely punctate.

b. Heads on scaly peduncles: involucres mostly less than $6 \mathrm{~mm}$. high.

B. Bracts of the involucre acute, acuminate or mucronate.

Heads 3-14-flowered.

Involucres $1 \mathrm{~cm}$. high or less, except when the bracts have lax acuminate color tips.

Bracts of the involucre with erect or appressed tips.

Leaves gradually decreasing in length from the base of the stem to the inflorescence.

Pappus-bristles not plumose, at least to the naked eye.

Rachis of the spike or raceme glabrous: outer bracts of the involucre glabrous or ciliolate.

Bracts of the involucre mainly acute :

Bracts thin, sparingly fine-punctate or epunctate.

Middle involucral bracts less than $2 \mathrm{~mm}$. wide: leaves erect or ascending.

Middle involucral bracts over $2 \mathrm{~mm}$. wide: leaves spreading.

Bracts very thick, copiously and coarsely punctate.

Bracts of the involucre mainly abruptly acuminate.

Rachis or the spike or raceme pubescent : outer bracts of the involucre pubescent, at least ciliate or resinous-atomiferous.

Involucres 7-8 mm. high, about $3 \mathrm{~mm}$. thick: heads closely sessile.

Involucres $9-10 \mathrm{~mm}$. high, about $5 \mathrm{~mm}$. thick: heads usually short-peduncled.

Pappus-bristles plumose to the naked eye.

Spike or raceme slender, neither dense nor leafy-bracted.

Inner bracts of the involucre with firm green tips: involucres 7-9 $\mathrm{mm}$. high.

Inner bracts of the involucre with pink scarious tips: involucres 10-12 $\mathrm{mm}$. high.

Spike or raceme stout, dense, leafy-bracted.

Bracts of the involucre eciliate.

Bracts of the involucre ciliate.

Leaves abruptly smaller near the base of the stem, the lower ones very much elongated, the stem thus scape-like.

Involucres mostly less than $7 \mathrm{~mm}$. high: blades of the lower leaves 1-3 mm. wide.

Involucres mostly over $7 \mathrm{~mm}$. high : blades of the lower leaves 4-11 mm. wide.

Bracts of the involucre with recurved-spreading tips.

Heads not contiguous: involucres $6-7 \mathrm{~mm}$. high, the bracts with firm tips.

Heads contiguous and crowded: involucres $8-12 \mathrm{~mm}$. high, the bracts with scarious tips.

Involucres $10-12 \mathrm{~mm}$. high ; bracts with acuminate tips, scarcely if at all ciliate.

Involucres $8-9 \mathrm{~mm}$. high ; bracts acute or mucronate, ciliate.

Involucres much over $1 \mathrm{~cm}$. high.

Stems pubescent: achenes over $5 \mathrm{~mm}$. long.

Stems glabrous: achenes less than $5 \mathrm{~mm}$. long.

Heads 16-60-flowered.

Bracts of the involucre appressed, rounded or merely mucronate.

Heads in an open cyme : bracts of the involucre mucronulate.

Heads in a spike or raceme: bracts of the involucre acuminate.

Bracts of the involucre with rigid acuminate spreading tips.

14. L. elongata.

15. L. Earlei.
16. L. Helleri.

17. L. Smallii.

18. L. Regimontis.

19. L, carinata.

20. L. platylepis.

21. L. Nashii.

22. L. Halei.

23. L. Boykinii.

24. L. acidota.

25. L. punctata.

26. L. tenuifolia.

27. L. laevigata.

28. L. Garberi.

29. L. pycnostachya.

30. L. Langloisii.

31. L. Chapmanii.

32. L. pauciflora.

33. L. cymosa.

34. L. cylindracea.

35. L. squarrosa.

1. Laciniaria élegans (Walt.) Kuntze. Stems $3-12 \mathrm{dm}$. tall, normally simple, finely pubescent. Leaves numerous ; blades linear or nearly so, $1.5-15 \mathrm{~cm}$. long, acute or acutish, the upper ones reflexed, the lower ones narrowed into margined petioles: spikes or racemes 1-5 dm. long, dense: involucres $1.5-2 \mathrm{~cm}$. high ; bracts of 2 kinds, the outer linear or linear-lanceolate, inconspicuous, coarsely pubescent, the inner longer, with showy rose-red pappus-bristles plumose.

In dry or sandy soil, Virginia to Florida and Texas. Summer and fall.

2. Laciniaria flabellàta Small. Stems 3-6 dm, tall, simple, lanuginous, angled, usually solitary : leaves rather numerous; blades linear or nearly so, the lower ones 5-10 cm. long, acute or acutish, spreading, narrowed into margined petioles, the upper ones much reduced, reflexed, all densely punctate, glabrous : racemes conspicuous, $1-2 \mathrm{dm}$. long, $3 \mathrm{~cm}$. thick : involucres $1.5 \mathrm{~cm}$. high : bracts various, the outer somewhat keeled, with spreading entire or denticulate acuminations, the inner with pale magenta fan-shaped erose-dentate tips: achenes densely pubescent: pappus-bristles somewhat plumose, rather few.

In dry open woods, St. Helena Island, South Carolina. Fall.

3. Laciniaria scariòsa (L.) Hill. Stems $2-16 \mathrm{dm}$. tall, sometimes branched above : leaves various, the Jower ones with linear or elliptic blades longer than the petioles, the upper reduced, linear or linear-lanceolate : heads solitary, or numerous, in elongated some- 
times interrupted spikes or racemes : involucres 1-1.5 cm. high and about as broad; bracts rhombic-obovate to broadly spatulate, herbaceous or scarious-margined, obtuse, often erose at the top : achenes 3-4 mm. long: pappus-bristles barbellulate.

In dry soil, Maine to Manitoba, south to Florida and Texas. Summer and fall.

4. Lacinlaria spicàta (L.) Kuntze. Stems 6-15 dm. tall, simple, glabrous or sparingly hirsute. Leaves numerous; blades linear or nearly so, very variable in length : spikes 1-7 dm. long, often dense : involucres sessile, rounded at the base, $9-11 \mathrm{~mm}$. high ; bracts ovate to narrowly oblong, or linear in the inner series, mostly obtuse, ciliolate, appressed, copiously punctate : achenes $3.5-4 \mathrm{~mm}$. long, pubescent : pappus-bristles barbellulate.

In moist soil, Massachusetts to Wisconsin, south to Florida and Louisiana. Summer and fall.

5. Laciniaria vittàta Greene. Resembling L. spicata in habit, but seldom as tall. Leaves mainly below the middle of the stem ; blades of the lower cauline leaves channeled : involucres campanulate, $6-8 \mathrm{~mm}$. high; bracts obtuse, ciliolate at the narrowly scarious apex, obscurely, if at all, punctate.

In woods or meadows, southern Mississippi. Fall.

6. Laciniaria láxa Small. Stems 4-6 dm. tall, thinly tomentulose. Leaves rather numerous ; blades linear, sometimes rather broadly so, 1-2 dm. long, the upper ones often ciliate to near the tip, the lower narrowed into short margined petioles, the upper much reduced, sessile : peduncles villous, some of them longer than the heads : racemes lax : involucres about $5 \mathrm{~mm}$. high, campanulate; bracts oblong to oblong-lanceolate, or broadly linear in the inner series, obtuse, conspicuously ciliate, becoming lax, the outer keeled, purple, the inner purple-tipped : achenes $3-3.5 \mathrm{~mm}$. long, rather densely pubescent : pappus-bristles scarcely barbellulate.

In sand, Cape Florida, Florida. Spring.

7. Laciniaria grácilis (Pursh) Kuntze. Stems $2-10 \mathrm{dm}$. tall, simple or paniculately branched above, cinereous-pubescent. Leaves numerous; blades linear, the lower ones petioled, the upper rather abruptly reduced and sessile : involucres $5-8 \mathrm{~mm}$. high, turbinate, on spreading peduncles ; bracts ovate to oblong or linear-oblong, obtuse, densely glandular-truncate and pubescent, at least ciliate : achenes $2.5-3 \mathrm{~mm}$. long, pubescent : pappusbristles minutely barbellulate.

In sandy pine lands, Georgia to Alabama and Florida. Summer and fall.

8. Laciniaria serótina Greene. Stems about $6 \mathrm{dm}$. tall, rather slender, hirsute to somewhat tomentose with white hairs. Leaves mainly on the lower part of the stem, with narrow almost glabrous blades : heads in a loose spike : involucres cylindric ; bracts ovate to oblong, the inner acutish, glabrous, slightly scarious-margined : achenes appressedpubescent : pappus-bristles barbellulate.

In low pine lands, near Covington, Louisiana. Late fall.

9. Laciniaria polyphýlla Small. Stems usually tufted, 2-7 dm. tall, slender. Leaves numerous ; blades narrowly linear or linear-filiform, 2-10 $\mathrm{cm}$. long, gradually but much reduced above, the lower ones spreading, the upper ascending : racemes virgate: peduncles very slender, 4-10 $\mathrm{mm}$. long, erect or ascending : involueres cylindric, $5-6 \mathrm{~mm}$. high ; bracts broadly ovate to oblong, or cuneate-oblong, obtuse, ribbed, scarious-margined : achenes 3.5-4 mm. long: pappus-bristles minutely barbellulate.

In rocky soil, Stone Mountain, Georgia. Summer.

10. Laciniaria microcéphala Small. Stems rather slender, $3-7 \mathrm{dm}$. tall, solitary or tufted, strict, simple at least below the inflorescence: leaves numerous; blades linear, very narrowly so except those of lower leaves, 5-10 cm. long or shorter above, erect or strongly ascending, sparingly punctate, the lower ones narrowed into sparingly ciliate petioles: heads numerous, short-peduncled or the peduncles sometimes elongated and minutely scaly : involucres cylindric, 6-8 mm. high ; bracts glabrous or nearly so, erect, appressed, obtuse, the outer ovate, the inner oblong or cuneate-linear, much longer than the outer, pappusbristles coarsely barbellulate : achenes cuneate, 4-5 mm. long, densely pubescent.

In sandy soil, Tennessee and Georgia. summer.

11. Laciniaria graminifolia (Walt.) Kuntze. Stems often tufted, $2-12 \mathrm{dm}$. tall, rarely branched. Leaves numerous; blades linear or nearly so, sparingly ciliate near the base : racemes 1-4 dm. long: heads sometimes crowded : involucres turbinate, 10-12 $\mathrm{mm}$. high ; bracts oblong-ovate to oblong-cuneate or linear-cuneate or nearly linear, ciliolate, scariousmargined : achenes $4 \mathrm{~mm}$. long, pubescent : pappus-bristles minutely barbellulate.

In dry soil, Virginia to Florida. Summer and fall.

12. Laciniaria pilòsa (Ait.) Heller. Stems $2-7 \mathrm{dm}$. tall, simple. Leaves rather numerous, the basal often fully $\frac{1}{2}$ as long as the stem, with broadly linear or linear-oblong blades, upper stem-leaves much smaller, with linear blades, all more or less ciliate near the 
base: involucres turbinate, 11-14 mm. high, sessile or short-peduncled ; bracts purple, the outer ovate or oval, the middle ones with oval or ovate blades and short claws, the inner linear or linear-spatulate, all obtuse and rather broadly margined : achenes 5-6 $\mathrm{mm}$. long: pappus barbellulate.

In dry or rocky soil, Virginia and West Virginia to Georgia and Alabama. Summer and fall.

13. Laciniaria elegántula Greene. Stems often slender, 5-12 dm. tall, glabrous or nearly so, simple or rarely with many short branches above. Leaves usually quite few; blades linear or nearly so, $5-15 \mathrm{~cm}$. long, with few cilia near the base : heads scattered in a spike or raceme, or rarely paniculate, the peduncles naked: involucres turbinate, about $6-7.5 \mathrm{~mm}$. high, or the terminal ones a little larger; bracts ovate to oblong-oblanceolate or nearly linear, with dark-green and rounded tips: achenes $3.5-4 \mathrm{~mm}$. long, hispidulous : pappus-bristles not plumose.

In pine lands, Georgia and Florida to Mississippi. Summer.

14. Laciniaria elongàta Greene. Resembling L. elegantula in habit, but with the lower cauline leaves greatly elongated ; blades narrowly linear, sometimes $3 \mathrm{dm}$. long, less than $4 \mathrm{~mm}$. wide, those of the upper cauline leaves linear-filiform or nearly filiform, all obscurely punctate: heads loosely borne in a spike : involucres turbinate, $6.5-7.5 \mathrm{~mm}$. high ; bracts ovate to broadly linear, obscurely punctate, faintly striate near the base, the inner glabrous or obscurely ciliolate, all obtuse: achenes $5-5.5 \mathrm{~mm}$. long: pappus-bristles barbellulate.

In low pine lands, southern Mississippi. Summer and fall.

15. Laciniaria Eàrlei Greene. Stems often short, 5-9 dm. tall, racemose or even paniculate above, striate-ridged : leaves rather numerous; blades broadly linear or linearlanceolate below and 1-2 dm. long or more, narrowly linear on the upper part of the stem and there much smaller, usually sparingly ciliate near the base : ous : peduncles, except the shorter upper ones, scaly : involucres broadly turbinate, 4.5-6 $\mathrm{mm}$. high; bracts suborbicular to broadly oblong or cuneate, obtuse : pappus-bristles merely barbellulate : achenes $3.5-4 \mathrm{~mm}$. long, hispidulous.

In dry or sandy soil, Alabama and Florida. Summer and fall.

16. Laciniaria Hélleri Porter. Stems often tufted, 1-4 dm. tall, glabrous or nearly so. Leaves rather few ; blades linear, $5-20 \mathrm{~cm}$. long, or shorter on the upper part of the stem, sometimes very sparingly ciliate near the base : heads few, rather distant : involucres turbinate, 8-9 mm. high; bracts lanceolate to oblong-linear, green, acute or acuminate, barely ciliolate: achenes 4-5 $\mathrm{mm}$. long, finely pubescent : pappus-bristles barbellulate.

In rocky soil or on cliffs, in the mountains, Virginia and North Carolina. Summer and fall.

17. Laciniaria Smállii Britton. Similar to L. Helleri in habit, but leaves much fewer, often rather remote and spreading, the basal and lower cauline with broadly linear abruptly acute blades : heads few, sessile, separated from each other : involucres turbinate, $9-10 \mathrm{~mm}$. high ; bracts lanceolate to oblong, oblanceolate or linear, acute or acutish, nearly glabrous: achenes 4-4.5 $\mathrm{mm}$. long: pappus-bristles barbellulate.

On mountain slopes, southwestern Virginia and North Carolina. Summer and fall.

18. Laciniaria Regimóntis Small. Stems $3-9 \mathrm{dm}$. tall, usually paniculately branched, sometimes spicately racemose. Leaves rather few, 1-2 dm. long or longer, reduced above ; blades narrowly linear, narrowed into winged sparingly ciliate petioles below, sessile above, all erect or ascending : involucres numerous, cylindric, becoming obconic, $8-10 \mathrm{~mm}$. high, conspicuous on account of the thick lax-tipped bracts, erect or ascending, short-peduncled or some nearly sessile; bracts oblong-ovate to obovate or cuneate, acute to mucronate or the inner slightly hooded, the outer sometimes obtuse, all glandular-punctate, ciliolate, mostly with wing-like margins: achenes $4-4.5 \mathrm{~mm}$. long, ribbed, sparingly pubescent: pappus barbellulate.

On wooded slopes, North Carolina to Georgia. Summer and fall.

19. Laciniaria carinàta Small. Stems $7-11 \mathrm{dm}$. tall, finely pubescent, sometimes copiously branched near the middle. Leaves rather few ; blades narrowly linear, $2-8 \mathrm{~cm}$. long, glabrous, acute : heads sessile, approximate, but not crowded, 3-5-flowered : involucres turbinate, $8-10 \mathrm{~mm}$. high ; bracts ovate-lanceolate to oblong and linear, glabrous, acute or somewhat acuminate, the outer keeled, the inner scarious-margined : achenes 3-4 $\mathrm{mm}$. long, pubescent: pappus-bristles short, plumose.

In pine lands, North Carolina and South Carolina. Summer.

20. Laciniaria platýlepis Snall. Stems $8-9 \mathrm{dm}$. tall, simple, glabrate below, pubescent with white hairs above. Leaves relatively few ; blades narrowly linear, $2-10 \mathrm{~cm}$. long, or longer near the base of the stem, glabrous or nearly so: heads rather approximate, sessile, surpassing the subtending bracts : involucres cylindric-campanulate, $7-9 \mathrm{~mm}$. high ; 
the outer bracts often ovate, acute, the inner longer and broader, broadest above the middle, abruptly pointed, ciliolate: achenes $4-4.5 \mathrm{~mm}$. long: pappus-bristles pale, not plumose.

In sandy soil, Louisiana. Summer.

21. Laciniaria Náshii Small. Stems slender, $2-5 \mathrm{dm}$. tall, hirsute, simple. Leaves relatively few ; blades narrowly linear, the lower ones $10-15 \mathrm{~cm}$. long, petioled, the upper much reduced, erect, sessile, passing into the bracts : racemes $5-10 \mathrm{~cm}$. long, very narrow : involucres cylindric, $8-10 \mathrm{~mm}$. high ; bracts ovate and acute to oblong-cuneate or linearcuneate and acuminate, sometimes abruptly so, all viscid, glandular-punctate : achenes 2.5 $\mathrm{mm}$. long, minutely pubescent: pappus-bristles barely barbellulate.

In pine lands, Manatee, Florida. Summer and fall.

22. Laciniaria Hàlei Small. Stems 6-9 dm. tall, simple or sparingly branched, glabrous or nearly so. Leaves various, the lower with linear blades 1-2 dm. long, the upper blades narrowly linear, much shorter than the lower, not ciliate at the base: heads shortpeduncled or nearly sessile, in interrupted racemes : involucres becoming narrowly turbinate, 7-9 mm. high ; bracts ovate-lanceolate to oblong-lanceolate, oblong or cuneate, acuminate, ciliolate, rigid : achenes $3.5-4 \mathrm{~mm}$. long, closely pubescent : pappus-bristles plumose.

On prairies, Louisiana. Summer.

23. Laciniaria Boykínii (T. \& G.) Kuntze. Stems 3-6 dm. tall, nearly glabrous. Leaves relatively few ; blades narrowly linear, $5-15 \mathrm{~cm}$. long, punctate, much reduced and acerose above the middle of the stem : heads numerous in a strict spike-like raceme : involucres cylindric, 10-12 mm. high ; bracts lanceolate to linear, erect, acuminate, the inner with light pink scarious tips and margins: achenes $3-3.5 \mathrm{~mm}$. long, pubescent : pappusbristles plumose.

In dry or sandy soil, Georgia. Summer.

24. Laciniaria acidòta (Engelm. \& Gray) Kuntze. Stems 3-6 dm. tall, glabrous. Leaves numerous; blades linear-filiform, 3-15 cm. long, acute, commonly glabrous : heads usually numerous, in dense strict spikes : involucres cylindric, 1-1.5 cm. high ; bracts lanceolate to linear-lanceolate or oblong-lanceolate, acuminate or cuspidate-acuminate, glabrous or nearly so : achenes 7-8 mm. long, quite pubescent : pappus-bristles short-plumose On prairies, Texas. Summer.

25. Laciniaria punctàta (Hook.) Kuntze. Stems 2-8 dm. tall, sometimes tufted. Leaves numerous; blades linear to almost acerose, 2-12 cm. long, acute, punctate, sometimes sparingly ciliate : heads usually very numerous, in dense partially leafy-bracted spikes and racemes : involucres cylindric or oblong, 1-1.5 cm. long; bracts ovate to oblong or oblong-cuneate, short-acuminate to cuspidate, lanuginose-ciliate : achenes 5-6 mm. long, somewhat pubescent: pappus-bristles plumose.

On plains and prairies, Saskatchewan to Minnesota and Montana, south to Texas and New Mexico. Bummer and fall.

26. Laciniaria tenuifòlia (Nutt.) Kuntze. Stems 6-12 dm. tall, scape-like, glabrous or nearly so. Leaves numerous, especially on the lower part of the stem; blades linearfiliform, 5-25 cm. long, or shorter above, where they are much reduced and scattered: spikes or racemes slender : involucres $5-7 \mathrm{~mm}$. high ; bracts ovate to ovate-oblong, linear or oblong-cuneate, acute or acutish, or the inner mucronulate glabrate, the outer keeled : achenes $3 \mathrm{~mm}$. long, densely pubescent : pappus-bristles minutely barbellulate.

In dry pine lands, North Carolina to Florida. Summer and fall.

27. Lacinaria laevigàta (Nutt.) Small. Stems 6-10 dm. tall, scape-like. Leaves mainly basal; blades narrowly linear, 1-4 dm. long, lustrous, abruptly reduced and few above the base of the stem : spikes or racemes rather stout: involucres 7-10 $\mathrm{mm}$. high ; bracts ovate to oblong or linear-oblong, glabrous, the inner mucronulate at the apex, not keeled, usually purple: achenes $4 \mathrm{~mm}$. long, densely hirsute: pappus-bristles minutely barbellulate.

In low pine lands, Florida. Summer and fall.

28. Laciniaria Gárberi (A. Gray) Kuntze. Stems 3-6 dm. tall, hirsute-tomentose. Leaves rather numerous ; blades narrowly linear, $5-15 \mathrm{~cm}$. long, or shorter above, glabrate in age : heads not contiguous, in narrow racemes : involucres $6-7 \mathrm{~mm}$. high ; bracts lanceolate to oblong or oblong-cuneate, the outer acute, the inner mucronulate, glandularpunctate and gland-tipped, ciliate, slightly squarrose : achenes $3-3.5 \mathrm{~mm}$. long: pappusbristles minutely barbellulate.

In sand, Tampa, Florida. Fall.

29. Laciniaria pycnostáchya (Michx.) Kuntze. Stems solitary or clustered, 6-15 dm. tall. Leaves numerous; blades linear or nearly so, $2-6 \mathrm{dm}$. long near the base of the 
stem, much reduced above: spikes dense, cylindric, $3-4.5 \mathrm{~cm}$. long, the heads crowded: involucres 10-12 $\mathrm{mm}$. high; bracts ovate to oblong or linear-oblong, the acuminate tips scarious and irregularly spreading: achenes $5 \mathrm{~mm}$. long, minutely pubescent: pappusbristles minutely barbellulate.

In dry soil, Minnesota to Illinois, Arkansas and Texas. Summer and fall.

30. Laciniaria Langloisii Greene. Resembling $L$. pycnostachya in habit, but typically more slender, the foliage glaucescent-green : the heads in a narrower and less dense spike : involucres $8-9 \mathrm{~mm}$. high ; bracts pubescent, with scarious ciliate margins, acute or mucronate, the tips more or less spreading: achenes $4 \mathrm{~mm}$. long, pubescent: pappusbristles barbellulate.

On prairies, Louisiana and Texas. Summer and fall.

31. Laciniaria Chapmánii (T. \& G.) Kuntze. Stems 2-6 dm. tall, strict, rigid. Leaves numerous; blades narrowly linear, $3-10 \mathrm{~cm}$. long, much reduced and sessile above the middle of the stem : spikes commonly dense, plumose at maturity : involucres narrow, erect, 12-14 mm. high : bracts ovate to oblong-lanceolate to linear-lanceolate, acute, apiculate or slightly acuminate : achenes $5.5-6 \mathrm{~mm}$. long: pappus-bristles elongated, firm, barbellulate near the base.

On sand hills, Georgia and Florida. Summer and fall.-The taller form with elongated basal and lower cauline leaves, is L. Chapmanii longifòlia Nash.

32. Laciniaria pauciflòra (Pursh) Kuntze. Stems 2-9 dm. long, sometimes reclining. Leaves firm; blades narrowly linear, 5-10 cm. long, or the upper shorter: racemes secund, hardly dense: involucres narrow, 12-14 mm. high; bracts thinnish, appressed, ovate to oblong-ovate, oblong or oblong-oblanceolate or cuneate-oblanceolate, acute or acuminate : achenes $4-4.5^{\circ} \mathrm{mm}$. long, minutely pubescent: pappus-bristles minutely barbellulate.

In dry sand, South Carolina to Florida. Summer and fall.

33. Laciniaria cymòsa $H$. Ness. Stems $2.5-8 \mathrm{dm}$. tall, cymosely branched above, more or less pubescent. Leaves rather few; the basal and lower cauline with broadly linear more or less acuminate blades $1-2.5 \mathrm{dm}$. long, the upper cauline with narrowly linear thick blades : heads few or numerous : involucres cylindric, about $1.5 \mathrm{~cm}$. high, peduncled ; bracts orbicular to broadly cuneate and broadly oblong-linear, mucronulate: achenes 6.5-7 mm. long; pappus-bristles plumose.

In dry ground, central Texas. Fall.

34. Laciniaria cylindràcea (Michx.) Kuntze. Stems 3-5 dm. tall, simple, mostly glabrous. Leaves rather numerous; blades linear, often narrowly linear, $3-20 \mathrm{~cm}$. long, acute, often ciliolate near the base: heads usually few : involucres cylindric, $1.5-2.5 \mathrm{~cm}$. high; bracts ovate to cuneate oblong and narrowly linear, short-acuminute or abruptly acuminate, erose-ciliate, appressed : achenes 5-6 $\mathrm{mm}$. long, pubescent : pappus-bristles plumose.

In dry soil and on prairies, Ontario to Minnesota, south to Ohio and Arkansas. Summer.

35. Laciniaria squarròsa (L.) Hill. Stems often tufted and partly spreading, 1-6 dm. tall, pubescent. Leaves numerous; blades linear, $3-30 \mathrm{~cm}$. long, often with scattered hairs : heads solitary or few, subtended by leaf-like bracts : involucres cylindric, $1.5-2$ $\mathrm{cm}$. high ; bracts lanceolate to oblong-cuneate, oblong and narrowly linear, acuminate, the upper portion more or less abruptly spreading : achenes $5-6 \mathrm{~mm}$. long, pubescent : pappusbristles plumose.

In dry sandy soil, Ontario to Minnesota, south to Florida and Texas. Summer.

\section{GARBËIA A. Gray.}

Low shrubs. Leaves numerous, alternate, vertical : blades leathery, narrowed to a short jointed base. Heads in rather dense corymbose cymes. Involucres about 5 -flowered : bracts herbaceous, in about 5 series of 3-4 each, acute. Receptacle naked. Corollas regular, widened at the throat. Anthers appendaged at the top. Stigmas elongated, rather obtuse. Achenes slender, 10-ribbed. Pappus copious, the scabro-barbellulate bristles in 2 or more series, the inner longer.

1. Garberia fruticòsa (Nutt.) A. Gray. A branching shrub 1-2 m. tall, with puberulent young foliage. Leaves numerous; blades spatulate or obovate, $2-3 \mathrm{~cm}$. long, pale, narrow, $10-12 \mathrm{~mm}$. high ; bracts puberulent, linear-lanceolate to linear, acute : achenes 7 $\mathrm{mm}$. long, finely pubescent : pappus much surpassing the involucres.

In sandy soil, peninsular Florida. Spring to fall. 


\section{CARPHÉPHORUS Cass.}

Perennial herbs, with scape-like stems simple below the inflorescence. Leaves alternate, conspicuously larger at the base of the stem : blades narrow, flat or acerose, entire. Heads showy, discoid, in terminal corymbose cymes. Involucres hemispheric to campanulate, many-flowered: bracts imbricated in several series, appressed, sometimes scariousmargined. Receptacle nearly flat, with deciduous chaff. Corollas regular. Anthers notched or emarginate at the apex. Stigmas clavate, obtuse. Achenes 10-ribbed. Pappus in 1 or several series, the hair-like bristles plumose or barbellate.

Leaves with acerose blades, erect or appressed. Leaves with flat blades.

Stems manifestly-pubescent.

Bracts of the involucres densely pubescent, acute or acutish.

Bracts of the involucres glabrous, the inner scarious-margined and erose at the apex.

Stems glabrous or nearly so.

1. C. Pseudo-Liatris.

2. C. tomentosus.

3. C. corymbosus.

4. C. bellidifolius.

1. Carphephorus Pseùdo-Liàtris Cass. Foliage cinereous-pubescent. Stems 3-7 dm. tall, wand-like : leaves mostly crowded at the base of the stem; blades acerose, 1-3 dm. long, slightly keeled, half sheathing the stem, reduced to scales above : involucres 7$9 \mathrm{~mm}$. high; bracts ovate-lanceolate to lanceolate, acute or acuminate, pectinate-ciliate : achenes $3 \mathrm{~mm}$. long, minutely pubescent : pappus-bristles slightly plumose.

In grassy pine lands, Georgia and Florida to Louisiana. Fall.

2. Carphephorus tomentòsus (Michx.) T. \& G. Foliage tomentulose, or hirsute below, and there glabrate in age. Stems 3-7 dm. tall : leaves numerous; blades linearspatulate below to oblong-oval or obovate on the upper part of the stem, often acutish, the upper sessile : heads few : involucres $6-10 \mathrm{~mm}$. high ; bracts ovate to oblong, 4-10 mm. long, acute or acutish, densely pubescent : achenes $4 \mathrm{~mm}$. long, strigose: pappus-bristles barely plumose.

In low pine lands, North Carolina to Florida. Summer and fall.

3. Carphephorus corymbòsus (Nutt.) T. \& G. Foliage pubescent. Stems 3-9 dm. tall : basal and lower stem-leaves with spatulate or narrowly oblong-spatulate obtuse blades, 6-15 cm. long; upper stem-leaves alternate ; blades cuneate, oblong or ovate, sessile : heads numerous : involucres 6-9 mm. high ; bracts oval to oblong, 4-8 $\mathrm{mm}$. long, obtuse, glabrous, scarious-margined, the inner erose at the apex : achenes $4 \mathrm{~mm}$. long, sharply ribbed, pubescent : pappus-bristles barely plumose.

In sandy pine lands, North Carolina to Florida. Summer and fall.

4. Carphephorus bellidifòlius (Michx.) T. \& G. Foliage minutely pubescent or glabrate below. Stems 3-5 dm. tall : leaves fleshy ; blades linear-spatulate to linear, 2-10 $\mathrm{cm}$. long, obtuse, 3-5-nerved, sessile: heads few : involucres 10-12 mm. high; bracts oblong, 5-12 $\mathrm{mm}$. long, obtuse, ciliate : achenes $5 \mathrm{~mm}$. long, sparingly pubescent : pappusbristles plumose.

In sandy pine lands, North Carolina to Florida. Summer and fall.

\section{CoLeOSÁNTHUS Cass.}

Herbs or shrubby plants, with upright branching stems. Leaves opposite or alternate : blades broadest below the middle, usually toothed, prominently nerved beneath. Heads several or numerous, or rarely solitary, discoid. Involucres oblong to campanulate, fewmany-flowered: bracts narrow, striate, in several series, the inner successively longer, Receptacle naked. Corollas regular. Anthers obtuse at the base. Stigmas elongated. obtuse. Achenes 10-ribbed or 10-striate. Pappus of one series of scabrous barbellate or nearly smooth hair-like bristles. [Brickellia Ell.]

Heads with 9-25 flowers: inflorescence racemose or paniculate.

Leaves mainly alternate: involucres $7-8 \mathrm{~mm}$. high.

Leaves mainly opposite : involucres $10-11 \mathrm{~mm}$. high.

Heads with $30-50$ flowers : inflorescence corymbose.

1. C. Riddellii.

2. C. cylindraceus.

3. C. cordifolius.

1. Coleosanthus Riđdéllii (T. \& G.) Kuntze. Cinereous-pubescent. Stems 5-12 dm. tall, nearly simple or fastigiately branched above: leaves mainly alternate, very numerous; blades lanceolate or oblong-lanceolate, 1-4 cm. long, acute, mainly entire, or coarsely dentate-serrate, rugose : heads numerous : involucres $7-8 \mathrm{~mm}$. high, 15-20-flowered : bracts ovate to linear or linear-lanceolate, acute or mucronate, pubescent : achenes 4-4.5 mm. long, glabrous or nearly so: pappus-bristles barbellate.

On river banks, Texas. Summer and fall. 
2. Coleosanthus cylindràceus (Gray \& Engelm.) Kuntze. Minutely pubescent or somewhat scabrous. Stems rather rigid, 5-12 dm. tall, often branching above: leaves numerous, mainly opposite ; blades lanceolate to ovate, firm, $2-5 \mathrm{~cm}$. long, acute, or obtuse at both ends, serrate or serrate-crenate, 3-nerved, usually rugose: involucres 10-11 mm. high, 10-flowered; bracts oblong to ovate without, linear within, mucronate or acute, ribbed : achenes $4 \cdot \mathrm{mm}$. long, pubescent: pappus-bristles nearly smooth.

In thickets, Texas. Summer and fall.

3. Coleosanthus cordifòlius (Ell.) Kuntze. Puberulent or minutely tomentulose. Stems 6-12 dm. tall, corymbosely branched : leaves opposite; blades ovate to deltoid-ovate, or nearly lanceolate above, $5-10 \mathrm{~cm}$. long, acute or sometimes acuminate, crenate or nearly entire, truncate or cordate at the base, or the upper ones rounded: heads few : involucres about $10 \mathrm{~mm}$. high; bracts linear, finely ribbed, rather firm, obtuse : achenes 5-5.5 mm. long: pappus-bristles rufous or tawny.

In rich soil, Georgia, Alabama and Florida. Summer and fall.

\section{KÙHNIA L.}

Perennial caulescent herbs, with puberulent or pubescent foliage. Leaves alternate : blades narrow, resinous-dotted. Heads discoid, in open or crowded clusters. Involucres narrow, few-flowered: bracts narrow, in few series, striate, the inner successively longer. Receptacle naked. Corollas white or purplish. Anthers obtuse and entire at the base. Stigmas slender, rather obtuse. Achenes 10-striate, columnar. Pappus of one series of very plumose hair-like bristles. False Boneset.

Leaf-blades narrowly linear, entire, at least those of the upper leaves.

Leaf-blades lanceolate to linear-lanceolate, usually toothed.

Involucres 5-7 mm. high.

Involucres 8-10 $\mathrm{mm}$. high.

1. K. paniculata.

2. $K$. eupatorioides.

3. K. glutinosa.

1. Kuhnia paniculàta Cass. Finely pubescent or puberulent. Stems $3-8 \mathrm{dm}$. tall, wand-like and simple to the inflorescence, or sometimes widely branched: leaf-blades spreading or drooping, narrowly linear, $1.5-3 \mathrm{~cm}$. long, entire, at least above, sessile : involucres $7-8 \mathrm{~mm}$. high; bracts linear-lanceolate to linear, prominently ribbed at maturity : achenes $3.5-4 \mathrm{~mm}$. long : pappus brownish or nearly white.

In pine lands, Florida to Alabama. Summer and fall.

2. Kuhnia eupatoríoìdes L. Puberulent. Stems 5-10 dm. tall, branching above : leaf-blades oblong-lanceolate to linear, $2-10 \mathrm{~cm}$. long, acute or acuminate, sparingly serrate or sinuate, short-petioled or nearly sessile by the narrow bases : involucres $5-7 \mathrm{~mm}$. high ; bracts subulate without, lanceolate to linear within, acute or cuspidate, ribbed: achenes 4-5 mm. high, minutely pubescent: pappus whitish or tawny.

On hillsides, New Jersey to Ohio, Florida and Texas. Summer and fall.

3. Kuhnia glutinòsa Ell. Rather densely and rough-pubescent. Stems 5-12 dm. tall, branching above : leaf-blades lanceolate to linear-lanceolate, or ovate-lanceolate below, 1-4 cm. long, acute or acuminate, shallowly serrate, sessile by the broad bases or partly clasping: involucres $8-10 \mathrm{~mm}$. high ; bracts subulate without, lanceolate to linear within and cuspidate-acuminate: achenes $5 \mathrm{~mm}$. long: pappus tawny or brownish.

In Ary soil, South Dakota to Illinois, Alabama and Texas. Summer and fall.

\section{GYMNOSPÉRMA Less.}

Perennial shrubby plants, with glabrous, but sometimes partially glutinous foliage. Leaves alternate : blades narrow, entire, punctate. Heads numerous, radiate, in corymbose cymes. Involucres ovoid to oblong, several-flowered : bracts few, concave, obtuse. Rayflowers few, pistillate, fruit producing, with very small ligules. Disk-flowers perfect, sometimes fruit producing: corollas yellow. Receptacle small. Anthers obtuse at the base. Stigmas of the perfect flowers flattened. Achenes oblong or nearly so, slightly flattened, 4-5-ribbed. Pappus wanting or obsolete.

1. Gymnosperma corymbòsa DC. Woody at the base, puberulent. Stems 3-10 dm. tall, branching : leaf-blades linear or nearly so, 1-6 cm. long, acute, entire, sessile, the lower ones 3-nerved : involucres 3-4 mm. high, oblong; bracts chaffy, slightly broadened upward, obtuse and scarious at the apex : achenes slightly flattened, about $1 \mathrm{~mm}$. high : pappus wanting.

In rocky soil, Texas and adjacent Mexico. Fall. 


\section{GUTIERREZIA Lag.}

Annual or perennial herbs or shrubby plants, commonly with glutinous foliage. Leaves alternate: blades narrow, entire. Heads radiate, often numerous, mostly in crowded terminal corymbs. Involucres campanulate to turbinate or oblong-clavate, fewmany-flowered: bracts leathery, in few series. Receptacle small. Ray-flowers few, pistillate. Disk-flowers perfect, or some of the central ones staminate. Corollas yellow. Anthers obtuse at the base. Stigmas flattened, the appendages narrow. Achenes oblong or obovate, terete or 5-angled. Pappus of many scales, at least in the disk, that of the ray smaller than that of the disk and occasionally wanting.

Pappus of the rays, and the disk-flowers similar or nearly so.

Perennial plants: heads in clustered or panicled cymes.

Involucres over $4 \mathrm{~mm}$. high, with 3-6 flowers in both disk and ray.

Involucres less than $3 \mathrm{~mm}$. high, with usually 1 or 2 flowers in both disk and ray.

Annual plants: heads terminating the branches singly, and paniculate.

Pappus of 5 or 6 partially united ovate scales.

Pappus of 12 or more narrow mostly distinct scales.

Pappus wanting in the ray-flowers.

1. G. Sarothrae.

2. G. microcephala.

3. G. sphaerocephala.

4. G. eriocarpa.

5. G. Texana.

1. Gutierrezia Saróthrae (Pursh) Britt. \& Rusby. Perennial, glabrous or sometimes pubescent. Stems often bushy, 2-6 dm. tall : leaf-blades narrowly linear, 2-6 cm. long, acute : heads numerous, short-peduncled or several together in clusters and sessile : involucres 4-5 mm. high, commonly 6-12-flowered; bracts oblong, concave, obtuse: achenes 1-1.5 mm. long: pappus of both the ray and disk similar or nearly so.

In dry soil, Manitoba to Minnesota, Texas, Mexico and California. Summer.

2. Gutierrezia microcéphala (DC.) A. Gray. Perennial, glabrous or sparingly fine-pubescent. Stems slender, $2-5 \mathrm{dm}$. tall, more or less branched : leaf-blades narrowly linear or linear-filiform, 1-4 cm. long: heads numerous : involucres $2.5-3 \mathrm{~mm}$. high, 2-4flowered : bracts fewer and narrower than in $G$. Sarothrae.

On rocky plains and hills, southern Texas to southern California and adjacent Mexico. Summer.

3. Gutierrezia sphaerocéphala A. Gray. Annual, glabrous or nearly so. Stems branched, $2-5 \mathrm{dm}$. tall : leaf-blades linear, narrowly so above, $1-5 \mathrm{~cm}$. long, acute : heads numerous, terminating the branches singly and paniculate: involucres hemispheric or obovoid-hemispheric, $4 \mathrm{~mm}$. high ; bracts linear or oblong, acute or acutish, often greentipped : achenes about $2 \mathrm{~mm}$. long, densely pubescent : pappus of the ray and disk similar, of 5 or 6 ovate, crown-like partially concreted scales barely $\frac{1}{2}$ as long as the achene.

On plains and prairies, Arkansas, Texas and New Mexieo. Summer.

4. Gutierrezia eriocárpa A. Gray. Similar to G. sphaerocephala, but commonly lower. Stems branched, often widely so : pappus of 12 or more linear-lanceolate or subulate mostly distinct scales about $\frac{1}{2}$ as long as the achene.

On plains and prairies, southern Texas and adjacent Mexico. Summer.

5. Gutierrezia Texàna (DC. ) T. \& G. Annual, puberulent or glabrate. Stems 3$9 \mathrm{dm}$. tall, effusely branched : leaf-blades narrowly linear or linear-filiform, $1-4 \mathrm{~cm}$. long, acute : heads numerous : involucres turbinate-campanulate, $2-3 \mathrm{~mm}$. high, 16-20-flowered; bracts oblong to linear, obtuse or acutish : achenes fully $1 \mathrm{~mm}$. long, hairy : pappus wanting in the ray, that of the disk consisting of ovate or subulate scales shorter than the thickness of the achene.

On plains, Arkansas and Texas. Summer.

\section{AMPHIÁCHYRIS DC.}

Annual or perennial caulescent herbs, with glabrous foliage. Leaves alternate : blades narrow, entire. Heads very numerous, radiate. Involucres hemispheric to ovoid, fewmany-flowered : bracts leathery, in few series. Receptacle naked. Ray-flowers pistillate and fruit producing. Disk-flowers usually perfect but not fruit producing. Stigmas flattened, the appendages lanceolate. Achenes pubescent. Pappus various; that of the ray crown-like or obsolete; that of the disk of 5-20 subulate or awn-like scales, often slightly united at the base.

1. Amphiachyris dracunculoìdes (DC.) Nutt. Annual. Stems $3-7 \mathrm{dm}$. tall, effusely branched above : leaf-blades narrowly linear to linear-filiform above, $1-5 \mathrm{~cm}$. long, acute: heads solitary at the ends of slender branches: involucres hemispheric, 3-4 mm. high ; bracts ovate, oblong or oval, acute, lustrous : disk-flowers 10-20, each with a sterile ovary and bristle-like pappus-scales united at the base : ray-flowers 3-10; ligules yellow, oblong or oval, 3-4 mm. long: achenes of the ray-flowers with a crown-like pappus.

On plains, Missouri and Kansas to Texas. Summer and fall. 


\section{GRINDËLIA Willd.}

Perennial or rarely annual or biennial herbs, or shrubby plants, usually with glabrous or glutinous foliage. Leaves alternate: blades mostly spinulose-toothed, sessile or clasping. Heads relatively large, radiate or rarely discoid, often in corymbs. Involucres hemispheric or depressed, many-flowered : bracts in several series, usually with subulate tips. Receptacle pitted. Ray-flowers pistillate, fruit producing, rarely wanting. Diskflowers perfect or sometimes staminate. Stigmas narrow, flattened, with linear or lanceolate appendages. Achenes 4-5-ribbed, sometimes flattened. Pappus of 2-8 awns or bristles, early deciduous. Gum-Plant.

Stems pubescent, at least above.

Involucres less than $1 \mathrm{~cm}$. broad.

Involucres over $1 \mathrm{~cm}$. broad.

1. G. microcephala.

Stems glabrous throughout.

Achenes without teeth or auricles at the top.

Involucres less than $1.5 \mathrm{~cm}$. broad: leaf-blades with gland-tipped teeth.

Involucres over $1.5 \mathrm{~cm}$. broad : leaf-blades with very sharp, sometimes spinulose, teeth.

Achenes with 1 or 2 teeth or auricles at the top.

2. G. inuloides.

3. G. squarrosa.

4. G. grandiflora.

5. G. lanceolata.

1. Grindelia microcéphala DC. Stems minutely pubescent, $2-5 \mathrm{dm}$. tall, branched. Leaf-blades oblanceolate to oblong or oblong-ovate, 1-4 cm. long, acute or acutish, closely toothed to the partly clasping base, the teeth gland-tipped : involucres $5-7 \mathrm{~mm}$. high ; bracts linear or nearly so, with green spreading tips : achenes $3 \mathrm{~mm}$. long, oval, ridged.

On plains, Texas. Spring and summer.

2. Grindelia inuloìdes Willd. Stems minutely pubescent, $3-7 \mathrm{dm}$. tall, simple or sparingly branched. Leaf-blades oblong, oblong-lanceolate or nearly ovate, or sometimes broadest above the middle near the base of the stem, $1,5-5 \mathrm{~cm}$. long, acute, closely toothed to the partly clasping base, the teeth gland-tipped: involucres about $1 \mathrm{~cm}$. high ; bracts linear or nearly so, with green spreading tips: achenes $4 \mathrm{~mm}$. long, broadest near the rounded truncate top.

On plains, Arkansas and Texas. Summer and fall.

3. Grindelia squarròsa (Pursh) Dunal. Stems glabrous, $3-8 \mathrm{dm}$. tall, branched above. Leaf-blades oblong-spatulate to oblong, $2-5 \mathrm{~cm}$. long, acutely or spinose-serrate, partly clasping: heads sometimes numerous : involucres about $1.5 \mathrm{~cm}$. broad, glutinous; bracts linear-lanceolate, prolonged into slender leathery tips, the inner erect or ascending, the outer spreading or recurved: ray-flowers usually present; ligules bright yellow: achenes with 2-3 pappus-awns.

In dry soil, Minnesota and Manitoba, to Illinois, Texas, Nevada and Mexico. Summer and fall.

4. Grindelia grandiflòra Hook. Stems glabrous, pale red and shining, 5-12 dm. tall, usually simple below. Leaf-blades lanceolate to oblong-ovate or ovate, $1.5-5 \mathrm{~cm}$. long, sharply and closely toothed, sessile, or the upper ones partly clasping : heads showy : invo-
lucres about $1.5 \mathrm{~cm}$. broad, $1 \mathrm{~cm}$. high; bracts linear-lanceolate to linear: ray-flowers present; ligules yellow, $1.5-2.5 \mathrm{~cm}$. long: achenes with $2-3$ pappus-awns.

On plains and prairies, Texas. Spring and summer.

5. Grindelia lanceolàta Nutt. Stems $5-8 \mathrm{dm}$. tall, glabrous, sparingly branched above. Leaf-blades lanceolate to linear-lanceolate, $2-8 \mathrm{~cm}$. long, acute or slightly acuminate, sessile, serrate, sometimes shallowly so, or those near the base of the stem laciniate: heads showy : involucres about $1.5 \mathrm{~cm}$. broad; bracts produced into linear-filiform tips, the outer bracts with spreading tips : achenes with 1-2 tooth-like pappus scales at the top.

On plains or prairies, Missouri and Kansas to Tennessee, Louisiana and Texas. Summer.

\section{HETEROTHÈCA Cass.}

Annual or biennial caulescent herbs, with pubescent foliage. Leaves alternate: blades flat, entire or toothed, commonly sessile above the base of the stem. Heads radiate, showy, in panicles. Involucres hemispheric or campanulate, many-flowered : bracts narrow, in several series, the inner successively longer. Receptacle flat, pitted. Ray-flowers pistillate. Disk-flowers numerous, perfect, or some of them staminate. Corollas yellow. Stigmas with triangular or lanceolate appendages. Achenes various, those of the disk more flattened than those of the ray. Pappus various, that of the ray of few caducous bristles, or obsolete, that of the disk double, the outer of scales or stout bristles, the inner of numerous rough hair-like bristles. 
1. Heterotheca subaxillàris (Lam.) Britt. \& Rusby. Heavy-scented, hirsute or hispid. Stems 3-12 dm. tall, corymbose above : basal leaves several ; blades oblong to ovate-oblong, 3-6 cm. long, acute, shallowly serrate, petioled: stem-leaves alternate ; blades oblong to oblong-lanceolate, $1-7 \mathrm{~cm}$. long, serrate or repand, acute, mostly sessile, partly clasping : involucres $7-8 \mathrm{~mm}$. high ; bracts linear-lanceolate to linear, acuminate : pappus of the ray-flowers crown-like, that of the disk-flowers conspicuous.

In sandy soil, Delaware to Kansas, south to Florida and Texas. Summer and fall.

\section{CHRÝ́SOPSIS Nutt.}

Biennial or perennial caulescent herbs, usually conspicuously pubescent. Leaves alternate : blades very narrow or sometimes broad, entire and sessile or somewhat toothed, and petioled near the base of the stem. Heads showy, radiate, or rarely discoid, typically in corymbs. Involucres many-flowered : bracts narrow, in several series, the inner successively longer. Receptacle pitted. Ray-flowers several, pistillate. Disk-flowers mostly perfect. Corollas yellow. Stigmas with linear or subulate appendages. Achenes flattened. Pappus double, the outer series of small scales or bristles, the inner of numerous rough hairlike bristles. GoLden Aster.

Leaf-blades elongated linear, or if relatively broad, with parallel veins : leaves and stems silky or rarely glabrous.

Leaf-blades about $2 \mathrm{~mm}$. wide or less.

Involucres 5-6 mm. high : leaves glabrous.

Involucres $8-10 \mathrm{~mm}$, high: leaves silky.

Leaf-blades much over $2 \mathrm{~mm}$. wide.

Pubescence of the stem and leaves lead-colored.

Pubescence silvery.

Stems conspicuously zigzag.

Stems strict or essentially so.

Peduncles, branches and stem woolly.

Lower cauline leaves not markedly longer than the upper.

Lower cauline leaves conspicuously longer than the upper. Involucres 10-12 $\mathrm{mm}$. high.

Involucres 4-7 mm. high.

Peduncles. branches and even the stem glandular.

Lower cauline leaves not markedly longer than the upper.

Lower cauline leaves conspicuously longer than the upper.

Stem-leaves numerous, approximate; blades narrow: ligules of the ray-fowers less than $1 \mathrm{~cm}$. long.

Stem-leaves mostly $2-4$, distant; blades relatively broad : ligules of the ray-flowers over $1 \mathrm{~cm}$. long.

Leaf-blades not elongated linear, relatively broad, or if narrow pinnately veined : foliage woolly, cottony, hispid or villous.

Achenes 3-5-nerved.

Pubescence woolly or cottony, sometimes deciduous, at least above the basal leaves, and leaving a glandular scabrous or glabrous surface.

Bracts of the involucre glabrous.

Bracts of the involucre prolonged into subulate tips.

Bracts of the involucre acute or merely slightly acuminate.

Cauline leaves with spatulate, oblong or oblong-lanceolate blades. Cauline leaves with narrowly linear blades.

Bracts of the involucre glandular or cobwebby.

Bracts of the involucre without cobwebby hairs, copiously glandular. Pubescence deciduous : foliage rough-glandular. Pubescence persistent: 1oliage smooth or soft-glandular.

Bracts of the involucre $1 \mathrm{~mm}$. wide or less.

Stem and leaves cobwebby-pubescent: upperstem-leaves acute. 15. C. Mariana.

Stem and leaves white cottony-lanate : upper stem-leaves obtuse. 16. $C$. Floridana.

Bracts of the involucre $2 \mathrm{~mm}$. wide or more. 17. C. latisquama.

Bracts of the involucre with cobwebby hairs.

Peduncles glandular: bracts of the involucre sparingly cobwebby. 18. C. decumbens.

Peduncles densely villous-cobwebby : heads of the involucre densely villous-cobwebby.

Pubescence hispid or villous.

Upper cauline leaves mostly less than $5 \mathrm{~mm}$. wide.

Stem and leaf-surfaces mainly strigose.

Stem and leaf-surfaces mainly hispid.

Upper cauline leaves mostly over $8 \mathrm{~mm}$. wide.

Achenes 10-nerved.

19. C. pilosa.

20. C. Berlandieri.

21. C. stenophylla.

22. C. camporum.

23. C. Nuttallii.

1. Chrysopsis pinifòlia Ell. Foliage early glabrate. Stems $2-4 \mathrm{dm}$. tall, slender, branched, the ultimate branches nearly filiform: leaves numerous, the basal with narrowly linear blades 5-15 cm. long; stem-leaves with linear-filiform blades mostly less than $1 \mathrm{~mm}$. wide, all merely acute : heads few : involucres $5-6 \mathrm{~mm}$. high ; bracts lanceolate to linear, acute or acuminate, ridged on the back, glabrous : ray-flowers few ; ligules yellow, 6-7 mm. long.

On sand hills, Georgia. Fall. 
2. Chrysopsis Tràcyi Small. Foliage finely silvery silky. Stems wire-like, $3-5 \mathrm{dm}$. tall, sparingly branched above : leaves few, but the basal and lower cauline conspicuous on account of their extreme narrowness and great length ; blades mostly less than $1 \mathrm{~mm}$. wide, $1.5-3 \mathrm{dm}$. long, the upper cauline leaves much shorter, all terminating in a tuft of hairs: heads few, mostly 2 or 3 : involucres $8-10 \mathrm{~mm}$. high ; bracts lanceolate to almost linear, more or less cobwebby : ray-flowers rather numerous; ligules yellow, 9-11 mm. long.

In sand, Palma Sola, Florida. Winter.

3. Chrysopsis argéntea Pers. Foliage silky with appressed graphite-lustrous hairs. Stems 3-7 dm. tall, nearly simple or with few erect branches above: leaves numerous ; blades narrowly linear, erect or appressed, $2-10 \mathrm{~cm}$. long or $2-3 \mathrm{dm}$. long at the base of the stem : heads rather few : involucres $6-8 \mathrm{~mm}$. high ; bracts subulate, more or less villous, ridged on the back; ligules $5-8 \mathrm{~mm}$. long, pubescent.

In dry soil, South Carolina to Florida. Summer.

4. Chrysopsis flexuòsa Nash. Foliage silky-lanate. Stems $2-4 \mathrm{dm}$. tall, zigzag, branching above : leaves various, the lower ones with oblong blades $2-5 \mathrm{~cm}$. long, usually scabrous above; upper leaves spreading or ascending; blades narrowly linear-lanceolate or linear, 2-6 cm. long, often curved, usually 5-nerved: heads few : involucres 10-12 mm. high; bracts linear-subulate, acuminate, sometimes with few long hairs, keeled : ray-flowers few ; ligules linear to oblong, 7-9 $\mathrm{mm}$. long.

In pine woods, Leon County, Florida. Summer and fall.

5. Chrysopsis latif òlia (Fernald) Small. Foliage silky or silky-floccose. Stems 1.5-6 dm. tall, sometimes tufted, often branched above, relatively stout: leaves various, completely elothing the stem with their sheathing bases; the lower ones with broadly linear linear-lanceolate or oblong undulate blades $5-12 \mathrm{~cm}$. long, the upper relatively narrower but not conspicuously shorter : heads few or many, terminating woolly peduncles : involucres 8-10 mm. high ; bracts linear-subulate, acuminate, more or less cobwebby : ray-flowers several; ligules linear, sometimes broadly so. [C. graminifolia var. latifolia Fernald.]

In dry sandy soil, peninsular Florida. Throughout the year.

6. Chrysopsis graminif òlia (Michx.) Nutt. Foliage silvery-silky. Stems $3-9 \mathrm{dm}$. tall, corymbosely branched: leaves various, the basal with narrowly linear blades 1-4 $\mathrm{dm}$. long, many times longer than the upper ; stem-leaves not clothing the stem, with linear-lanceolate, linear or linear-subulate blades, the upper erect : involucres cylindric, 10-12 $\mathrm{mm}$. high, $5 \mathrm{~mm}$. thick; bracts linear-subulate, glabrate or glandular-pubescent on the back : ray-flowers with narrow ligules $8-12 \mathrm{~mm}$. long.

In sandy soil, Maryland to Florida and Texas. Summer and fall.

7. Chrysopsis microcéphala Small. Foliage silvery-silky. Stems usually solitary, 4-7 dm. tall, producing conspicuous offsets, the very slender corymbose-paniculate branches somewhat woolly : leaves numerous, the basal with linear blades 1-2.5 dm. long : stem-leaves linear-lanceolate, $2-8 \mathrm{~cm}$. long, approximate, acuminate, partly clasping : involucres narrowly cylindric, $3 \mathrm{~mm}$. thick, $6 \mathrm{~mm}$. high; bracts linear-subulate, woolly : ray-flowers with yellow ligules $3-4 \mathrm{~mm}$. long.

In sandy soil or pine lands, South Carolina to Florida and Texas. Summer and fall.

8. Chrysopsis Rùthii Small. Foliage silvery-silky. Stems tufted, diffusely branched, $1-3 \mathrm{dm}$. tall, densely leafy above : leaves numerous, usually completely clothing the stem; blades linear or narrowly linear-lanceolate, $2-5 \mathrm{~cm}$. long, acuminate, sessile : peduncles densely glandular : involucres $7-8 \mathrm{~mm}$. high ; bracts linear-subulate, glandular on the back, bearded at the apex, pale-margined : ray-flowers few ; ligules elliptic-spatulate, 7-8 mm. long: pappus dirty white.

On rocks, Hiawassee Valley, eastern Tennessee. Fall.

9. Chrysopsis áspera Shuttl. Foliage silvery-silky below, glandular above. Stems 3-7 dm. tall, corymbosely branched above : leaves not clasping the stem; basal-leaves with narrowly linear blades $1-3 \mathrm{dm}$. long; stem-leaves shorter; blades linear to narrowly linto linear-subulate, rough glandular on the back.

In dry sand or clay, North Carolina to Florida and Louisiana. Summer andifall.

10. Chrysopsis oligántha Chapm. Foliage silvery silky below, glandular above. Stems 3-6 dm. tall, sparingly corymbose above : basal leaves with narrowly linear blades 2-3 dm. long: stem-leaves few ; blades linear or oblong, 3-10 cm. long, clasping : heads few, long-peduncled: involucres $8-10 \mathrm{~mm}$. high, campanulate; bracts linear-subulate, glandular-pubescent : ray-flowers with linear or linear-oblong yellow ligules.

In low pine lands, Florida. Spring.

11. Chrysopsis trichophýlla Nutt. Foliage villous. Stems $3-7 \mathrm{dm}$. tall, corymbose above: leaves numerous, the basál with spatulate blades $3-7 \mathrm{~cm}$. long; cauline leaves 
with oblong-spatulate, oblong or linear blades 1-5 $\mathrm{cm}$. long: heads often numerous : involucres $5-8 \mathrm{~mm}$. high ; bracts lanceolate to linear, acute or acuminate, ciliolate.

In pine lands, North Carolina to Florida and Louisiana. Summer and fall.

12. Chrysopsis gigantèa Small. Foliage somewhat woolly, the hairs partially deciduous. Stems 8-15 dm. tall, corymbosely branched above: leaves numerous, the basal and lower stem-leaves with spatulate to oblanceolate or oblong-oblanceolate blades $5-10 \mathrm{~cm}$. long ; upper stem-leaves much smaller, narrowly oblong to oblong-lanceolate, or somewhat broadest above the middle, often serrulate, sometimes apiculate, sessile : involucres 7-9 $\mathrm{mm}$. high, many-flowered; bracts linear-lanceolate to linear, acute or slightly acuminate, glabrous, becoming rigid.

In pine lands, Florida and Alabama. Fall.

13. Chrysopsis hyssopifòlia Nutt. Foliage glabrous above the basal leaves. Stems 3-9 dm. tall, nearly simple or corymbose at the top: leaves numerous, the basal in a dense rosette, with spatulate or linear-spatulate blades 2-5 cm. long; stem-leaves often crowded; blades narrowly linear to linear-filiform, 1-6 $\mathrm{cm}$. long: involucres about $8 \mathrm{~mm}$. high; bracts linear-lanceolate to linear, rigid, ciliolate, with erect or spreading sharp tips.

In pine lands, Florida. Summer.

14. Chrysopsis scabrélla T. \& G. Foliage rough-glandular. Stems $3-8 \mathrm{dm}$. tall, corymbosely branched above : leaves rather numerous; blades linear-spatulate to linear, acute, entire, sessile : involucres 6-9 $\mathrm{mm}$. high; bracts linear-subulate to linear, rigid, firm-pointed.

In dry sand, Florida. Fall.

15. Chrysopsis Mariàna (L.) Nutt. Foliage cobwebby-villous, and glandular above. Stems 1-6 dm. tall, simple or corymbose above : leaf-blades spatulate to elliptic or oblong, $2-12 \mathrm{~cm}$. long, often acute, entire or remotely toothed, the lower ones narrowed into broad petioles : heads showy : involucres $8-10 \mathrm{~mm}$. high ; bracts linear, acute, glandular, ciliolate.

In sandy soil, New York to Florida and Louisiana. Summer and fall.

16. Chrysopsis Floridàna Small. Foliage white-cottony and persistently so. Stems usually branched at the base, the branches curved, $2.5-4 \mathrm{dm}$. long, corymbose above : leaves regularly disposed along the stem or branches (the basal ones not seen); blades cuneate to oblong-cuneate, $1.5-2.5 \mathrm{~cm}$. long, obtuse, densely pubescent but not as pale as the stem except the margins, partly clasping : heads few, terminating somewhat glandular peduncles : involucres 6-8 mm. high; bracts linear-lanceolate to linear, firm, glandular, merely acute : ray-flowers with ligules about $1 \mathrm{~cm}$. long.

In sandy soil, near Braidentown, Florida. Fall.

17. Chrysopsis latisquàma Pollard. Foliage woolly below, glandular above. Stems 3-7 dm. tall, corymbose above, the branches often elongated : basal and lower stemleaves with spatulate or oblanceolate blades, 5-8 $\mathrm{cm}$. long: upper stem-leaves smaller; blades oblong or nearly so, serrate : involucres $7-8 \mathrm{~mm}$. high ; bracts mostly broadest above the middle, not woolly, glandular, deep green, the outer rather foliaceous, usually acute : ray-flowers with ligules about $1 \mathrm{~cm}$. long.

In low pine lands, peninsular Florida. Spring to fall.

18. Chrysopsis decúmbens Chapm. Foliage densely cobwebby. Stems decumbent, 6-12 dm. long, corymbose above : basal leaves in dense rosettes; blades spatulate to linear-spatulate, 4-8 cm. long, sparingly toothed : stem-leaves numerous; blades oblong to linear-oblong, 1-2 cm. long, obtuse, entire : heads showy, in loose corymbs : involucres 8-10 mm. high ; bracts linear-lanceolate to linear, glandular-pubescent, acute or acuminate; ray-flowers about 25 .

In sand, St. Vincent Island, Florida. Fall.

19. Chrysopsis pilòsa (Walt.) Britton. Foliage lanate. Stems $3-7 \mathrm{dm}$. tall, corymbose above : leaves numerous ; blades oblong to oblong-spatulate, 1-6 cm. long, obtuse or apiculate, entire or sparingly toothed, often partly clasping: heads showy: involucres about $1 \mathrm{~cm}$. high; bracts linear to linear-spatulate, acute or acuminate : ray-flowers with spatulate ligules about $1 \mathrm{~cm}$. long.

In pine lands, Virginia to Florida and Alabama. Fall.

20. Chrysopsis Berlandièri Greene. Foliage rather canescent. Stems 2-15 dm. tall, more or less branched above : leaves numerous; blades linear-oblanceolate or oblongoblanceolate, 1-4 cm. long, acute, entire, hirsute-ciliate near the base, sessile : heads showy : involucres 6-8 mm. high; bracts linear or linear-subulate, acute, strigillose and somewhat canescent : ray-flowers with bright yellow ligules. [C. canescens T. \& G., not DC.]

On rocky prairies, Texas. Spring to fall. 
21. Chrysopsis stenophýlla (A. Gray) Greene. Foliage finely hispid. Stems often tufted, 1-4 dm. tall, rigid, usually branched above : leaf-blades linear or linearspatulate, $2-4 \mathrm{~cm}$. long, acute, entire, bristly ciliate near the base, sessile : heads showy : involucres $7-8 \mathrm{~mm}$. high; bracts linear-subulate to narrowly linear, acute; ray-flowers with light yellow ligules 4-7 mm. long.

In rocky soil or on sand hills, Nebraska to Arkansas and Texas. Summer and fall.

22. Chrysopsis campòrum Greene. Foliage hirsute. Stems $3-9 \mathrm{dm}$. tall, branched above : leaves numerous; blades oblong to linear-oblong, 3-7 cm. long, acute, sessile : heads showy : involucres $9-12 \mathrm{~mm}$. high ; bracts linear-subulate, acuminate, hirsute-strigose : ray-flowers with deep yellow ligules $9-14 \mathrm{~mm}$. long.

On prairies, Illinois and Missouri, south to Kentucky and Arkansas. Summer.

23. Chrysopsis Nuttállii Britton. Foliage villous or softly hirsute. Stems $3-8 \mathrm{dm}$. tall, branching : leaves $1.5-4.5 \mathrm{~cm}$. long; blades oblong to linear-oblong, entire or distantly toothed, acute, sessile, or the lower ones oblong-oblanceolate and commonly incised : heads showy : involucres $8-10 \mathrm{~mm}$. high ; bracts linear or linear-subulate, acuminate : rayflowers with ligules $1-1.5 \mathrm{~cm}$. long: achenes 10 -nerved.

In open woods, Missouri and Kansas, south to Louisiana and Texas. Summer.

\section{XANTHÍSMA DC.}

Annual or biennial caulescent herbs. Leaves alternate : blades narrow, entire. Heads radiate, solitary at the ends of branches. Involucres campanulate to subglobose, manyflowered : bracts closely imbricated, leathery at the base, herbaceous at the tip. Receptacle flat. Flowers fertile. Corollas yellow. Stigmas tipped with filiform appendages. Achenes turbinate, 4-5-ribbed or 4-5-angled, pubescent. Pappus of 10-12 main scales prolonged into slender scabrous tips, usually accompanied by 10-12 shorter scales and an external series of 5 still shorter scales, all persistent.

Bracts of the involucre acute or acuminate: lower leaves with pinnatifid-toothed blades.

Bracts of theinvol

Bracts of the involucre rounded : lower leaves with 1-2-pinnatifid or 1-2-pinnately parted blades.

2. X. Berlandieri.

1. Xanthisma Texànum DC. Stems 3-9 dm. tall, usually branched. Leaf-blades narrowly oblanceolate to linear, $1.5-6 \mathrm{~cm}$. long, acute, the lower ones pinnatifid-toothed, the upper entire or nearly so: heads few, but showy: involucres about $1 \mathrm{~cm}$. high ; bracts elliptic, acute or acuminate : achenes $2 \mathrm{~mm}$. long, pubescent.

On prairies, Texas. Summer.

2. Xanthisma Berlandièri (A. Gray) Small. Stems $2-4 \mathrm{dm}$. tall, sparingly branched. Leaves numerous ; blades 1-6 $\mathrm{cm}$. long, various, those below the branches 1-2-pinnatifid or 1-2-pinnately parted, the upper ones merely serrate or entire, appressed: heads few, showy : involucres about $1 \mathrm{~cm}$. high; bracts oblong or oval, rounded. $[X$. Texanum var. Berlandieri A. Gray.]

On plains, Texas. Spring and summer.

\section{CHONDRÓPHORA Raf.}

Perennial rigid caulescent herbs, often glutinous. Leaves alternate: blades narrow, entire. Heads discoid, often in corymbs. Involucres narrow, few-flowered : bracts in several series, firm. Receptacle flat, sometimes with teeth about the depressions. Corollas yellow. Anthers obtuse at the base. Stigmas flattened. Achenes slightly flattened, 1-2ribbed on each side. Pappus of 1 or 2 series of rigid hair-like bristles.

Stem-leaves with linear or linear-spatulate blades. Stem-leaves with filiform blades.

1. C. nudata.

2. C. virgata.

1. Chondrophora nudàta (Michx.) Britton. Stems $2-6 \mathrm{dm}$. tall, corymbosely branched above. Leaves mainly basal ; blades spatulate to linear-spatulate or linear above, 3-12 cm. long, thickish, sparse on the stem : heads numerous : involucres nearly cylindric, $5-6 \mathrm{~mm}$. high; bracts oblong to linear, acute or acutish, the inner triangular at the apex : achenes about $2 \mathrm{~mm}$. long. [Bigelovia nudata (Michx.) DC.]

In pine lands, New Jersey to Florida and Texas. Summer.

2. Chondrophora virgàta (Nutt.) Greene. Similar to C. nudata. Stems corymbose above, or sometimes thyrsoid : leaves mainly basal ; blades narrowly linear-spatulate or
filiform on the stem : involucres narrowly cylindric ; bracts lanceolate to linear, the inner \begin{tabular}{l} 
truncate and mucronate at the apex. [Bigelovia nudata var. virgata (Nutt.) T. \& G.] \\
\hline
\end{tabular}

In sandy pine lands, North Carolina to Florida and Texas. Summer, 
28. BRINTÒNIA Greene.

Perennial caulescent herbs with pubescent foliage. Leaves alternate: blades broad, coarsely toothed or partially entire, with broad petiole-like bases. Heads discoid. Involucres campanulate, 10-20-flowered : bracts in several series. Receptacle naked, pitted. Corollas regular, with rather long lobes. Stigmas with lanceolate appendages. Achenes ribbed. Pappus of rough hair-like bristles, the inner club-shaped at the apex.

1. Brintonia discoìdea (Ell.) Greene. Stems finely hirsute with gray hairs, 8-15 dm. tall, often widely branched above. Leaf-blades oval, ovate or oblong-ovate, 4-9 cm. long, acute or slightly acuminate, coarsely serrate or the upper ones entire, all rather abruptly narrowed into broad petiole-like bases : racemes open : heads rayless, yellowish white : involucres $6-8 \mathrm{~mm}$. high : corollas various, the outer with shorter lobes than the inner: pappus-bristles with the club-shaped tips often purple-tinged. [Solidago discoidea (Ell.) T. \& G.]

In dry soil, Georgia and Florida to Louisiana. Summer and fall.

\section{PRIONÓPSIS Nutt.}

Annual or biennial caulescent glabrous herbs. Leaves alternate: blades spinulosetoothed, sessile. Heads radiate, showy. Involucres broadly hemispheric, many-flowered : bracts in several series, the outer often slightly spreading, the inner successively longer. Receptacle naked. Ray-flowers numerous, pistillate. Disk-flowers perfect. Corollas yellow. Anthers obtuse at the base. Stigmas with linear-lanceolate appendages. Achenes glabrous, those of the ray stouter and broader than those of the disk. Pappus of few firm hair-like bristles, the outer often shorter, all deciduous.

1. Prionopsis ciliàta Nutt. Stems $8-15 \mathrm{dm}$. tall, sparingly branched. Leaves numerous ; blades obovate to oblong or oval, $2-9 \mathrm{~cm}$. long, acutish or rounded at the apex, closely dentate-serrate, sessile : heads few, in contracted corymbs, showy : involucres hemispheric, about $1 \mathrm{~cm}$. high, $2-2.5 \mathrm{~cm}$. broad ; bracts linear-lanceolate to linear, acuminate : ray-flowers numerous; ligules yellow, $1-1.5 \mathrm{~cm}$. long: achenes $2.5-3 \mathrm{~mm}$. long.

On river banks and billsides, Missouri and Kansas to Texas. Summer and fall.

\section{SIDERÁNTHUS Fraser.}

Annual or perennial herbs or shrubs. Leaves alternate : blades flat, spinulose-toothed or lobed, or pinnatifid, commonly sessile. Heads radiate and showy or rarely discoid. Involucres hemispheric or campanulate, many-flowered : bracts in several series, the inner successively larger. Receptacle flat or nearly so, naked, generally pitted. Ray-flowers pistillate. Disk-flowers mostly perfect. Corollas yellow: tube scarcely dilated into a throat. Anthers obtuse at the base. Stigmas flattened, with lanceolate appendages. Achenes obtuse, pubescent, mostly 8-10-nerved. Pappus of 1-3 series of many unequal hair-like bristles, persistent. [Eriocarpum Nutt.]

Plants annual or biennial.

Bracts of the involucre acute or acuminate.

Inner bracts of the involucre about $1.5 \mathrm{~cm}$. long.

Inner bracts of the involucre $6-9 \mathrm{~mm}$. long.

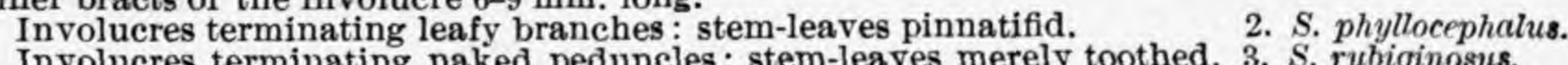

Involucres terminating naked peduncles: stem-leaves merely toothed. 3. S. rubiginosus.

Bracts of the involuere obtuse or rounded at the apex.

Plants perennial, often woody at the base.

$\begin{array}{ll}\text { Stem glabrous or merely minutely puberulent. } & \text { 5. S. glaberrimus. }\end{array}$

Stem woolly or glandular.

Stem glandular-pubescent.

Leaf-blades bipinnatifid.

Leaf-blades $1-2 \mathrm{~cm}$. long, the segments mostly less than $1 \mathrm{~mm}$. wide. 6. S. Cotula.

Leaf-blades $2.5-4.5 \mathrm{~cm}$. long, the segments mostly over $1 \mathrm{~mm}$. wide.

Leaf-blades incised or merely pinnatifid.

Stem woolly-canescent with white hairs.

7. S. Machaera nthera.

8. S. australis.

9. S. spinulosus.

1. Sideranthus megacéphalus (Nash) Small. Stems finely pubescent, 8-12 dm. tall, much branched. Leaves numerous; blades lanceolate to linear-oblong, 2-7 cm. long, with distant spreading or recurved teeth, sessile : heads showy, on stout hirsute peduncles: involucres about $1 \mathrm{~cm}$. high ; bracts linear-lanceolate to linear, acute, ciliate : ray-flowers with linear or oblong-linear ligules about $1 \mathrm{~cm}$. long. [Eriocarpum megacephalum Nash.]

In sandy soil, Florida and Texas. Summer and fall. 
2. Sideranthus phyllocéphalus (DC.) Small. Stems pubescent, 1-4 dm. tall, branched at the base and often diffuse : leaf-blades $2-8 \mathrm{~cm}$. long, those of the cauline leaves pinnatifid, the segments tipped with bristle-like teeth: heads showy, solitary and sessile at the ends of the leafy branches : involucres $6-9 \mathrm{~mm}$. high, the outer bracts more or less foliaceous : ray-flowers with narrow ligules $8-11 \mathrm{~mm}$. long.

On sandy beaches, Texas and adjacent Mexico. Summer and fall.

3. Sideranthus rubiginòsus (T. \& G.) Britton. Stems viscid and pubescent, 2-9 $\mathrm{dm}$. tall, branching: leaf-blades oblong to lanceolate, $3-5 \mathrm{~cm}$. long, remotely dentate with awn-tipped teeth, mostly sessile : heads terminating naked peduncles, corymbose : involucres campanulate, 7-9 mm. high ; bracts lanceolate to linear, acuminate, with green spreading tips, glandular without : ray flowers with oblong or slightly oblanceolate ligules $6-7 \mathrm{~mm}$. long.

On plains and prairies, Nebraska and Colorado, south to Texas. Fall.

4. Sideranthus aùreus (A. Gray) Small. Stem thinly lanuginous and glandular, 1-2.5 dm. tall, branched at the base, the branches sometimes decumbent: leaves rather few ; blades linear or slightly linear-spatulate, 1-2.5 cm. long, pinnatifid, dentate at least near the base : involucres campanulate, about $1 \mathrm{~cm}$. high ; bracts linear to linear-oblong, glandular, blunt, the outer with green tips, the inner almost scarious : ray-flowers 18-25 ; ligules barely $1 \mathrm{~cm}$. long, golden yellow : achenes turbinate, with 10-12 stout pappus bristles. [Aplopappus aureus A. Gray.]

On prairies, Houston, Texas. Summer.

5. Sideranthus glabérrimus Rydb. Stems more or less branched from the woody base, the branches mostly ascending, 1-4 dm. long, corymbose above, glabrous or merely a little puberulent, but wholly destitute of woolly pubescence: leaf-blades pinnatifid or pinnately parted, the segments usually entire, acute: involucres about $5 \mathrm{~mm}$. high; bracts linear-lanceolate to linear, glabrous or essentially so, most of them terminating in pale subulate tips : ray-flowers with ligules $4-7 \mathrm{~mm}$. long.

In dry soil, South Dakota to Wyoming and the Indian Territory. Spring to fall.

6. Sideranthus Cótula Small. Similar to $S$. glaberrimus in habit. Stems and branches copiously glandular-pubescent: leaf-blades $1-2 \mathrm{~cm}$. long, finely bipinnatifid, the segments mostly less than $1 \mathrm{~mm}$. wide : involucres $4-5 \mathrm{~mm}$. high ; bracts glandular-pubescent, acute or acuminate : ray-flowers with narrow ligules 4-6 mm. long.

In dry soil, the Indian Territory. Summer.

7. Sideranthus Machaeránthera Small. Stems clustered on a woody base, about 1.5 $\mathrm{dm}$. tall, sparingly corymbose above, finely glandular-pubescent : leaf-blades much larger and coarser than those of $S$. Cotula, $2.5-4.5 \mathrm{~cm}$. long: involucres $5-6 \mathrm{~mm}$. high ; bracts minutely glandular, acuminate : ray-flowers with ligules $6-9 \mathrm{~mm}$. long.

In dry soil, along the Brazos River, Texas. Summer.

8. Sideranthus austràlis (Greene) Rydb. Stems branched at the woody base, the branches 1-4 dm. tall, mostly ascending, thinly pale-canescent, sparingly branched above : leaf-blades $1-2.5 \mathrm{~cm}$. long, coarsely toothed or pinnatifid, the teeth or segments slenderly spine-tipped : involucres 5-6 mm. high; bracts more or less subulate-tipped, pubescent : ray-flowers with ligules about $1 \mathrm{~cm}$. long.

In dry or rocky soil, Texas to New Mexico and adjacent Mexico. Spring to fall.

9. Sideranthus spinulòsus (Pursh) Sweet. Stems woolly-canescent, 1-3 dm. tall, commonly branched: leaf-blades $1-3 \mathrm{~cm}$. long, pinnately parted, the segments mostly toothed or pinnatifid : involucres $8-9 \mathrm{~mm}$. high ; bracts appressed, oblong-lanceolate to linear, acute : ray-flowers with oblong ligules $5-6 \mathrm{~mm}$. long.

On plains, Northwest Territory to North Dakota, Texas, Arizona and Mexico. Summer and fall.

\section{IsocòmA Greene.}

Herbaceous or woody plants, often with viscid foliage. Leaves alternate : blades entire toothed or pinnately parted. Heads radiate, solitary or clustered. Involucres mainly campanulate, several- to many-flowered: bracts leathery or firmer, obtuse or merely acute -at the more or less thickened tip, imbricated. Receptacle pitted. Ray-flowers usually several, pistillate. Disk-flowers more numerous than the rays, perfect. Corollas yellow, the throat much inflated. Stigmas somewhat flattened and slightly broadened upward, hairy at the tip. Achenes broadened upward, silky. Pappus of numerous slender barbellulate bristles. 
1. Isocoma Drummóndii (T. \& G.) Greene. Stems branched at the base, $2-3 \mathrm{dm}$. tall, corymbose above. Leaves numerous; blades linear or slightly broadened upward, 2-5 $\mathrm{cm}$. long, entire or nearly so: heads rather conspicuous : involucres campanulate or turbinate-campanulate, 8-9 mm. high ; bracts narrowly oblong to linear, acute or acutish, with green viscid tips: achenes about $3 \mathrm{~mm}$. long.

In the lower Rio Grande valley and on the coast of Texas. Spring.

2. Isocoma coronopif òlia (A. Gray) Greene. Stems $2-6 \mathrm{dm}$. tall, freely branching and corymbose above. Leaves numerous; blades $1-3 \mathrm{~cm}$. long, pinnately parted, the segments 3-9, about as broad as the rachis : heads clustered, at the ends of short peduncles : involucres campanulate, $5-6 \mathrm{~mm}$. high ; bracts oblong, linear-oblong or slightly broadened upward, obtuse: achenes about $2 \mathrm{~mm}$. long.

On plains, Texas. Spring and summer.

\section{ISOPÁPPUS T. \& G.}

Annual or biennial caulescent herbs, with rough-pubescent foliage. Leaves alternate : blades narrow, often coarsely and remotely toothed, 1-nerved. Heads radiate, paniculate, peduncled. Involucres many-flowered : bracts narrow, in 2-3 series. Receptacle pitted. Ray-fluwers 5-12, pistillate. Disk-flowers 7-20, perfect : corollas yellow. Stigmas narrow, pubescent. Achenes terete, broadened upward, pubescent. Pappus a single series of rough nearly equal hair-like bristles.

Peduncles glandular: bracts of the involucres glandular: ray-flowers 5-8: disk-flowers 7-14.

1. I. divaricatus.

Peduncles pubescent: bracts of the involucres glabrous : ray-flowers 10-12: disk-flowers 18-20.

2. I. Hookerianus.

1. Isopappus divaricàtus (Nutt.) T. \& G. Stems 3-12 dm. tall, hispid and more or less glandular. Leaf-blades linear-oblanceolate to narrowly linear, 2-10 cm. long, acute or acuminate, remotely but sharply toothed, or entire near the top of the stem, copiously ciliate: heads often numerous : involucres oblong-campanulate, $6-6.5 \mathrm{~mm}$. high ; bracts linear-lanceolate to linear, acuminate, glandular-pubescent : ray-flowers with oblong or elliptic-oblong ligules : achenes $2 \mathrm{~mm}$. long, pubescent.

In dry soil, South Carolina and Kansas, south to Florida and Texas, Summer and fall.

2. Isopappus Hookeriànus T. \& G. Stems $3-5 \mathrm{dm}$. tall, sparingly rough-pubescent. Leaf-blades narrowly linear, sometimes broadest below or above the middle, $2-6 \mathrm{~cm}$. long, acuminate, ciliate near the base, serrulate above the middle, prominently nerved beneath: heads few : involucres campanulate, $5-6 \mathrm{~mm}$. high ; bracts linear-subulate, glabrous or nearly so, firm, sharp-pointed.

On prairies, Texas. Summer.

\section{MAÙCHIA Kuntze.}

Annual caulescent branching herbs. Leaves alternate: blades narrow, entire. Heads radiate. Involucres campanulate, relatively small: bracts thin, scarious-margined, appressed, abruptly acuminate. Ray-flowers fruit producing, often 12, with short styles. Disk-flowers not fruit producing, about 12, the stigmas filiform. Receptacle flat. Anthers obtuse at the base. Achenes various, those of the ray perfect, thickened upward, 3-angled, with a rib at each angle, and pappus of unequal hair-like bristles about as long as the achene; those of the disk abortive, their pappus usually of 2 bristles, somewhat chaffy, dilated at the base. [Bradburya T. \& G., not Raf.]

1. Mauchia hirtélla (T. \& G. ) Kuntze. Foliage hispid. Stems 2-5 dm. tall, slender : leaves various, $1-4 \mathrm{~cm}$. long, those of the basal and lower stem-leaves with narrowly spatulate blades ; upper stem-leaves with blades varying from linear-spatulate to linear-filiform : heads solitary at the ends of slender branches: involucres $7-9 \mathrm{~mm}$. high ; bracts chaffy, oblong-lanceolate to linear, acuminate, glabrous except the midrib: ligules of the ray-flowers yellow, $6-8 \mathrm{~mm}$. long : achenes $3 \mathrm{~mm}$. long, strigillose.

On prairies, Texas. Summer.

\section{STANFIÈLIA Small.}

Branching caulescent herbs. Leaves alternate, relatively few : blades narrow, rather thick. Heads conspicuous, many-flowered, terminating stout peduncles which are enlarged at the top. Involucre of 3-4 series of loosely imbricated leathery striate-ribbed thin-margined bracts. Disk yellow. Stigmas scarcely flattened, with ovoid appendages. Achenes 10-ribbed, the ribs slightly pubescent. Pappus of sordid scabrous bristles. 
1. Stanfieldia Nealleỳi (Coulter) Small. Stems 3-6 dm. tall, glabrous or nearly so, branched above, somewhat glaucous. Leaf-blades narrowly linear, $2.5-5 \mathrm{~cm}$. long, entire : involucral bracts oblong, obtuse, longitudinally striate with dark lines, thin-margined, the inner ones $5-7 \mathrm{~mm}$. long : disk $1.5-2 \mathrm{~cm}$. broad : achenes black $2.5 \mathrm{~mm}$. long, 10-ribbed. [Aplopappus Nealleyi Coulter.]

In valleys, Cameron county, Texas.

\section{OLIGONEÙRON Small.}

Perennial caulescent usually balsamic herbs, the stem usually simple below, terminating in a more or less compound corymbose top. Leaves alternate: blades relatively broad or narrow and elongated, entire, the basal and lower cauline narrowed into petiole-like bases, the upper sessile and clasping. Heads radiate, in terminal corymbs. Involucres severalflowered, campanulate: bracts in several series, thickish, longitudinally few-ribbed. Receptacle pitted. Ray-flowers pistillate, in 1 series; ligules yẹllow. Disk-flowers usually perfect : corollas yellow, 5-lobed, the tube dilated into a short throat. Anthers obtuse at the base. Stigmas flat, with oblong appendages. Achenes few-several-nerved. Pappus of rather many capillary bristles. The plants bloom in summer and fall.

Leaf-blades not 3-ribbed, relatively broad, rough-pubescent: involucre rounded at the base.

Involucre over $5 \mathrm{~mm}$. thick: achene about $3 \mathrm{~mm}$. long.

Involucre less than $5 \mathrm{~mm}$. thick: achene about $2 \mathrm{~mm}$. long.

Leaf-blades 3-ribbed, linear, smooth and glabrous : involucre acute at the base.

1. O. rigidum.

2. 0 . corymbosum.

3. O. nitidum.

1. Oligoneuron rígidum (L.) Small. Stems 4-15 dm. tall, relatively stout, more or less striate below, angled above, rough-pubescent, sometimes hoary: leaves firm, thick, rough-pubescent, the basal often copiously clustered about the stem, with oblong, oblonglanceolate or rarely spatulate shallowly toothed blades, 1-3 dm. long, narrowed into more or less elongated petiole-like hases; blades of the upper stem-leaves oblong to ovate, 2-13 $\mathrm{cm}$. long, obtuse or acute, shallowly toothed or essentially entire, sessile or partly clasping: heads numerous, disposed in a flat-topped corymb-like inflorescence : involucres broadly campanulate, 8-9 mm. high, over $5 \mathrm{~mm}$. thick; bracts ovate to oblong, obtuse, ribbed in age, the outer at least puberulent: achenes 12-15-ribbed. [Solidago rigida L.]

In dry sandy or gravelly soil, Ontario to the Northwest Territory, Georgia, Texas and Colorado.

2. Oligoneuron corymbòsum (Ell.) Small. Similar to O. rigidum in habit, but more slender. Stems glabrous or nearly so below, rather softly and finely pubescent above: leaves thinnish, somewhat scabrous at least above and about the edges, serrulate, otherwise similar to those of the next preceding species : heads few or many, in a terminal flat-topped corymb-like inflorescence : involucres broadly campanulate, about $7 \mathrm{~mm}$. high, less than 5 $\mathrm{mm}$. thick; bracts mainly oblong, rounded at the apex, thickish, manifestly ribbed in age, glabrous or essentially so: achenes 12-15-ribbed.

In dry or stony soil, middle Ohio to Georgia and Alabama.

3. Oligoneuron nítidum (T. \& G.) Small. Stems 4-9 dm. tall, smooth and glabrous below the inflorescence, striate-ribbed: leaves rather numerous; blades leathery, firm in age, prominently ribbed, smooth and somewhat lustrous, those of the basal and lower cauline leaves linear or narrowly linear-elliptic, 1-3 dm. long, narrowed into petiole-like bases, those of the upper cauline linear, erect, gradually smaller towards the inflorescence, partly clasping by the narrow bases, all entire: heads few or numerous, in a rather compact corymb-like inflorescence with densely fine pubescent branches : involucres narrowly campanulate, 6-7 mm. high, 4-5 mm. thick : bracts mainly oblong, obtuse, thick, markedly ribbed in age, the outer at least puberulent: ackenes glabrous, 10-ribbed.

In pine woods and dry soil, the Indian Territory to Louisiana and Texas.

\section{CHRYSÒMA Nutt.}

Shrubby caulescent herbs, with somewhat glutinous foliage. Leaves alternate : blades fleshy-leathery, narrow, conspicuously pitted, mostly 1-nerved. Heads radiate, numerous. Involucres narrow, few-flowered: bracts in few series. Receptacle pitted. Ray-flowers 1-3, pistillate. Disk-flowers mostly perfect. Corollas yellow : tube scarcely dilated above. Anthers obtuse at the base. Stigmas flattened, with lanceolate appendages. Achenes pubescent. Pappus of 1-2 series of numerous brownish hair-like bristles.

1. Chrysoma pauciflosculòsa (Michx.) Greene. Stems 3-9 dm. tall, freely branching at least above. Leaves numerous; blades linear-spatulate to linear-oblong, 3-6 cm. long, obtuse, with copious rounded or angular depressions: involucres narrowly oblong, 
4-6 mm. high ; bracts oblong-lanceolate to linear-lanceolate, obtuse or acutish : ray-flowers with ligules $4-6 \mathrm{~mm}$. long: achenes $3-4 \mathrm{~mm}$. long.

In low sandy soil, South Carolina to Florida and Mississippi. Fall.

\section{EUTHÀMIA Nutt.}

Perennial caulescent herbs, with elongated rootstocks. Leaves alternate: blades narrow, entire or nearly so. Heads very numerous, radiate, in broad corymbs. Involucres narrow, several-flowered: bracts narrow, often obtuse, glutinous, closely imbricated. Receptacle pubescent or fimbrillate. Ray-flowers pistillate, usually more numerous than those of the disk, with inconspicuous ligules. Corollas yellow. Stigmas with lanceolate appendages. Achenes broadened upward, pubescent. Pappus of long equal bristles. The plants bloom in summer and fall.

Leaf-blades manifestly 3-5-ribbed : ray-flowers 12-30.

Leaf-blades 1-ribbed: ray-flowers 5-10.

Leaf-blades mostly over $3 \mathrm{~mm}$. broad : disk-flowers $3-4$.

Leaf-blades mostly less than $3 \mathrm{~mm}$. broad : disk-flowers $5-6$.

1. E. graminifolia.

2. E. leptocephala.

1. Euthamia gramínifòlia (L.) Nutt. Stem 3-14 dm tall, corymbose above finely pubescent or glabrate below : leaf-blades linear, over $4 \mathrm{~mm}$. wide, $3-5$-ribbed, finely pubescent, at least along the ribs or margins : heads numerous : involucres campanulate, mostly 4-4.5 mm. high : ray-flowers 12-30. [Solidago lanceolata L.]

In rich soil or thickets, Nova Scotia to the Northwest Territory, Florida and Kansas.

2. Euthamia leptocéphala (T. \& G.) Greene. Stems 4-11 dm. tall, glabrous or merely puberulent near the corymbose top: leaf-blades linear, mostly over $3 \mathrm{~mm}$. wide, 1-ribbed, glabrous except the seabrous margins: heads rather numerous : involucres turbinate, mostly 5.5-6 mm. high : ray-flowers $6-10$.

In moist soil, Missouri to Mississippi and Texas.

3. Euthamia Caroliniàna (L. ) Greene. Stems $2-8 \mathrm{dm}$. tall, glabrous or sometimes sparingly and minutely pubeseent, more or less copiously corymbose above: leaf-blades narrowly linear to linear-filiform, mostly less than $3 \mathrm{~mm}$. wide, 1-ribbed, essentially glabrous, except the margins : heads numerous, sometimes extremely so : involucres cylindric to turbinate-cylindric, $4.5-6 \mathrm{~mm}$. high : ray-flowers 5-8. [Solidago tenuifolia Pursh.]

In sandy soil, Massachusetts, Florida and Texas, and locally in the interior.

\section{SOLIDÀGO L.}

Perennial caulescent herbs, sometimes shrubby near the base, with the stems usually simple below the inflorescence. Leaves alternate: blades simple, often toothed. Heads radiate, relatively small, paniculate or thyrsoid. Involucres several-flowered, campanulate, turbinate or cylindric : bracts in several series, ribless, the inner successively longer, the outer sometimes extending well down the peduncle. Receptacle small, usually alveolate. Ray-flowers pistillate, in 1 series : ligules yellow or rarely white. Disk-flowers mostly all perfect. Corollas usually yellow, tubular to narrowly campanulate, 5-lobed. Anthers obtuse and entire at the base. Stigmas flattened, the appendages lanceolate. Achenes terete or angled, generally ribbed. Pappus of several or many rough capillary bristles in 1 or 2 nearly equal series. GoLdenRod.

A. Heads in axillary short or raceme-like clusters subtended by leaf-like bracts, if aggregated at the end of the stem or its branches forming a conspicuously leafy-bracted thyrsus.

a. Involucre $2.5-6 \mathrm{~mm}$. high.

Achenes copiously pubescent: bracts of the involucreobtuse.

Stems and branches terete.

Leaf-blades mostly less than $2 \mathrm{~cm}$. wide: involucres $3.5-4 \mathrm{~mm}$. high, $1.5-2 \mathrm{~mm}$. thick.

Leaf-blades mostly over $2.5 \mathrm{~cm}$. wide : involucres $4-5 \mathrm{~mm}$. high, $2.5-3$ mm. thick.

Stems and branches angled.

Leaf-blades tess than twice as long as broad.

Leaf-blades over twice as long as broad.

Stem glabrous.

Leaf-blades $2.5-4$ times as long as broad.

Leaf-blades 5-8 times as long as broad.

Involucre narrowly campanulate, $4.5-5 \mathrm{~mm}$. high, about 2 $\mathrm{mm}$. thick; inner bracts linear.

Involucres broadly campanulate, $5-6 \mathrm{~mm}$. high, about $3 \mathrm{~mm}$. thick ; inner bracts oblong.

Stem manifestly pubescent.

1. S. caesia.

2. S. asterifolia.

3. S. flexicaulis.

4. S. flaccidifolia.

5. S. Curtisii.

6. S. lancifolia.

7. S. pubens.

Achenes glabrous: bracts of the involucre acute. 
Leaf-blades acute at the apex, the bases broad.

Leaf-blades more or less acuminate at the apex, the bases narrow, b. Involuere $7-8 \mathrm{~mm}$. high.

B. Heads in a terminal inconspicuously bracted, rarely contracted, panicle or thyrsus.

Inflorescence consisting of a round-topped contracted panicle.

Inflorescence pyramidal or elongated.

Tips of the involucral bracts, at least some of them, spreading or recurved.

Blades of the lower stem-leaves mainly over $5 \mathrm{~cm}$. wide, smooth or nearly so.

Blades of the lower stem-leaves mainly less than $3 \mathrm{~cm}$. wide, manifestly scabrous.

Leaves dull green.

Leaves with a metallic lustre, often silvery.

Tips of the involucral bracts erect or appressed.

Inflorescence equilateral or essentially so: heads not secund on the branches.

Upper stem-leaves not abruptly smaller than the lower, more or less spreading.

Bracts of the involucre decidedly obtu se.

Achenes glabrous.

Stems copiously pubescent.

Ray-flowers with white ligules.

Ray-flowers with yellow ligules.

Stems glabrous or merely puberulent.

Involucre $4-6.5 \mathrm{~mm}$. high, $2-4 \mathrm{~mm}$. thick ; the bracts glabrous or nearly so.

Bracts of the involucre $1 \mathrm{~mm}$. broad or broader near the rounded tip.

Leaf-blades, at least the majority of them, toothed. Involucres $4.5-5.5 \mathrm{~mm}$. high, 3-3.5 mm. thick, the inner bracts barely $1 \mathrm{~mm}$. wide.

Involucres $5.5-6.5 \mathrm{~mm}$. high, 4-4.5 $\mathrm{mm}$. thick, the Leaf-blades entire.

Bracts of the involucre less than $1 \mathrm{~mm}$. broad near the somewhat narrowed apex.

Involucre $7-7.5 \mathrm{~mm}$. high, fully $5 \mathrm{~mm}$. thick, the bracts pubescent.

Achenes pubescent.

Heads short-peduncled or sessile : inflorescence compact.

Heads slender-peduncled : inflorescence open.

Bracts of the involucre acute or acutish.

Heads relatively few, in a lax panicle or thyrsus.

Stems and leaves glabrous: upper stem-leaves with linear blades.

Stems and leaves softly puberulent: upper stem-leaves with broader blades.

Heads relatively numerous, in a compact panicle or thyrsus.

Involucres $2.5-3 \mathrm{~mm}$. thick ; bracts linear.

Involucres narrowly campanulate, $3 \mathrm{~mm}$. thick.

Involucres turbinate-campanulate, $2.5 \mathrm{~mm}$. thick.

Involucres $4 \mathrm{~mm}$. thick ; bracts oblong.

Upper stem-leaves abruptly smaller than the lower, erect or appressed.

Inflorescence 1-sided: heads manifestly secund on the branches.

* Leaf-blades pinnately veined, not 3-ribbed.

Plants maritime: leaves fleshy-leathery.

Involucres $3.5-4 \mathrm{~mm}$. high.

Involucres $5-6 \mathrm{~mm}$. high.

Involucres campanulate.

Involucres turbinate.

Plants not maritime: leaves not fleshy-leathery.

Internodes of the stem prominently angled below the leaves.

Involucres broadly campanulate, $4.5-5 \mathrm{~mm}$. high, about 3 mm. thick.

Involucres narrowly campanulate, $4 \mathrm{~mm}$. high, $2.5 \mathrm{~mm}$ thick.

Internodes of the stem terete or essentially so.

Leaf-blades commonly about as broad as long, clasping or their petiole-like bases clasping.

Leaf-blades, at least the lower ones, much longer than broad. † Stem manifestly pubescent, rarely only in lines. Leaves glabrous except the ciliate margins.

Leaf-blades entire.

Stem pubescent in lines: leaf-blades 6-7 times longer than wide.

Stem pubescent all over: leaf-blades 2-5 times. longer than wicle.

Leaf-blades toothed.

Inner bracts of the involucre linear : leaves green.

Inner bracts of the involucre oblong: leaves glaucescent.

Leaves pubescent.

Leaf-blades not rugose-veiny.

Leaves of a linear type.

Leaves of an oblong elliptic oval or ovate type. Stem-leaves with clasping blades. Stem-leaves not clasping.

15. S. bicolor.

16. S. hispida.

17. S. erecta.

18. S. speciosa.

19. S. rigidiuscula.

20. S. plumosa.

21. S. Porteri.

22. S. uliginosa.

23. S. dispersa.

24. S, Chrysopsis.

25. S. verna.

26. S. puberula.

27. S. pulverulenta.

28. S. Lindheimeriana.

29. S. stricta.

30. S. angustifolia.

31. S. sempervirens.

32. S. flavovirens.

33. S. patula.

34. S. salicina.

35. S. amplexicaulis.

36. S. odora.

37. S. Chapmanii.

38. S. brachyphylla.

39. S. pallescens.

40. S. tortifolia.

41. S. fistulosa. 
Involucres cylindric-turbinate or cylindriccampanulate, about $2 \mathrm{~mm}$. thick.

Bracts of the involucre obtuse: stems and leaves somew hat shaggy-pubescent: leaf-blades appressed-serrate.

Bracts of the involucre acute: stems and leaves scabrous-pubescent: leafblades sharply serrate.

Involucres campanulate, about $3 \mathrm{~mm}$. thick.

Leaf-blades rugose-veiny.

Leaf-blades decidedly acute or acuminate, mostly over thrice as long as broad.

Leaf-blades obtuse or acutish, mostly about twice as long as broad.

++ Stem glabrous, at least below the inflorescence.

Branches of the inflorescence pubescent.

Involuere cylindric, few-flowered.

Involucre not spirally twisted.

Inner bracts of the involucre $3 \mathrm{~mm}$.long, obtuse. 46. S. ulmifolia .

Inner bracts of the involucre $4 \mathrm{~mm}$. long, acute. 47. S. microphylla. Involucre spirally twisted.

Involucre campanulate, many-flowered.

Leaf-blades relatively thick, singly serrate except in robust plants of $S$. strigosa.

Branches of the inflorescence short and approximate, forming a compact pyramidal panicle.

Branches of the inflorescence elongated and remote, when abbreviated, the head-clusters in an elongated interrupted thyrsus.

Involucre 3-4 mm. high. Leaf-blades glabrous, smooth. Leaf-blades strigose, scabrous.

Involucre 5-6 mm, high.

Cauline leaves, or some of them, with finely and closely toothed blades : leaves of the inflorescence-branches linear to linear-lanceolate.

Cauline leaves, or some of them, with coarsely or remotely toothed blades: leaves of the inflorescence-branches elliptic to cuneate.

Leaf-blades relatively thin, mainly doubly serrate with spreading teeth.

Involucres $3.5-4.5 \mathrm{~mm}$. high, 2-2.5 mm. thick.

Involucres 5-6 mm. high, 3-4 mm. thick.

Branches of the inflorescence glabrous.

Involucre less than $5 \mathrm{~mm}$. high.

Bracts of the involucre obtuse : involucre campanulate.

Inner bracts of the involucre $0.5 \mathrm{~mm}$. wide : basal leaves with serrate blades.

Inner bracts of the involucre $1 \mathrm{~mm}$. wide: basal leaves with crenate blades.

42. S. Earlei.

43. S. pendula.

51. S. strigosa.

44. S. rugosa.

45. S. celtidifolia.

48. S, Helleri.

49. S. Elliottii.

50. S. Boottii.

51. S. strigosa.

52. S. Yadkinensis.

53. S. Ludoviciana.

54. S. arguta.

55. S. Vaseyi.

56. S. juncea.

57. 'S. gracillima.

Bracts of the involucre acute: involucre cylindric. 58. S. delicatula.

Involucre over $5 \mathrm{~mm}$. high.

Lower leaves with romotely toothed blades: achenes $2.5-3 \mathrm{~mm}$, long.

Lower leaves with closely toothed blades: achenes $1.5-2 \mathrm{~mm}$. long.

** Leaf-blades manifestly 3 -ribbed.

Stem glabrous.

Cauline leaves abruptly smaller from near the base of the stem : leaves erect or appressed : achenes glabrous.

Cauline leaves not abruptly smaller above the base of the stem: achenes pubescent.

Branches of the inflorescence glabrous.

Involucres campanulate: species trans-Alleghenian. Involucres cylindric-campanulate: species Carolinian.

Branches of the inflorescence pubescent.

Stem pubescent, rarely minutely so, or only in lines.

Cauline leaves with relatively long blades, acuminate or attenuate.

Involucres 5-6 mm. high.

Involucres $2-4 \mathrm{~mm}$. high Cauline leaves with blades of a linear type.

Involucre about $4 \mathrm{~mm}$. high.

Involucre turbinate-campanulate: leaf-blades longattenuate.

Involucre broadly campanulate: leaf-blades acuminate.

Involucres 2-3 mm. high.

Cauline leaves with blades of a lanceolate or oblong-lanceolate type.

59. S. austrina.

60. S. neglecta.

61. S. Gattingeri.

62. S. Missouriensis.

63. S. pinetorum.

64. S. serotina.

65. S. Shortii.

66. S. Nashii.

67. S. Leavenworthii. 68. S. rupestris.

69. S. Canadensis.

Cauline leaves with relatively short blades, obtuse or merely acute.

Blades of the upper leaves narrow, or if relatively broad closely sessile. 
Leaves near the inflorescence with oblanceolate or spatulate blades.

Involucre $3.5-4 \mathrm{~mm}$. high : bracts thin.

Involucre $4.5-5.5 \mathrm{~mm}$. high : bracts thick.

Leaves near the inflorescence with ovate or oval or obovate blades.

Heads mostly over 12-flowered : foliage gray.

Heads mostly less than 12-flowered: foliage green.

Blades of the upper leaves narrowed into petiole-like bases: involucres $3 \mathrm{~mm}$. high.

70. S. nemoralis.

71. S. longipetiolata.

72. S. mollis.

73. S. radula.

74. S. Drummondii.

1. Solidago caèsia L. Stems $3-11 \mathrm{dm}$. tall, terete, glabrous, more or less glaucous, simple or widely branched : leaf-blades spatulate on the lower part of the stem to broadly linear, or narrowly or linear-lanceolate above, $6-14 \mathrm{~cm}$. long, mostly less than $2 \mathrm{~cm}$. wide, acute or acuminate, serrate, sometimes coarsely or sharply so, above the entire base, pale green beneath, glabrous: heads in axillary, often raceme-like, clusters : involucre cylindric-campanulate, 3.5-4 $\mathrm{mm}$. high, $1.5-2 \mathrm{~mm}$. thick; bracts obtuse : achenes pubescent.

In woods and thickets, Maine to Ontario, Minnesota, Florida and Texas. Summer and fall.

2. Solidago asterif òlia Small. Similar to S. caesia, in habit, but somewhat stouter : leaf-blades elliptic, sometimes narrowly so, $2.5-9 \mathrm{~cm}$. long, mostly over $2.5 \mathrm{~cm}$. wide, acuminate, coarsely and sharply serrate above the entire cuneate base, paler beneath than above, somewhat pubescent about the nerves beneath, or glabrous at maturity : heads in axillary clusters : involucres narrowly campanulate, $4-5 \mathrm{~mm}$. high, $2.5-3 \mathrm{~mm}$. thick; bracts obtuse : achenes pubescent.

In thickets and on hillsides, Georgia to Louisiana. Summer and fall.

3. Solidago flexicaùlis L. Stems $2-9 \mathrm{dm}$. tall, angled, usually simple, glabrous : leaf-blades ovate to oval above the petiole-like base, $5-15 \mathrm{~cm}$. long, acuminate, sharply and often doubly serrate with more or less flaring narrow teeth, somewhat pubescent beneath : heads in axillary clusters which are sometimes aggregated into a bracted thyrsus : involucres cylindric-campanulate, 4-5 mm. high, 2-2.5 mm. thick; bracts obtuse: achenes pubescent.

In rich woods or on rocky hillsides, New Brunswick to South Dakota, Georgia and Kansas. Summer and fall.

4. Solidago flaccidifòlia Small. Stems 6-13 dm. tall, angled, glabrous, simple or nearly so: leaf-blades elliptic-obovate on the lower part of the stem to elliptic above, 6-19 $\mathrm{cm}$. long, acuminate, coarsely serrate above the entire base, light green above, pale green beneath, glabrous : heads in axillary clusters : involucres campanulate, $3 \mathrm{~mm}$. high, about $2 \mathrm{~mm}$. thick; bracts obtuse : achenes pubescent.

On hillsides, northwestern Georgia. Fall.

5. Solidago Curtísii T. \& G. Stems 5-14 dm. tall, angled, usually simple, glabrous : leaf-blades relatively long, spatulate-elliptic on the lower part of the stem to narrowly elliptic or linear-elliptic above, 8-20 cm. long, acuminate, coarsely serrate above the entire base, finely pubescent beneath : heads in axillary, sometimes raceme-like clusters : involucres narrowly campanulate, $4.5-5 \mathrm{~mm}$. high, about $2 \mathrm{~mm}$. thick; bracts mainly linear, rather obtuse : achenes pubescent.

In mountain woods, Virginia and West Virginia to Georgia and Tennessee. Late summer and fall.

6. Solidago lancifòlia T. \& G. Stems 5-13 dm. tall, angled, simple or sparingly branched, glabrous : leaf-blades relatively long, similar to those of $S$. Curtisii, but glabrous or essentially so: heads in axillary, commonly raceme-like clusters : involucres broadly campanulate, 5-6 mm. high, about $3 \mathrm{~mm}$. wide ; bracts mainly oblong, rounded at the apex: achenes pubescent.

On shaded mountain slopes or summits, North Carolina and Tennessee. Summer and fall.

7. Solidago pùbens M. A. Curtis. Stems 4-15 dm. tall, angled, mostly simple, pubescent : leaf-blades oblong-spatulate at the base of the stem, to elliptic-spatulate, elliptic or linear-elliptic above, $5-16 \mathrm{~cm}$. long, acuminate, appressed or sharply serrate, manifestly pubescent beneath: heads in axillary, often raceme-like clusters : involucres cylindriccampanulate, about $4 \mathrm{~mm}$. high, $2 \mathrm{~mm}$. thick; bracts copiously pubescent, the inner linear, all obtuse : achenes pubescent.

In rich mountain woods, North Carolina, Tennessee and Georgia. Summer and fall.

8. Solidago Buckleỳi T. \& G. Stems apparently over $5 \mathrm{dm}$. tall, angled, pubescent : leaf-blades oblong or elliptic-oblong, 5-9 $\mathrm{cm}$. long, acute at both ends, appressedserrate above the broadly cuneate base, pubescent beneath : heads in small axillary clusters : involucres campanulate, about $4 \mathrm{~mm}$. high, $2-2.5 \mathrm{~mm}$. thick; bracts lanceolate to linearlanceolate, acute, the outer pubescent : achenes glabrous.

On mountain slopes, middle Alabama. Fall. 
9. Solidago montícola T. \& G. Stems $2-8 \mathrm{dm}$. tall, angled, usually simple, sparingly pubescent or glabrate in age : leaf-blades spatulate on the lower part of the stem to elliptic or linear-elliptic above, more or less acuminate at both ends, rather sparingly appressed serrate, commonly glabrous : heads in axillary often raceme-like clusters which are sometimes aggregated into a terminal thyrsus : involucres eylindric-campanulate, about 4 $\mathrm{mm}$. high, nearly $2 \mathrm{~mm}$. thick; bracts linear or linear-lanceolate, acute : achenes glabrous.

In deep mountain woods, Maryland and West Virginia to Georgia and Alabama. Summer and fall.

10. Solidago glomeràta Michx. Stems 3-11 dm. tall, very stout, angled, glabrous, sometimes branched: leaf-blades ample for the genus, spatulate and 2-3 dm. long on the lower part of the stem, smaller and broadly or narrowly elliptic above, acuminate, rather sharply and coarsely serrate, more or less pubescent, especially near the margins: heads in thick axillary clusters which are sometimes aggregated into a terminal thyrsus : involucres broadly campanulate, 7-8 $\mathrm{mm}$. high, 5-6 $\mathrm{mm}$. thick; bracts obtuse or acutish, the outer ovate, the inner linear: achenes glabrate.

On high mountain slopes and summits, North Carolina and Tennessee. Summer and fall.

11. Solidago spithamaèa M. A. Curtis. Stems often clustered, $1-3 \mathrm{dm}$. tall, simple below the inflorescence, somewhat angled, pubescent: leaf-blades spatulate and 5-10 cm. long on the lower part of the stem, somewhat smaller and elliptic or oblong above, acute, appressed-serrate or sharply serrate, often finely pubescent beneath : heads in raceme-like clusters which are aggregated into a round-topped panicle : involucres campanulate, 4-5 mm. high, about $5 \mathrm{~mm}$. thick; bracts narrow, acute : achenes pubescent.

On rocky mountain summits and slopes, North Carolina and Tennessee. Summer and fall.

12. Solidago squarròsa L. Stems $4-15 \mathrm{dm}$. tall, stout, striate-angled, usually somewhat pubescent above, usually simple : leaves various, the basal and lower cauline with elliptic oval or ovate coarsely toothed blades 1-2 dm. long, terminating, long petiole-like bases, the upper cauline leaves smaller, with mainly oblong or elliptic less coarsely toothed or merely undulate blades: involucres long-campanulate, 6-7 $\mathrm{mm}$. long, 4-5 $\mathrm{mm}$. thick ; bracts numerous, all but the inner with spreading or recurved tips: achenes glabrous.

In rocky soil or on banks, New Brunswick to Ontario, Georgia and Ohio. Summer and fall.

13. Solidago petiolàris Ait. Stems $3-16 \mathrm{dm}$. tall, often branched, striate ridged, finely pubescent throughout: leaves various, the basal and lower cauline with spatulate or narrowly cuneate remotely appressed serrate blades 4-11 $\mathrm{cm}$. long, the upper cauline smaller with oblong, elliptic or oblong-ovate blades entire or shallowly toothed near the apex, all green : heads in an elongated panicle : involucres $5-6 \mathrm{~mm}$. high, about $4 \mathrm{~mm}$. thick; bracts fewer than in S. squarrosa, some of the outer ones at least, with spreading or recurved tips: achenes glabrous.

In dry or stony soil, North Carolina to Kansas, Florida and Texas.-A form from Arkansas, Louisiana and Texas, with narrow entire or nearly entire leaf-blades, is $S$. petiolaris angústa (T. \& G.) A. Gray.

14. Solidago Wárdi Britton. Similar to $S$. petiolaris in habit. Leaves with a metallic luster, often silvery : heads in a terminal thyrsus : involucres long-campanulate, 6-7 $\mathrm{mm}$. high, 4-5 mm. thick : ray-flowers with very brilliant yellow ligules.

In sandy or rocky woods, Missouri and Kansas to Texas. Summer and fall.

15. Solidago bícolor L. Stems $2-12 \mathrm{dm}$. tall (sometimes dwarf at high altitudes), striate, more or less hirsute, simple or branched: leaf-blades various, those of the basal and lower cauline leaves obovate, oval, elliptic or spatulate, mostly 1-2 dm. long, narrowed into petiole-like bases, coarsely but shallowly crenate-serrate, those of the upper cauline smaller, elliptic, oblong or oblanceolate, shallowly toothed or entire, all somewhat coarsely pubescent, especially beneath : heads in a terminal thyrsus, the upper clusters contiguous, the lower remote or disposed on spreading or ascending branches : involucres campanulate, 4-4.5 mm. high, 3-3.5 mm. thick; bracts obtuse, often green-tipped : ray-flowers with white ligules: achenes glabrous. fall.

In dry or rocky soil, New Brunswick to Ontario, Minnesota, Georgia and Missouri. Summer and

16. Solidago hispida Muhl. Similar to $S$. bicolor in habit, but usually less robust. Stems often densely hirsute and sometimes widely branched : leaf-blades more prominently toothed, the upper owes rarely entire, all usually copiously pubescent : heads in a terminal often branched thyrsus: involucres campanulate, $4.5-5 \mathrm{~mm}$. high, $4-4.5 \mathrm{~mm}$. thick; bracts obtuse, sometimes a little narrowed at the tip: ray-flowers with yellow ligules: achenes glabrous.

In dry soil, Nova Scotia to Ontario, Minnesota, Georgia and Arkansas. Summer and fall.

17. Solidago erécta Pursh. Stems $3-13 \mathrm{dm}$. tall, striate, glabrous or merely puberulent near the inflorescence, simple and wand-like or sometimes branched, often purple or purpletinged : leaf-blades various, those of the basal and lower cauline leaves spatulate to oblong 
or elliptic, 1-1.5 dm. long, narrowed into winged petiole-like bases, appressed serrate, glabrous or essentially so, those of the upper cauline smaller, linear-elliptic to oblong or oblanceolate, entire or shallowly toothed: heads in a terminal thyrsus, the lower clusters often remote and elongated : involucres campanulate, $4.5-5.5 \mathrm{~mm}$. long, 3-3.5 mm. thick; bracts obtuse, often conspicuously green-tipped: ray-flowers with bright yellow ligules: achenes glabrous.

In dry soil or open woods, New Jersey and Pennsylvania to Georgia and Alabama. Also reported from farther west. Summer and fall.

18. Solidago speciòsa Nutt. Stems $7-19 \mathrm{dm}$. tall, somewhat angled especially above, not copiously leafy, glabrous at least from near the inflorescence, often purple, usually simple : leaf-blades deep green, those of the basal and lower cauline leaves elliptic or oval, 1-2 dm. long, acute, shallowly toothed, those of the upper cauline leaves smaller, mainly elliptic to elliptic-lanceolate, all finely reticulate-veiny beneath : heads in a terminal, sometimes elongated or much branched thyrsus: involucres cylindric-campanulate, $5.5-6.5 \mathrm{~mm}$. high, 4-4.5 mm. thick; bracts obtuse, partially green or green-tipped : ray-flowers with bright yellow ligules: achenes glabrous. and fall.

In dry or rich soil, Nova Scotia to Minnesota, Nebraska, North Carolina and Arkansas. Summer

19. Solidago rigłdiúscula (T. \& G.) Porter. Similar to S. speciosa in habit, but smaller, and more stocky. Stems 4-12 dm. tall, striate-ridged, copiously leafy : leaf-blades thick, bright green, those of the basal and lower cauline leaves spatulate oblong or elliptic, those of the upper cauline oblong to linear-oblong, all entire : heads in a terminal cylindric thyrsus or on raceme-like lateral branches: involucres campanulate, 4-5 mm. high, about $3 \mathrm{~mm}$. thick: ray-flowers in yellow ligules: achenes glabrous.

In dry soil, Minnesota and South Dakota to Ohio, Nebraska and Texas. Summer and fall.

20. Solidago plumòsa Small. Stems solitary or tufted, $2-9 \mathrm{dm}$. tall, glabrous, striate, purple at least below : leaf-blades bright green, those of the basal and lower cauline leaves narrowly or linear-spatulate to linear, 1-2 dm. long, crenate-serrate near the apex or essentially entire, glabrous, narrowed into slender petiole-like bases, those of the upper cauline linear or nearly so, often $2-4 \mathrm{~mm}$. wide, entire, acuminate : heads in a terminal narrow, conic or oblong thyrsus, very showy : involucres broadly campanulate, $5.5-6.5 \mathrm{~mm}$. high, 4-4.5 mm. thick; bracts somewhat decurrent on the peduncle, thick, obtuse, keeled, the keel and tip green : achenes glabrous.

In sandy soil, falls and narrows of the Yadkin River, middle North Carolina. Summer and fall.

21. Solidago Pórteri Small. Stem 6-14 dm. tall, relatively stout, striate-angled, purplish, glabrous, usually simple : leaf-blades finely but rather copiously pubescent, those of the basal and lower cauline leaves spatulate to elliptic, narrowed into long petiole-like bases, 1-2 dm. long, those of the upper cauline mainly elliptic, all appressed serrate, somewhat acuminate : heads relatively few, in a rather open narrow thyrsus sometimes in open cymes terminating long peduncles : involucres broadly campanulate, $7 \mathrm{~mm}$. high, fully 5 $\mathrm{mm}$. thick ; bracts slightly decurrent on the peduncle, oblong, obtuse, green or green-tipped, broadly keeled : achenes glabrous.

In dry woods, middle Georgia. Summer and fall.

22. Solidago uliginòsa Nutt. Stems 4-12 dm. tall, glabrous, striate-angled, purple or purplish, usually simple: leaf-blades fleshy, those of the basal and lower cauline leaves spatulate to elliptic, entire or shallowly toothed, glabrous, narrowed into broad petiole-like bases, like those of the upper cauline much smaller, often entire, their bases, like those of the lower, clasping the stem : heads in a terminal narrow or rarely slightly dilated thyrsus, often crowded : involucres narrowly campanulate or cylindric-campanulate, $4.5-5.5 \mathrm{~mm}$. high, 3-3.5 mm. thick; bracts barely decurrent on the peduncle, obtuse, thickish, rounded on the back : achenes sparingly pubescent.

In swamps or on moist rocks, Newfoundland to Minnesota and North Carolina. Summer and fall.

23. Solidago dispérsa Small. Stems $8-11 \mathrm{dm}$. tall, relatively slender, striate-ridged, purplish, glabrous: leaf-blades sparingly pubescent, those of the basal and lower cauline leaves spatulate to elliptic-spatulate, $5-15 \mathrm{~cm}$. long, appressed serrate, narrowed into
petiole-like bases, those of the upper cauline much smaller, ellipticor elliptic-lanceolate, less prominently serrate or those near the inflorescence entire, all acute or those of the lower cauline leaves slightly acuminate : heads relatively few, in a lax terminal branching thyrsus, not at all crowded: involucres turbinate-campanulate, about $5 \mathrm{~mm}$. high, 3-3.5 mm. thick; bracts lax, narrowed to the tip but obtuse, flat: achenes pubescent.

In dry soil, Louisiana. Summer and fall.

24. Solidago Chrysópsis Small. Stems about $3 \mathrm{dm}$. tall, striate, glabrous, simple, very slender: leaf-blades various, glabrous, thick, those of the basal and lower cauline 
leaves linear, entire, the longer ones fully or nearly one-half as long as the stem, those of the very few cauline leaves narrowly linear, $1-8 \mathrm{~cm}$. long, all acute : heads relatively few, in a lax narrow terminal thyrsus, not at all crowded: involucres turbinate-campanulate, 4.5-5 mm. high, nearly $4 \mathrm{~mm}$. thick; bracts thin, rather lax, acute : achenes finely pubescent.

In sand, Pine Key, Florida.

25. Solidago vérna M. A. Curtis. Stems $6-9 \mathrm{dm}$. tall, striate-ridged, purple-tinged, softly puberulent, usually simple below the more or less widely branched inflorescence : leaf-blades puberulent like the stem, those of the basal and lower cauline leaves oval to ovate, 5-9 cm. long, acute, serrate or crenate-serrate, narrowed into slender petiole-like bases which equal or surpass them in length; blades of the upper cauline leaves smaller, slightly narrower and with short petiole-like bases: heads relatively few, in a lax or irregularly spreading terminal thyrsus, the branches often 'remote: involucres broadly campanulate, 4-4.5 mm. high, about $4 \mathrm{~mm}$. thick; bracts thinnish, acute, rather lax: achenes finely pubescent.

In open sandy pine woods, eastern North Carolina. Spring.

26. Solidago pubérula Nutt. Stems $3-9 \mathrm{dm}$. tall, more or less copiously puberulent, striate-ridged or somewhat angled, purple or purple-tinged, simple or copiously branched above: leaf-blades thinnish, puberulent, those of the basal and lower cauline leaves spatulate to oblanceolate, 1-2 dm. long, appressed serrate or crenate-serrate, narrowed into sometimes slender petiole-like bases, those of the upper cauline narrow, oblanceolate to elliptic or linear-elliptic, much smaller than the lower and less prominently toothed, or entire : heads numerous, in a terminal, branching or sometimes narrow thyrsus : involucres narrowly campanulate, $3.5-4 \mathrm{~mm}$. long, about $3 \mathrm{~mm}$. thick: bracts thinnish, acute, flat : achenes glabrous.

In dry or moist soil, New Brunswick to Florida and Mississippi. Summer and fall.

27. Solidago pulverulénta Nutt. Similar to $S$. puberula in habit but rather smaller, the foliage, especially the stem, cinereous-puberulent: leaf-blades thickish, those of the basal and lower cauline leaves ovate to oval or rarely nearly spatulate, less than $1 \mathrm{dm}$. long, obtuse or apiculate, shallowly few-toothed near the apex, cuneately narrowed into winged petiole-like bases, those of the upper cauline much reduced in size, commonly only 1 or 2 $\mathrm{cm}$. long: heads numerous, in a narrow or somewhat branched terminal thyrsus: involucres turbinate-campanulate, $4 \mathrm{~mm}$. high, $2.5 \mathrm{~mm}$. thick : bracts thinnish, acute, nearly flat: achenes glabrous.

In pine woods, North Carolina to Florida and Alabama. Summer and fall.

28. Solidago Lindheimeriàna Scheele. Stems 4-9 dm. tall, pale-puberulent, striateridged, copiously leafy, usually simple: leaf-blades firm at maturity, pale or silvery, scabrous with very short rigid hairs, those of the upper cauline leaves oblong to oblonglanceolate, $3-7 \mathrm{~cm}$. long, acute, entire, sometimes undulate, ciliate: heads numerous in a compact usually cylindric terminal thyrsus : involucres narrowly campanulate, $6 \mathrm{~mm}$. high, about $3.5 \mathrm{~mm}$. thick, the body green, the margins pale: achenes glabrous.

On rocky bluffs and in old stream beds, Texas. Fall.

29. Solidago strícta Ait. Stems 7-27 dm. tall, striate, glabrous, simple, strict: leaf-blades fleshy-leathery, glabrous, those of the basal and lower cauline spatulate to narrowly oblong, $5-15 \mathrm{~cm}$. long, obtuse, entire or rarely sparingly toothed, blades of the upper cauline leaves abruptly much smaller than the hasal, erect or appressed to the stem, mainly acute, entire, gradually merging into the bracts of the inflorescence: heads numerous, in a strict or narrow terminal thyrsus : involucres narrowly campanulate or nearly cylindriccampanulate, about $5 \mathrm{~mm}$. high, $3 \mathrm{~mm}$. thick; bracts thinnish in age, acute, rounded on the back : achenes glabrous.

In low pine lands, New Jersey to Florida and Louisiana. Also in Cuba. Summer and fall.

30. Solidago angustif òlia Ell. Stems 8-21 dm. tall, striate, glabrous, mainly simple: leaf-blades fleshy-leathery, glabrous, those of the basal and lower cauline leaves 1.5-3 dm. long, linear to linear-lanceolate, acute or acutish, narrowed into petiole-like bases, entire; blades of the upper cauline leaves abruptly much smaller than the lower, narrowly oblong to linear or linear-subulate near the inflorescence, acute, entire, erect or appressed to the stem : heads numerous, in a terminal one-sided pyramidal or elongated thyrsus conspicuously secund on the branches: involucres narrowly campanulate, $3.5-4 \mathrm{~mm}$. high, 3 mm. thick; bracts thickish, rather obtuse, rounded on the back or slightly keeled : achenes finely pubescent.

In salt marshes and on brackish shores, North Carolina to Florida and Texas. Summer and fall.

31. Solidago sempérvirens L. Stems 6-25 dm. tall, striate, mostly simple, usually purple or purple-tinged, glabrous below the inflorescence: leaf-blades fleshy-leathery, 
those of the basal and lower cauline leaves broadly linear, elliptic-linear or oblong-lanceolate, commonly $2-5 \mathrm{dm}$. long, acute or obtusish, entire, narrowed into long petiole-like bases, those of the upper cauline smaller and narrower, more gradually narrowed to the apex, often undulate: heads numerous, in a more or less branched terminal one-sided thyrsus, conspicuously secund on the branches : involucres campanulate, sometimes broadly so, $5 \mathrm{~mm}$. high, $3-3.5 \mathrm{~mm}$. thick; bracts thickish, acute or acutish, rounded on the back or slightly keeled : achenes pubescent.

In salt marshes, on beaches and along tidal rivers, New Brunswick to Florida and Mexico. Also in Bermuda. Summer and fall.

32. Solidago flavóvirens Chapm. Stems 6-19 dm. tall, striate, glabrous, simple : leaf-blades fleshy-leathery, glabrous, those of the basal and lower cauline leaves spatulate to elliptic-lanceolate, commonly 1-2 dm. long, shallowly toothed, narrowed into petiolelike bases, those of the upper cauline much reduced in size, oblong to elliptic, 1-2 cm. long, entire : heads numerous, in a more or less elongated one-sided terminal thyrsus, the branches spreading or recurved : involucres turbinate, $5-6 \mathrm{~mm}$. high, 3-3.5 mm. thick; bracts thickish, keeled, acutish : achenes finely pubescent.

In brackish marshes, Apalachicola, Florida. Summer and fall.

33. Solidago pátula Muhl. Stems 6-15 dm. tall, glabrous, at least below the inflorescence, purple or purple-tinged, more or less widely branched, the internodes strongly angled below the leaves: leaf-blades exceedingly rough above, glabrous beneath, those of the basal and lower cauline leaves spatulate to elliptic or oblong, 1-3 dm. long, serrate, narrowed into broad petiole-like bases, those of the upper cauline leaves smaller, oblanceolate to oblong or elliptic, finely serrate, all drying thin and very fragile : heads numerous, often crowded toward the ends of the more or less elongated branches of the inflorescence : involucres broadly campanulate, $4.5-5 \mathrm{~mm}$. high, about $3 \mathrm{~mm}$. high; bracts thinnish, obtuse : achenes pubescent.

In swamps and low woods, Maine and Ontario to Minnesota, Georgia and Texas. Summer and fall.

34. Solidago salicina Ell. Similar to $S$. patula in habit but more slender. Stem pale, scarcely if at all branched : leaf-blades narrower and smaller than those of $S$. patula, often conspicuously reduced in size on the upper part of the stem and there entire or nearly so: heads disposed like those of $S$. patula, but less densely so: involucres narrowly campanulate, $4 \mathrm{~mm}$. high, $2.5 \mathrm{~mm}$. thick; bracts obtuse : achenes minutely pubescent.

In low grounds, North Carolina to Florida and Louisiana. Summer and fall.

35. Solidago amplexicaùlis T. \& G. Stems $3-13 \mathrm{dm}$. tall, relatively slender, finely pubescent, often densely so above, striate, widely branched above : leaf-blades mainly ovate, usually narrower near the inflorescence, acute or short-acuminate, sharply and usually coarsely serrate, more or less pubescent on both sides, those of the lower cauline leaves with a flat petiole-like base which is dilated and toothed where it clasps the stem : heads numerous, secund along the rather slender and more or less elongated branches of the inflorescence: involucres narrowly turbinate, $3.5-4.5 \mathrm{~mm}$. long, $2-2.5 \mathrm{~mm}$. thick; bracts not tightly appressed, acute : achenes pubescent.

In dry woods, Tennessee to Arkansas, Florida and Texas. Summer and fall.

36. Solidago odòra Ait. Stems often tufted, 5-13 dm. tall, usually simple, minutely pubescent, sometimes only in lines, striate : leaf-blades anise-scented, glabrous, entire, those of the basal and lower cauline leaves linear-spatulate to linear-oblong, 4-11 $\mathrm{cm}$. long, acute, early disappearing, those of the upper cauline, lanceolate to linear-lanceolate or linear, acute or slightly acuminate, sessile: heads numerous in broad one-sided panicles, slender-peduncled, secund on the branches : involucres cylindric, $4.5-5.5 \mathrm{~mm}$. long, about $2 \mathrm{~mm}$. thick; bracts linear-lanceolate to narrowly linear, acute or acutish, keeled along the back : achenes pubescent.

In dry soil, Nova Scotia to New York, Florida, Arkansas and Texas. Summer and fall.

37. Solidago Chapmánii A. Gray. Similar to $S$. odora in habit, but stouter. Stems copiously pubescent, striate : leaf-blades slightly anise-scented,"glabrous, those of the basal and lower cauline leaves spatulate or oblong, $3-9 \mathrm{~cm}$. long, early disappearing, those of the upper cauline lanceolate to oblong-ovate, obtuse or acutish, sessile or partly clasping, those near the inflorescence or on the branches much reduced and relatively broad : heads numerous, usually in an ample one-sided panicle, slender-peduncled, secund on the branches : involucres cylindric, $4-4.5 \mathrm{~mm}$. high, about $2 \mathrm{~mm}$. thick; bracts mainly linear to linear-lanceolate, acute, somewhat keeled along the back : achenes pubescent.

In pine lands, Florida. Summer and fall.

38. Solidago brachyphýlla Chapm. Stems solitary or several together, $5-13 \mathrm{dm}$. tall, finely pubescent, striate-ridged: leaves rather numerous, more or less pubescent; 
spatulate, $7-11 \mathrm{~cm}$. long, obtuse or acutish, rather bluntly serrate, narrowed into petiolelike bases, those of the upper cauline sessile, oblong, oval, ovate or suborbicular, appressedserrate, or those high up on the stems entire, those on the branches ovate or suborbicular : heads numerous, in a usually widely spreading panicle, secund on the slender branches: involucres cylindric-campanulate, $4 \mathrm{~mm}$. high, $2 \mathrm{~mm}$. thick; bracts thick, rather angled on the back, the inner linear: achenes pubescent.

In dry soil, Georgia, Alabama and Florida. Summer and fall.

39. Solidago palléscens C. Mohr. Similar to S. brachyphylla in habit. Stems often widely branched : leaves almost glabrous except the ciliolate margins; blades thick, firm at maturity, those of the basal and lower cauline oblong-lanceolate to spatulate, shallowly serrate and narrowed into petiole-like bases, those of the upper cauline oblong-elliptic to oblong-ovate, indistinctly toothed, all glaucescent, those on the branches much reduced in size and cuneate to obovate-spatulate: heads rather numerous, secund on the widely spreading branches : involucres cylindric-campanulate, $4 \mathrm{~mm}$. high, $2 \mathrm{~mm}$. thick; bracts thick, rounded on the back, the inner oblong: achenes pubescent.

On dry hillsides, Alabama. Fall.

40. Solidago tortifòlia Ell. Stems relatively slender, 6-11 dm. tall, pale, roughpubescent: leaf-blades pubescent and roughish, more or less twisted and often reflexed, merely sessile, those of the basal and lower cauline leaves linear or linear-spatulate, 2-8 $\mathrm{cm}$. long, acute or sometimes acuminate, remotely and shallowly serrate above the middle, those of the upper cauline linear, linear-oblong or linear-lanceolate, often entire: heads numerous, in a one-sided usually wide panicle, slender-peduncled, secund on the branches : involucres cylindric, $4 \mathrm{~mm}$. high, $1.5 \mathrm{~mm}$. thick; bracts narrowly linear, obtuse or acutish, keeled along the back: achenes minutely pubescent.

In dry sandy soil, along or near the coast, Maryland to Florida and Texas. Fall.

41. Solidago fistulòsa Mill. Stems relatively stout, $9-21 \mathrm{dm}$. tall, purple or purpletinged, rough-pubescent : leaves numerous; blades rough-pubescent, those of the basal and lower cauline spatulate to oblong-spatulate, $8-12 \mathrm{~cm}$. long, somewhat truncate at the base, shallowly serrate, those of the upper cauline oblong to ovate-oblong, much smaller than those of the lower, mainly entire, acute or abruptly narrowed into a twisted tip, partly clasping by a broad base : heads numerous, in an open or dense one-sided panicle, shortpeduncled, secund on the spreading or recurving branches : involucres narrowly campanulate, $3.5-4 \mathrm{~mm}$. high, $2-2.5 \mathrm{~mm}$. thick ; bracts linear-lanceolate to narrowly linear, mainly acute, rounded or keeled on the back : achenes minutely pubescent.

In moist pine lands, New Jersey to Florida and Louisiana. Summer and fall.

42. Solídago Eàrlei Small. Stems about $9 \mathrm{dm}$. tall, striate or striate-angled, loosely pubescent, purple-tinged: leaves few ; blades loosely pubescent along the veins beneath and the edges, those of the lower cauline leaves spatulate to oblong-spatulate, $6-9 \mathrm{~cm}$. long, acute, remotely appressed-serrate, gradually narrowed to the base, those of the upper cauline elliptic to elliptic-lanceolate, acute or slightly acuminate, appressed-serrate, merely sessile : heads numerous, in a one-sided panicle, secund and erect on the ascending branches: involucres cylindric-campanulate, 4-4.5 mm. high, about $2 \mathrm{~mm}$. thick; bracts thickish, obtuse, keeled on the back, the inner linear : achenes minutely pubescent.

In dry soil, Alabama. Fall.

43. Solidago péndula Small. Stems 6-11 dm. tall, slightly striate, scabrous-pubescent with short rigid hairs: leaves relatively few ; blades very scabrous-pubescent, bright green, those of the cauline leaves elliptic-oblanceolate to elliptic and elliptic-lanceolate, 2-6 $\mathrm{cm}$. long, acute, sharply serrate, or quite reduced in size near the inflorescence and entire, sessile: heads numerous, secund on the branches of the panicle and more or less drooping: involucres cylindric-turbinate, $5-5.5 \mathrm{~mm}$. high, about $2 \mathrm{~mm}$. thick; bracts linear-lanceolate to linear, acute, decurrent on the peduncles : achenes minutely pubescent.

In dry soil, northwestern Arkansas. Summer and fall.

44. Solidago rugòsa Mill. Stems 3-22 dm. tall, simple or widely branched above, pubescent, striate: leaves rather numerous; blades relatively thin, somewhat pubescent, especially beneath, those of the basal and lower cauline leaves spatulate to oblong or elliptic, 1-2 dm. long, narrowed into petiole-like bases, those of the upper cauline elliptic, lanceolate or oblong-ovate, all acute or acuminate, sharply toothed, rugose-veiny at least in age : heads numerous, in a one-sided panicle, secund on the more or less elongated branches: involucres cylindric, or campanulate at maturity, about $4 \mathrm{~mm}$. high, $2 \mathrm{~mm}$. thick'; bracts linear or oblong-linear, acute or obtuse, rounded or somewhat keeled on the back : achenes pubescent.

In dry soil or low woods, Newfoundland to Ontario, Florida and Texas. Summer and fall. 
45. Solidago celtidif òlia Small. Similar to $S$. rugosa in habit. Stems often more purple and more prominently striate and rather less pubescent: leaves numerous; blades thick and firm, somewhat pubescent, those of the basal and lower cauline spatulate to ovalor oblong-spatulate, $6-13 \mathrm{~cm}$. long, those of upper cauline oval to ovate or rarely oblong, 2-6 cm. long, or shorter on the branches, crenate or appressed serrate-crenate, obtuse or acutish, rugose-veiny at least in age : heads numerous, secund on the more or less spreading branches of the panicle: involucres cylindric, or campanulate at maturity, $3-3.5 \mathrm{~mm}$. high, about $2 \mathrm{~mm}$. thick; bracts narrowly linear, obtuse or acutish, keeled on the back: achenes pubescent.

In sandy soil or dry woods, Alabama and Florida to Arkansas and Texas. Summer and fall.

46. Solidago ulmifòlia Muhl. Stems 5-12 dm. tall, striate or striate-angled, glabrous below the branches of the inflorescence: leaves relatively few ; blades thinnish, more or less pubescent, those of the basal and lower cauline spatulate, mainly 1-2 dm. long, narrowed into petiole-like bases, those of the upper cauline elliptic to oblong or elliptic- or oblong-lanceolate, acute or somewhat acuminate, more or less sharply serrate, conspicuously veined beneath : heads few or numerous, secund on the spreading or recurved branches of the inflorescence : involucres cylindric, not spirally twisted, $3-3.5 \mathrm{~mm}$. high, $2 \mathrm{~mm}$. thick; bracts mainly linear, obtuse or obtusish, slightly keeled along the back : achenes pubescent.

In dry soil and woods, Maine to Minnesota, Georgia, Kansas and Texas. Summer and fall.

47. Solidago microphýlla Engelm. Stems 8-13 dm. tall, striate-ridged, more or less branched, glabrous : leaves rather numerous, deep green; blades somewhat pubescent, often becoming thick and firm, those of the basal and lower cauline leaves spatulate to oblanceolate-spatulate, $6-11 \mathrm{~cm}$. Iong, rather shallowly serrate, narrowed into petiole-like bases, those of the upper cauline elliptic to oblong or oblong-ovate, acute or slightly acuminate, shallowly toothed or entire: heads numerous, often very numerous, secund on the more or less elongated curved slightly pubescent branches of the inflorescence : involucres cylindric-turbinate, $4-4.5 \mathrm{~mm}$. high, about $2 \mathrm{~mm}$. thick, not spirally twisted; bracts linear-lanceolate to narrowly linear, acute : achenes pubescent.

In dry soil, Kansas to Arkansas and Texas. Summer and fall.

48. Solidago Hélleri Small. Stems 7-16 dm. tall, striate-angled, purplish, glabrous : leaves rather numerous, deep green; blades slightly pubescent beneath, especially about the veins; those of the cauline leaves elliptic to oblong, $3-10 \mathrm{~cm}$. long, acute, serrate with often appressed teeth, rigidly ciliate : branches of the inflorescence bearing numerous narrow leaves mainly $1-1.5 \mathrm{~cm}$. long: heads numerous, secund on the elongated curved pubescent branches : involucres cylindric, spirally twisted, 6-7 mm. high, $2.5 \mathrm{~mm}$. thick ; bracts linear to linear-lanceolate, acute or acutish, keeled on the back: achenes pubescent.

In sandy woods, Arkansas and adjacent Texas. Summer and fall.

49. Solidago Ellióttii T. \& G. Stems $8-18 \mathrm{dm}$. tall, striate or striate-angled, simple or branched above: leaves numerous, often approximate; blades thickish, glabrous or merely puberulent on the veins beneath, those of the basal and lower cauline leaves spatulate, mostly 1-2 dm. long, shallowly serrate, those of the upper cauline elliptic to ellipticnumerous, secund and crowded on the approximate pubescent branches of the inflorescence : involucres campanulate, 4-5 mm. high, about $2 \mathrm{~mm}$. thick; bracts mainly linear, obtuse, somewhat keeled along the back: achenes finely pubescent. fall.

In swamps, mainly near the coast, New Hampshire and Massachusetts to Georgia. Summer and

50. Solidago Boòttii Hook. Stems 6-15 dm. tall, purple, striate-ridged, glabrous below the inflorescence, usually widely branched above: leaves relatively few ; blades thickish, glabrous, those of the basal and lower cauline spatulate to oblong- or ellipticspatulate, shallowly but sharply and sometimes finely serrate, narrowed into petiole-like bases, those of the upper cauline leaves gradually smaller, narrowly elliptic to ellipticlanceolate, acute or acuminate, shallowly toothed or undulate: heads rather numerous, secund but not crowded on the usually greatly elongated and widely spreading pubescent branches of the inflorescence : involucres broadly campanulate, $3.5-4 \mathrm{~mm}$. high, about 3 $\mathrm{mm}$. thick; bracts linear to oblong-linear, decidedly obtuse, angled on the back: achenes pubescent.

In woods, Maryland to Florida and Texas. Summer and fall.

51. Solidago strigòsa Small. Stems $6-13 \mathrm{dm}$. tall, finely pubescent, or essentially glabrous below the inflorescence, purple-tinged, striate-ridged : leaves few ; blades strigose, those of the basal and lower cauline ovate, oval or elliptic, 4-12 cm. long, rather coarsely serrate-crenate, or more serrate west of the Mississippi River, narrowed into slender petiolelike bases, those of the upper cauline much smaller, relatively narrower, ovate to elliptic 
or elliptic-lanceolate, shallowly toothed or essentially entire, acute or somewhat acuminate, often contracted into a narrow base : heads relatively few, secund on the usually short more or less spreading, pubescent branches of the panicle : involucres campanulate, $3.5-4 \mathrm{~mm}$. high, about $3 \mathrm{~mm}$. thick; bracts linear, somewhat narrowed to the apex but obtuse or acutish, keeled along the back: achenes pubescent.

In woods or sandy soil, Georgia to Louisiana and Arkansas. Summer and fall.

52. Solidago Yadkinénsis (Porter) Small. Stems 5-14 dm. tall, striate-angled, purple-tinged, glabrous below the inflorescence: leaves relatively few ; blades thickish, glabrous, those of the basal and lower cauline leaves elliptic, oblong, or oblong-ovate or rarely narrower and narrowed into long petiole-like bases, crenate-serrate, those of the upper cauline broader than those of $S$. Boottii, crenate or crenate-undulate, acute or acutish : heads not very numerous, secund and merely approximate on the short or somewhat elongated pubescent branches of the inflorescence: involucres campanulate, $6-7 \mathrm{~mm}$. high, about $4 \mathrm{~mm}$. thick; bracts oblong to almost linear, obtuse, somewhat keeled along the back : achenes pubescent.

In woods and low grounds, North Carolina to Florida. Summer and fail.

53. Solidago Luđoviciàna (A. Gray) Small. Resembling S. Yadkinensis in habit but more robust. Stem 8-16 dm. tall, striate-angled, purple-tinged, glabrous below the inflorescence: leaves relatively few, glabrous; blades thick, those of the basal and lower cauline leaves 1-2 dm. long, sharply toothed, those of the upper cauline elliptic to ovateelliptic, $2.5-7 \mathrm{~cm}$. long, acute, coarsely serrate, the teeth flaring or rarely appressed : heads rather numerous, secund and approximate-crowded on the recurved pubescent branches of the inflorescence ; involucres campanulate, 5-6 $\mathrm{mm}$. high, about $4 \mathrm{~mm}$. thick ; bracts linear, obtuse, keeled along the back: achenes pubescent.

In moist soil or woods, Arkansas and Louisiana. Summer and fall.

54. Solidago argùta Ait. Stems 3-12 dm. tall, glabrous below the inflorescence, purple or purple-tinged, somewhat angled: leaves relatively few; blades thin, glabrous, doubly and prominently serrate, those of the basal and lower cauline leaves spatulate to oblong, elliptic, oval or ovate, narrowed into petiole-like bases, those of the upper cauline mainly elliptic, sometimes narrowly so, more or less acuminate, more finely serrate than those of the lower leaves: heads often numerous, in an open or contracted one-sided panicle, secund on the more or less recurved branches : involucres campanulate, 3.5-4.5 $\mathrm{mm}$. high, $2-2.5 \mathrm{~mm}$. thick; bracts mainly linear-oblong, obtuse, slightly keeled on the back : achenes pubescent.

In woods, Maine and Ontario to North Carolina and Ohio. Summer and fall.

55. Solidago Vaseỳi Heller. Similar to S. arguta in habit. Leaves sometimes larger; blades rather thicker : involucres campanulate, $5-6 \mathrm{~mm}$. high, 3-4 mm. thick ; bracts mainly oblong, obtuse, somewhat keeled on the back : achenes finely pubescent.

On mountain slopes, Virginia and Kentucky to Georgia and Alabama. Summer and fall.

56. Solidago júncea Ait. Stems 4-15 dm. tall, glabrous, somewhat angled, commonly spirally-zigzag: leaves rather numerous; blades glabrous, except the more or less ciliate margin, those of the basal and lower canline leaves spatulate to oblong or elliptic, 1-3 dm. long, narrowed with petiole-like bases, shallow-serrate, those of the upper cauline mainly elliptic, or sometimes linear-lanceolate or nearly linear, finely serrate or merely undulate, often twisted, acute or acuminate: heads numerous, slender-peduncled and secund on the glabrous approximate, more or less curved branches of the panicle: involucres campanulate, 4-4.5 mm. high, $2.5-3 \mathrm{~mm}$. thick; bracts narrowly oblong or those of the inner series linear, obtuse, rounded on the back : achenes finely pubescent.

In dry or rocky soil, New Brunswick to Manitoba, Georgia and Missouri. Spring and summer.

57. Solidago gracíllima T. \& G. Stems 4-8 dm. tall, slender, glabrous, striateridged, simple or with few virgate branches: leaves few; blades thick, glabrous, those of the basal and lower cauline leaves spatulate, mostly less than $10 \mathrm{~cm}$. long, appressed-or crenate-serrate, mainly obtuse, narrowed into petiole-like bases, those of the upper cauline linear-spatulate or linear, shallowly toothed or entire, acute: heads rather numerous, secund and approximate on the glabrous distant spreading branches: involucres campanulate, $4.5 \mathrm{~mm}$. high, 2.5-3 mm. thick ; bracts oblong, sometimes rather narrowly so, broadly obtuse at the apex, rounded on the back: achenes pubescent.

In sandy soil, Georgia and Florida. Summer and fall.

58. Solidago delicátula Small. Stems $5-11 \mathrm{dm}$. tall, striate-ridged, glabrous, more or less branched above: leaves numerous; blades firm, glabrous except the scabrous margins, those of the upper cauline leaves linear-elliptic to narrowly elliptic, $3-7 \mathrm{~cm}$. long, sharply serrate, acuminate, lustrous but paler green beneath and less lustrous than above 
less distinctly 3-ribbed than the lower : heads numerous, slender-peduncled, secund on the slender glabrous recurving branches of the inflorescence: involucres narrowly cylindric, 4-4.5 mm. high, barely $2 \mathrm{~mm}$. thick; bracts linear-subulate, acute, rounded on the back: achenes finely pubescent.

In dry soil, northern Texas. Summer and fall.

59. Solidago austrìna Small. Stems $5-18 \mathrm{dm}$. tall, glabrous, green or purple-tinged, striate-ridged: leaves rather numerous; blades thick, glabrous, those of the basal and lower cauline leaves elongated, broadly linear to oblong, or sometimes slightly broadest above or below the middle, remotely and appressed-serrate or with flaring teeth, narrowed into petiole-like bases, those of the upper cauline much smaller, erect or appressed to the stem, mainly linear-lanceolate or oblong-lanceolate, entire or indistinctly toothed : heads numerous, secund on the short more or less recurved glabrous branches of the panicle: involucres canpanulate, fully $5 \mathrm{~mm}$. high, $3-3.5 \mathrm{~mm}$. thick; bracts linear-oblong to linear, obtuse, slightly keeled on the back: achenes pubescent.

In swamps, middle North Carolina to Georgia. Summer and fall.

60. Solidago neglécta T. \& G. Stems 5-12 dm. tall, glabrous, purple or purpletinged, striate-angled or angled above : leaves rather numerous; blades thickish, glabrous, those of the basal and lower cauline leaves often much elongated, oblong or oblong-elliptic to spatulate, 1-3 dm. long, serrate, narrowed into petiole-like bases, those of the upper cauline much smaller, oblong, oblong-elliptic or linear-lanceolate, ascending, entire or shallowly toothed, minutely veiny beneath: heads numerous, secund on the approximate glabrous, more or less curved branches of the one-sided panicle : involucres campanulate, fully $5 \mathrm{~mm}$. high, $3 \mathrm{~mm}$. thick; bracts oblong, sometimes almost linear-oblong, obtuse, rounded or slightly keeled on the back: achenes sparsely pubescent.

In swamps, New Brunswick to Wisconsin, North Carolina and Illinois. Summer and fall.

61. Solidago Gattíngeri Chapm. Stems $5-9 \mathrm{dm}$. tall, striate, rather strict, glabrous : leaves rather numerous; blades scabrous above, those of the basal and lower cauline narrowly spatulate, or oblong-elliptic, shallowly toothed or nearly entire, acute, narrowed into petiole-like bases, those of the upper cauline leaves abruptly much smaller than those of the lower, erect or appressed to the stem, linear or linear-oblanceolate or linear-lanceolate, entire, acute or acuminate: heads rather numerous, secund on the ascending glabrous branches of the panicle: involucres campanulate, $4 \mathrm{~mm}$. high, $3 \mathrm{~mm}$. thick; bracts oblong or linear-oblong, obtuse, rounded on the back : achenes glabrous.

In dry or rocky soil, Tennessee to Missouri and Texas. Summer and fall.

62. Solidago Missouriénsis Nutt. Stems $1.5-14 \mathrm{dm}$. tall, striate, glabrous : leaves rather numerous; blades thickish, glabrous or essentially so, except the ciliate margins, those of the basal and lower cauline leaves mainly spatulate, often narrowly so, serrate, those of the upper cauline mainly linear or linear-lanceolate, acute or slightly acuminate, sharp- or appressed-serrate, sometimes with clusters of small leaves in the axils, all 3ribbed but the upper ones less distinctly so: heads numerous, rather crowded, secund on the more or less curved glabrous branches of the panicle: involucres campanulate, 3.5-4 $\mathrm{mm}$. high, 2.5-3 mm. thick; bracts linear or oblong-linear, obtuse, rounded on the back achenes finely pubescent.

In dry soil, Manitoba to Minnesota, Tennessee, Texas and Washington. Summer and fall.

63. Solidago pinetòrum Small. Stems 4-11 dm. tall, angled, glabrous, purpletinged: leaves rather numerous; blades glabrous, smooth, those of the basal and lower cauline broadly linear to linear-spatulate, $1-2.5 \mathrm{dm}$. long, serrate, sometimes sharply so, acute or slightly acuminate, prominently 3-ribbed, narrowed into petiole-like bases, those of the upper cauline leaves linear or slightly broadest above the middle, mainly entire or undulate, often with clusters of smaller ones in the axils : heads numerous, secund on the spreading or recurved glabrous branches of the panicle : involucres cylindric-campanulate, about $4 \mathrm{~mm}$. long, $2.5 \mathrm{~mm}$. thick; bracts mainly linear, sometimes broadly so, obtuse, thickened along the back : achenes almost glabrous.

In pine woods, middle North Carolina. Summer and fall.

64. Soliaago serótina Ait. Stems 6-25 dm. tall, more or less striate, glabrous : leaves rather numerous; blades thinnish, glabrous or slightly pubescent, those of the upper cauline leaves elliptic, oblong or oblong-lanceolate, mostly $5-15 \mathrm{~cm}$. long, acuminate, serrate, prominently 3-ribbed: heads numerous, secund on the spreading or recurved pubescent branches of the panicle: involucres broadly campanulate, $4 \mathrm{~mm}$. high, about 3 mm. thick; bracts mainly linear, obtuse, rather thin : achenes minutely pubescent.

In moist soil, Newfoundland to British Columbia, Florida, Texas and Oregon. Summer and fall.

65. Solidago Shórtii T. \& G. Stems $5-13 \mathrm{dm}$. tall, striate or striate-ridged, finely puhescent: leaves rather numerous; blades thickish, prominently 3-ribbed, those of the 
lower cauline spatulate to oblong-oblanceolate, sharply serrate, those of the upper cauline linear-oblong to linear-lanceolate, acute or short-acuminate, entire or shallowly serrate : heads numerous, slender-pedicelled, secund on the recurved pubescent branches of the panicle: involucre turbinate-campanulate, $5-6 \mathrm{~mm}$. high, about $3.5 \mathrm{~mm}$. thick ; bracts linear or mainly so, acutish, keeled on the back : achenes finely pubescent.

On rocks, about the Falls of the Ohio River and in northwestern Arkansas. Summer.

66. Solidago Náshli Small. Stems 6-9 dm. tall, striate, finely pubescent, purpletinged : leaves relatively numerous ; blades thinnish, glabrous, except the ciliate margins, those of the lower cauline leaves linear-spatulate, $7-12 \mathrm{~cm}$. long, often rather sharply serrate, those of the upper cauline linear or narrowly linear-lanceolate, 4-11 cm. long, attenuate, shallowly serrate or entire, less prominently 3-ribbed than those of the lower leaves: heads numerous, secund on the recurved pubescent branches of the panicle: involucres turbinate-campanulate, about $4 \mathrm{~mm}$. high, 3-3.5 mm. thick; bracts mainly linear, rather obtuse, somewhat keeled on the back : achenes minutely pubescent.

In hammocks and low grounds, southern Georgia and Florida. Spring and summer.

67. Solidago Leavenwórthii T. \& G. Stems 5-12 dm. tall, striate, roughish pubescent: leaves numerous; blades thin, glabrous or nearly so, except the ciliate margins, those of the lower cauline leaves linear-spatulate or linear-oblanceolate, 7-14 cm. long, sharply serrate above the entire base, those of the upper cauline narrowly linear-lanceolate or nearly linear, slightly acuminate, serrate from about the middle to the apex, less prominently serrate toward the inflorescence : heads numerous, secund on the spreading or recurved pubescent branches of the one-sided panicle : involucres broadly campanulate, about $4 \mathrm{~mm}$. high, $2.5 \mathrm{~mm}$. thick; bracts mainly linear, rather obtuse, thin : achenes minntely pubescent.

In damp soil, South Carolina to Florida. Summer and fall.

68. Solidago rupéstris Raf. Stems $5-11 \mathrm{dm}$. tall, finely or minutely pubescent, striate, more or less branched above: leaves numerous; blades thin, glabrous, those of the basal and lower cauline narrow, slightly broadest above the middle manifestly serrate, those of the upper cauline narrowly linear-lanceolate to almost linear, 3-9 $\mathrm{cm}$. long, less strongly seriate than those of the lower, long-acuminate, all manifestly 3-ribbed: heads numerons, conspicuously small, secund on the spreading or recurved branches of the panicle : involucres narrowly or cylindric-campanulate, 2-3 mm. high, 1-1.5 mm. thick; bracts narrowly linear or linear-subulate, acute : achenes minutely pubescent. and fall.

On rocky banks of streams, Pennsylania to Indiana, District of Columbia and Tennessee. Summer

69. Solidago Canadénsis L. Stems 6-25 dm. tall, pubescent or sometimes rather puberulent, striate : leaves numerous; blades rather thin, scabrous, prominently 3-ribbed, more or less pubescent, especially beneath, those of the basal and lower cauline leaves narrow, broadest above the middle, sharply serrate, early perishing, those of the upper cauline oblong-lanceolate to lanceolate, acuminate, sharply serrate or nearly entire : heads numerous, secund on the pubescent branches of the one-sided panicle : involucres campanulate, 3-4 mm. long, 2-3 mm. thick ; bracts linear, acutish or sometimes obtuse. and fall.

In dry or moist soil, New Brunswick to the Northwest Territory, Florida and Arizona. Summer

70. Solidago nemoràlis Ait. Stems 1-9 dm. tall, finely pubescent or puberulent, often pale or greenish : leaves few or numerous; blades thick, firm in age, roughish pubescent, those of the basal and lower cauline mainly spatulate, manifestly appressed-serrate, acute or abruptly pointed, narrowed into usually relatively short petiole-like bases, those of the upper cauline leaves much smaller than those of the lower, less prominently toothed or entire : heads numerous, secund on the slender pubescent branches of the panicle : involucres campanulate, $3.5-4 \mathrm{~mm}$. long, about $1.5 \mathrm{~mm}$. thick: bracts mainly linear, flat, obtuse : achenes finely pubescent.

In dry or stony soil, Quebec to the Northwest Territory, Florida and Texas. Summer and fall.

71. Solidago longipetiolàta Mackenzie \& Bush. Similar to S. nemoralis in habit, the foliage often more gray. Stems rigid : leaves firm, the main ones usually with fascicles of smaller ones in their axils; blades of the basal and lower cauline with usually markedly elongated petiole-like bases : heads disposed as in S. nemoralis, but larger: involucres narrowly campanulate, $4.5-5.5 \mathrm{~mm}$. high, $2-2.5 \mathrm{~mm}$. thick; bracts oblong or linear-oblong, rounded on the back, obtuse : achenes pubescent.

In dry or sandy soil, Michigan to Wyoming and Texas. Summer and fall.

72. Solidago móllis Bartl. Stems $1-4 \mathrm{dm}$. tall, rigid, commonly tufted, finely graypubescent, sometimes roughish, usually simple: leaves approximate, pale like the stem; blades thick, firm, scabrous, usually prominently ribbed and veiny, those of the basal and 
lower cauline leaves spatulate, $5-11 \mathrm{~cm}$. long, often shallowly or undulated toothed, those of the upper cauline somewhat smaller, commonly entire, obtuse or acute, those near the inflorescence ovate, oval or obovate: heads numerous, approximate or crowded and secund on the pubescent branches of the compact panicle: involucres narrowly campanulate, about $5 \mathrm{~mm}$. high, $2-2.5 \mathrm{~mm}$. thick; bracts oblong or linear-oblong, thin, obtuse, barely keeled on the back : achenes pubescent.

In dry soil, the Northwest Territory to Minnesota, Texas and Mexico. Summer and fall.

73. Solidago rádula Nutt. Stems $3-11 \mathrm{dm}$. tall, rough-pubescent, nearly simple or branched : leaves not markedly approximate, very scabrous, often prominently ribbed and veiny, firm in age, those of the basal and lower cauline leaves spatulate or oblong-spatulate, 8-15 cm. long, serrate, those of the upper cauline gradually smaller, and less prominently toothed or those near the inflorescence entire, mainly oval or obovate : heads numerous, secund and approximate on the more or less recurved branches of the panicle: involucres narrowly campanulate, $4-5 \mathrm{~mm}$. high, $2-2.5 \mathrm{~mm}$. thick; bracts mainly linear, thick, rather obtuse : achenes finely pubescent.

In dry or stony soil, Illinois and Missouri to Louisiana and Texas. Also in middle North Carolina. Summer and fall.

74. Solidago Drummóndii T. \& G. Stems $3-9$ dm. tall, softly pubescent, mostly zigzag, sometimes branched: leaves not numerous; blades thinnish, sparingly pubescent, those of the basal and lower cauline early disappearing, those of the upper cauline oval to ovate or oblong-ovate, 3-8 cm. long, acute, or slightly acuminate, rather sharply serrate, narrowed in short petiole-like bases: heads rather numerous, secund and approximate on the often recurved pubescent branches of the one-sided panicle : involucres narrowly campanulate, about $3 \mathrm{~mm}$. high, $2 \mathrm{~mm}$. thick; bracts mainly oblong to linear-oblong, obtuse, somewhat keeled on the back : achenes pubescent.

In rocky soil, Illinois to Missouri and Louisiana. Fall.

\section{BRACHYCHAìtTA T. \& G.}

Perennial pubescent herbs, resembling species of Solidago. Leaves alternate: blades broad, toothed, those of the basal leaves often ample and long-petioled, those of the upper stem-leaves short-petioled or sessile. Heads numerous, radiate, thyrsoid. Involucres narrow, few-flowered : bracts leathery, the inner successively longer. Receptacle naked. Rayflowers pistillate. Disk-flowers perfect. Corollas yellow. Anthers obtuse at the base. Stigmas with lanceolate appendages. Achenes 8-10-ribbed. Pappus a row of scale-like bristles shorter than the achene. False Goldenrod.

1. Brachychaeta sphacelàta (Raf.) Britton. Stems 6-15 dm. tall, finely pubescent, narrowly or widely paniculate above : leaves various; blades thin, those of the basal and lower cauline leaves orbicular-ovate to ovate, 6-10 cm. long, coarsely toothed, truncate or subcordate at the base, long-petioled, those of the upper cauline leaves ovate to oval or elliptic, sessile or with short petiole-like bases, all slightly acuminate : heads numerous, in small clusters on one side of the branches : involucres $3.5-4 \mathrm{~mm}$. high, cylindric, the inner bracts obtuse.

In woods, Virginia to Indiana, Georgia and Alabama. Summer and fall.

\section{BÉLLIS L.}

Annual or perennial, caulescent or scapose herbs. Leaves alternate, sometimes all basal : blades commonly broadest above the middle, entire or toothed. Heads radiate, solitary or several, terminating branches. Involucres broadly campanulate or hemispheric : bracts narrow, herbaceous, in 1 or 2 series, nearly equal in length. Receptacle conic or convex, naked. Ray-flowers numerous, pistillate, with white, pink, purple or violet ligules. Disk-flowers perfect, with yellow corollas. Anthers obtuse at the base. Stigmas with triangular appendages. Achenes flattened, with nerves near the margins. Pappus wanting or obsolete. DAISY.

1. Bellis integrifòlia Michx. Annual or biennial, pubescent. Stems $0.5-4 \mathrm{dm}$. tall, sometimes much branched. Leaf-blades spatulate to oblong, 1-4 cm. long, entire, the lower ones petioled, the upper sessile : peduncles slender : involucral bracts oblong-lanceo-
late, $2.5-3 \mathrm{~mm}$. long, acuminate, scarious-margined : ray-flowers many, with pale purple or pale violet ligules $6-14 \mathrm{~mm}$. long.

In low grounds, Kentucky and Arkansas, south to Tennessee and Texas. Spring and summer. 


\section{APHANÓSTEPHUS DC.}

Annual or biennial, or probably perennial caulescent herbs, with pubescent foliage. Leaves alternate: blades entire, toothed or pinnately lobed. Heads radiate. Involucres many-flowered, hemispheric: bracts narrow, in few series, scarious-margined. Receptacle convex or conic. Ray-flowers pistillate, with white violet or purple ligules. Disk-flowers perfect, yellow. Anthers obtuse at the base. Stigmas with obtuse appendages. Achenes many-ribbed. Pappus an entire toothed or ciliate crown.

Pappus a toothed or laciniate crown: base of the corolla-tube hard and thick. Pappus a short ciliate crown: base of the corolla-tube barely thickened.

Stems softly pubescent: inner achenes prominently ribbed.

Stems hispidulous : inner achenes obscurely if at all ribbed.

1. A. skirrobasis.

2. A. humilis.

3. A. ramosissimus.

1. Aphanostephus skirróbasis (DC.) Trelease. Foliage cinereous-pubescent. Stems more or less diffiusely branched at the base, 1-4 dm. long : leaf-blades spatulate, oblong or linear, 1.5-6 cm. long, the lower ones sharply toothed or incised, the upper entire : heads showy, long-peduncled : involucres $5-6 \mathrm{~mm}$. high, hemispheric ; bracts linear or narrowly linear-lanceolate, the outer ones minutely pubescent : ray-flowers many; ligules linear: achenes pubescent with a pappus of several lobes or teeth.

On plains, Kansas to Texas and in Florida. Spring and summer.

2. Aphanostephus hùmilis (Benth.) A. Gray. Foliage softly pubescent. Stems branched at the base ; branches 1-3 dm. long, often decumbent : leaf-blades pinnatifid, or entire above, 1-6 cm. long: i heads slender-peduncled: involucres hemispheric, 3-4 mm. high ; bracts linear, acute, ribbed, minutely pubescent : ligules of the ray-flowers 4-8 mm. long, linear-oblanceolate.

In dry ground, Texas and adjacent Mexico.

3. Aphanostephus ramosíssimus DC. Foliage hispidulous. Stems often diffusely branched at maturity, 1-3 dm. long; leaf-blades various, those of the basal or lower stemleaves 5-10 cm. long, spatulate, pinnatifid or incised ; those of the upper leaves linear, mostly entire, sessile: heads long-peduncled: involucres hemispheric, 4-5 mm. high; bracts linear or narrowly linear-lanceolate, the outer often pubescent : ligules of the rayflowers 6-10 $\mathrm{mm}$. long, linear-spatulate.

On sandy or rocky prairies, Texas and adjacent Mexico.

\section{DICHAETÓPHORA A. Gray.}

Annual relatively low caulescent or scapose herbs. Leaves alternate, sometimes mainly basal : blades broadened upward, entire. Heads radiate, sometimes solitary. Involucres many-flowered : bracts in about 1 series. Receptacle a little convex, pitted. Ray-flowers numerous, pistillate, fruit producing, with white or pink ligules. Disk-flowers perfect. Anthers entire and obtuse at the base. Stigmas flattened, with triangular-lanceolate appendages. Achenes flattened, broadened upward, pubescent. Pappus of 2 spreading awns and several minute scales, usually hidden by the pubescence of the achene.

1. Dichaetophora campéstris (T. \& G.) A. Gray. Plant finely hirsute, at first acaulescent, with a single scape, later somewhat branched, each branch terminating in a peduncle 3-6 $\mathrm{cm}$. long which bears a single head : leaf-blades spatulate to oblong-spatulate, 1-3 cm. long, entire : involucre $3-4 \mathrm{~mm}$. high; bracts linear, slightly acuminate, sparingly pubescent : ray-flowers $10-20$, with white or pink ligules $5-8 \mathrm{~mm}$. long : achenes cuneate, $1.5 \mathrm{~mm}$. long, margined, ciliate.

In dry soil, southern Texas and adjacent Mexico. Spring to fall.

\section{BOLTÒNIA L'Her.}

Perennial large caulescent herbs, with glabrous foliage. Leaves alternate: blades narrow, entire, sessile and sometimes decurrent. Heads often numerous, radiate. Involucres broadly campanulate or hemispheric, many-flowered : bracts in few series. Receptacle convex or conic, pitted. Ray-flowers often numerous, pistillate. Disk-flowers perfect. Anthers obtuse and entire at the base. Stigmas flattened, with relatively short appendages. Achenes flattened, broadest above the middle, with winged or thickened margins. Pappus a series of short scales, usually accompanied by $2-4$ slender bristles.

a. Leaf-blades merely sessile. 
Bracts of the involucre broadest below the middle, acute.

Bracts of the involucre broadest above the middle, obtuse or mucronulate.

2. B. asteroides.

b. Leaf-blades decurrent on the stem as broad wings.

3. B. latisquama.

4. B. decurrens.

1. Boltonia diffùsa Ell. Stems slender, 1-2 m. tall, much-branched: leaf-blades linear to linear-subulate, or broader near the base of the stem, $2.5-8 \mathrm{~cm}$. long, acute : involucres $2-2.5 \mathrm{~mm}$. high; bracts numerous, linear or nearly so, acute: disk about $4 \mathrm{~mm}$. broad : ray-flowers numerous, with white ligules : achenes barely $1.5 \mathrm{~mm}$. long.

In low grounds, South Carolina and Illinois, south to Florida and Texas. Fall.

2. Boltonia asteroìdes L'Her. Stems 1-2 m. tall, branching above : leaf-blades linear, oblong or slightly broadest above the middle, $3-12 \mathrm{~cm}$. long, acute, sessile : involucres $2.5-3 \mathrm{~mm}$. high; bracts acute, broadest below the middle : disk $6-12 \mathrm{~mm}$. broad : ray-flowers numerous, with white or pale ligules : achenes fully $1.5 \mathrm{~mm}$. long.

In low grounds and along streams, New Jersey to Minnesota, south to Florida, Louisiana and Nebraska. Summer and fall.

3. Boltonia latisquàma A. Gray. Stems much branched, 1-2 m. tall : leaf-blades linear or nearly so, $2-10 \mathrm{~cm}$. long, acute, sessile : involucres about $4 \mathrm{~mm}$. high ; bracts oblong to rhomboidal above the middle, obtuse or mucronate : ray-flowers numerous, with violet-blue ligules: achenes obovate, $1.5 \mathrm{~mm}$. long: pappus-bristles nearly as long as the achene.

In river valleys, Minnesota to Kansas and Arkansas. Summer and fall.

4. Boltonia decúrrens (T. \& G.) Wood. Similar to B. latisquama in habit, but stouter and taller. Stem more or less branched, conspicuously winged by the decurrent leaf-blades, glabrous or nearly so : leaf-blades spatulate to narrowly oblong or linear-oblong, 5-15 cm. long, obtuse or acutish, undulate, sessile and decurrent: involucres 3-3.5 mm. high ; bracts linear-spatulate to linear, acute or acuminate : ray-flowers numerous, with violet or pale ligules: achenes cuneate, about $2 \mathrm{~mm}$. long: pappus-bristles somewhat shorter than the achene.

In low grounds, Illinois to Missouri and Arkansas. Summer and fall.

\section{KEERIIA A. Gray.}

Annual or perennial caulescent pubescent herbs. Leaves alternate : blades broadest above the middle or oblong to linear, entire or serrulate. Heads radiate, few, slenderpeduncled. Involucres narrow, few-flowered : bracts thin, scarious-margined, in few series, pointed. Receptacle flat. Ray-flowers 5-15, pistillate. Disk-flowers several, perfect. Stigmas with short or long appendages. Achenes flattened, 2-3-nerved, those of the disk mostly imperfect. Pappus a crown-like border sometimes evanescent.

Annual: foliage minutely and somewhat scabro-pubescent : leaf-blades ciliate. Perennial : foliage hispid : leaf-blades spinulose-serrulate.

1. K. bellidifolia.

2. K. effusa.

1. Keerlia bellidifòlia Gray \& Engelm. Annual, minutely pubescent. Stems 1-2 dm. tall, sometimes diffusely branched: leaf-blades spatulate below to linear above, 1-3 $\mathrm{cm}$. long, acute or acuminate, entire : involucres narrowly campanulate, $2.5-3 \mathrm{~mm}$. high ; bracts oblong-lanceolate to linear-oblong, cuspidate, scarious-margined : ray-flowers 6-15; ligules blue : achenes oblong-clavate, $2 \mathrm{~mm}$. long, slightly flattened.

In moist soil, Texas. Spring and summer.

2. Keerlia eff ùsa A. Gray. Perennial, hispid. Stems $3-7 \mathrm{dm}$. tall, simple below, effusely branched above, the branches usually filiform: leaf-blades oblong to ovate, $1-3 \mathrm{~cm}$. long, acute or cuspidate, revolute, sessile and partly clasping: involucres oblong, $4 \mathrm{~mm}$. high; bracts oblong-ovate to narrowly oblong, cuspidate, scarious-margined : ray-flowers 4-5; ligules white, narrowly oblong : achenes obovoid, 1-1.5 mm. long, flattish, the margins with 1 or 2 nerves.

On hillsides, Texas. Spring and summer.

\section{THURÒvIA Rose.}

Low annual herbs, with spreading branches, and glabrous. Leaves alternate : blades narrow, inconspicuous. Heads mostly solitary and sessile in the axils of the leaves, discoid, few-flowered. Involucres somewhat distended in age : bracts in 2 series, usually 8 , those of the inner series fewer than those of the outer. Flowers perfect, fruit producing. Corollas funnelform at the throat, 5-lobed. Filaments not appendaged. Stigmas short, with slender appendages. Achenes turbinate, silky, nerveless. Pappus of about 10 acuminate scales. 
1. Thurovia trifl òra Rose. Stems $2-4.5 \mathrm{dm}$. tall, slender, with straggling or bushy branches: leaves few ; blades linear, 6-18 $\mathrm{mm}$. long, acute, entire: involucres about 3 $\mathrm{mm}$. high, 3-flowered; bracts few, the outer with green linear acute tips: corolla-lobes spreading: achenes turbinate, $1 \mathrm{~mm}$. long: pappus-scales $2 \mathrm{~mm}$. long, the base oblong, the tips slender, shorter than the bases, sometimes barbed.

On prairies, Texas. Fall.

\section{ChaftopápPa DC.}

Annual or biennial very slender caulescent herbs. Leaves alternate : blades entire, ciliate or spinulose-serrulate. Heads small, radiate. Involucres narrow : bracts in few series, acute or acuminate. Receptacle flat, naked. Ray-flowers in 1 row, pistillate. Disk-flowers perfect or the central staminate. Anthers obtuse and entire at the base. Stigmas with narrow obtuse appendages. Achenes nearly terete, 5-ribbed, sometimes narrowed at both ends. Pappus of 5 or more scales alternating with 5 scabrous bristles.

Involucres $4 \mathrm{~mm}$. high : achenes pubescent : pappus-scales narrowly oblong. Involucres $6 \mathrm{~mm}$. high : achenes glabrous or nearly so; pappus-scales cuneate.

1. C. asteroides.

2. C. Parryi.

1. Chaetopappa asteroìdes (Nutt. ) DC. Stems slender, $0.5-3 \mathrm{dm}$. tall, minutely pubescent, more or less diffusely branched. Leaf-blades spatulate to linear, $0.5-2 \mathrm{~cm}$. long, the lower ones slender-petioled : involucres $4 \mathrm{~mm}$. high, oblong or oblong-turbinate ; bracts linear, glabrous, scarious-margined, spreading in age : ray-flowers $5-12$; ligules narrowly oblong, 2-3 $\mathrm{mm}$. long: achenes $1.5 \mathrm{~mm}$. long: pappus-scales oblong, hyaline.

In dry soil. Missouri to Texas. Spring and summer.-A form without pappus-awns in any flowers and the pappus-scales crown-like, is C. asteroides imbérbis A. Gray. Eastern Texas.

2. Chaetopappa Párryi A. Gray. Stems 1-2 dm. tall, nearly glabrous, corymbose above, the branches wiry, leaf-blades somewhat leathery, spatulate to linear-oblanceolate. 1-2 cm. long, acutish or apiculate, ciliate : involucres cylindric, $6 \mathrm{~mm}$. high ; bracts linearlanceolate to linear, acute, with broad scarious margins : ray-flowers $6-7$, with oblong ligules : achenes $2.5 \mathrm{~mm}$. long, glabrous or nearly so: pappus-scales cuneate, 4-5.

In dry soil, Texas. Spring and summer.

\section{DISTÀsIS DC.}

Annual relatively low caulescent herbs, with pubescent foliage. Leaves alternate : blades entire or sparingly toothed. Heads small, radiate, peduncled. Involucres hemispheric or campanulate, many-flowered : bracts scarious-margined, in few series. Receptacle flat, slightly pittıd. Ray-flowers pistillate, in about 1 series. Disk-flowers perfect, fruitproducing. Anthers obtuse and entire at the base. Style-branches flattened, with narrow appendages. Achenes flattened, with slightly margined nerves. Pappus a series of hyaline scales alternating with as many bristles.

1. Distasis modésta DC. Stems commonly branched at the base, $0.5-3 \mathrm{dm}$. tall, hirsute and strigillose. Leaf-blades spatulate to linear, $0.5-1.5 \mathrm{~cm}$. long, acute or acutish : involucres $3 \mathrm{~mm}$. high, hemispheric; bracts linear, acute or acuminate, often sparingly pubescent: achenes $2 \mathrm{~mm}$. long, pubescent : pappus-scales 5 , truncate or eroded at the apex, alternating with 5 bristles.

In dry soil, Texas and adjacent Mexico.

\section{TOWNSÉNDIA Hook.}

Tufted scapose or caulescent herbs, often with caudex-like stems or branches. Leaves alternate: blades narrow, often crowded and broadest above the middle, entire. Heads relatively large, showy, sessile or peduncled. Involucres campanulate to hemispheric : bracts herbaceous, in several series. Receptacle nearly flat. Ray-flowers pistillate, with white or pink ligules. Disk-flowers mostly perfect. Anthers obtuse and entire at the base. Stigmas flattened, each with a lanceolate or narrow appendaged. Achenes various, those of the ray mostly 3-angled, those of the disk flattened. Pappus a single series of firm bristles or scales.

1. Townsendia Wilcoxiàna Wood. Depressed, tufted. Leaves several or numerous, crowded on the short caudex-like stems ; blades linear-spatulate, $2-4.5 \mathrm{~cm}$. long, sparingly pubescent : heads sessile: involucres about $1 \mathrm{~cm}$. high; bracts lanceolate to linearlanceolate, the inner 11-13 mm. long, like the outer ciliate and of ten magenta-tipped : rayflowers numerous, with narrow ligules $1-1.5 \mathrm{~cm}$. long.

In dry soil, Colorado to the Indian Territory and Arizona. Spring and summer. 


\section{PSILÁCTIS A. Gray.}

Annual caulescent herbs, glandular, pubescent or glabrate. Leaves alternate, various, those of the basal or lower stem-leaves with pinnatifid blades; those of the upper leaves often entire. Heads radiate. Involucres hemispheric : bracts in 2-3 series, wholly herbaceous or with herbaceous tips. Receptacle flattish. Ray-flowers pistillate in a single series. Disk-flowers more numerous that those of the ray, perfect. Stigmas with puberulent or hispidulous appendages. Achenes narrow, pubescent, those of the ray sometimes with a mere ring representing the pappus, those of the disk with a single series of short. hair-like bristles.

1. Psilactis asteroìdes A. Gray. Stems 3-10 dm. tall, scabrous-puberulent, or glabrate, branching above : leaf-blades 1-7 $\mathrm{cm}$. long, narrowly spatulate and toothed at the base of the stem, oblong or linear and entire above : involucres $3 \mathrm{~mm}$. high, becoming rather flat at maturity; bracts oblong to linear: ray-flowers with linear ligules 4-5 mm. long: achenes $2 \mathrm{~mm}$. long, minutely pubescent.

In dry soil, Texas to Arizona and adjacent Mexico.

\section{SERICOCÁRPUS Nees.}

Perennial caulescent herbs. Leaves alternate : blades various, entire or toothed. Heads radiate, in corymbs. Involucres ovoid to campanulate or cylindric, several-flowered : bracts leathery, in few series, with erect or spreading tips. Receptacle naked, pitted. Ray-flowers pistillate, with white or pink ligules. Disk-flowers chiefly perfect, with yellowish or purplish corollas. Anthers entire and obtuse at the base. Style-branches with narrow appendages. Achenes flattened, 1-nerved on each side. Pappus of numerous scabrous bristles, the inner ones longer.

Leaf-blades entire.

Foliage glabrous or nearly so.

Foliage manifestly pubescent.

Bracts of the involucres obtuse, firm : peduncles rigid. stout.

Bracts of the involucres acute, lax: peduncles weak, slender.

1. S. linifolius.

2. S. bifoliatus.

3. S. acutisquamosus. Leaf-blades toothed.

4. S. asteroides.

1. Sericocarpus linifolius (L.) B.S.P. Stems often tufted, $2-7 \mathrm{dm}$. tall, glabrous or nearly so. Leaf-blades spatulate or linear-spatulate at the base of the stem to linear above, $2-6 \mathrm{~cm}$. long, entire, sessile or short-petioled : involucres narrowly cylindric, 5-7 $\mathrm{mm}$. high ; bracts ovate-oblong, to linear-oblong, obtuse, often with erose green tips : rayflowers with linear involute ligules: pappus whitish, copious. [S. solidagineus Nees.]

In sandy soil, Canada, south to Georgia, Ohio and Louisiana. Summer and fall.

2. Sericocarpus bifoliàtus (Walt.) Porter. Stems cinereous-pubescent, $3-7 \mathrm{dm}$. tall, sometimes branched below. Leaf-blades spatulate to obovate, 1-3 cm. long, obtuse or apiculate, vertical, sessile : involucres about $6 \mathrm{~mm}$. high, cylindric ; bracts ovate to linearoblong, obtuse, sometimes minutely pubescent: pappus white, copious. [S. tortifolius Nees.]

In dry sandy pine lands, Virgina to Florida and Louisiana. Summer and fall.

3. Sericocarpus acutisquamòsus (Nash) Small. Similar to S. bifoliatus in habit, but less robust. Leaf-blades oblong-spatulate, 1-3.5 cm. long, rather weak, acutish or apiculate, entire, scabrous, sessile : involucres narrowly cylindric or cylindric-turbinate, $6.7 \mathrm{~mm}$. high ; bracts narrowly linear-lanceolate, acute, the outer ones rather densely pubescent : pappus white, copious. [S. bifoliatus acutisquamosus Nash.]

In pine lands, peninsular Florida. Summer.

4. Sericocarpus asteroìdes (L.) B.S.P. Stems $3-8 \mathrm{dm}$. tall, glabrous at least to the sometimes viscid-pubescent peduncles. Leaf-blades 4-15 cm. long, toothed, those of the basal and lower stem-leaves spatulate, oblong or oval, those of the upper stemleaves broadest at or above the middle or sometimes lanceolate : involucres 6-9 mm. high, cylindric or oblong-cylindric ; bracts ovate to linear, with appressed or spreading green tips : ray-flowers with whitish ligules 6-8 mm. long. [S. conyzoides Nees.]

In rocky woods, Maine to Ohio, south to Florida to Alabama. Summer.

\section{1. ÁSTER L. ${ }^{1}$}

Perennial branching glabrous or pubescent herbs, various in habit, but seldom annual, unbranched, shrubby or spinescent. Leaves alternate : blades broad or narrow, often en-

${ }^{1}$ Contributed by Professor Edward S. Burgess. 
larged and cordate at the base, either entire or toothed. Rootstock usually horizontal (sometimes short and erect) and bearing for several years a subterminal tuft of leaves (radicals); these are often smaller, often larger, than the usually dissimilarly shaped leaves (basal leaves) which finally encircle the base of the rising stem. Lower, middle and upper cauline leaves often gradually transitional to each other in form, often of dissimilar types. At the axils of the branches the subtending leaves (axiles) are gradually reduced from the upper leaf-form of the stem; but on the branches themselves the leaves (rameals or bracteals) are usually profoundly modified or of a new type. Heads with both tubular and radiate flowers, either corymbed, racemed or panicled and borne on erect, spreading or secund ultimate branchlets (pedicel), rarely solitary. Involucre hemispheric, campanulate, cylindric or turbinate; its components (bracts) imbricated in several series; the outer usually smaller or shorter than the inner, and somewhat herbaceous or otherwise much modified at or toward the apex (this modified portion constituting the green tip) which is itself either erect, spreading or squarrose. Receptacle flat or convex, alveolate and often delicately fimbrillate. Ray-flowers pistillate, with white, pink, purple, blue or violet ligules (rays). Disk-flowers perfect, consisting of a tubular base (the tube), swollen above into the shape of an erect bell, urn or funnel (the bell), bearing a short fivelobed spreading or erect border: disks typically yellow, usually changing to red, brown or purple. Anthers obtuse and entire at the base. Stigmas flattened, their appendages subulate, lanceolate or ovate, acute. Achenes more or less flattened and nerved or ribbed, either glabrous or pubescent. Pappus-bristles usually numerous, slender in one series or rarely in two series, the tips of the inner ones sometimes thickened. Aster.

Basal and lower cauline leaves with relatively narrow blades, etc. Species Nos. 41-102.

Basal and lower cauline leaves with relatively broad blades, mainly of an ovate-cordate type and longpetioled; upper cauline leaves essentially similar, but with shorter petioles or even sessile blades.

Species Nos. 1-40.

Upper cauline leaves sessile and cordate-clasping, etc. Diversifolial Asters, Nos. 29-40.

Upper cauline leaves not cordate-clasping : lower petioles not dilated-clasping.

Rays white or occasionally roseate: leaves polymorphous: no glandular hair present. White Biotian Asters, Nos. 1-8.

Predominant leaves long-acuminate, their teeth very sharp: inflorescence broadly corymbose. Predominant leaves incurved-acuminate, their teeth curving-backed, very salient. Predominant leaves ovate-lanceolate: upper axile leaves short or not greatly prolonged.

Predominant leaves more oblong, larger, darker; upper axiles or some of them greatly prolonged.

Predominant leaves straight-acuminate, their teeth straight-backed. Predominant leaves not long-acuminate.

Inflorescence-clusters convex.

Sinus (of cordated leaves) deep, enlarged : leaves oblong-lanceolate, curvescent-serrate: disk often crimson.

Sinus usually absent: leaves ovate-lanceolate, slit-serrate: disk often chestnut-color.

Inflorescence narrow, irregular or scanty.

Bracts very broad and short, scale-like, chiefly green.

Bracts narrow-linear, green tipped only. Sinus broad, enlarged: leaves chiefly oblong-acuminate. Sinus sharp: leaves ovate-acute.

Rays violet, purple or blue.

Coarse radical leaves present, larger than the cauline : plants (except

No. 13) glandular. Violet Biotian Asters.

Plant not very rough: leaves not very thick: glandular ,hairs minute-tipped.

Lower leaves serrate; sinus deep, narrow.

Lower leaves coarsely dentate; sinus shallow, broad.

Plant extremely rough: leaves very thick: glands broadly capitate. Sinus strongly developed : bracts neither squarrose nor slender.

Sinus usually absent : bracts squarrose. Bracts narrow, acute.

Bracts broad, obtuse.

Radical leaves not large, smaller than the cauline: plants not glandu-

lar. Heterophyllous Asters, Nos. 14-28.

Bracts widely squarrose, spreading or recurved.

Bracts erect or appressed.

Leaves entire or chiefly so, thick or firm.

Involucre campanulate: bracts mainly linear, thin: leatblades dull and scabrous above.

Involucre cylindric-campanulate : bracts mainly linear-subulate, rigid: leaf-blades lustrous and smooth above.

Leaves serrate or otherwise toothed. at least the lower ones.

A. Leaves not rough, or not rough on both sides, membranous. Bracts linear-obtuse or obtusish.

Leaves smooth, firm: chief petioles winged: inflorescence narrow-racemose.

1. A. divaricatıs.

2. A. tenebrosus.

3. A. stilettiformis.
4. A. excavatus.
5. A. castaneus.
6. A. chlorolepis.
7. A. Boykinii.
8. A. flexilis.

9. A. multiformis.

10. A. riciniatus.

11. A. macrophyllus.

12. A. commixtus.

13. A. mirabilis.

14. A. anomalus.

15. A. Shortii.

16. A. Camptosorus.

17. A. Lowricanue. 
Leaves rough, thin : chief petioles not winged : inflorescence broad-panicled.

Bracts linear-acute or subulate.

Pubescence downy or absent.

Tall : chief leaves ovate-lanceolate, thin : sinus open : heads compound-racemed.

Low: chief leaves falcate-lanceolate: sinus obsolescent: heads thyrsoid.

Cinereous or canescent pubescence present.

Plants tomentulose, very rough above: sinus broad. Leaves cordate-ovate, crenate in the middle, thinnish.

Leaves prolonged, sharp-toothed, thick.

Plants but lightly pubescent.

Leaves oval-acute, thinnish: sinus deep and narrow.

Leaves long-triangular, thick : sinus little developed.

B. Leaves rough on both sides, of a spongy, crumbling texture. Chief leaves moderately broad: rays blue.

Chief leaves oblong-lanceolate, shallow-serrate, short: pedicels bracteate.

Chief leaves elliptic-lanceolate, crenate: pedicels conspicuous, nude.

Chief leaves grass-like : branches very diffusely decompound. Radical leaf-blades chiefly with truncate bases.

Radical leaf-blades chiefly with taper bases.

No dilated-clasping petioles. Biotian and Heterophyllous Asters, Nos. 1-28.

Some petioles dilated, leaf-like and clasping around the stem, tapering narrowly toward the blade. Diversifolial Asters.

Polymorphous leaf-forms present, no one type strongly predominant.

Leaves not delicate, pubescent, rough when dry: inflorescence broad, divergently compound.

Leaves delicate, firm, rough, with little hair: inflorescence narrowly racemose.

Some predominant leaf-form present.

Predominant leaves broad, not greatly elongated.

Predominant leaves tomentulose beneath. ovate-oblong, thick and rough, diminutive.

Predominant leaves sparse-pubescent beneath, petioled, short-cordate, thinnish.

Predominant leaves elongated.

Predominant leaves triangular-attenuate.

Slender plants : leaves chiefly petioled and clasping.

Robust when fully developed : leaves chiefly sessile.

Leaf-bases narrow : axils usually foliose.

Leaf-bases broad: leaves very rough.

Predominant leaves not triangular.

Predominant leaves linear-oblong with straight sides.

Leaves soft, thinnish: many long strap-like petioles : inflorescence racemose.

Leaves very rough, thick, usually sessile : inflorescence decompound.

Plant not glandular: leaves strap-shaped or thong-like.

Plant somewhat glandular : leaves grass-like, narrower.

Predominant leaves ovate-oblong to elongated-lanceolate.

Leaves firm, crisp: stem bearing stalked glands : inflorescence irregular, narrow, often clavate.

Leaves thinnish: plant without glands: inflorescence somewhat thyrsoid.

Basal and lower cauline leaves with relatively broad blades, ovate-cordate, long-petioled, etc. Biotian, Heterophyllous and Diversifolial Asters, Nos. 1-40.

Basal and lower cauline leaves with relatively narrow blades, with more or less contracted petiole-like bases but not cordate: upper cauline leaves with sessile or clasping blades.

Blades of the cauline leaves more or less clasping by auriculate-cordate bases. Amplexicaul Asters, Nos. 41-63.

a. Chief bracts rigid, closely appressed (unless at the tip).

Stem glabrous: leaves firm, sleek or subsucculent.

Involucre campanulate.

Leaves glabrous except the edges.

Bracts oblong-linear with broad rhomboid or deltoid green tips.

Cauline leaf-blades oblong or oval-lanceolate: inflorescence tending to the racemose panicle.

Cauline leaf-blades linear or elongated-lanceolate : inflorescence tending to the corymbose panicle.

Bracts linear, their green tips narrowly lanceolate.

Cauline leaves linear or narrow-lanceolate.

Cauline leaves very narrowly linear': heads very small.

Leaves glabrous above, often with minute hair beneath.

Leaves entire, short, oblong-elliptical, remote.

Leaves often coarsely toothed, prolonged, linear in type.

Involucre turbinate or clavate: leaf-blades scarcely clasping.

Stem and leaves pubescent with short hair : involucre campanulate or turbinate.
18. A, cordifolius.

19. A. sagittifolius.

20. A. plumarius.

21. A. hirtellus.

22. A. Drumnondii.

23. A. Texanus.

24. A. trigonicus.

25. A. azureus.

26. A. capillaceus.

27. A. vernalis.

28. A. poaceus.

29. A. undulatus.

30. A. Protcus.

31. A. asperifolius.

32. A. sylvestris.

33. A. truellius.

34. A. corrigiatus.

35. A. triangularis.

36. A. linguiformis.

37. A. loriformis.

38. A. Mohrii.

39. A. claviger.

40. A. gracilescens.

41. A. laevis.

42. A. concinnus.

43. A. purpuratus.

44. A. attenuatus.

45. A. ursinus.

46. A. falcidens.

47. A. turbinellus. 
Stem low : leaves rough : inflorescence broad.

Heads long-peduncled, somewhat remote.

Involucre turbinate.

Bracts linear, acute, not woolly.

Bracts broad, scale-like, obtuse, canescent.

Involucre campanulate.

Bracts broad, oblong; tips spreading: branches divaricate. Bracts narrow-linear; branches diffuse.

Heads chiefly short-peduncled, subsecund.

Stem tall: leaves soft: inflorescence narrow.

b. Chief bracts thin, narrow, loosely appressed (at least the upper half spreading): stem usually pubescent.

Leaf-blades entire.

Heads under $2.5 \mathrm{~cm}$. broad : leaf-blades but narrowly clasping.

Plant widely branched and divaricate: spreading hair abundant on young stems.

Plant fastigiately branched, rougher, little pubescent.

Heads over $2.5 \mathrm{~cm}$. broad : leaf-blades broadly clasping.

Leaves not greatly elongated, oblong, soft-pubescent: stem tall, erect.

Leaves various, not soft-pubescent.

Stem extensively trailing or climbing: leaves short.

Stem erect, slender, profusely branched: leaves elongated.

Leaves strongly clasping.

Leaves slightly clasping.

Stem rigid: leaves narrowly oblong-lanceolate.

Stem weak : leaves bayonet-like, narrowly linear.

Leaf-blades sharply serrate.

Inflorescence irregularly congested or corymbed: pubescence often scanty.

Upper leaves little clasping: bract-tips linear-subulate.

Upper leaves sheathing the axils: bract-tips deltoid.

Inflorescence broadly panicled, diffuse. leafy : heads somewhat remote.

Leaves with nearly straight sides, little constricted below.

Tubercular-based hair scattered over the stem.

No tubercular-based hair.

Leaves contracted into a broad petiolar portion: hair present in lines on the upper stem.

Blades of the cauline leaves elasping, etc. Amplexicaul Asters. Nos. 41-63.

Blades of the cauline leaves merely sessile or essentially so, Nos. 64-102.

* Leaves not succulent or fleshy : plants not spiny-armed.

Basal and lower cauline leaves not grass-1ike, Nos. 64-95.

Leaves silky or canescent on both sides, entire or nearly so, short. Brevifolial Asters, Nos. 64-69.

Heads corymbose-paniculate: outer bracts of the involucre oblong, ovate-lanceolate or lanceolate: achenes glabrous.

Leaves silky : outer bracts of the involucre canescent-silky.

Leaves canescent: outer bracts hirsute.

Heads racemed : bracts linear : achenes pubescent.

Leaves glabrous or pubescent. but neither silky or canescent.

Rays typically purple, blue, pink or violet.

Tips of the involucral bracts spreading or recurved.

Leaves relatively small and very mumerous.

Leaves erect and adnate to the stem and its branches.

Leaves more or less reflexed, not adnate to the stem.

Heads small, few : bracts but slightly spreading.

Heads large: bracts squarrose, glandular.

Leaves relatively large and few.

Upper cauline leaves broad, chiefly ovate.

Upper cauline leaves narrow, narrow-oblong, varying to oblanceolate, lanceolate or linear; section Calliastrum T. \& G., Nos. 70-73.

Involucre hemispheric or campanulate.

Tips of the involucral bracts foliaceous.

Tips of the involucral bracts merely spreading or squarrose.

Bracts glandular.

Bracts glabrous or merely ciliate.

Involucre turbinate.

Tips of the involucral bracts erect or appressed.

Bracts coriaceous, obtuse.

Bracts herbaceous, acute or acuminate.

Rays typically white: sometimes purplish.

† Heads in panicles or terminating elongated branches or racemes: plants profusely ramuliferous and twiggy. Vimineal Asters, Nos. 74-87.

Heads more or less scattered, their pedicels prolonged, copiously and minutely leafy.

Rameal leaves merely firm: most pedicels not over $3 \mathrm{~cm}$. long.

Rameal leaves rigid, spreading, very conspicuous but minute: pedicels often $12 \mathrm{~cm}$ long.

Heads paniculate or racemose, on branchlets which are relatively inconspicuous and not copiously foliolose.

Bracts, at least the lower ones, very obtuse: plants very lough-pubescent.

48. A. continuนs.

49. A. patentissimus.

50. A. patens.

51. A. tenuicaulis.

52. A. subsessilis.

53. A. phlogifolius.

54. A. oblongifolius.

55. A. Kumleinii.

56. A. Novae-Angliae.

57. A. Carolinianus.

58. A. puniceus,

62. A. Novi-Belgii,

63. A. elodes.

59. A. Elliottii.

60. A. conduplicatus.

58. A. puniceus.

62. A. Novi-Belgii.

61. A. prenanthoides.

64. A. sericens.

65. A. phyllolepis.

66. A. concolor.

67. A. adnatus.

68. A. squarrosus.

69. A. grandiflorus.

13. A. mirabilis.

70. A. Curtisii.

71. A. spectabilis.

72. A. surculosus.

73. A. gracilis.

47. A. turbinellus.

86. A. Priceae.

74. A. dumosus.

75. A. coridifolius. 
Stem and branches with appressed pubescence: leaves nearly glabrous.

Stem and branches with spreading pubescence: leaves manifestly pubescent and ciliate.

Bracts acute or merely obtusish.

Racemes or panicles secund.

Cauline leaves linear to linear-lanceolate, minutely hack-toothed.

Plants sparsely branched, and with few heads.

Plants profusely branched, heads very numerous.

Cauline leaves oblong or lanceolate, dentate or serrulate.

Stem and branches sparingly pubescent or glabrate.

Stem and branches villous; as also the midrib beneath.

Racemes or panicles not definitely one-sided.

Cauline leaves oval.

Cauline leaves narrow.

Cauline leaves entire, somewhat linear or linearlanceolate.

Heads white (sometimes becoming purplish). Heads numerous, 8-14 mm, broad: leaves of the upper parts of the stem and branches subulate.

Heads more scattered, 12-18 mm. broad: upper cauline leaves linear.

Branches divaricate, rigid, prolonged : rameals subulate.

Branches often upturned or subcorymbose : many rameals flat, linear.

Heads chiefly colored.

Rays crimson or pink.

Rays violet.

Leaves rough-pubescent all over, above.

Leaves smooth and glabrous, except the margins.

Cauline leaves serrate. Longifolial Asters, Nos. 88-92.

Heads mostly less than $16 \mathrm{~mm}$. broad. Heads abundant, closely panicled. Heads remotely panicled or sparse.

Heads mostly over $16 \mathrm{~mm}$. broad.

Rays usually white: leaves scarcely firm. Leaves smoothish, elongated.

Leaves and stem minutely pubescent.

Rays usually bluish violet.

Leaves firm, rough or roughish, chiefly hack-serrate, the margins not thickened.

Leaves with thickened and scabrous margins, but smooth and glabrous elsewhere.

† Heads numerous, in a terminal umbel-like corymb.-Miscellaneous Asters. Nos. 93-102, begin here.

Leaves typically linear, entire or nearly so : bracts linearoblong, obtuse.

Leaves typically oblong-acuminate to elliptic, coarsely toothed: bracts linear-subulate.

Basal and lower cauline leaves grass-like.

Leaf-blades entire.

Leaf-blades with few or several spinuliform teeth.

Heads sessile and subremote in the upper axils.

Heads terminal, solitary or clustered.

** Leaves fleshy or succulent: plants sometimes armed with spines.

Stem solitary, its base not woody: plant unarmed.

Plants perennial from a caudex or rootstock: heads mostly over 12 mm. wide.

Leaves chiefly basal and linear, long-petioled.

Leaves scattered, linear and sessile.

Plants annual : heads mostly less than $10 \mathrm{~mm}$. wide.

Involucre campanulate: rays fewer than the disk-flowers.

Involucre cylindraceous: rays more numerous than the diskflowers.

Stems several from the woody persistent base : plant spine-armed.

76. A. multiflorus.

77. A. exiguus.

78. A. racemosus.

79. A. vimineus.

80. A. lateriflorus.

81. A. hirsuticaulis.

82. A. spatelliformis.

83. A. ericoides.

84. A. juniperinus.

85. A. Faxoni.

86. A. Priceae.

87. A. Baldwinii.

63. A. elodes.

88. A.Tradescanti.

89. A. agrostifolius.

90. A. paniculatus.

91. A. Missouriensis.

92. A. salicifolius.

62. A. Novi-Belgii.

93. A. ptarmicoides.

94. A. acuminatus.

95. A. paludosus.

96. A. spinulosus.

97. A. eryngiifolius.

98. A. Chapmani.

99. A. tenuifolius.

100. A. exilis.

101. A. subulatus.

102. A. spinosus.

1. Aster divaricàtus L. Stems tufted, 4-6 dm. tall, assurgent, flexuous, brittle, terete, glabrate at maturity : leaf-blades thin, smoothish, slender-petioled, ovate-lanceolate, closely and saliently dentate with sharp teeth, incurved-acuminate, the basal sinus moderately large, broad and deep: leaves of the inflorescence (bracteals) typically small, sessile, short, ovate-acute to short-oval, nearly entire : corymb broad, flattish, repeatedly and widely forked, the slender branches long, divergent : heads $18-25 \mathrm{~mm}$. broad : ray-flowers chiefly $6-9$; ligules white, or rarely roseate or slightly crimson : young involucre short-cyl- 
indric ; bracts broad, ciliate, the rounded or subtruncate tips with a broad green spot : disk turning reddish brown.

In open woodlands and thickets, in rather dry soil, Canada to Manitoba, Georgia and Tennessee. Fall.

2. Aster tenebròsus Burgess. Stem glabrate, striate, wide-branched : leaf-blades large, very thin and smooth, broadly oblong and conspicuously cut with coarse remote acuminate curvescent teeth, then abruptly long-acuminate and entire; most leaves with a broad rounded sinus and slender petiole; those of the inflorescence prolonged, lanceolate, subentire and sessile : inflorescence broadly corymbose, often proliferously branched : rays long, usually 9-12: disk pale yellow, turning purplish brown: outer bracts green, acute, elongated-triangular, the others linear, obtusish. Resembles $A$. divaricatus L., but is larger and thinner in all its parts, and with a different leaf-form.

In moist shaded places, Massachusetts and Lake Erie to North Carolina. Late summer and fall.

3. Aster stilettiformis Burgess. Stem greenish, slender, weak and often decumbent : predominant leaf-blades deep green, often roughened above, linear-oblong and long-acuminate, with subtruncate base and short petioles, and closely set with conspicuous sharp straight-backed teeth ; some lower leaves broader, ovate-acuminate with moderate sinus and with double-curved or couchant teeth ; axile leaves divaricate, straight-tapered from a sessile truncate base, everywhere closely slit-toothed, suggesting a harbed stiletto : inflorescence remotely diffused, but with short pedicels : bracts lingual, nearly uniform, green or mostly so : rays often 7 , sometimes reddening at the tips : disks turning brownish red. Differs from $A$. divaricatus L., especially in leaf-form, bracts and stem.

On shaded banks, Massachusetts to South Carolina and Tennessee. Fall.

4. Aster excavàtus Burgess. Stems as in A. divaricatus L.: leaf-blades thin, smooth, all nearly alike, oblong-lanceolate with the rounded base abruptly excavated into a deep narrow sinus ; their margins continuously low-serrate with curvescent teeth ; petioles very short and slender, shorter than the leaf-breadth, replaced by short broad wings at the principal axils; the upper axils often clasped by divaricate triangular-linear bracteals : heads forming convex clusters borne on long suberect branches or reduced to a few distant enlarged heads : bracts ciliate, smooth-backed, pale and thin, short-oblong and obtuse on some subsolitary heads, narrow and acutish on the smaller clustered heads, the inner attenuate and without green tips : rays white, or sometimes reddened: disk broad, turning usually purplish-crimson. Resembles $A$. divaricatus L., but the narrower less-attenuate more uniform leaves differ in outline, sinus and teeth.

In mountain or hillside woods, New York to North Carolina and Georgia. Early fall.

5. Aster castàneus Burgess. Stem glabrate, terete, graceful and wandlike, reddishbrown or greenish, with about 12 delicate straight darker striae, and becoming sinuous in the inflorescence : predominant leaf-blades dull green, remote, very thin, of a dense and hard texture, minutely granular-roughened when dry, ovate-lanceolate, closely slit-serrate, often unequally decurrent upon the short slender petiole; the lowest leaves much shorter, ovate-acuminate, coarsely serrate and with a moderate sinus; rameal leaves lanceolateattenuate or often all crescent-like and decurved, sessile by a short cuneate base : inflorescence nearly naked, narrow, composed of several upcurved slender unequal branches bearing close convex clusters, all in flower at once and very short-lived : pedicels long, filiform, upcurved, sometimes bearing small circular bracteals or discules : bracts narrow, linear-obtuse, pale, with bright-green tips: rays often 9 , linear, snow-white, excessively thin, and soon pendulous : disks soon turning to rose-brown, sienna or chestnut-color. Resembles $A$. divaricatus L.; differs in all the above characters, especially in form of inflorescence, bracts and leaves.

In clayey spots, swamps, near New York City ; also Connecticut and Lake Erie to North Carolina. Early fall.

6. Aster chlorólepis Burgess. Stem strong, glabrate, brownish, terete below, angulate-striate above: leaf-blades large, smooth, very thin, brownish green, pale beneath, ovate-acute, very coarsely serrate with outflung teeth ; sinus deep and sharp; petioles short, slender : axile leaves also large, oblong-lanceolate, serrate with long forward-directed teeth, the upper ones sessile : inflorescence loose and irregular: heads large, long-peduncled, inclined to be widely separated : rays nearly twice the length of the involucre: bracts quite uniform, thick, broad, short and scale-like, with very little ciliation or hair, chiefly golden brown with a short broad dark-green rounded tip : disks turning crimson. Resembles $A$. tenebrosus in its large heads, leaves, teeth and bracts; differs especially in having the sinus sharp, and bracts rounded, and in the absence of greatly prolonged entire bracteals.

In the mountains, New York, West Virginia, and North Carolina, reaching altitudes respectively of $300,1,000$ and 1,850 meters. Fall.

7. Aster Boykínii Burgess. Stems slender, greenish and glabrate, much flexed; leaf-blades ovate to oblong-acuminate, with broad enlarged sinus, set with strong and 
somewhat outflung teeth; petioles slender: inflorescence lax and irregular, composed of short branches given off at a wide angle, often continued in clusters among the lower axils ; the upper axils often conspicuous with ovate or subcircular sessile bracteals : disks turning reddish brown: rays shorter than in its ally, $A$. divaricatus L., from which it differs especially in its more straggling habit, narrow irregular inflorescence and less-coarsely toothed less prolonged leaves.

In the mountains, Georgia. Summer.

8. Aster fléxilis Burgess. Stem low, slender, smooth and virgate: leaf-blades small, short, thin, dull, dark green, ovate-acute with the broad double-rounded base bisected by a deep sharp sinus; margins crenate-serrate with low obscure teeth; petioles short : inflorescence scanty, tuft-like, or of a few slim-peduncled heads: bracts narrowly linear, obtuse, quite uniform : plant almost destitute of hair (under lens); otherwise much as A. divaricatus L. Differs from A. Boykinii (with which it grows) especially in its smaller shorter dull leaves, the sharp sinus, crenate margins and obtuse bracts.

In the mountains, eastern Ten nessee, Georgia and Alabama. Late summer and fall.

9. Aster multifórmis Burgess. Stem 3-6 dm. high, minutely glandular, erect, slender, terete, or angular-striate in drying : radical leaves usually 2 , their blades large, cordateoblong; cauline leaves of several forms, their blades sharply serrate, rough above, minutely puberulent beneath, those of the lower ones ovate, acuminate, usually with a narrow sinus, those of the upper oval to ovate-lanceolate, petioled, the uppermost elliptic-lanceolate, serrulate, sessile or nearly so: corymb small, its branches upwardly directed : heads 30-40 $\mathrm{mm}$. broad : ray-flowers about 13 ; ligules rounded and retuse at the apex : bracts green : inflorescence-glands few, almost hidden by the minutely strigose pubescence of the peduncles. Resembles A. macrophyllus L.; but its leaves thinner, narrower, more polymorphous, with narrower sinus, and much less harsh ; glands fewer, smaller, pale, less continuous down the stem : inflorescence more level-topped, obconic when passed : rays bluer, though fading out early.

In moist shaded places, Maine to New York, Pennsylvania and North Carolina. Summer and fall.

10. Aster riciniàtus Burgess. Stem smooth, red, terete, often $3 \mathrm{dm}$. high : radical leaves usually two, unequal ; blades deltoid-cordate or ovate-cordate, with long low curvescent or crenate teeth; basal leaf smaller, the blade orbicular-ovate, without sinus; lower cauline leaves ovate in type, with slight broad open sinus; the others lanceolate or oblong, with sessile tapered base; leaf-margins dentate below, becoming sharp-serrulate above; petioles slender or with narrow strap-like wings: inflorescence a small loose terminal tuft, with slender ascending pedicels: bracts uniform, lingual: rays rose-purplish and then transiently violet, soon turning whitish, linear-biacuminate. Plant very smooth and pale; much purplish-red occurs on stem and veins and especially along the bracts ; glandularpubescence very short, with small capitate glands, continuing down the stem to the base; strigose pubescence discoverable by lens on the upper leaves. Resembles A. multiformis; but the whole plant smoother and paler, with more red and less violet;; leaves smaller, shorter, and often dentate ; bracts narrower and more uniform; its colors neither sharp nor dull, but as if seen through a veil.

In moist mountain woods, North Carolina. Late summer.

11. Aster macrophýllus L. Stems 6-9 dm. high, reddened, angular : radical leaves developed in large colonies, usually 3 to each rhizome, larger and coarser than the similarly shaped lower cauline leaves (which are developed a subsequent year from the same rhizome); blades broad, cordate with a large irregular sinus, rough above, harsh, thick, the teeth broad, curved, somewhat crenate : upper stem-leaves with oblong blades and short broadly winged petioles, those of the uppermost sessile, acute: inflorescence strigose and glandular, broadly corymbose, irregular : heads $15-30 \mathrm{~mm}$. broad : peduncles short, rigid, thickish : ray-flowers about 12-16; ligules 10-14 mm. long, chiefly lavender, sometimes violet, or rarely pale : bracts conspicuously green-tipped, the outer acute, the inner oblong, obtuse : disk turning reddish brown.

In moderately dry soil, in shaded places, Canada to Minnesota and North Carolina. Summer.

12. Aster commíxtus (Nees) Kuntze. Stem 5-6 dm. high, rather robust, glandular-pubescent over the upper half and strigose above : leaf-blades rough, thick, dull green, paler beneath, ovate-acute in type, low-serrate or with curvescent teeth, and with slender petioles; only the basal leaves, if any, slightly cordate : upper leaves diminished, finally lanceolate and sessile; bracteals oval, small and few : inflorescence loosely corymbose, with long-ascending pedicels : bracts narrow and acute or subulate, ciliate and minutely puberulent, the apex squarrosely recurved : rays pale violet becoming white: disk becoming copper-brown. From its congeners A. mirabilis and the northern A. Herveyi, this is distinguished by the long acumination of its squarrose bracts ; and from $A$. mirabalis by its capitate glands.

In dry woods, Georgia and Alabama. Late summer and fall. 
13. Aster mirábilis T. \& G. Stem $3-7 \mathrm{dm}$. tall, sparingly branched above, manifestly pubescent, the branches and especially the branchlets closely and finely pubescent : leaves various, the basal and lower cauline little known, the upper cauline rather remote; blades ovate to oblong-ovate, $2.5-9 \mathrm{~cm}$. long, or those on the branchlets smaller, mostly acute, firm, serrate with appressed subcrenate teeth, mainly sessile, rough-pubescent, with appressed scattered hairs, those of the upper surface fewer, shorter, often spinescent : heads solitary or few in terminal clusters : involucres $8-10 \mathrm{~mm}$. high ; bracts firm, linear-oblong to linear, pubescent without and ciliate, the recurved herbaceous broadly obtuse tips pubescent on both sides: ray-flowers about 20 ; ligules violet, $1.5-3 \mathrm{~cm}$. long: achenes about $3.5 \mathrm{~mm}$. long, glabrous or nearly so, shorter than the tawny pappus whose inner bristles are thickened at the apex. Resembles $A$. multiformis Burgess, but the bracts squarrose and leaves hispidulous above; cordation seems wanting but will probably yet be found on some basal leaves.

Near Columbia, South Carolina. Fall.

14. Aster anómalus Engelm. Stem 3-9 dm. high, rough, rather stout, branched above : leaf-blades thin, those of the basal and lower cauline leaves deeply cordate, ovate or ovate-lanceolate, entire or slightly repand, rough-pubescent on both surfaces, acute or acuminate, 7-10 cm. long, 2-5 cm. wide, with slender naked petioles; those of the upper cauline leaves with short petiole-like bases, or sessile, lanceolate, oblong, or linear, much smaller: heads $26-30 \mathrm{~mm}$. broad : involucre hemispheric; bracts lanceolate, acute, or acuminate, hirsute, imbricated in several series, their foliaceous tips spreading or reflexed : ray-flowers 30-45; ligules $10-12 \mathrm{~mm}$. long, bright blue-violet : pappus whitish. Resembles A. undulatus L., but with squarrose bracts.

On limestone cliffs, Illinois to Missouri and Arkansas. Fall.

15. Aster Shórtii Hook. Stem 6-12 dm. high, roughish or smooth, slender, paniculately branched above : leaf-blades thick, glabrous or nearly so above, finely and sparingly pubescent beneath ; those of the basal and lower cauline leaves ovate or ovate-lanceolate, cordate, rounded or even acuminate at the base, often wholly entire, 5-15 cm. long, dull and scabrous above, borne on slender naked petioles; those of the upper cauline leaves lanceolate, entire, sessile or with short petiole-like bases, not cordate, those of the branches small and scale-like : heads numerous, $25-30 \mathrm{~mm}$. broad : involucre broadly campanulate : bracts linear, acute, puberulent, imbricated, their green tips appressed: rayflowers 10-15; ligules linear, violet, 10-12 mm. long : pappus tawny.

On banks and edges of woods, Pennsylvania to Illinois, Virginia, Georgia and Tennessee. Fall.

16. Aster Camptosòrus Small. Stem 4-8 dm. tall, simple and glabrous below the inflorescence, slightly flexuous : leaf-blades lanceolate, attenuate, $6-16 \mathrm{~cm}$. long, resembling those of Camptosorus rhizophyllus, entire, undulate and sometimes crisped, dark green, smooth and lustrous above, paler and hispidulous beneath, those of the lower cauline leaves deeply cordate at the rounded auricled base, slender-petioled, those of the upper cauline subcordate or truncate at the base: heads relatively few, $25-30 \mathrm{~mm}$. broad : peduncles minutely scaly, scabrous-pubescent : involucres cylindric-campanulate and more or less constricted at the middle, or turbinate when dry, 5-6 mm. high ; bracts linear-subulate, incurved, the middle and the acute tip deep green : ray-flowers numerous; ligules deep purple, about $1 \mathrm{~cm}$. long. Resembles $A$. Shortii, but leaves narrower, darker and shining.

In open woods, Tennessee and Alabama. Fall.

17. Aster Lowrieànus Porter. Stem 3-12 dm. tall, glabrous or nearly so through out, branched : leaf-blades thickish, firm, a little succulent, those of the basal leaves slender-petioled, ovate to ovate-lanceolate, cordate, acute or obtusish, serrate, $5-15 \mathrm{~cm}$. long, those of the cauline leaves ovate to oblong, often cordate, contracted into winged petioles, the uppermost lanceolate: heads usually not very numerous, $15-25 \mathrm{~mm}$. broad, loosely panicled : involucre turbinate; bracts obtuse or obtusish, appressed : ray-flowers 12-20 ; . ligules light blue, $6-8 \mathrm{~mm}$. long, but variable in length. Resembles $A$. cordifolius L.; but leaves smooth and glabrous, more wing-petioled, and inflorescence more glabrons.

In woods, Connecticut to Iowa, North Carolina and Kentucky. Fall.

18. Aster cordifolius L. Stem 3-15 dm. high, glabrous or nearly so, muchbranched and bushy: leaf-blades thin, rough, more or less pubescent, sharply serrate, acuminate, those of the basal and lower cauline leaves slender-petioled, broadly ovate-cordate, $5-12 \mathrm{~cm}$. long, those of the upper cauline leaves short-petioled or sessile, ovate or lanceolate : heads very numerous, small, 12-18 $\mathrm{mm}$. broad, handsome : involucre turbinate to cylindric ; bracts oblong-linear, obtuse or obtusish, green-tipped, appressed : ray-flowers 10-20; ligules 6-8 mm. long, blue or violet, sometimes pale, rarely white: pappus whitish.

In woods and thickets, New Brunswick to Minnesota, Georgia and Missouri. Late summer to winter.-A. cordifolius alvedrius Burgess, has the thin leaf-blades usually smoothish, cordate, triangular-lanceolate, or broader: inflorescence dense, thyrsoid, not leafy, in form resembling that of the lilac: bracts linear, acute: heads medium sized: rays blue. On shaded banks, Massachusetts to North Carolina and Tennessee. 
19. Aster sagittifolius Willd. Stem rather slender, $6-15 \mathrm{dm}$. high, strict, glabrous, or sparingly pubescent above, the inflorescence tall and paniculate with ascending branches: leaf-blades thin, glabrous above or but slightly roughened, usually glabrate beneath, those of the basal and lower cauline leaves ovate-lanceolate to lanceolate, with cordate or rarely sagittate base, sharply serrate, acuminate, $7-15 \mathrm{~cm}$. long, with slender naked or narrowly margined petioles; blades of the upper cauline leaves lanceolate, sessile, or on short and usually margined petioles, serrate or entire, those of the branches very much smaller, linearsubulate : heads 16-20 mm. broad, numerous, crowded, racemose: involucre turbinate ; bracts linear-subulate, glabrous or nearly so, their tips green and slightly spreading : rayflowers 10-15; ligules light blue or purplish, 6-8 $\mathrm{mm}$. long: pappus whitish. Resembles A. cordifolius L.; but its bracts narrower, subulate-acuminate, and its inflorescence almost without leafiness, the axile leaves being reduced, narrowed and stringy rather than foliaceous.

In dry soil, New Brunswick to North Dakota, North Carolina, Tennessee and Kansas, Late sum mer and fall.--Aster sagittifolius dissitifiorus Burgess, differs from the typical form of the species in its broader looser pyramidal inflorescence, the somewhat larger and longer-peduncled heads, the leafblades less serrate, often none cordate. New York to Florida, Mississippi and Oklahoma.

20. Aster plumàrius Burgess. Plants about $3 \mathrm{dm}$. high, chiefly composed of the dense plume-like violet inflorescence : stem smooth, zigzag : leaf-blades very smooth and firm, thickish, chiefly lanceolate-acuminate and slit-serrate, inclined to be strongly falcate at apex and unequal at the slightly cordate broadish base, measuring $7 \times 1.5 \mathrm{~cm}$. or less ; veins strongly incurved; petioles narrow-margined; lower axile leaves conspicuous, but rapidly diminished, soon becoming narrowly falcate-lanceolate and entire, sessile by a taper subcuneate base : inflorescence otherwise naked, ovate-lanceolate in outline : bracts narrow, acute, their distinct enlarged green tips chiefly spatulate. Resembles a dwarf A. sagittifolius, but differs in leaves, bract-tips, absence of bracteoles, etc.

On mountain tops, North Carolina, chiefly on balds at 1500-1550 m. Fall. Plume Aster.

21. Aster hirtéllus Lindl. Plant cinereous-green, finely tomentulose, profusely branched and racemose-panicled : stem $6 \mathrm{dm}$. high or more; leaf-blades very rough and dull dark green above, soft-hairy and pale beneath, thinnish; leaf-blades cordate-ovate in type, crenate-serrate in the middle, $4 \times 3 \mathrm{~cm}$. or Iess; leaf-form varying to cordate-orbicular and obtuse below, and oblong-acute above; axiles rounded, oval or lance-elliptic, minute, sessile; rameals oval, remotish, thin, spreading or deflexed; similar oval leaves clothe sprouts in the axils: inflorescence forming half of the plant or more, repeatedly ramuliferous, with long pedicels (often $3 \mathrm{~cm}$.) which grow closer and shorter at the summit: heads $2.5 \mathrm{~cm}$. broad : rays about 16 , pale purplish, soon becoming whitish : disks soon deep purple: bracts linear-subulate, rather loose, cont nued in similar bractlets down the pedicels; the faint green tips hardly at all enlarged.

On plains or prairies, Missouri and Kansas to Texas. Fall.

22. Aster Drummóndii Lindl. Stem 6-15 dm. high, usually stout, finely and densely canescent : leaf-blades mostly thin, ovate or ovate-lanceolate, sharply toothed, $5-10$ $\mathrm{cm}$. long, acuminate, rough above, canescent beneath, those of the basal and lower cauline leaves with cordate sinus, and slender naked petioles, those of the upper cauline cordate or rounded at the base, usually on margined petioles, those of the branches chiefly sessile, entire and lanceolate, much smaller : heads $12-25 \mathrm{~mm}$. broad, numerous or crowded on the racemose branches : involucre turbinate; bracts linear, slightly pubescent, acute or somewhat acuminate, their green tips appressed : ray-flowers $8-15$; ligules purplish blue, $6-8$ mm. long: pappus whitish. Resembles $A$. cordifolius L.; but rougher, more hairy, and decidedly gray.

In dry soil; borders of woods and prairies, Ohio to Minnesota, Kansas, Arkansas and Texas. Fall.

23. Aster Texànus Burgess. Plants but slightly pubescent, with long lax foliolose branches : stem glabrate: leaves roughened and dull above, pale and somewhat cinereous beneath, prevailingly similar in size, shape and slender petiole; leaf-form of oval-acute type with deep narrow sinus, regularly crenate-serrate to the obtusely-acute apex, $5 \times 4 \mathrm{~cm}$. or less; radicals oval ; upper-cauline leaf-blades smaller, truncate at base into a narrow strap-like wing ; the uppermost sessile, very small and numerous, ovate or narrowly elliptical, so continuing throughout the inflorescence : heads small, $0.5 \mathrm{~cm}$. high, subracemosely long-pedicelled on the slender stem or its branches : bracts somewhat lax, smoothish, linear-acute, the green tips narrowly elliptic: achenes often pubescent. Confused with $A$. Drummondii; but its heads seattered, not massed, its leaf-form different, broader, smaller and non-acuminate, its marginal teeth stronger, sinus deep and narrow, its leaves less rough and thick.

In thickets, Louisiana and Texas. Fall.

24. Aster trigónicus Burgess. Plants profusely branched, with rigid glabrate brownish stems and long flagellate ascending branches, which are closely short-branched or are 
spiciform and beset with small remotish subsessile heads : stem $8 \mathrm{dm}$. high or less: leafblades thick and heavy, somewhat canescent, hispid above, velvety-hispidulous below ; leafform elongated triangular; the truncate base slightly rounded at the corners, and sometimes a little subcordate ; leaf-blades $3 \times 1 \mathrm{~cm}$. or more, acute or obtusish, the sides straight, serrate or crenate ; petiole short, forming a narrow cuneate wing : rameals stiff, very numerous, overlapping and appressed, linear-elliptic: heads small, hardly $2 \mathrm{~cm}$. broad : bracts linear-acute, the green tip lanceolate. Resembles $A$. hirtellus; but has the predominant leaves thick, triangular : stems more smooth, flagellate spiciform ; branches more frequent: rameals appressed, narrower and closer, and the green tips of the bracts much broader. Repeatedly collected for A. undulatus, A. azureus, A. Baldwinii, A. Drummondii, and A. sagittifolius.

On plains and prairies, Alabama to Kansas and Texas. Fall.

25. Aster azùreus Lindl. Stem $3-12 \mathrm{dm}$. high, slender, stiff, rough, with numerous ascending or patent branches : leaf-blades thick, of a peculiar crusty texture when dry, scabrous on both sides, those of the basal and lower cauline leaves cordate, ovate to oblong-lanceolate in type, shallow-serrate, usually acute, $5-15 \mathrm{~cm}$. long, with slender often pubescent petioles ; those of the upper cauline leaves with short petiole-like bases or sessile, lanceolate or linear, entire ; those of the branches reduced to small appressed scales : heads numerous, 20-25 mm. broad : involucre turbinate; bracts glabrous, linear-oblong, abruptly acute, imbricated, their broad sharp green tips appressed : ray-flowers 10-20; ligules bright blue, 6-8 mm. long: pappus tawny. Resembles A. undulatus L.; but leaves hispidulous on both surfaces ; flowers smaller; rays darker and bluer; pubescence scanty.

On prairies and along borders of woods, New York to Minnesota, Georgia, Kansas and Texas. Summer and fall.-A. azureus scábrior Engelm. principal leaves with elliptical lanceolate entire longpetioled non-cordate blades; branches more erect; stem extremely rough. Ontario and Minnesota through Missouri to Louisiana.

26. Aster capillàceus Burgess. Stem about $6 \mathrm{dm}$. high, terete, rough in parts, often polished-smooth in others, sometimes manifestly pubescent: leaves much as in $A$. azureus, but the blades thinner, less roughened, almost never cordated, bearing bristles which rise each from a small papilla; lower leaf-blades large and very long petioled, elliptic-lanceolate, coarsely crenate (in some small plants entire) ; others enlarged upward, oblong-spatulate or linear-spatulate and entire ; upper cauline leaves linear-lanceolate; axiles subulate ; radical leaves several, often four, their type broadly oval or oblong, obtuse or rounded at base and apex, coarsely shallow-dentate, suggesting Erigeron annuus: inflorescence almost naked from lack of bracteals, the filiform pedicels therefore conspicuous : heads somewhat remote, rather large, $2 \mathrm{~cm}$. broad, blue-violet, with turbinate base : bracts broad, abruptly triangular-pointed or cuspidate. Resembles $A$. azureus; but thinner, and less roughened; the heads fewer, larger, and their peduncles nude; peculiar in its tendency to develop Erigeron-like radicals and spatulate caulines.

In dry grounds, Wisconsin and Illinois through Missouri to Texas. Late summer and fall.

27. Aster vernàlis (Engelm.) Burgess. Stem $4 \mathrm{dm}$. high, or more, densely racemosely branched : leaf-blades entire, of heavy firm texture, very rough, with close short stout bristles abruptly papillose-thickened. at the base; the radical blades oblong-acuminate, with a truncate square-shouldered base and slender petiole $7 \mathrm{~cm}$. long or nearly as long as the blade : caulines linear and grass-like, biacuminate, often with slender petioles $2 \mathrm{~cm}$. long: inflorescence irregular, racemosely compound, elongated and narrow, its branches not so long and straggling as in $A$. poaceus, not so fastigiate or scoparial as in $A$. azureus: heads $0.5 \mathrm{~cm}$. high, $1 \mathrm{~cm}$. broad : bracts linear-acute or acuminate. Between $A$. azureus and $A$. poaceus in leaf-form and inflorescence. [A. azureus var.? vernalis Engelm.]

In open woods and on prairies west of Houston, Texas, Spring and summer.

28. Aster poàceus Burgess. Stem diffusely and repeatedly much-branched, $8 \mathrm{dm}$. high or less: leaves very rough and stiff, of grass-like form; chief leaf-blades linearelongate or falcate, often $13 \mathrm{~cm}$. long, $0.5 \mathrm{~cm}$. in uniform breadth, usually also with a narrow-margined petiole of $2-5 \mathrm{~cm}$., apt to be erect, and with stout papillose-based bristles; radicals oblong-elliptic, measuring $8 \times 1 \mathrm{~cm}$. or less : inflorescence irregular, on very long and straggling branches, which are often for 1.5 to $3 \mathrm{dm}$. clothed with minute subulate subappressed bractlets : heads small, little over $1 \mathrm{~cm}$. broad : bracts linear, with long sharp tips. Represents the extreme of attenuation among the kindred of $A$. azureus.

On plains and prairies, Missouri to Alabama, Oklahoma and Texas. Summer and fall,

29. Aster undulàtus L. Stem stiff, $3-10 \mathrm{dm}$. high, closely rough-pubescent, divaricately branched above : leaf-blades usually thick, rough on both sides when dry, pubescent beneath, dentate, undulate or entire, acute or acuminate, those of the radical leaves small, orbicular to ovate, soft-downy ; the lower cauline leaves ovate, with cordate base, $5-12 \mathrm{~cm}$. long, the naked petioles expanding into a clasping base, at least in some leaves; middle 
cauline leaves similar, lanceolate or oblong; upper cauline leaves sessile or clasping, chiefly lance-oblong; branch-leaves subulate, small and suddenly reduced : heads numerous, racemose and somewhat secund on the spreading branches, $16-20 \mathrm{~mm}$. broad: involucre broadly turbinate : bracts linear-oblong, slightly pubescent, acute or acutish, their broad green tips appressed : ray-flowers 8-15; ligules usually pale violet, $6-10 \mathrm{~mm}$. long : pappus whitish.

In dry soil, New Brunswick and Ontario to Florida, Alabama and Arkansas. Fall.

30. Aster Pròteus Burgess. Plants small, racemose, with many cordated leaves, of firm roughish texture but with little hair : stem slender, apt to be glabrate, and $3 \mathrm{dm}$. high, sometimes $7 \mathrm{dm}$., virgate and little branched, but sometimes forking near the base : leaves somewhat remote; blades delicate, polymorphous, not thick nor thin ; radicals numerous, resembling violet leaves, $4.5 \times 2.5 \mathrm{~cm}$. or less, cordate-ovate, almost acute, finely subcrenate, often nodding on their prolonged and very slender petioles : cauline leaves tend to assume about 4 types; the first, or basal, all similar to the radical, but with straighter sides, narrowly cordate-triangular and acutish, minutely serrulate, soon becoming entire; second form, triangular-lanceolate, sloping into a distinct winged petiole; third, narrowly linear or lanceolate, sessile by a short broad taper base; fourth, oblong-acute, sessile by a broad base or with very short broad wing, numerous, much-reduced and disappearing among the middle axils : inflorescence nearly nude, a simple open raceme with spreading heads, or each head replaced by a racemose subsecund branch : rays violet: disks not so dark as in related species: bracts linear, briefly acuminate, closely imbricated, the green tips conspicuous, narrow diamond-form or narrow lanceolate.

In dry ground toward the coast, North Carolina and Florida to Mississippi. Summer and fall.

31. Aster asperifòlius Burgess. Plants small, racemose, minutely tomentulose throughout, very rough and heavy in texture : stem often but $3 \mathrm{dm}$. high : leaves subcoriaceous; blades hispid, subentire, obtuse, ovate-oblong and longer than their short petioles; rameal leaves minute, adnate, subulate-filiform; radial leaves and chief caulines sometimes subcordate; petioles slender, naked or narrowly margined; amplexicaul dilation absent or rare : inflorescence a loose simple or compound naked raceme, or several racemes which may become more short-peduncled and leafy : heads smaller than in $A$. undulatus: bracts fewer, slightly pubescent, appressed, linear-oblong, acute, with distinct rhomboid green tips. Most hispid-pubescent and rounded-leaved of the southern correlatives of $A$. undulatus L. [A. asperulus T. \& G., not Wall.]

In dry or sandy soil, South Carolina and Florida to Louisiana. Fall.

32. Aster sylvéstris Burgess. Stem slender, scabrous, erect, pale-green, usually 4 $\mathrm{dm}$. high, minutely pubescent : leaves resemble $A$. undulatus, but blades broader, shorter, thinner, deeper green, more uniformly petioled ; predominant leaf-form broadly shortcordate, acute, with rounded basal lobes, deep or excavated sinus, broadly crenate or entire margin : petioles narrow, long and numerous, dilated at the base, seldom otherwise winged : upper leaves oblong-acute, soon sessile ; rameals uniform and spreading as in A. undulatus, oval to linear-elliptic ; radicals small, orbicular, short-petioled; pilose and webby hair present on the leaves beneath but not velvety : inflorescence irregularly spreading or ascending, of long racemose branches : heads rather few : pedicels distinct, often $3 \mathrm{~cm}$. long : rays full violet: bracts linear, triangular-acute at apex, with large and broad rhomboid green tips.

In open woodlands, New York and Pennsylvania to South Carolina and Alabama. Fall.

33. Aster truéllius Burgess. Plants small, erect, with little hair : stem erect, strong but slender, rough : leaves subentire, $5 \times 2 \mathrm{~cm}$., thickish, firm, rough, typically triangular-lanceolate with sides straight-tapered from the prominently shouldered truncate or cordate base, in form suggesting a mason's trowel : plant remarkable for its numerous short narrow petioles with large basal dilation, and above these, its strap-like petioles with slight basal dilation; radicals cordate-orbicular, crenate, somewhat velvety; axiles often deflexed, narrow-ovate; rameals spreading: rays short, purplish blue: disks soon reddish brown : bract-tips diamond-shaped, broad and bright green.

In sandy thickets, Vermont and Kentucky to Georgia and Alabama. Fall.

34. Aster corrigiàtus Burgess. Plants tall, robust, rough, with little hair, with predominantly narrow spearhead-shaped much-ruffled sessile leaves, foliose in the axils, and with long and high inflorescence, small blue-violet heads and lozenge-tipped bracts. Stem about $12 \mathrm{dm}$. high, or more, brown, terete-striate, rough, with short scattered strigose hair above: leaves tending to be narrowly lanceolate and broad-based, slanting straight both ways from near the base, tending to the form of an acute narrow spearhead, about 7 or $12 \times 2 \mathrm{~cm}$., very slowly diminished through the inflorescence; radicals small, short and broad, somewhat cordate-oval ; a very few lower cauline leaves develop obscure corda- 
tion and a narrow petiole ; rameals not conspicuous, linear-acute, somewhat appressed : inflorescence irregularly compound-racemose, long and rather narrow, disproportionately large for the plant; its branches tend to be spreading and short, its peduncles long or at least distinct, its heads medium-sized or less, its rays much darker than in typical $A$. undulatus. Peculiar in its strong tendency to become corrigiate, or cross-tied, by developing two conspicuous divaricate narrow-lanceolate leaf-blades (branch-form leaves) in the lower or middle axils of the cauline leaves.

On dry hillsides, Connecticut and New York to Ohio, Alabama and Louisiana. Fall.

35. Aster triangulàris Burgess. Plants cinereous green, tall, robust, very rough, with little or no obvious hair, like A. corrigiatus; but with leaves ovate-triangular-acuminate, thicker and with very pronounced acumination. Stem dull reddish brown, somewhat terete, $9 \mathrm{dm}$. high or more : leaves very numerous, sometimes foliosely corrigiate in the axils; blades not ciliate, beneath with slight short scattered strigose hair, on the upper surface close-set with pale slender rigid aculei pointing chiefly away from the midrib and thickened at the base ; leaf-form ovate-triangular, long-acuminate, suddenly contracted at the sessile base, subclasping only : inflorescence rather narrow, of loosely-ascending branches with a brushy top, uniformly close-set or catenate with conspicuous appressed overlapping oblong chain-like bracteals : heads small : rays purple-blue : bracts linear-oblong, their tips apt to be of broad diamond form. [A. undulatus triangularis Burgess.]

On open sandy slopes, New York to South Carolina and Alabama. Fall.

36. Aster linguifórmis Burgess. Small racemose plants with little hair, or cordation, of soft thin texture, tending to great development of elongated linguiform leaves, partly with long strap-like winged petioles, and the upper ones sessile by a broad auricled base ; stem 4-5 dm. high, minutely pubescent only; leaves tend to be remarkably entire and obtuse, sage-green, closely approximate; radicals few, narrowly ovate-oblong, but slightly cordated, with rather long slender petioles; lower caulines lance-oblong, $7 \times 2 \mathrm{~cm}$. or less, abruptly rounded and obtuse at base and apex, often surpassed by the strap-like petiole ; other caulines and branch-leaves sessile-auriculate, prolonged linear-oblong or pandurateoblong, often rounded-truncate at apex ; axiles linear-acutish : inflorescence usually a loose and nearly simple raceme with small distinct long-pedicelled heads: bracts lax, linear, acute, the green tips rhomboid.

In dry fertile thickets, near Jacksonville, Florida. Summer and fall.

37. Aster lorifórmis Burgess. Plants rough, with but little hair, tall and narrow, with strap-like leaves seldom developing petioles or cordation : stem somewhat purple, terete, erect, brittle, slender, and 4-6 dm. high, or stout and even $12 \mathrm{dm}$. high : leaves dull green; blades thick, rigid when dry, rough, only minutely pubescent beneath, their type linear-oblong and obtuse, with sides nearly straight from a sessile clasping base ; margins apt to be much ruffled, often minutely and closely erose, occasionally gashed with a few coarse remote blunt protruding teeth; petioles slightly developed, though often a few lower leaves slope into a strap-like petiole; radicals apt to be oval-oblong, with little or no cordation ; upper caulines and axiles linear-lanceolate, acutish, more contracted at the base: as in $A$. corrigiatus, the inflorescence is tall and narrow, the heads smaller than in $A$. undulatus and the rays more a blue-purple; bracts narrower, the green tips diamond-form or lanceolate. [A. undulatus loriformus Burgess.]

In sand-barrens, Martha's Vineyard, and along the coast to Florida and Alabama.

38. Aster Mòhrii Burgess. Plants profusely and flagellately branched with very naked bushy inflorescence : stem rough, rigid, with many small dark capitate slender-stalked glands intermixed among strigose hairs; many of the latter are viscid, becoming broken down and irregularly incrassate : leaf-blades long, narrowly linear and grass-like, thickish, harsh, of uniform breadth, minutely rugulose above, obtuse or slightly acute; petioles obscure, slender or winged; occasional radical or basal leaves are shorter broader, somewhat cordate-lanceolate, and at the slightly shouldered base are contracted into a distinct petiole; with but obscure or rare sinus and amplexicaul enlargement; axile leaves and rameal chiefly linear-oblong, clasping by a broad base : heads small, long-peduncled ( $5-7$ cm.), racemosely compounded: bracts linear-oblong, acute, green-tips prominent, lanceelliptic: rays reddish purple, $12-15$ or less. Fine strigose tomentum extends down the peduncles and much of the stem. Represents the extreme attenuation of the $A$. undulatus types. [A. Baldwinii $\beta$ T. \& G.]

In sandy soil, Georgia and Florida to Louisiana. Fall.

39. Aster cláviger Burgess. Plants wand-like, apt to spring several from a common base, with glandular pubescence along the middle of the stem, and with leaves of a crisp firm texture: stem greenish, moderately and finely pubescent, or glabrate, smooth to the eye, about $6 \mathrm{dm}$. high or more: leaves quite uniform; blades ovate-oblong, thickish, sub- 
entire or crenulate, acute, chiefly with a short strap-]ike wing broadest at its base ; the slight pubescence becoming a little rough in drying and the leaves spongy-coriaceous; a very few basal leaves cordate : inflorescence irregular and narrow-oblong or club-shaped, sometimes narrowly pyramidal : heads rather small : rays full violet or purplish violet : bracts linearacute with the medium-sized tips broad-lanceolate to diamond-form; scattered capitate glandular hairs are mingled on the stem with dry strigose hair and also with broken down strigose hairs which become irregularly glandular-thickened; the definitely formed capitate glands are colored violet, only slightly thicker than their stiff stub-like stalks.

In wood borders, Connecticut and New York to Alabama. Fall.

40. Aster graciléscens Burgess. Plant thinner and les s pubescent, less rough and more thy rsoid than its congener $A$. undulatus : stem slender, often $6 \mathrm{dm}$. high and somewhat arching : leaves quite uniform ; blades large and conspicuous, thin, soft, elongated-lanceolate, chiefly sessile, $12 \times 4 \mathrm{~cm}$. or less, scantily soft-pubescent, not velvety like $A$. undulatus, only a little rough when dry, subentire, pale green with paler midrib; axiles narrow-ovate, rameals oblong-linear or spreading; cordation of leaf-base and dilation of petiole-base usually little developed; radicals sagittiform-cordate with acute sinus : inflorescence loose, ovoid or thyrsoid, with distinct pedicels $3 \mathrm{~cm}$. long or less : heads larger and remoter than in its relative $A$. undulatus: bracts linear-oblong, suddenly acute, the tips chiefly conspicuous, short, incurved-triangular-aculeate.

In half-shade or edges of rich woods, Ithaca, New York, to the Carolinas, where it occurs on balds, quite common and rather showy. Late summer and fall.

41. Aster laèvis L. Stem 6-12 dn. high, usually stout, glabrous, often glaucous, branched or simple: leaf-blades thick and almost leathery, very smooth, entire or serrate, slightly rough-margined, the upper all sessile and strongly cordate-clasping, oblong-lanceolate, oblanceolate or ovate, acute or obtusish, $2-10 \mathrm{~cm}$. long; those of the basal and lower cauline leaves gradually narrowed into winged petiolar bases, those of the branches often small and scale-like : heads usually numerous, about $25 \mathrm{~mm}$. broad : involucre campanulate; bracts rigid, acute, appressed, broadly green-tipped, imbricated in several series: ray-flowers 15-30; ligules blue or violet: pappus tawny : achenes glabrous or nearly so. Remarkable among asters for its smooth, cool, polished surfaces.

In dry or stony soil, Maine and Ontario, to North Dakota, Georgia, Louisiana and Kansas. Fall.

42. Aster concínnus Willd. Similar to narrow-leaved forms of $A$. laevis in habit, the stem glabrous or sparingly pubescent above, $3-9 \mathrm{dm}$. high, paniculately branched : leafblades light green, lanceolate to linear, entire (or sometimes serrulate), $2-7 \mathrm{~cm}$. long, those of the upper cauline leaves sessile, somewhat clasping, those of the basal and lower cauline leaves spatulate, or oblong, narrowed into margined petiole-like bases : heads usually numerous, about $25 \mathrm{~mm}$. broad : bracts of the involucre with rhomboid acute herbaceous tips : ray-flowers with violet to purple ligules. Resembles A. laeris L., but more corymbed, the heads smaller and leaves narrow.

In open woods or dry soil, Connecticut to North Carolina and Arkansas. Fall.

43. Aster purpuràtus Nees. Stem 4-12 dm. high, slender, glabrous, simple, or branched above, the branches sometimes puberulent: leaf-blades firm, glabrous, darkgreen, entire, the upper sessile and clasping at the base, elongated-lanceolate or long-linear, $5-12 \mathrm{~cm}$. long, acuminate; basal and lower cauline leaves petioled, oblong-lanceolate, obtusish; those of the branches very small : heads rather few, loosely racemose, $16-25 \mathrm{~mm}$. broad : involucre campanulate to turbinate : bracts coriaceous, lance-acuminate, appressed, imbricated in several series, the green tips lanceolate : ray-flowers 5-10, their ligules blue or violet, $6-10 \mathrm{~mm}$. long : pappus tawny : achenes glabrous. Resembles A. laevis L.; but its heads more racemed, apt to be solitary upon long branches, the bracts narrower-tipped, the leaves greatly narrowed, long-linear.

In dry soil, or open woods, Virginia to Georgia, Texas and Arkansas. Late summer and fall.

44. Aster attenuàtus Lindl. Stem glabrous, $6 \mathrm{dm}$. high or less : leaf-blades very narrowly linear with straight sides almost from the sessile base to the acute apex, very smooth but with hispid revolute margin, $1.5 \mathrm{dm}$. long or less, about $1 \mathrm{~cm}$. broad, mostly sessile : inflorescence spicate-racemose, attenuate: bracts as in $A$. purpuratus in form, from which it differs in its leaves, its smaller heads, more narrowed inflorescence of short branches, and somewhat squarrose lower bracts which pass gradually into spreading bractlets on the pedicels. [A. virgatus $\gamma$ T. \& G.]

In dry soil. Alabama and Louisiana. Fall.

45. Aster ursìnus Burgess. Stem stout, smooth and glabrous beneath the inflorescence, very peculiar in the crowded nodes of its base and inflorescence, there $1 \mathrm{~cm}$. or less apart, and in the abruptly remote nodes of the stem between, nearly $10 \mathrm{~cm}$. apart: leaves 
oblong-elliptical, chiefly fascicled at the base and there often short-lanceolate or spatulate, sometimes serrulate and 1-2 $\mathrm{cm}$. broad, with ciliate petioles; minute stubby pubescence covers some even of the larger leaves beneath, and occurs on the main stem and branches throughout the inflorescence, which tends to ellipsoid and broadly racemose type: heads chiefly solitary on virgate branches, twice the size of A. attenuatus, $3 \mathrm{~cm}$. broad, $1 \mathrm{~cm}$. high : involucre loose, broad and short: pedicels shaggy with conspicuous uniform closely-imbricated bractlets, which are $1 \mathrm{~cm}$. long, each appressed half-way and with outcurved tip ; upper bractlets more spreading and furry and passing indistinguishably into the bracts of the involucre ; the involucral bracts chiefly linear-attenuate, tapering from the base, their green tips large, lanceolate, and conspicuous. [A. virgatus $\beta$ T. \& G. not Banks.]

Mountains of Georgia. Late summer and fall.

46. Aster fálcidens Burgess. Plant of firm smooth texture like A. laevis, with similar rays and bracts: stem slight or delicate, not rigid, generally arcuate, terete, reddened, usually under $5 \mathrm{dm}$. high; leaf-blades very thin, of linear type, apple-green, glaucescent, of dense opaque texture, remarkable for the absence of veins (unless under a strong lens), varying from exceedingly smooth and glabrous (even with the margin without ciliation or roughness) to leaves with minute hair beneath and some scabrous hair at the margins: radical leaves very pale and glaucous, with oval or oboval blades, the apex rounded or obtuse, a few acutish, their petioles narrow and longer; lower cauline leaf-blades lanceelliptic, entire, $7 \times 2 \mathrm{~cm}$., equalled by the narrow petiole (and resembling Pogonia ophioglossoides ) ; middle caulines linear, often $2 \mathrm{dm}$. long by only $1 \mathrm{~cm}$. broad, sessile, short-acuminate, frequently with several large projecting teeth which are nearly opposite or remotely scattered; these notches may be increased till the leaf is pinnatifid, or reduced to many shallow crenations, or may be replaced by prolonged oblanceolate-linear entire leaves: upper cauline leaves often numerous, 10-15 or more, ascending or spreading, entire, linear, straight-sided, tapering slightly to each end but not acuminate, $15 \mathrm{~cm}$. by $1.5 \mathrm{~cm}$., finally becoming short, linear-acute and erect, still $5 \mathrm{~cm}$. long: axiles subulate, rapidly reduced, leaving the inflorescence nearly naked: rameals minute, mostly erect-appressed, almost overlapping, broadly subulate or setaceous ; branches ascending, short and filiform, reaching $5 \mathrm{~cm}$. and bearing a single head, or $10 \mathrm{~cm}$. and bearing several : heads often few, forming a short raceme : rays pale blue : disks early turning deep crimson : bracts linear-elongate, suddenly acute, their green tips rhomboid. Differs from the allied $A$. laevis, $A$. concinnus, etc., in its longer linear straight-sided leaves and its coarse teeth. [A. gracilentus T. \& G., not Banks. ]

Mountains of Pennsylvania, to North Carolina, Alabama and Arkansas. Fall.

47. Aster turbinéllus Lindl. Stems $6-9 \mathrm{dm}$. high, slender, paniculately branched, glabrous below, puberulent above : leaf-blades firm, lanceolate, or oblong-lanceolate, 5-7 $\mathrm{cm}$. long, entire, ciliate, acute or acuminate, those of the basal and lower cauline petioled, those of the upper sessile, those of the branches much smaller : heads about $25 \mathrm{~mm}$. broad, mostly solitary at the ends of the branches : involucre turbinate ; bracts oblong, coriaceous, obtuse, appressed, imbricated in 5 or 6 series, their tips green only at the apex : ray-flowers 10-20; ligules 6-10 $\mathrm{mm}$. long, violet: pappus tawny : achenes finely pubescent. Resembles $A$. continuus Small, but the leaves softer; heads larger, pubescence slight or absent.

In dry soil, especially on prairies, Illinois to Kansas, Louisiana and Arkansas. Summer and fall.

48. Aster contínuus Small. Stems $5-11 \mathrm{dm}$. tall, pubescent with short upcurved hairs, much branched above : leaf-blades spreading, more or less fiddle-shaped or oblong, $2-\tilde{c m}$. long, acute, shallowly serrate or nearly entire, ciliolate, scabrous-pubescent on both sides, sessile and clasping at the base : heads showy, solitary or clustered at the end of the spreading closely pubescent branches : involucre turbinate, relatively short before anthesis, becoming 1-1.5 cm. long at maturity; bracts numerous, linear or nearly so, erect or with slightly spreading green tips, acute, passing into the numerous scales of the peduncle : rayflowers 12-15; ligules violet, 1-1.5 cm. long: achenes pubescent. Resembles A. patens Ait., but its bracteoles closer ; involucre taller, larger, straight-sided, and more narrowly turbinate.

In dry soil, Kansas to Arkansas and Texas. Fall.

49. Aster patentíssimus Lindl. Resembles $A$. patens, but its involucre canescent, larger, browner, with broader, almost woolly and scale-like bracts. Branches usually long and flagelliform and very numerous: leaf-blades small, triangular-oblong, acutish, rigid with hirtellous pubescence, scabrous both above and beneath; rameal leaves all nearly alike, very small, $2 \times 0.5 \mathrm{~cm}$. or less; axiles very small, chiefly deflexed : heads usually terminating long branches or branchlets : involucre somewhat turbinate ; bracts in 5-6 series, obtuse, apt to be recurvate at the tip which is set with stubby or subglandular hairs, 
both bracts and pedicels canescent or even white with loose webby hair : rays dark violet; bract-tips diamond-form to deltoid.

In dry soil, Kansas to Mississippi and Texas. Summer and fall.

50. Aster pàtens Ait. Stem 3-9 dm. tall, slender, rough, divergently branched : leaf-blades sessile, ovate-oblong or oval, rough-pubescent, thick and somewhat rigid, strongly auriculate-clasping at the broad base, entire, acute, or the lower ones obtuse, 2.5-7.5 cm. long, those of the branches much smaller and bract-like, their margins roughciliate: heads $25 \mathrm{~mm}$. broad or more, solitary at the ends of the branches: involucres. campanulate; bracts linear-oblong, finely pubescent or scabrous, often somewhat glandular, imbricated, their green acute tips spreading: ray-flowers 20-30; ligules purplishblue or deep violet, $8-12 \mathrm{~mm}$. long: pappus tawny : achenes pubescent.

In dry open places, Massachusetts to Minnesota, Florida, Louisiana and Texas. Summer and fall.

51. Aster tenuicaùlis (C. Mohr) Burgess. Resembles A. patens; but its branches. long and slender, flagelliform and diffuse when well developed : leaves and heads smaller : pedicels longer, often 1-4 cm. : bracts and their tips much narrower, narrowly linear; bractlets mucronate-acute, catenate or forming a chain-like series along the pedicels, appressed or slightly spreading. [A. patens var. gracilis Hook. A. patens tenuicaulis $\mathrm{C}$. Mohr. 7

In dry soil, Georgia to Texas and Oklahoma. Summer and fall.

52. Aster subséssilis Burgess. Stem strong, erect, with several or many long parallel subhorizontal divaricate branches: leaves as in $A$. patens, but with obovate radicals and some obovate middle caulines; and many heads short-pedicelled, sessile and secund; axile leaves very short and broad, pale; bracteals oval-oblong to lanceolate: heads nearly as in $A$. patens, with broad and nearly sessile base : peduncles usually only 0.5 . cm. long: bracts very broad, short, bluntly rounded, puberulent, not ciliate nor glandular. Differs from $A$. patens especially in its bracts and its secund subsessile heads.

On plains or prairies, Missouri and Arkansas : also in Alabama. Fall.

53. Aster phlogif òlius Muhl. Similar to A. patens in habit, but when well developed much taller, more slender and soft: leaves larger; blades lanceolate to oblonglanceolate, entire, thin or membranous, acuminate at the apex, strongly auriculate, clasping at the base, roughish above, pubescent beneath, usually narrowed below the middle, sometimes $15 \mathrm{~cm}$. long: heads usually numerous, $3-5 \mathrm{~cm}$. broad, panicled or somewhat racemose on the branches: involucre campanulate; bracts lanceolate, glabrate, rather loose, with herbaceous tips: ray-flowers numerous; ligules purple-blue. Resembles $A$. patens Ait.; but softer and taller; heads larger; inflorescence narrow ; leaves elongated.

In woods and thickets, New York to Ohio, Georgia and Tennessee. Later summer and fall.

54. Aster oblongif òlius Nutt. Stem much branched, $3-7 \mathrm{dm}$. high, hirsute-pubescent, smooth with age, the branches divaricate or ascending; leaves numerous, often crowded; blades oblong or oblong-lanceolate, sessile by a broad or slightly clasping base, usually rigid, entire or mucronulate at the apex, rough or hispidulous on both sides, rough margined, those of the stem $3-5 \mathrm{~cm}$. long, 4-8 mm. wide, those of the branches gradually smaller : heads corymbose, nearly $25 \mathrm{~mm}$. broad : involucre hemispheric; bracts much imbricated, glandular-aromatic, linear or linear-oblong, the acute green tips. spreading: ray-flowers $20-30$; ligules violet-purple, rarely rose-pink, $6-10 \mathrm{~mm}$. long : pappus becoming light brown : achenes canescent.

On prairies and bluffs, Pennsylvania to Minnesota, Nebraska, Virginia, Tennessee, and Texas. Summer and fall.

55. Aster Kumleìnii Fries. Plant resembling A. oblongifolius, but low, chiefly $3 \mathrm{dm}$. high, with fastigiate bushy top of numerous subcorymbose branches, paler, harsher and more rigid, smaller in all its parts, and much less pubescent : bracts looser and continued into investing bractlets below. Stem brown, brittle, terete : leaves hispidulous; blades oblong to linear, $4 \mathrm{~cm}$. long, or less, obtuse or rounded at apex : inflorescence decompound : heads $2 \mathrm{~cm}$. broad or less : rays violet-blue; outer bracts recurvate, with much green tissue, their green tips linear-spatulate; bracteals uniform, decurved, linear ; glands very shortstalked; strigose pubescence little developed, all surfaces short-scabrous or hirtellous, or the stem finally glabrate.

In dry exposed places, Wisconsin to Alabama, Colorado and Texas. Summer and fall.

56. Aster Nòvae-Ángliae L. Stem stout, 6-25 dm. high, hispid-pubescent, corymbosely branched above, very leafy : leaf-blades oblong-lanceolate, entire, acute, pubescent, $5-12 \mathrm{~cm}$. long, 12-25 mm. wide, each clasping by an auriculate base: heads numerous, $3-5 \mathrm{~cm}$. broad, clustered at the ends of the branches : involucre hemispheric ; bracts linear-
subulate, somewhat unequal, green, spreading, pubescent and more or less glandular-viscid : 
ray-flowers 40-50; ligules linear, 10-16 mm. long, violet-purple (typically a royal-purple, rarely replaced by rose-color, or white) : achenes pubescent : pappus becoming reddish white.

In fields, and along swamps, Quebec to the Northwest Territory, south to South Carolina, and Alabama, Missouri, Arkansas and Colorado. Summer and fall.

57. Aster Caroliniànus Walt. Stem widely or diffusely branched, 1-4 m. long, finely and softly more or less grayish pubescent: leaves relatively few, those of the stem and main branches with elliptic or oblong to oblong-lanceolate entire blades 4-11 cm. long, acute or acuminate at the apex and usually somewhat sagittate and clasping at the base, minutely pubescent: heads solitary or clustered at the ends of spreading conspicuously leafy branches: involucre hemispheric, $6-8 \mathrm{~mm}$. high; bracts narrow, the outer more or less spatulate, the inner linear, all with spreading or recurved and more or less foliaceous dark-green tips minutely pubescent within and without: ray-flowers numerous; ligules pale purplish or pinkish, $1.5-2 \mathrm{~cm}$. long: achenes glabrous.

In and about swamps, South Carolina to Florida. Fall and continuing long in flower.

58. Aster puníceus L. Stems $9-25 \mathrm{dm}$. tall, usually stout, purplish, broadly corymbosely or racemosely branched above, hispid with rigid hairs rising from a reddened tubercular base : leaf-blades lanceolate to oblong-lanceolate, 7-15 cm. long, acuminate, sessile and clasping by a broad or narrowed base, sharply serrate (or some upper ones entire, usually very rough above, pubescent on the midrib beneath : heads generally numerous, 2-4 cm. broad : involucre nearly hemispheric ; bracts linear or oblong, attenuate, imbricated in about 2 series, glabrous or ciliate, green, loose, spreading, nearly equal, sometimes broadened : ray-flowers 20-40; ligules light-violet (sometimes purplish or pale), 10-14 mm. long, showy: pappus nearly white: achenes pubescent.

In swamps. Nova Scotia to Ontario, Minnesota, North Carolina, Georgia, Alabama, Ohio and Michigan. Summer and fall.

59. Aster Ellióttii T. \& G. Stem 5-11 dm. tall, glabrous or pubescent in lines, corymbosely paniculate above : leaves rather numerous; blades thickish, various, those of the basal and lower cauline oblong to oblanceolate, 2-3 dm. long, with shallow appressed or rounded teeth, narrowed into broad petiole-like bases, those of the upper cauline elliptic to oblong-lanceolate, appressed-serrate, acute or acuminate, sessile or with petiole-like bases : heads numerous, chiefly crowded at the end of each branch : bracts very narrow, lax and often recurved, their tips linear-oblong or linear-subulate, and spreading : ray-flowers numerous; ligules narrowly linear, 9-11 $\mathrm{mm}$. long, bright purple : achenes glabrous or nearly so. Resembles $A$. puniceus L.; but inflorescence more corymbosely crowded and level-topped; bracts more attenuate and more spreading; rays deeper-colored; hairs with tubercular bases little or not at all developed.

In swamps, North Carolina to Florida. Fall.

60. Aster conduplicàtus Burgess. Plant chiefly pale green and smooth; the purplered stem nearly smooth but with some lines of straggling thick-based bristles; branches short, rigidly spreading, congested toward their ends with irregularly crowded heads : leafblades sessile, spatulate-linear, thick, smooth beneath, very rough above, without obvious veins except the pale green midrib, entire or remotely crenulate-serrulate above the middle ; axils sheathed by the conduplicate bases of the upper leaves : rameal leaves short, crowded, spreading and irregular : heads almost sessile: rays blue or violet, fading whitish : bracts linear, with triangular-acute apex, white scarious edges and bright green conspicuous deltoid tip. Allied to A. Novi-Belgii and A. puniceus.

In moist soil near Biltmore, North Carolina. Fall.

61. Aster prenanthoides Muhl. Stem $3-6 \mathrm{dm}$. high, glabrous or pubescent in lines above, flexuous, much branched : leaf-blades thin, oblong to ovate-lanceolate, $7-15 \mathrm{~cm}$. long, sharply and coarsely serrate, scabrous above, glabrous or nearly so beneath, acuminate, abruptly narrowed below into a broad-margined entire petiole, the base dilated and auriculate-clasping: heads usually numerous, $25 \mathrm{~mm}$. broad or more : involucre hemispheric ; bracts linear, acute, green, spreading, imbricated in 3 or 4 series, the outer shorter: ray-flowers 20-30; ligules violet, 8-12 mm. long: pappus tawny : achenes pubescent. Unlike other asters in its leaf-form, characteristically a suborbicular base and an ovateacuminate end, connected by a strap-like middle.

In moist soil, Massachusetts to Wisconsin, Tennessee and Iowa. Summer and fall.

62. Aster Nòvi-Bélgii L. Stem slender, 3-9 dm. high, usually much branched, glabrous or slightly pubescent above: leaf-blades lanceolate, oblong-lanceolate or linearlanceolate, 5-12 cm. long, firm, entire, or slightly serrate, glabrous or very nearly so, acuminate at the apex, narrowed, sessile, and more or less clasping at the base, those of the lower ones petioled : heads corymbose-paniculate, usually numerous, $2-3 \mathrm{~cm}$. broad : 
involucre hemispheric to campanulate ; bracts linear, acute, green, somewhat spreading, in 3-5 series, the outer shorter : ray-flowers $15-25$; ligules violet, $8-10 \mathrm{~mm}$. long : pappus whitish : achenes glabrous or nearly so.

In swamps, mainly near the coast, Newfoundland to Maine and Alabama. Summer and fall.-A. Novi-Belgii litòreus A. Gray, is low and spreading, more or less fleshy, much branched: leaf-blades shorter and broader, thickish, acute, 3-6 $\mathrm{cm}$. long: principal bracts of the involucre obtuse, loose, spatulate. Along salt marshes, Prince Edward Island and Quebec to Georgia.-A. Novi-Belgii Atlànticus Burgess, has leaf-blades lanceolate, tapering from the middle to an acuminate base and apex, sometimes $25 \mathrm{~mm}$. wide : heads usually fewer : inflorescence racemose-corymbose. In shaded swamps, Massachusetts to North Carolina.

63. Aster elòdes T. \& G. Tall, slender, smooth, little-branched plants : stem terete, $7 \mathrm{dm}$. high or less, pale and reddened : leaf-blades narrowly linear, entire, shining and firm, smooth and coriaceous when dry, 5-15 $\mathrm{cm}$. long, often not more than $1 \mathrm{~cm}$. broad, scarcely clasping by the contracted sessile base, divaricately spreading and becoming deflexed ; rameal leaves very numerous, approximate, oblong-oval to linear, divaricate-recurvate, with abruptly contracted base and apex, diminished to $1 \mathrm{~cm}$. long on the pedicels : leaves (especially the rameal) with their margins hardened, thickened, minutely spinulose and revolute : inflorescence loosely panicled, with domed, flattened or irregular top : heads often approximate ; chief bracts closely imbricated, rigid, erect, their tips lanceolate, erect or spreading, with pale or purple margin ; some green spreading foliaceous outer bracts occur, but they are usually few or inconspicuous.

In swamps, especially in pine lands, Massachusetts to North Carolina. Summer and fall.

64. Aster seríceus Vent. Stem 3-6 dm. high, slender, paniculately or corymbosely branched, stiff, glabrous, leafy : basal and lowest leaves oblanceolate, narrowed into margined petioles; cauline leaves sessile, with a broad base, oblong, entire, mucronate, 1-4 $\mathrm{cm}$. long, erect or ascending, with a dense silvery-white silky pubescence on hoth sides : heads numerous, about $35 \mathrm{~mm}$. broad : involucre turbinate; bracts oblong, or the inner lanceolate, canescent, imbricated in 3 or 4 series, their tips green, acute, spreading : rayflowers 15-25; ligules reddish violet, becoming violet-blue, $12-16 \mathrm{~mm}$. long: pappus tawny : achenes glabrous.

In dry open soil, Manitoba to Illinois, Minnesota, south to Tennessee, Kansas and Texas. Late summer and fall.

65. Aster phyllólepis T. \& G. Stem 3-8 dm. tall, more or less canescent, commonly with a few simple slender branches : leaves various, the basal with oblong or oblongspatulate blades narrowed at the base, the cauline rather approximate but often early deciduous; blades lanceolate, oblong or linear-oblong, 1-3 cm. long, acute or obtusish, or those on the branches cuspidate-acuminate, entire or nearly so, rough-pubescent, sessile: heads solitary, or few in clusters : involucres $6-7 \mathrm{~mm}$. high ; bracts various, the outer resembling the upper leaves, with ovate or ovate-lanceolate cuspidate-acuminate green blades, the inner linear or linear-lanceolate, acuminate : ray-flowers 16-26; ligules 1-1.5 cm. long, violet : achenes glabrous. Resembles $A$. sericeus Vent. ; but the heads and branches more approximated, the leaf-bases more narrow.

In sandy woods. Louisiana and Texas. Fall.

66. Aster cóncolor L. Stem 3-7 dm. high, leafy, simple, or with few erect branches : leaf-blades oblong or linear-oblong, finely and densely canescent on both sides, or the lower glabrate, sessile, obtuse or mucronate, $4-5 \mathrm{~cm}$. long: heads in an elongated narrow raceme resembling that of species of Laciniaria: involucre broadly turbinate ; bracts linear or linear-oblong, appressed, canescent, imbricated in 4 or 5 series, their tips green, acute, the outer shorter: ray-flowers 10-15; ligules lilac, drying violet-blue, $6-8$ mm. long: pappus tawny : achenes villous. Resembles $A$. sericeus Vent. ; but more wandlike and spicate, and more canescent than silky.

in dry sandy soil, mainly near the coast, Massachusetts and Rhode Island to Florida and Louisiana. Late summer and fall.

67. Aster adnàtus Nutt. Stem 2-8 dm. tall, hispidulous, virgately more or less branched, especially above : leaves various, the basal few, with obovate thinnish blades $1.5-2.5 \mathrm{~cm}$. long, the cauline very numerous, approximate on the lower part of the stem, more or less imbricated above and on the branches; blades oblong to lanceolate, 3-12 mm. long, firm, scabrous, erect and adnate to the stem and branches, sessile: heads relatively few, scattered, singly terminating the scaly branchlets : involucres 4-6 mm. high ; bracts linear or slightly broadened upward, the dark green tips slightly spreading: ray-flowers numerous; ligules $7-10 \mathrm{~mm}$. long, violet : achenes glabrous. Remarkable among asters in its minute adnate scale-like leaves.

In dry pine lands, Georgia, Florida and Alabama. Fall.

68. Aster squarròsus Walt. Stem $2-6 \mathrm{dm}$. tall, loosely branched above or throughout, nearly glabrous: leaves very numerous, the basal spatulate to cuneate, entire, the 
cauline approximate or contiguous, rigid, reflexed; blades oblong-lanceolate to ovate or subulate-ovate, $2-9 \mathrm{~mm}$. long, ciliate, serrate, closely sessile : heads few, widely scattered, terminating scaly branchlets : involucre $5-6 \mathrm{~mm}$. high ; bracts broadened upward, the dark green acute or acutish tips slightly spreading : ray-flowers $14-24$; ligules $6-9 \mathrm{~mm}$. long, violet: achenes glabrous.

In dry pine lands, North Carolina to Florida. Fall.

69. Aster grandiflòrus L. Stem 3-7 dm. high, rather stiff, divaricately much branched, hispid with short hairs : leaf-blades oblong, linear, or somewhat spatulate, rigid, sessile by a broad sometimes slightly clasping base, reflexed, entire, obtusish, hispid, the larger $5 \mathrm{~cm}$. long, those of the branches very numerous 4-10 $\mathrm{mm}$. long: heads about 5 $\mathrm{cm}$. broad, terminating the branches: involucre hemispheric ; bracts very squarrose and foliaceous, imbricated in 5-7 series, linear, or linear-oblong, glandular, the outer obtusish, the inner acute : rays very numerous; ligules deep violet, nearly $25 \mathrm{~mm}$. long, $3 \mathrm{~mm}$. wide : pappus becoming brownish : achenes ribbed, canescent. Resembles A. oblongifolius Nutt.; but heads larger and fewer, more glandular.

In dry soil, Virginia, east of the mountains, to Florida. Late summer and fall.

70. Aster Curtísii T. \& G. Stem 4-18 dm. tall, glabrous, at least below the inflorescence, angled, corymbose or paniculate above, the panicle sometimes raceme-like : leaves various, sometimes all with linear or nearly linear blades and entire or partially serrate, sometimes the lower cauline with lanceolate, elliptic, oval or ovate sharply serrate blades and petiole-like base and the upper cauline linear and less toothed, occasionally all of them relatively broad, all thickish, dark green and glabrous : heads solitary or clustered at the end of the stem or its branches : involucre hemispheric, 6-9 mm. high, conspicuous ; bracts often slightly ciliolate, pale below the more or less dilated dark green spreading, or reflexed tips: ray-flowers 18-28; ligules violet-purple, often brilliant, $1-3 \mathrm{~cm}$. long: achenes glabrous, shorter than the sordid pappus. Resembles A. spectabilis Ait.; but leaves more polymorphous; stem taller; heads more diffused, and glands lacking.

In mountain woods, especially in the Blue Ridge, North Carolina, Tennessee and Georgia. Fall.

71. Aster spectábilis Ait. Stem stiff, $3-6 \mathrm{dm}$. tall, simple, or corymbosely branched above, puberulent, or rough below, more or less glandular above : leaf-blades firm, thickish, those of the basal and lower cauline leaves oval, acute or acutish, 7-12 cm. long, 2-4 $\mathrm{cm}$. wide, sparingly serrate with low teeth, narrowed at the base into slender petioles; blades of the upper cauline leaves sessile, entire or very nearly so, acute, linear-oblong: heads several or numerous, about $35 \mathrm{~mm}$. broad, corymbose, very showy : involucre nearly hemispheric ; bracts linear-oblong or slightly spatulate, glandular, imbricated in about 5 series, the green obtusish tips spreading: ray-flowers $15-30$; ligules bright violet, $12-20$ $\mathrm{mm}$. long: pappus whitish : achenes slightly pubescent.

In dry sandy soil, near the coast, Massachusets to North Carolina. Late summer and fall.

72. Aster surculòsus Michx. Stem $2.5-4.5 \mathrm{dm}$. tall, slender, from elongated-filiform rootstocks, minutely scabrous-pubescent, corymbosely branched above : leaf-blades firm, lanceolate or linear, those of the lower cauline petioled, 5-7 cm. long, rough-margined, slightly scabrous above, sparingly dentate, those of the upper narrower, sessile, entire: heads few, or sometimes solitary, about $3 \mathrm{~cm}$. broad: involucre turbinate-hemispheric ; bracts coriaceous, imbricated in about 5 series, ciliate, but scarcely glandular, their green tips spreading : ray-flowers $15-30$; ligules violet : pappus whitish : achenes nearly glabrous. Resembles $A$. spectabilis Ait.; but the rootstocks more persistent and therefore conspicuous, the glands obsolescent, leaf-blades narrower and heads smaller.

In sandy or gravelly soil, North Carolina, Georgia and Tennessee. Reported from New Jersey. Late summer and fall.

73. Aster grácilis Nutt. Stem slender, $3-4 \mathrm{dm}$. high, finely puberulent and scabrous, corymbosely branched above : leaf-blades minutely scabrous, those of the basal and lower cauline leaves oblong, acute or obtusish, 5-7 cm. long, toothed, narrowed into slender petioles, those of the upper leaves linear, linear-oblong, or slightly oblanceolate, acute, entire, sessile or a little clasping : heads usually numerous, $12-20 \mathrm{~mm}$. broad : involucre narrowly turbinate; bracts coriaceous, glabrous or very nearly so, imbricated in about five series, their tips green and spreading, obtusish : ray-flowers $9-15$; ligules violet, $6-9 \mathrm{~mm}$. long: pappus nearly white : achenes minutely pubescent. Resembles A. spectabilis Ait.; but the heads much smaller, more numerous, more crowded, the glands lacking.

In dry sandy soil, New Jersey to Kentucky, Tennessee and North Carolina. Summer and fall.

74. Aster dumòsus L. Stem 3-9 dm. high, glabrous or very nearly so throughout, paniculately much branched : leaf-blades firm, those of the stem linear or linear-lanceolate, $2-7 \mathrm{~cm}$. long, entire, acute or obtusish, roughly margined, often reflexed, those of the branches very numerous, small and scale-like, those of the basal leaves spatulate, dentate: 
heads $8-14 \mathrm{~mm}$. broad, terminating the usually divergent slender branches and branchlets, usually numerous : involucre broadly campanulate; bracts linear-subulate, appressed, imbricated in about four series, obtuse in type, with green spatulate tips tapered at their apex : ray-flowers $15-30$; ligules white (rarely pale pink or pale violet), $4 \mathrm{~mm}$. long: pappus white: achenes minutely pubescent.

In sandy soil or swamps, Maine to western New York, Ontario, Florida, Louisiana and Missouri. Late summer and fall.-The following forms are distinguishable: $\rightarrow A$. dumosus subulaefòlius T. \& G.: more rigid, with long straggling branches; heads somewhat larger; rameal leaves linear with subulate apex, rigid and sharp or even punctate, erect or slightly spreading; bracts acute, their narrow green tips lanceolate to spatulate. In pine lands and copse-borders, South Carolina and Florida to Arkansas and Texas. A. dumosus graciléntus T. \& G.: more slender.and effuse, the small heads often solitary upon the prolonged divergent branches; rameal leaves scattered, spreading, minute, entire, obtuse or acutish. Woodlands, Martha's Vineyard to Florida and Alabama. A. dumosus strictior T. \& G.: branches not very numerous, often aggregated above and ascending; leaf-blades acuminate and entire. Moist thickets, Massachusetts to Maryland and Tennessee.

75. Aster coridifòlius Michx. Resembles $A$. dumosus, but the stem more rigid, diffusely decompound with slender flagellate branches and branchlets; cauline leaves as in $A$. dumosus; rameal and ramular leaves uniform, and minute, greatly and abruptly reduced from the cauline, spreading or divaricate or reflexed, linear, usually not over $1 \mathrm{~cm}$. long, very numerous, crowded and bract-like, giving the plant its characteristic aspect: heads small, many of them solitary on prolonged branchlets : bracts more rigid, obtusish, their tips broad-spatulate, rounded and then apiculate.

In pine lands chiefly, North Carolina and Florida to Louisiana ; and northward in sand barrens to Martha's Vineyard. Summer and fall.

76. Aster multiflòrus Ait. Stem 3-20 dm. high, strict, much branched and bushy, the branches ascending or spreading: leaf-blades rigid, linear, entire, mostly obtuse, sessile or slightly clasping at the base, strigose or glabrate, those of the cauline leaves 1-2.5 $\mathrm{cm}$. long; those of the branches very small and crowded : heads $6-8 \mathrm{~mm}$. broad, densely crowded, nearly sessile : involucre turbinate, 4-6 $\mathrm{mm}$. high ; bracts coriaceous, pubescent, in 3 or 4 series, their short green tips obtuse or mucronate, spreading: ray-flowers 10-20; ligules white, 3-4 mm. long: pappus becoming brownish white : achenes puberulent.

In dry open places, Maine and Ontario to South Dakota, Georgia, Texas and Mexico. Late summer and fall.

77. Aster exíguus (Fernald) Rydb. Stem 3-10 dm. high, much branched and bushy, rough-pubescent with short divaricate hairs, the branches spreading, often secund: leaves as in the next preceding species, but more pubescent, the hairs spreading, ciliate: heads as in A. multiflorus, but usually on shorter branchlets : bracts of the involucre broader, and each with a thick, broad, oval or obovate green portion, hispid and ciliate.

On prairies, plains and other open places, Vermont to Washington, Pennsylvania, Texas and Arizona. Rare eastward. Late summer and fall.

78. Aster racemòsus Ell. Stem apparently tall, somewhat scabrous-pubescent on the ascending rather slender branches : leaves firm; blades linear or nearly so, relatively small, acute, the upper entire : heads not very numerous, racemosely or spicately disposed, rather crowded toward the ends of the branches, distant below : involucre about $4 \mathrm{~mm}$. high ; bracts firm, subulate to narrowly linear, acuminate : ray-flowers few ; ligules purplish, 2-3 mm. long: achenes minutely pubescent.

Along or near the coast, South Carolina to Florida and Louisiana. Summer and fall.

79. Aster vimíneus Lam. Stem 6-15 dm. high, glabrous or nearly so, slender, divergently branched : cauline leaves linear-acuminate, $7-12 \mathrm{~cm}$. long, regularly minutely hack-serrate, slightly narrowed at the sessile base, those of the branches much smaller: heads very numerous, $6-10 \mathrm{~mm}$. broad, generally densely racemose-secund, short-peduncled: involucre broadly turbinate ; bracts linear, acute or acutish, green-tipped, appressed : rayflowers numerous; ligules about $4 \mathrm{~mm}$. long, narrowly linear, white, often roseate in fading : pappus white : achenes minutely pubescent.

In moist soil, Ontario to Massachusetts, Minnesota, Kansas, Florida and Arkansas. Late summer and fall.

80. Aster lateriflòrus (L.) Britton. Stem 3-15 dm. tall, puberulent or nearly glabrous, slender, divergently branched, often bushy : basal leaves few; blades ovate, shortpetioled ; cauline leaves numerous; blades broadly lanceolate or oblong-lanceolate, 5-12 $\mathrm{cm}$. long, mostly acuminate, serrate, those of the branches smaller, oblong or linear-oblong: heads $6-10 \mathrm{~mm}$. broad, racemosely unilateral on the branches, short-peduncled or sessile, usually numerous and crowded : involucre turbinate ; bracts linear-oblong, obtuse or acutish, imbricated in about 4 series, their short green tips appressed or slightly spreading: rayflowers numerous; ligules short, whitish or pale purple, rounded at the apex: disk-flowers purple : pappus white: achenes minutely pubescent. 
In dry or moist soil, Nova Scotia to Ontario, North Carolina and Alabama to Arkansas, Louisiana and Texas. Late summer and fall.-The following forms are distinguishable: A. lateriflorus glomeréllus (T. \& G.) Burgess: chiefly unbranched; leaves hispidulous above, oblong-lanceolate, dull green, the teeth very sharp and straight; heads glomerate in the axils or spicate above, or scattered upon short branches. Woodlands, New York to North Carolina. A. lateriflorus thyrsoideus (A. Gray) Sheldon : ashy-pubescent; leaves ovate to lanceolate; branches ascending, bearing crowded or thyrsoid-paniculate heads. Open thickets, New York and Ontario to Illinois and Tennessee. A. lateriflorus horizontàlis (Desf.) Burgess: branches long, divaricate or widely spreading; leares firm, subsucculent, those of the branches very small, mostly entire; heads very numerous. Southern New York to Virginia and Arkansas. A. lateriflorus péndulus (Ait.) Burgess : leaves narrower, linear-elliptic, conspicuously drooping, remotely appressed-serrulate; branches long, slender, horizontal or becoming pendulous; heads long-peduncled. Thickets, New York to North Carolina and Alabama.

81. Aster hirsuticaùlis Lindl. Stem 4-9 dm. tall, slender, erect, pubescent, nearly or quite to the base ; branches usually short, spreading or ascending: leaf-blades thin, glabrous above, usually densely pubescent on the midvein beneath, serrate with a few appressed teeth, or entire, of linear type, sometimes $15 \mathrm{~cm}$. long, sessile or the basal ones spatulate and petioled : heads more or less secund on the branches, chiefly loosely clustered, often also solitary or few in the lower axils : involucre narrow; bracts of the involucre in 3 or 4 series, linear-lanceolate, acuminate or acute: ray-flowers several, white; ligules about 4 $\mathrm{mm}$. long, narrow. Unlike A. lateriflorus in its hirsute stem and its long linear straightsided leaf-blades which are hirsute on the midrib beneath.

In woods and thickets, Maine to Pennsylvania and Tennessee. Late summer and fall.

82. Aster spatellifórmis Burgess. Stem much branched, glabrous, $6 \mathrm{dm}$. high or more : leaf-blades dull green and crenate, thickish, glabrous, the upper surface usually finely impressed with reticular veins: leaf-form suggesting a small rounded spatula, oval with a rounded apex, tapering into a short entire cuneate-winged petiole ; basal and rameal leaves as well as cauline all of nearly the same type, $5 \times 3 \mathrm{~cm}$. or less; the axiles half as large and oval-oblong, with a short cuneate base; the rameals half as large as the axiles, but very uniform, numerous and characteristic: heads small, scattered along the prolonged or sarmentose branches, usually short-pedicelled : bracts rigid, linear, with whitish sides and acute apex, the narrow dark green tips lance-triangular. Differs from $A$. lateriflorus in leaf-form, etc.

Near swamps, Jacksonville, Florida. Fall.

83. Aster ericoìdes L. Stem $3-9 \mathrm{dm}$. tall, glabrous or very nearly so, paniculately branched, usually bushy, the branches racemose, and the branchlets often somewhat secund: leaf-blades firm or rigid, those of the basal leaves spatulate, obtuse, dentate, narrowed into margined petioles, glabrous or ciliate, those of the cauline leaves narrowly linear, acute, entire, 2-7 cm. long, those of the branches linear-subulate, numerous : heads usually very numerous, 8-12 mm. broad: involucre campanulate to hemispheric ; bracts coriaceous, closely appressed, lanceolate or linear-lanceolate, abruptly acute or acuminate, green-tipped, imbricated in about 3 series : ray-flowers $15-25$; ligules white, or purplish-tinged : pappus white : achenes finely pubescent.

In dry soil, Maine and Ontario to Wisconsin, Florida and Kentucky. Fall and winter-The following forms are distinguishable: A ericoides pilòsus (Willd.) Porter: stem, branches and often the leaves villous-hirsute ; leaf-blades linear-lanceoate. Ontario to Pennsylvania, North Carolina, Georgia and Mississippi, Minnesota and Missouri. Spreading as a weed in cultivated soil, Ohio to Illinois. $A$. ericoides platyphyllus T. \& G. densely villous-hirsute; blades of the stem-leaves much broader, lanceolate or oblong-lanceolate, $2-5 \mathrm{~cm}$. long. Indiana to North Carolina and Georgia. A. ericoides Reevesii A. Gray : rigid, stout, nearly glabrous; heads and rays larger; bracts and their lanceolate green tips apt to be falcately one-sided. Tennessee.

84. Aster juniperìnus Burgess. Stem robust, brittle, glabrous, pale brown, about 6 $\mathrm{dm}$. high, the branches numerous, prolonged, chiefly horizontal and parallel, sometimes 4 $\mathrm{dm}$. long: cauline leaves dull green; blades thin, linear-biacuminate, $10 \times 1 \mathrm{~cm}$; rameal and ramular leaves subulate and all nearly alike, wide-spreading, juniper-like, greatly reduced and very numerous and crowded, diminishing rapidly on the elongated pedicels and passing insensibly into the small spreading green outer bracts of the broad hemispherical head; the other bracts longer and broader, linear with triangular-acuminate summit, coriaceous and very smooth, bright white except the broadly deltoid sharp-angled green tip : heads small : rays white: disk turning reddish brown. Unlike its congener $A$. ericoides in its numerous heads solitary on long branches or branchlets. Unlike A. Faxoni in its tendency to divaricate, not corymbose, branching.

In loose sandy soil, in the sun, Maryland to Alabama. Late summer and fall.

85. Aster Faxòni Porter. Stem 6-15 dm. high, glabrous throughout, paniculately or corymbosely branched, rather stout : cauline leaves various; blades lanceolate or linearlanceolate, 5-12 cm. long, acute, or acuminate, narrowed to a sessile base or those of the lower ones into margined petioles, entire or nearly so, firm, those of the branches gradually smaller: basal leaves with oblong to spatulate, obtuse, dentate blades: heads 12-18 mm. broad : involucre hemispheric, nearly $8 \mathrm{~mm}$. high ; bracts linear-lanceolate, acute or subu- 
late, green-tipped or green on the back, imbricated in about 3 series, the outer shorter: ray-flowers several ; ligules bright white, $6-8 \mathrm{~mm}$. long: pappus white: achenes minutely pubescent. Resembles $A$. ericoides L.; but leaf-blades larger, thicker ; heads larger ; earlier. On moist cliffs, Vermont and Massachusetts to Wisconsin, Pennsylvania and North Carolina. Late summer and fall.

86. Aster Prìceae Britton. Stem 3-7 dm. high, pubescent, widely branched : basal leaves with oblanceolate obtuse or acutish entire petioled blades, 3-7 cm. long, the petioles ciliate, broad : cauline leaves relatively few ; blades linear-lanceolate, sessile, ciliate, acuminate, $2-5 \mathrm{~cm}$. long, those of the branches similar but smaller: involucres nearly hemispheric, about $6 \mathrm{~mm}$. high ; bracts linear, the outer gradually acuminate, green, the inner a little broader, abruptly acuminate, acute or obtusish : heads about $2.5 \mathrm{~cm}$. broad : ray-flowers numerous; ligules bright crimson or pink. Resembles $A$. ericoides but the rays much longer and deeply reddened.

In dry soil, Kentucky and North Carolina. Fall.

87. Aster Baldwínii T. \& G. Stem diffusely panicled, somewhat pubescent : leaves rigid ; blades linear, sessile, entire, rough with minute hispidulous hair beneath and especially so above; bracteals similar but very much reduced and more acute, tending to become crowded and appressed : heads loosely racemed on the branches: bracts linear, acute, imbricated in about four series, whitish and coriaceous, with rather conspicuous green tips which are narrow diamond form, with distinct lateral angles, or without them and becoming lanceolate ; unlike the spatulate or oboval tips of its congener $A$. dumosus : rays narrow, deep blue-violet; unlike the groups typified by $A$. undulatus and $A$. azureus, with which it has been compared in the general agreement of its lower leaves with $A$. dumosus; unlike the latter species, in its bract-tips, its violet rays, its hispidulous entire leaves.

In moist soil, North Carolina and Georgia to Louisiana.

88. Aster Tradescánti L. Stem $6-15 \mathrm{dm}$. tall, slender, paniculately branched, the branches usually ascending and often pubescent in lines : cauline leaves numerous; blades linear-lanceolate or lanceolate, $7-15 \mathrm{~cm}$. long, acuminate, narrowed to the sessile base, glabrous or nearly so on both sides, commonly thin, sharply serrate in the middle with low teeth, or sometimes entire : heads very numerous, racemose but not secund on the branches, 10-16 $\mathrm{mm}$. broad: involucre hemispheric to broadly turbinate, 4-6 mm. high; bracts linear, acute, appressed, green-tipped, imbricated in 4 or 5 series : ray-flowers numerous ; ligules white or nearly so, 4-6 mm. long: pappus white : achenes minutely pubescent.

In fields and swamps, Ontario to the Northwest Territory, Florida and Minnesota. Late summer and fall.

89. Aster agrostifòlius Burgess. Stem terete, greenish or straw-colored, $6 \mathrm{dm}$. or often $8 \mathrm{dm}$. high, slender, erect or straggling, sparingly but widely branched : leaves grass-like, dull green above and beneath ; blades very thin, chiefly entire, linear-acuminate, tapering to the sessile base and especially to the apex, $10 \mathrm{~cm}$. or even $15 \mathrm{~cm}$. long, by $1 \mathrm{~cm}$. wide; some lower cauline leaves become broader, lanceolate or oblong and slightly appressedserrulate; axils generally corrigiate or occupied by two little divaricate branch-leaves: heads very small and pale, about $1.5 \mathrm{~cm}$. broad: rays whitish : bracts linear-acuminate, very pale, with narrow linear green tips.

In low grounds, under light shade and about copse-borders, Martha's Vineyard to Florida and Arkansas ; also on river banks at Knoxville, Tennessee. Fall.

90. Aster paniculàtus Lam. Stem 6-25 dm. high, glabrous or nearly so, paniculately much branched : leaf-blades lanceolate to oblong-lanceolate, $7-15 \mathrm{~cm}$. long, acuminate at the apex, narrowed to a sessile or slightly clasping base, glabrous, thin, roughish margined, those of the cauline leaves sparingly serrate in the middle, or sometimes very nearly entire, the upper and those of the branches gradually smaller: heads numerous, 16-20 $\mathrm{mm}$. broad : involucre nearly hemispheric, $6-8 \mathrm{~mm}$. high ; bracts narrowly linearlanceolate, acute or acuminate, appressed, green-tipped, imbricated in 4 or 5 series : rayflowers numerous; ligules white (or faintly tinged with violet), 6-8 $\mathrm{mm}$. long: pappus white or nearly so: achenes minutely pubescent.

In moist soil, New Brunswick to western Ontario and Montana, south to New Jersey, Virginia, Louisiana and Kansas. Late summer and fall. $-A$. paniculatus bellidiflòrus (Willd.) Burgess : leafblades narrowly linear, acuminate at both ends, entire, or remotely appressed-serrate, chiefly $10 \mathrm{~cm}$. long and $7 \mathrm{~cm}$. wide, or less: heads numerous, rather densely clustered on ascending branches of the large panicle. In open places, New Brunswick to Ontario, North Carolina, Tennessee, Missouri and Kansas.

91. Aster Missouriénsis Britton. Whole plant pubescent, much branched : stem 6 $\mathrm{dm}$. high or more: leaf-blades thin, oblanceolate and acute in type, dull or cinereous-green, sharply serrate above the middle, with long-tapering entire sessile base, finely pubescent beneath : heads irregularly panicled or scattered along leafy branches : bracts linear, acute, closely imbricated. Differs from $A$. paniculatus Lam. especially in its pubescence.

In moist places, Kansas and Missouri to Texas. Fall. 
92. Aster salicifòlius Lam. Stem $6-15 \mathrm{dm}$. high, rather slender, paniculately much branched, usually very leafy, glabrous, or somewhat pubescent above : leaf-blades somewhat firm, lanceolate or linear-lanceolate, $5-10 \mathrm{~cm}$. long, rough-margined, acute or acuminate, narrowed and sessile or slightly clasping at the base, entire or sparingly dentate with low teeth, glabrous or nearly so, those of the lower leaves sometimes with petiole-like bases, those of the branches gradually smaller : heads numerous, $16-25 \mathrm{~mm}$. broad : involucre broadly turbinate ; bracts linear-oblong, appressed, imbricated in 4 or 5 series, their green tips acute or obtuish : ray-flowers numerous ; ligules violet, or violet-purple, or sometimes white, $6-8 \mathrm{~mm}$. long: pappus white : achenes minutely pubescent.

In moist soil, Maine and Ontario to Massachusetts and Florida, west to Montana, Missouri, Oklahoma, and Texas. Late summer and fall.-The following forms are distinguishable: $A$. salicifolius subásper (Lindl.) A. Gray : stem scabrous; leaves more or less so. Indiana to Missouri, Louisiana and Texas. A. salicifolius caeruléscens (DC.) A. Gray : strict and rigid; leaves all entire; inflorescence more naked; heads larger; bracts narrower, acute. Rocky banks, Texas.

93. Aster ptarmicoìdes (Nees) T. \& G. Stems tufted, $3-6 \mathrm{dm}$.' high, slender, rigid, usually rough above, corymbosely branched near the summit: leaf-blades linear-lanceolate, 3-ribbed, entire, or with a few distant teeth, firm, shining, rough-margined or ciliate, sometimes scabrous, acute, narrowed to a sessile base, or those of the lower leaves petioled; the lowest and basal ones $7-15 \mathrm{~cm}$. long, the upper smaller, those of the branches linearsubulate : heads 16-25 mm. broad, terminating the branches of the corymb: involucre nearly hemispheric, 4-6 mm. high ; bracts linear-oblong, obtuse, appressed, nearly green, imbricated in about 4 series : ray-flowers $10-20$; ligules snow-white, narrow, $6 \mathrm{~mm}$. long: pappus white : achenes glabrous. Remarkable among asters for its profuse linear shining rough-edged leaf-blades and small level-topped white flowers.

In dry or rocky soil, Massachusetts, Vermont and Ontario to the Northwest Territory, Illinois Missouri and Colorado. Summer and fall. - A. ptarmicoides Georgianus Gray, is taller with smaller heads : lower leaves $15-18 \mathrm{~cm}$. long, often denticulate. Georgia and Arkansas.

94. Aster acuminàtus Michx. Stem 3-9 dm. high, pubescent or puberulent, zigzag, corymbosely branched, often leafless below : leaf-blades thin, broadly oblong or elliptic, $7-15 \mathrm{~cm}$. long, acuminate at the apex, narrowed to a cuneate sessile base, sharply and coarsely dentate, strongly pinnately veined, glabrous or pubescent above, pubescent at least on the veins beneath, in low shaded plants often approximate above, and appearing whorled: heads several or numerous, $25-37 \mathrm{~mm}$. broad: involucre nearly hemispheric; bracts subulate-linear, acuminate, the outer much shorter : ray-flowers 12-18; ligules narrow, 12-16 mm. long, white or slightly purplish : pappus copious, soft and fine, very white : achenes pubescent. Remarkable for its soft-pubescent limp subviscid leaves and its decurved buds becoming erect and fragrant in flower. fall.

In moist woods, Labrador to Ontario, New York and in the mountains to Georgia. Summer and

95. Aster paludòsus Ait. Stems 3-7 dm. high, roughish, or rough-pubescent, slender, virgate and simple, or somewhat branched above, pale or purplish, leafy in the axils ; leaf-blades linear-acuminate or nearly so, $5-15 \mathrm{~cm}$. long, entire, glabrous, rather rigid, mostly 1-nerved, acute, the lower part commonly narrowed and sheathing, the margins rough or ciliate: heads few or several, racemose or paniculate, $3-5 \mathrm{~cm}$. broad : involucre broadly campanulate or hemispheric ; bracts imbricated in about 5 series, foliaceous, ciliate, the outer lanceolate, acute, often thickened-subulate at the tip, the inner oblong or spatulate : ray-flowers 20-30; ligules deep violet, 10-14 mm. long : pappus tawny : achenes 8-10-nerved, glabrous or nearly so.

In swamps, Missouri and Kansas to North Carolina, Florida and Texas. Late summer and fall.

96. Aster spinulòsus T. \& G. Plant nearly or quite smooth to the touch, and almost without hair. Stem pale, slender, 5-6 dm. high, from a short erect tuberous rootstock shaggy with marcescent leaf-bases : basal leaves tufted, very numerous, long and slender, linear and attenuate below, often $3 \mathrm{dm}$. long, with occasional long slender teeth ; stemleaves bract-like, erect, $4 \mathrm{~cm}$. long or commonly half that : axile leaves upcurved, stiff and pungent : heads sessile and subremote in the upper axils, each subtended by an upturned carinate pungent involucral leaf : rays violet, little over $1 \mathrm{~cm}$. long, broader, the diskflowers fewer and the bracts paler-margined than in $A$. paludosus, which this otherwise resembles: pappus tawny, becoming ferruginous. Unlike $A$. paludosus in its smaller, spicate heads, longer narrower basal leaves, more pungent upper leaves, and less conspicuous teeth.

In wet pine lands, Florida. Summer.

97. Aster eryngiifolius T. \& G. Plant nearly smooth to the touch, sparsely villous above : rootstock tuberous-thickened : stem rigid, erect, 3-7 dm. high, unbranched, with one terminal head or sometimes several large heads closely approximate: leaves grass-like, linear-acute with narrowed base, the numerous basal leaves spreading, chiefly $1 \mathrm{dm}$. long 
or less, the others soon reduced to one-third the length, suberect, subulate-linear, sessile and bract-like; both set below the middle with long slender subremote subulate teeth: involucres broadly hemispherical; bracts nearly of the same length but of many series, linear-subulate, flat, and appressed, the upper third slender, bristle-like and spreading: rays $3 \mathrm{~cm}$. long, tapering below, light violet, blue or white : disk-flowers very numerous : pappus becoming ferruginous in the herbarium : alveolae deep and pronounced.

In low coastal pine lands, Florida. Summer.

98. Aster Chapmánii T. \& G. Stems rigid, arising from a short caudex, glabrous, usually with few slender or nearly filiform branches above: leaves mainly crowded on the caudex, 1-3 dm. long, glabrous, the linear or linear-spatulate blades longer or shorter than the slender petiole-like base, entire, obscurely nerved in drying; lower cauline-leaves nearly like the basal, the upper gradually reduced to subulate-filiform erect scales, and subulate on the branches : heads few, solitary at the ends of the branches: involucres campanulate, 7-8 mm. high ; bracts firm, oblong-lanceolate to broadly linear and linear-oblanceolate, erect, acute, sometimes abruptly pointed : ray-flowers numerous; ligules $1.5-2 \mathrm{~cm}$. long, violet: achenes glabrous.

In pine-land swamps, western Florida. Fall.

99. Aster tenuifòlius L. Perennial, glabrous and fleshy. Stem 3-6 dm. tall, flexuous, striate, at least when dry, sparingly and loosely branched : cauline leaves linear, 5$15 \mathrm{~cm}$. long, entire, sessile, or slightly clasping at the base, the lowest lanceolate-linear, those of the branches minute, scale-like, appressed : heads rather few, 12-25 mm. broad, terminating the branches: involucre turbinate, about $8 \mathrm{~mm}$. high; bracts lanceolate, acuminate or mucronate, glabrous, green on the back or tips, appressed, imbricated in about 5 series, the outer shorter: ray-flowers numerous; ligules longer than the pappus, pale purple or nearly white : pappus tawny, achenes hispid-pubescent, 5-nerved.

In salt marshes, coast of Massachusetts to Florida. Summer and fall.

100. Aster exilis Ell. Annual, glabrous, fleshy. Stem $3-12 \mathrm{dm}$. tall, slender, usually much branched, the branches usually divergent: cauline leaves linear to linearlanceolate, $2-10 \mathrm{~cm}$. long, entire, sessile, acute or acuminate, or the lower narrowly oblong, 6-8 mm. wide, usually petioled, those of the branches subulate : heads numerous, panicled, about $1 \mathrm{~cm}$. broad : involucre campanulate, about $6 \mathrm{~mm}$. high ; bracts linear-subulate, appressed, imbricated in 3 or 4 series: ray-flowers mostly fewer than those of the disk; ligules purplish, about $4 \mathrm{~mm}$. long, longer than the pappus : achenes somewhat pubescent.

In moist or wet soil, especially in saline situations, Kansas to Texas, South Carolina and Florida. Summer and fall.

101. Aster subulàtus Michx. Annual, glabrous and fleshy. Stems $3-18 \mathrm{dm}$. tall, paniculately branched, flexuous above, slightly angled, sometimes $25 \mathrm{~mm}$. in diameter at the base, but usually smaller : cauline leaves linear-lanceolate, $5-8 \mathrm{~cm}$. long, acute, entire, sessile by a broad or slightly clasping base, those of the branches very small and subulate : heads numerous, $6-10 \mathrm{~mm}$. broad : involucre campanulate, or at length hemispheric, 4-6 $\mathrm{mm}$. high ; bracts linear-subulate, green, imbricated in 3 or 4 series, the outer shorter: ray-flowers $20-30$, more numerous than the disk-flowers; ligules purplish, scarcely exceeding the nearly white, soft, copious pappus : achenes compressed, minutely pubescent.

In salt marshes, coast of New Hampshire to Florida. Summer and fall.

102. Aster spinòsus Benth. Stem woody at the base, divided into striate pliable bright green branches, $1-2.5 \mathrm{~m}$. tall, these branches paniculate : leaves inconspicuous, those of the main branches linear or linear-spatulate, mainly $2-4 \mathrm{~cm}$. long, those of the branchlets reduced to subulate scales or obsolete, all or some of them with soft subulate spines in or above their axils: heads scattered : involucres turbinate, $4-4.5 \mathrm{~mm}$. high ; bracts lanceolatesubulate, attenuate: ray-flowers few ; ligules about $4 \mathrm{~mm}$. long, white : achenes glabrous. and fall.

In moist grounds or on banks of streams, Texas to southern California and Mexico. Summer

\section{MACHAERÁNTHERA Nees.}

Annual, biennial or perennial caulescent branching herbs. Leaves alternate: blades serrate or pinnatifid, the teeth or lobes usually bristle-tipped. Heads radiate. Involucre of many series of imbricated bracts with herbaceous or foliaceous tips. Receptacle pitted, the pits with toothed or lacerate edges. Ray-flowers pistillate, numerous, with violet red or purple ligules. Disk-flowers perfect, the corollas yellow, turning red or brown. Anthers rounded at the base. Stigmas with subulate or lanceolate appendages. Achenes turbinate, pubescent. Pappus of numerous firm unequal rough bristles.

1. Machaeranthera tanacetifòlia (H.B.K.) Nees. Annual or biennial. Stem 3-6 dm. tall, glandular-pubescent and often viscid, much branched : leaves numerous; blades 
various, those of the lower leaves 2-7 cm. long, 2-3-pinnatifid, those of the upper leaves smaller, and 1-pinnatifid or merely toothed : heads showy: involucre hemispheric, 8-12 $\mathrm{mm}$. high ; bracts mainly linear, glandular, with spreading green tips : ray-flowers $15-25$, with ligules $10-16 \mathrm{~mm}$. long.

In dry soil, Nebraska to California, Texas and Mexico. Summer.

\section{ERÍGERON L.}

Annual, biennial or perennial caulescent or almost scapose herbs. Leaves alternate : blades flat, entire or toothed. Heads conspicuously radiate, often showy, solitary or variously disposed. Involucres broad : bracts narrow, in 1-2 series, nearly equal, reflexed at maturity. Receptacle nearly flat, naked. Ray-flowers pistillate, with narrow white pink violet or purple ligules. Disk-flowers perfect, with yellow corollas. Anthers entire and obtuse at the base. Stigmas flattened, with obtuse appendages. Achenes flattened, usually 2nerved. Pappus a single series of hair-like, or scabrous bristles, or sometimes with a series of shorter bristles without. Fleabane.

Plants perennial by offsets, stolons or creeping stems.

Rav-flowers much fewer than 100.

Leaves glabrous: bracts of the involucre 3-4 mm. long: ligules of the ray-flowers 4-6 $\mathrm{mm}$. long.

Leaves pubescent: bracts of the involucre $5-7 \mathrm{~mm}$. long : ligules of the rayflowers $10-15 \mathrm{~mm}$. long.

Ray-flowers 100 or more.

Stems decumbent or creeping.

Longer involucral bracts over $6 \mathrm{~mm}$. long: leaf-blades coarsely crenate.

Longer involucral bracts less than $6 \mathrm{~mm}$. long: leaf-blades coarsely serrate.

Stems erect.

Longer involucral bracts less than $4 \mathrm{~mm}$. long: ligules of the ray-flowers less than $5 \mathrm{~mm}$. long.

Longer involucral bracts over $4 \mathrm{~mm}$. long: ligules of the ray-flowers over $5 \mathrm{~mm}$. long.

Plants annual or biennial.

Leaf-blades entire, toothed or lobed.

Lower leaves with entire blades.

Lower leaves with toothed or lobed blades.

Heads solitary. terminating long peduncles.

Heads in terminal corymbs.

Pappus of the ray-and disk-flowers alike.

Pappus of the ray-and disk-flowers unlike.

Upper stem-leaves with entire blades: ray-flowers with white ligules.

Upper stem-leaves with sharply-toothed blades : ray-flowers with

Leaf-blades pinnately parted.

1. E. vernus.

2. E. pulchellus.

3. E. myrionactis.

4. E. repens.

5. E. quercifolius.

6. E. Philadelphicus.

7. E. Bellidiastrum.

8. E. nudiflorus.

9. E. tenuis.

10. E. ramosus.

11. E. annuus.

12. E. Neo-Mexicanus.

1. Erigeron vérnus (L.) T. \& G. Perennial, by stolons or offsets, glabrous or slightly pubescent above. Stems scape-like, solitary or tufted, 1-6 dm. tall, corymbosely branched above, 1-6 dm. tall : leaves mainly basal; blades somewhat fleshy, glabrous, spatulate, elliptic-oblong, or oval, entire or repand, petioled, or those of the stem reduced to linear or subulate scales : heads not showy : involucres about $3 \mathrm{~mm}$. high ; bracts linear or nearly so, acute, usually pubescent : ray-flowers $20-30$, with white or pink ligules 4-6 mm. long. [E. nudicaulis Michx.]

In sand near the coast, Virginia to Florida and Louisiana. Spring and summer.

2. Erigeron pulchéllus Michx. Perennial, by stolons and offsets, villous or hirsutevillous. Stems usually solitary, 1-5 dm. tall, simple or sparingly branched : leaves mainly basal ; blades spatılate, obovate or elliptic, 3-12 $\mathrm{cm}$. long, entire or toothed, pubescent, or those of the stem-leaves oblanceolate, oblong or lanceolate : heads solitary or few, showy : involucres 6-8 mm. high ; bracts linear or nearly so, acute or acuminate : ray-flowers numerous, with violet or bluish purple ligules $1-1.5 \mathrm{~cm}$. long. [E. bellidifolius Muhl.]

In open woods and on hillsides, Nova Scotia to Minnesota, Florida and Louisiana. Spring.

3. Erigeron myrionáctis Small. Perennial, strigose with white or whitish hairs, sometimes almost acaulescent. Stems short, creeping: leaves clustered or approximate ; blades oval, 1-3 cm. long, crenate or serrate-crenate with few teeth, rather cuneately narrowed into broad petioles: peduncles $6-10 \mathrm{~cm}$. long, simple: heads few, rather showy : involucres hispid, 3-4 mm. high ; bracts narrowly linear, attenuate : ray-flowers exceedingly numerous, with white or pink ligules $6-7 \mathrm{~mm}$. long.

In sandy soil, about Corpus Christi Bay, Texas. Spring.

4. Erigeron rèpens A. Gray. Perennial, gray-pubescent. Stems at first very short, becoming several $\mathrm{cm}$. long and decumbent: leaves not approximate; blades narrowly or 
broadly spatulate, 1-4 cm. long, coarsely toothed, cuneately narrowed into the margined petioles : peduncles often scape-like, 4-5 $\mathrm{cm}$. long: heads solitary : involucres 4-6 $\mathrm{mm}$. high; bracts linear-subulate, slender-tipped: ray-flowers numerous, with white ligules about $6 \mathrm{~mm}$. long.

On sandy coasts, Louisiana and Texas. Spring and summer.

5. Erigeron quercifòlius Lam. Perennial, more or less hoary-pubescent. Stems 1-7 dm. tall, solitary or several together, usually branched above : basal and lower stemleaves with oblanceolate, spatulate or oblong pinnatifid or sinuate-pinnatifid blades 4-12 $\mathrm{cm}$. long, narrowed into margined petioles; upper stem-leaves few, with oblong or lanceolate blades: heads rather few, relatively small, but showy: involucres $2-4 \mathrm{~mm}$. high ; bracts linear or nearly so, acute or prolonged into slender tips : ray-flowers numerous ; ligules purplish, blue or white, 3-4 mm. long.

In pine woods, South Carolina to Tennessee, Florida and Texas. Spring and summer.

6. Erigeron Philadélphicus L. Perennial, softly hirsute. Stems $1-12 \mathrm{dm}$. tall, solitary or loosely tufted, more or less branched above : basal and lower stem-leaves with spatulate or oblong entire or coarsely toothed blades $3-15 \mathrm{~cm}$. long; upper stem-leaves with oblanceolate, oblong, fiddle-shaped or lanceolate half-clasping blades : heads relatively few, showy : involucres $3-4 \mathrm{~mm}$. high ; bracts linear or nearly so, acute : ray-flowers 100 or more ; ligules bright pink to white, $5-8 \mathrm{~mm}$. long.

In thickets and fields, nearly throughout North America, but locally rare. Spring and summer.

7. Erigeron Bellidiástrum Nutt. Annual, finely but rather roughly pubescent. Stems 1-5 dm. tall, simple and erect, or diffusely branched from the base : leaf-blades spatulate to linear, 1-3 cm. long, entire or some of the lower ones 3-toothed : heads several or numerous: involucres $2-3 \mathrm{~mm}$. high : bracts hispidulous, the outer green, the inner scarious-margined : ray-flowers 40-70; ligules light purple or almost white.

On low plains or prairies, Nebraska to Texas and New Mexico. Spring to fall.

8. Erigeron nudiflòrus Buckl. Annual, finely hispid. Stems branched at the base, the branches more or less spreading, 1-3 dm. long: leaves various, those of the basal and lower stem-leaves with spatulate coarsely toothed blades $2-3 \mathrm{~cm}$. long and slender-petioled; upper stem-leaves mostly entire : heads few, slender-peduncled : involucres $1-1.5 \mathrm{~cm}$. broad; bracts scarious-margined, hispidulous : ray-flowers very numerous; ligules pink or whitish, 5-6 mm. long.

In dry soil or on rocky bluffs, Arkansas to Texas. Spring.

9. Erigeron ténuis T. \& G. Annual or biennial, gray-pubescent or finely hirsute. Stems 1-3 dm. tall, simple and erect or somewhat widely branched at the base, corymbose above: leaf-blades oblanceolate to oblong or lanceolate, $2-8 \mathrm{~cm}$. long, sinuate-lobed or entire : involucres $2-3 \mathrm{~mm}$. high ; bracts linear or subulate-linear, acute : ray-flowers numerous ; ligules white or purplish.

In low grounds, Arkansas to Louisiana and Texas. Spring and summer.

10. Erigeron ramòsus (Walt.) B.S.P. Annual or biennial, roughish pubescent. Stems 2-10 dm. tall, sometimes clustered, branching above : leaf-blades spatulate or oblong to linear, the lower ones commonly toothed and long-petioled, the upper ones usually entire: heads generally numerous : involucres $2-3 \mathrm{~mm}$. high ; bracts linear, acute or acuminate, scarious-margined : ray-flowers numerous ; ligules white or rarely pale pink, 4-7 mm. long. [E. strigosus Muhl.]

In dry soil, Nova Scotia to the Northwest Territory, Florida and Texas. Spring to fall.

11. Erigeron ánnuus (L.) Pers. Annual or biennial, hirsute or glabrate. Stems 3-12 dm. tall, more or less branched above: leaf-blades oval, oblong or lanceolate, 4-10 $\mathrm{cm}$. long, mostly coarsely toothed or incised, the lower ones with winged petioles: heads sometimes numerous : involucres $3-4 \mathrm{~mm}$. high ; bracts linear to linear-spatulate : rayflowers numerous; ligules pink or purplish, or rarely white, 5-8 $\mathrm{mm}$. long.

In fields and open places, Nova Scotia to Alaska, Georgia and Missouri. Spring to fall.

12. Erigeron Neo-Mexicànus A. Gray. Mostly biennial, 1-6 dm. tall. Stem hispid or hispidulous : leaf-blades pinnately parted into 3-9 narrow segments : heads solitary or usually corymbose : involucres $3.5-4.5 \mathrm{~mm}$. high ; bracts acuminate, pubescent : rayflowers with narrow white or purple-tinged ligules 8-10 $\mathrm{mm}$. long.

In dry soil or on hillsides, Texas to Arizona and adjacent Mexico. Summer and fall.

\section{LÉPTILON Raf.}

Annual or biennial caulescent herbs. Leaves alternate : blades narrow, entire, or sparingly toothed. Heads small, radiate or discoid. Involucres usually campanulate : bracts several, in 2-3 series. Receptacle naked. Ray-flowers few, pistillate, with short white 
or purplish ligules. Disk-flowers several, perfect, the corollas usually with 4 lobes. Anthers obtuse at the base. Stigmas flattened, with short appendages. Achenes flattened, often pubescent. Pappus of many brittle hair-like bristles in one series.

Inner bracts of the involucre copiously pubescent.

Inner bracts of the involeure glabrous or nearly so.

Stems diffusely branched at the base : ray-flowers with purplish ligules.

Stem usually simple below the inflorescence: ray-flowers with white ligules.

Stem-leaves with mainly entire or merely few-toothed blades.

Stem-leaves with mainly pinnatifid or pinnatifid-toothed blades.

1. L. linifolium.

2. L. divaricatum.

3. L. Canadense.

4. L. Bonariense.

1. Leptilon linif òlium (Willd.) Small. Stems 2-7 dm. tall, hirsute, racemose or paniculate above. Leaf-blades narrowly spatulate to linear, 1.5-10 $\mathrm{cm}$. long, the lower ones incised or laciniate, slender-petioled, the upper entire or sparingly toothed : involucres 2-3 mm. high ; bracts linear to linear-subulate.

In waste places, South Carolina to Florida and Alabama. Spring to fall.

2. Leptilon divaricàtum (Michx.) Raf. Stems diffusely much branched, $1-3 \mathrm{dm}$. tall, finely hirsute and somewhat cinereous. Leaf-blades narrowly linear to subulate, $1-4.5$ $\mathrm{cm}$. long, entire : involucres $1.5-2 \mathrm{~mm}$. high ; bracts narrowly linear to linear-subulate ray-flowers with purplish ligules which rarely surpass the style-branches.

In dry soil, Minnesota to Illinois, Alabama, Nebraska and Texas. Summer and fall.

3. Leptilon Canadénse (L.) Britton. Stems glabrate or sparsely birsute, $3-20 \mathrm{dm}$. tall, or sometimes diminutive, simple to the paniculate inflorescence : leaf-blades linear or nearly so, or spatulate near the base of the stem, entire or coarsely few-toothed, conspicuously ciliate near the base : heads normally very numerous : involucres $3-3.5 \mathrm{~mm}$. high ; bracts in 1 series, linear-subulate to linear, the outer ones often pubescent : corollas of the disk-flowers usually 4-lobed : ray-flowers with white or whitish little-exserted ligules.

In various situations, nearly throughout North America. Also widely distributed in Europe and South America. Spring to fall.

4. Leptilon Bonariénse (L.) Small. Similar to $L$. Canadense in habit : leaf-blades finely pubescent, mainly pinnatifid or pinnatifid-toothed, but those of the branches or near the inflorescence entire or nearly so : involucres $3-4 \mathrm{~mm}$. high ; bracts in 3 series : corollas of the disk-flowers usually 5-lobed; ligules of the ray-flowers scarcely, if at all, exserted.

In waste ground. Pensacola, Florida. Introduced from tropical and South America.

\section{DOELIINGÈrIA Nees.}

Perennial caulescent herbs. Leaves alternate: blades firm, entire, ciliate, sessile. Heads in corymbose cymes, several or many. Involucres campanulate to hemispheric, several- to many-flowered: bracts imbricated in 2-4 series, narrow, appressed, neither herbaceous nor foliaceous at the tip. Receptacle pitted. Ray-flowers few or several, pistillate : ligules white or nearly so. Disk-flowers perfect : corollas narrow, expanded into a 5 -lobed throat. Anthers obtuse at the base. Stigma-appendages typically ovate or subulate. Achene nearly terete or flattened, sometimes nerved, slightly broadened upward. Pappus double, the outer series of short bristles or scales, the inner of capillary bristles, all or some of them thickened at the tip.

Ray-flowers with linear ligules over $10 \mathrm{~mm}$. long: inner bracts of the involucre acuminate.

Ray-flowers with oblong ligules less than $10 \mathrm{~mm}$. long: inner bracts of the invo-

1. D. reticulata.

lucre merely acute or obtuse.

Achenes nearly terete, ribless. less than $1 \mathrm{~mm}$. wide.

Ovary and achene pubescent : outer involucral bracts ciliate near the tip. Involucral bracts acute or acutish, the inner linear, ciliate at the tip. Involucral bracts obtuse, the inner oblong, eciliate.

Ovary and achene glabrous: outer involucral bracts ciliate all around.

Achenes much flattened, ribbed, over $1 \mathrm{~mm}$. wide.

2. D. umbellata.

3. D. humilis.

4. D. sericocarpoides.

5. D. infirma.

1. Doellingeria reticulàta (Pursh) Greene. Stems $3-12 \mathrm{dm}$. tall, finely soft-pubescent, fastigiate-corymbose above : leaves rather numerous; blades oblong or oval, varying to oblong-obovate or narrowly oblong, 4-8 cm. long, or shorter on the upper part of the stem, obtuse or merely acutish, entire or essentially so, sometimes undulate, prominently fine-reticulate beneath, manifestly reticulate above: heads few or numerous, slender-peduncled : involucres about $6 \mathrm{~mm}$. high; bracts linear to narrowly linear-lanceolate, acute or acuminate, the tips erect : ray-flowers $9-13$; ligules $11-15 \mathrm{~mm}$. long: achenes $4 \mathrm{~mm}$. long, pubescent.

In low pine lands, South Carolina to Florida. Spring and summer.

2. Doellingeria umbellàta (Mill.) Nees. Stems 6-25 dm. tall, glabrous or somewhat pubescent above, corymbosely branched : leaves numerous; blades membranous, narrowly 
elliptic to linear-elliptic or elliptic-lanceolate, $7-14 \mathrm{~cm}$. long, usually acuminate, roughmargined : heads usually numerous, peduncled : involueres 4-5 $\mathrm{mm}$. high ; bracts pubescent at the tip, the outer lanceolate, the inner almost linear : ray-flowers several ; ligules oblong, 4-6 mm. long : achenes columnar, 4-4.5 mm. long, manifestly pubescent.

In moist soil or thickets, Newfoundland to the Northwest Territory, Georgia and Arkansas. Summer and fall.

3. Doellingeria hùmilis (Willd.) Britton. Similar to D. umbellata in habit, but more stocky and less branched. Stems seldom over $12 \mathrm{dm}$. tall, the branches finely pubescent: leaves less numerous; blades firm, often thin-leathery, broadly elliptic to ovate-elliptic, $2,5-7 \mathrm{~cm}$. long, acute, very rough-margined : heads numerous, their peduncles copiously pubescent : involucres $4-5 \mathrm{~mm}$. high ; bracts obtuse, the outer ovate-oblong, the inner oblong, all glabrous or essentially so: ray-flowers several ; ligules oblong, 5-8 $\mathrm{mm}$. long: achenes columnar, narrowed at the base, $3-3.5 \mathrm{~mm}$. long, sparingly pubescent.

In moist soil, New Jersey and Pennsylvania to Florida and Texas. Summer and fall.

4. Doellingeria sericocarpoìdes Small. Stems $8-12 \mathrm{dm}$. tall, finely ridged, corymbosely branched above, glabrous to the ultimate branches : leaves numerous; blades relatively firm, elliptic to lanceolate-elliptic, acute or slightly acuminate at the apex, somewhat scabrous above, glabrous and paler beneath or minutely pubescent on the nerves, ciliate : heads numerous : involucres cylindric-campanulate, about $4 \mathrm{~mm}$. high, 2-2.5 mm. thick ; bracts very sparingly pubescent, the outer linear-lanceolate, the inner linear, ciliate at the tip : ray-flowers few ; ligules white, 5-6 mm. long: achenes almost glabrous.

In low grounds, Arkansas and Texas. Fall.

5. Doellingeria infírma (Michx.) Greene. Stems 4-12 dm. tall, glabrous, or the branches of the inflorescence, minutely pubescent: leaves relatively few; blades thin but firm, elliptic to ovate-elliptic or obovate-elliptic, 3-11 cm. long, short-acuminate, rough-margined, deep green above, pale beneath : heads few, often scattered : involucres short-peduncled, about $5 \mathrm{~mm}$. high; bracts ciliolate, the outer triangular-ovate, the inner nearly linear, twice as long as the outer : ray-flowers several; ligules broadly oblong, 7-9 mm. long: achenes oblong or slightly oblong-obovoid, flattened, 5-5.5 mm. long, ribbed.

In dry woods or thickets, Massachusetts to New York, Georgia and Tennessee. Summer and fall.

\section{IONÁCTIS Greene.}

Perennial caulescent rigid herbs. Leaves alternate: blades narrow, entire. Heads radiate, solitary or in corymbs, showy. Involucres campanulate or turbinate, of 5-6 series of firm imbricated appressed bracts. Ray-flowers pistillate, numerous, with typically violet ligules. Disk-flowers perfect, each corolla with a campanulate throat. Anthers obtuse at the base. Stigmas with subulate ciliate appendages. Achenes pubescent. Pappus double, the inner series of long capillary bristles, the outer series much shorter.

1. Ionactis linariifòlia (L.) Greene. Stem tufted, 1.5-6 dm. tall, rough-pubescent: leaves evenly disposed along the stem, spreading; blades linear-spatulate to linear, acute, scabrous-margined : involucres campanulate, or turbinate when dry, 8-10 mm. high, the outer bracts acute, the inner often obtuse : ray-flowers 10-15, with bright violet or rarely white ligules $8-14 \mathrm{~mm}$. long.

In dry or rocky soil, Newfoundland to Minnesota, Florida and Texas. Summer and fall.

\section{BÁCCHARIS L.}

Perennial caulescent herbs or shrubs, usually with glabrous or resinous foliage below the inflorescence. Leaves alternate : blades often leathery, entire or toothed. Heads discoid, dioecious, in corymbs or panicles. Involucres often campanulate : bracts in several
series. Receptacle flat, pitted, naked. Corollas various, those of the staminate heads tubular, those of the pistillate heads filiform. Anthers entire and obtuse at the base. Stigmas slender, those of the staminate flowers with broad appendages. Achenes flattened, ribbed. Pappus various, that of the staminate flowers short, that of the pistillate flowers copious, of long hair-like bristles. 
b. Leaf-blades linear or nearly so.

Leaf-blades entire.

Leaf-blades toothed.

Achenes 10-nerved: pappus of the pistillate heads conspicuously elongated. 5. B. neglecta.

Achenes 5-nerved: pappus of the pistillate heads barely elongated. $\quad 6$. B. glutinosa.

1. Baccharis Texàna (T. \& G.) A. Gray. Foliage glabrous. Stems 2-9 dm. tall, rigid, branched : leaves numerous ; blades tirm, linear, $1-5 \mathrm{~cm}$. long, acute, entire, sessile : heads rather few, corymbose : involucres campanulate; staminate $5 \mathrm{~mm}$. high, with oblonglanceolate to linear bracts ; pistillate $8-10 \mathrm{~mm}$. high, with lanceolate to linear acute bracts, the outer sparingly glandular: pappus twice or thrice as long as the involucre, that of the pistillate flowers in several series : achenes $4 \mathrm{~mm}$. long, glabrous or nearly so.

On dry prairies, Texas. Summer.

2. Baccharis halimifòlia L. A much-branched shrub 1-4 m. tall, with resinous foliage. Leaves numerous ; blades leathery, suborbicular to oblong or linear-elliptic, coarsely toothed or the upper ones entire: heads numerous, in peduncled clusters of $3-5$ : involucres various; staminate campanulate, $5 \mathrm{~mm}$. high, with oblong or linear obtuse bracts ; pistillate ovoid, $6 \mathrm{~mm}$. high, with ovate to linear-oblong bracts, the outer obtuse, the inner acute: pappus of the pistillate heads about twice as long as the involucre: achenes $1 \mathrm{~mm}$. long, ribbed.

Along the coast or rarely inland, Massachusetts to Florida and Texas. Summer and fall.

3. Baccharis glomeruliflòra Pers. A branching shrub 1-3 m. tall, with light green barely resinous foliage. Leaves rather few ; blades leathery, spatulate to cuneate-obovate, $2-5 \mathrm{~cm}$. long, entire, or sharply toothed above the middle: heads solitary and sessile in the upper axils or few in sessile or short-peduncled clusters : involucres various ; staminate campanulate, $4 \mathrm{~mm}$. high, with ovate to oblong-ovate obtuse bracts ; pistillate ovoid, 5-6 $\mathrm{mm}$. high, with ovate to oblong obtuse bracts: pappus barely twice as long as the involucre : achenes $1.5 \mathrm{~mm}$. long.

In and about pine-land swamps, North Carolina to Florida. Fall and winter.

4. Baccharis angustif òlia Michx. A much-branched shrub 1-2.5 m. tall, with resinous foliage. Leaves numerous ; blades leathery, linear, 1-8 cm. long, entire or nearly so, acute, sessile : heads numerous, solitary on short peduncles or 2-4 in peduncled clusters : involucres various; staminate campanulate, $2.5 \mathrm{~mm}$. high, with ovate to oblong-lanceolate, obtuse bracts ; pistillate oblong to ovoid, 4-5 $\mathrm{mm}$. high, with ovate to almost linear obtuse or acutish bracts: pappus nearly twice as long as the involucre: achenes about $1 \mathrm{~mm}$. long.

In brackish marshes, North Carolina to Florida and Texas. Fall.

5. Baccharis neglécta Britton. A branching shrub several $\mathrm{dm}$. tall, with light green foliage. Leaves numerous ; blades linear, 2-10 cm. long, acute, remotely toothed, sessile or short-petioled: heads numerous : involucres various ; staminate campanulate, 4 $\mathrm{mm}$. high, with oblong to oblong-lanceolate obtuse bracts; pistillate ovoid or oblong-ovoid, $4 \mathrm{~mm}$. high, with ovate to lanceolate acute bracts : pappus of the pistillate heads conspicuously elongated : achenes $1.5 \mathrm{~mm}$. long.

On plains or prairies, Nebraska to Texas and Mexico. Summer and fall.

6. Baccharis glutinòsa Pers. A branching shrub 1-3 m. tall, with resinous-coated foliage. Leaves numerous; blades linear, acute or acuminate, remotely serrate with sharp or blunt teeth : heads numerous : involucres various ; staminate oblong, $3.5 \mathrm{~mm}$. high, with ovate to linear obtuse or acute bracts ; pistillate ovoid or oblong-ovoid, $5 \mathrm{~mm}$. high, with ovate to narrowly linear-lanceolate acute or acutish ciliate bracts : pappus of the pistillate heads barely elongated.

In moist soil, Texas to California and Mexico. Summer and fall.

\section{FILÀGO L.}

Annual or sometimes perennial caulescent herbs, with white-woolly foliage. Leaves alternate: blades entire, commonly narrow. Heads discoid, in dense clusters. Involucres woolly : bracts few, scarious or sometimes herbaceous, in several series. Receptacle high or conic, chaffy. Pistillate flowers marginal, fruit-producing, with filiform corollas. Perfect flowers few, mostly not fruit-producing, with tubular corollas. Anthers sagittate, the auricles acuminate. Pappus wanting. [Evax Gaertn.]

Flower-clusters less than $1 \mathrm{~cm}$. broad : involucres campanulate: staminate flowers with a vestige of a pistil.

Flower-clusters over $1 \mathrm{~cm}$. broad : involucres fusiform or cylindric : staminate flowers

with abortive pistils.

1. F. nivea.

1. Filago nìvea Small. Stems simple and erect or much branched from the base, 2-15 cm. tall. Leaf-blades oblong to oblong-oblanceolate, 5-12 $\mathrm{mm}$. long, obtuse, entire, 
sessile or some of them partly clasping : flower-clusters less than $1 \mathrm{~cm}$. in diameter : involucres campanulate, $2-3 \mathrm{~mm}$. high : bracts various, those of staminate flowers spatulate, those of pistillate flowers oblong or oval, all cottony at the apex : staminate flowers with a vestige of a pistil.

In dry or stony soil, Georgia to Texas and California. Introduced eastward. Spring and summer.

2. Filago prolifera (Nutt.) Britton. Stems $2-20 \mathrm{~cm}$. high, simple or branched at the base, often with 2-6 simple or proliferous ascending branches at the summit: leaf-blades spatulate, 5-14 mm. long, obtuse : flower-clusters over $1 \mathrm{~cm}$. in diameter : involucres fusiform or cylindric : bracts various, those of staminate flowers herbaceous, woolly at the apex, those of pistillate flowers firmer, glabrous or nearly so: staminate flowers with slender stipe-like abortive pistils.

In dry soil, South Dakota to Arkansas and Texas. Spring and summer.

59. CALYMMÁNDRA T. \& G.

Small caulescent plants resembling species of Filago. Leaves alternate : blades broadened upward. Heads in closely sessile bracted or somewhat involucrate clusters, heterogamous. Involucre of few scarious externally woolly bracts which grade into the bractlets of the disk. Receptacle hemispheric. Pistillate flowers in several series, fruit-producing, each with slender truncate corollas. Perfect flowers 5, central, fruit-producing, each enclosed in a convolute woolly bractlet, with a somewhat inflated 4-lobed corolla. Anthers sagittate at the base. Achenes broadened upward, obscurely obcompressed, glabrous. Pappus wanting.

1. Calymmandra cándida T. \& G. Foliage silvery white with appressed woolly hairs. Stems 1-4 dm. tall, simple or much branched from the base : leaf-blades spatulate, 1-3 cm. long, entire : heads solitary or clustered in the axils: involucres campanulate, 1.5-2 mm. high : bracts including those of the pistillate flowers narrowly oblong-spatulate, densely woolly without: achenes about $0.5 \mathrm{~mm}$. long, smooth.

In dry soil, Texas. Spring and summer.

\section{Gífola Cass.}

Annual caulescent herbs, resembling species of Filago. Leaves alternate : blades entire, commonly sessile. Heads discoid, in small dense sometimes proliferous clusters. Involucres narrow, sessile: bracts scarious, in several series. Receptacle subulate to obconic, chaffy. Pistillate flowers marginal, fruit-producing, each with filiform corollas and rudimentary or no pappus. Perfect flowers central, few, each with tubular corollas and several scabrous hair-like pappus-bristles. Between the pistillate and perfect flowers are some similar to the marginal, byt with pappus like the central. Anthers sagittate at the base. Achenes terete or slightly flattened. [Filago L. 1758; not L. 1753.] Cudweed.

1. Gifola Germànica (L.) Dumort. Foliage silvery with dense woolly pubescence. Stems commonly branched at the base, $5-35 \mathrm{~cm}$. tall, proliferous above, or rarely simple: leaves numerous ; blades erect, lanceolate to linear, 1-2 cm. long, acute : heads numerous, in dense globular clusters : involucres oblong or ovoid-oblong, $3 \mathrm{~mm}$. high: bracts ovatelanceolate to oblong-lanceolate, acuminate to cuspidate : achenes about $0.8 \mathrm{~mm}$. long.

In dry soil or waste places, New York to Georgia. Naturalized from Europe. Spring to fall.

\section{PLÙCHEA Casś.}

Annual or perennial caulescent herbs, or shrubs. Leaves alternate: blades usually toothed, often prominently nerved, petioled, or the upper sessile or clasping. Heads discoid, commonly in cluster-like cymes. Involueres turbinate, hemispheric or campanulate, with pistillate and perfect flowers: bracts broad, in few series. Receptacle flat, naked. Pistillate flowers marginal, fruit-producing. Perfect flowers central, mostly not fruit-producing. Anthers sagittate, the auricles tailed. Stigmas united or distinct. Achenes 45-angled. Pappus a single series of scabrous hair-like bristles. Marsh Fleabane. 
Plants annual.

Bracts of the involucre thin, sparingly pubescent.

Bracts of the involucre thick, densely pubescent.

Leaves not decurrent on the stem.

Involucres 4-5 mm. high or less, 3-4 mm. wide. Involucres $6-8 \mathrm{~mm}$. high, 6-7 mm. wide.

Leaves decurrent on the stem as wings.

5. P. petiolata.

6. P. purpurascens

7. P. camphorata.

8. P. Quitoc.

1. Pluchea odoràta Cass. Perennial, closely pubescent. Stems several dm. tall, woody : leaf-blades oblong or nearly so, $8-15 \mathrm{~cm}$. long, obtuse or apiculate, entire, petioled : heads numerous, in rounded corymbs : involucres $2-2.5 \mathrm{~mm}$. high ; bracts oblong or slightly broadened upward, pubescent, ciliate, obtuse : achenes.

In sandy soil, peninsular Florida and the Keys. Also the West Indies, Central and northern South America. Throughout the year.

2. Pluchea foètida (L.) B.S.P. Perennial, minutely pubescent. Stems 3-10 dm. tall, simple or branching above : leaf-blades oblong to ovate-oblong, 3-8 cm. long, acute, serrate, sessile and clasping: heads in sessile or short-peduncled clusters : involucres campanulate, $4 \mathrm{~mm}$. high : bracts oblong to linear or narrowly linear-lanceolate, the inner acute, the outer acuminate, ciliate near the tips : corollas of the pistillate flowers $3 \mathrm{~mm}$. long. $[P$. bifrons DC. $]$

In low grounds, New Jersey to Florida and Texas. Spring and summer.

3. Pluchea longifòlia Nash. Perennial, softly pubescent, densely so above. Stems 6-10 dm. tall, bran ching above : leaf-blades firm, oblong, 5-16 mm. long, mucronate, unevenly toothed, sessile and partly clasping, the upper ones but little shorter than the lower : heads numerous in rather dense terminal clusters: involucres campanulate, 7-10 mm. high ; bracts broadly ovate to linear, ciliate, the outer obtuse or apiculate, the inner acute or slender-apiculate : corollas of the pistillate flowers $6 \mathrm{~mm}$. long: pappus white.

In swamps, peninsular and middle Florida. Summer.

4. Pluchea imbricàta (Kearney) Nash. Perennial, finely pubescent and somewhat resinous. Stems 1-2.5 m. tall, branched above: leaf-blades ovate-oblong to triangularovate, 3-6 mm. long, firm, mucronulate, rather coarsely serrate, sessile and partly clasping, the upper ones much shorter than the lower, the nerves prominent and red beneath : heads numerous, in dense terminal clusters: involucres campanulate, $7-8 \mathrm{~mm}$. high ; bracts oblong to linear-lanceolate or linear, the outer obtuse, the inner mucronate : corollas of the pistillate flowers $6 \mathrm{~mm}$. long : pappus buff.

In swamps or borders of ponds, Georgia and Florida. Summer.

5. Pluchea petiolàta Cass. Annual, puberulent or finely pubescent. Stems 5-11 dm. tall, more or less branched: leaves numerous ; blades elliptic or narrowly elliptic, 8$25 \mathrm{~cm}$. long, thin, acuminate at both ends, rather coarsely serrate-dentate, petioled : heads numerous : involucres campanulate or ovoid-campanulate, $3.5-4 \mathrm{~mm}$. high ; bracts granulose, ovate to oblong or nearly linear, acute to acuminate, ciliolate : corollas of pistillate flowers $3 \mathrm{~mm}$. long: pappus whitish, sometimes purple-tinged.

In moist soil, Virginia and Illinois to Florida and the Indian Territory. Summer and fall.

6. Pluchea purpuráscens (Sw.) DC. Annual, finely pubescent and somewhat glandular. Stems 3-14 dm. tall, branching above : leaf-blades ovate-lanceolate to elliptic or oblong, 4-10 cm. long, rather blunt, coarsely crenate, short-petioled: heads few or numerous : involucres $3.5-4 \mathrm{~mm}$. high : bracts granulose, oblong to narrowly linear-lanceolate, ciliolate, the outer mucronate, the inner acute or acuminate: corollas of the pistillate flowers about $3 \mathrm{~mm}$. long.

In sandy soil, Georgia and Florida to Texas. Also in tropical America. Summer and fall.

7. Pluchea camphoràta (L.) DC. Annual, puberulent. Stems $3-15 \mathrm{dm}$. tall. corymbosely branched above : leaf-blades thickish, elliptic, lanceolate or oblong, 3-15 cm, long, acute, irregularly serrate, usually petioled on the lower part of the stem : heads numerous, light purple : involucres hemispheric, about $5 \mathrm{~mm}$. high; bracts puberulent, oblong, acute or acuminate, ciliate : corollas of the pistillate flowers $3 \mathrm{~mm}$. long.

In salt marshes, Massachusetts to Florida, Texas and Mexico. Summer and fall.

8. Pluchea Quitoc DC. Annual, puberulent. Stems 7-20 dm. tall, branched, winged by the decurrent leaf bases : leaf-blades oblong, narrowly elliptic, lanceolate or linearlanceolate, 4-16 cm. long, finely toothed : heads numerous, pale purple: involucres 4-6 $\mathrm{mm}$. high, the bracts more or less lacerate in age.

In marshy places, about Pensacola, Florida. Native of tropical America.

\section{2. chafnólobus Cass.}

Perennial or sometimes biennial caulescent herbs, with tomentose or woolly foliage. Leaves alternate: blades entire, often glabrate above, decurrent on the stem. Heads dis- 
coid, sessile, usually densely crowded. Involucres rather narrow, densely flowered : bracts narrow, few, in few series, mostly deciduous at maturity. Receptacle naked, sometimes merely pubescent. Pistillate flowers marginal, fruit-producing, with slender corollas. Perfect flowers central, mostly not fruit-producing, with tubular corollas. Anthers sagittate, the auricles tailed. Stigmas united or distinct. Achenes 4-5-angled, pubescent. Pappus a single series of equal hair-like bristles. [Pterocaulon Ell.] BLAck-Root.

Blades of the upper leaves of a linear type: panicle of more or less remote heads or clusters.

Blades of the upper leaves of an oblong or lanceolate type: panicle continuous, thick

1. C. virgatus. and dense.

2. C. undulatus.

1. Chaenolobus virgàtus (L.) Cass. Stems 4-11 dm. tall, from fusiform rootstocks, simple or virgately branched. Leaf-blades linear or sometimes lanceolate below, $2-13 \mathrm{~cm}$. long, acute, serrulate : spikes peduncled : involucres $2.5 \mathrm{~mm}$. high: bracts linear or nearly so, acute or acuminate, villous-cottony. [Pterocaulon virgatum (L.) DC.]

In dry soil, Texas and Mexico. Also in the West Indies.

2. Chaenolobus undulàtus (Walt.) Small. Stems $2-7 \mathrm{dm}$. tall from fusiform sometimes clustered rootstocks, white-tomentose, usually simple. Leaf-blades oblong to lanceolate or rarely narrower, 4-12 cm. long, acute, undulate, decurrent on the stem as glabrous wings : spikes stout, simple or compound, $2-10 \mathrm{~cm}$. long : involucres hemispheric or campanulate, $4 \mathrm{~mm}$. high ; bracts linear to narrowly linear-lanceolate, acuminate, with straight erect hairs on the back. [Gnaphalium undulatum Walt. Pterocaulon pycnostachyum (Michx) Ell. ]

In sandy pine lands, North Carolina to Florida and Mississippi. Spring and summer.

\section{ANTENNÀRIA Gaertn. ${ }^{1}$}

Perennial woolly and sometimes partially glandular herbs, stoloniferous, at least in our species. Leaves alternate, the basal forming a rosette and persistent through the winter, the cauline much smaller than the basal : blades entire. Heads relatively small, discoid, usually in terminal corymbs. Involucre many-flowered : bracts imbricated in several series, scarious, the outer somewhat petaloid, appressed. Receptacle flat or convex, not chaffy. Flowers dioecious or polygamous. Staminate flowers crowded: corolla truncate or nearly so : anthers caudate : style and pappus rudimentary, the latter of thickened bristles. Pistillate or perfect flowers with slender 5-lobed corollas and pappus of smooth capillary bristles slightly united at the base. Achenes oblong, terete or nearly so. The staminate plants are less common than the pistillate. EverLasting.

Stolons assurgent, leafy : heads corymbose.

Blades of the basal leaves oblong to obovate, tapering gradually to the petiole-like base. $\begin{array}{ll}\text { Blades of the basal leaves rhombic-ovate, rather abruptly contracted at the base. } & \text { 2. A. Alalophylla. } \\ \text { Stolons procumbent, nearly leafless: head solitary. } & \text { 3. A. solitaria. }\end{array}$

1. Antennaria plantaginif òlia (L.) Richards. Plants gregarious, woolly throughout when young, the upper surface of the basal leaves glabrate in age. Flowering stems $15-40$ $\mathrm{cm}$. tall, or those of the staminate plants shorter : stolons assurgent, leafy, sometimes 7-8 $\mathrm{cm}$. long: basal leaves and those at the tips of the stolons, with oblong or obovate distinctly 3-ribbed mucronate blades $3-5 \mathrm{~cm}$. long, tapering gradually into petioles of about the same length : cauline leaves erect, or nearly so; blades lanceolate, acute, sessile, those of the lower $2-3 \mathrm{~cm}$. long, the upper considerably reduced and distant : heads few to several : involucres, before expanded, about $6 \mathrm{~mm}$. high; bracts pale green, except the whitish subacute tips : achenes minutely glandular.

Usually in dry woods, Ontario to Georgia and Texas. Rare in the coastal plain. - A. nemoralis Greene,described from specimens from eastern Tennessee, can hardly be separated from this species. Spring.

2. Antennaria calophýlla Greene. Similar to the preceding species in habit, but usually larger, at least southward; readily distinguished by the thick rhombic-ovate blades of the basal leaves which are broadest near the base, and by the broader spreading cauline leaves.

In woods or dry soil, Illinois and Missouri to Georgia and Louisiana. Spring.

3. Antennaria solitaria Rydb. Plants less woolly than those of the preceding species, the upper surface of the basal leaves soon glabrous. Flowering stems 1-2 dm. tall : stolons procumbent, elongated, sometimes $15-30 \mathrm{~cm}$. long, nearly leafless except

${ }^{1}$ Contributed by Mr. Roland M. Harper. 
at the apex, densely white-woolly: basal leaves several; blades thin, variable, but usually oblong, 3-6 cm. long, and $2-4 \mathrm{~cm}$. wide, 3-ribbed, mucronate, rather abruptly contracted into petiole-like bases less than $\frac{1}{2}$ their length : cauline leaves erect, remote; blades linear-lanceolate, about $1 \mathrm{~cm}$. long, acute: head solitary : involucre about $10 \mathrm{~mm}$. high at maturity ; bracts purplish except the white petaloid tips. Spring.

In rich woods, mostly in the mountains, Pennsylvania to middle Georgia. Also in Louisiana.

\section{ANÁPHALIS DC.}

Perennial caulescent herbs, with woolly or tomentose foliage. Leaves alternate : blades narrow, entire, sessile. Heads discoid, dioecious, in terminal corymbs. Involucres thick : bracts in several series, scarious, pearly or white. Receptacle convex, not chaffy. Staminate flowers with slender or filiform corollas, united stigmas and pappus of several hair-like bristles. Anthers tailed at the base. Pistillate flowers with tubular corollas, distinct stigmas and pappus of copious hair-like bristles. Achenes oblong or nearly so.

1. Anaphalis margaritàcea (L.) Benth. \& Hook. Foliage white-woolly throughout. Stems usually tufted, 2-4 dm. tall : leaf-blades linear or nearly so, 5-15 cm. long, acute, entire, sessile: heads numerous, conspicuous : involucres campanulate to subglobose, 5-6 mm. high : bracts numerous, ovate to oblong, mostly obtuse, pearly white, spreading in age : pappus-bristles of the pistillate flowers distinct, falling away separately.

In dry soil or open woods, Newfoundland to Alaska, North Carolina, Kansas and California. Summer and fall. Pearly Everlasting.

\section{FACÈLIS Cass.}

Annual caulescent woolly herbs. Leaves alternate: blades narrow, entire. Heads heterogamous, axillary or in clusters. Involucre oblong or ovoid, of several series of narrow bracts, the inner mainly scarious and elongated. Receptacle flat, naked. Pistillate flowers marginal, each with a slender truncate or obscurely lobed corolla. Perfect flowers central, some of them fruit-producing, each with a 5-lobed corolla. Anthers sagittate at the base, the auricles acuminate. Achenes pubescent, beakless. Pappus of numerous white plumose bristles, concreted at the base.

1. Facelis apiculàta Cass. Stem commonly branched at the base, the branches 2$12 \mathrm{~cm}$. tall, leafy, lanate : leaf-blades linear-spatulate to linear, $0.5-1 \mathrm{~cm}$. long, apiculate, revolute, more woolly beneath than above: involucres mostly clustered : bracts ovate to oblong or linear, scarious except a green midrib, the outer woolly, the inner $5-7.5 \mathrm{~mm}$. long, glabrous : achenes 1-1.5 mm. long, the hairs merging into the pappus which is several times longer than the achene.

In grassy commons and waste places, eastern Georgia. Native of southern South America.

\section{GNAPHALIUM L.}

Annual, biennial or perennial caulescent herbs, with woolly or sometimes glandular foliage. Leaves alternate: blades entire, often sessile or decurrent, usually narrow. Heads discoid, variously disposed. Involucres with both pistillate and perfect flowers: bracts scarious, in several series. Receptacle not chaffy, usually pitted. Pistillate flowers in several series, with filiform corollas. Anthers sagittate, with tailed auricles. Achenes terete or slightly flattened, not ribbed. Pappus a single series of hair-like bristles either distinct or cohering at the base, not plumose, deciduous. Cudweed. Everlasting.

Pappus-bristles distinct, falling away separately.

Leaf-blades merely sessile.

Foliage pubescent, not viscid.

Upper surface of the leaf-blades glabrous or glabrate: stems erect from an annual root.

Upper surface of the leaf-blades persistently woolly : stems diffusely branched from a perennial root.

Foliage glandular-viscid.

Leaf-blades decurrent on the stem.

Pappus-bristles united at the base, falling away together.

Leaf-blades manifestly more pubescent beneath than above, spatulate, sometimes broadly so.

Leaf-blades thin: stems cobwebby : involucre-clusters copiously woolly.

Leaf-blades thick : stems densely woolly or felty : involucre-clusters sparingly

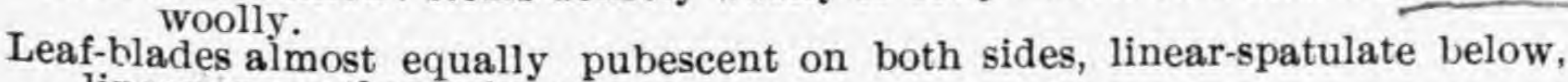
linear or mostly so above.

1. G. obtusifolium.

2. G. Wrightii.

3. G. Helleri.

4. G. decurrens.

5. G. spathulatum.

6. G. purpureum.

7. G. falcatum. 
1. Gnaphalium obtusifòlium L. Annual, white-woolly nearly throughout. Stems 2-6 dm. tall, simple below, or sparingly branched : leaf-blades various; those of the basal leaves oblanceolate, those of the stem linear or oblong-linear, 2-10 cm. long, acute, undulate-crisped, sessile, the upper surface glabrous or glabrate : heads numerous, barely crowded: involucres ovoid, 6-7 mm. high; bracts scarious, glabrous, white or early rusty, ovate to oblong, obtuse, spreading in age : pappus bristles distinct, falling away separately : achenes glabrous.

In dry soil, Nova Scotia to Manitoba, Florida and Texas. Summer and fall. Rabbit Tobacco.

2. Gnaphalium Wrìghtii A. Gray. Perennial, white-woolly throughout. Stems tufted, $2-5 \mathrm{dm}$. tall, often diffusely branched: leaf-blades spatulate to linear, $2-8 \mathrm{~cm}$. long, acute, entire, sessile, the upper surface persistently woolly: heads numerous: involucres oblong to ovoid, 4-5 mm. high, very woolly at the base ; bracts elliptic-spatulate to linearspatulate, acute, or the inner apiculate: achenes about $0.6 \mathrm{~mm}$. long.

In dry soil, Arkansas to Texas and Arizona. Summer and fall.

3. Gnaphalium Hélleri Britton. Annual or biennial, whitish tomentose and glandular viscid especially on the stem. Stems 1-6 dm. tall, branching above : leaf-blades linear to oblong, 3-11 cm. long, acute or acuminate, undulate-crisped, sessile : heads usually numerous : involucres ovoid to oblong, 5-6 $\mathrm{mm}$. high, woolly at the base ; bracts oblanceolate to linear, whitish, obtuse or the inner minutely apiculate : achenes about $0.5 \mathrm{~mm}$. long.

In sandy soil, Virginia and Kentucky to Georgia. Summer and fall.

4. Gnaphalium decúrrens Ives. Annual or biennial, whitish woolly and more or less glandular. Stems 2-9 dm. tall, branching above : leaf-blades linear or slightly broadened upward, $6-12 \mathrm{~cm}$. long, acute, becoming thinly pubescent above, sessile and decurrent : heads numerous, sometimes crowded: involucres oval or ovoid, 4-5 mm. high, woolly at the base ; bracts elliptic to oblong or linear, or slightly broadened upward, acute or slightly acuminate : achenes about $0.8 \mathrm{~mm}$. long, glabrous.

In dry soil or on rocky slopes, Nova Scotia to British Columbia, Pennsylvania, Texas and Arizona. Summer and fall.

5. Gnaphalium spathulàtum Lam. Annual or biennial, thinly but quite completely clothed with gray pubescence. Stems erect or decumbent, $2-4 \mathrm{dm}$. long, often branched, cobwebby : leaf-blades spatulate, $2-8 \mathrm{~mm}$. long, apiculate, entire, relatively thin : heads often crowded, in sparingly woolly clusters : involucres flat at the base, $3-4 \mathrm{~mm}$. high; bracts linear or linear-lanceolate, acute or acutish, scarious : achenes about $0.5 \mathrm{~mm}$. long.

In waste places or cultivated grounds, chiefly in the Gulf States. Spring to fall.

6. Gnaphalium purpùreum L. Annual or perennial, white-woolly or silvery. Stems 1-4 dm. tall, simple or diffusely branched, densely woolly or felty-pubescent: leaf-blades spatulate to linear, $2-8 \mathrm{~cm}$. long, acute or apiculate, relatively thick : heads numerous, crowded in narrow copiously woolly spikes or racemes: involucres oblong or ovoid-oblong, or sometimes conic, $4 \mathrm{~mm}$. high ; bracts scarious, ovate-lanceolate to linear, acute or acuminate: achenes about $0.5 \mathrm{~mm}$. long, scabrous.

In various situations in the Atlantic, Gulf and Pacific States. Also in Central and South America. Spring and fall.

7. Gnaphalium falcàtum Lam. Somewhat similar to G. purpureum, but more slender. Stems simple or branched at the base, the branches densely white-woolly, 1-4 dm. tall : leafblades usually about equally woolly on both sides, those of the lower cauline leaves linearspatulate, $2-6 \mathrm{~cm}$. long, acute, those of the upper cauline leaves linear or narrowly linearspatulate: heads in compact clusters whieh are usually disposed in racemes: involucres 3-4 mm. high, the outer bracts woolly.

In pine lands or cultivated grounds, Tennessee to Florida, Texas and Mexico. Also in tropical America. Throughout the year.

\section{7. ÍNULA L.}

Perennial caulescent, often relatively large herbs. Leaves alternate, sometimes mainly basal : blades toothed, those of the basal or lower stem-leaves usually petioled. Heads radiate, often showy. Involucres hemispheric or campanulate: bracts in several series, sometimes foliaceous. Receptacle flat or convex, pitted, not chaffy. Ray-flowers pistillate, often numerous: ligules yellow, 3-toothed. Disk-flowers perfect, with tubular corollas. Anthers sagittate, the auricles tailed. Stigmas narrow, those of the disk-flowers obtuse. Achenes 5-ribbed. Pappus of several scabrous hair-like bristles. Elecampane.

1. Inula Helènium L. Roots mucilaginous. Foliage pubescent: stems $0.5-2 \mathrm{~m}$. tall, branching : leaf-blades various, those of the basal leaves oblong or elliptic, denticulate, $2-4 \mathrm{dm}$. long, petioled, those of the stem-leaves oblong-lanceolate to ovate, acute or acumi- 
nate, tomentose beneath, sessile or the upper clasping: heads showy, on stout peduncles : involucres $1-1.5 \mathrm{~cm}$. long : bracts ovate to oblong or spatulate, acutish or obtuse, tomentose without: ray-flowers numerous; ligules narrowly linear, $2-3 \mathrm{~cm}$. long: achenes $4-5 \mathrm{~mm}$. long.

In waste places, Nova Scotia to Ontario and Minnesota, North Carolina and Missouri. Summer.

\section{POLÝMNIA L.}

Perennial large caulescent herbs, or shrubby plants. Leaves opposite or mainly so : blades membranous, toothed, angled or usually lobed, petioled. Heads usually radiate. Involucres many-flowered, double, an outer of about 5 loose bracts and an inner of as many or more thin bracts subtending but not embracing the adjacent achenes. Receptacle flat. Ray-flowers with short pubescent tubes and white or yellow ligules which are sometimes very small. Disk-flowers not fruit-producing, subtended by chaffy bractlets. Anthers 2toothed at the base. Achenes swollen, relatively short, glabrous. Pappus wanting. The plants flower in summer and fall. LEAF-CUP.

Leaf-blades palmately lobed or angled: ray-flowers with yellow ligules: achenes prominently striate.

Leaf-blades pinnately lobed : ray-flowers with white, often small, ligules : achenes 3-

5 -ribbed or angled.

Foliage manifestly or copiously pubescent : achenes 3-ribbed or angled.

Ray-flowers conspicuous: ligules $5-10 \mathrm{~mm}$. long.

Ray-flowers inconspicuous: ligules $1-2 \mathrm{~mm}$. long.

Foliage glabrous or the stem with merely puberulent nodes : achenes 5-ribbed.

2. $P$. radiata.

3. P. Canadensis.

4. P. laevigata.

1. Polymnia Uvedàlia L. Stems 1-3 m. tall, commonly tufted, pubescent or nearly glabrous: leaf-blades 1-5 dm. in diameter, 3-5-lobed or angled, decurrent on the short petioles, which are often fully $\frac{1}{2}$ as long as the blades : outer bracts of the involucre ovate to elliptic, $9-14 \mathrm{~cm}$. long, obtuse, mucronulate or notched, ciliate : ray-flowers $10-14$; ligules yellow, linear-oblong to elliptic, $1.5-2 \mathrm{~cm}$. long: disk yellow : achenes obovoid, black, $5-6 \mathrm{~mm}$. long, laterally flattened, prominently striate, bluntly apiculate.

In moist soil or thickets, New York to Missouri, Florida and Texas.

2. Polymnia radiàta (A. Gray) Small. Stems $0.5-1.5 \mathrm{~m}$. tall, viscid-pubescent, somewhat branched : leaf-blades oblong to oval or oblong-ovate, 1.5-3 dm. long, acute or acuminate, pinnately lobed : outer bracts of the involucre linear-lanceolate to lanceolate, 9-12 mm. long, acute or acuminate, glandular-pubescent and ciliate : ray-flowers few ; ligules white, conspicuous, cuneate to oval-cuneate, 5-10 mm. long, 3-lobed: achenes oblong-obovoid, nearly $5 \mathrm{~mm}$. long, with 3 sharply margined angles.

On damp hillsides, New York to Wisconsin, Georgia and Missouri.

3. Polymnia Canadénsis L. Stems branching, 0.5-1.5 m. tall, viscid-hirsute : leafblades 1-2 dm. long, oblong, oval or ovate, mainly pinnately lobed, the lobes toothed or sinuate : heads drooping : outer bracts of the involucres lanceolate, pubescent : ray-flowers few ; ligules inconspicuous, whitish or greenish, suborbicular to orbicular-reniform, 1-2 $\mathrm{mm}$. long or shorter, slightly 3-lobed: achenes obovoid, about $3 \mathrm{~mm}$. long, obtusely 3-angled.

In thickets and on damp hillsides, Ontario to Minnesota, Georgia and Missouri.

4. Polymnia laevigàta Beadle. Stems $0.5-1 \mathrm{~m}$. tall, branching, glabrous or merely puberulent at the nodes: leaf-blades thin, the lower ones oval, pinnately 5-7-lobed, the lobes acuminate; upper ones deltoid, laciniate-dentate or repand, all slender-petioled : heads nodding : outer bracts of the involucre oblong-lanceolate : ray-flowers $3-5$ : ligules white, 2-3 mm. long, 3-lobed : disk light yellow: achenes 5-ribbed.

On hillsides, Tennessee and Georgia. Summer.

\section{MELAMPÒDIUM L.}

Annual or perennial small caulescent herbs, or shrubby plants. Leaves opposite: blades often narrow, thickish, entire, toothed or pinnatifid. Heads radiate, sometimes conspicuous. Involucre double, the outer of 4-5 partially united flat bracts, the inner of a series of bracts, each embracing an achene and deciduous with it, but unarmed. Receptacle convex or conic. Ray-flowers in 1 series, pistillate : ligules white or yellow. Diskflowers perfect but not fruit-producing. Anthers entire at the base. Achenes broadened upward, somewhat incurved. Pappus wanting. The plants flower mainly in the spring and summer.

Leaf-blades entire: ray-flowers with ligules 8-10 mm. long.

Leaf-blades pinnatifid: ray-flowers with ligules about $5 \mathrm{~mm}$. long. 
1. Melampodium cinèreum DC. Stems tufted, 1-3 dm. tall, closely gray-pubescent or strigose, simple or sparingly branched. Leaf-blades linear-spatulate to linear, 2$10 \mathrm{~cm}$. long, entire, sessile : peduncles slender, $2-12 \mathrm{~cm}$. long : heads rather showy : involucres campanulate or saucer-shaped, pubescent : outer bracts ovate, $5-6 \mathrm{~mm}$. long, acute, united to the middle: ray-flowers $7-9$; ligules oval to cuneate-oblong, 8-10 $\mathrm{mm}$. long: disk-corollas 4-5 $\mathrm{mm}$. long, their bractlets fringed at the apex : mature bracts of the inner series of the involucre $2 \mathrm{~mm}$. long, tuberculate-wrinkled, each surmounted by a cup-like hood.

In dry soil, Kansas to Arkansas, Texas and Arizona.

2. Melampodium ramosíssimum DC. Stems 1-3 dm. tall, tufted, loosely pubescent or somewhat hirsute, diffusely branched : leaf-blades oblong to linear, 2-7 em. long, pinnatifid : outer bracts of the involucre ovate, $4-4.5 \mathrm{~mm}$. long, acutish, united to below the middle : ray-flowers 8-11; ligules white, oblong to cuneate-oblong, about $5 \mathrm{~mm}$. long: disk-corollas about $2 \mathrm{~mm}$. long, their spatulate bracts erose at the apex : mature bracts of the inner series of the involucre cornucopia-like, $2 \mathrm{~mm}$. long, tuberculate, each surmounted by a fringed hood.

In dry soil, southern Texas.

\section{ACANTHOSPÉRMUM Schrank.}

Annual rather coarse herbs, with pubescent foliage and erect or creeping stems. Leaves opposite : blades broad, often leathery, toothed. Heads radiate but inconspicuous, axillary to leaf-like bracts. Involucre double, an outer one of five flat herbaceous bracts, and an inner one of several smaller bracts which become bur-like and fall away enclosing an achene at maturity. Receptacle concave or convex. Ray-flowers few, in one series: ligules very small, yellowish, concave or hooded. Disk-flowers perfect but not producing fruit. Anthers entire at the base. Achenes broadest above the middle, slightly curved. Pappus wanting. The plants flower from spring to fall or throughout the year in the extreme South.

Petioles broadly winged or leaf-blades sessile by cuneate bases: involucral bracts with 2 large spines in addition to the prickles.

Petioles not broadly winged: involucral bracts uniformly prickly. $\quad$ 2. A. australe.

1. Acanthospermum hùmile (Sw.) DC. Stems erect or ascending, several dm. tall. Leaf-blades deltoid-ovate to fiddle-shaped, 1-3 cm. long, obtuse, crenate-dentate : heads short-peduncled or nearly sessile : involucres campanulate; bracts oblong to oblongspatulate, obtuse, ciliate, with 2 large spines above, in addition to the prickles: disk-flowers with corollas about $1 \mathrm{~mm}$. long, glabrous : mature inner bracts of the involucre hard, cuneate, truncate, with hooked prickles and 1-2 stout spines at the top.

In sand, Florida and about sea-port towns further north.

2. Acanthospermum austràle (L.) Kuntze. Stems branching at the base ; branches prostrate or creeping, 1-6 dm. long : leaf-blades ovate, oval or rhombic, $1-2.5 \mathrm{~cm}$. long, acute, serrate-dentate above the middle, cuneate at the base : peduncles shorter than the subtending bracts : involucres campanulate : bracts broadly ovate, obtuse, $2-3 \mathrm{~mm}$. long, uniformly prickly : disk-flowers with corollas $2 \mathrm{~mm}$. long, puberulent : mature inner bracts of the involucre forming a starfish-like fruit, each lobe $8-10 \mathrm{~mm}$. long, densely beset with uniform blunt weak prickles. [A. xanthioides DC.]

In waste places and dry soil, North Carolina to Florida and Louisiana.

\section{SÍLPHIUM L.}

Perennial usually large caulescent herbs, the sap often resinous. Leaves alternate: blades entire, toothed or 1-2-pinnately parted, sometimes connate-perfoliate. Heads radiate, showy. Involucres campanulate or hemispheric, many-flowered : bracts broad, in few series. Receptacle flat or nearly so, with numerous bractlets subtending the diskflowers. Ray-flowers pistillate, in 2-3 series, fruit-producing: ligules yellow or rarely white. Anthers usually 2-toothed or entire at the base. Achenes flat and broad, 2-winged, often notched at the apex. Pappus wanting, or of 2 small awns confluent with the wings of the achene. Rosin-wEed. 
b. Ray-flowers with yellow ligules: stems over $1 \mathrm{~m}$. tall.

B. Leaf-blades entire, toothed or pedately parted, or if pinnately parted not borne on rough-pubescent stems.

Stems scape-like, leafless or nearly so.

Involucres less than $2 \mathrm{~cm}$. broad: ligules of the ray-flowers less than 2 $\mathrm{cm}$. long.

Blades of the basal leaves variously parted or pinnatifid.

Petioles of the basal leaves shorter than the midrib; blades conspicuously veined.

Petioles of the basal leaves longer than the midrib; blades not conspicuously veined.

Leaf-blades pedately parted or lobed: achenes cuneate-obovate, $5-6 \mathrm{~mm}$. broad.

Leaf-blades pinnately parted or lobed: achenes"suborbicular, about $1 \mathrm{~cm}$. broad.

Blades of the basal leaves merely toothed.

Achenes about $10 \mathrm{~mm}$. broad: leaf-blades thin, much narrower than the length of the midrib.

Achenes 5-7 mm. broad : leaf-blades thick, often broader than the length of the midrib.

Involucres over $2 \mathrm{~cm}$. broad : ligules of the ray-flowers over $2 \mathrm{~cm}$. long.

Leaf-blades merely toothed.

Outer bracts of the involucre broader than long: leaf-blades narrowed at the base.

Outer bracts of the'involucre longer than broad: leaf-blades cordate.

Leaf-blades pinnatifid or pinnately parted.

Stems typically leafy.

Upper cauline leaves with manifestly petioled?blades.

Upper cauline leaves with sessile or essentially sessile blades.

Leaves whorled.

Leaves alternate or opposite.

Bracts of the involucre ciliate, otherwise glabrous or nearly so.

Stems smooth and glabrous or essentially so.

Leaf-blades smooth and glabrous, except the margins.

Leaves regularly disposed along the stem.

Leaves mainly crowded at the base of the stem.

Leaf-blades very rough-pubescent.

Leaf-blades clasping by the cordate bases.

Leaf-blades narrowed at the base.

Leaf-blades entire.

Leaf-blades coarsely toothed.

Blades of the upper cauline leaves lanceolate or ovate-lanceolate, gradually or abruptly narrowed at the base.

Blades of the upper cauline leaves ovate, sometimes broadly so, half-clasping by the broad base.

Stems rough-pubescent.

Leaves predominatingly opposite.

Leaves predominatingly alternate.

Bracts of the involucre with pubescent surfaces as well as ciliate margins.

Leaves all alternate.

Leaves predominatingly opposite.

Stem and petioles pubescent, but not shaggy.

Stems sparingly rough-pubescent: blades of the upper cauline leaves narrowed at the base.

Stems closely rough-pubescent: blades of the upper cauline leaves cordate and clasping.

Involucre about $2 \mathrm{~cm}$. broad at maturity: achenes narrowly winged, except at the top, the teeth about $3 \mathrm{~mm}$. long.

Involucre about $3 \mathrm{~cm}$. broad at maturity: achenes broadly winged, the teeth less than $1 \mathrm{~mm}$. long.

Stem and petioles shaggy-hirsute or hispid.

Bracts of the involucre merely ciliate, the inner obtuse.

3. S. laciniatum.

5. S. compositum.

6. S. ovatifolium.

6. S. ovatifolium.

7. S. reniforme.

8. S. rumicifolium.

9. S. terebinthinaceum.

10. S. pinnatifidum.

11. S. brachiatum.

12. S. trifoliatum.

13. S. glabrum.

14. S. confertifolium.

15. S. speciosum.

16. S. Elliottii.

17. S. dentatum.

18. S. Simpsonii.

19. S. Asteriscus.

20. S. angustum.

21. S, Gatesii.

23. S. integrifolium.

24. S. asperrimum.

25. S. gracile.

Bracts of the involucre shaggy-hispid, the inner acute. 26. S. Mohrii.

1. Silphium perfoliàtum L. Stems 1-2.5 m. tall, branching, smooth and glabrous. Leaf-blades, ovate, ovate-lanceolate or lanceolate, 2-6 dm. long, or shorter above, connateperfoliate, dentate-serrate with mucronate-tipped teeth : heads showy : involucres $1-2 \mathrm{~cm}$. high, broader than high; bracts ovate-lanceolate to ovate or oval, or the inner broadly spatulate: ray-flowers mostly 15-25; ligules bright yellow, $2.5-3 \mathrm{~cm}$. long: achenes obovate, emarginate, 11-13 mm. long.

On prairies or in moist soil, Ontario to Minnesota, Georgia, Louisiana and Nebraska. Also naturalized eastward. Summer. CUP-PLANT.

2. Silphium albiflòrum A. Gray. Stems $3-10 \mathrm{dm}$. tall, simple or sparingly branched above, zigzag, very rough with rigid prickle-like hairs. Leaf-blades ovate in outline, 1-1.5 $\mathrm{dm}$. long, sometimes about as broad as long, very scabrous, the dilated bases of the petioles entire : involucres hemispheric, $1.5-2 \mathrm{~cm}$. high : involucres rather foliaceous ; bracts with 
oval, suborbicular or rhombic ciliate bodies and involute curved or recurved acuminations : ray-flowers numerous ; ligules white, $2-2.5 \mathrm{~cm}$. long: achenes oblong-oval, $15-18 \mathrm{~mm}$. long, the wings prolonged above, the sinus U-shaped.

In limestone soil, Texas. Summer.

3. Silphium laciniàtum L. Stems stout, 1-3.5 m. tall, coarsely hispid. Leaves mainly basal ; blades 1-4 dm. long, the segments lanceolate to linear, entire or pinnatifid, the dilated bases of the petioles often pinnatifid : heads showy : involucres $2-2.5 \mathrm{~cm}$. high; bracts broadly lanceolate or ovate-lanceolate, $2.5-4 \mathrm{~cm}$. long : ray-flowers numerous ; ligules yellow, 3-5.5 $\mathrm{cm}$. long: achenes oval to suborbicular, about $10 \mathrm{~mm}$. long, narrowly winged, each with a shallow notch at the top.

On prairies, Ohio to South Dakota, Alabama and Texas. Summer. Compass-Plant.

4. Silphium venòsum Small. Stems scape-like, $8-12 \mathrm{dm}$. tall, glabrous or nearly so, glaucous. Leaves mainly basal ; blades ovate to oblong, 1-3 dm. long, conspicuously redveined, pinnately parted, the segments linear to linear-oblong, coarsely and irregularly toothed or incised; petioles about $\frac{1}{2}$ as long as the blades, dilated at the base: heads few, showy, corymbose : involucres campanulate, about $1 \mathrm{~cm}$. high; bracts broadly oblong to orbicular-oval, rounded at the apex, ciliolate : ray-flowers several ; ligules yellow, 1-1.5 cm. long: achenes suborbicular, about $1 \mathrm{~cm}$. long, the wings produced above, thus forming a narrow U-shaped sinus.

In sand, southeastern Georgia. Spring and summer.

5. Silphium compósitum Michx. Stems 1-2 m. tall, scape-like, more or less branched above. Leaves mainly basal and on the lower part of the stem; blades mostly pedately parted, 1-3 dm. long, not conspicuously veined; petioles longer than the midnerves : heads of ten numerous : involucres campanulate, about $1 \mathrm{~cm}$. high ; bracts ovate to broadly oblong, obtuse, ciliolate, dull without, lustrous within : ray-flowers several ; ligules bright yellow, 14-20 $\mathrm{mm}$. long : achenes cuneate-obovate, 5-6 mm. broad.

In dry soil, North Carolina and Tennessee to Georgia and Alabama. Summer and fall.

6. Silphium ovatif òlium (T. \& G.) Small. Stems 0.5-2 m. tall, glabrous or nearly so, branching above, rather scape-like. Leaves mainly basal; blades ovate to oblong-ovate, 1-3 dm. long, mainly pinnately parted or pinnatifid, or irregularly and coarsely toothed and incised on the upper part of the stem; petioles longer than the midnerves on the lower part of the stem : involucres campanulate, about $1 \mathrm{~cm}$. high : bracts oblong, oval or oblong-ovate, rounded at the apex : ray-flowers several ; ligules yellow, 1-1.5 $\mathrm{cm}$. long: achenes suborbicular, about $10 \mathrm{~mm}$. broad.

In sandy soil, southern Georgia and Florida. Spring and summer.

7. Silphium renifórme Raf. Stems scape-like, 1-2 m. tall, glabrous or nearly so, corymbosely branched above. Leaves mostly basal; blades ovate to reniform, 1-3.5 dm. long, obtuse, coarsely dentate, deeply cordate at the base; petioles longer than the blades on the lower part of the stem : involucres campanulate, $5-7 \mathrm{~mm}$. high; bracts ovate or broadly oblong to narrowly oblong or oblong-spatulate, obtuse : ray-flowers several ; ligules yellow, $1-1.5 \mathrm{~cm}$. long : achenes suborbicular or orbicular-obovate, $7 \mathrm{~mm}$. long; wings prolonged enough to form a shallow sinus.

In dry or stony soil, mountains of North Carolina. Summer.

8. Silphium rumicifolium Small. Stems 4-8 dm. tall, reddish purple, scape-like, corymbose above. Leaves mainly basal ; blades leathery, oblong to oblong-ovate, 1-1.5 long, rounded at the apex, repand-undulate, smooth, red-veined above, rather cuneate at the base; petioles shorter than the blades, dilated and sheathing at the base: involucres hemispheric, fully $2 \mathrm{~cm}$. broad ; bracts varions, the outer suborbicular, broader than long, the inner oblong, rounded at apex : ray-flowers several ; ligules yellow, $1.5-2 \mathrm{~cm}$. long: achenes oblong-obovoid, 9-10 $\mathrm{mm}$. long, narrowly winged and notched at the apex.

In dry sterile soil, near Knoxville, Tennessee. Summer and fall.

9. Silphium terebinthinàceum Jacq. Stems scape-like, 1-3 m. tall, branching near the top. Leaves mainly basal ; blades ovate, oblong-ovate or oblong, 1-6 dm. long, dentate, with more or less prolonged teeth, cordate at the base: heads showy, relatively few : involucres broadly campanulate, $1-1.5 \mathrm{~cm}$. high ; bracts various, the outer ovate or oval, the inner oblong, much broader than the outer, all obtuse and longer than broad : rayflowers 15-25; ligules yellow, 2-3 cm. long: achenes cuneate, 8-9 mm. long, with sharp teeth at the top.

In open grounds, Michigan to Iowa, Ohio, Georgia and Louisiana. Summer and fall.

10. Silphium pinnatífidum Ell. Stems $0.5-3 \mathrm{~m}$. tall, scape-like, often widely branched above, pubescent. Leaves mainly basal ; blades pinnatifid or pinnately parted, 
the segments entire or incised, or rarely some of them merely undulate; petioles shorter than the blades: heads showy : involucres hemispheric, about $1 \mathrm{~cm}$. high ; bracts various, the outer suborbicular, the inner oblong, about twice as long as the outer, all obtuse : rayflowers 12-20 ; ligules yellow, $1.5-2 \mathrm{~cm}$. long : achenes cuneate to oblong-cuneate, 9-10 $\mathrm{mm}$. long, without teeth at the top.

In open grounds, Ohio to Georgia and Alabama. Summer.

11. Silphium brachiàtum Gattinger. Stems 1-2 m. tall, square, smooth and glaucous, dichotomous above : leaf-blades scabrous above, $8-15 \mathrm{~cm}$. long, the lower ones triangular-hastate, truncate or subcordate at the base, repand-toothed, acute, with petioles $\frac{1}{2}$ as long as the blades, conspicuously ciliate, the upper ovate-lanceolate to lanceolate, entire or nearly so: involucres campanulate, about $1 \mathrm{~cm}$. high; bracts ovate to oblong, obtuse, ciliate, the tips often somewhat spreading : ray-flowers several ; ligules yellow, $1-1.5 \mathrm{~cm}$. long : achenes suborbicular, $6.5-7.5 \mathrm{~mm}$. broad, narrowly winged and notched at the apex.

On hillsides, Cumberland Mountains, Tennessee. Summer.

12. Silphium trifoliàtum L. Stems 1-2 m. tall, smooth, glabrous and glaucous, often widely branched above. Leaves in whorls of 3 , or rarely opposite or alternate above ; blades lanceolate to linear-lanceolate, $8-10 \mathrm{~cm}$. long, remotely serrate or nearly entire, acute or slightly acuminate, scabrous on both sides: heads often numerous, rather showy: involucres campanulate, about $1 \mathrm{~cm}$. high ; bracts oblong-lanceolate to ovate and oblong, ciliate, the outer acutish, the inner obtuse : ray-flowers few ; ligules yellow, $2-2.5 \mathrm{~cm}$. long: achenes obovate or oblong-obovate, $8-10 \mathrm{~mm}$. long, narrowly winged, with 2 acute teeth.

On hillsides, Pennsylvania and Ohio to Alabama. Summer.

13. Silphium glàbrum Eggert. Stems $9-15 \mathrm{dm}$. tall, smooth, regularly leafy to the top, simple or 'sparingly branched above. Leaves opposite or the upper ones sometimes alternate; blades ovate-lanceolate to lanceolate, 8-20 cm. long, acute or short-acuminate, remotely dentate, smooth and glabrous except along the margins : heads few : involucres campanulate, about $1 \mathrm{~cm}$. high ; bracts oblong-lanceolate to ovate or oblong, obtuse, ciliate : ray-flowers several; ligules yellow, $2-2.5 \mathrm{~cm}$. long: achenes obovate, $7 \mathrm{~mm}$. long, with narrow wings and short acute teeth.

In dry soil, North Carolina and Tennessee to Alabama and Georgia. Summer and fall.

14. Silphium confertifòlium Small. Stems 1-6 dm. tall, smooth and glabrous, simple or with few ascending branches above. Leaves mainly on the lower part of the stem, and there approximated or crowded; blades firm, oblong to ovate-lanceolate, 6-12 $\mathrm{cm}$. long, acute or cuspidate, ciliate, nearly entire or shallowly toothed, slightly scabrous except near the center : involucres campanulate, $7-10 \mathrm{~mm}$. high ; bracts broadly oblong, or oblong-obovate, obtuse, merely ciliate, with spreading or recurving tips at maturity : rayflowers several; ligules yellow, 1.5-2 cm. long: achenes orbicular-cuneate, 6-7 mm. long, margined, with 2 ascending teeth.

In dry soil, Alabama. Summer and fall.

15. Silphium speciòsum Nutt. Stems $6-12 \mathrm{dm}$. tall, smooth, glabrous, glaucous, rather corymbosely branched above, the branches sometimes pubescent. Leaves mostly opposite ; blades broadly lanceolate to oblong- or ovate-lanceolate or sometimes ovate, 6-16 cm. long, acute or slightly acuminate, usually shallowly toothed, partly clasping by a rounded or somewhat cordate base, scabrous above, smooth beneath : heads rather crowded or approximate: involucres $12-15 \mathrm{~mm}$. high ; bracts more or less pubescent, the outer broadly lanceolate to triangular, the inner broadly ovate or nearly reniform: ray-flowers 14-26; ligules bright yellow, 2-2.5 cm. long: achenes oval, 11-13 mm. long, rather narrowly winged, each with a broad sinus at the top.

On pleins and prairies, Missouri and Kansas to Texas. Summer and fall.

16. Silphium Ellióttii Small. Stems 8-13 dm. tall, scabrous or nearly smooth in age, corymbosely branched above. Leaves alternate, or few sometimes opposite; blades lanceolate to broadly oblong-lanceolate or rarely oval, 6-12 cm. long, entire, or occasionally with few indistinct teeth, conspicuously ciliate; petioles of the lower leaves more conspicuously ciliate than the blades: heads showy, often in terminal elusters : involucres 10-12 mm. high; bracts oblong to suborbicular and obovate, merely ciliate, obtuse, or the outer acutish : ray-flowers several; ligules $1.5-2 \mathrm{~cm}$. long, yellow : achenes obovate or oblong-obovate, 6-8 $\mathrm{mm}$. long, narrowly winged, each with a U-shaped sinus.

In dry soil, North Carolina to Alabama. Summer.

17. Silphium dentàtum Ell. Stems 6-15 dm. tall, glabrous or sparingly pubescent near the top. Leaves opposite or the upper rarely alternate, or in whorls of 3 ; blades oblong to lanceolate or ovate-lanceolate, $5-15 \mathrm{~cm}$. long, acute, commonly coarsely dentate or 
dentate-serrate : heads corymbose : involucres about $1 \mathrm{~cm}$. high ; bracts ovate-lanceolate to suborbicular, oblong or oblong-cuneate, merely ciliate, the outer ones acute, the inner obtuse : ray-flowers several ; ligules yellow, $2-3 \mathrm{~cm}$. long : achenes obovate to oval, 6-8 $\mathrm{mm}$. long, winged, the teeth rounded, or the sinus nearly obsolete.

In sandy soil, South Carolina to Florida and Alabama.

18. Silphium Simpsònii Greene. Stems 9-12 dm. tall, less densely pubescent above than below, often sparingly branched above. Leaves whorled or opposite, or alternate above ; blades various, those of the basal leaves oblong to lanceolate-oblong, 10-15 $\mathrm{cm}$. long, on short-margined petioles, those of the upper part of the stem ovate or broadly ovate, 3-10 $\mathrm{cm}$. long, sessile and half-clasping by broad bases, all coarsely crenate-serrate or slightly repand: heads few : involucres $2-2.5 \mathrm{~cm}$. broad ; bracts suborbicular to ovate, merely ciliolate: ray-flowers 12-16; ligules yellow, $2.5-3 \mathrm{~cm}$. long: achenes obovate or orbicular-obovate, $10-13 \mathrm{~mm}$. long.

In sandy pine lands, southern peninsular Florida. Summer.

19. Silphium Asteríscus L. Stems 6-15 dm. tall, corymbose above, scabrous-pubescent. Leaves opposite or sometimes alternate on the upper part of the stem; blades oblong to oblong-lanceolate or ovate-lanceolate, more or less distinctly serrate, those of the lower leaves petioled: heads showy : involucres campanulate, about $1 \mathrm{~cm}$. high : bracts oblong-lanceolate to oval and oblong, obtuse, or the outer ones acutish, merely ciliate : rayflowers 11-15; ligules 1.5-2 cm. long: achenes oval or obovate-oval, 7-9 mm. long, surmounted by acute teeth.

In dry soil, Virginia to Ohio, Florida and Mississippi. Summer and fall.

20. Silphium angústum (A. Gray) Small. Stems 6-12 dm. tall, simple or sparingly branched above, scabrous-pubescent. Leaves mostly alternate, few on the upper part of the stem ; blades narrowly oblong or narrowly oblong-lanceolate, $2-10 \mathrm{~cm}$. long, repandserrate or nearly entire, the upper ones sessile or partly clasping: heads solitary or few, showy : involucres campanulate, barely $1 \mathrm{~cm}$. high; bracts ovate to orbicular or broadly spatulate, ciliate, the outer acute, the inner obtuse : ray-flowers several ; ligules yellow, 2-2.5 $\mathrm{cm}$. long: achenes broader than high, 9-19 $\mathrm{mm}$. broad, surmounted by short teeth.

In sandy soil, western Florida. Summer.

21. Silphinm Gatèsii Mohr. Stems 6-15 dm. tall, hispid, simple or sparingly branched above. Leaves alternate; blades broadly linear to oblong-lanceolate or lanceolate, 5-14 cm. long, acute, remotely serrate, scabrous-pubescent, the lower ones shortpetioled : heads showy : involucres campanulate, barely $1 \mathrm{~cm}$. high ; bracts lanceolate to ovate and oblong, hispid, the onter acute and short-acuminate, the inner obtuse : rayflowers several; ligules yellow, 12-20 mm. long]: achenes suborbicular or broader than high, the teeth forming a broad sinus.

In dry soil, Missouri to Tennessee and Alabama. Spring and summer.

22. Silphium scabérrimum Ell. Stems $9-15 \mathrm{dm}$. tall, glabrous, or sparingly pubescent above. Leaves opposite or the upper ones sometimes alternate : blades oblong-lanceolate, ovate-lanceolate or narrowly ovate, $10-20 \mathrm{~cm}$. long, or rather shorter high up on the stem, acute or somewhat acuminate, sharply serrate, scabrous on both sides; petioles about $\frac{1}{2}$ as long as the blades near the base of the stem, gradually shorter above: heads usually few, showy : involucres campanulate, about $1 \mathrm{~cm}$. high ; bracts oblong-lanceolate to ovate or oblong, not conspicuously pubescent, but ciliate, obtuse or the outer ones acutish, the inner with recurved tips: ray-flowers several ; ligules about $1.5 \mathrm{~cm}$. long, yellow : achenes suborbicular, 5-7 $\mathrm{mm}$. broad, broadly winged, with a deep notch at the apex.

In open woods and fields, Virginia and Tennessee to Georgia and Mississippi. Summer.

23. Silphium integrifòlium Michx. Stems $8-15 \mathrm{dm}$. tall, rough-pubescent, 4-angled or striate-ridged. Leaves opposite or mainly so ; blades ovate to broadly lanceolate, quite uniform in size, 7-12 cm. long, scabrous on both sides, acute, often shallowly toothed on the lower part of the stem, mostly entire above : heads in rather open corymbs : involucres $1-1.5 \mathrm{~cm}$. high ; bracts more or less pubescent, the outer triangular-ovate to lanceolate, acute, the inner broader, obtuse : ray-flowers $15-23$; ligules bright yellow, $2-3 \mathrm{~cm}$. long: achenes narrowly obovate, about $1 \mathrm{~cm}$. long, broadly winged only near the top, the broad teeth forming a V-shaped sinus.

On plains and prairies, Wisconsin to Illinois, Mississippi and Texas. Summer and fall.

24. Silphium aspérrimum Hook. Stems 7-14 dm. tall, closely scabrous-pubescent, branching above. Leaves pubescent like the stem, the lower opposite, the upper alternate; blades ovate to lanceolate, $5-10 \mathrm{~cm}$. long, acute, entire or undulate, sessile and often partly clasping: heads showy, on densely white-bristly peduncles: involucres $1-1.5 \mathrm{~cm}$. high; 
bracts lanceolate to ovate, acute, ciliate: ray-flowers several, ligules yellow, $3-3.5 \mathrm{~cm}$. long: achenes broadly obovate or orbicular-obovate, $7-10 \mathrm{~mm}$. long.

On plains or prairies, Arkansas to Louisiana and Texas. Summer and fall.

25. Silphium grácile A. Gray. Stems 3-9 dm. tall, shaggy-hispid, sparingly corymbose above. Leaves opposite ; blades oblong-lanceolate, ovate-lanceolate or elliptic, 5-30 $\mathrm{cm}$. long, acute at both ends or slightly acuminate, remotely dentate-serrate, those on the lower part of the stem with petioles $\frac{1}{2}$ as long as the blades, those on the upper part of the stem sessile or nearly so : involucres about $1 \mathrm{~cm}$. high; bracts inconspicuously pubescent, ciliolate, oblong-lanceolate to ovate and oval-spatulate, obtuse, or the outer acutish : achenes orbicular-oval, 11-12 mm. long, very broadly winged, terminating above in 2 short teeth.

In rocky soil or on prairies, Alabama to Texas. Summer.

26. Silphium Mòhrii Small. Stems 6-12 dm. tall, simple below, usually branched above, shaggy-hispid, stout. Leaves alternate; blades ovate-lanceolate to narrowly ovate, $5-14 \mathrm{~cm}$. long, acuminate, remotely serrate with prominent teeth except near the base : heads showy, but relatively few : involucres campanulate, about $1 \mathrm{~cm}$. high ; bracts lanceolate to ovate-lanceolate, acute or slightly acuminate, densely hispid : ray-flowers several ; ligules yellow, 10-14 mm. long: achenes obovate, more or less constricted at both ends, about $6 \mathrm{~mm}$. long, surmounted by 2 acutish teeth.

In dry soil, Tennessee and Alabama. Summer and fall.

\section{CHRYSÓGONUM L.}

Perennial caulescent pubescent herbs. Leaves opposite : blades broad, toothed, petioled. Heads radiate, peduncled. Involucres hemispheric, double: an outer of 5 foliaceous bracts broadest above the middle ; an inner of firmer bracts, each subtending a rayflower. Ray-flowers pistillate, with broad yellow toothed ligules. Disk-flowers perfect, not fruit-producing, each partly embraced by a bractlet. Anthers nearly entire at the base. Achenes flattened, with acute margins, 1-ribbed on the back, 1-2-ridged on the inner face, adnate to the subtending bract. Pappus a half cup-shaped crown.

1. Chrysogonum Virginiànum L. Stems becoming 1-3 dm. tall, hirsute, often branching. Leaf-blades oblong, ovate or oval, $2-5 \mathrm{~cm}$. long, obtuse, serrate or crenate, the teeth more or less mucronate ; petioles about as long as the blades or longer: peduncles about as long as the subtending bracts: heads conspicuous, few : involucres hirsute ; outer bracts oblong-spatulate, 7-9 mm. long, the inner firmer, obovate, 4-5 mm. long, ciliolate: raỳ-flowers about 5 ; ligules bright yellow, oval or orbicular-oval, about $1 \mathrm{~cm}$. long : achenes 4-4.5 mm. long.

In sandy soil, Pennsylvania to Florida. Spring and summer.

\section{BERLANDIÈRA DC.}

Perennial pubescent caulescent or rarely scapose herbs. Leaves alternate, sometimes basal : blades toothed or pinnatifid. Heads radiate, conspicuous, solitary or corymbose. Involucres hemispheric or depressed, many-flowered : bracts in about 3 series, the inner becoming thin, reticulated. Receptacle flat or nearly so, chaffy. Ray-flowers 5-12, pistillate, fruit-producing : ligules yellow. Disk-flowers perfect, not fruit-producing. Anthers entire or minutely 2 -toothed at the base. Stigmas of the disk-flowers united. Achenes flat, broadened upward, wingless, 1-ribbed within, more or less adnate to the adjacent bracts of the involucre. Pappus obsolete, early deciduous or of 2 caducous awns.

Leaf-blades merely toothed or slightly pinnatifid near the base.

Plants with stems leafy to near the inflorescence.

Stems tomentose or hirsute, or somewhat villous.

Upper part of the stem and peduncles villous or villous-tomentose.

Upper part of the stem and peduncles hirsute with purple hairs.

1. B. Texana.

2. B. betonicifolia.

Stems closely woolly.

Stem-leaves few, pubescent beneath, like the stem, with gray wool: species

of the eastern Gulf region.
Stem-leaves numerous, pubescent beneath, like the stem, with white wool: species of the western Gulf region.

Plants with scapes.

Leaf-blades pinnatifid throughout.

Stems hispidulous : Floridian species.

Stems tomentose: Texan species.

3. B. pumila.

4. B. dealbata.

5. B. humilis.

6. B. subacaulis.

7. B. lyrata.

1. Berlandiera Texàna DC. Stems 6-12 dm. tall, villous or villous-tomentose, espe cially above, corymbose above. Leaf-blades ovate-oblong to triangular-lanceolate or lanceo- 
late, 5-15 cm. long, acute or acutish, crenate, tomentose beneath, cordate at the base, the upper sessile and partly clasping: involucres flattish, about $3.5 \mathrm{~cm}$. broad ; bracts spatulate-linear to oblong, slightly broadened upward or obovate, rather obtuse, ciliolate : ligules of the ray-flowers about $2 \mathrm{~cm}$. long : disk-corollas about $4 \mathrm{~mm}$. long : achenes obovate, $5-6$ $\mathrm{mm}$. long, ciliate.

On hillsides, Missouri to Louisiana and Texas. Spring and summer.

2. Berlandiera betonicifolia (Hook.) Small. Similar to B. Texana in habit, but more harshly pubescent. Stem commonly more slender: leaf-blades triangular-ovate to triangular, acute, crenate, truncate or cordate at the base, finely hirsute beneath : bracts of the involucre spatulate-obovate to cuneate-obovate : ligules of the ray-flowers about 1.5 cm. long. [Silphium betonicifolia Hook.]

In dry or sandy soil, Louisiana.

3. Berlandiera pùmila (Michx.) Nutt. Stems $2.9 \mathrm{dm}$. tall, pubescent with gray wool, simple or sparingly corymbose. Leaf-blades oblong, ovate or oval, 4-10 cm. long, obtuse, crenate, truncate or subcordate at the base or rarely narrowed, pubescent with gray wool beneath, the upper ones sessile or nearly so: involucres flattish, $2-2.5 \mathrm{~cm}$. broad; bracts oblong, oval or obovate, obtuse, ciliolate : ligules of the ray-flowers yellow, 1-1.5 $\mathrm{cm}$. long: disk-corollas about $3 \mathrm{~mm}$. long: achenes $6 \mathrm{~mm}$. long, ciliate. $[B$. tomentosa Nutt.]

In sandy soil, North Carolina to Georgia and Florida.

4. Berlandiera dealbàta (T. \& G.) Small. Stems 7-12 dm. tall, pubescent with white wool, more or less widely branched above. Leaf-blades broadly ovate, oval or deltoid, crenate, pubescent with white wool beneath, truncate or cordate at the base, the upper ones sessile: involucres flattish, about $1.5 \mathrm{~cm}$. broad ; bracts ovate to oblong and obovate, obtuse, those of the two outer series strongly ribbed: ligules of the ray-flowers yellow, 1-1.5 cm. long: disk-corollas $4 \mathrm{~mm}$. long: achenes obovate or elliptic-obovate, 5-6 mm. long. [B. tomentosa var. dealbata T. \& G.]

In dry soil, Arkansảs to Louisiana, Texas and Mexico. Summer.

5. Berlandiera hùmilis Small. Plants acaulescent, 1-2 dm. tall, tomentose. Leafblades oblong to ovate, $3-8 \mathrm{~cm}$. long, rounded at the apex, unevenly crenate, pale beneath, more or less lyrate-pinnatifid near the base, or some of them merely cordate : scapes simple or corymbosely branched, the heads thus solitary or several together: involucres 1.5-2 $\mathrm{cm}$. broad; bracts oblong or lanceolate to ovate or orbicular, closely soft-pubescent : ligules of the ray-flowers $1.5-2 \mathrm{~cm}$. long : achenes obovate, $5-6 \mathrm{~mm}$. long, woolly.

In pine lands, Florida. Throughout the year.

6. Berlandiera subacaùlis Nutt. Plants usually tufted, 1-5 dm. tall, hispidulous. Leaf-blades deeply sinuate-pinnatifid or lyrate-pimnatifid, oblong to oblanceolate, $4-12 \mathrm{~cm}$. long, the lobes obtuse, entire or toothed : involucres about $2 \mathrm{~cm}$. broad; bracts oblong or oblong-spatulate to obovate and cuneate, obtuse, ciliolate: ligules of the ray-flowers $1-1.5$ $\mathrm{cm}$. long : disk-corollas 3-3.5 mm. long : achenes elliptic or nearly so, 5-6 mm. long, ciliolate.

In sand, Florida. Spring to fall.

7. Berlandiera lyràta Benth. Plants commonly tufted, pale cinereous-pubescent. Stems 1-4 dm. tall, striate : leaf-blades narrow in outline, pinnatifid, often lyrate-pinnatifid, 4-13 cm. long, the segments usually toothed: heads long-peduncled, rather showy : involucres about $2 \mathrm{~cm}$. broad; bracts canescent, the outer ovate to obovate, the inner much longer, broadly cuneate : ligules of the ray-flowers yellow with darker stripes, oblong to narrowly cuneate, $1-1.5 \mathrm{~cm}$. long : achenes $5-6 \mathrm{~mm}$. long, obovate, finely strigillose.

On plains and rocky hills, Arkansas to Texas and Arizona. Spring to fall.

\section{LINDHEIMERA Gray \& Engelm.}

Annual caulescent herbs, with pubescent foliage. Leaves alternate below, opposite above: blades sinuate-toothed, or some of them entire. Heads conspicuously radiate. Involucres double, the outer of 4-5 foliaceous bracts, the inner of 4-5 broader bracts becoming parchment-like. Receptacle flat, chaffy, the outer bractlets broadened upward, the inner narrower. Ray-flowers 4-5, pistillate, fruit-producing, with yellow ligules. Disk-flowers perfect, not fruit-producing. Achenes flat, broadened upward, 1-ribbed on each face, not coherent with the subtending bracts, winged. Pappus of 3 teeth, 2 of them confluent with the achene-wing.

1. Lindheimera Texàna Gray \& Engelm. Stems 1-6 dm. tall, hirsute or hispid, often branched. Leaves various, the lower ones with spatulate or cuneate-obovate petioled 
blades, the upper with oblong-lanceolate or ovate sessile blades : heads few, showy : involucres campanulate, $1-2 \mathrm{~cm}$. high ; bracts linear-lanceolate or lanceolate to ovate or oblong, ciliate and with a few stalked glands on the margins, the outer acute, the inner obtuse : rayflowers 4-5 ; ligules bright yellow, $1.5 \mathrm{~cm}$. long : achenes obovate, $6-7 \mathrm{~mm}$. long, with the wing prolonged in 2 horn-like teeth.

In open woods and sandy soil, Texas.

\section{ENGELMÁNNIA T. \& G.}

Perennial caulescent herbs, with pubescent foliage. Leaves alternate : blades pinnatifid, the segments often toothed. Heads radiate, peduncled. Involucres hemispheric or campanulate: bracts in 2-3 series, the outer narrow, the inner broader, and subtending the ray-flowers. Receptacle flat, chaffy. Ray-flowers $8-10$, pistillate, fruit-producing. Diskflowers several, perfect, not fruit-producing, partly embraced by the bractlets. Anthers minutely 2-toothed at the base. Achenes flat, broadened upward, 1-ribbed on each face. Pappus an irregular persistent crown.

1. Engelmannia pinnatífida T. \& G. Roots stout. Stems $3-7 \mathrm{dm}$. tall, hirsute or hispid, more or less widely branched above : leaf-blades $3-15 \mathrm{~cm}$. long, deeply pinnatifid, the lower ones long-petioled, the upper sessile : heads showy : involucres 7-8 mm. high; bracts various, the outer linear, those of the second series with suborbicular bodies and linear tips, those of the inner series oval or obovate, short-tipped, all ciliate, obtuse : rayflowers 8-10 ; ligules golden yellow, about $1 \mathrm{~cm}$. long : achenes oblong-ovate, $4 \mathrm{~mm}$. long, ciliate.

On prairies or open hillsides, Kansas to Arkansas, Louisiana and Arizona. Spring.

\section{PARTHÈNIUM L.}

Perennial or sometimes annual caulescent herbs, or shrubs. Leaves alternate: blades toothed, pinnatifid or dissected. Heads radiate, but not conspicuous. Involucres hemispheric, campanulate or flat, peduncled : bracts in 2-3 series, appressed, obtuse. Receptacle convex or conic, chaffy. Ray-flowers usually 5, pistillate, fruit-producing: ligules broad but very short, white or whitish. Disk-flowers perfect, not fruit-producing, embraced by the bractlets. Anthers entire at the base. Achenes flattened, margined, keeled on the inner face, tipped with the persistent ray-flower. Pappus of 2-3 scales or awns.

Leaf-blades 1-2-pinnatifid : heads not firm at maturity.

Leaf-blades pinnately parted, the segments pinnatifid or toothed.

Leaf-blades lyrately pinnatifid.

Leaf-blades merely toothed: heads very firm at maturity.

1. P. Hysterophorus.

2. P. lyratum.

3. P. integrifolium.

1. Parthenium Hysteróphorus L. Annual, strigose or sometimes slightly hirsute. Stems 3-7 dm. tall, more or less diffusely branched : leaf-blades oblong to ovate in outline, 1-2-pinnately parted, the segments lanceolate to linear, pinnatifid or toothed : heads numerous : involucres saucer-like, 4-5 $\mathrm{mm}$. broad; bracts concave, the outer rhombic or elliptic-rhombic, the inner broader, cuneate at the base : ray-flowers few ; ligules whitish, reniform, less than $1 \mathrm{~mm}$. broad: disk-corollas $1-1.5 \mathrm{~mm}$. long: achenes obovate, 1-1.5 $\mathrm{mm}$. long.

In sandy soil and waste places, Florida and Alabama to Texas. Also in tropical America.

2. Parthenium lyràtum A. Gray. Perennial, canescent or somewhat hirsute. Stems 1-4 dm. tall, solitary or tufted, branching above: leaf-blades ovate, suborbicular or obovate in outline, palmately lobed or lyrately pinnatifid, 1-3 cm. long, the lower ones longpetioled : heads numerous : involucres flattish, $5-6 \mathrm{~mm}$. broad ; bracts various, the outer oval, obtuse, the inner broader than high, notched at the apex, truncate at the base : rayflowers few ; ligules cup-like, about $1 \mathrm{~mm}$. long: disk-corollas 2-2.5 mm. long: achenes obovate or rhombic-obovate, $3 \mathrm{~mm}$. long, with 2 ovate teeth at the top.

In dry soil, Texas. Spring to fall.

3. Parthenium integrifòlium L. Perennial, scabrous-pubescent. Stem 4-12 dm. tall, sometimes clustered, corymbose above : leaf-blades 1-3 dm. long, various, those of the basal and lower stem-leaves oblong or lanceolate, long-petioled; the upper stem-leaves elliptic, oblong ovate or oval, sessile, all acute, singly to triply dentate or crenate-dentate : heads several or numerous, often crowded : involucres campanulate, becoming globular, 4-6 mm. high ; bracts oblong, ovate or suborbicular, obtuse : ray-flowers few ; ligules white or cream-colored, cornucopia-like, $2 \mathrm{~mm}$. broad, retuse : disk-corollas $2.5 \mathrm{~mm}$. long: achenes $3.5-4 \mathrm{~mm}$. long.

In dry or stony soil, Maryland to Minnesota, Georgia and Texas. Spring and summer. 


\section{CRÁSSINA Scepin.}

Annual or perennial caulescent herbs or shrubby plants. Leaves opposite: blades commonly narrow, entire or sparingly toothed. Heads radiate, often showy. Involucres campanulate or somewhat cylindric: bracts in 3-4 series, firm, appressed, rather dry. Receptacle conic or cylindric, chaffy. Ray-flowers pistillate, fruit-producing: ligules red, purple or yellow, or variegated. Disk-flowers perfect, fruit-producing, enveloped in the bractlets. Stigmas of the disk-flowers truncate or subulate. Achenes various; those of the ray 3-angled; those of the disk flattened. Pappus of one or several awns or teeth, or wanting. [Zinnia L.]

Annual: leaves few : achene usually with 1 awn: ray-flowers conspicuous.

Perennial : leaves numerous : achene with 2-4 awns : ray-flowers with ligules shorter than the disk, or these wanting.

1. C. Peruviana.

2. C. anomala.

1. Crassina Peruviàna (L.) Kuntze. Stems 1-6 dm. tall, finely pubescent or glabrous, often branched. Leaf-blades linear-oblong to ovate, $2-5 \mathrm{~cm}$. long, acute, entire, sessile : peduncles somewhat club-shaped: heads showy: involucres cylindric-campanulate, 1-1.5 cm. high ; bracts ovate to oblong, obtuse, glabrous, the tips barely spreading: ray-flowers several ; ligules linear to oblong-spatulate, $1-1.5 \mathrm{~cm}$. long, red, purple or yellow, thickish : bractlets of the disk nearly linear, $1.5 \mathrm{~cm}$. long, eroded at the apex : achenes nearly linear, $1 \mathrm{~cm}$. long, glabrous. [Zinnia pauciflora L.]

In dry soil, Louisiana to Texas and Arizona. Also in Mexico and South America.

2. Crassina anómala (A. Gray) Kuntze. Stems $5-18 \mathrm{~cm}$. tall, scabrous-pubescent, often much branched at the base. Leaf-blades linear, 1-2 cm. long, acute, entire : peduncles shorter than the subtending bracts: heads not showy: involucres cylindric, 10-12 mm. high ; bracts suborbicular to oblong, obtuse, ciliate, the inner ones only at the apex : rayflowers 4-6 ; ligules yellow or orange, 2-6 mm. long, or wanting: achenes 5-6 mm. long, pubescent, each with a short and long awn, and sometimes with other rudimentary ones.

In dry soil, Texas. Summer.

78. SANVITALIA Lam.

Annual, or rarely perennial, caulescent herbs, low or spreading in habit. Leaves opposite: blades flat, mostly entire, petioled. Heads radiate, seldom showy. Involucres broad and shallow : bracts in 1-3 series, dry or somewhat herbaceous. Receptacle flat, or becoming somewhat elevated, chaffy. Ray-flowers pistillate, fruit-producing: ligules often much reduced. Disk-flowers perfect, the corollas with glabrous lobes. Stigmas with truncate or capitate tips. Achenes various, all, or only the outer ones, with thick walls, those of the ray usually 3 -angled, with 3 rigid awns or horns, those of the disk flat or 4-angled, with a pappus of 1 or 2 awns or teeth, or pappus wanting.

Bracts of the involucre in 2-3 series.

Bracts of the involucre in 1 series.

1. S. ocymoides. 2. S. Abertii.

1. Sanvitalia ocymòides DC. Stems usually branched at the base, the branches erect or spreading, 1-4 dm. long, hirsute or hispid. Leaf-blades oval, ovate or elliptic, $1-2 \mathrm{~cm}$. long, entire, commonly abruptly contracted at the base : involucres campanulate, about $5 \mathrm{~mm}$. high ; bracts mostly oblong, cuspidate, ciliate, in 2 or 3 series : ray-flowers several ; ligules yellow, about $2 \mathrm{~mm}$. long: disk-corollas $1.5 \mathrm{~mm}$. long: achenes $3 \mathrm{~mm}$. long; those of the ray glabrous, with 3 rigid spines; those of the disk pubescent, spineless or nearly so.

In woods or thickets, southern Texas and adjacent Mexico.

2. Sanvitalia Abértii A. Gray. Stems 1-4 dm. tall, simple or sparingly branched, hispidulous or glabrate. Leaf-blades almost linear to lanceolate, $1.5-5 \mathrm{~cm}$. long, repand or nearly entire, narrowed into margined petioles: involucres hemispheric, about $5 \mathrm{~mm}$. high : bracts firm, ovate-oblong to oblong-lanceolate, acute, in 1 series : ray-flowers several ; ligules $3 \mathrm{~mm}$. long: disk-corollas about $2 \mathrm{~mm}$. long: achenes $3 \mathrm{~mm}$. long; those of the ray nearly terete, with 3 stout spines; those of the disk 4 -sided, tuberculate, each sometimes with a tubercle-like spine.

In dry soil, Texas to Arizona.

\section{HELIÓPSIS L.}

Perennial, or rarely annual, caulescent herbs. Leaves opposite : blades broadest below the middle, toothed, petioled. Heads radiate, showy, solitary or in open corymbs. Invo- 
lucres campanulate to hemispheric: bracts rather narrow, in 2-3 series. Receptacle convex or conic, chaffy. Ray-flowers pistillate, fruit-producing : ligules yellow. Disk-flowers perfect, fruit-producing, enveloped in the bractlets. Stigmas tipped by hirsute appendages. Achenes 3-4-angled, truncate. Pappus a low crown, 2-4 teeth, or wanting.

Foliage, especially the leaf-blades, smooth or very slightly scabrous.

Heads usually over $1 \mathrm{~cm}$. high: achenes glabrous.

Heads usually less than $1 \mathrm{~cm}$. high: achenes pubescent above. Foliage, especially the leaf-blades, very scabrous.

1. H. helianthoides.

2. H. minor.

3. H. scabra.

1. Heliopsis helianthoìdes (L.) B.S.P. Stems 3-15 dm. tall, usually branched, smooth and glabrous or nearly so. Leaf-blades thinnish, ovate to lanceolate, $8-20 \mathrm{~cm}$. long, sharply serrate, cuneate to truncate at the base: heads showy, with a rounded disk usually over $1 \mathrm{~cm}$. high : bracts of the involucre oblong-lanceolate to oblong, ciliate, acute or acutish, the outer with spreading or reflexed tips : ray-flowers several; ligules bright yellow, 2-3 cm. long: bractlets dilated and erose at the apex : achenes glabrous, truncate or obscurely $2-4$-toothed at the apex. [H. laevis Pers.]

In thickets or open woods, Ontario to Illinois, Florida and Alabama. Summer.

2. Heliopsis mìnor (Hook.) C. Mohr. Stems 2-7 dm. tall, simple or sparingly branched, smooth and glabrous. Leaf-blades thinnish, lanceolate, elliptic or oblong-lanceolate, 3-10 cm. long, sharply serrate, cuneate, rounded or truncate at the base : heads with disks usually less than $1 \mathrm{~cm}$. high : bracts of the involucre lanceolate to oblong, rather obtuse, the outer, at least, with spreading or reflexed tips : ray-flowers few ; ligules bright yellow, 1-2 cm. long: achenes 2.5-3 mm. long: pappus short. [H. gracilis Nutt.]

In woods or on hillsides, Georgia and Florida to Arkansas. Summer and fall.

3. Heliopsis scàbra Dunal. Stems $8-12 \mathrm{dm}$. tall, simple or sparingly branched, scabrous-hispidulous like the leaves. Leaf-blades thick, deltoid to ovate or broadly lanceolate, 5-15 cm. long, serrate, cuneate to truncate at the base: heads showy, with broadly conic disks : bracts of the involucres linear-oblong to oblong, acutish or obtuse : ray-flowers several; ligules $2-2.5 \mathrm{~cm}$. long, bright yellow : bractlets slightly dilated and barely erose at the tip: achenes pubescent on the margins, at least when young, each with a pappus of 1-3 short awns, or a laciniate crown.

In dry soil, Maine to British Columbia, New Jersey and Arkansas. Summer.

\section{TETRAGONOTHÈCA L.}

Perennial caulescent herbs, with pubescent foliage. Leaves opposite : blades coarsely toothed or pinnatifid, sessile or connate-perfoliate. Heads radiate, showy. Involucres broad, many-flowered: bracts various, the 4 outer foliaceous, the inner $6-15$, small, each subtending a ray-flower. Receptacle conic, chaffy. Ray-flowers pistillate, fruit-producing : ligules yellow. Disk-flowers perfect, fruit-producing, enclosed in the bractlets. Stigmas of the disk-flowers hispid, their appendages elongated. Achenes 4-angled or nearly terete, truncate. Pappus of several short scales or wanting.

Achenes nearly terete or obscurely 4-sided : pappus wanting.

Achenes manifestly 4-angled : pappus of several scales, or rarely obsolete.

Leaf-blades saliently toothed.

Leaf-blades pinnatifid or repand.

Corolla-tube glabrous : leaf-blades mainly repand.

Corolla-tube pubescent : leaf-blades mainly pinnatifid.

1. T. helianthoides.

2. T. Ludoviciana.

3. T. repanda.

4. T. Texana.

1. Tetragonotheca helianthoides L. Stems commonly tufted, $3-10 \mathrm{dm}$. tall, hirsute or somewhat villous. Leaf-blades oblong to oval, or sometimes broadest above the middle, acute or acuminate, remotely but sharply toothed, ciliate, the upper ones partly clasping : heads showy, long-peduncled: involucres 4-angled, the outer bracts ovate to ovate-lanceolate, acute, ciliate, cordate, $2-3 \mathrm{~cm}$. long : ray-flowers with yellow ligules $3-4 \mathrm{~cm}$. long : achenes turgid, nearly terete, or obscurely 4 -sided, 5-6 mm. long, without pappus.

In dry soil, Virginia to Florida and Alabama. Spring to fall.

2. Tetragonotheca Ludoviciàna (T. \& G.) A. Gray. Stems 5-12 dm. tall, glabrous or nearly so, more or less branched. Leaf-blades oblong, oval or ovate, 5-17 cm. long, acute, closely and saliently-toothed, the lower with broad; bases, the upper sessile or connate-perfoliate : heads rather showy : involucres scarcely angled : the outer bracts ovate to orbicular, not cordate : ligules of the ray-flowers $1-2 \mathrm{~cm}$. long: achenes manifestly 4angled, 5-6 $\mathrm{mm}$. long, mostly with a crown-like pappus.

In sandy soil, Louisiana and Texas. Spring and summer. 
3. Tetragonotheca repánda (Buckl.) Small. Stems $3-5 \mathrm{dm}$. tall, minutely pubescent, sparingly, branched if at all : leaf-blades ovate to ovate-lanceolate or rarely narrow toward the top of the stem or spatulate near the base of the stem, mostly acute, repand, narrowed into slender petiole-like bases : heads slender-peduncled, show $\mathrm{y}$ : involucres about $2 \mathrm{~cm}$. broad, the outer bracts ovate to triangular-ovate or broader, partially united, the lobes merely acute : ray-flowers with ligules $2-2.5 \mathrm{~cm}$. long: achenes about $2 \mathrm{~mm}$. long, 4angled, minutely pubescent. [Halea repanda Buckl.]

In dry soil, southern Texas. Spring to fall.

4. Tetragonotheca Texàna (A. Gray) Gray \& Engelm. Stems solitary or tufted, 3-7 dm. tall, finely pubescent or glabrate. Leaf-blades oblong, elliptic or oval in outline, pinnatifid, incised or repand, $3-10 \mathrm{~cm}$. long, the lower with cuneate bases, the upper sessile and connate-perfoliate by a toothed disk : heads showy, on elongated peduncles : involucres $2-2.5 \mathrm{~cm}$. broad ; the outer bracts ovate, at least $1 \mathrm{~cm}$. long, united below the middle, the lobes acute or slightly acuminate : ray-flowers with ligules about $1 \mathrm{~cm}$. long: achenes 4angled, obpyramidal, $3 \mathrm{~mm}$. long, pubescent.

In rocky soil, Texas and adjacent,Mexico. Spring to fall.

\section{ECLÍPTA L.}

Annual caulescent herbs. Leaves opposite: blades narrow, entire or somewhat toothed. Head radiate but inconspicuous, short-peduncled. Involucres hemispheric or campanulate : bracts in about 2 series, the outer sometimes longer than the inner. Receptacle flat or convex, chaffy. Ray-flowers pistillate, fruit-producing : ligules small, white. Disk-flowers perfect, chiefly fruit-producing. Bractlets awn-like. Stigmas of the diskflowers with obtuse or triangular tips. Achenes various : those of the ray 3-angled : those of the disk flattened. Pappus of several short teeth, or wanting.

Eclipta álba (L.) Hassk. Stems erect or procumbent, 2-9 dm. long, finely pubescent, somewhat fleshy. Leaf-blades elliptic, oblong or lanceolate, sometimes nearly linear, $3-10 \mathrm{~cm}$. long, acute or somewhat acuminate, remotely toothed or undulate, sessile: heads inconspicuous : involucres broadly campanulate; bracts united to about the middle, the lobes ovate, acute, ciliolate: ray-flowers with white or nearly white ligules: achenes cuneate, $2.5 \mathrm{~mm}$. long, rugose, often truncate at maturity.

In wet places, New York to Nebraska, Florida, and tropical America. Summer and fall.

\section{SCLEROCÁRPUS Jacq.}

Annual or perennial caulescent herbs with pubescent foliage. Leaves alternate or opposite : blades often toothed. Heads radiate, peduncled. Involucres campanulate or hemispheric : bracts distinct, in several series, the outer ones loose and spreading. Receptacle convex or conic, chaffy. Ray-flowers several, neutral : ligules relatively broad. Disk-flowers perfect, fruit-producing, permanently enveloped in the accrescent bractlets which fall away with the achene. Stigmas usually subulate-appendaged. Achenes smooth. Pappus a low crown, or wanting.

Ligules of the ray-fiowers 6-12 $\mathrm{mm}$. long : achenes 3-4 mm. Iong.

Ligules of the ray-flowers $17-28 \mathrm{~mm}$. long : achenes 5-6 $\mathrm{mm}$. long.

1. S. uniserialis.

2. S. major.

1. Sclerocarpus uniseriàlís (Hook.) B. \& H. Annual, strigose-hispid. Stems 2-6 $\mathrm{dm}$. tall, usually simple: leaves alternate; blades $1.5-5 \mathrm{~cm}$. long, deltoid or rhombicovate, or the upper ones lanceolate, acute or acuminate, coarsely serrate-dentate, cuneate or nearly truncate at the base: heads showy, long-peduncled : involucres lax; bracts 6-8 $\mathrm{mm}$. long: ray-flowers 5-8; ligules yellow, 6-12 $\mathrm{mm}$. long, orbicular to oval; bractlets of the disk becoming cartilaginous or bony, nearly terete, tuberculate-roughened : achenes 3-4 mm. long.

In moist soil, Texas and adjacent Mexico.

2. Sclerocarpus màjor Small. Similar to $S$. uniserialis in habit, but larger throughout. Leaf-blades mainly 6-9 $\mathrm{cm}$. Iong and somewhat acuminate, commonly broadly cuneate at the base, long-petioled: bracts of the involucre 9-11 mm. long: ray-flowers with oblong or ovate ligules $17-28 \mathrm{~mm}$. long: achenes $5-6 \mathrm{~mm}$. long.

In rich soil, southern Texas and adjacent Mexico.

\section{MELANTHÈRA Rohr.}

Perennial caulescent herbs, with scabrous or pubescent foliage. Leaves opposite : blades entire, toothed or hastately lobed, petioled. Heads discoid, rather inconspicuous, 
peduncled. Involucres hemispheric, several-flowered: bracts imbricated in 2-3 series, ovate to lanceolate, nearly equal in length. Receptacle hemispheric. Ray-flowers wanting. Disk-flowers perfect, fruit-producing: corollas with wide throats. Anthers not caudate. Stigmas with pubescent subulate appendages. Achenes 4-angled, broadened upward, truncate. Pappus of $\mathbf{2}$ or several caducous awns.

Leaf-blades manifestly hastately lobed.

Bracts of the involucres scale-like, shorter than the disk.

Mature leaf-blades less than $5 \mathrm{~cm}$. long ; middle lobe broadened upward.

Mature leaf-blades much over $5 \mathrm{~cm}$. long ; middle lobe narrowed upward.

Bracts of the involucres foliaceous, surpassing the disk.

Leaf-blades triangular, ovate, rhombic or broadened upward, without hastate lobes.

Leaf-blades linear or broadest above the middle, several times longer than broad.

Leaf-blades broadest below the middle, rarely twice as long as broad.

Bracts of the involucres rhombic to ovate, shorter than the disk.

Bracts of the involucres lanceolate, fully as long as the disk.

1. M. parvifolia.

2. M. nivea.

3. M. lobata.

4. M. lanceolata.

5. M. deltoidea.

6. M. Carpenteri.

1. Melanthera parvifòlia Small. Foliage hispidulous. Stems $3-8 \mathrm{dm}$. tall, simple or branching: leaves opposite ; blades $2-5 \mathrm{~cm}$. long, ovate-lanceolate in outline, 3-lobed, sessile or short-petioled, the middle lobe elongated, more or less broadened above the middle, sparingly serrate, the lateral lobes short, often tooth-like, entire or toothed: peduncles densely hispidulous : heads not showy : involucral bracts not foliaceous, oblong to ovate-lanceolate, scabrous-hispidulous, acute, ciliate : disks about $1 \mathrm{~cm}$. broad; achenes 2 mm. long, nearly smooth.

In sand, peninsular Florida and the Keys.

2. Melanthera nìvea (L.) Small. Foliage scabrous. Stems 8-24 dm. tall, blotched with purple, branched : leaves opposite ; blades ovate to lanceolate in outline, hastate or hastately 3 -lobed, with the middle lobe narrowed upward, 8-15 cm. long, irregularly serrate, finely pubescent beneath : peduncles scabrous : heads not showy : involucral bracts not foliaceous, ovate to ovate-lanceolate, surpassed by the disk, scabrous : disks $1.5 \mathrm{~cm}$. broad : achenes nearly $3 \mathrm{~mm}$. long, tuberculate. [Bidens nivea L. $M$. hastata Michx.」

In wet soil, South Carolina to Florida and Louisiana. Also in tropical America. Spring to fall.

3. Melanthera lobàta Small. Foliage scabrous and hispidulous. Stems 8-18 dm. tall, branching, blotched with purple : leaves opposite; blades ovate in outline, 8-15 cm. long, scabrous on both sides, finely pubescent beneath, 3-lobed, the lateral lobes basal, spreading, each with an erect lobe, margins of all the lobes crenate, the teeth sometimes apiculate: peduncles densely hispidulous: heads not showy : involucral bracts foliaceous, lanceolate or linear-lanceolate, 9-10 $\mathrm{mm}$. long, surpassing the disk, hispidulous : disks flat, about $1.5 \mathrm{~cm}$. broad.

About lakes and ponds, peninsular Florida. Summer.

4. Melanthera lanceolàta Benth. Foliage strigillose. Stems 2-8 dm. tall, more or less branched : leaves opposite, sometimes clustered; blades linear or linear-oblanceolate, 4-8 cm. long, acute or somewhat acuminate, rather coarsely serrate, or sometimes repand, attenuate into slender petioles : heads not showy : peduncles densely strigillose : involucral bracts not foliaceous, broadly linear to oblong-lanceolate, surpassed by the disk, acute, minutely ciliolate.

In sand, peninsular Florida. Spring to fall.

5. Melanthera deltoidea Michx. Foliage more or less scabrous or strigillose. Stems 3-10 dm. tall, branched : leaves opposite; blades firm, deltoid, ovate, or lanceolate above, acute or somewhat acuminate, serrate-dentate or crenate, cuneate to truncate at the base : peduncles slender, strigillose : heads not showy : involucral bracts ovate to rhombic, acute or rather obtuse, strigillose and ciliate: disk surpassing the involucral bracts: achenes broadly cuneate, $2 \mathrm{~mm}$. long, tuberculate-roughened.

In sandy soil, peninsular Florida and the Keys.

6. Melanthera Carpénteri Small. Foliage strigillose and scabrous. Stems 3-11 dm. tall : leaves opposite ; blades membranous, ovate to ovate-lanceolate, $8-15 \mathrm{~cm}$. long, acuminate, dentate or crenate-dentate, broadly cuneate at the base : peduncles slender, densely strigillose: heads not showy: involucral bracts not foliaceous, lanceolate, acuminate, ciliate : disks about $1 \mathrm{~cm}$. broad, equalled by the involucral bracts or surpassed by them.

In pine thickets, Louisiana. Summer.

\section{ISOCÁRPHA R. Br.}

Annual or perennial caulescent herbs. Leaves opposite or alternate: blades flat, sometimes 3-nerved. Heads discoid, solitary or clustered. Involucres low, several-flow- 
ered : bracts narrow, few, appressed. Receptacle conic or oblong, manifestly chaffy. Rayflowers wanting. Disk-flowers perfect, fruit-producing : corollas white or whitish. Bractlets similar to the bracts of the involucre. Stigmas subulate-tipped. Achenes narrow, or 4-5-angled. Pappus wanting.

1. Isocarpha oppositifòlia (L.) R. Br. Stem finely pubescent, $3-10 \mathrm{dm}$. tall, branched above : leaf-blades spatulate-oblong, oblong-lanceolate or ovate, $2.5-9 \mathrm{~cm}$. long, entire or shallowly toothed, 3-ribbed, narrowed into petiole-like bases: heads solitary or clustered : involucres turbinate-campanulate, 3-4 mm. high ; bracts firm, ribbed, the outer subulate, the inner linear: disk ovoid, higher than the involucre : achenes $1.5 \mathrm{~mm}$. long, sharply angled.

In dry soil, southern Texas. Also in the West Indies and Mexico. Spring to fall.

\section{VARÍLLA A. Gray.}

Shrubs or shrubby herbs, with glabrous foliage. Leaves opposite or alternate : blades fleshy, narrow, entire, sessile. Heads discoid, solitary or several in corymbose cymes. Involucres short, several-flowered : bracts few, narrow, appressed, usually striate. Receptacle becoming conic or oblong, chaffy. Ray-flowers wanting. Disk-flowers perfect. fruit-producing : corollas tubular, yellow. Bractlets similar to the bracts of the involucre, Stigmas with obtuse or apiculate conic tips. Achenes terete, 8-15-nerved, smooth. Pappus of several bristles, or wanting.

1. Varilla Texàna A. Gray. Shrubby, several dm. tall, glabrous or nearly so, finally diffusely branched. Leaves numerous, approximate on the caudex-like stem or its branches ; blades terete, linear, 1-2.5 cm. long, obtuse : peduncles slender : involucre broad ; bracts subulate to linear-subulate, the inner $5-6 \mathrm{~mm}$. long, acuminate : disk rounded, much surpassing the involucre : pappus wanting.

In saline soil, southern Texas and adjacent Mexico.

\section{SPILÁNTHES Jacq.}

Annual or perennial, often acrid caulescent herbs, usually with spreading branches. Leaves opposite : blades flat, often toothed, petioled. Heads radiate or discoid, peduncled. Involucres campanulate : bracts narrow, in about 2 series, rather loosely appressed. Receptacle convex or elongated, chaffy. Ray-flowers pistillate, fruit-producing : ligules white or yellow. Disk-flowers perfect, fruit-producing, each embraced by a bractlet with which the achene falls away : corollas yellow. Stigmas of the disk-flowers elongated, sometimes brush-like. Achenes various : those of the ray 3-angled or somewhat flattened: those of the disk flattened, margined. Pappus of 1 or several awns.

1. Spilanthes rèpens (Walt.) Michx. Stems decumbent or creeping, $2-8 \mathrm{dm}$. long, hirsute or glabrate. Leaf-blades ovate to lanceolate, $2-6 \mathrm{~cm}$. long, denticulate to coarsely serrate, each gradually, or usually abruptly, narrowed into a short petiole : peduncles 2-10 $\mathrm{cm}$. long : involucres campanulate or becoming rather flat ; bracts lanceolate to oblong, 4-5 $\mathrm{mm}$. long, acute : ray-flowers with yellow ligules $5 \mathrm{~mm}$. long: disk ovoid, $1 \mathrm{~cm}$. high at maturity: achenes $1.5 \mathrm{~mm}$. long, tuberculate and hispidulous in age.

In low grounds, North Carolina to Missouri, Florida and Texas. Spring to fall.

\section{GYMNOLÒMIA H.B.K.}

Annual or perennial caulescent herbs or shrubby plants, with pubescent foliage. Leaves alternate or opposite: blades narrow, entire or toothed. Heads radiate, rather conspicuous. Involucres hemispheric or campanulate : bracts narrow, in 2-3 series, the inner ones somewhat longer than the outer. Receptacle more or less conic, chaffy. Ray-flowers pistillate, not fruit-producing: ligules yellow. Disk-flowers perfect, fruit-producing, with yellow or brownish corollas. Stigmas of the disk-flowers obtuse or with acute appendages. Achenes of the ray inane, those of the disk 4-angled, either somewhat flattened or turgid, truncate. Pappus a denticulate crown, or wanting.

Annual plant : receptacle conic, becoming columnar : Georgian species. Perennial plant: receptacle low-convex: Texano-Mexican species.

1. Gymnolomia Pórteri A. Gray. Annual, herbaceous. Stems 2-10 dm. tall, loosely branching, sparingly hispid : leaves mostly alternate; blades narrowly linear to narrowly 
linear-lanceolate, $3-15 \mathrm{~cm}$. long, acute, entire : heads showy : involucres flattish in age ; bracts narrowly linear-lanceolate to lanceolate-subulate, $6-10 \mathrm{~mm}$. long, serrulate with spine-like teeth : receptacle conic, becoming columnar : ray-flowers 5-8; ligules golden yellow to light orange, $1-2 \mathrm{~cm}$. long: achenes obovoid, turgid, $3 \mathrm{~mm}$. long, striate.

On granite rocks, Stone Mountain and vicinity, Georgia. Summer and fall.

2. Gymnolomia tenuifòlia (A. Gray) B. \& H. Perennial, shrubby. Stems 5-10 dm. tall, scabrous-puberulent, much branched: leaves numerous, the lower alternate, the upper opposite ; blades 3-10 cm. long, pinnately or pedately 3-7-parted, the segments narrowly linear: peduncles $5-15 \mathrm{~cm}$. long: heads rather showy : involucres nearly hemispheric, 4-5 mm. high ; bracts various, the outer with a cuneate or obovate body and a lanceolate tip, the inner oblong to linear: receptacle low-convex : ray-flowers 9-15; ligules yellow, 5-7 $\mathrm{mm}$. long, recurving: achenes $3 \mathrm{~mm}$. long.

In dry soil, Texas and adjacent Mexico.

\section{RUDBÉCKIA L. ${ }^{1}$}

Perennial, or rarely annual or biennial, caulescent herbs. Leaves alternate : blades entire, toothed or pinnatifid, either petioled, sessile or clasping. Heads (in our species) radiate, showy, many-flowered. Involucres hemispheric : bracts imbricated in 2 or more series, rarely foliaceous. Receptacle convex or conic, chaffy. Ray-flowers neutral : ligules yellow, rarely discolored (in one species crimson). Disk-flowers perfect, fruit-producing with 5-lobed corollas. Stigmas with blunt or subulate pubescent tips. Achenes 4-angled, obtuse or truncate. Pappus of 2-4 short teeth, a low coroniform border, or wanting. CONE-FLOWER.

A. Stigmas with short, obtuse tips: pappus present, except in No. 7 .

Chaff of the receptacle acute, mucronate or obtuse.

Chaff canescent or pubescent at the apex.

Leaf-blades, at least those of the lower leaves, deeply lobed or divided. LaciniataE.

Plants glabrous or glabrate.

Plants cinereous-pubescent.

Disk greenish yellow.

Disk brown-purple, anise-scented.

Leaf-blades entire or merely toothed.

Disk globose-ovoid, ovoid-conic or hemispheric: plants pubescent: corolla-lobes reflexed after anthesis. HeLIOPSIDEs.

Cauline ieaves petioled.

Heads small, the disks $1 \mathrm{~cm}$. in diameter or less.

Heads large, the disks $1-2 \mathrm{~cm}$. in diameter.

Stems glabrous or glabrate.

Stems hispid or scabrous.

Cauline leaves closely sessile or partly clasping.

Disk cylindric or conic-cylindric at maturity: plants glabrous: corolla-lobes erect after anthesis. LAEVIGATAE.

Leaves glaucous, the blades oval, broadly ovate or oblong.

Leaves lustrous, the blades narrower.

Leaf-blades ovate-spatulate to lanceoat e-oblong.

Leaf-blades elongated-lanceolate, attenuate at both ends.

Chaff ciliate, denticulate or entire at the apex.

Chaff ciliate or fimbriate at the tip. FULGIDAE.

Basal and lower stem-leaves cordate or truncate.

Chaff $1.5-2.5 \mathrm{~mm}$. broad, densely ciliate at the tip.

Chaff narrower, sparsely ciliate at the tip.

Basal and lower stem-leaves not cordate or truncate.

Involucral bracts ciliate, glabrous above: leaves large, long-acuminate.

Stems glabrate or glabrous.

Stems strigose.

Involucral bracts ciliate, pubescent above : leaves small to medium size, acute or short-acuminate.

Uppermost leaves cuneiform or oblong-lanceolate.

Well developed disks over $1 \mathrm{~cm}$. in diameter: ligules relatively short.

Well developed disks smaller: ligules relatively large.

Uppermost leaves conspicuously dilated.

Chaff with entire, hyaline or erose-denticulate tips.

a. Leaf-blades various, but not elongated-linear. SPECIOsaE.

Ligules large and showy, much exceeding the diameter of the disk.

Leaf-blades laciniate, or very coarsely dentate. Prevailing leaves of an ovate type. Prevailing leaves narrower.

Leaf-blades remotely or shallowly dentate or entire. Plants glabrous or nearly so. Plants densely hirsute.

1. R. laciniata.

2. R. heterophylla.

3. R. subtomentosa.

4. R. Heliopsidis.

5. R. alismaefolia.

6. $R$. grandiflora.

7. $R$. mollis.

8. R. maxima.

9. $R$. nitida.

10. R. glabra.

11. $R$, umbrosa.

12. R. Chapmanii.

13. $R$. palustris.

14. $R$. acuminata.

15. R. fulgida.

16. $R$. foliosa.

17. R. spathulata.

18. R. Sullivantii

19. R. speciosa.

20. R. truncata.

21. R. Missouriensis.

${ }^{1}$ Contributed by Mr. C. L. Boynton \& Mr. C. D. Beadle. 
Ligules short, often less than the diameter of the disk.

b. Leaf-blades elongated-linear. GRAMINIFOLIAE.

Plants pubescent: ligules crimson.

Plants glabrous: ligules yellow.

Chaff of the receptacle aristate or subulate. TRILOBAE.

Blades of the lower stem-leaves, or some of them, palmately 3-lobed or 3parted, sometimes undivided.

Disk 5-13 mm. broad : ray-flowers with ligules $1.5-2.5 \mathrm{~cm}$. long.

Disk $15-20 \mathrm{~mm}$. broad : ray-flowers with ligules $2-3.5 \mathrm{~cm}$, long.

Blades of the lower stem-leaves, or some of them, pinnately 5-7-lobed or 57-parted.

Bracts of the involucres, or most of them, as long as the ligules of the ray-flowers: Alleghenian species.

Bracts of the involucres, or most of them, not half as long as the ligules of the ray-flowers: Floridan species.

B. Stigmas with slender subulate tips: pappus wanting.

Plants of annual or biennial duration. BICOLORES.

Lower cauline leaves with blades $1-3 \mathrm{~cm}$. broad.

Lower cauline leaves broader.

Plants of perennial duration. HirtaE.

Well developed disks $1 \mathrm{~cm}$. in diameter or more: ligules of the ray-flowers large and showy.

Leaf-blades never of an ovate type.

Petioles!of the basal leaves not exceeding $1 \mathrm{dm}$. in length.

Leaf-blades broader than linear.

Main axis or stem not divergently branched.

Upper stem-leaves elliptic-lanceolate, lanceolate or narrower. Upper stem-leaves oblong, subcordate-clasping.

Main axis or stem divergently branched, usually from near the base.

Leaf-blades linear or linear-lanceolate, elongated.

Petioles of the basal leaves, or somelof them, conspicuously elongated.

Leaf-blades, or some of them, of an ovate type.

Basal leaves $5-6 \mathrm{~cm}$. wide : involucral bracts often foliaceous.

Basal leaves narrower: involucral bracts not foliaceous.

Well developed disks smaller: ligules of the ray-flowers short.
22. R. tenax.

23. R. graminifolia.

24. R. Mohri.

25. R. triloba.

26. R. rupestris.

27. R. Beadlei.

28. R. pinnatiloba.

29. R. bicolor.

30. R. flexuosa.

31. R. hirta

32. $R$. amplectens.

33. $R$. divergens.

34. R. sericea.

35. $R$. longipes.

36. R. Brittonii.

37. R. monticola.

38. R. Floridana.

1. Rudbeckia laciniàta L. Stems $6-20 \mathrm{dm}$. tall, usually branched above, glabrous or nearly so : leaf-blades various, rather thin, veiny; those of the basal and lower stem-leaves pinnately 3-7-foliate or divided, those of the upper stem-leaves successively less deeply parted or lobed, or the upper ones merely toothed, incised or cleft, sometimes entire : heads several or numerous, showy : bracts of the involucre oblong or lanceolate, reflexed : rayflowers 6-10, conspicuous ; ligules bright yellow, 2-4 cm. long, soon drooping : disk greenish yellow, becoming oblong-conic: achenes quadrangular: pappus a short 4-toothed or nearly entire crown : chaff truncate, pubescent or canescent at the apex.

In moist thickets, Quebec to Manitoba, Florida and westward. Summer and fall.

2. Rudbeckia heterophýlla Torr. \& Gray. Stems $4-16 \mathrm{dm}$. tall, cinereous-pubescent, sparingly branched above : leaves various; blades of the basal and lower stem-leaves petioled, pinnately 3-5-parted or divided, the oval or oblong divisions toothed; those of the upper stem-leaves ovate, simple or lobed, coarsely toothed, borne on short petioles : heads few or sereral, not very showy : bracts of the involucre oblong or oblong-lanceolate : rayflowers few ; ligules yellow, 1-2.5 cm. long, eventually drooping: disks subglobose, 1-1.5 $\mathrm{cm}$. in diameter, greenish yellow : achenes prismatic, with a short coroniform pappus accentuated at the angles: chaff canescent at the apex.

In swamps and damp places, Florida. Summer.

3. Rudbeckia subtomentòsa Pursh. Stems 6-15 dm. tall, cinereous-pubescent, branched above : leaves with petioled blades, some or all of the lower ones 3-lobed or 3parted, the terminal lobe elliptic to lanceolate, acuminate, serrate, the lateral lobes smaller and narrower, those of the upper stem-leaves mostly undivided : heads numerous, showy : bracts of the involucre linear or nearly so, acuminate : ray-flowers several; ligules yellow, 2-3 cm. long: disks hemispheric or ovoid-conic, brown-purple, anise-scented : achenes crowned with the crenately toothed pappus : chaff canescent at the apex.

On prairies and in open grounds, Illinois to Missouri, Louisiana and Texas. Summer and fall.

4. Rudbeckia Heliópsidis T. \& G. Stems 3-7 dm. tall, glabrate or softly pubescent, usually branched above: leaves various, the basal and lower ones borne on long slender petioles, the upper with short petioles ; blades rather thin oblong-ovate to ovatelanceolate, $3-10 \mathrm{~cm}$. long, mostly acute or acuminate at the apex, serrate, cuneate or more abrubtly contracted at the base : heads rather small, few or several : bracts of the involucre shorter than the disk : ray-flowers few ; ligules light yellow : disks subglobose, about $\mathbf{1} \mathrm{cm}$. in diameter : achenes quadrangular, the pappus nearly obsolete : chaff blunt, canescent at the apex.

In woods and low grounds, Georgia and Alabama. Summer and fall. 
5. Rudbeckia alismaef òlia T. \& G. Stems 5-9 dm. tall, glabrous or glabrate below, hispidulous or scabrous towards the furrowed summit, usually simple : leaf-blades oval or elliptic, $5-12 \mathrm{~cm}$. long, short-pointed or obtuse, repand-denticulate or nearly entire, 3-5nerved; the basal leaves with long petioles: heads showy, rather large : bracts of the involucre linear, short: ray-flowers 10-15; ligules yellow, 3-4 cm. long, eventually drooping: disks subglobose, $1.5-2 \mathrm{~cm}$. thick: chaff obtuse, canescent at the summit: pappus conspicuous, toothed.

In pine woods and on prairies, Arkansas to Louisiana and Texas. Summer and fall.

6. Rudbeckia grandiflòra C. C. Gmelin. Stems 5-9 dm. tall, scabrous or hispid throughout: leaves mainly on the lower part of the stem, very rough on both surfaces; blades ovate-elliptic to lanceolate, $6-15 \mathrm{~cm}$. long, acute or acuminate at the apex, cuneate or more abruptly contracted at the base, shallowly serrate or denticulate; petioles of the lower cauline and basal leaves as long as the blades or longer: heads large, solitary or few, showy : bracts of the involucre linear, acuminate: ray-flowers several; ligules yellow, 3-3.5 cm. long, drooping : disks ovoid or ovoid-globose, $1.5-2.5 \mathrm{~cm}$. thick : chaff obtuse, canescent or pubescent at the summit: pappus conspicuous, crenate or toothed.

On dry prairies, Missouri to the Indian Territory, Louisiana and Texas. Summer.

7. Rudbeckia móllis Ell. Stems $3-10 \mathrm{dm}$. tall, often widely branched above, densely hirsute with light gray hairs: leaf-blades elliptic, oblong, or spatulate-oblong, $1.5-6 \mathrm{~cm}$. long, mostly obtuse, crenate-dentate or entire, clothed on both surfaces with soft, fine and close pubescence : heads showy : bracts of the involucre linear to linear-lanceolate, shorter than the disk : ray-flowers 10-15; ligules bright yellow, $2-3.5 \mathrm{~cm}$. long: disks brownpurple, $1.5-2 \mathrm{~cm}$. in diameter : chaff pointed, pubescent at the summit: pappus wanting.

In pine lands and dry fertile soil, Georgia and Florida. Spring and summer.

8. Rudbeckia máxima Nutt. Stems 1-3 m. tall, simple or branched above, smooth, glaucous : leaf-blades oblong, oval or ovate, $6-20 \mathrm{~cm}$. long, mostly obtuse, undulate, repanddenticulate or entire, the upper sessile and partly clasping : heads large : bracts of the involucres linear or linear-lanceolate, acute, short: ray-flowers several ; ligules yellow, 1.5$4 \mathrm{~cm}$. long: disks oblong to conic-cylindric, $2.5-6 \mathrm{~cm}$. long : chaff abruptly short-pointed, pubescent at the summit : achenes $6-8 \mathrm{~mm}$. long, prismatic : pappus conspicuous, denticulate, accentuated at the angles.

In moist soil, Arkansas and the Indian Territory to Louisiana and Texas. Spring and summer.

9. Rudbeckia nítida Nutt. Stems 6-12 dm. tall, simple or branched, glabrous : leafblades ovate-spatulate to lanceolate-oblong, 8-15 cm. long, mostly acute, denticulate or entire; petioles of the lower and basal leaves longer than the blades : heads large, showy : bracts of the involucre relatively short, obtuse or obtusish : ray-flowers several; ligules yellow, drooping : disks cylindric or conic-cylindric, $3-4.5 \mathrm{~cm}$. long : chaff pubescent at the summit, pointed: achenes $6-8 \mathrm{~mm}$. long, prismatic: pappus conspicuous, denticulate, accentuated at the angles.

In low grounds, Georgia to Florida and Texas. Spring to fall.

10. Rudbeckia glàbra DC. Stems 6-12 dm. tall, glabrous, more or less branched above: leaf-blades elongated-lanceolate to linear-lanceolate, attenuate at both ends, 1-3 $\mathrm{dm}$. long, lustrous, repand-dentate or undulate, prominently veined and reticulated ; basal and lower stem-leaves borne on winged petioles as long as the blades or longer, the upper short-petioled or sessile: heads large and very showy: bracts of the involucre linear, acute or acutish, relatively short : ray-flowers several to many, 3-5 cm. long; ligules bright yellow, drooping: disks cylindric or conic-cylindric, $2-4 \mathrm{~cm}$. long: chaff pointed, pubescent at the summit : achenes $6-8 \mathrm{~mm}$. long, crowned by the conspicuous, toothed pappus.

In swamps and low grounds, Georgia to Florida and Alabama. Spring to fall.

11. Rudbeckia umbròsa Boynton \& Beadle. Stems 4- $10 \mathrm{dm}$. tall, striate, somewhat pubescent, simple or branehed: leaf-blades of the basal and lower stem-leaves ovate, coarsely serrate, rounded, truncate or cordate at the base, acute at the apex : the upper stem-leaves diminished in size, short-petioled or subsessile, the blades narrower and more entire than the lower : heads mostly several, showy : involucral bracts oblong to linear-oblong, 10-15 mm. long, pointed : ray-flowers 8-12; ligules yellow or orange-yellow, 1.5-2 $\mathrm{cm}$. long: disks $1-1.5 \mathrm{~cm}$. wide, $8-12 \mathrm{~mm}$. high : chaff broad, densely ciliate at the apex : achenes displaying prominent coroniform pappus.

In moist soil and woodlands, Kentucky, Tennessee and northwestern Georgia. Summer.

12. Rudbeckia Chapmánii Boynton \& Beadle. Stems 4-10 dm. tall, branched above, glabrous or glabrate: leaf-blades ovate-lanceolate, those of the basal and lower cauline leaves long-petioled, truncate or cordate at the base, dentate or coarsely crenate-dentate, the upper gradually reduced in size, remotely dentate or nearly entire, sparingly pubescent 
on both surfaces : heads several or few, showy : involucral bracts 6-12 mm. long : ray-flowers 12-16 ; ligules 1.5-2.5 cm. long, yellow or orange-yellow : disks hemispheric or shortconic, $8-15 \mathrm{~mm}$. high, $1-1.5 \mathrm{~cm}$. broad : chaff short-pointed, ciliate with a few short hairs at the tip : pappus a shallow coroniform border.

In the mountains of Georgia and Alabama. Summer.

13. Rudbeckia palústris Eggert. Stems $5-7 \mathrm{dm}$. tall, usually branched, glabrous or glabrate, except at the summit : leaf-blades ovate-lanceolate, remotely serrate or dentate or nearly entire, acuminate at the apex, narrowed or contracted at the base; those of the basal and lower cauline leaves borne on winged petioles, the upper gradually diminishing in size, sessile or short-petioled, nearly entire : heads several, showy : involucral bracts linear or linear-oblong, mostly obtuse, ciliate, smooth on the upper surface : ray-flowers 8-12 ; ligules 1-2 cm. long, yellow : disks hemispheric or short-conic, $8-12 \mathrm{~mm}$. high, 1-1.5 cm. wide : chaff pointed, sparingly ciliate at the apex : pappus a low coroniform border accentuated at the angles.

In low grounds, Kentucky, Tennessee and Missouri. Summer and fall.

14. Rudbeckia acuminàta Boynton \& Beadle. Stems $5-8 \mathrm{dm}$. tall, strigose, simple or branched : leaf-blades lanceolate, acuminate, remotely serrate with low teeth, or entire, sparsely pubescent on both surfaces; those of the basal and lower cauline leaves slenderpetioled, the upper gradually diminished in size and borne on winged petioles, or the uppermost subsessile : heads few or several, showy : involucral bracts lanceolate, acute, ciliate on the margins, smooth above : ray-flowers 10-14; ligules 1-2.5 cm. long, yellow or orange-yellow : disks hemispheric or short-conic, $1-1.5 \mathrm{~cm}$. wide : chaff pointed, ciliate at the apex : pappus a low coroniform border toothed at the angles.

In woods, middle Tennessee. Summer.

15. Rudbeckia fúlgida Ait. Stems stout, 3-7 dm. tall, hirsute or somewhat hispid, usually much branched : leaf-blades lanceolate, oblong-lanceolate or cuneiform, hispid, remotely toothed or entire, 3-12 $\mathrm{cm}$. long, 1-4 cm. wide, those of the uppermost leaves with narrow subcordate bases, the lower on winged petioles : heads mostly several, showy : involucral bracts linear to linear-lanceolate : ray-flowers 10-15; ligules relatively short, orange or deep yellow : disks hemispheric or short-conic, 1-1.5 cn. wide: chaff pointed, ciliate at the apex : pappus a low coroniform border accentuated at the angles.

In woods and meadows, Pennsylvania to Virginia and North Carolina. Summer and fall.

16. Rudbeckia foliòsa Boynton \& Beadle. Stems slender, $3-7 \mathrm{dm}$. tall, pubescent or somewhat hispid, much branched and very leafy : leaf-blades lanceolate, oblong-lanceolate, elliptic or cuneiform, 2-7 cm. long, 5-15 mm. wide, sparingly serrate or entire, those of the basal and lower cauline leaves borne on very slender petioles, the uppermost sessile: heads several or numerous, small, showy : involucral bracts linear to oblong-linear : ray-flowers 8-13; ligules relatively large, yellow : disks hemispheric or short-conic, mostly less than $1 \mathrm{~cm}$. wide : chaff pointed, ciliate at the apex : pappus a coroniform border toothed at the angles.

In woods, North Carolina to Florida. Summer and fall.

17. Rudbeckia spathulàta Michx. Stems $3-7 \mathrm{dm}$. tall, minutely pubescent, simple or branched : leaf-blades entire or minutely and remotely toothed, pubescent with short hairs on both surfaces: those of the basal leaves oval, mostly obtuse, cauline leaves lanceolate, elliptic or oblanceolate, $2-6 \mathrm{~cm}$. long, 5-18 mm. wide, acute at the apex, wedgeshaped or more abruptly contracted at the base, the uppermost sessile or subsessile and with shorter apices: heads solitary or few : involucral bracts linear, mostly acute : rayflowers about 8 ; ligules orange-yellow or yellow : disks hemispheric or short-conic, about $1 \mathrm{~cm}$. wide : chaff pointed, ciliate at the apex : pappus a low coroniform border.

In woods and along streams, North Carolina, Georgia and Alabama. Summer and fall.

18. Rudbeckia Sullivántii Boynton \& Beadle. Stems $5-10 \mathrm{dm}$. tall, hispid or glabrate, branched near the top : leaf-blades more or less pubescent, coarsely and irregularly serrate or serrate-dentate ; those of the basal and lower cauline leaves oval, ovate or ovatelanceolate, petioled, acute or acuminate at the apex, either narrowed, rounded, truncate or subcordate at the base, of the upper cauline leaves, narrower and shorter petioled, or of the uppermost subsessile and entire : heads several, showy : involucral bracts linear-oblong, obtusish, 8-12 mm. long: ray-flowers 10-15; ligules $2-4 \mathrm{~cm}$. long, yellow with an orange base : disks hemispheric or short-conic, 12-18 mm. wide : chaff' mostly naked at the erose summit, or the outermost erose-denticulate : achenes $3-4 \mathrm{~mm}$. long with coroniform pappus toothed at the angles.

In low grounds, Michigan and Ohio to Tennessee and Alabama. Summer and fall. 
19. Rudbeckia speciòsa Wender. Stems $5-10 \mathrm{dm}$. tall, hirsute or somewhat hispid, branched above : leaf-blades sparingly rough-hairy, those of the basal leaves elliptic, 2.5-5 $\mathrm{cm}$. broad, acute at the apex, narrowed at the base and prolonged into slender petioles ; of the cauline leaves, elongated-lanceolate, often falcate, 1-4 cm. broad, coarsely and irregularly serrate or laciniately dentate, acuminate, narrowed at the base, subsessile or petioled, or those of the uppermost leaves sessile, entire or nearly so: heads few or several, showy : involucral bracts linear to linear-lanceolate, acute: ray-flowers 12-20 ; ligules $2-3.5 \mathrm{~cm}$. long, yellow or orange-yellow at the base: disks hemispheric or shortconic, $13 \mathrm{~mm} .-2 \mathrm{~cm}$. broad : chaff pointed, smooth at the erose or erose-denticulate apex : pappus a coroniform border accentuated at the angles.

In woods and low grounds, Pennsylvania to Georgia, Alabama and Missouri. Summer and fall.

20. Rudbeckia truncàta Small. Stems 3-8 dm. tall, sparingly hirsute or glabrate, mostly branched above : leaf-blades remotely and shallowly dentate or entire; those of the basal leaves narrowiy elliptic, 5-10 cm. long, acute or acuminate at both ends, borne on winged petioles; those of the cauline narrowly lanceolate to oblong or oblong-linear, 3-10 cm. long, acute or acuminate, borne on winged petioles or sessile by a narrowed, truncate or subclasping base: heads several to many, showy : involucral bracts linear to linear-lanceolate, mostly acute : ray-flowers $10-14$; ligules yellow or deep yellow : disks hemispheric or short-conic, $1-1.5 \mathrm{~cm}$. wide : chaff pointed, naked at the erose apex : pappus a low crown-like border accentuated at the angles.

In woods and low grounds, Georgia to Alabama and Tennessee. Fall.

21. Rudbeckia Missouriénsís Engelm. Stems 4-6 dm. tall, more or less hirsute, fastigiately much-branched, or occasionally simple: leaf-blades rough-pubescent on both surfaces; those of the basal leaves linear-lanceolate to oblong-lanceolate, $4-8 \mathrm{~cm}$. long, entire, or with an occasional minute, callous tooth, borne on slender, hirsute petioles; of the stem leaves, linear to linear-lanceolate, entire, nearly or quite sessile by a tapering base, gradually reduced in size upward or at least on the branches : heads mostly several, showy : involucral bracts 8-10 mm. long, linear to linear-oblong: ray-flowers usually 1214 ; ligules $1.5-2.5 \mathrm{~cm}$. long: disks hemispheric, $1-1.5 \mathrm{~cm}$. broad, $8-12 \mathrm{~mm}$. high : chaff pointed, the apex naked and entire : achenes with very short coroniform pappus.

In dry or rocky soil, Missouri and Arkansas to northern Louisiana. Summer and fall.

22. Rudbeckia tènax Boynton \& Beadle. Stems 4-8 dm. tall, sparingly hirsute or pubescent, simple or branched: leaf-blades more or less pubescent; those of the basal leaves ovate-lanceolate to oblong-lanceolate or elliptic, mostly acute, $3-10 \mathrm{~cm}$. long, borne on margined petioles often longer than the blades ; of the cauline leaves ovate-lanceolate to lanceolate or elliptic-lanceolate, 2-8 cm. long, 1-3 cm. wide, acute or acuminate, remotely and shallowly dentate or entire, borne on winged petioles or the uppermost sessile : heads solitary or several : involucral bracts oblong to lanceolate, $6-10 \mathrm{~mm}$. long, usually pointed : ray-flowers 8-14; ligules short, 6-12 mm. long, yellow with an orange base : disks hemispheric, 10-18 mm. wide : chaff acute, the hyaline tip erose or denticulate : pappus a low crown toothed at the angles.

In fields and woods, middle Tennessee and Alabama. Summer and fall.

23. Rudbeckia graminifòlia (T. \& G.) Boynton \& Beadle. Stems 6-8.5 dm. tall, simple, pubescent : leaf-blades elongated-linear, $6-25 \mathrm{~cm}$. long, $4 \mathrm{~mm} .-1 \mathrm{~cm}$. wide, 3 nerved, the lateral nerves at the extreme borders, acute, narrowed below and passing insensibly into apparent petioles; those of the upper leaves gradually diminished in size, sometimes only $2-4 \mathrm{~cm}$. long, appearing sessile : heads solitary : involucral bracts $6-9 \mathrm{~mm}$. long, acuminate from a broad base : ray-flowers 8-10; ligules 8-12 $\mathrm{mm}$. long, deep crimson: disk hemispheric to oblong-ovoid: chaff mucronate, entire at the apex : pappus a low border toothed at the angles.

On the margins of ponds in pine lands, southern Georgia and adjacent parts of West Florida. Spring and summer.

24. Rudbeckia Mònrii A. Gray. Stems 4-12 dm. tall, smooth and glabrous, often loosely branched: leaf-blades linear or elongated-linear, acuminate, 1-3 dm. long, 1-12 $\mathrm{mm}$. wide, prominently nerved, the lower narrowed into winged petioles: heads few or several : bracts of the involucre linear to linear-lanceolate, 3-6 mm. long, acute or acuminate : ray-flowers $6-12$; ligules yellow, $1.5-3 \mathrm{~cm}$. long: disks ovoid-conic to conic-cylindric at maturity : chaff conspicuously mucronate, smooth and entire at the apex : pappus a coroniform border accentuated at the angles. [R. bupleuroides A. Gray.] Summer.

On the borders of ponds in pine lands, southern Georgia and adjacent portions of West Florida.

25. Rudbeckia tríloba L. Stems 6-15 dm. tall, hispid or hirsute, branched : leaves various, the basal with ovate or oblong-ovate, serrate, cordate, long-petioled blades ; stem- 
leaves 3-10 cm. long; blades of the lower, or some of them, palmately 3-lobed or 3-parted, sometimes undivided; of the upper ovate, ovate-lanceolate or lanceolate, mostly acuminate, narrowed into a sessile base or into short winged petioles, serrate or entire; heads several or numerous: involucral bracts linear to linear-lanceolate, 7-11 $\mathrm{mm}$. long, ultimately reflexed : disks subglobose or conic-globose, $5-13 \mathrm{~mm}$. broad : ray-flowers $8-12$, conspicuous ; ligules 1.5-2.5 cm. long, yellow, or the base orange : chaff aristate or subulate, smooth : pappus a minute crown or border.

In moist soil or thickets, New Jersey to Michigan, Kansas, Georgia, Louisiana and Texas. Summer and fall.

26. Rudbeckia rupéstris Chickering. Stems $7-15 \mathrm{dm}$. tall, stout, sparingly pubescent, branched : leaves various, the basal with ovate, cordate, crenate or crenate-dentate, petioled, undivided blades; the lower stem-leaves palmately 3-lobed or 3-parted, 7-10 cm. long, borne on margined petioles ; upper leaves with ovate, oblong-ovate or ovate-lanceolate, short-petioled or sessile blades: heads few or several, large and showy : bracts of the involucre lanceolate or oblong-lanceolate, mostly acute : disks hemispheric or ovoid-conic, $15-20 \mathrm{~mm}$. broad : ray-flowers $10-13$; ligules $2-3.5 \mathrm{~cm}$. long, yellow or orange yellow: chaff aristate or subulate, smooth : pappus a low crown or border. and fall.

On rocky slopes, Roan Mountain and adjacent peaks, North Carolina and Tennessee. Summer

27. Rudbeckia Beàdlei Small. Stems 6-15 dm. tall, hirsute, usually much branched : leaf-blades various, those of the basal leaves oblong to ovate, coarsely crenate-toothed or unequally pinnatifid, $5-10 \mathrm{~cm}$. long, long-petioled; those of the lower stem-leaves, or some of them, deeply pinnately 5-7-lobed or 5-7-parted: the upper lanceolate, acute or acuminate, $1.5-7 \mathrm{~cm}$. long, 5-10 $\mathrm{mm}$. wide, narrowed into winged petioles, or sessile : heads small, several or numerous, showy : bracts of the involucre linear to linear-lanceolate, 8$20 \mathrm{~mm}$. long, somewhat foliaceous : ray-flowers 8-12; ligules 1-2 cm. long, bright yellow : disks ovoid-conic or hemispheric, $5-10 \mathrm{~mm}$. wide: chaff aristate or subulate, smooth : pappus a low crown or border accentuated at the angles.

In rocky woods, at elevations above $1000 \mathrm{~m}$., western North Carolina. Summer.

28. Rudbeckia pinnatíloba (T. \& G.) Beadle. Stems 6-12 dm. tall, softly hirsute, branched above : leaf-blades various; those of the basal and lower stem-leaves, or some of them, 5-7-pinnately lobed or divided, 3-8 cm. long: those of the upper stem-leaves ovate-lanceolate, relatively short and broad, 1.5-4 cm. long, 5-20 mm. wide, either lobed or undivided, toothed or entire, short-petioled or sessile, often with brown margins : heads small, several or numerous, showy : bracts of the involucre linear to linear-lanceolate, $5-7 \mathrm{~mm}$. long, not foliaceous : ray-flowers about 8 ; ligules $1-1.5 \mathrm{~cm}$. long, yellow or with an orange base : disks hemispheric or ovoid-conic, 6-9 mm. broad : chaff aristate or subulate, smooth : pappus a low crown or border accentuated at the angles. $[R$. triloba var. pinnatiloba T. \& G.]

In calcareous soil, West Florida. Summer and fall.

29. Rudbeckia bícolor Nutt. Annual or biennial. Stems $3-7 \mathrm{dm}$. tall, hispid, simple or branched: leaf-blades lanceolate, oblong to oval-elliptic, $2-10 \mathrm{~cm}$. long, serrate or entire, the lower ones with winged petioles, the upper sessile and partly clasping : heads showy : bracts of the involucre oblong-lanceolate to linear, 1-2 cm. long : ray-flowers 1014 ; ligules $1.5-2.5 \mathrm{~cm}$. long, yellow, with a brown-purple base, or sometimes clear yellow : disks short-conic to conic-cylindric: chaff pointed, ciliate at the apex : pappus wanting.

In woods and sandy soil, Arkansas to Alabama and Texas. Spring and summer.

30. Rudbeckia flexuòsa T. V. Moore. Annual or biennial, resembling $R$. bicolor. Stems 3-7 dn. tall, somewhat hispid, flexuous, rather widely branched, often a short distance from the base : leaf-blades various, hispidulous, those of the basal and lower cauline leaves oval or oblong-spatulate, remotely crenate-serrate, of the upper leaves cuneateobovate to oval, oblong or oblong-lanceolate, mostly sessile, remotely toothed or entire : heads showy : bracts of the involucre ovate-lanceolate to linear, $10-15 \mathrm{~mm}$. long : ray-flowers $8-10$; ligules $1-2 \mathrm{~cm}$. long, yellow, sometimes with a brown-purple base : disks ovoid-
conic or short-cylindric, $10-15 \mathrm{~mm}$. wide : chaff pointed, ciliate at the apex : pappus none.

In dry or sandy soil, Texas. Spring and summer.

31. Rudbeckia hírta L. Stems $3-7 \mathrm{dm}$. tall, usually branched, hirsute and hispid: leaf-blades elliptic, lanceolate, narrowly-oblong or oblong-spatulate, 3-12 cm. long, strigosepubescent, entire or sparingly serrate with low teeth, mostly acute ; those of the lower leaves narrowed into winged or margined petioles $4-10 \mathrm{~cm}$. long, the upper with short, broadwinged petioles, or sessile : heads showy : bracts of the involucre linear, linear-lanceolate, 
or linear-oblong, 1-2 cm. long : ray-flowers 12-20 ; ligules $2-3.5 \mathrm{~cm}$. long, yellow or orange : disks ovoid or conic, $10-18 \mathrm{~mm}$. wide: chaff pointed, ciliate at the tip : pappus wanting.

In woods and fields, Quebec to Florida, Oklahoma and South Dakota. Summer and fall.

32. Rudbeckia ampléctens T. V. Moore. Stems $3-6 \mathrm{dm}$. tall, simple or sparingly branched, hispidulous : leaf-blades entire or remotely denticulate, appressed-pubescent, mostly acute, 2-8 cm. long, those of the lower stem-leaves elliptic-lanceolate, contracted into broad, winged petioles, the upper oblong, sessile by a subcordate, clasping base : heads showy : involucral bracts 8-14 mm. long, linear-oblong or linear-lanceolate : ray-flowers 8-12 ; ligules 1-2 cm. long, yellow : disk hemispheric or short-conic : chaff pointed, ciliate at the tip : pappus none.

In dry soil, South Carolina and Georgia. Summer.

33. Rudbeckia divérgens T. V. Moore. Stems $3-10 \mathrm{dm}$. tall, divergently branched, usually from near the base, hirsute or hispid: leaf-blades strigose-hirsute; those of the basal leaves oblanceolate, petioled, remotely toothed; of the lower stem-leaves oblong to lanceolate, remotely serrate-denticulate or entire : the upper oblong to lanceolate or almost linear, serrate-denticulate or entire, sessile and often slightly clasping : peduncles usually elongated : heads showy : bracts of the involucre linear or linear-lanceolate, $6-11 \mathrm{~mm}$. long: ray-flowers $8-14$; ligules $1.5-3 \mathrm{~cm}$. long, yellow or with a darker base, fading greenish : disks $12-18 \mathrm{~mm}$. broad, hemispheric : chaff pointed, ciliate at the tip : pappus none.

In pine woods and fields, South Carolina to Florida, near the coast. Spring and summer.

34. Rudbeckia serícea T. V. Moore. Stems $5-12 \mathrm{dm}$. tall, simple or branched, more or less hispid: leaf-blades linear to linear-lanceolate, elongated, $6-15 \mathrm{~cm}$. long, remotely toothed or entire, strigose-pubescent ; those of the basal and lower cauline leaves petioled, broader than the sessile upper stem-leaves: heads showy : bracts of the involucre $1-2 \mathrm{~cm}$. long, linear to oblong-linear or lanceolate : ray-flowers 10-15; ligules yellow, $2-4 \mathrm{~cm}$. long: disks 12-20 mm. wide, ovoid-conic : chaff relatively long and narrow, pointed, ciliate at the tip ; pappus wanting.

In dry wøods and fields, South Dakota to Missouri, Alabama and Georgia. Summer.

35. Rudbeckia lóngipes T. V. Moore. Stems 3-10 dm. tall, simple or branched, hispid : leaf-blades lanceolate, hispid; those of the basal leaves $6-20 \mathrm{~cm}$. long, remotely toothed, tapering at both ends, borne on long, slender petioles, sometimes $2 \mathrm{dm}$. long; the upper reduced in size, sessile or short-petioled, toothed or entire : heads showy : bracts of the involucre linear-lanceolate to oblong-lanceolate, 1-2 cm. long : ray-flowers 10-14 ; ligules $2-3.5 \mathrm{~cm}$. long, yellow : disks short-conic, about $1.5 \mathrm{~cm}$. broad : chaff pointed, ciliate at the tip: pappus none.

In woods and fields, New York to Iowa and Alabama. Summer and fall.

36. Rudbeckia Brittònii Small. Stems 5-8 dm. tall, simple or branched, hispid or hirsute-hispid : leaf-blades various; those of the basal leaves ovate, $8-12 \mathrm{~cm}$. long, with broad petioles ; those of the stem-leaves ovate, ovate-lanceolate or elliptic, toothed or rarely lobed, short-petioled or sessile and partly clasping : heads showy : bracts of the involucre oblong to lanceolate, 1-3 cm. long, often foliaceous : ray-flowers 10-14; ligules yellow, $2.5-3.5 \mathrm{~cm}$. long: disks hemispheric to short-conic, $1-2 \mathrm{~cm}$. broad : chaff pointed, ciliate at the tip: pappus none.

On mountain slopes, Virginia to North Carolina, Tennessee and Alabama. Summer.

37. Rudbeckia montícola Small. Stems $3-10 \mathrm{dm}$. tall, simple or branched, more or less densely hirsute or hispid : leaf-blades ovate, ovate-lanceolate, oval or elliptic, 5-10 cm. long, serrate or entire ; those of the upper leaves sessile and partly clasping by broad bases : heads showy : bracts of the involucre linear to linear-lanceolate, $1-1.5 \mathrm{~cm}$. long: ray-flowers 10-14; ligules yellow, $2-3.5 \mathrm{~cm}$. long: disks hemispheric or ovoid, $12-18 \mathrm{~mm}$. broad : chaff pointed, ciliate at the tip : pappus wanting.

In woods, in or near the mountains, Pennsylvania to Georgia, Tennessee and Alabama. Summer and fall.

38. Rudbeckia Floridàna T. V. Moore. Stems 3-6 dm. tall, simple or branched, hispid : leaf-blades oblong to oblong-lanceolate, spatulate or broadly linear, 3-9 $\mathrm{cm}$. long, usually serrate-dentate, scabrous or hispid, those of the cauline leaves borne on winged petioles, or the uppermost sessile and often partly clasping : heads small : involucral bracts oblong to linear-oblong, 6-10 mm. long: ray-flowers 8-12; ligules $1-2 \mathrm{~cm}$. long, yellow, fading greenish : disks mostly less than $1 \mathrm{~cm}$. in diameter, hemispheric: chaff pointed, ciliate at the tip : pappus none.

In sandy soil, Florida to Arkansas and Texas. Spring to fall.-A variety, $R$. Floridana angustifolia T. V. Moore, is distinguished by its more slender habit and narrower leaves. 


\section{DRACOPIS Cass.}

Annual caulescent herbs, with smooth and glaucous foliage. Leaves alternate: blades broad, thickish, entire or slightly serrate, 1-ribbed, clasping. Heads radiate, showy. Involucres many-flowered, of few somewhat foliaceous bracts. Receptacle slender. Rayflowers few, neutral : ligules yellow or often brownish purple at the base. Disk-flowers perfect, fruit-producing, brownish. Stigmas with small pubescent appendages. Achenes terete, striate and minutely transversely wrinkled. Pappus wanting.

1. Dracopis amplexicaùlis Vahl. Stems $3-7 \mathrm{dm}$. tall, usually branched above. Stem-leaves with spatulate, oblong, oblong-lanceolate or ovate sessile and clasping blades 4-10 $\mathrm{cm}$. long: bracts of the involucres lanceolate to linear-lanceolate, $6-10 \mathrm{~mm}$. long: ray-flowers 5-9; ligules yellow or brownish purple at the base, 1-2.5 cm. long: disk oblong-cylindric at maturity : achenes about $2 \mathrm{~mm}$. long.

In moist soil, Georgia to Louisiana and Texas. Introduced eastward. Spring and summer.

\section{RATIBIDA Raf.}

Annual biennial or perennial caulescent herbs, with pubescent foliage. Leaves alternate: blades pinnately parted or divided, the segments often narrow. Heads radiate, showy, long-peduncled. Involucres flat: bracts in 2-3 series. Receptacle subulate or columnar, chaffy. Ray-flowers several, neutral : ligules yellow, or brown near the base, spreading or drooping. Disk-flowers perfect, fruit-producing, subtended by or enveloped in the bractlets : corollas gray or yellowish, becoming brown : bractlets thickened, truncate or hooded at the apex. Stigmas with blunt or lanceolate-subulate tips. Achenes flattened, broad-margined or winged, deciduous with bractlets. Pappus 1 or 2 teeth, or wanting. [Lepachys Raf.] CONE-FLOWER.

Annual or biennial : achenes with flat faces.

Leaf-blades pinnately parted: ray-flowers with yellow ligules.

Leaf-blades lyrately parted : ray-flowers with brown-purple and yellow-margined ligules.

Perennial: achenes with convex or angled faces.

Stigmas with short obtuse tips.

Disk globose, oval or ovoid.

Disk cylindric.

Stigmas with lanceolate-subulate tips.

1. $R$. peduncularis.

2. R. picta.

1. Ratibida pedunculàris (T. \& G.) Barnhart. Annual or biennial, rather graypubescent, $2-9 \mathrm{dm}$. tall. Stems often branched at the base: leaves rather crowded, 4-10 cm. long; blades pinnately or 2-pinnately parted, the segments linear-oblong or narrowly obovate, entire or incised : peduncles $2-6 \mathrm{dm}$. long : disk cylindric, $2-4 \mathrm{~cm}$. long : ray-flowers few ; ligules yellow, 1-2 cm. long, obovate : achenes obliquely obovate, broadly or narrowly winged, scaly-fimbriate at least on the inner edge, notched at the apex by the projection of the unequal teeth. [Lepachys peduncularis T. \& G.]

In low grounds, Texas. Summer.

2. Ratibida pícta (A. Gray) Small. Annual or biennial and similar to the preceding species in habit, the foliage more cinereous-pubescent : leaf-blades lyrately pinnately parted into usually 5-7 merely incised segments, the terminal segment obovate to oblong-ovate : disk becoming $2.5-3.5 \mathrm{~cm}$. long; ligules of the ray-flowers about $12 \mathrm{~mm}$. long, brown-purple with a yellow margin. [Lepachys peduncularis var. picta A. Gray.]

In sand or sandy woods, along or near the coast, Texas. Summer.

3. Ratibida Tagètes (James) Barnhart. Perennial, 1-4 dm. tall, gray-strigose. Stems commonly much branched : leaves numerous ; blades $2-6 \mathrm{~cm}$. long, pinnately parted into 3-7 narrowly linear thickish segments : peduncles $2-5 \mathrm{~cm}$. long: disk subglobose or oval, about $1 \mathrm{~cm}$. long; ligules of the ray-flowers soon reflexed, $5-9 \mathrm{~mm}$. long, mainly brown-purple.

On plains and prairies, Arkansas to Texas and New Mexico. Spring to fall.

4. Ratibida columnàris (Sims) D. Don. Perennial, 3-7 dm. tall, scabrous-strigose. Stems often branched at the base : leaves $5-12 \mathrm{~cm}$. long ; blades pinnately parted, the 5-9 segments oblong to linear, often pinnatifid or 2-3-cleft : peduncles $5-20 \mathrm{~cm}$. long : heads showy : disks cylindric-conic or columnar, $2.5-4 \mathrm{~cm}$. long; ligules of the ray-flowers yellow, or yellow and brown-purple at the base, $2-4 \mathrm{~cm}$. long.

On dry plains or prairies, the Saskatchewan to Minnesota. Tennessee and Arizona. Spring to fall.

5. Ratibia pinnàta (Vent.) Barnhart. Perennial, strigillose and scabrous, $6-15 \mathrm{dm}$. tall. Stems more or less branched : leaves $5-20 \mathrm{~cm}$. long; blades pinnately 3-7-foliolate 
or parted: heads showy: disk subglobose to oblong-oval, 1-2 cm. long: ray-flowers few; ligules bright yellow, $4-5 \mathrm{~cm}$. long, early drooping.

On plains or prairies, in dry soil, New York to Iowa, Florida and Texas. Summer and fall.

\section{BRAUNÈRIA Neck. ${ }^{1}$}

Perennial caulescent herbs. Leaves normally alternate : blades simple, entire or toothed. Heads radiate, solitary or few, conspicuous. Involucres many-flowered, rather flat: bracts in 2-4 series, narrow. Receptacle depressed, hemispheric, chaffy. Ray-flowers several, neutral, often with imperfect styles : ligules spreading or drooping, purple or rose, rarely yellow or white. Disk-flowers perfect, fruit-producing : chaff awned, surpassing the flowers, persistent. Achenes acutely 4-angled, stout. Pappus a crown, more or less producedinto triangular teeth at the angles. CONE-FLOWER.

Awn of the chaff about as long as the body : root horizontal or horizontally inclined. fibrous.

Awn of the chaff shorter than the body : root vertical, fusiform.

Plants giabrous or glabrate.

Leaf-blades lanceolate to oblanceolate, the upper dentate.

Leaf-blades elongated-lanceolate to narrowly elliptic, entire.

Plants hirsute or hispid.

Ray-flowers with drooping ligules $4-8 \mathrm{~cm}$. long.

Ray-flowers with spreading ligules $2-3 \mathrm{~cm}$. long.

Pubescence short and harsh: leaf-blades 3-5-ribbed.

Pubescence shaggy-hispid : leaf-blades 1-3-ribbed.

1. B. purpurea.

1. Brauneria purpùrea (L.) Britton. Root horizontal or horizontally inclined, fibrous. Stem somewhat scabrous-pubescent, 6-12 dm. tall, rarely branched: leaf-blades ovate to lanceolate, $\tilde{\delta}-12 \mathrm{~cm}$. long, acute or acuminate, serrate or dentate-serrate, or those on the upper part of the stem entire, cuneate to subcordate at the base ; petioles of the lower stems and basal leaves longer than the blades: heads showy : disks $2-2.5 \mathrm{~cm}$. high ; bracts of the involucre linear to linear-lanceolate, finely hispid, lax : ray-flowers 12-20 : ligules $2.5-5 \mathrm{~cm}$. long or rarely shorter, purple or somewhat crimson or whitish : awns of the chaff about as long as the body: achenes $4-5 \mathrm{~mm}$. long, wrinkled.

In rich soil, woods or fields, Virginia to Missouri, North Carolina, Alabama and Louisiana. Summer.

2. Brauneria laevigàta Boynton \& Beadle. Perennial from a long, vertical black root. Stem smooth, striate, about $1 \mathrm{~m}$. tall, leafy at the base, sparsely leafy up to the long, naked peduncle : basal and lower cauline leaves petioled, 1-3 dm. long, smooth, their blades oblanceolate, oblong or lanceolate, $1.5-3.5 \mathrm{~cm}$. wide, entire or shallowly toothed, those of the upper stem-leaves lanceolate, acuminate, glabrous, mostly dentate with shallow teeth, petioled or the uppermost sessile: involucral bracts lanceolate to oblong-lanceolate, imbricated, finely ciliate on the margins, otherwise smooth : ray-flowers 10-15; ligules rose-color, 3-6 $\mathrm{cm}$. long, spreading: chaff aristate, the awn shorter than the body: disk-flowers numerons, the florets dark purple : achenes 4 -sided, crowned by the unequally toothed pappus.

In woods and fields, near Seneca, South Carolina. Summer.

3. Brauneria atrorùbens (Nutt.) Boynton \& Beadle. Root vertical, black, not fibrous. Stem simple, striate, stout, 5-8 dm. tall, glabrous or the upper portion sparingly pubescent with short, appressed hairs : leaves petioled, the blades elongated-lanceolate or narrowly elliptic, 1-2 dm. long, 1-2 cm. wide, entire, finely ciliate on the margins, glabrate ; petioles of the lower leaves often as long as the blades: involucral bracts lanceolate, ciliate : ray-flowers $12-20$; ligules $2-4 \mathrm{~cm}$. long, purple or yellow : awn of the chaff shorter than the body: achenes stout: pappus a toothed border accentuated at the angles.

In dry soil, Arkansas and Missouri. Summer.

4. Brauneria pállida (Nutt.) Britton. Root vertical, fusiform. Stem more or less hispid, 5-10 dm. tall : leaf-blades broadly linear or narrowly elliptic, or somewhat broader at the base of the stem, $5-20 \mathrm{~cm}$. long, entire, the lower ones narrowed into slender petioles : heads showy : disks $1.5-2 \mathrm{~cm}$. high : bracts of the involucre lanceolate, hispid, the tips lax : ray-flowers 10-15; ligules pale or deep rose-color, 4-8 cm. long, slender, drooping, 2-cleft at the apex: awns of the chaff shorter than the body.

In dry soil, New England to Minnesota, Kentucky, Alabama and Texas. Summer.

5. Brauneria angustifòlia (DC.) Heller. Root vertical, not fibrous. Stem hispid, 4-6 dm. tall : leaf-blades narrowly elliptic to broadly linear, $3-15 \mathrm{~cm}$. long, prominently $3-5$-ribbed, entire, the lower ones narrowed into slender petioles : heads conspicuous : disks about $2 \mathrm{~cm}$. high : bracts of the involucres linear-lanceolate, copiously hispid, with lax tips :

${ }^{1}$ Contributed by Mr. C. L. Boynton and Mr. C. D. Beadle. 
ray-flowers usually 10-12; ligules purplish or white, $2-2.5 \mathrm{~cm}$. long, spreading, 2-3-cleft : awn of the chaff shorter than the body.

On plains and prairies, Saskatchewan to Arkansas, Texas and Wyoming. Summer.

6. Brauneria Tennesseénsis Beadle. Root vertical, fusiform. Sten shaggy-hispid, often tufted, $2-3 \mathrm{dm}$. tall : leaf-blades linear, $5-18 \mathrm{~cm}$. long, acute, entire, the upper 1-ribbed: heads conspicuous : disks about $1.5 \mathrm{~cm}$. high : bracts of the involucre lanceolate, bristly, hispid, and ciliate, with lax tips: ray-flowers 10-15; ligules purplish, $1.5-2.5 \mathrm{~cm}$. longspreading, 2-cleft at the apex : achenes with the angles of the side winged: pappus a toothed border with 4 prominent points over the angles of the achenes: awn of the chaff shorter than the body.

On gravelly hillsides, Tennessee and Arkansas. Summer.

\section{STEMMODÓNTIA Cass.}

Perennial caulescent commonly maritime herbs or shrubby plants. Leaves opposite : blades often fleshy, entire or toothed. Heads radiate, peduncled. Involucres broadly campanulate: bracts somewhat foliaceous, in 1 or 2 series. Receptacle flat or convex. Ray-flowers pistillate, fruit-producing: ligules mainly yellow, not much longer than the height of the involucre. Disk-flowers perfect, fruit-producing. Stigmas of the disk-flowers pubescent. Achenes turgid, cuneate or pear-shaped; those of the disk more or less 4angled. Pappus cup-like, the edge commonly lobed.

1. Stemmodontia trilobàta (L.) Small. Stems branched at the base; branches creeping, pubescent or glabrate in age. Leaf-blades fleshy, elliptic to cuneate, $3-10 \mathrm{~cm}$. long, acute, coarsely few-toothed or slightly 3-5-lobed, sessile: heads solitary on strigose peduncles: involucres about $1 \mathrm{~cm}$. high, the outer bracts longer and thicker than the inner, obtuse or abruptly acute: ligules of the ray-flowers 8-12 $\mathrm{mm}$. long. [Silphium trilobatum L.]

In sand or coral rock, southern peninsular Florida and the Keys. Also in tropical America.

\section{PASCÀLIA Ortega.}

Perennial caulescent herbs, with glabrous or somewhat scabrous-pubescent foliage. Leaves opposite : blades entire, toothed or somewhat lobed. Heads conspicuous, solitary at the ends of the branches, heterogamous, radiate. Involucres hemispheric : bracts in about 2 series, the outer herbaceous, the inner membranous. Receptacle chaffy. Rayflowers pistillate, each with a spreading yellow ligule. Disk-flowers perfect, each with a short tube and an elongated throat. Anthers truncate at the base. Stigmas with pubescent acutish appendages. Achenes various; those of the ray 3-angled; those of the disk rather 4-angled, each with a thick somewhat fleshy pericarp. Pappus of several fimbriate scales and often 2 short awns.

1. Pascalia glaùca Ortega. Plant glaucous. Stem simple or branched above: leafblades 3-ribbed, $1 \mathrm{dm}$. long, or shorter on the upper part of the stem, those of the lower cauline leaves ovate-lanceolate or narrowly ovate, shallowly toothed, those of the upper cauline often linear-lanceolate or narrowly lanceolate, repand or entire : heads showy : involucre $1.5-2 \mathrm{~cm}$. broad ; bracts lanceolate to linear, $1-1.5 \mathrm{~cm}$. long: ligules of the rayflowers bright yellow, $1-1.5 \mathrm{~cm}$. long: achenes $5-6 \mathrm{~mm}$. long.

In waste places, near Pensacola, Florida. Native of Chili.

\section{BORRÍCHIA Adans.}

Perennial caulescent fleshy herbs or shrubby plants inhabiting seashores. Leaves opposite : blades simple, thick. Heads radiate, peduncled. Involucres hemispheric, manyflowered : bracts in 2 or 3 series, the inner more leathery than the outer. Receptacle convex, chaffy. Ray-flowers pistillate, fruit-producing: ligules yellow, short. Disk-flowers perfect, fruit-producing, subtended by or enveloped in the rigid bractlets. Stigmas of the disk-flowers hispid. Achenes various; those of the ray 3-angled; those of the disk 4angled. Pappus a more or less toothed crown. SEA Ox-Eye.

Outer bracts of the involucre spreading or reflexed at maturity : bractlets of the receptacle spine-tipped.

Outer bracts of the involucre appressed at maturity : bractlets of the receptacle obtuse or barely mucronate.

Leaf-blades and peduncles permanently and densely silky.

Leaf-blades and peduncles perfectly glabrous.

1. B. frutescens.

2. B. arborescens.

3. B. glabrata. 
1. Borrichia frutéscens (L.) DC. A somewhat fleshy branching shrub 2-7 dm. tall, the young foliage pale-tomentose. Leaf-blades linear-spatulate to obovate, $2-6 \mathrm{~cm}$. long, cuspidate, entire or spiny-toothed especially near the base: heads rather conspicuous, on stout club-shaped peduncles : involucres about $1.5 \mathrm{~cm}$. broad; bracts various, the outer with merely acute herbaceous spreading or reflexed tips, the inner with rigid subulate spreading tips: ray-flowers few ; ligules about $1 \mathrm{~cm}$. long.

On sandy seashores and in salt marshes, Virginia to Florida and Texas. Summer and fall.

2. Borrichia arboréscens (L.) DC. A branching shrub $2-12 \mathrm{dm}$. tall, with silkycanescent foliage. Leaf-blades oblanceolate or spatulate-oblanceolate, $3-6 \mathrm{~cm}$. long, with dark rigid cuspidate tips, entire, densely silky, sessile: heads not conspicuous, on clubshaped peduncles: involucres $1.5-2 \mathrm{~cm}$. broad; bracts various, the outer keeled, acute, appressed at maturity ; the inner larger, rounded at the apex : ray-flowers few ; ligules $6-8$ mm. long.

In salt marshes and on sandy beaches, peninsular Florida and the Keys. Also in the West Indies.

3. Borrichia glabràta Small. A branching shrub 1-2 m. tall, with glabrous foliage. Leaf-blades spatulate to linear-oblanceolate, $3-6 \mathrm{~cm}$. long, entire, each with a rigid cuspidate tips: heads hardly conspicuous, on somewhat club-shaped peduncles : involucres 8-12 $\mathrm{mm}$. broad ; bracts various, the outer keeled, obtuse, the inner broader, with minute cusps : ray-flowers few ; ligules $6-8 \mathrm{~mm}$. long.

On sandy coasts and in salt marshes, southern Florida and the Keys.

\section{VIGUI亡ेRA H.B.K.}

Perennial caulescent herbs or shrubby plants. Leaves opposite, or usually opposite on the lower part of the stem and alternate above : blades broadest at the base, toothed or incised. Heads slender-peduncled. Involucre campanulate to hemispheric, more or less flattened in age: bracts narrow, in few series. Receptacle more or less convex, chaffy. Ray-flowers neutral : ligules yellow. Disk-flowers perfect, fruit-producing; corollas usually yellow. Stigmas with slender tips. Achenes flattened, commonly pubescent. Pappus of a chaffy awn or scale over each prominent angle of the achene and occasionally 1 or 2 more, with 2 or several scales between them, persistent or deciduous.

1. Viguiera helianthoìes H.B.K. Stem $6-20 \mathrm{dm}$. tall, often widely branched above, glabrous or sparingly pubescent, often purple or purple-tinged : leaf-blades triangular or ovate, $9-14 \mathrm{~cm}$. long or shorter above, serrate, sometimes saliently and irregularly so, scabrous above, abruptly narrowed, truncate or cordate at the base, petioled: heads quite numerous : involucres about $1 \mathrm{~cm}$. broad during anthesis : bracts lanceolate, abruptly narrowed above the middle, 4-6 mm. long: ligules of the ray-flowers oblong to elliptic, 1-1.5 cm. long: achenes $3.5-4 \mathrm{~mm}$. long.

In dry soil and thickets, Texas to Arizona and Mexico.

\section{HELIÁNTHUS L.}

Annual or perennial caulescent herbs. Leaves alternate or opposite : blades simple, entire or toothed. Heads conspicuous. Involucres flat, hemispheric or cylindric : bracts in several series, fleshy or leathery. Receptacle flat, convex or conic, chaffy. Ray-flowers neutral : ligules yellow. Disk-flowers perfect, fruit-producing : corollas brownish or purple. Stigmas with pubescent appendages. Achenes flattened or somewhat 4-angled. Pappus of 2 awns or scales, and these sometimes accompanied by 2-4 shorter ones, all early deciduous. The plants flower in the summer and fall, unless otherwise stated. Sunflower.

Plants annual: receptacle flat or nearly so.

Stem branched at the base, the branches weak, diffusely spreading or decumbent.

Branches green : ligules of the ray-flowers mostly less than $1.5 \mathrm{~cm}$. long.

Branches glabrous or a little scabrous: leaf-blades repand or shallowly and broadly toothed.

Branches hirsute: leaf-blades sharply or prominently toothed.

Branches purple-mottled : ligules of the ray-flowers mostly over $1.5 \mathrm{~cm}$. long. Stem rigid and essentially erect.

Foliage pubescent with silky wool, sometimes floccose in age.

Foliage hispid, hirsute or scabrous.

Leaf-blades of a broad or narrowly ovate type.

Bracts of the involucre not hirsute: leaf-blades oblong-lanceolate to ovate-lanceolate.

Bracts of the involucre hirsute : leaf-blades broadly ovate.

Leaf-blades of a linear or linear-lanceolate type.

Plants perennial: receptacle convex or low-conic.

1. $H$. debilis.

2. H. praecox.

3. H. cucumerifolius.

4. H. argophyllus.

5. H. petiolaris.

6. H. annuนs.

7. H. Floridanus. 
Bracts of the involucre with long slender spreading or recurved tips.

Leaves very numerous, often over 100 on the stem, scattered.

Stem smooth and glabrous.

Leaves linear-filiform: bracts of the involucre scarcely ciliolate.

Leaves narrowly linear: bracts of the involucre manifestly ciliate. Stem copiously pubescent near the base.

Leaves few, opposite or merely alternate on the upper part of the stem. Stem not scape-like, evenly leafy to the top: bracts of the involucre barely if at all ciliolate.

Stem scape-like, with several elongated leaves near the base and few much smaller ones above: bracts of the involucre ciliate.

Bracts of the involucre obtuse or acute, or slightly acuminate.

Leaves evenly disposed along the stem.

Stem smooth and glaucous.

Stem scabrous, hirsute or hispid.

Inner bracts of the involucre acuminate, less than $10 \mathrm{~mm}$. long : upper leaves alternate.

Inner bracts of the involucre acute, over $10 \mathrm{~mm}$. long: upper leaves opposite.

Leaves mostly near the base of the stem, few above.

Ray-flowers with conspicuous ligules.

Stem and leaves glabrous.

Stem and leaves pubescent.

Bracts of the involucre acuminate : upper cauline leaves narrow.

Bracts of the involucre obtuse or mucronate: upper cauline leaves broad.

Ray-flowers with ligules scarcely surpassing the bracts of the involucre, or obsolete.

Disk of the head yellow.

Stem more or less scape-like : leaves mainly near the base of the stem.

Leaf-blades very scabrous : bracts of the involucre ciliate.

Leaf-blades smooth: bracts of the involucre ciliolate.

Stem not scape-like: leaves evenly disposed along the stem.

A. Leaf-blades petioled, with petiole-like bases, or if sessile, narrowed at the base.

Main stem smooth and glabrous.

Peduncles smooth and glabrous, except sometimes just under the involucre.

Bracts of the involucre ciliate: blades of the upper cauline leaves toothed.

Leaf-blades glaucous beneath: inner bracts of the involucre 13-14 mm. long, over $4 \mathrm{~mm}$. broad at the base.

Leaf-blades green beneath: inner bracts of the involucre 9-11 $\mathrm{mm}$. long, less than $3 \mathrm{~mm}$. broad at the base.

Bracts of the involucre eciliate: blades of the upper cauline leaves entire.

Peduncles pubescent.

Bracts of the involucre uniformly ciliolate or ciliate.

Leaves merely opposite; blades of a lanceolate type.

Leaf-blades membranous: stems green or purple: inner bracts of the involucre acute.

Leaf-blades thicker: stems glaucous : inner bracts of the involucre acuminate.

Leaves mainly whorled; blades of a linear-lanceolate type.

Bracts of the involucre conspicuously more copiously ciliate below the middle.

Bracts of the involucre much longer than the height of the disk : upper surface of the leaf-blades quite smooth.

Leaf-blades leathery : corolla-tube about $1 \mathrm{~mm}$. long.

Leaf-blades membranous: corolla-tube about $0.5 \mathrm{~mm}$. long.

Bracts of the involucre about equalling the top of the disk. Leaf-blades glabrous or essentially so beneath, quite smooth above.

Leaf-blades manifestly pubescent beneath, very scabrous above.

Leaf-blades scarcely paler beneath than above : inner bracts of the involucre dilated about the middle.

Leaf-blades pale beneath: inner bracts of the involucre scarcely dilated, rather abruptly contracted below the middle.

Main stem copiously or markedly pubescent.

Leaf-blades canescent or tomentose beneath.

Disk of the head less than $1.5 \mathrm{~cm}$. wide.

Leaf-blades attenuate: leaves alternate on the upper part of the stem or branches,

Leaf-blades acute: leaves opposite.

Disk of the head over $2 \mathrm{~cm}$. wide.

Leaf-blades hirsute, hispid or hispidulous, at least about the midrib beneath.

Leaf-blades prevailingly ovate or lanceolate-ovate.

Stem hirsute or scabrous : leaf-blades narrowed into petiolelike bases.

Stem softly pubescent: leaf-blades sessile.

Leaf-blades prevailingly lanceolate.

a. Leaf-blades as scabrous beneath as above.

8. H. filiformis.

9. H. orgyalis.

10. H. polyphyllus.

11. H. angustifolius.

12. H. elongatus.

13. H. ciliaris.

14. H. undulatus,

15. H. scaberrimus.

16. H. carnosus.

17. H. heterophyllus.

18. H. atrorubens.

19. H. Radula.

20, H. occidentalis.

21. H. Dowellianus.

22. H. Eggertii.

23. H. laevigatus.

24. H. longifolius.

25. H. microcephalus.

26. H. glaucus.

27. $H$. verticillatus.

28. H. grosse-serratus.

29. $H$. decapetalus.

30. H. saxicola.

31. H. australis.

32. H. strumosus.

33. H. Schweinitzii.

34. $H$. cinereus.

35. H. tomentosus.

36. H. tuberosus.

37. $H$. doroconoides.

38. H. Maximilianii. 
b. Leaf-blades merely hirsute beneath.

Leaf-blades narrowed into petiole-like bases.

Leaves prevailingly alternate.

Leaves prevailingly opposite.

Bracts of the involucre acute or slightly acuminate.

Bracts of the involucre with slender, lax tips.

B. Leaf-blades closely sessile and partly clasping.

Leaf-blades rounded at the base and markedly petioled.

Stem glabrous or merely scabrous: leaf-blades 3-ribbed from the base.

Stem hirsute: leaf-blades 3-ribbed from a point below the middle.

39. H. giganteus.

40. H. resinosus.

41. H. tracheliifolius.

42. H. hirsutus.

43. H. divaricatus.

44. H. mollis.

1. Helianthus débilis Nutt. Annual, more or less scabrous. Stems branched at the base, the branches decumbent or spreading, 3-9 dm. long: leaves mostly alternate ; blades deltoid or somewhat hastate to ovate-lanceolate, $4-8 \mathrm{~cm}$. long, acute or acuminate, repand or shallowly and broadly toothed, broadly cuneate to cordate at the base, the petioles glabrous or sparingly pubescent, bracts of the involucre lanceolate or linear-lanceolate, $8-10 \mathrm{~mm}$. long, acuminate or subulate-tipped : ray-flowers several; ligules yellow, $1-1.5 \mathrm{~cm}$. long : disk $1.5-2 \mathrm{~cm}$. broad.

In sandy soil, Florida to Texas. Spring and summer.

2. Helianthus praècox Engelm. \& Gray. Similar to the preceding species in habit. Branches, petioles and peduncles hirsute, sometimes copiously so: leaf-blades sharply or prominently toothed.

In sandy soil, near the coast, Florida to Louisiana and Texas. Spring and summer.

3. Helianthus cucumerifolius T. \& G. Annual, similar to the two preceding species in habit. Branches mottled : leaves mostly alternate; blades deltoid to ovate or ovatelanceolate, 3-8 cm. long, acuminate or sometimes only acute, sharply, irregularly and saliently toothed, truncate or subcordate at the base, petioled: bracts of the involucre narrowly lanceolate to linear-lanceolate, $1-1.5 \mathrm{~cm}$. long, attenuate into filiform tips: rayflowers several; ligules mostly $2-3 \mathrm{~cm}$. long: disks $2-2.5 \mathrm{~cm}$. broad.

In open woods, Texas. Spring and summer.

4. Helianthus argophýllus T. \& G. Annual, clothed with white, often somewhat floccose silky wool. Stems 5-12 dm. tall, branched: leaves alternate except some of the lower ones; blades various, those of the lower leaves very broad, those of the upper leaves ovate or lanceolate, $5-15 \mathrm{~cm}$. long, acute, undulate or somewhat serrate, rounded or cordate at the base, petioled: bracts of the involucre oblong, ovate or fiddle-shaped, spreading, $1-1.5 \mathrm{~cm}$. long, acuminate, sometimes sharply so : ray-flowers several; ligules $2.5-3.5 \mathrm{~cm}$. long : disk $2-4 \mathrm{~cm}$. broad.

In dry soil, Texas.

5. Helianthus petiolànis Nutt. Annual, more or less scabrous-pubescent. Stem 3$9 \mathrm{dm}$. tall, usually branched, scabrous : leaves alternate above the lower part of the stem ; blades oblong-lanceolate to ovate-lanceolate, 3-9 $\mathrm{cm}$. long, merely undulate or shallowly toothed, narrowly or broadly cuneate at the base, long-petioled : bracts of the involucre not hirsute, lanceolate to oblong-lanceolate, 8-12 mm. long, acute or slightly acuminate : rayflowers several ; ligules $1.5-2.5 \mathrm{~cm}$. long : disk $2-3 \mathrm{~cm}$. broad.

:In dry soil, Saskatchewan to Minnesota, Texas and Arizona, and rarely naturalized eastward.

6. Helianthus ánnuus L. Annual, markedly pubescent. Stem hispid or hirsute, 1-2 m. tall, or taller in cultivation, branched above : leaves mainly alternate ; blades broadly ovate, 7-30 cm. long, or smaller above, usually slightly acuminate at the apex, decidedly toothed, those of the lower leaves cordate at the base, those of the upper cuneate : bracts of the involucre ovate to oblong or oblong-lanceolate, long-acuminate, hirsute : ligules of the ray-flowers $2.5-5 \mathrm{~cm}$. long: disk flat, $3-5 \mathrm{~cm}$. broad. All the parts are often much larger in cultivated forms.

In dry soil, Saskatchewan to Minnesota, Texas and Mexico. Adventive eastward.

7. Helianthus Floridànus A. Gray. Annual, sparingly pubescent. Stem 1-2 m. tall, branched above, smooth and glabrous almost to the peduncles: leaf-blades thin, narrowly lanceolate to linear-elliptic, linear-oblong or broadly linear, 4-11 cm. long, acute or slightly acuminate at both ends, remotely and shallowly but quite evenly toothed, often with scattered marginal cilia and spreading hairs along the midrib beneath : bracts of the involucre lanceolate, each prolonged into a slender tip, glabrous except the margins, the larger ones fully $1 \mathrm{~cm}$. long: disk dark purple, $1.5-2 \mathrm{~cm}$. broad ; ligules of the ray-flowers bright yellow, $2-3 \mathrm{~cm}$. long.

In sandy, often moist soil, peninsular Florida. Throughout the year.

8. Helianthus filiformis Small. Perennial, glabrous to the inflorescence. Stems 4-8 dm. tall, simple or sparingly branched above : leaves very numerous : approximate ; blades very narrowly linear or coarsely filiform by the revolute margins, 5-10 cm. long, curved, 
each sessile by a slightly dilated base: bracts of the involucre filiform-subulate, $1.5-2 \mathrm{~cm}$. long, loosely spreading, scarcely ciliolate and somewhat granular, attenuate into very slender tips which greatly surpass the disk in length: disk about $1 \mathrm{~cm}$. broad; ligules of the ray-flowers $1-2 \mathrm{~cm}$. long.

On limestone bluffs and in limestone soil, Texas. Fall.

9. Helianthus orgyàlis DC. Perennial, smooth and glabrous. Stems 1-3 m. tall, glaucous, branching above : leaves numerous, alternate ; blades narrowly linear, $10-40 \mathrm{~cm}$. long, attenuate, entire or serrulate, short-petioled or nearly sessile : bracts of the involucre 1-1.5 cm. long, linear or linear-lanceolate, ciliate, attenuate into filiform tips, which slightly surpass the disks in length ; ligules of the ray-flower $2-2.5 \mathrm{~cm}$. long : disk 1-1.5 cm. broad.

On plains, Nebraska to Colorado, Arkansas and Texas.

10. Helianthus polyphýllus Small. Perennial, deep green. Stems $9-20 \mathrm{dm}$. tall, branching above, densely hirsute near the base, glabrous and often smooth above : leaves numerous ; blades narrowly linear, $5-16 \mathrm{~cm}$. long, entire, strongly revolute and apparently thick, filiform, curved: bracts of the involucres linear-subulate, attenuate into subulate tips, about $1 \mathrm{~cm}$. long, some drooping or recurving: ray-flowers few; ligules $1.5-2 \mathrm{~cm}$. readily shrivelling : disks $1-1.5 \mathrm{~cm}$. broad, depressed.

In thickets, Georgia and Arkansas. Fall.

11. Helianthus angustifòlius L. Perennial, scabrous or hispidulous. Stems 6-18 dm. tall, more or less branched : leaves few, alternate; blades linear or narrowly linear on the lower part of the stem, entire, somewhat revolute, 8-20 cm. long, sessile, or the lower one on winged petiole: bracts of the involucre linear-lanceolate to linear-subulate, attenuate into slender tips, 8-12 $\mathrm{mm}$. Jong, minutely pubescent or hispidulous : ray-flowers several ; ligules about $2 \mathrm{~cm}$. long, not readily shrivelling : disks $1-1.5 \mathrm{~cm}$. broad.

In moist soil or swamps, New York and Missouri to Florida and Texas. Late summer and fall.

12. Helianthus elongàtus Small. Perennial, tufted. Stems 6-12 dm. tall, simple, or branched above : leaves opposite ; blades elliptic-oblong to linear, 5-20 cm. long, entire, very scabrous on both sides, the lower ones petioled, the upper sessile : heads showy, solitary or few, long-peduncled : involucres about $2 \mathrm{~cm}$. broad; bracts lanceolate, attenuate into slender tips, ciliate, and more or less hispid : ray-flowers $15-25$; ligules $2-4 \mathrm{~cm}$. long : disks brown-purple.

In pine lands, Florida to Louisiana.

13. Helianthus ciliàris DC. Perennial, smooth. Stems $3-7 \mathrm{dm}$. tall, more or less branched: leaves mostly opposite; blades linear or linear-lanceolate, acute, undulate, repand or bristly on the margins : heads not showy : involucres $1.5-2 \mathrm{~cm}$. broad; bracts svate to lanceolate, 5-7 mm. long, obtuse, acute or mucronate, pectinately hispid-ciliate : ray-flowers $14-19$; ligules $1-1.5 \mathrm{~cm}$. long or smaller, or obsolete : disk brownish, 1-2 cm. broad.

In low or brackish soil, Texas to Arizona and adjacent Mexico.

14. Helianthus undulàtus Chapm. Perennial, scabrous. Stems $6-18 \mathrm{dm}$. tall, simple or branching above : leaves numerous, opposite on the lower part of the stem, alternate above ; blades lanceolate, oblong or linear-lanceolate, 3-10 dm. long, usually abruptly acute, entire or nearly so, slightly revolute, paler beneath and less scabrous than above, shortpetioled or nearly sessile : heads showy : involucres $1.5-2 \mathrm{~cm}$. broad ; bracts oblong to lanceolate, the inner acuminate, $5-8 \mathrm{~mm}$. long: ligules of the ray-flowers $2-3.5 \mathrm{~cm}$. long: disk becoming brown, 1-1.5 cm. broad.

In sandy soil, Florida and Alabama. Fall.

15. Helianthus scabérrimus Ell. Perennial, scabrous. Stems rigid, $5-25 \mathrm{dm}$. tall, simple or sparingly branched : leaves few, opposite; blades leathery, those of the lower cauline leaves elliptic to ovate-elliptic, 1-2 dm. long, those of the upper lanceolate or elliptic-lanceolate, all exceedingly scabrous, 3-ribbed, shallowly serrate or serrulate : heads usually few, but conspicuous : involucres $2-2.5 \mathrm{~cm}$. broad; bracts ovate to lanceolate and linear-oblong, the inner acute, over $10 \mathrm{~mm}$. long; ligules of the ray-flowers $2.5-4 \mathrm{~cm}$. long : disk brown-purple, $2-3 \mathrm{~cm}$. broad.

On prairies, Minnesota to Illinois, Georgia and Texas.

16. Helianthus carnòsus Small. Perennial, smooth and glabrous, somewhat fleshy. Stems 3-10 dm. tall, sometimes tufted, simple : leaves few, opposite below, alternate above ; blades linear-oblong to linear, acutish, entire, sometimes undulate, the lower ones on stout petioles, the upper sessile: heads long-peduncled, showy, solitary : involucres about $2 \mathrm{~cm}$. broad; bracts fleshy, oblong-lanceolate, slightly acuminate, glabrous : disk yellowish, $1.5-2 \mathrm{~cm}$. broad : ray-flowers $12-18$; ligules $1.5-2 \mathrm{~cm}$. long; achenes $3-3.5 \mathrm{~mm}$. long.

On sandy beaches, northeastern Florida. Summer. 
17. Helianthus heterophýllus Nutt. Perennial, hirsute or hispid. Stems 4-12 dm. tall, simple or rarely much branched : leaves mostly opposite; blades various, those of the basal leaves oblong, elliptic or spatulate, $6-30 \mathrm{~cm}$. long ; those of the stem-leaves linear or nearly so, mostly shorter than those of the basal leaves, all entire : heads showy : involucres $1.5-2 \mathrm{~cm}$. broad ; bracts lanceolate, 8-12 $\mathrm{mm}$. long, slightly acuminate, sparingly pubescent and ciliate : ray-flowers about 20 ; ligules $2.5-3.5 \mathrm{~cm}$. long : disk brown-purple, $1.5-2.5 \mathrm{~cm}$. broad.

In low pine lands, North Carolina to Florida and Louisiana. Fall.

18. Helianthus atrorùbens L. Perennial, hirsute to hispid, or glabrate above. Stems 6-18 dm. tall, or rarely shorter, sparingly branched above : leaves opposite, mainly on the lower part of the stem; blades ovate, oval, elliptic or lanceolate, 5-20 cm. long, more or less toothed, cuneate to truncate at the base; petioles winged, shorter than the blades : heads rather showy : involucres broadly campanulate, about $1 \mathrm{~cm}$. high; bracts leathery, oblong to oblong-obovate, obtuse or mucronate: ray-flowers several ; ligules bright yellow, $1.5-2 \mathrm{~cm}$. long : disk about $1.5 \mathrm{~cm}$. broad.

In and about open woods, Virginia and Missouri to Florida and Louisiana.

19. Helianthus Rádula (Pursh) T. \& G. Perennial, hispid or hirsute. Stems simple and erect or branched at the base, the branches ascending or decumbent, 2-9 dm. long, terminated by long peduncles: leaves mainly basal or near the base of the stem; blades suborbicular to spatulate, or sometimes elliptic or rhombic, 3-8 cm. long, strongly 3 -ribbed, often cuneately narrowed into broad petioles : heads solitary, not showy : bracts of the involucres oblong to lanceolate, $8-10 \mathrm{~mm}$. long, abruptly acuminate, more or less ciliate : ray-flowers few ; ligules inconspicuous or obsolete : disk brownish purple, 1.5-2.5 cm. broad : achenes $4-4.5 \mathrm{~mm}$. long.

In low pine lands, Georgia to Florida and Alabama. Fall.

20. Helianthus occidentàlis Riddell. Perennial, hispidulous and scabrous. Stems $6-15 \mathrm{dm}$. tall, sparingly branched above, the peduncles elongated : leaves few, opposite ; blades oblong, elliptic or ovate-lanceolate, $6-15 \mathrm{~cm}$. long, entire or denticulate, narrowed into long margined petioles, the upper ones more or less reduced : heads showy : involucres campanulate, 7-9 mm. high ; bracts ovate-lanceolate to cuneate, more or less prolongedacuminate, nearly glabrous : ray-flowers $11-17$; ligules yellow, $1.5-2 \mathrm{~cm}$. long : disk yellow, $1 \mathrm{~cm}$. broad.

In dry soil, Ohio to Minnesota, Georgia, Florida and Texas.

21. Helianthus Dowelliànus M. A. Curtis. Perennial, glabrate or finely pubescent but not scabrous. Stems $8-15 \mathrm{dm}$. tall, more or less branched, the long peduncles reddish : leaves opposite or a few of the upper ones alternate ; blades ovate to ovate-lanceolate, 8-12 $\mathrm{cm}$. long, rather blunt, shallowly toothed, paler beneath than above, with narrowly cuneate bases and petioles as long as the blades on the lower part of the stem : heads showy : involucres hemispheric, slightly over $1 \mathrm{~cm}$. broad ; bracts mainly lanceolate, acute or somewhat acuminate, ciliolate, finely ribbed : ray-flowers $12-15$; ligules bright yellow, 2.5-3.5 $\mathrm{cm}$. long: disk yellow, fully $1 \mathrm{~cm}$. broad.

In open woods, District of Columbia and along the mountains to Georgia. Summer.

22. Helianthus Eggértii Small. Perennial essentially smooth and glabrous, except the ciliate leaf-blades and involucral bracts. Stems $8-15 \mathrm{dm}$. tall, sparingly branched above, more or less glaucescent: leaves opposite to the inflorescence; blades narrowly lanceolate or linear-lanceolate, 7-14 cm. long, acuminate, nearly entire, glaucous beneath : heads conspicuous : involucres hemispheric, $1.5 \mathrm{~cm}$. broad; bracts mainly lanceolate, acute or slightly acuminate, ciliate, the inner 13-14 mm. long, over $4 \mathrm{~mm}$. wide at the base : ray-flowers $8-16$; ligules $2-2.5 \mathrm{~cm}$. long: disk about $1.5 \mathrm{~cm}$. wide.

On rocky hills, Dickson County, Tennessee.

23. Helianthus laevigàtus T. \& G. Perennial, smooth and glabrous or nearly so. Stems 5-18 dm. tall, sometimes purple, often branching: leaves opposite; blades rather firm, lanceolate to oblong-lanceolate, $5-14 \mathrm{~cm}$. long, acuminate, remotely serrate or nearly entire, smooth on both sides, pale green beneath, short-petioled : heads conspicuous : involucres campanulate, $1 \mathrm{~cm}$. broad; bracts lanceolate to oblong-lanceolate, acuminate, appressed, ciliate, the inner $9-11 \mathrm{~mm}$. long, less than $3 \mathrm{~mm}$. broad at the base : ray-flowers few ; ligules 2-2.5 $\mathrm{cm}$. long, bright yellow : disk 10-13 $\mathrm{mm}$. broad.

On mountain slopes, Virginia and North Carolina. Summer.

24. Helianthus longifolius Pursh. Perennial, bright green, smooth and glabrous. Stems erect or ascending, 6-12 dm. tall, often purple-spotted : leaves opposite, sometimes approximate near the base of the stem; blades 3-ribbed, those of the basal leaves oblong or oblong-lanceolate, rather blunt, often distinctly toothed, narrowed into margined petioles, those of the stem-leaves almost linear to narrowly linear-lanceolate, more or less contracted 
below the junction of the 3 ribs, entire: involucres less than $1 \mathrm{~cm}$. broad ; bracts nearly subulate to linear-lanceolate, ecilate, lax : disk fully $1 \mathrm{~cm}$. broad : ray-flowers 9-15; ligules bright yellow, $1.5-2.5 \mathrm{~cm}$. long : disk about $1 \mathrm{~cm}$. broad.

In rocky glades, Alabama.

25. Helianthus microcéphalus T. \& G. Perennial, bright green. Stems 4-18 dm. tall, smooth and glabrous: leaves opposite; blades membranous, lanceolate to oblonglanceolate, 8-18 cm. long, acuminate, remotely serrate or nearly entire, slender-petioled: involucres campanulate, $6-7 \mathrm{~mm}$. high ; bracts linear-lanceolate, lanceolate to oblong, ciliate, the inner acute : ray-flowers 5-10; ligules yellow, 1-1.5 cm. long: disk 7-9 cm. broad : achenes cuneate or oblong-cuneate, $4 \mathrm{~mm}$. long, with 2 lanceolate teeth.

On hillsides or river banks, Pennsylvania to Missouri, Georgia and Louisiana.

26. Helianthus glaùcus Small. Perennial, deep green. Stems $9-18 \mathrm{dm}$. tall, widely branched, smooth, glabrous, glaucous : leaves opposite ; blades thick, or somewhat leathery, lanceolate, acuminate, sharply serrate, very scabrous above, tomentulose beneath, shortpetioled : involucres campanulate, $8-10 \mathrm{~mm}$. high ; bracts few, lanceolate to oblong-lanceolate, the inner acuminate, white-ciliate, more or less spreading : ray-flowers $5-7$; ligules yellow, $1-1.5 \mathrm{~cm}$. long : disk becoming about $1 \mathrm{~cm}$. broad.

In dry sandy soil, North Carolina to Florida and Alabama.

27. Helianthus verticillàtus Small. Perennial, deep green. Stems $9-18 \mathrm{dm}$. tall, branching above, smooth and glabrous almost to the heads : leaves in whorls of 3 ; blades firm, broadly linear or linear-lanceolate, $8-12 \mathrm{~cm}$. long, somewhat acuminate, entire, revolute, shagreen-like above, sparsely pubescent beneath, nearly sessile: peduncles strigillosehispidulous under the heads : involucres turbinate-campanulate, about $10 \mathrm{~mm}$. high ; bracts linear-lanceolate, ciliolate, somewhat spreading: ray-flowers several ; ligules deep yellow, about $2 \mathrm{~cm}$. long: disk about $1.5 \mathrm{~cm}$. broad : achenes about $5 \mathrm{~mm}$. long.

In wet sandy soil, western Tennessee. Summer. ,

28. Helianthus grósse-serràtus Martens. Perennial, bright green. Stems $9-30 \mathrm{dm}$. tall, smooth and glabrous below the inflorescence and often glaucous, branching above: leaves alternate or sometimes opposite ; blades leathery, lanceolate or oblong-lanceolate, 1-3 dm. long, acuminate, serrate, sometimes saliently so, short-petioled above the base of the stem : involucre-body about $1.5 \mathrm{~cm}$. broad; bracts linear-lanceolate to lanceolate, or oblong to cuneate with a lanceolate tip, 1-2 cm. long : ray-flowers numerous ; ligules $2.5-4$ cm. long : disk $1.5-2 \mathrm{~cm}$. wide.

On dry plains and prairies, Long Island and Pennsylvania to South Dakota and Texas.

29. Helianthus decapétalus $\mathrm{L}$. Perennial, deep green. Stems $5-16 \mathrm{dm}$. tall, smooth and glabrous below the inflorescence: leaves opposite; blades membranous, ovate to oblong-lanceolate, 8-20 cm. long, acuminate, coarsely serrate, cuneate or truncate at the base, somewhat scabrous on the upper surface : heads conspicuous : involucral bracts linear to linear-lanceolate, $1.5-2 \mathrm{~cm}$. long, ciliate : disk becoming about $1.5 \mathrm{~cm}$. broad : rayflowers several ; ligules bright yellow, oblong to linear-oblong, $2.5-3 \mathrm{~cm}$. long.

In thickets and on banks, Quebec to Michigan, Georgia and Kentucky. Summer.

30. Helianthus saxícola Small. Perennial, glabrous or nearly so to the inflorescence. Stems sometimes tufted, 8-15 dm. tall, simple or rarely sparingly branched near the top: leaves opposite below, alternate above; blades ovate-lanceolate to lanceolate, acuminate, shallowly serrate, deep green and quite smooth above, whitish green and essentially glabrous beneath: heads solitary or few, showy : peduncles sparingly pubescent : involucral bracts linear-lanceolate, attenuate, ciliate, more or less recurved: disk yellowish, about $1.5 \mathrm{~cm}$. broad : ray-flowers often 8-10; ligules light yellow, $2-3 \mathrm{~cm}$. long.

On exposed mountain summits, North Carolina and Georgia. Summer.

31. Helianthus austràlis Small. Perennial, deep green. Stems 6-15 dm. tall, smooth and glabrous to the inflorescence or near it, branched above : leaves mainly alternate; blades lanceolate, often narrowly so, 10-15 $\mathrm{cm}$. long, or shorter on the upper part of the stem, acuminate, shallowly toothed, very scabrous above, paler beneath and pubescent at least along the nerves, short-petioled : peduncles scabrous-pubescent : involucral bracts lanceolate to broadly lanceolate, acuminate, ciliate, otherwise glabrous or nearly so, the inner dilated about the middle: disk yellowish, about $1.5 \mathrm{~cm}$. broad : ray-flowers 10-15; ligules bright yellow, $1.5-2 \mathrm{~cm}$. long.

In stony or sandy soil, Georgia to Florida and Louisiana.

32. Helianthus strumòsus L. Perennial, bright green. Stems $6-18 \mathrm{dm}$. tall, smooth and glabrous, or nearly so, to the inflorescence, often glaucous : leaves opposite; blades thinnish, ovate to lanceolate or oblong-lanceolate, 8-20 cm. long, acuminate, entire or serrate, whitish beneath and sometimes tomentulose : heads showy: involucral bracts lance- 
late to oblong-lanceolate, attenuate, ciliate, the tips more or less spreading, the inner ones scarcely dilated, rather abruptly contracted below the middle: ray-flowers 11-15; ligules bright yellow, $2.5-4 \mathrm{~cm}$. long : disk $1.5-2 \mathrm{~cm}$. wide.

In dry woods and on shaded banks, Maine to Ontario and Minnesota, Georgia and Arkansas.

33. Helianthus Schweinítzii T. \& G. Perennial, deep green. Stems 4-18 dm. tall, branched, scabrous and hispidulous : leaves opposite below, alternate on the upper part of the stem ; blades firm, lanceolate or linear-lanceolate, attenuate, serrulate or nearly entire, shagreen above, canescent beneath : heads relatively small : involucral bracts linearlanceolate to lanceolate, acuminate, hispid : ray-flowers 9-13; ligules yellow, 2-2.5 cm. long : disk becoming about $1.5 \mathrm{~cm}$. broad.

In dry soil, North Carolina to Georgia and Alabama.

34. Helianthus cinèreus T. \& G. Perennial, minutely dull cinereous-pubescent. Stems 3-6 dm. tall, mostly simple : leaves opposite, mostly near the middle of the stem ; blades leathery, elliptic to elliptic-lanceolate, $2-8 \mathrm{~cm}$. long, acute, serrulate, narrowed at the base, but sessile: heads showy : involucral bracts lanceolate or oblong-lanceolate, 8-12 $\mathrm{mm}$. long, attenuate : ray-flowers 11-16 ; ligules yellow, 2-2.5 cm. long : disk yellow, 1.5$1.8 \mathrm{~cm}$. broad.

In dry soil, Texas. Summer.

35. Helianthus tomentòsus Michx. Perennial, pubescent. Stems 9-30 dm. tall, scabrous to hispid, branching above: leaves mostly alternate; blades ovate to lanceolate, 1-3 dm. long, acute or acuminate, undulate or shallowly toothed, narrowed into winged petioles: heads showy : involucral bracts linear-lanceolate, $1.5-2 \mathrm{~cm}$. long, acuminate, bristly, the outer ones spreading or recurved : ray-flowers numerous ; ligules bright yellow, $2.5-3 \mathrm{~cm}$. long : disk yellow, $2-2.5 \mathrm{~cm}$. broad.

On hillsides, Virginia to Georgia and Alabama.

36. Helianthus tuberòsus L. Perennial, pubescent. Stems 6-30 dm. tall, scabrous to hirsute, often branching above : leaves mostly alternate; blades thickish, ovate to lanceolate, $8-20 \mathrm{~cm}$. long, acuminate, more or less serrate, cuneate to subcordate at the base, commonly pubescent beneath, scabous above, terminating petiole-like bases: heads showy : involucral bracts rather foliaceous, linear to linear-lanceolate, $1.5-2.5 \mathrm{~cm}$. long, ciliate, long-attenuate, often pubescent on the back : ray-flowers numerous; ligules bright yellow, $2.5-4 \mathrm{~cm}$. long: disk yellow, $1.5-2 \mathrm{~cm}$. broad.

In alluvial soil, New Brunswick and Ontario to the Northwest Territory, Georgia and Arkansas.

37. Helianthus doroconoides Lam. Perennial, pubescent all over. Stems 1-2 m. tall, sparingly branched above, softly pubescent : leaves opposite on the lower part of the stem, alternate above; blades leathery, ovate to ovate-lanceolate, 1-3 dm. long, about equally scabrous-pubescent on both sides, acute or slightly acuminate, shallowly serrate, sessile : heads showy : involucral bracts linear-lanceolate to lanceolate, attenuate hispidulous and ciliate, the inner about $1 \mathrm{~cm}$. long: ray-flowers $11-19$; ligules $2.5-4 \mathrm{~cm}$. long : disk yellow, about $1.5 \mathrm{~cm}$. broad.

In dry soil, Michigan to Ohio, Missouri and Arkansas.

38. Helianthus Maximiliànii Schrad. Perennial, scabrous-hispidulous. Stems 6$36 \mathrm{dm}$. tall, usually branched above: leaves mostly alternate; blades firm, lanceolate, varying to linear or oblong-lanceolate, $8-15 \mathrm{~cm}$. long, acute or acuminate at both ends, entire or denticulate, the lower ones narrowed into petiole-like bases : heads showy : involucral bracts gray-pubescent, linear-lanceolate to lanceolate, $1.5-2.5 \mathrm{~cm}$. long, each attenuate into a slender tip : ray-flowers $15-30$; ligules golden yellow, $2.5-3.5 \mathrm{~cm}$. long: disk $1.5-2 \mathrm{~cm}$. broad.

On plains and prairies, Manitoba and the Northwest Territory to Minnesota and Texas.

39. Helianthus gigantèus L. Perennial, scabrous or hispidulous. Stems 9-30 dm. tall, sometimes smooth and glabrous below, branched above : leaves alternate, opposite or whorled; blades lanceolate to oblong- or linear-lanceolate, $5-15 \mathrm{~cm}$. long, acuminate, serrate or dentate, or nearly entire : heads showy : involucral bracts lanceolate or ellipticlanceolate, $8-13 \mathrm{~mm}$. long, acuminate, ciliolate : ray-flowers $9-20$; ligules yellow, $1.5-2 \mathrm{~cm}$. long: disk yellow, $1-1.5 \mathrm{~cm}$. broad.

In low grounds, Maine to Ontario and the Northwest Territory, Florida and Louisiana.

40. Helianthus resinòsus Small. Perennial, dull green. Stems $8-15 \mathrm{dm}$. tall, branching above, rigidly hispidulous : leaves mainly opposite; blades lanceolate to oblonglanceolate, $5-12 \mathrm{~cm}$. long, acute or somewhat acuminate, entire or undulate, very scabrous above, rough pubescent beneath and with numerous minute resinous glands : heads showy : involucral bracts lanceolate or oblong-lanceolate, acute or slightly acuminate, scabrouspubescent and glandular like the lower surfaces of the leaves, hispid-ciliate : ray-flowers 915 ; ligules bright yellow, about $2.5 \mathrm{~cm}$. long : disk becoming $2 \mathrm{~cm}$. broad.

In swamps and meadows, near River Junction, Florida. Summer. 
41. Helianthus tracheliifòlius Willd. Perennial, deep green. Stems 7-20 dm. tall, pubescent, but commonly only roughened by the remains of the hair-bases in age : leaves mainly opposite; blades lanceolate to oblong-lanceolate, $8-18 \mathrm{~cm}$. long, acuminate, sharply serrate, or with the teeth obscured by the revolute margins, scabrous above, more or less pubescent beneath, narrowed into petiole-like bases : heads showy : involucral bracts linearlanceolate to lanceolate, with slenderly elongated lax tips, pubescent and finely ciliate : ray-flowers $9-19$; ligules yellow, $3-4 \mathrm{~cm}$. long : disk about $1.5 \mathrm{~cm}$. wide.

In dry soil, Pennsylvania to Wisconsin, North Carolina and Arkansas.

42. Helianthus hirsùtus Raf. Perennial, hirsute or hispid. Stems 5-12 dm. tall, sometimes branching: leaves opposite; blades usually firm, lanceolate, 5-15 cm. long, acuninate, serrate or nearly entire : heads showy : involucral bracts linear-lanceolate, lanceolate or oblong-lanceolate, each attenuate into long spreading tips, hispidulous : rayflowers 12-15; ligules $2.5-3.5 \mathrm{~cm}$. long: disk $1.5-2 \mathrm{~cm}$. broad.

In dry soil, Pennsylvania to Wisconsin, Georgia and Texas.

43. Helianthus divaricàtus L. Perennial, deep green. Stems $3-12 \mathrm{dm}$. tall, simple or with slender branches above, commonly smooth, and glabrous, sometimes glaucescent: leaves opposite, spreading; blades lanceolate or ovate-lanceolate, acuminate, entire or sharply and coarsely serrate, sessile or nearly so: heads rather showy : involucral bracts lanceolate or oblong-lanceolate, $8-10 \mathrm{~mm}$. long, acuminate, ciliate : ray-flowers 7-15 ; ligules $2-2.5 \mathrm{~cm}$. long: disk $1-1.5 \mathrm{~cm}$. broad.

In dry, open woods, Ontario to the Northwest Territory to Florida and Louisiana. Summer.

44. Helianthus móllis Lam. Perennial, canescent. Stems 6-10 dm. tall, often branched above: leaves opposite ; blades ovate to ovate-lanceolate, $5-15 \mathrm{~cm}$. long, acute or acuminate, nearly entire or serrate, sessile or clasping : heads showy : involucral bracts oblong-lanceolate to lanceolate, or cuneate with a lanceolate tip, 1-1.5 cm. long, acuminate, bristly, the outer ones spreading: ray-flowers $13-26$; ligules yellow, $2-3 \mathrm{~cm}$. long: disk 2-3 cm. broad.

In dry often barren grounds, New York to Iowa, Georgia and Texas. Summer.

\section{ENCÈLIA Adans.}

Annual or perennial herbs or shrubby plants, with usually pubescent or glandular foliage. Leaves alternate or opposite : blades mainly of an ovate type. Heads radiate or rarely discoid, often showy, peduncled. Involucres hemispheric or flattish : bracts mainly lanceolate or linear-lanceolate. Receptacle somewhat convex, chaffy. Ray-flowers several, neutral: ligules yellow. Disk-flowers perfect, fruit-producing: corollas yellow or brown. Anthers slightly sagittate at the base. Stigmas with elongated pubescent appendages. Achenes flattened. Pappus wanting, or a small awn at each margin of the achene. The plants flower from spring to fall.

Achenes pilose, ciliate above : pappus of 2 short awns.

Achenes glabrous: pappus wanting.

1. E. subaristata.

2. E. calva.

1. Encelia subaristàta A. Gray. Foliage hispidulous and somewhat canescent. Stems 3-11 dm. tall, branching : leaves opposite; blades ovate to hastate, $3-7 \mathrm{~cm}$. long, crenate-serrate, subcordate at the base: peduncles elongated : heads solitary, rather showy : involucral bracts linear-lanceolate to lanceolate : ray-flowers 13-19; ligules yellow, 8-10 $\mathrm{mm}$. long : achenes $5-6 \mathrm{~mm}$. long, pilose, ciliate near the top, with 2 rigid hispidulous awns $\frac{1}{2}$ as long as the achene or shorter.

On plains and prairies, Texas and adjacent Mexico.

2. Encelia cálva (Engelm. \& Gray) A. Gray. Foliage scabrous to hispidulous. Stems 3-9 dm. tall, branching : leaves opposite; blades deltoid-ovate to hastate, $2-7 \mathrm{~cm}$. long, serrate, broadly cuneate or subcordate at the base : peduncles elongated : heads solitary, showy : involucral bracts linear-lanceolate to almost linear, the outer with spreading tips, densely hispidulous : ray-flowers 11-17; ligules 10-12 mm. long: achenes 5-6 mm. long, glabrous, without pappus.

On stony hills, Texas and adjacent Mexico.

98. HELIANTHÉLIA T. \& G.

Perennial caulescent herbs with tuber-bearing roots. Leaves alternate or opposite : blades entire or sparingly toothed. Heads radiate, heterogamous, showy, peduncled. Involucres often hemispheric : bracts imbricated in 2 or 3 series, the outer often longer than the inner. Ray-flowers neutral : ligules yellow. Disk-flowers perfect, fruit-producing: 
corollas yellow or purplish brown. Anthers entire at the base. Stigmas linear-lanceolate. Achenes of the disk more or less flattened, margined or barely winged, truncate or notched. Pappus of several scales between the chaffy teeth or awns. The plants flower in summer and fall.

Leaf-blades linear or linear-lanceolate: involucral bracts appressed : ray-flowers 16-20.

Leaf-blades linear-filiform : involucral bracts spreading : ray-flowers 10-15.

1. H. grandiflora. 2. H. tenuifolia.

1. Helianthella grandiflòra T. \& G. Stems 6-12 dm. tall, simple or sparingly branched. Leaves mostly alternate; blades linear or slightly tapering, 2-6 cm. long, acute, entire, somewhat revolute: heads showy : involucral bracts linear-subulate to lanceolate or lanceolate, or oblong with lanceolate tips, hispidulous, the tips rather lax : ray-flowers $16-20$; ligules yellow, 3-4.5 cm. long: disks $1.5-2 \mathrm{~cm}$. broad : achenes $5 \mathrm{~mm}$. long, wing-margined, pubescent about the upper edge, each side surmounted by a tooth, and one or both prolonged into an awn.

In pine lands, Florida.

2. Helianthella tenuifolia T. \& G. Stems 3-8 dm. tall, simple or corymbosely branched above : leaves alternate or opposite, or whorled on the lower part of the stem; blades linear-filiform, 3-8 cm. long, acute, entire, revolute, very scabrous : heads showy : involucral bracts linear-subulate to linear-lanceolate, attenuate, spreading: achenes 4angled, $3 \mathrm{~mm}$. long, minutely pubescent, the margins prolonged into triangular scales.

On sand hills, Florida.

\section{ZEXMÈnIA Llave \& Lex.}

Perennial caulescent herbs or shrubby plants. Leaves opposite, or rarely alternate : blades simple. Heads radiate, often showy. Involucres campanulate or hemispheric: bracts in several series, relatively broad, dry, the outer sometimes broader than the rest and spreading. Receptacle flat or convex, chaffy. Ray-flowers pistillate, fruit-producing : ligules yellow. Disk-flowers several, perfect, fruit-producing: corollas yellow. Anthers entire or slightly sagittate at the base. Stigmas of the disk with acute pubescent appendages. Achenes various; those of the ray and edge of the disk 3-angled, the others more or less flattened, sometimes winged. Pappus of 1-3 awns, these sometimes accompanied by several distinct or partially united scales.

1. Zexmenia híspida (H.B.K.) A. Gray. Stems strigose or strigose-hispid, branched at the base; branches 2-7 dm. long. Leaf-blades rhombic to lanceolate, acute or acuminate, repand-serrate, somewhat cuneate at the base, sessile : peduncles elongated : heads rather showy : involucres $6-7 \mathrm{~mm}$. high ; bracts lanceolate in the outer series, oblong to ovate in the inner, acute or acuminate : ray-flowers with orange-yellow ligules about $1 \mathrm{~cm}$. long: disk barely $1 \mathrm{~cm}$. broad : achenes obovate, winged.

In dry soil, Texas and adjacent Mexico.

\section{ACTINÓMERIS Nutt.}

Perennial caulescent rough-pubescent, rather coarse herbs. Leaves alternate or opposite : blades simple, more or less toothed, usually decurrent on the stem. Heads radiate or discoid. Involucres small, of few spreading or recurved narrow bracts. Receptacle convex or conic, becoming globose, chaffy. Ray-flowers neutral, or wanting: ligules yellow or white. Disk-flowers perfect, fruit-producing embraced by the bractlets. Anthers entire at the base. Stigmas of the disk with acute appendages. Achenes flattened, more or less winged. Pappus of two finally spreading awns, these sometimes accompanied by $2-3$ smaller awns or scales. The plants flower in summer and fall.

Ray-flowers 2-8: disk-corollas yellow.

Ray-flowers wanting: disk-corollas white.

1. A. alternifolia.

2. A. paniculata.

1. Actinomeris alternifolia (L.) Britton. Foliage finely pubescent. Stems 6-25 $\mathrm{dm}$. tall, winged, corymbose above : leaf-blades oblong or elliptic, 1-3 dm. long, acuminate at both ends, serrate: heads rather showy : involucres flattish ; bracts linear to linearlanceolate, acute : ray-flowers $2-8$ : disks $1-1.5 \mathrm{~cm}$. broad : corollas yellow, $5 \mathrm{~mm}$. long : achenes obovate, 5-6 mm. long, winged : pappus of 2 , or in the case of marginal achenes 3 , awns.

In thickets and rich soil, New York to Iowa, Florida and Louisiana.

2. Actinomeris paniculàta (Walt.) Small. Foliage scabrous, but barely pubescent. Stems 6-24 dm. tall, corymbose above, becoming smooth : leaf-blades linear to oblong or 
narrowly elliptic, 1-3 dm. long, acuminate at both ends, serrate : heads not showy : involucres flattish; bracts narrowly linear : ray-flowers wanting : disks about $1 \mathrm{~cm}$. broad : corollas white, $4 \mathrm{~mm}$. long: achenes elliptic-obovate, $5 \mathrm{~mm}$. long, winged or wingless : pappus of 3-4 awns with smaller ones commonly interposed, or scales in their places.

In alluvial soil, South Carolina to Florida and Louisiana.

\section{VERBESINNA L.}

Perennial caulescent herbs or shrubby plants. Leaves alternate or opposite; blades simple, flat, entire or toothed, more or less decurrent on the stem. Heads several or numerous, radiate or discoid. Involucres hemispheric or campanulate : bracts imbricated in few series, narrow, somewhat appressed. Receptacle convex or conic, chaffy. Ray-flowers neutral or fruit-producing: ligules white or yellow, rather inconspicuous, or wanting. Disk-flowers perfect, mostly fruit-producing, embraced by the bractlets. Anthers obtuse at the base. Stigmas of the disk with papillose appendages. Achenes various; those of of the ray 3-angled; those of the disk flattened, winged or wingless. Pappus of 1-3 awns which are sometimes accompanied by as many scales. Crownbeard.

Involucres campanulate, 4-6 mm, broad.

Leaves alternate: ray-flowers with white ligules.

Leaf-blades undulate, sinuate or serrate.

Involucres about $6 \mathrm{~mm}$. high : leaf-blades acute or acuminate, usually fully thrice as long as broad.

Involucres about $4 \mathrm{~mm}$. high : leaf-blades blunt, usually less than twice as long as broad.

Leaf-blades pinnatifid or pinnately lobed.

Leaves opposite: ray-flowers with yellow ligules.

Involucres hemispheric, 12-15 $\mathrm{mm}$. broad.

Stems winged by the decurrent leaves.

Leaf-blades hirsute beneath: stems leafy to the inflorescence.

Leaf-blades hispidulous beneath : stem sparingly scaly above the middle. Stems not winged.

Foliage scabrous: leaf-blades shallowly toothed : involucres $10 \mathrm{~mm}$. high.

Foliage hirsute or hispid: leaf-blades coarsely toothed: involucres 5-6 mm. high.

1. V. Virginica.

2. V. Texana.

3. V. laciniata.

4. $V$. occidentalis.

5. V. helianthoides.

6. V. heterophylla.

7. V. pauciflora.

8. V. aristata.

1. Verbesina Virgínica L. Stems 6-18 dm. tall, tomentulose or puberulent, branching above, more or less prominently winged. Leaves alternate ; blades membranous, lanceolate to oval or ovate, $0.5-2 \mathrm{dm}$. long, acute or acuminate, serrate or nearly entire, narrowed into winged-petioles: heads corymbose: involucres about $6 \mathrm{~mm}$. high, narrowly campanulate or cylindric ; bracts linear, erect ; ligules of the ray-flowers white, oval, 4-7 $\mathrm{mm}$. long : disk-corollas pubescent : achenes oblong-obovate, $3 \mathrm{~mm}$. long, ciliate : pappusawns very slender, often as long as the achene.

In dry soil, Pennsylvania to Missouri, Florida and Texas. Summer.

2. Verbesina Texàna Buckl. Stems 4-11 dm. tall, tomentulose, winged, branching. Leaves alternate; blades thickish, ovate, oval, elliptic or lanceolate, $0.5-1 \mathrm{dm}$. long, obtuse or acute, repand, on broadly winged petioles : heads corymbose : involucres about 4 $\mathrm{mm}$. high, broadly campanulate, or flattish ; bracts linear, oblong-linear, or slightly broadened upward, mostly obtuse; ligules of the ray-flowers white, oval, about $2 \mathrm{~mm}$. long: disk-corollas glabrous : achenes clavate in outline, and obcordate by the broad wings, $4 \mathrm{~mm}$. long, with 2 subulate pappus-awns.

In sandy soil, Texas and adjacent Mexico.

3. Verbesina laciniàta (Poir.) Nutt. Stems 7-16 dm. tall, tomentulose, winged or ridged. Leaves alternate; blades pinnately incised, lobed or parted, $0.5-2 \mathrm{dm}$. long, the segments repand or entire; petioles winged: heads not showy : involucres narrowly campanulate; bracts linear, acute or acutish, often minutely pubescent : ligules of the rayflowers white, oval, $4 \mathrm{~mm}$. long: disk-corollas glabrous.

In sandy soil, South Carolina to Florida. Summer.

4. Verbesina occidentàlis (L.) Walt. Stems 9-20 dm. tall, smooth and glabrous or minutely pubescent, winged above, like the branches: leaves opposite; blades ovate to oblong-lanceolate, $5-20 \mathrm{~cm}$. long, acuminate, serrate, abruptly and cuneately narrowed at the base ; petioles winged: involucral bracts few, lax, linear or slightly broadened upward, 4-8 mm. long; ligules of the ray-flowers linear, 1-1.5 cm. long: achenes oblong-obovate, $5 \mathrm{~mm}$. long, pubescent, with 2 ascending or spreading pappus-awns.

On hillsides and in thickets, Pennsylvania to Illinois and Florida. Summer and fall.

5. Verbesina helianthoìdes Michx. Stems 5-10 dm. tall, finely pubescent, sparingly branched, leafly to the inflorescence, winged. Leaves mostly alternate; blades lanceolate to elliptic, 4-12 cm. long, acute or acuminate, serrate, hirsute beneath, sessile 
and decurrent: heads showy, solitary or clustered: involucral bracts linear to linear-lanceolate; ligules of the ray-flowers yellow, $2-3 \mathrm{~cm}$. long: achenes 4-5 mm. long, winged, pubescent, with 2 small pappus-awns.

In open woods and on prairies, Iowa to Ohio, Georgia and Texas. Summer and fall.

6. Verbesina heterophýlla (Chapm.) A. Gray. Stems hirsute or scabrous-hispidulous, 5-10 dm. tall, winged, sparingly leafy above the middle. Leaves mostly opposite, approximate on the lower part of the stem ; blades firm, elliptic, oblong or oblong-lanceolate, 2-6 cm. long, or much reduced above, serrate-dentate, sessile and decurrent: heads showy : involucres campanulate, 5-6 mm. high ; bracts lanceolate to narrowly elliptic, acute, pubescent ; ligules of the ray-flowers bright yellow, linear, 1.5-2 cm. long: achenes obovate, $7 \mathrm{~mm}$. long, winged, the body often ridged : pappus of 2 small awns.

In dry pine lands, Florida. Spring and summer.

7. Verbesina pauciflòra (Nutt.) Small. Stems scabrous to hispidulous, $3-7 \mathrm{dm}$. tall, simple or nearly so, almost leafless above the middle. Leaves scattered; blades leathery, lucid, oblong or slightly broadest above the middle, $3-9 \mathrm{~cm}$. long, obtuse at both ends, aften apiculate at the apex, reticulated, shallowly serrate, sessile : heads usually solitary : involucres about $10 \mathrm{~mm}$. high ; bracts linear or slightly broadest above the middle, mostly acute. [Actinomeris pauciflora Nutt. Verbesina Warei A. Gray.]

In low pine lands, near the coast, western Florida. Summer.

8. Verbesina aristàta (Ell.) Heller. Stems hirsute to hispid, 5-10 dm. tall, not winged, usually branching above. Leaves rather remote, opposite ; blades firm, oblong to oblong-ovate or oblong-lanceolate, 3-10 cm. long, scabrous, coarsely serrate, sessile : heads showy, corymbose: involucres campanulate, $5-6 \mathrm{~mm}$. high ; bracts thick, narrowly linearlanceolate, or linear: ray-flowers $7-12$; ligules bright yellow, linear, $2-3 \mathrm{~cm}$. long: achenes obovate or oblong-obovate, $4 \mathrm{~mm}$. long: pappus of 2 short awns. [ $\mathrm{V}$. nudicaulis (Nutt. ) A. Gray.]

In sandy pine lands, Georgia, Florida and Alabama. Spring and summer.

\section{XIMENÈSIA Cav.}

Annual caulescent herbs, with pubescent foliage. Leaves alternate or sometimes opposite : blades broadest below the middle, simple, toothed or somewhat laciniate. Heads solitary or few, radiate, showy, peduncled. Involucres rather flat, of narrow spreading bracts. Receptacle convex, chaffy. Ray-flowers pistillate, fruit-producing, numerous : ligules yellow. Disk-flowers numerous, perfect, fruit-producing. Anthers somewhat sagittate at the base. Stigmas with slender pubescent appendages. Achenes flat, winged. Pappus of short and straight, or at least not of hooked, awns.

1. Ximenesia encelioìdes Cav. Foliage pale or gray-strigillose. Stems 3-7 dm. tall, freely branching : leaves mostly alternate; blades deltoid or lanceolate, $5-10 \mathrm{~cm}$. long, acute or acuminate, coarsely serrate or incised, broadly cuneate to subcordate at the base, the broader winged petioles with dilated toothed appendages near the base : heads showy : involucres foliaceous; bracts linear, $1.5-2 \mathrm{~cm}$. long: ligules of the ray-flowers bright yellow, as long as the involucral bracts or longer : achenes $6-7 \mathrm{~mm}$. long, winged, sometimes with 2 small awns.

In low grounds, Colorado to Florida, Texas and Arizona.

\section{SYNEDRÉLIA Gaertn.}

Annual caulescent pubescent herbs. Leaves opposite : blades simple, usually toothed. Heads radiate, inconspicuous. Involucres several-flowered : bracts few, 1 or 2 herbaceous, several chaffy. Ray-flowers pistillate, fruit-producing: ligules-yellow. Disk-flowers perfect, fruit-producing : corollas with 4 lobes. Stigmas of the disk-flowers with elongated appendages. Achenes of the ray flattened, 2-winged; those of the disk flattened or 3-angled. Pappus of 2-3 naked awns.

1. Synedrella nodiflòra (L.) Gaertn. Stems simple at the base, upright, $3-8 \mathrm{dm}$. tall, more or less branched above. Leaf-blades ovate to elliptic, 5-10 $\mathrm{cm}$. long, acute or slightly acuminate, serrate, narrowed into hispid-ciliate winged petioles : heads several, clustered in the axils of the leaves or on short branchlets : involucres 7-9 mm. high ; bracts chaffy, rather rigid, linear to linear-lanceolate : achenes 4-5 $\mathrm{mm}$. long; those of the ray oblong, with ascending marginal bristles and two short awns; those of the disk barely 1 $\mathrm{mm}$. broad, slightly broadened upward with two bristle-like awns.

In waste places and sandy soil, Florida. Native of tropical America. 


\section{CALYPTROCÁRPUS Less.}

Herbs, similar to species of Synedrella in habit. Involucres of few herbaceous bracts. Achenes of the ray and disk alike, or some of those of the ray 3-angled, all wingless. Pappus of 2 or 3 awns with a rim at the base.

1. Calyptrocarpus Tampicàna (DC.) Small. Stems branched at the base, the branches prostrate or creeping, 1-3 dm. long. Leaf-blades ovate, 1-3 cm. long, acute, shallowly serrate, broadly cuneate to subcordate at the base, petioled : peduncles $1-5 \mathrm{~mm}$. long: heads inconspicuous: involucres $5-8 \mathrm{~mm}$. high; bracts broadly oblong: achenes about $5 \mathrm{~mm}$. long, those of the ray with several marginal bristles. [Calyptrocarpus vialis Less.]

In dry soil and waste places, southern Texas. Also in tropical America.

\section{COREÓPSIS L. ${ }^{1}$}

Annual or perennial herbs. Leaves various. Heads terminating the peduncle-like branches, consisting of both tubular and radiate flowers, the ray-flowers neutral, yellow, particolored, or in two species pink. Disk flowers perfect, fruit-producing. Involucres campanulate or hemispheric, their bracts in two series, all more or less united at the base, those of the outer series usually narrow and herbaceous, the inner series broad, variously colored, either thin and scarious or with scarious margins. Receptacle flat or slightly convex, chaffy, the chaff flat or slightly concave. Achenes flat or more or less convex on the back, from oblong to orbicular, winged or wingless. Pappus of two fimbriolate scales, delicate awns, minute teeth, a mere coroniform border, or none. TickseEd.

Stigmas with acute or cuspidate tips.

Leaf-blades, or their divisions, with entire margins.

Stigma-tips cuspidate: chaff of the receptacle with broad bases and attenuate filiform tips: leafblades simple or pinnately lobed. EucorEOPSIs.

Ligules uniformly yellow : perennial plants.

Achenes with broad outspread wings.

Stems leafy near the base, bearing long, naked, peduncle-like branches. Plants glabrous except the ciliate bases of the leaves. Plants pubescent except near the inflorescence.

Stems leafy to near the summit: peduncle short. Leaf-blades broad, simple or with 1-5 small, lateral lobes.

Leaf-blades pinnately parted into narrow divisions.

Leaf-segments linear-lanceolate.

Leaf-segments linear or filiform.

Achenes with strongly incurved entire wings, which become callusthickened at maturity.

Ligules discolored: annual plants.

Stigma-tips acutely conical : chaff of the receptacle linear or with slightly

dilated tips: leaf-blades palmately lobed or divided. ANACIs.

Leaves with petioled blades.

Leaves with sessile blades.

Leaf-blades 3-cleft to about the middle, the basal portion 3-veined.

Leaf-blades divided to the base.

Disk-flowers with yellow corollas.

Divisions of the leaf-blades broader than linear.

Divisions of the leaf-blades linear or filiform.

Disk-flowers with purple-brown corollas.

Divisions of the leaf-blades comparatively few, $2-4 \mathrm{~mm}$. broad : internodes mostly longer than the leaves.

Divisions of the leaf-blades very numerous, appearing in dense fascicles, 1-2 mm. broad: internodes mostly shorter than the leaves.

Leaf-blades regularly toothed. SILPHIDIUM.

Stigmas with truncate or obtusely conical tips. Calliopsis.

Achenes wingless.

Ligules of the ray-flowers yellow with crimson-brown base : flowers of the disk with dark red corollas.

Outer involucral bracts much shorter than the inner : achenes narrowly oblong, thin, flat.

Outer involucral bracts mostly about as long as the inner: achenes obovate, thick, convex.

Ligules of the ray-flowers pink : flowers of the disk with yellow corollas. Achenes winged.

A. Achenes with entire scarious wings.

Pappus of minute teeth or wanting. Ligules discolored. Ligules uniformly yellow.

Pappus of conspicuous awns (sometimes deciduous at maturity).

a. Leaf-blades, or some of them, lobed: internodes mostly shorter than the leaves.

Ligules discolored (Texan species).

1. C. lanceolata.

2. C. crassifolia.

3. C. pubescens.

4. C. grandiflora.

5. C. Harveyana.

6. C. auriculata.

7. C. Nuecensis.

8. C. tripteris.

9. C. palmata.

10. C. major.

11. C. verticillata.

12. C. delphinifolia.

13. C. pulchra.

14. C. latifolia.

15. C. tinctoria.

16. C. Drummondii. 17. C. rosea.

18. C. cardaminefolia. 19. C. stenophylla.

20. C. similis.

${ }^{1}$ Contributed by Mr. F. E. Boynton. 
Ligules uniformly yellow (Floridan species).

b. Leaf-blades simple and entire : internodes mostly much longer than the leaves.

B. Achenes with fimbriate or dissected winged margins.

Leaves not rush-like: ligules yellow.

Blades of the larger leaves of an oblong or lanceolate type.

Lower leaves shorter or little longer than the internodes.

Lower leaves much longer than the internodes.

Blades of the basal leaves linear or lanceolate, mostly pointed.

Leaf-blades simple and entire : achenes elliptic-oblong, about

$4 \mathrm{~mm}$. long, the wing about one-third as wide as the body.

Leaf-blades often lobed: achenes narrowly oblong, about 5 $\mathrm{mm}$. long, the wing as wide as the body.

Blades of the basal leaves oblong or elliptic, obtuse.

Blades of the larger leaves of an ovate type.

Leaves opposite: petioles and blades (when young) ciliate-margined.

Leaves alternate: margins of the blades and petioles naked.

Leaves rush-like, without proper blades: ligules pink.

21. C. Leavenworthii.

22. C. Lewtonii.

23. C. angustifolia.

\section{C. longifolia.}

25. C. falcata.

26. C. gladiata.

27. C. integrifolia.

28. C. helianthoides.

29. C. nudata.

1. Coreopsis lanceolàta L. Perennial, glabrous, except the ciliate bases of the leaves. Stems erect or ascending, 2-6 dm. tall, round or slightly angled, striate, branched, leafly only near the base : leaves opposite; blades of the lower petioled, spatulate to linearoblanceolate, commonly simple, rarely with one or two small lateral lobes : heads 4-6 cm. broad including the rays: outer involucral bracts lanceolate, 6-8 $\mathrm{mm}$. long, the inner lance-ovate, about $1 \mathrm{~cm}$. long : ligules obovate or cuneate, 3 -lobed at the apex, the middle lobe notched : achenes orbicular, $2.5-3 \mathrm{~mm}$. long, usually bearing callosities on the inner face, the broad wing slightly incurved : pappus a pair of small fimbriolate squamellae.

In dry soil, Ontario to Florida. Spring and summer.-C. lanceolata glabélla Michx. is a variety with very narrow leaves (4-8 mm. wide) all crowded at the base of the short stems.

2. Coreopsis crassifòlia Ait. Perennial, pubescent throughout. Stems ascending, 2-4 dm. tall, simple or branched near the base, leafy below, naked above : leaves opposite ; blades of the lower ones petioled, simple, entire, obovate-spatulate to oblong, the upper sessile, oblong, acute : heads $4-6 \mathrm{~cm}$. broad including the rays : outer involucral bracts lance-ovate, 6-8 mm. long, the inner broadly ovate, about $1 \mathrm{~cm}$. long: ligules obovate or cuneate, 3-lobed at the apex, the middle lobe notched : achenes orbicular-oblong, 2.5-3 $\mathrm{mm}$. long, the wing slightly incurved: pappus of small fimbriolate squamellae, often wanting at maturity.

In dry soil, Illinois to Louisiana, east to the Atlantic. Spring and summer.

3. Coreopsis pubéscens Ell. Perennial, more or less pubescent or hirsute. Stems erect, 6-12 dm. tall, usually branched : leaves opposite ; blades various, from oval to elliptic-lanceolate, either entire or with one or two pairs of small lateral leaflets, the lower petioled : heads $4-5 \mathrm{~cm}$. broad including the rays : outer involucral bracts linear-lanceolate, 8-10 $\mathrm{mm}$. long, the inner ovate, about the length of the outer: ligules cuneate, 3lobed at the apex, the middle lobe notched: achenes orbicular, about $3 \mathrm{~mm}$. long; wings slightly incurved: pappus of two small fimbriolate squamellae, sometimes wanting at maturity.

In dry woodlands, Virginia and southern minois to Florida. Summer and fall.

4. Coreopsis grandiflòra Hogg. Perennial, glabrous except the ciliate petioles. Stems erect or ascending, 3-6 dm. tall, often branched : leaves opposite; blades of the basal and lower stem-leaves petioled, spatulate or lanceolate, entire, or like those of the upper leaves, parted or divided into linear or linear-lanceolate segments: heads 4-6 cm. broad including the rays : outer involucral bracts lanceolate, 6-9 $\mathrm{mm}$. long, the inner ovate, slightly longer than the outer: ligules obovate or cuneate, 3-lobed at the apex, the middle lobe toothed : achenes orbicular, about $2.5 \mathrm{~mm}$. long; callosities usually conspicuous; wings slightly incurved : pappus a pair of small fimbriolate squamellae, often wanting at maturity.

In dry soil, Missouri to Georgia, Texas and New Mexico. Spring and summer.

5. Coreopsis Harveyàna A. Gray. Perennial, glabrous. Stems erect or ascending 3-6 dm. tall, often branched: leaves opposite; blades pinnately divided into narrowly linear (almost filiform) segments: heads 4-5 cm. broad including the rays : outer involucral bracts linear-lanceolate, about $4 \mathrm{~mm}$. long, the inner ovate, slightly longer than the outer: ligules obovate or cuneate, 3-lobed at the apex, the middle lobe toothed : achenes orbicular, about $2 \mathrm{~mm}$. long; callosities usually present; wing slightly incurved : pappus a pair of fimbriolate squamellae.

In dry soil, western Arkansas, Indian Territory, Oklahoma and Kansas. Summer.

6. Coreopsis auriculàta L. Perennial, propagating freely by stolons. Stems erect or ascending, 2-5 dm. tall, simple or branched, leafy only near the base, pubescent or hirsute, at least below : leaves opposite; blades petioled, from round-oval to elliptic-ovate, 
either simple or with one or two small basal lobes: heads 4-5 $\mathrm{cm}$. broad including the rays: outer involucral bracts linear-oblong. $7-9 \mathrm{~mm}$. long, the inner ovate, commonly about the length of the outer: ligules obovate to broadly cuneate, 3-lobed, the middle lobe notched : achenes oval, $2-2.5 \mathrm{~mm}$. long, the margins incurved, the narrow wing strongly involute and callous-thickened at maturity : pappus a pair of inconspicuous squamellate scales, mostly wanting at maturity.

In dry soil, Virginia to Florida. Spring and summer.

7. Coreopsis Nuecénsis Heller. Annual, sparsely hirsute to nearly glabrous. Stems erect, 2-4 dm. tall, branching near the leafy base, naked above : leaves opposite ; blades of all except the uppermost petioled, broadly oval to oblong-spatulate, entire, or more commonly with one or two pairs of lateral lobes : heads about $4 \mathrm{~cm}$. broad including the rays : outer involucral bracts lanceolate, $6-8 \mathrm{~mm}$. long, the inner broadly ovate, somewhat longer than the outer: ligules cuneate, 3-lobed, the middle lobe deeply notched, bright yellow with purple-brown markings near the base : achenes orbicular, about $4 \mathrm{~mm}$. long, the wings slightly incurved; callosities conspicuous; pappus of two small fimbriolate squamellae.

In dry or moist soil, eastern Texas. Spring and summer.

8. Coreopsis trípteris L. Perennial. Stems glabrous or nearly so, erect, 1-3 m. tall, terete, much branched above, leafy throughout: leaves opposite; blades petioled and divided into three elliptic-lanceolate or lanceolate segments (frequently the middle one is again parted or divided), either glabrous or pubescent ; or blades of the uppermost leaves simple, lanceolate and entire : heads $4-5 \mathrm{~cm}$. broad including the rays : outer involucral bracts linear, obtuse, $2-3 \mathrm{~mm}$. long, the inner ovate, about $5 \mathrm{~mm}$. long: ligules ellipticoblong, entire or somewhat notched at the apex : chaff of the receptacle linear-spatulate, obtuse, marked with purple lines : achenes elliptic oblong, $5-6 \mathrm{~mm}$. long, narrowly winged: pappus a short fimbriate border.

In moist thickets, Pennsylvania to Florida and Louisiana. Summer and fall.

9. Coreopsis palmàta Nutt. Perennial. Stems erect, glabrous, $5-9 \mathrm{dm}$. tall, angled and striate, simple or somewhat branched, leafy : leaves opposite; blades sessile, thick and rigid, 3-cleft to about the middle, the divisions linear-oblong (the middle one sometimes 3-lobed), or those of the uppermost leaves often simple and entire : heads 4-5 cm. broad including the rays: outer involucral bracts linear, rigid, obtuse, $7-9 \mathrm{~mm}$. long, the inner oblong-obovate, slightly longer than the outer : ligules oblong-obovate, more or less irregularly notched at the apex : chaff of the receptacle linear, acute: achenes elliptic-oblong, $5-6 \mathrm{~mm}$. long, narrowly winged : pappus a slight extension of the wings.

In dry soil, Illinois to Louisiana and Texas. Summer.

10. Coreopsis màjor Walt. Stems erect, pubescent, $5-9 \mathrm{dm}$. high, round or somewhat angled and branched above, leafy : leaves opposite; blades sessile, 3-divided to very near the base, the divisions elliptic-lanceolate or lanceolate, or blades of the uppermost leaves simple and entire : heads $3-5 \mathrm{~cm}$. broad including the rays : outer involucral bracts linear-oblong, obtuse, 5-6 mm. long, the inner lance-ovate, about the length of the outer : ligules elliptic-oblong, entire or slightly toothed at the apex : chaff of the receptacle linear, acute : achenes elliptic-oblong, $5-6 \mathrm{~mm}$. long, bordered by a narrow wing : pappus a short extension of the wings.

In dry soil, Virginia to Florida. Summer and fall.-C. major Oemleri (Ell.) Britton. Like the above but glabrous throughout. Range of the species. C. major rígida (Nutt.) F. E. Boynton. A glabrous form with the divisions of the leaf-blades very narrow. North Carolina to Florida.

11. Coreopsis verticillàta L. Perennial. Stems glabrous, erect, 5-9 dm. high, striate, round or somewhat angled and usually much branched above, leafy : leaves opposite; blades palmately 3-divided, the divisions once or twice pinnately parted into linear-filiform segments : heads $4-5 \mathrm{~cm}$. broad including the rays : outer involucral bracts linear, 5-6 mm. long, obtuse, the inner elliptic-oblong, slightly longer than the outer : ligules elliptic-oblong, entire or slightly notched at the apex : chaff of the receptacle linear, acute : achenes oblong-obovate, 4-5 $\mathrm{mm}$. Iong : pappus a short lacerate extension of the wings.

In dry soil, Canada to Nebraska, North Carolina and Kansas. Summer and fall.

12. Coreopsis delphinifolia Lam. Perennial. Stems erect, glabrous, $8-15 \mathrm{dm}$. high, angled and striate, branched above, leafy : leaves opposite; blades palmately 3 -divided, the middle segment commonly again divided into 3-5 linear, acute divisions, or blades of the uppermost leaves often simple and entire : internodes mostly much longer than the leaves : long, the inner ovate, slightly longer than the outer: ligules elliptic-oblong, entire or slightly toothed at the apex : chaff linear or slightly dilated at the tip : achenes ellipticoblong, 5-6 mm. long, narrowly winged : pappus of short fimbriate teeth.

In dry woods, Virginia to Alabama and Georgia. Summer. 
13. Coreopsis púlchra F. E. Boynton. Perennial. Stems erect, glabrous, 4-7 dm. high, striate, round or slightly angled and branched above, very leafy : leaves opposite ; blades palmately divided into linear segments, which are again subdivided, and appearing fascicled : internodes mostly shorter than the leaves: heads $3-4 \mathrm{~cm}$. broad including the rays : outer involucral bracts linear, obtuse, $5-6 \mathrm{~mm}$. long, the inner ovate, slightly longer than the outer: ligules elliptic-oblong, entire or slightly notched at the apex : chaff of the receptacle linear or with slightly dilated tips : achenes oblong-obovate, about $4 \mathrm{~mm}$. long, narrowly winged : pappus a minute lacerate border.

In rocky woodlands, northern Alabama. Summer.

14. Coreopsis latifòlia Michx. Perennial. Stems 1-1.5 m. high, slender, erect, branched near the summit, round, striate, pubescent or glabrate, leafy : leaves opposite; blades short-petioled, membranous, ovate to ovate-lanceolate, acuminate, cuneate at the base, $0.5-2 \mathrm{dm}$. long, 2-10 $\mathrm{cm}$. wide, coarsely toothed, the teeth apiculate: heads about $4 \mathrm{~cm}$. broad, including the rays : involucre narrowly campanulate, the outer bracts herbaceous, narrowly linear, obtuse, about $5 \mathrm{~mm}$. long, the inner bracts membranous, oblong, bluntly pointed, 6-9 mm. long : disk florets about twelve, yellow, about $12 \mathrm{~mm}$. long, including the exserted anthers : chaff of the receptacle linear, thin, obtuse : ray-flowers four or five ; ligules elliptic-oblong, entire or slightly toothed at the apex : achenes narrowly elliptic-oblong, wingless, about $7 \mathrm{~mm}$. long : pappus none.

On mountain slopes, North Carolina and East Tennessee. Summer.

15. Coreopsis tinctòria L. Annual, glabrous. Stems erect, $6-12 \mathrm{dm}$. high, round, striate, much branched, leafy throughout: leaves opposite; blades of the lower twice pinnately parted into linear-lanceolate or linear segments, blades of the upper leaves with few lateral linear divisions or undivided: heads numerous, $2-3 \mathrm{~cm}$. broad including the rays : outer involucral bracts triangular-lanceolate, about $2 \mathrm{~mm}$. long, the inner elliptic or ovate-lanceolate, 5-6 mm. long: ligules obovate, 3 -lobed at the apex : chaff of the receptacle linear, acute : achenes linear-oblong, about $2 \mathrm{~mm}$. long, wingless : pappus none.

In moist soil, Minnesota to the Northwest Territory, Louisiana and Arizona. Summer and fall.

16. Coreopsis Drummóndii (D. Don. ) T. \& G. Annual, pubescent with jointed hairs or nearly glabrous. Stems erect, $2-4 \mathrm{dm}$. high, grooved and striate, branched above : leaves opposite ; blades of all but the uppermost slender-petioled, ovate, oval or lanceolate ; the lower frequently simple, or, like those of the upper stem-leaves, divided into several elliptic-oblong or linear-lanceolate segments: heads terminating the branches, 3-4 cm. broad including the rays : exterior involucral bracts linear-lanceolate, $5-9 \mathrm{~mm}$. long, the inner ovate, slightly longer than the outer: ligules obovate, 3-lobed at the apex : chaff of the receptacle bottle-shaped, with obtuse tips: achenes obovate, about $2 \mathrm{~mm}$. long, convex on the back, the inner face bordered by a strongly incurved, cartilaginous margin : pappus none.

In dry soil, Texas. Summer.-C. Drummondii Wrightii A. Gray. A form with the divisions of the leaf-blades very narrow. In dry soil, western Texas and New Mexico.

17. Coreopsis ròsea Nutt. Perennial by slender rootstocks. Stems erect, $2-5 \mathrm{dm}$. high, round, striate or slightly angled above, branched, leafy : leaves opposite; blades linear, entire or somewhat two- or three-parted, connate-clasping at the sessile bases: heads about $2 \mathrm{~cm}$. broad, including the rays : outer involucral bracts lanceolate, $2-3 \mathrm{~mm}$. long, the inner ovate-oblong, about $5 \mathrm{~mm}$. long: ligules pink or occasionally white, oblong-obovate, slightly toothed at the apex : chaff of the receptacle linear, acute: achenes narrowly elliptic-oblong, about $2 \mathrm{~mm}$. long, wingless : pappus a slight coroniform border.

In moist or wet soil, Massachusetts to Georgia. Summer.

18. Coreopsis cardaminefòlia (DC.) T. \& G. Annual, glabrous. Stems erect, 2-5 $\mathrm{dm}$. high, round, striate, branched, leafy throughout : leaves opposite, remote, shorter than the internodes; blades of the lower ones once or twice pinnately divided into elliptic-oblong to linear-lanceolate segments; of the upper either few-lobed, or, simple and linear : heads about $2 \mathrm{~cm}$. broad, including the rays : outer involucral bracts lanceolate, 3-4 mm. long, inner ovate, about twice as long as the outer: ligules obovate, 3-lobed at the apex : chaff of the receptacle linear, acute : achenes elliptic-oblong, with a wing about one-third as broad as the body : pappus a pair of minute teeth, or none.

In low grounds, Texas and Kansas to Arizona. Summer.

19. Coreopsis stenophýlla F. E. Boynton. Annual, glabrous. Stems erect, stift and wiry, very leafy, branched : leaves opposite, erect or ascending, mostly longer than the internodes; blades of the lower petioled, sometimes $2 \mathrm{~mm}$. broad, simple or with one or two narrow lateral segments, those of the upper leaves narrowly linear to filiform, either simple or with one or more filiform lobes : heads $2-3 \mathrm{~cm}$. broad including the rays : exterior involucral bracts lanceolate, $1-2 \mathrm{~mm}$. long, the inner ovate, $5-6 \mathrm{~mm}$. long : ligules 
obovate, with three rounded lobes at the apex: chaff of the receptacle linear, acute: achenes elliptic-oblong, 1.5-2 $\mathrm{mm}$. long, bordered by a wing about one-third as broad as the body : pappus a pair of blunt teeth.

In pine lands, Louisiana. Summer and fall.

20. Coreopsis símilis F. E. Boynton. Annual, glabrous. Stems 1-3 dm. high, grooved and striate, branched : leaves opposite, various; blades of all but the upper ones slender-petioled, those of the lower leaves either divided into ovate or elliptic-oblong. segments ( the terminal one the larger and often $1 \mathrm{~cm}$. broad), or simple; those of the upper leaves with linear or linear-oblong segments : heads $2-2.5 \mathrm{~cm}$. broad including the rays: exterior involucral bracts subulate-lanceolate, about $2 \mathrm{~mm}$. long, the inner ovate, about 5 $\mathrm{mm}$. long : chaff of the receptacle linear, acute: ligules obovate, 3-lobed at the summit: achenes orbicular, $2-2.5 \mathrm{~mm}$. high, the wing as wide as the body : pappus a pair of slender awns.

In moist soil, Texas. Spring and summer.

21. Coreopsis Leavenwórthii T. \& G. Annual, glabrous. Stems erect, $5-15 \mathrm{dm}$. high, terete, striate, branched, leafy throughout: leaves opposite; the lower and middle stem-leaves with blades mostly divided into two or more narrowly linear segments, the upper mostly simple and very narrow : heads $2-3 \mathrm{~cm}$. broad including the rays : exterior involucral bracts subulate-lanceolate, 1-2 $\mathrm{mm}$. long, the inner ovate, 5-7 mm. long : ligules obovate, with three rounded lobes at the apex: chaff of the receptacle linear, acute : achenes roundish-oval, $2.5-3 \mathrm{~mm}$. long, the wing as broad as the body: pappus a pair of erect, slender awns.

In moist soil, Florida. Summer.-C. Leavenworthii Gárberi T. \& G. A form with the divisions of the leaf-blades much broader than the species. Possibly a distinct species. Florida.

22. Coreopsis Lewtònii Small. Perennial, glabrous. Stems slender, erect or ascending, 3-5 dm. high, round, striate, branched at the base : leaves opposite, approximate below, distant above ; blades linear or narrowly cuneate, 1-3 cm. long, simple and entire, longer than the slender petioles: heads $2.5-3 \mathrm{~cm}$. broad including the rays : exterior involucral bracts ovate-lanceolate, 1-1.5 mm. long, obtuse, the inner oblong or oblong-lanceolate, 5$6 \mathrm{~mm}$. long: ligules obovate or broadly cuneate, 3-lobed at the apex, the middle lobe notched : chaff of the receptacle linear, acute : achenes suborbicular, the wing as broad as the body : pappus a pair of slender awns.

In low, sandy soil, peninsular Florida. Summer.

23. Coreopsis angustif òlia Ait. Perennial, glabrous. Stems $5-7 \mathrm{dm}$. high, slender, erect, branched above, more or less 4-angled. striate: leaves opposite or sometimes the lower alternate, shorter or little longer than the internodes; blades of the basal and lower stem-leaves petioled, spatulate or oblanceolate, 4-9 $\mathrm{mm}$. broad, rounded at the apex; the upper sessile, linear, much reduced in size, or the upper ones mere subulate scales : heads $2-3 \mathrm{~cm}$. broad including the rays : outer involucral bracts ovate, rigid, $2-3 \mathrm{~mm}$. long, the inner ovate-lanceolate, $5-8 \mathrm{~mm}$. long: ligules obovate, 3-lobed at the apex, the middle lobe notched : chaff of the receptacle linear, acute : achenes broadly oval, $2.5-3 \mathrm{~mm}$. long, bordered by an irregularly lacerate wing: pappus a pair of slender awns.

In wet soil, North Carolina to Florida. Summer and fall.

24. Coreopsis longif òlia Small. Perennial, glabrous. Stems 7-10 dm. high, ereect, simple or sparingly branched at the summit, round, striate-grooved: leaves alternate, the basal and lower stem-leaves (including the petioles) much longer than the internodes, their blades linear-oblong, linear-lanceolate or linear, 2-10 $\mathrm{mm}$. broad, acutish, those of the upper stem-leaves sessile, reduced to inconspicuous scales : heads $3-4 \mathrm{~cm}$. broad including the rays: outer involucral bracts lanceolate, $2-4 \mathrm{~mm}$. long, the inner $2-3$ times longer than the outer, oblong-elliptic: ligules obovate, 3-lobed at the apex, the middle lobe rounded or notched : chaff of the receptacle linear, acute : achenes obovoid or spatulate in outline, about $4 \mathrm{~mm}$. long, bordered by a pectinate wing : pappus a pair of fugacious awns.

In low grounds, southern Georgia and Florida. Fall.

25. Coreopsis falcàta F. E. Boynton. Perennial, glabrous. Stems $8-12 \mathrm{dm}$. high, stout, erect, corymbosely branched near the summit, round, striate : leaves alternate, the basal and lower stem-leaves with petioles 1-1.5 dm. long, their blades scythe-shaped, 1-1.5 $\mathrm{dm}$. long, 1-2 cm. broad, tapering toward the apex, but terminating in an obtuse tip, entire or with one or more narrow, ascending lobes ; blades of the upper stem-leaves narrower, sessile, usually with two or more narrow, lateral lobes; those of the branches reduced and scale-like: heads $3-5 \mathrm{~cm}$. broad including the rays : outer involucral bracts lanceolate, 5-7 mm. long, the inner about one-third longer than the outer, elliptic-oblong to ovate : ligules obovate, 3 -lobed, the middle lobe rounded or notched : chaff of the receptacle linear, acute : achenes oblong, nearly $5 \mathrm{~mm}$. long, the broad wing cut into very fine fringe-like segments : pappus a pair of awns less than $1 \mathrm{~mm}$. long.

In swamps, eastern North Carolina. Early summer. 
26. Coreopsis gladiata Walt. Perennial. Stems erect, 6-12 dm. high, terete or slightly angled, striate, branched above, glabrous : leaves mostly alternate, the basal and lower stem-leaves petioled, their blades entire, elliptic-oblong to oblanceolate, 1-2 cm. broad, rounded at the apex; upper stem-leaves with sessile blades, abruptly reduced to small scales : heads $4-6 \mathrm{~mm}$. broad including the rays : outer involucral bracts broadly triangular, 3-4 mm. long, the inner ovate-lanceolate, 9-12 $\mathrm{mm}$. long : ligules obovate, 3-lobed at the apex, the middle lobe rounded or more commonly notched : chaff of the receptacle linear, acute : achenes elliptic-oblong, about $3.5 \mathrm{~mm}$. long, with a lacerate marginal wing : pappus a pair of slender awns.

In wet soil, North Carolina to Florida. Fall.

27. Coreopsis integrifòlia Poir. Perennial. Stems erect, 6-9 dm. high, round or somewhat angled and corymbosely branched above, striate, leafy throughout: leaves opposite ; blades entire, glabrous at maturity, the margins and midrib as well as the edges of the petioles, ciliate, at least when young, basal and lower stem-leaves petioled, their blades ovate, acute ; of the upper stem-leaves short-connate, petioled or sessile, ovate to ellipticoblong, gradually reduced in size upward : heads $3-4 \mathrm{~cm}$. broad including the rays : outer involucral bracts oblong, 4-6 mm. long, obtuse, ciliate; the inner about twice as long as the outer, ovate, bluntly pointed : ray-flowers about 8 ; ligules obovate, 3 -lobed at the apex.

In moist soil, Georgia and Florida. Fall.

28. Coreopsis helianthoides Beadle. Perennial. Stems erect, $5-12 \mathrm{dm}$. high, glabrons, furrowed, freely branched above the middle : leaves alternate, sparingly pubescent with jointed hairs ; blades of the basal and lower stem-leaves long-petioled, entire, ovate to ovate-lanceolate, $2-6 \mathrm{~cm}$. broad, acute, scarious-margined; blades of the upper stemleaves abruptly reduced, becoming mere scales on the branches: heads $3-4 \mathrm{~cm}$. broad including the rays : outer involucral bracts lanceolate, 5-9 mm. long, the inner ovate, 8-12 $\mathrm{mm}$. long: ray-flowers about 8 ; ligules 3 -lobed, the middle lobe rounded or notched: achenes oblong-spatulate, about $3 \mathrm{~mm}$. long, bordered by a narrow irregularly pectinate wing : pappus a pair of short awns.

In low grounds, southern Georgia and northern Florida. Fall.

29. Coreopsis nudàta Nutt. Perennial, glabrous throughout. Stems erect, 6-12 $\mathrm{dm}$. high, terete, flexuous, striate, corymbosely-branched near the summit: leaves terete, rush-like ; the basal and lower stem-leaves 7-30 cm. long, the upper stem-leaves subulate, minute : heads $4-6 \mathrm{~cm}$. broad including the rays : outer involucral bracts lanceolate, 4-6 $\mathrm{mm}$. long, the inner ovate, about $1 \mathrm{~cm}$. long: ligules pink, obovate-cuneate, with three rounded lobes at the apex : achenes oblong-elliptic, about $3 \mathrm{~mm}$. long, bordered by an irregularly lacerate wing : pappus a pair of minute awns.

In wet pine lands, southern Georgia and Florida. Spring and summer.

\section{BIDENS L. ${ }^{1}$}

Erect branching herbs, ours all annual or biennial. Leaves opposite, or the upper sometimes alternate: blades simple or divided. Heads numerous, radiate or rarely discoid, each with a double involucre, the outer one foliaceous, the inner scarious and appressed. Receptacle flat or nearly so, chaffy. Ray-flowers neutral, the ligules white or yellow. Disk-flowers perfect, fruit-producing. Achenes firm, flat, 4-angled or nearly terete, beakless. Pappus of 2-4 rigid barbed awns or teeth, or rarely none. BEgGar-Ticks. BurMARIGOLD.

Achenes spindle-shaped, gradually tapering above: ligules of the ray-flowers nearly white.

Leaves 1-3-pinnately dissected, the divisions incised or lobed ; ray-flowers with inconspicuous, en-

tire ligules.
Leaves 1-pinnate or undivided, the segments regularly serrate : ray-flowers with

showy and lobed ligules.
Achenes flattened, broadest above the middle: ligules of the ray-flowers yellow.

Rays inconspicuous and caducous or wanting.

Leaves usually undivided: pappus-awns 3 or 4 .

Disk-corollas pale, 4-lobed: achene-margins strongly, retrorsely barbed

throughout; involucre long.
Disk-corollas orange, 5 -lobed: barbs of the achene-margins few, directed both ways : involucre short.

Leaves 3-5-divided: pappus-awns 2 .

Awns long, usually retrorsely barbed : achenes $6-8 \mathrm{~mm}$. long.

Outer involucral bracts 10-16, ciliate, the inner constricted at the tip:

corollas pale.
Outer bracts $6-8$, nearly glabrous, the inner not constricted : corollas

orange.
Awns short, erect-barbed : achenes $4.5 \mathrm{~mm}$. long : leaf-blades long-acuminate.

1. B. bipinnata.

2. B. leucantha.

3. B. comosa.

4. B. connata.

5. B. vulgata.

6. B. frondosa.

7. B. discoidea.

${ }^{1}$ Contributed by Dr. Karl M. Wiegand. 
Rays showy or conspicuous.

Leaf-blades undivided: pappus awns 2-4, retrorsely barbed.

Outer involucral bracts exceeding the disk, foliaceous: ray-flowers with ligules twice the length of disk or less : achenes dilated at the summit.

Outer bracts rarely exceeding the disk : ray-flowers with ligules 2-4 times the length of disk: achenes not dilated above.

Leaf-blades lanceolate, sharply serrate, not fleshy.

Leaf-blades elliptical or oblanceolate, minutely serrate, slightly fleshy. 10 . B. Nashii.

Leaf-blades pinnately divided: pappus-awns 2 or none.

Achenes 6-8 mm. long, ciliate:

In fruit broadly obovate.

Involucres nearly glabrous : pappus-awns slender or wanting.

Involucres hispid : achenes bidentulate.

In fruit narrowly cuneate-oblong, $2-2.5 \mathrm{~mm}$. wide, short-awned.

Achenes 2-4 mm. long, not ciliate, bidentulate or naked.

8. B. cernua.

9. B. laevis.

11. B. aristosa.

12. B. involucrata.

13. B. trichosperma.

14. B. coronata.

1. Bidens bipinnàta L. Stem glabrous or nearly so, 4-angled, branched and rather slender, 3-17 dm. high : primary leaf-segments thin, deltoid, the ultimate one lanceolate, incised or lobed: outer involucral bracts 7-10, linear, shorter than the acute inner ones: rays few, the ovaries awnless and glabrous, the ligules yellowish white, about equalling the disk, mostly entire : disk-corolla 5-lobed: stamens included : achenes spindle-shaped, in fruit much longer than the involucre, the outer slightly shorter ; awns $3-4$, yellow, retrorsely barbed.

In damp soil, often a weed, Rhode Island to Nebraska, Florida and Arizona. Also in Mexico and tropical America. Summer and fall.

2. Bidens leucántha (L.) Willd. Stem branched, 4-10 dm. high, nearly or quite glabrous: leaves firm, the segments ovate, or ovate-lanceolate, 2-8 cm. long, evenly crenate-serrate : outer bracts of the involucre about 8 , linear-oblong, usually shorter than the inner: rays white, the ligules $1-2 \mathrm{~cm}$. long, broadly cuneate, $2-3$-lobed, the ovaries awnless and few-barbed above : disk-corollas 5-toothed : stamens barely exserted : achenes in fruit spindle-shaped, very unequal, the inner much longer than the involucre; awns $2-4$, short, yellow, retrorsely barbed.

In sandy soil, common in waste places, Florida. Also in the West Indies and Mexico, and widely distributed in tropical countries.

3. Bidens comòsa (A. Gray) Wiegand. Stem pale throughout, stout, $3-8 \mathrm{dm}$. high, glabrous, the branches short, stout : leaves undivided, $8 \mathrm{~cm}$. long, elliptic-lanceolate, regularly serrate, acute, each attenuate into a margined petiole, or the upper sessile : heads large : peduncles short and stout : outer bracts of the involucre $6-8$, often 2-5 times the length of the disk, erect : rays wanting : disk-corollas funnelform, pale yellow, 4-lobed : stamens included : achenes large and flat, $8-10 \mathrm{~mm}$. long, $3 \mathrm{~mm}$. wide, brown or olive, nearly smooth and glabrous, the margins to the base, the 3 long awns retrorsely barbed.

In damp soil, Maine to Minnesota, Colorado, Georgia and Louisiana. Fall.

4. Bidens connàta Muhl. Stem tall, sparingly branched, $3-14 \mathrm{dm}$. high, glabrous, bright-green : leaf-blades undivided or some of the lower deeply parted, lanceolate to elliptical, acuminate, tapering to the petiole, coarsely and saliently serrate : heads medium; outer bracts of the involucre 4-5, linear-spatulate, rarely exceeding the disk, glabrous : rays rarely present, the ligules one-half longer than the disk, the ovaries awnless, and hairy: disk-corollas campanulate above, 5-lobed, orange : achenes 4-6 $\mathrm{mm}$. long, rather narrow and thick, nearly black, covered with yellowish warts; some or all marginal barbs erect; awns 4 , slender, with erect or retrorse barbs.

In swamps, New Hampshire to Minnesota, North Carolina and Missouri. Fall.

5. Bidens vulgàta Greene. Stem tall, much branched, nearly glabrous : leaf-blades commonly 5-divided, the segments lanceolate, straight-veined, acute, serrate with numerous regular sharp or bluntish teeth: heads large, 15-25 mm. wide: outer bracts of the involucre $10-16$, unequal, usually longer than the disk, ciliate, the inner with abruptly narrowed tips: rays pale-yellow, the ligules equaling the disk, the ovaries awnless and nearly glabrous: disk-corollas funnelform, pale, 4-5-lobed: stamens included : achenes large, 7.5-9 mm. long, 4.5-5 mm. wide, very flat, brown or olive, nearly smooth, the 2 long awns and the upper part of the achene-margins retrorsely barbed.

In damp soil, Ontario to British Columbia, North Carolina, Míssouri and California. Fall.

6. Bidens frondòsa $L$. Stem slender, bushy-branched, nearly glabrous, $5-10 \mathrm{dm}$. high or more : leaf-blades pinnately 3 -divided or rarely 5-divided, the segments lanceolate, serrate with sharp spreading teeth, acuminate : heads not large: outer bracts of the involucre $6-8$, subequal, spatulate, sparsely ciliate, usually exceeding the disk: rays usually present, golden yellow, the ligules equaling the disk, the ovaries hairy and with 2 short retrorsely barbed awns: disk-corollas orange, 5-lobed : stamens exserted : achenes black, $6 \mathrm{~mm}$. long, $3.25 \mathrm{~mm}$. wide, cuneate, flattish, sparsely hairy and often tuberculate, the barbs on the margins erect, those on the 2 awns either erect or reflexed.

In damp soil, often a weed, New Brunswick to Nebraska, Florida and Texas. Summer and fall. 
7. Bidens discoìdea (T. \& G.) Britton. Stem slender, diffusely branched, nearly or quite glabrous, 3-15 dm. high : leaf-blades 3-divided, the segments lanceolate or ovatelanceolate, 4-9 $\mathrm{cm}$. long, sharply and coarsely serrate below the entire long-acuminate tip : heads very small and numerous, $8-10 \mathrm{~mm}$. broad : outer bracts of the involucre mostly 4, spatulate-linear, rarely exceeding the disk, glabrous : rays none: disk-corollas orange, 5-lobed : achenes small, 4-5.5 mm. long, black, cuneate, thickish, tuberculate or nearly smooth, hairy, the margins and the 2 short awns erect-barbed. [Coreopsis discoidea T. \& G.]

In swamps, Massachusetts to Michigan, North Carolina and Texas. Late summer and fall.

8. Bidens cèrnua L. Stem low, pale green, 2-7 dm. high, nearly glabrous, the branches very short, decreasing down the stem: leaf-blades undivided, 6-16 cm. long, lanceolate or linear-lanceolate, more or less connate by the broad bases, acuminate, serrate, with coarse distant teeth : heads very large, broader than high, nodding in fruit: outer bracts of the involucre $7-8$, unequal, exceeding the disk and spreading: rays usually present, bright yellow, the ligules about one-half longer than the disk, the ovaries glabrous except the margin, and awnless : disk-corollas orange, 5-lobed : achenes narrowly cuneate, slightly dilated at the summit, 4-angled, the margins retrorsely barbed and tuberculate, the awns 4 , slender, retrorsely barbed.

In swamps, Nova Scotia to North Carolina, Missouri and Oregon. Also in Europe and Asia. Summer and fall.

9. Bidens laèvis (L.) B.S.P. Stem glabrous, 5-10 $\mathrm{mm}$. high, the branches all toward the summit of the stem, slender, ascending: leaf-blades undivided, $7-13 \mathrm{~cm}$. long, elliptic-lanceolate, serrate with small inconspicuous teeth, acute, contracted toward the sessile base : heads medium, nearly globular, erect or nodding in fruit : outer bracts of the involucre $7-8$, rarely longer than the disk: rays very large, the ligules $2-3 \mathrm{~cm}$. long, golden yellow, the ovaries as in the last : disk-corollas orange, 5 -lobed : achenes cuneate, neither dilated nor contracted at the top, not tuberculate, the margins and 2-4 awns retrorsely barbed. [B. chrysanthemoides Michx.]

In swamps, mainly near the coast, Massachusetts to Georgia. Summer and fall.

10. Bidens Náshii Small. Similar to the next preceding species but slightly succulent, less branched : leaves ascending; blades broader and thicker, oblong-lanceolate or oblanceolate, with very broad but scarcely connate bases, finely serrate or entire : achenes slightly contracted at the summit.

In swamps, Florida to Texas. Summer and fall.

11. Bidens aristòsa (Michx.) Britton. Annual or biennial, much branched, 3-10 $\mathrm{dm}$. high : leaf-blades pinnately 5-7-divided, the segments lanceolate, acuminate, serrate, incised or pinnatifid, slightly pubescent beneath : heads numerous, $2-5 \mathrm{~cm}$. broad : outer bracts of the involucre 8-10, linear-spatulate, rarely ciliate, not surpassing the inner: rays $6-10$, the ligules golden yellow, the ovaries ciliate and awnless : achenes obovoid, flat, strigose and hispid-ciliate; awns 2, slender, as long as the achene-body or shorter, the barbs erect or reflexed. [Coreopsis aristosa Michx.]

In swamps, Illinois to Kansas, Arkansas and Texas. Summer and fall. $-B$. aristosa mùtica (A. Gray) Wiegand. A form with pappus-awns wanting. Mississippi and Louisiana.

12. Bidens involucràta (Nutt.) Britton. Annual or biennial, much branched, 3-10 dm. high, minutely pubescent; leaf-blades pinnately divided, the segments narrow, linear-lanceolate, incised or pinnatifid, long-acuminate : heads $3-5 \mathrm{~cm}$. broad : outer bracts of the involucre 12-20, linear, acutish, hispid on back and margins, mostly surpassing the inner : rays several, the ligules golden yellow, the ovaries awnless, ciliate throughout : disk-corollas 5-lobed : stamens exserted : achenes very flat, obovoid, slightly contracted at the top, strigose-ciliate, bidentulate. [Coreopsis involucrata Nutt.]

In swamps, Illinois to Kansas, Arkansas and Texas. Also in Delaware. Summer and fall.

13. Bidens trichospérma (Michx.) Britton. Annual or biennial, tall and glabrous, much branched, $6-15 \mathrm{dm}$. high : leaf-blades pinnately divided, with 4-8 narrowly lanceolate, serrate or incised, acute or acuminate segments : heads 4-6 cm. broad: outer bracts of the involucre linear-spatulate, rarely ciliate, equalling the disk: rays several, the ligules bright yellow, 12-25 $\mathrm{mm}$. long, the ovaries bidentulate at the summit : disk-corollas deep yellow, 5-lobed: stamens exserted: achenes narrowly cuneate, slightly strigoseciliate above; awns 2, about equalling the breadth of the achene, erect-barbed. [Coreopsis trichosperma Michx.]

In swamps, Masachusetts to Illinois, Kentucky and Georgia. Summer and fall.

14. Bidens coronàta (L.) Fisch. Annual, glabrous or nearly so, branched, 3-10 dm. high : leaf-blades 7-12 cm. long, 3-5-divided or rarely mostly simple, the segments lanceolate, acuminate, serrate, the lateral much smaller : heads $2-5 \mathrm{~cm}$. broad : outer bracts 
of the involucre linear-spatulate, equalling the disk, glabrous, the inner usually blackpunctate : rays several, the ligules $1-3 \mathrm{~cm}$. long, golden yellow, the ovaries glabrous and awnless : disk-corollas 5-lobed: stamens exserted: achenes very small, 2-4 mm. long, glabrous; awns very short, tooth-like. [Coreopsis aurea Ait.]

In wet soil, Virginia to Florida and Alabama. Summer and fall-B. coronata leptophýlla (Nutt.) C. Mohr, a form with narrowly linear and almost or quite entire leaf-segments : and awnless achenes, occurs in brackish places from Florida north ward.

\section{Cósmos Cav.}

Annual or perennial caulescent herbs. Leaves opposite: blades entire, lobed or 2-3pinnately dissected. Heads radiate, peduncled. Involucres nearly hemispheric : bracts thin, imbricated in two series and united at the base, the outer sometimes smaller than the inner. Receptacle flat or scarcely convex. Ray-flowers neutral : ligules pink, purple (or rarely orange-yellow). Disk-flowers perfect, fruit-producing : corollas yellow. Anthers entire or minutely 2-toothed at the base. Stigmas of the disk-flower with slender or tufted appendage. Achenes 5-angled or flattened on the back, beaked. Pappus of 2-4 more or less persistent barbed awns or a crown.

1. Cosmos caudàtus H.B.K. Annual, glabrous or nearly so. Stems 7-14 dm. tall, branched: leaf-blades 2-pinnately parted, the segments lanceolate or linear: involucral bracts linear, acute, the inner often longer than the outer : ray-flowers 7-12; ligules rosecolored, 1-2 cm. long, 3-cleft : achenes fusiform, about $2 \mathrm{~mm}$. long, the beak about as long as the body, with 2 awns.

In sand, Keys of Florida. Native of tropical America.

\section{THELESPÉRMA Less.}

Annual or perennial herbs, with glabrous or nearly glabrous foliage. Leaves opposite : blades narrow, entire, toothed or finely dissected. Heads radiate or sometimes discoid, peduncled. Involucres campanulate or hemispheric : bracts in two series, the outer distinct, spreading, the inner larger, partially united into a cup, the tips scarious. Receptacle flat, chaffy. Ray-flowers neutral : ligules yellow, or wanting. Disk-flowers perfect, fruit-producing. Anthers entire at the base. Stigmas with acute cones or cusps. Achenes narrow, terete or slightly flattened, wingless, some or all of them papillose on the back. Pappus of two retrorsely hispid awns or scales, or wanting.

Disk-corollas with linear or lanceolate lobes longer than the campanulate throat. Annual or biennial : outer involucral bracts linear-subulate.

Perennial : outer involucral bracts ovate or oblong.

Disk-corollas with ovate or oblong lobes, shorter than the cylindric throat.

1. T. trifidum.

2. T. gracile.

3. T. subsimplicifolium.

1. Thelesperma trífidum (Poir.) Britton. Annual or biennial. Stems $2-7 \mathrm{dm}$. tall, loosely branched : leaf-blades 3-10 cm. long, 2-pinnately divided, the segments linearfiliform or filiform, not broader than the rachis: involucral bracts various, the outer linear-subulate, the inner united to the middle, usually fully as long as the outer : rayflowers 6-9; ligules yellow, 1-1.5 cm. long: disk purple, turning brown : achenes of the outer part of the disk $4 \mathrm{~mm}$. long, strongly papillose on the back : pappus-scales triangularsubulate, as long as the width of the achene.

On dry hills and plains, Arkansas and Texas. Spring and summer.

2. Thelesperma grácile (Torr.) A. Gray. Perennial. Stems 3-8 dm. tall, sparingly branched : leaf-blades 3-7 dm. long; blades 1-2-parted or divided, the segments entire, filiform or narrowly linear : involucral bracts various, the outer 4-6, ovate or oblong, the inner united to above the middle; ligules of the ray-flowers yellow, 4-6 mm. long, or wanting: disk yellow, turning brown: achenes $6-6.5 \mathrm{~mm}$. long, the slender awns longer than the width of the achenes.

On plains, Wyoming to Nebraska, Texas and Arizona. Spring and summer.

3. Thelesperma subsimplicifolium A. Gray. Perennial. Stems $3-7 \mathrm{dm}$. tall, loosely branched : leaf-blades $3-8 \mathrm{~cm}$. long, entire and narrowly linear or linear-filiform, or 3-5-parted, the segments as wide as the rachis entire: involucral bracts various, the outer linear to oblong, the inner united to about the middle: ligules of the ray-flowers yellow, cuneate, $10-12 \mathrm{~mm}$. long : achenes fusiform, 4-5 mm. long: pappus obsolete, or of 2 minute pubescent teeth.

In dry or stony soil, Texas to Arizona and adjacent Mexico. Spring and summer. 


\section{ENDORIMA Raf.}

Perennial caulescent sometimes sparingly branched herbs. Leaves alternate, somewhat fleshy : blades narrow, entire, sessile. Heads long-peduncled, conspicuous. Involucre many-flowered. Receptacle convex-conic, covered with a honey-combed body formed by the concreted bractlets. Ray-flowers numerous, in 1 series, neutral, the ligules narrow. Disk-flowers perfect, fruit-producing. Anthers sagittate. Stigmas flattish, each with a crown of hairs and a subulate appendage. Achenes immersed in the pits of the receptacle. Pappus of 7-9 oblong-lanceolate nerveless scales in a single series. [Baldwinia Nutt.]

Disk dark purple: lower cauline leaves $10-12 \mathrm{~cm}$. long.

Disk yellow: lower cauline leaves $4-6 \mathrm{~cm}$. long.

1. Endorima atropurpùrea (Harper) Small. Stems 6-8 dm. tall, simple or with 1-7 erect branches : leaf-blades linear-spatulate, the lower ones 10-12 cm. long, the upper gradually shorter: involucre nearly as in the following species: ray-flowers numerous; ligules spatulate, 3-4 cm. long, 2-3-toothed at the apex, pale yellow : disk-corollas dark purple : achene and pappus nearly like that of E. uniflora. [Baldwinia atropurpurea Harper.]

In moist pine lands, southern Georgia. Fall.

2. Endorima uniflòra (Nutt.) Barnhart. Stems 3-9 dm. tall, simple or rarely branched. Leaf-blades spatulate to linear, 1-6 cm. long, obtuse, entire, 1-1.5 mm. high : involucral bracts ovate to oblong-lanceolate, acute in about 4 series : ray-flowers $20-30$; ligules yellow, linear-cuneate or tubular, over $2.5 \mathrm{~cm}$. long, usually 3-toothed at the apex : diskcorollas yellow, 5-6 mm. long: achenes cylindric-obconic, $2 \mathrm{~mm}$. long, with 7-9 oblong pappus-scales. [Baldwinia uniflora Nutt.]

In low pine lands, South Carolina to Florida and Louisiana. Summer and fall.

\section{ACTINOSPÉRMUM Ell.}

Annual, biennial or perennial caulescent herbs. Leaves alternate : blades flat, narrow, entire. Heads radiate, solitary or corymbose. Involucres hemispheric: bracts imbricated in several series, appressed, the inner longer than the outer. Receptacle convex, covered with the concreted bractlets and honey-combed. Ray-flowers neutral: ligules yellow. Disk-flowers perfect, fruit-producing. Anthers sagittate at the base. Stigmas flattened, each with a crown of hairs and a subulate appendage. Achenes broadened upward, silky villous. Pappus of 7-12 scarious obovate-orbicular nerveless scales.

1. Actinospermum angustifollium (Pursh) T. \& G. Stems $2-5 \mathrm{dm}$. tall, branching above. Leaf-blades narrowly linear or slightly broadened upward, 1-4 $\mathrm{cm}$. long, acute, entire : heads showy, 6-10 mm. high : involucral bracts lanceolate to linear, acuminate : ray-flowers 8-10; ligules bright yellow, cuneate, less than $2 \mathrm{~cm}$. long, 3-4-toothed at the apex : disk-corollas 4-4.5 $\mathrm{mm}$. long: achenes turbinate, $2 \mathrm{~mm}$. long, each with about 12 obovate or suborbicular pappus-scales.

On sand hills and in pine lands, Georgia and Florida. Summer and fall.

\section{MARSHÁLIIA Schreb.}

Perennial caulescent herbs. Leaves alternate : blades simple, flat, entire, more or less distinctly 3-nerved. Heads discoid, long-peduncled. Involucres mostly campanulate, or hemispheric : bracts narrow, nearly equal, in 1 or 2 series. Receptacle convex, sometimes becoming conic, chaffy. Ray-flowers wanting. Disk-flowers perfect, fruit-producing: corollas white, pink or purple, the tube very slender. Anthers minutely sagittate at the base. Stigmas elongated, truncate. Achenes broadened upward, 5-angled. Pappus of 5 or 6 acute or acuminate nearly equal scales.

Bracts of the involucre attenuate or subulate-tipped.

Basal and lower cauline leaves with elongated linear-attenuate 3-ribbed blades.

Heads few-flowered: longer involucral bracts less than $6 \mathrm{~mm}$. long: pappus-scales ovate.

Heads many-flowered: longer involucral bracts over $6 \mathrm{~mm}$. long: pappusscales lanceolate.

Basal and lower cauline leaves with spatulate, oblong or oblong-ovate, obtuse blades.

Bracts of the involucre obtuse or merely acute, or apiculate.

A. Corolla-tube not swollen into a throat.

Bractlets of the receptacle spatulate.

Bractlets of the receptacle linear.

Pappus-scales mainly over $2 \mathrm{~mm}$. long.

Pappus-scales mainly less than $2 \mathrm{~mm}$. long.

1. M. laciniarioides.

2. M. Williamsonii.

3. M. graminifolia.

4. M. obovata.

5. M. caespitosa. 
Involucral bracts oblong, apiculate: achene $1.5 \mathrm{~mm}$. long: cauline leaves relatively many and narrow.

Involucral bracts oblong-elliptic or elliptic-lanceolate, acute : achene 2.5-3 mm. long: cauline leaves few and broad.

B. Corolla-tube swollen into a throat.

Upper cauline leaves greatly reduced: achenes $4-5 \mathrm{~mm}$. long.

Upper cauline leaves not much reduced : achenes about $2 \mathrm{~mm}$. long.

6. M. ramosa.

7. M. Mohrii.

8. M. grandiflora.

9. M. trinervia.

1. Marshallia laciniarioìdes Small. Stems 3-4 dm. tall, often sparingly branched above, leafy to near the top: leaves numerous, the basal and those on the lower part of the stem 10-12 cm. long, with linear, or sometimes broadly linear blades, which are attenuate at both ends, prominently 3-ribbed, entire ; upper stem-leaves narrowly linear, sessile : peduncles slender: heads few-flowered : involucres about $5 \mathrm{~mm}$. high ; bracts rigid, attenuate, winged below the middle: corolla-tube less than $5 \mathrm{~mm}$. long, villous : achenes $1-1.5 \mathrm{~mm}$. long.

In the low country, North Carolina to Georgia. Summer.

2. Marshallia Williamsònli Small. Similar to $M$. laciniarioides in habit, but about twice as large. Leaves fewer: heads many-flowered : involucres about $8 \mathrm{~mm}$. high ; bracts attenuate, the longer ones mainly over $6 \mathrm{~mm}$. long: corolla-tube over $5 \mathrm{~mm}$. long: achenes 2.5-3 mm. long.

In open woods, eastern North and South Carolina. Spring to fall.

3. Marshallia graminifolia (Walt.) Small. Stems $2-7 \mathrm{dm}$. tall, simple or branching above : leaves alternate; blades $2-8 \mathrm{~cm}$. long, spatulate to oblong, oblong-ovate at the base of the stem, to narrowly linear above, entire: involucres many-flowered; bracts linearlanceolate to linear-elliptic, slender-tipped : corolla-tube 5-6 mm. long: achenes $1-1.5 \mathrm{~mm}$. long, often glabrate at maturity, longer than the pappus.

In pine lands, North Carolina to Florida and Louisiana. Summer.-The form with a simple stem and a small head, is $M$. graminifolia cyananthera (Ell.) Beadle \& Boynton.

4. Marshallia obovàta (Walt.) Beadle \& Boynton. Stems 1-3 dm. tall, usually simple : leaves mainly at or near the base of the stem; blades spatulate to oblong or linear-spatulate, 1-5 cm. long, or those above the base of the stem longer $(5-10 \mathrm{~cm}$. $)$ : peduncles pubescent under the heads, greatly elongated : involucres many-flowered; bracts oblong or obtuse, $7-8 \mathrm{~mm}$. long : corolla-tube $7-8 \mathrm{~mm}$. long, tomentulose : achenes turbinate, 2 $\mathrm{mm}$. long, pubescent, much longer than the pappus.

In open woods, North Carolina to Florida and Alabama. Spring and summer.-The more common form is M. obovata platyphýlla (M. A. Curtis) Beadle \& Boynton; it is represented by larger plants commonly 4-6 dm. tall, with the stem often as long as the peduncle, longer and broader leaf-blades and larger heads.

5. Marshallia caespitòsa Nutt. Stems $2-4 \mathrm{dm}$. tall, often tufted, simple or sparingly branched : leaves mainly at the base of the stem; blades spatulate or linear-spatulate to linear-lanceolate or linear, 2-10 $\mathrm{cm}$. long, acute, entire : peduncles greatly elongated, pubescent under the heads : involucres many-flowered: bracts narrowly linear-lanceolate acute, 7-9 $\mathrm{mm}$. long: corolla-tube $6-7.5 \mathrm{~mm}$. long, tomentulose : achenes obpyramidal, 2-2.5 mm. long, pubescent on the angles, shorter than the pappus.

In calcareous soil, Kansas to Arkansas, Louisiana and Texas. Spring and summer.-M. cutspitosu signata Beadle \& Boynton, is usually branched, and with the stem or branches as long as the peduncles longer.

6. Marshallia ramòsa Beadle \& Boynton. Stems 1.5-2 dm. tall, sometimes clustered, corymbosely much-branched above : leaves relatively numerous, the basal and lower cauline 5-15 cm. long, with linear-spatulate or nearly linear blades narrowed into petiole-like bases, upper cauline leaves more nearly linear : peduncles slender : heads many-flowered : involucres 4-6 $\mathrm{mm}$. high; bracts oblong, rounded and minutely apiculate at the apex : corolla-tube about $5 \mathrm{~mm}$. long: achenes about $1.5 \mathrm{~mm}$. long: pappus-scales shorter than the achene, lacerate above.

In moist pine lands, southern Georgia. Spring and summer.

7. Marshallia Mòhrii Beadle \& Boynton. Stem 4-7 dm. tall, simple or with several short branches near the top: leaves few, the basal and lower cauline $1-2.5 \mathrm{dm}$. long, with narrowly oblong, narrowly elliptic or somewhat ispatulate 3-ribbed blades narrowed into petiole-like bases, upper cauline leaves remote, with oblong or lanceolate sessile blades: heads slender-peduncled, several- to many-flowered : involucres 5-8 mm. high; bracts oblong-elliptic to narrowly elliptic-lanceolate, acute : corolla-tube about $7 \mathrm{~mm}$. long : achenes 2.5-3 mm. long: pappus-scales about $2 \mathrm{~mm}$. long, sharply few-toothed. summer.

In moist soil or pine woods, in the Lookout Mountain region, Georgia and Alabama. Spring and

8. Marshallia grandiflòra Beadle \& Boynton. Stem 3.5-7 dm. tall, usually simple : leaves few, the basal and lower cauline $5-30 \mathrm{~cm}$. long, with spatulate, oblong or elliptic 
3-5-ribbed thick blades, narrowed into petiole-like bases, upper cauline leaves rather remote, much reduced : heads long-peduncled, many-flowered : involucre 7-10 $\mathrm{mm}$. high ; bracts nearly oblong, or oblong-lanceolate, acute : corolla-tube about $10 \mathrm{~mm}$. long, the upper third dilated into a throat: achenes $3.5-5 \mathrm{~mm}$. long : pappus-scales about $\frac{1}{2}$ as long as the achene, entire.

In moist soil, in the mountains, Pennsylvania to West Virginia and North Carolina. Summer.

9. Marshallia trinérvia (Walt.) Porter. Stem 3-7 dm. tall, usually simple: leaves few, the basal and lower cauline 5-12 cm. long with mainly spatulate or oblanceolate thin 3 -ribbed blades, the upper cauline slightly smaller than the lower, elliptic, ovate or ovatelanceolate, distinctly 3-ribbed : heads long-peduncled, many-flowered : involucre about 1 $\mathrm{cm}$. high ; bracts linear-lanceolate, decidedly acute : corolla-tube 7-8 $\mathrm{mm}$. long, the upper third or fourth dilated into a throat: achenes $2-2.5 \mathrm{~mm}$. long: pappus fully $\frac{1}{2}$ as long as the achene, entire.

In dry or moist soil, Virginia to Tennessee, Alabama and Mississippi. Spring and summer.

\section{GALINSÒGA R. \& P.}

Annual caulescent herbs. Leaves opposite : blades simple, toothed. Heads radiate, inconspicuous. Involucres campanulate or hemispheric : bracts imbricated in two series, thin, the inner sometimes longer than the outer. Receptacle conic, or somewhat elongated, chaffy. Ray-flowers 4-5, pistillate, fruit-producing: ligules white, very short. Disk-flowers perfect, fruit-producing: corollas yellow. Anthers sagittate at the base. Stigmas with acute appendages. Achenes broadened upward, 4-5-angled, or the outer ones slightly flattened. Pappus various; that of the ray of several bristles, or wanting; that of the disk of several lacerate or fimbriate scales.

1. Galinsoga parviflòra Cav. Foliage hispidulous or glabrate. Stems 1-7 dm. tall, succulent, often branched : leaf-blades ovate to ovate-lanceolate, $2-5 \mathrm{~cm}$. long, acute, serrate-dentate or undulate, petioled : heads inconspicuous : involucres campanulate, 2-2.5 $\mathrm{mm}$. high ; bracts ovate, ciliate : ray-flowers few ; ligules white, $1-1.5 \mathrm{~mm}$. long, the segments ovate : achenes cuneate, barely $2 \mathrm{~mm}$. long, the inner ones with 8-15 pappus scales.

In waste places, Massachusetts to Oregon, Georgia and Mexico. Naturalized from South America.

\section{TRIDAX L.}

Perennial caulescent herbs, usually branched at the base. Leaves opposite: blades incised-toothed or pinnately dissected into narrow segments. Heads heterogamous, longpeduncled, radiate. Involucre ovoid to campanulate : bracts in few series. Receptacle flat or somewhat convex, chaffy. Ray-flowers pistillate, fruit-producing. Disk-flowers perfect, fruit-producing. Anthers auricled-sagittate at the base. Stigmas of the perfect flowers pubescent at the apex and with subulate appendages. Achenes broadened upward, usually pubescent. Pappus of numerous aristate-aeuminate plumose-ciliate scales.

1. Tridax procúmbens L. Stem branched at the base, the branches spreading or decumbent, more or less hirsute : leaf-blades ovate in outline, 2-5 cm. long, acute, incised or incised-lobed, copiously pubescent, cuneate at the base : peduncles mostly $2-3 \mathrm{dm}$. long : involucres solitary, 5-7 $\mathrm{mm}$. high : bracts hispidulous, the outer lanceolate, acuminate, the inner broadly oblong or oblong-obovate, mucronate: disk almost $1 \mathrm{~cm}$. broad at maturity : achenes silky, $2 \mathrm{~mm}$. long.

In sand or coral rock, Florida Keys. Native of tropical America.

\section{CLÁPPIA A. Gray.}

Perennial shrubby but fleshy plants. Leaves alternate : blades entire or pinnately 3-5-parted. Heads radiate, peduncled. Involucres hemispheric : bracts leathery, imbricated in 2-3 series, broad, obtuse. Receptacle convex, bristly-fimbrillate. Ray-flowers 12-15, pistillate, fruit-producing : ligules narrow, yellow. Disk-flowers perfect, fruit-producing. Anthers entire at the base. Stigmas of the disk with triangular appendages. Achenes narrow, terete, 8-10-nerved, hairy on the nerves. Pappus of 20-25 scale-like hispidulous bristles longer than the achene.

1. Clappia suaedaef òlia A. Gray. Shrubby, glabrous. Stems $2-4 \mathrm{dm}$. tall, widely branched : leaf-blades linear, terete, $1-1.5 \mathrm{~cm}$. long, entire or the lower ones pinnately 3-5-parted, sessile : heads solitary : involucre $6-8 \mathrm{~mm}$. high ; bracts narrow, soon reflexed : 
achenes 3-3.5 mm. long, hispidulous: pappus sordid, the bristles much longer than the achene.

In sandy soil, southern Texas and New Mexico. Summer.

\section{HYMENOPÁPPUS L'Her.}

Biennial or perennial caulescent herbs, sometimes with woolly foliage. Leaves alternate, sometimes mainly basal : blades pinnatifid or dissected or rarely entire. Heads discoid, often corymbose. Involucres campanulate or hemispheric : bracts more or less petallike, 6-12 in 1-2 series. Receptacle small, naked. Ray-flowers wanting. Disk-flowers perfect, fruit-producing: corollas white or yellow. Anthers entire at the base. Stigmas with conic appendages. Achenes broadened upward, 4-5-angled, the faces 1-3-nerved. Pappus of 10-20 thin obtuse scales, or sometimes obsolete.

Corolla-lobes as long as the throat.

Pappus-scales much shorter than the breadth of the top of the achene.

Bracts of the involucre bright white: achenes pubescent.

Bracts of the involucre whitish or sulphur-yellow at the top: achenes puberulent.

Leaf-segments, at least those of the lower leaves, oblong or broadly linear. Leaf-segments narrowly linear.

Pappus-scales about as long as the breadth of the top of the achene.

1. H. Carolinensis.

2. H. corymbosus.

3. H. sulphureus.

4. H. artemisiaefolius. Corolla-lobes shorter than the throat.

Foliage densely tomentose: corollas yellow; throat slightly longer than the lobes.

Foliage thinly tomentose : corollas dull white; throat much longer than the

5. H. flavescens. lobes.

6. H. tenuifolius.

1. Hymenopappus Carolinénsis (Lam.) Porter. Foliage thinly tomentose. Stems 3-7 dm. tall, corymbose above : leaf-blades once or twice pinnately parted, or those at the base of the stem rarely entire : involucral bracts oblong to obovate, thin, mostly bright white : corolla-lobes about as long as the throat : achenes $2.5-3 \mathrm{~mm}$. long, obconic, ribbed, minutely pubescent: pappus-scales obovate, much shorter than the breadth of the top of the achene. [H. scabiosus L'Her. ]

In dry soil or pine lands, South Carolina and Kansas to Florida and Texas. Spring.

2. Hymenopappus corymbòsus T. \& G. Foliage sparsely pubescent. Stems 2-7 dm. tall, corymbose above: leaf-blades once or twice pinnately parted, the segments narrowly linear: involucral bracts oblong-obovate or obovate, the tips greenish white : corollalobes as long as the throat or longer: achenes obconic, $3 \mathrm{~mm}$. long, puberulent, finely ribbed : pappus-scales shorter than the breadth of the top of the achene.

On prairies, Nebraska to Arkansas and Texas. Spring and summer.

3. Hymenopappus sulphùreus Rydb. Foliage more or less permanently whitewoolly. Stems 3-6 dm. tall, branched above : leaf-blades white-woolly beneath, glabrate above, those of the lower leaves pinnately divided into oblong or broadly linear often obtuse segments, those of the upper leaves twice pinnately divided into narrower segments than the lower: involucral bracts mainly obovate, the tips light or pale sulphur yellow, otherwise as in $H$. corymbosus.

On prairies, Kansas to Texas. Summer.

4. Hymenopappus artemisiaefolius DC. Foliage felty or floccose-tomentose. Stems 2-8 dm. tall, corymbose above : leaf-blades various, oblong to lanceolate in outline, undulate, pinnatifid, sometimes lyrately so, or pinnately parted, the segments broadly linear or narrowly oblong, toothed or lobed: involucral bracts obovate-oblong, white or the lower pale green : corolla-lobes about as long as the throat: achenes about $3 \mathrm{~mm}$. long, hirsute : pappus-scales obovate-spatulate, about as long as the breadth of the top of the achene.

On plains or prairies, Texas. Spring.

5. Hymenopappus flavéscens A. Gray. Foliage densely white-tomentose. Stems 2-6 dm. tall, corymbose above ; leaf-blades once, twice or rarely thrice pinnately parted ; the segments narrowly to broadly linear: involucral bracts ovate to oblong-ovate, with greenish white or yellowish margins: corolla-lobes about as long as the campanulate throat: achenes $2.5-3 \mathrm{~mm}$. long, villous-pilose : pappus-scales spatulate.

On sandy plains, Texas to Arizona and adjacent Mexico. Spring and summer.

6. Hymenopappus tenuifòlius Pursh. Foliage thickly tomentose. Stems $3-7$ or those at the base of the stem thrice pinnately parted, the segments narrowly linear or
linear-filiform : involucres hemispheric, $5 \mathrm{~mm}$. high ; bracts oblong-obovate : corollas dull 
white ; lobes somewhat shorter than the throat : achenes obconic, 3.5-4 mm. long, appressedpubescent.

On plains and prairies, Nebraska to Texas. Summer and fall.

\section{FLORESTINA Cass.}

Annual caulescent herbs. Leaves alternate : blades pinnately or pedately 3-7-parted or entire towards the top of the stem. Heads discoid, numerous, corymbose. Involucres turbinate-campanulate: bracts few, nearly equal, broadened upward. Receptacle flat, naked. Ray-flowers wanting: disk-flowers perfect, fruit-producing: corollas white or purplish. Anthers slightly sagittate at the base. Stigmas with pubescent attenuate-subulate appendages. Achenes narrow, nearly terete, 4-5-ribbed. Pappus of 8-10 hyaline obtuse or retuse scales.

1. Florestina trípteris DC. Foliage cinereous-pubescent. Stems $3-7 \mathrm{dm}$. tall, often extensively branched, striate-ridged : leaf-blades various, those of the lower leaves entire, ovate to oblong, 1-5 cm. long, those of the upper leaves almost pinnately compound, the segments similar to the blades of the lower leaves but smaller: peduncles shorter than the involucres : heads not showy : involucres $4-5 \mathrm{~mm}$. high; bracts linear to spatulate, dull white at the tip, minutely pubescent : achenes enlarged upward, $3.5-4 \mathrm{~mm}$. long, strigillose.

On hillsides and prairies, Texas and adjacent Mexico.

\section{POLÝPTERIS Nutt.}

Annual or perennial, usually pubescent caulescent herbs. Leaves mainly alternate or opposite on the lower part of the stem: blades narrow, mostly entire. Heads discoid or radiate, disposed in corymbs. Involucres campanulate to turbinate : bracts narrow, imbricated in one or two series. Receptacle flat, naked. Ray-flowers pistillate, fruit-producing, or wanting: ligules deeply colored. Disk-flowers perfect, fruit-producing: corollas colored. Anthers entire or emarginate at the base. Stigmas elongated, glandular. Achenes rather narrow, 4-angled. Pappus of 8-12 narrow ribbed scales, that of the outer achenes more or less reduced.

Perennial : bracts of the involucre scarious: corolla-throat campanulate.

Annual: bracts of the involucre mainly herbaceous: corolla-throat obsolete or nearly

1. P. integrifolia. so.

Heads homogamous: achenes much broadened upward, less than $4 \mathrm{~mm}$. long. Involucres 10-12-flowered: achenes less than $5 \mathrm{~mm}$. long.

Involucres 20-30-flowered : achenes over $5 \mathrm{~mm}$. long.

Heads heterogamous: achenes scarcely broadened upward, over $6 \mathrm{~mm}$. long.

Bracts of the involucre about $1 \mathrm{~cm}$. long at maturity: leaf-blades indistinctly 3-nerved.

Bracts of the involucre $1.5-2 \mathrm{~cm}$. long at maturity : leaf-blades prominently 3ribbed.

2. P. callosa.

3. P. Texana.

4. P. Hookeriana.

5. P. maxima.

1. Polypteris integrifolia Nutt. Perennial, glabrous or sparingly pubescent. Stems 5-15 dm. tall, corymbose above : leaf-blades linear or linear-lanceolate, 3-7 cm. long, rather obtuse, entire, short-petioled : peduncles enlarged under the heads, often with several scales: heads homogamous : involucral bracts oblong to spatulate, mostly 5-11 $\mathrm{mm}$. long, mainly scarious and petalloid, obtuse : ray-flowers wanting: corollas white or flesh-colored, achenes narrowly obpyramidal, about $4 \mathrm{~mm}$. long, pubescent : pappus scales linear-subulate, about as long as the achenes or longer.

In dry pine lands, Georgia and Florida. Summer and fall.

2. Polypteris callòsa (Nutt.) A. Gray. Annual, pubescent. Stems $3-7 \mathrm{dm}$. tall, often widely branched above : leaf-blades narrowly linear, $2-7 \mathrm{~cm}$. long, acute, entire, sessile or short-petioled: peduncles glandular-pubescent : heads homogamous : involucres 10-12-flowered: bracts linear or linear-oblong, 3-4 mm. long, strigillose, herbaceous: achenes narrowly obpyramidal, $3.5-4 \mathrm{~mm}$. long, commonly pubescent : pappus-scales suborbicular or obovate, obtuse or retuse, the costae scarcely reaching the apex.

In various situations, Missouri to Texas. Spring to fall.

3. Polypteris Texàna (DC.) A. Gray. Annual, finely pubescent. Stems $2-6 \mathrm{dm}$. tall, more or less branched: leaf-blades lanceolate, linear-lanceolate or linear-oblong, 2-8 cm. long, entire, often undulate, acute or attenuate, manifestly petioled : peduncles glandular : heads homogamous: involucres 20-30-flowered; bracts linear or linear-oblanceolate: achenes gradually narrowed to the base, $5.5-6 \mathrm{~mm}$. long.

In dry or gravelly soil, Texas, New Mexico and adjacent Mexico. Spring and summer.

4. Polypteris Hookeriàna (T. \& G.) A. Gray. Annual, glandular-pubescent and somewhat viscid. Stems 3-12 dm. tall, branched : leaf-blades lanceolate or linear-lanceo- 
late, 3-10 cm. long, acute or acuminate, indistinctly 3-nerved, entire ; petioles 1-2 cm. long: heads showy : involucral bracts linear or linear-spatulate, about $10 \mathrm{~mm}$. long at maturity, acute or acutish, glandular : ray-flowers $8-10$, ligules rose-red, $1-1.5 \mathrm{~cm}$. long, 5 -cleft, or sometimes much reduced : achenes $6-8 \mathrm{~mm}$. long, angled : pappus-scales various ; those of the ray spatulate or oblong-spatulate; those of the disk narrowly lanceolate, nearly as long as the achene, attenuate into slender tips or awns.

On sandy plains, Nebraska to Texas. Summer and fall.

5. Polypteris máxima Small. Annual, glandular-pubescent. Stems $3-8 \mathrm{dm}$. tall, corymbose above : leaf-blades lanceolate to linear-lanceolate, $5-8 \mathrm{~cm}$. long, acute or acuminate, entire, ciliate, prominently 3-nerved, petioles $1-1.5 \mathrm{~cm}$. long: involucral bracts linear to linear-lanceolate, $1.5-2 \mathrm{~cm}$. long at maturity : ray-flowers numerous ; ligules 8-12 $\mathrm{mm}$. long, 3-cleft : achenes 6-7 mm. long, angled.

On prairies, Texas. Summer.

\section{PALAFóxia Lag.}

Annual or perennial caulescent sometimes shrubby herbs, with pubescent foliage. Leaves alternate or opposite : blades narrow, entire, the lower ones petioled. Heads discoid, in corymbs. Involucres campanulate or oblong, several-flowered: bracts narrow, embracing the approximate achenes: bracts narrow: receptacle flat, naked. Ray-flowers wanting. Disk-flowers perfect, fruit-producing : corollas colored : lobes longer than the cylindric throat. Anthers entire or emarginate at the base. Stigmas slender, obtuse puberulent. Achenes 4-angled. Pappus of 4-8 unequal strongly ribbed scales.

1. Palafoxia Feaỳi A. Gray. Shrubby, minutely pubescent. Stems $6-15 \mathrm{dm}$. tall, widely branching : leaf-blades oblong to oblong-lanceolate, $2-7 \mathrm{~cm}$. long, obtuse or acutish, entire, commonly rounded at the base; petioles $1-5 \mathrm{~mm}$. long : involucral bracts linear or linear-spatulate, $5-8 \mathrm{~mm}$. long, obtuse : corollas 7-8 $\mathrm{mm}$. long; lobes at least $\frac{1}{2}$ as long as the throat: achenes $5-6 \mathrm{~mm}$. long.

In sandy soil, peninsular Florida. Summer and fall.

\section{BÀHIA Lag.}

Shrubby plants or more or less woody perennial herbs, with white or pale, woolly or more rarely glandular-pubescent foliage. Leaves opposite or alternate : blades dissected or lobed, or the upper ones sometimes nearly or quite entire. Heads heterogamous, radiate. Involucre ovoid to hemispheric : bracts in about two series, relatively broad, not embracing the approximate achenes. Receptacles flat, naked or nearly so. Ray-flowers pistillate, fruit-producing, with yellow ligules. Disk-flowers perfect, fruit-producing. Anthers obtuse at the base or merely emarginate. Stigmas of the perfect flowers linear, dilated at the apex or with slender appendages. Achenes narrow, 4-angled. Pappus of 4-10 obovate, oblong, or lanceolate, scarious scales.

1. Bahia absinthifòlia Benth. Stem mainly herbaceous, 2-4 dm. tall, diffusely branched, canescent-tomentose : leaves pale, opposite, or the upper alternate : blades pedately or sometimes palmately 3-5-parted into lanceolate or linear segments : heads longpeduncled : bracts of the involucre $5-7 \mathrm{~mm}$. long, variable in shape, acute or slightly acuminate, lax : ligules of the ray-flowers yellow, 8-11 mm. long : achenes 4-5 mm. long.

In dry soil, southern Texas to Arizona. Summer and fall.

\section{TETRANEÙRIS Greene.}

Annual or perennial caulescent or mainly scapose herbs. Leaves alternate, sometimes crowded on the branches of a woody caudex : blades entire, narrow. Heads heterogamous, typically radiate. Involucres of 2-3 series of separate bracts. Receptacle convex or conic, naked. Ray-flowers pistillate, fruit-producing, with yellow ligules. Disk-flowers perfect, fruit-producing. Anthers entire or minutely sagittate at the base. Stigmas truncate and brush-like at the apex. Achenes broadened upward, 5-10-ribbed or angled, pubescent. Pappus of 5-12 truncate or aristate scarious scales.

Plants annual or perhaps biennal, caulescent.

Plants scapose: scapes tufted from branching perennial caudices.

1. T. linearifolia.

2. T. linearis.

1. Tetraneuris linearifollia (Hook.) Greene. Annual or perhaps biennial, somewhat villous-hirsute or glabrate. Stems simple and erect or diffusely branched, the 
branches spreading, 1-3 dm. long : leaves alternate ; blades linear or linear-spatulate, 1-4 $\mathrm{cm}$. long, entire : peduncles very slender or filiform, $3-12 \mathrm{~cm}$. long : involucral bracts oblong or almost linear, 3-3.5 cm. long: ligules of the ray-flowers 6-8 $\mathrm{mm}$. long.

In dry rocky soil, Kansas to Louisiana, Texas and New Mexico. Spring and summer.

2. Tetraneuris lineàris (Nutt.) Greene. Perennial, pubescent. Caudex branched at the base, the branches tufted : leaves crowded on the caudex-branches; blades linear or narrowly linear-spatulate, $2-5 \mathrm{~cm}$. long, acute, entire : scapes erect, 1-3 dm. tall, usually several together, simple: involucral bracts oblong or oblong-cuneate, 3-4 $\mathrm{mm}$. long, obtuse : ligules of the ray-flowers $8-15 \mathrm{~mm}$. long.

In dry soil, Arkansas to New Mexico and adjacent Mexico. Spring to fall.

\section{PICRADÈNIA Hook.}

Annual caulescent herbs, usually pubescent. Leaves alternate: blades pinnately divided, the segments narrow. Heads heterogamous, radiate. Involucre of 2 series of bracts, those of the outer series united at the base. Receptacle convex or conic, naked. Ray-flowers pistillate, fruit-producing, with yellow ligules. Disk-corollas perfect, fruitproducing. Stigmas truncate and brush-like at the apex. Achenes broadened upward, pubescent. Pappus of several awned or merely acuminate scarious scales.

1. Picradenia odoràta (DC.) Britton. Annual, more or less pubescent. Stem 3-6 dm. tall, usually branched at the base and above, the branches ascending : leaf-blades 1-3parted into linear-filiform ultimately entire segments: heads few or numerous, slenderpeduncled : involucre broadly campanulate, $3-4 \mathrm{~mm}$. high ; bracts various, the outer ovate or oblong-ovate beyond the slightly contracted and slightly united bases, the inner broader, acute : ligules of the ray-flowers cuneate, $5-8 \mathrm{~mm}$. long.

In dry soil, Kansas to California, Texas and Mexico. Spring and summer.

\section{FLAVÈRIA Juss.}

Annual caulescent herbs. Leaves opposite : blades entire or toothed, sessile. Heads small, radiate or discoid, usually sessile. Involucres narrow, 1-several-flowered : bracts

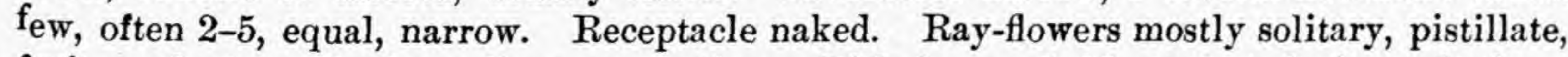
fruit-producing: ligules yellow, or wanting. Disk-flowers 1-15, perfect, fruit-producing : corollas yellow or yellowish. Anthers entire at the base. Stigmas of the disk-flowers truncate. Achenes narrow, 8-10-ribbed. Pappus wanting.

Involucres of 3-5 principal bracts, 4-15-flowered.

Involucres mostly of 5 bracts.

Involucres mostly of 3 bracts.

Involueres of 1-3 principal bracts, 1-2-flowered.

1. F. linearis.

2. F. angustifolia.

1. Flavorla lineàris Lag. Foliage somewhat pubescent. Stems $2-9 \mathrm{dm}$. long, sometimes decumbent, corymbose above: leaf-blades narrowly linear or lanceolate, $3-10 \mathrm{~cm}$. long, narrowed above the connate bases, entire: heads numerous: involucres narrow, 4 mm. high; bracts mostly 5 , oblong or lanceolate, acute : ray-flowers usually solitary ; ligule oblong to oval, $2-3.5 \mathrm{~mm}$. long: disk-flowers usually 5-8.

In sand, peninsular Florida. Also in the West Indies.

2. Flaveria angustifòlia (Cav.) Pers. Foliage nearly glabrous. Stems $3-9 \mathrm{dm}$. tall, branching above : leaf-blades linear to lanceolate or oblong-lanceolate, 3-7 cm. long, acute or acuminate, serrate or nearly entire, lightly 3 -nerved, sessile: heads in terminal involucrate clusters : involucres 4-5 mm. high; bracts usually 3 : ray-flowers mostly solitary ; ligule oblong-cuneate, 1.5-2.5 mm. long: disk-flowers 1-4.

In alkaline soil, Kansas and Colorado to Texas, New Mexico and Mexico.

3. Flaveria repánda Lag. Foliage glabrous. Stems $2-9 \mathrm{dm}$. tall, widely branched : leaf-blades linear-elliptic to broadly linear, $3-10 \mathrm{~cm}$. long, acute or somewhat acuminate, serrate, 3-nerved, narrowed to the sessile but barely connate bases : heads in axillary or involucrate clusters : involucres 1-2-flowered, narrow, 3-4 mm. high ; bracts 1-3, or sometimes accompanied by a few accessory ones : ray-flowers usually solitary in the outer heads.

In sandy soil, Florida and Texas to adjacent Mexico.

\section{LAPHÀMIA A. Gray.}

Perennial caulescent herbs or shrubby plants, with pubescent foliage. Leaves opposite or alternate above : blades toothed or incised. Heads radiate or rarely discoid, sometimes in corymbs. Involucres campanulate or nearly hemispheric: bracts imbricated, in 
1 or 2 series, nearly equal. Receptacle convex, naked. Ray-flowers pistillate, fruit-producing : ligules yellow, or rarely wanting. Disk-flowers perfect, fruit-producing : corollas with 4 lobes. Anthers sagittate at the base. Stigmas of the disk-flowers with pubescent subulate appendages. Achenes flattened, with ciliate or cartilaginous margins. Pappus of 1 or 2 longer bristles often with small bristles between, or sometimes crown-like.

1. Laphamia Lindheìmeri A. Gray. Foliage finely but closely pubescent. Stems 1-3 dm. tall, corymbosely branched : leaf-blades ovate to oblong, 1-2 cm. long, glabrate, acute, entire or shallowly serrate, cuneate or truncate at the base, petioled : heads about $5 \mathrm{~mm}$. high : involucres campanulate; bracts linear or slightly enlarged upward : rayflowers 3-6 or wanting: pappus a slender bristle about as long as the corolla-tube.

On rocky banks, Texas.

\section{HELÈNIUM L.}

Annual, biennial or perennial caulescent bitter herbs. Leaves alternate : blades entire or toothed, often decurrent on the stem. Heads radiate or rarely discoid, peduncled. Involucres flattish: bracts narrow, in 1 or 2 series, spreading or reflexed. Receptacle convex, oblong or subglobose, naked. Ray-flowers pistillate and fruit-producing, or neutral : ligules yellow or brown at the base. Disk-flowers perfect, fruit-producing : corolla yellow, purple or brown, with glandular lobes. Anthers 2-toothed or sagittate at the base. Stigmas of the disk flattened and truncate. Achenes broadened upward, truncate. Pappus of 5-8 entire, toothed or lacerate acuminate or awn-tipped scales. SNEEzewEed.

Ray-flowers pistillate.

Plants annual or sometimes biennial.

Leaf-blades narrowly linear or linear-filiform, not decurrent.

Disk yellow: leaves with entire blades.

Disk purple-brown: some of the lower cauline leaves with pinnately parted blades.

Leaf-blades broader, all or some of them conspicuously decurrent on the stem.

Disk oblong or ovoid.

Receptacle conic or oblong-cylindric: disk becoming much longer than thick.

Receptacle ovoid :- disk but little longer than thick.

Disk globular.

Mature disk 4-6 mm. in diameter.

Receptacle depressed: pappus-scales shorter than the width of the achene.

Receptacle conic-ovoid: pappus-scales about $1 / 2$ the length of the achene.

Mature disk 8-10 mm. in diameter.

Plants perennial.

Receptacle ovoid or conic.

Wings of the upper part of the stem and the branches $1 \mathrm{~mm}$. wide or less: receptacle ovoid.

Receptacle 2.5-3.5 mm. high : ligules of the ray-flower 6-15 mm. long. Disk yellow. Disk brown or purple.

Receptacle 6-7 mm. high: ligules of the ray-flowers $25-30 \mathrm{~mm}$. long. Wings of the upper part of the stem and the branches over $2 \mathrm{~mm}$. wide: receptacle conic.

Receptacle hemispheric or depressed.

Ray-flowers neutral.

Receptacle ovoid or ovoid-conic : disk globular or globose-spheroidal.

Disk about $1.5 \mathrm{~cm}$. broad : ligules with slender, acute segments : pappusscales dissected to about the middle.

Disk about $2 \mathrm{~cm}$. broad: ligules with broad, obtuse segments: pappusscales nearly entire.

Receptacle flattish or depressed-hemispheric : disk similar.

Disk yellow.

Leaf-blades entire or merely undulate.

Leaf-blades sinuate-dentate or pinnatifid. Achenes glabrous. Achenes pubescent.

Disk purple or brown.

'1. H. tenuifolium.

2. H. badium.

3. H. quadridentatum.

4. H. ooclinum.

\section{H. elegans.}

6. H. microcephalum.

7. H. amphibolum.
8. H. parviflorum.

9. H. nudiflorum.

10. H. campestre.

11. H. polyphyllum.

12. $H$. autumnale.

13. H. fimbriatum.

14. H. Curtisii.

15. H. Helenium.

16. H. incisum.

17. $H$. vernale.

18. H. brevifolium.

1. Helenium tenuifolium Nutt. Annual, glabrous or sparingly pubescent above. Stems 2-4 dm. tall, often branched into a bushy head : leaves numerous; blades narrowly linear, 1-5 cm. long, usually entire, not decurrent : heads showy : involucral bracts linearsubulate, 4-6 mm. long, spreading or reflexed : ray-flowers few ; ligules yellow, 6-7 mm. long, 3-4-toothed : disk yellow, 6-8 mm. broad : pappus-scales ovate, prolonged into slender tips.

In waste places and moist soil, Virginia and Missouri to Florida and Texas. Naturalized eastward. Summer and fall. 
2. Helenium bàdium (A. Gray) Greene. Similar to $H$. tenuifolium in habit, but usually more slender, the lower cauline and basal leaves, or some of them, pinnately parted into slender segments : disk purplish brown.

In dry soil, the Indian Territory and Texas. Summer and fall.

3. Helenium quadridentàtum Labill. Annual or biennial, glabrous or nearly so. Stems 3-10 dm. tall, loosely branched: leaf-blades various, those of the lower leaves pinnatifid, $8-15 \mathrm{~cm}$. long, those of the upper shorter, entire, narrowly oblong-lanceolate, acute or acuminate, all usually decurrent as wings : involucral bracts narrowly linear or linearsubulate, soon reflexed, 3-5 $\mathrm{mm}$. long: ligules of the ray-flowers yellow, broadly cuneate, 3-5 mm. long : disk ovoid, becoming conic or oblong : receptacle conic or cylindric-oblong : pappus-scales orbicular-oval, obtuse.

In low grounds, South Carolina to Florida and Texas. Spring to fall.

4. Helenium ooclinum A. Gray. Similar to $H$. quadridentatum in habit, the leafblades, at least those of the lower leaves, less deeply lobed : disk short-ovoid : receptacle ovoid : pappus-scales relatively large, ovate, obtuse, almost as long as the achene.

In low places, in the vicinity of the Rio Grande, Texas, and in northern Mexico. Spring to fall.

5. Helenium élegans DC. Annual or biennial, glabrate. Stems 3-9 dm. tall, branching above : leaf-blades oblong to lanceolate or linear-lanceolate, $3-8 \mathrm{~cm}$. long, acute, sessile and decurrent, those of the lower leaves shallowly toothed : peduncles minutely pubescent : heads small but showy : involucral bracts linear-subulate, $2-3 \mathrm{~mm}$. long : ligules of the ray-flowers yellow, or often brown at the base, cuneate, 5-7 mm. long, 3-toothed : disk brown or purplish, subglobose, 4-5 $\mathrm{mm}$. in diameter: pappus-scales oval-ovate, shorter than the width of the achene.

In moist soil, Louisiana and Texas. Spring and summer.

6. Helenium microcéphalum DC. Annual or biennial, glabrate. Stems $2-8 \mathrm{dm}$. tall, loosely branched above: leaf-blades oblong-lanceolate to ovate-oblong, 3-6 cm. long, acute, sessile and decurrent, those of the lower leaves often toothed : involucral bracts linear to linear-subulate, 3-4 $\mathrm{mm}$. long, reflexed : ligules of the ray-flowers yellow, 3-5 mm. long: disk subglobose, $5-6 \mathrm{~mm}$. in diameter, yellow or fuscous : pappus-scales ovate, about $\frac{1}{2}$ as long as the achene.

In moist soil, Texas. Spring and summer.

7. Helenium amphíbolum A. Gray. Similar to the two preceding species in habit, but stouter. Stems usually freely branching : leaves various, the lower cauline with mainly oblong, toothed or pinnatifid blades, the upper with lanceolate or linear entire blades: disk 8-10 mm. in diameter, reddish purple : ligules of the ray-flowers as long as the disk or longer : pappus-scales barely as long as the width of the achene.

In low grounds, along the Rio Grande, southern Texas and adjacent Mexico. Spring and summer.

8. Helenium parviflòrum Nutt. Perennial, glabrous or nearly so. Stems $2-8 \mathrm{dm}$. tall, much branched: leaf-blades oblong to oblong-lanceolate, $3-12 \mathrm{~cm}$. long, acute or acuminate, shallowly toothed, more or less contracted near the base, decurrent on the stem as narrow wings: heads relatively small : involucral bracts linear-subulate or nearly filiform, 5-9 mm. long: ligules of the ray-flowers yellow, 6-10 $\mathrm{mm}$. long: disk yellow, subglobose, 6-10 $\mathrm{mm}$. in diameter : receptacle ovoid, $2.5-3 \mathrm{~mm}$. high.

In low grounds, Georgia and Florida to Texas and Arkansas. Summer and fall.

9. Helenium nudiflòrum Nutt. Perennial, more or less puberulent. Stems 2-10 dm. tall, corymbosely branched above : leaves few ; blades oblanceolate to oblong or linear, $2.5-12 \mathrm{~cm}$. long, acute, sessile and decurrent on the stem as narrow wings, those of the lower leaves often toothed : involucral bracts narrowly linear or linear-subulate, 5-7 mm. long: ray-flowers neutral ; ligules yellow or brown-purple or sometimes discolored, 1-1.5 $\mathrm{cm}$. long : disk purplish, less than $10 \mathrm{~mm}$. in diameter : receptacle ovoid, 2.5-3.5 high.

In swamps and low grounds, Virginia to Missouri, Florida and Texas. Spring and summer.

10. Helenium campéstre Small. Similar to $H$. nudiflorum, but much larger. Stems mostly $1 \mathrm{~m}$. tall or more, sparingly branched above, broadly winged : leaves few ; blades various, those of the lower cauline leaves $5-9 \mathrm{~cm}$. long, spatulate, pinnately lobed or pinnatifid above the middle, those of the upper cauline leaves linear or linear-lanceolate, often minutely denticulate : heads showy : involucral bracts oblong to oblong-lanceolate, 6-10 $\mathrm{mm}$. long: ligules of the ray-flowers $2.5-3 \mathrm{~cm}$. long : disk purplish, over $10 \mathrm{~mm}$. in diameter : receptacle broadly ovoid, $6-7 \mathrm{~mm}$. high.

In low grounds, near Little Rock, Arkansas. Spring.

11. Helenium polyphýllum Small. Perennial, finely pubescent. Stems $3-8 \mathrm{dm}$. tall, much branched : leaves numerous; blades oblong to linear-lanceolate, 2-10 cm. long, acute, undulate or remotely toothed, decurrent, the wings they form as broad as the blades 
or nearly so ; involucral bracts narrowly linear or linear-subulate, 5-8 mm. long : ray-flowers neutral : ligules yellow, 6-12 mm. long: disk purplish, globose-ovoid, 6-8 mm. in diameter: receptacle conic.

In fields and thickets, northwestern Georgia and Tennessee. Summer and fall.

12. Helenium autumnàle L. Perennial, more or less pubescent. Stems relatively stout, 2-7 dm. tall, branched : leaves not conspicuously numerous ; blades oblong to elliptic, or slightly broadest above or below the middle, $3-12 \mathrm{~cm}$. long, commonly acuminate, rather prominently toothed, sessile and decurrent as narrow wings: involucral bracts linearlanceolate to linear-subulate, $5 \mathrm{~mm}$. long : ligules of the ray-flowers bright yellow, 1-2 $\mathrm{cm}$. long : disks subglobose, $10-16 \mathrm{~mm}$. in diameter.

In low grounds, Quebec to the Northwest Territory. Florida, Texas and Arizona.

13. Helenium fimbriàtum (Michx.) A. Gray. Perennial, glabrous below. Stems 4-8 dm. tall, usually simple : leaf-blades linear-spatulate to broadly linear, 4-12 cm. long, acute, entire, sessile and decurrent as narrow wings : peduncle pubescent under the head: involucral bracts linear or linear-subulate, $7-10 \mathrm{~mm}$. long: ray-flowers neutral; ligules linear-cuneate, $1.5-2 \mathrm{~cm}$. long: disk $1.5-2 \mathrm{~cm}$. broad : receptacle conic-ovoid : pappusscales broad, dissected to below the middle into capillary bristles.

In low pine lands, Florida to Texas. Spring.

14. Helenium Curtísii A. Gray. Perennial, nearly glabrous. Stems 5-9 dm. tall, simple or sparingly branched above : leaf-blades oblanceolate to linear, 4-10 cm. long, obtuse or acutish, undulate, decurrent as narrow wings: heads showy: involucral bracts lanceolate or subulate-lanceolate, $5-8 \mathrm{~mm}$. long, disk about $2 \mathrm{~cm}$. broad:- ray-flowers neutral : ligules $1.5-2 \mathrm{~cm}$. long : pappus-scales nearly entire.

In low grounds, North Carolina. Spring and summer.

15. Helenium Helènium (Nutt.) Small. Perennial, glabrous or puberulent, somewhat fleshy. Stems 3-7 dm. tall, simple : leaves often mainly basal ; blades linear or nearly so, 5-15 cm. long, sometimes undulately toothed, narrower and more or less reduced on the upper part of the stem : head showy : involucral bracts linear or linear-lanceolate, 5-7 mm. long, spreading : ray-flowers rather numerous : ligules yellow, 10-17 mm. long, cuneate : disk depressed-hemispheric, $1.5-2 \mathrm{~cm}$. broad, yellow : achenes resinous-dotted: pappus-scales erose or laciniate.

About pine-land ponds, South Carolina to Florida and Louisiana. Spring.

16. Helenium incisum (T. \& G.) Small. Perennial, glabrous. Stems $5-7 \mathrm{dm}$. tall, simple : leaf-blades narrowly oblong or linear, pinnatifid, 5-10 cm. long, acutish, the segments alternate: peduncle elongated: head showy : involucral bracts linear-subulate, 5-8 $\mathrm{mm}$. long: ligules of the ray-flowers yellow, $1-1.5 \mathrm{~cm}$. long: disk yellow, $2 \mathrm{~cm}$. broad: achenes glabrous, about $2 \mathrm{~mm}$. Iong.

In low pine lands, Georgia. Spring.

17. Helenium vernàle Walt. Perennial, puberulent or tomentulose and somewhat viscidulous. Stems 3-7 dm. tall, simple : leaves mainly basal ; blades spatulate to linear, 6-15 cm. long, shallowly toothed or incised-pinnatifid, acute, the segments opposite : heads showy : involucral bracts lanceolate to linear-lanceolate, $3-5 \mathrm{~mm}$. long: ligules of the rayflowers yellow, 6-10 mm. long, rather slender, deeply cleft : disk yellow, 8-20 mm. broad : achenes $1.5-2 \mathrm{~mm}$. long, pubescent : pappus-scales spatulate to obovate, fimbriate or lacerate.

In pine-land swamps, North Carolina to Florida and Alabama. Spring.

18. Helenium brevifollium (Nutt.) A. Gray. Perennial, glabrous or glabrate. Stems 3-8 dm. tall, simple or sparingly branched : leaf-blades spatulate to linear, $2-8 \mathrm{~cm}$. long, obtuse or acutish, entire, or sometimes merely undulate, decurrent as narrow wings : heads showy : involucral bracts linear-lanceolate or linear, 8-10 mm. long, acute : ligules of the ray-flowers yellow, 1-1.5 cm. long: disk purple or brown, 1-1.5 $\mathrm{cm}$. broad: achenes pubescent : pappus-scales nearly entire.

In pine-land swamps, North Carolina to Florida and Alabama. Spring.

\section{AMBLYÓLEPIS DC.}

Annual caulescent herbs, fragrant in drying. Leaves alternate : blades membranous, entire, the upper sessile and partly clasping, never punctate. Heads radiate, showy. Involucres broad : bracts of 2 kinds, those of the outer series foliaceous, spreading or reflexed, those of the inner series resembling the pappus-scales. Receptacle convex. Ray-flowers pistillate, fruit-producing. Disk-flowers perfect, fruit-producing : corollas with tube and throat of equal length; lobes glabrous. Achenes broadened upward, with 10 stout ribs. Pappus of several nerveless mostly obtuse scales. 
1. Amblyolepis setígera DC. Stems smooth and glabrous or sparingly villous-hirsute, 1-5 dm. tall, simple or loosely branched. Leaf-blades spatulate at the base of the stem to oblong or oblong-ovate above, entire, ciliate, the upper ones more or less clasping : heads peduncled: involucral bracts lanceolate to elliptic-lanceolate, acuminate, ciliate, acute : ligules of the ray-flowers golden yellow, $2-2.5 \mathrm{~cm}$. long, 3-4-lobed : achenes 3-4 $\mathrm{mm}$. long, silvery-pubescent: pappus-scales broadly ovate, about $\frac{1}{2}$ as long as the achene.

On prairies, Texas.

\section{GAILLÀRDIA Foug.}

Annual, biennial or perennial, scapose or caulescent herbs with pubescent foliage. Leaves alternate, sometimes basal : blades entire, toothed or pinnatifid. Heads radiate, or discoid, long-peduncled. Involucres broad : bracts in $2-3$ series, at least those of the outer series spreading or reflexed. Receptacle convex or subglobose, bristly, fimbrillate, the bractlets slender. Ray-flowers neutral, or rarely pistillate, or wanting: ligules yellow or purple, or both. Disk-flowers perfect, fruit-producing : corollas tubular; lobes with jointed hairs. Anthers sagittate or auricled at the base. Stigmas appendaged. Achenes broadened upward, 5-ribbed, pubescent at least near the base. Pappus of 6-12 1-nerved awned scales, exceeding the achene in length.

Stigmas tipped with glabrous appendages rarely twice as long as the.brush-like tuft.

Leaf-blades pinnately yeined and pinnatifid.

Leaf-blades 3-ribbed, merely toothed.

Stigmas tipped with filiform pubescent appendages.

Fimbrillae of the receptacle obsolete, or merely short teeth.

Disk yellow.

Disk purple or brown.

Heads long-peduncled: branches pliable, widely spreading.

Heads short-peduncled: branches rigid, erect or nearly so.

Fimbrillae of the receptacle bristle-like or subulate.

Disk-corollas with subulate acute lobes, which sometimes have bristle-like or apiculate cusps.

Disk-corollas with broad, obtuse or obscurely apiculate lobes.

Leaf-blades entire or shallowly toothed: achenes villous only at the base.

Leaf-blades pinnatifid: achenes villous all over.

1. G. suavis.

2. G. trinervata.

3. G. chrysantha.

4. G. lanceolata.

5. G. fastigiata.

6. G. pulchella.

7. G. amblyodon.

8. G. pinnatiflda.

1. Gaillardia suàvis (A. Gray) Britton \& Rusby. Annual or biennial, sparingly pubescent. Leaves basal ; blades spatulate or oblong-spatulate, $3-12 \mathrm{~cm}$. long, bipinnatifid: scapes solitary or several together, 2-7 dm. tall, simple: involucral bracts oblong to lanceolate, 6-9 mm. long, acute: ray-flowers wanting or abortive, or sometimes present : achenes cuneate, $2.5 \mathrm{~mm}$. long, densely pubescent: pappus-scales twice as long as the achenes, with oblong or obovate bodies and slender tips as long as the bodies.

On prairies, Texas. Spring.

2. Gaillardia trinervàta Small. Similar to G. suavis in habit. Leaf-blades spatulate or oblong-spatulate, 6-9 $\mathrm{cm}$. long, merely toothed, 3-ribbed : scape closely pubescent under the head, simple : involucral bracts reflexed: ray-flowers wanting or obsolete.

In dry soil, the Indian Territory and Texas. Spring.

3. Gaillardia chrysántha Small. Annual or biennial, finely pubescent. Stems 3-6 dm. tall, usually with few elongated more or less spreading branches: leaf-blades spatulate or oblong-spatulate on the lower part of the stem to linear or oblong-linear above, 2-8 cm. long, undulate or remotely sinuate-toothed : heads long-peduncled : involucral bracts $7-11$ $\mathrm{mm}$. long, the outer triangular or lanceolate-triangular, the inner lanceolate: ligules of the ray-flowers yellow, $1-1.5 \mathrm{~cm}$. long, 3-cleft, the middle lobe the narrowest : disk light yellow, $1.5-2 \mathrm{~cm}$. broad : achenes about $1.5 \mathrm{~mm}$. long : pappus-scales about 4 times as long as the achene, the tips longer than the bodies.

On dry or sandy prairies, Texas. Spring to fall.

4. Gaillardia lanceolàta Michx. Annual or sometimes biennial, cinereous-pubescent. Stems 3-7 dm. tall, loosely branched, the branches long and spreading : leaf-blades spatulate to oblong or linear, $1.5-8 \mathrm{~cm}$. long, acute, entire or remotely serrate, sessile, at least ahove the base of the stem : involucral bracts oblong to lanceolate, 8-12 mm. long, acute or acuminate: heads long-peduncled: ligules of the ray-flowers yellow, $1.5-2 \mathrm{~cm}$. long, 3-cleft : disk purple, $1.5-2 \mathrm{~cm}$. broad : receptacle naked or nearly so : achenes $1.5-2 \mathrm{~mm}$. long: pappus-scales 3-4 times as long as the achene, the very slender tips longer than the bodies. summer.

In pine lands and on prairies, South Carolina and Kansas to Florida and Texas. Spring and

5. Gaillardia fastigiàta Greene. Annual or biennial, finely cinereous-pubescent. Stem 2-4 dm. tall, simple or with few or several rigid erect or nearly erect branches: leaf-blades 
elliptic or spatulate at the base of the stem to oblong or linear above, those of the lower leaves sharply but shallowly and remotely serrate: heads relatively short-peduncled: bracts of the involucre ovate-lanceolate to lanceolate, $8-11 \mathrm{~mm}$. long: ligules of the rayflowers yellow, $1.5-2 \mathrm{~cm}$. long : disk purple or brown : achenes $1.5-2 \mathrm{~mm}$. long : pappusbristles 4 times as long as the achene, slender-tipped.

On dry prairies, Arkansas to Oklahoma and Texas. Spring to fall.

6. Gaillardia pulchélla Foug. Annual, hirsute. Stems 1-3 dm. tall, diffusely branched at the base : leaf-blades spatulate to oblong or linear, $2-10 \mathrm{~cm}$. long, entire or pinnatifid : involucral bracts lanceolate to linear-lanceolate, 1-1.5 $\mathrm{cm}$. long, acuminate : ligules of the ray-flowers conspicuous, $1-2.5 \mathrm{~cm}$. long, yellow beyond the red-purple base : disk-corollas with subulate acute lobes sometimes ending in apiculate or bristle-like cusps: achenes obconic, $2 \mathrm{~mm}$. long: pappus-scales with the slender tips longer than the broad bodies.

On plains and prairies, Kansas to Louisiana and Arizona. Spring and summer.

7. Gaillardia amblỳodon Gay. Annual, hirsute or hispid. Stems $2-6 \mathrm{dm}$. tall, simple or sparingly branched: leaf-blades spatulate to oblong or nearly linear, 2-7 cm. long, entire or nearly so, sessile by the slightly auricled base : involucral bracts lanceolate to linear-lanceolate, acuminate, hispid: ligules of the ray-flowers brownish red or maroon, 1.5-2.5 cm. long, oblong-cuneate : achenes glabrous or nearly so above, not overtopped by the basal hairs: pappus-scales various, those of the ray awnless.

On prairies, Texas. Summer and fall.

8. Gaillardia pinnatífida Torr. Perennial, cinereous-pubescent. Stems solitary or tufted, 1-4 dm. tall, simple above : leaves mainly basal, or on the lower part of the scapelike stems ; blades various, linear to spatulate, 4-12 $\mathrm{cm}$. long, repand-pinnatifid to pinnatifid, the segments linear or nearly so: involucral bracts narrowly linear to linear-lanceolate, $7-9 \mathrm{~mm}$. long: ligules of the ray-flowers yellow, $1.5-2 \mathrm{~cm}$. long or much reduced : achenes with long hairs all over : pappus-scales lanceolate or oblong, prolonged into slender tips.

On plains, Colorado to Texas and Arizona. Summer and fall.

\section{BOÈBERA Willd.}

Annual or perennial caulescent strong-scented herbs. Leaves alternate or opposite : blades commonly parted or dissected. Heads radiate, not showy. Involucres often narrow : bracts in 1 series, united at the base, usually accompanied by several small scales. Receptacle flat or nearly so, often with hairs or short bristles. Ray-flowers pistillate, fruitproducing: ligules short. Disk-flowers perfect : corollas tubular. Anthers entire or minutely 2-toothed at the base. Stigmas of the disk flowers somewhat elongated, hirsute, occasionally abruptly apiculate. Achenes broadened upward, 3-5-angled. Pappus of 10 or more partially united scales, the free portions divided into stiff slender segments. [Dysodia Lag., not Cav.]

1. Boebera pappòsa (Vent.) Rydb. Annual, ill-scented, more or less pubescent. Stems 1-4 dm. tall, widely branched: leaves opposite; blades 1-3 cm. long, once or twice pinnately parted, the segments linear : heads short-peduncled : involucres 5-8 mm. high ; bracts oblong or oblong-obovate, obtuse, greenish or purplish, scarious-margined : ligules of the ray-flowers inconspicuous: achenes $3.5-4 \mathrm{~mm}$. long, pubescent. [Dysodia chrysanthemoides Lag.]

In waste places and on roadsides, Minnesota to Ohio, Louisiana, Mexico and Arizona. Summer and fall. Introduced eastward.

\section{THYMOPHÝLLA Lag.}

Annual or perennial caulescent usually pleasant-scented herbs or shrubby plants, with glandular-dotted foliage. Leaves alternate or opposite : blades entire or pinnately parted. Heads radiate, heterogamous, often disposed in corymbs. Involucres campanulate : bracts mostly united into a cup usually accompanied by several scales at its base. Receptacle naked or merely fimbrillate. Ray-flowers pistillate, fruit-producing. Disk-flowers perfect, fruit-producing : corollas often yellow. Anthers truncate or obtuse at the base. Stigmas obtuse or truncate, or sometimes minutely apiculate. Achenes terete or nearly so, striate. Pappus of several or many truncate or 1-5-awn-tipped scales. [Hymenatherum Cass.] 
Scales accompanying the involucres lax and conspicuous: pappus-scales much shorter than the diskcorollas.

Scales accompanying the involucres very small or wanting: pappus-scales as long as the disk-corollas or longer.

Pappus simple or nearly so, the scales 3-awned.

Pappus-scales 18-20.

Pappus-scales mostly 10.

Involucres with 16-20 lobes.

Involucres with about 12 lobes.

Pappus double, the scales obtuse.

Perennial : foliage glabrous or minutely pubescent, not woolly.

Shrubby: foliage pubescent: involucres less than $5 \mathrm{~mm}$. high.

Herbaceous : foliage glabrous or nearly so: involucres over $5 \mathrm{~mm}$. high.

Annual: foliage woolly.

1. T. tagetoides.

1. Thymophylla tagetoìdes (T. \& G.) Small. Annual or perennial, glabrous. Stems rigid, 1-4 dm. tall, solitary or tufted : leaves alternate ; blades narrowly linear, 3-8 $\mathrm{cm}$. long, remotely spiny-toothed : heads showy : involucres oblong or oblong-campanulate, $6-8 \mathrm{~mm}$. high ; bracts united to near the tips, acute : ligules of the ray-flowers yellow, $1-1.5 \mathrm{~cm}$. long : achenes $3.5-4 \mathrm{~mm}$. long: pappus simple; scales about 10 , rigid, with 1-3 awns shorter than the disk-corollas. [Hymenatherum tagetoides T. \& G.]

On prairies, Texas. Spring and summer.

2. Thymophylla polychaèta (A. Gray) Small. Annual, sparingly pubescent. Stems $0.5-1.5 \mathrm{dm}$. tall, with several or many ascending branches : leaves alternate; blades 1-3 cm. long, pinnately parted into several narrowly linear or linear-filiform segments : heads relatively small : involucre $4-6 \mathrm{~mm}$. high, broadly campanulate; bracts united to above the middle, acute; ligules of the ray-flowers yellow, 3-7 mm. long: achenes 4-4.5 mm. long: pappus-scales 18-20, various, the smaller terminating in a single awn, the larger with a more elongated awn and a shorter one at each side of its base.

On prairies, southern Texas, New|Mexico and adjacent Mexico. Summer and fall.

3. Thymophylla Wrightii (A. 'Gray) Small. Annual or probably perennial, glabrate. Stems erect, or branched at the base, the branches decumbent, 5-20 $\mathrm{cm}$. long: leaves alternate; blades narrowly linear, 1-3 cm. long, bristle-tipped, entire or with few pinnate lobes: involucres campanulate, $5-6.5 \mathrm{~mm}$. high ; lobes $16-20$, ovate or triangular : ligules of the ray-flowers bright yellow, $5-9 \mathrm{~mm}$. long: achenes about $4 \mathrm{~mm}$. long : pappus simple or nearly so; scales about 10 , each with three awns from a lanceolate or oblong base, the middle awn about twice as long as the lateral. [Hymenatherum Wrightii A. Gray.]

In sandy soil or on prairies, Texas. Spring.

4. Thymophylla tenuiloba (DC.) Small. Annual or perennial, minutely pubescent. Stems 1-3 dm. long, more or less diffusely branched : leaves numerous, rigid; blades pinnately parted into 7-11 subulate-filiform segments $3-8 \mathrm{~mm}$. long and bristletipped : involucres campanulate, $5-6 \mathrm{~mm}$. high ; lobes 12 , ovate : ligules of the ray-flowers yellow, 4-6 mm. long: achenes 3-3.5 $\mathrm{mm}$. long: pappus simple or nearly so ; scales about 10, 3-awned, the middle awn about as long as the body. [Hymenatherum tenuilobum DC.]

In sandy soil, Texas and adjacent Mexico. Spring and summer.

5. Thymophylla pentachaèta (DC.) Small. Perennial, pubescent. Stems shrubby, more or less densely branched at the base, the branches 1-2 dm. long: leaves numerous; blades 1-2.5 cm. long, the segments subulate or nearly filiform: involucres campanulate, $4 \mathrm{~mm}$. to nearly $5 \mathrm{~mm}$. high: ligules of the ray-flowers bright yellow, 4-6.5 $\mathrm{mm}$. long: achenes 3.5-4 mm. long: pappus double, the outer scales thin, erose at the top. [Hymenatherum pentachaetum DC.]

On dry hills, Texas to Utah and Mexico. Summer and fall.

6. Thymophylla Trecùlii (A. Gray) Small. Perennial, but rather herbaceous and nearly glabrous. Stems diffusely branched, the branches lax : leaves numerous; blades pectinately parted, the segments linear-subulate, 4-6 $\mathrm{mm}$. long : heads scattered : involucres $5-6 \mathrm{~mm}$. high : achenes, and pappus, similar to those of the next preceding species.

In dry soil, southeastern Texas.

7. Thymophylla gnaphaloìdes (A. Gray) Small. Annual, densely woolly. Stems branched at the base, the branches $0.5-2 \mathrm{dm}$. long, depressed or diffusely spreading : leaves numerous; blades spatulate to linear-spatulate, $1-1.5 \mathrm{~cm}$. long, completely clothed with wool : heads rather showy: involucres $6-7 \mathrm{~mm}$. high; bracts united to near the top, the lobes acute or slender-tipped, punctate : ligules of the ray-flowers yellow, oval or oblong, 4-5 mm. Iong: achenes 3-3.5 mm. long: pappus double, the inner series of lanceolate palae. [Hymenatherum gnaphaloides A. Gray.]

On dry hills and plains, Texas and adjacent Mexico. Spring to fall. 


\section{PÉCTIS L.}

Annual or perennial caulescent often heavy-scented herbs, usually glandular-dotted and glabrous. Leaves opposite: blades narrow, entire, usually bristly ciliate. Heads small, radiate, in cymes. Involucres narrow, several-flowered : bracts distinct, in 1 series, keeled. Receptacle naked. Ray-flowers pistillate, fruit-producing : ligules broad. Diskflowers perfect: corollas sometimes 2-lipped. Anthers entire at the base. Stigmas of the disk-flowers obtuse. Achenes narrow, terete or angled. Pappus of several scales, awns or bristles, or rarely obsolete. Our species are annuals.

Pappus of awn-tipped or subulate-tipped scales, 2-3 in the ray, 4-6 in the disk.

Heads sessile or nearly so: leaf-blades over $1 \mathrm{~mm}$. wide.

Ray-flowers 5: achenes of the ray with 2 pappus-scales.

Ray-flowers $2-3$ : achenes of the ray with 3 pappus-scales.

Heads long-peduncled: leaf-blades less than $1 \mathrm{~mm}$. wide.

Pappus of $1-6$ upwardly barbed awns, or a mere chaffy crown.

Pappus of 3-6 slender awns.

Pappus a scaly crown, sometimes accompanied by 1 or 2 awns.

1. P. prostrata.

2. P. ciliaris.

3. P. Lessingii.

4. P. tenella.

5. P. angustifolia.

1. Pectis prostràta Cav. Foliage nearly glabrous. Stems usually branched at the base, the branches procumbent or prostrate, $0.5-2 \mathrm{dm}$. long: leaf-blades oblanceolate to linear-spatulate, 1-2 cm. long, entire, sparingly bristly near the base: heads sessile or nearly so, more or less clustered : involucres prismatic, 6-7 $\mathrm{mm}$. long; bracts concave and keeled : ray-flowers 5: achenes $2-2.5 \mathrm{~mm}$. long: pappus-scales ovate-lanceolate or lanceolate, often unequal, short-awned, 2 in the ray, $4-5$ in the disk.

In waste places, about seaports, Florida. Also from southern Texas to Arizona and Mexico. Also $\mathrm{i}^{\mathrm{n}}$ the West Indies.

2. Pectis ciliàris $\mathrm{L}$. Foliage minutely pubescent, Melissa-scented. Stems $1-4 \mathrm{dm}$. tall, erect or diffusely branched: leaf-blades linear or nearly so, over $1 \mathrm{~mm}$. wide, acute, entire, with few bristles near the base : heads sessile or nearly so, few in clusters: involucres prismatic, 4-5 mm. high; bracts 4-6, linear or oblong: ray-flowers 2-3 ; ligules 2-2.5 mm. long: achenes slender, $3 \mathrm{~mm}$. long, pubescent : pappus-scales subulate-lanceolate, slender-tipped, 3 in the ray, 5 in the disk.

In sand, peninsular Florida. Spring to fall.

3. Pectis Lessíngii Fernald. Foliage nearly glabrous. Stems more or less diffusely branched, slender, 1-4 dm. long : leaf-blades narrowly linear, 1-3 cm. long, less than 1 $\mathrm{mm}$. wide, acute, entire, with few bristles below the middle: heads commonly solitary on filiform peduncles $1-2.5 \mathrm{~cm}$. long: involucres narrow, $4-5 \mathrm{~mm}$. high; bracts linear or nearly so: achenes slender, $3 \mathrm{~mm}$. long: pappus-scales ovate or ovate-lanceolate, often abruptly narrowed into slender awns. [P. linifolia Less., not L. ] .

In sand, peninsular Florida.

4. Pectis tenélla DC. Foliage nearly glabrous. Stems commonly branched at the base, the branches erect or spreading, $0.5-2.5 \mathrm{~cm}$. long, fastigiate or cymose near the tips: leaf-blades narrowly linear, 1-5 cm. long, acute, with few bristles near the base : heads not showy : involucres cylindric, $4 \mathrm{~mm}$. high; bracts linear, finally involute : ray-flowers relatively conspicuous ; ligules mainly ovate, $2.5-3.5 \mathrm{~mm}$. long: achenes slender, $3 \mathrm{~mm}$. Iong, ribbed : pappus-scales $3-6$, slender, about as long as the achene, the crown wanting.

In sandy soil, Texas and adjacent Mexico. Spring to fall.

5. Pectis angustifòlia Torr. Foliage nearly glabrous, Iemon-scented. Stems erect or branched at the base, the branches spreading, 0.5-2 dm. long: leaf-blades narrowly linear, $2-4.5 \mathrm{~cm}$. long, entire, with few bristles near the base : heads nearly sessile, in clusters : involucres cylindric, $3-3.5 \mathrm{~mm}$. high ; bracts about 8 , linear or nearly so, involute, obtuse : achenes $4 \mathrm{~mm}$. long, slender: pappus a crown of $4-5$ usually united scales, sometimes accompanied by 2 slender awns.

On plains and dry hills, Colorado to Texas and Arizona. Spring to fall.

\section{ANTHÈMIS L.}

Annual or perennial caulescent, often heavy-scented herbs. Leaves alternate: blades pinnatifid or dissected, the segments slender. Heads radiate, long-peduncled. Involucres hemispheric, many-flowered : bracts in several series, appressed, scarious-margined. Receptacle convex, conic or oblong, chaffy, at least near the top. Ray-flowers pistillate, fruit-producing, or neutral : ligules white or yellow. Disk-flowers perfect, fruit-producing: corollas yellow. Anthers entire and obtuse at the base. Stigmas of the disk-flowers truncate. Achenes angled, ribbed or striate. Pappus wanting or a mere border. 
1. Anthemis Cótula L. Annual, often finely pubescent, heavy-scented. Stems 1-8 dm. tall, more or less branched : leaf-blades finely thrice pinnately dissected: involucres flattish : bracts linear to oblong, pubescent, 3-5 mm. long: ray-flowers mostly neutral ; ligules white, linear or oblong, 1-2 cm. long: disk yellow : receptacle conic: achenes about $1 \mathrm{~mm}$. long, 10-ribbed, rugose or tuberculate.

In various situations, nearly throughout North America, except the extreme north. Naturalized from Europe. Spring to fall. MAYWEED. DOG'S CAMOMILE. DOG FENNEL.

\section{ACHILLÈA L.}

Perennial caulescent strong-scented herbs. Leaves alternate : blades toothed, pinnatifid or dissected. Heads radiate, in corymbs. Involucres short, several-flowered : bracts appressed, in several series, distinct. Receptacle more or less convex : bractlets membranous. Ray-flowers pistillate, fruit-producing: ligules white or pink. Disk-flowers perfect, fruitproducing. Anthers obtuse and entire at the base. Stigmas of the disk-flowers obtuse. Achenes slightly flattened, more or less broadened upward. Pappus wanting.

1. Achillea Millefòlium L. Foliage villous and cottony, bright green. Stems 2-9 dm. tall, sometimes branched, angled : leaf-blades twice or thrice pinnately parted, 5-20 $\mathrm{cm}$. long, mostly oblong in outline, the lower ones petioled: corymbs many-flowered, compound, $2-10 \mathrm{~cm}$. broad : involucres $4-5 \mathrm{~mm}$. high ; bracts oblong to lanceolate, in 3-4 series, with transparent margins : ray-flowers 4-5; ligules white, suborbicular, crenate.

In dry or stony soil, nearly throughout temperate North America, especially eastward. Naturalized from Europe and Asia. Summer and fall. YARrow. MilfoIL.

\section{CHRYSÁNTHEMUM L.}

Annual or perennial caulescent herbs, often heavy-scented. Leaves alternate : blades toothed, incised or dissected, the segments coarse. Heads usually radiate. Involucres flat or hemispheric : bracts in several series, the inner longer than the outer. Receptacle flat or hemispheric, naked. Ray-flowers pistillate, fruit-producing: ligules white, pink or yellow. Disk-flowers perfect, fruit-producing : corollas with terete or winged tubes. Anthers entire and obtuse at the base. Stigmas of the disk-flowers truncate, brush-like. Achenes terete or angled. Pappus a scaly cup, or wanting.

1. Chrysanthemum Leucánthemum L. Perennial, glabrous or nearly so. Stems 2-9 dm. tall, usually simple : leaf-blades spatulate to linear, $2-10 \mathrm{~cm}$. long, serrate or pinnatifid : heads showy, long-peduncled : involucre flattish ; bracts linear-lanceolate to linear, 4-7 mm. long, obtuse : ray-flowers numerous; ligules white or pink, $1-2.5 \mathrm{~cm}$. long, rarely tubular: disk light yellow, 1-2 cm. broad : pappus wanting.

In fields, meadows and waste grounds, nearly throughout North America. Naturalized from Europe and Asia. Spring to fall. DAISY.

\section{MATRICÀrIA L.}

Annual or perennial caulescent odorous herbs. Leaves alternate : blades 1-3-dissected, the segments filiform or narrowly linear. Heads radiate or rarely discoid. Involucres hemispheric : bracts in few series, appressed, the inner longer than the outer. Reeptacle conic or more elongated, or ovoid, naked. Ray-flowers pistillate, fruit-producing: ligules white. Disk-flowers perfect, fruit-producing: corollas yellow. Anthers obtuse and entire at the base. Stigmas of the disk-flowers truncate, brush-like. Achenes 3-5-ribbed or 35-nerved. Pappus wanting or a mere border, sometimes slightly toothed. Camomile.

1. Matricaria Chamomílla L. Annual, aromatic, resembling Anthemis Cotula. Foliage glabrous or nearly so: stems $2-4 \mathrm{dm}$. tall, sometimes branched at the base, and the branches decumbent : leaf-blades $2-8 \mathrm{~cm}$. long, twice or thrice pinnately-parted : heads 5-6 $\mathrm{mm}$. high : involucral bracts oblong, 2-2.5 mm. long : ray-flowers $15-21$; ligules white, linear or linear-oblong, 5-7 mm. Iong: disk ovoid or conic: achenes $1.5-2 \mathrm{~mm}$. long, the inner face unequally 5-ribbed : pappus an obscure border or wanting.

In waste places and fields, New York to Georgia. Spring and summer.-M. Chamomilla corondita Gay, has a scarious, cleft, toothed or one-sided pappus surmounting the achenes of the ray and most of those of the disk, it occurs in southern Texas and adjacent Mexico. Like the species, native of Europe.

134. TANACÈTUM L.

Perennial or sometimes annual caulescent often strongly aromatic herbs. Leaves alternate: blades 1-3-pinnately dissected or divided. Heads discoid or rarely slightly 
radiate, corymbose. Involucres hemispheric or flattened: bracts in several series, appressed. Receptacle flat or convex, naked. Ray- or marginal-flowers pistillate, fruitproducing. Disk-flowers perfect, fruit-producing: corollas tubular. Anthers obtuse and entire at the base, usually blunt at the apex. Stigmas truncate, brush-like. Achenes 3-5angled, or 5-ribbed, often truncate. Pappus a crown-like border.

1. Tanacetum vulgàre L. Plant acrid-aromatic. Stems $3-10 \mathrm{dm}$. long, sometimes branched : leaf-blades $0.5-2 \mathrm{dm}$. long, the divisions linear or oblong, pinnatifid, the segments sharply toothed: heads commonly numerous, in flat-topped corymbs : involucres depressed-hemispheric, 6-8 $\mathrm{mm}$. broad ; bracts oblong to linear-lanceolate : corollas yellow, the marginal ones often with oblique 3 -toothed ligules: disk flat: achenes $2 \mathrm{~mm}$. long: pappus-crown 5-toothed.

In waste places and on roadsides, Nova Scotia and Ontario to Minnesota, Georgia and Missouri. Naturalized from Europe. Summer and fall. TANSY.

\section{ARTEMÍSIA L.}

Annual or perennial caulescent herbs, or low shrubs, the foliage usually pubescent, Leaves alternate : blades entire, toothed, laciniate or dissected. Heads relatively small, discoid, often numerous, drooping or erect. Involucres various in shape: bracts in several series, the inner ones successively longer. Receptacle flat or hemispheric, naked or sometimes pubescent, but never chaffy. Flowers various, sometimes all perfect and fruitproducing, sometimes the marginal pistillate and fruit-producing, the central perfect and sometimes neutral. Anthers entire and obtuse at the base, usually subulate-tipped. Achenes 2-ribbed, or striate, each topped by a disk. Pappus wanting. Wormwood. Mugwort.

Flowers about the center of the disk perfect, but not producing fruit.

Herbaceous biennial or perennial plants.

Leaf-blades pinnately dissected into narrowly linear segments.

Leaf-blades entire, or those of the basal and lower cauline leaves cleft.

Woody perennial shrub.

Flowers about the center of the disk perfect and fruit-producing.

Leaves glabrous or sparingly pubescent, green, not tomentose.

Leaf-blades 2-3-pinnately divided: ultimate divisions of the panicle lax racemes : involucres about $1 \mathrm{~mm}$. high.

Leaf-blades pinnately divided, the segments pinnatifid: ultimate divisions of the panicle dense spike-like racemes : involucres about $2 \mathrm{~mm}$. high.

Leaves densely white-tomentose, at least beneath.

Leaf-blades 2-pinnatifid or 2-pinnately parted.

Leaf-blades entire or shallowly toothed, or some of those of the lower leaves pinnatifid.

Leaf-blades about equally pale and pubescent on both sides.

Leaf-blades green and glabrate on the upper surface.

1. A. caudata.

2. A. dracunculoides.

3. A. filifolia.

4. A. annua.

5. A. biennis.

6. A. vulgaris.

7. A. gnaphalodes.

8. A. Mexicana.

1. Artemisia caudàta Michx. Biennial, glabrous. Stems 5-18 dm. tall, often with ascending branches at the base : leaves numerous ; blades once to thrice pinnately divided, the segments nearly filiform : heads very numerous, about $2 \mathrm{~mm}$. in diameter, in elongated panicles : involucres with the central flowers perfect but not producing fruit ; bracts ovateoval or broadly oblong.

In sandy soil, Quebec to Manitoba, Florida and Texas. Summer and fall.

2. Artemisia dracunculoides Pursh. Perennial, glabrous. Stems 6-12 dm. tall, usually much branched, the branches nearly erect: leaves numerous ; blades narrow, commonly linear, mostly less than $4 \mathrm{~mm}$. wide, entire, shallowly toothed or some of the lower cauline cleft: heads very numerous, $2-3 \mathrm{~mm}$. in diameter, in ample panicled racemes: involucres with the central flowers perfect, but not producing fruit: bracts ovate to broadly oblong, green and scarious-margined.

On dry plains and prairies, Manitoba and the Northwest Territory to Texas, California and British Columbia. Summer and fall.

3. Artemisia filifòlia Torr. Shrubby, thinly pale-pubescent. Stems $3-8 \mathrm{dm}$. tall, with rigid, nearly erect branches : leaves numerous, $2-5 \mathrm{~cm}$. long; blades mainly parted into 3 entire filiform segments usually less than $1 \mathrm{~mm}$. wide, some of the upper leaves undivided : heads exceedingly numerous, $1-1.5 \mathrm{~mm}$. in diameter in panicled racemes : involucres 3-5-flowered; bracts densely woolly-canescent.

On dry plains, South Dakota to Utah and Mexico. Summer and fall.

4. Artemisia ánnua L. Annual or biennial, glabrous, very aromatic. Stems 4-10 dm. tall, much branched : leaves numerous ; blades twice or thrice pinnately divided, 3-11 $\mathrm{cm}$. long, the segments oblong or incised or pinnatifid : panicle-branches ending in loose racemes: heads subglobose, scattered, nodding: involucres about $1 \mathrm{~mm}$. high, with the central flowers perfect and fruit-producing; bracts mostly oval or ovate.

In waste places, Ontario to Kansas and Tennessee. Naturalized from Europe. Summer. 
5. Artemisia biénnis Willd. Biennial, glabrous, inodorous, insipid. Stems 2-10 dm. tall, nearly simple or sparingly branched: leaves numerous; blades once or twice pinnately divided, the segments lanceolate or linear, incised-pinnatifid or pinnatifid : paniclebranches ending in spike-like racemes: heads not drooping, crowded in axillary clusters : involucres about $2 \mathrm{~mm}$. high, with the central flowers perfect and fruit-producing; bracts oblong or oblong-lanceolate : achenes oblong or oblong-obovoid, barely $1 \mathrm{~mm}$. long.

In rocky soil, Nova Scotia to the Northwest Territory to Pennsylvania, Tennessee and Missouri, mainly naturalized eastward. Summer and fall.

6. Artemisia vulgàris L. Perennial, lanate-tomentose. Stems $3-12 \mathrm{dm}$. tall, paniculately branched : leaves numerous ; blades various, twice pinnatifid or pinnately parted, the segments lanceolate or linear : heads cylindric-campanulate : involucres 4-5 mm. high, with the central flowers fruit-producing; bracts oblong to oblong-lanceolate : achenes $1.5-2$ mm. long.

In waste places, Nova Scotia to Ontario, Michigan, New Jersey and Tennessee. Summer and fall

7. Artemisia gnaphalòdes Nutt. Perennial, lanate-tomentose. Stems $3-13 \mathrm{dm}$. tall, more or less branched: leaves numerous ; blades oblong, linear or linear-lanceolate, 3-7 cm. long or those clustered in the axils shorter, all entire or incised-serrate, about equally white-woolly or tomentose on both sides : heads numerous, loosely racemose, paniculate at maturity, over $3 \mathrm{~mm}$. in diameter : involucres oblong-campanulate; bracts densely woolly.

On dry plains and prairies, Ontario to British Columbia, Texas and Mexico. Summer and fall.

8. Artemisia Mexicàna Willd. Perennial, less densely pubescent than A. gnaphalodes. Stems 6-12 dm. tall, paniculately branched : leaves numerous; blades linear to narrowly lanceolate, entire or those of the lower leaves incisely 3-cleft, or pinnatifid to pinnately 3-5cleft, densely white woolly beneath, green and partially glabrous above: heads numerous, about $2 \mathrm{~mm}$. in diameter : involucres campanulate; bracts canescent or woolly.

On prairies or hillsides, Arkansas to Arizona and Mexico. Summer and fall.

\section{SOLİvA R. \& P.}

Annual caulescent herbs low in habit. Leaves mainly alternate: blades pinnately dissected, petioled : heads heterogamous, discoid, sessile in the axils. Involucres thick: bracts about equal, $5-12$ in 1 or 2 series. Receptacle flat. Flowers mainly pistillate, and without corollas, few, perfect, commonly at the center of the disk. Corollas greenish. Anthers obtuse at the base. Achenes flattened, with firm wings or callous margins, these terminating in spines, the persistent style spine-like. Pappus wanting.

1. Soliva nasturtiifòlia (Juss.) DC. Foliage minutely pubescent. Stems very short : leaf-blades 4-10 mm. long, pinnately parted into 5-9 oblong or linear, entire or fewtoothed segments; petioles as long as the blades or longer : heads not showy, subglobose, 3-6 mm. in diameter : involucral bracts linear to linear-spatulate, 2-2.5 mm. Iong : achenes numerous, cuneate, $1.5-2 \mathrm{~mm}$. long, the margins thickened and tubercular-rugose.

In waste places, North Carolina to Florida.

\section{HAPLOÉSTHES A. Gray.}

Perennial caulescent, partly woody and partly fleshy plants. Leaves opposite : blades narrow, entire, the lower connate-sheathing. Heads corymbose, heterogamous, radiate. Involucre of few broad many-nerved bracts. Receptacle flat or slightly convex, naked. Ray-flowers pistillate, fruit-producing, with yellow ligules. Disk-flowers perfect, fruitproducing. Anthers obtuse and entire at the base. Stigmas of the disk-flowers capitatetruncate. Achenes narrow, 10-ribbed. Pappus of 1 series of slender scabrous bristles.

1. Haploesthes Gréggii A. Gray. Stems usually branched at the base, the branches 3$6 \mathrm{dm}$. tall, glabrous, striate, corymbose above: leaves fleshy, the lower ones connate and sheathing the stem; blades narrowly linear or linear-filiform, 2-4 cm. long, entire : heads short-peduncled, few together in cymes: involucres $3-3.5 \mathrm{~mm}$. high; bracts few, oval to orbicular, rounded at the apex, thin-margined: ligules of the ray-flowers yellow, 2-4 mm. long: achenes $\mathbf{2} \mathrm{mm}$. long.

In saline soil, southeastern Colorado to Texas and adjacent Mexico. Spring to fall.

\section{8. ÁRNICA L.}

Perennial caulescent herbs, with simple or sparingly branched stems. Leaves normally opposite, sometimes mainly basal : blades flat, entire or toothed. Heads peduncled, radi ate or rarely discoid, solitary or several. Involucres many-flowered : bracts narrow, nearly 
equal, in one or two series. Receptacle flat, naked, fimbrillate or pubescent. Ray-flowers pistillate, fruit-producing : ligules yellow. Disk-flowers perfect, fruit-producing : corollas tubular. Anthers sometimes slightly sagittate. Achenes narrow, more or less pubescent, 5-10-ribbed. Pappus a single series of scabrous or barbellate firm bristles.

1. Arnica acaùlis (Walt.) B.S.P. Foliage hirsute. Stems $2-10 \mathrm{dm}$. tall, simple or sparingly branched above, commonly bearing 1 or 2 pairs of leaves with nearly oblong blades : leaves mainly basal; blades spreading on the ground, oblong to oval or ovate, 5$12 \mathrm{~cm}$. long, shallowly toothed or nearly entire, sessile : heads showy, long-peduncled : involucral bracts linear or linear-lanceolate, about $1 \mathrm{~cm}$. long, acute: ligules of the rayflowers deep yellow, $1.5-2.5 \mathrm{~cm}$. long: achenes $4 \mathrm{~mm}$. long. [A. nudicaulis Nutt.]

In pine lands and open woods, Pennsylvania to Florida. Spring. LeOPARD's-BANE.

\section{ERECHTITES Raf.}

Annual caulescent normally coarse herbs. Leaves alternate: blades flat, not rigid, usually toothed or pinnatifid. Heads heterogamous, discoid, in corymbs or panicled corymbs. Involucres narrow, somewhat swollen at the base : bracts mostly in 1 series, narrow, the main series sometimes accompanied by smaller ones. Receptacle flat or concave, naked. Pistillate flowers marginal. Perfect flowers central, like the pistillate, fruit-producing. Corollas tubular, white or greenish. Anthers obtuse at the base. Achenes narrow, angled or striate. Pappus copious, conspicuous, of soft white elongated bristles.

1. Erechtites hieracifòlia (L.) Raf. Foliage glabrous or sparingly hirsute. Stems 2-20 dm. tall, simple or much branched : leaf-blades flimsy, spatulate-oblong or lanceolate, 5-20 cm. long, acute or acuminate, coarsely toothed, incised or pinnatifid, the lower ones with winged petioles, the upper sessile and partly clasping: heads not showy : involucres cylindric, 12-15 mm. Iong; bracts narrowly linear : achenes $1.5 \mathrm{~mm}$. long, ribbed : pappus bright white, silky.

In open woods, and especially on burnt soil, Newfoundland to the Northwest Territory, Florida, Louisiana and Mexico. Summer and fall. FrRE-WEED.

\section{MESADÈNIA Raf. ${ }^{1}$}

Perennial herbs, with mostly glabrous foliage and sometimes a milky sap. Stems corymbosely branched above. Leaves alternate: blades various, sometimes ample, undulate or toothed, commonly petioled. Heads often numerous, discoid, corymbose. Involucres cylindric or nearly so : bracts narrow, about 5 in 1 series, but commonly accompanied by a few small ones at the base of the involucre. Receptacle flat, with a fleshy projection at the center, not chaffy. Corollas tubular, white, pinkish or yellowish : lobes usually with a midnerve. Anthers not tailed at the base. Achenes narrow, 5-11-ribbed. Pappus copious, of soft scabrous white bristles. Indian Plantain.

Bracts of the involucre wingless.

Corolla-lobes fully twice as long as the throat.

Leaf-blades pedately or digitately veined, those of the lower leaves broader than long.

Leaves green on both sides or glaucous beneath; blades.pedately veined. Leaves green : stem furrowed.

Leaves glaucous beneath.

Stem furrowed.

Stem terete.

Leaves glaucous on both sides: blades digitately veined.

Leaf-blades parallel-veined or subpinnately veined : stem terete.

Leaf-blades ovate, commonly broadly so.

Leaf-blades linear to lanceolate.

Corolla-lobes but slightly longer than the throat.

Bracts of the involuere winged along the midrib.

Stems terete, merely striate: blades of the upper stem-leaves hastate.

Stems channeled or angled : blades of the upper stem-leaves not hastate.

Lower leaves with 7-9-veined entire or crenate|blades.

Leaf-blades entire or nearly so.

Leaf-blades crenate.

Lower leaves with 3-5-veined sinuate-dentate blades.

1. M. reniformis.

2. M. similis.

3. M. atriplicifolia.

4. M. maxima.

5. M. ovata.

6. M. lanceolata.

7. M. diversifolia.

8. M. difformis.

9. M. tuberosa.

10. M. Floridana.

11. M. sulcata.

1. Mesadenia renifórmis (Muhl.) Raf. Stems 1-3 m. tall, sometimes tomentulose above, angled : leaf-blades ample, reniform, 1-6 dm. broad, repand or angulately lobed, deeply cordate to cuneately truncate, green : heads of ten numerous : involucral bracts of ten 5 , oblong to lanceolate, 8-11 mm. long: corollas with lobes fully twice as long as the throat: achenes $5 \mathrm{~mm}$. long, black.

In rich woods, New Jersey to Minnesota, Georgia and Tennessee. Summer and fall.

\footnotetext{
${ }^{1}$ Prepared with the assistance of $\mathrm{Mr}$. Roland M. Harper.
} 
2. Mesadenia símilis Small. Similar to $M$. atriplicifolia in habit. Stem relatively stout, furrowed, corymbosely branched above : leaf-blades green above, glaucous beneath, those of the basal and lower stem-leaves much larger than those of the upper, undulatesinuate, deeply cordate, long-petioled: heads rather smaller than those of $M$. atriplicifolia.

On prairies and in low grounds, Arkansas. Summer.

3. Mesadenia atriplicifòlia (L.) Raf. Stems 1-2 m. tall, glabrous, terete : leafblades various, those of the basal leaves orbicular-reniform or broadly ovate, $10-15 \mathrm{~cm}$. broad, those of the stem-leaves smaller, ovate or triangular, or narrower above, all angulately 3-7-lobed or coarsely and sharply toothed, cordate to cuneate at the base, all glaucous beneath : heads numerous : involucral bracts linear, oblong-linear, oblong-lanceolate, 8-11 $\mathrm{mm}$. long, wingless : achenes $4-4.5 \mathrm{~mm}$. long.

In open woods and thickets, Ontario to Minnesota, Florida and Kansas. Summer and fall.

4. Mesadenia máxima Harper. Stem about $1.5 \mathrm{~m}$. tall, terete, glaucous: leafblades thickish, those of the lower leaves about $25 \mathrm{~cm}$. long and $20 \mathrm{~cm}$. broad, truncate at the base, long-petioled, those of the upper gradually reduced in size and proportionately narrower, all glaucous on both sides, very coarsely sinuate-toothed, more or less digitately veined, the veins forking and often anastomosing: heads in a terminal compound corymb $5-6 \mathrm{dm}$. long and nearly as broad : involucral bracts bright green, about $1 \mathrm{~cm}$. long, wingless.

In dry pine lands, Sumter County, Georgia. Summer.

5. Mesadenia ovàta (Walt.) Raf. Stems $8-12 \mathrm{dm}$. tall, terete: leaf-blades thinnish, ovate to oval, $8-20 \mathrm{~cm}$. long, entire or repand-undulate, truncate and cuneate and palmately nerved at the base; petioles of the basal and lower stem-leaves as long as the blades : heads often numerous : involucral bracts narrowly oblong or linear-lanceolate, 8-10 $\mathrm{mm}$. long: corollas with very little throat.

In damp woods or swamps, Georgia and Florida to Louisiana.

6. Mesadenia lanceolàta (Nutt.) Raf. Stems 8-15 dm. tall, terete : leaf-blades linear, narrowly lanceolate or linear-oblong, 5-30 cm. long, entire or repand-denticulate ; petioles margined, the lower ones longer than the blades : heads relatively few : involucral bracts linear or narrowly oblong-lanceolate, $8-10 \mathrm{~mm}$. long : achenes about $5 \mathrm{~mm}$. long.

In wet pine lands, Georgia and Florida to Louisiana. Spring to fall.

7. Mesadenia diversif òlia (T. \& G.) Greene. Similar to $M$. atriplicifolia in habit, but not glaucous : corolla-lobes but little longer than the throat. Little known.

In swamps, South Carolina to Florida. Summer.

8. Mesadenia diffórmis Small. Stems $7-11 \mathrm{dm}$. tall, terete : leaf-blades various, those of the lower cauline leaves ovate, some of them narrowly ovate, undulate or merely sinuate, $2-4.5 \mathrm{~cm}$. long, obtuse, on greatly elongated petioles, those of the upper cauline leaves ovate in outline but hastate and sharply dentate or dentate-lobed, $2.5-4 \mathrm{~cm}$. long, even the uppermost one like the others nearly truncately narrowed into petiole-like bases: heads few in the terminal corymb : involucral bracts winged.

In swamps, western Florida. Summer.

9. Mesadenia tuberòsa (Nutt.) Britton. Stems 6-12 dm. tall, sulcate or angled : leafblades thickish, ovate, oval, oblong-lanceolate or narrowly elliptic, 5-20 cm. long, 5-9nerred, entire, denticulate or repand-dentate, attenuate or truncate at the base ; petioles margined, those of the basal and lower stem-leaves as long as the blades or much longer : involucral bracts narrowly oblong, winged, $8-10 \mathrm{~mm}$. long: achenes $4.5-5 \mathrm{~mm}$. long, granular, ribbed.

On damp prairies, Ontario to Minnesota, Alabama and Louisiana. Summer.

10. Mesadenia Florłdàna (A. Gray) Greene. Stems 7-12 dm. tall, channeled : leafblades thickish, ovate, oval or oblong, 5-15 cm. long, coarsely crenate or crenate-dentate, cuneately constricted at the base, the upper ones sessile or nearly so : heads numerous: involucral bracts oblong or nearly so, 10-12 mm. long, winged : corollas with lobes slightly longer than the throat: achenes about $5 \mathrm{~mm}$. long.

In low pine lands, Florida. Spring and summer.

11. Mesadenia sulcàta (Fernald) Small. Stem 1-1.5 m. tall, deeply channeled : leaf-blades ovate to oblong-ovate, narrowly elliptic or oblong-lanceolate, $8-20 \mathrm{~cm}$. long, or shorter toward the inflorescence, those of the basal and lower cauline leaves sinuate-dentate, narrowed into long petioles, the upper closely sessile, usually sharply and deeply toothed: heads numerous : involucral bracts oblong or oblong-lanceolate, $8-10 \mathrm{~mm}$. long, winged.

In sandy bogs or wet woods, southern Georgia and northern Florida. Summer and fall. 


\section{SYNÓSMA Raf.}

Perennial caulescent glabrous or nearly glabrous herbs. Leaves alternate: blades toothed, often triangular or hastate. Heads homogamous, discoid, corymbose. Involucres nearly cylindric : bracts narrow, 12-15 in 1 series, with few subulate ones at their bases. Receptacle flat, naked. Corollas tubular, white or pink. Anthers not tailed at the base. Stigmas obtuse or truncate, unappendaged. Achenes narrow, 5-10-ribbed. Pappus copious, of soft hair-like bristles. The plants flower in summer and fall. Indian Plantain.

1. Synosma suavèolens (L.) Britton. Stems 6-15 dm. tall. Leaves numerous; blades narrowly or broadly hastate, $8-20 \mathrm{~cm}$. long, acute or acuminate, sharply and often doubly serrate or dentate-serrate, the lower ones cordate at the base, slender-petioled, the upper ones truncate or cuneate at the base, sessile or nearly so: involucral bracts glabrous, the larger ones about 12, linear or slightly broadened upward, 7-11 $\mathrm{mm}$. long, acute or acuminate : achenes slender, $7-8 \mathrm{~mm}$. long.

In low grounds or shaded soil, Connecticut to Minnesota, Florida and Tennessee.

\section{SENÈCIO L.}

Annual or perennial caulescent herbs. Leaves alternate, sometimes mainly basal : blades various, entire, toothed, pinnatifid or pinnately parted. Heads solitary, or numerous and variously disposed, radiate or rarely discoid. Involucres campanulate to cylindric: bracts narrow, mainly in one series, the few outer irregular. Receptacle flat or slightly convex, usually naked or pitted. Ray-flowers pistillate, fruit-producing. Diskflowers fruit-producing: corollas tubular, yellow. Anthers obtuse at the base or rarely slightly sagittate. Stigmas, at least in the disk-flowers, spreading or recurving. Achenes terete, or those in the disk slightly flattened, 5-10-ribbed. Pappus copious, of slender or capillary smooth or rough bristles. SQUAW-WEed. Ragwort. Rag-Weed. Groundsel.

Involucre over $12 \mathrm{~mm}$. high.

Involucre less than $12 \mathrm{~mm}$. high.

Annual or merely biennial plants.

Leaf-blades lyrately and pinnately divided : involucre less than $6 \mathrm{~mm}$. high. Stem simple at the base, or if branched, the terminal leaf-segment is lobed not toothed.

Terminal leaf-segments reniform, few-lobed.

Terminal leaf-segments not reniform, several-many-toothed. Stem branched at the base.

Leaf-blades entire or repand-toothed : involucre over $6 \mathrm{~mm}$. high.

Perennial sometimes shrubby plants.

A. Plants herbaceous: leaves mainly crowded on a caudex, from which arises the much less leafy flowering stem.

Blades of the basal leaves cordate or truncate at the base.

Blades of the basal leaves predominatingly lanceolate or oblong-lanceolate, sharply serrate.

Blades of the basal leaves predominatingly orbicular or ovate, crenate. Involucres over $5 \mathrm{~mm}$. high. Involucres less than $5 \mathrm{~mm}$. high.

Blades of the basal leaves gradually narrowed or cuneate at the base. Blades of the basal leaves scarcely longer than broad.

Blades of the basal leaves manifestly or markedly longer than broad. Basal leaves with merely toothed or partially and slightly lyratepinnatifid blades.

Blades of the basal leaves wholly, or predominatingly, narrowly or broadly spatulate: achenes glabrous.

Leaf-blades toothed or pinnatifid, like the stem, essentially glabrous.

Leaf-blades entire, like the stem, persistently grayish-white tomentose.

Blades of the basal leaves wholly or predominatingly oblong, oval or lanceolate: achenes pubescent.

Bracts of the mature involucre less than $6 \mathrm{~mm}$. long. Blades of the basal leaves mainly $1 \mathrm{~cm}$. wide. Blades of the basal leaves mainly $2 \mathrm{~cm}$. wide.

Bracts of the mature involucre over $6 \mathrm{~mm}$. long. Receptacle $3 \mathrm{~mm}$. broad at maturity. Receptacle 4-5 mm. broad at maturity.

Main stem and leaf-blades persistently more or less pubescent.

Bracts of the involucre becoming glabrous: blades of the basal leaves serrate.

Bracts of the involucre persistently pubescent: blades of the basal leaves crenate.

Main stem and leaf-blades glabrous.

Blades of the basal leaves pinnately parted and twice or thrice pinnatifid or dissected.
1. S. Rugelia.

\section{S. Mississippianus.}

3. S. lobatus.

4. S. Greggii.

5. S. ampullaceus.:

\section{S. Robbinsii.}

7. S. aureus.

8. $S$. gracilis.

9. S. rotundus.

10. S. obovatus.

11. S. Purshianus.

12. S. Balsamitae.

13. S. Earlei.

14. S. Smallii.

15. S. Plattensis.

16. S. tomentosus.

17. S. Alabamensis. 
Primary leaf-divisions 1-2-pinnatifid.

Primary leaf-divisions dissected, the ultimate divisions mainly linear.

B. Plants woody : leaf-blades pinnately parted into 3-9 linear or filiform-

18. S. Memmingeri.

19. S. Millefolium.

linear segments.

20. S. Fremontii.

1. Senecio Rugélia A. Gray. Perennial, villous-hirsute. Stems $2-5 \mathrm{dm}$. tall, sometimes sparingly branched above : leaves mainly basal ; blades ovate to oblong-oval, $8-15$ $\mathrm{cm}$. long, acute, denticulate or dentate, abruptly narrowed or subcordate at the base ; petioles commonly longer than the blades, margined, the stem leaves usually with smaller blades and shorter petioles: heads long-peduncled : involucres over $1 \mathrm{~cm}$. high ; bracts about 12, linear-lanceolate, the larger $12 \mathrm{~mm}$. long, glabrous or nearly so: achenes slender, $6 \mathrm{~mm}$. long.

In thickets at very high altitudes, North Carolina and Tennessee. Summer.

2. Senecio Mississippiànus DC. Annual and similar to $S$. lobatus in habit. Stem 1.5-5 dm. tall, usually simple below the infiorescence : leaf-blades 4-9 $\mathrm{cm}$. long, pinnately parted or divided, the segments few-lobed, the terminal lobe reniform, flat at the apex and 3-5-lobed: heads few or several, conspicuous : involucres $4-5 \mathrm{~mm}$. high; bracts acuminate: ligules of the ray-flowers oblong to oblong-spatulate, $3.5-5 \mathrm{~mm}$. long: achenes 1.5 $\mathrm{mm}$. long, hispidulous.

In low grounds, Arkansas and the Indian Territory to Louisiana and Texas. Spring and summer.

3. Senecio lobàtus Pers. Annual or biennial, succulent, thinly woolly, or glabrous at maturity. Stems 1-9 dm. tall, hollow, more or less branched above : leaf-blades 3-20 cm. long, pinnately parted or divided, the segments cuneate to suborbicular, coarsely toothed: heads showy : involucres less than $6 \mathrm{~mm}$. high ; bracts linear, acute, 5-6 mm. long: ray-flowers 6-12 : ligules yellow, linear or linear-oblong, 5-8 mm. long: achenes 1.5 $\mathrm{mm}$. long, hispidulous on some of the angles.

In wet soil and river bottoms, Illinois and Missouri to North Carolina, Florida, Texas and Mexico. Spring to fall.

4. Senecio Gréggii Rydb. Annual or biennial, bright green. Stems branched at the base, the branches several together and tufted, 1.5-3 dm. tall, somewhat scape-like : leaf-blades 2-7 cm. long, pinnately divided, except the few very early ones, the segments mainly obovate, each shallowly few-lobed: heads showy, in a compound cyme : involucres 4-5 mm. high ; bracts linear, acuminate : ligules of the ray-flowers $3-4 \mathrm{~mm}$. long : achenes hispidulous, nearly $2 \mathrm{~mm}$. long.

In low grounds, Texas and Mexico. Spring and summer.

5. Senecio ampullàceus Hook. Annual or biennial, woolly when young, smooth and glabrous in age. Stems 2-6 dm. tall, corymbose above : leaf-blades oblong, oval or oblong-lanceolate, $5-15 \mathrm{~cm}$. long, entire or denticulate, the lower ones contracted into petiole-like bases, the upper ones sessile : heads showy, often numerous : involucres over 6 $\mathrm{mm}$. high ; bracts narrowly linear, 7-10 $\mathrm{mm}$. long: ligules of the ray-flowers yellow, 9-15 mm. long: achenes $4 \mathrm{~mm}$. long, scabrous, contracted under the top.

On sandy prairies, Texas. Spring and summer.

6. Senecio Robbínsit Oakes. Perennial, glabrous or nearly so. Stems often tufted, 3-10 dm. tall, corymbose above : leaf-blades thinnish, those of the basal leaves lanceolate or oblong-lanceolate, 3-8 cm. long, acute, serrate or incised-serrate, subcordate or truncate at the base ; petioles often several times longer than the blades : stem-leaves mostly dilated, incised, partly clasping by stipule-like bases : involucres glabrous; bracts linear-subulate, 5-6 mm. long, acute : ligules of the ray-flowers linear, 4-5 mm. long: achenes nearly 3 mm. long, sharply ribbed.

In mountain meadows, New Hampshire and Vermont to New York and on Roan Mountain, North Carolina and Tennessee. Summer.

7. Senecio aùreus L. Perennial, glabrous at least below the inflorescence. Stems solitary or clustered, 3-7 dm. tall, corymbose above : leaf-blades of the basal leaves ovate, oval or suborbicular, $2-12 \mathrm{~cm}$. long, rounded at the apex, crenate or serrate-crenate, cordate; petioles longer than the blades: stem-leaves with pinnatifid or lyrate-pinnatifid blades, the segments often cuneate, sometimes toothed: heads showy, slender-peduncled: involucres $6-7 \mathrm{~mm}$. high ; bracts linear, fully $1 \mathrm{~mm}$. broad: ligules of the ray-flowers linear or linear-oblong, deep yellow, 5.5-7.5 mm. long : achenes $3 \mathrm{~mm}$. long.

In swamps and meadows, Newfoundland to Ontario, Missouri, Florida and Texas. Spring and summer.

8. Senecio grácilis Pursh. Similar to $S$. aureus in habit but smaller and more slender : heads few, about one-half as large as those of $S$. aureus: involucres $3.5-4.5 \mathrm{~mm}$. high : ligules of the ray-flowers broadly oblong or oval, $3.5-5 \mathrm{~mm}$. long.

In wet grounds, Pennsylvania to Georgia. Spring. 
9. Senecio rotúndus (Britton) Small. Perennial, glabrate. Stems $3-6 \mathrm{dm}$. tall, corymbose above : leaves mainly basal ; blades suborbicular to orbicular-ovate, $3-7 \mathrm{~cm}$. in diameter, coarsely crenate-serrate, truncate at the base, decurrent into the margined petioles, these as long as the blades or longer: heads in open corymbs : involucres 4-5 mm. high ; bracts linear-subulate, $5 \mathrm{~mm}$. long, acute : ligules of the ray-flowers light yellow, linear, about $8-10 \mathrm{~mm}$. long: achenes $2.5 \mathrm{~mm}$. long. [S. obovatus rotundus Britton.]

In low grounds or on wet rocks, Ohio to Missouri, Louisiana and Texas. Spring.

10. Senecio obovàtus Muhl. Perennial, nearly glabrous. Stems solitary or loosely clustered, 1-5 dm. tall, corymbose above : leaves mainly basal or near the base of the stem; blades spatulate to obovate, $2-10 \mathrm{~cm}$. long, rounded at the apex, coarsely toothed or partly lyrate-pinnatifid, narrowed into broad petioles : stem-leaves with pinnatifid blades: heads in open corymbs: involucres $4-5 \mathrm{~mm}$. high; bracts narrowly linear or subulate-linear: ligules of the ray-flowers deep yellow, $5-7 \mathrm{~mm}$. long: achenes $3-5 \mathrm{~mm}$. long.

In moist soil, Nova Scotia to Ontario, Michigan, Florida and North Caroiina. Spring.

11. Senecio Purshiànus Nutt. Perennial, densely and persistently grayish white tomentose to the involucres. Stems usually tufted, 1-2 dm. tall : leaves mostly crowded on the caudex-like rootstocks, these mainly basal ; blades spatulate, $3-6 \mathrm{~cm}$. long, entire, obtuse, narrowed into slender petiole-like bases: heads solitary or few, showy: involucres 6-8 mm. high ; bracts narrowly linear, merely cobwebby in age : ligules of the ray-flowers oblong or oval-oblong, 5-7 $\mathrm{mm}$. long: achenes $3 \mathrm{~mm}$. long, glabrous.

In dry soil, Manitoba to British Columbia, Minnesota, Texas and Utah. Spring and summer.

12. Senecio Balsámitae Muhl. Perennial, densely and often permanently woolly at the base of the stem and about its nodes. Stems solitary or tufted, 2-6 dm. tall, sometimes sparingly branched above : leaves mainly basal; blades oblong to oblong-spatulate, 2-5 cm. long, toothed, sometimes with a few more salient teeth near the base; petioles commonly longer than the blades : stem-leaves 1-2-pinnatifid: heads in rather close corymbs : involucres 4-5 $\mathrm{mm}$. high ; bracts narrowly linear, becoming glabrous : ligules of the ray-flowers 4-5 mm. long: achenes about $2 \mathrm{~mm}$. long, hispidulous.

In stony or dry soil, Nova Scotia to British Columbia, North Carolina and Texas. Spring and early summer.

13. Senecio Eàrlei Small. Perennial, bright green, densely cottony below, sparingly so and glabrate above. Stems usually tufted, 2-5 dm. tall, corymbosely branched above: leaves various, the basal quite numerous : blades oval or oblong, $1.5-6 \mathrm{~cm}$. long, serrate, obtuse or retuse, often crimson beneath; petioles longer than the blades: stemleaves with pinnatifid linear-lanceolate or oblong blades, the upper sessile: peduncles slender : involucres hemispheric, $8-9 \mathrm{~mm}$. broad, $8-10 \mathrm{~mm}$. high ; bracts linear or nearly so, 5-5.5 mm. long, acute, hyaline-margined : rays oblong, 4-6 $\mathrm{mm}$. long, bright yellow : style glabrous: achenes $3 \mathrm{~mm}$. long, scabro-pubescent on the angles.

In dry soil, Tennessee and Alabama. Spring and summer.

14. Senecio Smállii Britton. Perennial, woolly, permanently so below. Stems usually tufted, 3-6 dm. tall, corymbose above : leaves mainly basal or near the base of the stem; blades narrowly oblong, linear-oblong or linear-lanceolate, 5-10 cm. long, finely toothed or pinnatifid near the base, as long as the petioles or shorter; stem leaves similar to the basal or wholly pinnatifid, short-petioled or sessile : heads small, usually conspicuous by their great number: involucres fully $6 \mathrm{~mm}$. high ; bracts narrowly linear, acuminate: receptacle about $3 \mathrm{~mm}$. broad: ligules of the ray-flowers $4-6 \mathrm{~mm}$. long: achenes 1.5-2 mm. long, hispidulous.

In dry soil and meadows, Virginia to Tennessee, middle Georgia and Mississippi. Spring.

15. Senecio Platténsis Nutt. Perennial, the stem and leaves persistently woolly. Stems 2-4.5 dm. tall, corymbose above : leaves mainly basal; blades oblong, ovate-oblong or ovate, $2.5-4.5 \mathrm{~cm}$. long, some or all of them pinnatifid or lyrate-pinnatifid, the terminal segments toothed: heads showy : involucre $6.5-7.5 \mathrm{~mm}$. high ; bracts linear, usually cobwebby : ligules of the ray-flowers bright yellow, broadly oblong, 5-8 mm. long: achenes 2 $\mathrm{mm}$. long.

In dry soil, South Dakota and Wyoming to Illinois, Texas and Colorado. Spring.

16. Senecio tomentòsus Michx. Perennial, more or less densely pale tomentose. Stems 2-7 dm. tall, corymbose above : leaves mainly basal; blades oblong or oblonglanceolate, $3-15 \mathrm{~cm}$. long, usually obtuse, crenate to nearly entire; petioles longer than the blades: stem-leaves few, rarely pinnatifid, the upper sessile and partly clasping: heads at first clustered : involucres 7-8 mm. high; bracts narrowly linear-lanceolate, acuminate; becoming glabrous, or nearly so: ligules of the ray-flowers deep yellow, 7-9 $\mathrm{mm}$. long: achenes nearly $2.5 \mathrm{~mm}$. long.

In sandy soil, New Jersey to Florida, Arkansas and Texas. Spring. 
17. Senecio Alabaménsis Britton. Perennial, similar to $S$. tomentosus in habit, but the stem and leaves glabrous or essentially so. Stem 3-5 dm. tall, with few elongated branches above: leaves mainly basal; blades narrowly ovate to ovate-lanceolate, firm, finely veiny, the small teeth terminating in black glands: heads relatively few, showy; involucres $7-9 \mathrm{~mm}$. high ; bracts more or less persistently cobwebby : ligules of the ray, flowers deep yellow, 5-8 mm. long: achenes about $3 \mathrm{~mm}$. long.

In moist pine woods, Henry County, Alabama. Spring.

18 Senecio Memmíngeri Britton. Perennial, glabrous or nearly so. Stems solitary or tufted, 3-6 dm. tall, corymbosely branched above, accompanied by tufts of basal leaves : basal leaves 1-2 dm. long; blades bipinnatifid, longer than the petioles, the segments oblong or obovate in outline, more or less cuneate at the base, coarsely toothed or incised, the teeth entire or with 1 or 2 small teeth : blades of the stem-leaves similar but usually more finely divided : heads usually numerous : involucres $5-6 \mathrm{~mm}$. high : bracts linear, the longer $5 \mathrm{~mm}$. long, acute, scarious-margined : ligules of the ray-flowers yellow, linear-oblong, 5-6 mm. long, 3-toothed at the apex : achenes grooved, $1.5 \mathrm{~mm}$. long, pubescent.

On cliffs or in dry soil, mountains, of North Carolina and Alabama. Spring and summer.

19. Senecio Millefòlium T. \& G. Perennial, early glabrate. Stems 3-7 dm. tall, sometimes tufted, corymbose above : leaves conspicuous ; blades $6-15 \mathrm{~cm}$. long, bipinnately dissected into narrowly linear segments, those of the basal and lower stem-leaves petioled; heads several or many : involucres $5-6 \mathrm{~mm}$. high ; bracts linear with lanceolate tips, 4-5 $\mathrm{mm}$. Iong: ligules of the ray-flowers yellow, linear or linear-oblong, 2-4 $\mathrm{mm}$. long: achenes.

On cliffs in the mountains, North Carolina and South Carolina. Summer.

20. Senecio Fremóntii (T. \& G.) Rydb. Woody, at least below, glabrous or nearly so. Stems more or less branched, $3-18 \mathrm{dm}$. tall, copiously leafy : leaves $2-7 \mathrm{~cm}$. long; blades, except some of those near the inflorescence, pinnately parted into 3-9 linear or filiform-linear segments : heads showy : involucres cylindric, $8-10 \mathrm{~mm}$. high ; bracts linear, acute or acuminate: ligules of the ray-flowers about $10 \mathrm{~mm}$. long: achenes $3.5-4$ $\mathrm{mm}$. long, finely pubescent.

In dry soil, Nebraska to Texas and Mexico. Summer and fall.

\section{3. ÁRCTIUM L.}

Biennial, coarse caulescent herbs, with pubescent foliage. Leaves alternate : blades often ample, entire, repand, or rarely laciniate or pinnatifid. Heads discoid, racemose, paniculate or corymbose. Involucres ovoid to globose : bracts narrow, in many series, each terminated by a slender hooked tip. Receptacle flat, densely bristly. Corollas tubular, white or purple. Filaments glabrous. Anthers sagittate at the base. Achenes somewhat flattened and 3-angled, ribbed, truncate. Pappus of numerous rigid or scale-like short serrulate bristles. Burdock. Clotbur.

1. Arctium minus Schk. Stems 4-16 dm. tall, striate, widely branched, rigid : leafblades ovate, often broadly so, those of the lower cauline leaves 2-4.5 dm. long, those of the upper smaller, all undulate or shallowly toothed, often crisped : heads often numerous: involucres $1-1.5 \mathrm{~cm}$. long at maturity : bracts glabrous or sparingly cottony, the outer with spreading spine-tips, the inner with erect spines : achenes $4 \mathrm{~mm}$. long.

In waste places and on roadsides, nearly throughout the United States and southern British America. Native of Europe. Summer and fall.

\section{CÁRDUUUS L.}

Biennial or perennial caulescent or rarely scapose herbs, with pubescent, often woolly foliage. Leaves alternate, sometimes chiefly or wholly basal; blades toothed, lobed or pinnatifid, the teeth or segments commonly spine-tipped. Heads discoid, homogamous or rarely dioecious, solitary or several and variously disposed. Involucres ovoid to globose : bracts in many series, wholly or partially spine-tipped. Receptacle flat or convex, bristly. Corollas tubular, mostly purple, yellow or white. Filaments mostly pubescent. Anthers sagittate at the base. Stigmas obtuse. Achenes flattened or 4-angled, glabrous, smooth, sometimes ribbed. Pappus of slender plumose serrulate or smooth bristles in several series, often united at the base. THistue. 
Heads not involucrate, but sometimes approximate to one or few leaves.

Bracts of the involucre not spine-tipped, the outer ones often cuspidate.

Bracts of the involucre, at least the outer ones, spine-tipped.

Spines of the involucral bracts appressed or erect.

Body of the involucre $2 \mathrm{~cm}$. thick or less.

Leaf-margins densely spiny: glutinous line of the involucral bracts narrow.

Leaf-margins not densely spiny : glutinous line of the involucral bracts broad.

Body of the involucre $3 \mathrm{~cm}$. thick or more.

Spines of the involucral bracts spreading.

Inner bracts of the involucre narrow, with flattened soft tips.

Involucre less than $1.5 \mathrm{~cm}$. thick.

Leaf-blades merely spiny-toothed.

Leaf-blades pinnatifid or sinuate-pinnatifid.

Tips of the outer involucral bracts $2 \mathrm{~mm}$. long or more.

Leaves woolly on both sides.

Leaf-blades thin, repand or repand-pinnatifid, with weakly spiny margins.

Leaf-blades thick, deeply pinnatifid, with rigidly spiny margins.

Leaves glabrous above, tomentose or woolly beneath.

Leaf-blades thick, revolute, with rigidly spiny margins.

Leaf-blades thin, flat, with weakly spiny margins.

Tips of the outer involucral bracts $1 \mathrm{~mm}$. long or less.

Involucre over $1.5 \mathrm{~cm}$. thick.

Leaf-blades, except those near the heads, merely toothed.

Leaf-blades 1-2-pinnatifid.

Inner bracts of the involucre, as well as the outer, spine-tipped.

Heads involucrate, completely surrounded by a whorl of copiously spine-armed bracts.

Bracts subtending the head much shorter than the inner involucral bracts.

Bracts subtending the heads, at least the longer, surpassing the involucre.

1. C. muticus.

2. C. repandus.

3. C. LeContei.

4. C. odoratus.

5. C. Virginianus.

6. C. Helleri.

7. C. austrinus.

8. C. revolutus.

9. C. flaccidus.

10. C. Nuttallii.

11. C. altissimus.

12. C. discolor.

13. C. lanceolatus.

14. C. pinetorum.

15. C. spinosissimus.

1. Carduus mùticus (Michx.) Pers. Stem 1-2.5 m. tall, branching, ridged, lanuginous or glabrate : leaves numerous ; blades oblong or oblong-ovate in outline, deeply 1-2pinnatifid, 2-4 dm. long or shorter on the upper part of the stem, glabrate above or sparingly pubescent, thinly woolly-lanuginose beneath, all the divisions spine-tipped : heads often numerous : involucres campanulate, woolly at the base; bracts various, the outer rather obtuse and cuspidate, the inner more elongated, with slender, slightly recurved tips : disk purple : achenes 4-4.5 mm. long, shining: pappus-bristles plumose.

In woods and thickets, Newfoundland to Saskatchewan, Florida and Texas. Summer and fall.

2. Carduus repándus (Michx.) Pers. Stem 1.5-5 dm. tall, simple or sparingly branched, copiously leafy, more or less densely webby-lanate: leaves spreading; blades spatulate to narrowly oblong or broadly linear in outline, $5-12 \mathrm{~cm}$. long, pinnately many lobed, and copiously spiny along the edge, pubescent beneath like the stem, somewhat floccose above : involucre $3-3.5 \mathrm{~cm}$. high, the outer bracts $3-4 \mathrm{~mm}$. wide, the tips of the inner ones curled.

In dry pine lands, North Carolina to Florida. Spring to fall.

3. Carduus Le Cóntel (T. \& G.) Pollard. Stem 6-11 dm. tall, simple, more or less floccose-woolly : leaves rather approximate, erect or ascending; blades lanceolate in outline, or those at the base of the stem oblanceolate, $8-12 \mathrm{~cm}$. long on the lower part of the stem, gradually reduced and generally very small and remote above, pinnatifid and with relatively few spines on the margins : involucre $3.5-4 \mathrm{~cm}$. high, the outer bracts $3-4 \mathrm{~mm}$. wide, the inner with erect tips.

In low pine lands, Georgia and Florida to Louisiana. Spring to fall.

4. Carduus odoràtus Muhl. Stem $3-10 \mathrm{dm}$. tall, webby tomentulose, equally leafy, sparingly, if at all branched: leaves usually quite numerous, the basal spreading; blades oblanceolate in outline, 1-2-pinnatifid, 1-2.5 dm. long, the divisions and teeth spine-tipped, cauline leaves essentially similar to the basal but gradually smaller, partly clasping the stem : heads solitary or few, conspicuous: involucre $3-4.5 \mathrm{~cm}$. high, the outer bracts $4-5$ $\mathrm{mm}$. broad : achenes 4-4.5 mm. long.

In fields and on hillsides, Maine to Pennsylvania and North Carolina. Summer.

5. Carduus Virginiànus L. Stem $0.5-1 \mathrm{~mm}$. tall, often sparingly branched, somewhat arachnoid: leaves relatively few ; blades rather membranous, linear to linearoblong, or those of the lower eauline and basal leaves spatulate, 1-2.5 dm. long or shorter above, acute, merely spinulose-toothed, otherwise entire, glabrous or nearly so above, closely white pubescent or tomentose beneath : heads few, relatively small : involucres $10-15 \mathrm{~mm}$. high, slightly arachnoid, the outer bracts $1.5-2 \mathrm{~mm}$. broad, tipped with slender rather weak spines : achenes $3-3.5 \mathrm{~mm}$. long.

In open woods and thickets, Virginia and Kentucky to Florida and Alabama. Spring and summer. 
6. Carduus Hélleri Small. Stem $0.6-1 \mathrm{~m}$. tall, simple or sparingly branched above, somewhat floccose : leaves relatively few and distant; blades membranous, narrowly oblong or lanceolate in outline, 1-1.5 dm. long, arachnoid above, lanuginose beneath, sinuatepinnatifid, the teeth or segments spine-tipped: heads few, relatively small : involucres about $2 \mathrm{~cm}$. high, thinly pubescent, the outer bracts lanceolate, $3-3.5 \mathrm{~mm}$. broad, each tipped with a rather weak somewhat spreading spine.

On plains or prairies, Texas. Spring.

7. Carduus austrìnus Small. Stems 4-11 dm. tall, simple or sparingly branched above, rather closely floccose : leaves quite numerous; blades thickish, narrowly oblong to narrowly lanceolate in outline, arachnoid above, rather felty beneath, 1-2-pinnatifid, the segments spine-tipped : heads solitary or few, relatively small : involucres about $15 \mathrm{~mm}$. high, sparingly pubescent, the outer bracts about $2 \mathrm{~mm}$. broad, each tipped with a spreading or recurved weak spine.

In bottom lands, Texas. Spring.

8. Carduus revolùtus Small. Stem $0.5-2 \mathrm{~m}$. tall, simple or sparingly branched above, rigid, more or less floccose : leaves conspicuously narrow and often relatively elongated ; blades leathery, 1-3 dm. long or shorter above, glabrous or essentially so and dark green above, closely white-woolly or tomentose beneath, pinnatifid, the teeth or segments sometimes remote, each tipped with a rigid spine, entire or spiny-toothed : heads solitary or few, relatively small : involucres $20-25 \mathrm{~mm}$. high, somewhat woolly, the outer bracts $2-2.5 \mathrm{~mm}$. broad, each tipped with a weak spreading or recurved spine : achenes $4 \mathrm{~mm}$. long.

In low pine lands, South Carolina, Georgia and Florida. Summer and fall.

9. Carduus fláccidus Small. Stem 7-16 dm. tall, sparingly floccose, almost simple or sparingly branched above, slender : leaves few, remote, the basal and lower cauline, 1$3 \mathrm{dm}$. long; blades thin, narrowly oblanceolate or linear-spatulate in outline, 1-2-pinnatifid, the segments and their teeth spine-tipped, those of the upper cauline leaves nearly similar to those of the lower, but usually less deeply pinnatifid, all glabrous or essentially so above, thinly gray tomentose-woolly beneath : heads relatively small : involucres about $1.5 \mathrm{~cm}$. high, sparingly webby, the outer bracts $1.5-2 \mathrm{~mm}$. broad : achenes $3.5-4 \mathrm{~mm}$. long.

In woods and on dry banks, Georgia to Arkansas and Texas. Spring.

10. Carduus Nuttallii A. Gray. Stem 1-4 m. tall, early glabrate, winged by the decurrent leaf-bases, more or less branched : leaves numerous, evenly and closely distributed along the stem; blades various, those of the basal and lower cauline leaves 1.5-3.5 $\mathrm{dm}$. long, broadly oblong or oblong-spatulate in outline, 2-pinnatifid, the segments and teeth rigidly spine-tipped, those of the upper cauline leaves gradually reduced in size, commonly pinnatifid, the segments often rather distant : heads relatively small : involucres $1.5-2 \mathrm{~cm}$. high, sparingly pubescent, the outer bracts about $2 \mathrm{~mm}$. broad, each terminating in a spine about $1 \mathrm{~mm}$. long: achenes about $4 \mathrm{~mm}$. long.

In dry soil, coastal plain, South Carolina to Florida and Mississippi. Spring and summer.

11. Carduus altíssimus L. Stem 1-3 m. tall, more or less pubescent, usually much branched: leaves numerous, the basal and lower cauline 1.5-3 dm. long; blades oblong or elliptic, or broadest below or above the middle, finely or coarsely toothed, the teeth spinetipped, the upper cauline leaves smaller, mainly oblong-lanceolate, toothed like the lower ones, or those on the branches pinnatifid, all sparingly pubescent above, densely whitetomentose beneath : heads showy : involucres about $3 \mathrm{~cm}$. high ; the outer bracts 3-4 mm. broad, each terminating in a spreading or reflexed spine : achenes $4.5-5 \mathrm{~mm}$. long.

In fields and thickets, Massachusetts to South Dakota, Florida and Texas. Summer and fall.

12. Carduus díscolor (Muhl.) Nutt. Similar to C. altissimus in habit, but rarely over $2 \mathrm{~m}$. tall : leaf-blades mainly oblong-lanceolate or ovate-lanceolate, 1-2 dm. long, or those of the basal and lower cauline leaves longer and those of the branches smaller, all quite finely pinnatifid, densely white-tomentose beneath : heads showy : involucres $2.5-3$ $\mathrm{cm}$. high, the outer bracts $3-3.5 \mathrm{~mm}$. broad, each with a subulate spreading or reflexed tip 4-5 mm. long: achenes 3-4 mm. long.

In fields and on hillsides, Quebec to South Dakota and Georgia. Summer and fall.

13. Carduus lanceolàtus L. Stem 1-1.5 mm. tall, rigid, more or less branched, winged by the decurrent leaf-bases, pubescent: leaves numerous, often rather crowded; blades 1-2-pinnatifid, the segments and teeth rigidly spine-tipped, those of the basal and lower cauline leaves 1-3.5 dm. long, those of the upper cauline smaller, lanceolate in outline, all strigose above, grayish woolly beneath : heads showy : involucre $2.5-3 \mathrm{~cm}$. high, 
the outer bracts $2-2.5 \mathrm{~mm}$. broad, all terminating in spines: achenes $3.5-4 \mathrm{~mm}$. long. In waste grounds, fields and pastures, Newfoundland to Minnesota, Florida and Kansas. Native of Europe and Asia. Summer and fall.

14. Carduus pinetòrum Small. Stem 4-9 dm, tall, mainly simple, thinly pubescent, especially at the nodes: leaves few on the stem ; blades glabrous or nearly so above, thinly woolly beneath, those of the basal and lower cauline 1-2 dm. long, spatulate-oblong or narrowly oblong in outline, 1-2-pinnatifid, the segments and teeth spine-tipped, those of the upper cauline leaves smaller and narrower than those of the lower, the terminal spines of the segments directed forward : involucre $3-3.5 \mathrm{~cm}$. high, the inner bracts much surpassing the subtending leafy spine-armed involucre : achenes $5-5.5 \mathrm{~mm}$. long.

In pine lands, between the everglades and Biscayne Bay, Florida. Spring to fall.

15. Carduus spinosíssimus Walt. Stem $3-11 \mathrm{dm}$. tall, woolly at least when young, simple or sparingly branched: leaves thinly pubescent on both sides, but rather green; blades various, those of the basal and lower cauline spatulate or oblong-spatulate in outline, 1-4 dm. long, 2-pinnatifid, the segments and teeth rigidly spine-tipped, those of the upper cauline smaller, oblong to lanceolate in outline, often 1-pinnatifid, the spines terminating the segments spreading : involucres $3.5-5 \mathrm{~cm}$. high, the inner bracts surpassed by the spine-armed leafy bracts of the involucre: disk yellow : achenes $5-5.5 \mathrm{~mm}$. long.

In dry or moist sandy soil, Maine to Florida and Texas. Spring to fall.-The form with purple corollas is C. spinosissimus Ellióttii (T. \& G.) Porter.

\section{CENTAURÈA L.}

Annual or perennial caulescent herbs. Leaves alternate : blades entire, toothed or pinnatifid. Heads sometimes homogamous. Involucres globose to ovoid : bracts in several series, appressed, irregularly toothed or fimbrillate. Receptacle flat, densely bristly. Flowers various, either all perfect and fruit-producing, or the marginal ones larger and neutral. Corollas with slender tubes and regular or oblique limbs, violet, purple, white or rarely yellow. Anthers sagittate at the base. Stigmas obtuse. Achenes flattened or obtusely 4-angled, smooth, obliquely or laterally attached. Pappus of several series of bristles or scales, or rarely obsolete. Our species are annuals. The plants flower from spring to fall. Star Thistle.

Bracts of the involucre, at least the intermediate ones armed with spines.

Stems woolly : pappus present and double.

Stems more or less pubescent, not woolly: pappus obsolete.

Bracts of the involucre with pectinate-fimbrillate appendages.

1. C. solstitialis.

2. C. Calcitrapa.

3. C. Americana.

1. Centaurea solstitialis L. Stems $3-6 \mathrm{dm}$. tall, more or less woolly, often widely branched: leaf-blades various, those of the basal leaves 1-2 dm. long, lyrate-pinnatifid, those of the stem-leaves shorter, oblong-lanceolate or linear, entire or somewhat toothed, decurrent on the stem as narrow wings: heads sessile : involucres subglobose, $5-10 \mathrm{~mm}$. in diameter; bracts various, the outer with palmate prickles, the inner ones with scarious tips, the intermediate ones with long spreading spines each of which often have 1 or 2 spinules at their base : corollas yellow : pappus double.

In waste places and on roadsides, adventive in the southern United States. Native of Europe.

2. Centaurea Calcitràpa L. Stems $3-4 \mathrm{dm}$. tall, much branched, more or less pubescent, but not woolly : leaf-blades various, those of the basal and lower cauline 1-2 dm. long, 1-2-pinnatifid, the segments or teeth spinulose, the upper cauline leaves smaller and less divided : heads sessile : involueres ovoid, 8-10 mm. high : outer bracts terminating in short spreading spines, the intermediate in long spines pinnate at the base, the inner erose at the apex : corollas purple, none of them radiant : pappus obsolete.

In waste places, Massachusetts to North Carolina. Also on the Pacific coast. Native of Europe.

3. Centaurea Americàna Nutt. Stems 5-18 dm. tall, striate-ridged or channeled, often simple, glabrous or nearly so: leaf-blades oblanceolate, oblong or linear-lanceolate, $2-8 \mathrm{~cm}$. long, acuminate or mucronate, entire or remotely denticulate, sessile: heads showy : involucres hemispheric, $1.5-2.5 \mathrm{~cm}$. high ; bracts numerous, pectinate-fringed : neutral-flowers forming a conspicuous ray by their narrowly linear lobes, these $1.5-2.5 \mathrm{~cm}$. long: perfect flowers forming a disk $2.5-8 \mathrm{~cm}$. broad : corollas pink or deep rose-colored : achenes 5-6 mm. long, hairy : pappus of unequal bristles surpassing the achene in length.

On plains and prairies, Missouri to Louisiana, Texas, Arizona and Mexico.

\section{CNİCUs L.}

Annual caulescent pubescent herbs. Leaves alternate: blades sinuate-toothed or pinnatifid, with spiny teeth or segments. Heads homogamous, solitary and sessile at the 
ends of the branches. Involucres bristly: bracts in several series, the inner narrower than the outer, and tipped with pinnately branched spines. Receptacle flat, bristly. Flowers perfect: corollas tubular, yellow. Anther tailed at the base. Stigmas unappendaged. Achenes laterally attached, terete, striate. Pappus double, the outer series of naked awns, the inner of shorter fimbriate scales.

1. Cnicus benedíctus L. Foliage hirsute or villous. Stems 1-4 dm. tall, branched : leaf-blades papery, reticulated, irregularly spiny dentate or sinuate-pinnatifid, $5-15 \mathrm{~cm}$. long, those of the basal or lower stem-leaves narrowed into winged petioles, those of the upper leaves sessile and partly clasping: involucres $4-5 \mathrm{~cm}$. high ; bracts thin, ovate, lanceolate or linear-lanceolate, each tipped with a spine with pectinately prickly margins : receptacle densely beset with hair-like bristles: outer pappus-awns alternating with the inner scales.

In waste places, Nova Scotia to Georgia and Alabama. Spring and summer. Blessed Thistle.

147. GOCHNÀTIA H.B.K.

Shrubby plants, with more or less tomentose or glutinous foliage. Leaves alternate: blades leathery, entire. Heads homogamous, few-many-flowered, cymose or paniculate. Involucre of several dry or leathery imbricated bracts. Receptacle flat, naked. Corollas essentially regular. Anthers sagittate at the base, the auricles tailed. Stigmas relatively short, roundish obtuse or nearly truncate at the apex. Achenes oblong or nearly so, more or less 5-ribbed, pubescent. Pappus copious, of rather rigid scabrous or barbellulate bristles.

1. Gochnatia hypoleùca (DC.) A. Gray. A rigid branching shrub 2-3 m. tall, or a small tree, the branchlets pale or white-canescent. Leaf-blades oblong, elliptic or oval, 1-3.5 cm. long, dark green and glabrous above, finely white-tomentose beneath, shortpetioled: heads in leafy-bracted panicles: involucres cylindric-campanulate, $5-6 \mathrm{~mm}$., high, 5-7-flowered; bracts ovate to oblong-elliptic, acutish : flowers perfect : corollas white : achenes $3 \mathrm{~mm}$. long.

On hillsides, southern Texas and adjacent Mexico. Throughout the year.

\section{THYRSÁNTHEMA Neck.}

Perennial scapose herbs, with floccose-tomentose foliage. Leaves basal: blades flat persistent pubescent beneath. Heads heterogamous, radiate, solitary and terminal, nodding when young. Involucre many-flowered : bracts narrow, in few series, the inner successively larger. Ray-flowers pistillate, fruit-producing: ligules about $\frac{1}{2}$ as long as the style, sometimes rose-purple. Disk-flowers perfect, wholly or partially neutral : corollas white or purplish, more or less 2-lipped, the outer with 3 lobes to the lower lip, the inner with 2 lobes. Achenes 5-nerved, columnar or fusiform. Pappus of numerous soft hairlike bristles. [Chaptalia Vent.]

All achenes perfect, each with a beak as long as the body : leaf-blades lyrate or repand-lyrate.

Achenes of perfect flowers abortive, those of the pistillate flowers each narrowed 1. $C$. nutans.

into a neck: leaf-blades entire or remotely denticulate.

2. C. semiflosculare.

1. Thyrsanthema nùtans (L.) Kuntze. Leaves basal ; blades oblanceolate or oblongoblanceolate, 5-15 cm. long, acute or apiculate, lyrate or repand-lyrate, thinly floccose or glabrate above: scapes solitary or tufted, $1-5 \mathrm{dm}$. tall, simple: involucral bracts subulate to narrowly linear, acuminate : achenes all perfect, pubescent, the beak as long as the body.

In open woods and on prairies, Texas and Mexico.

2. Thyrsanthema semiflosculàre (Walt.) Kuntze. Leaves basal : blades oblong to oblanceolate, 4-10 $\mathrm{cm}$. long, apiculate, entire or remotely denticulate, green and glabrous above, densely white tomentose beneath: scapes 1-3 dm. tall, sometimes tufted, simple: involucral bracts subulate to linear: ligules of the ray-flowers usually purple, broadly linear, $7-10 \mathrm{~mm}$. long: achenes of the pistillate flowers perfect, glabrous, $3 \mathrm{~mm}$. long, each constricted into a short neck. [Chaptalia tomentosa Vent.]

In moist pine lands, North Carolina to Florida and Texas.

\section{PERÈzIA Lag.}

Perennial caulescent herbs, often woolly near the base. Leaves alternate. Heads homogamous, the flowers perfect and fruit-producing. Involucre few-or many-flowered : 
bracts in several series, dry, leathery or parchment-like. Receptacle flat, naked or rarely pubescent or fimbrillate. Corollas rose-purple, white or rarely blue, all 2-lipped, those at the margin of the disk with larger lower lips. Stigmas flattened, truncate or brush-like. Achenes terete or slightly angled, usually papillose-puberulent, sometimes narrow near the apex, but not beaked. Pappus of numerous scabrous, sometimes rigid hair-like bristles.

Caulescent: leaf-blades merely toothed.

Acaulescent : leaf-blades runcinate-pinnatifid.

1. P. nana.

2. P. runcinata.

1. Perezia nàna A. Gray. Caulescent, the foliage glabrous. Leaves alternate ; blades parchment-like, orbicular to ovate or obovate, $2.5-5 \mathrm{~cm}$. long, spiny-toothed, sessile and partly clasping: involucre lax; bracts ovate to oblong-ovate and broadly linear, the outer 4-5 mm. long, the inner 10-15 mm. long: achenes 5-5.5 $\mathrm{mm}$. long.

On dry plains and rocky bluffs, southern Texas to Arizona and Mexico. Spring to fall.

2. Perezia runcinàta Lag. Acaulescent, the foliage scabrous-pubescent or glabrate. Leaves basal ; blades papery, oblong to oblanceolate in outline, $5-20 \mathrm{~cm}$. long, runcinatepinnatifid, the segments spinulose-fringed : involucres lax ; bracts mainly oblong to lanceolate and linear, with acuminate or bristle tips, the outer $3-4 \mathrm{~mm}$. long, the inner sometimes $20 \mathrm{~mm}$. long: central corollas purple, the tube about $1 \mathrm{~cm}$. long : achenes $5-6 \mathrm{~mm}$. long.

In dry soil, Texas and adjacent Mexico. Spring and summer.

\section{FAMILy 3. CICHORIÀCEAE Reichenb. Chicory FAMily.}

Annual or perennial scapose or caulescent herbs, with a bitter acrid or milky sap. Leaves alternate, sometimes all basal; blades entire, or variously toothed or parted. Flowers perfect, all alike in peduncled or rarely sessile involucrate heads. Involucres of 1 or several rows of bracts. Receptacle flat or flattish, naked or scaly, smooth, pitted or honeycombed. Pappus of scales or hair-like or plumose bristles, sometimes both together. Corollas gamopetalous, commonly yellow, sometimes white, pink, blue, or purple : tubes variable in length ; limb a strap-shaped usually 5-toothed ligule. Anthers connate around the style : sacs sagittate or auricled at the base, not tailed, usually appendaged at the top. Pollen-grains mostly 2-sided. Ovary 1-celled. Stigmas 2. Ovules solitary, anatropous. Fruit an achene. Seed erect. Endosperm wanting. Embryo with the radicle narrower than the cotyledons.

Pappus of simple hair-like bristles.

Achenes smooth or merely papillose.

Achenes cylindric or prismatic.

Achenes narrowed at the base.

Top of achenes truncate.

Disks or ligules pale, cream-color or purple.

Disks or ligules yellow, orange or red.

Top of achenes narrowed or beaked.

Pappus-bristles surrounded by a ring of villous hairs at the base, receptacle naked.

Pappus-bristles not surrounded by a ring of hairs; receptacle chaffy. Achenes terete, cylindric, not narrowed at either end. Achenes flattened.

Achenes narrowed at the top or beaked.

Achenes truncate at the top.

Achenes tuberculate or spinulose, or with spine-like processes.

Pappus of scales, or scales and bristles, or wanting.

Pappus at least in part of plumose bristles.

Pappus of scales or of both scales and bristles or wanting.

Disk and ligules yellow or orange.

Pappus of broad scales, with or without bristles.

Pappus wanting or obsolete.

Disk and ligules white, pink, blue or purple.

1. Nabalus.

2. Hieracium.

3. Sitilias.

4. PinaropapPUS

5. LYGODESMIA.

6. LACTUCA.

7. SONCHUS.

8. TARAXACUM.

9. Tragopogon.

10. ADOPOGON.

11. SERINEA.

12. CICHORIUM.

\section{NÁBALUS Cass.}

Perennial caulescent herbs with racemosely or paniculately branched stems. Leaves alternate : blades toothed, lobed or pinnatifid, sometimes divided, petioled or the upper ones clasping. Heads small, usually nodding, often clustered. Involucres narrow, cylindric, double; inner of 1 or 2 series of nearly equal bracts; outer of few very small bracts. Receptace flat, naked. Corollas pale, cream-colored or purplish; ligules truncate and toothed at the apex. Anthers sagittate at the base. Stigmas slender. Achenes oblong to 
columnar, terete or 5-angled, often 10-ribbed, truncate. Pappus of numerous hair-like rather rigid pale or brown bristles. Rattlesnake-Root. White Lettuce.

Bracts of the involucres glabrous or sometimes with a few scattered hairs.

Involucres slender, about $2 \mathrm{~mm}$. thick, 5-7-flowered, light green : pappus light straw-colored.

Involucres stout, 3-6 mm. thick, 8-16-flowered. deep green, glaucous or purple. Pappus deep cinnamon-colored.

Pappus straw-color or light brown.

Leaf-blades merely toothed or somewhat incised.

Larger bracts of the outer involucre lanceolate : lower leaf-blades oblong to oval, not cordate.

Larger bracts of the outer involucre orate: lower leaf-blades hastate, cordate.

Leaf-blades, at least some of them pinnatifid, lobed or divided.

Inflorescence paniculate.

Panicles much broadened upward : bracts of the involucres, at least the longer ones, glabrous.

Larger bracts of the outer involucre lanceolate: pappus surpassing the inner involucral bracts.

Larger bracts of the outer involucre ovate, or triangular-ovate : pappus and inner involucral bracts about equal in length.

Panicles cylindric : bracts of the involucres sparingly hairy.

Inflorescence raceme-like.

Bracts of the involucres copiously pubescent.

Involucres 8-16-flowered : inflorescence thyrsoid.

Involucres 20-25-flowered : inflorescence corymbose-paniculate.

1. N. altissimus.

2. N. albus.

3. $N$. integrifolius.

4. N. Roanensis.

1. Nabalus altíssimus (L.) Hook. Perennial, glabrous or nearly so, not glaucous. Stems erect, 1-2 m. tall, narrowly branched above : leaf-blades thin, usually light green, $5-15 \mathrm{~cm}$. long, the lower usually hastately $3-5$-lobed on long slender petioles, the upper hastate, deltoid, ovate or oblong-lanceolate, more or less strongly dentate, rounded or cordate at the base or those of the inflorescence attenuate below : involucres 5-7-flowered, slender, 10-12 mm. long, about $2 \mathrm{~mm}$. thick; inner bracts narrowly linear, glabrous: ligules greenish or yellowish: achenes slender, 4-5 mm. long: pappus light straw-colored. [Prenanthes altissimus L.]

In woods and on hillsides, Newfoundland to Manitoba, Georgia and Tennessee. Summer and fall.

2. Nabalus álbus (L.) Hook. Perennial, glabrous or nearly so, often glaucescent. Stems erect, 3-16 dm. tall, narrowly branched above, finely ridged in age : leaf-blades deltoid, triangular or sometimes broader than long, more or less deeply hastate; segments lobed or dentate : involucres 10-12 $\mathrm{mm}$. long; outer bracts triangular to lanceolate, the inner linear, glabrous or puberulent : ligules dull white or cream-colored : achenes about $5 \mathrm{~mm}$. long: pappus cinnamon or cinnamon-brown. [Prenanthes alba L.]

On banks or in woods, Maine to Ontario, Manitoba, Georgia and Kentucky. Summer and fall.

3. Nabalus integrlfòlius Cass. Perennial, hirsute or glabrate. Stems 4-18 dm. tall, more or less branched above, the branches often sharply ridged : leaf-blades oblong, varying to oval-oblong or oblong-lanceolate, sometimes slightly sagittate at the base, sinuate or sinuate-dentate, more or less abruptly narrowed into winged petioles or the upper sessile : involucres 11-15 mm. long; inner bracts linear, bristly-hirsute or glabrate : achenes $4.5-5 \mathrm{~mm}$. long : pappus dirty brown.

On mountain slopes or in woods, New York to North Carolina and Georgia. Late summer and fall.

4. Nabalus Roanénsis Chickering. Perennial, more or less hirsute. Stems erect, 3-5 dm. tall, topped by a narrowly cylindric panicle: leaf-blades triangular-hastate to hastate-lanceolate, 3-10 cm. long, acuminate, dentate or incised and dentate, pale beneath, truncate to cordate at the base; petioles as long as the blades, or shorter: involucres 8-10 $\mathrm{mm}$. long; inner bracts linear, more or less hirsute : achenes $4-4.5 \mathrm{~mm}$. long: pappus dingy straw-colored.

On the summit of Roan Mountain, North Carolina, and on neighboring peaks. Summer and fall.

5. Nabalus serpentàrius (Pursh) Hook. Perennial, glabrous or nearly so. Stems 3-10 dm. tall, branching above, the branches often widely spreading: leaf-blades 5-30 $\mathrm{cm}$. long, pinnately or hastately 3-7-lobed, narrowed into winged petioles or the upper sessile ; lobes toothed or incised : involucres 10-12 mm. long; outer bracts mostly lanceolate, occasionally pubescent ; inner bracts linear, glabrous: achenes $4.5-5 \mathrm{~mm}$. long : pappus straw-colored. [Prenanthes serpentaria Pursh.]

In open woods, fields or thickets, Ontario to Florida, Kentucky and Alabama. Summer and fall.

6. Nabalus trifoliàtus Cass. Perennial, deep green, glabrous. Stems erect, 8-26 dm. tall, more or less widely branching above : leaves various; blades thinnish, those of basal and lower stem-leaves 1-3 dm. long, usually 3-divided, long-petioled; segments lobed or toothed, sessile or stalked : blades of the upper leaves gradually less lobed, and on the upper part of the stem they are sometimes lanceolate and entire: heads 7-12-flowered, 
drooping, rather few in each cluster : involucres glabrous, purplish or pale green ; larger bracts of the outer involucre ovate or triangular-ovate; inner bracts glabrous, about as long as the pappus : corollas pale yellow or whitish : achenes 4-6 $\mathrm{mm}$. long : pappus light brown.

In woods and thickets, Maine to Pennsylvania and North Carolina. Summer and fall.

7. Nabalus cylíndricus Small. Perennial, deep green. Stems $3-9$ dnı. tall, nearly simple, glabrous, finely ridged, each topped with a narrowly cylindric panicle: leafblades triangular or ovate-triangular in outline, 5-10 $\mathrm{cm}$. long, acute or acuminate, 3-lobed or 3-cleft and sinuate or angularly toothed, truncate or cordate at the base, lower ones on long slender petioles, the upper shorter-petioled : heads in axillary clusters, thus forming a narrowly cylindric panicle : involucres narrow, about $10-11 \mathrm{~cm}$. high ; inner bracts linear or linear-lanceolate, with few scattered hairs, slightly shorter than the pappus: achenes 5-6 mm. long, glabrous.

On mountain slopes, Kentucky to North Carolina and Tennessee. Fall.

8. Nabalus virgàtus (Michx.) DC. Perennial, glabrous, glaucescent. Stems 6-12 dm. tall, wand-like : leaf-blades various, those of the basal and lower stem-leaves 1-3 dm. long, sinuate-pinnatifid or pinnately parted; segments entire or toothed; blades of the upper leaves gradually smaller and narrower, entire, sessile : panicle narrow and racemelike, 2-5 dm. long, sometimes much reduced : involucres about $10 \mathrm{~mm}$. high ; inner bracts linear, glabrous : ligules white or pink : achenes about $4 \mathrm{~mm}$. long, brown : pappus strawcolored. [Prenanthes virgata Michx.]

In pine lands, New Jersey to Florida. Fall.

9. Nabalus ásper (Michx.) T. \& G. Perennial, sometimes scabro-pubescent. Stems erect, 1-2 dm. tall, narrowly branched above : leaf-blades oblong to lanceolate or elliptic, 4-20 cm. long, irregularly often sharply toothed, sessile, sometimes slightly clasping : involucres $12-14 \mathrm{~mm}$. high : bracts linear or small, outer ones linear-subulate, all more or less distinctly hirsute : ligules cream-colored, often fully $1 \mathrm{~cm}$. long : achenes $5-6 \mathrm{~mm}$. long: pappus sordid brown or pale straw-colored. [Prenanthes aspera Michx.]

On dry prairies, Minnesota, south to Kentucky, Kansas and Louisiana. Summer and fall.

10. Nabalus crepidíneus (Michx.) DC. Perennial, minutely pubescent or glabrate. Stems 1-2 m. tall, branching above : leaf-blades varying from hastate at the base of stem to ovate-hastate or oblong above, 1-3 dm. long, gradually or abruptly narrowed into winged petioles, coarsely and irregularly dentate: involucres about $12 \mathrm{~mm}$. long; bracts linear, copiously strigose-hirsute on the back, the outer triangular lanceolate to linear-lanceolate: ligules ochroleucous : achenes $4-5 \mathrm{~mm}$. long, 12-15-ribbed, 4 or 5 ribs stronger than the rest: pappus dirty brown. [Prenanthes crepidineus Michx.]

In rich soil and thickets, Minnesota to Pennsylvania, Tennessee and Kansas. Summer and fall.

\section{HIERÀCIUM L.}

Perennial, caulescent or scapose herbs, with pubescent, often glandular, or rarely glabrous foliage. Leaves sometimes all basal: blades simple, entire or toothed. Heads solitary, or in corymbs, racemes or panicles, yellow, or orange or red. Involucres various, often double ; inner of narrow bracts in 1-3 series, outer abruptly or gradually smaller. Receptacle flat, naked or slightly fimbrillate. Ligules truncate and toothed at the apex. Anthers sagittate at the base. Stigmas slender. Achenes oblong, fusiform or columnar, 10-15-ribbed, truncate or narrowed into a neck. Pappus of 1-2 rows of brown or rarely white bristles. HAwKWEED.

Stems regularly leafy to the broad, more or less effuse panicle: leaf-blades not of a spatulate type.

Blades of the lower leaves narrowed at the base: involucres $4-5.5 \mathrm{~mm}$. high : achenes columnar, $\mathrm{mm}$. long.

Blades of the lower leaves subcor date at the base: involucres 7-9 mm. high : achenes fusiform, $3 \mathrm{~mm}$. long.

Stems more or less scape-like, corymbose or narrowly cylindric-campanulate

above: leaves mainly basal, or on the lower part of the stem, some of the

lower blades of a spatulate type.

A. Achenes columnar.

Longer involucral bracts glabrous or nearly so. Pappus shorter than the involucre.

Pappus surpassing the involucre.

Stems nearly naked, glabrous: peduncles glabrous or sparingly glandular-pubescent.

Stems leafy and pubescent at least below : peduncles densely glandular pubescent.

Longer involucral bracts copiously pubescent.

Pappus shorter than the involucre.

Pappus longer than the involucre.

a. Stems scape-like, glabrous to the inflorescence.

1. H. paniculatum.

2. H. Floridanum.

3. H. Scribneri.

4. H. venosum.

5. H. Marianum.

3. H. Scribneri.

6. H. Greenii. 
b. Stems leafy below, hirsute at least below.

B. Achenes fusiform, or constricted below the summit.

7. H. scabrum.

Pappus tawny or straw-colored.

Foliage shaggy with conspicuously long, coarse hairs: species campestrian.

Foliage glabrous or somewhat pubescent but never shaggy: species not typically campestrian.

Inflorescence narrowly paniculate.

Inflorescence corymbose.

Pappus silvery-white.

8. H. longipilum.

9. H. Gronovii.

10. H. megacephalon.

11. H. argyraeum.

1. Hieracium panículàtum L. Foliage nearly glabrous, often glaucescent. Stems erect, 3-12 dm. tall, commonly widely branched above, villous at the base: leaf-blades linear-elliptic to broadly elliptic, 4-12 cm. long, acute or acuminate at both ends, repanddentate : panicle usually wide-spreading : peduncles filiform : involucres 4-5.5 mm. high ; inner bracts linear or nearly so: pappus pale-tawny, surpassing the involucres: achenes columnar, $2 \mathrm{~mm}$. long.

In dry woods, Quebec and Ontario to Maine, Georgia and Alabama. Summer and fall.

2. Hieracium Floridànum Britton. Foliage decidedly pubescent, green. Stems mostly over $1 \mathrm{~m}$. tall, rather widely branched above, copiously leafy, shaggy with somewhat rufous hairs below the inflorescence: leaf-blades thickish, oval-oblong on the lower part of the stem, ovate above, 2.5-9 cm. long, sparingly pubescent with long hairs, obtuse, obscurely glandular-denticulate, sessile by the truncate or subcordate bases : peduncles slender, glandular-pubescent : involucres $8-9 \mathrm{~mm}$. high; inner bracts acute : pappus somewhat tawny : achenes fusiform, $3 \mathrm{~mm}$. long.

In sandy soil, Florida. Summer.

3. Hieracium Scríbneri Small. Foliage glaucescent. Stems erect, 3-7 dm. tail, branching above, more or less densely pubescent below with spreading silvery hairs: leaf-blades spatulate or oblong-spatulate below, narrowly spatulate to lanceolate above, remotely denticulate, ciliate, $3-12 \mathrm{~cm}$. long, the lower ones narrowed into winged petioles : inflorescence corymbose : heads showy : involucres about $1 \mathrm{~cm}$. high; inner bracts linearsubulate, acuminate, more or less glandular: achenes columnar, $3-3.5 \mathrm{~mm}$. long, the ribs not prominent, barbed upward: pappus tawny, surpassed by the involucre.

On hillsides, Tennessee to Georgia and Alabama. Spring.

4. Hieracium venòsum L. Foliage nearly glabrous. Stems erect, solitary or several together, scape-like, 3-6 dm. tall, corymbosely branched above : leaves mainly basal, or 1 or 2 on the stem ; blades obovate or spatulate, $5-15 \mathrm{~cm}$. long, commonly purple-veined, undulate or repand-denticulate, more or less villous on the nerves beneath, ciliate, sessile or narrowed into winged petioles : peduncles slender, often slightly glandular-pubescent : involucres $6-8 \mathrm{~mm}$. long; inner bracts linear, tapering to the apex: achenes columnar, about $3 \mathrm{~mm}$. long : pappus surpassing the involucres.

In open woods and thickets, Maine to Ontario, Manitoba, Georgia and Nebraska. Spring to fall.

5. Hieracium Marlànum Willd. Foliage softly hirsute below. Stems rather stout, 5-10 dm. tall, more or less widely branched into a corymbose panicle : leaves basal, and few or several along the stem ; blades spatulate to oblong-obovate or nearly oblong, $6-20$ $\mathrm{cm}$. long, ciliate, undulate or repand-denticulate, narrowed into winged petioles or the upper sessile : peduncles slender, more or less densely glandular-pubescent : involucres 6-7 $\mathrm{mm}$. long ; inner bracts narrowly linear-lanceolate, glabrous or slightly pubescent : achenes columnar, $2.5 \mathrm{~mm}$. long.

In dry open woods and thickets, Rhode Island to New York and Kentucky, south to Florida and Alabama. Spring and early summer.

6. Hieracium Greènii Porter \& Britton. Foliage hirsute, or shaggy below. Stems scape-like, erect, solitary or tufted, 3-9 dm. tall, corymbose above, naked or nearly so : leaves basal, or rarely 1 or 2 on the stem ; blades spatulate or oblong-spatulate, $5-20 \mathrm{~cm}$. long, obtuse, ciliate, undulate, narrowed into winged petioles : peduncles glandular-pilose : involucres 6-7 $\mathrm{mm}$. long ; inner bracts linear or narrowly linear-lanceolate, acute : achenes $3-3.5 \mathrm{~mm}$. long, columnar : pappus tawny.

On mountain slopes, Pennsylvania to Georgia. Spring.

7. Hieracium scábrum Michx. Foliage hirsute-hispid below. Stems erect, 3-9 $\mathrm{dm}$. tall, paniculately branched and glandular-hirsute above, leafy to the inflorescence: leaf-blades thickish, spatulate to obovate or oblong, 3-12 cm. long, acute or apiculate, undulate or repand-denticulate, the lower narrowed into winged petioles, the upper sessile by narrow bases : panicle commonly elongated: peduncles rather rigid : involucres 5-6 mm. long; inner bracts narrowly linear-lanceolate : achenes columnar, 2-2.5 mm. long : pappus tawny.

In dry woods and clearings, Nova Scotia to Minnesota, south to Georgia, Missouri and Kansas. Summer and fall. 
8. Hieracium longípilum Torr. Foliage conspicuously shaggy with long coarse hairs. Stems erect, 4-12 dm. tall, leafy to the middle, paniculately branched above : leafblades thickish, spatulate to narrowly oblong-spatulate, or varying to lanceolate or linearlanceolate above, apiculate or acute, narrowed into winged petioles, or the upper ones sessile : peduncles glandular-pilose and tomentose : involucres 7-10 $\mathrm{mm}$. long; inner bracts narrowly linear-lanceolate, somewhat acuminate: pappus fuscous : achenes fusiform, 3.5-4 mm. long.

On prairies or in woods, Ontario to Minnesota, Illinois, Nebraska and Texas. Summer and fall.

9. Hieracium Gronòvii L. Foliage more or less pubescent with slender hairs especially below. Stems erect, $3-10 \mathrm{dm}$. tall, paniculately branched above, leafy below, rather naked below the panicle: leaves commonly hirsute; blades spatulate to oblong, oval or obovate, 4-15 $\mathrm{cm}$. long, undulate or repand, the inner narrowed into winged petioles, the upper closely sessile by broad bases : panicle ample or sometimes much reduced : peduncles slender, glandular-pubescent : involucres 5-7 $\mathrm{cm}$. Iong; inner bracts linear or narrowly linear-lanceolate : achenes fusiform, 3-3.5 mm. long : pappus tawny.

In sandy soil, Ontario to Massachusetts, Indian Territory, south to Florida and Louisiana. :Summer and fall.

10. Hieracium megacéphalon Nash. Foliage purplish and glandular above, hirsute. Stems erect, usually tufted, $2-6 \mathrm{dm}$. tall, angled, corymbosely branched above : leaves mainly basal ; blades oblong-oblanceolate, 4-12 cm. long, acute or apiculate, ciliate, narrowed into short winged petioles, or those on the stem oblong to ovate, sessile by a broad truncate or cordate base : peduncles densely glandular-pilose : involucres 8-10 $\mathrm{mm}$. long, inner bracts linear or slightly narrowed upward : achenes fusiform, 4-4.5 $\mathrm{mm}$. long : pappus pale tawny.

In dry sandy pine lands, peninsular Florida. Spring.

11. Hieracium argyraèum Small. Foliage pubescent throughout. Stems 2.5-5 dm. tall, usually several together, corymbose and glandular above: leaves mainly basal ; blades spatulate to oblong, 2-9 $\mathrm{cm}$. long, quite shaggy with hairs similar to those on the lower part of the stem, those of the upper stem-leaves with broad bases and sessile : peduncles glandular-pubescent: involucres $10-11 \mathrm{~mm}$. high; inner bracts attenuate: pappus silvery white : achenes fusiform, 3-3.5 mm. long.

In pine lands, peninsular Florida. Spring.

\section{SITÍLIAS Raf.}

Biennial or perennial caulescent or scapose usually upright herbs. Leaves sometimes all basal; blades irregularly toothed, pinnatifid or sometimes entire. Heads yellow, long-peduncled. Involucres oblong to campanulate, double; inner of several narrow slightly united bracts; outer of several series of much smaller bracts. Rays yellow, truncate and toothed at the apex. Anthers sagittate at the base. Stigmas stout, rather obtuse. Achenes oblong to fusiform, beaked, usually 5-ribbed, pubescent or scabrous. Pappus of numerous brownish hair-like bristles accompanied by a ring of hairs at their bases. [ Pyrrhopappus DC.] False Dandelion.

Caulescent: stems branching: heads several.

Bracts of the outer involucres fully $1 / 3$ to over $1 / 2$ as long as the inner: heads fully $2.5 \mathrm{~cm}$. long at maturity.

Bracts of the outer involucres less than $1 / 3$ as long as the inner: heads $2 \mathrm{~cm}$. long at maturity or shorter.

Scapose: scapes simple: head solitary.

1. S. Caroliniana.

2. S. multicaulis.

3. S. grandiflora.

1. Sitilias Caroliniàna (Walt.) Raf. Foliage glabrous or nearly so. Stems erect, $1-1.5 \mathrm{dm}$. tall, usually branched : leaves various ; blades more or less deeply pinnatifid, sometimes merely denticulate or nearly entire, these conspicuously elongated: involucres $12-26 \mathrm{~mm}$. long; inner bracts narrowly linear; outer bracts narrower, fully $\frac{1}{3}$ to over $\frac{1}{2}$ as
long as the inner: ligules yellow : achenes about $5 \mathrm{~mm}$. long, ribbed, somewhat rufous. [Pyrrhopappus Carolinianus (Walt.) DC.]

In dry soil, Delaware and Missouri, south to Florida and Texas. Spring to fall.

2. Sitilias multicàulis (DC.) Greene. Foliage minutely pubescent, or glabrate. Stems solitary or tufted, ascending or spreading, 1-4 dm. long, more or less branched: leaves mainly basal, $5-15 \mathrm{~cm}$. long; blades sinnate or irregularly pinnatifid, the segments entire or toothed ; upper leaves narrower, deeply pinnatifid or merely toothed: involucres $1-1.5 \mathrm{~cm}$. long; inner bracts narrowly linear, acute; outer bracts linear-subulate, $\frac{1}{4}$ to nearly $\frac{1}{3}$ as long as the inner bracts : ligules bright yellow, oblong or linear-oblong, 1.5-2 $\mathrm{cm}$. long : achenes $3.5-4 \mathrm{~mm}$. long, reddish, transversely wrinkled.

In dry soil, Florida to Texas, Arizona and adjacent Mexico. Spring and summer. 
3. Sitilias grandiflòra (Nutt.) Greene. Foliage minutely pubescent. Leaves basal, blades $3-20 \mathrm{~cm}$. long, pinnatifid ; segments entire or sinuate : scapes erect or ascending, solitary, tufted, 1-3 dm. tall, simple : involucres about $1.5 \mathrm{~cm}$. long : inner bracts narrowly linear, outer bracts less than $\frac{1}{2}$ as long as the inner: ligules linear or linear-oblong, 1.5-2 cm. long.

On prairies, Kansas to Arkansas and Texas. Spring to fall.

\section{PINAROPÁPPUS Less.}

Perennial caulescent herbs, with leafy or scape-like stems. Leaves sometimes basal : blades narrow, remotely pinnately-toothed or pinnatifid, or entire. Heads pink or white, long-peduncled. Involucres campanulate : bracts in several series, the inner narrower than the outer. Receptacle flat, somewhat chaffy. Ligules of the ray-flowers truncate and toothed at the apex. Anthers sagittate at the base. Stigmas slender. Achenes narrow, terete or somewhat angled, 10-15-ribbed, glabrous. Pappus of many very slender bristles.

1. Pinaropappus ròseus Less. Foliage glabrous, glaucescent. Stems erect, or branched at the base, the branches often ascending, 1-3 dm. tall, nearly naked, or leafy near the base, upper parts elongated: leaf-blades linear to lanceolate, 3-10 cm. long, entire or pinnatifid, acute or acuminate : involucres campanulate, about $1 \mathrm{~cm}$. high; bracts oblong to linear-lanceolate or linear, the outer obtuse, the inner acute : ligules linear, 1-1.5 $\mathrm{cm}$. long, rose or white : achenes slender, 4-5 $\mathrm{mm}$. long.

On stony prairies, Texas and adjacent Mexico. Spring and summer.

\section{LYGODÉSMIA D. Don.}

Annual or perennial caulescent herbs, or somewhat shrubby plants, with rigid, sometimes rush-like stems. Leaves alternate: blades narrow, entire or remotely pinnatelytoothed, sometimes reduced to inconspicuous scales. Heads pink or purple, 3-12-flowered, short- or long-peduncled. Involucres cylindric, double; inner of 5-8 slightly united bracts ; outer of several very small bracts. Receptacle flat, notched. Ligules toothed at the apex. Anthers sagittate at the base. Stigmas slender. Achenes narrow, smooth or slightly ribbed. Pappus of many nearly equal very slender bristles.

Leaves reduced to scales, or sometimes with few linear blades at the base of the stem: achenes 10-13 mm. long, nearly as long as the pappus.

Leaves, all or some of them, with pinnately-lobed blades: achenes $14-15 \mathrm{~mm}$. long, often

longer than the pappus.

1. L. aphylla.

1. Tón (Nutt.) DC. Stem . or tufted, rush-like, naked or nearly so, forking above : leaves wanting, or represented by narrow scales, or a few elongated linear blades at base of stem : involucres cylindric, about $2 \mathrm{~cm}$. long : bracts various, the outer small, 1-3 mm. long, the inner linear : ligules rosecolored, $1.5-2 \mathrm{~cm}$. long, toothed at the apex : achenes narrow, 10-13 $\mathrm{mm}$. long, nearly as long as the white pappus.

In dry pine lands, Georgia and Florida. Summer.

2. Lygodesmia Texàna (T. \& G. ) Greene. Stems erect, $2-6$ dm. tall, solitary, forking above : leaves mainly at the base of the stem; blades linear or linear-filiform, entire or remotely pinnately lobed ; lobes small, 1-7 cm. long, entire : involucres about $1.5 \mathrm{~cm}$. long : bracts various, the outer small, the inner linear, scarious-margined : ligules rose-colored, about $1.5 \mathrm{~cm}$. long, toothed at the apex : achenes narrow, 14-15 $\mathrm{mm}$. long, often longer than the pappus. [L. aphylla var. Texana T. \& G.]

In rocky hills, Texas. Summer.

\section{LACTÙCA L.}

Annual, biennial or perennial often coarse herbs, with glabrous or sometimes prickly foliage. Stems often tall, racemose or paniculate above. Heads white, yellow or blue, rather small, often numerous. Involucres cylindric: bracts disposed in 2 involucres, the inner of 1 or 2 series of nearly equal bracts, the outer of several series of much shorter bracts, or the outer and inner bracts gradually merging. Receptacle flat, naked. Ligules often inconspicuous, truncate and toothed at the apex. Anthers sagittate at the base. Stigmas usually slender. Achenes flattened, oval to linear, 3-5-ribbed, narrowed above, sometimes into a neck, sometimes into a slender beak. Pappus copious, of hair-like white or brown bristles. Lettuce. Wood Lettuce. Wild Lettuce. 
Pappus bright white.

Leaf-blades spiny-tnothed and often spiny along the midrib beneath : corollas yellow.

Involucres 6-i2-flowered.

Involucres 12-20-flowered.

Involucres over $1.5 \mathrm{~cm}$. high : beak fully as long as the body of the achene.

Involucres less than $1.5 \mathrm{~cm}$. high : beak shorter than the body of the achene.

Leaf-blades without spines on the margins or midribs.

Achenes thin, each prolonged into a slender beak.

Involucre of 2 sets of bracts; outer very short ; inner much longer : corollas vellow to reddish, except sometimes in No. 6.

Leaf-blades, at least some of them, pinnatifid.

Leaves glabrous.

Leaves hirsute, at least their midribs.

Lower leaf-blades all pinnatifid : beak of achene fully as long as the body.

Lower leaf-blades usually both entire and pinnatifid: beak of achene much shorter than the body.

Leaf-blades entire or merely toothed.

Involucre with the outer and inner bracts connected by intermediate series: corollas blue.

Achenes thick, beakless, sometimes contracted into a neck.

Leaf-blades toothed : achene-body not narrowed into a neck.

Leaf-blades pinnatifid: achene-body narrowed into a slender neck. Pappus brown.

1. L. virosa.

2. L. Ludoviciana.

3. L. sagittifolia.

I. Lactuca viròsa L. Biennial, bright green, glaucous. Stems erect, 6-20 dm. tall, rigid, glabrous at least above the more or less hirsute base, paniculate above: leaves numerous; blades oblong to oblong-lanceolate, or oblanceolate, 1-3 dm. long or shorter above, denticulate, and spinulose beneath, sessile and clasping: heads 6-12-flowered, 4-8 $\mathrm{mm}$. broad : involucre 10-13 mm. high; inner bracts $\frac{2}{3}$ longer than the outer, narrowly linear, green : ligules yellow : achenes ribbed, thick-margined, the body fully $3 \mathrm{~mm}$. long, sometimes surpassed in length by the slender beak.

In waste places, fields and thickets; New York to Kansas, south to Georgia and Tennessee. Summer and fall.

2. Lactuca Ludoviciàna (Nutt.) DC. Biennial, glabrous. Stems erect, $4-15 \mathrm{dm}$. tall, paniculately branched above: leaves numerous; blades oblong-oblanceolate to oblong or oblong-lanceolate, 5-20 cm. long, acute or short-acuminate, sinuate-lobed or pinnatifid, spinulose along the margins as well as the midnerve beneath, elasping: peduncles with few scales: heads in close or open panicles: involucres $16-20 \mathrm{~mm}$. high ; inner bracts linear-lanceolate, scarious-margined : ligules yellow : achenes brown or black, the body obovate or oval, $4 \mathrm{~mm}$. long, 3-ribbed, the beak fully as long as the body.

On plains and prairies, Minnesota to North Dakota, Arkansas and Texas. Summer and fall.

3. Lactuca sagittifolia Ell. Biennial, glabrous. Stems erect, 1-3 m. tall, paniculate above : leaf-blades spatulate, oblanceolate to oblong-elliptic, or lanceolate, 1-3 dm. long, acute or somewhat acuminate, irregularly dentate, narrowed at the base but sessile and partly clasping: peduncles more or less scaly : involucres $10-20 \mathrm{~mm}$. high ; inner bracts linear to linear-lanceolate: ligules yellow or reddish: achenes $5 \mathrm{~mm}$. long, not wing-margined, strongly ribbed, the body longer than the beak.

On banks and in dry soil, New Brunswick to Ontario, Nebraska and Georgia. Summer and fall.

4. Lactuca Canadénsis L. Biennial, glabrous. Stems erect, 1-3 m. tall, paniculate above, often mottled : leaf-blades various, those of basal-leaves spatulate or oblong, dentate or pinnatifid, sometimes shorter than the petioles, those of stem-leaves $1-3 \mathrm{dm}$. long, sinuate-pinnatifid, the edges entire or irregularly toothed : peduncles often with small scales : involucres 10-12 mm. high; bracts ovate-lanceolate to linear-lanceolate : ligules yellow : achenes oval-oblong, $3 \mathrm{~mm}$. long, the beak fully as long as the body.

In open ground, Nova Scotia to Saskatchewan, Florida and Louisiana. Summer and fall.

5. Lactuca hirsùta Muhl. Biennial, hirsute or rarely glabrate. Stems erect, 6-12 dm. tall, paniculate above : leaf-blades oblanceolate to oblong in outline, sinuate-pinnatifid, 1-2 dm. long, sometimes hirsute only near the base; segments more or less angulately toothed : peduncles naked or nearly so : involucres $12-15 \mathrm{~mm}$. long, often purplish ; bracts lanceolate to narrowly linear, the inner scarious-margined: ligules purplish yellow to white : achenes oblong or elliptic, 3-5 $\mathrm{mm}$. long, the body shorter than the beak.

In dry soil, Maine to Ontario and Minnesota, south to Alabama and Texas. Summer and fall.

6. Lactuca graminifòlia Michx. Biennial or perennial, glabrous or nearly so, glaucescent. Stems erect, 6-15 dm. tall, paniculately branched above: leaf-blades elongated-linear or narrowly linear-lanceolate, $10-40 \mathrm{~cm}$. long, entire or with a few spreading or deflexed lobes; both the entire and pinnatifid types often on the same plant: peduncles often with minute scales: involucres $12-15 \mathrm{~mm}$. high ; bracts linear-lanceolate to lanceolate, the inner scarious-margined: ligules purple, blue or rarely white or yellowish : achenes elliptic or elliptic-oblong, 4-4.5 mm. long, the beak much shorter than the body.

In fields or woods, South Carolina to Florida and Texas. Spring to fall. 
7. Lactuca pulchélla (Pursh) DC. Perennial, glabrous, more or less glaucous. Stems erect, 3-7 dm. tall, corymbosely paniculate above : leaves $5-20 \mathrm{~cm}$. long, numerous ; blades linear to lanceolate, entire, toothed or pinnatifid, acute or obtuse, those of basal and lower stem-leaves sometimes with winged petioles, those of upper stem-leaves sessile and partly clasping: peduncles often copiously scaly : involucres $16-20 \mathrm{~mm}$. long; inner bracts linear-lanceolate, acute or obtusish : ligules blue or violet : achenes black, the body rather elliptic, ribbed, $4 \mathrm{~mm}$. long; beak shorter than the body.

In moist places, Ontario to the Northwest Territory and British Columbia, south to the Indian Territory, New Mexico and California. Spring to fall.

8. Lactuca villòsa Jacq. Annual or biennial, rather slender. Stems erect, 1-2 m. tall, paniculately branched above, glabrous : leaf-blades elliptic, oval or oblong-lanceolate, $8-20 \mathrm{~cm}$. long, acuminate, irregularly dentate, narrowed into winged petioles or nearly sessile : peduncles commonly with few scales: involucres 10-13 mm. high; bracts linearlanceolate to lanceolate, often purple: ligules blue : achenes elliptic, $4 \mathrm{~mm}$. long, with thick margins and 3 ribs on each face, beakless, not narrowed into a slender neck.

On banks or in thickets, New York to Illinois, south to Florida and Kentucky. Summer and fall.

9. Lactuca Floridàna (L.) Gaertn. Annual or biennial, stout or stoutish. Stems 1-3 m. tall, paniculately branched above, often mottled : leaf-blades thin, commonly ample, $36-45 \mathrm{~cm}$. long, lyrate-pinnatifid; segments irregularly toothed, the terminal one usually triangular: involucres 10-12 mm. high; bracts linear-lanceolate to linear, deep green or purplish : ligules blue : achenes curved, $6-7 \mathrm{~mm}$. long, each narrowed into a neck.

On hillsides and open grounds, New York to Nebraska, Florida and Louisiana. Summer and fall.

10. Lactuca spicàta (Lam.) A. S. Hitchcock. Biennial, glabrous. Stems erect, 1$3.5 \mathrm{~m}$. tall, paniculately branched above: leaf-blades $1-4.5 \mathrm{dm}$. long, merely toothed or sinuately or uncinately pinnatifid; segments coarsely and irregularly dentate : peduncles often sparingly scaly : involucres $9-11 \mathrm{~mm}$. high ; bracts lanceolate to linear-lanceolate, pale or scarious-margined : ligules white, bluish or yellowish : achenes $5 \mathrm{~mm}$. long, each with a wing-like margin and thinly ribbed faces, narrowed into a very short neck. $[L$. leucophaea A. Gray.]

In dry or moist soil, Newfoundland to Manitoba, North Carolina, Tennessee and Iowa. Summer and fall.-The variety with merely toothed leaf-blades, is $L$. spicata integrifolia (A. Gray) Britton.

\section{SÓNCHUS L.}

Annual or perennial caulescent weedy herbs, with succulent tissues. Leaves alternate ; blades entire, toothed or pinnatifid, often clasping, the edges and midnerve beneath often prickly. Heads yellow, peduncled, disposed in corymbose panicles. Involucres various, glabrous or pubescent: bracts herbaceous or membranous, in several rows of gradually differing lengths. Receptacle flat, naked. Ligules yellow, often numerous, truncate and toothed at the apex. Anthers sagittate at the base. Stigmas slender. Achenes more or less flattened, linear to oval, truncate, beakless, 10-20-ribbed, the ribs often undulate or toothed. Pappus conspicuous, of numerous white hair-like bristles, deciduous. Sow Thistle.

Stem-leaves with rounded auricles: achenes ribbed, or the base smooth.

Stem-leaves with acute auricles : achenes striate and transverse-wrinkled.

1. S. asper.

2. S. oleraceus.

1. Sonchus ásper (L.) All. Annual, nearly glabrous. Stem erect, 2-15 dm. tall, simple or somewhat branched : leaf-blades tender, spatulate to oblong, 5-25 $\mathrm{cm}$. long, with copiously spine-tipped teeth, the upper ones clasping by rounded bases : peduncles often glabrous : involucres about $1 \mathrm{~cm}$. high ; bracts linear to linear-lanceolate : heads pale yellow, $2.5 \mathrm{~cm}$. broad or smaller : achenes about $2 \mathrm{~mm}$. long, margined, 3-ribbed on each side.

In waste places, throughout most parts of North America and; the civilized world. Naturalized from Europe. Spring to fall.

2. Sonchus oleràceus L. Annual, nearly glabrous. Stems erect, 1-18 dm. tall, more or less widely branched: leaf-blades various, those of basal or lower stem-leave, lyrately-pinnatifid, with a triangular terminal segment; those of upper leaves shorters runcinately or lyrately-pinnatifid, the teeth tipped with soft spine-like teeth, the basal lobes acute : peduncles often glandular-hirsute : involucres about $1 \mathrm{~cm}$. high ; bracts lanceolatesubulate to lanceolate: heads pale yellow, $3 \mathrm{~mm}$. broad or smaller: achenes $2.5-3 \mathrm{~mm}$. long, striate, finely transverse-wrinkled.

In waste places and fields, throughout North America, except the extreme north, and the civilized world. Naturalized from Europe. Spring to fall. 


\section{TARÁXACUM Hall.}

Perennial low acaulescent herbs, with a bitter sap. Leaves basal, often numerous : blades sinuate-toothed to runcinate-pinnatifid, or rarely entire, the segments entire or toothed. Heads yellow, usually solitary at the ends of hollow elongated sometimes tufted peduncles. Involucres double; inner of 1 series of erect nearly equal slightly united bracts ; outer of several series of shorter spreading or reflexed bracts. Receptacle flattish, naked. Rays yellow, often numerous, truncate and toothed at the apex. Anthers sagittate at the base. Stigmas slender, rather obtuse. Achenes oblong or somewhat fusiform, 4-5-angled, 5-10ribbed, of ten tuberculate or spinulose at least below the slender beak. Pappus of numerous white hair-like bristles, persistent. DANDELION.

1. Taraxacum Taráxacum (L.) Karst. Foliage glabrous or nearly so. Leaves spreading; blades spatulate to oblanceolate or oblong, irregularly dentate to runcinatepinnatifid, $3-30 \mathrm{~cm}$. long, more or less pubescent especially when young: scapes solitary or tufted, erect or ascending, 1-2 dm. long, or much longer after flowering: heads with 150-200 golden-yellow flowers: involucres $1.5-2 \mathrm{~cm}$. high : bracts acute, linear to linearoblanceolate; inner much longer than the outer: achenes about $3 \mathrm{~mm}$. long, rather fusiform ; body spinulose near the top; beak about $\frac{1}{2}$ as long as the body. [ $T$. officinale Weber.]

On open grounds and waste places, in nearly all parts of the civilized world. Throughout the year.

\section{TRAGOPÒGON L.}

Biennial or perennial caulescent herbs, with slender tap-roots and rather succulent tissues. Leaf-blades narrow, long-attenuate, clasping or sheathing at the base. Heads peduncled, relatively large, expanding in the early morning, usually closing by noon. Involucre cylindric or campanulate: bracts in one series, nearly equal, united at the base. Corollas yellow or purplish: rays sometimes surpassed by the involucral bracts : ligules truncate, 5-toothed at the apex. Anthers sagittate at the base. Stigmas slender. Achenes narrow, terete or 5-angled, 5-10-ribbed, slender-beaked or the outer ones beakless. Pappus-bristles in one series, united at the base, plumose, the plume-branches interwebbed. Salsify. Oyster Plant.

1. Tragopogon porrffòlius L. Foliage glabrous, more or less glaucous. Stems erect, 4-15 dm. tall : leaves elongated, tapering from the clasping or sheathing base to a slender tip : peduncles stout and hollow for several $\mathrm{cm}$. below the heads, erect : heads showy, $5-$ $10 \mathrm{~cm}$. broad: involucre surpassing the rays: bracts linear-lanceolate, acuminate, ascending or spreading during anthesis: rays purple : achenes $3.5-4 \mathrm{~mm}$. long, the outer with scale-like tubercles especially along the ribs.

In fields and waste places, Ontario to Minnesota and Nebraska, south to Georgia. Native of Europe. Summer and fall.

\section{ADOPÒGON Neck.}

Annual or perennial caulescent or scapose herbs, with pale green or glaucous foliage. Leaves mainly basal, sometimes completely so : blades entire, or pinnately toothed or pinnatifid. Heads yellow or orange, solitary or corymbed. Involucres campanulate : bracts herbaceous, in 1 or 2 series, not accompanied by smaller ones without. Receptacle flat, naked. Ligules yellow, sometimes numerous or truncate and toothed at the apex. Anthers sagittate at the base. Stigmas slender, rather obtuse. Achenes oblong to turbinate, 1520-ribbed, beakless. Pappus mostly in 2 series, the outer of thin broad scales, the inner of slender bristles, or rarely wanting. [Krigia Schreb.] Dwarf Dandelion.

Annual plants.

Involucres of 5-8 bracts, firm and keeled at maturity.

Involucres of 9-18 thin, nerveless bracts.

Perennial plants.

Plants caulescent, sometimes apparently acaulescent: heads 2-many. Stems simple below the inflorescence or nearly so: peduncles branching. Stems diffusely branched: peduncles simple.

Plants scapose: head solitary.

1. A. occidentalis.

2. A. Carolinianus.

3. A. Virginicus.

4. A. montanus.

5. A. Dandelion.

1. Adopogon occidentàlis (Nutt.) Kuntze. Annual, minutely pubescent or glabrate, acaulescent. Leaf-blades obovate, spatulate or oblong, 1-4 cm. long, entire or ly rate-lobed, or pinnatifid, the segments broad; petioles as long as the blades or longer: scapes slender, $0.5-2 \mathrm{dm}$. tall, often numerous, glandular-hispidulous : bracts of the involucres 5-8, oblong 
to ovate-lanceolate, 4-5 mm. long, becoming keeled, firm : achenes barely $1.5 \mathrm{~mm}$. long, ribbed and transversely wrinkled : pappus-scales broadly obovate, the bristles alternating with those over the stronger ribs about as long as the pappus-scales or wanting.

On prairies, Missouri to Arkansas and Texas. Spring.

2. Adopogon Caroliniànus (Walt.) Britton. Annual, often pubescent, glaucescent. Leaf-blades spatulate or nearly linear in outline, $2-12 \mathrm{~cm}$. long, coarsely toothed, deeply pinnatifid : scapes erect or ascending, $3-40 \mathrm{~cm}$. tall, usually glandular-hirsute under the head : involucres glabrous; bracts 9-18, linear to lanceolate, 4-5 $\mathrm{mm}$. long, thin, nerveless : achenes $1.5 \mathrm{~mm}$. long, 5-angled, narrowly turbinate : pappus-bristles about twice as long as the achenes and many times longer than the rounded obovate scales. [Krigia Virginica Willd.]

In dry soil, Maine to Ontario and Minnesota, south to Florida and Texas. Spring and summer.

3. Adopogon Virgínicus (L.) Kuntze. Perennial, glabrous or nearly so. Stems erect, 1-7 dm. tall, simple or branched, sometimes scape-like : leaf-blades spatulate, oblong or oval, 5-20 cm. long, obtuse or acute, entire, repand or somewhat lyrate, often narrowed into broadly-winged petioles; stem-leaves with small sessile partly clasping blades: peduncles sometimes glandular-hirsute under the heads: involucres glabrous; bracts linear or linear-lanceolate: heads $1-1.5 \mathrm{~cm}$. long, orange to reddish orange: achenes $2 \mathrm{~mm}$. long, nearly oblong: pappus 10-15 small oblong scales and as many or more bristles longer than the achene. [Krigia amplexicaulis Nutt.]

In meadows and moist open woods, Massachusetts to Ontario, Manitoba, Georgia, and Kansas. Spring to fall.

4. Adopogon montànus (Michx.) Kuntze. Perennial, glabrous or nearly so. Stems erect or decumbent, more or less branched : leaves often numerous ; blades linear or linear-spatulate, elongated, 8-20 cm. long, entire or pinnatifid ; segments acute or narrow : scapes few or numerous, 1-3 dm. long, sometimes glandular-hirsute under the head : involucres glabrous ; bracts linear to linear-lanceolate or oblong-lanceolate, $8-10 \mathrm{~mm}$. long: heads bright yellow, $2.5-3 \mathrm{~cm}$. broad : achenes $2.5-3 \mathrm{~mm}$. long, finely ribbed : pappusbristles barely twice as long as the achene. [Krigia montana (Michx.) Nutt.]

On cliffs, on the Blue Ridge, North Carolina to Georgia. Summer and fall.

5. Adopogon Dandèlion (L.) Kuntze. Perennial, producing tubers. Stems wanting or very short : leaves usually clustered ; blades spatulate to linear-oblong or linear, 5$15 \mathrm{~cm}$. long, acute, undulate, denticulate or pinnatifid, the segments acute or narrow : scapes erect or ascending, 0.5-5 dm. tall, often glandular-hirsute under the head: involucres glabrous; bracts linear or narrowly linear-lanceolate: heads yellow, $2.5-3 \mathrm{~cm}$. broad: achenes slightly over $2 \mathrm{~mm}$. long, glandular-ribbed : pappus-bristles twice as long as the achene. [Krigia Dandelion (L.) Nutt.]

In moist soil, Maryland to Kansas, Florida and Texas. Spring and summer.

\section{SERÍNEA Raf.}

Annual herbs, with low branching stems. Leaves sometimes apparently opposite : blades entire or pinnatifid, some or all of them clasping. Heads small, commonly broadly so : bracts often 8 , membranous, all similar, concave at maturity. Receptacle flat, naked. Flowers few ; ligules yellow or orange, truncate and toothed at the apex. Anthers sagittate at the base. Stigmas slender. Achenes broadest above the middle, 8-10-ribbed. Pappus wanting or obsolete. [Apogon Ell.]

Corollas pure yellow, slightly surpassing the involucre: heads less than $5 \mathrm{~mm}$. high at maturity.

Corollas orange, about twice the length of the involucres : heads over $5 \mathrm{~mm}$. high at maturity.

Achenes about $1 \mathrm{~mm}$. long.

Achenes about $1.5 \mathrm{~mm}$. loug.

1. S. oppositifolia.

1. Serinea oppositifòlia (Raf.) Kuntze. Foliage glabrous, or glandular on the peduncles under the head. Stems commonly branched at the base; branches erect or spreading, $0.5-3 \mathrm{dm}$. long, usually weak : leaf-blades various, spatulate to linear, $2-12 \mathrm{~cm}$. long, entire or sinuate-pinnatifid, conspicuously irregular: involucres $4 \mathrm{~mm}$. high at maturity ; bracts linear-lanceolate to ovate, acute: heads pure yellow : corollas slightly surpassing the involucres: achenes oblong-obovate, $1.5 \mathrm{~mm}$. long, ribbed and minutely wrinkled: pappus wanting. [Apogon humilis Ell.]

In sandy soil and fields, South Carolina to Kansas, Florida and Texas. Spring.

2. Serinea grácilis (DC.) Kuntze. Foliage glabrous to the more or less copiously glandular-pubescent peduncles. Stems branched at the base ; branches ascending or 
spreading, 1-2 dm. long: leaf-blades various, spatulate to linear, sometimes broadly so, sinuate-pinnatifid or the upper ones entire: involucres $6 \mathrm{~mm}$. high at maturity; bracts oblong to lanceolate: ligules orange : achenes about $1 \mathrm{~mm}$. long, prominently ribbed and minutely transversely wrinkled: pappus wanting, or a mere vestige.

On rocky prairies, Texas. Spring.

3. Serinea Wríghtii (A. Gray) Kuntze. Foliage glabrous, or slightly glandularpubescent along the peduncles under the heads. Stems more or less diffusely branched at the base; branches erert or spreading, often less than $1 \mathrm{dm}$. long: leaves few; blades spatulate to Jinear-spatulate, $2-6 \mathrm{~cm}$. long, usually acute, entire or undulate: peduncles slender, sometimes longer than the rest of the branches: involucres 5-6 mm. high at maturity; bracts broadly oblong to ovate: achenes about $1.5 \mathrm{~mm}$. long, usually with an obscure vestige of pappus. [A pogon Wrightii A. Gray.]

In river valleys, eastern Texas. Spring.

\section{CICHÒRIUM L.}

Perennial herbs, with rigid branching stems. Leaves sometimes mainly basal : blades toothed or pinnatifid, of ten crisped. Heads showy, white, pink, blue or purple, peduncled or sessile and often clustered. Involucres herbaceous : bracts in 2 series, the outer more or less spreading, the inner erect. Receptacle flat, naked or sparingly fimbrillate. Ligules narrow, toothed and truncate at the apex. Anthers sagittate at the base. Stigmas slender, rather obtuse. Achenes short, 5-ribbed or 5-angled, beakless, more or less completely enclosed by the inner bracts of the involucre. Pappus of 2 or 3 rows of short scales.

1. Cichorium Íntybus L. Tap-root tough, elongated. Foliage hirsute or hispidulous at least below : stems erect, $3-15 \mathrm{dm}$. tall, rigidly branched : leaf-blades various ; basal spreading, usually runcinate, 1-2 dm. long; those of the stem oblong to lanceolate, entire, coarsely toothed or pinnatifid : involucres about $1 \mathrm{~cm}$. Iong; bracts lanceolate to linearlanceolate, glandular-ciliate above : heads sky-blue or white, $2.5-4 \mathrm{~cm}$. broad, closing by noon : achenes slightly enlarged upward, 2-2.5 mm. long, minutely wrinkled.

In waste places, fields or on roadsides, Nova Scotia to Minnesota, Nebraska and Florida. Summer and fall. CHICORY. WILD SUCCORY. 


\section{APPENDIX.}

This appendix contains descriptions of additional plants found within the region covered by this work during the several years the book has been in press, and corrections.

Page 31, for the second " appressed" in the key under Taxodium read "erect."

Page 170, after Cyperus speciosus, insert :

44a. Cyperus longispicàtus Norton. Perennial. Leaves much overtopped by the scape ; blades 1-2 cm. wide, or sometimes narrower: scape erect, mainly 1-2 m. tall, smooth : bracts of the involucre several, $1 \mathrm{~cm}$. wide, often $1 \mathrm{~m}$. long: umbel compound; rays $15 \mathrm{~cm}$. long or less : spikes mainly $2-3 \mathrm{~cm}$. long : spikelets $2-4 \mathrm{~cm}$. long, slender, 20-40-flowered, light yellowish brown; scales ovate, short-tipped, nerved between the green back and membranous margins : achenes 3 -angled, obpyramidal, about $1 \mathrm{~mm}$. long, light brown, abruptly pointed.

In water or low grounds, Florida to Texas and Mexico. Spring to fall.

Page 172, after Cyperus ovularis, insert:

55a. Cyperus globulòsus Aubl. Similar to C. ovularis in habit, but commonly more robust. Heads 11-21 mm. long, echinate, yellow-brown : spikelets much larger than those of $C$. ovularis; plants somewhat resembling those of $C$. echinatus, but achenes narrow.

In fields and open woods, Florida and Alabama. Also in tropical America. Summer and fall.

Page 172, after Cyperus retrorsus, insert :

56a. Cyperus Pollárai Britton. Perennial by small corms. Leaves shorter than the scape ; blades usually less than $3 \mathrm{~mm}$. wide : scapes $6-13 \mathrm{dm}$. tall, smooth : inflorescence of few unequally peduncled heads : bracts of the involucre usually 4 , one or sometimes two of them surpassing the heads: spikelets 3-4.5 $\mathrm{mm}$. long, the scales loose, or deciduous at maturity : achenes linear-oblong, about $1.5 \mathrm{~mm}$. long.

In pine woods and on prairies, peninsular Florida. Spring to fall.

56b. Cyperus Náshii Britton. Perennial, mostly tufted. Leaves shorter than the scape; blades less than $4 \mathrm{~mm}$. wide : scapes $4-11 \mathrm{dm}$. tall, smooth : inflorescence of numerous $(15-20)$ slender-peduncled heads : bracts of the involucre typically $7-11$, several of them surpassing the heads : heads $1 \mathrm{~cm}$. long or a little less, often compound: spikelets rather crowded, $2-3 \mathrm{~mm}$. long, acute, the scales appressed, persistent : achenes linear or nearly so, $2 \mathrm{~mm}$. long.

In pine lands, peninsular Florida. Spring to fall.

Page 176, in second line of the key under Scirpus strike out "or rarely 2 in No. 5," and add "smooth" after "perianth-bristles" in the last line.

Page 195, after Rynchospora Curtissii, insert :

18a. Rynchospora fúsca (L.) Ait. f. Stems slender, $1.5-4.5 \mathrm{dm}$. tall, smooth : leaf-blades filiform-setaceous, channeled, shorter than the stems: spikelets fusi orm, about $5 \mathrm{~mm}$. long, acute, in 1-4 loose clusters; scales brown, shining : perianth-bristles 6 , often unequal, upwardly barbed: achenes narrowly obovoid, smooth, shining ; tubercle triangular-subulate, nearly as long as the achene-body. Summer.

In bogs and about pine-land ponds, New Brunswick to Michigan and Georgia. Also in Europe.

Page 196, after Rynchospora gracilenta, insert :

22a. Rynchospora Smállii Britton. Stems relatively stout, 8-14 dm. tall, tufted: leaf-blades flat, $2-5 \mathrm{~mm}$. wide: spikelets numerous in several rather loose clusters, fusiform, 3-4 mm. long; scales brown, lax, and deciduous at maturity : perianth-bristles upwardly barbed, as long as the achene and tubercle: achenes narrowly obovate, brown, smooth and shining, $1.5 \mathrm{~mm}$. long excluding the tubercle, the tubercle smooth, about $\frac{1}{2}$ as long as the achene-body.

In bogs and on damp hillsides, Pennsylvania and western North Carolina. Summer and fall. 
Page 268, in the eleventh and twelfth lines of the key under Convallariaceae interchange the words "slender" and "dilated."

Page 297, for " attentuate" in third line under Sisyrinchium capillare, read, "attenuate."

Page 305, in third line from top, read "clavate" for "cavate."

Page 308, at the end of Marantaceat insert :

\section{MARÁNTA L.}

Caulescent herbs, with branching stems. Leaves alternate: blades commonly of an ovate or a lanceolate type, often abruptly bent at the base: petioles partly sheathing. Flowers solitary or few in panicles. Perianth double : sepals 3, herbaceous, equal, distinct : corolla often white, the 3 petals partially united. Staminodia conspicuous, 2 of them surpassing the corolla. Anthers 1-celled. Ovary 1-celled but with 2 additional abortive cavities. Style stoút, curved. Stigma oblique. Capsule utricle-like. Seed erect, solitary.

1. Maranta arundinàcea L. Stems 1-2 m. tall, from starchy copiously scaly rootstocks, more or less branched and rather weak, sometimes reclining, zigzag: leaf-blades lanceolate to ovate-lanceolate, $8-25 \mathrm{~cm}$. long, acute, many-veined: flowers few, fugacious : sepals green, lanceolate or linear-lanceolate, $10-12 \mathrm{~mm}$. long: corolla white, about $2 \mathrm{~cm}$. long; lobes lanceolate : staminodia flabellate-cuneate, surpassing the corolla, erose, notched: capsules broadly oblong, commonly $1 \mathrm{~cm}$. long.

In moist soil and damp hammocks, southern peninsular Florida. Introduced from tropical America.

Page 351, under Quercus Catesbaei; the cup of the acorn is sometimes nearly or quite turbinate. In the key, this species should also be contrasted with Q. Texana and Q. coccinea.

Page 351, after Quercus coccinea insert :

15a. Quercus boreàlis Michx. f. A large tree, commonly $20 \mathrm{~m}$. tall. Leaves similar to those of $Q$. rubra; blades 7-13-lobed to the middle or beyond it, somewhat lustrous and deep green above, dull, paler and glabrous or nearly so beneath : acorn resembling that of $Q$. coccinea, about $\frac{1}{2}$ as large as that of $Q$. rubra, short-peduncled; cup turbinate, its scales appressed ; nut ovoid, commonly about $2 \mathrm{~cm}$. long, between twice or thrice as long as the cup.

In woods and on open slopes, Quebec and Ontario to the mountains of North Carolina. GRAY OAK.

Page 403, at bottom of page insert :

2. Rivina laèvis L. Similar to $R$. humilis in habit, but with glabrous foliage, and commonly with smaller flowers and fruit; it may be specifically distinct. It occurs in the Gulf States and tropical America.

Page 404, before Allioniaceac, insert:

\section{Family 6a. Basellàceae Moq. Madeira-vine Family.}

Somewhat succulent vines, with tuber-bearing rootstocks. Leaves alternate : blades relatively broad, often cordate, entire. Flowers perfect in spike-like racemes. Calyx of 2 sepals, sometimes winged in fruit. Corolla of 5 often somewhat colored petals. Androecium of 5 stamens borne opposite the petals. Filaments terete or flattened, sometimes united below. Gynoecium 3-carpellary. Ovary superior, 1-celled. Styles 3, distinct. Stigmas entire or cleft. Ovule solitary, campylotropous, erect. Fruit utricular. Seed with a membranous testa.

Sepals oblong, shorter than the petals, wingless : stigmas cleft.

Sepals boat-shaped, as long as the petals, broadly winged on the back at maturity : stigmas entire.

1. Boussingaultia.

2. ANREDERA.

\section{BOUSSINGAÙLTIA H.B.K.}

Vines, with much-branched stems. Leaf-blades of an ovate type, rather fleshy. Flowers in axillary and terminal spike-like racemes. Sepals 2, nearly flat, not winged, Petals 5, longer than the sepals. Filaments terete, somewhat enlarged, but not dilated, at the base. Stigmas cleft.

1. Boussingaultia baselloìdes H.B.K. A glabrous vine climbing over other plants. Stem much branched : leaf-blades ovate, $2 . \overline{5}-6 \mathrm{~cm}$. long, acute, entire, abruptly 
narrowed or subcordate at the base, short-petioled: racemes slender, simple or compound, $5-17 \mathrm{~cm}$. long: petals greenish white or maroon, oval or elliptic-oval, $1.5-2.5 \mathrm{~mm}$. long, spreading during anthesis. America.

In waste places, thickets and woods, peninsular Florida and Texas. Introduced from tropical

\section{ANREDÈRA Juss.}

Vines, with fleshy much-branched stems. Leaf-blades of an ovate type, fleshy. Flowers in mainly axillary spike-like racemes. Sepals 2, boat-shaped, broadly winged at maturity. Petals 5, not longer than the sepals. Filaments flattened, and dilated below. Stigmas entire.

1. Anredera scándens Moq. A glabrous diffuse and high-climbing vine. Stem much branched: leaf-blades ovate, acute or acutish, $3-5 \mathrm{~cm}$. long, abruptly narrowed or truncate at the base, short-petioled : racemes stout, mainly simple, $2-11 \mathrm{~cm}$. long : petals pale, elliptic or oval-elliptic, $1.5-2 \mathrm{~cm}$. long: sepal-wings 4-5 $\mathrm{mm}$. long at maturity.

In chapparal, about hedges and fences, southern Texas to northern south America.

Page 406, for "Allionia bracteosa" in key and description, read "Allionia bracteata."

Page 412, between Cypselea and Trianthema insert :

\section{3a. GALÈNIA L.}

Herbs or shrubs, with spreading or prostrate branches, the foliage glabrous, pubescent or scaly. Leaves opposite or alternate, often very variable in size. Flowers perfect, inconspicuous, axillary. Sepals 4 or 5 . Stamens 8 or 10 , in pairs at the sinuses of the perianth. Ovary 3-5-celled, or 1-celled by abortion, often depressed at the apex. Styles erect. Ovules pendulous. Capsule 3-5-angled, leathery.

1. Galenia secunda Sond. Stem branched at the base, the branches radially spreading, several $\mathrm{dm}$. long, much branched : leaves numerous; blades rhombic, cuneate-obovate or spatulate-obovate, mainly 1-2 cm. long: calyx about $3 \mathrm{~mm}$. long; lobes oblong or lanceolate-oblong, ciliate near the tip and pubescent without : filaments shorter than the calyx-lobes.

In waste places, about Pensacola, Florida. Native of southern Africa.

Page 468, between Synthlipsis and Lesquerella insert :

\section{4a. DITHYRÀ̀A Harv.}

Herbs, with stems often branched at the base. Leaves alternate, often mainly basal : blades sinuate or pinnatifid. Flowers in terminal racemes. Sepals narrow, deciduous. Petals white or purplish, clawed. Style very short. Pod 2-lobed, the lobes conspicuously margined, each cavity 1 -seeded.

1. Dithyraea Wislízeni Engelm. Stem 2-6 dm. tall, closely pubescent, often branched at the base, the branches ascending or spreading, rather copiously leafy : leafblades lanceolate, varying to ovate-lanceolate or linear-lanceolate, 3-8 cm. long, or shorter near the inflorescence, sinuate or pinnatifid, those of the lower leaves narrowed into petiolelike hases, those of the upper merely sessile : racemes becoming 1-4 dm. long and lax at maturity : pedicels elongating, reflexed at maturity : sepals linear or linear-lanceolate, $3.5-4.5 \mathrm{~mm}$. long, ciliate : petals $6-7 \mathrm{~mm}$. long, the blades suborbicular, longer than the claws : pods 12-14 mm. wide, notched at the base, finely pubescent.

On dry or sandy hillsides, Arkansas to southern Utah, Texas, Arizona and adjacent Mexico. Spring and summer.

Page 460, after description of Berberis Swazeyi, insert :

3. Berberis trifoliolata Moric. A rigid much-branched shrub 0.5-2 m. tall, the bark pale. Leaves numerous ; leaflets 3 , the blades rigid, leathery, oblong to lanceolate in outline, with 3-7 pale-margined spine-tipped pinnate teeth, sessile at the end of the petiole which is usually $2-3 \mathrm{~cm}$. long: flowers in fascicles on scaly spur-like branches: pedicels slender, 5-10 mm. long : outer sepals ovate, obtuse; inner sepals obovate, much longer than the outer : petals yellow, 3-4 mm. long: berries globular, 4-5 mm. in diameter, red.

In dry or stony soil, Texas and adjacent Mexico. Fall, winter and early spring.

Page 462, for "Argemone delicatula" read "Argemone pinnatifida Norton." 
Page 484, after Arabis patens, insert :

5a. Arabis Georgiàna Harper. Biennial. Stem $3-5 \mathrm{dm}$. tall, with few erect branches mostly from the base, minutely hirsute below, glabrous or nearly so above : basal leaves 6-8 cm. long, in a flat rosette; blades oblanceolate or spatulate, coarsely toothed: cauline leaves spreading or ascending; blades $3-6.5 \mathrm{~cm}$. long, oblong-lanceolate to lanceolate or linear-lanceolate near the inflorescence, sessile and half-clasping, bright green, the lower surface and the margins sparsely pubescent with both simple and forked hairs: racemes becoming 3 or $4 \mathrm{dm}$. long: pedicels ascending, glabrous, becoming $1 \mathrm{~cm}$. long: sepals ovate, $4 \mathrm{~mm}$. long, acute, narrowly scarious-margined: petals $9-10 \mathrm{~mm}$. long, white, obtuse : style $1 \mathrm{~mm}$. long: pods linear-filiform, flattened, 6-7 mm. long, about $1 \mathrm{~mm}$. wide, erect or nearly so, the valves 1-nerved : seeds narrow!y winged, in 1 row.

On shaded banks. along the Chattahoochee River, Georgia. Spring.-Differs from A. patens in the longer pods and the glabrous upper surface of the leaves and the upper part of the stem, and from $A$. hirsuta in its larger corolla, evident style and longer pods.

Page 494, in second division of the key to Rosales, after "perianth present," add "except in Liquidambar.",

Page 502, extend the range of Lepuropetalum spatulatum to Texas and Mexico.

Page 522, in fourth and fifth lines of the key under Geum, interchange the words "glabrous" and "bristly."

Page 555, in fifth line under Crataegus dispar, read " petioles" for " pedicels."

Page 604, after Medicago Arabica, insert :

4. Medicago sativa L. Stem decumbent or ascending, 3-5 dm. long, more or less branched, usually sparingly pubescent : leaflets 3 , the blades cuneate-obovate to cuneate or oblanceolate, mainly $1-1.5 \mathrm{~cm}$. long, sharply toothed near the apex, rather prominently but finely veined : racemes several-flowered, peduncled : calyx 4-5 mm. long; lobes nearly subulate, about as long as the tube, sparingly ciliolate : corolla violet or blue, 7$8.5 \mathrm{~mm}$. long; standard oblong-obovate; wing-petals each with a hooked spur at the base of the blade: pods 2 or 3 times spirally twisted, finely pubescent, the valves delicately reticulated.

In fields and waste places, Quebec to Manitoba, Virginia and Texas. Naturalized from Europe. Summer.

Page 620, after Xylophacos Missouriensis insert :

\section{6a. ARAGÁLLUS Neck.}

Herbs or shrubby plants, similar to species of Astragalus in habit ; but keel petals acuminate, abruptly pointed or appendaged at the apex.

1. Aragallus Lambértii (Pursh) Greene. Stems very short, severai from a branched caudex, clothed with the persistent leaf-bases: leaves erect or ascending, 0.5-1.5 dm. tall; leaflets several, the blades linear or nearly so, 1.5-2.5 cm. long, acute or slightly acuminate, silky on both sides : scapes $1.5-3 \mathrm{dm}$. tall, silky strigose : bracts narrowly linear-lanceolate: calyx densely pubescent, $10-11 \mathrm{~mm}$. long; lobes nearly subulate, the lower one markedly longer than the others : corolla violet, purple or white, 16-19 mm. long ; standard rounded at the apex, cuneately narrowed at the base; blades of the keel and wing-petals longer than the claws, about thrice as long as broad : pods narrowly conic, 18-20 mm. long, subulate-tipped.

On plains, the Northwest Territories to Minnesota, British Columbia, Texas and New Mexico. Spring and summer.

Page 678, at the end of Rutaceae add :

\section{TRIPHÀSIA Lour.}

Shrubs, with smooth green branches, more or less thorny. Leaves alternate, persistent, 3-foliolate, the leaflets with leathery shallowly toothed blades. Flowers perfect, regular. Sepals united into a 3-5-lobed shallow calyx. Petals 3-4, narrow. Stamens 6 or 8 , borne at the base of a fleshy disk: filaments dilated at the base : anthers narrow. Ovary 3-celled : styles united. Ovules solitary and pendulous in each cavity. Berry relatively small, 1-3-celled. Seeds imbedded in pulp. Embryo with unequal, often lobed, cotyledons.

1. Triphasia Aurantiola Lour. A much-branched armed shrub. Leaves numerous, glabrous; leaflets 3 , the blades ovate to nearly oblong or oval, $1.5-3.5 \mathrm{~cm}$. long, obtuse, 
shallowly crenate: flowers fragrant, short-pedicelled: calyx 2-2.5 mm. high, the lobes acute : petals linear or oblong-linear, $9-12 \mathrm{~mm}$. long, white : berries oblong or globularoblong, about $15 \mathrm{~mm}$, long.

In fields and thickets, Florida to Texas. Introduced from the tropics.

Page 759, for the second " a" in the fourth from the last line of the description of Tillaceae, read "or."

Page 760, in fourth line of the description of Triumfetta semitriloba, for "leaves" read "blades."

Page 766, in first line under Callirrhoè after "Perennial " insert "or annual."

Page 772, before Malachra, insert :

\section{8a. ANÒdA Cav.}

Annual or perhaps rarely perennial herbs, similar to Sida in habit. Leaves alternate: blades commonly deltoid or hastate, toothed or rarely cleft. Flowers perfect, solitary at the ends of relatively long pedicels. Calyx persistent, enlarged and spreading under the fruit. Corolla showy. Carpels 5-20, radiately spreading and forming a capsulelike fruit whose partitions and sides break down, the firmer top and back bearing a spreading cusp. Ovule and seed mostly resupinate-horizontal, the latter partially exposed at maturity.

1. Anoda pentachísta A. Gray. Stem $3-7 \mathrm{dm}$. tall, slender, paniculately branched, puberulent-pubescent, when copiously so usually cinereous : leaf-blades thickish, those on the lower part of the stem ovate, angulate at the base or somewhat hastate, $1-4 \mathrm{~cm}$. long, subcordate or truncate at the base, those of the upper cauline leaves narrower, hastate-lanceolate or hastate-linear, or sometimes without basal lobes, short-petioled, more pubescent than the stem : calyx stellate-pubescent, 4-5 mm. high during anthesis and with lanceolate lobes, $8-9 \mathrm{~mm}$. wide at maturity, with the lobes very broad and partially involute : petals bright yellow, cuneate, about $5 \mathrm{~mm}$. long: carpels 5 , or rarely $6-9$, the top of each one $3-$ $3.5 \mathrm{~mm}$. long, finely stellate-pubescent : seed $3 \mathrm{~mm}$. high.

On plains and prairies, Texas to Arizona and northern Mexico. Spring to fall.

Page 818, in the description of Thymeleales, instead of "Ovary inferior," read "Ovary superior."

Page 836 extend range of Ludvigia simulata to Florida.

Page 857, in twelfth line from bottom of page add or " rarely purple."

Page 957, in the ordinal key, for character of Verbenacene instead of "Ovary 2celled " read, "Ovary 2-several-celled."

Page 980, after Gilia rubra add :

4. Gilia longiflòra (Torr.) G. Don. Annual, glabrous. Stem 2-7 dm. tall, paniculately branched, firm : leaves alternate ; blades pinnately parted into slenderly linear segments 1-4 cm. long: flowers in corymbs : calyx about $6 \mathrm{~mm}$. long; lobes lanceolate-subulate, shorter than the tube : corolla white; tube slender, $3-3.5 \mathrm{~cm}$. long; lobes oval to orbicular-oval, fully $1 \mathrm{~cm}$. long: capsule oblong, 11-13 mm. long.

On plains and prairies, often in pine woods, Nebraska and Colorado to Texas and Arizona. Spring and summer.

Page 1034, after "Perennial" in first line under Salvia lanceolata, add "or annual."

Page 1108, after Houstonia purpurea, insert :

10a. Houstonia montàna (Chickering) Small. Similar to Houstonia purpurea in habit, typically smaller: leaf-blades ovate, $0.5-1.5 \mathrm{~cm}$. long, acute, sessile : hypanthium becoming larger than that of $H$. purpurea: sepals lanceolate or oblong-lanceolate : corolla purple, sometimes deeply so, 9-11 $\mathrm{mm}$. long: capsules fully $2 \mathrm{~mm}$. thick. [H. purpurea var. montana Chickering.] Summer.

On and about cliffs, summit of Roan Mountain and adjacent peaks, North Carolina and Tennessee. 


\section{LIST OF GENERA AND SPECIES PUBLISHED IN THIS FLORA ${ }^{1}$}

Caryopitys Small. (Kápvov, nut: and $\pi i \tau v s$, pine, i. e., nut pine, the common name of several of the species.) Type, Pinus edulis Engelm.

Caryopitys edulis (Engelm.) Small. Pinus edulis Engelm.

Strobus Strobus (L.) Small. Pinus Strobus L.

Picea australis Small. Type, Grandfather Mt., N. C., Small, Aug. 1891, in Herb. C. U.

Sabina Barbadensis (L.) Small. Juniperus Barbadensis L.

Sabina sabinoides (H.B.K.) Small. Cupressus sabinoides H.B.K.

Potamogeton Floridanus Small. Type, Blackwater River, Fla., Curtiss, May, 1886, in Herb. N. Y. B. G.

Naias gracilis (Morong) Small. Naias marina var. gracilis Morong.

Sagittaria australis (J. G. Smith) Small. Sagittaria longirostra australis J. G. Smith.

Manisuris Chapmanii (Hack.) Nash. Rottboellia rugosa var. Chapmani Hack.

Schizachyrium oligostachyum (Chapm.) Nash. Andropogon oligostachyus Chapm.

Schizachyrium scoparium (Michx.) Nash. Andropogon scoparius Michx.

Schizachyrium acuminatum Nash. Type, Starkville, Miss., Tracy, Nov. 11, 1890, in Herb. Nash.

Schizachyrium villosissimum (Kearn.) Nash. Andropogon scoparius villosissimus Kearney

Schizachyrium maritimum (Chapm.) Nash. Andropogon maritimus Chapm.

Schizachyrium stoloniferum Nash. Type, Fla., Chapman, in Herb. C. U.

Schizachyrium triaristatum Nash. Type, Fla., Chapman, in Herb. Nash.

Schizachyrium gracile (Spreng.) Nash. Andropogon gracilis Spreng.

Andropogon perangustatus Nash. Andropogon Virginicus var. viridis, subvar. stenophyllus Hack., not $A$. stenophyllus R. \& S.

Andropogon gracilior (Hack.) Nash. Andropogon Elliottii var. gracilior Hack.

Andropogon subtenuis Nash. Type, Biloxi, Miss., Tracy 2243, 1896, in Herb. Nash.

Amphilophis exaristatus Nash. Andropogon saccharoides var. submuticus Vasey, not $A$. submuticus Steud.

Amphilophis barbinodis (Lag.) Nash. Andropogon barbinodis Lag.

Amphilophis perforatus (Trin.) Nash. Andropogon perforatus Trin.

Sorghastrum nutans (L.) Nash. Andropogon nutans L.

Sorghastrum Linnaeanum (Hack.) Nash. Andropogon nutans var. Linnaeanus Hack.

Sorghastrum secundum (Ell.) Nash. Andropogon secundus Ell.

Vetiveria zizanioides (L.) Nash. Phalaris zizanioides L.

Rhaphis pauciflorus (Chapm.) Nash. Sorghum pauciflorum Chapm.

Hilaria Texana (Vasey) Nash. Hilaria cenchroides var. Texana Vasey.

Limnodea Arkansana pilosa (Trin.) Nash. Sclerachne pilosa Trin.

Paspalum blepharophyllum Nash. Type, Nash, Pl. Cent. Penins. Fla. no. 1426, in Herb. Nash.

Paspalum epile Nash. Type, Key West, Blodgett, in Herb. C. U.

Paspalum gracillimum Nash. Type, Key West, Blodgett, in Herb. C. U.
Paspalum praelongum Nash. Type, Washington, D. C., Nash, Sept. 5, 1894, in Herb. Nash.

Paspalum glaberrimum Nash. Type, Nash, Pl. Cent. Penins. Fla., no. 1619, in Herb. Nash.

Paspalum tardum Nash. Type, Nash, Pl. Fla. no. 2047, 1895, in Herb. Nash.

Paspalum laeviglume Scribn. Paspalum remotum var. glabrum Vasey.

Paspalum Kearneyi Nash. Type, Nicholson, Miss., Kearney, no. 357, 1896, in Herb. C. U.

Paspalum amplum Nash. Type, Mariana, Fla., Tracy, no. 3682, 1897, in Herb. Nash.

Paspalum solitarium Nash. Paspalum monostachyum Vasey, not Walp. Garden.

${ }^{1}$ In this list C. U. $=$ Columbia University and N. Y. B. G. $=$ New York Botanical 
Dimorphostachys ciliifera Nash. Type, Manatee, Fla., Simpson, no. 97, 1890, in Herb. U. S. Dept. Agric.

Anastrophus platycaulis (Poir.) Nash. Paspalum platycaule Poir.

Brachiaria platyphylla (Munro) Nash. Panicum platyphyllum Munro.

Trichachne saccharatum (Buckl.) Nash. Panicum saccharatum Buckl.

Echinochloa longearistata Nash. Type, [La.], Hale, in Herb. C. U.

Panicum Gattingeri Nash. Panicum capillare var. campestre Gattinger, not $P$. campestre Nees.

Panicum condensum Nash. Type, Curtiss, Second Distr. Pl. So. U. S., no. 5576, in Herb. C. U.

Panicum gracilicaule Nash. Type, Sand Mt., Jackson Co., Ala., Harbison, no. 2415, 1900, in Herb. N. Y. B. G.

Panicum chrysopsidifolium Nash. Type, Curtiss, N. Am. Pl., no. D, in Herb. N. Y. B. G.

Panicum mutabile Scribn. \& Sm. Type, Biloxi, Miss., Tracy, no. 3074, 1896, in Herb. Nash.

Phanopyrum Nash. Panicum, subgenus Phanopyrum Raf.

Phanopyrum gymnocarpon (Ell.) Nash. Panicum gymnocarpon Ell.

Steinchisma hians (Ell.) Nash. Panicum hians Ell.

Cenchropsis Nash. Type, Cenchrus myosuroides H.B.K.

Cenchropsis myosuroides (H.B.K.) Nash. Cenchrus myosuroides H.B.K.

Aristida subuniflora Nash. Type, N. Mex., Vasey, in Herb. Nash.

Aristida Wrightii Nash. Type, Dallas, Tex., Reverchon, no. 1061, in Herb. Nash.

Aristida micrantha (Vasey) Nash. Aristida purpurea var. micrantha Vasey.

Aristida Chapmaniana Nash. Type, Apalachicola, Fla., Chapman, in Herb. C. U.

Ortachne Floridana (Chapm.) Nash. Streptachne Floridana Chapm.

Sporobolus attenuatus Nash. Type, Starkville, Miss., Kearney, no. 83, 1896, in Herb. C. U.

Agrostis Scribneriana Nash. Agrostis intermedia Scribn., not Balb.

Triathera aristidoides (H.B.K.) Nash. Dinebra aristidoides H.B.K.

Polyodon Texanus (S. Wats.) Nash. Boutelowa Texana S. Wats.

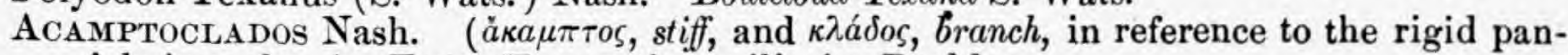
icle-branches.) Type, Eragrostis sessilispica Buckley.

Acamptoclados sessilispicus (Buckl.) Nash. Eragrostis sessilispica Buckl.

Tridens eragrostoides (V. \&'S.) Nash. Triodia eragrostoides V. \& S.

Tridens Texanus (Thurb.) Nash. Triodia Texana Thurb.

Tridens Langloisii Nash. Tricuspis Langloisii Nash.

Tridens seslerioides (Michx.) Nash. Poa seslerioides Michx.

Tridens Drummondii (S. \& K.) Nash. Triodia Drummondii S. \& K.

Tridens strictus (Nutt.) Nash. Windsoria stricta Nutt.

Tridens congestus (L. H. Dewey) Nash. Sieglingia congesta L. H. Dewey.

Tridens muticus (Torr.) Nash. Tricuspis mutica Torr.

Tridens elongatus (Buckl. ) Nash. Iralepis elongata Buckl.

Tridens Buckleyanus (Vasey) Nash. Triodia Buckleyana Vasey.

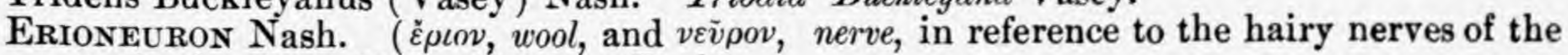
scales.) Type Uralepis pilosa Buckl.

Erioneuron pilosum (Buckl.) Nash. Uralepis pilosa Buckl.

Poa glabrescens Nash. Poa arachnifera var. glabrata Torr., not P. glabrata Kunth.

Cyperus Floridanus Britton. Type, Key West, Fla., Blodgett, in Herb. C. U.

Cyperus Pollardi Britton. Pollard \& Collins, Pl. Subtrop. Fla., no. 257, in Herb. N. Y. B. G.

Cyperus Nashii Britton. Nash, Pl. Cent. Penins. Fla., no. 1196, in Herb. C. U.

Cyperus Plankii Britton. Type, Corrigan, Tex., Plank, July 24, 1894, in Herb. N. Y. B. G.

Cyperus subuniflorus Britton. Cyperus uniformis var. pumilus Britton, not C. pumilus L.

Eleocharis praticola Britton. Osceola, Fla., Fredholm, no. 5820, in Herb. N. Y. B. C.

Eleocharis macrostachya Britton. Type, Indian Territory, Palmer, no. 264a, in Herb. C. U.

Eleocharis Ravenelii Britton. Type, Corpus Christi, Tex., Ravenel, no. 83 in Herb. C. U.

Fimbristylis Drummondii (Torr. \& Hook.) Britton. Isolepis Drummondii Torr. \& Hook.

Fimbristylis perpusilla Harper. Type, Harper, Ga. Pl., no. 1729, in Herb. N. Y. B. G.

Stenophyllus coarctatus (Ell.) Britton. Scirpus coarctatus Ell.

Rynchospora Indianolensis Small. Type, Indianola, Tex., Ravenel, no. 160, in Herb. C. U.

Rynchospora intermedia (Chapm.) Britton. Rynchospora plumosa var. intermedia Chapm.

Rynchospora microcephala Britton. Rynchospora axillaris var. microcephala Britton.

Rynchospora Curtissii Britton. Type, Curtiss, Second Distrib. Pl. So. U. S., no. 929, in Herb. N. Y. B. G.

Rynchospora Smallii Britton. Type, Hendersonville to Solola Mt., Small \& Huger, Oct. $2-3$, 1901, in Herb. N. Y. B. G. 
Rynchospora Plankii Britton. Type, Benton Co., Ark., Plank, no. 29, in Herb. N. Y. B. $G$.

Rynchospora Earlei Britton. Type, Marshallville, Ga., Earle, no. 2977, in Herb. C. U.

Rynchospora perplexa Britton. Type, Florida, Chapman, no. 2, in Herb. C. U.

Rynchospora mixta Britton. Type, Marshallville, Ga., Earle, June 8, 1895, in Herb. C. U.

Rynchospora prolifera Small. Type, Harper, Ga. Pl. no. 408, in Herb. N. Y. B. G.

Scleria Curtissii Britton. Type, C'urtiss, Second Distr. Pl. So. U. S., no. 4793, in Herb. N. Y. B. G.

Scleria glabra (Chapm.) Britton. Scleria pauciflora var. glabra Chapm.

Carex radiata (Dewey) Small. Carex rosea var. radiata Dewey.

Carex reniformis (Bailey) Small. Carex straminea var. reniformis Bailey.

Sabal megacarpa (Chapm.) Small. Sabal Adansonii var. (?) megacarpa Chapm.

Arisaema acuminatum Small. Type, Clearwater, Fla., Tracy, no. 6781, in Herb. N. Y. B. G.

Muricauda Small. (Mus, mouse, or rat, and cauda, tail, in reference to the prolonged spadix.) Type, Arum Dracontium L.

Muricauda Dracontium (L.) Small. Arum Dracontium L.

Lemna trinervis (Austin) Small. Lemna perpusilla var. trinervis Austin.

Xyris arenicola Small. Xyris torta Kunth, not J. E. Smith.

Xyris pallescens (C. Mohr) Small. Xyris torta pallescens C. Mohr.

Lachnocaulon Floridànum Small. Type, Nash, Pl. Fla., no. 1891, in Herb. C. U.

Lachnocaulon eciliatum Small. Type, Curtiss, N. A. Pl., no. 3022, in Herb. C. U.

Lachnocaulon minor (Chapm.) Small. Lachnocaulon Michauxii var. minor Chapm.

Eriocaulon lineare Small. Type, Harper, Ga. Pl., no. 830, in Herb. N. Y. B. G.

Cuthbertia Small. (In honor of A. Cuthbert, collector and student of the flora of the eastern United States.) Type, Tradescantia rosea Vent.

Cuthbertia graminea Small. Type, Augusta, Ga., Small, June 27-July 1, 1895, in Herb. C. U.

Cuthbertia rosea (Vent.) Small. Tradescantia rosea Vent.

Tradescantella Small. (Diminutive of Tradescantia.) Type, Tradescantia Floridana S. Wats.

Tradescantella Floridana (S. Wats.) Small. Tradescantia Floridana S. Wats.

Tradescantella incarnata Small. Type, Tracy, no. 3087, in Herb. C. U.

Commelina Nashii Small. Type, Nash, Pl. Fla., no. 2465, in Herb. C. U.

Commelina saxicola Small. Type, Stone Mt., Ga., Small, no. 124, in Herb. C. U.

Tillandsia Baileyi Rose. Type, Cameron Co., Tex., Bailey, no. 26, in Herb. U. S. Nat. Mus.

Triantha racemosa (Walt.) Small. Melanthium racemosum Walt.

Schoenocaulon dubium (Michx.) Small. Helonias dubia Michx.

Tracyanthus Small. (In honor of S. M. Tracy, collector and student of the North American flora.) Type, Helonias angustifolia Michx.

Tracyanthus angustifolius (Michx.) Small. Helonias angustifolia Michx.

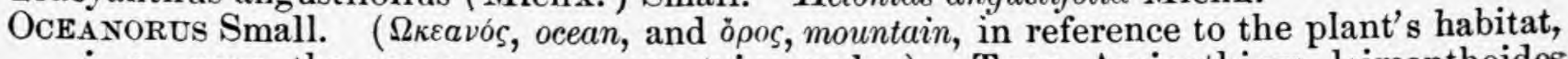
i. e., near the ocean or on mountain peaks.) Type, Amianthium leimanthoides A. Gray.

Oceanorus leimanthoides (A. Gray) Small. Amianthium leimanthoides A. Gray.

Toxicoscordion Texense Rydb. Type, Tex., Drummond, III, 420, in Herb. C. U.

Juncus aristulatus pinetorum Coville. Type, Nash, Pl. Cent. Penins. Fla., no. 958, in U. S. Nat. Herb.

Allium continuum Small. Type, Macon, Ga., Small, May 18-24, 1895, in Herb. C. U.

Allium microscordion Small. Type, Ala., Buckley, May, in Herb. C. U.

Allium Helleri Small. Type, Heller, Pl. So. Tex., no. 1469, in Herb. C. U.

Allium Cuthbertii Small. Type, Cuthbert, no. 332, in Herb. N. Y. B. G.

VAlidallium Small. (Validus, powerful, and Allium.) Type, Allium tricoceum Ait.

Validallium tricoccum (Ait.) Small. Allium tricoccum Ait.

Vagnera australis Rydb. Type, Auburn, Ala., Earle \& Underwood, Apr. 22, 1896, in Herb C. U.

OAKEsIElla Small. (Diminutive of Oakesia.) Type, Uvularia sessilifolia L.

Oakesiella puberula (Michx.) Small. Uvularia puberula Michx.

Oakesiella Floridana (Chapm.) Small. Uvularia Floridana Chapm.

Oakesiella sessilifolia (L.) Small. Uvularia sessilifolia L.

Trillium Hugeri Small. Type, Tryon Mt., N. C., Huger, May, 1896, in Herb. C. U.

Nemexia ecirrhata (Engelm.) Small. Coprosmanthus herbaceus var. ecirrhatus Engelm.

Nemexia Hugeri Small. Type, Stone Mt., Ga., Small, May 1-18, 1895 (fl.) ; Hickory

Nut Gap, N. C., Small \& Huger, Oct. 3, 1901, in Herb. N. Y. B. G.

Nemexia Biltmoreana Small. Type, Biltmore Herbarium, no. $906 \mathrm{~b}$, in Herb. N. Y. B. G. 
Nemexia diversifolia Small. Smilax diversifolia Small.

Nemexia pulverulenta (Michx.) Small. Smilax pulverulenta Michx.

Nemexia tenuis Small. Smilax tenuis Small.

Nemexia herbacea (L. ) Small. Smilax herbacea L.

Nemexia tamnifolia (Michx.) Small. Smilax tamnifolia Small.

Smilax lata Small. Type, Pollard \& Collins, Pl. Subtrop. Fla., no. 241, in Herb. N. Y. B. G.

Hypoxis mirantha Pollard. Type, Cartaret Co., N. C., McCarthy, no. 8, in U. S. Nat. Herb.

Hypoxis Curtissii Rose. Type, Curtiss, Second Distr. Pl. So. U. S., no. 4727, in U. S. Nat. Herb.

Hypoxis grandis Pollard. Type, Auburn, Ala,, Pollard \& Maxon, no. 72, in U. S. Nat. Herb.

Manfreda tigrina (Engelm.) Small. Agave Virginica var. tigrina Engelm.

Atamosco longifolia (Hemsl.) Small. Zephyranthes longifolia Hemsl.

Sisyrinchium fibrosum Bicknell. Sisyrinchium Carolinianum Bicknell, not Klotzsch.

Sisyrinchium recurvatum Bicknell. Type, Tracy, no. 6675, in Herb. N. Y. B. G.

Sisyrinchium longifolium Bicknell. Type, Tracy, no. 6672 , in Herb. N. Y. B. G.

Sisyrinchium violaceum Bicknell. Type, Walton Co., Fla., Curtiss, 1885, in Herb. N. Y. B. G.

Thalia barbata Small. Type, Opelousas, La., Carpenter, 1839, in Herb. C. U.

Apteria aphylla (Nutt.) Barnhart. Lobelia aphylla Nutt.

Fissipes Small. (Findo, to divide, and pes, foot, in reference to the cleft lip.) Type, Cypripedium acaule Ait.

Fissipes acaulis (Ait.) Small. Cypripedium acaule Ait.

Blephariglottis conspicua (Nash) Small. Habenaria conspicua Nash.

Blephariglottis Chapmanii Small. Type, Apalachicola, Fla., Chapman, in Herb. C. U.

Habenaria Nuttallii Small. Type, Curtiss, N. A. Pl., no. 2772, in Herb. C. U.

Habenaria Simpsonii Small. Type, Manatee, Fla., Simpson, Aug. 23, 1890, in Herb. C. U.

Habenaria Habenaria (L.) Small. Orchis Habenaria L.

Habenella Small. (Diminutive of Habena.) Type, Habenaria Garberi Porter.

Habenella Garberi (Porter) Small. Habenaria Garberi Porter.

Gyrostachys laciniata Small. Type, Nash, Pl. Fla. no. 1967, in Herb. C. U.

Gyrostachys xyridifolia Small. Type, Curtiss, Second Distr. Pl. So. U. S. no. 4856, in Herb. N. Y. B. G.

BEADLEA Small. (In honor of C. D. Beadle, curator of the Biltmore Herbarium and student of the North American flora.) Type, Spiranthes Storeri Chapm.

Beadlea Storeri (Chapm.) Small. Spiranthes Storeri Chapm.

Limodorum Simpsonii (Chapm.) Small. Calopogon Simpsonii Chapm.

Limodorum graminifolium (Ell.) Small. Calopogon pulchellus var. graminifolius Ell.

Epidendrum erythronioides Small. Type, Key Largo, Fla., Curtiss, in Herb. N. Y. B. $\mathrm{G}$.

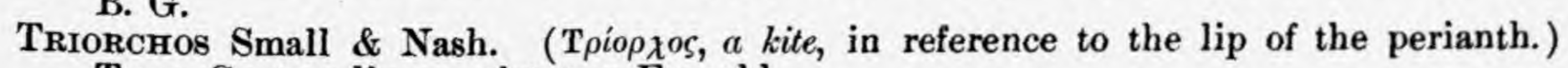
Type, Cyrtopodium ecristatum Fernald.

Triorchos ecristatus (Fernald) Small. Cyrtopodium ecristatum Fernald.

Platypus Small \& Nash. (Пגatís, wide, and $\pi$ wós, foot, in reference to the broad foot of the column.) Type, Platypus papilliferus Small.

Platypus papilliferus Small. Type, Everglades, Fla., Small \& Nash, no. 141, in Herb. N. Y. B. G.

Polystachya minuta (Aubl.) Britton. Epidendrum minutum Aubl.

Morella pumila (Michx.) Small. Myrica cerifera $\gamma$ pumila Michx.

Morella cerifera (L.) Small. Myrica cerifera L.

Morella Carolinensis (Mill.) Small. Myrica Carolinensis Mill.

Morella inodora (Bartr.) Small. Myrica inodora Bartr.

Quercus hybrida (Chapm.) Small. Quercus aquatica var. hybrida Chapm.

Quercus austrina Small. Type, Gallion, Hale Co., Ala., Mohr, in Herb. N. Y. B. G.

Adicea herniarioides (Sw. ) Small. Urtica herniarioides Sw.

Boehmeria scabra (Porter) Small. Boehmeria cylindrica var. scabra Porter.

Boehmeria decurrens Small. Type, Florida, Chapman, in Herb. C. U.

Boehmeria austrina Small. Type, Heller, Pl. So. Tex. no. 1900, in Herb. C. U.

Parietaria obtusa Rydb. Type, Palmer, Fl. So. Utah, etc., no. 226, in Herb. C. U.

Celtis Smallii Beadle. Type, Macon, Ga., Small, May 18-24, 1895, in Herb. C. U.

Trema Floridana Britton. Type, Miami, Fla., Small \& Nash, no. 32, in Herb. N. Y. B. G

Eriogonum Floridanum Small. Type, Nash, Pl. Cent. Penins. Fla., no. 704, in Herb. C. U* 
Persicaria emersa (Michx.) Small. Polygonum amphibium var. emersum Michx.

Persicaria Portoricensis (Bertero) Small. Polygonum Portoricense Bertero.

Persicaria longistyla Small. Polygonum longistylum Small.

Persicaria Mexicana Small. Polygonum Mexicanum Small.

Persicaria Pennsylvanica (L.) Small. Polygonum Pennsylvanicum L.

Persicaria incarnata (Ell.) Small. Polygonum incarnatum Ell.

Persicaria segeta (H.B.K.) Small. Polygonum segetum H.B.K.

Persicaria persicarioides (H.B.K.) Small. Polygonum persicaivioides H.B.K.

Persicaria Persicaria (L.) Small. Polygonum Persicaria L.

Persicaria Opelousana (Ridd.) Small. Polygonum Opelousanum Ridd.

Persicaria hydropiperoides (Michx.) Small. Polygonum hydropiperoides Michx.

Persicaria setacea (Baldw.) Small. Polygonum setaceum Baldw.

Persicaria hirsuta (Walt.) Small. Polygonum hirsutum Walt.

Persicaria hirsuta glabrescens (Meisn.) Small. Polygonum hirsutum var. glabrescens Meisn.

Persicaria punctata (Ell.) Small. Polygonum punctatum Ell.

Persicaria punctata leptostachya (Meisn.) Small. Polygonum acre var. leptostachyum Meisn.

Persicaria punctata robustior Sinall. Polygonum punctatum var. robustior Small.

Persicaria punctata eciliata Small. Polygonum punctatum var. eciliatum Small.

Tracaulon Beyrichianum (Cham. \& Schlecht.) Small. Polygonum Beyrichianum Cham. \& Schlecht.

Tracaulon sagittatum (L.) Small. Polygonum sagittatum L.

Tiniaria cilinodis (Michx.) Small. Polygonum cilinode Michx.

Tiniaria scandens (L.) Small. Polygonum scandens L.

Tiniaria cristata (Engelm. \& Gray) Small. Polygunum cristatum Engelm. \& Gray.

Chenopodium albescens Small. Type, Heller, Pl. So. Tex. no. 1928, in Herb. C. U.

Brayulinea Small. (In honor of W. L. Bray and E. B. Uline, monographers of the

North American Amaranthaceae.) Guilleminea H.B.K., not Neck.

Brayulinea densa (Willd.) Small. Illecebrum densum Willd.

-Gossypianthus Sheldonii (Uline \& Bray) Small. Gossipianthus lanuginosus var. Sheldonii Uline \& Bray.

Alternanthera Floridana (Chapm.) Small. Telanthera Floridana Chapm.

Froelichia campestris Small. Type, Bush, Pl. Ind. Terr., no. 484, in Herb. C. U.

Paronychia Wardi Rydb. Type, Alva, Oklo., Ward, no. 62 , in Herb. N. Y. B. G.

Anychiastrum Small. (Anychia, and à $\sigma \tau \rho o v$, star.) Type, Paronychia riparia Chapm.

Anychiastrum herniarioides (Michx.) Small. Paronychia herniarioides Michx.

Anychiastrum Baldwinii (T. \& G.) Small. Paronychia Baldwinii T. \& G.

Anychiastrum riparium (Chapm.) Small. Paronychia riparia Chapm.

(O)ontonychia Small. (ódovs, tooth, and Anychia.) Type, Siphonychia erecta Chapm.

Odontonychia erecta (Chapm.) Small. Siphonychia erecta Chapm.

Odontonychia corymbosa Small. Siphonychia corymbosa Small.

Siphonychia pauciflora Small. Type, Harper, Ga. Pl., no. 967, in Herb. N. Y. B. G.

Allionia Texensis (Coulter) Small. Allionia corymbosa var. Texensis Coulter.

Allionia comata Small. Type, Wright, Coll. N. Mex., no. 1718, in Herb. C. U.

Allionia oblongifolia (A. Gray) Small. Oxybaphus nyctagineus $\gamma$ oblongifolius A. Gray.

Pisonia Floridana Britton. Type, Key West, Fla., Blodgett, in Herb. C. U.

Talinum reflexum sarmentosum (Engelm.) Small. Talinum sarmentosum Engelm.

Tissa bracteata (Robinson) Small. Spergularia salsuginea var. bracteata Robinson.

Alsinopsis Small. (Alsine, and ò $\psi$ 's, resemblance.) Alsine Wahl., not L.

Alsinopsis uniflora (Walt.) Small. Stellaria uniflora Walt.

Alsinopsis Nuttallii (T. \& G.) Small. Stellaria Nuttallii T. \& G.

Alsinopsis Groenlandica (Retz) Small. Stellaria Groenlandica Retz.

Alsinopsis brevifolia (Nutt.) Small. Arenaria brevifolia Nutt.

Alsinopsis glabra (Michx.) Small. Arenaria glabra Michx.

Alsinopsis patula (Michx.) Small. Arenaria patula Michx.

Alsinopsis Texana (Robinson) Small. Arenaria stricta var. Texana Robinson.

Alsinopsis stricta (Michx. ) Small. Arenaria stricta Michx.

Alsinopsis Caroliniana (Walt.) Small. Arenaria Caroliniana Walt.

Alsine Baldwinii Small. Arenaria prostrata Baldw., not Alsine prostrata Forsk.

Alsine Tennesseensis (C. Mohr) Small. Alsine pubera Tennesseensis C. Mohr.

Viticella Viticella (L.) Small. Clematis Viticella L.

Viorna crispa (L.) Small. Clematis crispa L.

Viorna crispa Walteri (Pursh) Small. Clematis Walteri Pursh.

Viorna Simsii (Sweet) Small. Clematis Simsii Sweet.

Viorna Gattingeri Small. Clematis Gattingeri Small.

Viorna reticulata (Walt.) Small. Clematis reticulata Walt. 
Viorna versicolor Small. Clematis versicolor Small.

Viorna coccinea (Engelm.) Small. Clematis coccinea Engelm.

Viorna obliqua Small. Type, St. Augustine, Fla., Reynolds, 1872, in Herb. C. U.

Viorna flaccida Small. Clematis faccida Small.

Viorna Viorna (L.) Small. Clematis Viorna L.

Viorna glaucophylla Small. Clematis glaucophylla Small.

Viorna Addisonii (Britton) Small. Clematis Addisonii Britton.

Viorna ochroleuca (Ait.) Small. Clematis ochroleuca Ait.

Viorna ovata (Pursh) Small. Clematis ovata Pursh.

Viorna Baldwinii (T. \& G.) Small. Clematis Baldwinii T. \& G.

Thalictrum Texanum (A. Gray) Small. Thalictrum debile var. Texanum A. Gray.

Tulipastrum cordatum (Michx.) Small. Magnolia cordata Michx.

Tulipastrum acuminatum (L.) Small. Magnolia acuminata L.

Lepidium austrinum Small. Type, Heller, Pl. So. Tex., no. 1651, in Herb. C. U.

Lepidium oblongum Small. Type, Bush, Pl. Ind. Terr., no. 1163, in Herb. C. U.

Lesquerella sessilis (S. Wats.) Small. Lesquerella gracilis var. sessilis S. Wats.

Cakile Harperi Small. Type, Harper, Pl. Ga.. no. 923, in Herb. N. Y. B. G.

Draba Helleri Small. Type, Heller, Pl. So. Tex., no. 1379, in Herb. C. U.

Dentaria furcata Small. Type, Tuscaloosa, Ala., Johnson, in Herb. C. U.

Dentaria incisa Small. Type, Lookout Mt., Ala., Chapman, 1872, in Herb. C. U.

EUklisia Rydb. Streptanthus, subgenus Euklisia Nutt.

Euklisia hyacinthoides (Hook.) Small. Streptanthus hyacinthoides Hook.

Selenia aperta (S. Wats.) Small. Selenia aurea var. aperta S. Wats.

Moringa Moringa (L.) Small. Guilandina Moringa L.

Sedum Roanense Britton. Type, Roan Mt., N. C., Small \& Heller, July 16, 1891, in Herb. N. Y. B. G.

Astilbe crenatilobata (Britton) Small. Astilbe decandra var. crenatilobata Britton.

Micranthes Virginiensis (Michx.) Small. Saxifraga Virginiensis Michx.

Micranthes Texana (Buckl.) Small. Saxifraga Texana Buckl.

Micranthes Tennesseensis Small. Saxifraga Tennesseensis Small.

Micranthes Careyana (A. Gray) Small. Saxifraga Careyana A. Gray.

Micranthes Grayana (Britton) Small. Saxifraga Grayana Britton.

Micranthes micranthidifolia (Haw.) Small. Robertsonia micranthidifolia Haw.

Spatularia Michauxii (Britton) Small. Saxifraga Michauxii Britton.

Tiarella macrophylla Small. Type, Tryon Mt., N. C., Huger, June, 1896, in Herb. C. U.

Heuchera aceroides Rydb. Type, Asheville, N. C., Hogg, May, 1886, in Herb. C. U.

Heuchera calycosa Small. Type, Mountains of Ga., Chapman, in Herb. C. U.

Fothergilla parvifolia Kearney. Type, Jesup, Ga., Kearney, June 4, 1893, in Herb. C. U.

Rubus betulifolius Small. Type, Äla. Biological Surv., no. 1590, in Herb. N. Y. B. G.

Rubus rhodophyllus Rydb. Type, Pt. St. Martin, Miss., Tracy, no 4107, in Herb. N. Y.

B. G.

Rubus carpinifolius Rydb. Type, Ball, Pl. La., no. 428, in Herb. N. Y. B. G.

Rubus persistens Rydb. Type, Biloxi, Miss., Tracy, no. 4108, in Herb. N. Y. B. G.

Rosa lancifolia Small. Type, Nash, Pl. Cent. Penins, Fla., no. 1695, in Herb. C. U.

Butneria Mohrii Small. Type, Lookout Mt., Ala., Allen, June, 1870, in Herb. C. U.

Prunus normalis (T. \& G.) Small. Prunus Chicasa $\beta$ normalis T. \& G.

Padus eximia Small. Prunus eximia Small.

Padus serotina neomontana (Sudw.) Small. Prunus serotina neomontana Sudw.

Padus Cuthbertii Small. Prunus Cuthbertii Small.

Padus Alabamensis (C. Mohr) Small. Prunus Alabamensis C. Mohr.

Padus australis Beadle. Prunus australis Beadle.

Poinciana pauciflora (Griseb.) Small. Lebidibia pauciflora Griseb.

Guilandina Crista (L.) Small. Caesalpinia Crista L.

Guilandina major (DC.) Small. Guilandina Bonduc var. majus DC.

Thermopsis Hugeri Small. Baptisia Hugeri Small.

Baptisia hirsuta Small. Baptisia calycosa var. villosa Canby, not B. villosa Nutt.

Baptisia Gibbesii Small. Type, Charleston, S. C., Manigault, July 10, 1861, in Herb. N. Y. B. G.

Baptisia Nuttalliana Small. Baptisia confusa Pollard \& Ball, not Sweet./Y

Baptisia elliptica Small. Type, Curtiss, N. A. Pl., no. 689, in Herb. N. Y. B. G.

Baptisia albescens Small. Type, Macon, Ga., Small, May 18-24, 1895, in Herb. C. U.

Baptisia Bushii Small. Type, Bush, Pl. Brazos River, Tex., no. 68, in Herb. N. Y. B. G.

Cracca latidens Small. Type, Nash, Pl. Cent. Penins. Fla., no. 1072, in Herb. C. U.

Cracca holosericea (Nutt.) Small. Tephrosia holosericea Nutt.

Cracca Chapmanii (Vail) Small. Cracca chrysophylla Chapmanii Vail. 


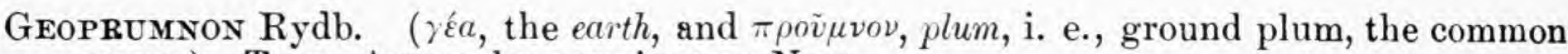
name.) Type, Astragalus crassicarpus Nutt.

Geoprumnon Tennesseense (A. Gray) Rydb. Astragalus Tennesseensis A. Gray.

Geoprumnon Plattense (Nutt.) Rydb. Astragalus Plattensis Nutt.

Geoprumnon pachycarpum (T. \& G.) Rydb. Astragalus pachycarpus T. \& G.

Geoprumnon Mexicanum (A. DC.) Rydb. Astragalus Mexicanus A. DC.

Geoprumnon crassicarpum (Nutt.) Rydb. Astragalus crassicarpus Nutt.

Hamosa leptocarpa (T. \& G.) Rydb. Astragalus leptocarpus T. \& G.

Hamosa Lindheimeri (Engelm.) Rydb. Astragalus Lindheimeri Engelm.

Hamosa Nuttalliana (DC.) Rydb. Astragalus Nuttallianus DC.

Hamosa macilenta Small. Type, along the Rio Blanco, Tex., Wright, in Herb. C. U.

Hamosa austrina Small. Type, Rio Fronteras, Tex., Thurber, no. 417, in Herb. N. Y. B. G.

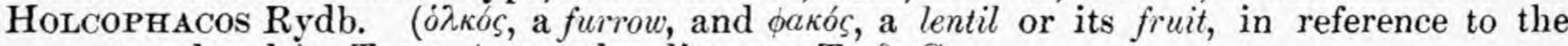
ground pod.) Type, Astragalus distortus T. \& G.

Holcophacos Engelmannii (Sheldon) Rydb. Astragalus Engelmannii Sheldon.

Holcophacos distortus (T. \& G.) Rydb. Astragalus distortus T. \& G.

Tium intonsum (Sheldon) Rydb. Astragalus intonsus Sheldon.

Tium obcordatum (Ell.) Rydb. Astragalus obeordatus Ell.

Tium apilosum (Sheldon). Astragalus apilosus Sheldon.

Phaca Reverchonii (A. Gray) Rydb. Astragalus Reverchonii A. Gray.

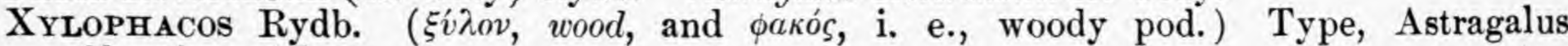
Shortianus Nutt.

Xylophacos Missouriensis (Nutt.) Rydb. Astragalus Missouriensis Nutt.

Psoralea macrophylla Rowlee. Type, Tryon Mt., N. C., Rowlee, June 18, 1897, in Herb. N. Y. B. G.

Petalostemon albidus (T. \& G.) Small. Petalostemon carneus $\beta$ albidus T. \& G.

Petalostemon Porterianus Small. Type, Leavenworth, Ark. to El Paso, Tex., Diffenderfer, in Herb. Lafayette Col.

Petalostemon Stanfieldii Small. Type, San Marcos, Tex., Stanfield, 1897, in Herb. N. Y. B. G.

Lespedeza Texana Britton. Type, Heller, Pl. So. Tex., no. 1914, in Herb. C. U.

Lespedeza prairea (Mackenzie \& Bush) Britton. Lespedeza violacea prairea Mackenzie \& Bush.

Erythrina arborea (Chapm.) Small. Erythrina herbacea var. arborea Chapm.

Galactea brevipes Small. Type, near Traders Hill, Ga., Small, July 24-26, 1895, in Herb. C. U.

Bradburya arenicola Small. Type, Nash, Pl. Cent. Penins. Fla., no. 1366, Herb. C. U.

Strophostyles Missouriensis (S. Wats.) Small. Strophostyles angulosa var. Missouriensis S. Wats.

Vicia Texana (T. \& G.) Small. Vicia Caroliniana $\beta$ Texana T. \& G.

Linum Harperi Small. Type, Harper, Ga. PI., no. 455, in Herb. N. Y. B. G.

Linum marginatum Small. Type, Texas, Drummond, 1833, in Herb. C. U.

Linum sanctum Small. Type, San Antonio, Tex., Thurber (?), 1853, in Herb. C. U.

Ionoxamis Small. (iov, violet, and Oxalis, i. e., Oxalis with violet corollas.) Type, Oxalis violacea $\mathrm{L}$.

Ionoxalis violacea (L.) Small. Oxalis violacea $\mathrm{L}$.

Ionoxalis Martiana (Zucc.) Small. Oxalis Martiana Zucc.

Ionoxalis vespertilionis (T. \& G.) Small. Oxalis vespertilionis T. \& G.

Monoxamis Small. ( $\mu$ óvos, single, and Oxalis, in reference to the single leaflet of each leaf.) Type, Oxalis dichondraefolia A. Gray.

Monoxalis dichondraefolia (A. Gray) Small. Oxalis dichondraefolia A. Gray.

Lotoxalis Small. (Lotus, and Oxalis, $i$. e., an Oxalis resembling Lotus in habit.) Type, Oxalis Berlandieri Torr.

Lotoxalis Berlandieri (Torr.) Small. Oxalis Berlandieri Torr.

Xanthoxamis Small. ( $\xi a v \theta o ́ s$, yellow, and Oxalis, $i$. e., Oxalis with yellow corollas.) Type, Oxalis stricta $\mathrm{L}$.

Xanthoxalis corniculata (L.) Small. Oxalis corniculata L.

Xanthoralis Langloisii Small. Type, St. Martinsville, La., Langlois, Mar. 15, 1897, in Herb. C. U.

Xanthoxalis filipes Small. Oxalis filipes Small.

Xanthoxalis macrantha (Trelease) Small. Oxalis corniculata var. ? macrantha Trelease.

Xanthoxalis Texana Small. Type, Alvin, Tex., Plank, Apr. 20, 1894, in Herb. N. Y. B. G.

Xanthoxalis stricta (L.) Small. Oxalis stricta L.

Xanthoxalis Bushii Small. Oxalis Bushii Small.

Xanthoxalis rufa Small. Oxalis rufa Small. 
Xanthoxalis colorea Small. Type, Stone Mt., Ga., Small, May 1-18, 1895, in Herb. C. U.

Xanthoxalis recurva (Ell.) Small. Oxalis recurva Ell.

Xanthoxalis Brittoniae Small. Oxalis Brittoniae Small.

Xanthoxalis interior Small. Type, Benton Co., Ark., Plank, 1899, in Herb. N. Y. B. G.

Xanthoxalis grandis Small. Oxalis grandis Small.

Xanthoxalis cymosa Small. Oxalis cymosa Small.

Xanthoxalis hirsuticaulis Small. Oxalis hirsuticaulis Small.

Xanthoxalis Priceae Small. Oxalis Priceae Small.

Kallstroemia hirsutissima Vail. Type, Dona Ana Co., N. Mex., Wooton, no. 564, in Herb. N. Y. B. G.

Fagara Fagara (L.) Small. Schinus Fagara L.

Fagara fruticosa (A. Gray) Small. Xanthoxylum Carolinianum var. fruticosum A. Gray.

Fagara Clava-Herculis (L.) Small. Xanthoxylum Clava-Herculis L.

Polygala Hugeri Small. Type, Andrews, N. C., Huger, Aug., 1900, in Herb. N. Y. B. G.

Polygala sparsiflora (Wheelock) Small. Polygala Boykinii var. sparsiflora Wheelock.

Polygala Harperi Small. Type, Harper, Ga. Pl., no. 896, in Herb. N. Y. B. G.

Phyllanthus Garberi Small. Type, Cedar Keys, Fla., Garber, Apr., 1876, in Herb. C. U.

Phyllanthus Drummondii Small. Type, Texas, Drummond, III, 336, in Herb. C. U.

Phyllanthus radicans (Muell. Arg.) Small. Phyllanthus Niruri var. radicans Muell. Arg.

Tragia saxicola Small. Type, Curtiss, N. A. Pl., no. 2517, in Herb. C. U.

Stillingia linearifolia (Muell. Arg.) Small. Stillingia sylvatica $\gamma$ linearifolia Muell. Arg.

Stillingia spathulata (Muell. Arg.) Small. Stillingia sylvatica a spathulata Muell. Arg.

Stillingia salicifolia (Torr.) Small. Stillingia sylvatica $\beta$ salicifolia Torr.

Mozinna sessiliflora (Hook.) Small. Mozinna spathulata var. sessiliflora Hook.

Cnidoscolus Texanus (Muell. Arg.) Small. Jatropha Texana Muell. Arg.

Chamaesyce polygonifolia (L.) Small. Euphorbia polygonifolia L.

Chamaesyce Ingallsii Small. Type, New Orleans, La., Ingalls, 1835, in Herb. C. U.

Chamaesyce Geyeri (Engelm.) Small. Euphorbia Geyeri Engelm.

Chamaesyce ammannioides (H.B.K.) Small. Euphorbia ammannioides H.B.K.

Chamaesyce Nashii Small. Type, Nash, Pl. Fla., no. 2427, in Herb. C. U.

Chamaesyce Chiogenes Small. Type, Key West, Fla., Blodgett, in Herb. C. U.

Chamaesyce serpens (H.B.K.) Small. Euphorbia serpens H.B.K.

Chamaesyce cordifolia (Ell.) Small. Euphorbia cordifolia Ell.

Chamaesyce brachypoda Small. Type, Pollard \& Collins, Pl. Subtrop. Fla., no. 244, in Herb. N. Y. B. G.

Chamaesyce Laredana (Millsp.) Small. Euphorbia Laredana Millsp.

Chamaesyce Garberi (Engelm.) Small. Euphorbia Garberi Engelm.

Chamaesyce cinerascens (Engelm.) Small. Euphorbia cinerascens Engelm.

Chamaesyce deltoidea (Engelm.) Small. Euphorbia deltoidea Engelm.

Chamaesyce albomarginata (T. \& G.) Small. Euphorbia albomarginata T. \& G.

Chamaesyce Fendleri (T. \& G.) Small. Euphorbia Fendleri T. \& G.

Chamaesyce adicioides Small. Type, East of Bahia Honda, Fla., Simpson, no. 464, in Herb. C. U.

Chamaesyce lata (Engelm.) Small. Euphorbia lata Engelm.

Chamaesyce angusta (Engelm. ) Small. Euphorbia angusta Engelm.

Chamaesyce revoluta (Engelm.) Small. Euphorbia revoluta Engelm.

Chamaesyce polyclada (Boiss.) Small. Euphorbia polyclada Boiss.

Chamaesyce Nuttallii (Engelm.) Small. Euphorbia petaloidea var. Nuttallii Engelm.

Chamaesyce petaloidea (Engelm.) Small. Euphorbia petaloidea Engelm.

Chamaesyce buxifolia (Lam.) Small. Euphorbia buxifolia Lam.

Chamaesyce Porteriana Small. Type, Miami, Fla., Garber, 1877, in Herb. C. U.

Chamaesyce villifera (Scheele) Small. Euphorbia villifera Scheele.

Chamaesyce Stanfieldii Small. Type, San Marcos, Tex., Stanfield, 1898, in N. Y. B. G.

Chamaesyce Blodgettii (Engelm.) Small. Euphorbia Blodgettii Engelm.

Chamaesyce serpyllifolia (Pers.) Small. Euphorbia serpyllifolia Pers.

Chamaesyce glyptosperma (Engelm.) Small. Euphorbia glyptosperma Engelm.

Chamaesyce nutans (Lag.) Small. Euphorbia nutans Lag.

Chamaesyce Brasiliensis (Lam.) Small. Euphorbia Brasiliensis Lam.

Chamaesyce Tracyi Small. Type, Biloxi, Miss., Tracy, no. 2913, in Herb. C. U.

Chamaesyce humistrata (Engelm.) Small. Euphorbia humistrata Engelm.

Chamaesyce pergemena Small. Euphorbia pergemena Small.

Chamaesyce prostrata (Ait.) Small. Euphorbia prostrata Ait.

Chamaesyce malaca Small. Type, Heller, Pl. So. Tex., no. 1918, in Herb. C. U.

Chamaesyce maculata (L.) Small. Euphorbia maculata L.

Chamaesyce conferta Small. Type, Cocoanut Grove, Fla., Small \& Nash, Nov. 2 \& 5, 1901, in Herb. N. Y. B. G. 
Chamaesyce stictospora (Engelm.) Small. Eupl.orbia stictospora Engelm.

Chamaesyce stictospora Guadalupensis Small. Euphorbia stictospora var. Texensis Millsp., not E. Texana Boiss.

Chamaesyce adenoptera (Bertol.) Small. Euphorbia adenoptera Bertol.

Chamaesyce pilulifera (L.) Small. Euphorbia pilulifera L.

Chamaesyce pilulifera procumbens (Boiss.) Small. Euphorbia pilulifera var. procumbens Boiss.

ZygopHyllidium Small. Euphorbia, subgenus Zygophyllidium Boiss.

Zygophyllidium hexagonum (Nutt.) Small. Euphorbia hexagona Nutt.

Tithymalopsis polyphylla (Engelm.) Small. Euphorbia polyphylla Engelm.

Tithymalopsis Ipecacuanhae (L.) Small. Euphorbia Ipecacuanhae L.

Tithymalopsis gracilis (Ell.) Small. Euphorbia gracilis Ell.

Tithymalopsis eriogonoides Small. Euphorbia eriogonoides Small.

Tithymalopsis mercurialina (Michx.) Small. Euphorbia mercurialina Michx.

Tithymalopsis Curtisii (Engelm.) Small. Euphorbia Curtisii Engelm.

Tithymalopsis exserta Small. Type, Coast of West Fla., Chapman, in Herb. C. U.

Tithymalopsis Joorii (Norton) Small. Euphorbia corollata var. Joorii Norton.

Tithymalopsis zinniiflora Small. Euphorbia zinniiflora Small.

Tithymalopsis apocynifolia Small. Euphorbia apocyrifolia Small.

Tithymalopsis discoidalis (Chapm.) Small. Euphorbia discoidalis Chapm.

Tithymalopsis olivacea Small. Euphorbia olivacea Small.

Tithymalopsis corollata (L.) Small. Euphorbia corollata L.

Tithymalopsis paniculata (Ell.) Small. Euphorbia paniculata Ell.

Tithymalus sphaerospermus (Shuttlw.) Small. Euphorbia sphaerosperma Shuttlw.

Tithymalus inundatus (Torr.) Small. Euphorbia inundata Torr.

Tithymalus telephioides (Chapm. ) Small. Euphorbia telephioides Chapm.

Tithymalus Darlingtonii (A. Gray) Small. Euphorbia Darlingtonii A. Gray.

Tithymalus Helleri (Millsp.) Small. Euphorbia Helleri Millsp.

Tithymalus longicuris (Scheele) Small. Euphorbia longicuris Scheele.

Tithymalus commutatus erectus (Norton) Small. Euphorbia commutata var. erecta Norton.

Tithymalus austrinus Small. Type, Walton Co., Fla., Curtiss, 1885, in Herb. N. Y. B. G.

Tithymalus Peplidion (Engelm.) Small. Euphorbia Peplidion Engelm.

Tithymalus tetraporus (Engelm.) Small. Euphorbia tetrapora Engelm.

Tithymalus Roemerianus (Scheele) Small. Euphorbia Roemeriana Scheele.

Tithymalus Missouriensis (Norton) Small. Euphorbia Arkansana var. Missouriensis Norton.

Tithymalus leiococcus (Engelm.) Small. Euphorbia dictyosperma leiococca Engelm.

Poinsettia cuphosperma (Boiss.) Small. Euphorbia cuphosperma Boiss.

Poinsettia dentata (Michx.) Small. Euphorbia dentata Michx.

Poinsettia barbellata (Engelm.) Small. Euphorbia barbellata Engelm.

Poinsettia geniculata (Ortega) Small. Euphorbia geniculata Ortega.

Poinsettia Havanensis (Willd.) Small. Euphorbia Havanensis Willd.

Poinsettia heterophylla (L.) Small. Euphorbia heterophylla L.

Metopium Metopium (L.) Small. Rhus Metopium L.

Rhus rhomboidea Small. Type, Heller, Pl. So. Tex., no. 1670, in Herb. C. U.

Schmaltzia trilobata (Nutt.) Small. Rhus trilobata Nutt.

Schmaltzia microphylla (Engelm.) Small. Rhus microphylla Engelm.

Schmaltzia lanceolata (A. Gray) Small. Rhus copallina var. lanceolata A. Gray.

Schmaltzia copallina (L.) Small. Rhus copallina L.

Schmaltzia obtusifolia Small. Type, Nash, Pl. Cent. Penins. Fla., no. 1659, in Herb. C. U.

Schmaltzia virens (Lindh.) Small. Rhus virens Lindh.

Sehmaltzia hirta (L.) Small. Rhus hirta L.

Schmaltzia glabra (L.) Small. Rhus glabra L.

Schmaltzia Ashei Small. Rhus Caroliniana Ashe, not Mill.

Schmaltzia Michauxii (Sargent) Small. Rhus Michauxii Sargent.

Crossopetalum Floridanum Gardner. Type, Pine Key, Fla., Btodgett, in Herb. C. U.

Crossopetalum austrinum Gardner. Type, Key West, Fla., Blodgett, in Herb. C. U.

Rulac Texana (Pax) Small. Acer Negundo var. Texana Pax.

Ceanothus pubescens (T. \& G.) Rydb. Ceanothus ovatus var. pubescens T. \& G.

Colubrina colubrina (L.) Small. Rhamnus colubrina L.

Vitis Helleri (Bailey) Small. Vitis cordifolia var. Helleri Bailey.

Vitis austrina Small. Vitis cinerea var. Fioridana Munson, not $\dot{V}$. Floridana Raf.

Vitis Linsecomii lactea Small. Vitis Linsecomii var. glauca Munson, not V. glauca Wight \& Arn.

Vitis rufomentosa Small. Type, Nash, Pl. Cent. Penins. Fla., no. 525, in Herb. C. U. 
Muscadinia Small. Vitis, subgenus Muscadinia Planch.

Muscadinia Munsoniana (Simpson) Small. Vitis Munsoniana Simpson.

Muscadinia rotundifolia (Michx.) Small. Vitis rotundifolia Michx.

Parthenocissus hirsuta (Donn) Small. Ampelopsis hirsutus Donn.

Parthenocissus laciniata (Planch.) Small. Parthenocissus quinquefolia var. laciniata Planch. Tilia australis Small. Type, Blount Co., Ala., Eggert, June 20, 1897, in Herb. N. Y. B. G. Tilia Floridana Small. Type, Curtiss, N. A. Pl., no. 401*, in Herb. C. U.

Tilia leptophylla (Vent.) Small. Tilia pubescens var. leptophylla Vent.

GayoIDEs Small. Abutilon, subgenus Gayoides A. Gray.

Gayoides crispum (L.) Small. Sida crispa L.

Gayoides imberbe (Griseb.) Small. Sida imberbis DC.

Sida Texana (T. \& G.) Small. Sida Elliottii var. Texana T. \& G.

Riedlea glabrescens (Presl) Small. Riedlea serrata var. glabrescens Presl.

Ascyrum tetrapetalum (Lam.) Vail. Hypericum tetrapetalum Lam.

Crookea Small. (In honor of J. J. Crooke, patron of science.) Type, Ascyrum microsepalum T. \& G.

Crookea microsepala (T. \& G.) Small. Ascyrum microsepalum T. \& G.

Hypericum turgidum Small. Type, Huntsville, Ala., Canby, no. 14, in Herb. N. Y. B. G. Malachodendron pentagynum (L'Her.) Small. Stuartia pentagyna L'Her.

Piriqueta viridis Small. Type, Nash, Pl. Cent. Penins. Fla., no. 830a, in Herb. C. U.

Piriqueta glabrescens Small. Piriqueta glabra Chapm., not Turnera glabra DC.

Helianthemum thyrsoideum Barnhart. Type, Sutherland, Fla., Barnhart, May 1, 1899, in Herb. Barnhart.

Cactus hemisphaericus (Engelm.) Small. Mamillaria hemisphaerica Engelm.

Cactus Texanus (Engelm.) Small. Mamillaria pusilla var. Texana Engelm.

Cactus similis (Engelm.) Small. MIamillaria similis Engelm.

Cactus robustior (Engelm.) Small. Mamillaria similis var. robustior Engelm.

Cactus sulcatus (Engelm.) Small. Mamillaria sulcata Engelm.

Cactus Neo-Mexicanus (Engelm.) Snall. Mamillaria vivipara $\beta$ Neo-Mexicana Engelm.

Echinocereus dubius (Engelm.) Small. Cereus dubius Engelm.

Echinocereus Fendleri (Engelm.) Small. Cereus Fendleri Engelm.

Echinocereus Berlandieri (Engelm.) Small. Cereus Berlandieri Engelm.

Echinocereus procumbens (Engelm.) Small. Cereus procumbens Engelm.

Echinocereus Poselgeri (Coulter) Small. Cereus Poselgeri Coulter.

Echinocactus Schottii (Engelm.) Small. Echinocactus bicolor var. Schottii Engelm.

Echinocactus Wrightii (Engelm.) Small. Echinocactus uncinatus var.? Wrightii Engelm.

Opuntia grandiflora (Engelm.) Small. Opuntia Rafinesquei var. grandiflora Engelm.

Opuntia austrina Small. Type, Miami, Fla., Small \& Nash, no. 198, in Herb. N. Y. B. G.

Persea littoralis Small. Type, Daytona, Fla., Small \& Nash, no. 357, in Herb. N. Y. B. G.

Rhexia Nashii Small. Type, Nash, Pl. Cent. Pen.ns. Fla., no. 863, in Herb. C. U.

Rhexia delicatula Small. Type, Ellijay, Ga., Small, Aug. 13-16, 1895, in Herb. C. U.

Lythrum linearifolium (A. Gray) Small. Lythrum alatum var. linearifolium A. Gray.

Parsonsia procumbens (Cav.) Small. Cuphea procumbens Cav.

Parsonsia ly throides Small. Cuphea aspera Chapm., not Willd.

Ludwigia simulata Small. Type, Biltmore Herb., western Fla., in Herb. C. U.

Anogra Nuttallii (Sweet) Rydb. Oenothera Nuttallii Sweet.

Kneiffia arenicola Small. Type, Biltmore Herb., no. 5649d, in Herb. N. Y. B. G.

Kneiffia riparia (Nutt.) Small. Oenothera riparia Nutt.

Kneiffia pratensis Small. Type, Jefferson Co., Mo., Eggert, June 11, 1878, in Herb. N. Y. B. G.

Lavauxia Watsonii (Britton) Small. Lavauxia triloba Watsonii Britton.

Galpinsia lavendulaefolia (T. \& G.) Small. Oenothera lavendulaefolia T. \& G.

Galpinsia interior Small. Type, Ft. Niobrara, Neb., Wilcox, June 25, 1888, in Herb. C. U.

Meriolix intermedia Rydb. Type, Bush, Pl. Mo., no. 321, in Herb. C. U.

Meriolix Drummondiana (Spach) Small. Calylophis Drummondiana Spach.

Meriolix capillifolia (Scheele) Small. Oenothera capillifolia Scheele.

Meriolix melanoglottis Rydb. Type, Heller, Pl. S. Tex., no. 1600, in Herb. C.U.

Meriolix Hillii Small. Type, Edwards Co., Tex., Hill, June 30, 1895, in Herb. N. Y. G. B.

Gaura Pitcheri (T. \& G.) Small. Gaura biennis $\beta$ Pitcheri T. \& G.

Gaura brachycarpa Small. Type, San Diego, Tex., Croft, no. 109, in Herb. C. U.

Nyssa acuminata Small. Type, Darien Junction, Ga., Small, June 25-27, 1895, in Herb. C. U.

Svida alternifolia (L. f.) Small. Cornus alternifolia L. f.

Svida candidissima (Marsh.) Small. Cornus candidissima Marsh.

Svida stricta (Lam.) Small. Cornus stricta Lam. 
Svida microcarpa (Nash) Small. Cornus microcurpa Nash.

Svida Priceae Small. Cornus Priceae Small.

Svida asperifolia (Michx.) Small. Cornus asperifolia Michx.

Svida Amomum (Mill.) Small. Cornus Amomum Mill.

Centella repanda (Pers.) Small. Hydrocotyle repanda Pers.

Centella repanda Floridana (Coult. \& Rose) Small. Hydrocotyle Asiatica var. Floridana

Coult. \& Rose.

Eryngium compactum Small. Type, Mex. Bound. Surv., no. 412a, in Herb. C. U.

Oxypolis longifolia (Pursh) Small. Sium longifolium Pursh.

Hypopitys Americana (DC.) Small. Hypopitys multiflora $\beta$ Americana DC.

Dendrium prostratum (Loud.) Small. Leiophyllum prostratum Loud.

Azalea oblongifolia Small. Type, Grapeland, Tex., Tweedy, May, 1879, in Herb. C. U.

Azalea serrulata Small. Type, Nash, Pl. Cent. Penins. Fla., no. 967, in Herb. C. U.

Biltia Small. (In honor of George W. Vanderbilt, patron of science.) Type, Rhododendron Vaseyi A. Gray.

Biltia Vaseyi (A. Gray) Small. Rhododendron Vaseyi A. Gray.

Kalmia Caroliniana Small. Type, Flat Rock, N. C., Gibbes, June 12-16, 1858, in Herb. N. Y. B. G.

Kalmiella Small. (Diminutive of Kalmia.) Type, Kalmia hirsuta Walt.

Kalmiella hirsuta (Walt.) Small. Kalmia hirsuta Walt.

Xolisma foliosiflora (Michx.) Small. Andromeda paniculata var. foliosiflora Michx.

Batodendron andrachneforme Small. Type, Bush, Pl. Mo., no. 87, in Herb. N. Y. B. G.

Polycodium neglectum Small. Type, Wilson, Ga. Pl., no. 159, in Herb. N. Y. B. G.

Polycodium candicans (C. Mohr) Small. Vaccinium melanocarpum candicans C. Mohr.

Polycodium melanocarpum (C. Mohr) Sınall. Vaccinium stamineum var. melanocarpum C. Mohr.

Vaccinium australe Small. Type, Liberty Co., Ga., Small, June 18-21, 1895, in Herb. C. U.

Vaccinium simulatum Small. Type, White Top Mt., Va.. Britton, May 29, 1892 (fl.), Harlan Co., Ky., Kearney, Aug., 1893 (fr.), in Herb. C. U.

Hugeria Small. (In honor of A. M. Huger, collector and student of the flora of the Southern States.) Type, Vaccinium erythrocarpum Michx.

Hugeria erythrocarpa (Michx.) Small. Vaccinium erythrocarpum Michx.

Dodecatheon Hugeri Small. Type, Gainesville, Ga., Huger, April 22, 1897, in Herb. C. U.

Dodecatheon brachycarpa Small. Type, Red River prairies, Leavenworth, in Herb. C. U.

Dodecatheon Stanfieldii Small. Type, San Marcos, Tex., Stanfield, 1896, in Herb. N. Y. B. G.

Adelia parvifolia (A. Gray) Small. Forestiera acuminata var. parvifolia A. Gray.

Coelostylis Lindheimeri (A. Gray) Small. Spigelia Lindheimeri A. Gray.

Sabbatia grandiflora (A. Gray) Small. Sabbatia gracilis var. grandifora A. Gray.

Sabbatia Harperi Small. Type, Harper, Ga., Pl., nos. 964, 1196, in Herb. N. Y. B. G.

Lapithea Boykinii (A. Gray) Small. Sabbatia Boykinii A. Gray.

Gentianella quinquefolia (L.) Small. Gentiana quinquefolia L.

Gentianella quinquefolia occidentalis (A. Gray) Small. Gentiana quinquefolia var. occidentalis A. Gray.

Dasystephana puberula (Michx.) Small. Gentiana puberula Michx.

Dasystephana parvifolia (Chapm.) Small. Gentiana Elliottii var. parvifolia Chapm.

Dasystephana latifolia (Chapm.) Small. Gentiana Elliottii var. latifolia Chapm.

Dasystephana decora (Pollard) Small. Gentiana decora Pollard.

Dasystephana Saponaria (L.) Small. Gentiana Saponaria L.

Dasystephana Andrewsii (Griseb.) Small. Gentiana Andrewsii Griseb.

Dasystephana villosa (L.) Small. Gentiana villosa L.

Dasystephana Porphyrio (J. F. Gmel.) Small. Gentiana Porphyrio J. F. Gmel.

Bartonia lanceolata Small. Type, Fla., Chapmin, in Herb. C. U.

Amsonia Ludoviciana Vail. Type, La., Hale, in Herb. C. U.

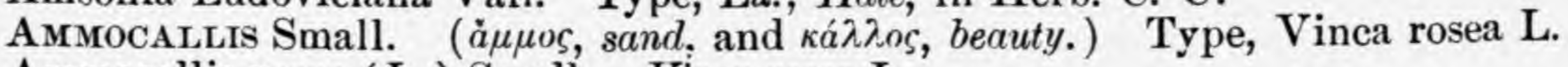

Ammocallis rosea (L.) Small. Vinca rosea L.

Urechites Andrewsii (Chapm.) Small. Echites Andrewsii Chapm.

Urechites neriandra (Griseb.) Small. Echites neriandra Griseb.

Rhabdadenia Sagraei (A. DC.) Small. Echites Sxgraei A. DC.

Rhabdadenia biflora (Jacq.) Muell. Arg. Echites biflora Jacq.

Asclepias Rolfsii Britton. Type, Miami, Fla., Britton, Apr. 1, 1903, in Herb. N. Y. B. G.

Breweria trichosanthes (Michx.) Small. Convolvulus trichosanthes Michx.

Calonyction Bona-nox (L.) Small. Ipomoea Bona-nox L.

Pharbites Lindheimeri (A. Gray) Small. Ipomoea Lindheimeri A. Gray. 
Cuscuta glandulosa (Engelm.) Srmall. Cuscuta obtusifolia var. glandulosa Engelm.

Phacelia dissecta (A. Gray) Small. Phacelia congesta var. dissecta A. Gray.

Phlox villosissima (A. Gray) Small. Phlox Drummondii var. villosissima A. Gray.

Phlox Lighthipei Small. Type, So. Jacksonville, Fla., Lighthipe, Apr. 2, 1896, in Herb. N. Y. B. G.

Phlox detonsa (A. Gray) Small. Phlox pilosa var. detonsa A. Gray.

Physalis Floridana Rydb. Type, Walton Co., Fla., Curtiss, 1885, in Herb. N. Y. B. G.

Physalis pendula Rydb. Physalis lancifolia Rydb. in part, not Nees.

Physalis sinuata Rydb. Type, Fla., Chapman, in Herb. C. U.

Perizoma rhomboidea (Hook.) Small. Atropa rhomboidea Hook.

Lithospermum mirabile Small. Type, San Antonio, Tex., Thurber, no. (b), in Herb. C. U.

Onosmodium Helleri Small. Type, Heller, Pl. So. Tex., 1682, in Herb. C. U.

Verbena Neo-Mexicana (A. Gray) Small. Verbena canescens var. Neo-Mexicana A. Gray.

Verbena pumila Rydb. Type, Bush, Pl. Ind. Terr., no. 1275 , in Herb. C. U.

Verbena ambrosifolia Rydb. Type, Rock Ford, Colo., Osterhout, June 8, 1900, in Herb. N. Y. B. G.

Helleranthus Small. (In honor of A. A. Heller, collector and student of the North American and Hawaiian floras.) Type, Verhena quadrangulata Heller.

Helleranthus quadrangulatus (Heller) Small. Verbena quadrangulata Heller.

Phyla incisa Small. Type, Heller, Pl. So. Tex., no. 1806, in Herb. C. U.

Goniostachyum Small. Lippia, Subgenus Goniostachyum Schauer.

Goniostachyum graveolens (H.B.K.) Small. Lippia graveolens H.B.K.

Aloysia ligustrina (Lag.) Small. Lippia ligustrina Lag.

Melosmon Cubense (L.) Small. Teucrium Cubense L.

Melosmon laevigatum (Vahl) Small. Teucrium laevigatum Vahl.

Melosmon laciniatum (Torr.) Small. Teucrium laceniatum Torr.

Scutellaria Mellichampii Small. Type, Bluffton, S. C., Mellichamp, in Herb. C. U.

Scutellaria Helleri Small. Type, Heller, Pl. So. Texas, no. 1503, in Herb. C. U.

Physostegia veroniciformis Small. Type, near Sunbury, Ga., LeConte, in Herb. C. U.

Stachys lythroides Small. Type, Tallahassee, Fla., Berg, 1895, in Herb. N. Y. B. G.

Stachys salvioides Small. Type, White Cliff Springs, Tenn., Kearney, July 12, 1894, in Herb. C. U.

Stachys Clingmanii Small. Type, Clingman's Dome, N. C., Beardslee \& Kofoid, Aug. 20, 1891, in Herb. C. U.

Monarda hirsutissima Small. Type, Texas (Chapman Herb.), in Herb. C. U.

Monarda Stanfieldii Small. Type, San Marcos, Tex., Stanfield, 1897, in Herb. N. Y. B. G.

Monarda lasiodonta (A. Gray) Small. Monarda punctata var. lasiodonta A. Gray.

Monarda dispersa Small. Type, Bush, Pl. Mo., no. 122, in Herb. C. U.

Monarda tenuiaristata (A. Gray) Small. Monarda citriodora var. tenuiaristata A. Gray.

Hedeoma lata Small. Type, Curtiss, N. A. Pl, no. 2020, in Herb. C. U.

Stach ydeoma Small. Hedeoma, Subgenus Stachydeoma A. Gray.

Stachydeoma ciliata (Benth.) Small. Hedeoma ciltata Benth.

Stachydeoma graveolens (Chapm.) Small. Hedeoma graveolens Chapm.

Pycnothymus Small. Satureia, Subgenus Pyenothymus Benth.

Pycnothymus rigidus (Bart.) Small. Satureia rigida Bart.

Micromeria pilosiuscula (Benth.) Small. Micromeria Brownei var. pilosiuscula.

Clinopodium macrocalyx Small. Type, Curtiss, N. A. Pl., no. 2012, in Herb. C. U.

Koellia leptodon (A. Gray) Small. Pycnanthemum pilosum var. leptodon A. Gray.

Koellia Hugeri Small. Type, Hendersonville, N. C., Huger, Sept., 1900, in Herb. N. Y. B. G.

Koellia dubia (A. Gray) Small. Pycnanthemum Tullia var. dubium A. Gray.

Lycopus pubens Britton. Type, Curtiss, N. A. Pl., no. $1990^{*}$, in Herb. C. U.

Lycopus velutinus Rydb. Type, Tyler, Tex., Reverchon, Sept. 20, 1900, in Herb. N. Y. B. G.

Mesosphaerum spicatum (Poir.) Small. Hyptis spicata Poir.

Scrophularia serrulata Small. Type, Ga., Chapman, in Herb. C. U.

Scrophularia neglecta Rydb. Type, Riley Co., Kans., Norton, no. 779, in Herb. N. Y. B. G.

Chelone Cuthbertii Small. Type, Highlands, N. C., Cuthbert, no. 283, in N. Y. B. G.

Pentstemon australis Small. Type, Nash, Pl. Fla., 1822, in Herb. C. U.

Pentstemon pallidus Small. Type, Bedford, N. Y., Britton, June, 1900, in Herb. N. Y. B. G.

Pentstemon tenuis Small. Type, La., Hale, Apr., in Herb. C. U.

Septilia Caroliniana (Walt.) Small. Obolaria Caroliniana Walt.

Septilia crenulata Small. Monniera crenulata Small.

Mecardonia acuminata (Walt.) Small. Gratiola acuminata Walt. 
Mecardonia procumbens (Mill.) Small. Erinus procumbens Mill.

Mecardonia viridis Small. Type, Heller, Pl. So. Tex., no. 1460, in Herb. C. U.

Mecardonia peduncularis (Benth.) Small. Herpestis peduncularis Benth.

Mecardonia tenuis Small. Type, Key West, Fla., Blodgett, in Herb. C. U.

Gratiola Torreyi Small. Type, Wright, Mex. Bound. Surv., in Herb. C. U.

Sophronanthe pilosa (Michx.) Small. Gratiola pilosa Michx.

Afzelia Texana (A. Gray) Small. Seymeria bipinnatisecta var. Texana A. Gray.

Brachygene Small. Seymeria, Subgenus Brachygene Benth.

Brachygene macrophylla (Nutt.) Small. Seymeria macrophylla Nutt.

Otophylla auriculata (Michx.) Small. Gerardia auriculata Michx.

Otophylla densiflora (Benth.) Small. Gerardia densiflora Benth.

Gerardia microphylla (A. Gray) Small. Gerardia Plukenetii var. microphylla A. Gray.

Gerardia Gattingeri Small. Type, Curtiss, N. A. Pl., no. 1910*, in Herb. C. U.

Gerardia asperula (A. Gray) Small. Gerardia tenuifolia var. asperula A. Gray.

Tubiflora acuminata Small. Type, Corpus Christi, Tex., Edwards (?), no. 719b, in Herb. C. U.

Stenandrium Floridanum (A. Gray) Small. Stenandrium dulce var. Floridanum A. Gray.

Yeatesia viridiflora (Nees) Small. Rhytiglossa viridiflora Nees.

Dianthera angusta (Chapm.) Small. Dianthera ovata var. angusta Chapm.

Croftia Small. (In honor of Mary A. Croft, collector of the flora of eastern Texas.) Type, Schaueria parvifolia Torr.

Croftia parvifolia (Torr.) Small. Schaueria parvifolia Torr.

Cosmiza longeciliata (A. DC.) Small. Utrieularia longeciliata A. DC.

Utricularia radiata Small. Utricularia inflata var. minor Chapm., not U. minor L.

Myzorrhiza Ludoviciana (Nutt.) Rydb. Orobanche Ludoviciana Nutt.

Oldenlandia fasciculata (Bertol.) Small. Hedyotis fasciculata Bertol.

Houstonia minor pusilla (A. Gray) Small. Houstonia patens var. pusilla A. Gray.

Houstonia montana (Chickering) Small. Houstonia purpurea var. montana Chickering.

Houstonia tenuis Small. Type, San Saba, Tex., Thurber, no. 67, in Herb. C. U.

Houstonia filifolia (A. Gray) Small. Houstonia angustifolia var. filifolia A. Gray.

Galium Texanum (T. \& G.) Wiegand. Galium Californicum var. Texanum T. \& G.

Viburnum Nashii Small. Type, Nash, Pl. Fla., no. 2593, in Herb. C. U.

Lonicera flavescens Small. Type, Franklin Co., Tenn., Eggert, May 5, 1898, in Herb. N. Y. B. G.

Siphonella Small. Fedia, subgenus Siphonella Krok.

Siphonella longiflora (T. \& G.) Small. Fedia longiflora T. \& G.

Siphonella Nuttallii (T. \& G.) Small. Fedia Nuttallii T. \& G.

Hexastylis callifolia Small. Asarum callifolium Small.

Ibervillea tenella (Naud.) Small. Sicydium tenellum Naud.

Ibervillea tenuisecta (A. Gray) Small. Sicydium Lindheimeri var. tenuisectum A. Gray.

Campanulastrum Small. (Campanula, and astrum, a star.) Type, Campanula Americana $\mathrm{L}$.

Campanulastrum Americanum (L.) Small. Campanula Americana L.

Lobelia glandulifera (A. Gray) Small. Lobelia amoena var. glandulifera A. Gray.

Lobelia elongata Small. Type, Heller, Pl. So. Va., no. 1246, in Herb. C. U.

Lobelia Halei Small. Lobelia Ludoviciana A. Gray, not L. syphilitica var. Ludoviciana A. DC.

Lobelia bracteata Small. Type, Gwinnett Co., Ga., Small, July 11, 1893, in Herb. C. U.

Vernonia Texana (A. Gray) Small. Vernonia angustifolia var. Texana A. Gray.

Vernonia Blodgettii Small. Type, Pine Key, Fla., Blodgett, in Herb. C. U.

Stevia foliosa Small. Type, Mex. Bound. Surv., in Herb. C. U.

Osmia ivaefolia (L. ) Small. Eupatorium ivaefolium L.

Osmia heteroclina (Griseb.) Small. Eupatorium heteroclinum Griseb.

Osmia conyzoides (Vahl) Small. Eupatorium conyzoides Vahl.

Eupatorium Eugenei Small. Eupatorium Smithii Greene \& Mohr, not Robinson.

Eupatorium pectinatum Small. Type, Leon Co., Fla., Chapman, 1836, in Herb. C. U.

Eupatorium recurvans Small. Type, Nush, Pl. Cent. Penins. Fla., no. 1196, in Herb. C. U.

Eupatorium lancifolium (T. \& G. ) Small. Eupatorium parviftorum var. lancifolium T. \& G.

Eupatorium Chapmanii Small. Type, Fla., Chapman, in Herb. C. U.

Conoclinum Greggii (A. Gray) Small. Eupatorium Greggii A. Gray.

Conoclinum integrifolium (A. Gray) Small. Eupatorium betonicum var. integrifolium A. Gray.

Willugbaeya heterophylla Small. Type, Curtiss, N. A. Pl., no. $1213^{*}$, in Herb. C. U.

Willugbaeya Halei Small. Type, La., Hale, no. 342, in Herb. C. U.

Laciniaria polyphylla Small. Type, Stone Mt., Ga., Small, Sept. 6-12, 1894, in Herb. C. U.

Laciniaria Nashii Small. Type, Nash, PI. Fla., no. 2430, in Herb. C. U. 
Laciniaria laevigata (Nutt.) Small. Liatris laevigata Nutt.

Chrysopsis Tracyi Small. Type, Tracy, Pl. Gulf St., no. 7713, in Herb. N. Y. B. G.

Chrysopsis latifolia (Fernald) Small. Chrysopsis graminifolia var. latifolia Fernald.

Chrysopsis microcephala Small. Type, Curtiss, Second Distr. Pl. So. U. S., no. 5319, in Herb. C. U.

Chrysopsis gigantea Small. Type, Fla., Leavenworth, in Herb. C. U.

Chrysopsis Floridana Small. Type, Tracy, Pl. Gulf'St., no. 7344, in Herb. N. Y. B. G.

Xanthisma Berlandieri (A. Gray) Small. Xanthisma Texanum var. Berlandieri A. Gray.

Sideranthus megacephalus (Nash) Small. Eivocarpum megacephalum Nash.

Sideranthus phyllocephalus (DC.) Small. Aplopappus phyllocephalus DC.

Sideranthus aureus (A. Gray) Small. Aplopappus aureus A. (Gray.

Sideranthus Cotula Small. Type, Palmer, Ind. Terr., no. 442a., in Herb. C. U.

Sideranthus Machaeranthera Small. Type, Schott, Mex. Bound. Surv., no. 508a, in Herb. C. U.

Sideranthus australis (Greene) Rydb. Eriocarpum australe Greene.

Stanfieldia Small. (In honor of S. W. Stanfield, educator, and student of the Texan flora.) Type, Aplopappus Nealleyi Coulter.

Stanfieldia Nealleyi (Coulter) Small. Aplopappus Nealleyi Coulter.

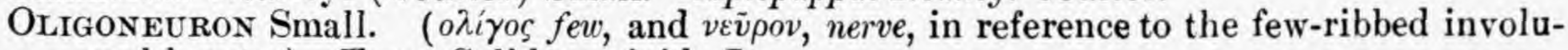
cral bracts. ) Type, Solidago rigida L.

Oligoneuron rigidum (L.) Small. Solidago rigida L.

Oligoneuron corymbosum (Ell.) Small. Solidago corymbosa Ell.

Oligoneuron nitidum (T. \& G.) Small. Solidago nitida T. \& G.

Solidago Porteri Small. Type, Middle Ga., Porter, Sept., 1846, in Herb. C. U.

Solidago Earlei Small. Type, Earle, Ala. Biological Surv., no. 1012, in Herb. N. Y. B. G.

Solidago pendula Small. Type, Benton Co., Ark., Plank, 1899, in Herb. N. Y. B. G.

Solidago celtidifolia Small. Type, Biloxi, Miss., Tracy, no. 5058, in Herb. N. Y. B. G.

Solidago strigosa Small. Type, La., Hale, in Herb. N. Y. B. G.

Solidago Ludoviciana (A. Gray) Small. Solidago Boottii var. Ludoviciana A. Gray.

Solidago austrina Small. Type, near Loganville, Ga., Small, Sept. 11, 1894, in Herb. N. Y. B. G.

Solidago pinetorum Small. Type, Gold Hill to Falls of the Yadkin, N. C., Small \& Heller, Aug. 18, 1891, in Herb. N. Y. B. G.

Sericocarpus acutisquamosus (Nash) Small. Sericocarpus bifoliatus acutisquamosus Nash.

Aster stilettiformis Burgess. ${ }^{1}$ Type, Hunter, N. Y., Sept. 5, 1899, Burgess, in Herb. Burgess.

Aster excavatus Burgess. Type, Yonkers, N. Y., Sept. 16, 1899, Burgess, in Herb. Burgess.

Aster castaneus Burgess. Type, Hillview, N. Y., Sept. 15, 1897, Burgess, in Herb. Burgess.

Aster chlorolepis Burgess. Type, Grandfather Mt., N. C., Heller, no. 1290, in Herb. C. U.

Aster Boykinii Burgess. Type, Ga., Boykin, Aug., 1840, in Herb. C. U.

Aster flexilis Burgess. Type, Buckley, 1840, in Herb. C. U.

Aster riciniatus Burgess. Type, Biltmore Herbarium, no. $44 a$, in Herb. N. Y. B. G.

Aster plumarius Burgess. Type, Nantahalah Mts., N. C., Huger, Sept. 10-16, 1900, in Herb. N. Y. B. G.

Aster Texanus Burgess. Type, Tex., Lindheimer, 1842, (?) in Herb. Mo. B. G.

Aster trigonicus Burgess. Type, Oyster, no. 3642, in Herb. N. Y. B. G.

Aster capillaceus Burgess. Type, Mo., Engelmann, Sept., 1838, in Herb. Mo. B. G.

Aster vernalis Burgess. Type, Tex., Lindheimer, Mar., 1842, in Herb. Mo. B. G.

Aster poaceus Burgess. Type, Mo., Iron Mt., Engelmann, 1845, in Herb. Mo. B. G.

Aster Proteus Burgess. Type, Curtiss, no. 1278 in part, in Herb. U. S. Nat. Mus., no. 19043.

Aster asperifolius Burgess. Type, Columbia, S. C., Gibbes, 1837 (?), in Herb. N. Y. B. G.

Aster sylvestris Burgess. Type, Washington, D. C., Burgess, Oct., 1886, in Herb. Burgess.

Aster truellius Burgess. Type, Washington, D. C., Burgess, Oct., 1886, in Herb. Burgess. Aster corrigiatus Burgess. Type, Yonkers, N. Y., Burgess, Oct., 1896, in Herb. Burgess. Aster triangularis Burgess. Type, Washington, D. C., Burgess, Oct., 1886, in Herb. Bur-

gess.
Aster linguiformis Burgess. Type, Jacksonville, Fla., Curtiss, Oct. 27, 1894, in Herb. C. U.

${ }^{1}$ Type specimens cited for Aster exhibit most of the chief characters of the species, but by no means all characters; for not all of the normal species-characters are to be expected in a single herbarium sheet of Aster. 
Aster loriformis Burgess. Type, Yonkers, N. Y., Burgess, Oct., 1896, in Herb. Burgess. Aster Mohrii Burgess. Type, Talladega Co., Ala., Mohr, Oct. 22, 1892, in Herb. Burgess. Aster claviger Burgess. Type, Yonkers, N. Y., Burgess, Oct., 1898, in Herb. Burgess.

Aster gracilescens Burgess. Type, Washington, D. C., Burgess, Oct. 4, 1886, in Herb. Burgess.

Aster ursinus Burgess. Type, Ga., Boykin, 1840 (?) in Herb. C. U.

Aster falcidens Burgess. Aster gracilentus T. \& G., not Banks.

Aster tenuicaulis (C. Mohr) Burgess. Aster patens var. gracilis Hook., not A. gracilis Nutt. Aster patens tenuicaulis C. Mohr.

Aster subsessilis Burgess. Type, Benton Co., Ark., Plank, 1899, in Herb. N. Y. B. G. Aster conduplicatus Burgess. Type, Biltmore Herbarium, no. 6358, in Herb. N. Y. B. G. Aster spatelliformis Burgess. Type, Jacksonville, Fla., Curtiss, 1895, in Herb. N. Y. B. $\mathrm{G}$.

Aster juniperinus Burgess. Type, Choctaw Co., Ala., Schuchert, Oct. 13, 1898, in Herb. N. Y. B. G.

Aster agrostifolius Burgess. Type, Marthas Vineyard, Mass., Burgess, Sept., 1888, in Herb. Burgess.

Erigeron myrionactis Small. Type, Heller, Pl. So. Tex., no. 1538, in Herb. C. U.

Leptilon linifolium (Willd.) Small. Erigeron linifolius Willd.

Leptilon Bonariense (L.) Small. Erigeron Bonariensis L.

Chaenolobus undulatus (Walt.) Small. Gnaphalium undulatum Walt.

Polymnia radiata (A. Gray) Small. Polymnia Canadensis var. radiata A. Gray.

Silphium ovatifolium (T. \& G.) Small. Silphium compositum $\gamma$ ovatifolium T. \& G.

Silphium glabrum Eggert. Type, Cullman Co., Ala., Eggert, Sept. 22, 1898, in Herb. N. Y. B. G.

Silphium confertifolium Small. Type, Cocoa, Ala., Schuchert, Oct. 13, 1896, in Herb. N. Y. B. G.

Silphium Elliottii Small. Type, Earle, Ala., Biological Surv., no. 984, in Herb. C. U.

Silphium angustum (A. Gray) Small. Silphium Asteriscus var. angustum A. Gray.

Berlandiera betonicifolia (Hook.) Small. Silphium betonicifolium Hook.

Berlandiera dealbata (T. \& G. ) Small. Berlandiera tomentosa var. dealbata T. \& G.

Berlandiera humilis Small. Type, St. Augustine, Fla., Reynolds, 1875, in Herb. C. U.

Tetragonotheca repanda (Buckl.) Small. Halea repanda Buckl.

Sclerocarpus major Small. Type, Linthsimor, Fl. Tex. Exsic., no. 432, in Herb. C. U.

Melanthera parvifolia Small. Type, Pine Key, Fla., Blodgett, in Herb. C. U.

Melanthera nivea (L.) Small. Bidens nivea L.

Melanthera lobata Small. Type, Nash, Pl. Cent. Penins. Fla., no. 1141, in Herb. C. U.

Melanthera Carpenteri Small. Type, Felicinia, La,, Carpenter, July, in Herb. C. U.

Rudbeckia acuminata Boynton \& Beadle. Type, Biltmore Herbarium, No. 14723, in Bilt. Herb.

Rudbəckia folio за Boynton \& Baadle. Type, Biltmore Herbarium, No. 14722, in Bilt. Herb.

Rudbeckia tenax Boynton \& Beadle. Type, Biltmore Herbarium, No. 851a, in Bilt. Herb.

Ratibida picta (A. Gray) Small. Lepachys peduncularis var. picta A. Gray.

Brauneria laevigata Boynton \& Beadle. Type, U. S. Nat. Herb., Nos. 239563 and 26903.

Stemmodontia trilobata (L.) Small. Silphium trilobatum L.

Borrichia glabrata Small. Type, Curtiss, N. A. Pl., no. 1412, in Herb. C. U.

Helianthus filiformis Small. Type, Reverchon, Tex. Fl., no. 1635, in Herb. C. U.

Helianthus elongatus Small. Type, Nash, Pl. Fla., no. 2541, in Herb. C. U.

Helianthus Eggertii Small. Type, Dickson Co., Tenn., Eggert, Aug. 19, 1897, in Herb. N. Y. B. G.

Helianthus saxicola Small. Type, Thom ss Bıld, Ga., Small, Aug. 19, 1893, in Herb. N. Y. B. G.

Helianthus resinosus Small. Type, Nash, Pl. Fla., no. 2581, in Herb. C. U.

Actinomeris paniculata( Walt.) Small. Athanasia paniculata Walt.

Verbesina pauciflora (Nutt.) Small. Actinomeris pauciflora Nutt.

Calyptrocarpus Tampicanus (DC.) Small. Oligogyne Tampicana DC.
Coreopsis major rigida (Nutt.) F. E. Boynton. Coreopsis senifolia var. rigida Nutt.

Coreopsis pulchra F. E. Boynton. Type, Biltmore Herbarium, no. 14728, in Bilt. Herb.

Coreopsis similis F. E. Boynton. Type, near Brazos Santiago, Tex., Nealley, 1899, in U. S. Nat. Herb.

Endorima atropurpurea (Harper) Small. Baldwinia atropurpurea Harper.

Endorima uniflora (Nutt.) Barnhart. Baldwinia uniflora Nutt.

Marshallia Williamsonii Small. Type, Wilmington, N. C., Williamson, Sept. 2, 1900, in Herb. N. Y. B. G.

Polypteris maxima Small. Type, Tex., Lindheimer, in Herb. C. U. 
Helenium campestre Small. Type, Little Rock, Ark., Hasse, May 25, 1885, in Herb. N. Y. B. G.

Helenium polyphyllum Small. Type, Bain, Pl. Tenn. Occ., no. 77, in Herb. C. U.

Helenium Helenium (Nutt.) Small. Leptopodum Helenium Nutt.

Helenium incisum (T. \& G.) Small. Leptopoda incisa T. \& G.

Gaillardia trinervata Small. Type, Palmer, Ind. Terr., no. 448, in Herb. C. U.

Gaillardia chrysantha Small. Type, Bowie Co., Tex., Eggert, June 13, 1898, in Herb. N. Y. B. G.

Thymophylla tagetoides (T. \& G.) Small. Hymenatherum tagetoides, T. \& G.

Thymophylla polychaeta (A. Gray) Small. Hymenatherum polychaetum A. Gray.

Thymophylla Wrightii (A. Gray) Small. Hymenatherum Wrightii A. Gray.

Thymophylla tenuiloba (DC.) Small. Hymenatherum tenuilobum DC.

Thymophylla pentachaeta (DC.) Small. Hymenatherum pentachaetum DC.

Thymophylla Treculii (A. Gray) Small. Hymenatherum Treculii A. Gray.

Thymophylla gnaphaloides (A. Gray) Small. Hymenatherum gnaphaloides A. Gray.

Mesadenia similis Small. Type, Benton Co., Ark., Plank, 1899, in Herb. N. Y. B. G.

Mesadenia maxima Harper. Type, Harper, Ga. Pl., no. 1164, in Herb. N. Y. B. G.

Mesadenia difformis Small. Type, Waiton Co., Fla., Curtiss, 1885, in Herb. N. Y. B. G.

Mesadenia sulcata (Fernald) Small. Cacalia sulcata Fernald.

Senecio rotundus (Britton) Small. Senecio obovatus rotundus Britton.

Carduus Helleri Small. Type, Heller, Pl. So. Texas, no. 1720, in Herb. C. U.

Carduus austrinus Small. Type, Wright, Coll. N. Mex., no. 1291, in Herb. C. U.

Carduus revolutus Small. Type, Fla., Chapman, in Herb. C. U.

Carduus flaccidus Small. Type, La., Carpenter, in Herb. C. U.

Carduus pinetorum Small. Type, Cocoanut Grove, Fla., Small \& Nash, Nov. 2 \& 5, 1901, in Herb. N. Y. B. G.

Nabalus cylindricus Small. Type, Roan Mt., Tenn., Britton, Sept. 9, 1885, in Herb. C. U. 
TABLE OF THE ORDERS AND FAMILIES.

1. Ophioglossales.

2. Filicales.

1. Ophioglossaceae,

2. Hymenophyllaceae,

3. Osmundaceae,

4. Schizaeaceae,

5. Ceratopteridaceae,

6. Polypodiaceae,

3. Salviniales.

7. Marsileaceae,

8. Salviniaceae,

4. Equisetales.

9. Equisetaceae,

5. Lycopodiales.

10. Lycopodiaceae,

11. Psilotaceae,

12. Selaginellaceae,

6. Isoetales.

13. Isoetaceae,

7. Cycadales.

14. Cycadaceae,

8. Pinales.

15. Pinaceae,

16. Juniperaceae,

9. Pandanales.

17. Taxaceae,

18. Typhaceae,

10. Naiadales.

19. Sparganiaceae,

20. Zannichelliaceae,

21. Zosteraceae,

11. Alismales.

22. Naiadaceae,

23. Scheuchzeriaceae,

24. Alismaceae,

12. HYDROCHARITALES.

25. Elodeaceae,

13. Poales.

3

27. Poaceae,

28. Cyperaceae,

14. Arecales.

29. Arecaceae,

15. Arales.

30. Araceae,

16. Xyridales.

31. Lemnaceae,

32. Mayacaceae,

33. Xyridaceae,

34. Eriocaulaceae,

35. Commelinaceae,

36. Pontederiaceae,

17. Limiales.

37. Bromeliaceae,

38. Melanthaceae,

39. Juncaceae,

40. Alliaceae,

$\begin{array}{cr}\text { Gen. } & \text { Sp. } \\ & \\ & 9 \\ 1 & 2 \\ 1 & 3 \\ 2 & 3 \\ 1 & 1 \\ 30 & 81\end{array}$

2

1

1

1

1

1

1

6

5

2

1

1

3

1

1

1

4

3
2

121

21

597

360

8

15

7

4

11

1

3

38

14
41. Liliaceae,

42. Convallariaceae,

43. Dracaenaceae,

44. Trilliaceae,

45. Roxburghiaceae,

46. Smilacaceae,

18. Amaryllidales.

47. Leucojaceae,

48. Tamaceae,

49. Ixiaceae,

50. Haemodoraceae,

19. Scitiminales.

51. Cannaceae,

52. Marantaceae,

20. Orchidales.

53. Burmanniaceae,

54. Orchidaceae,

21. Piperales.

55. Saururaceae,

56. Piperaceae,

22. Casuarinales.

57. Casuarinaceae, $\quad 1 \quad 1$

23. Juglandales.

58. Juglandaceae,

24. LEITNERIALES.

59. Leitneriaceae,

25. Myricales.

60. Myricaceae,

26. Salicales.

61. Salicaceae,

27. Fagales.

62. Corylaceae,

63. Betulaceae,

64. Fagaceae,

28. Urticales.

65. Urticaceae,

66. Cannabinaceae,

67. Artocarpaceae,

68. Ulmaceae,

29. Polygonales.

69. Polygonaceae,

30. Chenopodiales.

70. Chenopodiaceae,

71. Scleranthaceae,

72. Amaranthaceae,

73. Corrigiolaceae,

74. Petiveriaceae,

75. Batidaceae,

76. Basellaceae,

77. Allioniaceae,

78. Tetragoniaceae,

79. Portulacaceae,

80. Alsinaceae,

81. Caryophyllaceae,

31. Ranales.

82. Ceratophyllaceae,

83. Ranunculaceae,

Gen. Sp.

$5 \quad 15$

$10 \quad 18$

$3 \quad 16$

$2 \quad 21$

11

224

$9 \quad 34$

11

$\begin{array}{ll}6 & 67\end{array}$

11

12

24

23

$37 \quad 90$

11

12

$2 \quad 16$

11

$2 \quad 5$

$\begin{array}{ll}2 & 27\end{array}$

34

25

348

$5 \quad 17$

22

$4 \quad 9$

$\begin{array}{ll}5 & 17\end{array}$

$13 \quad 71$

$7 \quad 26$

11

$13 \quad 45$

$6 \quad 20$

34

1

$2 \quad 2$

$8 \quad 33$

$7 \quad 10$

$3 \quad 15$

$11 \quad 37$

$\begin{array}{ll}5 & 17\end{array}$

1342

\begin{tabular}{l}
7 \\
2 \\
9 \\
\hline 7
\end{tabular}

.

(

(n)

(

(1)

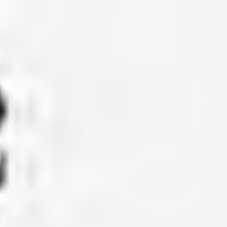

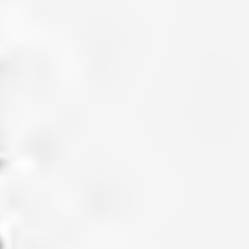

(

6

1

5

7

4


84. Anonaceae,

85. Magnoliaceae,

86. Menispermaceae,

87. Cabombaceae,

88. Nelumbonaceae,

89. Nymphaeaceae,

90. Podophyllaceae,

32. Papaveralles.

91. Papaveraceae,

92. Fumariaceae,

93. Brassicaceae,

94. Capparidaceae,

95. Moringaceae,

33. SARRACENIALES.

96. Droseraceae,

97. Dionaeaceae,

98. Sarraceniaceae,

34. Rosales.

99. Podostemaceae,

100. Sedaceae,

101. Penthoraceae,

102. Parnassiaceae,

103. Saxifragaceae,

104. Escalloniaceae,

105. Iteaceae,

106. Altingiaceae,

107. Grossulariaceae,

108. Platanaceae,

109. Rosaceae,

110. Calycanthaceae,

111. Malaceae,

112. Amygdalaceae,

113. Mimosaceae,

114. Cassiaceae,

115. Krameriaceae,

116. Fabaceae,

35. Geraniales.

117. Geraniaceae,

118. Balsaminaceae,

119. Linaceae,

120. Oxalidaceae,

121. Zygophyllaceae,

122. Koeberliniaceae,

123. Malpighiaceae,

124. Rutaceae,

125. Surianaceae,

126. Simarubaceae,

127. Burseraceae,

128. Meliaceae,

36. Polygalales.

129. Polygalaceae,

37. Euphorbiales.

130. Euphorbiaceae,

38. SAPINDALEs.

131. Callitrichaceae,

132. Buxaceae,

133. Empertaceae,

134. Limnanthaceae,

135. Spondiaceae,

136. Cyrillaceae,

137. Aquifoliaceae,

138. Celastraceae,

139. Hippocrateaceae,

140. Dodonaeaceae,

Ge

Ge

(6)

29

1

(1)
141. Staphyleaceae, 142. Aesculaceae, 143. Aceraceae, 144. Sapindaceae,

39. RhamNales. 145. Frangulaceae, 146. Vitaceae,

40. Malvales.

147. Tiliaceae, 148. Malvaceae, 149. Buettneriaceae,

41. Hypericales.

150. Canellaceae,

151. Clusiaceae,

152. Elatinaceae,

153. Tamaricaceae,

154. Fouquieriaceae,

155. Hypericaceae,

156. Theaceae,

157. Turneraceae,

158. Bixaceae,

159. Cistaceae,

160. Violaceae,

42. Passiflorales.

161. Papayaceae,

162. Passifloraceae,

43. Opuntiales.

163. Loasaceae,

164. Opuntiaceae,

44. Begoniales.

165. Begoniaceae,

45. Proteales.

166. Proteaceae,

46. Thymeleales.

167. Daphnaceae,

168. Elaeagnaceae,

169. Lauraceae,

170. Cassythaceae,

47. Myrtales.

171. Melastomaceae,

172. Lythraceae,

173. Punicaceae,

174. Terminaliaceae,

175. Myrtaceae,

176. Rhizophoraceae,

177. Epilobiaceae,

178. Gunneraceae,

48. Ammiales.

179. Nyssaceae,

180. Hederaceae,

181. Ammiaceae,

49. Ericales.

182. Clethraceae,

183. Pyrolaceae,

184. Monotropaceae,

185. Ericaceae,

186. Vacciniaceae,

187. Diapensiaceae,

188. Galacaceae,

50. Primulales.

189. Armeriaceae,

190. Primulaceae,

191. Theophrastaceae,

192. Ardisiaceae,
Gen. Sp

11

16

211

$8 \quad 14$

1120

$5 \quad 33$

$3 \quad 11$

$18 \quad 86$

$7 \quad 9$

1

11

2

$1-1$

543

44

25

11

$3 \quad 22$

$3 \quad 38$

$1 \quad 1$

$1 \quad 11$

$4 \quad 7$

5. 39

11

11

1

11

$5 \quad 10$

11

$1 \quad 14$

$8 \quad 18$

11

34

48

11

$19 \quad 91$

26

$4 \quad 14$

35

$43 \quad 98$

13

24

35

$17 \quad 46$

733

$\begin{array}{ll}1 & 1 \\ 2 & 2\end{array}$

27

$7 \quad 25$

11

2 
51. Ebenales.

193. Ebenaceae,

194. Sapotaceae,

195. Symplocaceae,

196. Styracaceae,

52. Oleales.

197. Oleaceae,

53. Gentianales.

198. Spigeliaceae,

199. Gentianaceae,

200. Menyanthaceae,

54. Asclepiadales.

201. A pocynaceae,

202. Asclepiadaceae,

55. Polemoniales.

203. Dichondraceae,

204. Convolvulaceae,

205. Cuscutaceae,

206. Hydroleaceae,

207. Polemoniaceae,

208. Solanaceae,

209. Borraginaceae,

210. Ehretiaceae,

211. Heliotropiaceae,

212. Verbenaceae,

213. Phrymaceae,

214. Lamiaceae,

215. Rhinanthaceae,

216. Acanthaceae,

217. Pinguiculaceae,

218. Orobanchaceae,

219. Bignoniaceae,

220. Martyniaceae,

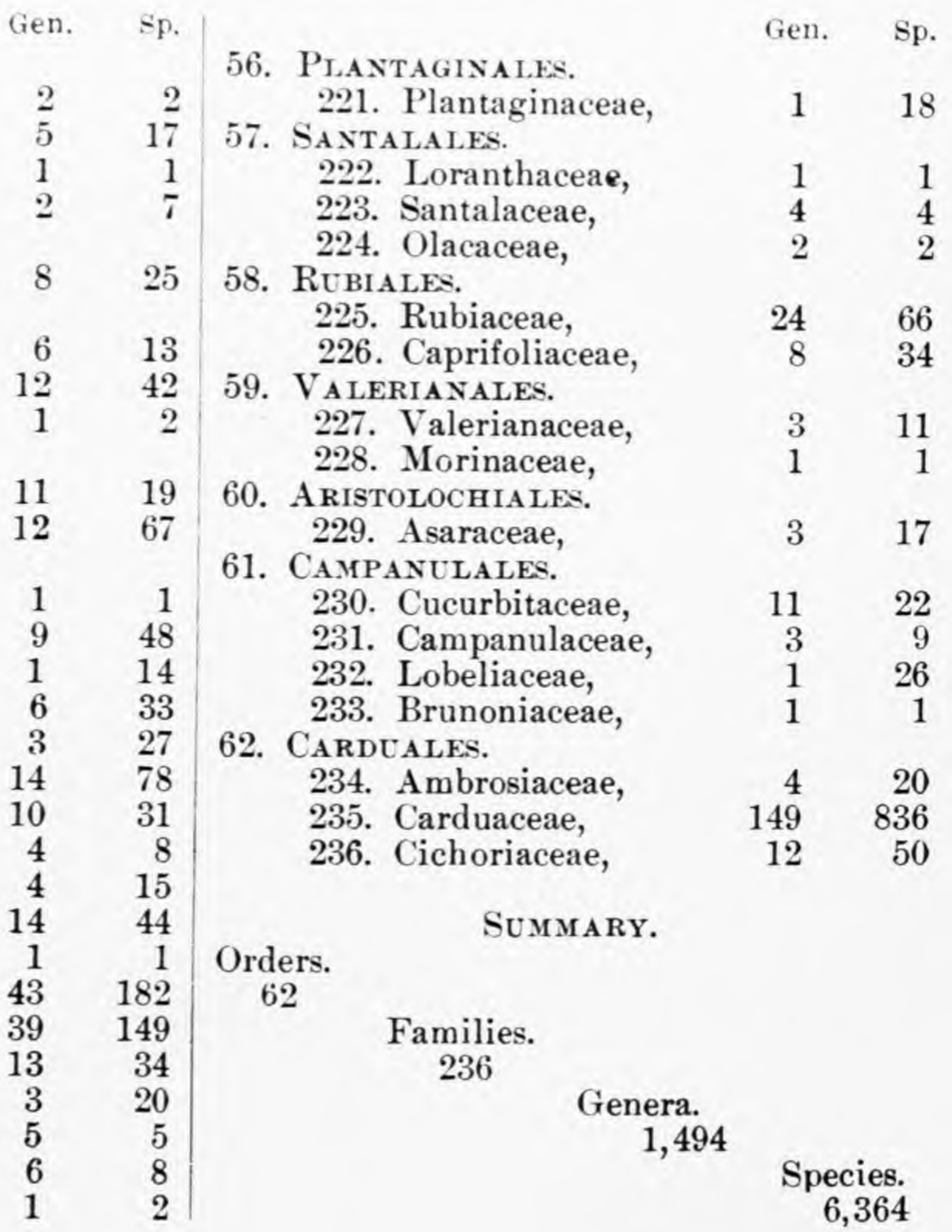




\section{INDEX.}

Abena, 1013

Abies, 30

Abildgaardia, 190

Abronia, 408

Abutilon, 762

Acacia, 577

Acacia, 578

Acalypha, 700

Acamptoclados, 139

ACANTHACEAE, 1081

Acanthochiton, 394

Acanthospermum, 1240

Acanthus Family, 1081

Acer, 740

Acer, 743

ACERACEAE, 740

Acerates, 940

Achillea, 1297

Achroanthes, 324

Achyranthes, 394

Acleisanthes, 408

Acnida, 393

Aconitum, 434

Acorus, 228

Acrostichum, 6

Actaea, 432

Actinomeris, 1271

Actinomeris, 1273

Actinospermum, 1283

Acuan, 579

Adam-and-Eve, 326

Adder's Mouth, 324

Adder's-tongue, 1

Adder's-tongue Family, 1

Adelia, 919

Adiantum, 8

Adicea, 357

Adlumia, 463

Adonis, 445

Adopogon, 1318

Aeschynomene, 632

A ESCULACEAE, 738

Aesculus, 739

Afzelia, 1072

Agastache, 1025

Agati, 614

Agave, 288

Agave, 287

Ageratum, 1163

Agrimonia, 524

Agrimony, 524

A gropyron, 158

Agrostemma, 427

Agrostis, 126

Ague Tree, 821

Ailanthus, 680

Aira, 128

Air Plant, 245

Albizzia, 576

Alchemilla, 524

Aldenella, 488

Alder

Black, 732

Dwarf, 509

Mountain, 346, 742
Alder

Smooth, 346

White, 877

Aletris, 285

Alisma, 41

ALISMACEAE, 41

Alismales, 40

Allegheny Mountain Spurge, 724

Allegheny Vine, 462

ALliaceae, 262

Alligator Pear, 820

Alligator-tree, 510

Allionia, 406

ALLIONIACEAE, 404

Allium, 262

Allium, 264

Alnus, 346

Aloe, 286

American, 288

Alopecurus, 122

Aloysia, 1013

ALSINACEAE, 416

Alsine, 421

Alsine, 419

Alsinopsis, 419

Alternanthera, 395

ALTINGIACFAE, 508

Alum-root, 503

Alyssum, Sweet, 478

Alyssum, 478

Amaranth, 390

Globe, 398

AMARANTHACEAE, 389

Amaranth Family, 389

Amaranthus, 390

AMARYLLIDACEAE, 285

AMARYLLIDALES, 285

Amaryllis, 289

Amaryllis Family, 285

Amblyolepis, 1292

Ambrosia, 1150

A MBRosiaceAE, 1148

Amelanchier, 531

American Aloe, 288

American Bugbane, 432

American Chestnut, 348

American Columbo, 931

American Cowslip, 905

American Holly, 733

Ameriean Ipecac, 515

American Ivy, 758

American White Hellebore, 251

Amianthium, 250

Ammannia, 825

Ammi, 869

A MMIACEAE, 856

AMMIALES, 851

Ammoeallis, 935

Ammophila, 128

Ammoselinum, 867

A moreuxia, 795

Amorpha, 624

Ampelopsis, 758
Ampelopsis, 758, 759

Amphiachyris, 1179

Amphianthus, 1069

Amphicarpaea, 651

Amphicarpon, 79

Amphilophis, 65

Amsonia, 934

AMYGDALACEAE, 569

Amygdalus, 570

Amyris, 677

ANACARDIACEAE, 725

Anagallis, 905

Anamonis, 832

Anantherix, 949

Anaphalis, 1237

Anastrophus, 78

Anchistea, 11

Andrachne, 691

Andromeda, 888, 889

Andropogon, 60

Andropogon, 58, 65

Androstephium, 265

Anemia, 4

Anemone, 435

Anemonella, 436

Angelica, 873

Angelico, 872

ANGIOSPERMAE, 34

Anisacanthus, 1086

Anise Tree, 450

Anoda, 1324

Anogra, 841

Anona, 449

Anonaceae, 447

Anredera, 1323

Antennaria, 1236

Anthaenantia, 79

Anthemis, 1296

Anthopogon, 929

Anthoxanthum, 114

Antirrhinum, 1056

Ants-wood, 911

Anychia, 401

Anychiastrum, 400

Aphanostephus, 1203

Aphyllon, 1093

Apiastrum, 865

A pios, 652

Apium, 866

Aplectrum, 326

Aplopappus, 1188

A POCYNACEAE, 933

A pocynum, 936

Apogon, 1319

Apple, 530

Balsam, 1136, 1139

Crab, 530

Custard, 449

Gopher, 570

Indian, 458

May, 458

Thorn, 993

Apple Family, 529

Apteria, 309

AQUIFOLIACEAE, 731 
Aquilegia, 432

Arabis, 483, 1323

Araceae, 226

Aragallus, 1324

Arales, 225

Aralia, 855

Araliaceae, 855

Arbor Vitae, 32

Arbutus, Trailing, 890

Aretium, 1305

Ardisia, 907

Ardisiaceae, 906

A RECACEAE, 221

Arecales, 221

Arenaria, 420

Arenaria, 421

Arethusa, 324

Argemone, 461

Arisaema, 226

Arisaema, 227

Aristida, 114

Aristida, 119

Aristolochia, 1132

ARIstolochiaceae, 1130

ARISTOLOCHIALES, 1130

Armeriaceae, 898

Arnica, 1299

Aronia, 531

Arrhenatherum, 130

Arrow-arum, 227

Arrow-grass, 41

Arrow-grass Family, 40

Arrow-head, 42

Arrowroot Family, 307

Arrow-wood, 1121

Artemisia, 1298

ArtocarpaCEAE, 360

Arum Family, 226

Aruncus, 514

Arundinaria, 160

Arundo, 141

Asaraceate, 1130

Asarum, 1131

Asarum, 1131

ASClEPIADACEAE, 937

ASClEPIAdales, 933

Asclepias, 941

Asclepiodora, 949

Ascyrum, 784

Ash, 917

Black, 918

Blue, 918

Brown, 918

Cane, 919

Flowering, 920

Green, 918

Prickly, 674, 675, 856

Pop, 918

Poppy, 918

Pumpkin, 918

Red, 918

Sea, 675

Swamp, 918

Water, 676, 918

White, 919

Asimina, 447

Asparagus, 269

Aspicarpa, 673

Aspidium, 15

Asplenium, 12

Asprella, 160

Aster, 1206

acuminatus, 1227

adnatus, 1222
Aster

agrostifolius, 1226

anomalus, 1213

asperifolius, 1216

attenuatus, 1216

azureus, 1215

Baldwinii, 1226

Boykinii, 1211

Camptosorus, 1213

capillaceus, 1215

Carolinianus, 1221

castaneus, 1211

Chapmanii, 1228

chlorolepis, 1211

claviger, 1217

commixtus, 1212

concinnus, 1216

concolor, 1222

conduplicatus, 1221

continuus, 1219

cordifolius, 1224

corrigiatus, 1216

Curtisii, 1223

divaricatus, 1210

Drummondii, 1214

dumosus, 1223

Elliottii, 1221

elodes, 1222

ericoides, 1225

eryngiifolius, 1227

excavatus, 1211

exiguus, 1224

exilis, 1228

falcidens, 1219

Faxoni, 1225

flexilis, 1212

gracilescens, 1218

gracilis, 1223

grandiflorus, 1223

hirsuticaulis, 1225

hirtellus, 1214

Juniperinus, 1225

Kumleinii, 1220

laevis, 1218

lateriflorus, 1224

linguiformis, 1217

loriformis, 1217

Low rieanus, 1213

maerophyllus, 1212

mirabilis, 1213

Missouriensis, 1226

Mohrii, 1217

multiflorus, 1224

multiformis, 1212

Novae-Angliae, 1220

Novi-Belgii, 1221

paludosus, 1227

paniculatus, 1226

patens, 1220

patentissimus, 1219

phlogifolius, 1220

phyllolepis, 1222

plumarius, 1214

poaceus, 1215

prenanthoides, 1221

Priceae, 1226

Proteus, 1216

ptarmicoides, 1227

puniceus, 1221

purpuratus, 1218

racemosus, 1224

riciniatus, 1212

sagittifolius, 1214

salieifolius, 1227
Aster

sericeus, 1222

Shortii, 1213

spatelliformis, 1225

spectabilis, 1223

spinosus, 1228

spinulosus, 1227

squarrosus, 1222

stilettiformis, 1211

subsessilis, 1220

subulatus, 1228

surculosus, 1223

sylvestris, 1216

tenebrosus, 1211

tenuicaulis, 1220

tenuifolius, 1228

Texanus, 1214

Tradescanti, 1226

triangularis, 1217

trigonicus, 1214

truellius, 1216

turbinellus, 1219

undulatus, 1215

ursinus, 1218

vernalis, 1215

vimineus, 1224

Aster

Golden, 1181

Plume, 1214

Astilbe, 499

Astragalus, 616

Astragalus, $615,616,617,618$ 619,620

Atamasco Lily, 289

Atamosco, 289

Atheropogon, 137

Atragene, 439

Atriplex, 386

Atropa, 992

Avacado Pear, 820

Avena, 130

Avens, 522

Avicennia, 1016

Ayenia, 780

Azalea, 882

Azalea

Flame, 883

Mountain, 883

Azolla, 20

Baccharis, 1232

Bachelor's Button Wild, 689

Bahia, 1288

Bald Cypress, 31

Balloon-vine, 744

Balm

Bee, 1036

Field, 1044

Horse, 1051

Lemon, 1041

Balsam, 29, 30

$\mathrm{He}, 29$

She, 30

Balsam Apple, 1136, 1139

BALSAMINACEAE, 660

Balsam-tree Family, 782

Bamboo, 283

Baneberry

Red, 432

White, 432

Baptisia, 597

Baptisia, 596

Barbarea, 475 
Barberry Family, 458, 459

Baretta, 676

Barley, 159

Barren Oak, 350

Barren Strawberry, 522

Bartonia, 931

BASEllacea E, 1322

Basil, 1042, 1053

Basket Oak, 354

Basswood, 760

Bastard Oak, 353

Bastard Toad-flax, 1102

BATIDACEAE, 404

Batis, 404

Batis Family, 404

Batodendron, 892

Batrachium, 440

Bay

Bull, 452

Loblolly, 794

Red, 820

Swamp, 820

Swamp Red, 820

Sweet, 452, 820

Tan, 794

Bayberry, 337

Bayberry Family, 336

Bay-star Vine, 450

Beach-sap, 478

Beadlea, 319

Beak Rush, 191

Bean

China, 654

Wild, 653:

Indian, 1095

Bean-vine, 653

Bearberry, 732

Beard Grass, 54, 58, 60, 125

Beard-tongue, 1059

Bear Huckleberry, 892

Bear Oak, 352

Bedstraw, 1117

Rough, 1119

Sweet-scented, 1120

Bee Balm, 1036

Beech, 347

Beech-drops, 1093 False, 880

Beech Family, 346

Beech Fern, 17

Beech Heather, 797

Beefwood, 332

Beefwood Family, 332

Beetle-weed, 898

Bee-tree, 760

Beggar's Ticks, 634, 1279

Begonia, 817

BEgONIACEAE, 817

Begonia Family, 817

BEgoniales, 817

Bejaria, 881

Belamcanda, 293

Bellflower, 1140

Bellflower Family, 1140

Bellis, 1202

Bell tree, 915

Benjamin-bush, 821

Bent Grass, 126

Benzoin, 821

Berberis, 459, 1323

Berchemia, 749

Bergamot, Wild, 1037

Bergia, 783

Berlandiera, 1245
Bermuda Grass, 132

Bernardia, 700

Berula, 870

Bess-root, 276

Beth, 278

Betula, 345

BETULACEAE, 345

Bicuculla, 463

Bidens, 1279

Bidens, 1251

Bifora, 865

Bignonia, 1094

BIGNONIACEAE, 1094

Big Shag-bark, 335

Bilsted, 510

Biltia, 884

Bindweed, 965

Black, 382

Birch, 345

Black, 346

Cherry, 346

Gray, 346

Red, 345

River, 345

Sweet, 346

West Indian, 681

Yellow, 346

Birch Family, 345

Birth-root, 276

Birthwort Family, 1130

Bishop's Cap, 505

Bishop-weed, 870

Bitter Cress, 481

Bittersweet, 989

Climbing, 735

Shrubby, 735

Bitter-sweet Orange, 678

Bitter-wood, 680

BIXACEAE, 795

Bixa Family, 795

Black Alder, 732

Black Ash, 918

Blackberry, 515

Blackberry Lily, 293

Black Bindweed, 382

Black Birch, 346

Black-cap, 516

Black Cherry, 574

Black Cohosh, 432

Black Grama, 69

Black Gum, 852

Black Haw, 913, 1123

Black Huckleberry, 892

Black Ironwood, 747

Black Jack, 350

Black Laurel, 794

Black Mangrove, 1016

Black Maple, 741, 742

Black Mustard, 476

Black Oak, 352

Black Oat Grass, 120

Black Olive Tree, 830

Black Persimmon, 909

Black Raspberry, 516

Black-root, 1236

Black Sloe, 572

Black Spruce, 29

Black Snake-root, 432, 860

Black Titi, 730

Black Walnut, 333

Bladdernut, 738

Bladdernut Family, 738

Bladder-pod, 468

Bladderwort, 1090
Bladderwort Family, 1089

Blazing-star, 249, 1171

Blechnum, 11

Bleeding-heart, 464, 734

Blephariglottis, 313

Blephilia, 1038

Blessed Thistle, 1309

Bletia, 329

Blood-leaf, 398

Bloodroot, 460

Bloodwort Family, 306

Blue Ash, 918

Blue'Beech, 344

Bluebells, 997

Blueberry, 894

Mountain, 896

Tall, 895

Blue Cohosh, 459

Blue-eyed Grass, 293

Blue Flag, 305

Blue Gladiole, 306

Blue Grape, 755

Blue Grass, 152

Blue-hearts, 1070

Blue Huckleberry, 896

Blue Palmetto, 224

Blue-stem, 223

Blue Tangle, 892

Bluets, 1107

Blueweed, 1002

Bluewood, 748

Boebera, 1294

Boehmeria, 358

Boerhaavia, 409

Bog Torches, 228

Boltonia, 1203

Boneset, 1169

False, 1178

Bonnets, 450

Borage Family, 995

BORRAGINACEAE, 995

Borreria, 1116

Borrichia, 1262

Boston Fern, 17

Botrychium, 2

Bottle-brush, 160

Bottle Gourd, 1138

Bouchetia, 995

Bouncing Bet, 425

Bourreria, 1003

Boussingaultia, 1322

Bouteloua, 136

Bouteloua, 137, 138

Bowlesia, 859

Bowman's root, 515

Bow Maple, 742

Box-elder, 742

Box Family, 724

Boykinia, 500

Brachiaria, 80

Brachychaeta, 1202

Brachyelytrum, 121

Brachygyne, 1073

Bracken, 8

Bradburya, 651

Bradburya, 1187

Bradleia, 612

Brake, 8

Brasenia, 455

Brassica, 476

BRASSICACEAE, 465

Brauneria, 1261

Brayodendron, 908

Brayulinea, 394 
Brazilian Blady-grass, 54 Brazoria, 1026

Breweria, 958

Brickellia, 1177

Brintonia, 1185

Brome Grass, 156

BROMELIACEAE, 244

Bromus, 156

Brook feather, 431

Brookweed, 901

Broom Grass, 60

Broom-rape, 1093

Broom-rape Family, 1092

Broussonetia, 362

Brown Ash, 918

Brunnichia, 382

BRUNoniaCeAe, 1147

Bryophyllum, 498

Buchnera, 1079

Buckbean Family, 932

Buckberry, 893

Buckeye, 739

Large, 740

Ohio, 740

Red, 739

Shrubby, 740

Spanish, 746

Stinking, 740

Sweet, 740

Texas, 746

Yellow, 740

Buckeye Family, 738

Buckleya, 1103

Buckthorn, 747, 750, 910, 912 Texas, 749

Tough, 913

Buckwheat, 380

False, 382

Hedge, 382

Buckwheat Family, 367

Buckwheat-tree 730

Buddleia, 924

BUETTNERIACEAE, 779

Buffalo Currant, 512

Buffalo Grass, 140

Buffalo-nut, 1103

Bugbane American, 432

False, 440

Bugle-weed, 1048

Bugloss, 1001 Viper's, 1002

Bug-seed, 383

Bulbilis, 140

Bullace Grape, 757

Bullace Plum, 572

Bull Bay, 452

Bulrush, 176

Bumelia, 910

Bunch-flower, 253

Bunch-flower Family, 248

Bupleurum, 866

Burdock, 1305

Bur Gherkin, 1137

Bur Grass, 108

Burmannia, 308

BURManNiaCEAE, 308

Burmannia Family, 308

Bur Marigold, 1279

Burning Bush, 734

Bur-nut, 669

Bur Oak, 355

Bur-reed, 35

Bur-reed Family, 35
Bursa, 467

Burseed, 996

Bursera, 681

Burseraceae, 680

Burweed, 1148

Bush-clover, 640

Bush Honeysuckle, 1127

Butneria, 528

Butter-and-eggs, 1056

Buttereup, 441

Butterfly Pea, 651, 652

Butterfly Weed, 942

Butternut, 333

Butterwort, 1089

Button-ball, 512

Button-bush, 1111

Button Snake-root, 861, 1171

Button-weed, 1115, 1116

Buttonwood, 512, 831

White, 831

BUXACEAE, 724

Byrsonima, 672 .

Cabbage Palmetto, 223

Cabbage Tree, 223

Cabomba, 455

CABOMBACEAE, 454

Cactaceae, 810

Cactus, 811

Cactus Family, 810

Caesalpinia, 591

Cakile, 477

Calabash, 1138

Calamagrostis, 127

Calamagrostis, 128

Calamintha, 1042

Calamovilfa, 128

Calamus, 229

Calamus-root, 229

Calceolaria, 805

Calibracilla, 1138

Calico-bush, 886

Calico Wood, 915

Callicarpa, 1015

Callirrhoë, 766

Callitrichaceae, 722

Callitriche, 723

Calonyction, 961

Calophanes, 1082

Calopogon, 322

Caltha, 430

Caltrop, 669, 670

Caltrop Family, 669

Calycanthaceae, 528

Calycanthus, 528

Calyeocarpum, 453

Calydorea, 292

Calymmandra, 1234

Calyptrocarpus, 1274

Camassia, 267

Camelina, 471

Camellia Family, 792

Camomile, 1297

Dog's, 1297

Campanula, 1140

Campanula, 1141

CAMPandlaceae, 1140

CAMPandLales, 1134

Campanulastrum, 1141

Campion, Starry, 426

Campsis, 1095

Camptosorus, 14

Campulosus, 132

Campyloneuron, 7
Canadian Blue Grass, 154

Canary Grass, 113

Canavalia, 654

Cane, 161

Cane Ash, 919

Canella, 782

Canellaceae, 782

Cane Reed, 161

Canker-root, 900

Canna, 307

Cannabis, 360

CanNabinaCeaE, 359

CANNACEAE, 307

Canna Family, 307

Cantaloupe, 1137

Caper Family, 487

Capnoides, 464

CAPPARIDACEAE, 487

Capparis, 490

Capraria, 1069

CAPRIFOLIACEAE, 1120

Capriola, 131

Capsella, 467

Capsicum, 992

Cardamine, 481

Cardinal-flower, 1143

Cardiospermum, 744

CARDUACEAE, 1152

Carduales, 1148

Carduus, 1305

Carex, 201

aestivalis, 211

alata, 220

albolutescens, 220

amphibola, 212

Arkansana, 219

Asa-Grayi, 206

Atlantica, 219

Austro-Caroliniana, 214

Baileyi, 207

Baltzellii, 215

Bicknellii, 221

Brittoniana, 220

bromoides, 219

brunnescens, 219

bullata, 207

Caroliniana, 211

cephalophora, 218

Chapmanii, 216

Cherokeensis, 212

Collinsii, 206

comosa, 207

conoidea, 213

costellata, 211

Crawei, 213

crinita, 210

Crus-corvi, 217

dasycarpa, 216

Davisii, 211

debilis, 212

decomposita, 217

digitalis, 214

Elliottii, 206

festucacea, 220

filifolia, 216

filiformis, 209

flaccosperma, 212

Floridana, 215

folliculata, 206

Frankii, 208

Fraseri, 216

fusca, 209

glaucodea, 213

gracillima, 211 
Carex

grandis, 207

granularis, 213

gravida, 217

grisea, 212

gynandra, 210

hirta, 209

hystricina, 207

interior, 219

intumescens, 206

Jamesii, 216

Joorii, 209

juncea, 212

lanuginosa, 209

laxiculmis, 214

laxiflora, 214

Leavenworthii, 218

leptalea, 216

littorales, 210

Louisianica, 206

lupulina, 207

lurida, 207

macrokolea, 210

Meadii, 213

microdonta, 213

mirabilis, 220

Muhlenbergii, 218

nigro-marginata, 215

oblita, 212

oligocarpa, 213

oxylepis, 211

pedicellata, 215

Pennsylvanica, 215

picta, 216

planostachys, 215

plantaginea, 214

polymorpha, 213

prasina, 210

ptychocarpa, 214

radiata, 218

reniformis, 220

retroflexa, 218

riparia, 208

rosea, 218

Sartwellii, 217

scabrata, 208

scoparia, 219

Shortiana, 208

sparganioides, 213

squarrosa, 208

sterilis, 219

stipata, 217

straminea, 220

striatula, 214

stricta, 210

styloflexa, 214

tenera, 220

tenuis, 212

tetanica, 213

Texensis, 213

torta, 210

triangularis, 217

tribuloides, 219

triceps, 211

trichocarpa, 208

turgescens, 207

typhinoides, 208

umbellata, 215

varia, 215

venusta, 212

verrucosa, 210

vestita, 209

virescens, 211

vulpinoidea, 217
Carex

Walteriana, 209

Willdenovii, 216

xanthocarpa, 217

Carica, 806

Carolina Hemlock, 30

Carolina Pink, 923

Carpet Grass, 91

Carpet-weed, 412

Carpet-weed Family, 411

Carphochaete, 1171

Carphephorus, 1177

Carpinus, 344

Carrot, 876

Carrion-flower, 281

Caropitys, 29

Carrot Family, 856

Carya, 333

CARYOPHYLlaCEAE, 424

Cassada, 910

Cassandra, 887

Cassia, 584

CAssiaceae, 583

Cassie, 578

Cassine, 733

Cassytha, 822

CASSYTHACEAE, 821

Cassytha Family, 821

Castalia, 457

Castanea, 347

Castela, 679

Castilleja, 1079

Castor-beau, 705

Castor Oil Plant, 705

Casuarina, 332

CASUARINACEAE, 332

Casuarinales, 331

Catalpa, 1095

Catbrier, 281

Cateh-fly Grass, 113

Catesbaea, 1111

Cat-gut, 609

Catmint, 1026

Catnep, 1026

Catopsis, 247

Catsclaw, 575

Texas, 578

Cat-tail, 35

Cat-tail Family, 34

Caulophyllum, 459

Cayaponia, 1138

Ceanothus, 750

Cebatha, 454

Cedar

Mountain, 33

Red, 33

Stinking, 33

White, 32

Cedar Pine, 28

Cedronella, 1025

Celandine, 461

Celandine Poppy, 461

Celastraceae, 733

Celastrus, 735

Celosia, 390

Celtis, 364

Celtis, 366

Cenchropsis, 109

Cenchrus, 108

Cenchrus, 109

Centaurea, 1308

Centaury, 925

Centella, 859

Centrosema, 651
Centunculus, 905

Century-plant, 288

Cephalanthus, 1111

Cerastium, 423

Ceratiola, 725

Ceratophyllaceae, 428

Ceratophyllum, 428

Ceratopteridaceae, 5

Ceratopteris, 5

Cereidium, 590

Cercis, 584

Cereus, 813

Cereus, 813

Cestrum, 993

Cevallia, 810

Chaenolobus, 1235

Chaerophyllum, 863

Chaetopappa, 1205

Chaetospora, 190

Chamaecrista, 586

Chamaecyparis, 32

Chamaedaphne, 887

Chamelirium, 249

Chamaenerion, 839

Chamaesaracha, 988

Chamaesyce, 707

adenoptera, 714

adicioides, 710

albomarginata, 710

ammannioides, 709

angusta, 711

Blodgettii, 712

brachvpoda, 709

Brasiliensis, 712

buxifolia, 711

Chiogenes, 709

cinerascens, 710

conferta, 713

cordifolia, 709

deltoidea, 710

Fendleri, 710

Garberi, 710

Geyeri, 709

glyptosperma, 712

humistrata, 713

Ingallsii, 713

Laredana, 709

lata, 710

maculata, 713

malaca, 713

Nashii, 709

nutans, 712

Nuttallii, 711

pergemena, 713

petaloidea, 711

pilulifera, 714

polyclada, 711

polygonifolia, 708

Porteriana, 711

prostrata, 713

revoluta, 711

serpens, 709

serpyllifolia, 712

Stanfieldii, 712

stictospora, 714

Tracyi, 713

villifera, 712

Chapmania, 634

Chapote, 909

Chaptalia, 1309

Charlock, 477

Cheeses, 766

Cheilanthes, 10

Cheilogramma, 8 
Cheiroglossa, 2

Chelidonium, 461

Chelone, 1058

Chenopodiaceat, 384

CHENOPODIALES, 383

Chenopodium, 384

Cherry, 907

Cherry

Black, 574

Choke, 573

Dwarf, 571

Ground, 981

Indian, 750

Jerusalem, 981

May, 531

Pigeon, 571

Pin, 571

Rum, 574

Sweet, 571

Sour, 571

Wild, 573, 574

Wild Red, 571

Birch, 346

Chervil, 863

Chestnut, 438

American, 348

Chestnut Oak, 354

Chickasaw Plum, 573

Chicken Grape, 754

Chickweed, 421

Forked, 401

Indian, 411

Jagged, 419

Mouse-car 423

Chickweed Family, 416

Chicory, 1320

Chilopsis, 1096

Chimaphila, 878

China Bean, 654

Chinabrier, 283

China-tree, 681

Chinese Honeysuckle, 1125

Chinese Parasol Tree, 781

Chinquapin, 348

Chinquapin Oak, 354

Chiococca, 1112

Chiogenes, 896

Chionanthus, 920

Chloris, 133

Chloris, 135

Chocolate Family, 779

Chokeberry, 531

Choke Cherry, 573

Chondrophora, 1184

Choripetalae, 330

Christmas Fern, 15

Christmas-green, 23

Chrosperma, 250

Chrysanthemum, 1297

Chrysobalanus, 569

Chrysogonum, 1245

Chrysoma, 1188

Chrysophyllum, 909

Chrysopsis, 1181

Chytraculia, 833

Chrysosplenium, 505

Chufa, 169

Cichoriaceae, 1310

Cichorium, 1320

Cicuta, 868

Cienfuegosia, 777

Cigar-tree, 1095

Cimicifuga, 431

Cinna, 125
Cinnamou-bark, 782

Cinnamon Fern, 4

Cinnamon Fern Family, 3

Cinquefoil, 521

Circaea, 849

Cissus, 757

Cissus, 758

Cistaceae, 795

Citharexylum, 1014

Citron, 678

Citrullis, 1137

Citrus, 678

Chaetochloa, 105

Cladium, 191

Cladothrix, 396

Cladrastis, 596

Clammy-weed, 489

Clappia, 1285

Clearweed, 357

Claytonia, 415

Cleavers, Spring, 1118

Clematis, 436

Clematis, 437, 438, 440

Cleome, 490

Cleomella, 490

Clethra, 877

Clethraceae, 877

Cliff-brake, 9

Cliftonia, 730

Climbing Bittersweet, 735

Climbing Fern, 4

Climbing Fumitory, 463

Climbing Rose, 526

Clinopodium, 1042

Clintonia, 269

Clitoria, 651

Clotbur, 1148, 1305

Clover, 605

Bush, 640

Prairie, 628

Sweet, 604

Club-mosses, 21

Club-moss Family, 21

Clusia, 782

Clusiaceae, 782

Club-rush, 176

Cnicus, 1308

Cnidoscolus, 706

Coccolobis, 383

Coccothrinax, 222

Cocculus, 454

Cochranea, 1007

Cockle, Corn, 428

Cockspur, 108

Cocklebur, 1148

Coco Palm, 225

Coco-nut Palm, 225

Cocoa Plum, 570

Cocos, 225

Coeloglossum, 312

Coelostylis, 922

Cohosh

Black, 432

Blue, 459

White, 432

Coldenia, 1004

Coleosanthus, 1177

Colic-root, 286

Collinsia, 1057

Collinsonia, 1051

Collinsonia, 1051

Columbine, 432

Colubrina, 751

Columbo, American, 931
Comandra, 1102

Comfry, 1001

Wild, 996

Commelina, 241

COMmelinacea E, 236

Common Cotton, 778

Common Nightshade, 989

Common Reed, 141

Compass-plant, 1242

Comptonia, 337

Condalia, 748

Cone-flower, 1253, 1260, 1261

Conioselinum, 873

Conobea, 1063

Conocarpus, 830

Conoclinum, 1169

Conopholis, 1092

Conradina, 1041

Convallaria, 272

CONVAllariacea, 268

Convolvulaceae, 958

Convolvulus, 965

Coontie, 26

Cooperia, 290

Coptis, 431

Coral-bead, 454

Coralberry, 1124

Corallorhiza, 325

Coral-root, 325

Coral Sumach, 726

Corchorus, 759

Cordia, 1002

Coreopsis, 1274

angustifolia, 1278

auriculata, 1275

cardaminefolia, 1277

crassifolia, 1275

delphinifolia, 1276

Drummondii, 1277

falcata, 1278

gladiata, 1279

grandiflora, 1275

Harveyana, 1275

helianthoides, 1279

integrifolia, 1279

lanceolata, 1275

latifolia, 1277

Leavenworthii, 1278

Lewtonii, 1278

longifolia, 1278

major, 1276

Neucensis, 1276

nudata, 1279

palmata, 1276

pubescens, 1275

pulchra, 1277

rosea, 1277

similis, 1278

stenophylla, 1277

tinctoria, 1277

tripteris, 1276

verticillata, 1276

Coreopsis, 1281

Coriander, 865

Coriandrum, 865

Corispermum, 387

Cornaceae, 851

Corkwood Family, 336

Corn Cockle, 428

Cornel, 853

Corn Gromwell, 999

Corn Rose, 428

Corn Salad, 1128

Corn Spurry, 418 
Cornus, 853, 854

Coronopus, 466

Corrigiolaceae, 399

Corydalis, 464

CORYlacea E, 343

Corylus, 344

Cosmiza, 1089

Cosmos, 1282

Cotinus, 726

Cotoneaster, 569

Cotton, 778

Common, 778

Sea-island, 778

Cotton-grass, 175

Cotton Gum, 853

Couch Grass, 158

Coursetia, 614

Covillea, 670

Cow-bane, 875

Cowberry Family, 724

Cow-herb, 425

Cow licks, 915

Cow Oak, 354

Cow Parsnip, 876

Cow Pea, 654

Cowslip, American, 905

Crab Apple, 530

Crab Grass, 81, 138

Crabwood, 703

Cracea, 609

Crag Hemlock, 30

Cranberry, 897

Mountain, 897

Crane's-bill, 659

Crane-fly Orchis, 327

Crantzia, 871

Crassina, 1248

Crassulaceae, 496

Crataegus, 532

abdita, 548

abstrusa, 545

adunca, 552

adusta, 556

aemula, 541

aestivalis, 539

agrestina, 548

Alabamensis, 553

albicera, 567

algens, 568

Allegheniensis, 547

alma, 544

amica, 554

amnicola, 541

ancisa, 544

anisophylla, 555

annosa, 551

apiifolia, 539

aprica, 547

arcana, 564

arborea, 568

arguta, 556

Arkansana, 562

armata, 568

armentalis, 561

$\operatorname{arrogans,~} 550$

arta, 566

Ashei, 563

assimilis, 546

attrita, 554

audens, 559

austrina, 543

austromontana, 563

basilica, 564

berberifolia, 565
Crataegus

Biltmoreana, 562

bisulcata, 561

Boyntonii, 542

brachyacantha, 539

Brazoria, 540

Buckleyi, 542

Bushii, 569

callida, 564

calva, 551

Chapmanii, 538

cibaria, 562

cirrata, 556

clara, 554

collina, 541

colonica, 556

communis, 542

compitalis, 553

concinna, 546

condigna, 559

consanguinea, 549

constans, 552

contrita, 543

cordata, 539

Craytonii, 563

erocea, 559

crocina, 567

Crus-Galli, 567

Cullasagensis, 555

curva, 557

dapsilis, 552

denaria, 567

dispar, 555

dolosa, 552

Earlei, 561

edita, 565

edura, 566

egens, 551

egregia, 550

exilis, 548

eximia, 544

extraria, 548

fera, 565

flava, 547

florens, 553

fortis, 553

frugalis, 555

frugiferens, 547

furtiva, 550

galbana, 548

geniculata, 560

Georgiana, 564

gilva, 543

gravida, 562

gregalis, 561

Harbisonii, 563

ignava, 547

illudens, 558

illustris, 546

impar, 547

inanis, 544

incana, 558

incilis, 546

ingens, 541

inopina, 557

inops, 554

insidiosa, 553

integra, 552

interior, 540

invicta, 560

iracunda, 564

lacera, 562

lacrimata, 559

lanata, 551
Crataegus

lassa, 558

laxa, 556

lenis, 545

lepida, 559

limata, 549

luculenta, 539

macilenta, 545

macra, 568

macrosperma, 564

maleoides, 539

Margaretta, 542

mendosa, 545

meridiana, 559

Michauxii, 551

mira, 549

Mohri, 565

mollis, 561

munda, 560

neofluvialis, 536

nubicola, 565

opima, 546

pallens, 543

paludosa, 540

panda, 552

penita, 542

pexa, 560

pinetorum, 545

pulcherrima, 545

pulla, 554

punctata, 541

pyracanthoides, 566

quaesita, 550

rava, 553

Raleighensis, 561

Ravenelii, 554

recurva, 557

regalis, 568

resima, 558

rigens, 541

rimosa, 557

Roanensis, 565

robur, 546

rubella, 543

rustica, 56

Sargentii, 543

segnis, 549

senta, 555

signata, 567

silvicola, 540

sinistra, 567

sodalis, 550

sororia, 548

spathulata, 539

straminea, 542

subviridis, 540

tecta, 544

teres, 555

tersa, $\mathbf{5 6 6}$

tetrica, 566

Texana, 562

tomentosa, 538

torva, 566

triflora, 563

tristis, 550

uniflora, 560

Vailiae, 561

valida, 549

venusta, 544

versuta, 558

viaria, 556

vicana, 556

vicinalis, 564

villaris, 557 
Crataegus

viridis, 540

visenda, 549

vulsa, 540

Yadkinensis, 560

Crawley-root, 325

Creeping Cucumber, 1135

Creeping Wintergreen, 890

Cupania, 745

Creosote Bush, 671

Crescentia, 1096

Cress

Bitter, 481

Mouse-ear, 475

Rock, 483

Swine, 467

Wall, 475

Wart, $467^{\circ}$

Water, 472

Winter, 475

Cressa, 959

Crested Iris, 305

Crinum, 290

Cristatella, 488

Croftia, 1088

Crookea, 786

Croomia, 279

Crossopetalum, 735

Crotalaria, 601

Croton, 693

Crotonopsis, 698

Crow-foot, 138

Crow foot Family, 429

Crow-poison, 250, 251

Crownbeard, 1272

Cruciferae, 466

Crusea, 1115

Cryptanthe, 997

Cryptotaenia, 869

Ctenium, 133

Cubelium, 805

Cucumber

Creeping, 1135

Star, 1140

Cucumber-root, Indian, 276

Cucumber-tree, 451

Cueumis, 1137

Cucurbitaceae, 1134

Cudweed, 1234, 1237

Culver's-root, 1071

Cunila, 1048

Cuphea, 829

Cueurbita, 1138

Curly-grass Family, 4

Currant, 510

Buffalo, 512

Fetid, 512

Golden, 512

Missouri, 512

Cuscuta, 967

Cuscutaceae, 966

Custard-apple, 449, 806

Custard-apple Family, 447

Cut Grass, 112

Cuthbertia, 237

Cupania, 745

Cup-plant, 1241

Cup-seed, 453

CYCADACEAE, 26

Cycadales, 25

Cycas Family, 26

Cyclanthera, 1139

Cycloloma, 386

Cymopterus, 874
Cynoctonum, 923

Cynodon, 131

Cynoglossum, 996

Cynosciadium, 871

Cynoxylon, 854

CyPeraceat, 161

Cyperus, 162, 1321

acuminatus, 167

articulatus, 169

bipartitus, 165

Blodgettii, 174

brunneus, 174

Buckleyi, 167

Bushii, 167

Careyi, 166

cephalanthus, 168

compressus, 166

cylindricus, 172

cylindrostachys, 172

cyrtolepis, 167

dentatus, 169

diandrus, 164

digitatus, 170

dissitiflorus, 172

distans, 168

Drummondii, 167

echinatus, 174

Eggersii, 171

elegans, 167

Engelmannii, 170

erythrorhizos, 169

esculentus, 169

ferax 170

filiculmis, 173

flavescens, 164

flavicomus, 166

flavus, 173

Floridanus, 170

fuligineus, 173

Gatesii, 165

globulosus, 1321

Grayi, 174

Halei, 170

Hallii, 169

Haspan, 168

helvus, 165

Hochstetterii, 166

inflexus, 166

Iria, 166

laevigatus, 166

Laneastriensis, 173

ligularis, 174

longispicatus, 1321

Martindalei, 171

microdontus, 165

multiradiatus, 169

Nashii, 1321

Nuttallii, 165

ochraceus, 167

Ottonis, 174

ovularis, 172

oxycarioides, 171

Plankii, 172

Pollardi, 1321

polystachyus, 165

pseudovegetus, 168

pumilus, 165

reflexus, 168

refractus, 171

retrofractus, 172

retrorsus, 172

rivularis, 165

rotundus, 169

setigerus, 171
Cyperus

speciosus, 170

stenolepis, 171

strigosus, 171

subuniflorus, 173

Surinamensis, 168

squarrosus, 166

tetragonus, 173

uniflorus, 173

virens, 167

Cypress, 31, 32

Bald, 31

Pond, 31

Cypress Vine, 961

Cypripedium, 311

Cypripedium, 312

Cypselea, 412

Cyrilla, 730

Cyrillaceae, 729

Cyrtopodium, 329

Cyrtopodium, 328

Cystopteris, 18

Dactylis, 152

Dactyloctenium, 138

Dahoon, 733

Daisy, 1202, 1297

Dalea, 626

Dalbergia, 620

Dandelion, 1318

Dwarf, 1318

False, 1314

Dangleberry, 892

Danthonia, 131

DAPHNACEAE, 818

Diapensia Family, 897

Darling Plum, 748

Darnel, 158

Dasylirion, 275

Dasystephana, 930

Dasystoma, 1073

Date Plum, 908

Datura, 993

Daubentonia, 615

Daucus, 876

Day-flower, 241

Day Lily, 265

Dead Nettle, 1029

Decodon, 827

Decumaria, 508

Deerberry, 893

Delonix, 590

Delphinium, 433

Dendrium, 882

Dendrophylax, 327

Dendropogon, 244

Dennstaedtia, 18

Dentaria, 480

Deringa, 868

Deschampsia, 129

Desmanthus, 579

Desmodium, 634

Dewberry, 518

Dew-flower, 241

Devil's bit, 249

Devil's Claws, 578

Devilwood, 920

Diamorpha, 497

Dianthera, 1087

Dianthera, 1089

Dianthus, 424

Diapedium, 1085

DIAPENSIACEAE, 897

Diarrhena, 151 
Dicentra, 463

Dicerandra, 1044

Dichaetophora, 1203

Dichondra, 957

DICHONDRACEAE, 957

Dichondra Family, 957

Dichromena, 189

Dichrophyllum, 715

Dicksonia, 18

Diclytra, 463

DICOTYLEDONES, 330

Didiplis, 825

Diervilla, 1126

Digitaria, 81

Dilly, Wild, 913

Dimorphostachys, 78

Dioclea, 647

Diodia, 1115

Dionaea, 493

DIONAEACEAE, 492

Dioscorea, 291

Dioscoreaceae, 291

Diospyros, 908

Diospyros, 909

Dipholis, 910

Diphylleia, 459

Diplachne, 145

Dipsacus, 1130

Direa, 818

Discanthera, 1139

Discopleura, 870

Disporum, 270

Distasis, 1205

Distichlis, 152

Ditany, 1048

Ditaxis, 698

Ditch Grass, 37

Ditch Millet, 74

Ditch Stonecrop, 498

Dithyraea, 1323

Dittany, 1048

Dock, 368

Doctor Gum, 726

Dodder, 967

Dodder Family, 966

Dodecatheon, 905

Dodonaea, 738

DODONAEACEAE, 737

Dodonaea Family, 737

Doellingeria, 1231

Dogbane, 936

Dogbane Family, 933

Dogberry, 511

Dog's Camomile, 1297

Dog-fennel, 1297

False, 1294

Dog Grass, 138

Dog's-tooth Violet, 267

Dogwood, 853, 854

False, 745

Flowering, 854

Poison, 727

Striped, 742

Dogwood Family, 851

Dolicholus, 643

Dondia, 388

Doorweed, 374

Downy Grape, 755

Downward Plum, 911

Draba, 479

DRACENACEAE, 273

Dragon-head, 1027

Dragon Root, 227

Dracopis, 1260
Drosera, 492

DROSERACEAE, 491

Duranta, 1015

Drymocallis, 519

Dryopteris, 15

Drypetes, 693

Duc Acorn, 455

Duchesnea, 520

Duckweed, 230, 416

Duckweed Family, 229

Dulichium, 162

Dupatya, 235

Dutchman's Breeches, 463

Dutchman's Pipe, 1134

Dwarf Alder, 509

Dwarf Cherry, 571

Dwarf Dandelion, 1318

Dwarf Ginseng, 855

Dwarf Huckleberry, 891

Dwarf Palmetto, 223

Dwarf Sumac, 728

Dysodia, 1294

Easter Lily, 289

Eatonia, 149

EBenaCeae, 908

EBENALES, 908

Ebony, Texan, 576

Ebony Family, 908

Echinacea, 1261

Echinocactus, 814

Echinocereus, 812

Echinocloa, 84

Echinocystis, 1139

Echinodorus, 41

Echinospermum, 996

Echites, 937

Echium, 1001

Eelipta, 1250

Eel-grass, 39, 47

Eel-grass Family, 39

Egg-plant, 990

Ehretia, 1003

EHRETIACEAE, 1002

Ehretia Family, 1002

Eichornia, 244

ElaEAGNACEAE, 819

Elaeagnus, 819

ELATINACEAE, 783

Elatine, 783

Elder, 1120

Box, 742

Marsh, 1151

Poison, 727

Elecampane, 1238

Eleocharis, 180

acicularis, 184

aeuminata, 186

albida, 185

arenicola, 186

atropurpurea, 183

Baldwinii, 185

bicolor, 183

capillacea, 182

capitata, 183

cellulosa, 182

Chaetaria, 184

cylindrica, 186

elongata, 182

Engelmannii, 183

glaucescens, 184

interstincta, 181

lanceolata, 183

macrostachya, 184
Eleocharis

maculosa, 182

melanocarpa, 185

microcarpa, 185

mutata, 182

nodulosa, 183

obtusa, 183

ochreata, 182

olivacea, 182

praticola, 182

prolifera, 185

Ravenelii, 184

Robbinsii, 182

rostellata, 186

tenuis, 186

Torreyana, 185

tortilis, 184

tricostata, 185

tuberculosa, 184

vivipara, 184

Elephant's Ear, 817

Elephantopus, 1161

Eleusine, 138

Eleusine, 138

Elionurus, 57

Elk-wood, 451

Elliottia, 881

Ellisia, 971

Elm, 363

Slippery, 364

Water, 364

White, 364

Witch, 510

Elm Family, 362

Elytraria, 1082

Elymus, 159

EMPETRACEAE, 724

Encelia, 1270

Enchanter's Nightshade, 849

Endorima, 1283

Engelmannia, 1247

Enslenia, 952

Elodea, 792

ElodeaceAE, 46

Epicampes, 125

Epidendrum, 327

Epigaea, 890

EPILOBIACEAE, 834

Epilobium, 839

Epilobium, 830

Epipactis, 323

Epiphegus, 1093

EQUisetaceat, 20

EQUisetales, 20

Equisetum, 20

Eragrostis, 146

Eragrostis, 140

Erechthites 1300

Erianthus, 54

ERICACEAE, 880

ERICALES, 876

Erigenia, 865

Erigeron, 1229

Eriocarpum, 1185

EriocaUlacea E, 234

Eriocaulon, 235

Eriochloa, 80

Eriogonum, 367

Erioneuron, 143

Eriophorum, 175

Erithalis, 1112

Ernodea, 1115

Frodium, 660

Eryngium, 861 
Eryngo, 861

Erysimum, 475

Erythraea, 925

Erythrina, 647

Erythronium, 267

EsCALlONIACEAE, 505

Eucnide, 810

Eugenia, 831

Euklisia, 486

Eulophus, 869

Euonymus, 734

Eupatorium, 1164

Eupatorium, 1164, 1169

Euphorbia, 708, 714, 715, 716, 718,721

EUPHORBIACEAE, 690

EUPHORBIALES, 690

Euploca, 1006

Eurytaenia, 871

Eustachys, 134

Eustoma, 926

Euthamia. 1189

Evax, 1233

Evening-primrose, 839, 840, 841

Evening-primrose Family, 834

Evening Trumpet-flower, 921

Evergreen Winterberry, 731

Everlasting, 1236, 1237

Pearly, 1237

Everlasting Grass, 80

Evolvulus, 960

Exostema, 1110

Exothea, 745

Eysenhardtia, 626

FabACEAE, 593

Facelis, 1237

Fagaceat, 346

FAGALES, 343

Fagara, 675

Fagopyrum, 380

Fagus, 347

Falcata, 650

False Aloe, 287

False Beech-drops, 880

False Boneset, 1178

False Buckwheat, 382

False Bugbane, 440

False Dandelion, 1314

False Dog-fennel, 1294

False Dogwood, 745

False Flax, 471

False Foxglove, 1073

False Garlic, 264

False Goat's-beard, 500

False Goldenrod, 1202

False Gromwell, 1000

False Hellebore, 251

False Mallow, 768

False Mermaid, 725

False Mitrewort, 502

False Nettle, 358

False Oat, 129

False Pennyroyal, 1019

False Pimpernel, 905-1068

False Rue Anemone, 431

False Mermaid Family, 725

Farkleberry, 892

Featherfoil, 901

Fedia, 1129

Fennel, 872

Dog, 1297

Fern

Beech, 17
Fern

Boston, 17

Christmas, 15

Cinnamon, 4

Climbing, 4

Floating, 5

Grass, 7

Lip, 10

Maidenhair, 8, 9

Oak, 17

Ostrich, 17

Royal, 4

Sensitive, 15

Shield, 15

Sweet, 337

Sword, 17

Walking, 14

Fern Allies, 1

Fern Family, 5

Ferns, 1

Fescue Grass, 155

Festuca, 155

Fetid Currant, 512

Fetterbush, 888

Fever-bush, 732

Ficus, 362

Field-balm, 1044

Field Larkspur, 433

Field Sorrel, 369

Fig, 362

Figwort, 1057

Figwort Family, 1053

Filago, 1233

Filago, 1234

Filicales, 3

Filix, 18

Filmy Fern Family, 3

Fimbristylis, 186

Fir, 30 Silver, 30

Fire Pink, 427

Fire-weed, 839, 1300

Firmiana, 781

Fissipes, 311

Flag, 305

Blue, 305

Sweet, 229

Flame Azalea, 883

Flaveria, 1289

Flax, 662

False, 471

Flax Family, 661

Flaxweed, 485

Fleabane, 1229

Marsh, 1234

Fleur-de-lis, 305

Floating Fern, 5

Floating Fern Family, 5

Floating Heart, 933

Floerkia, 725

Florestina, 1287

Florida Mahogany, 820

Florida Moss, 245

Flowering Ash, 920

Flowering Dogwood, 854

Flowering Moss, 897

Flowering Wintergreen, 685

Fly Honeysuckle, 1224

Fly-poison, 250

Flytrap, 493

Venus', 493

Foeniculum, 872

Fog-fruit, 1011

Forestiera, 919
Forget-me-not, 997

Forked Chickweed, 401

Fothergilla, 509

Fouquiera, 784

FOUQUIERACEAE, 784

Four-o'clock, 405

Four-o'clock Family, 404

Foxgrove, False, 1073

Fox Grape, 756

Foxtail, 105, 122

Foxtail Grass, 105

Fragaria, 520

Fragrant Sumac, 728

Frangulaceae, 747

Franklinia, 793

Franseria, 1149

Frasera, 931

Fraxinus, 917

Fringed Gentian, 929

Fringed Milkwort, 685

Fringed Orchis, 313

Fringe tree, 920

Froelichia, 397

Frog's-bit, 48

Frost Grape, 754

Frost-weed, 786

Fuirena, 175

Fumaria, 456

FUMARIACEAE, 462

Fumitory, 465

Climbing, 463

Fumitory Family, 462

Gaertneria, 1149

Gaillardia, 1293

GALACACEAE, 898

Galactia, 647

Galax, 898

Galax Family, 898

Galaxy, 898

Galenia, 1323

Galeopsis, 1029

Galeorchis, 312

Galinsoga, 1285

Galium, 1117

Galpinsia, 844

Gamma Grass, 54

GamopetalaE, 876

Garberia, 1176

Garden Larkspur, 433

Garden Poppy, 461

Garlic, 262

False, 264

Meadow, 263

Wild, 263

Garrya, 851

Gaultheria, 890

Gastridium, 127

Gaura, 846

Gaurella, 844

Gaylussacia, 891

Gayoides, 764

Gelsemium, 921

Gemmingia, 293

Genipa, 1110

Gentian, 930

Horse, 1123

Spurred, 931

GENTIANACEAE, 924

Gentianales, 921

Gentianella, 929

Gentian Family, 924

Geoprumnon, 615

Georgia Pine, 27 
GeraniaCEAE, 658

GERANIALES, 658

Geranium, 659

Rock, 503

Wild, 659

Geranium Family, 658

Gerardia, 1075

Germander, 1018

German Knotgrass, 389

Geum, 522

Geum, 523

Gherkin

Bur, 1137

West Indian, 1137

Giant-hyssop, 1025

Gibbesia, 402

Gifola, 1234

Gilia, 979, 1325

Gillenia, 515

Ginseng, 855

Dwarf, 855

Glasswort, 388

Glecoma, 1026

Gleditsia, 588

Glinus, 412

Globe Amaranth, 398

Glottidium, 615

Glyceria, 154

Gnaphalium, 1237

Goat's-beard, 514

False, 500

Goatbush, 679

Goat's Rue, 609

Gochnatia, 1309

Golden Aster, 1181

Golden-club, 228

Golden Currant, 512

Goldenrod, 1189

False, 1202

Golden Saxifrage, 505

Golden Seal, 430

Golden Slipper, 311

Gold-thread, 431

Gomphrena, 398

Goniostachyum, 1012

Goniopteris, 17

Gonolobus, 951

Gonobolus, 952

Gonopyrum, 373

Goodyera, 321

Goodenia Family, 1147

Gooseberry, 510, 892

Gooseberry Family, 510

Gooseberry Gourd, 1137

Goosefoot, 384

Goosefoot Family, 384

Goose-grass, 1118

Gopher Apple, 570

Gopher Plum, 570

Gordonia, 793

Gordonia, 793

Gossypianthus, 394

Gossypium, 778

Gouania, 752

Gourd, 1138

Bottle, 1138

Gooseberry, 1137

Gourd Farmily, 1134

Gramineae, 49

Grape, 753

Blue, 755

Bullace, 756

Chick:en, 754

Downy, 755
Grape

Fox, 756

Frost, 754

Mountain, 754

Mustang, 756

Plum, 756

Riverside, 755

Sand, 754

Sea, 383

Shore, 383

Sugar, 754

Summer, 756

Winter, 755

Grape Family, 752

Grass

Arrow, 41

Beard, 54, 58, 60, 125

Bent, 126

Bermuda, 132

Black Oat, 120

Blue, 152

Blue-eyed, 293

Brome, 156

Broom, 60

Buffalo, 140

Bur, 108

Canadian Blue, 154

Canary, 113

Carpet, 91

Catch-fly, 113

Cotton, 175

Couch, 158

Crab, 81, 138

Cut, 112

Ditch, 37

Dog, 138

Eel, 39, 47

Everlasting, 80

Fescue, 155

Foxtail, 105

Gamma, 54

Gooose, 1118

Hair, 128, 129

Holy, 114

Hungarian, 107

Indian, 66

Johnson, 66

June, 153

Kentucky Blue, 153

Lizard-tail, 57

Lyme, 159

Manna, 154

Marsh, 132

Meadow, 152

Melic, 150

Mesquite, 136

Mission, 110

Oat, 131

Orange, 791

Orchard, 152

Plume, 54

Poverty, 114, 115

Quitch, 158

Rat-tail, 56

Reed, 125, 126

Rib, 1100

Rice, 112

Rice Cut, 113

Rush, 132

Rye, 158

Salt Meadow, 132

Salt Reed, 132

Sand, 60, 144

Saw, 191
Grass

Scorpion, 997

Scurvy, 475

Shore, 110

Skunk, 148

Sour, 666

Spear, 152

Spike, 152

Stagger, 289

Star, 286

Sweet Vernal, 114

Switch, 93

Tape, 47

Toothache, 132

Vanilla, 114

Velvet, 128

Water, 90

Wheat, 158

White, 113

Whitlow, 479

Wild Oat, 131

Wire, 114, 138

Witch, 92

Yard, 138

Yellow-eyed, 232

Grass Family, 48

Grass Fern, 7

Grass-of-Parnassus, 499

Grass-of-Parnassus.Family, 498

Grass-pink, 322

Grass-wrack, 39

Gratiola, 1065

Gratiola, 1067

Gray Birch, 346

Greater Duckweed, 230

Great Laurel, 884:

Greek Valerian, 980

Green Ash, 918

Greenbrier, 281

Green Dragon, 227

Green Hellebore, 430

Green Milkweed, 940

Green Violet, 805

Grevillea, 818

Grindelia, 1180

Gromwell, 998

Corn, 999

False, 1000

Grossula RIACEAE, 510

Ground Cherry, 981

Ground Ivy, 1026.

Ground-nut, 652, 855

Ground Oak, 570

Ground Pine, 22

Ground Pink, 978

Groundsel, 1302

Guaiacum, 671

Guava, 833

Guettardia, 1112

Guiana Plum, 693

Guilandina, 591

Guilandina, 491

Guilleminea, 394

Gum

Black, 852

Cotton, 853

Doctor, 726

Red, $\mathbf{5 1 0}$

Sweet, 510

Star-leaved, 510

Sour, 852, 890

Tupelo, 853

Gumbo, 776

Gumbo Limbo, 680, 681 
Gum Flastic, 913

Gum Elemi, 681

Gum-plant, 1180

GUNNERACEAE, 849

Gutierrezia, 1179

Gyminda, 736

Gymnadenia, 316

Gymnadeniopsis, 316

Gymnandropsis, 489

Gymnanthes, 703

Gymnocladus, 589

Gymnolomia, 1252

Gymnopogon, 135

Gymnosperma, 1178

GYMNOSPERMAE, 25

Gyrostachys, 317

Gyrotheca, 306

\section{Habenaria, 314}

Habenaria, 312, 313, 316

Habenella, 316

Hackberry, 364

Hackelochloa, 57

HAEMODORACEAE, 306

Hagbrier, 282

Hair Grass, 128, 129

Hairy Pipewort, 234

Hairy Sumac, 729

Halerpestes, 441

Halesia, 915

Halophila, 47

Haloragidaceae, 849

Hamamelidaceae, 509

Hamamelis, 509

Hamelia, 1111

Hamosa, 617

Haploesthes, 1299

Harbinger of Spring, 866

Hardhack, 514

Hard Maple, 742

Hare's Ear, 866

Hare's-tail, 175

Hartmannia, 843

Hart's Tongue, 14

Hartwrightia, 1172

Havardia, 576

Haw, 532

Black, 913, 1123

Possum, 732

Purple, 748

Hawkweed, 1312

Hazel-nut, 344

Hazel Family, 343

Heal-all, 1026

Healing-herb, 1001

Heather, Beech, 797

Heath Family, 880

He Balsam, 29

Hedeoma, 1039

Hedera, 855

Hederaceae, 854

Hedge Buckwheat, 382

Hedge-hyssop, 1066

Hedge Mustard, 473

Hedge Nettle, 1030

Hedge-parsley, 864

Hedge Pink, 425

Hedyotis, 1106

Heimia, 826

Helenium, 1290

Helianthella, 1270

Helianthemum, 796

Helianthus, 1263

angustifolius, 1266
Helianthus

annuus, 1265

argophyllus, 1265

atrorubens, 1267

australis, 1268

carnosus, 1266

ciliaris, 1266

cinereus, 1269

cucumerifolius, 1265

debilis, 1265

decapetalus, 1268

divaricatus, 1270

doroconoides, 1269

Dowellianus, 1267

Eggertii, 1267

elongatus, 1266

filiformis, 1265

Floridanus, 1265

giganteus, 1269

glaucus, 1268

grosse-serratus, 1268

heterophyllus, 1267

hirsutus, 1270

laevigatus, 1267

longifolius, 1267

Maximilianii, 1269

microcephalus, 1268

mollis, 1270

occidentalis, 1267

orgyalis, 1266

petiolaris, 1265

praecox, 1265

polyphyllus, 1266

Radula, 1267

resinosus, 1269

saxicola, 1263

scaberrimus, 1266

Schweinitzii, 1269

strumosus, 1268

tomentosus, 1269

tracheliifolius, 1270

tuberosus, 1269

undulatus, 1266

verticillatus, 1268

Helietta, 676

Heliopsis, 1248

Heliotrope, 1005

Heliotrope Family, 1004

HELIOTROPIACEA E, 1004

Heliotropium, 1005

Hellebore, 251 American White, 251

False, 251

Green, 430

Helleborus, 430

Helleranthus, 1011

Hemerocallis, 265

Hemianthus, 1069

Hemicarpha, 162

Hemlock, 30

Carolina, 30

Crag, 30

Water, 868

Hemlock Parsley, 873

Hemp, 360

Indian, 936

Hemp Family, 359

Hemp Nettle, 1029

Hepatica, 435

Heracleum, 876

Herbertia, 304

Hercules' Club, 856

Hermannia, 779

Herpestis, 1064, 1065
Hesperis, 474

Heteranthera, 243

Heteropogon, 67

Heteropogon, 57

Heterotheca, 1180

Heuchera, 503

Hexalectris, 329

Hexastylis, 1131

Hibiseus, 774

Hickory

Pig-nut, 338

Shell-bark, 335

Water, 334

Hicoria, 333

Hieracium, 1312

High Bush Huckleberry, 892

High-ground Willow Oak, 350

Hilaria, 68

Hippocratea, 737

HIPPOCRATEACEAE, 737

Hippocratea Family, 737

Hippomane, 705

Hoarhound, 1025

Water, 1048

Hobble-bush, 1121

Hoffmanseggia, 591

Hog Peanut, 651

Hog Plum, 572

Holcophacos, 618

Holcus, 128

Holly, 733

American, 733

Mountain, 733

White, 733

Holly Family, 731

Holosteum, 419

Holy Grass, 114

Homalocenchrus, 112

Honewort, 868

Honey Locust, 589

Honeysuckle, 1125

Bush, 1127

Chinese, 1125

Fly, 1124

Japanese, 1125

Swamp, 883

Wild, 883

Honeysuckle Family, 1120

Hop, 360

Hop Family, 359

Hop-hornbeam, 344

Hop-tree, 676

Hordeum, 158

Hornbeam, 344

Hornwort Family, 428

Horse-balm, 1051

Horsebrier, 281

Horse-chestnut, 739

Horse Gentian, 1123

Horse Mint, 1037, 1045

Horse Plum, 573

Horseradish Tree, 491

Horseradish Tree Family, 491

Horse Sugar, 914

Horsetail, 20

Horsetail Family, 20

Hosackia, 607

Hottonia, 901

Hound's Tongue, 996

Houstonia, 1106, 1325

Huajillo, 576

Huckleberry, 891

Bear, 892

Black, 892 
Huckleberry

Blue, 896

Dwarf, 891

High-bush, 892

Squaw, 893

Tree, 892

Huckleberry Family, 890

Hudsonia, 797

Hugeria, 896

Huisache, 578

Humulus, 360

Hungarian Grass, 107

Hyacinth

Pine, 439

Water, 244

Wild, 267

Hydrangea, 506

Hydrangea Family, 505

Hydranthelium, 1065

Hydrastis, 430

HYDROCHARITACEAE, 47

HYDROCHARITALES, 46

Hydrochloa, 110

Hydrocotyle, 858

Hydrocotyle, 859

Hydrolea, 975

HYDROLEACEAE, 969

Hydrophyllaceae, 969

Hydrophyllum, 970

Hygrophila, 1082

Hymenatherum, 1294

Hymenocallis, 290

Hymenopappus, 1286

HYMENOPHYLLACEAE, 3

Hypelate, 746

HYPERICACEAE, 784

HYPERICALES, 781

Hypericum, 786

Hypericum, 786, 791

Hypopitys, 879

Hypoxis, 286

Hyptis, 1052

Hyssop, 1044

Giant, 1025

Hedge, 1066

Hyssopus, 1044

Hystrix, 160

Ibervillea, 1136

Icacorea, 907

Ichthyomenthia, $f^{-}$)

Ilex, 731

Ilicaceae, 731

Illecebraceae, 399

Illicium, 450

Ill-scented Sumac, 728

Ilysanthes, 1068

Impatiens, 661

Imperata, 54

Indian Apple, 458

Indian Bean, 1095

Indian Cherry, 750

Indian Chickweed, 411

Indian Cucumber-root, 276

Indian Grass, 66

Indian Hemp, 936

Indian Mallow, 763

Indian Physic, 515

Indian Pink, 923

Indian Pipe, 879

Indian-pipe Family, 879

Indian Plantain, 1300, 1302

Indian Poke, 251

Indian Rice, 112
Indian-root, 856

Indian-shot, 307

Indian Strawberry, 520

Indian Tobacco, 1146

Indian Turnip, 226

Indian Wheat, 91

Indigofera, 608

Indigo, Wild, 597

Indigo-plant, 608

Inkberry, 404

Inkwood, 746

Innocence, 1107

Inula, 1238

Iodanthus, 474

Ionactis, 1232

Ionoxalis, 665

Ipecac, American, 515

Ipomoea, 961

Ipomoea, 961, 964

Iresine, 396

Iridaceae, 292

Iris, 305

Crested, 305

Violet, 305

Iron Oak, 355

Iron-weed, 1157

Ironwood, 344, 730, 746, 913

Black, 747

Red, 748

White, 746

Isanthus, 1019

Isnardia, 835

Isocarpha, 1251

Isocoma, 1186

ISOETACEAE, 24

ISOETALES, 24

Isoetes, 24

Isolepis, 187, 188

Isopappus, 1167

Isopyrum, 431

Isotria, 322

Italian Millet, 107

Itea, 508

ITEACEAE, 508

Iva, 1151

Ivy, 855,876

American, 728

Ground, 1026

Poison, 726, 727

Ivy Family, 854

IXIACEAE, 292

Jack-in-the-Pulpit, 226

Jack Oak, 350

Jacquemontia, 965

Jacquinia, 906

Jacquinia Family, 906

Jagged Chickweed, 419

Jamestown Weed, 993

Japanese Honeysuckle, 1125

Japanese Varnish Tree, 781

Jatropha, 706

Jatropha, 706

Jeffersonia, 458

Jersey Pine, 28

Jerusalem Cherry, 981, 990

Jerusalem Oak, 386

Jewel-weed Family, 660

Jimson Weed, 993

Joe-pye Weed, 1169

Joew ood, 906

Johnson Grass, 66

Joint Vetch, 632

Jointweed, 372
Juba's Bush, 398

Judas-tree, 584

JUGLANDACEAE, 332

JUGLANDALES, 332

Juglans, 332

JUNCACEAE, 254

Junco, 672

Junco Family, 671

Juncoides, 261

Juncus, 254

abortivus, 269

acuminatus, 261

aristulatus, 258

Arizonicus, 257

brachycarpus, 260

brachyphyllus, 257

bufonius, 256

Canadensis, 260

debilis, 261

dichotomus, 257

diffusissimus, 260

Dudleyi, 257

effusus, 255

Elliottii, 261

filipendulus, 258

Georgianus, 257

Gerardi, 256

gymnocarpus, 256

interior, 256

marginatus, 256

megacephalus, 259

polycephalus, 259

repens, 256

robustus, 261

Roemerianus, 256

scirpoides, 259

secundus, 256

setaceus, 258

setosus, 258

tenuis, 257

Texanus, 259

Torreyi, 259

trifidus, 256

trigonocarpus, 260

validus, 260

June-berry, 531

June Grass, 153

Juniper, 32

JUNIPERACEAE, 30

Juniper Family, 30

Juniperus, 32

Juniperus, 33

Jussiaea, 838

Justicia, 1087

Justicia, 1087

Kallstroemia, 670

Kalmia, 885

Kalmia, 886

Kalmiella, 886

Karwinskia, 749

Keerlia, 1204

Kentucky Blue Grass, 153

Kentucky Coffee-tree, 589

Kickxia, 1055

King-nut, 335

Knawel, 389

Knawel Family, 389

Kneiffia, 841

Knight's-spur, 433

Knotgrass, 374

German, 389

Knotweed, 374

Koeberlinia, 672 
KOEBERLINIACEAE, 671

Koeleria, 150

Koellia, 1045

Koniga, 478

Koryearpus, 150

Kosteletzkya, 777

Krameria, 592

Krameria Family, 592

KRAMERIACEAE, 592

Kriga, 1318

Kuhnia, 1178

Kuhnistera, 632

Kyllinga, 174

Labiatae, 1017

Lachnocaulon, 234

Laciniaria, 1171

acidota, 1175

Boykinii, 1175

carinata, 1174

Chapmanii, 1176

cylindracea, 1176

cymosa, 1176

Earlei, 1174

elegans, 1172

elegantula, 1174

elongata, 1174

flabellata, 1172

Garberi, 1175

gracilis, 1173

graminifolia, 1173

Halei, 1175

Helleri, 1174

laevigata, 1175

Langloisii, 1176

laxa, 1173

microcephala, 1173

Nashii, 1175

pauciflora, 1176

pilosa, 1173

platylepis, 1174

polyphylla, 1173

punctata, 1175

pycnostachya, 1174

Regimontis, 1174

scariosa, 1172

serotina, 1173

Smallii, 1174

spicata, 1173

squarrosa, 1176

tenuifolia, 1175

vittata, 1173

Lactuca, 1315

Ladies' Slipper, 311.

Ladies' Tresses, 317

Lady's Thumb, 378

Lagenaria, 1137

Lagerstroemia, 827

Laguncularia, 831

Lambkill, 885

Lamb's Quarters, 385

LAMIACEAE, 1016

Lamium, 1029

Lantana, 1013

Laphamia, 1289

Lapithea, 929

Laportea, 357

Lappula, 996

Large Buckeye, 740

Lark-heel, 433

Larkspur

Field, 433

Garden, 433

Lashhorn, 29, 30
Lathyrus, 657

LAURACEAE, 819

Laurel, 452, 886

Black, 794

Great, 884

Poison, 886

Rose Bay, 884

Sheep, $885^{\circ}$

Wild, 914

Laurel Family, 819

Laurel Oak, 350

Laurel Tree, 820

Laurocerasus, 574

Lavauxia, 843

Lavender, Sea, 900

Leaf-eup, 1239

Leather-flower, 439

Leather-wood, 730,818

Leavenw orthia, 482

Lechea, 798

Leersia, 112

Leiophyllum, 882

Leitneria, 336

LEITNERIACEAE, 336

Lemna, 229

Lemna, 231

LEMNACEAE, 229

Lemon, 678

Lemon-balm, 1041

Lentibulariaceae, 1089

Leonotis, 1030

Leonurus, 1029

Leopard Oak, 351

Leopard's-bane, 1300

Lepachys, 1260

Lepidium, 467

Leptamnium, 1093

Leptandra, 1071

Leptilon, 1230

Leptocaulis, 867

Leptochloa, 138

Leptopoda, 1292

Leptorchis, 325

Lepuropetalon, 502

Lespedeza, 640

Lesquerella, 468

Lettuce, 1315

Mountain, 500

Water, 228

White, 1311

Wild, 1314

Wood, 1315 .

Leucaena, 578

LEUCOJACEAE, 285

Leucophyllum, 1055

Leucothoë, 886

Lever-wood, 344

Liatris, 1171

Lignum-vitae, 671

Ligusticum, 872

Ligustrum, 920

Lilac, 916

Lilaeopsis, 871

LILIACEAE, 265

LILIALES, 247

Lilium, 265

Lily

Atamasco, 289

Blackberry, 293

Day, 265

Easter, 289

Prairie, 290

Pond, 457

Spider, 290
Lily

Water, 457

Lily Family, 265

Lily-of-the-Valley, 272

Lily-of-the-Valley Family, 268

Lime, 678

Wild, 675

Lime-tree, 760

LIMNANTHACEAE, 725

Limnanthemum, 933

Limnobium, 48

Limnodea, 69

Limodorum, 321

Limonium, 899

LINACEAE, 661

Linaria, 1056

Linden, 760

Linden Family, 759

Lindera, 821

Lindheimera, 1246

Linn, 760

Linum, 661

Liparis, 325

Lip Fern, 10

Lipocarpha, 162

Lippia, 1012

Lippia, 1012, 1013

Liquidambar, 510

Liquorice, Wild, 1118

Liriodendron, 453

Listera, 320

Lithophila, 398

Lithospermum, 998

Litsea, 821

Live Oak, 353

Liver-leaf, 435

Lizard's-tail, 331

Lizard's-tail Family, 330

Lizard-tail Grass, 57

LOASACEAE, 808

Loasa Family, 808

Lobelia, 1142

Lobelia, 309

LOBELIACEAE, 1142

Lobelia Family, 1142

Loblolly Bay, 794

Loblolly Pine, 28

Locust, 613

Honey, 589

Water, 589

Loeflingia, 417

Loganiaceae, 921

Logania Family, 921

Logwood, 748

Lolium, 158

Lomatium, 875

Long-leaf Pine, 27

Long Moss, 245

Lonicera, 1125

Lonicera, 1124, 1125

Loosestrife, 827, 902, 903

Swamp, 827

Loosestrife Family, 825

Lophanthus, 1025

Lophiola, 286

Lophotocarpus, 42

Lopseed, 1016

Lopseed Family, 1016

LORANTHACEAE, 1101

Lorinseria, 14

Lotoxalis, 666

Lotus, 607

Lotus Family, 455

Louseworts, 1080 
Love Vine, 967

Ludwigia, 835

Ludwigia, 835

Ludwigiantha, 835

Lungwort, 997

Lupine, 603

Lupinus, 603

Luziola, 111

Luzula, 261

Lycium, 992

Lycopersicon, 991

LYCOPODIACEAE, 21

LYCOPODIALES, 21

Lycopodium, 21

Lycopsis, 1001

Lycopus, 1048

Lygodesmia, 1315

Lygodium, 4

Lyme Grass, 159

Lysias, 312

Lysiloma, 577

Lysimachia, 902

LYTHRACEAE, 825

Lythrum, 827

Macbridea, 1027

Machaeranthera, 1228

Maclura, 362

Macranthera, 1072

Macrocalyx, 971

Madder Family, 1105

Madeira Red-wood, 682

Madeira-vine Family, 1322

Magnolia, 451

Magnolia, 451

MagnoliaCEAE, 449

Magnolia Family, 449

Mahogany, 682

Florida, 820

Mahogany Family, 681

Maianthemum, 270

Maidenhair Fern, 8, 9

Maid-of-the-Mist, 445

MALACEAE, 529

Malachodendron, 793

Malachra, 772

Malapoenna, 821

Mallow

False, 768

Indian, 763

Poppy, 766

Rose, 774

Mallow Family, 762

Mallow Rose, 775

Malpighia, 672

MALPIGHIACEAE, 672

Malpigia Family, 672

Malus, 530

Malva, 765

MALVACEAE, 762

Malvales, 759

Malvastrum, 768

Malvaviscus, 773

Mamillaria, 811

Manchineel, 705

Manfreda, 287

Mangrove, 834

Black, 1016

White, 831

Mangrove Family, 833

Manihot, 706

Manisuris, 56

Manisuris, 57

Manna Grass, 154
Maple, 740

Black, 741,742

Bow, 742

Hard, 742

Mountain, 742

Red, 741

River, 741

Rock, 742

Scarlet, 741

Silver, 741

Soft, 741

Striped, 742

Sugar, 742

Swamp, 741

Water, 741

White, 741

Maple Family, 740

Maranta, 1322

MARANTACEAE, 307

Marigold

Bur, 1279

Marsh, 430

Marilaunidium, 973

Marlberry, 907

Marrubium, 1024

Marshallia, 1283

Marsh Elder, 1151

Marsh Fleabane, 1234

Marsh Grass, 132

Marsh-marigold, 430

Marsh Millet, 112

Marsh Parsley, 867

Marsh Pennywort, 858

Marsh Purslane, 835

Marsh Rice, 112

Marsh Rosemary, 900

Marsh St. John's-wort, 792

Marsilea, 19

Marsilea Family, 19

MARSIleaCEAE, 19

Martynia, 1097

MARTYNIACEAE, 1006

Mastic, 910

Matricaria, 1297

Matrimony Vine, 992

Matteucia, 17

Mauchia, 1187

Maurandia, 1057

Maximoviezia, 1135

Mayaca, 231

MAYACACEAE, 231

Mayaca Family, 231

May Apple, 458

May Cherry, 531

Mayflower, 890

May-pop, 807

Maytenus, 735

Mayweed, 1297

Meadia, 905

Meadow-beauty, 823

Meadow-beauty Family, 822

Meadow Garlic, 263

Meadow-gowan, 430

Meadow Grass, 152

Meadow Parsnip, 872

Meadow Queen, 514

Meadow Rue, 445

Meadow-sweet, 514

Mecardonia, 1064

Medeola, 275

Medic, 604

Medicago, 604, 1324

Meehania, 1025

Megapterium, 844
Meibomia, 634

Melampodium, 1239

Melampyrum, 1080

MELANTHACEAE, 248

Melanthera, 1250

Melanthium, 253

Melanthium, 251

MelastomaCEA E, 822

Melia, 681

Meliacea e, 681

Melica, 150

Melic Grass, 150

Melilotus, 604

Melissa, 1041

Melochia, 779

Melon, 1137

Melosmon, 1019

Melothria, 1134

MENISPERMACEA E, 453

Menispermum, 454

Menodora, 916

Menodora, 917

Menodoropsis, 917

Mentha, 1049

Mentzelia, 809

Mentzelia, 809

MENYANTHACEAE, 932

Menziesia, 885

Mercurialis, 699

Meriolix, 845

Mermaid-weed, 850

Mertensia, 997

Mesadenia, 1300

Mesosphaerum, 1052

Mesquite Grass, 136

Metastelma, 950

Metopium, 726

Mexican Persimmon, 909

Mexican Poppy, 462

Mexican Tea, 386

Mezereon Family, 818

Micheliella, 1050

Micrampeles, 1139

Micranthemum, 1069

Micranthes, 500

Micromeria, 1042

Microstylis, 324

Midas' Ears, 228

Mikania, 1170

Milfoil, 1297

Water, 850

Milk Pea, 648

Milkweed, 941

Green, 940

Milkweed Family, 937

Milkwort, 683

Fringed, 685

Milkwort Family, 682

Millet

Ditch, 74

Italian, 107

Marsh, 112

Texas, 91

Water, 112

Mimosa, 581

Mimosacea e, 575

Mimosa Family, 575

Mimulus, 1062

Mimusops, 913

Mint, 1049

Horse, 1037, 1045

Mountain, 1045

Stone, 1048

Mint Family, 1016 
Mirabilis, 405

Mission Grass, 110

Missouri Currant, 512

Mist-flower, 1169

Mistletoe, 1102

Mistletoe Family, 1101

Mitchella, 1114

Mitella, 505

Mitreola, 923

Mitrewort, 505, 923

False, 502

Moccasin Flower, 311, 123

Mock Apple, 1139

Mock Orange, 912, 507

Modiola, 276

Mohrodendron, 915

Mollugo, 411

Momisia, 366

Momordica, 1136

Monanthochloë, 140

Monarda, 1036

Monkey-flower, 1062

Monkshood, Wild, 434

Monniera, 1063

Monniera, 1064

MONOCOTYLEDONES, 34

Monotropa, 879

MONOTROPACEAE, 879

Monotropsis, 880

Monoxalis, 665

Moon-seed, 454

Moonseed Family, 453

Moonwort, 2

Moose-wood, 818

Morella, 337

MORINACEAE, 1130

Morinda, 1114

Moringa, 491

MORINGACEAE, 491

Morning-glory, 961, 964 Red, 961

Morning-glory Family, 958

Morongia. 580

Mortonia, 737

Morus, 360

Moss

Florida, 245

Flowering, 897

Long, 245

Spanish, 245

Moss Pink, 978

Mossy-cup Oak, 355

Motherwort, 1030

Mountain Alder, 346, 742

Mountain Ash, 529

Mountain Azalea, 883

Mountain Bluberery, 896

Mountain Cedar, 33

Mountain Cranberry, 897

Mountain Grape, 754

Mountain Holly, 733

Mountain Lettuce, 500

Mountain Maple, 742

Mountain Mint, 1045

Mountain Oak, 353

Mountain Sumac, 728

Mouse-ear Chickweed, 423

Mouse-ear Cress, 475

Mouse-tail, 440

Mozinna, 705

Mud Plantain, 243, 244

Mugwort, 1298

Muhlenbergia, 120

Mulberry, 361
Mulberry

Paper, 362

Múlberry Family, 360

Mullen, 1054

Munroa, 140

Muricauda, 227

Muscadinia, 726

Museniopsis, 866

Muskmelon, 1137

Musquash-root, 868

Mustang Grape, 756

Mustard

Black, 476

Hedge, 473

Tansy, 485

White, 476

Wild, 477

Wormseed, 476

Mustard Family, 465

Myginda, 736

Myosotis, 997

Myosurus, 440

Myrica, 337

MYRICACEAE, 336

Myricales, 336

Myriophyllum, 850

Myrsine, 907

Myrsine Family, 906

MYRTACEAE, 831

MYRTALES, 822

Myrtle

Sand, 882

Myrtle Family, 831

Myzorrhiza, 1093

Nabalus, 1310

NaIAdaCeaE, 39

NaIAdales, 36

Naias, 39

Naias Family, 39

Nailwort, 400

Naked Stopper, 832

Nakedwood, 832

Naked-wood, 752

Nama, 974

Nama, 975

Nanny-berry, 1125

Nasturtium, 472

Nazia, 68

Nectandra, 820

Needle Palm, 224

Negundo, 743

Nelumbo, 455

NELUMBONACEAE, 455

Nemastylis, 292

Nemexia, 280

Nemophila, 970

Nepeta, 1025

Nepeta, 1026

Nephrolepis, 17

Nephropetalum, 781

Neptunia, 582

Nerium, 936

Nesaea, 827

Nestronia, 1103

Nettle, 356

Dead, 1029

False, 358

Hedge, 1030

Hemp, 1029

Spurge, 706

Wood, 357

Nettle Family, 356

Neviusia, 524
New Jersey Tea, 751

New Zealand Spinach, 413

Nicandra, 981

Nicotiana, 994

Nightshade

Common, 989

Enchanter's, 849

Nimble Kate, 1140

Ninebark, 513

Nintooa, 1125

Nodding-cap, 323

Nolina, 274

Nondo, 872

Notholaena, 11

Nothoscordium, 264

Nuphar, 456

Nut Pine, 29

Nut Rush, 199

Nyctaginia, 408

Nymphaea, 456

Nymphaea, 457

NYMPHAEACEAE, 456

Nyssa, 852

NysSACEAE, 851

Oakesia, 271

Oakesiella, 271

Oak

Barren, 350

Basket, 354

Bastard, 353

Bear, 352

Black, 352

Bur, 355

Chestnut, 344

Chinquapin, 354

Cow, 354

Ground, 570

High-ground Willow, 350

Iron, 355

Jack, 350

Laurel, 350

Leopard, 351

Live, 353

Mossy-cup, 355

Mountain, 353

Overcup, 355

Pin, 350

Poison, 726, 727

Post, 355

Red, 351, 352

Rock Chestnut, 354

Running, 352

Scarlet, 351

Serub, 352

Scrub Chestnut, 354

Shin, 354

Shingle, 350

Spanish, 352, 351

Swamp, 351

Swamp Post, 355

Swamp White, 354, 355

Switch, 353

Turkey, 351

Water, 350

White, 354, 355

Willow, 350

Yellow, 354

Oak Fern, 17

Oat, 130

False, 129

Sea, 125

Water, 112

Wild, 67 
Oat Grass, 131

Obolaria, 932

Oceanoros, 252

Ocimum, 1053

Ocotea, 820

Odontonychia, 401

Oenothera, 840

Oenothera, 840, 841, 842, 843, $844,845,846$

Ogeeche Plum, 852

Ohio Buckeye, 740

Oil-nut, 1103

Okra, 776

OLACACEAE, 1103

Oldenlandia, 1106

Old-field Pine, 28

Old Man's Beard, 920

OLEACEAE, 916

OLEALES, 916

Oleander, 936

Oleaster Family, 819

Oligoneuron, 1188

Olive

Wild, 910, 920

Olive Family, 916

Olyra, 110

Onagra, 839

Onagraceae, 834

Onion, 262

Wild, 263

Onion Family, 262

Onoclea, 14

Onoclea, 17

Onosmodium, 1000

OPHIOGLOSSALES, 1

Ophioglossum, 1

Ophioglossum, 2

Opium Poppy, 461

Oplismenus, 84

Opopanax, Yellow, 578

Opossum Wood, 915

Opulaster, 513

Opuntia, 815

OPUNTIACEAE, 810

OPUNTIALES, 808

Orache, 386

Orange

Bitter-sweet, 678

Mock, 507

Osage, 361

Sweet, 678

Orange-grass, 791

Orange-root, 430

Orchard Grass, 152

ORCHIDACEAE, 309

ORCHIDALES, 308

Orchid Family, 309

Orehis

Crane-fly, 327

Fringed, 313

Showy, 312, 313

Tree, 327

Orchis, 312

Oreodoxa, 225

Ornithopteris, 4

OROBANCHACEAE, 1092

Orobanche, 1093

Orontium, 228

Orpine Family, 496

Ortachne, 119

Oryza, 112

Osage Orange, 361

Osmanthus, 920

Osmia, 1163
Osmorrhiza, 864

Osmunda, 3

OSMUNDACEAE, 3

Ostrich Fern, 17

Ostrya, 344

Oswego Tea, 1036

Otophylla, 1075

Overcup Oak, 355

OXALIDACEAE, 664

Oxalis, 664

Oxalis, 665, 666, 667

Oxybaphus, 406

Oxycoceus, 897

Oxydendron, 890

Oxypolis, 874

Oxytria, 268

Oyster Plant, 1318

Pachysandra, 724

Pachystima, 735

Padus, 573

Paepalanthus, 235

Painted-cup, 1079

Palafoxia, 1288

Palm

Coco, 225

Coco-nut, 225

Needle, 224

Royal, 225

Palma Christi, 705

Palmae, 221

Palmetto, 223

Blue, 224

Cabbage, 223

Dwarf, 223

Saw, 224

Scrub, 223

Palm Family, 221

Panax, 855

PANDANALES, 34

Panicularia, 154

Panicum, 85

agrostoides, 93

albomarginatum, 98

amarum, 93

angustifolium, 95

annulum, 96

arenicola, 95

Ashei, 102

Atlanticum, 101

Baldwinii, 97

barbulatum, 96

brachyanthum, 91

capillare, 92

capillarioides, 93

Chapmanii, 91

chrysopsidifolium, 100

ciliatum, 94

ciliatissimum, 91

ciliiferum, 101

ciliosum, 99

clandestinum, 103

Combsii, 93

Commonsianum, 101

commutatum, 103

cognatum, 92

condensum, 93

consanguineum, 95

curtifolium, 97

curtivaginum, 97

Cuthbertii, 97

depauperatum, 94

dichotomum, 96

diffusum, 92
Panicum

digitarioides, 91

Earlei, 96

ensifolium, 97

epilifolium, 101

equilaterale, 102

erectifolium, 100

fasciculatum, 91

filiculme, 99

filipes, 92

flavovirens, 98

flexile, 92

fuscum, 91

Gattingeri, 92

glabrifolium, 94

glabrissimum, 98

gracilicaule, 98

Hallii, 92

halophilum, 93

Helleri, 102

inflatum, 100

Joorii, 103

lanuginosum, 99

latifolium, 104

laxiflorum, 95

leucothrix, 99

linearifolium, 94

Lindheimeri, 100

longiligulatum, 98

lucidum, 97

macrocarpon, 104

malacon, 102

malacophyllum, 103

Manatense, 102

Mattamuskeetense, 96

miliaceum, 92

molle, 90

mutabile, 103

maximum, 93

Nashianum, 95

nemopanthum, 96

neuranthum, 95

nitidum, 99

nudicaule, 97

obtusum, 90

octonodum, 98

oligosanthes, 103

ovale, 102

parvispiculum, 99

paspaloides, 90

patentifolium, 95

paucipilum, 98

pedicellatum, 101

perlongum, 94

pernervosum, 103

Philadelphicum, 92

polyanthes, 100

polycaulon, 94

Porterianum, 104

proliferum, 92

prostratum, 90

pseudanceps, 93

pseudopubescens, 100

pubifolium, 104

pyriforme, 95

ramisetum, 91

Ravenelii, 104

repens, 93

Reverchonii, 91

Roanokense, 95

rostratum, 94

scabriusculum, 102

scoparium, 102

Scribnerianum, 103 
Panieum

sphaerocarpon, 100

sphagnicola, 97

stenodes, 92

stipitatum, 94

strictifolium, 101

strigosum, 94

Tennesseense, 99

Texanum, 91

Thurowii, 99

trifolium, 98

unciphyllum, 100

verrucosum, 91

villosissimum, 101

virgatum, 93

Webberianum, 96

Wrightianum, 97

xanthospermum, 101

Yadkinense, 96

Panicum, 80, 82, 83, 104, 105

Papaver, 461

Papaveraceae, 460

Papaverales, 460

Papaw, 449, 806

Papaw Family, 805

Papayaceae, 805

Paper Mulberry, 362

Papilionaceae, 593

Pappophorum, 140

Paradise Flower, 578

Paradise-tree, 680

Parietaria, 359

Parkinsonia, 589

Parnassia, 499

Parnassiaceae, 498

Paronychia, 399

Paronychia, 401

Parosela, 626

Parsley

Hedge, 864

Hemlock, 873

Marsh, 867

Sand, 867

Parsnip

Cow, 876

Meadow, 872

Water, 870

Wild, 875

Parsonsia, 829

Parthenium, 1247

Parthenocissus, 758

Partridge-berry, 1114

Pascalia, 1262

Paspalum, 69

altissimum, 75

amplum, 77

angustifolium, 74

australe, 74

bifidum, 77

blepharophyllum, 71

Blodgettii, 75

Boscianum, 75

Buckleyanum, 76

Chapmanii, 72

ciliatifolium, 72

circulare, 74

conjugatum, 77

Curtisianum, 77

dasyphyllum, 74

difforme, 75

dilatatum, 77

distichum, 78

Eggertii, 72

elatum, 73
Paspalum

epile, 72

Floridanum, 76

geminum, 75

giganteum, 76

glaberrimum, 76

glabratum, 76

gracillimum, 73

Hallii, 75

Kearneyi, 77

Kentuckiense, 72

laeve, 74

laeviglume, 75

latifolium, 73

lividum, 76

longepedunculatum, 72

longieilium, 76

longipilum, 74

membranaceum, 71

mueronatum, 71

Muhlenbergii, 73

plicatulum, 75

praecox, 76

praelongum, 74

propinquum, 71

pubescens, 73

rigidifolium, 72

serobiculatum, 74

setaceum, 73

Simpsonii, 74

solitarium, 77

stramineum, 72

tardum, 76

vaginatum, 78

Vaseyanum, 77

villosissimum, 73

Paspalum, 78, 79

Passiflora, 806

Passifloraceate, 806

PAssiflorales, 805

Passion-flower, 807

Passion-flower Family, 806

Pastinaca, 875

Paulownia, 1062

Pavonia, 773

Pea

Butterfly, 651, 652

Cow, 645

Milk, 648

Sensitive, 586

Peach, 570

Pea Family, 593

Pear, 529

Alligator, 820

Avacado, 820

Prickly, 815

Pearly Everlasting, 1237

Pearlwort, 419

Pea Vine, 655

Pecan, 334

Pectis, 1296

Pedicellaria, 489

Pedicularis, 1080

Pellaea, 9

Pellitory, 359

Peltandra, 227

Pencil-flower, 633

Penicillaria, 110

Pennisetum, 109

Pennyroyal, 1039

False, 1019

Pennywort, 932

Marsh, 858

Water, 858
Penthoraceate, 498

Penthorum, 498

Pentodon, 1109

Pentstemon, 1059

Peperomia, 331

Pepperbush 877

Sweet, 877

Pepper Family, 331

Peppergrass, 467

Peppermint, 1050

Pepperidge, 852

Pepper-vine, 758

Pepper Wood, 675

Peramium, 321

Perezia, 1309

Perilla, 1051

Periploca, 938

Periwinkle, 935

Perizoma, 991

Persea, 819

Persicaria, 376

Persimmon, 908

Black, 909

Mexican, 909

Perularia, 312

Petalostemon, 628

Petalostemon, 632

Petiveria, 403

Petiveriace $\mathrm{E}, 403$

Petunia, 995

Phaca, 619

Phacelia, 971

Phalaris, 113

Phanopyrum, 104

Pharbitis, 964

Pharus, 111

Phaseolus, 652

Phaseolus, 654

Phegopteris, 17

Phellopterus, 874

Philadelphus, 506

Philibertella, 938

Philotria, 47

Philoxerus, 398

Phlebodium, 7

Phleum, 122

Phlox, 976

Phlox Family, 976

Phoradendron, 1102

Phragmites, 141

Phryma, 1016

Phry máceae, 1016

Phyla, 1011

Phyllanthus, 691

Phymatodes, 7

Physalis, 981

Physalodes, 981

Physocarpus, 513

Physostegia, 1027

Physurus, 320

Phytolacea, 404

Phytolaccaceae, 403

Piaropus, 244

Picea, 29

Pickerel-weed, 244

Pickerel-weed Family, 243

Picradenia, 1289

Picramnia, 680

Pieris, 888

Pigeon-berry, 404

Pigeon Cherry, 571

Pig-nut Hickory, 335

Pigweed, 384, 390

Pilea, 357 
Pilularia, 19

Pimpernel, 869, 905

False, 905, 1068

Water, 901

Pinaceae, 26

Pinales, 26

Pinaropappus, 1315

Pin Cherry, 571

Pinckneya, 1106

Pine

Cedar, 28

Georgia, 27

Ground, 22

Jersey, 28

Loblolly, 28

Long-leaf, 27

Nut, 29

Old-field, 28

Pitch, 28

Pond, 28

Poverty, 28

Prince's, 879

Sand, 28

Scrub, 28

Slash, 28

Spruce, 28, 30

Table-mountain, 29

Walter's, 28

White, 28, 29

Yellow, 27, 28

Yew, 29

Pine-apple Family, 244

Pine Family, 26

Pine Hyacinth, 439

Pine Needle, 660

Pine-sap, 880

Sweet, 880

Pine-tassle, 791

Pine-weed, 791

Pinguicula, 1089

Pinguiculaceae, 1089

Pink, 424

Carolina, 923

Fire, 427

Ground, 978

Hedge, 425

Indian, 923

Moss, 978

Wild, 427

Pink Family, 424

Pink-root, 923

Pin Oak, 351

Piñon, 29

Piscidia, 620

Pisonia, 410

Pistia, 228

Pinus, 27

Pinus, 29

Pin-weed, 798

Piperaceae, 331

Piperales, 330

Pipewort, 236

Hairy, 234

Pipewort Family, 234

Pipsissewa, 879

Piriqueta, 794

Pitcheria, 643

Pitcher-plant, 493

Pitcher-plant Family, 493

Pitch Pine, 28

Pithecolobium, 575

Pithecolobium, 576

Planera, 364

Planer Tree, 364
Plane-tree, 512

Plane-tree Family, 512

PlantaginaCEAE, 1097

Plantaginales, 1097

Plantago, 1097

Plantain, 1098

Indian, 1300, 1302

Mud, 243, 244

Rattlesnake, 321

Water, 41

Plantain Family, 1097

Platanaceae, 512

Platanthera, 312, 313

Platanus, 512

Platypus, 329

Pleea, 249

Pleurisy-root, 942, 943

Pluchea, 1234

Plum

Bullace, 572

Chickasaw, 573

Coca, 570

Darling, 748

Downward, 911

Gopher, 570

Guiana, 693

Hog, 572

Horse, 573

Ogeeche, 852

Red, 573

Saffron, 911

Sand, 572

Sow, 572

Wild Goose, 573

Wild Yellow, 573

Plumbaginaceae, 699

Plumbago, 899

Plumbago Family, 899

Plume Aster, 1214

Plume Grass, 54

Plum Family, 569

Plum Grape, 756

Plyllitis, 14

Poa, 152

Poaceae, 48

POALES, 48

Podophyllaceae, 458

Podophyllum, 458

Podostemaceae, 495

Podostemon, 495

Podostigma, 939

Pogonia, 323

Pogonia, 323

Poinciana, 590

Poinciana, 590

Poinsettia, 731

Poison Dogwood, 727

Poison Elder, 727

Poison Ivy, 726, 727

Poison Laurel, 886

Poison Oak, 726, 727

Poison Sumac, 727

Poisonwood, 703, 726

Poke, 404

Indian, 251

Pokeweed Family, 403

Polanisia, 489

Polanisia, 488

Polecat-tree, 750

Polemoniaceae, 976

Polemoniales, 956

Polemonium, 980

Polycarpon, 418

Polycodium, 893
Polygala, 682

alba, 686

ambigua, 687

Baldwinii, 689

Boykinii, 686

brevifolia, 688

Chapmanii, 686

cruciata, 688

Curtissii, 687

cymosa, 689

grandiflora, 684

Harperi, 688

Hookeri, 688

Hugeri, 686

incarnata, 685

leptostachys, 687

Lewtonii, 685

Lindheimeri, 684

lutea, 689

Mariana, 687

nana, 688

Nuttallii, 687

ovatifolia, 684

paludosa, 686

paucifolia, 685

polygama, 685

puberula, 684

ramosa, 689

Rugelii, 689

Senega, 685

setacea, 685

sparsifolia, 686

Texensis, 684

Tweedyi, 684

verticillata, 687

viridescens, 687

Polygalaceae, 682

Polygalales, 682

Polygonaceae, 367

Polygonales, 366

Polygonatum, 272

Polygonella, 372

Polygonella, 373

Polygonum, 374

Polygonum, 376, 381, 382

Polymnia, 1239

Polyodon, 137

PolyPodiaceae, 5

Polypodium, 6

Polypodium, 7

Polypody, 6

Polypogon, 125

Polypompholyx, 1090

Polypremum, 924

Polypteris, 1287

Polystachya, 329

Polytaenia, 873

Polystichum, 15

Pomaceae, 529

Pomegranate Family, 829

Pomegranate, 830

Pond Cypress, 31

Pond Lily, 457

Pond Pine, 28

Pond Rush, 191

Pondweed, 37

Pondweed Family, 36

Pontederia, 244

Pontederiaceae, 243

Ponthieva, 321

Poor Man's Weather-glass, 905

Pop Ash, 918

Poplar, 338

White, 453 
Poppy, 461 Celandine, 461 Garden, 461 Mexican, 462 Opium, 461 Prickly, 462 Rock, 461 Yellow, 461 Poppy Ash, 918 Poppy Family, 460 Poppy Mallow, 766 Populus, 338 Porlieria, 671 Porteranthus, 515 Portulaca, 415

Portulacaceae, 413

Possum Haw, 732

Possumwood, 908

Post Oak, 355

Potamogeton, 37

Potato Family, 980

Potentilla, 521

Poterium, 526

Poverty Grass, 114, 115

Poverty Pine, 28

Powder-horn, 424

Prairie-clover, 628

Prairie Lily, 290

Prairie Rose, 526

Prenanthes, 1311

Prickly Ash, 674, 675

Prickly Pear, 815

Prickly Poppy, 462

Pride-of-India, 681

Primrose, 843, 844, 845

Evening, 839, 840, 841

Primrose Family, 900

Primulaceae, 900

Primulales, 898

Prince's Feather, 380

Prince's Pine, 879

Prionopsis, 1185

Priva, 1013

Privet, 920

Prosartes, 271

Proserpinaca, 849

Prosopis, 583

Proteaceae, 818

Protea Family, 818

Proteales, 817

Prunella, 1026

Prunus, 570

Prunus, 573

Pseudophoenix, 225

Psidium, 833

Psilactis, 1206

Psilocarya, 189

Psilotaceae, 23

Psilotum, 23

Psilotum Family, 23

Psoralea, 620

Psychotria, 1113

Ptelea, 676

PTERIDOPHYTA, 1

Pteridium, 8

Pteris, 8

Pteris, 8

Pterocaulon, 1236

Ptilimnium, 870

Puccoon, 460, 998

Pumpkin, 1138

Pumpkin Ash, 918

Punica, 830

Punicaceae, 829
Purple Haw, 74s

Purple Rocket, 474

Purple Slipper, 312

Purple Virgin's Bower, 40

Purslane, 416

Marsh', 835

Sea, 413

Water, 825

Purslane Family, 413

Pussley, 416

Putty-root, 326

Pycnanthemum, 1045

Pyenothymus, 1042

Pyrola, 878

Pyrolaceae, 878

Pyrrhopappus, 1314

Pyrularia, 1103

Pyrus, 529

Pyrus, 531

Pyxidanthera, 897

Pyxie, 897

Quamasia, 267

Quamoclit, 961

Quassia Family, 679

Queen of the Prairie, 523

Queenroot, 704

Queen's Delight, 704

Quercitron, 352

Quercus, 348, 1322

Quillwort, 24

Quillwort Family, 24

Quincula, 987

Quitch Grass, 158

Rabbit Tobacco, 1238

Ragweed, 1150, 1320

Ragweed Family, 1148

Ragwort, 1302

Ramie, 359

RANALES, 428

Randia, 1110

RANUNCULACEAE, 429

Ranunculus, 441

Ranunculus, 440

Rapanea, 907

Raspberry, 515

Black, 516

Red, 517

Ratibida, 1260

Rat-tail Grass, 56

Rattle-box, 601, 915

Rattlesnake Plantain, 321

Rattlesnake-root, 1311

Rattle-wood, 432

Red Ash, 918

Red Baneberry, 432

Red Bay, 820

Red Birch, 345

Red Buckeye, 739

Red bud, 584

Red Cedar, 33

Redfieldia, 144

Red Gum, 510

Red Ironwood, 748

Red Maple, 741

Red Morning-glory, 961

Red Oak, 351, 352

Red Plum, 573

Red Raspberry, 517

Red-root, 307, 751

Red Titi, 730

Red-top, 126, 142

Red-wood, Madeira, 682
Reed, 161

Bur, 35

Cane, 161

Common, 141

Sea Sand, 128

Reed Grass, 125, 128

Reed Mace, 35

Reeds, 112

Reimaria, 69

Remirea, 191

Reverchonia, 693

Reynosia, 748

Rhabdadenia, 937

Rhamnaceae, 747

RHAMNALES, 747

Rhamnidium, 747

Rhamnus, 750

Rhaphis, 67

Rhapidophyllum, 224

Rhexia, 822

RHINANTHACEAE, 1053

Rhizophora, 833

RHIZOPHORACEAE, 833

Rhombolytrum, 146

Rhododendron, $\mathbf{8 8 4}$

Rhododendron, 884

Rhus, 726

Rhus, 726, 728

Rhynchosia, 643

Ribes, 510

Rib-grass, 1100

Rice, 112

Indian, 112

Marsh, 112

Wild, 112

Rice Cut-grass, 112

Rice Grass, 112

Richardia, 1114

Richweed, 357

Ricinella, 699

Ricinus, 705

Riedlea, 780

River Birch, 345

River Maple, 741

Riverside Grape, 755

Riverweed Family, 495

Rivina, 403, 1322

Robinia, 613

Rock Cress, 483

Rock Chestnut Oak, 354

Rocket, 474, 475

Purple, 474

Sea, 477

Rock Geranium, 503

Rock Maple, 742

Rock Poppy, 461

Rock-rose Family, 795

Roripa, 472

Rosa, 526

ROSACEAE, 512

ROSALES, 484

Rose, 526

Climbing, 526

Corn, 428

Mallow, 775

Prairie, 526

Rose Bay Laurel, 884

Rose Family, 512

Rose-lip, 324

Rose-mallow, 774

Swamp, 775

Rose-of-Sharon, 775

Rosin-weed, 1240

Rotala, 826 
Rottboellia, 56

Rough Bedstraw, 1119

Rouliniella, 951

Rouliniella, 951

RoXBURGHiACEAE, 279

Roxburghia Family, 279

Royal Fern, 4

Royal Palm, 225

Roystonia, 224

Rubacer, 515

RUBIACEAE, 1105

RUBIALES, 1104

Rubus, 515

Rubus, 515

Rudbeckia, 1253

acuminata, 1256

alismaefolia, 1255

amplectens, 1259

Beadlei, 1258

bicolor, 1258

Brittonii, 1259

Chapmanii, 1255

divergens, 1259

flexuosa, 1258

Floridana, 1259

foliosa, 1256

fulgida, 1256

glabra, 1255

graminifolia, 1257

grandiflora, 1255

Heliopsidis, 1254

heterophylla, 1254

hirta, 1258

laciniata, 1254

longipes, 1259

maxima, 1255

Missouriensis, 1257

Mohrii, 1257

mollis, 1255

monticola, 1259

nitida, 1255

palustris, 1256

pinnatiloba, 1258

rupestris, 1258

sericea, 1259

spathulata, 1256

speciosa, 1257

subtomentosa, 1254

Sullivantii, 1256

tenax, 1257

triloba, 1257

truncata, 1257

umbrosa, 1255

Rue

False, 431

Goat's, 609

Wind, 436

Rue Anemone, 436

Rue Family, 673

Ruellia, 1083

Rulac, 742

Rum Cherry, 574

Rumex, 368

Running Oak, 352

Ruppia, 36

Rush, 254

Beak, 191

Club, 176

Grass, 122

Nut, 199

Pond, 191

Spike, 180

Twig, 191

White, 132
Rush

Wood, 261

Rush Family, 254

Ruta, 674

RUTACEAE, 673

Rye Grass, 158

Rynchospora, 191, 1321

alba, 194

axillaris, 195

Baldwinii, 196

brachychaeta, 196

caduca, 197

Chapmanii, 194

ciliata, 196

compressa, 197

corniculata, 193

Curtissii, 195

cymosa, 197

decurrens, 198

distans, 196

divergens, 193

dodecandra, 196

Earlei, 197

fascicularis, 196

filifolia, 195

fusca, 1321

fuscoides, 195

glomerata, 194

gracilenta, 195

Grayi, 196

Indianolensis, 193

inexpansa, 198

intermedia, 194

leptorhyncha, 195

microcarpa, 196

microcephala, 195

miliacea, 198

mixta, 197

oligantha, 194

pallida, 194

patula, 197

perplexa, 197

Plankii, 196

plumosa, 194

prolifera, 196

punctata, 198

pusilla, 193

rariflora, 196

schoenoides, 198

semiplumosa, 194

Smallii, 1321

solitaria, 193

stenophylla, 198

stipitata, 198

Torreyana, 197

Tracyi, 193

Sabal, 222

Sabbatia, 926

Sabina, 32

Sacciolepis, 105

Saffron Plum, 911

Sage, 1033

Sageretia, 749

Sagina, 419

Sagittaria, 42

Sagittaria, 42

St. John's-wort, 786

Salad, Corn, 1128

SALICACEAE, 338

SALICALES, 338

Salicornia, 388

Salix, 340

Salomonia, 272
Salsify, 1318

Salsola, 389

Salt Meadow Grass, 132

Salt Reed Grass. 132

Saltwort, $389, \leq 04$

Salvia, 1032

Salviastrum, 1035

SAlviniaceae, 20

Salvinia Family, 20

Salviniales, 19

Sambucus, 1120

Samolus, $908=9 \circ$ ?

Samphire, 388

Sand Bur, 108

Sand Grape, 754

Sand Grass, 60,144

Sand Myrtle, 882

Sand Parsley, 867

Sand Pine, 28

Sand Plum, 572

Sand Spur, 108

Sand Spurry, 418

Sandwort, 421

Sang, 855

Sanguinaria, 460

Sanguisorba, 525

Sanicula, 859

SANTALACEAE, 1102

SANTALALES, 1101

Sanvitalia, 1248

SAPINDACEAE, 743

SAPINDALES, 723

Sapindus, 745

Sapium, 703

Sapodilla, Wild, 913

Sapodilla Family, 909

Sapónaria, 425

SAPOTACEAE, 909

Sarothra, 791

Sarracenia, 493

SARRACENIACEAE, 493

SARRACENIALES, 491

Sarsaparilla, 855

Wild, 856

Sassafras, 820,821

Sassafrax, 821

Satinleaf, 909

Satin-wood, 675

Satureia, 1042

SAURURACEAE, 330

Saururus, 330

Savastana, 114

Savin, 33

Saw-grass, 191

Saw Palmetto, 224

Saxifraga, 501, 502

SAXIFRAGACEAE, 499

Saxifrage, 500

Golden, 505

Saxifrage Family, 499

Scaevola, 1147

Scarlet Maple, 741

Scarlet Oak, 351

Scarlet Sumac, 729

Schaefferia, 736

Schaueria, 1089

Schedonnardus, 136

SCHEUCHZERIACEAE, 40

Schizachyrium, 58

SCHIZAEACEAE, 4

Schizandra, 450

Schoenocaulon, 250

Schoenolirion, 268

Schoenus, 190 
Sehoepfia, 1104 Schmaltzia, 727

Schrankia, 580

Schwalbea, 1081

Schweinitzia, 880

Seirpus, 176

Scirpus, 180

SCITAMINALES, 307

SCleranthaCEAE, 389

Scleranthus, 389

Scleria, 199

Sclerocarpus, 1250

Sclerolepis, 1162

Scoke, 404

Scolopendrium, 14

Seoparia, 1070

Scorpion-grass, 997

Scouring Rush, 21

Scrophularia, 1057

Scrophulariaceae, 1053

Scrub Chestnut Oak, 354

Scrub Oak, 352

Scrub Palmetto, 223

Scrub Pine, 28

Scurvy-grass, 475

Scutellaria, 1020

Sea Ash, 675

Sea-grape, 383

Sea-island Cotton, 778

Sea Lavender, 900

Sea Oats, 152

Sea Ox-eye, 1262

Sea Purslane, 413

Sea Rocket, 477

Sea Sand Reed, 128

Sebastiana, 703

SEDACEAE, 496

Sedge, 201

Sedge Family, 161

Sedum, 496

Seed-bearing Plants, 25

Selaginella, 23

SELAGINELLACEAE, 23

Salaginella Family, 23

Selenia, 486

Senebiera, 467

Seneca Snakeroot, 685

Senecio, 1302

Senna, 585

Senna Family, 583

Sensitive Fern, 15

Sensitive Pea, 586

Sensitive Plant, 586

Septilia, 1064

Serenoa, 223

Sericocarpus, 1206

Serinea, 1319

Serjania, 743

Service-berry, 531

Sesban, 614

Sesbania, 614

Sesuvium, 413

Setaria, 105

Seutera, 952

Seymeria, 1072, 1073

Shag-bark, 335 Big, 335

She Balsam, 30

Sheep Laurel, 885

Sheep Sorrel, 369

Shell-bark Hickory, 335

Shepherd's Purse, 467

Shepherd's Weather-glass, 905

Shield-fern, 15
Shingle Oak, 350

Shin-leaf, 878

Shin Oak, 354

Shittimwood, 912, 913

Shooting star, 905

Shore-grape, 383

Shore Grass, 110

Shortia, 898

Showy Orehis, 312,313

Shrub Yellow-root, 431

Shrubby Althaea, 775

Shrubby Bittersweet, 735

Shrubby Buckeye, 740

Shrubby Trefoil, 676

Sibbaldiopsis, 519

Sicyos, 1139

Sida, 769

Sideranthus, 1185

Siderocarpos, 576

Sideroxylon, 909

Side-saddle Flower, 493

Sieversia, 523

Silene, 425

Silk Vine, 938

Silphium, 1240

Silphium, 1246, 1262

Silverbell Tree, 915

Silver Fir, 30

Silver Maple, 741

Simaruba, 679

SimarUbaCEAE, 679

Simmon, 908

Sinapis, 476

Sinapis, 476

Siphonella, 1129

Siphonoglossa, 1086

Siphonychia, 402

Siphonychia, 402

Sisymbrium, 473

Sisymbrium, 475, 485

Sisyrinchium, 293

Sitanion, 159

Sitilias, 1314

Sium, 869

Sium, 875

Skulcap, 1020

Skunk Bush, 728

Skunk Cabbage, 228

Skunk Grass, 148

Slash Pine, 28

Sleepy Catchfly, 426

Slippery Elm, 364

Small Cane, 104

Smart Weed, 376

SmilacaceaE, 280

Smilacina, 269:

Smilax, 280, 281

Smilax, 280

Smilax Family, 280

Smoke Tree, 726

Smooth Alder, 346

Smooth Sumac, 728, 729

Snakeroot, 860,1133

Black, 432, 860

Button, 861, 1171

Seneca, 685

Snapdragon, 1055

Sneezeweed, 1290

Snowberry, 896, 1124

Snowdrop Tree, 915

Soapberry, 745

Soapberry Family, 743

Soapwort, 425

Soft Maple, 741
Solanaceat, 980

Solanum, 988

Soldier's-cap, 464

Solidago, 1189

amplexicaulis, 1196

angustifolia, 1195

arguta, 1199

asterifolia, 1192

austrina, 1200

bicolor, 1193

Boottii, 1198

brachyphylla, 1196

Buckleyi, 1192

Canadensis, 1201

caesia, $\mathbf{1 1 9 2}$

celtidifolia, 1198

Chapmanii, 1196

Chrysopsis, 1194

Curtisii, 1192

delicatula, 1199

dispersa, 1194

Drummondii, 1202

Earlei, 1197

Elliottii, 1198

erecta, 1198

fistulosa, 1197

flaccidifolia, 1192

flavovirens, 1196

flexicaulis, 1192

Gattingeri, 1200

glomerata, 1193

gracillima, 1199

Helleri, 1198

hispida, 1193

juncea, 1199

lancifolia, 1192

Leavenworthii, 1195

Lindheimeriana, 1195

longipetiolata, 1201

Ludoviciana, 1199

microphylla, 1198

Missouriensis, 1200

mollis, 1201

monticola, 1193

Nashii, 1201

neglecta, 1200

nemoralis, 1201

odora, 1196

pallescens, 1197

patula, 1196

pendula, 1197

petiolaris, 1193

pinetorum, 1200

plumosa, 1194

Porteri, 1194

pubens, 1192

puberula, 1195

pulverulenta, 1195

radula, 1201

rigidiuscula, 1194

rugosa, 1197

rupestris, 1201

salicina, 1196

sempervirens, 1195

serotina, 1200

Shortii, 1200

speciosa, 1194

spithamea, 1195

squarrosa, 1193

stricta, 1195

strigosa, 1198

tortifolia, 1197

uliginosa, 1194

ulmifolia, 1198 
Solidago

Vaseyi, 1199

verna, 1195

Wardi, 1193

Yadkinensis, 1199

Solidago, 1185, 1188, 1189

Solea, 805

Soliva, 1299

Solomon's Seal, 372

Two-leaved, 270

Sonchus, 1317

Sophia, 484

Sophora, 595

Sophronanthe, 1067

Sorbus, 529

Sorghastrum, 66

Sorghum, 66

Sorghum, 66, 67

Sorrel, 368

Field, 369

Sheep, 369

Sorrel-tree, 890

Sour Cherry, 571

Sour-grass, 666

Sour Gum, 852

Sour-wood, 890

Sow Plum, 572

Sow Thistle, 1317

Spanish Bayonet, 273

Spanish Buckeye, 746

Spanish Moss, 245

Spanish Oak, 351, 352

SPARGANIACEAE, 35

Sparganium, 35

Sparkleberry, 892

Spartina, 132

Spathyema, 228

Spatularia, 501

Spear Grass, 152

Spearmint, 1050

Specularia, 1141

Speedwell, 1070

Spergula, 418

SPERMATOPHYTA, 25

Spermacoce, 1116

Spermolepis, 867

Spice-bush, 821

Spider Flower, 490

Spider Lily, 290

Spiderwort, 238

Spiderwort Family, 236

Spigelia, 922

Spigelia, 922

Spigeliaceat, 921

Spike Grass, 152

Spikenard, 855

Wild, 269

Spike Rush, 180

Spilanthes, 1252

Spinach, New Zealand, 413

Spindle Tree, 734

Spiraea, 513

Spiraea, 513, 514, 523

Spiranthes, 317,320

Spirodela, 230

Spatter Dock, 456

Spleenwort, 12

SPONDIACEAE, 725

Spoonwood, 886

Sporobolus, 122

Spotted Wintergreen, 879

Spring Beauty, 415

Spring Cleavers, 1118

Spruce, Black, 29
Spruce Pine, 28, 30

Spurge, 707, 714, 715, 718, 721

Allegheny Mountain, 724

Spurge Family, 690

Spurge Nettle, 706

Spurred Gentian, 931

Spurry, 418

Corn, 418

Sand, 418

Squaw Huckleberry, 893

Squaw-root, 1092

Squaw-weed, 1302

Squirrel Corn, 463

Stachydeoma, 1040

Stachys, 1030

Stachytarpheta, 1013

Staff-tree, 735

Staff-tree Family, 733

Stagger Grass, 289

Staghorn Sumac, 729

Stanfieldia, 1186

Staphylea, 738

STAPHYLEACEAE, 738

Star Anise, 450

Star Cucumber, 1140

Star-grass, 286

Water, 243

Star-lance, 432

Star-leaved Gum, 510

Star of Bethlehem, 286

Starry Campion, 426

Star Thistle, 1308

Starwort, 421

Water, 723

Statice, 900

Steeple-bush, 514

Steinchisma, 105

Steironema, 903

Stellaria, 420, 421

Stemmodontia, 1262

Stemodia, 1063

Stenandrium, 1085

Stenanthium, 251

Stenolobium, 1094

Stenophragma, 474

Stenophyllus, 188

Stenorhynchus, 320

Stenosiphon, 849

Stenotaphrum, 110

Stevia, 1163

Stickseed, 996

Stillingia, 704

Stinking Buckeye, 740

Stinking Cedar, 33

Stipa, 119

Stipulicida, 417

Stitchwort, 421

Stokesia, 1162

Stone-crop, 496

Ditch, 498

Virginia, 498

Stone Mint, 1048

Stone-root, 1050, 1051

Stopper, 831, 833

Naked, 832

Storax, 914

Stork's-bill, 660

Stramonium, 993

Strawberry, 520

Barren, 522

Bush, 734

Indian, 520

Yellow, 520

Strawberry-shrub, 528
Strawberry-shrub Family, 528

Streptanthus, 485

Streptanthus, 486

Streptopus, 270

Stretchberry, 283

Striped Dogwood, 742

Striped Maple, 742

Strobus, 29

Strombocarpa, 583

Strophostyles, 653

Strumpfia, 1113

Stuartia, 793

Stuartia, 793

Sturshum, 472

Stylophorum, 460

Stylosanthes, 633

STYRACACEAE, 914

Styrax, 914

Succory, Wild, 1320

Sugar-berry, 364

Sugar Grape, 754

Sugar Maple, 742

Sugar-tree, 742

Sumac, 727

Dwarf, 728

Fragrant, 728

Hairy, 729

Ill-scented, 7:28

Mountain, 728

Poison, 727

Smooth, 728, 729

Scarlet, 729

Staghorn, 729

Sumac Family, 725

Summer Grape, 756

Sundew, 492

Sundew Family, 491

Sundrops, 841

Sunflower, 1263

Sunflower Tree, 920

Suriana, 678, 679

SURIANACEAE, 678

Svida, 853

Swamp Ash, 918

Swamp Bay, 820

Swamp Honeysuckle, 883

Swamp Loosestrife, 827

Swamp Maple, 741

Swamp Oak, 351

Swamp Post Oak, 355

Swamp Red Bay, 820

Swamp Rose-mallow, 775

Swamp White Oak, 354, 355

Sweating-weed, 776

Sweet Alyssum, 478

Sweet Bay, 452, 820

Sweet Birch, 346

Sweetbrier, 527

Sweet Buckeye, 740

Sweet Cherry, 571

Sweet Cicely, 864

Sweet Clover, 604

Sweet Fern, 337

Sweet Flag, 229

Sweet Gum, 510

Sweet-leaf, 913

Sweet-leaf Family, 913

Sweet Orange, 678

Sweet Pepperbush, 877

Sweet Pine-sap, 880

Sweet-scented Bedstraw, 1120

Sweet Vernal Grass, 114

Sweet William, 979

Swietenia, 682 
Swine Cress, 467 Switch Grass, 93 Switch Oak, 353 Sword Fern, 17 Symphoricarpos, 1124 Symphytum, 1001 SYMPLOCACEAE, 913 Symplocarpus, 228 Symplocos, 913 Synandra, 1028 Syndesmon, 436 Synedrella, 1273 Syngonanthus, 235 Synosma, 1302 Syntherisma, 81 Synthlipsis, 468 Syringa, 507, 916

Table Mountain Pine, 29 Taenidia, 869 Taenitis, 8

Talinum, 414

Tall Blueberry, 895

TAMACEAE, 291

TAMARICACEAE, 783

Tamarack, 29

Tamarind,. Wild, 577

Tamarisk, 784

Tamarix, 783

Tamarix Family, 783

Tanacetum, 1297

Tan Bay, 794

Tangleberry, 892

Tansy, 1298

Tansy Mustard, 485

Tape-grass, 47

Tape-grass Family, 46

Taraxacum, 1318

Tar-weed, 829

TAXACEAE, 33

Taxodium, 31

Taxus, 33

Tea

New Jersey, 751

Oswego, 1036

Tear-thumb, 380

Teasel, Wild, 1130

Teasel Family, 1130

Tectaria, 15

Tecoma, 1095

Telanthera, 396

Tephrosia, 609

Terminalia, 830

TERminaliaCeaE, 830

Tetragonia, 413

TETRAGONIACEAE, 411

Tetragonotheca, 1249

Tetragonanthus, 931

Tetramerium, 1085

Tetraneuris, 1288

Teucrium, 1018

Teucrium, 1019

Texan Ebony, 576

Texas Buckeye, 746

Texas Buckthorn, 749

Texas Catsclaw, 578

Texas Millet, 91

Thalassia, 48

Thalesia, 1093

Thalia, 307

Thalictrum, 445

Thamnosma, 674

Thaspium, 872

THEACEAE, 792
Thelesperma, 1282

Thely podium, 474

THEOPHRASTACEAE, 906

Thermopsis, 596

Therofon, 500

Thespesia, 777

Thevetia, 934

Thistle, 1305

Blessed, 1309

Sow, 1317

Star, 1308

Thistle Family, 1152

Thorn Appel, 462, 993

Three-seeded Mercury, 700

Thrinax, 221

Thrinax, 222

Thryallis, 673

Thuja, 31

Thunder-wood, 727

Thurberia, 69

Thurovia, 1204

Thyme, 1045

Thymeleaceae, 818

THYMELEALES, 818

Thymophylla, 1295

Thymus, 1045

Thysanthema, 1309

Thysanella, 373

Tiarella, 502

Tickseed, 1274

Tick-trefoil, 634

Tiedemannia, 875

Tilia, 760

TILIACEAE, 759

Tillaea, 496

Tillandsia, 245

Tillandsia, 245

Timothy, 122

Tinantia, 237

Tiniaria, 381

Tipularia, 326

Tissa, 417

Tisswood, 820, 915

Titi, 730, 890

Black, 730

Red, 730

White, 730

Titi Family, 729

Tithymalopsis, 715

Tithymalus, 718

Tium, 618

Toad-flax, 1056

Bastard, 1102

Tobacco, 994

Indian, 1146

Rabbit, 1238

Wild, 1146

Tofieldia, 248

Tofieldia, 249

Tomato, 991

Toothache Grass, 132

Toothache-tree, $674,675,856$

Toothwort, 480

Torch-wood, 677

Torch-wood Family, 680

Torilis, 864

Torreya, 33

Tovara, 375

Touch-me-not, 661

Tough Buckthorn, 913

Tournefortia, 1004

Touterea, 809

Townsendia, 1205

Toxicoscordion, 252
Toxylon, 361

Tracaulon, 380

Trachelospermum, 937

Trachy pogon, 57

Tracyanthus, 250

Tradescantella, 237

Tradescantia, 238

Tradescantia, 237, 238

Tragia, 701

Tragopogon, 1318

Trailing Arbutus, 890

Trailing Wolf bane, 435

Trautvetteria, 440

Tread-softly, 706

Tree Huckleberry, 892

Tree-of-Heaven, 680

Tree Orchis, 327

Trefoil

Shrubby, 676

Tick, 634

Treleasea, 241

Trema, 366 :

Trepocarpus, 866

Triadenum, 792

Triantha, 248

Trianthema, 412

Trianthera, 137

Tribulus, 669

Trichachne, 83

Tricherostigma, 714

Trichloris, 135

Trichocoronis, 1162

Trichomanes, 3

Trichostema, 1019

Tridax, 1285

Tridens, 141

Trifolium, 605

Triglochin, 40

Trilisa, 1170

TRILliaCEAE, 275

Trillium, 276

Trillium Family, 275

Triodia, 142

Triorchos, 328

Triosteum, 1123

Triphasia, 1324

Triphora, 323

Triplasis, 144

Tripsacum, 53

Trisetum, 129

Triumfetta, 760

Trumpet-creeper, 1095

Trumpet-creeper Family, 1094

Trumpet-flower, 1094, 1095 Evening, 921

Trumpets, 494

Tsuga, 30

Tubiflora, 1081

Tulipastrum, 451

Tulip-tree, 453

Tumble Weed, 92, 392

Tumion, 33

Tupelo, 852 Water, 852

Tupelo Gum, 853

Turnera, 795

Turnera Family, 794

TURNERACEAE, 794

Turnip, 477

Indian, 226

Turkey-beard, 249

Turkey Oak, 351

Turtle-head, 1058

Twayblade, 320,325 
Twifole, 320

Twig Rush, 191

Twin-leaf, 458

Two-leaved Solomon's Seal, 270

Typha, 35

TYPHACEAE, 34

ULMACEAE, 362

Ulmaria, 523

Ulmus, 363

UMBELLIFERAE, 856

Umbrella-leaf, 459

Umbrella-tree, 452

Umbrella-wort, 406

Ungnadia, 746

Unicorn-plant, 1097

Unicorn-plant Family, 1096

Unifolium, 270

Uniola, 151

Urechites, 936

Urena, 772

Urtica, 356

URTICACEAE, 356

URTICALES, 355

Urticastrum, 357

Urvillea, 743

Utricularia, 1090

Utricularia, 1090

Uvularia, 271

Vaccaria, 425

VACCINIACEAE, 890

Vaccinium, 893, 897

Vaccinium, 894

Vachellia, 578

Vagnera, 269

Valerian, 1128

Greek, 980

Valerian Family, 1127

Valeriana, 1128

VALERI ANACEAE, 1127

VALERIANALES, 1127

Valerianella, 1128

Validallium, 264

Vallesia, 934

Vallisneria, 47

Vanilla, 324

Vanilla Grass, 114

Varilla, 1252

Vase-vine, 439

Velvet Grass, 128

Velvet Leaf, 763

Venus' Flytrap, 493

Venus' Flytrap Family, 492

Venus' Looking-glass, 1141

Veratrum, 251

Verbascum, 1054

Verbena, 1008

Verbena, 1011, 1013

VERBENACEA E, 1007

Verbesina, 1272

Vervain Family, 1007

Vetch, 655

Joint, 632

Vernonia, 1157

Veronica, 1070

Veronica, 1072

Vetiveria, 67

Viburnum, 1121

Vicia, 655

Vigna, 654

Viguiera, 1263

Vinca, 935

Vincetoxicum, 952
Viola, 800

affine, 802

Alabamensis, 802

amorphophylla, 802

blanda, 805

Canadensis, 804

Carolina, 802

denticulosa, 803

emarginata, 803

faleata, 801

fimbriatula, 802

hastata, 804

heterophylla, 801

lanceolata, 803

Langloisii, 802

LeConteana, 803

Missouriensis, 802

multicaulis, 804

odorata, 803

palmata, 801

papilionacea, 802

pedata, 801

primulaefolia, 803

pubescens, 804

Rafinesquii, 805

rostrata, 805

rotundifolia, 803

sagittata, 802

scabriuseula, 804

septemloba, 801

striata, 804

subsinuata, 801

tenuipes, 804

tripartita, 804

vicinalis, 801

villosa, 802

vittata, 803

VIOLACEAE, 800

Violet, 800

Dog's-tooth, 267

Green, 805

Violet Family, 800

Violet Iris, 305

Violet Wood-sorrel, 665

Viorna, 437

Viper's Bugloss, 1002

Virginia Creeper, 758

Virginia Stonecrop, 498

Virginia Stonecrop Family, 498

Virginia Willow, 508

Virginia Willow Family, 508

Virgin's Bower, 437

Purple, 440

VITACEAE, 752

Vitex, 1015

Vitis, 753

Vitis, 757

Viticella, 437

Vittaria, 7

Voyria, 932

Waahoo, 734

Wahoo, 760

Wake-robin, 276

Waldsteinia, 521

Walking Fern, 14

Walking Leaf, 14

Wall Cress, 475

Walnut, 333

Black, 333

White, 333

Walnut Family, 332

Walter's Pine, 28
Waltheria, 780

Wampee, 244

Warea, 487

Wart Cress, 467

Washingtonia, 864

Watches, 494

Water Ash, 676, 918

Water-carpet, 505

Water Chinquapin, 455

Water-cress, 472

Water Dropwort, 875

Water Elm, 364

Water Grass, 90

Water Hemlock, 868

Water-hemp, 393

Water Hickory, 334

Water Hoarhound, 1048

Water Hyacinth, 244

Water-leaf, 970

Water-leaf Family, 969

Water Lettuce, 228

Water Lily, 457

Water Lily Family, 456

Water Locust, 589

Water Maple, 741

Watermelon, 1137

Water Milfoil, 850

Water Milfoil Family, 849

Water Millet, 112

Water Oak, 350

Water Oats, 112

Water Parsnip, 870

Water Pennywort, 858

Water Pepper, 380

Water Pimpernel, 901

Water-plantain, 41

Water-plantain Family, 41

Water Purslane, 825

Water-shield, 455

Water-shield Family, 454

Water Star-grass, 243

Water Starwort, 723

Water Starwort Family, 722

Water Tupelo, 852

Water-weed, 47

Water Willow, 1087

Water-wort Family, 783

Wauhoo, 451

Wax-myrtle, 337

Wax-weed, 829

Waxwork, 735

Websteria, 189

Wedelia, 407

West Indian Birch, 681

West Indian Gherkin, 1137

Whahoo, 676

Wheat Grass, 158

White Alder, 877

White Alder Family, 877

White Ash, 919

White Baneberry, 432

White Buttonwood, 831

White Cedar, 32

White Cohosh, 432

White Elm, 364

White Grass, 113

White Holly, 733

White Ironwood, 746

White Lettuce, 1311

White Mangrove, 831

White Mangrove Family, 830

White Maple, 741

White Mustard, 476

White Oak, 354,355 
White Pine, 28, 29

White Poplar, 453

White Rush, 132

White Titi, 730

White Walnut, 333

White Wicky, 885

Whitewood, 693, 782

Whitlow Grass, 479

Whitlow-wort, 399

Whitlow-wort Family, 399

Wicky, 885

Wild Bachelor's Button, 689

Wild Bean, 653

Wild Bergamont, 1037

Wild Cherry, 573,574

Wild China, 745

Wild China Tree, 745

Wild Cinnamon, 762

Wild Cinnamon Family, 782

Wild Comfrey, 996

Wild Dilly, 913

Wild Garlie, 263

Wild Geranium, 659

Wild Ginger, 1131, 1132

Wild Goose Plum, 573

Wild Honeysuckle, 883

Wild Hyacinth, 267

Wild Indigo, 597

Wild Laurel, 914

Wild Lettuce, 1315

Wild Lime, 675

Wild Liquorice, 1118

Wild Mandrake, 458

Wild Monkshood, 434

Wild Mustard, 477

Wild Oat Grass, 131

Wild Oats, 67

Wild Olive, 910, 920

Wild Olive Tree, 915

Wild Onion, 263

Wild Parsnip, 875

Wild Pink, 427

Wild Red Cherry, 571

Wild Rice, 112

Wild Rye, 159

Wild Sapodilla, 913

Wild Sarsaparilla, 856

Wild Spikenard, 269

Wild Succory, 1320

Wild Tamarind, 577

Wild Teasel, 1130
Wild Tobaceo, 1146

Wild Yam-root, 292

Willow, 340

Virginia, 508

Water, 1087

Willow Family, 338

Willow-herb, 839

Willow Oak, 350

Willugbaeya, 1170

Wind Rue, 436

Winter Cress, 475

Winterberry, 732

Evergreen, 731

Winter Grape, 755

Wintergreen, 878

Creeping, 890

Flowering, 685

Spotted, 879

Wintergreen Family, 878

Wire Grass, 114, $13 \mathrm{~s}$

Wissadula, 764

Wistaria, 612

Wisteria, 612

Witch Elm, 510

Witch Grass, 92

Witch Hazel Family, 508

Withe-rod, 1122

Wolf bane, Trailing, 435

Wolffia, 229

Wolffiella, 229

Wood Lettuce, 1315

Wood Nettle, 357

Wood-rush, 261

Woodsia, 18

Wood-sorrel, 664, 666

Violet, 665

Yellow, 666

Wood-sorrel Family, 665

Woodwardia, 12

Wormseed, 386

Wormseed Mustard, 476

Wormwood, 1298

Xanthisma, 1184

Xanthium, 1148

Xanthorrhiza, 430

Xanthoxalis, 666

Xanthoxylum, 674, 675, 677

Xerophyllum, 249

Ximenia, 1104

Ximenisia, 1273
Xolisma, 889

Xylophacos, 619

Xilosteon, 1124

XYRIDACEAE, 231

XYRIDALES, 230

Xyris, 231

Yam, 292

Yam Family, 291

Yam-root, Wild, 292

Yarrow, 1297

Yard Grass, 138

Yaupon, 733

Yeatsia, 1087

Yellow Birch, 346

Yellow Buckeye, 740

Yellow-eyed Grass, 232

Yellow-eyed Grass Family, 231

Yellow Jessamine, 921

Yellow Oak, 354

Yellow Opopanax, 578

Yellow Pine, 27, 28

Yellow Poppy, 461

Yellow-root, Shrub, 431

Yellow Strawberry, 520

Yellow-wood, 596, 675, 750, 914

Yellow Wood-sorrel, 666

Yew, 34

Yew Family, 33

Yew Pine, 29

Yucca, 273

Yucca Family, 273

Zamia, 26

Zannichellia, 36

ZANNICHELLIACEAE, 36

Zenobia, 888

Zephyranthes, 289

Zexmenia, 1271

Zizia, 867

Zizania, 112

Zizaniopsis, 111

Zizyphus, 748

Zornia, 633

Zostera, 39

ZOSTERACEAE, 39

Zygadenus, 253

Zygadenus, 252

ZYGOPHYLLACEAE, 669

Zygophyllidium, 714 